\title{
ABSTRACTS OF DOCUMENTS IN THIS SUPPLEMENT
}


00001 A BRIEF HISTORY OF AID WEST AFRICA, (3890) (APR 92), 577. IN THE 1970'S. THE INDUSTRIALIZED WORLD VIEHED FOREIGN AID IN A POSITIVE LIGHT, AS BENEFICIAL TO BOTH TME DONOR AND THE RECIPIENT. DURING THE 1980'S, REAGANOMICS AND THATCHERISM WERE INTRINSICALLY HOSTILE TO THE IDEA OF OFFICIAL AID, AND STRUCTURAL ADJUSTMENT BECAME THE ORDER OF THE DAY IN THE THIRD WORLD. MOW THE DEVELOPMENT INDUSTRY IS SLOWLY RECOVERING ITS BALANCE; THE NEW STRESS ON EASING THE SOCIAL PROBLEMS OF ADJUSTMENT AND THE REASSERTION OF REDUCING POYERTY AS A MAJOR DEVELOPMENT OB JECTIVE ARE SIGMS OF A RETURN TO A MORE BALANCED YIEH.

00002

A BRIEF HISTORY OF AID: PART 2

THE RELUCTANCE OF U.S. PRESIDENT GEORGE BUSH TO ATTEND IHE 1992 EARTH SUMMIT COUPLED WITH THE JAPANESE FOREIGN MINISTER'S DECLARATION THAT JAPAN IS REAOY TO ASSUME WORLD MINISTER'S DECLARATION THAT JAPAN IS READY TO ASSUME WORLD LEADERSHIP IN ENVIRONMENTAL PROTECTION AND DEVELOPMENT AID IS A HARBINGER OF THE NATURE OF WORLD POLITICS OVER THE
FEW YEARS. WITHOUT THE COMPLICATIONS OF IDEOLOGY, THE COMPETITION AMONG THE RICH COUNTRIES FOR SPHERES' OF INFLUENCE IS LIKELY TO BECOME MORE INTENSE.

00003

A CHARTER FOR DEMOCRACY: CONCLUDING DOCUMENT CSCE, COPENHAGEN

WORLD AFFAIRS, 153(1) (SUM 90), 28-40

AT THE MOST RECENT MEETING ON THE SUBJECT OF HUMAN RIGHTS IN COPENHAGEN, THE CONFERENCE ON SECURITY AND COOPERATION IN EUROPE (CSCE) PRODUCED A GROUND-BREAKING DOCUMENT. THIS ARTICLE REPROOUCES THAT DOCUMENT IN ITS ENTIRELY. THE DOCUMENT INCLUDES PROVISIONS CALLING FOR FREE AND FAIR ELECTIONS, RULE OF LAN, AND PROTECTION OF

FUNDAMENTAL HUMAN RIGHTS.

00004

A CONGOLESE COMEBACK

WEST AFRICA, (3885) (MAR 92), 369

PASCAL LISSOUBA, ONCE PRESIDENT MASSEMBA-DEBAT'S RIGHTHAND MAN, HAS RESUMED A ROUGH AND TUMBLE POLITICAL CAREER HAND MAN, HAS RESUMED A ROUGH AND TUMBLE POLITICAL CAREER PREMIERSHIP TO THE DEPTHS OF PUBL IC VILIFICATION AND

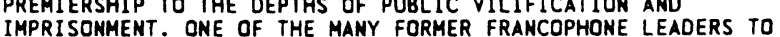
IMPRI SONMENT. ONE OF THE MANY FORMER FRANCOPHONE LEADERS TO REAPPEAR WITH THE EMERGENCE OF POLITICAL PLURALISM, LISSOUBA NOW LEADS THE UNION PANAFRICAINE POUR LA DEMOCRATIE AND HOPES TO BE HIS PARTY
PRESIDENTIAL ELECTION.

00005

A CONVERSATION WITH FERDINAND MOUN

FREEDOM REVIEW, 23(2) (MAR 92) 13-15.

IN THIS INTERVIEW, THE EDITOR OF THE "TIMES LITERARY SUPPLEMENT" DISCUSSES RECENT BRITISH POLITICS. HE SUGGESTS THAT THE BRITISH LEFT SHOULD IDENTIFY ITSELF AS "THE PARTY OF THE POOR."

00006

A DISUNITED HAR FRONT

THE MIDOLE EAST, (197) (MAR 91), 21-22.

THIS ARTICLE' exAMINES THE "WAR FRONT" PRESENTED BY THE EUROPEAN LEADERS DURING THE GULF HA. THE POSITIONS OF THE MAJOR EUROPEAN NATIONS ARE OISCUSSED; THE AUTHOR CONCLUDES THAT BENEATH AN UMBRELLA OF UNITY, DISUNITY AND DIVERGING FEARS AND GOALS PREDOMINATED AMONG THE EUROPEAN NATIONS.

00007

A FUTILE ULTIMATUM?

WEST AFRICA (3920) (NOY 92) 1868-1869.

EVEN BEFORE THE LIBERIAN PEACE TALKS BEGAN ON OCTOBER 19 , 1992, IT WAS EVIDENT THAT THE WARRING FACTIONS WERE NOT READY TO DISARM, MOR WAS THE NPFL READY TO ACCEPT THE TERMS OF THE YAMOUSSOUKRO ACCORDS. REPORTS INDICATE AN ESCALATION IN FIGHTING AROUND MONROVIA AND ITS OUTSKIRTS, WITH ECOMOG IROOPS, UNDER ATTACK BY THE NPFL, BATTLING TO HOLD THEIR POSITIONS.

00008

A GLIMMER OF LIGHT

WEST AFRICA (3877) (JAN 92), 5

THE ORIVE TOWARD MORE ACCOUNTABLE FORMS OF GOVERNMENT IN AFRICA SEEMS VIRTUALLY IRREVERSIBLE. EVEN IN THOSE COUNTRIES WHERE PERSOMAL OR MIL ITARY DICTATORSHIPS STILL HOLD POHER. THE MOMENTUM FOR CHANGE EXISTS. IT IS ONLY A MATTER OF TIME. BUT THERE IS A DANGER IN THIS NEW-FOUND FAITH IN DEMOCRACY. AT THE LEVEL OF MASS COMPREHENSION THE CLAMOR FOR DEMOCRACY IS AN EXPRESSION OF OISSATISFACTION NOT ONLY WITH OSSIFIED POLITICAL ARRANGEMENTS BUT WITH THE ECONOMIC REALITY. DEMOCRACY HAS BECOME A PANACEA FOR ALL PROBLEMS. THEREIN LIES THE DANGER. IF DEMOCRACY FAILS TO DELIVER ECONOMY PROSPERITY, THERE COULD BE A QUICK RETURN TO THE DISENCHANTMENT THAT COULD LEAD TO THE RE-EMERGENCE OF
DICTATORSHIP

00009

A GLOBAL 'GREEN GIANT'?

JAPAN TIMES (HEEKLY INTERNATIONAL EDITION), 32(15) (APR 92), 10.

JAPAN'S BID TO ASSUME INTERNATIONAL ECO-LEADERSHIP IS BEING MELD HOSTAGE TO BUREAUCRATIC TURF BATTLES AMONG THE MINISTRY OF INTERNATIONAL TRADE AND INDUSTRY, THE

ENVIRONMENTAL AGENCY, AND THE HEALTH AND WELFARE MINISTRY-ALL OF WHICH HAVE STAKED A CLAIM TO ENFORCING ENVIRONMENTAL REGULATIONS.

00010

A LOOK BEHIND THE RECENT BOMBINGS

LATIN AMERICAN WEEKLY REPORT, (23) (JUN 92), 8-9.

IN LESS THAN A WEEK TWO BOMBS SHATTERED URUGUAY'S PEACEFUL RETURN TO CONSTITUTIONAL RULE. THE FIRST ONE, ON APRIL 29, 1992, DAMAGED THE OFFICE OF FORMER PRESIDENT JULIO MARIA SANGUINETTI. ON MAY 1 , THE SECOND DAMAGED A RAILWAY BRIDGE IN LAVALLEJA. TWO GROUPS, THE GUARDIA DE ARTIGAS AND THE COMMANDO LAVALLEJA, CLAIMED RESPONSIBILITY FOR THE BOMBINGS.

0001

A MIXED BLESSING

WEST AFRICA, (3915) (SEP 92), 1619

THE IMPORTANCE OF OIL TO THE NIGERIAN ECONONY CANMOT BE OVERSTATED. OIL CONTRIBUTED $86.4 \%$ OF THE GOVERNMENT'S TOTAL REVENUE IN THE FIRST HALF OF 1992. BUT THE OIL-PRODUCING COMMUNITIES ARE RESTIVE. THEY COMPLAIN THAT MODERNITY HAS PASSED THEM BY, THAT OIL PRODUCTION HAS DESTROYED THEIR TRADITIONAL LIVELIHOOD DUE TO THE SPILLAGE THAT POLLUTES THEIR LAND AND WATER, AND THAT THEY DESERVE MORE THAN THEY ARE GETTING NOW. IN THEIR BID TO IMPROVE THEIR LOT, THEY TRY NEGOTIATING WITH THE GOVERNMENT AND, WHEN THAT FAILS, THEY TURN TO VIOLENCE.

00012

A NON-NUCLEAR KOREAN IN SIGHT

JAPAN TIMES (WEEKLY INTERNATIONAL EDITION), 32(2) (JAN 92),

10.

NORTH AND SOUTH KOREA HAVE TAKEN AN HISTORIC STEP TOHARO PEACE AND REUNIFICATION BY INITIALING A DRAFT JOINT DECLARATION ON A NON-NUCLEAR KOREAN PENINSULA. IN THE DECLARATION, BOTH COUNTRIES AGREED TO THE FOLLOWING: (1) NOT O MANUFACTURE, INTRODUCE, POSSESS, OR USE NUCLEAR WEAPONS 2) MOT TO POSSESS FACILITIES FOR NUCLEAR REPRDCESSIMG AND VERIFY COMPL IANCE.

00013

A POSITIVE WORD ON NEGATIVE POLITICS

WORLD PRESS REVIEW, 39(5) (MAY 92), 13-14.

SOME OBSERVERS ARGUE THAT POLITICAL CAMPAIGNS ARE INCREASINGLY DOMINATED BY TWO DEBILITATING DRUGS: NEGATIVE ADVERTISEMENTS AND THE DEMANDS OF TELEVISION. NEITHER NEGATIVE ADVERTISING NOR TELEVISION ARE NEW, BUT TWO THINGS HAVE CHANGED RECENTLY. THE FIRST IS THAT TELEVISION NEWS HAS BEEN INFILTRATED BY POLITICAL COMMERCIALS. THE SECOND HAS BEEN IN ACADEMIC EXPLANATIONS OF THE IMPACT OF TELEYISION ON POLITICS.

00014

A QUIET REVOLUTION

HEST AFRICA, (3893) (APR 92), 709

THE AUTHOR PROFILES SIMON ACHIDI ACHU, WHO WAS APPOINTED PRIME MINISTER AND HEAD OF GOVERNMENT IN CAMEROON ON APRIL 9 , 1992, BECOMING THE FIRST ANGLOPHONE TO HOLD THAT POST SINCE THE ENGLISH-SPEAKING STATE OF WEST CAMEROON REUNITED WITH THE FRENCH-SPEAKING STATE OF EAST CAMEROON IN 1961.

00015

A REBEL WITH A CAUSE

WEST AFRICA, (3899) (JUN 92 ), 953.

DR. THOMAS ADEBAYO KUMOLU-JOHNSON, THE SECRETARY-GENERAL OF THE NIGERIA COUNCIL FOR NATIONAL AWARENESS BELIEVES THAT NIGERIANS SHOULD DEPEND UPON THEMSELVES, THAT THEY SHOULD NIGERIANS SHOULD DEPEND UPON THEMSELVES, THAT THEY SHOULD
LET TOLERANCE REIGN. THAT THEY HOLD THEIR DESTINY IN THEIR LEY HANDS. THAT THEY SHOULD BE AHARE OF THEIR RIGHTS, AND OWN HANDS, THAT THEY SHOULD BE AWARE OF THEIR RIGHTS,

00016

A SALUTARY SHOCK

THE MIDDLE EAST, (195) (JAN 91) 23-35.

SINCE AUGUST, 1990 , BANKS IN THE PERSIAN GULF HAVE BEEN FIGHTING A BATTLE FOR SURVIVAL. CENTRAL BANK FIGURES REVEAL THAT MORE THAN \$22 BILLION OF DEPOSITS HAVE BEEN SIPHONED OFF FROM GULF BANKS SINCE THE END OF JULY. NO AMOUNT OF POSITIVE TALKING BY BANKING OFFICIALS OR GOVERNMENT LEADERS CAN REVERSE THE CONSIDERABLE DAMAGE DONE TO THE CONFIDENCE OF THE PRIVATE SECTOR. THIS IS A GENERAL CONSENSUS BOTH IN AND OUT OF THE GULF THAT THE REGION WILL NEVER BE THE SAME CLOSED PENINSULA. MOST GULF BANKERS AGREE THAT THE MARKET 
WHICH EMERGES FROM THE CRISIS WILL REQUIRE FEHER, BUT LARGER, INSTITUTIONS, SUPPORTED BY STRONGER CAPITAL AND FUNDING RESOURCES.

00017

A SPECIAL OLYMPICS

EW REPUBLIC, 206(10) (MAR 92), 7.

THE AUTHOR LOOKS AT THE RESULITS OF THE 1992 NEW

HAMPSHIRE PRIMARY ELECTION AND WHAT THE OUTCOME REVEALS

ABOUT BOTH THE DEMOCRATIC AND REPUBLICAN PARTY CANDIDATES. 00018

A TALE OF TWO TRANSITIONS

WEST AFRICA, (3878) (JAN 92), 57

FOR GHANA AND NIGERIA, 1992 WILL BE AN IMPORTANT

HISTORICAL MILESTONE, AS BOTH WILL CONSUMMATE THE PROCESS OF TRANSITION FROM MILITARY TO CIVILIAN RULE, ALTHOUGH THEY ARE TAKING DIFFERENT POLITICAL ROUTES TO THE SAME DESTINATION. THE NIGERIAN PROCESS, HAVING STARTED EARLIER, IS MUCH

FARTHER ALONG THAN GHANA'S 00019

A THOUSAND CUTS

MEH REPUBLIC, 206 (9) (MAR 92), 9

PRESIDENT GEORGE BUSH'S TAX PROPOSALS ARE A CASE STUDY

IN POLICY INCOHERENCE. BECAUSE THE ECONOMY IS SLOW, THE

PRESIDENT INCOHERENCE. BECAUSE THE ECONOMY IS SLOH, THE

INVESTMENT HAMPERS LONGER-TERM GROWTH, THE PRESIDENT WANTS

TO STIMULATE INVESTMENT. FOR MOST PURPOSES, THESE ARE

CONFLICTING GOALS.

00020

A UNITED NATIONS FOR DUR TIMES

HEST AFRICA, (3882) (FEB 92), 229.

THE END OF THE COLD WAR AND THE BEGINNING OF THE NEH

WORLD ORDER ARE RAISING MANY QUESTIONS ABOUT THE FUTURE ROLE OF THE UNITED NATIONS IN INTERNATIONAL AFFAIRS

00021

A VIEW FROM MAIN STREET AMERIC

OURNAL OF STATE GOVERNMENT, 65(1) (JAN 92), 15-19.

THIS ARTICLE INCLUDES EXCERPTS FROM A REPORT, "CITIZEMS

ANO POLITICS: A VIEW FROM MAIN STREET AMERICA," PREPARED FOR

THE KETTERING FOUNDATION. THE REPORT SUGGESTS THAT THE

PUBLIC IS NEITHER APATHETIC NOR UNINFORMED ABDUT POL ITICAL

LIFE IN AMERICA: RATHER AMERICANS FEEL REMOVED FROM THE

DECISION-MAKING SYSTEM. 00022

A YEAR ON, PEACE ELUDES COLOMBIA

LATIN AMERICAN HEEKLY REPORT, (29) (JUL 92), 6-7.

COLOMBIA IS FAR FROM ACHIEYING INTERMAL PEACE. TALKS

BETWEEN THE GOVERMMENT AND THE FUERZAS ARMADAS REVOLUCIONARIAS DE COLOMBIA (FARC) AND THE EJERCITO DE
LIBERACION NACIONAL (ELN) HAVE BRDKEN DOWN. ALTHOUGH THE LIBERACION NACIONAL (ELN) HAVE BRDKEN DOWN. ALTHOUGH THE
DRUG LORDS OF THE MEDELLIN CARTEL HAVE SURRENDERED, THE CAL DRUG LORDS OF THE MEDELLIN CARTEL HAVE SURRENDERED, THE CALI CARTEL IS STILL ACTIVE AND A MINI-WAR IS UNDERWAY BETHEEN RIVAL DRUG TRAFFICKERS. PARAMILITARY GROUPS ARE ACTIVE AND
OIRECTING THEIR EFFORTS AGAINST SUSPECTED GUERRILLAS, THEIR COLLABORATORS, AND SYMPATHIZERS

00023

ABDUCTION ROW GETS EVEN STRANGER

LATIN AMERICAN WEEKLY REPORT, (27) (JUL 92), 5

THE U.S. SUPREME COURT'S RULIMG THAT THE UMITED STATES

MAY ESSENTIALLY KIDNAP FOREIGN SUSPECTS WHO ARE NOT BEIMG

EXTRADITED BY THEIR HOME COUNTRIES HAS ELICITED VARIED

RESPONSES IN LATIN AMERICA.

00024

ABE INDICTED ON GRAFT CHARGES

JAPAN TIMES (WEEKLY INTERNATIDNAL EDITION), 32 (6) (FEB 92),

ON FEBRUARY 1, 1992, PROSECUTORS INDICTED DIET MEMBER

FUMIO ABE ON CHARGES OF ACCEPTING \$635,000 IN BRIBES FROM

KYOWA COMPANY AFTER THE FIRM ASKED FOR OFFICIAL FAVORS. ABE

TOSHIKI KAIFU FROM AUGUST 1989 TO FEBRUARY 1990. 00025

ABIMAEL GUZMAN'S CAPTURE: AFTER THE ELATION, A LOOK AT THE PROSPECTS

LATIN AMERICAN WEEKLY REPORT, (37) (SEP 92),

ON SEPTEMBER 12, 1992, PERUVIAN POLICE CAPTURED ABIMAEL

GUZMAN, LEADER OF THE SENDERO LUMIMOSO. THEY ALSO CAUGH

SEVERAL MEMBERS OF SENDERO'S CENTRAL COMMITTEE AND THE

THESE ARRESTS

ON THE SENDERO LUMINOSO'S ACTIVITIES IS HARD TO PREDICT. 00026

ACCELERATING REFORM AND OPENING UP

BEIJING REVIEW, 35(43) (OCT 92), 10-33.

ON OCTOBER 12, 1993, JIANG ZEMIN, GENERAL SECRETARY OF

THE CENTRAL COMMITTEE OF THE CHINESE COMMUNIST PARTY,
ADDRESSED THE PARTY'S 14TH NATIONAL CONGRESS. HE DISCUSSED WAYS TO ACCELERATE CHINA'S REFORM POLICIES AND TO "ACHIEV GREATER SUCCESSES IN BUILDING SOCIALISM WITH CHINESE CHARACTERISTICS."

00027

ACHIEVEMENTS MADE BY ESCAP

BEIJING REVIEW, 35(17) (APR 92), 12-14.

THIS ARTICLE INCLUDES EXCERPTS FROM SPEECHES MADE BY

CHINESE PREMIER LI PENG, UNITED NATIONS SECRETARY-GENERAL

BOUTROS BOUTROS-GHALI, AND CHINESE FOREIGN MINISTER QIAN

QICHEN AT THE 48TH SESSION OF THE ECONOMIC AND SOCIAL

COMMISSION FOR ASIA AND THE PACIFIC (ESCAP) IN APRIL 1992.

THE THREE LEADERS DISCUSSED THE SOCIAL AND ECONOMIC

OPPORTUNITIES AND CHALLENGES IN THE REGION.

00028

ACTION HOMAN

WEST AFRICA, (3878) (JAN 92), 65

ELLEN JOHNSON-SIRLEAF IS AN EXECUTIVE OF THE LIBERAL

ACTION PARTY AND THE ONLY WOMAN TO BE CONTINUOUSLY IN THE

LIMELIGHT OF POLITICAL AND ECONOMIC AFFAIRS IN LIBERIA FOR

NEARLY THO DECADES. NICKNAMED "ACTION WOMAN," SHE IS

RESPECTED AS AN ACCOMPLISHED ECONOMIST AND POLITICIAN WHO

HAS STOOD THE TEST OF TIME.

00029

ACTIVE PARL IAMENTARY DIPLOMACY

BEIJING REVIEW, 35(2) (JAN 92), 32-35.

THE NATIONAL PEOPLE'S CONGRESS (NPC), CHINA'S HIGHEST

LEGISLATIVE BOOY, IS AN IMPORTANT CHANNEL FOR CHINESE

DIPLOMATIC CONTACTS WITH OTHER COUNTRIES. IT HAS ESTABLISHED

TIES WITH THE PARLIAMENTS OF NEARLY 120 COUNTRIES AND SET UP

BILATERAL FRIENDSHIP GROUPS WITH 23 FOREIGN PARLIAMENTS. IN

1991 THE NPC PLAYED HOST TO 57 DELEGATIONS REPRESENTING

SPECIAL COMMITTEES AND THE PARLIAMENTS OF OTHER COUNTRIES.

00030

ADB MOVES ON TREATY

ST AFRICA, (3883) (FEB 92), 288.

THE AFRICAN DEVELOPMENT BAHK HAS ESTABLISHED A TASK

FORCE ON THE AFRICAN ECONOMIC COMMUNITY (AEC) TO ASSIST THE

BANK IN IDENTIFYING AREAS IN WHICH IT CAN INTERVENE TO

ENSURE THE SUCCESSFUL IMPLEMENTATION OF THE TREATY

ESTABLISHING THE AEC, WHICH WAS SIGNED BY MEMBERS OF THE

ORGANIZATION OF AFRICAN UNITY IN 1991. THE TREATY REFLECTS

THE GROWING REALIZATION THAT THE INTEGRATION OF AFRICAN

ECONOMIES IS A NECESSARY STEP TOWARD STRENGTHENING THEM AND

SOLYING THE PROBLEMS BESETTING THE REGIONAL ECONOMY.

00031

ADM-19 PULLS OUT, OTHERS UTTER DISSENT

ATIN AMERICAN WEEKLY REPORT, (48) (DEC 92), 10 WHEN PRESIDENT CESAR GAYIRIA DECLARED 92 ), 10.

EMERGENCY AND ALL-OUT HAR AGAINST THE GUERRILLAS ON NOVEMBER 8 , 1992, HE WAS STRONGLY SUPPORTED BY BUSINESS LEADERS, THE ROMAN CATHOLIC HIERARCHY, POLITICAL LEADERS, AND THE MAINSTREAM MEDIA. LESS THAN A MONTH LATER, VOICES OF DISSEN HAVE BEGUN TO SURFACE FROM THE ADM-19, THE CATHOLIC BISHOP OF SAN GIL, AND THE LABOR UNIONS.

00032

ADVANTAGE FOR RULING CONCERTACION IN CHILEAN MUNICIPAL ELECTIONS

LATIN AMERICAN WEEKLY REPORT, (26) ( JUL 92), 1

THE RULING CONCERTACION WON CHILE'S MUNICIPAL ELECTIONS

ON JUNE 28, 1992. THE CHRISTIAN DEMOCRATIC PARTY, THE MAJOR

PARTNER IN THE CONCERTACION, TOOK THE SINGLE LARGEST SHARE

OF THE VOTE. HOWEVER, THE CHRISTIAN DEMOCRATS' SHARE HAS

LOHER THAN EXPECTED WHILE THE PARTIDO POR LA DEMOCRACIA AND

THE PARTIDO SOCIALISTA RECEIVED MORE VOTES THAN THE POLLS

HAD FORECAST.

00033

AOVICE FOR THE YOUNG TURKS

(AUG 92), 1308

UNITED NATIONS UNDER-SECRETARY-GENERAL FOR POLITICAL

AFFAIRS JAMES JONAH IS FROM SIERRA LEONE. IN THIS INTERVIEW,

HE DISCUSSES THE REGIME OF CAPTAIN VALENTINE STRASSER AND

THE PROSPECTS FOR A RETURN TO DEMOCRATIC RULE IN HIS

HOMELAND.

00034

AFFIRMING ECOWAS' MANDATE

MEST AFRICA (3922) (MOY 92), 1969

THIS ARTICLE REPRINTS THE FULL TEXT OF THE FINAL

COMMUNIOUE ISSUED AT THE SUMMIT MEETING OF THE COMMITTEE OF NINE ON THE LIBERIAN CRISIS ON NOVEMBER 7, 1992. THE

COMMUNIQUE REAFFIRMS THE ECOHAS COMMITTEE'S COMMITMENT TO A

PEACEFUL RESOLUTION OF THE LIBERIAN CRISIS, CONDEMNS THE

NPFL ATTACK ON ECOMOG, AND CALLS FOR A CEASEFIRE.

00035

AFRICA'S EXPERIMENTS 
WEST AFRICA, (3897) (MAY 92), 870-871.

THE AUTHOR REPORTS ON THE STATUS OF THE DEMOCRATIC TRANSITION IN SUB-SAHARAN AFRICA, USING A COUNTRY-BY-COUNTRY CHECKLIST.

00036

AFTER THE COUP..

WEST AFRICA, (3897) (MAY 92), 878-879.

THE NATIONAL PROVISIONAL RULING COUNCIL (NPRC) LED BY CAPTAIN VALENTINE STRASSER IS NOW IN CONTROL OF SIERRA LEONE. STRASSER HAS VOWED TO RUN A CORRUPTION-FREE GOVERNMENT AND TO PROSECUTE THE OFFICIALS WHO STOLE MILLIONS OF LEONES FROM STATE FUNDS DURING THE MOMOH ADMINISTRATION.

00037

AFTER THE SMITH VERDICT: PUBLIC IMAGE OF THE KENNEDYS AT A NEW LOW

GALLUP POLL MONTHLY, (315) (DEC 91), 37-41.

THIS ARTICLE RECORDS RESPONSES TÓ SEVERAL QUESTIONS IN A PUBLIC OPINION SURVEY CONDUCTED AFTER THE JURY DELIVERED ITS PUBLIC OPINION SURVEY CONDUCTED AFTER THE JURY DELIVERED ITS VERDICT IN THE WILLIAM KENNEDY SMITH RAPE TRIAL. IT INCLUDE RANKING OF PRESIDENTS THAT PLACES ABRAHAM LINCOLN AS THE GREATEST U.S. PRESIDENT, FOLLOHED CLOSELY BY JOHN F. KENNEDY. 00038

AFTER THE TORRICELLI ACT, WHAT CAN THE REGION EXPECT FROM WASHINGTON?

LATIN AMERICAN WEEKLY REPORT, (43) (NOV 92), 1

IN OCTOBER 1992, U.S. PRESIDENT GEORGE BUSH SIGNED THE

TORRICELLI ACT, WICH TIGHTENS THE EMBARGO AGAINST CUBA

THROUGH PROCEDURES THAT WILL IMEVITABLY LEAD TO CLASHES WITH

SOME OF THE UNITED STATES' MAJOR ALLIES IN LATIN AMERICA.

00039

AFTER VENEZUELA, A DOMINO EFFECT?

ATIN AMERICAN WEEKLY REPORT, (8) (FEB 92), 6-7

FORMER VENEZUELAN PRESIDENT RAFAEL CALDERA HAS WARNED THAT THE FAILED COUP OF FEBRUARY 1992 COULD BE A PRECURSOR OF ADDITIONAL REVOLTS IN HIS COUNTRY. OTHER OBSERVERS HAVE BEGUN TO SPECULATE ON A SIMILAR SCENARIO: THAT WHAT HAPPENED IN VENEZUELA COULD BE THE BEGINNING OF A WIDER RETURN OF THE MILITARY, RIDING ON A TIDE OF DISCONTENT CREATED BY THE

SEVERE ECONOMIC ADJUSTMENT POLICIES ADOPTED THROUGHOUT LATIN AMERICA IN THE PAST FIVE YEARS.

00040

AGAIN, THE UGLY FACE OF APARTHEID

WEST AFRICA, (3913) (SEP 92), 1557. SOUTH AFRICA IN SEPTEMBER 1992 WHEN THE SECURITY FORCES OF SOUTH AFRICA IN SEPTEMBER 1992 WHEN THE SECURITY FORCES OF
THE CISKEI HOMELAND KILLED 28 ANC DEMONSTRATORS. THE CISKEI THE CISKEI HOMELAND KILLED 28 ANC DEMONSTRATORS. THE CI
MASSACRE REPRESENTS A TURNING POINT IN THE HISTORY OF APARTHEID BECAUSE IT UNMASKED THE HIDDEN AGENDA BEHIND APARTHEID BECAUSE IT UNMASKED
PRETORIA'S BANTUSTAN POLICY.

00041

AGREEMENT ON SOCIAL POLICY CONCLUDED BETWEEN THE MEMBER STATES OF THE EUROPEAN COMMUNITY WITH THE EXCEPTION OF THE UNITED KINGOOM OF GREAT BRITAIN AND NORTHERN IRELAND GOVERNMENT AND OPPOSITION, 27(2) (SPR 92), 260-263.

THIS ARTICLE REPRINTS THE SOCIAL POLICY AGREEMENT SIGNED BY THE MEMBER STATES OF THE EUROPEAN COMMUNITY, WITH THE EXCEPTION OF GREAT BRITAIN AND NORTHERN IRELAND. THE AGREEMENT ENUMERATES THE FOLLOWING SOCIAL POLICY OBJECTIVES: THE PROMOTION OF EMPLOYMENT, IMPROVED LIVING AND WORKING CONDITIONS, PROPER SOCIAL PROTECTION, DIALOGUE BETHEEN MANAGEMENT AND LABOR, THE DEVELOPMENT OF HUMAN RESOURCES WITH A VIEW TO LASTING HIGH EMPLOYMENT, AND THE COMBATING OF EXCLUSION.

00042

AID TO THE FORMER SOVIET UNIOM

CONGRESSIONAL DIGEST, 71(8-9) (AUG 92), 194.

THE MEMBERS OF THE COMMONHEALTH OF INDEPENDENT STATES ARE EXPERIENCING ACUTE POLITICAL AND ECONOMIC INSTABILITY, SEVERE SHORTAGES OF CONSUMER GOODS, HYPERINFLATION, HARD CURRENCY SHORTAGES, AND FAILING PUBLIC HEALTH SYSTEMS. THESE CIRCUMSTANCES HAVE' LED MANY OBSERVERS TO CALL FOR A MORE PROMINENT U.S. ROLE IN EASING THE COURSE OF CHANGE IN THE REGION. PRESIDENT BUSH HAS PROPOSED THE FREEDOM SUPPORT ACT, WHICH WOULO PROVIDE U.S. SUPPORT THROUGH AGRICUL TURAL. HUMANITARIAN, AND TECHMOLOGICAL ASSISTANCE AND PROMOTE U.S. HUMANITARIAN, AND TECHNOLOGICAL ASSIS
TRADE AND INVESTMENT IN THE REGION.

00043

ALAN GARCIA YERSUS THE NEO-LIBERALS

LATIN AMERICAN WEEKLY REPORT, (2) (JAN 92), 6-7. FORMER PERUVIAN PRESIDENT ALAN GARCIA IS BANKING ON SIGNS THAT THE POPULARITY OF NEO-LIBERAL POLICIES HAS ALREADY PEAKED IN LATIN AMERICA. GARCIA SAYS THAT THE NEOLIBERAL MODEL IS UNABLE TO ACHIEVE ITS AIMS. INSTEAD OF NEOLIBERAL POLICIES, HE PROPOSES A FREE MARKET WITH STRONG STATE PARTICIPATION "IN ORDER TO CORRECT HARMFUL TRENDS."
00044

ALARM BELLS IN LOME

WEST AFRICA, (3910) (AUG 92), 1429

OBED ASAMOAH, THE PNDC SECRETARY FOR FOREIGN AFFAIRS,

HAS WARNED THAT THERE IS A GROWING RISK OF CIVIL WAR IN TOGO.

GHANA'S HEAD OF STATE, JERRY RAWLINGS, HAS EXPRESSED HIS

CONCERN AND OFFERED TO HELP RESOLVE THE CONFLICT.

00045

ALBERTO FUJIMORI HITS CAMPAIGN TRAIL

ATIN AMERICAN WEEKLY REPORT, (36) (SEP 92), 10.

PRESIDENT ALBERTO FUJIMORI HAS SAID THAT HE WILL BACK A

LIST OF CANDIDATES MOMINATED BY CAMBIO 90 AND BY INDEPENDENT GROUPS THAT SUPPORT HIS POLICIES IN THE NOVEMBER 1992

CONSTITUENT ASSEMBLY ELECTIONS. HE IS ALREADY ON THE

CAMPAIGN TRAIL, PROMISING IMMEDIATE ACTION ON PUBLIC WORKS

DISTRIBUTING SUPPLIES TO SCHOOLS, AND GIVING AWAY SECOND-

HAND CLOTHES DONATED BY JAPAN. SOME POLITICIANS HAVE

THAT HE IS IN BLATANT VIOLATION OF THE LEGAL BAN ON
OFFICIALS' USING THEIR POSITIONS OR PUBLIC FUNDS TO FURTHER ELECTORAL AIMS.

00046

ALGERIAN MILITARY BLOCKS ISLAMIC BID TO LEAD GOVERMMENT

CHURCH AND STATE, 45(2) (FEB 92), 16(40)-17(41).

IN THE WAKE OF NATIONAL ELECTIONS DOMINATED BY THE

ISLAMIC SALVATION FRONT, ALGERIA TOTTERED TO THE BRINK OF

CIVIL WAR. FOLLOWING THE FRONT'S VICTORY IN THE FIRST ROUND

OF VOTING, ALGERIAN OFFICIALS CANCELED THE SECOND PHASE OF

THE COUNTRY'S FIRST MULTI -PARTY ELECTIONS. UNDER PRESSURE

FROM THE ARMY, PRESIDENT CHADLI BENJEDID RESIGNED, YIELDING

CONTRDL TO A COMMITTEE OF CABINET MINISTERS AND GENERALS.

THE NEW GOVERNMENT STATED THAT IT PLANS TO RULE THE COUNTRY

FOR AT LEAST TWO YEARS, DASHING HOPES FOR NEN ELECTIONS.

00047

ALJEERS

NEW REPUBLIC, 206 (4) (JAN 92), 7-8.

THE AUTHOR DISCUSSES THE MEANING OF THE ISLAMIC

FUNDAMENTALIST VICTORY IN THE ALGERIAN ELECTIONS AND WHY THE

VICTORS HAVE NOT BEEN ALLOWED TO ASSUME POWER.

00048

ALL SIDES REJECT INDIAN LAND GRANT

LATIN AMERICAN WEEKLY REPORT, (19) (MAY 92), 11.

TO END AN EMBARRASSING PROTEST BY INDIANS ENCAMPED IN

QUITO, PRESIDENT RODRIGO BORJA ANNOUNCED THAT HIS GOVERNMENT WOULD GRANT THREE ETHNIC GROUPS LEGAL TITLE TO 1.1 M HECTARES OF LAND IN PASTAZA. BUT THE INITIATIVE BACKFIRED ON THO FRONTS. FIRST. THE INDIANS REJECTED IT BECAUSE IT DIO NOT MEET THEIR SPECIFICATIONS. SECONDLY, IT WAS ATTACKED BY BIO LANDOWNERS, BECAUSE IT MIGHT BE THE FIRST STEP TOWARDS AM INOIAN STATE-WITHIN-A-STATE.

00049

ALLIANCE SEEKS LARGER POLITICAL ROLE FOR WOMEN JAPAN TIMES (WEEKLY INTERNATIONAL EDITION), 32 (10) (MAR 92), 4.

IN JAPAN, SEVEN DIET MEMBERS AND 61 LOCAL ASSEMBLY MEMBERS, MOSTLY WOMEN, HAVE LAUNCHED AN EFFORT TO BOOST THE NUMBER OF LEGISLATIVE SEATS HELD BY WOMEN FROM THE CURRENT FOUR PERCENT TO 30 PERCENT.

00050

AMID THE CRISIS, SIGNS OF GROWTH

LATIN AMERICAN WEEKLY REPORT, (19) (MAY 92), 8.

DESPITE A POOR SUGAR CROP, CUBAN OFFICIALS PREDICT THAT

THE ISLAND'S ECONOMY WILL GROW AT ABOUT THE SAME RATE IN

1992 AS IN 1991. ALTHOUGH SUGAR PRODUCTION AND LACK OF FUELS HAVE BEEN A PROBLEM, NICKEL PRODUCTION AND REVENUES FROM TOURISM WERE UP IN THE FIRST OUARTER OF 1992. THE GOVERNMENT IS PURSUING A POLICY OF ATTRACTING FOREIGN INVESTMENT FOR JOINT VENTURES BUT IS INSISTING THAT THIS IS "A SOCIALIST APERTURA DESIGNED TO REINSERT CUBA IN TODAY'S WORLD"--NOT A REINTRODUCTION OF CAPITALISM.

00051

AN EXCLUSIVE INTERVIEW WITH SAUD NASIR AL-SABAH, KUWAIT'S AMBASSADOR TO THE UNITED STATES

MIDOLE EAST INSIGHT, VIII(4) (MAR 92), 15-19.

IN THIS INTERVIEW, KUHAITI AMBASSADOR TO THE UNITED

STATES, SAUD NASIR AL-SABAH, DISCUSSES A VARIETY OF ISSUES. AMONG THOSE MENTIONED ARE THE EFFECTS OF THE GULF HAR. THE CONT INUED THREAT OF IRAOI AGGRESSION THE ROLE OF IRAY IM THE REGION, THE FUTURE OF U.S.-KUWAITI RELATIONS

DEMOCRATIZATION IN KUWAIT, THE ARAB-ISRAELI CONFLICT AND PEACE NEGOTIATIONS, KUWAITI OIL POLICY, AND THE STATUS OF KUWAITI PRISONERS OF WAR.

00052

AN OFFICE, A BOMB AND A PAYMASTER

THE MIDDLE

THIS ARTICLE EXAMINES THE U.S. EFFORTS TO STEM THE 
THREAT OF GULF-CRISIS-RELATED TERRORISM. THE APPEARANCE OF SUCH GROUPS AS THE POPULAR FRONT FOR THE LIBERATION OF PALESTINE (PFLP) ABU NIDAL'S FAFEH REVOLUTIONARY COUNCIL, AND THE PALESTINIAN LIBEATION FRONT IN IRAO IS AN AND THE PALESTINIAN LIBERATION FRONT IN IRAQ IS AN INDICATION THAT IRAQ INTENDS TO USE ALL POSSIBLE WEAPONS AND TACTICS IN ITS WAR AGAINST THE WEST. THE FACT THAT SYRIA, A PAST SUPPORTER OF MANY TERRORIST FACTIONS, IS A MEMBER OF THE ANTI-IRAD CDALITION COMPLICATES MATTERS CONSIDERABLY. THE U.S. HAS IMPROVED ITS ANTI-TERRORISM APPARATUS SIGNIFICANTLY, ESPECIALLY IN THE AREA OF CIVIL AVIATION. FURTHERMORE, STATE DEPARTMENT OFFICIALS HAVE BEGUN A "REWARDS FOR TERRORISM IMFORMATION PROGRAM" IN AN EFFORT TO IMPROVE INTELLIGENCE.

00053

NEST AFRICA, (3902) (JUN 92) 1106.

THE ANC HAS WITHDRAWM FROM THE CONVENTION FOR A

DEMOCRATIC SOUTH AFRICA (CODESA) TO PROTEST THE MASSACRE AT BOIPATONG ON JUNE 17,1992 . THE GOVERNMENT HAS EXPRESSED ITS REGRET ABOUT THE ANC'S DECISION AMD HANTS IMMEDIATE TALKS TO TRY TO REMEDY THE SITUATION. 00054

AND NOH, THE PAN SPLITS APART

LATIN AMERICAN WEEKLY REPORT, (48) (DEC 92), 4

ON NOVEMBER 20, 1992 , MORE THAN 800 DISGRUNTLED PAN MEMBERS LED BY THE FORO DOCIRIMARIO Y DEMOCRATICO MET TO YOICE THEIR DISCONTENT WITH THE POLICY OF APPROACHEMENT WITH THE PRI AND ANNOUNCED THAT THEY WOULD BREAK AWAY AND FORM ANOTHER POLITICAL PARTY.

00055

ANGOLA: SAVIMBI IN S.A.

WEST AFRICA, (3882) (FEB 92), 258

DURING A TRIP TO SOUTH AFRICA, UNITA LEADER JONAS

SAVIMBI DECLARED THAT SOUTH AFRICA AND ANGOLA HILL TOGETHER

PILOT THE OEVELOPMENT OF SOUTHERN AFRICA IN THE YEARS TO

COME. WHILE IN SOUTH AFRICA, SAVIMBI HELD TALKS WITH

PRESIDENT F.W. DEKLERK AND FOREIGN MINISTER PIK BOTHA.

00056

ANGOLA'S ANXIETY

AST AFRICA, (3919) (OCT 92), 1810

ANGOLA'S OCTOBER 1992 ELECTIONS HAVE FAILED TO BRING THE TRANQUILITY THE PUBLIC HOPED FOR. WHEN THE ELECTORAL DEFEAT OF UNITA LEADER JONAS SAVIMBI BECAME APPARENT, HE THREATENED TO RESUME FIGHTING. UNLESS INTENSE DIPLOMATIC PRESSURE IS BROUGHT TO BEAR ON SAVIMBI THE SITUATION COULD QUICKLY BRTERIORATE INTO WAR. THE DAU MUST CONYINCE SAYIMBI TO DETERIORATE INTO WAR. THE DAU MUS

00057

ANMUAL POLL RATES LOCAL GOVERNMENT "BEST FOR THE MONEY" MATIONAL CIYIC REYIEH, 80(4) (FAL 91), 431-432.

THE ADVISORY COMMISSSION ON INTERGOVERMMENTAL RELATIONS' 1991 POLL ON PUBLIC ATTITUDES TOWARD GOVERNMENT AND DIFFERENT LEVELS OF GOVERNMENT FOUND THE GREATEST PUBLIC SATISFACTION WITH LOCAL GOVERNMENT.

00058

ANOTHER SCANDAL ROCKS JAPAN

JAPAN TIMES (WEEKLY INTERNATIONAL EDITION), 32 (8) (FEB 92 ),

1,5 .

ON FEBRUARY 14, 1992, PROSECUTORS ARRESTED THE FORMER PRESIDENT OF TOKYÓ SAGAHA KYUBIN COMPANY AND THREE OTHERS FOR ALLEGEDLY FINANCIALLY DAMAGING THE COMPANY, WHICH IS AT THE CENTER OF A CASH-FOR-FAYORS SCANDAL. ONLY DAYS BEFORE FORMER TOP AIDE TO PRIME MINISTER KIICHI MIYAZAWA WAS ARRESTED FOR ALLEGEDLY TAKING BRIBES. THIS SCANDAL IS BEING COMPARED TO A SIMILAR SCANDAL THAT LED TO THE DOWNFALL OF FORMER PRIME MINISTER NOBORU TAKESHITA.

00059

ANYAOKU FINDS A NEH ROLE

HEST AFRICA, (3906) ( JUL 92), 1241.

FOR MANY YEARS, THE BRITISH COMMONWEALTH HAS BEEN UNITED BY ITS OPPOSITION TO APARTHEID. NOW, WITH CHANGE UNDERHAY IN SOUTH AFRICA. THE ORGANIZATION IS CHANGING ITS FOCUS TO THE ISSUES OF DEMOCRACY AND HUMAN RIGHTS. CHIEF EMEKA ANYAOKU, THE COMMONWEALTH'S SECRETARY-GENERAL. HAS IDENTIFIED THE THE COMMONWEALTH'S SECRETARY-GENERAL, HAS IDENTIFIED THE ELECTORAL PROCESS AND BUILDING CONFIDENCE IN ELECTORAL SYSTEMS AS CRU

00060

APATHY RULES IN LIBERAL PARTY

LATIN AMERICAN WEEKLY REPORT, (25) (JUL 92), 11

ON JUNE 20 AND 21, 1992, THE LIBERAL PARTY HELD CONVENTIONS IN ALL OF COLOMBIA'S 33 DEPARTMENTS TO ELECT DELEGATES TO AN UPCOMING NATIONAL CONVENTION. ONE PARTY OFFICIAL DESCRIBED THE RESPONSE AS "GENERALIZED APATHY."
00061

APRIL FAILS TO BRING SIGNS OF UPTURN

LATIN AMERICAN WEEKLY REPORT, (18) (MAY 92), 4-5.

IN APRIL 1992, THE GOVERMMENT OF PRESIDENT FERNANDO

COLLOR DE MELLO HOPED TO PROVE THO THINGS: THAT THE RECENT

CABINET RESHUFFLE HAD PRODUCED SUFFICIENT BACKING IN

CONGRESS TO ENSURE THAT IMPORTANT LEGISLATION WOULD BE

PASSED AND THAT THE ECONOMY HAD BEGUN TO PULL OUT OF THE

RECESSION. THERE WERE INDICATIONS OF PARTIAL SUCCESS REGARDING THE GOVERMMENT'S FIRST OBJECTIVE, BUT LITTLE REASON TO BE OPTIMISTIC ABOUT THE ECONOMY.

00062

ARGENTINA BOUNCES BACK

HORLD PRESS REVIEW, 39(8) (AUG 92), 43.

IN ARGENTINA, INFLATION HAS FALLEN TO ITS LOWEST POINT

IN 20 YEARS AND PRESIDENT CARLOS SAUL MENEM'S GOVERNMENT IS INTROOUCING FREE-MARKET REFORMS THAT PROMISE TO GIVE THE COUNTRY ONE OF THE WORLD'S MOST OPEN ECONOMIES. MOREOVER, ARGENTINA PLANS TO PRIVATIZE MORE ENTERPRISES MORE QUICKLY THAN ANY OTHER CDUNTRY IN LATIN AMERICA.

00063

ARISTIDE AMD CONGRESS AGREE ON PREMIER

LATIN AMERICAN WEEKLY REPORT, (3) (JAN 92), 5.

THE OAS MEDIATORS SEEM TO HAVE FOUND A FORMULA THAT WILL

EVENTUALLY LEAD TO THE REINSTATEMENT OF JEAN-BERTRAND ARISTIDE AS PRESIDENT OF HAITI ON JANUARY AMNOUNCED THAT ARISTIDE HAD ACCEPTED RENE THEODORE TO HEAD NEW GOVERNMENT AND THAT THEODORE HAD BEEN ENDORSED BY CONGRESSIONAL LEADERS. IF CONGRESS CONFIRMS THEODORE AS PRIME MINISTER, HE WILL THEN NAME A "NATIONAL UNITY" CABINET. FINALLY, WHEN IT IS DEEMED SAFE, ARISTIDE WILL RETURN.

00064

ARISTIDE TORPEDOES NEW INITIATIVE

LATIN AMERICAN HEEKLY REPORT, (24) (JUN 92), 3

AN ATTEMPT TO BRING TOGETHER ALL THE PARTIES TO HAITI'S

POLITICAL DEADLOCK HAS BEEN SCUTTLED BY DEPOSED PRESIDENT

JEAN-BERTRAND ARISTIDE BECAUSE THE INITIATIVE, UNDER THE

OFFICIAL AUSPICES OF THE OAS, WOULD HAVE DELAYED HIS RETURN TO POHER.

00065

ARMY EMBARRASSED, R.N. BADLY DAMAGED

LATIN AMERICAN WEEKLY REPORT, (46) (NOY 92), 8-9.

AN ARMY CAPTAIN HAS ADMITTED USING MILITARY EQUIPMENT TO

TAPE A COMPROMISING CONVERSATION BETHEEN RENOVACION NACIONAL

(RN) PRESIDENTIAL HOPEFUL SEBASTIAN PINERA AND A FRIEND.

CONGRESSWOMAN EVELYN MATTHEI, PINERA'S RIVAL FOR THE RN'S

PRESIDENTIAL NOMINATION, ARRANGED FOR THE TAPE TO BE

BROADCAST, DASHING PINERA'S CHANCES.

00066

AS GOVERMMENT AND BOJ TAKE ACTION: STOCK MARKET TAKES THE PLUNGE

JAPAN TIMES (WEEKLY INTERNATIONAL EDITION), 32(15) (APR

$92), 1,5$.

ON APRIL 7, 1992, THE TOKYO STOCK EXCHANGE PLUNGED BELOH THE 18,000 LEVEL FOR THE FIRST TIME IN MORE THAN FIVE YEARS, EVEN THOUGH THE GOVERMMENT OF PRIME MINISTER KIICHI MIYAZAWA HAD RECENTLY ADOPTED AN EMERGENCY
TD STIMULATE THE SLOWING ECONOMY.

00067

ASSEMBLY RUSHES THROUGH REFORM

LATIN AMERICAN HEEKLY REPORT, (28) (JUL 92), 10

CUBA'S ASAMBLEA NACIONAL DEL PODER POPULAR HAS APPROVED

34 AMENDMENTS AND 42 "UPDATINGS" OF THE CURRENT CONSTITUTION.

SOME OF THE NEW PROVISIONS EXPAND THE POHER OF PRESIDENT FIDEL CASTRO.

00068

ASYLUM BILL

SURVEY OF CURRENT AFFAIRS, 21(12) (DEC 91), 438-440.

THE BRITISH GOVERMMENT HAS PROPOSED NEH RULES GOVERNING

THE GRANTING OF ASYLUM TO IMMIGRANTS.

00069

ATTACK OF NERVES

FAR EASTERN ECONOMIC REVIEW, 155(46) (NOV 92) 20-21.

BILL CLINTON'S VICTORY IN THE U.S. PRESIDENTIAL ELECTION

STIRRED IMMEDIATE WORRIES ABOUT A MORE PROTECTIONIST TRADE

POLICY AND THE THREAT OF INCREASED EMPHASIS BY THE NEW

ADMINISTRATION ON HUMAN-RIGHTS ISSUES. REACTION IN

INDIVIO'JAL COUNTRIES WAS VARIED. SOME JAPANESE GOVERMMENT

LEADER APPEAR TO SEE CLINTON AS A BITTER MEDICINE THAT

COULD UL TIMATELY BE GOOD FOR RELATIONS WITH THE UNITED

STATES HOWEYER. THE NEH ADMINISTRAITION HILL ALMOST

CERTAINLY PUT GREATER PRESSURE ON TOKYO OVER TRADE ISSUES.

CHINA'S OFFICIAL REACTION TO CLINTON'S VICTORY WAS NON-

COMMITTAL, BUT SOME CHINESE OFFICIALS PRIVATELY SPOKE OF

OPTIMISM ABOUT CLINTON'S PLANS FOR THE ECONOMY. COMMENTATORS

IN INDONESIA AND MALAYSIA EXPRESSED FEARS THAT CLINTON COULD 
AFFECT BILATERAL RELATIONS BY TAKING A HARDER LINE ON HUMANRIGHTS ISSUES. SINGAPORE EXPRESSED ITS WISH THAT CLINTON WILL SEE "PARTNERS AND NOT POTENTIAL ADVERSARIES ACROSS THE PACIFIC." VIETHAM DEMONSTRATED ITS HOPE THAT CLINTON WOULD CONTINUE MOVES TO EASE THE U.S. TRADE EMBARGO AND NORMALIZE DIPLOMATIC RELATIONS. IN SOUTH KOREA CLINTON'S VICTORY WAS WELCOMED AS A SIGN OF CHANGE BY OPPOSITION PRESIDENTIAL CANDIDATE KIM DAE JUNG. ON THE OTHER HAND, BUSINESSMEN AND BUREAUCRATS REACTED WITH A MIXTURE OF GLOOM AND CAUTION.

00070

AUDITOR FREEZES 'HANDOUT' FUNDS

LATIN AMERICAN WEEKLY REPORT, (24) (JUN 92), 8-9.

UPON ASSUMING HIS DUTIES IN THE SPRING OF 1992, JORGE GARCIA HURTADO, THE AUDITOR-GENERAL OF THE NATIONAL TREASURY, FROZE ALMOST ALL OF THE GOVERNMENT'S AUXILIARY FUNDS, THEREBY CREATING POLITICAL HAVOC AT ALL LEVEL OF THE ADMINISTRATION. HE ESTIMATES THAT, IN THE PAST, 18\% OF THESE ADMINISTRATION. HE ESTIMATES THAT, IN THE

00071

AUGUST BRING A SERIES OF OMINOUS WARNINGS IN VENEZUELA ATIN AMERICAN NEEKLY REPORT, (32) (AUG 92), 1.

VENEZUELA'S ECONOMY IS SLOWING DOWN, AND' THERE IS CONSIDERABLE PUBLIC ANXIETY DUE TO THE GOVERMMENT'S ANMOUNCEMENT OF AN IMMINENT "RELAUNCH" OF ITS ECONOMIC ADJUSTMENT PROGRAH. THE PEREZ ADMINISTRATION HAS REQUESTED NEH TAXES, BUT IT IS VERY UNLIKELY THAT THE CONGRESS WILL APPROVE THEM.

00072

AYLWIN SUFFERS HIS FIRST CASUALTY

LATIN AMERICAN WEEKLY REPORT, (44) (NOV 92), 5

ON OCTOBER 30, 1992, HEALTH MINISTER JORGE JIMENEZ

BECAME THE FIRST CASUALTY OF PRESIDENT PATRICIO AYLWIN'S

CABINET. AYLHIN HAD ASKED FOR JIMENEZ'S RESIGNATION WHEN IT

BECAME CLEAR THAT THE MINISTER COULD NOT HANDLE THE CRISIS

THAT AROSE DUE TO MASS RESIGNATIONS OF EMERGENCY ROOM

DOCTORS. THE PHYSICIANS WERE RESIGNING TO PROTEST THEIR

WORKING CONDITIONS IMCLUDIMG LOMG HOURS, LOH PAY, AMD

SUBSTANDARD EQUIPMENT.

00073

BABANGIDA'S REPORT

WEST AFRICA (3904) (JUL 92), 1163-1164.

THIS ARTICLE CONTAINS EXCERPTS FROM AN ADORESS GIVEN BY

GENERAL IBRAHIM BADAMASI BABANGIDA, PRESIDENT OF THE FEDERAL

REPUBL IC OF NIGERIA, AT THE 28TH ORDINARY ASSEMBLY OF OAU

HEADS-DF-STATE-AMD-GOYERMMENT IN DAKAR SENEGAL ON JUNE 29

1992. BABANGIDA DISCUSSED THE CHANGES UNDERWAY IN AFRICA AND THE ACHIEVEMENTS OF THE OAU.

00074

BACK TO SHOOTING HAR ON TWO FRONTS

LATIN AMERICAN HEEKLY REPORT, (44) (NOV 92), 11.

IN MID-1991 IT APPEARED THAT THE GOVERMMENT OF PRESIDENT

CESAR GAVIRIA HAD A HANOLE ON THE GUERRILLA AND DRUG

VIOLENCE IN COLOMBIA. BUT BY LATE 1992, THE COORDINADORA

NACIONAL GUERRILLERA WAS ON THE OFFENSIVE, AND THE

GOVERNMENT WAS ONCE AGAIN IN A SHOOTING WAR WITH THE DRUG TRAFFICKERS.

00075

BACK TO THE BATTLEFIELD IN COLOMBIA

LATIN AMERICAN WEEKLY REPORT, (27) (JUL 92), 6-7.

IN THEORY, THE PEACE NEGOTIATIONS BETHEEN THE GOVERNMENT

OF PRESIDENT CESAR GAVIRIA AND THE COORDINADORA NACIONAL

GUERRILLERA SIMON BOLIVAR HAVE BEEN MERELY ADJOURNED UNTIL

OCTOBER 1992 . IN FACT. THERE SEEMS TO HAVE BEEN A DECISIVE
TURN AWAY FROM NEGOTIATIONS AND TOWARDS ARMED CONFRONTATION.

00076

BACKGROUND AND SUMMARY OF H.R. 5231

CONGRESSIONAL DIGEST, $71(12)$ (DEC 92), 299-300, 314

THE NATIONAL COMPÉTITIVENESS ACT OF 1992 (H.R. 5231)

ADORESSES SOME OF THE PRESSING STRUCTURAL PROBLEMS THAT

INHIBIT AMERICAN INDUSTRY FROM COMPETING EFFECTIVELY IN THE

GLOBAL ECONOMY. IT REFLECTS THE CONCLUSION THAT, UNLESS U.S.

COMPETITIVENESS PROBLEMS ARE ADORESSED FORTHRIGHTLY, ANY

ECONOMIC RECOVERY WILL BE SHORT-LIVED AND LONG-TERM' ECONOMIC

DECLINE WILL CONTINUE. IT FURTHER REFLECTS THE CONVICTION

DECLINE WILL CONTINUE. IT FURTHER REFLECTS THE CONVICTION

THAT, ALTHOUGH ANY LONG-TERM ECONOMIC GROWTH MUST BE LED

THE PRIVATE SECTOR, THERE IS AN IMPORTANT AND APPROPRIATE

FEDERAL ROLE IN A NATIONAL COMPETITIVENESS STRATEGY. THAT

ROLE IS TO ENSURE THAT MODERN INFRASTRUCTURE IS IN PLACE

AVAILABLE TO ALL COMPANIES, THAT IT DRAHS ON THE U.S.
SCIENTIFIC AND TECHNOLOGICAL BASE, AND THAT IT PERMITS THE RAPID INTRODUCTION OF NEW PRODUCTS AND MANUFACTURING PROCESSES.

00077

BACKING THE WRONG HORSE

THE MIDDL

THIS ARTICLE INVESTIGATES THE RESULTS OF THE PALESTINIAN
LIBERATION ORGANIZATION'S (PLO) BACKING OF SADDAM HUSSEIN IN THE GULF WAR. THIS CHOICE IS DESCRIBED AS A GRAVE ERROR THAT HAS, AMONG OTHER THINGS, WEAKENED EUROPE'S SUPPORT FOR THE PLO AS A NEGOTIATOR IN THE MIDOLE EAST.

00078

BACKLASH OR REARGUARD ACTION?

WEST AFRICA, (3880) (JAN 92), 137

THE AUTHOR LOOKS AT RECENT POLITICAL DEVELOPMENTS IN

CONGO, BENIN, AND TOGO. HE SAYS THAT THEY ADD TO THE

SUSPICION THAT A BACKLASH TO AFRICA'S DEMOCRACY MOVEMENT MAY

BE UNDERWAY.

00079

BAD START FOR NEW POLITICAL REFORM

LATIN AMERICAN WEEKLY REPORT, (46) (NOV 92), 10-11. ON NOVEMBER 8, 1992 , ELECTIONS WERE HELD IN FOUR MEXICAN STATES: PUEBLA, SINALOA, TAMAULIPAS, AND OAXACA. ALTHOUGH THE RUL ING PARTIIDO REVOLUCIONARIO INSTITUCIONAL CLAIMED ANDSLIDE YICTORIES IN ALL FOUR STATES, ALLEGATIONS OF

ELECTORAL FRAUD WERE MADE IN TAMAULIPAS AND SINALOA.

00080

BAMAKO AND FREETOWM

WEST AFRICA, (3900) (JUN 92), 1001

MALI EXPERIENCED A PEACEFUL TRANSITION TO CIVILIAN RULE

ON JUNE 8, 1992, HEN A DULY-ELECTED CIVILIAN PRESIDENT,

ALPHA OUMAR KONARE, TOOK OVER FROM THE MILITARY REGIME O

COLONEL AMADOU TOUMANI TOURE.

00081

BANKING REFORM LEGISLATION

CONGRESSIONAL DIGEST, 71(1) (JAN 92), 2-32.

THE EVOLUTION OF U.S. BANKING LEGISLATION, THE ROLE OF

FEDERAL BANKING REGULATORS, BANKING RESTRICTIONS, THE BUSH ADMINISTRATION'S PROPOSAL FOR BANKING REFORM, AND

CONGRESSIONAL ACTION ON BANKING REFORM ARE DISCUSSED. THEN

PRO AND CON ARGUMENTS MADE BY U.S. CONGRESSMEN ON THE

QUESTION OF "SHOULD THE WYLIE-NEAL AMENDMENT TO H.R. 2094 BE APPROVED?" ARE GIVEN.

00082

BATTLE FOR CONTROL OF THE GOVERNMENT

LATIN AMERICAN WEEKLY REPORT, (32) (AUG 92), 2-3.

BRAZILIAN PRESIDENT FERNANDO COLLOR DE MELLO HAS

MUSTERED ENOUGH VOTES IN CONGRESS TO AVOID IMPEACHMENT, AT

LEAST TEMPORARILY. NOW THE BIG QUESTION IS WHETHER COLLOR,

IN SEEKING TO ENSURE THE SURVIVAL OF HIS PRESIDENCY, HAS

STRENGTHENED THE HAND OF THE PARTIDO DA FRENTE LIBERAL (PFL).

COLLOR'S ABILITY TO CONTINUE GOVERNING WILL BE DETERMINED

LARGELY BY WHETHER HE CAN RETAIN MARCILIO MARQUES MOREIRA AS

BID BY PFL LEADER ANTONIO MAGALHAES.

00083

BAZIN REGIME IS PUT TO ITS FIRST TESTS

LATIN AMERICAN WEEKLY REPORT, (29) (JUL 92), 11.

UPON TAKING OFFICE, PRIME MINISTER MARC BAZIN ANNOUNCED

THAT HIS GOVERMMENT WOULD RESPECT MUMAN RIGHTS AND SEEK TO

DEFUSE TENSIONS AND THAT HE WOULD BE OPEN TO NEGOTIATIONS

WITH JEAN-BERTRAND ARISTIDE. HIS SUBSEQUENT ACTIONS HAVE

RAISED QUESTIONS ABOUT HIS SINCERITY ON BOTH COUNTS.

00084

BEHIND THE TOUGH TALK, SOME CHANGES

LATIN AMERICAN WEEKLY REPORT, (8) (FEB 92), 2-3.

THE OFFICIAL STANCE ADOPTED BY THE GOVERNMENT OF

PRESIDENT CARLOS ANORES PEREZ IS THAT THE FEBRUARY 4, 1992,

COUP ATTEMPT HAD NOTHING TO DO WITH HIS ECONOMIC POLICIES,

WHICH WILL CONTINUE TO BE IMPLEMENTED. IN REALITY, HOWEVER,

A SERIES OF ADJUSTMENTS ARE BEING CONSIDERED, INDICATING

OFFICIAL RECOGNITION THAT POPULAR DISCONTENT WITH THE SOCIAL

THE PUBLIC'S LESS-THAN-WHOLEHEARTED REJECTION OF THE

MILITARY UPRISING.

00085

BEIJING DECLARATION

BEIJING REVIEW, 35(18) (MAY 92), 13.

THE CLOSE OF THE 48TH SESSION OF THE ECONOMIC AND

SOCIAL COMMISSION FOR ASIA AND THE PACIFIC IN APRIL 1992

THE PARTICIPANTS SIGNED THE BEI JING DECLARATION, HHICH

COMMITS THEM TO CONTINUED EFFORTS TO ENHANCE ECONOMIC

COOPERATION IN THE REGION.

00086

BEMUSED PARTIES HAVE ANOTHER GO

LATIN AMERICAN WEEKLY REPORT, (35) (SEP 92), 3

IN PERU, 13 POLITICAL PARTIES HAVE ISSUED A JOINT

STATEMENT DEMANDING A CHANGE IN THE ELECTORAL SYSTEM AND THE

FUNCTIONS OF THE CONSTITUENT ASSEMBLY TO BE REDEFINED AND

ITS MANDATE TO BE LIMITED TO SIX MONTHS, AFTER WHICH NEW

GENERAL ELECTIONS WOULD BE HELD. THEY HOPE TO PERSUADE THE 
OAS TO BACK THEIR STANCE. MEANWHILE, FUJIMORI HAS NOT EVEN ACKNOWL EDGED THEIR DEMAMDS.

00087

BICAMERALISM: WITHOUT A SECOND CHAMBER, IS PARLIAMENTARY DEMOCRACY DOOMED?

PARLIAMENTARIAN, LXXIII(1) (JAN 92), 56-58.

REPRESENTATIVES AT THE 37TH COMMONWEALTH PARLIAMENTARY CONFERENCE DEBATED THE NEED FOR BICAMERAL LEGISLATURES, ESPECIALLY IN SMALL COUNTRIES. CRITICS DECLARED THAT UPPER CHAMBERS ARE UNDEMDCRATIC, INEFFECTIVE, A NEEDLESS DUPLICATION OF EFFORT, AND A WASTE OF MONEY AND MAMPOWER. ALTHOUGH IT WAS GENERALLY AGREED THAT UPPER HOUSES COULD PERFORM USEFUL FUNCTIONS IN SOME CIRCUMSTANCES AND THAT EACH COUNTRY SHOULD HAVE THE FORM OF GOVERMMENT THAT BEST SUITS ITS INDIVIDUAL NEEDS, THE OVERWHELMING VIEW WAS THAT A BICAMERAL PARLIAMENT IS NOT MORE DEMOCRATIC AND A UNICAMERAL SYSTEM IS MORE SUITABLE FOR SMALL COUNTRIES.

00088

BLACKER CLAIMS OAS VICTORY

ATIN AMERICAN WEEKLY REPORT, (16) (APR 92), 2

SPEAKING ON THE EVE OF AN EMERGENCY OAS MEETING IN APRIL

1992, PERUVIAN PRESIDENT ALBERTO FUJIMORI SAID HIS NEW GOVERNMENT WOULD HOLD A PLEBISCITE HITHIN SIX MONTHS TO SEEK APPROVAL FOR HIS ACTIONS IN DISSOLVING CONGRESS. THIS WOULO BE THE FIRST STEP TOWARDS ELECTIONS FOR A NEW, SMALLER CONGRESS. AT ITS MEETING. THE OAS DECIDED TO S SMALL DELEGATION TO LIMA "TO RE-ESTABLISH A DEMOCRATIC DIALOGUE" WHILE INDIVIDUAL OAS MEMBER STATES REEVALUATED THEIR RELATIONS HITH THE FUJIMORI GOVERMMENT.

00089

BLANCO FACTIONS AGAINST LACALLE

LATIN AMERICAN WEEKLY REPORT, (15) (APR 92), 3

A FACTION HITHIN URUGUAY'S RULING BLANCO' PARTY HAS ANNOUNCED THAT IT WILL BREAK AWAY AND FORM A NEW PARTY, THE POLO PROGRESISTA. THE NEW PARTY WILL OPPOSE THE ECONOMIC POLICIES OF PRESIDENT LUIS ALBERTO LACALLE.

00090

BOJ UNDER POLITICAL FIRE TO LOWER KEY MONEY RATE 92 ) $, 1,7$.

THE BANK OF JAPAN IS UNDER MOUNTING POLITICAL PRESSURE TO EASE CREDIT FURTHER AS THE GOVERMMENT OFFICIALLY ACKNOWLEDGES THAT THE JAPANESE ECONOMY IS NOW ON A DOWNSHING.

CALLS FOR ANOTHER CUT IN THE OFFICIAL DISCOUNT RATE

CONTINUE TO MOUNT WITHIN THE GOVERNING LIBERAL DEMOCRATIC 00091

BOTH SIDES SLOW DOWN IN EL SALVADOR

ATIN AMERICAN WEEKLY REPORT (19) (MAY 92), 6-7

IN EL SALVADOR. THERE HAS, BEEN IMAY 92), 6-7. IMPLEMENTING THE PEACE AGREEMENT BETWEEN THE GOVERNMENT OF PRESIDENT ALFREDO CRISTIANI AND THE FRENTE FARABUNDO MARTI DE LIBERACION NACIONAL (FMLN). THE FMLN HAS NOT COMPLETED THE FIRST PHASE OF ITS DEMOBILIZATION BECAUSE GUERRILLA LEADERS BELIEVE THAT THE GOVERNMENT HAS FAILED TO LIVE UP TO ITS COMMITMENTS, PART ICULARLY THOSE INVOLVING THE REDUCTION OF THE SECURITY FORCES. IF THE TWO SIDES DO NOT MEET THE 00092

BOTH SIDES HILL MISS DEADLINES

LATIN AMERICAN WEEKLY REPORT, (43) (NOV 92), 10.

THE GOVERMMENT OF PRESIDENT ALFREDO CRISTIANI AND THE FRENTE FARABUNDO MARTI PARA LA LIBERACION NACIONAL (FMLN) HAVE AGREED TO THE UNITED NATIONS ' PROPOSAL TO EXTEND THE 1992.

00093

DOUROS-GHALI: TALKS HERE 'POSITIVE'

BEIJING REVIEH, 35(17) (APR 92), 7

UNITED NATIONS SECRETARY-GENERAL BOUTROS BOUTROS-GHALI VISITED BEIJING IN APRIL 1992. HE DESCRIBED HIS DISCUSSIONS WITH CHINESE LEADERS AS "POSITIVE AND CONSTRUCTIVE." HE STATED THAT HE HAD OBTAINED "CLEAR AND STRONG SUPPORT" FROM CHINA FOR THE U.N.'S NEW ROLE IN MAINTAINIMG WORLD PEACE AND PROMOTING INTERMATIONAL COOPERATION IN ECOMOMIC AND SOCIAL PROMOTING INTER 00094

BRAZIL TAKES NOTE OF SEPARATISTS

ATIM AMERICAM HEEKLY REPORT (1) (JAM 92), 6-7. IN LATE 1991. A MOVEMENT HAS ORGANIZED IO PROMOTE SECESSION OY BRAZIL'S THREE SOUTHERM STATES--RIO GRANDE DO SUL, SANTA CATARINA, AND PARANA. HOWEVER, A PUBLIC OPINION POLL REVEALED THAT THE SEPARATISTS REPRESENTED A DEFINITE MINORITY AND BRAZILIAN POLITICIANS DOWNPLAYED THE POSSIBILITY OF SECESSION.
00095

BRAZILIAN MILITARY SEEK NEW THREAT

LATIN AMERICAN WEEKLY REPORT, (48) (DEC 92), 6-7.

THERE ARE INDICATIONS THAT THE BRAZILIAN ARMED FORCES ARE SEARCHING FOR A NEW ROLE SINCE THEY JETTISONED THEIR "NATIONAL SECURITY DOCTRINE. SOME MILITARY LEADERS HAVE SPOKEN OF A NEED TO COUNTER THE THREAT DF "SOCIAL WAR" CAUSED BY A UNEMPLOYMENT, INFLATION, AND POLITICAL FRUSTRATION.

00096

BRAZILIAN MILITARY WAVE 'RISKS'

LATIN AMERICAN WEEKLY REPORT, (18) (MAY 92), 6-7.

SINCE THE COUP IN PERU AND THE ATTEMPTED COUP IN

VENEZUELA, BRAZILIANS HAVE BEEN WONDERING IF A REBELLION COULD HAPPEN IN THEIR COUNTRY. THE CONSENSUS SEEMS TO BE THAT A COUP IS NOT IN THE OFFING; BUT THERE COULD BE ONE OR MORE "QUARTELADA"--A BARRACKS UPRISING TO DEMAND GOVERMMENT ACTION. PRESIDENT FERNANDO COLLOR DE MELLO HAS INDICATED HIS AWARENESS OF SOME DISCONTENT HITHIN THE MIL ITARY OVER WAGES

BY APPOINTING A COMMISSION TO STUDY THE MATTER.

00097

BRIEF SUMMIT SETS NEW TIMETABLE

LATIN AMERICAN WEEKLY REPORT (24) (JUN 92), 5

ON JUNE 11, 1992. THE PRESIDENTS OF VENEZUUELA, COLOMBIA,

ORGANIZATION, THE GROUP OF THREE $(G-3)$, BACK ON TRACK.

0009

BURST OF ENERGY

NEW REPUBLIC, 207(17) (OCT 92), 7.

CONGRESS SHOULD PASS PRESIDENT GEORGE BUSH'S NATIONAL

ENERGY STRATEGY IN THE FORM PRESENTLY BEFORE THAT

LEGISLATIVE BODY. THE PRESENT BILL INCLUDES REAL ENERGY

CONSERVATION PLANS, ELECTRIC UTILITY DEREGULATION

EQUALIZATION BETWEEN MASS TRANSIT ALLOWANCES AND THE TAX

BREAKS THAT SUBSIDIZE PARKING, GLOBAL WARMING PROVISIONS, SIMPLIFIED LICENSING FOR NUCLEAR POHERPLANTS, AND OTHER PROGRESSIVE PROPOSALS.

00099

USH ADMINISTRATION SEEKS HALF $8 I L L I O N$ FOR PAROCHIAL SCHOOLS

CHURCH AND STATE, 45(4) (APR 92), 11(83)-12(84).

DESPITE THE RISING FEDERAL BUDGET DEFICIT AND OTHER ECONOMIC DIFFICULTIES, THE BUSH ADMINISTRATION CONTINUES TO THE ADMINISTRATION'S LATEST EFFORT IS A HALF-BILLION DOLLAR YOUCHER PLAN INCLUOED IN THE EDUCATION COMPONENT OF THE 1993 PATRONS OF PAROCHIAL AND OTHER PRIVATE SCHOOLS WOULD RECEIVE $\$ 1,000$ GRANTS TO PAY FOR TUITION.

00100

BUSH AND CLINTON SPEAK OUT ON EUROPE

EUROPE, (320) (OCT 92), 22-29.

IN THESE INTERVIEWS, THE U.S. PRESIDENTIAL CANDIDATES, GEORGE BUSH AND BILL CLINTON, GIVE THEIR VIEWS ON CAMPAIG ISSUES INVOLVING EUROPE. THEY DISCUSS THE EUROPEAN SINGLE MARKET, THE EUROPEAN COMMUNITY, GATT, THE NORTH AMERICAN FREE TRADE AGREEMENT, NATO'S NEW ROLE, EASTERN EUROPE AND THE FIGHTING IN YUGOSLA LIA, RUSSIA AND THE FORMER SOVIET REPUBLICS, THE MAASTRICHT AGREEMENT, AND AMERICAN INVESTMENT IN EUROPE.

00101

BUSH CAMPAIGM SWERVES TO THE RIGHT TO TRY TO PICK UP EVANGELICAL VOTE

CHURCH AND STATE, 45(4) (APR 92), 12(84)-13(85)

FACED WITH A DETERMINED GOP PRIMARY CHALLENGE FROM ARCHCONSERVATIVE PATRICK BUCHANAN, PRESIDENT GEORGE BUSH HAS ESCALATED HIS EFFORTS TO WIN THE SUPPORT OF THE CHRISTIAN RIGHT. HE HAS FORCED THE RESIGNATION OF JOHN FROHNMAYER FROM THE NATIONAL ENDOWMENT FOR THE ARTS, VETOED AN IRS PROPOSAL TO CATCH TAX CHEATERS BY REQUIRING CHURCHES TO REPORT LARGE DONORS, AND INCREASED HIS APPEARANCES BEFORE EVANGELICAL AUDIENCES.

00102

BUSH GIVES NAFTA ELECTORAL PUSH

LATIN AMERICAN WEEKLY REPORT (41) (OCT 92) 9

ON OCTOBER 7, 1992 , U.S. PRESIDENT GEORGE BUSH, MEXICAN PRESIDENT CARLOS SALINAS DE GORTARI AND CANADIAN PRIME MINISTER BRIAN SALINAS DE GORTARI, AND CANADIAN PRIME INITIAL THE NORTH AMERICAM FREE TRADE AGREEMENT (NAFTA). THE CEREMONY HAS STAGED TO HELP BUSH'S RE-ELECTION BID IN TEXAS, WHERE THE AGREEMENT IS POPULAR. BEFORE THE CEREMONY,

DEMOCRATIC PRESIDEMT POPULAR. BEFORE THE CEREMONY, $A M$ THAT HE HOULD SIGN THE AGREEMENT IF HE WAS ASSURED THAT IT WOULD NOT HARM U.S. WORKERS AND THAT THE PARALLEL ENVIRONMENTAL PACT WOULD BE ENFORCED. THE MEXICAN GOVERNMENT WELCOMED CLINTON'S POSITION BUT RULED OUT THE POSSIBILITY OF ADOITIONAL NEGOTIATIONS. 
00103

BUSH, BUCHANAN TOUT MORAL REVIVIAL AT RELIGIOUS RIGHT RALLY CHURCH AND STATE, 45(9) (OCT 92), 8(210)-9(211) DURING AN AUGUST 1992 ADORESS TO RELIGIOUS RIGHT ACTIVISTS, PRESIDENT GEORGE BUSH CALLED FOR "A MORAL REVIVAL" IN THE UNITED STATES AND BLASTED THE DEMOCRATIC PARTY FOR NOT MENTIONING GOD IN ITS PLATFORM. SPEAKING AT THE SAME CONVENTION, PAT BUCHANAN DECLARED THAT AMERICANS WITH BIBLICAL VALUES "HAVE BEEN LOSING THE CULTURAL HAR FOR THE SOUL" OF THE USA.

00104

BUSH'S ABDUCTION LINE FUELS CONCERM

LATIN AMERICAN WEEKLY REPORT, (15) (APR 92), 8.

COLOMBIANS ARE PUZZLED ABOUT U.S. PRESIDENT GEORGE BUSH'S RECENT PUBLIC DEFENSE OF HIS COUNTRY'S RIGHT TO ABDUCT DRUG TRAFFICKERS AND OTHER CRIMINALS BEYOND U.S. BORDERS AND TRY THEM IN U.S. COURTS. THEY ARE WONDERING IF

THIS SIGMALS A LESSENING OF HASHINGTON'S SUPPORT FOR COLOMBIA'S EFFORTS TO REFORM AND STRENGTHEN ITS OWM JUDICIARY SYSTEM.

00105

BUSINESS RALLIES TO BACK MARQUES

LATIN AMERICAN WEEKLY REPORT, (28) (JUL 92),

BRAZILIAN BUSINESS LEADERS, PARTICULARLY' THOSE FROM SAO PAULO, HAVE LAUNCHED A CAMPAIGN DESIGNED TO SEPARATE THE

MANAGEMENT OF THE ECONOMY FROM THE IMMEDIATE POL ITICAL

CRISIS. THEY HAVE ESTABLISHED A MOVEMENT CALLED "BRASIL S.A.

aND ARE TAKING PAINS TO AVOID ANY GESTURE THAT COULD BE

INTERPRETED AS SUPPORT FOR PRESIDENT FERNANDO COLLOR DE MELLO.

00106

CABINET PRESSES WAR ON AIDS

JAPAN TIMES (WEEKLY INTERNATIONAL EDITION), 32(14) (APR 92 ) 4 .

IN VIEW OF THE RECENT INCREASE IN THE NUMBER OF AIDS AND HIV CASES IN JAPAN, THE GOVERNMENT IS REVISING ITS AIDS PREVENTION PROGRAM. AIDS EDUCATION WILL BE EMPHASIZED AND WILL FOCUS ON JAPANESE TRAVELING OR LIVING ABROAD AND ON FOREIGNERS ENTERING JAPAN. THE JAPANESE GOVERNMENT HILL COLLABORATE WITH THE HORLD HEALTH ORGANIZATION TO PREVENT AIDS, RECEIVE RESEARCHERS FROM SOUTHEAST ASIAN COUNTRIES, AND PROMOTE DEVELOPMENT OF A VACCINE AND TREATMENT FOR AIDS.

00107

CALL FOR EXTRADITION TO WORK BOTH WAYS

LATIN AMERICAN WEEKLY REPORT, (29) (JUL 92), 8.

IN RESPONSE TO THE UNITED STATES DECLARATION OF ITS RIGHT TO ABDUCT SUSPECTED DRUG-TRAFFICKERS FROM FOREIGN COUNTRIES, SOME BOLIVIAN POLITICIANS ARE DEMANDING RECIPROCITY. THEY WANT TO QUESTION U.S. DRUG ENFORCEMENT AGENCY OPERATIVES ABOUT THEIR INVOLVEMENT IN VIOLENT INCIDENTS IN BOLIVIA. IN ADOITION, SOME BOLIVIAN CONGRESSMEN HAVE CLAIMED THAT U.S. MILITARY FORCES IN BOLIVIA ARE ENGAGING IN SECRET ACTIVITIES.

00108

CALL TO INVESTIGATE PAZ AND BANZER

LATIN AMERICAN WEEKLY REPORT, (15) (APR 92), 5

THE OPPOSITION MOVIMIENTO NACIONALISTA REVOLUCIONARIO

(MNR) HAS CALLED ON UNITED NATIONS SECRETARY-GENERAL BOUTROS

GHALI TO ORDER AN INVESTIGATION OF LINKS BETHEEN DRUG

TRAFFICKERS AND BOLIVIAN PRESIDENT JAIME PAZ ZAMORA AND

PRESIDENTIAL CANDIDATE HUGO BANZER. BOLIVIA'S CONGRESS HAS

ALREADY INVESTIGATED THESE CHARGES AND DISMISSED THEM. THE

GOVERNMENT CLAIMS THAT THE MRN REQUEST IS AN ATTEMPT TO

INVESTIGATIONS INVOLYING MMR POLITICIAHS.

00109

CAMBODIA ASKS SDF HELP

JAPAN TIMES (WEEKLY INTERNATIONAL EOITION), 32(4) (JAN 92), 3.

CHEA SIM, CHAIRMAN OF CAMBODIA'S MATIONAL ASSEMBLY, HAS ASKED JAPAN TO SEND THE SELF-DEFENSE FORCES TO CAMBODIA TO HELP REBUILD THE WAR-RAVAGED COUNTRY. CHEA SIM MADE HIS REQUEST DURING A MEETING WITH MAKOTO TANABE, CHAIRMAN OF JAPAN'S SOCIAL DEMOCRATIC PARTY. TAMABE DECLINED TO USE HIS JAPAN'S SOCIAL DEMOCRATIC PARTY. TANABE DECLINED TO USE HIS JAPAN'S SUPPORT FOR THE UNITED NATIONS' TRANSITIONAL AUTHOR SUPPORT FOR THE UNITED NATIONS TRANSITIONAL

00110

CAMBODIA NEEDS SDF PERSONMEL

JAPAN TIMES (WEEKLY INTERNATIONAL EDITION), 32(15) (APR 92) 3.

KOJI KAKIZAWA, JAPAN'S PARLIAMENTARY VICE FOREIGM MINISTER, HAS DECLARED THAT JAPAN'S CONTRIBUTIONS TO THE UNITED MATIONS PEACEKEEPING OPERATIONS IN CAMBODIA WOULD BE "USELESS" WITHOUT SELF-DEFENSE FORCES PERSONNEL.

NEVERTHELESS, HE HAS CONCEDED THAT JAPAN CDULD ASSIST IN
MINE DISPOSAL, MEDICAL CARE, TRANSPORTATION, AND

COMMUNICATIONS EVEN IF THE SDF DOES NOT PARTICIPATE IN THE U. $N$. PEACEKEEPING FORCE.

00111

CAMEROON: CABINET RESHUFFLE

WEST AFRICA, (3892) (APR 92), 689

CAMEROON'S MUCH-AWAITED CABINET RESHUFFLE WAS ANNOUNCED

IN MID-APRIL 1992 BUT WAS NOT AS FAR-REACHING AS HAD BEEN

EXPECTED. SIMON ACHIDI ACHU, A VETERAN POLITICIAN FROM

ANGLOPHONE NORTH-WEST PROVINCE, WAS APPOINTED TO THE POST OF PRIME MINISTER.

00112

CAMEROON: ELECTIONS POSTPONEMENT

WEST AFRICA, (3878) (JAN 92),80.

CAMEROON'S GOVERMMENT HAS' AGREED TO OPPOSITION DEMANDS

TO POSTPONE THE LEGISLATIVE ELECTIONS SCHEDULED FOR FEBRUARY

16 UNTIL MID-MAY 1992. OPPOSITION LEADERS HAD WARNED THAT

THE CONSTITUTION NEEDED TO BE AMENDED BEFORE THE ELECTIONS

AND THAT THE ELECTORAL LAW HAD TO BE CLARIFIED.

00113

CAMPAIGN FINANCE REFORM

CONGRESSIONAL DIGEST, 71(3) (MAR 92), 67-96,

THE EVOLUTION OF CAMPAIGN REFORM LEGISLATION, THE

CURRENT FEDERAL CAMPAIGN FINANCE LAH, 1990 CONGRESSIONAL

CAMPAIGN SPENDING, AND PROPOSED REFORM LEGISLATION ARE

SUMATARI ZED. THEN PRO AND CON ARGUMENTS MADE BY U.S

CONGRESSMEN ON THE QUESTION OF "SHOULD THE CAMPAIGN SPENDING

LIMIT AND ELECTION REFORM ACT BE APPROVED?" ARE REPRINTED.

00114

CAMPAIGN TO FORCE CHANGE OF COURSE

LATIN AMERICAN WEEKLY REPORT, (32) (AUG 92), 8

THE U.S. STATE DEPARTMENT IS BACKING A MOVE BY SENATOR

JESSE HELMS TO SUSPEND AID TO NICARAGUA AND RESUME IT ONLY

SANDINISTAS WHO RUN THE ARMY AND POLICE FORCE.

00115

CAPPING FEDERAL ENTITLEMENT PROGRAMS

CONGRESSIONAL DIGEST, 71(6-7) (JUN 92), 162-192.

MAJOR ENTITLEMENT PROGRAMS AND RECENT CONGRESSIONAL

ACTION ON ENTITLEMENT PROGRAMS ARE DISCUSSED. THEN SENATE

DEBATE ON "SHOULD CONGRESS PLACE LIMITS ON ENTITLEMENT

SPENDING?" IS SUMMARIZED. STATEMENTS ARE INCLUDED BY

SENATORS PETE $V$. DOMENICI, LARRY CRAIG, WARREN B. RUDMAN,

ALAN $X$. SIMPSON, SAM NUNN, DONALD H. RIEGLE JR., PAUL S.

SARBANES, LLOYD BENTSEN, EDWARD M. KENHEDY, AND PAUL SIMON.

00116

CARRYING A STICK

FAR EASTERN ECONOMIC REVIEW, 151(19) (MAY 91), 54

THE BUSH ADMINISTRATION HAS TAKEN ITS TOUGH TALK WITH

TRADING PARTNERS TO A HIGHER PITCH IN A BID TO MAKE FRIENDS

IN THE U.S. CONGRESS, BUT THE STRATEGY COULD BACKFIRE. ASIAN

COUNTRIES CHARGED WITH TRADE INFRACTIONS BY TRADE

REPRESENTATIVE CARLA HILLS ON 26 APRIL APPEAR READY TO FIGHT

BACK THAN TO ACCEPT SANCTIONS. HILLS CITED CHINA, THAILAND

AND INDIA FOR INADEQUATE PROTECTION OF INTELLECTUAL-PROPERTY

RIGHTS AND OTHER VIOLATIONS OF COPYRIGHTS AND PATENTS AND

NAMED THEM "PRIORITY FOREIGN COUNTRIES" UNDER THE SPECIAL

301 PROVISION OF THE OMNIBUS TRADE AND COMPETITIVENESS ACT

OF 988. IF THE ALLEGATIONS ARE PROVEN, THE COUNTRIES FACE

TRADE RETALIATION FROM THE U.S. ONLY QUICK NEGOTIATION MAY

AVERT FURTHER CONFLICT AND RESTRICTION OF THE WORLD FREE

TRADE REGIME.

00117

CAUGHT BETHEEN HAR AND PEACE

THE MIDDLE EAST, (195) (JAN 91) 5-7.

DIPLOMATICALLY AND MILITARILY, GEORGE BUSH AND JAMES

BAKER HAVE BEEN REMARKABLY SUCCESSFUL IN CAJOLIMG THE

INTERNATIONAL COMMUNITY TO ISOLATE IRAQ. WHERE THEY SEEM TO

BE FAILING IS IN GIVING THEIR (MORE OR LESS) RELUCTANT

ALLIES A CLEAR INDICATION OF WHERE U.S. POLICY IN THE GULF

IS HEADING. OIFFERENT PERCEPTIONS OF EVENTS AND DECISIONS IN

WASHINGTON ANO BAGHDAD ARE A KEY FACTOR IN THE CONTINUING

GAME OF POL ITICAL MANEUVER. IN THE EYES OF MOST OBSERVERS

OUTSIDE OF HASHINGTON, SADDAM HUSSEIN IS WINMING THIS WAR

WORDS BY BRINGING THE PALESTINIAN ISSUE INTO THE AGENDA,

POSSIBILITY OF USE OF FORCE. AND STALLING FOR TIME.

00118

CAUGHT IN THE MIDDLE

THE MIDOLE EAST, (196) (FEB 91) 25-28,

THIS ARTICLE CONSIDERS THE IMPACT OF JORDAN OF IRAQ'S

INVASION OF KUHAIT AND THE SUBSEQUENT CHAIN OF EVENTS IT SET

IN MOTION. THE AUTHOR ARGUES THAT THE EVENTS HAVE HAD A

PROFOUND EFFECT ON JORDAN'S ECONOMIC AND SOCIAL LIFE,

LEAVING VIRTUALLY EVER SECTOR OF THE ECONOMY DAMAGED. SOME

OF THE SPECIFIC EFFECTS DISCUSSED ARE REVENUE LOSSES FOR OIL 
AND GAS PRODUCTION AND NEAR PARALYSIS OF AGRICULTURAL EXPORTS.

00119

CEASEFIRE AND DATE FOR FINAL PEACE ACCORD

LATIN AMERICAN WEEKLY REPORT, (2) (JAN 92), 4-5.

IN EL SALVADOR, 1991 ENDED WITH THE FMLN AND THE

CRIST IANI GOVERMMENT AGREEING ON A CEASEFIRE AND SETTING A

DATE FOR THE SIGNING OF A FINAL PEACE AGREEMENT. SOME ISSUES

WERE LEFT UNRESOLVED, BUT BOTH PARTIES AGREED TO A PROCEDURE

THAT SHOULD ENSURE THAT THE DEADLINE HILL BE MET.

00120

CEE ESCALATES HAR ON PUBLIC EDUCATION, HALL OF SEPARATION CHURCH AND STATE, 45(8) (SEP 92), 14(182)-15(183).

CITIZENS FOR EXCELLENCE IN EDUCATION (CEE), A CALIFORNIABASED GROUP HEADED BY ROBERT SIMONDS, EXPLOITS VOTER APATHY TO WIN SCHOOL BOARD SEATS FOR FUNDAMENTALIST CHRISTIANS. CEE CLAIMS TO HAVE ELECTED 1965 SCHOOL BOARD MEMBERS SINCE 1989 AND HOPES TO ELECT ANOTHER 3100 THIS YEAR. SIMONDS CALLS THE SEPARATION OF CHURCH AND STATE "A SOCIALIST MYTH," SAYS PUBLIC SCHOOLS MUST EXPUNGE ALL ANTI-BIBLICAL MATERIAL, SHDO TEAC CREATION SCIENCE HUMANISM, AND CURTAIL SEX EDUCATION PROGRAMS.

00121

CESAR PREPARES TO RAISE THE STAKES

LATIN AMERICAN HEEKLY REPORT, (47) (DEC 92), 4

ALFREDO CESAR, PRESIDENT OF NICARAGUA'S CONSTITUENT ASSEMBLY HAS SERVED MOTICE THAT HE WILL INYOKE THE LEGISLATURE'S HOUSE RULES TO RESCIND THE MANDATES OF THE LEGISLATURE'S HOUSE RULES TO RESCIND THE MANDATES OF THE CONGRESSMEN WHO HAVE BOYCOTTED SESSIONS FOR 90 DAYS OR LONGER. CESAR'S TARGET IS THE EIGHT MEMBERS OF THE GRUPO DE CENTRO, A BREAKAWAY FACTION OF THE UNIDN NACIONAL OPOSITORA (UNO), THE COALITION THAT ELECTED PRESIDENT VIOLETA CHAMORRO
BY REPLACING THE GRUPO DE CENTRO REPRESENTATIVES, UNO IS ASSURED OF A QUORUN AND THE SANDINISTAS ARE DENIED ONE.

00122

CHAD: CLAMPDOWN DEATHS

WEST AFRICA, (3879) (JAN 92), 121.

AT LEAST 10 PEOPLE WERE KILLLD IN NDJAMENA ON JANUARY 8

AND 9, 1992, AS THE GOVERMMENT CARRIED OUT A WAVE OF ARRESTS THE CLAMPDOWN CAME IN THE AFTERMATH OF A REBELLION LAUNC

PRESIDENT HISSEIN HABRE.

00123

CHAD: HINTS OF PEACE

WEST AFRICA, (3903) (JUL 92), 1144.

CHAD'S GOVERNMENT HAS SIGNED A PEACE AGREEMENT WITH THE

CHAD'S GOVERNMENT HAS SIGNED A PEACE AGREEMENT WITH THE

REBEL MOVEMENT FOR DEMOCRACY AND DEVELOPMENT (MDD) BOTH

SIDES REPORTEDLY AGREED

00124

CHAMORRO FACES CONFLICT OF POWERS

ATIN AMERICAN HEEKLY REPORT (40) (OCT 92), 8-9.

PRESIDENT VIOLETA CHAMORRO'S CRISIS-MANAGEMENT SKILLS

ARE BEING PUT TO THE TEST ONCE MORE--THIS TIME ON THREE

FRONTS AT ONCE. SHE MUST DEAL WITH A CONFLICT BETHEEN THE

THREE BRANCHES OF GOVERMMENT, WITH AUSTERITY MEASURES

MECESSITATED BY THE STOPPAGE OF U.S. AID, AND WITH TOP-LEVEL

RESIGNATIONS THAT HAVE FORCED HER TO RESHUFFLE HER CABINET.

00125

CHAMORRO'S UNEASY SECOND ANMIVERSARY

LATIN AMERICAN WEEKLY REPORT, (17) (MAY 92), 9

ON APRIL 25, 1992, THE GOVERMMENT OF PRESIDENT VIOLETA

CELEBRATED AN UNEASY SECOND ANNIVERSARY. AMONG

CHAMORRO'S PROBLEMS WERE PROTESTS BY THE REVUELTOS (FORMER

CONTRA AND SANDINISTA FIGHTERS) AND HER GOVERNMENT'S

CONTINUED INABILITY TO IMPLEMENT LEGISLATION.

00126

CHILEAN MILITARY SLAM REFORMS AMD CLAIM A ROLE AS

INSTITUTIONAL COUNTERHEIGHT

LATIN AMERICAN HEEKLY REPORT, (30) (AUG 92), 1

PRESIDENT PATRICIO AYLWIN PROBABLY EXPECIED THE

RENOVACION NACIONAL AND THE UNION DEMOCRATA INDEPENDIENTE TO

OPPOSE HIS PROPOSED CONSTITUTIONAL REFORMS, BUT HE MAY HAVE

BEEN OUITE DISTURBED BY REPORTS THAT THE MILITARY WILL ISSUE

BEEN QUITE DISTURBED BY REPORTS THAT THE

00127

CHINA ACCEDES TO MUCLEAR NON-PROL IFERATION TREATY

BEIJING REVIEW, 35(12) (MAR 92), 16

THE CHINESE' FOREIGN MINISTRY' RELEASED CHINA'S INSTRUMENT OF ACCESSION TO THE TREATY ON THE NON-PROLIFERATION OF MUCLEAR WEAPONS ON MARCH 11, 1992. THE DOCUMENT WAS HANDED OVER TO BRITISH PRIME MINISTER, JOHN MAJOR, IN LONDON. BRITAIN, ALONG WITH THE UNITED STATES AMD RUSSIA, ARE THE THREE COUNTRIES PRESERVING THE TREATY. THIS ARTICLE CONTAINS THE FULL TEXT OF THE INSTRUMENT OF ACCESSION.
00128

CHINA HOPES TO KEEP POST-COLD WAR POT ON THE HEAT JAPAN TIMES (WEEKLY INTERNATIONAL EDITION), 32(13) (MAR 3 2) 3.

CHIMA'S COMMUNIST PARTY HAS INSTRUCTED ITS MEDIA TO FOCUS ON DISAGREEMENTS BETHEEN JAPAN, THE UNITED STATES, AND WESTERN EUROPE IN THE POST-COLD WAR ERA. THE PARTY

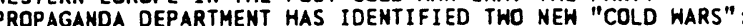
(1) DISPUTES BETWEEN JAPAN, THE USA, AND WESTERN EUROPE, WHICH HAVE LOST THEIR COMMON FOE DUE TO THE BREAKUP OF THE SOVIET UNION, AMD (2) THE CONFLICT BETWEEN THE IMPERIALIST STATES AND THE THIRD WORLD AND SOCIALIST COUNTRIES THAT HAVE SURVIVED THE FALL OF COMMUNISM. THE PROPAGANDA DEPARTMENT HAS ALSO INSTRUCTED THE MEDIA TO EMPHASIZE THE OWINDLING POWER OF THE UNITED STATES.

00129

CHINA NEVER SEEKS HEGEMONY

BEIJING REVIEH, 35(50) (DEC 92), 7,9.

PREMIER LI PENG HAS DECLARED THAT CHINA IS OPPOSED TO HEGEMONY AND POWER POLITICS. ACCORDING TO PENG, CHINA WILL NEVER SEEK HEGEMONY ITSELF, EVEN WHEN THE COUNTRY BECOMES FULLY DEYELOPED ECONOMICALLY AND POLITICALLY.

00130

CHINA PREPARES TO RE-ENTER GATT

BEIJING REYIEW, $35(48)$ (NOY 92).

CHINA'S SEAI IN GATT WILL SOON BE RESTORED, AND THE COUNTRY IS STEPPING UP ITS PREPARATIONS TO RE-ENTER THE INTERMATIONAL ORGANIZATION. RETURNING TO GATT WILL ENABLE THE CHIMESE ECOMOMY TO PARTICIPATE MORE FULLY IN

TMTERMATIOMAL TRADE THIS WIL MOT ONLY BENEFIT CHINA BUT WILL CONTRIBUTE TO WORLD-WIDE ECONOMIC GROWTH.

00131

CHINA READY TO WORK WITH CLINTON

BEI JING REVIEW, 35(46) (NOV 92),

DESPITE SENDING BILL CLINTON A CONGRATULATORY MESSAGE

UPON HIS ELECTION AS PRESIDENT OF THE UNITED STATES AND

DECLARING THEIR READINESS TO IMPROVE BILATERAL RELATIONS,

CHINESE LEADERS HAVE WARNED THE USA NOT TO ALTER CHINA'S

MOST-FAVORED NATION STATUS AND CONTINUE TO OPPOSE U.S.-SOUTH

KOREAN MILITARY EXERCISES ON THE KDREAN PENINSULA.

00132

CHIMA SEEKS CLOSE TIES HITH ASEAN NATIONS

CIJING REVIEH, 35(3) (JAN 92), 7-9.

CHINESE PRESIDENT YANG SHANGKUN, MADE STATE YISITS TO

SINGAPORE AND MALAYSIA, BEGINNIMG JANUARY 7 FOR

STRENGTHENIMG THE BILATERAL RELATIONS AND CO-OPERATION WITH THE TWO COUNTRIES. YANG SAID THAT CHINA WILL, TOGETHER HITH THE MEMBER NATIONS OF THE ASSOCIATION OF SOUTHEAST ASIAN MATIONS MAKE FURTHER EFFORTS FOR PEACE AMD DEVELOPMENT IN THE ASIA-PACIFIC REGION AS WELL AS IN THE WORLD.

00133

CHINA STANDS FIRM ON H.K. ISSUE

BEI ING REVIEW, 35 (48) NOL 92 , 9 (STER JOHN MAJOR, CHINESE IN TALKS WITH BRITISH PRIME MINISTER JOHN MAJOR, CHINESE VICE-PREMIER ZHU RONGJI STATED THAT THE BRITISH GOVERMMENT SHOULD GIVE PRIORITY TO THE PROSPERITY AND STABILITY OF HONG KONG AND THE INTERESTS OF BOTH BRITATN AND CHINA AND RETURM TO CONSUL LTATIONS AND COOPERATION IN THE SPIRIT OF THE SINOBRITISH JOINT DECLARATION. ZHU ALSO CRITICIZED THE CURREMT HONG KONG GOVERNMENT FOR PROPOSING MAJOR CHANGES IN THE TERRITORY'S POLITICAL
SOVEREIGNTY IN 1997.

0013

CHINA TO OVERHAUL TRADE RULES

BEIJING REVIEH, 35(49) (DEC 92), 9-10.

CHINA PLANS TO REVAMP ITS IMPORT AND EXPORT POLICIES TO FACILITATE ITS EFFORTS TO REJOIN THE GATT. THE MAIN TARGETS IN THIS RESTRUCTURING WILL BE THE ELIMINATION OF RED TAPE AND BUREAUCRATIC INTERVENTION IN BUSINESS AFFAIRS. THE STRUCTURAL RECONFIGURATION HILL MESH WITH BOTH CHINA'S SOCIALIST MARKET ECONOMY AND INTERNATIONAL TRADE NORMS.

00135

ATIN AMERICAN WEEKLY REPORT, (44) (NOV 92), 6-7.

CHINA IS ATTEMPTING TO MAKE UP LOST GROUND IN LATIM AMERICA. AT THE TOP OF ITS AGENDA IS AN ATTEMPT TO REDRESS AT LEAST PART OF ITS TRADE IMBALANCE HITH THE REGION ANO TO RECRUIT LATIN AMERICAN SUPPORT FOR ITS BID TO JOIN GATT. ONE PRONG OF CHINA'S DRIVE WILL STRENGTHEN TIES WITH LATIN PRONG OF CHINA'S DRIVE WILL STRENGTHEN TY HAS DIPLOMATIC AMERICAN COUNTRIES WITH HHICH IT ALREADY HAS DIPLOMATIC RELATIONS. THE SECOND WILL PURSUE LATIN AMERICAN COUNTRIES--INCLUDING COSTA RICA, EL SALVADOR, TAIHAN ONLY. 
00136

CHINA, PAKISTAN FOSTER CODPERATION

BEIJING REYIEW, 35(42) (OCT 92),

PAKISTANI PRIME MINISTER NAHAZ SHARIF PAID AN OFFICIAL

VISIT TO CHINA IN OCTOBER 1992. SHARIF DESCRIBED SINO-

PAKISTANI RELATIONS AS "AN ALL-WEATHER FRIENDSHIP" AND

DECLARED THAT HE REGARDS THOSE RELATIONS AS A CORNERSTO

HIS FOREIGN POLICY. CHINESE PREMIER LI PENG EXPRESSED
CHINA'S SUPPORT FOR PAKISTAN'S PLAN TO ESTABLISH A NUCLEAR-

FREE ZONE IN SOUTH ASIA.

00137

CHINA'S CONDOLENCES WITH VICTIMS OF YUGOSLAVIAN CONFLICT

BEIJING REVIEW, 35(33) (AUG 92), 41

ON JULY 29, 1992 , CHINA'S AMBASSADOR FAN GUOXIANG

ADDRESSED THE' INTERMATIONAL MEETING ON HUMANITARIAN AID FOR

VICTIMS OF THE CONFLICT IN THE FORMER YUGOSLAVIA. HE

DECLARED THAT CHINA SUPPORTS INTERNATIONAL EFFORTS TO TAKE

ALL NECESSARY MEASURES TO SEND HUMANITARIAN ASSISTANCE INTO THE WAR-TORN AREAS.

00138

CHINA'S REFORM CALLED A 'REYOLUTION'

BEIJING REVIEW, 35 (25) (JUN 92). 7 .

JIANG ZEMIN, GENERAL SECRETARY OF THE CENTRAL COMMITTEE

OF THE CHINESE COMMUNIST PARTY, HAS DESCRIBED CHINA'S REFORM

JIANG HAS STATED THAT CHINA SHOULD SEIZE FAVORABLE

OPPORTUNITIES AND SEEK TO DEVELOP AT A FASTER PACE BECAUSE

OVERCAUTIOUSNESS HAMPERS PROGRESS.

00139

CHINESE SPOKESMAN EXPLAINS DOCUMENTS

BEIJING REYIEW, 35(46) (NOY 92) 12-14.

IN EARLY OCTOBER 1992, GOVERNOR CHRISTOPHER PATTEN

PROPOSED SWEEPING CHANGES IN HONG KONG'S POLITICAL SYSTEM.

ON OCTOBER 28, CHINA MADE PUBLIC SEVEN DIPLOMATIC DOCUMENTS

ON CONSULTATIONS BETHEEN CHINESE LEADERS AND HONG KONG

OFFICIALS ON THE ISSUE OF THE POLITICAL STRUCTURE IN HONG

KONG. IN THIS ARTICLE, A SPOKESMAN EXPLAINS WHY CHINA IS

OPPOSED TO PATTEN'S PROPOSED REFORMS.

00140

CIVIC STRIKE SHUTS DOWN CAPITAL

ATIN AMERICAN HEEKLY REPORT, (8) (FEB 92 ), 3.

THE GOVERNMENT OF PRESIDENT JAIME PAZ ZAMORA WAS UNABLE TO STOP A ONE-DAY STRIKE ON FEBRUARY 14, 1992, ORGANIZED BY THE COMITE CIVICO, A HODGE-PODGE OF CULTURAL ASSOCIATIONS, SPORTING CLUBS, NEIGHBORHOOD COMMITTEES, AND LOCAL TRADE UNIONS. THE STRIKERS, WHO DEMANDED A GREATER SHARE OF THE CENTRAL GOVERNMENT'S BUDGET FOR LA PAZ, WERE OPENLY BACKED
BY THE MAYOR OF LA PAZ, JULIO MANTILLA OF THE CONCIENCIA OE PATRIA CONDEPA.

00141

CLINTON FOR PRESIDEN

NEH REPUBLIC, 207(20) (NOV 92), 7-9

THE AUTHOR LOOKS AT THE GEORGE BUSH'S RECORD AS

PRESIDENT AND CONCLUDES THAT BILL CLINTON WOULD BE A BETTER CHOICE IN THE 1992 PRESIDENTIAL ELECTION.

00142

CNGSB LAUNCHES COUNTRYHIDE ATTACK

LATIN AMERICAN WEEKLY REPORT, (43) (NOY 92) 3

THE COORDINADORA NACIONAL GUERRILLERA SIMON BOL IVAR (CNGSB) LAUNCHED A MAJOR OFFENSIVE ON OCTOBER 21, 1992, REPORTEDLY TO FORCE THE GOVERMMENT TO RESUME PEACE TALKS. BUT, FAR FROM PERSUADING THE GAVIRIA GOVERNMENT TO RETURN TO THE NEGOTIATING TABLE, THE CNGSB STRENGTHENED THE ARGUMENTS OF THOSE IAO INSIST THAT THE GUERRILA GROUP MUST BR SOUNDIY DEFEATED ON THE BATTLEFIELD.

00143

COLLOR COULD GO BY END OF SEPTEMBER

LATIN AMERICAN WEEKLY REPORT, (37) (SEP 92), 3.

PRESIDENT FERMANDO COLLOR DE MELLO'S TACTICS TO DELAY

POTENTIAL IMPEACHMENT PROCEEDINGS AGAINST HIM HAVE EARNED

HIM AN ADDITIONAL FIYE DAYS TO RESPOND TO THE CHARGES

HIM AN ADDITIONAL FIVE DAYS TO RESPOND TO THE CHARGES

AGAINST HIM, BUT THE CHAMBER OF

0014

COLLOR IS UNSEATED BY THE BOOK

LATIN AMERICAN WEEKLY REPORT, (50) (DEC 92), 5

AS 1992 ENDED, THE LENGTHY, PAINFUL IMPEACHMENT

PROCEDURE AGAINST PRESIDENT FERMANDO COLLOR DE MELLO WAS

DRAHING TO A CLOSE, HITH HIS REMOVAL FROM OFFICE SEEMINGLY

CERTAIN. THE IMPEACHMENT PROCESS EFFECTIVELY LED TO THE

POSTPONEMENT OF ALL KEY DECISIONS ON BRAZIL'S ECONOMY

HOWEVER, A SITUATION THAT IN THE PAST WOULD ALMOST

AUTOMATICALLY HAVE TRIGGERED A MILITARY COUP WAS CONDUCTED

HITH GREAT CARE FOR PROCEDURAL PROPRIETY. WHILE STILL

AWAITING COLLOR'S FATE, THE INTERIM ADMINISTRATION HEADED BY

ITAMAR FRANCO HINTED AT A NEH APPRDACH TO BRAZIL'S ECONOMIC
AND SOCIAL PROBLEMS, PUTTING REACTIVATION AND THE ALLEVIATION OF POVERTY BEFORE THE DEMANDS OF FOREIGN CREDITORS.

00145

COLLOR LOSES THE

BLACK CARNIVAL

LATIN AMERICAN WEEKLY REPORT, (33) (AUG 92), 1

PRESIDENT FERNANDO COLLOR OE MELLO OBVIOUSLY MISJUDGED

THE MAGNITUDE OF PUBLIC OPPOSITION TO HIS ADMINISTRATION

WHEN HE ASKED BRAZILIANS TO WEAR THE NATIONAL COLORS TO SHOW

SUPPORT FOR HIM AS CORRUPTION CHARGES THREATEN TO BRING DOWN

HIS GOVERNMENT. INSTEAD OF WEARING GREEN AND YELLOW,

THOUSANDS OF BRAZILIANS WORE BLACX, THE COLOR OF MOURNING,

OR HHITE REPRESENTING GHOSTS AND ALLUDING TO THE FICTITIOUS

COMPANIES FORMED BY ONE OF COLLOR'S AIDES.

00146

COLLOR STIFFENS RESISTANCE BID

LATIN AMERICAN WEEKLY REPORT, (36) (SEP 92), 2

PRESIDENT FERNANDO COLLOR' DE MELLO, WHO IS RESISTING

CALLS FOR HIS RESIGNATION, HAS DISMISSED A SUGGESTION THAT

HE PROMISE TO STEP DOWN AFTER CONGRESS APPROVES HIS DRAFT

LEGISLATION FOR ECONOMIC MODERNIZATION.

00147

COLLOR'S CHANCES GET NARROWER

LATIN AMERICAN WEEKLY REPORT, (38) (OCT 92), 2.

PROCURATOR-GENERAL ARISTIDES JUNOUEIRA HAS CONCLUDED

THAT THERE IS PRIMA FACIE EVIDENCE THAT PRESIDENT FERNANDO

COLLOR DE MELLL COMMITTED OFFENSES AGAINST THE

ADMINISTRATION AND AGAINST THE "PUBLIC FAITH"--BOTH

PUNISHABLE UNDER BRAZIL'S PENAL CODE. THE PRESIDENT'S

SURVIVAL STRATEGY HINGES ON THE CHAMBER OF DEPUTIES, HHERE

HE HOPES TO MUSTER ENOUGH VDTES TO BLOCK THE ELEVATION OF

POLITICAL CHARGES TO THE SENATE OR CRIMINAL CHARGES TO THE

SUPREME COURT.

00148

COLLOR'S REBUTTAL DEFLATED BY WITNESS

LATIN AMERICAN WEEKLY REPORT, (27) (JUL 92), 2

PRESIDENT FERNANDO COLLOR DE MELLO HAS PRESENTED LITTLE

EVIDENCE TO REFUTE CHARGES AGAINST HIM, BUT HE HAS VOWED NOT

TO RESIGN BEFORE THE END OF HIS TERM.

00149

COLOMBIAN GUERRILLAS COUNTER-ATTACK WITH HIGH-VISIBILITY URBAN RAIDS

LATIN AMERICAN WEEKLY REPORT, (23) (JUN 92), 1

THE COUNTER-INSURGENCY DRIVE LAUNCHED BY THE GOVERNMENT OF PRESIDENT CESAR GAVIRIA IN MAY 1992 SEEMS TO BE HURTING THE REBELS OF THE COORDINADORA NACIONAL GUERRILLERA SIMON BOLIVAR, WHO HAVE RESPONDED WITH A SERIES OF ATTACKS ON HIGHLY-VISIBLE URBAN TARGETS.

00150

COLON JOBS PROTEST IS SPREADING

LATIN AMERICAN WEEKLY REPORT, (19) (MAY 92), 9

PROTESTORS HAVE BEEN DEMONSTRATING IN COLON, CHIRIQUI

AND OTHER PLACES TO CALL ATTENTION TO THE HIGH UNEMPLOYMENT

THROUGHOUT PANAMA. FOR THE FIRST TIME, AN ANTI-ENDARA

ALLIANCE HAS MATERIALIZED IN CONGRESS AND REJECTED PRESIDENT ENDARA'S PRIVATIZATION PLAN.

00151

COMPETITION AND SERVICE (UTILITIES) BILL

SURVEY OF CURRENT AFFAIRS, 21(12) (DEC 91), 455-457

THE BRITISH PARL IAMENT IS CONSIDERING A BILL THAT WOULD

EXTEND THE PONERS OF THE REGULATORS OF PRIVATIZED UTILITIES.

UNDER THE COMPETITION AND SERVICE (UTILITIES) BILL

CUSTOMERS OF FORMERLY STATE-OWNED UTILITIES WOULD RECEIVE

FAIRER TREATMENT FROM THOSE INDUSTRIES. REGULATORS FOR

TELECOMHUNICATIONS, GAS, ELECTRICITY, AND WATER HOULD HAVE

MORE POWER; CUSTOMERS WOULD BE COMPENSATED HHEN STANDARDS

ARE NOT MET; A AND GREATER C

00152

CONCERTACION WILL RUN ON SIMGLE SLATE

LATIN AMERICAN WEEKLY REPORT, (8) (FEB 92), 10

CHILE'S RIGHT-WING OPPOSITION HAD HOPED' THAT THE RULING

CONCERTACION WOULD SPLIT UP AND RUN SEVERAL SLATES OF

CANDIDATES IN THE JUME 28, 1992 , MUNICIPAL ELECTIONS. BUT ON

FEBRUARY 12 THE 11 ORGANIZATIONS COMPRISING THE COALITION

REACHED AN AGREEMENT ON A COMMON SLATE.

00153

CONFUSING FLURRY OF CONSPIRACY CHARGES

LATIN AMERICAN WEEKLY REPORT, (18) (MAY 92), 10.

THE AUTHOR DESCRIBES A SERIES OF CONSPIRACIES THAT ARE

RUMORED TO BE PLANNED TO EITHER SUPPORT OR TOPPLE

VENEZUELA'S PRESIDENT CARLOS ANDRES PEREZ. 
00154

CONGRESS CLASHES AGAINST WITH BORJA

LATIN AMERICAN WEEKLY REPORT, (17) (MAY 92), 3.

THE CONFRONTATION BETWEEN ECUADOR'S CONGRESS AND THE EXECUTIVE CONTINUES. ON APRIL 22, 1992 , THE CONGRESS FORMALLY ASKED THE SUPREME COURT TO INSTITUTE IMPEACHMENT PROCEEDINGS AGAINST PRESIDENT RODRIGO BORJA. THE INCIDENT PRECIPITATING THE IMPEACHAENT REQUEST WAS A BILL DESIGNED TO REFORM THE COUNTRY'S MONETARY SYSTEM.

00155

CONGRESS DOUBTFUL OM TAX PROPOSALS

LATIN AMERICAN WEEKLY REPORT, (29) (JUL 92), 4.

PRESIDENT CARLOS ANDRES PEREZ WANTS CONGRESS TO RAISE THE TAXES PAID BY VENEZUELANS BECAUSE THE COUNTRY IS TOO DEPENDENT ON OIL REVENUES. BUT THE OPPOSITION IS HESITANT BECAUSE MANY VENEZUELANS FEAR THAT THEIR TAX MONEY HILL END UP IN THE POCKETS OF CORRUPT OFFICIALS.

00156

CONGRESS FAILS TO APPROVE NEW PLAN

LATIN AMERICAN HEEKLY REPORT, (20) (MAY 92), 11.

THE POLITICAL SITUATON IN HAITI SEEMS TO BE DEADLOCKED. ANTI-ARISTIDE CONGRESSIONAL LEADERS TRIED TO PASS AN

ALTERNATIVE TO THE PLAN BACKED BY THE OAS BUT FAILED. FOR ITS PART, THE OAS RATIFIED ITS SUPPORT FOR THE HASHINGTOM PPOTOCO , FEBRUARY 231992 BUT FAILED TO TIGHTEN THE SANCTIONS AGAINST THE INTERIM GOVERNMENT.

00157

CONGRESS OBJECTS TO EMERGENCY POHERS

LATIN AMERICAN WEEKLY REPORT, (47) (DEC 92),

PRESIDENT CESAR GAVIRIA HAS DECREED "A STATE OF INTERMAL COMHOT ION" AND ASSUMED EXTRAORDI INARY POHERS TO DEAL WI TH THE UPSURGE IN GUERRILLA AND NARCO VIOLENCE, BUT HE IS MEETING RESISTANCE IN THE CONGRESS.

00158

CONGRESSIONAL REDISTRICTING AND THE 1990 CENSUS CONGRESSIONAL DIGEST, 71(10) (OCT 92), 228-229.

THIS ARTICLE EXPLAINS THE CONGRESSIONAL REDISTRICIING PROCESS, INCLUDING THE CONSTITUTIONAL REQUIREMENTS GERRYMANDERING, AND THE POPULATION TRENDS IDENTIFIED IN THE 1990 CENSUS.

00159

CONVENTION THESIS: COMMUNIST PARTY OF CANADA

POLITICAL AFFAIRS, 71(11) (NOV 92), 34-36.

THIS ARTICLE CONSISTS OF EXCERPTS OF THE DISCUSSION DOCUMENT OF CPC. IT STATES THE AT THE CRISIS THROUGH WHICH DOCUMENT OF CPC. IT STATES THE AT THE CRISIS THROUGH THE PARTY HAS JUST PASSED WAS THE DEEPEST AND THE MOST BOTH SOCIALISM AND CAPITALISM, THEORETICAL STAGNATION, AND BOTH SOCIALISM AND CAPITALISM, THEORET ICAL STAGNATION, AND, AL THOUGH THEIR GOAL OF SOCIALISM SEEMS FURTHER AHAY TODAY THAN EVER BEFORE, ITS VALUE TO THE WORKING CLASS HAS NOT DIMINISHED.

00160

COPEI AGREES TO SPEED TAX PACKAGE

LATIN AMERICAN WEEKLY REPORT, (27) (JUL 92), 10-11. COPEI, THE MAIN OPPOSITION PARTY, MAY HAVE WITHDRAWN FROM THE GOVERNMENT COALITION, BUT IT IS STILL WILLING TO COOPERATE HITH THE PEREZ ADMINISTRATION ON SOME MATTERS. THE PEREZ GOVERMMENT CLAIMS THAT BOTH COPEI AND THE ACCION DEMOCRATICA LEADERS WILL HELP TO PASS ITS TAX PACKAGE IN CONGRESS. THE PACKAGE INCLUDES A NEW GENERAL SALES TAX AND A TWO PERCENT TAX ON COMPANY ASSETS.

00161

COPEI NOW BACKS MANDATE-CUTTING

LATIN AMERICAN WEEKLY REPORT, (28) (JUL 92), 5

COPEI'S ON-OFF SUPPORT FOR THE EMBATTLED GOVERMMENT OF

PRESIDENT CARLOS ANDRES PEREZ TOOK A NEH TURN ON JULY 7 ,

1992, WHEN PARTY LEADER EDUARDO FERNANDEZ ANMOUNCED THAT

COPEI WOULD VOTE FOR A REFERENDUM TO DECIDE WHETHER PEREZ'S

TERH WILL BE SHORTENED.

00162

COPEI WITHDRAWAL HEIGHTENS CRISIS

LATIN AMERICAN WEEKLY REPORT (24) (JUM 92), 4-5.

COPEI, VENEZUELA'S MAIN OPPOSITION PARTY, HAS HAD SECOND THOUGHTS ABOUT ITS PACT WITH THE GOVERMMENT OF CARLOS ANDRES PRERZ. ON JUNE IT PACT WITH THE GOVERMMENT OF CARLOS ANDRES PEREZ. ON JUNE 11, 1992, COPEI'S SECRETARY-GENERAL A THAT THE PARTY WAS WITHDRAHING THE THO COPEYANOS WHO INDICATED THAT HE HOULD NOT COMPLY HITH REQUESTS FOR HIS INDICATED THAT

00163

COPING WITH THE CARNAGE

THE MIDDLE EAST, (195) (JAN 91), 10-11.

MEY

MEDICAL TEAM KNOWN AS M-MART, MEDICAL-MOBILIZATION AND
READINESS TEAM, TO PREPARE FOR EXPECTED CASUALTIES IN ANY CONFLICT BETWEEN IRAQ AND THE ANTI-IRAQ COALITION. ESTIMATES OF POTENTIAL CASUALTIES RANGE FORM 10,000 TO 20,000 DEAD, A NUMBER THAT WOULD SHAMP REGIONAL HOSPITALS AND FORCE DOCTORS TO WORK AROUND THE CLOCK. THE U.S. NAYY IS FEVERISHLY PREPARING FOR THIS POSSIBILITY IN COOPERATION WITH BAHRAIN.

00164

COTE D'IVOIRE: HOUPHOUET HOLDS OUT

HEST AFRICA, (3888) (MAR 92), 517

ON MARCH 14, 1992, PRESIDENT FELIX HOUPHOUET-BOIGNY

WARNED THAT HE "WILL NOT YIELD" TO DEMANDS THAT HE RELEASE

LAURENT GBAGBO AND OTHER POLITICAL PRISONERS. HOUPHOUET-

BOIGNY STATED, "THE SUBVERSION WHICH IS BEING SOWN

EVERYHHERE IN AFRICA UNDER THE COVER OF DEMOCRATISATION WILL

NOT BE ALLONED TO SUCCEED IN COTE D'IVOIRE."

00165

COULD 'COLLORGATE' HAPPEN ELSEWHERE?

LATIN AMERICAN HEEKLY REPORT, (40) (OCT 92), 6-7

THE IMPEACHMENT PROCEEDINGS INITIATED BY THE BRAZILIAN

CONGRESS AGAINST PRESIDENT FERNANDO COLLOR DE MELLO WERE A

MAJOR TEST FROM WHICH BRAZIL'S INSTITUTIONS HAVE THUS FAR

EMERGED WITH TOP MARKS. BOTH THE LEGISLATURE AND THE

JUDICIARY ACTED WITH INDEPENDENCE IN LARGELY UMCHARTED

TERRITORY, WITH GREAT RESPECT FOR LEGAL FORMALITIES.

MOREOVER, THE MILITARY STUCK TO ITS FORMAL INSTITUTIONAL

ROLE INSTEAD OF ACTING AS IF IT WERE THE "FOURTH POWER." IN SEVERAL LATIN AMERICAN COUNTRIES, POL ITICIANS HAVE POINTED TO COLLOR'S FATE AS BOTH AN EXAMPLE OF DEMOCRATIC PROPRIETY AND A SALUTARY WARNING TO THEIR OWN RULERS.

00166

COULD DURAN PICK THE PRE AS ALLY?

LATIN AMERICAN WEEKLY REPORT, (30) (AUG 92), 5

PRESIDENT-ELECT SIXTO DURÁN BALLEN SEEMS TO HAVE

REDEFINED HIS PROMISE TO SET UP A "GOVERNMENT OF NATIONAL

CONCERTACION" BY CHOOSING THREE OF HIS CLOSEST COLLABORATORS

FROM THE PARTIDO UNIDAD REPUBLICANA AND THE PARTIDO

CONSERYADOR. THERE REMAINS MUCH SPECULATION OVER WHAT TYPE

OF CONGRESSIONAL ALLIANCE DURAN WILL FORM IN ORDER TO SECURE

A MAJORITY IN CONGRESS.

00167

COUP FOR GAVIRIA AS WAR ESCALATES

LATIN AMERICAN WEEKLY REPORT, (49) (DEC 92), 2.

IN DECEMBER 1992, THE GOVERMMENT OF PRESIDENT CESAR

GAVIRIA CAPTURED THO MAJOR GUERRILLA LEADERS. NEVERTHELESS,

THE COORDINADORA NACIONAL GUERRILLA SIMON BOLIVAR STEPPED UP

ITS HOSTILITIES AGAINST CIVILIAN TARGETS. MEANWHILE, THE

GOVERMMENT ADOPTED THE STRATEGY OF PORTRAYING ITS TWO

ONGOING STRUGGLES-AGAINST THE GUERRIILAS AND AGAINST DRUG

TRAFFICKERS--AS A SINGLE WAR CLAIMING THAT IN SOME CASES

TRAFFICKERS--AS A SINGLE WAR, CLAIMING THAT IN SOME CASES THE GUERR
CARTEL.

00168

CPPCC CHAIRMAN LI XIANHIAN DIES

BEIJING REVIEH, 35 (26) (JUN 92).

LI XIANMIAN, CHAIRMAN OF THE NATIONAL COMMITTEE OF THE

CHINESE PEOPLE'S POLITICAL CONSULTATIVE CONFERENCE, DIED ON

JUNE 21, 1992, AT AGE 83. LI HAD JOINED THE CHINESE

COMMUNIST PARTY IN 1927, FOUGHT AS A REVOLUTIONARY, AND

DIRECTED THE ADVANCED DETACHMENT OF THE FOURTH FRONT ARMY

DURING THE LONG MARCH. FOR MORE THAN 60 YEARS HE HELD

POSITIONS OF LEADERSHIP IN THE REVOLUTIONARY ARMY AND IN

CHINA'S GOVERMMENT.

00169

CRIME AND PUNISHMENT

NEW REPUBLIC, 207 (16) (OCT 92), 7

BILL CLINTON HAS ENDORSED A HATE-CRIMES BILL PENDING

BEFORE CONGRESS THAT WOULD REQUIRE HARSHER SENTENCES FOR

CRIMES "IN WHICH THE DEFENDANT'S CONDUCT HAS MOTIYATED BY

HATRED, BIAS, OR PREJUDICE BASED ON THE ACTUAL OR PERCEIVED RACE, COLOR, RELIGION, NATIONAL ORIGIN, ETHNICITY, GENDER, OR SEXUAL ORIENTATION OF ANOTHER INDIVIDUAL OR GROUP OF INDIVIDUALS." THE BILL IS LIKELY TO PASS, BUT THERE ARE QUESTIONS ABOUT ITS CONSTITUTIONALITY AND WHETHER IT IS REALLY A GOOD IDEA.

00170

CRISIS HORSENS AT GAYIRIA'S MID-TERM

LATIN AMERICAN WEEKLY REPORT, (33) (AUG 92), 4.

AS PRESIDENT CESAR GAVIRIA REACHES THE MID-POINT IN HIS FIRST TERM, HE IS BEING ACCUSED OF MAKING "THE GREATEST MUMBER OF MISTAKES IM HISTORY" DRUG LORD PABLO ESCOBAR IS STILL FREE. THERE IS NO PROGRESS IN THE COUNTER-INSURGENCY FIGHT; NATIONHIDE POHER CUTS FOR UP TO NINE HOURS PER DAY ARE LIKELY TO CONTINUE INTO 1993. ECONOMIC LIBERALIZATION IS STUMBLING AT EVERY HURDLE WHILE COMPANIES THAT HAVE NOT BEEN FORCED TO CLOSE BY THE POWER CUTS ARE STRAINING UNDER INCREASED TAX BURDENS. 
00171 CRUNCH

NEW REPUBLIC, $207(18)$ (OCT 92), 9.

BILL CLINTON'S AMBITIOUS ECONOMIC PROPOSALS REPRESENT FISCAL WISHFUL THINKING MATCHED IN RECENT YEARS ONLY BY RONALD REAGAM'S. IRONICALYY CLIMTON'S CAMPAIGM LEAD IS STRENGTHENED BY THE TENACITY OF THE CURRENT RECESSION, WHICH HAS BEEN PROLONGED BY THE DEFICIT CLINTON WILL EXACERBATE. ANY COUNTRY THAT ALLOWS THIS KIND OF ECONOMIC-POL ITICAL CYCLE TO CONTINUE FOR LONG WILL SOON FIND ITSELF PAUPERIZED.

00172

CUCKOO'S NEST

NEW REPUBLIC, 207(21) (NOV 92), 7.

ROSS PEROT WAS NOT A SERIOUS CAMDIDATE FOR THE U.S.

PRESIDENCY. A WEEK BEFORE THE ELECTION, THE REAL PEROT

EMERGED: A FANTASIST WHOSE GULLIBILITY' IS INDISTINGUISHABL

FROM WILLFUL DECEPTION, A NATURAL TYRANT WHO CANNOT CONTAIM

HIS RAGE IN THE FACE OF CRITICISM. HE IS INTERESTING SOLELY

BECAUSE HIS CANDIDACY REPRESENTED A NEW AND DANGEROUS

ATTEMPT AT A POPULIST, MEDIA-BASED COUP. A VOTE FOR PEROT WAS NOT A LEGITIMATE ACT OF DEMOCRATIC PROTEST; IT WAS AN AFFIRMATION OF THE POLITICS OF PATHOLOGY.

00173

DEBY TESTED

WEST AFRICA, (3878) (JAN 92), 69-70.

REPORTS FROM CHAD INDICATE THAT THE REGIME OF IDRISS

DEBY HAS REBUFFED THE REBEL ARMY WHOSE RAPID ADVANCE HAD

CAUSED CONSTERNATION IN BOTH NDJAMENA AND PARIS. DEBY'S

MINISIRY OF DEFENSE HAS CLAIMED ALL-OUT VICTORY OVER THE

"MOUVEMENT POUR LA DEMOCRATIE ET LE DEVELOPPEMENT" (MOD).

WHILE THE MDO DENIES IT HAS BEEN DEFEATED, FRANCE APPEARS TO

WHILE THE MOD DENIES IT HAS BEEN DEFEATED, FRANCE APPEARS TO

BELIEVE THE CRISIS IS OVER AND IS HII

00174

DEFENSE AND SECURITY OFFICIALS IN THE BALTIC STATES AND THE CIS

RFE/RL RESEARCH REPORT, 1(12) (MAR 92), 57-61.

THIS ARTICLE OFFERS A LIST OF MAJOR DEFENSE OFFICIALS IN THE BALTIC STATES AND THE COMMONWEALTH OF INDEPENDENT STATES AS OF MARCH 1992.

00175

DEFENSE SPENDING AND BUDGET CATEGORY REFORM

CONGRESSIONAL DIGEST, 71(5) (MAY 92), 130-160.

THE U.S. ECONOMIC AND BUDGET OUTLOOK, U.S. DEFENSE

POLICY, PRESIDENT BUSH'S FY1993 DEFENSE BUDGET, AND RECENT

CONGRESSIONAL ACTION ON DEFENSE SPENDING ARE DISCUSSED. THEN

THE ARTICLE SUMMARIZES THE SENATE DEBATE ON "SHOULD 5.2399

TO MODIFY THE 1990 BUDGET ENFORCEMENT ACT BE APPROVED?"

00176

DEFICITS' MAR MENEM S MID-POINT

LATIN AMERICAN WEEKLY REPORT, (28) (JUL 92), 2.

PRESIDENT CARLOS SAUL MENEM HAS REACHED THE MID-POINT OF HIS TERM IN OFFICE. WHILE TOUTING HIS ECONOMIC ACHIEVEMENTS IN A CELEBRATORY ADDRESS, MENEM ALSO PLEDGED "MORE PROFOUND" ACTION ON SOCIAL MATTERS AND MORE FUNDING FOR HEALTH,

EDUCATION, AND PUBLIC SECURITY.

00177

DELAYED ELECTIONS MAY BE IN OCTOBER

LATIN AMERICAN WEEKLY REPORT, (34) (SEP 92 ), 9.

THE TWICE-POSTPONED GUYANÉSE GENERAL ELECTIONS MAY BE

HELD IN OCTOBER 1992, FOLLOWING THE CONVENTION OF THE RULING

PEOPLE'S NATIONAL CONGRESS PARTY.

00178

DEMOCRACY INTERDICTED

COMMONHEAL, CXIX(4) (FEB 92), 3-4.

THE BUSH ADMINISTRATION'S POLICY THAT HAS LED TO THOUSANDS OF HAITIAN REFUGEES BEING RETURNED TO THEIR HOMELAND BY THE U.S. COAST GUARD IS A MORAL AND POLITICAL HOMELAND BY THE U.S. COAST GUARD IS A MORAL AND POLITICAL IS A BONA FIDE POL ITICAL REFUGEE. OF COURSE, NOT ALL THE POL ICIES OF ARISTIDE WERE MODELS OF THE DEMOCRATIC BUT THESE FACTS REMAIH. THE ARISTIDE GOVERNMENT HAS

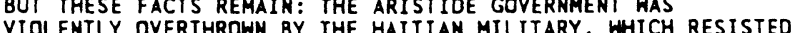
VIOLENTLY OVERTHROWN BY THE HAITIAN MILITARY, WHICH RESISTED HIS REFORMS AT EVERY TURN; THIS USURPER GOVERNMENT CON

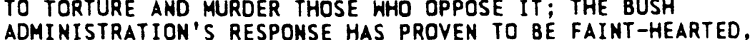
ADMINISTRATION'S RESPONSE HAS
INADEOUATE, AND MISDIRECTED.

00179

DIFFICULTIES OF DEMOCRACY

HEST AFRICA, (3879) (JAN 92 ), 97

THE SUSPENSION OF ALGERIA'S ELECTIONS, THE FIRST MULTIPARTY POLL IN NEARLY 30 YEARS, IS A SERIOUS SETBACK TO THE CAUSE OF DEMOCRACY IN ALGERIA AND ELSEHHERE. THE REASON FOR THE "CONSTITUTIONAL CDUP" IS CLEAR--FEAR OF A VICTORY THAT WOULD TURM THE COUNTRY OVER TO THE ISLAMIC SALVATION FRONT. THERE ARE TWO LESSONS THAT MAY TENTATIVELY BE DRAWN FROM
ALGERIA'S SITUATION. THE FIRST IS THAT ISLAM MUST DETERMINE THE BEST WAY FOR IT TO FUNCTION IN A MODERNIZING WORLD AND THAT ITS OWN REALITY IS TOO IMPORTANT TO BE TREATED WITH THE SUSPICION THAT SOMETIMES SEEMS TO SURROUND IT. THE SECOND IS THAT DEMOCRACY MAY PRODUCE UNPALATABLE GOYERMMENTS, BUT ONLY WHEN SUCH GOVERNMENTS DESTROY DEMOCRACY CAN THEY BE JUSTIFIABLY OVERTHROWH.

00180

DIOUF'S OAU CHALLENGES

HEST AFRICA, (3904) (JUL 92), 1161

SENEGALESE PRESIDENT ABDOU DIOUF HAS ASSUMED THE CHAIRMANSHIP OF THE ORGANIZATION OF AFRICAN UNITY AT A PARTICULARLY CRUCIAL TIME, BOTH FOR THE FUTURE OF THE AFRICAN CONTINENT AND FOR HIS OWN POLITICAL FUTURE IN SENEGAL.

00181

DOCUMENTS ON DEMOCRACY

JOURNAL OF DEMOCRACY, 3(4) (OCT 92), 134-139

THIS ARTICLE CONTAINS EXCERPTS FROM THE FOLLOWING

DOCUMENTS: THE CLOSING STATEMENT OF THE IRAQI NATIONAL

CONGRESS (JUNE 16-19, 1992); THE CHARTER FOR AMERICAN-

RUSSIAN PARTNERSHIP AND FRIENDSHIP (JUNE 17, 1992); THE INAUGURAL ADORESS OF PRESIDENT FIDEL RAMOS OF THE PHILIPPINES (JUNE 30, 1992); A PASTORAL LETTER BY THE ROMAN CATHOL IC BISHOPS OF MALAWI CALLING FOR GREATER FREEDOM (MARCH 8, 1992); AND THE DECLARATION OF CARACAS CONDEMNING THE ATTEMPTED COUP AGAINST THE GOVERNMENT OF VENEZUELA (FEBRUARY 8, 1992).

00182

DOMESTIC NEEDS STALL GATT TALKS

JAPAN TIMES (WEEKLY INTERNATIONAL EDITION), 32(11) (MAR $92), 10$.

TRADE DIPLOMACY IS A NERYE-RACKING BLEND OF TACTICAL STUBBORNMESS AND LAST-MINUTE COMPROMISE. AFTER FIVE YEARS OF DRAWN-OUT NEGOTIATIONS, A LAST-MINUTE CDMPROMISE SEEMS UNLIKELY IN THE URUGUAY ROUND OF THE GENERAL AGREEMENT ON TARIFFS AND TRADE. ONLY TACTICAL STUBBORNNESS PERSISTS, AND TARIFFS AND TRADE. ONLY TACTICAL STUBBORNNESS PERSISTS, AND IT DOES SO FOR GOOD REASONS. THE UNITED STATES, ALONG WITH OF THE EUROPEAH COMMUNITY, FAILED TO MEET THE MARCH 1,1992 , OF THE EUROPEAN COMMUNITY, FAILED TO MEET THE MARCH 1,1992 , DISTS OF PROPOSED TARIFF REDUCTIONS. DOMESTIC POLITICAL LISTS OF PROPOSED TARIFF REDUCTIONS. DOMESTIC POLITICAL CONSIDERATIONS WERE A MAJOR FACTOR IN THE FAI TO MEET THE UEATED STAT

00183

DON'T BRING UP REACTOR CHECKS, PYONGYANG WARNS JAPAN TIMES (WEEKLY INTERNATIONAL EDITION), 32(17) (APR 92 ) 3.

LI SAM RO, NORTH KOREA'S CHIEF DELEGATE TO MORMALIZATION TALKS WITH JAPAN, HAS CAUTIONED TOKYO NOT TO BRING UP INSPECTIONS OF HIS COUNTRY'S NUCLEAR FACILITIES WHEN THE NEGOTIATIONS RESUME IN MAY 1992. HE HAS ALSO WARNED TOKYO AGAINST RAISING THE ISSUE OF A MISSING JAPANESE WOMAN WHO MAY HAYE BEEN KIDNAPPED BY NORTH KOREAN AGENTS.

00184

DUMP 'ROE'

NEW REPUBLIC, 206(20) (MAY 92), 7

THE FREEDOM OF CHOICE ACT SAYS THAT "A STATE MAY NOT RESTRICT THE RIGHT OF A WOMAN TO CHOOSE TO TERMINATE A PREGNANCY (1) BEFORE FETAL VIABILITY OR (2) AT ANY TIME IF SUCH TERMINATION IS NECESSARY TO PROTECT THE LIFE OR HEAL OF THE WOMAN." CONGRESS SHOULD PASS THIS ACT AS SOON AS
POSSIBLE AND FORCE THE PRESIDENT'S VETO WELL BEFORE NOVEMBER,
WHICH WOULD TURN THE 1992 PRESIDENTIAL ELECTION INTO A NATIONAL REFERENDUM ON ABORTION.

00185

DURAN AND NEBOT GO TO RUN-OFF IN ECUADOR; BUCARAM MISSES BY A WHISKER

LATIN AMERICAN WEEKLY REPORT, (20) (MAY 92), 1.

IN ECUADOR'S MAY 1992 PRESIDENTIAL ELECTION, SIXTO DURAN BALLEN OF THE PARTIDO UMIDAD REPUBL ICANA LED THE FIELD WITH BALLEN OF THE PART IDO UNIOAD REPUIME NEBOT SAADI OF THE PART ONE-THIRO OF THE CAME IN SECDND. WHILE ASSAD BUCARAM PARTIDO SOCIAL CRISTIANO CAME IN SECOND, WHILE ASSAD BUCARAM OF THE PARTIDO ROLOUSISTA ECUATORIAND

00186

DURAN BALLEN'S REAL CHALLENGE

LATIN AMERICAN HEEKLY REPORT, (38) (OCT 92), 6-7

ECUADOR HAS DECIDED TO REMAIN IN OPEC BUT AS A NON-

VOTING, NON-PAYING ASSOCIATE MEMBER. MEANWHILE, THE CONGRESS

HAS VOTED AGAINST THO OF THE FOUR "URGENT" COMPONENTS OF

PRESIDENT SIXTO DURAN BALLEN'S ECONOMIC PACKAGE.

00187

DURAN PICXS THE CORE OF HIS CABINET

LATIN AMERICAN HEEKLY REPORT, (28) (JUL 92), 3. 
ON JULY 11, 1992, PRESIDENT-ELECT SIXTO DURAN BALLEN ANMOUNCED THE NAMES OF SEVEN MEMBERS OF HIS CABINET. FIVE OF THEM ARE DRAWN FROM THE BUSINESS COMMMUNITY, SUGGESTING THAT DURAN'S GENERAL ORIENTATION WILL CONTRAST SHARPLY WITH THAT OF HIS PREDECESSOR, SOCIAL DEMOCRAT RODRIGO BORJA.

00188

DURAN WEATHERS FIRST STRIKE

LATIN AMERICAN WEEKLY REPORT, (39) (OCT 92), 3.

THE GOVERNMENT OF PRESIDENT SIXTO DURAN BALLEN SURVIVED

ITS FIRST CHALLENGE FROM ORGANIZED LABOR, THANKS TO LASTMINUTE NEGOTIATIONS THAT LED TO THE DEFECTION OF A NUMBER OF KEY GROUPS WITHIN THE FRENTE UNITARIO DE TRABAJADORES (FUT). A GENERAL STRIKE PROVED INEFFECTIVE WHEN PUBLIC TRANSPORT

HORKERS AND GOVERMMENT EMPLOYEES REFUSED TO PARTICIPATE. 00189

DURAN HINS IN ECUADOR, PRI IN CAMPECHE, PRIVATISERS IN

URUGUAY
LATIN AMERICAN HEEKLY REPORT, (27) (JUL 92), 1.

JULY 5, 1992, WAS ELECTION DAY IN ECUADOR, MEXICO, AND URUGUAY. 1 , 1992 , WAS ELECTION DAY IN ECUADOR, MEXICO, AND URUGUAY. IN ECUADOR, SIXTO DURAN BALLEN OF THE PARTIDO

REPUBLICANA WON THE PRESIDENCY. IN MEXICD, THE RULING PARTIDO REVOLUCIONARIO INSI ITUCIONAL WON $80 \%$ OF THE VOTE IN THE CAMPECHE LEGISLATIVE ELECTIONS. IN URUGUAY, ONLY A SMALL PERCENTAGE OF THE ELECTORATE TURNED OUT
TO HOLD A REFERENDUM ON PRIVATIZATION. 00190

E.C. PLEDGES AID FOR NAMIBIA

WEST AFRICA, (3892) (APR 92), 681.

DURING THE FIRST FIVE YEARS DF THE FOURTH LOME

CONVENTION, THE EUROPEAN COMMUNITY WILL DONATE 45 MILLION

ECU'S TO NAMIBIA FOR AGRICULTURE AND RURAL DEVELOPMENT,

EDUCATION, HEALTH, AMD HUMAN RESOURCES. AN ADOITIONAL 6

MILLION ECU'S WILL BE AVAILABLE FOR THE DEVELOPMENT OF

PRIVATE SECTOR ACTIVITIES IN AGRO-PROCESSING, MANUFACTURING, AND PROOUCTION INFRASTRUCTURES.

00191

EARTH SUMMIT: THE PROMISE... THE HYPE

WEST AFRICA, (3899) (JUN 92 ), 949

THE UNITED NATIONS CONFERENCE ON ENVIRONMENT AND

DEVELOPMENT IS BEING BILLED AS PERHAPS THE MOST IMPORTANT

CDNFERENCE EVER BECAUSE NOTHING LESS THAN THE SURVIVAL OF

HUMANKIND IS AT STAKE. UNFORTUNATELY, EVEN BEFORE THE

HUMANKIND IS AT STAKE. UNFORTUNATELY, EVEN BEFORE THE
CONFERENCE OPENS, THERE IS FEAR THAT GOOD INTENTIONS AND

CONFERENCE OPENS, THERE IS FEAR THAT GOOD INTENTIONS
COMMON SENSE ARE BEING JETTISONED. THE CONFERENCE IS

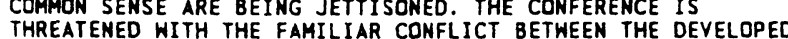

THREATENED WITH THE FAMILIAR CONFLICT BETWEEN THE DEVELOPED
AND DEVELOPING COUNTRIES. ONE WORD ACCOUNTS FOR THE SPLIT:

AND DEVEI
MONEY.

00192

ECONOMY NEEDS PROMPT ACTION

JAPAN TIMES (WEEKLY INTERNATIONAL EDITION), 32(12) (MAR 92), 10 .

ALTHOUGH NO ONE DENIES THAT JAPAN IS IN THE MIDST OF A RECESSION, THERE IS A LACK OF CONSENSUS ABOUT HOW TO CORRECT THE PROBLEM. THE POLITICAL STALEMATE THAT BEGAN WITH THE ERUPTIONS OF THE FINANCIAL SCANDALS INVOLVING TOP GOVERNMENT OFFICIALS HAS INFLICTED BOTH PSYCHOLOGICAL DAMAGE ON THE PUBLIC AND REAL DAMAGE ON THE ECONOMY.

00193

ECOHAS CONSOLIDATES

WEST AFRICA, (3906) (JUL 92), 1253-1269

THIS SPECIAL FEATURE LOOKS AT THE FUNCTIONS AND

DIRECTION OF THE ECONOMIC COMMUNITY OF WEST AFRICAN STATES

(ECOWAS). IT INCLUDES INTERVIEWS HITH HIGH-RANKING ECOHAS

OFFICIALS, INCLUDING EXECUTIVE SECRETARY ABASS BUNDU.

00194

ECOWAS TURNING POINT

HEST AFRICA, (3908) (AUG 92), 1337

THE ECOWAS RESOLUTION ON LIBERIA, WHICH GIVES AM

ULTIMATUM TO CHARLES TAYLOR TO COMPLY WITH ECOWAS AGREEMENTS ON ENCAMPMENT AND DISARMING WITHIN ONE MONTH OR FACE

ECONOMIC SANCTIONS, REVEALS AN UNUSUAL FIRMNESS IN POLITICAL HILL AMONG THE WESTERN AFRICANS. FROM A DISTANCE, THIS ULTIMATUM LOOKS LIKE A PRELUDE TO ACTION, WITH ALL THE RISKS THAT COULD ENTAIL.

00195

ELECTION WATCH: ELECTION RESULTS (JUNE 1992-SEPTEMBER 1992 JOURYAL OF DEMOCRACY $3(4)$ (OCT 92 ) 130-133.

THIS ARTICLE SUMMARIIES THE RESULTS OF ELECTIONS HELD IN JUNE-SEPTEMBER 1992 IN THE BAHAMAS, BURKINA FASO, THE CONGO, CROATIA, THE CZECH AND SLOVAK FEDERATIVE REPUBLIC, ECUADOR, INDONESIA, MONGOLIA, NIGERIA, PAPUA NEW GUINEA, AND THE PHILIPPINES.

00196

ELECTIONS IN ALMOST HALF THE STATES

LATIN AMERICAN WEEKLY REPORT, (4) (JAN 92), 2.
ALTHOUGH NO FEDERAL ELECTIONS ARE SCHEDUL ED IN MEXICO IN 192. THERE IS A BUSY CALEMDAR OF LOCAL ELECTIONS, SOME OF WHICH COULD HAVE CONSIDERABLE IMPACT ON THE COUNTRY'S POLITICAL FUTURE. THELVE OF THE COUNTRY'S 31 STATES WILL CHOOSE NEW GOVERNORS WHILE SIX WILL SELECT LOCAL

LEGISLATURES AND MUNICIPAL AUTHORITIES.

00197

ELECTORAL CONTESTS IN 1993

ATIN AMERICAN HEEKLY REPORT, (50) (DEC 92), 6-7.

IN 1993, PRESIDENTIAL ELECTIONS WILL BE HELD IN FIVE

LATIN AMERICAN COUNTRIES-PARAGUAY, BOLIVIA, HONDURAS, CHILE, AND VENEZUELA. CUBA AND ARGENTINA WILL HOLD IMPORTANT

LEGISLATIVE ELECTIONS IN 1993. NINE MEXICAN STATES WILL HAVE GUBERNATORIAL CONTESTS, WHILE THERE HILL BE KEY MUNICIPAL

ELECTIONS IN PERU AND BELIZE IN 1993. REFERENDA ARE

SCHEDULED IN BRAZIL, GUATEMALA, AND PERU.

00198

EMERGENCY FISCAL PLAN ANMOUNCED

LATIN AMERICAN WEEKLY REPORT, (42) (OCT 92), 8-9.

ON OCTOBER 15, 1992, THE GOVERNMENT HEADED BY INTERIM

PRESIDENT ITAMAR FRANCO ANNOUNCED AN EMERGENCY FISCAL

PROGRAM FOR THE LAST QUARTER OF THE YEAR. THE PLAN INCLUDES

NEH TAXES ON FINANCIAL TRANSACTIONS, A TAX ON SELECTED

CONSUMER GOODS, AND SUSPENDING FINANCIAL ASSISTANCE TO BANKS OWNED BY STATE GOVERNMENTS.

00199

EMPEROR'S VISIT A MILESTONE

BEIJING REVIEW, 35(44) (NOV 92), 7,9

JAPANESE EMPEROR AKIHITO PAID AN OFFICIAL VISIT TO CHINA

IN OCTOBER 1992. DURING HIS MEETING WITH CHINESE PRESIDENT

YANG SHANGKUN, THE EMPEROR SAID THAT HE DEEPLY DEPLORES THE

SUFFERING HIS COUNTRY INFLICTED ON THE CHINESE PEOPLE DURING

WORLD HAR II. YANG AND AKIHITO AGREED THAT THE EMPEROR'S

VISIT SHOULD MARK THE BEGINNING OF A NEH STAGE IN THE

DEVELOPMENT OF FRIENDLY SINO-JAPANESE RELATIONS.

00200

END IN SIGHT FOR INTERNAL THREAT

THE GOVERMMENT OF PRESIDENT VIOLETA CHAMORRO SEEMS TO

HAVE SUCCESSFULLY DEFUSED THE THREAT OF A NEH INTERHAL

CONFLICT BETWEEN RECONTRAS (REARMED CONTRAS) AND RECOMPAS

(SANDINISTAS), WHICH HAS BEEN BUILDING UP SINCE EARLY 1991.

IN A SERIES OF NEGOTIATIONS, THE GOVERMMENT HAS PERSUADED

LEADERS OF BOTH SIDES TO LAY DOWN THEIR WEAPONS. ANY

RECONTRAS OR RECOMPAS RETAINING THEIR ARMS AFTER FEBRUARY 20,

1992. WILL BE TREATED AS "DEL IOUENTS."

00201

END OF PINDLING'S QUARTER-CENTURY

LATIN AMERICAN WEEKLY REPORT, (34) (SEP 92), 8-9.

THE AUGUST 1992 ELECTION IN THE BAHAMAS ENDED THE LONG

POLITICAL CAREER OF LYMDEN PINOLING. THE OPPOSITION FREE

NATIONAL MOVEMENT TOOK 33 OF THE 49 SEATS IN PARLIAMENT

PA TAL HOVEMENT TOOK 33 OF THE 49 SEA TS IN PARLIAMENT,

PROGRESSIVE LABOR PARTY HAD HELD. PINDLING'S SUCCESSOR HILL BE HUBERT INGRAHAM.

00202

END OF THE LINE FOR THE GOVERMMENT OF FERNANDO COLLOR DE MELLO

LATIN AMERICAN WEEKLY REPORT, (39) (OCT 92), 1.

WHETHER THE IMPEACHMENT TRIAL OF PRESIDENT FERNANDO

COLLOR DE MELLO PROCEEDS IN THE SENATE OR COLLOR'S

SUPPORTERS MANAGE TO BLOCK THE IMPEACHMENT AND THE

PROCURATOR-GENERAL BRINGS CRIMIMAL CHARGES AGAINST HIM, THE

COLLOR GOVERMMENT HAS ALREADY EFFECTIVELY COME TO AN END.

BECAUSE 70\% OF THE POPULACE HANTS COLLOR REMOVED FROM OFFICE,

THE OPPOSITION WILL MAKE GREAT GAINS IN THE UPCOMING

MUNICIPAL ELECTIONS AND WILL TAKE ITS ANTI-COLLOR CAMPAIGN

TO THE STREETS.

00203

ENDARA UMMOYED BY RESOUNDING "NO"

LATIN AMERICAN WEEKLY REPORT, (47) (DEC 92), 5.

VOTERS IN PANAMA'S REFERENOUM ON CONSTITUTIONAL REFORM

OVERHHELMINGLY REJECTED THE REFORMS PASSED BY THE

LEGISLATIYE ASSEMBLY THE FRENTE POR EL MO (FREMO) WHICH

LED THE CAMPAIGY AGAIMST THE REFORMS IS ALRADY SEEKIMG

SUPPORT FOR A CALL FOR A NEW CONSTITUENT ASSEMBLY. MEANWHILE,

PRESIDENT GUILLERMO ENDARA IS ADAMANT THAT HE WILL NOT

INTERPRET THE VOTE AS A CONDEMNATION OF HIS POLICIES; HE

WILL NOT OPEN UP HIS CABINET TO THE OPPOSITION; NOR WILL HE

CHANGE HIS ECONOMIC POLICIES.

00204

ENDARA VETO AGAIN IGHITES COLON

LATIN AMERICAN WEEKLY REPORT, (32) (AUG 92), 9.

AFTER A SERIES OF PROTESTS IN COLON PROVINCE, WHERE THE

UNEMPLOYMENT RATE OFTEN REACHES 20\%. PANAMA'S LEGISLATURE

PASSED A BILL MAKING THE ENTIRE PROVINCE A FREE PORT. BUT 
PRESIDENT ENDARA VETOED THE BILL, REIGNITING THE PROTESTS. 00205

ENDING THE BAN

NEW REPUBLIC, 207(24) (DEC 92), 7.

PRESIDENT-ELECT BILL CLINTON HAS PLEDGED TO END THE BAM ON HOMOSEXUALS IN THE U.S. MILITARY THROUGH AN EXECUTIVE ORDER. ALTHOUGH ENDING THE BAN IS THE RIGHT THING TO DO, IT WILL NOT BE AS SIMPLE AS A STROKE OF THE PEN. THE MILITARY WILL NEED TIME AND SPACE TO ADJUST BUT THIS NEED NOT COMPROMISE THE ESSENCE OF THE NEH POLICY.

00206

EQUIVOCATION HIDES CRISTIANI'S ARMY PLOY

LATIN AMERICAN WEEKLY REPORT, (44) (NOV 92), 11

ON OCTOBER 28, 1992 , GOVERNMENT SPOKESMEN ANMOUNCED THAT PRESIDENT ALFREDÓ CRIST IANI HAD TOLD U.N. SECRETARY-GENERAL BOUTROS GHALI THAT THE NEW CALENDAR FOR COMPLIANCE WITH THE PEACE TREATY WAS UNACCEPTABLE. BUT AN FMLN LEADER SAID THAT CRISTIANI HAD DELIVERED "A NO THAT ACTUALLY MEANT YES."

00207

ERADICATING CORRUPTION

WEST AFRICA, (3901) (JUN 92), 1052

THE NATIONAL PROVISIONAL RULING COUNCIL HAS ESTABLISHED

THREE SEPARATE COMMISSIONS OF ENOUIRY TO INVESTIGATE THE

CORRUPTION THAT PERVADED THE LAST YEARS OF THE MOMOH REGIME IN SIERRA LEONE.

00208

ESCALATION LEADS TO RULE BY DECREE

LATIN AMERICAN WEEKLY REPORT, (45) (NOV 92), 11

ON NOVEMBER 8, 1992, DUE TO THE CONTINUING ESCALATION OF VIOLENCE, PRESIDENT CESAR GAVIRIA PROCLAIMED A 90-DAY STATE OF EMERGENCY, WHICH ALLOWS HIM TO RULE BY DECREE. HE PROMISED TO TAKE MEASURES TO "HIT AT THE HEARTS AND THE CHEQUE-BOOKS" OF THE GUERRILLAS. HE ALSO BANNED ATTEMPTS BY POLITICIANS TO HOLO REGIONAL PEACE TALKS WITH THE

COORDINADORA NACIONAL GUERRILLERA SIMON BOLIVAR.

00209

ESQUEMA PC WAS ALSO A BID FOR POWER

LATIN AMERICAN HEEKLY REPORT, (46) (NOV 92), 3 .
IT APPEARS THAT THE "ESOUEMA PC" (THE HUGE, PERVASIVE

NETHORK OF EXTORTION AND INFLUENCE-PEDOLING ESTABLISHED BY PAULO CESAR FARIAS) WAS NOT A MERE GET-RICH-QUICK SCHEME. IT ALSO HAD A LONG-TERM POL ITICAL PURPOSE. TO FERNANDO COLLOR DE MELLO AT THE HEAD OF AN UNBEATABLE POWER STRUCTURE FOR A VERY LONG TIME.

00210

EUROPA, EUROPA

NEW REPUBLIC, 206(18) (MAY 92), 7

THE 1992 ELECTIONS ACROSS EUROPE--FROM SCOTLAND TO SICILY--WERE THE FIRST TO TAKE ACCOUNT OF THE NEW WES EUROPEAN REALITY. IF THE PROMISE OF THE TREATY OF MAASTRICHT IS FULFILLED AND THE WEST EUROPEAN NATION-STATE IS LARGELY DISSOLVED, THEY COULD BE THE LAST MEANINGFUL ELECTIONS EVER HELD IN BRITAIN, FRANCE, ITALY, AND GERMANY. WHAT THEY REFLECTED WERE THO TURNING POINTS FOR EUROPE: THE END OF
EUROPEAN SOCIALISM AS A LEADING FORCE IN ITS POLITICS AND THE REBIRTH OF WEST EUROPEAN REGIONALISM.

00211

EUROPEAN COMMUNITY

SURVEY OF CURRENT AFFAIRS, 21(12) (DEC 91), 445-449.

BRITISH PRIME MINISTER JOHN MAJOR HAS PRESENTED HIS

GOVERNMENT'S STRATEGY FOR FUTURE RELATIONS HITH THE EUROPEAN

COMMUNITY TO PARL IAMENT MAJOR BELIEYES THAT THE BRITISH

GOVERMMENT SHOULD WORK FOR AN AGREEMENT WHICH WILL DELAY THE

DEVELOPMENT OF A FEDERAL EUROPE, HIL ENABLE BRITAIN TO

EXERT THE GREATEST INFL EURO OE, HIL ENABE BRITAIN TO

THE EUROPEAM COMMUN TY WHIE PRESERYING THE RIGHT ION OF

AT A LATER DATE WHETHER TO ADOPT THE SINGLE EUROPEAN

CURREACY

CURRENCY, WALS

THOSE ISSUES THAT CANNOT BE HANDLED MORE EFFECTIVELY AT THE

NATIONAL LEVEL, WILL DEVELOP A EUROPEAN SECURITY POLICY THAT

IS COMPATIBLE WITH NATO AND SAFEGUARDS BRITAIN'S NATIONAL

INTERESTS, AND WILL
EUROPEAN COMMISSION.

00212

EUROPEAN PUBLIC OPINION AND THE MAASTRICHT TREATY

WORLD AFFAIRS, 154 (2) (FAL 11 ) 73-80

THIS ARTICLE SURVEYS PUBLIC OPINION ON THE MAASTRICHT

TREATY IN FRANCE, SPAIN THE NETHERLANDS, ITALY, BELGIUM,

GREECE, LUXEMBOURG, GREAT BRITAIN, DENMARK, PORTUGAL, AND IRELAHD.

00213

EVOLUTION OF FEDERAL CONSUMER LEGISLATION

CONGRESSIONAL DIGEST, 71(11) (NOV 92), 262-263.

THE AUTHOR SUMMARIZES THE PROVISIONS OF MAJOR COMSUMER

PROTECTION LEGISLATION PASSED BY CONGRESS FROM 1887 TO THE
PRESENT.

00214

EVOLUTION OF FEDERAL INYOLVEMENT

CONGRESSIONAL DIGEST, 71(12) (DEC 92), 290-291.

THE AUTHOR TRACES THE EVOLUTION OF THE GOVERNMENT'S ROLE

IN HELPING U.S. WORKERS AND INDUSTRIES HURT BY FOREIGN

COMPETITION. RESPONDING TO FEAR THAT A PROLONGED LOSS OF

INDUSTRIAL COMPETITIVENESS WOULD HARM AMERICA'S STANDARD OF

LIVING AND DEFENSE PREPAREDNESS, THE FEDERAL GOVERNMENT HAS

ADOPTED SEVERAL MEASURES TO IMPROVE THE CLIMATE FOR

INNOVATION IN THREE STRATEGIC INDUSTRIES: SEMI-CONDUCTOR

DEVICES AND RELATED EQUIPMENT AND MATERIALS, MACHINE TOOLS,

AND STEEL MILL PRODUCTS. SOME CONGRESSMEN WANT TO SEE THE

GOVERNMENT OFFER MORE SUBSIDIES TO THESE AND OTHER CRUCIAL MARKET FORCES.

00215

EXILES HANT FREE HAND TO ATTACK

LATIN AMERICAN WEEKLY REPORT, (3) (JAN 92), 5.

CUBANS IN MIAMI ARE CIRCULATING A PETITION ASKING U.S.

PRESIDENT GEORGE BUSH TO AUTHORIZE THE RESUMPTION OF ARMED

ACTION BY CUBAN EXILES AGAINST THE CASTRO REGIME. OH

DECEMBER 28, 1991, THE CUBAN GOVERMMENT ANNOUNCED THE ARREST OF THREE EXILES WHO HAD ATTEMPTED TO LAND IN MATANZAS WITH AN ASSORTMENT OF WEAPONS AND INCENDIARY DEVICES.

00216

EXPANDING FOREIGN TRADE RELATIONS

BEI JING REVIEH, 35(10) (MAR 92), 12-14.

IN AN INTERVIEH, LI LANOING, MINISTER OF FOREIGH

CONOMIC RELATIONS AND TRADE, EXPLAINED CHINA'S FOREIGN

TRADE POLICY AND DISCUSSED SINO-U.S. TRADE RELATIONS. HE

AND EXPECTS TO BE RESTORED TO GATT MEMBERSHIP.

00217

EXTERMAL AFFAIRS AMD DEFENCE: NATO SUMMIT

SURVEY OF CURRENT AFFAIRS, 21(12) (DEC 91), 441-445.

AT A SUMMIT MEETING IN NOVEMBER 1991, THE NATO HEADS OF GOVERMMENT AGREED TO CHANGES IN THE ALLIANCE'S STRATEGY TO REFLECT THE NEW REALITY OF INTERNATIONAL POLITICS. THE NEW STRATEGY ACKNOWLEDGES THAT THE THREAT OF A SIMULTANEOUS, FULL-SCALE ATTACK ON ALL NATO'S EUROPEAN FRONTS HAS BEEN EFFECTIVELY REMOVED, BUT RISKS STILL EXIST AND MUST BE MET. THESE INCLUDE THE POSSIBILITY THAT ETHNIC UNREST OR TERRITORIAL DISPUTES IN EASTERN AND CENTRAL EUROPE COULO SPREAD TO WESTERM EUROPE.

00218

EXTRA EARNINGS ROW SPREADS

LATIN AMERICAN WEEKLY REPORT, (46) (NOV 92), 2

PRESIDENT CARLOS MENEM'S ADMINISTRATION CONTINUES TO BE PLAGUED BY CHARGES OF CORRUPTION. IT SEEMS TO BE STANDARD PRACTICE IN THE HIGHER ECHELONS OF THE ADMINISTRATION TO SUPPLEMENT OFFICIAL SALARIES WITH EARNINGS FROM OTHER SOURCES, AND OFFICIALS OF ARGENTINA'S ANTI-NARCOTICS AGENCY, THE SECRETARIA PARA LA PREVENCION Y REPRESION DEL TRAFICO DE DROGAS, HAVE BEEN ACCUSED OF INVOLVEMENT IN DRUG TRAFFICKING.

00219

FACING UP TO SURPRISES

ST AFRICA, (3902) (JUN 92), 1085

THE AUTHOR PROFILES BELLO BOUBA MAIGARI, CAMEROON'S

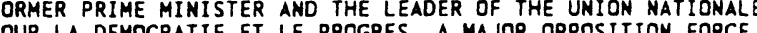

00220

FARMING AND FORRESTRY

SURYEY OF CURRENT AFFAIRS, 21(12) (DEC 91), 453-455. ON NOVEMBER 15, 1991, THE BRITISH GOVERMMENT ISSUED A POLICY STATEMENT CONCERNING THE CHALLENGES THAT WILL FACE THE BRITISH AGRICULTURAL INDUSTRY IN THE 1990's. THE GOVERMMEMT PLAMS TO REPLACE THE FARM WOODL AND SCHEME WITH THE FARM HOODLAMD PREMIUM SCHEME. THE GOVERMMENT HAS ALSO DESIGMATED 16 ADDITIONAL REGIONS IN EMGLAMD AMD WALES AS

"ENIGHATED 16 ADDITIONAL REGIONS IN

00221

FEARS OF CLASH OVER LAND TENURE

LATIN AMERICAN WEEKLY REPORT, (8) (FEB 92), 8.

THE OUESTION OF LAND TENURE IN THE AREAS CONTROLLED BY THE FRENTE FARABUNDO MART I PARA LA LIBERACION NACIONAL (FMLN) IS BECOMING THE FIRST MAJOR PROBLEM FOR PEACETIME EL SALVADOR. ACCORDING TO THE TERMS OF THE PEACE TREATY, THE GOVERNMENT MUST HELP KEEP THE LAND IN THE HANDS OF THE PRESENT OCCUPIERS BY OFFERING TO BUY IT FROM ITS ORIGINAL OWNERS. SHOULO THEY REFUSE TO SELL, THE GOVERNMENT WILL RESETTLE THE PEASANTS WITHIN THE SAME GENERAL AREA. EACH SIDE IS ACCUSING THE OTHER OF TRYING TO PREEMPT THE AGREEMENT. 
00222 FEDERAL COURT BARS TAX-FUNDED INSTRUCTION AT PAROCHIAL SCHOOLS

CHURCH AND STATE, 45(2) (FEB 92), 13(37).

A FEDERAL COURT HAS RULED THAT THE SAN FRANCISCO UNIFIED SCHOOL DISTRICT MUST STOP ITS PRACTICE OF OFFERING REMEDIAL EDUCATION CLASSES ON PAROCHIAL SCHOOL GROUNDS. THE COURT STATED THAT PLACING MOBILE VANS ON SECTARIAN SCHOOL PROPERTY CREATES AN IMPERMISSIBLE SYMBOLIC UNION BETWEEN CHURCH AND STATE. THE COURT ALSO STRUCK DOWM THE CITY'S PRACTICE OF RENTING PROPERTY FROM CHURCHES OR RELIGIOUS SCHOOLS FOR REMEDIAL EDUCATION CLASSES FUNDED THROUGH THE FEDERAL

GOVERMMENT'S CHAPTER ONE PROGRAM.

00223

FEDERAL COURT ORDERS REMOVAL OF CRECHE FROM VIRGINIA TOWM CENTER

CHURCH AND STATE, 45(2) (FEB 92), 15(39)-16(40). RECENT COURT CASES INVOLVING THE DISPLAY OF RELIGIOUS SYMBOLS ON PUBLIC PROPERTY HAVE BROUGHT MIXED RULINGS. IN SYMBEMBER 1991 A FEDERAL COURT ORDERED THE TOWM OF VIEMMA DECEMBER 1991, A FEDERAL COURT ORDERED THE TOWN OF VIENAA, CENTER BECAUSE IT VIOLATED THE CONSTITUTIONAL SEPARATION OF CHURCH AND STATE. EVEN THOUGH THO PLASTIC SNOWMEN AND A CFERCH AND STATE. EVEN THOUGH THO PLASTIC SNOWMEN AND RELIGIOUS SYMBOLS OF THE CRECHE SCENE WERE THE FOCUS OF THE REL GIOUS SYMBOLS OF THE CRECHE SCENE WERE THE FOCUS OF THE ARRAY. IN JANUARY 1992, A FEDERAL COURT IN SAN FRANCISCO UPHELD THE CITY GOVERNMENT'S DISPLAY OF A LATIN CROSS OH PUBLIC PROPERTY ATOP MOUNT DAVIDSON, RULING THAT THE SYMBOL HAS HISTORIC VALUE AND DOES NOT SUGGEST GOVERMMENT APPROVAL OF ONE FAITH OVER OTHERS.

0022

FIGUEIREDO BREAKS HIS LONG SILENCE

LATIN AMERICAN WEEKLY REPORT, (20) (MAY 92), 9

IN A RECENT INTERVIEN, FORMER PRESIDENT JOAD FIGUEIREDO WARNED THAT AN UPRISING AMONG BRAZIL'S URBAN POOR COULD PRODUCE "A SOCIAL EXPLOSION" THAT THE MILITARY WOULD BE INCAPABLE OF HANDLING. FIGUEIREDO'S WORDS MIRRORED CONCERNS BEING EXPRESSED BY MILITARY OFFICERS WHO FEEL THAT PRESIDENT FERNANDO COLLOR DE MELLO'S ECONOMIC POLICIES ARE INADEQUATE AND THREATEN INTERNAL SECURITY.

00225

FIRMENICH REVEALS "PACT" WITH MENEM

LATIN AMERICAN WEEKLY REPORT, (23) (JUN 92), 9

PRESIDENT CARLOS MENEM CONTINUES TO BE HAUNTED BY

SCANDALS INVOLYING HIS FAMILY AND BY ALLEGATIONS FROM SUCH

INDIVIDUALS AS MARIO EDUARDO FIRMENICH, THE FORMER LEADER OF THE MONTONEROS GUERRILLAS. 00226

FISCAL REFORM PACKAGE UNVEILED

LATIN AMERICAN WEEKLY REPORT, (45) (NOV 92), 3

ON MOYEMBER 6E RE THE G ITAMAR FRANCO UNVEILED ITS ECONOMIC PROGRAM, WHICH PROPOSES THE ELIMINATION OF FIVE TAXES AND THE INTRODUCTION OF FOUR NEW ONES, INCLUDING A VALUE-ADDED TAX AND A PROVISIONAL TAX ON FINANCIIAL TRANSACTIONS.

00227

FIT OF PIQUE FROM RODRIGUEZ AS ASSEMBLY ENSURES HE CAN'T BE REELECTED

LATIN AMERICAN WEEKLY REPORT, (25) (JUL 92), 1

TO ENSURE THAT PRESIDENT ANDRES RODRIGUEZ WILL NOT SEEK REELECTION IN 1993, PARAGUAY'S CONSTITUENT ASSEMBLY HAS ADDED A CLAUSE TO THE NEW CONSTITUTION SPECIFICALLY BARRING ANOTHER TERM FOR RODRIGUEZ. THE OPPOSITION JOINED WITH SUPPORTERS OF THE COLORADO PARTY'S LUIS MARIA ARAGANA, WHO

PLANS TO RUN FOR PRESIDENT IN 1993, TO PASS THE MEASURE.

00228

FMLN'S "UNITY IN DIVERSITY" DRIFT

LATIN AMERICAN WEEKLY REPORT, (15) (APR 92), 11.

THE FRENTE FARABUNDO MARTI PARA LA LIBERACION NACIONAL (FMNL) HAS AFFIRMED THAT IT HAS ADJUSTED ITS IDEOLOGY AND WILL FORM A NEH "FRONT" OR "UMBRELLA" PARTY WITH THE SAME NAME. IN ADDITION, THE FIVE MEMBER ORGANIZATIONS OF THE FMLN HILL CONTINUE IN EXISTENCE AS SEPARATE PARTIES IN THEIR OWN RIGHT. 00229

FOLLOW THE CRUZEIROS

HORLD PRESS REVIEW, 39(8) (AUG 92), 37.

THE AUTHOR DISCUSSES THE CHARGES OF CORRUPTION AMD ACCEPTING ILLEGAL CAMPAIGM COMTRIBUTIONS THAT HAVE BEEM MADE AGAINST BRAZILIAN PRESIDENT FERNANDO COLLOR DE MELLO. 00230

FOREVER IN DEBT TO YOU

THE MIDDLE EAST, (195) (JAN 91), 29-30.

THIS ARTICLE' EXAMINES THE FOREIGN DEBT SITUATION IN THE MIDOLE EAST WITH EMPHASIS ON EGYPT. EGYPT HAD BECDME THE MOST INDEBTED COUNTRY IN AFRICA AND THE MIDDLE EAST. THE
GOVERNMENT HAD MADE TENTATIVE STEPS TOHARDS REFORM INCLUDING UNIFIED EXCHANGE RATES, HIGHER CONSUMER PRICES AND THE STREAMLINING OF THE CUMBERSOME, DEBT-RIDDEN AMD HEAVILY SUBSIDIZED PUBLIC SECTOR, BUT PRESIDENT HOSNI MUBARAK WARNED THAT HIS PEOPLE WOULD HAVE TO ENDURE FURTHER HARDSHIPS AND BELT-TIGHTENING. THEREFORE, THE U.S. ANNOUNCEMENT OF FORGIVENESS OF CAIRO'S $\$ 7$ BILLION MILITARY DEBT WAS MET WITH EUPHORIA. PLEDGES OF FOREIGN AID FROM OTHER MATIONS HAVE FURTHER RAISED SPIRITS IN EGYPT. HOWEVER, EGYPT'S DEBT REMAINS SIGNIFICANT AND POSES GREAT CHALLENGES IN THE SHORTTERM FUTURE.

00231

FORMAL ELECTORAL CALENDAR IS SET

LATIN AMERICAN WEEKLY REPORT, (31) (AUG 92), 10

DN JULY 26, 1992, PRESIDENT ALBERTO FUJIMORI FORMALLY ANMOUNCED THE TIMETABLE FOR PERU'S ELECTIONS, AGAIN DELAYING HIS PROMISED SURRENDER OF HIS DICTATORIAL POWERS. ELECTIONS FOR THE CONSTITUENT ASSEMBLY WILL BE HELD ON NOVEMBER 22 ,
1992 . WHILE THE MUNICIPAL ELECTIONS WILL BE POSTPONED UNTIL 1992 , WHILE THE
FEBRUARY 7 , 1993.

00232

FOURTH ESTATE FALTERS

INSIGHT, 7(11) (MAR 91), 54-55

NEVER BEFORE EYENTS IN THE PERSIAN GULF HAVE THE MEDIA COVERED THE CONFLICT IN REAL TIME AND AROUND THE CLOCK--AND IT SHOWS. SOME OF THE REPORTIMG HAS BEEN STELLAR, BUT MUCH OF IT, ESPECIALLY ON TELEVISION, HAS RANGED FROM THE LAMENTABLE TO THE LAUGHABLE. THIS ARTICLE PRESENTS SOME OF THE BEST OF THE WORST MOMENTS OF THE COVERAGE.

00233

FRANCO ADOPTS A HANDS-ON STYLE

LATIN AMERICAN WEEKLY REPORT, (47) (DEC 92), 3.

THE GOVERNMENT OF ACTING PRESIDENT ITAMAR FRANCO MAY BE A SORT OF DRY RUN FOR THE PARLIAMENTARY SYSTEM FRANCO FAVORS BUT ONLY TO THE EXTENT THAT HE HAS INCLUDED MEMBERS OF CONGRESS IN HIS CABINET. FRANCO IS MAKING IT QUITE CLEAR THAT HE IS HIS OWN PRIME MINISTER AND THAT HE INTENDS TO SYSTEM IS NOT FORMALLY CHAMGED.

00234

FRANCO PRODUCES A SURPRISE CABINET

LATIN AMERICAN HEEKLY REPORT, (40) (OCT 92), 2

BRAZIL'S CONGRESS OVERWHELMINGLY VOTED TO SUSPEND

PRESIDENT FERNANDO COLLOR DE MELLO FOR SIX MONTHS WHILE THE

SENATE HEARS THE IMPREACHMENT CASE AGAINST HIM. MEANHHILE,

ACTING PRESIDENT ITAMAR FRANCO HAS ANMOUNCED SOME OF HIS

CABIMET APPOINTMENTS AND HIS ECONOMIC TEAM.

00235

FRANTIC BID TO KEEP COLLOR IN THE CLEAR

LATIN AMERICAN WEEKLY REPORT, (22) (JUN 92), 4.

BRAZIL'S PRESIDENT FERMANDO COLLOR DE MELLO IS

ATTEMPTING TO DISTANCE HIMSELF FROM HIS FORMER CAMPAIG FUNDER, PAULO CESAR FARIAS, WHO HAS BEEN ACCUS
INFLUENCE-TRAFFICKING AND ILLICIT ENRICHMENT.

00236

FREETOWN AMD DEMOCRACY

WEST AFRICA, (3895) (MAY 92), 785

THE APRIL 1992 COUP IN SIERRA LEONE WAS LONG OVERDUE.

DEGENERATING SOCIAL AND ECONOMIC CONDITIONS HAD SET THE

STAGE FOR THE OVERTHROW OF THE ALL PEOPLES' CONGRESS'S

PROTRACTED ONE-PARTY RULE.

00237

FRENCH FIGHTER SALE ENRAGES BEIJING

BEIJING REVIEW, 35(49) (DEC 92), 11-12.

ON NOVEMBER 26, 1992, CHINA LODGED A STRONG PROTEST WITH

FRANCE BECAUSE THE WEST EUROPEAN POWER SIGNED A CONTACT TO

SELL 60 MIRAGE 2000-5 FIGHTER PLANES TO TAIWAN.

00238

FROM MAASTRICHT TO MINSK

NEW REPUBLIC 206(1-2) (JAN 92) 7-8.

THE COURSES RECENTLY EMBARKED UPON BY THE COMMONWEALTH

OF INDEPENDENT STATES AND BY THE EUROPEAN COMMUNITY ARE

CHAMGIMG ASSUMPTIONS ABOUT THE NATURE OF THE MATIOM-STATE

AND ABOUT NATIONALISM.

00239

FRUITLESS TRIP BY H.K GOVERNOR

BEIJING REVIEH, 35(46) (NOV 92) 10

CHINA AND GREAT BRITAIN REMAIN DIVIDED ON THE POLITICAL REFORM PROPOSED BY HONG KONG'S GOVERMOR CHRIS PATTEN.

CHINESE FOREIGN MINISTER OIAN QICHEN HAS ACCUSED PATTEN OF "JEOPARDIZING THE PROSPERITY AND STABILITY OF HONG KONG" AND ENDANGERING THE SMOOTH TRANSITION TO CHINESE SOVEREIGNTY IN 1997. LU PING, THE CHINESE OFFICIAL IN CHARGE OF HONG KONG AFFAIRS, HAS THREATENED TO REPLACE THE HONG KONG GOVERNMENT IN 1997 IF THE GOVERNOR PRESSES AHEAD WITH HIS REFORM PLAN. 
00240

FSLN (AND FRIENDS) PARALYSE CONGRESS

LATIN AMERICAN WEEKLY REPORT, (31) (AUG 92), 11

NICARAGUA FACES A SERIOUS RISK OF INSTI IUTIONAL DEADLOCX

IN THE WAKE OF FINDINGS ABOUT OFFICIAL INVOLVEMENT IN THE

MISUSE OF PUBLIC FUNDS. THE SANDINISTA LEGISLATORS, JOINED

BY DISSIDENT UNO CONGRESSMEN, HAVE DECIDED TO DEPRIVE THE

ASSEMBLY OF

00241

FUJIMORI AGAIN MOVES GOALPOSTS

LATIN AMERICAN HEEKLY REPORT, (28) (JUL 92), 4

IN A SPEECH TO REGIONAL MILITARY COMMANDERS ON JULY 8 ,

1992 PRESIDENT ALBERTO FUJIMORI SUGGESTED THAT PERU'S

1992. PRESIOENT ALBERT POSTPONED FOR ONE OR THO YEARS AND,

IN OPEN CONTRAST TO THE CONCILIATORY LANGUAGE ADOPTED BY HIS

PRIME MINISTER, ATTACKED THE LEADERSHIP OF THE MAJOR

POLITICAL PARTIES.

00242

FUJIMORI AND THE MILITARY STAGE A TEXTBOOK BORDABERRYSTYLE COUP

LATIN AMERICAN WEEKLY REPORT, (15) (APR 92), 1.

ON APRIL 6, 1992, PERUVIAN PRESIDENT ALBERTO FUJIMORI

OISSOLVED CONGRESS AND PLACED TOP CONGRESSIONAL LEADERS

UNDER HOUSE ARREST, REORGANIZED THE JUDICIARY, AND ANNOUNCED

THAT AN "EMERGENCY GOVERMMENT OF NATIONAL RECONSTRUCTION"

WOULD TAKE OVER, HEADED BY HIMSELF AND HIS CABINET.

00243

FUJIMORI CALLS OFF MUNICIPAL ELECTIONS

LATIN AMERICAN WEEKLY REPORT, (25) (JUL 92), 10.

PRESIDENT ALBERTO FUJIMORI HAS POSTPONED ELECTIONS FOR

THE CONSTITUENT ASSEMBLY UNTIL NOVEMBER 22, 1992, AND

ANNOUNCED THAT MUNICIPAL ELECTIONS WILL BE OELAYED UNTIL

ANNOUNCED THAT MUNICIPAL ELECTIONS WILL BE DELAYED
SOME UNSPECIFIED DATE "NO LATER THAN MARCH 1993."

00244

FUJIMORI LAUMCHES CAMPAIGN AGAINST ALLEGED SENDERISTA METHORK ABROAD

LATIN AMERICAN WEEKLY REPORT, (38) (OCT 92), 1

PERUVIAN PRESIDENT ALBERTÓ FUJIMORI HAS LAUNCHED A DIPLDMATIC OFFENSIVE TO TAKE THE WAR AGAINST SENDERO LUMINOSO TO EUROPE. FUJIMORI HAS ALSO ISSUED A DECREE AUTHORIZING THE TRIAL IN ABSENT IA OF ALLEGED SENDERISTAS ABROAD ON CHARGES OF TERRORISM AND TREASON. FOREIGN GOVERNMENTS WILL BE ASKED TO EXTRADITE THE ACCUSED, AND THOSE REMAINING ABROAD MAY BE STRIPPED OF THEIR PERUVIAN CITIZENSHIP.

00245

FUJIMORI LAUNCHES RE-ACTIVATION PLAM

LATIN AMERICAN WEEKLY REPORT, (33) (AUG 92), 11.

PRESIDENT ALBERTO FUJIMORI IS LAUNCHING A US\$400 MILLION ECONOMIC REVITALIZATION PLAN. THE MONEY WILL COME FROM THE GOVERNMENT TAX REVENUE WINDFALL AND WILL BE USED TO BOOST THE SALARIES OF PUBLIC SECTOR EMPLOYEES AND PROYIDE ADDITIONAL PUBLIC WORKS. FUJIMORI HAS ALSO ISSUED DECREES CLASSIFYING ACTS OF TERRORISM AS TREASON, BUT SKEPTICS SAY HARSHER PENALTIES WILL NOT DETER THE SENDERO LUMINOSO.

00246

FUJIMORI MAKES YET ANOTHER CHANGE

LATIN AMERICAN HEEKLY REPORT, (26) (JUL 92) 8-9.

ON JUNE 25, 1992. THE FUJIMORI GOVERNMENT ANMDUNCED YET ANOTHER CHANGE IN THE TIMETABLE FOR THE RESTORATION OF

ANOTHER CHANGE IN THE TIMETABLE FOR THE RESTORATION OF
CONSTITUTIONAL RULE. THE CONSTITUENT ASSEMBLY, WHICH WILL BE
ELECTED IN NOVEMBER 1992 , WILL ACT AS PERU'S LEGISLATURE

ULECTED IN NOVEMBER 1992, WILL ACT AS PERU'S

00247

FUJIMORI MEETS BORJA HALF-WAY

LATIN AMERICAN WEEKLY REPORT, (3) (JAN 92), 3.

IN A JANUARY 1992 VISIT TO ECUADOR, PERUVIAN PRESIDENT

ALBERTO FUJIMORI ATTEMPTED TO DEFUSE THE BORDER DISPUTE

BETHEEN THE THO COUNTRIES. FUJIMORI SUGGESTED THAT THE

DISPUTE BE SUBMITTED TO ARBITRATION BY AN EXPERT THAT THE

DISPUTE BE SUBMITTED TO ARBITRATION BY AN EXPERT THAT THE

TWO COUNTRIES AND THE GUARANTORS OF THE RIO PROTOCOL WOUL

ASK THE VATICAN TO APPOINT. ECUADOR'S PRESIDENT

00248

FUJIMORI PITCHES PERU IN JAPAN

JAPAN TIMES (WEEKLY INTERNATIONAL EDITION), 32(13) (MAR 92), 17

DURING A STATE VISIT IN MARCH 1992, PERUVIAN PRESIDENT ALBERTO FUJIMORI CALLED DN JAPANESE BUSINESS LEADERS TO PROMOTE ECONOMIC RELATIONS BETHEEN THE THO COUNTRIES. HE TRIED TO DISPEL CONCERN ABOUT POLITICAL INSTABILITY IN HIS COUNTRY THAT MIGHT JEOPARDIZE FOREIGN INVESTMENT.
00249

FUJIMORI PRESSES ADVANTAGE HOME

LATIN AMERICAN WEEKLY REPORT, (39) (OCT 92 ) 4

THE GOVERNMENT OF PRESIDENT ALBERTO FUJIMORI IS PUSHING TO TAKE FULL ADVANTAGE OF THE CAPTURE OF SENDERO LUMINOSO LEADER ABIMAEL GUZMAN BEFORE HIS FOLLOWERS MANAGE TO REARRANGE THEIR COMMAND STRUCTURE AND MOUNT A COUNTEROFFENSIVE. THE MAIN OBJECTIVES ARE TO DEMORALIZE THE SENDERISTAS AND NEUTRALIZE HHAT SUPPORT SENDERO MAY HAVE GAINED THROUGH ITS AURA OF INVINCIBILITY.

00250

FUJIMORI REJECTS BUDGET BILL

LATIN AMERICAN WEEKLY REPORT, (2) (JAN 92), 10

THE CONFRONTATION BETWEEN' PRESIDENT ALBERTO FUJIMORI AND THE PERUVIAN CONGRESS SHOWS NO SIGN OF ABAIING. FUJIMORI'S LAST PUBLIC ACT IN 1991 WAS TO RETURN TO CONGRESS ITS PROPOSED BUDGET FOR 1992. HE EMPHASIZED THAT HE BELIEVES THE PROPOSED BUS THOUGH THE CHAMBER OF DEPUTIES HAD ALREADY SLASHED U.S.\$40 MILLION FROM THEIR ORIGINAL ALLOCATION, IN RESPONSE TO FUJIMORI'S EARLIER CRITICISM.

00251

FUJIMORI SETS DATE FOR ELECTIONS

LATIN AMERICAN WEEKLY REPORT, (22) (JUN 92), 10.

PRESIDENT ALBERTO FUJIMORI HAS ANNOUNCED THAT ELECTIONS

WILL BE HELD IN 1992 FOR A CONSTITUENT ASSEMBLY THAT WILL

REFORM PERU'S CONSTITUTION AND ACT AS A LEGISLATURE UNTIL A

NEH CONGRESS IS ELECTED IN 1993. FUJIMORI'S ANNOUNCEMENT

LACKED CLARITY REGARDING ONE POINT THAT HE HAD DISCUSSED

WITH OAS MEDIATORS: WHETHER HE WOULD ABANDON HIS PLANS FOR A

PLEBISCITE BEFORE THE CONSTITUENT ASSEMBLY ELECTIONS.

00252

FUJIMORI TRIES TO NARROW THE ODDS

LATIN AMERICAN WEEKLY REPORT, (44) (NOV 92), 10-11.

PRESIDENT ALBERTO FUJIMORI IS SERIOUSLY CONCERNED ABOUT

THE DECLINING POPULARITY OF JAIME YOSHIYAMA, WHO HEADS THE

LIST OF THE NUEVA MAYORIA-CAMBIO 90 COALITION CANDIDATES FOR

THE NOYEMBER 1992 CONSTITUENT ASSEMBLY ELECTIONS.

00253

FUJIMORI HINS/LOSES WITH NASSAU GAMBIT

LATIN AMERICAN WEEKLY REPORT, (21) (JUN 92), 4-5

ON MAY 18, 1992 , PERUVIAN PRESIDENT ALBERTO FU JIMORI

ADDRESSED THE OAS, ATTACKING HIS COUNTRY'S POLITICAL SYSTEM AS BEIMG BASICALIY UNDEMOCRATIC. HE ALSO ANNOUNCED THAT HE WOULD CALL ELECTIONS TO CHOOSE A CONSTITUENT DEMOCRATIC CONGRESS IN "NO MORE THAN APPROXIMATELY FIVE MONTHS."

0025

FUJIMORI: POLITICISING OR CLEANING UP

LATIN AMERICAN WEEKLY REPORT, (3) (JAN 92), 6-7.

PRESIDENT ALBERTO FUJIMORI'S ENEMIES, PARTICULARLY THOSE IN UNIFORM, ARE ACCUSING HIM OF TRYING TO POLITICIZE PERU'S ARMED FORCES.

00255

G.I. BILL FOR KIDS: PRESIDENT BUSH'S MISGUIDED MANEUVER CHURCH AND STATE, 45(8) (SEP 92), 12(180).

PRESIDENT BUSH HAS PROPOSED A NEW PLAN THAT CALLS FOR SPENDING A HALF-BILLION TAX DOLLARS TO START STATE AND LOCAL VOUCHER PROGRAMS TO FUND PAROCHIAL AND NONRELIGIOUS PRIVATE SCHOOLS. THE PRESIDENT CLAIMS THAT HIS PLAN IS SIMILAR TO THE G.I. BILL AFTER WORLD WAR II. IN FACT, BUSH'S G.I. BILL FOR KIDS IS ONLY SUPERFICIALLY SIMILAR TO THE ORIGINAL G.I. BILL; IT IS UNCONSTITUTIONAL UNDER SUPREME COURT PRECEDENTS; IT WOULD SUBSIDIZE EVANGELISM WITH TAX OOLLARS; AND IT WOULD UNDERMINE THE INDEPENDENCE OF PRIVATE RELIGIOUS SCHOOLS.

00256

G.I. BILL OR G.I. BULL? THE BUSH ADMINISTRATION'S NEW VOUCHER OFFENSIVE

CHURCH AND STATE, 45(8) (SEP 92), 7(175)-11(179).

PRESIDENT BUSH HAS ANNOUNCED A NEW FEDERAL PLAN, A G.I. BILL FOR CHILDREN, THAT WOULD ALLOCATE \$500 MILLION FOR PRIVATE SCHOOL CHOICE PROGRAMS. THE NEW PROPOSAL RAISES QUESTIONS ABDUT HOW IT WILL IMPACT THE BUDG

00257

GAVIRIA ORDERS AN ALL-OUT OFFENSIYE

LATIN AMERICAN WEEKLY REPORT, (22) (JUN 92), 3

HHIL OPPOS ITION PARTIES, UNIONS, AND A CONGRESSIONAL COMHITE ARE CAL ING FOR PEACE TALKS WITH THE INSURGENTS OF THE THE GOYERMHENT TO PREFER A MILITARY SOLUTION TO THE CONFLICT OR AT LEAST HOPES TO DEAL A DECISIVE BLOW TO THE GUERRILLAS ON THE BATTLEFIELD BEFORE RETURNING TO THE NEGOTIATING TABLE. 00258

GENERAL DISCUA WINS A SECOND TERH 
LATIN AMERICAN WEEKLY REPORT, (40) (OCT 92), 9.

THE HONDURAN MILITARY HAS ONCE AGAIN SHOWN JUST HOW MUCH POLITICAL CLOUT IT WIELDS. ON SEPTEMBER 29, 1992, MILITARY LEADERS PUSHED THROUGH CONGRESS A BILL REPEALING THE CLAUSE IN THE ARMED FORCES LAW THAT BANNED THE COMMANDER-IN-CHIEF FROM HOLDING THAT POSITION FOR MORE THAN THREE YEARS. THIS CLEARS THE WAY FOR GENERAL LUIS ALONSO DISCUA TO REMAIN IN THAT JOB.

00259

GENERAL HUMBERTO ORTEGA PLAYS PINOCHET TO MANAGUA AUDIENCE LATIN AMERICAN WEEKLY REPORT, (44) (NOV 92), 1. ON OCTOBER 27, 1992, GENERAL HUMBERTO ORTEGA MADE A PUBLIC STATEMENT DECLARIMG THAT THE ARMY STAMDS SQUARELY BEHIND THE CHAMORRO GOVERNMENT AND WILL RESIST ALL ATTEMPTS TO DESTABILIZE IT: THAT THERE WILL BE NO FURTHER REDUCTIONS OF MILITARY STRENGTH OR OF THE DEFENSE BUDGET; AND THAT HE WILL OVERSEE THE ENTIRE PROCESS OF REORGANIZING THE ARMED FORCES, WHICH MEANS THAT HE WILL REMAIN IN HIS POST AT LEAST UNTE TOU DIN RESPONSE, PRESIDENT CHAMORRO AM OUNCED THAT SHE NEEDED MORE TIME TO STUDY HIS REMARKS.

00260

GENERAL ORTEGa TRIES TO DEFUSE TALK OF A nICARAGUAM 'FUUIMORAZO'

LATIN AMERICAN WEEKLY REPORT, (22) (JUN 92), 1

LEGISLATORS OF THE UNION MACIONAL OPOSITORA HAVE CHARGED THAT NICARAGUAN PRESIDENT VIOLETA CHAMORRO IS CONTEMPLATING A "FUJIMORAZO," BACKED BY GENERAL HUMBERTO ORTEGA, THE CHIEF OF THE EJERCITO POPULAR SAMDINISTA. ORTEGA HAS DENIED THE RUMORS THAT THEY ARE PLANNING A SELF-INFLICTED, MILITARYBACKED COUP SIMILAR TO THE ONE STAGED BY PERUVIAN PRESIDENT ALBERTO FUJIMORI IN APRIL 1992.

00261

GETTING READY FOR IMPEACHMENT BATTLE

LATIN AMERICAN WEEKLY REPORT, (31) (AUG 92), 8

DESPITE CHARGES OF CORRUPTION AGAINST HIS ADMINISTRATION, BRAZILIAN PRESIDENT FERNANDO COLLOR DE MELLO HAS DECLARED THAT HE WILL NOT RESIGN. HIS ADVISERS ARE CONVINCED THAT CONGRESS WILL ATTEMPT TO IMPEACH HIM AND ARE PREPARING FOR THE BATTLE, WHICH THEY BELIEVE COLLOR CAN WIN.

00262

GHANA : DEBATE OF CONFUSION

WEST AFRICA, (3877) (JAN 92 ) 38.

GHANA'S CONSUL TATIVE ASSEMBLY HAD THE MOST TURBULENT SESSION IN ITS THREE-MONTH HISTORY DURING THE DEBATE ON THE SUPREMACY OF THE CONSTITUTION AND HOW TO DEFEND AND ENFORCE SUPREMACY OF THE CONSTITUTION AND HOW TO DEFEND AND ENFORCE IT. IN ADDITION, THE ASSEMBLY RAN FAR BEHIND SCHEDULE AND WAS NOT EXPECTED

00263

GHANA: PARTY LAW CONTROVERY

WEST AFRICA, (3897) (MAY 92), 890

GHAYA'S BAY 3897 ) (MAY 92) 890 .

POLITICAL PARTIES ARE STILL UMABLE TO REGISTER BECAUSE A POLITICAL PARTIES ARE STILL UNABLE TO REGISTER BECAUSE

CERTAIN PROVISIONS IN THE POLITICAL PARTY LAW THAT BARS THE USE OF ALL SYMBOLS, COLORS, ANO SLOGANS ASSOCIATED WITH THE BANNED OLD POLITICAL PARTIES.

00264

GHANA: RAWLINGS FRONT DIVIDED

WEST AFRICA, (3900) (JUN 92), 1021-1022

ON JUNE 5, 1992, THE FRONT CLUB, THE RAHLINGS FAN CLUB, FRIENDS OF THE PROGRESSIVE DECADE CLUB, AND THE DEVELOPMEN UNION MERGED TO FORM THE UNITED CLUBS FOR RAWLINGS (UNICRAWL). NANA BOATEN ABORA, UNICRAHL'S SPOKESMAN, SAID THAT THE ORGANIZATION WILL SPONSOR A POLITICAL PARTY. HE CALLED ON ALL ACCREDITED MEMBERS AND SYMPATHIZERS TO VOTE FOR "CHAIRMAN RAWLINGS, IN WHOM IS EMBODIED AND ENSHRINED THE NEW CONCEPT OF REDEMPTION IN THE FORTHCOMING PRESIDENTIAL ELECTIONS."

00265

GHANA: SAM NUJOMA HOLDS TALKS IN ACCRA

WEST AFRICA, (3883) (FEB 92) 294 .

GHANA AND NAMIBIA HAVE AGREED TO ESTABLISH CLOSER ECONOMIC, CULTURAL, EDUCATIONAL. AND TECHNOLOGICAL TIES IN OROER TO HELP MAMIBIA CONSOL IDAIE HER IMDEPEMDENCE. THE THO COUNTRIES HAVE ALSO AGREED TO FIND WAYS OF ESTABLISHING COUNTRIES HAVE ALS

00266

GHANA'S TRANSITION: SOME DEBRIS IN THE FLOW

WEST AFRICA (3914) (SEP 2 ) 1597

ALTHOUGH, GHANAIANS OVERHHEL 1597 .

CONSTITUTION OF THE FOURTH REPUBLIC, EFFECTIVELY ENOING

SPECULATION ABOUT THE GOVERNMENT'S INTENTIONS VIS-A-VIS THE

RETURN TO CIVILIAN CONSTITUTIONAL RULE, IT DID NOT DISPEL

EVERY DOUBT THAT IT WOULD BE FOLLOWED THROUGH TO ITS LOGICAL
CONCLUSION, SINCE THE CONSTITUTIONAL REFERENDUM, MUCH POL ITICAL WATER HAS PASSED UNDER THE BRIDGE. THROWING UP DEBRIS AND MUCK IN THE PROCESS.

00267

GIVE ANGOLA A CHANCE

HEST AFRICA, (3917) (OCT 92), 1706

HOPE THAT ANGOLA'S 1992 PRESIDENTIAL ELECTION WOULD

SIGNAL THE END OF THE COUNTRY'S LONG, TORTUOUS WAR APPEARS

TO HAVE BEEN PREMATURE. AS HIS DEFEAT BECAME CERTAIN, UNITA

LEADER JONAS SAVIMBI BEGAN TO CAST DOUBT ON THE INTEGRITY OF THE VOTE COUNT AND ALLEGED THAT THE GOVERHMENT'S SECURITY

FORCES HAD INTIMIDATED SOME VOTERS. MEANHWILE UNITA GENERALS IN THE NEW NATIONAL ARMY, WHICH HAD BEEN FORMED ON THE EVE OF THE ELECTIONS, ANNOUNCED THE WITHDRAWAL OF THEIR TROOPS FROM THE ARMED FORCES IN A MOVE THAT COULD RETURN THE COUNTRY TO ITS PRE-CEASEFIRE DAYS.

00268

NEW REPUBLIC, 206(7) (FEB 92 ) 7 .

REAL ESTATE DEVELOPERS ARE HINNING BIPARTISAN SUPPORT IN CONGRESS FOR CHANGING THE TAX CODE TO ALTER DEPRECIATION AND PASSIVE-LOSS RULES. THE CURRENT RULES WILL RAISE $\$ 8$ BILLION
FOR THE U.S. TREASURY IN 1991 ALONE, WHILE THE PROPOSED FOR THE U.S. TREASURY IN 1991 ALONE, WHILE THE PROPOSED REFORM WOULD BE A BOON TO THE REAL ESTATE INDUSTRY AND WOULD

00269

GLOBAL MEDIATION

PARLIAMENTARIAN, LXXIII(1) (JAN 92), 59-60.

SMALNTARIAN, LXXIII SETTLING POLES CAN OFFER A HUMAN, COMMON-SENSE APPROACH TO

ON THE HORI GAINED BY POLITICAL LEADERS IN GUIDING THEIR SMALL STATES TO IMOEPENDENCE OR IN DELICATE NEGOTIATIONS WITH LARGER NEIGHBORS MAKE THEM ESPECIALLY HELL-SUITED IN LARGE-SCALE MEDIATIONS.

00270

GORBACHEV SAYS CIS NEEDS SUPPORT

JAPAN TIMES (WEEKLY INTERNATIONAL EDITION), $32(16)$ (APR

$92), 5$.

DURIMG A VISIT WITH JAPANESE PRIME MINISTER KIICHI MIYAZAHA ON APRIL 14, 1992, FORMER SOVIET PRESIDENT MIKHAIL GORBACHEV STATED THAT SUPPORT FROM JAPAN AND THE WEST IS ESSENTIAL TO THE SUCCESS OF THE REFORMS UNDERHAY IN THE COMMONWEALTH OF INDEPENDENT STATES. GORBACHEV CITED THE TAX SYSTEM, ASSISTANCE FOR LOW-INCOME CITIZENS, AND

MANUFACTURING AS AREAS THAT REQUIRE THE URGENT ATTENTION OF COMMONHEALTH LEADERS.

00271

GORBACHEY: DEGAULLE WAS OLOER

JAPAN TIMES (WEEKLY INTERNATIONAL EDITION), 32(18) (MAY

92), 3.

FORMER SOVIET PRESIDENT MIKHAIL GORBACHEV HAS INOICATED

THAT HE MAY SEEK TO PLAY A CENTRAL ROLE IN RUSSIAN POLITICS

AT SOME POINT IN THE FUTURE, BUT NOT WITHIN THE NEXT THREE

AO FIVE YEARS.

00272

GOVERMMENT AND ADMINISTRATION: EXTENSION OF COMPETITION FOR PUBLIC SERVICES

SURVEY OF CURRENT AFFAIRS, 21(12) (DEC 91), 437-438.

ON NOVEMBER 18, 1991, THE BRITISH GOVERMMENT PUBLISHED A WHITE PAPER ENTITLED "COMPETING FOR QUALITY: BUYING BETTER PUBLIC SERVICES." THE DOCUMENT OUTLINES PLANS FOR INCREASING PRIVATIZATION AND STIMULATING COMPETITION IN THE PROVISION OF PUBLIC SERVICES

00273

GOVERMMENT BACKS SDF FOR CRISIS AIRLIFTS

JAPAN TIMES (HEEKLY INTERNATIONAL EDITION), 32(12) (MAR $92), 3$.

THE MIYAZAWA GOVERMMENT HAS APPROVED A PLAN TO REVISE THE SELF-DEFENSE LAH TO ALLOW SDF AIRCRAFT TO EVACUATE JAPANESE FROM OYERSEAS IN TIMES OF EMERGENCY. UNDER THE PROPOSAL, HHICH MUST BE APPROVED BY THE DIET, THE DEFENSE AGENCY'S DIRECTOR GENERAL. AT THE REQUEST OF THE FOREIG MINISTER, COULD AUTHORIZE THE USE OF SDF AIRCRAFT TO TRANSPORT JAPANESE AND FOREIGNERS WHO REQUIRE EMERGENCY ASSISTANCE.

00274

GOVERNMENT SEES SILVER LINING

LATIN AMERICAN WEEKLY REPORT, (2) (JAN 92), 2

THE BRAZILIAN GOVERMMENT SAYS THAT THE ECONOMY IMPROVED IN SUMS UP 1991 MORE PESSIMISTICALLY, NOTING THAT THERE WAS NO REAL GRONTH, HITH SLIGHT RECOVERY IN ONLY A FEH SECTORS AND AN INORDINATELY HIGH RATE OF JOB LOSSES. 
00275

GOVERMMENTS URGE DEFENCE OF DEMOCRACY

ATIN AMERICAN WEEKLY REPORT, (16) (APR 92), 6-7 FOLLOWING ALBERTO FUJIMORI'S COUP IN PERU, BOLIVIAN PRESIDENT JAIME PAZ ZAMORA WARNED POLITICIANS IN HIS COUNTRY TO GET TO WORK OR FACE THE MUSIC. IN A DIRECT REFERENCE TO PERU, PAZ ZAMORA SAID THAT THE CONGRESS MUST FUNCTION

PROPERLY SO THERE WOULD BE NO REASON TD ELIMINATE IT.

00276

GRASSROOTS/LOCAL ENVIRONMENTAL ACTION

NATIONAL CIVIC REVIEW, 81(1) (WIN 92), 36.

THE AUTHORS DISCUSS WHETHER CITIZENS GROUPS AND LOCAL GOVERNMENTS--ACTING IN THEIR IMMEDIATE PHYSICAL ORBITS OR SERYICE AREAS-CAY IN THEIR IMMEDIATE PHYSICAL ORBIT MEANINGFUL IMPACT ON THE GLOBAL PROBLEM OF ENVIRONMENTAL PROTECTION. THEY ALSO ASK IF THE PLANETARY SCALE OF PROTECTION. THEY ALSO ASK IF THE PLANETARY SCALE OF
ENVIRONMENTAL PROBLEMS IS A REASON TO NEGLECT THEM.

00277

GREEN TICKET OR THICKET?

COMAONWEAL, CXIX(14) (AUG 92), 4-5.

THE AUTHOR LOOKS AT BILL CLINTON'S CHOICE OF SENATOR AL

GORE JR. AS HIS RUNAING MATE IN THE 1992 PRESIDENTIAL

ELECTION AND CONSIDERS WHETHER GORE'S ENVIRONMENTALISM WILL

BE AN ASSET OR A DRAHBACK.

00278

GRINGO AND INDIO TICKET FOR MNR

LATIN AMERICAN WEEKLY REPORT, (48) (DEC 92), 11 THE OPPOSITION MOVIMIENTO NACIONALISTA REVOLUCIONARIO

HAS SELECTED AN UNEXPECTED VICE-PRESIDENTIAL CANDIDATE FROM OUTSIDE ITS OWN RANKS FOR THE UPCOMING ELECTION. VICTOR HUGO CARDENAS, LEADER OF THE INDIGENIST MOVIMIENTO REVOLUCIONARIO TUPAJ KATARI, WILL RUN WITH PRESIDENTIAL CANDIDATE GONZALO SANCHEZ DE LOSADA. THE PAIR REPRESENT BOLIVIA'S INOIAN MAJORITY AND THE TECHNOCRATIC ELITE.

00279

GROWING DEMAND FOR CHANGE OF COURSE

LATIN AMERICAN WEEKLY REPORT, (32) (AUG 92), 6-7 WILL THE "NEO-LIBERAL" POLICIES EMBRACED BY MANY LATIN AMERICAN GOVERMMENTS SURVIVE, OR WILL THEY BE ABANDONED AMERICAN GOVERNMENTS SURVIVE, OR WILL THEY BE ABANOONE

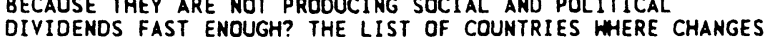
DIVIOENDS FAST ENOUGH? THE LIST OF COUNTRIES WHERE CHANGES SOCIAL REASONS IS GROHING.

00280

GROWTH LIKELY TO SLOW DOWN IN 1992

LATIN AMERICAN WEEKLY REPORT (1) (JAN 92), 2

IN 1992, MEXICO'S ECONOMIC GROWTH RATE MUST SLOH DOWN IN ORDER TO AVOID OVERHEATING THE ECONOMY AND ENCOURAGIMG INFLATION. IN 1991, MEXICO ENJOYED AN ANNUAL GROWTH RATE OF APPROXIMATELY $4.7 \%$ AND EXPERIENCED A $19.3 \%$ INFLATION RATE, FAILING TO MEET THE GOVERNMENT'S GOAL OF REDUCING INFLATION TO $14 \%$.

00281

GUATEM

LATIN AMERICAN HEEKLY REPORT, (21) (JUN 92), 1.

SOME OPPOSITION LEADERS IN GUATEMALA ARE SPECULATING THAT A MILITARY COUP MAY BE IN THE CARDS, DUE TO THE BREAKDOWN IN PUBLIC ORDER.

00282

GUIDE TO PROFESSIONAL ETHICS IN POLITICAL SCIENCE PS: POLITICAL SCIENCE AND POLITICS, $X X V(2)$ (JUN 92), $238-252$

THIS ARTICLE REPRINTS THE NEWLY-REVISED "GUIDE TO PROFESSIONAL ETHICS IN POLITICAL SCIENCE" FORMULATED BY THE APSA'S COMMITTEE ON PROFESSIONAL ETHICS, RIGHTS, AND FREEDOMS. THE PURPOSE OF THE GUIDE IS TO PROYIDE AN AUTHORITATIVE STATEMENT OF ETHICAL PRINCIPLES FOR POLITICAL SCIENTISTS, PARTICULARLY THOSE NEW TO THE PROFESSION.

00283

HARLEM BRIDGEBUILDER

WEST AFRICA, (3904) (JUL 92), 1167

BALOZI R. HARYEY IS THE NATIOMAL SPOKESMAM IN THE UMITED STATES FOR THE ASKED TO HELP H. ROSS PEROT'S CAMPAIGN, WORKING WITH MINORITY GROUPS.

00284

HAUNTED HOUSES

NEW REPUBL IC 206(15) (APR 92) 7

PRESIDENT, $206(15)$ (APR 92), 7 . FOR PESIOENT GEORGE BUSH HAS OFFERED THO HAJOR PROPOSALS TERM LIMITS FOR LEGISLATORS. THE FORMER MIGHT HELP A LITTLE, BUT IT HOULD REQUIRE A CONSTITUTIONAL AMENDMENT INITIATED BY CONGRESS, SO IT'S UNLIKELY TO BE ENACTED. TERM LIMITS, ON THE OTHER HAND, ARE A USELESS IDEA. THE CONSTITUTION HAS
ALREADY PROVIDED A MEANS FOR THE VOTERS TO LIMIT CONGRESSIONAL TERMS: REPRESENTATIVES RUN FOR OFFICE EVERY TWO YEARS, SENATORS EVERY SIX. MORE MEANINGFUL REFORM HOULD INCLUDE BETTER CONGRESSIONAL LEADERSHIP, CAMPAIGN FINANCE REFORM, ETHICS REFORM, THE ABOLITION OF COMMITTEES, AND REDUCTION OF CONGRESSIONAL STAFF.

00285

HEALTHY COMMUNITIES: GRANTS TO SUPPORT INNOVATIVE CHILDREN'S MENTAL HEALTH INITIATIVES IN SEVEN STATES

NATIONAL CIVIC REVIEN, 81(3) (SUM 92): 378-380.

SEVEN STATES WILL RECEIVE GRANTS TOTALING \$6.4 MILLION

TO SUPPORT PIONEERING REFORMS IN SERVICE DELIVERY SYSTEMS

FOR FAMILIES WITH CHILDREN AND ADOLESCENTS WITH SERIOUS

EMOTIONAL DISORDERS. THIS ARTICLE BRIEFLY DESCRIBES THE

STATE DEMONSTRATION PROJECTS TO BE FUNDED IN CALIFORNIA, KENTUCKY,

00286

HEART AND SOUL

COMMONWEAL, CXIX(9) (MAY 92 ), 3-4.

PENHSYLVANIA GOVERNOR ROBERT P. CASEY REPRESENTS A LARGELY - IGNORED SEGMENT OF HIS PARTY BECAUSE HE IS AN ANTIABORTION DEMOCRAT. HE BELIEVES THAT THE DEMOCRATS HAVE INFLICTED DAMAGE ON THEMSELVES BY MAKING ABORTION ON DEMAND A LITMUS TEST FOR ANY CANDIDATE SEEKING THE PARTY'S PRESIDENTIAL NOMINATION.

00287

HELP FOR THREATENED SPECIES

JAPAN TIMES (WEEKLY INTERNATIONAL EDITION), 32(9) (MAR 92),

JAPAN'S ENVIRONMENT AGENCY IS PREPARING TO ENACT A BILL AIMED AT PROTECTING ENDANGERED SPECIES OF PLANTS AND ANIMALS THIS IS A RATHER REMARKABLE TURNAROUND FOR A COUNTRY OFTEN CRITICIZED BY ENVIRONMENTALISTS AND NATURALISTS FOR BEING OBLIVIOUS TO THE PLIGHT OF PLANTS AND ANIMALS FACING EXTINCTION.

00288

HIGH COST SOLUTION TO POLICE STRIKE

LATIN AMERICAN WEEKLY REPORT, (47) (DEC 92), 10

URUGUAY'S FOUR-DAY POLICE' STRIKE ENDED ON NOVEMBER 20,

1992. AT CONSIDERABLE COST TO THE GOVERMMENT OF PRESIDENT

LUIS ALBERTO LACALLE. THE CONGRESS PASSED LEGISLATION

INCREASING POLICE AND MILITARY PAY BY UP TO 50\%, CRUSHING

THE ADMINISTRATION'S HOPES OF LIMITING PAY INCREASES TO 35\% IN 1992 .

00289

HIGH COURT APPEALS AIRPORT SOLICITATION CASE FROM NEW YORK CHURCH AND STATE, 45(2) (FEB 92), 15(39).

IN A CASE THAT COULD ESTABLISH NEH GUIDELINES FOR STATE REGULATION OF RELIGIOUS SPEECH, THE U.S. SUPREME COURT HAS AGREED TO DECIDE WHETHER AUTHORITIES MAY BAN GROUPS, SUCH AS THE HARE KRISHNAS, FROM SOLICITING CASH DONATIONS IN AIRPORTS. IN OTHER CASES INVOLVING FREE EXERCISE, A FEDERAL COURT HAS STRUCK DOWN BOSTON'S BAN ON LITERATURE

DISTRIBUTION IN THE CITY'S SUBWAY SYSTEM; ANOTHER FEDERAL

COURT HAS RULED THAT AN EVANGELIST MAY DISPLAY A RELIGIOUS

BANNER AT A PROFESSIONAL FOOTBALL GAME; AND CHARGES OF

DISORDERLY CONDUCT AGAINST THO STREET PREACHERS WERE

DISMISSED IN NEW YORK CITY.

00290

HIGH-RANKING OFFICIAL ON SINO-U.S. TRADE

(

CHINA HILL CONTINUE TO BRING HER TRADE SYSTEM INTO LINE WITH INTERNATIONAL STANDARDS, BUT IT IS NOT POSSIBLE TO MEET THE EXPECTATIONS OF THE UHITED STATES, ACCORDING TO TONG ZHIGUANG, VICE-MINISTER OF FOREIGN ECONOMIC RELATIONS AND OUT BETHEEMINA. WHEN ASKED HETHER A TRADE WAR WILL BREAK OUT BETHEEN CHINA AND THE UNITED STATES, TONG SAID THAT THIS IS DEPENDENT SOLELY ON THE COURSE TAKEN BY THE AMERICANS. HE ADDED THAT A TRADE WAR WOULD BE BAD FOR BOTH CHINA AND THE BACKWARDS IF TRADE HAR BROKE OUT.

00291

HISTORICAL SOCIAL FEMINIST

WEST AFRICA, (3888) (MAR 92), 499.

THE AUTHOR PROFILES DR. NAHEL EL SAADAHI, AN EGYPTIAN PHYSICIAN WHO DEVOTES HER TIME TO WRITING AND SPEAKING ON WOMEN'S ISSUES. NAWEL HO WAS IMPRISONED DURING THE SADAT REGIME IS PRESIDENT OF THE ARAB WOMEN'S SOL IDARITY

ASSOCIATION AND SEES HOMEN'S ISSUES AS AN INTEGRAL PART OF NATIONAL AND INTERNATIONAL POLITICS.

00292

HISTORY UNFETTERED

FREE CHINA REVIEW, 42 (3) (MAR 92 ), 1 .
POPULAR SENTIMENT IS PUSHING THE TAIHANESE GOVERMMENT AND ACADEMIA TO PLACE MORE EMPHASIS ON THE STUDY OF TAIWAN'S 
HISTORY AND CULTURE. THE NEW INTEREST IN TAIWAN'S PAST HAS BEEN STIMULATED BY THE LIBERALIZED SOCIAL AND POLITICAL ENVIRONMENT THAT HAS ARISEN SINCE MARTIAL LAW WAS LIFTED IN 1987. THE GROWTH OF A GENUINELY PLURALISTIC SOCIETY IS ALSO ENCOURAGING GREATER ACADEMIC FREEDOM, AND THE ATMOSPHERE OF
FREE INOUIRY IS MAKING IT POSSIBLE FOR STUDENTS AND SCHOLARS FREE INQUIRY IS MAKING IT POSSIBLE FOR
TO PROBE DEEPER INTO TAIHAN'S HISTORY.

00293

HOST OF HARNINGS BEHIND THE TEAR GAS THAT UPSET BUSH'S PANAMA WHISTLESTOP

LATIN AMERICAN WEEKLY REPORT, (24) (JUN 92), 1.

ON JUNE 11,1992 , U.S. PRESIDENT GEORGE BUSH WAS FORCED

TO FLEE AN OPEN-AIR RALLY IN THE PLAZA PORRAS BECAUSE HE HAS

AFFECTED BY THE TEAR GAS POLICE FIRED AT DEMONSTRATORS.

PRIOR TO HIS ARRIVAL PANAMA CITY HAD EXPERIENCED PROTESTS

BY STUDENTS, BY RELATIVES OF THOSE KILLED IN THE 1989

INYASION, AND BY PEOPLE WHO HAVE NOT BEEN COMPENSATED FOR

THE LOSS OF THEIR HOMES OR LIVELIHOOOS. 00294

HOW COALITION ALLIES PLAY THE GAME

LATIN AMERICAN WEEKLY REPORT, (40) (OCT 92), 10-11.

THE FINAL RESULTS OF CHIL''S JUNE 1992 MUNICIPAL

ELECTIONS WERE NOT KNOWN UNTIL SEPTEMBER, HHEN THE TOWM COUNCILS FINALLY ELECTED THE MAYORS. COUNCILLORS OF THE RULING CONCERTACION WERE UNDER STRICT ORDERS TO VOTE ACCORDING TO A "PROTOCOL" THAT DOLED OUT THE MAYORAL JOBS IN LINE WITH PARTY QUOTAS. AS MANY AS 289 MUNICIPALITIES FOLLOWED THE SCENARIO, BUT IN THE REMAINING 45, LOCAL AMBITIONS, LOYALTIES, AMD

00295

HOW MUCH BETTER ON THE DEBT FRONT?

LATIN AMERICAN HEEKLY REPORT, (2) (JAN 92), 8-9.

ALTHOUGH THE LATIN AMERICAN DEBT CRISIS HAS RECEDED FROM THE FOREFRONT OF PUBLIC ATTENTION. IT IS STILL VERY REAL. AS DEMONSTRATED BY THE WORLD BANK'S "WORLD DEBT TABLES 1991-92. " AS A WHOLE, LATIN AMERICA AND THE CARIBBEAN OWE ALMOST 78\% MORE THAN IN 1980, THO YEARS BEFORE THE DEBT CRISIS ERUPTED. MOREOVER, THE REGION HAS IMCREASED ITS INOEBTEDNESS BY A TENTH SINCE 1985.

00296

HOW THE ENVIRONMENT IS HELPING COLLOR

LATIN AMERICAN WEEKLY REPORT, (23) (JUN 92), 6-7 BRAZIL'S INVOLVEMENT IN THE RIO DE JAMEIRO EARTH SUMMIT STOLE THE HEADLINES AHAY FROM THE CONGRESSIONAL

STOLE THE HEADLINES AHAY FROM THE CONGRESSIONAL

INVESTIGATION INTO ALLEGATIONS OF MISCONDUCT BY PRESID
FERNANDO COLLOR DE MELLO'S CAMPAIGN FINANCE MANAGER.

00297

HOW THE WAR HAS BEEN CHANGING IM PERU

LATIN AMERICAN WEEKLY REPORT, (4) (JAN 92), 6-7.

DBSERVERS HAVE NOTED A DECREASE IN MILITARY ACTIVITY BY SENDERO LUMINOSO, BUT THEY DISAGREE ABOUT THE REASON; SOME ATTRIBUTE IT TO A REDUCTION IN SENDERO'S OFFENSIVE CAPACITY DUE TO THE SECURITY FORCES SUCCESSES AGAINST THE LEADERSHIP STRUCTURE; OTHERS SAY SENDERO HAS ADOPTED A DELIBERATE SHIFT IN STRATEGY. THE SENDERISTAS HAVE MOVED INTO THE CENTRAL HUALLAGA REGION, WHERE THEY ARE CLASHING HITH PERU'S OTHER GUERRILLA BAMD. THE MOVIMIENTO REVOLUCIONARIO TUPAC AMARU (MRTA). THIS HAS TURNED INTO A FULL-SCALE WAR-WITHIN-A-WAR.

00298

HOW THEY ARE LINING UP FOR JUNE

LATIN AMERICAN WEEKLY REPORT, (17) (MAY 92), 10-11.

THE UNION DEMOCRATA INDEPENDIENTE, RENOVACION NACIONAL,

PARTIDO NACIONAL, THE CHRISTIAN DEMOCRATS, AND THE

SOCIALISTS ARE AMONG THE PARTIES FIELDING CANDIDATES IN

CHILE'S JUNE 28, 1992, MUNICIPAL ELECTIONS. POLLS SHOW THAT

SECURITY ISSUES-INCLUDING STREET LIGHTS AND MORE POLICE

STATIONS--ARE THE VOTERS' MAJOR CONCERN.

00299

HOW'S THE REVOLUTION?

WEST AFRICA, (3916) (OCT 92), 1656-1657

THE REVOLUTION IN SIERRA LEONE HAS AFFECTED DIFFERENT

PEOPLE DIFFERENTLY DURING THE FIRST FIVE MONTHS OF THE NRPC

REGIME. MANY INDIVIDUALS HAVE BENEFITTED FROM THE CHANGE,

WHILE OTHERS HAVE SUFFERED. THE BECCLES-DAVIES COMMISSION OF

ENOUIRY IS CONTINUING TO UNCOVER MASSIVE CORRUPTION BY

FORMER MINISTERS AMD OTHER OFFICIALS OF EX-PRESIDENT J.S.

MOMOH'S ADMINISTRATION.

00300

HUMAN RIGHTS WATCH HORLD REPORT 1992: THE ISRAELI-OCCUPIED WEST BANK AND GAZA STRIP

OURNAL OF PALESTINE STUDIES, XXI(4) (SUM 92), 113-129.

THIS ARTICLE INCLUDES EXCERPTS FROM A REPORT ISSUED BY

HUMAN RIGHTS WATCH. TOPICS INCLUDE HUMAN RIGHTS DEVELOPMENTS

IN THE OCCUPIED TERRITORIES IN 1991, HOW THE GULF WAR

AFFECTED CONDITIONS AMONG THE PALESTINIANS, U.S. FOREIGN
POLICY AS IT RELATES TO HUMAN RIGHTS IN THE OCCUPIED TERRITORIES, AND STATISTICS ON THE NUMBER OF PALESTINIANS SUBJECTED TO DETENTION, OEPORTATION, AND $/ O R$ HOUSE DEMOLITIONS.

00301

I'D SAY THAT'S A 'NO'

COMMONHEAL, CXIX(21) (DEC 92), 6-8

ON OCTOBER 26, 1992, CANADIANS WENT TO THE POLLS TO VOTE ON THE FRAMENORK FOR A NEW CONSTITUTIONAL AGREEMENT. THE CAMPAIGN AGAINST THE AGREEMENT REVEALED A MASSIVE

DISENCHANTMENT WITH CANADA'S POLITICAL LEADERSHIP, AND THE

FINAL NATIONHIDE VOTE WAS 53.7 PERCENT AGAINST IT.

00302

IDENTIFYING WARNING SIGNALS

WEST AFRICA, (3910) (AUG 92), 1433

THE AUTHOR PROFILES J. ISAWA ELAIGWU, DIRECTOR GENERAL

OF THE NATIONAL COUNCIL ON INTERGOVERNMENTAL RELATIONS OF

NIGERIA. ELAIGWU IS A STAUNCH SUPPORTER OF FEDERALISM, AND

HIS COUNCIL HAS THE RESPONSIBILITY FOR FINE-TUNING

INTERGOVERMMENTAL RELATIONS WITH A VIEM TOHARD REDUCING

FRICTION IN THE FEDERAL STRUCTURE.

00303

IMPROVING THE STATUS OF WOMEN IN POLITICAL SCIENCE: A REPORT HITH RECOMMENDATIDYS

PS: POLITICAL SCIENCE AND POLITICS, XXV(3) (SEP 92),

SINCE ITS INCEPTION, THE APSA COMMITTEE ON THE STATUS OF WOMEN IN THE PROFESSION HAS IDENTIFIED STRATEGIES FOR ACHIEVING EQUITY BETWEEN MEN AND WOMEN IN THE POLITICAL

SCIENCE PROFESSION. IN THIS REPORT, THE COMMITTEE CONSIDERS

THE PROBLEMS ASSOCIATED HITH TRAINING, RECRUITING, NURTURING, AND RETRAINING WOMEN AS ACADEMIC POLITICAL SCIENTISTS.

00304

IN THE WORLD BUT NOT OF IT

JAPAN TIMES (WEEKLY INTERHATIONAL EDITION), 32(10) (MAR

92) 10.

OEMONSTRATES HOW POORLY PREPARED JAPAN IS FOR

THE NEW DEMANDS OF THE POST-COLD WAR WORLD THAN ITS QUANDRY REGARDING UNITED NATIONS PEACEKEEPING OPERATIONS. MEMORIES OF THE PERSIAN GULF WAR MAY BE GROWING FAINT ELSEWHERE, BUT THE CONFLICT HAS LEFT JAPAN WITH A SET OF POLICY CONUNDRUMS THAT IT IS NO NEARER TO SOLYING THAN IT WAS WHEN THE CRISIS BEGAN.

00305

INDIGNATION AT U.S. KIDNAP-RIGHT RULING

LATIN AMERICAN WEEKLY REPORT, (25) (JUL 92), 8-9.

THERE WAS A WAVE OF INDIGNATION THROUGHOUT LATIN AMERICA AND THE CARIBBEAN OVER THE U.S. SUPREME CDURT RULING THAT APPEARED TO ENDORSE WASHINGTON'S RIGHT TO TAKE A PERSON FORCIBLY FROM THE TERRITORY OF ANOTHER NATION AND TRANSPORT HIM TO THE USA TO STAMD TRIAL MOST GOVERMMENTS OF THE RIM TO THE USA TO STAND TRIAL. MOST GOVERMMENTS OF INTERMATIONAL LAH, PARTICULARLY EXISTING EXTRADITION INTERNATION
TREATIES.

00306

INSIDE VIEW OF THE REFORM PACXAGE

LATIN AMERICAN WEEKLY REPORT, (23) (JUN 92), 5.

CHILE'S PRESIDENT PATRICIO AYLWIN PRESENTED A PACKAGE OF 30 CONSTITUTIONAL REFORMS TO CONGRESS ON MAY 21, 1992. THE REFORMS WOULD EMPOWER THE PRESIDENT TO REMOVE THE MILITARY COMMANDERS-IN-CHIEF, LIMIT THE POHERS OF THE CONSTITUTIONAL TRIBUNAL, AND ADO ANOTHER CIVILIAN TO THE CONSEJO NACIONAL DE SEGURIDAD. OTHER PROPOSALS WOULD REFORM THE ELECTORAL SYSTEM AND ENLARGE THE CONGRESS.

00307

INSIGHT INTO AYLHIN'S AGENDA

LATIN AMERICAN WEEKLY REPORT, (1) (JAN 92), 4-5.

THE GOVERMMENT OF PRESIDENT PATRICIO AYLWIN HOPES TO

GAIN SUPPORT AT THE LOCAL LEVEL IN THE JUNE 1992 MUNICIPAL

ELECTIONS. THE AYLWIN ORGANIZATION'S MAJOR CAMPAIGH PROMISES ARE SUMMED UP IN TWO SLOGANS: TO CONSOLIDATE DEMOCRACY AND TO ASSURE GROWTH WITH EOUITY.

00308

INTERFAITH WRANGLING MAY SPARK DRIVE FOR CHURCH-STATE SEPARATION IN DOMINICAN REPUBLIC CHURCH AND STATE, $45(2)$ (FEB 92), 18(42).

RAPIDLY-GROWING PROTESTANT EVANGEL ICAL GROUPS ARE CHALATELIMG THE ROMAH CATHOL IC CHURCH'S GRIP OM THE DOMINICAN REPUBLIC. THROUGH A SPECIAL CONCORDAT BETWEEN THE VATICAN AMD THE DOMINICAN REPUBLIC'S GOVERNMENT, THE CATHOLIC CHURCH OCCUPIES A SPECIAL PLACE AND RECEIVES CERTAIN FINANCIAL BENEFITS. THE EVANGELICALS HAVE PREPARED A PROCLAMATION THAT CALLS FOR PLACING ALL RELIGIONS ON EQUAL FOOTING IN THE EYES OF THE GOVERMMENT. 
00309

INTERMEDIARY ROLE HAS ITS RISKS

GRMAN TRIBUHE, (1475) (JUL 91), 1-2.

GERMAN CHANCELLOR HELMUT KOHL'S EFFORTS TO AID SOVIET

PRESIDENT MIKHAIL GORBACHEV AND TO CONVINCE OTHER MEMBERS OF THE GROUP OF SEVEN INDUSTRIALIZED NATIONS TO HEAR AND ANSWER GORBACHEV'S PLEAS FOR AID IS AN EVIDENCE OF GERMANY'S INCREASING INVOL YEMENT IN INTERNATIONAL AFFAIRS. THE INCREASING GERMAN INTEREST IN HORLD AFFAIRS HAS NOT FOLLOWED THE TRADITIONAL PATTERN OF MILITARY MIGHT OR INTERNATIONAL ORGANIZATIONS SUCH AS THE UN, HOWEYER, KOHL'S MOVES ARE NOT WITHOUT RISK. THE FAILURE OF GORBACHEY'S REFORMS COULD CAUSE KOHL TO LOSE SIGNIFICANT POLITICAL CLOUT. IRONICALLY THE SUCCESS OF KOHL'S ATTEMPTS TO AID THE SOYIET UNIOM COULD ALSO DAMAGE THE ALREADY STRAINED GERMAN ECONOMY BY DRAINING MORE CAPITAL AND MONEY.

00310

INTERNATIONAL: BANDA UNDER PRESSURE

HEST AFRICA, (3888) (MAR 92), 518

PRESSURE IS MOUNTING OM MALAHI'S VETERAM PRESIDENT

HASTINGS KAMUZU BANDA TO INTRODUCE MULTIPARTY DEMOCRACY. THE OPPOSITION UNITED FRONT FOR MULTIPARTY DEMOCRACY, OPERATING FROM NEIGHBORING ZAMBIA, IS URGING PEACEFUL DEMONSTRATIONS AGAINST BANDA.

00311

INTERVIEW: DAVID COLTART, TRUSTEE OF ZIMBABWE'S FORUM FOR DEMOCRATIC REFORM TRUST

AFRICA REPORT, 37(6) (NOV 92), 10-11.

WITH ZIMBABHE'S ECONOMY REELING FROM THE EFFECTS OF THE DROUGHT THAT IS GRIPPING SOUTHERN AFRICA, A DIVERSE

OPPOSITION--INCLUDING STUDENTS, LABOR UNIONS, CHURCHES, AND BUSINESSMEN--HAS SPRUNG UP TO POSE A SERIOUS THREAT TO THE ZANU GOVERNMENT. A POLITICAL PRESSURE GROUP, THE FORUM FOR DEMOCRATIC REFORM TRUST, HAS BEEN LAUNCHED TO TRY TO RALLY THESE DIVERSE FORCES UNDER ONE BANNER. IN THIS INTERVIEW, A FORUM OFFICIAL OISCUSSES THE POLITICAL SITUATION IN ZIMBABWE AND THE ROLE THE FORUM HOPES TO PLAY.

00312

INTO AFRICA

NEW REPUBLIC, 207(27) (DEC 92), 7-8.

THE AMERICAN MILITARY INTERVENTION IN SOMALIA IS THE FIRST ONE IN RECENT HISTORY TO BE JUSTIFIED SOLELY ON MORAL BEING SERVED. AS SUCH, IT PLACES U.S. FOREIGN POLICY ON AN OFTEN OPERATES.

00313

IS FERNANDO COLLOR CRACKING UP?

ITIN AMERICAN WEEKLY REPORT, (8) (FEB 92),

PRESIDENT FERNANDO COLLOR'S PERSONAL APPEARANCE AND CHANGES IN HIS ROUTINE HAVE PROMPTED SPECULATION THAT BRAZIL'S CHIEF EXECUTIVE IS SUFFERING FROM A HEALTH PROBLEMPERHAPS DEEP DEPRESSION BROUGHT ON BY THE PRESSURES OF HIS OFFICE.

00314

IS IT A BIRO? IS IT AN ELECTION BUDGET?

WEST AFRICA, (3883) (FEB 92), 273.

IF GHANA'S TRANSITIONAL PROGRAM IS EXECUTED ON SCHEDULE, THE NEW BUDGET HILL BE THE LAST ONE FROM THE PNDC. THE PNDC CLAIMS THAT THE OBJECTIVE OF ITS BUDGET AND ECONOMIC STRATEGY IS TO PREPARE THE GROUND FOR THE TRANSITION. THE PNDC ALSO CONTENDS THAT NEITHER THIS BUDGET NOR ANY OTHER ECONOMIC MEASURE HAS BEEN TAKEN WITH AN EYE ON ELECTORAL POSSIBILITIES. AFTER AMALYZING THIS BUDGET, THERE ARE SOME HHO DO NOT AGREE.

00315

ISLANDS ELAIM GETS A RUSSIAN NOD OF APPROYAL

JAPAN TIMES (WEEKLY INTERNATIONAL EDITION), 32(8) (FEB 92),

ACCORDING TO JAPAN'S DEPUTY FOREIGN MINISTER KUNIHIKO SAITO, RUSSIA HAS INDICATED "TACIT SUPPORT" FOR JAPAN'S CLAIM TO FOUR ISLANDS OFF HOKKAIDO, HICH WERE HELD BY THE PRESUMABLY ARE NOW PART OF RUSSIA.

00316

JAPAN IS DEEPLY INVOLYED

JAPAN TIMES (WEEKLY INTERNATIONAL EDITION), 32(12) (MAR 92), 10 .

THERE IS AN IMPORTANT SUBTEXT TO THE 1992 PRESIDENTIAL PRIMARY ELECTIONS IN THE UNITED STATES, AND IT IS JAPANESEAMERICAN RELATIONS. NEARLY ALL THE CANDIDATES OF BOTH PARTIES HAVE BEEN FREE IN THEIR CRITICISM OF WHAT THEY REGARD AS JAPANESE PROTECIIONISM. FOR MANY AMERICANS ECONOMIC RIVALRY HITH JAPAN IS NOW A KEY TEST OF NATIONAL VIRILITY AND CONFIDENCE. THIS NEW UNHAPPY CHAPTER IN JAPAN'S TIES WITH ITS MOST IMPORTANT ALLY AND TRADING PARTNER HAS ITS ROOTS IN THE POSTHAR PERIOO.
00317

JAPAN TOUR BOOSTS RELATIONS

BEIJING REVIEH, 35(16) (APR 92), 7

IN APRIL 1992, CHINESE PREMIER JIANG ZEMING PAID AN OFFICIAL VISIT TO JAPAN. IN TALKS WITH JAPANESE LEADERS, HE BETHEEN THE COUNTRIES.

00318

JAPAN TRIES TO SHAKE OFF PERUVIAN LINK

ITIN AMERICAN WEEKLY REPORT, (20) (MAY 92) 6-7.

JAPAN IS TRYING HARD TO DISSOCIATE ITSELF FROM THE IMAGE CREATED BY ITS REFUSAL TO ADOPT A TOUGH STANCE AGAINST PERUVIAN PRESIOENT ALBERTO FUJIMORI. CONTACTS BETHEEN TOP JAPANESE AND PERUVIAN OFFICIALS ARE BEING CURTAILED WHILE JAPAN PURSUES A HIDER DIPLOMATIC INITIATIVE IN LATIN AMERICA. JAPAN IS CLOSELY COORDINATING ITS PERUVIAN POLICY WITH WASHINGTON, WHICH HAS ADOPTED A TWO-TRACK POLICY OF CONTINUING SOME COOPERATION, SUCH AS THE WAR ON DRUGS 00319

JAPAN UNHAPPY ABOUT CAMBODIA TALKS EXCLUSION JAPAN TIMES (WEEKLY INTERNATIONAL EDITION), 32(7) (FEB 92),

A FOREIGN MINISTRY SPOKESMAN STATED THAT JAPAN IS DISAPPOINTED BECAUSE IT IS BEING EXCLUDED FROM TALKS ON UNITED NATIONS' PEACEKEEPING OPERATIONS IN CAMBODIA. THE MINISTRY HAS PROTESTED THAT IT IS UNJUST THAT JAPAN IS EXPECTED TO SUPPLY MASSIVE FINANCIAL SUPPORT FOR THE CAMBODIAN PEACEKEEPING OPERATIONS BUT IS NOT ALLOWED TO PARTICIPATE IN THE CONSULTATIONS.

00320

JAPAN WANTS CSCE OBSERVER SEAT

JAPAN TIMES (WEEKLY INTERNATIONAL EDITION), 32(17) (APR 92) 3 .

PRIME MINISTER KIICHI MIYAZAWA WILL ASK FRANCE AND GERMANY TO SUPPORT JAPAN'S REQUEST FOR OBSERVER STATUS IN THE CONFERENCE ON SECURITY AND COOPERATION IN EUROPE (CSCE) WHEN HE VISITS EUROPE IN APRIL 1992. THE JAPANESE FOREIGN MINISTRY HOPES TO 8 E ALLOWED TO PARTICIPATE IN THE CSCE BY MINISTRY HOPES TO BE ALLOWED TO PARTICIPATE IN THE CSCE BY
JULY 1992, WHEN THE GROUP'S LEADERS WILL MEET IN HELSINKI.

00321

JAPAN HILL HAVE TO BENO: ZERO HOUR FOR GATT

JAPAN TIMES (WEEKLY INTERNATIONAL EDITION), 32(1) (JAN 92), 10.

IRADE DIPLOMACY IS A MERVE-RACKING BLEND OF TACTICAL STUBBORNAESS AND LAST-MINUTE COMPROMISES. THESE TACTICS HAVE PRODUCED AN AIR OF CRISIS AS THE FINAL PHASE OF THE URUGUAY ROUND OF GATT TALKS APPROACHES. THE ORGANIZERS OF THE URUGUAY ROUND HOPE TO ACHIEVE SWEEPING BREAKTHROUGHS IN THE INTERNATIONAL COMMERCE OF GOODS AND SERVICES THROUGH 30 SEPARATE AGREEMENTS. ALTHOUGH THERE IS CONTROVERSY APLENTY IN ALL THESE PROPOSALS, IT IS THE DEMANDS FOR MASSIVE REDUCTIONS IN FARM SUBSIDIES THAT HAVE DRAWN THE MOST LIGHTNING.

00322 JAPAN TIMES (HEEKLY INTERNATIONAL EDITION), 32 (8) (FEB 92), ACCORDING TO SINGAPORE'S PRIME MINISTER GOH CHOK TONG, THE JAPANESE INVASION OF ASIAN COUNTRIES IN HORLD WAR II WAS HELPFUL IN BUILDING A NATIONALIST SENTIMENT THAT SOON ENDED THE HESTERN PONERS AT THE START OF WWI JAPANESE CHALLENGED SPIRIT OF CONFIDENCE IN ASIANS, WHO HAD' BEEN MORALLY SUPPRESSED FOR DECADES UNDER BRITISH, FRENCH, AND DUTCH COLONIAL RULE. HITHIN 15 YEARS, THE ENTIRE EUROPEAN IMPERIAL PRESENCE WAS EFFECTIVELY REMOVED FROM ASIA.

00323

JAHARA WINS AGAIN

(3895) (MAY 92), 811.

ON MAY 11, 1992, SIR DAWDA JAWARA WILL BEGIN HIS FOURTH CONSECUTIVE TERM AS PRESIDENT OF GAMBIA. JAHARA. WHO HAS

HEADED THE GAMBIAN GOVERNMENT SINCE INDEPENDENCE, IS ALSO

LEADER OF THE PEOPLE'S PROGRESSIVE PARTY. HIS CLOSEST

OPPONENT IN THE APRIL PRESIDENTIAL ELECTION SHERIFF

MOUSTAPHA DIBBA OF THE NATIONAL CONVENTION PARTY, WON $22 \%$ OF THE VOTES.

0032

JIANG, MANDELA HAIL SOLIO RELATIONSHIP

BEI JING REVIEW, $35(42)$ (OCT 92), 11-12.

DURING A VISIT WITH ANC LEADER NELSON MANDELA, JIANG

ZEMIN DECLARED THAT THE CHINESE GOVERNMENT AND PEOPLE

SUPPORT THE STRUGGLE FOR EQUALITY, FREEDOM, AND DEMOCRACY IN SOUTH AFRICA. 
00325

JIANG: IMPROVE SINO-U.S. RELATIONS

BEI JING REVIEW, $35(49)$ (DEC 92), 9

ON NOVEMBER 30, 1992, JIANG ZEMIN, GENERAL SECRETARY OF THE CHINESE COMMUNIST PARTY CENTRAL COMMITTEE TOLD A

DELEGATION OF U.S. CONGRESSMEN THAT CHINA WANTS TO SEE "MORE MUTUAL TRUST AND LESS PROBLEMS, MORE COOPERATION AND NO CONFRONTATION" WITH THE UNITED STATES.

00326

JITTERS OVER MILITARY DISCONTENT IN BRAZIL

LATIN AMERICAN HEEKLY REPORT, (17) (MAY 92), 6-7

THE GOVERMMENT OF PRESIDENT FERMANDO COLLOR DE MELLO IS

WORRIED ABOUT RISING DISCONTENT WITHIN THE MILITARY FORCES.

INCOME IS A MAJOR SOURCE OF UNREST, DUE TO THE DISPARITY

BETWEEN WAGES FOR THE MILITARY AND OTHER GOVERNMENT

EMPLOYEES AS WELL AS THE GROWING GAP BETWEEN MILITARY PAY

AND PRICES FOR CONSUMER GOODS.

00327

JOURNEYING TOWARDS DEMOCRACY

WEST AFRICA, (3895) (MAY 92), 787

THE AUTHOR PROFILES ALPHA OUMAR KONARE, MALI'S NEWLY-

ELECTED PRESIDENT. ALTHOUGH HE IS A RELATIVELY YOUNG LEADER,

KONARE HAS BEEN ACTIVELY INVOLVED IN PUBLIC LIFE SINCE 1978, WHEN HE JOINED THE MOUSSA TRAORE REGIME AS MINISTER OF YOUTH,
SPORTS, AND CULTURE.

00328

JUDGE ORDERS ARREST OF TOP M-19 LEADERS

ATIN AMERICAN WEEKLY REPORT, (21) (JUN 92), 3

PRESIDENT CESAR GAYIRIA'S' PACIFICATIOM PLAN FOR THE

MOVIMIENTO 19 DE ABRIL (M-19) HAS SUFFERED A SETBACK BECAUSE

M-19 LEADERS, WHO THOUGHT THEY WERE IMMUNE FROM PROSECUTION

UNDER THE 1990 LAN OF AMNESTY AND PARDON. HAVE BEEN INDICTED

FOR TERRORISM AND ARSON. MEANWHILE, SOME UNIONS, OPPOSITION

POLITICAL PARTIES, AND THE CONGRESS ARE SEEKING TO START

PEACE TALKS WITH THE COORDINADORA NACIONAL GUERRILLERA SIMON BOLIVAR.

00329

KEEPING AN UMEASY PEACE

HEST AFRICA, (3911) (AUG 92), 1470-1471.

AUGUST 24, 1992, MARKED THE SECOND ANNIVERSARY OF THE

LANDING OF THE ECOHAS PEACE-KEEPING FORCE IN LIBERIA. PLANS

CALLED FOR THE WITHDRAWAL OF THE TROOPS AFTER ONE YEAR, BUT

THE LACK OF PROGRESS ON A POL ITICAL SOLUTION HAS DICTATED

THAT THEY STAY INDEFINITELY. THE PEACE PLAN OBJECTIVES HAVE

BEEN ONLY PARTIALLY ACHIEYED LARGELY DUE TO THE

INTRANSIGENCE OF THE REBEL LEADER, CHARLES TAYLOR.

00330

KENYA--A SHAP ELECTION?

MEW AFRICAN, (282) (MAR 91) 17-18

RUMORS ARE GROWIMG IN KENYA THAT THE GOVERNMENT MAY BE PREPARING FOR A SHAP ELECTION, POSSIBLY IN JUNE 1990. SOME POLITICIANS HAVE ALREADY BEEN CAUTIONED FROM STARTING PREMATURE CAMPAIGNS. ALTHOUGH THE ELECTIONS ARE NOT DUE UNTIL 1993, PRESIDENT MOI MAY CALL FOR AN ELECTION AT ANY TIME: SOME OBSERVERS INDICATE THAT THE COMPARATIVE TRANQUILITY OF THE COUNTRY IS A PRIME REASON FOR MOI'S POTENTIAL DECISION.

00331

KEY OFFICIALS IN CZECHOSLOVAKIA

RFE/RL RESEARCH REPORT, 1(13) (MAR 92), 69

THE NAMES AND TITLES OF CZECHOSLOVAKIA'S KEY OFFICIALS

AS OF MARCH 1992 ARE LISTED. THE PRESIDENT, THE CHANCELLERY

OFFICERS, THE COMAAMDANT OF THE MILITARY OFFICE, THE FEDERAL

ASSEMBLY LEADERS, THE PRIME MINISTER, THE DEPUTY PRIME

MINISTERS, AND THE CABINET MINISTERS ARE INCLUDED.

00332

KEY OFFICIALS IN THE RUSSIAN FEDERATION: EX

THIS ARTICLE LISTS THE KEY OFFICIALS IN THE RUSSIAM

FEDERATION AS OF APRIL 3, 1992, INCLUDING THE PRESIDENT, THE

VICE PRESIDENT, THE STATE SECRETARY, THE STATE COUNSELORS,

AND THE ADVISERS TO THE PRESIDENT. 00333

KEY OFFICIALS IN THE RUSSIAM FEDERATION: EXECUTIVE BRANCH RFE/RL RESEARCH REPORT 1 (29) (JUL 92) 68-72

THIS ARTICLE LISTS THE TOP EXECUTIVE BRANCH OFFICIALS GF THE RUSSIAN FEDERATION AS OF JUIY 1992 INCLUDING THE THE RUSSIAN FEDERATION AS OF JULY 1992, INCLUDING THE PRESIDENTIAL COUNSELORS, THE SECURITY COUNCIL MEMBERS, PRESIDENTIAL CONSULTATIVE COUNCIL, AND THE CHAIRMEN OF
COMMISSIONS AND COMMITTEES ATTACHED TO THE PRESIDENT'S OFFICE.

0033

KEY OFFICIALS IN THE RUSSIAN FEDERATION: LEGISLATIVE BRANCH RFE/RL RESEARCH REPORT, 1 (15) (APR 92), 52-55.

THIS ARTICLE LISTS THE KEY OFFICIALS IN THE LEGISLATIVE
BRANCH OF THE RUSSIAN FEDERATION GOVERMMENT, INCLUDING THE OFFICERS OF THE FEDERATION'S SUPREME SOVIET AND THE LEADERS OF THE COUNCIL OF THE REPUBLIC.

00335

KEY OFFICIALS IN THE RUSSIAN FEDERATION: LEGISLATIVE BRANCH RFE/RL RESEARCH REPORT, 1(30) (JUL 92), 69-71.

THIS ARTICLE LISTS TOP-RANKING OFFICIALS IN THE RUSSIAN

FEDERATION SUPREME SOVIET, THE COUNCIL OF THE REPUBLIC, THE

COUNCIL OF NATIONALITIES, THE COMMITTEES OF THE RUSSIAN

FEDERATION SUPREME SOVIET, THE COMMISSIONS OF THE PRESIDIUM

OF THE RUSSIAN FEDERATION SUPREME SOVIET, AND THE APPARATUS

OF THE PRESIDIUM OF THE RUSSIAN FEDERATION SUPREME SOVIET.

00336

KOMEITO AT LOGGERHEADS WITH DSP

JAPAN TIMES (WEEKLY INTERNATIONAL EDITION), 32(18) (MAY

) 4 .

THE SECRETARY GENERAL OF KOMEITO, JAPAN'S SECOND-LARGEST

OPPOSITION PARTY, HAS CRITICIZED A DEMOCRATIC SOCIALIST

PARTY PROPOSAL TO PLACE JAPANESE PEACEKEEPING FORCES UNDER

UNITED NATIONS COMMAND. AT THE SAME TIME, HE SHOWED A

PEACEKEEPING FORCES NOT BE DISPATCHED WITHOUT PRIOR APPROVAL BY THE DIET.

00337

KOREA'S ELECTION UPSET: DLP LOSES MAJORITY

JAPAN TIMES (WEEKLY INTERNATIONAL EDITION), 32(14) (APR 92), 10 .

IN SOUTH KOREA'S MARCH 24, 1992, NATIONAL ASSEMBLY ELECTION, PRESIDENT ROH TAE WOO'S GOVERNING PARTY LOST ITS MAJORITY IN THE ASSEMBLY. THE ELECTION RESULTS HAVE THROWN THE COUNTRY INTO A PERIOD OF DOMESTIC POLITICAL FLUIDITY, BUT NO MAJOR CHANGE IS EXPECTED IN ITS RELATIONS WITH CLOSE ALLIES, SUCH AS JAPAN AND THE UNITED STATES.

00338

LAME-DUCK PLAN AIMED AT VOTERS

LATIN AMERICAN WEEKLY REPORT, (1) (JAN 92), 10-11.

THE GOVERNMENT OF PRESIDENT RODRIGO BORJA HAS SUBMITTED A LETTER OF INTENT TO THE INTERNATIONAL MONETARY FUND THAT PROPOSES AN INCREASE IN PUBLIC SPENDING AND GREATER AVAILABILITY OF CREDIT TO THE PRIVATE SECTOR. THE LETTER ALSO SETS AMBITIOUS TARGETS FOR DRAMATICALLY REDUCING INFLATION. MOST OF THE PROPOSALS ARE CLEARLY DESIGNED TO IMPRESS THE ELECTORATE, AND INDEPENDENT ANALYSTS ARE OPENLY VOICING DOUBTS ABOUT THE GOVERMMENT'S ABILITY TO ACHIEVE ITS GOALS.

00339

LAST-MINUTE FLURRY OF LEGISLATION

LATIN AMERICAN WEEKLY REPORT, (26) (JUL 92), 4

IN JUNE 1992 COLOMBIA'S CONGRESS EMBARKED ON A FLURRY

OF LAWMAKING ACTIVITY, APPROVING A TAX REFORM BILL,

APPROVING A BILL TO BLOCK THE INITIATION OF COURT

PROCEEDINGS AGAINST FORMER GUERRILLAS WHO HAD BEEN GRANTED

PARDON OR AMNESTY AT THE TIME THEIR ORGANIZATIONS AGREED TO

DISARM. AND REJECTING THE 1988 VIENNA CONVENTION ON INTERNATIONAL COOPERATION IN FIGHTING ORUG TRAFFICKING.

00340

LAW INTRODUCES DIRECT, SECRET VOTE

TIN AMERICAN WEEKLY REPORT, (44) (NOV 92), 8

CUBA'S NATIONAL ASSEMBLY HAS PASSED A NEW ELECTORAL LAW, WHICH INTRODUCES THE DIRECT ELECTION BY SECRET BALLOT OF REPRESENTATIVES TO THE MUNICIPAL, PROVINCIAL, AND NATIONAL ASSEMBLIES. HOWEVER, THIS IS NOT EXPECTED TO PRECIPITATE MAJOR CHANGES SINCE DISSENT IS DISCOURAGED AND CANDIDATES MUST BE APPROVED BY VARIOUS OFFICIAL ELECTION COMMISSIONS.

00341

LDP UNVEILS REFORM PLAN: HOW CLOSE IS REAL REFORM? 92) 10

(WEEKLY INTERNATIONAL EDITION), 32(13) (MAR DO NOT HAVE A SENSE OF CRISIS ABOUT THE PARTY'S RECENT DEFEATS IN THE BY-ELECTIONS. IF THEY WERE TRULY WORRIED THAT THE LDP BY-ELECTION LOSSES PORTEND THEIR OWN DEFEAT, THEY WOULD BE MORE SERIOUS ABOUT POLITICAL REFORMS. BUT THEY APPARENTLY DO NOT RECOGNIZE THE URGENT NEED TO MEET THE PUBLIC DEMANDS FOR REFORMS TO ELIMINATE THE ROLE OF MONEY IN POL ITICS, TO STRENGTHEM POI ITICAL ETHICS, AND TO RECTIFY THE OUTRAGEOUS DISPARITY IN REPRESENTATION AMONG LOHER HOUSE CONSTITUENCIES.

00342

LEADERSHIP BATTLE LOOMING IN FSLN?

LATIN AMERICAN HEEKLY REPORT, (35) (SEP 92), 10

BECAUSE PRESIDENT VIOLETA CHAMORRO IS BEGINNING TO BOH

TO U.S. PRESSURE ON SUCH MATTERS AS THE SANOINISTA CONTROL

OF THE POLICE, DANIEL ORTEGA HAS BEEN TALKING ABOUT

CONVENING AN EXTRAORDINARY CONGRESS OF THE FRENTE SANDINISTA

DE LIBERACION NACIONAL. HIS AGENDA HOULD BE TO ANALYZE THE 
CURRENT SITUATION AND PROMOTE GREATER COHESION AMONG SANDINISTA MILITANTS. THE INITIATIVE HAS BEEN WELCOMED BY SOME PARTY STALWARTS, BUT WHAT THEY HAVE IN MIND IS UNLIKELY TO PROMOTE COHESION BECAUSE THEY WANT TO ELECT NEW LEADERSHIP

00343 LEFT TAKES

LATIN AMERICAN WEEKLY REPORT, (49) (DEC 92 ), 1 ABSENTEEISM AMONG VOTERS WAS HIGH IN VENEZUELLA'S DECEMBER 1992 LOCAL GOVERNMENT ELECTIONS, DESPITE PREDICTIONS OF A LARGE TURNOUT. THE RULING ACCIOH DEMOCRATICA (A.D.) LOST SEYERAL KEY RACES, WHILE COPEI, THE SECOND-LARGEST PARTY, CLAIMED TO HAVE INCREASED ITS CONTROL OF STATE GOVERNORSHIPS FROM SIX TO 12 AND TO HAVE WON ROUGHLY 100 OF THE 282 MAYORALTIES.

00344

LEFT-WING ALLIANCE HAS FALLEN APART

LATIN AMERICAN WEEKLY REPORT, (20) (MAY 92), 11

CONVERGENCIA DEMOCRATICA. THE ALLIANCE OF LEFT-OF-CENTER PARTIES CREATED IN 1987 HAS FALLEN APART CONFLICTING AMBITIONS AMONG THE LEADERS OF THE MEMBER PARTIES-MOVIMIENTO NACIONALISTA REVOLUCIONARIO, MOVIMIENTO POPULAR SOCIAL CRISTIANO, AND PARTIOO SOCIAL DEMOCRATA--ARE APPARENTLY THE CAUSE OF THE BREAKUP.

00345

LI'S EUROPEAN TRIP 'SIGNIFICANT'

BEI JING REYIEW, 35(7) (FEB 92) 10-11.

CHINESE PREMIER LI PENG PAID OFFICIAL VISITS TO ITALY,

SWITZERLAND, SPAIN, AND PORTUGAL DURING JANUARY AND FEBRUARY

1992. THE PURPOSE OF HIS TRIP WAS TO IMPROVE BILATERAL

RELATIONS AND REAFFIRM CHINA'S COMMITMENT TO ECONOMIC AND

POLITICAL REFORH AND OPENING TO THE OUTSIDE WORLD.

00346

LI'S VIETNAM TOUR: CLOUD WITH A SILVER LINING

BEIJING REVIEW, 35(50) (DEC 92), 7.

IN LATE 1992, CHINESE PREMIER LI PENG PAID AN OFFICIAL

VISIT TO VIETNAH, WHERE HE MET WITH PRIME MINISTER VO VAN

KIET AND OTHER LEADERS. BOTH SIDES AGREED TO EXERCISE

RESTRAINT AND TO SEEK A PEACEFUL RESOLUTION TO THEIR

TERRITORIAL DISPUTES.

00347

LIBERIA: NPFL OBSTRUCTS ECOMOG

WEST AFRICA, (3898) (JUN 92) 931

CONTRARY' TO EARLIER REPORTS OF THE SMOOTH DEPLOYMENT OF ECOMOG PEACEKEEPING TROOPS IN REBEL NPFL AREAS, THE NPFL HAS IN FACT BEEN OBSTRUCTING ECOMOG'S EFFORTS TO STABILIZE THE SITUATION IN LIBERIA. NEARLY THREE NEEKS INTO THE DEPLOYMENT, ECOMOG HAS BEEN ABLE TO DISPATCH ADVANCED CONTINGENTS INTO
RURAL AREAS WITH SOME SUCCESS ONLY ON THE BUFFER BETWEEN RURAL AREAS WITH SOME SUCCE

0034

LIBERIA: TAYLOR FORMS PARTY

WEST AFRICA, (3877) (JAN 92), 40

REBEL LEADER CHARLES TAYLOR HAS REPORTEDLY FORMED A

POLITICAL PARTY CALLED "THE NATIONAL PATRIOTIC FRONT." HE

HAS ALSO DENIED ALLEGIATIONS THAT HE DELIBERATELY REFUSED TO

ENCAMP AND DISARM HIS TROOPS IN ORDER TO TORPEDO THE PEACE

PROCESS SET IN MOTION AT YAMOUSSOUKRO.

00349

LIBERIA: TAYLOR OFFERED VICE PRESIDENCY

ST AFRICA, (3883) (FEB 92), 296.

IN A MESSAGE TO THE LIBERIAN PEOPLE, INTERIM PRESIDENT AMOS SAWYER OFFERED TO GIVE CHARLES TAYLOR, THE LEADER OF THE NATIONAL PATRIOTIC FRONT OF LIBERIA (NPFL), THE POST OF AND PNCAHPS AGREEMENT. SAWYER ALSO OFFERED KEY CABINET POSITIONS AND SEATS IN THE LEGISLATIVE ASSEMBLY TO THE NPFL.

00350

LIBERIA: TROOPS RETURN TO BASE

HEST AFRICA, (3901) (JUN 92) 1064

HITHDRAWH FROM THE LOFA REGION AND RETURNED TO MONROVIA

FOLLOWING CLASHES THAT KILLED SIX SENEGALESE SOLDIERS.

MEANWHILE, REBEL LEADER CHARLES TAYLOR HAS DECLARED THAT HE

WILL EVENTUALLY BECOME PRESIDENT OF LIBERIA AND THAT COUPS

IN GHANA AND NIGERIA WILL CAUSE BOTH THOSE COUNTRIES TO

WITHORAW FROM THE ECOMOG PEACEKEEPING FORCE.

00351

LIFE FOR GUZMAN AS TRIAL BEATS DEADLINE

LATIN AMERICAN WEEKLY REPORT, (41) (OCT 92), 11.

THE TRIALS OF ABIMAEL GUZMAN AND OTHER SÉNDERO LUMINOSO

LEADERS ARE PROCEEDING SPEEDILY THROUGH THE COURTS, MUCH TO

THE DELIGHT OF MOST PERUVIANS. ON OCTOBER 8, 1992, PRESIDENT
ALBERTO FUJIMORI ANNOUNCED THAT TWO ADDITIONAL GUERRILLA LEADERS, OSMAN MOROTE AND VICTOR POLAY, MAY FACE LIFE

TE, THE SENDERO LUMINOSO HAS BEEN

STEADILY ESCALATING ITS STRATEGY OF SELECTIVE ASSASSINATIONS.

00352

LIMA'S POPULATION REFUSES TO BOW TO THREATS OF SENDERO REPRISALS

LATIN AMERICAN WEEKLY REPORT, (8) (FEB 92), 1.

THE GUERRILLAS OF THE MAOIST SENDERO LUMINOSO ORDERED A

"PARO ARMADO" (STRIKE UNDER THREAT OF ARMED REPRISALS) FOR

FEBRUARY 14, 1992, IN LIMA. DESPITE SOME VIOLENCE, MOST OF

LIMA'S POPULATION DISREGAROED THE SENDERO'S THREATS AYD WENT

ABOUT THEIR DAILY ROUTINES WITHOUT TOO MUCH INCONVENIENCE.

00353

LOOK TO ASIA, SIMGAPORE URGES

JAPAN TIMES (WEEKLY INTERNATIONAL EDITION), 32(16) (APR

92), 3

GEDRGE YEO, A SINGAPOREAN CABINET MINISTER, HAS CALLED

ON JAPAN AND THE REST OF ASIA TO STRIVE TO UNDERSTAND EACH OTHER BETTER. HE HAS URGED THE TWO SIDES TO STRENGTHEN THEIR TIES AND CALLED ON JAPAN TO "RE-ASIANIZE" POL ITICALLY, ECONOMICALLY, AND CULTURALLY AFTER DECADES OF LOOKING TO THE WEST FOR A MODEL.

00354

LOOSE CANNOM

REASON, 24(7) (DEC 92 ), 56-57

HUNGARY'S FASCIST RESURGENCE, WHICH IS UNFOLDING MOSTLY

IN LOCAL PAPERS AND PARLIAMENTARY DEBATE, HAS ATTRACTED

LITTLE INTERNATIONAL ATTENTION. THE MOVEMENT IS BEING LED BY

ISTVAN CSURKA, A FOUNDER AND VICE PRESIDENT OF THE HUNGARIAN DEMOCRATIC FORUM.

00355

LOOTINGS HEIGHTEN CALLS FOR CHANGE

LATIN AMERICAN WEEKLY REPORT, (19) (MAY 92), 4.

THE ROMAN CATHOLIC BISHOPS' CONFERENCE, THE LABOR UNIOMS,

AND THE LEFTIST PARTIES ARE BLAMING BRAZIL'S FEDERAL

GOVERNMENT FOR "INTOLERABLE" LEVELS OF UNEMPLOYMENT AND

POGES THAT ARE WOEFULLY INADEQUATE. STATE GOVERNORS AND

POLITICIANS ARE COMPLAINING THAT THE FEDERAL GOVERNMENT IS

NOT MAKING THE PUBLIC INVESTMENTS THAT COULD ALLEVIATE THE

SITUATION. EVEN SOME MEMBERS OF THE GOVERNMENT'S ECONOMIC

TEAM ARE PRIVATELY SUGGESTING THAT
HAVE LOST FAITH IN ITS POLICIES.

00356

LOW TURMOUT FOR REFERENDUM

WEST AFRICA, (3895) (MAY 92), 809

GHANA REPORTS A $43.7 \%$ TURNOUT IN ITS APRIL 28, 1992,

REFERENDUM THAT OVERHHELMINGLY RATIFIED THE DRAF

CONSTITUTION AND THE LIFTING OF THE BAN ON PARTY POLITICS.

DURING THE CAMPAIGN PRECEDING THE REFEREMDUM, ALL MAJOR

POLITICAL GROUPS, THE RULING PNDC, RELIGIOUS LEADERS, AND

OPPOSITION LEADERS URGED THE PEOPLE TO VOTE "YES" BUT FOR VERY DIFFERENT REASONS.

00357

LOWER SERVICE BILLS FOR MOST IN 1992

LATIN AMERICAN WEEKLY REPORT, (4) (JAN 92), 8-9.

EXTERNAL DEBTS HAVE BEEN RISING IN LATIN AMERICA. BUT

THAT IS ONLY PART OF THE PICTURE; ON THE PLUS SIDE, MOST

COUNTRIES IN THE REGION WILL FACE LOWER PAYMENTS ON THEIR

EXTERNAL DEBTS IN 1992, ACCORDING TO A WORLD BANK REPORT.

00358

MAJOR SUCCESSES IN COUNTER-INSURGENCY

LATIN AMERICAN WEEKLY REPORT, (24) (JUN 92) 2-3.

PERU'S INTERNAL WAR REACHED A NEW PEAK OF INTENSITY IN

MAY 1992. IN EARLY JUNE 1992, THE GOVERNMENT OF PRESIDENT ALBERTO FUJIMORI CLAIMED TWO MAJOR SUCCESSES IN ITS COUNTERINSURGENCY EFFORTS: THE CAPTURE OF THE LEADER OF THE MOVIMIENTO REVOLUCIONARIO TUPAC AMARU AND THE DISMANTLING OF

SENDERO LUMINOSO BASE CAMPS IN THE UPPER HUALLAGA VALLEY. 00359

MAKING THE BEST OF IT

THE MIDDLE EAST, (195) (JAN 91), 25-28,

THIS ARTICLE EXAMINES THE ECONOMIC FUTURE OF THE PERSIAM

GULF REGION. IT CONCLUDES THAT AS LONG AS OIL REVENUES

CONTINUE TO FLOW, BUSINESS WILL CONTINUE TO BE GENERATED

THROUGHOUT THE GULF. THE GENERAL CONSENSUS IN THE EUROPEAN

COMHUNITY IS THAT THERE REMAIN CONSIDERABLE OPPORTUNITIES

FOR THE EUROPEAN COMPANIES, ESPECIALLY IN THE GULF

COOPERATION COUNCIL STATES AND DEVELOPING NATIONS SUCH AS

YEMEN. IRAO, ON THE OTHER HAND, FACES A DIRE POST-CRISIS YEMEN.

00360

MAKING THE OAU WORK

WEST AFRICA, (3912) (SEP 92), 1513.

THE AUTHOR LOOKS AT THE ROLE OF THE ORGANIZATION FOR 
AFRICAN UNITY (OAU) IN SOLVING PROBLEMS LIKE THE CRISES IN SOMALIA AMD LIBERIA.

00361

MALI: PEACE ACCORD

WEST AFRICA, (3890) (APR 92), 601.

a "NATIONAL PACT" HAS BEEN SIGNED BY THE MALIAN

GOVERNMENT AND TUAREG REPRESENTATIVES WITH THE GOAL OF

FINALLY ENDING THE CONFLICT IN MALI'S NDRTHERN PROVINCES. A

TRUCE HAS BEEN IN EFFECT SIMCE FEBRUARY 8, 1992, BUT EACH

SIDE HAS ACCUSEO THE OTHER OF VIOLATIONS. A FULL PEACE

ACCORD WILL BE SIGNED ON APRIL 9, 1992.

00362

MaNAGING CHANGE IN a dIFFICULT ERA: GLOBAL PARTNERSHIP ADVOCATED

JAPAN

THE FIRST SUMMIT MEETING BETWEEN PRIME MINISTER KIICHI

MIYAZAWA AND PRESIDENT GEORGE BUSH PRODUCED AGREEMENTS THAT

OBLIGE JAPAN AND THE UNITED STATES TO COORDINATE EFFORTS TO

SOLVE THEIR BILATERAL AND MULTILATERAL PROBLEMS. IN THE

EMERGING NEW WORLD ORDER. ECONOMIC ISSUES WILL PROBABLY

DOMINATE FUTURE RELATIONS BETHEEN THE TWO COUNTRIES,

ESPECIALLY IN U.S. ELECTION YEARS. AS LONG AS JAPAN' RETAINS

AN ECONOMIC ADVANTAGE, IT WILL BE FORCED TO MAKE CONCESSIONS TO HELP PREVENT U.S. DOMESTIC ECONOMIC DIFFICULTIES FROM IMPEDING AMERICA'S ABILITY TO PLAY THE LEADERSHIP ROLE EXPECTED OF IT IN THE GLOBAL COMMUNITY. THE HAGGLING OVER $U$. S. DEMANDS FOR MORE ACCESS TO THE JAPANESE MARKET DURING BUSH'S JANUARY 1992 VISIT PROBABLY SET A PRECEDENT FOR FUTURE U.S.-JAPANESE SUMMITS.

00363

MARC BAZIN SHORN IN AS NEH PREMIER

LATIN AMERICAN HEEKLY REPORT, (25) (JUL 92), 3

ON JUNE 16, 1992, MARC BAZIN WAS SWORN IN AS HAITI'S NEN PRIME MINISTER. THE VATICAN WAS THE ONLY STATE TO RECOGNIZE THE NEH GOVERMMENT.

00364

MARKETS ARE NOT REASSURED BY COLLOR

LATIN AMERICAN WEEKLY REPORT, (30) (AUG 92), 9.

ANALYSTS ARE NO LONGER SURE THAT PRESIDENT FERNANDO

COLLOR DE MELLO HAS ENOUGH SUPPORT IN CONGRESS TO BLOCK THE

VOTE FOR HIS IMPEACHMENT. RUMORS ARE FLYING ABOUT A SPLIT IN

THE RANKS OF THE PARTIDO DA FRENTE LIBERAL, A BLOC OF VOTES

THE RANKS OF THE PARTIDO DA FRENTE LIBERAL,
NEEDED BY COLLOR TO STAVE OFF IMPEACHMENT.

00365

MASS HARDSHIP

WEST AFRICA, (3890) (APR 92), 595

THE NIGERIAN GOVERNMENT HAS AMMOUNCED RELIEF MEASURES TO EASE THE ECONOMIC HARDSHIPS CAUSED BY THE DEREGULATION OF THE FOREIGN EXCHANGE MARKET. DUTIES ON ESSENTIAL ITEMS IN WILL BE SUBSTANTIALLY REDUCED OR ELIMINATED ALTOGETHER.

00366

MEASURE TO PROTECT WILDLIFE TO ENTER PIPELINE JAPAN TIMES (WEEKLY INTERNATIONAL EDITION), 32(15) (APR 92), 14 .

PRIME MINISTER KIICHI MIYAZAHA'S GOVERMMENT HAS DECIDED TO INTRODUCE A BILL THAT WOULD PROTECT ENDANGERED ANIMAL AND PLANT SPECIES. IF APPROVED BY THE DIET, IT WOULD BECOME JAPAN'S FIRST LAW THAT FORHULATES A SYSTEM TO PROTECT INSECTS, FRESHWATER FISH, FROGS, AND TOADS AS WELL AS FLOWERING PLANTS.

00367

MENEM CHANGES TUNE ON CORRUPTION

LATIN AMERICAN WEEKLY REPORT, (4) (JAN 92), 11.

PRESIDENT CARLOS MENEM HAS BACKTRACKED ON THE QUESTION

OF THE CORRUPTION CHARGES LEVELLED AGAINST HIS GOVERNMENT.

HE HAS ADMITTED THAT AN INVESTIGATION IS PROPER AND HAS

ORDERED THE ATTORNEY GENERAL TO SPEED UP ALL CORRUPTION

CASES AGAINST OFFICIALS AND FORMER OFFICIALS OF HIS

GOVERMMENT.

00368

MENEM GOVERMMENT LAPSES INTO HUNT FOR "SMEAR CAMPAIGN" CONSPIRATORS

LATIN AMERICAN WEEKLY REPORT, (3) (JAN 92), 1

PRESIDENT CARLOS MENEM CLAIMS THAT THERE IS A CONSPIRACY AFOOT INSPIRED BY THE OPPOA AFOOT, INSPIRED BY THE OPPOSITION UNION CIVICA RADICAL AND AIMED AT DISCREDITING HIS GOVERNMENT BY ALLEGING CORRUPTION AMONG HIS CLOSE ADVISORS. HITH AT LEAST THREE TOP OFFICIALS FACING COURT ACTION ON CORRUPTION CHARGES, IT IS

00369

MENEM SLAMS LIES ABOUT POVERTY

LATIN AMERICAN HEEKLY REPORT, (36) (SEP 92), 3. PRESIDENT CARLOS MENEM HAS BRANDED A GOVERMMENT MINISTER,
A ROMAN CATHOLIC BISHOP, A U.S. DIPLOMAT, A TRADE UNION AEADER AMD A PROMINENT BANKER AS "LIARS" BECAUSE THEY HAVE AL PUBLICLY STATED THAT POVERTY HAS RISEN DRAMATICALLY IN ARGENTINA AND THAT SOCIAL INEQUALITIES HAVE INCREASED. MENEM HAS ALSO SUGGEST THAT THESE "LIES" ARE PART OF A CONSPIRACY BY THE OPPOSITION UNION CIVICA RADICAL.

00370

MERCOSUR TARGETS CALLED INTO QUESTION

LATIN AMERICAN WEEKLY REPORT, (20) (MAY 92), 3 .

THERE ARE MANY QUESTIONS CONCERNING THE READINESS OF THE SOUTHERN CONE COUNTRIES TO FORM A FREE-TRADE ASSOCIATION BY 1995.

00371

MIGUEL RODRIGUEZ IS FINALLY JETTISONED

LATIN AMERICAN WEEKLY REPORT, (15) (APR 92),

PRESIDENT CARLOS ANDRES PEREZ HAS GIVEN IN TO PRESSURE

FROM HIS OWN PARTY THE ACCION DEMOCRATICA, AMD JETTISOMED

MIGUEL ROORIGUEZ THE MAN HIDELY HELD RESPONSIBLE FOR THE

MIGUEL RODRIGUEZ, THE MAN HIDELY HELD RESPONSIBLE FOR THE

ECONOMIC ADJUSTMENT PROGRAM. REPLACING ROORIGUEZ

ANAA KRIVOY, A MEMBER OF THE SPECIAL PRESIDENTIAL

CONSULTATIVE COUNCIL FORMED TO ADVISE PEREZ OM

00372

MILITARY CHALLENGE TO FUJIMORI?

LATIN AMERICAN WEEKLY REPORT, (30) (AUG 92), 2-3.

ACCORDIMG TO A NEWSPAPER REPORT, PERUVIAN MILITARY

LEADERS HAVE DECIDED TO OITCH PRESIDENT ALBERTO FUJIMORI,

WHO ASSUMED DICTATORIAL POWERS ON APRIL 5, 1992, WITH THEIR

BACKING. THE REPORT STATED THAT THE TOP BRASS MAY DEMAND

FUSIMORI'S RESIGNATION AND INSTALL VICE-PRESIDENT MAXIMO SAN

ROMAN IN HIS PLACE, AS A FIRST STEP TOWARDS RESTORING

CONSTITUTIONAL RULE.

00373

MTERS OPT FOR GOVERNABILITY PACT

LATIN AMERICAN WEEKLY REPORT, (35) (SEP 92), 2-3."

MINISTERS, POLITICIANS, BUSINESSMEN, AND STATE GOVERNORS

HAVE BEEN FORMING GOVERNABILITY GROUPS IN ORDER TO

"ITALIANIZE" THE CRISIS, ENABLING THE GOVERMMENT TO GO ON

FUNCTIONING REGARDLESS OF PRESIDENT FERNANDO COLLOR DE

MELLO'S FATE. ECONOMY MINISTER MARCILIO MAROUES MOREIRA HAS

BECOME THE YIRTUAL PRIME MINISTER BECAUSE HE HAS BEEM

ENDORSED AS THE SYMBOL OF COMTINUITY BY BOTH POL ITICIAMS AMD

BRAZIL'S CREDITOR BANKS.

00374

MISGIVINGS OVER MOGADISHU

WEST AFRICA, (3926) (DEC 92), 2134-2135.

THE US UN INTERVENTION IN' SOMALIA BREAKS GROUND IN TWO

SENSES: IT IS THE FIRST TIME THE UMITED MATIONS HAS EVER

APPROYED A MIL ITARY OPERATION FOR PURELY HUMANITARIAM

PURPOSES, AND THE MILITARY OPERATION REPRESENTS THE FIRST

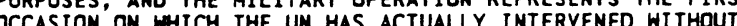
HAVING BEEN INVITED.

00375

MISSION LEAVES TO PREPARE RESUMPTION OF AIO TO VIETHAM

JAPAN TIMES (WEEKLY INTERNATIOMAL EDITION), 32(3) (JAN 92), 3.

ON JANUARY 11, 1992, A JAPANESE GOVERMMENTAL DELEGATION WENT TO VIETHAM TO DISCUSS RESUMING ECDNOMIC ASSISTANCE,

WHICH WAS SUSPENDED IN 1979. BEFORE THE JAPANESE HILL MAK

MEH LOANS TO VIETNAM. AGREEMENT MUST BE REACHED ON THE

REPAYMENT OF OLD VIETNAMESE DEBTS, WHICH HAVE SWELLED TO

HUNDREDS OF MILLIONS OF DOLLARS DUE TO OVERDUE INTEREST.

00376

MITTERAMD, AFRICA, AND THE CFA FRANC

ST AFRICA, (3916) (OCT 92), 1654

THE FRANCO-AFRICAN SUMMIT IN OCTOBER 1992 WILL

INEYITABLY SPOTLIGHT FRANCE'S UNUSUALLY HIGH ECONOMIC,

CULTURAL, AND MILITARY PROFILE ON THE AFRICAN CONTINENT. BUT THE SPOTLIGHT WILL BE SOMEWHAT DIMMED BECAUSE PRESIDENT MITTERAND HILL NOT ATTEND, DUE TO HEALTH PROBLEMS. THE QUESTION OF THE DEVALUATION OF THE CFA FRANC IS ONE ISSUE THAT IS CERTAIN TO SURFACE AT THE SUMAIT.

00377

MIXED BALANCE FOR DURAN'S 100 DAYS

LATIN AMERICAN WEEKLY REPORT, (47) (DEC 92), 8.

THE GOYERMMENT OF SIXTO DURAN BALLEN CLAIMS THAT, IN ITS

FIRST 100 DAYS, IT REDUCED INTEREST RATES, INCREASED

INTERMATIOMAL, RESERVES ALMOST FOURFOLD, AND REDUCED

INFLATION MORE RAPIDLY THAN FORECAST. MOREOVER, IT SURVIVED

A GENERAL STRIKE STAGED BY THE FEDERACION UNITARIA DE TRABAJADORES.

00378

MIXED BALANCE FOR RAFAEL CALDERON

LATIN AMERICAN WEEKLY REPORT, (19) (MAY 92), 9. 
THE GOVERMMENT OF PRESIDENT RAFAEL ANGEL CALDERON CELEBRATED ITS SECOND ANNIVERSARY IN OFFICE ON MAY 8, 1992. THE GOVERNMENT WAS ABLE TO CITE AN IMPRESSIVE LIST OF ECONOMIC ACHIEVEMENTS, INCLUDING REDUCING THE TRADE DEFICIT, INCREASING THE COUNTRY'S INTERNATIONAL RESERVES, AND REDUCING INFLATION. HOWEVER, ALL THE ECONOMIC NEWS WAS NOT GOOD AND CRITICS ARGUED THAT CALDERON HAS FAILED TO DELIVER ON HIS PROMISES REGARDING SOCIAL POLICY.

00379

MIYAZAWA ADDRESSES POLITICAL REFORM

JAPAN TIMES (WEEKLY INTERNATIONAL EDITION), 32(12) (MAR

$92), 1,5$.

ALARMED BY HIS SAGGING APPROVAL RATING, JAPANESE PRIME MINISTER KIICHI MIYAZAHA IS AT LAST POISED TO ADDRESS THE NEED FOR REFORM. THE PRESSURE FOR REFORM FORCED MIYAZAWA'S PREDECESSOR FROM OFFICE, BUT THIS TIME THE OPPOSITION IS PREDECESSOR FROM OFFICE, BUT THIS TIME THE OPPOSITION
STRANGELY QUIET. PERHAPS THIS IS BECAUSE THE LARGEST STRANGELY QUIET. PERHAPS THIS IS BECAUSE THE LARGEST TOO BUSY DEFENDING ITSELF AND ITS THO SENIOR MEMBERS WHO HAVE BEEN IMPLICATED IN CORRUPTION CASES.

00380

MIYAZAWA DEFINES POLICY GOALS

JAPAN TIMES (WEEKLY INTERNATIONAL EDITION), 32(5) (FEB 92), 1,6 .

IN HIS ADORESS TO THE OPENING SESSION OF THE OROINARY DIET SESSION ON JANUARY 24, 1992, PRIME MINISTER KIICHI MIYAZAHA EMPHASIZED THAT JAPAN SHOULD MAKE A GREATER CONTRIBUTION TO THE WORLD COMMUNITY AND THAT HE WANTS IT TO BECOME A "GREAT PLACE TO LIVE." MIYAZAWA'S WORDS SEEM TO FALL ON DEAF EARS AMONG OPPOSITION PARTY LEADERS AND MEMBERS OF HIS OWN PARTY WHOSE PRIMARY CONCERN IS POLITICAL

CORRUPTION AND ETHICS.

00381

MIYAZAWA MEETS JIANG; PRIME MINISTER RELUCTANT TO COMMIT EMPEROR TO BEIJING VISIT

JAPAN TIMES (WEEKLY INTERNATIONAL EDITION), 32(15) (APR

92 ) 1,6 .

CHINESE PREMIER JIANG ZEMIN PAID AN OFFICIAL VISIT TO

JAPAN IN APRIL 1992 AND MET HITH PRIME MINISTER KIICHI

MIYAZAWA. THE THO LEADERS DISCUSSED MATTERS OF MUTUAL

INTEREST. INCLUDING A PROPOSED VISIT BY JAPAN'S EMPEROR TO

CHINA, THE POSSIBILITY OF JAPAN'S SELF-DEFENSE FORCES

JOINING UNITED NATIONS PEACEKEEPING OPERATIONS,

00382

MIYAZAWA SAID TO FAVOR RICE TARIFFS

JAPAN TIMES (WEEKLY INTERNATIONAL EDITION), 32(5) (FEB 92),

JAPANESE PRIME MINISTER KIICHI MIYAZAHA HAS SAID THAT IT IS TOO EARLY TO MAKE A FINAL DECISION ON RICE TARIFFS BECAUSE OF ONGOING NEGOTIATIONS BETWEEN THE UNITED STATES AND THE EUROPEAN COMMUNITY, BUT GOVERNMENT SOURCES HAVE INDICATED THAT MIYAZAWA WILL ACCEPT A PROPOSAL TO SUBSTITUTE TARIFFS FOR JAPAN'S PRESENT VIRTUAL BAN ON RICE IMPORTS

00383

MIYAZAHA'S OFFICIAL VISIT TO SEOUL: A FUTURE-ORIENTED RELATIONSHIP

JAPAN TIMES (WEEKLY INTERNATIONAL EDITION), 32(4) (JAN 92),

10.

SINCE THE NORMALIZATION OF DIPLOMATIC RELATIONS BETWEEN JAPAN AND SOUTH KOREA IN 1965, THE TWO NATIONS HAVE BEEN STRUGGLING WITH THE DOUBLE BURDEN OF SETTLING PROBLEMS STEMMING FROM THE PAST AND NEWLY-EMERGING ISSUES. THESE PAST AND PRESENT PROBLEMS HAVE CONTIMUED TO DEFINE SUCCESS AND FAILURE IN ALL SUMMIT TALKS BETWEEN THE THO COUNTRIES. PRIME MINISTER MIYAZAWA'S JANUARY 1992 VISIT TO SEOUL WAS NO EXCEPTION TO THE RULE.

00384

MORE AUTONOYY GIVEN TO STATE ENTERPRISES

BEIJING REVIEH, 35(32) (AUG 92), 7

THE CHINESE GOVERMMENT HAS OUTLINED A PLAN TO FREE STATEOWNED INDUSTRIES FROM CENTRALIZED CONTROL BY PERMITTING THEM TO COMPETE MORE FREELY IN THE MARKET. THE DEFICIT-RIDDEN STATE ENTERPRISES WILL BE GIVEN MORE INDEPENDENCE AND STATE ENTERPRISES WILL BE GIVEN MORE INDEPENDENCE AND EDICTS FROM CENTRAL PLANHING AUTHORITIES, MANAGERS IN STATEOWNED COMPANIES WILL HAVE GREATER FREEDOM IN DETERMINING MEASURES ON IMPORTS AND EXPORTS, INVESTMENTS, AND EMPLOYMENT. THEY WILL ALSO HAVE THE RIGHT TO REJECT STATE-APPOINTED WORKERS, PRICING, AND MARKETING.

00385

MORE RUMOURS OF PLANNED COUPS

LATIN AMERICAN WEEKLY REPORT, (33) (AUG 92), 10.

RUMORS ARE CIRCULATING ABOUT AMOTHER COUP ATTEMPT

AGAINST THE GOVERMMENT OF CARLOS ANORES PEREZ, THIS TIME

INVOLVING UNNAMED CIVILIAN INTERESTS. GENERAL PEDRO REMIGI

RANGEL HAS STRONGLY DENIED ACCUSATIONS THAT THE MILITARY IS
INVOLVED IN COUP PLANS.

00386

MORE SII MEASURES IN THE WORKS

JAPAN TIMES (WEEKLY INTERNATIONAL EDITION), 32(10) (MAR

92), 18.

SENIOR TRADE OFFICIALS FROM TOKYO AND WASHIMGTON MET RECENTLY TO DISCUSS NEW PLANS TO REMOVE STRUCTURAL BARRIERS TO TRADE AND INVESTMENT STEMMING FROM THE STRUCTURA IMPEDIMENTS INITIATIVE. U.S. OFFICIALS SAID THE PROPOSALS HOULD REOUIRE TOKYO TO PASS NEW LEGISLATIVE MEASURES. THE TALKS ALSO FOLLOHED UP ON TRADE INITIATIVES LAUNCHED BY PRESIDENT GEORGE BUSH AND PRIME MINISTER XIICHI MIYAZAWA IN JANUARY 1992. INCLUDING MEASURES TO MODIFY JAPAN'S

DISTRIBUTION' SYSTEM AND ALLEGED EXCLUSIONARY BUSINESS

PRACTICES.

00387

MORE TO-ING AND FRO-ING FROM FUJIMORI

LATIN AMERICAN WEEKLY REPORT, (37) (SEP 92), 2.

PRESIDENT ALBERTO FUJIMORI HAS CONFUSED HIS ADVERSARIES WITH A SUCCESSION OF UNEXPECTED SHIFTS. HE HAS ANNOUNCED THAT CAMBIO 90 WILL NOT CONTEST THE UPCOMING CONSTITUENT
ASSEMBLY ELECTIONS BUT WILL SUPPORT A SLATE OF INDEPENDENT, ASSEMBLY ELECTIONS BUT WILL
PRO-GOVERMENT CANDIDATES

00388

MORE UNREST, PLUS UNEASE OVER MONEY

LATIN AMERICAN WEEKLY REPORT, (17) (MAY 92), 2-3.

THE SOCIAL AND POLITICAL SCENE IN VENEZUELA CONTINUES TO

BE UNSETTLED. PROTESTS AND RIOTS HAVE FLARED AGAIN; REPORTS

ARE CIRCULATING ABOUT VARIOUS CONSPIRACIES AGAINST PRESIDENT

PEREZ; THE OPPOSITION COPEI IS THREATENING TO HALT ITS

COLLABORATION WITH THE PEREZ ADMINISTRATION; AND THERE IS

00389

MOROCCO: FIFTY YEARS LATER

FREEDOM REVIEW, 23(3) (MAY 92), 24-28.

IN THIS INTERVIEW, ANDRE SOUSSAN, A NOVELIST AND THE

CONTEMPIRECTOR OF POLITIQUE INTERNATIONALE, DISCUSSES THE

00390

MOST JAPANESE BELIEVE PATRIOTISM SHOULD COME BEFORE PERSONAL GAIN

JAPAN TIMES (WEEKLY INTERNATIONAL EDITION), 32(16) (APR

92), 4 .

THREE-FOURTHS OF JAPANESE SAY THAT THERE IS A NEED TO BECOME MORE PATRIOTIC BECAUSE THE YOUNGER GENERATIONS ARE ABANDONING THEIR PARENTS' BELIEF THAT DUTY TO THE NATION SHOULD PRECEDE PERSONAL GAIN, ACCORDING TO A SURVEY CONDUCTED BY THE PRIME MINISTER'S OFFICE. THE POLL SHOWS THAT JAPANESE IN THEIR TWENTIES AND THIRTIES ARE LESS LIKELY TO WANT TO CONTRIBUTE TO SOCIETY OR TO REGARD THEMSELVES AS MORE PATRIOTIC THAN OTHERS. NEVERTHELESS, SIXTY PERCENT OF JAPANESE IN THEIR TWENTIES AGREED THAT IT IS IMPORTANT TO CULTIVATE A LOVE FOR THEIR COUNTRY.

00391

MR. GORBACHEY AND HIS LEGACY

JAPAN TIMES (WEEKLY INTERNATIONAL EDITION), 32(18) (MAY 92), 10.

THE AUTHOR ENDEAYORS TO EYALUATE MIKHAIL GORBACHEV'S LEGACY IN THE FORMER SOVIET UNION AND IN WORLD AFFAIRS. 00392

MR. JIANG SOLIDIFIES TIES

JAPAN TIMES (WEEKLY INTERNATIONAL EDITION), 32(16) (APR 2), 10.

CHINESE COMHUNIST PARTY GENERAL SECRETARY JIANG ZEMIM MARKED THE 2OTH ANHIVERSARY OF DIPLOMATIC RELATIONS BETHEEN JAPAN AND CHINA BY PAYING AN OFFICIAL VISIT TO TOKYO IN APRIL 1992. JIANG'S TALKS WITH JAPANESE LEADERS ILLUSTRATED BOTH THE SOL IDITY AND THE FRAGILITY OF BILATERAL RELATIONS BETWEEN THE THO ASIAN SUPERPOWERS.

00393

MUCH FREER, BUT DANGER IS LURKING

LATIN AMERICAN HEEKLY REPORT, (3) (JAN 92), 8-9.

LATIN AMERICA AND THE CARIBBEAN ARE MUCH FREER THAN THEY

WERE FIVE YEARS AGO, BUT IN 1991 POLIIICAL IMPROVEMENT WAS

OVERSHADOWED BY INSTANCES OF DETERIORATION. CITIZENS OF

HAITI AND ANTIGUA AND BARBUDA WERE AMONG THOSE WHO

EXPERIENCED LESS FREEDOM AND WORSENING HUMAN RIGHTS

CONDITIONS IN 1991 .

0039

MULTI-PARTY POLITICS: A RECIPE FOR DEMOCRACY?

PARLIAMENTARIAN, LXXIII (2) (APR 92), 107-109.

THE CURRENT RUSH TO MULTI-PARTY POLITIICS MAY BE SOCIALLY AND ECONOMICALLY JUSTIFIED, BUT IT IS IMPORTANT NOT TO CONFUSE PARTISAN POLITICAL COMPETITION WITH DEMOCRACY. ONEPARTY PARLIAMENTS HAVE BEEN AND CAN CONTINUE TO BE EXTREMELY 
EFFECTIVE DEMOCRATIC INSTITUTIONS. MOREOVER, PARLIAMENTS FUNCTIONING IN A NON-PARTY SYSTEM CAN ACHIEVE RESPONSIBLE DEMOCRATIC GOVERNMENT BY REACHING CONSENSUS SOLUTIONS DEBATED ON THE MERITS OF A CASE, RATHER THAN ON PARTISAM DIFFERENCES.

00395

MUZZLE ON THE PRESS; ARMY AS POLICE

LATIN AMERICAN WEEKLY REPORT, (46) (NOY 92), 4.

AFTER PROCLAIMING THAT HE WAS ASSUMING EMERGENCY POHERS, PRESIDENT CESAR GAVIRIA ANNOUNCED A COMPLETE BAN ON THE PUBLICATION OR BROADCAST OF ANY COMMUNIQUES FROM GUERRILLA OR CRIMINAL ORGAMIZATIONS. HE ALSO AUTHORIZED THE MILITARY TO PERFORM THE TASKS OF THE JUDICIARY POLICE IN

INVESTIGATING CRIME AND COLLECTING EVIDENCE IN REMOTE AREAS. 00396

NAFTA PACT AGREED AT LAST

ATIN AMERICAN WEEKLY REPORT, (33) (AUG 92), 2-3.

THE NEGOTIATIONS ON THE NORTH AMERICAN FREE TRADE

AGREEMENT (NAFTA) HAVE BEEN COMPLETED, BUT LAWYERS STILL

HAVE TO HRITE THE FINAL VERSION OF THE TEXT, HHICH WILL BE

SUBMITTED TO EACH COUNTRY FOR APPROVAL. RATIFICATION IS
EXPECTED TO BE AN EASY PROCESS IN CANADA AND MEXICO, BUT THE

EXPECTED TO BE AN EASY PROCESS IN CANADA AND MEXICD, BUT
$U . S$. CONGRESS HAS CONCERNS ABOUT PARTS OF THE AGREEMENT,

ESPECIALLY THE PACT'S ENVIRONMENTAL PROVISIONS. AMONG THE

AREAS COVERED IN THE AGREEMENT ARE TARIFF REDUCTIONS,

TEXTILES, THE AUTOMOTIVE INDUSTRY, AND THE ENERGY SECTOR.

00397

NAFTA TALKS ON POLITICAL BRINK

LATIN AMERICAN WEEKLY REPORT, (31) (AUG 92), 6-7.

DESPITE REPORTS INDICATING THAT THE NORTH AMERICAN FREE TRADE AGREEMENT (NAFTA) HAS BEEN FINALIZED, THERE IS STILL NO ACCORD ON THE FIVE MOST CONTENTIOUS ISSUES: ENERGY, GOVERNMENT PURCHASES, AGRICULTURE, THE MOTOR VEHICLE

INDUSTRY, AND TEXTILES.

00398

NAM GOES HOME

WEST AFRICA, (3911) (AUG 92), 1469

THE AUTHOR DRAWS PARALLEL'S BETHEEN THE 1955 BANDUNG

CONFERENCE, WHICH WAS THE FORERUNMER OF THE NON-ALIGNED

MOVEMENT (NAM). AND THE 1992 NAM SUMMIT. SINCE THE BEGINNING,

MAM LEADERS HAVE ARGUED THAT UNDERDEVELOPMENT AND LACK OF

EQUITY IN INTERMATIOMAL ECONOMIC RELATIONS ARE AS MUCH A

SOURCE OF CONFLICT AS THE ARMS RACE AND THE SUPERPOWER

STRUGGLE FOR GLOBAL SUPREMACY.

00399

NATIONAL ELECTIONS

ELECTORAL STUDIES, 11(4) (DEC 92), 377-381

THIS ARTICLE SUMMARIZES THE RESULTS OF THE FOLLOWING

1992 BALLOTS: AUSTRIA'S PRESIDENTIAL ELECTION, THE

CZECHOSLOVAK FEDERAL ASSEMBLY ELECTIONS, THE CZECH AND

SLOVAK NATIONAL COUNCIL ELECTIONS, ITALY'S CHAMBER OF

DEPUTIES ELECTIONS, SOUTH KOREA'S NATIONAL ASSEMBLY

ELECTIONS, AND THE UNITED KINGDOM'S HOUSE OF COMMONS

ELECTIONS.

00400

NATIONAL INDUSTRIAL POLICY

CONGRESSIONAL DIGEST, 71 (12) (DEC 92), 296-298, 314.

THIS ARTICLE IS A SUMMARY OF A REPORT ENTITLED "THE

DEBATE OVER A NATIONAL INDUSTRIAL POLICY TOHARD TECHNOLOGY

AND ECONOMIC GROHTH, "ISSUED BY THE LIBRARY OF CONGRESS

CONGRESSIONAL RESEARCH SERVICE.

00401

WEST AFRICA, (3883) (FEB 92), 291.

THE NATIONAL ELECTORAL COMMISSION (NEC) HAS RELEASED THE GUIDELINES FOR NIGERIA'S UPCOMING PRIMARY ELECTIONS. THE NEC HAS WARNED THAT IT WILL SUMMARILY DISQUALIFY AMY PRESIDENTIAL CANDIATE WHO RECEIVES THE SUPPORT OF POLITICAL PARTY EXECUTIVES DURING THE PRIMARIES BECAUSE IT WOULD BE "AGAINST THE PRINCIPLE OF FAIR PLAY AND NATURAL JUSTICE" A PARTY EXECUTIVE TO DECL ARE HIS SUPPORT FOR A POTENTIAL PRESIDENTIAL CANDIDATE.

00402

MEGARA BRUNEI DARUSSALAM IN 1991: RELEGITIMIZING TRADITION ASIAN SURYEY XXXII (2) (FEB 92 ) $126-130$

THIS ART XXXIT OF BRUNEI DURING 1991. NO MAJOR CHALLENGES TO BRUNEI'S POLITICAL STABILITY EMERGED DURING THE YEAR. THERE HAS BEEN NO REPEAT OF THE EXPERIMENT WITH REPRESENTATIVE GOVERNMENT WHICH OCCURRED IN 1984 AND NO SUGGESTION THAT THE TENETS OF ABSOLUTE MONARCHY WOULD BE LOOSENED. RATHER, THE TREND TOWARD RE-ISLAMICIZATION OF THE COUNTRY'S INSTITUTIONS BECAME MORE APPARENT. THE SMALL, OIL-RICH ISLAMIC STATE HEEDED THE LESSONS OF THE GULF WAR TO THE EXTENT THAT RENEHED EMPHASIS HAS PLACED ON DEFEHSE AND SECURITY. IN ADOITION, BRUNEI FURTHER LOCKED ITSELF INTO CLOSER ECONOMIC
COOEPRATION WITH ITS ASEAN PARTMERS, DESPITE THE FACT THAT THE VERY CONCEPT OF DEVELOPMENT AND MODERNIZATION APPEARS TO BE PERPLEXING IN CERTAIN QUARTERS.

00403

MEN BURDENS IN POST-SOVIET WORLD: JAPAN MUST BE READY 10.

EFFAPAN MUST BE READY TO DO ITS SHARE IN THE FOREIGN AID

YIOLENCE IN THE FORMER SOVIET UNION. IT MUST ALSO BE AWARE

OF THE DANGER POSED BY THE SOVIET NUCLEAR HEAPONS. 00404

NEH ECONOMIC PLAN PROPOSED

JAPAN TIMES (WEEKLY INTERNATIONAL EDITION), 32(5) (FEB 92),

10.

PRIME MINISTER KIICHI MIYAZAHA HAS PROPOSED A NEW FIVEYEAR ECONOMIC PLAN THAT WILL. ALLOW THE ORDINARY JAPANESE CITIZEN TO EN JOY A RICHER, MORE FULFILLING LIFESTYLE. THE PRIME MINISTER HAS STATED' THAT THE PLAN HILL DEVELOP A MORE BALAMCED ECONOMY AND WILL PERMIT THE AVERAGE CITIZEN TO EXPERIENCE A FEELING OF REAL PROSPERITY.

00405

NEW GRDUPS FAIL TO MAKE THE GRAD

LATIN AMERICAN WEEKLY REPORT, (43) (NOV 92), 2-3

PERU'S NACIONAL DE ELECCIONES HAS RULED ON THE

ELIGIBILITY OF SEVERAL PARTIES TO PARTICIPATE IN THE NOVEMBER 1992 CONSTITUENT ASSEMBLY ELECTIONS, BUT MORE THAN 20 STILL AWAIT A RULING. MEANHHILE, THE FUJIMORI GOVERMMEN HAS BEEN SUCCESSFUL IN CAPTURING SEVERAL LEADERS OF THE SENDERO LUMINOSO.

00406

NEH LEASE OF LIFE FOR VIOLETA CHAMORR

LATIN AMERICAN WEEKLY REPORT, (37) (SEP 92), 6-7.

PRESIDENT VIOLETA CHAMORRO SEEMS TO HAVE GAINED A NEW

LEASE ON LIFE WITH YET ANOTHER BALANCING ACT THAT KEEPS THE KEY ACTORS FROM ROCKING THE BOAT WHILE LEAVING EVERYONE ONLY HALF-SATISFIED. CHAMORRO'S NEW FORMULA FOR DISTRIBUTING CONFISCATED PROPERTY INCLUDES A COMMITMENT TO RETURN SUCH PROPERTY OR COMPENSATE THE OHNERS FOR IT, TO EXTEND THE POWERS OF THE OFICINA DE ORDENAMIENTO TERRI TORI

00407

NEW PARTY LEADERSHIP FORMED

BEI JING REVIEH, 35(43) (OCT 92), 5-7

THE RTH PARTY CONGRESS OF THE CHINESE COMMUNIST PARTY

FLECTED A NEH CENTRAL COMMITTEE WITH 189 MEMBERS AND 130

ALTERMATES. THE NEW COMMITTEE THEN CHOSE A 22-MEMBER

POLITICAL BUREAU. IN ADOITION, JIANG ZEMIN, LI PENG, OIAO

SHI, LI RUIHUAN. ZHU RONGJI IIU HUAOING, AND HU JINTAO WERE

SELECTED TO SERVE AS A STANDING COMMITTEE WITHIN THE BUREAU.

00408

NEW PARTY LEADERSHIP LINE-UP

BEIJING REVIEH, 35(44) (NOV 92), 13-17.

THIS ARTICLE PROFILES THE SEVEN TOP ELECTED COMMUNIST

PARTY LEADERS IN CHINA, INCLUDING JIANG ZEMIN, GENERAL

SECRETARY OF THE CPC CENTRAL COMMITTEE.

00409

LATIN AMERICAN WEEKLY REPORT, (21) (JUN 92), 8-9.

PRESIDENT CARLOS MENEM HAS TOLD HIS CABINET MEMBERS THAT HE IS NO LONGER WILLING TO SUPPORT HIGH OFFICIALS ACCUSED OF IMPROPER DEALINGS. THE MOST RECENT CASE INYOL VES THE IRREGULAR ISSUANCE OF DOCUMENTS, FROM IDENTITY CARDS TO CITIZENSHIP PAPERS AND DIPLOMATIC PASSPORTS, TO PERSONS ALLEGEDLY INVOLVED IN DRUG-TRAFFICKING AND GUN-RUNMING. IN RESPONSE TO A SERIES OF SCANDALS, SOME ARGENTINIANS HAVE PROPOSED REFORMS THAT LIMIT PRESIDENTIAL POWERS AND CREATE THE POST OF PRIME MINISTER.

00410

HEN SOUEEZE ON VIOLETA CHAMORRO

LATIN AMERICAN WEEKLY REPORT, (49) (DEC 92) 8-9,

NICARAGUAN PRESIDENT VIOLETA CHAMORRO CONTINUES TO BE

PRESSURED ON SEVERAL FRONTS. DESPITE A SUPREME COURT RULING

PRESSURED ON SEVERAL FRONTS. DESPITE A SUPREME COURT RULING

AGAINST THE RUMP LEGISLATURE HEADED BY ALFREDO CESAR, THE

LEGISLATURE CONTINUES TO FUNCTEN AND CESAR HAS DECLARED

THAT THE SUPREME COURT HAS NO JURISOICTION OVER IT. THE UNITED STATES RELEASED SOME FOREIGN AID TO NICARAGUA BUT EMPHASIZED THAT ADDITIONAL ASSISTANCE IS CONTINGENT UPON THE GOVERMMENT MAKING "PROGRESS IN CRUCIAL AREAS. IN ADDI

THE SANDINISTAS HAVE BEEN FLEXING THEIR MUSCLES AND DEMANDING PAY INCREASES, GUARANTE
REPEAL OF THE CONSUMPTION TAX.

00411

NEW TECHNOLOGY: THE SOCIOLOGICAL AND ECONOMIC IMPACT OF NEW TECHNOLOGY AND EQUIPMENT ON SMALL STATES 
PARLI AMENTARIAN, LXXIII(1) (JAN 92), 50-51,

NEW TECHNOLOGY CAN BE AN ECONOMIC AND SOCIAL BOON, BUT SMALL STATES MUST ALSO BE AWARE OF ITS NEGATIVE EFFECTS. THERE WILL BE CULTURAL AND ENVIRONMENTAL PRICES TO PAY FOR THE POSITIVE RESULTS ACHIEVED BY INTRODUCING NEW TECHNOLOGY AND EQUIPMENT TO SMALL STATES. THESE NEGATIVE EFFECTS ARE NOT SUFFICIENT TO CAUSE COUNTRIES TO SHUN PROGRESS, BUT NEWCOMERS TO THE HIGH-TECH WORLD MUST MAKE CAREFUL, PROVISION TO PROTECT THEIR SOCIETIES FROM PROBLEMS ASSOCIATED WITH NEH TECHMOLOGY.

00412

NEW WORLD DISORDER

EW REPUBLIC, 207(13) (SEP 92), 7

NOW THAT THE COLD WAR IS OVER, U.S. FOREIGN POLICY CAM

NO LONGER BE FORMULATED IN THE SIMPLE TERMS OF DEMOCRACY

VERSUS COMMUNISM, OR EAST VERSUS WEST. THIS LEADS TO

CONFUSION ABOUT WHAT U.S. FOREIGN POLICY SHOULD BE IN PLACES

LIKE SOMALIA OR THE FORMER YUGOSLAY REPUBLICS.

00413

NICARAGUAN EVANGELICALS PROTEST GOVERNMENT'S TIES TO ROMAN CATHOLIC CHURCH

CHURCH AND STATE, 45(11) (DEC 92), $19(259)$.

EVANGELICAL CHRISTIANS IN NICARAGUA ARE PROTESTING GOVERNMENT DECREE IMPOSING TAXES ON SOME OF THEIR ACTIVITIES, BECAUSE THEY BELIEVE THE MOVE WAS PROMPTED BY PRESIDENT VIOLETA BARRIOS DE CHAMORRO'S CLOSE TIES TO THE ROMAN CATHOLIC CHURCH. ALTHOUGH GOVERMMENT OFFICIALS AT FIRST DECLARED THAT CATHOLIC CHURCHES WOULD BE TAXED THE SAME AS EVANGELICALS, A HIGH-RANKING OFFICIAL LATER STATED THAT HE KNEW OF NO CATHOLIC INSTITUTION THAT WOULD HAVE TO PAY THE NEW FEES.

00414

NIGER: GOVERNMENT DISSOLVED

WEST AFRICA, (3889) (MAR 92), 560.

PRIME MINISTER AMADOU CHEIFFOU DISSOLVED NIGER'S

TRANSITIONAL GOVERNMENT ON MARCH 23, 1992. HE SAID HIS DECISION WAS PROMPTED BY THE GENERAL REFUSAL TO MAKE THE SACRIFICES NECESSARY FOR ECONOMIC RECOVERY, THE UNJUSTIFIED EXPECTATIONS OF THE ARMY, THE LACK OF A SPIRIT OF SELFSACRIFICE WITHIN THE TRADE UNIONS, AND THE REFUSAL OF TOUAREG REBELS TO LAY DOWN THEIR ARMS.

00415

NIGERIA: BOYCOTT WARNING

HEST AFRICA, (3885) (MAR 92), 379.

THE NATIONAL COUNCIL OF WOMEN'S SOCIETIES HAS WARNED THAT NIGERIA'S FEMALE YOTERS WILL BOYCOTT THE 1992

PRESIDENTIAL ELECTION IF THE CIVILIAN GOVERNORS DO NOT "CO-

OPT" A SIGNIFICANT NUMBER OF WOMEN IN THEIR ADMINISTRATIONS.

00416

NIGERIA: CABINET DISSOLVED

WEST AFRICA, (3878) ( JAN 92), 75

NIGERIA'S MILITARY GOVERMMENT DISSOLVED THE FEDERAL

EXECUTIVE COUNCIL ON JANUARY 2, 1992. VICE PRESIDENT

AUGUSTUS AIKHOMU, WHO ANNOUNCED THE DISSOLUTION OF THE

CABINET, SAID THAT PRESIDENT IBRAHIM BABANGIDA WOULD

ANMOUNCE NEW MINISTERS SOON.

00417

NIGERIA: DECEMBER TRANSITION

WEST AFRICA, (3881) (FEB 92), 208.

ON DECEMBER 5, 1992, NIGERIA'S THIRD REPUBLIC WILL COME

INTO BEING AND MILITARY RULE WILL END WITH THE ELECTION OF A

CIVILIAN PRESIDENT. THE PRESIDENTIAL POLL WILL BE PRECEDED

BY THE ELECTION OF THE NATIONAL ASSEMBLY ON MOYEMBER 7.

00418

NIGERIA: JANUARY HANDOVER

ST AFRICA, (3882) (FEB 92), 251.

PRESIDENT IBRAHIM BABANGIDA'S CIVILIAN SUCCESSOR WILL BE SHORN IN ON JANUARY 2, 1993. THE ANNOUNCEMENT OF THE DATE SHOULD ALLAY FEARS THAT ELECTION PETITIONS IN THE LAST ROUND OF VOTING UNDER THE TRANSITION PROGRAM MIGHT UPSET THE

TIMETABLE FOR A RETURN TO DEMOCRACY.

00419

NIGERIA: NEW CABINET

WEST AFRICA, (3879) (JAN 92), 115.

ON JANUARY 13, 1992, PRESIDENT IBRAHIM BABANGIDA SHORE

IN A NEW CABINET OF 21 MINISTERS TO REPLACE THE FEDERAL

EXECUTIVE COUNCIL, WHICH HAD BEEN DISSOLVED ON JANUARY 2. 00420

NIGERIA: PRESIDENTIAL RACE

WEST AFRICA, (3880) (JAN 92), 155.

THE RACE FOR THE PRESIDENCY OF NIGERIA'S THIRD REPUBLIC BEGAN IN EARNEST IN MID-JANUARY 1992. IT IS SHAPING UP TO $B E$ A CONTEST AMONG MANY CANDIDATES REPRESENTING BOTH THE OLD AND THE NEW BREEDS OF AFRICAN POLITICIANS.
00421

NIGERIA: TRANSITION AMENDMEN

WEST AFRICA, (3889) (MAR 92),

NIGERIA'S NATIONAL ASSEMBLY ELECTIONS HAVE BEEN

RESCHEDULED FOR JULY 4, 1992, AND THE ASSEMBLY WILL BE

INAUGURATED ON JULY 27

00422

NIGERIA: TRANSITION AMENDMENT

(AUG 92), 1316.

ON JULY 22, 1992, THE ARMED FORCES RULING COUNCIL (AFRC) SLIGHTLY REVISED THE TIMETABLE FOR NIGERIA'S TRANSITION TO DEMOCRACY. THE INAUGURATION OF THE NATIONAL ASSEMBLY, ORIGINALLY SCHEDULED FOR JULY 1992, WAS POSTPONED UNTIIL JANUARY 2, 1993.

00423

NIGERIA: TRANSITION PANEL

WEST AFRICA, (3894) (MAY 92), 763.

ON APRIL 24, 1992, AN INTERMINISTERIAL COMMITTEE WAS IMAUGURATED TO' GUIDE' MIGERIA'S TRANSITION TO DEMOCRACY IN JANUARY 1993.

00424

no 'CARACazo,' at least not yet

LATIN AMERICAN WEEKLY REPORT, (37) (SEP 92), 11

THE GOVERMMENT OF PRESIDENT SIXTO DURAN BALLEN FEARED

THAT ITS SEPTEMBER 1992 PACKAGE OF ECONOMIC ADJUSTMENT

MEASURES MIGHT TRIGGER DOMESTIC VIOLENCE. THEREFORE, THE

MEASURES WERE ACCOMPANIED BY A PRESIDENTIAL ORDER MOBILIZINC

THE ARMED FORCES. ONLY A FEH LOH-KEY PROTESTS MATERIALIZED,

BUT FUT, THE MAJOR LABOR ORGANIZATION, AND CONIAE, THE INDIAN ORGANIZATION, ARE DISCUSSING THE POSSIBILITY OF A GENERAL STRIKE.

00425

NO CENSURE FOR GAVIRIA, EITHER

LATIN AMERICAN WEEKLY REPORT, (31) (AUG 92), 11

PRESIDENT CESAR GAVIRIA HAS PERSUADED COLOMBIA'S

CONGRESS NOT TO CENSURE HIM OR HIS MINISTERS OVER THE

EMBARRASSING ESCAPE OF DRUG LORD PABLO ESCOBAR. HOWEVER, THE

CONGRESS WILL APPOINT A COMMISSION OF INQUIRY

APPORTION BLAME FURTHER DOWN THE HIERARCHY.

00426

NO MORE U.S. TROOPS, CURBS ON DEA

LATIN AMERICAN WEEKLY REPORT, (31) (AUG 92), 11

PRESIDENT JAIME PAZ ZAMORA HAS MANAGED TÓ AVERT THE

THREAT OF A COMGRESSIONAL VOTE OF CENSURE AGAINST THREE OF

HIS MINISTERS. HE HAS ALSO ANNOUNCED THAT, IN THE FUTURE,

HIS GOVERNMENT WILL ASK CONGRESS TO APPROVE THE ACTIVITIES

OF $U$. TROOPS IN BOL IVIA BEFORE THEY ARE ALIOWED TO ENTER

THE COUNTRY. IN ADOITION, HE ANNOUNCED THAT DEA FIELD AGENTS

WILL NO LONGER ENJOY DIPLOMATIC IMMUNITY IN BOLIVIA AND NEH

REGULATIONS GOVERNING DEA ACTIVITIES WILL BE DRAWN UP.

0042

NORTH KOREA ON THE BRINK

SWISS REVIEW OF WORLD AFFAIRS, 42(5) (AUG 92), 13-14.

THE AUTHOR DESCRIBES A RECENT VISIT TO NORTH KOREA AND

HIS SEARCH FOR SIGNS THAT NORTH KOREA HAS BEEN AFFECTED BY

THE DRAMATIC CHANGES IN THE COMMUNIST WORLD.

00428

NOT EVERYONE IS CELEBRATING PEACE

LATIN AMERICAN WEEKLY REPORT, (3) (JAN 92 ) 4.

THE GOVERNMENT OF PRESIDENT ALFREDO CRISTIANI AND THE LEADERSHIP OF THE FRENTE FARABUNDO MARTI PARA LA LIBERACION NACIONAL (FMLN) ARE SCHEDULED TO SIGN THE FINAL PEACE TREATY ON JANUARY 16, 1992. MOST PEOPLE ARE HAPPY AT THE PROSPECT OF PEACE, BUT THE RIGHT-WING PRESS HAS CRITICIZED THE PEACE WING TERRORIST GROUPS HAVE THREATENED MORE YIOLENCE. 00429

NOW THE RECOMPA THREAT GOES SOUTH

JUST WHEN THE GOVERNMENT OF PRESIDENT VIOLETA CHAMORRO

THOUGHT IT HAD OUELLED THE "REVUEL TO" (THE REBEL ION OF

FORHER CONTRA AND SANDINISTA FIGHTERS DEMANDING LAND, CREDIT,

AND HOUSING), IT HAS BEGUN TO CROP UP ELSEWHERE. APPARENTLY

ENCOURAGED BY' THE SUCCESS OF THEIR PEERS IN THE NORTH,

RECOMPAS IN THE CENTRAL PART OF NICARAGUA HAVE STARTED TO

STAGE THEIR OWN PROTEST ACTIONS.

00430

MOW THE SEMATE TRIES IMPEACHMENT

LATIN AMERICAN WEEKLY REPORT, (47) (DEC 92), 8-9.

BECAUSE OTHER TACTICS TO SHORTEN PRESIDENT CARLOS ANDRES PEREZ'S TERM HAVE FAILED, VENEZUELA'S SENATE HAS DECIDED TO TRY TO IMPEACH HIM. A SENATE COMMITTEE HAS ACCUSED PEREZ OF MISUSING US\$3 MILLION IN SECRET INTERIDR MINISTRY FUNDS. 
00431

NOW... MOVING ON TO RIO

WEST AFRICA (3886) (MAR 92), 401

THE EARTH SUMMIT SCHEDULED FOR RIO DE JANEIRO IN JUNE

1992 WILL BE A HUGE INTERNATIONAL CONFERENCE OF STATES,

INSTITUTIONS, AND NONGOVERMMENTAL ORGANIZATIONS CONCERNED

WITH THE ENVIRONMENT. IT WILL COVER MANY DISPARATE ISSUES

RELATED TO THE ENVIRONMENT: POLLUTION, POVERTY,

OVERPOPULATION, INDUSTRIALIZATION, WOMEN AND DEVELOPMENT,

RACISM, AND WAR.

00432

OAS SOLUTION IS LOOKING SHAKY

ATIN AMERICAN WEEKLY REPORT, (8) (FEB 92), 9

THE OAS-BROKERED DEAL TO NORMALIZE THE SITUATION IN

LOOKING VERY SHAKY - IN PART BECAUSE OF THE U.S. DECISIONS TO

LOOKING VERY SHAKY--IN PART BECAUSE OF THE U.S. DECISIONS

COMPANIES EXPORTING TO THE USA. SOME HAITIAN CONGRESSMEN ARE

ALSO COMPL ICATING THE SITUATION BY OPENLY OPPOSING THEODORE

DR ATTACHING CONDITIONS TO THEIR APPROVAL OF HIM.

00433

OAS STALLS ON SANCTIONS BUT PERU'S ECONOMIC OUTLOOK STILL REMAINS GRIM

LATIN AMERICAN WEEKLY REPORT, (16) (APR 92), 1

THE DAS'S DECISION TO CONDEMN, BUT NOT IMPOSE SANCTIONS

AGAINST, PRESIDENT ALBERTO FUJIMORI'S "GOVERNMENT OF

NATIONAL RECONSTRUCTION" IS UNLIKELY TO SAVE PERU FROM ADVERSE ECONOMIC CONSEQUENCES. ALTHOUGH SOME GOVERNMENT OFFICIALS SAY IT HILL NOW BE EASIER TO INSTITUTE ECONOMIC REFORMS PREVIOUSLY TORPEDOED BY PERU'S CONGRESS, OTHERS FEEL LESS CERTAIN. THE UNCERTAINTY CREATED BY FUJIMORI'S COUP WILL DETER MUCH-NEEDED FOREIGN INVESTMENT AND DOES NOT BODE WELL FOR PERU'S ECONOMIC HEALTH.

00434

OAS STRENGTHENS THE EMBARGO

LATIN AMERICAN WEEKLY REPORT, (15) (APR 92), 10.

ON APRIL 1, 1992, THE ORGANIZATION OF AMERICAN STATES VOTED TO STRENGTHEN SANCTIONS AGAINST HAITI. WASHINGTON'S SHIFT TOWARDS STRICTER OBSERVATION OF THE EMBARGO WAS A MAJOR FACTOR IN THE OAS DECISION TO ENFORCE THE SANCTIONS MORE YIGOROUSLY.

00435

OF IMAGE AND DROUGHT POLITICS

HEST AFRICA (3893) (APR 92) 705

SOME AFRICANS FEAR THAT DROUGHT POL ITICS HAS TAKEM

PRECEDENCE OVER HUMANITARIAN AND ECONOMIC FACTORS. WITHOUT A DOUBT SOUTH AFRICA IS A MAJOR, IF NOT THE MAJOR, PLAYER II THE REGION. DESPITE THE DROUGHT'S EFFECTS IN THE TRAMSYAAL AND THE ORANGE FREE STATE, SOUTH AFRICA IS BETTER OFF THAN MANY OF ITS MEIGHBORS ESPECIALY ZIMAABWE UNDER NORMAL CONDITIONS, IT HOULD BE NATURAL TO EXPECT SOUTH AFRICA TO PLAY A LEADING ROLE IN THE RELIEF EFFORT FOR THE STRICKEN CDUNTRIES, AND IT IS CLEAR THAT SOME MEMBERS OF THE INTERNATIONAL COMMUNITY WOULD LIKE TO ASSIGN SUCH A ROLE TO PRETORIA. BUT THE SITUATION IN SOUTHERN AFRICA IS FAR FROM NORMAL, AND SOUTH AFRICA'S NEIGHBORS ARE SUSPICIOUS OF PRETORIA'S INTENTIONS.

00436

OFFICIAL REQUEST FOR E.C. MEMBERSHIP

SHISS REVIEN OF HORLD AFFAIRS, 42(4) (JUL 92), 32 SWITZERLAND'S FEDERAL COUNCIL HAS OFFICIALLY DECIDED TO

SEEK MEMBERSHIP IN THE EUROPEAN COMMUNITY. THIS DECISION HAS

RAISED SOME QUESTIONS ABOUT THE MEMBERSHIP APPLICATIONS OF

OTHER COUNTRIES, INCLUDING AUSTRIA AND SWEDEN, AND ABOUT

SHISS RELATIONS WITH LIECHTENSTEIN.

00437

OLD FACES IN NEW CABINET

LATIN AMERICAN WEEKLY REPORT, (16) (APR 92), 10

PRESIDENT FERNANDO COLLOR DE MELLO HAS COMPLETED HIS

CABINET HITH THE APPOINTMENT OF MINISTERS WHO HAD SERVED IN

FORMER MILITARY GOVERMMEMTS FRUSTRATED IN HIS ATTEMPTS TO

INCLUDE THE SOCIAL DEMOCRATS IM HIS MEH GOYERMHENT COLLOR

HAS CHOSEN CABINET MEMBERS FROM POLITICAL PARTIES THAT

ALREADY SUPPORT HIM.

00438

OLD GUERRILLAS BLAMED FOR UMREST

DATIY AMERICAN WEEKLY REPORT (22) (JUN 92) 5 .

THE YENEZUELAN GOVERMMENT, HAS DECLARED THAT'

CONTINUING DISCONTENT AND PROTEST DEMONSTRATIONS ARE PART OF

A SUBVERSIVE CONSPIRACY BY SMALL GROUPS OF LEFT-WING

EXTREMISTS AND HAS ARRESTED TWO FORMER GUERRILLA LEADERS

WHO HAD GIVEN UP THEIR ARMS DURING THE PRESIDENCY OF LUIS HERRERA CAMPINS $(1979-1984)$.

00439

OLD SCANDAL BACK AFTER COUP RUMOURS

LATIN AMERICAN WEEKLY REPORT, (31) (AUG 92), 9.
DESPITE THE REPORTED DISMISSAL OF TWO PROMINENT

POLITBURO MEMBERS AND RUMORS OF A COUP, THE POLITICAL SCENE SEEMS TO BE CALM IN CUBA.

00440

OMNIBUS CRIME CONTROL ACT

CONGRESSIONAL DIGEST, 71(4) (APR 92), 98-128.

THIS ARTICLE DISCUSSES VIOLENT CRIME IN THE UNITED

STATES, FEDERAL CRIME CONTROL LAWS, FEDERAL HABEAS CORPUS,

THE USE OF THE EXCLUSIONARY RULE, AND RECENT CONGRESSIONAL

ACTION REGARDING CRIMINAL LAW. THEN IT SUMMARIZES

CONGRESSIONAL DEBATE ON THE OMNIBUS CRIME CONTROL ACT OF

1991.

00441

ONE-TIME FRIEND SAYS COLLOR KNEN

ATIN AMERICAN WEEKLY REPORT, (26) (JUL 92), 2-3.

PRESIDENT FERNANDO COLLOR' DE MELLO HAS BECOME THE

PRIMARY TARGET OF INCREASINGLY HARSH CHARGES. WITH THE

COUNTRY FOCUSED ON EACH AND EVERY DEVELOPMENT IN THE FARIAS

SCANDAL, MUCH GOVERNMENT AND LEGISLATIVE ACTIVITY SEEMS TO

BE GRINDING TO A HALT.

00442

OPINION POLL: CONFIDENCE IN ALL LEVELS OF GOVERMMENT IS

DOWN BUT LOCAL GOVERMMENT STILL MOST TRUSTED

NATIONAL CIVIC REVIEW, 81(4) (FAL 92), 518-519.

THE U.S. ADVISORY COMMISSION ON INTERGOVERNMENTAL

RELATIONS (ACIR) RECENTLY RELEASED THE RESULTS OF ITS 1992

POLL ON PUBLIC ATTITUDES TOWARD GOVERNMENT. ALTHOUGH THE

PUBLIC'S TRUST AMD CONFIDENCE IN ALL LEVELS OF GOVERMMENT

ARE LOW, THE POLL INDICATES THAT LOCAL GOVERNMENT IS TRUSTED MORE THAN OTHER LEVELS.

00443

OPPOSITION GROHS AGAINST GAYIRIA

LATIN AMERICAN HEEKLY REPORT, (20) (MAY 92), 2

PRESIDENT CESAR GAVIRIA'S APPROVAL RATING HAS BEEN

PLUMMETING. ONE CABINET MINISTER HAS ALREADY RESIGNED, AND

THERE ARE RUMORS OF ADDITIONAL DEFECTIONS, INCLUDING THE

MINISTERS OF AGRICULTURE, ECONOMIC DEVELOPMENT, HEALTH,

PUBLIC WORKS, AND FOREIGN AFFAIRS. SOME OF THE DEFECTIONS

COULD BE THE RESULT OF THE COALITION OF THE CONSERVATIVE AND

ALIAMZA DEMORATICA M-19 PARTIES WITH THE COMHUMSTS AND THE

ALREE UMBRELA

FRONT.

00444

OUTGOING PEREZ DE CUELLAR GETS CRISTIANI TO ATTEND "FINAL PUSH" FOR PEACE

LATIN AMERICAN HEEKLY REPORT, (1) (JAN 92), 1.

SIGHS OF AN APPARENT BREAKTHROUGH IN THE EL SALVADOR

PEACE PROCESS EMERGED ON DECEMBER 27, 1992, WHEN U.N.

SECRETARY-GENERAL JAVIER PEREZ DE CUÉ 1992, WHEN PERSONALLY INVITED

PRESIDENT ALFREDO CRISTIANI TO TRAVEL TO NEW YORK TO GIVE

THE NEGOTIATIONS A "FINAL PUSH." CRISTIANI ACCEPTED THE INVITATION AFTER REQUESTING, AND
ASSURANCES FROM PEREZ DE CUELLAR.

00445

OVERSEAS PAROCHIAID VIOLATES FIRST AMENDMENT, FEDERAL COURT SAYS

CHURCH AND STATE, 45(1) (JAN 92), 15-16.

A U.S. FEDERAL APPEALS COURT HAS STRUCK DOWM FEDERAL GRANTS TO OVERTLY RELIGIOUS SCHOOLS AND HOSPITALS ABROAD BUT HAS CRAFTED GUIDELINES THAT MAY PERMIT THE GOVERNMENT TO FUND SUCH INSTITUTIONS IN CERTAIN CIRCUMSTANCES

00446

DAN TEES ECONOMIC RECOVERY

JAPAN TIMES (WEEKLY INTERNATIONAL EDITION), 32(16) (APR

92) 6 . 6

AT A NEWS CONFERENCE ON APRIL 13, 1992, PRIME MINISTER KIICHI MIYAZAWA DISCUSSED THE PROSPECTS FOR JAPAN'S ECONOMIC TO PARTICIPATE IN UNITED NATIONS PEACEKEEPING MISSIONS, AND POLITICAL REFORM.

00447

PAN STARTS LOOKING LIKE AN ALTERNATIVE

LATIN AMERICAN HEEKLY REPORT, (29) (JUL 92), 9

STATE ELECTIONS IN CHIHUAHUA AND MICHOACAN ON JULY 12

1992 PRODUCED ONE VICTORY FOR THE RULING PARTY AND ONE FOR

THE OPPOSITION FRANCISCO BARRIO OF THE CONSERVATIVE PARTIDO

ACCION MACIONAL WON THE GOVERNORSHIP IN CHIHUAHUA. EDUARDO

VILLASENDR OF THE PARTIDO DE LA REVOLUCION DEMOCRATICA WON THE TOP SPOT IN MICHOACAN.

00448

PANDER TIME

NEW REPUBLIC, 206(11) (MAR 92), 7

CURRENT U.S. FARM POLICY IS INSTITUTIONALIZED

PENALIZATION OF CONSUMERS. ANY POL ITICAL PARTY THAT CLAIMS

TO SUPPORT "THE FORGOTTEN MIDDLE CLASS" SHOULD HAVE NO USE 
FOR A POLICY THAT HARMS AMERICAN PRODUCTIVITY, INCREASES FOOD PRICES FOR MIDDLE- AND LOW-INCOME FAMILIES, AND COSTS THE TAXPAYER BILLIONS OF DOLLARS YEARLY. THE DEMOCRATIC PARTY SHOULD TAKE A LOOK AT ITS POLICY OF ENRICHING THE RICH AT THE EXPENSE OF THE POOR, AND SHITCH SIDES.

00449

PARAGUAY'S ASSEMBLY ASSERTS ITSELF

LATIN AMERICAN WEEKLY REPORT, (22) (JUN 92), 6-7.

PARAGUAY'S CONSTITUENT ASSEMBLY HAS PROVED ITSELF TO BE INDEPENDENT AND WILLING TO GO AGAINST PRESIDENT ANDRES RODRIGUEZ DESPITE RODRIGUEZ'S DESIRE FOR ANOTHER TERM, IT HAS INCLUDED AN OUTRIGHT BAM ON THE RE-ELECTION OF THE HAS INCLUDED AN OUTRIGHT BAN ON THE RE-ELECTION OF THE PRESIDENT IN THE CONSTITUTION. IN ADDITION, THE ASSEMBLY VOTED TO RETAIN THE CONCEPT OF THE PRESIDENT AS COMMANDER-INLEADERS TO GIVE THAT POSITION TO A MILITARY OFFICER.

00450

PAROCHIAID PLANS STALL IN CONGRESS DESPITE LAST-MINUTE BUSH PUSH

CHURCH AND STATE, 45(1) (JAN 92), 14-15

THUS FAR, THE BUSH ADMINISTRATION'S EFFORTS TO REDEFINE PUBLIC SCHOOLS AND OPEN THE DOOR FOR PUBLIC FUNDING OF PRIVATE SCHOOLS HAVE BEEN UNSUCCESSFUL IN CONGRESS. CHURCHSTATE SEPARATIONISTS AND PUBLIC SCHOOL ADVOCATES ARE SLIGHTLY MORE OPTIMISTIC THAN BEFORE THAT FEDERAL FUNOING WILL BE RESTRICTED TO PUBLIC SCHOOLS. AN INCREASING NUMBER OF SENATORS HAVE EXPRESSED CONCERNS ABOUT THE CONSTITUT IONAL AND PUBLIC POLICY IMPLICATIONS OF DIVERTING TAX MONEY FROM PUBLIC SCHOOLS TO PRIVATE SCHOOLS.

00451

PARTIES AGREE ON REFORM CALENDAR

LATIN AMERICAN WEEKLY REPORT, (28) (JUL 92), 5.

ON JULY 9, 1992, BOLIVIA'S EIGHT LARGEST POLITICAL

PARTIES AGREED ON A TIMETABLE FOR GOVERNMENTAL REFORM. THEY

AGREED IN PRINCIPLE TO REFORM THE CONSTITUTION, THE

JUDICIARY, THE ELECTORAL LAW, AND THE EDUCATIONAL SYSTEM.

THEY ALSO AGREED TO IMPLEMENT ADMINISTRATIVE

DECENTRALIZATION AND PASS NEH LAWS GOVERNING POLITICAL

PARTIES AND THE INDUSTRIALIZATION OF COCA.

00452

PARTIES DECIDE TO TALK ABOUT TALKS

LATIN AMERICAN WEEKLY REPORT, (27) (JUL 92), 10.

MOST OF PERU'S POLITICAL PARTIES SEEM TO' HAVE DECIDED AT LEAST INFORMALLY IF NOT FORMALLY TO JOIN THE FUJIMORI GOVERMMENT'S "MATIONAL DIALOGUE." HOWEVER, MOST OF THE PARTIES ARE ALSO DEMANDING A FORMAL AGENDA FOR THE TALKS, AND THE REAL HEAVYWEIGHTS ARE CALLING FOR THE FUJIMORI REGIME TO RESCIND ITS DECISION TO POSTPONE THE MUNICIPAL ELECTIONS UNTIL 1993.

00453

PARTIES LEFT OUT OF RULE-MAKING

LATIN AMERICAN HEEKLY REPORT, (34) (SEP 92), 4

PERU'S MAJOR POLITICAL PARTIES AND PRESIDENT ALBERTO

FUJIMORI REMAIN UNABLE TO REACH A CONSENSUS ABOUT THE DATE

FOR ELECTIONS AND THE REFORM OF THE CONSTITUENT ASSEMBLY.

EFFORTS TO BRING ALL INTERESTED PARTIES TOGETHER FOR A

DIALOGUE HAVE THUS FAR FAILED.

00454

PARTIES WALK AWAY AT LATEST TACK

LATIN AMERICAN HEEKLY REPORT, (29) (JUL 92), 10

PERUVIAN PRESIDENT ALBERTO FUJIMORI HAS AMHOUNCED THAT

HIS DRAFT ELECTORAL LAW IS ALMOST COMPLETE AND WILL BE

ENACTED SOON. THO LARGE POL ITICAL PARTIES, APRA AND ACCION,

HAVE REFUSED TO PARTICIPATE IN THE "DIALOGUE" FUJIMORI HAS

AND LIBERTAD ACCEPTED THE INVITATION TO TALKS BUT THEN

HITHDREW.

00455

PARTY CHIEF STRESSES NATIONAL UNITY

BEIJING REVIEH, 35(4) (JAN 92),

JIANG ZEMIN, GENERAL SECRETARY OF THE COMMUNIST PARTY OF CHINA, MADE THE KEYNOTE SPEECH AT THE FIRST NATIONAL

CONFERENCE ON NATIONALITY AFFAIRS IN JANUARY 1992. JIANG

OUTL INED PLANS FOR THE COUNTRY'S NATIONALITY POLICY IN THE

1990'S AND STRESSED THE IMPORTANCE OF NATIONAL UNITY. HE

URGED CHINA'S MATIONALITY AFFAIRS WORKERS TO PROMOTE

ECONOMIC GROWTH, SOCIAL HELFARE, AND REGIONAL AUTONOMY OF

ECONOMIC GROWTH, SOCIAL HELFARE, AND REGIONAL AUTDNOMY OF

MINORITY AREAS. HOWEVER, HE ALSO DECLARED THAT CHAUVINIS

AND LOCAL NATIONALISH WILL BE STRONGLY OPP

00456

PARTY POSITIONS ON NATIONAL ISSUES

CONGRESSIONAL DIGEST, 71(10) (OCT 92), 235, 237, 239, 241,

THIS ARTICLE GIVES EXCERPTS FROM THE PLATFORM ADOPTED BY

THE REPUBLICAN NATIONAL CONVENTION ON AUGUST 17, 1992.
00457

PARTY POSITIONS ON NATIONAL ISSUES: DEMOCRATIC PLATFORM CONGRESSIONAL DIGEST, $71(10)$ (OCT 92 ), $234,236,238,240,$.
THIS ARTICLE CONTAINS EXCERPTS FROM THE PLATFORM ADOPTED BY THE DEMOCRATIC NATIONAL CONVENTION ON JUNE 27, 1992.

00458

PARTY TIME IN GHANA

WEST AFRICA, (3896) (MAY 92), 829.

ON MAY 18, 1992, POLITICAL PARTIES ONCE AGAIN BECAME

LEGAL IN GHANA, AFTER BEING BANNED FOR A DECADE. THE DEMANDS

ON THE PARTIES WILL BE IMMENSE AND WHETHER THEY CAN LIVE UP

TO EXPECTATIONS WILL DEPEND ON A VARIETY OF FACTORS--THE

MOST IMPORTANT BEING THEIR ABILITY TO CUL TIVATE TOLERANCE

AND THE SPIRIT OF COMPROMISE.

00459

PAT ROBERTSON FORCES ASSAIL HALL OF SEPARATION, ORGANIZE GRASSROOTS

CHURCH AND STATE, 45(4) (APR 92), 16(88)-17(89).

LEADERS OF PAT ROBERTSON'S RELIGIO-POLITICAL MOVEMENT ARE ESCALATING THEIR ATTACKS ON THE HALL OF SEPARATIOH BETWEEN CHURCH AND STATE AS THEY GEAR UP FOR THE NOVEMBER 1992 ELECTIONS. ROBERTSON ALLIES ARE PROMOTING IN-CHURCH VOTER REGISTRATION DRIVES WITH THE HOPE OF REGISTERING A QUARTER-MILLION NEW VOTERS. CHRISTIAN COALITION ACTIVISTS ARE HOPING FOR MAJOR SUCCESSES IN CALIFORNIA, WHERE RELIGIOUS RIGHT GROUPS HAVE MADE PROGRESS IN THEIR EFFORTS TO CONTROL THE STATE REPUBLICAN PARTY.

00460

PC INQUIRY COMES CLOSER TO COLLOR

LATIN AMERICAN WEEKLY REPORT, (25) (JUL 92), 4

PRESIDENT FERNANDO COLLOR DE MELLO'S POSITION HAS BECOME DISTINCTLY SHAKIER DUE TO STATEMENTS MADE TO THE

CONGRESSIONAL COMMISSION INVESTIGATING CHARGES OF ILLICIT

ENRICHMENT AGAINST PAULO CESAR FARIAS, WHO WAS THE FINANCIAL

AND ADMINISTRATIVE COORDINATOR FOR COLLOR'S ELECTIOH

CAMPAIGN.

00461

PEACE PROCESS IS NOW BACK ON TRACK

LATIN AMERICAN WEEKLY REPORT, (27) (JUL 92), 11.

OVERSEEN BY A UNITED NATIÓNS MISSION, ON JUNE 30, 1992,

AN ESTIMATED 1600 FIGHTERS OF THE FRENTE FARABUNDO MARTI

PARA LA LIBERACION NACIONAL MANDED OVER THEIR WEAPONS AND

RECEIVED "CERTIFICATES OF REINCORPORATION TO THE CIVILIAN,

POLITICAL, AND INSTITUTIONAL LIFE" OF EL SALYADOR.

00462

PENNSYLVANIA HOUSE DERAILS VOUCHER 8 ILL

CHURCH AND STATE, 45(1) (JAN 92), 15.

IN NOVEMBER 1991, THE PENHSYLVANIA SENATE PASSED A

BROADLY-BASED SCHOOL CHOICE PLAN INCLUDING VOUCHERS FOR

PAROCHIAL AND OTHER PRIVATE SCHOOLS. IN JANUARY 1992, THE

HOUSE KILLED THE PLAN BY TABLING IT. A MAJORITY OF HOUSE

MEMBERS SAID THAT THE BILL WOULD VIOLATE PENMSYLVANIA'S

CONSTITUTION, WHICH STRICTLY FORBIDS DIVERSION OF PUBLIC

FUNDS TO SECTARIAN SCHOOLS.

00463

PEREZ CLEAR TO COMPLETE MANDATE

LATIN AMERICAN WEEKLY REPORT, (37) (SEP 92), 10.

THE HAY IS NOW CLEAR FOR PRESIDENT CARLOS ANDRES PEREZ

TO COMPLETE HIS TERM. ON SEPTEMBER 10, 1992, THE SENATE

REJECTED A PROPOSAL THAT COULD HAVE LED TO THE SHORTENING OF

THE PRESIDENTIAL MANDATE.

00464

PEZ DEBUNKS RESIGNATIOM REPORTS

CATIN AMERICAN WEEKLY REPORT, (25) (JUL 92), 5.

PRESIDENT CARLOS AMDRES PEREZ HAS DENIED REPORTS THAT HE

MIGHT RESIGN. IN ADDITION, HE HAS REINFORCED THE TIES

BETWEEN HIS ADMINISTRATION AMD THE MILITARY BY APPOINTIHG

GENERAL FER

00465

PEREZ FACES GROHING MILITARY UNREST AND RENEWED OPPOSITION FROM HIS OWH PARTY

LATIN AMERICAN WEEKLY REPORT, (42) (OCT 92), 1

AL THOUGH PRESIDENT CARLOS ANDRES PEREZ HAS IEARNED TO SHRUG OFF THE CONSTANT OPPOSITION CALLS FOR HIS RESIGNATION,

HE IS NOW FACING THO THREATS HE CANNOT AFFORD TO IGNORE. ONE IS THE GROWING EVIDENCE OF MILITARY UNREST. THE OTHER IS THE STRONGEST CHALLENGE YET FROM CONGRESSIONAL LEADERS OF HIS OWN PARTY.

00466

PEREZ SAVES HIS SKIN, BUT HIS RESCUERS FACE REPRISALS FROM THE VOTERS

LATIN AMERICAN WEEKLY REPORT, (31) (AUG 92), 1

PRESIDENT CARLOS ANDRES PEREZ HAS SAVED WHAT IS LEFT OF

HIS TERM IN OFFICE THROUGH SKILLFUL POLITICAL MANOEUVRING 
BUT, IN THE PROCESS, MAY HAVE TRIGGERED MAJOR POLITICAL REALIGMMENTS IN VENEZUELA, TO THE DETRIMENT OF HIS OWN RELLIES.

00467

PEREZ SURVIVES SECOND, BIGGER COUP BID; DECEMBER ELECTIONS IN DOUBT

LATIN AMERICAN WEEKLY REPORT, (48) (DEC 92), 1

IN NOVEMBER 1992, PRESIDENT CARLOS ANDRES PEREZ SURVIVED THE SECOND COUP ATTEMPT IN LESS THAN A YEAR. THE SECOND UPRISING INVOLVED MUCH LARGER NUMBERS OF BOTH TROOPS AND CIVILIANS AND RESULTED IN AT LEAST 170 DEATHS. ALTHOUGH PEREZ ASSUMED EMERGENCY POWERS AND SUSPENDED CONSTITUTIONAL RIGHTS, HE ALSO ANNOUNCED THAT THE ELECTIONS SCHEDULED FOR DECEMBER 6 WOULD BE HELD.

00468

PEREZ TO SLASH THE SIZE OF THE CABINET

LATIN AMERICAN HEEKLY REPORT, (19) (MAY 92), 10.

PRESSED TO DO SOMETHING ABOUT WHAT HE HIMSELF HAS CALLED

"A DEEP, STRUCTURAL, HISTORICAL CRISIS," PRESIDENT CARLOS

ANDRES PEREZ HAS ANWOUNCED THAT HE WILL STREAMLINE HIS

CABINET, REDUCING ITS SIZE BY MORE THAN TWO-THIRDS.

MEANHHILE, SOME CONGRESSMEN HAVE ANNOUNCED THEIR OWN PLAN

MEA GOVERMMENT REFORM: A BILL THAT WOULD CUT ONE YEAR OFF

FOR GOVERHMENT
PEREZ'S TERM.

00469

PERU BLOCKS ANDEAN GROUP'S GREAT LEAP

LATIN AMERICAN WEEKLY REPORT, (25) (JUL 92), 6-7

AT A MEETING IN JUNE 1992, PERU DERAILED PLANS FOR THE FORMAL ADOPTION OF A COMMON EXTERNAL TARIFF BY MEMBERS OF THE ANDEAN GROUP. PERU REFUSED TO VOTE FOR THE FREE-TRADE AREA AND THE CUSTOMS UNION AS LONG AS VENEZUELA REFUSES TO RESUME DIPLOMATIC RELATIONS. VENEZUELA AND PANAMA ARE THE ONLY THO LATIN AMERICAN GOVERMMENTS TO SEVER TIES HITH PERU
AS A RESULT OF PRESIDENT ALBERTO FUJIMORI'S COUP ON APRIL 5 . 00470

PERU TO RECEIVE $\$ 130$ MILLION AID

JAPAN TIMES (WEEKLY INTERNATIONAL EDITION), 32(13) (MAR 92) 3 .

DURING A STATE VISIT BY PERUVIAN PRESIDENT ALBERTO

FUJIMORI, PRIME MINISTER KIICHI MIYAZAWA ANMOUNCED THAT JAPAN WILL EXTEND APPROXIMATELY S30 MILLION IN GRANT AID AND S100 MILLION IN NEW OFFICIAL LOANS TO PERU. 00471

PERU: IN NEED OF LUCK AND WISDOM

FREEDOM REYIEH, 23(6) (NOY 92), 3, 25

IN THIS INTERVIEW, HERNANDO OE' SOTO, THE PRESIDENT OF IN THIS INTERVIEW, HERNANDO DE SOTO, THE PRESIDENT OF
PERU'S INSTITUTE FOR LIBERTY AND DEMOCRACY, DISCUSSES THE FUTURE OF THE SENDERO LUMINOSO NOW THAT ABIMAEL GUZMAN HAS BEEN ARRESTED AND PROSPECTS FOR DEMOCRACY UNDER PRESIDENT ALBERTO FUJIMORI.

00472

PHILIPPINE FAILURE TO USE ODA MAY LEAD JAPAN TO CUT FUNDING JAPAN TIMES (HEEKLY INTERNATIONAL EDITION), 32(6) (FEB 92), 3.

THE PHILIPPINE GOVERNMENT HAS NOT FULLY UTILIZED JAPANESE FOREIGN AID DURING THE PAST FIVE YEARS. A JAPANESE DIPLOMAT HAS WARMED THAT THIS CONTINUED INABILITY TO MAXIMIZE USE OF JAPANESE OFFICIAL DEVELOPMENT ASSISTANCE WILL LEAD TO A REDUCTION IN CONCESSIONAL LOANS AND GRANTS FROM TOKYO.

00473

PINERA'S PULL-OUT REALIGNS THE RIGHT

LATIN AMERICAN WEEKLY REPORT, (37) (SEP 92), 4

THE SUDOEN WITHDRAHL OF SENATOR SEBASTIAN PINERA FROM

THE PRESIDENTIAL RACE WAS A SERIOUS BLOW TO THE MOPES OF THE "MODERN RIGHT," HHICH HE REPRESENTED WITHIN THE RENOVACION NACIONAL. PINERA RAN AFOUL OF THE PARTY'S VETERAN STRONGMAN, SERGIO ONOFRE JARPA, AND OF THE TRADITIONAL PINOCHETISTA SECTOR, HO RESENTED PINERA'S POLITICAL AND FINANCIAL INDEPENDENCE.

00474

PITAZO RIOTS AFTER FAILED STRIKE

LATIN AMERICAN WEEKLY REPORT, (16) (APR 92), 2-3.

THE GOVERMMENT MAIMTAINED' THAT IT WAS "UNCONCERNED" WHEN RIOTING ERUPTED ON APRIL 8,1992 , IN CARACAS ANO OTHER MAJOR CITIES. ALTHOUGH THIS HAS MEANT TO BE THE BEGINNING OF A GENERAL STRIKE CALLED BY THE MOYIMIENTO AL SOCIALISHO AND SOME OTHER GROUPS. THE RESPONSE WAS VERY LIMITED AND MOST BUSINESSES OPENED FOR THE DAY. THE MAJOR TRADE UNION GROUP BUSINESSES OPENED FOR THE DAY. THE MAJOR TRADE UNION GROUP, CONFEDERACIOM

00475

PLANS FOR REGIONAL ECONOMY

BEIJING REVIEW, 35(31) (AUG 92), 18-22.

TO SPUR ITS ECONOMIC GROWTH, CHINA WILL DIVIDE ITS
TERRITORY INTO ECONOMIC DEVELOPMENT REGIONS, AS FOLLOWS: (1) THE YANGTZE RIVER WITH THE PUDONG NEW AREA IN SHANGHAI, (2) THE PEARL RIVER DELTA, (3) THE LAND ENCIRCLING THE BOHAI SEA, (4) SELECT PROVINCES AND REGIONS IN SOUTHWEST AND SOUTHEAST CHINA, (5) NORTHWEST CHINA, (6) CENTRAL CHINA, AND (7) MORTHEAST CHINA. THIS WILL ENABLE PLANNERS TO MAP OUT ECONOMIC PROGRAMS FOR EACH REGION ON A MUCH LARGER SCOPE, BASED ON EACH REGION'S PARTICULAR STRENGTHS AND WEAKNESSES, THUS INJECTING MORE YIGOR INTO CHINA'S ECONOMY.

0047

PLAYING TO WIM

THE MIDDLE EAST, (198) (APR 91), 5-7.

THIS ARTICLE CONSIDERS THE STAKES FOR THE US IN THE GULF WAR AND HOW THE US IS TRYING TO SEIZE THE INITIATIVE IN THE POST-WAR PERIOD TO ACHIEVE FOREIGN POLICY GOALS IN THE MIDDLE EAST. THE REDISTRIBUTION OF POWER IN REGION AFTER THE WAR IS REVIEWED. THE US "PEACEMAKER" ROLE RECEIVES SPECIAL ATTENTION.

00477

PLRA AGREES TO ALLIANCE FOR 1993

LATIN AMERICAN WEEKLY REPORT, (31) (AUG 92), 3

PARAGUAY'S OPPOSITION KNOWS THAT IT CAN ONLY HOPE TO BEAT THE RUL ING PARTIDO COLORADO IN THE 1993 PRESIDENTIAL ELECTION IF IT MANAGES TO PUT UP A UNITED FRONT. TO THAT END, THE PARTIDO LIBERAL RADICAL AUTENTICO HAS DECIDED TO ALLY ITSELF WITH THE ASUCION PARA TODOS, PARAGUAY PARA TODOS, AND ITSLF WIT THE ASUCION PARA TODOS, PARAGUAY PARA TODOS, AMD CHRISTIAN DEMOCRAT PARTY.

00478

POLICY BY FIAT

FAR EASTERM ECONOMIC REYIEW, 156(23) (JUN 92), 16-18. THE COLLAPSE OF THE SOVIET UNION SEEMS TO HAVE LEFT THE NEW RULERS OF RUSSIA TOO CONCERNED WITH INTERNAL POWER STRUGGLES TO WORRY ABOUT RELATIONS WITH CHINA. BUT IT HAS ALSO REMOVED MOST OF THE INHIBITIONS ON FORMER SOVIET DIPLOMATS FROM DISCUSSING THE RELATIONSHIP IN PUBLIC. THIS ARTICLE CONTAINS EXCERPTS FROM AN ACCOUNT OF A SENIOR RUSSIAN CHINESE SPECIALIST. THIS OFFICIAL DESCRIBES OVER TEN YEARS OF POLICY SHIFTS. THE ARTICLE OUTLINES IN DETAIL THE PRESSURES OF WORKING FOR A GOVERMMENT WHICH CONSTANTLY TRIED TO FORCE THE FACTS INTO A MOLD SUITED FOR ITS OWN POLICIES. IT REVEALS A SURREAL WORLD OF POLICYMAKING WHERE SENIOR OFFICIALS ON OPPOSITE SIDES OF AN ISSUE DEMAND POSITION PAPERS FROM THE SAME SPECIALISTS TO SUPPORT THEIR CASES.

00479

POLITBURO URGES BOLDER REFORMS

BEIJING REVIEH, 35(12) (MAR 92), 6.

CHINA'S POLITBURO RECENTLY REITERATED ACCELERATION OF REFORM AND OPENING THE DOOR WIDER TO THE OUTSIDE WORLD. THE PARTICIPANTS OF THE MEETING AGREED THT IT IS NECESSARY TO FURTHER EMANCIPATE THE MIND AND ADHERE TO THE PRINCIPLE OF SEEKING TRUTH FROM FACTS. FURTHER, THEY AGREED THAT THE PROUCTIE FORES SHOU DUT ALSO BE LIBERATED THROUGH REFORM. CONDITION OF SOCIALISM BUT ALSO BE LIBERATED THR

THE MEETING CALLED ON ALL THE PARTY MEMBERS TO CONSCIENTIOUSLY STUDY THE SERIES OF EXPOSITIDNS OF DENG ZIAOPING ON BUILDING SOCIALISM WITH CHINESE CHARACTERIC AND FURTHER ENHANCE THEIR CONSCIOUSNES

00480

POLITICAL AND SOCIAL COMMITMENT IN EVANGELICALS' YERSIOI OF MEDELLIN

LATIN AMERICAN WEEKLY REPORT, (36) (SEP 92), 1 .
EVANGELICAL CHRISTIAN CHURCHES ARE A GROWING FORCE IN LATIN AMERICA. IN SEPTEMBER 1992 THEY HELD A CONFERENCE IM MEDELLIN AND OPENLY DECIDED TO COMMIT THEMSELVES TO SOCIAL AND POLITICAL ACTION.

00481

POLITICAL REFORM, NEXT TARGET

BEIJING REVIEW, 35(51) (DEC 21), 7.

CHINA MUST PRESS AHEAD WITH POLIITICAL REFORM TO

FACILITATE FURTHER ECONOMIC REFORM AND DEVELOPMENT,

ACCORDING TO OIAO SHI, A MEMBER OF THE CHINESE COMMUNIST

PARTY POLITBURO CHIMA MUST "FURTHER IMPROYE THE PEOPLE'S COMGRESS BY STREMGTHENIMG ITS LEGISLATIVE AMD SUPERVISORY ROLE AND GIVING MORE PLAY TO THE ROLE OF CONGRESSIONAL DEPUTIES AT ALL LEYELS," SAID OIAO.

00482

POLITICAL REFORMS ON AGENDA

JAPAH TIMES (HEEKLY INTERMATIONAL EDITION), 32(18) (MAY 92), 10.

JAPAN'S POLITICAL SYSTEM NEEDS A MAJOR OVERHAUL TO ELIMINATE CORRUPTION AND RESTORE PUBLIC CONFIDENCE IN THE COUNTRY'S LEADERS. UNFORTUNATELY, THERE IS NO PROSPECT OF MEANINGFUL POLITICAL REFORM UNDER THE PRESENT CIRCUMSTANCES. 
00483

POLITICS OF REBELLION

WEST AFRICA, (3914) (SEP 92), 1608-1609.

THE AUTHOR REVIEWS THE PROGRESS OF FIGHTING BETWEEN A GOVERNMENT FORCES AN D LIBERIAN REBELS WHO CROSSED INTO SIERRA LEONE BEGINNING IN MARCH 1991.

00484

POSTS FOR VOTES, ITAMAR'S WAY

LATIN AMERICAN WEEKLY REPORT, (41) (OCT 92), 2

THE MAIN FEATURE OF THE CABINET APPOINTED BY ACTING PRESIDENT ITAMAR FRANCO IS THAT IT IS "POL ITICAL" RATHER THAN "TECHNOCRATIC." MEMBERS WERE CHOSEN SPECIFICALLY TO HELP GET THE GOVERNMENT'S DRAFT LEGISLATION APPROVED AS SWIFTLY AS POSSIBLE BY CONGRESS.

00485

POWER-SHARING DEAL IN MICARAGUA?

LATIN AMERICAN WEEKLY REPORT (15) (APR 92), 6-7, CONTROYERSY SURROUNDS THE ROLE OF THE FRENTE SANDINISTA DE LIBERACION NACIONAL (FSLN) IN THE GOVERNMENT OF PRESIDENT VE LIBERACION NACIONAL (FSLN) IN THE GOVERNHENT OF PRESIOEM HAYE SUGGESTED THAT THE URCES, INCLUDING DANIEL ORTEGA, HAVE SUGGESTED THAT THE SAMDINISTAS HAVE A "POWER-SHARING" ARRANGEMENT WITH THE CHAMORRO GOVER HMENT. OTHER MEMBERS OF THE RULING COALITIDN HAVE VIGOROUSLY OBJECTED TO
SANDINISTA A MAJOR ROLE IN NICARAGUAN POLITICS.

00486

PRD HELPS ENDARA WIN IN LEGISLATURE

LATIN AMERICAN WEEKLY REPORT, (36) (SEP 92), 9

BECAUSE THE CHRISTIAN DEMOCRATS WITHDREW FROM THE

COALITION GOVERNMENT, PRESIDENT GUILLERMO ENDARA'S

ADMINISTRATION HAD TO RELY ON VOTES FROM THE OPPOSITION

PARTIDO REVOLUCIONARIO DEMOCRATICO TO RETAIN CONTROL OF THE

KEY POSTS IN THE LEGISLATURE. THE CHRISTIAN DEMOCRATS BECAME

THE ARCHITECTS OF THEIR OWN DEFEAT WHEN THEY REFUSED TO

ENTER AN ALLIANCE WITH THE NINJAS, DISSIDENT MEMBERS OF THE PRO-GOVERNMENT BLOC.

00487

PRD WILL NOT GET BENEFIT OF DOUBT

LATIN AMERICAN WEEKLY REPORT, (30) (AUG 92), 10.

THE PARTIDO DE LA REVOLUCION DEMOCRATICA HAS PROTESTED

THE RESULTS OF RECENT ELECTIONS IN MICHOACAN, BUT PRESIDENT

CARLOS SALINAS DE GORTARI DOES NOT SEEM TO BE INCLINED TO

CARLOS SALINAS DE
ORDER NEW POLLS.

00488

PREPARING FOR HAR?

WEST AFRICA, (3913) (SEP 92), 1568

CHARLES TAYLOR, LEADER OF'LIBERIA'S NPFL REVEL FORCES

IS PREPARING FOR M LEADER OF LIBERIA'S ' PPFL REVEL FORCES RECEIVING SHIPMENTS OF NEW ARMAMENTS, AND IT HAS BEEN REPORTED THAT TAYLOR HAS HIRED WHITE MERCENARIES TO MAN HIS NEW, MORE SOPHISTICATED WEAPONS. OBSERVERS FEAR FOR THE SAFETY OF THE ECOMOG PEACEKEEPING FORCES.

00489

PRESIDENT'S UNCLE ON BANZER'S TICKET

LATIN AMERICAN WEEKLY REPORT, (47) (DEC 92), 10-11.

ON NOVEMBER 18, 1992, BOL IVIA'S RULING COALITION

ANNOUNCED THAT IT HAD SELECTED FORMER LABOR MINISTER OSCAR

ZAMORA TO BE GENERAL HUGO BANZER'S RUNNING MATE.

00490

PRESSURES AND CLAIMS OF COUP ATTEMPTS

LATIN AMERICAN WEEKLY REPORT, (45) (NOV 92), 4-5.

PRESIDENT ALFREDO CRISTIANI IS HAVING A HARD TIME

GETTING THE MILITARY TO ACCEPT THE REVISED DEMOBILIZATION

SCHEDULE AND THE PURGE OF THE OFFICER CORPS OUTLINED IN THE

U.N. -SUPERVISED PEACE TREATY IN ADDITION, THERE HAYE BEEN REPORTS OF "STRONG PRESSURES" FROM THE MILITARY AND TWO OR THREE COUP ATTEMPTS.

00491

PRINCIPLES OF RELATIONS WITH THE CIS

BEIJING REYIEH, 35(50) (DEC 92), 13-14.

DURING A NEWS CONFERENCE IN MOSCOW ON NOVEMBER 26,1992 CHINESE FOREIGN MINISTER OIAN OICHEN EXPLAINED CHINA'S POSITION ON DEVELOPING RELATIONS WITH THE COMMONHEALTH OF INDEPENDENT STATES AND DISCUSSED THE INFLUENCE OF THOSE

RELATIONS ON THE INTERNATIONAL SITUATION.

00492

PROFIT AND LOSS

THE MIDDLE EAST, (195) (JAN 91), 12

FOR BOTH IRAO AND KUWAIT THE ECONOMIC COST OF SADDAM'S AGGRESSION HAS BEEN HEAVY. ONE HAS BEEN SYSTEMATICALLY LOOTED, AND BOTH ARE IN THE GRIP OF PERHAPS THE MOST STRINGENT TRADE EMBARGD THE WORLD HAS EVER SEEN. THE FINANCIAL IMPACT OF THE CRISIS, HOWEVER, IS BEING FELT THROUGHOUT THE REGION, WITH SOME OF THE POOREST COUNTRIES STANDING TO LOSE THE MOST. FOUR STATES--EGYPT, TURKEY, YEMEN, AND JORDAN--HAVE BEEN THE HARDEST HIT. THE COST OF
SANCTIONS, RISING OIL PRICES, AND LOST HORKER REMITTANCES ALL COMBINE TO MAKE SADDAM HUSSEIN'S AGGRESSION VERY EXPENSIVE.

00493

PROGRESS SEEN IN RUSSO-JAPANESE TIES

JAPAN TIMES (WEEKLY INTERNATIONAL EDITION), 32(6) (FEB 92),

1,6 JAPAN'S RELATIONS WITH RUSSIA SEEM TO BE IMPROVING.

RUSSIAN PRESIDENT BORIS YELTSIN HAS INDICATED THAT HE IS

WILLING TO DISCUSS THE LONGSTANDING TERRITDRIAL DISPUTE OVER

FOUR JAPANESE ISLANDS TAKEN BY THE SOYIETS AFTER WORLD WAR

II AND TO BEGIN NEGOTIATIONS FOR A BILATERAL PEACE TREATY.

IN TURN, JAPANESE PRIME MINISTER KIICHI MIYAZAWA HAS

DECLARED THAT RUSSIAN RESIDENTS WILL BE ALLOWED TO CONTINUE

LIVING ON THE ISLANDS IF THEY REVERT TO JAPAN.

00494

PROMISES, PROMISES

COMMONWEAL, CXIX(17) (OCT 92), 3-4.

WHETHER CLINTON OR BUSH HINS THE 1992 U.S. PRESIDENTIAL

ELECTION, THE MEXT PRESIDENT HILL HAVE TO MAKE UNPOPULAR

ELECTION, THE NEXT PRESIDENT WILL HAVE TO MAKE UNPOPULAR

ORDER TO REINYIGORATE THE ECONOMY, RE-EDUCATE THE WORK FORCE, AND REVITALIIE THE COMMON LIFE. THUS FAR, NEITHER CANDIDATE HAS SAID THE HARD THINGS THAT NEED SAYING.

00495

PROPOSED F-15 SALE DRAHS STRONG PROTEST

BEI JING REVIEW, 35(37) (SEP 92), 7,9-10.

IN SEPTEMBER 1992 THE PEOPLE'S REPUBLIC OF CHINA REACTED

STRONGLY TO U.S. PRESIDENT GEORGE BUSH'S DECISION TO SELL

150 F-16 FIGHTER JETS TO TAIWAN. CHINA WARNED THAT THE

DECISION, WHICH REVERSED A 10-YEAR-OLD COMMITMENT BY THE U.S.

GOVERNMENT TO REDUCE ITS ARMS SALES TO TAIWAN, COULD LEAD

TO A MAJOR RETROGRESSION IN SINO-U.S. RELATIONS AND HAVE A

NEGATIVE IMPACT ON SINO-U.S. COOPERATION IN THE UNITED

NATIONS AND OTHER INTERNATIONAL ORGANIZATIONS.

00496

PURCHASE TARGET AGREEMENT SET: JAPAN-U.S. PACT DRANS CRITICISH

JAPAN TIMES (WEEKLY INTERNATIONAL EDITION), 32(3) (JAN 92),

1,5 .

THE JANUARY 1992 SUMMIT BETWEEN U.S. PRESIDENT GEORGE BUSH AND JAPANESE PRIME MINISTER KIICHI MIYAZAHA SENT ONE SIMPLE MESSAGE: ECONOMIC ISSUES WILL SET THE TONE FOR BLLATERAL RELATIONS IN THE POST-COLD WAR WORLD. THE THO PEADERS AGREED TO WORK TOGETHER TO ADORESS BOTH BILATERAL ARE A NEW INTERNATIONAL ORDER. IN DOCUMENTS ISSUED AT THE CLOSE OF THE SUMHIT JAPAN NOTED THAT ITS DOMESTIC AUTOMAKERS PLAN TO MORE THAN DOUBLE PURCHASES OF U.S ${ }^{\circ}$ AUTO PARTS BY FISCAL 1994. THE DOCUMENTS ALSO CITED JAPAN'S PLANS TO IMPORT ABOUT
20,000 U.S. CARS ANMUALLY "HITHIN A FEW YEARS."

00497

PYONGYANG TIES CALL FOR RESTRAINT

JAPAN TIMES (WEEKLY INTERNATIONAL EDITION), 32(17) (APR 92), 10.

THE AUTHOR EXAMINES THE PROGRESS OF MEETINGS INTENDED TO PROMOTE THE NORMALIZATION OF RELATIONS BETWEEN JAPAN AND NORTH KOREA.

00498

QIAN QICHEN ON CHINA'S FOREIGN POLICY

BEIJING REVIEW, 35(14) (APR 92), 13-15.

THIS ARTICLE CONTAINS A TRANSCRIPT OF A PRESS CONFERENCE GIVEN BY CHINESE FOREIGN MINISTER QIAN QICHEN ON MARCH 23 ,

1992. IT INCLUDES OIAN'S COMMENTS ABOUT THE HONG KONG QUESTION, RELATIONS WITH JAPAN. THE SITUATION IN CAMBODIA, THE ROLE OF THE UNITED NATIONS IN INTERNATIONAL AFFAIRS, AND OTHER MAJOR ISSUES.

00499

QUARTERLY CHRONICLE AND DOCUMENTATION

CHINA QUARTERLY, (131) (SEP 92) 846-907.

THIS REPORT SUMMARIZES MAJOR POLITICAL DEVELOPMENTS IN

CHINA DURING APRIL THROUGH JUNE 1992. IT DISCUSSES DENG

XIAOPING'S CALL FOR ACCELERATED REFORM, THE FIFTH SESSION OF XIAOPING'S CALL FOR ACCELERATED REFORM, THE FIFTH SESSION OF
THE SEVENTH NATIONAL PEOPLE'S CONGRESS, THE 26TH SESSION OF THE SEVENTH NPC STANDING COMMITTEE, AND CHINA'S

THE SEVENTH NPC STANDING

00500

QUARTERLY CHRONICLE AND DOCUMENTATION (OCTOBER-DECEMBER $1991)$

CHINA QUARTERLY, (129) (MAR 92), 263-288

THIS REPORT SUMMARIZES MAJOR' POLITICAL AND ECONOMIC DEVELOPMENTS IN MAINLAND CHINA DURING OCTOBER THROUGH DECEMBER 1991. TOPICS INCLUDE THE 22ND AND 23RD SESSIONS OF THE SEVENTH NATIONAL PEOPLE'S CONGRESS STANOING COMHITTEE, THE EIGHTH PLEMARY SESSION OF THE 13TH CHINESE COMMUNIST PARTY CENTRAL COMMITTEE, AND CHINA'S RELATIONS WITH OTHER 
COUNTRIES.

00501

QUINTESSENTIAL APPARATCHIK

HEST AFRICA, (3892) (APR 92), 667

THE AUTHOR PROFILES JAMES OMOTAYO CHRISTIAN JOMAH, WHO WAS RECENTLY APPOINTED ASSISTANT SECRETARY-GENERAL, OFFICER FOR RESEARCH AND THE COLLECTION OF INFORMATION, AT THE UNITED NATIONS.

00502

RACE AGAINST TIME

NEW REPUBLIC, 206(21) (MAY 92), 1, 7-9

THE 1992 RIOTS IN LOS AMGELÉS PROVIDED A GLIMPSE OF THE AMERICAN RACIAL AND URBAN CRISIS, WHICH IS STEADILY GROWING IN INTENSITY. NEITHER REPUBLICAN NEGLECT NOR TRADITIONAL DEMOCRATIC LIBERALISM CAN COME CLOSE TO SOLVING IT. IT'S TIME TO START OVER, RECOGNIZING THE REALITY OF TODAY'S CITIES.

00503

\section{READY FOR REFERENDUM}

WEST AFRICA, (3885) (MAR 92), 386

MARCH 17, 1992. HAS BEEN SET AS THE DATE ON WHICH WHITE VOTERS WILL APPROVE OR REJECT THE REFORMS INTRODUCED BY PRESIDENT F.W. DEKLERK OVER THE PAST THO YEARS AND HIS GOVERNMENT'S CONTINUED INVOLVEMENT IN NEGOTIATIONS THAT WILL PRODUCE A NEW CONSTITUTION AND A TRANSITIONAL GOVERNMENT. PRESIDENT DEKLERK HAS PROMISED TO CALL AM ELECTIOM IF HE LOSES THE REFERENDUM. 00504

REAGAN AND THE POPE: A HOLY ALLIANCE?

CHURCH AND STATE, 45(4) (APR 92), $10(82)$

A CLOSE, SECRET RELATIONSHIP DEVELOPED BETHEEN U.S

PRESIDENT RONALD REAGAN AMD POPE JOHN PAUL II DURING THE

$1980^{\prime} S$. THE REAGAN ADMINISTRATION AND THE VATICAN COOPERATED

IN SUPPORTING ANTI-COMMUNIST DISSIDENTS IN POLAND AS WELL AS

IN ATTEMPTING TO LIMIT THE RIGHTS OF ABORTION AND BIRTH CONTROL.

00505

REBUFFED OAS WILL NOT GET TOUGHER

LATIN AMERICAN WEEKLY REPORT, (19) (MAY 92), 2-3.

THE SECOND OAS MISSION TO PERU FOLLOWIMG THE

PRESIDENTIAL COUP LEFT THE COUNTRY ON MAY 6, 1992, WITHOUT

MAKING AMY HEADWAY IN ITS ATTEMPT TO PERSUADE ALBERTO

FUJIMORI TO RESTORE CONSTITUTIONAL RULE. AFTER THE OAS

REPRESENTATIVES DEPARTED, FUJIMORI ANMOUNCED A NEW SERIES OF

TOUGH MEASURES TO COMBAT' INSURGENTS. 00506

RECENT ACTION IN THE CONGRESS

CONGRESSIONAL DIGEST

IN THE FAL OF 1989 THE U.S. CONGRESS PASSED THE

SUPPORT FOR EAST EUROPEAN DEMOCRACY ACT TO PROVIDE AID FOR

POLAND AND HUNGARY. ON APRIL 1, 1992, THE CONGRESS PASSED CONTINUING RESOLUTION FOR FOREIGN OPERATIONS APPROPRIATIONS FR THE REMAINDER OF FY1992, WHICH ALLOWED THE ADMINISTRATION TO TRANSFER ECONOMIC SUPPORT FUND MONEY TO FINANCE PROGRAMS IN THE FORMER SOVIET UNION.

00507

RECENT ACTION IN THE CONGRESS

CONGRESSIONAL DIGEST, $71(12)$ (DEC 92), 301.

SINCE THE 1970'S, CONGRESS HAS BEEN WORKING TO FASHION

COHERENT FEDERAL SCIENCE AND TECHNOLOGY POLICY TO PROMOTE

INVESTMENT AND ECONOMIC GROHTH. MAJOR LEGISLATION HAS

INCLUDED THE STEVENSON-WYDLER TECHNOLOGY INMOVATION ACT, THE

BAYH-DOLE ACT TO AMEND THE PATENT AND TRADEMARK LAHS, THE

NATIONAL COOPERATIVE RESEARCH ACT TO ENCOURAGE JOINT

RESEARCH BY RELAXING ANTI-TRUST LAWS, AND THE TECHNOLOGY

TRANSFER ACT OF 1986.

00508

BID REACHES FIRST BASE

LATIN AMERICAN WEEKLY REPORT, (8) (FEB 92), 11

UNION LEADERS, SOME MAYORS, THE LEFT-WING FRENTE AMPLIO, THE OPPOSITION PARTIDO COLORADO, AND DISSIDENTS WITHIN THE RULING PARTIDO BLANCO HAVE ORGANIZED A CAMPAIGN TO HAVE THE LACALLE GOVERMMENT'S PRIVATIZATION LAH REPEALED BY A REFERENDUM.

00509

REFERENDUM FALLOUT HITS ARIAS CALDERON

LATIN AMERICAN HEEKLY REPORT (48) (DEC 92) 5.

PRESIDENT GUILLERMO ENDARA HAS CHOSEN TO' IGNORE THE DEFEAT SUFFERED IN THE RECENT REFERENDUM ON CONSTITUTIONAL REFORMS AND HAS INDICATED THAT HE WILL REMAIN IN OFFICE UNTIL THE END OF HIS TERM. THE LOCAL PRESS HAS CALLED ON ARIAS CALDERON, ENDARA'S FIRST VICE PRESIDENT AND LEADER THE CHRISTIAN DEMOCRATS, TO RESIGN
00510

REFORM OF STATE ENTERPRISES IN VOGUE

BEIJIMG REVIEH 35(47) (MOV 92) 10-11.

A MAJORITY OF CHINA'S STATE-OHNED ENTERPRISES HAVE ADOPTED MANAGEMENT REFORMS. AS A MAJOR PART OF CHINA'S ECONOHIC RESTRUCTURING, REFORM OF STATE ENTERPRISES FOCUSES ON THE RENOVATION OF MANAGERIAL TECHNIQUES, REQUIRING INDUSTRIES TO FREE THEMSELVES FROM A PLANNED ECONOMY WITH STATE RESPONSIBILITY FOR PROFITS AND LOSSES.

00511

REFORMS IN SOUTH AFRICA: THE ROLE OF COMMONHEALTH PARLIAMENTS IN ACCELERATING CHANGES TOWARDS DEMOCRACY WHICH WILL ALLOW SOUTH AFRICA TO REJOIN THE COMMONWEALTH PARLIAMENTARIAN, LXXIII(1) (JAN 92), 9-11.

THE AUTHOR REPORTS ON THE DEBATE WITHIN THE BRITISH COMMONHEALTH OVER THE PACE OF REFORMS IN SOUTH AFRICA AMD HOW COMAONWEALTH MEMBERS CAN HELP TO ACCELERATE

DEMOCRATIZATION IN SOUTH AFRICA.

00512

REFORMS REVIVE BIG STATE FIRMS

BEIJING REVIEN, 35(2) (JAN 92), 36-37.

CHINA'S LARGE AND MEDIUM-SIZZED STATE-OWNED ENTERPRISES

HAVE BEEN HEALTHIER SINCE THE ADOPTION OF 12 NEW POLICIES,

INCLUDING MORE GOVERMMENT AID TO DEVELOP BETTER TECHNOLOGY,

SMALLER MANDATORY STATE PRODUCTION TARGETS, HIGHER

DEPRECIATION RATES BIGGER INVESTMENTS FOR MEN PRODUCT

RESEARCH AND DEVELOPMENT, AND LOWER INCOME-TAX RATES.

00513

REFORMS SECURE PEREZ MANDATE

LATIN AMERICAN WEEKLY REPORT, (30) (AUG 92), 4

THE PROCEDURES FOR CONSTITUENT ASSEMBLY ELECTIONS--A KEY FEATURE IN THE PACKAGE OF CONSTITUTIONAL AMENDMENTS

CURRENTLY BEFORE THE VENEZUELAN CONGRESS--HAS BEEN APPROVED SO AS TO ENSURE THAT PRESIDENT CARLOS ANDRES PEREZ HILL REMAIN IN OFFICE UNTIL WELL INTO 1993.

00514

REHUFFLE FOLLOHS REBUFF ON PENSIONS

ATIN AMERICAN WEEKLY REPORT, (4) ( JAN 92), 3.

COUNTRY'S PENSIONERS A 147\% INCREASE. ARGUING THAT THE

GOVERMMENT SIMPLY DID NOT HAVE THE MONEY, PRESIDENT FERNANDO

COLLOR DE MELLO SUMMONED THE CONGRESS TO CONSIDER A

COMPROMISE THAT WOULD HAVE PROVIDED A MUCH SMALLER PENSION

INCREASE. BUT THE CONGRESS OVERWHELMINGLY DEFEATED THE

COMPROMISE MEASURE. FOLLOHING THIS, COLLOR DECIDED TO

RESHUFFLE HIS CABINET.

00515

REINSTATEMENT BID GRINDS TO A HALT

ATIM AMERICAN WEEKLY REPORT (17) (MAY 92), 8.

ALMOST THO MONTHS AFTER AN AGREEMENT WAS REACHED FOR A PHASED REINSTATEMENT OF OUSTED PRESIDENT JEAN-BERTRAND ARISTIDE, THE SITUATION SEEMS TO BE COMPLETELY DEADLOCKED.

00516

REINTERPRETATION OF CONSTITUTION MAY PROVIDE SDF WITH U.N. ROLE

JAPAN TIMES (WEEKLY INTERNATIONAL EDITION), 32(2) (JAN 92),

3. ACCORDING TO THE JAPANESE GOVERMMENT'S PRESENT

INTERPRETATION OF THE CONSTITUTION. THE USE OF FORCE IS

PERMITTED ONLY FOR SELF-DEFENSE AND IS NOT PERMITTED TO

DEFEND ANOTHER COUNTRY WITH WHICH JAPAN HAS AN ALLIANCE. BUT

A NEW REPORT BY THE LIBERAL DEMOCRATIC PARTY RESEARCH

COMMISSION SAYS THE SPIRIT OF THE CONSTITUTION IS NOT

PASSIVE PACIFISM BUT POSITIVE AND ACTIVE PACIFISM. THIS

SEEMS TO OPEN THE DOOR FOR FUTURE JAPAMESE PARTICIPATION IN

UNITED NATIONS' PEACE-KEEPING FORCES.

00517

REINTERPRETING THE CONSTITUTION: LAW ALLOWS SDF TO PLAY U. N. ROLE

JAPAN TIMES (WEEKLY INTERMATIONAL EDITION), 32(9) (MAR 92),

1,6

A LIBERAL DEMOCRATIC PARTY (LDP) PANEL HAS CONCLUDED

THAT JAPAN'S SELF-DEFENSE FORCES (SDF) COULD JOIN UNITED

NATIONS FORCES IF PROVISIONS OF THE CONSTITUTION WERE

REINTERPRETED. THE PANEL HAS ALSO DECIDED THAT JAPAN COULD

JOIN A MULTINATIONAL FORCE SUCH AS THAT FORMED DURING THE

GULF WAR I - ITS PARTICIPATION WERE RESTRICTED TO NON-

MILITARY R ES. THE LDP'S CONCLUSIONS HAYE ELICITED STRONG REACTIONS $=$ - EOM OPPOSITION PARTIES.

00518

RELATIONS WITH LIBYA

SURVEY OF CURRENT AFFAIRS, 21(12) (DEC 91), 449-450.

GREAT BRITAIN AND THE UNITED STATES HAVE CALLED ON THE LIBYAN GOVERNMENT TO SURRENDER TWO LIBYAN NATIONALS TO FACE TRIAL FOR THEIR ALLEGED INYOLVEMENT IN THE BOMBING OF A UNITED STATES AIRLINER OVER LOCKERBIE, SCOTLAND, IN 1988 
00519

RELATIONS WITH U.S. AT THEIR LOWEST YET

LATIN AMERICAN WEEKLY REPORT, (26) (JUL 92), 10 RELATIONS BETHEEN MEXICO AND THE UNITED STATES CLEARLY ARE NOT AT THEIR BEST. THE NEGOT IATIONS THAT BEGAN ON JUNE 15, 1992, IN THE WAKE OF THE U.S. SUPREME COURT DECISION ENDORSING THE ABDUCTION OF A MEXICAN NATIONAL, HAVE TURNED INTO A JERKY SHUTTLE. AT STAKE ARE THE REVISION OF THE EXTRADITION TREATY BETWEEN THE THO COUNTRIES AND THE NEH GROUND RULES FOR DEA AGENTS STATIONED IN MEXICO.

00520

RELIGIOUS LIBERTY AND THE CONGRESS: FACING A TWO-PART TEST CHURCH AND STATE, 45(1) (JAN 92), 13.

MEMBERS OF CONGRESS FACE TWO IMPORTANT TESTS OF THEIR COMMITMENT TO RELIGIOUS LIBERTY AND CHURCH-STATE SEPARATION: THE RELIGIOUS FREEDOM RESTORATION ACT AND PRIVATE SCHOOL VOUCHER LEGISLATION. IF THE CONGRESSIONAL REPRESENTATIVES BELIEVE IN THE RELIGIOUS FREEDOM PROVISIONS OF THE FIRS LATTER.

00521

RELIGIOUS RIGHT 'FANATICS' MAY HURT REPUBLICANS, EXPRESIDENT NIXON WARNS

CHURCH AND STATE, 45(10) (NOV 92), 17(233)-18(234)

FORMER PRESIDENT RICHARD NIXON HAS WARNED HIS FELLOW REPUBLICANS THAT GOP CANDIDATES CAN'T WIN UNLESS THEY DISASSOCIATE THEMSELVES FROM THE RELIGIOUS RIGHT AND START PROJECTING A MORE POSITIVE MESSAGE. NIXON CALLED PAT ROBERTSON ANO JERRY FALHELL "FANATICS" AND RECOMMENDED THAT PRESIDENT GEORGE BUSH DISTANCE HIMSELF FROM THEM IF HE WANTS TO BE RE-ELECTED.

00522

REPORT ON IMPLEMENTATION OF THE 1991 STATE BUDGET AND DRAFT 1992 STATE BUDGE

BEI JING REVIEW, 35(16) (APR 92), VI-VIII.

IN THIS REPORT, STATE COUMCILLOR AND MINISTER OF FINANCE WANG BINGOIAN DISCUSSES THE IMPLEMENTATION OF CHINA'S 1991 STATE BUDGET AND OUTLINES THE DRAFT 1992 STATE BUDGET.

00523

REPORT ON THE IMPLEMENTATION OF THE 1991 PLAN FOR NATIONAL ECONOMIC AND SOCIAL DEVELOPMENT AND THE DRAFT 1992 PLAM

BEIJING REVIEW, 35(16) (APR 92), I-V.

THIS REPORT BY ZOU JIAHUA, VICE-PREMIER OF THE STATE COUNCIL AND MINISTER IN CHARGE OF THE STATE PLANHING

COMMISSION, REVIEWS THE IMPLEMENTATION OF CHINA'S 1991 PLAN

COMMISSION, REVIEWS THE IMPLEMENTATION OF CHINA'S 1991 PLAN

FOR NATIONAL AND SOCIAL DEVE
TARGETS FOR THE 1992 PLAN.

00524

REPORT ON THE WORK OF THE GDVERMMENT

BEI TIMG REYIEH $35(15)$ (APR O2) I-XYI

CHINESE PREMIER 15) PENG 92), I-XVI.ं FIFTH SESSION OF THE SEVENTH MATIONAL PEOPLE'S CONGRESS ON MARCH 20,1992 . HE DISCUSSED CHINA'S POLITICAL STABILESS ON MARCH 20, 1992. HE THE NEED TO ACCELERATE REFORM AND CREATE A BETTER SOCIAL AND POLITICAL ENVIRONMENT FOR ECONOMIC DEVELOPMENT, THE PROSPECTS FOR PEACEFUL REUNIFICATION OF THE MOTHERLAND, AND CHINA'S INTERNATIONAL RELATIONS.

00525

RESCUE BOSHIA

NEW REPUBLIC, 207 (8-9) (AUG 92), 7

THE BUSH-CLINTON TIFF OVER U.S. POLICY TOWARD BOSNIA

EXEMPLIFIES THE POST-COLD WAR PARADIGM SHIFTS TAKING PLACE

IN THE FOREIGN POLICIES OF THE DEMOCRATIC AND REPUBLICAN

PARTIES. THE AMERICAN FOREIGN POLICY DEBATE IN THE NEW WORLD

ORDER SEEMS LIKELY TO BE IN PART A DEBATE BETWEEN DEMOCRATIC

INTERVENTIONISH IN THE NAME OF HIGH IDEALS AND REPUBLICAN

WORLD-WEARINESS ABOUT POTENTIAL QUAGMIRES LIKE BOSNIA.

00526

RESHUFFLE LAUNCHES SUCCESSION RACE

LATIN AMERICAN WEEKLY REPORT, (4) (JAN 92) 2-3.

MEXICAN PRESIDENT CARLOS SALINAS DE GORTARI BEGAN THE

YEAR 1992 WITH A CABINET RESHUFFLE THAT INVOL VED A FEW,

IMPORTANT MINISTERS AND WAS SEEN AS THE OPENING GAMBIT' IN

THE PREPARATION FOR SALINAS'S SUCCESSION. 00527

RESHUFFLE LIKELY AFTER COLLOR VOTE

LATIN AMERICAN WEEKLY REPORT, (49) (DEC 92),

THE SENATE HAS ENDORSED THE FORMAL CHARGÉS AGAINST

SUSPENDED PRESIDENT FERNANDO COLLOR DE MELLO, CLEARING THE

WAY FOR HIS IMPEACHMENT TRIAL, WHICH IS EXPECTED TO CONCLUDE

ON DECEMBER 22, 1992. MEANWHILE, ACTIING PRESIDENT ITAMAR

FDMINISTRATION AFTER COLLOR IS CONVICTED, WHICH SEEMS TO BE
AD CERTAINTY.
00528

RESTORATION PLAN PLUS REPRESSION

LATIN AMERICAN WEEKLY REPORT, (17) (MAY 92), 4-5.

EMBOLDENED BY THE OAS'S WEAK RESPONSE TO HIS COUP

PERUVIAN PRESIDENT ALBERTO FUJIMORI HAS ADOPTED A THO-

PRONGED PROGRAM: (1) A RETURN TO DEMOCRACY WITHIN 12 MONTHS,

WITH LEGISLATIVE ELECTIONS FOLLOWING A STAGE-MANAGED REFORM

OF THE CONSTITUTION; AND (2) MEASURES TO QUASH ATTEMPTS BY

CONGRESS AND OTHER INSTITUTIONS TO CONTINUE ACTING AS

REPOSITORIES OF CONSTITUTIONAL ACTIVITY.

00529

RESULTS OF GUYANESE ELECTIONS DELAYED BY RIOTING PNC MOBS LATIN AMERICAN WEEKLY REPORT, (40) (OCT 92), 1

INTERNATIONAL OBSERVERS EXPECTED IRREGULARITIES IN

GUYANA'S OCTOBER 1992 GENERAL ELECTIONS, BUT THEY WERE

PROBABLY NOT PREPARED FOR THE RIOTING THAT BROKE OUT AT THE

ELECTORAL COMNISSION BUILDING IN GEORGETOWN. SIMILAR RIOTS

ERUPTED IN LINDEN AND ANNA REGINA. IN ALL CASES, MOST OF THE

RIOTERS WERE SUPPORTERS OF THE PEOPLE'S NATIONAL CONGRESS.

PRESIDENT DESMOND HOYTE ORDERED THE POLICE AND THE ARMY TO

00530

REVERSING THE DECLINE

WEST AFRICA, (3905) (JUL 92), 1211-1212.

THE ECONOMIC REFORMS INTRODUCED DURING THE LAST TWO

YEARS IN SIERRA LEONE'S STRUCTURAL ADJUSTMENT PROGRAM HAVE

YIELDED POSITIVE RESULTS. VIRTUALLY ALL CONTROLS ON INTERNAL

AND EXTERNAL TRADE AS WELL AS ON PRICES HAVE BEEN ELIMINATED

A MARKET-DETERMINED EXCHANGE RATE HAS BEEN INTRODUCED; THE

LENDING RATES OF COMMERCIAL BANKS HAVE BEEN FREED FROM

CONTROLS WHILE DEPOSIT RATES HAVE BEEN SET AT MORE REALISTIC

LEVELS. ON THE FISCAL MANAGEMENT SIDE, THE GOVERNMENT HAS

ADOPTED MEASURES TO STRENGTHEN REVENUE COLLECTION AND

CONTROL EXPENDITURES.

00531

RIGHT-KIN URUGUAY

LATIN AMERICAN WEEKLY REPORT, (19) (MAY 92), 1

IN MAY 1992, URUGUAY SUFFERED A GENERAL STRIKE

PROTESTING PRESIDENT LUIS ALBERTO LACALLE'S POLICIES OF WAGE CONTAINMENT AND PRIVATIZATION OF STATE ENTERPRISES. AT THE

SAME TIME, THE COUNTRY WAS TRYING TO COPE WITH THE EMERGENCE

OF RIGHT-WING TERRORIST GROUPS CLAIMING LINKS WITH THE

MILITARY AND A CAMPAIGN BY RETIRED MILITARY OFFICERS

DEMANDING ACTION AGAINST GOVERMMENT CORRUPTION.

00532

RIO-CON

NEW REPUBLIC, 207(2) (JUL 92), 7

ALTHOUGH HASHINGTON WAS SOUNDLY CRITICIZED FOR ITS ACTIONS AT THE 1992 EARTH SUMMIT, U.S. INVOL VEMENT ACTUALLY IMPROVED THE GREENHOUSE GASES TREATY. MOREOVER, SOME OF THE CRITICISA OF THE UNITED STATES CAME FROM COUNTRIES AND GROUPS THAT WERE PURSUING THEIR OWN OBJECTIVES IN ORDER TO REDUCE THE IMPACT OF ENVIRONMENTAL PROTECTION ON THEIR ECONOMIES.

0053

RIVAL CGT FACTIONS TO BURY HATCHET

LATIN AMERICAN HEEKLY REPORT, (8) (FEB 92), 10

SHORTLY AFTER PRESIDENT CARLOS MENEM TOOK OFFICE IN 1989,

THE UMBRELLA LABOR ORGANIZATION CONFEDERACION GENERAL DEL

TRABAJO SPLIT INTO TWO FACTIONS, ONE SUPPORTING AND THE

OTHER OPPOSING MENEM'S ECONOMIC POLICIES. BY FEBRUARY 1992,

THE PRO-MENEM FACTION HAD PROGRESSED FROM SUPPORT TO

DISENCHANTMENT TO OUTRIGHT DEFECTION. AFTER A SERIES OF

CONGRES" ON MARCH 26, 1992.

00534

ROW IN CONGRESS OVER U.S. TROOPS

LATIN AMERICAN HEEKLY REPORT, (30) (AUG 92) 5

THE PRESENCE OF U.S. TROOPS IN BOLIVIA'S AMAZONIAN

REGION CONTINUES TO STIR UP CONTROVERSY BECAUSE PRESIDENT

JAIME PAZ ZAMORA ALLOWED THE FOREIGN MILITARY INTO BOLIVIA

WITHOUT FIRST SEEKING CONGRESSIONAL APPROVAL, AS MANDATED BY

THE CONSTITUTION. THREE GOVERMMENT MINISTERS HAVE BEEN

SUMMONED FOR QUESTIONING BY THE CONGRESS, WHICH COULD VOTE

TO CEMSURE THEM. 00535

RUMOURS FLY OF A COUP IN THE MAKING

LATIN AMERICAN WEEKLY REPORT, (32) (AUG 92), 10

PRESIDENT ALBERTO FUJIMORI IS WORRIED ABOUT THE

POSSIBILITY OF MILITARY INVOLVEMENT IN A COUP ATTEMPT. HE

HAS BEEN MEETING WITH MILITARY COMMANDERS, SEEKING

RECONFIRMATION OF THEIR SUPPORT FOR HIS ONE-MAN RULE.

MOREOVER, HE IS NO LONGER IGNORING CALLS BY POLITICIANS FOR

THE MILITARY TO OVERTHROW HIM BUT IS INITIATING LEGAL

PROCEEDINGS AGAINST POLITICAL FIGURES WHO DO SO. 
00536

SALINAS IMPOSES NEH PRICE-PAY PACT

SAIN AMERICAN WEEKLY REPORT, (43) (NOV 92), 5

(1992, THE MEXICAN GOVERNMENT RENEWED ITS ANTI-INFLATION POLICY, CHANGING THE NAME FROM "THE PACTO PARA LA ESTABILIDAD Y EL CRECIMI ENTO ECONOMICO" TO "THE PACTO PARA LA ESTABILIDAD, LA COMPETITIVIDAD Y EL EMPLED." IS NO LONGER AN IMMEDIATE PRIORITY FOR THE MEXICAN GOVERNMENT. STABILITY, INCLUDING THE REDUCTION OF INFLATION, IS THE MOST IMPORTANT TARGET. THE MAIN OBJECTIVE OF THE NEH PACT IS TO ACHIEVE ONE-DIGIT INFLATION IN THE NEAR FUTURE.

00537

SANDINISTA POLICE AGREE TO REFORM

LATIN AMERICAM WEEKLY REPORT, (28) (JUL 92), 11.

THE UPRISING THREATENED BY SANOINISTA LEADER DANIEL

ORTEGA IF THE GOVERMMENT PROCEEDED WITH ITS PLAN FOR

REFORMING THE POLICE SEEMS TO HAVE BEEN SHELVED. ON JULY 7 ,

1992. THE SANDIMISTA CHIEF OF THE POLICE FORCE AMMOUMCED

THAT' A CONSENSUS HAD BEEN REACHED BETHEEN THE POLICE

COMMANDERS AND THE GOVERNMENT.

00538

SANDINISTAS STILL RULE THE COUNTRY

LATIN AMERICAN WEEKLY REPORT (36) (SEP 92), 8-9.

DUE TO A REPORT BY U.S. SENATOR JESSE HELIMS, U.S. AID TO MICARAGUA HAS BEEN HALTED. HELMS ISSUED A REPORT ACCUSING THE CHAMORRO GOVERNMENT OF BEING RUN BY THE SANDINISTAS, BEING CORRUPT, TOLERATING HUMAN RIGHTS ABUSES, AND HAVING THE LARGEST, MOST SOPHISTICATED MILITARY APPARATUS IN CENTRAL AMERICA. THE CHAMORRO GOVERMMENT HAS SAID THAT THE REPORT IS FULL OF ERRORS AND OUTRIGHT LIES.

00539

SAVING LIVES?

COMMONHEAL, CXIX(12) (JUN 92), 3-4.

THE AUTHOR EXAMINES THE ARGUMENT FOR LIFTING THE BAN ON MEDICAL RESEARCH USING FETAL TISSUE DERIVED FROM ABORTIONS ANO EXPLAINS WHY SOME CONGRESSMEN WHO ARE NORMALLY ANTIABORTION ARE IN FAVOR OF FETAL-TISSUE RESEARCH.

00540

SAWYER'S PEACE CALL

HEST AFRICA, (3918) (OCT 92), 1766

LIBERIA'S INTERIM GOVERNMENT HEADED BY DR. AMOS SAWYER HAS CALLED ON THE TWO WARRING FACTIONS, ULIMO AND THE NPFL, TO IMMEDIATELY STOP THE VIOLENCE AND ALLOW ECOMOG TO ESTABLISH A DEMIL ITARIZED ZONE SEPARATING THEM FROM ONE ESTABLISH A DEMILITARIZED ZONE SEPARATING THEM FROM ONE
ANOTHER IN ALL AREAS WHERE THEY ARE IN DIRECT CONFRONTATION. 00541

SCIENTIST CLAIMS THAT THE BURMING OF AMAZONIA HAS EXCEEDED

LATIN AMERICAN WEEKLY REPORT, (2) (JAN 92), 1.

PHILIP FEARNSIDE, A U.S. SCIENTIST BASED IN MANAUS DISPUTES THE BRAZILIAN GOVERNMENT'S CLAIM THAT IT IS CONTINUING TO REDUCE THE SLASH-AND-BURN DESTRUCTION OF THE AMAZONIAN RAINFDREST. FEARNSIDE'S EMBARRASSING CLAIMS COME AT A MOST INOPPORTUNE TIME BECAUSE BRAZIL'S GOVERMMENT PLANS TO PROCLAIM ITS SUCCESS IN HALTING THE DESTRUCTION OF THE RAINFOREST AT THE WORLDWIDE ENVIRONMENTAL CONFERENCE IN RIO IN JUNE 1992 .

00542

SDF'S ROLE ABROAD PROPOSED

JAPAN TIMES (WEEKLY INTERNATIONAL EDITION), 32(9) (MAR 92), 10.

A LIBERAL DEMOCRATIC PARTY PANEL HAS ADVOCATED REVISING THE INTERPRETATION OF JAPAN'S CONSTITUTION TO ALLOW THE SELFDEFENSE FORCES TO PARTICIPATE IN UNITED NATIONS-SPONSORED PEACEKEEPING OPERATIONS. THE PANEL HAS PROPOSED THAT THE GOVERNMENT RESORT TO END-JUSTIFIES-THE-MEANS MEASURES TO FACILITATE SDF PARTICIPATION IN U.N. PEACEKEEPING ACTIVITIES INVOLVING ARMS.

00543

SECOND ROUND BECKONS

WEST AFRICA, (3919) (OCT 92), 1824

ON OCTOBER 17, 1992. ANGOLA'S NATIONAL ELECTORAL

COMMISSION PUBLISHED THE RESULTS OF THE PRESIDENTIAL

ELECTION. ALTHOUGH JOSE EDUARDO DOS SANTOS CLAIMED THE MOST

YOTES, HE FELL SHORT OF THE 5O PERCENT MEEDED TO AYOID A RUH

OFF ELECTION WITH RIVAL CANDIDATE JONAS SAVIMBI. DUE TO

SAYIMBI'S ALLEATIONS OF YOTING FRAUDAS SAVIMBI. DUE YO

EXPECTED TO MONITOR THE RUM-OFF ELECTION VERY CLOSELY.

00544

SECOND ROUND FOR FUJIMORI IN JANUARY

LATIN AMERICAN WEEKLY REPORT, (49) (DEC 92), 6-7.

THE OAS AND THE RIO GROUP HAVE ENDORSED PRESIDENT

ALBERTO FUJIMORI'S CONSTITUENT ASSEMBLY ELECTIONS AS A STEP

TOWARDS THE RESTORATION OF DEMOCRATIC RULE. ALTHDUGH THIS

OID NOT IMMEDIATELY SECURE PERU'S READMISSION TO THE RIO
GROUP, PERU'S RE-ENTRY IS ONLY A MATTER OF TIME, AND IT REMOYES POSSIBLE DIPLOMATIC OBJECTIONS TO THE RESTORATION OF FINAMCIAL ASSISTANCE TO PERU.

00545

SECRET REAGAN-POPE PACT ACHIEVED GOALS, SAYS "TIME"

CHURCH AND STATE, 45(4) (APR 92), 14(86)-15(87).

FORMER U.S. PRESIDENT RONALD REAGAN COLLABORATED WITH

POPE JOHN PAUL II IN THE 1980'S TO DESTABILIZE AND

EVENTUALLY HELP BRING DOWN THE COMMUNIST GOVERNMENT OF

POLAMD, ACCORDING TO "TIME" MAGAZINE. IN ADDITION, THE

VATICAN PERSUADED THE UNITED STATES TO IMPLEMENT ROMAN

CATHOLIC CHURCH POLICY ON BIRTH CONTROL OVERSEAS, RESULTING

IN A CUTOFF OF U.S. AID TO INTERMATIONAL FAMILY PLAMNING

AGENCIES THAT FUND BIRTH CONTROL AND ABORTIONS.

00546

SENOER TARGETS LIMA'S CIVILIANS IN WEEK OF UNREMITTING,

CALE BOMBINGS

LATIN AMERICAN WEEKLY REPORT, (29) ( JUL 92), 1

DESPITE AN EFFORT BY THE FUJIMORI GOVERNMENT TO END THE

VIOLENCE. THE SENDERO LUMINOSO CONTINUED ITS CAR-BOMBIMGS

AND OTHER ATTACKS DURING JUNE AND JULY 1992.

00547

SENEGAL AND THE OAU

WEST AFRICA (3901) (JUN 92), 1041

SENEGAL HAS ALWAYS BEEN ONE OF THE ORGANIZATION OF

AFRICAN UNITY'S (OAU) MAINSTREAM COUNTRIES, DESPITE THE

RIVAL CLAIMS OF ITS FRANCOPHONE CONNECTIONS.

00548

SERRANO HILL NOT EMULATE FUJIMORI

LATIN AMERICAN WEEKLY REPORT, (38) (OCT 92), 9

IN MID-SEPTEMBER 1992 THE' GOVERNMENT OF PRESIDENT JORGE

SERRANO WAS PLAGUED HITH RUMORS THAT HE HAS SERIDUSLY

CONSIDERING A "FUJIMORAZO," THE DISSOLUTION OF CONGRESS AND

THE ASSUMPTION OF LEGISLATIVE POWERS BY THE EXECUTIVE. A

GOYERMMENT SPOKESMAN DENIED THE RUMORS, SAYING THAT SERRANO

HAD CONTEMPLATED SUCH A MOVE BUT HAD BEEN TALKED OUT OF IT.

00549

SETTING THE TIME IN FREETOWM

WEST AFRICA, 75,3923) (NOV 92), 2002.

WITH MOST AFRICAN COUNTRIES IN THE REGION RETURNING TO

CIVILIAN, CONSTITUTIONAL RULE HITHIN THE NEXT THO YEARS,

SIERRA LEONE HILL BE THE UNIQUE EXCEPTION WITHOUT A CREDIBLE

TRANSITION IN SIGHT. WHATEVER THE NPRC WILL DO NOW, UNLESS

THEY GIVE IN TO THE KIND OF TEMPTATION OTHERS HAVE BEEN

UNABLE TO RESIST, WITH DIRE CONSEQUENCES FOR THEIR COUNTRIES,

SIERRA LEONE'S YOUTHFUL LEADERS HILL GO DOHN IN HISTORY AS

PEOPLE WHO GAVE HOPE TO THEIR COUNTRY WHEN DESPONDENCY HAD

PREYIOUSLY RULED.

00550

SEX AND THE CAMDIDATE

MEH REPUBLIC 206(4) (JAN 92) 7-8.

THE AUTHOR CONSIDERS THE QUESTION OF WHETHER

CAMDIDATE'S SEX LIFE IS AN IMPORTANT CLUE TO HIS CHARACTER

AND THEREFORE A LEGITIMATE ISSUE IN A POLITICAL CAMPAIGN.

0055

SHAMIR PUTS UP A ROADBLOCK

THE MIDDLE EAST, (201) (JUL 91), 15-16

THE AUTHOR OUTLINES REASONS FOR PESSIMISM ON THE

PROSPECT OF ARAB-ISRAELI NEGOTIATION. THESE REASONS INCLUDE

A) AMERICAN PRE-OCCUPATION WITH SELECTION OF PRESIDENTIAL

CANDIDATES FOR 1992; B) ISRAEL: REFUSAL (PARTICULARLY ON THE

PART OF YITZHAK SHAMIR) TO CONSIDER RELINQUISHING TERRITORY

TO ACHIEVE PEACE; C) THE ISSUE OF FINANCING SOVIET JEHISH

IMMIGRATION; D)REUNIFICATION OF THE PLO; AND E) THE

CONFLICTING AGENDAS OF SYRIAN AND PALESTIAN LEADERS, AS WELL AS THOSE OF THE GULF STATES.

00552

SIDE-EFFECTS OF ANTI-DRUGS EFFORT

ATIN AMERICAN WEEKLY REPORT, (30) (AUG 92), 6-7.

THE SIGMATORIES OF THE 1991 SAN ANTONIO DECLARATION WILL

MEET IN WASHINGTON ON JULY 29-31, 1992, TO REVIEN THE

PRESENTED TO SHOW SUCCESS, IN ORDER TO SECURE A CONTINUING

PRESENTED TO SHOW SUCCESS, IN ORDER TO SECURE A CONTINUING

FLOW OF U.S. AID TO LATIN AMERICA. BUT MANY EXPERTS SAY THAT

THE EFFORT HAS FAILED TO MAKE A SIGNIFICANT DIFFER

00553

SIERRA LEONE: PRESIDENTIAL INITIATIVE

WEST AFRICA, (3878) (JAN 92 ) 80

PRESIDENT JOSEPH SAIDU MOMOH INVITED THE LEADERS OF SIERRA LEONE'S SEYEN REGISTERED POLITICAL PARTIES TO A MEETING ON DECEMBER 16, 1991. DURING THE MEETING, MOMOH VOICED HIS SUPPORT FOR THE 1991 CONSTITUTION AND EMPHASIZED THAT EVERYONE MUST COOPERATE IF DEMOCRACY IS TO SUCCEED IN SIERRA LEONE. 
00554

SILENT ECONOMIC REVOLUTION

WEST AFRICA, (3889) (MAR 92), 551-552.

A GROWING NUMBER OF SUB-SAHARAN COUNTRIES ARE

UNDERTAKING CORRECTIVE ACTION AND SUSTAINED POLICY EFFORTS

TO IMPROVE THEIR ECONOMIC SITUATIONS, ACCORDING TO THE

INTERNATIONAL MONETARY FUND (IMF). THE IMF TAKES CREDIT FOR

HELPING AFRICAN DEVELOPMENT EFFORTS AND NOTES THAT A "SILENT

REVOLUTION" IN POLICY HAS HELPED TO PROMOTE BETTER

UNDERSTANDING BETWEEN SUB-SAHARAN COUNTRIES AND FOREIGN AID DONORS.

00555

SINO-ASEAN CHOICE: COOPERATION AND PROGRESS

BEIJING REVIEW, 35(31) (AUG 92), 7

AT THE 1992 ANNUAL CONFERENCE OF ASEAN FOREIGN MINISTERS, CHINESE FOREIGN MINISTER OIAN OICHEN SUGGESTED THAT CHINA

AND ASEAN SIGN AN AGREEMENT MODELLED ON THE SINO-EUROPEAN

AND ASEAN SIGN AN AGREEMENT MODELLED ON THE SINO-EUROP

COMMUNITY COOPERATION TREATY. HE CATEGORICALLY DENIED

SOUTHEAST ASIA CREATED BY THE END OF THE COLD HAR AND

DECLARED THAT CHINA ABHORS HEGEMONISM AND POWER POLITICS.

00556

SINO-CAMBODIAN JOINT COMMUNIQUE

BEIJING REVIEH, 35(17) (APR 92), 16-17.

ON APRIL 11, 1992, CHINESE AND CAMBODIAN LEADERS SIGNED

A JOINT COMMUNIQUE ON THE STATUS OF BILATERAL RELATIONS,

FOLLOWING AN OFFICIAL STATE VISIT BY SAMDECH PREAH NORODOM SIHANOUK TO BEI JING.

00557

SINO-GERMAN TIES BACK ON AN EVEN KEEL

BEIJING REVIEW, 35(46) (NOY 92), 7

GERMAN FOREIGN MINISTER KLAUS KINKEL CONCLUDED AN

OFFICIAL VISIT TO BEIJING ON NOVEMBER 2, 1992, BY DECLARING THAT SINO-GERMAN TIES HAVE RETURNED TO NORMAL AND THAT EUROPEANS NEED TO UNDERSTAND THE DYNAMISM OF CHINA'S DEVELOPMENT. HE NOTED THAT GERMANY REGARDS CHINA AS ONE OF ITS MAJOR INTERNATIONAL PARTNERS AND PLANS TO EXPAND BILATERAL COOPERATIOH.

00558

SINO-ROK TIES PRAISED

BEIJING REVIEW, 35(41) (OCT 92) 7 .

IN SEPTEMBER 1992, SOUTH KOREAN PRESIDENT ROH TAE WOO

PAID AN OFFICIAL VISIT TO BEIJING, THE FIRST SUCH VISIT IM

FOUR DECADES. DURING THEIR MEETINGS WITH ROH, CHINESE

LEADERS DECLARED THAT CHINA SUPPORTS THE PEACEFUL

REUNIFICATION OF THE TWO KOREAS AND WILL CONTINUE TO WORK

FOR PEACE AND STABIL ITY ON THE KOREAN PENINSULA AND IN NORTHEAST ASIA.

00559

SINO-U.S. TIES IN 1991

BEI JING REVIEW, $35(2)$ (JAN 92), 29.

DESPITE DIFFICULTIES AND UNSOLVED PROBLEMS, POSITIVE

ELEMENTS WERE EVIDENT IN SINO-U.S. RELATIONS IN 1991. ONE OF

THE MAJOR DEVELOPMENTS IN BILATERAL RELATIONS WAS U.S.

SECRETARY OF STATE JAMES BAKER'S OFFICIAL VISIT TO CHINA IN NOVEMBER 1991

00560

SINO-U.S. TRADE RELATIONS RESTORED

BEI JING REVIEW, 35(52) (DEC 92) 5-6.

IN THE INTEREST OF BETTER RELATIONS, CHINA AND THE

UNITED STATES HAVE AGREED TO PUT ASIDE THEIR TRADE

DIFFERENCES. AT THE SEVENTH SESSION OF THE SINO-U.S. JOINT

COMMISSION ON COMMERCE AND TRADE IN DECEMBER 1992

REPRESENTATIVES OF BOTH SIDES AGREED TO DISCARD "THE

UNPLEASANT PAST" AND START "A NEH EPOCH" FEATURING MORE

INTERACTION AT ALL LEVELS.

00561

SIXTO DURAN UNVEILS ADJUSTMENT PLAN

CATIN AMERICAN WEEKLY REPORT, (36) (SEP 92), 4.

PRESIDENT SIXTO DURAN BALLEN HAS RELEASED THE DETAILS OF HIS ECONOMIC ADJUSTMENT PLAN. IT INCLUDES MEASURES TO SOFTEN THE IMPACT ON LOWER-INCOME INDIVIDUALS ALONG WITH

DEVALUATION OF THE SUCRE, INCREASED ELECTRICITY RATES, A

REDUCTION IN GOVERNMENT SPENDING, AND HIGHER TAXES.

00562

SLOW MARCH ON THE NEW COLLOR CABINET

ITIN AMERICAN HEEKLY REPORT (2) (JAN 92),

PRESIDENT FERNANDO COLLOR DE MELLO IS DELIBERATELY

TAKING HIS TIME IN FORMING A NEH CABINET. HIS OBJECTIVE IS

TO FORM A LIMITED COALITION, WITH THE PARTIDO DA SOCIAL

DEMOCRACIA BRASILEIRA AS THE PREFERRED PARTNER. 00563

SLOW THAH IN MONGOLIA

WORLD PRESS REVIEW, 39(5) (MAY 92), 42
AFTER SEVEN DECADES OF SOVIET-STYLE COMMUNISM, MONGOLIA IS STRUGGLING TO CREATE A MARKET ECONOMY. BUT PROGRESS IS SLOW, AND THE MONGOLIANS ARE SUFFERING ECONOMIC HARDSHIPS, INCLLUDING HIGH UNEMPLOYMENT, RISING PRICES, AND EMPTY SHELVES IN THE STORES. SOCIALISM IS BREAKING DOWN FASTER THAN CAPITALISM CAN GET STARTED. PRESIDENT PUNSALNAAGIYN OCHIRBAT HAS DECLARED THAT HIS COUNTRY WILL ESTABLISH "A STATE-CONTROLLED MARKET ECONOMY AS THE BASIS OF A DEMOCRATIC, CIVIL SOCIETY." HOW MUCH CONTROL AND HOW MUCH MARKET ARE STILL UNCLEAR.

00564

SMALL ENVIRONMENTS: HOW BEST TO DEFEND AND PRESERVE THE ENVIRONMENT OF SMALL STATES IN AN AGE OF GROWING ECOLOGICAL PROBLEMS?

PARLIAMENTARIAN, LXXIII(1) (JAN 92), 52-55.

SMALL STATES MUST CONTRIBUTE TO GLOBAL ENVIRONMENTAL

PROTECTION BY CLEANING UP THEIR OWN COMPUNITIES, EDUCATING

THEIR CITIZENS ABOUT POLLUTION, PASSING AND ENFORCING STRICT

LAND USE REGULATIONS, AND UNITING TO LOBBY THE REST OF THE

HORLD TO FOLLOW THEIR EXAMPLE.

00565

SMALL STATES: STRENGTHENING DEMOCRACY, SECURITY, AND ECONOMIC DEVELOPMENT OF SMALL COMMONWEALTH STATES PARL IAMENTARIAN, LXXIII(1) (JAN 92), 26-29.

A RESPONSIVE DEMOCRATIC GOVERMMENT IS THE STRONGEST DEFENSE FOR A SMALL STATE, BUT THAT IN ITSELF IS NOT ENOUGH TO SECURE SMALL NATIONS AGAINST TODAY'S VARIED THREATS TO THEIR SOVEREIGNTY. SMALL STATES NEED TO BAND TOGETHER TO GAIN MORE INFLUENCE IN ECONOMIC, DIPLOMATIC, AND POLITICAL SPHERES.

00566

SO HOW BADLY HAS SENDERO BEEN HIT?

ATIN AMERICAN WEEKLY REPORT, (38) (OCT 92), 3 ,

ACCORDING TO PERUVIAN PRESIDENT ALBERTO FUJIMORI, THE SENDERO LUMINOSO IS AT LEAST MORIBUND, IF NOT ALREADY DEAD, AFTER THE CAPTURE OF LEADER ABIMAEL GUZMAN. FUJIMORI'S RATIONALE IS THAT THE SENDERO'S COMMAND STRUCTURE IS HIGHLY CENTRALIZED AND GUZMAN SYSTEMATICALLY REMOVED ALL EMERGING

LEADERS WHO THREATENED TO OVERSHADOW HIM.

00567

SOCIALISM OR BARBARISM?

POLITICAL AFFAIRS, 71(11) (NOV 92), 25-33.

THE BASIC DEFICIENCIES OF CAPITALISM CANMOT BE HEALED.

THEY DRIVE MANKIND INTO CATASTROPHES, FINALLY MENACING

HUMANITY AS A WHOLE. THIS DRAFT THES IS OF THE GERMAN

COMMUNIST PARTY ARGUES THAT THE ALTERNATIVE TO THE CRISIS OF CAPITALISM IS NOT GIVEN BY REFORMING CAPITALISM, BUT BY A NEW SOCIAL ORDER, BY SOCIALISH DEVELOPING ITSELF TOWARD COMMUNISM. THE THESIS ADDRESSES THE RESPONSIBILITIES OF THE WORKING CLASS ANO CHANGES IN CLASS STRUCTURE. IT DISCUSSES THE ROLE OF THE PARTY AND GERMAM IMPERIAL ISM.

00568

SOCIALIST MARKET ECONOMY--A NEH TERM IN REFORM

BEI JING REVIEW, $35(35)$ (AUG 92), 7

A NEW TERM, THE "SOCIALIST MARKET ECONOMY," HAS BEEN FREQUENTLY READ IN RECENT CHINESE PRESS IN REPORTING ON THE COUNTRY'S ECONOMIC RESTRUCTURING. ONE SENIOR CHINESE LEADER REGARDS MARKET ECONOMY AS THE ONLY PATH TO TAKE FOR THE COUNTRY DURING ITS PRIMARY STAGE OF SOCIALISH. IN THE PAST MONTHS, THE CENTRAL GOVERNMENT HAS PROMULGATED A SERIES OF RULES AND REGULATIONS TO DEVELOP A MARKET ORIVEN ECONOMY BASED ON EFFICIENT MEANS DF PRODUCTION, WHOLESALE TRADING AND RETAIL DEMAND.

00569

SOUTH AFRICA ON THE AGENDA

WEST AFRICA, (3902) ( JUN 92), 1081.

SOUTH AFRICA IS BACK ON THE INTERNATIONAL AGENDA ON TERMS MANY HAD HOPED WERE GONE FOREVER. THE REFORMS LAUNCHED BY PRESIDENT F.W. DEKLERK HAVE OFTEN BEEN DESCRIBED AS IRREVERSIBLE, BUT NOW THIS SEEMS LESS CERTAIN. THE CATALYST FOR THE THREATENED SLIDE BACK INTO THE BAD OLD DAYS WAS THE HEDIOUS MASSACRE AT BOIPATONG IN JUNE 1992.

00570

SOUTH AFRICA: ALL OUT FOR THE "YES" VOTE

WEST AFRICA, (3886) (MAR 92 ), 430

THE GOVERMMENT IS WORKING HARD FOR A "YES" VOTE IN SOUTH

AFRICA'S UPCOMING WHITES-ONLY REFERENDUM ON CONTINUING

NEGOTIATIONS BETHEEN THE RACES WITH THE GOAL OF ENDING

APARTHEID. PRESIDENT F.W. DEKLERK HAS SCHEDULED 56 PUBLIC

APPEARANCES IN 10 DAYS, TO CARRY HIS MESSAGE TO THE VOTERS.

00571

SOUTH AFRICA: DEKLERK'S AGENDA

WEST AFRICA, (3881) (FEB 92), 215

PRESIDENT F.W. DEKLERK'S ADORESS TO PARLIAMENT ON

JANUARY 24, 1992, HAS BEEN STRONGLY CRITICIZED BY THE ANC,

HHICH CLAIMS THAT THE PRESIDENT'S PLANS FOR CONSTITUTIONAL 
REFERENDA COULD UNDERMINE THE WORK OF THE CONVENTION FOR A DEMOCRATIC SOUTH AFRICA AMD ALLOH THE WHITE MA JORITY A DE FACTO VETO OVER REFORMS.

00572

SOUTH AFRICA: INTERIM OPTIMISM

WEST AFRICA, (3884) (FEB 92), 346

ON FEBRUARY 17, 1992, ANC PRESIDENT NELSON MANDELA

DECLARED THAT A MULTIRACIAL INTERIM GOVERNMENT COULD BE IM PLACE IN SOUTH AFRICA WITHIN THREE MONTHS. HE ALSO STATED THAT NATIONALIZATION IS NOT THE SOLUTION TO SOUTH AFRICA'S ECONOMIC PROBLEMS.

00573

SOUTH AFRICA: PRIZE TIME

WEST AFRICA, (3882) (FEB 92), 258.

ON FEBRUARY 3, 1992, SOUTH AFRICAN PRESIDENT F.W. DEKLERK AND ANC LEADER NELSON MANDELA WERE JOINTLY HONORED WITH THE FELIX HOUPHOUET-BOIGNY PRIZE FOR PEACE RESEARCH. THE THO RECIPIENTS USED THE OCCASION TO EMPHASIZE THE COMMON GROUND BETWEEN THEM.

00574

SOUTH AFRICA: S.A. CONSERVATIVES MAINTAIN BOYCOTT

WEST AFRICA, (3889) (MAR 92), 561.

THE CONSERVATIVE PARTY OF SOUTH AFRICA HAS ANMOUNCED

THAT IT WILL CONTIMUE ITS BOYCOTT OF THE COUNTRY'S

CONSTITUTIONAL NEGOTIATIONS. THE PARTY'S PARLIAMENTARY

CAUCUS HAS DECLARED THAT IT WILL CONTINUE TO BACK DR.

NEGOTIATIONS PROMISING RACIAL "SELF-DETERMINATION."

00575

SOUTH AFRICA: TALKS GET STARTED

SST AFRICA, (3880) (JAN 92), 162.

REPRESENTATIVES OF 19 ORGANIZATIONS GATHERED FOR THE

INITIAL SESSION OF THE CONVENTION FOR A DEMOCRATIC SOUTH

AFRICA (CODESA), WHICH WILL DRAFT A NEW CONSTITUTION. FIVE WORKING GROUPS, EACH COMPOSED OF 80 MEMBERS FROM ACROSS THE POLITICAL SPECTRUM, HILL WORK TOWARD AGREEMENT ON TRANSITIONAL ARRANGEMENTS, A TIMETABLE FOR CHANGE, AND CONSTITUTIONAL PRINCIPLES. IN ADOITION, THEY ARE TO PROPOSE

A CLIMATE THAT WILL PERMIT FREE POLITICAL PARTICIPATION.

00576

SPEECH THERAPY

NEH REPUBLIC 207(3-4) (JUL 92), 7 .

THE REHMQUIST COURT HAS UNANIMOUSLY VOIDED MINMESOTA'S

BIAS-MOTIVATED CRIME ORDINANCE, OR HATE CRIMES LAH. BY

DECLARING UNEQUIVOCALLY THAT EVEN RACIST AND SEXIST SPEECH

IS PROTECTED BY THE FIRST AMENDMENT, THE COURT HAS EXPOSED

THE UNCONSTITUTIONALITY OF MANY STATE BIAS LAHS AND

YIRTUALLY ALL CAMPUS HATE SPEECH CODES. IT HAS NOT ONLY

REAFFIRMED BUT DRAMATICALLY EXTENDED THE PRINCIPLE THAT

GOYERMMENT MAY NOT SIIEMCE SPEECH OM THE BASIS OF ITS

CONTENT AND THAT INSULTS, NO MATTER HOW SHARPLY THEY STING MAY NOT BE SINGLED OUT FOR PUNISHMENT.

00577

SPEEDING UP ECONOMIC REFORM IN 192

BEI JING REVIEH, 35(12) (MAR 92), 15-17

RECENTLY, A LEADING MEMBER OF THE STATE COMMISSION FOR RESTRUCTURING THE ECONOMIC SYSTEM ANSWERED OUESTIONS REGARDING SPEEDING UP ECONOMIC REFORM THIS YEAR. THIS REPORT DETAILS THE KEY POINTS OF THIS YEARS REFORM, AND THE NEW OPERATING MECHANISM WHICH WILL BE INITIATED FOR ENTERPRISES, AND THE INTERNAL EMPLOYMENT SYSTEM, AND THE SHAREHOLDING SYSTEM.

00578

SQUARE ONE

NEW REPUBLIC, 206(17) (APR 92), 7

IN THE FUTURE, U.S ARMED FORCES HILL FACE A LESSPREDICTABLE AND MORE-DEMANDING WORLD, WHICH CAMMOT BE GRASPED BY THE TRADITIONAL SCENARIO-PLANNING FAVORED BY THE PENTAGON. THERE ARE TWO OPTIONS FOR A NEH KIND OF DEFENSE STRATEGY: BASING THE SIZE OF ONE'S FORCES ON THE SIZE OF THE NEXT-LARGER POWERS' (EVEN IF THEY'RE NOT OPPONENTS) AND THINKING STRATEGICALLY IN TERMS OF COMPETITIVE POSITION AND PURPOSES. THE LATTER IS MORE SUITABLE TODAY IN A HORLD WHERE THE UNITED STATES' MAJOR RIVALS ARE LIBERAL DEMOCRACIES.

00579

STARTLING DISCLOSURES

WEST AFRICA, (3906) (JUL 92), 1242-1243

THREE COMMISSIOUS ARE 92 ) $1242-1243$. AFFAIRS OF THE FORMER MOMOH REGIME. THE BECCLES DAYIS COMMISSION OF INOUIRY IS INVESTIMG THE ASSETS AND RELATED MATTERS OF THE FORMER PRESIDENT YICE PRESIDENTS, MINISTERS, MINISTERS OF STATE, AND DEPUTY MINISTERS. THE LYNTOH NYLANDER COMMISSION IS PROBING THE FINANCIAL ACTIVITIES OF THE GOVERNMENT MINISTRIES, LOCAL AUTHORITIES, PARASTATALS, AND THE BANK OF SIERRA LEONE. THE MARCUS-JONES COMMISSION' IS EXAMINING THE ASSETS AND RELATED MATTERS OF ALL PUBLIC
DFFICERS, PARASTATAL BOARD MEMBERS AMD EMPLOYEES, POLICE OFFICERS, AND THE ARMED FORCES.

00580

STATEMENT ON LOS ANGELES REBELLION

POLITICAL AFFAIRS, 71(4) (MAY 92), 31-32.

THIS ARTICLE CONTAINS THE COMMUNIST PARTY (USA)'S

STATEMENT ON THE LOS ANGELES RIOTS. IT STATES THAT THE

RODNEY KING VERDICT IS A DISGRACE AND A TRAVESTY OF JUSTICE.

IT IS AN OVERT ACT OF RACISM WHICH, INTENT IONALLY OR NOT,

SENDS A MESSAGE THAT POLICE BRUTALITY IS NOH SANCTIONED,

ESPECIALLY WHEN DIRECTED AGAINST AFRICAN AMERICANS.

FURTHERMORE. THE EXPLOSION OF RAGE IN SOUTH CENTRAL LOS

ANGELES SHOULD SURPRISE NO ONE. THE VERDICT MERELY RUBBED

SALT INTO THE ALREADY DEEP WOUNDS OF LONG TERM JOBLESSNESS,

POOR HOUSING, INFERIOR SCHOOLS, INADEQUATE HEALTH CARE,

POVERTY, PROLONGED ECONOMIC DEPRESSION, A 60\% YOUTH

UNEMPLOYMENT RATE, AN OVER 50\% POVERTY RATE FOR SENIORS,

ECONOMIC DESPAIR, POLICE HARASSMENT, VIOLENCE, AMD

GOVERMMENT NEGLECT.

00581

STEALTH NO MORE

CHURCH AND STATE, 45(11) (DEC 92), 15(255)

REPUBLICAN STEVE BALDHIN IS A LEADING EXPONENT OF WHAT

HAS BECOME KNOWM AS "STEALTH" POLITICS. THE SAM DIEGO

ACTIVIST AND HIS ALLIES HAVE PERFECTED A CAMPAIGM STRATEGY

IN WHICH CHRISTIAN RIGHT CANDIDATES RUN FOR PUBLIC OFFICE BUT AVOID DISCUSSING THEIR RADICAL VIENS WITH MOST VOTERS. THEY SKIP MOST PUBLIC FORUMS AND SHARE THEIR "CHRISTIAN" AGENDA ONLY HITH THE MEMBERS OF FUNDAMENTALIST CHURCHES. IN 1990, THIS STRATEGY WORKED REMARKABLY WELL FOR RELIGIOUS RIGHT CANDIDATES, BUT ITS PRACTITIONERS DID NOT FARE WELL IN 1992.

00582

STEP BACKHARDS ON COMMON TARIFF

THE AMERICAN WEEKLY REPORT, (1) (JAN 92), 11.

THE ANDEAN GROUP FREE TRADE ZONE WILL GO INTO EFFECT AS

SCHEDULED ON JANUARY 1 , 1992, BUT WITHOUT A COMMON EXTERMAL

TARIFF. COLOMBIA AND VENEZUELA HAVE ANMOUNCED THEIR

INTENTION OF HARMONIZING THEIR OWN NATIONAL TARIFF

STRUCTURES, BUT THE GROUP AS A WHOLE WILL HAVE TO RETURN TO

THE NEGOTIATING TABLE IN EARLY 1992 TO TALK FURTHER ABOUT

THE PROPOSED CUSTOMS UNION.

00583

STILL HOOKED ON ACTION

LATIN AMERICAN HEEKLY REPORT, (16) (APR 92), 3.

DESPITE THE RECENT DEMOCRATIZING TREND IN LATIN AMERICA, THE REGION'S MILITARY LEADERS REMAIN READY TO RETURN TO

POWER IF THE OCCASION ARISES. IN 1990-92. THE MILITARY

PARTICIPATED IN OR OUIETLY SUPPORTED SUCCESSFUL OR ATTEMPTED

COUPS IN PERU, VENEZUELA, HAITI, AND SURINAME. IN ADDITION,

ARGENTINA'S CARAPINTADAS MUTINIED ON FOUR DIFFEREMT

OCCASIONS BETHEEN 1987 AMD 1990.

00584

STRIKE IS A DRAW, BUT CAVALLO IS HIT

LATIN AMERICAN WEEKLY REPORT, (45) (NOV 92), 2-3.

THE FIRST GENERAL STRIKE STAGED BY THE CONFEDERACION

GENERAL DEL TRABAJO (CGT) AGAINST THE GOVERNMENT OF

PRESIDENT CARLOS MENEM WAS ALMOST A DRAW. IT WAS CERTAINLY

NOT THE OVERHHELMING CONDEMMATION OF OFFICIAL POLICY

EXPECTED BY THE CGT LEADERS, NOR WAS IT THE REJECTION OF THE

UNION PROTEST THAT THE GOVERMMENT HAD HOPED FOR. THE PERSON

MOST DAMAGED BY THE STRIKE WAS ECONOMY MINISTER DOMINGO CAYALLO.

00585

STRONG CHARGES AGAINST TOP OFFICIALS

ITIN AMERICAN WEEKLY REPORT, (29) (JUL 92), 10-11.

IN JULY 1992, THE GOVERMMENT OF PRESIDENT VIOLETA

CHAMORRO WAS SHAKEN BY CHARGES OF CORRUPTION AGAINST TWO

HIGH-RANKING OFFICIALS: MINISTER OF THE PRESIDENCY ANTONIO

LACAYO AND ARMY CHIEF GENERAL HUMBERTO ORTEGA.

00586

STUDENTS BACK DENG ON REFORM

BEIJING REVIEW, 35 (36) (SEP 92) 7,9

FOR THE FIRST TIME SINCE 1989, UNIVERSITY STUDENTS IN

BEI JING HAVE VOICED THEIR SUPPORT OF DENG ZIAOPING'S REFORM

AND OPEN POLICIES, WHICH INDICATED THAT THE STUDENTS HAVE

ONCE AGAIM REACHED AN UNDERSTANDING HITH THE SENIOR LEADER.

IT ALSO MEANS THAT REFORM AND OPENING TO THE OUTSIDE HORLD

HAVE BECOME A POPULAR TREND IN CHINA. THIS ARTICLE REPORTS

ON STUDENT RESPONSE TO THE NEW POLICIES.

00587

SUCCESS CLAIMED IN BOLIVIA AND VENEZUELA

LATIN AMERICAN HEEKLY REPORT, (1) (JAN 92), 3

THE GOVERMMENTS OF BOLIVIA AND VENEZUELA HAVE RELEASED

REPORTS DOCUMENTING THEIR SUCCESSES IN THEIR ANTI-DRUGS

CAMPAIGNS. THE BOLIVIAN GOVERNMENT HAS CLAIMED SUCCESS FOR 
ITS "REPENTANCE" POLICY, WHICH GUARANTEES DRUG TRAFFICKERS WHO VOLUNTARILY SURRENDER THAT THEY HILL NOT BE EXTRADITED TO THE UNITED STATES.

00588

SUCCESS OR TROUBLE FOR CAVALLO?

LATIN AMERICAN WEEKLY REPORT, (2) (JAN 92), 2-3. ALTHOUGH ARGENTINA'S ECONOHY MINISTER DOMINGO CAVALLO HAS BEEN SUCCESSFUL IN HIS EFFORTS TO ATTAIN AN EXTENDED CEASED THEIR ATTACKS ON HIM.

00589

SUDAN--RUDOERLESS REGIME

NEW AFRICAN, (282) (MAR 91), 21-22.

IN SUDAN' FAMINE WORSENS, THE ECONOMY DETERIORATES AND

HUMAN RIGHTS ABUSES BECOMING INCREASINGLY SERIOUS WHILE THE GOVERNMENT STUMBLES FROM CRISIS TO CRISIS. ITS ONLY

CONSISTENT OBJECTIVE SEEMS TO BE TO PURSUE THE FUTILE HAR IN THE SOUTH. SUDAN'S LEADER, OMAR HASSAN, BASHIR, DECLARED HIS SUPPORT FOR SADDAM HUSSEIN IN THE GULF, CRISIS AND IS REAPING THE RESULTS OF INTERNATIOMAL ISOLATION.

00590

SUDDEN ABOUT-FACE BY COPEI LEADERS

LATIN AMERICAN WEEKLY REPORT (21) (JUN 92),

COPEI, VENEZUELA'S MAIN OPPOSITION PARTY, HAS ABRUPTLY CHANGED ITS POSITION REGARDING A CONSTITUTIONAL AMENDMENT TO ALTER THE PRESIDENTIAL TERM. IN EARLY MAY 1992, COPEI FAVORED AMENDING THE CONSTITUTION TO SHORTEN THE PRESIDENTIAL MANDATE. IN LATE MAY, THE PARTY DECLARED THAT IT OPPOSES ANY ATTEMPT TO SHORTEN PRESIDENT CARLOS ANDRES PEREZ'S MANDATE OR SEEK HIS RESIGNATION BECAUSE SUCH ACTION WOULD PRECIPITATE A COUP.

00591

SUMMARY OF 5.2532

CONGRESSIONAL DIGEST, 71(8-9) (AUG 92), 200-203.

THIS ARTICLE SUMMARIZES THE MAJOR PROVISIONS OF THE FREEDOM FOR RUSSIA AND EMERGING EURASIAN DEMOCRACIES AND OPEN MARKETS SUPPORT ACT OF 1992.

00592

SUMMARY OF $\$ .640$

CNGRESSIONAL DIGEST, 71(11) (NOV 92), 268, 288

THE PRESENT SYSTEM FOR RESOLVING PRODUCT LIABILITY

DISPUTES AND COMPENSATING VICTIMS OF DEFECTIVE PRODUCTS IS

COSTLY, SLOW, INEQUITABLE, AND UNPREDICTABLE. IT DOES NOT

BENEFIT MANUFACTURERS, PRODUCT SELLERS, OR INJURED PERSONS.

A BILL, S.640, THAT WOULO ADDRESS THESE PROBLEMS HAS BEEN

PROPOSED TO THE U.S. CONGRESS. THIS BILL WOULD MAKE A NUMBER

PROPOSED TO THE U.S. CONGRESS. THIS BILL WOULD MAKE A NUMBER

COSTS, PROVIDE GREATER CERTAINTY AS TO THE RIGHTS AND

RESPONSIBILITIES OF THOSE INVOLVED IN PRODUCT LIABILITY

DESPUTES, ENCDURAGE IHNSE INVOLVED IN PRODUCT LIABI

COMPETITIVENESS OF U.S. FIRMS.

00593

SUMMIT OVER, AND PEDRO AFFAIR RETURNS

LATIN AMERICAN WEEKLY REPORT, (24) (JUN 92), 8

FOLLOWING PRESIDENT FERMANDO COLLOR DE MELLO'S RETURM

FROM THE 1992 EARTH SUMMIT IN RIO DE JANEIRO, ATTENTION HAS

TURNED TO THE CONGRESSIONAL INQUIRY INTO THE ACTIVITIES OF

ONE OF THE PRESIDENT'S ASSOCIATES.

00594

SUPPORT FOR MIYAZAHA PLUMMETS TO UNDER THENTY-FIVE PERCENT JAPAN TIMES (WEEKLY INTERNATIONAL EDITION), 32(15) (APR

ACCORDING TO A POLL RELEASED ON APRIL 1,1992 , PUBLIC

SUPPORT FOR THE CABINET OF PRIME MINISTER KIICHI MIYAZAHA

HAS PLUNGED TO 24.1 PERCENT. THE RATING MARKS A STEEP DROP

00595

SWIFT COUP CLAIMED AGAINST BOMBERS

LATIN AMERICAN WEEKLY REPORT, (47) (DEC 92 ), 2

ON NOVEMBER 18-19, 1992, BUENOS AIRES WAS ROCKED BY

THREE BOMBING ATTACKS, WITH THE ORGANIZACION REVOLUCIONARIA

DEL PUEBLO (ORP) CLAIMING CREDIT FOR THO OF THEM. A DAY

LATER, OFFICIALS ANNOUNCED THAT SEVERAL ORP LEADERS HAD BEEN

DETAINED AND THAT A CACHE OF EXPLOSIVES HAD BEEN SEIZED. 00596

TAJIKISTAN: FAILED COUP

MIDDLE EAST INTERNATIONAL (437) (NOY 92), 15

IN OCTOBER 24, 1992 . TAJKISTAN'S COAL ITIOH GOVERMMENT OF ISLAMIC AND CENTRIST PARTIES HAS THE TARGET OF A FAILED COUP BY SUPPORTERS OF EX-PRESIDENT MABIYEY. THE GOVERMMENT WILL PROBABLY USE THE COUP AS AN OPPORTUNITY TO STRENGTHEN ITS CONTROL OVER DUSHANBE AND SOME SURROUNOING REGIONS. TAJIKISTAN'S ALREADY-DETERIORATHE SURROUNOING REGIONS. FURTHER AS THE ETHMIC RUSSIANS ECONOMIC BACKBONE, EMIGRATE TO OTHER AREAS.
00597

TAKING OFF THE STRAITJACKET

WEST AFRICA, (3884) (FEB 92), 319

MANY PEOPLE OUTSIDE ZAMBIA HAD NEVER HEARD OF FREDERICK

CHILUBA WHEN HE WAS SWORN IN AS PRESIDENT OF ZAMBIA IN

NOVEMBER 1991. BUT WITHIN THE COUNTRY ITSELF, THE NAME AND

THE MAN HAD LONG BEEN THE SYMBOL OF A GALVANIZING FORCE FOR

HORKERS' RIGHTS AND POLITICAL PLURALISM. CHILUBA ROSE FROM

HUMBLE BEGINMINGS TO CHALLENGE THE POHER OF KENMETH KAUNDA,

ONE OF AFRICA'S LEADING STATESMEM.

00598

TALKS WITH U.S. AND CANADA HEAT UP

LATIN AMERICAN WEEKLY REPORT, (3) (JAN 92), 11

ON JANUARY 7, 1992, NEGOTIATORS FROM THE USA, MEXICO,

AND CANADA SAT DOWN FOR A MARATHON SESSION INTENDED TO

PRODUCE THE FIRST DRAFT OF THE NORTH AMERICAN FREE-TRADE

PROPOSAL. AMONG THE PROBLEM AREAS ARE MEXICO'S DESIRE TO

PROTECT ITS OIL INDUSTRY AND PROTECTIONIST BARRIERS AGAINST

THE IMPORTATIOM OF MEXICAN TEXTILES.

00599

TANZANIA: DEMOCRATS DEMAND A VOICE

NEW AFRICAN (287) (AUG 91), 16

A TANZANIAN PRESIDENTIAL COMMISSION HAS BEEN COLLECTING

PEOPLE'S VIEWS ON WHETHER THE COUNTRY SHOULD ADOPT PLURALISM

OR REMAIN A ONE-PARTY STATE. PRESIDENT MHINYI HAS DECLARED

THAT THE PEOPLE ARE FREE TO EXPRESS THEIR POLITICAL OPINIONS.

HOHEVER, SEVERAL DEMOCRATIC GROUPS HAVE BEEN BANNED OR

REPRESSED, AND MANY PEOPLE IN ZANZIBAR AND IN IRINGA REGION

HAVE COMPLAINED OF INTIMIDATION BY GOVERNMENT MEN WHO WERE

MAKING HOUSE TO HOUSE VISITS TELLING PEOPLE TO SUPPORT A ONE-

PARTY SYSTEM BEFORE THE PRESIDENTIAL COMMISSION ARRIVED TO

ASSESS THEIR OPINIONS.

00600

TAYLOR EXPLAINS

WEST AFRICA, (3892) (APR 92), 674.

IN THIS INTERVIEW, NPFL LEADER CHARLES TAYLOR DENIES

THAT HE IS USING DELAYING TACTICS

00601

TELEPHONE STRIKE COMES TO AN END

LATIN AMERICAN WEEKLY REPORT, (18) (MAY 92), 10-11.

ON APRIL 28, 1992, THE GOVERMMENT OF COLOMBIA AND LABOR

CAME TO AN AGREEMENT' TO END THE NATIONAL TELECOMMUNICATIONS STRIKE. UNDER THE AGREEMENT, A NEGOT IATING GROUP INCLUDING REPRESENTATIVES OF THE MINISTRY OF COMMUNICATIONS, TELECOM, AND TELECOM WORKERS WILL REYIEW THE GOYERMMENT'S AND TELECOM WORKERS WILL REVIEN THE

00602

TENSE RUN-UP TO THE CRUCIAL VOTE

TEN

THO AMERICAN WEEKLY REPORT, (39) (OCT 92), 2

THO EVENTS DOMINATED THE RUN-UP TO THE CRITICAL

IMPEACHMENT VOTE AGAINST PRESIDENT FERNANDO COLLOR DE MELLO

IN THE CONGRESS: THE SUPREME COURT RULED THAT THE BALLOTING

SHOULD BE OPEN, NOT SECRET, AND THAT THE PROCEEDINGS SHOULD

NOT BE DELAYED UNTIL AFTER THE MUNICIPAL ELECTIONS; THE

FEDERAL POLICE FORMALLY ANNOUNCED THAT CHARGES WERE BEING

FILED AGAINST PAULO CESAR FARIAS, THE PRESIDENT'S CAMPAIGH FUNDRAISER.

00603

TENSE WAIT FOR RED OCTOBER ONSLAUGHT

LATIN AMERICAN WEEKLY REPORT, (40) (OCT 92) 5

WHEN SENDERO LUMINOSO LEADER ABIMAEL GUZMAN WAS ARRESTED, PERUVIAN POLICE BRACED FOR A ROUNO OF RETALIATORY VIOLENCE, WHICH FAILED TO MATERIALIZE. NOW AUTHORITIES EXPECT "RED OCTOBER" OFFENSIVE BY THE TERRORISTS WHEN GUZMAN'S COURT MARTIAL BEGINS ON OCTOBER 1, 1992. MEANWHILE, THE GOVERNMENT OF PRESIDENT ALBERTO FUJIMORI IS AGAIN ATTEMPIING TO TRY

FORMER PRESIDENT ALAN GARCIA ON CORRUPIION CHARGES. 00604

TESTING THE WATERS

FAR EASTERN ECONOMIC REVIEW, 155(10) (MAR 92), 8-9. CHINA'S DECISION TO LEGISLATE SOVEREIGNTY OVER THE SPRATLY, PARACEL, AND DIAOYUTAI ISLAND GROUPS HAS RENEWED THE LONG-SIMHERING DISPUTES WITH NEIGHBORING COUNTRIES. JAPAN AND SEVERAL SOUTHEAST ASIAN COUNTRIES, SURPRISED AT THE NEW CHINESE LAW, PROMPTLY LODGED THEIR PROTESTS, THOUGH IN A LOW KEY, AS IF TO TEST BEI INING S RESPONSE. SINCE THE SATE 1970S, THESE ISLANDS HAVE HITNESSED OCCASIONAL SCALE FIGHTING BETWEEN RIVAL NAVIES--FOLLOWED BY THE CONCERNED. THE PARACEL GROUP IS CLAIMED BY CHINA, TAINAN AND CONCERNED. THE PARACEL GROUP IS CLAIMED BY CHINA, TAIWAN AND VIETNAM. THE SPRATLYS ARE CLAIMED BY CHINA AND TAIHAN, AND IN PART BY VIETNAM, BRUNEI, MALAYSIA, AND THE PHILIPPINES. THESE UNINHABITED ISLAND CHAINS IN THE SOUTH CHINA SEA, STRADDLING VITAL SEA ROUTES, ARE BELIEVED TO CONTAIN MAJOR OIL DEPOSITS. SMALL ISOLATED GARRISONS OF THE CDUNTRIES 
INVOL VED OCCUPY SOME OF THE MAJOR ISLANDS. AMALYSTS MAINTAIN THAT CHINA DOES NOT HAVE THE MILITARY MUSCLE TO FORCIBLY OCCUPY ALL THE ISLANDS IT CLAIMS. THEREFORE, THE LATEST LAW COULD BE A PLOY BY BEIJING TO DRAH OUT THE LEGAL AND NEGOTIATING STRATEGIES OF OTHER COUNTRIES BEFORE CHINA ITSELF DECIDES ON ITS OWN COURSE OF ACTION.

00605

TEXT OF U.S. SUPREME COURT DECISION: ROBERT E. LEE ET AL $V$. DANIEL WEISMAN

JOURNAL OF CHURCH \& STATE, 34(3) (SUM 92), 666-701.

THIS ARTICLE INCLUDES THE TEXT OF THE U.S. SUPREME COURT OECISION IN THE WEISMAN CASE, WHICH INYOLYED THE RECITATION OF PRAYERS AS PART OF THE FORMAL GRADUATION CEREMONIES FOR MIDDLE AND HIGH SCHOOLS IN PROVIDENCE, RHODE ISLAND. THE COURT CONSIDERED THE QUESTION OF WHETHER THESE PRAYERS WERE CONSISTENT WITH THE RELIGION CLAUSES OF THE FIRST AMENDMENT, WHICH THE FOURTEENTH AMENDMENT APPLIES WITH FULL FORCE TO

THE STATES AND THEIR SCHOOL DISTRICTS. 00606

THE BAKER STRATEGY

NEW REPUBLIC, $207(11-12)$ (SEP 92), 9

ALTHOUGH GEORGE BUSH'S SUPPORTERS FREQUENTLY CITE

FOREIGN AFFAIRS AS THE PRESIDENT'S GREATEST STRENGTH, U.S.

FOREIGN POLICY UNDER BUSH AND SECRETARY OF STATE JAMES BAKER HAS OFTEN BEEN INEFFECTIVE AND MISGUIDED. BUSH AND BAKER SEEM LIKELY TO REPEAT THEIR PAST MISTAKES AS THEY PLAN THE PRESIDENT'S RE-ELECTION CAMPAIGN.

00607

THE BRITISH ONE-PARTY STATE

WEST AFRICA, (3892) (APR 92), 661.

THE AUTHOR DISCUSSES THE IMPACT OF THE TORY VICTORY IN

GREAT BRITAIN'S 1992 PARLIAMENTARY ELECTIONS ON BRITISH

POLICY TOWARD AFRICA.

00608

THE CARING PRESIDENT

NEW REPUBLIC, 206 (6) (FEB 92), 7.

GEORGE BUSH'S NEW MESSAGE FOR THE 1992 CAMPAIGN TRAIL

WILL BE "I CARE" AND "I FEEL." HE HILL FREQUENTLY INYOKE

FAMILY VALUES AND FAITH IN GOD AS HE TROLLS FOR VOTES.

00609

THE CASE AGAINST CASEY

NEW REPUBLIC, 207(5) (JUL 92), 7

THE AUTHOR LOOKS AT THE REASONING OF SUPREME COURT

JUSTICES O'CONMOR, KENNEDY AND SOUTER IN THE PLANMED

PARENTHOOD V. CASEY DECISIÓN.

00610

THE CENTRE FOR SCIENCE AND ENVIRONMENT STATEMENT ON GLOBAL

ALTERNATIVES, 17(2) (SPR 92), 261-279.

WITH THE NATIONS OF THE WORLD JOINTLY FACING A GLOBAL

ECOLOGICAL CRISIS BUT SHARPLY DIVIDED, IN ECONOMIC TERMS AND WITH POSSIBLITIES FOR CONFLICT IMMENSE, THERE NEVER WAS A GREATER NEED FOR HUMANITY TO LIVE AS ONE. THE CENTER FOR SCIENCE AND ENVIRONMENT PRESENTS ELEMENTS FOR A SYSTEM OF GLOBAL ENVIONMENTAL GOVERNANCE, BASED NOT ON TARGETS AND OBJECTIVES, BUT ON BASIC HUMAN' RIGHTS--A FORM OF GOVERNANCE IN WHICH NATURAL RESOURCE USE WILL BE CONTROLLED BY A SYSTEM OF DEMOCRATIC CHECKS AND BALANCES, AND IN WHICH INDIVIDUALS, COMMUNITIES AND NATIONS HAVE BEEN EFFECTIVELY EMPONERED TO PROTECT, MANAGE AND USE THEIR RESOURCES IN A A FAIR AND OEMOCRATIC MANNER. THIS PAPER EXPLORES THE ELEMENTS OF A COMMUNITY, NATIONAL AND GLOBAL ENVIRONMENTAL DEMOCRACY.

00611

THE CHANGING SHAPE OF VIOLENCE

THE MIDOLE EAST, (195) (JAN 91), 20-21.

WHEN ISRAELI SECURITY FORCES PANICKED AND KILLED 18 PALESTINIANS DEMONSTRATING MEAR THE AL AOSA MOSOUE IN OCTOBER 1990, THEY EXPECTED A NEW SURGE IN INTIFADA ACTIVITY TO AVENGE THE DEATHS. WHILE THE RESISTANCE AND VIOLENCE HAS NOTICEABLY SPREAD TO JERUSALEM, EVEN LARGER THREATS LOOM OUTSIDE. THE UNSETTLED SITUATION PRODUCED BY THE GULF CRISIS HAS PUT INTO QUESTION ALL BOUNDARIES. A SERIES OF INCURSIOKS ACROSS ALL BORDERS, FROM LEBANON TO ELIAT, IN ADOITION TO ATTEMPTS TO LAUNCH ATTACKS BY SEA, HAS POSED TO ISRAEL A GREATER RISK THAN THAT OF AY SEA, HAS POSED TO ISRAEL A ISRAELIS CONSIDER IT THE START OF A NEW HAR OF ATTRITION.

00612

THE CHARACTER THING

NEW REPUBLIC, 207 (19) (NOV 92), 7

THE AUTHOR LOOKS AT HOW THE REPUBLICANS ARE ATTEMPTING TO USE THE SO-CALLED "CHARACTER ISSUE" AGAINST GOVERNOR BILL CLINTON IN THE FINAL WEEKS OF THE 1992 PRESIDENTIAL CAMPAIGN. 00613

THE CHURCH MAKES A COMEBACK

NEW AFRICAN, (282) (MAR 91), 11
FOR THE PAST DOZEN YEARS, THE ETHIOPIAN ORTHODOX CHURCH HAS SMARTED UNDER AN UNPRECEDENTED ANTI-CLERICAL BARRAGE FROM ETHIOPIA'S MARXIST RULERS. DESPITE NATIONALIZATION OF ITS LANDS, THE CHURCH PROVED TO BE MORE RESILIENT THAN IMAGINED. IT BECAME A SECRET REFUGE FOR SILENT AND OFTEN YOUTHFUL OISSIDENTS. NOW MARXISM IS IN RETREAT AND PRESIDENT MENGISTU'S GOVERMMENT SEEKS TO BIND AN INCREASINGLY POPULAR CHURCH TO ITS SIDE. IT PARTICULARLY WANTS CHURCH SUPPORT IN ITS LIFE OR DEATH STRUGGLE AGAINST FURTHER DISINTEGRATION OF THE ETHIOPIAN STATE.

00614

THE COUP ATTEMPT THAT WASN'T QUITE HHAT FUJIMORI MADE IT DUT TO BE

LATIN AMERICAN WEEKLY REPORT, (46) (NOV 92), 1.

ON NOVEMBER 13,1992, A COUP ATTEMPT AGAINST PRESIDENT ALBERTO FUJIMORI FAILED. IT HAS MASTERMINDED BY JAIME SALINAS SEDO, A RETIRED ARMY COMMANDER WHO CLAIMED THAT HE WANTED TO CAPTURE FUJIMORI, HAND OVER POWER TO

CONSTITUTIONAL PRESIDENT MAXIMO SAN ROMAN, AND CALL GENERAL

ELECTIONS HITHIN A YEAR.

00615

THE CRY OF SUDAN

COMMONWEAL CXIX(19) (NOV 92), 3-4.

SUDAN IS A LAND OF BITTER CIVIL WAR, FAMINE, AND ANGUISH LARGELY UNMOTICED BY THE REST OF THE WORLD. THE FAMINE AND CIVIL WAR ARE THE BLOOOY HARVEST OF AM AMALGAM OF INTERPOLITICAL IDEOLOGIES, TRIBALISM, AND SOCIAL CASTE.

00616

THE CURE

NEH REPUBLIC, 206(22) (JUN 92), 9.

THE CURE FOR THE UNITED STATES' HEALTH CARE PROBLEMS

COULD BE A HYBRID APPROACH, A MIX OF PUBLIC PROVISION AND PRIVATE CHOICE. A COMPREHENSIVE SYSTEM BUILT AROUND THE MODEL OF COMMUNITY HEALTH PLANS AND THE ELIMINATION OF PRIVATE INSURANCE MAY BE THE BEST WAY TO BRING MARKET FORCES TO BEAR BY COMBINING VOUCHERS, GROUP BUYING POWER, AND A MEASURE OF DEVOLVED DEMOCRATIC DECISION MAKING.

00617

THE DEMOCRATIC AGENDA

AFRICA REPORT, 37(5) (SEP 92), 18-20.

GOVERNOR BILL CLINTON, THE 1992 DEMOCRATIC CANDIDATE FOR

PRESIDENT, SAYS THAT U.S. FOREIGH POLICY REQUIRES A NEM

STRATEGY TO ENCOURAGE THE CONSOLIDATION OF DEMOCRACY IN

HE ALSO CALLS FOR A NEW

APPROCH TO FOREIGN AID, A TOUGH STANCE TOWARD SOUTH AFRICA ROLE FOR THE UNITED NATIONS IN SOMALIA AND SIMILAR CRISES.

00618

THE DEMOCRATIC CHALLENGE

PARLIAMENTARIAN, LXXIII(4) (OCT 92), 247-248

THE PARLIAMENTARY SYSTEM OF GOVERNMENT HAS EVOLVED

THROUGH CENTURIES OF MONUMENTAL EVENTS AND CULTURAL

TRANSITIONS THE LATEST STEPS IN THAT EVOLUTIONARY PROCESS

ARE UNDER WAY TOOAY THROUGHOUT THE WORLD AS CENTRAL EUROPE

EMERGES FROM COMMUNIST RULE AND MANY DEVELOPING STATES

EMBRACE MULTIPARTY DEMOCRACY. THIS ARTICLE EXPLORES WHETHER

PARLIAMENTARY WILL SURVIVE THIS LATEST CHALLENGE. IT REPORTS

ON THE THOUGHT OF THE QUEBEC NATIONAL ASSEMBLY THAT ITS

250TH ANNIVERSARY WAS THE IDEAL TIME TO POSE THIS QUESTION

AT AN EMINENT GLOBAL GATHERING.

00619

THE DUST SETTLES

HEST AFRICA, (3896) (MAY 92), 840-841.

AS THE DUST SETTLES AFTER WHAT HAS BEEN WIDELY ACCLAIMED AS A PEACEFUL COUP, THE NATIONAL PROVISIONAL RULING COUNCIL (NPRC) HAS EMBARKED ON A MAJOR REHABILITATION OF SIERRA LEONE'S GOVERNMENT. THE NPRC'S FIRST ACTION WAS TO LEGALIZE ITS CONTROL BY ISSUING A PROCLAMATION SUSPENDING ALL PROVISIONS OF THE 1991 CONSTITUTION THAT ARE INCONSISTENT WITH THE PROCLAMATION OR ANY OTHER DECREE ISSUED BY THE COUNCIL. THE PROCLAMATION PROVIDES FOR A GOVERHING COUNCIL TO BE COMPRISED OF A CHAIRMAN, DEPUTY CHAIRMAN, AND UP TO 30 ADOITIONAL MEMBERS.

00620

THE ECONOMIC TRANSFORMATION OF THE BALTIC STATES

TORMAL

THE TERRA BALTICA CONFERENCE INCLUDED SEVERAL SESSIONS

ON ECONOMIC TOPICS. THIS ARTICLE IS A RECONSTRUCTION OF

REMARKS MADE AT THE PANEL DISCUSSION. IT HAS ARGUES THAT A SOUND DOMESTIC CURRENCY IS A PREREQUISITE TO THE EFFICIENT OPERATION OF ANY MARKET ECONOMY. BANKING IS DISCUSSED, AS WELL AS THE IMPORTANCE OF INTERHATIONAL RELATIONS.

00621

THE EEA: A TEST OF STRENGTH FOR SHITZERLAND

SHISS REVIEH OF WORLD AFFAIRS, 42(9) (DEC 92), 30-31. 
THE AUTHOR LOOKS AT THE CONTROVERSIES IN SHITZERLAND AND LIECHTENSTEIN OVER THE ISSUE OF JOINING THE EUROPEAN ECONOMIC AREA.

00622

THE FORCE IS WITH MALICE

WEST AFRICA, (3907) (AUG 92), 1297

THE CONTINUANCE OF VIOLENCE IN SOUTH AFRICA IS

THREATENING THE PROGRESS TOWARD MAJOR POLITICAL REFORMS. THE PROMISING RAPPORT BETWEEN NEL SON MANDELA AND PRESIDENT F.H.

DEKLERK HAS COMPLETELY EVAPORATED.

00623

THE GLOBAL ENYIRONMENTAL FACILITY

FINANCE AND DEVELOPMENT, 28 (1) (MAR 91), 24

IN NOVEMBER 1990. TWENTY-FIVE DEVELOPED AND DEVELOPING NATIONS AGREED TO ESTABLISH A GLOBAL ENVIRONMENTAL FACILITY (GEF) HHICH WOULD BE RUM JOINTLY BY THE WORLD BANK AND BY UN AGENCIES. THE GOAL OF THE GEF IS TO PROVIDE MDOEST UN AGENCIES. THE GOAL OF THE GEF IS TO PROVIDE MODEST RESOURCES TO HELP FINANCE PROGRAMS AND PROJECTS AFFECTI THE GLOBAL ENVIRONMENT, ANO TO DO SO IN A MANNER THAT EXPLORES HOH DEVELOPING COUNTRIES CAN DEAL PRAGMATICALLY WITH THESE ISSUES, AT LOW COST, AND WITHOUT IMPEDING DEVELOPMENT. THE GEF SELECTED TO CONCENTRATE ON FOUR AREAS PROTECTING THE OZONE LAYER; LIMITING GREENHOUSE GAS EMISSIONS; PROTECTING BIODIVERSITY; AND PROTECTING INTERNATIONAL WATERS.

00624

THE GOOD WAR

NEH REPUBLIC, 206 (25) (JUN 92), 7-8.

IN 1967, THE ARAB STATES STARTED THE SIX-DAY WAR. AFTER DAZZLING DEFENSIVE MANEUVERS, ISRAEL OCCUPIED THE LAND FROM WHICH EGYPT, SYRIA, AND JORDAN HAD LAUNCHED THEIR

COORDINATED ACTS OF AGGRESSIDN. MEMORY PLAYS TRICKS OM HISTORY, AND DOUBTLESS THERE ARE MILLION HHO BELIEVE THAT THE ISRAEL I OCCUPATION OF THE OISPUTED TERRITORIES IS A CAUSE OF THE ARAB-ISRAELI CDNFLICT RATHER THAN ONE OF ITS CONSEQUENCES.

00625

THE IMPORTANCE OF BEING EARNEST

NEW REPUBLIC, 207 (6) (AUG 92), 7 .

DUE TO THE FAILURES OF THE BUSH ADMINISTRATION,

ESPECIALIY IN ECONOMIC AND SOCIAL POLICIES, DEMOCRAIIC

CAMDIDATES BILL CLINTON AND AL GORE HAVE A CHANCE OF HINNING THE 1992 ELECTION.

00626

THE NEED FOR URBAN REFORM

RIPON FORUM, (DEC 90), 7-11.

THIS ARTICLE DISCUSSES NEW AND INNOVATIVE APPROACHES TO

THE HOUSING CRISIS IN THE CONTEXT OF URBAN REFORM. THE

HOUSING BILL OF THE 101ST CONGRESS, JACK KEMP'S HOPE (HOME

OWNERSHIP FOR PEOPLE EVERYWHERE) PROGRAM, THE BOTTOM-UP

PROGRAM THE ENTERPRISE FOUNDATION, AND MANNA'S PROGRAM FOR

PURCHASING AND REHABILITATING DILAPIDATED HOUSING ARE

DESCRIBED. THE ARTICLE ALSO DESCRIBES THE CONCEPT AND

PRACTICE OF NEIGHBORHOOD ECONOMIC DEVELOPMENT. FINALLY, THE

PROBLEMS OF AND POTENTIAL SOLUTIONS FOR URBAN HEALTH CARE

ARE EXAMINED.

00627

THE NEW POLITICS OF THIRST

WRLD PRESS REVIEW, 39(11) (NOV 92) 18-20.

IN MANY REGIONS OF THE WORLD, THE FIGHT FOR ACCESS TO

DHINDLING WATER RESERVES THREATENS TO BECOME THE MOST

DANGEROUS STRATEGIC ISSUE IN THE COMING DECADES AS THE

PLANET'S RAPIDLY GROWING POPULATION INCREASES THE DEMAND FOR

WATER AT AN INSANE PACE. DESPITE THE THREAT, THE WORLD'S

POL ITICAL LEADERS DO NOT SEEM ABLE TO ENYISION THE SCOPE OF

THE PROBLEM.

00628

THE NIGERIAN FACTOR

WEST AFRICA, (3889) (MAR 92), 533.

PRESIDENT BABANGIDA OF NIGERIA HAS ATTRIBUTED FEAR AND

SUSPICION ABOUT THE SERIOUSNESS OF HIS REGIME'S TRANSITION

PROGRAM AND HHETHER HE REALLY INTENDS TO STEP ASIDE IN

JANUARY 1993 TO "THE NIGERIAN FACTOR," WHICH ALLUDES TO THE

JANUARY 1993 TO "THE NIGERIAN FACTOR, WHICH ALLUDES TO THE

REASONS TO EVERY MOTIYE " IN SOME CASES. THE NIGERIAN FACTOR

IS A POLITICAL VIRTUE; IN OTHERS, IT IS DOWNRIGHT

IS A POLITICAL

00629

THE OTHER MINORITY

MEH REPUBL IC 206 (13) (MAR 92), 7

PAT BUCHANAN'S CANDIDACY FOR THE REPUBLICAN PRESIDENTIAL NOMINATION HAS RAISED A NUMBER OF STICKY ISSUES, INCLUDING BUCHANAN'S VOCAL DISTASTE FOR HOMOSEXUALS AND THE REPUBLICAN PARTY'S RESPONSE TO IT. THROUGHOUT GEORGE BUSH'S

ADMINISTRATION, THE PRESIDENT HAS TRIED TO APPEASE BOTH THE GAYS AND THE RIGHT WING OF HIS PARTY. NOW THE QUESTION IS
WHETHER BUSH'S REPUBLICAN PARTY APPROVES OF BUCHANAN'S HATEMONGERING OR WHETHER THE PRESIDENT HAS THE DECENCY TO REPUDIATE IT.

00630

THE OUTSIDERS

MEN REPUBLIC, 206 (16) (APR 92), 9.

HOSS PEROT'S POSSIBLE THIRD-PARTY CANDIDACY FOR THE PRESIDENCY IN 1992 AND JERRY BROWN'S CANDIDACY FOR THE DEMOCRATIC PRESIDENTIAL NOMINATION ARE SYMPTOMATIC OF MEITHER PEROT NOR BROWN WOULD MAKE A GOOD LEADER.

0063

THE POLITICAL SCIENCE COURSE SYLLABI PROJECT SELECTIONS FROM THE EDITORS' INTRODUCTIONS TO FIVE INTRODUCTORY COURSE COLLECTIONS

PS: POLITICAL SCIENCE AND POLITICS, $X X V(3)$ (SEP 92), $541-545$.

THE APSA IS CONDUCTING A PROJECT TO COLLECT AMD DISTRIBUTE EXEMPLARY SYLLABI FOR 10 POL ITICAL SCIENCE CDURSES. THIS ARTICLE OFFERS EDITORS' COMMENTS ABOUT THE FOLLOWING SYLLABI : GENERAL INTRODUCTORY COURSES IN POLITICAL SCIENCE ("INTRODUCTION TO POLITICAL SCIENCE" AND

"INTRODUCTION TO POLITICS AND/OR GOVERMMENT") BY JOHN C.

WAHLKE; "INTROOUCTORY COURSES IN AMERICAN POL ITICS: BEYOND

BOREDOM AND IRRITATION" BY MARJORIE RANDOM HERSHEY;

"INTRODUCTORY COURSE IN COMPARATIVE POLITICS" BY FRANK L.

WILSON; "TEACHING INTROOUCTION TO INTERNATIONAL RELATIONS:

MODEL SYLLABI" BY L.P. BRADY, AND "INTRODUCTORY POLITICAL

THEORY SYLLABI" BY PETER STILLMAN.

00632

THE PRESENT DANGER

NEW REPUBLIC, 206(26) (JUN 92), 7

H. ROSS PEROT IS THE CLOSEST AMERICAN APPROXIMATION OF FASCISM EVER TO HAVE A REAL SHOT AT THE PRESIDENCY. INDEED, THE ONLY IMPORTANT CHARACTERISTICS OF FASCISM THAT A MISSING THESE HE IS ALMOST COMICALIY LACKIMG.

00633

THE PRESIDENTIAL ELECTION PROCESS

CONGRESSIONAL DIGEST, 71 (10) (OCT 92), 226, 256

THIS ARTICLE SUMMARIZES A CONGRESSIONAL RESEARCH SERVICE

REPORT ENTITLED "THE PRESIDENTIAL ELECTION PROCESS." THE

PROCESS IS DESCRIBED IN DETAIL, INCLUDING THE

CONSTITUTIONALLY-PRESCRIBED OUALIFICATIONS FOR PRESIDENT,

THE DEMOCRATIC AND REPUBLICAN NOMINATION PROCEDURES, AND THE FUNCTION OF PRIMARIES AND CAUCUSES.

0063

THE PRICE OF LIBERATION

THE MIDDLE EAST, (195) (JAN 91), 8.

THE GULF COUNTRIES HAVE ALREADY PAID \$12 BILLION TO

OFFSET THE COST OF STATIONING 250,000 U.S. TROOPS IN THE

AREA. HOWEVER, THIS AMOUNT IS NOTHING COMPARED WITH WHAT THE

GULF STATES WOULD BE REQUIRED TO SPEND IF AND WHEN WAR

BREAKS OUT; ESTIMATES RUN AS HIGH AS $\$ 1$ BILLION A DAY.

FURTHERMORE, KUWAITI GOVERNMENT OFFICIALS FEAR A HIGH

CIVILIAN DEATH TOLL AS IRAQ MAKES CLEAR ITS INTENTION TO USE

KUWAITI CIVILIANS AS A HUMAN SHIELD.

00635

WEST AFRICA, ( 3917 ) (OCT 92), 1711.

THE AUTHOR PROFILES JOSE EDUARDO DOS SANTOS, WHO HAS

HEADED ANGOLA'S GOVERMMENT SINCE 1979 AMD WAS ELECTED

PRESIDENT IN ANGOLA'S FIRST GENERAL ELECTIONS IN SEPTEMBER 1992.

00636

THE QUOTA PARTY

NEH REPUBLIC, 206(19) (MAY 92), 7.

ON APRIL 7, 1992, DISTRICT JUDGE CHARLES R RICHEY

WANDD DOWN A DECISION THAT COULD FUMDAMENTALLY CHAMGE THE

EXISTING STRUCTURE OF THE REPUBL ICAN PARTY. HIS RUL ING

STATES THAT THE FEDERAL ELECTION COMMISSION MUST APPLY TITLE

YI OF THE TIYIL RIGHTS ACT OF 1964 TO THE REPUBL ACAM PARTY

AS A COMDITIS FOR DISBURSING THE

NEEDS TO FINANCE ITS 1992 CONVENTION. TITLE VI OUTLAHS ANY

DESIGNATION OF PEOPLE BY RACE, RELIGION, ETHNICITY, OR

NATIONAL ORIGIN--EVEN IF BENEVOLENTLY INTENDED. BUT THE

REPUBLICAN NATIONAL COMMITTEE HAS DESIGMATED SEATS ON ITS

EXECUTIVE COUNCIL FOR A BLACK REPUBLICAN, A HISPANIC, A

JEHISH-AMERICAN, AND A REPRESENTATIVE OF HERITAGE GROUPS

00637

THE RACE IS ON FOR 1993 NOMINATIONS

LATIN AMERICAN HEEKLY REPORT, (27) (JUL 92), 3

ON JUNE 28, 1992, CHILEANS WENT TO THE POLLS TO VOTE FOR MUNICIPAL OFFICIALS. THE RESULTS WERE 53.35\% FOR THE RULING COALITION, 29.36\% JOINTLY FOR RENOYACION NACIONAL AND THE UNION DEMOCRATA INDEPENOIENTE, 8.1\% FOR THE UNION CENTRO 
CENTRO, AND 6.6\% FOR MIDA, THE LEFT-WING COALITION. 00638

THE RAWLINGS PARADOX

HEST AFRICA, (3922) (NOY 92), 1954-1955.

GHANA'S NOVEMBER 1992 PRESIDENTIAL ELECTION WAS THE PENULTIMATE PHASE IN THE POLITICAL NORMALIZATION PROCESS AFTER THE PARLIAMENTARY ELECTIONS IN DECEMBER, THERE ONLY REMAINS THE FORMAL TRANSFER OF POHER IN JANUARY 1993. BUT THE OPPOSITION PARTIES ARE CLAIMING THAT THE NOVEMBER ELECTION WAS RIGGED AND ARE THREATENING TO BOYCOTT THE PARLIAMENTARY ELECTIONS.

00639

THE REALITY OF MONEY-SOAKED POLITICS: PUBLIC DISTRUST

JAPAN TIMES (WEEKLY INTERNATIONAL EDITION), $32(10)$ (MAR

2), 10.

TESTIMONY GIVEN IN THE DIET BY FORMER PRIME MINISTER ZENKO SUZUKI AND FORMER STATE MINISTER JUN SHIOZAKI DID NOT HELP TO CLARIFY THE KYOWA BRIBERY SCANDAL BUT DID DEEPEN PUBLIC DISTRUST OF JAPAN'S POLITICIANS. THEIR REVELATIONS DEMONSTRATED IN A DRAMATIC WAY THAT A STRANGE SENSE OF ETHICS ABOUT MONEY, WHICH IS TOTALLY FOREIGH TO ORDINARY CITIZENS, PREVAILS IN THE POLITICAL WORLD. WITHOUT ORASTIC MONEY.

00640

THE REBUILDING OF KUWAIT

THE MIDDLE EAST, (198) (APR 91), 8-10

THIS ARTICLE' OISCUSSES THE PROSPECTS FOR AND

DIFFICULTIES FACING KUWAIT IN THE POST-GULF WAR PERIOD.

HUMAN RIGHTS ISSUES ARE EXAMINED, AS WELL AS KUWAIT

ATTITUDES TOWARDS EGYPTIANS AND OTHERS WHO HELPED KUHAITIS

INSIDE KUWAIT DURING THE WAR. THE LIKELIHOOD OF REDUCTION OF

THE KUHAITI BUREAUCRACY IS EXPLORED, AND THE WILLINGNESS OF

KUWAITIS TO PERFORM MENIAL WORK INSIDE KUWAIT THAT WAS

PREVIOUSLY LEFT TO FOREIGNERS IS CONSIDERED.

00641

THE REPRESENTATIVE FUNCTION OF THE SENATE: THE SOCIODEMOGRAPHIC DIMENSION

CANADIAN PARLIAMENTARY REVIEW, (WIN 91), 32-33.

THIS ARTICLE BRIEFLY EXAMINES THO DEMOGRAPHIC ISSUES WITH REGARDS TO THE CANADIAN SENATE: AGE AND GENDER. IT CALCULATES THE AVERAGE AGE OF CANADA'S SEMATORS (ONE OF THE CALCULATES THE AVERAGE AGE OF CANADA'S SENATORS (ONE OF THE CONDITIONS FOR APPOINTMENT IS THAT SENATORS MUST BE AT LEAST FEMALE SEMATORS (WOMEN WOH ADMITTANCE TO THE SENATE ONLY FEMALE SENATORS (WO
SIXTY YEARS AGO).

00642

THE RISE AND FALL OF RUBEN BLADES

LATIN AHERICAN WEEKLY REPORT, (3) (JAN 92), 4-5 PERHAPS MOTHING ILLUSTRATÉS THE UNSETTLÉD NATURE OF PANAMANIAN POLITICS MORE THAN THE SHIFT RISE, AND EVEN SHIFTER FALL, OF PRESIDENTIAL ASPIRANT RUBEN BLADES, WHO IS BEST KMOHN AS A SALSA COMPOSER AND PERFORMER. IN 1991 BLADES ANNOUNCED THE FORMATION OF A NEN POL ITICAL MOVEMENT, PAPA EGORD, WHICH WAS TO BE HIS BASE FOR RUNNING FOR PRESIDENT IN 1994. BLADES' SONGS, WHICH REFLECT HIS POLITICAL BELIEFS FORMED A SORT OF READY MADE PLATFORM. BUT HIS FORAY INTO POLITICS WAS SHORT-LIVED BECAUSE HE LEFT FOR THE USA TO RECORD A NEH ALBUM AND MAKE A PROMOTIONAL TOUR.

00643

THE SIERRA LEONE COUP

TH AFRICA, (3895) (MAY 92), 788-790.

THE AUTHOR DETAILS THE OVERTHROW OF THE GOVERNMENT OF PRESIDENT JOSEPH SAIDU MOMOH IN A MILITARY COUP LED BY MIDOLE-RANK OFFICERS OF THE REPUBLIC OF SIERRA LEONE TROOPS IN APRIL 1992.

00644

THE STATE OF THE SOVIET ECONOMY

FINANCE AND DEYELOPMENT 2811) (MAR 91) 10-11.

AT THE JULY 1990 "HOUSTON SUMMIT," THE HEADS OF STATE

AND GOVERNMENT OF THE SEVEN PRINCIPAL INDUSTRIAL DEMOCRACIES

AND THE PRESIDENT OF THE COMMISSION OF EUROPEAN COMAUNITIES

REQUESTED THE INTERNATIONAL MONETARY FUND, THE WORLD BANK,

THE ORGANI ZATION FOR ECONOMIC COOPERATION AND DEVELOPMENT,

THE ORGANIZATION FOR ECONOMIC COOPERATION AND DEVELOPMEM

RECONSTRUCT TON EMD PRESIDENT OF THE EUROPEAN BANK FOR

THE SOYIET ECONOHY. THIS ARTICLE CONTAIMS SOME OF THE

RESULTS OF THAT STUDY AHD INCLUDES INFORMATION ON THE

DISTRIBUTION OF POPULATION, NEH MATERIAL PROOUCT, AND BUDGET

REVENUE; OUTPUT AND EXPENDITURES; FISCAL AND EXTERNAL

IMBALANCE; EXTERMAL DEBT; AND MONEY, INCOME, AND PRICES.

00645

THE SWISS SCENE

SWISS REYIEW OF WORLO AFFAIRS, 42(4) (JUL 92), 31.

THE SHISS PARLIAMENT HAS RECENTLY HAO TO OEAL HITH THO
CONTROVERSIAL MILITARY ISSUES: THE PURCHASE OF 34 MCDONELLDOUGLAS F/A-18 COMBAT JETS AND THE OUESTION OF THE ENVIRONMENTAL IMPACT OF CONSTRUCTING NEW MILITARY BASES.

00646

THE TALLY

INSIGHT, 7(4) (JAN 91), 18-19.

THIS ARTICLE PRESENTS A VOTE-BY-VOTE DEPICTION OF HOW U.

S. SENATORS AND REPRESENTATIVES YOTED ON RESOLUTIONS CALLING

FOR CONTINUED SANCTIONS AGAINST IRAQ (SJRES 1, HCONRES 33)

A MEASURE APPROVING THE USE OF FORCE IN THE GULF CRISIS

(SJRES 2, HJRES 77); AND A REAFFIRMATION OF COMGRESS'S WAR

POWERS. (HCONRES 32).

00647

THE TEMPTER

NEW REPUBLIC, 206(24) (JUN 92) 7

THE CENTRAL OBJECTION TO H. ROSS PEROT'S CANDIDACY FOR

PRESIDENT IS SIMPLE ENOUGH: PEROT HIMSELF. HIS EXECUTIVE

ENERGY IS NOT ALIGNED WITH MUCH ELSE AND, INSOFAR AS IT IS

EXERCISED, IT IS OFTEN IN THE WRONG DIRECTION. PEROT'S

DEEPEST BELIEFS ABOUT THE ECONOMY ARE THOSE OF A NEO-

PROTECTIONIST, A MAN WHO OPPOSES FREE TRADE WHENEVER IT

HIMDERS THE PLANS OF AN INTERVENTIONIST GOVERNMENT. HE

ARGUES FOR A CLUMSY INDUSTRIAL POLICY THAT WOULD HARM,

RATHER THAN HELP. AMERICAM GLOBAL COMPETITIVENESS. IN

ADOITION, THERE IS A PROFOUND CHARACTER ISSUE WITH PEROT

BECAUSE HIS PAST SHOWS HIM TO BE PERSONALLY VICIOUS, SELF-

OBSESSED, AND BORDERLINE PARANOID. MOREOVER, HE SHOWS EVERY

SIGN OF NOT UNDERSTANDING THE POLITICAL CONTEXT IN WHICH THE PRESIDENT MUST OPERATE.

00648

THE TRAGEDY OF THE GULF WAR

SOCIALIST REVIEN, 21(1) (JAN 91), 8-10.

THIS ARTICLE EXAMINES THE GULF WAR AND THE UNDERLYING

REASONS FOR U.S. MILITARY ACTION. IT ARGUES THAT THE U.S.

SEIZED A RARE WINDON OF OPPORTUNITY CREATED BY THE DECLINE

OF SOVIET POWER TO ESTABLISH ITS PRESENCE IN THE MIDDLE EAST

AND DICTATE AFFAIRS IN THE REGION ON ITS OWN TERMS. THE GULF

WAR IS, THEN, THE FIRST ACT IN WHAT WILL SURELY BE A MORE

PROTRACTED AND CONTENTIOUS U.S. INVOLVEMENT IN THE MIDDLE

EAST.

00649

THE U.S. AND AFRICA: THE REPUBLICAN RECORD

AFRICA REPORT, 37(5) (SEP 92), 13-17.

IN THIS INTERVIEH, U.S. PRESIDENT GEORGE BUSH HIGHLIGHTS HIS ADMINISTRATION'S' POLICY ACHIEVEMENTS IN AFRICA, CITING EFFORTS AT CONFLICT RESOLUTION IN AHGOLA, ETHIOPIA,

MOZAMBIOUE, AND LIBERIA AS EXAMPLES. HE CLAIMS THAT SUPPORT FOR BURGEONING DEMOCRACIES AND HUMAN RIGHTS ANO ASSISTING IN MIMANITARIAN CRISES HAVE BEEM HIS POLICY PRIORITIES IN AFRICA.

00650

THE U.S. LOOKS TO LATIM AMERICA

ORLD PRESS REVIEW, 39(9) (SEP 92), 16-17.

THE END OF THE COLD WAR HAS LEFT THE UNITED STATES AS

THE CHIEF INTERNATIONAL ARMS MERCHANT. IN ORDER TO PROTEC

ITS MILITARY-INDUSTRIAL COMPLEX, THE USA IS SELLING MORE

ARMS TO THIRD WORLD COUNTRIES. THE BUSH ADMINISTRATION PLANS

TO SELL PLANES TO BOTH CHILE AND ARGENTINA. MEANHHILE,

SOPHISTICATED U.S. HELICDPTERS, MACHINE GUNS, AND RIFLES

WILL GO TO BOLIVIA, PERU, AND COLOMBIA TO HELP CONTROL DRUG TRAFFICKING.

00651

THE U.S. STATE DEPARTMENT FILES

WEST AFRICA, (3922) (NOV 92), 1966-1967.

THIS ARTICLE INCLUDES EXCERPTS FROM CONFIDENTIAL

CORRESPONDENCE BETHEEN THE U.S. STATE DEPARTMENT AND U.S.

EMBASSIES IN SOME WEST AFRICAN CAPITALS REGARDING LIBERIA,

WHICH WAS LEAKED TO THE PRESS IN THE FALL OF 1992.

00652

NEW REPUBLIC, 206(23) (JUN 92), 7 .

BUSH STANDS FIRMLY ON THE SIDE OF THE OPPRESSORS. BY

REFUSING TO ACKNOWLEDGE TIBET'S STATUS AS AN OCCUPIED

COUNTRY OR TO CONDEMN CHINESE ABUSES THERE, BUSH NOT ONLY PERPETUATES A GRAVE HISTORICAL INJUSTICE. HE ENSURES THE CONTINUATION OF THE BRUTALITY THAT HAS ALREADY CLAIMED MORE THAN A MILLION LIVES AMD THREATENS TO EXTINGUISH TIBETAY CULTURE ALTOGETHER.

00653

THE UMDERHORLD OVERLORD

JAPAN TIMES (WEEKLY INTERNATIONAL EDITION), 32(17) (APR 92), 12-13.

SUSUMU ISHII, WHO DIED IN THE FALL OF 1991, WAS A WELL-

KMOHN ORGANIZED CRIME FIGURE WHO HAD TIES WITH JAPANESE

POLITICIANS. HIS DEATH CAUSED COMPLEX REPERCUSSIONS IN THE 
POLITICAL AND BUSINESS WORLDS AND WILL GREATLY ALTER THE MAP OF JAPAN'S UNDERHORLD.

00654

THE UNITED NATIONS: COMING TO GRIPS HITH A NEW WORLD ORDER WORLD PRESS REVIEW, 39(10) (OCT 92), 9-10.

THE AUTHOR LOOKS AT THE UNITED NATIONS' PEACEKEEPING ROLE AND HOH THE INTERNATIONAL ORGANIZATION IS COMING TO GRIPS WITH THE NEW WORLD ORDER.

00655

THE WEST ON THE HORNS OF A BALKANS DILEMMA

GERMAN TRIBUNE, (1524) (JUL 92), 1 .

THE WEST IS STEPPING UP ITS MILITARY COMMITMENT IN THE BALKANS LITTLE BY LITTLE, BUT UNMISTAKABLY, ESPECIALLY FOR THE BELLIGERENTS IN BOSNIA-HERCEGOYIMA. HOHEVER MOST LEADING STATESMEN INCLUDING U.S. PRESIDENT GEORGE BUSH AND BRITISH PRIME MINISTER JOHN MAJOR ARE RELUCTANT TO RISK DIRECT INTERVENTION. EVEN SO, THE DECISION TO SEND WARSHIPS AND RECONNAISSANCE AIRCRAFT TO THE ADRIATIC IS MORE THAN JUST A SIGHAL. IT HILL MAKE THE UN EMBARGO OF SERBIA EASIER TO ENFORCE. HOWEVER, CONFLICTS AMONG THE WESTERN POWERS
HOW TO BEST END THE FIGHTING IN THE BALKANS ARE GROWING.

00656

THE WHITES VOTE "YES"

WEST AFRICA, (3888) (MAR 92), 518.

BY THE AFTERNOON OF MARCH 18, 1992, IT WAS OBVIOUS THAT

THE MAJORITY OF SOUTH AFRICA'S WHITES HAD VOTED TO CONTINUE

THE REFORM PROCESS THAT WILL EVENTUALLY LEAD TO A NEW

CONSTITUTION. NEVERTHELESS, CONSERVATIVE PARTY LEADERS

DENOUNCED THE REFERENDUM AND VOWED TO CONTINUE THEIR FIGHT

FOR WHITE SUPREMACY.

00657

THE HILDERNESS YEAR

NEW REPUBLIC, 207(10) (AUG 92), 9.

WITH PERVERSE DEXTERITY, PRESIDENT GEORGE BUSH HAS

ABANDONED VIRTUALLY EVERY BATTLE-PROVEN REPUBLICAN WEAPON.

MOREOVER, BUSH'S MEDIOCRE PRESIDENCY HAS BEEN A REFLECTION

OF A DEEPER REPUBLICAN CRISIS. THE CONSERVATIVE MOVEMENT

THAT GALYAIZED

CLEARLY ENTERING ITS DEATH THROES.

00658

THE YOPOUGON EFFECT

WEST AFRICA, (3884) (FEB 92), 313.

THE IMPRESSION OF POLITICAL TRANQUILITY IN COTE D'IVOIRE

HAS BEEN DECEPTIVE. THE OPPOSITION HAS KEPT UP A CONSTANT

BARRAGE OF CRITICISM AGAINST BOTH HOUPHOUET-BOIGNY AND THE

MAN HE BROUGHT IN TO REVIVE THE CRUMBLING ECONOMY, PRIME

MINISTER ALASSANE OUATTARA. MOREOVER, THE OPPOSITION'S

PROFILE HAS RISEN DRAMATICALLY SINCE THE PUBLICATION OF THE

REPORT ON YOPOUGON AND HOUPHHOUET-BOIGNY'S RESPONSE TO IT.

ALTHOUGH THE REPORT SUBSTANTIATES CLAIMS THAT SENIOR

MILITARY FIGURES AND MINISTERS PERMITTED BRUTALITY THAT

CULMINATED IN THE RAPE AND ASSAULTS OF STUDENTS IN YOPOUGON

IN MAY 1991, HOUPHOUET HAS REJECTED THE REPORT'S

RECOMMENDATION THAT HE SACK HIS CHIEF OF STAFF, GENERAL

ROBERT GUEI.

00659

THINGS TURN NASTY FOR PRESIDENT PEREZ

LATIN AMERICAN HEEKLY REPORT, (40) (OCT 92), 3

ONLY DAYS AFTER HAVING SECURED THE REST OF HIS MANDATE

THROUGH HORSE-TRADING IN CONGRESS, PRESIDENT CARLOS ANDRES

PEREZ HAS COME IN FOR ANOTHER BOUT OF PUBLIC QUESTIONING--

THIS TIME ABOUT CORRUPTION WITHIN HIS ADMINISTRATION, HIS

TREATMENT OF THE MEDIA, AND A SUSPICIOUS TERRORIST ATTACK ON

A PROMINENT MEDIA FIGURE.

00660

THIRD BID TO SHORTEN PEREZ'S MANDATE

LATIN AMERICAN WEEKLY REPORT, (45) (NOV 92), 10.

FOR THE THIRD TIME, VENEZUELA'S POLITICAL OPPOSITION HAS

MADE A BID TO SHORTEN'PRESIDENT CARLOS ANDRES PEREZ'S

MANDATE, BUT IT LOOKS AS IF THIS WILL BE NO MORE SUCCESSFUL

THAN THE PREVIOUS ATTEMPTS.

00661

THORN IN THE FLESH

WEST AFRICA, (3911) (AUG 92), 1475

IN THE CONTINUING CRISIS OVER DEMOCRATIZATION IN ZAIRE,

ONE MAH- CTINE TSHISEKEDI OHER DEMOCRATIZATION IN ZAI

PERMANENT THORN IN THE SIDE OF PRESIDENT MOBUTU. RECENTLY

ELECTED TO SERVE AS TRANSITIONAL PRIME MINISTER, TSHISEKEDI

MUST IMMEDIATELY CONFRONT THE CRISIS OVER SHABA AND THE

COUNTRY'S INCREASING INTER-ETHNIC STRIFE.

00662

THOUGHT OF THE LAST OPTIMIST

JAPAN TIMES (HEEKLY INTERNATIONAL EDITION), 32(11) (MAR

92), 10.

iHe aUthor muses about francis fukuYama's thesis in "THE
END OF HISTORY AND THE LAST MAN" AND CHARACTERIZES FUKUYAMA AS THE LAST OPTIHIST.

00663

THREE LEADERS, THREE GOALS

THE MIDDLE EAST, (197) (MAR 91), 5-7.

THIS ARTICLE EXAMINES THE GOALS, MOTIVES, AND STRATEGIES

IN THE GULF HAR OF THE THREE MAIN LEADERS INVOLVED: SADDAM

HUSSEIN, KING FAHD, AND PRESIDENT GEDRGE BUSH. HUSSEIN IS

DESCRIBED AS A POOR STRATEGIST BUT A SHREWD TACTICIAN. KING

FAHO IS SEEN AS HORKING FROM AN UNCOMFORTABLE POSITION.

PRESIDENT BUSH IS CONSIDERED AS INCONSISTENT IN HIS GOALS.

00664

THREE MINISTERS GO IN CABINET SHAKE-UP

ATIN AMERICAN HEEKLY REPORT (49) (DEC 92), 4-5

ON DECEMBER 2, 1992 , PRESIDENT CARLOS MENEM DISMISSED

THREE CABINET MEMBERS--THE MINISTERS OF INTERIOR, LABOR, AND

EDUCATION. FOREIGN MINISTER GUIDO DI TELLA KEPT HIS JOB,

DESPITE RUMORS THAT HE WOULD ALSO BE REMOVED.

0066

THREE YEARS ON, CARLOS ANDRES PEREZ LAUNCHES A NEW BELTTIGHTENING PACKAGE

LATIN AMERICAN HEEKLY REPORT, (34) (SEP 92), 1

THREE YEARS AFTER LAUNCHING HIS FIRST SHOCK ADJUSTMENT

PROGRAM, PRESIDENT CARLOS ANDRES PEREZ HAS ANNOUNCED A

SECOND SWEEPING AUSTERITY DRIVE. IN ADDITION TO SLASHING THE GOVERNMENT PAYROLL AND OTHER EXPENSES, THE PROGRAM INCLUDES NEW TAXES TO COMPENSATE FOR THE DWINDLING CONTRIBUTION FROM THE OIL INDUSTRY.

00666

TIBET: ITS OHNERSHIP AND HUMAN RIGHTS SITUATION

BEIJING REVIEW, 35(39) (SEP 92), 10-43.

THIS ARTICLE PREPARED BY THE INFORMATION OFFICE OF THE

STATE COUNCIL OF THE PEOPLE'S REPUBLIC OF CHINA EXPLAINS THE

"OWNERSHIP" OF TIBET UNDER THE YUAN, MING, AND QING

DYNASTIES, UNDER THE REPUBLIC OF CHINA, AND UNDER COMMUNIST

CHINA. IT DISCUSSES THE QUESTION OF TIBETAN INDEPENDENCE,

THE 1959 ARMED REBELLION, THE DALAI LAMA'S "SEPARATIST

ACTIVITIES," AND THE RIGHTS OF THE TIBETAN PEOPLE UNDER THE

CHINESE COMMUNISTS.

00667

TIBETANS ENJOY ALL HUMAN RIGHTS

BEI JING REVIEH, 35(15) (APR 92), 15-17

SINCE ITS PEACEFUI LIBERATIDN IN 1951 AND ESPECIALLY

SINCE THE IMPLEMENTATION OF REFORM 13 YEARS AGO, TIBET HAS MADE REMARKABLE PROGRESS IN ECONOMIC CULTURAL, AND OTHER FIELDS THE TIBETAN PEOPLE EM JOY "ALI HUMAN RIGHTS"

NEVERTHELESS, A FEW TIBETAN SEPARATISTS IN SELF-EXILE ABROAD AND SOME INTERNATIONAL GROUPS HAVE ACCUSED THE CHINESE GOVERNMENT OF CONSISTENTLY VIOLATING HUMAN RIGHTS IN TIBET.

00668

TIBETANS ON HUMAN RIGHTS IN TIBET

BEIJING REVIEH, 35(40) (OCT 92), 7,

THE CHINESE GOVERNMENT HAS PUBLISHED A WHITE PAPER

ENTITLED "TIBET: ITS OWNERSHIP AND HUMAN RIGHTS SITUATION"

TO PROVE THAT TIBET HAS BEEN A PART OF CHINA FOR MORE THAN 700 YEARS AND TO DISPROVE ALLEGATIONS OF HUMAN RIGHTS

VIOLATIONS. XERBA NYIMA, DEPUTY DIRECTOR OF THE RESEARCH

INSTITUTE OF TIBETOLOGY, HAS DECLARED THAT WESTERN

ACCUSATIONS REGARDING HUMAN RIGHTS IN TIBET ARE ERRONEOUS AND THAT CONDITIONS ARE BETTER NOW THAN THEY WERE BEFORE 1959.

00669

TIME FOR SERIOUS POLITICAL REFORM

LATIN AMERICAN HEEKLY REPORT, (44) (NOV 92), 4

PRESIDENT CARLOS SALINAS DE GORTARI HAS DECLARED THAT

MEXICO'S ELECTORAL SYSTEM NEEDS FURTHER REFORM, INCLUDING

REVEALING THE SOURCES OF ALL PARTY FUNDING, PLACING LIMITS

ON THE COST OF ELECTORAL CAMPAIGNS, AND GUARANTEEING "THE

IMPARTIALITY OF ELECTORAL PROCESSES."

00670

TIME-WASTING EXERCISE?

HEST AFRICA 75(3909) (AUG 92), 1387.

MUCH WAS EXPECTED OF THE NATIONAL CONFERENCE ORGANIZED

BY THE ALLIANCE OF DEMOCRATIC FORCES A COALITION OF

BY THE ALLIANCE OF DEMOCRATIC FORCES, A COALIT BROADENING

THE TRANSITION BY GENERAL CONSENSUS, NOT MUCH WAS ACHIEVED.

TO MAKE MATTER WORSE FOR THE ALLIANCE, THE FORMER PRESIDENT.

DR HILLA LIMANN APPEARED TO HAVE BROKEN RANKS WHEN HE

VIRTUALLY EXONERATED RAHLINGS OF THE SERIOUS CHARGE OF BEING A COUP MAKER.

00671

TOGO: KOFFIGOH'S CONTRACT

WEST AFRICA, (3878) (JAN 92), 80.

TOGO'S PROVISIOMAL LEGISLATURE, THE HIGH COUNCIL OF THE

REPUBLIC, HAS APPROVED A 1O-POINT PROGRAM OUTLINED BY PRIME 
MINISTER JOSEPH KOKOU KOFFIGOH. CALLED "THE NEH SOCIAL CONTRACT FOR A PEACEFUL TRANSITION," THE PLAN WILL INCLUDE HAS EXPRESSED ITS SUPPORT FOR THE PRIME MINISTER'S PROGRAM. 00672

TOGO: NEW GOVERMMENT

WEST AFRICA, (3877) (JAN 92), 41.

TOGO'S PRIME MINISTER KOKOU KOFFIGOH ANHOUNCED THE

FORMATION OF A NEW GOVERMMENT OF NATIONAL UNITY ON DECEMBER

31. 1991. THE EXILED PRESIDENT OF THE HIGH COUNCIL OF THE

REPUBLIC, MONSIGNOR FANOKO KPODZRO, RETURNED TO LOME ON

DECEMBER 20, 1991.

00673

TOKYO SAYS RELATIONS WITH PYONGYANG HINGE ON ALLOWIMG NUCLEAR INSPECTIONS JAPA 3 .

NOBORU MAKAHIRA, JAPAN'S CHIEF NEGOTIATOR, HAS WARMED THAT JAPANESE-NORTH KOREAN TALKS ON NORMALIZING RELATIONS WILL MAKE NO SUBSTANTIAL PROGRESS UNTIL PYONGYANG IMPLEMENTS ITS PROMISE TO ALLOW INSPECTIONS OF ITS NUCLEAR FACILITIES. 00674

TOKYO SAYS TRIPOLI RISKS SAMCTIONS

JAPAN TIMES (WEEKLY INTERNATIONAL EDITION), 32(15) (APR 92 ) 3

ON APRIL 2,1992 JAPAN WARMED THAT LIBYA COULD FACE SANCTIONS IF IT FAILS TO COMPLY WITH A U.N. RESOLUTION DEMANDING THAT TRIPOLI SURRENDER SUSPECTS IN BOMB ATTACKS ON AIRLINERS. JAPAN ALSO CALLED ON TRIPOLI TO ALLOW JAPANESE AND OTHER FOREIGN NATIONALS TO LEAVE LIBYA.

00675

TOP REFORMIST GETS THE BOOT

LATIN AMERICAN WEEKLY REPORT, (39) (OCT 92), 8-9.

IN SEPTEMBER 1992, CUBAN COMMUNIST PARTY MEMBERS WERE INFORMED THAT CARLOS ALDANA, THE REPUTED LEADER OF THE REFORMIST FACTION WITHIN THE PARTY, HAD BEEN DISMISSED FROM HIS POSITION AS HEAD OF THREE KEY DEPARTMENTS: IDEOLOGY, INTERNATIONAL RELATIONS, AND EDUCATION, SCIENCE, AND CULTURE. DESPITE ALDANA'S DISMISSAL. THERE HAS NOT YET BEEN AMY SIGN OF A MAJOR PURGE WITHIN THE PARTY. 00676

TOUGHER PENALTIES FOR TERRORISH

LATIN AMERICAN WEEKLY REPORT, (18) (MAY 92), 2-3.

ON APRIL 30, 1992 , PERUVIAN PRESIDENT ALBERTO FUJIMORI ANNOUNCED STIFFER PENALTIES FOR TERRORISM AND PROPOSED TO INTRODUCE LEGISLATION IMPOSING A LIFE SENTENCE FOR ANYONE INTRODUCE LEGISLATION IMPOSING A LIFE SENTENCE FOR ANYONE SENDERO LUMINOSO STAGED A SERIES OF ATTACXS IN LIMA. ALSO ON SENDERO LUMINOSO STAGED A SERIES OF ATTACXS IN LIMA. ALSO THAT DATE, PRESIDENT-DESIGNATE MAXIMO SAN ROMAN APPEARED LEADERS TO EXPLAIN HIS ALTERMATIVE TO FUJIMORI'S PLAN FOR LEADERS TO EXPLAIN HIS ALTER
RETURNING TO ELECTED RULE.

00677

TOWARDS A PAN-AFRICAN COMMUNITY

HEST AFRICA, (3886) (MAR 92), 19-420.

THE AFRICAN DEVELOPMENT BANK IN ABIDJAN HAS ESTABLISHED A TASK FORCE TO HELP IT DECIDE HOH TO INTERVENE TO ENSURE THE REALIZATION OF THE PROPOSED AFRICAN ECONOMY COMMUNITY (AEC), WHICH IS TO BE FULLY OPERATIONAL BY THE YEAR 2025 THE RELATIONSHIP OF THE AEC TO THE EXISTING SOUTH AFRICAN DEVELOPMENT COORDINATION CONFERENCE IS ONE PROBLEM THAT MUST BE WORKED OUT.

00678

TRACKING THE TRANSITION

WEST AFRICA, (3897) (MAY 92), 869.

WITH THE MAJORITY OF AFRICAN COUNTRIES EITHER ALREADY IN

A DEMOCRATIC TRANSITIION OR CONTEMPLATING IT, IT IS NOT

OVERLY OPTIMISTIC TO STATE THAT THE CONTINENT IS

EXPERIENCING AN IRREVERSIBLE CHANGE. THE VAST MAJORITY OF

THE AFRICAN PEOPLE ACCEPT A DEMOCRATIC DESTINY, NOT LEAST

BECAUSE IT GUARANTEES BOTH HUMAN RIGHTS AND PARTICIPATION IN

DEVELOPMENT POLICIES.

00679

TRANSFORMATION OF THE SOVIET UNION

CONGRESSIONAL DIGEST $71(8-9)$ (AUG 92) 197-199.

THIS ARTICLE REVIEHS THE RECENT POLITICAL HISTORY OF THE SOVIET UNION AND SPECULATES ABOUT THE IMPACT OF THE SOVIET

COLLAPSE ON U.S. FOREIGN POLICY AND INTERNATIONAL RELATIONS 00680

TREATY IN HAND, THE FMLN STARTS TO WORK ON ITS FUTURE AS A LEGAL PARTY

ATIN AMERICAN WEEKLY REPORT, (4) (JAN 92), 1.
THE PEACE TREATY BETHEEN THE GOVERNMENT OF PRESIDENT

ALFREDO CRISTIANI AND THE FRENTE FARABUMDO MARTI PARA LA

LIBERACION NACIONAL (FMLN) WAS SIGNED ON JANUARY 16, 1992.
THE FMLN WILL FORM A POLITICAL PARTY UNDER THE SAME NAME, AND ITS LEADERS WILL BE THE COMHANDERS OF THE FORMER FIGHTING ORGANIZATIONS. HOWEYER, THE FMLN DOES NOT INTEND TO PRESIDENTIAL CANDIDATE OF ITS OHN BUT WILL SEEK TO JOIN A COALITION OF "A PROGRESSIVE NATURE."

00681

TRIPARTITE PLAN FAILS IN CONGRESS

LATIN AMERICAN WEEKLY REPORT, (23) (JUN 92 ), 11

IN JUNE 1992, PROVISIONAL PRESIDENT JOSEPH NERETTE AHD SYMPATHETIC CONGRESSIONAL LEADERS ATTEMPTED TO PUSH THEIR TRIPARTITE POLITICAL PLAN THROUGH CONGRESS. BUT THEY WERE UNABLE TO MUSTER THE NECESSARY OUORUM FOR A VOTE IN THE CHAMBER OF DEPUTIES BECAUSE PRO-ARISTIDE LEGISLATORS BOYCOTTED IT. MEANWHILE, THE GOVERNMENT STEPPED UP ITS REPRESSION OF THE OPPOSITION.

00682

U.N. PLAN TO BREAK DE-MOB DEADLOCK

LATIN AMERICAN WEEKLY REPORT, (42) (OCT 92), 10

A PLAN DEVISED BY THE UNITED NATIONS MAY BREAK THE DEADLOCK IN THE IMPLEMENTATION OF THE SALVADOREAN PEACE AGREEMENT. THE U.N. PLAN CALLS FOR THE DISTRIBUTION OF 237, OOO MANZANAS OF LAND TO FORMER GUERRILLAS, FORMER SOLDIERS, AND PEASANT SOUATTERS. THE GOVERNMENT HAS WELCOMED THE PLAN, BUT THE FMLN HAS BEEN LUKEWARM, BECAUSE IT DOES NOT MEET ALi OF THEIR DEMANDS.

00683

U.S. CATHOLIC BISHOPS USE POLITICAL CLOUT TO BLOCK BIRTH CONTROL ACCESS, GROUP SAYS

CHURCH AND STATE, 45(1) (JAN 92), 17.

CATHOLICS FOR A FREE CHOICE (CFC) STATES THAT THE UNITED STATES CATHOL IC CONFERENCE, THE POLITICAL ARM OF THE

CATHOLIC HIERARCHY, IS A LITTLE-KNOHN BUT EFFECTIVE LOBBYINC FORCE THAT ROUTINELY HORKS TO SHAPE PUBLIC POLICY IN WAYS THAT DO NOT REPRESENT MOST AMERICAN CATHOLICS. THEY CHARGE THAT THE DECISIONS ON SPENDING AND LOBBYING PRIORITIES AND THE OPINIONS THAT EMANATE FRDM THE LOBBY ARE MOT THOSE OF THE 55 MILLION AMERICAN CATHOLICS, BUT THOSE OF THE 300 BISHOPS. THEY ALSO CHARGE THAT THE BISHOPS' OPPOSITION TO BIRTH COMTROL IS SOMETIMES EXTREME.

00684

U.S. CONGRESSMEN CALL BROKER RESTRICTIONS UNFAIR

JAPAN TIMES (HEEKLY INTERMATIONAL EDITION), 32(13) (MAR

92), 18.

ON BEHALF OF U.S. BROKERAGES OPERATING IN JAPAN, THREE U. S. CONGRESSMEN HAVE ASKED FINANCE MINISTER TSUTOMU' HATA TO "OMEROUS AND UNFAIR" RESTRICTIONS ON FUTURES AND OTHER SECURITIES TRADING ACTIVITIES. THE CONGRESSMEN CLAIM THAT MEW RULES FOR FUTURES AND DERIVATIVES TRADING ARE SKEWED AGAINST FOREIGM BROKERAGES THAT HAVE SUCCESSFULLY PENETRATED THE JAPANEST MARKET.

00685

U.S. IS EMBROILED IN TAMAUL IPAS DISPUTE

LATIN AMERICAN WEEKLY REPORT, (47) (DEC 92),

INCREASINGLY IT SEEMS THAT MEXICAN POLITICS WILL BE

PLAYED BEFORE A U.S. AUDIENCE. THE MOST RECENT INSTANCE IS

THE FALLOUT FROM THE DISPUTED STATE ELECTIONS IN TAMAULIPAS

WHICH HAS BECOME A DELICATE DIPLOMATIC ISSUE BETHEEN THE THO COUNTRIES.

00686

U.S. PREPARED FIGHTERS SALE CRITICIZED

BEIJING REVIEH, $35(38$ ) (SEP 92), 7

ON SEPTEMBER 2, 1992, THE BUSH ADMINISTRATION ANNOUNCED

THAT IT HAD DECIDED TO SELL 150 F-16 FIGHTER AIRCRAFT TO

TAIWAN. COMMUNIST CHINA STRONGLY DENOUNCED THE DECISION

CLAIMING THAT IT VIOLATES THE SINO-U.S. SHANGHAI COMMUNIQUE,

THE SINO-U.S. COMMUNIQUE ON ESTABLISHING DIPLOMATIC TIES,

AND THE SINO-U.S. JOINT COMMUNIQUE OF AUGUST 17, 1982.

00687

U.S. -BOLIVIAN RELATIONS UNDER FIRE

LATIN AMERICAN WEEKLY REPORT, (33) (AUG 92), 6-7.

THE BOLIVIAN GOVERNMENT AND CONGRESS ARE REVIEWING THE

STATUS OF RELATIONS WITH THE UNITED STATES, DUE TO

CONTROVERSY OVER THE PRESENCE OF U.S. TROOPS IN BOLIVIA. THE

THO COUMTRIES MUST DEVELOP A LEGAL FRAMEWORK OF BILATERAL

COOPERATION FOR THE U.S. DRUG ENFORCEMENT AGENCY IN BOLIVIA,

DISCUSS THE POSSIBILITY OF A NEW EXTRADITION TREATY, AND

DEFINE THE PARTICIPATION OF U.S. TROOPS IN THE ANTI-DRUG

CAMPAIGN IM BOLIVIA.

00688

U.S. - MEXICO FREE TRADE AGREEMENT

CONGRESSIONAL DIGEST, 71 (2) (FEB 92), 34-64.

THE EVOLUTION OF U.S. TRADE LEGISATION, U.S. RELATIONS WITH MEXICD, THE NORTH AMERICAN FREE TRADE AGREEMENT, AND RECENT CONGRESSIONAL ACTION REGARDING FREE TRADE ARE DISCUSSED. THEN CONGRESSIONAL DEBATE ON WHETHER CONGRESS 
SHOULD EXTEND FAST-TRACK NEGOTIATING AUTHORITY TO THE BUSH ADMINISTRATION IS SUMMARIZED. ARGUMENTS ARE PRESENTED BY SENATORS LLOYO BENTSEN, MAX BAUCUS, BILL BRADLEY, DENNIS DECONCINI, PETER V. DOMENICI, ERMEST HOLLINGS, JESSE HELMS, PAUL SARBANES, hOWARD METZENBAUM, AND DANIEL PATRICK MOYNIHAN.

00689

UNGUARANTEED

NEW REPUBLIC, 206 (12) (MAR 92), 7.

BY WHATEVER STANDARD ONE MEASURES IT, THE BUSH-BAKER

POLICY TOWARD ISRAEL IS A FAILURE. THE BUSH ADMINISTRATION IS THREATENING TO WITHHOLD LOAN GUARANTEES FOR HOUSING IN THE OCCUPIED TERRITORIES AND IS HAM-FISTEDLY TRYING TO REPLACE ISRAEL'S GOVERNMENT. IT IS SIDING WITH ISRAEL'S ENEMIES IN THE PEACE TALKS THAT THE UNITED STATES IS SUPPOSED TO BE BROKERING HONESTLY, AND IT IS SEEKING TO UNDERMINE ISRAEL'S SUPPORT IN CONGRESS AND AMONG AMERICANS BY EXAGGERATING THE COST OF AID TO ISRAEL. MOREOVER, THESE POL ICIES ARE LIKELY TO BE COUNTERPRODUCTIVE.

00690

UNITED NATIONS COLLECTIVE SECURITY

PARLIAMENTARIAN, LXXIII (1) (JAN 92), 6-8.

THIS IS A SUMMARY OF A OISCUSSION AMONG REPRESENTATIVES

OF THE BRITISH COMMONWEALTH COUNTRIES ON THE EFFECTS OF THE UNITED NATIONS' ACTIONS DURING THE GULF CRISIS, ESPECIALLY AS THEY IMPACTED ON COMMONHEALTH MEMBERS, SUCH AS INDIA AND CYPRUS.

00691

UNITED STATES FOREIGN AID

(AUG 92), $195,224$.

THIS ARTICLE IS A CONDENSATION OF A MARCH 1992 REPORT ENTITLED "FOREIGN AID: ANSHERS TO BASIC QUESTIONS" BY THE IBRARY OF CONGRESS, CONGRESSIONAL RESEARCH SERVICE. THE REPORT OUTLINES THE FYI991 FOREIGN AID BUDGET IN FIVE CATEGORIES, INCLUDING BILATERAL DEVELOPMENT ASSISTANCE, MUL IILATERAL DEVELOPMENT ASSISTANCE, AND FOOD ASSISTANCE.

00692

UNITY JITTERS: HOW DOES EUROPE GET THERE FROM HERE?

WORLD PRESS REVIEW, 39(8) (AUG 92), 9-10.

THE EUROPEAN COMMUNITY (E.C.) SHOULD BE A BEACON OF

STABILITY IN THE AFTERMATH OF COMMUNISH'S DEMISE. BUT THE COMMUNITY IS IN DISARRAY, DUE TO THE DANISH YOTERS'

REJECTION OF ITS MAASTRICHT TREATY REFORMS IN JUNE, 1992.

ONCE AGAIN, EUROPE IS THREATENING TO BECOME THE WORLO'S

PROBLEM CONTINENT AS THE E.C. GOVERMMENTS ENDORSE A TREATY THAT MANY VOTERS HAVE DOUBTS ABOUT.

00693

UNREST ESCALATES THROUGHOUT REGION

LATIN AMERICAN WEEKLY REPORT, (50) (DEC 92), 3

THE YEAR 1992 WAS ONE OF CONFLICT IN THE ANDEAN REGION.

COLOMBIA CONTINUED TO BE PLAGUED BY NARCO-TERRORISM AND

GUERRILLA VIOLENCE. IN PERU, PRESIDENT ALBERTO FUJIMORI

ASSUMED DICTATORIAL POHERS AND CAPTURED ABIMAEL GUZMAN, THE

LEGENDARY LEADER OF THE SENDERO LUMINOSO. THE TENSION THAT

HAD BEEN BUILDING IN VENEZUELA ERUPTED IN AN ABORTIVE

MILITARY UPRISING, WHICH HAS FOLLOWED BY ANOTHER COUP

ATTEMPT AND A SUCCESSION OF STRATEGIES DESIGNED TO FORCE

PRESIDENT PRESIDENT PEREZ TO RESIGN.

00694

UNSUPERMARIO

NEW REPUBLIC, 206 (3) (JAN 92), 7-8.

NEW YORK GOVERMOR MARIO CUOMO'S INDECISION ABOUT WHETHER

OR NOT TO SEEK THE DEMOCRATIC PARTY'S NOMINATION FOR

PRESIDENT IN 1992 BECAME AN ABSURD AND SERIOUS LIABILITY TO

HIS PARTY ALTHOUGH SOME DEMOCRATS SIILL SEE CUOMO AS THEIR

PARTY'S BEST HOPE FOR CHARISHATIC LEADERSHIP, HE IS ACTUALLY

AN INTELLECTUAL AND POL ITICAL OEAD-END.

00695

UNUSUAL SUSPECTS

NEW REPUBLIC, 207(23) (NOV 92), 7

IN CHOOSING HIS TRANSITION TEAM AND HIS TOP-LEVEL

APPOINTEES, BILL CLINTON SHOULD REMEMBER THAT HE RAN AS AN

"OPIINTEES, BILL CLINTON SHOULD REMEMBER THAT HE RAN AS AN

ARE TIRED OF BUSINESS AS USUAL IN WASHINGTON. THEREFORE,

CLINTON MUST AVOID THE TRAP OF APPOINTING TOO MANY

WASHINGTON INSIDERS TO THE TOP ECHELONS OF HIS

ADMINISTRATIOM.

00696

UPDATE ON 1991 ISSUES

CONGRESSIONAL DIGEST 71 (1) (JAN 92 ), 1.

THIS ARTICLE GIVES BRIEF SUMMARIES OF THE STATUS OF 10

MAJOR LEGISLATIVE PROPOSALS BEFORE CONGRESS, INCLUDING A

NATIONAL ENERGY POLICY, GUN CONTROL, AND THE BUSH

ADMINISTRATION'S CHOICE PLAN FOR SCHOOLS.
00697

UPPER HOUSE BY-ELECTION LOST

10

(WEEKLY INTERNATIONAL EDITION), 32(8) (FEB 92),

ON FEBRUARY 9, 1992, THE LIBERAL DEMOCRATIC PARTY'S

CANDIDATE IN THE NARA PREFECTURE BY-ELECTION LOST BY A LARGE MARGIN. THIS SEEMS TO SIGNAL THE ELECTORATE'S OISGUST WITH POLITICAL CORRUPTION, AND THE ADMINISTRATION OF PRIME MINISTER KIICHI MIYAZAWA MAY BE DOOMED UNLESS IT TAKES RESOLUTE STEPS TO COUNTERACT THE KYOWA SCANDAL.

00698

VEDOHAS SAY NO TO COLONIZATION PLAM

CULTURAL SURVIVAL QUARTERLY, 16(2) (SPR 92), 11-12.

THE VEDDHAS, A CULTURE OF NOMADIC HUNTERS, ARE

STRUGGLING TO PRESERVE THEIR ANCESTRAL IDENTITY IN THE FACE OF THE GOVERNMENT'S AMBITIOUS PLANS TO ASSIMILATE AND

INTEGRATE THEM INTO THE MAJORITY COMMUNITY. IN RECENT YEARS, THE VEDDHA HAVE HAD TO DEAL WITH OFFICIAL DEMANDS TO HAND OVER THEIR LAST ANCESTRAL HUNTING GROUNDS IN EASTERN SRI OANKA TO GOVERMMENT AGENCIES CLAIMING TO BE ANXIOUS TO PROTECT THEIR RESOURCE-RICH FORESTS. SOME VEDOHA FAMILIES HAVE ALREADY BEEN RESETTLED IN THE MASSIVE MAHAWELI

HYDROELECTRIC AND IRRIGATION DEVELOPMENT PROJECT. BUT TRIBAL

LEADERS, FED UP WITH OFFICIAL EXPLOITATION AND CORRUPTION,

HAVE ANHOUNCED A DECISION TO TERMINATE THIS EXPERIMENT WITH COLONY LIFE AND RETURN TO THEIR HOMELAND IN THE FOREST. THE LEADERS ALLEGE THAT CORRUPT OFFICIALS HAVE BARRED VEDDHAS FROM THE FORESTS, BRAZENLY PROFITING FROM ILLEGAL LOGGING AND UNLICENSED COMMERCIAL HUNTING AND DEPRIVING THE VEDDHAS OF ACCESS TO THEIR TRADITIONAL LIVELIHOOO, DIET, AND SACRED DANCING GROUNDS.

00699

VENEZUELA IN CRISIS: AN INTERVIEW WITH RAFAEL CALDERA HEMISPHERE, 4(3) (SUM 92), 30-31.

IN THIS INTERVIEH, RAFAEL CALDERA, WHO IS EXPECTED TO RUN FOR THE PRESIDENCY OF VENEZUELA IN 1993 AS AN

INDEPENDENT CANDIDATE, DISCUSSES THE STATE OF THE COUNTRY UNDER THE PEREZ ADMINISTRATION. HE BLAMES CORRUPTION AND

EXTERNAL DEBT FOR MANY OF VENEZUELA'S PROBLEMS

00700

VERE BIRD OPEN UP SUCCESSION SEASON

LATIN AMERICAN HEEKLY REPORT, (17) (MAY 92), 8-9.

IT IS NOT QUITE THE CLOSE OF A DYHASTY, BUT IT COULD BE

THE BEGINNING OF THE END. ANTIGUA'S PRIME MINISTER VERE BIRD HAS REJECTED CALLS FOR HIS IMMEDIATE RESIGNATION BUT SAYS THAT HE WILL RETIRE IN 1994. THERE IS THE POSSIBILITY THAT THE OYNASTY WILL CONTINUE BECAUSE ONE OF THE CONTENDERS IN THE 1994 ELECTION WILL BE LESTER BIRD, THE PRIME MINISTER'S SON. IT IS EXPECTED THAT AT LEAST THO ADOITIONAL CANDIDATES, JOHN LUCE AND ADOLPHUS FREELAND, WILL RUN.

0070

VICTIM OF RACISM?

WEST AFRICA, (3890) (APR 92), 584.

VERONA MARFO LEFT BRITAIN'S LABOUR PARTY BECAUSE SHE THOUGHT IT WAS NOT DOING ENOUGH FOR "THE SILENT MAJORITY" AND BECAME A LIBERAL DEMOCRATIC PARTY CANDIDATE FOR PARLIAMENT. BUT TWO WEEKS BEFORE THE 1992 PARLIAMENTARY ELECTIONS, SHE RESIGNED FROM HER NEW PARTY, ACCUSING THE LIBERAL DEMOCRATIC HIERARCHY OF BEING UNHILLING TO TAKE ACTION TO CORRECT THE RACISM SHE HAD ENCOUNTERED AMONG THE PARTY'S RANK-AMD-FILE.

00702

VICTORY WITH A SOUR TASTE?

WEST AFRICA, (3918) (OCT 92), 1767

UNOFFICIAL RESULTS INOICATE THAT PRESIDENT PAUL BIYA

I

PRESIDENTIAL ELEC

00703

VIOLENCE CREATES TENSION

WEST AFRICA, 75(3923) (NOV 92), 2004-2005.

THE FOURTH EXPLOSIVE DEVICE SINCE THE CONTESTED NOVEMBER PRESIDENTIAL ELECTIONS, WENT OFF ON THE CAMPUS OF THE UNIVERSITY OF GHANA ON NOVEMBER 10. VIOLENT CONFRONTATION UNIVERSITY OF GHANA ON NOVEMBER 10. VIOLENT CONFRONTATION HAS BEEN A QUIVERING STRAND RUNIING THROUGH THE ELECTION CAMPAIGN. THE PROTESIS IN KUMASI AGAINST THE RESULTS

ELECTIONS, THE EXPLOSIONS SINCE AND THE INCIDENTS OF POLIICAL IOLENCE HAVE CONSIDERABLY HEIGHTENED POLITICAL TENSIONS. THE ATMOSPHERE OF TENSION HAS DRAWN FORTH A RE SECURITY ALERT WITHIN WHICH THE VERY FAINT LINE BETH

0070

VOTER TURMOUT AND REGISTRATION RATES CONTINUE TO DECLINE; EVIDENCE OF OISAFFECTION GREATER AMONG MINORITIES NATIONAL CIVIC REVIEW, 80(4) (FAL 91), 421-422

ACCOROING TO A CENSUS BUREAU REPORT $45 \%$ OF THE NATION'S VOTING AGE POPULATION REPORTED THAT THEY VOTED IN THE 1990 
CONGRESSIONAL ELECTION, COMPARED HITH 46\% IN 1986. THE VOTIMG PATE AMONG WHITES REMAIMED STEADY AT 47\% WHILE AFRICAN-AMERICAN TURNOUT DROPPED FROM 43 TO 39\% AND HISPANIC TURNOUT DROPPED FROM 24 TO 21\%. VOTER TURNOUT ALSO DROPPED AMONG YOUNG ADULTS, WHILE FEMALE TURNOUT MOVED AHEAD OF MALE TURNOUT.

00705

YOUCHER BATTLES LOOM IN KENTUCKY AND NEW JERSEY

CHURCH AND STATE, 45(2) (FEB 92), 13(37)-14(38)

THE AUTHOR LOOKS AT EFFORTS TO INSTITUTE VOUCHER

PROGRAMS TO DIVERT PUBLIC FUNDS FROM PUBLIC TO PRIVATE,

PAROCHIAL SCHOOLS IN KENTUCKY AND NEW JERSEY.

00706

WAITING FOR THE WHITES

HEST AFRICA, (3885) (MAR 92) 361.

THE AUTHOR EXPLAINS THE STRATEGY BEHIMD PRESIDENT F.W.

DEKLERK'S DECISION TO HOLD A WHITES-ONLY REFERENDUM ON

WHETHER TO CONTINUE THE NEGOTIATIONS ON A NEW CONSTITUTION

AND A POST-APARTHEID GOVERMMENT FOR SOUTH AFRICA. HE ALSO

LOOKS AT THE POSITIONS OF THE NATIONAL AND CONSERVATIVE

PARTIES REGARDING THE REFERENDUM.

00707

WAN'S VISIT KNITS SINO-JAPANESE TIES

BEI JING REVIEW, 35(23) (JUN 92), 7

HAN LI, CHAIRMAN OF THE STAMDING COMMITTEE OF THE

NATIONAL PEOPLE'S CONGRESS, PAID AN OFFICIAL VISIT TO JAPAN

IN MAY 1992. WAN NOTED THAT THE DEVELOPMENT OF SINO-JAPANESE

RELATIONS OVER THE PAST TWO DECADES HAS BENEFITED THE TWO

COUNTRIES AND ALSO CONTRIBUTED TO THE PEACE AND STABILITY OF

ASIA AS A WHOLE. HE EXPRESSED CHINA'S HOPE THAT FRIENDSHIP
BETWEEN THE THO COUNTRIES HILL BE STRENGTHENED IN THE FUTURE

00708

WARMING THAT SECURITY BREAKDOWN COULD LEAD TO EMERGENCY RULE IN GUATEMALA

LATIN AMERICAN WEEKLY REPORT, (18) (MAY 92), 1.

RAMIRO DE LEON CARPIO, GUATEMALA'S HUMAN'RIGHTS

PROCURATOR, HAS WARNED THAT THE DETERIORATING SECURITY

SITUATION, INCLUDING BOMBINGS AND MASS DEMONSTRATIONS, COULD

LEAD THE GOVERMMENT TO DECREE A STATE OF EMERGENCY AND

SUSPEND CIVIL RIGHTS.

00709

WARNINGS AFTER NORIEGA VERDICT

LATIN AMERICAN WEEKLY REPORT, (16) (APR 92), 4

THE U.S. COURT'S GUILTY VERDICT AGAINST GENERAL MANUEL

ANTONIO NORIEGA ON EIGHT COUNTS OF DRUG TRAFFICKING AND

MONEY LAUMDERING WAS RECEIVED WITH JOY IN PANAMA CITY'S

RESTIDENTIAL AREAS AND BANKING SECTOR BUT WITH INDIFFERENCE

IN THE POORER NEIGHBORHOODS. PRESIDENT GUILLERMO ENDARA

CALLED THE VERDICT AN "ACT OF JUSTICE."

00710

WASHINGTON, PARIS AND LIBERIA

WEST AFRICA, $75(3924)$ (NOV 92), 2046-2047.

THE LIBERIAN CIVIL WAR MARKS ITS THIRD ANNIVERSARY IN

1992. IT DREH LITTLE ATTENTION AT THE TIME BUT OVER THE PAST

THREE YEARS HAS SPREAD OVER THE WHOLE SUB-REGION AND NOH

THREATENS TO BECOME A MAJOR INTERNATIONAL BONE OF CONTENTION.

THE LONGER THE LIBERIAN SICKNESS CONTINUES, THE GREATER THE

RISKS OF INFECTION THROUGHT WEST AFRICA AND BEYOND. THIS IS

WHY THE INTERNATIONAL COMMUNITY, INCLUDING THE AMERICANS,

HAVE LARGELY COME TO FEEL THAT ECOMOG PRESENTED THE BEST ALTERNATIVE.

00711

WE HAVEN'T REACHED THERE

WEST AFRICA, (3877) (JAN 92), 8-9.

IN THIS INTERVIEW, KWESI BOTCHWEY, GHANA'S SECRETARY FOR

FINANCE AND ECONOMIC PLANMING, DISCUSSES HIS COUNTRY'S

EXTERNAL DEBT, THE ECONOMIC RECOVERY PROGRAM, ANO THE

REDEFINITION OF THE STATE'S ROLE IN GHANA'S ECONOMY.

00712

WE WILL ADAPT TO CHANGE

(3900) (JUN 92), 1013-1014.

GOUKHOUNI HEDDEYE, CHAD'S FORMER PRESIDENT, IS CURRENTLY LEADING THE EXILE GROUP FROLINAT FROM HIS HEADQUARTERS IN ALGERIA. IN THIS INTERYIEH, HE DISCUSSES WHAT HAS HAPPENED TO CHAD IN THE TEN YEARS SINCE HE WAS OYERTHROWN AND THE PROSPECTS FOR HIS RETURN TO CHAD.

00713

WEIGHING THE COST OF TACKLING POVERTY

LATIN AMERICAM COST OF TACKLING POVERTY 92), 6-7.

THE ISSUE OF POVERTY HAS RECENTLY RETURNED TO POLITICAL
TH CENTER STAGE IN LATIN AMERICA. THE CURRENT REGIONAL POVERTY RATE IS ESTIMATED AT $62 \%$ OF THE POPULATION, BUT THERE ARE SOME RAYS OF HOPE FOR IMPROVEMENT IN THE 1990's.
00714

WEIZSACKER AND BUSH SEE EYE TO EYE IN WASHINGTON GERMAN TRIBUNE, (1514) (MAY 92), 1.

AYM PRESIDENT RICHARD VON HEIZSACKER TO WASHINGTON--THE FIRST VISIT TO THE U.S. OF THE HEAD OF STATE OF A UNITED GERMANY - WAS OVERSHADOWED BY THE LOS ANEGELES RIOTS. HOWEVER, VON WEIZSACKER AND AMERICAM PRESIDENT GEORGE BUSH WERE ABLE TO REITERATE THE STRONG DEGREE OF AGREEMENT AND COOPERATION THAT CHARACTERIZES RELATIONS BETHEEN THE TWO COUNTRIES. THE GERMAN PRESIDENT REAFFIRHED THE CLOSE NATURE OF THE RELATIONSHIP, THANKED THE U.S. FOR ITS ROLE IN FOSTERING UNIFICATION, AND CALLED FOR CONTINUATION OF THE AMERICAN PRESENCE IN EUROPE. BUSH SPOKE OF THE NEED FOR THE U.S. AND GERMANY TO COOPERATE IN LEADING THE POLITICAL ANO ECONOMIC TRANSFORMATION OF EASTERN EUROPE AND THE FORMER SOVIET UNION.

00715

WESTERN EUROPE DISCOVERS ITS "BALTICS"

WORLD PRESS REVIEN, 39(1) (JAN 92), 16-17.

CDULD THE EXPLOSIVE RESURGENCE OF NATIONALISM IN EASTERN

EUROPE AFFECT WESTERN EUROPE? IN LIGHT OF EVENTS IN THE

EASTERN PART OF THE CONTINENT. THIS IS ONE OF THE THORNIEST

QUESTIONS NOW BEING DISCUSSED WITHIN THE EUROPEAN COMMUNITY. OFFICIALLY, THE ANSWER IS THAT THERE IS NO CONNECTION

BETWEEN EVENTS EAST AND WEST, BECAUSE THE POL ITICAL

HISTORIES OF THE THO REGIONS ARE SO DIFFERENT. NEVERTHELESS

THE SITUATIOM IM THE EAST

COUNTRIES THAT HAVE ONGOING CONFLICTS WITH ETHNIC ELEMENTS.

00716

WHAT FOREIGK POLICY?

NEW REPUBLIC, 206(8) (FEB 92), 7

THE FALL OF COMMUNISM HAS GIVEN THE BUSH ADMINISTRATION

A UNIQUE OPPORTUNITY TO SHAPE A NEW AMERICAN FOREIGN POLICY.

BUT THE ADMINISTRATION HAS FAILED TO DECISIVELY SEIZE THE

MOMENT AND SEEMS CONFUSED AND OVERLY CAUTIOUS.

00717

WHAT THEY SAID: PALESTINIAN SPOKESHOMAN HANAN ASHRANI SAYS U.S. LOAN GUARANTEES IN ABSENCE OF ISRAELI SETTLEMENT

FREEZE HOULD ABORT PEACE PROCESS

WASHIN3.

IN THIS INTERYIEH, PALESTINIAN SPOKESWOMAN HANAN ASHRAHI

DISCUSSES THE STATUS OF THE ARAB-ISRAEL I PEACE NEGOTIATIONS.

00718

WHO IS SPENDING MORE ON DEFENCE

LATIN AMERICAN WEEKLY REPORT, (43) (NOV 92), 8-9.

LATIN AMERICA DOES NOT, IN COMPARISON WITH OTHER PARTS

OF THE WORLD, SPEND INORDINATE SUMS OF MONEY ON ITS MILITARY ESTABLISHMENTS. AS A PERCENTAGE OF MATIONAL PRODUCT, NOT

EVEN CUBA, HICH IS THE REGION'S BIGGEST SPENDER, CAN MATCH

THE UMITED STATES. THE LATIN AMERICAN AYERAGE IS 1.6 PERCENT OF GDP.

00719

WHO WILL BE PRESIDENT?

WEST AFRICA, (3917) (OCT 92), 1719

FIVE CANDIDATES HAVE FILED THEIR NOMINATION PAPERS FOR

GHANA'S NOVEMBER 1992 PRESIDENTIAL ELECTION. THE MUCH-

BALLYHOOED ALLIANCE AMONG THE NKRUMAIST PARTIES FAILED TO

HOLD TOGETHER, BUT THERE IS STILL TALK OF A POSSIBLE

ELECTORAL PACT AMONG THEM.

00720

WHOSE GULF IS IT ANYHAY?

THE MIDDLE EAST, (201) (JUL 91), 5-8.

THE CHANGING POLITICAL DIMENSION OF THE PERSIAN GULF IS

EXAMIMED. FOUR PROBLEMS WHICH HAVE EXISTED IN THE REGION

SINCE THE GULF WAR ARE ADDRESSED: A) THE RISKY SITUATION OF

THE KURDS AND THE EVEN MORE DANGEROUS POSITION OF THE SHIA

DISSIDENTS IN SOUTHERN IRAO; B) THE ROLE OF IRAN IN THE GULF

AND THE DECISIONS OF ITS LEADERS; C) GROWING POLITICAL

TENSION IN KUWAIT; AND D) INCREASING DIVISIONS IN SAUDI

ARABIA WHERE ISLAMIC PREACHERS HAVE OPENLY CRITICIZED THE

RULING FAMILY.

00721

WHY PANAMANIANS FOLLON THE POLLS

LATIM AMERICAN WEEKLY REPORT, (21) (JUN 92), 6-7

PANAMA'S NEXT PRESIDENTIAL ELECTIOM IS STILL THO YEARS

AHAY, BUT THE POPULARITY RATINGS OF POSSIBLE CANDIDATES HAVE

BEEN OCCUPYING PUBLIC ATTENTION FOR SOME TIME NOW. SALSA

SINGER RUBEN BLADES AND MAYIN CORREA, THE MAYOR PANAMA CITY, ARE BOTH SHOWING STRENGTH IN THE POLLS.

00722

WHY REPARATIONS?

WEST AFRICA, (3898) (JUN 92), 910-911.

THE AUTHOR ARGUES THAT THE HESTERN INDUSTRIALIZED WORLD

OWES AFRICA REPARATIONS BECAUSE WESTERNERS COLONIZED THE

CONTINENT AND ENSLAVED MANY AFRICANS. 
00723

WHY THE UNITED STATES DOES NOT haVE A NATIONAL HEALTH PROGRAM: THE MEDICAL-INDUSTRY COMPLEX AND ITS PAC CONTRIBUTIONS TO CONGRESSIONAL CANDIDATES, JANUARY 1, 1981 THROUGH JUNE 30, 1991

INTERMATIONAL JOURMAL OF HEALTH SERVICES, 22(4) (1992), 619-644.

THIS SUMMARY OF MEDICAL PAC CONTRIBUTIONS TO CONGRESSIONAL CANDIDATES LISTS THE TOP 25 CONGRESSIONAL RECIPIENTS, THE TOP 25 SENATE RECIPIENTS, AND THE TOP 50 HOUSE OF REPRESENTATIVE RECIPIENTS OF CONTRIBUTIONS FROM MEDICAL-INDUSTRY PAC'S; MEDICAL-INDUSTRY PAC CONTRIBUTIONS TO MEMBERS OF THE FOUR KEY CONGRESSIONAL COMMITTEES AND TO THE CONGRESSIONAL LEADERSHIP; AND TOP CONGRESSIONAL THE CONGRESSIONAL LEADERSHIP; AND TOP CONGRESSIONAL
RECIPIENTS OF CONTRIBUTIONS FROM MEDICAL PROFESSIONALS RECIPIENTS OF CONTRIBUTIONS FROM MEDICAL PROFESSIONALS'
PAC'S, INCLUDING THE AMERICAN MEDICAL ASSOCIATION. THE PAC'S, INCLUDING THE AMERICAN MEDICAL ASSOCIATION. THE
APPENDICES OFFER STATE-BY-STATE LISTS OF MEDICAL-INDUSTRY APPENDICES OFFER STATE-BY-STATE LISTS OF MEDICAL-INDUSTRY
PAC CONTRIBUTIONS TO SENATORS AND REPRESENTATIVES, INCLUDING PAC CONTRIBUTIONS TO SENATORS AND REPRESENTATIVES, CONTRIBUTIONS.

00724

WIDER PLOT ALLEGED AS UNREST CONTINUES

LATIN AMERICAN WEEKLY REPORT, (23) (JUN 92), 2-3.

THE VENEZUELAN GOVERMMENT HAS ATTRIBUTED VIOLENT STUDENT-

LED PROTESTS TO A WIDE-RANGING SUBVERSIVE CONSPIRACY. DISIP,

THE POLITICAL POLICE UNIT, HAS BLAMED THE CONTINUING UNREST

ON A CONSPIRACY INVOLVING FORMER GUERRILLA LEADERS

ENVIRONMENTALISTS, MAOIST ORGANIZATIONS, MEMBERS OF THE

MILITARY, AND LEADING INTELLECTUALS.

00725

NEW REPUBLIC, 206(14) (APR 92), 7.

THE AUTHOR LOOKS AT ARKANSAS GOVERNOR BILL CLINTON, WHO IS LIKELY TO BE THE DEMOCRATIC NOMINEE FOR PRESIDENT IN 1992 HE ALSO DISCUSSES CLINTON'S STANCE ON SEVERAL ISSUES,

INCLUDING HELFARE REFORM, THE DEFICIT, AND FOREIGN POLICY.

00726

WITH 38\% OF THE VOTE, FUJIMORI GETS A 55\% MAJORITY IN THE ASSEMBLY

LATIN AMERICAN WEEKLY REPORT, (47) (DEC 92), 1

PRELIMINARY COUNTS GIVE PRESIDENT ALBERTÓ FUJIMORI $38.6 \%$ OF THE VALID VOTES IN PERU'S NOVEMBER 22, 1992 , ELECTION.

FU THE VALID VOTES IN PERU'S NOVEMBER 22, 1992 , ELECTION.

45 SEATS OUT OF 80 IN THE CONSTITUENT ASSEMBLY.

00727

WORLD SITUATION AND SINO-JAPANESE RELATIONS

BEIJING REVIEW, 35(16) (APR 92), 10-13.

JIANG ZEMIN, GENERAL SECRETARY OF THE CENTRAL CDMMITTEE OF THE COMMUNIST PARTY OF CHINA, SPOKE TO A MEETING

SPONSORED BY THE COMMITTEE OF NONGOVERMMENTAL ORGANIZATIONS IN JAPAN ON APRIL 7, 1992. JIANG FOCUSED ON INTERNATIONAL

AFFAIRS AND SINO-JAPANESE RELATIONS. HE SAID THAT WITH JOINT

EFFORT THE RELATIONS BETHEEN CHINA AND JAPAN WILL CONTINUE

TO IMPROVE AND THAT THE FRIENDSHIP BETWEEN THE TWO COUNTRIES

WILL CONTINUE FROM GENERATION TO GENERATION.

00728

YEAR-END MARKS NEW LOW FOR COLLOR

LATIN AMERICAN WEEKLY REPORT, (1) (JAN 92), 5

AT THE END OF 1991, PRESIDENT FERNANDO COLLOR DE MELLO'S PUBLIC APPROYAL RATING HAD PLUMMETED TO ONLY EIGHT PERCENT. IN HIS YEAR-END MESSAGE TO THE NATION, COLLOR EMPHASIZED THE NEED FOR A BROAD "UNDERSTANDING" AND PROPOSED "AN AGENDA FOR CONSENSUS." HIS AODRESS RECEIVED LITTLE POSITIVE RESPONSE. AND CONGRESS WENT INTO RECESS.

00729

YELTSIN'S CHINA VISIT: A NEW ERA

BEIJING REVIEW, $35(52)$ (DEC 92) $4-5$.

IN DECEMBER 1992, RUSSIAN PRESIDENT BORIS YELTSIN PAID

AN OFFICIAL VISIT TO COMMUNIST CHINA TO MEET WITH TOP

OFFICIALS. YELTSIN AND THE CHINESE LEADERS AGREED TO

OVERLOOK DIFFERENCES IN IDEOLOGY AND POLITICAL SYSTEMS IN

ORDER TO FORGE PRINCIPLES FOR A NEH ERA IN SIMO-RUSSIAM

RELATIONS.

00730

YES--AND BEYOND

WEST AFRICA, (3888) (MAR 92), 493

THE RESOUNDING "YES" YOTE' IM SOUTH AFRICA'S MARCH 1992 REFERENDUM MEANS THAT THE VAST MAJORITY OF WHITES HAYE REJECTED APARTHEID. BUT THE ENDORSEMENT OF REFORM AMD NEGOTIATION SETTLES ONLY ONE QUESTION-DTE WHITE ATTITUDE TOWARDS THE FUTURE OF THE COUNTRY. THE REAL HORK OF TRANSFERRING POWER MUST NOH BEGIN. PRESIDENT DEKLERK CAN NO LONGER USE THE RESTIVENESS OF HIS RIGHT FLANK AS AN EXCUSE FOR DELAY. FURTHERMORE, THERE HILL BE NO JUSTIFICATION FOR ANY FURTHER TESTING OF WHITE OPINION, EXCEPT IN THE NORMAL POLITICAL MANNER OF GAUGING OPINIONS.
00731

YES, SAYS CPI, COLLOR WAS INVOLVED

LATIN AMERICAN WEEKLY REPORT, (34) (SEP 92), 2-3.

THE CONGRESSIONAL COMMISSION INVESTIGATING PRESIDENT

COLLOR HAS RELEASED A REPORT IMPLICATING HIM IN INFLUENCE-

PEDDLING AND CORRUPTION CHARGES AGAINST HIS CAMPAIGN FINANCE

MANAGER. THE REPORT PROVIDES GROUNDS FOR AN IMPEACHMENT AND

POSSIBILITY FOR A CRIMINAL TRIAL AGAINST COLLOR.

00732

YES, THERE HILL BE MORE REDUCTION

LATIN AMERICAN WEEKLY REPORT, (45) (NOV 92), 4

THERE WILL BE NO FURTHER REDUCTIONS IN THE SIZE OF THE

NICARAGUAN ARMY, LET ALONE ANY ATTEMPT TO ABOLISH IT.

PRESIDENT VIOLETA CHAMORRO HAS "ESTABLISHED THAT HER

GOVERMMENT HILL GUARANTEE RESPECT FOR THE ARMY'S

INSTITUTIONALITY, HITHOUT DETRIMENT TO THE SUBORDINATION OF

ESTABLISHED IN THE POLITICAL CONSTITUTION."

00733

ZAIRE: THIRTY SHOT IN CAPITAL

HEST AFRICA, (3884) (FEB 92) 345.

ON FEBRUARY 16, 1992 , TROOPS BELONGING TO PRESIDENT

MOBUTU SESE SEKD'S SPECIAL PRESIDENTIAL DIVISION SHOT AND

KILLED A NUMBER OF DEMONSTRATORS AS THEY MARCHED IN KINSHASA.

THE KILLINGS HAVE BEEN FIERCELY CONDEMNED BY SEVERAL

FOREIGN GOVERMMENTS--NOTABLY FRANCE, BELGIUM, AND THE USA--

HHOSE AMBASSADORS ARE PRESSURING PRESIDENT MOBUTU TO

RECONVENE THE SUSPENDED NATIONAL CONFERENCE.

00734

ZAIRE: U.S. BACKS MOBUTU

(FT AFRICA, (3883) (FEB 92) 297.

SPEAKING BEFORE THE U.S. SENATE SUBCOMAITTEE ON AFRICAN AFFAIRS ON FEBRUARY 7, 1992, ASSISTANT SECRETARY OF STATE HERMAN COHEN STRESSED THAT THE UNITED STATES HOLDS PRESIDENT MOBUTU SESE SEKO RESPONSIBLE FOR THE DETERIORATING SITUATION IN ZAIRE AND HAS TOLD HIM THAT IT WOULD BE IN THE COUNTRY'S BEST INTERESTS FOR HIM TO GIVE UP HIS POWER TO SOMEONE ELSE, IN ORDER TO FACILITATE FREE AND FAIR ELECTIONS. HOWEVER, THE TO COHEM.

00735

ZHAO'S CASE BROUGHT TO AN END

BEIJING REVIEH, 35(42) (OCT 92), 10

AFTER THREE YEARS OF INVESTIGATION, THE CENTRAL

COMAITTEE OF THE COMMUNIST PARTY OF CHINA (CPC) HAS DECIDED TO SUSTAIN THE VERDICT IN THE CASE OF FORMER CPC GENERAL SECRETARY ZHAO ZIYANG AND TO END THE PROBE. IN A COMMUNIQUE ISSUED BY THE NINTH PLENUM, THE CENTRAL COMMITTEE AFFIRMED "THE CONCLUSION REACHED BY THE FOURTH PLENARY SESSION OF THE 13TH CENTRAL COMMITTEE ON COMRADE ZHAO ZIYANG'S MISTAKES."

00736

ZIMBABHE--MUGABE CURBS UNIVERSITY FREEDOM

NEW AFRICAN, (282) (MAR 91), 19-20

IN ZIMBABWE, PRESIDENT ROBERT MUGABE HAS SIGNED AN ACT WHICH SEVERELY CURBS ACADEMIC FREEDOM AND INCREASES GOVERNMENT CONTROL OF UNIVERSITIES. THIS WAS MET BY VIOLENT PROTESTS BY STUDENTS AND A PETITION BY ACADEMIC STAFF. BOTH WERE IGNORED BY THE GOVERMMENT WHICH WANTS TO SUPPRESS UNIVERSITY CRITICISM. SOME SEE THE MOVE AS A PRECURSOR TO MUGABE INSTITUTIONALIZING A ONE-PARTY STATE.

00737 AARON, H.J.

THE CAPITAL GAINS TAX CUT: ECONOMIC PANACEA OR JUST PLAIN SHAKE OIL?

BROOKINGS REVIEN, 10(3) (SUM 92), 30-33.

ADVOCATES OF REDUCED STATUTORY RATES FOR CAPITAL GAINS TAXES OFFER FOUR LINES OF ARGUMENT: REDUCING THE TAX RATE ON REALIZED CAPITAL GAINS WILL PROMOTE GROHTH, MITIGATE FLAHS IN THE TAX SYSTEM, INCREASE TAX EQUITY, AND GENERATE BENEFITS BUT NO COSTS. HOWEVER, NONE OF THESE ARGUMENTS IS VALID. EACH IS EITHER DEMONSTRABLY FALSE OR IGNORES ALTERNATIVE, BETTER POLICIES.

00738 AARTS, $P$

OIL, MONEY, AND

RENTIER STAT

MOST 32(1) (1991), 205-216.

MOST OIL-PRODUCING STATES ARE NOW SHOWING ALL

CHARACTERISTICS OF A RENTIER STATE: A ONE-SIDED ECONOMY GASED ON EXTERMAL RENT INCOME, WHERE THE STATE IS THE MOST TH THERE A RENTIER MENTALITY OERIVED FROM THAT PREVAILS. DUE TO THE FACT THAT THE STATE IS NOT DEPENDENT ON THE TAXATION OF ITS OWN CITIZENS, THOSE SAME CITIZENS FIND IT HARD TO DEMAND PARTICIPIION. THESE ARE THE RULES OF THE GAME AND THIS IS HOW IT IS GENERALLY PLAYED, EXCEPT IN KUWAIT. THE ANALYSIS OF KUWAIT'S OEVIANT POSITION IN THIS SUBJECT MATTER IS CENTRAL TO THIS ESSAY, WHICH CONCLUDES THAT THE EMIRATE IS 

DEEPLY ENTANGLED IN A PROCESS OF POLITICAL ARTICULATION AS A
RESULT OF WHICH CERTAIN STEPS IN THE DIRECTION TOWARD DEMOCRACY HAVE BEEN TAKEN WHICH CANNOT BE EASILY REVERSED.

00739 ABADAN-UNAT, $N$.

EAST-WEST VERSUS SOUTH-NORTH MIGRATION: EFFECTS UPON RECRUITMENT AREAS OF THE $1960 \mathrm{~S}$

INTERNATIONAL MIGRATION REVIEH, XXVI(2) (SUM 92), 401-412. THE END OF THE COLD HAR HAS BEEN MARKED BY THE REEMERGENCE OF NATIONALISM. THIS ARTICLE IS FOCUSED ON TURKEY AND TURKISH EMIGRATION ABROAD. IT EXAMINES INTEGRATION OF SECOND GENERATION IMMIGRANTS IN WESTERN EUROPE AND VARIOUS FORCES FOSTERING ISLAMIC IDENTITY. IT THEN COMPARES POLITICAL DISCOURSE ON IMMIGRATION IN FRANCE AND GERMANY. IT CONCLUDES THAT THE RESURGENCE OF ETHNIC IDENTITY AS THE
BASIS FOR EFFECTIVE POLITICAL ACTION IN WIDELY DIVERGENT SOCIETIES IS A KEY FEATURE OF THE POST-COLD WAR PERIOD. IMMI GRANTS HAVE BEEN ACTIVELY INVOL VED IN THIS GENERAL PROCESS AS HITNESSED BY THE ROLE OF IMMIGRANTS IN RECENT CONFLICT IN YUGOSLAVIA AND TURKEY.

00740 ABAFFY, J.

LITTLE REASON FOR SATISFACTION OVER SANCTIONS ON SERBIA GERMAN TRIBUNE, (1518) (JUN 92), 1-2.

AFTER MONTHS OF CIVIL WAR AND THOUSANDS OF DEATHS, IT SEEMS THAT SERBIAN PRESIDENT MILOSEVIC IS BEGINNING TO REALIIE THAT HE CANNOT SURVIVE MUCH LONGER. THE DIPLOMATIC REALIZE THAT HE CANNOT SURVIVE MUCH LONGER. THE DIPLOMATIC ECONOMIC SANCTIONS OF THE UNITED NATIONS ARE TAKING THEIR ECONOMIC SANCTIONS OF THE UNITED NATIONS ARE TAKING THEIR
TOLL. HOHEVER. THIS CHANGE OFFERS LITTLE SATISFACTION DUE TO TOLL. HOHEVER, THIS CHANGE OFFERS LITTLE SATISFACTION DUE AGO. NOW, THE HORLD-CAND ESPECIALLY EUROPE--MUST START THINKING ABOUT HOW A POLITICALLY NEW SERBIA AND MONTENEGRO CAN BE BROUGHT BACK INTO THE INTERNATIONAL FOLD. THE EUROPEAN COMMUNITY, A MISERABLE FAILURE DURING THE FIGHTING, MAY HAVE A LEADING' ROLE IN RE-ESTABLISHING POLITICAL AND ECONOMIC RELATIONS.

00741 ABD AL-JABBAR, F.

WHY THE UPRISIMGS FAILED

MIDDLE EAST REPORT, 22 (3) (MAY 92), 2-14.

THE ROOTS OF THE FAILURE OF THE IRAOI 1991 MARCH UPRISING CAN BE FOUND IN THE PERIOD OF THE HAR BETWEEN IRAO AND IRAN, WHEN THE OPPOSITION DEVELOPED A BELIEF THAT WAR AND REVOLUTION WERE INDIVISIBY LINKED. THE IRAOI OPPOSITION UNDERESTIMATED THE EXTENT TO WHICH SADDAM HUSSEIN HAD SUCCEEDED IN FORGING A NEW IRAQI PATRIOTISM OF NATIONAL SELFDEFENSE. THE OPPOSITION WAS UNPREPARED FOR THE SPONTANIOUS DEFENSE. THE OPPOSITION WAS UNPREPARED FOR THE SPONTAMI
AND POPULAR UPRISINGS OF MARCH 1991. IN THAT LACK OF AND POPULAR UPRISINGS OF MARCH 1991. IN THAT LACK OF
PREPARATION LAY SOME SEEDS OF THE REBELLION'S FAILURE. THIS PREPARATION LAY SOME SEEDS OF THE REBELLION'S FAILURE.
ARTICLE EXPLORES THE FIRST GULF WAR AND THE OPPOSITION, ARTICLE EXPLORES THE FIRST GULF WAR AND THE OPPOSITION,
EXHAUSTION OF IRAQI PATRIOTISM, EXHAUSTION OF THE ARMY, REGIME FANTASIES, OPPOSITION BLINDNESS, AND, THE RISE UP OF REGIME FANTASIES, OPPOSITION BLINDNESS, AND, THE RISE UP OF US SCHEMES AND HIDDEN AGENDAS SHOULD HAVE BEEN COMPLEMENTED US SCHEMES AND HIDDEN AGENDAS SHOULD HAVE BEEN COMPLEMENTED BY A DEFENSE OF THE IRAQI PEOPLE'S LEGITIMATE RIGHT TO
DEMOCRATIC FREEDOMS AND THEIR RIGHT TO DECIDE MATTERS OF DEMOCRATIC FREED
PEACE AND WAR.

00742 ABDO, N.

RACISM, ZIONISM, AND THE PALESTINIAN WORKING CLASS, 19201947

STUDIES IN POLITICAL ECONOMY: A SOCIALIST REVIEW, $37(1)$ (SPR 92$)$, 59-94

THE ROLE OF ZIONISM AS THE IDEOLOGY AND PRACTICE OF THE DOMINANT EUROPEAN (JEWISH) SETTLER CLASS IN PALESTINE IS EXPLORED. THE PAPER EXAMINES THE ROLE OF ZIONISM BOTH AS RACIST IDEOLOGY AND AS STATE OR "OFFICIAL" MATIONALISM. THE DEVELOPMENT OF ZIONIST SETTLER RULE IS EXAMINED WITHIN THE BROADER CONTEXT OF THE SOCIAL, ECONOMIC AND POLITICAL TRANSFORMATION OF PALESTINE BETWEEN 1920-47, WITH AN EMPHASIS ON THE ROLE OF ZIONISM IN SHAPING AND INTENSIFYING INDIGENOUS PALESTINIAN CLASS FORMATION.

00743 ABED, G.

THE PALESTINIANS IN THE PEACE PROCESS: THE RISKS AND THE OPPORTUNITIES

JOURMAL OF PALESTINE STUDIES, 22 (85) (FAL 92), 5-17.

THE ADVENT OF A LABOR-LED COALITION GOVERNMENT IN ISRAEL FOLLOWING THE 1992 GENERAL ELECTIONS MAY HAVE CHANGED SOME OF THE PARAMETERS IN THE ARAB-ISRAELI PEACE EQUATION. ISRAEL OF THE PARAMETERS IN THE ARAB-ISRAELI PEACE EQUATION. ISRAEL
COMES TO THE RENEWED PEACE PROCESS WITH A STROMG HAND AMD COMES TO THE RENEHED PEACE PROCESS WITH A STRONG HAND AND
WHATEYER MEAGER CAPACITY THE PALESTINIANS MAY HAVE POSSESSED WHATEVER MEAGER CAPACITY THE PALESTINIANS MAY HAVE POSSESSED
TO SHAPE THE AGENDA OF THE PEACE NEGOTIATIONS WAS BLOWN AHAY TO SHAPE THE AGENDA OF THE PEACE NEGOTIATIONS WAS BLOWN AHAY BY THE FALLOUT OF THE GULF WAR. THIS ARTICLE EXPLORES THE
IMPACT OF THE RABIN VICTORY AND PRESENTS POSSIBLE SCENARIOS IMPACT OF THE RABIN VICTORY ANO PRESENTS POSSIBLE SCENARID OF THE LIKELY OUTCOME. LONG-TERM VISION AND MEDIUM-TERM
POSSIBILITIES ARE OFFERED AS WELL AS A PALESTINIAN STRATEGY.

00744 ABEYRANTNE, R.

THE UNITED NATIONS DECADE OF INTERMATIONAL LAW

INTERNATIONAL JOURNAL OF POLITICS, CULTURE AND SOCIETY, 5(3) (SPR 92), 511-524.

THE POSITION OF INTERMATIONAL LAW IN THE EYES OF STATES
IS EXAMINED AS WELL AS HOW IT COULD HELP ACHIEYE THE GOALS OF THE UNITED NATIONS IF THE CONTENTS OF RESOLUTION $44 / 23$ ATTAIN FRUITION AT THE END OF THE DECADE. THE LEGAL POSSIBILITIES THAT UNITED NATIONS GENERAL ASSEMBLY RESOLUTION $44 / 23$ HOULD OPEN TO PERSUADE STATES TO ACCEPT INTERNATIONAL LAW AND ITS PRINCIPLES AS A STRONGER SOURCE OF DISPUTE SETTLEMENT ARE REVIEWED. THE ARTICLE DETERMINES WHETHER MORE BINDING AUTHORITY MAY BE ATTRIBUTED TO THE PRINCIPLES OF INTERNATIONAL LAH BY THE SUSTAINED PROGRAM OF AWARENESS PLANNED BY THE UNITED NATIONS OVER THE NEXT DECADE.

00745 ABEYSINGHE, A.

SAARC: FROM DHAKA TO COLOMBO, 1985-1991

SCANDINAVIAN JOURNAL OF DEVELOPMENT ALTERNATIVES, XI(2)

( JUN 92), 33-48.

THE AUTHOR SUMMARIZES THE EVOLUTION OF SAARC, FOCUSING IN BANGALORE IN 1986, IN KATHMANDU IN 1987

IN ISLAMABAD IN 1989, AND IN MALE IN 1990.

00746 ABIZADEH, S.: GRAY, J.A.

POLITICS AND PROVINCIAL GOVERNMENT SPENDING IN CANADA

CANADIAN PUBLIC ADMINISTRATION, 35(4) (HIN 92), 519-533.

OVER THE PAST QUARTER-CENTURY, GOVERMMENT SPENDING IN

CANADA HAS GROWN MORE RAPIDLY AT THE PROVINCIAL LEVEL THAN

AT THE FEDERAL LEVEL. THIS PAPER DEVELOPS AND TESTS AN

ECONOMETRIC MODEL OF PROVINCIAL GOVERMMENT EXPENDITURE THAT INCORPORATES ECONOMIC, SOCIAL, AND POL ITICAL FACTORS. IN PARTICULAR, THE INFLUENCE OF THE POL ITICAL PARTY IN POWER ON PROVINCIAL GOVERNMENT SPENDING IS EXAMINED. SURPRISINGLY, IN MOST CANADIAN PROVINCES THE POLIIICAL PARTY IN POWER IS FOUND TO HAVE NO SIGNIFICANT IMPACT ON THE LEVEL OR GROWTH OF PROVINCIAL GOVERNMENT SPENDING OVER THE LAST 25 YEARS. INSTEAD, THE GROWTH OF PROVINCIAL GOVERMMENT SPENDING HAS BEEN STIMULATED BY THE GROWTH OF THE PRIVATE SECTOR

PROVINCIAL GDP. THE PROVINCIAL GOVERNMENTS HAVE RESPONDED TO

CHANGE IN THE STATE OF THE PROVINCIAL ECONOMY AND TO PROVINCIAL UNEMPLOYMENT BY INCREASING THEIR OWN LEVEL OF EXPENDITURES.

00747 ABO, K.

DEFINING DEMOCRACY

WEST AFRICA, 75(3923) (NOV 92), 2015.

FORMER TANZANIAN PRESIDENT, JULIUS NYERERE HAS EXPRESSED RESERVATIONS ABOUT THE CURRENT DEMANDS FOR MULTI-PARTY DEMOCRACY IN AFRICA. HE SUGGESTS THAT DEMOCRACY CANMOT BE "GIVEN" TO A COUNTRY, BUT THAT RATHER THAT THE ORGANIZATION "GIVEN" TO A COUNTRY, BUT THAT RATHER THAT THE ORGANIZAT OF DEMOCRACY HAS TO BE IN ACCORDANCE WITH THE PEOPLE'S
CULTURE, HISTORY AND DEVELOPMENT. HE ALSO CRITICIZED THE CULTURE, HISTORY AND DEVELOPMENT. HE ALSO CRITICIZED THE
ORIGINS OF CURRENT MULTIPARTYISM IN KENYA WHICH, HE SAID, ORIGINS OF CURRENT MULTIPARTYISM IN
HAS THE RESULT OF WESTERN PRESSURE.

00748 ABO, K.

DEMOCRATIC SUNRISE

WEST AFRICA, (3900) ( JUN 92), 1012.

THE INVESTITURE OF PRESIDENT ALPHA OUMAR KONARE ON JUNE 8, 1992, MARKED THE BEGINNING OF A NEW ERA FOR MALI. BUT THE NEW ADMINISTRATION MUST COPE WITH MANY SERIOUS PROBLEMS, INCLUDING THE ECONOMY AND THE TRIAL OF THE LEADERS RESPONSIBLE FOR THE BLOODY SUPPRESSION OF THE PRO-DEMOCRACY DEMONSTRATION IN BAMAKO IN MARCH 1991.

00749 ABO, K.

EYADEMA AGAIN

WEST AFRICA, (3915) (SEP 92), 1609

PRESIDENT EYADEMA CAN ONCE AGAIN PRESIDE OVER CABINET MEETINGS, AS A RESULT OF NEGOTIATIONS AMONG THE PRESIDENT'S SUPPORTERS, PRIME MINISTER JOSEPH KOKOU KOFFIGOH'S

GOVERNMENT, AND EIGHT OPPOSITION PARTIES. EYADEMA'S

POLITICAL PARTY, THE REASSEMBLEMENT DU PEUPLE TOGOLAIS, HAS GAINED CONTROL OF THE KEY MINISTRIES OF DEFENSE AND THE INTERIOR.

00750 ABO, K

POSITIYE SIGNALS

WEST AFRICA, (3904) ( JUL 92), 1171.

THE FRENCH SOCIALIST PARTY ANO THE IVORIAN OPPOSITIOM PARTY, THE FRONT POPULAIRE IVORIEN, HAVE INDICATED THAT THE RELEASE OF IMPRISONED OPPOSITION LEADER LAURENT GBAGBO AND HIS ASSOCIATES IS IMMINENT.

00751 ABO, K.

QUAINT CHANGE OF GUARO

WEST AFRICA, (3912) (SEP 92), 1526

ON AUGUST 31, 1992, PASCAL LISSOUBA BECAME THE CONGO'S SIXTH PRESIDENT' SINCE' INDEPENDENCE. IN HIS INAUGURAL ADORESS, LISSOUBA PROMISED TO FORM AN ENLARGED GOVERNMENT OF NATIONAL UNION RICH IN DIVERSITY AND NOURISHED BY A SPIRIT OF NATIOHAL CONSENSUS.

00752 ABO, K

RADICAL DEMOCRAT

WEST AFRICA, (3910) (AUG 92), 1442.

TAVIO AMORIN, THE FIRST SECRETARY OF THE PAN-AFRICAN

SOCIALIST PARTY AND PRESIDENT OF THE POLITICAL AND HUMAN 
RIGHTS COMMISSION OF TOGO'S INTERIM PARLIAMENT, WAS ASSASSINATED ON JULY 23, 1992.

00753 ABO, K.

TAUREGS AND OOLLAR DIPLOMACY

WEST AFRICA, (3918) (OCT 92), 1773-1774.

THE FATE OF THE SO-CALLED "BLUE PEOPLE" OR TAUREGS IS AMONG THE PROBLEMS CONFRONTING NIGER'S INTERIM PRIME MINISTER AMADOU CHEIFFOU. THE ISSUE HAS ITS ROOTS IN PREMINISTER AMADOU CHEIFFOU. THE ISSUE HAS ITS ROOTS IN PREOF THE SAHARA. AFTER THE FRENCH DEPARTED, THE SOUTHERNERS TOOK OVER NIGER TO THE EXCLUSION OF THE TAUREGS BECAUSE THE TOOK OVER NIGER TO THE EXCLUSION OF THE TAUREGS BECAUSE THE SCHOOL AND, THEREFORE, COULD NOT EXERCISE MODERN ADMINISTRATIVE FUNCTIONS.

00754 ABRAHAM, I

IMDIA'S' "STRATEGIC ENCLAVE": CIVILIAN SCIENTISTS AND MILTARY TECHNOLOGIES

ARMED FORCES AND SOCIETY, 18(2) (WIN 92), 231-252.

THE INOIAN SECURITY COMPLEX HAS BECOME A DIVERSIFIED SET OF ESTABLISHMENTS, HHICH HAVE GROWN UP AROUMD TWO MODELS. THE FIRST MODEL IS BASED ON A TOP-DOWN SYSTEM WHICH CONCENTRATES ON LICENSED PRODUCTION AND PRODUCTION FOR THE CIVILIAN MARKET. THE SECOND MODEL IS A FLEXIBLE, PROJECTORIENTED SYSTEM. THIS ARTICLE EXAMINES SOME FACTORS DRIVING THE LATTER MODEL. THE FOCUS IS ON THE EFFORTS OF A CIVILIAN SCIENTIFIC ELITE, WHICH ENTERED THE SECURITY SECTOR DUE TO ITS CONTROL OF DUAL-USE HIGH TECHNOLOGIES AND THE FAILURE TO FULFILL ITS ORIGINAL MANDATE OF CHEAP NUCLEAR POWER.

00755 ABRAHAMS, $N$.

TOWARDS RECONCEPTUALIZING POLITICAL ACTION SOCIOLOGICAL INOUIRY, 62(3) (SUM 92), 327-347.

THE OISCIPLINE OF' SOCIOLOGY FACES IMPORTANT CHALLENGES THAT MAY RESULT IN A TRANSFORMATION OF THE FIELD. FOR EXAMPLE, THE PRACTICE OF SPECIALIZATION POTENTIALLY TAKES ON A NEW MEANING IN THE CONTEXT OF GROWING INTERDISCIPLINARY STUDIES, THE GROWTH OF FEMINIST SCHOLARSHIP, AND RENEWED STUOIES, THE GROWTH OF FEMINIST SCHOLARSHIP, AND EFFORTS AT MICRO-MACRO LINKAGES. IN ESSENCE, MORE
COMPREHENSIVE ACCOUNTS OF SOCIAL PHENOMENA ARE MADE POSSIBLE COMPREHENSIVE ACCOUNTS OF SOCIAL PHENOMENA ARE MADE POSSIBLE WHICH SUCH APPROACHES MAY LEAD TO ADVANCES IN THE STUDY OF WHICH SUCH APPROACHE

00756 ABRAHAMSON, P.

WELFARE AND POVERTY IN THE EUROPE OF THE 1990S: SOCIAL PROGRESS OR SOCIAL DUMPING?

INTERHATIONAL JOURNAL OF HEALTH SERVICES, 21(2) (1991),

237-264.

SOCIAL POLICY IN EUROPE IS CHANGING FUNDAMENTALLY FROM A SYSTEM OF PUBLIC (GOVERNMENT) SUPPORT TO A WELFARE PLURALISM, OR A "WELFARE MIX" SUPPORTED BY THE PRIVATE AND PUBLIC SECTORS AND BY VOLUNTARY AGENCIES. THE OVERALL TENDENCIES ARE PRIVATIZATION, DECENTRALIZATION, AND DEBUREAUCRATIZATION. WITH THE PROSPECT OF A SINGLE-MARKET ECONOMY HITHIN THE EUROPEAN COMMUNITIES IN 1993, THE FIGHT AGAINST POVERTY IN MEMBER NATIONS MAY LEAD TO "SOCIAL DUMPING." THO MAJOR PROBLEMS ARE IDENTIFIED: THE LACK OF GUARANTEED MINIMUM INCOME SCHEMES IN THE SO-CALLED "LATIN RIM" COUNTRIES, AND THE EFFECT ON WORKERS' AND CITIZENS' RIGHTS IN AN INTEGRATED EUROPE. THE FIGHT AGAINST POVERTY IS--DESPITE SOME EFFORTS FROM THE COMMISSIOM OF THE EUROPEAN COMMUNITIES--BASICALLY LEFT TO THE INDIVIDUAL MEMBER STATES. THIS PORTENDS A GLOOMY SCENARIO FOR THE POORER POPULATIONS OF EUROPE IN THE 1990 S. THE AUTHOR EXAMINES WELFARE STATE TYPES WITHIN CLUSTERS OF COUNTRIES: THE MODERN (SCANDIMAVIA) THE CORPORATIST (FEDERAL REPUBLIC OF GERMANY), THE RESIDUAL (BRITAIN), AND (FEDERAL REPUBLIC OF GERMANY), THE RESIDUAL (BRITAIN), AND
THE RUDIMENTARY (LATING RIM). THE CONCLUSION, UNFORTUNATELY, THE RUDIMENTARY (LATING RIM) T THE CONCLUSION, UNFORTUNAT
IS THAT FUTURE OVERALL DEVELOPMENT OF EUROPEAH WELFARE IS THAT FUTURE OVERALL DEVELOPMENT OF EUROPEAM
SYSTEMS IN THE 1990 S WILL PROBABLY BE TOWARD

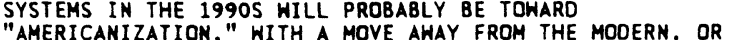
"AMERICANIZATION," WITH A MOVE AHAY FROM THE MOOERN, OR
SCANDINAVIAN, MODEL TOHARD A CORPORATIST MODEL FOR WELFARE SCANDINAY
POLICY.

00757 ABRAMOHITZ, A.

IMCUMBENCY, CAMPAIGM SPENDING, AND THE DECLINE OF INCUMBENCY, CAMPAIGN SPENDING, AND

THE JOURAL OF POLITICS, 53(1) (FEB 91), 34-56

THE 1986 AND 1988 U.S. HOUSE ELECTIONS SET ALL-TIME RECORDS FOR REELLCTION OF INCUMBENTS. THIS PAPER PROPOSES AND TESTS A COMPREHEMSIVE MODEL OF HOUSE ELECTION OUTCOMES AND USES THIS MODEL TO EXPLAIN COMPETITION FOR HOUSE SEATS THE RESULTS INDICATE THAT THE EXTRAORDINARILY LOW LEVEL OF COMPETTIS INOACET HOUSE LLCTIONS IS DIRECTLY ATTRIBUTABLE TO TWO TRENDS WHICH AFFECTED THESE ELECTIONS DURING THE 1980S: THE INCREASING COST OF HOUSE CAMPAIGNS AND THE DECLINING ABILITY OF HOUSE CHALLENGERS TO RAISE CAMPAIGM FUNDS. AFTER CONTROLLING FOR INFLATION, A DOLLAR OF CAMPAIGN SPENDING IN 1984 OR 1986 YIELDED A MUCH LOWER RATE OF ELECTORAL RETURN FOR HOUSE CHALLENGERS THAN A DOLLAR OF CAMPAIGN SPENDING IN 1974 OR 1976. IN ADDITION, BETHEEN 1980 AND 1988 AYERAGE SPENDING BY HOUSE CHALLENGERS DECLINED BY MORE THAN 30 PERCENT IN REAL DOLLARS, PUBLIC FINANCING OF
CAMPAIGNS COULD INCREASE COMPETITION FOR HOUSE SEATS, BUT ONLY IF A VERY HIGH LEVEL OF FUNDING WAS PROVIDING.

00758 ABRAMOWITZ, M.

DOLEDRUMS

NEW REPUBLIC, 206(13) (MAR 92), 16-18.

CURRENT WELFARE REFORMS ARE LIKELY TO FALL AS FAR SHORT AS PAST PLANS. ALTHOUGH THEY ARE POLITI ICALLY APPEALING AND MAY HELP STATES CUT THEIR BUDGETS, NONE OF THE PLANS IS BOLD ENOUGH TO BRING MORE THAN MARGINAL IMPROVEMENT IN UNDERCLASS POVERTY. MOST RELY ON ANTICIPATED CHANGES IN BEHAVIOR THAT ARE NOTORIOUSLY DIFFICULT TO EFFECT, WHILE THEY SHRINK FROM SWEEPING REFORMS THAT MIGHT MAKE A REAL DIFFERENCE. THE CALIFORNIA AND NEW JERSEY REFORMS ARE TYPICAL BECAUSE THEY SUFFER FROM THE SAME BASIC LACK OF VISION.

00759 ABRAMS, E.

AN AMERICAN VICTORY

NATIONAL REVIEW, XLIV(2) (FEB 92), 39-40.

THE PEACE TREATY SIGNED BY THE GOVERNMENT OF EL SALVADOR WITH THE COMMUNIST FMLN CONSTITUTES A GREAT VICTORY FOR SALVADORANS, AND FOR U.S. FOREIGN POL ICY. ESPECIALLY RESPONSIBLE' IS RONALD REAGAN. THE REAGAN POLICY IN EL SALVADOR HAD TWO PARTS. FIRST, THE FMLN HAD TO BE PREVENTED FROM ACHIEVING A MILITARY VICTORY OVER THE GOVERNMENT. A LARGE MILITARY-AID PROGRAM WAS ESTABLISHED, WITH THE AIM OF INCREASING THE SIZE AND COMPETENCE OF THE SALVADORAN ARMY. SECOND, POLITICAL REFORM HAS NEEDED IN THE COUNTRY, TO PROVE TO ITS CITIZENS THAT THEIR GRIEVANCES--AGAINST CORRUPTION, INJUSTICE, OPPRESSION--COULD BE REDRESSED WITHIN THE SYSTEM. BOTH PARTS SUCCEEDED.

00760 ABRAMS, E.

CAN DEMOCRACY DRIVE FOREIGM POLICY?

NATIONAL REVIEH, XLIV(9) (MAY 92), 25-28.

THE U.S. IS COMMITTED TO ENCOURAGING DEMOCRACY. BUT EVENTS IN PERU AND THE ISLAMIC HORLD FORCE THE QUESTION: MIGHT AN OBSTINATE INSISTENCE ON DEMOCRATIC FORMS WORK AGAINST WHAT WE PRIZE IN DEMOCRACY? THIS ARTICLE DISCUSSES

00761 ABRAMS, E.

GOOD-BYE TO THE NEW WORLD ORDER

MATIONAL REVIEW, XLIV(23) (NOV 92), 42-44.

THE BUSH WHITE HOUSE NEVER MANAGED TO SOUND VERY ENTHUSIASTIC ABOUT DOMESTIC AFFAIRS. FOREIGN POLICY WAS ITS FORTE. THIS ARTICLE STATES THAT BUSH'S SUPREME MOMENT WAS DESERT STORM GEORGE BUSH WIL HAYE MUCH TO BE THANKFUL FOR IF HE IS BEST REMEMBERED FOR HIS DECISION TO REVERSE THE IRAQI TAKEDVER OF KUWAIT.

00762 ABRAMS, E.

POLICY CONFRONTS REALITY

NATIONAL REVIEH, XLIV(4) (MAR 92), 38-39.

U.S. POLICY WITH REGARDS TO THE MILITARY COUP WHICH OUSTED HAITI'S PRESIDENT JEAN-BERTRAND ARISTIDE HAS BEEN RIFE HITH ERROR. THE FIRST AMERICAN MISTAKE WAS TO EQUATE ARISTIDE WITH DEMOCRACY. THE SECOND U.S. MISTAKE HAS TO ALLOW AMERICAN POLICY TO BE VERY LARGELY MADE IN LATIN AMERICA, A REGION WELL KNOWN FOR ITS IMPLACABLE AVERSION TO COUPS. THE THIRD U.S. MISTAKE HAS TO IMPOSE ON HAITI AN EMBARGO THAT FURTHER IMPOVERISHED THE POOR AND LED TO A WAVE OF BOAT PEOPLE, WITHOUT HAVING MUCH IMPACT ON THE RICH. THE END RESULT WAS THAT THE EMBARGO HAD TO BE "MODIFIED," WHICH WAS A SIGNAL TO HAITI'S POLITICAL ACTORS THAT THE UNITED STATES HAD DECIDED TO BACK AWAY FROM THE FRENCH AND VENEZUELAN EMBRACE OF ARISTIDE.

00763 ABRAMS, E.

WHY AMERICA MUST LEAD

NATIONAL INTEREST, 28 (SUM 92), 56-62.

BEFORE ACCEPTING THE ARGUMENTS THAT THE WORLO'S PROBLEMS ARE SOLVED, OR IRRELEVANT TO U.S. SECURITY, OR LIKELY TO REGULATE THEMSELVES IN A NEW AND INTERDEPENDENT HORLD POLITICAL SYSTEM, THEY SHOULD BE SUBJECTED TO CLOSE SCRUTINY AND WHEN THIS IS DONE, THEY APPEAR SERIOUSLY FLAHED. THIS AND WHEN THIS IS DONE, THEY APPEAR SERIOUSLY FLAHED. THIS
ARTICLE EXPLORES THE QUESTIONS OF THE TRIUMPH OF DEMOCRACY AND SELF-REGULATING SYSTEMS. THE END OF VIOLENCE AND THE INVULNERABILITY OF AMERICA. IT CONCLUDES THAT AMERICAN INVULNERABILITY OF AMERICA. IT CONCLUDES THAT AMERICAN

O0764 ABRAMSON, G.

RISE OF THE CRESCENT

AFRICA REPORT 37(2) (MAR 92), 18-21.

FROM ALGERIA TO SUDAN. ISLAMIC FUNDAMENTALISM IS GROWING POL ITICAL ROOTS IN AFRICA. HOWEVER, IN THE AFTERMATH OF THE ALGERIAN MILITARY'S SUPPRESSION OF THE ISLAMIC SALYATION FRONT, FUNDAMENTALIST MOVEMENTS IN OTHER NORTH AFRICAN NATIONS ARE UNLIKELY TO CHALLENGE THEIR RESPECTIVE GOVERMMENTS IN THE NEAR FUTURE. WITH THE EXCEPTION OF SUDAN, WHERE SHARI'A LAH IS BEING IMPOSED, FUNDAMENTALISTS ACROSS THE REGION HAVE BEEN KEPT UNDER TIGHT CONTROL, WITH MANY OF THEIR LEADERS EXILED OR IMPRISONED. 
00765 ABRAMSON, P.; CLAGGETT, W.

THE QUALITY OF RECORD KEEPING AND RACIAL DIFFERENCES IN VALIDATED TURNOUT

THE JOURNAL OF POLITICS, 54(3) (AUG 92), 871-882.

THE ELECTION ADMINISTRATION STUDIES AND THE VOTE

VALIDATION STUDIES CONDUCTED AS PART OF THE 1986 AND 1988 NATIONAL ELECTION STUDIES ARE EMPLOYED TO DETERMINE HHETHER THE TENDENCY OF BLACKS MORE OFTEN TO OVERREPORT VOTING THAN WHITES RESULTS FROM THE POOR QUALITY OF RECORD KEEPING IN ELECTION OFFICES WHERE BLACK REGISTRATION AND VOTING RECDRDS ARE MAINTAINED. BOTH OBJECTIVE INDICATORS OF RECORD-KEEPING QUALITY AND THE SUBJECTIVE ASSESSMENTS BY THE SURVEY RESEARCH CENTER FIELD STAFF ARE EMPLOYED. THE ANALYSIS SUGGESTS THAT THE TENDENCY OF BLACKS TO OVERREPORT VOTING DOES NOT RESULT FROM INFERIOR RECORD KEEPING IN AREAS WHERE BLACKS LIVE.

00766 ABRAMSON, P.R.; ALDRICH, J.H.; PAOLINO, P.; ROHDE, D.H. "SOPHISTICATED" VOTING IN THE' 1988 PRESIDENTIAL PRIMARIES AMERICAN POLITICAL SCIENCE REVIEW, 86(1) (MAR 92), 55-69. VOTERS IN MULTI-CANDIDATE CONTESTS MAY CONFRONT
VOTS VOTERS IN MULTI-CANDIDATE CONTESTS MAY CONFRONT
CIRCUMSTANCES UNDER WHICH IT IS IN THEIR INTEREST TO VOTE FOR A SECOND- OR EVEN LOWER-RANKED CANDIDATE. THE U.S. FOR A SECOND- OR EVEN LOWER-RANKED CANDIDATE. THE U.S. ELECTORAL SYSTEM, TYPICALLY OFFERING A CHOICE BETHEEN ONLY
TWO MAJOR CONTENDERS, RARELY PRESENTS OPPORTUNITIES FOR THIS "WO MAJOR CONTENDERS, RARELY PRESENTS OPPORTUNITIES "SOPHISTICATED" VOTIMG. AN EXCEPTION IS PRESIDENTIAL PRIMARIES IN WHICH MANY PLAUSIBLE CANDIDATES MAY COMPETE. THE AUTHORS INVESTIGATE THE USE OF SOPHISTICATED VOTING IN THE 1988 PRESIDENTIAL PRIMARIES, BASED ON DATA FROM THE
NATIONAL ELECTION STUDY'S SUPER TUESOAY SURVEY. THEY EXAMINE PATTERNS OF VOTING TYPES BASED ON ORDINAL MEASURES OF PREFERENCES AMONG CAMDIDATES AMD ASSESSMENTS OF THEIR CHANCES OF WINNING THEIR PARTY'S NOMINATION AND ESTIMATE SEVERAL MODELS OF CHOICE, TESTING THE MULTI-CANDIDATE CALCULUS OF VOTING. AMONG BOTH REPUBLICANS AND DEMOCRATS, RESPONDENTS' CHOICES WERE CONSISTENT HITH
VOTING AND THUS WITH SOPHISTICATED VOTING.

00767 ABRAMSON, P.R.; IMGLEHART, R. GENERATIONAL REPLACEMENT AND VALUE CHANGE IN EIGHT WEST EUROPEAN SOCIETIES

BRITISH JOURNAL OF POLITICAL SCIENCE, 22(2) (APR 92), 183-228.

GENERATIONAL REPLACEMENT IS PLAYING A MAJOR ROLE IN THE CHANGING POLITICAL VALUES OF WEST EUROPEAN POPULATIONS. IN THIS PAPER, THE AUTHORS USE SURVEYS SPONSORED BY THE COMMISSION OF THE EUROPEAN COMMUNITIES TO STUDY VALUE CHANGE IN WEST GERMANY, BRITAIN, THE NETHERLANDS, FRANCE, BELGIUM, IN WEST GERMANY, BRITAIN, THE NETHERLANDS, FRANCE, BELGIUM,
AND ITALY FROM 1970-71 TO 1990 AND IN DENMARK AND IRELAND AND ITALY FROM 1970-71 TO 1990 AND IN DENMARK AND IREL
FROM 1973 TO 1990 . DURING THESE YEARS, GENERATIONAL

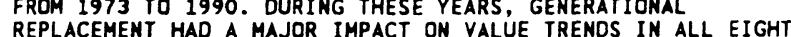
REPLACEMENT HAD A MAJOR IMPACT ON VALUE TRENDS IN ALL EIGHT SOCIETIES. IN GERMANY, BRITAIN, THE NETHERLANDS, AND DEMM
GENERATIONAL REPLACEMENT CONTRIBUTED TO THE GROHTH OF POSTMATERIALISM; IN FRANCE, ITALY, AND IRELAND, REPLACEMENT POSTMATERIALISM; IN FRANCE, ITALY, AND IRELAND POSTMATERIALISM. EVEN IN BELGIUM. WHERE THERE WAS ONLY A POSTMATERIALISM. EVEN IN BELGIUM, WHERE THERE WAS ONLY A SLIGHT MOVE TOWARDS POSTMATERIALISM, REPLACEMENT MAY HAVE PREVENTED A MOVEMENT TOWARDS MATERIALISM. FOR THE EUROPEAN
PUBLIC AS A WHOLE, REPLACEMENT CONTRIBUTED TO THE GROHTH OF POSTMATERIALISM. IN THE NEXT THO DECADES, THE IMPACT OF REPLACEMENT IS LIKELY TO BE SMALLER BECAUSE RELATIVELY LOW BIRTHRATES DURING THE LATE 1970'S AND 1980'S HILL CONTRIBUTE TO LOWER RATES OF GENERATIONAL REPLACEMENT.

00768 ABRAMSON, P.R.

OF TIME AND PARTISAN INSTABILITY IN BRITAIM

BRITISH JOURNAL OF POLITICAL SCIENCE, 22(3) (JUL 92), 381-395.

THE AUTHOR EXAMINES THE THEORY PRESENTED IN "OF TIME AND PARTISAN STABILITY" BY PHILIP E. CONVERSE, WHO ARGUES THAT PARTISANSHIP DEVELOPS OVER THE COURSE OF THREE GENERATIONS, STABILIZING IN THE THIRD GENERATION.

00769 ABRAMSON, R.; CLAGGETT, $H$.

RACIAL DIFFERENCES IN SELF-REPORTED ANO VALIDATED TURNOUT IN THE 1988 PRESIDENTIAL ELECTION

THE JOURNAL OF POLITICS, 53(1) (FEB 91), 186-197.

THE AUTHORS' PREVIOUS (1964-1986) OF VOTE VALIDATION STUDIES QUESTIONED THE CONCLUSION THAT LOW LEVELS OF ELECTORAL PARTICIPATION BY BLACKS RESULT SOLELY FROM RADIAL DIFFERENCES IN SOCIOECONOMIC STATUS AND BECAUSE BLACKS ARE MORE LIKELY THAH WHITES TO LIVE IN THE SOUTH. THE 1988 NES MORE LIKELY THAH WHITES TO LIVE IN THE SOUTH. THE 198
VOTE VALIDATION STUDY IS USED TO UPDATE THE AUTHORS' VOTE VALIDATION STUDY IS USED TO UPDATE THE AUTHORS
FINDINGS, AND THE RESULTS ARE CONSISTENT WITH THEIR PREVIOUS FINDIYGS, AND THE RESULTS ARE CONSISTENT WITH THEIR PR ANALYSES. ALTHOUGH CONTROLS FOR REGION AND LEVEL OF EDUCATION EL IMINATE RACIAL DIFFERENCES IN REPORTED ELECTORAL PARTICIPATION, SIGNIFICANT RACIAL DIFFERENCES REMAIN WHEN PARTICIPATION IS MEASURED BY THE VOTE VALIDATION PROC IN ADOITION, THE 1988 NES SURVEY SUGGESTS THAT RACIAL
DIFFERENCES IN BOTH REPORTED AND VALIDATED TURNOUT INCREASED IN 1988. THE AUTHORS SPECULATE ON THE REASONS THAT BLACK TURNOUT DECLINED INT THE 1988 PRESIDENTIAL ELECTION.
00770 ABSHIRE, $D$. STRATEGIC CHALLENGE: CONTINGENCIES, FORCE STRUCTURES DETERRENCE

WASHINGTON QUARTERLY, 15(2) (SPR 92), 33-42.

THE END OF THE COLD WAR MEANS THE PASSING NOT JUST OF THE SOVIET THREAT BUT OF AN ENTIRE WAY OF THINKING ABOUT INTERNATIONAL SECURITY AND THE INTERNATIONAL

RESPONSIBILITIES OF THE UNITED STATES. U.S. STRATEGY, SO LONG BASED ON THE MILITARY AND POLIIICAL DICTATES OF CONTAINMENT, MUST BE RECONCEPTUALIZED IF THE U.S. NATIONAL INTEREST IS TO BE WELL SERVED IN THE YEARS AHEAD. THIS ARTICLE STATES THAT THE PRINCIPAL LONG-RANGE THREAT IS ON A GRAND SCALE; THAT THE ATLANTIC AND PACIFIC DEMOCRATIC ALLIES WILL DEVELOP CONFLICTS AMONG THEMSELVES AND, IN EFFECT, RETURN THE U.S. TO A SITUATION SIMILAR TO THAT OF THE EIGHTEENTH AND NINETEENTH CENTURIES.

00771 ABU-LABAN, Y.; STASIULIS, D.

ETHNIC PLURALISM UNDER SIEGE: POPULAR AND PARTISAM OPPOSIIION TO MUL ICUL TURAL ISM

CANADIAN PUBLIC POLICY--ANALYSE DE POLITIQUES, 18(4) (DEC

92), 365-386.

THIS ARTICLE EXAMINES THE CURRENT CRITIQUES OF

MULTICUL TURALISM POLICY BY ACADEMICS, THE SPICER COMMISSION,

FEDERAL PARTIES, AND ETHNIC MINORITIES. FACTORS ACCOUNTING

FOR ATTACKS ON THE POLICY INCLUDE THE CONSTITUTIONAL IMPASSE,

ALONG WITH A SHIFTING. THOUGH RESISTANT ETHNIC POHER

STRUCTURE, AND THE FEARS LINKED TO GROWING IMMIGRATION AND

REFUGEE PRESSURES FROM THIRD WORLD COUNTRIES IN A GLOBAL

CONTEXT OF ECONOMIC DECLINE.

00772 ABUL-FADL, M.

FROM GREED TO JUSTICE: AMERICAN POLICY IN THE MIDOLE EAST (REFLECTIONS FROM A MUSLIM PERSPECTIVE, 1 )

AMERICAN JOURNAL OF ISLAMIC SOCIAL SCIENCES, 9(3) (FAL 92), 86-107.

THE AUTHOR IOENTIFIES SOME OF THE FLAHS THAT TAINT AND CONSTRAIN U.S. FOREIGN POLICY IN THE MIDOLE EAST AND, MORE GENERALLY, IN THE MUSLIM WORLD. ALTHOUGH AMERICA'S MIDDLE EAST POLICY IS LARGELY MOTIVATED BY CONSIDERATIONS OF NATIONAL SELF-INTEREST AND EXPEDIENCY, HHICH MIGHT BE SUBSUMED UNDER THE CATEGORY OF "GREED," THERE REMAINS A RECURRENT UNDERTONE AND PREOCCUPATION HITH A MORAL SELFJUSTIFICATION THAT SEEKS GRDUNDS OF JUSTICE AND RIGHT FOR ALL ITS PURSUITS. IN THE REALM OF ATTITUDES TOWARD THE MUSLIM WORLO, AMERICANS ARE ENCUMBERED WITH A HEAVY LEGACY THAT LIES AT THE ROOT OF THE MANY ENTHUSIASMS AND COMPLACENCIES THAT HAVE TIME AND AGAIN BEEN REFLECTED IN U.S. FOREIGN POLICY AND IN AMERICAN REACTIONS TO EVENTS IN THE MIDDLE EAST.

00773 ACHARYA, A.

INTERNATIONAL TRADE POLICY: BENEVOLENT DICTATORS AND INTERNATIONAL TRADE POLIC

PUBLIC CHOICE, 74(1) (1991), 1-16.

THE LIBERAL TRADITION THAT UNDERLIES THE NEO-CLSSICAL MODEL OF INTERNATIONAL TRADE EXPOUNDS THE YIRTURE OF CONSUMPT ION OF THE FOREIGNERS' GOODS, AND PROPOSES FREE TRADE, AND PRODUCTION SPECIALIZATION. THIS ARTICLE CONTRASTS THIS VIEN WITH THE CLASSICAL TRADITION OF INTERNATIONAL TRADE POLICY. IT BEGINS BY DISCUSSING CLASSICAL EXEPTIONS TO THE CASE FOR FREE TRADE AND STRATEGIC TRADE POLICY. ALSO
DISCUSSED ARE EUROPE 1992 AND SOCIALIST INTERNATIONAL TRADE.

00774 ACHARYA, A.

REGIONAL MILITARY-SECURITY COOPERATION IN THE THIRD WORLD: A CONCEPTUAL ANALYSIS OF THE RELEVANCE AND LIMITATIONS OF

ASEAN (ASSOCIATION OF SOUTHEAST ASIAN NATIONS

JOURMAL OF PEACE RESEARCH, 29(1) (FEB 92), 7-22. IN THE THIRD WORLD, REGIONAL MILITARY-SECURITY COOPERATION HAS EVOLVED THROUGH THREE FRAMEHORKS. THE OF THE COLD WAR SAW THE EMERGENCE OF THO COMPETING FRAMEWORKS, ONE OF WHICH MAY BE TERMED "AUTONOMOUS" AND THE OTHER "HEGEMONIC." A REVIEW OF THESE FRAMEWORKS AND THEIR PRACTICAL MANIFESTATIONS POINTS TO SOME IMPORTANT LESSONS CONCERNING THE LIMITATIONS OF REGIONAL MILITARY-SECURITY CODPERATION IN THE THIRD HORLD. BY USING THESE LESSONS AS A CONCEPTUAL FRAMEWORK. THIS PAPER ANALYZES THE ROLE OF ASEAN, WHICH THE PAPER FINDS AS A THIRD FRAMEWORK IN THE EVOLUTIONARY ADAPTATIOH OF REGIONAL MILITARY-SECURITY COOPERATION IN THE THIRD WORLD. WITHIN THIS FRAMEWORK, THE FOUR MAIN CRITERIA OF EVALUATION APPLIED TO ASEAN ARE: FOUR MAIN CRITERIA OF EVALUATION APPLIED TO ASEAN ARE: ASEAN'S ROLE IN INTRA-MEMBER CONFLICT RESOLUTION; THE STRUCTURE OF MILITARY-SECURITY COOPERATION WITHIN ASEAN; THE
TYPES OF MILITARY-SECURITY COOPERATION UNDERTAKEN BY THE TYPES OF MILITARY-SECURITY COOPERATION UNDERTAXEN BY THE
ASEAN MEMBERS; AND THE COMFLICT BETHEEN ASEAN'S PROFESSED ASEAN MEMBERS; AND THE COMFLICT BETHEEN ASEAN'S PROFESSED ASPIRATIONS FOR REGIONAL AUTONOMY VERSUS THE NEED FELT BASIS OF SUCH AN EVALUATION. THE PAPER ESTABLISHES THE MAJOR FEATURES AND LIMITATIONS OF ASEAN AND EXAMINES WHETHER THESE ARE SIMILAR TO SOME OTHER CONTEMPORARY SUBREGIONAL GRDUPINGS IN THE THIRD WORLD GROUPINGS. 
00775 ACHEN, C.H.

SOCIAL PSYCHOLOGY, DEMOGRAPHIC VARIABLES, AND LINEAR REGRESSION: BREAKING THE IRON TRIANGLE IN VOTING RESEARCH POLITICAL BEHAVIOR, 14(3) (SEP 92), 195-212.

ACCORDING TO A PREVIOUS PAPER, A SIMPLE PROSPECTIVE MODEL OF VOTING AND PARTY IDENTIFICATION SUBSUMES MUCH OF THE SOCIAL-PSYCHOLOGICAL AND RETROSPECTIVE VOTING LITERATURES, IN THE SENSE THAT IT RIGOROUSLY IMPLIES THEIR KEY FINDINGS AND ADOS MANY NEW ONES AS WELL. THIS PAPER EXTENDS THE ARGUMENT BY SHOWING THAT THE SAME PROSPECTIVE VOTING MODEL HAS DRAMATIC IMPLICATIONS FOR CONVENTIONAL STATISTICAL SPECIFICATIONS IN VOTING RESEARCH. FIRST, LINEAR MOOELS SHOULD BE DISCARDED IN FAVOR OF A PARTICULAR NONLINEAR SPECIFICATION. SECONDLY, DEMOGRAPHICS SHOULD BE DROPPED FROM THE LIST OF INDEPENDENT VARIABLES.

00776 ACKELSBERG, M.A.

FEMINIST ANALYSES OF PUBLIC POLICY

COMPARATIVE POLITICS, 24(4) (JUL 92), 477-493.

THE AUTHOR SURVEYS RECENT LITERATURE IN THE AREA OF FEMINIST ANALYSIS OF PUBLIC POLICY AND OUTLINES PERTINENT RESEARCH QUESTIONS. SHE EXPLORES FOUR CONCERNS: WHAT ROUTES HAVE WOMEN TAKEN TO GAIN ACCESS TO POLITICAL POWER AND HOW DO THESE ROUTES AFFECT POLICY OUTCOMES? HOW HAVE GENDER EXPECTATIONS AFFECTED THE IDENTIFICATION OF POLICY PROBLEMS AND PUBLIC POLICIES TO ADORESS THEM? HOW IS GENDER IMPLICATED IN THE CONSTRUCTION OF THE WELFARE STATE? WHAT ARE THE IMPLICATIONS OF THESE STUDIES FOR UNDERSTANDING THE NATURE OF WOMEN'S CITIZENSHIP?

00777 ADADE, C.Q.

RECOVERING ' SECRET DEBTS'

WEST AFRICA, (3899) (JUN 92), 962.

BORIS YELTSIN'S RUSSIAN GOVERNMENT SAYS THAT IT PLANS TO RECOVER AFRICA'S "SECRET DEBTS" TO THE FORMER SOVIET UNION. RUSSIA'S NEH LEADERS HAVE MAPPED SEVERAL ALTERNATIVE STRATEGIES FOR RETRIEVING THE MORE THAN 45 BILLION CONVERTIBLE ROUBLES OWED TO THE FORMER USSR BY DEVELOPING COUNTRIES. BUT SOME OBSERVERS CLAIM THAT THE AFRICAN COUNTRIES ARE MERELY BEING USED AS SCAPEGOATS FOR RUSSIA'S OWN ECONOMIC PROBLEMS.

00778 ADAM, H.; MOODLEY, $K$

POLITICAL VIOLENCE, "TRIBALISM," AND INKATHA

JOURMAL OF MODERN AFRICAN STUDIES, 30(3) (SEP 92) 485-510.

PROBABLY NO OTHER ASPECT OF THE SOUTH AFRICAN CONFLICT HAS ELICITED MORE DIVERGENT EXPLANATIONS AND HAS ELICITED MORE DIVERGENT EXPLANATIONS AND
MISINTERPRETATIONS THAN THE OUTGOING POLITICAL VIOLENCE. MISINTERPRETATIONS THAN THE OUTGOING POLITICAL VIOLENCE. THIS ANALYSIS REFUTES SINGLE-CAUSE EXPLANATIONS. IT DE-
EMPHASIZES A PRIMARY FOCUS ON THE POLICIES OF LEADERS IN FAVOR OF PREDISPOSING SOCIAL CONDITIONS, SUCH AS THE RURALURBAN DIVIDE, THE INTER-GENERATIONAL CLEAVAGES, AND THE URBAN DIVIDE, THE INTER-GENERATIONAL CLEAVAGES, AND
OIFFERENTIAL LIVING CONDITIONS, SOCIAL STATUS, AND

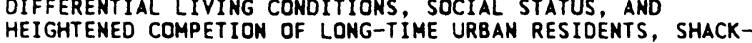
DWELLERS, AND MIGRANTS IN SINGLE-MEN HOSTELS.

00779 ADAM, H.; MOODLEY, K.

THE BACKGROUND TO CANADA'S ACTIVIST POLICY AGAINST APARTHEID: THEORETICAL AND POLITICAL IMPLICATIONS JOURNAL OF COMMONWEALTH AND COMPARATIVE POLITICS, 3013 (NOV 92 ), 293-315.

IN CANADA THE CONSERVATIVE MULRONEY GOVERNMENT HAS ADOPTED ONE OF THE MOST PROGRESSIVE AND ACTIVIST POLICIES IN SOUTH AFRICA AMONG ALL WESTERN NATIONS AND HAS TAKEN THE LEADERSHIP IN THE COMMONWEALTH ON SANCTIONS. THIS ARTICLE EXPLORES WHY. THIS CANADIAN CASE STUDY CAN SHED EMPIRICAL LIGHT ON THE ACCURACY OF THE BUREAUCRATIC PARADIGM. CANADIAN POLICY ON SOUTH AFRICA UNDER THE DIRECTIDN OF THE PRIME MINISTER CAN IDEALLY TEST THE CONVENTIONAL WISDOM OF BUREAUCRATIC INTERPRETATIONS IN A REAL SITUATION.

00780 ADAM, $W$.

NEW PRIORITIES EMERGE AS THE SOVIET MONOLITH FRAGMENTS GERMAN TRIBUNE, (1491) (NOV 91), $1,3$.

AFTER DECADES AS A MONOLITHIC BLOC, THE SOVIET UNION HAS GROWN MORE COMPLEX AS ITS CONSTITUENT REPUBLICS STRIVE FOR MORE AUTONOMY. THIS IS WHY GERMANY'S FOREIGN MINISTER HANSDIETRICH GENSCHER MET IN MOSCOW HITH BOTH PRESIDENT GORBACHEY AND SOVIET FORIEGN MIMISTER BORIS PANKIN (ON DISARMAMENT TREATIES THAT HAVE YET TO BE RATIFIED) AND WITH FOREIGN MINISTER ANDREI KOSYRIEY OF RUSSIA, WHICH WANTS FOREITN MINISTER ANDREI KOSYRIEV OF RUSSIA, WHICH WANTS
GREATER POWER. RUSSIAN PRESIDENT BORIS YELTSIN IS ALSO GREATER POWER. RUSSIAN PRESIDENT BORIS YELTSIN IS ALSO
SCHEDULED TO VISIT GERMANY. RUSSIA'S INCREASINGLY FORCEFUL SCHEDULED TO VISIT GERMANY. RUSSIA'S INCREASINGLY FORCEFUL
CLAIM TO SUCCEED THE SOVIET UNION IS BASICLY VIEWED AS A CLAIM TO SUCCEED THE SOVIET UNION IS BASICLY VIEHED
POSITIVE DEVELOPMENT, ESPECIALLY IN LIGHT OF THE POSITIVE DEVELOPMENT, ESPECIALLY IN LIGHT OF THE
INTERNATIONAL DISARMAMENT AND DEBT REPAYMENT COMMITMENTS OF INTERNATIONAL DISARMAMENT AND DEBT REPAYMENT COMMITMENTS OF A MULTINATIONAL STATE IN THE PROCESS OF DISINTEGRATION, AND ABOVE ALL. IN VIEW OF UNCERTAINTY ABOUT HOH
STRATEGIC POTENTIAL ARE TO BE CONTROLLED.

00781 ADAM, $H$.

WARS OF ATTRITION THREATEN TO ERUPT FROM SOVIET HISTORY GERMAN TRIBUNE, 31(1541) (NOV 92) 2 .

THE HISTORICAL LEGACY OF THE SOVIET UNION IS COMING TO
LIFE. BARELY A YEAR AFTER THE COLLAPSE OF THE EASTERN EMPIRE, THE DAYS OF ITS SUCCESSOR. THE COMMONWEALTH OF INDEPENDENT STATES, ARE OBVIOUSLY ALSO NUMBERED. THE GREATEST DANGERS OF FURTHER FRAGMENTATION ARE BECOMING APPARENT AGAINST THE BACKGROUND OF EVENTS IN THE CAUCASUS. THE RUSSIANS WANT EVERYTHING DEALT WITH IN THE GREAT RUSSIAN MANNER. THAT IS CAUCASUS INTO A CONFLAGRATION.

00782 ADAMS, $D$.

ECONOMICS OF THE ARMS RACE

POLITICAL AFFAIRS, LXX(9-10) (SEP 91), 16-22.

THE PURPOSE OF THIS ARTICLE IS TO SHOW HOW SOVIET ECONOMIC PROBLEMS HAVE BEEN CAUSED IN LARGE PART BY THE ECONOMIC PROBLEMS HAVE BEEN CAUSED IN LARGE PART BY THE
DEL IBERATE POLICY OF U.S. IMPERIALISH TO BANKRUPT THEIR

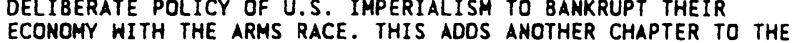
ECONOMY HITH THE ARMS RACE. THIS ADOS ANOTHER CHAPTER TO
LONG STORY OF HOW THE RULING CLASS USES MILITARISM TO LONG STORY OF HOW THE RULING CLASS USES MILITARISM TO MAINTAIN ITS POHER AND INCREASE ITS EXPLOITATION OF THE WHE SAME TIME AS IT HAS BANKRUPTED THE SOCIALIST COUNTRIES THE SAME TIME AS IT HAS BANKRUPTED THE SOCIALIST COUNTRIES IT IS ALSO BANKRUPTING THE U.S. ECONOMY. THE U.S. WORKING THE FORM OF UNEMPLOYMENT, UNDER-EMPLOYMENT, AND LOSS OF SOCIAL SERVICES.

00783 ADAMS, F.G.

REMOVING THE IMPEDIMENTS TO ECONOMIC RECOVERY

CURRENT HISTORY, 91(564) (APR 92), 156-161.

THE ECONOMIC DOLDRUMS THAT ARE' PLAYING A PIVOTAL ROLE IN

THE 1992 PRESIDENTIAL CAMPAIGN ARE THE RESULT OF SHORT-

SIGHTED ECONOMIC POLICIES. THE SOLUTION IS NOT TO "FINE

TUNE" THE ECONOMY BUT TO UNDERSTAND THE STRUCTURAL FACTORS

THAT HAVE HAMPERED ECONOMIC GROWTH AND POSE A THREAT TO LONG-

TERM ECONOMIC PROSPERITY IN THE UNITED STATES.

00784 ADAMS, F.G.; ALANIS, M.; DELRIO, A.B.

THE MEXICO-UNITED STATES FREE TRADE AND INVESTMENT AREA PROPOSAL: A MACROECONOMETRIC EVALUATION OF IMPACTS ON MEXICO

JOURNAL OF POLICY MOOELING, 14(1) (FEB 92), 99-119.

THE AUTHORS UTILIZE A MACRO MODEL OF THE MEXICAN ECONOMY

TO APPRAISE THE IMPACT OF THE NORTH AMERICAN FREE TRADE AREA

(NAFTA) PROPOSAL ON MEXICO. THEY OUTLINE THE AOVANTAGES OF

(NAFTA) PROPOSAL ON MEXICO. THEY OUTLINE THE ADVANTAGES OF

USING MACROECONOMETRIC MODELING TO ANALYZE SUCH A PROPOSAL.

THEN THEY SUMMARIZE THE SALIENT FEATURES OF THE CIEMEX MODEL
OF MEXICO THAT THEY ARE USING AND EXPLAIN THE ASSUMPTIONS

OF MEXICO THAT THEY ARE USING AND EXPLAIN THE ASSUMPTIONS
UNDERLYING THE SIMULATIONS. FINALLY, THEY PRESENT THE

RESULTS AND EVALUATE THE IMPLICATIONS OF THESE RESULTS.

00785 ADAMS, G.B.

ENTHRALLED WITH MODERNITY: THE HISTORICAL CONTEXT OF

KNOWLEDGE AND THEORY DEVELOPMENT IN PUBLIC ADMINISTRATION

PUBLIC ADMINISTRATION REVIEH, 52(4) (JUL 92), 363-373.

THE AUTHOR ARGUES THAT THE AMERICAN CULTURAL

PREOCCUPATION WITH MODERNITY HAS SHAPED THE STUOY OF PUBLIC ADMINISTRATION INTO AN AHISTORICAL AND ATEMPORAL FIELD THAT STRESSES TECHNICAL RATIONALITY AND HAS LIMITED CAPACITY TO ADORESS CRITICAL QUESTIONS FACING SOCIETY. THIS APPROACH TO PUBLIC ADMINISTRATION PLACES ITS EMPHASIS ON PROFESSIONALISM AND THE SCIENTIFIC AND RIGOROUS STUDY OF THE FIELD. THE AUTHOR CALLS FOR GREATER ATTENTION TO HISTORY THAT PROOUCES A GENUINELY OPEN INQUIRY IN THE FIELD.

00786 ADAMS, J.R.

CLINTON'S BERT LANCE?

AMERICAN SPECTATOR, 25(10) (OCT 92), 18-24.

ARKANSAS BANKER JACKSON STEPHENS, WHO HAS DEEPLY INVOLVED WITH THE BANK OF CREDIT ANO COMMERCE INTERNATIONAL (BCCI). HAS HAD ACCESS TO THE LAST THREE PRESIDENTS, INCLUDING GEORGE BUSH. IN ADDITION, STEPHENS HAS BEEN A MAJOR FINANCIAL CONTRIBUTOR TO BILL CLINTON'S CAMPAIGNS AND HAS BEEN MENTIONED AS A POSSIBLE SENIOR FINANCIAL APPOINTEE, PERHAPS EVEN SECRETARY OF THE TREASURY, IF CLINTON HINS THE 1992 PRESIDENTIAL ELECTION.

00787 ADAMS, J.S.

CUBA AND THE POST-SOVIET STATES

RFE/RL RESEARCH REPORT, 1 (33) (AUG 92), 24-27

SINCE THE COLLAPSE OF THE USSR, THE ESSENTIALLY UNITARY AND SUPPORTIVE SOVIET POLICY TOWARD CUBA HAS GIVEN WAY TO MORE COMPLEX NETHORK OF RELATIONS BETHEEN CASTRO'S ISLAND AND THE FORMER SOVIET REPUBLICS. CUBA HAS ESTABLISHED DIPLOMATIC RELATIONS WITH ALL THE FORMER SOVIET REPUBLICS, SOME OF WHICH ARE SEEKING TO PROFIT COMMERCIALLY FROM THE NEW CIRCUMSTANCES. RUSSIA, WHICH IS TRYING TO WESTERNIZE AND HUMANIZE ITS GLOBAL IMAGE, HAS INHERITED THE BULK OF THE SOVIET-CUBAN LEGACY, INCLUDING ITS PROBLEMS. MEANWHILE,
RUSSIAN POLICYMAKERS SEEM TO BE PLANNING FOR AN EVEN GREATER RUSSIAN POLICYMAKERS SEEM TO BE PLANNING FOR
CHANGE IN THE FUTURE--A CUBA WITHOUT CASTRO.

00788 ADAMS, $P$.

ALGERIA, ISLAM AND NORTH AFRIC

SOUTH AFRICA INTERNATIONAL, 23(1) (JUL 92), 18-25. THE RECENT DECLARATION DF MARTIAL LAH AND CANCELLATION 
OF THE ELECTIONS IN ALGERIA BECAUSE OF FEARS OF MUSLIM FUNDAMENTALISM HAS RAISED QUESTIONS NOT JUST FOR THE REGION, BUT FOR THE WEST AND THE REST OF AFRICA. ALGERIA'S TROUBLED EXPERIENCE OF DEMOCRATIZATION AND ECONOMIC REFORM AGAINST A BACKGROUND OF POOR ECONOMIC PERFORMANCE AND HIGH POPULATION GROWTH SOUNDS A CAUTIONARY NOTE FOR OTHER DEVELOPING SOCIETIES ON A SIMILAR PATH.

00789 ADAMS, $P$

HUMAN RIGHTS IN THE TERRITORIES

MIDOLE EAST INTERNATIONAL, (415) (DEC 91), 7.

TWO RECENT REPORTS CAST DIFFERING LIGHTS ON HUMAN RIGHTS ABUSES IN THE OCCUPIED TERRITORIES. THE PALESTINE HUMAN RIGHTS INFORMATION CENTER (PHRIC) IN A DETAILED 80-PAGE REPORT, DOCUMENTS WHAT IT DESCRIBES AS "THE SYSTEMATIC USE OF ELECTRIC SHOCK TORTURE" BY THE ISRAELI AUTHORITIES. IT REFERS TO EIGHT FORMER PRISONERS, AGED BETWEEN 14 AND 23, INTERROGATION. MEANWHILE, IN ITS LATEST BIANNUAL REPORT, THE ISRAELI HUMAN RIGHTS GROUP BETSELEM SAYS THAT THE LAST THO YEARS OF THE INTIFADA HAVE SEEN A "CONSIDERABLE DECLINE IN
THE NUMBER OF CASUALTIES INFLICTED BY SECURITY FORCES." BUT THE NUMBER OF CASUALTIES INFLICTED BY SECURITY FORCES."
IT ADDS THAT "DESPITE THESE PARTIAL GAINS, HUMAN RIGHTS IT ADDS THAT "DESPITE THESE PARTIAL GAIM
CONTINUE TO BE VIOLATED EXTENSIVELY."

00790 ADAMS, $P$.

PALESTINIAN FEARS

MIDOLE EAST INTERMATIONAL, (405) (JUL 91), 6-7

U.S. SECRETARY OF STATE JAMES BAKER'S LATEST PEACE PROPOSAL HAS RECEIVED WIDESPREAD PRAISE AND APPROVAL FROM SEVERAL ARAB STATES. HOWEVER, IN EAST JERUSALEM, PALESTINIAN LEADERS VOICED THE FEAR THAT BAKER'S STRATEGY MIGHT STILL BE FLAHED. AMONG THE STILL UNRESOLVED ISSUES IS THE IMPORTANT MATTER OF PALESTINIAN REPRESENTATION AT THE CONFERENCE. ISRAEL HAS YET TO BUDGE ON ITS DEMANDS THAT NO REPRESENTATIVES FROM JERUSALEM BE ALLOWED TO PARTICIPATE IN THE CONFERENCE. PALESTINIANS ALSO FEAR ISRAELI DUPLICITY, A POSSIBILITY MADE EVIDENT BY THE RECENT CRACKDOWN ON THE CITY OF NABLUS BY ISRAELI MILITARY OFFICIALS AT A TIME WHEN THE GOVERNMENT WAS PROMISING TO MAKE LIFE EASIER FOR THE GENERAL POPULACE.

00791 ADAMS, T.

CHARTER iT AND THE WORKERS' DEFENSE COMMITTEE (KOR): THE STRUGGLE FOR HUMAN RIGHTS IN CZECHOSLOVAKIA AND POLAND

EAST EUROPEAN QUARTERLY, XXVI (2) (SUM 92), 219-238. THE DECADE OF THE 1970'S WITNESSED THE CULMINATION OF A 30-YEAR STRUGGLE ON THE PART OF THE EAST EUROPEAN CITIZENRY 30-YEAR STRUGGLE ON THE PART OF THE EAST EUROPEAN CITIZENAY
TO ESTABLISH A GENUINE CIVIL SOCIETY: A SPHERE IN WHICH TO ESTABLISH A GENUINE CIVIL SOCIETY: A SPHERE IN WHICH
CITIZENS' ACTIVITIES EXISTED OUTSIDE THE CONTROL OF PARTY CI I ZENS ACTIVITIES EXISTED OUTSIDE THE CONTROL OF PART
AND STATE AUTHORITIES AND IN HHICH GENUINE INDIVIDUAL AND STATE AUTHORITIES AND IN WHICH GENUINE INDIV
EXPRESSION SUPERSEDED THE MENDACIOUS AND UTTERLY

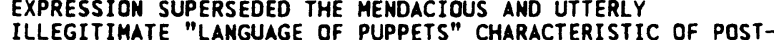
ILLEGITIMATE "LANGUAGE OF PUPPETS" CHARACTERISTIC OF POSTWAR COMUUNIST REGIMES. MOWHERE DID THIS STRUGGLE FOR HUMAM RIGHTS AND CIVIL LIBERTIES ASSUME MORE DRAMATIC AND FARREACHING DIMENSIONS THAN IN CZECHOSLOVAKIA
PERIOD FROM SEPTEMBER 1976 TO JANUARY 1977.

00792 ADBALLA, A.

HUMAN RIGHTS AND ELUSIVE DEMOCRACY

MIDDLE EAST REPORT, 22 (1) (JAN 92), 6-8.

IN THE GLOBAL TREND TOWARDS NEO-LIBERALISM, THE MIDDLE EAST IS NO EXCEPTION. THIS ARTICLE SUGGESTS THAT THE PRACTICE OF HUMAN RIGHTS CANNOT WAIT UNTIL ALL POLITICAL SYSTEMS HAVE BECOME DEMOCRATIC. THE ACTUAL SCORES ATTAINED IN THE BROAD REALM OF DEMOCRATIC CHANGE REMAIN SUBJECT TO ASSESSMENT AND FOUR AVENUES HELP TO TRACE WHAT HAS TAKEN PLACE. FIRST, A STUDY OF THE DIALECTICS OF FORM AND CONTENT CAN GAUGE THE SUBSTANCE AND SIGNIFICANCE OF FORMAL ADOPTION OF SUCH ITEMS OF DEMOCRACY AS CONSTITUTIONS, ELECTIONS, PARL IAMENTS, PARTIES AND A FREE PRESS. SECOND, A STUDY' OF THE DIALECTICS OF PAST AND PRESENT BY EXAMINING THE INERTIA OF DAILY PRACTICES OF DESPOTISM TELLS HOW LITTLE A MEASURE OF DEMOCRACY MOST COUNTRIES IN THE MIDDLE EAST HAVE ATTAINED. THIRD, A STUDY OF THE DIALECTICS OF ELITES AND MASSES CAN OUTLINE A CODE OF CONDUCT BETHEEN THE THO. AND FOURTH, A STUDY OF THE DIALECTICS OF THE WHOLE AND THE PART INDICATES THAT IMPLANTATION OF FRAGMENTED ITEMS OF DEMOCRACY DOES NOT NECESSARILY PROVIDE A DEMOCRATIC WHOLE.

00793 ADDI, L

ALGERIA'S DEMOCRACY BETHEEM THE ISLAMISTS AMD THE ELITE MIDDLE EAST REPORT, $22(2)$ (MAR 92), 36-38.

ALGERIA'S EXPERIENCE OVER THE PAST THREE YEARS HAS SHOWN THAT IN A MUSLIM LAND THE PROCESS OF DEMOCRATIZATION GIVES RISE TO CURRENTS WHICH SEEK TO DESTROY IT. BUT NEUTRALIZING THESE CURRENTS BY FORCE ENTAILS HALTING THE DEMOCRATIZATION PRDCESS AND ENCLOSES SOCIETY IN REPRESSION. SOCIETY CAN ESCAPE THAT ENCLOSURE ONLY IF ISLAM IS DEPOLITICIZED--THAT IS, IF IT NO LONGER SERVES AS A POLITICAL RESOURCE IN THE STRUGGLE FOR POWER. THE ELECTORAL VICTORY OF THE ISLAMIC SAL VATION FRONT (FIS) BROUGHT HOME FOR MANY THE CONSTRAINTS OF "PUBLIC" RELIGION. BUT ALGERIA'S SOCIAL ELITE, FEARING THE POLITICAL DYNAMICS WHICH THE FIS ACCESSION TO POWER
MIGHT SET IN MOTION, PRESSED THE MILITARY TO INTERVENE, PUTTING ALGERIA TO A TEST WHICH WILL CERTAINLY BE OIFFICULT IN THE SHORT TERM BUT PROBABLY PRODUCTIVE IN THE LONG RUN.

00794 ADOI, L.

ISLAMICIST UTOPIA AND DEMOCRACY

ANNALS OF THE AMERICAN ACADEMY OF POLITICAL AND SOCIAL SCIENCE, (524) (NOV 92), 120-130.

THE AUTHOR STUDIES DEMOCRATIC CONSTRUCTION IN ISLAMIC SOCIETIES, UTILIZING THE EXPERIENCE OF ALGERIA. IN ALL MUSLIM SOCIETIES, THERE EXISTS AN ISLAMICIST UTOPIA THAT STANDS AS AN OBSTACLE NOT ONLY TO DEMOCRACY BUT ALSO TO POLITICAL MODERNITY. UNTIL NOW, THIS UTOPIA HAS BEEN CONTAINED ONLY BY REPRESSION, WHICH IMPEDES DEMOCRATIZATION. ISLAM PRESENTS ITSELF AS A PUBLIC RELIGION THAT PARTICIPATES IN THE LEGITIMIZATION OF POLITICAL POWER, BUT THE DEMOCRATIC IDEOLOGY IS COMPATIBLE ONLY HITH RELIGION THAT IT IS LIVED AS A PRIVATE CONCERN. THE ISLAMICIST UTOPIA AND THE PUBLIC ASPECT OF ISLAM AIM AT MAINTAINING SOCIETY'S COMMUNAL STRUCTURES. THEY REFUSE TO MAKE THE SIMGULARITY OF THE POL ITICAL ARENA INDEPENDENT AND REJECT DIFFERENTIATION POLITICAL ARENA INDEPENDENT AND RE ECCT OIFFERENTIATION FRATERNAL.

00795 ADDI, L.

RELIGION AND MODERNITY IN ALGERIA

JOURNAL OF DEMOCRACY 3(4) (OCT 92) 75-84.

THE AUTHOR EXPLAINS HOW THE RELIGIOUS OUESTION IN ALGERIA IS CONNECTED TO THE ECONOMIC QUESTION, IN THE SENSE THAT THE ECONOMY IS NOT IDEOLOGICALLY NEUTRAL BUT CAN BE SAID TO EXPRESS A GIVEN CONCEPTIDN OF SOCIAL RELATIONS IN
THE SPHERE OF PRDOUCTION AND EXCHANGE. HE ALSO ENDEAVORS TO SHOW THAT DEMOCRATIZATION IN MUSLIM COUNTRIES MUST NECESSARILY PASS THROUGH AND BEYOND POLITICAL ISLAM.

00796 ADEDEJI, A.

ISSUES AND QUESTIONS

WEST AFRICA, (3915) (SEP 92), 1617

AFRICAN COUNTRIES WILL NOT BECOME MORE DEMOCRATIC SIMPLY BY TALKING ABOUT DEMOCRACY. AFRICANS, INCLUDING NIGERIANS, MUST ACT MORE AND TALK LESS. A COUNTRY CANMOT MOVE FROM TOTALITARIANISM TO DEMOCRATIC PRACTICE IN ONE DAY. UNLESS THERE IS AN ENABLING ENVIRONMENT, DEMOCRACY WILL NOT FLOURISH.

00797 ADEDEJI, A.

SUSTAINING DEMOCRACY

AFRICA REPORT, 37(1) (JAN 92), 29-32.

MORE THAN EVER BEFORE, AFRICA NEEDS FUNDAMENTAL

POLITICAL, ECONOMIC, SOCIAL, AND CULTURAL CHANGE. SUCH

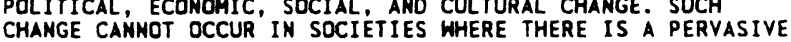

CHANGE CANMOT OCCUR IN SOCIETIES WHERE THERE IS A PERVA

LACK OF DEMOCRACY, WHERE EXISTING PATTERNS OF SOCIAL NARROH BASE FOR DECISION-MAKING AND WHERE THERE IS NO PAPULAR DEBATE OVER BASIC MATIONAL DEVELOPMENT POLICIES AND POPULAR OEBATE OVER BASIC NATIONAL OEVELOPMENT POLLCIES A THEIR IMPLEMENTATION. THEREFORE, AFRICA MUST UNDERGO A EMPOWERMENT, ACCOUNTABILITY, AND ECONOMIC JUSTICE TO PREVAIL.

00798 ADEFUYE, A.

NIGERIA AND THE BLACK WORLD

WEST AFRICA, (3883) (FEB 92), 276-277

THE AUTHOR LOOKS AT THE HISTORIC AND CONTEMPORARY

IMPORTANCE OF NIGERIA AS A LEADER IN AFRICA AND IN OTHER REGIONS WITH LARGE BLACK POPULATIONS.

00799 ADEFUYE, A.

THE COMMONWEALTH AND NIGERIA

WEST AFRICA, (3896) (MAY 92), 834-836

THE AUTHOR DEFINES WHAT IS MEANT BY THE NEW WORLD ORDER,

LINKS IT WITH THE PRINCIPLES AND OBJECTIVES OF NIGERIA'S

FOREIGN POLICY, AND DEMONSTRATES HOH THE COMMONWEALTH--BY

THE NATURE OF ITS STRUCTURE, ORGANIZATION, AND ACTIVITIES--

HAS BEEN RELEVANT AND HAS CONTRIBUTED TO THE PURSUIT AND

ATTAINMENT OF NIGERIA'S FOREIGN POLICY GOALS.

00800 ADELMAN, K.L.; AUGUSTINE, N.R.

DEFENSE CONVERSION: BULLDOZING THE MANAGEMENT

FOREIGN AFFAIRS, $71(2$ ) (SPR 92 ), $26-47$.
THE EAST EUROPEAN COUNTRIES AND THE FORMER SOVIET

REPUBLICS FACE SEEMINGLY INSURMOUNTABLE HURDLES AS THEY

ATTEMPT TO CONVERT THEIR DEFENSE-BASED ECONOMIES TO CIVILIAN

ATTEMPT TO CONVERT THEIR DEFENSE-BASED ECONOMIES TO CIVILIAN

INDUSTRIES. IN THIS ARTICLE, THE AUTHORS EXPLAIN WHY THE

PRESENT RUSSIAN APPROACH

00801 ADELMAN, M.

OIL FALLACIES

FOREIGN POLICY, (82) (SPR 91), 3-16.

THIS ARTICLE CONSIDERS THE' SEEMINGLY EVER-PRESENT

PROBLEMS RESULTING FROM OIL PRICE FLUCTUATIONS AND SHORTAGES

IT ARGUES THAT MOST OF THE PROBLEMS STEM FROM

MISCONCEPTIONS ABOUT THE MATURE OF OIL RESOURCES AND THE OIL MARKET. THE HIGHLY VOLATILE PRICE OF OIL HAS NOT BEEN 
CREATED BY "THE MARKET," BUT RATHER BY UMCHECKED MONOPOLY POWER, THE DESIRE FOR QUICK PAYOFF, QUARRELS OVER BURDEN SHARING, AND IMPRECISE CONTROL. THOSE WHO WANT THE UNITED STATES TO PRODUCE ITS WAY OUT OF THE "PROBLEMS," AND THOSE WHO WANT TO SEE AMERICANS CONSERVE THEIR WAY OUT, ARE BOTH HIGH PRICE. WHILE THESE ARGUMENTS DIMINISH THE EFFECTIVENESS OF TRADITIONAL SOLUTIONS, THE ARTICLE ADVOCATES CONTINUED FEDERAL SUPPORT FOR RESEARCH AND FOR THE EXPANSION AND USE OF THE STRATEGIC PETROLEUM RESERVE.

00802 ADEYEMI, B.A.

PROSPECTS FOR A NUCLEAR-WEAPON-FREE-ZONE IN AFRICA OISARMAMENT, XIV (3) (1991),97-111.

THE NWFZ, WHEN REINFORCED WITH OTHER ARMS CONTROL AND DISARMAMENT' INITIATIVES, IS A WAY OF REDUCING THE DANGERS OF NUCLEAR WAR, THE PROLIFERATION OF NUCLEAR WEAPONS, AND OTHER THREATS TO WORLD PEACE AND SECURITY. NWFZ'S PRESENT AN INCREMENTAL BUT IMPORTANT ACHIEVEMENT TOHARDS INTERNATIONAL STABILITY. IF THE REALIZATION OF THE GOALS OF GENERAL AND COMPLETE DISARMAMENT SEEMS UNATTAINABLE IN A HORLD GOVERNED BY POLITICAL TENSION, MISTRUST, AND LACK OF NEGOTIATIONS ON FUMDAMENTAL ARMS CONTROL AND ARMS REDUCTION MEASURES, NWF 'S CAN LAY THE GROUNDWORK FOR A BETTER FUTURE BY INCREASING CONFIDENCE AMONG STATES.

00803 ADLER, E.

THE EMERGENCE OF COOPERATION: NATIONAL EPISTEMIC COMMUNITIES AND THE INTERNATIONAL EVOLUTION OF THE IDEA OF NUCLEAR ARMS CONTROL

INTERNATIONAL ORGANIZATION, 46(1) (WIN 92), 101-146. AN AMERICAN EPISTEMIC COMMUNITY PLAYED A KEY ROLE IN

CREATING THE INTERNATIONAL SHARED UNDERSTANDING AND PRACTICE OF NUCLEAR ARMS CONTROL. THIS STUDY ANALYZES HOW THE THEORETICAL AND PRACTICAL IDEAS OF ARMS CONTROL EPISTEMIC COMMUNITY BECAME POLITICAL EXPECTATIONS, WERE DIFFUSED TO THE SOVIET UNION, AND WERE ULTIMATELY EMBODIED IN THE 1972 THE SOVIET UNION, AND WERE ULTIMATELY EMBODIED IN THE ANTIBALLISTIC MISSLE (ABM) CONTROL TREATY. THE STUDY
STRESSES THE NOTION THAT DOMESTICALLY DEVELOPED THEORETICAL STRESSES THE NOTION THAT DOMESTICALLY DEVELOPED THEORETICAL
EXPECTATIONS WHICH WERE WORKED OUT BY A NATIONAL GROUP OF EXPECTATIONS WHICH WERE WORKED OUT BY A NATIONAL GROUP OF
EXPERTS AND SELECTED BY THE AMERICAN GOVERMMENT AS THE BASIS EXPERTS AND SELECTED BY THE AMERICAN GOVERMMENT AS THE BAS
FOR NEGOTIATIONS WITH THE SOVIETS, BECAME THE SEED OF THE FOR NEGOTIATI
ABM REGIME.

00804 ADLER, E. (ED.)

THE INTERMATIONAL PRACTICE OF ARMS CONTROL

JOHNS HOPKINS UNIVERSITY PRESS, $1992,288$.

THIS BOOK CONSIDERS WHETHER CLASSIC ARMS CONTROL IDEAS STILL MAKE SENSE IN TODAY'S WORLD; WHETHER ARMS CONTROL HAS INCREASED U.S. SECURITY; HOW THE WORLD HAS CHANGED SINCE 1960; AND WHAT THE NATURE, GOALS, AND MEANS OF ARMS CONTROL AGREEMENTS SHOULD BE. REPRESENTING THE VIEWS OF BOTH EARLY AND LATE ARMS CONTROL THEORISTS, THE AUTHORS OFFER OPINIONS FROM THE FORMER SOVIET UNION AS WELL AS THOSE OF TODAY'S MAJOR EUROPEAN STRATEGISTS. AMONG THE TOPICS DISCUSSED ARE INCENTIVES, ALTERNATIVE DETERRENCE POSTURES, NEW FORUMS OF COMMUNICATION AND CONSULTATION, REGULATION OF PEACEFUL COMPETITION, AND THE EXTENSION OF ARMS CONTROL TO THE THIRD WORLD. THE AUTHORS CONCLUOE THAT, DESPITE THE LESSENING OF INTERNATIONAL TENSIONS THAT HERE ASSOCIATED HITH THE COLD WAR, ARMS CONTROL WILL CONTINUE TO BE A VITAL INTERNATIONAL ISSUEE.

00805 AFTERGOOD, 5 .

SPACE NUCLEAR POWER AND THE UN--A GROWING FIASCO

SPACE POLICY, 8(1) (FEB 92), 9-12.

THE WORK OF THE UN COMMITTEE ON PEACEFUL USES OF OUTER SPACE HAS INTENSIFIED FOLLOWING THE ACCIDENTAL RE-ENTRY OF THE SOVIET COSMOS 954 NUCLEAR-POWERED SATELITE IN 1978. THIS ARIICLE SUGGESTS THAT ANYONE THINKING THE PURPOSE OF THE COMMITTEE'S ACTIVITY HAS TO PREVENT THE RECURRENCE OF SUCH AN ACCIDENT WILL HAVE BEEN DISABUSED BY THE USA'S RECENT REPUDIATION OF THE GUIDELINES FOR THE SAFE USE OF NUCLEAR POWER SUPPLIES. THE UN IS GOOD FOR POLITICAL MANOEUVRING, ARGUES THE AUTHOR, BUT REAL PROGRESS TOWARDS THE SAFE
OF NUCLEAR POIWER IN SPACE WILL ORIGINATE ELSEWHERE.

00806 AGBESE, $P$.

MORAL ECONOMY AND THE EXPANSION OF THE PRIVATIZATION MORAL ECONOMY AND THE EXPA

JOURNAL OF COMMONHEALTH AND COMPARATIVE POLITICS, 30(3) (NOY 92 ), 335-357.

THIS PAPER ANALYYSES THE EFFORTS MADE BY THE NIGERIAN GOVERNMENT TO EXPAND THE POLITICAL CONSTITUENCY FOR PRIVATIZATION. IT ARGUES THAT THE GOVERNMENT ATTEMPTED TO DIFFUSE OPPOSITION TO PRIVATIZATION BY EXPANOING THE NARROW CIRCLE OF SUPPORTERS OF PRIVATIZATION. IT HOPED THAT IT COULD SUBSTITUTE VICARIOUS MORAL SATISFACTIN FOR MATERIAL GAINS FOR THOSE NIGERIANS WHO WOULD NOT DERIVE TANGIBLE BENEFITS FROM THE PRIVATISATION PROGRAM. IN THIS WAY, THE CIRCLE OF SUPPORTERS OF PRIVATIZATION HOULD BE ENLARGED WITHOUT ADDITIONAL MATERIAL COSTS TO THE STATE.
00807 AGBESE, $P$.

THE MILITARY AND THE PRIVATIZATION OF REPRESSION IN NIGERIA CONFLICT, 10(3) (1990), 239-266.

NIGERIAN SOLDIERS FREQUENTLY ATTACK THE CIVILIAN POPULATION AND ENGAGE IN BRIBERY AND LOOTING OF THE GENERAL POPULACE. THIS ARTICLE USES A CLASS FRAMEHORK TO ARGUE THAT THESE ACTIONS REPRESENT THE PRIVATIZATION OF REPRESSION BY RANK AND FILE SOLDIERS. MILITARY OFFICERS USE THEIR CONTROL OF THE STATE APPARATUS TO AMASS PRIVATE WEALTH. ALTHOUGH RANK AND FILE SOLDIERS ARE ALSO IN THE MILITARY, THEIR CLASS POSITION PRECLUDES THEM FROM LEGITIMATELY USING THE STATE AS POSITION PRECLUDES THEM FROM LEGITIMATELY USING THE STATE AN INSTRUMENT FOR PRIVATE CAPITAL ACCUMULATION. HOWEVER,
THEY CAN CAPITALIZE ON THEIR MEMBERSHIP IN THE ARMED FORCES THEY CAN CAPITALIZE ON THEIR MEMBERSHIP IN THE ARMED FORCES
TO ATTEMPT TO DERIVE MATERIAL BENEFITS BY USING UNSANCTIONED TO ATTEMPT TO DERIVE MATERIAL 8 ENEFIT

00808 AGBESE, P. 0

SANTIZING DEMOCRACY IN NIGERIA

TRANSAFRICA FORUM, $9(1)$ (SPR 92), 41-55

NIGERIA IS SET TO RETURN TO CIVILIAN RULE BY THE END OF 1992. THE PRESENT MILITARY REGIME IS DETERMINED THAT THE NEW GOVERNMENT WILL NOT BE AS CORRUPT AND INEPT AS PREVIOUS CIVILIAN GOVERNMENTS. THEREFORE, IT HAS PROMULGATED REGULATIONS INTENDED TO RESTORE MORALITY AND ETHICS IN GOVERMMENT. DECREE 25. THE MOST FAR-REACHING RULE, IS DESIGNED TO SANITIZE NIGERIAN POLITICS. BUT THE DECREE SEEMS DESTINED TO FAIL BECAUSE IT ADORESSES THE SYMPTOMS RATHER THAN THE ROOTS OF NIGERIA'S POLITICAL PROBLEMS. IT IS ALSO DOOMED BECAUSE OF INHERENT CONTRADICTIONS IN ITS

CONCEPTUALIZATION. IT EMPHASIZES THE SAMITATION OF

INDIVIDUALS INSTEAD OF THE PROCESSES AND STRUCTURES THAT HAVE DERAILED NIGERIA'S POLITICAL ANO ECONOMIC DEVELOPMENT.

00809 AGUILA, J.M.D.

WHY COMMUNISM HANGS ON IN CUBA

GLOBAL AFFAIRS, 6(1) (WIN 91), 87-102.

THE AUTHOR ARGUES THAT IT IS FIDEL CASTRO'S INFLATED

VIEW OF HIS PLACE IN HISTORY THAT MAKES IT POSSIBLE FOR HIM

TO STAY ON COURSE IN CUBA. THE RELATIONSHIP BETWEEN CASTRO'S

GOVERMMENT AND THE MILITARY IS DISCUSSED, CONCLUDING THAT NO

GOVERMMENT AND THE MILITARY IS DISCUSSED, CONCLUDING THAT NO

MILITARY REBELLION AGAINST CASTRO IS LIKELY.
THE FUTURE OF CUBA AND CASTRO ARE PRESENTED.

00810 AGYEMAN, 0

THE SUPREME COURT AND ENFORCEMENT OF AFRICAN-AMERICAM RIGHTS: MYTH AND REALITY

BLACK SCHOLAR, 21(3) (SUM 91), 22-22.

THE OFT-REPEATED CLAIM THAT THE U.S. SUPREME COURT IS THE PROTECTOR OF MINORITY RIGHTS CONTRADICTS OTHER IMPORTANT ASSUMPTIONS ABOUT THE ROLE AND FUNCTIONING OF THE COURT. IN TURN, THESE CONTRADICTIONS SHED THEORETICAL LIGHT ON THE TENUOUSNESS OF THE CLAIM THAT THE SUPREME COURT IS THE GUARDIAN OF THE RIGHTS OF DISADVANTAGED MINORITIES. AFTER AN ANALYSIS OF THE RELATION BETHEEN THE SUPREME COURT AND AFRICAN AMERICAN RIGHTS, THIS ARTICLE ARGUES THAT IT IS DIFFICULT NOT TO CONCLUDE THAT THE NOTION OF THE COURT'S ROLE AS GUARDIAN OF MINORITY RIGHTS HAS BEEN CONJURED UP TO MASK THE MORE FUNDAMENTAL, ENDURING ROLE OF THE COURT AS THE PROTECTOR OF PROPERTY RIGHTS.

00811 AHADY, A.

CONFLICT IN POST-SOVIET-OCCUPTATION AFGHANISTAN

JOURNAL OF CONTEMPORARY ASIA, 21(4) (1991), 513-538.

ALTHOUGH THE WITHDRAWAL OF SOVIET FORCES FROM

AFGHANISTAN HAS NOT LED TO PEACE IN THIS COUNTRY YET, DIRECT AND INTENSIVE INYOL VEMENT BY SUPERPOWERS IN THE AFGHAN CONFLICT IS NOT LIKELY TO CONTINUE FOR LONG. THIS MAY BRING THE CURRENT PHASE OF THE WAR BETHEEN THE KABUL GOVERMMENT AND THE RESISTANCE TO AN END. HOHEVER, THE AFGHAN POLITY IS LIKELY TO CONTINUE TO SUFFER FROM SEVERE FORMS OF POLITICAL IIKELY TO CONTINUE TO SUFFER FROM SEVERE FORMS OF POLITICAL INSTABILITY BECAUSE AFGANISTAN CURRENTLY SUFFERS FROM THE SIMULTANEOUSLY. THIS ARTICLE EXPLORES THE TREMENDOUS WEAKENING OF THE AFGHAN STATE, A DIRECT CONSEOUENCE OF THE WEAKT ELEVEN YEARS OF WARFARE. A WEAK STATE MAKES THE MANAGEMENT OF THESE CRISES EXTREMELY DIFFICULT.

00812 AHADY, A.

THE DÉCLINE OF ISLAMIC FUMDAMENTALISM

JOURNAL OF ASIAN AND AFRICAN STUDIES, XXVII (3-4) (1992), 229-243.

ISLAMIC FUNDAMENTALISM HAS EITHER DECLINED OR STAGNATED SINCE THE MID-1980's. THIS IS EVIDENT IN THE DECLINING ELECTORAL STRENGTH OF MANY FUNDAMENTALIST POLITICAL PARTIES, IN THE ABILITY OF THE AUTHORITARIAN NATIONALIST REGIMES TO SUPPRESS FUNDAMENTALIST CHALLENGERS, IN THE DECLINING POPULARITY OF THE ISLAMIC REGIME IN IRAN, IN THE CONTINUING RISE OF MODERNITY IN THE ISLAMIC WORLD, AND IN ATTITUDE SURVEYS OF MUSLIM STUDENTS. THE DECLINE OF ISLAMIC FUNDAMENTALISM IS RELATED TO THREE FACTORS: (1) FUNDAMENTALISH OFFERS A PECULIAR CONCEPTION OF ISLAM THAT IS NOT SHARED BY MOST MUSLIMS; (2) FUNDAMENTALISM'S REJECTION OF CERTAIN ELEMENTS OF MODERNITY IS QUITE UNPOPULAR; ANO (3) AS A SOCIO-POLITICAL ALTERHATIVE, FUNDAMENTALISH IS BOTH 
IMCOMPLETE AND INCOHERENT.

00813 AHMED, D.S

THE CHANGING global geostrategic theatre and the zones of PEACE AND NUCLEAR WEAPON FREE ZONES: A REVIEH

SCANDINAVIAN JOURNAL OF DEVELOPMENT ALTERNATIVES, XI $(2)$ JUN 92$), 61-82$

THE AUTHOR DISCUSSES THE NEED FOR ZONES OF PEACE AND NUCLEAR HEAPON FREE ZONES, PARTICULARLY IN THE THIRD HORLD. HE DIVIDES COUNTRIES INTO THREE CATEGORIES: INTERNATIONALLYRECOGNIZED NUCLEAR POWERS, STATES POSSESSING NUCLEAR CAPABILITY, AND STATES HITHOUT REQUISITE MILITARY OR NUCLEAR TECHNOLOGY. HE ALSO ASSESSES THE POTENTIAL FOR REGIONAL CONFLICTS IN AFRICA, THE MIDOLE EAST, AND ASIA.

00814 AHMED, M; SUMMERS, L.

A TENTH ANNIVERSARY REPORT ON THE DEBT CRISIS

FINANCE AND DEVELOPMENT, 29 (3) (SEP 92 ), 2-5.

THE AUTHORS ENUMERATE SOME OF THE LESSONS OF THE DEBT

CRISIS, INCLUDING THE FOLLOWING: (1) SYSTEMIC THINKING IS

CRUCIAL TO AVOID BAD LENDING DECISIONS; $(2)$ HEAVY BORROWING

THAT IS NOT ACCOMPANIED BY PRODUCTIVE INVESTMENT IS A

THAT IS NOT ACCOMPANIED BY PRODUCTIVE INVESTMENT IS A
DISASTER FOR CREDITOR AND OEBTOR ALIKE: (3) ECONOMIC

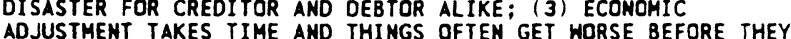

GET BETTER, SO ATTENTION TO THE POLITICAL AND ECONOMIC SUSTAINABILITY OF REFORM IS IN THE INTEREST OF BOTH THE CREDITORS AND DEBTORS. THEY CONCLUDE THAT, WHILE THE DEBT CRISIS MAY NO LONGER BE THE PRINCIPAL PREOCCUPATION OF THE INTERNATIONAL COMMERCIAL BANKS, IT IS FAR FROM OVER FOR
OF THE DEBTOR COUNTRIES, INCLUDING SOME OF THE POOREST.

00815 AHN, B.

THE POSSIBILITIES OF CHANGE IN NORTH KOREA

KOREA \& WORLD AFFAIRS, 16(3) (FAL 92), 421-435.

NORTH KOREA IS MOVING TOWARD CHANGE, OPTING FOR THE CHINESE MODEL OF REFORM AND OPENING TO THE OUTSIDE WORLD, REJECTING BOTH THE SOVIET AND EAST EUROPEAN MODELS. NORTH KDREA IS ON THE DEFENSIVE AGAINST THE REVOLUTIONARY CHANGES
EMERGING IN THE FORMER SOVIET BLOC AND IS TRYING TO FIND ITS OWN WAY OF ORDERLY CHANGE. FACTORS THAT MAY FACILITATE CHANGE IN NORTH KOREA IMCLUDE THE URGENT NEED TO BREAK OUT OF PYONGYANG'S SELF-IMPOSED ISOLATION, THE WIDENING GAP BETHEEN THE MORTH AND THE SOUTH, NORTH KOREA'S ECOMOMIC STAGNATION AND THE GROWING ROLE OF TECHNOCRATS AMD THE PROSPECTS OF A SUCCESSION STRUGGLE AFTER KIM IL SUNG'S DEATH. IN TRYING TO EMULATE THE CHINESE MODEL, NORTH KOREA IS FACING A NUMBER OF DILEMMAS BETWEEN THEORY AND PRACTICE, UNIFICATION AND FOREIGN POLICY, AND SELF-RELIANCE AND UNIFICATION AND FOREIGN POLICY, AND SELF-RELIANCE AND
OPENING. IT IS IN THE INTERESTS OF SOUTH KOREA AND ALL OTHER OPENING. IT IS IN THE INTERESTS OF SOUTH KOREA AND ALL OTHER
CONCERNED PARTIES THAT NORTH AND SOUTH KOREA MOVE TOWARD CONCERNED PARTIES THAT NORTH ANO SOUTH KOREA MOVE TOWARD PEACEFUL COEXISTENC

00816 AHNLID, A.

FREE OR FORCED RIDERS? SMALL STATES IN THE INTERNATIONAL POL ITICAL ECONOMY: THE EXAMPLE OF SWEDEM COOPERATION \& CONFLICT: NORDIC JOURMAL OF INTERNATIONAL POLITICS, 27 (3) (SEP 92), 241-276.

USING CASES FROM SHEDISH TRADE POLICY, THIS PAPER DISCUSSES THE ROLE OF SMALL INDUSTRIAL STATES IN THE INTERNATIONAL POLITICAL ECONOMY, WITH EMPHASIS ON THEIR POLICIES UNDER THE GENERAL AGREEMENT ON TARIFFS AND TRADE. ACCORDING TO DERIVATIONS FROM VARIANTS OF HEGEMONIC STABILITY THEORY, SMALL STATES ARE PREDICTED TO PURSUE MERCANTILIST FREE-RIDER POLICIES--THAT IS, IMPLEMENTING PROTECTION AT HOME HITH IMPUNITY WHILE ENJOYING FREE TRADE ABRDAD. SINCE THE TRADE POLICIES OF SMALL INDUSTRIAL STATES ARE OFTEN VERY OPEN, THIS PREDICTION IS INACCURATE. THE FAILURE OF THE TRADITIONAL THEORIES MAY BE EXPLAINED BY THEIR NEGLECT OF THE COERCIVE NATURE OF INTERMATIONAL LEADERSHIP. UNDER COERCIVE LEADERSHIP SMALL STATES BECOME FORCED RIDERS WHO FIND IT NECESSARY TO GIVE UP THE MERCANTILIST POLICY OPTION. HOWEYER, THE SYSTEMIC OPPORTUNITIES TO FREE RIDE STILL AFFECT THE TRADE POLICIES OF SMALL INDUSTRIAL STATES, EVEN THOUGH MORE INDIRECTLY THAM TRADITIONALLY ASSUMED.

00817 AHONEN, $P$.

DOMESTIC TURMOIL AND OIPLOMATIC ISOLATION: THE LAPUA MOVEMENT AND FINMISH FOREIGN POLICY, 1929-1932

EAST EUROPEAN OUARTERLY, XXVI (4) (WIN 92), 499-523.

IN THEIR EXPLANATIONS OF FINLAND'S INTER-WAR ISOLATION, MOST HISTORIANS HAVE FOCUSED ON EXTERHAL FACTORS. BUT THIS MOST HISTORIANS HAVE FOCUSED ON EXTERHAL FACTORS. BUT
SIMPLISTIC APPROACH MAKES LITTLE SENSE. A CRITICAL SIMPLISTIC APPROACH MAKES LITTLE SENSE. A CRITICAL INTERDEPENDENCE OF INTERMAL AND EXTERNAL AFFAIRS IN SHAPING INTEROEPENDENCE OF INTERMAL AND EXTERMAL AFFAIRS IN THE COUNTRY'S FOREIGN POLICY. THE IMPACT OF DOMESTIC
POLITICS ON FINLAND'S FOREIGM RELATIONS WAS PARTICULARLY POLITICS ON FINLAND'S FOREIGN RELATIONS WAS PARTICULARLY
PRONOUNCED BETHEEN LATE 1929 AND EARLY 1932. HHEN THE RIGHTWING RADICAL LAPUA MOVEMENT PLAYED A PROMINENT ROLE IN FINHISH SOCIETY.

00818 AJAMI, R.; ARCH, G.

TURKEY AND THE EMERGING GLOBAL ECONOMY: PROSPECTS AND
PROMISE

MIDOLE EAST INSIGHT, 8(3) (1991), 39-42

THE PROSPECTS AND PROMISE OF THE TURKISH ECONOMY MUST CONFRONT OUTDATED IMAGES OF THE COUNTRY AND ITS GLOBAL BUSINESS POSSIBILITIES. TURKEY'S NEW REALITY NEEDS A NEW AND PROPER IMAGE. MANY AN OPPORTUNITY WILL BE LOST IF THIS OLD IMAGE PERSITS. TURKEY IS POISED FOR TAKE OFF AND THE WINDOW OF OPPORTUNITY IS NOW. THIS ARTICLE REVIEWS THE HISTORY OF TURKEY; THE 1980S, WHICH WERE A DECADE OF TRANSITION; AND THE TURKISH ADVANTAGE.

00819 AKAKPO, B.

BLAZING A TRAIL

WEST AFRICA, (3890) (APR 92), 583.

IN 1987, DIANE ABBOTT BECAME THE FIRST BLACK WOMAN EVER ELECTED A MEMBER OF THE BRITISH PARLIAMENT. IN 1992, SHE IS RUNNING FOR REELECTION IN HER CONSTITUENCY, HACKNEY' NORTH AND STOKE NEWINGTON, ONE OF THE POOREST BOROUGHS IN GREATER LONDON.

00820 AKARO, P.J.

CORPORATE MOBILIZATION AND POLITICAL POWER: THE

CORPORATE MOBILIZATION AND POLITICAL POWER: THE
TRANSFORMATION OF U.S. ECONOMIC POLICY IN THE 1970's AMERICAN SOCIOLOGICAL REVIEH, 57(5) (OCT 92), 597-615. THE AUTHOR EXAMINES BUSINESS UNITY AND POLITICAL INFLUENCE IN THE CONTEXT OF RECENT U.S. POLICY HISTORY TRACING THE LEGISLATIVE HISTORIES OF THE UNSUCCESSFUL LABOR LAW REFORM AND CONSUMER PROTECTION AGENCY BILLS OF THE 1970 'S ALONG WITH THE SUCCESSFUL ECONOMIC RECOVERY TAX ACT OF 1981, HE FINDS SUPPORT FOR A CLASS-BASED, CORPORATE POWER STRUCTURE PERSPECTIVE. HE ALSO DISCUSSES THE HISTORICAL CONDITIONS FOSTERING THE POLITICAL MOBILIZATION AND INTRACLASS COHESION OF BUSINESS IN THE 1970'S AND THE THEORETICAL IMPLICATIONS OF THE BREAKDOWN OF BUSINESS UNITY AFTER 1981.

00821 AKE, C

DEVALUING DEMOCRACY

JOURNAL OF DEMOCRACY, 3(3) (JUL 92), 32-36.

THIS ARTICLE BRIEFLY CONSIDERS TWO QUESTIONS. THE FIRST IS WHETHER SOCIALISM OR CAPITALISM IS THE MORE PRODUCTIVE ECONOMIC SYSTEM. IT CONCLUDES THAT HISTORY HOULD UNEQUIVOCALLY ANSHER THAT CAPITALISM IS A MORE PRODUCTIVE ECONOMIC SYSTEM. THE SECOND MORE DIFFICULT, OUESTION IS WHETHER CAPITALISM OR SOCIALISM IS THE BETTER SYSTEM POLITICALLY, IN THE SENSE OF BEING MORE CONDUCIVE TO DEMOCRACY. IT ARGUES THAT ATTEMPTS TO ANSWER THIS QUESTIOM DEFOCRACY. IT ARGUES THAT ATTEMPTS TO ANSWER THIS QUESTION OFTEN ONLY COMPOUND CONFUSION. THOSE WHO GRAPPLE WITH THE QUESTION OFTEN SHOW TENDENCIES TO APPROPRIATE DEMOCRAT LEGITIMACY TO HISTORIC "DEMOCRATIC" PRACTICE, AND TO
CONFLATE DEMOCRACY AS SUCH WITH LIBERAL DEMOCRACY. ONCE THIS CONFLATE DEMOCRACY AS SUCH WITH LIBERAL DEMOCRACY. ONCE THIS
CONFLATION IS MADE, THE CORRELATION BETWEEN CAPITALISM AND DEMOCRACY IS EASILY ESTABLISHED, BUT ONLY ON THE BASIS OF AM DEMOCRACY IS EASILY ESTABLISHED, BUT ONLY ON THE BASIS OF AM ASSUMPTION THAT DEVALUES DEMOCRACY TO THE POINT OF
JEOPARDIZING ITS STATUS AS AN EMANCIPATORY PROJECT.

00822 AKHAVI, S.

THE CLERGY'S CONCEPTS OF RULE IN EGYPT AND IRAN ANNALS OF THE AMERICAN ACADEMY OF POLITICAL AND SOCIAL SCIENCE, (524) (NOV 92), 92-102.

IN THE CURRENT CYCLE OF ISLAMIC RESURGENCE, THE QUESTION OF RULE HAS BEEN AT THE CENTER OF CLERICAL DISCOURSE. THIS PAPER DISCUSSES HOW THE EGYPTIAN AND IRANIAN ULAMA SEE THIS ISSUE. WHILE THEY AGREE UPON THE PERCEPTION OF ISLAM AS BOTH RELIGION AND STATE AND UPON THE NEED TO BASE PUBLIC LAH UPON THE SHARI'A, THEY DIFFER ON THE ROLE OF SECULAR RULERS, THE RELEVANCE OF JIHAD, IDENTIFYING APOSTATES, CALLING FOR REBELLION, AUTHORIZING THE ULAMA TO RULE SOCIETY, AND ENDOWING ISLAMIC STATES WITH EXTRAORDINARY POWERS. IN THE FUTURE, THE DEBATE WILL CONTINUE TO FOCUS ON THESE ISSUES AS ISLAMIC GROUPS PRESS THE CASE FOR FULL IMPLEMENTATION OF THE SHARI'A IN ALL AREAS OF LIFE AND IN ALL MUSLIM SOCIETIES.

00823 AKWETEY, E.O.

ENSURING FAIR PLAY

WEST AFRICA, (3913) (SEP 92), 1566-1567

IN GHANA, THERE HAVE BEEN CALLS FOR THE REOPENING OF THE NATIONAL VOTERS' REGISTER. THE ALLIANCE OF DEMOCRATIC FORCES OF GHANA HAS ARGUES THAT THE REOPENING OF THE REGISTER IS NECESSARY BECAUSE IT IS INFLATED AND IMACCURATE AND COULO NOT BE THE BASIS FOR FAIR, DEMOCRATIC ELECTIONS, THE INTERIM NOT BE THE BASIS FOR FAIR, DEMOCRATIC ELECTIONS, "THE INTERIM
NATIONAL ELECTORAL COMHISSION HAS DECLARED THAT "TIME AND NATIONAL ELECTORAL COMISSION HAS DECLARED THAT "TIME AND FINANCIAL

00824 AL-ALLAF, M.

PEACE TALKS WITH ISRAEL: THE SYRIAN PERSPECTIVE MIDOLE EAST INSIGHT, VIII (4) (MAR 92), 20-23.

MOUAFFAK AL-ALLAF, HEAD OF THE SYRIAN DELEGATION TO THE MIDEAST PEACE TALKS, DISCUSSES THE TALKS' PROGRESS AND PROSPECTS FOR SUCCESS. HE EMPHASIZES THE IMPORTANCE OF THE LAND FOR PEACE EQUATION. HE DISCUSSES CONFLICTS OVER VENUE, EXCHANGE OF DOCUMENTS, THE STATUS OF LEBANON, THE MULTILATERAL TALKS, AND THE MATURE OF A COMPREHENSIVE 
SETTLEMENT. HE CONCLUDES THAT UNLESS THE ISRAELIS REALIZE THAT IT IS IN THEIR OHN INTEREST TO RESPOND TO RECENT ARAB PEACE OVERTURES AND THAT IT IS IN THEIR INTEREST TO HAVE A COMPREHENSIVE, JUST SETTLEMENT TO THE ARAB-ISRAELI CRISIS, THERE WILL BE NO REAL PROGRESS IN THE PEACE PROCESS.

\section{AL-ASHTAL, A.}

"EVENTUALLY THERE CAN ONLY BE AN ARAB SOLUTION"

MIDDLE EAST REPORT, 22(2) (MAR 91), 8-10.

ABDALLAH AL-ASHTAL, YEMEN'S AMBASSADOR THE UNITED

NATIONS, SPEAKS OF THE EVENTS OF THE PAST FEW MONTHS WITH

EMPHASIS ON THE GULF CRISIS. HE DISCUSSES THE ROLE OF THE UN

IN THE CRISIS, THE CONFLICT BETHEEN THOSE FOR AND AGAINST

THE USE OF FORCE IN THE REGION, THE U.S. PRESSURE ON ALL

MEMBERS OF THE SECURITY COUNCIL TO VOTE FOR FORCE, YEMEN'S
DECISION TO YOTE AGAINST THE PROPOSAL, AND THE FUTURE OF THE

DECISION TO VOT
MIDEAST REGION.

00826 AL-RASHEED, $M$

POLITICAL MIGRATION AND DOWNWARD SOCIO-ECONOMIC MOBILITY: THE IRAQI COMMUNITY IN LONDON

NEW COMMUNITY, 18(4) (JUL 92), 537-550.

THE AUTHOR FOCUSES ON THE HISTORY OF IRAQI SETTLEMENT IN LONDON AND SHOWS HOW POLITICAL EVENTS IN IRAQ OVER THE PAST FOUR DECADES HAVE SHAPED THE FORMATION OF THIS MIGRANT COMMUNITY. AS POLIITICAL MIGRANTS WHO LEFT HOME UNDER VARIOUS PRESSURES, THE IRAOIS' EXPERIENCE DIFFERS IN MANY WAYS FROM THE CLASSICAL ECONOMIC MIGRATION. THE AUTHOR STUDIES THE RELATIONSHIP BETHEEN POLITICAL MIGRATION AND THE TREND TOWARDS DOWNWARD SOCIO-ECONOMIC MOBILITY, WHICH IS PREVALENT AMONG A SUB-SECTION OF THE MIGRANT COMMUNITY. SHE DRAWS ATTENTION TO THE INTERNAL CONSTRAINTS AND THE OBSTACLES IMPOSED BY THE HOST SOCIETY THAT PERPETUATE THE DECLINE IN THE COMMUMITY'S STANDARD OF LIVING.

00827 ALAM, S.

LANGUAGE AS POLITICAL ARTICULATION: EAST BENGAL IN 1952 JOURNAL OF CONTEMPORARY ASIA, 21(4) (1991), 469-487.

AN ANALYSIS OF THE ROLE PLAYED BY THE 1952 LANGUAGE MOVEMENT IN EAST BENGAL IN THE DEVELOPMENT OF A BENGALI NATIONALIST DISCOURSE IS ANALYZED. THE LANGUAGE MOVEMENT NATIONALIST OISCOURSE IS ANALYZED. THE LANGUAGE MOVEMENT FORGED A CONSCIDUS LINK BETWEEN VARIOUS SUBALTERN SOCIAL GROUPS, ENABLING THEM TO TRANSCEND EXISTING BARRIERS ANO TRANSFORM THEM INTO FORMIDABLE POLITICAL ACTORS. USING THE CONCEPT OF COUNTER HEGEMONIC STRIVING, THIS PAPER ARGUES THAT THE LANGUAGE MOVEMENT WAS A OEFINITE OUTCOME OF YEARS OF COUNTER HEGEMONIC ACTIVITIES OF THE BENGALI SUBALTERNS. ALTHOUGH THE UNIT FORGED BY THE LANGUAGE MOVEMENT WAS SHOR LIVED. IT NONETHELESS, UNDERSCORED THE EXISTENCE OF AN INDIGENOUS POLITICAL CULTURE TO THE SUBALTERNS AND PAVED THE WAY FOR THE HISTORIC EMERGENCE OF A SEPARATE NATION-STATE IN BANGLADESH.

00828 ALAMOUDI, A.; AL-MARAYATI, S.; HOSEIN, I.N.

CAN MUSLIM PARTICIPATION IN THE POLITICAL SYSTEM MAKE A DIFFERENCE? THREE VIEWS

WASHINGTON REPORT ON MIDDLE EAST AFFAIRS, XI(3) (AUG 92), 52-54.

THE AUTHORS DEBATE OVER WHAT ROLE ARAB-AMERICANS SHOULD PLAY IN THE U.S. POLITICAL PROCESS AND HOW THEY CAN INFLUENCE U.S. POLICY TOWARD THE MUSLIM WORLD.

00829 ALAN, $R$.

L.A. AS SEEN FROM EUROPE

NEW LEADER, LXXV(6) (MAY 92), 7.

MAHY IN EUROPE SEE THE LOS ANGELES RIOTS AS AN EYENT AKIN TO THE OISORDERS THAT SHOOK SEVERAL ENGLISH COMMUNITIES IN THE 1980S. HOHEVER, MANY SAW THE L.A. TURMOIL AS SOMETHING MORE SINISTER. THE GROTESOUE INJUSTICE THAT DETONATED IT COULD HAVE BEEN CORRECTED IN THE COURT SYSTEM. THERE WERE A FAR GREATER NUMBER OF DEATHS THAN IN ENGLAND-MAINLY BECAUSE OF THE PLETHORA OF GUNS, BUT ALSO BECAUSE OF SLOPPY CRISIS MANAGEMENT. AND OPINION POLLS SUGGEST THAT THE SLOPPY CRISIS MANAGEMENT. AND OPINION POLLS SUGGEST
OUTBURST EXPRESSED THE ANGER OF A HIGH PROPORTION OF AMERICA'S BLACK CITIZENS.

00830 ALARCON, E.

THE LQS ANGELES REBELLION

POLITICAL AFFAIRS, 71 (4) (JUN 92), 1-5, 24

POL ITICAL AFFAIRS, 71(4) (JUN 92 ) 1 1-5, 24.
THE LOS ANGELES RIOTS OF 1992 HERE TRIGGERED BY A COURT VERDICT WHICH APPARENTLY SANCTIONED POLICE VIOLENCE AGAINST AFRICAN AMERICANS. HOWEVER, THE UNDERLYING CAUSES OF THE AFRICAN AMERICANS. HOWEVER, THE UNDERLYING CAUSES OF THE THIS ARTICLE ARGUES THAT LOS ANGELES HAS A LONG-STANDING THIS ARTICLE ARGUES THAT LOS ANGELES HAS A LONG-STANDING TRADITION OF RACIALLY-MOTIVATED POLICE BRUTALITY. IN ADDITION, THE DECLINE IN THE CITY'S ECONOMIC CONDITIONS-RISING UNEMPLOYMENT AND HOMELESSNESS, AND CLOSING FACTORIES
AND PLANTS--ADDED FUEL TO THE LONG-SIMMERING FIRES IN LOS AND PLANTS--ADDED FUEL TO THE LONG-SIMMERING FIRES IN LOS
ANGELES. THE SOLUTIONS TO THESE UNDERLYING PROBLEMS ARE NOT FOUND IN THE BUSH ADMINISTRATION'S "LAW AND ORDER" AND "FAMILY VALUES" RHETORIC, BUT IN POLICIES AND PROGRAMS DESIGNED TO FOSTER UNITY IN A CITY WHICH IS SHARPLY DIVIDED ALONG ETHNIC AND RACIAL LINES. THE COMMUNIST PARTY (USA) WENT INTO ACTION IMMEDIATELY FOLLONING THE OUTBREAK OF CHAOS ;
IT CALLED FOR INCREASED UNITY AND EMPHASIZED THE IMPORTANCE OF GRASS ROOTS MOVEMENTS AND REFORM.

00831 ALAUDDIN, M.; MENDIS, P.

THE DEBATE ON SIZE AND PRODUCTIVITY IN DEVELOPED AND DEVELOPING COUNTRIES

JOURNAL OF CONTEMPORARY ASIA, 22(1) (1992), 73-81.

THE ISSUE OF WHETHER LARGE FARMS ARE MORE PRODUCTIVE AND EFFICIENT THAN SMALL FARMS HAS IMPORTANT IMPLICATIONS FOR AGRICULTURAL DEVELOPMENT POLICY IN DEVELOPING AND DEVELOPED COUNTRIES. THIS ARTICLE ANALYZES THE KNOWN STUDIES ON LAND SIZE, PROOUCTIVITY, AND ECONOMIC EFFICIENCY IN LABORINTENSIVE DEVELOPING COUNTRIES, PART I CULARLY IN ASIA, AND AMERICA AND AUSTRALIA. IT CONCLUDES THAT THE DEBATE OVER AMERICA AND AUSTRALIA. IT CONCLUDES THAT THE DEBATE OVER
OPTIMUM FARM SIZE IN BOTH DEVELOPED AND DEVELOPING COUNTRIES OPTIMUM FARM SIZE IN BOTH DEVELOPED AND DEVELOPING COUNTRIES IS INCONCLUSIVE. HOWEVER, SOME EVIDENCE SUGGESTS THAT SMALL FARMS ARE MORE PRODUCTIVE AND EFFICIENT BECAUSE SMALL FARM USE FAMILY LABOR WHICH HAS GREATER INCE
THAN DOES WAGE LABOR ON LARGER FARMS.

00832 ALBELDA, R.; MACEWAN, A.

THE STATE OF THE STATES: FISCAL CRISIS IN THE $1990 \mathrm{~S}$ CRITICAL SOCIOLOGY, 18(2) (SUM 91), 3-30.

THE FIRST PURPOSE OF THIS ARTICLE IS TO TELL THE STORY OF THE DEVELOPMENT OF THE FISCAL CRISIS OF THE UNITED STATES AND TO EXAMINE WHY IT HAS TAKEN ON A NEW ECONOMIC AND POLITICAL IMPORTANCE. THEN, ON THE BASIS OF THAT ANALYSIS, THE AUTHORS ARGUE THAT PROGRESSIVE FORCES HAVE AN OPPORTUNITY NOW TO AFFECT BOTH IMMEDIATE RESPONSES TO THE CRISIS AND THE ECONOMIC ROLE OF GOVERNMENT. THE EXAMINATION OF THE U.S. FISCAL CRISIS LEADS TO SOME PROPOSALS FOR A PROGRESSIVE RESPONSE - - A RESPONSE BASED ON PRINCIPLES OF

DEHOCRACY AND EQUALITY.

00833 ALBERBACK, J.; ROCKMAN, B.

DOES GOVERMANCE REALLY MATTER--AND IF SO, HOW?

GOVERNANCE, 5(2) (APR 92), 135-153.

THE CONMECTION BETWEEN POLITICAL PROCESS, PERFORMANCE, AND OUTCOMES IS EXPLORED. THIS ARTICLE LAYS OUT A SET OF KEY ANALYTIC DISTINCTIONS AND THEN LOOKS AT CONCEPTUAL PROBLEMS IN DEFINING GOVERNMENTAL OUTCOMES, PERFORMANCE, AND PROCESS. IN DEFINING GOVERNMENTAL OUTCOMES, PERFORMANCE, AND PROCESS IT GIVES ATTENTION TO THE CRITERIA OF EFFECTIVE GOVERNANCE
AND TO THE COMPLEX RELATIONSHIP OF PERFORMANCE, VALUES, AND AND TO THE COMPLEX RELATIONSHIP OF PERFORMANCE, VALUES, AND GOVERNMENTAL PERFORMANCE BY MANIPULATING MODES OF GOVERNANCE.

00834 ALBRIGHT, D.; HIBBS, M.

BULLETIN OF THE ATOMIC SCIENTISTS, 47(2) (MAR 91), 26-28.

THE AUTHORS ARGUE THAT PRESIDENT GEORGE BUSH EXAGGERATED THE THREAT OF IRAQ'S NUCLEAR WEAPONS POTENTIAL AT THE START OF THE GULF WAR. THEY CONTEND THAT ANOTHER FIVE TO TEN YEARS ARE NEEDED FOR IRAQ TO BE ABLE TO PRODUCE WEAPON-GRADE URANIUM. THE ARTICLE DISCUSSES MEDIA MISREPRESENTATION AND MISINTERPRETATION OF ALLEGED URANIUM MINING AND OTHER NUCLEAR-WEAPON PRODUCING ACTIVITY.

00835 ALBRIGHT, D.; HIBBS, M.

IRAQ ANO THE BOMB: WERE THEY EVEN CLOSE?

BULLETIN OF THE ATOMIC SCIENTISTS, 47(2) (MAR 91), 16-25.

THE AUTHORS ARGUE THAT SADOAM HUSSEIN WAS MANY' YEARS AWAY FROM DEVELOPING USABLE NUCLEAR WEAPONS AT THE TIME OF THE GULF WAR. THE ARTICLE DESCRIBES PROGRAMS THAT THREE GERMAN FIRMS HAD BEEN CONDUCTING FOR IRAQI ENGINEERS WHICH WERE STOPPED AT THE COMMENCEMENT OF THE WAR. IRAQ'S PUBLIC ATTITUDES TOWARD ACOUISITION OF A NUCLEAR BOMB ARE OISCUSSES.

00836 ALBRIGHT, D.; HIBBS, M.

IRAO'S SHOP-TILL-YOU-DROP NUCLEAR PROGRAM

BULLETIN OF THE ATOMIC SCIENTISTS, 48(3) (APR 92), 26-37. HUSSEIN GOT HELP FROM MANY WESTERN COUNTRIES. IAEA INSPECTORS SAY THERE ARE GERMAN FINGERPRINTS ON MUCH OF IRAQ'S NUCLEAR TECHNOLOGY. LIKE THE MANHATTAN PROJECT THAT BUILT THE FIRST ATOMIC BOMBS IN THE UNITED STATES, IRAQ'S PROGRAM SIMULTANEOUSLY PURSUED A NUMBER OF DIFFERENT PROGRAM SIMULTANEQUSLY PURSUED A NUMBER OF DIFFERENT
TECHNICAL AVENUES TO THE BOMB. NOT KNOWING WHICH EFFORTS TECHNICAL AVENUES TO THE BOMB. NOT KNOWING WHICH EFFORTS
WOULD SUCCEED, IRAQ POURED BILLIONS OF DOLLARS INTO ITS WOULD SUCCEED, IRAQ POURED BILLIONS OF DOLLARS INTO ITS
MULTIFACTED QUEST. THE IRAQIS BOUGHT MATERIALS WHENEVER THEY MULTIFACTED QUEST. THE IRAQIS BOUGHT MATERIALS WHENEVER THEY
WERE AVAILABLE, WHETHER OR NOT THEY WERE REAOY TO USE THEM, WERE AVAILABLE, WHETHER OR NOT THEY WERE READY TO USE THEM,
AND WESTERN GOVERNMENTS THAT BACKED IRAO AGAINST IRAN LOOKED AND WESTERN GOVERNMENTS THAT BACKED IRAQ AGAINST IRAN LOOK
THE OTHER WAY WHEN FIRMS SENT DUAL-USE ITEMS TO BAGHDAD. THE OTHER WAY WHEN FIRMS SENT DUAL-USE ITEMS TO BAGHDAD.
THIS ARTICLE CONCLUDES THAT UNLESS THE IAEA AMD THE U.N. THIS ARTICLE CONCLUDES THAT UNLESS THE IAEA AND THE U.N. ROOTS OF IRAQ'S CLANDESTINE NUCLEAR PROGRAM MAY STILL BEAR RRUIT.

00837 ALBRIGHT, D.; HIB8S, M.

NORTH KOREA'S PLUTONIUM PUZZLE

BULLETIN OF THE ATOMIC SCIENTISTS, 48(9) (NOV 92), 36-40.

NORTH KOREA HAS SIGNED AN AGREEMENT DECLARING THAT IT

WILL NOT SEPARATE PLUTONIUM IN A NUCLEAR REPROCESSING PLANT, BUT THE SPENT FUEL FROM ITS NUCLEAR-POWER REACTORS COULD 
EVENTUALLY REQUIRE SEPARATION FOR SAFETY REASONS. IF IT PROCEEDS WITH ITS CURRENT REACTOR-BUILDING PLANS AND FINISHES A REPROCESSING PLANT AT YONGBYON, IT COULD BE SEPARATING MORE THAN 200 KILOGRAMS OF PLUTONIUM ANNUALLY BY THE MID- TO LATE-1990'S. THAT PLUTONIUM COULD SIMPLY ADD TO THE WORLD'S GLUT OF AN ELEMENT THAT NO ONE KNOWS WHAT TO DO WITH, OR IT COULD BE USED TO MAKE NUCLEAR WEAPONS. IN EITHER CASE, VERIFYING THAT NORTH KOREA IS NOT DIVERTING ENOUGH PLUTONIUM TO BUILD WEAPONS COULD BECOME INCREASINGLY DIFFICULT.

00838 ALBRIGHT, D.; HIBBS, M. PAKISTAN'S BOMB: OUT OF THE CLOSET

BULLETIN OF THE ATOMIC SCIENTISTS, 48(6) (JUL 92), 38-43. PAKISTANI FOREIGN SECRETARY SHAHRYAR KHAN ADDMITTED IN 1992 THAT HIS COUNTRY HAD THE COMPONENTS TO ASSEMBLE AT LEAST ONE NUCLEAR BOMB. THIS REVELATION CAME AS NO SURPRISE TO EXPERTS WHO HAVE TRACKED PAKISTAN'S CLANDESTINE PROGRAM. THIS ARTICLE RECOUNTS PAKSITAN'S DEVELOPMENT OF NUCLEAR ARMS FROM THE FIRST ACQUISITION OF URANIUM AND CENTRIFUGES, TO THE DEVELOPMENT OF REPROCESSING FACILITIES; AND THE FIMAL WEAPONIZATION OF NUCLEAR MATERIALS.

00839 ALBRITTON, R.B.

SUPPORT FOR POLITICAL PARTIES IN THAILAND: 1983 AND 1986 PARLIAMENTARY ELECTIONS; ASSOCIATION FOR ASIAN STUDIES 1992 ANNUAL MEETING

ASSOCIATION FOR ASIAN STUDIES, 1992, 152.

THIS PAPER EXAMINES POLITICAL PARTICIPATION AND SUPPORT FOR PARTIES IN THO ELECTIONS, BASED ON ANALYSIS OF DEMOGRAPHIC CHARACTERISTICS AND ELECTION OUTCOMES IN 72 CHANGWAT (THE ENTIRE KINGDOM). FACTOR ANALYSIS OF 18 DEMOGRAPHIC CHARACTERISTICS SHOWS THAT URBAMIZATION, CULTURE, AND EDUCATION ARE IMPORTANT DETERMINANTS OF POLITICAL PARTICIPATION AND PARTY SUPPORT. ANALYSIS SENSITIVE TO REGIONALITY IDENTIFIES SOME PARTIES AS BEING REGIONALLY BASED. A CHARACTERISTIC OF CANDIDATES (INCUMBENCY) ADDS SIGNIFICANTLY TO THE EXPLAHATION OF SUPPORT FOR PARTIES. MORE THAN HALF THE VARIANCE IN THE SUPPORT FOR THE MAJOR PARTIES CAN BE ACCOUNTED FOR BY THIS MODEL. THE ANALYSIS REPLICATES AND EXTENDS AN EARLIER PAPER THAT HAS BASED UPON ANALYSIS OF CHARACTERISTICS OF AMPHURS IN FIVE SOUTHERH CHANGHAT. NOT ONLY ARE THOSE CONCLUSIONS CONFIRMED, BUT THIS MORE EXTENSIYE AMALYSIS ACHIEVES AN EVEN HIGHER LEYEL OF EXPLAMATION AND DEMONSTRATES THAT GENERAL THEORETICAL MODELS ARE USEFUL FOR ANALYZING THAI ELECTION DATA.

00840 ALDEN, E.; SCHURMANN, F.

NEO-NATIONALIST FALLACIES

FOREIGN POLICY, (87) (SUM 92), 105-122.

IN THE 1992 PRESIDENTIAL ELECTION CAMPAIGN SEVERAL CANDIDATES, BOTH LEFTAND RIGHT-WING, HAVE ARGUED FOR "AMERICA FIRST." THEY CALL FOR CUTBACKS IN FOREIGN AID AND INTERVENTION AND A RETURN TO DOMESTIC PRIORITIES. SOME SEE THIS "NEO-NATIONALISM" AS A KEY TO ELECTORAL SUCCESS AND A MOVEMENT VITAL TO THE INTERESTS OF THE UNITED STATES. THIS ARTICLE ARGUES THAT WHILE THE NEW NATIONALISM SPEAKS TO GENUINE ECONOMIC AND SOCIAL PROBLEMS IN THE UNITED STATES, THERE ARE FOUR REASONS WHY NEO-NATIONALISM CANNOT PROVIDE NEH DIRECTION FOR POL ITICIANS OR THE COUNTRY. THE FIRST REASON IS ELECTORAL: NATIONALIST FOREIGN POLICIES HAVE BEEN A CONSISTENT AND CONSPICUOUS FAILURE AT THE POLLS. SECONO BY ABRUPTLY TURNING INHARD, NEO-NATIONALISTS IGNORE THIRD, INTERNATIONAL ISSUES OF GREAT IMPORTANCE TO VOTERS. THIRD, THE NEO-NATIDNALISTS HITCH ON TO THE NAIION-STAIE AND NATIONAL GOVERNMENT WHEN BOTH ARE IN DECLINE. FINALLY, THE YEARS HERE SOMETHING OF AN ABERRATION. THAT THE HORLD WILL RETURN TO THE KIND OF MULTIPOLAR BALANCE OF POWER THAT EXISTED IN 1935.

00841 ALDERMAN, R.K.; CARTER, N.

THE LOGISTICS OF MINISTERIAL RESHUFFLES

PUBLIC ADMINISTRATION (LONDON), 70(4) (WIN 92), 519-534.

MINISTERIAL RESHUFFLES, A FREQUENT OCCURRENCE IN BRITISH GOVERMMENT, ARE COMPLEX EXERCISES REQUIRING CAREFUL HANDLING. PRIME MINISTERS ATTACH GREAT IMPORTANCE TO MAXIMIZING THE POL ITICAL ADVANTAGES TO BE GAINED FROM THEM, AND THIS IS THE CHIEF DETERMINANT OF THE LOGISTICS, HHICH EMPHASIZE SECRECY IN ADVANCE AND SPEED IN EXECUTING THE CHANGES. THESE FEATURES - AS MUCH AS THE FREQUENCY OF MINISTERIAL CHANGES PER SE--MAY DISRUPT THE POL ICY PROCESS AND HAVE SERIDUS PER SE--MAY DISRUPT THE POL ICY PROCESS AND HAVE SERIOUS
IMPLICATIONS FOR MINISTER-CIVIL SERVANT POHER RELATIONS. IMPLICATIONS FOR MINISTER-CIVIL SERVANT POHER RELATIONS.
SUCH PROBLEMS COULD BE ALLEVIATED BY GIVING MINISTERS SUCH PROBLEMS COULD BE ALLEVIATED BY GIVING MINISTERS
ADVANCE NOTICE OF CHANGES OF POST. THE INSTITUTION OF A PROCESS OF MINISTERIAL HANDOVERS WOULD STRENGTHEN THE PROCESS OF MINISTERIAL HANDOVERS
POSITION OF INCOMING MINISTERS.

00842 ALDRED, $M$.

LESSONS OF THE GULF HAR

RUSI JOURNAL, $137(6)$ (DEC 92), 10-14

HITH THE GULF WAR OVER FOR ALMOST TWO YEARS, IT IS

POSSIBLE TO LOOK DISPASSIONATELY AT THE CONFLICT AND TRY AND

DRAW LESSONS FROM IT. MARGARET ALDRED HERE EVALUATES THE
RELATIONSHIP BETWEEN THE MOD AND COMMANDERS IN THE FIELD, THE POL ITICAL IMPERATIVES INYOL VED, COALITION WARFARE, THE ROLE OF MILITARY HEADQUARTERS AND THE MEDIA, CONCLUDING THA ALTHOUGH THE GULF CONFLICT WAS IN MANY WAYS ATYPICAL, IT IS IMPORTANT TO RECOGNIZE BOTH WHAT CAN BE LEARNT FROM IT AND WHEN THIS MAY OR MAY NOT BE APPLICABLE IN THE FUTURE.

00843 ALESAMDRAVICIUS, E.

PRINCIPLE GOALS OF LITHUANIANS, 1863-1918

JOURNAL OF BALTIC STUDIES, 23(3) (FAL 92), 227-239.

THE PURPOSE OF THIS ARTICLE IS TO RAISE ALTERHATIVES TO ESTABLISHED CONCEPTIONS OF THE HISTORY OF THE LITHUANIAN MOVEMENT DURING THE 19TH CENTURY. THIS INTERPRETATION IS JURIDICAL-STATE ASPECTS OF THE LITHUANIAN MOVEMEMT FHICH, IM MANY WAYS, INFLUENCED THE DEVELOPMENT OF POLITICAL THOUGHT AND THE ADVOCACY OF AN INDEPENDENT LITHUANIAN STATE.

00844 ALEXANDER, A.

JAPAN INC. FACES REALITY

FAR EASTERN ECONOMIC REVIEW, 156(19) (MAY 92), 52

THERE HAVE BEEN INCREASING CALLS FOR A NEW BUSINESS

DOCTRINE IN JAPAN. SOME PROPOSE THAT JAPANESE COMPANIES BE LESS AGGRESSIVE IN PROMOTING EFFICIENCY AND IN DRIVING FOR MARKET SHARE, SHOW GREATER CONCERN FOR WORKER WELFARE IN JAPAN AND TURM OVER A LARGER SHARE OF PROFITS TO

STOCKHOLDERS. IN THIS WAY, THE UNLOVED JAPANESE CORPORATION WILL BE MORE AT PEACE WITH THE WORLD AMD WILL GENERATE A LESS HOSTILE REACTION TO ITS ACCOMPLISHMENTS. HOWEVER, SUCH A POLICY IS UNHECESSARY BECAUSE A GRADUAL TRANSFORMATION OF THE JAPANESE ECONOMY IS ALREADY BRINGING ABOUT THESE CHANGES.
FURTHERMORE, SUCH A POL ICY IGNORES THE CHIEF COMPLAINT OF JAPAN'S COMPETITORS: THE CONTINUED BARRIERS TO OUTSIDERS IN THE JAPANESE ECONOMY.

00845 ALEXANDER, A.J.

AN IMPORTANT FUTURE ROLE FOR JAPAN: RESPONSIBILITY FOR AN OPEN INTERNATIONAL TRADING SYSTEM

KOREAN JOURNAL OF DEFENSE ANALYSIS, IV(2) (WIN 92 ), 149-174.

RECENT WORLDWIDE POLITICAL, MILITARY AND ECONOMIC CHANGES ARE ALTERING JAPAN'S POSTHAR STRATEGIC ENVIRONMENT IN A FUMDAMENTAL HAY. HITH THE END OF THE COLD WAR AND SHIFTS IN THE RELATIVE ECONOMIC STRENGTH BETWEEN THE UNITED SHIFTS IN THE RELATIVE ECONOMIC STRENGTH BETWEEN THE UNI
STATES AND JAPAN, THE POSTHAR ALLOCATION OF BURDENS AND RESPONSIBILITIES IN A BROAD RANGE OF INTERNATIONAL ISSUES IS RESPONSIBILITIES IN A BROAD RANGE OF INTERNATIONAL ISSUES IS
UNDER REVIEW. AT THE CENTER OF THE SEARCH FOR GLOBAL ROLES UNDER REVIEW. AT THE CENTER OF THE SEARCH FOR GLOBAL ROLES
IS JAPAN'S APPROACH TO PURSUING OPEN INTERNATIONAL ECONOMIC IS JAPAN'S APPROACH TO PURSUING OPEN INTERNATIONAL ECONOMIC
ACTIVITY. THE VERY SUCCESS OF INDUSTRIAL NATIONS' POSTHAR ACTIVITY. THE VERY SUCCESS OF INDUSTRIAL NATIONS' POSTHAR BCNEFITS TO ADVANCED TRADIMG NATIONS BUT ALSO IMPOSED COSTS BENEFITS TO ADVANCED TRADING NATIONS BUT ALSO IM ON SPECIFIC INDUSTRIES AND REGIONS. AS A RESULT, COUNTER THE NEGATIVE EFFECTS OF ECONOMIC GLOBALISM. NATIONS HAVE ATTEMPTED TO SEIZE THE GENERAL BENEFITS OF AN OPEN TRADING REGIME WHILE TILTING THE BALANCE OF REWARDS IN THEIR FAVOR. AS THE STRUGGLE BETHEEN AN OPEN INTERNATIONAL ECONOMY AND THE RISE OF PROTECTIONISM UNFOLDS, JAPAN'S ACTIONS WILL BE A GUIDE POINTING TO ITS FUTURE BEHAVIOR AND ASSUMPTION OF GLOBAL RESPONSIBILITY IN OTHER AREAS. MOST ANALYSTS AGREE, HOWEVER, THAT AN ACTIVIST LEADERSHIP POSITION BY JAPAN ON THE ISSUE OF A MORE OPEN MULTILATERAL WORLD TRADING SYSTEM REQUIRES POSITIVE STEPS BY THAT COUNTRY TO FURTHER REDUCE ITS OWN ECONOMIC INSULARITY.

00846 ALEXANDER, J.

THE UNSETTLED LAND: THE POLITICS OF LAND DISTRIBUTION IN MATABELELAND, 1980-1990

JOURNAL OF SOUTHERN AFRICAN STUDIES, 17(4) (DEC 91), 581-610

IN THE QUESTION OF LAND REDISTRIBUTION THIS PAPER TAKES INSIZA DISTRICT AS A CASE STUDY TO ILLUSTRATE THE ATYPICAL EXPERIENCE OF THE WESTERN MATABELELAND PROVINCES REGION. IN 1980 AND 1981 A SHORTAGE OF GRAZING LAND AND DEARTH OF ABANDONED RANCHES HAS PRECEIVED LOCALLY. SUBSEQUENTLY, CONFLICT BETHEEN ZAPU AND ZANU-PF LED TO SEVERE MILITARY AND POLITICAL REPRESSION. COMMUNAL AREA CATTLE OWNERS, UNDER SEVERE PRESSURE FROM DROUGHT, USED ENCROACHMENT TACTICS TO GAIN ACCESS TO NEIGHBORING RANCH LAND. PARTY POLITICAL UNITY IN 1987 RENEWED DEBATE BUT PATRONAGE POLITICS AND ILLEGAL IN 1987 RENEHED DEBATE BUT PATRONAGE POLITICS AND ILLEGAL
ENCROACHMENT ARE LIKELY TO REMAIN THE DOMINANT MEANS OF ENCROACHMENT ARE LIKELY TO R
ACHIEVING ACCESS TO LAND.

00847 ALEXANDER, $M$.

DID THE DEUXIEME BUREAU HORK? THE ROLE OF INTELLIGENCE IN FRENCH DEFENSE POLICY AND STRATEGY, 1919-1939 INTELLIGENCE AND NATIONAL SECURITY, 6(2) (APR 91), 293-333. THIS STUDY DISCUSSES THE DIFFICULTIES OF DETERMINING THE CONTRIBUTIONS MADE BY INTELLIGENCE TO FRENCH DEFENSE CHOICES BETWEEN THE TWO WORLD WARS. THE FOCUS WILL NOT BE ON JUST THE FAMILIAR FIVE OR SIX YEARS FROM HITLER'S SEIZURE OF POWER UNTIL THE FALL OF FRANCE, BUT ON THE INTER-HAR DECADES IN GENERAL. BY MEANS OF THIS LONGER CHRONOLOGICAL 
CONTEXTUALIZED MORE SATISFACTORILY THAN IF ONLY THE CRISISRIDOEN LATER 1930S ARE STUDIED.

00848 ALEXANDER, $M$. 1992 AND ALL THAT TRADE

WEST AFRICA, (3902) (JUN 92), 1091.

THIRD WORLD LEADERS ARE WORRIED ABOUT THE IMPACT ON THEIR STRUGGLING ECONOMIES WHEN THE SINGLE EUROPEAN MARKET BEGINS TO OPERATE AT THE END OF 1992.

00849 ALEXANDER, Y. (ED.); PLUCHINSKY, D.A. (ED.)

EUROPEAN TERRORISM: TODAY AND TOMORROH

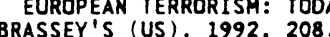

SINCE THE 1970's, EUROPE HAS BEEN ONE OF THE REGIONS MOST PLAGUED BY TERRORISH. IRONICALLY, THE POSITIVE

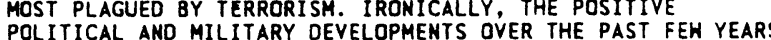
POL ITICAL AND MILITARY DEVELOPMENTS OVER THE PAST FEN YEARS HAVE NOT OIMINISHED THE THREAT OF TERRORISM IN EUROPE. IN LARGE PART, THE ROOTS OF REGIONAL CONFLICTS AND EXTERNAL PROBLEMS THAT GENERATE TERRORISM REMAIN INTACT. MOREOVER, NEW THREATS ARE BEING CREATED BY THE FORCES OF NATIONALISM AND ETHNICITY UNLEASHED BY THE COLLAPSE OF THE SOVIET BLOC. EUROPEAN UNIFICATION HAS THE POTENTIAL TO PRODUCE EITHER
SECURITY VULNERABILITIES OR OPPORTUNITIES FOR INCREASED COUNTER-TERRORIST COOPERATION

00850 ALEXANDROVA, 0.

GEOSTRATEGIC RECONSTRUCTURING IN THE FORMER USSR

AUSSEN POLITIK, 43(4) (1992), 324-333.

THE DISINTEGRATION OF THE SOVIET UNION IS AN EPOCHMAKING EVENT. THE INITIATED RESTRUCTURING OF THE POLITICAL AND STATE STRUCTURES ON THE TERRITORY OF THE FORMER USSR IS OF PARAMOUNT IMPORTANCE AND WILL HAVE REGIONAL AND GLOBAL IMPLICATIONS. OLGA ALEXANDROVA MAKES AN INTERIM ASSESSMEN AND OUTLINES PERSPECTIVES FOR FUTURE DEVELOPMENTS. SHE EXPLORES THE EMERGENCE OF BELORUSSIA, MOLDOVA AND THE UKRANE WHICH HAS CHAMGED THE ENTIRE SYSTEM OF THE EUROPEAH RELATIONS, AND SUGGESTS THAT THE HEST CAN HELP THE NEH

STATES THROUGH A POLICY OF CAUTIOUS AND BALANCED INFLUENCE.

00851 ALEXEEY, M.; GADOY, C. ; LEITZEL, J.

GETTING THE PICTURE RIGHT: SOVIET COLLAPSE, TRANSITION TROUBLES, AND WESTERN AID

BROOKIMGS REYIEW, 10(1) (WIN 92) 14-17

THE AUTHORS ENDEAVOR TO PROVIDE AN ACCURATE PICTURE OF

THE POST-SOVIET ECONOMY IN RUSSIA AHD THE OTHER FORMER SOVIET REPUBLICS.

00852 ALEXEEY, M.

SAVING BEHAVIOR AND SOVIET REFORM

CONTEMPORARY POLICY ISSUES, X(3) (JUL 92), 39-48.

THE AUTHOR ARGUES AGAINST USING THE FORCED SAVINGS

CONCEPT TO EXPLAIN THE SAVING BEHAVIOR OF SOVIET CONSUMERS.

HE DISCUSSES REASONS FOR CONSUMERS IN A TRADITIONAL SOVIET

ECONOMY TO SAVE LESS THAN THEIR COUNTERPARTS IN MARKET

ECONOMIES AT SIMILAR ECONOMIC DEVELOPMENT STAGES. THESE

REASONS INCLUDE LOW VARIABILITY OF LIFE-CYCLE INCOME, LARGE STATE SUBSIDIES FOR MAJOR CONSUMPTION ITEMS, THE ABILITY OF RETIREES TO COMPENSATE FOR LOW MONEY INCOME BY ACOUIRING GOODS AT STATE-CONTROLLED PRICES, AND A LIMITED CHOICE OF FINANCIAL INSTRUMENTS. WHEN TRANSITION TO A MARKET ECONOMY OCCURS OR IS EXPECTED TO OCCUR, CONSUMERS TEND TO INCREASE THEIR SAVINGS. THE WAY TO DEAL HITH THE SOVIET SYSTEM'S INEFFICIENCIES IS TO LIBERALIZE CURRENTLY CONTROLLED PRICES AND TO IMPLEMENT OTHER MARKET REFORMS, WHICH WOULD RESULT IN LIFTING RESTRICTIONS ON EXISTING MARKET FORCES. MARKET REFORMS, IN TURN, WOULD HELP ACHIEVE FINANCIAL STABILITY. RATHER THE EXCESSIVE ROLE OF THE STATE.

00853 ALFORD, J.R.; HIBBING, J.R.

THE 1990 CONGRESSIONAL ELECTION RESULTS AND THE FALLACY THAT THEY EMBODIED AN ANT I INCUMBENT MOOD

PS: POL ITICAL SCIENCE AMD POLITICS, XXV(2) (JUN 92),

217-219.

THE AUTHORS DISPUTE THE COMMON VIEH THAT THE NOVEMBER 1990 ELECTIONS WERE DOMINATED BY AN ANTI-INCUMBENT SENTIMENT 1990 ELECTIONS WERE DOMINATED BY AN ANTI-INCU

00854 ALgANARAZ, J.; SAMPER, D.

A CRISIS OF FAITH THREATEMS DEMOCRACY

A CRISIS OF FAITH THREATENS DEMOCRACY 16

THE KEY TO PERMANENT DEMOCRATIZATION IN LATIN AMERICA

CAY BE SUMMED UP IN A FEH WORDS: POL ITICAL MODERMIZATION,

CAN BE SUMMED UP IN A FEN WORDS: POLITICAL MODERMIZATION,

ELIMINATION OF CORRUPTION, CIVILIAN CONTROL OF THE ARMED

FORCES, AND A FAIR DISTRIBUTION OF THE BENEFITS OF NEO-

LIBERAL ECONOMIC POLICIES THAT FAVOR THE FREE MARKET. IF

AND CREATE JUSTICE, IT WILL BE OPENING THE WAY FOR ITS ENEMIES.

00855 ALI, M.M.

AFGHANISTAN IN TRANSITION

WASHINGTON REPORT ON MIDOLE EAST AFFAIRS, XI(1) (JUN 92), 45,85
THE AUTHOR REPORTS ON RECENT EVENTS IN AFGHANISTAN AND THE PROPOSED SCHEDULE FOR ELECTIONS, WHICH WILL BE MONITORED BY THE UNITED NATIONS.

00856 ALI, S.

AID OUT TRADE IN

FAR EASTERN ECONOMIC REVIEW, 151(24) (JUN 91), 19-20.

PAKISTAN HAS BEGUN REORIENTING ITS FOREIGM POLICY TO INCREASE EMPHASIS ON ECONOMIC RELATIONS IN AN EFFORT TO OFFSET A REDUCTION IN WESTERN FINANCIAL AID. IN ADDITION, THE NEN POLICY IS SEEN AS HELPING TO CONTAIN SUCH POLITICAL ISSUES AS PAKISTAN'S ROLE IN THE AFGHAN CIVIL HAR AND ITS NUCLEAR WEAPONS. PAKISTAN HAS INCREASED IS EMPHASIS ON TRADE RUCLEAR WEAPONS. PAXISTAN HAS INCREASED IS EMPHASIS ON TRADE THE ENTIRE ASIA-PACIFIC REGION. THERE HAS ALSO BEEN A RENEHED EMPHASIS ON REGIONAL ORGANIZATIONS INCLUDING THE ECONOMIC CDOPERATION ORGANIZATION (PAKISTAN, IRAN, AND ECONOMIC CDOPERATION ORGANIZATION (PAKISTAN, IRAN, AND TURKEY), AND THE SOUTH ASIAN ASSOCIATION FOR REGIONAL COCPERAIION. THE NEW POLICY SEEMS TO STEM FROM THO PRIMARY FACTORS: THE FAST DETERIORATING FOREIGN-AID CLIMATE, AND THE EMPHASIS PLACED BY PRIME MINISTER NAHAZ SHARIF ON GRADUALLY PHASING OUT FOREIGN LOANS

00857 ALI, S.

BARGAINING CHIP

FAR EASTERN ECONOMIC REVIEW, 151(16) (APR 91), 21.

THE FALL OF THE KHOST GARRISON TO AFGHANISTAN'S REBEL

MUJAHIDEEN FORCES AFTER MORE THAN A DECADE OF ON-OFF SIEGES IN AN IMPORTANT PSYCHOLOGICAL BLOW TO THE REGIME OF AFGHAN PRESIDENT NAJIBULLLAH, WHO, CONTRARY TO ALL PREDICTIONS, HAS SHOWM NO SIGN OF GIVING UP THE FIGHT IN THE HAKE OF THE SOVIET MILITARY PULLOUT IN EARLY 1989. REGARDLESS OF KABUL'S VOW TO RECAPTURE KHOST, SOME OBSERVERS CONTEND THAT THE FALL OF THE GARRISON WILL ENCOURAGE OTHER GUERRILLA GROUPS TO STEP UP THEIR OPERATIONS AND THEREBY PAVE THE WAY FOR A MILITARY SOLUTION. BUT GIVEN THE MUJAHIDEEN TRACK RECORD SINCE THE SOVIET PULLOUT, OTHER OBSERVERS SEE KHOST NOT A S THE START OF A MIULYY BREAKTHROUGH BUT THE GAINING OF AN ADVANTAGEOUS NEGOTIATING POSITION IN A POLITICAL SETTLEMENT AITH KABUL.

00858 ALI, S.

CITY UNDER SIEGE

FAR EASTERN ECONOMIC REVIEN, 155(48) (DEC 92), 17-18.

MASSIVE CAMPAIGN OF POL ITICAL AGITATION MOUNTED BY PAKISTANI OPPOSITION LEADER BENAZIR BHUTTO, COMBINED WITH THE GOYERMMENT'S OWH RUTHLESSNESS IN SUPPRESSING

DEMONSTRATIONS, HAS LEFT PRIME MINISTER NAHAZ SHARIF FACING HIS HORST CRISIS SINCE TAKING OFFICE TWO YEARS AGO. AT STAKE IS NOT ONLY THE FUTURE OF THE SHARIF GOVERNMENT, BUT THE FUTURE OF PAKISTAN'S NASCENT DEMOCRATIC ORDER. HHILE THE COUNTRY'S POWERFUL MILITARY HAS SO FAR STOOD ASIDE FROM THE CRISIS, ANALYSTS SPECULATE THE ARMY COULO BE FORCED TO INTERVENE IF SHARIF FAILS TO COME UP WITH A WAY OF DEFUSING OPPOSITION DEMANDS FOR FRESH ELECTIONS AND THE RELEASE OF POL ITICAL PRI SONERS. THE LATEST CLASH BETHEEN SHARIF AND BHUTTO TOOK PLACE WHEN GOVERNMENT FORCES BLOCKED A PLANNED MARCH TO THE CAPITAL.

00859 ALI, S.

KHYBER BYPASS

FAR EASTERN ECONOMIC REVIEN, 151(23) (JUN 91), 44.

A DISPUTE BETWEEN AFGHAN GUERRILLA GROUPS ABOUT HOW TO SHARE PAYOFFS FROM LOCAL TRIBESMEN IS BELIEVED TO HAVE BEEN RESPONSIBLE FOR A SHARP CUT SINCE 21 MAY IN THE ESTIMATED US \$100 MILLION ANNUAL TRADE IN GOODS BEING SMUGGLED FROM AFGHANISTAN TO PAKISTAN. A MEETING OF 14 AFGHAN GUERRILLA COMMANDERS IN MID-MAY DECIDED TO SHUT DOWN THE BUSIEST SHUGGLING ROUTE FROM KABUL TO TORKHAM WHICH PASSES THROUGH GUERRILLA TERRITORY. SOME ARGUE THAT THE SHUTDOWN PRESAGES A FRESH GUERRILLA OFFENSIVE NEAR JALALABAD. OTHERS ARGUE THAT THE GUERRILLAS SIMPLY ARE REASSERTING CONTROL OVER THE LUCRATIVE SMUGGLING OPERATIONS. WHATEVER THE REASON FOR THE CLOSURE, IT CANMOT LAST FOR TOD LONG BECAUSE THE GUERRILLAS NEED THE REVENUE TO FUND THEIR OWN ACTIVITIES.

00860 ALI, S.

RACE AGAINST TIME

FAR EASTERH ECONOMIC REVIEW, 155(16) (APR 92), 12-13.

EFFORTS TO END THE AFGHAH CIVIL HAR ARE NOW AT A CRUCIAL STAGE FOLLOWING AGREEMENT, BY A MAJORITY OF INTERESTED PARTIES, FOR A UN-SPONSORED 15-MEMBER COUNCIL OF NEUTRAL AFGHANS TO TAKE OVER FROM THE KABUL REGIME, POSSIBLY BY THE END OF APRIL. BUT THE PROSPECT OF PEACE, AT LEAST ON PAPER, HAS NOT PUT A STOP TO FIGHTING AS MUJAHIDEEN GUERRILLAS HAS NOT PUT A STOP TWO MORE CITIES TO THE NORTH OF KABUL. THE MUJAHIDEEN OFFENSIVE IS A CLEAR BID TO TAKE THE LEAD IN THE RACE AGAINST TIME AS A PEACE SETTLEMENT NEARS. THE SAME IMPATIENCE IS EVIDENT ON THE DIPLOMATIC FRONT.

00861 ALI, S.; RASHID, A.

SEPARATE WAYS 
FAR EASTERN ECONOMIC REVIEN, 155(38) (SEP 92), 18, 20. THE DISINTEGRATION OF AFGHANISTAN THAT MANY EXPERTS FEARED WOULD FOLLOW THE FALL OF THE NAJIBULLAH REGIME IN APRIL HAS MOVED A STAGE CLOSER AS A RESULT OF ACTIONS BY THE MUJAHIDEEN FACTIONS AND THEIR SUPPORTERS OUTSIDE THE COUNTRY. THE GROWING RIFT IS EVIDENT ON BOTH THE DIPLOMATIC AND MILITARY FRONTS. WHILE THE MAJOR MUJAHIDEEN LEADERS SECRETLY EXPLORE OPTIONS FOR A POSSIBLE PARTITION OF THE COUNTRY ALONG ETHNIC LINES, THEIR GUERRILLAS HAVE CLASHED REPEATEDLY IN ATTEMPTS TO CONSOLIDATE CONTROL OVER TERRITORY AS A PRELUDE TO POSSIBLE PARTITION. AFGHANISTAN IS NOW RULED BY MUTUALLY ANTAGONISTIC ARMED GROUPS IN THREE DISTINCT REGIONS PASHTUNS IN THE EASTERN AND SOUTHERN AREAS ADJACENT TO PAKISTAN: PERSIAN-SPEAKING HAZARAS OF THE SHIA FAITH IN THE CENTRAL REGION EXTENDING WESTWARD UP TO THE IRANIAN BORDER: AND AN UNEASY ALLIANCE OF TAJIKS AND UZBEKS IN THE NORTHERN REGION BETWEEN KABUL AND THE BORDERS OF THE CENTRAL ASIAN REPUBLICS. TURKOMAN, KYRGHYZ AND OTHER NATIONALITIES, WHOSE BASIC LANGUAGE IS PERSIAN, ARE ALSO PRESENT LARGELY IN THE MORTH. NEARBY STATES INCLUDING PAKISTAN, IRAN, SAUDI ARABIA AND THE CENTRAL ASIAN REPUBLICS ARE ALL BACKING DIFFERENT GROUPS FOR DIFFERING REASONS. THE PROSPECT OF A PEACEFUL RESOLUTION OF THE CONFLICT IS POOR.
REST

00862 ALI, S

STATE AND RELIGION

FAR EASTERN ECONOMIC REVIEW, 155(6) (FEB 92), 18-19.

A RECENT LAHORE HIGH COURT OECISION UPHOLDING THE SUPREMACY OF ISLAMIC LAWS OYER THOSE OF THE COUNTRY'S CONSTITUTION HAS PUT PAKISTAN IN A BIND. THE DECISION HAS FAR-REACHING IMPLICATIONS FOR DOMESTIC POLITICS AS WELL AS DIPLOHATIC AND ECONOMIC RELATIONS WITH OTHER COUNTRIES. ISLAMABAD IS ALREADY BEGINNING TD FEEL EXTERNAL PRESSURE TO REIN IN THE IMPACT OF ISLAMIC ASPIRATIONS ON THE AFFAIRS OF STATE SO THAT PAKISTAN CAN COMFORTABLY DEAL WITH NATIONS OF OIFFERENT LEGAL AND NON-REL IGIOUS CONSTITUT IONAL SYSTEMS. JURISTS SAY THAT THE HIGH COURT'S JUDGMENT HAS IMPLICITLY STRUCK DOWN MANY ARTICLES OF THE CONSTITUTION.

00863 ALI, S

THE FACADE CRACKS

FAR EASTERN ECONOMIC REVIEN, 155(28) (JUL 92), 12.

FIVE WEEKS AFTER THE START OF A MASSIVE CRACKDOWH BY THE ARMY ON ALLEGED CRIMINAL ELEMENTS IN SIND PROVINCE, TENSIONS BETWEEN THE ARMY AND PAKISTAN'S RULING ISLAMIC DEMOCRATIC ALLIANCE (IDA) HAVE REACHED A POINT WHERE THE GOVERMMENT'S ALLIANCE (IDA) HAVE REACHED A POINT WHERE THE GOVERMMENT'S
FUTURE SEEMS TO BE IN DANGER. COOPERATION BETHEEN THE RUL ING TROIKA CONSISTING OF THE ARMY, PRESIDENT GHULAM ISHAQ KHAN AND PRIME MINISTER NAHAZ SHARIF HAS CONSIDERABLY DIMINISHED. AND PRIME MINISTER NAHAZ SHARIF HAS CONSIDERABLY DIMINISHED.
UNLIKE A PREVIOUS CONFLICT WHEN THE ARMY AND THE PRESIDENT UNL IKE A PREVIOUS CONFLICT WHEN THE ARMY AND THE PRESIDENT
WERE PITTED AGAINST THE PRIME MINISTER, THE ARMY IS NOH IN WERE PITTED AGAINST THE PRIME MINISTER, THE ARMY IS NOH IM
DISAGREEMENT WITH THE BOTH THE OTHER TWO TROIKA MEMBERS. THIS COULD MEAN THAT THE COUNTRY IS FACED WITH A MUCH GRAYER THIS COULD MEAN THAT THE COUNTRY IS FACED WITH A MUCH GRAVER
CRISIS THAN THE 1990 UPHEAVAL WHICH LED TO THE SACKING OF THE PAKISTAN PEOPLE'S PARTY (PPP) GOVERNMENT UNDER BENAZIR BHUTTO AND THE EMERGENCE OF THE CURRENT LEADERSHIP.

00864 ALI, $S$.

THE HONEST BROKER

FAR EASTERN ECONOMIC REVIEW, 151(14) (APR 91), 16

PAKISTAN'S PRIME MINISTER NAWAZ SHARIF HAS PULLE DOFF A REMARKABLE COUP IN HAMMERING OUT A POLITICAL SOLUTION TO AM OLD AND INTRACTABLE NATIONAL PROBLEM. HE HAS PREVAILED UPOM THE COUNTRY'S FOUR SQUABBLING PROVINCES--THE DISPUTE IS AT LEAST SEVENTY YEARS OLD--TO AGREE ON SHARING THE WATERS OF THE INDUS RIVER. THE WATER ACCORD HAS CLEARED THE WAY FOR RESOLVING OTHER INTER-PROVINCIAL DISPUTES, SUCH AS ROYALTY FOR NATURAL GAS AND POWER GENERATION AND THE PROVINCIAL SHARES IN FEDERAL TAXES.

00865 ALI, S.

THE' MEN AND THEIR TRIBES

FAR EASTERN ECONOMIC REVIEH, 156 (18) (MAY 92), 10-11.

THE AFGHAN CONFLICT HAS, SINCE THE LATE 1970S, SPAWMED MANY ETHNIC, POLITICAL AND RELIGIOUS GROUPS THAT FOUGHT THE SOVIETS AND LATER THE KABUL REGIME. NOW THEY ARE PITTED AGAINST EACH OTHER EITHER SINGLY OR IN NEW ALLIANCES. OF THE ESTIMATED 15 MILLION AFGHAN POPULATION IN THE LATE 1970S, MORE THAN A THIRD FLED ABROAD, MOSTLY TO PAKISTAN AND IRAK. THE NORTH AND WEST OF THE COUNTRY IS HOME TO TAJIK, UZBEK AND TURKOMAN GROUPS. CENTRAL AFGHANISTAN IS PEOPLED BY THE HAZARAS. IN THE EAST AND THE SOUTH LIVE THE DOMINANT PASHTUN TRIBES HHICH SPEAK PUSHTO. MOST OTHER TRIBES SPEAK DIALECTS TRIBES WHICH SPEAK PUSHTO. MOST OTHER TRIBES SPEAK DIALECTS OF PERSIAN. HAZARAS AND SOME OTHERS ARE SHIA MUSLIMS. THE
OTHER AFGHANS ARE SUMNI. IN ADOITION TO MANY GUERRILLA GROUPS WHICH DID NOT ACKNOWLEDGE ANY AUTHORITY BEYOND THEIR GROUPS WHICH DID NOT ACKNOWLEDGE ANY AUTHORITY BEYOND THE SMALL TERRITORIAL PATCHES, THERE ARE 16 RELATIVELY LARGE GROUPS OF MUJAHIDEEN. NINE OF THESE HAVE BEEN BASED IN IRAM,
WHICH FORGED THEM INTO AN UMBRELLA BODY CALLED THE HIZBE WAHADAT. THE OTHER SEVEN, PAKISTAMI-BASED SUNMI GROUPS, WERE ROUGHLY DIVIDED INTO THO CAMPS: THREE MODERATE ONES WHICH FAVORED THE RESTORATION OF MONARCHY AND WERE CONSIDERED PROHEST, AND FOUR HARDLINERS LABELLED FUNDAMENTALIST BY THE MEDI $i$.
00866 ALI, S

THREE'S A CROWD

FAR EASTERN ECONOMIC REVIEW, 151(23) (JUN 91), 20

THE TRIANGULAR RELATIONSHIP THAT LINKS THE OFFICES OF PRIME MINISTER AND PRESIDENT WITH THE MILITARY AND REPRESENTS THE BASIS OF POLITICAL POWER IN PAKISTAN IS NOW UNDER STRAIN FROM A VARIETY OF SOURCES. TURMOIL AMONG THE RULING TROIKA-CPRIME MINISTER NAHAZ SHARIF, ARMY CHIEF MIRZA ASLAM BEG AND PRESIDENT GHULAM ISHAO KHAN--IS BRENING JUST AS SHARIF IS CLAIMING TO BE HEADING FOR THE APEX OF DOMESTIC AND OVERSEAS APPROVAL. DISAGREEMENT AMONG THE TROIKA OVER HOW TO DEAL WITH THE PARL IAMENTARY OPPOSITION (NOTABLY THE PAKISTAN PEOPLE'S PARTY) AND HOH TO END THE NEAR NANARCHY IM THE SINDH PROVINCE ARE AT THE TOP OF THE ISSUES THAT DIVIDE IT. CALLS FOR A RETURN TO MILITARY RULE ARE INCREASING AS LAW AND ORDER THROUGHOUT PAKISTAN DECLINES.

00867 ALIBONI, R.

ITALIAN SECURITY POLICY IN A CHANGING INTERNATIONAL

JERUSALEM JOURNAL OF INTERMATIONAL RELATIONS, 14(2) (JUN 92 ) 90-101.

THIS ARTICLE DISCUSSES ITALY'S GROWING ACTIVITIES IN THE FIELD OF SECURITY AND DEFENSE POLICY AND ITS NEH INITIATIVES TOHARD EASTERN EUROPE AND THE MEDITERRANEAN. IT ARGUES THAT THIS INCREASED DYNAMISM REMAINS FIRMLY BOUND TO THE FRAMEWORK OF ATLANTIC AND EUROPEAN ALLIANCES.

00868 ALIOTTA, J.M.

THE UNFINISHED FEMINIST AGENDA: THE SHIFTING FORUM AMNALS OF THE AMERICAN ACADEMY OF POLITICAL AND SOCIAL SCIENCE, (515) (MAY 91), 140-150.

FROM 1960 TO 1980 , THE LEGAL STATUS OF AMERICAN WOMEN CHANGED DRAMATICALLY. FEDERAL POL ICY SHIFTED FROM REINFORCING SDCIAL AND ECONOMIC DISCRIMINATION TO PROVIDING REMEDIES FOR THOSE WHO EXPERIENCED DISCRIMINATION. HHILE CONGRESS HAS ACTIVE IN INITIATING MANY OF THESE CHANGES, MUCH OF THE CREDIT FOR THEIR IMPLEMENTATION MUST GO TO THE FEDERAL COURTS, ESPECIALLY THE U.S. SUPREME COURT. THEN, IN THE 1980'S, THE FEDERAL COURTS, INCLUDING THE SUPREME COURT, BECAME LESS RECEPTIVE TO THE FEMINIST AGENDA. THIS SITUATION HAS FORCED WOMEN'S GROUPS TO APPEAL TO CONGRESS AND STATE LEGISLATURES TO REVERSE OR LIMIT THE DAMAGE CREATED BY LEGISLATURES TO REVERSE OR LIMIT THE OAMAGE CREATED BY
UNFAVORABLE COURT DECISIONS. THE CASE HISTORIES OF LEGALIZED
ABORTION AND OF TITLE IX OF THE 1972 EDUCATION AMENDMENTS

ABORTION AND OF TITLE IX OF THE
ILLUSTRATE THIS SHIFT IN FORUM.

00869 ALKER, JR. H

THE HUMANI'́STIC MOVEMENT IN INTERMATIONAL STUDIES:

REFLECTIONS ON MACHIAVELLI AND LAS CASAS

INTERNATIONAL STUDIES QUARTERLY, 36(4) (DEC 92), 347-372.

THIS REVIEW SEEKS TO RECOVER THE HUMANIST IDEALS AND APPRACHES WHICH SOMETIMES GET LOST IN OUR MODERN STRIVINGS FOR SCIENTIFIC RIGOR. NICCOLO MACHIAVELLI HUMANISTICALLY ARGUED FROM CONTRASTING PRACTICAL/MORMATIVE/ONTOLOGICAL POSITIONS. THE CIVICALLY HUMANISTIC MACHIAVELLIAN MOVEMENT STILL FINDS CONTEMPORARY EXPRESSION. THE ARTICLE SUGGESTS WE NEED MORE FULLY TO RECOGNIZE AND DEVELOP THE CONTRIBUTIONS OF THE HUMANITIES TO OUR INTERDISCIPLINE OF INTERNATIONAL STUDIES IN ORDER TO BETTER UNDERSTAMD MODERNITY'S SUCCESSES AND EXCESSES, AMELIORATE ITS RECURRING FAILURES, AND ANTICIPATE SUBSEQUENT ERAS OF HUMAN HISTORY.

00870 ALLAN, P.; LUTERBACHER, U.

FEWER GUNS AMD CHEAPER BUTTER: ANALYZING THE IMPACT OF DISARMAMENT AND AGRICULTURAL FREE TRADE PRESSURES ON SWITZERLAND WITH A POL ITICO-ECONOMIC MODEL

INTERNATIONAL POLITICAL SCIENCE REVIEH, 13(2) (APR 92), 123-148.

THE CLASSICAL GUNS VS. BUTTER TRADE-OFF IS CHANGING. THE QUESTION IS ASKED: WHAT ARE THE CONSEQUENCES OF A

LIBERALIZATION OF SWISS AGRICULTURE COUPLED WITH DISARMAMENT MEASURES? THIS PAPER ADDRESSES THESE ISSUES WITH THE HELP OF AN EMPIRICAL POLITICO-ECDNOMIC MODEL. THE OVERALL CONSEQUENCES ARE POSITIVE FOR SHITZERLAND AS A HOLE: THE ECONOMY WOULD BE SIGNIFICANTLY STIMULATED, AND THESE MAJOR POLICY CHANGES APPEAR POLITICALLY BEARABLE. CONSUMERS WOULD BENEFIT MOST FROM THE DIRECT AND INDIRECT EFFECTS OF THESE BENEFIT MOST FROM THE DIRECT AND INDIRECT EFFECTS OF THESE
POLICIES. THE AUTHORS POSTUALTE THAT THE GOVERMMENT MAKES POLICIES. THE AUTHORS POSTUALTE THAT THE GOVERMMENT MAKT
LARGE TRANFER PAYMENTS TO MINIMIZE DISCONTENT. THESE LARGE TRANFER PAYMENTS TO MINIMIZE DISCONTENT. THESE PAYMENTS CAN BE READIIY MADE, GIVEN THE AGRIC
LIBERALIZATION POLICIES AND A PEACE DIVIDEND.

00871 ALLEN, B.

THE SPIRAL OF SILENCE AND INSTITUTIONAL DESIGN:

TOCQUEVILLE'S ANALYSIS OF PUBLIC OPINION ANO DEMOCRACY POLITY, XXIV(2) (WIN 91), 242-267.

THIS ARTICLE EXAMINES THE "SPIRAL OF SILENCE" IN PUBLIC OPINION. DERIVED BY ELISABETH NOELLE-NEUMANN FROM THE WORK OF TOCQUEYILLE AND OTHERS, THIS THESIS OFFERS AN EXPLANATION OF CHANGE IN GLOBAL PUBLIC OPINION. THE AUTHOR CRITIQUES THE NOELLE-MEUMANN VIEW AND FINDS THAT, WHILE TOCQUEVILLE ADYANCES A SIMILAR HYPOTHESIS, UNLIKE MOELLE-NEUMAKN, HE 
TIES HIS ACCOUNT TO THE STRUCTURE OF POLITICAL RELATIONSHIPS POLITY.

00872 ALLEN, C

AMERICA RESTRICTED TERRITORY

INSIGHT, 8(11) (MAR 92), 6-11; 36-37

THE PLIGHT OF HAITIANS BLOCKED FROM AMERICA'S SHORES

HIGHLIGHTS A U.S. IMMIGRATION STANCE THAT HAS BEEN

COMPLICATED FOR DECADES BY POLITICS AMD FOREIGM POLICY

OBJECTIVES. UP AGAINST A MAZE OF ALLOTMENTS AND RULES, THE

HAITIANS ARE CHALLENGING A SYSTEM THAT HAS NO ROOM FOR

ECONOMIC REFUGEES. THEY ARE ALSO A DRAMATIC TEST OF THE

CURRENT MOOO ON WHO SHOULD QUALIFY FOR ENTRY. IT IS

SUGGESTED THAT THE U.S. HAS CREATED AN ECONOMIC DISASTER IN

HAITI AND THAT IT SHOULD DO SOMETHING FOR THEM THAT'S

PROBABLY MORE ON A HHUMANITARIAN BASIS BUT NOT GIVE THEM

REFUGEE STATUS, BUT THAT THE TIME MIGHT COME WHEN

INDIVIDUALS WOULD REALLY NEED THE PROTECTION OF THAT STATUS.

00873 ALLEN, C.

BOYS ONLY $206(10)$ (MAR 92), 16-18

SEX-SPECIFIC ABORTION IS BECOMING AN ISSUE AMONG

GENETICISTS, MEDICAL ETHICISTS, AND SOME FEMINISTS BECAUSE

SEX-SELECTION ALMOST ALWAYS MEANS THE ABORTION OF A FEMALE

FETUS. BUT SEX-SELECTIION ABORTION IS NOT ONE OF THE ISSUES

THAT WILL BE ARGUED BEFORE THE SUPREME COURT WHEN THE

CHALLENGE TO PENMSYLVANIA'S ABORTION LAN IS HEARD IN APRIL

1992. THE ACLU CONCLUDED THAT SEX-SELECTION IS NOT AN ISSUE

IN PENNSYLVANIA BECAUSE IT COULD NOT FIND A SINGLE WOMAN

CLAIMING INJURY FROM THAT STATE'S BAN ON SEX-SELECTION

ABORTIONS.

00874 ALLEN, $C$

EISENHOWER'S CONGRESSIDNAL DEFEAT OF 1956; LIMITATIONS OF TELEVISION AND THE GOP

PRESIDENTIAL STUDIES OUARTERLY, 22(1) (WIN 92), 57-72.

DWIGHT EISENHOWER'S LANDSLIDE VICTORY OVER ADLAI

DWIGHT EISENHOWER'S LANDSLIDE VICTORY OVER ADLAI

STEVENSON IN 1956 WAS THE FIRST ELECTION IN WHICH A

POLITICAL PARTY COOROINATED A TRULY NATIONAL TELEVISION
CAMPAIGN. THE MEW INSTRUMENT OF POLITICAL TELEVISION PLAYED

CAMPAIGN. THE NEW INSTRUMENT OF POLITICAL TELEVISION PLAYED

A ROLE IN EISENHOWER'S CONGRESSIONAL DEFEAT IN 1956. IN TIME,

SHOWED FOR THE FIRST TIME THAT TELEVISION HAD LIMITATIONS AS

A VOTE-GETTING DEVICE. THIS ARTICLE STUDIES A REPUBLICAN

NUMBERS PROBLEM, CHANNELING MODERN REPUBLICANISH, PORTENTS

OF CONGRESSIONAL DEFEAT, AND WHAT REMAINS TO BE LEARNED.

00875 ALLEN, C.

GOODBYE TO ALL THAT: THE SHORT AND SAD STORY OF SOCIALISM IN BENIN

JOURNAL OF COMMUNIST STUDIES, 8(2) (JUN 92), 63-81.

DEMOCRATIZATION OF THE FORMER PEOPLE'S REPUBLIC OF BENIN PASSED THROUGH THREE STAGES: FIRST, POPULAR DISCONTENT AROSE OVER NONPAYMENT OF PUBLIC SECTOR SALARIES AND SHIFTED TO DEMANDS FOR HUMAN RIGHTS AND DEMOCRATIZATION (1988-89); SECONDLY, A NATIONAL CONFERENCE APPOINTED A NEW INTERIM GOVERMMENT (FEBRUARY 1990); THIRDLY, THERE HAS A

TRANSITIONAL PERIOD DURING WHICH A NEW CONSTITUTION WAS APPROVED AND ELECTIONS WERE HELD (1990-91). HOWEYER, BECAUSE THESE ELECTIONS WERE DOMINATED BY PARTIES BASED ON PATRONAGE POL ITICS AND BECAUSE THE ECONOMIC CRISIS IS CONTINUING, THE WEAKNESS OF THE STATE MAY UNDERMINE DEMOCRATIC RULE.

00876 ALLEN, $C$

ORDERS FROM THE COURT

ORDERS FROM THE COURT
INSIGHT, 6(52) (JAN 91$), 42-44$

NSIGHT, 6(52) ( JAN 91), 42-44.
THO ISSUES ARE LIKELY TO PUT LIFE INTO 1991 FOR THE U.S. SUPREME COURT: BUSING AND PUNITIVE DAMAGE AWARDS BY JURIES.

SUPREME COURT: BUSING AND PUNITIVE DAMAGE AWARDS BY JURIES. THE JUSTICES WILL CONSIDER ENDING THE ATTEMPT TO CURE SCH
SEGREGATION IN OKLAHOMA CITY AND LIMITING THE AMOUNTS OF SEGREGATION IN OKLAHOMA CITY AND LIMITING THE AMOUNTS OF
PUNITIVE AWAROS. THE DECISIONS MAY WELL TURN UPON THE NEW PUNITIVE AWAROS. THE DECISIONS MAY WELL TURN UPON THE

JUSTICE DAVID SOUTER, WHO MAY SIDE HITH THE COURT'S

00877 ALLEN, C.

PROFILE: C. BOYDEN GRAY

INSIGHT, 7 (32) (AUG 91) 34-37

AS WHITE HOUSE CHIEF OF STAFF, JOHN SUNUNU, AND BUDGET DIRECTOR RICHARD DARMAN LOSE INFLUENCE IN THE WHITE MOUSE, THE MOST OBVIOUS RISIMG STAR IS PRESIDENTIAL COUNSEL C. BOYDEN GRAY. THIS WEALTHY, PATRICIAN SOUTHERNER HAS STEADILY BUILT A POWER BASE IN HIS EVER-EXPANDING ROLE BEHIND THE SCENES AS PRESIDENTIAL COUNSEL. HIS STATUS DATE BACK A DECADE, TO THE DAWN OF THE REAGAN ERA AND GEORGE BUSH'S PRESIDENCY.

00878 ALLEN, C.

SADDAM'S NEXT FIGH

INSIGHT, $7(10)$ (MAR 91) 12-15

WITH AN END TO COMBAT SEEMINGLY WITHIN THE GRASP OF THE COALITION FORCES, THE NEXT BATTLE SADDAM HUSSEIN FIGHTS MAY BE TO DEFEND HIMSELF AGAINST CHARGES OF WAR CRIMES. THERE SEEM TO BE CLEAR YIOLATIONS OF THE GEMEYA COMVENTIONS FOR
PROSECUTORS TO CHOOSE FROM, BUT THE WORLD HAS BECOME A MORE COMPLEX PLACE IN THE TWO GENERATIONS FOLLOWING THE NUREMBERG TRIALS. A MORE COMPLEX ISSUE IS THE POSSIBILITY OF REPARATIONS FOR WAR DAMAGES. IF IRAO IS TO BE HELD ACCOUNTABLE, IT WILL HAVE TO BE AN INTERMATIONAL EFFORT.

00879 ALLEN, C

THE FRENCH CORRECTION

AMERICAN SPECTATOR, 24(7) (JUL 91), 19-20.

THE RU-486 "IMPORT ALERT" IMPOSED BY THE FOOD AND DRUG ADMINISTRATION HAS NOT RESULTED IN THE EXPECTED WAVE OF BLACK MARKET DISTRIBUTION OF THE FABLED FRENCH ABORTION PILL. PART OF THE REASON FOR THE APPARENT DECLINE IN DEMAND IS THAT THE DELETERIOUS SIDE EFFECTS OF THE PILL BEGAN TO BE KNOWN. NOW, PROPONENTS OF THE PILL ARE CANPAIGNING TO ALLOH HOST OF DISEASES RANGING FROM BREAST CANCER TO AIDS. HOWEVER, HOST OF DISEASES RANGING FROM BREAST CANCER TO AIDS. HOWEVER, PHE FDA ALREADY ALLOWS IMPORTATION OF RU-486 FOR RESEARCH PURP.

00880 ALLEN, $D$

STATE SUPREME COURT VOTING BEHAVIOR: A COMPARATIVE ANALYSIS SOCIAL SCIENCE JOURNAL, 29(1) (1992), 31-52.

SCALOGRAM ANALYSIS OF NONUNANIMOUS CRIMINAL AND ECONOMIC LIBERTIES CASES IN 14 STATE SUPREME COURTS IMDICATES THAT BETWEEN 1971-1981 POLICY PREFERENCES STRUCTURED VOTING BEHAVIOR. PREFERENCE BASED VOTING DECLINES AFTER 1981-WITH THE DECLINE MOST NOTICEABLE IN ECONOMIC CASES. THIS DECLINE MAY BE THE RESULT OF PREFERENCE COMPLEXITY RATHER THAN A COMPLETE ABSENCE OF PREFERENCE BASED VOTING. NEITHER COURT DURATION, CASES AVAILABLE FOR SCALING, CONSENSUS NOR THREE OUT OF FOUR INSTITUTIONAL FACTORS EXPLAIN PREFERENCE BASED VOTING. A FOURTH INSTITUTIONAL FACTOR, OPINION ASSIGNEMNT PROCEDURES IS RELATED TO PREFERENCE BASED VOTING.

00881 ALLISON, G.T. JR.; BESCHEL, R.P. JR. CAN THE UNITED STÁTES PROMOTE DEMOCRACY? POLITICAL SCIENCE OUARTERLY, 107 (1) (SPR 92), 81-98. CAN THE UNITED STATES PROMOTE DEMOCRACY ANO PLURALISM AROUND THE WORLD? MANY SCHOLARS HAVE CONCLUDED THAT THE ANSWER IS "NO," BUT IN THIS PAPER THE AUTHORS ARGUE THAT THE ANSWER IS "NO," BUT IN THIS PAPER THE AUTHORS ARGUE THAT THE
UNITED STATES CAN PROMOTE DEMOCRACY. THEY PRESENT EVIDENCE UNITED STATES CAN PROMOTE DEMOCRACY. THEY PRESENT EVIDENCE THAT, IN FACT, THE USA HAS AND IS PROMOTING DEMOCRACY. THEY OUTLINE 57 SPECIFIC INITIATIVES THAT U.S. GOVERNMENT CAN CHANGE IN OTHER COUNTRIES.

00882 ALLISON, $W$

BILLIONAIRE POPULISM: STRANGE ADVENTURE

NATIONAL REVIEW, XLIV(8) (APR 92), 39-4).

IHIS STRANGE POLITICAL YEAR IS ABOUT TO GET STRANGER, SUGGESTS HICK ALLISON, OF THIS ELECTION YEAR. HE EVALUATES THE POL ITICAL CHANGES OF PRESIDENTAL CANDIDATE, ROSS PEROT AND CONCLUDES THAT PEROT HOLDS BETTER CARDS THAN MOST PUNDITS THINK. A DEMOCRAT MUST CARRY TEXAS TO WIN THE PRESIDENCY, AND PEROT'S ENTRY MIGHT ALLOW IT. THE THREE STATES THAT WILL MAKE THE DIFFERENCE ARE CALIFORNIA, TEXAS, AND FLORIDA. THESE STATES ARE EVALUTED AND THIS ARICLE CONCLUDES THAT THE REVOLUTIONARY THRUST THAT PEROT CAN SET IN MOTION WILL DO MORE TO DAMAGE AN ENTRENCHED LIBERAL ESTABLISHMENT THAN ANYONE SINCE RONALD REAGAN.

00883 ALLISON, W.

HOH BUSH CAN WIN

NATIONAL REVIEH, XLIV(13) (JUL 92), 36-37.

THE TIDAL WAVE OF CAUSED BY ROSS PEROT'S 8 ID FOR THE PRESIDENCY HAS THE REPUBLICAN ESTABL I SHAENT IN A STATE OF PANIC. THIS ARTICLE STATES THAT GEORGE BUSH MUST ADAPT TO THE NEW SITUATION OR LOSE THE RACE. THE AUTHOR MAKES SEVERA SUGGESTIONS OF CHANGES THE PRESIDENT'S CURRENT CAMPA DEMONSTATE CONSISTENCY; AND AVOID GOING ON TELEVISION.

00884 ALM, J.: EVERS, M.

THE ITEM VETO AND STATE GOVERNMENT EXPENDITURES

PUBLIC CHOICE, 68(1-3) (JAN 91), 1-16.

IT IS OFTEN ARGUED THAT THE ITEM VETO HAS BEEN AT THE STATE LEVEL--AND NOULD BE AT THE FEDERAL LEVEL--AN EFFECTIVE TOOL FOR REDUCING THE LEVEL OF EXPENDITURES CAUSED BY "PORK BARREL" LEGISLATION AND BY THE LEGISLATOR'S PROPENSITY FOR BARREL" LEGISLATION AND BY THE LEGISLATO IS TO INVESTIGATE THESE CLAIMS USING OATA ON THE STATES' EXPERIENCE WITH THE ITEM YETO. THE PAPER ANALYZES THE ITEM VETO AS A POTENTIAL ITEM VETO. THE PAPER ANALYZES THE ITEM VOTER MOOEL OF STATE GOYERMMENT EXPENDITURES. THE EMPIRICAL RESULTS INDICATE THAT GOVERNMENT EXPENDITURES. THE EMPIRICAL RESULTS INDICATE THE IMPACT OF THE ITEM VETO DEPENDS LARGELY UPON THE POLITICAL PARTIES OF THE GOVERNOR ANO THE LEGISLATURE, WITH EXPENDITURES IN THOSE STATES IN WHICH THE PARTIES OIFFER.

00885 ALMBERG, M.

"SOCIAL IST: PLURALISM?

POLITICAL AFFAIRS, $71(11)$ (NOV 92), 16-24. 
PLURALISM IS A WORD THAT HAS MAHY MEANINGS TO MANY PEOPLE. IT IS THE MORE SPECIALIZED MEANINGS AND CONMOTATIONS THAT CONTAIN THE GREATEST PERILS TO THE INTERESTS OF THE WORKING CLASS. THIS ARTICLE SUGGESTS THAT IT IS EMBUMBENT ON ANY SERIOUS WORKING-CLASS FIGHTER TO STUDY THE VARIOUS MEANINGS OF THIS POPULAR TERM, AS IT HAS BECOME THE MAIN
BATTLE CRY OF THOSE WHO WOULD DESTROY SOCIALISM AND PUSH THE BATTLE CRY OF THOSE WHO WOULD DESTROY SOCIALISM AND PUSH
REVOLUTIONARY PARTIES OFF THEIR WORKING-CLASS COURSE.

00886 ALMOND, $M$.

EUROPE'S IMMIGRATION CRISIS

NATIONAL INTEREST, 29 (FAL 92), 53-61.

IT IS AN IRONY WHICH WESTERM EUROPEAN LEADERS HAVE BEEN SLOW TO RECOGNIZE THAT THEIR MOVEMENT TOWARD AN INTEGRATED SINGLE EUROPEAN MARKET AND A PAN-EUROPEAN CITIZENSHIP HAS BEEN MATCHED BY DISINTEGRATION ALL AROUND THE EUROPEAN
PERIPHERY. UNL IKE THE UNITED STATES, WESTERN EUROPEAN COUNTRIES HAVE NEVER BEEN COMFORTABLE WITH THE IDEA OF MASS IMHIGRATION. THE MOTIVATIONS BEHIMD THE INTEGRATION OF THE IMHIGRATION. THE MOTIVATIONS BEHIND THE INTEGRATION OF THE
EC STATES HAVE BEEN FAR FROM OUTWARD-LOOKING. KEEPING THE EC STATES HAVE BEEN FAR FROM OUTWARD-LOOKING. KEEPING THE
FLOOD OF ECONOMIC AND POLITICAL REFUGEES FROM THE EAST AND FLOOD OF ECONOMIC AND POLITICAL REFUGEES FROM THE EAST AND
SOUTH WILL BE DIFFICULT. ALL AROUND WESTERN EUROPE, PROFOUND SOUTH WILL BE DIFFICULT. ALL AROUND WESTERN EUROPE, PROF
DEMOGRAPHIC, POLITICAL, AND ECDNOMIC CHANGES ARE TAKING DEMOGRAPHIC, POLITICAL, AND ECDNOMIC CHANGES ARE TAKING
PLACE. IT IS ALREADY TOO LATE TO REVERSE THE UNDERLYING PLACE. IT IS ALREADY TOO LATE TO REVERSE THE UNDERLYING
CAUSES OF MASS MIGRATION. THIS ARTICLE SUGGESTS THAT THE CAUSES OF MASS MIGRATION. THIS ARTICLE SUGGESTS THAT THE THAT IS SHIRLING WITH INCREASING TURBULENCE AROUND THEM.

00887 ALONI, M.; BERMAN, P.; HAUSER, R.; KLARE, M.; MACK, J.; $0 Z$, A.; YARIV, A.

ROUNDTABLE ON THE WAR

TIKKUN, 6(1) (MAR 91), 15-22.

THIS ARTICLE IS A ROUNDTABLE DISCUSSION OF ISRAELI AND AMERICAN PEACE ACTIVISTS. THEY DISCUSS THEIR DIFFERENCES ON THE GULF CRISIS, THE WAR, AND ITS LIKELY CONSEQUENCES FOR ISRAEL. THE ISRAELI PEACE ACTIVISTS EXPLAIN THEIR SUPPORT FOR THE WAR AS THE MOST LIKELY ROUTE TO LASTING PEACE. HOWEVER, SOME FEAR THAT AN EXTENDED, BLOODY CONFLICT HILL EVENTUALLY LEAD AMERICANS TO HANT TO WASH THEIR HANOS OF ANY INVOLVEMENT IN THE MIDOLE EAST, LEAVING ISRAEL ALONE AND UNPROTECTED.

00888 ALOZIE, $N$.

THE ELECTION OF ASIANS TO CITY COUNCILS

SOCIAL SCIENCE QUARTERLY, 73(1) (MAR 92), 90-100.

THIS STUDY INTRODUCES ASIANS INTO THE MASSIVE LITERATURE WHICH SEEKS TO EXPLAIN VARIATIONS IN MINORITY ACCESS TO CITY COUNCILS. THE DATA SHOW THAT THE PERCENT ASIAN POPULATION COUNCILS. THE DATA SHOH THAT THE PERCENT ASIAN POPULATION
PLAYS A CRUCIAL ROLE, ALTHOUGH NOT AS POWERFUL A ROLE AS PLAYS A CRUCIAL ROLE, ALTHOUGH NOT AS POWERFUL A ROLE AS
OTHER RESEARCH HAS ASCRIBED TO THE PERCENT BLACK POPULATION. OTHER RESEARCH HAS ASCRIBED TO THE PERCENT BLACK POPULATION
SOME EVIDENCE LINKS ASIAN PRESENCE ON THE COUNCIL TO THE SOME EVIDENCE LINKS ASIAN PRESENCE ON THE CDUNCIL TO THE
MAGNITUDE OF ASIAN INCOME, BUT BLACK AND HISPANIC COUNCIL MAGNITUDE OF ASIAN INCOME, BUT BLACK AND HISPANIC COUNCIL PORTFOLIOS ARE OF NO SIGNIFICANT CONSEQUENCE TO ASIANS. DEGREE OF ASIAN REPRESENTATION, BUT LARGER COUNCILS PROVIDE DEGREE OF ASIAN REPRESENTATION, BUT LARGER
A GREATER CHANCE FOR ASIAN RECRUITMENT.

00889 ALPER, D.K.; MONAHAN, R.L. WESTERN AMERICAN PERCEPTIONS OF QUEBEC AMERICAN REVIEN OF CANADIAN STUDIES, 22(3) (FAL 92), 387-406.

IN ORDER TO ASSESS WESTERN AMERICAN PERCEPTIONS OF QUEBEC AND SOME OF ITS MAJOR DOMESTIC ISSUES, THE AUTHORS POLLED A SAMPLE OF ELITES DRAWN FROM BUSINESS, GOVERNMENT, EDUCATION, FINE ARTS, AND THE MEDIA IN CALIFORNIA, OREGON, AND WASHINGTON. THE SURVEY ASKED THE RESPONDENTS ABOUT THEIR VIEWS ON BILINGUALISM, QUEBEC'S LANGUAGE POLICIES, QUEBEC SEPARATISM, AND OTHER ISSUES.

00890 ALPEROVITZ, G.

MEMO TO CLINTON

TIKKUN, 7(6) (NOV 92), 13-18.

THIS ARTICLE SUGGESTS A TOUGH-MINDED POLITICAL STRATEGY

FOR THE CLINTON PRESIDENCY -- DNE THAT ALSO DRAMATIZES A NEW "VISION." IT STATES THAT GIVEN THE DANGEROUS POLITICALECONOMIC CONTEXT AND SMOLDERING SOCIAL PROBLEMS FACING THE UNITED STATES, THE PRESIDENCY COULD EASILY END UP FAR WORSE THAN EITHER CARTER'S OR BUSH'S. ON THE OTHER HAND, IF CLINTON IS WILLING TO SEIZE THE STRATEGIC INITIATIVE. THE ARTICLE STATES THAT MUCH GOOD MIGHT BE ACCOMPLISHED.

00891 ALSE, J.; BAHMANI-OSKOEE, M.; MILLER, S.M.: RUSSEK, F.S. ARE THE THIN DEFICITS REALIY'RELATED? A COMMENT AMD ARE THE THIN DEF

CONTEMPORARY POL ICY ISSUES, $X(1)$ (JAN 92), 108-113.

JANARDHANAN ALSE AND MOHSEN BAHMANI-OSKOOEE COMMENT ON STEPHEN S. MILLER AND FRANK 5 . RUSSEK'S FINDINGS REGARDING THE RELATIONSHIP BETHEEN THE U.S. BUDGET AND TRADE DEFICITS. THEN MILLER AND RUSSEK RELY.

00892 ALSHAYEJI, A.K.

KUWAIT AT THE CROSSROADS: THE QUEST FOR DEMOCRATIZATION

MIDOLE EAST INSIGHT, VII(5) (MAY 92), 41-46.

KUWAITIS ARE RAISING FUNDAMENTAL OUESTIONS ABOUT THEIR
VERY IDENTITY AND THE LEGITIMACY OF THEIR POLITICAL SYSTEM. THERE IS A GROWING SENSITIVITY IN THE COUNTRY THAT IF THE SOCIETY REMAINS DIVIDED AGAINST ITSELF AND THAT IF THERE IS A CONTINUING GAP BETHEEN THE LEADERSHIP AND THE PEOPLE, THEN KUWAIT'S CAPACITY TO SURVIVE AS AN INDEPENDENT NATION-
IS SERIOUSLY COMPROMISED. GIVEN THIS SITUATION, THE ELECTIONS FOR THE NATIONAL ASSEMBLY IN OCTOBER ASSUME A SIGNIFICANCE OF ENORMOUS PROPORTIONS. THIS ARTICLE EXAMINES THE POLITICS OF POST-LIBERATION KUWAIT WITH EMPHASIS ON THE CHALLENGE OFFERED BY VARIOUS OPPOSITION GROUPS.

00893 ALTAYEY, $V$.

THE USSR ARMED FORCES: AT THE END OF THE PATH

SOCIOLOGICAL PERSPECTIVES, (6) (1990), 27-31.

THIS ARTICLE DESCRIBES THE RELATIONSHIP BETHEEN THE SOVIET ARMY AND SOVIET SOCIETY IN THE ERA OF PERESTROIKA. A REVERSAL OF ROLES IS DESCRIBED, IN WHICH THE ARMY IS SHRINKING AND THE SOVIET CITIZENRY IS ARMING ITSELF TO WAGE MILITARY ACTIONS AGAINST THE ARMY IN VARIOUS REGIONS. THE TRADITIONAL ROLE OF THE ARMED FORCES TO OEFEND THE NATION AGAINST EXTERMAL THREATS IS PORTRAYED AS OBSOLETE. THE AGAINST EXTERMAL THREATS IS PORTRAYED AS OBSOLETE. TH
FEASIBILITY OF "RESTRUCTURING" THE ARMY IS EXPLORED.

00894 ALTENSTETTER, C.

HEALTH POLICY REGIMES AND THE SINGLE EUROPEAN MARKET JOURNAL OF HEALTH POLITICS, POLICY AND LAH, 17(4) (WIN 92), 813-846.

THE AUTHOR EXAMINES THE POTENTIAL EFFECTS OF THE CREATION OF A SINGLE EUROPEAN MARKET ON THE HEALTH POLICY REGIMES OF THE TWELVE MEMBER STATES OF THE EUROPEAN COMMUNITY (EC), ARGUING THAT FEW CHANGES CAN BE EXPECTED IN THE BASIC NATURE OF THOSE REGIMES AND THAT A COMMUNITY-WIDE HEALTH POLICY REGIME IS UNLIKELY TO EMERGE IN THE NEAR FUTURE. DOMESTIC HEALTH POLICY REGIMES AND CARE SYSTEMS WILL REMAIN THE DOMINANT APPROACH TO HEALTH CARE DELIVERY, AND IT IS NOT LIKELY THAT THE AMERICAN APPROACH WILL BE ADOPTED. HOWEVER, EC LEGISLATION DESIGNED TO CREATE FAYORABLE TRADE, ECONOMIC, AND FISCAL CONDITIONS MAY EFFECT KEY INDUSTRIES LIKE PHARMACEUTICALS AND HEALTH INSURANCE, hITH CONSEQUENCES FOR NATIONAL HEALTH POLICY REGIMES. PATTERNS IN COMMUNITYWIDE POLICY-MAKING SUGGEST THAT IT WILL BECOME INCREASINGLY DIFFICULT TO DEFINE HEALTH ISSUES IN PURELY DOMESTIC OR INTERNATIONAL TERMS.

00895 ALTMANN, F.

EX-YUGOSLLYVIA'S NEIGHBOURS: WHO WANTS WHAT?

WORLD TODAY, 48(8-9) (AUG 92), 163-165.

THE AUTHOR SUMMARIZES THE FOREIGN POLICY POSITIONS OF

YUGOSLAVIA'S NEIGHBORS AS THEY WATCH THE COUNTRY

DISINTEGRATE. HE DISCUSSES THE INTERESTS AND STANCES OF

DISINTEGRATE. HE DISCUSSES THE INTERESTS AND STANCES OF
AUSTRIA, HUNGARY, ROMANIA, BULGARIA, GREECE, ALBANIA, ITALY,

AUSTRIA, HUNGA
AND TURKEY.

00896 ALTSTADT, A.

THE AZERBAIJJANI TURKS--POWER AND IDENTITY UNDER RUSSIAN RULE

HOOVER INSTITUTION PRESS, 1992, 334

THIS BOOK IS A HISTORY OF AZERBAIJAN AND ITS PEOPLE. SINCE THE EARLY NINETEENTH CENTURY, ITS MUSLIM AND TURKISH PEOPLE HAVE BEEN RULED BY RUSSIA, FIRST BY THE IMPERIAL TSARS AND THEN BY THE SOVIET REGIME. THO CENTURIES OF HARSH DOMINATION CULMINATED IN BLACK JANUARY 1990, WHEN SOVIET TROOPS OPENED FIRE ON THE CIVILIAN POPULATION OF BAKU. THE FOLLONING YEAR, AZERBAI JAN DECLARED ITS INDEPENDENCE AND BEGAN REBUILDING ITS POLITICAL AND ECONOMIC SYSTEM. FORMER COMMUNISTS AND OPPOSITION LEADERS CONTINUE TO STRUGGLE FOR DOMINANCE. DRAWING ON MANY SOURCES NEVER USED BEFDRE IN WESTERN STUDIES, THE AUTHOR IDENTIFIES KEY ACTORS AND DOCUMENTS A PATTERN OF CONTINUAL STRUGGLE AGAINST COLONIAL RULE FROM THE INITIAL CONQUEST TO THE POLITICAL MOVEMENTS OF THE LATE TWENTIETH CENTURY.

00897 ALVARO, A.

WHY PROPERTY RIGHTS WERE EXCLUDED FROM THE CANADIAN CHARTER OF RIGHTS AND FREEDOMS

CANADIAN JOURNAL OF POLITICAL SCIENCE, XXIV(2) (JUN 91), 309-330.

CANADA'S "CONSTITUTION ACT, 1867," CONTAINED WHAT WERE INTENDED TO BE STRONG PROTECTIONS OF PROPERTY OWNERSHIP. THESE PROTECTIONS GRADUALLY ERODED, AS PROPERTY WAS SUBOROTHATED "PROPERTY RIGHTS" DEBATE TOOK PLACE IN THIS CONTEXT. THOSE PROVINCES WHICH OPPOSED THE PROPERTY RIGHTS CLAUSE WANTED TO PROVINCES WHICH OPPOSED THE PROPERTY RIGHTS CLAUSE WANTED TO
SAFEGUARD THE SUPREMACY OF DEMOCRATIC INSTITUTIONS FROM THE SAFEGUARD THE SUPREMACY OF DEMOCRATIC INSTITUTIONS FROM THE POTENTIAL RAMIFICATIONS POSED BY SUCH A CLAUSE. THE FEDERAL GOVERNMENT, THE PROPONENT OF THE CLAUSE, DID NOT INTEND
SUCH SUPREMACY BE USURPED. HOWEVER, THE CLAUSE WAS NEVER SUCH SUPREMACY BE USURPED. HOWEVER, THE CLAUSE WAS NEVER CRUCIAL TO THE CHARTER AND THE FEDERAL GOVERMMENT ABANDON
THE CLAUSE IN ORDER TO ACHIEVE PROVINCIAL AGREEMENT ON PATRIATION OF THE CONSTITUTION.

00898 AMAR, A.R.

SOME' COMMENTS ON 'THE BILL OF RIGHTS AS A CONSTITUTION' HARYARO JOURNAL OF LAW AMD PUBLIC POLICY, 15(1) (WIN 92). 
99-112.

IF ONE LOOKS CAREFULLY AT THE U.S. RIGHT OF BILLS, IT IS MUCH LESS DISCONTINUOUS WITH THE ORIGINAL CONSTITUTION THAN OFTEN THOUGHT. MOST SCHOLARS EMBRACE THE CONVENTIONAL READING THAT THE BILL OF RIGHTS IS FUNDAMENTALLY, PARADIGMATICALLY, NOT ABOUT STRUCTURE--THAT IS, NOT ABOUT FEDERALISM, BICAMERALISM, REPRESEMTATION, CONSTITUTIONAL AMENDMENT, AMD SUCH. MOST ALSO ARGUE THAT THE BILL OF RIGHTS IS NOT ABOUT MAJORITARIANISH. RATHER, THEY THINK THE BILL OF RIGHTS IS DELIBERATELY COUNTER-MAJORITARIAN AT ITS CORE-THAT IT IS ABOUT INDIVIDUAL RIGHTS, NOT MAJORITY RIGHTS. HOWEVER, THE ESSENCE OF THE BILL OF RIGHTS AND THE ESSENCE HONEVER, THE ESSENCE OF THE BILL OF RIGHTS AND CONSTITUTION ARE PROFOUNDLY POPULIST, DEMOCRATIC, MAJORITARIAN, AND STRUCTURAL.

00899 AMAHI, A.

DEMOCRACY DILEMMAS IN JORAN

MIDDLE EAST REPORT, 22(1) (JAN 92), 26-29.

NONE OF THE CRITERIA DEFINED IN THE DEFINITION OF DEMOCRACY HAYE YET BEEN ENTIRELY MET IN JORAN. CERTAIN ASPECTS OF JORDANIAN POLITICAL LIFE HAVE BEEN LIBERALIZED, BUT NOT OTHERS. THE LIBERALIZATION PROCESS IS STILL IN A PRECARIOUS STATE. IT IS INTEGRALLY LINED WITH BOTH THE ECONOMIC CRISIS AND PEACE PROCESS. OTHER FACTORS WHICH THREATEN THIS PROCESS INCLUDE POPULAR APATHY, GROWING POLARIZATION BETWEEN FUNDAMENTALISTS AND LIBERALS/LEFTISTS, CONSERVATIVE FOES OF THE LIBERALIZATION PROCESS AND, FINALLY, POPULAR SUSPICIONS ABOUT ITS AUTHENTICITY. THE GREAT TASK AHEAD IS TO CRAFT INSTITUTIONAL AND CONSTITUTIONAL LIMITS TO PROTECT INDIVIDUAL RIGHTS WHILE ADVANCING THE PRINCIPLE OF MAJORITY RULE.

00900 AMES, D.L.; BROWN, N.C.; CALlaHAN, M.H.; CUMmings, S.B.; SMOCK, S.M. ; ZIEGLER, J.M.

RETHINKING AMERICAN URBAN POLICY

JOURMAL OF URBAN AFFAIRS, 14(3-4) (1992), 197-216.

SINCE THE $1960^{\prime} S$, SHEEPING CHANGES HAVE OCCURRED IN U.S

CITIES. DEMOGRAPHIC SHIFTS HAVE INCREASED THE POPULATION AND

POLITICAL STRENGTH OF SUBURBS. THE ECONOMY HAS BECOME

GLOBALIZED, AND MANY URBAN AREAS HAVE BEEN SERIOUSLY

GLOBALIZED, AND MANY URBAN AREAS HAVE BEEN SERIOU

AFFECTED BY THE REORGANIZATION OF BASIC INDUSTRY.

ADDITIONALLY, THE NATION IS CONFRONTED WITH A BUDGET DEFICIT

OF IMMENSE PROPORTIONS. THIS PAPER EXAMINES THE INFLUENCE OF

THESE TRENDS ON URBAN POLICY INITIATIVES OVER THE PAST FOUR
DECADES. THE NEED FOR A NAT IONAL URBAN POLICY IS STRESSED.

DECADES. THE NEED FOR A NATIONAL URBAN POLICY IS STRESSED.

FAILED TO PLACE CITIES AT THE CENTER OF DOMESTIC POLICY

FAILED TO PLACE CITIES AT THE CENTER OF DOMESTIC POLICY

ISSUES,
POLICY.

00901 AMES, L.J.

LEGISLATION EQUITY: A COMPARISON OF PROVINCIAL LEGISLATION IN MANITOBA AND ONTARIO REQUIRING PAY EQUITY

INTERNATIONAL JOURNAL OF PUBLIC ADMINISTRATION, 14(5)

(1991), 871-892.

A GREAT DEAL OF ACTIVITY IS CURRENTLY UNDERHAY IN CANADA SURROUNDING PAY EQUITY. SEVERAL PROVINCES HAVE PASSED LEGISLATION REQUIRING SOME FORM OF ASSESSMENT OR IMPLEMENTATION OF EQUITY FOR PUBLIC AND/OR PRIVATE SECTOR EMPLOYERS. HOWEVER, DEFINITIONS OF WHAT CONSTITUTES EOUITY HAVE NOT BEEN CONSISTENT ACROSS PROVINCES. THIS PAPER EXAMINES THE LEGISLATION IN MANITOBA AND ONTARIO IN TERMS OF HOW EACH PROVIDES FOR EQUITY. EACH PIECE OF LEGISLATION CONTAINS PROVISIONS WHICH MAY COMPROMISE THE RESULTING EQUITY, EITHER IN THE WAY GENDER-DOMINATION IS DEFINED, THE WAY COMPARABLE WORTH IS ESTIMATED, OR THE WAY EQUITY IS ACHIEVED. THE LESSONS TO BE LEARNED (OR RE-LEARNED) FROM THESE PROVISIONS ARE DETAILED.

00902 AMIAR, J.

IN ALGERIA tHe AGENDA IS VIOLENCE, NO NEW IDEAS, AND A HAR IN ALGERI

HASHINGTON REPORT ON MIODLE EAST AFFAIRS, XI(3) (AUG 92),

ALGERIA'S NEW PRESIDENT IS ALI KAFI AND ITS NEW PRIME MINISTER IS BELAID ABDESLAM, BUT NEITHER IS NEW TO ALGERIAM POLITICS. ABDESLAM WAS THE FATHER OF THE ALGERIAN INDUSTRIALIZATION POLICY, WHICH WAS A MAJOR CAUSE OF THE COUNTRY'S PRESENT PROBLEMS. ABDESLAM HAS LONG COMPLAINED OF FRENCH AND AMERICAN DOMINATION OF ALGERIA, AND THIS CDULD DRENCH AND AMERICAN DOMINATION OF ALGERIA, AND THIS COULD DISCOURACE THE FOREIGN INVESTMENT ALEEDED TO CREATE JOBS ABDESLAM AOVOCATES THE ESTABLISHMENT OF A WAR ECONOMY, CUTTING IMPORTS AND SUBSIDIZING PRICES OF LOCALLY-PRODUCED GOOOS. FOR NEIGHBORING MOROCCD, ABDESLAM'S RETURN TD POWER MEANS THO THINGS: THE POSSIBILITY OF RENEWED ALGERIAN SUPPORT FOR THE POLISARO FRONT IN THE WESTERN SAHARA DISPUTE AND AN ECONOMIC POLICY THAT WILL ALMOST CERTAINLY REDUCE ALGERIAN IMPORTS OF MOROCCAN GOOOS.

00903 AMIN, S.

CAN ENVIRONMENTAL PROBLEMS BE SUBJECT TO ECONOMIC CALCULATIONS

HORLO DEVELOPMENT, 20(4) (APR 92), 523-530.

ENVIRONMENTAL CRITIQUES OF UNSUSTAINABLE DEVELOPMENT ARE
NOT NOVEL FORMULATIONS BUT REDISCOVERIES OF TRADITIONAL SOCIALIST CRITIQUES OF THE CAPITALIST ECONOMIC SYSTEM. WHILE THE NECESSITY FOR ECONOMIC CALCULATIONS IS NOT IN DOUBT, THESE SHOULD NOT BE UNDERTAKEN WITHIN A CAPITALIST SYSTÉ THAT DIVORCES THE ECONOMIC FROM THE SOCIAL. RATHER, THE FRAMEHORK SHOULD IDENTIFY NEEDS PRIOR TO PROOUCTION, RECOGNIZE THE MULTIDIMENSIONAL NATURE OF HUMANKIND, AND OPERATE ON A GLOBAL SCALE.

00904 AMIN, S.

EMPIRE OF CHAOS

MONTHLY REVIEH PRESS, 1991, 128.

THIS ESSAY ANALYZES THE' CRISIS OF CONTEMPORARY

CAPITALISM AND DEFENDS THE CAUSE OF ITS FORGOTTEN PEOPLES.

THE AUTHOR ARGUES THAT CAPITALISM HAS, FROM ITS EARLIEST

CENTURIES, ASPIRED TO BE A WORLD SYSTEM. THE RESULTING

STRUGGLES HAVE ALWAYS BEEN FUNDAMENTALLY BETWEEN NORTH AND

SOUTH, BETWEEN THE DEVELOPED CENTER AND THE UNDERDEVELOPED PERIPHERY. THE AUTHOR SITUATES U.S. INTERVENTIONISM

INCLUDING THE GULF WAR, IN THE CONTEXT OF THE U.S. INTENTION TO CREATE A NEW WORLD ORDER, HHICH THE AUTHOR ARGUES IS DESTINED TO BE "AN EMPIRE OF CHAOS." THE CONTEMPORARY CRISIS OF THE THIRD WORLD, HE ARGUES, ARISES NOT FROM ANY FAILURE TO INTEGRATE INTO THE CAPITALIST HORLD ECONOMY, BUT FROM THE REALITIES OF A HISTORICALLY DEPENDENT STATUS IN A SYSTEM THAT NO LONGER HAS MUCH USE FOR SUCH COUNTRIES OR THEIR PEOPLES. THE AUTHOR'S PROGRAM FOR THE AREAS NOW BEING, OR SOON TO BE, DISCARDED BY GLOBAL CAPITALISM IS BUILT AROUND POPULAR DEMOCRACY AND PARTICIPATORY SOCIALISM. HE ARGUES STRENUOUSLY THAT THIRD WORLD COUNTRIES MUST PUT THEIR OWN CONCERNS BEFORE THOSE OF FOREIGN CAPITAL, DRIVING OUT THEIR COMPRADOR RULERS AND EMPOWERING A POLITICS OF GENUINE NATIONAL INDEPENDENCE.

00905 AMIN, $S$.

THE ISSUE OF DEMOCRACY IN THE CONTEMPORARY THIRD WORLD SOCIALISM AND DEMOCRACY, (12) (JAN 91), 83-104.

THE RECENT PAST HAS SHOWN A GLOBAL TREND TO

DEMOCRATIZATION OF POLITICAL REGIMES ON A SCALE THAT MAY WELL BECOME IRREVERSIBLE. HOWEVER, IN THIRD HORLD CAPITALIST COUNTRIES THE CALL FOR OEMOCRACY HAS NOT REACHED THE SAME POPULAR DIMENSION ANO IS FREQUENTLY LIMITED TO THE MIDOLE CLASS AND SEGMENTS OF ORGANIZED URBAN SOCIETY SUCH AS UNIONS. CLASS AND SEGMENTS OF ORGANIZED URBAN SOCIETY SUCH AS UNIONS.
EVEN ON SUCH A NARROW SCALE THE REND SIGNALS A QUALITATIVE EVEN ON SUCH A NARROW SCALE THE REND SIGNALS A QUALITATIVE
LEAP IN THE EXTENT TO WHICH DEMOCRATIC CONSCIOUSNESS HAS LEAP IN THE EXTENT TO WHICH DEMOCRATIC CONSCIOUSNESS HAS
PENETRATED THE POLITICAL SYSTEM OF A GREAT MANY THIRD WORLD PENETRATED
COUNTRIES.

00906 AMINUZZAMAN, S.

ADMINISTRATIVE REFORMS AND THEIR IMPACT ON TRAINING THE PUBLIC BUREAUCRACY IN BANGLADESH GOVERNANCE, 5(4) (OCT 92) $38-458$

THE AUTHOR REVIEWS BANGLADESH REFORM EFFORTS AND THEIR IMPACT ON THE OVERALL PUBLIC ADMINISTRATION TRAINING CURRICULUM AND ACADEMIC PROGRAMS OF THE TRANING INSTITUTIONS AS WELL AS WITH THE UNIVERSITIES. IT CONCLUDES HITH A SUGGESTION TO REVIEW ALL ENTRY-LEVEL TRAINING PROGRAMS AND IDENTIFY SOME THEMATIC AREAS TO MAKE THE TRANING PROGRAMS "PRACTICAL, PRO-ACTIVE AND ACTION-ORIENTED." A CLOSE COLLABORATION BETHEEN THE UNIVERSITIES AND THE PUBLIC

00907 AMIRAHMADI, H.

TOWARD A MULTI-GAP APPROACH TO MEDIUM-TERM ECONOMIC GROWTH IN IRAN

ORIENT, 33(1) (1992), 97-118.

THE PURPOSE OF THIS PAPER IS TO REVIEH SOME OF THE MOST SIGNIFICANT MACRO, MICRO, AND STRUCTURAL IMBALANCES THAT THE IRANIAN ECONOMY FACES AS IT ENTERS THE 1990 S AND TO OFFER A SET OF REMEDIAL POLICIES. IT IS ARGUES THAT THE ECONOMY SUFFERS FROM A MULTITIDE OF "GAPS" AND THAT A, ,MULTI -GAP" APPROACH TO ECONOMIC GROWTH IN THE MEDIUM-TERM IS PREFERABLE TO THE , THREE-GAP" MODEL HHICH PERFECTS EARLY GAP MODELS AND WAS 'RECENTLY DEVELOPED BY THE WIDER GROUP. THE APPROACH ACCOUNTS FOR THE CURRENT GLOBAL RESTRUCTURING AND THE OPPORTUNITIES AND CONSTRAINTS IT IS CREATING FOR A COMPLETE RETHINKING OF THIRD WORLD DEVELOPMENT MODELS.

00908 AMMANH, B.

THE BASQUES: LOOKING FOR A WAY OUT

SWISS REVIEW OF HORLD AFFAIRS, 41(12) (MAR 92), 8-9. WISS REVIEH OF HORLD AFFAIRS, 11 (12) (MAR 92), 8-9.' BASOUE REGION. YET THOSE WHO REGARD THE ARMED STRUGGLE AS A BASOUE REGION. YET THOSE WHO REGARD THE ARMED STRUGGLE AS A LEGITIMATE POLITICAL TOOL ARE 8Y NO MEANS AS STRONG AS ONCE WERE. THE TERRORIST ORGANIZATION ETA (EUSKADI TA ASKATASUNA" OR BASOUE HOMELAND AND FREEDOM SEEMS TO BE AN INCREASINGLY ISOLATED FORCE, PITTING THE BASQUES AGAI

00909 AMMON, $P$.

INTERNAL POLITICS AND THE TECHNOLOGICAL REVOLUTION AT A TURNING POINT

AUSSEN POLITIK, 43(2) (1992), 115-121.

THE THIRD INOUSTRIAL REVOLUTION OF COMPUTER AND 
COMMUNICATIONS TECHNOLOGY MAY PRODUCE A SITUATION WHICH COULD UNDERMINE THE ECONOMIC EFFICIENCY, SOCIAL PROSPERITY AND ENVIRONMENTAL CORRECTIVE CAPACITY OF THE EURDPEAN CONT INENT DURING THE NEXT DECADE. INSOFAR AS THIS CHALLENGE HAS BEEN REALIZED, THE WORRIED HESTERN EUROPEANS HARDLY STAND A CHANCE OF REVERSING THE TREND IN VIEW OF THE STRAINS RESULTING FROM THE COLLAPSE OF THE SOCIALIST SYSTEM. THI ARTICLE EXAMINES THE PROBLEM AND COMES TO THE CONCLUSION THAT BOTH CHALLENGES, RECONSTRUCTION IN THE EAST AND THE PROCESS OF TECHNOLOGICALLY CATCHING UP, ABOVE ALL WITH THE JAPANESE CAN BE TACKLED SUCCESSFULLY IF THE NECESSARY INSIGHTS ARE GAINED AND THE AVAILABLE MEANS POOLED ACCORDINGLY-RATHER THAN PUT TO DIFFERENT USE.

00910 AMDO, S.G. SEARCHING FOR REGIONAL PEACE

WEST AFRICA, (3897) (MAY 92), 882-883

THE ORGANIZATION OF AFRICAN UNITY (OAU) APPEARS TO HAVE BEEN BENUMBED INTO ACUTE PARALYSIS BY ESCALATING REGIONAL CONFLICTS. THE CURRENT PATTERN OF CONFLICTS CHALLENGES AN IMPORTANT TENET OR THE ORGANIZATION: TO DEFEND THE STATUS IMPORTANT TENET OR THE ORGANI ZATION: TO DEFEND THE STATUS
QUO OF THE CONSTITUENT UNITS AS PERSONIFIED BY THE CURRENT QUO OF THE CONSTITUENT UNITS AS PERSONIFIED BY THE CURRENT
HEADS OF GOVERNMENT OR HHOEVER CONTROLS THE CAPITAL OF AN HEADS OF GOVERNMENT OR HHOEVER CONTROLS THE CAPITAL OF AN
AFRICAN STATE. BUT THE CURRENT SPATE OF AFRICAN CONFLICTS IS AFRICAN STATE. BUT THE CURRENT SPATE OF AFRICAN CONFLICTS BEING PRECIPITATED BY A CRISIS OF POLITICAL LEGITIMACY IN
THE AFRICAN STATE AND THE NEED TO MANAGE CHANGE AND PROVIDE TRANSITION TO STABLE STATES WITH RESPONSIBLE, LEGITIMATE GOVERNMENTS.

00911 AMOTT, T.

CAUGHT IN THE CRISIS: WOMEN AND THE U.S. ECONOMY TODAY MONTHLY REVIEW PRESS, 1992, 144.

THIS BOOK EXPLORES THE EFFECTS OF THE REAGAN/BUSH YEARS ON WOMEN WORKERS IN THE UNITED STATES. AFTER A BRIEF HISTORICAL OVERVIEW OF THE DEVELOPMENT OF WOMEN'S ECONOMIC ROLES, IT COMPARES THE POSITION OF WOEMN IN OCCUPATIONS RANGING FROM MANAGERIAL AND PROFESSIONAL TO CLERICAL AND MANUFACTURING, AS WELL AS THOSE WORKING IN THE INFORMAL ECONOMY--UNDOCUMENTED AND UNDERGROUND LABOR. IT SHOWS HOH MOST WOMEN IN THE UNITED STATES TODAY ARE BEING FORCED TO CARRY A LARGER ECONOMIC BURDEN THAN THEY HERE TWO DECADES AGO. THE BOOK ALSO EXAMINES WOMEN'S UNPAID WORK IN THE HOME, FOCUSING ON THE WAY IN HHICH RECENT ECONOMIC CHANGES HAVE INCREASED THE BURDEN OF THE DOUBLE DAY. IT THEN SURVEYS THE EFFECTS OF CONSERVATIVE ECONOMIC PROGRAMS ON THE UNDERMINING OF STATE POLICIES THAT HELP HOMEN IN AREAS OF HEALTH, EMPLOYMENT, OCCUPATIONAL SAFETY, WELFARE, AND CHILDCARE. IT CONCLUDES HITH AN EXAMINATION OF THE DETRIMENTAL IMPACT OF THE CONSERVATIVE SOCIAL AND LEGAL AGENDA IN THE AREA OF REPRODUCTIVE RIGHTS, COMPARABLE WORTH AND AFFIRMATIVE ACTION.

00912 AMUZEGAR, J.

WESTERN DEMOCRACIES AT A CROSSROADS

SAIS REVIEW, 11 (1) (HIN 91) 27-44.

THE BREAKUP OF THE EASTERN BLOC THE ABSENCE OF A SOVIET THREAT, AHD THE END OF THE ARMS RACE SHOULD HOLD FORTH THE HOPE OF A MORE PROMISING RELATIONSHIP AMONG THE INDUSTRIAL DEMOCRACIES. YET, IRONICALLY, THE POTENTIAL FOR SUCH N OUTCOME CANNOT BE TAKEN FOR GRANTED. THIS ARTICLE CHRONICLES THE OFTEN TROUBLED HISTORY OF ECONOMIC COOPERATION BETHEEN THE WESTERN INDUSTRIALIZED DEMOCRACIES WITH EMPHASIS OF THE GROUP OF SEVEN INDUSTRIALIZED NATIONS (G7). IT TRACES THE HISTORICAL FAILINGS OF ECONDMIC COOP ERATION FROM THE POSTWAR BEGINNINGS TO THE 1990 HOUSTON SUMMIT. IT ALSO ASSESSES THE CHALLENGES AND PROSPECTS THAT LIE AHEAD. IT CONCLUDES THA CONSTANT VIGILANCE IS STILL NEEDED TO MAINTAIN
SOLIDARITY IN THE POLITICAL AND ECONOMIC ARENAS.

00913 AN, T.S. THE RISE AND DECLINE OF NORTH KOREA'S NUCLEAR WEAPONS PROGRAM

KOREA \& WORLD AFFAIRS, 16(4) (WIN 92), 670-684.

THE AUTHOR DISCUSSES THE STATUS OF NORTH KOREA'S NUCLEAR WEAPONS PROGRAM, THE EFFECTIVENESS OF I.A.E.A. INSPECTIONS, AND HOW REALIZATION OF NORTH KOREA'S NUCLEAR AMBITIONS WOULD AFFECT THE BALANCE OF PONER IN NORTHEAST ASIA AND GLOBALLY.

00914 ANANIEVA, N.; RAZVIGORA, E. WOMEN IN STATE ADMINISTRATION IN THE PEOPLE'S REPUBLIC OF BULGARIA

WOMEN AND POLITICS, 1(4) (1991), 31-40.

HISTORICALLY BUL GARIAN WOMEN HAYE BEEN POLITICALIY ACTIVE IN THE ANTI-FASCIST AND NATIONAL LIBERATION STRUGGLE OF THE BULGARIAN PEOPLE. THE MAJOR FORCE MOTIVATING WOMEN TO JOIN THE PAID LABOR FORCE IN THE WAKE OF THE SOCIALIST REVOLUTION IN BULGARIA WAS THE GOVERMMENT'S ACCELERATED DRIVE FOR SOCIO-ECONOMIC BACKWARDNESS. THE NEEDS OF THE BULGARIAN FAMILY ALSO ENCDURAGED HOMEN'S PARTICIPATION IN THE PAID LABOR FORCE. A THIRD FACTOR WAS WOMEN'S DESIRE FOR SELF-FULFILLMENT, ESPEC
ORIENTED YOUNG HOMEN.

00915 ANAYAOKU, E.

THE COMMONHEALTH AND THE NEW WORLD ORDER
ROUND TABLE, 324(324) (OCT 92), 411-416.

THE 1991 HARARE DECLARATION' SAW A REAFFIRMATION OF CONFIDENCE IN THE FUTURE OF THE COMMONWEALTH BY ALL THE COMMONWEAL TH HEADS OF GOVERMMENT, AND ALSO SAH WHAT THE AUTHOR DESCRIBES AS A RELAUNCHING OF THE COMMONWEALTH AS AN INPORTANT INTERMATIONAL ORGANIZATION. HE SKETCHES FIVE KEY AREAS WHERE THE COMMONHEALTH IS PLAYING AND STILL CAN PLAY AN EVEN MORE IMPORTANT ROLE IN THE NEW HORLD ORDER. THESE AREAS ARE: PROMOTING FUNDAMENTAL VALUES; CHALLENGING NEGATIVE TENDENCIES; POVERTY ALLEVIATION AND DEVELOPMENT; ENVIRONMENT; AND, CONSENSUS AND LINKAGE.

00916 ANCKAR, D.

NORDIC POLITICAL SCIENCE: TRENDS, ROLES, APPROACHES EUROPEAN JOURNAL OF POLITICAL RESEARCH, 20(3-4) (DEC 91), 239-261.

THE AUTHOR STUDIES THE HISTORY OF POLITICAL SCIENCE IN SCANDINAVIA, THE RELATIONSHIP BETWEEN NORDIC SOCIETY AND POLITICAL SCIENCE, AND TRENDS IN POL ITICAL SCIENCE SCHOLARSHIP. POSTWAR NORDIC POLITICAL SCIENCE TURNED TO SCHOLARSHIP. POSTWAR NORDIC POL ITICAL SCIENCE TURNED TO
BEHAVIORALISM IN TERMS OF PROBLEMS, METHODS, AND IDEAS IN BEHAVIDRALISM IN TERMS OF PROBLEMS, METHODS, AND IDEAS IN
THE BEGINNING OF THE $1960^{\prime} \mathrm{s}$. NOW, BEHAVIORALISM IS CLEARLY THE BEGINNING OF THE 1960'S. NOW, BEHAVIORALISM IS CLEARLY
OUTMODED AS A SEPARATE, DISTINCTIVE OUTLOOK IN THE NORDIC OUTMODED AS A SEPARATE, DISTINCTIVE OUTLOOK IN THE NORDIC OISCIPLINE OF POLITICAL SCIENCE IS STILL FIRMLY ANCHORED IN DISCIPLINE OF POLITICAL SCIENCE IS STILL FIRMLY ANCHORED IN BASED ON THE AMBITION TO UNCOVER INVARIANCES OF POLITICAL LIFE AND TO BUILD AN EMPIRICAL THEORY OF POLITICS.

00917 ANDERBERG, B.; BRING, O.E.; MOLBARSHT, M.L.

BLINDING LASER WEAPONS AND INTERNATIONAL HUMANITARIAN LAH JOURNAL OF PEACE RESEARCH, 29(3) (AUG 92), 287-297.

THE HUMANITARIAN LAW APPROACH TO MULTILATERAL ARMS REGULATIONS RESTRICTS OR PROHIBITS THE USE OF WEAPONS THAT ARE EXCESSIVELY INHUMANE OR INDISCRIMINATE IN THEIR EFFECTS. THE ST. PETERSBURG DECLARATION OF 1868 STATES THAT HHENEVER SCIENTIFIC DEVELOPMENTS LEAD TO IMPROVEMENT IN ARMAMENTS, THE CONTRACTING PARTIES WILL "COME TO AN UNDERSTANDING" IN ORDER TO "CONCILIATE THE NECESSITIES OF WAR HITH THE LAWS OF HUMANITY." IN THIS PAPER, THE AUTHORS DISCUSS THE PROSPECTS FOR AND THE LEGAL ARGUMENTS AGAINST BATTLEFIELD LASER WEAPONS THAT CAN CAUSE PERMANENT BLINDNESS IN HUMAN BEINGS. SINCE AGGRESSIVE USE OF FORCE IS FORBIDOEN UNDER THE U.N. CHARTER, IT FOLLOWS THAT ANY USE OF ANY WEAPON IS PROHIBITED WITHIN THE CONTEXT OF AGGRESSION. MOREOVER, THE RIGHT OF PARTIES TO CHOOSE METHODS AMD MEANS OF WARFARE IS NOT UNLIMITED EVEN WHEN INTERNATIONAL LAN DOES PERMIT THE USE OF ARMED FORCE--AS IN THE CASE OF SELF-DEFENSE OR SECURITY COUNCIL-MANDATED ACTIONS. THUS, THE AUTHORS ARGUE THAT THE SYSTEMATIC USE OF LASER BEAMS AGAINST THE EYESIGHT OF SYSTEMATIC USE OF LASER BEAMS AGAINST THE EYESIGHT OF
INDIVIDUALS IS PROHIBITED UNDER THE EXISTING LAW OF WARFARE INDIVIDUALS IS PROHIBITED UNDER THE EXISTING LAW OF WARFARE
BUT THIS NEEDS TO BE CONFIRMED IN A MULTILATERAL DOCUMENT.

00918 ANDERSON, $B$

THE NEW WORLD DISORDER

NEW LEFT REVIEW, (193) (MAY 92 ), 3-14.

THE AUTHOR QUESTIONS THE VISION OF A NEW PEACEFUL WORLD ORDER. HE FOCUSES ON THE PROBLEMS OF MINORITY COMAUNITIES IM A WORLD WHERE THE ECONOMIC DEMANO FOR MIGRANT LABOR HAS NOT BEEN MATCHED BY THE DEVELOPMENT OF A TOLERANT, OPEN POLITICAL CULTURE AND WHERE THE DANGERS OF INSTABILITY AND MILITARISM ARE GROWING.

00919 ANDERSON, C.

PRAGMATISM ANO LIBERALISM, RATIONALISM AND IRRATIONALISM: A RESPONSE TO RICHARD RORTY

POLITY, XXIII (3) (SPR 91), 357-372.

RICHARD RORTY HAS SOUGHT TO ASSOCIATE PRAGMATISM AND LIBERALISM WITH POSTMODERNIST CRITICAL ANALYSIS. THIS ARTICLE CHALLENGES RORTY, ARGUING THAT HIS EFFORT RESTS ON A DISPUTABLE CONCEPTION OF PRAGMATISM AND LEADS TO AN INADEOUATE VERSION OF LIBERAL POLITICAL THEORY. THE AUTHOR INSISTS THAT A PEIRCEAN PRAGMATIC RATIONALISM YIELDS A VERY DIFFERENT KIND OF LIBERAL POLITICAL THEORY THAN THAT PRODUCED BY RORTY'S IRRATIONALISM.

00920 AMDERSON, C.H.

TOWARD A MATHEMATIC THEORY OF OFFENSIVE/DEFENSIVE BALANCE

INTERNATIONAL STUDIES QUARTERLY, 36(1) (MAR 92), 75-100. JACK LEVY ARGUES THAT THE OFFENSIVE/DEFENSIVE BALANCE NEEDS TO BE DEFINED MORE EXPLICITLY AND RIGOROUSLY BEFORE IT CAN BE USED IN HISTORICAL ANALYSIS. THIS ARTICLE OFFERS A MORE EXPLICIT AND RIGOROUS THEORY OF THE OFFENSIVE/ DEFENSIVE BALANCE BASED ON HEMBOLD CONVENTIONAL HAR EQUATIONS AND INTRILIGATOR NUCLEAR WAR EQUATIONS. IT OPERATIONALLY DEFINES THE OFFENSIVE/ DEFENSIVE BALANCE BASED ON WEAPONS CHARACTERISTICS, GEOGRAPHY, MILITARY ORGANIZATION, PERCEPTIONS OF DECISIONMAKERS, AND, TO SOME EXTENT, TACTICS. ITS OFFENSIVE/DEFENSIVE THEORY ILLUSTRATES THE VALIDITY OF MANY OF LEVY'S CRITICISMS OF OFFENSIVE/DEFENSIVE CONCEPT IN HISTORICAL STUDIES, SOLVES SOME OF THE CONCEPTUAL PROBLEMS,
AND PROVIDES A STRONGER THEORETICAL FOUNDATION FOR ANALYSTS WHO WILL EMPLOY THE CONCEPT IN FUTURE STUDIES. 
00921 ANDERSON, D.

FINISHING THE UNIFINISHED REVOLUTION

CANADIAN FORUM, LXX(806) (JAN 92), 6-8.

TWENTY-FIVE YEARS AFTER THE ESTABLISHMENT OF THE COUNTRY'S FIRST ROYAL COMMISSION ON THE STATUS OF WOMEN, DORIS ANDERSON, THE AUTHOR OF "THE UNFINISHED REVOLUTION: THE STATUS OF NOMEN IN THELVE COUTRIES "FEMINISM IS THE OF FEMINISM IN THIS ARTICLE. IT STATES: "FEMINISM IS FEMINISTS HAVE TO HAVE A VISION OF THE KIND OF WORLD THEY WANT TO LIVE IN." ANDERSON STATES THAT DIRECT ACTION HAS ALWAYS ACHIEYED RESULTS MORE QUICKLY THAN LOBBYING,

PETITIONING AND WORKING FOR LEGISLATIVE CHANGE.

00922 ANDERSON, G.L.

THE UNITED STATES IN 2042

THE UNITED STATES IN 2042
INTERNATIONAL SOCIAL SCIENCE REVIEN, 67(4) (FAL 92), INTERNATIOR $159-166$.

BY THE YEAR 2042, SOCIETY IN THE UNITED STATES IS LIKELY EITHER TO DETERIORATE OR IMPROVE DRAMATICALLY. DEPENDING ON WHETHER CULIURAL AND EDUCATIONAL TRENDS CAN BE CHANGED IN THE 1990'S. IN THE FUTURE, THERE WILL BE PLENTY OF OPPORTUNITIES FOR PEOPLE WHO ARE WELL EDUCATED AND SELFMOTIVATED, BUT EMPLOYMENT OPPORTUNITIES FOR THE LESS EDUCATED WILL DECREASE IN THE POST-INDUSTRIAL SOCIETY. UNFORTUNATELY, PRESENT TRENDS SHOW THAT THE UNDERCLASS OF POORLY EDUCATED PEOPLE IS GROWING. FURTHER, THE BREAKDOWN OF AFFLUENT FAMILIES AND COMMUNITIES IS PSYCHOLOGICALLY HANOICAPPING MANY OF THOSE WHO SHOULD TAKE LEADERSHIP ROLES IN SOCIETY AND GOVERNMENT. ONLY A CHANGE IN THE PRIORITIES OF THE CULTURE AS A WHOLE AND THE QUALITY OF EDUCATION AVAILABLE TO THE MASSES WILL ENSURE BOTH CONSTRUCTIVE USE OF TECHNOLOGY AND THE CONTINUATION OF AMERICAN DEMOCRACY.

00923 ANDERSON, G.M.

A SOBER LOOK AT THE COSTS OF INTOXICATION

CONTEMPORARY POLICY ISSUES, X(2) (APR 92), 111-115.

ADVOCATES OF INCREASED GOVERMMENT REGULATION OF

INTOXICATING SUBSTANCES OFTEN CITE THE "SOCIAL COST" OF SUCH GOOOS. A CLOSE EXAMINATION OF STUDIES THAT CALCULATE THE SOCIAL COST OF INTOXICATION REVEALS A VARIETY OF RECURRING METHODOLOGICAL ERRORS. THESE STUDIES DO NOT CLEARLY DISTINGUISH EXTERNAL COSTS FROM PRIVATE COSTS. MOREOVER,

THEY DO NOT SYSTEMATICALLY COMPARE THE COSTS ASSOCIATED WITH THE REGULATION OF INTOXICANT USE WITH THE COSTS OF

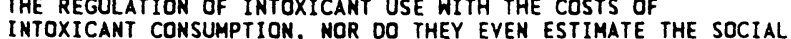
INTOXICANT CONSUMPTION, NOR DO THEY EVEN ESTIMATE THE SOCIAL
BENEFITS ASSOCIATED WITH INTOXICATION OR COMPARE THEM WITH BENEFITS ASSOCIATED WITH INTOXICATION OR COMPARE THEM
THE SOCIAL COSTS. UNLESS THESE PROBLEMS ARE ADDRESSED, THE SOCIAL COSTS. UNLESS THESE PROBLEMS ARE ADDRESSED, POLITICAL LOBBYING.

00924 ANDERSON, $K$.

LENIN, HEGEL, AND WESTERN MARXISM: FROM THE 1920'S TO THE

STUDIES IN SOVIET THOUGHT, 44(2) (SEP 92), 79-130.

THE AUTHOR DISCUSSES LENIN'S WRITINGS ON HEGEL. THEN HE SURVEYS WESTERN VIEWS OF LENIN'S INTERPRETATION OF HEGEL'S WORK. INCLUDING THOSE OF KARL KORSCH, GEORG LUKACS, ERNST BLOCH, HENRI LEFEBVRE, NORBERT GUTERMAN, HERBERT MARCUSE, $C$. L.R. JAMES, FREDDIE FÓREST, AND GRACE LEE.

00925 ANDERSON, R.D.; HERMANH, C.; HERMANH, M.G. EXPLAINING SELF-DEFEATING FOREIGN POLICY DECISIONS: INTERPRETING SOVIET ARMS FOR EGYPT IN 1973 THROUGH PROCESS OR DOMESTIC BARGAINING MODELS?

AMERICAN POLITICAL SCIENCE REVIEW, 86(3) (SEP 92), 759-766.

IN THIS COMMENT AND REPLY, RICHARD ANDERSON CRITIQUES A PAPER BY MARGARET AND CHARLES HERMANN, WHO THEN DEFEND THEIR WORK. STEWART AND THE HERMANNS HAVE PROPOSED A THREE-LEVEL PROCESS MODEL OF FOREIGN POLICY TO EXPLAIN THE SOVIET BEHAVIOR TOWARDS EGYPT IN 1973. THEIR ANALYSIS HAS CONTINUING INTEREST BECAUSE IT INTERPRETS THE PUZZLING BEHAVIOR AS A MANIFESTATION OF GENERAL PROBLEMS OF INFORMATION PROCESSING IN MAKING FOREIGN POLICY CHOICES. ANOERSON SUGGESTS THAT A THO-LEVEL MOOEL OF DOMESTIC BARGAINING BETTER ACCOUNTS FOR THE CAUSAL SEQUENCE IN SOVIETEGYPTIAN RELATIONS AND IS IN GENERAL MORE PARSIMONIOUS.

00926 ANDERSON, $S$.

A DOLLAR TO POLAND IS A DOLLAR TO RUSSIA: UNITED STATES ECONOMIC DIPLOMACY TOWARD POLAND, 1945-1950

EAST EUROPEAN OUARTERLY, XXYI(1) (SPR 92) 77-108.

FOLLOWING HORLD WAR II, U.S. ECONOMIC AID AND TRADE HITH POLAND WAS GRADUALIY PHASED OUT ON THE THEORY THAT "A DOLLAR POLAND WAS GRADUALLY PHASED OUT ON THE THEORY THAT "A DOLLAR FOR OUESTIONING THIS ASSUMPTION. ALTHOUGH AMERICAN POLICY FOR QUESTIONING THIS ASSUMPTION. AL THOUGH AMERICAN POLICY TOWARD POLAND WAS LARGELY FORMULATED ON THE BASIS OF SOVIETU.S. RELATIONS, POLAND DESPERATELY TRIED TO MAINTAIN ITS EREEDOM OF ACTION IN THE ECONOMIC SPHERE AND SOUGHT TO ESTABLISH ITSELF AS A RELIABLE COMMERCIAL PARTHER OF THE UNITED STATES AND WESTERN EUROPE. UNLIKE THE SOVIET UNION, POLAND COOPERATED IN INTERNATIONAL ECONOMIC ORGANIZATIONS, SIIPULATIONS TO BE PLACED ON THE USE OF FOREIGN LOANS. IT
WAS NOT UNTIL THE END OF 1949, WHEN THE KREMLIN CRACKED DOWN ON NATIONAL COMMUNISTS, THAT POLISH FOREIGN ECONOMIC POLICY WAS FORCED TO MARCH CLOSELY IN STEP WITH SOVIET POLICY. IN TRYING TO ACHIEVE VARIOUS POLITICAL ANO STRATEGIC OBJECTIVES THROUGH ECONOMIC PRESSURE, THE UNITED STATES LOST WHAT LITTLE INFLUENCE IT HAD IN POLAND AND AIDED THE SOVIET UNION IN INTEGRATING THE POLISH ECONOMY INTO ITS OWN.

00927 AMDERSON, S.; GLOMM, G.

INCUMBENCY EFFECTS IN POLITICAL CAMPAIGNS

PUBLIC CHOICE, 74(2) (1992), 207-220.

IN THIS PAPER THE AUTHORS EXAMINE TWO EFFECTS OF

INCUMBENCY. FIRST, AN INCUMBENT MAY HAVE AN ADVANTAGE IN

CREATING A FAVORABLE IMAGE IN THE EYES OF THE VOTERS. SECOND,

THE INCUMBENT MAY HAVE TO CHOSE A POSITION BEFORE THE

CHALLENGER. IT FINDS THAT THE INCUMBENT'S EQUILIBRIUM

CHALLENGER. IT FINDS THAT THE INCUMBENT'S EQUILIBRIUM
POSITION IS CLOSER TO HIS/HER OWN IDEAL POINT THAN THE

EQUILIBRIUM POSITION OF THE GAME WHEN MOVES ARE SIMULTANEOUS.

ALSO, FOR SUFFICIENTLY LARGE CHARISMATIC DIFFERENCES A CHARISMATA IS SMALL BOTH PLAYERS PREFER TO BE FOLLOHERS.

00928 ANDERSON, S.J.

THE POLICY PROCESS AND SOCIAL POLICY IN JAPAN

PS: POLITICAL SCIENCE AND POLITICS, XXV(1) (MAR 92), 36-43.

THE MEDIA IMAGES OF JAPANESE SOCIETY OFTEN SUGGEST THAT THE COUNTRY REMAINS CLOSED AND RIGID DESPITE THE CHANGING WORLD ORDER AND THAT MODELS OF OTHER COUNTRIES CANNOT APPLY TO JAPAN. BUT ANALYSTS SEE INCREASING DIVERSITY WITHIN JAPAN AS IT EMERGES AS A LEADING INDUSTRIAL DEMOCRACY. AN EXAMINATION OF THE POLICY PROCESS, IN GENERAL, AND SOCIAL POLICY, IN PARTICULAR, CAN SHED NEW LIGHT ON THE POPULAR MYTHS ABOUT JAPAN.

00929 ANDERSON, $T$.

COMPARATIVE EXPERIENCE FACTORS AMONG BLACK, ASIAM, AND HISPANIC AMERICANS: COALITIONS OR CONFLICTS?

JOURNAL OF BLACK STUDIES, 23(1) (SEP 92) 27-38.

RACE, ETHNICITY, AND COLOR ARE CATALYTIC SOCIAL FACTORS IN THE UNITED STATES, CAUSING CLASS ANTAGONISM, CONTROVERSY AND CONFLICT AMONG ITS DIVERSE POPULATION. THIS ARTICLE IS AN ATTEMPT TO PRESENT IN A SUMMARY MANNER SOME OF THE COMPARATIVE ASPECTS OF THE CULTURE, SOCIOLOGY, POLITICS, AND ECONOMICS OF AMERICA'S PRIMARY AND MORE CONSPICUOUS RACIALETHNIC MINORITY POPULATIONS, NAMELY, BLACKS, HISPANICS, AND

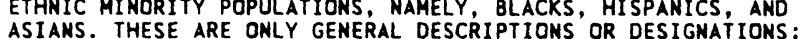
SEVERAL VARIANT, BUT SIMILAR, POPULATIDNS EXIST WITHIN EACH; SEVERAL VARIANT, BUT SIMILAR, POPULATIONS EXIST WI

00930 ANDERSON, T.L.; LEAL, D.R.

FREE MARKET VERSUS POLITICAL ENVIRONMENTALISH HARVARD JOURNAL OF LAH AND PUBLIC POLICY, 15(2) (SPR 92), 297-310

FREE MARKET ENVIRONMENTALISM CONSIOERS THE POTENTIAL FOR MARKET SOLUTIONS AND THE PROBLEMS WITH POLITICAL ONES. FREE MARKET ENVIRONMENTALISH CHALLENGES BOTH THE GOVERNMENT PLANHER'S MOTIVATION ANO HIS ABILITY. THE APPROACH RECOGNIZES TWO FACTS: FIRST, INCENTIVES AFFECT ALL HUMAN BEHAVIOR; SECOND, INFORMATION COSTS ARE POSITIVE.

00931 ANDERTON, $N$.

SOUTH AFRICA AND EASTERM EUROPE--THE FORGING OF A NEW RELATIONSHIP

SOUTH AFRICA INTERNATIONAL, 23(1) (JUL 92), 26-38.

SINCE THE FALL OF THE BERLIN HALL, SOUTH AFRICA HAS RAPIDLY DEVELOPED DIPLOMATIC AND OTHER TIES WITH EASTERN EUROPE. DISPITE THE DIFFICULTIES OF DOING BUSINESS HITH THE FORMERLY COMMUNIST WORLD, BILATERAL TRADE HAS GROWN APPRECIABLY. SOME PROBLEMS REMAIN, NOT THE LEAST OF THESE THE TROUBLED RELATIONSHIP BETWEEN POLITICAL PARTIES HITHIN SOUTH AFRICA CLOSE TO THE FORMER COMMUNIST REGIMES, AND THE SUSPICIONS OF THE NEW GOVERMMENTS IN EASTERN EUROPE BECAUSE OF THESE CLOSE TIES.

00932 ANDEWEG, $R$.

EXECUTIVE-LEGISLATIVE RELATIONS IN THE METHERLANDS: CONSECUTIVE AND COEXISTING PATTERNS

LEGISLATIVE STUDIES QUARTERLY, 27(2) (MAY 92), 161-182.

IN MANY DUTCH AND COMPARATIVE STUDIES OF EXECUTIVE-

LEGISLATIVE RELATIONS THE DUTCH CASE ELUDES STRAIGHTFORHARD LEGISLATIVE RELATIONS THE DUTCH CASE ELUDES STRAIGHTFORWARD
CLASSIFICATION. APPLICATION OF KING'S TYPOLOGY OF MODES OF EXECUTIVE-LEGISLATIVE RELATIONS SHOW THAT THE PATTERN OF
INTERACTIONS BETWEEN MINISTERS AND MEMBERS OF PARLIAMENT HAS EVOLVED FROM A PRIMARILY NONPARTY MODE TO A PREDOMINANTLY INTERPARTY MODE. HOWEVER, DUTCH EXECUTIVE-LEGISLATIVE RELATIONS APPEAR AMBIGUD
EXIST TO SOME EXTENT.

00933 ANDOH, D. MAJOR TURNING POINT WEST AFRICA, (3910) (AUG 92 ), 1438

THE AUTHOR OUTLINES GAMBIA'S $1992-93$ BUDGET, WHICH INCLUDES AN EXPENDITURE OF 249 MILLION DALASIS ON ECONOMIC DEVELOPMENT PROGRAMS. 
00934 ANDOH, D.

UPSURGE IN POLITICAL VIOLENCE

HEST AFRICA (3918) (OCT 92 ) 1772

GHANA'S RECENT POLITICAL CAMPAIGNS HAVE BEEN MARKED BY A DISTURBING TREND TOHARD YIOL ENCE. INCLUDING A MOB AITACK ON THE PRESIDENTIAL CANDIDATE OF THE NEH PATRIOTIC PARTY. MOST OF THE VIOLENCE HAS INVOLVED GHANA'S THO LEADING PARTIES, THE NDC AND THE NPP.

00935 ANDONI, L.

CHANGE IS INEVITABLE

MIDDLE EAST INTERNATIONAL, (395) (MAR 91), 4.

A HEEK AFTER THE GULF WAR, THE ONLY THING SURE AMONG IRAQIS IS THAT A RETURN TO THE STATUS QUD ANTE IS OUT OF THE QUESTION. SORTING THROUGH THE RUBBLE AND DEVASTATION, MANY IRAOIS ARE QUESTIONING EVERYTHING, INCLUDING THEIR OWM POL ITICAL SYSTEM, AND EVEN THE CONCEPT OF ARAB NATIONALISM. THEIR ANGER IS DIRECTED AT ALL PARTIES--THE U.S., THE WEST, THE ARABS, AMD THEIR OWN LEADERSHIP. IN AN EFFORT TO MAINTAIN ORDER AND THEIR GRIP ON POWER, THE IRAQI LEADERSHIP IS PROMISING SOME DEGREE OF POLITICAL NORMALIZATION AMD IS PROMISING SOME DEGREE OF POLITICAL NORMALIZATION AND
FRANTICALLY WORKING TO RESTORE ELECTRICITY AND TO SECURE FRANTICALLY WORKING TO RESTORE ELECTRICITY AND TO SECURE
BASIC FOOD SUPPLIES AT REASONABLE PRICES. THE FUTURE REMAINS BASIC FOOD SUPPLIES AT REASONABLE PRICES. THE FUTURE REMAI
UNCERTAIN, BUT IT SEEMS LIKELY THAT IRAO WILL CHOOSE TO UNCERTAIN, BUT IT SEEMS LIKELY THAT IRAQ WILL CHOOSE
WITHDRAW INTO ITSELF AND ABANDON ITS MUCH-VAUNTED WITHDRAW INTO ITSELF AND ABANDON
CHAMPIDNSHIP OF PAN-ARAB CAUSES.

00936 ANDONI, L.

IRAQ--NATION IN DESPAIR

MIDDLE EAST INTERNATIONAL (405) (JUL 91), 8-9.

A YEAR AFTER ITS INVASION OF KUWAIT, IRAO HAS BEEN REDUCED FROM A REGIONAL POWER TO A COUNTRY STRUGGLING JUST TO STAND ON ITS FEET AS ITS PEOPLE FACE THE THREAT OF STARVATION. ITS LEADER, SADDAM HUSSEIN, HAS SURVIVED A CRUSHING MILITARY DEFEAT, INTERNATIONAL AND ARAB POLITICAL ISOLATION, AN ECONOMIC EMBARGO AND INTERNAL STRIFE, BUT HE STILL AT THE HELM OF A NATION IN DESPAIR AND A PEOPLE WHOSE LIVES HAVE BEEN REDUCED TO STRUGGLING FOR EXISTENCE. UNLESS A FOREIGN MILITARY OPERATION OR A MAJOR DISRUPTION TAKES PLACE, THE REGIME SEEMS TO HAVE CONSOLIDATED ITS POSITION. THOSE WO FORESEE AN EXPLOSION OF ANTI-GOVERNMENT FERVOR OFTEN STATE THAT EVEN A FULL SCALE REVOLUTION MAY NOT BRING ABOUT CHANGES FOR THE BETTER.

00937 ANDONI, L.

KHALID AL-HASSAN'S PLAN

MIDOLE EAST INTERNAT IONAL, (398) (APR 91), 14-15.

AS THE U.S. AND ISRAEL PURSUE THEIR VARIOUS PROPOSALS FOR THE FUTURE OF THE OCCUPIED TERRITORIES, THE PLO

FOR THE FUTURE OF THE OCCUPIED TERRITORIES, THE PLO

LEADERSHIP HAS FAILED SO FAR TO RECAPTURE THE POL ITICAL

INITIATIVE. AGAIN FEELING ITS ROLE THREATENED BY AMERICAN DIPLOMACY, THE ORGANIZATION WOULD BE EXPECTED TO AGAIN ADOPT A POLICY OF EITHER BLOCKING THE PROCESS OR ENSURING ITS OWN PARTICIPATION. KHALID AL HASSAN, HO WAS THE MOST OUTSPOKEN PALESTINIAN LEADER AGAINST THE OPPOSITION'S SUPPORT FOR IRAQ,
HAS COME OUT HITH THE ONLY PALESTINIAN PLAN SO FAR TO GET HAS COME OUT WITH THE ONLY PALESTINIAN PLAN SO
THE PLO OUT OF THE TRAP. HOWEVER HIS CALLS FOR THE PLO OUT OF THE TRAP. HOHEVER HIS CALLS FOR

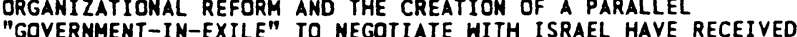
"GOVERMMENT-IN-EXILE" TO NEGOTIAT
LITTLE ACCEPTANCE IN PLO CIRCLES.

00938 ANDONI, L.

PALESTINIAN HORRIES AND AIMS

MIDDLE EAST INTERNATIONAL, (413) (NOV 91), 4

AFTER THE MADRID PEACE TALKS, MANY PALESTINIANS,

INCLUDING MEMBERS OF THE NEGOTIATING TEAM AND PLO OFFICIALS, HAVE RAISED THE QUESTION OF WHETHER THE PALESTINIANS HAVE BEEN LURED INTO A TRAP THAT HILL CURB THEIR NATIONAL ASPIRATIONS, OR WHETHER THE CONFERENCE PRESENTED A HISTORIC OPENING TO ATTAIN INDEPENDENCE. BEYOND THE UNDOUBTED SUCCESS OF ASSERTING THE PALESTINIAN POLITICAL PRESENCE LIES THE REALIZATION THAT THE PALESTINIANS HAVE ENTERED THE NEGOTIATIONS UMDER AMERICA AND ISRAEL'S TERMS. SOME ARE ESPECIALLY CRITICAL OF THE PALESTINIAN ACCEPTANCE OF THE TRANSITIONAL PERIOD AND IMPLIED APPROVAL OF THE PRE-1967 BORDERS. IN ORDER TO MINIMIZE THE DAMAGE DONE BY THESE AND OTHER CONCESSIONS, THE PALESTINIAN NEGOTIATORS AND THE PLO HAVE ESTABLISHED THE FOLLOWING GOALS FOR THE NEXT ROUNDS OF MEGOT IATION. TO ENSURE THAT THE DELEGATIOM CONTIMUES TO BE SEEN AS REPRESENTATIVE OF PALESTINIANS BOTH INSIDE AND OUTSIDE THE OCCUPIED TERRITDRIES: TO BUILD PRESSURE OM

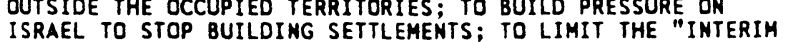
ISRAEL TO STOP BUILDING SETTLEMENTS; TO LIMIT THE "INTERIM PERIOD" OF POWER TRANSFER FROM FIVE TO THO YEARS; TO SECURE ARAB COMMITMENT THAT THERE WILL BE NO BILATERAL AGREEMENTS TO ENSURE THAT THE REFUGEE PROBLEM IS PART OF THE BILATERAL TO ENSURE
TALKS.

00939 ANDONI 1 .

PEACE TALKS--U,S. ATTACKS PALESTIMIANS

MIDOLE EAST INTERNATIONAL, (421) (MAR 92), 5-6.

THE U.S. STATE DEPARTMENT'S STRONGLY WORDED CRITICISM OF THE PALESTINIAN PERFORMANCE, IMMEDIATELY AFTER THE
CONCLUSION OF THE FOURTH ROUND OF ARAB-ISRAELI PEACE TALKS IN WASHINGTON, WAS VERY REVEALING OF WHERE THE U.S. STANDS IN WASHINGTON, WAS VERY REVEALING OF WHERE THE U.S. STANDS ON PALESTINIAN NATIONAL RIGHTS AND SELF-DETERMINATION. THE STATE DEPARTMENT WAS EVIDENTLY CONCERMED NOT TO APPEAR TO BE TAKING SIDES IN FAVOR OF THE ARABS, ESPECIALLY AFTER JAMES BAKER'S FIRM INSISTENCE ON A HALT TO THE ISRAELI SETTLEMENTS AS A PRECONDITION TO GRANTING U.S. LOAN GUARANTEES TO ISRAEL. BUT THE PUBLIC BLAST AGAINST THE PALESTINIANS WENT BEYOND THE PERCEIVED BALANCING ACT TO REVEAL THAT VERY LITTLE HAS
CHANGED IN THE U.S. POSITION ON PALESTINE. IN SHORT, THE U.S. CHANGED IN THE U.S. POSITION ON PALESTINE. IN SHORT, THE U.S. STATEHOOD OR SELF-DETERMINATION.

00940 ANDONI, L.

PLO WARY OF RABIN

MIDDLE EAST INTERNATIONAL, (429) (JUL 92), 6-7.

ALTHOUGH MOST ARAB OFFICIALS WERE HAPPY TO SEE THE DOWNFALL OF ISRAEL'S HARD-LINE LIKUD PARTY, MANY REALIZE THAT DEALING WITH YITZHAK RABIN WILL NOT NECESSARILY BE ANY EASIER THAN WITH HIS PREDECESSOR, YITZHAK SHAMIR. SHAMIR, AS HE HIMSELF ADMITTED, HAS DELIBERATELY STALLING THE MIDDLE EAST PEACE TALKS, BUT RABIN SEEMS KEEN ON PUSHING THE PROCESS FORWARD. BUT THE CHALLENGE FOR ARAB NEGOTIATORS IS TO PREVENT A COURSE, IMPOSED BY ISRAEL, BASED ON EXTRACTING MAXIMUM CONCESSIOYS FROM THE ARAB SIDE. RABIN IS PLACED IN AN ALMOST IDEAL POSITION TO COME OUT WITH PROPOSALS WHICH AN ALMOST IDEAL POSITION TO COME OUT WITH PROPOSALS WHICH WILL SOUND "CONCILIATORY" AND "FLEXIBLE," BUT WHICH ACTUALL FALL SHORT OF THE MINIMAL TERMS THE ARABS ACCEPTED TO TAKE
PART IN THE PEACE PROCESS. SHAMIR'S UNCOMPROMISING POSITION WILL MAKE ANY PROPOSAL BY RABIN SEEM EXTREMELY GENEROUS, WILL MAKE ANY PROPOSAL BY RABIN SEEM EXTREMELY GENEROUS,
PLACING ARAB NEGOTIATORS UNDER IMMENSE AMERICAN PRESSURE TO PLACING ARAB NEG

00941 ANDONI, $L$.

RESISTING CHANGE

MIDOLE EAST INTERNATIONAL, (397) (APR 91), 12

THE END OF THE GULF WAR, AND MORE SIGNIFICANTLY IRAO'S DEFEAT, BROUGHT THE PLO A POLITICAL NIGHTMARE AS IT FOUND ITSELF AN ALMOST ISOLATED TARGET FOR U.S. -LED ATTEMPTS TO EXCLUDE IT FROM THE SCENE ONCE AND FOR ALL. THE PLO HAS NEVER BEEN IN SUCH A VULNERABLE POSITION. THE INTERNATIONAL POLITICAL STANDING IT GAINED FROM THE INTIFADA AND ITS OWN DIPLOMATIC INITIATIVE HAS BEEN UNDERMINED BY ITS SUPPORT FOR IRAQ. THE GULF STATES HAVE FOUND AN OPPORTUNITY TO STOP THEIR ALWAYS RELUCTANT FINANCIAL AID, WHILE THE WAR PROVIDED ISRAEL WITH A COVER TO CRACK DOWN ON THE INTIFADA. HOWEVER, SOME PLO MEMBERS SPEAK CONFIDENTLY OF THE NEW OPPORTUNITIES PROVIDED BY THE CLOSE OF THE GULF WAR, MOST NOTABLY THE ARAB-ISRAELI DISPUTE.

00942 ANDONI, L.

SHATTERED AND TORN APART

SHATTERED AND TORN APART (398) (APR 91), 9-11
MIDDLE EAST INTERMATIONAL, (398) (APR

MIDDLE EAST INTERMATIONAL, (398) (APR 91), 9-11.
ALTHOUGH A HUMILIATING MILITARY DEFEAT AND AN ARMED REBELLION HAVE FAILED TO PUT AN END TO THE BA'THIST REGIME IN IRAQ, IT COULD STILL BE UNDERMINED BY THE VERY HIGH COST OF ITS SURVIVAL: POSTWAR IRAQ HAS LOST ITS INDEPENDENCE AND IS SHATTERED BY ISOLATION, MASSIVE DESTRUCTION, AND INTERNAL FRACTION. ITS SUCCESS IN KEEPING THE COUNTRY PHYSICALLY TOGETHER HAS GIVEN THE BA'THIST LEADERSHIP A BREATHING SPACE TO ADJUST AND FOCUS ITS EFFORTS ON THE RECONSTRUCTION COUNTRY AND ITS REINTEGRATION INTO THE INTERNATIONAL
COMMUNITY. HOWEVER, THE LEADERSHIP, AND PROBABLY THE IRAQI COMMUNITY. HOWEVER, THE LEADERSHIP, AND PROBABLY THE

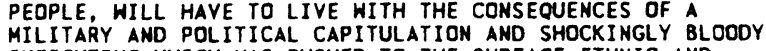
INFIGHTING WHICH HAS PUSHED TO THE SURFACE ETHNIC AND SECTARIAN DIVISIONS.

00943 ANDONI, L.

THE PEACE PROCESS--A POSITIVE START

MIDDLE EAST INTERHATIONAL, (424) (MAY 92), 5-6.

THE FIFTH ROUND OF MIDDLE EAST BILATERAL NEGOTIATIONS OPENED ON TIME IN WASHINGTON ON 27 APRIL IN AN UNUSUALLY POSITIVE MOOD. AS EXPECTED, THE ISRAELIS FORMALLY PRESENTED THEIR PROPOSALS FOR MUNICIPAL ELECTIONS IN THE WEST BANK AND GAZA STRIP, AND THE SYRIAN-ISRAELI TRACK OF MEGOTIATIONS WAS GIVEN A MUCH-NEEDED BOOST WHEN SYRIA AGREED TO LIFT RESTRICTIONS ON ITS JEWISH POPULATION. HOWEVER, THERE IS GROWING DOUBT AMONG PALESTINIANS AS TO THE EFFICACY AND UTILITY OF THE PEACE PROCESS. MANY ARE BEGINNING TO FEEL THAT THE TACTICS OF YASSER ARAFAT AND THE PLO ARE HEAVILY INFLUENCED BY AMERICAN DEMANDS AND ARE ACTUALLY

MARGINALIZING THE PLO.

00944 ANDONI, L.

THE PLO--A GO-AHEAD DESPITE THE RIFTS

MIDDLE EAST INTERNATIONAL, (425) (MAY 92), 6.

BY GIVING THE GREEN LIGHT FOR CONTINUED PALESTINIAN PARTICIPATI THE GREE LIGHT FOR CONTINUED PALESTINIAN MIDOLE EAST PEACE TALKS, THE PLO LEADERSHIP HAS ONCE AGAIN OPTED FOR PUTTING ITS POSITION AT RISK RATHER THAN LEAVING REGIONAL AND INTERNATIONAL POWERS TO DETERMINE THE FUTURE OF
THE PALESTINIAN PEOPLE IN THEIR ABSENCE. THE MAJOR DECISION 
THAT THE 100-MEMBER PLO CENTRAL COUNCIL, WHICH MET IN TUNIS ON 8 APRIL, HAD TO MAKE WAS WHETHER TO TAKE THE RISK OF NEGOTIATING AHAY THE NATIONAL RIGHTS OF THE PALESTINIAN PEOPLE OR TO STEP BACK AND RISK THE ELIMINATION OF THOSE RIGHTS FROM THE AGENDA OF THE PEACE PROCESS. THE FINAL VOTE, 54 OUT OF 100 IN FAVOR, REFLECTED THE REALIZATION THAT AT THIS STAGE THE PALESTINIANS STOOD TO LOSE MORE BY WITHDRANING FROM THE GAME, REGARDLESS OF THE UNFAIRNESS OF WITHDRANING FROM THE GAME, REGARDLESS OF THE UNFAIR ITS RULES. THE VOTE, HOWEVER, ALSO REFLECTED THE
RESERVATIONS ABOUT THE COURSE THAT THE PEACE PROCESS HAS TAKEN.

00945 ANDONI, L.

THE PLO--THE THREAT TO THE PEACE TALKS

MIDOLE EAST INTERMATIONAL (432) (AUG 92), 6.

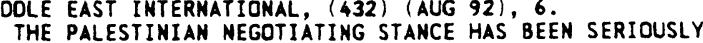
UNDERMINED BY HASHINGTON'S DECISION TO GRANT \$10 BILLION IN LOAN GUARANTEES TO ISRAEL WITHOUT INSISTING ON A TOTAL HALT TO ISRAEL I SETTLEMENT IN THE OCCUPIED TERRITORIES. THE AMERICAN MOVE SEEMS DESTINED TO REINFORCE ISRAELI EFFORTS TO AVOID AN EQUIVOCAL COMMITMENT TO UN RESOLUTION 242. THE FUTURE OF THE TALKS WILL LARGELY DEPEND ON PLO PERFORMANCE AND UNITY IN THE OCCUPIED TERRITORIES. OPPOSITION TO THE PEACE PROCESS IS EXPECTED TO WIDEN IF THE UNITED STATES MAINTAINS ITS POSITION. THE PLO AND THE PALESTINIAN DELEGATION ARE TAKING A GREAT RISK BY ACCEPTING CONCESSIONS THAT ARE ERODING THE LEADERSHIP'S CREDIBILITY IN THE EYES OF ITS PALESTINIAN CONSTITUENCY--AND WHICH COULD PROMPT SOME DELEGATION MEMBERS TO PULL OUT OF THE TALKS.

00946 ANDONI, L.

THE WASHINGTON TALKS: DEADLOCK OR THE END?

MIDDLE EAST INTERNATIOMAL (420) (MAR 91) 3-4.

THAT THE BILATERAL ARAB-ISRAELI TALKS ARE DEADLOCKED

LESS THAN SIX MONTHS AFTER THEY STARTED WAS MOST PREDICTABLE. YET THE REPERCUSSIONS OF EITHER THEIR CONTINUING HITHOUT PROGRESS OR OF THEIR COLLAPSE WILL BE SERIOUS THROUGHOUT THE REGION. THE FOURTH ROUND OF TALKS, HHICH CONCLUDED IN HASHINGTON ON 4 MARCH, HAS PROVED DNCE AGAIN THAT ISRAEL IS SEEKING TO LEGITIMIZE ITS DE FACTO RECOGNITION BY MUCH OF THE ARAB WORLD WITHOUT GIVING UP THE OCCUPIED TERRITORIES-LET ALONE ADDRESSING PALESTINIAN NATIONAL RIGHTS. IN EACH OF THE BILATERAL NEGOTIATIONS BETWEEN ISRAEL AND ITS ARAB NEIGHBORS--THE PALESTINIANS, JORDAN, SYRIA, AND LEBANON-OTHE STORY WAS THE SAME: ARAB CALLS FOR TERRITORIAL COMPROMISE AND THE ADHERENCE TO UN RESOLUTION 242 WERE IGNORED BY ISRAELI NEGOTIATORS WHO CONCENTRATED ON SECURITY CONCERNS.

00947 ANDOR, L.

HUNGARY 1992: THE YEAR OF BANKRUPTCIES

JOURNAL OF COMMUNIST STUDIES, 8(4) (DEC 92), 302-306. ACCORDING TO MOST OBSERVERS, HUNGARY IS DEVELOPING INTO A REGIONAL BUSINESS CENTER FOR FINANCE AND TRADE--A KIND OF SINGAPORE OF EASTERN EUROPE. NEVERTHELESS, IN APRIL 1992 , THE HUNGARIAN GOVERMMENT ANNOUNCED THAT ONE-THIRD OF HUNGARIAN FIRMS AND HALF OF THE COUNTRY'S COLLECTIVE FARMS WOULD BE FACING BANKRUPTCY WITHIN A YEAR.

00948 ANDOR, L.

THE NEW RIGHT IN EASTERN EUROPE: A VISION OF DECLINE AND DECAY

FUTURES, 24(2) (MAR 92), 122-129.

DESPITE MUCH THAT HAS BEEN SAID ABOUT DEMOCRACY CONCERHING THE HISTORICAL TURNING POINTS IN EASTERN EUROPE IN 1989, THIS STUDY IS BASED ON THE OBSERVATION THAT THE MOST IMPORTANT INTENTION OF THE MAIN PROMOTERS OF THESE CHANGES HAS THE REDUCTION OF COLLECTIVISM AND WELFARE REDISTRIBUTION. THIS ALLOWS THE AUTHOR TO USE THE ANALOGY OF THE CHANGES OF 1979-1980 IN WESTERN CDUNTRIES. THE COMMON THE CHANGES OF 1979-1980 IN HESTERN CDUNTRIES. THE FEATURES OF THE TWO PERIODS ARE SUMMARI ZED AND SOME
CONCLUSIONS ABOUT THE FUTURE OF EASTERN EUROPE ARE DRAWN.

00949 ANDREAS, P.R.; SHARPE, K.E.

COCAINE' POLITICS IN THE ANDES

COCAINE POLITICS IN THE ANDES
CURRENT HISTORY, $91(562)$ (FEB 92), 74-79.

THE BUSH ADMINISTRATION'S MILITARIZATION OF THE DRUG WAR HAS HAD LITTLE EFFECT ON COCAINE PRODUCTION IN THE ANDEAN HAS HAD LITTLE EFFECT ON CDCAINE PRODUCTION IN THE ANDEAN COUNTRIES, HHERE THE ECONOMIES AND POLIIICS ARE INCREASINGLY DRIVEN BY NARCO-DOLLARS. THE CURRENT BDOH IN COCAINE EXPORT SINGLE MOST IMPORTANT SOURCE OF FOREIGN EXCHANGE FOR THE REGION'S DEBT-BURDENED ECONOMIES.

00950 ANDREJEVICH, M.

BOSNIA AND HERZEGOVINA: A PRECARIOUS PEACE RFE/RL RESEARCH REPORT, I(9) (FEB 92), 6-14. THE SITUATION IN BOSNIA ANO HERZEGÓVINA BECAME INCREASINGLY CRITICAL IN JANUARY 1992 AS LEADERS OF THE MULTI-ETHNIC REPUBLIC STEPPED UP THEIR EFFORTS TO FIND SOLUTION TO THE BOSNIAH CRISIS. THE SERBS, WHO REMAIMED STRONGLY OPPOSED TO BOSNIAN INDEPENDENCE, THREATENED TO DECLARE A SERBIAN REPUBLIC IF BOSNIA AND HERZEGOVINA WERE GRANTED RECOGNITION AND SOVEREIGNTY. TOWARD THE END OF JANUARY, THE RIFT BETWEEN THE SERBS, ON THE ONE HAND, AND
THE MUSLIMS AND CROATS, ON THE OTHER, DEEPENED WHEN MUSLIM AND CROATIAN DEPUTIES IN THE NATIONAL ASSEMBLY OF BOSNIA AND HERZEGOVINA PASSED A MEASURE CALLING FOR A REFERENOUM ON INDEPENDENCE, WHICH COULD PAVE THE WAY FOR RECOGNITION BY THE EUROPEAN COMMUNITY. THESE AND OTHER DEVELOPMENTS HAVE INCREASED FEARS THAT CIVIL WAR WILL BREAK OUT IN THE REPUBLIC.

00951 ANDREJEVICH, M.

ELECTIONS IN SLOVENIA MAINTAIN STATUS QUD

RFE/RL RESEARCH REPORT, 1 (50) (DEC 92), 28-31.

DESPITE GROHING PUBLIC DISSATISFACTION WITH THE ECONOMY, THE RESULTS OF SLOVENIA'S FIRST ELECTIONS SINCE THE DECLARATION OF INDEPENDENCE IN JUNE 1991 INDICATED VOTER CONFIDENCE IN THE CURRENT LEADERSHIP. NO SINGLE PARTY WON MAJORITY IN THE PARLIAMENT, BUT THE FIRST-PLACE SHOWING OF THE LIBERAL DEMOCRATS ENSURES THAT THE CURRENT COALITION THE LIBERAL DEMOCRATS ENSURES THAT THE CURRENT COALIYION GOVERNMENT OF JANEZ DRNOVSEK WILL BE MAINTAINED. DRNOVSEK MUST NOW REORGANIZE HIS ADMINISTRATION, WHICH FACES TASKS AS BEFORE: REINFORCING POLITICAL STABILITY

REVITALIZING THE ECONOMY, AND INTEGRATING SLOVENIA WITH EUROPE. IN A SOMEWHAT UNEXPECTED DEVELOPMENT, THE RIGHT-WING SLOVENIAN NATIONAL PARTY PLACED FOURTH IN THE ELECTIONS AND WILL BE REPRESENTED IN PARLIAMENT.

00952 ANDREJEVICH, $M$.

MORE GUNS, LESS BUTTER IN BOSNIA AND HERZEGOVINA RFE/RL RESEARCH REPORT, 1(11) (MAR 92), 10-17

THE SITUATION IN MULTI-ETHNIC BOSNIA AND HERZEGOVINA HAS HORSENED. LEADERS OF THE THREE RULING PARTIES HAVE STEPPED UP THEIR EFFORTS TO FIND A SOLUTION TO THE REPUBLIC'S POLITICAL CRISIS AND THEREBY AVERT A CIVIL WAR. THE REPUBLIC IS CURRENTLY BESET WITH ECONOMIC AND SOCIAL PROBLEMS, WHICH HAVE BEEN OVERSHADOWED BY THE CONTINUING DEBATE ON THE FUTURE SHAPE OF THE REPUBLIC. ON FEBRUARY 29 AND MARCH 1, 1992. THE CITIZENS OF BOSNIA AND HERZEGOVINA VOTED OVERWHELMINGLY IN FAVOR OF INDEPENDENCE. HOWEVER, EVEN IF BOSNIA AND HERZEGOVINA WERE GRANTED RECOGNITION IN THE NEAR FUTURE, THERE IS NO GUARANTEE THAT IT WILL BE ABLE TO MAINTAIN ITS AUTONOMOUS STATUS.

00953 ANDREJEVICH, M.; BARDOS, G.N.

SERBIA AND MONTENEGRO
RFE/RL RESEARCH REPORT, 1(39) (OCT 92), 86-91.

CONTROL OVER THE MEDIA HAS BEEN A FOCAL POINT IN THE POWER STRUGGLE BETWEEN THE GOVERNMENT AND THE OPPOSITION IN SERBIA AND MONTENEGRO. SINCE JANUARY 1989, THE SERBIAN OPPOSITION HAS MADE THE RULING SOCIALIST PARTY'S CONTROL OVER THE MEDIA THE CENTERPIECE OF ITS ATTACKS. FREEDOM OF THE PRESS HAS BECOME THE SINE QUA NON FOR THE OPPOSITION: BECAUSE IT HAS LACKED ACCESS TO THE MEDIA, ESPECIALLY TELEVISION, IT HAS BEEN HOPELESSLY DISADVANTAGED IN ITS STRUGGLE WITH THE REGIME. CONVERSELY, THE SOCIALISTBENEFITS TO BE GAINED FROM TIGHT CONTROL OF THE MEDIA AND HAS SHOWN ITS INTENT TO MAINTAIN THIS CONTROL. HOWEVER, CHALLENGES FROM WITHIN THE SOCIALIST PARTY HAVE SURFACED WITHIN THE PAST SIX MONTHS; AT THE FOREFRONT OF THIS DRAMATIC TURMAROUND IS THE POLITIKA PUBLISHING HOUSE. HHICH HAD PREVIOUSLY HELPED FOSTER THE RISE OF SLOBODAN MILOSEVIC, THE SERBIAN PRESIDENT.

00954 ANDREJEVICH, M.

SLOVENIA

RFE/RL RESEARCH REPORT, 1(39) (OCT 92), 58-61.

THE TRANSITION FROM THE COMMUNIST TO THE POSTCOMMUNIST

ERA WAS NOT AN ABRUPT ONE FOR THE SLOVENIAN MEDIA BECAUSE IT

BEGAN IN THE $1980^{\prime}$ 'S DURING THE RULE OF THE LEAGUE OF

COMMUNISTS. ALTHOUGH MULTIPARTY ELECTIONS UNSEATED THE

COMMUNISTS IN APRIL 1990, MUCH-NEEDED LEGISLATION ON THE COMMUNISTS IN APRIL 1990, MUCH-NEEDED LEGISLATION ON THE
FINANCING AND RESTRUCTURING OF THE MEDIA, WHICH WOULD EASE
THE TRANSITION FROM STATE TO PRIVATE OWMERSHIP, HAS NOT YET PASSED DUE TO DISPUTES AMONG THE MAJOR POLITICAL PARTIES.

00955 ANDREJEVICH, $M$.

SLOVENIA: POLITICS AND THE ECONOMY IN THE YEAR ONE

RFE/RL RESEARCH REPORT, 1 (36) (SEP 92), 15-23.

HAVING DECLARED ITS INDEPENDENCE FROM FEDERAL YUGOSLAVIA, THE REPUBLIC OF SLOVENIA FACES A DIFFICULT FUTURE. ALTHOUGH THE REPUBLIC OF SLOVENIA FACES A DIFFICUL T FUTURE. ALTHOUGH
SLOVENIA'S ROAD TO STATEHOOD HAS THUS FAR BEEN RELATIVELY SLOVENIA'S ROAD TO STATEHOOD HAS THUS FAR BEEN RELATIVELY SMOOTH, THE REPUBLIC CONTINUES TO

00956 ANDREJEYICH, M.

THE SAMDZAK: THE MEXT BALKAY THEATER OF WAR? THE SANDZAK: THE NEXT BALKAN THEATER OF WAR?

THE INTERNATIONAL COMMUNITY IS CONCERNED THAT THE WAR IN BOSNIA AND HERZEGOVINA WILL SPREAD TO THE PREDOMINANTLY MUSLIM REGION OF THE SANDZAK. IN THE PAST, THIS REGION WAS A STRATEGIC LINK BETWEEN BOSNIA AND HERZEGOVINA, KOSOVO, AND MACEDONIA; IT WAS ALSO THE CAUSE OF MILITARY CONFRONTATIONS AND MUCH DIPLOMATIC ACTIVITY. TODAY THE MUSLIMS AND THE SERBS OF THE SANDZAK FEAR THAT HAR WILL BREAK OUT IN THE 
policy of "ethnic Cleansing" in the region.

00957 AMDREJEVICH, M.

WHAT FUTURE FOR SERBIA?

RFE/RL RESEARCH REPORT, 1(50) (DEC 92), 7-17

SERBIA IS CONFRONTED WITH A DEEPENING POLITICAL AND

SOCIAL CRISIS. GIVEN THE SERBS' INVOLVEMENT IN THE WAR STILL

RAGING IN BOSNIA AND HERZEGOVINA, THE THREAT OF RENEWED

FIGHTING IN CROATIA, AND THE POSSIBILITY OF THE CONFLICT

SPREADING TO OTHER PARTS OF THE FORMER YUGOSLAVIA, IT IS

CLEAR THAT THE SITUATION IN SERBIA WILL REMAIN FRAUGHT HITH

VIOLENCE AND UNCERTAINTY, EVEN IF PRESIDENT SLOBODAN

MILOSEYIC SHOULD DEPART FROM THE SCENE.

00958 ANDREWS, $\mathrm{G}$.

BLACK POLITICAL PROTEST IN SAO PAULO, 1888-1988

JOURNAL OF LATIN AMERICAN STUDIES, 24 (1) (FEB 92), 147-172.

THIS ARTICLE EXPLORES SOME OF THE CONNECTIONS BETWEEN

RACE AND POLITICS IN BRAZIL BY EXAMINING FOUR MOMENTS IN THE HISTORY OF BLACK POLITICAL MOBILIZATION IN THAT COUNTRY. IT HISTORY OF BLACK POLITICAL MOBILIZATION IN THAT
FOCUSES ON THE SOUTHEASTERN STATE OF SAO PAULO.

FOCUSES ON THE SOUTHEASTERN STATE OF SAD PAULO.
CHRONOLOGICALLY, IT EXAMINES: THE RISE AND FALL OF THE CHRONOLOGICALLY, IT EXAMINES: THE RISE AND FALL
FRENTE NEGRA BRASILEIRA IN THE 1930S: THE BLACK

FRENTE NEGRA BRASILEIRA IN THE 1930S; THE BLACK
ORGANIZATIONS OF THE SECOND REPUBLIC; AND THE MOST RECENT ORGANIZATIONS OF THE SECOND REPUBLIC; AND THE MOST RECENT WAVE OF BLACK PROTEST, FROM THE MID-1970S TO 1988. IT SEEKS
TO RELATE THE HISTORY OF BLACK PROTEST TO THE LARGER HISTORY TO RELATE THE HISTORY OF BLACK PROTEST TO THE LARGER HISTORY
OF STATE-SOCIETY RELATIONS IN BRAZIL DURING THE LAST HUNDRED OF STA
YEARS.

00959 ANDREWS, $M$

LIFETIMES OF COMMITMENT: AGEING, POLITICS, PSYCHOLOGY CAMBRIDGE UNIVERSITY PRESS, 1991, 229

THE MAIN PURPOSE OF THIS BOOK' IS A CRITICAL ANALYSIS OF THE NATURE OF POLITICAL COMMITMENT AND ITS ROLE THROUGHOUT THE LIFETIME OF THE AUTHOR'S RESPONDENTS. IT OFFERS A CONTRIBUTION TO THE CURRENT DEBATE ABOUT THE URGENCY OF DEVISING STRATEGIES FOR "POSITIVE AGEING." THE AUTHOR ARGUES THAT DEVELOPMENTAL PSYCHOLOGY IS GUILTY OF A REDUCTIONISM WHICH REFLECTS ONLY TOO CLOSELY THE IMPERATIVES OF HESTERN CAPITALIST DEMOCRACIES: AN ENDEMIC INDIVIDUALISH HHICH PATENTLY IGNORES THE "SOCIETY-INDIVIDUAL DIALECTIC." THE AUTHOR'S INTERVIEWS REVEAL THAT PERSONAL DEVELOPMENT INTO OLD AGE IS NOT NECESSARILY A PROCESS OF INCREASING PREOCCUPATION WITH THE INDIVIDUAL SELF BUT MAY ALSO INVOLVE, AND INDEED LEGITIMATELY DEMAND, AN ABANDONMENT OF THE BELIEF IN THE SELF AS AN ESSENTIALLY INDIVIDUAL ACTOR. THE WIDER MESSAGE IN THIS STUDY OF POLITICAL COMMITMENT IS THAT POSITIVE AGEING CANNOT TAKE PLACE IN A PRIVATIZED INDIVIDUAL VACUUM BUT NECESSARILY REQUIRES GROUP SUPPORT.

00960 ANDROUMAS, E.

THE STRUGGLE FOR CONTROL OVER SOVIET TELEVISION JOURNAL OF COMMUNICATION, 41(2) (SPR 91) 185-200

THIS ARTICLE EXAMINES THE ONGOING STRUGGLE BETWEEN CONSERYATIVE AND IABERAL FORCES IN THE SOVIET UNION FOR CONTROL OF A KEY PROPAGANDA WEAPON: TELEVISION. IT OUTLINES CONTROL OF A KEY PROPAGANDA WEAPON: TELEVISION. IT OUTLINES THE ACTORS AND CONFLICTS INVOLVED II.E. CENTRAL GOVERNAEN VS. REPUBLICS, OLD GUARD VS. REFORMERS, AND CONFL ICTS
BETWEEN ELEMENTS OF THE TELEVISION INDUSTRY ITSELF). IT ALSO EXAMINES THE NEWLY STATED "ROLE OF THE MEDIA," TO "INFORM, TO CONVINCE, AND TO COMFORT." IT CONCLUDES THAT WHILE GOVERMMENT LEADERS STRESS THE ROLE OF TELEVISION IN "COMFORT ING" THE PEOPLE, AN ANALYSIS OF KEY CHALLENGES TO THE CENTRALIZED AUTHORITY SUGGESTS THAT SUCH COMFORT MAY COME AT THE EXPENSE OF LOCAL AND REGIONAL PARTICIPATION.

00961 ANECHIARICD, F.; JACOBS, J.B.

THE CONTINUING SAGA OF MUNICIPAL REFORM: NEW YORK CITY AND THE POLITICS OF ETHICS LAH

URBAN AFFAIRS QUARTERLY, 27(4) (JUN 92), 580-603.

THE AUTHORS PRESENT A CASE STUDY OF NEW YORK CITY'S RESPONSE TO A SEVERE CORRUPTION SCANDAL IN THE LATE 1980'S, IN ORDER TO ILLUSTRATE HOW PUBLIC ADMINISTRATION IS DRIVEN BY SCANDALS AND ATTEMPTS TO DETER THEM. ETHICS REFORMS FROM THE PROGRESSIVE ERA TO THE PRESENT FIT INTO THREE IDEALTYPICAL ANTI-CORRUPTION STRATEGIES. THE AUTHORS EXPLAIN HOH THESE STRATEGIES HAVE CHANGED OVER TIME AND FOCUS ON THE INCREASING DOMINANCE OF THE CRIME-CONTROL STRATEGY.

00962 ANGLIN, R.; HOLCOMB, B.

POVERTY IN URBAN AMERICA: POLICY OPTIONS

JOURNAL OF URBAN AFFAIRS, 14(3-4) (1992) 447-468.

THE AUTHORS SUMMARIZE DEMOGRAPHIC CHANGES IN THE NATURE OF POVERTY IN THE UNITED STATES AND RECENT GOVERNMENT

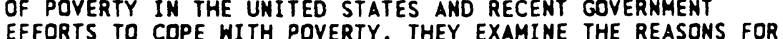
EFFORTS TO COPE WITH POVERTY. THEY EXAMINE THE REASONS THE PERSISTENCE OF POVERTY AND DESCRIBE POLICIES HITH DEMONSTRATED SUCCESS IN REDUCING POVERTY. THEY CONTEND THAT RECENT URBAN POLICIES HAVE BEEN LIMITED IN SCOPE AND EF WHAT IS NEEDED IS A FOCUSED, COMPREHENSIVE EFFORT THAT
ADORESSES THE CHANGES NOW OCCURRING IN CITIES. IN PARTICULAR, ADORESSES THE CHANGES NOW OCCURRING IN CITIES. IN PARTICULAR,
NEW INITIATIVES ARE NEEDED IN FAMILY POLICY AND COMHUNITY DEVELOPMENT.
00963 ANGRESANO, J.

POLITICAL AND ECONOMIC OBSTACLES INHIBITING COMPREHENSIVE POLITICAL AND ECO

EAST EUROPEAN QUARTERLY, XXVI(1) (SPR 92), 55-76.

THE AUTHOR EVALUATES THE HUNGARIAN REFORM PROCESS, FOCUSING ON POL ITICAL AND ECONOMIC OBSTACLES THAT HAVE PREVENTED AUTHORITIES FROM INTROOUCING COMPREHENSIVE REFORM MEASURES DESIGNED TO SATISFY THE NATION'S GOALS. HE SUMMARIZES THE NATION'S ULTIMATE AND INSTRUMENTAL GOALS AS ARTICULATED BY HUNGARIANS, ESPECIALLY THE COUNTRY'S RESEARCH ECONOMISTS AND POLITICAL AUTHORITIES. THEN HE OUTLINES THE MAJOR ECONOMIC AND POLITICAL PROBLEMS AND IDENTIFIES THE OBSTACLES THAT HAVE BEEN PREVENTING REFORM MEASURES FROM ACHIEVING THEIR ULTIMATE GOALS. FINALLY, HE OFFERS SOME CONCLUDING REMARKS ABOUT THE DIFFICULTIES FACING HUNGARIAN REFORMERS.

00964 ANIN, T.E.

IN SEARCH OF THE MAGIC CURE

WEST AFRICA, (3879) (JAN 92), 101.

GHANA'S ECONOMIC POLICY SHOULO BE FOCUSED ON ACHIEVING

TWO OBJECTIVES. THE FIRST GOAL IS TO CONCENTRATE ON

ATTAINING NATIONAL SELF-SUFFICIENCY, WITH THE POSSIBILITY OF

PRODUCING SURPLUSES FOR EXPORT, IN THE FOLLOWING SHORT-TERM

TROPICAL CROPS: COTTON, SUGAR, RICE, MAIZE, SORGHUM, SOYA

TROPICAL CROPS: COTS, BANANAS, GROUNDNUTS, PINEAPPLES, TOBACCO, AND TREE

BEANS, BANANAS, GROUMDNUTS, PINEAPPLES, TOBACCO, AND TRE

OB.PSTIVE IS TO EXPAND THE ONGOING REJUVENATION OF GHANA'S

GOLD AND OTHER MINERAL INDUSTRIES.

00965 ANIZ, J

EL SALVADOR'S UNEASY TRUCE

WORLD PRESS REVIEH, 39(11) (NOV 92), 37

THE SALVADORAN PEACE PROCESS HAS BEEN PLAGUED WITH DIFFICULTIES, BUT IT HAS SURVIVED. TRANSFORMING THE FARABUNDO MARTI NATIONAL LIBERATION FRONT (FMLN) FROM GUERRILLA FIGHTERS TO A CIVILIAN POLITICAL PARTY IS A SLOW PROCESS, BUT IT IS PROGRESSING.

00966 ANKDHAM, B.

AFRICA'S IMAGE ABROAD

NEW AFRICAN, (282) (MAR 91), 13.

NOTHING AFRICAN SEEMS TO CATCH THE EYE OF THE WORLD MEDIA SAVE COUPS, FAMINE, DISEASE, AND DISASTERS. THE FACT THAT AFRICA IS FILLED WITH REAL, BEAUT IFUL PEOPLE WHO LIVE REAL AND SOMETIMES COZY LIVES GOES UNREPORTED AND AFRICANS ABROAD ARE ANGRY. HOWEVER, SOME ACKNOWLEDGE THAT WHILE THE WORLD'S MEDIA COVERAGE OF AFRICA IS SOMEWHAT ONE-SIDED,

AFRICANS ARE NOT TOTALLY FREE FORM BLAME FOR THE BAD PRESS.

00967 ANLEU, $S$.

RECRUITMENT PRACTICE AND HOMEN LAWYERS' EMPLOYMENT: AN

EXAMINATION OF IN-HOUSE LEGAL DEPARTMENTS IN THE UNITED STATES

SOCIOLOGY, 26(4) (NOV 92), 651-672.

THIS PAPER EXAMINES THE WAY ORGANIZATIONAL PRACTICES AFFECT THE RECRUITMENT OF MEN AND WOMEN LAWYERS BY COMPARING THELVE IN-HOUSE LEGAL DEPARTMENTS IN MANUFACTURING AND TWELVE IN-HOUSE LEGAL DEPARTMENTS IN MANUFACTURING AND FINANCIAL SERVICES CORPORATIONS. ON THE WHOLE, WOMEN LAWYERS CAE BE EXPLAIMED BY THE DIFFERENT REOUIREMENTS OF EACH CAN BE EXPLAINED BY THE DIFFERENT REQUIREMENTS OF EACH SECTOR FOR SPECIFIC LEGAL SKILLS AND THEIR RECRUITMENT OF
LAWYERS FROM VARIOUS SEGMENTS OF THE LABOR MARKET IN WHICH WOMEN AND MEN ARE DIFFERENTIALLY DISTRIBUTED.

00968 AMNAN, L.

DO BROADCASTERS OWE A DUTY TO THE STATE?

TERRORISM AND POLITICAL VIOLENCE, 2(4) (WIN 90), 529-0543.

THIS ARTICLE CONSIDERS WHETHER JOURNALISTS HAVEE ANY DUTY TO THE STATE (AS OPPOSED TO SOCIETY OF THE GOVERNMENT). IT

EXAMINES CLASHES BETWEEN THE MASS MEDIA REPORTERS AND THE

STATE IN GREAT BRITAIN SUCH AS THE FALKLANDS WAR AND

COVERAGE OF THE IRISH REPUBLICAN ARMY IN IRELAND. THE AUTHOR CONCLUDES THAT A DUTY TO THE STATE EXISTS AND SHOULD BE UPHELD.

00969 ANMER, $M$.

EL SALVADOR: STATE TERROR CONTINUES DESPITE PEACE TALKS

NICARAGUAN PERSPECTIVES, (19) (FAL 90), 8-9

THIS ARTICLE EXPLORES THE LACK OF DEMOCRATIC PROGRESS IN EL SALYADOR IN LIGHT OF OTHER INTERNATIONAL SIGNS OF PROGRESS SUCH AS MANDELA'S RELEASE FROM PRISON IN SOUTH AFRICA AND THE FALL OF THE BERLIN WALL IN GERMANY. WHILE EL SALVADOR IS DESCRIBED AS NOT ENJOYING SIMILAR PROGRESS, SOME PALVADR IS DESCRIBED AS NOT ENJOYING SIMILAR PRDGR

POTENTIAL FOR IT IS NOTED, PARTICULARLY REGARDING NEGOTIATIONS BETHEEN FMLN AND THE SALVADORAN GOVERMMENT. THE AUTHOR PLACES THE BLAME FOR LACK OF DEMOCRATIC PROGRESS WI
THE SALVADORAN GOVERMMENT, EXPLAINS THE REASONS FOR THIS POSITION, AND PRESENTS EVIDENCE TO SUPPORT IT.

00970 ANMIS, $S$.

EVOLVING CONMECTEDNESS AMONG ENVIRONMENTAL GROUPS AND GRASSROOTS ORGANIZATIONS IN PROTECTED AREAS OF CENTRAL AHERICA 
HORLD DEVELOPMENT, 20(4) (APR 92), 587-595. THE AUTHOR DISCUSSES THE CONVERGENCE OF TWO POTENTIALLY POSITIVE TRENDS THAT MAY HELP TO REDUCE POVERTY AND ENVIRONMENTAL DETERIORATION IN CENTRAL AMERICA: (1) THE CREATION OF NETWORKS BY GRASSROOTS AND ENVIRONMENTAL ORGANIZATIONS AND (2) THE SPREAD OF INFORMATION AND COMMUNICATIONS TECHNOLOGY. BASED ON RESEARCH IN SIX HIGHLYENDAHGERED, PROTECTED AREAS IN CENTRAL AMERICA, HE IDENTIFIES EMERGING TRENDS IN "CONMECTEDNESS" AT THE LOCAL NATIOMAL, REGIONAL, AND INTERMATIONAL LEVELS. LOOKING TO THE FUTURE, HE COMCLUDES THAT IMFORMATIOMAL EMPOWERMENT CAN BE A PRACTICAL STRATEGY FOR REDUCING POVERTY AND ENYIRONMENTAL DEGRADATION.

00971 ANSELMO, L.; BERTOTTI, B.; FARINELLA, P. INTERNATIONAL SURVEILLANCE OF OUTER SPACE FOR SECURITY INTERNAT
PURPOSES

PURPOSES
SPACE POLICY, 73 (AUG 91), 184-198.

THE MONITORING OF DANGEROUS AND FORBIDDEN SPACE ACTIVITIES IS TO OY CARIED OUT EFFECTIVELY AND SYSTEMATICALLY ONLY BY THE USA AND USSR. THIS ARTICLE STATES THAT THE SITUATION SHOULD BE REMEDIED BY DEVELOPING INTERNATIONAL MEANS OF SURVEILLANCE OF SPACE ACTIVITIES. DIFFERENT SCENARIOS FOR THE ESTABLISHMENT OF AN INTERNATIONAL AGENCY FOR SPACE SURVEILANCE (IASS) ARE CONSIDERED AND AN ATTEMPT IS MADE TO ASSESS THE MAI

00972 ANSOLABEHERE, S.; BRADY, D.; FIORINA, M. THE VANISHING MARGINALS AND ELECTORAL RESPONSIVENESS BRITISH JOURNAL OF POLITICAL SCIENCE, 22(1) (JAN 92), 21-38.

THE AUTHORS ARGUE THAT THE MARGINAL DISTRICTS IN ELECTIONS FOR THE U.S. HOUSE OF REPRESENTATIVES HAVE DIMINISHED, THAT THE SWING RATIO HAS DECLINED, AND THAT PARTY COMPETITION FOR HOUSE SEATS HELD BY INCUMBENTS HAS LESSENED. WHILE FEARS THAT THE VANISHING MARGINALS PHENOMENON WOULD LEAD TO LOWER RESPONSIVENESS ON THE PART OF "SAFE" HOUSE INCUMBENTS HAVE PROVED GROUNDLESS, THE COLLECTIVE COMPOSITION OF CONGRESS DOES APPEAR TO BE LESS RESPONSIVE TO CHANGES IN POPULAR SENTIMENTS. THUS, THE RESPONSIVE TO CHANGES IN POPULAR SENTIMENTS. THUS, THE VANISHING MARGINALS HAVE CDNTRIBUTED TO THE CONTINUAT
DIVIDED GOVERNMENT IN THE UNITED STATES AND IN ALL DIVIDED GOVERMMENT IN THE UNITED STATES AND IN ALL
LIKELIHOOD DO HAVE THE EFFECTS ON CONGRESSIONAL LEADERSHIP AND POLICY-MAKING THAT MANY ANALYSTS HAVE CLAIMED.

00973 ANSON, $S$.

THE POSTCOLONIAL FICTION

ARENA, (96) (SPR 91), 64-68.

THIS ARTICLE ARGUES THAT THE WORLD WE LIVE IN IS STILL MANIFESTLY COLONIAL, ALTHOUGH IT MIGHT BE BETTER TO CALL IT NEOCOLONIAL, IN RECOGNITION THAT THE CRUDE ANNEXATIONS OF THE PAST HAVE BEEN SUPERSEDED BY SUBTLER IMPOSITIONS, OF WHICH THE VERY NOTION OF POST-COLONIALISM IS ONE. IN THE NAME OF POST-COLONIALISM THE TYPES AND CATEGORIES OF THE METROPOLIS ARE ONCE AGAIN BEING PROJECTED ONTO THE PERIPHERY, ONLY THIS TIME IT IS POSTMODERN RATHER THAN ENLIGHTENMENT VERITIES THAT ARE ASSUMED TO BE VALID FOR ALL PEOPLES PERIODS AND PLACES. POSTMODERNISM SEIZES ON ASPECTS OF THE NEOCOLONIAL EXPERIENCE-HYBRIDITY, SIMULATION, MARGINALITY ROOTLESSNESS-DAND UNIVERSALIZES THEM. LOCAL DISTINCTIONS ARE SQUEEZED BETWEEN THE COLONIALISM OF THE PAST AND THE COSMOPOL ITANISM OF THE FUTURE AS POSTMODERNISM BECOMES A TRANSITIONAL AND TRANSHISTORICAL FORMULARY ACTUALLY OBLIVIOUS TO THE HETEROGENEITY TO WHICH IT APPEALS FOR AUTHORITY.

00974 ANSPACH, M.

VIOLENCE AGAINST VIOLENC: : ISLAM IN COMPARATIVE CONTEXT TERRORISM AND POLITICAL VIOLENCE, 3(3) (FAL 91), 9-29. TO STUDY VIOLENCE WITHIN RELIGION IS TO CONFRONT A PARADOX. THIS ARTICLE EXPLORES THE NATURE AND IMPLICATIONS OF THIS PARADOX, FOCUSING FOR THE MOST PART, ON THE PLACE OF VIOLENCE IN THE RELIGION OF PRIMITIVE OR PRE-STATE SOCIETIES. IT ADDRESSES THE QUESTION OF VIOLENCE IN A NON-WESTERN HORLD RELGION ISLAH ESTABL ISHED EARLY IN, HITHIN THE COMPARATIVE CONTEXT ESTABLISHED EARLY IN THE ARTICLE AND CONCLUDES THE THE SACRIFICIAL CHANNELING OF VIOLENCE AGAINST VIOLENCE IS ALWAYS IN DANGER OF SPILLING OVER INTO RENEWED REVENGE CYCLES OF VIOLENCE AGAINST VIOLENCE,

00975 ANTHONY, J.D.

BETWIXT WAR AND PEACE: THE 12TH GCC HEADS OF STATE SUMMIT MIDDLE EAST INSIGHT, VIII (6) (JUL 92), 54-61.

THE DECEMBER 199; GUL COOPERATION COUNCI HEADS-OF-

STATE SUMMIT ADORESSED FIVE BROAD CATEGORIES OF CONCERNS:

IRAQ, INTRA-GCC AFFAIRS, THE GCC PLUS THO (EGYPT AND SYRIA),

IRAN, AND RELATIONS WITH THE FIVE PERMANENT MEMBERS OF THE $U$. N. SECURITY COUNCIL.

00976 ANTIC, 0

CANONIZATION OF THE LAST TSAR UNDER CONSIDERATION

RFE/RL RESEARCH REPORT, 1 (28) (JUL 92), 70-72.
IN APRIL 1992, THE RUSSIAN ORTHODOX BISHOPS DECIDED TO CONSIDER WHETHER TO CANONIZE TSAR NICHOLAS II. THE CHURCH'S MOVE TO CANONIZE NEW MARTYRS, ESPECIALLY THE LAST TSAR, HAS POLITICAL AS WELL AS ECCLESIASTICAL SIGNIFICANCE AND CAN BE EXPECTED TO HAVE FAR-REACHING, POSITIVE RESULTS IN SEVERAL AREAS. IT WOULD DEMONSTRATE THE READINESS OF THE CHURCH TO FACE A PART OF ITS HISTORY THAT UNTIL NOW HAS NOT BEEN CAUSED SOME CRITICS TO ACCUSE IT OF AN INABILITY TO ADJUST TO THE CHANGES OCCURRING IN RUSSIA'S MORAL AND POLITICAL CLIMATE. FURTHERMORE, CANONIZATION OF THE NEW MARTYRS BY THE MOSCOW PATRIARCHATE IS ONE OF THE CONDITIONS SET BY THE RUSSIAN ORTHODOX CHURCH ABROAD FOR THE UNIFICATION OF THE THO RUSSIAN ORTHODOX GROUPS.

00977 ANTIC, 0.

DEVELOPMENTS IN CHURCH LIFE
RFE/RL RESEARCH REPORT, 1(1) (JAN 92), 32-34.

WITH THE IMPLEMENTATION OF THE LAH ON FREEDOM OF CONSCIENCE AND RELIGIOUS ORGANIZATIONS, THE CHURCHES IN THE SOVIET UNION ACOUIRED A NEW STATUS IN 1991. BOTH THE LARGER CHURCHES, SUCH AS THE RUSSIAN ORTHODOX, AND THE SMALLER RELIGIOUS DENOMINATIONS ENTERED A NEW ERA. THE MOST REMARKABLE PROGRESS WAS MADE BY THE ROMAN CATHOLIC CHURCH, WHICH SUCCEEDED IN ESTABLISHING NEW HIERARCHICAL STRUCTURES IN THE USSR. THE VATICAN APPOINTED SEVERAL ROMAN CATHOLIC BISHOPS, WHICH CAUSED TENSION IN ORTHOOOX-CATHOLIC RELATIONS.

00978 ANTIC, 0.

REVIVAL OF ORTHODOX BROTHERHOODS IN RUSSIA

RFE/RL RESEARCH REPORT, 1(11) (MAR 92), 62-63.

MORE THAN 100 RUSSIAN ORTHODOX BROTHERHODOS AND OTHER RELIGIOUS ORGANIZATIONS HAVE SPRUNG UP IN RUSSIA IN THE PAST FEN YEARS. AN UMBRELLA ORGANIZATION, THE ALLIANCE OF ORTHODOX BROTHERHOODS, WAS FOUNDED IN THE FALL OF 1990. ALTHOUGH THE ACTIVITIES OF THESE BROTHERHOODS ARE LARGELY RELIGIOUS AND HUMANITARIAN. THEY ALSO OCCASIONALLY TAKE A POSITION ON POLITICAL MATTERS. THE BROTHERHOODS COULD PLAY A SIGNIFICANT ROLE AS THE COUNTRY STRUGGLES TOWARD MORAL AND SPIRITUAL REVIVAL.

00979 ANTIC, 0.

SUCCESSORS TO THE USSR COUNCIL FOR RELIGIOUS AFFAIRS

RFE/RL RESEARCH REPORT, 1(35) (SEP 92), 52-53.

THE NOTORIOUS USSR COUNCIL FOR RELIGIOUS AFFAIRS, USED TO GREAT EFFECT BY THE COMMUNIST REGIME TO SUPPRESS

RELIGIOUS ACTIVITIES IN THE SOVIET UNION, WAS DISBANDED IN DECEMBER 1991. NOW, THE NEWSPAPER "REITING" CONTENOS THAT STRUCTURES ENABLES THE GOVERNMENT TO EXERT CONTROL OVER RELIGIOUS ACTIVITIES ARE BEING RESURRECTED IN THE RUSSIAN FEDERATION. ORGANIZATIONS, STAFFED IN PART BY FORMER EMPLOYEES OF THE COUNCIL FOR RELIGIOUS AFFAIRS, ARE BEINC SET UP TO ASSUME SOME OF THE FUNCTIONS OF THE DEFUNCT SOVIET COUNCIL.

00980 ANTONELLI, C.

INFORMATION TECHNOLOGY AND THE DERIVED DEMAND FOR TELECOMHUNICATION SERVICES IN THE MANUFACTURING INDUSTRY INFORMATION ECONOMICS AND POLICY, 4(1) (1990), 45-56.

THIS PAPER AIMS AT EXAMINING THE FACTORS WHICH INFLUENCE THE GROWTH IN DEMAND FOR TELECOMMUNICATION SERVICES IN THE ITALIAN MANUFACTURING SECTOR. THE MARSHALLIAN NOTION OF DERIVED OEMAND IS USED TO TRACE THE EFFECTS OF THE DIFFUSION OF NEW INFORMATION TECHNOLOGY ON TELECOMMUNICATIONS DEMAND. SPECIAL ATTENTION HAS BEEN PAID TO ADOPTION OF INFORMATION TECHNOLOGY BROUGHT ON BY WAGE LEVELS AND THE SIZE OF FIRHS. IN FACT THE EMPIRICAL ANALYSIS--BASED ON THE COEFFICIENTS OF INPUT--OUTPUT TABLES FOR COMMUNICATIONS SERVICES- SHOWS THAT THE DERIVED DEMAND FOR TELECOMMUNICATION SERVICES IS LARGER IN INDUSTRIES WITH HIGHER WAGES, LARGER SIZED FIRMS, LOVER LEVELS OF VERTICAL INTEGRATION AND GREATER PRODUCT DIFFERENTIATION.

00981 ANYADIKE-DANES, M.K.; ANYADIKE-DANES, M.N. THE GEOGRAPHIC ALLOCATION OF THE EUROPEAN DEVELOPMENT FUND UNDER THE LOME CONVENTIONS

WORLD DEVELOPMENT, 20(11) (NOV 92), 1647-1661.

THE BULK OF THE FINANCIAL ASSISTANCE PROVIDED BY THE
THE EUROPEAN COMHUNITY TO MEMBERS OF THE AFRICAN, CARIBBEAN, AND PACIFIC GROUP OF STATES UNDER THE LOME CONVENTION HAS BEEN PACIFIC GROUP OF STATES UNDER THE LOME CONVENTION HAS BEEN
CHANNELLED THROUGH "NATIONAL INDICATIVE PROGRAMS." A CHANNELLED THROUGH "MATIONAL INDICATIVE PROGRAMS." A COUNTRIES REYEALS THAT IT MAY BE RELATED NOT ONLY TO A

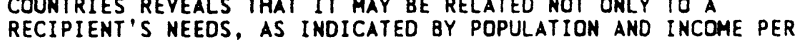
RECIPIENT'S NEEDS, AS INOICATED BY POPULATION AND INCOME PER NATURE OF A RECIPIENT'S PRIOR ASSOCIATION WITH THE COMMUNITY.

00982 AMYAOKU, E. COMMONHEALTH COMMITMENT: DEMOCRACY AND DEBT PARLIAMENTARIAN, LXXIII(1) (JAN 92), 44-48.

IN THIS ADORESS TO THE 37TH COMMONHEALTH PARLIAMENTARY CONFERENCE, THE AUTHOR DISCUSSES THE COMMONWEALTH'S ROLE IN SUCH AREAS AS INSURING HUMAN RIGHTS, OBSERVING ELECTIONS IN MEMBER STATES, ANO SOLVING THE PROBLEM OF EXTERNAL DEBT. 
00983 ANYAOKU, E.

THE COMMONHEALTH AND THE CHALLENGE OF DEMOCRACY DEVELOPMENT POL ICY REVIEW, 10(2) (JUN 92), 99-106. THE AUTHOR DISCUSSES THE COMMONWEALTH'S ROLE IM BREATHING NEH LIFE INTO THE RESURGENT DEMOCRATIC ASPIRATIONS OF SOME OF ITS MEMBERS. HE COMMENTS ON WHAT WENT WRONG WITH DEMOCRACY DURING THE IMMEDIATE POST-COLONIAL PERIOD AND OFFERS SOME LESSONS FROM THAT EXPERIENCE.

00984 APAPELBAUM, R.; HENDERSON, J.

STATES, DEVELOPMENT IN THE ASIAN PACIFIC RIM SAGE PUBLICATIONS, 1992, 320.

AFTER SITUATING THE STATE IN THE EAST ASIAN DEVELOPMENT PROCESS, THIS 8OOK EXPLORES THEORETICAL ISSUES, ECONOMIC POLICY AND SOCIAL POLICY IN THE ASIAN PACIFIC RIM. IT OFFERS A COMPARATIVE ANALYSIS OF THE STATE, ECONOMY, AND SOCIETY, ANO, NEW REALITIES OF INDUSTRIAL DEVELOPMENT IN EAST ASIA AND LATIN AMERICA, INCLUDING GLOBAL, REGIONAL, AND NATIONAL TRENDS. IT EXPLORES THE DEVELOPMENTAL STATE AND CAPITAL ACCUMULATION IN SOUTH KOREA, MALAYSIA, AND JAPAN. THE BOOK CONCLUDES WITH A STUDY OF WOMEN, THE FAMILY, AND THE STATE IN HONG KONG, TAIWAN, AND SINGAPORE.

00985 APONTE, W.L.

FULL PRETORIA TIES A "SLAP IN THE FACE" FOR BLACK AFRICA JAPAN TIMES (WEEKLY INTERMATIONAL EDITION), 32 (9) (MAR 92), 3.

JERRY MATSILA, THE TOKYO REPRESENTATIVE OF THE AFRICAN NATIONAL CONGRESS, BELIEVES JAPAN'S DECISION TO ESTABLISH FULL DIPLOMATIC TIES WITH SOUTH AFRICA IS A MAJOR SETBACK FOR JAPANESE DIPLOMACY AND THAT JAPAN IS MISSING A GOLDEN OPPORTUNITY TO REDEFINE ITS IMAGE IN THE EYES OF BLACK AFRICA. MEANWHILE, THE JAPANESE GOVERNMENT IS CONSIDERING INVITING SOUTH AFRICAN PRESIDENT F.W. DEKLERK TO VISIT JAPAM TO DEMONSTRATE SUPPORT FOR HIS REFORMS AIMED AT ESTABLISHING A NON-RACIST DEMOCRACY.

00986 APOSTOLAKIS B.

WARFARE-WELFARE EXPENDITURE SUBSTITUTIONS IN LATIN AMERICA, 1953-87

JOURHAL OF PEACE RESEARCH, 29(1) (FEB 92), 85-98.

THIS STUOY PRESENTS AN OVERALL VIEH AND AN EMPIRICAL TESTING OF THE ALLEGED TRADE-OFF BETWEEN DEFENSE AND OTHER PUBLIC MEEDS (HEALTH, EDUCATION, SOCIAL SECURITY, AND PUBLIC WORKS) IN NINETEEN LATIN AMERICAN NATIONS DURING THE PERIOD 1953-1987. VIA THREE ALTERMATIVE ECONOMETRIC SPECIFICATIONS BASED ON TIME-SERIES DATA, THE AUTHOR CONCLUDES THAT, BASED ON TIME-SERIES DATA, THE AUTHOR CONCLUDES THAT,
OVERWHELMINGLY, MILITARY EXPENDITURES CROWD OUT THE POTENTIAL ALLOCATIONS FOR SOCIAL UPGRADING. THE AUTHOR ALSO POTENTIAL ALLOCATIONS FOR SOCIAL UPGRADING. THE AUTHOR
FINDS A POSITIVE LINK ONLY IN THE DEFENSE-PUBLIC WORKS FINDS A POSITIVE LINK ONLY IN THE DEFENSE-PUBLIC WORKS
SPENDING. IN ITS MAJORITY, THEREFORE, THE WARFARE-WELFARE SPENDING. IN ITS MAJORITY, THEREFORE, THE WARFARE-WELFARE
(GUNS VS. BUTTER) TRADE-OFF IN THE REGION IS CONFIRMED. THE (GUNS VS. BUTTER) TRADE-OFF IN THE REGION IS CONFIRMED. PATTERN OF THESE 35 YEARS STRONGLY SUGGESTS THAT LATIN MOTIVES OF MATIONAL OR PERSONAL SOVEREIGNTY, AND MOTIVES OF NATIONAL OR PERSONAL SOVEREIGNTY, AND OCCASIONALLY ON THE POTENTIAL FOR CONFLICTS WI
RATHER THAN ON ANY OTHER THREAT OF AGGRESSION.

00987 APOSTOLOU, R.; BROOKS, R.; HILDRETH, W. RESEARCH AND TRENDS IN GOVERMMENTAL ACCOUNTING AND REPORTING

INTERNATIONAL JOURMAL OF PUBLIC ADMINISTRATION, 15(5) 1992), 112-1150.

BUDGETING IS A FORM OF FINANCIAL REPORTING USING ACCOUNTING INFORMATION. IN THIS PAPER THE CONTRIBUTIONS OF THE GOVERMMENTAL ACCDUNTING STANDARDS BOARD ARE REVIWED AS WELL AS DEVELOPMENTS THAT ARE EXPECTED TO HAVE A SIGNIFICANT IMPACT ON BUDGETING IN THE FUTURE. THE PAPER ALSO REVIEWS ACCOUNTING RESEARCH IN FOUR DISTINCT AREAS: CAPITAL MARKETS FINANCIAL REPORTING; BEHAVIORAL EXPERIMENTS; AND, PUBLIC CHOICE. THE FUTURE OF GOVERNMENTAL ACCOUNTING AND REPORTING WILL REFLECT CHANGES IN THE STANDARDS OF PRACTICE AND THE USE OF THEORY TO DIRECT RESEARCH.

00988 APPELBAUM, R.; CASTELLS, M.; HEMDERSON, J. FOUR ASIAN TIGERS WITH A DRAGON HEAD: A COMPARATIVE ANALYSIS OF THE STATE, ECDNOMY, AND SOCIETY IN THE ASIAN PACIFIC RIM; STATES AND DEVELOPMENT IN THE ASIAN PACIFIC RIM

SAGE PUBLICATIONS, 1992, 33-70.

THE FOUR ASIAN TIGERS, (HONGKONG, TAIWAN, SINGAPORE, AND SOUTH KOREA) ASIAN TIGERS, (HONGKONG, TAIWAN, SINGAPORE, STATES IN WHICH STRONG AND OFTEN REPRESSIVE STATES SINGLESTATES IN WHICH STRONG AND OFTEN REPRESSIVE STATES SINGLEPREYALING IMAGES, NOHE OF THESE COUNTRIES CAN BE REGARDED AS PREVALING IMAGES, NONE OF THESE COUNTRIES CAN BE REG BASTIONS OF FREE ENTERPRISE CAPITALISM. A DETAILED EXAMINATION OF THE FOUR COUNTRIES LEADS THE AUTHOR TO CONCLUDE THAT THERE ARE, IN FACT, MARKED DIFFERENCES IN THE
DEVELOPMENTAL PATHS OF EACH, AS HELL AS SOME COMMON FEATURES

00989 APPELBAUM, R.; HENDERSON, J.; LUBECK, P.

MALAYSIAN INDUSTRIALIZATION, ETHNIC DIVISIONS, AND THE NIC MODEL: THE LIMITS TO REPLICATION: STATES AND DEVELPMENT IN
THE ASIAN PACIFIC RIM

SAGE PUBLICATIONS, 1992, 176-198.

PAUL LUBECK ADORESSES THE QUESTION OF THE REPLICABILITY OF THE EAST ASIAM MODEL, FOCUSING OM THE EXPERIENCE OF MALAYSIA. HE TRACES THE HISTORICAL ROOTS OF ETHNIC IDENTITIES AND CLEAVAGES TO THE ETHNIC DIVISION OF LABOR IMPOSED BY BRITISH COLONIALISH, WHICH UTILIZED SCIENTIFIC RACIAL THEORIES TO ALLOCATE: THE INDUSTRIOUS CHINESE TO BUSINESS AND TRADE ACTIVITIES; THE DOCILE INDIANS TO RUBBER PLANTATION LABOR; AND THE INDOLENT BUT COURTEOUS MALAYS TO FARMING. THIS STRATIFICATION SYSTEM REIMFORCED PRE-EXISTING ECONOMIC ROLES, CONTRIBUTING TO A STEREOTYPING THAT REMAINS STRONG TODAY. HE CONCLUDES THAT UNTIL THE MALAYSIAN STATE FULLY COMAITS ITSELF TO A BROAOLY BASED DEVELPMENT EFFORT, IT CANNOT BE TERMED DEVELOPMENTAL ALONG THE LINES OF THE OTHER EAST ASIAN NICS.

00990 APPELBAUM, R.; GEREFFI, G.; HENDERSON, J.

NEW REALITIES OF INDUSTRIAL DEVELOPMENT IN EAST ASIA AND

LATIN AMERICA: GLOBAL, REGIONAL AND NATIONAL TRENDS;

STATES AND DEVELOPMENT IN THE ASIAN PACIFIC RIM

SAGE PUBLICATIONS, 1992, 85-112.

NEWLY INDUSTRIALIZING COUNTRIES ARE PLAYING INCREASINGLY SPECIALIZED ROLES IN EXPORTING MANUFACTURED GOODS TO THE DEVELOPED NATIONS. BY COMPARING EAST ASIA AND LATIN AMERICA, THE AUTHOR IS ABLE TO SHED LIGHT ON THE DEGREE TO WHICH THESE DIFFERING ROLES CONTRIBUTE TO OVERALL INDUSTRIAL DEVELOPMENT IN THE NICS OF THE THO REGIDNS. HE ARGUES THAT IN THE GLOBAL DIVISION OF LABOR, CAPITALISTS IN CORE IN THE GLOBAL DIVISION OF LABOR, CAPITALISTS IN CDRE COUNTRIES STILL DICTATE WHERE MUCH OF THE MANUFACTURING WILL OCCUR, IN KEEPING WITH THEIR OWN PROFIT CONSIDERATIONS. THE CHAPTER IS CONCLUDED HITH AN IDENTIFICATION OF THE
ROLE THAT THE NICS CAN PLAY IN THE WORLD ECONOMY.

00991 APPELBAUM, R.; GEREFFI, G.; HENDERSON, J. NEH REALITIES OF INDUSTRIAL DEVELOPMENT IN EAST ASIA AND LATIN AMERICA: GLOBAL, REGIONAL, AND NATIONAL TRENDS STATES AND DEVELOPMENT IN THE ASIAN PACIFIC RIM SAGE PUBLICATIONS, 1992, 85-112.

IN ORDER TO BETTER UNDERSTAND THE ROLE OF THE STATE IN ECONOMIC DEVELOPMENT, IT IS NECESSARY TO UNDERSTAND THE CHANGING NATURE OF CAPITALISM IN AN EXPORT-BASED GLOBAL ECONOMY. GARY GEREFFI PROVIDES THIS ANALYSIS AS HE DEVELOPS THE CONCEPT OF THE COMMOOITY CHAIN AS THE KEY PRODUCTION UNIT IN THE EMERGING GLOBAL MANUFACTURING SYSTEM. HE ARGUES THAT COMMODITY CHAINS ARE RESHAPING THE GEGRAPHY OF CAPTITALISM, CREATING NEW AND DISTINCT REGIONAL DIVISIONS OF LABOR. PROFITS ARE INCREASINGLY REALIZED THROUGH DESIGN, MARKETING AND RETAILING WHILE MANUFACTURING CAN BE DONE' WITH UNSKILLED LABOR AT LOW RELATIVELY COSTS.

00992 APPELBAUM, R.; CHON, S.: HENDERSON, J.

POL ITICAL ECONOMY OF REGIONAL DEVELOPMENT IN KOREA; STATES POLITICAL ECONOMY OF REGIONAL DEVELOPHEN

SAGE PUBLICATIONS, 1992 , 150-175.

SINCE 1961, THE KOREAN GOVERNMENT HAS PLANNED AND

MONITORED THE ECONOMIC GROWTH OF THE COUMTRY. THIS CHAPTER IS AN ATTEMPT TO EXPLAIN HOW RAPID ECONOMIC GROWTH AND STATE INTERYENTION HAYE AFFECTED SPATIAL ECONOMIC DEVELOPMENT. THE AUTHOR HAS SOUGHT TO FIND EXPLANATIONS USING: THE ECONOMIC STRUCTURAL TRANSFORMATIONS THAT FAVORED REGIONS HITH INDUSTRIAL BASES: THE RELATIVE AGRICULTURAL INCOME GROWTH AMONG DIFFERENT REGIONS IN KOREA; AND, THE POLITICAL AND ELITE POHER STRUCTURE
FROM THE SOUTHEAST.

00993 APPELBAUM, R.; HENDERSON, J.

STATES AND DEVELOPMENT IN THE ASIAN PACIFIC RIM SAGE PUBLICATIONS, 1992,320

THE POST-WORLD WAR II ECDNOMIC TRANSFORMATION OF EAST ASIA HAS PROVEN PERPLEXING TO DEVELOPMENT ANALYSTS INFLUENCED BY THE AFRICAN AND LATIN AMERICAN EXPERIENCES. THIS BOOK QUESTIONS THE SIMPLISTIC ASSUMPTION THAT THE EAST ASIAN MIRACLE IS A VINDICATION OF FREE MARKET CAPITALISM. THE CHAPTERS IN THIS BOOK, DEVELOP THE CASE FOR THE STATE IN DETAIL WITH REGARD TO PARTICULAR FACETS OF STATE ACTION IN JAPAN, THE FOUR TIGERS, AND IN MALAYSIA, THE SOCIETY HITH THE GREATEST RECENT POTENTIAL FOR LATE INDUSTRIALIZATION. THE BOOK EXAMINES THEORETICAL ISSUES, ECONOMIC POLICY AND SOCIAL POLICY IN THE ASIAM PACIFIC RIM.

00994 APPELBAUM, $R$

STATES AND DEYELOPMENT IN THE ASIAN PACIFIC RIM SAGE PUBLICATIONS, $1992,320$.

THE AUTHORS SUGGEST THAT WE HAVE MOT YET REACHED THE POINT WHERE SOME GENERAL THEORY OF EAST ASIAN LATE INDUSTRIALIZATION CAN BE ADVANCED; FOR THE MOMENT, THEY TRY TO PROVIDE POINTERS IN THAT DIRECTION. THEY OFFER ONE POINTER BY TRYING TO SITUATE THE STATE, IN A PRELIMINARY FASHION, IN RELATION TO OTHER POTENTIAL CANDIDATES FOR THE DETERMINATION OF EAST ASIAN DEVELOPMENT. CHAPTERS IN THIS BOOK DEVELOP THE CASE FOR THE STATE IN DETAIL WITH REGA

PARTICULAR FACETS OF STATE ACTION IN JAPAN, THE "FDUR
TIGERS" (SOUTH KOREA, TAIWAN, HONG KONG, AND SINGAPORE), AND 
IN MALAYSIA, THE SOCIETY WITH THE GREATEST RECENT POTENTIAL FOR LATE INDUSTRIALIZATION. THEDRETICAL ISSUES, ECONOMIC POLICY AND SOCIAL POLICY OF THIS REGION ARE EACH EXPLORED.

00995 APPELBAUM, R.; HARRIS, N.; HENDERSON, J.

STATES, ECONOMIC DEVELOPMENT, AND THE ASIAN PACIFIC RIM; STATES AND DEVELOPMENT IN THE ASIAN PACIFIC RIM SAGE PUBLICATIONS, 1992, 71-84.

THE NOTION THAT INDEPENDENT STATES EXIST IN A WORLD MARKET IS QUESTIONED IN THIS CHAPTER. THE AUTHOR ARGURES THAT THERE IS SIGNIFICANT INTERPENETRATION OF GLOBAL CAPITAL AND MARKETS THROUGHOUT THE WORLD. HOWEVER, STATES CANNOT BE IGNORED. THERE EXISTS TOOAY A WORLD POLITICAL-ECONOMIC ORDER OF COMPETING STATES AND COMPANIES, IN WHICH THE FORMER OFTEN CONTEND ALONG GEOGRAPHIC AND MILITARY LINES. WHILE NATIONAL RIVALRIES AND MILITARY ADVENTURISM AT ONE TIME WENT HAND-INMECESSARILY TRUE.

00996 APPELBAUM, R.; HARRIS, N.; HENDERSON, J.

STATES, ECONOMIC DEVELPOMENT, AND THE ASIAN PACIFIC RIM; STATES AND DEVELPMENT IN THE ASIAN PACIFIC RIM SAGE PUBLICATIONS, 1992, 71-84.

A NUMBER OF MYTHS CONCERNING THE RELATIONSHIP BETWEEN STATE POLICY AND ECONOMIC DEVELOPMENT IN SOUTH KOREA, TAIWAN, AND SINGAPORE ARE DISPELLED. THE AUTHOR QUESTIONS THE VERY NOTION THAT INDEPENDENT STATES EXIST IN A HORLD MARKET. HE ARGUES THAT THERE IS SIGNIFICANT INTERPENETRATION OF GLOBAL CAPITAL AND MARKETS THROUGHOUT THE HORLD. ALSO, HE NOTES THAT PARADOXICALLY THE VERY SUCCESS OF EOI NOW' THREATENS TO UNDERMINE THE STRONG STATES THAT INITIALLY MADE IT POSSIBLE. ONCE FREE TO DO AS THEY WISHED, THE STATES IN THESE COUNTRIES NOW FIND THEMSELVES CHALLENGED BY THE POWERFUL CORPORATIONS THEY HELPED TO SPAWN AND NUTURE.

00997 APPELBAUM, R.; HENDERSON, J.; KIM, E.; KDO, H.

THE DEVELOPMENTAL STATE AND CAPITAL ACCUMULATION IN SOUTH KOREA; STATES AND DEVELOPMENT IN THE ASIAN PACIFIC RIM SAGE PUBLICATIONS, $1992,121-149$.

THE MAJOR AIM OF THIS CHAPTER IS TO PROVIDE AN ANALYSIS OF THE SPECIFC WAYS IN WHICH THE SOUTH KOREAN DEVELOPMENTAL STATE HAS SHAPED THE CAPITAL ACCUMULATION PROCESS IN INTERACTIONS WITH ECONDMIC AND POLITICAL ACTORS IN THE INTERACTIONS WITH ECONDMIC AND POL ITICAL ACTORS IN THE
CHANGING INTERNATIONAL AND DOMESTIC ECONOMIC ENVIRONMENTS CHANGING INTERNAT IONAL AND DOMESTIC ECONOMIC ENVIRONMENTS.
THE ANALYIIC FOCUS IN ON THE PROCESS OF CAPITAL ACCUMULATION THE ANALYTIC FOCUS IN ON THE PROCESS OF CAPITAL ACCUMULATION
AND IN THIS ANALYSIS THE DEVELOPMENTAL STATE IS TAKEN AS A POL ITICAL PROCESS. FOCUSING ATTENTION ON THE PROCESS OF POPITAL ACCUMULATION RATHER THAN ECONOMIC GROWTH PROVIDES A CLOSER LOOK AT THESE DYNAMIC PROCESSES OF ECONOMIC CLOSER LOOK
DEVELOPMENT.

00998 APPELBAUM, R.; HENDERSON, J.; KIM, E.; KOO, H. THE DEVELOPMENTAL STATE AND CAPITAL ACCUMULATIOH IM SOUTH KOREA; STATES AND DEVELOPMENT IN THE ASIAN PACIFIC RIM SAGE PUBLICATIONS, $1992,121-149$

THE RELATIONSHIP BETWEEN STATE POLICY AND CAPITAL ACCUMULATION IN SOUTH KOREA IS THE FOCUS OF THIS CHAPTER. THE AUTHORS ARGUE THAT THE STRONG KOREAN STATE HAS BEEN LARGELY AUTONOMOUS FROM CIVIL SOCIETY, AND THEREFORE HAS BEEN ABLE TO EXERT SIGNIFICANT CONTROL OVER BOTH DOMESTIC AND FOREIGN CAPITAL IN THE INTERESTS OF SPURRING ECONOMIC DEVELOPMENT. IN EXAMINING THE WAYS IN WHICH THE KOREAN STATE HELPED TO SECURE ACCUMULATION FOR THE LARGE CONGLOMERATES, THE AUTHORS LOOK AT DIFFERING POLICIES DURING FOUR PHASES OF POSTWAR KOREAN HISTORY.

00999 APPELBAUM, R.; FUKUI, H.; HENDERSOM, J.

THE JAPANESE STATE AND ECONOMIC DEVELLPMENT: A PROFILE OF A NATIONALIST-PATERNALIST CAPITALIST STATE; STATES AND DEVELOPMENT IN THE ASIAN PACIFIC RIM

SAGE PUBLICATIONS, 1992, 199-226.

TO DISCUSS SELECTED ASPECTS OF THE ECONOMIC DEVELOPMENT

OF MOOERN JAPAN IN ORDER TO ILLUSTRATE AND HIGHLIGHT THE

ROLE OF THE STATE AS THE DESIGNER AND PRDPAGATOR, AND

PRIVATE ENTERPRISE AS THE MAIN BENEFICIARY OF AN' IDEOLOGY

CONDUCIVE TO RAPID ECONOMIC GROHTH AT CERTAIN STAGES OF A

NATIONAL ECONOMY IS THE MAIN PURPOSE OF THIS CHAPTER. THE AUTHOR DISCUSSES THE ORIGINS AND EVOLUTION OF THE IDEOLOGY IN POST-TOKUGUAH AND PRE-HORLD WAR II JAPAN, THEN TRACES ITS TRANSFORMATION AND IMPACTS ON THE DEVELOPMENT OF THE POSTHAR TRANSFORMATION AND IMPACTS ON THE DEVELOPMENT OF THE
JAPANESE ECONOMY. IT CONCLUDES BY TOUCHING ON RECENT

POLITICAL-ECONOMIC CHANGES AND THEIR IMPLICATIONS FOR THE

FUTURE OF JAPANESE CAPITALISM IN GENERAL AND ITS IDEOLOGICAL

FUTURE OF JAPANESE CAP.
BASIS IN PARTICULAR.

01000 APPELBAUM, R. ; FUKUI, H.; HENDERWSON, J.

THE JAPANESE STATE AND ECONOMIC DEVELPMENT: A PROFILE OF A NATIONALIST-PATERNALIST CAPITALIST STATE; STATES AND DEVELPMENT IN THE ASIAN PACIFIC RIM

SAGE PUBLICATIONS, 1992, 199-226.

SOME REFLECTIONS ON THE ROLE OF THE JAPANESE STATE THAT PROVIDES IMPORTANT INSIGHTS INTO THE NATURE OF STATE-DRIVEN CAPITALISM IN THE FOUR TIGER NATIONS ARE OFFERED. THE AUTHOR, HARUHIRO FUKUI, ARGUES THE JAPANESE CAPITALISM IS AN
UNORTHODOX AND DEVIANT FORM, ONE THAT HAS MUTED CLASS DIFFERENCES AND EMPHASIZED NATIONAL PURPOSE AND UNITY, A PATTERN THAT IS REPEATED TO VARYING DEGREES IN THE EAST ASIAN NICS. HE ALSO ARGUES THAT SYSTEMATIC INDOCTRINATION OF YOUTH INTD THE SHINTOIST EMPERDR CULT AND CONFUCIANIST BELIEFS IN STATE LOYALTY HELPED TO PROMOTE NATIONAL HARMONY AND UNITY. HE CONCLUDES THAT DESPITE JAPAN'S PHENOMENAL SUCCESS IN CREATING ONE OF THE MOST RAPIDLY GROWING AND ECONOMICALLY EGALITARIAN INDUSTRIAL ECONOMIES IN THE WORLD, THERE ARE NONETHELESS PROBLEMS BELOW THE SURFACE THAT WILL LIKELY CHANGE THE NATURE OF JAPANESE-STYLE-CAPITALISM DURING THE LAST DECADE OF THIS CENTURY.

01001 APPELBAUM, R.; DEYO, F.; HENDERSON, J.

THE POLITICAL ECONOMY OF SOCIAL POLICY FORMATION: EAST ASIA'S NEWLY INDUSTRIALIZED COUNTRIES; STATES AND DEVELOPMENT IN THE ASIAN PACIFIC RIM

SAGE PUBLICATIONS, 1992, 289-306.

FREDERIC DEYO UNDERTAKES A BROAD COMPARATIVE REVIEW OF THE VARIOUS FORMS OF SOCIAL POLICY THAT HAVE BEEN USED BY THE EAST ASIAN STATES TO SECURE LEGITIMACY. HE ARGUES THAT UNDER EIO, ECONOMIC POLICIES TYPICALLY DRIVE SOCIAL FOUR DIFFERENT FORMS OF SOCIAL POLICY ARE EXAMINED: ECONOMIC DEVELOPMENT ITSELF, WHICH, DEYO ARGUES, HAS SIGNIFICANT WELFARE IMPLICATIONS AS EMPLOYMENT AND WAGES RISE; DIRECT SOCIAL WELFARE EXPENDI IURES ON HEALTH, HOUSING,
EDUCATION, TRANSPORTATION, FOOD AND VARIOUS FORMS OF PUBLIC EDUCATION, TRANSPORTATION, FOOD AND VARIOUS FORMS OF PUDLI
ASSISTANCE; INCOMES POLICIES, WHICH INFLUENCE WAGES AND BENEFITS; AND INCOME SECURITY PROGRAMS. THROUGH PENSION PROGRAMS, UNEMPLOYMENT CONPENSATION, DISABILITY AND HEALTH INSURANCE, AND OTHER FORHS OF SOCIAL SECURITY. ALL FOUR FORMS OF SOCIAL POLICY HAVE BEEN EFFECTIVELY UTILIZED TO PROMOTE ECONOMIC DEVELOPMENT GOALS.

01002 APPELBAUM, R.; CHENG, L.; HENDERSON, J.; HSIUNG, P. WOMEN, EXPORT-OREINTED GROWTH, AND THE STATE: THE CASE OF TAIHAN; STATES AND DEVELOPMENT IN THE ASIAN PACIFIC RIM SAGE PUBLICATIONS, $1992,233-266$

THIS CHAPTER IS AN EFFORT TO CONTRIBUTE TO THE ONGOING DISCUSSION OF THE RELATIONSHIP BETHEEN ECONOMIC DEVELOPMENT AND THE SYSTEM OF MALE DOMINATION. THE AUTHORS ARGUE THAT AS PATRIARCHY AND CAPITALISM HAVE PENETRATED THE FAMILY, PATRIARCHY AND CAPITALISM HAVE PENETRATED THE FAMILY
ENTERPRISES, AND THE STATE THEY HAVE PROMOTED THE ENTERPRISES, AND THE STATE THEY HAVE PROMOTED THE
EXPLOITATION OF WOMEN AS LOH-WAGED AND NON WAGED DOMESTIC EXPLOITATION OF WOMEN AS LOH-WAGED AND NON WAGED DOMESTIC
WORKERS RESPONSIBLE FOR THE REPRODUCTION OF LABOR AND THE WORKERS RESPONSIBLE FOR THE REPRODUCTION OF LABOR AND THE
CARE OF THE ELDERLY. THE DISCUSSION IS GROUNDED ON THE CARE OF THE ELDERLY. THE DISCUSSION IS GROUNDED ON THE
PERIOD OF RAPID ECONOMIC GROWTH IN TAIWAN FROM THE MID-1960S TO THE LATE 1970 S.

01003 APPELBAUM, R.; CHENG, L.; HENDERSON, J.; HSIUNG, P. WOMEN, EXPORT-ORIENTED GROWTH, AND THE STATE: THE CASE OF TAIHAN; STATES AND DEVELPMENT IN THE ASIAN PACIFIC RIM SAGE PUBLICATIONS, 1992, 233-266.

THE CENTRAL ROLE PLAYED BY FEMALE LABOR IN THE RECENT GROWTH OF THE TAIWANESE ECONOMY IS DOCUMENTED. THE AUTHORS ARGUE THAT PATRIARCHY AND CAPITALISM HAVE REINFORCED ONE ANOTHER TO PROMOTE ECONOMIC OEVELOPEMENT. IN TAINAN, WOMEN ARE SHOWN TO BEAR THE DOUBLE BURDEN OF PROVIDING LABOR IN THE LARGER ECONOMY AS WELL AS AT HOME; TAIWANS'S ECONOMIC SUCCESS RESULTS IN LARGE PART FROM THE SPECIFIC USE OF WOMEN'S LABOR AS CHIEF HAGE HORKERS, UNHAGED FAMILY WORKERS, AND UNPAID SERVICE PROVIDERS. THEY CONCLUDE THAT YET WHILE WOMEN PROVIDED THE CHEAP LABOR THAT UNDERPINNED TAIH
THEY HAVE NOT REAPED THE FRUITS OF THEIR EFFORTS.

01004 APPELBAUM, R.; HENDERSOH, J.; SALAFF, J.

WOMEN, THE FAMILY, AND THE STATE IN HONG KONG, TAIWAN. STATES AND DEVELOPMENT IN THE ASIAN PACIFIC RIM SAGE PUBLICATIONS, 1992, 267-288. JANET SALAFF EXAMINES THE CRITICAL ROLE PLAYED BY WOMEN IN THE ECONOMIC DEYELOPMENT OF HONG KONG, SINGAPDRE, AND TAIWAN. SHE EXAMINES THE THREEFOLD NATURE OF THE CHINESE FAMILY. SHE SUGGESTS THAT FAMILY CYCLE, DEMOGRAPHICS, AND ASSOCIATED WITH EIO IN EAST ASIAN NICS. WHILE THE ROLE OF ASSOCIATED WITH EIO IN EAST ASIAN NICS. WHILE THE ROLE FEMALE LABOR WAS KEY TO EARLY DEVELOPMENT, IN TOOAY'S
MATURING ECONOMIES AN INCREASING NUMBER OF WOMEN ARE DEMANDING EDUCATION AND HIGHER WAGES. AS A RESULT, GROWING NUMBERS OF HOMEN ARE CHOOSING TO WORK OUTSIDE THE HOME. THIS WILL HAVE AN EFFECT ON FAMILY FAMILY STRUCTURE AND ECONDMIC WILL HAVE AN EFFECT ON FAMILY FAMI
DEVELOPMENT IN THE COMING YEARS.

01005 APPELBAUM, R.: HENDERSOH, J.; SALAFF, J.

WOMEN, THE FAMILY, AND THE STATE IN HONG KONG, TAHAN, AND SINGAPORE. STATES AMD DEYELOPMENT IN THE ASIAY PACIFIC RIM SAGE PUBLICATIONS, $1992,267-288$.

HONG KONG, SINGAPORE, AND TAINAN HAVE SINCE THE EARLY 1970 S ENTERED THE RANKS OF THE NEWLY INDUSTRIALIZED COUNTRIES BASED ON MANUFACTURING FOR EXPORT, IN WHICH WOMEN PLAY KEY ROLES. THIS CHAPTER ANALYZES THE STRONG CHINESE FAMILY, CONDUIT FOR STATE POLICIES THAT DEAL WITH THE ECONONY AND THE SEXUAL DOMAIN. PARTICULAR SOCIAL-HISTORICAL INSTITUIONS TO CHART THEIR COURSE. PRESENTED IS HOW THE 
FAMILY PRESSES WOMEN TO HORK AT THREE STAGES OF THEIR LIFE CYCLES TO MEET A NUMBER OF FAMILY GOALS.

01006 APPLBAUM, A.I.

DEMOCRATIC LEGITIMACY AND OFFICIAL DISCRETION

PHILOSOPHY AND PUBLIC AFFAIRS, 21 (3) (SUM 92), 240-274.

THE AUTHOR EXAMINES JUSTIFIED OFFICIAL DISSENT AND

DISCRETION, DIVIDING HIS ARGUMENT INTO THREE PARTS. FIRST,

ALTHOUGH THERE IS TRUTH IN POLITICAL REALISH, THE MORAL

AUTHORITY OF A POLITICAL MANDATE IS AT LEAST' PARTLY

INDEPENDENT OF BOTH THE FORMAL MANDATE ON THE BOOKS--LAWS,

RULES, POLICY DECLARATIONS--AND THE EFFECTIVE MANDATE--WHÁT

IS POLITICALLY POSSIBLE AND SUSTAINABLE. SECONDLY, POLITICAL

ACTORS CAN, AND INDEED OUGHT TO, MAKE JUDGMENTS ABOUT THE

MORAL AUTHORITY OF POLITICAL MANDATES AND JUDGMENTS ABOUT

THEIR MORAL AUTHORITY TO ACT ON THOSE JUDGMENTS. THIRDLY,

REASONABLE CRITERIA TO GUIDE THE EXERCISE OF SUCH JUDGMEN

CAN BE FORMULATED. THEORIES OF LEGISLATIVE CHOICE IN THE

FACE OF THE OPPOSING WILL OF CONSTITUENTS ARE HELPFUL IN
FORMULATING AN ACCOUNT OF ADMINISTRATIVE CHOICE IN THE FACE

OF THE OPPOSING WILL OF LEGISLATORS OR SUPERIORS; THEORIES

OF THE OPPOSING WILL OF LEGISLATORS OR SUPERIORS; THEOR

OF CIVIL. DISOBEDIENCE IN THE FACE OF LEGAL MANDATES ARE
HELPFUL IN FORMULATING AN ACCOUNT OF OFFICIAL DISCRETION IN

HELPFUL IN FORMULATING AN ACCOUNT OF OFFICIAL DISCRETION
THE FACE OF POLITICAL MANDATES. THE AUTHOR STUDIES THREE

THE FACE OF POLITICAL MANDATES. THE AUTHOR STUDIES
CASES IN THE EXERCISE OF OFFICIAL DISCRETION: JOSEPH

CASES IN THE EXERCISE OF OFFICIAL DISCRETION: JOSEPH

JOHNSON'S HAR ON POVERTY, AND COVERT MILITARY AID FOR THE

NICARAGUAN CONTRAS.

01007 APPLEGATE, J.S.

WORST THINGS FIRST: RISK, INFORMATION, AND REGULATORY STRUCTURE IN TOXIC SUBSTAMCES CONTROL

ALE JOURNAL ON REGULATION, 9 (2) (SUM 92), 277-354

TOXIC SUBSTANCES CONTROL IS CHARACTERIZED BY SCIENTIFIC UNCERTAINTY BECAUSE REGULATORS LACK THE RESOURCES TO RESOLVE OR SIGNIFICANTLY REDUCE UNCERTAINTY REGARDING ALL THE RISKS THEY MUST ADDRESS. THE ENVIRONMENTAL PROTECTION AGENCY (EPA) IS INTENSELY INTERESTED IN SETTING PRIORITIES AMONG ITS RESPONSIBILITIES BUT LACKS A COHERENT FRAMEWORK FOR IMPLEMENTINGS ITS FINDINGS. IN THIS ESSAY, THE AUTHOR PROPOSES THAT THE CURRENT REGULATORY REGIME FOR TOXIC SUBSTANCES BE RESTRUCTURED TO EMPHASIZE THOUGHTFUL PRIORITYSETTING RATHER THAN UNREALISTIC RISK STANDARDS AND DEADLINES CONGRESS SHOULD PROVIDE BROAD PARAMETERS FOR AGENCY ACTION IN PARTICULAR CASES WHILE GIVING SPECIFIC DIRECTIONS TO THE AGENCY FOR SETTING PRIORITIES AND GOALS. THIS RECOMMENDATION IMPLICATES BROADER ISSUES OF CONGRESSIONAL SPECIFICITY IN REGULATORY STATUTES, PRESIDENTIAL CONTROL OF ADMINISTRATIVE REGULATORY STATUTES, PRESIDENTIAL CONTROL OF ADMINISTRATIVE
AGENCIES, AND JUDICIAL REVIEW IN THE EARLY PHASES OF THE AGENCIES, AND JUDICIAL REVIEW IN THE EARLY PHASES OF THE
REGULATORY PROCESS. THE AUTHOR EXPLORES THESE LARGER ISSUES REGULATORY PROCESS. THE AUTHOR EXPLORES THESE LARGER ISSUES
AS THEY RELATE TO HIS PROPOSAL AND EVALUATES ITS FEASIBILITY AS THEY RELATE TO HIS PROPOSAL AND EVALUATES ITS FEASIBILITY
BY COMPARING IT TO LEGISLATIVELY YMANDATED PLANNING IN FOREST MANAGEMENT.

01008 APPLETON, A.

MAASTRICHT AND THE FRENCH PARTY SYSTEM: DOMESTIC IMPLICATIONS OF THE TREATY REFERENDUM

FRENCH POL ITICS AND SOCIETY, 10(4) (FAL 92), 1-18.

ALTHOUGH THE AUTHOR RECOGNIZES THAT PRESIDENT

MITTERAND'S DECISION TO SEEK RATIFICATION OF THE MAASTRICHT ACCORDS THROUGH A REFERENDUM CANNOT BE EXPLAINED BY ONE FACTOR ALONE, HE CHOOSES TO FOCUS ON A SINGLE FACTOR: THE ADOPTION OF THE REFERENDUH AS THE INSTITUTIONAL DEVICE THAT WOULD POSE THE MAXIMUM DIFFICULTY FOR THE OPPOS ITION PARTIES AND THEIR LEADERS HITH PRESIDENTIAL AMBITIONS. THE CHOICE OF THE REFERENDUM AND THE SUBSEOUENT HANDL ING OF THE CAMPAIGN,
WHILE ACHIEVING THE AIM OF DIVIDING THE PRINCIPAL OPPOSITION PARTIES, FAILED TO PROVIDE POSITIVE BENEFITS FOR THE SOCIALIST PARTY. INDEED, THE MAASTRICHT CAMPAIGN ONCE AGAIN DEMONSTRATED THE WEAKNESSES OF CONTEMPORARY FRENCH POLITICAL PARTIES AMD RAISES OUESTIONS ABOUT THE SD-CALLED

"REVITALIZATION OF THE PARTY SYSTEM." FAR FROM BEING "PARTYFRIENDLY," THE REFERENDUM IS ESSENTIALLY AN ANTI-PARTY DEVICE; THE LONG-TERM CONSEQUENCE OF ITS MOST RECENT USAGE CAN ONLY BE TO PLACE MORE STRAIN ON THE EXISTING PARTY SYSTEM AND TO FURTHER REDUCE THE ABILITY OF THE MAJOR

PARTIES TO CONTROL THE SCOPE OF POLITICAL CONFLICT IN FRANCE.

01009 ARAM, B.

EXPORTING RHETORIC, IMPORTING OIL: UNITED STATES RELATIONS WITH VENEZUELA, 1945-1948

WORLD AFFAIRS, 154(3) (WIN 92), 944-106.

A CAREFUL REVIEW OF THE RECDRD SHOHS THAT THE UNITED STATES DID INFLUENCE VENEZUELA'S TURN AHAY FROM DEMOCRACY.
AMERICAN DIPLOMATS, ALTHOUGH SYMPATHETIC TO VENEZUELA'S AMERICAN DIPLOMATS, ALTHOUGH SYMPATHETIC TO VENEZUELA'S DEMOCRATS WERE PREVENTED EVEN RELAT IVELY MINOR EFFORTS TO REPRESENTATIVES BECAME INCREASINGLY FRIENDLY HITH DISCONTENTED VENEZUELAN OFFICERS. WHILE STRENGTHENING VENEZUELA AGAINST AN EXTERNAL THREAT, MILITARY ASSISTANCE AND NONINTERVENTIONIST DECLARATIONS LEFT VENEZUELA'S DEMOCRATIC GOVERMMENT VULNERABLE TO INTERNAL FORCES. HOHEVER, IN 1948 THE UNITED STATES POSTPONED BUT DID NOT ABANDON SUPPORT FOR VENEZUELAN DEMOCRACY.
01010 ARATO, A.

FROM NEO-MARXISM TO DEMOCRATIC THEORY--ESSAYS ON THE CRITICAL THEORY OF SOYIET-TYPE STUDIES

M. E. SHARPE, 1993, 256.

THE ESSAYS IN THIS VOLUME TRACE THE SEARCH FOR A GENUINELY CRITICAL THEORY OF MARXISH. THE AUTHOR BEGINS WITH THE QUESTION OF WHY THE FRANKFURT SCHOOL AS WELL AS OTHER NEO-MARXIST AND POST-MARXIST ANALYSTS, BOTH IN THE HEST AND IN DISSIDENT CIRCLES IN THE EAST, FAILED TO PRODUCE A CRITICAL THEORY OF SOVIET SOCIALISM OR TO ESTABLISH A DYMAMIC RELATIONSHIP WITH CONTEMPORARY SOCIAL MOVEMENTS. AS THE POLITICAL STRUGGLE IN EASTERN EUROPE INTENSIFIED, THE AUTHOR GRADUALLY DISENGAGED FROM HIS OWN EFFORT TO CONSTRUCT A CRITICAL MARXISM. INSTEAD, HE ATTEMPTS A RECONSTRUCTION OF DEMOCRATIC THEORY BASED ON CIVIL SOCIETY RATHER THAN CLASS CATEGORIES, AND WITH A CRITICAL RELEVANCE NOT ONLY TO THE TRANSITION FROM STATE SOCIALISM BUT MORE GENERALLY TO THE UNIVERSAL GOAL OF EMANCIPATION.

01011 ARBLASTER, A.

THE DEATH OF SOCIALISM--AGAIN

POLITICAL QUARTERLY (THE), 62 (1) (JAN 91), 45-51.

THIS ARTICLE LOOKS AT THE CURRENT "DEATH OF SOCIALISM" AND COMPARES IT TO VARIOUS TIMES IN THE PAST WHEN THE END OF SOCIALISH WAS PROCLAIMED. THE AUTHOR ARGUES THAT THE TRANSFORHATIONS IN THE SOVIET UNION AND EASTERN EUROPE MAKE THE CURRENT CLAIM MORE ACCURATE AND THAT SIMILAR CLAIMS IN THE PAST AROSE FROM POLITICAL AND SOCIAL TRENDS, RATHER THAT FROM ACTUAL TURNS OF EVENTS. THE DISINTEGRATION OF THE EASTERN BLOC IS DESCRIBED.

01012 ARCHDEACON, T.J.

REFLECTIONS ON IMMIGRATION TO EUROPE IN LIGHT OF U.S. IMMIGRATION HISTORY

INTERNATIONAL MIGRATION REVIEW, XXVI(2) (SUM 92), 525-548. RECENT IMMIGRATION FROM THE SOUTH AND THE EAST HAS UNDERMINED THE POPULAR BELIEF THAT EUROPE IS A SET OF ETHNICALLY AND CULTURALLY UNCHANGING STATES. IN RESPONSE EUROPEANS HAVE TURNED TO AMERICAN HISTORY FOR INSIGHTS INTO MANAGING DIVERSITY. EXTRAPOLATING FROM AMERICA'S EXPERIENCE, HOWEVER, REQUIRES CAREFUL ANALYSIS. THE SUCCESS OF THE UNITED STATES IN INTEGRATING PEOPLES RESTED PARTLY IN POLITICAL AND SOCIOECONOMIC CONDITIONS THAT MAY NOT HOLD IN ALL PLACES AT ALL TIMES. MOREOVER, CURRENT DISCUSSIONS OF "MULTICULTURALISM" MAY BE MISLEADING IN REGARD BOTH TO THE CONMOTATIONS OF THE TERM AND TO THE HISTORY OF IMMIGRANT GROUP ASSIMILATION IN THE UNITED STATES.

01013 ARCHER, C

DENMARK SAYS 'NO'

WORLD TODAY, 48(8-9) (AUG 92), 142-143.

ON JUNE 2, 1992 . DENMARK HELD A REFERENDUM GIVING THE VOTERS THE 2, 1992, DENAARK HELD A REFERENDUM GIVING THE RATIFICATION OF THE MAASTRICHT TREATY, WHICH AIMS TO PRODUCE EUROPEAN UNION. BY A NARROW MARGIN, THE DANISH ELECTORATE VOTED TO REJECT MAASTRICHT.

01014 ARCHIBUGI, D. MODELS OF' INTERNATIONAL ORGANIZATION IN PERPETUAL PEACE PROJECTS

REVIEW OF INTERNATIONAL STUDIES, 18(4) (OCT 92), 295-318. PERPETUAL PEACE PROJECTS CONSTITUTE A LARGELY UNDERVALUED INTELLECTUAL TRADITION THAT HAS ATTRACTED MANY POLEMICAL ARROWS. KEY PROBLEMS RAISED IN THIS AREA ARE ALL PART OF THE SPECIFICALLY JURIDICAL STRAND IN PACIFIST THOUGHT. THE AUTHOR LINKS THEM TO ONE OF THREE SEPARATE MODELS OF INTERNATIONAL ORGANIZATION. THESE MODELS, IDENTIFIED AS (A) PYRAMIDAL, (B) DIFFUSED, AND (C) COSMOPOLITAN MODELS, ARE CONSIDERD IN THIS STUDY. THE FINAL SECTION EXPLAINS THE RELEVANCE OF THESE MODELS FOR AN
UNDERSTANDING OF CONTEMPORARY INTERNATIONAL RELATIONS

01015 ARCOS, C.

HEY MISTER TALLYMAN

HEMI SPHERE, 5(1) (FAL 92), 35-37.

CENTRAL AMERICAN COUNTRIES HAVE INSTITUTED SIGNIFICANT FREE-MARKET REFORMS. HONDURAS, FOR EXAMPLE, HAS LOWERED ITS TARIFFS, CONTROLLED DEFICIT SPENDING, ESTABLISHED A REALISTIC EXCHANGE RATE, SECURED LAND TENURE RIGHTS, AND ENACTED AN INVESTMENT REFORM LAH. UNFORTUNATELY, JUST AS CENTRAL AMERICA IS POISED TO TAKE ADVANTAGE OF THE OPEN
MARKET, THE DOOR TO THE WEST EUROPEAN MARKET IS SLAMMING MARKET, THE DOOF
SHUT IN 1992 .

01016 ARDS, S.: WOODARD, M.C.

AFRICAN AMERICANS IN THE POLITICAL SCIENCE PROFESSION PS: POLITICAL SCIENCE AND POLITICS, XXV(2) (JUN 92), 252-259.

OVER THE PAST 15 YEARS, MINORITY GROUPS--WITH THE EXCEPTION OF AFRICAN AMERICANS--HAVE SHOWN TREMENDOUS GAINS IN THE PROPORTION OF DOCTORATES GRANTED BY U.S. UNIVERSITIES. IN POLITICAL SCIENCE, THERE HAS BEEN A DECLINE FROM 143 
PERIOD ENDING IN 1980 TO 86 OVER A THREE-YEAR PERIOD ENOING IN 1991. THIS PAPER EXAMINES THE PROCESS OF PRODUCING NEW AFRICAN-AMERICAN PH.O.'S IN POLITICAL SCIENCE AND RELATED FIELDS AND ANALYZES THE INCREMENTAL GAINS OF AFRICANAMERICAN TENURE-TRACK PROFESSORS IN POLITICAL SCIENCE DEPARTMENTS.

01017 ARENANDER, 1.

SWEDEN AND THE E.C.

EUROPE, 315 (APR 92), 22.

THE ELECTION OF CARL BILDT, THE LEADER OF A MODERATE FOUR PARTY COALITIDN, AS THE NEH PRIME MINISTER HAS SET SHEDEN ON THE COURSE TO GREATER PRIVATIZATION. IN LAST SEPTEMBER'S ELECTION, BILDT'S COALITION HANDED THE SOCIAL DEMOCRATIC PARTY ITS WORSE LOSS IN A NATIONAL ELECTION SINCE 1928. BILDT HAS ALREAOY BEGUN THE MOVE AWAY FROM SWEDEN'S SOCIAL IST TRADITAN THROUGH MASSIVE CUTS IN GOYERUMENT SOCIALIST TRADITION THROUGH MASSIVE CUTS IN GOVERNMENT SPENDING AND A CAMPAIGN TO PRIVATIZE MAJOR STATE-OHM INOUSTRIES. THIS ARTICLE ASSESSES THESE CHANGES AND CONCLUDES THAT THE AMBITION TO KEEP CUTTING TAXES IS A MAJOR HILL BE DIFFICULT TO REALIZE.

01018 ARENDELL, T.; ESTES, C.

TH TESTES, C. PEAGAN ERA

INTERNATIONAL JOURNAL OF HEALTH SERVICES, 21(1) (1991),

THIS ARTICLE EXPLORES THE SOCIAL, ECONOMIC, AND INSTITUTIONAL FACTORS THAT AFFECT OLDER WOMEN THROUGHOUT THE LIFE CYCLE, AND RECENT POLICY AND IDEOLOGICAL CHANGES THAT WILL CONTINUE TO AFFECT OLDER WOMEN IN THE DECADES AHEAD. THE SITUATION OF THE OLDER WOMAN IS SHOWN TO RESULT FROM LIFELONG PATTERNS OF SOCIOECONOMIC AND GENOER STRATIFICATION IN THE LARGER SOCIETY. THE CONSEQUENCES FOR HOMEN FLOW FROM THE LABOR MARKET, AND THE STATE AND ITS SOCIAL POLICY. THE FEMALE ROLES OF WORKER, UNPAID CAREGIVER, AND BENEFICIARY OF PUBLIC POLICIES CONTINUE TO BE SYSTEMICALLY UNEQUAL TO THOSE OF MEN. THE PATRIARCHAL STRUCTURE OF (AND CONTROL OVER) THE LABOR MARKET AND POL ICY-MAKING PROMOTES THE INFORMALIZATION OF LONG-TERM CARE, AGEISM AND SEXISM TOHARD OLOER WOMEN ATTEMPTING TO REENTER THE LABOR MARKET, AND THE DEVALUING OF FEMALE HORK THAT IS NOT ECONOMICALLY REMUNERATED. THE FAILURE OF SOCIAL PROBLEMS TO ADORESS THE UNDERLYING STRUCTURAL INEQUITIES OF WOMEN PERPETUATES THEIR DISADVANTAGED ECONOMIC AND HEALTH SITUATION THROUGHOUT OLD AGE. CHANGES IN SOCIAL POLICIES ARE REQUIRED TO ADDRESS THE PROBLEM OF ACCESS TO BASIC RESOURCES, INCLUDING SOCIAL PROBLEM OF ACCESS TO BASIC RESOURCES, INCLUDING SOCIAL
SECURITY, MOUSING, HEALTH, AND LONG-TERM CARE, BUT MOST SECURITY, HOUSING, HEALTH, AND LONG-TERM CARE, BUT MOST
IMPORTANTLY, TO ABRIDGE AND COMPENSATE FOR THE GENDERED OIVISION OF' LABOR AND THE LIFELONG OISCRIMINATION THAT WOMEN EXPERIENCE.

01019 ARGENTI, $N$

THE SOGLO STYLE

WEST AFRICA, (3890) (APR 92), 589-590

THE AUTHDR DESCRIBES PRESIDENT NICEPHORE SOGLO'S MOTORCADE VISITS TO SOME TOWNS TO SPEAK TO HIS CONSTITUENTS.

01020 ARIAN, A.; SHAMIR, M.; VENTURA, R.

PUBLIC OPINION AND POLIITICAL CHANGE: ISRAEL AND THE INTI FADA

COMPARATIVE POLITICS, 24(3) (APR 92), 317-334.

USING PANEL DATA, THE AUTHORS PROBE THE RELATIONSHIP

BETWEEN PUBLIC OPINION AND POLITICS BY ANALYZING CHANGES IN ISRAELI PUBLIC OPINION AS A RESULT OF THE INTIFADA. THEY FIND THAT THE INTIFADA HAS HAD A CLEAR IMPACT ON THE ISRAELI PUBLIC. THREE SIMULTANEOUS PROCESSES SEEM TO BE OPERATING: A GENERALIZED HARDENING OF POSITIONS ON SHORT-TERM ISSUES REGARDING ISRAELI-ARAB RELATIONS: A STEADY AND IMCREASIMG MODERATION OF OPINIONS ON CERTAIN LONG-TERM ISSUES OF SECURITY POLICY; AND A GROWING POLARIZATION OF ATTITUDES AND POLITICAL POWER BETWEEN THE MORE CONCILIATORY LEFT AND THE MORE HARD-LINE RIGHT. THEY ALSO FIND THAT PEOPLE'S AITITUDES HAVE TENDED TO CHANGE IN THE SAME DIRECTION IN HHICH THEY HERE ALREADY LEANING. AFTER ANALYZING THE EMPIRICAL FINDINGS, THEY SHOW HOW CHANGES IN PUBLIC OPINION ARE LINKED TO DEYELOPMENTS IN ISRAELI POLITICS, GOVERNMENT, POLICY, AND PARTY ALIGNMENY.

01021 ARIAN, A.

SECURITY AND POLITICAL ATTITUDES IN ISRAEL: 1986-1991 PUBLIC OPINION QUARTERLY (CHICAGO), 56(1) (SPR 92), 116-128.

THE AUTHOR ANALYZES THE TRENDS IN PUBLIC ATTITUDES AMONG ISRAELIS TOWARD THE PERCEIVED ARAB THREAT, SECURITY, AND ISRAELIS TOWARD THE PERCEIVED
PEACE FROM 1986 THROUGH 1991.

01022 ARICO, J

RETHINK EVERYTHING (MAYBE ITS ALHAYS BEEN THIS WAY) REPORT ON THE AMERICAS, 25(5) (MAY 92), 21-23.

SOCIALISTS CAN NO LONGER THINK IN TERMS OF AN IDEAL MODEL WITH CERTAIN CHARACTERISTICS DEFINED BY THE EXPERIENCE OF EXISTING SOCIALIST COUNTRIES. THEY MUST CEASE TO THINK OF REVOLUTION AS AN ACT THAT CHANGES REALITY. RATHER IT OUGHT
TO BE THOUGHT OF AS A PROCESS OF CHANGING PEOPLE'S MENTALITY. SOCIALISM IS THUS A COUNTER CUL TURAL FORCE, A FORCE FOR CHANGING CULTURE, RATHER THAN ONE THAT SEEKS PARTICULAR GOALS. THE GREAT ISSUES ARE BEFORE THE LEFT ANO IN

01023 ARINGTON, M.

ENGLISH-ONLY LAHS AND DIRECT LEGISLATION: THE BATTLE IN THE STATES OVER LANGUAGE MINORITY RIGHTS

JOURNAL OF LAW \& POLITICS, VIII(2) (WIN 91), 325-351.

AN EFFORT TO ESTABLISH ENGLISH AS THE OFFICIAL LANGUAGE OF GOVERMMENT AND PUBLIC OISCOURSE IN THE UNITED STATES HAS GATHERED MOMENTUM IN THE PAST DECADE, CAUSING HEATED

POL ITICAL BATTLES ACROSS THE COUNTRY'. THIS ARTICLE SURVEYS THE HISTORY OF LANGUAGE POLICY IN THE U.S. AND DISCUSSES WHICH RIGHTS OF NON-ENGLISH SPEAKING CITIZENS ARE ALREADY DEFINED AND PROTECTED UNDER FEDERAL LAW. IT ALSO EXAMINES ON STATE OFFICIA-ENGLISH LEGISLATION AND THE EFFECTS OF THESE STATE OFFICIA-ENGLISH LEGISLATION AND THE EFFECTS OF THESE TH THE MOST POTENTIALLY RESTRICTIVE ENGLISH-ONLY LAWS ARE THOSE PASSED OY INIALLY RESTRICTIVE ENGLISH DNLY LAHS ARE ISSUE IS ONE OF MINORITY RIGHTS.

01024 ARIYO, A.

TARIFF HARMONIZATION, GOVERNMENT REVENUE, AND ECONOMIC INTEGRATION WITHIN ECOWAS: SOME REFLECTIONS DEVELOPMENT POLICY REVIEW, 10(2) (JUN 92), 155-174. THE ECONOMIC COMMUNITY OF WEST AFRICAN STATES (ECOWAS) WAS ESTABLISHED IN 1975 TO PROMOTE AND EXPAND INTRACOMMUNITY TRADE. ONE OF THE MAJOR GOALS WAS THE ELIMINATION OF TARIFFS AMONG THE MEMBER STATES. BUT, AFTER MORE THAN 15 YEARS OF ECOWAS OPERATION, THIS BASIC OBJECTIVE REMAINS UNFULFILLED BECAUSE THE MEMBER STATES LACK THE POLITICAL WILL TO IMPLEMENT THE DECISIONS OF THE ORGANIZATION REGARDING TARIFF HARMONIZATION. ECOHAS RECENTLY ESTABLISHED A COMMITTEE TO REVIEW THE POLITICAL STATUS OF MEMBER STATES, AND RECOMHEND MEASURES TO ENHANCE THE REALIZATION OF ECOWAS' OBJECTIVES. BUT THIS LACK OF POLITICAL WILL MAY PERSIST WITH RESPECT TO TARIFF HARMONIZATION BECAUSE OF ITS POTENTIAL SIGNIFICANT NEGATIVE EFFECT ON THE FISCAL OPERATIONS OF THE MEMBER STATES. IF TARIFFS ARE ELIMINATED, MOST STATES FACE THE RISK OF AN IMMEDIATE LOSS OF SIGNIFICANT REVENUE, EVEN TO THE EXTENT THAT THEIR FISCAL POLICIES MIGHT BE SERIOUSLY TO THE EXTENT THAT THEIR FISCAL POL ICIES MIGHT BE SERIDUSLY
DISRUPTED. THEREFORE, ECOWAS LEADERS WOULD BE WISE TO SHIFT DISRUPTED. THEREFORE, ECOWAS LEADERS WOULD BE WISE TO SHIF
THEIR FOCUS TO OTHER ISSUES, IN ORDER TO ENSURE THE LONGTHEIR FOCUS TO OTHER ISSUES, IN ORDER TO ENSU
TERM SURYIVAL OF THE REGIONAL ORGAHIZATION.

01025 ARKES, $H$

THE ESSENCE OF CLINTONISM

NATIONAL REVIEW, XLIV(20) (OCT 92), 32-35.

THIS ANALYSIS OF BILL CLINTON SUGGESTS THAT BILL CLINTON TEATICENCES AS BY HIS STATEMENTS OF POLICY--NOT THE LEAST ON THE QUESTION OF WHICH BRANCH OF GOVERNMENT WOULD DOMINATE IN A CLINTON ADMINISTRATION. THE ARTICLE ASKS--GOOD OL' BOY OR RHODES SCHOLAR? NEW COVENANTER OR SLICK WILLIE? IT THEN SUGGESTS THAT THE ELUSIVE MR. CLINTON'S TRUE NATURE CAN BE FOUND IN A THEME COMMON TO HIS PERSONA AND HIS POLICIES.

01026 ARKES, H.

THE MAN FROM NOWHERE

NATIONAL REVIEW, XLIV(15) (AUG 92), 24-29.

THE SURPRISE APPEAL OF ROSS PEROT TO A LARGE SEGMENT OF THE AMERICAN PEOPLE IS PARTIALLY DUE TO HIS IMAGE AS A MAM WHO KNOWS HIS BUSINESS AND TO HIS LACK OF ENCUMBERING ALLIANCES. HOWEVER, A CLOSER LOOK AT PEROT'S SOLUTIONS TO THE PROBLEMS FACED IN AMERICA--UNEMPLOYMENT, TAXES, THE DEFICIT, GUN CONTROL - REYEALS THAT HE HOLDS FEW ANSHERS HIS REPLY IS USUSALLY SOME VARIATION OF THE "GET THE EXPERTS TOGETHER" OR HIS "ASK THE PEOPLE" THEMES. THE END RESULT IS THAT A POTENTIAL VOTER CAN NEVER BE CERTAIN WHAT TYPES OF
POLICY, OR EVEN WHAT TYPE OF MIND SET, PEROT WOULD BRING TO WASHINGTON.

01027 ARKES, $H$

THE THILIGHT OF THE CAMPAIGN

NATIONAL REVIEH, XLIV(22) (NOV 92), 36-40

GEORGE BUSH IS NO GREAT COMMUNICATOR AND HAS PERMITED

HIS ADVERSARIES IN THE MEDIA TO SPEAK IN HIS PLACE AND

SUPPLY THE MOST IMPLAUSIBLE CARICATURES OF HIS POLICIES.

THIS ARTICLE SUGGESTS THAT WE MUSTN'T FORGET HOW MUCH OF THE

REAGAN COALITION HE HAS LISTEN TO, AND WHAT BILL CLINTON

WOULD TELL IT INSTEAD. IT ALSO SUGGESTS THAT IF CLINTON WINS

THE ELECTION THAT REPUBLICANS WHO SECRETLY WOULD BE RELIEYED

TO SEE BUSH GO, MAY DISCOVER HOH MUCH THEY MISS GEORGE BUSH.

01028 ARKES, $H$.

WHO'S THE LAISSEZ-FAIREST OF THEM ALL? THE TRADITION OF NATURAL RIGHTS IN AMERICAN LAH POLICY REVIEW, (60) (SPR 92), 78-85.

THE AUTHOR LOOKS AT THE TRADITION OF MATURAL RIGHTS IN THE U.S. SUPREME COURT AND ARGUES THAT THIS TRADITION PROTECTS FREEDOM AS THE FOUNDING FATHERS AND THE U.S. 
CONSTITUTION INTENDED. HE DISAGREES WITH THE VIEW OF LIBERALS, SUCH AS SENATOR JOE BIDEN OF DELAWARE, THAT THIS POWERFUL AT THE EXPENSE OF THE WORKER.

01029 ARKIN, W.; DURRANT, D.; KRISTENSEN, H. MUCLEAR WEAPONS HEADED FOR THE TRASH

BULLETIN OF THE ATOMIC SCIENTISTS, 47(10) (DEC 91), 14-19. PRESIDENT GEORGE BUSH'S 27 SEPTEMBER ANNOUNCEMENT REGARDING NUCLEAR WEAPONS AND PRESIDENT MIKHAIL GORBACHEV'S ANSWER ON 5 OCTOBER ARE IN RESPONSE TO A RAPIDLY CHANGING WORLD. BUSH PUT FORWARD AN IMPRESSIVE PACKAGE--ACCELERATING THE ELIMINATION OF STRATEGIC NUCLEAR WEAPONS COVERED BY START, ENDING GROUND ALERT FOR NUCLEAR-LADEN BOMBERS, REMOVING GROUND-LAUNCHED NUCLEAR WEAPONS FROM EUROPE AND SOUTH KOREA, REMOVING MUCLEAR WEAPONS FROM COMBATANT SHIPS AND ATTACK SUBMARINES, HALTING THE DEVELOPMENT OF MOBILE LAND-BASED MISSILES AND NEW AIR-LAUNCHED MISSILES. GORBACHEV HAS ANSWERED IM KIND AMD FURTHER PROPOSED ELIMINATING ALL NONSTRATEGIC NUCLEAR HEAPONS AND ENDING NUCLEAR TESTING AND FISSIONABLE MATERIALS PRODUCTION. THE INITIATIVES FUNDAMENTALLY ALTERED THE NUCLEAR STANCE OF BOTH NATIONS. FUNDAMENTALLY ALTERED THE NUCLEAR STANCE OF BOTH NATIONS. MOTION IN AN ALMOST BUSINESSLIKE MANNER. NEITHER LEADER
TRULY FRAMED THE MOVES AS AN END TO THE NUCLEAR AGE. BUT TRULY FRAMED THE MOVES AS AN END TO THE NUCLEAR AGE. BUT
THEY DIDN'T NEED TO. THE STEPS THEY HAVE TAKEN PRACTICALLY THEY DIDN'T MEE
GUARANTEE IT

01030 ARKIN, H.; NORRIS, R.

TINYNUKES FOR MINI MINDS

BULLETIN OF THE ATOMIC SCIENTISTS, 48(3) (APR 92), 24-25.

ALARMED BY THE END OF THE COLD WAR, NUCLEAR WEAPONS

DESIGNERS AND STRATEGISTS WANT TO BUILD MINI-AND MICRO-NUKES TO TARGET A HOST OF THIRD WORLD ENEMIES--WHETHER REAL OR
IMAGINARY. THIS ARTICLE SUGGESTS THAT ALTHOUGH NUCLEAR WARRIOR'S SCENARIOS EVOKE IMAGES OF A NUCLEAR-ARMED SADDAM HUSSEIN OR SOME UNHAMED DESPOSTIC THIRD WORLD POWER, THESE NUCLEAR ADVOCATES ARE ACTULALLY SEARCHING FOR ANY BROADBASED RATIONALE THAT CAN BE USED TO PERPETUATE THE NUCLEAR MACHINE AND ITS ANTIQUATED DOCTRINE. IT CONCLUDES THAT WHETHER THESE PROPOSALS STEM FROM A GENUINE BELIEF IN THE MILITARY NEED FOR NEW NUCLEAR WEAPONS, OR FROM THE PERCEIVED NEED TO MAINTAIN POL ITICAL INFLUENCE, THEY DEMONSTRATE INDFFERENCE TO THE EFFECTS OF HOLDING THE NUCLEAR SWORD OVER THE THIRD WORLD, AND THE WILLINGNESS TO CREATE DELIBERATE AMBIGUITY ABOUT THE POSSIBLE USE OF U.S. NUCLELAR WEAPONS IN ANY FUTURE CONFLICT.

01031 ARLEDGE, P.C.; HECK, E.Y.

A FRESHMAN JUSTICE CONFRONTS THE CONSTITUTION: JUSTICE A FRESHMAN JUSTICE CONFRONTS THE

HESTERN POL ITICAL QUARTERLY, 45(3) (SEP 92), 761-772.

RECENT STUDIES OF THE SOCIALIZATION OF SUPREME COURT JUSTICES HAVE SHOWN THAT MOST JUSTICES APPOINTED SINCE 1953 HAVE JOINED WITH IDEOLOGICAL ALLIES TO FORM VOTING BLOCS EARLY IN THEIR JUOICIAL CAREERS. IN AN EFFORT TO LOOK BEYOND BLOC-VOTING PATTERNS FOR EVIDENCE OF "FRESHMAN EFFECTS," THE AUTHORS STUDY THE OPINIONS OF JUSTICE SANDRA DAY O'CONNOR IN CASES DECIDED ON FIRST AMENDMENT GROUMDS DURING HER FIRST FIVE TERMS ON THE COURT. ANALYSIS SUGGESTS THAT HER APPRENTICESHIP IN THIS AREA LASTED NO MORE THAN ONE OR TWO TERMS. BY THE END OF HER FIFTH TERM, O' CONNOR HAD TAKEN HER POSITION AS A FULL-FLEDGED MEMBER OF THE COURT WHO HAD WRITTEN MAJOR OPINIONS AND DEVELOPED NEH DOCTRIMAL APPROACHES IN AN AREA WHERE SHE HAD HAD ALMOST NO EXPERIENCE AS A STATE COURT JUDGE. ALTHOUGH O'CONNOR GENERALLY VOTES WITH THE COURT'S CONSERVATIVES ON FIRST AMENDMENT ISSUES, SHE HAS ESTABLISHED HER INDEPENDENCE FROM JUSTICE REHMOUIST IN HER OPINIONS.

01032 ARMITAGE, J.

PROSPECTS FOR GULF SECURITY

RUSI JOURMAL, $137(5)$ (OCT 92), 61-65.

AS THE GULF REMAINS A FOCAL POINT TO INTERNATIONAL

CONCERN, THE AUTHOR EXAMINES HOW THE COUNTRIES OF THE GULF, LESS IRAO, ARE SEEKING A MODUS VIVDENDI AND ARE ADORESSIMG THEIR PROBLEMS OVER WHICH HANGS THE EVER PRESENT SHADOW OF THE PALESTINE QUESTION. WHILST THE COUNTRIES OF THE GULF COOPERATION COUNCIL REMAIN DEPDENDENT UPON THE UMBRELLA PROTECTION STILL MAINTAINED BY THE U.S. AND ALLIES, A SUCCESSOR PEACEKEEPING FORCE UNDER THE UN FLAG IS AN ESSENTIAL STEP TOWARDS GULF SECURITY. THE THURST OF MR. ESSENTIAL STEP TOWARDS GULF SECURITY. THE THURST OF MR. ARTITAGE'S ARGUMENT IS THAT TOWARDS THIS GOAL, CHANGE IN IRAQ IS THE MAIN REQUIREMENT, THAT THIS CAN ONLY COME FRO WITHIN, WHATEVER THE AMBITIONS
OPPOSITION GROUPS IN EXILE.

01033 ARNASON, G.

BACK TO NORMAL? THE ICELANDIC ELECTION OF 20 APRIL 199 WEST EUROPEAN POLITICS, 14(4) (OCT 91), 181-184.

IT APPEARS AS IF ICELANIC POLITICS ARE REVERTING TO NORMAL AGAIN, AFTER A LONG PERIOD OF INCREASED FLUIDITY AND INSTABILITY. THE OLD FOUR ARE BACK WITHIN THE RANGE OF THEIR NORMAL SUPPORT. THE IP IS THE CLEAR VICTOR. HOWEVER THE
PARTY DID NOT GET BACK ALL THE SUPPORT IT HAD LOST IN THE LAST ELECTION. THE HASTE IN WHICH THE GOVERNMENT FORMED SUGGESTS THAT THE SDPS LEADERSHIP WAS ANXIOUS TO REVIVE THE COALITION PATTERM THAT HAS LASTED FOR 12 YEARS.

01034 ARNETT, E.

WELCOME TO HYPERWAR

BULLETIN OF THE ATOMIC SCIENTISTS, 48(7) (SEP 92), 14-21. IN THE AFTERMATH OF THE GULF WAR, NEW BATTLE LINES HAVE BEEN DRAHN IN THE WORLD OF U.S. MILITARY PLANMING. THE
OUTCOME OF THE MACHINES V. PEOPLE CONTROVERSY IS CRITICALLY OUTCOME OF THE MACHINES $V$. PEOPLE CONTROVERSY IS
IMPORTANT, NOT ONLY BECAUSE IT WILL DETERMINE THE RELATIONSHIP BETWEEN HUMAN AND COMPUTER-BASED INTELLIGENCE AT THE BEGINNING OF AN ERA THAT MANY OBSERVERS SEE AS MARKED BY COMPETITION BETWEEN THE TWO, BUT BECAUSE IT WILL DETERMINE THE NATURE OF FUTURE WARS. THE ISSUE IS HOW THE POHER OF TECHNOLOGY HILL BE APPLIED TO MILITARY PROBLEMS AND WHAT ROLE HUMAN OPERATORS HILL PLAY.

01035 ARNOLD, M.

ENGAGIMG SOUTH AFRICA AFTER APARTHEID

FOREIGN POLICY, (87) (SUM 92) 139-156.

IN SPITE OF POTENTIAL OBSTACLES, SOUTH AFRICA IS POISED

TO ESTABLISH A MULTIRACIAL, DEMOCRATIC GOVERNMENT. THE RAPID PACE OF CHANGE AND ITS IMPLICATIONS REQUIRE A CRITICAL

REASSESSMENT OF U.S. POLICY. THIS ARTICLE CONSIDERS SEVERAL ISSUES: IS AN ACTIVE AMERICAN POLICY STILL REQUIRED AND, IF ISSUES: IS AN ACTIVE AMERICAN POLICY STILL REQUIRED

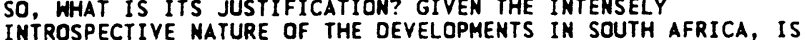
INTROSPECTIVE NATURE OF THE DEVELOPMENTS IN SOUTH AFRICA, IS THERE A LEGITIMATE AND EFFECTIVE ROLE SHOULD THE REMAINING U. TO PLAY? AND, MORE SPECIFICALLY. WHEN SHOULD THE REMAINING S. SANCTIONS BE LIFTED? THE ARTICLE ARGUES THAT THE UNITED STATES MUST DESIGN A POLICY TO ASSIST SOUTH AFRICA IN ITS TRANSITION TO DEMOCRACY, ADORESS THE LEVEL OF VIOLENCE IM THE COUNTRY, PROMOTE GROH
REGIONAL OPPORTUNITIES

01036 ARONSEN, L.

AN OPEN DOOR TO THE NORTH: THE LIBERAL GOVERNMENT AND THE EXPANSION OF AMERICAN FOREIGN INVESTMENT, 1945-1953 AMERICAN REVIEW OF CANADIAN STUDIES, $22(2)$ (SUM 92 ), 167-198

BY 1954 AMERICAN INVESTMENT REACHED A HIGH POINT OF NEARLY 80 PERCENT OF ALL FOREIGN INVESTMENT IN CANADA. THIS INVESTMENT HAS BEEN SINGLEO OUT BY VARIOUS NATIONALIST CRITICS FOR IT'S NEGATIVE IMPACT ON THE ECONOMY AND POLITICAL SOVEREIGNTY. THIS ARTICLE ASSESSES THIS NATIONALIST CRITICISM BY EXAMINING THE EXTENT OF THE POSTWAR LIBERAL GOVERMMENT'S ROLE IN DIRECTING CAPITAL FLOWS NORTHWARD AND, WHAT IF ANY, NEGATIVE IMPACT THIS INVESTMENT HAS HAD ON THE CANADIAN ECONOMY.

01037 ARONSON, G.: SHAHAK, I. : THORPE, JR., M. LABOR'S SETTLEMENT POL ICY IN GREATER' JERUSALEM MIDDLE EAST POLICY, $1(4)(1992), 37-42$.

THE COMMON ASSUMPTION THAT ISRAEL'S LABOR-LED GOVERMMENT HAS REUPDIATED THE SETTLEMENT DRIVE PURSUED BY LIKUD HAS REUPDIATED THE SETTLEMENT DRIVE PURSUED BY LIKUD THE NEW POLICIES OF PRIME MINISTER YIZHAK RABIN. THIS THE NEW POLICIES OF PRIME MINISTER YT SUGGESTS THAT RABIN WILL NOT SEEK TO DO MORE THAN RATIONALIZE THE RADICAL SETTLMENT POLICIES OF THE PREVIOUS GOVERMMENT. THIS ARTICLE SUGGESTS THAT JEWISH SETTLEMENT IN EAST JERUSALEM HAS NOT BEEN FROZEN, AND THAT THERE IS EVERY CHANCE THAT IT WILL BE SUBSTANTIALLY THICKENED. THE LABOR PARTY, NOT THE LIKUD GAVE BIRTH TO THE IDEA OF SETTLEMENT IN EAST JERUSALEM.

01038 ARONSON, G. SOVIET JEWISH EMIGRATION, THE UNITED STATES, AND THE OCCUPIED TERRITORIES

JOURNAL OF PALESTINE STUDIES, XIX(4) (SUM 90), 30-45.

ISRAELI PRIME MINISTER YITZHAK SHAMIR'S CONFIDENT

DECLARATION ABOUT THE NEED FOR A "BIG ISRAEL" DREW

INTERNATIONAL ATTENTION TO THE SPIRAL ING NUMBERS OF SOVIET JEWS MAKING THEIR WAY TO ISRAEL AS OF THE LATTER MONTHS OF 1989. BY CLEARLY ARTICULATING THE CONHECTION BETHEEM IMMIGRATION, SETTLEMENT, AND SOVEREIGNTY IN ANNEXED JERUSALEM AND THE EST BANK, SHAMIR FORCED THE INTENTIONAL COMAUNITY, AND PARTICULARLY THE UNITED STATES, TO FOCUS ON THE SETTLEMENT POLICIES OF THE ISRAELI GOVERNMENT AND ISRAEL; S CLAIM UPON THE TERRITORIES THAT IT HAS RULED FOR A

GENERATION. THIS ARTICLE CONSIDERS THE ISSUED OF SOVIET

JEHISH EMIGRATION AND ITS IMPLICATIONS BOTH FOR ARAB-ISRAELI

RELATIONS AND FOR ISRAELI-U.S. RELATIONS.

01039 ARONSON, $R$.

SOUTH AFRICA AS APARTHEID UNHINDS

SOCIALIST REVIEW, 22(2) (APR 92), 97-118.

RATHER THAN RESOLVING THE CONFLICT IN SOUTH AFRICA, THE DISHANTL ING OF STRUCTURES OF APARTHEID POSES SHARP CHALLENGES FOR MOVEMENTS OF RESISTANCE. MANY PEOPLE MAY BECOME DISILLUSIONED BY THE CONFLICTS INHERENT IN THIS PROCESS. THIS ARITCLE SUGGESTS THAT NO MATTER WHAT THE SHAPE OF POSTAPARTHEID SOCIETY OR ITS GOVERNMENT, THAT WE ARE 
WITNESSING A MOVEMENT OF PROFOUND HISTORICAL ACHIEVEMENT. THAT AS THE MOVEMENT THAT BROUGHT ABOUT THIS TRANSFORMATION FRAGMENTS INTO OPPOSING CAMPS, AND AS EVERYONE'S MIND TURNS TO THE NEXT CRUCIAL SET OF TASKS, IT IS WORTH CELEBRATING THE END OF COLONIAL RULE AND THE CHANCE TO STRUGGLE OPENLY AND DIRECTLY AGAINST ITS LEGACY.

01040 AROSTEGUI, M.

CASTRO'S SCAPEGOATS

NATIONAL REVIEW, XLIV(25) (DEC 92), 33-35.

IT CAN NOW BE REVEALED THAT FIDEL CASTRO'S 1989 COURT MARTIAL OF 14 OF HIS OFFICERS ON DRUG-SMUGGLING CHARGES WAS TRIGGERED BY A DEA ATTEMPT TO KIDNAP HIS INTERIOR MINISTER AND BRING HIM TO JUSTICE IN THE UNITED STATES. PATRICIO DE AND GUARDIA, WHO WAS FOUND GUILTY AT THAT COURT MARTIAL AND LA GUARDIA, WHO WAS FOUND GUILTY AT THAT COURT MARTIAL AND CLOSET-SIZED CELL, A LETTER WHICH EXPLOSES THE CASTRO CLOSET-SIZED CELL, A LETTER WHICH EXPLOSES THE CASTRO REGIME'S EFFORTS TO COVER UP ITS DEEPENING INVOLVEMENT IN
NARCDIICS TRAFFICKING. THE DOCUMENT, ADDRESSED TO LEADING NARCOIICS TRAFFICKING. THE DOCUMENT, ADDRESSED TO LEADING
MEMBERS OF CASTRD'S POLITBURO, HAS BEEN AUTHENTICATED BY DE LA GUARDIA'S SON WHO HAS DISTRIBUTED IT ABROAD. LARGELY LA GUARDIA'S SON WHO HAS DISTRIBUTED IT ABROAD. LARGELY IGNORED BY THE MEDIA, IT PROVIDES UNIQUE INSIGHTS INTO THE
INNER WORKINGS OF CUBA'S INTERIOR MINISTRY. WHICH IS ON THE FRONT LINE OF THE DRUG WAR AGAINST THE UNITED STATES.

01041 AROSTEGUI, $M$.

MARCHING TO BAGHDAD

NATIONAL REVIEH, XLIII(7) (APR 91), 20-21.

FRANCE IS THE ONLY MEMBER OF THE ANTI-IRAQ COALITION

STILL MAINTAINING A PRESENCE IN SOUTHERN IRAQ ALONG WITH THE U.S. ARMY'S VII CORPS. THE CONTINUING FRENCH PRESENCE COULD BE MORE THAN MERELY SYMBOLIC. IN THE UNITED NATIONS SECURITY COUNCIL, FRANCE IS PUSHING FOR A RESOLUTION TO STOP THE MASSACRE OF KURDISH AND SHI'A REBELS IN IRAQ. HOWEVER, IT MAY ALL ADD UP TO LITTLE MORE THAN POSTURING IF WASHINGTON

CONTINUES TO HOLD TO ITS POLICY OF INACTION. BAGHOAD, ONLY
AN HOURS FLIGHT AHAY, MAY REMAIN TANTALIZINGLY OUT OF REACH.

01042 ARP, H.; CESAR, H.; PARKER, J.

ENVIRONMENTAL POLICY COOPERATION BETWEEN EASTERM AND HESTERN EUROPEAN COUNTRIES

ENVIRONMENT, 33(6) (JUL 91), 44-45

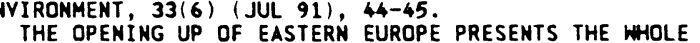

THE OPENING UP OF EASTERN EUROPE PRESENTS THE WHOLE
CONTINENT WITH A UNIQUE OPPORTUNITY TO TACKLE THE ROUGH

CONTINENT WITH A UNIQUE OPPORTUNITY TO TACKLE THE ROUGH
ENYIROMMENTAL PROBLEMS TRANSCENDING NATIONAL BOUNDARIES ENVIRONMENTAL PROBLEMS TRANSCENDING NATIONAL BOUNDARIES.
AGAINST THIS FAST CHANGING BACKGROUND, THE CONFERENCE ON AGAINST THIS FAST CHANGING BACKGROUND, THE CONFERENCE "ENVIRONMENTAL POLICY COOPERATION BETWEEN EASTERN AND CONFERENCE PARTICIPANTS SHOWED THAT, DESPITE CONSIDERABLE OBSTACLES, INTERNATIONAL ENVIRONMENTAL COOPERATION IS POSSIBLE. HONEVER, A UNIFORM APPROACH TO ENVIRONMENTAL POLLUTION IS USUALLY NOT FEASIBLE.

01043 ARQUILLA, J.

LOUDER THAN WORDS: TACTIC COMMUNICATION IN INTERNATIONAL CRISES

POLITICAL COMMUNICATION, 9(3) (1992), 155-172.

CLEAR COMHUNICATION IS GENERALLY VIEWED AS REQUISITE TO THE PEACEFUL RESOLUTION OF INTERNATIONAL CRISES. THE SUCCESS OF BARGAINING, DETERRENT, AND COMPELLENT STRATEGIES HINGES ON THE CREDIBILITY AFFORDED BY UMAMBIGUOUS SIGNALS EXCHANGED BETWEEN OPPONENTS. DESPITE THE ACKNONLEDGED IMPORTANCE OF THE COMMUNICATION FACTOR, LITTLE EFFORT HAS BEEN MADE TO EVALUATE THE RELATIVE EFFECTIVENESS OF THE VARIOUS MODES OF COMMUNICATION THAT MAY BE EMPLOYED IN CRISIS. BY MEANS OF THEORETICAL AND COMPARATIVE CASE ANALYSIS, THIS STUDY FINDS A SUBSTANTIAL DIFFERENCE BETHEEN THE EFFICACY OF TRADITIONAL DIPLOMATIC NEGOTIATION AND TACIT MEASURES, SUCH AS THE DEPLOYMENT OF MILITARY FORCES NEAR THE SCENE OF CRISIS. WHERE NEGOTIATION ALONE OFTEN FAILS, FOLLOWING, PRECEDING, OR REPLACING OIPLOMACY WITH TACIT MEASURES MAY AFFORD THE GREATEST CHANCES FOR SUCCESS. THE POLICY IMPLICATIONS OF THIS FINDING ARE EXPLORED, PARTICULARLY AS THEY APPLY TO U.S. REGIONAL EXTENDED DETERRENT STRATEGIES FOR PROTECTING GEOGRAPHICALLY DISTANT FRIENDS AND INTERESTS.

01044 ARRAU, $P$.

ENDOGENOUS GROWTH IN A LIFE-CYCLE MODEL: THE ROLE OF POPULATION GROWTH AND TAXATION

JOURNAL OF POLICY MODELING, 14(2) (APR 92), 167-186,

THE AUTHORS INTEGRATE THE ROLE OF HUMAN CAPITAL AS AN
THA THE AUTHORS INTEGRATE THE ROLE OF HUMAN CAPITAL AS AN
ENGINE OF GROWTH AND AS A DETERMINANT OF LIFE-CYCLE PROFILES OF EARNINGS AND LABOR SUPPLY. THEY EXTEND THE AUERBACHOF EARNINGS AND LABOR SUPPLY. THEY EXTEND THE AUERBACHDECISIONS AND ENDOGENOUS GRONTH. THE IMPACT OF DEMOGRAPHICS DECISIONS AND ENDOGENOUS GROHTH. THE IMPACT OF DEMOGRAPHICS
AND TAXATION ON THE ENDOGENOUS RATE OF GROWTH IS STUDIED. AND TAXATION ON THE ENDOGENOUS RATE OF GROWTH IS STUDIED.
UNLIKE INFINITE HORI ZON MODELS OF GROWTH, INCOME GROWTH PER UNLIKE INFINITE HORIZON MODELS OF GROWTH, INCOME GROWTH UNLIKE FERTILITY-BASED MODELS, THE DIRECTION OF CAUSALITY GOES FROM THE EXOGENOUS POPULATION GROWTH TO THE ENDOGENOUS ECONOMIC GROWTH. TAXATION POLICY THAT FAVORS HUMAN CAPITAL AS OPPOSED TO PHYSICAL CAPITAL TRANSLATES INTO HIGHER INCOME GROWTH PER CAPITA.
01045 ARRINGTON, T.S.; MEAD, T.D.

OUTREACH PROGRAMS AND VOTER REGISTRATION IN NORTH CAROLINA STATE AND LOCAL GOVERNMENT REVIEH, 24(3) (FAL 92), 113-116. USING NORTH CAROLINA AS A CASE STUDY, THE AUTHORS ASSESS THE EXTENT TO WHICH COUNTY BOARDS OF ELECTIONS HAVE BEEN SUCCESSFUL IN REGISTERING WHITES AND NON-HHITES TO VOTE. THEY FIND THAT SPECIFIC OUTREACH EFFORTS BY THE BOARDS HERE NOT STRONGLY, CONSISTENTLY, NOR, IN MOST CASES,

SIGNIFICANTLY RELATED TO SUCCESS IN INCREASING REGISTRATION OF EITHER RACE OR IN CLOSING THE GAP IN REGISTRATION BETHEEN THE RACES. OTHER FACTORS--CULTURAL, SOCIAL, ECONOMIC, AND POLITICAL--LARGELY DETERMINE THE RELATIVE SUCCESS OR' FAILURE OF REGISTRATION EFFORTS. THIS CASTS DOUBT ON THE EFFICACY OF PROPOSED OUTREACH EFFORTS, SUCH AS MAIL OR MOTOR-VOTER REGISTRATION.

01046 ART, R.

A DEFENSIBLE DEFENSE: AMERICA'S GRAND STRATEGY AFTER tHE COLD WAR

INTERNATIONAL SECURITY, 15(4) (SPR 91), 5-53.

THIS ARTICLE SEEKS TO DETERMINE HHAT FOREIGN POLICY GOALS THE UNITED STATES SHOULD PURSUE IN THE POST-COLD WAR ERA AND TO DETERMINE THE INSTRUMENTS BEST SUITED TO ATTAIN THEM. THE AUTHOR MAKES SIX ARGUMENTS. FIRST, FOR THE INDEFINITE FUTURE, THE U.S. HAS FIVE SPECIFIC INTERESTS: PROTECTION OF THE U.S. HOMELAND, AN OPEN HORLD ECONOMY, ACCESS TO PERSIAN GULF OIL, PREVENTION OF WAR IN THE FAR EAST AND EUROPE, AND WHERE FEASIBLE, THE PROMOTION OF DEMOCRATIC GOVERNMENTS. SECOND, THE U.S. DOES NOT HAVE AN INTEREST IN SPREADING DEMOCRACY BY INTERVENING MILITARILY IN THE INTERNAL AFFAIRS OF STATES. THIRD: NUCLEAR WEAPONS HAS INVALIDATED TRADITIONAL GEOPOLITICAL LOGIC. FOURTH: THERE IS A CASE FOR A U.S. MILITARY PRESENCE IN THE FAR EAST AND EUROPE TO HELP PRESERVE THE OPEN ECONOMIC ORDER. FIFTH: ASSURED ACCESS TO THE PERSIAN GULF REQUIRES SOME SORT OF MILITARY PRESENCE. SIXTH: THE U.S. NEEDS A MUCH SMALLER PEACETIME MILITARY PRESENCE THAN IT HAS HAD.

01047 ARTER, A.

THE FINNISH ELECTION OF 17 MARCH 1991: A VICTORY FOR THE OPPOSITION

WEST EUROPEAN POLITICS, 14(4) (OCT 91), 174-180.

A SUCCESSION OF DRAMATIC EXTERNAL EVENTS IN THE MONTHS A SUCCESSION OF DRAMATIC EXTERNAL EVENTS IN THE MONTHS
LEADING UP TO POLLING ON 17 MARCH 1991 SERVED TO UNDERLINE LEADING UP TO POLLING ON 17 MARCH 1991 SERVED TO UNDERLINE
THE EXTENT TO WHICH THE BASIC TERMS OF POLITICAL REFERENCE THE EXTENT TO WHICH THE BASIC TERMS OF POLITICAL REFERENCE
IN FINLAND HAD ALTERED SINCE THE FORMATION OF HARRI HOLERO'S CONSERVATIVE-SOCIAL DEMOCRATIC COALITION FOLLOWING THE GENERAL ELECTION FOUR YEARS EARLIER. TWO QUESTIONS WILL BE GENERAL ELECTION FOUR YEARS EARLIER. TWO QUESTIONS WILL BE HIGH ON THE POLITICAL AGENOA. FIRST, WILL THE NEH CABIN
ABLE TO GENERATE THE CONSENSUS NECESSARY TO MANAGE THE FINNISH ECONOMY OUT OF THE RECESSION? SECOND, WILL THE NEW GOVERNMENT FOLLOW SWEDEN IN MAKING FORMAL APPLICATION TO JOIN THE EC? THE FEELING REMAINS THAT THERE IS LITTLE REALISTIC ALTERNATIVE TO FULL MEMBERSHIP.

01048 ARTER, D

BLACK FACES IN THE BLOND CROWD: POPULIST RACIALISM IN SCANDINAVIA

PARLIAMENTARY AFFAIRS, 45(3) (JUL 92), 357-372.

RACIAL QUESTIONS ARE FIRMLY ON THE SCANDIMAYIAN

POLITICAL AGENDA: IMMIGRATION LEGISLATION HAS BEEN AMENDED TO MAKE ENTRY MORE DIFFICULT AND APPLICATIONS FOR ASYLUM ARE BEING PROCESSED MORE EXPEDITIOUSLY. ALTHOUGH SOCIOECONOMIC CONDITIONS HAVE NOT YET PRECIPITATED RACE RIOTS AND THE RACISM OF SOCIOECONOMIC DEPRIVATION, A NUMBER OF MASS RACE AND ANTI-RACIST RALLIES HAVE TAKEN PLACE, VESTING THE POLITICAL CULTURE OF THE REGION WITH AN INCREASINGLY DEMONSTRATIVE CHARACTER.

01049 ARTER, D.

THE SHEDISH LEFTIST PARTY: "ECO-COMMUNISM" OR COMMUNIST ECHO?

PARLIAMENTARY AFFAIRS, 44(1) (JAN 91), 60-78.

IN MAY 1990, THE SWEDISH LEFT-PARTY COMMUNISTS (VPK) BECAME THE FIRST PARTY TO FOLLOW THE EXAMPLE OF ITS

FRATERNAL PARTIES IN THE EASTERN BLOC AND CHANGE ITS NAME.

THIS ARTICLE EXAMINES THE ELECTORAL, DOMESTIC, AND

THIS ARTICLE EXAMINES THE ELECTORAL, DOMESTIC, AND
PROGRAMMATIC SIGNIFICANCE OF THIS DECISION. IT SETS THE

PROGRAMMATIC SIGNIFICANCE OF THIS DECISION. IT SETS THE
RENAMING IN THE BROADLY COMPARATIVE CONTEXT OF MODERNIZING

RENAMING IN THE BROADLY COMPARATIVE CONTEXT OF MODERNIZ
PARTIES IN GENERAL AND THE CRISIS OF LEGITIMACY FACING

PARTIES IN GENERAL AND THE CRISIS OF LEGITIMACY FACING
COMMUNISM IN EUROPE IN PARTICULAR. IT CONSIDERS CHANGES OF

COMMUNISM IN EUROPE IN PARTICULAR. IT CONSIDERS CHANGES OF
IDEOLOGY AND PLATFORM OF THE RULING SOCIAL DEMOCRATS AS AN IOEOLOGY AND PLATFORM OF THE RULING SOCIAL DEMOCRATS AS AN
IMPETUS FOR CHANGE ON THE LEFT. AND IT CONSIDERS WHETHER A IMPETUS FOR CHANGE ON THE LEFT. AND IT CONSIDERS WHETHER A JUDICIOUS ADMIXTURE OF "RED" AND "GREEN" POLICIES CAN A CREDIBLE SYNTHESIS IN THE FORM OF A

01050 ARTS, $H$.

COMMUNITY, MARKET, AND STATE: REFLECTIONS ON THEIR POTENTIAL FOR ACHIEVING ECONOMIC JUSTICE

SOCIAL JUSTICE RESEARCH, 5(2) (JUN 92), 137-154. THIS PAPER INVESTIGATES THE POTENTIAL OF DISTINCT SOCIETAL DECISION-MAKING AND COORDINATING MECHANISMS AS 
DIVERSITY OF ACTUAL INSTITUTIONAL ARRANGEMENTS THAT GUIDE AND SHAPE WHATEVER HAPPENS IN ECONOMIES, THREE OVERARCHING IDEAL TYPES OF MECHANISMS WHICH SEPARATELY OR IN COMBINATION IDEAL TYPES OF MECHANISMS WHICH SEPARATELY OR IN COMBINAT DISCERNIBLE: COMMUNITIES, MARKETS, AND STATES. EACH OF THESE IDEAL TYPES REPRESENTS A DIFFEREMT WAY IN WHICH ECONOMIC DECISIONS ARE MADE AND THE ECONOMIC ACTIONS OF MEMBERS OF DECISIONS ARE MADE AND THE ECONOMIC ACTIONS OF MEMBERS SDCIETY ARE COORDINATED. THE SPECIFIC QUESTION TO BE ANSWERED IS HOW EACH OF THESE MECHANISMS CAN CONTRIBUTE TO THE SOLUTION OF THE PROBLEM OF ECONOMIC JUSTICE IN MODERN TIMES.

01051 ARUIRRE, $M$

DISCRIMINATE INTERVENTION: DEFINING NATO FOR THE '9OS MIDDLE EAST REPORT, 22 (4) (JUL 92), 28-37.

NATO, THE LONG-TIME DIRECTOR OR WESTERH MILITARY

OPERATIONS IN EUROPE, SHOULD BE PREPARED TO INTERVENE IN THE THIRD WORLD, EASTERN EUROPE AND THE FORMER USSR. WITH THE END OF THE COLD WAR, NATO IS SEARCHING FOR A NEW MISSION. THERE IS A DEBATE OVER INTERVENTION POLICIES WHICH OCCURS IN A SETTING WHERE THE U.S. INTENDS TO BE THE ONLY POWER WITH GLOBAL REACH, IN A PERIOD HHEN JAPAN AND EUROPE HAVE EMERGED AS ECONOMIC POWERS. THE U.S. IS WORKING TO MAINTAIN NATO AS AS ECONOMIC POWERS. THE U.S. IS WORKING TO MAINTAIN NATO
THE BODY AROUND WHICH A POST-COLD-WAR WESTERN MILITARY

THE BODY AROUND WHICH A POST-COLD-WAR WESTERN MILITARY
SYSTEM IS ORGANIZED, ONE EMBODYING CONTINUED U.S. LEADERSHIP.

01052 ARURI, $N$

THE ROAD TO MADRID ANO BEYOND: BAKER ANO THE PALESTINIANS

NEW POL ITICAL SCIENCE, 21-22 (SPR 92), 137-158.

THIS STUDY ENDEAVORS TO EXPLAIN THE NATURE AND
OBJECTIVES OF UNITED STATES MIDDLE EAST DIPLOMACY DURING THE OBJECTIVES OF UNITED STATES MIDDLE EAST DIPLOMACY DURING THE
BUSH PRESIDENCY. IT ATTEMPTS TO ANSHER A NUMBER OF QUESTIONS BUSH PRESIDENCY. IT ATTEMPTS TO ANSWER A NUMBER OF
ABOUT THAT PROCESS, FOCUSING ON ITS LINCHPIN, THE ABOUT THAT PROCESS, FOCUSING ON ITS LINCHPIN, THE PALESTINIAN DIMENSION. IT EXPLORES HOH AND WHY THE MADRID
CONFERENCE CONVENED IN SEPTEMBER 1991 AND WHO PAVED THE ROAD, AND THE CIRCUMSTANCES. ALSO, IT EXAMINES THE BASIS FOR THE INVESTMENT OF SO MUCH U.S. POLITICAL CAPITAL IN THAT PROCESS AND THE DIPLOMATIC REFLECTION OF THE MILITARY VICTORY SO IMPORTANT FOR THE CONSOL IDATION OF U.S. GAINS. THE REASONS THAT THE VARIOUS PARTIES TO THE CONFLICT AGREED TO PARTICIPATE AND THE MEANS OF PRESSURE AND PERSUASION THAT WERE EMPLOYED TO GUARANTEE THEIR INVOLVEMENT ARE EXPLORED.

01053 ARVELO-JIMENEZ, M. ; COUSINS, A.L.

FALSE PROMISES

CULTURAL SURVIVAL QUARTERLY, 16(1) (WIN 92), 10-13.

ON AUGUST 1, 1991. PRESIDENT ANDRES PEREZ OF VENEZUELA

SIGNED A DECREE SETTING ASIDE MORE THAN 30,000 SQUARE MILES AS A "BIOSPHERE RESERVE" TO PROTECT THE ENVIRONMENT AND THE
INDIGENOUS PEOPLE OF THE UPPER ORINOCO AND CASIQUIARE RIVERS INDIGENOUS PEOPLE OF THE UPPER ORINOCO AND CASIQUIARE RIVER FROM THE UNCONTROLLED DEVELOPMENT COMMON IN THE BRAZILIAM
AMAZON. THE DECREE DEFINITELY ADVANCES THE STRUGGLE FOR AMAZON. THE DECREE DEFINITELY ADVANCES THE STRUGGLE FOR
INDIGENOUS RIGHTS, BUT INITIAL EUPHORIC REACTION TO THE INDIGENOUS RIGHTS, BUT INITIAL EUPHORIC REACTION TO THE DECLARATION WAS PREMATURE. ALTHOUGH IT APPEARS THAT THE TERRITORY ALONG THE BORDER HITH BRAZIL, APPEARANCES CAN BE TERRITORY
DECEIVING.

01054 ASA-EL, A.

BALLOTS FOR PEACE

FREEDOM REVIEH, 23(5) (SEP 92), 13-15

IN JUNE 1992, ISRAEL HELD DEMOCRATIC ELECTIONS AND, FOR THE SECOND TIME' IN ITS HISTORY, CHOSE FUNDAMENTAL POLITICAL CHANGE. BY REJECTING THE LIKUD AND YITZHAK SHAMIR AND RETURNING YITZHAK RABIN AND THE LABOR PARTY TO OFFICE AFTER A LONG EXILE, THE ISRAELIS HAVE IMDICATED THAT THEY ARE READY FOR PEACE.

01055 ASA-EL, A.

LETTER FROM ISRAEL: UNITY AGAIM

FREEDOM REYIEW, 23(3) (MAY 92), 34-36.

FOR THE FIRST TIME SIMCE IT CAME TO POWER 15 YEARS AGO,

ISRAEL'S RULING LIKUD PARTY MIGHT LOSE ITS POLITICAL

PREDOMINANCE. CHANGES IN THE SOCIAL COMPLEXION, ECONOMIC

MENTALITY, AND DEMOCRATIC METHODS OF THE JEWISH STATE ARE FAST TRANSFORMING THE POLITICAL LANDSCAPE AND REINYIGORATING THE DEMORALIZED LABOR PARTY. THE DEEPEST CHANGE IS THE SUBSTITUTION OF THE ONCE POTENT AND INCITABLE SEPHARDIC VOTE WITH THE SIZABLE AND POLITICALLY-VIRGIN CONSTITUENCY OF MEHLY-ARRIVED SOYIET JEHS. THE DIFFEREMCE IN HOW THE SEPHAROIM ARE YIEHED IN ISRAEL TODAY AND IMDEED THE DIFFEREMCE IN HOW THEY SEE THEMSELVES WIL GO A LONG WAY DIFFERENCE IN HOW THEY SEE THEMSELVES WILL GO A LONG WAY

01056 ASBJORNSEN, N.; VOGT, G

MEASURING POL ITICAL COMPETENCE. AN AMALYSIS WITH REFERENCE MEASURING POLITICAL

SCANDINAVIAN POLITICAL STUDIES, 15(1) (MAR 92), 61-78.

POLITICAL ALIENATION HAS BEEN AN IMPORTANT CONCEPT IN THEORIES OF PARTICIPATION AMD DEMOCRATIC POLICIES.

SUBJECTIVE POLITICAL COMPETENCE (INTERNAL POLITICAL

EFFICACY) IS CONSIDERED TO BE A MAIN ELEMENT WITHIN THE BROADER CONCEPT OF POLITICAL ALIENATION AND AN IMPORTANT DETERMINANT OF POLITICAL PARTICIPATION. THE AUTHORS TEST
STATISTICALLY THE ASSUMPTION OF SIMILARITY IN MOOEL STRUCTURE FOR MEN AND WOMEN-I.E., THE RELATION BETWEEN POLITICAL COMPETENCE AND VOTING TURNOUT. ON THE BASIS OF A COMMON SURVEY OUESTIONNAIRE ITEM, THEIR FINDINGS SHOW THAT SUBJECTIVE COMPETENCE HAS DIFFERENT SIGNIFICANCE FOR MEN AND WOMEN. FOR MEN, IT HAS AN EXPECTED SUBSTANTIVE MEANING. FOR DRELEYANT HITH RESPECT SOURCES AMD CONSEQUENCES. GIVEN THIS APPARENT

INCOMPARAB ILITY IN MEASUREMENT, IT IS INAPPROPRIATE TO USE IDENTICAL MODELS FOR MEN AND WOMEN. POLITICAL COMPETENCE SHOULD BE CONCEIVED OF AS CONTAINING A COGNITIVE ELEMENT "OBJECTIVE POL ITICAL COMPETENCE." EMPIRICAL ANALYSIS SHOHS THAT THIS CONCEPT IS GENDER NEUTRAL WITH RESPECT TO POLITICAL INVOLVEMENT.

01057 ASCHAUER, A.

HAMMERS, SICLES, AND SCISSORS

SOCIETY, 29(4) (MAY 92), 11-14.

AMERICA'S ABILITY TO MEET ITS PRESSING PROBLEMS WILL DEPEND ON A STRONG AND STEAOY PERFORMANCE BY THE NATIONAL ECONOMY. OVER THE LAST THENTY YEARS, THE ECONOMY HAS NOT BEEN PERFORMING WELL AND IN PARTICULAR, PUBLIC INVESTMENT IN THE NATION'S CORE INFRASTRUCTURES HAS DROPPED. THIS ARTICLE ARGUES THAT EVEN THROUGH IT MIGHT SEEM THAT BECAUSE OF THE CURRENT BUDGET DEFICIT WE CANNOT AFFORD TO MAKE SUBSTANTIAL INVESTMENTS IN INFRASTUCTURE, THE FACT IS THAT WE CANNOT AFFORD NOT TO INVEST IN OUR PUBLIC CAPITAL STOCK. THE AFFORD NOT TO INVEST IN OUR PUBLIC CAPITAL STOCK. THE ARTICLE EXPLORES: THE TRADITIONAL VIEW; INFRASTRUCTURE
SUPPLY; NATIONAL NEEDS, OTHER SOURCES OF FINANCE; AND, SUPPLY; NATIONAL NEEDS,
SPENDING TO MEET NEEDS.

01058 ASH, R.F.

THE AGRICULTURAL SECTOR IN CHINA: PERFORMANCE ANO POLICY DILEMMAS DURING THE $1990^{\circ} \mathrm{S}$

CHINA QUARTERLY, (131) (SEP 92), 454-576.

THE AUTHOR LOOKS AT THE IMPACT OF EFFORTS TO REFORM CHINESE AGRICULTURE IN THE 1980'S AND SPECULATES ABOUT THE FUTURE OF THE AGRICULTURAL SECTOR IN THE 1990's.

01059 ASH, T.N.

EAST EUROPEAN AGRICULTURE AT A CROSSROADS

RFE/RL RESEARCH REPORT, 1(4) (JAN 92), 33-38,

AGRICULTURAL REFORM HAS REACHED VARIOUS STAGES IN THE COUNTRIES OF EASTERN EUROPE. ONE OF THE GREATEST PROBLEMS IS HOW TO MOVE FROM COMMUNALLY-BASED AGRICULTURAL SYSTEMS TO PRIVATE FARMS. IN THIS ARTICLE, THE AUTHOR OFFERS AM OVERVIEW OF THE EFFORTS TO REFORM AGRICULTURE, THE SOCIAL IMPACT OF REFORMS, AND ATTEMPTS TO INCREASE EXPORTS OF AGRICULTURAL PRODUCTS FROM EASTERN EUROPE TO THE WEST.

01060 ASH, T.N.

PROBLEMS OF RUBLE CONVERTIBILITY

RFE/RL RESEARCH REPORT, 1(29) (JUL 92), 26-32. INTRODUCING A CONYERTIBLE CURRENCY HAS OFTEN BEEN CITED AS A PREREOUISITE FOR THE SUCCESSFUL ECONOMIC REFORM OF THE CENTRALLY -PLANNED ECONOMIES OF EASTERN EUROPE AND THE FORMER SOVIET UNION. ON JULY 1 , 1992, RUSSIA FINALLY INTRODUCED ITS SOVIET UNION. ON JULY 1, 1992, RUSSIA FINALLY INTRODUCED ITS MUCH-PUBLICIZED CURRENCY REFORH. CURRENCY CONVERTIBILITY IS ONLY ONE OF A SERIES OF MEASURES THAT MUST BE INTRODUCED IF SUCCESSFUL ECONDMIC REFORM IS TO BE

01061 ASHFORD, D.

DEMOCRATIC DILEMMAS: WHAT FUTURE FOR THE LEFT? PEMOCRATIC DILEMMAS: WHAT FUTURE FOR THE LEFT?

IN A DEMOCRACY, ONE OF THE LESS NOTICED TRENDS HAS BEEN THE EROSION OF THE DEMOCRATIC LEFT IN THE MOST STABLE WESTERN DEMOCRACRIES, BRITAIN BEING THE PRIME ILLUSTRATION, AND THE PERSISTENCE OF SINGLE-PARTY RULE IN SEVERAL MAJOR DEHOCRACIES. THERE ARE AT LEAST THO POSSIBLE EXPLANATIONS OF THE MALAISE OF THE LEFT. THE MORE COMPLACENT IS SIMPLY THAT THE LEFT HAS ALWAYS BEEN THE PARTY OF OPPOSITION ANO SACRIFICE. AN ALTERNATIVE VIEH IS MORE REVEALING. THIS POSITIION ARGUES THAT POLITICIANS OF THE LEFT HAVE BECOME LAREGLY REACTIVE IF NOT OPPORTUNISTIC IN A WAY THAT PROVIDES LITTLE DIRECTION FOR INNOVATIVE THINKING AND FEW GROUNDS FOR A MORE CRITICAL EVALUATION FOR FUTURE SOCIAL DEMOCRATIC POLTICAL STRATEGY. AN HISTORICAL ANALYSIS OF THE SOCIAL DEMOCRATIC IMAGINATION MAY SHOW THAT IT WAS NOT SO MUCH THE LACK OF SOCIO-ECONOMIC PROPOSALS THAT DOOMED THE LEFT TO DECLINE, BUT ITS INABILITY TO GRAPS SOME FUNDAMENTALS OF DEMOCRATIC POL ITICAL INSTITUTIONS THAT MADE IT APPEAR UNDECIDED AND WEAK.

01062 ASHFORTH, B.

THE PERCEIVED INEQUITY OF SYSTEMS

ADMINISTRATION AND SOCIETY, 24(3) (NOV 92), 375-408

IT IS ARGUED THAT FORMAL, MAN-MADE SYSTEMS TEND TO $B E$ PERCEIVED AS INEOUITABLE BY INDIVIDUALS TRANSACTING WITH THEM COGNITIVE AND MOTIVATIONAL BIASES PREDISPOSE SYSTEM CLIENTS TO VIEW SYSTEMS AS MUCH LESS EQUITABLE THAN DO SYSTEM ADMINISTRATORS. PERCEIVED INEQUITIES LEAD TO UNMET EXPECTATIONS, REDUCED SYSTEM LEGITIMACY, REACTANCE, ETC.
THIS ANALYSIS SUGGESTS THAT THE VERY ATTEMPT TO ORGANIZE AM 
ACTIVITY MAY LEAD TO STRUCTURES AND PROCESSES THAT UNDERMINE THE ACTIVITY. GENERAL MEANS AND A PROCESS FOR REDUCING PERCEIYED INEQUITIES ARE DISCUSSED.

01063 ASHWORTH, T

SOLDIERS NOT PEASANTS: THE MORAL BASIS OF THE FEBRUARY REVOLUTION OF 1917

SOCIOLOGY, 26 (3) (AUG 92), 455-470.

THE AUTHOR DISCUSSES THE DUAL MATURE OF MILITARY POHER-THE MATERIAL AND THE MORAL. HE SHOWS HOW MORAL POWER PLAYED A DECISIVE ROLE IN THE FEBRUARY 1917 REVOLUTION IN RUSSIA. HE RECOUNTS EVENTS DURING THE FIRST FOUR DAYS OF THE

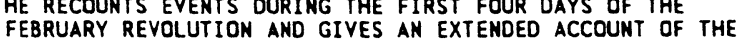
FEBRUARY REVOLUTION AND GIVES AN EXTENDED ACCOUNT OF THE
SOLDIERS. MUTINY ON THE FIFTH DAY. HE COMPARES THE STRENGTH SOLDIERS ' MUTINY ON THE FIFTH DAY. HE COMPARES THE STRENGTH
OF THE SOLDIERS' SOLIDARITY WITH THE WORKERS' SOL IDARITY. HE OF THE SOLDIERS SOLIDARITY WITH THE WORKERS SOL IDARITY. HE AN ALTERNATIVE EXPLANATION. FINALLY, HE DISCUSSES THE RELEVANCE OF THE STUDY FOR SOME WIDER THEORETICAL ISSUES.

01064 ASIKOGLU, Y, UCTUM, M.

A CRITICAL EVALUATION OF EXCHANGE RATE POLICY IN TURKEY WORLD DEVELOPMENT, 20(10) (OCT 92), 1501-1514.

THE AUTHORS REVIEW AND EVALUATE' TURKEY'S REFORMED EXCHANGE RATE POLICY SINCE 1980. THEY CONCLUDE THAT THE NEW EXCHANGE RATE POLICY HAS BEEN AN ESSENTIAL INGREDIENT IN TURKEY'S REGAINING ITS CREDITWORTHINESS. FURTHERMORE, IT HAS POSITIVELY CONTRIBUTED TO THE GROWTH OF OUTPUT AND EXPORTS AND TO THE EXPANSION OF TRADABLES PRODUCTION RELATIVE TO NONTRADABLES. THE PERSISTENCE OF INFLATION AND THE HEAKNESS OF PRIVATE INVESTMENT IN TRADABLES OVERSHADOH THE SUCCESSES RECORDED IN OTHER AREAS AND CAST DOUBT OVER THE

SUSTAINABILITY OF TURKEY'S OUTHARD ORIENTATION. THE AUTHORS ARGUE THAT THE ROOT CAUSE OF THESE PROBLEMS HAS BEEN INCONSISTENCIES IN OVERALL ECONOMIC POLICIES RATHER THAN THE EXCHANGE RATE POLICY ITSELF. THEY COMPARE THE PERIDD OF REAL APPRECIATIONS SINCE LATE 1988 WITH THE EARLIER PERIOD OF REAL DEPRECIATIONS AND DRAH POLICY IMPLICATIONS.

01065 ASLUND, A.

RUBLE-SHOOTERS

MEH REPUBLIC, 206 (18) (MAY 92), 13-14.

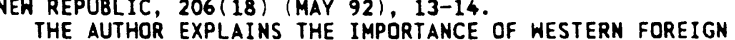
AID TO INSURE RUSSIA'S POITICAL STABILIIY AND ECONOMIC AID TO INSURE

01066 ASLUMD A.

RUSSIA'S ROAD FROM COMMUNISM

DAEDALUS, $121(2)$ (SPR 92), 77-95.

THE AUTHOR DISCUSSES THE END OF COMMUNISM IN THE SOVIET UNION, FOCUSING ON GORBACHEY'S FAILURES AND YELTSIN'S RISE TO POWER. HE ALSO CONSIDERS THE LESSONS TO BE LEARNED FROM THE IMPENDING BREAKUP OF YUGOSLAVIA AND OFFERS SUGGESTIONS ABOUT HOW THE WEST SHOULD HELP RUSSIA.

01067 ASSMANM, H.

THE STRANGE IMPUTATION OF VIOLENCE TO LIBERATION THEOLOGY TERRORISM AND POLITICAL VIOLENCE, 34(4) (WIN 92), 80-99.

LIBERATION THEOLOGY IDENTIFIES THE EXISTING DISTRIBUTION OF POWER AS A FORM OF OPPRESSIVE DOMINATION ROOTED IN VIOLENCE. THE CRITICS OF LIBERATION THEOLOGY, NOTING THE REFERENCE TO VIOLENCE IN THE LITERATURE OF LIBERATION THEOLOGY, FALSELY ASSERT THAT IT PREACHED REVOLUTIONARY VIOLENCE AND THAT LIBERATION THEOLOGIANS ARE ENEMIES OF THE POOR. OVER THE PAST FEW YEARS, THESE ARGUMENTS HAVE BECOME LESS PERSUASIVE: THE VATICAN HAS RECOGNIZED THE NEED TO CORRECT STRUCTURALLY-DETERMINED INEQUALITIES, AND POLITICAL CANDIDATES LINKED TO LIBERATION THEOLOGY HAVE MADE BETTER SHOWINGS IN POLLS. UNFAIR CRITICISM CONTINUES, BUT

LIBERATION THEOLOGY SHOWS PROMISING GLIMMERS OF SUCCESS IN LATIN AMERICA.

01068 ASTIER, H.

AMERICANS AND CONSPIRACY THEORIES

CONTEMPORARY REVIEH, 261 (1521) (OCT 92), 169-178.

THIS ARTICLE EXPLORES HHAT MAKES CONSPIRACY THEORIES
THE POPULAR; WHAT THEIR COMMON THEMES ARE; AND THEIR POLITICAL POPULAR; WHAT THEIR COMMON THEMES ARE; AND THEIR POLITICAL IMPACT IT EXAMINES THEIR POPUL IST NATURE AND AS AN ANTITHE ILLUSION OF OMNIPOTENECE, AND INSTITUTIONAL FACTORS ARE THE ILLUSION OF OMNIPOTENECE, AND INSTITUTIONAL FACTORS ARE
PRESENTED AND WHETHER CONSPIRACY THERORISTS HAVE POWER IS PRESENTED AND WHETHER CONSPIRACY THERORISTS HAVE POWER IS THE DISCUSSION.

01069 ATHERTON, A.

THE SHIFTING SANDS OF MIDDLE EAST PEACE

FOREIGH POLICY SANDS OF MIDOLE EAST PEACE

THIS ARTICLE EXAMINES THE MIDDLE EAST PEACE CONFERENCE, ITS ORIGINS, IMPLICATIONS, AND PROSPECTS. IT ARGUES THAT SEVERAL MAJOR DEVELOPMENTS IN THE REGION SET THE STAGE FOR THE ARAB-ISRAELI TALKS: THE SIX DAY ARAB-ISRAELI WAR; THE 1979 REVOLUTION IN IRAN; THE OUTBREAK OF THE INTIFADA WHICH BEGAN IN 1987; AND THE GULF WAR. NOH ALL EYES LOOK EXPECTANTLY TO THE UNITED STATES TO BROKER SOME SORT OF ARABISRAELI AGREEMENT. WHILE THE POTENTIAL ROLE OF THE UNITED
STATES IS SIGNIFICANT, AMERICAN POLICYMAKERS WOULD DO WELL TO REMEMBER THREE BASIC PRINCIPLES: THE CLOSE COOPERATION ON MIDDLE EAST ISSUES BETWEEN THE UNITED STATES AND THE FORMER SOVIET UNION MUST CONTINUE BETHEEN THE U.S. AND THE RUSSIAN FEDERATION; THE UNITED STATES MUST WALK A FINE LINE BETWEEN PROVIDING LEADERSHIP AND SEEKING TO IMPOSE A "PAX AMERICANA" ON THE REGION; AND THE UNITED STATES SHOULD AVOID THE PITFALL OF VIEWING THE MIDDLE EAST AS A ONE-ISSUE AREA AND CONCENTRATING ONLY ON THE ARAB-ISRAELI CONFLICT.

01070 ATKINS, B.M.

DATA COLLECTION IN COMPARATIVE JUDICIAL RESEARCH: A NOTE ON THE EFFECTS OF CASE PUBLICATION UPON THEORY BUILOING AND HYPOTHESIS TESTING

WESTERN POLITICAL QUARTERLY, 45(3) (SEP 92), 793-809.

MUCH OF THE THEORY AND DATA SCHOLARS HAVE DEVELOPED FOR UNDERSTANDING LEGAL SYSTEMS ARE LARGELY THE PRODUCT OF THE INEVITABLE PECULIARITIES OF THE U.S. CONTEXT. THEREFORE, A VIGOROUS AGENDA OF CROSS-NATIONAL JUDICIAL RESEARCH MUST BE ENCOURAGED. HOWEVER, SCHOLARS MUST BE ALERT TO PROBLEMS REGARDING THE AVAILABILITY OF DATA THAT MAY INTERFERE WITH THE ABILITY TO DRAH ACCURATE INFERENCES ABOUT COURTS AND JUDICIAL BEHAVIOR. ONE SUCH PROBLEM CONCERNS WHETHER THE SELECTIVE PUBLICATION OF APPELLATE CASES BIASES OBSERVATIONS REGARDING THE KINDS OF DECISIONS THAT COURTS MAKE. THIS PAPER EXAMINES THE EFFECTS OF SELECTIVE REPORTING OF DECISIONS HANDED DOWN BY THE ENGLISH COURT OF APPEAL. AN ANALYSIS OF ITS JUDGMENTS HANDED DOWH OVER A THREE-YEAR PERIOD SHOWS THAT STATISTICALLY-SIGNIFICANT DIFFERENCES EXIST BETWEEN PUBLISHED AND UNPUBLISHED DECISIONS IN TERMS OF A VARIETY OF VARIABLES MEASURING THE COURT'S INTRA- AND INTER-INSTITUTIONAL DECISION-MAKING DYNAMICS. THUS, INFERENCES ABOUT THE COURT OF APPEAL WILL VARY, DEPENDING UPON WHETHER SCHOLARS HAVE ACCESS TO UNPUBLISHED DECISIONS.

01071 ATKINS, P.S.; WILSON-GENTRY, L.

AN ETIQUETTE' FOR THE 1990 'S REGIONAL COUNCIL

NATIONAL CIVIC REVIEH, 81(4) (FAL 92), 466-487

THE RULES OF THE GAME FOR REGIONAL COUNCILS IN THE $1960^{\circ}$ 'S AND 1970'S WERE SHAPED BY THEIR CENTRAL ROLE IN FEDERAL POLICIES PROMOTING SUB-STATE REGIONALISM. WHEN MONEY STOPPED FLONING FROM THE FEDERAL TAP IN THE 1980'S, REGIONAL COUNCILS BECAME ENTREPRENEURIAL AND SOUGHT TIES WITH STATE COUNCILS BECA
GOVERNMENT.

01072 ATKINSON, M.; DOCHERTY, D.

MOVING RIGHT' ALONG: THE ROOTS OF AMATETEURISM IN THE CANADIAN HOUSE OF COMMONS

CANADIAN JOURHAL OF POLITICAL SCIENCE, XXV(2) (JUN 92), 295-319

IT HAS BEEN ARGUED THAT RAPID MEMBERSHIP TURNOVER IN THE CANADIAN HOUSE OF COMMONS ROBS THE INSTITUTION OF A DEDICATED AND EXPERIENCED GROUP OF MPS AND PRODUCES A PARLIAMENT STOCKED HITH POLITICAL AMATEURS. BOTH ELECTORAL DEFEAT AND VOLUNTARY RETIREMENT HAVE BEEN SEEN TO PLAY A ROLE IN THE AMATEURISH PHENOMENON. THE AUTHORS EXPLORE THE ROOTS OF AMATEURISM AND CRITICALLY EXAMINE THE ARGUMENT
A FRUSTRATING CAREER STRUCTURE IN THE HOUSE OF COMHONS ENCOURAGES VOLUNTARY VACANCIES. USING A RANDOM SAMPLE OF FORMER MPS, THE AUTHORS FIND SUPPORT FOR BOTH A "FRUSTRATION" AND AN "EXHAUSTION" MODEL OF CAREER CHOICE. THE ARTICLE CONCLUDES THAT WHILE AMATEURISM MAY BE PROBLEMATIC, NOT ALL MPS ARE AMATEURS AND THE PROBLEM OF AMATEURISM CANNOT BE ADDRESSED SIMPLY BY SATISFYING FRUSTRATED AMBITION.

01073 ATKINSON, M.; COLEMAN, $W$.

POLICY NETHORKS, POLICY COMMUNITIES AND THE PROBLEMS OF GOVERNANCE

GOVERMANCE, 5(2) (APR 92), 154-180.

THE CONCEPTS IN THE LITERATURE ON POLICY NETHORKS AND COMMUNITIES ARE IMPORTANT BECAUSE THEY SUGGEST A RENEWED ATTEMPT TO BE BOTH ENCOMPASSING AND DISCRIMINATING IN DESCRIBING THE POLICY PROCESS. HOWEVER, IF THE CONCEPTS ARE GOING TO CONTINUE TO MAKE A CDNTRIBUTION, SOME PROBLEMS MUST BE RESOLVED. THIS ARTICLE SUGGESTS THREE THAT ARE PARTICULARLY IMPORTANT: 1) NETWORK AND COMMUNITY CONCEPTS ENCOUNTER OBSTACLES IN INCORPORATING THE INFLUENCE OF ENCOUNTER OBSTACLES IN INCDRPORATING THE INFLUENCE OF MACROPOLITICAL INSITITUIONS AND THE POHER OF POLITICAL
OISCOURSE; 2) THEY HAVE HAD SOME DIFFICULTY IN ACCOMODATING DISCOURSE; 2) THEY HAVE HAD SOME DIFFICULTY IN ACCOMODATING
THE INTERNATIONALIZATION OF MANY POLICY DOMAINS; AND, 3) THEY HAVE NOT ADDRESSED WELL THE ISSUES OF POLICY INHOVATION AND POLICY CHANGE.

01074 ATTEH, S

A COMPARATIVE ANALYSIS OF NIGERIAN EDUCATIONAL POLICIES FOR NATIONAL INTEGRATION, 1842-1990

SCANDINAVIAN JOURNAL OF DEVELOPMENT ALTERNATIVES, 11(3) SEP 92 ), $137-174$.

THROUGHDUT THE HISTORY OF NIGERIA, THE PROBLEM OF NATIONAL INTEGRATION HAS BEEN A FUNDAMENTAL ISSUE IN ITS GOVERMMENT AND POLITICS. IN A COMPARATIVE ANALYSIS, THIS STUDY EXPLORES THE DIFFERENTIAL ROLE OF EDUCATION IN THE 
PAPER DESCRIBES THE PROBLEMS OF NATIONAL INTEGRATION AND INVESTIGATES WHAT MOTIVATED THE POLICY MAKERS TO USE OR NOT TO USE EDUCATION FOR INCULCATING NATIONAL VALUES INTO NIGERIAN YOUTHS. IT EXPLAINS THE VARIATIONS BY COMPARING THE DEGREE TO WHICH POLITICAL LEADERS ACTUALLY CONTRIBUTED TO NATIONAL INTEGRATION THROUGH EDUCATIONAL POLICIES

01075 ATHOOD, C.; KAYE, L.

THE HAN HORDES

FAR EASTERN ECONOMIC REVIEH, 155(14) (APR 92), 18-19.

MONGOL DISSIDENTS IN THE CHINESE "AUTDNOMOUS REGION" OF INNER MONGOLIA COMPLAIN THAT BEIJING SWAMPS THEM WITH HAN CHINESE SETTLERS, GERRYMANDERS THEM OUT OF A MAJORITY IN ANY DISTRICT, AND PACKS THE ADMINISTRATION AT EVERY LEVEL WITH HAM OFFICIALS. FURTHERMORE, RUMORS OF A "SECRET CAMPAIGN OF REPRESSION AGAINST ETHNIC MONGOLIAN INTELLECTUAL" ARE BEGINNING TO LEAK OUT OF CHINA. DESPITE THIS INCREASE IM REPRESSION, ETHNIC MONGOLS OF INNER MONGOLIA REMAIN WARY OF THEIR NEWLY-FREED COUSINS IN OUTER MONGOLIA. BOTH SIDES REGARD THE OTHER WITH DISTASTE AND MISTRUST.

01076 AUDIBERT, D.

HUNGARY'S CRUMBLING CASTLE

WORLD PRESS REVIEH 39(4) (APR 92) 44

HUNGARY IS HAVING TROUBLE CONCEALING THE PROBLEMS OF ITS POL ITICAL AND ECONOMIC TRANSITION. VOTER TURNOUTS HAVE REACHED AN ALL-TIME LOW IN RECENT ELECTIONS, AND POLLS REVEAL THAT 60 PERCENT OF HUNGARIANS BELIEVE THAT THEIR COUNTRY'S POSITION IS HORSE NOW THAN IT WAS BEFORE THE 1990 ELECTIONS. HUNGARY IS EMERGING FROM ITS PAST WITH A WHOLE NEH POLITICAL APPARATUS, HORTHY OF A PROSPEROUS SOCIAL DEMOCRACY BUT UNRELATED' TO ITS CRISIS-RIDDEN SOCIAL REALITY.

01077 AUER, J.; CALDER, K.; JANSEN, M.; LINCOLN, E. U.S.-JAPAN RELATIONS: THE END OF' INTERDEPENDENCE? SAIS REVIEN, 11(1) (HIN 91), 93-112.

THE AUTHORS OF THIS ARTICLE WERE ASKED TO RESPOND TO THE QUESTION OF WHETHER OR NOT JAPANESE AND AMERICAN NATIONAL INTERESTS ARE INHERENTLY IN CONFLICT, AND IF SO, WHETHER THOSE DIVERGING INTERESTS CAN BE RECONCILED AND PURSUED BY BOTH COUNTRIES COOPERATIVELY UNDER THE EXISTING STRUCTURE OF THE BILATERAL RELATIONSHIP. THE AUTHORS CONSIDER VARIOUS FACETS OF THE RELATIONSHIP: SECURITY, MILITARY, ECONOMIC INTERESTS DO EXIST, BUT NONE ARE INSURMOUNTABLE.

01078 AUER, $M$

ENVIRONMENTAL RESTORATION, ECONOMIC TRANSITION AND

NATIONALISM IN ESTONIA

JOURNAL OF BALTIC STUDIES, 23(4) (WIN 92), 377-386.

HOW TO RESTORE THE DAMAGED ESTONIAN ENVIRONMENT RECEIVES LESS ENGLISH-LANGUAGE MEDIA ATTENTION THAT ITS ECONOMIC TRANSFORMATION AND NATIONALISM. THE RELATIONSHIP BETHEEN THESE THREE ELEMENTS ARE INTERHINED. THIS ARTICLE EXPLORES THESE ELEMENTS AND DRAHS THIS CONCLUSION: SUCCESSFUL ENVIRONMENTAL REMEDIATION IN ESTONIA IS DEPENDENT ON THE NATION'S ECONOMIC HEALTH AND THE RESOLUTION OF ETHNIC PROBLEMS.

01079 AUERBACH, $P$.

ON SOCIALIST OPTIMISM

MEH LEFT REVIEH, (192) (MAR 92), 5-36

THE AUTHOR DISCUSSES THE ROLE OF EDUCATION IN DIFFERENT

POLITICAL CULTURES AND THE IMPORTANCE OF EDUCATIONAL ISSUES

IN REFORMULATING THE PROGRAMS OF THE LEFT. HE ARGUES THAT

SOCIALIST TRANSFORMATION STRATEGIES HAVE TRADITIONALLY

CONCENTRATED TOO MUCH ON THE OWNERSHIP OF ECONOMIC ASSETS

AND TOO LITTLE ON THE FULL IMPLICATIONS OF PROVIDING

UNIVERSAL EDUCATION. IN THE UNITED STATES AND BRITAIN TODAY,

ONE CAN SEE THE FAILURE OF THE PHILISTIME EXPERIMENT--THAT

IS, OF POLITICAL CULTURES THAT HAVE LONG UNDERESTIMATED THE

VALUE OF EDUCATION. THE STINGY, HAPHAZARD APPROACH OF THE AUTHORITIES IN THE ANGLO-SAXON COUNTRIES TOWARDS THE PROVISION OF EDUCATION AND TRAINING HAS REFLECTED A BLIND SPOT IN INDIVIDUALIST AND UTILITARIAN THINKING THAT CANNOT BE REMEDIED IN A NARROWLY INSTRUMENTAL HAY. IN A MODERN ECONONY, EDUCATION CAN PLAY A CENTRAL ROLE IN SOCIALIST PROGRAMS OF TRANSFORMATION. FEW GOALS WOULD BE AS REYOLUTIONARY IN TODAY'S HORLD AS THAT OF PROVIDING ALL CHILDREN WITH THE MANY-SIDED PROPERLY-RESOURCED EDUCAIION THAT WOULD ALLOW THEM LO REALIZE THEIR POTENTIAL TO BECOME THAT WOULD ALLOH
FULL CITIZENS.

01080 AUGUSTIN, E.

CHANGES IN STRUCTURE AND POLITICS OF THE WEST BANK WOMEN'S MOVEMENT DURING THE INTIFADA HEW POLITICAL SCIENCE, 21-22 (SPR 92), 69-90.

THE FOCUS OF THIS PAPER IS AN EVALUATION OF THE PROCESS OF CHANGE OCCURRING HITHIN WOMEN'S COMMITTEES IN THE HEST BANK. IT ATTEMPTS TO ANALYZE SOME OF THE CHANGES HHICH HAVE TAKEN PLACE SINCE THE BEGINNING OF THE INTIFADA IN 1987 IN THE THREE REALMS OF ORGANIZATIDNAL STRUCTURE, MOBILIZATION STRATEGIES, AND IDEOLOGY, OF THE FOUR COMMITTEES OF THE HEST
INTERYIEWS WITH LOCAL ACTIVIST WOMEN AND KEY-INFORMANTS CONDUCTED FROM 1988 TO 1990.

01081 AUNG SAN, $S$

BURMA'S QUEST FOR DEMOCRACY

JOURNAL OF DEMOCRACY, 3(1) (JAN 92), 3-14.

NOBEL PEACE PRIZE WINMER AUNG SAN SUU KYI DISCUSSES THE

CAUSES OF BURMA'S CURRENT TOTALITAARIAN STATE AND THE

POSSIBILITIES OF OVERCOMING IT. SHE ARGUES THAT EXPLANATION OF FOUR CAUSES OF DECLINE IN BURMA CAN BE FOUND IN THE WORKS OF THE BUDOHA: THE FAILURE TO RECOVER THAT WHICH HAS BEEN LOST, OMISSION TO REPAIR THAT WHICH HAS BEEN DAMAGED, DISREGARD OF THE NEED FOR REASONABLE ECONOMY, AND THE ELEVATION TO LEADERSHIP OF MEN HITHOUT MORALITY OR LEARNING. TRANSLATED INTO CONTEMPORARY TERMS: WHEN DEMOCRATIC RIGHTS HAD BEEN LOST TO MILITARY DICTATORSHIP, SUFFICIENT EFFORTS HAD NOT BEEN MADE TO REGAIN THEM; MORAL AND POLITICAL VALUES HAVE BEEN ALLOWED TO DETERIORATE WITHOUT CONCERTED ATTEMPTS HAVE BEEN ALLOWED TO DETERIORATE WI THOUT CONCERTED ATTEMPTS
TO SAVE THE SITUATION: THE ECONOHY HAD BEEN BAOLY MANAGED; TO SAVE THE SITUATION; THE ECONOHY HAD BEEN BADLY MANAGED; HISDOM.

01082 AUNG, S

FREEDOM FROM FEAR

FAR EASTERN ECONOMIC REVIEH, 151(29) (JUL 91), 15-16. BURMESE DEMOCRATIC OPPOSITION LEADER, AUNG' SAN SUU KYI, DEFENDS THE REPRESSED MOVEMENT FOR FREEDOM AND DEMOCRACY IN HER COUNTRY. SHE ARGUES THAT WHILE PUBLIC DISSATISFACTION WITH ECONOMIC HARDSHIPS HAS BEEN SEEN AS THE CHIEF CAUSE OF THE MOVEMENT FOR DEMOCRACY, THE "MUMILIATION OF A WAY OF IFE DISFIGURED BY CORRUPTION AND FEAR" IS AT THE HEART OF THE DEMOCRATIC MOVEMENT. THE CURRENT SYSTEM OF GOVERNMENT IN BURMA, WHERE THE MILITARY GOVERNMENT RULES IN FEAR LOSING ITS POWER, HAS DIMINISHED THE QUALITY OF LIFE FOR ALL OF BURMA'S PEOPLE AND THREATENS TO ELIMINATE ALL CAPACITY FOR SELF-IMPROVEMENT AND CIVILIZATION.

01083 AUSTEN-SMITH, 0.

EXPLAINING THE VOTE: CONSTITUENCY CONSTRAINTWS ON SOPHISTICATED VOTING

AMERICAN JOURNAL OF POLITICAL SCIENCE, 36(16) (FEB 92) 68-95.

A MODEL OF LEGISLATIVE VOTE AND EXPLANATION IS DEVELOPED TO EXPLORE HOW LEGISLATOR'S VOTING DECISIONS ARE AFFECTED BY BY THE NEED TO JUSTIFY THESE DECISIONS TO HOME CONSTITUENTS THE PRINCIPAL FINDING IS THAT THE NEED TO EXPLAIN VOTES IMPROVES THE DISTRICT'S PAYOFFS RELATIVE TO THE CASE OF NO EXPLANATION. THIS OCCURS IN THO HAYS, DEPENDIMG ON THE PENALTIES FOR LEGISLATORS BEING DISCOVERED NOT TO HAVE TOLD THE TRUTH WHEN JUSTIFYING THEIR LEGISLATIVE BEHAVIOR TO CONSTITUENTS.

01084 AUSTEN-SMITH, D

STRATEGIC MODELS OF TALK IN POLITICAL DECISION MAKING INTERNATIONAL POLITICAL SCIENCE REVIEW, 13(1) (JAN 92), 45-58.

TALK IN POLITICS IS EFFECTIVE ONLY INSOFAR AS THE SPEAKER IS ABLE TO PERSUADE HIS AUDIENCE OF THE RELEVANCE OF SOME POINT, OR THE VALIDITY OF SOME CLAIM, CONTAINED IN THE SPEECH. FROM A RATIONAL CHOICE PERSPECTIVE, THEREFORE, SUCH SPEECH MAKING IS A STRATEGIC ACTIVITY IN WHICH SPEAKERS SEEK TO INFLUENCE THE BELIEFS OF DECISION MAKERS. THIS PAPER IS AN INFORMAL INTRODUCTION TO RATIONAL CHOICE MOOELS OF POLITICAL DECISION MAKING INVOLVING THE STRATEGIC USE OF SPEECH.

01085 AUSTER, L.

OUR DISAPPEARING COMMON CULTURE: THE FORBIDOEN TOPIC NATIONAL REVIEW, XLIV(8) (APR 92), 42-44.

MUST IMMIGRATION DESTROY AMERICA? NEOCONSERVATIVES AGREE THAT MULTICUL TURALISM THREATENS OUR HERITAGE, BUT BLAME IT ON THE LEFT. WISHFUL THINKING, ARGUES LAHRENCE AUSTER, WHO SUGGESTS THAT SOME CONSERVATIVES DON'T WANT TO KNOW ABOUT THE LINK BETHEEN MULTICULTURALISM AND IMMIGRATION. MAINSTREAM MEDIA AND EDUCATIONISTS DESCRIBE THE DIVERSITY MOVEMENT AS, IN PART, AN EFFORT TO BE MORE INCLUSIVE OF AMERICA'S HISTORIC MINORITIES; IN ITS LARGER DIMENSIONS HOWEVER, THEY SEE IT AS A RESPONSE TO THE PRODIGIOUS CHANGES HOWEVER, THEY SEE IT AS A RESPONSE TO THE PRODIGIOUS CHANGES
THAT ARE OCCURRING IN AMERICA'S EHTNIC COMPOSITION. AMERICA THAT ARE OCCURRING IN AMERICA'S EHTNIC COMPOSITION. AMERICA IS RAPIDLY BECOMING MULTIRACIAL AND WHITE-MINORTITY, AND OUR NATIONAL IDENTITY IS CHANGING IN RESPONSE. IF THA IMMIGRATION IS ITSELF THE ULTIMATE DRIVING FORCE BEHIND MULIGRATION IS ITSE

01086 AVINERI, S.

ISRAEL IN THE POST-COLD WAR ERA

MIDOLE EAST INSIGHT, 8(2) (SEP 91), 31-34.

THE POLITICAL CHANGES THAT HAVE SWEPT THROUGH EASTERN EUROPE AND THE SOVIET UNION HAVE HAD A DRAMATIC IMPACT OM THE RELATIONS BETHEEN THESE AREAS ANO ISRAEL. VIRTUALLY EVERY EAST EUROPEAN STATE AND THE SOVIET UNION HAVE RESUMED DIPLOMATIC, TRADE AND CULTURAL RELATIONS WITH ISRAEL. THE SOVIETS HAVE CEASED TO GIVE HARD-LINE ARAB STATES THE 
UNCONOITIONAL IDEOLOGICAL, FINANCIAL, AND MILITARY BACKING THAT THEY SO CRAVE. THE SOVIETS HAVE ALSO RELAXED IMMIGRATION STANDARDS WHICH HAS RESULTED IN A FLOOD OF SOVIET JEWS LEAVING FOR ISRAEL. THE IMPACT OF RENEWED TIES WITH EASTERN EUROPE AND THE SOVIET UNION-THE ORIGINAL HOMELAND OF MANY ISRAELIS-WILL LIKELY INCREASE IN THE YEARS TO COME AS THE CUL TURAL AND POLITICAL MIX OF THE NATION IS ALTERED. THESE CHANGES GIVE ISRAEL A UNIQUE CHANCE FOR PEACE WITH ITS IMMEDIATE NEIGHBORS, WITH THE WORLD, AND WITH ITS TROUBLED JEHISH HERITAGE.

01087 AVINERI, S.

THE RETURN TO HISTORY: THE BREAKUP OF THE SOVIET UNION BROOKINGS REVIEH, 10(2) (SPR 92), 30-33.

WITH THE DEMISE OF COMMUNISM IN EASTERN EUROPE AND THE SOVIET UNION, SOME WESTERN ANALYSTS WENT SO FAR AS TO ANMOUNCE "THE END OF HISTORY." BUT DEVELOPMENTS IN EASTERN EUROPE AND THE COMMONWEALTH OF INDEPENDENT STATES ADVISE CAUTION. ALTHOUGH THERE IS NO DOUBT THAT THE COMMUNIST SYSTEM AS SUCH IS DEAD AND BURIED IN CENTRAL AND EASTERN SYSTEM AS SUCH IS DEAD AND BURIED IN CENTRAL AND EASTERN EUROPE, IT IS LESS CERTAIN THAT THE EMERGING ALTERNATIVE WILL BE A DEMOCRATIC, FREE-MARKET SOCIETY. DIFFERENCES IN THAT THEY ARE NOT ALL TRAVELING ON THE SAME TRACKS OR EVEN MOVING IN THE SAME DIRECTION. IT IS CLEAR THAT THE MOST PRONOUNCED DETERMINANTS IN THESE DIFFERENT DEVELOPMENTS ARE HISTORICAL FACTORS. FAR FROM SEEING AN END OF HISTORY

EASTERN EUROPE IS GOING THROUGH A MASSIVE RETURN OF HISTORY AND TO HISTORY.

01088 AWANOHARA, S.

BUSH BOOST FOR KAIFU

FAR EASTERN ECONOMIC REVIEH, 151(30) (JUL 91), 13. FOR JAPANESE PRIME MINISTER TOSHIKI KAIFU, THE INVITATION TO VISIT U.S. PRESIDENT GEORGE BUSH IN HIS VACATION HOME IN MAINE, ON 10 AND 11 JULY. HAS A GODSEND. KAIFU WILL USE THE "FAMILY-LIKE" MAINE VISIT, AND THE PROMISE FROM BUSH THERE THAT HE WOULD VISIT JAPAN LATE IN 1991, AS ASSETS IN HIS UPCOMING BATTLE TO REMAIN PRIME MINISTER BEYOND HIS CURRENT TERH WHICH ENDS IN OCTOBER. APART FROM THE USEFUL SYMBOLISH HE TOOK HOME, VIA THE LONDON G-7 SUMMIT, KAIFU HAS HAD SOME SUCCESS IN PUTTING THE G-7 SUMMIT, KAIFU HAS HAD SOME SUCCESS IN PUTTING THE
STRAINED JAPAN-U.S. RELATIONSHIP BACK ON TRACK TOWARDS STRAINED JAPAN-U.S. RELATIONSHIP BACK ON TRACK TOWARDS
"GLOBAL PARTNERSHIP." A KEY ISSUE THAT WAS RESOLVED WAS A DISAGREEMENT OYER THE AMOUNT OF AID TO THE GULF WAR EFFORT THAT JAPAN STILL OWED THE UNITED STATES AND ITS ALLIES.

01089 AHANOHARA, S.; BURTON, J.

CLINTON'S TAX HIKE

FAR EASTERN ECONOMIC REVIEW, 155 (47) (NOV 92), 48-50.

BILL CLINTON ANMOUNCED DURING THE ELECTION CAMPAIGN THAT HE COULD SQUEEZE USS45 BILLION IN EXTRA TAX REVENUE OUT OF FOREIGN COMPANIES OVER THE NEXT FOUR YEARS. HOHEVER, IF CLINTON TRIES TO MAKE GOOD ON HIS CAMPAIGN PROMISES, HE WILL LIKELY INTRODUCE A SIEGE MENTALITY AMONG JAPANESE AND OTHER ASIAN FIRMS OPERATING IN THE U.S., AT A TIME WHEN THEIR DIRECT INVESTMENT IS DROPPING SHARPLY. IN ADDITION, MANY ANALYSTS PREDICT THAT GREATER ENFORCEMENT BY THE IRS COULD GENERATE EXTRA RECEIPTS OF ONLY USS3 BILLION A YEAR FROM FOREIGN FIRMS, A FAR CRY FROM CLINTON'S FIGURE.

01090 AWANOHARA, S.

DEAL ON MY TERMS

FAR EASTERN ECONOMIC REVIEW, 151(16) (APR 91), 13-14.

IN AN ATTEMPT TO "JUMP START" THE CAMBODIAM PEACH PROCESS, WHICH HAS LOST MOMENTUM IN RECENT MONTHS, THE U.S. HAS PRESENTED A DETAILED BLUEPRINT TO THE VIETNAMESE INDICATING WHAT HANOI AND THE GOVERNMENT IN PHNOM PENH ARE EXPECTED TO DO AT VARIOUS STATES OF THE SETTLEMENT PLAN AND EXPECTED TO DO AT VARIOUS STATES OF THE SETTLEMENT PLAN AND
WHAT BENEFITS WILL BE RECEIVED IN RETURN. THE NEH BLUEPRINT POSITS FOUR MAJOR PHASES: AGREEMENT TO SIGN THE PEACE PLAN: SIGNING OF THE PLAN; IMPLEMENTATION OF THE PLAN; AND FREE ELECTIONS. AT EACH PHASE, HHEN HANOI COOPERATES WITH THE PEACE PLAN, THE U.S. WILL RESPOND, EASING STEP-BY-STEP ITS
TRADE EMBARGO AND BLOCKING OF OFFICIAL MULTILATERAL LENDING, AND, IN THE END, FULLY NORMALIZING RELATIONS WITH HANOI.

01091 AWAMOHARA, S.

ENTER THE LATIN DRAGON

FAR EASTERN ECONOMIC REVIEH, 151(28) (JUL 91), 42-43. NEGOTIATIONS AMONG THE UNITED STATES, CANADA. AND MEXICO ON THE SETTING UP OF A NORTH AMERICAN FREE TRADE AGREEMENT ARE CAUSING JITTERS THROUGHOUT ASIA. CONCERNING IS MOUNTING ARE CAUSING JITTERS THROUGHOUT ASIA. CONCERNING IS MOUNTI INDEBTED BASKET CASE JUST TEN YEARS AGD, WILL REPLACE ASIAN EXPORTS BASKET CASE JUST TEN YEARS AGO, WILL REPLACE ASI EXPORTS TO THE UNITED STATES AND THAT MEXICO HILL ATTRAC INVESTMENT THAT ASIAN COUHTRIES WOULD HAVE ATTRACTED
OTHERHISE. SUCH A TRADE BLOC WOULD HAVE SEEMED FAR-FETCHED A YEAR AGO, BUT AFTER THE BREAKDOWN OF GLOBAL TRADE TALKS IN BRUSSELS, AN INCREASINGLY FRUSTRATED UNITED STATES HAS TURNED TO ITS NEIGHBORS.

01092 AWAMOHARA, S.

FALLING FROM FAVOR
FAR EASTERN ECONOMIC REVIEH, 151 (18) (MAY 91), 10-11. AFTER A BRIEF PERIOD OF COOPERATION AND WARMTH BEFORE THE GULF HAR, U.S. - CHINA RELATIONS ARE TAKING A SUDDEN TURN FOR THE WORSE. TENSION IN MOUNTING ON ALL SIDES, IN THE AREAS OF HUMAN RIGHTS, WEAPONS PROLIFERATION AND TRADE. AS USUAL, CONGRESS IS PRESSURING PRESIDENT GEORGE BUSH'S ADMINISTRATIONS TO TAKE STRONG ACTION--SUCH AS REVOKING CHINA'S MOST-FAVORED-NATION (MFN) TRADING STATUS--TO RETALIATE AGAINST WHAT ARE SEEN AS PEKING'S TRANSGRESSIONS. BUSH'S DECISION TO MEET WITH THE DALAI LAMA-THE FIRST U.S. PRESIDENT TO DO SO--IS AN INDICATION THAT EVEN THE ADMINISTRATION'S PATIENCE IS GROWING THIN. MANY ANALYSTS PREDICT THAT AS CHINA'S STRATEGIC IMPORTANCE TO THE U.S. DECLINES IN THE FADING DAYS OF THE COLD WAR, TENSIONS DECLINES IN THE FADING DAYS OF THE COLD WAR, TENSIONS
BETWEEN THE THO NATIONS ARE LIKELY TO COME EVEN MORE VISIBLY BETWEEN THE THD
TO THE FORE.

01093 AWAMOHARA, S.

FAR RIGHT, FAR OUT

FAR EASTERN ECONOMIC REVIEH, 154(52) (JAN 92), 11.

WELL-KNOWN U.S. COLUMNIST AND TELEVISION COMMENTATOR PATRICK BUCHANAN'S CHANCE OF WINHING THE 1992 REPUBLICAN PRESIDENTIAL NOMINATION AGIANST THE INCUMBENT GEORGE BUSH IS VERY SMALL. YET, BUCHANAN REPRESENTS THE TIP OF AN ICEBERG OF AMERICAN DISCONTENT AND ITS ISOLATIONIST, PROTECTIONIST AND TRIBALIST REACTIONS. BUCHANAN'S CAMPAIGN WILL HELP GAU
SUCH REACTIONS AND THE IMPLICATIONS THEY HAVE FOR ASIA.

01094 AWAMOHARA, S.; ALI, S.

FEAR OF ISLAM

FAR EASTERN ECONOMIC REVIEN, 155(4) (JAN 92), 20-22. THE THO MOMENTOUS EVENTS OF 1991--THE GULF WAR AND THE BREAK-UP OF THE SOVIET UNION-ARE CASTING THEIR LONG SHADOW OVER RELATIONS BETHEEN THE UNITED STATES AND THE ARC OF PREDOHINANTLY ISLAMIC COUNTRIES RANGING FROM CENTRAL ASIA IN THE EAST TO NORTH AFRICA IN THE WEST. THE COLLAPSE OF THE SOVIET UNION HAS MADE THE WEST, LED BY THE U.S., INTO THE PRINCIPAL EXTERNAL ENEMY OF PAN-ISLAMISTS. ONCE REGARDED AS POTENTIALLY USEFUL ALLIES, MANY ISLAMIC STATES ARE NOH SEEN AS GROWING THREATS. EXAMPLES INCLUDE PAKISTAN, ALGERIA, AND KAZAKHSTAN--ALL WHO ARE DEVELOPING (OR ALREADY HAVE) NUCLEAR WEAPONS. SOME PAN-ISLAMISTS ARE CALLING FOR A ANTI-WESTERN
STRATEGIC CONSENSUS INVOLVING CENTRAL ASIA, PAKISTAN, IRAN, STRATEGIC CONSENSUS INVOLVING

01095 AWANOHARA, S.

GOOD MORNING, ASIA
FAR EASTERN ECONOMIC REVIEH, 155(66) (JUL 92), 25-26.

THE PROPOSAL FOR THE CREATION OF A RADIO FREE ASIA HAS RUN INTO FIERCE OPPOSITION FROM CHINA--THE KEY TARGET OF THE CAMPAIGN--AND FROM DISSIDENT COMMUNITIES ACROSS ASIA. THE DEBATE OVER RADIO FREE ASIA ALSO CONCERNS THE ROLE OF THE UNITED STATES IN ASIA. EVEN AS DOMESTIC ECONOMIC AND SOCIAL PROBLEMS ARE MAKING MANY AMERICANS LOOK INHARD, OTHERS--OLD COLD WARRIORS ON THE RIGHT AND THE LIBERALS CHAMPIONING HUMAN RIGHTS ON THE LEFT--ARE SAVORING THE RECENT TRIUMPH OF THE WEST OVER COMHUNISM IN EUROPE AND ARE ADVOCATING TOTAL, GLOBAL VICTORY. CRITICS OF THE PROPOSAL ARGUE THAT IT WILL PROVE COUNTERPRODUCTIVE AND THAT IT AMOUNTS TO LITTLE MORE THAN ELITISM AND CULTURAL IMPERIALISM. PROPONENTS OF THE PRDJECT WERE SET BACK BY CHINA'S RESTRICTIONS ON THEIR ACTIONS. HOWEVER, THEY STILL HOPE TO ESTABLISH RADIO FREE ASIA IN TAIWAN, HONGKONG, THAILAND, AND, PERHAPS, SOUTH KOREA.

01096 AWANOHARA, S.

HIT BY A BACKLASH

FAR EASTERN ECONOMIC REVIEN, 155(12) (MAR 92), 30-31. AFTER A DECADE AND A HALF OF FRANTIC EXPANSION, THE ASIAN AMERICAN POPULATION IS FEELING THE FIRST SERIOUS BACKL LASH FROM A GRUMPY MAINSTREAM AMERICA WHICH IS WORRIED ABOUT THE ECONOMIC CONSEQUENCES OF ACCEPTING SO MANY NONEUROPEAN IMMIGRANTS (MAINLY FROM ASIA AND LATIN AMERICA). MAINSTREAM AMERICA'S "IMMIGRATION FATIGUE" IS EVIDENT IM MAINSTREAM AMERICA'S "IMMIGRATION FATIGUE" IS EVIDENT IN CALIFORNIA, NOW HOME TO $40 \%$ OF THE TOTAL 7.3 MILLION ASIAN
AMERICANS. IT IS CAUSED MOST IMMEDIATELY BY A FISCAL CRISIS, RESULTING FROM THE COMBINATION OF A SHARP DROP IN STATE RESULTING FROM THE COMBINATION OF A SHARP DROP IN STATE
REVENUE AND EVER RISING SPENDING ON HELFARE AND EDUCATION REVENUE AND EVER RISING SPENDING ON WELFARE AND EDUCATION
PROGRAMS. A RECENT STUDY INDICATES THAT ASIAN AMERICANS HAVE PROGRAMS. A RECENT STUDY INDICATES THAT ASIAN AMERICANS
GROUNDS TO FEAR THAT THE BACKLASH WILL TAKE THE FORM OF GROUNDS TO FEAR THAT THE BACKLASH WILL TAKE THE FORM OF
INCREASED HOSTILITY, AND POSSIBLY HATE CRIMES AGAINST

INCREASED HOSTILITY, AND POSSIBLY
MINORITIES AND AMONG MINORITIES.

01097 AWANOHARA, S.

INVOICE OF AMERICA

FAR EASTERN ECONOMIC REVIEN, 155(15) (APR 92), 19. AS HARD SELL REPLACES THE COLD WAR IN FOREIGN RELATIONS U.S. AMBASSADORS ARE FINDING THEMSELVES REQUIRED TO ACT MORE AS BOOSTERS AND PROMOTERS OF THE NATION'S COMMERICAL INTERESTS AND LESS AS THE COUNTRY'S FRONTLINE DIPLOMATIC WARRIORS. THIS SHITCH IN EMPHASIS IS PARTICULARLY MARKED IN ASIA, WHERE U.S. ENYOYS ARE NOH ACTIVELY PROMOTING THEIR COUNTRY'S PRODUCTS AND SERYICES. RECENT EXAMPLES INCLUDE THE WORK DONE BY AMBASSADOR JOHN MONJO IN INDONESIA AND WILLIAM 
CLARK IN INDIA THAT HELPED U.S. COMPANIES CLINCH MAJOR DEALS WHICH OTHERWISE WOULO HAVE GONE TO FOREIGN COMPETITORS. IN THE FIRST LARGE-SCALE EXERCISE OF THEIR ENHANCED COMMERCIAL ROLE, U.S. AMBASSADORS TO FIVE ASEAN COUNTRIES PUT ON AN UNPRECEDENTED ROADSHOW ACROSS THE UNITED STATES IN LATE MARCH TO PROMOTE EXPORTS AND INVESTMENT INTO THE SOUTHEAST ASIAN GROUPING.

01098 AWANOHARA, $S$

LOSS OF PATIENCE

FAR EASTERN ECONOMIC REVIEW, 156(23) (JUN 92), 8.

SINCE JUNE 1989, THE DEMOCRAT-CONTROLLED U.S. SENATE HAS CONSISTENTLY VOTED TO ATTACH CONDITIONS FOR RENEHAL OF MOST FAVORED NATION (MFN) STATUS FOR CHINA. THEIR ATTEMPTS HAVE BEEN REPEATEDLY VETOED BY PRESIDENT GEORGE BUSH, WHO DECIDED ON 2 JUNE TO EXTEND PEKING'S MFN STATUS ANOTHER YEAR HITHOUT CONDITIONS. HHAT IS NEW IN THIS ELECTION YEAR IS THE

WAVERING BY A GROUP OF DEMOCRATIC SENATORS, WHICH UNTIL LAST YEAR HAD SIDED WITH BUSH TO THWART CONGRESS, ATTEMPTS TO RESTRICT TRADE WITH CHINA. FURTHERMORE, SOME CONGRESSIONAL CHINA CRITICS ARE MODERATING THEIR CHINA MFN PROPOSALS IN AN EFFORT TO BROADEN SUPPORT AMD THUS GAIM A VETO-PROOF MAJORITY IN THE SENATE AS WELL AS THE HOUSE. DEPENDING ON HOW PEKING BEHAVES, BUSH COULD FOR THE FIRST TIME LOSE A HOW PEKING BEHAVES, BUSH COULD FOR THE F
VETO-SUSTAINING COALITION IN THE SENATE.

01099 AHAMOHARA, S.; SHIM, J.H.

MELTING POT BOILS OVER

AR EASTERN ECONOMIC REVIEW, 156(19) (MAY 92), 10.

AS LOS ANGELES CITIZENS PICK UP THE PIECES AND START TO REUILD FOLLOWING THE DEVASTATING RIOTS OF 29 APRIL. THE KOREAN-AMERICAN COMMUNITY STAMDS POLARIZED, STILL SHELLSHOCKED AND ENRAGED BY THE DESTRUCT ION WROUGHT ON IT. KOREANAMERICAN ENTREPRENEURS WERE BY NO MEANS THE ONLY VICITMS OF THE RIOTING, BUT THERE IS NO QUESTION THAT THE LONG STANDOFF BETHEEN KOREAN-AMERICANS AND BLACKS IN LOS ANGELES HAS TURNED INTO OYERT CONFRONTATION AND THAT UNLESS THE SITUATION IS HANDLED DELICATELY, MORE TROUBLE COULD FOLLOW. OBSERVERS WORRY THAT KOREAN-AMERICAN DEMANDS FOR SEPARATE COMPENSATION AND THE SEOUL GOVERMMENT'S REPORTED CALL FOR "REPARATIONS" FOR KOREAN-AMERICAN BUSINESSES COULD PROVE COUNTERPRODUCTIVE.

01100 AHAMOHARA, S.; BURTON, J.

MORE MONEY THAN VOTES

FAR EASTERN ECONOMIC REVIEW, 155(43) (OCT 92), 50-54. DESPITE ITS GROWING NUMBERS, THE ASIAN-AMERICAN COMMUNITY HAS YET TO REACH A STATE OF "EMPOWERMENT." THE COMHUNITY'S BASIC GOALS TO HAVE ITS MEMBERS NATURALIZE, REGISTER AND VOTE AMD TO FIMD CANDIDATES OF ITS OWM WHO CAM WIN ELECTIONS HAVE NOT BEEN EASY TO FULFIL. THE NUMBER OF YOTERS IN THE COMMUNITY HAS BEEN RELATFIL. THE NUMBER OF AMERICANS HAVE EMERGED AS IMPORTANT PLAYERS IN FUND RAISING. AMERICANS HAVE EMERGED AS IMPORTANT PLAYERS IN FUND RAISINC. BOTH MAJOR POLITICAL PARTIES HAVE COURTED ASIAN-AMERICANS
WITH THE REPUBLICAN PARTY BEING CONSIDERABLY MORE SUCCESSFUL. WITH THE REPUBLICAN PARTY BEING CONSIDERABLY MORE SUCCESSFUL
HOWEVER, THE SURPRISINGLY LARGE DEGREE OF SUPPORT FOR ROSS HOWEVER, THE SURPRISINGLY LARGE DEGREE OF SUPPORT FOR ROSS PEROT AMONG ASIAN-AMERICANS IS
NEGLECTED BY POLITICS AS USUAL.

01101 AWANOHARA, $S$.

NEH ASIA HANDS

FAR EASTERN ECONOMIC REVIEW, 155(9) (MAR 92), 23

IN A SHUFFLE OF SENIOR U.S. DIPLOMATS, SECRETARY OF STATE JAMES BAKER HAS DECIDED TO PUT A JAPAN EXPERT II CHARGE OF HIS DEPARTMENT'S ASIA POLICY. ALTHOUGH THESE CHANGES ARE DUE MAIMLY TO DOMESTIC AND DEPARTMENTAL POLITICAL REASONS IN A PRESIDENTIAL ELECTION YEAR, THEY COULD ENHANCE THE EXECUTION OF A COHERENT U.S. POLICY ON ASIA AND STABILIZE THE VOLATILE RELATIONS BETWEEN TOKYO AND WASHINGTON. WILLIAM CLARK, CURRENTLY AMBASSADOR TO INDIA, IS TO BECOME BAKER'S "ASSISTANT FOR ASIA." THE INCUMBENT, RICHARD SOLOMON HAS BEEN OFFERED AMBASSADORSHIP TO THE PHILIPPINES. THE HIGH-PROFILE U.S. AMBASSADOR TO THE UNITED NATIONS, THOMAS PICKERING, IS SLATED TO REPLACE CLARK IN NEW DELHI. CLARK'S LONG DIPLOMATIC CAREER HAS CENTERED ON JAPAN, INCLUDING STINTS AS DEPUTY CHIEF OF MISSION IN TOKYO AND DEPUTY ASSISTANT SECREATRY FOR NORTHEAST ASIA, DEALING WITH JAPAN AND KOREA.

01102 AHANOHARA, S.; HIEBERT, M.

OPEN DOOR' IN DIISPUTE

FAR EASTERN ECONOMIC REVIEW, 151(17) (APR 91), 10-11.

THE FACT THAT VIETNAMESE OFFICIALS HAVE BEEN SLOW TO RESPOND TO THE U.S. OFFER OF A FOUR-STAGE PLAN OF NORMALIZATION OF RELATIONS BASES DN THE RESOLUTION OF THE CAMBODIAN PROBLEM DOES NOT SEEM TO BOTHER AMERICAN POLICY MAKERS. HOHEVER, OFFICIALS OF INTERNATIONAL FINANCIAL INSTITUTIONS SYMPATHETIC TOWARDS HANOI ARE SHOWING SINGS OF IMPATIENCE WITH THE PACE OF THE NEGOTIATIONS. IF THE U.S. CONTINUES TO BLOCK ACCESS BY VIETNAM TO FUNDING FROM INTERMATIONAL INSTITUTIONS, THESE OFFICIALS SAY THAT THERE IS A STRONG POSSIBILITY THAT THE EUROPEAN COMMUNITY AND JAPAN WILL ABANDON THE U.S. LINE AND ACT ON THEIR OWN TO
THERE IS ALSO GROWING DOMESTIC PRESSURE IN THE U.S. TO SPEED UP ECONOMIC AND BUSINESS TIES WITH VIETNAM; AMERICAM LEGISLATORS AND BUSINESSMEN FEAR BEING LEFT OUT OF POTENTIAL MARKETS DUE TO GOVERNMENT INTRANSIGENCE.

01103 AWANOHARA, S.

PARADIGM PARANOIA

FAR EASTERN ECONOMIC REVIEN, 151(26) (JUN 91), 15.

A U.S. CIA-FUNDED REPORT WARNING OF JAPAN'S DRIVE TO DOMINATE THE WORLD ECONOMY HAS ELICITED EMBARRASSED DISCLAIMERS FROM THOSE ALLEGEDLY I NVOL VED WITH IT, INCLUDING THE INTELLIGENCE AGENCY ITSELF. THE REPORT STRESSES JAPAN'S UNIQUENESS AND WARNS OF THE THREATENED COLLISION OF TWO "PARADIGMS": THE TRADITIONAL WESTERN PARADIGM BASED ON INDIVIDUAL FREEDOM AND THE MORE COLLECTIVIST JAPANESE PARADIGM "OF STUNNING POWER, DENSITY, INTERNAL CONSISTENCY AND COHESION." SOME ARE OUICK TO POINT OUT THAT THE REPORT WAS WRITTEN AT A TIME WHEN THE ROLE OF THE U.S. INTELLIGENCE APPARATUS WAS BEING REVIEWED. THE REDUCED SOVIET THREAT MEANS THE INTELLIGENCE SERVICE MUST JUSTIFY ITSELF. SOME HAVE ADVOCATED THAT THE INTELLIGENCE APPARATUS SHOULD BE ENGAGED IN COMMERCIAL INTELLIGENCE.

01104 AWANOHARA, S.

PRESIDENT' CLINTON

FAR EASTERN ECONOMIC REVIEH, 155(45) (NOV 92), 10-11. BILL CLINTON HON THE U.S. PRESIDENTIAL ELECTION HITH A CAMPAIGN THAT FOCUSED HEAVILY ON DOMESTIC ISSUES. HOWEVER, CLINTON ALSO OUTLINED AN ACTIVIST FOREIGN POLICY, THOUGH CONFLICTING SIGNALS EMANATING FROM IT HAVE BAFFLED MANY ASIAN DIPLOMATS AND EXPERTS. FROM WHAT CLINTON AND HIS MANY ADVISERS HAVE SAID DURING THE CAMPAIGN, IT IS DIFFICULT TO DETERMINE CLINTON'S POSITION ON A HOST OF IMPORTANT ISSUES INCLUDING FREE TRADE, DEMOCRACY, HUMAN RIGHTS, SECURITY

01105 AWANOHARA, S.

QUESTION OF FAITH

FAR EASTERN ECONOMIC REVIEN, 155(10) (MAR 92), 49 A MORE ASSERTIVE JAPAN IS FLEXING ITS MUSCLE AT THE WORLD BANK, CHALLENGING HHAT IT VIEWS AS THE INSTITUTION'S UNDUE FAITH IN MARKET MECHANISMS. JAPANESE AT THE BANK ARE ARGUING THAT SELECT GOVERMMENT INTERVENTION CAN ALSO PROMOTE ECONOMIC DEVELOPMENT. THEY ARE INSISTING, WITH SOME SUCCESS, THAT HORLD BANK ECONOMISTS EXAMINE THE POSITIVE ROLE THAT THE GOVERNMENTS OF JAPAN AND EAST ASIAN NICS HAVE PLAYED IN THE GOVERNMENTS OF JAPAN AND EAST ASIAN NICS HAVE PLAYED IN
THEIR COUNTRIES' ECONOMIC DEVELOPMENT. IMPLICIT IN THIS IS THEIR COUNTRIES' ECONOMIC DEVELOPMENT. IMPLICIT IN THIS IS
CRITICISM OF THE BANK'S RECENT BLANKET PRESCRIPTION FOR CRITICISM OF THE BANK'S RECENT BLANKET PRESCRIPTION FOR
ECONOMIC DEVELOPMENT--DEREGULATION AND LIBERALIZATION-DAT ECONOMIC DEVELOPMENT--DEREGULATION AND LIBERALIZATION--AT
THE EXPENSE OF GOVERMMENT INDUSTRIAL AND CREDIT-ALLOCATION THE EXPENSE OF GOVERMMENT INDUSTRIAL AND CREDIT-ALLOCATION
POLICIES. JAPAN BASES SOME ITS ARGUMENTS OH A RECENT STUDY POLICIES. JAPAN BASES SOME ITS ARGUMENTS ON A RECENT STUDY OF THE INDUSTRIAL STRATEGY OF SOUTH KOREA, INDONESIA, AND INDIA. THE STUDY POINTS OUT THAT THE WORLD BANK CONCENTRATEO ON FREEING UP PRICES AND NOT ON NURTURING INFANT INSTITUTIONAL AND TECHNOLOGICAL CAPABILITIES OF DEVELOPING COUNTRIES IN ORDER TO INTERVENE MORE EFFECTIVELY IN THE MARKET.

01106 AHANOHARA, S. SHRINKING OCEAN

FAR EASTERN ECONOMIC REVIEW, 151(23) (JUN 91), 48-50. NOWHERE IN THE UNITED STATES IS THE IMPORTANCE OF ASIA MORE UMDERSTOOD THAN ON THE HEST COAST. THE STATES OF CALIFORNIA, OREGON AND WASHINGTON HAVE A TRADITION OF FREE TRADE, AND ARE RELATIVELY UNINHIBITED BY SUNSET INDUSTRIES OR UNIONIZED LABOR. BESIDES EXPORTING THEIR OWN AGRICULTURAL PROOUCTS AND NATURAL RESOURCES TO ASIA, THE HEST COAST STATES SERVE AS A GATEWAY FOR TRADE BETWEEN ASIA AND THE REST OF THE UNITED STATES. ALL THREE HAVE ORAWN UP STRATEGIES TO MAXIMIZE THESE BEMEFITS. BUT ASIA-PACIFIC TRADING PARTNERS HILL NOT GET A FREE RIDE. THE WEST COAST STATES HANT TO MOVE TO HIGHER VALUE-ADDED EXPORTS, AND SOME U.S. CRITICS SEE RAPID GROWTH AND INIMICAL TO ENVIRONMENTAL PROTECTION.

01107 AHANOHARA, S. FAR EASTERN ECONOMIC REVIEW, 155(12) (MAR 92), 11.
RECESSION AND THE INWARD-LOOKING MOOD OF YOTERS IN AN RECESSION AND THE INWARD-LOOKING MOOD OF VOTERS IN AN
ELECTION YEAR HAVE FORCED PRESIDENT BUSH TO VIRTUALLY DROP ELECTION YEAR HAVE FORCED PRESIDENT BUSH TO VIRTUALLY DROP ISSUES. BUT ALARMED AT THIS SUDOEN REVERSAL, THOSE WHO STILL BELIEVE IN THE US' LEADERSHIP ROLE IN HORLD AFFAIRS ARE PUTTING PRESSURE ON THE PRESIDENT TO CORRECT HIS STANCE. AT SUCH A TIME, A CONTROVERSIAL US DEFENSE DEPARTMENT DOCUMENT, CALLING ON THE COUNTRY TO MAINTAIN ITS POSITION AS THE PREEMINENT HORLD POHER AND PREVENT CURRENTLY FRIENDLY POWERS-INCLUDING THOSE IN EAST AND SOUTHWEST ASIA--FROM BECOMING NEW THREATS TO PEACE, IS STIMULATING A HEATED DEBATE ON THE US' APPROPRIATE ROLE' IN THE POST-COLD WAR ERA. THE PENTAGON DOCUMENT ADVOCATES AN ACTIVE US ROLE AS THE SOLE SUPERPOWER. WHAT SOME FIND STRIKING ABOUT THE DOCUMENT IS ITS EXPLICIT DISLIKE FOR MULTILATERAL APPROACHES TO WORLD PROBLEMS IN 
MULTIPOLAR WORLD.

01108 AWANOHARA, $S$.

TIES FRAYED BY RESENTMENT

FAR EASTERN ECONOMIC REVIEW, 151(25) (JUN 91), 54-56.

THE JAPAN-U.S. RELATIONSHIP SUFFERED A SETBACK IN THE GULF WAR. MANY JAPANESE APPEAR TO ACKNOWLEDGE THAT THEIR COUNTRY FAILED TO RESPOND SWIFTLY AND CONVINCINGLY TO THE GULF CRISIS. ADOITIONALLY, THE JAPANESE NOW KNOW THAT THEY MUST MOVE BEYOND "CHECXBOOK DIPLOMACY" TO HIN INTERNATIONAL RESPECT. AT THE SAME TIME THERE IS DEEP RESENTMENT AMONG SOME JAPANESE TOWARDS THE UNITED STATES FOR HAVING, IN THEIR VIEW, FORCED THEM TO PAY FOR A HAR IT HAD STARTED AND

ESCALATED HITHOUT CONSULTATION AND THEN INSTEAD OF THAMKING THEM JEERED THEM COR THEIR "SLOH AMD MEAGER" COMTRIBUTION THE CONFLICT DURING THE GULF CRISIS OMLY EXACERBATED GRONING TENSION ON BOTH SIDES, AND A PERIOD OF FURTHER COOLING SEEMS TENSION ON

01109 AHANOHARA, $S$.

UNGUIDED MISSILE

FAR EASTERN ECONOMIC REYIEW, 151(14) (APR 91), 13-14.

THE U.S. ADMINISTRATION CLAIMS TO SEE NO INCONSISTENCY IN CALLING FOR ARMS CONTROL IN A POST -GULF HAR MIDDLE EAST AND BOOSTING ARMS SALES TO ITS MIDOLE EASTERN ALLIES IN THE WAR WITH IRAQ. BUT CRITICS SAY THAT UNLESS THIS CONTRADICTION IS CONVINCINGLY RESOLVED, THE BIGGEST ARMS EXPORTERS TO THE REGION WILL NOT TAKE SERIOUSLY ANY U.S. PROPOSAL FOR A REGIONAL SECURITY ARRANGEMENT RESTRAINING FURTHER MILITARIZATION OF THE MIDOLE EAST.

01110 AWANOHARA, S.

FAR EASTERN ECONOMIC REVIEN, 155(28) (JUL 92) 11. PRIME MINISTER KIICHI MIYAZAWA'S EFFORTS TÓ GLOBALIZE JAPAN'S LONG-STANOING TERRITORIAL DISPUTE HITH RUSSIA OVER THE SO-CALLED NORTHERN TERRITORIES HAS PRODUCED A MEASURE OF SUCCESS. THE SUMMIT OF SEVEN ADVANCED INDUSTRIAL ECONOMIES OR G-7 MEETING IN MUNICH ON 6-7 JULY FIMALLY RECOGNITED THE OISPUTE AS A SERIOUS INTERNATIONAL PROBLEM THAT NEEDS TO BE RESOLVED PROMPTLY. BUT RUSSIAN PRESIDENT BORIS YELTSIN CAN BE EXPECTED TO RESIST THE PRESSURE AND TOKYO IS STILL WARY OF WHAT IT SEES AS THE WEST'S PENCHANT TO GIVE MOSCOW MORE THAN ITS DUE. TOKYO FIRST ADOPTED A STRATEGY OF PUTTING MORE THAN ITS DUE. TOKYO FIRST ADOPTED A STRATEGY OF PUT

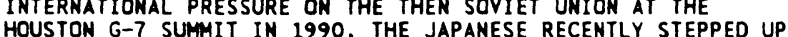
HOUSTON G-7 SUMAIT IN 1990. THE JAPANESE RECENTLY STEPPED LOBBYING ACTIVITIES IN PREPARATION FOR YELTSIN'S SCHEDULED POSI TO JAPAN IN SEPTEMBER. MONEVER, THERE IS STILL THE POSSIBILITY THAT TOKYO HILL SEE THE UNITED STATES ANO OTHER G-7 COLLEAGUES MERELY PAYING LIP SERVICE TO ITS CAUSE, WHILE INCREASED BY U.S. PRESIDENT GEORGE BUSH'S SURPRISE INCREASED BY U.S. PRESIDENT GEORGE BUSH'S SURPRISE ANNOUNCEMENT THAT HE IS
REORGANIZED "G-8" FORUM.

01111 AYENI, 0.

A DYNAMIC TUR

WEST AFRICA, (3897) (MAY 92), 874

NIGERIA'S FOREIGN POLICY SEEMS TO HAVE TAKEN A DYNAMIC

NEW TURN AHAY FROM ISOLATIONISM AND COLD ALOOFNESS TO

FRIENDLY DIALOGUE WITH OTHER COUNTRIES. NIGERIA IS DARING TO

MOVE AWAY FROM ITS FENCE-SITTING POSITIION TO ASSUME A

LEADERSHIP ROLE IN AFRICAN AFFAIRS. ITS RECENT INITIATIVES

ON ISRAEL AND SOUTH AFRICA ARE EXAMPLES OF NIGERIA'S NEH STANCE.

01112 AYENI, 0.

A NEIGHBOUR'S CALL

WEST AFRICA, (3888) (MAR 92) 504.

THE AUTHOR DESCRIBES AN OFFICIAL YISIT PAID BY BENIN'S

PRESIDENT NICEPHORE SOGLO TO NIGERIA IN MARCH 1992.

01113 AYENI, 0.

A PRESIDENT'S TREATISE

WEST AFRICA, (3908) (AUG 92), 1344-1345.

ON JULY 27, 1992, PRESIDENT BABANGIDA ADDRESSED THE

NEWLY-ELECTED MEMBERS OF THE NATIONAL ASSEMBLY ON THE

IMPORTANCE OF CONTINUING NIGERIA'S STRUCTURAL ADJUSTMENT

PROGRAM, EVEN THOUGH IT IS VERY UNPOPULAR WITH THE PUBLIC

BECAUSE OF THE ECONOMIC HARDSHIPS IT ENTAILS. THE FUTURE OF

THE STRUCTURAL ADJUSTMENT PROGRAM IS UNCERTAIN, SINCE MOST

OF THE NEH LEGISLATIMS CAMPAIGNED ON PROMISES OF ABANDONING

OF THE NEW LEGISLATORS CAMPAIGKED

01114 AYENI, 0.

CONFUSION AND CONTROYERSY

WEST AFRICA (3916) (OCT 92), 1664-1665.

TEN OF THE 12 PRESIDENTIAL ASPIRANTS OF THE SOCIAL

DEMDRAT

THE LAST OF THE PRIMARIES. NEVERTHELESS, THE PARTY HELD THE PRIMARIES, WHICH ATTRACTED FEW VOTERS.

01115 AYENI, 0

CONSOLIDATING OLD PATTERNS
WEST AFRICA, (3904) ( JUL 92), 1168-1169

ON JULY 4, 1992, NIGERIANS WENT TO THE POLLS TO ELECT NATIONAL ASSEMBLY MEMBERS. THE SDP STRENGTHENED ITS HOLD ON THE WESTERN STATES. THE NRC MANAGED TO ELECT ONLY A FEW MEMBERS OF THE HOUSE OF REPRESENTATIVES BUT GAINED SEVERAL SENATE SEATS IN THE NORTHERN STATES.

01116 AYENI, 0.

THE RECENT (3892) (APR 92), 662-664.

THAWIMGCENT POLITICAL CHANGES IN SOUTH AFRICA HAVE LED TO

EVIDENCED BY THE OFFICIAL VISIT OF SOUTH

H. DEKLERK TO ABUJA IN APRIL 1992.

01117 AYENI, 0.

DEMOCRACY AT WORK?

WEST AFRICA, (3884) (FEB 92), 321.

NIGERIA'S NEW GOVERNORS MAY NOT HAVE BARGAINED FOR THE SURPRISES THEY HAVE HAD SINCE TAKING OFFICE IN EARLY 1992. THEIR HEADACHES INCLUDE EMPTY TREASURIES, INEPTITUDE IN THE CIVIL SERVICE, HOSTILE LEGISLATORS, AND THE THREAT OF CIVIL SERVICE, HOSTILE LEGISLATORS, AND THE THREAT OF REMOVAL FROM OFFICE THAT IS POSED BY THE LEGION OF PETITIONERS PROTESTING THEIR ELECTIONS. SO FAR, TWO GOVERNORS HAVE HAD THEIR ELECTIONS NULLIFIED WHILE SIX OTHERS HAVE HAD THEIR VICTORIES CONFIRMED. THE REMAINDER
WHOSE CASES HAVE NOT YET BEEN DECIDED BY THE ELECTION WHOSE CASES HAVE NOT YET BEEN DECIDED BY THE EL
TRIBUNAL, HAVE BEEN SLEEPING WITH ONE EYE OPEN.

01118 AYENI, 0

FINE-TUNING FEDERALISM

WEST AFRICA, (3911) (AUG 92), 1477

ONE OF THE REASONS FOR THE FAILURE OF NIGERIA'S SECOND REPUBLIC WAS THE PLETHORA OF DISAGREEMENTS EVOLVING FROM INTERGOVERNMENTAL FRICTION, WHICH CRIPPLED MANY PROGRAMS. THE RECENT ESTABLISHMENT OF THE NATIONAL COUNCIL ON INTERGOVERMMENTAL RELATIONS IS INTENDED TO PROVIDE A NEUTRAL BODY TO COORDINATE RELATIONS AMONG THE EXECUTIVE,

LEGISLATIVE, AND JUDICIAL BRANCHES OF GOVERNMENT.

01119 AYENI, 0

IN SEARCH OF LAH MAKERS

HEST AFRICA, (3902) (JUN 92), 1088-1089.

DESPITE SOME INITIAL APATHY AMONG POTENTIAL CANDIDATES,

NIGERIA'S ELECTIONS TO THE SENATE AND HOUSE OF

REPRESENTATIVES ON JULY 4, 1992, NOW PROMISE TO BE EXCITING.

THE THO POLITICAL PARTIES HAVE KICKED OFF THEIR CAMPAIGNS

AFTER SETTLIMG INTERNAL PROBLEMS.

01120 AYENI, 0.

MOYING INTO A MIXED GRILL

MOVING INTO A MIXED GRILL
WEST AFRICA, (3899) (JUN 92), 954-955

THIRD REPUBLIC POLITICS MOVED A STEP FORWARD IN MID-1992 WHEN THE TWO POLITICAL PARTIES HELD THEIR PRIMARIES TO ELECT THOSE WHO WILL BE CANDIDATES FOR THE SENATE AND HOUSE OF REPRESENTATIVES IN THE GENERAL ELECTION.

01121 AYENI, 0

NIGERIA'S SEARCH FOR DEMOCRACY

WEST AFRICA, 75(3924) (NOY 92), 2048-2049

IF EVENTUALLY THE MILITARY ADMINISTRATION IN NIGERIA FINALLY RELINQUISHES POWER TO THE CIVILIANS IN 1993, IT MAY INDEED BE "THE LAST" TO SNATCH POWER FROM AN ELECTED GOVERMMENT. THE POLITICAL CLASS HAS LEARNED THAT IT IS LESS PAINFUL TO WAIT FOUR GRUELING YEARS TO OUT-VOTE A BAD GOVERMMENT THAN TO WOO THE MILITARY, WHOSE TENURE MAY BECOME TOO ELASTIC FOR COMFORT, TO TAKE OVER POWER. THE JOURNEY
TOWARDS DEMOCRACY HAS BEEN TORTUOUS AND BORING SINCE THE INTERVENTION OF THE MILITARY IN 1984. DURING ALL THE PAINSTAKING PROCESSES, MANY PEOPLE FELT THAT THE TUTORING PERIOD SHOULD BE BEEN SPREAD OVER A LONG PERIOD DURING WHICH POLITICIANS, THE EVENTUAL BENEFACTORS DF THE PAINFUL PROCESS SHOULD HAVE BEEN GIVEN THE CHANCE TO PERFECT THEIR ACTS.

01122 AYENI, 0.

NORTH VERSUS SOUTH?

WEST AFRICA, (3888) (MAR 92), 500-501.

THE QUESTION OF WHAT QUALITIES A PRESIDENT NEEDS HAS BECOME SECONDARY IN NIGERIA'S POLITICS AS THE QUESTION OF WHERE HE COMES FROM HAS TAKEN PRIORITY. WESTERNERS BELIEVE WHERE HE COMES FROM HAS TAKEN PRIORITY. WESTERNERS BEL THAT THE NEXT PRESIDENT SHOULD COME FROM THEIR REGION
BECAUSE A HESTERNER HAS NOT SERVED IN THE HIGHEST OFFICE BECAUSE A WESTERNER HAS NOT SERVED IN THE HIGHEST OFFICE
SINCE INDEPENDENCE. THE NORTH HAS A LARGER POPULATION, BUT EASTERNERS BELIEVE THAT ELECTING ONE OF THEIR OWN WOULD HELP EASTERNERS BELIEVE THAT ELECT
HEAL THE WOUNDS OF THE WAR.

01123 AYENI, 0.

NOW THE BIG STICK

WEST AFRICA. (3911) (AUG 92) 1476

THE AUTHOR REPORTS ON THE PROGRESS OF NIGERIA'S PRIMARY ELECTION PROCESS, WHICH HAS BEEN MARRED BY CORRUPTION ANO UNETHICAL CAMPAIGN PRACTICES. 
01124 AYENI, 0.

ONE LEG UP, ONE LEG DOHN

WEST AFRICA, (3926) (DEC 92), 2139

NIGERIA'S PRESIDENT IBRAHIM BABANGIDA HAS CONVENED THE NATIONAL ASSEMBLY OF 91 SENATORS AND 589 MEMBERS OF THE HOUSE OF REPRESENTATIVES. ALTHOUGH THE ASSEMBLY HAS BEEN GIVEN THE GO-AHEAD BY THE PRESIDENT, THE MILITARY IS CLOSELY MONITORING ITS ACTIVITIES AND BILLS PASSED BY THE ASSEMBLY MUST HAVE MILITARY APPROVAL BEFORE BECOMING LAW.

01125 AYENI, 0 POL ITICAL WRANGLINGS

WEST AFRICA, (3903) (JUL 92), 1128

GHANA HAS A NEW POLITICAL ORGANIZATION, THE POPULAR

PARTY FOR DEMOCRACY AND DEVELOPMENT (PPDO), HHICH CLAIMS TO DERIVE ITS INSPIRATION FROM THE LATE OSAGYEFO DR KHAME NKRUMAH. THE PARTY PLANS TO BUILD "A NEH DEMOCRATIC PLATFORM OF MKRUMAHISTS AMD OTHER GHANAIANS WHO SHARE THE SAME VIEH OF SOCIETY."

01126 AYENI, 0.

PRESIDENCY FOR SALE?

HEST AFRICA, 75(3909) (AUG 92), 1386-1387.

THE DECISION TO CANCEL ALL THE RESULTS OF THE PRIMARIES IN NIGERIA WAS TAKEN TO ENHANCE THE CREDIBILITY OF THE INTRA PARTY ELECTORAL PROCESS AND THE TRANSITION PROGRAM. WITH THE PARTY ELECTORAL PROCESS AND THE TRANSITION PROGRAM. WITH
RE-SCHEDULING OF THE PARIMARIES IT IS NOT LIKELY THE NEC RE-SCHEDULING OF THE PARIMARIES IT IS NOT LIKELY THE NEC WILL HAVE TO STEP IN TO ORGANIZE THE PRIMARIES AS IT
BEING CALLED UPON TO DO. MASSIVE VOTE RIGGING IN THE PRIMARIES IS DESCRIBED IN THIS REPORT.

01127 AYENI, 0.

SEARCH FOR A PRESIDENT

WEST AFRICA, (3905) (JUL 92), 1206-1207

IN NIGERIA'S 1992 CONGRESSIONAL ELECTIONS, THE SOCIAL DEMOCRATIC PARTY WON 52 SEATS IN THE SENATE AND 314 IN THE HOUSE OF REPRESENTATIVES. THE NATIONAL REPUBLICAN CONVENTION WON 37 SENATE SEATS AND 275 IN THE HOUSE OF REPRESENTATIVES. MEANWHILE, THE PRESIDENTIAL ASPIRANTS ARE WAITING FOR THE NATIONAL ELECTORAL COMMISSION TO RELEASE THE VERIFIED LIST OF THOSE WHO HAVE OUALIFIED FOR THE UPCOMING PRESIDEMTIAL ELECTION.

01128 AYENI, 0.

SECOND TIME LUCKY?

WEST AFRICA, (3914) (SEP 92), 1602-1604.

NIGERIA'S RESCHEDULED PRIMARY ELECTIONS HERE "PASSABLY

FREE AND FAIR." OFFICIALS ENFORCED DECREE \#27 TO ENSURE

PEACEFUL ELECTIONS AND ORDERLY CONDUCT BY THE 23

PEACEFUL ELECTIONS AND ORDERLY CONDUCT BY THE 23
PRESIDENTIAL ASPIRANTS AND THEIR SUPPORTERS. THE EARLY

PRESIDENTIAL ASPIRANTS AND THEIR SUPPORTERS. THE EARLY
RESULTS FROM 10 STATES INDICATED THAT THE FRONTRUNNERS WERE

RESULTS FROM 10 STATES INDICATED THAT THE FRONTRUNNERS WERE

ADAMU CIROMA, AND ALHAJI UMARU SHINKAFI.

01129 AYENI, 0

THE JOURNEY SO FAR

WEST AFRICA, (3915) (SEP 92), 1612-1613

THE AUTHOR LOOKS AT THE HISTORY OF NIGERIA AND ITS

STATUS AFTER 32 YEARS OF INDEPENDENCE.

01130 AYENI, 0.

THE RISE OF THE MINORITIES

WEST AFRICA, 75(3887) (MAR 92), 456-467

UNTIL VERY RECENTLY, THE MINORITY GROUPS WITHIN NIGERIA

MAVE OFTEN FELT OUT-SCHEMED IN A LOT OF WAYS DESPITE THE

PURSUIT OF THE POLICY OF FEDERAL CHARACTER BY THE GOVERMMENT.

WITHER BY OMISSION OR COMMISSION. THE COUNTRY HAS BEEN SEEN AS A TRIPOLAR ENTITY WITH THE MAJORITY GROUPS CONSTITUTING THE TRIPOD OF WHICH THE NATION STATE DELICATELY RESTS. THIS ARTICLE SUGGESTS THAT NOW, IN WHAT CAN BE DESCRIBED AS A NEW FOUND FERVOR, THE MINORITY GROUPS MAY HAVE SMUGGLED

THEMSELVES INTO POLITICAL RECKONING AFTER ALL. THEIR DESIRE IS TO POOL TOGETHER THEIR RESOURCES TO EDGE OUT THE MAJORITIES.

01131 AYEMI, 0

TRAHSITION CREDIBILITY CRISIS?

WEST AFRICA, 75(3923) (NOV 92) 2012-2014.

THERE IS A CREDIBILITY CRISIS HAUNTIMG THE MILITARY ADMINISTRATION IN NIGERIA. WHEN PROMISES ARE MADE, IT IS WITH FULL INTENTIONS THAT THEY WILL BE KEPT EXCEPT SOMETHING DRASTIC HAPPENS, OR ELSE SOMEBODY WILL BE ACCUSED OF LYING DRASTIC HAPPENS, OR ELSE SOMEBODY WILL BE ACCUSED OF LYING. DID HAPPEN IN THE MANMER THE CANCELLED PRESIDENTIAL DID HAPPEN IN THE MANNER THE CANCELLED PRESIDENTIAL PRIMARIES WERE CONDUCTED. THIS ARTICLE SUGGESTS THAT FOR NOW THAT THE HANDOVER DATE HAS BEEN JUSTIFIABLY SHIFTED THEY MAY HAVE TO WAIT FOR ANOTHER NINE MONTHS TO BE PROVED THEY MAY HAVE TO

01132 AYENI,

TRANSITION SETBACK?

WEST AFRICA, (3919) (OCT 92), 1819-1820.

NIGERIA'S ARMED FORCES RULING COUNCIL (AFRC) HAS
SUSPENDED THE COUNTRY'S CONTROVERSIAL PRESIDENTIAL PRIMARIES, WHICH WERE PLAGUED BY VOTING IRREGULARITIES. THE MAJOR POLITICAL PARTIES HAVE BEEN ORDERED TO ELECT NEW EXECUTIVE

OFFICERS, AND IT IS PROBABLE THAT NIGERIA'S NATIONAL
ELECTIONS HILL HAVE TO BE POSTPONED UNTIL 1993.

01133 AYENI, 0

UNBRIDLED SIEGE

WEST AFRICA, (3890) (APR 92), 588

NIGERIA'S POLITICAL PARTIES MUST CONTEND WITH A PLETHORA

OF WOULD-BE CANDIDATES FOR THE COUNTRY'S UPCOMING ELECTION

FOR THE PRESIDENCY OF THE THIRD REPUBLIC.

01134 AYENI, 0.

WATCHING THE HATCH-DOG

WEST AFRICA, 75(3887) (MAR 92), 456-457.

FOR THE NEC, IT HAS NOT BEEN AN EASY JOURNEY SINCE

DECREE 23 OF SEPTEMBER, 1987 LEGALLY ESTABL ISHED THE

COMMISSION REPLACING THE FEDERAL ELECTORAL COMMISSION ACT OF

1977. AS AN ESSENTIAL TOOL OF THE FEDERAL GOVERMMENT'S

1977. AS AN ESSENTIAL TOOL OF THE FEDERAL GOVERMMENT'S

CYNOSURE OF ATTENTION. OILING THE TRANSITION, ELECTIONS HAVE,

CYNOSURE OF ATTENTION. OILING THE TRANSITION, ELECTIONS HAVE,

FOR THE FIRST TIME EVER BEEN CONDUCTED BY THE NEC WITH LESS ABSENT.

01135 AYENI, 0

WHEN WILL IBB GO?

WEST AFRICA, (3922) (NOV 92), 1956

AS NIGERIANS WAIT FOR THE PROMISED TRANSITION TO A MORE

DEMOCRATIC POLITICAL SYSTEM, THE OVERRIDING ISSUE IS THE

QUESTION OF WHEN PRESIDENT IBRAHIM BABANGIDA WILL STEP DOWN.

01136 AYERS, $L$

PERCEPTIONS OF AFFIRMATIVE ACTION AMONG ITS BENEFICIARIES SOCIAL JUSTICE RESEARCH, 5(3) (SEP 92), 223-238.

USING DATA OBTAINED THROUGH A SEPARATE STUDY, INTERVIEWS WITH WOMEN OF COLOR ASSOCIATED HITH AND INVOLVED IN THE DEVELOPMENT OF AN AFFIRMATIVE ACTION (AA) PROGRAM WERE ANALYZED IN LIGHT OF TYLER'S THEORIES OF PROCEDURAL JUSTICE. BENEFICIARIES PERCEIVE AA TO BE FAIR, ALTHOUGH FAIRER IN PRINCIPLE THAN IN PRACTICE. THE ISSUE OF COMMITMENT WAS RAISED IN SEVERAL CONTEXTS AS A SALIENT CONCERN OF MANY OF THE RESPONDENTS, AND SEVERAL CONCRETE EXAMPLES OF DEFICIENCIES AND SUCCESSES IN THE WAYS AA IS IMPLEMENTED ARE REPORTED.

01137 AYISH, M.I.

INTERNATIONAL COMMUNICATION IN THE 1990'S: IMPLICATIONS FOR THE THIRD WORLD

INTERNATIONAL AFFAIRS, 68(3) (JUL 92), 487-510,

FOR 30 YEARS THIRD' WORLD NATIONS HAVE BEEN CENTRAL PARTIES TO THE GLOBAL DEBATE ON THE VITAL ISSUE OF INTERNATIONAL COMNUNICATIONS. SUPPORTED BY THE FORMER SOVIET UNION, THEY PREVIOUSLY CALLED FOR A NEW WORLD INFORMATION AND COMMUNICATION ORDER IN WHICH THE NEGATIVE EFFECTS OF THE WESTERN DOMINANCE OF THE INTERNATIONAL COMPUNICATION SCENE WOULD BE ALLEVIATED. DUE TO THE BREAKUP OF THE SOVIET UNION AND THE REINVIGORATION OF THE UNITED NATIONS, INTERNATIONAL COMMUNICATION IS LIKELY TO REMAIN ON THE AGENDA OF WORLD DEBATES IN THE $1990^{\circ} \mathrm{S}$, BUT IT WILL BE FAR LESS IDEOLOGICAL AND MORE PRAGMATIC.

01138 AYISI, R.A.

AND NOW THE PEACE

AFRICA REPORT, 37(6) (NOY 92), 31-34.

THE MOZAMBICAN GOVERMHENT AND THE RENAMO REBELS SIGNED A CEASEFIRE ON OCTOBER 4, 1992. BUT MANY MOZAMBICANS GREETED THE CEASEFIRE CYNICALLY, AHARE THAT MAINTAINING THE PEACE WILL NOT BE EASY. THE WARRING TROOPS MUST BE INTEGRATED INTO ONE ARMY; JOBS MUST BE FOUND FOR DISPLACED SOLDIERS AND RETURNING REFUGEES; NORMAL LIFE MUST BE RESTORED.

RECONCILIATION WILL TAKE A GREAT EFFORT.

01139 AYISI, R.A.

DROUGHT AND DESPERATION

AFRICA REPORT, 37(3) (MAY 92) 33-35.

THE NEGOTIÁTIONS TO END THÉ HAR BETHEEN RENAMO AND THE

FRELIMO GOVERMMENT DRAG ON, WHILE THE DROUGHT IS INCREASING

THE WIDESPREAD SUFFERING IN MOZAMBIQUE. IN MARCH 1992, A

THE HIDESPREAD SUFFERING IN MOZAMBIQUE. IN MARCH 1992 ,
PROTOCOL WAS SIGNED ON A FUTURE SYSTEM OF PROPORTIONAL

REPRESENTATION AND FOR ELECTIONS TO TAKE PLACE ONE YEAR

AFTER A NATIONHIDE CEASE-FIRE, IF AND WHEN THE THO SIDES CAM AGREE TO STOP SHOOTING.

01140 AYISI, R.A.

THE PATH TO PRIYATIZATION

AFRICA REPORT, 37 (1) (JAN 92), 55-57.

MOZAMBIQUE' IS UNDERGOING A'PAINFUL TRANSITION FROM

SOCIALIST MATION AT WAR WITH ITSELF TO A SOCIETY OPENING UP TO THE PRIVATE SECTOR. MARKET FORCES ARE NOW PERMITTED TO OPERATE IN SOME AREAS, BUT THERE IS CONFUSION OVER WHETHER FREE ENTERPRISE IS REALLY FREE AND HOW MUCH OPENING UP WILL BE ALLOWED. 
01141 AYISI, R.A.

WAITING FOR THE GIANT

AFRICA REPORT, $37(2)$ (MAR 92), 65-67.

DURING ITS DOZEM YEARS IN EXISTENCE, THE SOUTH AFRICAH DEVELOPMENT COORDINATION CONFERENCE HAS ACHIEVED SOME OF ITS GOALS--MAINLY IN TRANSPORT, ENERGY, COMMUNICATIONS, AND AGRICUL TURAL RESEARCH. BUT REGIONAL ECONOMIC INTEGRATION REMAINS ELUSIVE, AND THE 10 MEMBER-STATES ARE HAITING TO SEE WHETHER A POST-APARTHEID SOLTH
UNION OR MERELY DOMINATE IT.

01142 AYUBI, N.M.

STATE' ISLAM AND COMMUNAL PLURALITY

ANNALS OF THE AMERICAN ACADEMY OF POLITICAL AND SOCIAL SCIENCE, (524) (NOY 92), 79-91.

IN THE PAST, THE ISLAMIC STATE DEVELOPED INTERESTING METHODS OF QUASI-CONSOCIATIONAL AND SEMI-CORPORATIST AGGREGATION OF COMMUNITIES. FROM QUITE EARLY ON, SUNNISM BECAME THE RELIGION OF THE RULING ELITE AND OF THE STATE AS WELL AS PART OF THE STATE'S LEGAL AND CULTURAL SYSTEM. SUBSEQUENTLY, THE GEOGRAPHICAL DISTRIBUTION AND THE POLITICAL ECONOMY OF THE ISLAMIC SECTS AND OF THE RELIGIOUS MINORITIES MANIFESTED QUITE DISTINCT FEATURES THAT HERE MAINLY A FUNCTION OF THEIR RELATIONSHIP TO THE STATE. WHEREAS THE ISLAMIC SECTS DID NOT COME TO TERMS IDEOLOGICALLY AND ORGANIZATIONALLY WITH THE STATE, THE RELIGIOUS MINORITIES, ON THE WHOLE, ADJUSTED THEMSELVES MENTALLY AND BEHAVIORALLY TO ITS REQUIREMENTS. BY COMPARISON, THE CONTEMPORARY MIDDLE EASTERN STATES, BOTH SECULAR AND ISLAMIC, HAVE BEEN LESS SUCCESSFUL IN DEALING WITH COMMUNAL PROBLEMS. CERTAIN GROUPS ARE EXCLUDED IN THE FORMER TYPE IN SPITE OF THE SECULARIST SLOGANS, HHILE CERTAIN GROUPS ARE EXCLUDED IN THE LATTER BECAUSE OF THE IDEOLOGICAL OR RELIGIOUS NATURE OF THE STATE. MUSLIM STATESMEN AND INTELLECTUALS MAY NEED TO GO BEYOND, AND EVEN OUTSIDE, CONYENTIONAL ISLAMIC JURISPRUDENCE IN ORDER TO DEAL WITH THIS ISSUE.

01143 AZAD, B.

OPPORTUMISM, REFORMISH AMD SOCIAL DEMOCRACY POLITICAL AFFAIRS, 71(2) (FEB 92), 35-39.

RECENT GLOBAL TRENDS, WHICH OPERATE OM THE PREMISE OF THE "DEFEAT OF SOCIALISM, "THE "PERMANENCY" OF CAPITALISM, AND THE UNI-POLARITY OF THE PRESENT WORLD, MANIFEST THEMSELVES IN THREE MAIN TENDENCIES: OUTRIGHT SUBMISSION TO CAPITALISM, REFORMISM, AND WHAT CAN BE CALLED "BORN-AGAIN SOCIAL DEMOCRACY." MANY OF THESE "BORN AGAIN" SOCIAL DEMOCRATS ARE EX-COMMUNISTS. THIS ARTICLE EXAMINES THIS PMENOMENON AND SEEKS TO EXPLAIN THE MOTIVES OF SUCH LEADERS. IT CONCLUDES THAT SOCIAL DEMOCRATIC MOVEMENTS ARE COMPOSED OF CAPITALISTS WEARING SOCIALIST MASKS. THOSE SOCIAL DEMOCRATS WHO PROMISE THE WORKING CLASS A BETTER FUTURE WHILE AT THE SAME TIME ADVOCATING THE "DEATH OF COMMUNISM" AND THE "END OF CLASS STRUGGLE," ARE NOT ONLY STRENGTHENING THE HAND OF MONOPOLY CAPITAL, BUT ARE ALSO SHOOTING THEMSELVES IN THE FOOT. THEY FAIL TO SEE THAT IN A UNIPOLAR WORLD DOMINATED BY MONOPOLY CAPITAL, THERE CAN BE NO ROOM FOR SOCIAL DEMOCRACY EITHER.

01144 AZNAM, $S$.

MAVERICK

FAR EASTERN ECONOMIC REYIEW, 151(29) (JUL 91), 23-25. IN TEN YEARS AS MALAYSIA'S PRIME MINISTER, MAHATHIR MOHAMAD HAS CAJOLED AND NUDGED HIS COUNTRYMEN TOWARDS AECOMING A NEWLY INDUSTRIALIZED NATION. NOT LEAST AMONG HIS OFTEN CONTROVERSIAL ACHIEVEMENTS HAS BEEN THE RADICAL CFTEN CONTROVERSIAL ACHIEVEMENTS HAS BEEN THE RADICAL CHANGES HE HAS WROUGHT UPON THE MALAYSIAN SOCIETY IN GENERAL MUMERICALLY DOMINANT MALAYS IN PARTICULAR. ALTHOUGH MAHATHIR HAS LEARNED TO OCCASIONALLY SIDE-STEP "FATHER OF MODERM MALAYSIA" STILL SHOWS NO SIGM OF SLOHING "FATHER OF MODERN MALAYSIA" STILL

01145 AZNAM, S

NO SURPRISES

FAR EASTERN ECONOMIC REVIEW, 155(25) (JUN 92), 14-15.

INDONESIA'S SIXTH GENERAL ELECTION SINCE INDEPENDENCE IN 1945 RETURNED THE RUL ING GOLKAR PARTY WITH $68 \%$ OF THE POPULAR VOTE. THE RESULT HAS FIVE PERCENT LOWER THAN THAT OF POPULAR VOTE. THE RESULT WAS FIVE PERCENT LOWER THAN

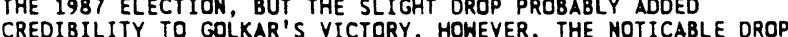
CREDIBILITY TO GOLKAR'S VICTORY. HOWEVER, THE NOTICABLE DROP IN JAVANESE VOTES WILL PROBABLY EMERGE AS THE PARTY'S MAIN AREA OF IMMEDIATE CONCERN. APART FROM THIS SMALL HARNING, MANY OBSERVERS NOTED THAT THE ELECTIONS WERE THE CALMEST, MOST ORDERLY, AND POSSIBLY THE MOST PREDICTABLE IN THE COUNTRY'S HISTORY. WHILE THE 25-DAY CAMPAIGN WAS LIVELY, THERE WERE NO OBYIOUS SIGNS OF ACRIMONY BETHEEN THE CONTENDING GROUPS. THIS WAS IN CONTRAST TO THE 1982 AND 1987 POLLS, WHEN CLASHES BETHEEN RIVAL PARTIES LED TO DEATHS DURING THE ELECTION CAMPAIGN. THREE POLITICAL PARTIES-GOLKAR, THE OPPOSITION UNITED DEVELOPMENT PARTY (PPP), AND THE IMDONESIA DEMOCRATIC PARTY (PDI)--CONTESTED THE 9 JUME
ELECTION FOR 400 ELECTED SEATS IN THE PEOPLE'S

REPRESENTATIVE ASSEMBLY, WHOSE MEMBERS WILL ALSO SIT IN THE 1, OOOMEMBER PEOPLE'S CONSULTATIVE ASSEMBLY WHICH ELECTS THE PRESIDENT NEXT MARCH.

01146 AZOMGA, T.

A POISONED GIFT

WEST AFRICA, 75(3887) (MAR 92), 459

THE RULING CAMEROON PEOPLE'S DEMOCRATIC MOVEMENT (CPDM) JUST BARELY HON THE COUNTRY'S FIRST PARLIAMENTARY ELECTION IN 30 YEARS. ALTHOUGH THE PARTY IS CELEBRATING ITS VICTORY, IT IS LOW-KEY. SOME OPPOSITION MEMBERS HAVE ACCUSED THE CPOM IT IS LOW-KEY. SOME OPPOSIT CONTENTION IS THAT IF TWO OF THE FOUR MAIN OPPOSITION PARTIES HAD NOT BOYCOTTED THE ELECTIONS FOUR MAIN OPPOSITION PARTIES HAD NOT BOYCOTTED THE ELECTIONS THERE IS NO WAY THE CPDM COULD HAVE BEEN THE PARTY WITH THE
MOST VOTES. THE TWO MAIN OPPOSITION PARIES WHICH TOOK PART MOST VOTES. THE THO MAIN OPPOSITION PARIES WHICH TOOK PART COUNTING.

01147 AZONGA, T.

BIYA'S TEST ELECTIONS

WEST AFRICA, 75(3885) (MAR 92), 362-364

THE MARCH 1 PARLIAMENTARY ELECTIONS, INTENDED TO USHER IN PEACE AND STABILITY FIND THE COUNTRY IN AN ATMOSPHERE OF APPREHENSION AND FOREBODING, AND ARE WITH MASSIVE BOYCOTTS BY MAJOR POLITICAL PARTIES. ALREADY, OBSERVERS ARE WONDERING WHETHER THE EXERCISE HAS BEEN WORTH THE TROUBLE. THE COUNTRY'S NOW 68 OPPOSITION PARTIES WERE FORMED LESS THAN THO YEARS AGO WITH ONE EXCEPTION. THESE PARTIES ARE DESCRIBED IN THIS ARTICLE.

01148 AZONGA, T.

CAMEROON: BIYA SHUFFLES CABIMET

WEST AFRICA, 75(3925) (DEC 92), 2099-2100.

THE LONG AWAITED CABINET RESHUFFLE WAS ANMOUNCED IN CAMEROON A FEH DAYS AFTER THE PRESIDENT REAPPOINTED SIMON ACHU AS PRIME MINISTER AND HEAD OF GOVERNMENT, AND INDICATED THAT ATE REST OF THE CABINET WOULD BE ANMOUNCED AFTER HE HAS CHAT THE REST OF THE CABINET NOULD BE ANNOUNCED AFTER HE HAS HAYE BEEM RETAIMED THE RESHUFFIE IS STIUL SURPRISING. HHILE HAVE BEEN RETAINED, THE RESHUFFLE IS STILL SURPRISING. WHILE THO OPPOSITION PARTIES GOT CABINET POSTS, WITH ALLIANCES AND DEFECTION ON THE PARTS OF OTHER OPPOSITION PARTIES THERE IS NOW NO OPPOSITION PARTY IN THE NATIONAL ASSEMBLY. THE SDF, THE ONLY SERIOUS OPPOSTION PARTY IN THE COUNTRY, SUFFERS THE LEGISLATIVE ELECTIONS.

01149 AZONGA, T.M.

BIYA DRAHS THE LINE

HEST AFRICA, (3901) (JUN 92), 1054

CAMEROON'S PRESIDENT PAUL BIYA HAS MOVED TO COUNTER CRITICISM DUE TO HIS APPOINTMENT OF SIMON ACHIDI ACHU AS PRIME MINISTER. IN ORDER TO PREVENT MISUNDERSTANDING, BIYA HAS SIGNED DECREES DETAILING THE ROLES OF THE PRIME MINISTER, THE SECRETARY-GENERAL AT THE PRESIDENCY, AND THE DEPUTY PRIME MINISTER.

01150 AZONGA, T.M

BIYA NAMES THE DAY

WEST AFRICA, (3913) (SEP 92), 1561.

CAMEROON'S PRESIDENT PAUL BIYA HAS CALLED EARLY

PRESIDENTIAL ELECTIONS, MOVING THE DATE FORWARD TO OCTOBER 1992. HE SAID THAT HE WAS RESPONDING TO CALLS FOR AN EARLY ELECTION, BECAUSE THE UNCERTAINTY OVER LEADERSHIP WAS HINDERING THE ECONOMIC RECOVERY AND REVIVAL. BIYA, WHO HAS ALREADY SERVED NEARLY 10 YEARS AS PRESIDENT, WILL BE AMONG THE PRESIDENTIAL CANDIDATES ON THE BALLOT.

01151 AZONGA, T.M.

BIYA'S CRITICAL MOMENTS

(3895) 92 ) 795-796.

CAMEROON'S FIRST MULTI-PARTY ELECTIONS IN MORE THAN 25 YEARS, PRESIDENT PAUL BIYA FOUND IT NECESSARY TO FORM AN ALLIANCE WITH THE MOVEMENT FOR DEMOCRACY AND THE REPUBLIC (MOR) IN ORDER TO SECURE A MAJORITY IN THE ASSEMBLY BIYA HAS REWARDED

01152 AZONGA, T.M.

JOSTLING FOR POWER

JOSTLING FOR POWER
WEST AFRICA, (3879) (JAN 92), 105-106

OM MARCH, 1992. CAMEROONIANS WILI GO TO THE POLLS TO ELECT MEMBERS OF THE NATIONAL ASSEMBLY, THE OLD ASSEMBLY HAVING BEEN DISSOLVED A YEAR BEFORE THE END OF ITS TERM. THE FIERCEST ELECTION BATTLE IS LIKELY TO BE FOUGHT IN MEZAM DIVISION, WHERE THE CAMEROON NATIONAL UNION, THE CAMEROON PEOPLE'S DEMOCRATIC MOVEY
FRONT WERE ALL FOUNDED.

01153 AZONGA, T.M. ROBBED OF VICTORY?

WEST AFRICA, (3920) (NOV 92), 1870-1871

PAUL BIYA, HHO RAN ON THE TICKET OF THE RULING CAMEROON PEOPLE'S DEMOCRATIC MOVEMENT, WAS PROCLAIMED THE WINHER OF 
THE OCTOBER 1992 PRESIDENTIAL ELECTION. THE REACTION AMONG THE PEOPLE HAS DISBELIEF, AND RIOTS BROKE OUT AS PROTESTORS ACCUSED BIYA OF STEALING THE ELECTION.

01154 AZONGA, T.M.

SHOW OF STRENGTH

HEST AFRICA, (3910) (AUG 92), 1439-1440

ON JULY 17, 1992, PRESIDENT PAUL BIYA DISMISSED GENERAL BENOIT ASSO'O EMANE AS THE SUPREME COMMANDER OF THE YAOUNDE MILITARY HEADOUARTERS. THE MOVE WAS SURPRISING SINCE ASSO'O WAS BIYA'S MOST TRUSTED ADVISOR AND RUMORED TO BE THE MAN WHO ACTUALLY RAN CAMEROON. HE WAS REPLACED BY COLONEL RENECLAUDE MEKA.

01155 AZONGA, T.M.

UNEASY' CALM

WEST AFRICA, (3919) (OCT 92), 1825

A WEEK AFTER CAMERDON'S PRESIDENTIAL ELECTION, THE

TOTALS STILL HAD NOT BEEN ANNOUNCED. OBSERVERS REPORTED THE MOVEMENT OF GOVERMMENT TROOPS TO PARTS OF THE COUNTRY

BELIEVED TO BE SYMPATHETIC TO THE OPPOSITION, PRESUMABLY IN PREPARATION FOR POSSIBLE VIOLENCE WHEN THE ELECTION OF PAUL BIYA IS ANMOUNCED.

01156 BABANGIDA, I.

THE CHALLENGES AHEAD

WEST AFRICA, (3886) (MAR 92), 406.

IN HIS CAPACITY AS CHAIRMAN OF THE ORGANIZATION OF AFRICAN UNITY, NIGERIAN PRESIDENT IBRAHIM BABANGIDA

ADDRESSED WEST GERMANS ON A STATE VISIT TO THEIR COUNTRY. HE SPOKE OF THE DESIRE FOR GREATER DEMOCRACY AMONG AFRICANS AND OF THE CHALLENGES THAT LIE AHEAD AS AFRICANS STRIVE FOR FREEDOM.

01157 BABBITT, E.

GULF WAR MEDIATION EFFORTS OFFERED TOO LITTLE, TOO LATE

NEGOTIATION JOURNAL, 8(1) (JAN 92), 37-41.

THE MAJOR LESSON OF THE GULF HAR IS ITS IMDICTMENT OF CURRENT APPROACHES TO DIPLOMACY AND FOREIGN POLICY. HAITING UNTIL A CRISIS ERUPTS ONLY CUTS DOHA ON THE OPTIONS AVAILABLE AND MAKES THE USE OF MILITARY FORCE MORE LIKELY. THE HARNING SIGMALS WERE PRESENT IN IRAQ WHEN SADDAM ASKED THE UNITED STATES FOR ASSISTANCE IN DEALING WITH ECOMOMIC HOSTILITY FROY KUHAIT HE TOLO HIM IT HAS NOT OUR COMCERM. HOSTILE TUTURE KUHAIT. HE TOLD HIM IT WAS NOT OUR CONCER SHOULD NOT BE' OUR ANSWER.

01158 BACHMAN, D.

THE LIMITS TO LEADERSHIP IN CHINA; ASSOCIATION FOR ASIAM STUDIES 1992 ANNUAL MEETING

ASSOCIATION FOR ASIAN STUDIES, 1992, 53

THIS PAPER EXAMINES THE LIKELY COMPOSITION OF CHINA'S

POST-DENG POLITICAL ELITE. WHILE CHINA'S NEW LEADERSHIP WILL BE BETTER EDUCATED THAN DENG XIAOPING AND HIS GENERATION OF LEADERS, THEIR CAREER PATHS AND OTHER FACTORS WILL MEAN THE NEW LEADERSHIP WILL BE EVEN LESS ABLE TO CONTROL THE CHINESE POLITICAL SYSTEM THAN WAS DENG. THIS DOES NOT MEAN THAT CHINA'S NEAR TERM POLITICAL FUTURE WILL NECESSARILY RESEMBLE THAT OF EASTERN EUROPE, AND THE MAJORITY OF THE PAPER FOCUSES ON WHY THIS IS LIKELY TO BE SO.

01159 BACIA, H.

A THIRD OF ETHNIC GERMANS IN THE SOVIET UNION SAID THEY WANT TO GO TO GERMANY

GERMAN TRIBUNE, (1477) (JUL 91), 15.

A RECENT VISIT OF A GERMAN OFFICIAL TO AREAS IN THE SOVIET UNION WHICH HAVE CONCENTRATIONS OF ETHNIC GERMANS REVEALED THAT ONE THIRD OF THEM WANT TO MOVE TO GERMAHY. ANOTHER THIRD ARE WATCHING THE POLITICAL DEVELOPMENTS BEFORE THEY MAKE UP THEIR MINDS. FOR THOSE WHO DESIRE TO STAY, THE RUSSIAN REPUBLIC IS BEGINNING TO SUPPORT MEASURES WHICH WOULD CREATE AUTONOMOUS GERMAN REGIONS IN AREAS HITH A HIGH CONCENTRATION OF ETHNIC GERMANS. ONE SUCH AREA IS ALTAI. IN HESTERN SIBERIA. ANOTHER POSSIBILITY IS THE GERMAN VOLGA REPUBLIC, DISBANDED INCREASINGLY UNFAMILIAR WITH THE GERMAN LANGUAGE, BUT SOME STILL WANT TO FLEE THE POL ITICAL DISORDER AND ECONOMIC DECAY THEY SEE AROUMD THEM THEY WERE REASSURED BY THE GERMAN VISITING OFFICIAL THAT "THE DOOR IS ALHAYS OPEN."

01160 BACON, E.

GULF WAR AMALYSIS: THE FORMER SOVIET UNION AMD ANALYSIS OF GULF WAR ANALYSIS:

JOURNAL OF SOVIET MILITARY STUDIES, 5(2) (JUN 92), 169-186.

THE WAR TO LIBERATE KUWAIT WAS ANALYSED WITHIN THE THE WAR TO LIBERATE KUHAIT WAS ANALYSED WITHIN THE
SOVIET UNION IN TERMS OF ITS DECLINE AS A SUPERPOWER. THE MARGINALIZATION OF SOVIET MILITARY, TECHNOLOGICAL, ECONOMIC, AND DIPLOMATIC STATUS HAS SEEN TO HAVE BEEN AGGRAVATED BY THE CONFLICT. SUCH PERCEIVED MARGINALIZATION MEANT THAT THE ALLIED VICTORY OVER IRAO WAS ALSO, TO MANY IN THE ARMED FORCES OF THE FORMER SOVIET STATE, A VICTORY OVER THE USSR.

01161 BAE, $Y$.

SOVIET-SOUTH KOREA ECONOMIC COOPERATION FOLLOWING
RAPPROCHEMENT

JOURNAL OF NORTHEAST ASIAN STUDIES, 10(1) (SPR 91), 19-34. THE ESTABLISHMENT OF DIPLOMATIC TIES BETHEEN THE SOVIE UNION AND THE REPUBLIC OF KDREA APPEARS TO BE NOT ONLY A CORNERSTONE FOR PEACE-KEEPING IN THE KOREAN PENNINSULA BUT ALSO A CATALYST TOWARD IMPROVING ECONOMIC COOPERATION BETWEEN THE THO COUNTRIES. THE OUTCOMES OF DEMOCRATIZATION AND MARKETIZATION IN THE SOVIET UNION ARE NOT CERTAIN. KDREA IS DEEPLY CONCERNED ABOUT THE SUCCESS OR FAILURE OF THE SOVIET ECONOMY BECAUSE THIS WILL INFLUENCE THE EXTENT TO WHICH THE KOREAN ECONOMY WILL BENEFIT OR SUFFER.

01162 BAER, D.; GRABB, E.; JOHNSTON, $W$.

ECONOMIC OISSATISFACTION, POTENTIAL UNIONISM, AND ATIITUDES TOWARD UNIONS

CANADIAN REVIEW OF SOCIOLOGY AND ANTHROPOLOGY, 28(1) (FEB $91), 67-83$.

THIS PAPER REPRESENTS THE FIRST ATTEMPT TO ASSESS THE RELATIONSHIP BETWEEN ECONOMIC DISSATISFACTION AND SUPPORT FOR UNIONS, USING PANEL DATA COLLECTED AT THE NATIONAL LEVEL. A LATENT VARIABLE (LISREL) MODEL IS EMPLOYED TO EXAMINE THE ATTITUDES OF A REPRESENTATIVE SAMPLE OF CAMADIAN RESPONDENTS DURING THE PERIOO FROH 1977 TO 1981. THE FINDINGS INDICATE CONSIDERABL E STABILITY IN ATTITUDES ABOUT UNION RIGHTS AND POHERS OVER TIME. THERE IS SOME TENDENCY FOR ECONOMIC DISSATISFACTION TO PRODUCE MORE NEGATIVE PERCEPTIONS OF
UNIONS AHONG UNION MEMBERS. SIGNIFICANTLY DIFFERENT PATTERNS ARE FOUND FOR UNION MEMBERS AND 'POTENTIAL' UNION MEMBERS, ON THE ONE HAND, AND INDIVIDUALS WHO ARE NOT POTENTIAL MEMBERS, ON THE OTHER HAND.

01163 BAEV, P.

A NEW RUSSIAN CHALLENGE TO EUROPE

BULLETIN OF PEACE PROPOSALS, 23(1) (MAR 92), 17-22.

THIS ARTICLE OUTLINES THE POLITICAL, ECONOMIC, MILITARY AND SECURITY DIMENSIONS OF THE ONGOING BREAK-UP OF THE SOVIET UNION. IT ARGUES THAT GORBACHEY'S UNION TREATY (AND ANYTHING AKIN TO IT) IS DOOMED TO FAILURE. THEREFORE, THE NATIONS OF EUROPE NEED TO LEARN HOW TO DEAL WITH EX-SOVIET REPUBLICS ON AN INDIVIDUAL BASIS. IN ADDITION, WHAT IS NEEDED IS WESTERN ENGAGEMENT (NOT CONTAINHENT OR CONFRONTATION) IN A LONG AND RESOURCE-CONSUMING EFFORT TO INTEGRATE RUSSIA AND THE OTHER POST-SOVIET REPUBLICS WITH THE REST OF EUROPE.

01164 BAGCHI, A.

LAND TAX, PROPERTY RIGHTS AND PEASANT INSECURITY IN COLONIAL' INOIA

JOURNAL OF PEASANT STUDIES, 20(1) (OCT 92), 1-50.

THE QUESTION OF PRIVATE PROPERTY IN IAND IN THE EASTERM LANDS INCLUDING INDIA HAS BEEN DEBATED IN EUROPE AT LEAST SINCE THE SEVENTEENTH CENTURY. IT HAS BEEN CLAIMED THAT THE BRITISH RULERS HAD, FOR THE FIRST TIME, CREATED PRIVATE PROPERTY IN LAND AMO THEREBY CONFERRED SECURITY ON THE OWNERS. THIS CLAIM IS EXAMINED BY ANALYZING ACTUALLY HOW LAND LANS AND LAND TAX IN THE BOMBAY DECCAN DISTRICTS OPERATED IN THE NINETEENTH CENTURY. THIS CASE THROWS LIGHT ON THE HIDER ISSUE OF HOW PEASANT SECURITY IS SUBVERTED IN OTHER AREAS OF THE WORLD WHERE THE PROBLEM OF A VULNERABLE ECOLOGY AND UNCERTAIN PEASANT PRODUCTION IS COMPOUNDED BY STATE POLICIES REGARDING PROPERTY RIGHTS AND TAXATION.

01165 BAGCI, $H$.

THE CYPRUS POLICY OF THE MENDERES GOVERMMENT 1950-1960. A

TURNING POINT IN TURKISH FOREIGN POLICY

ORIENT, 33(1) (1992), 119-138.

THE' OUTCOME OF THE CYPRUS QUESTION IS A MILESTONE IN TURKISH FOREIGN POLICY. IT BECAME AN IMPORTANT FACTOR IN THE FOREIGN POLICY DECISION-MAKING PROCESS OF THE MENDERES GOVERNMENT SINCE THE MID-50S. UNTIL 1954 THERE EXISTED NO SUCH QUESTION FOR TURKEY, HOWEVER SHORTLY AFTER THIS, THE MENDERES GOVERNMENT UNDERTOOK NECESSARY MEASURES WITH REGARO TO THIS STRATEGICALLY IMPORTANT ISLAND. IT COULD NOT ACHIEVE A FINAL SOLUTION BUT WAS ABLE TO SECURE THE TURKISH SECURITY INTERESTS ON THE ISLAND DURIMG THAT PERIOD.

01166 BAGNOLI, M.; LIPMAN, 8.

PRIVATE PROVISION OF PUBLIC GOODS CAN BE EFFICIENT PUBLIC CHOICE, $74(1)$ (1991) 59-78

ECONOMISTS HAVE LONG BELIEVED THAT PRIVATE PROVISION OF PUBLIC GOODS WILL BE INEFFICIENT, THOUGH RECENTLY SOME HAVE PUBLIC GOODS WILL BE INEFFICIENT, THOUGH RECENTLY SOM ARGUED THAT ALTRUISM MAY MITIGATE THE INEFFICIENCIES. MARGINAL COST EQUALS THEIR PRIYATE MARGINAL BENEFITS. HITH MARGINAL COST EQUALS THEIR PRIVATE MARGINAL BENEFITS. WITH ALTRUISM, THEY CONTRIBUTE MORE AND HENCE ARE CLOSER TO THE MORE AND HENCE ARE CLOSER TO THE POINT WHERE MARGINAL COST AND TOTAL MARGINAL BENEFITS ARE EQUATED.

01167 BAHAI JOUB, A.

THE ENDLESS GAME

WEST AFRICA, (3922) (NOV 92), 1957.

THE AUTHOR LOOKS AT THE HISTORICAL BACKGROUND TO THE

PRESENT COMFLICT OVER HESTERN SAHARA AND REITERATES 
MOROCCO'S OFFICIAL POSITION THAT IT IS COMMITTED TO THE U.N. REFERENDUM AND WILL COMPLY HITH THE RESULTS.

01168 BAHL, R.; MARTINEZ-VAZQUEZ, J.; SJOQUIST, D.L.

CITY FINANCES AND THE NATIONAL ECONOMY

UBLIUS: THE JOURNAL OF FEDERALISM, 22(3) (SUM 92), 49-66. CITY GOVERNHENTS WERE BETTER PREPARED TO FACE THE 199092 RECESSION THAN WERE STATE GOVERNMENTS, AND THEY ADJUSTED THEIR BUDGETS WITH RELATIVELY LESS FANFARE. NEVERTHELESS, THE FISCAL POSITION OF CITIES HAS DETERIORATED AND SOME OF THE NECESSARY ADJUSTMENTS WERE PAINFUL. SERVICES WERE REDUCED AS REAL PER CAPITA EXPENDITURE GROWTH DECLINED, TAXES WERE INCREASED, AND THE ENTIRE LOCAL GOVERNMENT SECTOR REMAINED IN DEFICIT DURING THE LAST ISX YEARS. THE PROBLEM HAS NOT BEEN SOFTENED BY FEDERAL OR STATE POLICIES; IN FACT, THE FLOH OF BOTH FEDERAL AND STATE FUNDS SLOHED MARKEDLY DURING THE LATE 1980'S. A COMBINATION OF ECONOMIC ANO SOCIAL FORCES SUGGESTS THAT MANY OF THE NATION'S OLDER CITIES WILL NOT OUTGROW THIS FISCAL STRESS AND THEIR BUDGETARY WELLBEING WILL BE MORE DEPENDENT ON STATE AND FEDERAL POLICIES

01169 BAHL, R.; DUNCOMBE, $W$.

ECONOMIC CHANGE AND FISCAL PLANNING: THE ORIGINS OF THE FISCAL CRISIS IN NEW YORK STATE

PUBLIC ADMINISTRATION REVIEH, 52(6) (NOV 92), 547-558. BY MOST MEASURES, NEW YORK STATE HENT FROM A POSITION OF FISCAL STRENGTH IN THE EARLY 1980'S TO FISCAL CRISIS BY THE END OF THE DECADE. IN THEIR ANALYSIS OF DEHOGRAPHIC, SOCIAL, ECONOMIC, AND FISCAL PATTERNS, THE AUTHORS SHOH THAT THE LACK OF LONG-TERM FISCAL PLANHING AND SHORT-TERM DISCIPLINE WERE THE ROOT CAUSES OF THE REVERSAL. THEY CALL FOR GREATER USE OF BOTH, AS WELL AS TAX REFORMS THAT WILL BETTER REFLECT THE CHANGING REALITY OF LOCAL AND STATE ECONOMIES.

01170 BAHNEY, $Y$

A DIFFICULT TRANSITION: THE CRASH OF THE SOCIALIST EXPERIMENT IN BULGARIA

PARLIAMENTARIAN, LXXIII(3) (JUL 92), 155-157.

BULGARIA'S SOCIALIST EXPERIMENT FAILED NOW THE BULGARIAN GOVERMMENT IS WRESTLING WITH THE TRANSITION FROM STATE CONTROL OF ALL ASPECTS OF LIFE TO A MORE DEMOCRATIC SYSTEM THAT HILL ULTIMATELY ALLOW THE PEOPLE TO CONTROL THEIR OWN DESTINY.

01171 BAHRO, G.

"ARAL-KUM"--AN ENVIRONMENTAL-POLITICAL CHALLENGE

ORIENT, $32(4)$ (DEC 91), 605-614.

THE STATE PLANIING APPARATUS AND THE MILITARY CARRY THE RESPONSIBILITY FOR HAVING CREATED AN ECOLOGICAL DISASTER RESPONSIBILITY FOR HAVING CREATED AN ECOLOGICAL DISASTER AREA WHICH INCLUDES SALT STORMS, CLIMATIC FLUCTUATIONS AND
DOUBLE SALINIZATION OF THE GROUND, BECAUSE OF THE DRYING UP DOUBLE SALINIZATION OF THE GROUNO, BECAUSE OF THE DRYING OF THE ARAL SEA IN CENTRAL ASIA. THIS SITUATION WHICH REGAROING THE HEALTH AND SOCIAL CONSEQUENCES FOR THE
INHABITANTS CAN ONLY BE COMPARED TO THE SITUATION IN THIRD INHABITANTS CAN ONLY BE COMPARED TO THE SITUATION IN THIRD WORLD COUNTRIES. THE THREATENING DANGER OF DESERTIFICATI
WHICH COULD LIKEWISE THREATEN EUROPE CAN NO LONGER BE CONTROLLED THROUGH THE ACTIONS OF LOCAL ENVIRONMENTAL CONTROLLED THROUGH THE ACTIONS OF LOCAL ENVIRONMENTAL
PROTECTION GROUPS. INSTEAD IT IS NECESSARY TO CALL IM WORLDWIDE ENYIRONMENTAL PROTECTION MANAGEMENT TO KEEP THIS DEVELOPMENT WITHIN BOUNDARIES.

01172 BAILEY, $K$.

PROBLEMS WITH A CHEMICAL WEAPONS BAN

ORBIS, 36(2) (SPR 92), 239-252.

WITH THE PRESSURE MOUNTING FOR COMPLETION OF A CHEMICAL

WEAPONS CONVENTION (CWC) BY MAY 1992, THE DANGER EXISTS THAT GENEVA NEGOTIATORS WILL AGREE HASTILY ON A COSTLY BUT INEFFECTIVE VERIFICATION REGIME. THIS ARTICLE STUDIES: CHEMICAL AGENTS; THAT A BAN IS NOT VERIFIABLE; COSTS VERSUS BENEFITS; POLITICAL QUESTIONS; HHETHER DESERT STORM DISCREDITED CHEMICAL WEAPONS; THE POSSIBILITIES OF A BAN WITHOUT VERIFICATION; AND THE GENEYA PROTOCOL ALTERNATIVE. IT CONCLUOES THAT THE UNITED STATES IS LIKELYY TO CONTINUE ITS SUPPORT FOR A CHEMICAL WEAPONS BAN AND MUST CONTINUE TO MAINTAIN A STRONG CONVENTIONAL DETERRENT.

01173 BAILEY, $R$.

CAPTAIN PLANET FOR VEEP

NATIONAL REVIEW, XLIV(18) (SEP 92), 40,42-46.

FROM A REPUBLICAN PARTY PERSPECTIVE, THE AUTHOR LDOKS AT SENATOR AL GORE'S RECORD AND HIS VIEWS ON THE ENVIRONMENT AND ENDEAVORS TO ASSESS GORE'S IMPACT AS THE DEHOCRATIC VICEPRESIDENTIAL CANDIDATE IN THE 1992 ELECTION.

01174 BAINERMAN, J

ISRAEL: THE RUSSIANS ARE COMING

REASON, $23(8)$ (JAN 92$)$ 4 4-45.

FOR' INCREASING NUMBERS OF SOVIET IMMIGRANTS TO ISRAEL, THE FUTURE IS BLEAK. THE UNPRECEDENTED ARRIVAL OF THOUSANDS THE FUTURE IS BLEAK. THE UNPRECEDENTED ARRIVAL OF THOUSAMD OF IMMIGRANTS FROM THE SOVIET UNION HAS INVIGORATED THE
DEGBATE OVER WHETHER ISRAEL'S ECONOWY SHOULD BE DIRECTED BY GOVERNMENT PLANNERS OR BY THE FREE MARKET. THIS ARTICLE SUGGESTS THAT ISRAELI SOCIALISM HILL KEEP MANY SOVIET
IMMIGRANTS UNEMPLOYED AND HOMELESS. UNTIL IT IS UNDERSTOOD WHICH SYSTEM PROVIDES THE BEST INCENTIVES AND DISCIPLINE NECESSARY TO MAKE THE ECONOMY PRODUCTIVE AND EQUITABLE, ISRAEL'S ECONOMY WILL CONTUNUE TO FLOUNDER. THE SUCCESS OF SOVIET-JEWISH IMMIGRATION AND THE REFORM OF ISRAEL'S ECONOMIC SYSTEM ARE PART AND PARCEL OF THE SAME PROBLEM.

01175 BAINERMAN, J.

SHOCK TREATMENT

NATIONAL REVIEH, XLIY(7) (APR 92), 41-43.

ISRAEL'S ECONOMY HAS LONG BEEN IN DIRE NEED OF DRASTIC REFORM. SHOCK TREATMENT IS THE ONLY METHOD OF JOLTING ISRAELI POLITICIANS OUT OF THEIR DEPENDENCE. THIS ARTICLE SUGGESTS THAT THE U.S. SHOULD CUT ISRAEL'S YEARLY AID OF $\$ 3$ BILLION. AS LONG AS THE YEARLY OVERDRAFTS ARE MET BY FOREIGNERS, THE POLITICIANS WILL NEVER VOLUNTARILY RELEASE THEIR CONTROL OVER THE COUNTRY.

01176 BAINERMAN, J.

THE ECONOMIC ASPECTS OF SOVIET JEWISH IMMIGRATION TO ISRAEL MIDOLE EAST FOCUS, 13(2) (SUM 91), 12-14.

THE AUTHOR CONSIDERS THE SUCCESSFUL ABSORPTION BY ISRAEL OF THE EXTENSIVE WAVE OF JEWISH IMHIGRANTS FROM THE SOVIET UNION TO BE AN ECONOMIC, RATHER THAN AN IDEOLOGICAL (ZIONIST), ISSUE. PROBLEMS ASSOCIATED WITH THE CREATION OF ADEQUATE JOBS AND HOUSING IN THE CONTEXT OF ISRAEL'S WEAK ECONOMY ARE EXPLORED.

01177 BAIRD, D.

THE RELIGION THING: PRESSING CANDIDATES ON THEIR FAITH COLUMBIA JOURNALISM REVIEW, 31(3) (SEP 92), 53-54.

IN RECENT YEARS, THE CANDIDACIES OF JOHN F. KENNEDY, JIMMY CARTER, AND PAT ROBERTSON HAVE DEMONSTRATED THAT RELIGIOUS ISSUES CAN PLAY AN IMPORTANT ROLE IN PRESIDENTIAL ELECTION CAMPAIGNS. BUT OCCASIONAL PRESS COVERAGE OF RELIGIOUS CONFLICT OR CONTROVERSY DURING A CAMPAIGN IS NOT A SUBSTITUTE FOR STORIES THAT TRACE THE CONTOURS OF A CANDIDATE'S RELIGIOUS HERITAGE AND VALUES--AN EXERCISE THAT, THOUGH RARELY ATTEMPTED, CAN ADO AN IMPORTANT DIMENSION TO THE POLITICAL DIALOGUE.

01178 BAISSA, L.

THE OROMO AND THE QUEST FOR PEACE IN ETHIOPIA

TRANSAFRICA FORUM, $9(1)$ (SPR 92), 41-55.

BEFORE THEIR CONQUEST, THE OROMO WERE AN INDEPENDENT PEOPLE WITH AN INDIGENOUS SYSTEM OF DEMOCRATIC RULE. DURING THE CREATION OF THE ETHIOPIAN EMPIRE, THE OROMO WERE VICTIMIZED AMO CONOUERED. ATTEMPTS HERE MADE TO DEPRIVE THEM OF THEIR CULTURAL HERITAGE, TO EXCLUDE THEM FROM POLITICAL LIFE, AND TO SUBJUGATE THEM IN VARIOUS WAYS. THE OROMO RESPONDED TO THE DISCRIMINATION AND LAND EXPROPRIATION FIRST WITH PEACEFUL RESISTANCE AND THEN HITH ARMED STRUGGLE. THIS HAS LED TO INCREASED MILITARIZATION OF THE STATE--A SITUATION THAT ETHIOPIA CAN ILL AFFORD.

01179 BAJPAI, K.

INDIA IN 1991: NEH BEGINMINGS

ASIAN SURVEY, XXXII (2) (FEB 92), 207-216.

FOR INDIA, THE PROBLEMS OF GOVERNANCE, COMPOUNDED BY A FINANCIAL CRISIS LEADING TO FUNDAMENTAL CHANGES IN THE ECONOMY, DOMINATED THE THINKING AND ENERGIES OF THE COUNTRY THROUGHOUT 1991. AFTER THE ASSASSINATION OF CONGRESS PARTY LEADER RAJIY GANDHI, CONGRESS HENT ON TO WIN THE MATIONAL ELECTIONS, BUT WAS ABLE TO FORM ONLY A MINORITY GOVERNMENT. IN ORDER TO AVERT IMPENDING FINANCIAL CRISIS, PRIME MINISTER NARASIMHA RAO WAS FORCED TO ADOPT DRASTIC FREE MARKET REFORMS DEMANDED BY THE IMF. THE PREOCCUPATION WITH DOMESTIC AFFIARS MEANT THAT THERE WAS LITTLE RECONSIDERATION OF FOREIGN RELATIONS. TENSION WITH PAKISTAN OVER THE KASHMIR REGION AND HITH SRI LANKA OVER TREATMENT OF TAMIL MILITANTS IN THE NORTHERN PART OF THE ISLAND CONTINUED TO CLOUD INDIA'S RELATIONS WITH ITS NEIGHBORS. THE BREAK-UP OF THE SOVIET UNION PROMISES ECONOMIC PAIN FOR INDIA AND WILL LIKELY FORCE A MAJOR FORIEGN POLICY REORIENTATION IN THE NEAR FUTURE.

01180 BAKAN, J.; CAMERON, D. ; CREAN, S.; HOULE, F.; JACKSON, A.; JENSON, J.; JHAPPAN, R.; SMITH, M.

LOADING THÉ DICE: CONSTITUTIONALIZING THE TORY AGENDA CANADIAN FORUM, LXX(804) (NOV 91), 14-22. CANADA'S CONSERYATIVE GOVERMMENT'S 59-PAGE CONSTITUTIONAL PAPER, "SHAPING CANADA'S FUTURE TOGETHER: PROPOSALS" IS VERY MUCH A POLITICAL DOCUMENT. THERE IS PROPOSALS" IS VERY MUCH A POLITICAL DOCUMENT. THERE IS
SOMETHING IN IT FOR THE GROUPS THAT HAVE SUPPORTED THE SOMETHING IN IT FOR THE GROUPS THAT HAVE SUPPORTED THE
TORIES IN THE PAST AND THAT THEY HOPE WILL SUPPORT THEM IN TORIES IN THE PAST AND THAT THEY HOPE WILL SUPPORT THEM IN
THE FUTURE. THIS ARTICLE CONSIDERS VARIOUS ASPECTS OF THE THE FUTURE. THIS ARTICLE CONSIDERS VARIOUS ASPECTS OF THE
REFORM PROPOSAL INCLUDING THE PREAMBLE, PROPERTY RIGHTS, REFORM PROPOSAL INCLUDING THE PREAMBLE, PROPERTY RIGHTS,
DISTINCT SOCIETY, EOUALITY RIGHTS, CULTURE, ECONOMIC UNION, CONSTITUTIONAL DEMOCRACY, ABORIGINAL SELF-GOVERNMENT, AND INSTITUTIONAL REFORM AND DEMOCRATIZATION.

01181 BAKAR, 0.

SOUTHEAST ASIA IN 2042 WITH SPECIAL REFERENCE TO MALAYSIA'S 2020 VISION 
INTERMATIONAL SOCIAL SCIENCE REVIEH, 67(4) (FAL 92), 167-175.

THE AUTHOR OISCUSSES THE PROSPECTS FOR ASEAN

(ASSOCIATION OF SOUTHEAST ASIAN NATIONS) EVOLVING INTO A GLOBAL POWER WITHIN THE NEXT 50 YEARS. HE PREDICTS THAT ASEAN--WHICH PRESENTLY INCLUDES BRUNEI, MALAYSIA, INDONESIA, THE PHILIPPINES, SINGAPORE, AND THAILAND--WILL BECOME A LARGER ENTITY INCORPORATING VIETNAM, LAOS, KAMPUCHEA, AND POSSIBLY MYAMMAR. BY 2042, THIS ENLARGED ASEAN WILL EMERGE
AS A POWERFUL ECONOMIC UNION AND MOST LIKELY AS A POLITICAL FORCE AS HELL.

01182 BAKER. D; GAMBLE, A.; LUDLAM, S. MORE \&CLASSLESS' AND LESS \&THATCHERITE'? CONSERVATIVE MINISTERS AND NEW CONSERYATIVE MPS AFTER THE 1992 ELECTION PARLIAMENTARY AFFAIRS, 45(4) (OCT 92), 656-668.

THE POPULAR MEDIA IMAGE OF THE CONSERVATIVE PARTY UMDER JOHN MAJOR AFTER THE 1992 ELECTION IS OF A MORE MERITOCRATIC AND LESS THATCHERITE PARTY AND GOVERNMENT. IN THIS ARTICLE THE AUTHORS TEST BOTH ASSUMPTIONS. THEIR DATABASE ON CONSERVATIVE MPS AND MINISTERS HAS BEEN USED TO UPDATE THE EARL EARLEAL WORK OF BURCH AND MORAN ON BEE REVEALED IN THE 1979-1983 COHORTS OF NEH CONSERVATIVE MPS. IN ADDITION, THEY EMPLOY NDRTON'S TAXONOMY OF CONSERVATIVE MPS TO EVALUATE HOW
GOVERMMENT REMAINS.

01183 BAKER, H.H. JR.; FROST, E.L.

RESCUING THE U.S. - JAPAN ALLIANCE

OREIGN AFFAIRS, 71(2) (SPR 92), 97-113.

THE AUTHOR LOOKS AT RECENT DEVELOPMENTS IN U.S.-JAPANESE RELATIONS AND HOW THOSE RELATIONS COULD BE IMPROVED.

01184 BAKER, T.E.

WHY CONGRESS SHOULD REPEAL THE FEDERAL EMPLOYERS

LIABILITY ACT OF 1980

HARVARD JOURNAL OF LEGISLATION, 29(1) (WIN 92), 79-122.

THE 1908 FEDERAL EMPLOYERS' LIABILITY ACT (FELA)

ESTABLISHES A FAULT-BASED SYSTEM OF RECOVERY FOR RAILROAD EMPLOYEES SUFFERING WORKPLACE INJURIES. FELA REOUIRES THAT INJURED WORKERS SHOW THAT THEIR INJURIES ARE ATTRIBUTABLE, IN WHOLE OR IN PART, TO THE NEGLIGENCE OF OFFICERS, AGENTS OR EMPLOYEES OF THE RAILROAD IN ORDER TO BE COMPENSATED. IN THIS PAPER, THE AUTHOR ARGUES THAT THE SOCIETAL, INDUSTRIAL, AND LEGAL ENVIRONMENTS THAT WARRANTED FELA'S ENACTMENT IN 1908 DO NOT JUSTIFY THE STATUTE'S CONTINUED EXISTENCE TODAY. HE ARGUES THAT FELA FAILS WHEN MEASURED AGAINST THE HE ARGUES THAT FELA FAILS WHEN MEASURED AGAINST THE
CONTEMPORARY PUBLIC POLICY CRITERIA OF ENCOURAGING SAFETY, ASSURING JUST COMPENSATION AND REHABILITATION, PROVIDING ADMINISTRATIVE EFFICIENCY, AND PURSUING SOUND TRANSPORTATION ADMINISTRATIVE EFFICIENCY, AND PURSUING SOUND TRANSPORTATION POLICY. HE CONCLUDES THAT FELA SHOULD BE REPEALED AND THAT
RAILWAY EMPLOYEES' CLAIMS SHOULD BE SUBSUMED UNDER STATE RAILWAY EMPLOYEES' CLAIMS SHOUL
WORKERS' COMPENSATION STATUTES.

01185 BALAKRISHNAN, $N$.

RELIANT ON UHCLE SAM

SINGAPORE IS FORECASTING 5-7\% ANNUAL GDP GROHTH FOR 1992 THE LOH END OF THIS PREDICTION WOULD BE THE CITY-STATE'S WORST ECONOMIC SHOWING SINCE 1986, WHEN THE GDP ROSE 1.8\%. BUT PRIVATE SECTOR ECONOMISTS ARE TARGETING THE YEAR'S GROWTH AT 5.5\%, PERHAPS THE SAFER FORECAST IF THE U.S ECONOMY STAYS ON ITS SLOW COURSE TO RECOVERY. THE RECESSION IN THE UNITED STATES IS HAVING A STRONG EFFECT ON SINGAPORE, AS THE COUNTRY IS THE CITY-STATE'S LARGEST TRADING PARTNER. ONE OF THE MORE GLOOMY NOTES ABOUT SINGAPORE'S ECONOMY IN 1991 WAS THE SLOWDOWN OF THE INCREASINGLY IMPORTANT IMANCIAL SERVICES SECTOR. THE SECTOR WAS HURT BY REDUCED FOREIGN-BANK LENDING THAT RESULTED IN LOWER-THAN-EXPECTED GROWTH OF THE ASIAN DOLLAR MARKET.

01186 BALBI, M.; CAYCHO, V.; SAKUDA, A.

FUJIMORI DEFENDS THE SELF COUP

WORLD PRESS REVIEW, 39(7) (JUL 92), 16-17

IN THIS INTERVIEH, PERUVIAN PRESIDENT ALBERTO FUJIMORI

DEFENDS HIS ACTIONS WHEN HE SEIZED POWER AND DISMISSED THE CONGRESS ON APRIL 5, 1992. HE ALSO DISCUSSES HIS PLANS FOR THE FUTURE.

01187 BALCOM, J.

INTERPRETATIONS IN CONFLICT

FREE CHINA REYIEH 42(2) (FEB 92), 48-55

THIS IS AN ABRIDGED TRANSCRIPT OF A DISCUSSION BY SEVERAL TAIWANESE EXPERTS ON THE BUSH ADMINISTRATION'S FOREIGN POLICY REGARDING COMMUNIST CHINA AND HOW IT IS LIKELY TO IMPACT TAIWAN.

01188 BALDIA, C.

ASSESSING FISCAL STRAIN DIFFERENCES BETHEEN FORMS OF MUNICIPAL GOVERNMENT

MICHIGAN JOURNAL OF POLITICAL SCIENCE, 15(15) (FAL 92), 37-63.

THE AUTHOR INVESTIGATES WHETHER THE MODERN COUNCIL-

MANAGER FORM OF GOVERNMENT IS BETTER ABLE TO MANAGE THE
PROBLEMS FACED BY MUNICIPAL GOVERMMENTS THAN THE TRADITIONAL MAJOR-COUNCIL MODEL. AFTER DISCUSSING BOTH SYSTEMS OF GOVERMMENT, HE ANALYZES THE EFFECTIVENESS OF EACH MODEL. TO DO THIS, HE USES URBAN FISCAL STRAIN AS THE PRIMARY INDICATOR OF THE MODEL'S EFFICIENCY. HE RELIES ON THIS INDICATOR TO DRAW CONCLUSIONS ABOUT THE COMPARATIVE ABILITY OF EACH MODEL TO SUCCESSFULLY CONTROL DEBT.

01189 BALFOUR, $F$.

MEXICAN STAND-OFF

FAR EASTERN ECONOMIC REVIEN, 155(30) (JUL 92), 54-55. WHEN MEXICO BEGAN NEGOTIATIING THE NORTH AMERICAN FREE TRADE AGREEMENT (NAFTA) WITH THE UNITED STATES AND CANADA, IT HAD HIGH HOPES THAT ASIAN, ESPECIALLY JAPANESE, INVESTORS WOULD RUSH TO MEXICO TO TAKE ADVANTAGE OF THE PROSPECT OF DUTY-FREE ACCESS TO ITS NORTHERN NEIGHBORS. HOWEVER, THE ASIAN RESPONSE, WITH THE EXCEPTION OF THAT OF SOUTH KOREA, HAS BEEN SLOW AND DISAPPOINTING TO MEXICAN PRESIDENT CARLOS SALINAS DE GOTARI. HE AND HIS ELITE CORPS OF FOREIGNEDUCATED TECHNOCRATS HAVE YET TO CONVINCE JAPAN AND OTHER NATIONS OF THE WORLD THAT MEXICO HAS SHED ITS PROTECTIONIST COCOON, AND THAT THE COUNTRY IS ABLE TO OVERCOME THE PROBLEMS POSED BY INFRASTRUCTURE AND POOR QUALITY SUPPLIERS. THE FEH JAPANESE COMPANIES THAT HAVE INVESTED IN MEXICO HAVE DONE SO WITH AN EYE ON THE LONG-TERM FUTURE PROSPECT OF MEXICO AS A MARKET IN ITS OWN RIGHT, NOT AS A GATEWAY TO THE MEXICO AS A MARKET IN ITS OWN RIGHT, NOT AS A GATENAY TO THE SIOHED TO A TRICKLE AND NOW AMDUNTS TO LESS THAN $\%$ OF ITS TOTAL FOREIGN INVESTMENT.

01190 BALL, C.

VENEZUELA: FRACAS IN CARACAS

REASON, 24 (5) FRACAS IN CARACAS

THE PEOPLE OF VENEZUELA ARE TIRED OF THEIR GOVERMMENT'S

INABILITY OR UNHILLINGNESS TO COMBAT STREET CRIME, REMEDY

MUSHROOMING BUREAUCRATIC SORRUPTION, IMPROVE HORENDOUS

PUBLIC SERVICES, OR BRING ORDER TO THE COURTS. THE COUNTRY

NEEDED A LUDWIG ERHARD, A MARGARET THATCHER, OR A VACLAV

KLAUS. INSTEAD IT GOT AN DOD MINESTRONE OF PARTY COMRADES,

KENNESIAN ACADEMICS, AND YOUNG TECHNOCRATS WITH SUCCESSFUI

EXPERIENCE IN THE PRIVATE SECTOR. VENEZUELA HAS BEEN TURNED

INTO A SOCIALIST NIGHTMARE OF PRICE CONTROLS, IMPORT

SUBSTITUTIONS, AND PROTECTIOHISM. CARLOS BALL CONCLUDES THAT IF POLITICIANS KEEP INSISTING ON PUTTING THE CART BEFORE THE HORSE, CONDITIONS WILL NOT IMPROVE.

01191 BALL, H.

GOVERMMENT FAILURE TO TAKE DUE CARE IN A RISKY TECHNOLOGY AND THE QUESTION OF REDRESS

PUBLIC ADMINISTRATION REVIEW, 52(3) (MAY 92), 281-287.

THE POST-HORLD WAR II WORK OF THE ATOMIC ENERGY

COMMISSION IN PRODUCING AND TESTING NUCLEAR WEAPONS WAS

COMMISSION IN PRODUCING AND TESTING NUCLEAR WEAPONS WAS

GIVEN A "OISCRETIONARY FUNCTION" EXCEPTION UNDER THE FEDERAL

TORT CLAIMS ACT. A MAJOR TEST OF THAT EXCEPTION CAME IN 1981, MINING COMPANIES AND THE U.S. GOVERNMENT, CLAIMING THE

MINING COMPANIES AND THE U.S. GOVERNMENT, CLAIMING THE

MINERS SHOULD HAVE BEEN WARNED ABOUT RADIATION HAZARDS.
WHILE THE CASE AGAINST THE MINING COMPANIES WAS SETTLED OUT

OF COURT, THE CASE AGAINST THE FEDERAL GOVERNMENT HAS

DISMISSED UNDER PROVISIONS OF THE FEDERAL TORT CLAIMS ACT

EXCEPTION FOR THE EXERCISE OF AGENCY DISCRETION. IN SUCH

CASES, THE ONLY RECOURSE IS CONGRESSIONAL RELIEF.

01192 BALL, W.; LEUTHOLD, D.

ESTIMATING THE LIKELIHOOD OF AN UNPOPULAR VERDICT IN THE

ELECTORAL COLLEGE

PUBLIC CHOICE, 70(2) (MAY 91), 215-224.

THE AUTHORS OF THIS PAPER USE HISTORICAL DATA TO

ESTIMATE THE PROBABILITY THAT A PRESIDENTIAL CANDIDATE COULD

WIN THE POPULAR VOTE AND SUBSEQUENTLY LOSE IN THE ELECTORAL

COLLEGE (A DIVIDED VERDICT). THEY REPLICATE THE MODEL

CONSTRUCTED BY MERRILL (1987), AND IMPROVE ITS ROBUSTNESS BY

REPLACING THE NORMAL DISTRIBUTIION WITH THE BETA DISTRIBUTION,

AND BY EXTENDING THE HISTORICAL TIME PERIOD TO 19880-1984.

THE CHANGES INDICATE GREATER INEFFICIENCY FOR THE DEMOCRATIC

PARTY, WHICH HAS MORE LIKELY TO HAVE UNNECESSARILY LARGE

MAJORITIES IN PARTICULAR (SOUTHERM) STATES. DYHAMIC PARTY

REALIGNMENTS HAVE DECREASED THE PROBABILITY OF DIVIDED

VERDICTS IN MODERATELY CLOSE ELECTIONS.

01193 8ALLECK, B.J.

WHEN THE ENDS JUSTIFY THE MEANS: THOMAS JEFFERSON AND THE LOUISIANA PURCHASE

PRESIDENTIAL STUDIES QUARTERLY, XXII(4) (FAL 92), 679-696. ARESIDENTIAL STUDIES QUARTERLY, XXII(4) (FAL 92) $679-696$.
ALTHOUGH THOMAS JEFFERSON PERCEIVED THE U.S. PRESIDENCY ALTHOUGH THOMAS JEFFERSON PERCEIVED THE U.S. PRESIDENCY

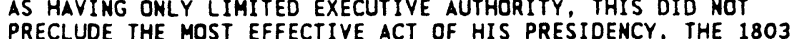
PRECLUDE THE MOST EFFECTIVE ACT OF HIS PRESIDENCY, THE 1803 LOUISIANA PURCHASE, WHICH EXTENDED THE AMERICAN WESTERN

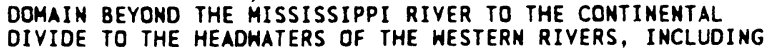
DIVIDE TO THE HEADWATERS OF THE WESTERN RIVERS, INCLUDING THE MISSOURI, FLOWING THEREIN. A LIFE-LONG FRIEND OF FRANCE AND FOE OF BRITAIN, HE WAS PLEASED THAT THIS PURCHASE FROM NATION'S BEST INTERESTS DEMANDED THE EXTENSION OF THE EMPIRE 
FOR LIBERTY." YET HE WAS MORE VILIFIED THAN PRAISED FOR HIS ACTION.

01194 BALLOCH, H.; ANGELL, D.

FOREIGN POLICY PLANNING AND COORDINATION IN CANADA: THE POLICY PLANKING STAFF AT EXTERNAL AFFAIRS

CANADIAN PUBLIC ADMINISTRATION, 35(4) (WIN 92), 449-463.

THE AUTHORS VIEW CANADIAN POLICY PLANNING FROM THE PERSPECTIVE OF PRACTITIONERS AND COMPARE THE EVOLUTION OF POLICY PLANNING WITH THE PLANNING STAFFS' ORIGINAL OBJECTIVES. THEY CONTRAST THE PRACTICE OF POLICY PLANNING AT EXTERNAL AFFAIRS WITH POL ICY PLANHING THEORY AND ARGUE THAT
THE POLICY PLANNERS' CONTRIBUTION TO THE POLICY PROCESS LIES LESS IN FORECASTING AND MORE IN POLICY INTEGRATION,

CHALLENGING EXISTING POLICY, DEVELOPING NEW INITIATIVES, AND

SERVING THE DEPARTMENT'S POLICY-MAKING MACHINERY.

01195 BALOYRA, E.

SALVAGING EL SALVADOR

JOURNAL OF DEMOCRACY 3(2) (APR 92), 70-80.

IN ORDER TO JUDGE' WHETHER THE AGREEMENTS OF DECEMBER

1991, RATIFIED IN MEXICO CITY IN JANUARY 1992, ARE LIKELY TO FORM AN ENDURING BASIS FOR THE CONSOL IDATION OF DEMOCRACY IN EL SALVADOR, IT IS NECESSARY TO REVIEW THE SOCIOHISTORICAL ANO GEOPOLITICAL CHANGES THAT HAVE TAKEN PLACE SINCE THE DUAL CRISIS OF CIVIL HAR AND POLITICAL TRANSITION BEGAN IN 1979. THIS ARTICLE EXPLORES: THE TRANSITION AND CIVIL WAR; THE MOVE TOWARD NEGOTIATION; PROMISING STEPS TOWARD DEMOCRACY; AND, THE LESSONS FOR THE SALVADORAN CASE. IT CONCLUDES THAT THE APPROACH OF TRANSITION ANALYSIS ACCURATELY DIAGNOSES WHAT WAS HAPPENING IN EL SALVADOR AS AN ATTEMPTED REGIME TRANSTION IN THE MIDST OF A CIVIL WAR, AND THAT THIS ANALYSIS PROVIDES A USEFUL AND REALISTIC FRAMEWORK FOR EVALUATING THE SITUATION.

01196 BALQAZIZ, A.

THE ARABS, THE US AND SOMALIA:

MIDDLE EAST INTERNATIONAL, 440(440) (DEC 92), 21-22. THE UN DECISION TO SEND TROOPS TO SOMALIA TO END THE GRINDING INTERNAL CONFLICT THERE HAS DANGERIOUS IMPLICATIONS AND UNMISTAKABLE CONSEQUENCES. IT IS APPARENT THAT NEH CONSIDERATIONS AND NEEDS HAVE ARISEN IN THE HORN OF AFRICA AND THE SOUTHERN ENTRANCE TO THE RED SEA HHICH, AS FAR AS WASHINGTON IS CONCERNED, ARE COMPELLING ENOUGH TO WARRANT INTERVENTION DURING THE DYING DAYS OF A REPUBLICAN ADMINISTRATION. THE MOST IMPORTANT OF THESE HAVE BEEN THE ADMINISTRATION. THE MOST IMPORTANT OF THESE HAVE BEEN THE
CHANGES IN SUDAN AND ITS POLITICAL ORIENTATION, FOLLOWED BY CHANGES IN SUDAN AND ITS POLITICAL ORIENTATI
IRAN'S INTENSIFIED ACTIVITY IN THE REGION.

01197 BANAC, I

THE FEARFUL ASYMMETRY OF WAR: THE CAUSES AND CONSEQUENCES DF YUGOSLAVIA'S DEMISE

DAEDALUS, $121(2)$ (SPR 92), 141-174.

THE AUTHOR REVIEWS THE RECENT HISTORY OF YUGOSLAVIA TO

EXPLAIN THE ORIGINS OF THE PRESENT CIVIL WAR.

01198 BAMASZAK, L.; LEIGHLEY, J.

HOW EMPLOYMENT AFFECTS WOMEN'S GENDER ATIITUDES: THE WORKPLACE AS A LOCUS OF CONTEXTUAL EFFECTS

POLITICAL GEOGRAPHY OUARTERLY, 10(2) (APR 91), 174-185.

THIS PAPER EXPLORES HOW WOMEN'S EMPLOYMENT' CONTEXT

AFFECTS THEIR ATTITUDES TOWARDS THE HOMEN'S MOVEMENT. THE

AUTHORS EXAMINE THREE MECHANISMS WHICH MIGHT ACCOUNT FOR THE

RELATIONSHIP BETWEEN EMPLOYMENT AND GENDER ATTITUDES: THE

SOCIAL STATUS OF SOME OCCUPATIONS PROVIDES SPECIFIC BENEFITS

WHICH CAUSE WOMEN TO ADOPT MORE NON-TRADITI IONAL ATTI ITUDES;

EMPLOYMENT EXPERIENCES SUCH AS ENTERING THE WORKFORCE AND

WORKING IN A NON-TRADITIONAL OCCUPATION INCREASE FEMINIST

ATTITUDES; AND SOCIAL NETWORKS AND CONTEXT ACQUIRED THROUGH EMPLOYMENT ALTER TRADITIONAL SEX-ROLE ATTITUDES. A

REGRESSION ANALYSIS OF SURVEY DATA FROM SOUGHT BEND, INDIANA,

FINDS THAT EXPERIENCES IN MALEDOMINATED JOBS AND SOCIAL NETHORKS WITH EMPLOYED WOMEN SIGNIFICANTLY INCREASE SUPPORT FOR THE HOMEN'S MOVEMENT.

01199 BANDOW, D.

A NEW KOREA POLICY FOR A CHANGED HORLD

KOREAN JOURNAL OF DEFENSE ANALYSIS, IV(2) (WIN 92),

259-278.

THE CDLLAPSE OF THE USSR AND THE END OF THE COLD WAR PROVIDES AMERICA WITH A UNIQUE CHANCE TO REASSESS ITS ROLE IN THE WORLD AND THE CHANGES ON THE KOREAN PENINSULA HAVE PROVIDED BOTH THE U.S. AND SOUTH KOREA HITH AN IMPORTANT OPPORTUNITY TO REDUCE TENSIONS WITH THE NORTH. THIS ARTICLE ARGUES THAT THE SIGNS OF CHANGE IN NORTH KOREA ARE ARGUES THAT THE SIGNS OF CHANGE IN NORTH KOREA ARE
SIGNIFICANT ENOUGH TO HARRANT NEW INITIATIVES ON THE PART OF SIGNIFICANT ENOUGH TO WARRANT NEW INITIATIVES ON THE PART OF PRONGED INITIATIVE TO OFFER THE NORTH CARROTS AS HELL AS PRONGED INITIATIVE TO OFFER THE NORTH CARROTS AS WELL AS REDUCED. SECOND, THE UNITED STATES AND SOUTH KOREA SHOULD REDUCED. SECOND, THE UNITED STATES AND SOUTH KOREA SHOUL OFFER NEW PROPOSALS TO ADVANCE NEGOTIATIONS DESIGNED TO
REDUCE NUCLEAR HEAPONS. THIRD, SEOUL AND HASHINGTON SHOULD REDUCE NUCLEAR WEAPONS. THIRD, SEOUL AND WASHINGTON SHO
PRESS FOR SERIDUS TALKS ON CONVENTIONAL ARMS REDUCTION. FOURTH, WESTERN POWERS SHOULD EXPANO BOTH ECONOMIC AND
POLITICAL TIES WITH PYONGYANG. FINALLY, BOTH AMERICA AND THE SOUTH SHOULD END RESTRICTIONS ON PRIVATE CONTACTS WITH THE NORTH.

01200 BANDOW, $D$.

AVOIDING WAR

FOREIGN POLICY, (89) (WIN 93), 156-174.

THE COLLAPSE OF THE SOVIET UNION AND END OF THE COLD WAR ARE FORCING A LONG-OVERDUE REEVALUATION OF U.S. SECURITY POLICY. TRADITIONAL CONTAINMENT IS DEAD, AND THE SEARCH FOR A REPLACEMENT IS ON. THE QUESTION IS WHETHER THE UNITED STATES SHOULD MOVE FROM COLLECTIVE DEFENSE, WHICH IS DIRECTED AT A SPECIFIC AGGRESSOR, TO COLLECTIVE SECURITY, WHICH IN PRINCIPLE IS DIRECTED AGAINST ALL UNNAMED AGGRESSORS WHO VIOLATE INTERNATIONAL NORMS. SOME WHO FAVOR THIS STEP WANT TO UPDATE AMERICA'S COLD WAR ALLIANCES, PARTICULARLY NATO, FOR THE POST-COLD WAR WORLD. OTHERS WOULD GARTICULARLY NATO, FOR THE POST-COLD WAR WORLD. OTHERS WOULD GRANT THE UNITED NATIONS MORE AUTHORITY TO MOUNT MILITARY
OPERATIONS AGAINST AGGRESSORS AND PERHAPS SETTLE CIVIL WARS.

01201 BANDOW, $D$.

SOUNDING THE RETREAT

FAR EASTERN ECONOMIC REVIEN, 155(13) (APR 92), 31

DESPITE CONGRESSIONAL PRESSURE TO PARE MILITARY SPENDING, THE BUSH ADMINISTRATION SEEMS COMMITTED TO KEEPING SIGNIFICANT MILITARY FORCES IN SOUTH KOREA, JAPAN--AND EVEN THE PHILIPPINES IF MANILA CHANGES ITS MIND ON HOSTING U.S. BASES. HOWEVER, THE UNDERLYING RATIONALE FOR A U.S. MILITARY PRESENCE IN EAST ASIA-CCONTAINMENT--HAS LOST ITS APPEAL. IN A WHIRLWIND THREE YEARS, THE SOVIET UNION AND ITS EAST EUROPEAN ALLIES HAVE COLLAPSED AND THE ASIAN COMMUNIST STATES HAVE GROWN INCREASINGLY WEAK. THE PACIFIC IS LIKELY TO ONLY GROW IN IMPORTANCE TO THE UNITED STATES IN THE COMING YEARS. HOWEVER, THIS MAKES IT EVEN MORE ESSENTIAL FOR WASHINGTON TO REDUCE THE MILITARY BURDEN ON THE COUNTRY'S ECONOHY, NOT LEAST BECAUSE A HIGH LEVEL OF DEFENSE SPENDING WILL PLACE A CONTINUING BURDEN ON U.S. FIRHS AND JEOPARDIZE THEIR EFFORTS TO COMPETE IN--AND WITH--THE REGION.

01202 BANKS, J.; WEINGAST, B

THE POLITICAL CONTROL OF BUREAUCRACIES UNDER ASYMMETRIC INFORMATION

AMERICAN JOURNAL OF POLITICAL SCIENCE, 36(2) (MAY 92), 509-524.

THE AUTHORS OF THIS ARTICLE ANALYZE A MODEL OF INTEREST GROUP INFLUENCE WHERE THIS INFLUENCE ARISES FROM A GROUP'S ABILITY TO PROVIDE RELEVANT INFORMATION TO POLITICAL ACTORS ABOUT REGULATORY PERFORMANCE. THE MODEL RESTS ON THREE PREMISES: (1) BUREAUCRATS POSESS AN INFORMATIONAL ADVANTAGE, VIS-A-VIS THEIR POLITICAL OVERSEERS, CONCERNING POLICY RELEVANT VARIABLES; (2) THIS INFORMATIONAL ADYANTAGE IS
POTENTIALLY EXPLOITABLE BY THE AGENCY; AND (3) POLITICIANS POTENTIALLY EXPLOITABLE BY THE AGENCY; AND (3) POLITICIANS
ANTICIPATE THIS EXPLOITATION AND ADAPT TO IT IN THEIR DESIGN ANTICIPATE THIS EXPLOITATION AND ADAPT TO IT IN THEIR DESIGN OF AGENCIES. THE AUTHORS SHOW THAT A MAJOR CONSEQUENCE OF
THIS ANTICIPATION IS SERVICE TO ORGANIZED INTEREST GROUPS.

01203 BANTING, K.

NEOCONSERVATISM IN AN OPEN ECONOHY: THE SOCIAL ROLE OF THE CANADIAN STATE

INTERNATIONAL POLITICAL SCIENCE REVIEW, 13(2) (APR 92), 149-170

THE IMPACT OF NEOCONSERVATIVE IDEAS HAS VARIED CONSIDERABLY AMONG WESTERN NATIONS. THIS PAPER EXAMINES SOME OF THE FACTORS AT WORK BY EXPLORING CANADIAN EXPERIENCE. FEDERAL LEVEL AND IN SEVERAL PROVINCES, THE CONSEQUENCES FOR SOCIAL POLICY HAVE BEEN MORE LIMITED THAN ELSEWHERE. THE REASONS FOR THIS PATTERN ARE EMBEODED IN DISTINCTIVE FEATURES OF THE POLITICAL ECONOMY OF THE CANADIAN WELFARE STATE. THE INTENSITY OF LINGUISTIC AND REGIONAL DIVISIONS WITHIN THE FRAGILE FEDERAL SYSTEM, AND THE COUNTRY'S CONSTRAIN A RADICAL NEOCONSERVATIVE AGENDA.

01204 BAOSEN, C.

A CHINESE VIEH OF BUSH'S ASIA-PACIFIC TOUR

BEIJING REVIEK, 35(8) (FEB 92), 32-34.

THE U.S. PRESIDENT, GEORGE BUSH'S, VISIT TO AUSTRALIA, SINGAPORE, SOUTH KOREA AND JAPAN IN 1992 OCCURRED DURING A TIME WHEN THE COLD WAR CURTAIN HAD DISAPPEARED AND THE AMERICAN DOMESTIC ECONOMY CONTINUED TO FACE A DEEP RECESSION. THIS ARTICLE SUGGESTS THAT BUSH HAS MADE SEVERAL BLUNDERS. THIS ARTICLE SUGGESTS THAT BUSH HAS MADE SEVERAL BLUNDERS.
ONE, THAT HE HAS PAID MORE ATTENTION TO FOREIGN AFFAIRS THAN ONE, THAT HE HAS PAID MORE ATTENTION TO FOREIGN AFFAIRS THAN DOMESTIC ONES; AND ANOTHER, THAT HE HAS NEGLECTED ASIA. IT YLCOUM LEFT BY THE DISAPPEARANCE OF THE BI-POLAR POL ITICAL AND ECONOMIC SYSTEM, AND HAS HON THE FIRST ROUND IN THE COMPETITON FOR THE LEADING ECONOMIC ROLE IN ASIA.

01205 BAOTHE, G.

SLOVENIA FACES THE FUTURE

CONTEMPORARY REVIEW, 260(1516) (MAY 92), 229-232.

SLOVENIA PROCLAIMED ITS INDEPENDENCE ON JUNE 25,199

AND THIS EVENT MARKED AN END TO THE FIRST STAGE OF THE 
PAINFUL PROCESS OF YUGOSLAY DISINTEGRATION. THERE IS HOPE THAT ENOUGH POTENTIAL IS HIDDEN IN THE SLOVENES WHICH WILL HELP A YOUNG DEMOCRACY STAND ON ITS OWN FEET AND WILL ENCOURAGE CREATIVE FORCES IN THE ECONOMIC SPHERE TO PULL THE COUNTRY OUT OF RECESSION. THIS ARTICLE SUGGESTS THAT FOREIGN CAPITAL INVESTMENTS COULD BE OF GREAT HELP IN THE REVIVAL OF THE SLOVENE ECONOMY. IIT CAN BE EXPECTED THAT AFTER DIPLOMATIC RECOGNITION OF SLOVENIA, SLOVENIA'S POLITICAL RISKS WILL BE CONSIDERABLY REDUCED. PRODUCTION QUALITY, INNOVATIONS, BETTER DELIVERY TERMS AND CONSIDERABLE REDUCTION OF COSTS ARE THE ELEMENTS WHICH SLOVENE COMPANIES WILL NEED IN THEIR FUTURE BATTLES FOR FOREIGN MARKETS.

01206 BAOZHONG, D.

MALAYSIA PROMOTES SOUTH-SOUTH COOPERATION

BEI JING REVIEW, 35(2) (JAN 92) 14-15.

THE AUTHOR LOOKS AT MALAYSIA'S ROLE IN ASIA AND THE INTERNATIONAL COMMUNITY AS IT PURSUES A FOREIGN POLICY AIMED

AT PROMOTING SOUTH-SOUTH COOPERATION.

01207 BAR-ILLAN, D.

WHY LIKUD LOST--AND WHO WOH

COMMENTARY, $94(2)$ (AUG 92), 27-30.

HAD ISRAEL VOTED ITS POCXETBOOK IN THE JUNE 23 ELECTIONS,

HAD ISRAEL VOTED ITS POCKETBOOK IN THE JUNE 23 ELECTIONS
IHE LIKUD PARTY, LED BY YITZHAK SHAMIR, WOULD HAVE WON

THE LIKUD PARTY, LED BY YITZHAK SHAMIR, WOULD HAVE WON

EASILY. THE FACT WAS THAT THE ISRAELI ECONOMY HAD MADE
REMARKABLE PROGRESS IH THE SIX YEARS OF SHAMIR'S PREMIERSHIP

REMARKABLE PROGRESS IN THE SIX YEARS OF SHAMIR'S PREMIERSH
IN SPITE OF THIS. THE CONVENTIONAL WIDSOM WAS THAT THE ECONOMY WAS IN A HOPELESS CONDITION AND THAT THE ABSORPTION ECONOMY WAS IN A HOPELESS CONDITION AND THAT THE ABSORPTIC EFFORT WAS A TOTAL DISASTER. RATHER THAN DEFENDING ITS POLICIES, LIKUD CONCENTRATED INSTEAD ON TRYING TO SMEAR
LABOR'S CANDIDATE, YITZHAK RABIN. THE TWO DECISIVE FACTORS LABOR'S CANDIDATE, YITZHAK RABIN. THE THO DECISIVE FACTOR IN THE LIKUD DEFEAT HAD LITTLE TO DO WITH ECONOMIC AND DEFENSE POLICIES OR INTERNAL BICKERING. THE MOST TELLING
BLOW TO LIKUD WAS OF ITS OWN CREATION. THE PEOPLE'S TRUST THAT RABIN ENJOYED AS DEFENSE MINISTER UNDER SHAMIR WAS WHAT DEFEATED LIKUD. LIKUD WAS BEATEN NOT BY LABOR BUT BY ONE MAN- AND A MAN FOR THE CREATION OF WHOSE FAVORABLE IMAGE IT HAD ITSELF LARGELY BEEN RESPONSIBLE.

01208 BARAL, L.

INDIA-NEPAL RELATIONS: CONTINUITY AND CHANGE

ASIAN SURVEY, XXXII(9) (SEP 92), 815-829.

THE RELATIONS BETWEEN INDIA AND NEPAL HAVE BEEN LARGELY DETERMINED BY UNCHANGING GEOGRAPHICAL FEATURES BUT ALSO BY SHIFTING GEOSTRATEGIC CONSIDERATIONS. THIS ARTICLE CONSIDERS THIS CONTINUITY AMD CHAMGE WITHIN THE PARAMETERS SET BY THIS CONTINUITY AND CHANGE WITHIN THE PARAMETERS SET BY
NATURE, HISTORY, ECONOMY, SOCIETY, CULTURE, AND CHANGING NATURE, HISTORY, ECONOMY, SOCIETY, CULTURE, AND CHANGING
SITUATIONS, BOTH NATIONAL AND INTERNATIONAL. IT FOCUSES ON SITUATIONS, BOTH NATIONAL AND INTERNATIONAL. IT FOCUSE THE FOLLOWING ASPECTS: THE STRUCTURE OF INDIA-NEPAL
RELATIONS, THE ENVIRONMENT, NATIONAL AND TRANSNATIONAL RELATIONS, THE ENVIRONMENT, NATIONAL AND TRANSNATIONAL ACTORS, FOCUS, AND THE QUESTION OF RELATIONS AS USUAL.
EMPHASIS IS PLACED ON THE IMPLICATIONS OF THE WIDE-RANGING CHANGES THAT HAVE SWEPT THROUGH NEPAL IN RECENT YEARS.

01209 BARAM, A.

ISRAELI DETERRENCE, IRAQI RESPONSES

ORBIS, $36(3)$ ( SUM 92), 397-410.

THE SIMGLE MOST IMPORTANT CONSEQUENCE OF ISRAEL'S

MILITARY INACTION DURING THE GULF HAR IS IRAQ'S BELIEF THAT

IT HAS REMOVED A PSYCHOLOGICAL BARRIER OF FEAR FROM THE ARAB SIDE, WHILE INSTILLING FEAR IN ISRAEL FOR THE FIRST TIME SINCE ISRAEL'S INCEPTION. THIS ARTICLE EXPLORES THE FAILURE AND SUCCESS OF ISRAELI DETERRENCE, AND PRESENTS THE CASE AGAINST SADDAM'S RATIONALITY. IT CONCLUDES THAT AS LONG AS THE ARAB-ISRAEL I AND ISLAMIC-ISRAEL CONFLICT IS ACUTE, A NUCLEAR BALANCE OF TERROR IN THE MIDDLE EAST IS BOUND 'TO INCREASE INSTABILITY AND THAT THIS REALIZATION SHOULD SERVE AS A POHERFUL INCENTIVE FOR THE INTERNAT IONAL COMMUNITY TO DO ITS UTMOST TO PREVENT NUCLEAR PROLIFERATION IN THE MIDOLE EAST.

01210 BARAM, A.

TERRITORIAL NATIONALISM IN THE ARAB WORLD

MIDDLE EASTERN STUDIES, 26(4) (OCT 90) $425-448$

THIS ARTICLE EXAMINES TWO OFTEN OPPOSING TRENDS IN THE MIDDLE EAST: PAN-ARABISM AND TERRITORIAL NATIONALISM. IT CONSIDERS THE EXPERIENCE OF IRAQ, SYRIA, EGYPT, JORDAN, AND THE MAGHREB THROUGHOUT THIS CENTURY. IT CHRONICLES THE CULTURAL AND SOMETIMES POL ITICAL "REAHAKENING" OF NATIONS TO THEIR PRE-ISLAM AND (IN SOME CASES) PRE-ARAB PAST. THESE THEIR PRE-ISLAM AND (IN SOME CASES) PRE-ARAB PAST. THESE
ATTEMPTS TO FOSTER A NATIOMAL IDENTITY RUM COUNTER TO THE ATTEMPTS TO FOSTER A NATIONAL IDENTITY RUN COUNT

01211 BARAM, $H$

A JUBILANT SHAMIR GETS WHAT HE WANTEO

MIDOLE EAST INTERNATIONAL, (405) (JUL 91), 3

ISRAELI PRIME MIHISTER, YITZHAK SHAMIR, WAS ABLE TO SECURE TREMENDCUS ARAB, ESPECIALLY SYRIAN CONCESSIONS ON THE ISSUE OF ARAB-ISRAELI PEACE NEGOTIATIONS WITHOUT EVEN MAKING A TOKEN GESTURE TO HIS TRADITIONAL FOES. IN ADDITION, HE MANAGED TO SUPPORT AMERICAN DEMANDS FOR PROGRESS TOWARDS PEACE WITHOUT ALIENATING HIS RIGHT-WING COALITION PARTHERS.
OPEMING OF AN INTERMATIONAL CONFEREMCE ON PEACE IN THE REGION, FOLLONED BY BILATERAL TALKS BETWEEN ISRAEL AND EACH OF ITS ARAB NEIGHBORS. IN ADOITION SHAMIR HAS GIVEN WIDE RANGING AUTHORITY TO DETERMIME THE MEMBERSHIP OF ANY PALESTINIAN DELEGATION TO THE TALKS.

01212 BARAM, $H$

ISRAEL--GLEEFUL AND UNASHAMED

MIDDLE EAST INTERNATIONAL, (419) (FEB 92), 4-5

BOTH THE ISRAELI DEFENSE FORCE (IDF) AMD ISRAEL'S SURROGATE SOUTH LEBANON ARMY (SLA) ARE BRACING THEMSELVES TO DEAL WITH HIZBULLAH'S EXPECTED RETALIATION FOR THE KILLING OF ITS LEADER, SHAIKH ABBAS MUSAWI, ON 16 FEBRUARY. HOWEVER, WAS JUBILANT ABOUT THE ASSASSINATION. HE CLAIMED THAT ISRAEL HAS "DELIVERED A MESSAGE TO ALL TERRORIST ORGANIZATIONS." SOME SEE THE ATTACK AND THE RESULTING CELEBRATION IN ISRAEL AS AIMED AT PLO LEADER YASIR ARAFAT. HOWEVER, A GROWING MINORITY IN ISRAEL IS BEGINNING TO QUESTION THE MORALITY AND VALIDITY OF THE USE OF VIOLENCE IM ANY FORM.

01213 BARAM, H.

ISRAEL: SHAMIR IN HIGH SPIRITS

MIDDLE EAST INTERNATIONAL, 417 (JAN 92), 8

THE PRINCIPAL REASON FOR SHAMIR'S HIGH SPIRITS AND MORALE HAS NOTHING TO DO WITH THE ECONOMY OR THE THE INTERNATIONAL SITUATION. THE WANING PEACE PROCESS IS THE SOURCE OF PLEASURE FOR THE ISRAELI LEADER. SHIMON PERES OFFERED TOUGH AND TRUE TALK IN SUGGESTING THAT THE PARTY SUPPORT THE HALTING OF THE PEACE TALKS WHICH GAVE SHAMIR IDEAL AMMUNITION FOR THE COMING ELECTIONS. LIKUD WILL DEPICT ITSELF AS THE TRUE CENTRE PARTY ABANDONED BY THE LUNATIC RIGHT AND BESIEGED BY THE UNPATRIOTIC LEFT.

01214 BARAM, $\mathrm{H}$.

SHAMIR TRIUMPHANT

MIDOLE EAST INTERMATIONAL, (418) (FEB 92), 6-7.
ISRAELI PRIME MINISTER YITZHAK SHAMIR INCREASED HIS RULING LIKUD PARTY'S ELECTION PROSPECTS WITH HIS BEHAVIOR DURING THE PEACE MEGOTIATIONS. SHAMIR HAS SUCCESSFUL IN MAINTAINING ISRAEL'S POSITIONS IN THE TALKS. HE HARNESSED THE AMERICANS INTO HIS POLICIES, AND HAS MANAGED TO HOLD THE SO-CALLED PEACE TALKS IN MADRID, WASHINGTON AND MOSCOW, WITH EVER-WIDENING PARTICIPATION OF NEH, FORMERLY HOSTILE ENTITIES, AMD PAID ABSOLUTELY NOTHING FOR IT. SHAMIR CURTAILED AHD MANIPULATED THE PALESTIMIAN LEADERSHIP. HE HAS CONTINUED HIS MASSIVE SETTLEMENT DRIVE IN THE OCCUPIED TERRITORIES. SHAMIR'S OPPOSITION, THE LABOR PARTY, HILL

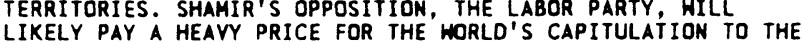
LIKELY PAY A HEAVY PRICE FOR THE WORLD'S CAPITULATION TO KNESSET WHICH HILL BE HELD ON 23 JUNE.

01215 BARANY, Z.D

EAST EUROPEAN ARMED FORCES IN TRANSITIONS AND BEYOND EAST EUROPEAN QUARTERLY, XXVI(1) (SPR 92), 1-30.

THE AUTHOR SETS OUT TO ACCOMPLISH THREE OBJECTIVES. FIRST, IN ORDER TO APPRECIATE THE ROLE OF THE MILITARY FORCES IN THE RECENT TRANSITIONS WITHIN THE NON-SOVIET WARSAW PACT (NSWP), HE BRIEFLY DISCUSSES THEIR TRACK RECORDS IN TIMES OF DOMESTIC POLITICAL UPHEAVAL DURING THE COMHUNIS PERIOD. SECONDLY, HE ANALYZES THE PERFORMANCE OF THE NSWP ARMIES IN THE 1989 TRANSITIONS AND EXPLAINS THE DISCREPANCIES IN THEIR BEHAVIOR. FINALLY, HE ASSESSES THE ACCOMPLI ISHMENTS AND FAILURES OF THE EAST EUROPEAN STATES IN THE DEMOCRATIZATION AND DEPOLITICIZATION OF THEIR ARMED FORCES SINCE THE REGIME CHANGES OF 1990-91.

01216 BARASH, D.P

THE L WORD

HILLIAM MORROH \& COMPANY, 1992, 223.

THIS BOOK PARTIALLY EXPLORES THE EVOLUTION OF LIBERALISM SINCE ITS EUROPEAN GENESIS, AND EXPLAINS WHY THE IDEOLOGY HAS BEEN MALIGNED IN 2OTH CENTURY AMERICA. IT HIGHLIGHTS LIBERAL DOMESTIC AND FOREIGN POLICY ACHIEVEMENTS IN AMERICAN HISTORY, AND CONTRASTS THEM WITH CONSERVATIVE FAILURES. THE EMPHASIS OF THE WORK IS ON RECENT AMERICAN HISTORY AND ON WHY LIBERALISH AS A THEORY, AND DEMOCRATIC POLITICIANS AS ACTORS, ARE ACCEPTED LOCALLY, YET REJECTED NATIONALLY. THE AUTHOR ARGUES THAT DEMOCRATS ANO LIBERALS IN AMERICA DO NOT NEED TO CHANGE THEMSELVES TO BE MORE CONSERVATIVE, INSTEAD, NEED TO CHANGE THEMSELVES TO BE MORE CONSERVATIVE, INST
THEY SHOULD SIMPLY FIGHT REPUBLICAN AND CONSERVATIVE THEY SHOULD SIMPLY FIGHT REPUBLICAN AND CONSERYATIVE
PROPAGANDA WITH THE TRUTH OF LIBERALISH'S ACCOMPLISHMENTS PROPAGANDA WITH THE TRUTH OF LIBERALISM'S ACCOMPLISHMENTS. THE AUTHOR'S DISCUSSION OF IBERALISM'S ACHIEVEMENTS CDVER ALL IMPORTANT NATIONAL ISSUES: CRIME,
POLICY, EDUCATION AND THE ENVIRONMENT.

01217 BARBER, J TROUBLED ZIMBABWE

WORLD TODAY, 48(6) (JUN 92), 94-95.

ZIMBABWE' IS SUFFERING THROUGH THE WORST DROUGHT IN LIVING MEMORY. THE PROSPECTS ARE BLEAK, EVEN THOUGH IT IS RECEIVING HELP FROM FOREIGN DONORS AND FROM AFRICAN NEIGHBORS, SUCH AS ZAMBIA AND SOUTH AFRICA. CRITICS ASSERT 
THAT ZIMBABWE'S PROBLEMS ARE PARTIALLY SELF-IMPOSED AND THAT THE FAILURE OF SOCIALIST POLICIES LED TO THE ECONOMIC STRUCTURAL ADJUSTMENT PROGRAMME, WHICH IS EXACERBATING THE NATURAL HARDSHIPS. THEY ACCUSE THE GOVERNMENT OF MISGUIDED POLICIES, OF ECONOMIC INCOMPETENCE, AND OF CONDONING CORRUPTION AMONG POLITICAL LEADERS AND OFFICIALS.

01218 BARBER, L.

A NEW HORLD ORDER: THE VIEH FROM AMERICA

EUROPE, (304) (MAR 91), 6-8.

THE CREATION OF A NEH INTERNATIONAL ORDER NOW RANKS AS A U.S. OBJECTIVE IN THE GULF ALONGSIDE MORE IMAEDIATE POSTWAR GOALS HOHEVER, A CLOSE EXAMINATION OF U.S. RHETORIC DOESN'T REVEAL MUCH MORE TO THE MEH WORLD ORDER THAN AN EMPHASIS ON REVEAL MUCH MORE TO THE NEH WORLD ORDER THAN AN EMPHASIS OM COLLECTIVE SECURITY ARRANGEMENTS. AN ALTERNATIVE DEFINIT AMERICAH LEADERSHIP AND AMERICAN STRENGTH. IT IS FAR FROM AMERICAN LEADERSHIP, AND AMERICAN STRENGTH. IT IS FAR CLEAR WHETHER THE REST OF THE NORLD SHARES THAT VIEK. REMAINS HILLING TO PLAY A SUPERPOHER ROLE IN WORLO AFFAIRS.

01219 BARBER, $L$.

INTEGRATION VS. DISINTEGRATION: TWIN CHALLENGES FACING EUROPE

EUROPE, 315 (APR 92), 6-9

STICKING TO A VISION OF A EUROPE BASED ON THELVE WEST EUROPEAN NATIONS IS NO LDHGER VIABLE. THE END OF THE COLD WAR HAS OFFERED THE WEST AN HISTORIC OPPORTUNITY AND ALSO AN HISTORIC CONTRADICTION: AT THE VERY MOMENT WHEN WESTERN EUROPEAN NATIONS ARE PRESSING AHEAD WITH GREATER ECONOMIC AND POLITICAL INTEGRATION, THE FORCES OF DISINTEGRATION ARE GATHERING PACE IN EASTERN EUROPE, FROM YUGOSLAVIA TO THE REPUBLICS OF THE FORMER SOVIET UNION. THIS ARTICLE EXPLORES HOW TO RECONCILE THESE CONFLICTING TRENDS--INTEGRATION AND OISINTEGRATION--AND CONCLUDES THAT THIS WILL MOST LIKELY BE THE E.C.' 'S GREATEST CHALLENGE IN THE COMING DECADES.

01220 BARBER, L.

THE ARMS RACE IN REVERSE

EUROPE, (311) (NOV 91), 6-9.

PRESIDENT GEORGE BUSH'S NUCLEAR ARMS CONTROL OFFER MARKS THE FIRST SIGNIFICANT RESPONSE FROM THE WEST TO THE FAILURE OF THE KREMLIN PUTSCH AGAINST PRESIDENT MIKHAIL GORBACHEV OF THE KREMLIN PUTSCH AGAINST PRESIDENT MIKHAIL GORBACHE POLITICAL LEADERSHIP IN MOSCOW. COVERING AIR-, LAND-. AND POLITICAL LEADERSHIP IN MOSCOW. COVERING AIR-, LAND-, AND SEA-BASED NUCLEAR SYSTEMS, THE U.S. INITIATIVE COMBINED UNILATERAL CUTS IN KARHEADS NITH PROPOSALS FOR NEGOTIATED REDUCTIONS IN U.S. AND SOVIET ARSENALS. BUSH, OFTEN ACCUSED OF LACKING VISION, SUODENLY FOUND HIMSELF ACCLAIMED FOR SETTING IN MOTION THE MOST IMPORTANT CHANGES TO U.S. NATIONAL SECURITY AND NUCLEAR POSTURE IN 40 YEARS. THE BUSH PROPOSAL IS AN INDICATION THAT BUSH HAS REALIZED THAT THE SECOND RUSSIAN REVOLUTION RENDERED THE TRADITIONAL PLOODING METHODS OF ARMS CONTROL IRRELEVANT.

01221 BARBIER, H.

G7 SUMMIT HORKS ON A DEAL FOR MOSCOW

GERMAN TRIBUNE, (1476) (JUL 91), 1-2.

SOVIET PRESIDENT MIKHAIL GORBACHEY PRESENTED TO THE G7 SUMMIT OF THE WORLD'S MAJOR INDUSTRIALIZED NATIONS IN LONDON HIS REQUEST FOR HELP FOR THE SOVIET ECONOMY. GERMANY'S CHANCELLOR KOHL, WHO IS STRONGLY BACKING GORBACHEV, SAID THE SOVIET UNION COULD EXPECT TECHNICAL ASSISTANCE AND EASIER TRADE CONDITIONS BUT NOT BILLIONS OF DOLLARS IN CASH. ONE OF THE MOST DIVISIVE ISSUES SURROUNDING GORBACHEV'S APPEAL WAS WHETHER THE INDUSTRIALIZED STATES SHOULD AID THE MORE REFORMMINDED REPUBLICS, OR CONTINUE TO SUPPORT THE POLITICALLY VACILLATING CENTRAL GOVERNMENT.

01222 BARDI, L.

ITALY'

EUROPEAN JOURNAL OF POLITICAL RESEARCH, 22(4) (DEC 92), 449-460.

AS OF JANUARY 1, 1991, THE CHRISTIAN DEMOCRATS WERE IN THE MAJORITY IN ITALY'S PARLIAMENTARY CHAMBERS AND IN PRIME MINISTER ANDREOTTI'S CABINET. ALSO REPRESENTED WERE THE SOCIALIST, REPUBL ICAN, SOCIAL DEMOCRATIC, AND LIBERAL PARTIES.

01223 BARDOS, G.N.

THE SERBIAN CHURCH AGAINST MILOSEVIC

RFE/RL RESEARCH REPORT 1 (31) (JUL 92 ) $8-13$

THE SERBIAN ORTHODOX CHURCH HAS BECOME AN OPEN OPPONENT OF THE GOVERMMENT OF PRESIDENT SLOBODAN MILOSEVIC AND, IN OF THE GOVERNMENT OF PRESIDENT SLOBODAN MILOSEVIC AND, IN DOING SO, HAS JOINED FORCES WITH OTHER OPPOSITION GROUPS TRYING TO OUST THE PRESIDENT. AS A RESULT, IT RISKS DAMAG THE POSITION IT HAS HITHERTO TRIED TO FOSTER: THAT OF A NEUTRAL, NONPARTISAN INSTITUTION WHOSE ONLY INTEREST IS THE GENERAL GOOO OF THE ENTIRE SERBIAN NATION. THE CHURCH'S NEW POLITICAL ROLE MAY PRON
MILOSEVIC COALITION.

01224 BARHOUM, K.

THE WAR'S MESSAGE NEEDS TO BE ADDRESSED
MIODLE EAST INTERNATIONAL, (395) (MAR 91), 22.

THE U.S. AND IT HESTERN ALLIES CANNOT ESCAPE THE REALITY THAT THE FESTERING PALESTINIAN-ISRAELI PROBLEM IS A MAJOR POLITICAL COMPONENT OF THE MIDDLE EAST LANDSCAPE THAT MUST BE DEALT WITH IF PEACE IS EVER TO PREVAIL IN THAT TROUBLED REGION. ALTHOUGH FEW PEOPLE BELIEVE THAT IRAQ ACTUALLY INVADED KUWAIT TO LIBERATE PALESTINE, IT HAS NEVERTHELESS BECOME ABUNDANTLY CLEAR THAT THE ISSUES RAISED BY SADDAM HUSSEIN (ESPECIALLY LINKAGE WITH ISRAEL'S OCCUPATION OF ARAB LAND) HAVE GAINED ACCEPTANCE BY A MAJORITY OF THE WORLD'S ONE BILLION MUSLIMS. UNFORTUMATELY, THE U.S. HAS APPARENTLY SIGNALED TO ARABS THAT A MEH HORLO OROERS MEANS MORE OF HHAT THEY HAVE COME TO DEEPLY RESENT: A STATUS QUD REPLETE WITH SOCIAL POL ITICAL AMD ECOMOMIC UM JUSTICES-OSO FAR ALL CONDONED, CONSOLIDATED AND PROTECTED BY THE WEST.

01225 BARKAN, J. (ED.); GORDON, D. (ED.) BEYOND CAPITALISM AND SOCIALISH IN KENYA AND TANZANIA BEYOND CAPITALISM AND SOCIALISH IN
LYNNE RIENNER PUBLISHERS, $1992,240$.

FOR NEARLY THENTY YEARS, KENYA AND TANZANIA WERE REGARDED AS PARADIGMS OF CAPITALIST AND SOCIALIST DEVELOPMENT IN AFRICA AND WERE COMPARED FREQUENTLY TO DETERMINE WHICH MODEL WAS MOST APPROPRIATE FOR THE CONTINENT AND OTHER POST-COLONIAL SOCIETIES. THE EXPERIENCE OF THE $1980 S$, HOWEVER, SUGGESTS THAT IT IS THE COMMON STRUCTURAL FEATURES OF THESE TWO COUNTRIES AND THE COMMON CHALLENGES THEY FACE--RAPID POPULATION GROWTH, SLUGGISH AGRICULTURAL SECTORS, THE OVERDEVELOPMENT OF THE STATE, THE POLITICS OF SUCCESSION, MOUNTING EXTERNAL DEBT AND STRUCTURAL ADJUSTMENT-THAT MOST DETERMINE THEIR PROSPECTS FOR DEVELOPMENT. IN THIS BOOK, EIGHT LEADING SPECIALISTS ON EAST AFRICA CONSIDER HOW EACH COUNTRY HAS RESPONDED TO THESE COMMON CHALLENGES BY MODIFYING ITS ORIGINAL APPROACH TO DEVELOPMENT

01226 BARKDOLL, G.L.

SCOPING VERSUS COPING: DEVELOPING A COMPREHENSIVE AGENCY VISION

PUBLIC ADMINISTRATION REVIEW, 52(4) (JUL 92), 330-338.

THROUGH A "SCOPING INITIATIVE" BEGUN IN 1989, THE U.S. FOOD AND ORUG ADMINISTRATION DEVELOPED A COMPREHENSIVE AND ANALYTIC VISION OF THE AGENCY'S FUTURE AND THE FORCES THAT WOULD SHAPE IT. THE RESULT HAS BEEN A MDOEST ENHANCEMENT OF THE BUDGETING PROCESS AS WELL AS A LONG-RANGE STRATEGIC PLAN FOR THE AGENCY. IN THIS ARTICLE, THE AUTHOR REVIEWS BOTH THE POSITIVE AND THE NEGA
SCOPING INITIATIVE.

01227 BARKER, $R$.

CIVIL DISOBEDIENCE AS PERSUASION: DHORKIN AND GREENHAM COMMON

POLITICAL STUDIES, XL(2) (JUN 92), 290-298.

PROTESTS AGAINST NUCLEAR WEAPONS HICH INVOLVE CONFLICT WITH THE LAW HAVE BEEN CRITICIZED AS "BLACKMAIL" OR OBSTRUCTION BY RONALD DHORKIN AND HENCE NOT AS AN ACCEPTABLE FORM OF CIVIL DISOBEDIENCE. THIS IS TO MISUNDERSTAND BOTH THEIR NATURE AND THAT OF CIVIL DISOBEDIENCE. SUCH PROTESTS ARE AN EXAMPLE OF A PARTICULAR KIND OF PERSUASIVE CIVIL DISOBEDIENCE WHICH CANNOT BE DISALLONED WITHOUT DISALLOHING CIVIL DISOBEDIENCE ITSELF.

01228 BARKER, $R$.

LEGITIMACY IN THE UNITED KINGDOM: SCOTLAND AND THE POLL TAX BRITISH JOURNAL OF POLITICAL SCIENCE, 22(4) (OCT 92),

521-533.

THE COMMUNITY CHARge haS beEN DESCRIBED AS "THE fLAGSHIP OF THATCHERISM." IT HAS ALSO THE ISSUE THAT, TOGETHER WITH EUROPEAN UNITY, BROUGHT THE PRIME MINISTER'S VOYAGE TO AN END AND SET HER ADRIFT AS A POLITICAL CAPTAIN BLIGH WHILE HER CABINET AND PARLIAMENTARY CREW SAILED ON WITHOUT HER. ALTHOUGH THE PROSPECT OF ELECTORAL DISASTER WAS THE MOST IMMEDIATE AND OBVIOUS POLITICAL EFFECT OF THE POLL TAX, ITS IMMEDIATE AND OBVIOUS POLITICAL EFFECT OF THE POLL TAX, LASTING CONSEQUENCES.

01229 BARLETT, D.; SOLMAN, P.; STEELE, J.

DUMB QUESTIONS, SMART QUESTIONS

COLUMBIA JOURNAL ISH REVIEK, 30(6) (MAR 92), 28-32.

DUE TO A LINGERING RECESSION AND THE GROWING PERCEPTION AMONG AMERICANS THAT THEIR COUNTRY SUFFERS FROM SOME SERIOUS AMONG AMERICANS THAT THEIR COUNTRY SUFFERS FROM SOME SERIOUS
DISEASE, ECONOMIC POL ICY BECAME THE CENTERPIECE OF THE 1992 DISEASE, ECONOMIC POLICY BECAME THE CENTERPIECE OF THE
PRESIDENTIAL ELECTION CAMPAIGN. IN THIS ARTICLE, THREE PRESIDENTIAL ELECTION CAMPAIGN. IN THIS ARTICLE, THREE
REPORTERS DISCUSS HOW BEST TO COVER ECONOMIC ISSUES AS PART OF A POLITICAL CAMPAIGN.

01230 BARNARD, B.

CURRENCY CHAOS

EUROPE, (320) (OCT 92), 10-13.

THE EUROPEAN COMMUNITY IS FIGHTING HARD TO SALVAGE ITS GRAND DESIGN FOR POLITICAL AND MONETARY UNION. THE TURBULENT CURRENCY CRISIS THAT ENGULFED THE COMMUNITY IN MID-SEPTEMBER 1992, STRAINING THE EUROPEAN MONETARY SYSTEM, HAS LED TO A REASSESSMENT AMONG GOVERNMENTAL AND FINANCIAL LEADERS IN E.C. COUNTRIES. ALTHOUGH THE FINANCIAL TURMOIL EASED AS SPECULATORS RAN OUT OF CURRENCIES TO MAUL. IT LEFT BEHIND A 
TRAIL OF ANGER AND RECRIMINATION.

01231 BARNARD, $B$

GOING TO MARKET

EUROPE, (314) (MAR 92), 6-7.

THE EUROPEAN COMMUNITY IS FACING ONE OF ITS TOUGHEST CHALLENGES EVER AS ITS EAST EUROPEAN NEIGHBORS ATTEMPT AN UNPRECEDENTED MOVE FROM A COMMUNIST PLANNED ECONOMY TO A MARKET ECONOMY. THE COMMUNITY IS ALREADY DEEPLY INVOLVED IN HELPING EASTERN AND CENTRAL EUROPE'S TRANSITION TO CAPITALISM THROUGH A MIXTURE OF FINANCIAL AID PACKAGES, TECHMICAL ASSISTANCE AND TRADE AGREEMENTS. THE EC HAS TAKEN OVERALL CHARGE OF THE WEST'S ASSISTANCE TO EASTERN AND CENTRAL EUROPE THROUGH ITS COORDINATION OF THE SO-CALLED GROUP OF 24. THE COMMUNITY ALSO PLAYED A PIONEERING ROLE IN ESTABLISHING THE EUROPEAN BANK FOR RECONSTRUCTION AND DEVELOPMENT (EBRD). BUT THE SHEER SCALE OF ECONOMIC AND POL ITICAL TRANSFORMATION MEANS THAT THE EC HILL HAVE TO DEEPEM ITS AMMITHATION MEANS THAT THE EC WILL HAVE TO THE THE REST OF THE DECADE. BRUSSELS WILL BE DISTRACTED BY OTHER
EVENTS, NOT LEAST THE ECONOMIC RESCUE OF THE FORMER SOVIET EVENTS.

01232 BARNARD, P.

ARMING SADDAM HUSSEIN: A WASHINGTON COVER-UP

ARMING SADDAM HUSSEIN: A HASHING

THE HOUSE BANKING COMMITTEE' 'S INVESTIGATION INTO THE BANCA NAZIONALE DEL LAVORO (BNL) AFFAIR HAS REVEALED THAT, FOR MORE THAN FIVE YEARS, LARGE AMOUNTS OF U.S. TAX MONEY WERE MISAPPROPRIATED TO HELP ARM SADDAM HUSSEIN. MOREOVER, THE INQUIRY HAS RAISED SERIOUS QUESTIONS CONCERNING THE POSSIBLE INVOLVEMENT OF THE BUSH ADMINISTRATION.

01233 BARNARD, $P$

THE BURDENSOME COSTS OF "VICTORY": THE MORLD THAT CAME IN FROM THE COLD WAR

COMMONWEAL, CXIX(1) (JAN 92), 9-11.

PRESIDENT BUSH'S PROCLAMATION OF A NEW WORLD ORDER ATTEMPTED TO ENCAPSULATE THE MASSIVE CHANGE SWEEPING THE GLOVE AND TO PUT THE UNITED STATES IN A POSITION OF ACTIVELY LEADING THIS HISTORICAL TRANSFORMATION. THIS ARTICLE EXPLORES WHY THE ANHOUNCEMENT OF A MEH AGE SEEMS TENUDUS EVEN HOLLOW. IT SUGGESTS THAT THE UNITED STATES FINDS ITSELF IN A RADICALLY DIFFERENT ECONOMIC POSITION FROM THE ONE WHICH IT OCCUPIED IN EITHER 1920 OR 1050. IT CONCLUDES THAT WE ARE IN THE FOURTH PERIOD OF GREAT CHANGE, AND THAT SO FAR IT HAS ALL THE CHARACTERISTICS OF AN INTERREGNUM, RATHER THAN A REALLY NEH ERA.

01234 BARNDS, W.J.

ASIA: PROGRESS, STALEMATES, AMD A SETBACK

FREEDOM REVIEH, 23(1) (JAN 92) 36-40

THE AUTHOR SURVEYS THE PROGRESS TOHARD DEMOCRACY AND IMPROVED HUMAN RIGHTS IN ASIA IM 1991. HE ALSO LOOKS AT THE STALEMATES AND SETBACXS IN A REGION THAT HAS UNDERGONE PROFOUND CHAHGES IN THE PAST FEH YEARS.

01235 BARNES, $F$.

AL GORE'S CAMPAIGN MAKEOVER: WHAT IT TAKES

NEW REPUBLIC, 207 (17) (OCT 92 ), 22-24

AS AN ENVIRONMENTAL EVANGELIST, SENATOR AL GORE MAY THRILL THE SIERRA CLUB AND FRIENDS OF THE EARTH, BUT HE WON'T WIN MANY ELECTIONS. HE'S BOLD IN THE EXTREME, POL ITICALLY INDISCREET, AND INCLINED TO BE A SCOLDINTOLERANT OF HIS CRITICS, HIS OPPONENTS, AND EVEN HIMSELF AT TIMES. BUT CANDIDATE GORE IS DRAMATICALLY DIFFERENT--A KIND OF CONVENTIONAL, UNREFLECTIVE TWIN BROTHER OF THE INTENSE "REAL" GORE. ON THE CAMPAIGN TRAIL, HE'S CAUTIOUS AND UNSHERVINGLY MAINSTREAM.

01236 BARNES, $F$.

BASIC INSTINCT

NEW REPUBLIC, 206(17) (APR 92), 12, 14-15

ALTHOUGH BILL CLINTON IS EAGER TO CURRY FAVOR WITH PRACTICALLY EVERYONE IN HIS RACE FOR THE DEMOCRATIC NOMINATION FOR PRESIDENT, THERE IS A LIMIT. HE HAS BEEN CAREFUL NOT TO COMPROMISÉ HIMSELF BY ENDORSING THE AGENDA OF EVERY DEMOCRATIC INTEREST GROUP. CLINTON RECOGNIZES THAT PAST DEMOCRATIC PRESIDENTIAL MOMINEES HAVE CATERED TO LIBERAL GROUPS AND HAVE SUFFERED WITH THE GENERAL ELECTORATE FOR HAVING EMBRACED TOO MANY SPECIFIC LIBERAL POSITIONS.

01237 BARNES, $F$.

BELTHAY FOR HIRE

BELTWAY FOR HIRE
NEW REPUBLIC, $206(26)$ (JUN 92), 11-13.

H. ROSS PEROT HAS HIRED ED ROLLIII. REPUBLICAN CAMPAIGN STRATEGIST, TO HEI P MANAGE HIS THIRDPARTY CAMPAIGN FOR THE PRESIDENCY. BUT ROLLINS IS ONE OF THE FEH TO SIGN ON WITH PEROT BECAUSE MOST HASHINGTON INSIDERS ARE TIED TOO CLOSELY TO THE DEMOCRATIC OR REPUBLICAN PARTY.

01238 BARNES, $F$.

CHURCHILL SYNDROME

NEH REPUBLIC, 207 (18) (OCT 92), 12, 14.
PRESIDENT GEORGE BUSH'S EFFORTS TO CAPITALIZE ON HIS FOREIGM POL ICY SUCCESSES IN THE COLD WAR AND DESERT STORM ARE BEING THWARTED BY VOTER APATHY. HE IS SUFFERING FROM THE CHURCHILL EFFECT, THE TENDENCY OF VOTERS TO TUNE OUT WARTIME LEADERS OMCE THE WAR'S OVER. BECAUSE WINSTON CHURCHILL AND THE TORIES DIDN'T ADJUST TO THE POSTWAR WORLD SOON ENOUGH, THEY LOST IN A LANDSLIDE IN 1945

01239 BARNES, $F$.

COOL HAND BILL

NEW REPUBLIC, 207(21) (NOV 92), 12-13.

THE AUTHOR PROFILES PRESIDENTIAL CANDIDATE BILL CLINTON AND DISCUSSES THE ARKANSAS GOVERNOR'S CALM, COOL APPROACH TO CAMPAIGNING.

01240 BARNES, F.

NEH REPUBLIC,

206(6) (FEB 92), 10-11.

THE AUTHOR EXAMINES THE ASSUMPTIONS PRESIDENT GEORGE BUSH AND HIS ADVISERS ARE RELYING ON AS THEY PLAN HIS 1992 RE-ELECTION CAMPAIGN.

01241 BARNES, $F$.

HALF-BAKERED

NEH REPUBLIC, 207(7) (AUG 92), 10-12.

JAMES BAKER WILL HAVE HIS WORK CUT OUT FOR HIM WHEN HE MOVES FROM THE STATE DEPARTMENT TO THE WHITE HOUSE TO MANAGE GEORGE BUSH'S REELECTION CAMPAIGN. HE MUST TAKE CHARGE OF BUSH AS HELL AS THE CAMPAIGN. DISCIPLINED, FOCUSED, TASKORIENTED IN THE FIRST 33 MONTHS
LOST CONTROL IN THE LAST NINE.

01242 BARNES, $F$. HEIR APPARENT

NEW REPUBLIC, 206(13) (MAR 92), 20-22.

PAT BUCHANAN'S BID FOR THE REPUBLICAN PRESIDENTIAL NOMINATION HAS DIVIDED THE CONSERVATIVE WING OF THE PARTY, SPLITTING IT INTO THREE CAMPS. ONE GROUP, INCLUDING NEOCONSERVATIVES AND THOSE PLOTTING PRESIDENTIAL RACES FOR THEMSELVES IN 1996, ARE STICKING WITH BUSH. ANOTHER GROUP HAS BALKED AT ENDORSING BUCHANAN PUBLICLY BUT IS PRIVATELY CHEERING HIS ATTACKS ON BUSH. THE THIRD FACTION OPENLY SUPPORTS BUCHANAM.

01243 BARNES, F.

INSURRECTIOH

NEW REPUBLIC, 206(25) (JUN 92), 12-13.

THE AUTHOR CONTRASTS VICE PRESIDENT DAN QUAYLE'S BRASH, CONTROVERSIAL STYLE OF CAMPAIGHING WITH WHAT SEEMS TO BE A MEN TIMIDITY ON PRESIDENT GEDRGE BUSH'S PART SEUSH SEEMS TO BE WILLING TO LET QUAYLE BLAZE THE TRAIL ON ISSUES LIKE BE WILLING TO

01244 BARNES, $F$

JUST FINE

NEW REPUBLIC, 207(10) (AUG 92), 15-16, 18.

PRESIDENT' GEORGE BUSH IS OFF TO A SLOH START ON HIS REELECTION CAMPAIGN BECAUSE HE LOATHES POLITICS. BEING PRESIDENT ENERGIZES HIM; BEING A CANDIDATE DOESN'T. TO BUSH, THE CAMPAIGM TRAIL IS THE LOW ROAD.

01245 BARNES, $F$.

KEMP VS. DOLE

NEW REPUBLIC, 207(24) (DEC 92), 14, 16-17.

THE REAL SPLIT IN THE CLINTON-ERA REPUBLICAN PARTY WILL BE BETWEEN THE DOLE WING AND THE KEMP WING--A DIVISION THAT HAS BEEN DEVELOPING FOR YEARS. THE BIGGEST DISAGREEMENT BETWEEN THE SUPPORTERS OF ROBERT DOLE AND JACK KEMP INVOLYES ECONOMIC ISSUES. DOLE IS A DEFICIT HAWK WHILE KEMP IS A SUPPLY-SIDE ADVOCATE OF TAX CUTS. FOR THE NEXT YEAR OR SO, THE DOLE AND KEMP WINGS WILL PROBABLY CONCENTRATE ON OPPOSING PRESIDENT CLINTON RATHER THAN ONE ANOTHER. BUT BY 1994. AS THEY LOOK FORWARD TO THE NEXT PRESIDENTIAL CAMPAIGN, THEY'LL CLASH OPENLY.

01246 BARNES, $F$.

LAST CALL

NEW REPUBLIC, 207 (27) (DEC 92), 11-13.

PRESIDENT GEORGE BUSH HAS CONYINCED TO SEND U.S. TROOPS

TO ALLEVIATE THE SUFFERING IN SOMALIA AFTER HE RECEIVED A

LETTER FROM U.N. SECRETARY-GENERAL BOUTROS BOUTROS-GHALI

DETAILING HOH DESPERATE THE SITUATION REALLY HAS.

01247 BARNES, $F$.

LOGJAM
NEW REPUBLIC, 206(19) (MAY 92), 10-11

THE BUSH HHITE HOUSE IS DOMINATED BY INERTIA, DITHERING,

CYNICISM, AND FEAR OF FAILURE AMONG THE PRESIDENT'S SENIOR

AIDES AND CABINET. IT IS NO WONDER THAT BUSH IS HAVING

TROUBLE PACKAGING A COHERENT DOMESTIC PROGRAM THAT APPEALS

TO THE AMERICAN PEOPLE.

01248 BARHES, $F$.

LOSER 
NEW REPUBLIC, 206 (18) (MAY 92), 19-21.

AS THE 1992 DEMOCRATIC PRESIDENTIAL NOMINEE, BILL CLINTON WILL BE DOGGED BY PROBLEMS IN FOUR SEPARATE AREAS: THE CHARACTER ISSUE, VOTER TURNOUT. THE SOUTH, AND FOREIGN POLICY.

01249 BARNES, F.

NEW REPUBLIC, 207 (15) (OCT 92), 10-11. STRATEGY TO DEFEAT GOVERNOR BILL CLINTON AND WIN RE-ELECTION TO THE HHITE HOUSE.

01250 BARNES, $F$.

MAJORITY COMPLEX

MEW REPUBLIC, $207(11-12$ ) (SEP 92), 12, 14

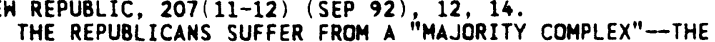

BEL IEF THAT HAYING A REPUBLICAN IN THE WHITE HOUSE IS A

BELIEF THAT HAVING A REPUBLICAN IN THE WHITE HOUSE IS A PERMANENT FACT OF NATURE. DEMOCRATS MAY CONTROL CONGRESS, BUT THERE'S A SETTLED ELECTORAL MAJORITY IN FAVOR PRESIDENTS. THE TRICK IS ACTIVATING THAT MAJORITY. REPUBLICANS ONLY HAVE TO TOU
GENERALLY CONSERVATIVE ONES.

01251 BARNES, $F$.

NO TRUMAN

NEW REPUBLIC, $207(14$ ) (SEP 92), 9-10.

TOGETHER, THE BUSH-REAGAN FORCES PRODUCED THREE

CAMPAIGNS (1980, 1984, AND 1988) WITH IDEOLOGICAL INTENSITY AND AN APPEAL TO A BROAD BASE, FROM CONSERVATIVES TO REAGA

DEMOCRATS AND INDEPENDENTS. IN 1992, THE REAGANITES ARE GONE, AND IT SHOWS. THE 1992 CAMPAIGN, LIKE BUSH, HAS NO IDEOLOGICAL CENTER. BUSH TAKES HIS BEARINGS FROM CLINTON, AND COUNTERPUNCHING CLINTON TAKES PRECEDENCE OVER SELLING A POSITIVE IMAGE OF HIMSELF. A GOOD EXAKPLE IS BUSH'S

INSISTENCE ON COMPARING HIMSELF TO HARRY S. TRUMAN.

01252 BARNES, $F$.

NO WOMB FOR DEBATE

MEW REPUBLIC 207 (5) (JUL 92), 36, 38

NEW REPUBLIC, 207 (5) (JUL 92), 36 , 38 .

OFFICIALLY PRO-CHOICE FOR THO DECADES. SINCE 1989, WHEN THE

SUPREME COURT'S WEBSTER DECISION ALLOWED RESTRICTIONS ON A

SUPREME COURT'S WEBSTER DECISION ALLOWED RESTRICTIONS ON

ISSUE HIGHER PRIORITY. THIS RAISES QUESTIONS ABOUT THE ROLE

OF ANTI-ABORTION DEMOCRATS, SUCH AS GOVERNOR CASEY OF

OF ANTI-ABORTION DEMOCRATS,
PENNSYLVANIA, IN THE PARTY.

01253 BARNES, $F$.

PANIC MODE

NEW REPUBLIC, 206 (8) (FEB 92), 8-9.

PRESIDENT GEORGE BUSH'S STATE OF THE UNION ADDRESS WAS

HASTILY REWRITIEN BEFORE IT WAS DELIVERED ON JANUARY 28 ,

1992, WITH AN EYE TOWARD THE UPCOMING PRIMARY ELECTIONS AND

KEEPING THE CONSERVATIVE WING OF THE REPUBLICAN PARTY IN BUSH'S CORNER.

01254 BARNES, F.

PARADIGM REGAINED

NEH REPUBLIC, 206 (15) (APR 92), 8-10

PRESIDENT GEORGE BUSH SUFFERS FROM MODERATE REPUBLICAN'S

DISEASE: HE HAS NOTHING TO SAY. SO HE IS RELYING ON VAGUE

CALLS FOR CHANGE, REFORM, AND A HEAVY DOSE OF CONGRESS-

BASHING.

01255 BARNES, $F$.

PARDON ME

NEH REPUBLIC, 207(26) (DEC 92), 11-12.

THE AUTHOR EXAMINES THE QUESTION OF WHETHER IRAN CONTRA

PROSECUTOR LAWRENCE WALSH HAD A POL ITICAL MOTIVE IN ISSUING

HIS SECOND INDICTMENT OF FORMER DEFENSE SECRETARY CASPAR

WEINBERGER ONLY DAYS BEFORE THE NOVEMBER 3,1992,

PRESIDENTIAL ELECTION. HE ALSO OISCUSSES PRESIDENT GEORGE

BUSH'S DECISION TO PARDON WEINBERGER.

01256 BARNES, F.

PAT PENDING

NEH REPUBLIC, 206(5) (FEB 92), 20-21.

THE AUTHOR LOOKS AT PAT BUCHANAN'S CAMPAIGN IN THE NEH

HAMPSHIRE REPUBLICAM PRIMARY AND SPECULATES ABOUT HOH HE

HAMPSHIRE REPUBL ICAN PRIMARY AND SPECULATES ABOUT HOW
WILL FARE IN THE VOTING AGAIMST PRESIDENT GEORGE BUSH.

01257 BARNES, F.

PRO, ER, PRO-LIFE

NEW REPUBLIC, $206(20)$ (MAY 92), 10-11.

BECAUSE PRESIDENT BUSH'S TOP RE-ELECTION CAMPAIGM ADVISORS ARE CONCERNED THAT HIS ANTI-ABORTION STANCE IS NOT IN TUNE WITH THE MAJORITY OF THE AMERICAN PUBLIC, BUSH'S STRATEGY WILL BE TO "NARROWCAST" HIS POSITION. HE HILL EMPHASIZE HIS ANTI-ABORTION VIEWS BEFORE RECEPTIVE AUDIENCES, SUCH AS EVANGELICAL CHRISTIANS, BUT WILL DOWNPLAY IT BEFORE OTHER GROUPS.
01258 BARNES, $F$.

SCHIZO

NEW REPUBLIC, 207(3-4) (JUL 92), 11-12.

BILL CLINTON'S POLITICAL SCHIZOPHRENIA PERMEATES HIS CAMPAIGN. THERE STILL HASN'T BEEN A REAL DEBATE AMONG CLINTON STRATEGISTS OVER WHETHER TO AIM THE CAMPAIGN AT THE LIBERALS AND TRY TO WIN A THREE-WAY RACE WITH 34 TO 40 PERCENT OF THE VOTE OR TO GO FOR AN OUTRIGHT MAJORITY. SO CLINTON IS DOING BOTH AT ONCE. BUT THE FACT IS THAT THE TWO SIDES OF CLINTON'S POLITICAL PSYCHE DON'T MESH WELL. HE'S ADEPT AT BEING A DEMOCRATIC LEADERSHIP COUNCIL REFORMER, AND HE'S PRETTY CONYINCING AS A LIBERAL, TOO. BUT WHEN HE TRIES
TO BE BOTH AT THE SAME TIME, HE GETS INTO TROUBLE. CLINTON'S CANDIDACY WOULD BE MORE HONEST AND COHERENT IF HE GAVE IN TO HIS DLC IMPULSES AND STOPPED PLACATING THE LIBERALS, WHOSE HIS DLC IMPULSES AND STOPPED PLA
VOTES HE CAN TAKE FOR GRANTED.

01259 BARNES, $F$

SKIMNER DIPPING

NEW REPUBLIC, 206 (3) (JAN 92 ), 10.

FORMER TRANSPORTATION SECRETARY SAMUEL SKINMER REPLACED JOHN SUNUNU AS WHITE HOUSE CHIEF-OF-STAFF ON DECEMBER 16 1991, BUT NOT MUCH HAS CHANGED. THERE HAS BEEN NO INSTANT REJUVENATION OF PRESIDENT BUSH OR HIS RE-ELECTION PROSPECTS. THE SMALL EMBARRASSMENTS, THE UNSURE FOOTING, AND THE POLICY QUANDARY ARE CONTINUING.

01260 BARNES, $F$.

TEETERING

NEW REPUBLIC, 206(14) (APR 92), 8-10

THE AUTHOR LOOKS AT THE EARLY STAGES OF PRESIDENT GEORGE

BUSH'S REELECTION CAMPAIGN AND HIS REELECTION ADVISORS.

01261 BARNES, F.

THE CLINTON GAP

NEW REPUBLIC, 206(10) (MAR 92), 25-27

THE AUTHOR ANALYZES WHY ARKANSAS GOVERNOR BILL CLINTON

LOST THE 1992 NEW HAMPSHIRE DEMOCRATIC PRIMARY TO FORMER

MASSACHUSETTS SENATOR PAUL TSONGAS.

01262 BARNES, $F$.

THE NEH COVENANT

NEW REPUBLIC, 207 (20) (NOV 92), 32-33.

WEW REPUBLIC, $207(20)$ (NOV 92) 32-33.

ELECTION CAMPAIGN IT HIL PROBABLY HAVE MORE INFLUENCE ON

THE OUTCOME THAN ANY OTHER ISSUE EXCEPT THE ECONOMY.

01263 BARNES, F.

NEW REPUBLIC, 206 (24) (JUN 92), 10-11.

H. ROSS PEROT IS BILL CLINTON'S ONLY CHANCE TO WIN THE PRESIDENCY IN 1992. IN A ONE-ON-ONE CONTEST BETWEEN GEORGE BUSH AND BILL CLINTON, BUSH IS THE SURE WINNER. BUT WITH PEROT IN THE RACE, THE GOP COALITION THAT WON THE PRESIDENCY IN 1980, 1984, AND 1988 IS LIKELY TO BE SPLIT.

01264 BARNES, F.

NEW REPUBLIC, 207(6) (AUG 92), 12, 14

MANY OF THE NEOCONSERVATIVES, OR "Reagan DEMOCRATS," WHO LEFT THE DEMOCRATIC PARTY IN THE 1980'S ARE RETURNING BECAUSE THEY LIKE BILL CLINTON.

01265 BARNES, $F$.

UNKEMPT

NEH REPUBLIC, 206(22) (JUN 92), 11

IN THE WAKE OF THE LOS ANGELES RIOTS, PRESIDENT GEORGE

BUSH TURNED TO HOUSING SECRETARY JACK KEMP FOR ADVICE.

ALTHOUGH KEMP WAS PREVIOUSLY LARGELY IGNORED BY THE BUSH ADMINISTRATIOY MAYY REGARD HIS IDEAS AS INMOYATIYE AMO ADMINISTRATION, MANY REGARD HIS IDEAS AS INNOVATIYE

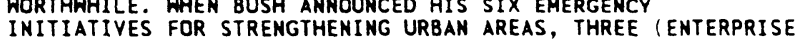

ZONES, WELFARE REFORM, AND TENANT OWNERSHIP DF PUBLIC

HOUSING) WERE STRAIGHT FROM KEMP'S PLAYBOOK.

01266 BARNES, F.

WAR FOOTING

NEW REPUBLIC, 206(11) (MAR 92), 10-11.

THE BUSH CAMPAIGN HAS DECIDED TO CRUSH POLITICAL RIVAL

PAT BUCHANAN AND DRIVE HIM OUT DF THE RACE FOR THE

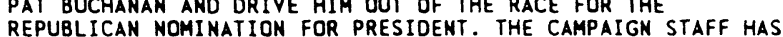

REPUBLICAN NOMINATION FOR PRESIDENT. THE CAMPAIGN STAFF HA

DECIDED TO GO NEGATIVE ON BUCHANAN

01267 BARMES, F.

WHITE HOUSE WATCH: STUNAED

NEHIT HOUSE WATCH: STUNED

PRESIDENT GEORGE BUSH'S INSTINCTS IN THE EARLY HOURS OF A CRISIS ARE NOTHING TO BRAG ABOUT. BUT HIS SECOND-HAVE REACTION IS INYARIABLY TOUGHER AND POLITICALLY SHREWDER. THIS HABIT OF STUMBLING, THEN RECOVERING, RECURRED AS BUSH RESPONDED TO THE RODNEY' KING VERDICT AND THE RIOTING IN LOS ANGELES. 
01268 BARMES, $F$.

WHY LIBERALS HATE POLITICS

AMERICAN SPECTATOR 24(8) (AUG 91), 24-25.

LIBERAL CRIIICISM OF THE 1988 PRESIDENTIAL ELECTION ARGUES THAT THE CAMPAIGN FOCUSED ON EMPTY, MEANINGLES ISSUES. THIS ARTICLE ARGUES THAT THE LIBERALS' REAL ARGUMENT IS THAT THE CAMPAIGH CONCENTRATED ON ISSUES THAT LIBERALS TEND TO LOSE. THEREFORE, THE GROWING ARGUMENT THAT THE PRESS NOT THE CANDIDATES--SHOULD DETERMINE THE ELECTION AGENDA, IS SIMPLY A WAY FOR THE LIBERALS TO STEER AWAY FROM ISSUES THAT THEY ARE LIKELY TO LOSE. THE "NEW" AGENDA: URBAN PROBLEMS, DRUGS, EDUCATION, THE ENVIRONMENT, AND THE BANKING CRISIS, ARE ALL ISSUES HHICH CRY OUT FOR GOVERNMENT (READ LIBERAL) SOLUTIONS.

01269 BARNES, J.A.

PROPORTIONAL DECEPTION

NATIONAL REVIEH, XLIV(14) (JUL 92), 18-19.

THIS ARTICLE BRIEFLY EXAMINES THE CLAIMS MADE BY

PROPONENTS OF PROPORTIONAL REPRESENTATION (PR) IN THE UNITED STATES. ADVOCATES OF PR CLAIM THAT IT WILL SOLVE PROBLEMS OF LOW VOTER TURNOUT, GERRYMANDERING, LACK OF MINORITY LOW VOTER TURNOUT, GERRYMANDERING, LACK OF MINORITY REPRESENTATION AND RACIAL AND ETHNIC TENSIONS. THE AUTHOR OF THIS ARTICLE, HOWEVER, CONCLUDES THAT MOVING FROM FIRS THE-POST TO PR MEANS MOVING FROM A SYSTEM IN WHICH THE
GOVERMMENT IS FORMED BY THE PARTY WINMING THE MOST YOTES TO GOVERMMENT IS FORMED BY THE PARTY WINNING THE MOST VOTES TO PARTIES WINNING THE FENEST. THE ONLY GUARANTEED RESULT OF PR PART IES WINNING THE FEWEST
IS INCREASED GOVERNMENT.

01270 BARNES, L.

H. ROSS PEROT: HIS CANDIDACY IS MORE SERIOUS THAN HIS MIDEAST POLICY

WASHINGTON REPORT ON MIDOLE EAST AFFAIRS, XI(1) (JUN 92), 20-21, 85.

THE AUTHOR DISCUSSES THE PRESIDENTIAL CANDIDACY OF $H$

ROSS PEROT, FOCUSING ON HIS MIDOLE EAST POLICY.

01271 BARNES, L.

ISRAEL LOBBY ECSTATIC OVER GORE SELECTION

WASHINGTON REPORT ON MIDOLE EAST AFFAIRS, XI(3) (AUG 92), 27-28.

PRO-ISRAEL LOBBYISTS ARE PLEASED WITH GOVERNOR BILL CLINTON'S SELECTION OF SENATOR AL GORE, JR., AS HIS RUNHING MATE IN THE 1992 PRESIDENTIAL ELECTION. THE LOBBYISTS SEE GORE AS A TRIED AND TRUE FRIEND OF ISRAEL.

01272 BARNETT, R.; LEVAGGI, R.; SMITH, $P$.

DOES THE FLYPAPER MODEL ŚTICK? A TEST OF THE RELATIVE PERFORMANCE OF THE FLYPAPER AND CONYENTIONAL MODELS OF LOCAL GOVERMMENT BUDGETARY BEHAVIOR

LOCAL GOVERMMENT BUDGETARY BEHAVIOR

TWO OF THE MOST WIDELY REFERRED TO MODELS OF LOCAL IOR STATE) BUDGETARY BEHAVIOR ARE DEVELOPED AND TESTED. THE MODELS CONSIDERED ARE A YARIANT OF THE FLYPAPER MODEL (SEE, FOR EXAMPLE, COURANT ET AL. 1979 AND OATES, 1979) AND A FOR EXAMPLE, COURANT ET AL., 1979 AND OATES, 1979) AND A
CONYENTIONAL MODEL WHICH BUILDS ON THE SEMINAL WORK OF WILDE CONVENTIONAL MODEL WHICH BUILDS ON THE SEMINAL WORK OF WILD ALLOWS THEM TO BE TESTED EMPIRICALLY USING DATA FOR ENGLISH LOCAL GOVERMMENTS. THO TYPES OF TEST ARE EMPLOYED: THE ABILITY OF THE TWO MODELS TO EXPLAIN THE VARIATIONS IN EXPENDITURE LEVELS ACROSS LOCAL GOVERHMENTS WITHIN ANY GIVEN FISCAL YEAR; THE ABILITY OF THE MODELS TO PREDICT FUTURE LEVELS OF EXPENDITURE GIVEN CHANGES TO LOCAL GOVERMMENT BUDGET CONSTRAINTS (AS BROUGHT ABOUT, FOR EXAMPLE, BY CHANGES IN GRANTS-IN-AID FROM CENTRAL GOVERNMENT).

01273 BARNETT, R.R.; KNOX, C.

ACCOUNTABILITY AND LOCAL BUDGETARY POLICY: UNITARY PRINCIPLES?

POLICY AND POLITICS, 20(4) (OCT 92), 265-276.

THE DESIRE TO IMPROVE LOCAL ACCOUNTABILITY HAS BEEN AT THE HEART OF RECENT REFORMS TO LOCAL GOVERNMENT FINANCE IN BRITAIN, BUT THESE SAME REFORMS HAVE NOT BEEN IMPLEMENTED IN NORTHERN IRELAND, BECAUSE THE GOVERNMENT CONTENDS THAT THE SAME PROBLEM DOES NOT EXIST THERE. IN THIS PAPER, THE AUTHORS REVIEH THE GOVERNMENT'S ARGUMENTS AND DEVELOP MEASURES OF LOCAL ACCOUNTABILITY. THEN THEY EXAMINE THE CLAIM THAT LOCAL GOVERNMENT IN NORTHERM IRELAND IS OIFFERENT AND, THEREFORE, UNITARY PRINCIPLES OF ACCOUNTABILITY IN LOCAL GOVERMMENT DO NOT APPLY THROUGHOUT THE UNITED KINGDOM. MEASURES OF ACCDUNTABILITY ARE DEVEL OPED USING THE

GOVERNMENT'S OWN, ESSENTIALLY PUBLIC-CHOICE-BASED, ARGUMENTS.

01274 BARNETT, S. : GABER, I.

COMMITTEES ON CAMERA: MP'S AND LOBBY YIEWS ON THE EFFECTS OF TELEVISING COMMONS SELECT COMMITTEES

PARLIAMENTARY AFFAIRS, 45(3) (JUL 92), 409-419.

THE AUTHORS ENDEAVOR TO ASSESS THE IMPACT OF TELEVISING THE PROCEEDINGS OF HOUSE OF COMMONS SELECT COMMITTEES. THEY UTILIZE A SURVEY SENT TO EVERY MEMBER OF PARLIAMENT SERVING ON A SELECT COMMITTEE AND ANOTHER SURVEY CONDUCTED AMONG PRINT AND BROADCAST JOURNALISTS. THEY ALSO REFER TO PERSONAL INTERVIEWS THEY CONDUCTED WITH EXPERIENCED POLITICAL
REPORTERS, IN ORDER TO EXPLORE SOME OF THE ISSUES IN MORE DETAIL.

01275 BARON, A.

CHANGING PRIORITIES AS TURKEY BECOMES MORE SELF-CONFIDENT GERMAN TRIBUNE, (1511) (APR 92), 2

GERMANY AND TURKEY ARE TRYING TO SETTLE THEIR CONFLICT OVER THE POLICY TOWARDS THE KURDS DIPLOMATICALLY, BUT THE LONGER-TERM CONSEOUENCES OF THE DISPUTE BETWEEN THE TWO NATIONS LOOM ON THE HORIZON. ANKARA'S ORIENTATION TO EUROPE IS BECOMING LESS LINEAR. TURKISH PRIME MINISTER DEMIREL WAS RECENTLY QUOTED AS SAYING, "WE ARE NOT AFRAID OF THE WEST. THE GOVERNMENT LEADER HAS NOT ONLY REPUDIATING WESTERN CRITICISH OF HIS COUNTRY'S POLICY TOWARDS THE KURDS, BUT ALSO WAS ARTICULATING TURKEY'S NEW SELF-CONFIDENCE. EVIDENCE OF THIS CHANGE OF HEART IS ALSO FOUND IN INCREASINGLY BOLD PRONOUNCEMENTS ABOUT TURKEY'S ROLE AS A POLICING POWER IN THE REGION AND ITS CLOSER TIES WITH THE UNITED STATES.

01276 BARON, S

A NEH, HIDDEN COLD WAR REPLACES THE OLD ONE

GERMAN TRIBUNE, (1519) (JUN 92), 2

IT IS BECOMING INCREASINGLY CLEAR THAT, IN THE MINDS OF EADING POLITICIANS OF THE UNITED STATES AND ELSEWHERE, THAT THE COLD WAR LIVES ON. THIS IS INDICATED BY THE U.S. REFUSAL TO SUBSTANTIALIY REDUCE ITS OHN MILITARY FORCE AND BY THE U S. POLICY OF ALLOWING THE COMMONHEALTH OF INDEPENDENT STATES TO DISINTEGRATE. WHILE GERMANY AND JAPAN--TWO STATES WITH A SIGNIFICANT INTEREST IN MAINTAINING ORDER AND DEVELOPMENT IN THE CIS--STRIVE TO SAVE THE COMMONHEALTH, THEY ARE

DISCOURAGED AND PRESSURED AT EVERY TURN BY THE UNITED STATES. IN SHORT, THE AMERICANS SEEM TO BELIEVE THAT ON THE TERRITORY OF THE FORMER SOVIET UNION THEY ARE FIGHTING A BATTLE FOR POLITICAL AND ECONOMIC SUPREMACY IN THE WORLD.

01277 BARONE, $M$.

THE NEW FACE OF AMERICAN POLITICS

NATIONAL REVIEW, XLIV(8) (APR 92), 38-39.

AMERICAN VOTERS MAY BE MAD, BUT THEY'RE NOT FLAKY, SUGGESTS MICAHAEL BARONE. NEITHER ARE THEY DISPOSED TO CONTINUE POLITICS AS USUAL. THIS ARTICLE EXPLORES THE SIGNS THAT THE SERIOUS CANDIDATES ARE STARIING TO LISTEN TO THEM. IT CONCLUDES THAT IT IS IMPORTANT THAT VOTERS AMD

POLITICIANS TAKE SERIOUSLY THE REFORM INITIATIVE ADVANCED BY BUSH AND CLINTON AND NOT GET TRANSFIXED AS ONE ROMAN CANDLE AFTER ANOTHER FLIES UP TO THE SKY AND THEN SPUTTERS BACK TO EARTH.

01278 BARRACLOUGH, C.

ASIAN REPUBLICS A TURKISH DELIGHT
INSIGHT, $8(47)$ (NOV 92$), 14-16 ; 38-39$

INSIGHT, $8(47)$ (NOV 92 ), $14-16 ; 38-39$.
THE COLLAPSE OF THE SOVIET UNION LEFT THE CENTRAL ASIAN REPUBLICS LOOKING FOR A MODEL. RATHER THAN THE ISLAMIC RADICALISM OF IRAN OR PAKISTAN, TURKEY'S SECULARISM AND WESTERN-STYLE ECONOMY ARE EMERGING AS THE CHOICE. HOWEVER, NOMEN WHO WEAR TRADITIONAL ISLAMIC GRAB REMAIN IN THE MINORITY, BUT SOME SECULAR HOMEN FEAR THAT HILL CHANGE. THIS ARTICLE REPORTS THAT SOME ISLAMIC LEADERS ACKNOWLEDGE THAT STRICT RELGIOUS DOGHAS WILL NOT PLUCK THE CENTRAL ASIAN REPUBLICS FROM THEIR DIRE ECONOMIC STRAITS.

01279 BARRAL, G.

THE LOST TABLETS: an analysis of the CONCEPt OF MINIMUM DETERRENCE

ARMS CONTROL, 13(1) (APR 92), 58-84.

THE AUTHOR BEGINS WITH TWO ASSUMPTIONS: (1) VERY LITTLE IS KNOWN ABOUT THE CONCEPT OF MINIMUM DETERRENCE, AND (2) MANY WRITERS HAVE BEEN CONSTRAINED BY A DEFINITION OF ASSURED DESTRUCTION CONSTRUCTED BY ROBERT MCNAMARA FOR THE KENHEDY AND JOHNSON ADMINISTRATIONS. THE AUTHOR ENDEAYORS TO DEFINE THE CONCEPT, TO REDISCOVER THE FORGOTTEN HISTORY OF MINIMUM DETERRENCE, TO REVIEW THE MAJOR PROPOSALS FOR MINIMUM DETERRENCE, AND TO ILLUSTRATE SOME MECHANISMS FOR ACHIEVING SUFFICIENCY.

01280 BARRELL, $H$.

THE TURM TO THE MASSES: THE AFRICAN NATIONAL CONGRESS STRATEGIC REVIEH OF 1978-79

JOURNAL OF SOUTHERN AFRICAN STUDIES, 18(1) (MAR 92), 64-92. IN 1978-79 THE ANC LEADERSHIP UNDERTOOK A FORMAL REVIEH OF ITS REVOLUTIONARY STRATEGY. THE CHANGES THAT RESULTED HAD AN INFLUENCE BEYOND THE ANC. THEY CAME TO AFFECT THE AN INFLUENCE BEYOND THE ANC. THEY CAME TO AFFECT THE THE 1980S INCLUDING THE UHITED DEMOCRATIC FRONT. THIS PAPER THE $1980 S$, INCLUDING THE UNITED DEMOCRAIIC FRONT. THIS PAPER RECOVERS THE STORY OF THIS REVIEW, HITHERTO A LARGELY HIDDEN CHAPTER IN ANC HISTORY. IT CRITICALLY EXAMINES THE REVIEN AND, BRIEFLY, ARGUES THE
INFLUENCE AND IMPORTANCE.

01281 BARRELL, R.

ECONOMIC CONVERGENCE ANO MONETARY UNION IN EUROPE SAGE PUBLICATIONS, 1992, 263.

PROGRESS TOWARD MONETARY UNION IN EUROPE HAS BEEN ACCELERATING, AND THE MAASTRICHT SUMMIT SET OUT THE 
PRECONDITIONS FOR A SUCCESSFUL UNION. THIS BOOK IS THE FIRST SUBSTANTIAL OVERVIEW OF THE PROSPECTS FOR MONETARY UNION IN EUROPE POST-MAASTRICHT. IT PROVIDES CAREFUL AND THOROUGH ANALYSIS FOR THE BUSINESS, INDUSTRIAL AND GOVERNMENT COMMUNITIES FOR WHOM UNION, AND PROGRESS TOWARDS IT, WILL BE A KEY FACTOR IN THEIR SUCCESS IN THE 1990 S AND BEYOND. THE EXTERNAL ROLE OF A EUROPEAN CURRENCY IS ASSESSED, AS WELL AS EUROPEAN COHESION AS A WHOLE, RELATIONS WITH THE EAST, ANO THE COSTS OF CONVERTING TO A COMMON CURRENCY.

01282 BARRET, L.

ECOWAS BITES THE BULLET

WEST AFRICA, (3908) (AUG 92), 1340

CHARLES TAYLOR APPEARS TO UNDERSTAND THAT HIS ABILITY TO MANIPULATE THE ECOWAS NEGOTIATING PROCESS HAS COME TO AN END. DESPITE INTENSE LOBBYING BEFORE THE 15TH ECOWAS SUMMIT, TAYLOR WAS UNABLE TO STOP THE GROUP FROM ADOPTING A FIRM TAYLOR WAS UNABLE TO STOP THE GROUP FROM ADOPTING A FIRM
RESOLUTION DEMANDING THAT HE COMPLY WITH PREVIOUS AGREEMENTS RESOLUTION DEMANDING THAT HE COMPLY WITH PREVIOUS AGR
OR FACE ECONOMIC SANCTIONS. THE RESULTS OF THE SUMMIT DELIBERATIONS SEEM TO REFLECT A DESIRE ON THE PART OF THE WEST AFRICAN LEADERSHIP TO FORCE THE LIBERIAN SITUATION TO A CLIMAX--SOONER RATHER THAN LATER.

01283 BARRETT, D.M.

SECRECY AND OPENNESS IN LYNDON JOHNSON'S WHITE HOUSE: POLITICAL STYLE, PLURALISM, AND THE PRESIDENCY

REVIEW OF POLITICS, $54(1)$ (WIN 92), 72-111.

THO DOMINANT CHARACTERISTICS OF'PRESIDENT LYNDON JOHNSON'S POLITICAL STYLE WERE (1) OPENNESS TO DIVERSE VIEWS AND INFORMATION AND (2) EXTREME SECRECY SURROUNDING THE ADVISORY PROCESS. ALTHOUGH THE TWO CHARACTERISTICS WERE IN TENSION, THEY WERE INEXTRICABLY LINKED AND SERVED SERIOUS PURPOSES: OPENNESS BROUGHT JOHNSON POLICY PROPOSALS AND POLITICAL ANALYSES FROM DIVERSE, CREDIBLE SOURCES, HHILE SECRECY KEPT HIS OPTIONS OPEN UNTIL THE MOMENT OF PRESIDENTIAL DECISION AND IMPROVED THE CHANCES OF TURNING PROPOSALS INTO GOVERNMENT POLICY. THE ROOTS OF JOHNSON'S STYLE RESEMBLE THOSE OF POST-WORLD WAR II PLURALISTS, WHO (LIKE LBJ) WERE INFLUENCED BY FRANKLIN ROOSEYELT'S PRESIDENCY. THEY AND JOHNSON SAW PRESIDENTS FACING A DEADLOCKED DEMOCRACY AND HEADING AN UNRESPONSIVE EXECUTIVE BRANCH; ONLY POLITICALLY SKILLFUL AND ASSERTIVE PRESIDENTS COULD ÓVERCOME THAT DILEMMA.

01284 BARRETT, L.

FAHNBULLEH INDICTS LIBERIANS

WEST AFRICA, (3884) (FEB 92) 317

H. BOIMA FAHNBULLEH JR. ' LIBERIA'S FORMER FOREIGN MINISTER, RECENTLY RETURNED TO HIS HOMELAND FROM EXILE IN GHANA AND GREAT BRITAIN. IN A PUBLIC STATEMENT, HE DECLARED THAT ALL LIBERIANS SHOULD BE HELD RESPONSIBLE FOR THE OISASTER THAT HAS BEFALLEN THEIR NATION. HE ALSO EMPHASIZED THE PROFOUND IMMORALITY OF THE LIBERIAN NATIONAL CONDITION, WHICH WAS CAUSED BY YEARS OF CORRUPT LEADERSHIP, PSYCHOTIC GREED, AND DISORDER. HE WARNED THAT ETHNIC POLITICS IS THE BANE OF NATIONAL UNITY.

01285 BARRETT, L

OF ARMS AND LEGITIMACY

WEST AFRICA, (3916) (OCT 92), 1671

THE RECENT ESCALATION OF THE FIGHTING BETWEEN ULIMO AND THE NPFL IN LIBERIA'S HINTERLAND AND THE SUGGESTION THAT U.N. OBSERVERS BE SENT TO INSURE ECOMOG'S NEUTRALITY HAVE GENERATED INTERESTING REACTIONS IN MONROVIA'S MILITARY CIRCLES. SUDDENLY IT IS IMPORTANT THAT NATIONAL RESISTANCE TO TYRANNY BECOME AN INTEGRAL PART OF THE INTERIM GOVERMMENT'S FORMULA FOR MAINTAINING ITS OWN INTEGRITY. HOWEVER, SINCE INTERIM PRESIDENT AMOS SAWYER HAS MADE THE CALL FOR DISARMAMENT HIS OWN WATCHWORD AND THE PREROGATIVE OF HIS GOVERNMENT. HE IS IN NO POSITION TO ADVOCATE THE IMMEDIATE RELEGITIMIZATION OF THE ARMED FORCES OF LIBERIA.

01286 BARRETT, L.

THE SEIGE OF MONROYIA

WEST AFRICA, 7513923) (NOY 92), 2008-2010.

WHEN CHARLES TAYLOR'S MPFL ATTACKED ECOMOG ON OCTOBER 24 , THE RESPONSE OF THE PEACEKEEPING FORCE WAS EXTREMELY EFFECTIVE IN SPITE OF THE FACT THAT THE REBEL INVADERS PROVED TO BE MUCH MORE COMMITTED AND HIGHLY TRAINED THAN WAS GENERALLLY EXPECTED. NO EVIDENCE HAS BEEN UNCOVERED WHICH SUGGESTS THAT EITHER THE AFL OR ULIMO HAD BEEN INVOL VED IN ANY MAJOR COLLABORATIVE EFFORT WITH ECOMOG IN ANY OF THE MAIN BATTLES BETWEEN THE PEACE-KEEPING FORCES AND NPFL. HOWEVER, DURING THE FIRST ATTACK WHICH WAS MOUNTED ON FOUR FRONTS, UNITS OF AFL PRECEDED THE MAIN BODY OF GHANAIAN TROOPS BASED IN THE CAMP SCHIEFFLIN SECTOR AND UTILIZED TROOPS BASED IN THE CAMP SCHIEFFLIN SECTOR AND UTILIZED ARTILLERY COYER PROYIDE

01287 BARRILLEAUX, C.; CREH, JR., R.; FEIOCK, R. MEASURING AND COMPARING AMERICAN STATES' ADMINISTRATIVE CHARACTERISTICS

STATE AND LOCAL GOVERMMENT REVIEW, 24(1) (WIN 92), 12-18. SEVERAL CHARACTERISTICS OF STATE ADMINISTRATION DURING
THE 1980 S ARE MEASURED AND COMPARED TO SIMILAR MEASURES REPRESENTING STATE ADMINISTRATION ABOUT 1970. WHERE POSSIBLE, EACH 1980 S MEASURE IS REGRESSED UPON ITS 1970 COUNTERPART. THE MAJORITY OF THE NEHER INDICATORS ARE EXPLAINED WELL BY THE LAGGED MEASURES, BUT OTHERS (MIMORITY REPRESENTATION AND MERIT SYSTEMS PROTECTIONS) ARE NOT. THE QUANTITIVE RESULTS OF THE CORRELATIONS ANALYSES INDICATE THAT SOME STATE ADMINISTRATIVE CHARACTERISTICS ARE LARGELY FUNCTIONS OF STATE POLITICAL, SOCIAL, AND ECONOMIC DEVELOPMENT AND THAT OTHERS ARE RESULTS OF OUTSIDE FORCES.

01288 BARROH, $C$

FROM MARX TO MADISON: THE SELIGMAN CONMENTION IN CHARLES BEARD'S CONSTITUTIONAL THEORY

POLITY, 24(3) (SPR 92), 379-398

CHARLES BEARD STEADFASTLY DENIED THAT HIS "ECONOMIC INTERPRETATION OF THE CONSTITUTION" WAS MARXIST IN ITS ORIGIN OR IMPACT. MANY SCHOLARS HAVE DISMISSED BEARD'S OISCLAIMERS AS A POLEMICAL MANEUVER, BUT THIS ARTICLE DISCLAIMERS AS A POLEMICAL MANEUVER, BUT THIS ARTICLE ASORTENDS THAT BEARD'S HISTORIOGRAPHY AND POLITICAL THOUGHT IS ROOTED IN THE WORK OF E.R.A. SELIGMAN, WHOSE "THE IS ROOTED IN THE WORK OF E.R.A. SELIGMAN, WHOSE "THE ECONOMIC INTERPRETATION OF HISTORY" IS THE KEY TO UNDERSTANDING HOW BEARD'S METHDD

01289 BARRY, $D$.

TOWARD THE "RULE OF LAW" IN THE SOVIET UNION?

M. E. SHARP, INC., 1992, 500.

THE CONTRIBUTORS TO THIS VOLUME OFFER A COMPREHENSIVE EXAMINATION OF THE EFFORT TO CREATE A LAH-BASED STATE IN THE GORBACHEV-ERA USSR, THUS EFFECTING A FUNDAMENTAL CHANGE IN THE RELATIONSHIP BETWEEN THE STATE AND PRIVATE GROUPS AND INDIVIDUALS. THE CONTRIBUTORS DISCUSS CONCEPTUAL, HISTORICAL, SOCIAL, CULTURAL, AND INSTITUTIONAL ASPECTS OF SOVIET LEGAL DEVELOPMENT, AND SUPPLY DETAILED ANALYSIS OF RECENT DEVELOPMENTS IN THE AREAS OF CIVIL, CRIMINAL, AND LABOR LAH AND THE RIGHTS OF INDIVIDUALS, ECONOMIC ORGANIZATIONS, AND POLITICAL AND SOCIAL GROUPS.

01290 BARRY, D.D. (ED.)

TOWARD THE "RULE OF LAH" IN RUSSIA? POLITICAL AND LEGAL REFORM IN THE TRANSITION PERIDD

M. E. SHARPE, 1992, 448 .

THIS VOLUME OFFERS A COMPREHENSIVE EXAMINATION OF THE EFFORT TO CREATE A "LAH-BASED" STATE IN THE GORBACHEV-ERA USSR, AN EFFORT WHICH EFFECTED A FUNDAMENTAL CHANGE IN THE RELATIONSHIP BETWEEN THE STATE AND PRIVATE GROUPS AND INDIVIDUALS. THE CONTRIBUTORS DISCUSS CONCEPTUAL, HISTORICAL, SOCIAL, CULTURAL, AND INSTITUTIONAL ASPECTS OF RUSSIAM LEGAL DEVELOPMENT, AND SUPPLY DETAILED ANALYSIS OF DEVELOPNENTS IN THE AREAS OF CIVIL, CRIMINAL, AND LABOR LAH AND THE RIGHTS OF INDIVIDUALS, ECONOMIC ORGANIZATIONS, AND POLITICAL AND SOCIAL GROUPS.

01291 BARSH, R.

DEMOCRATIZATION AND DEVELOPMENT

HUMAN RIGHTS QUARTERLY, 14(1) (FEB 92), 120-134.

THE RELATIONSHIP BETHEEN DEMOCRACY AND DEVELOPMENT HAS BEEN THE SUBJECT OF INTENSE DEBATE SINCE THE EARLY PART OF THE LAST CENTURY. DEMOCRACY IS A COMPLEX PHENOMENON. THE TERM DEMOCRACY HAS BEEN GIVEN VARIDUS MEANINGS AND HAS BEEN APPLIED TO QUALITATIVELY DIFFERENT STRUCTURES. HOWEVER, A CONCLUSIVE DEMONSTRATION OF THE RELATIONSHIP BETWEEN DEMOCRACY AND DEVELOPMENT IS NOT ONLY BEYOND THE SCOPE OF THIS PAPER, BUT PROBABLY IS NOT REALISTICALLY FEASIBLE. HHAT IS ATTEMPTED HERE, IS A CLARIFICATION OF THE QUESTION, ACCOMPANIED BY A CRITICAL REVIEH OF SOME RECENT COMPARATIVE RESEARCH AND SOME SUGGESTIONS FOR INTERNATIONAL ECONOMIC POLICY IN LIGHT OF LIMITED KNOWLEDGE.

01292 BARTEL, R.D.

TELL THE PENTAGON: THE COLD HAR IS OVER

CHALLENGE, 35(4) (JUL 92), 24-29.

IN THIS INTERVIEW, JOHN TEPPER MARLIN, THE DIRECTOR OF THE CONVERSION INFORMATION CENTER OF THE COUNCIL ON ECONOMIC PRIORITIES, DISCUSSES THE LEVEL OF U.S. DEFENSE SPENDING AND HOW THE COLLAPSE
DEFENSE CUTS.

01293 BARTEL, R.D.

THE ECONOMIC PENDULUM: $1962 \ldots 1982 \ldots 1992(?)$

THE ECONOMIC PENDULUM: 1962,19
CHALLENGE, $35(2)$ (MAR 92 ), $9-16$.

IN THIS INTERVIEW, JAMES TOBIN, A NOBEL LAUREATE IM ECONOMICS COMPARES THE EFFECTS OF THE KEMNEDY - JOHNSOM ECONOMIC POLICIES WITH THOSE OF THE REAGAN-BUSH ERA.

01294 BARTH, T.J.

THE PUBLIC INTEREST AND ADMINISTRATIVE DISCRETION AMERICAN REVIEH OF PUBLIC ADMINISTRATION, $22(4)$ (DEC 92), 289-300.

THE PUBLIC INTEREST IS A MUCH NEGLECTED CONCEPT THAT HAS POWERFUL SYMBOLIC AND INSTRUMENTAL VALUE. BUILDING ON THE WORK OF GOOOSELL, THE AUTHOR PROVIDES A FRAMENORK FOR 
EXAMINING THE DEGREE TO WHICH A POLICY OR PROGRAM IS IN THE PUBLIC INTEREST. HE SUMMARIZES FOUR CASES THAT ILLUSTRATE HOW SERVING THE PUBLIC INTEREST IN A DEMOCRACY REQUIRES ONGOING CONCERN WITH NOT ONLY WHAT IS DONE BUT ALSO WITH HOW IT IS DONE. FURTHERMORE, THE CASES DEMONSTRATE THAT PUBLIC ADMINISTRATORS CAN HEAVILY INFLUENCE THE DEGREE TO WHICH A POLICY OR PROGRAM IS IN THE PUBLIC INTEREST.

01295 BARTHOLOMEH, J.

CARROTS FOR' GORBACHEV

FAR EASTERN ECONOMIC REVIEW, 151(30) (JUL 91), 13.

THE ANNUAL G-7 SUMMIT MEETING IS BECOMING A FORUM FOR JAPANESE LEADERS TO GAIN INTERNATIONAL ATTENTION. IN THE OTHER PART ICIPANTS. BUT AT THE IONDON SUMIIT HELD ON 15-16 JULY THE JAPANESE DELEGATION HAD PLENTY TO SAY FOR ITSELF. ON THE DOMINANT ISSUE AT THE LONDON SUMMIT, AID TO THE SOVIET UNION, JAPAN CLEARLY OPPOSED ANY MAJOR HAND-OUT UNTIL MOSCOW HAS MADE CHANGES. ECONOMICALLY, JAPAN WANTED THE MOSCOW HAS MADE CHANGES. ECONOMICALLY, JAPAN WANTED THE
SOVIET UNION TO MOVE TOWARDS A MARKET ECONOMY; POLITICALLY, SOVIET UNION TO MOVE TOWARDS A MARKET ECONOMY; POLITICALLY, BETWEEN THE UNION AND THE REPUBLICS; AND IN FOREIGN POLICY, JAPAN WISHED THAT THE SOVIET UNIDN WOULD MATCH THE LOWERING OF TENSIONS IN EUROPE WITH SOMETHING SIMILAR IN THE FAR
JAPAN'S STATUS AS AN ASIAN POWER AND AS AN IMPORTANT FOREIGN AID DONOR BOTH ADDED TO ITS STATURE IN THE SUMMIT.

01296 BARTKY, E.

PLATO AND THE POLITICS OF ARISTOTLE'S "POETICS" REVIEW OF POLITICS, 54(4) (FAL 92), 589-619.

THE AUTHOR CHALLENGES THE VIEW THAT ARISTOTLE'S "POETICS" PROVIDES A DEFENSE AGAINST PLATO'S ASSAULT OH POETRY. HE ARGUES THAT ARISTOTLE'S DISCUSSION OF POETRY IS AT LEAST AS CRITICAL AS THE POETIC DEPICTION OF THE CITY AND THE GODS AS THE PLATONIC ACCOUNT. IN THE "POETICS," ARISTOTLE DOES BREAK WITH PLATO IN ORDER TO ESTABLISH POETRY'S INDEPENDENCE FROM PHILOSOPHY. HOWEYER, ARISTOTLE'S ACCOUNT OF POETRY AS AN INDEPENDENT ACTIVITY SHOULD NOT BE READ AS A DEFENSE OF POETRY AGAINST PLATO'S SUBORDINATION OF POETRY TO PHILOSOPHY. INSTEAD, ARISTOTLE ESTABLISHES POETRY'S INDEPENDENCE FROM PHILOSOPHY AS A CORRECTIVE TO PLATO'S RESORT TO POETRY, THEREBY ESTABLISHING THAT PHILOSOPHY IS COMPLETELY' AUTONOMOUS FROM POETRY.

01297 BARTZ, $D$.

THE OAS: A REBORN FORCE IN THE HEMISPHERE?

REPORT ON THE AMERICAS, 26(1) (JUL 92), 10-11.

THREE YEARS AGO, THE 100-YEAR-OLD ORGANIZATION OF AMERICAN STATES (OAS) SEEMED ON THE BRINK OF EXTINCTION. TODAY, HOWEVER, THERE IS RENEHED INTEREST IN THE OPGANIZATION, IN PART BECAUSE THE COLLAPSE OF THE SOVIET UNION MAY HAVE REMOVED SECURITY ISSUES AS A MAJOR CONCERM GOVERNING THE U.S. VIEH OF LATIN AMERICA. ONE IMMEDIATE EFFECT IS THAT THE FINANCIAL PICTURE IS LESS BLEAK. IT IS NOT CLEAR WHAT THE NEW WORLD ORDER HOLDS IN STORE FOR RELATIONS BETWEEN WASHINGTON AND THE REST OF THE HEMISPHERE BUT THERE IS HOPE IN SOME QUARTERS THAT THE OAS HAS FINALLY FOUND AN EFFECTIVE DIPLOMATIC VOICE.

01298 BARUA, $P$

ETHNIC CONFLICT IN THE MILTARY OF DEVELOPING NATIONS: A CONPARATIVE ANALYSIS OF INDIA AND NIGERIA

ARMED FORCES AND SOCIETY, 19(1) (FAL 92), 123-138.

MOST ARMIES OF MULTIETHAIC COUNTRIES HAVE EXPERIENCED ETHNIC TENSION WITHIN THEIR RANKS. THIS ARTICLE SEEKS TO CONTRIBUTE TO AN UNDERSTANDING OF THE DYNAMICS OF SUCH CONFLICT THROUGH A COMPARATIVE ANALYSIS OF ETHMIC CONFLICT IN THE ARMIES OF NIGERIA AND INDIA. IN 1966 AND 1984, THE NIGERIAN AND INDIAN ARMIES EXPERIENCED SERIOUS MUTINIES THAT WERE DIRECT RESULTS OF THE VIOLENT ETHNIC CONFLICT PREYALENT IN THE THO COUNTRIES AT THE TIME. THE ARTICLE EXPLAIMS HOH, DESPITE SUPERFICIAL SIMILARITIES SIGNIFICANT DIFFERENCES IN THE EVDLUTIOH AND CHARACTERISTICS OF THE TWO ARMIES WERE RESPONSIBLE FOR THE DIFFERENT OUTCOMES.

01299 BARYLSKIL, R.

THE SOVIET MILITARY BEFORE AND AFTER THE AUGUST COUP: DEPARTIZATION AND DECENTRALIZATION

DEPARTIZATION AND DECENTRALIZATION
ARMED FORCES AND SOCIETY, 19(1) (FAL 92), 27-46

GORGBACHEV LOST CONTROL AND FELL FROM POWER WHILE

ATTEMPTING TO HARNESS RISING DEMAND FOR POLITICAL PLURALISM AND REPUBLICAN SELF-GOVERMMENT WHILE THE SOVIET MILITARY STRUGGLED TO CONTAIN THE SAME FORCES AT THE TIME OF THE AUGUST COUP. THIS ARTICLE IS A BRIEF POLITICAL HISTORY OF THE SOVIET MILITARY'S ADJUSTMENT TO POLITICAL PLURALISM ANO REPUBLICAN POL ITICAL POWER FROM MARCH 1990 THROUGH SEPTEMBER
1991 . IT CHRCN ICLES THE END OF THE POL ITICAL COMMISSARS AND THE BEGINNING OF THE BREAKDOWN OF THE USSR'S UNIFIED.

EXTRATERRITORIAL, MULTINATIONAL ARMED FORCES.

01300 BARZELAY, M.; ARMAJANI, B.

BREAKIMG THROUGH BUREAUCRACY--A NEH YISION FOR MAMAGING IN GOVERNMENT

INIVERSITY OF CALIFORNIA PRESS, 1992, 280.
THIS BOOK ATTACKS THE CONVENTIONAL HISDOM THAT BUREAUCRATS ARE BUMGLERS ANO THE SYSTEM CANNOT BE CHANGED. THE AUTHORS TRACE THE SOURCE OF MUCH POOR PERFORMANCE IN GOVERNMENT TO THE PERSISTENT INFLUENCE OF WHAT THEY CALL THE BUREAUCRATIC PARADIGM-A THEORY BUILT ON SUCH NOTIONS AS CENTRAL CONTROL, ECDNOMY AND EFFICIENCY, AND RIGID ADHERENCE TO RULES. THE BOOK TELLS THE STORY OF HOW PUBLIC OFFICIALS IN ONE STATE, MINHESOTA, CAST OFF THE CONCEPTUAL BLINDERS OF THE BUREAUCRÁTIC PARADIGM AND EXPERIMENTED WITH IDEAS SUCH AS CUSTOMER SERVICE, EMPOWERING FRONT-LINE EMPLOYEES TO RESOLVE PROBLEMS, AND SELECTIVELY INTRODUCING MARKET FORCES WITHIN GOVERNMENT. GENERALIZING FROM THE MINNESOTA EXPERIENCE AND FRON SIMILAR EFFORTS NATIONHIDE, THE BOOK PROPOSES A NEH PARADIGM THAT HILL REFRAME THE PERENMIAL DEBATE ON PUBLIC MANAGEMENT.

01301 BARZILAI, G.; INBAR, E.

DO WARS HAVE' IMPACT' ISRAELI PUBLIC OPINION AFTER THE GULF WAR

JERUSALEM JOURNAL OF INTERNATIONAL RELATIONS, 1411) (MAR 92) $48-64$

THE IMPACT OF THE GULF WAR ON THE ATTITUDES OF THE POLARIZED ISRAELI PUBLIC TOWARD NATIONAL SECURITY ISSUES IS ASSESSED. THIS ARTICLE COMPARES THE FINDINGS OF A SURVEY CONDUCTED IN MAY 1990 WITH ONE CONDUCTED IN JUNE 1991 AND
EXAMINES ATTITUDES CONCERNING THREAT PERCEPTIDN, THE SENSE OF URGENCY IN REACHIMG A POLITICAL SOLUTION, THE USE OF MILITARY FORCE, THE SALIENCE OF THE PALESTINIAN PROBLEM, AND THE PREFERRED INTERIM AND PERMANENT SOLUTION. THE MAIN CONCLUSION IS THAT THERE WAS LITTLE CHANGE IN ISRAELI PUBLIC OPINION ON THESE ISSUES AFTER THE WAR AND MOSTLY IN A CENTRIPETAL DIRECTION.

01302 BASHIR, A.; WRIGHT, $S$.

SAUDI ARABIA: FOREIGN FOREIGN POLICY AFTER THE GULF WAR MIDOLE EAST POLICY, 1(1) (1992), 107-116.

IRAQ'S INVASION OF KUWAIT FORCED SAUDI ARABIA TO REVIEH ITS PREVIOUS FOREIGN POLICY AND REEVALUATE ITS OBJECTIVES IN THE POST-GULF WAR WORLD. IN THIS ARTICLE, THE AUTHORS BRIEFLY CONSIDER THE BASIC OBJECTIVES OF' SAUDI FOREIGN POLICY AND THEN MOVE ON TO THE PRIMARY PURPOSE, WHICH IS TO CONSIDER THE ELEMENTS OF BOTH CONTINUITY AND CHANGE IN THE
POST-WAR ENVIRONMENT, AND HHAT, IF ANY, THE NEN EMPHASES OF POST-WAR ENVIRONMENT, AND WHAT, IF ANY, THE NEW EMPHAS
SALDI POL ICY WILL BE. THEY TRY TO PROVIDE POLITICAL,

SALDI POL ICY WILL BE. THEY TRY TO
ECONOMIC AND STRATEGIC SCENARIOS.

01303 BASOM, K.E.

CLASS AND HATION IN SLOVENIA: EDVARD KARDLJ VERSUS JOSIP VIDMAR

EAST EUROPEAN QUARTERLY, XXVI(2) (SUM 92), 209-218.

THE AUTHOR PRESENTS AND ANALYZES SOME IMPORTANT ASPECTS OF EDVARD KARDELJ'S EARLY LIFE AND HIS EARLIEST CONTRIBUTIONS TO THE DEBATE ON THE YUGOSLAV NATIONAL QUESTION. DURING THE 1930'S AND WORLD WAR II, KARDELS RAPIDLY BECAME ONE OF THE INNER CORE OF THE YUGOSLAV COMMUNIST LEADERSHIP. HE LATER BECAME THE PRIMARY AUTHOR OF YUGOSLAVIA'S POST-WAR CONSTITUTIONS, A LEADING THEORIST OF WORKERS' SELF-MANAGEMENT AND DECENTRALIZED SOCIALISM, AND THE REGIME'S LEADING EXPERT ON THE NATIONAL QUESTION. HIS LATER STATEMENTS ON THE PERSISTENCE AND IMPORTANCE OF NATIONS INDICATE THAT HE EVENTUALLY ABSORBED SOME IDEAS FROM HIS IDEOLOGICAL OPPONENTS, SUCH AS JOSIP VIDMAR, A LEFT-WING SLOVENE NATIONALIST.

01304 BASTAR, T.

TREUHAMDANSTALT PRIVATIZATION IS DRIVIMG ECONOMY TO RUIN, TRADE UNION WARNS

GERMAN TRIBUNE, 1487 (OCT 91) 6

THIS ARITICLE, DISCUSSES TREHANDANSTALT, AND EAST GERMAN AGENCY COMMISSIONED BY THE GOVERMMENT TO PRIVATIZE VIABLE AND CLOSE DOWN UNVIABLE STATE-OWNED COMPANIES IN THE FORMER GDR. THE ORGANIZATION HAS RECEIVED MUCH CRITICISM, FROM TRADE UNIONS AND THOSE EAST GERMANS WHO HILL BE LOSING THEIR JOBS.

01305 BASU, A.

TWO FACES OF PROTEST--CONTRASTING MODES OF HOMEN'S ACTIVISM IN INDIA

UNIVERSITY OF CALIFORNIA PRESS, 1992, 230.

DRAHING ON CASE STUDIES OF THE COMMUNIST PARTY OF INDIA (MARXIST) IN WEST BENGAL AND SHRAMIL SANGATHANA IN MAHARASHTRA, THIS BOOK EXAMINES INDIAN WOMEN'S POLITICAL ACTIVISM. INVESTIGATING INSTITUTIONAL CHANGE AT THE STATE LEVEL AND PROTEST AT THE VILLAGE LEVEL, THE AUTHOR TRACES THE PATHS OF TWO KINOS OF POLITICAL ACTIVISM AMONG THESE WOMEN. WITH INSIGHTS GLEANED FROM EXTENSIVE INTERVIEWS WITH ACTIVISTS, GOVERNMENT OFFICIALS, AND ORDINARY MEN AND WOMEN SHE FINDS THAT MILITANCY HAS BEEN FUELED BY PRONOUNCED SEXUAL AND CLASS CLEAVAGES COMBINED WITH POTENTIALLY RANCOROUS ETHNIC DIVISION.

01306 BATES, A.

NEH REPUBLIC, 206(5) (FEB 92), 17-18. 
A NEW SPECIALTY WITHIN THE FIELD OF LAW IS CALLED "MEDICAID ESTATE PLANNING." IT HELPS MIDDLE- AND UPPERINCOME SENIOR CITIZENS SHELTER THEIR ASSETS SO THEY CA QUALIFY FOR MEDICAID COVERAGE. THE PRACTICE, WHICH IS ENTIRELY LEGAL, IS PUTTING EXTRA PRESSURE ON THE ALREADY FINANCIALLY STRAPPED MEDICAID PROGRAM BY SQUANDERING PRECIOUS RESOURCES ON THOSE WHO SHOULD NOT EXPECT U.S TAXPAYERS TO FINANCE THEIR HEALTH CARE.

01307 BATES, A.

\section{THE KEATING 535}

WASHINGTON MONTHLY, 23(4) (APR 91), 35-39.

THANKS LARGELY TO THE EXPLOITS OF THE KEATING FIVE, THE IDEA OF CAMPAIGN FIMANCE REFORM HAS OUIETLY INCHED ITS WAY IN FROM THE FRINGES, CLAIMING A PLANK IN AMERICA'S MAINSTREAM POLICY AGENDA FOR THE FIRST TIME SINCE WATERGATE. HOWEVER. THE FIRST WOEFUL EFFORTS AT CAMPAIGN REFORM HAVE DOWEV IN, CONFERENCE NEGOTIATIONS. MEANINGFUL REFORM HOULD OIED IN CONFERENCE NEGOTIATIONS. MEANINGFUL REFORM WOULD ADS; SET OUT-DF-STATE CONTRIBUTION LIMITS; BAN ALL PAC ADS; SET OUT-DF-STATE CONTRIBUTION LIMITS; BAN ALL PAC
CONTRIBUTIONS; VIRTUALLY ABOLISH THE FRANKING PRIVILEGE; AND PUT SOME BITE INTO THE FEDERAL ELECTION COMMISSION (FEC).

01308 BATES, R.H.; CURRY, A.F.

COMMUNITY VÉRSUS MÁRKET: A NOTE ON CORPORATE VILLAGES AMERICAN POLITICAL SCIENCE REVIEW, 86(2) (JUN 92), 457-463. STUDIES OF CORPORATE VILLAGES ARE CENTRAL TO THE LITERATURE ON PEASANT REBELLIONS. IN THIS PAPER, THE AUTHORS REEXAMINE THE CENTRAL ARGUMENTS OF THE LITERATURE ON COLLECTIVE VILLAGES, FOCUSING ON AN INSTITUTION FOR ALLOCATING LAND THAT THEY CALL "THE RULE." ACCORDING TO ITS ADVOCATES, THE RULE SECURES LANO ALLOCATIONS THAT PRODUCE OUTCOMES DIFFERING FROM THOSE THAT WOULD BE ACHIEVED BY MARKETS. THE OUTCOMES ARE NOT CONSTRAINED TO BE EFFICIENT. BUT THE ECONOMIC COSTS PAID FAIL TO SECURE THE ATTAINMENT OF GUARANTEES OF SUBSISTENCE, GREATER EQUALITY, OR A GREATER SENSE OF COMMUNITY RESULTING FROM THE ELIMINATION OF ENVY. HOWEVER, IN THE FACE OF HIGH LEVELS OF RISK, THE FORM OF COLLECTIVE PROPERTY RIGHTS EMBODIED IN THE RULE MAY CREATE WHAT THE AUTHORS CALL "COMMUNITIES OF (MIS) FORTUNE," IN WHICH NO ONE CAN ENVY OTHERS' GAINS OR LOSSES RESULITING FROM THE RANDOM SHOCKS OF NATURE.

01309 BATES, S.; DIAMOND, E.

DAMNED SPOTS

NEW REPUBLIC, $207(11-12)$ (SEP 92), 14, 16, 18.

THE AUTHORS LIST COMMON COMPLAINTS ABOUT CAMPAIGM

ADVERTISING AND DEFEND ADS AS A LEGITIMATE SOURCE OF INFORMATION FOR VOTERS.

01310 BATES, T.D.

PAYING FOR VALUES

COMMONWEAL, CXIX(17) (OCT 92), 6-7

ALTHOUGH VICE PRESIDENT DAN QUAYLE HAS BROUGHT THE ISSUE OF FAMILY VALUES TO THE FOREFRONT OF THE 1992 PRESIDENTIAL ELECTION, HE FAILS TO UNDERSTAND THE REAL PROBLEMS OF AMERICAN FAMILIES. THE UNITED STATES NEEDS SOCIAL POLICIES BASED ON THE FOLLOWING: (1) SOCIAL SERVICE PROGRAMS SHOULD BE ANALYZED FROM THE PERSPECTIVE OF THEIR POTENTIAL IMPACT ON FAMILIES, BECAUSE TOO OFTEN FEDERAL AND STATE PROGRAMS HAVE INADYERTENTLY REHARDED FAMILIES FOR BREAKING UP OR MOTHERS FOR REMAINING SINGLE; (2) MINIMUM LEVELS OF INCOME, HEALTH CARE, NUTRITION, AND SHELTER SHOULD BE ESTABLISHED AND FUNDED; (3) THE KNOWLEDGE AND SOCIAL SERYICES THAT ENABLE FAMILIES TO CARE FOR THEMSELVES MUST BE READILY AVAILABLE.

01311 BATHURST, $B$.

WESTERN EUROPEAN UNION: A MILITARY PERSPECTIVE RUSI JOURNAL, 137 (5) (OCT 92), 8-11.

THE AUTHOR EXAMINES THE RE-EMERGENCE OF THE HESTERN EUROPEAN UNION AS A MILITARY OPTION, AND OUTLINES HOW IT MIGHT FUNCTION SPECIFICALLY AS A COOPERATIVE EUROPEAN BODY, UNDER THE UMBRELLA OF NATO, IN RESPONSE TO THE VARYING DEMANDS OF FUTURE CONFLICTS AROUND THE WORLD. HE ARGUES THAT IN ORDER TO PROYIDE A CREDIBLE MILITARY SIGNAL OF EUROPEAN RESOLYE, EMPHASIS SHOULD BE PLACED, AS FAR AS POSSIBLE, ON A MULTINATIONAL APPROACH.

01312 BATTERSBY, J.

INTO THE NEW SOUTH AFRICA

SOUTH AFRICA FOUNDATION REVIEW, 18(1, 2) (JAN 92), 4-5.

SOUTH AFRICA'S RULING NATIOMAL PARTY (NP) AND THE AFRICAN NATIONAL CONGRESS (ANC) ARE MOVING TOWARDS A DEAL ON THE ANC'S DEMAND FOR AN ELECTED CONSTITUENT ASSEMBLY. UNTIL ELECTIONS ARE HELD, IT WILL BE IMPOSSIBLE TO END VIOLENCE AND STABILIZE THE POLITICAL PROCESS. PRESIDENT DE KLERK'S AGREEMENT TO HOLD AN ELECTION BEFORE A CONSTI IUTION IS DRAWN UP IS THE MOST IMPORTANT CONCESSION THAT THE NATIONAL PARTY GOVERNMENT HAS MADE SINCE IT CHANGED POLITICAL COURSE IN 1990. IT MEANS, IN EFFECT, THAT THE GOVERMMENT HAS DROPPED ITS PRINCIPLED OBJECTION TO AN ELECTED CONSTITUTENT ASSEMBLY FOR THE ANC'S PART, NESLON MANDELA HAS MAINTAINED THAT
THERE IS NO COMPROMISE ON THE PRINCIPLE OF MAJORITY RULE,
BUT THERE IS THE POSSIBILITY OF MODIFYING IT IN PRACTICE FOR A SUBSTANTIAL PERIDD TO PLACATE WHITES AND OTHER MINORITY GROUPS.

01313 BATTERSBY, J.

PROSPECTS FOR DEMOCRACY

SOUTH AFRICA FOUNDATION REVIEW, 18(3) (MAR 92), 1-2. MANY OBSERVERS OF SOUTH AFRICA HAVE ASSUMED' THAT THE ABOLITION OF APARTHEID WILL AUTOMATICALLY LEAD TO THE CREATION OF A DEMOCRATIC REGIME IN SOUTH AFRICA. THIS
ARTICLE ARGUES THAT SUCH AN OUTCOME IS NOT GUARANTEED. WHILE THE AFRICAN NATIONAL CONGRESS (ANC) AND THE RULING NATIONAL PARTY (NP) ARE IN GENERAL AGREEMENT ABOUT THE NEED FOR AN INTERIM GOVERNMENT, THERE IS HIDESPREAD DISAGREEMENT AS TO ITS NATURE AND TIMING. WHAT SEEMS CLEAR IS THAT THE NP AND ITS NATURE AND TIMING. WHAT SEEMS CLEAR IS THAT THE
THE ANC ARE ABOUT TO ENTER INTO A DE FACTO GOVERNING THE ANC ARE ABOUT TO ENTER INTO A DE FACTO GOVERNING
COALITION DURING THE RUN-UP TO THE ADOPTION OF A DEMOCRATIC COALITION DURING THE RUN-UP TO THE ADOPTION OF A DEMOCRATIC
CONSTITUTION. HOWEVER, THE VICTORY OF THE PRO-APARTHIED CONSERVATIVE PARTY (CP) IN A RECENT BY-ELECTION MAKES THE PROSPECT OF AN UNDEMOCRATIC HOLDING OPERATION BY A NP-ANC COALITION MORE LIKELY. THE MOVE AWAY FROM APARTHEID IS NOT COALITION MORE
IRREVERSIBLE.

01314 BATTISTA, A.

POLITICAL DIVISIONS IN ORGANIZED LABOR, 1968-1988 POLITY, XXIV(2) (WIN 91), 173-198.

THE AMERICAN LABOR MOVEMENT IS NO MONOLITH UNITED BEHIND A SINGLE COURSE OF POLITICAL ACTION. IT IS, AS THIS ARTICLE DEMONSTRATES, BESET BY INTERNAL DIVISIONS. IN THE THO DECADES BETWEEN 1968 AND 1988, WHICH ARE THE FOCUS OF THIS ANALYSIS, A NUMBER OF ISSUES DIVIDED LABOR'S LEADERSHIP INTO DOMINANT AND DISSIDENT WINGS THAT OFTEN PLAYED OPPOSING ROLES IN AMERICAN POLITICS. THE AUTHOR ARGUES THAT THE DIVISION AROSE FROM THE EXPANDING SOCIAL BASE AND AGENDA OF THE DEMOCRATIC PARTY AND THAT THE SCHISM WITHIN LABOR WEAKENED DEMOCRATIC LIBERALISM AS WELL AS THE UNION MOVEMENT.

01315 BAUBOCK, R.

MIGRATION AND CITIZENSHIP

NEW COMMUNITY, 18(1) (OCT 91), 27-48

THE AUTHOR PROPOSES A CONCEPT OF CITIZENSHIP THAT GOES BEYOND ITS NOMINAL MEANING OF "MEMBERSHIP OF A STATE." CITIZENSHIP IS SEEN AS A NORMATIVE AS WELL AS AN ANALYTICAL CITIZENSHIP IS SEEN AS A NORHATIVE AS WELL AS AN ANALYTICAL
CONCEPT, WHICH REFERS TO THE EQUALITY AND UNIVERSALITY OF CONCEPT, WHICH REFERS TO THE EQUALITY AND UNIVERSALITY OF
RIGHTS EMBEDDED IN THE INSTITUTIONS OF POLITICAL COMMUNITIES RIGHTS EMBEDDED IN THE INSTITUTIONS OF POLITICAL COMMUNI
CITIZEN RIGHTS OF MIGRANTS MUST BE ANALYZED WITHIN A

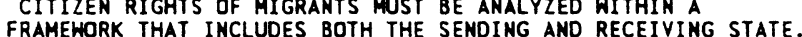
FRAMEWORK THAT INCLUDES BOTH THE SENDING AND RECEIVING STATE. THE AUTHOR CATEGORIZES RIGHTS ACCORDING TO THEIR DEPENDENCE
ON NOMINAL CITIZENSHIP AND ON RESIDENCE INTO UNIVERSAL HUMAN ON NOMINAL CITIZENSHIP AND ON RESIDENCE INTO UNIVERSAL HUMAN
RIGHTS, INTERNAL AND EXTERNAL CITIZENSHIP, ALIEN RIGHTS, AND RIGHTS, INTERNAL AND EXTERNAL CITIZENSHIP, ALIEN RIGHTS, AND SPECIAL RIGHTS OF LONG-TERM RESIDENT ALIEN CIITIZENS. THE NORMATIVE CONTENT OF CITIZENSHIP CAN BE INVOKED TO CHALLENGE THE LEGITIMATION OF INEQUALITIES AND BOUNDARIES BETHEEN THE
POSITIONS OF CITIZENSHIP, HELD BY IMMIGRANTS AND NATIVE POPULATIONS. THE AUTHOR DISCUSSES TWO DIFFERENT APPROACHES TO POLICY CHANGES ALONG THESE LINES--AN EGALITARIAN ONE, PROPOSING THE ADJUSTMENT OF LOWER LEVELS OF RIGHTS TOWARDS ALREADY-ESTABLISHED HIGHER ONES, AND A LIBERAL ONE, FOCUSING ON THE POSSILIBITIES OF UPWARD MOBILITY.

01316 BAUER, J.

INDUSTRIAL RESTRUCTURING IN THE NIES: PROSPECTS AND CHALLENGES

ASIAN SURVEY, XXXII(11) (NOV 92), 1012-1025.

RAPIDLY RISING LABOR COSTS HAVE BEGUN TO RADICALLY ALTER THE COMPARATIVE ADVANTAGE OF ASIA'S NEWLY-INDUSTRIALIZING ECONOMIES (NIES)--HONG KONG, SOUTH KOREA, SIMGAPORE AND TAIWAN. PRODUCERS IN TRADITIONALLY LOH-WAGE, LABOR INTENSIVE MAHUFACTURING HAVE FOUND IT MORE DIFFICULT TO COMPETE WITH LOWER COST PRDOUCERS IN SOUTHEAST ASIA AND CHINA. THIS ARTICLE EXAMINES THE FACTORS RESPONSIBLE FOR INCREASING LABOR COSTS IN THE NIES. THEY INCLUDE RECENT ECONOMIC AND POLITICAL PHENOMENA, SUCH AS CURRENCY APPRECIATION AND A RESURGENCE OF LABOR MOVEMENTS, AND LONGER-RUN PHENOMENA, SUCH AS DECLINING LABOR FORCE GROWTH RATES. THE AUTHOR ARGUES THAT PROJECTED LONG-RUN DEMOGRAPHIC TRENDS WIL ARGUES THAT PROJECTED LONG-RUN DEMOGRAPHIC TRENDS WILL RESTRUCTURING PROCESS. THE AUTHOR THEN EXAMINES THE RESPONSE TO THE NIES' DECLINING COMPETITIVENESS IN LABOR-INTENSIVE TO THE NIES DECLINING COMPETITIVENESS IN LABDR-INTENSI
MANUFACTURING AND CONCLUDES BY DISCUSSING THE POTENTIAL MANUFACTURING AND CONCLUDES BY DISCUSSING THE POTENTIAL
IMPACT THAT FUTURE RESTRUCTURING MAY HAVE ON WORKERS IN IMPACT THAT FUTURE
THESE COUNTRIES

01317 BAUER, J.

THE POLITICAL THOUGHT OF THE FRAMERS: AMBIGUITIES AND INTERPRETATIONS

PERSPECTIVES ON POLITICAL SCIENCE, 20(1) (WIN 91), 11-16. THE POLITICAL WRITINGS OF THE FRAMERS, INCLUDING THE FEDERALIST ESSAYS, ARE SUFFICIENTLY AMBIGUOUS THAT THEY HAVE E GENERATED MULTIPLE INTERPRETATIONS. THE PURPOSE OF THIS ESSAY IS TO SUGGEST A TYPOLOGY OF INTERPRETATIONS OF THE POLITICAL THOUGHT OF THE FRAMERS THAT MIGHT BE INCORPORATED AMERICAN CONSTITUTION. THESE FOUR BROAD INTERPRETATIONS ARE: 
THE ANTIDEMOCRATIC INTERPRETATION; THE LIBERAL

NTERPRETATION; THE REPUBLICAN INTERPRETATION; AND THE CONSTITUTIONALIST INTERPRETATION.

01318 BAUER, $R$.

THE DARK ROAD OF ABIMAEL GUZMAM

SHISS REVIEW OF WORLD AFFAIRS, 2 (8) (NOY 92), 28 HIS YEARS OF TEACHING AT THE UNIVERSITY OF AYACUCHO DURING THE 1960'S DECISIVELY INFLUENCED THE POLITICAL AND IDEOLOGICAL DEVELOPMENT OF ABIMAEL GUZMAN, LEADER OF THE SENDERO LUMINOSO. BOTH PERU'S COMMUNIST TRADITIONS AND THE MODEL OF CHINA HERE EXTREMELY SIGNIFICANT IN GUZMAN'S REVOLUTIONARY CAREER. HE ENVISIONED HIMSELF STANDING BESIDE MARX, LENIN, AMD MAO AS THE FOURTH SHORD OF THE INTERNATIONAL COMAUNIST REVOLUTION.

01319 BAUM, J.

A FAVOUR OF SORTS

FAR EASTERN ECONOMIC REVIEW, 153(32) (AUG 91), 8-9.

A U.S. STATEMENT INDICATING SUPPORT FOR TAINAN'S

APPLICATION TO JOIN GATT HAS RAISED HOPES FOR A LONG OVERDUE IMPROVEMENT IN THE COUNTRY'S TRADE RELATIONS. BUT THE DIRECT IMPACT ON TRADE MAY BE LESS IMPORTANT THAN SIGNS THAT THE U. IMPACT ON TRADE MAY BE LESS IMPORTANT THAN SIGNS THAT THE U. FUTURE POLITICAL STATUS. TO ENSURE THE SUCCESS OF A VETO ON FOMGRESSLITAL STATUS. TO ENSURE THE SUCCESS OF A VETO ON EXTENDING CHINA'S MOST-FAVORED-NATION (MFN) TRADE STATUS, EXTENOING CHINA'S MOST-FAVORED-NATION (MFN) TRADE STATUS, PRESIDENT BUSH CALCULATED HE HAD NO CHOICE BUT TO LINK TAIWAN'S GATT MEMBERSHIP WITH THE CHINA MFN ISSUE. THIS POLITICAL DEAL-MAKING ANGERS TAIWAN'S GOVERNMENT OFF CONSIDERED ON ITS MERITS AND NOT AS A POLITICAL CONCESSION.

01320 BAUM, J.; CHEUNG, T.M.; KAYE, L.

ANCIENT FEARS

FAR EASTERN ECONOMIC REVIEN, 155(48) (DEC 92), 8-10

SEEN FROM PEKING, MUCH OF WHAT HAS BEEN HAPPENING IN ITS RELATIONS WITH THE HEST OR ON ITS ASIAN PERIPHERY LOOKS LIKE PART OF A COMMON STRATEGY TO WEAKEN CHINA AND DESTROY ITS SOCIALIST SYSTEM. FROM JAPAN'S ACOUISTION OF SURVEILLANCE AIRCRAFT TO TAIWAN'S ARMS BUILD-UP, AND FROM ASEAN AND WESTERN CRITICISM OF CHINA'S ACTIONS IN THE SOUTH CHINA SEA TO GROWING WARMTH IN INDIAN-U.S. RELATIONS, A NUMBER OF RECENT DEVELOPMENTS ARE VIEWED BY THE CHINESE WITH SERIOUS APPREHENSION. CHINA IS PARTICULARLY ANXIOUS ABOUT WARMING RELATIONS BETWEEN TAIWAN AND THE REST OF THE HORLD. INDICATIONS OF THIS CHANGE INCLUDE THE BUSH ADMINSTRATION'S INDICATIONS OF THIS CHANGE INCLUDE THE BUSH ADMINSTRATION'S LIFTING OF THE BAN ON HIGH-LEVEL EXCHANGES WITH TAIWAN, THE
VISIT OF GERMANY'S ECONOMICS MINISTER TO THE ISLAND, THE VISIT OF GERMANY'S ECONOMICS MINISTER TO THE ISLAND, THE AGREEMENT BETHEEN TAIWAN'S AIR FORCE AND A GROUP OF FRENCH COMPANIES TO BUY 60 MIRAGE 2000-5E JETS AND AT LEAST 1,000 MICA AIR-TO-AIR MISSILES, AND PROPOSED SALES OF SUBMARIMES TO TAIWAN FROM DUTCH AND GERMAN SHIPYARDS. NONE OF THIS AMOUNTS TO A PLOT AGAINST CHINA, BUT PEKING HAS REACTED WITH PARANOIA TO THIS PROCESS OF ADJUSTMENT. AS A RESULT, IT HAS
SHOWN INTRANSIGENCE ON A SERIES OF ISSUES, RANGING FROM SHOWN INTRANSIGENCE ON A SERIES OF ISSUES, RANGING FROM DEMOCRATIC REFC
MIDOLE EAST.

01321 BAUM, J.

BACK FROM THE BRINK

FAR EASTERN ECONOMIC REYIEN, 155(12) (MAR 92), 8-9.

AFTER HOLDING THE MOST OPEN POLICY DEBATE IN ITS HISTORY, TAIWAN'S RULING KUOMINTANG (KMT) HAS OPTED FOR UNITY AND DUCKED A DECISION ON HOW TO CHOOSE THE NEXT PRESIDENT OF THE COUNTRY. THE STALEMATE CAME AT A HIGHLY CHARGED MEETING OF THE PARTY'S CENTRAL COMHITTEE, WHICH ACCEPTED A LAST-MINUTE COMPROMISE ON CONSTITUTIONAL REFORMS BY ENDORSING MANY LESSER CHANGES TO TAIHAN'S CONSTITUTION BUT DODGING THE ARGER ISSUES. AS EXPECTED THE KMT AGREED TO POPULAR ELECTION OF THE GOVERNOR OF TAIWAN AND THE MAYORS OF TAIPEI AND KAOHSIUNG, TO STRENGTHENING THE ROLE OF THE NATIONAL ASSEMBLY AND TO SHORTENING THE PRESIDENTIAL TERM FROM SIX YEARS TO FOUR, BEGINNING WITH THE NEXT PRESIDENTIAL POLL IN 1996. HOWEVER THERE WAS NO AGREEMENT OVER THE PRINCIPAL DISPUTE OF WHETHER TO ELECT THE PRESIDENT BY DIRECT POPULAR BALLOT OR BY PROXY VOTE.

01322 BAUM, J.

BRIDGE TO THE MAINLAMD

FAR EASTERN ECONOMIC REYIEH, 151(18) (MAY 91), 8-9.

MORE THAN FOUR DECADES OF CIVIL HAR BETWEEN TAIWAN AND CHINA ENDED OFFICIALLY ON 1 MAY 1991--AT LEAST AS FAR AS TAINAN IS CONCERNED-WHEN PRESIDENT LEE TEN-HUI SIGNED A DECREE TERMINATING THE "PERIOD OF COMMUNIST REBELLION" ON THE MAINLAND. THE PRESIDENTIAL DECISION EASES LEGAL AND THE MAINLAND. THE PRESIDENTIAL DECISION EASES LEGAL AND
IDEOLOGICAL CONSTRAINTS ON OFFICIAL POLICY TOHARD MAINLAND IDEOLOGICAL CONSTRAINTS ON OFFICIAL POLICY TOHARD MAINLAND APPROACH. BUSINESSMEN AND OPPOSITION POLITICIANS EXPECT THAT THE OFFICIAL EMD OF THE CIVIL WAR WILL BRING A DRAMATIC SHIFT IN RELATIONS. HOWEVER, LEE EMPHASIZED THAT ANY CONCRETE CHANGE HILL STILL DEPEND ON PEKING'S RESPONSE TO HIS INITIATIVES.
01323 BAUM, J.

FLAGS FOLLOW TRADE

FAR EASTERN ECONOMIC REVIEH, 155(37) (SEP 92), 20-21. TAIWAN'S LONG-STANDING POLICY OF PROHIBITING TRADE AND INVESTMENT WITH THE MAINLAND IS RAPIDLY BEING UNDERMINED. MANIFESTATIONS OF THIS CHANGE ARE FOUND IN THE TAIHANESE BUSINESS COMMUNITY'S ABILITY TO EFFECTIVELY NULLIFY THEIR OWN GOVERMMENT'S POLICIES. RECENTLY THERE HAS BEEN AN ESTIMATED US\$ B BILLION IN PRIVATE INVESTMENT MADE IN CHINA RULES. IN ADDITION, A FURTHER US\$7 BILLION IN GOODS ARE EXPECTED TO BE INDIRECTLY TRADED WITH CHINA, AN AMOUNT EQUAL TO 25\% OF TAIWAN'S TOTAL TRADE SURPLUS FOR 1992. THESE PRACTICES ARE STILL ILLEGAL, BUT SOME OF TAIWAN'S CABINET MINISTERS AND SENIOR PRESIDENTIAL ADVISERS APPEAR TO BE WORKING AT CROSS PURPOSES WITH THE OFFICIAL BAH ON COMMERICAL LINKS BY URGING BUSINESSMEN AND OTHER PRIVATE GROUPS TO STRENGTHEN THEIR TIES WITH CHINA.

01324 BAUM, J.

GOOD MEIGHBORS

FAR EASTERN ECONOMIC REVIEH, 155(16) (APR 92), 32-33. TAWIAN HAS TURNED ONE MORE CORNER IN ITS UNEASY AND UNRULY RELATIONS WITH CHINA FOLLOWING THE ACQUITTAL OF A MAN CHARGED WITH CONSPIRING TO COMMIT SEDITION PURELY ON THE BASIS OF HIS MEMBERSHIP IN THE CHINESE COMMUNIST PARTY. IN THE PAST, ANY KNOWN COMAUNIST IN TAIWAN WAS JUOGED A "REBEL APRIL. A COURT LIFTED A TEN-YEAR PRISON SENTENCE ON HONG KONG BUSINESSMAN LI HAO-GAN BECAUSE IT DETERMINED HE HAD COMMITTED NO VIOLENT ACT AND HAD NO INTENTION TO COMMIT SEDITION. THE CASE SHOWS HOW TAIWAN IS GRADUALLY REMOVING THE BARRIERS TO FREE EXCHANGE HITH CHINA AND OPENING THE WAY FOR VISITS BY ACADEMICS, ARTISTS, JOURNALISTS AND GOVERNMENT OFFICIALS.

01325 BAUM, J.

GUNS FOR BUTTER

FAR EASTERN ECONOMIC REVIEH, 155(27) (JUL 92), 8-9.

TAIHAN'S PERCEPTION OF WHO ITS REAL FRIENDS ARE MAY HAVE CHANGED FOLLOWING THE HIGH PROFILE VISIT IN LATE JUNE OF A FORMER COMMANDER OF THE SOVIET PACIFIC FLEET ON A MISSION TO SEEK AID AND INVESTMENT. ADMIRAL VLADIMIR SIDOROV AND HIS PARTY WERE THE FIRST SENIOR MILITARY OFFICERS FROM RUSSIA TO COME TO TAIWAN SINCE THE NATIONAL IST GOVERNMENT WAS

ESTABL ISHED ON THE ISLAND IN THE LATE 1940S. SIDOROY'S COMMENTS ON ARMS SALES TO CHINA AND ON FORCE REDUCTIONS FOR THE PACIFIC FLEET HAVE GIVEN TOP DEFENSE OFFICIALS IN TAIHAN THE PACIFIC FLEET HAVE GIVEN TOP DEFENSE OFFICIALS IN TAINAM A FIRST-HAND TASTE OF THE CHANGES THAT HAVE SHEPT THROUGH
THE RUSSIAN FAR EAST. SIDOROV SAID THAT THE RUSSIAN FLEET IN THE RUSSIAN FAR EAST. SIDOROV SAID THAT THE RUSSIAN
THE PACIFIC WOULD BE REDUCED BY $40 \%$ BY 1996 AND, IF

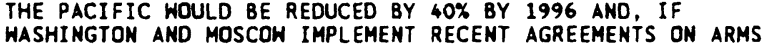
WASHINGTON AND MOSCOW IMPLEMENT RECENT AGREEMENTS ON ARMS
CUTS, BY AS MUCH AS $70 \%$ BY THE END OF THE DECADE. THE VISIT ALSO ILLUSTRATES THE USES OF PRESIDENT LEE TENG-HUI'S ALSO ILLUSTRATES THE USES OF PRESIDENT LEE TENG-HUI'S WASHINGTON'S COMFORT' BY OPENLY COURTING RUSSIA AS WASHINGTON'S COMFORT. BY OPENLY COURTING RUSSIA AS A POSSIBLE, THOUGH UNLIKELY, SOURCE FOR ARMS AND DEFENSE TECHNOLOGY, SOME EXPERTS SAY THAT TAIWAN'S MILITARY ESTABLISHMENT IS REMINDING WASHINGTON THAT IT HAS OTHER OPTIONS AND THAT IT WILL NOT REMAIN PASSIVE WHILE CHINA BUYS
ACCESS TO THE FORMIDABLE ARSENAL OF THE FORMER SOVIET STATES.

01326 BAUM, J.

KMT BARES ITS TEETH

FAR EASTERN ECONOMIC REVIEH, 155(8) (FEB 92), 21. LEADERS OF TAIWAN'S MAIN OPPOS ITION PARTY' ARE TAKING SERIOUSLY THREATS FROM THE GOVERNMENT THAT IT COULD BE BANNED FOR ADVOCATING INDEPENDENCE DURING THE 1991 NATIONAL ELECTION CAMPAIGN. SENIOR GOVERNMENT OFFICALS HAVE WARNED THE DEMOCRATIC PROGRESSIVE PARTY (DPP) THAT IT MUST REVISE ITS CHARTER OR FACE AN ORDER TO DISSOLVE. MANY OBSERVERS ASSUMED THAT THE RULING KUOMINTANG (KMT) WOULD AVOID CONFRONTATION OVER THE ISSUE AHD NOT RISK PUBLIC PROTESTS AND INTERNATIONAL CRITICISM. HITH THE SPOTLIGHT OFF TAIWAN'S ELECTION CAMPAIGN, HOWEVER, THE KMT'S POLITICAL TOLERANCE IS IN SERIOUS DOUBT AND ITS REPUTATION AS A REFORM-MINDED GOVERMMENT IS ON THE LINE.

01327 BAUM, J.

LOCAL LEVERAGE

FAR EASTERN ECONOMIC REVIEH, 155(1) (JAN 92), 28

THE STUNNING SUCCESS OF TAIHAN'S RUL ING KUOMINTANG (KMT) AT THE NATIONAL ASSEMBLY ELECTIONS IN LATE DECEMBER HAS CALMED POLITICAL TENSIONS IN TAIHAN AND IS EXPECTED TO HELP CALMED POLITICAL TENSIONS IN TAIHAN AND IS EXPECTED TO HELP EASE RELATIONS ACROSS THE TAIWAN STRAIT. THE OUTCOME HAS GIVEN THE KMT ITS STRONGEST POSSIBLE MANDATE SINCE ARRIVING IN TAIHAN MORE THAN FOUR DECADES AGO, AS WELL AS A FREE STRENGTHENED THE PARTY'S REFORMIST WING UNDER PRESIDENT LEE TENG-HUI. WHOSE NAME MANY SUCCESSFUL CANDIDATES INVOKED IN THEIR CAMPAIGN SPEECHES. ACCORDING TO TAIPEI NEHSPAPERS, PEKING WAS ESPECIALLY RELIEVED THAT THE PRO-INDEPENDENCE DEMOCRATIC PROGRESSIVE PARTY (DPP) HAS BEEN DEFEATED FOR NOW. SOME OBSERVERS SAID THAT THE DECISIVE SHING OF VOTER 
SENTIMENT AGIANST THE INDEPENDENCE MOVEMENT HAS BOUGHT TIME FOR TAIWAN TO HORK TOWARDS OEMOCRATIC REFORMS WITHOUT INTERFERENCE FROM CHINA.

01328 BAUM, J.

PARTING OF THE WAYS

FAR EASTERN ECONOMIC REVIEW, 155(45) (NOY 92), 16-19. TAIWAN'S 19 DECEMBER ELECTION TO THE LEGISLATIVE YUAN WILL BE THE MOST DEMOCRATIC IN TAIHAN'S HISTORY WITH MORE CANDIDATES AND MORE ISSUES AT STAKE THAN AT ANY TIME SINCE THE CHIMESE NATIONALISTS ARRIVED ON THE ISLAND IN 1945. BY THE SAME TOKEN IT COULD PROVIDE THE MOST CRUCIAL TEST TO THE SAME TOKEN IT COULD PROVIDE THE MOST CRUCIAL TEST DATE OF TAIWAN'S EVOLVING RELATIONSHIP WITH CHINA. THE RESPONSE FROM CHINA COULD BE SEVERE IF THE POLL PROVIDES EVIDENCE OF GROWING PUBLIC SUPPORT FOR A "ONE CHINA, ONE TAIWAN" POLICY, AT THE EXPENSE OF THE "ONE CHINA" POLICY FAVORED BY BOTH PEKING AND THE MORE CONSERVATIVE WING OF THE RULING KUOMINTANG (KMT). ONE CRUCIAL DIFFERENCE BETHEEN THE 1992 ELECTIONS AND ALL OF ITS POST-1949 PREDECESSORS IS THAT THE POLL WILL MARK THE FIRST OCCASION ON WHICH THE ENTIRE PARLIAMENT HAS BEEN CHOSEN FROM WITHIN TAIWAN. THE FORCED RETIREMENT LAST YEAR OF ELDERLY MAINLAND PARLIAMENTARIANS WHO HAD LAST BEEN ELECTED IN 1947 HAS CLEARED THE WAY FOR REJUVENATING THE LEGISLATIVE BRANCH, AND HAS GIVEN TAIWANESE VOTERS A NEW SENSE OF PARTICIPATION IN THE ELECTORAL PROCESS THE RESULT HAS BEEN A RECORD NUMBER OF CANDIDATES AND RECORD LEVELS OF CAMPAIGN SPENDING.

01329 BAUM, J.

UNF INISHED BUSINESS

FAR EASTERN ECONOMIC REVIEW, 155(11) (MAR 92), 30-31. THE TAIWAN GOVERNMENT IS MOVING OUICKLY TO PACIFY MORE THAN FOUR DECADES OF RESENTMENT OVER A 1947 UPRISING THAT COST THE LIVES OF SEVERAL TENS OF THOUSANDS OF NATIVE CITIZENS AND HAS HAUNTED RELATIONS BETWEEN TAIWANESE AND CHINESE MAINLANDERS EVER SINCE. A YEAR-LONG OFFICIAL CHINESE MAINLANDERS EVER SINCE. A YEAR-LONG OFFICIAL INVESTIGATION OF THE EPISODE WAS MADE PUBL IC IN LATE
FEBRUARY AND LEADERS OF THE RULING KUOMINTANG (KMT) HAVE FEBRUARY AND LEADERS OF THE RULING KUOMINTANG (KMT) HAVE EXPRESSED THEIR REGRET, PRESIDENT LEE TENG-HUI AND PREMIER
HAU PEI-TSUN HAVE BOTH MET THE FAMILIES OF VICTIMS OF THE "2HAU PEI-TSUN "HAVE BOTH MET THE FAMILIES OF VICTIMS OF
28 INCIDENT." THE FEAR AND SUSPICION THE 2-28 INCIDENT 28 INCIDENT MONG TAINANESE STILL AFFLICT THE SOCIETY AND MANY INSTILLED AMONG TAIWANESE STILL AFFLICT THE SOCIETY AND MANY OF THE OLDER GENERATION TAIWANESE HILL NOT DISCUSS WHAT HAPPENED WITH YOUNGER FAMILY MEMBERS. IN ADDITION, SOME STIRRING UP SOCIAL AND ETHNIC DIVISIONS FOR ULTERIOR STIRRING UP SOCIAL

01330 BAUM, L.

MEMBERSHIP CHANGE AND COLLECTIVE VOTING CHANGE IN THE UNITED STATES SUPREME COURT

THE JOURNAL OF POLITICS, 54(1) (FEB 92), 3-24.

OBSERVERS OF THE SUPREME COURT GENERALLY PERCEIVE THAT CHANGES IN THE COURT'S MEMBERSHIP IS THE PRIMARY SOURCE OF CHANGE IN ITS POLICIES AND DECISIONAL PATTERNS. THIS ARTICLE IS AN EFFORT TO TEST THAT PERCEPTION BY EXAMINING THE SOURCES OF COLLECTIVE VOTING CHANGE IN CIVIL LIBERTIES DECISIONS DURING THE 1946-1985 TERMS OF THE COURT. FOCUSING ON PERIODS OF CHANGE IN COLLECTIVE VOTING BEHAVIOR DURING THIS ERA, THE ANALYSIS SHOWS THE MEMBERSHIP CHANGE WAS THE PRIMARY SOURCE OF VOTING CHANGE BUT THAT CHANGE IN THE VOTING BEHAVIOR OF CONTINUING MEMBERS PLAYED A MAJOR ROLE IN PRODUCING COLLECTIVE VOTING CHANGE DURING SOME PERIODS.

01331 BAUM L.

ON THE UNPREDICTABILITY OF THE SUPREME COURT PS: POL ITICAL SCIENCE AMD POLITICS, $25(4)$ (DEC 92), 683-688.

THE UNITED STATES SUPREME COURT TOOAY IS AN OBJECT OF INTENSE SPECUALTION. THE AUTHOR SUGGESTS THAT EVEN THE MOST PERCEPTIVE OBSERVERS HAVE A LIMITED CAPACITY TO PREDICT THE PERCEPTIVE OBSERVERS HAVE A LIMITED CAPACITY TO PREDICT THE
COURT'S DIRECTION AS A POLICY MAKER. HE OFFERS A PERSPECTIVE
ON THE SUPREME COURT AND EXAMINES THE PATTERNS THAT HELP TO EXPLAIN THE ROLES THAT THE SUPREME COURT ADOPTS AS A POLICY EXPLAI

01332 BAUM, $R$.

POLITICAL STABILTIY IN POST-DENG CHINA: PROBLEMS AND

ASIAN SURVEY, 32(6) (JUN 92), 491-505.

THE REASONS FOR CHINA'S POLITICAL RESTABILIZATION IN THE PERIOD FOLLONING THE TIANANMEN CRACKDOWN ARE CONSIDERED AND THEN THE DOMINANT POLICY COALITIONS AND FACTIONAL CLEAVAGES THAT HAVE CHARACTERIZED CHINA'S POST-TIANANMEN LEADERSHIP ARE EXAMIMED. FOCUSING ON THE DIVISIVE ISSUE DF IHE SUCCESSION TO DENG XIAOPING, THIS ARTICLE EXPLORES THE SUCCESSION TO DENG XIAOPING, THIS ARTICLE EXPLORES THE INTENSIFICATION OF POLITICAL AND IDEOLOGICAL CONFLICT THAT HAS MARKED THE RUNUP TO THE FOURTEENTH NATIONAL CONGRESS OF 1992. IN CONCLUSION, A NUMBER OF POSSIBLE SCENARIOS FOR CHINA'S FUTURE POLITICAL DEVELOPMENT ARE CONSIDERED.

01333 BAUM, R.J.

STOPPING AIRBORNE DRUG TRAFFICKERS
HEMISPHERE, 4(3) (SUM 92), 8-9.

THE U.S. LAH ENFORCEMENT AGENCIES NEVER CAPTURE A DRUGTRAFFICKING PILOT. TRAFFICKER TACTICS, COMBINED WITH THE LEGAL CONSTRAINTS WITHIN WHICH U.S. AGENCIES WORK, HAVE MADE TRAFFICKING PILOTS THE UNTOUCHABLES OF THE DRUG TRADE. IT IS TIME THE UNITED STATES ESCALATED THE WAR AGAINST DRUGS BY GIVING FEDERAL DRUG-INTERDICTION AGENCIES THE AUTHORITY TO SHOOT DOWN AIRPLANES CARRYING ILLEGAL DRUGS.

01334 BAUMEISTER, E.J. JR.; RYERSON, D.R.; TUCKER, C.; HARREN,

REGIONAL VIENS OF FOREIGN POLICY

FOREIGN POLICY, (88) (FAL 92), 38-56

IN THIS ROUND-UP OF U.S. PUBLIC OPINION, JOURHALISTS

REPORT FROM NEW JERSEY, GEORGIA, IOWA, AND CALIFORNIA ON HOH AMERICANS VIEW THE IMPORTANCE OF FOREIGN POLICY IN THE 1992 ELECTION YEAR. THEY WRITE THAT, DESPITE REGIONAL VARIATIONS, APPREHENSIVE VOTERS ARE CONCENTRATING ON THE TROUBLED DOMESTIC ECONOMY AND ARE NOTICEABLY LESS INTERESTED IN TRADITIONAL WAR-AND-PEACE ISSUES NOW THAT THE COLD WAR HAS ENDED. THEY ALSO REPORT GROWING POPULAR SENTIMENT FOR INVESTING AT HOME MUCH OF THE MONEY THAT IS NOW SPENT ABROAD TO MAINTAIN AMERICA'S ALLIIANCES. BUT, OF COURSE, FOREIGN POLICY CONCERNS WILL NOT BE COMPLETELY ABSENT FROM THE 1992 CAMPAIGH.

01335 BAUZON, K.D.

SOCIAL KMOWLEDGE AND THE LEGITIMATION OF THE STATE: THE PHILIPPINE EXPERIENCE IN HISTORICAL PERSPECTIVE

POLITICAL COMMUNICATION, $9(3)$ (1992), 173-189.

THE PURVEYORS OF SOCIAL KNOWLEDGE, INCLUDING THE SOCIAL

SCIENCES, IN THE PHILIPPINES FROM THE SPANISH COLONIAL PERIOD TO THE PRESENT HAVE SERVED, EITHER WILLINGLY OR UNWILLINGLY, TO LEGITIMIZE AND VALIDATE THE EXISTING POLITICAL ORDER BY ELABORATING ON THE POLITICAL ORDER'S IDEOLOGICAL BASIS, CONTRIBUTING TO THE FORMULATION AND IMPLEMENTATION OF POLICIES, REFUSING TO CHALLENGE THE POLIIICAL ORDER, OR BY SIMPLY BEING ACOUIESCENT TO ITS PRESENCE. THE PHILIPPINE EXPERIENCE REINFORCES THE OBSERVATION THAT OBJECTIVITY IS RELATIVE TO THE PARADIGM TO WHICH THE PRACTITIONER BELONGS. IN THE WAKE OF THE POSTBEHAVIORALIST MOVEMENT IN THE SOCIAL SCIENCES, THE SOCIAL BEHAVIORALIST MOVEMENT IN THE SOCIAL SCIENCES, THE SOCIAL
SCIENTIST'S ROLE IN THE PHILIPPINES IS INFLUENCED NOT SO SCIENTIST'S ROLE IN THE PHILIPPINES IS INFLUENCED NDT SO
MUCH BY THE DRIVE TO BE OBJECTIVE BUT RATHER BY THE NEED TO MUCH BY THE DRIVE TO BE OBJECTIVE BUT RATHER BY THE NEED CHOOSE BETWEEN COMPETING VALUES THAT WOULD
DETERMINE HIS OR HER RELEVANCE TO SOCIETY.

01336 BAXTER, C.

BANGLADESH IN 1990: ANOTHER NEW BEGINHING?

ASIAN SURVEY, XXXI(2) (FEB 91), 146-152.

FOR THE FIRST TEN MONTHS OF 1990, IT SEEMED THAT

BANGLADESH WAS HAVING A RELATIVELY UNEVENTFUL YEAR. THEN, IN THE FINAL TWO MONTHS OF THE YEAR, A POPULAR SURGE OF OPPOSITION AGAINST PRESIDENT HUSSAIN MUHAMMAD ERSHAD SWEPT HIM AND HIS GOVERMMENT FROM OFFICE AND INSTALLED A CARETAKER REGIME CHARGED WITH HOLDING AN ELECTION NO LATER THAN MARCH 1991. THE ECONOMY WAS, AT BEST, STAGNANT ANO WAS HIT BY THE SHARP INCREASE IN THE COST OF OIL AFTER THE IRAQI INVASION OF KUWAIT, WHICH ALSO LED TO THE RETURN OF BANGLADESHI WORKERS FROM MUCH OF THE GULF AREA AND THE LOSS OF THEIR REMITTANCES. IN FOREIGN AFFAIRS, DESPITE THE TRAVELS OF ERSHAD AND VISITS BY INOIAN AND PAKISTANI FOREIGN MINISTERS, NOTHING CONRETE WAS ACCOMPLISHED IN THE DISPUTES BANGLADESH HAS WITH THE TWO OTHER SUCCESSORS TO THE FORMER BRITISH INDIAN EMPIRE.

01337 BAXTER, C.

BANGLADESH IN 1991: A PARLIAMENTARY SYSTEM

ASIAN SURVEY, XXXII(2) (FEB 92), 162-167.

IN 1991, BANGLADESH CONDUCTED THE "FREE AND FAIR" ELECTION THAT HAD BEEN PROMISED WITH THE FALL OF PRESIDENT ERSHAD IN DECEMBER 1990. THE COUNTRY CHANGED ITS ERSHAD IN DECEMBER 1990. THE COUNTRY CHANGED ITS PRESIDENTIAL SYSTEM WITH A PRIME MINISTER AS HEAD OF GOVERNMENT AND A PRESIDENT AS A CEREMONIAL HEAD OF STATE. ALMOST IMMEDIATELY, THE NEW GOVERNMENT--LED BY PRIME MINISTER BEGUH ZIA--HAS FACED WITH THE TASKS OF RELIEF AND MINISTER BEGUH ZIA--HAS FACED WITH THE TASKS OF REL IEF AND
RECDVERY FROM A DEVASTATING CYCLONE, AND ECONOMIC CONDITIONS RECOVERY FROM A DEVASTATING CYCLONE, AND ECONOMIC CONDITIONS
SHOWED LITTLE IMPROVEMENT DURING THE YEAR DESPITE FURTHER SHOWED LITTLE IMPROVEMENT DURING THE YEAR DESPITE FURTHER
STEPS TOWARD PRIVATIZATION AND ENCOURAGEMENT OF FOREIGN STEPS TOWARD
INVESTMENT.

01338 BAXTER, C.

BANGLADESH: A PARLIAMENTARY DEMOCRACY, IF THEY CAN KEEP IT CURRENT HISTORY, 91 (563) (MAR 92), 132-136.

BANGLADESH HAS ABANDONED ITS AUTHORITARIAN GOVERNMENT AND REVERTED TO THE PARL IAMENTARY SYSTEM IT ORIGINALLY CHOSE WHEN THE COUNTRY BECAME INDEPENDENT IN 1971. THE MILITARY GOVERMMENT IS GONE AND THE COUNTRY HAS REENGAGED ITSELF IN THE DEMOCRATIC PROCESS, HOHEVER TENTATIVELY. ECONOMIC PROGRESS IS SLOW, AND FUTURE GAINS HILL REQUIRE SUBSTANTIAL, CONCERTED FOREIGN AID AND INVESTMENT. 
01339 BAXYER, D.

MARX, CLASS CONSCIOUSNESS, AND THE TRANSITION OF SOCIALISM CRITICAL SOCIOLOGY, 19(1) (1992), 19-44.

THE PURPOSE OF THIS PAPER IS TO TRACE, FIRST, THE IRADITIONAL MARXIAN ARGUMENT (IN CAPITAL, VOLUME 1, AND THE TRADITIONAL MARXIAN ARGUMENT (IN CAPITAL , VOLUME
"COMMUNIST MANIFESTO") REGARDING THE EVOLUTIONARY

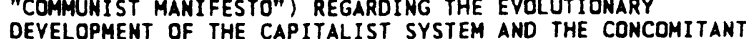
DEVELOPMENT OF THE CAPITALIST SYSTEM AND THE CONCOMITANT
EMERGENCE OF A REVOLUTIONARY CLASS-CONSCIOUSNESS. IT HILL BE EMERGENCE OF A REVOLUTIONARY CLASS-CONSCIOUSNESS. I

SUGGESTED THAT THESE ARGUMENTS ARE THEORETICALLY INCOMPATIBLE WITH OTHER ASSUMPTIONS MARX MAKES REGARDING THE ROLE OF THE STATE. SECOND, AN ALTERNATIVE ARGUMENT WILL BE OUTLINED FOCUSING ON COMMENTS MARX MADE CONCERNING THE REVOLUTIONARY POTENTIAL OF SELF MANAGED COOPERATIVE ENTERPRISES. IT WILL BE ARGUES THAT THIS LATTER ARGUMENT PROVIDES VALID CONCEPTUAL GROUNOS FOR A NEW STRATEGY LEADING TO THE ESTABLISHMENT OF SOCIALIST SOCIETY.

01340 BAYES, J.

HOMEN IN PUBLIC ADMINISTRATION IN THE UNITED STATES

WOMEN AND POLITICS, $1(4)$ (1991), 85-110.

THE STATUS OF HOMEN IN PUBLIC ADMINISTRATION IN THE

UNITED STATES IS DISCUSSED IN THIS ARTICLE. FIRST A

BACKGROUND IS GIVEN OF TRENDS IN THE LABOR FORCE FOR WOMEN.

IT REVIEWS FEDERAL LAWS GOVERNING WOMEN'S EMPLOYMENT

DISCUSSES THE JOB SITUATION, AND CONCLUDES WITH GENERAL

DISCUSSES THE JOB SITUATION
STRATEGIES FOR IMPROVEMENT.

01341 BAYME, $N$

THE COURSE OF SUMAITRY

WORLD TODAY

THE G-7 ECONOMIC SUMMITS CANMOT BE REGARDED AS SELFCONTAINED EVENTS BECAUSE THEY FORM PART OF A WHOLE SEQUENCE OF INTERNATIONAL CONSULTATIONS, INVOLVING A GROWING RANGE OF INTERGOVERMMENTAL ORGANIZATIONS. THE SUMMITS SERVE TO STIMULATE WORK IN THESE INTERNATIONAL ORGANIZATIONS, TO POINT THEM IN FRESH DIRECTIONS, AND OCCASIONALLY TO PROMOTE NEN INSTITUTIONS.

01342 BAZELL, R.

TISSUE ISSUE

NEH REPUBLIC, 206 (26) (JUN 92), 10-11.

GEORGE BUSH IS OFFERING MILLIONS OF SICX AND DESPERATE AMERICANS AN ENDURING CIVICS LESSON. THE ADMINISTRATION'S BAN ON FEDERAL FUNDING FOR FETAL TISSUE TRANSPLANTS WILL DENY HOPE TO THOSE WITH PARKINSON'S DISEASE, DIABETES, AND DOZENS OF OTHER INFIRMITIES. BUSH HAS ACCEPTED THE ARGUMENT OF THE STAUNCHEST ANTI-ABORTION GROUPS THAT THE

WOULD LEGITIMIZE AND EVEN ENCOURAGE ABDRTION.

01343 BAZHANOV, E.; BAZHANOV, $N$.

SOVIET VIEWS ON MORTH KOREA: THE DOMESTIC SCENE AND SOVIET VIEHS ON

ASIAN SURVEY, 31(12) (DEC 91), 1123-1138.

HITH THE EVOLUTION OF THE SOVIET SOCIETY AWAY FROM DOGMA AND TOWARD A MARKET-ORIENTED IDEOLOGICALLY DIVERSE SOCIETY ONE MAY EXPECT THAT THE IMAGE OF NORTH KOREA WILL BECOME LESS AND LESS ATTRACTIVE TO THE SOVIET PUBLIC. THIS ARTICLE ATTEMPTS TO SHOH NEW TRENDS ON THE BASIS DF VIEWS EXPRES IN SCHOLASTIC PAPERS, AT CONFERENCES AND SEMINARS. IT EXAMINES APPROACHES OF SOVIET SPECIALISTS TO SPECIFIC ASPECTS OF THE NORTH KOREAN SCENE. IT CONCLUDES THAT FOR MORTH KOREA, EVENTUALLY ECONOMIC
MORTH TO CONSIDER REUNIFICATION.

01344 BEACH, H.

MINIMUM DETERRENCE AND THE PROTECTION OF THE INNOCENT: A DISCUSSION PAPER

BULLETIN OF PEACE PROPOSALS, 23(1) (MAR 92), 29-34. THIS ARTICLE EXAMINES THE CONCEPT OF MINIMUM NUCLEAR DETERRENCE (MND), THE IDEA THAT THE BEST CHANCES OF SAFETY LIE IN THE POSSESSION OF THE SMALLEST NUMBER OF WEAPONS BY THE SMALLEST NUMBER OF NATIONS. ONE POTENTIAL PROBLEM HITH MND IS THAT IT IS BY NATURE AND NECESSITY AND DOCTRINE OF RETALIATION, AND SUCH A RETALIATION WILL INVOLVE PLANNING TO STRIKE CIVILIANS. THE AUTHOR CONCLUDES THAT, DESPITE THIS POTENTIAL MORAL DILEMMA, MND IS NO WORSE THAN ANY CONCEIVABLE ALTERNATIVES. IN ADDITION, MND SEEMS TO BE THE NUCLEAR DOCTRINE MOST LIKELY TO BE USED BY NUCLEAR STATES IN THE HORLD.

01345 BEAUDRY, P.; DINARDO, T.

THE EFFÉCT OF IMPLICIT CONTRACTS ON THE MOVEMENT OF WAGES OVER THE BUSINESS CYCLE: EVIDENCE FROM MICRO DATA JOURNAL OF POLITICAL ECONOMY, 99(4) (AUG 91), 665-688.

THIS PAPER ADDRESSES THE QUESTION OF WHETHER WAGES ARE AFFECTED BY ADORESSES THE QUESTION OF WHETHER WAGES AFFECTED BY LABOR MARKET CONDITIONS IN A MANNER MORE CONSISTENT WITH A CONTRACT APPROACH THAN WITH A STANDARD SPOT MARKET MODEL. FROM A SIMPLE IMPLICIT CONTRACT MOOEL, PAST LABOR MARKET CONDITIONS. USING INDIVIDUAL OATA FROM THE CURRENT POPULATION SURVEY AND THE PANEL STUDY OF INCOME DYNAMICS IT IS FOUND THAT AN IMPLICIT CONTRACT MODEL WITH COSTLESS MOBILITY DESCRIBES THESE LINKS BETTER THAN EITHER A SIMPLE SPOT MARKET MODEL OR AN IMPLICIT CONTRACT MODEL WITH
COSTLY MOBILITY.

01346 BECK, E.M.; TOLNAY, S.E.

LYNCHING: A LABOR CONTROL MODEL

INTERNATIONAL REYIEW OF SOCIAL HISTORY, XXXVII(1) (1992),

$1-24$.

THIS PAPER EXPLORES THE HYPOTHESIS THAT MONTHLY YARIATION IN WHITE MOB VIOLENCE AGAINST BLACKS IN THE AMERICAN SOUTH WAS AFFECTED BY SEASONAL VARIATION IN THE DEMAND FOR LABDR IN SOUTHERN AGR ICULTURE. USING MONTHLY DATA ON BLACK LYNCHINGS THAT OCCURRED BETHEEN 1882 AND 1930 THE AUTHORS FIND THAT MOB VIOLENCE WAS MORE FREQUENT DURING TIMES OF STRONGER LABOR DEMAND THAN DURING SLACK PERIOOS. WHILE THE MANIFEST FUNCTION OF LYNCHINGS MIGHT WELL HAVE BEEN TO RID THE WHITE COMMUNITY OF OFFENDING BLACKS WHO VIOLATED THE MORAL ORDER, THE AUTHORS SUGGEST THAT THE LATENT FUNCTION WAS TO TIGHTEN THE REINS OF CONTROL OVER THE BLACK POPULATION, ESPECIALLY DURING TIMES WHEN WHITES MOST NEEDED BLACK LABOR TO HORK FIELDS OF COTTON OR TOBACCO.

01347 BECK, $N$.

THE ILLUSION OF CYCLES IN INTERNATIONAL RELATIONS

INTERNATIONAL STUDIES QUARTERLY, 35(4) (DEC 91), 455-476.

THIS PAPER EXAMINES HHETHER THERE ARE LONG CYCLES IN HAR

SEVERITY, AND WHETHER THOSE CYCLES ARE RELATED TO INFLATION.

IT ARGUES THAT METHODS BASED ON FIXED PERIODICITY AND, IN PARTICULAR, SPECTRAL ANALYSIS ARE APROPRIATE TOOLS FOR THE PARTICULAR, SPECTRAL ANALYSIS ARE APROPRIATE TOOLS FOR THE
STUDY OF SOCIAL CYCLES. IT IS ALSO ARGUED THAT ANALYSTS OF STUDY OF SOCIAL CYCLES. IT IS ALSO ARGUED THAT ANALYSTS OF WAR ARE NEVER GOING TO GATHER A LONG ENOUGH DATA SER

01348 BECK, P.A.; BAUM, L.; CLAUSEN, A.R.; SMITH, C.E. JR. PATTERNS AND SOURCES OF TICKETS SPLITTING IN SUBPRESIDENTIAL VOTING

AMERICAN POLITICAL SCIENCE REVIEW, 86(4) (DEC 92), 916-928. ALTHOUGH THE PRIMARY SOURCE OF DIVIDED GOVERNMENT IN THE UNITED STATES IS VOTERS WHO SPLIT THEIR BALLOTS BETHEEN PARTIES, THERE HAS BEEN LITTLE COMPREHENSIVE EXAMINATION OF EITHER PATTERNS OR SOURCES OF TICKET-SPLITTING IN RECENT YEARS. INSTEAD, DIVERGENT LINES OF RESEARCH HAVE EMPHASIIED SUCH ELEMENTS AS VOTER PARTISANSHIP, INCUMBENCY, ANO A "NEH" (YOUNG, HELL-EDUCATED, EVEN PARTISAN) KIND OF TICKETSPLITTER, AMD THE FOCUS HAS TOO OFTEN BEEN RESTRICTED TO THE ATYPICAL PRESIDENT-CONGRESS PAIR. THE AUTHORS UNIFY THESE RESEARCH TRADITIONS IN A COMPREHENSIVE MODEL OF SPLIT-TICKET VOTING AND TEST IT ACROSS THE PARTISAN BALLOT IN A TYPICAL ELECTION SETTING--THE CONTESTS FOR FIVE OHIO STATEWIDE OFFICES IN 1990. THE MODEL INCORPORATES PARTISAN STRENGTH, CANDIDATE VISIBILITY, AND THE INDIVIDUAL CHARACTERISTICS THAT DISTINGUISH THE "NEW" TICKET-SPLITTERS. THE RESULTS SUPPORT THE PARTISAN-STRENGTH AND CANDIDATE-VISIBILITY EXPLANATIONS BUT PROVIDE LITTLE SUPPORT FOR THE EMERGENCE OF A NEH TYPE OF TICKET-SPLITTER.

01349 BECK, R.; HENDON, D.W.

NOTES ON CHURCH-STATE AFFAIRS

NOTES ON CHURCH-STATE AFFAIRS (SUM 92), 633-665.

THE AUTHORS SUMMARIZE IMPORTANT DEVELOPMENTS REGARDING CHURCH-STATE AFFAIRS IN THE SPRING OF 1992 IN ALGERIA, ARGENTINA, BURMA, CANADA, CHINA, CIECHOSLOYAKIA, EGYPT, EL SALVADOR, FRANCE, GERMANY, GUATEMALA, HAITI, HUNGARY, INDIA, IRELAND, IRAN, ISRAEL, ITALY, IVORY COAST, LEBANON, MALAHI, MEXICO, MONGOL IA, NICARAGUA, PAKISTAN, POLAND, RUSSIA, SAUDI ARABIA, SOUTH AFRICA, SPAIN, SUTAN, UYREKI', TURKEY, THE VATICAN, UNITED KINGDOM,

01350 BECK, R.; HENDON, D.W. NOTES ON CHURCH-STATE AFFAIRS

JOURNAL OF CHURCH \& STATE, 34(4) (FAL 92), 897-937. THE AUTHORS SUMMARIZE RECENT DEVELOPMENTS INVOLVING CHURCH-STATE RELATIONS IN AFGHANISTAN, ALBANIA, ALGERIA, ANGOLA, BRAZIL, CANADA, CHINA, CZECHOSLOVAKIA, EGYPT GERMANY, GUATEMALA, INOIA, INDONESIA, IRAN, IRAQ, IRELAND, ISRAEL, MONGOLIA, NICARAGUA, NIGERIA, PAKISTIAN, SAUDI ARABIA, THE UNITED KINGDOM, THE UNITED STATES, AND YUGOSLAVIA.

01351 BECK, R.; HENDON, D.W.

NOTES ON CHURCH-STATE AFFAIRS

JOURNAL OF CHURCH \& STATE, 34(1) (HIN 92), 175-202. THE AUTHORS SUMMARIZE RECENT DEVELOPMENTS IN CHURCH-

STATE RELATIONS IN ALBANIA, ARGENTINA, BRAZIL, CANADA, HAITI,

ISRAEL, MEXICO, TURKEY, YUGOSLAVIA, AND SEVERAL OTHER

COUNTRIES. THE SECTION ON THE UNITED STATES INCLUDES

COMMENTS ON THE ABORTION ISSUE AND ON RECENT SUPREME COURT DECISIONS.

01352 BECK, R.; CURRY, J.A.; ROSS, M.L.

NOTES ON CHURCH'STATE' AFFAIRS

JOURNAL OF CHURCH \& STATE 34(2) (SPR 92), 411-451.

THE AUTHORS REPORT ON EVENTS AFFECTING CHURCH-STATE RELATIONS AROUND THE WORLD IN EARLY 1992. THEY SURYEY DEVELOPMENTS IN ALGERIA, BRAZIL, CANADA, CHINA, ISRAEL, MEXICO, RUSSIA, GREAT BRITAIN, THE UNITED STATES, AND 
SEVERAL OTHER COUNTRIES.

01353 BECKERLEGGE, G

"STRONG CULTURES" AND DISTIMCTIVE RELIGIONS: THE INFLUENCE OF IMPERIALISM UPON BRITISH COMMUNITIES OF SOUTH ASIAN ORIGIN

NEW COMMUNITY, 17(2) (JAN 91), 201-210.

THE ARTICLE BEGINS WITH A DISCUSSION OF CONTRASTS DRAWM BETWEEN "WEAK" AFRO-CARIBBEAN AND "STRONG" SOUTH ASIAN CULTURES IN BRITAIN AND THE ASSOCIATION FREQUENTLY POINTED TO IN SUCH CONTRASTS BETWEEN "STRONG" SOUTH ASIAN CULTURES AND THE PERSISTENCE OF DISTINCTIVE REL IGIDUS BEHAVIOR. IT IS ARGUED THAT THE MERE FACT OF DISTINCTIVENESS DOES NOT IN ITSELF EXPLAIN THE PROMINENT ROLE TAKEN BY RELIGION IN THE CREATION OF FORMAL ASSOCIATIONS BY SOUTH ASIAN GROUPINGS,
ESPECIALLY WHEN THE RELIGIOUS DIVERSITY OF SOUTH ASIANS IS ESPECIALLY WHEN THE RELIGIOUS DIVERSITY OF SOUTH
RECOGNIZED. THE ARTICLE PROCEEDS TO ARGUE THAT AN

RECOGNIZED. THE ARTICLE PROCEEDS TO ARGUE THAT AN
EXAMINATION OF BRITISH POLICY IN INDIA DURING THE PERIOD OF EXAMINATION OF BRITISH POLICY IN INDIA DURING THE PERIDD OF
EMPIRE CAN DISCLOSE REASONS FOR THE RELIANCE BY A VARIETY OF EMPIRE CAN DISCLOSE REASONS FOR THE RELIANCE BY A VARIETY
SOUTH ASIAN GROUPS UPON RELIGION AS A SOURCE OF SOCIAL COHESION. IT IS SUGGESTED IN CONCLUSION THAT THE CONTRAS BETWEEN "WEAK" AFRO-CARIBBEAN AND "STRONG" SOUTH ASIAN CULTURES IS DOUBLY MISLEADING DUE TO ITS NEGATIVE VALUATION OF AFRO-CARIBBEAN CULTURES AND THE UNCRITICAL VIEN IT ENCOURAGES OF THE ELEMENTS UPON WHICH IT IMPLIES "STRONG" SOUTH ASIAN CULTURES ARE BASED.

01354 BECKERMAN, $W$.

ECONOMIC GROWTH AND THE ENVIRONMENT: WHOSE GROWTH? WHOSE ENVIRONMENT?

NORLD DEVELOPMENT, 20(4) (APR 92), 481-496

THE WIOESPREAD CLAMOR FOR IMMEDIATE DRACONIAN ACTION TO REDUCE THE DANGER OF GLOBAL WARMING IS AN UNJUSTIFIABLE DIVERSION OF ATTENTION FROM THE FAR MORE SERIOUS ENVIRONHENTAL PROBLEMS FACING DEVELOPING COUNTRIES. RESOURCE CONSTRAINTS DO NOT CONSTITUTE LIMITS TO GROWTH, AND THE LIKELY ECONOMIC DAMAGE DONE BY CLIMATE CHANGE WOULD BE A NEGLIGIBLE PROPORTION OF WORLD OUTPUT. THE LOSSES IN DEVELOPING COUNTRIES TODAY DUE TO URBAN AIR POLLUTION OR INADEQUATE ACCESS TO SAFE DRINKING WATER AND SANITATION ARE GREAT AND SHOULD BE GIVEN PRIORITY OVER THE INTERESTS OF EITHER MORALIY INDEFENSIBLE OR TOTALIY NONOPERATIONAL.

01355 BECKMAN, $N$.

THE GOVERNORS AND THE NATIONAL GUARD IN PERPICH V. DEFENSE PUBLIUS: THE JOURNAL OF FEDERALISM, 21(3) (SUM 91), 109-124.

THE MATIONAL GUARD IS A LARGELY SUCCESSFUL

INTERGOVERNMENTAL INSTITUTION IN THE UNITED STATES. IN SEPTEMBER 1989, HOWEVER, THE GOVERNOR OF MINHESOTA ASKED THE U.S. SUPREME COURT TO STRIKE DOWN FEDERAL LEGISLATION THAT GIVES THE DEPARTMENT OF DEFENSE AUTHORITY TO ASSIGN STAT
NATIONAL GUARD UNITS TO ACTIVE-DUTY OVERSEAS TRAINING NATIONAL GUARD UNITS TO ACTIVE-DUTY OVERSEAS TRAINING
WITHOUT THE CONSENT OF THE GOVERNOR. IN PERICH (1990), THE SUPREME COURT UPHELD THE MONTGOMERY AMENDMENT ALLOHING THE PRESIDENT TO ORDER MEMBERS OF A STATE'S GUARD TO ACTIVE DUTY
FOR TRAINING OUTSIDE THE UNITED STATES EVEN DURING PEACETIME FOR TRAINING OUTSIDE THE UNITED STATES EVEN DURING
WITHOUT EITHER THE CONSENT OF THE GOVERNOR OR THE WITHOUT EITHER THE CONSENT OF THE GOVERNOR OR THE
DECLARATION OF A NATIONAL EMERGENCY. THE COURT DID NOT ADDRESS THE FACT THAT THE PRESIDENT HAS AMPLE AUTHORITY
UNDER OTHER STATUTES FOR CALLING UP THE NATIONAL GUARD. THE DEDER OTHER STATUTES FOR CALLING UP THE NATIONAL GUARD. THE DECISION DEALT ONLY WITH THE AUTHORITY FOR CALLING GUARD EFFECT OF THIS INTERPRETATIDN OF THE MILITIA CLAUSES OF THE EFFECT OF THIS INTERPRETATIDN OF THE MILITIA CLAUSES OF THE U.S. CONSTITUTION IS TO REDUCE THE STATES AUTHORITY FOR
TRAINING TO, AT BEST, A MINISTERIAL FUNCTION, EVEN WHEN TRAINING TO, AT BEST, A MINISTERIAL FUNCTION, EVEN WHEN FOR THE PURPOSE OF TRAINING.

01356 BECKWITH, $K$.

COMPARATIVE RESEARCH AND ELECTORAL SYSTEMS: LESSONS FROM FRANCE AND ITALY

HOMEN AND POLITICS, 12(1) (1992), 1-33.

FOCUSING ON FEMALE REPRESENTATION IN THE FRENCH NATIONAL ASSEMBLY AND IN THE ITALIAN CHAMBER OF DEPUTIES SINCE 1946, THE AUTHOR EXPLORES THE RELATIONSHIPS AMONG ELECTORAL SYSTEMS, ECONOMIC CHANGE, AND TYPE OF POLITICAL PARTY IN EXPLAINING HOMEN'S ACCESS TO LEGISLATIVE OFFICE. SHE STRONGLY CAUTIONS AGAINST ACCEPTING CLAIMS THAT PROPORTIONAL REPRESENTATION SYSTEMS BENEFIT HOMEN RUNNING FOR OFFICE AND CONCLUDES THAT AGGREGATE DATA ANALYSIS ACROSS MANY NATIONS FOCUSING ON ELECTORAL STRUCTURE AT THE EXPENSE OF OTHER IMPORTANT FACTORS, HAS OBSCURED UNDERSTANDING OF THE MECHANISMS THAT IMPEDE OR FACILITTATE WOMEN'S ACCESS TO ELECTIYE OFFICE. SHE ALSO OFFERS REFLECTIONS ON DOING COMPARATIVE RESEARCH ON WOMEN AND POLITICS.

01357 BEDARD, $P$

THEY'D RATHER BE HUNTIMG

NATIONAL REVIEW, XLIV(23) (NOV 92), 34-37.

THE BUSH 1992 CAMPAIGN IS DISCUSSED IN THIS ARTICLE. IT FOCUSES ON JAMES BAKER TAKING OVER THE CAMPAIGN. WHEN BAKER ARRIVED WITH HIS TEAM, IT OUICKLY BECAME CLEAR THAT HE
WANTED ONLY TO HANOLE THE BIG DECISIONS, SUCH AS PREPARING MAJOR BUSH SPEECHES AND SCHEDUL ING THE DEBATES. BAKER ESSENTIALLY WENT INTO SECLUSION, AS HE STRUGGLED TO UNTANGLE THE MESS HE HAD WALKED INTO.

01358 BEDESKI, R.E.

NORDPOL ITIK IN SOUTH KOREA: REACHING OUT TO THE USSR AND CHINA; ASSOCIATION FOR ASIAN STUDIES 1992 ANNUAL MEETING ASSOCIATION FOR ASIAN STUDIES, 1992, 116-117.

THIS PAPER EXAMINES SOUTH KOREA'S POLICY OF NORDPOLITIK, THE EFFORT TO NORMALIZE RELATIONS WITH THE SOVIET UNION AND CHINA. SEDUL HAS CULTIVATED RELATIONS WITH COMMUNIST COUNTRIES FOR SEVERAL REASONS. FIRST, THE ROK HAS BEEN IN CONFLICT AND COMPETITION WITH NORTH KOREA FOR DIPLOMATIC ADVANTAGE. EACH COMMUNIST COUNTRY THAT RECOGNIZES SOUTH KOREA IS A TESTIMONY THAT PYONGYANG IS NOT THE ONLY LERITIMATE GOVERNMENT ON THE KOREAN PENINSULA. THIS PROCESS LES HELPED TO ISOLATE THE NORTH KOREAN GOVERNMENT. SECOND, THE BREAKDOWN OF THE COLD WAR SYSTEM AIDS IN PACIFICATION OF THE REGION BY REDUCING TENSIONS AND THE POSSIBILITY OF THE REGION BY REDUCING TENSIONS AND THE POSSIBILITY OF
RENEWED WAR. THE END OF THE COLD WAR HAS REDUCED THE RENEWED WAR. THE END OF THE COLD WAR HAS REDUCED THE
STRATEGIC VALUE OF NORTH KOREA FOR SOVIET SECURITY. THIRD, STRATEGIC VALUE OF NORTH KOREA FOR SOVIET SECURITY. THIRD,
THE EMERGING REPUBLICS IN EASTERN EUROPE AND THE NEW ORDER THE EMERGING REPUBLICS IN EASTERN EUROPE AND THE NEW ORDER
IN THE SOVIET UNION REPRESENT A NEW MARKET FOR SOUTH KOREAN IN THE SOVIET UNION REPRESENT A NEW MARKET FOR SOUTH KOREAM PRODUCTS AND INVESTMENT. FOURTH, CULTIVATION OF TIES WITH
MOSCOW CAN HELP IN MODERATING THE STALEMATE WITH NORTH KOREA. MOSCOW CAN HELP IN MODERATING THE STALEMATE WITH NORT FINALLY, SOVIET RECOGNITION SIGNIFICANTLY REDUCES
PYONGYANG'S DIPLOMATIC LEVERAGE BETHEEN THE USSR ANO CHINA. PYONGYANG'S DIPLOMATIC LEVERAGE BETHEEN THE USSR ANO CHINA. THE PAPER ALSO EXAMINES THE IMPACT OF NOROPOL.T
PROSPECTS FOR RELATIONS WITH CHINA AND JAPAN.

01359 BEDNAR, $M$.

MASARYK, CZECHOSLOVAKNESS AND EUROPEANHOOD

EAST EUROPEAN REPORTER, 5(1) (JAN 92), 47-48.

WITH THE PRESENT SITUATION IN CENTRAL AND EASTERN EUROPE CLOSELY RESEMBLING THE YEARS AFTER THE FIRST WORLD WAR WHEN THE COLLAPSE OF EMPIRES WAS FOLLOWED BY THE BIRTH OF A NUMBER OF NEW STATES, IT IS WORTH RECALLING THE IDEAS OF TOMAS GARRIGUE MASARYK (1850-1937) HHO TIRED HARD TO PROMOTE FRAMEWORKS THAT HOULD RECONCILE THE EXISTENCE OF SO MANY ETHNICALLY INTERWOVEN COUNTRIES SIDE BY SIDE. THE EMPHASIS OF THIS ARTICLE IS ON CZECHOSLOVAKIA. ACCORDING TO MASARYK, THE SPECIFIC CZECH AND SLOVAK CONTRIBUTION TO THE WORLD SHOULD BE CHARACTERIZED IN TERMS OF THE EMPHASIS PLACED ON THE UNIQUENESS OF INDIVIDUAL RELIGIOUS AND SECULAR CONSCIOUSNESS. THUS, HIS VIEW OF THE CZECHOSLOVAK NATION ASSUMES SPIRITUAL AND ETHICAL ELEMENTS, DISTANCING IT FROM NATIONALISM. MASARYK'S IDEAS CAN SERVE AS THE BASIS FOR A HISTORY BOTH INDIVIDUALIZED AND DEMOCRATIC, IN WHICH INDIYIDUAL NATIONAL BOOIES ARE ORGANICALLY ABSORBED INTO A WIDER INTERNATIONAL UNIT BASED ON THE NATIONS' MUTUALITY AND ON THE SUPPORT OF HUMAN AND CIVIC RIGHTS.

01360 BEENSTOCK, $M$.

THE DETERMINANTS OF US ASSISTANCE TO ISRAEL JERUSALEM JOURNAL OF INTERNATIONAL RELATIONS, 14(1) (MAR $92), 65-97$.

THE CENTRAL CONCERN OF THE AUTHOR HERE IS TO TRY TO EXPLAIN U.S. GOVERNMENT ASSISANCE TO ISRAEL, WITH SPECIAL REFERENCE TO THE REMARKABLE DEGREE OF GENEROSITY THAT THE UNITED STATES HAS BESTOWED ON IT. USING DATA FROM 1950 TO 1990, THIS ARTICLE SHOWS THAT U.S. ASSISTANCE TO ISRAEL WAS SYSTEMATICALLY INFLUCENCED BY ISRAEL'S DEFENSE BURDEN AND BY ISRAEL'S INDEBTEDNESS TO THE U.S. OGOVERNMENT. THIS RESULT HOLDS FOR TOTAL ASSISTANCE ONLY, SUGGESTING THAT THE STATES REGARDS ECONOMIC AND MILITARY ASSISTANCE AS SUBSTITUTES. THE RESULTS SUGGEST THAT THE UNITED STATES IS
CURRENTLY PREPARED TO COVER SOME 20 CENTS OF THE MARGINAL CURRENTLY PREPARED TO COVER SOME

01361 BEETHAM, D.

LIBERAL DEMOCRACY AND THE LIMITS OF DEMOCRATIZATION POLITICAL STUDIES, 40 (1992), 40-53.

LIBERAL ISM HAS PROYIDED BOTH A NECESSARY BASIS FOR MODERN DEMOCRACY AND ALSO A CONSTRAINT UPON IT. THIS DUALITY MAKES A DEMOCRATIC CRITIQUE OF LIBERALISM BOTH IMPERATIVE AND PROBLEMATICAL. IN SO FAR AS IT THREATENS THE CONDITIONS OF LIBERAL DEMOCRACY ITSELF. THO OF THESE CONDITIONS ARE EXAMINED--THE INSTITUTION OF REPRESENTATION AND THE PRIMCIPLE OF THE LIMITED STATE--TO DISCOVER WHAT LIMITS THE MIGHT IMPOSE ON THE JUSTIFIABLE AMBITIONS OF DEMOCRATIZERS, SOCIAL AGENDA FOR DEMOCRATIZATION ON THE OTHER.

01362 BEETHAM, $D$

THE PLANT REPORT AND THE THEORY OF POLITICAL REPRESENTATION POLITICAL QUARTERLY (THE), 63(4) (OCT 93), 460-467.

ELECTORAL SYSTEMS SERVE TWO DIFFERNT PURPOSES; THE REPRESENTATION OF THE POPULATION AND THE CONSTUCTION OF A GOVERNMENT. HOW THEY DO EACH, AND WITH WHAT CONSEQUENCES, MUST BE CONSIDERED IN AKY EVALUATION OF THEM. THIS ARTICLE CDNCENTRATES OF THE FIRST OF THESE PURPOSES. IT ARGUES THERE IS A THEORY OF POL ITICAL REPRESENTATION IMPLICIT IN ALL 
ABOUT THE GOVERMMENT-CREATING ASPECT OF ELECTORAL SYSTEMS.

01363 BEGALA, J.A.; BETHEL, C.

A TRANSFORMATION WITHIN THE WELFARE STATE

JOURNAL OF STATE GOVERNMENT, 65(1) (JAN 92), 25-30.

MANY STATE GOVERNMENTS HAVE RECENTLY MADE MAJOR CHANGES

THAT HILL HAVE A LONG-TERM IMPACT ON THE UNITED STATES'

WELFARE SYSTEM. THIS REPORT GIVES AN OVERVIEN OF THE CHANGES

MADE DURING THE 1991 STATE LEGISLATIVE SESSIONS.

01364 BEHAR, $N$.

EASTERn EUROPEAN tRanSformation and a "NEH PEACEFUL STRUCTURE' OF EUROPE

PEACE AND THE SCIENCES, 3 (SEP 91), 4-11.

1989 WAS A CRUCIAL YEAR FOR EUROPE. THERE ARE SOME COMMON FEATURES CARACTERIZING ALL OF THE EASTERN EUROPEAN COUNTRIES UNDERTAKING THE COURSE OF TRANSFORMATION. AMONG THESE ARE: RADICAL CHANGES IN THE POLITICAL STRUCTURES AND THESE ARE: RADICAL CHANGES IN THE POLITICAL STRUCTURES AND
THE INTRODUCTION OF MULTIPARTY SYSTEMS; THE TREND TOWARD THE INTRDDUCTION OF MULTPARTY SYSTEMS; THE TREND TOWARD
MARKETIZATION OF THE ECONOMY; AND THE SEARCH FOR GREATER MARKETIZATION OF THE ECONOMY; AND THE SEARCH FOR GREATER
ACCESS TO THE EUROPEAN ECONOMY. THE MAIN ASSUMPTION OF THIS ACCESS TO THE EUROPEAN ECONOMY. THE MAIN ASSUMPTION OF THIS
PAPER IS THAT EAST EUROPEAN MODERMIZATION, MARKETIZATION AMD PAPER IS THAT EAST EUROPEAN MODERMIZATION, MARKETIZATION AND
OPENMESS TO THE WORLD MARKET ARE COMDUCIVE TO THE STRUCTURE OF A PEACEFUL EUROPE IN THE FUTURE, BASED MAINLY ON NONOF A PEACEFUL EUROPE IN THE FUTURE, BASED MAII
MILITARY FACTORS OF INTERNATIONAL SECURITY.

01365 BEHM, A.; PALMER, M.

COORDINATING COUNTERTERRORISH: A STRATEGIC APPROACH TO A CHANGING THREAT

TERRORISM, 14(3) (1991), 171-194

A NATIONAL APPROACH TO COMBATING TERRORISM MUST BE STRATEGIC, COMPREHENDING BOTH PREVENTIVE AND RESPONSE MEASURES, ARGUES THIS ARTICLE. TO BE SUCCESSFUL. THE STRATEGY MUST ENYISAGE A CRISIS MANAGEMENT STRUCTURE THAT FACILITATES INTERAGENCY COOPERATION AND MINIMIZES COMPETITION AND DISPUTATION. THE ARTICLE OUTLINES THE PRINCIPLES THAT ENCOURAGE INTERAGENCY COORDINATION, AND A NUMBER OF AVENUES FOR PUTTING THE PRINCIPLES INTO PRACTICE. FINALLY, THE ARTICLE SUGGESTS THAT THERE ARE THO KEY PERFORMANCE INDICATORS AGAINST HHICH COORDINATION ARRANGEMENTS CAN BE ASSESSED: STREAMLINED ORGANIZATIONAL STRUCTURES AS THE TEST FOR EFFICIENCY, AND POSITIVE PERSONNEL ATTITUDES AS THE TEST FOR EFFECTIVENESS.

01366 BEHM, A.J.

TERRORISM, VIOLENCE AGAINST THE PUBLIC, AND THE MEDIA: THE AUSTRALIAN APPROACH

POLITICAL COMHUNICATION AND PERSUASION, 8(4) (1991),

233-246.

AUSTRALIA'S COUNTERTERRORISM STRATEGY IS HOLISTIC, GOING BEYOND THE IDEA OF A COMPREHENSIVE CAPABILITY FOR RESPONSE TO ACTUAL INCIDENTS TO INCLUDE PREVENTIVE MEASURES AND ENHANCEMENT OF THE NATIONAL SECURITY ENVIRONMENT, SUGGESTING THAT ALI ELEMENTS OF SOCIETY, INCLUDING THE MEDIA, REGARD SECURITY AS A COOPERATIVE ENDEAVOR. THESE ELEMENTS HAVE BEEN INCLUDED IN THE NATIONAL ANTI-TERRORIST PLAN (NATP) DEYELOPED BY AUSTRALIA'S STANDING ADVI SORY COMMITTEE ON COMMONWEALTH/STATE COOPERATION FOR PREVENTION AGAINST VIOLENCE (SAC-PAV). THE SAC-PAY HAS AGREED THAT THE NATP REQUIRES A FOURFOLD STRATEGY FOR DEALING WITH THE MEDIA: (1) PUBLIC COMMUNICATION POLICIES AND GUIDELINES, (2) INCORPORATING MEDIA RESPONSE AND INCIDENT MANAGEMENT STRATEGIES, (3) MEDIA TRAINING, AND (4) PHYSICAL CONTROLS. IN ADDITION, THE SAC-PAV HAS FORMULATED A SET OF GUIDELINES FOR THE MEDIA TO APPLY WHEN COVERING TERRORIST INCIDENTS, INDICATING CLEARLY WHAT CRISIS MANAGERS AND COUNTERTERRORISMRESPONSE ORGANIZATIONS EXPECT OF MEDIA HANDLING PUBLIC CRISES.

01367 BEHN, R.D. MANAGEMENT AND THE NEUTRINO: THE SEARCH FOR MEANINGFUL METAPHORS

PUBLIC ADMINISTRATION REVIEW, 52(5) (SEP 92), 409-419. THE AUTHOR ARGUES THAT PUBLIC MANAGEMENT RESEARCHERS SHOULD EMULATE THE SCIENTIFIC APPROACHES OF PHYSICISTS AND OTHER SCIENTISTS, AS LONG AS THEY UNDERSTAND AND APPRECIATE THE METAPHORICAL NATURE OF THOSE SCIENTIFIC METHODS, USING EXAMPLES FROM PHYSICS AMD EMGIMEERIMG HE SHOWS THAT THE CREATIVE USE OF LAMGUAGE AMD STORIES UMDERLIES MANY OF THE GREAT ADVANCES IN THOSE AREAS AND THAT THE ADOPTION OF CERTAIN CONCEPTS IS RELATED TO THEIR PRACTICAL USEFULNESS. CERTAIN CONCEPTS IS RELATED TO THEIR PRACTICAL USEFULNESS. ADOPTING THIS PERSPECTIVE HILL GIVE SOCIAL SCIENTISTS A
GREATER APPRECIATION OF THE CONTRIBUTIONS MADE BY TOM PETERS GREATER APPRECIATION OF THE CONTRIBUTIONS MADE BY TOM PETERS AND OTHER POPULAR HRITERS ON MANAGEMENT. IT WILL ALSO HELP CONCEPTS THAT CAN ENHANCE THE VALUE OF THEIR WORK.

01368 BEHREND, H

EAST GERMANY UNDER THE FEDERAL GERMAN EAGLE NEH POLITICS, 3(4) (WIN 92), 115-127

THE EAST GERMAN WOMEN'S MOVEMENT IS AT PRESENT UNDERGOING A DIFFICULT PHASE AND ADJUSTMENT TO THE NEW SITUATION. STRUCTURES HILL HAVE TO BE DEVELOPED HHICH FULLY GUARANTEE THE DEMOCRATIC RIGHTS OF GRASS ROOTS MEMBERSHIP
WHILE PREVENTING DEADLOCXS OVER GENERAL POLICY ISSUES. THE WOMEN'S MOVEMENT IN THE EX-GDR MUST COME TO GRIPS WITH THE FACT THAT THEY HILL BE UNABLE TO BUILD A FEMINIST NEW JERUSALEM ON GERMAN'S GREY AND, AT PRESENT, UNPLEASANT LAND. THEY WILL HAVE TO LEARN TO STAND UP FOR THEMSELVES IN A SOCIETY OF RUTHLESS COMPETITION, MAKING FULL USE OF THE POLITICAL OPPORTUNITIES OFFERED BY PARLIAMENTARY DEMOCRACY. AND YET PRESERVE AS MUCH OF THE FEELING OF SOLIDARITY THAT INSPIRED THEM IN THE AUTUMN OF 1989.

01369 BEHRENS, M.; RAUCH, $A$

SOUTH AFRICA ON THE ROAD TO DEMOCRACY

AUSSEN POLITIK, 42(4) (1991), 402-411

SOUTH AFRICA IS CURRENTLY PASSING THROUGH A TRANSITION PHASE: THE SYSTEM OF RACIAL SEGREGATION MAY BE DEAD, BUT A NEW POLITICAL SYSTEM PALATABLE TO ALL PARTIES HAS YET TO BE CREATED. AT THE BEGINNING OF JULY 1991, ALMOST 80 YEARS AFTER ITS FOUNDATION, THE AFRICAN NATIONAL CONGRESS (ANC) FORMULATED NEW GUIDELINES FOR A POLITICAL AND ECONOMIC STRATEGY BASED ON DIALOGUE. THE DEFACTO INTEGRATION OF THE STRATEGY BASED ON DIALCGUE. THE DEFACTO INTEGRATION OF THE PLACK MA NOR SEEMS IMMINENT. THE PROCESS NOW SEEMS IMMINENT. THE BLOOOY CLASHES BETWEEN BLACK SECTIONS OF THE POPULATION, HOWEVER, INDICATE THE POSSIBLE LIMITS TO DEMOCRACY IN SOUTH AFRICA. THIS ARTICLE CONSIDERS SEVERAL QUESTIONS WITH REGARDS TO THIS TRANSITION PHASE: WHAT CONSTITUTIONAL POLICY CONCEPIS ARE PURSUED BY PRESIDENT DE KLERK AND HIS CHIEF OPPOSITE NUMBER, NELSON MANDELA; WHAT IS THE NATURE OF THE POLITICAL AND ECONOMIC REFORM EFFORTS OF THE CURRENT WHITE GOVERNMENT; AND HOW IS SOUTH AFRICA'S FOREIGN POLICY DEVELOPING, ESPECIALLY VIS-A-VIS THE EUROPEAN COMMUNITY, AND HOW IS THE INTERHATIONAL COMMUNITY RESPONDING TO REFORMS?

01370 BEHUNIAK-LONG, S

JUSTICE SANDRA DAY O'CONNOR AND THE POWER OF MATERNAL LEGAL THINKING

REVIEW OF POLITICS, 54(3) (SUM 92), 417-444.

SANDRA DAY O'CONNOR. THE FIRST FEMALE JUSTICE ON THE U.S. SUPREME COURT, HAS BEEN CRITICIZED BY SOME FOR FAILING TO BRING A WOMAN'S PERSPECTIVE TO THE COURT AND BY OTHERS FOR ACTING TOO MUCH LIKE THE STEREOTYPICAL WOMAN WHO CANNOT MAKE UP HER MIND. BOTH CRITICISMS OVERLOOK THE POSSIBILITY THAT O'CONMOR'S IMPACT AS A FEMALE IS DERIVED FROM THE FACT THAT SHE IS PROMULGATING A VERY SPECIFIC JURISPRUDENCE--THAT OF THE FEMININE. HOWEVER, IT IS IN EMPLOYING THIS JURISPRUDENCE THAT SHE UNDERMINES THE POTENTIAL FOR BOTH A FEMINIST JURISPRUDENCE AND FOR A COHESIVE CONSERVATIVE BLOC ON THE COURT.

01371 BEINART, $W$.

POLITICAL AHD COLLECTIVE VIOLENCE IN SOUTHERN AFRICAN POLITICAL AND COL

JOURNAL OF SOUTHERN AFRICAN STUDIES, 18(3) (SEP 92),

VIOLENCE APPEARS NOT AS A SINGLE PHENOMENON BUT AS AN EXPRESSION OF A HIDE RANGE OF CONFLICTS, CRISES OR CATHARSES. THIS ARTICLE INTRODUCES THIS ISSUE WHICH IS DEDICATED TO DEVELOP FURTHER DEBATE AND NEW PERSPECTIVE ON VIOLENCE IN SOUTH AFRICA. THE ARTICLE EXPLORES COLONIAL AND ANTICOLONIAL EXPLANATIONS OF VIOLENCE, OFFERS EXPLANATIONS OF VIOLENCE WITHIN OR BETHEEN AFRICAN COMMUNITIES, AND EXAMINES SOME FURTHER EXPLANATORY PATHS: LITERARY REPRESENTATIONS OF AFRICAN VIOLENCE. THE ARTICLE CONCLUDES THAT IT IS IMPORTANT THAT ROUTES BE FOUND OUT OF A REACTIVE MOMENTUM WHICH IS SET DEEP IN THE HISTORICAL EXPERIENCE BOTH OF BLACK AND WHITE.

01372 BEINER, $R$

WHAT'S THE MATTER WITH LIBERALISM?

UNIVERSITY OF CALIFORNIA PRESS, 1992, 208.

THIS CRITIQUE OF LIBERAL THEORY AND LIBERAL PRACTICES TAKES ON THE SHIBBOLETH'S OF MODERN WESTERN DISCOURSE. THE AUTHOR CONFRONTS THE ARIDITY OF LIBERAL SOCIETIES THAT pOSSESS INCOMMENSURABLE "VALUES" and "RIGHTS," BUT No PRINCIPLES. TO THE AUTHOR. THIS NEUTRALIST VIEN IS BOTH A FALSE DESCRIPTION OF LIBERAL SOCIETY AND AN INCOHERENT POLITICAL IDEAL. RATHER, HE ENCOURAGES THE THEORIST TO REMAIN FAITHFUL TO THE IMPORTANT TASK OF QUESTIONING AND CRITICISM, INSTEAD OF SERVING AS A SOURCE OF IDEOLOGICAL REASSURANCE ABOUT OUR OWN SUPERIORITY. THE AUTHOR LOOKS TO THE SOCRATIC TRADITION FOR GUIDANCE. PERMITTING ETHOS TO REPLACE VALUES, AND DISCOURSE ABOUT "THE GOOD" TO REPLACE TALK ABOUT "RIGHTS, "THE THEORIST IS ABLE TO REORDER SOCIAL TALK ABOUT "RIGHTS, "THE THEORIST IS ABLE TO REORDER SOC
PRIORITIES. CONSIDERED IN THIS LIGHT, LIBERAL POLITICAL PRIORITIES. CONSIDERED IN THIS LIGHT, LIBERAL POLITICAL PHILOSOPHY OF THE 1970 S AND 1980 S APPEARS INSUFFICIENTLY
SOCRATIC, AS DOES A LIBERAL WAY OF LIFE THAT PRESENTS ITSELF AS A MODEL OF IMITATION.

01373 BEISEL, D.

JAPAN AND THE AMERICAN UMCONSCIOUS

JOURNAL OF PSYCHOHISTORY, 20(2) (FAL 92), 185-196.

THE NEW WAVE OF VISUAL AND VERBAL ASSAULTS ON JAPAN,

UNLEASHED IN PUBLIC STATEMENTS IN EARLY 1992, HAS BEEN

EXPLAINED MOST OFTEN IN TERMS OF ECONOMICS, AS A PRODUCT OF FRUSTRATED AMERICAN WORKERS FRIGHTENED BY A SAGGING ECONOMY. 
AND, WHETHER OR NOT POLITICIANS WERE MOLDING OR MERE FOLLOHERS OF PUBLIC OPINION--THEIR WORDS HELPED CRYSTALLIZE OPINIONS, REINFORCED IMAGES OF JAPAN AS A SUITABLE TARGET, AND GAVE PERMISSION, BY EXAMPLE, TO A PUBLIC EAGER TO EXPRESS ITS ANGER. THIS ARTICLE SUGGESTS THAT SCAPEGOATS HAVE BEEN NEEDED TO ACCOUNT FOR AMERICA'S ECONOMIC HOES AND JAPAN-BASHING HAS BEEN PART OF THE ON-AGAIN, OFF-AGAIN,

POLITICAL RHETORIC.

01374 BEIT-HALLAHMI, B.

ISRAEL'S ULTRA-ORTHODOX: A JEWISH GHETTO WITHIN THE ZIONIST STATE

MIDOLE EAST REPORT, 22(6) (NOV 92), 22-23; 28.

THE ULTRA-ORTHODOX IN ISRAEL HAVE NOT ACCEPTED THE ZIONIST DEFINITION OF THE JEWS AS A NATION IN SEARCH OF A HOMELAND, AND HAVE REMAINED FAITHFUL TO THE ANCIENT DEFINITIOM OF JEHS REMAINED FAITHFUL TO THE ANCIENT OR A MESSIAH. THEY ARE CHARACTERIZED BY A UNIOUE OCCUPATIONAL STRUCTURE, HHICHE CHARACTERIZED BY A UNIQUE OCCUPATIONAL STRUCTURE, WHICH REFLECTS ITS REJECTION OF THE ZIONIST
PROJECT. THIS ARTICLE EXPLORES THEIR STRATEGY AND CONCLUDES THAT THEY REMAIN a GHETTO AND ARE HAPPY TO BE JUST THAT.

01375 BEKKAR, $R$.

THE SHRINKING SPACE OF ALGERIAN POLITICS

FREEDOM REVIEW, 23(3) (MAY 92 ), 24-30.

THE AUTHOR EXPLAINS HOW THE' POLICIES OF ALGERIA'S RULING NATIONAL LIBERATION FRONT HAVE LED TO WIDESPREAD ECONOMIC PROBLEMS, DISILLUSIONMENT, AND POLITICAL DISCONTENT AMONG YOUNG ALGERIANS.

01376 BELADI, H.; MARJIT, S.

FOREIGN CAPITAL, UNEMPLOYMENT AND NATIONAL HELFARE JAPAN AND THE WORLD ECONOMY 4(4) (DEC 92) 311-318. THE AUTHORS OF THIS ARTICLE CONSIOER A SITUATION HHERE FOREIGN CAPITAL IS ALLOWED TO FLOW ONLY INTD THE EXPORTPROCESSING ZONE OF AN ECONOMY CHARACTERIZED BY UNEMPLOYMENT ANO PURSUING PROTECTIONIST POLICY. THEY DERIVE CONDITIONS UNDER HHICH GROWTH INDUCED BY AN INCREASE IN THE FLON OF FOREIGN CAPITAL HILL BE IMMISERIZING. THE RESULTS ARE DERIVED WHEN FOREIGN CAPITAL DOES NOT DIRECTLY FLOW INTO THE
PROTECTED SECTOR BUT ALTERS THE COMPOSITION OF OUTPUTS IN THE OTHER TRADED SECTORS THROUGH INTER-SECTORAL REALLOCATION OF OTHER RESOURCES

01377 BELIKOY, I.; BELYAEY, A.

FRAMING SOVIET POLICY TOWARDS SOUTH AFRICA

FOUAHING SOVIET POLICY TOWARDS SOUTH AFRICA

SOUTH AFRICA INTERMATIONAL, $22(2)$ (OCT 91), 86-97, SOVIET POLICY TOFARD SOUTH AFRICA. THE AUTHORS OF THIS ARTICLE TRACE THE HISTORY OF SOYIET POLICIES TOWAROS SOUTH ARTICLE TRACE THE HISTORY OF SOVIET POLICIES TOHARDS SOUTH
AFRICA UP TO THE PRESENT DAY. IN DOING SO THEY IDENTIFY THE VARIOUS ACTORS INFLUENCING SOVIET POLICY TOWARDS SOUTH AFRICA, AND LIKELY FUTURE POLICY DIRECTIONS. IN PARTICULAR, THEY EXAMINE PROSPECTS FOR SOVIET-SOUTH AFRICAN COOPERATIOH IN THE INTERHATIONAL MARKET IN GOLD, DIAMONDS AND RARE METALS, DIRECT ECONOMIC TIES AND THE PRACTICAL PROBLEMS THEY ENTAIL, AND PROPOSALS FOR USING SOUTH AFRICAN EXPERTISE IN THE REGION ON A TRILATERAL BASIS, PARTICULARLY IN THOSE SOUTHERM AFRICAN CDUNTRIES HITH LARGE OUTSTANDING DEBTS TO THE SOVIET UNION.

01378 BELL, C.

WHY RUSSIA SHOULD JOIN NATO

NATIONAL INTEREST, (22) (WIN 91), 37-47

THE FURTHER EXTENSION OF THE EXISTING HESTERM SECURITY COMMUNITY OFFERS THE MOST PROMISING OPTION FOR MATO IF THAT ORGANIZATION IS TO AVOID OBSOLESCENCE. THIS ARTICLE ARGUES THAT IT COULO BE DOE BY ONE QUITE SIMPLE THOUGH RADICAL STEP THE OFFER OF MEMBERSHIP TO RUSSIA AND THE OTHER MAJOR MEMBERS OF THE NOW-DEFUNCT WARSAW PACT. SUCH A MOVE WOULD BE THE BEST CHANCE AT MAINTAINING STABILITY AND BALANCE IN AN ERA OF UNCERTAINTY AND CHANGE. IT ALSO MIGHT BE THE FIRST FOUNDATION FOR THE MUCH TOUTED "NEW WORLD ORDER."

01379 BELL, $D$.

THE FRENCH COMAUNIST PARTY IN THE 1992 DEPARTMENTAL AND REGIONAL ELECTIONS

JOURNAL OF COMHUNIST STUDIES, 8(3) (SEP 92), 135-139.

THE 1980 S WERE PARTICULARLY BAD YEARS FOR THE FRENCH COMMUNIST PARTY (PCF) AND THE BEGINNING OF THE 1990 S WERE EVEN WORSE FOR THE FREMCH CDMMUNISTS. THE STATE WAS WELL SET ON 22 MARCH FOR A PROTEST VOTE AGAINST THE SOCIALIST PARTY. AS HAS BECOME HABITUAL AFTER ELECTIONS, IT WAS ANNOUNDED THAT THE RESUL TS SHOWED THAT THE CURVE THAT IS CALLED THE PCF'S DECLINE HAD STARTED TO TURH, AND THE PARTY DAILY WAS TRIUMPHANT INE HAD STARTED TO TURN, AND THE PARTY DAILY WAS FUTURE OF A PARTY LCTION RESULTS CALL INTO QUESTION THE WHETHER ANYTHING CAM BE GAINED FROM ITS CONTRIBUTION TO THE WHETHER ANYTHING CAN BE GAINED FROM ITS
DESTRUCTION OF THE ALLIANCE OF THE LEFT.

01380 BELL, $H$.

CHANGE IN U.S. EMPHASIS IS PERCEIVED

GERMAN TRIBUNE, 1679 (AUG 91) 2 .

THIS ARTICLE DISCUSSES A HIGHLY SIGNIFICANT CHANGE OF
COURSE IN U.S. FOREIGN POLICY. RATHER THAN RIGIDLY RETAINING NATO AS THE BASIS OF ITS EUROPEAN PRESENCE, WASHINGTON NOW ENVISAGES A EURO-ATLANTIC COMMUNITY INCORPORATING A EUROPE THAT IS UNITED AND FREE. THE U.S. IS ALSO CONSIDERING A COMMUNITY OF VALUES THAT HOULD INCLUDE THE SOVIET UNION AND BE BASED, ON COMMON DEMOCRATIC, POLITCAL AND ECONOMIC DENOMINATORS. FUNDAMENTAL ISSUES SUCH AS DEFENSE, TRADE, MONETARY MATTERS, HUMAN AND MINORITY RIGHTS ARE TO TACKLED ON THE BROADEST POSSIBLE BASIS WITHIN THIS FRAMEWORK.

01381 BELL, $H$.

CSCE PAVES THE WAY FOR A NEW PEACE ORDER

GERMAN TRIBUNE, (1502) (FEB 92), 1

THE PRAGUE SUMMIT MEETING OF THE COUNCIL OF CONFERENCE ON SECURITY ANO COOPERATION IN EUROPE (CSCE) FOREIGM MINISTERS WAS A RESOUNDING SUCCESS. IT PAYED THE WAY FOR A COMPREHENSIVE PEACE AND STABILITY ORDER FROM VANCOUVER TO VLADIVOSTOK. EUROPE'S STABILITY HAS BEEN CONSOLIDATED IN A CRITICAL SITUATION, AND THERE ARE GROWING HOPES OF BEING ABLE TO KEEP UNDER CONTROL THE TREMENDOUS CHANGES TAKING PLACE IN THE EAST. THE FOURTH CSCE FOLLOH-UP CONFERENCE, TO BE HELD IN HELSINKI IN MARCH, WILL SEE THE NEXT MAJOR STEP: FRESH OISARMAMENT ANO ARMS CONTROL DECISIONS AND THE CONCE
FOR THE FINAL SHAPE OF CSCE INSTRUMENTS AND STRUCTURES.

01382 BELL, $\boldsymbol{H}$.

EDINBURGH SUMMIT WILL NEED TO SET SOME SIGNPOSTS

GERMAN TRIBUNE, 31(1544) (DEC 92), 1-2.

A WEEK BEFORE THE EUROPEAN COMMUNITY'S EOINBURGH SUMMIT, THE JOINT DECLARATION THAT PARIS AND BONN WANT NEITHER A EUROPE A LA CARTE NOR A CONVOY TRAVELING AT THE SPEED OF THE SLOWEST VESSEL NOT UNMATURALLY CARRIED SOME CLOUT. ONLY THE EDINBURGH SUMMIT WILL SHOW WHAT THAT MEANS IN PLAIN POL ITICAL FACT. THE SUMMIT HILL OEAL MAINLY WITH THE SPECIAL ROLE TO WHICH DENMARK LAYS CLAIM AND WITH BRITAIN'S HESITANT APPROACH. IT MUST BE MADE CLEAR THAT THEY CANMOT BE ALLOWED TO CALL THE MAASTRICHT TREATY INTO OUESTION NOH THAT THE OTHER MEMBER-STATES ARE ALL IN THE PROCESS OF RATIFYIMG IT

IN TIME FOR THE YEAR'S END OEADLINE.

01383 BELL, $W$.

GERMANS WILL SHOULDER RESPONSIBILITY, GENSCHER TELLS GENERAL ASSEMBLY

GERMAN TRIBUNE, 1487 (OCT 91), 1

GERMAN FOREIGN MINISTER, HANS-DIETRICH GENSCHER,

ADDRESSING THE UN GENERAL ASSEMBLY FOR THE FIRST TIME AS THE FOREIGN MINISTER OF A UNITED GERMANY, TOLD DELEGATES OF THE OTHER 165 UN MEMBER-STATES THAT THE FEDERAL REPULBIC SAH ITS GREATER HEIGHT AS COMUITIMG IT TO A GREATER RESPONSIBIL IYY FOR FREEDOM, DEMOCRACY AND HUMAN RIGHTS IN A EUROPEAN GERMANY THAT HAD LEFT BEHINO IN THE NATION-STATE OUTLOOK OF THE PAST. HE DEFINED GERMANY AS A EUROPEAN POWER WITHOUT EXAGGERATED AMBITION. ITS EMPHASIS, HE SAID, WAS ON ENLARGING THE EUROPEAN COMMUNITY TO MAKE IT A UNION OPEN FOR MEMBERSHIP TO ALL EUROPEAN DEMOCRACIES.

01384 BELL, W.

Nato, THE CSCE and hOH to maINTAIN PEACE GERMAN TRIBUNE, (1519) (JUN 92), 2

THE SPRING CONFERENCE OF NATO FOREIGN MINISTERS IN BRUSSELS TOOK PLACE FOR ONE REASON ONLY: TO DEVELOP THE NORTH ATLANTIC PACT'S TIES HITH THE CONFERENCE ON SECURITY AND COOPERATION IN EUROPE (CSCE) AND MAKE THE CSCE AN EFFECTIVE PEACE INSTRUMENT. ONCE THAT HAS BEEN SETTLED, THE EUROPEAN SECURITY DEBATE SHOULD RUN MORE SMOOTHLY. AN IMPORTANT ISSUE THAT REMAINS TO BE SETTLED IS GERMANY'S CONTINUED REFUSAL TO ALLOW ITS TROOPS TO PARTICIPATE IN UNITED NATIONS PEACEKEEPING MISSIONS. SUCH A POLICY IS NOT LIKELY TO LAST LONG AS THE CSCE TAKES ON A SECURITY ROLE. AMEND ITS CONSTITUTION ACCORDIMGLY.

01385 BELL, $N$.

MEED TO DEFUSE EMOTIVE ROH OVER THE NAME OF MACEDONIA

GERMAN TRIBUNE, 31(1541) (NOV 92), 2.

THE LONG-RUNNING ARGUMENT BETWEEN ATHENS AND SKOPJE OVER THE FUTURE NAME OF WHAT USED TO BE THE YUGOSLAY REPUBLIC OF MACEDONIA MUST BE BROUGHT TO A SHIFT CONCLUSION. THERE IS A DAILY-INCREASING DANGER THAT THE YUGOSLAV CONFLICT HILL DAILY-INCREASING DANGER THAT THE YUGOSLAV CONFLICT WILL OTHERWISE SPREAD ACROSS THE BALLINS. BONN HOPES TO ACHIEVE OFFICIAL RECOGNITION OF MACEDO

01386 BELL, $W$.

PRO-MAASTRICHT VOTE PUTS KOHL IN BOUYANT MOOD GERMAN TRIBUNE, 31(1544) (DEC 92),

ELATED BY THE TAILWIND OF AN OVERHHELMING BUNDESTAG MAJORITY IN FAYOR OF RATIFYING THE MAASTRICHT TREATY, CHANCELLOR KOHL SAID AFTER THE FRANCO-GERMAN TALKS IN BONN THAT THERE MUST BE NO STANDING STILL IN EUROPE AND THAT THE EOINBURGH SUMMIT MUST SOUND A CLARION CALL. UNTIL THE FRANCOGERMAN CONSULTATIONS THERE WERE FEARS IN BONN THAT THE FRENCH MIGHT NOT MUCH CARE IF THE GATT OEAL WERE NOT CLINCHED, BUT SINCE THE TALKS GERMAN GOVERNMENT OFFICIALS 
HAVE BEEN MORE CONFIDENT. THEY FEEL REASSURED THAT THIS PROBLEM CAN BE SOLVED AT THE LAST MINUTE, BUT WHICHEVER WAY YOU TURN, EUROPE REPEATEDLY SEEMS TO BE A TOUCH-AND-GO AFFAIR.

01387 BELL, $H$.

SIGNS OF PROGRESS IN EFFORT TO BAN CHEMICAL HEAPONS GERMAN TRIBUNE, (1502) (FEB 92), 2.

AFTER TWENTY YEARS OF NEGOTIATION--IN THE UNITED NATIONS AND ELSEWHERE-THERE SEEMS TO BE HOPE FOR TANGIBLE PROGRESS TOWARDS THE ELIMINATION OF CHEMICAL WEAPONS THROUGHOUT THE HORLD. THE FACT THAT AN ENTIRE UN GENEVA CONFERENCE IS DEVOTED TO THE ELIMINATION OF CHEMICAL WEAPONS (AND THE FACT THAT GERMANY IS THE CHAIR OF THE CONFERENCE) BODES WELL FOR FUTURE AGREEMENTS. THESE DEVELOPMENTS ARE ONLY THE LATEST IN A STRING OF POSITIVE EVENTS INCLUDING THE GENERAL LESSENING OF EAST-WEST TENSIONS, THE SUPPORT OF 149 NATIONS FOR THE GOAL OF BANMING CHEMICAL WEAPONS AT A 1989 PARIS CONFERENCE, AND THE AMERICAN DECISION TO DO WITHOUT A STRATEGIC

DETERRENCE RESERVE OF 500 TONS OF CHEMICAL WEAPONS INTENDED FOR SECOND-STRIKE USE.

01388 BELL, $W$.

VALUES AND THE FUTURE IN MARX AND MARXISM

FUTURES, 23(2) (MAR 91), 146-162.

THIS ARTICLE RE-EXAMINES FROY A FUTURIST'S PERSPECTIVE THE VALUES AND IMAGES OF THE FUTURE IN MARXIST THOUGHT AND ASSESSES THEIR VALIDITY AND VIABILITY OVER THE DECADES TO COME. IT CONCLUDES THAT MARXIST THOUGHT WAS NOT SIMPLY BETRAYED IN ACTION BY INCOMPETENT, CORRUPT OR POWER-MAD LEADERS, ALTHOUGH IT IS REASONABLE TO QUESTION WHETHER ANY REGIME CALLING ITSELF SOCIALIST ACTUALLY CONSTITUTED HHAT MARX HAD IN MIND. THE THEORY ITSELF AS A VISION OF A DESIRABLE FUTURE SOCIETY AND AS A BLUEPRINT FOR ATTAINING IT IS INHERENTLY FLAWED. NONE THE LESS, MARXISH WAS BASED ON SOME VALUES THAT HAVE UNIVERSAL VALIDITY AND THAT WILL CONTINUE TO HAVE WORLDWIDE APPEAL. THUS, PEOPLE CALLING THEMSELVES MARXISTS CAN BE EXPECTED TO CONTINUE TO PRODUCE REVISIONS OF THEORY AND POLITICAL PRACTICE. ADOITIONALLY, IT SPECIFIES SOME IMPLICATIONS OF MARXISM FOR MODERN FUTURISTS.

01389 BELL, $W$.

WEU SET TO TAKE ON BRIDGING ROLE BETWEEN EC AND NATO GERMAN TRIBUNE, (1475) (JUL 91), 2.

ON 1 JULY THE GERHAN GOVERMMENT TOOK OVER FOR A ONE-YEAR TURN IN THE CHAIR OF THE WESTERN EUROPEAN UNION (WEU). IT AIMS TO USE IT TO FURTHER THE DEVELOPMENT OF A EUROPEAN DEFENSE IDENTITY. IN PARTICULAR, IT IS KEEN TO FURTHER SPECIFY THE WEU'S FUTURE ROLE AND TO ELIMINATE THE REMAINING DOUBTS FELT BY INDIVIDUAL MEMBER-STATES. THE WEU SEES ITSELF, ON A PAR WITH THE EUROPEAN COMMUNITY, NATO, THE COUNCIL ON SECURITY AND COOPERATION IN EUROPE (CSCE) AND THE COUNC EUROPE, AS A MAJOR STABILITY FEATURE IN ALL-EUROPEAN IN RELATIONS BETHEEN THE EUROPEAN COMMUNITY AND NATO.

01390 BELL, W.J.

RAPIDLY GROWING COST OF PEACE MISSIONS HITS UN BUDGET GERMAN TRIBUNE, (1527) (AUG 92), 2.

BLUE-HELMETED UN FORCES, NEARLY 50-000 STRONG, ARE NOW SERVING ON PEACE MISSIONS OR AS OBSERVERS--MORE THAN EVER BEFORE IN THE UN'S HISTORY. THEY ARE SERVING IN THE MIDDLE EAST, AFGHANISTAN, PAKISTAN, THE IRAN-IRAO BORDER, ANGOLA, CENTRAL AMERICA, IRAQ, KUWAIT, EL SALVADOR, HEST SAHARA, SOMALIA, CAMBODIA AND YUGOSLAVIA. UNFORTUNATELY, THE 1992 PEACE MISSIONS WILL COST THO-AND-ONE-HALF TIMES THE REGULAR UN BUDGET AND WILL REACH NEARLY THE LEVEL OF ALL OTHER SPENDING. THIS BUDGETARY STRAIN IS COMPOUNDED BY THE FACT THAT OVER TWO-THIROS OF THE UN'S 179 MEMBERS ARE BEHIND IN THEIR CONTRIBUTIONS. BEFORE THE YEAR'S END, THE UNITED NATIONS COULD BE INSOLVENT.

01391 BELLAMY, C.

SOLDIER OF FORTUNE: BRITAIN'S NEW MILITARY ROLE

INTERNATIONAL AFFAIRS, 68(3) (JUL 92), 443-456.

THE DRAMATIC CHANGES IN EUROPE'S STRATEGIC GEOGRAPHY HAVE NOT ONLY REMOVED AN IDENTIFIABLE THREAT BUT HAVE ALSO CHANGED THE ENTIRE MATURE OF MILITARY PLANHING. THE AUTHOR ARGUES THAT BRITAIN IS NOW FREE TO CHOOSE HOW MUCH IT HILL SPEND ON MILITARY FORCES AND IT IS WELL-QUALIFIED, MOTIVATED, AND LIKELY TO HAVE A HIGH MILITARY PROFILE AS THE MERCENARY OF THE INTERMATIONAL COMHUNITY.

01392 BELLAVITA, C

THE PUBLIC ADMINISTRATOR AS HERO

ADMINISTRATION AND SOCIETY, $23(2)$ (AUG 91), 155-185.

IN RESPONSE TO THE DECLINING PRESTIGE OF GOVERMMENT JOBS, THIS ARTICLE USES THE FRAMEWORK OF "THE HERO'S JOURNEY" TO ANALYZE THE EXPERIENCE OF ADMINISTRATORS WHO HAVE HELPED TO REVITALIZE THE PUBLIC SECTOR. THE ADMINISTRATORS DISCUSSED ARE NOT FAMOUS PEOPLE. THEY ARE PROFESSIONALS WHO HAVE GONE BEYOND THE BOUNDARY OF ROUTINE PUBLIC SECTOR EXPERIENC
ACHIEVEMENT. THE STAGES OF THEIR JOURNEYS--THE CALL TO ADVENTURE, THE ORDEAL. AND THE RETURN-CAN BE USED TO
INTERPRET AND GUIDE BEHAVIOR OF OTHER PUBLIC ADMINISTRATORS.

01393 BELLO, W. ; BLANTZ, E. PERILS AND POSSIBILITIES: CARVING OUT AN ALTERMATIVE ORDER IN THE PACIFIC

ALTERNATIVES, 17 (1) (WIN 92), 1-22.

IN 1991, THE ASIA-PACIFIC REGION BEGAN TO ADJUST DRAMATICALLY, TO THE END OF THE CDLD WAR, MUCH TO THE DISMAY OF THE UNITED STATES. WITH THE COHESION PROVIDED BY THE COLD WAR DISAPPEARING, THE DEFINITIONS OF BOTH THE NATIONAL INTEREST AND THE REGIONAL INTEREST BEGAN TO BE EXTRICATED FROM THE NARROW PARAMETERS TO WHICH THEY HAD BEEN CONFINED BY ANTI-COMHUNIST IDEOLOGY. THO OF THE CENTRAL ISSUES IN THE SEARCH FOR A POST-COLD HAR ORDER INVOLYES THE FUTURE OF THE UNITED STATES AMD THE ROLE OF JAPAN. THEIR OLD ALLIANCE IS DISSOLVING IN ANTAGONISH, HITH THE ASIA-PACIFIC REGION BECOMING A PRIME AREA OF CONTENTION. FOR MANY PEOPLE IN THE AREA, THIS DEVELOPMENT SPELLS BOTH PROMISE AND PERIL. THIS ARTICLE EXPLORES THE DIMENSIONS OF EACH.

01394 BELLONE, C.J.; GOERL, G.F. RECONCILING PUBLIC ENTREPRENEURSHIP AND DEMOCRACY PUBLIC ADMINISTRATION REVIEW, 52(2) (MAR 92), 130-134. THE AUTHORS ASK WHETHER PUBLIC-SECTOR ENTREPRENEURSHIP AMONG PUBLIC ADMINISTRATORS CAN BE RECONCILED WITH THE AMONG PUBLIC ADMINISTRATORS CAN BE RECONCILED WITH THE
DEMANDS FOR ADHERENCE TO DEMOCRATIC VALUES IN GOVERMMENT DEMANDS FOR ADHERENCE TO DEMOCRATIC VALUES IN GOVERNMENT PERSONAL VISION OF THE FUTURE, SECRECY, AND RISK-TAKING PERSONAL VISION OF THE FUTURE, SECRECY, AND RISK-TAKING BEHAVIOR, DEMOCRATIC ADMINISTRATION DEMANDS ACCOUNTABILITY, CITIZEN PARTICIPATION, OPEN POL ICYMAKING PROCESSES, AND
STEWARDSHIP. BUT THESE PERSPECTIVES CAN BE BRIDGED THROUGH A STEWARDSHIP. BUT THESE PERSPECTIVES CAN BE BRIDGED THROUCH
CIVIC-REGARDING ENTREPRENEURSHIP THAT BUILDS ON A STRONG CIVIC-REGARDING ENTREP
THEORY OF CITIZENSHIP.

01395 BELLONI, F.

THE LABOR COMMUNITY AND THE BRITISH JUDICARY INTERNATIONAL POLITICAL SCIENCE REVIEH, 13(3) (JUL 92), 269-2B4.

THIS STUDY FOCUSES ON LABOR COMMUNITY VIEWS OF THE BRITISH COURTS IN DEALING WITH WORKING CLASS INDIVIDUALS AND ORGANIZATIONS. IT IS BASED MAINLY ON INTERVIEWS WITH MEMBERS OF THE LABOR COMMUNITY. ITS GENERAL FINDING IS THAT ELEMENTS OF THE LABOR COMMUNITY ARE CONYINCED THAT THE JUDICIAL SYSTEM IS BIASED AGAINST THE WORKING CLASS, TRADE UNIONS AND LOCAL GOVERNING COUNCILS CONTROLLED BY THE LABOR PARTY. JUDICIAL DECISIONS ARE SEEN AS BEING "POL ITICAL" AND BASICALLY HOSTILE TO THE VALUES AND INTERESTS OF THE LABOR COMMUNITY AND ITS ORGANIZATIONS.

01396 BENDERLY, J.

WHY I FAVOR INTERVENTION IN EX-YUGOSLAVIA

WHY I FAVOR INTERVENTION IN EX-YUGOSLAVIA
PEACE \& DEMOCRACY NEWS, 11(2) (HIN 92), 19

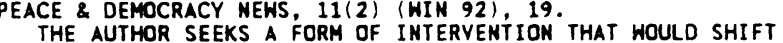
THE AUTHOR SEEKS A FORM OF INTERVENTION THAT WOULD SHIFT THE IMBALANCE IN THE THE WAR IN BOSNIA WITHOUT MOVING POH AWAY FRDM THE PROTAGONISTS AND INTO WESTERN HANDS. SHE IMPLEMENTING ANY CEASEFIRE AND THAT NO PEACE CAN BE MADE IMPLEMENTING ANY CEASEFIRE AND THAT NO PEACE CAN BE MADE UNTIL THE WAR ITSELF HAS STOPPED. THE ONLY ACCEPTABLE POLITICAL SOLTUION ENTAILS BRINGING THE EX-YUGOSLAV STATES INTO THE INTERNATIONAL COMHUNITY AND USING PEACEKEEP
ENFORCE THE OLD REPUBLICAN BORDERS FOR SOME YEARS.

01397 BENDIX, J.; MITCHELL, T.P.; OLLMAN, B.; SPARROH, B.H. GOING BEYOND THE STATE?

AMERICAN POLITICAL SCIENCE REVIEW, 86(4) (DEC 92), 1007-1021.

JOHN BENDIX, BARTHOLOMEW SPARROW, AND BERTELL OLLMAN OFFER CRITIQUES AND SUGGESTIONS FROM QUITE DIFFERENT POINTS OF VIEW REGARDING "THE LIMITS OF THE STATE" BY TIMOTHY MITCHELL, PUBLISHED IN 1991. IN RESPONSE, MITCHELL CLARIFIES THE DISTINCTIVENESS OF HIS OWN APPROACH AND ITS IMPLICATIONS.

01398 BENDIX, J

HOMEN'S SUFFRAGE AND POLITICAL CULTURE: A MODERN SWISS CASE HOMEN AND POLITICS, $12(3)$ (1992), 27-56.

SHITZERLAND DID NOT GRANT WOMEN THE NATIONAL FRANCHISE UNTIL 1971 AND EYEN AFTER THAT TIME THERE WAS CONTINUED RESISTANCE IN SEVERAL CANTONS TO EXTENDING THE FRANCHISE TO CANTONAL ELECTIONS. THE AUTHOR RECOUNTS THE LENGTHY PROCESS BY WHICH WOMEN CLAIMED A ROLE IN CANTONAL POLITICS IN APPENZELL AUSSERHODEN DESPITE RESISTANCE ON THE PART OF MEN TO GRANT FULL FRANCHISE TO THEM. INCLUSION WAS DELAYED THROUGH A COMPLEX ARRAY OF SOCIOPOLITICAL FACTORS, INCLUDING THROUGH A COMPLEX ARRAY OF SOCIOPOLITICAL FACTORS, INCLUDI FEDERAL PRESSURE AND HESITATION, CHANGES IN THE STATE'S
DEMOGRAPHY AND POLITICAL CULTURE, AND AN ISSUE DISPLACEMENT DEMOGRAPHY AND POLITICAL CULTURE, AND AN ISSUE DISPLACEMENT
FROM WHAT SHOULD HAVE BEEN A CASE OF HOMEN'S RIGHTS TO A FROM WHAT SHOULD HAVE BEEN A CASE OF HOMEN'S RIGHTS TO THREAT TO AN OLD, MALE-DOMINATED SOVEREIGN POLITICAL
INSTITUTION. THE CASE ILLUSTRATES SUCCESSFUL CONSERVATIVE INSTITUTION. THE CASE ILLUSTRATES SUCCESSFUL CONSERVATIVE
POL ITICAL ACTIVISM AMONG WOMEN ANO, HENCE, CHALLENGES THE ASSUMPTION THAT CHANGE CAN ONLY BE ACCOMPLI ISHED THROUGH RADICAL SOCIAL TRANSFORMATION.

01399 BENDOR, J.; HAMMOND, T.H. RETHINKING ALLISON'S MODELS 

AMERICAN POLITICAL SCIENCE REVIEW, 86(2) (JUN 92), 301-322. HAD AN ENORMOUS IMPACT ON THE STUDY AND TEACHING OF BUREAUCRACY AND FOREIGN POLICY-MAKING. WHILE ALLISON'S WORK HAS RECEIVED CONSIDERABLE CRITICAL ATTENTION, THERE HAS BEEN SURPRISINGLY LITTLE EXAMINATION OF THE CONTENT AND INTERNAL LOGIC OF HIS MODELS IN THIS PAPER. THE AUTHORS SUB JECT EACH OF ALLISON'S THREE MODELS TO A SYSTEMATIC CRITICAL ANALYSIS AND COMCLUDE THAT THE MODELS REQUIRE SUBSTANTIAL REFORMULATION.

01400 BENECKE, D.

EASTERN EUROPE--STIMULUS FOR INTEGRATION IN LATIN AMERICA AUSSEN POLITIK, 42(4) (1991), 336-343

AND LARGE UNNOTICED BY THE GENERAL PUBLIC, THE UPHEAVAL IN EASTERY EUROPE HAS NOT ONLY FUMDAMENTALYY CHANGED THE POLITICAL AND ECONOMIC SITUATION ON THE EUROPEAN CONTINENT BUT ALSO WORLDWIDE. THIS NOT ONLY RELATES TO DEVELOPMENTS WHICH--SUCH AS THE SCALING DOWN OF THE MILITARY PRESENCE AND THE POLITICAL COMMITMENTS OF THE USSR IN MANY THIRO WORLD COUNTRIES AND THE RESULTANT TRANSFORMATION OF POLITICAL CONDITIONS--DIRECTLY LED TO THE COLLAPSE OF THE SOCIALIST SYSTEM. THE EFFECTS WHICH INDIRECTLY RESULT FROM THE NEW OVERALL INTERNATIONAL CONSTELLATION ARE AT LEAST EQUALLY SIGNIFICANT ALBEIT MUCH MORE DIFFICULT TO IDENTIFY. THIS ARTICLE OUTLINES THE LINKS BETWEEN THE CHANGES IN EASTERN CENTRAL EUROPE, THE BALKANS, AND THE SOVIET UNION ON THE ONE HAND AND THE POLITICO-ECONOMIC REORIENTATION OF LATIN AMERICAN STATES ON THE OTHER. THE LATIN AMERICAN STATES HAVE SHED THEIR COMPLAINTS ABOUT THEIR DEPENDENCY ON THE NORTH AMERICANS IN FAVOR OF AN AGGRESSIVE POLICY OF PURSUING FOREIGN INVESTMENT. THE AUTHOR OF THIS ARTICLE EMPHASIZES THE EXTENT TO WHICH LATIN AMERICA COMPETES WITH NEEDY EASTERN EUROPEAN STATES ALSO TRYING TO ATTRACT FOREIGN CAPITAL.

01401 BENELLO, C.

FROM THE GROUND UP

SOUTH END PRESS, 1992, 251.

SHOULD TODAY'S ACTIVISTS AIM FOR MORE THAN REFORMIST CHANGES IN THE POLICIES AND PERSONNEL OF GIANT CORPORATIONS AND THE GOVERNMENT? IN THIS POSTHUHOUS COLLECTION OF CLASSIC ESSAYS, C. GEORGE BENELLO PERSUASIVELY ARGUES THAT MODERM ESSAYS, C. GEORGE BENELLO PERSUASIVELY ARGUES THAT

SPEARHEADING A RADICAL REORGANIZATION OF SOCIETY BASED ON

SPEARHEADING A RADICAL REORGANIZATION OF SOCIETY BASED ON THE PRINCIPLES OF DECENTRALIZATION, COMMUNITY CONTROL, AND PART ICIPATORY DEMOCRACY. INTEGRATING SOME OF THE BEST PERSPECTIVES, BENELLO'S ESSAYS AND THE COMMENTARIES OF PERSPECTIVES, BENELLO'S ESSAYS AND THE COMMENTARIES OF
OTHERS OFFER IMPORTANT INSIGHTS FOR TODAY'S NEW GENERATION OTHERS OFFER IMPORTANT
OF PRATICAL UTOPIANS

01402 BENENSON, H.

THE "FAMILY WAGE" AND WORKING WOMEN'S CONSCIOUSNESS IN BRITAIN, 1880-1914

POLITICS ANO SOCIETY, 19(1) (MAR 91), 71-108.

THE ARGUMENT THAT MEN COULD ACHIEVE AN INCOME SUFFICIENT TO "MAINTAIN A FAMILY" BY PROHIBITING WOMEN'S AND ESPECIALLY WIVES' JOBHOLDING, KNOWN AS THE "FAMILY WAGE" DOCTRINE, UNDERPINNED BRITISH MALE TRADE UNIONISTS' POLITICAL INITIATIVES BETWEEN 1842 AND 1942. JANE HUMPHRIES AND JANE LEWIS HAVE ACCEPTED THIS PROPOSITION AT FACE VALUE, CONTENDING THAT THE LABOR MOVEMENT'S FAMILY WAGE STRATEGY BENEFITTED AND GAINED ADHERENCE FROM WOMEN WORKERS. THIS ARTICLE CHALLENGES THEIR VIEH FIRST BY DEMONSTRATING THAT THE FAMILY WAGE DOCTRINE'S SECTIONAL ORIGIN AND PURPOSE AND SECOND BY EXAMINING THE LANCASHIRE WOMEN COTTON WORKER'S REACTION TO IT.

01403 BENJAMIN, $P$.

BATTLING MEDICAL CORPORATIONS

POLITICAL AFFAIRS, 71(9) (SEP 92), 1-6.

TO DATE, OF THE HORLD'S INDUSTRALIZED NATIONS ONLY SOUTH AFRICA AND THE UNITED STATES DO NOT HAVE A NATIONAL HEALTH CARE PROGRAM. THIS ARTICLE SUGGESTS THAT THE FAILURE OF SOCIALIST MEDICINE AND HEALTH CARE IN THE USSR ANO OTHER EASTERN EUROPEAN SOCIALIST COUNTRIES WAS CAUSED BY DECISIONS OF POLICY MAKERS, WHO, IN HINDSIGHT, WERE COMMITTED TO CHANGING THE SYSTEM TOWARD PROFITEERING INSTEAD OF DISEASE PREVENTION AND CURE. IT ARGUES THAT U.S. IMPERIALISM'S PREVENTION AND CURE. IT ARGUES THAT U.S. IMPERIALISM'S ATTEMPT TO PROMOTE ITS MARKET-BASED, PROFITEERING HEALTH
SYSTEM TO EVERY CDRNER OF THE WORLD MUST BE MET BY U.S. SYSTEM TO EVERY CDRNER OF THE WORLD MUST BE MET BY U.S.
ACTIVISTS EXPOSING ITS MINE FIELDS AND CARNAGE. THAT PERHAPS ACTIVISTS EXPOSING ITS MINE FIELDS AND CARNAGE. THAT PERHAPS AN INTERNATIONAL CONFERENCE ON HEALTH CARE ON TH
IS NEEDED TO BRING THIS POINT HOME TO EVERYONE.

01404 BENN, D.W.

GOEBBELS AND PROPAGANDA: THE PSYCHOLOGICAL DIMENSION WORLD TODAY, 48(10) (OCT 92), 177-178.

JOSEF GOEBBELS, HITLER'S PROPAGANDA CHIEF, IS RIGHTLY REMEMBERED AS UNSCRUPULOUS, AS MENDACIOUS, AS A DIRTY-TRICKS PRACTITIONER, AS A SYSTEMATIC REPRESSOR OF OISSENT, AND AS A SYMBOL OF TOTALITARIAN PROPAGANDA. NO MATTER WHAT HIS PROPAGANDA MESSAGE WAS AT A GIVEN MOMENT, GOEBBELS ALWAYS
PLANNED IT, IN A HIGHLY INTELLIGENT WAY, WITH REFERENCE TO ITS LIKELY IMPACT ON THE FEELINGS AND PREJUDICES OF THE TARGET AUDIENCE. HE ALWAYS PAID ATTENTION TO THE

PSYCHOLOGICAL DIMENSION OF HIS STRATEGY.

01405 BENNET, J.

SAND TRAP

WASHINGTON MONTHLY, 23(4) (APR 91), 25-28.

THIS ARTICLE ARGUES THAT TO HAVE ALTERNATIVES TO

MILITARY ACTION DOWN THE ROAD, IT WOULD SEEM USEFUL TO TRY

TO EXTRACT SOME LESSONS FROM THE "WHAT IFS" OF THE BRIEF,

TO EXTRACT SOME LESSONS FROM THE "WHAT IFS" OF THE BRIEF,
UNDIPLOMATIC HISTORY OF THE GULF CRISIS. IT CONCLUDES THAT,

CONTRARY TO SO MUCH THAT HAS BEEN WRITTEN ON THE CRISIS, THE

CONTRARY TO SO MUCH THAT HAS BEEN WRITTEN ON THE CRISIS, THE

GULF WAR WAS NOT "INEVITABLE." THE BUSH ADMINISTRATION

MERELY MADE IT LOOK THAT WAY BY FORECLOSING OTHER OPTIONS

AESIDEN CASE THAT U.S. DIPLOMATIC EFFORTS WERE MERELY AIMS AF ITS MILITARY STRATEGY

01406 BENMET, J.

THE SENATE'S LAME DOVES

WASHINGTON MONTHLY, 23(3) (MAR 91), 43-46.

THE ISSUE OF WHETHER TO SUPPORT THE USE OF FORCE IN THE PERSIAN GULF WAS A DIFFICULT AND SOUL-WRENCHING ISSUE FOR MANY, IF NOT MOST, U.S. LEGISLATORS. HOWEVER, THE U.S. SENATE WAS CHARACTERIZED BY A REMARKABLE LACK OF DEBATE ON THE SUBJECT. WHILE IMPRESSIVE AND OFTEN CONTRADICTORY SPEECHES WERE IN PROFUSION, THERE WAS VIRTUALLY NO ARGUMENT AMONG THE SENATORS. THE AUTHOR OF THIS ARTICLE FINDS THIS DISTURBING, ESPECIALLY CONSIDERING THE FACT THAT MANY SENATORS WERE ADMITTEDLY UNDECIDED ON THE ISSUE. THE LACK OF FIGHT IN THE SENATE'S DOVES IS REMINISCENT OF SOME SIMILAR DOVES TWENTY YEARS AGO.

01407 BENNETT, A.

SELECTING PRIME MINISTERS AND PRESIDENTS: A tRANS-ATLANTIC COMPARISON IN 1992

PRESIDENTIAL STUDIES QUARTERLY, XXII(2) (SPR 92), 279-294.

IN SELECTING THEIR LEADERS, BRITISH POLITICAL PARTIES

DISPLAY A NUMBER OF SIGNIFICANT DIFFERENCES FROM THE WAY

AMERICAN POL ITICAL PARTIES CHOOSE THEIR PRESIDENTIAL

CANDIDATES. THESE DIFFERENCES CONCERN QUALIFICATIONS,

NOMINATION PROCEDURES, PREVIOUS POLITICAL EXPERIENCE, THE

RIMING AND DURATION OF THE PROCESS, FINANCIAL OUTLAY

PARTICIPATES IN THE SELECTION AND THE ROLE GIVEN IN EACH

PARTICIPATES IN THE SELECTION AND THE ROLE GIVEN IN EACH
PROCESS TO PROFESSIONAL POLITICIANS AS OPPOSED TO PARTY PROCESS TO
"MEMBERS."

01408 BENNETT, C.J.

HOW STATES UTILIZE FOREIGN EVIDENCE

JOURNAL OF PUBLIC POLICY, 2(1) (JAN 91), 81-54.

THIS ARTICLE EXAMINES HOW EVIDENCE ABOUT PROGRAM A IN COUNTRY A MAY BE UTILIZED IN COUNTRY B, AND THUS HOW UTILIZATION MAY EXPLAIN THE ADOPTION OF THE SAME PROGRAM. ELITES AND ACTIVISTS HAVE A NUMBER OF INTERESTS IN USING POLICY EVIDENCE FROM ANOTHER COUNTRY: TO PUT AN ISSUED TO A
SYSTEMIC OR INSTITUTIONAL AGENDA, MOLLIFY POLITICAL PRESSURE, PROVIDE AN EXEMPLAR, INDICATE THE RANGE OF OPTIONS OR REINFORCE CONCLUSIONS ALREADY REACHED. THE INTERESTS OF THE IMPORTER DICTATE THE NATURE, TIMING AND ORIGINS OF THE EVIDENCE INJECTED INTO POLICY DEBATE. THIS FRAMEHORK IS APPLIED TO THE CASE OF FREEDOM OF INFORMATION POLICY. AN ANALYSIS OF HOW AND WHY EVIDENCE ABOUT THE UNITED STATES FREEDOM OF INFORMATION ACT (FOIA) WAS UTILIZED IN CANADA AND BRITAIN REVEALS THAT FOIA WAS USED AS AN EXEMPLAR IN CANADA AND THE REVERSE IN BRITAIN.

01409 BENMETT, C.J.; HOWLETT, M.

THE LESSONS OF LEARNING: RECONCILING THEORIES OF POLICY LEARNING AND POLICY CHANGE

POLICY SCIENCES, 25 (3) (AUG 92), 275-294.

SEVERAL DIFFERENT EXPLANATIONS OF POLICY CHANGE BASED ON NOTIONS OF LEARNING HAVE EMERGED IN THE POLICY LITERATURE TO CHALLENGE CONVENTIONAL CONFLICT-ORIENTED THEORIES. THESE INCLUDE CONCEPTS OF POLITICAL LEARNING, POLICY-ORIENTED LEARNING, LESSON DRAWING, SOCIAL LEARNING, AND GOVERNMENT LEARNING. THESE DIFFERENT CONCEPTS IDENTIFY DIFFERENT ACTORS AND OIFFERENT EFFECTS WITH EACH DIFFERENT TYPE OF LEARNING. SOME ELEMENTS OF THESE THEORIES ARE COMPATIBLE, WHILE OTHERS ARE NOT. THIS ESSAY EXAMINES EACH APPROACH IN TERMS OF WHO LEARNS, THAT THEY LEARN, AND THE EFFECTS OF LEARNING ON SUBSEQUENT POLICIES. THE CONCLUSION IS THAT THREE DISTINCT TYPES OF LEARNING HAVE OFTEN BEEN INCORRECTLY JUXTAPOSED.

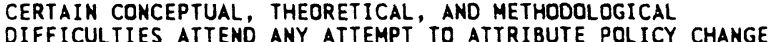
DIFFICULTIES ATTEND ANY ATTEMPT TO ATTRIBUTE POL ICY CHA
TO POLICY LEARNING, BUT THIS DOES NOT DETRACT FROM THE IMPORTANT REORIENTATION OF POLICY ANALYSIS THAT THIS APPROACH REPRESENTS.

01410 BENHETT, $G$

BRITISH POLICY IN THE FAR EAST 1933-1936: TREASURY AND FOREIGN OFFICE

MODERN ASIAN STUDIES, 26(3) (JUL 92), 545-568. 
THE NATURE OF BRITISH INTERESTS IN THE FAR EAST IN THE $1930 S$ MEANT THAT BOTH THE TREASURY AND THE BOARD OF TRADE WERE NECESSARILY CLOSELY INVOLVED WITH THE MAKING OF FOREIGN POLICY. WHLE FOREIGN OFFICE OFFICIALS RESENTED THIS INTRUSION INTO THEIR DOMAIN, THEY WERE THEMSELVES DISDAINFUL OF SO-CALLED "TECHNICAL" CONSIDERATIONS CONNECTED WITH TARIFFS OR CURRENCY REFORM, AND WERE WILLING TO LEAVE THEM TO THE SPECIALISTS. UNDER THE DYNAMIC IMPETUS OF THE CHANCELLOR OF THE EXCHEOUER, NEVILLE CHAMBERLAIN, AND THE PERMANENT SECRETARY TO THE TREASURY, SIR WARREN FISHER, THE TREASURY, ENCOURAGED BY THE APPARENT ABNEGATION OF THE FOREIGN OFFICE, MADE A BOLD AND AGGRESSIVE FORAY BETWEEN 1933 AND 1936 INTO THE REALMS OF FOREIGN POLICY-MAKING HITHERTO REAGRDED AS THE EXCLUSIVE SPHERE OF THE PROFESSIONAL DIPLOMAT. DESPITE THE CONCERTED EFFORT OF CHAMBERLAIN TO SECURE STRONGER ANGLO-JAPANESE RELATIONS, THREE YEARS OF MEDDLING IN FOREIGN POLICY YIELDED FEN RESULTS.

01411 BENNETT, R.; HISEMAN, $C$.

ECONOMIC PERFORMANCE AND U.S. SEMATE ELECTIONS, 1958-1986 PUBLIC CHOICE, 69(2) (FEB 91 ), 93-100.

THIS STUDY' EXTENDS THE LITERATURE ON THE EFFECT OF ECONOMIC CONDITIONS ON ELECTION OUTCOMES TO U.S. SENATORIAL ELECTIONS. ONE AREA EXPLORED IS THE POSSIBILITY OF ASYMMETRY IN VOTERS; RESPONSE TO ECONOMIC PERFORMANCE-DIN PARTICULAR, THE HYPOTHESIS THAT VOTERS WITHFOLD VOTES FROM INCUMBENT CANDIDATES WHEN ECONOMIC PERFORMANCE IS POOR, BUT DO NOT REWARD THEM FOR GOOD PERFORMANCE. THE GENERAL METHODOLOGY FOLLOWS THAT OF EARLIER STUDIES IN REGRESSING THE VOTE SHARE FOR THE INCUMBENT PARTY ON ONE OR MORE ECONOMIC PERFORMANCE MEASURES.

01412 BENNETT, S.; MCPHAIL, M.

POLICY PROCÉSS PERCEPTIONS OF SENIOR CANADIAN FEDERAL CIVIL SERVANTS: A VIEH OF THE STATE AND ITS ENVIRONMEN CANADIAN PUBLIC ADMINISTRATION, 35(3) (FAL 92), 299-316. BASED ON INTERVIEWS WITH SENIOR FEDERAL CIVIL SERVANTS IN OTTAHA. THE AUTHORS EXAMINE PERCEPTIONS OF VARIOUS ACTORS' INFLUENCE ON PUBLIC POLICY. THEY HYPOTHESIZE THAT PERCEIVED INFLUENCE PATTERNS WILL CHANGE AS ONE MOVES ACROSS THE MAJOR PHASES OF THE POLICY PROCESS. ALTHOUGH IT IS EXPECTED THAT ACTORS WITHIN THE STATE WILL BE OF PRIMARY IMPORTANCE THROUGHOUT THE PROCESS, IT IS ALSO ANTICIPATED THPT THE RELATIVE IMPORTANCE OF ACTORS OUTSIDE THE STATE WILL INCREASE AS ONE MOVES FROM FORMING A POLICY AGENDA AND SELECTING POLICY TOWARDS POLICY IMPLEMENTATION. THIS SHOULD BE PARTICULARLY TRUE OF THE PERCEIVED INFLUENCE OF PRIVATE BE PARTICULARLY TRUE OF THE PERCEIVED INFLUENCE OF PRIVA COMPANIES. DESPITE THIS CHANGE IN PERCEIVED LEVELS OF
INFLUENCE OF STATE VERSUS NON-STATE ACTORS, THE STRUCTURE OF INFLUENCE OF STATE VERSUS NON-STATE ACTORS, THE STRUCTURE OF
CORRELATION PATTERNS FOR PERCEIVED INFLUENCE PATTERNS WILL CORRELATION PATTERNS FOR PERCEIVED INFLUENCE PATTERNS WIL
PROBABLY NOT CHANGE DRAMATICALLY FROM ONE POLICY PROCESS PROBABLY NOT CHANGE DRAMATICALLY FROM ONE POLICY PROCES
PHASE TO THE NEXT. THE AUTHORS ALSO PRESENT RESULTS

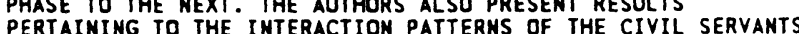
WHO WERE INTERVIEWED, AS WELL AS THE RELATION BETHEEN WHO WERE INTERVIEWED, AS WELL AS THE
INTERACTION AND PERCEIVED INFLUENCE.

01413 BENNETT, S.E.; BENMETT, L.L.M.

FROM TRADITIONAL TO MODERN CONCEPTIONS OF GENDER EQUALITY IN POLITICS: GRADUAL CHANGE AND LINGERING DOUBTS

WESTERN POLITICAL QUARTERLY, 45(1) (MAR 92), 93-112.

GENERAL SOCIAL SURVEYS FROM 1974 TO 1989 'SHOW THAT, ALTHOUGH TRADITIONAL CONCEPTS OF GENDER ROLES IN POLITICS DECLINED DURING THAT PERIOD, ONE-FIFTH OF THE PUBLIC STILL ADHERED TO OLDER BELIEFS IN' THE LATE 1980'S. MULTIVARIATE STATISTICAL ANALYSES SHOW THAT, AMONG WOMEN AND MEN, THE STRONGEST PREDICTORS OF ATTITUDES ABOUT POLITICAL GENDER ROLES ARE AGE, EDUCATION, RELIGIOUS IDEOLOGY, POLITICAL IDEOLOGY REGION AND FREOUENCY OF CHURCH ATTENDANCE. ALTHOUGH THE PERCENTAGE OF THE PUBLIC WITH MODERN VIEWS OF POLITICAL GENDER ROLES WILL INCREASE AS OLDER, LESSEREDUCATED PERSONS PASS FROM THE ELECTORATE, THERE IS CAUSE FOR CONCERN BECAUSE WELL-EDUCATED YOUNG MEN IN THE LATE $1980^{\prime}$ 'S WERE NO MORE COMMITTED TO GEMDER EOUAL ITY THAN WERE MEN WHO ATTENDED COLLEGE IN THE LATE 1960'S AND EARLY 1970's.

01414 BENMETT, W.J.; ARKES, H.; LIMBAUGH, R.

HOW GEORGE BUSH CAN WIN

NATIONAL REVIEW, XLIV(19) (OCT 92), 37-38, 40-43.

THREE REPUBLICAN STRATEGISTS GIVE PRESIDENT GEORGE BUSH

ADVICE ON HOW TO RESCUE HIS FALTERING RE-ELECTION CAMPAIGN.

01415 BENMION, L.

THE BUSINESS ETHIC OF THE WORLD RELIGIONS AND THE SPIRIT OF CAPITALISM

INTERMATIONAL JOURMAL OF POLITICS, CULTURE AND SOCIETY, 6(1) (FAL 92), 39-74.

LOWELL L. BENHION REVIEWS MAX WEBER'S SOCIOLOGY OF WORLD RELIGIONS FROM THE POINT OF VIEW OF THEIR IMPACT ON BUSINESS ETHICS. HE NOT ONLY ANALYZES THE ECONOMIC ANO COMHERCIAL CONSEQUENCES OF HINDUISM, CONFUCIANISM, BUDOHISM AND JUDAISM, SUGGESTS THAT HIS NOTES ON THE DEVELOPMENT OF MORMONISM SERVE TO SUBSTANTIATE WEBER'S THESIS THAT MATERIALISM AS AN
HISTORICAL METHOD IS INADEQUTE TO EXPLAIN EMPIRICAL REALITY.

01416 BENS, C.K.

RESTORING CONFIDENCE: EASIER SAID THEN DONE

MATIOHAL CIVIC REYIEH : EA (2) (SPR 91) 188-191.

THERE ARE MANY IMDICATIONS THAT THE PUBLIC HAS LOST

CONFIDENCE IN GOVERMMENT, AND THERE HAS BEEN A VIRTUAL FLOOD

OF IDEAS ABOUT HOW TO RESTTORE CONFIDENCE. IN THIS ARTICLE,

THE AUTHOR LOOKS AT THE LOSS OF CONFIDENCE IN ONTARIO AND

SOME OF THE REMEDIES FOR IT.

01417 BENS, C.K.

THE KEY TO CONFIDENCE IN GOVERMMENT: BETTER POLITICIANS

NATIONAL CIVIC REVIEW, 81(1) (WIN 92), 83-85

THE AUTHOR ENUMERATES SOME OF THE COMPLAINTS CITIZENS HAVE ABOUT POLITICIANS AND SOME OF THE TRAITS THAT VOTERS CONSIDER DESIRABLE IN ELECTED OFFICIALS.

01418 BENTON, J.

THE EFFECTS OF CHANGES IN FEDERAL AID ON STATE AND LOCAL GOVERNMENT SPENDING

PUBLIUS: THE JOURNAL OF FEDERALISM, 22(1) (WIN 92), 71-82. THAT FEDERAL GRANTS-IN-AID HAD AN IMPORTANT INFLUENCE ON STATE AND LOCAL GOVERMMENT SPENDING DURING THE 1960S AND STATE AND LOCAL GOVERNMENT SPENDING DURING THE 1960 S AND
MOST OF THE $1970 S$ IS SUGGESTED BY THIS STUDY. THIS POSITIVE MOST OF THE 1970 S IS SUGGESTED BY THIS STUOY. THIS POSITIVE STIMULATION ALSO SEEMS TO HAVE CONTINUED DURING 1982-1985, DESPITE THE REAGAN ADMINISTRATION'S EFFORTS TO CUT THE LEVEL OF FEDERAL AID TO STATES AND COMUNITIES. THE STIMULATIVE

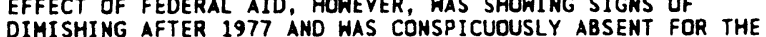
DIMISHING AFTER 1977 AND WAS CONSP
$1977-1981$ AND $1985-1988$ PERIODS.

01419 BENTON, J.E.; DALY, J.L.

A QUESTION-ORDER EFFECT IN A LOCAL GOVERNMENT SURVEY PUBLIC OPINION QUARTERLY (CHICAGO), $55(4)$ (WIN 91), 640-642.

THE AUTHORS STUDY THE QUESTION-ORDER EFFECT IN A LOCAL GOVERNMENT SURVEY IN FLORIDA. RESIDENTS OF TWO SMALL FLORIDA CITIES WERE ASKED A SERIES OF QUESTIONS, INCLUDING A GENERAL EVALUATION QUESTION ABOUT THE QUALITY OF MUNICIPAL SERVICES. TWO VERSIONS OF THE QUESTIONMAIRE WERE USED, WITH THE ONLY DIFFERENCE BEING THE PLACEMENT OF THE FOLLOWING GENERAL EVALUATION QUESTION: ON THE WHOLE, HOW WOULD YOU RATE THE SERVICES AND FACILITIES PROVIDED BY THE CITY--VERY GOOD, GOOD, ADEQUATE, POOR, OR VERY POOR?

01420 BENTON, J.E.; MENZEL, D.C.

CONTRACTING AND FRANCHISING COUNTY SERVICES IM FLORIDA URBAN AFFAIRS QUARTERLY, 27 (3) (MAR 92), 436-456. THIS STUDY EXAMINES THE PRIVATIZATION BEHAVIOR OF COUNTY GOVERMMENTS IN FLORIDA, TREATING CONTRACTING AND FRANCHISING GOVERMMENTS IN FLORIDA, TREATING CDNTRACTING AND FRAMC AS SEPARATE DECISION-MAKING ACTIVITIES. CONTRACTING DECISIONS ARE INFLUENCED PRIMARILY BY GROWTH PRESSURES, THE
DESIRE TO REDUCE PRODUCTION COSTS, AND A POLITICAL CULTURE DESIRE TO REDUCE PRODUCTION COSTS, AND A POLITICAL CUL
THAT FAVORS PROFESSIONAL ADMINISTRATION OVER PRIVATETHAT FAVORS PROFESSIONAL ADHINISTRATION OVER PRIVATE-
REGARDING POLITICS. FRANCHISING DECISIONS ARE INFLUENCED REGARDING POL ITICS. FRANCHISING DECISIONS ARE INFLUENC
HEAVILY BY GROWTH PRESSURES, POLITICAL IMPEDIMENTS TO HEAVILY BY GROWTH PRESSURES, POLITICAL IMPEDIMENTS TO
ALTERING THE TRADITIONAL PUBLIC PRODUCTION ARRANGEMENTS, A ALTERING THE TRADITIONAL PUBLIC PRODUCTION ARRANGEMEMT POLITICAL CULTURE THAT INSULATES ADMINISTRATION FROM POLITICS, AND A DESIRE TO KEEP TAX RATES DOWN. IN OTHER WORDS, FRANCHISING DECISIONS ARE PREDICATED EXTENSIVELY ON EFFORTS TO LIMIT THE SCOPE OF GOVERNMENT AND OPERAT

01421 BENTON, J.E.; DALY, J.L.

THE PARADOX OF CITIZEN SERVICE EVALUATIONS AND TAX/FEE PREFERENCES: THE CASE OF TWO SMALL CITIES

AMERICAN REVIEW OF PUBLIC ADMINISTRATION, 22(4) (DEC 92), 271-288.

THIS STUDY OF TWO SMALL CITIES IN FLORIDA ILLUMINATES THE PARADOX OF LOCAL CITIZENS HOLDING INCONSISTENT VIENS OF SERVICE EVALUATIONS AND TAX/FEE PREFERENCES. THE ANALYSIS SUGGESTS THAT THIS INCONSISTENCY RESULTS FROM CITIZEN ATTITUDES BEING PREDICATED ON DIFFERENT CONSIDERATIONS. WHEREAS SERVICE EVALUATIONS APPEAR TO BE BASED ON GENERAL ATTITUDES TOWARD CITY GOVERMMENT AND THE COMMUNITY, TAX/FEE PREFERENCES ARE INFLUENCED MORE BY SELF-INTEREST FACTORS. MOREOVER, SELF-INTEREST INDICATORS SEEM TO BE BETTER PREDICTORS OF TAX/FEE VIEWS FOR SERVICES THAT ARE ASSOCIATED WITH SPECIFIC GROUPS OF CITY RESIDENTS (E.G., PARKS AND RECREATION).

01422 BENTON, T

ECOLOGY, SOCIALISH, AND THE MASTERY OF NATURE: A REPLY TO REINER GRUNDMANM

NEW LEFT REVIEH, (194) (JUL 92), 55-74.

IN THIS REPLY TO "THE ECOLOGICAL CHALLENGE OF MARXISM" BY REINER GRUNDMANM, THE AUTHOR MAINTAINS THAT TRADITIONAL MARXISH, THOUGH NOT BLIND TO SOME ECOLOGICAL PROBLEMS, STILL RESTS ON A THEORY THAT FAILS TO REGISTER THE HAYS IN WHICH MATURAL PROCESSES OTHER THAN HUMAN LABOR CONTRIBUTE TO THE
LIFEHORLD UPON WHICH ALL MEN DEPEND. 
01423 BERCH, N. WHY DO SOME STATES PLAY THE FEDERAL AID GAME BETTER THAN OTHERS?

AMERICAN POLITICS QUARTERLY, 20(3) (JUL 92), 366-377. THIS ARTICLE IS A STUDY OF VARIATION IN THE RATE OF CHANGE IN FEDERAL AID FROM 1985 TO 1987 (THE PERIOD INFLUENCED BY THE 99 TH CONGRESS). THE AUTHOR FINDS THAT STATE-BASED VARIABLES LIKE THE GOVERNOR'S EXPERIENCE IN CONGRESS, INTRASTATE CONFLICT, AND WASHINGTON LOBBYING PRESENCE ARE QUITE USEFUL IN EXPLAINING THE RATE OF CHANGE IN FEDERAL AID TO THE STATES. THE FINDINGS SUGGEST THAT A
GREATER EMPHASIS ON THESE SO-CALLED DEMAND-SIDE VARIABLES IS IN ORDER.

01424 BERCOVITCH, J.

INTERNATIONAL MEDIATION AND DISPUTE SETTLEMENT: EVALUATING THE CONDITIONS FOR SUCCESSFUL MEDIATION

NEGOTIATION JOURNAL, $?(1)$ (JAN 91), 17-30.

ONCE A CONFLICT OCCURS. IT MAY BE DEALT WITHIN IN ONE OR MORE FOLLOWING METHODS: VIOLENCE AND COERCION; VARIOUS FORMS OF DIRECT OR INDIRECT NEGOTIATION; AND THE INYOLVEMENT OF A THIRD PARTY IN A BINDING OR NONBINDING FASHION. OF THESE THIRD PARTY IN A BINDING OR NONBINDING FASHION. OF THESE METHOOS, THE NONBINDING INTERVENTION OF A THIRD PARTY, NOTWITHSTANDING ITS PREVALENCE, VARIETY, LONGEVITY, ANO
IMPORTANCE, HAS BEEN STUDIED ONLY RECENTLY SYSTEMATICALLY AS IMPORTANCE, HAS BEEN STUDIED ONLY RECENTLY SYSTEMATICALLY AS AN ASPECT OF CONFLICT MANAGEMENT TITION AND HIGHLIGHTS, PARTICULAR ON INTERNATIONAL MEDIATION AND HIGHLIGHTS, THROUGH THE USE OF AN ORIGINAL DATA SET, THE DETERMI

01425 BERCOVITCH, J.

INTERNATIONAL NEGOTIATIONS AND CONFLICT MANAGEMENT: THE IMPORTANCE OF PRENEGOTIATIOM

JERUSALEM JOURNAL OF INTERNATIONAL RELATIONS, 13(1) (MAR $91), 7-21$.

IN SITUATIONS OF CONFLICT, PARTICULARLY CONFLICT THAT IS INTENSE AND PROTRACTED, PRENEGOTIATION CAN PLAY A KEY ROLE IN CREATING AND LEGITIMIZING THE CONDITIONS FOR A MUTUAL ATTEMPT AT CONFLICT AMEL IORATION. PRENEGOTIATION CAN ENABLE PARTIES TO PROCEED THROUGH STAGES OF CONCEPTUALIZATION, COMMITMENT, AND DESIGN TO NEGOTIATION ITSELF; OR, EVEN WHEN NOT WHOLLY' SUCCESSFUL, PRENEGOTIATION CAN LAY THE GROUNDWORK FOR CONFLICT RESOLUTIONS IN THE LONG TERM.

01426 BERCUSON, D.J.; COOPER, B.

DECONFEDERATION: CANADA HITHOUT QUEBEC

KEY PORTER BOOKS, 1991,180

THIS BOOK PROVIDES A FRESH NEH ANALYSIS OF CANADA'S INTERMINABLE "QUEBEC QUESTION." ARGUING THAT THE FOUNOATIONS OF THE POL ITICAL ORDER IN QUEBEC ARE INCONSISTENT WITH THE LIBERAL-DEMOCRATIC PRINCIPLES THAT REIGN ELSENHERE IN CANADA, THE AUTHORS MAINTAIN THAT IT IS NECESSARY THAT ENGLISHCANADIANS EXPEL QUEBEC. ADDITIONAL JUSTIFICATION IS FOUND IN THE FACT THAT THE QUEBEC OUESTION HAS VIRTUALLY PARALYZED THE FACT THAT THE QUEBEC QUESTION HAS VIRTUALLY PARALYZED CANADA'S CENTRAL GOVERMMENT; ONCE QUEBEC IS GIVEN ITS LONG
SOUGHT INDEPENDENCE, THE GOVERNMENT CAN MOVE ON TO MORE SOUGHT INDEPENDENCE, THE GOVERMMENT CAN MOVE ON TO MORE PRESSING (AND PERHAPS MORE IMPORTANT) ISSUES SUCH AS

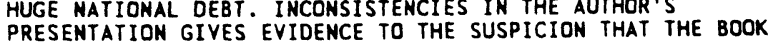
PRESENTATION GIVES EVIDENCE TO THE SUSPICION THAT THE BOOK
IS NOT INTENDED TO BE AN OBJECTIVE DISCUSSION OF THE QUEBEC IS NOT INTENDED TO BE AN OBJECTIVE DISCUSSION OF THE QUEBEC QUESTION, BUT A POLEMIC DESIGNED
THE POLITICAL DEBATE IN CANADA.

01427 BERDENMIKON, $M$.

RUSSIA AND HER SECURITY POLICIES

RUSI JOURNAL, $137(6)$ (DEC 92 ), 5-9.

RUSSIA IS NOW SEEKING TO TAKE ITS PLACE ONT HE WORLD STAGE AS AN INDEPENDENT STATE, PLAYING A LEADING ROLE IN THE NEW COMMONWEALTH OF INDEPENDENT STATES AND IN THE INTERNATIONAL COMMUNITY. MIKHAIL BERDENNIKOV DISCUSSES RUSSIA'S SECURITY POLICIES, HIGHLIGHTING ITS OWN SECURITY INTERESTS ON REGIONAL AND GLOBAL LEVELS, AND OUTLINING A WIDER STRATEGY BASED ON INTERNATIONAL COOPERATION, SPECIFICALLY ON ISSUES OF ARMS CONTROL AND BROADLY ON WORKING TOWARDS STABLE REGIONAL AND WORLD-WIDE SECURITY STRUCTURES.

01428 BEREJIKIAN, J. REVOLUTIONARY COLLECTIVE ACTION AND THE AGENT-STRUCTURE PROBLEM

AMERICAN POLITICAL SCIENCE REVIEW, 86(3) (SEP 92), 647-657. UNRAVELING THE NEXUS BETWEEN AGENTS AND STRUCTURES IS TO CHANGE. THE THO MOST PROMINENT METHODOLOGICAL APPROACHES TO EXPLAIN REVOLUTIONARY COLLETIVE ACTION INYOLVE EITHER INDIVIDUAL REDUCTIONISM OR STRUCTURAL REDUCTIONISM. BOTH APPROACHES INYOLVE THEORETICAL INCONSISTENCIES AND/OR EXPLANATORY ANOMALIES. IN THIS PAPER, THE AUTHOR PROPOSES AN EXPLANATORY ANOMA UTES IN THE CONCEPT OF FRAMING DEYELOPED IN REHAYIORAL DECISIOM THEORY PRIMARILY BY OUATRONE AND IN BESKY. BY DEVELOPING THE PROPOSITION THAT INDIVIDUALS EVOKE

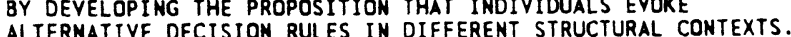
ALTERNATIVE DECISION RULES IN DIFFERENT STRUCTURAL CONTEXIS.
OF ANOMALOUS CASES. ADOITIONALLY, THIS MODEL BEGINS TO DEFINE A NEW ROLE FOR IDEOLOGY IN EXPLANATIONS OF REVOLUTIONARY COLLECTIVE ACTION.

01429 BEREND, I.T.

HUNGARY: EASTERN EUROPE'S HOPE?

HUNGARY: EASTERN EUROPE'S HOPE?
CURRENT HISTORY, $91(568$ ) (NOY 92), 381-384

IN HUNGARY, THE PROPOSED PROGRAMS OF THE VARIOUS PARTIES AMD THE GOVERMMENT ALL STRESS A COMMITMENT TO CREATING A AND THE GOVERMMENT ALL STRESS A COMMITMENT TO CREATING A SOCIAL-MARKET SYSTEM OR A NEH SOCIAL SAFETY NET. BUT MOS THESE AIMS ARE ERP TYMOMIC TRANSITION. THERE IS FEAR OF REALITIES OF THE ECONOMIC TRANSITION. THERE IS FEAR OF HUNGARY S "LATIN AMERICANIZATION, MAY STABILIZE AT $25 \%$ ARE UNEMPLOYMENT AND
NOT IMPLAUSIBLE.

01430 BERES, L.

AFTER THE GULF WAR: IRAQ, GENOCIDE, AND INTERNATIONAL LAW UNIVERSITY OF DETROIT LAW REVIEW, 69(1) (FAL 91), 13-32.

THE END OF THE LATEST GULF WAR OID NOT ELIMINATE CRIMES AGAINST HUMANITY WITHIN THE BORDERS OF SADDAM HUSSEIN'S OWN UNFORTUNATE STATE. ALTHOUGH INTERNATIONAL LAW IS OBL IGED TO PREVENT AND PUNISH SUCH CRIMES, IRAQ'S SYSTEMATIC POSTWAR MURDER OF KURDISH CIVILIAN POPULATIONS HAS CARRIED OUT WITH ESSENTIAL IMPUNITY. THIS ARTICLE ATTEMPTS TO ESTABLISH THAT THESE CRIMES MAY HAVE AMOUNTED TO AUTHENTIC INSTANCES OF GENOCIDE, AND SHOULD HAVE BEEN THE OBJECT OF PARTICULAR ATTENTION BY AUTHORITATIVE GLOBAL OPERATIONS AND INSTITUTIONS. IT CONCLUDES THAT ONE HAY OR ANOTHER, THE LEGAL COMMUNITY OF HUMANKIND MUST TAKE STEPS TO ENSURE THE TIMELY PROSECUTION OF IRAQI CRIMES.

01431 BERES, L.

8ERES, L.'. ARAQI DEEDS AND INTERNATIONAL LAW: THE QUESTION OF IRAQI DEEDS
PUNISHMENT PUNISHMENT
JERUSALEM JOURNAL OF INTERNATIONAL RELATIONS, 14(3) (SEP 92), 22-43.

THE PRINCIPLE OF NO CRIME WITHOUT A PUNISHMENT HAS LONG BEEN RECOGNIZED IN THE JURISPRUDENTIAL TRADITION, AND INTERNATIONAL LAW IS NO EXCEPTION. THE DEEDS OF SADDAM HUSSEIN AND HIS REGIME, BEFORE, DURING, AND AFTER THE GUL WAR, SEEM TO CALL FOR INTERNATIONAL ACTION. THIS ARTICLE
EXPLORES SOME OF THE LEGAL AND PRAGMATIC ISSUES THAT HOULD EXPLORES SOME
$B E$ INVOLVED.

01432 BERES, L.

ON ASSASSINATION AS ANTICIPATORY SELF-DEFENSE: IS IT PERMISSIBLE?

UNIVERSITY OF DETROIT MERCY LAW REVIEW, 70(1) (FAL 92), 13-36.

IN THE REALM OF WORLD POLITICS AND INTERNATIONAL LAW, EXECUTIONERS SOMETIMES FUNCTION AS ASSASSINS. ALTHOUGH SUCH FUNCTIONING IS ALMOST ALWAYS AN INSTANCE OF HRONGFUL EXECUTION, THERE ARE CERTAIN CAREFULLY CIRCUMSCRIBED AND RESIDUAL CASES WHERE IT MAY BE RIGHTFUL, PERMISSIBLE, AND EVEN DISTINCTLY LAW ENFORCING. THIS ARTICLE EXAMINES ONE SPECIFIC CATEGORY OF SUCH CASES--A CLASS OF TRANSNATIONAL ASSASSINATIONS UNDERTAKEN BY STATES AS SELF-DEFENSE BEFORE
AN ARMED ATTACK OCCURS--AS AN INSTANCE OF ANTICIPATORY SELFDEFENSE UNDER INTERNATIONAL LAW.

01433 BERESFORD, M.; FRASER, L.

POLITICAL ECONOMY OF THE ENVIRONMENT IN VIETNAM

JOURNAL OF CONTEMPORARY ASIA, 22(1) (1992), 3-19.

JOURMAL OF CONTEMPORARY ASIA, 22 (1) VIETMAM'S TRANSITION FROM A TRADITIONAL' SOCIALIST

VIETNAM'S TRANSITION FROM A TRADITIONAL SOCIALIST
ECONOMY TO A MORE MARKET-ORIENTED FORM OF SOCIALISM RAISES

ECONOMY TO A MORE MARKET-ORIENTED FORM OF SOCIALISM RAISES IMPORTANT QUESTIONS REGARDING ENVIRONMENTAL PROTECTION. PAPER OUTLINES SOME OF THE MAJOR ENVIRONMENTAL PROBLEMS FACING VIETNAM AND THE POLICIES WHICH HAVE BEEN PUT IN PLACE IN THE $1980 S$ TO OYERCOME THEM. IT ALSO EXAMINES THE REALITY OF HOW THESE PROBLEMS ARE HANDLED WITHIN THE PREVAILING POLITICAL ECONOMIC SYSTEM AND THE ACTUAL PROSPECTS FOR IMPLEMENTATION OF VIETNAM'S NATIONAL CONSERVATION STRATEGY (NCS). IT CONCLUOES THAT WHILE BOTH THE NEH SYSTEM A OLD HAVE ADVANTAGES AND DISADVANTAGES, THE GREATER POSSIBILITIES FOR ENVIRONMENTAL PROTECTION COMBINED WITH ECONOMIC GRONTH AND A RISING STANC

01434 BERGDOLL, U.

BONN WAITSS WITH CONFIDENCE FOR THE START OF THE CLINTON ERA GERMAN TRIBUNE, 1540 (NOY 92 ) 1 .

THE GERMAN GOVERMMENT IS NOW WAITING IN SUSPENSE TO SEE WHAT COURE "CLINTAN THE DEMOCRAT" HIT STEER FROM THE POINT OF VIEW OF HIS GERMAN ALLIES HE IS PURELY A DOMESTIC POLITICIAN, A MAN WHOSE ROLE WAS UP TILL NOW CONFINED TO BEING GOVERNOR OF ARKANSAS, WHO HAS NOW BEEN ELECTED PRESIDENT OF THE ONLY REMAINING WORLD POWER WITH GLOBAL INTERESTS.

01435 BERGOOLL, U.

FOREIGH MINISTER GENSCHER: WHEN THE FIXED COORDINATES OF WORLD AFFAIRS BEGIN TO DANCE

GERMAN TRI BUNE, 31(1499) (JAN 92), 3. 
FOREIGN MINISTER GENSCHER ARGUES THAT THE AIM OF GERMAN DIPLOMACY WILL BE TO INTEREST THE WEST IN THE EAST. IT MAY BE A NEW OBJECTIVE, BUT IT HAS A FAMILIAR RING. AS WELL AS DO THE FEARS FELT BY GERMANY'S WESTERN NEIGHBORS OF GERMAN PREDOMINANCE. GENSCHER MAKES A POINT OF TELLING OTHERS THAT THEIR FEARS OF GERMAN PREDOMINATION ARE UNJUSTIFIED. THE ADVICE HE THEN GIVES HIS OPPOSITE NUMBERS IS THAT IF THEY AREN'T PREPARED TO LEND A HAND IN EASTERN EUROPE THE EAST WILL COME TO RELY ENTIRELY ON GERMANY. GERMANY, HE REPEATEDLY REMINDS ITS EUROPEAN ALLIES, DOES NOT WANT TO BE THE EASTERNMOST MEMBER-COUNTY OF THE EUROPEAN COMMUNITY. IT WOULD PREFER A CENTRAL LOCATION.

01436 BERGDOLL, $U$.

GERMANY IS STILL SEEKING NEW STATURE

GERMAN TRIBUNE, (1475) (JUL 91 ), 2 .
GERMANY'S EFFORTS TO MEDIATE THE CRISIS IN YUGOSLAVIA REVEALS THAT THE NEWLY-UNITED NATION HAS YET TO ACHIEVE THE STATURE IT NEEDS TO FULFILL ITS ROLE AS A MEDIATOR OF CONFLICT AND GUARANTOR OF PEACE AND STABILITY IN EUROPE. CONFLICT AND GUARANTOR DF PEACE AND STABILITY IN EUROPE. GERMANY'S HALF-HEARTED SUPPORT FOR SELF-DETERMINATION IN CROATIA AND SLOVENIA AND ITS CALLS FOR AN END TO BLOOOSHED
IN YUGOSLAVIA WENT VIRTUALLY UNHEEDED. ADMITTEDLY, RESOLVING IN YUGOSLAVIA WENT VIRTUALLY UNHEEDED. ADMITTEDLY RESOLVING BUT GERMANY SEEMS TO HAVE SOME PROGRESS TO MAKE BEFORE IT CAN BE AN INFLUENTIAL FORCE IN THE REGION.

01437 BERGDOLL, $U$.

KINKEL, IN JERUSALEM, MOVES TO DISPEL ISRAELI FEARS GERMAN TRIBUNE, 31 (1542) (NOV 92), 1 .

IN GERMAN-ISRAELI RELATIONS, CHEQUE BOOK DIPLOMACY HAS HAD TO BOW OUT IN THE WAKE OF EMPTY COFFERS. THE GERMAN'S SPECIAL RESPONSIBLITY FOR ISRAEL'S SECURITY WILL IN FUTURE HAVE TO FIND OTHER THAN FINANCIAL EXPRESSION. THIS WILL CALL FOR A LEARNING PROCESS ON BOTH SIDES. FOREIGN MINISTER, KLAUS KINKEL'S VISIT TO ISRAEL CAME HARD ON THE HEELS OF A SERIES OF OUTBREAKS OF HOSTILITY IN GERMANY TOWARD FOREIGNERS AND OF ANTI-SEMITISM. THE ISRAELI FOREIGN MINISTER SAID THE GERMAN AUTHORIES WOULD BE JUDGED BY WHAT THEY DID TO END THE UNPLEASANT RIOTS.

01438 BERGER, $M$.

JAPAN'S DECEPTIVE DOWNTURN

NEW LEADER, LXXV(5) (APR 92) 7-8.

IN MARCH JAPANESE HERE SHOCKED BY WHAT WAS ONCE

UNTHINKABLE NEWS. AFTER MORE THAN 15 YEARS OF UNINTERRUPTED ECONOMIC GROWTH, THE COUNTRY'S GROSS NATIONAL PRODUCT ACTUALLY SHRANK BY 0.2 PERCENT IN THE FINAL QUARTER OF 1991. ACTUAL
A FEW WEEKS LATER, THE TOKYO STOCK EXCHANGE'S NIKKEI INDEX A FEW WEEKS LATER, THE TOKYO STOCK EXCHANGE'S NIKKEI
FELL TO ITS LOWEST LEVEL IN FIVE YEARS AND THE SLIDE FELL TO ITS LOWEST LEVEL IN FIVE YEARS AND THE SLIDE
CONTINUES. RECESSION HAS COME TO JAPAN. THE PROBLEMS BURDENING JAPAN'S ECONOMY ARE SAID TO DERIVE LARGELY FROM THE EXCESSES OF THE LATE 1980 S, WHEN STOCK PRICES DOUBLED IN THE EXCESSES OF THE LATE 1980 , WHEN STOCK PRICES DOUBLED IN PERCENT. THIS, IN TURN, LED TO UNSOUND INVESTMENTS AND AN UNHEALTHY PRICE SPIRAL. MOST ANALYSTS BELIEVE THAT AL REPAIRING THE DAMAGE DONE WILL BE PAINFUL, IT WILL ESSENTIALLY INVOLVE THREE TO FIVE YEARS OF SLUGGISH GROWTH. HOWEVER, THE RECESSION IN JAPAN IS DIFFERENT FROM THAT OF THE UNITED STATES. UNEMPLOYMENT ACTUALLY FELL TO 2
IN MARCH. JAPANESE INDUSTRY CHAIRMAN AND MANAGERS IN MARCH. JAPAMESE INDUSTRY CHAIRMAN AND MANAGERS
VOLUNTEERED FOR PAY CUTS UNTIL THE ECONOMY PICKS UP AGAIN.

01439 BERGER, M.

JAPAN'S PEARL HARBOR OPPORTUNITY

NEW LEADER, LXXIV (2) (JAN 91), 10-11.

THE FIFTIETH ANNIVERSARY OF THE JAPANESE ATTACK ON PEARL HARBOR IS STILL ALMOST A YEAR AWAY, BUT PEOPLE ON BOTH SIDES OF THE PACIFIC ARE SPEAKING OF ITS AS A POTENTIAL TIME BOMB BECAUSE OF THE HEIGHTENED TENSIONS BETWEEN JAPAN AND THE UNITED STATES. SOME REGARD THE ANNIVERSARY AS AN OPPORTUNITY FOR THE JAPANESE PRIME MINISTER TO ISSUE AN OFFICIAL APOLOGY FOR THE PEARL HARBOR ATTACK, A MOVE THAT WOULD GO LONG WAY TO DEMONSTRATE THAT JAPAN IS DETERMINED NOT TO REPEAT THE MISTAKES OF THE PAST. SOME CALL FOR JAPAN'S PRIME MINISTER TO TRAVEL TO PEARL HARBOR AND TO LAY A WREATH AT THE USS ARIZONA MEMORIAL. THEN, PRESIDENT BUSH SHOULD STOP AT HIROSHIMA, HHERE THE FIRST ATOMIC BOMB WAS DROPPED BEFORE THE WAR'S END IN 1945. SUCH SYMBOLIC GESTURES MAY AVERT THE GROHING FEELINGS OF ACRIMONY AND TENSION ON BOTH SIDES.

01440 BERGER, $M$.

KOREA AND JAPAN COMING TOGETHER
NEW LEADER, LXXV(10) (AUG 92), 9-10.

THE ENTHUSIASTIC REACTION OF MANY KOREANS TO JAPANESE POP CUL ENTE DOES JAPAN'S HARSH 35-YEAR OCCUPTION OF THE PENINSULA. THE COMMON VIEW IS THAT IT IS THE YOUNGER PEOPLE WHO ARE ATTRACTED TO THE JAPANESE. ACTUALLY, THE SITUATION IS MORE COMPLEX. MANY
OLDER KOREANS. WHO SUFFERED OIRECTLY AS A RESULT OF THE LONG OLDER KOREANS, WHO SUFFERED DIRECTLY AS A RESULT OF THE LONG
OCCUPATION OF THEIR NATION, ARE NEVERTHELESS MORE CONFIDENT OCCUPATION OF THEIR NATION, ARE NEVERTHELESS MORE CONFIDENT
INTERACTING WITH THE JAPANESE. MOST EXECUTIVES AND ECONOMIC PLANNERS CONCEDE THE IMPORTANCE OF JAPAN'S ROLE IN KOREA'S ECONOMY.
01441 BERGER, M.

PEROTISM ACROSS THE PACIFIC

MEN LEADER, LXXV(8) (JUN 92), 7-8.

THE ROSS PEROT PHENOMENON IS CATCHING ON IN EAST ASIA-FOR MANY OF THE SAME REASONS THAT THE TEXAS BUSINESSMAN HAS PROVED SO POPULAR IN THE UNITED STATES. SOUTH KOREA HAS CHUNG JU YUNG, THE WEALTHY INDUSTRIALIST WHO LAST YEAR ORGANIZED HIS OWN POLITICAL PARTY OUT OF FRUSTRATION WITH THE COUNTRY'S ENTRENCHED LEADERSHIP. HE APPEARS READY TO CHALLENGE THE TWO MAIN CONTENDERS IN THE FORTHCOMING PRESIDENTIAL ELECTION. WHILE JAPAN'S SURPRISE CHALLENGER MORIHIRD HOSOKAWA, DOESN'T QUITE FIT THE PEROT MOLD, THE 54YEAR OLD ARISTROCRAT HAS TAPPED INTO GROWING DISCONTENT WITH THE CURRENT GOVERMMENT AND ITS BUREAUCRATIC WRANGLINGS. ESPECIALLY POTENT IS THE DISGUST WITH HOW THE GOVERNMENT HAS HANDLED THE ISSUE OF SENDING JAPANESE SOLDIERS ON UNITED NATIONS PEACE-KEEPING OPERATIONS. HOSOKAHA'S SENSIBLE STANCE ON THE ISSUE-FORMING A GROUP OF CIVILIAN VOLUNTEERS FOR OVERSEAS RELIEF MISSIONS, WITH PARLIAMENTARY APPROVAL ON A CASE-BY-CASE BASIS- HAS STRUCK A RESPONSIVE CHORD AMONG THE CASE-BY-CASE BASIS-HAS STRUCK A
OISGRUNTLED JAPANESE POPULACE.

01442 BERGER, M.

WHY JAPAN HON'T "BUY AMERICAN"

NEW LEADER, LXXV(1) (JAN 92), 10-11.

FOR ECONOMIC AS WELL AS POLITICAL REASONS THE JAPANESE GOVERMMENT, IN THE FORM OF THE MINISTRY OF INTERNATIONAL TRADE AND INDUSTRY (MITI), IS MAKING SCORES OF JAPANESE COMPANIES "BUY AMERICAN." MITI'S ECONOMIC STRATEGY IS OBVIOUS. BY TRIGGERING A SURGE IN IMPORTS OF U.S. PRODUCTS, ESPECIALLY AUTO PARTS, IT HOPES TO DEFLECT CRITICISM THAT THE JAPANESE ARE RESPONSIBLE FOR THE TROUBLE IN DETROIT. THE POLITICAL STRATEGY IS EQUALLY TRANSPARENT. JAPANESE FEEL MORE COMFORTABLE WITH GEORGE BUSH, EVEN WHEN HE BRINGS HIS ABRASIVE FRIENDS ALONG, THAN THEY WOULD WITH ANY LIKELY DEMOCRATIC PRESIDENT. ALTHOUGH NONE OF THE CURRENT DEMOCRATIC CANDIDATES HAS MUCH OF AN IMAGE IN JAPAN, ALL HAVE BEEN IDENTIFIED IN MEDIA COVERAGE IN JAPAN AS INCLINED TOWARD PROTECTIONISM AND AS SUCH ARE VIEWED AS POTENTIALLY HOSTILE. MANY VIEW THE JAPANESE MEASURES AS MERE TOKENISM. HOHEVER, THEY ARE PROBABLY THE BEST THAT DETROIT--WHO IGNORED SEVERAL JAPANESE OVERTURES FOR JOINT PRODUCTION PROJECTS IN PAST DECADES--WILL SEE IN THE NEAR FUTURE.

01443 BERGER, P.L.

THE UNCERTAIN TRIUMPH OF DEMOCRATIC CAPITALISM

JOURNAL OF DEMOCRACY, 3(3) (JUL 92), 7-16.

IN THE HALF-CENTURY SIMCE IT FIRST APPEARED, JOSEPH SCHUMPETER'S "CAPITALISM, SOCIALISH, AND DEMOCRACY" HAS SCHUMPETER'S "CAPITALISM, SOCIALISH, AND DEMOCRACY" HAS
ATTAINED THE STATUS OF A MINOR CLASSIC, AN ODD FATE GIVEN ATTAINED THE STATUS OF A MINOR CLASSIC, AN ODD FATE GIVEN
THAT ALMOST EVERY ONE OF ITS MAIN PROPOSITIONS HAS BEEN THAT ALMOST EVERY ONE OF ITS MAIN PROPOSITIONS HAS
EMPIRICALLY FALSIFIED. THIS ARTICLE EXAMINES THE

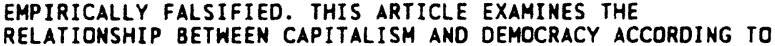
RELATIONSHIP BETWEEN CAPITALISM AND DEMOCRACY ACCORDING TO AN INTERPRETATION OF SCHUMPETER'S WORK. HE EMPHASIZES THE BY BIRTH, BUT BY TEMPRAMENT AND WORLD VIEW."

01444 BERGERSON, $P$.

ETHICS AND PUBLIC POLICY: AN ANALYSIS OF A RESEARCH TRADITION

INTERNATIONAL JOURNAL OF PUBLIC ADMINISTRATION, 15(7) 1992), 1369-1396.

THIS ARTICLE FOCUSES ON THE RELEVENT SCHOLARLY

ITTERATURE DEVOTED TO ETHICS AND PUBLIC POLICY. A LITERATURE SEARCH REVEALED AN EXTENSIVE BODY OF RESEARCH WHICH LACKED A COHERENT ORDERING. THIS ARTICLE PROVIDES A MODEL TO UNDERSTAND A FIELD OF ACADEMIC INQUIRY WHICH HAS A RICH TRADITION.

01445 BERGLUND, S.; DELLENBRANT, J.A. THE EVOLUTION OF PARTY SYSTEMS IN EASTERN EUROPE JOURNAL OF COMMUNIST STUDIES, 8(1) (MAR 92), 148-159. THE REVOLUTION OF 1989-90 WAS A BYPRODUCT OF A PERMANENT LEGITIMACY CRISIS IN EASTERN EUROPE COMPOUNDED BY A SERIES OF SERIOUS POLITICAL AND ECONOMIC MISTAKES. IN THE AFTERMATH OF THE ANTI-COMMUNIST REVOLUTION, A NEH PROCESS OF EVOLUTION AHAY FROM THE STALINIST SYSTEM HAS BEGUN, IN WHICH THE PARTY SYSTEMS OF EASTERN EUROPE HAVE UNDERGONE PROFOUND CHANGE AS NEW CLEAVAGES HAVE APPEARED AND OLD CLEAVAGES HAVE REASSERTED THEMSELYES.

01446 BERGMAN, $D$.

ENTERPRISE ZONES: A CURE FOR URBAN AMERICA?

MAIIONAL CIVIC REVIEH, 81(2) (SPR 91) 186-187

THE CONGRESS AND THE BUST ADMINISTRATION ARE TRYING TO HAMMER OUT A NEW URBAN AGENDA FOR THE 1990'S. ONE IDEA ALMOST CERTAIN TO BE INCLUDED IN THE ESTABLISHMENT OF FEDERAL ENTERPRISE ZONES (EZ'S). EZ'S OFFER TAX RELIEF AND OTHER INCENTIVES TO BUSINESSES THAT WILL LOCATE IN ECONOMICALLY-DISTRESSED URBAN AREAS, THEREBY CREATIMG HIGHQUALITY MANUFACTURING JOBS IN THE HEART OF URBAN AMERICAN. 
01447 BERGMAN, J.

SOVIET DISSIDENTS ON THE HOLOCAUST, HITLER, AND NAZISM: A STUDY OF THE PRESERVATION OF HISTORICAL MEMORY

SLAVONIC AND EAST EUROPEAN REVIEN, 70(3) (JUL 92), 477-504. IN THE 1960 'S SOVIET DISSIDENTS OFTEN CLAIMED THAT THE IN THE 1960 'S SOVIET DISSIDENTS OFTEN CLAIMED THAT THE
RIGHTS THE SOVIET GOVERMMENT DENIED THEM WERE UNIVERSAL RIGHTS THE SOVIET GOVERMMENT DENIED THEM WERE UNIVERSAL RIGHTS BELONGING TO EVERYONE REGARDLESS OF NATIONALITY,
RELIGION, OR RACE. IN THIS RESPECT, THEY WERE VERY MUCH LIKE THE INTELLIGENTSIA OF THE 19TH CENTURY, WHO ALWAYS CLAIMED THE MORAL PRINCIPLES THEY PROFESSED WERE APPLICABLE EVERYWHERE--NOT JUST IN RUSSIA. STILL, THE DISSIDENTS, LIKE THE INTELLIGENTSIA BEFORE THEM, SINGLED OUT CERTAIN GROUPS WHOSE OPPRESSION MOST CLOSELY RESEMBLED THEIR OWN: WHILE THE INTELLIGENTSIA PROFESSED A SPECIAL EMPATHY FOR THE PEASANTS
AND THE WORKERS, MANY DISSIDENTS IDENTIFIED WITH AND CLAIMED AND THE WORKERS, MANY DISSIDENTS IDENTIFIED WITH AND CLA
A SPECIAL EMPATHY FOR THE JEWS, HOSE PERSECUTION THEY BELIEVED WAS EMBLEMATIC OF THE SUFFERING THEY AND EVERYONE ELSE ENDURED IN THE SOVIET UNION.

01448 BERGMAN, J.

SOVIET DISSIDENTS ON THE RUSSIAN INTELLIGENTSIA, 1956-1985: THE SEARCH FOR A USABLE PAST

RUSSIAN REVIEW, 51(1) (JAN 92), 16-35.

MANY SCHOLARS HAVE NOTED SIMILARITIES BETWEEN THE SOVIET DISSIDENTS OF THE BREZHNEV YEARS AND THE REVOLUTIONARY INTELLIGENTSIA OF TSARIST RUSSIA. BOTH GROUPS CRITICIZED THE EXISTING POLITICAL ORDER IN MORAL TERMS, RECOGNIZED THE VALUE OF THE INDIVIDUAL AND THE ABSOLUTE INVIOLABILITY OF INDIVIDUAL CONSCIENCE, BEL IEVED THAT INDIVIDUAL LIBERATION REQUIRED THE ESTABLISHMENT OF SOCIAL JUSTICE, AND UNIVERSALIZED INDIVIDUAL PERSONAL GRIEVANCES INTO A BROADER POLITICAL AND PHILOSOPHICAL CRITIQUE OF THE WORLD AROUND POLITICAL AND PHILOSOPHICAL CRITIQUE OF THE HORLD AROUND
THEM. BY STUDYING THE HRITINGS AND PRONOUNCEMENTS OF SOVIET THEM. BY STUDYING THE HRITINGS AND PRONOUNCEMENTS OF SOVI
DISSIDENTS--ESPECIALLY THOSE ACTIVE BETWEEN 1956 AND THE DISSIDENTS--ESPECIALLY THOSE ACTIVE BETWEEN 1956 AND THE
ADVENT OF PERESTROIKA IN 1985--IT IS POSSIBLE TO BETTER ADVENT OF PERESTROIKA IN 1985--IT IS POSSIBLE TO BETTER
UNDERSTAND THE INFLUENCE OF THE RUSSIAN INTELLIGENTSIA ON UNDERSTAND THE INFLUENCE
THOSE WHO CAME LATER.

01449 BERGSTEN, $C$.

THE PRIMACY OF ECONOMICS

FOREIGN POL ICY, (87) (SUM 92), 3-24.

THIS ARTICLE ARGUES THAT SHEEPING GLOBAL CHANGES ARE RENDERING TRADITIONAL U.S. FOREIGN POLICY VIEWS OBSOLETE. FOREIGN POLICYMAKERS MUST ADAPT TO CHANGING REALITIES AND RISING TRENDS WHICH INCLUDE A SHIFT IN AMERICAN NATIONAL INTERESTS TOWARDS ECONOMICS; THE EMERGENCE OF THREE ROUGHLY EQUAL ECONOMIC SUPERPOWERS; THE SHIFT FROM COMPETITION BETHEEN CAPITALISM AND COMMUNISM TO COMPETITION AMONG ALTERNATIVE VERSIONS OF MARKET ECONOMIES; AND CHANGES IN ALLIANCE ARRANGEMENTS. AMERICAN RESPONSES TO THESE CHANGES WILL TAKE ONE OF TWO COURSES. THE FIRST IS COLLECTIVE LEADERSHIP BY THE MAJOR POWERS, OPERATING INFORMAL STEERING COMMITTEES WITHIN THE EXISTING INSTITUTIONAL FRAMEWORK. THE SECOND IS TOWARD REGIONAL BLOCS THAT WOULD BECOME INCREASINGLY RESTRICTIVE AND EXCLUSIONARY. THE AUTHOR OF THIS ARTICLE STRONGLY ADVOCATES THE TAKING OF THE FIRST COURSE.

01450 BERING-JENSEN, $H$.

A BOON TURHS TO BOONDOGGLE

INSIGHT, 7 (46) (NOV 91), 14-16, 39

OFFICIALS FROM EASTERN EUROPE ARE BEGINNING TO GRUMBLE ABOUT THE TYPE OF FORIEGN AID THEY ARE RECEIVING FROM THE NATIONS OF THE WEST. AT A TIME WHEN FOREIGN AID, NEYER POPULAR TO BEGIN WITH, IS UNDER INCREASING SCRUTINY FROM A CONGRESS EAGER TO BLAME THE PRESIDENT FOR NEGLECTING CONGRESS EAGER TO BLAME THE PRESIDENT FOR NEGLECTING
DOMESTIC NEEDS, THE COMMENTS OF THESE OFFICIALS RUN THE RISK DOMESTIC NEEDS, THE COMMENTS OF THESE OFFICIALS RUN THE RISK
OF BEING MISINTERPRETED. THE UNITED STATES HAS COMHITTED $\$ 1$. OF BEING MISINTERPRETED. THE UNITED STATES HAS COMMITTED $\$ 1.0$
5 BILLION IN GRANTS AND OTHER ASSISTANCE TO FORMER SOVIET 5 BILLION IN GRANTS AND OTHER ASSISTANCE TO FORMER SOVIET
SATELLITES. TO THIS ADD THE SUBSIDIZED LOANS GUARANTEED BY THE UNITED STATES THROUGH SUCH INSTITUTIONS AS THE

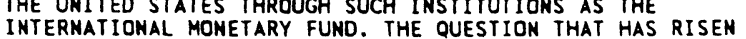
INTERMATIONAL MONETARY FUND. THE QUESTION THAT HAS RISEN
AMONG U.S. ISOLATIONISTS LEFT AND RIGHT IS: IF THE AMONG U.S. ISOLATIONISTS LEFT AND RIGHT IS: IF THE RECIPIIENTS ARE UNHAPPY, WHY GIVE ANY AID AT ALL? HOWEVER,
THE POINT EASTERN EUROPEAN NATIONS ARE TRYING TO MAKE IS NOT THE POINT EASTERN EUROPEAN NATIONS ARE TRYING TO MAKE IS
THAT THEY ARE AGAINST FOREIGN AID PER SE, BUT THEY ARE AGAINST CERTAIN KINDS OF FOREIGN AID THAT HAVE PROVED LES THAN HELPFUL. PRIME TARGETS FOR CRITICISM HAVE BEEN THE WORLD BANK AND THE INTERNATIONAL MONETARY FUND. THEY ARE FREE MARKET SOLUTIONS TO PROBLEMS.

01451 BERING-JENSEN, $H$.

A TILT FROM FREEDOM

INSIGHT, 7(31) (AUG 91), 20-21.

FOR MUCH OF THE SIXTEEN YEARS SINCE THE HELSINKI ACCORDS, U.S. FOREIGN POLICY LARGELY HAS BEEN FRAMED IN A MANNER THAT PLACES HUMAN RIGHTS AND ASPIRATIONS FOR FREEDOM AND DEMOCRACY IN THE FOREFRONT. HOWEVER. THE BUSH ADMINISTRATION SEEMS TO HAVE LOST SIGHT OF THIS GOAL, OPTING INSTEAD TO ACHIEVE POLITICAL STABILITY AROUND THE GLOBE. HIS POLICY TOWARDS YUGOSLAVIA. IRAQ. CHINA AND THE SOVIET UNIOM INDICATES THAT BUSH IS MORE THAN WILLING TO SUBORDINATE HUMAN RIGHTS TO THE DEMANDS OF REALPOLITIK.
01452 BERING-JENSEN, $H$.

AFRICA IN THE BALANCE

INSIGHT, 8(34) (AUG 92), 7-11; 34

THE COLD WAR AND SUPERPOWER LEVERAGING ARE DEAD, AND THE HEYDAY OF THE AFRICAN DICTATORS IS OVER. IN FACT, SO MANY NATIONS ARE BEATING BACK REPRESSION THAT SOME AFRICANS ARE CALLING THE NINETIES A SECOND ERA OF INDEPENDENCE. NATIONS CARE FLOCKING TO REPRESENTATIVE GOVERNMENT WITH MORE OPEN ECONOMIES. DESPITE MURDLES, AFRICA CAN SUCCEED BY CHANGING ECONOMIES. DESPITE MURDLES,
SOME FUNDAMENTAL ATTITUDES.

01453 BERING-JENSEN, $H$.

CRUSHED VELVET
INSIGHT, 8(22) (JUN 92), 7-11;34; 36.

MORE THAN TWO YEARS AFTER CZECHOSLOVAKIA MADE THE ACT OF THROWING OFF THE CLOAK OF COMMUNISM LOOK EASY THROUGH ITS "VELVET REVOLTUION," THE COUNTRY IS STILL TRYING TO GET THE WHEELS OF DEMOCRACY TURNING AT FULL SPEED. BUT THE ECONOMY AND A RISE IN SLOVAK NATIONALISM ARE MAKING IT TOUGH FOR PRESIDENT VACLAV HAVEL TO KEEP THE COUNTRY ON TRACT. UPCOMING ELECTIONS MAY BRING SOME CHANGES IN A FEDERAL
GOVERMMENT THAT OFTEN DEADLOCKS ON KEY ISSUES. HAVEL, THE GOVERNMENT THAT OFTEN DEADLOCKS ON KEY ISSUES. HAVEL, THE
ONETIME DISSIDENT AND INTELLECTUAL, HAS HAD TO REVISE HIS VIEWS SINCE TAKING POWER. 01454 BERING-JENSEN, H.
GERMANY RESURGENT

INSIGHT, 8(12) (MAR 92), 7-11; 36-37

HITH THE REMAKING OF EASTERN EUROPE AND REUNIFICATION OF EAST AND HEST, THE NEW GERMANY HAS A PIVOTAL ROLE ON THE CONTINENT. HELMUT KOHL IS EXERCISING HIS CLOUT. SOME FEAR THE NATION IS FLEXING TOO MUCH MUSCLE, BUT GERMANY SAYS IT IS NOT INTERESTED IN DOMINANCE. THIS ARTICLE SUGGESTS THAT SOME BELIEVE A SELF-RIGHTEOUS GERMANY, GIVEN TO HILSONIAN EMERGE THAN A FOURTH REICH.

01455 BERING-JENSEN, $H$.

IN EXCELSIS YELTSIN

INSIGHT, $7(36)$ (SEP 91), 21-23.

DISMISSED AS A HARD-DRINKING BUFFOON BY MANY OF THE SOVIET ELITE, AND BY LEADERS ABROAD, BORIS YELTSIN NOW ENJOYS HERD STATUS AS DEMOCRACY'S LATEST STAR. YELTSIN'S MAJOR ACCOMPLISHMENT HAS BEEN THE FORGING OF AN ALLIANCE BETWEEM TWD OPPOSED ELEMENTS OF SOVIET SOCIETY: THE INTELLIGENTSIA AND THE WORKING CLASS. HIS COMMON TOUCH AND PLAIN SPEAKING ENDEAR HIM TO THE CROWDS; HIS DEMOCRATIC AGENDA, TO THE INTELLECTUALS WHO ONCE LAUGHED AT HIM. THIS UNPARALLELED DEGREE OF SUPPORT ENABLED YELTSIN TO STRIDENTLY RESIST THE AUGUST COUP ATTEMPT BY HARDLINERS, A MOVE WHICH CATAPULTED YELTSIN INTO SUPERSTAR STATUS.

01456 BERING-JENSEN, $H$. ISLAMIC STATES OF SEIGE INSIGHT, 8(29) ( JUL 92), 6-11.

WITH THE ASSASSINATIOAN OF THE RULING COUNCIL'S LEADER, ALGERIA'S POLITICAL AND RELIGIOUS CRISIS HAS HIT A FEVER PITCH. THE ARMY HALTED JANUARY ELECTIONS AND TOOK OVER THE CONTROL.

01457 BERING-JENSEN, $H$.

KENYA IN THE GRIP OF MISRULE, DROUGHT

INSIGHT, 8(40) (OCT 92), 14-16.

KENYA HAS LONG BEEN ONE OF AFRICA'S MORE PROSPEROUS NATIONS. HOWEVER, THE ONE-PARTY RULE OF PRESIDENT DANIEL ARAP MOI IS TURNING OFF FOREIGN DONORS AT A TIME WHEN THE COUNTRY IS BEING RAVAGED BY ONE OF THE WORST DROUGHTS IN DECADES.

01458 BERING-JENSEN, $H$.

KOHLDRUMS
INSIGHT, 7 (13) (APR 91), 34-35.

GERHAN CHANCELLOR HELMUT KOHL'S PROMISE THAT GERMAN REUNIFICATION WOULD REQUIRE NO NEH TAXES DISAPPEARED IN FINANCIAL REALITY. DECLARING THAT THE COST OF REBUILOING THE EAST GERMAN ECONOMY WAS HIGHER THAN EXPECTED AND THAT THE
PERSIAN GULF CRISIS CAUSED FURTHER UNFORESEEN EXPENSES, KOHL PERSIAN GULF CRISIS CAUSED FURTHER UNFORESEEN EXPENSES, KOH
ANNOUNCED THAT THE NATION'S 544 BILLION BUDGET DEFICIT ANNDUNCED THAT THE NATION'S $\$ 44$ BILLION BUDGET DEFICIT REQUIRES FURTHER TAXATION POSTHAR HISTORY. KOHL'S DETRACTORS BIGGEST TAX INCREASE IN POSTWAR HISTORY C KOHL S DETRACTO WERE QUICK TO POUNCE ON THE ISSUE AND CLAIM THAT KOHL
DELIBERATELY MISLED THE PEOPLE AND THAT HE IS TAXING "READ MY LIPS" LESSONS FROM GEORGE BUSH. HOWEVER, ANALYSTS SAY KOHL SIMPLY COULD NOT
THE PROBLEMS AHEAD.

01459 BERING-JENSEN, H. MAASTRICHT TEETERS ON THE EDGE INSIGHT, $8(42)$ (OCT 92 ), 12-13; 38-39.

THE EUROPEAN COMMUNITY'S IDEAL OF A UNIFIED EUROPE HAS THREATENED WHEN THE MAASTRICHT TREATY CAME UP FOR A VOTE IN 
BUT NOT BEFORE THE CONTINENT AND BRITAIN DESCENDED INTO AN ECONOMIC CRISIS. THE OPPOSITION EVIDENCED IN FRANCE, AND IN

01460 BERING-JENSEN, $H$.

NO UNITY YET

INSIGHT, 7(7) (FEB 91), 30-31.

THE TWIN CRISES IN THE PERSIAN GULF AND THE BALTIC STATES HAVE SINCE CAUSED A SERIOUS SETBACK TO THE MOVEMENT TOWARDS POLITICAL UNION IN EUROPE. BOTH REPRESENT FUNDAMENTAL CHALLENGES TO THE STRATEGIC INTERESTS OF THE EUROPEAN COMMUNITY'S TWELVE MEMBER NATIONS. BOTH HAVE ALSO DEMONSTRATED ITS INABILITY TO AGREE ON WHAT THE COMMON INTEREST IS, LET ALONE ACT ON IT, LEAVING THE EC LOOKING IMPOTENT AND BESET BY PAROCHIALISM. BOTH FRANCE AND GERMANY HAVE RESISTED SOL IOARITY IN THE GULF HAR BUT FOR DIFFEREMT REASONS. GERMANY IS ALSO AN OBSTACLE TO THE COMMON MARKET.

01461 BERING-JENSEN, $H$.

PICKING A NEH COURSE
INSIGHT, $7(42)$ (OCT 91), 22-23.

WITH THE COLLAPSE OF COMMUMISM, THE PREDICTABILITY OF U. S. -FOREIGN POL ICY AND ITS PUNDITS' IS A THING OF THE PAST. TREND TOWARDS ISOLATIONISM HAS CREATED SOME STRANGE BEDFELLOWS OM THE RIGHT AND THE LEFT AND DOMESTIC CONCERNS BEDFELLOWS ON THE RIGHT AND THE LEFT, AND DOMESTIC CONCE
ARE LIKELY TO GAIN STATUS. FOREIGN POLICY EXPERTS ARE

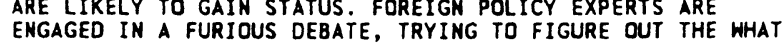
THE ROLE OF THE UNITED STATES (AND THEIR OWN ROLE) IN THE NEWLY EMERGING WORLD WILL BE, AND SOME INTERESTING COMBINATIONS ARE EMERGING. PEOPLE WHO IT SEEMED CERTAIN WOULD REMAIN ENEMIES TO THE DEATH SUDDENLY FIND THEMSELVES ON THE SAME SIDE OF THE KEY ISSUES, WHILE FORMER ALLIES ARE GUNMING AT EACH OTHER WITH ALL THEY HAVE. THE WATCHWORD NOW IS "SELECTIVE COMMITMENT."

01462 BERING-JENSEN, $H$.

PROSPERITY TAXES SHEDES

INSIGHT, 8(49) (DEC 92), 12-16, 36-39.

AFTER GROWING STEADILY SIMCE THE 1930 S, SWENDEN'S

SOCIALIST WELFARE SYSTEM IS COMING APART AT THE SEAMS. ITS CLIENTS, PROMPTED BY A SHRINKING ECONOMY AND A NEW,

CONSERVATIVE GOVERMMENT, ARE RETHINKING THE STATE'S ROLE IN THEIR DAILY EXISTENCE. THE RESULT COULD BE A NEW FREEDOM OF CHOICE FOR THE AVERAGE SWEDE.

01463 BERING-JENSEN, $H$.

RUSSIAN BEARS

INSIGHT, 7(11) (MAR 91), 22-23.

BORIS YELTSIN, FROM HIS POST AS RUSSIA'S PRESIDENT, HAS STEPPED UP EFFORTS TO BE MIKHAIL GORBACHEY'S SUPREME NEMESIS. ON A RECENT TELEYISED DEBATE, YELTSIN ACCUSED THE PRESIDENT OF THE SOVIET UNION OF STRIVING FOR ULTIMATE POWER AND BRING THE COUNTRY ON THE VERGE OF DICTATORSHIP. CAMOUFLAGING THIS THE COUNTRY ON THE VERGE OF DICTATORSHIP, CAMOUFLAGIMG AS PRESIDENTIAL RULE. HE IDENTIFIED GORBACHEV AS THE PRESERVER OF THE OLD ORDER AND THE CHIEF OBSTACLE TO REFORM. THE SPEECH LED TO EVEN MORE FERVENT EFFORTS BY HARD-LINERS TO FORCE YELTSIN OUT OF OFFICE. AMONG OTHER THINGS, THERE IS A CAREFULLY ORCHESTRATED KGB CAMPAIGN IN PLACE TO DISCR
THE EFFORTS OF REFORMERS BY LINKING THEM WITH CRIMINAL THE EFFORTS OF REFORMERS BY LINKING THEM WITH CRIMINAL ACTIVITIES, FOREIGN BANKS AND OTHER DARK FORCES--ALL
PORTRAYED AS PART OF A MONSTROUS CONSPIRACY AGAINST THE SOVIET ECONOMY AND WAY OF LIFE.

01464 BERING-JENSEN, H.

SHATTERED ALLI IANCE

INSIGHT, 7 (10) (MAR 91), 26-27.

WHEN MIKHAIL GORBACHEV ANNOUNCED THAT THE WARSAH PACT WAS TO BE FORMALLY DISSOLVED APRIL 1, THE BELEAGUERED SOVIET LEADER WAS MERELY BOWING TO REALITY. FOR ALL INTENTS AND PURPOSES, THE SOVIET-LED MILITARY ALLIANCE HAD LONG SINCE CEASED TO EXIST. ITS JOINT MILITARY STRUCTURES HAD NOT MET FOR MONTHS, AND ITS TROOPS HAD NOT HELD EXERCISES SINCE THE EASTERN EUROPEAN INDEPENDENCE MOVEMENTS OF 1989. SOME OF THE PACT'S MEMBERS, IMPATIENT WITH SOVIET STALLING ON THE ISSUE, SAID THEY WOULD WITHDRAH ON THEIR OWN IF ACITON WERE MOT TAKEN TO DISBAND THE GROUP. GORBACHEV MAY HAVE LET GO OF HIS EXTERNAL EMPIRE TO FOCUS ON KEEPING THE SOVIET UNION INTACT.

01465 BERING-JENSEN, $H$. SOVIETS ON THE EDGE

INSIGHT, 6(52) (JAK 91), 8-11.

THE SOVIET UNION IS EXHIBITING SIGNS OF GROWING OISORDER AND CHANGE. THE WEAKENING GOVERMMENT IS INCREASIMGLY UNDER AND CHANGE. THE WEAKENING GOVERMMENT IS INCREASINGLY UNDER FIRE FROM MINORITIES AND ITS FIFTEEN REPUBLICS, MANY OF WHICH DEMAND AUTONOMY OR OUTRIGHT IMDEPENDENCE. FOOD SHORTAGES HAVE LED TO RATIONING. TRYING TO SHORE UP HIS
WEAKENED GOVERMMENT, MIKHAIL GORBACHEY HAS SOUGHT GREATER WEAKENED GOVERNMENT, MIKHAIL GORBACHEV HAS SOUGHT GREATER
PRESIDENTIAL POWERS AND HAS EVEN PROPOSED RESTRUCTURING THE PRESIDENTIAL POWERS AND HAS EVEN PROPOSED RESTRUCTURING THE UNION. BUT INCREASINGLY THE LEADER SEEMS ISOLATED--MAKING LEADERS IN THE WEST ANXIOUS. SOME VIEH THE SOVIETS--ALONG WITH THE PERSIAN GULF AND TRADE PACTS--AS KEY PIECES IN A
NEW GLOBAL PUZZLE. THEY ARE HAITING ANXIOUSLY FOR THE DOMINO TO FALL.
01466 BERING-JENSEN, $H$.

THAWED U.S. HAS NEW HOPE

INSIGHT, 7(5i) (JAN 92), 14-16; 38

THE DEATH OF THE COLD WAR HAS GIVEN NEH LIFE TO THE UNITED NATIONS, WICH DRIFTED FOR DECADES WITHOUT VITAL PURPOSE. BUT THE U.N.'S RECENT PROMINENCE IN WORLD EVENTS SHOULD NOT OBSCURE THE MANY HURDLES AHEAD. A GREAT DEAL OF ORGANIZATIONAL REFORM IS STILL NEEDED, SUGGESTS THIS
ANALYSIS. A LOT DEPENDS ON THE U.N. SECRETARY GENERAL.

01467 BERING-JENSEN, H.

THREAT FROM THE EAST

INSIGHT, 7(5) (FEB 91), 34-35.

TRYING TO ESCAPE AILING ECONOMIES, IMMIGRANTS FROM THE FORMER EAST BLOC COUNTRIES ARE FLOODING HESTERN EUROPE. THE WAVE OF IMMIGRATION MAY BE THE LARGEST SINCE WORLD WAR II, EXPERTS SAY, AND MAY REACH TWENTY-FIVE MILLION BEFORE IT TAPERS OFF. WEST EUROPEAN COUNTRIES FEAR HOUSING SHORTAGES AND A SURPLUUS OF LABOR. MANY ADVOCATE A COMBINATION OF SENSIBLE IMMIGRATION LAHS HITH PLANS TO ENCOURAGE INVESTMENT SENSIBLE IMMIGRATION LAHS HITH PLANS TO ENCOURAGE INVESTH AND AID IN EASTER COUN

01468 BERING-JENSEN, H.

TOUGH TIMES, TOUGH VOTE FOR BRITAIN

TOUGH TIMES, TOUGH VOTE FOR

INSIGHT, 8(6) (APR 92), 14-16.

DAYS WHEN MARGARET THATCHER AND HER CONSERVATIVES COULD COUNT ON WINNING POWER IN BRITAIN TERM AFTER TERM. JOHN MAJOR AND THE TORIES, PRESIDING OVER THE WORST RECESSION IN DECADES, FACE A CLOSE RACE AGAINST LABOR IN APRIL. LABOR, LED BY KINNOCK, PRESENTS A FORMIDABLE CHALLENGE TO MAJOR AND THE TORIES. HOWEVER, THERE IS STILL A DISTINCT CHOICE BETWEEN LABOR'S EMPHASIS ON THE PUBLIC INTEREST, ON PUBLIC SERVICE, AND THE CONSERVATIVES' EMPHASIS ON SELF-INTEREST.

01469 BERING-JENSEN, $H$.

UNIFICATION OF EUROPE HITS SHAGS

INSIGHT, $7(49)$ (DEC 91), 14-16.

THE 12 MEMBER NATIONS OF THE EUROPEAN COMMUNITY ARE TO MEET IN DECEMBER IN THE DUTCH CITY OF MAASTRICHT TO PLAN THE NEXT MAJOR STEPS TOWARD THE EC'S GRAND VISION OF A FEDERATED EUROPE--WITH COMMON SOCIAL, ECONOMIC AND DEFENSE POL ICIES AND A SINGLE CURRENCY. IF THE PRECONFERENCE POSTURING OF THE PARTICIPANTS IS ANY INDICATION, THE EXPECTATIONS FOR THE CONFERENCE SHOULD NOT BE VERY HIGH. MONTHS OF BICKERING HAVE PRECEDED THE MEETING, MAINLY CENTERING ON HOW MUCH THE EC PRECEDED THE MEETING, MAINLY CENTERING ON HOH MUCH THE EC SHOULD INFRINGE UPON THE SOVEREINGTY OF ITS MEMBER STATES.
AS ALWAYS, THE BRITISH HAVE BEEN IN THE FOREFRONT OF THE AS ALWAYS, THE BRITISH HAVE BEEN IN THE FOREFRONT OF THE
RESISTANCE. HOWEVER, OTHER COUNTRIES HAVE JOINED BRITAIN IN RESISTANCE. HOWEVER, OTHER COUNTRIES HAVE JOINED BRITAIN IN
DEBATING JUST HOW MUCH SOVEREIGNTY THEY ARE WILLING TO GIVE UP.

01470 BERING-JENSEN, $H$.

URGING A PURGE

INSIGHT, 7 (48) (DEC 91), 14-16.

AS THE NATIONS OF THE FORMER COMMUNIST BLOC MOVE TOWARD DEMOCRACY AND MARKET ECONOMIES, THEY CONTINUE TO FIND THEMSELVES IN SOMETHING OF A TIGHT SPOT: WHAT SHOULD BE DONE ABOUT THE OLD COMMUNIST LEADERS? WHILE DEMANDS TO SEE THE COMRADES HANGING FROM LAMPPOSTS HAVE BEEN REMARKABLY FEW, MANY PEOPLE IN EASTERN EUROPE ARE BECOMING INCREASINGLY IMPATIENT IN THEIR CALLS FOR JUSTICE. HITH UNEMPLOYMEN RISING STEADILY IN THE REGION, PEOPLE RESENT SEEINC COMMUNIST BUREAUCRATS HANGING ON TO SAFE JOBS AND PRIVILEGES. NEITHER DO THEY ENJOY THE SIGHT OF FORMER BIGHIGS USING THEIR CONTACTS TO ARRANGE SOFT AND PROFITABLE LANDINGS IN THE MARKET ECONOMY. THE VARIOUS NATIONS OF EASTERN EUROPE HAVE ADOPTED DIFFERING APPROACHES TO THIS PROBLEM. HOWEVER, THEY ARE SEEMINGLY UNIFIED IN THE BELIEF THAT NO TRANSITION TO DEMOCRATIC INSTITUTIONS AND A MARKET ECONOMY IS LIKELY TO BE STABLE IF MANY CITIZENS BELIEVE THAT INJUSTICE HAS PREVAILED, THAT THE OVERLORDS WILL SIMPLY BE PERMITTED TO CARRY ON AS IF NOTHING HAS HAPPENED.

01471 BERING-JENSEN, $H$

WHILE THE WORLD IS PREOCCUPIED

INSIGHT, 7(5) (FEB 91), 20-22.

WITH THE WORLD PREOCCUPIED WITH THE HAR IN THE PERSIAM

GULF. THE SOVIET UNION HAS FOUND A CONVENIENT TIME TO

OISCIPLINE THE UNRULY, INDEPENDENT-MINDED BALTIC STATES. THE DISCIPLINE THE UNRULY, INDEPENDENT-MINDED BALTIC STATES. THE ATTACK AGAINST THE DEMOCRATIC MOVEMENT IS PART OF A BROAD
ASSAULT DESIGNED TO HOLO THE UNION TOGETHER. THE FIRST ASSAULT DESIGNED TO HOLD THE UNION TOGETHER. THE FIRST POLITICAL CASUALTIES ARE LIKELY TO BE
POLICIES OF GLASNOST AND PERESTROIKA.

01472 BERKELEY, B.

OUT OF AFRICA

NEH REPUBLIC, 206(14) (APR 92), 12, 14-15.

A LARGE NUMBER OF PRESIDENT' SAMUEL $K$. DOE'S HENCHMEN MANAGED TO FLEE LIBERIA AND ARE NOW LIVING IN THE UNITED STATES. SOME OF THESE MEN WERE CLOSELY LINKED WITH THE BRUTAL ITY OF DOE'S REGIME; OTHERS HERE MERELY IMPLICATED IN THE IMMENSE OFFICIAL CORRUPTION THAT BANKRUPTED THE COUNTRY. 
THE U.S. GOVERNMENT, WHICH HELPED SOME OF THESE MEN FLEE LIBERIA AND GET INTO THE USA, APPEARS UNPERTURBED ABOUT PROVIDING REFUGE TO THIS BAND OF MURDERERS AND THIEVES.

01473 BERKHOUT, F.; OIAKOV, A.; FEIVESON, H.; MILLER, M.; VONHIPPEL, $F$.

PLUTONIUM: TRUE SEPARATION ANXIETY

BULLETIN OF THE ATOMIC SCIENTISTS, 48(9) (NOV 92), 28-34. IN THE POST-COLD WAR WORLD, THERE SIMPLY IS NO WEAPONS USE FOR MOST OF THE FISSILE MATERIAL THAT WILL BECOME
AVAILABLE AS OLD WEAPONS ARE DISMANTLED. IF REDUCTIONS IN AVAILABLE AS OLD WEAPONS ARE DISMANTLED. IF REDUCTIONS IN THE NUCLEAR ARSENALS ARE TO BE PERMANENT, IT IS ESSENTIAL THAT THE UNITED STATES AND RUSSIA TAKE STEPS TO ASSURE EACH
OTHER, AND THE REST OF THE WORLD, THAT THE FISSILE MATERIAL OTHER, AND THE REST OF THE WORLD, THAT THE FISSILE MATERIAL RECOVERED FROM EXCESS WARHEADS WILL NOT BE REUSED IN FUTURE
WEAPONS. THE OUESTION OF WHAT TO DO WITH FISSILE MATERIALS WEAPONS. THE QUESTION OF WHAT TO DO WITH FISSILE MATERIAL FROM OLD WEAPONS PRES
POLITICAL PROBLEMS

01474 BERKI, R.

THE REALISM OF MORALISM: THE POLITICAL PHILOSOPHY OF ISTVAN BIBO

HISTORY OF POLITICAL THOUGHT, 13(3) (FAL 92), 513-534. IT IS A SAFE PREDICTION THAT HUMGARIAN THINKER, ISTVAN BIBO WILL SOON BE GIVEN FULL ACCOLADE AS ONE OF THE MOST OUTSTANDING POLITICAL THEORISTS OF THIS CENTURY. HIS POLITICAL THOUGHT CAN BE EPITOMIZED IN THE PHRASE 'THE REALISM OF MORALISM' OR THE ALMOST FLAHLESS SYNTHESIS OF A DEEPLY RADICAL, MORALLY INFUSED VISION AND VALUE-SYSTEM WITH THE HARD-NOSED, UNSENTIMENAL REALIST'S INSIGHT INTO ENDURING PROBLEMS OF POLITICS AND SOCIETY. THIS ARTICLE BEGINS WITH A BRIEF BIOGRAPHICAL INTROOUCTION AND CONCLUDES WITH CONSTRUCTIVELY CRITICAL REMARKS CONCERNING SOME QUESTIONABLE POINTS IN THE TRAJECTORY OF BIBO'S THOUGHT.

01475 BERKIN, $G$.

SECESSION BLUES

NATIONAL REVIEH, XLIII (16) (SEP 91), 22-23.

IN THE REPUBLIC OF MOLDOVA (FORMERLY IN THE SOVIET SOCIALIST REPUBLIC OF MOLDAVIA) NATIONAL ISM HAS GROWM LARGELY UNMOTICED BY THE WEST. TWO-THIRDS OF THE REPUBLIC'S LARGELY UNNOTICED BY THE WEST. TWO-THIRDS OF THE REPUBLIC TO SAY ROMANIAN THE RUSSIAN-SPEAKING THIRD OF THE POPUI ROMANAN. TRE RUSSIAN-SPEAKING THIRD OF THE PHERE BY THE CENTRAL GOVERNMENTS OF THE CZARS AND COMMISSARS TO "RUSSIFY" THE AREA. TWO YEARS AGO, THE LOCAL PARLIAMENT, TO "RUSSIFY" THE AREA. TWO YEARS AGO, THE LOCAL PARLIAMEN DOMINATED 8Y THE MOLDAVIAN POPULAR FRONT, DECLARED THAT MOLDAVIAN (NOT RUSSIAN) WOULD BE THE PUBLIC LANGUAGE AFTER A
TEN-YEAR TRANSITION PERIOD. THE LATIN ALPHABET HAS RESTORED. TEN-YEAR TRANSITION PERIOD. THE LATIN ALPHABET HAS RESTORE
STREET SIGNS BECAME BILINGUAL. HOWEVER, THE REPUBLIC IS MOVING VERY CAREFULLY TOWARDS FULL INDEPENDENCE. THEIR SENSITIVITY IS MOTIVATED BY SEVERAL FACTORS: THE WORRIES OF THE RUSSIAN THIRD OF THE POPULATION; THE FEAR OF THE SORT OF VIOLENCE THAT THE CENTRAL AUTHORITIES UNLEASHED IN THE BALTICS; AND THE MOLDAVIAN DEPENDENCE ON RUSSIAN OIL AND NATURAL GAS.

01476 BERKOVEC, J.; FULLERTON, D.

A GENERAL EQUILIBRIUM MODEL OF HOUSING, TAXES, AND PORTFOLIO CHOICE

JOURNAL OF POLITICAL ECONOMY, 100(2) (APR 92), 390-429.

THE AUTHORS DESCRIBE A MODEL IN WHICH RENTAL AND OHNER HOUSING ARE RISKY ASSETS, TENURE CHOICE IS ENDOGENOUS, AND EACH HOUSEHOLD IS CONSTRAINED TO CONSUME THE SAME AMOUNT OF OWNER HOUSING THAT IT HAS IN ITS INVESTMENT PORTFOLIO. AT EACH ITERATION IN THE SEARCH FOR AN EQUILIBRIUM, THE DOUSEHOLDS FROM THE SURVEY OF CONSUMER FINANCES AND USE HOUSEHOLDS FROM THE SURVEY OF CONSUMER FINANCES AND USE
STATUTORY SCHEDULES TO FIND THE MARGINAL RATE AND TAX PAID. EQUILIBRIUM NET RATES OF RETURN ARE MAJOR DETERMINANTS O THE AMOUNT OF OWNER HOUSING, BUT A LOGIT MODEL INDICATES THAT DEMOGRAPHIC FACTORS ARE THE MAIN DETERMINANTS OF
OWNERSHIP RATES. IN THE SIMULATION, TAXES ON OWNER HOUSING OWNERSHIP RATES. IN THE SIMULATION, TAXES ON OWNER HOUSING
HOULD RAISE WELFARE NOT ONLY BY REALLOCATING CAPITAL BUT HOULD RAISE WELFARE NOT ONLY BY REALLOCATING CAPITAL BUT
ALSO BY THE GOVERNMENT'S ASSUMING PART OF THE RISK FROM INDIVIDUAL PROPERTIES AND OIVERSIFYING IT AWAY. MEASURES TO INDIVIDUAL PROPERTIES AND DIVERSIFYING IT AWAY. MEASURES TO DISALLOH PROPERTY TAX OR MORTGAGE INTEREST DEDUCTIONS DO
HELP SHARE THIS RISK. SIMULATIONS OF THE 1986 TAX REFORM HELP SHARE THIS RISK. SIMULATIONS OF THE 1986 TAX REFORM INDICATE A SMALL SHIFT FROM RENTAL TO

01477 BERKOWITZ, B.; GOODMAN, A.

POLICY BRIEF: WHY SPY--AND HOW--IN THE $1990 \mathrm{~S}$

ORBIS, 36(2) (SPR 92) 269-280.

THE DEMANDS FOR INFORMATION HAVE GROWN IN THE POST-COLD WAR WORLD, AND MUCH OF THIS INFORMATION IS HARDER TO COLLECT OR TO ANALYZE. THIS ARTICLE EXPLORES THE NEW SOVIET THREAT, MONITORING THE REST OF THE WORLD, AND, MEETING THE NEW INTELLIGENCE REQUIREMENTS. IT CONCLUDES THAT A FIRST STEP TO CARRYING OUT A NEW AGENDA IS TO PROVIDE THE INTELLIGENCE COMMUNITY AND THE DCI HITH THE AUTHORITY AND ORGANIZATION NECESSARY TO ASSESS NATIONAL INTELLIGENCE NEEDS. HITH THIS AUTHORITY, AND THE RESPONSIBLITY THAT ACCOMPAINIES IT, THE
UNITED STATES CAN DEVELOP A STRATEGIC INTELLIGENCE PLAN THAT
WILL WORK FOR THE 1990S AND BEYOND.

01478 BERLIN, G.; MCALLISTER, $W$.

HOHELESSNESS: WHY NOTHING HAS WORKED--AND WHAT WILL BROOKINGS REVIEW, 10(4) (FAL 92), 12-17.

THE PUBLIC CONSIDERS HOMELESSNESS ONE OF THE NATION'S MOST PRESSING PROBLEMS AND THINKS THAT GOVERNMENT SHOULD SOLVE IT. LOCAL, STATE, AND FEDERAL GOVERNMENTS FORM COMMISSIONS, CHANGE POLICIES, AND SPEND BILLIONS. YET
HOMELESSNESS CONTINUES TO GROW. THE STRUCTURED-SHELTER OPTION CAN END HOMELESSNESS FOR SOME AND ASSUAGE THE PROBLEM FOR OTHERS, BUT IT CANNOT STOP PEOPLE FROM BECOMING HOMELESS TO DO THAT, THE MATION MUST FACE UP TO THE PROBLEMS OF TO DO THAT, THE NATION MUST FACE UP TO THE PROBLEMS OF
HOUSING THAT IS TOO EXPENSIVE AND INCOMES THAT ARE TOO LOW. HOUSING THAT IS TOO EXPENSIVE AND INCOMES THAT ARE TOO LOW.
THE NATION MUST DECIDE WHETHER TO PAY THE PRICE FOR EVERYONE THE NATION MUST DECIDE WHETHER TO PAY THE PRICE FOR EVERYONE TO HAVE DECENT HOUSING

01479 BERLOW, A.

FAST EDDIE

NEW REPUBLIC, 206(24) (JUN 92), 14-15

THE AUTHOR PROFILES FIDEL $\checkmark$. "EDOIE" RAMOS, WHO haS CORAZON AQUINO'S DEFENSE SECRETARY AND IS LIKELY TO BE THE PHILIPPINES' NEXT PRESIDENT.

01480 BERLOH, A.

QUEEN FOR A DAY

NEW REPUBLIC, 206(12) (MAR 92), 13-15

THE AUTHOR DISCUSSES THE RETURN OF IMELDA MARCOS TO THE PHILIPPINES AND THE UPCOMING FILIPINO ELECTIONS.

01481 BERMAN, D.R.; MARTIN, L.L.

THE NEH APPROACH TO ECONOMIC DEVELOPMENT: AN ANLYSIS OF INNOVATIYENESS IN THE STATES

POLICY STUDIES JOURAAL, 20(1) (1992), 10-21.

IN RECENT YEARS, SCHOLARS, INSTITUTIONS, ANO THINK TANKS HAVE ENCOURAGED THE STATE GOVERNMENTS TO TAKE A NEH, MULTIFACETED, AND COMPREHENSIVE APPROACH TO ECONOMIC DEVELOPMENT. THE EXTENT TO WHICH STATES HAVE DONE SO VARIES WIDELY. IN THIS PAPER, THE AUTHORS FOCUS ON HOW THIS WARIATION IS RELATED TO THE GENERAL TENDENCY OF THE STATES TOWARD INNOVATIVENESS. THEY ALSO EXPLORE THEORIES AND TOWARD INNOVATIVENESS. THEY ALSO EXPLORE THEORIES AND POL ITICAL VARIABLES RELATE TO THE ADOPTION OF THE NEW POL ITICAL VARIABLES RELATE TO THE

01482 BERMAN, E.M.

THE POLITICS OF FEDERAL TECHNOLOGY POLICY: $1980-88$ POLICY STUDIES REVIEW, 10(4) (WIN 92), 28-41.

THE AUTHOR EXAMINES THE POLITICS OF FEDERAL TECHNOLOGY INITIATIVES TO PROMOTE ECONOMIC COMPETITIVENESS DURING THE PERIOD 1980-88 AND DISCUSSES THE TREND TOWARD INDUSTRY-LED
TECHNOLOGY POLICY. HE FINDS THAT THE KEYS TO THE ADOPTIDN OF TECHNOLOGY POLICY. HE FINDS THAT THE KEYS TO THE ADOPTIDN OF NEW TECHNOLOGY INITIATIVES ARE THE IDEOLOGICAL CONSISTENCY OF NEW INITIATIVES WITH THE PREVAILING POLITICAL CLIMATE AND THE PRESENCE OF BUSINESS CONSTITUENCIES PROMOTING TECHNOLOGY
IN THE ABSENCE OF STRONG BUSINESS INTEREST, AGENCY POLITICS AND CONCERN ABOUT THE BUDGET DEFICIT DOMINATE.

01483 BERMEO, $N$.

DEMOCRACY AND THE LESSONS OF DICTATORSHIP

COMPARATIVE POLITICS, 24(3) (APR 92), 273-291.

THIS PAPER INVESTIGATES THE CULTURAL AND BEHAVIORAL LEGACIES OF DICTATORSHIP. IT ARGUES THAT THE EXPERIENCE OF DICTATORSHIP CAN LEAD TO A PROCESS OF POLITICAL LEARNING IN HHICH SOCIAL ACTORS REEVALUATE THEIR PAST PERSPECTIVES ON THE RELATIVE MERITS OF DEMOCRACY. IT BEGINS BY DEFINING POLITICAL LEARNING, USING EXAMPLES FROM EUROPE AND LATIN AMERICA; MOVES ON TO EXPLAIN WHY POLITICAL LEARNING IS KEY TO THE RECONSTRUCTION OF DEMOCRACY AND WHAT IT ADOS TO THE UNDERSTANDING OF EMPIRICAL DEMOCRATIC THEORY; AND CLOSES WITH A DISCUSSION OF HOW IT OCCURS AND WHY IT EMERGES IN SOME DICTATORSHIPS BUT NOT IN OTHERS. POLITICAL LEARNING COMES FROM THO PRINCIPAL SOURCES: (1) COMPARISONS WITH PREVIOUS REGIMES AND FOREIGN REFERENCE STATES AND (2)
INTERACTIONS IN EXILE COMMUNITIES, JAILS, OPPOSITION GROUPS, INTERACTIONS IN EXILE COMMUNITIES, JAILS, OPPOSITION GROUPS, AND THE ARENAS OF CIVIL SOCIETY LEFT RELATIVELY UNRESTRAINED
BY THE DICTATORSHIP. THE SOURCES OF POLITICAL LEARNING ARE AFFECTED BY THE LEVEL OF ECONOMIC DEVELOPMENT
IMPORTANT HISTORICAL AND CULTURAL COMPONENTS.

01484 BERMEO, N. (ED.)

IBERALIZATION AND DEMOCRATIZATION--CHANGE IN THE SOVIET UNION AND EASTERN EUROPE

JOHNS HOPKIMS UNIVERSITY PRESS, $1992,200$.

THE COMTRIBUTORS TO THIS YOIUME AHALYIE A SERIES OF

EVENTS THAT CAUGHT THE WORLD--AND THE EXPERTS--BY SURPRISE. ONE CONTRIBUTOR EXPLAINS HOW THE EAST EUROPEANS MANAGED TO MISLEAD EVERYONE, INCLUDING THEMSELVES, ABOUT THE POSSIBILITY OF SUCCESSFUL REVOLUTION AND PREDICTS THAT POLITICAL REVOLUTIONS HILL CONTINUE TO BE UNPREDICTABLE. ANOTHER ARGUES THAT DISSENT IN EASTERN EUROPE EXISTED NOT ONLY UNDERGROUND BUT AS A "VISIBLE CULTURAL AND EXISTENTIAL 
ACCEPTED WESTERN THEORIES OF COMMUNISM AND OFFERS A MORE COMPREHENSIVE FRAMEWORK FOR FUTURE COMPARISONS. DRAWING ON CASE STUDIES FROM LATIN AMERICA AND SOUTHERN EUROPE, ONE CONTRIBUTOR DEMONSTRATES THAT THE SOVIET UNION'S LIBERAL IZATION PROCESS FOLLOWED A MODEL FOUND IN OTHER PARTS OF THE WORLD. FINALLY, ONE EXAMINES THE HISTORIES OF SOVIET NATIONALITIES FOR DIVERSE SOURCES OF NATIONAL PROTEST.

01485 BERNAL, R.

DEBT, DRUGS, AND DEVELOPMENT IN THE CARIBBEAN

TRANSAFRICA FORUM, 9 (2) (SUM 92), 83-92.

SINCE THE MID-1970's, THE CARIBBEAN REGION HAS

EXPERIENCED A PROLONGED ECONOMIC DEPRESSION CHARACTERIZED BY LOW AND FLUCTUATING ECONOMIC GROWTH. SEVERE ECONOMIC CONTRACTION HAS CAUSED THE STANDARD OF LIVING TO FALL VERY SUBSTANTIALLY IN SOME COUNTRIES. CARIBBEAN COUNTRIES HAVE SMALL, UNDIVERSIFIED ECONOMIES DEPENDENT ON, AND DETERMINED LARGELY BY, EXTERNAL FACTORS AND THE FORTUNES OF ONE MAJOR EXPORT- INVARIABLY A PRIMARY PRODUCT OR A PRIMARY SERVICE. PERIODS OF ECONOMIC GROWTH HAVE NOT BEEN TRANSLATED INTO ECONOMIC DEVELOPMENT, WHEN AN ECONOMY CREATES THE CAPACITY FOR SELF-SUSTAINING GROWTH IN WHICH AN INCREASING SHARE OF THE POPULATION PARTICIPATES AND PROGRESSIVELY IMPROVES ITS
MATERIAL WELL -BEING BEYOND SUBSISTENCE. ONE OF THE PRINCIPAL MATERIAL WELL-BEING BEYOND SUBSISTENCE. ONE OF THE PRINCIPAL CONSTRAINTS TO ENHANCED ECONOMIC GROWTH AND DEVELOPMENT IS
THE HEAVY DEBT BURDEN. THE DEBT BURDEN MUST BE REDUCED TO THE HEAVY DEBT BURDEN. THE DEBT BURDEN MUST BE REDUCED FACILITATE THE ACCELERATION OF ECONOMIC DEVELOPMENT, OR
POVERTY WILL MAKE CARIBBEAN DEMOCRACY VULNERABLE TO THE CANCER OF CRIMINAL ACTIVITY ASSOCIATED WITH THE DRUG TRADE.

01486 BERNANICE, B.S.; PARKINSON, M.L. PROCYCLICAL LABOR PRODUCTIVITY AND COMPETING THEORIES OF THE BUSINESS CYCLE: SOME EVIDENCE FROM INTERWAR U.S. MANUFACTURING INDUSTRIES

JOURNAL OF POLITICAL ECONOMY, 99(4) (AUG 91), 439-459.

THIS PAPER STUDIES THE PHENOMENON OF SHORT-RUN

INCREASING RETURNS OF LABOR (SRIRL) IN A SAMPLE OF 10

INTERHAR U.S. MANUFACTURING INDUSTRIES. THE MAIN FINDINGS ARE THE SRIRL WAS COMMON IN THE INTERHAR PERIOD AND THAT THE PATTERN OF SRIRL ACROSS INDUSTRIES WAS SIMILAR TO THAT OBSERVED IN THE POSTHAR PERIOD. IT IS ARGUED THAT, SINCE PRESUMABLY THE DEPRESSION WAS NOT CAUSED BY TECHNICAL REGRESS. THESE FINDINGS ARE INCONSISTENT WITH THE CLAIM OF REAL BUSINESS CYCLE THEORISTS THAT SRIRL IS IN GENERAL DUE TO PROCYCLICAL TECHNOLOGICAL SHOCKS. TESTS ARE PROPOSED DISCRIMINATING BETWEEN THO DTHER LEADING EXPLANATIONS OF DISCRIMINATING BETHEEN THO DTHER LEADING EXPLANATIONS OF
SRIRL BUT FIND THAT OUR CONCLUSIONS DIFFER BY INDUSTRY.

01487 BERNARD, B.

THE EUROPEAN ECONOMIC AREA

EUROPE, 312 (DEC 91), 17, 19

THE EUROPEAN ECONOMIC AREA PAVES THE WAY TO A BARRIERFREE SINGLE MARKET. THE FUSION OF EUROPE'S SPLINTERED ECONOMIES INTO A GREAT SINGLE MARKET TOWERING OVER THE
UNITED STATES AND JAPAN IS FAST BECOMING A REALITY THE UNITED STATES AND JAPAN IS FAST BECOMING A REALITY. THE OUTLINES OF A SINGLE TRADING AREA WITH 380 MILLION CONSUMERS LATE OCTOBER TO CREATE A 19-NATION FREE-ZONE STRETCHING FROM THE ARTIC CIRCLE TO THE AEGEAN SEA. THIS ARTICLE SUGGESTS THAT THE PAYOFF FOR THE EFTA COUNTRIES WON'T COME FROM INCREASED EXPORTS, BUT FROM FIERCER COMPETITION IN THEIR DOMESTIC MARKETS.

01488 BERMARD, E.

CANADA'S HEALTH CARE SYSTEM

NEW POLITICS, 3(4) (HIN 92), 101-108

MANY SOCIALISTS HAVE POINTED TO THE CANADIAN HEALTH CARE SYSTEM AS A MODEL FOR THE UNITED STATES. ELAINE BERNARD DISCUSSES THE POLITICS OF CANADIAN HEALTH INSURANCE AND TAKES A CLOSE LOOK AT THE ORIGINS OF THEIR SYSTEM. IN THIS ARTICLE, SHE LOOKS AT THE SYSTEM WITH SIX QUESTIONS IN MIND: WHY CANADA? WHAT EXACTLY IS THE CANADIAN MOOEL? HOH WAS IT ACHIEVED POL ITICALLY? WHAT ARE SOME OF THE COMMON MYTHS ABOUT THE CANADIAN MODEL AND WHAT IS THE CURRENT STATUS OF THE SYSTEM? FINALLY, WHAT CAN AMERICANS LEARN FROM THE CANADIAN MODEL?

01489 BERMARD, E.

CANADA'S NEH DEMOCRATIC PARTY AT THIRTY

SOCIALIST REVIEW, 3(4) (1991), 133-154.

THE SUMMER OF 1991 MARKED THE 3OTH BIRTHDAY OF CANADA'S SOCIAL-DEMOCRATIC PARTY. THE NEW DEMOCRATIC PARTY (NDP). THE
NDP CONTINUES TO HAVE TREMENDOUS DIFFICUITY IN OFFERING A NDP CONTINUES TO HAVE TREMENDOUS DIFFICULTY IN OFFERING A CLEAR ALTERNATIVE TO THE NEOCONSERVATIVE AGENDA OF ECONOMIC
CONTINENTALISM, DEREGULATION, AND PRIVATIZATIOM. OPPONENTS CONTINENTALISM, DEREGULATION, AND PRIVATIZATION. OPPONENTS HAVE CONTENDED THAT AFFILIATION TO ONE POL ITICAL PARTY
COMPROMISES LABOR WHEN IT LOBBIES THE PARTY IN PONER. THE COMPROMISES LABOR WHEN IT LOBBIES THE PARTY IN POWER. THE
FACT THAT THE NDP IS ONLY A MINOR PARTY WITH LITTLE PROSPECT OF COMING TO POWER HAS NOT NECESSARILY BEEN DETRIMENTAL. THE QUESTION THAT THIS ARTICLE ATTEMPTS TO ANSWER IS: CAM CANADA'S DEMOCRATIC SOCIALISTS PARLAY THEIR RECENT SUCCESSES INTO LASTING CHANGE?
01490 BERMDTSON, E.

FINLANDIZATION: PARADOXES OF EXTERNAL AND INTERNAL DYNAMICS GOVERNMENT AND OPPOSITION, 26(1) (1991), 21-33.

THIS ARTICLE CONSIDERS ONE OF THE CONCEPTS THAT HAS BEEN USED IN DESCRIBING RELATIONS BETWEEN A SMALL AND A BIG NATION IN THE CONTEXT OF THE EAST-WEST CONFLICT: THE CONCEPT OF "FINLANDIZATION." THE AUTHOR ARGUES IT IS IMPORTANT TO FOCUS ON IT AT THIS MOMENT IN HISTORY BECAUSE (A) FINLANDIZATION HAS BEEN OFFERED AS AN ALTERNATIVE TO THE COUNTRIES THAT HAVE JUST BROKEN AHAY FROM THE SOVIET SPHERE OF INFLUENCE; (B) THE NEW INTERMATIONAL ATMOSPHERE GIVES A BETTER CHANCE THAN BEFORE TO EVALUATE THE CONCEPT

DISPASSIONATELY; AND (C) THERE ARE SOME LESSONS THAT MAY BE DRAWN FROM FINLAND'S FIMLANDIZATION. THE DEFINITION AND ORIGINS OF THE CONCEPT ARE GIVEN. THE CONCEPT IS APPLIED TO ACTUAL AND POTENTIAL SITUATIONS.

01491 BERNHARD, $M$.

BARRIERS TO FURTHER POLITICAL AMD ECONOMIC CHANGE IN POLAND STUDIES IN COMPARATIVE COMMUNISH, XXIII(3-4) (FAL 90), 319-340.

ON A POPULAR LEVEL IN THE WEST, THE CHANGES IN EAST CENTRAL EUROPE ARE COMMOMLY PRESENTED AS THE BEGINNING OF A NEW, LIBERAL, DEMOCRATIC AND CAPITALIST ERA IN THE REGION. POLAND, BY MOVING QUICKLY AND DECISIVELY TO MARKETIZE ITS ECONOMY, IS SERVING AS A KIND OF TEST CASE. IT IS ATTEMPTING
THIS JUMP UNDER CONDITIONS OF AN ACUTE ECONOMIC CRISIS, WITH THIS JUMP UNDER CONDITIONS OF AN ACUTE ECONOMIC CRISIS, ITS POLITICAL SYSTEM ALSO IN TRANSITION, AND DURING A RELATIVELY STABLE CIRCUMSTANCES THIS MARKETIZATION WOULD BE A COMPLEX TRANSFORMATION. THE PURPOSE OF THIS PAPER IS TO MAP OUT SOME OF THE MANY BARRIERS THAT SOLIDARITY NEEDS TO OVERCDME IF IT IS TO TRANSFORM POLAND INTO A PARLIAMENTARY REPUBLIC WITH A MARKET ECONOMY. THE AUTHOR ARGUES THAT THIS TRANSFORMATION IS FAR FROM COMPLETE AND THAT WHAT HAS BEEN ACCOMPLISHED IS VERY FRAGILE.

01492 BERNIER, L

DECENTRALIZING THE FRENCH STATE: IMPLICATIONS FOR POLICY JOURNAL OF URBAN AFFAIRS, 13(1) (1991), 21-32.

THE DEFFERRE LAH OF MARCH 2, 1982, BEGAN A DRAMATIC REFORM OF INTERGOVERMMENTAL RELATIONS IN FRANCE HHICH PROMISED TO HAVE SIGNIFICANT CONSEQUENCES AT ALL LEVELS OF
GOVERNMENT. THIS PAPER PRESENTS A QUALITATIVE ANALYSIS OF GOVERNMENT. THIS PAPER PRESENTS A QUAL ITATIVE ANALYSIS OF
OFFICIALS' REACTIONS AND ADAPTATIONS TO CHANGES IN THE RULES OFFICIALS' REACTIONS AND ADAPTATIONS TO CHANGES IN THE RUL
OF THE INTERGOVERNMENTAL GAME AS WELL AS A OUANTITATIVE OF THE INTERGOVERNMENTAL GAME AS WELL AS A OUANTITATIVE ANALYSIS OF THE REFORM'S
GOVERNMENTS IH THE 1980 S.

01493 BERNIER, L.L.

SOCIALIST INTERGOVERMMENTAL POLICY DURING THE MITTERAND ERA PUBLIUS: THE JOURNAL OF FEDERALISM, 22(4) (FAL 92), 47-66. MANY OBSERVERS OF FRENCH POLITICS SEE INTERGOVERNMENTAL DECENTRALIZATION AS PRESIDENT MITTERAND'S MOST IMPRESSIVE DOMESTIC POLICY ACCOMPLISHMENT. IN THIS ESSAY, THE AUTHOR ASSESSES THE CURRENT STATE OF AFFAIRS IN THE FRENCH INTERGOVERMMENTAL SYSTEM BY FOCUSING ON HOW SOCIALIST REFORMS HAVE ALTERED RELATIONS AMONG LEVELS SINCE THE EARLY $1980^{\prime} S$. SHE EXAMINES THE MITTERAND GOVERMMENT'S MOST RECENT EFFORT TO ADDRESS REMAINING NETTLESOME ISSUES IN A SYSTEM THAT, TEN YEARS AFTER THE FIRST LEGISLATION, IS STILL VERY MUCH IN FLUX. USING EVOLUTION IN INTERGOVERMMENTAL FINANCES
AS AN INDICATOR OF CHANGING CENTER/PERIPHERY RELATIONS, THIS STUDY REVEALS BOTH FUNDAMENTAL TRANSFORMATIONS AND SIGNIFICANT CONTINUITY IN THE FRENCH SYSTEM.

01494 BERNSTEIN, C.

THE IDIOT' CULTURE

NEH REPUBLIC, 206(23) (JUN 92), 22, 24-25, 28.

THE AUTHOR RECOUNTS THE ROLE OF THE PRESS IN THE

WATERGATE SCANDAL, WHICH LED TO THE RESIGNATION OF PRESIDENT RICHARD NIXON, AND REFLECTS ON THE STATUS OF U.S. JOLRNALISH IN THE POST-WATERGATE ERA.

01495 BERNSTEIN, J.

A FORCE TO BE RECKONED WITH

INSIGHT T(3) (JAN Q1)

RECENT DISCLOSURES BY DEFECTORS AND DISSENTING INSIDERS INOICATE THAT THE MORE THINGS CHANGE IN THE SOVIET UNION, INOICATE THAT THE MORE THINGS CHANGE IN THE SOVIET UNIDN,
THE MORE THE KGB STAYS THE SAME. MOTIVATED BY FAMILIAR THE MORE THE KGB STAYS THE SAME. MOTIVATED BY FAMILIAR
PERCEPTIONS OF WESTERN-INSPIRED PLOTS, THE SPY AGENCY IS AT PERCEPTIONS OF WESTERN-INSPIRED PLOTS, THE SPY AGENCY IS AT THE FOREFRONT OF A PUSH FOR REVIVING A HARD-LINE GOVERNMENT
STANCE. AND WHILE THERE HAVE BEEN ATTEMPTS TO SOFTEN THE STANCE. AND WHILE THERE HAVE BEEN ATTEMPTS TO SOFTEN THE
IMAGE OF THE KGB, THEY HAVE BEEN MOSTLY COSMETIC. KGB CHIEF VLADMIR KRYUCHKOV EXEMPLIFIES THIS OLD-SCHOOL THINKING.

01496 BERNSTEIN, J.

A MORE PERFECT DISUNION

INSIGHT, $7(36)$ (SEP 91), 12-16

THE AFTERMATH OF THE 19 AUGUST COUP ATTEMPT BY KREMLIN HARDLINERS REVEALS A SOVIET UNION WHICH IS IN THE PROCESS OF DECOMMUNIZATION AND DECOLONIZATION. NOT ONLY HAS THE COMMUNIST PARTY LOST WHAT LITTLE LEGITIMACY IT HAD. THE SOVIET REPUBLICS ARE OUICKLY MOVING TO DISSOCIATE THEMSELVES 
WITH ANY FORM OF CENTRAL GOVERNMENT. SOVIET REPUBLICS INCLUDING THE BALTIC STATES, ARMENIA, GEORGIA, UKRAINE, AND EVEN RUSSIA ARE TAKING STEPS TOWARDS AUTONOMY AND INDEPENDENCE. THESE CHANGES UNLEASH A WIDE ARRAY OF ETHNIC, SOCIAL, AND ECONOMIC FORCES WHICH THREATEN TO PLUNGE THE SOCIAL, AND ECONOMIC FORCES WHICH THR

01497 BERNSTEIN, J.

BALTICS REOCCUPIED

INSIGHT, 7 (5) (FEB 91), 17-19

CITING COMPLAINTS OF PRO-MOSCON FRONT GROUPS AS

JUSTIFICATION, THE SOVIET MILITARY HAS TAKEN UP ARMS AGAINST THE DEMOCRATIC MOVEMENTS IN THE BALTICS. THE MILITARY CRACKDOWN WITH ITS ATTENDANT DEATHS AND BEATINGS ENDED--FOR THE TIME BEING--ANY HOPE OF A PEACEFUL TRANSITION TO AUTONOMY OR INDEPENDENCE OF THE BALTIC STATES. IRONICALLY, THE MAN WHO BEGAN THE MOVE TOWARDS INDEPENDENCE, MIKHAIL GORBACHEV, HAS RECEIVED MOST OF THE BLAME FOR THE CRACKDOWN. HE HAS DENIED ADVANCE KNOWLEDGE OF THE SHOOTINGS.

01498 BERNSTEIN, J.

BIG BROTHER WAS WATCHING

INSIGHT, 7 (3) (JAN 91), 8-13.

WITH THE UNIFICATION OF GERMANY HAD COME A GLIMPSE OF THE INNER WORKINGS OF EAST GERMANY'S SECRET POLICE, THE STASI. THE EMERGING PICTURE IS REMINISCENT OF GEORGE ORHELL'S BIG BROTHER WITH STASI CREATING A SOCIETY OF BETRAYAL WITH AN EXTENSIVE NETWORK OF AGENTS AND INFORMANTS LINKED BY SOPHISTICATED TECHNOLOGY. ALLEGATIONS HAVE ARISEN THAT THE STASI'S INFLUENCE HAD REACHED TO THE TOP. EAST GERMAN LEADER LOTHAR DE MAIZIERE ALLEGEDLY WAS AN INFORMER, AND THE CHARGES COST HIM A JOB IN THE NEW UNIFIED GOVERMMENT. COLLABORATION HAS BECOME THE ISSUE OF THE DAY IN GERMAN POLITICS.

01499 BERNSTEIN, J.

CARRYING WATER FOR THE BAATH
INSIGHT, 8(17) (APR 92), 14-16,38.

DEFENDERS OF SADDAM HUSSEIN'S REGIME ARE RARE, BUT SEYERAL APPARENT ONES CAN BE FOUND AT THE ARMY WAR COLLEGE SEVERAL APPARENT ONES CAN BE FOUND AT THE ARMY WAR COLLEGE
IN PENMSYLANIA. SOME STAFF MEMBERS THERE HAVE PUBLISHED PROIN PENNSYLVANIA. SOME STAFF MEMBERS THERE HAVE PUBLISHED PRO IRAQI VIEWS ON EVERYTHING FROM SADDAM'S MOTIVATIONS FOR WAR TO HIS HUMAN RIGHTS RECORD WITH THE KURDS. HUSSEIN IS STILL IN POWER IN IRAQ AND THE BUSH ADMINISTRATION
THE DEFENSIVE BY THESE PRD-IRAQI STATEMENTS.

01500 BERNSTEIN, J.

SO FAR, SO GOOD

INSIGHT, 7 (15) (APR 91), 30-31.

THERE WAS A JUMP IN THE NUMBER OF TERRORIST INCIDENTS

WORLOWIDE DURING THE PERSIAN GULF WAR; A THREEFOLD INCREASE ACCOROING TO SOME ESTIMATES. HOWEVER, THE ATTACKS WERE UNCOORDINATED AND LARGELY THE WORK OF LOCAL EXTREMISTS--NOT, AS MANY OBSERVERS HAD EXPECTED, THE WORK OF TERRORISM'S HEAVY HITTERS. SOME CREDIT THE PRESSURE BY THE U.S. -LED COALITION ON NATIONS THAT HARBORED TERRORISTS WITH THE RELATIVE SUCCESS IN WHICH THE EXPECTED RASH OF TERRORIST ACTIVITIES WAS NIPPED IN THE BUD.

01501 BERNSTEIN, J.

TERRORIST' HAVENS

INSIGHT, 7(3) (JAN 91), 18-21.

EVIDENCE IS MOUNTING THAT THE FALLEN COMMUNIST REGIMES

OF EASTERN EUROPE AIDED TERRORISTS. INFORMATION FROM MAMY

NATIONS IS SPOTTY, BUT DETAILS ABOUT EAST GERMANY ARE

PLENTIFUL. FILES REVEAL THAT THE STASI, THE NATION'S SECRET

PLENTIFUL. FILES REVEAL THAT THE STASI, THE NATION'S

POLICE HAD TIES TO SOME OF THE WORLD'S MOST DREADED
TERRORISTS-INCLUDING LIBYANS, THE PLO, THE RED BRIGADES,

TERRORISTS--INCLUDING LIBYANS, THE PLO, THE RED BRIGAOE

AND THE IRA. EMERGI

01502 BERNSTEIN, J.

THE ANTICOMMUNIST PROLETARIAT

ABOUT 300,000 SOVIET MINERS HAVE BEEN ON STRIKE SINCE 1

MARCH 1991. THEIR DEMANDS HAVE GONE BEYOND BETTER CONDITIONS

AND HIGHER PAY TO POL ITICAL ISSUES SUCH AS CALLING FOR THE

RESIGNATION OF MIKHAIL GORBACHEV AND THE DISSOLUTION OF THE

SOYIET UNION. THE KREMLIN'S PROMISES TO THE MINERS ARE AN

INDICATION THAT IT VIEWS THE STRIKES IN THE SOVIET HEARTLAND

AS A POLITICAL THREAT OF THE FIRST OROER. ONE EXPERT SAYS IT

COULD LEAD TO A DEVASTATING GENERAL WORKERS STRIKE.

01503 BERNSTEIN, J.

THE CNN GLOBAL VILLAGE

INSIGHT, 7(7) (FEB 91), 8-11.

THE PERSIAN GULF WAR HAS HEIGHTENED THE STATUS OF THE

CABLE NEWS NETWORK (CNN), WHICH HAS BECOME A KEY COMPONENT

IN INTERNATIONAL DIPLOMACY THROUGH ITS GLOBAL REACH AND LIVE

REPORTING. WORLD LEADERS RELY ON THE NETHORK FOR INFORMATION.

BUT CNN'S INFLUENCE HAS ITS DETRACTORS. A RECENT POLL

SHOWS THAT MOST VIEWERS THINK THAT THE NETWORK IS OUTDOING

THE COMPETITION, BUT IT ALSO REVEALS SOME UNEASINESS ABOUT

ITS BROADCASTS FROM BAGHDAD, WHICH FIRST PASS THROUGH IRAQ'S
CENSORS.

01504 BERNSTEIN, J.

THE HONEYMOON ENDS FOR YELTSIN

INSIGHT, 8(3) (JAN 92), 13; 34-35.

THE ARDOR HAS COOLED BETHEEN BORIS YELTSIN AND THE

RUSSIAM PEOPLE. WITH THE NEW YEAR CAME STEEPLY HIGHER PRICES, AS RUSSIA'S PRESIDENT LIFTED PRICE CONTROLS AND LAUNCHED HIS NATION'S TRANSITION TO A FREE MARKET ECONOMY. HHILE THE PEOPLE ARE GRUMBLING IN FOOD LINES, YELTSON'S POLITICAL FOES ARE JOCKYING TO BE NEXT IN LINE FOR LEADERSHIP. NEW LAWS AND SECURITY MEASURES ARE BEING IMPLEMENTED AND THE PURPOSE

01505 BERNSTEIN, $R$

IMITED IDEOLIOGICAL ACCOUNTABILITY IN HOUSE RACES: THE LIMITED IDEOLOGICAL ACCQUNTABI

AMERICAN POLITICS OUARTERLY, 2012) (APR 92), 192-204.

AT BOTH THE INDIVIDUAL AND DISTRICT LEVELS OF ANALYSIS THERE IS EMPIRICAL CONFIRMATION OF THE CONDITIONING EFFEC OF PARTY ON THE ASSOCIATION BETWEEN HOUSE MEMBERS'

IDEOLOGICAL DEVIATION ANO CONSTITUENCIES' WITHDRAWL OF SUPPORT FOR REELECTION. OEMOCRATIC INCUMBENTS HURT THEIR REELECTION PROSPECTIONS IN GENERAL ELECTIONS BY BEING MORE LIBERAL THAN THEIR CONSTITUENCIES PREFER; REPUBLICAN INCUMBENTS, BY BEING MORE CONSERVATIVE. THE REVERSE IS TRUE IN PRIMARIES. AS INCUMBENTS TEND TO BE SERIDUSLY CHALLENGED ONLY IN GENERAL ELECTIONS, DEMOCRATS CAN GENERALLY TAKE MORE CONSERVATIVE, AND REPUBLICANS MORE LIBERAL, POSITIONS THAN THEIR CONSTITUENTS WOULD PREFER WITH LITTLE FEAR OF VOTER RETALIATION.

01506 BERNSTEIN, R.

THE SLEEPER WAKES: THE HISTORY AND LEGACY OF THE THENTYSEVENTH AMENDMENT

FORDHAM LAW REVIEW, LXI(3) (DEC 92), 497-558.

THIS ARTICLE TRACES THE TWENTY-SEVENTH AMENDMENT'S ORIGINS TO THE LEGISLATIONVE POLITICAL CULTURE OF THE LATE EIGHTEENTH CENTURY. IT ALSO EXAMINES THE CONTROVERSIES OVER EIGHTENTH CEN COMPENSATION IN AMERICAN HISTORY. FINALLY, IT CONGRESSIONAL COMPENSATION IN AMERICAN HISTORY. FINALL CONSEOUENCES BEYOND ITS EFFECTS ON CONGRESSIONAL CONSEQUENCES
COMPENSATION.

01507 BERNSTEIN, R.

HANDERING JEH

WEH REPUBLIC, 207 (13) (SEP 92), 12-13.

SEVERAL MAJOR NEW YORK POLITIICAL FIGURES HAVE ASKED NINETERM CONGRESSMAN STEPHEN J. SOLARZ TO WITHDRAW FROM THE DEMOCRATIC PARTY'S 1992 PRIMARY. IN THE RECENT

REAPPORTIONMENT, SOLARZ'S BROOKLYN CONSTITUENCY WAS DIVIDED UP AND HE IS NOW RUNNING IN A NEWLY-CREATED "HISPANIC DISTRICT." THE NEW DISTRICT'S COMPOSITION IS ROUGHLY 55 PERCENT BLACK.

01508 BERHSTEIN, R.A.

DETERMINANTS OF DIFFERENCES IN FEELINGS TOWARD SENATORS REPRESENTING THE SAME STATE

WESTERN POLITICAL QUARTERLY, 45(3) (SEP 92), 701-726.

THE AUTHOR EXPLORES HOH THE PUBLIC REACTS TO THO SEMATORS HITH OPPOSING IDEOLOGIES WHO REPRESENT THE SAME STATE. THIS STUDY OF RESPONSES TO THE 1988 SENATE ELECTION STUOY TREATS DIFFERENCES IN FEELINGS TOWARD SAME-STATE SENATORS AS THE DEPENDENT VARIABLE AND IDEOLOGICAL DISTANCE BETWEEN THE SENATORS AS THE INDEPENDENT VARIABLE. CONTROLS ARE INTRODUCED FOR OTHER DIFFERENCES BETWEEN SENATORS AND FOR DIFFERENCES AMONG RESPONDENTS. ANALYSIS OF VARIANCE AND COVARIANCE SHOWS THAT THE IDEOLOGICAL DISTANCE BETWEEN COVARIANCE SHOWS THAT THE IDEOLOGICAL DISTAYCE BETWEN SENATORS REPRESENTING A STATE HAS RELATIVELY LITTLE I ON THE FEELINGS THAT CONSTI TUENTS HAVE TOHARD THEM. INFEETES, IN FEELINGS ARE DETERMINED MSRE BY DIF AND BY IN SENATORS ATS INAES PAIRS OF SENATORS THAN BY OTHER DIFFERENCES BETWEEN PAIRS OF SE

01509 BERNSTEIN, R.J.

THE RESURGENCE OF PRAGMATISH

SOCIAL RESEARCH, 59(4) (WIN 92), 813-840.

THE RUTHOR PURSUES THREE THEMES. FIRST, HE ENDEAVORS TO EXPLAIN HHAT RICHARD RORTY AND HILARY PUTNAM MEAN WHEN THEY EXPLAIN WHAT RICHARD RORTY AND HILARY PUTNAM MEAN WHEN THEY ARGUE FOR THE CONT THUIT OF THE RECEIYED VIEW THAT ANALYTIC THEIR NARRATIVES CHALLENG THE RECEIVED VER CM PRAGMATISM. PHILOSOPHY BROKE SHARPLY WITH CLASSIC AMERICAN PRAGHATISH. SECONDLY, HE DESCRIBES THE RECENT RESURGENCE OF PRAGMATISH. FINALLY, HE SHOWS HOW THIS RESURGENCE CAN BE RELATED TO RECENT DEBATES ABOUT "MODERNITY" AND "POST-MODERNITY.

ARGUES THAT, CONTRARY TO THE WIDESPREAD BELIEF THAT PRAGMATISM IS OBOLETE, THE CLASSIC PRAGMATIC THINKERS WERE AHEAD OF THEIR TIME. MOREOVER, A PROPERLY DEVELOPED PRAGMATIC ORIENTATION CAN LEAD SCHOLARS BEYOND MANY OF THE STERILE IMPASSES OF THE MODERN/POST-MODERN DEBATES. 
01510 BERNTS, T.; D'ANJOU, L.; HOUTMAN, D. CITIZENSHIP AND SOCIAL JUSTICE SOCIAL JUSTICE RESEARCH, 5(2) (JUN 92), 195-212. IN THIS ARTICLE IT IS ARGUED THAT WHEREAS THE DOMINANT APPROACH IN SOCIAL JUSTICE IS ESSENTIALLY INDIVIDUALISTIC, THE CONCEPT OF CITIZENSHIP FOCUSES RATHER ON INDIVIDUALS AS MEMBERS OF A SOCIETAL COMMUNITY, FROM WHICH BOTH RIGHTS AND OBLIGATIONS ARE DERIVED. THIS FOCUS ON COMMUNAL MEMBERSHIP SUGGESTS IMPORTANT TOPICS FOR SOCIAL JUSTICE THEORY AND RESEARCH: (1) THE NEED TO DISTINGUISH BETWEEN A CIVIC AND A JUSTICE MOTIVE FOR HUMAN BEHAVIOR, (2) THE NEED TO SPECIFY THE FRAME OF REFERENCE RESPONDENTS SHOULD USE WHEN THEY MAKE THEIR JUSTICE JUDGMENTS, AND (3) THE NEED TO RECOGNIZE THE FACT THAT JUSTICE JUDGMENTS MAY RESULT FROM BOTH ADHERING TO CRITERIA OF JUSTICE AND CONSIDERING THE CONSEQUENCES OF THEIR APPLICATION.

01511 BERNTZEN, E.; SELLE, P.

VALUES COUNT' BUT INSTITUTIONS DECIDE: THE STEIN ROKKAN APPROACH IN COMPARATIVE POLITICAL SOCIOLOGY

SCANDINAVIAN POL ITICAL STUDIES, 15(4) (DEC 92), 289-306. THE AUTHORS OUTLINE THE MAJOR CHARACTERISTICS OF THE TRADITION OF COMPARATIVE POLITICAL SOCIOLOGY THAT STEIN

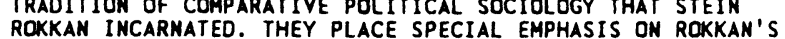
ROKKAN INCARNATED. THEY PLACE SPECIAL EMPHASIS ON ROKKAM SCIENTIFIC REASONING BASED ON THE ORGANIC RELATIONSHIP
BETHEEN THE CREATION OF INFRASTRUCTURES FOR RESEARCH AND RESEARCH EFFORTS. ROKKAN'S "OEUVRE" IS MARKED BY AN ACUTE AWARENESS OF THE HISTORICAL SOURCES OF INSTITUTIONAL VARIATION AND BY A CONCERN FOR CONSTRUCTING REGION-SPECIFIC MODELS REFLECTING CULTURALLY-MEANINGFUL CONTEXTS. ROKKAN'S USE OF COMPARISONS IS TREATED AT LENGTH BEFORE THE AUTHORS
IDENTIFY WHAT IS WORTH PRESERVING FROM THE ROKKAN TRADITION: THE HISTORICAL, INSTITUTIONAL, AND COMPARATIVE ASPECTS OF HIS APPROACH.

01512 BERRY, F.; BERRY, $W$.

TAX INMOVATION IN THE STATES: CAPITALIZING ON POLITICAL OPPORTUNITY

AMERICAN JOURNAL OF POLITICAL SCIENCE, 36(3) (AUG 92), 715-742.

THIS PAPER ASSESSES THE FACTORS THAT PROMPT STATES TO ADOPT TAXES DURING THE THENTIETH CENTURY. IT TESTS FIVE EXPLANATIONS OF STATE TAX INMOVATION DERIVED FROM THE LITEATURE - ECONOMIC DEVELOPMENT, FISCAL HEALTH, ELECTION CYCLE, PARTY CONTROL, AND REGIONAL DIFFUSION -- USING EVENT HISTORY ANALYSIS, A POOLED CROSS-SECTIONAL TIME SERIES TECHNIQUE. WHILE LITTLE SUPPORT IS FOUND FOR THE ECONOMIC DEVELOPMENT AND PARTY CONTROL EXPLANATIONS. THE EMPIRICAL RESULTS ARE HIGHLY CONSISTENT WITH A POLITICAL OPPORTUNITY RESULTS ARE HIGHLY CONSISTENT WITH A POL ITICAL OPPORTUNITY
EXPLANATION OF STATE TAX ADOPTIONS; THE PRESENCE OF A LONG EXPLANATION OF STATE TAX ADOPTIONS; THE PRESENCE OF A LONG CRISIS, AND THE PRESENCE OF NEIGHBORING STATES THAT HAVE CRISIS, AND THE PRESENCE OF NEIGHBORING STATES THAT HAVE PREVIOUSLY ADOPTED A TAX ALL CREATE OPPORTUNITIES FOR POLITICIANS TO SHIELD THEMSELVES FROM THE POLITICAL COSTS SUPPORTING A TAX INCREASE AND ARE ALL SHOWN BY EMPIRICAL
ANALYSIS TO INCREASE THE PROBABILITY OF A TAX ADOPTION. THIS ANALYSIS TO INCREASE THE PROBABILITY OF A TAX ADOPTION. EMPIRICAL EVIDENCE IS CONSISTENT ACROSS DIFFERNT TAX
IHSTRUMENTS AND DIFFERENT PERIODS OF ANALYSIS THROUGHOUT THE INSTRUMENTS AND DIFF

01513 BERRY, $M$

THE POLITICS OF AUSTRALIAN CITIES

ARENA, (91) (1990), 126-142.

AUSTRALIA'S MAJOR CITIES REFLECT THE ECONOMIC

RESTRUCTURING AND THE CRISIS TENDENCIES THAT ARE GENERATED GLOBALLY, BUT FOCUSED LOCALLY. VAST NEH TRACTS OF NEYER OR BARELY UTILIZED LAND ALONG THE COASTLINES ANO TO THE NORTH ARE BEING TRANSFORMED. THE ONGOING CHANGES REFLECT AND MASK DEEPER-LYING INFLUENCES ON AND THREATS TO THE LIVES OF PEOPLE LIVING AND HORKING IN THE NEWLY CONSTRUCTED URBAN ENVIRONMENTS. THEREBY SPARKING RESISTANCE AND THE CONSTRUCTION OF A NEW URBAN POLITICS. THIS ARTICLE CONSIDERS THIS PROCESS AND ITS SEVERAL IMPORTANT FACETS INCLUDING: A CHANGING GLOBAL CAPITALISM; NEH SPATIAL DIVISIONS OF LABOR COMPETITION WITHIN THE SPATIAL DIVISION OF LABOR; COMPETITION FOR COMMAND FUNCTIONS; COMPETITION HITHIN THE SPATIAL DIVISION OF CONSUMPTION; COMPETITION FOR

REDISTRIBUTION; AND THE CONSTRUCTING OF A NEH URBAN POLITICS.

01514 BERRY, $S$

LOBBYISTS: TECHNIOUES OF THE POLITICAL \$INSIDERS'

PARL IAMENTARY AFFAIRS, 45(2) (APR 92), 220-232.

TO MANY POLITICAL COMMENTATORS, 'LLBBYING' IS STILL

VIEWED AS ESSENTIALLY AN ALIEN CONCEPT NEVERTHELESS,

COMMERCIAL LOBBYING COMPANIES HAVE SUCCESSFULLY MARKETED THEMSELVES THROUGHOUT THE 1980 S AS EXPERTS INN PARLIAMENTARY PROCEDURE AND INFORMED OBSERVERS OF THE WIDER POLITICAL PROCESS. THEIR SUCCESS CAN IN LARGE PART BE ATTRIBUTED TO
THE PERSONNEL INYOLVED AND IN PARTICULAR THE BACKGROUNDS OF THE PERSONMEL INYOLVED AND IN PARTICULAR THE BACKGROUMC KEY COMPANY EMPLOYEES. AFTER AN EXAMINATION OF THESE LOBBYING COMPANIES, THIS ARTICLE CONCLUDES THAT WHILE THE REALITY BEHIND MUCH OF THE LOBBYING INDUSTRY'S ACTIVITY IN ACTIVITY IN BRITAIN REMAINS SURPRISINGLY MUNDANE, AND
LARGELY UNRECOGNIZABLE FROM THE SENSATIONALIST LOBBYIST EXCESSES SO OFTEN PORTRAYED IN THE MEDIA.

01515 BERRY, $S$

PARTY'STRATEGY AND THE MEDIA: THE FAILURE OF LABOUR'S 1992 ELECTION CAMPAIGM

PARLIAMENTARY AFFAIRS, 45(4) (OCT 92), 565-581.

THE 1992 GENERAL ELECTION WAS THE MOST ORCHESTRATED AND AMERICANIZED CAMPAIGN BRITAIN HAS EVER SEEN. MOST POLITICAL OBSERVERS BELIEVED THE LABOUR CAMPAIGN TO HAVE BEEN SLICK, POLISHED AND EFFECTIVE. HOWEVER, SUCH A VIEW UNDERESTIMATES THE EXTEND TO WHICH LABOUR LOST THE CAMPAIGN. LABOUR UNDERESTIMATED THE IMPACT OF CONSERVATIVE NEGATIVE CAMPAIGNING. THIS ARTICLE EXPLORES THE NATIONAL PRESS, LABOUR'S REPEAT OF THE 1987 CAMPAIGN, BROADCAST MEDIA, IV 8IAS, AND NEGATIVE ADVERTISING. THE LESSONS OF 1992, PARTICULARLY FOR THE LABOUR PARTY, REMAIN STARK. EFFECTIVE MEDIA AND CAMPAIGN STRATEGIES DO NOT END SEVEN DAYS BEFORE POLLING DAY.

01516 BERSTEIN, $B$

ECLIPSED BY HIROSHIMA AND NAGASKI: EARLY THINKING ABOUT ECLIPSED BY HIROSHIMA AMD

INTERMATIONAL SECURITY, 15(4) (SPR 91), 149-173.

THIS ARTICLE, BASED HEAVILY ON ARCHIVAL SOURCES

ANALYZES THE LARGELY UNKNOWN EARLY HISTORY OF TACTICAL

NUCLEAR WAR THINKING. IN DOING SO, IT EXAMINES OPPENHEIMER'S SPRING 1945 SUGGESTIONS ABOUT TACTICAL NUCLEAR WEAPONS, MARSHALL'S BRIEF OPPOSITION TO THE NUCLEAR TARGETING OF NONCOMBATANTS, AND HIS SUGGESTED ALTERNATIVE OF TARGETING MILITARY INSTALLATIONS INSTEAD, AND THE POLICY OF SECR
OF HAR HENRY L. STIMSON AND PRESIDENT HARRY S. TRUMAN, DESPITE SOME OUALMS, TO DROP THE A-BOMB ON HEAVILY POPULATED JAPANESE CITIES. THE ARTICLE ALSO CONSIDERS THE EFFORTS BY THREE LOS ALAMOS SCIENTISTS TO ACHIEVE TACTICAL USE OF THE WEAPON, HOW GROVES AND HIS AIDE UNDERSTOOD TACTICAL USE, AND THE EXPECTATIONS BY ADMIRAL CONOLLY FOR EMPLOYING THE WEAPON IN THE NOVEMBER 1 INVASION OF KYUSHU.

01517 BERSTEIN, J.

INDEPENDENCE: NOW THE WORK BEGINS

INSIGHT, $7(51)$ ( JAN 92) 4-9; 32-35.

IN A BOLD MOMENT, UKRAINIANS ON DEC. 1 ROUNDLY EMBRACED INDEPENDENCE. YET THEIR JOY WAS MUTED. A FORMER APPARATCHIK WAS PICKED TO LEAD THE NATION, AND A FUEL CRISIS KEPT CITIZENS WAITING FOR GASOLINE. IN THE STREETS AND ON THE COLLECTIVE FARMS, UKRAINIANS ARE ALREADY FEELING THE DAILY STRAIN OF AN UNCERTAIN FUTURE. IN ADOITION THE SHORT SUPPLY OF GASOLINE IN KIEV HAS FUELED FAMILIAR SPECULATION THAT AUTHORITIES ARE UP TO SOMETHING. CITIZENS ARGUE THAT WHEN THE OIL COMES INTO UKRANE IT GOES SOMEWHERE, BUT NOBODY KNOWS WHERE.

01518 BERSTEIN, J

LEANING TO THE LEFT

INSIGHT, $7(4)$ ( JAN 91), 14-15

SOME SOCIAL SCIENTISTS VIEW THE PRESS AS AN ELITE, WITH ITS OWN SET OF PRESUPPOSITIONS, BIASES AND CLASS INTERESTS. STUDIES FIND THAT, DESPITE PROFESSIDNS OF OBJECTIVITY, MANY JOURNALISTS LEAN TO THE LEFT. A CONTEMPORARY EXAMPLE IS PRESS COVERAGE OF THE PERSIAN GULF CRISIS. THOUGH POLLS SHOW WIDE PUBLIC SUPPORT FOR PRESIDENT BUSH'S POLICY, SOCIAL SCIENTISTS SAY NEWS REPORTS CONSISTENTLY HAVE BEEN CRITICAL, WITH DISPROPORTIONATE COVERAGE OF ANTI-WAR SENTIMENT.

01519 BERTRAM, $C$

DANISH VOTERS PUT THE CAT AMONG THE EC PIGEONS GERMAN TRIBUNE, (1519) (JUN 92), 1, 3

THE FACT THAT 50.7 PERCENT OF THE DANES VOTED IN A REFERENDUM AGAINST THE TREATIES OF MAASTRICHT CAME AS A SHOCK TO MANY OBSERYERS. SOME WILL ARGUE THAT THE DANISH DECISION HAS INVALIDATED THE TREATIES ON MONETARY AND POLITICAL UNION. THIS ARTICLE ARGUES THAT, DESPITE THE DANISH PLEBISCITE, THE OTHER ELEVEN EC STATES MUST CARRY ON TO RATIFY THE TREATIES AS THEY STANO. DESPITE ALL THE SHORTCOMIMGS, MAASTRICHT DECISIVELY SETS THE COURSE FOR THE FUTURE ORDER OF THE ENTIRE EUROPEAN CONTINENT. A RETURM TO SOUARE ONE IN NEGOTIATIONS WOULD SET BACK THE PROCESS OF INTEGRATION FOR YEARS, IF NOT DECADES.

01520 BERTRAM, C.

HELMUT KOHL: THE DECADE OF THE RESOLUTE STRATEGIST GERMAN TRIBUNE, (1535) (OCT 92) 4-5.

IN OCTOBER 1992 GERMAN CHAMCELLOR HELMUT KOHL CELEBRATED 10 YEARS IN OFFICE. KOHL, HHO HAS ALHAYS BEEN NOTED FOR HIS RESOLUTENESS, SEEMS TO HAVE BEEN CHASTENED BY TIME. HE STILL DEFENDS HIMSELF IN THE RESOLUTE MANMER THAT HAS ALWAYS BEEN HIS TRADEMARK, BUT HIS TONGUE SOUNDS MORE FURRED, HIS WORDS ARE CHOSEN MORE CAREFULLY, AND HE IS MORE TIGHT-LIPPED. WHAT MAKES THE CHANCELLOR LESS SELF-ASSURED THAN IN HIS EARLY YEARS IS LESS THE FEELING OF BEING MISUNDERSTOOD THAN THE IMPRESSION OF NO LONGER FULLY UNDERSTANDING WHAT IS GOING ON IN HIS COUNTRY. 
01521 BERTRAM, C.

U.S. -GERMAN RELATIONS IN A WORLD AT SEA

DAEDALUS, 121(4) (FAL 92), 119-128.

MANY OF THE CONOITIONS THAT ENCOURAGED WESTERN UNITY AMD U.S.-GERMAN AMITY HAVE DISAPPEARED, ADOING TO THE UNCERTAINTIES ABOUT THE SHAPE OF FUTURE U.S. -GERMAN AND U.S. EUROPEAN RELATIONS. BOTH GERMANY AND THE UNITED STATES HAYE SHIFTED THEIR PRIORITIES, AWAY FROM INTERNATIONAL AFFAIRS TOWARD DOMESTIC MATTERS. MOREOVER, WITH THE END OF THE COLD WAR, THE AUTHORITY OF DOMESTIC INSTITUTIONS IN MANY, IF NOT ALL, THE MAJOR COUNTRIES OF THE INDUSTRIALIZED WORLD, HAS DECLINED.

01522 BERTRAND, $M$.

EUROPEAN INTEGRATION IN A WORLD PERSPECTIVE

INTERMATIONAL SOCIAL SCIENCE JOURMALSPCTIVE INTERNATI
$69-78$.

THE BASIC FACT THAT EUROPE IS A "WORLD PROBLEM" SHOULD BE REGARDED AS COMMONPLACE. THIS ARTICLE SUGGESTS THAT THIS COMMONPLACE IS BEING OVERLOOKED BY THE VERY PEOPLE WHO ARE CONCERNED WITH BUILDING A NEW AND INTEGRATED EUROPE. THEY ARE TREATING THE PROBLEM AS A REGIONAL ISSUE. THE ERRORS OF SUCH AN INTERPRETATION IS PARTICULARLY OBVIOUS WHERE SECURITY, ECONOMICS, POLITICS, AND CULTURE ARE CONCERNED. THESE ISSUES ARE EXPLORED.

01523 BESCHEL, R.; FEAYER, P.

THE CHURCHES AND THE WAR

NATIONAL INTEREST, (23) (SPR 91), 69-75.

THIS ARTICLE EXAMINES THE REACTION OF AMERICAN CHURCHES TO THE PERSIAN GULF WAR. THE AMERICAN CHRISTIAN COMMUNITY HAS BEEN DIVIDED OVER THE MORALITY OF THE GULF WAR, WITH THE SPLIT TAKING PLACE ALONG LARGELY PREDICTABLE REACTIONS. ALONG THE SPECTRUM OF CHURCHES REACTION RANGED FROM SUPPORT FOR THE BUSH ADMINISTRATION, THROUGH DEBATE OVER THE JUST WAR DOCTRINE, TO STRIDENT DENUNCIATION OF U.S. MILITARY ACTIONS.

01524 BEST, J.

WHO TALKED WITH PRESIDENT KENNEDY? AN INTERACTION ANALYSIS PRESIDENTIAL STUDIES QUARTERLY, XXII(2) (SPR 92), 351-370. BASED PRINCIPALLY ON THE RECOROS OF PRESIDENT' JOHN F. KENMEDY'S APPOINTMENT SECRETARY, KENNETH D'DONNELL. THIS KENNEDY'S APPOINTMENT SECRETARY, KENNETH O'DONNELL, THIS
ARTICLE EXAMINES THE CONCERNS AND CONSULATIONS OF PRESIDENT ARTICLE EXAMINES THE CONCERNS AND CONSULATIONS OF PRESIDENT KENNEDY. THE RECORDS REVEAL HIS PRIMARY CONCERN WITH FOREIGN POLICY, AND INDICATE THE IMPORTANT ROLE OF HIS ASSISTAMY NATIONAL SECURITY AFFAIRS, MCGEORGE BUNDY, AS WELL AS
SECRETARY OF STATE RUSK AND SECRETARY OF DEFENSE MCNAMARA. HIS MOST FREQUENT COMMUNICATIONS WERE WITH HIS BROTHER, HIS MOST
ROBERT.

01525 BEST, K.

MY FIGHT FOR PRESS FREEDOM

NEW AFRICAN, (287) (AUG 91), 22-23

KENNETH BEST, A LIBERIAN' JOURNALIST, EDITOR AMD

PUBLISHER, TELLS THE REMARKABLE TALE OF HOW HE FOUGHT TO

KEEP HIS INDEPENDENT NEWSPAPER ALIVE UNDER SAMUAL DOE'S

TYRANMICAL REGIME. HE WAS HARASSED AND IMPRISONED. HIS PLANT

WAS ASSAULTED AND EVENTUALLY BURNED DOWN, BUT HE REMAINED

DEFIANT AND PROMISES TO RETURN TO THE PRESS AS SOON AS PEACE RETURNS TO LIBERIA.

01526 BETHELL, T.

BETTER DUKAKIS

AMERICAN SPECTATOR, 25(10) (OCT 92), 16-17.

GEDRGE BUSH'S PERFORMANCE AS PRESIDENT CAN BE

CONSISTENTLY EXPLAINED HITH ONE ASSUMPTION--THAT HE QUIETLY ACCEPTS THE PREMISES OF LIBERALISM AND ALL ALONG HAS REGARDED CONSERVATIVES AS THE GREAT OBSTACLE TO NATIONAL UNITY AND CONSENSUS. CONSERVATIVES, THEREFORE, MUST BE MARGINALIZED.

01527 BETHELL, T.

FIGHTING FOR THE UNION

NATIONAL REVIEH, XLIII(16) (SEP 91), 23-24.

THIS ARTICLE CHRONICLES THE EFFORTS OF THE "SACRAMENTO

UNION," A CONSERVATIVE PAPER, TO MAINTAIN A NECESSARY LEVEL

OF CIRCULATION AND ITS OWN "PECULIAR" IDEOLOGICAL STANCE.

THE COMPETITION AND CRITICISH HAS BEEN FIERCE; THE "UNION"

AND ITS EDITOR HAVE BEEN LABELLED AS "WACKD," "RIGHT-WING

EXTREMIST, "NARROH," AND "ANGRY" AMONG OTHER TERMS. THE

EDITOR, JOSEPH FARAH, RESPONDS THAT THE CORRECT APELLATION

SHOULD BE "INCORRECTLY BIASED": THE PAPER MERELY ADVOCATES A

AS MAINSTREAM (READ LIBERAL).

01528 BETHELL, T.

NOW THEY TELL US

NATIONAL REVIEW, XLIV(23) (NOV 92), 24-27.

THIS ARTICLE REVIEWS THE 1992 PRESIDENTIAL ELECTION. IT

POINTS OUT THAT ONCE THE ELECTION SEEMED DECIDED, THE MEDIA

BEGAN TO ACKNOWLEGE SOME AWKHARD TRUTHS. IT STATES THAT IT

WAS BUSH WHO SOUGHT A "KINDER, GENTLER AMERICA"; WHO IMPOSED
A HUGE TAX INCREASE IN A RECESSION; WHO PERMITTED SPENDING INCREASES TO BE CALLED SPENDING CUTS; WHO ABOLISHED A BASIC CIVIL RIGHT, THE PRESUMPTION OF INHOCENCE, AND WHO ADDED TENS OF THOUSANDS OF PAGES OF NEW REGULATION TO THE FEDERAL REGISTER. BUSH LOST THE ELECTION BY DEPARTING FROM THE POLICIES OF HIS PREDECESSOR, NOT BY ADHERING TO THEM.

01529 BETHELL, T.

PEROTIAN ECONOMICS

NATIONAL REVIEW, XLIV(15) (AUG 92), 29-31.

THIS ARTICLE SUMMARIZES THE OPINIONS OF SEVERAL ECONOMISTS ABOUT THE ECONOMIC POL ICIES A "PRESIDENT PEROT" MIGHT ENACT. MANY ARE CRITICAL OF PEROT'S RELUCTANCE TO MIGHT ENACT. MANY ARE CRITICAL OF PEROT'S RELUCTANCE TO PRINCIPLES. OTHERS CONTEND THAT THE FEN THINGS THAT PEROT PRINCIPLES. OTHERS CONTEND THAT THE FEN THINGS THAT HAS SPOKEN OUT ON INDICATE THAT HE WILL LIKELY BE PROTECTIONIST AND WILL FUEL THE GROWTH OF GOVERNMENT THROUGH HIS PROPOSED "ALLIANCE BETHEEN GOVERNMENT AND BUSINESS." MAS EVEN CONSIDERED THE PROBLEM OF RAMPANT GOVERNMENT AND HAS EVEN CONSIDERED THE PROB
ITS ECONOMIC IMPLICATIONS.

01530 BETHELL, T.

THE CASÉ FÓR BUCHANAN

NATIONAL REVIEH, XLIV(4) (MAR 92), 34-36, 38

WHEN THE COLUMNIST AND TV COMMENTATOR PATRICK J.

BUCHANAN DECLARED HIMSELF A PRESIDENTIAL CANDIDATE IN DECEMBER, HE WAS CONCERNED ABOUT ONE THING: WOULD HE BE
TAKEN SERIOUSLY AS A CANDIDATE? COLUMNISTS DON'T NORMALLY RUN FOR PRESIDENT AFTER ALL, AMD THERE WAS A REAL POSSIBILITY THAT HIS COLLEAGUES IN THE PRESS CORPS WOULD IGNORE HIS CANIOANCY. THIS ARTICLE DISCUSSES BUCHANAN'S VIEWS AS WELL AS COMPARES HIM TO GEORGE BUSH.

01531 BEVIR, M.

THE SOCIAL DEMOCRATIC FEDERATION: BRITAIN 1880-85 INTERNATIONAL REVIEW OF SOCIAL HISTORY, 37(2) (1992), 207-229.

A NUMBER OF BRONTERRE O'BRIEN'S DISCIPLES WERE THE LEADING LIGHTS OF THE LONDON CLUBS THAT PROVIDED THE SILENT MAJORITY TO THE SOCIAL DEMOCRATIC FEDERATION (S.D.F.). EVEN AFTER THE O'BRIENITES CAME TO ACCEPT THE NEED FOR COLLECTIVE OWNERSHIP OF THE MEANS OF PROOUCTION, THEIR POLITICAL

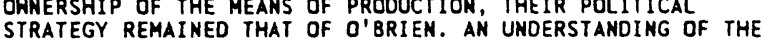
ROLE PLAYED BY THE O'BRIENITES HELPS TO EXPLAIN VARIOUS ROLE PLAYED BY THE O'BRIENITES HELPS TO EXPLAIN VARIOUS PROBLEMS IN THE HISTORY OF THE S.D.F. SUCH AS WHY MOST MEMBERS REMAINED WITH HYNDMAN RATHER THAN FOLLOW MORRIS INTO THE SOCIALIST LEAGUE AND WHY THE S.D.F. ADOPTE
ATTITUDE TO TRADE UNIONS AND TO PALLIATIVES.

01532 BEYERCHEN, A.

CLAUSEHITZ, NONLINEARITY, AND THE UNPREDICTABILITY OF WAR INTERNATIONAL SECURITY, 17(3) (WIN 92), 59-90.

THE AUTHOR OFFERS A' REVISION OF OUR PERCEPTION OF CLAUSEWITZ AND HIS WORK BY SUGGESTING THAT CLAUSEWITZ DISPLAYS AN INTUITION CONCERNING WAR THAT WE CAN BETTER COMPREHEND WITH TERMS AND CONCEPTS NEWLY AVAILABLE TO US. HIS SUGGESTION IS THAT IN A PROFOUNOLY UNCONFUSED HAY, CLAUSWITZ UNDERSTANDS THAT SEEKING EXACT ANALYTICAL SOLUTIONS DOES NOT FIT THE NONLINEAR REALITY OF THE PROBLEMS POSED BY WAR, AND HENCE THAT OUR ABILITY TO PREDICT THE CAUSE AND OUTCOME OF ANY GIVEN CONFLICT IS SEVERELY LIMITED. THE AUTHOR SUGGESTS THAT HIS INTERPRETATION MAY HELP UP REMOVE SOME UNSETTLING BLIND SPOTS THAT HAVE PREVENTED US FROM SEEING CRUCIAL IMPLICATIONS OF CLAUSEWITZ'S HORK.

01533 BEYERCHEN, A.

WHAT WE NOW KNOW ABOUT NAZISM AND SCIENCE

SOCIAL RESEARCH, 59(3) (FAL 92), 615-642.

THE AUTHOR ENDEAVORS TO LOOK BEYOND THE CLICHES AND ANECDOTES TO ACCURATELY DEPICT THE STATUS OF SCIENCE DURING THE NAZI ERA. HIS CONCLUSIONS EMPHASIZE THE DANGERS OF ENVELOPING SCIENCE WITHIN THE IDEOLOGY OF THE STATE. THEY ARE ALSO A REMINDER THAT SCIENCE POSSESSES THE POTENTIAL TO UNDERGRID AND SERVICE ENTIRELY POLITICAL GOALS.

01534 BEYLE, T.

BIG SPENDING IN THE QUEST FOR THE GOVERNORS' CHAIR BOURNAL OF STATE GOVERNMENT, 65(3) (SUM 92) 15-20. THE COST OF GUBERNATORIAL CAMPAIGNS HAS RISEN RAPIDLY. A SURVEY OF 202 ELECTIONS FOR STATE EXECUTIVE LEADERSHIP FROM SURV TO 202 ELECT AN AVERAGE COST OF 58.18 MILLION MEASURED IN 1991 DOLLARS. THE INCREASE HAS BEEN DRIVEN BY MEASURED IN 1991 DOLLARS. THE INCREASE HAS BEEN DRI SEVERAL FACTORS, INCLUDING GREATER POLITICAL AND ADMINISTRATIVE RESPONSIBILITY AT THE STATE LEVEL, HEIGHTENED PARTISAN RIVALY IN SOME STATES, AND THE GROWING INFLUENCE OF THE MEDIA IN CAMPAIGNS. THESE TRENDS ARE LIKELY TO CONTINUE
IN THE FORESEEABLE FUTURE, DRIVING THE COSTS OF BECOMING A GOVERNOR EVEN HIGHER.

01535 BHAGWATI, J.

OEMOCRACY AND DEVELOPMENT

JOURNAL OF DEMOCRACY, 3(3) (JUL 92), 37-44.

THIS ARTICLE CONCENTRATES ON TWO QUESTIONS: (1) DOES 
DEMOCRACY REQUIRE A MARKET ECONOMY? AND (2) CAN A MARKET ECONOMY EXIST WHEN DEMOCRACY DOES NOT? IT CONCLUDES THAT EMPIRICAL EVIDENCE TO DATE SHOWS NO EXAMPLE OF A DEMOCRACY THAT IS OR HAS FULLY SOCIALIST. THEREFORE, DEMOCRACY DOES REQUIRE A MARKET ECONOMY. EMPIRICAL EVIDENCE ALSO DEMONSTRATES THAT A MARKET ECONOMY CAN EXIST IN ABSENCE OF DEMOCRACY, THEREFORE, A MARKET ECONOMY IS A MECESSARY, BUT NOT A SUFFICIENT CONDITION FOR DEMOCRACY. THE ARTICLE' ALSO CONSIDERS THE "CRUEL CHOICE": WHETHER DEMOCRACY IS SUSTAINABLE IF IT DISCOURAGES ECONOMIC DEVELOPMENT. IT ALSO EXAMINES THE ISSUE OF SEQUENCING: WHETHER DEMOCRACY SHOULD PRECEDE OR FOLLOW A MARKET ECONOMY. IT CONCLUDES THAT BOTH HITH.

01536 BHAKTI, I.

LEARNING TO LIVE TOGETHER

FAR EASTERN ECONOMIC REVIEW, 155(10) (MAR 92), 14.

PAPUA NEW GUINEA'S PRIME' MINISTER RABBIE NAMALIU VISITED

INDONESIA IN JANUARY AND USHERED IN A NEW ERA IN JAKARTA-

INDONESIA IN JANUARY AND USHERED IN A NEW ERA IN JAKARTA-
PORT MORESBY RELATIONS. HOWEVER, THE BILATERAL GAINS ARE

PORT MORESBY RELATIONS. 'HOHEVER, THE BILATERAL GAINS ARE

STILL AS INTERESTED IN ASEAN MEMBERSHIP NOW AS IT WAS IN THE 1970S AND TOROS. IN THE DECADE AFTER PNG'S INDEPENDENCE IN $1970 S$ AND 1980 S. IN THE DECADE AFTER PNG'S INDEPENDENCE IN
SEPTEMBER 1975 THE TWO COUNTRIES EXPERIENCED TENSE RELATIONS SEPTEMBER 1975 THE THO COUNTRIES EXPERIENCED TENSE RELATIONS PARTICULARLY WITH RESPECT TO BORDER SECURITY. THE FOCUS
THIS TENSION WAS THE SEPARATIST FREE PAUPA MOVEMENT-THIS TENSION WAS THE SEPARATIST FREE PAUPA MOVEMENT--
ORGANISASI PAPUA MERDEKA (OPM). DURING THIS PERIOD, OPM UNDERTOOK SPORADIC OPERATIONS IN THE NEIGHBORING INDONESIAN PROVINCE OF IRIAN JAYA. SO FAR, PNG HAS BEEN INVITED TO JOIN THREE ASEAN COMMITTEES. BUT SOME OBSERVERS ARGUE THAT, IN VIEH OF ITS UNIQUE GEOGRAPHICAL POSITION, IT IS PROBABLY MORE BENEFICIAL FOR PNG TO MAINTAIN ITS STATUS AS A SPECIAL
OBSERVER RATHER THAN BECOME A FULL MEMBER OF ASEAN. BY DOING OBSERVER RATHER THAN BECOME A FULL MEMBER OF ASEAN. BY DOING SO IT CAN SERVE AS A BRIDGE BETWHEN ASEAN AND THE SOUTH
PACIFIC FORUM.

01537 BHARDWAJ, R.D.

SAARC: TOWARDS COLLECTIVE SELF-RELIANCE

BEI JING REVIEW, 35(1) (JAN 92), 13-14.

THE SIXTH SUMMIT MEETING OF'THE SOUTH ASIAN ASSOCIATION FOR REGIONAL COOPERATION (SAARC) ENDED ON DECEMBER 21, 1992 , WITH THE ADOPTION OF AN AGREEMENT REAFFIRMING THE MEMBERS AND TO PROMOTE CLOSER COOPERATION AMONG THEMSELVES.

01538 BHUYAN, A.R.

ON THE PROSPECT OF EXPORT-LED GRONTH

SOUTH ASIA JOURNAL 5(3) (JAN 92), 237-250.

HISTORICALLY, THO ALTERMATIVE TRADE STRATEGIES--

IDENTIFIED AS EXPORT PROMOTION (EP) AND IMPORT SUBSTITUTION (IS) - HAVE BEEN VARIOUSLY ADOPTED BY DEVELOPING COUNTRIES FOR PROMOTING INDUSTRIALIZATION. DESPITE THE SUCCESS OF SOUTH KOREA, TAIHAN, HONG KONG AND SINGAPORE IN IMPLEMENTING EP POLICIES, THE CHOICE BETHEEN ALTERNATIVE TRADE STRATEGIES HAS NOT YET BEEN CONCLUSIVELY RESOLVED. THIS PAPER SEEKS TO EXAMINE WHETHER OR NOT THERE IS STILL A CASE FOR EXPORT-LED GROWTH. THE ANALYSIS IS BASED ON THE CONCLUSIONS OF TRADE AND GROWTH THEORIES, HISTORICAL EXPERIENCE, AND EMPIRICAL EVIDENCE ON THE RELATIONSHIP BETWEEN TRADE AND ECONOMIC PERFORMANCE OF VARIOUS COUHTRIES. IT CONCLUDES THAT THERE IS NO VIABLE ALTERNATIVE TO OUTWARD-LOOKING DEVELOPMENT STRATEGIES.

01539 BI, L.

SADDAM HUSSEIN REMAINS IN POHER

BEI JING REVIEW, 35 (50) (DEC 92), 15-16.

THE AUTHOR EXPLAINS THE STRATEGY AND TACTICS USED BY SADDAM HUSSEIN TO RETAIN POWER IN IRAQ, DESPITE THE WIDESPREAD EXPECTATIONS THAT HE WOULD BE OUSTED AFTER DESERT STORM.

01540 BI, $X$.

YUGOSLAVIA: HESTERN DOUBTS ON ARMED INTERVENTION

BEI JING REVIEW, 35(35) (AUG 92), 17.

WESTERN NATIONS THAT ADVOCATED A MILITARY SOLUTION TO THE YUGOSLAY CRISIS HAVE BECOME HESITANT SINCE THE UNITED NATIONS AUTHORIZED LIMITED USE OF FORCE IF NECESSARY TO DELIVER HUMANITARIAN AID TO THE WAR-TORN REGION. BECAUSE THE WEST DIFFERS ON THE WISDOM AND SCOPE OF ANY POTENTIAL MILITARY INTERVENTION, NO WESTERN STATE THAT POSSESSES

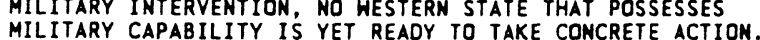
MILITARY CAPABILITY IS YET READY TO TAKE CONCRETE ACTION. HAVE BEEN INDECISIVE ON THE MATTER OF MILITARY INTERVENTION.

01541 BIANCHI, G.

THE IMPS: A MISSED OPPORTUNITY? AN APPRAISAL OF THE DESIGN AND IMPLEMENTATION OF THE INTEGRATED MEDITERRANEAN PROGRAMMES

REGIONAL POLITICS \& POLICY, 2(1,2) (SPR 92), 47-70. THE SEVEN-YEAR LIFESPAN OF THE INTEGRATED MEDITERRANEAN PROGRAMMES (IMPS) IS QUICKLY COMING TO AN END. A RECENT APPRAISAL OF THE COMMUNITY'S REGIONAL POL ICY HIGHLIGHTS THE
FROM THE INITIAL PERIOD DURING WHICH THE ISSUE OF REGIONAL DISPARITIES HAD TO BE TACKLED IN A SECONDARY WAY, TO THE TIME WHEN THE INTEGRATED APPROACH HAS BEEN ADOPTED. THESE VIEWS CORRESPOND TO THE CENTRAL THESIS OF THIS ARTICLE WHICH CONSIDERS THE IMPS AS A MAJOR BREAK WITH PREVIOUS TRENDS IN THE COMMUNITY'S REGIOHAL POLICY AND THE PRECURSOR TO THE FORMULATION OF THE COMMUNITY SUPPORT FRAMEWORKS. EVIDENCE SUPPORTING THE THESIS WILL BE DRAWN FROM THE FIRST MAJOR EMPIRICAL STUDY OF THE IMPS CONDUCTED WITHIN THE REGIONAL AND EUROPEAN COMMUNITY PROJECT'.

01542 BIBERAJ, E.

ALBANIA AT THE CROSSROADS

PROBLEMS OF COMMUNISM, XL(5) (SEP 91), 1-16.

SINCE EARLY 1990, ALBANIA HAS HITNESSED SIGNIFICANT DEMOCRATIC REFORMS AND HAS TAKEN REMARKABLY RAPID STEPS TO REJOIN THE INTERNATIONAL COMMUNITY AFTER DECADES OF SELFIMPOSED ISOLATION. GENUINE MULTIPARTY ELECTIONS HAVE BEEN HELD, A COALITION GOVERMMENT DOMINATED BY NONCOMMUNTISTS IS NOW IN POWER, AND EFFORTS HAVE BEEN MADE TO INSTITUTE A MARKET ECONOMY. HOWEYER, INTERMAL POLITICAL INSTABILITY, THE MARKET ECONOMY. HOWEVER, INTERMAL POLITICAL INSTABILITY, THE
SEVERITY OF THE ECONOMIC CRISIS, AND TURMOIL IN YUGOSLAVIA SEVERITY OF THE ECONOMIC CRISIS, AND TURHOIL IN YUGOSLAY THREATEN ALBANIA'S TRANSITION FROM COMMUNISM. WITHOUT
ASSISTANCE FROM THE HEST, ALBANIA'S INCIPIENT DEMOCRACY MAY ASSISTANCE FROM THE HEST,
BE DOOMED IN ITS INFANCY'

01543 BICANIC, I.; DOMINIS, I.

TUDJMAN REMAINS DOMINANT AFTER CROATIAN ELECTIONS RFE/RL RESEARCH REPORT, 1 (37) (SEP 92), 20-26.

CROATIA'S SECOND POSTCOMHUNIST MULTIPARTY ELECTIONS WERE HELD ON AUGUST 2, 1992. INCUMBENT PRESIDENT FRANJO TUDJMAN HAS RE-ELECTED, AND THE CROATIAN DEMOCRATIC COMMUNITY RETAINED ITS MAJORITY IN THE CHAMBER OF DEPUTIES. THE OPPOSITION, ESPECIALLY THE EXTREME RIGHT-HIMG PARTY, FARED BADLY IN THE ELECTIONS. THE LEGISLATURE IS LIKELY TO REMAIN QUIESCENT AND INEFFECTIVE, AT LEAST IN THE NEAR TERM, AS TUDJMAN'S DOMINANCE REMAINS UNCHANGED. HE STILL CONTINUES TO BE STRONGLY SUPPORTED BY THE CABINET, WHICH CONSISTS LARGELY OF TECHNOCRATS. THE ELECTION RESULTS ARE A VALIDATION OF TUDJMAN'S LEADERSHIP AND THE PUBLIC'S DESIRE FOR CONTINUITY, PEACE, AND STABILITY.

01544 BIEBER, H.

SAVING THE EARTH: ECONOMIC DEVELOPMENT VERSUS A CLEAN WORLD HORLD PRESS REVIEW, 39(6) (JUN 92), 9-11.

TWO DECADES AFTER THE STOCKHOLM CONFERENCE THAT ESTABLISHED PROTECTION OF THE ENVIRONMENT AS A TASK FOR NATIONAL GOVERNMENTS. THE 1992 UNITED NATIONS CONFERENCE ON ENVIRONMENT AND DEVELOPMENT IN RIO DE JANEIRO IS EXPECTED TO FORMULATE NEH INTERNATIONAL GUIDELINES. THE ALARMING RESULTS FORMULATE NEW INTERNATIONAL GUIDELINES. THE ALARMING RESULTS MAN MUST THI MEASUREMENTS MCTING GLOBALLY IS A PIOUS WISH, BORN IN THE INDUSTRIALIZED
NATIONS OF THE NORTH. THE DEVELOPING SOUTH REGARDS THE IDEA NATIONS OF THE NORTH. THE DEVELOPING SOUTH REGARDS THE IDEA OF ENVIRONMENTALLY-SOUND DEVELOPMENT AS AN ATTEMPT BY THE
RICH COUNTRIES TO PUT NEW FETTERS ON THE POOR COUNTRIES.

01545 BIENEN, H.; VAN DE WALLE, N. A PROPORTAIONAL HAZARD MODEL OF LEADERSHIP DURATION THE JOURAAL OF POLITICS, 54(3) (AUG 92), 685-717.

A SAMPLE OF 2,256 LEADERS FROM 167 COUNTRIES ARE ANALYZED TO ASCERTAIN THEIR DURABILITY IN POWER AND TO ACCDUNT FOR THEIR RISK OF LOSING POHER OVER TIME. A LIFE TABLE OF THE SAMPLE REVEALS THAT THE RISK OR HAZARD OF LOSING POHER DECREASED THROUGHOUT LEADERS' TENURE. THE STUDY DEVELOPS A PROPORTIONAL HAZARD MODEL LONGEVITY TO ACCOUNT FOR SAMPLE HETEROGENEITY AND FINDS STRONG EVIDENCE THAT THE HAZARD VARIES ACCORDING TO THE LEADERS' PAST TIME IN POWER.

01546 BIENKOWSKI, $W$.

CAN POLAND DEVIATE FROM IMF REQUIREMENTS?

RFE/RL RESEARCH REPORT, 1(31) (JUL 92), 49-53.

NEGOTIATIONS OVER THE FORMATION OF NEW GOVERMMENTS IN POLAND HAVE TENDED TO REVOLVE AROUND ECONOMIC ISSUES. FOREMOST AMONG THESE IS THE QUESTION OF THE VIABILITY OF ECONOMIC POLICIES THAT DO NOT RECEIVE THE APPROVAL OF THE INTERNATIONAL MONETARY FUND AND HORLD BANK. WHILE THE ISSUE OF THE COMDITIONALITY OF IMF AND WORLD BANK ASSISTANCE MAY BE A PAINFUL SUBJECT FOR POLISH POLITICIANS. THE FIRST THREE NONCOMMUNIST GOVERNMENTS EITHER ACCEPTED THE REQUIREMENTS OF NONCOMMUNIST GOVERMMENTS EITHER ACCEPTED THE REQUIREMENTS THESE FINANCIAL BODIES AT THE OUTSET OR PROVED UNABLE TO
ESCAPE THEIR IMPERATIVES LATER. THIS IS LIKELY TO HOLD TRUE ESCAPE THEIR IMPERATIVES

01547 BIENKOWSKI, $W$

POLAND'S BERMUDA TRIANGLE

RFE/RL RESEARCH REPORT, 1 (17) (APR 92), 22-24

OPPOSITION TO PRIVATIZING STATE ENTERPRISES IN POLAND CAN BE FOUND AT THE HEART OF THE ENTERPRISES THEMSELVES. A TRIANGLE CONSISTING OF ENTERPRISE MANAGERS, WORKERS' COUNCIL OFFICIALS, AND TRADE UNION REPRESENTATIVES' (SOMETIMES CALLED THE "BERMUDA TRIANGLE" BECAUSE OF ITS TENDENCY TO CAUSE FIRMS TO "VANISH") FORMS A POWERFUL NETWORK OF VESTED INTERESTS OPPOSED TO PRIVATIZATION. IN ADOITION TO 
THREATENING THE POLISH PRIVATIZATION PROCESS, THIS TRIANGLE HAS DAMAGED THE VERY INTEGRITY OF STATE ENTERPRISES.

01548 BIGEL, A.

PRESIDENTI IAL POWER AND POLITICAL QUESTIONS

PRESIDENTIAL STUDIES QUARTERLY, XXI(4) (FAL 91), 663-672. THE JUDICIARY, WROTE ALEXANDER HAMILTON, IS "THE WEAKEST OF THE THREE DEPARTMENTS OF POWER." DEPENOING ON BOTH THE DECISIONS, THE JUDICIARY "CAN NEVER ATTACX WITH SUCCESS EACH OF THE OTHER THO" AND MUST "WITH ALL POSSIBLE CARE OEFEND ITSELF AGAINST THEIR ATTACKS." HAMILTON DID NOT SUGGEST THAT THE JUDICIARY WAS INCAPABLE OF EXERTING A POWERFUL IMPACT ON THE SHAPING OF GOVERNMENTAL POLICY BUT RATHER THAT ITS THE SHAPING OF GOVERMMENTAL POLICY BUT RATHER THAT ITS
INTERPRETATION OF THE LAW WILL BE AFFECTED BY THE PERCEPTION INTERPRETATION OF THE LAW WILL BE AFFECTED BY THE PERCE
OF SUPPORT LIKELY TO BE ACCORDED BY CONGRESS AND THE OF SUPPORT LIKELY TO BE ACCORDED BY CONGRESS AND THE
PRESIDENT. EXAMINING THE MODE OF ADJUDICATION WHICH THE PRESIDENT. EXAMINING THE MODE OF ADJUDICATION WHICH THE UNITED STATES SUPREME COURT HAS PERIDDICALLY ADOPTED TO
AVOID HAVING ITS PRONOUNCEMENTS DISREGARDED BY UNSUPPORTIVE AVOID HAVING ITS PRONOUNCEMENTS DISREGARDED BY UNSUPPORTIVE
CHIEF EXECUTIVES, THIS STUOY SEEKS TO UNDERSTAND THE COURT'S CHIEF EXECUTIVES, THIS STUDY SEEKS TO UNDERSTAND THE COU
PERCEPTION OF ITS INSTITUTIONAL RELATIONSHIP WITH THE PERCEPTION
PRESIDENT.

01549 BILES, P.

ANARCHY RULES

AFRICA REPORT $37(4)$ ( JUL 92 ) 30-33.

THOUSANDS OF PEOPLE HAVE DIED IN FIGHTING BETWEEN THE TWO WARLORDS BATTLING FOR CONTROL OF MOGADISHU, SOMALIA' CAPITAL. THOUSANDS MORE ARE AT RISK OF STARVATION. IN MAY 1992, AFTER PROTRACTED NEGOTIATIONS, THE UNITED NATIONS FINALLY MANAGED TO DELIVER A SHIPLOAD OF FOOD TO THE STARVING SOMALIS. THE ARRIVAL OF FOOD CAME TWO MONTHS AFTER THE GREEDY WARLORDS-THE COUNTRY'S INTERIM PRESIDENT AND THE CHAIRMAN OF THE UNITED SOMALI CONGRESS--SIGNED A CEASE-FIRE AGREEMENT BROKERED BY THE UNITED NATIONS.

01550 BILES, $P$.

GOING IT ALONE

AFRICA REPORT, 37(1) ( JAN 92), 58-6).

AFTER THE DEVASTATING CIVIL WAR, SOMALILAND, THE NORTHERN PART OF SOMALIA, HAS RETURNED TD PEACE AND STABILITY. BUT THERE IS CONTINUING CHAOS IN MOGADISHU IN SOUTHERN SOMALIA, WHERE VIOLENCE IS STILL VERY EVIDENT. IN THE AFTERMATH OF THE OUSTER OF LONG-TIME DICTATOR MOHAMED SIAD BARRE, SOMAL ILAND HAS PROCLAIMED ITSELF INDEPENDENT. THE FORMER BRITISH COLONY HAS REESTABLISHED LAH AND ORDER, ATTEMPTING TO RECONSTRUCT THE AREAS DEVASTATED BY THE WAR.

01551 BILES, $P$.

LIVING ON THE EDGE

LFRICA REPORT, 37 (2) (MAR 92), 22-24,

ALTHOUGH YEARS OF TYRAMNY ÉNDED HITH THE COLLAPSE OF THE MENGISTU REGIME IN 1991 AND THE REPRESSIVE MACHINERY IS GONE, INSECURITY AND POVERTY CONTINUE TO PLAGUE MANY AREAS OF ETHIOPIA. THE TRANSITIONAL GOVERNMENT, RUN BY THE ETHIOPIAM PEOPLE'S REVOLUT IONARY DEMOCRATIC FRONT, IS COUNTING ON THE LOCAL REGIONS TO EXERCISE AUTONOMY AND ADDRESS THESE PROBLEMS, AS THE COUNTRY BEGINS THE COMPLEX PROCESS OF REORGANIZZATION.

01552 BILES, $P$

RIFTS IN THE OPPOSITION

AFRICA REPORT, 37 (4) (JUL 92), 20-23

IN MAY 1992, KENNETH MATIBA, WHO WAS A CABINET MINISTER BEFORE BEING IMPRISONED AND MOVING TO BRITAIN, RETURNED TO KENYA TO RUN FOR THE PRESIDENCY AS THE CANDIDATE OF THE FORUM FOR THE RESTORATION OF DEMOCRACY. THERE ARE SEVERAL OTHER CONTENDERS, LEADING TO FEARS THAT THE VOTE WILL BE SPLIT ALONG ETHNIC LINES. PRESIDENT DANIEL ARAP MOI'S PREDICTION THAT ETHNIC UNREST WOULD FOLLOW ADOPTION OF MULTI-PARTY SYSTEM HAS COME TRUE, LEADING SOME OBSERVERS TO SPECULATE THAT THE CLASHES HAVE BEEN INSTIGATED BY THE GOVERNMENT TO JUSTIFY DECLARING A STATE OF EMERGENCY.

01553 BILL, J.

THE RESURRECTION OF IRAN IN THE PERSIAN GULF

MIDOLE EAST INSIGHT, VIII(4) (MAR 92), 28-35.

DESPITE THE CLUMSY AND OCCASIONALLY COUNTERPRODUCTIVE U. S. POLICY TOWARDS IRAN OVER THE PAST FEW YEARS, U.S. DECISIOMMAKERS HAVE NOTED TWO REALITIES. FIRST, WITH THE DECLINE OF IRAQ, IRAN, MORE EVER THAN BEFORE, STANDS AS THE PREDOMINANT POWER IN THE PERSIAN GULF. SECOND. THE ISLAMIC REPUBLIC HAS NOW MOVED BEYOND THE HARSH AND EXTREME STAGES OF ITS REVOLUTION AND HAS SERVED NOTICE THAT IT SEEKS A OF ITS REVOLUTION AND HAS SERVED NOT ICE THAT IT SEEKS INTERNATIONAL COMMUNITY U.S COOPERATION HITH IRAN IS ESSENTIAL TO FUTURE STABILITY IN THE MIDOLE EAST IN GENERAL ESSENTIAL TO FUTURE STABILITY IN THE MIDOLE EAST IN GENERAL AND IN THE PERSIAN GULF IN PARTICULAR. ALTHOUGH THE UNITED STATES AND THE ISLAMIC REPUBLIC ARE SURE TO HAVE MANY POINTS OF DISAGREEMENT OVER MIDDLE EAST POLICY IN THE YEARS AHEAD, INCREASING COMMUNICATION AND POL ITICAL UNDERSTANDING STILL SEEMS POSSIBLE. SUCH RAPPROCHEMENT WILL REQUIRE LESS STRIDENCY AND AN END TO THE POLITICS OF POLEMICISM IN IRAN.
IT WILL ALSO REQUIRE A MORE SENSITIVE AND PRUDENT POLITICAL RESPONSE ON THE PART OF THE U.S. GOVERNMENT.

01554 BILLE, L. DENMARK

EUROPEAN JOURNAL OF POLITICAL RESEARCH, 22(4) (DEC 92 ),

387-390.

THE AUTHOR LISTS THE MEMBERS OF DENMARK'S CABINET AS OF JANUARY 1, 1991, ALONG WITH THEIR PARTY AFFILIATIONS. HE ALSO BRIEFLY OUTLINES THE MAJOR ISSUES IN DANISH DOMESTIC POLITICS.

01555 BILLINGSLEY, $K$.

WELFARE: FRAUD ON STEROIDS

FREEMAN, 42(4) (APR 92), 148-149.

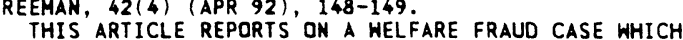
EXPLAINS THINGS BETTER THAN ANY BOOK. ACCORDING TO COURT DOCUMENTS TWO WOMEN WERE ABLE TO PULL IN UPWARDS TO A MILLION DOLLARS IN A PERIOD OF FOUR YEARS THROUGH PHONY MILLIAL SERVICES CASES IN CALIFORNIA. THEIR CON GAME PRDVIDES A PARABLE FOR THE ENTIRE WELFARE SYSTEM BY RAISING THE QUESTION "WHO BENEFITS?" THE ARTICLE ATTEMPTS TO ANSHER THIS QUESTION

01556 BIN, L.

MARKET PLAYS DOMINANT ROLE

BEIJING REVIEW, 35 (47) (NOV 92), 23-25.

THE CHINESE GOVERMMENT IS ATTACHING MORE IMPORTANCE TO

MARKET REGULATION IN ITS PROMOTION OF ECONOMIC DEVELOPMENT. THE STATE PRICING ADMINISTRATION AND OTHER GOVERMMENTAL DEPARTMENTS HAVE REDEFINED THE POWERS CONCERNING THE PRICING OF LIGHT INDUSTRIAL PRODUCTS, FARM PRODUCE AND AGRICULTURAL SIDE-LINE PRODUCTS, COMMUNICATION AND TRANSPORT SERVICES, AND THE MEANS OF PRODUCTION. ONLY THE PRICES OF A FEH PROOUCTS IN EACH SECTOR REMAIN UNDER STATE CONTROL.

01557 BINGHAM, R.; BOWEN, W.; CHANDLER, M.; CORNHELL, T.; DESARIO, J.: DOMMEL, P.

MANAGING LOCAL GOVERNMENT--PUBLIC ADMINISTRATION IN PRACTICE

SAGE PUBLICATIONS, 1991, 363.

THIS BOOK HAS THREE PARTS: AN OVERVIEW OF ADMINISTRATION AND LOCAL GOVERNMENT, THE DIMENSIONS OF ADMINISTRATION, AND ADMINISTRATIVE APPLICATIONS IN LOCAL GOVERMMENT. THE TWO CHAPTERS IN THE OVERVIEW INTRODUCE PUBLIC ADMINISTRATION AND CHAPTERS IN THE OVERVIEW INTRODUCE PUBLIC ADMINISTRATION AMD
LOCAL GOVERNMENT. THE AUTHOR'S DESCRIBE AMERICA'S UNIQUE POL IT ICAL AND ECONOMIC LANDSCAPE AND HOW IT HAS INFLUENCED POLITICAL AND ECONOMIC LANDSCAPE AND HOH IT HAS INFLUENCED

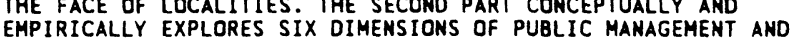
EMPIRICALLY EXPLORES SIX DIMENSIONS OF PUBLIC MANAGEMENT AND
ADMINISTRATION: THE LEGAL SIDE OF PUBLIC MANAGEMENT, HUMAN ADMINISTRATION: THE LEGAL SIDE OF PUBLIC MANAGEMENT, HUMAN RESOURCE MANAGEMENT, BUDGETING AND PUBLIC FINANCE, PUBLIC DECISION MAKING, INTERGOVERNMENTAL RELATIONS, AND ETHICAL CONSIDERATIONS IN PUBLIC ADMINISTRATION. THE THIRD PART CONSIST OF SEVEN CHAPTERS ILLUSTRATING THE APPLICATION OF
ADMINISTRATION IN LOCAL GOVERMMENT IN SUCH AREAS AS HOUSING AGENCIES, ECONOMIC DEVELOPMENT, PUBLIC SAFETY, RECREATION, TRANSPORTATION, AND INFRASTRUCTURE.

01558 BINION, G.

BABY M, SURROGATE PARENTING, AND PUBLIC POLICY POLICY STUDIES REVIEW, 11(1) (SPR 92), 126-140.

THE AUTHOR ANALYZES THE LEGAL AND POLITICAL

CONTROVERSIES THAT HAVE ARISEN IN RESPONSE TO SURROGATE PARENTING. ALTHOUGH AT LEAST 1,000 SURROGATE PARENTING AGREEMENTS HAD BEEN EFFECTED BY THE LATE 1980'S, NO RELEVANT STATUTES HAD BEEN PASSED BY STATE OR FEDERAL LEGISLATURES PRIOR TO THE "8ABY M" LITIGATION. THE PRACTICE EXISTED IN A VIRTUAL VACUUM OF PUBLIC POLICY WITH RESPECT TO ITS LEGALITY AND THE RELATIVE RIGHTS OF THE VARIOUS PARTIES INVOLVED. THE AUTHOR FOCUSES ON THE "BABY M" RULING OF THE NEW JERSEY SUPREME COURT AS A MODEL FOR PUBLIC POLICY ON THE SUBJECT. IN SHAPING SUBSEQUENT POLITICAL ACTIVITY ON SURROGACY.

01559 BINTER, J.

NEUTRALITY IN A CHANGING WORLD: END OR RENAISSANCE OF A CONCEPT

BULLETIN OF PEACE PROPOSALS, 23(2) (1992), 213-128.

IT IS ARGUED IN THIS ARTICLE THAT IN THE SHORT RUN THE ONGOING CHANGES IN THE INTERNATIONAL SYSTEM AND IN MILITARY ONGOING CHANGES IN THE INTERNATIONAL SYSTEM AND IN STRATEGY AND HARFARE MIGHT NOT BRING THE END BUT A
RENAISSANCE OF THE STATUS OF NEUTRALITY. EXPLORED ARE RENAISSANCE OF THE STATUS OF NEUTRALITY. EXPLORED ARE VARIOUS SCENARIOS NOW FORESEEABLE IN THE EUROPEAN LANDSCAPE, CERTAIN MODELS OF NEUTRALITY THAT MIGHT EVEN TAKE
IMPORTANT ROLES. OFFERED IS A HISTORICAL REVIEH OF IMPORTANT ROLES. OFFERED IS A HISTORICAL REVIEH OF NEUTRALITY WHICH IS VIENED IN REFERENCE TO EUROPEAN TRANSFORMATION, NATIONAL IDENTITY, AS AN OPTION FOR CENTRAL
AND EASTERN EUROPE, A FUTURE EUROPEAN PEACE PROCESS, AND AND EASTERN EUROPE, A
COOPERATIVE SECURITY.

01560 BINYAN, L.

CHINA'S BOURGEOIS LIBERATORS

FREEDOM REYIEH, 23(3) (MAY 92), 10-13.

THE AUTHOR LOOKS AT THE FACTORS UNDERLYING CHINA'S 
ECONOMIC REFORMS, AT CHINA'S ECONOMIC PROGRESS, AND AT THE POTENTIAL FOR OEMOCRACY. HE WARNS THAT BRINGING DEMOCRACY TO CHINA WILL BE AN ARDUOUS PROCESS BECAUSE THE SOCIETY WILL SPIRITUAL AND CULTURAL LIVES OF THE CHINESE PEOPLE.

01561 BINYAN, L.

THE FUTURE OF CHINA

NEW LEFT REVIEW, (194) (JUL 92), 5-16.

LIU BINYAN, A WELL-KNOWN CHINESE INTELLECTUAL, ARGUES

THAT STALINISM WILL COME TO NO GOOD END IN CHINA. HE SEES

CHINA'S RECENT ECONOMIC ADVANCE AS FURMISHING A MORE HOPEFUL CONTEST FOR POLITICAL REFORM AND ARGUES THAT THE HORKING PEOPLE OF THE TOWNSHIPS SHOULD BE GIVEN MOST OF THE CREDIT FOR THE NEW MOMENTUM OF DEVELOPMENT. FOLLOHING A SUCCESSION OF POLITICAL CAMPAIGNS THAT WEAKENED THE STRUCTURES OF THE COMMAND ECONOMY AND PARTY-STATE, POPULAR PRESSURE FROM THE RURAL TOWNSHIPS IN THE LATE 1970'S SUCCEEDED IN

CONSOL IDATING A MORE DECENTRALIZED, DEVOLVED MODEL OF

ECONOMIC ACTIVITY. LIU IS CRITICAL OF CONTINUING

BUREAUCRATIC REPRESSION AND THE OFTEN-CORRUPT RELATIONSHIP

BETWEEN FOREIGN INVESTORS AND STATE OFFICIALS. BUT HE DOES

BETWEEN FOREIGN INVESTORS AND STATE OFFICIALS. BUT HE DOES

SEE ENCOURAGING SIGNS IN THE GROWTH OF CIVIL SOCIETY FROM

BELOH, WHICH MIGHT IN THE FUTURE PERMIT A NEW OPENING TO

REFORM AND DEMOCRACY. HHILE HE HELCOMES MUCH OF THE SOCIAL
INITIATIVE RELEASED BY ECONOMIC REFORM. HE DENIES THAT THIS WILL HAVE TO ASSUME FULLY CAPITALIST FORMS.

01562 BIRD, E.

FROM THE DEMOCRATIC PARTY CONVENTION: ROOM IN THE TENT FOR EVERYONE BUT ARAB AMERICANS

WASHINGTON REPORT ON MIDDLE EAST AFFAIRS, XI(3) (AUG 92), 8-9.

ALL HUES IN THE SPECTRUM OF JEWISH OPINON, FROM AIPAC TO PEACE NOW, WERE DISCERNIBLE AT THE TABLE OF POWER AT THE 1992 DEMOCRATIC NATIONAL CONVENTION. MAINSTREAM JEWISH LEADERS EXPRESSED GREAT RELIEF THAT THE DEMOCRATIC PARTY WAS "BACK IN THE FOLD" AND THAT THERE WAS NO FLOOR DEBATE OVER SELF-DETERMINATION FOR THE PALESTINIANS. OF THE MAJOR CONVENTION SPEAKERS, ONLY JESSE JACKSON SPOKE OF PALESTINE ANO URGED ARAB-AMERICANS TO CONTINUE WORKING WITHIN THE PARTY.

01563 BIRD, E.

PEACE TALKS, NEW LOAN GUARANTEES, ISRAEL ARMS TRANSFER CHARGES

WASHINGTON REPORT ON MIDDLE EAST AFFAIRS, XI(1) (JUN 92), 19.

THE AUTHOR DISCUSSES THE PROGRESS IN THE MIDDLE EAST PEACE NEGOTIATIONS, REPORTS OF MASSIVE U.S. AID TO HELP PRIVATIZE THE ISRAELI ECONOMY AND CHARGES THAT ISRAEL HAS SECRETLY TRANSFERED U.S. WEAPONS TECHNOLOGY IN VIOLATION OF BILATERAL AGREEMENTS.

01564 BIRD, R.

TAX REFORM IN LATIN AMERICA: A REVIEW OF SOME RECENT EXPERIENCES

LATIN AMERICAN RESEARCH REVIEW, 27(1) (1992), 7-36.

TAX REFORM SEEMS TO BE CLIMBING HIGHER ON THE POLICY AGENDA OF MANY LATIN AMERICAN COUNTRIES. THE OBJECTIVE OF THIS ARTICLE DESCRIBES THE KEY FEATURES OF RECENT MAJOR TAX REFORMS IN BOLIVIA, ARGENTINA, MEXICO, AND COLOMBIA, PAYING PARTICULAR ATTENTION TO THE LARGELY SUCCESSFUL BOLIVIAM REFORM OF 1986 THESE FOUR COUNTRIES WERE CHOSEN FOR EXAMINATION BECAUSE THEIR DIVERSE EXPERIENCES OFFER USEFUL GENERAL LESSONS FOR WOULD-BE "TAX REFORMMONGERS" IN OTHER COUNTRIES.

01565 BIRDGES, $B$ JAPAN: HAITING FOR GORBACHEY

PACIFIC REVIEN, 4(1) (1991), 56-62

THIS ARTICLE ADDRESSES THE CHANGE IN THE SOVIET-JAPAM RELATIONSHIP BROUGHT ABOUT BY GORBACHEV. THE LONGSTANDING PROBLEMS OF THIS RELATIONSHIP ARE EXAMINED. THESE IMCLUDE THE DISPUTED STATUS OF THE FOUR "NORTHERN TERRITORIES," FISHING RIGHTS, AND THE DISAPPOINTING RESULTS DERIVED' FROM ECONOMIC INTERACTION. THE JAPANESE DOMESTIC ENVIRONMENT IS DESCRIBED.

01566 BIRLEY, R.

BRAYE NEH ORDER

NATIONAL REYIEH, XLIY(20) (OCT 92), 52:69.

FAR FROM PROMOTING DEMOCRACY AND PEACE IN MOZAMBIQUE, AMERICA'S FOREIGN-POLICY MAKERS HAVE SIDED WITH A AMERICA'S FOREIGN-POLICY MAKERS HAVE SIDED WITH A
"REFORMIST" MARXIST-LENINIST REGIME (FRELIMO) IN ITS 15 YEAROLD WAR AGAINST THE PRO-HESTERN, PRO-FREE-MARKET OPPOSITION FORCE (REMAMO). SINCE 1982 NEARLY HALF A BILLION U.S. TAXPAYER DOLLARS HAVE BEEN CHANNELED TO FRELIMO IN ECONOMIC AID AND NOW IN MILITARY ASSISTANCE. THE AUTHOR SUGGESTS THAT THE U.S SHOULD MAKE IT CLEAR TO FRELIMO THAT FURTHER AID WILL BE FORTHCOMING ONLY IF AN EARLY DATE IS SET FOR FREE AMD FAIR ELECTIONS.
01567 BIRMBAUM, C.

COALITION PARTIES REACH AGREEMENT ON PREVENTING ABUSE OF ASYLUM LAWS

GERMAN TRIBUNE, 31(1537) (OCT 92), 3.

THE PARTIES IN THE BONN COALITION HAVE AGREED ON NEW ASYLUM REGULATIONS UNDER WHICH POL ITICALLY PERSECUTED PERSONS WOULD CONTINUE TO RECEIVE RECOGNITION UNDER THE TERMS OF THE GENEVA CONVENTION ON REFUGEES. APPLICATION FROM NATIONS WHERE IT IS DECIDED NO POL ITICAL PERSCEUTION TAKES PLACE WOULD NOT BE ACCEPTED. THE OPPOSITION SPD IS NOT A PARTY TO THE DEAL.

01568 BIRNS, L.; LITTLEHALE, S. AFTERSHOCKS OF INTERVENTION

NICARAGUAN PERSPECTIVES, (19) (FAL 90), 12-14.

THE AUTHORS ARGUE THAT WASHINGTON'S REGIONALIZATION OF ITS CONFLICT WITH NICARAGUA'S SNLF HAS DAMAGED NOT ONLY THE AMERICAN POLITICAL PSYCHE BUT THE ECONOMIES AND SOCIAL FABRIC OF EVERY NATION IN THE REGION. THE HISTORY OF U.S. POLICY TOWARD CENTRAL AMERICA FROM 1982, WHEN THE REAGAN ADMINISTRATION TRIED TO OVERTHROH THE GOVERNMENT IN MANAGUA, ADMINISTRATION TRIED TO OVERTHROH THE GOVERNMENT IN MANAGUA,
IS REVIEHED. THE IMPACT OF THE VICTORY OF VIOLETA BARRIOS DE IS REVIEHED. THE IMPACT OF THE VICTORY OF VIOLETA BARRI
CHAMORRO IN NICARAGUA'S RECENT PRESIDENTIAL ELECTION IS CHAMORRO IN NICARAGUA'S RECENT PRESIDENTIAL ELECTION IS
EXPLORED. THE FUTURE OF U.S. BASES IN HONDURAS IS ALSO EXPLORED.
OISCUSSED.

01569 BISCHOPING, K.; SCHUMAN, H. PENS AND POLLS IN NICARAgua: an analysis of THE 1990 PREELECTION SURVEYS

AMERICAN JOURMAL OF POLITICAL SCIENCE, 36(2) (MAY 92), 331-350.

IN ORDER TO UNDERSTAND THE PROBLEMS OF INTERPRETING POLITICAL SURVEYS IN HIGHLY POLARIZED SOCIETIES, THIS ARTICLE ANALYZES THE RESULTS OF SEYENTEEN PRE-ELECTION POLLS CARRIED OUT DURING THE THREE MONTHS PRECEDING THE 1990 NICARAGUAN ELECTION. THE ARTICLE ALSO DRAHS ON FIMOINGS FROM A SURVEY-BASED EXPERIMENT ON RESPONSE BIAS ADMINISTERED IN THE LAST DAYS OF THE ELECTION CAMPAIGN. BOTH SETS OF DATA ARE USED TO EXPLORE FIVE HYPOTHESES THAT MIGHT ACCOUNT FOR THE LARGE INCONSISTENCIES BETWEEN MANY OF THE PRE-ELECTION SURVEYS AND THE ACTUAL ELECTION RESULTS: THE VOLATILITY OF THE NICARAGUAN ELECTORATE; SERIOUS PROBLEMS IN SAMPLING A DEVELOPING COUNTRY IN TURMOIL; EFFECTS OF THE ADMINISTRATION OR CONTEXT OF QUESTIONS; INTENTIONAL PARTISAN BIAS ON THE PART OF POLLING ORGANIZÁTIONS: AND RESPONSE EFFECTS DUE TO THE PARTISANSHIP OF THE POLLS AS PERCEIVED BY THE NICARAGIAN POPULATION. THE ANALYSIS INDICATES THAT THE MAIN EXPLANATION FOR THE FAILURE OF SOME POLLS AND THE SUCCESS OF OTHERS LIES FOR THE FAILURE OF SOME POLLS AND THE SUCCESS, OF OTHER IN AN UNUSUAL INTERACTION BETWEEN RESPONDENTS' VOTE PARADOXICALLY, BIAS ON THE PART OF A SURVEY ORGANIZATION WAS PARADOXICALLY, BIAS ON THE PART OF A SURVEY ORGANIZATION
NECESSARY TO REDUCE BIAS ON THE PART OF THE RESPONDENTS.

01570 BISHARA, A.

PALESTINE IN THE NEW ORDER

MIDLESTNE IN THE NEH OROER 22 , 2-8.

DOLE EAST REPORT, $22(2)$ (MAR 92), 2-8. ORDER" HAVE SOMEWHAT CHANGED THE POLITICAL LANDSCAPE OF THE MIDOLE EAST. THIS ARTICLE EXAMINES THE EFFECTS OF THE NEW ORDER ON THE QUESTION OF PALESTINE. IT ANALYZES THE ONGOING ARAB-ISRAELI PEACE PROCESS, THE CURRENT STATE OF THE INTIFADA, AND THE FUTURE OF THE DISPUTE. IT ARGUES THAT THE CURRENT EMPHASIS ON NEGOTIATING IN "STAGES" IS MISGUIDED. WHILE ISSUES SUCH AS SELF-RULE OR AUTONOMY ARE IMPORTANT, THE FUNDAMENTAL ISSUE AT STAKE IS EQUALITY--EITHER BETWEEN NATION-STATES, OR AMONG CITIZENS OF A BINATIONAL STATE. ONLY AFTER THE RIGHT TO EQUALITY IS RECOGNIZED CAN PHASES TOWARDS ITS IMPLEMENTATION--SUCH AS AUTONOMY--BE DISCUSSED.

01571 BISHKU, M.

ATATURK'S LEGACY VERSUS RELIGIOUS REASSERTION: SECULARISM AND ISLAM IN MODERN TURKEY

MEDITERRANEAN QUARTERLY: A JOURNAL OF GLOBAL ISSUES, 3(4)

(FAL 92), 75-93.

MUSTAFA KEMAL-DTATURK--DIED FIFTEEN YEARS AFTER HE ESTABLISHED THE TURKISH REPUBLIC AFTER SHAPING A MODERN COURSE FOR HIS COUNTRY. THE ISSUES OF ATATURK'S VIEHS ON NATION BUILDING AND ISLAM NOH THE RELIGION OF 98 TO 99 PERCENT OF TURKEY'S POPULATION (JUST A FEH MORE PERCENT THAN IN 1923). AND HOW HIS SUCCESSORS HAVE ATTEMPTED TO BALANCE SECULARISM WITH THE RESURGENCE OF RELIGIOUS CONSCIOUSNESS IS SECULARISH WITH THE RESURGENCE OF RELIGIOUS CONSCIOUSNESS ADDRESSED IN THIS ARTICLE. HOWEVER, BEFORE DISCUSSING POLICIES OF ATATURK AND HIS SUCCESSORS, THE ARTICLE ADDRESSES THE PERSOHALITY OF ATATURK AND HIS PATH TO POWER, IDEAS CONCERNING NATION BUIIDING AND ISLAM.

01572 BISHKU, M.

THE KENMEDY ADMINISTRATION, THE U.N. AND THE YEMENI CIVIL WAR

MIDOLE EAST POLICY, 1(4) (1992), 116-128.

THIS ARTICLE ADORESSES, IN SOME DETAIL, THE U.N. YEMEN OBSERVATION MISSION (UNYOM); IT ALSO REVIEWS AND ANALYZES 

AND THE INTERNATIONAL POLITICS ASSOCIATED WITH, AS WELL AS
THE EFFICACY OF, THE DISPATCH AND ACTIVIES OF THE SHORTLIVED UNYOM OPERATION. THE DETAILS OF THIS HISTORICAL PERIOD ARE INTRODUCED AND ASSESSMENTS ARE PRESENTED BY SOME WHO CLOSELY WITNESSED OR WERE INVOLVED IN THESE AFFAIRS.

01573 BISHOP, J.

BUSH VS. THE FACTS: HEALTH CARE THAT WORKS

COMMONWEAL, CXIX(6) (MAR 92), 6-7.

CANADA FUNDS HEALTH CARE THROUGH UNIVERSAL INSURANCE, ORGANIZED ON A PROVINCE-BY-PROVINCE BASIS, WITH FEDERAL'

SUPPORT TO ENSURE UNIFORM MINIMAL STANDARDS. DOCTORS ENGAGE IN PRIVATE PRACTICE AND ARE PAID ON A FEE-FOR-SERVICE BASIS, MUCH AS IN THE UNITED STATES. PATIENTS CAN CHOOSE THEIR MUCH AS IN THE UNITED STATES. PATIENTS CAN CHOOSE THEIR
DOCTORS AND BE ADMITTED TO ANY HOSPITAL. ALTHOUGH THE BASIC FUNDING VARIES FROM ONE PROVINCE TO ANOTHER. FOR EXAMPLE, IN FUNDING VARIES FROM ONE PROVINCE TO ANOTHER. FOR EXAMPLE, IN ONTARIO AND QUEBEC, PREMIUMS ARE PAID THROUGH PAYROLL TAXES. OXPENSIVE THAN GREAT BRITAIN'S NATIONAL HEALTH SERVICE BUT CONSIDERABLY LESS EXPENSIVE THAN HEALTH CARE IN THE UNITED CONSIDERAE
STATES

01574 BISHOP, J.; FORMBY, J.; SMITH, W.

INCOMPLETE INFORMATION, INCOME REDISTRIBUTION AND RISK AVERSE MEDIAN VOTER BEHAVIOR

PUBLIC CHOICE, 68(1-3) (JAN 91), 41-56.

THIS PAPER EXTENDS THE MEDIAN VOTER MODEL TO INCLUDE RISK AVERSION. AN EXPECTED UTILITY MAXIMIZING MEDIAN VOTER WITH AN AVERSION TO RISK MAY BEHAVE OIFFERENTLY THAN A MEDIAN VOTER WHO IS CERTAIN. A REFERENDUM ON INCOME REDISTRIBUTION FROM THE TOP OF THE DISTRIBUTION TO THE BOTTOM WHICH FAILS HHEN THE MEDIAN VOTER IS CERTAIN MAY PASS IN THE EXTENDED MEDIAN VOTER MODEL. ECONOMIC INEFFICIENCIES AND THE MET LOSSES ACCOMPANYING REDISTRIBUTION ARE SHOWN TO PLAY A PIVOTAL ROLE IN DETERMINING THE BEHAVIOR OF THE RISK AVERSE MEDIAN VOTER. THE MODEL IS ILLUSTRATED USING A ONE PERCENT DEMOGRANT REDISTRIBUTION.

01575 BISHOP, J.; FORMBY, J.; ZEAGAR, L. WELFARE EVALUATIONS OF' STATE INCOME DISTRIBUTIONS SOCIAL SCIENCE QUARTERLY, 73(1) (MAR 92), 166-176. SOCIAL SCIENCE QUARTERLY, 73(1) (MAR 92), 166-176.
THIS STUDY PROVIDES WELFARE EVALUATIONS OF INCOME DISTRIBUTIONS BASED UPON SEVERAL DISTINCT DIMENSIONS OF DISTRIBUTIONS BASED UPON SEVERAL DISTINCT DIMENSIONS OF
DISTRIBUTION FUNCTIONS. BY JOINTLY CONSIDERING POVERTY, DISTRIBUTION FUNCTIONS. BY JOINTLY CONSIDERING POVERTY,
INEQUALITY, AND THE LEVEL OF INCOME, THE METHODOLOGY AVOIDS INEQUALITY, AND THE LEVEL OF INCDME, THE METHODOLOGY AVOIOS
CONTROVERSIAL JUDGMENTS CONCERNING TRADE-OFFS AMONG THESE DIMENSIONS. MICRODATA FROM THE 1980 DECENMIAL CENSUS OF POPULATION ARE USED TO COMPARE INDIVIDUAL STATE INCOME POPULATION ARE USED TO COMPARE INDIVIDUAL STATE INCOME DECENTLY DEVELOPED STATISTICAL INFERENCE PROCEDURES THAT DO RECENTLY DEVELOPED STATISTICAL INFERENCE PROCEDURES THAT DO THE INCOME DISTRIBUTION FUNCTION ARE USED TO SIMULTANEOUSLY THE INCOME DISTRIBUTION FUNCTION ARE USED TO SIMUL TANEOUSLY INEQUALITY, AND LARGER ABSOLUTE INCOMES FOR THE POOR.

01576 BISWAS, B.; SAUNDERS, P.; TRIBEDY, G. FURTHER ANALYSIS OF THE THIN DEFICITS CONTEMPORARY POLICY ISSUES, $X(1)$ (JAN 92), 104-107. THE AUTHORS CONTINUE TO DELVE INTO THE CAUSAL RELATIONSHIP BETWEEN THE U.S. FISCAL AND TRADE DEFICITS. THEY GATHER ANNUAL DATA ON U.S. FEDERAL BUDGET DEFICITS AND NET EXPORTS FOR 1950-1988 AND DEFLATE THE NOMINAL VALUES BY THE GDP DEFLATORS TO EXAMINE THE CAUSAL RELATION BASED ON REAL VALUES. THEY MAKE A DISTINCTION BETWEEN STRUCTURAL AND ACTUAL BUDGET DEFICITS. INSTEAD OF AN ARBITRARY CHOICE OF LAG STRUCTURE, THEY USE HSIAO MINIMUM FINAL PREDICTION ERROR CRITERION TO DETERMINE THE OPTIMUM LAG LENGTHS OF THE EXPLANATORY VARIABLES. THE ANALYSIS REVEALS A UNIDIRECTIONAL CAUSAL RELATION RUNNING FROM STRUCTURAL BUDGET DEFICITS TO NET EXPORTS, CONFIRMING SOME PREVIOUS FINDINGS BY STEPHEN M. MILLER AND FRANK S. RUSSEK. HOHEVER, CONTRARY TO MILLER AND RUSSEK'S CONCLUSIONS, THE NEW FINOINGS INDICATE A BIDIRECTIONAL CAUSAL RELATION BETWEEN ACTUAL BUDGET DEFICITS ANO NET EXPORTS, SUGGESTING IMPORTANT POLICY IMPLICATIONS.

01577 BITTNER, G.

TOWARDS A NEW EUROPEAN IDENTITY AND STRUCTURE

PEACE AND THE SCIENCES, 1(1) (SEP 92), 6-9.

AMERICAN AND EUROPEAN HISTORIANS HÁVE TRADITIONALLY IGNORED THEIR RECIPROCAL INFLUENCES. THIS OVERSIGHT ALLOWS IGNORED THEIR RECIPROCAL INFLUENCES. THIS OVERSIGHT ALLOWS
EACH GROUP AN INDEPENDENCE WHICH, IN ADLER'S VIEW, FOSTERS EACH GROUP AN INDEPENDENCE WHICH, IN ADLER'S VIEW, FOSTERS THE PERCEPTION OF CULTURAL SUPERIORITY ON BOTH SIDES. THIS PAPER ATTEMPTS TO DESCRIBE SELECTED RECIPROCAL INFLUENCES, WITH EMPHASIS ON AMERICAN PERCEPTIONS OF EUROPE.

01578 BITZINGER, R.

ARMS TO GO: CHINESE ARMS SALES TO THE THIRD WORLO INTERNATIONAL SECURITY, 17(2) (FAL 92), 84-111.

IN THE PAST TWENTY YEARS THE DEVELOPING WORLD HAS BECOME A PROVIDER OF WEAPONS SYSTEMS TO THE THIRD WORLD. THE FIRS PART OF THIS ARTICLE EXAMINES RECENT CHINESE ARMS TRANSFERS TO THE THIRD WORLD AND DISCUSSES THE IMPACT OF THESE WEAPON SYSTEMS ON REGIONAL SECURITY DEVELOPMENTS, IN PARTICULAR HOW
THEY AFFECT WESTERN SECURITY INTERESTS. THE SECOND PART ANALYZES CHINESE ARMS MODERNIZATION EFFORTS AND THEIR PROSPECTS FOR REACHING FULLSCALE PRODUCTION, GIVEN LIMITS TO INDIGENOUS RESEARCH AND DEVELOPMENT CAPABILITIES AND TO IMPORTING FOREIGN TECHNOLOGY. CHINA IS NOT LIKELY TO ABANDON ITS AGGRESSIVE WEAPONS SALES WHICH COULD HAVE A VERY

SIGNIFICANT IMPACT ON MILITARY SITUATIONS IN THE THIRD WORLD.

01579 8JORKLUNO, T.

UNEMPLOYMENT AND PARTY CHOICE IN NORHAY

SCANDINAVIAN POLITICAL STUDIES, 15(4) (DEC 92), 329-352.

THE AUTHOR INVESTIGATES THE RELATIONSHIP BETWEEN UNEMPLOYMENT AND PARTY CHOICE, UTILIZING FOUR HYPOTHESIS: (1) THE INCUMBENCY THESIS, WHICH SUGGESTS THAT THE INCUMBENT PARTY RECEIVES SUPPORT IN ACCORDANCE WITH FLUCTUATIONS IN ECONOMIC CONDITIONS--I.E. II IS PUNISHED IN BAD TIMES AND REWARDED IN PROSPEROUS TIMES; (2) THE POLICY THESIS, WHICH PREDICTS THAT VOTERS CONCERNED ABOUT UNEMPLOYMENT PREFER THE LABOR PARTY; (3) THE SOCIAL COMPOSITION THESIS, WHICH ARGUES THAT THE FLUCTUATIONS BETWEEN UNEMPLOYMENT AND PARTY CHOICE ARE SIMPLY DUE TO CHANGES IN THE SOCIAL COMPOSITION OF THE UNEMPLOYED: AND (4) THE GENERATION THESIS, WHICH UNDERSCORES THAT THE IMPACT OF UNEMPLOYMENT ON PARTY CHOICE VARIES ACCORDING TO HISTORICAL GENERATION. THE AUTHOR FINDS SOME EMPIRICAL SUPPORT FOR THE INCUMBENCY THESIS, BUT THE GENERATION THESIS APPEARS TO BE THE MOST RELEVANT.

01580 BLACK, C.

CANADIAN CAPERS

NATIONAL INTEREST, 28 (SUM 92), 81-88.

DISCERNING OVERSEAS VISITORS TO CANADA HAVE LONG

INOUIRED INTO THE RATIONALE OF CANADA AS AN ENTITY

INDEPENDENT OF THE UNITED STATES. SO HAVE MANY CANADIANS. CONRAD BLACK REVIEHS HISTORICAL DIFFERENCES AND THE Radicalization of QUEBEC. "MEeCH LaKe and afTER" IS THEN EXAMINED AND THE "SOUTHERN OPINION" EVALUATED. HE CONCLUDES THAT WHETHER DELIBERATELY OR BY MISADVENTURE, JOINING THE UNITED STATES OR NOT IS THE CHOICE CANADA WILL MAKE IN THE NEXT FEW YEARS.

01581 BLACK, J.K.

BRAZIL'S LIMITED REDEMOCRATIZATION

CURRENT HISTORY, $91(562)$ (FEB 92), 85-89.

THE MODEL OF FULL-FLEDGED SOCIALISM THAT INSPIRED GREAT HOPES AND FEARS IN BRAZIL IN THE 1960'S HAS LOST ITS

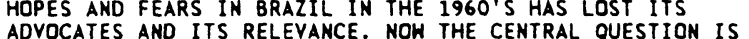
ADVOCATES AND ITS RELEVANCE. NOW THE CENTRAL QUESTION IS
WHETHER THE NON-AFFLUENT WILL HAVE SOME MEASURE OF EFFECTIVE REPRESENTATION AND SOME PROTECTION FROM THE VAGARIES OF THE MARKETPLACE OR WHETHER MONEY WILL BE THE ONLY CURRENCY THAT COUNTS IN POLITICAL AS WELL AS ECONOMIC TRANSACTIONS. BRAZILIANS MUST CONFRONT THE CHALLENGE OF RECLAIMING, FROM AN INTRANSIGENT TRANSNATIONAL CREDITOR CARTEL, A MEASURE OF AN INTRANSIGENT TRANSHATIONAL CREDITOR CARTEL,

01582 BLACKBURN, P.

THE POST-COLD HAR PUBLIC DIPLOMACY OF THE UNITED STATES WASHINGTON QUARTERLY, 15(1) (WIN 92), 75-90.

IN THE AFTERMATH OF THE COLD WAR, USIA MUST REEXAMINE ITS PURPOSES AND CHART A COURSE APPROPRIATE TO THE PRESENT MOMENT. IT FACES A POLICY ENVIRONMENT IN WHICH CONTAINMENT OF THE SOVIET UNION NO LONGER PROVIDES A FUNDAMENTAL ORGANIZING PRINCIPLE OF STRATEGIC THINKING. THIS ARTICLE EXPLORES THE SUCCESS RECORD OF USIA, AND THEN ITS MISSION FOR THE 1990S. IT THEN CONCLUDES THAT HITH STRONG LEADERSHIP THE USIA CAN MAKE A PROFOUND CONTRIBUTION TO THE NATIONAL AGENDA OVER THE COMING DECADES.

01583 BLACKBURN, R.

THE RUINS OF WESTMINSTER

NEW LEFT REVIEW, (191) (JAN 92), 5-36.
THE AUTHOR DISCUSSES THE CENTRALITY AND URGENCY OF THE DEMAND FOR PROPORTIONAL REPRESENTATION IN GREAT BRITAIN AND THE NEED FOR THE LEFT TO SEIZE THE OPPORTUNITIES REPRESENTED BY THE POST-MAASTRICHT PHASE OF EUROPEAN INTEGRATION. HE ARGUES THAT THE BRITISH LEFT SHOULD SEEK TO MAXIMIZE THE CHANCES OF CONSERVATIVE DEFEAT IN 1992 AND SHOULD SUPPORT ANY LABOUR-LIBERAL DEMOCRATIC AGREEMENT THAT INTRODUCE
PUTS TO A REFERENDUM, A SYSTEM OF GENUINE PROPORTIONAL PUTS TO A REFERENDUM, A SYSTEM OF GENUINE PROPORTIONAL
REPRESENTATION. HOWEVER DESIRABLE IT IS THAT LABOUR MAKE A REPRESENTATION. HOWEVER DESIRABLE IT IS THAT LABOUR MAKE A
GOOD SHOWING IN THE 1992 ELECTIONS, A KINHOCK GOVERMMENT GOOD SHOWING IN THE 1992 ELECTIONS, A KINNOCK GOVER
WOULD NOT BE PREPARED TO CONFRONT CAPITALIST POWER.

WOULD NOT BE PREPARED TO CONFRONT CAPITALIST POWER.
THEREFORE, IT WOULD BE UNABLE TO GIVE REAL PRIORITY TO THEREFORE, IT WOULD BE UNABLE TO GIVE REAL PRIORITY TO
PROMOTING SOCIAL EQUALITY OR MEETING THE DANGERS SPAWNED BY PROMOTING SOCIAL EQUALITY OR MEETING THE DANGERS SPAWNED BY
DEEPENING RECESSION IN A DIVIDED, ECOLOGICALLY-THREATENED, DEEPENING RECESSION IN A DIVIDED, ECOLOGICALLY-THREATENED, MILITARIZED WORLD. IN BRITAIN, AN ELECTION CAMPAIGN, WHICH IS SUPPOSEDLY A TIME OF HEIGHTENED DEBATE ON POLITICAL ANO SOCIAL ISSUES, ACTS IN SUCH A WAY AS SIMPLY TO SILENCE THE LEFT. THE AUTHOR CONCLUDES THAT A GENUINE DEMOCRATIC REFORM OF THE ELECTORAL SYSTEM WOULD BE HELCOMED BOTH FOR ITS OWH
SAKE AND BECAUSE IT WOULD ALLOW THE LEFT TO TEST ITS OWN IDEAS AND CAPACITIES.

01584 BLACKSHIRE-BELAY, C.

GERMAN IMPERIALISM IN AFRICA: THE OISTORTED IMAGES OF 
CAMEROON, MAMIBIA, TAZAMIA, AMD TOGO

JOURNAL OF BLACX STIDIES, 23i 2) (DEC 92), 235-246.

IN OROER TO GAIN AN OVERVIEW OF GERMANY'S COLONIAL PAST IN AFRICA, THIS ARTICLE BEGINS WITH A HISTORICAL DISCUSSION. IT EXAMINES FOUR FORMER GERMAN COLONIES: NAMIBIA, CAMEROON, TOGO, AND TANZANIA; AND THEN, THE RELATIONS OF AFRICA AND GERMANY TODAY. IT CONCLUDES THAT IT IS VITAL TO THE DISCUSSION OF AFRICAN HISTORY TO INCLUDE EUROPEAN COUNTRIES THAT COLONIZED THE CONTINENT OF AFRICA. WHEN AFRICAN AND AFRICANIST SCHOLORS CONTINUE TO LEAVE PERTINENT AND FACTUAL EVIDENCE ABOUT EUROPEAN OCCUPATION OF AFRICA (IN PARTICULAR GERMANY) OUT OF THE DISCUSSION, THEY FAIL TO RECOGNIZE THE FACTORS THAT HAVE CONTRIBUTED TO THE CONTEMPORARY SITUATION IN AFRICA.

01585 BLAIKIE, 8 ,

THE CAMAOIAN CLEARANCES

CANADIAN FORUM, LXXI (809) (MAY 92), 23.

THERE IS A CLASS OF PEOPLE IN CANADA THAT WANT TO ABROGATE THE FREE TRADE AGREEMENT BUT WANT TO STILL BE ABLE TO VOTE LIBERAL. THIS ARTICLE CLAIMS THAT THIS WILL BE BE A FATAL ILLUSION, FATAL FOR CANADA AND FATAL PERHAPS FOR THE NDP. BUT THE LIBERALS WILL NOT DO ANYTHING SIGNIFICANT TO CHANGE, LET ALONE ABROGATE, THE CAMAD-U.S. FREE TRADE AGREEMENT.

01586 BLAIR, D. CRITERIA FOR PLANHING THE TRANSITION TO LOWER DEFENSE SPENDING

ANNALS OF THE AMERICAN ACADEMY OF POLITICAL AND SOCIAL SCIENCE, (517) (SEP 91), 146-156

THE ANTICIPATED CUTS' IN DEFENSE SPENDING WILL HAVE A LIMITED IMPACT ON THE U.S. ECONOMY. NEVERTHELESS, THE UNITED STATES HAS INVESTED VAST RESOURCES IN DEVELOPING HUMAN AND PHYSICAL CAPITAL FOR MILITARY PRODUCTION. IF DEFENSE REQUIREMENTS, MILITARY PERSONNEL, AND INDUSTRIAL CAPACITY SHIFT RAPIDLY TO NONDEFENSE HORK, IT WILL BE DIFFICULT FOR THEM TO RETURN QUICKLY TO THE MILITARY SECTOR AND, THEREFORE, THE DEFENSE MOBILIZATION BASE WILL HAVE BEEN HEAKENED, IF NOT DESTROYED. THE TRANSITION SHOULD BE PLANNED IN ORDER TO MAINTAIN AN ADEQUATE MOBILIZATION AND SURGE CAPABILITY AND TO ENSURE THAT RESEARCH AND DEVELOPMENT DO NOT ATROPHY.

01587 BLAIS, A.; N NADEAU, R.

THE ELECTÓRAL BUDGET CYCLE

PUBLIC CHOICE, 74(4) (1992), 389-404.

THIS ARTICLE BEGINS WITH A REVIEH OF THE NOW SUBSTANTIAL

LITERATURE ON THE THESIS THAT POLITICIANS MANIPULATE

GOVERNMENTAL OUTPUTS SO AS TO FAVOR THEIR CHANCES OF

REELECTION. IT CONCLUDES THAT WHILE THIS ELECTORAL CYCLE

THESIS WAS INITIALLY OVERSTATED BY ITS PROPONENTS, IT

RETAINS MORE PLAUSIBILITY THAN RECENT CRITICS HAVE ALLOWED

THIS CONCLUSION IS THEN DEMONSTRATED THROUGH AN ANALYSIS OF EXPENDITURES BY THE TEM

01588 BLAIS, A.; NADEAU, $R$

TO BE OR NOT BE SOVERIGNIST: QUBECKERS' PERENHIAL DILEMMA CANADIAN PUBLIC POLICY--ANALYSE DE POLITIQUES, 188(1) (MAR $92)$, 89-103.

THIS PAPER EXAMINES THE REASONS HHICH INDUCE FRANCOPHONE QUEBECKERS TO SUPPORT OR REJECT SOVEREIGNTY-ASSOCIATION OR INDEPENDENCE. FEARS ABOUT POTENTI IAL ECONOMIC CONSEQUENCES OF SEPARATION PLAY AN IMPORTANT ROLE. SUPPORT FOR SOVEREIGNTY REFLECTS A GENERAL WILLINGNESS TO GIVE THE GOVERMMENT OF QUEBEC SOLE RESPONSIBLITY FOR THE BULK OF DOMESTIC POL ICIES,
WITH THE EXCEPTION OF ECONOMIC POLICIES ABOUT WHICH OPINIONS ARE AMBIVALENT OR DIVIDED.

01589 BLAKE, $S$

TOTAL ITARIANISM IN SANDINISTA NICARAGUA

STUDIES IN CONFLICT AND TERRORISM, 15(3) (1992), 201-224.

FROM ITS INCEPTION, A DEBATE RANGED IN POLICY AND

ACADEMIC CIRCLES AS TO THE FUNDAMENTAL POLITICAL

IDEOLOGICAL, AND STRUCTURAL NATURE OF THE SANDINISTA REGIME. THIS PAPER EMPLOYS THE TOTALITARIAN MODEL OF ANALYSIS AND EXAMINES SANDINISTA IDEOLOGY, SANDINISTA PARTY INSTITUTIONS, AND THE INSTRUMENTS OF COERCION. THEY SHOH HOH ANY AND ALL RIVALS TO THE FRONT POWER WERE PENETRATED, HARASSED, AKD IN SOME CASES CRUSHED. THE PAPER FINDS THAT BY CONSTRUCTING AM ELABORATE PARTY-ARMY-POLICE NEXUS, AND BY SEEKING TO ELABORATE PARTY-ARMY-POLICE NEXUS, AND BY SEEKING TO
PENETRATE EVERY ASPECT OF LIFE IN NICARAGUA, THE SAMDINISTA REGIME MET THE DEFINITION OF IN NICARAGUA, THE SAMDINISTA REGIME MET THE DEFINITION OF TOTALITARIAN AND THAT
WITHIN THE NUMEROUS EXPERIMENTS OF THE 2OTH CENTURY.

01590 BLAKELY, E.J.

CHANGING PLACES: AMERICAN PLANNING POLICY FOR THE 1990'S JOURNAL OF URBAN AFFAIRS, 14(3-4) (1992), 423-446.

MILLIONS OF AMERICANS HAVE CAST THEIR URBAN AGENDA BALLOTS BY VOTING WITH THEIR FEET ANO MOVING OUT OF THE INNER CITIES. AS THE NATION DIVIDES, IT REDUCES ITS CAPACITY TO ADDRESS THE FUNDAMENTAL REQUIREMENTS OF NATIONAL ASPIRATIONS FOR A JUST AND ECONOMICALLY EQUITABLE SOCIETY. THE LOS ANGELES RIOTS WERE A VIVID REFLECTION OF THE FLAWED
LOGIC OF CURRENT URBAN POLICY THAT INCREASES SOCIAL, ECONOMIC, AND PHYSICAL DISTANCE. IN THIS PAPER, THE AUTHORS OUTLINE THE PROBLEMS AND MAKE RECOMMENDATIONS FOR URBAN PLANNING AND POLICY TO ADORESS THE ISSUES OF URBAN DECLINE. BUT THERE ARE NO PANACEAS IN THEIR PRESCRIPTIONS. ONLY A TOTAL RETHINKING OF THE NATION'S PRIORITIES ANO A REINVESTMENT IN SOCIAL AND HUMAN CAPITAL CAN TRANSFORM URBAN LIFE. DUE TO THE MOMENTARY PUBLIC CONCERN OVER LOS ANGELES AND OTHER BIG CITIES, THE NATIONAL GOVERMMENT HAS PERHAPS ITS BEST AND LAST CHANCE TO ALTER THE FORTUNES OF U.S. URBAN AREAS.

01591 BLANCPAIN, J.

THE UNRESOLVED LEGACY OF THE DEBT CRISIS

SWISS REVIEW OF WORLD AFFAIRS, 42(7) (OCT 92), 28-29. AUGUST 1992 MARKED THE IOTH ANMIVERSARY OF MEXICO'S UNILATERAL FREEZE ON THE SERVICING OF ITS FOREIGN DEBTS, WHICH LAUNCHED THE GLOBAL DEBT CRISIS. THE BATTLE OF THE DEBT CRISIS HAS BEEN FOUGHT IN THREE PHASES. THE FIRST STEP WAS TO PROVIDE SHORT-TERM BRIDGING CREDITS TO INSURE THE ORDERLY FUNCTIONING OF THE INTERNATIONAL PAYMENTS SYSTEM. SECOND PHASE INVOLVED THE EFFORT TO PROVIDE THE DEBTOR NATIONS HITH FIMANCIAL REL IEF THROUGH DEBT RESCHEDUL ING AGREEMENTS AND, AT THE SAME TIME, TO HELP THEM RETURN TO AGREEMENTS AND, AT THE SAHE TIME, TO HELP THEM RETURN TO STABLE ECONOMIC CONDITIONS BY MEANS OF GROWTH-ORIENTED ADJUSTMENT PROGRAMS. FINALLY, A NUMBER OF INDUSTRIALIZED NATIONS ANMOUNCED THE REMISSION OF OUTSTANDING DEVELOPMENT CREDITS, OR THEIR CONVERSION INTO OUTRIGHT GRANTS.

01592 BLANK, S

NEW STRATEGISTS HHO DEMAND THE OLD ECONOMY ORBIS, 36(3) ( SUM 92), 365-378.

EXAMINING THE STRATEGIC DEBATE IN RUSSIA, ONE FINDS SOME GROUPS MOTIVATED BY PAROCHIAL SERVICE INTERESTS. PARTICULAR TO RUSSIA IS THE EXISTENCE OF THREE INTERCONHECTED DEBATES CONCERNING THE TECHNOLOGY OF HARFARE, MILITARY DOCTRINE, AND THE POL ITICAL-ECONOMIC UNDERPINMINGS OF SECURITY. IT WAS DESERT STORM THAT GAVE THEM A MORE THAN THEORETICAL INTEREST BY DECISIVELY UNDERMINING THE TRADITIONAL OUTLOOK OF THE SOVIET MILITARY ON ALL LEVELS. THIS ARTICLE EXPLORES THE LESSONS OF DESERT STORM. THE DEBATES OF TECHNOLOGY, DEFENSIVENESS, ANO POLITIICS ARE EACH EXAMINED. IT CONCLUDES THAT DESPITE THE AUGUST 1991 REVOLUTION, A DETERMINED STRUGGLE OVER REFORMING THE ENTIRE STRUCTURE AND COMPOSITION OF THE MILTARY ECONOMY DOCTRINE, AND FORCE ACOUISITION AND STRUCTURE IS STILL RAGING WITH NO CLEAR END IN SIGHT.

01593 BLANK, $S$.

RUSSIA AND IRAN IN A NEW MIDDLE EAST

MEDITERRANEAN QUARTERLY: A JOURNAL OF GLOBAL ISSUES, 3(4) (FAL 92), 108-129.

RUSSIA SHARES WITH IRAN THE STATUS OF BEING ONE OF THE MOST UNPREDICTABLE ACTORS IN THE MIDOLE EAST. THIS ARTICLE EXPLORES THESE NEIGHBOR'S RELATIONSHIP WHICH IS VOLATILE AND DYNAMIC AND IS MOVING INTO UNCHARTED WATERS. IT SUGGESTS THAT THE RELATIONSHIP AND ITS AGENDA ARE CRITICAL NOT ONLY FOR THESE THO COUNTRIES BUT FOR THE OTHER NEW STATES EMERGING FROM THE FORMER SOVIET UNION AND FROM THE ESTABLISHED NATIONALS OF THE MIDOLE EAST AS WELL. IT CONCLUDES THAT RUSSO-IRANIAN TIES COULD FORCE RUSSIA INTO UNHAPPY CHOICES BETWEEN OR AMONG IRAN AND OTHER LOCAL ALLIES AND EVEN THE UNITED STATES.

01594 BLANK, S

THE HEAVENLY MISSION OF SOVIET SPACE FORCES

DEFENSE ANALYSIS, 7(1) (MAR 91), 39-62.

THIS ARTICLE DISCUSSES THE POSSIBILITY THAT SOVIET MILITARY STRATEGY WOULD ALLOW SOVIET FORCES TO FIGHT IN, TO, AND FROM SPACE. EVIDENCE IS PROVIDED TO BACK THIS UP, INCLUDING AN ENTRY IN THE 1986 MILITARY ENCYCLOPEDIA DICTIONARY LABELING SPACE A THEATER OF STRATEGIC MILITARY OPERATIONS (TVD). THE AUTHOR DESCRIBES THREE POSSIBLE STRATEGIC MISSIONS FROM THAT TVD. U.S. REACTION TO THE

01595 BLANKE, B.; BENZLER, S.; HEINELT, H. EXPLAINING DIFFERENT APPROACHES TO LOCAL LABOUR MARKET POL ICY IN THE FRG

POLICY AND POLITICS, 20(1) (JAN 92), 15-28.

THE AUTHORS EXAMINE A CENTRAL PROBLEM OF LABOUR MARKET POL ICY IN THE FEDERAL REPUBL IC OF GERMANY AND OTHER COUNTRIES: HOW TO COORDINATE DIFFERENT POLICY LEVELS WITH THEIR SPECIAL PROGRAMS AND MANY LOCAL ACTORS TO DEVELOP EMPLOYMENT PROGRAMS APPROPRIATE TO A LOCALITY. WHILE FACING THE FINANCIAL DILEMMA OF FALLING TAX RECEIPTS AND RISING EXPENDITURES AND WHILE CENTRAL GOVERNMENT PREFERS NONDECISIONS, LOCAL AUTHORITIES ARE OBLIGED TO MAKE USE OF THE "RESOURCES OF COORDINATION"--DIFFERENT POL ICIES AND THEIR ASSOCIATED IMPLEMENTATION MEASURES--AND OF LOCAL ACTORS.
USING THE EXAMPLES OF BREMEN, HANOVER, DORTMUND, AND MUNICH, THE AUTHORS IDENTIFY THE FACTORS AND POLITICAL PROCESSES THAT SHAPE LOCAL POLICIES TO COMBAT UNEMPLOYMENT. 
01596 BLANKENSHIP, J.

ECUADOR: AN UNQUIET DISAPPEARANCE

REPORT ON THE AMERICAS, XXVI (2) (SEP 92), 12-15.

THE SUDDEN DISAPPEARANCE OF TWO TEEN-AGED BOYS IN QUITO PROMPTED AN INTERNATIONAL HUMAN RIGHTS COMMISSION TO INVESTIGATE THE CIRCUMSTANCES. AFTER THE COMMISSION CONCLUDED THAT THE EDUCADORIAN NATIONAL POLICE (SIC) HAD KILLED THE BOYS, PRESIDENT ROORIGO BORJA ISSUED A DECREE ABOLISHING THE SIC. BORJA ALSO ANNOUNCED THAT THE INTERNATIONAL COMMISSION WOULD INVESTIGATE ANOTHER 30 UNEXPLAINED DISAPPEARANCES.

01597 BLASER, A.W.

HOW TO ADVANCE HUMAN RIGHTS WITHOUT REALLY TRYING: AM ANALYSIS OF NONGOVERNMENTAL TRIBUNALS

HUMAN RIGHTS OUARTERLY, $14(3)$ (AUG 92), 339-370.

WHILE MAINTAINING A FOCUS ON WAR CRIMES, NONGOVERNMENTAL TRIBUNALS HAVE ALSO CONDEMNED A FULL RANGE OF VIOLATIONS OF CIVIL, POLITICAL AND ECONOMIC RIGHTS. THESE TRIBUNALS HAVE BEEN DESCRIBED AS "INTERNATIONAL COLLEGES CONSISTING OF HELLBEEN DESCRIBED AS "INTERNATIONAL COLLEGES CONSISTING OF WELL
KNOWN PERSONS. WHICH DO NOT HAVE LEGAL POWER, BUT AIM KNOWN PERSONS 9 . WHICH DO NOT HAVE LEGAL POWER, BUT AIM PAPER ASSESSES THAT CONTRIBUTION IIS PURPOSE IS FOURFOLD: FIRST TO TRACE THE DEVELOPMENT OF NONGOVERMMENTAL TRIBUNAL FIRST, TO TRACE THE DEVELOPMENT OF NONGOVERNMENTAL TRIBUNAL
ACTIVITY; SECOND, TO IDENTIFY AND DESCRIBE ORGANIZATIONS AND INDIVIDUALS WHO EXEMPLIFY THE VISIONARY SPIRIT OF THE TRIBUNALS; THIRD, TO ANALYZE THE TRIBUNALS AS QUASI-LEGAL PROCEEDINGS; AND FOURTH, TO ASSESS THE TRIBUNALS' PRESENT AND POTENTIAL IMPACT.

01598 BLAUSTEIN, $S$.

BURMA SHAVE

NEW REPUBLIC, 206(19) (MAY 92), 17-18

THE EXODUS OF TENS OF THOUSANDS OF BURMESE MUSLIMS INTO SOUTHEASTERN BANGLADESH HAS ENTANGLED ONE OF THE WORLD'S MOST OPPRESSED PEOPLES HITH ONE OF THE WORLD'S POOREST. SINCE BURMA GAINED INDEPENDENCE IN 1948, RANGOON HAS CARRIED OUT PERIODIC WAVES OF TERROR TARGETED AT EVICTING BURMA'S ARAKANESE MUSLIM POPULATION. THE CENTRAL GOVERNMENT HAS LONG SURVIVED BY BRUTALLY SUPPRESSING ETHNIC AND RELIGIOUS MINORITIES. THE LATEST SHEEP, CALLED "OPERATION PROSPEROUS LAND," BEGAN IN LATE 1991 AS PART OF RANGOON'S FIERCEST ANTI INSURGENCY CAMPAIGN SINCE 1988.

01599 BLAY-AMIHERE, $K$.

GHAMA SETS FOR NAM SUMMIT

NEW AFRICAN, (282) (MAR 91 ), 22

FOREIGN MINISTERS FROM THE 101 NON-ALIGNED STATES WILL

MEET IN ACCRA, THE CAPITAL OF GHANA, IN SEPTEMBER 1991. THE MEET IN ACCRA, THE CAPITAL OF GHANA, IN SEPTEMBER 1991.
CHOICE OF GHANA IS REGARDED AS A TRIBUTE TO THE ROLE OF KWAME NKEUMAH WHO FOUNDED THE NON-ALIGNED MOVEMENT IN 1961. GHANA NOW FACES THE DAUNTING TASK OF UPGRADING ITS FACILITIES TO ACCOMMODATE THE SUMMIT. THE PROPOSALS HAVE MET FITH CRITICISH OF EXTRAVAGANCE IN A TIME OF MISERY.

01600 BLAY, S.K.N.

NEW TRENDS IN THE PROTECTION OF THE ANTARCTIC ENYIRONMENT: THE 1991 MADRID PROTOCOL

AMERICAN JOURNAL OF INTERNATIONAL LAW, 86(2) (APR 92), 377-399.

THE AUTHOR DISCUSSES THE 1991 MAORIO PROTOCOL ON ENVIRONMENTAL PROTECTION TO THE ANTARCTIC TREATY AND ITS ANTECEDENT, THE 1988 CONVENTION FOR THE REGULATION OF ANTARCTIC MINERAL RESOURCE ACTIVITIES. HE LOOKS AT THE REACTION OF VARIOUS COUNTRIES, INCLUDING FRANCE AND AUSTRALIA, TO THE INTERMATIONAL NEGOTIATIONS.

01601 BLENEFELD, $M$.

FINAMCIAL DEREGULATION: DISARMING THE MATION STATE STUDIES IN POLITICAL ECONOMY: A SOCIALIST REYIEH, $37(1)$ (SPR 92), 31-58.

THIS DISCUSSION OF THE BENEFITS OF DEREGULATION LEADS TO THE CONCLUSION THAT FINANCIAL DEREGUATION CARRIES LARGE AND INCALCULABLE RISKS AND THAT ACCEPTANCE OF THESE RISKS CANHOT BE JUSTIFIED ON EFFICIENCY GROUNDS. THE PROMISE OF LARGE EFFICIENCY GAINS IS NOT SUPPORTED BY THE AVAILABLE EVIDENCE AND CANNOT LEGITIMATELY BE DERIVED FROM THEORY. THE CASE FOR FURTHER DEREGULATION CAN ONLY REST ON THE CLAIM THAT IT MUST BE ACCEPTED BECAUSE IT IS INEVITABLE. THE AUTHOR CONCLUDES THAT IF CANADA ACCEPTS THE CHALLENGE OF BECOMING COMPETITIVE WITHIN THE PARAMETERS DETERMINED BY TODAY'S UNREGULATED GLOBAL ECONOMY, THEY WILL EITHER FAIL, OR WILL SUCCEED THROUGH ACTIONS THAT WILL DESTROY MOST OF THAT WHICH IS WORTH PRESERVING.

01602 BLENSEN, $H$

THE NEW ISOLATIONISM
SOCIETY, 29(6) (SEP 92), 5-8.

THE NEW LEFT BELIEYES THAT THE US USUALIY ACTS FOOL ISHLY OR WITH EVIU INTENT IN THE WORLD AND FOR THE ISOLATIONISTS ON THE RIGHT, IT IS THE WORLD WHICH IS EVIL AND THREATENS TO PULL THE U.S. INTO IT. HOWEVER, THE RIGHT AND LEFT AGREE THAT AMERICAN INTERVENTIONISM USUALLY WORKS OUT TO $8 E$ COUNTERPRODUCTIVE TO AMERICAN GOALS. AFTER
OBSERVING THAT ISOLATION ON THE RIGHT WAXES AND WANES WITH THE STRENGTH OF THE AMERICAN ECONOMY AND THAT AN EXTENSIVE FOREIGN POLICY BASED ON A WEAK DOMESTIC ECONOMY CANNOT BE SUSTAINED, THIS ARTICLE CONCLUDES THAT FOREIGH POLICY DEBATES WILL BE PLAYED OUT WITHIN THE CONTEXT OF THE INTERNATIONAL AND DOMESTIC POLITICAL ECONOMY.

01603 BLINDER, E.; CHEUNG, C. ; KRINSKY, I SOUTH AFRICAN DIVESTMENT: THE CAMADIAN CASE CANADIAN PUBLIC POLICY--ANALYSE DE POLITIQUES, XVIII(1) (MAR 91), 25-36. THE DIVESTMENT OF STOCKS OF CANADIAN COMPANIES WHICH HAVE BUSINESS CONMECTIONS WITH SOUTH AFRICA HAS OFTEN BEEN SUGGESTED AS A WAY TO BRING ABOUT CHANGES IN THAT COUNTRY. THIS STUDY EVALUATES THE COST OF DIVESTMENT TO AN 'AVERAGE' CANADIAN PENSION FUND THE GENERAL IMPORTANCE OF SOUTH CANADIAN PENSION FUND THE GENERAL IMPORTANCE OF SOUTH AFRICAN STOCKS IN INTERNATIONAL PORTFOLIO DIVERSIFICATION IS FIRST EXAMINED. THE STUOY THEN GOES ON TO IOENTIFY SPECIFIC RETURN CHARACTERISTICS OF THE RESULTING PENSION PORTFOLIO IS RETURN CHARACTERISTICS OF THE RESULTING PENSION PORTFOLIO IS SCRUTINIZED AFTER EXCLUDING THE OIVESTMENT CANDIDATES FROM AN AVERAGE CANADIAN PENSION FUND. POLICY IMPLICATIONS ARE
SUGGESTED BASED ON THE DIFFERENCE IN THE PERFORMANCE OF THE FUND BEFORE AND AFTER THE REMOVAL OF DIVESTMENT CANDIDATES.

01604 8LITZ, M.; GAFFNEY, F.J. JR.; KIRKPATRICK, J.J.; LIND, M.; MORITZ, A.; MOSER, C.A.; PIPES, D.; PIPES, R.

TO DIE IN SARAJEVO

POLICY REVIEW, (62) (FAL 92), 37-40.

THE AUTHORS ENDEAVOR TO DEFINE U.S. INTERESTS IN THE STATES THAT FORMERLY MADE UP YUGOSLAVIA AND TO SPECIFY WHAT U.S. POLICY SHOULD BE TOWARD THE NEW BALKAN STATES.

01605 BLIX, H.

VERIFICATION OF NUCLEAR NONPROLIFERATION: THE LESSON OF IRAQ

WASHINGTON QUARTERLY, 15(4) (FAL 92), 57-66.

THIS ESSAY OFFERS AN INTERNATIONAL PERSPECTIVE OF THE CHANGING TIMES AND CHANGING CIRCUMSTANCES NOW INFLUENCING THE WORLD'S ATTEMPTS TO CONTROL THE SPREAD OF NUCLEAR WEAPONS. THE VIEWPOINTS ARE FROM THE VANTAGE POINT OF THE INTERNATIONAL ATOHIC ENERGY AGENCY, WHOSE EXPERIENCE IN IRAO MAY PROYIDE VALUABLE LESSONS FOR STRENGTHENING THE INSTITUTIONAL BASIS OF MULTILATERAL EFFORTS. IT ADDRESSES INSTITUTIONAL BASIS OF MULTILATERAL EFFORTS. IT ADDRESSES THE LESSONS FROM THE IRAQI CASE AND SOME SPECIAL QUEST
AND CONCERNS. IT CONCLUDES THAT THE GENERAL TREND IS AND CONCERNS. IT CONCLUDES THAT THE GENERAL TREND IS
POSITIVE FOR MAKING THE NONPROLIFERATION REGIME MORE POSITIVE FOR
EFFECTIVE.

01606 BLOCK, F.

CAPITALISM HITHOUT CLASS POHER

POLITICS AND SOCIETY 20(3) (SEP 92), 277-304.

THE SUDDEN END OF THE COLD HAR CREATES AN OPPORTUNITY FOR A RENEWAL OF THE UTOPIAN IMAGINATION THAT HAS BEEN IMPRISONED BY THE CENTURY-LONG STRUGGLE BETWEEN CAPITALISM AND SOCIALISM. THIS ARTICLE PROPOSES A REDESIGNING OF EXISTING MARKET SOCIEITES THAT DELIBERATELY AVOIDS THE VISIONS OF PERFECTION PROVIDED BY ABSTRACT UTOPIAS. IT PROPOSES REFORMS OF THE FINANCIAL STRUCTURE OF THE U.S. ECONOMY. THE PURPOSE OF THE REFORMS IS TO REORGANIZE THE FINANCIAL SYSTEM TO ELIMINATE THE STRUCTURAL POHER OF WEALTHHOLDERS TO INFLUENCE POLITICS WHILE ALSO RETAINING THE ADVANATAGES OF A DECENTRALIZED SYSTEM FOR ALLOCATING FINANCIAL CAPITAL. BECAUSE THE WAYS IN WHICH FINANCIAL INSTITUTIONS OPERATE HAVE PROFOUND POLITICAL AND ECONOMIC CONSEQUENCES, REFORMING THOSE INSTITUTIONS CAN SIMULTANEOUSLY INCREASE ECONOMIC EFFICIENCY AND OPEN UP POLITICAL SPACE FOR AN ONGOING PROCESS OF REFORM.

01607 BLOCK, F.

THE KEYNES MUTINY

TIKKUN, 7(2) (MAR 92), 17-18; 20.

GEORGE BUSH HAS THROWN OVERBOARD ANY HOPE OF A SERIOUS RECOVERY IN HIS EAGERNESS TO MAKE HARD TIMES KEEP PAYING FOR THOSE WHO GET RICH ON OTHER PEOPLE'S MONEY, CHARGES FRED BLOCK. JOHN MAYNARD KEYNES INSISTED THAT GOVERMMENTS ONLY DEFEAT THEIR OWN PLANS FOR RECOVERY FROM AN ECONOMIC DOWNTURN WHEN THEY INSTITITE AUSTERITY POLICIES. THESE TEACHINGS HAVE BEEN COMPLETELY FORGOTTEN. BLOCK CONCLUDES THAT THE UNNECESSARY HUMAN SUFFERING CAUSED BY THE CURRENT RECESSION IS A PATHETIC TRIBUTE TO THE POTENCY OF
MISTAKEN IDEAS THAT KEYNE CRITICIZED IN THE $1930 \mathrm{~S}$.

01608 BLOCK, $W$.

LABOR RELATIONS, UNIONS, AND COLLECTIVE BARGAINING: A LABOR RELATIONS, UNIONS, AND
POLITICAL ECONOMIC ANALYSIS

JOURNAL OF SOCIAL, POLITICAL AND ECONOMIC STUDIES, $16(4)$ (WIN 91) 477-507.

SOUND PUBLIC POLICY, IN THE BEST SENSE, CONSISTS NOT OF ALLOWING ILLEGITIMATE UNION ACTIVITIES, COUPLED WITH RESISTING THEM BY THE IMPOSITION OF SECRET BALLOTS, BUT RATHER OF STRIPPING THEM OF ALL COERCIVE POWERS. THE ONLY JUST UNIONS ARE THOSE THAT LIMIT THEIR ACTIVITIES TO BOYCOTTS, MASS WALKOUTS, AND SIMILAR ACTIVITIES THAT ANY ONE 
PERSON HAS A RIGHT TO ENGAGE IN. HHEN LABOR ORGANIZATIONS TRANSCEND THESE LIMITATIONS. THEY MUST BE REINED IN, IF ECONOMIC JUSTICE IS TO PREVAIL.

01609 BLODGETT, J.

KOREA: EXPLORING THE PATHS TO PEACE AND REUNIFICATION WASHINGTON QUARTERLY, 15(3) (SUM 92), 171-184.

THIS ARTICLE IS AN ATTEMPT TO PUT FLESH ON THE DREAM OF KOREAN UNIFICATION. IT CHARTS THE FLOW LINES OF MUTUAL ACCOMMODATION BETHEEN THE THO KOREAS THAT COULD PRODUCE A SINGLE KOREAN NATION WITH THE INTERNAL HARMONY, STRENGTH, AND COMMON PURPOSE TO BECOME A MAJOR FORCE FOR PEACE AND GROWTH IN THE PACIFIC WORLD. ITS TIMING IS MOTIVATED BY THE PROPOSITION THAT A VISION--HOWEVER SPECULATIVE-OF THE KOREAN UNITY THAT COULD LIE AHEAD WILL FURTHER ENHANCE THE MOMENTUM TOWARD THE INTERMEDIATE GOAL OF A NORTH-SOUTH PEACE TREATY.

01610 BLOOM, S.

IS LABOUR STILL LEFT?

IS LABOUR STILL LEFT?
FREEDOM REVIEW, 23(2) (MAR 92), 15-18

THE BRITISH LABOUR PARTY YIÉWS 1992 AS A YEAR OF OPPORTUNITY WHEN IT COULD REGAIN CONTROL OF THE GOVERMMENT. HAVING RID ITSELF OF MOST OF ITS FRINGE ELEMENTS, THE PARTY IS ENDEAVORING TO PRESENT A LESS RADICAL, MORE ACCEPTABLE IMAGE.

01611 BLUM, L.

BETHEEN FEMINISM AND LABOUR: THE SIGNIFICANCE OF THE COMPARABLE WORTH MOVEMEN

UNIVERSITY OF CALIFORNIA PRESS, 1991, 249

THE COMPARABLE WORTH MOVEMENT IN AMERICA CAME AFTER THE DEVELOPMENT OF A WIDESPREAD MIDOLE CLASS FEMINIST MOVEMENT AND THE RELATED ADOPIION OF AFFIRMATIVE ACTION PROGRAMS TO ENHANCE THE OPPORTUNITIES FOR LARGELY MIDDLE CLASS HOMEN TO MOVE UP INTO TRADITIONAL MALE JOBS. THIS BOOK ARGUES THAT COMPARABLE WORTH IS MUCH MORE RADICAL THAN WAS THE AFFIRMATIVE ACTION PROGRAM. THE MOVEMENT ADDRESSES CLASS AS WELL AS GENDER ISSUES AND HAS THUS A MORE IMMEDIATE INTEREST TO HORKIMG CLASS WOMEN THAN THE EQUAL OPPORTUNITIES AGENDA. THE BOOK EXAMINES THE STRUGGLE FOR COMPARABLE WORTH IN TWO COUNTIES IN NORTHERN CALIFORNIA; MAKES COMPARISONS BETWEEN THE MOVEMENTS IN THE UNITED STATES AND GREAT BRITAIN; AND DISCUSSES IN MORE GENERAL TERMS THE RADICAL OR CONSERVATIVE POTENTIAL OF COMPARABLE WORTH.

01612 BLUM, Y.Z.

U.N. MEMBERSHIP OF THE NEW YUGOSLAYIA: CONTINUITY OR BREAK? AMERICAN JOURHAL OF INTERNATIONAL LAH, 86(4) (OCT 92), 830-833.

AFTER SLOVENIA, CROATIA, AMD BOSNIA AND HERCEGOVINA HERE ADMITTED TO THE UNITED MATIONS IN MAY 1992, THE U.S.

AMBASSADOR TO THE U.N. DECLARED THAT SERBIA AND MONTENEGRO "SHOULD BE REOUIRED TO APPLY FOR MEMBERSHIP AND BE HELD TO THE SAME STANDARDS AS ALL OTHER APPLICANTS. SPECIFICALLY, THE SAME STANDARDS AS ALL OTHER APPLICANTS. SPECIFICALLY, THEY YUGOSLAVIA' IS A PEACE-LOVING STATE." THIS ATTEMPT TO
OF YLL INTO OUESTION THE LEGITIMACY OF RUMP YUGOSLAVIA AS A CALL INTO QUESTION THE LEGITIMACY OF RUMP YUGOSLAVIA AS A MEMBER OF THE U.N. IS AN EXPRESSION OF THE INTERNATIONAL REVULSION TO THE TRAGIC EVENTS IN YUGOSLAVIA, RESPONSIBILIT
FOR WHICH HAS GENERALLY BEEN LAID AT THE DOORSTEP OF THE SERBIAN-DOMINATED GOVERNMENT IN BELGRADE. WHAT MUST BE QUESTIONED IS THE COMPATIBILITY OF THE VIEWS EXPRESSED BY THE U.S. AMBASSADOR WITH THE PRACTICE THAT HAS DEVELOPED AND CRYSTALLIZED IN THIS REGARD SINCE THE U.N. HAS ESTABLISHED.

01613 BLUMENTHAL, S.

BILL AND TED

NEW REPUBLIC, 206(7) (FEB 92), 13, 16.

THE AUTHOR DISCUSSES THE REPORTS OF GOVERNOR BILL

CLINTON'S EXTRAMARITAL AFFAIRS, HOW THE CLINTON CAMPAIGN

HANOLED THEM, AND HOW THEY AFFECTED THE CAMPAIGN.

01614 BLUMENTHAL, S.

BROWNIAN MOTION

NEW REPUBLIC, 206(9) (MAR 92), 18-20.

THE AUTHOR PROFILES FORMER CALIFORNIA GOVERMOR JERRY BROHN AND EVALUATES HIS CAMPAIGN FOR THE 1992 DEMOCRATIC PRESIDENTIAL NOMINATION.

01615 BLUMENTHAL, S.

BUSH'S PLACE IN HISTORY: RUBBERS

BUSH'S PLACE IN HISTORY: RUBBERS

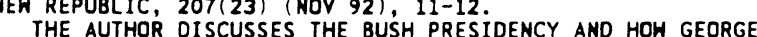
BUSH CONDUCTED HIMSELF AS PRESIDENT AND AS POLITICIAN.

01616 BLUMENTHAL, S.

FIRE BELL: CLINTON AND THE RIOT

NEH REPUBLIC, $206(21)$ (MAY 92), 11-12, 14

THE AUTHOR LOOKS AT HOW BILL CLINTON RESPONDED TO THE RIOTS IN LOS ANGELES FOLLOWING THE RODNEY KING VERDICT ANO HOW THE RIOTS MAY REORIENT ISSUES IN THE PRESIDENTIAL CAMPAIGN.
01617 BLUMENTHAL, S.

GOING NATIVE

NEW REPUBLIC, 207(14) (SEP 92), 10-11.

THE AUTHOR LOOKS AT PRESIDENT GEORGE BUSH'S RE-ELECTION CAMPAIGN STRATEGY AND AT HOW GOVERHOR BILL CLINTON IS RESPONDING TO IT.

01618 BLUMENTHAL, $S$.

HE'S BA-A-CKI

NEW REPUBLIC, $207(17)$ (OCT 92), 12, 14-15

THE AUTHOR DISCUSSES THE RETURN OF BILLIONAIRE H. ROSS

PEROT TO THE 1992 PRESIDENTIAL ELECTION CAMPAIGN.

01619 BLUMENTHAL, S.

I, BAKER

NEW REPUBLIC, 207(19) (NOV 92), 17-21

DURING THE LAST WEEKS OF HIS PRESIDENTIAL RE-ELECTION

BID, GEORGE BUSH TURNED TO JAMES BAKER TO RESCUE HIS

CAMPAIGN AND PUBLICLY PROMISED TO GIVE BAKER A YERY

INFLUENTIAL ROLE AS A SORT OF DOMESTIC POLICY CZAR IN HIS

SECOND TERM. BUT THE CONVENTIONAL VIEH OF THIS STRATEGY AS

TESTIMONY TO THE FAITHFUL FRIENDSHIP BETWEEN BUSH AND BAKER

IS A FANTASY. THEIR FRIENDSHIP HAS BEEN SHAPED BY THEIR

QUEST FOR POWER. IN THIS FINAL GAMBIT FOR POWER. THEY REMAIM

TRUE TO THE RUTHLESSNESS AND MUTUAL SUSPICION THAT HAS

CURDLED THEIR RELATIONSHIP ALMOST FROM THE BEGINNING.

01620 BLUMENTHAL, S.

JUST SAY

NEW REPUBLIC, 206 (25) (JUN 92), 11-12

THE AUTHOR LOOKS AT $H$. ROSS' PEROT'S SUDDEN UPSURGE IN SUPPORT IN CALIFORNIA AND HOW THE UNDECLARED PRESIDENTIAL CANDIDATE'S GAY-BASHING IS LIKELY TO AFFECT HIS CHANCES IN NOVEMBER 1992.

01621 BLUMENTHAL, S. LOSERS

NEW REPUBLIC, 206 (18) (MAY 92), 15-16, 18-19.

IN HASHIMGTON, MUCH OF THE CONGRESSIONAL DEMOCRATIC PARTY AND THOSE ARRAYED AROUND IT ARE RESENTFUL OF THE PRIMARY CAMPAIGN SPECTACLE. BEHIND THEIR PANIC ABOUT HAVING BILL CLINTON AS THE 1992 DEMOCRATIC PRESIDENTIAL NOMINEE LIES PANIC ABOUT THEMSELVES. ALREADY SUFFERING FROM A HOST OF CONGRESSIONAL SCANDALS, THEY SEE CLINTON DRAGGING A CHAIM OF ADOITIONAL CRISES THEIR WAY.

01622 BLUMENTHAL, S.

ON HINGS OF BULL

NEH REPUBLIC, 207 (3-4) (JUL 92), 12, 13, 18.

THE AUTHOR SUMMARIZES THE ACCOUNT' OF' H. ROSS PEROT'S

RESCUE OF THO AMERICANS FROM AN IRANIAN PRISON AS RECOUNTED

IN "ON WINGS OF EAGLES," A BOOK BY KEN FOLLETT. HE ARGUES

IN "ON WINGS OF EAGLES, A BOOK BY KEN FOLLETT. HE ARGUES

PENCHANT FOR SELF-DRAMATIZATION AND DISTORTION OF THE FACTS

01623 BLUMENTHAL, $S$

NEW REPUBLIC, 207(7) (AUG 92), 16-17.

ABOVE EVERYTHING ELSE, BILL CLINTON STANDS FOR A RETURN TO GOVERNMENT AS AN AGENT FOR HELPING THE MIDOLE CLASS. HE HAS SHIFTED AHAY FROM THE RHETORIC OF THE CONGRESSIONAL DEMOCRATS WHO TRADITIONALLY CHAMPION SOCIAL WELFARE PROGRAMS. HE WANTS TO TRANSFORM THE UNDERCLASS INTO MIDDLE-CLASS CITIZENS. ALL THIS, AND MUCH MORE, DISTANCES CLINTON FROM THE DEFAMATORY IMAGe OF THE "LIBERAL." BUT IN HIS FUNDAMENTAL BELIEF IN THE EFFICACY OF GOVERNMENT--NOT AS A SUBSTITUTE FOR ALL OTHER INSTITUTIONS BUT IN ITS ABILITY TO MAKE ALL SORTS OF SOCIAL AND ECONOMIC CHANGES--CLINTON IS IN THE TRADITIONAL MAINSTREAM OF HIS PARTY.

01624 BLUMENTHAL, S.

PEROTNOIA

NEW REPUBLIC, 206(24) (JUN 92), 23, 26-29.

H. ROSS PEROT IS A MAN WITH NO FIXED POLITICAL BELIEFS AND THE TEMPERAMENT OF A ZEALOT. HE OPERATES ACCORDING TO THE PRINCIPLES OF LOYALTY AND BETRAYAL, WHICH HE APPLIES MERCILESSLY TO EVERYONE BUT HIMSELF. IN THE PAST, HE HAS SHOWN A WILLINGNESS TO FINANCE COVERT OPERATIONS, SUCH AS AH ATTEMPT TO RANSOM THE CIA BUREAU CHIEF IN LEBANON WHO WAS KIDNAPPED BY HEZBOLLAH TERRORISTS.

01625 BLUMENTHAL, $S$.

SPRINGTIME' FOR BUCHANAM

SPRINGTIME FOR BUCHANAN

THE AUTHOR LOOKS AT THE 1992 NEW HAMPSHIRE PRIMARY

CAMPAIGN AND COMPARES THE MESSAGES AND CAMPAIGNING STYLES OF PRESIDENT GEORGE BUSH AND CHALLENGER PAT BUCHANAN.

01626 BLUMENTHAL, $S$.

THE AMOINTED

NEW REPUBLIC, 206 (5) (FEB 92), 24-27.

THE AUTHOR EXPLAINS WHY ARKANSAS GOVERNOR BILL CLINTON BECAME THE FRONTRUNNER FOR THE DEMOCRATIC NOMIMATION FOR PRESIDENT EVEN BEFORE THE FIRST VOTES WERE CAST IN THE NEH 
HAMPSHIRE PRIMARY.

01627 BLUMENTHAL, S.

THE BUSH WHIMPER

NEW REPUBLIC, $207(11-12)$ (SEP 92), 28, 30, 32 ;

THE AUTHOR DISCUSSES PRESIDENT GEORGE BUSH'S POLITICAL

STYLE AND HIS 1992 CAMPAIGN STRATEGY FOR RE-ELECTION.

01628 BLUMENTHAL, S.

THE COWARD

NEW REPUBLIC, 206(11) (MAR 92), 11-12, 14.

NEW REPUBLIC, $206(11)$ (MAR 92), 11-12, 14.
THE AUTHOR LOOKS AT NEW YORK GOVERNOR MARIO CUOMO'S

DECISION NOT TO SEEK THE DEMOCRATIC PRESIDENTIAL NOMINATION

IN 1992 AND SPECULATES ABOUT HOW IT MAY AFFECT HIS FUTURE.

01629 BLUMENTHAL, S.

THE MISSION

MEH REPUBLIC, 207(2) (JUL 92), 16-20, 23

THE AUTHOR DISCUSSES H. ROSS PEROT'S INVOLVEMENT IN THE POW/MIA ISSUE DURING THE VIETMAM WAR AND HIS LATER ROLE AS HEAD OF THE GOVERNOR'S TASK FORCE ON DRUG ABUSE IN TEXAS. HE FINDS THAT PEROT'S OBSESSIONS REVEAL UNSETTLING ASPECTS OF HIS CHARACTER.

01630 BLUMENTHAL, $S$.

THE POL

NEH REPUBLIC, 206(14) (APR 92), 16-19

THE AUTHOR PROFILES ARKANSAS GOVERNOR BILL CLINTON, THE POTENTIAL DEMOCRATIC NOMINEE FOR PRESIDENT IN 1992. HE SAYS THAT THE DISTINCTION BETWEEN THE PERSON BILL CLINTON AND THE POLITICIAN BILL CLINTON SIMPLY DOES NOT EXIST; THE CURTAIN DOES NOT COME DOWN. THAT CLINTON IS ALL OF A PEACE IS BOTH HIS STRENGTH AND HIS WEAKNESS. WHY MANY ARE DISCOMFORTED BY THE RISE OF CLINTON--HIS UNVARNISHED EXUBERANCE IN THE PRACTICE OF POLITICS--IS IN GREAT PART WHY HE IS SUCCEEDING.

01631 BLUMENTHAL, S.; KONDRACKE, M.

THE POLITICS OF SELF

NEW REPUBLIC, 206 (3) (JAN 92), 22-27.

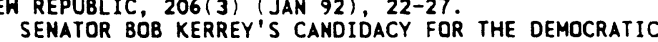

PARTY'S PRESIDENTIAL NOMINATION WAS WELCOMED BY MANY. BUT AS PARTY'S PRESIDENTIAL NOMINATION WAS WELCOMED BY MANY BUT AS
KERRY HAS TRAVELED AROUND THE UNITED STATES, HE HAS FAILED KERRY HAS TRAVELED AROUND THE UNITED STATES, HE HAS FAILED TO GALVANIZE THE POSITIVE RESPONSE THEY HAD ANTICIPATED
RHETORIC OFTEN SOARS INTO BLIND ALLEYS OF VAGUENESS OR RHETORIC OFTEN SOARS INTO BLIND ALLEYS OF VAGUENESS OR
ABSTRACTION: HIS PROGRAMS ARE A COMBINATION OF THE DETAILED ABSTRACTION; HIS PROGRAMS ARE A COMBINATION OF THE DETAIL AND THE SPOTTY; HIS MESSAGE IS WILDLY DIFFUSE. HE HAS NEVERTHELESS DISTANCES HIM FROM PEOPLE.

01632 BLUMENTHAL, S.

THE PURITAN

NEW REPUBLIC, 206(12) (MAR 92), 10-12

PAUL TSONGAS'S ENTRANCE INTÓ PRESIDENTIAL POLITICS IS NOT SO MUCH THE ACT OF SOMEONE WHO HAS GLIMPSED A PROPHETIC LIGHT AS IT IS RIP VAN WINKLE-LIKE, AN AWAKENING INTO A STRANGE WORLD. TSONGAS MISSED MUCH OF THE 1980'S AND HE WISHES TO RESTAGE IT ON HIS OWN TERMS. HE IS CERTAIN THAT HE IS A BETTER MANAGER THAN BUSH, A TRUER SUCCESSOR TO BOTH REAGAN AND CARTER. TSONGAS IS PART OF A LARGELY UNNOTICED REALIGNMENT: AS WORKING-CLASS WHITES HAVE DEFECTED FROM THE DEMOCRATIC PARTY, UPSCALE LIBERAL REPUBLICANS, LIKE TSONGAS, HAVE ENTERED IT.

01633 BLUMENTHAL, S.

NEW REPUBLIC, 207(5) (JUL 92), 10-12, 14.

BILL CLINTON'S EARLY, DRAMATIC FALL IN THE POLLS SENT HIM ON TWO JOURNEYS--EACH REPRESENTING SIDES OF HIS PERSONA. ONE TRACK CARRIED HIM THROUGH A POL ITICAL HAR--NOT ONLY AGAINST HIS RIVALS BUT AGAINST RUMORS AND ARTICLES THAT " RELENTLESSLY TOLD THE TALE OF HIS MISERABLE "CHARACTER." THE OTHER PATH WAS A SLOW SLOG OF EARNEST POLICY WONKERY, OF SPEECH AFTER SPEECH ON SERIOUS ISSUE AFTER ISSUE. THE THO JOURNEYS SEEMED DIVERGENT FOR MONTHS. YET, ON THE EVE OF THE DEMOCRATIC CONVENTION, THEY SUDDENLY CONVERGED TO FORM A HHOLE CAMDIDATE.

01634 BLUMENTHAL, $S$.

THE SURVIVÓR

NEH REPUBL IC 206(17) (APR 92) 15-18, 20.

NEH REPUBLIC, 206(17) (APR 92), 15-18, 20.

HIS CAMPAIGN FOR THE 1992 PRESIDENTIAL NOMINATION.

01635 BLUMENTHAL, S.

NEH REPUBLIC, 207(6) (AUG 92), 10-11.

THE AUTHOR LOOKS AT THE BACKGROUMDS OF DEMOCRATIC

CANDIDATES BILL CLINTON AND AL GORE AND HOW THEY WERE BOTH

INFLUENCED BY THE VIETNAM WAR. HE ALSO CONSIDERS CLINTON'S

STRATEGY IN CHOOSING GORE AS A RUNNING MATE.

01636 BLUMENTHAL, S.

TOMORROW BELONGS TO ME

NEW REPUBLIC, $206(1-2)$ (JAN 92), 24-26.
PATRICK J. BUCHANAN'S POLITICAL CONSERVATISM REFLECTS HIS MILITANT DOGMATIC CATHOLIC UPBRINGING. TO BUCHANAN EVERYONE MUST FALL INTO ONE OF THREE CAMPS: THE BELIEVERS, THE HERETICS, OR THE INFIDELS. IN HIS CAMPAIGN FOR THE REPUBLICAN PARTY'S NOMINATION FOR PRESIDENT, BUCHANAN HAS CAST GEORGE BUSH IN THE ROLE OF THE BETRAYER.

01637 BLUMENTHAL, $S$.

WAR STORY

NEW REPUBLIC, $207(16)$ (OCT 92), 17-20.

THE AUTHOR EXAMINES THE CONFLICTING STORIES OF PRESIDENT GEORGE BUSH'S MILITARY RECORD IN WORLD WAR II AND LOOKS AT BUSH'S EFFORTS TO MAKE BILL CLINTON'S LACK OF SERVICE IN VIETNAM AN ISSUE IN THE 1992 PRESIDENTIAL ELECTION CAMPAIGN.

01638 BLUMENTHAL, S.

EW REPUBLIC, 207(20) (NOV 92), 16, 18

PACT OF THE TELEVISED DEBATES AMONG CANDIDATES ON THE 1992 PRESIDENTIAL ELECTION.

01639 BLUMM, M.C.

THE FALLACIES OF FREE MARKET ENVIRONMENTALISM HARVARD JOURNAL OF LAW AND PUBLIC POLICY, 15(2) (SPR 92), 371-390.

PART I OF THIS ESSAY SUPPLIES BACKGROUND ON MARKETS AND ENVIRONMENTAL PROTECTION, SHOWING WHY MARKET FAILURE MAKES REGULATION NECESSARY AND REVEALING THE NEW ENVIRONMENTAL "PRIVATEERS" AS INTELLECTUAL DESCENDANTS OF RONALD COASE AND THE HALF-BROTHERS OF PUBLIC CHOICE THEORISTS. PART II CRITICIZES "FREE MARKET ENVIRONMENTALISM" FOR ITS FAILURE TO SEE THE INADEQUACIES INHERENT IN MARKETPLACE ORDERING OF ENVIRONMENTAL RESOURCES AND FOR ITS MISUNDERSTANDING OF THE REASONS UNDERLYING GOVERNMENTAL INTERVENTION. PART II I EXPLORES SOME OF THE COSTS OF PRIVATIZING ENVIRONMENTAL DECISIONMAKING. PART IV SUGGESTS THAT THE FUTURE ROLE OF RATHER THAN REPLACE, MODERN ENVIRONMENTAL REGULATION.

01640 BLUTH, C.

GERMANY: TOWARDS A NEW SECURITY FORMAT

WORLD TODAY, 48(11) (NOV 92), 196-198.

THE AUTHOR DISCUSSES GERMAMY'S PRESENT SECURITY DILEMMA AND ITS ROLE IN FORMULATING A NEW EUROPEAN SECURITY STRATEGY.

01641 BO, Z

E.C. SUMMIT TO RESCUE MAASTRICHT TREATY

BEI JING REVIEW, 35(45) (NOV 92), 17.

BEI JING REVIEW, $35(45)$ (NOV 92), 17 . SPECIAL SUMMIT ON OCTOBER 16, 1992, AND ISSUED A DECLARATION SUPPORTING THE RATIFICATION OF THE MAASTRICHT TREATY ON EUROPEAN UNION. EUROPEAN COMMISSION PRESIDENT JACQUES DELORS SAID THAT THE SUMMIT WAS DESIGNED TO HELP BRITAIN AND DENMARK RATIFY THE TREATY. THE DANISH GOVERNMENT SAID THAT IT WOULD ASK FOR "OPT-OUTS," OR EXCEPTIONS, TO POLICIES THAT HAYE PRODUCED THE DEADLOCK OVER TREATY RATIFICATION.

01642 BOAZ, D.

THE TICKET MADE OF THO TRUE INSIDERS

INSIGHT, 8(27) (SEP 92), 18

DEMOCRATIC CANDIDATES BILL CLINTON AND AL GORE PRESENT

THEMSELVES AS "OUTSIDERS" DEVOTED TO CHANGE AND PUBLIC

SERVICE. IN REALITY, CLINTON AND GORE ARE THE MOST TOTALLY

INSIDER TICKET EVER NOMINATED BY AN AMERICAN POLITICAL PARTY.

BOTH MEN HAVE HAD VIRTUALLY NO LIFE OUTSIDE POLITICS. IT

WOULD BE HARD TO IMAGINE TWO NATIONAL CANDIDATES WHO HAVE

LESS KNOWLEDGE OF HHAT IT MEANS TO OBEY LAWS RATHER THAN

WRITE THEM, TO PAY TAXES RATHER THAN RAISE THEM.

01643 BOCK, J.G.; DUNHAM, D.D. JR.

AN ACTIVE ÁPPROACH TO TEACHING THE POLITICAL ECONOMY OF DEVELOPMENT

PS: POLITICAL SCIENCE AND POLITICS, XXV(3) (SEP 92),

538-541.

THE AUTHORS DESCRIBE AN "ACTIVE LEARNING" METHODOLOGY

THAT IS EFFECTIVE IN TEACHING THE POLITICAL ECONOMY OF

DEVELOPMENT. THE METHOD EMPHASIZES FOUR PHASES: EXPOSURE,

DISCUSSION, PERFORMANCE, AND REFLECTION.

01644 BODDEN, R.

KEEPING IN TOUCH: REPRESENTING THE PEOPLE IN A SMALL CEEPING IN TOUT

PARLIAMENTARIAN, LXXIII(2) (APR 92), 122-123.

THE AUTHOR, WHO REPRESENTS BODDEN TOWN IN THE CAYMAN

ISLANDS PARL IAMENT, DISCUSSES WHAT CONSTITUENTS GENERALLY

EXPECT FROM THEIR LEGISLATIVE REPRESENTATIVES AND WHAT HIS

CONSTITUENTS, IN PARTICULAR, EXPECT FROM HIM.

01645 BODENHEIMER, T.; GRUMBACK, K.

FINANCING UNIVERSAL HEALTH INSURANCE: TAXES, PREMIUMS, AND THE LESSONS OF SOCIAL INSURANCE

JOURMAL OF HEALTH POLITICS, POLICY AND LAW, 17(3) (FAL 92), 439-462.

IN A SOCIETY WITH STRONG ANTITAX SENTIMENT AND LARGE 
GOVERMMENT DEFICITS, THE ENACTMENT OF UNIVERSAL HEALTH INSURANCE IS BLOCKED BY AN IMPASSE OVER FINANCING. OVER THE PAST CENTURY MOST INDUSTRIALIZED NATIONS HAVE DEVELOPED HIGHLY POPULAR SOCIAL INSURANCE PROGRAMS TO COVER PERIODS OF RETIRMENT, DISABILTIY, UNEMPLOYMENT, AND PAYMENT FOR MEDICAL CARE. SOCIAL INSURANCE CONSTITUTES A BLEND OF TAX-LIKE AND PREMIUM-LIKE FEATURES, OFFERING LESSONS THAT MIGHT ASSIST IN
BREAKING THE CURRENT IMPASSE OVER UNIVERSAL HEALTH INSURANCE BREAKING THE
FINANCING.

01646 BODIE, $W$

STRATEGY AND SUCCESSOR STATES: REPORT FROM KIEV

WORLD AFFAIRS, 154(3) (WIN 92), 107-114.

UKRAINE MAY BE THE NEXT LOCUS OF STRIFE WITHIN THE FORMER SOVIET UNION. FOR MANY UKRAINIANS, CREDIT FOR THE SUCCESSFUL REALIZATION OF INDEPENDENCE WAS DUE TO THE SHIFT CREATION OF A UKRAINIAN ARMED FORCES OUT OF THE REMNANTS OF THE RED ARMY BASED ON UKRAINIAN TERRITORY. THE STATUS OF UKRAINIAN DEFENSE INSTITUTIONS, WHILE MORE CLEARLY DEFINED THAN THEIR RUSSIAN OR CENTRAL ASIAN EQUIVALENTS, REMAINS EXTREMELY UNSETTLED. THIS ARTICLE EXPLORES UKRAINIAN FOREIGN POLICY, MILITARY FORCES, AND THE PROBLEMS OF DEFENSE POLICY, MILIT
CONVERSION.

01647 BOECKELMAN, $K$

THE IMFLUENCE OF STATES ON FEDERAL POL ICY ADOPTIONS

POLICY STUDIES JOURNAL, $20(3)(1992)$ (3) 365-375. "LABORATORIES OF DEMOCRACY" THAT INFLUENCE FEDERAL POLICY "LABORATORIES OF DEMOCRACY" THAT INFLUENCE FEDERAL POLICY ADOPTIONS. TAKING THE RECENT PAST AS THE TIME FRAME, HE BEGINS BY EXAMINING MAJOR FEDERAL LEGISLATION TO GAUGE THE EXTENT TO WHICH STATE MODELS WERE INFLUENTIAL. FOLLOWING
THIS, THE FOCUS SHIFTS TO IMPORTANT STATE INITIATIVES OF THE EALRY 1980'S AND THEIR IMPACT ON SUBSEQUENT FEDERAL

LEGISLATION. THE AUTHOR CONCLUDES THAT THE NATURE OF THE POLICY ISSUE AND THE ACCOMPANYING POLITICAL DYNAMICS ARE CRITICAL IN DETERMINING WHETHER STATES ACT AS LABDRATORIES OF DEMOCRACY.

01648 BOETTKE, P.J.

WHY PERESTROIKA FAILED

FREEMAN, 42(3) (MAR 92), 113-114.

AS A PROGRAM OF ECONOMIC RESTRUCTURING, PERESTROIKA MUST BE JUDGED AS AN UTTER FAILURE. ONE OF THE MAIN REASONS PERESTROIKA FAILED WAS THAT IT WASN'T ACTUALLY TRIED. DURING HIS SIX YEARS IN POWER, MIKHAIL GORBACHEV INTRODUCED AT SOVIET ECONOMY--NOT ONE OF WHICH WAS IMPLEMENTED. INSTEAD, ECONOMIC REFORM HAS LIMITED TO INCONSISTENT AND INCOHERENT HALF-MEASURES.

01649 BOGASON, P.

STRONG OR NEAK STATE? THE CASE OF DANISH AGRICULTURAL EXPORT POLICY 1849-1906

COMPARATIVE POL ITICS 24(2) (JAN 92), 219-227.

THE AUTHOR EXAMINES THE "NEH STATIST" INTERPRETATION OF THE DEVELOPMEMT OF THE DANISH STATE IN THE SECOND HALF OF THE 19TH CENTURY AND OUESTIONS ITS CONCLUSION THAT A STATE ELITE WAS INSTRUMENTAL IN ESTABLISHING A STATE AGRICULTURAL EXPORT STRATEGY. HE ARGUES THAT MOST EXPORT INITIATIVES WERE STARTED AND IMPLEMENTED BY THE FARMERS THEMSELVES IN LOCAL AND NATIONAL ORGANIZATIONS BASED ON A STRONG MOVEMENT TO STRENGTHEN CIVIL SOCIETY. IF THE STATE WERE INYOL VED, IT WAS MERELY TO SUPPORT EXISTING ACTIVITIES. HENCE, THE STRONG
DIVISION BETWEEN STATE AND SOCIETY IS HARDLY TENABLE IN THIS CASE.

01650 BOGDANOR, $V$

THE 1992 GENERAL ELECTION AND THE BRITISH PARTY SYSTEM GOVERNMENT AND OPPOSITION, 27(3) (SUM 92), 283-298.

THE AUTHOR DISCUSSES THE RELATIVE STRENGTH OF BRITAIN'S

TWO MAJOR PARTIES, LABOUR AND THE CONSERVATIVES, AND THE RESULTS OF THE 1992 GENERAL ELECTION.

01651 BOHLE, H.

HEATED MOMENTS AS YUGOSLAVIA MOVES CLOSER TO DISASTER GERMAN TRIBUNE, 1479 (AUG 91), 1-2.

THE EUROPEAN COMMUNITY HAS URGENTLY CONSIDERING WHAT TO DO AFTER THE BREAKDOWN OF ITS YUGOSLAV PEACE MISSION. GERMAN FOREIGN MINISTER HANS-DIETRICH GENSCHER HAS CALLING FOR A TOUGHER LINE ABAINST SERBIA. ITS LEADERSHIP HAD CLEARLY ASSUMED RESPONSIBILITY FOR WHAT WAS HAPPENING AND ECONOMIC ASSUMED RESPONSIBILITY FOR WHAT
SANCTIONS SHOULD BE CONSIDERED.

01652 BOHNET, A.; HONG, $Z$.

CONTRADICTIONS IM CHIMA'S ECONOMIC REFORM

SWISS REVIEW OF WORLD AFFAIRS, 41 (12) (MAR 92), 12-14.

CHINA'S AGED STRONGMAN DENG XIAOPING HAS CALLED FOR A

BOLD NEW HAVE OF REFORM IN THE PEOPLE'S REPUBLIC. HE HAS SIGNALLED BEIJING'S DETERMINATION TO CONTINUE ITS LONG PROCESS OF ECONOMIC REFORM, WHICH WAS SHELVED FOLLOHING THE SOCIAL AND POLITICAL UNREST OF 1988-89 IN ORDER TO INSURE THE CONTINUED SURVIVAL AND POHER OF THE COMMUNIST REGIME. BUT IT WOULD APPEAR THAT THE BEIJING LEADERSHIP IS STILL
UNCLEAR ABOUT PRECISELY HOW CHINA'S ECONOMY CAN BE REFORMED WITHOUT SIMULTANEOUS CHANGES IN THE COUNTRY'S SOCIAL AND POLITICAL SYSTEM. IN THIS ESSAY, THE AUTHORS EXAMINE THIS DILEMMA AND THE CONTRADICTIONS INHERENT IN CHINA'S ECONOMIC REFORM PROGRAM.

01653 BOKHARI, I.H.

EVOLUTION OF A DUAL NEGOTIATION PROCESS: AFGHANISTAN AMNALS OF THE AMERICAN ACADEMY OF POLITICAL AND SOCIAL SCIENCE, (518) (NOY 91), 58-68.

THE NEGOTIATIONS IN AFGHANISTAN FOLLOHING THE INTRODUCTION OF SOVIET TROOPS DURING A MILITARY COUP IN 1978 WERE PURSUED ALONG TWO TRACKS. THE FIRST CONSISTED OF SPORADIC NEGOTIATIONS BETHEEN THE SOVIET-SUPPORTED AFGHAN GOVERMMENT AND SEVERAL MUJAHIDIN RESISTANCE GROUPS. TO DATE, THESE TALKS HAVE NOT REACHED FRUITION. THE SECOND TRACK CONSISTED OF NEGOTIATIONS OFFICIALLY CONDUCTED BETWEEN PAKISTAN AND AFGHANISTAN (IN REALITY, BETWEEN THE UNITED STATES AKD THE SOVIET UNION) OVER THE WITHDRAWAL OF SOVIET TROOPS. THESE NEGOTIATIONS WERE CONDUCTED OVER A SEVEN-YEAR PERIOD UNDER U.N. MEDIATION. THE RESULT WAS THE GENEVA ACCORD OF APRIL 1988, WHICH PROVIDED FOR THE WITHDRAWAL OF SOVIET TROOPS AND THE TERMINATION OF ARMS SUPPLIES BY THE UNITED STATES AND THE SOYIET UNION, DEPENDENT UPON BOTH SIDES' COMPLIANCE. THE SUCCESS IN THE INTERMATIONAL

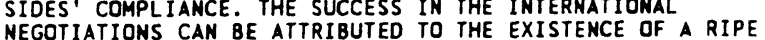
NEGOTIATIONS CAN BE ATTRIBUTED TO THE EXISTENCE OF A RIPE MOMENT AND THE SKILL OF THE TIN. MEDIATI

01654 BOL-ALIMA, G.

WEST AFRICA, (3908) (AUG 92), 1349.

CAMEROON'S COMMITMENT TO THE ENTRENCHMENT OF THE RULE OF LAW AND RESPECT FOR HUMAN RIGHTS IS IRREVERSIBLE. ONE EVIDENCE OF THIS IS THE EFFORT BEING MADE TO INSURE FREEDOM OF SPEECH FOR THE MEDIA. IN ADDITION, CAMEROON HAS CREATED A NATIONAL COUNCIL FOR HUMAN RIGHTS TO SERVE AS A WATCH-DOG IN THIS AREA.

01655 BOLCE, L.; DEMAIO, G.; MUZZIO, D.

BLACKS AND THE REPUBLICAN PARTY: THE 20 PERCENT SOLUTION POLITICAL SCIENCE QUARTERLY, 107(i) (SPR 92), 63-80.

THE AUTHORS LOOK AT THE DEMOCRATIC PARTY'S TRADITIONAL HOLD ON THE BLACK VOTE, ESPECIALLY IN PRESIDENTIAL ELECTIONS, AND AT THE REPUBLICAN PARTY'S RECENT GAINS AMONG BLACK VOTERS.

01656 BOLES, J.K.

FORM FOLLOHS FUNCTION: THE EVOLUTION OF FEMINIST STRATEGIES ANNALS OF THE AMERICAN ACADEMY OF POLITICAL AND SOCIAL SCIENCE, (514) (MAR 91), 38-49.

THE FEMINIST MOVEMENT THAT EMERGED IN THE MID-1960'S HAD DUAL ORIGINS: LIBERAL WOMEN'S RIGHTS ORGANIZATIONS THAT PURSUED LEGISLATIVE AND JUDICIAL REFORMS AND A RADICAL MOVEMENT THAT INCLUDED NUMEROUS SMALL, LOCAL GROUPS. OVER THE PAST 25 YEARS, BOTH MOVEMENTS HAVE BEEN TRANSFORMED IN WAYS THAT REFLECT AND COMPL EMENT AMERICAN FEDERALISM. IN ORDER TO INFLUENCE LEGISLATIVE POLICY-MAKING ON THE NATIONAL AND STATE LEVELS, WOMEN'S RIGHTS GROUPS HAVE BECOME PROFESTE LEVELS, HOMEN'S RIGHTS GROUP HAVE BECOME POLICY NETHORKS THAT PURSUE DIVERSE AGENDAS. BECAUSE URBAN POLITICS ARE UNIOUELY BUREAUCRATIC POL ITICS LOCAL FEMINISTS

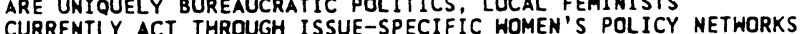
COMPOSED OF ADYOCACY GROUPS, ALTERNATIVE SERVICES RUN BY COMPOSED OF ADVOCACY GROUPS, AL ERSANSIBLE FOR FUNDING, WOMEN, AND URBAN BUREAUCRACIES RESPONSIBLE FOR FUNOING, DELIVERING, OR
NEEDS OF WOMEN.

01657 BOLKESTIEN, F.

A LAST CONVERSATION WITH ELIE KEDOURIE

FREEDOM REVIEN, 23(6) (NOV 92), 41-44.

IN THIS INTERVIEW, HISTORIAN ELIE KEDOURIE DISCUSSES SOME TURNING POINTS IN MIDOLE EASTERN HISTORY AND THE LARGELY-UNSUCCESSFUL ATTEMPT TO INTRODUCE WESTERN POLITICAL PHILOSOPHY INTO THE ISLAMIC WORLD.

01658 BOLSTEIN, R.

COMPARISON OF THE LIKELIHOOD TO VOTE AMONG PREELECTION

POLL RESPONDENTS AND NONRESPONDENTS

PUBLIC OPINION QUARTERLY (CHICAGO), 55(4) (WIN 91),

$648-650$.

THE AUTHOR COMPARES THE LIKELIHOOD TO VOTE AMONG

RESPONDENTS AND VARIOUS NONRESPONDENTS IN A 1988

PRESIDENTIAL PREELECTION POLL TAKEN ONE WEEK BEFORE THE VOTE

IN A SUBURBAN TOWN OF 22,000 NEAR WASHINGTON, D.C.

01659 BOLTUCK, R. : LITAN, R.E.

DOLTUCK, R.; 'LITAN, R.E. LAWS

BROOKINGS REVIEW, 10(2) (SPR 92), 42-45

THE UNITED STATES HAS DEVELOPED A MAJOR ADMINISTRATIVE

PROGRAM TO DISCOYER DUMPIMG AMD UMFAIR SUBSIOIZATION AMD

THEN TO APPLY REMEDIAL PENALTIES. RELATIVELY OBSCURE

TECHNICIANS IN THE INTERMATIONAL TRADE ADMINISTRATION WITHIN 
THE DEPARTMENT OF COMMERCE INVESTIGATE CHARGES OF UNFAIR TRADE. IF THEY RULE THAT A PRACTICE IS UNFAIR, THE INTERNATIONAL TRADE COMMISSION (ITC) OECIDES WHETHER IT CAUSES "MATERIAL INJURY" TO AN AMERICAN INDUSTRY. IF THE ITC FINDS SUCH INJURY, OFFSETTING DUTIES ARE IMPOSED. THUS FAR, THE USA HAS BEEN THE WORLD'S LEADING PROSECUTOR OF UNFAIR TRADE PRACTICES. BUT OTHER COUNTRIES--INCLUDING AUSTRALIA, CANADA, AND THE EUROPEAN COMMUNITY--ARE CATCHING UP.

01660 BONASSO, M.

latin america betheen "mODernization" and the neh EMAINCIPATION

LATIN AMERICAN PERSPECTIVES, 19(74) (SUM 92), 53-60 LATIN AMERICA FACES A UNIQUE AND UNREPEATABLE SITUATION, A FORK IN THE ROAD PRESENTING POLAR CHOICES; EITHER THE CONSOLIDATION OF AN ENDURING DEPENDENCY OR THE BEGINNING OF A SECOND EMANCIAPTION. THIS ARTICLE SUGGESTS THAT LATIN AMERICAN CULTURE NEEDS ITS OWN COMMON MARKET--AN INTEGRATION TO MAKE IT VIABLE AND ALLOW IT TO COMPETE WITH FOREIGN AND ALIENATING PRODUCTS. IT CONCLUDES THAT WHAT IS NECESSARY IS THE DEVELOPMENT OF A NEW CRITICAL LATIN AMERICAN CONSCIOUSNESS BY NEW ORGANIC INTELLECTUALS WHO, KNOWING HOW TO OVERCOME THE ERRORS OF THE PAST AND THE LIMITATIONS OF THE PRESENT, CAN ORIENT THE PEOPLES OF THE SUBCONTINENT TOWARD THAT QUALITATIVE LEAP THAT PRESENT HISTORICAL CIRCUMSTANCES SEEM TO MAKE POSSIBLE.

01661 BONHORST, $R$

AMERICA IS DISCOVERING A BRAND-NEW HORLD

GERMAN TRIBUNE, (1518) (JUN 92), 2.

IN THIS ARTICLE, AMERICAN "BRAIN TRUSTS" SUCH AS THE BROOKINGS INSTITUTE AND THE CARNEGIE FOUNDATION'S NATIONAL COMMISSION FOR AMERICA DISCUSS THE FUTURE OF RELATIONS BETWEEN THE UNITED STATES AND WESTERN EUROPE, AND GERMANY IN PARTICULAR. MANY SEE A DECLINE IN THE IMPORTANCE OF THE AMERICAN-GERMAN RELATIONSHIP AS BOTH NATIONS TURN TOWARDS DOMESTIC PROBLEMS AND SEEK INFLUENCE IN DIFFERENT REGIONAL SPHERES. IN ADOITION, THE CHANGE OF GENERATIONS IN AMERICAN POLITICAL LEADERSHIP' (FROM THE POST-WAR TO THE VIETNAM

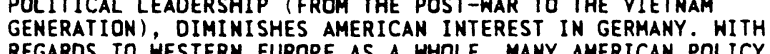
REGARDS TO WESTERN EUROPE AS A WHOLE, MANY AMERICAN POLICY THINKERS SEE AN ERA OF INTENSE, BUT PEACEFUL, COMPETITION.
THIS TREND INCREASES THE IMPORTANCE OF ECONOHIC POWER AND OF THIS TREND INCREASES THE IMPP
RESOLVING TRADE CONFLICTS.

01662 BONNEN, J.T

HHY IS THERE NO COHERENT U.S. RURAL POLICY?

POLICY STUDIES JOURNAL 20(2) (1992), 190-210.

THE AUTHOR LOOKS AT U.S. HISTORY IN ORDER TO UNDERSTAND WHY THE UNITED STATES HAS NEVER DEVELOPED A COHERENT, SUCCESSFUL RURAL POLICY.

01663 BONHER, E.

LOOKING TO THE FUTURE

CURRENT HISTORY, 91(567) (OCT 92), 305-309.

REVOLUTIONS OCCUR QUICKLY, BUT THE PROCESS OF CREATING THEM IS LONG AND TEDIOUS; IT TAKES MANY YEARS OF HARD WORK. TOOAY, THE RUSSIAN PEOPLE MUST RECREATE THEIR COUNTRY AND THEMSEL VES. THE COLLAPSE OF COMMUNISM AND THE DISINTEGRATION OF THE SOVIET UNION AND THE SOVIET BLOC ARE INDUBITABLY POSITIVE PHENOMENA; BUT EVERYTHING ELSE IS UNCLEAR.

01664 BONOSKY, $P$

FATE OF JEWS IN FASCIST ITALY

POLITICAL AFFAIRS, 71(3) (APR 92), 32-35.

THIS ARTICLE REVIEHS THE BOOK "BENEVOLENCE AND BETRAYAL. FIVE ITALIAN JEHISH FAMILIES UNDER FASCISM." THE BOOK PARTIALLY OPENS UP A WINDOW ON A SUBJECT WHICH HAS REMAINED RELATIVELY UNTOUCHED SINCE THE END OF WWII: THE ROLE OF JEWS IN FASCIST ITALY. TO MANY IT COMES AS A SURPRISE TO REALISE THAT JEWS SUPPORTED FASCISM IN ITALY. IT STATES THAT "LOG WOULD SEEM TO DICTATE THAT AS SOON AS THE FASCIST REGIME JEWS WOULD HAVE AUTOMATICALLY TURNED AGAINST THE REGIME. THEY DID NOT."

01665 BONTE-FRIEDHEIM, B.

IS SOMETHING ROTTEN IN THE STATE OF DEUTSCHMARK?

FREEDOM REVIEW, $23(4)$ (JUL 92), 24-25.

GERMANY'S 1992 ELECTIONS REVEALED AN EAST-HEST DIVIDE GERMANY'S 1992 ELECTIONS REVEALED AN EAST - HEST DIVIDE
AMONG VOTERS AND CONFIRMED THAT GERMANY'S POSTHAR CONSENSUS AMONG VOTERS AND CONFIRMED THAT GERMANY'S POSTWAR CONSENSUS
POLITICS HAS DISAPPEARED. THE NUB OF GERMANY'S POL ITICAL POLITICS HAS DISAPPEARED. THE NUB OF GERMANY'S POLITICAL MALAISE IS FINANCIAL: THE COSTS OF CORRECTING THE 45 YEARS OF COMMUNIST MISMANAGEMENT THAT HAVE BLIGHTED THE COUNTRY
EASTERN SECTION ARE STEEP EVEN FOR AN ECONOMIC POHERHOUSE EASTERN SECTION
LIKE GERMANY

01666 BONTE-FRIEDHEIM, R

MEN OF HONOR: ITALY'S WAR ON THE MOB

FREEDOM REVIEW, 23(6) (NOV 92), 32-34.

LEOLUCA ORLANDO IS AN ITALIAN PARL IAMENTARIAN ANO THE LEADER OF "LA RETE" (THE NETHORK), A NEW POLITICAL PARTY. LA RETE'S POLITICAL PLATFORM IS SIMPLE: FIGHT THE MAFIA AND RECLAIM THE TERRITORY UNDER ITS CONTROL.
01667 BONTE-FRIEDHEIM, R. NOT HITLER'S GRANDSON

FREEDOM REVIEW, 23(2) (MAR 92), 29-31.

THE AUTHOR PROFILES JORG HAIDER, THE LEADER OF THE AUSTRIAN FREEDOM PARTY AND CENTRAL EUROPE'S ANSWER TO DAVID DUKE. HE ALSO CONSIDERS THE RECENT SUCCESS OF HAIDER'S PARTY AND WHAT IT MEANS TO AUSTRIA'S MORE TRADITIONAL POLITICAL PARTIES.

01668 BOO, K.

BEYOND BEAUTY SCHOOLS

WASHINGTON MONTHLY, 23(3) (MAR 91), 26-31.

TODAY, MORE THAN 2 MILLION U.S.' STUDENTS ATTEND 4,000 ACCREDITED PRIVATE TRADE SCHOOLS, WITH THEIR SIX- TO THELVEMONTH COURSES FOR INCIPIENT TRUCKERS, COMPUTER REPAIRMEN, SECRETARIES, AND BEAUTICIANS, THOSE SCHOOLS CONSUME NEARLY 30 PERCENT OF THE FEDERAL GOVERMMENT'S GRANTS AND GUARANTEED LOANS FOR HIGHER EDUCATION. UNFORTUNATELY, NOT ONLY IS THE SYSTEM EXPENSIVE, IT DOESN'T WORK. WITH NO SAFEGUARDS ON
EDUCATIONAL QUALITY AND LITTLE CONNECTION TO LABOR MARKET EDUCATIONAL QUALITY AND LITTLE CONNECTION TO LABOR
NEEDS. THE SYSTEM OF PRIVATE, BUT FEDERALLY FUNDED, NEEDS, THE SYSTEM OF PRIVATE, BUT FEDERALLY FUNDED,
VOCATIONAL SCHOOLS ALL TOO OFTEN DOES NOT GIVE STUDENTS GENUINE, MARKETABLE SKILLS. THE ALTERNATIVE, QUALITYCONTROLLED, MARKET-CONSCIOUS FEDERAL JOB TRAINING, IS EXPENSIVE, BUT HOULD BE A WORTHWHILE INVESTMENT IN THE FUTURE.

01669 BOO, K.

WHAM, BAM, THANKS SADDAM

WASHINGTON MONTHLY, 23(4) (APR 91), 14-19.

FROM AN AMERICAN PERSPECTIVE, THE PERSIAN GULF WAR WAS "SHIFT, CLEAN, AND DECISIVE," WITH "ONLY" 323 AMERICAN DEAD. SUCH DECLARATIONS IGNORE THE OTHER SIDE TO THE WAR: THE FORTY YEARS IT HILL TAKE TO REBUILD IRAO AND KUWAIT; THE POSSIBLY IRREVERSIBLE ENVIRONMENTAL DAMAGE; AND THE STAGGERINGLY HIGH NUMBER OF IRAQI DEATHS (150,000 BY SOME ESTIMATES). FURTHERMORE, TRUE VICTORY-POLITICAL STABILITY, RESPECT FOR HUMAN RIGHTS, DEMOCRATIC LEADERSHIP, EVEN STABLE OIL PRICES-IS NO MORE ASSURED IN THE MIDDLE EAST THAN IT WAS BEFORE THE WAR BEGAN.

01670 BOOKMAN, J.T.

THE HISDOM OF THE MANY: AN ANALYSIS OF THE ARGUMENTS OF THE HISDOM OF THE MANY: AN ANALYSIS OF
BOOK III AND IV OF ARISTOTLE'S POLITICS

HISTORY OF POLITICAL THOUGHT, XIII(I) (SPR 92), 1-12.

ISTORY OF POLITICAL THOUGHT, XIII(1) (SPR 92), 1-12.
IN BOOK III OF "POLITICS," ARISTOTLE ADVANCES A HANDFUL OF ARGUMENTS EXPLAINING WHY "THE MANY" SHOULD BE ACCORDED ROLE IN GOVERNING. IN THIS PAPER, THE AUTHOR EXPLORES NUMBER OF ARISTOTLE'S ARGUMENTS REGARDING THE MANY INCLUDING THE ASSERTIONS THAT "A STATE IN WHICH MANY POOR MEN ARE EXCLUDED FROM OFFICE WILL NECESSARILY BE FULL OF ENEMIES" AND THAT THE COLLECTIVE JUDGMENT OF THE MANY MAY BE BETTER THAN THE JUDGMENT OF THE FEW GOOD.

01671 BOOT, $W$.

THE CLARENCE THOMAS HEARINGS

COLUMBIA JOURNALISM REVIEW, 30(6) (JAN 92), 25-29.

THE AUTHOR EXAMINES THE MEDIA'S ROLE IN THE SENATE CONFIRMATION HEARINGS FOR JUDGE CLARENCE THOMAS AS A U.S. SUPREME COURT JUSTICE.

01672 BOOTH, A.

SEUROPEAN COURTS PROTECT HOMEN AND WITCHES': COLONIAL LAH COURTS AS REDISTRIBUTORS DF POHER IN SWAZILAND 1920-1950 JOURAAL OF AMERICAN STUDIES, 18(2) (JUN 92), 253-275. THE IMPOSITION OF COLONIAL LAW ON SWAZILAND BY THE BRITISH ADMINISTRATION IN 1907 LED TO A REALLOCATION OF POWER AMONG VARIOUS ELEMENTS AND GROUPS OF TRADITIONAL SHAZI CITIZENRY. THE MAIN BENEFICIARIES WERE YOUNG, EDUCATED WOMEN WHO RESORTED TO THE COLONIAL COURTS FOR PROTECTION. AMONG THE GREATEST LOSERS WERE THOSE INDIVIDUALS PRACTISING FORMS OF RITUAL SPECIALIZATION, PRINCIPALLY HEALERS AND OIVINERS, BOTH OF WHOM WERE LOOKED UPON AS PRACTITIONERS OF WITCHCRAFT TO THE DEGREE THAT MANY OF THESE PRACTITIONERS WERE FEMALE, THE ACCESS OF SWAZI WOMEN TO

01673 BOOTH, C.

CANNED PINEAPPLE

CANNED PINEAPPLE
NEW REPUBLIC, 206(13) (MAR 92), 13-14, 16.

THE AUTHOR REPORTS ON THE TRIAL OF MANUEL MORIEGA, THE
THEPUBLIC, 206(13) (MAR 92), 13-14, 16 . FORMER RULER OF PANAMA. SHE STATES THAT AFTER THREE MONTHS FORMER RULER OF PANAMA. SHE STATES THAT AFTER THREE MONTHS OF TESTIMONY, THE DRUG TRAFFICKING CASE IS LOOKING MORE ANO
MORE LIKE A PUBLIC CORRUPTION CASE THAT SHOULD BE TRIED IN MORE LIKE A PUBLIC
PANAMA, NOT MIAMI.

01674 BOOTHE, P.; HARRIS, THE ECONOMICS OF CONSTITUIONAL CHANGE: DIVIDING THE FEDERAL DEBT

CANADIAN PUBLIC POLICY-ANALYSE DE POLITIQUES, XVII (4) DEC 91), 434-444.

THE TRANSITIONAL ANO LONG-RUN IMPLICATIONS OF ONE ASPECT

OF CHANGING CANADA'S CONSTITUTIONAL STRUCTURE--DIVIDING THE 
FEDERAL DEBT IS CONSIDERED. THIS PAPER ARGUES THAT IT MAY BE VERY DIFFICULT TO AGREE ON A DIVISION FORMULA AND PARTICULAR REGIONS MAY HAVE STRONG INCENTIVES TO FRUSTRATE AGREEMENT. THE DIVIDED DEBT MAY CARRY SUBSTANTIAL RISK PREMIUMS. DESIGNING INSTITUTIONS TO EFFECT THE DIVISION WILL REQUIRE AN UNPRECEDENTED DEGREE OF CO-OPERATION AND RISK SHARING AMONG THE REGIONS. FINALLY, POST-DIVISION FORCES MAY ENGENDER LARGE-SCALE MIGRATIONS OF LABOR AND CAPITAL FROM SOME REGIONS.

01675 BORDEN, T

BOSMIA--THE "MUJAHEDIN" ARRIVE

MIDDLE EAST INTERMATIONAL, (434) (SEP 92), 13.

THE ARRIVAL OF ARMS SHIPMENTS FROM IRAM AND THE INFILTRATION OF BANDS OF "MUJAHEDIN" FIGHTERS INTO BOSNIA HAVE FURTHER COMPLICATED THE ALREADY HOPELESSLY COMPLEX POL ITICAL AND MILITARY LANDSCAPE OF THE WAR-TORN AREA. THIS SHOW OF ISLAMIC SOLIDARITY AND SUPPORT HAS APPARENTLY NOT SOUGHT AFTER BY THE BOSNIAN GOVERNMENT AND WILL SERVE ONLY TO RAISE THE SPECTER OF A FUNDAMENTALIST BOSNIA, AND THUS WILL GIVE THE WEST AN EXCUSE TO AVOID DIRECT INVOLVEMENT ON SARAJEVO'S BEHALF. AT LEAST SOME OF THE ARMS SHIPMENTS WERE SARAJEVO'S BEHALF. AT LEAST SOME OF THE ARMS SHIPMENTS INTERDICTED BY UNITED NATIONS AND EUROPEAN COMMUNITY
OFFICIALS. HOWEVER, REPRESENTATIVES OF GROUPS PROBABLY NOT CONICIALS. HONEVER, REPRESENTATIVES OF GROUPS PROBABLY NOT ISLAM ARE TRYING TO GAIN INFLUENCE IN BOSNIA JUST WHEN IT IS ISLAM ARE TRYING TO GAIN INFLUENCE IN BOSNIA JUST WHEN IT IS AT ITS WEAKEST BY PROVIDING MILITARY AID. AS MANY AS 100 VOLUNTEERS HAVE BEEN SENT TO BOSNIA AND NOW FORM YET ANOTHER FREE-LANCE MILITIA IN AN AREA ALREADY TORN BY VIOLENCE AND BLOODSHED. THE BOSNIA GOVERNMENT DID NOT INVITE AND HAD APPARENTLY NOT EVEN BEEN CONSULTED ABOUT THE ARRIVAL OF THESE "MUJAHEDIN" FIGHTERS.

01676 BOREHAM, P.; COMPSTON, H.

ABOUR MOVEMENT ORGANIZATION AMD POLITICAL INTERVENTION: THE POLITICS OF UNEMPLOYMENT IN THE OECD COUNTRIES, $1974-$ 1986

EUROPEAN JOURMAL OF POLITICAL RESEARCH, 22(2) (AUG 92), 143-170.

THE AUTHORS ENDEAVOR TO GIVE AN EXPLANATION OF THE ABILITY OF ORGANIZED LABOR TO PROMOTE ITS POLITICAL INTERESTS THROUGH THE INSTITUTIOMAL OECISIOM-MAKING STRUCTURES OF MODERN CAPITALIST ECONOMIES. THEY ARGUE THAT, WHERE LABOR PARTICIPATION IS FORMALIZED IN THESE INSTI IUTIONAL ARRANGEMENTS, SPECIFIC POL ICY MEASURES INSTITUTIONAL ARRANGEMENTS, SPECIFIC POL ICY MEASURES
CONDUCIVE TO LOW UNEMPLOYMENT WILL BE FAVORED, INCLUDING CONDUCIVE TO LOW UNEMPLOYMENT WILL BE FAVORED, INCLUDING
RELATIVELY HIGH LEVELS OF PUBLIC CAPITAL EXPENDITURE AND THE RELATIVELY HIGH LEVELS OF PUBLIC CAPITAL EXPENDITURE AND
PROTECTION OF MANUFACTURING EMPLOYMENT. MOST COMPARATIVE PROTECTION OF MANUFACTURING EMPLOYMENT. MOST COMPARATIVE
STUDIES OF THE CONSEQUENCES OF COLLECTIVE ACTION AND OF STUDIES OF THE CONSEQUENCES OF COLLECTIVE ACTION AND
POLITICAL INTERVENTION IN THE MARKET EMPLOY A CROSSPOLITICAL INTERVENTION IN THE MARKET EMPLOY A CROSSSECT IONAL DESIGN THAT LIMITS THE NUMBER OF CASES IN
STATISTICAL ANALYSES TO THE NUMBER OF COUNTRIES COVERED. THE STATISTICAL ANALYSES TO THE NUMBER OF COUNTRIES COVERED. THE AUTHORS PRESENT THE RESULTS OF AN ANALYSIS OF COMPARATIVE DATA ON 11 OECD COUNTRIES USING A POOLED TIME-SERIES REGRESSION PROCEDURE THAT ENABLES THEM TO STUDY A LARGE
NUMBER OF CASES.

01677 BOREN, D.L.

THE INTELLIGENCE COMMUNITY: HOW CRUCIAL?

FOREIGN AFFAIRS, 71(3) (SUM 92), 52-62,

THE MOST SWEEPING INTERNATIONAL POL ITICAL CHANGES SINCE THE BEGINNING OF THE COLD WAR CALL FOR THE MOST SWEEPING CHANGES IN THE U.S. INTELLIGENCE APPARATUS SINCE THE CIA WAS CREATED IN 1947. IF THE INTELLIGENCE COMMUNITY FAILS TO MAKE THESE CHANGES, IT WILL BECOME AN EXPENSIVE AND IRRELEVANT DINOSAUR JUST WHEN THE UNITED STATES MOST NEEDS INFORMATION AND INSIGHT INTO THE COMPLEX NEW CHALLENGES IT MUST FACE.

01678 BORENSZTEIN, E.; MONTIEL, P

WHEN HILL EASTERN EUROPE CATCH UP WITH THE HEST? FINANCE AND DEVELOPMENT, 29(3) (SEP 92), 21-23.

THE AUTHORS DESCRIBE THE NATURE OF THE POLICY CHALLENGE

FACING EAST EUROPEAN COUNTRIES IN THE AREAS OF GROWTH,

SAVINGS, AND INVESTMENTS. THEY FOCUS ON THE RECENT

01679 BORER, D.A.

THE GENESIS OF A FORGOTTEN WAR: CONTAINMENT IN AFGHANISTAN 1947-1956

COMPARATIVE STRATEGY, 11(3) (JUL 92), 343-356.

THE SOVIET WITHDRAWAL FROM AFGHANISTAN WAS SEEN BY MANY WESTERN OBSERVERS AS A CONCRETE AFFIRMATION OF THE CONTINUED VALIDITY OF CONTAINMENT AS THE PRIMARY DOCTRINE IN U.S.
FOREIGN POLICY. THIS ESSAY CHALLENGES THIS CONCLUSION BY FOREIGN POLICY. THIS ESSAY CHALLENGES THIS CONCLUSION BY INVESTIGATING THE ROOTS OF CONTAINMENT IN SOUTH ASIA IN THE
FIRST DECADE FOLLOWING WORLD HAR II. THE AUTHOR ARGUES THAT FIRST DECADE FOLLOWING WORLD HAR II. THE AUTHOR ARGUE
CONTAINMENT WAS AN INADEQUATE POLICY GUIDE FOR THE CONVOLUTED POLITICS OF SOUTH ASIA AND ACTUALLY SERVED TO AGGRAVATE POLITICAL TENSIONS AMONG AFGHANISTAN, PAKISTAN, AND INDIA. IN DOING SO, THE UNITED STATES UNHITTINGLY DROVE BOTH AFGAHNISTAN AND INOIA INTO PARTNERSHIP WITH THE USSR, THEREBY CREATING THE EXACT SCENARIOS THAT CONTAIMMENT HAS INTENDED TO PREYENT.
01680 BORK, $R$

BESIDE THE LAW

NATIONAL REVIEW, XLIV(20) (OCT 92) 38; 40-42; 44.

THE LAST SUPREME COURT, SUGGESTS ROBERT BORK, MAY MARK THE FINAL VICTORY OF THE CULTURAL LEFT-OOR JUST THE TRIUMPH OF INCOMPETENCE. HE ARGUES THAT IN THE AREA OF INDIVIDUAL RIGHTS THE SUPREME COURT HAS SUBST ITUTED A FORH OF MORAL PHILOSOPHY, INTELLECTUAL THINMER THAN GRUEL, FOR THE ACTUAL PRINCIPLES OF THE CONSITUTION. IT HAS ADOPTED THE RADICAL JURISPRUDENCE OF TODAY'S LAW SCHOOLS, I.E. THAT THE INDIVIDUAL'S RIGHT TO DEFINE HIMSELF IS PARAMOUNT AND THAT THE COMMUNITY HAS ALMOST NO LEGITIMATE INTERESTS IN THAT AREA. HE HOPES THAT THE WORST FEATURES OF THE LAST TERM WERE AN ABERRATION AND WILL NOT BE REPEATED AND THAT IT HOULD TAKE A REAPPRAISAL BY ONLY ONE JUSTICE TO ENSURE THAT.

01681 BORK, R.

THE REACH OF AMERICAN LAW

NATIONAL INTEREST, 29 (FAL 92), 3-10.

SCHOLARLY DEBATE HAS SWIRLED AND WILL CONTINUE TO SHIRL AROUND EXERCISES OF EXTRATERRITORIAL JURDISDICTION BY THE UNITED STATES. JUDGE ROBERT BORK EVALUATES THE ALVAREZ CASE IN RELATION TO THE NOTION THAT OUR COURTS CAN TRY A MEXICAN CITIZEN HHOM THE UNITED STATES KIDNAPPED FROM HIS OWM CDUNTRY WHOM THE UNITED STATES KIDNAPPED FROM HIS OWN COUNTRY. BORK ARGUES THAT THE DECISION IS UNDOUBTEDLY OF COURTS AND THE EXECUTIYE BRANCH WITH RESPECT TO THE REACH OF U.S. LAN ABROAD. HE CONCLUDES THAT GIVEN THE NATURE OF THE PROBLEM, NO ENTIRELY SATISFACTORY RESOLUTION SEEMS POSSIBLE, AT LEAST WHERE SUCH JURISOICTION IS INVOKED BY STATES OR PRIVATE PARTIES.

01682 BORRELL, B.; CUTHBERTSON, $S$. E.C. BAMANA' POLICIES HEMISPHERE, 5(1) (FAL 92), 32-34.

WITHIN THE PRESENT EC TRADE REGIME, MOST EUROPEAN COMMUNITY (EC) COUNTRIES PURSUE INDEPENDENT AND QUITE DIFFERENT POLICIES ON BANANA IMPORTS. THESE POLICIES GIVE PREFERENCES TO SOME DEVELOPING COUNTRIES AT THE EXPENSE OF OTHER DEVELOPING COUNTRIES AND GIVE MONOPOLIES TO SOME LOCAL BANANA IMPORTERS AND WOLESALERS. IN COMPLETING THE EC COMMON MARKET IN 1992, THE DISPARATE NATIONAL BANANA POLICIES MUST BE UNIFIED. THIS WILL OFFER A UNIQUE POLICIES MUST BE UNIFIED. THIS WILL OFFER A UNI QUE
OPPORTUNITY TO ELIMINATE THE INEFFICIENCIES OF PRESENT OPPORTUNITY TO ELIMINATE THE INEFFICIENCIES OF PRESENT
POLICIES, BUT IT ALSO PROVIDES THE WORRISOME PROSPECT THAT POL ICIES, BUT IT ALSO PROVIDES THE WORRISOME PROSPECT THA THE LEAST EFFICIENT FEATURES OF EXISTING POL.ICIES MAY BE
EXTENDED TO ALL COUNTRIES, MAKING INTERVENTION WORSE THAN IT EXTENDED
IS NOW.

01683 BORRUS, M.; HEBER, S.; HILLIHMGANZ, J.; ZYSMAN, J. MERCHANTILISH AND GLOBAL SECURITY

NATIONAL INTEREST, 29 (FAL 92 ), 21-29.

THE CERTAINTIES OF THE BIPOLAR WORLD ARE GONE AND THE BONDS THAT WERE A PART OF THAT WORLO ARE LOOSENING. THE SECURITY SYSTEM THAT DEVELOPS OVER THE NEXT DECADE WILL REFLECT A WORLD THAT IS SLOWLY DIVIDING ITSELF INTO THREE POWERFUL TRADING GROUPS; ASIA, NORTH AMERICA, AND EUROPE. ECONOMIC RELATIONS AMONG THESE THREE TRADING REGIONS WILL SET THE PARAMETERS WITHIN WHICH SECURITY ISSUES ARE RESOLVED. THE VISIONS OF WHAT THE EMERGING SYSTEM COULD BE LIKE IS OFFERED IN THIS ART ICLE. THE PRINCIPAL FORCE THAT COULD
PROPEL THE REGIONS INTD BITTER ECONOMIC RIVALRY IS THE POSSIBILITY THAT THERE CAN BE ENDURING NATIONAL HINNERS AND LOSERS FROM TRADE COMPETITION. IT IS ARGUED THAT AMERICA NEEDS TO ACT NOT FROM THE BELIEF THAT IT IS AND CAN REMAIN DOMINANT, BUT FROM AN UNDERSTANDING OF HOW IT CAN BE

01684 BORTFELDT, $\mathrm{H}$.

AMERICA AND THE CHALLENGES WHICH HAVE EMERGED IN THE NEH FEDERAL LANDER

GERMAN TRIBUNE, (1513) (MAY 92), 5.

VIRTUALLY OVERMIGHT, DUE TO THE UNIFICATION OF GERMAMY THE UNITED STATES HAD 16 MILLION MORE ALLIES WITHIN THE NATO STRUCTURE. IT HOULD BE WRONG, HOWEVER, TO ASSUME THAT THE LINKS WHICH THE UNITED STATES ESTABLISHED WITH THE FEDERAL REPUBLIC OF GERMANY IN THE IMMEDIATE POST-WAR PERIOD COULD BE AUTOMATICALLY TRANSFERED TO THE NEW LANDER (PROVINCES) OF EAST GERMANY. THERE IS A GROWING AWARENESS IN THE UNITED EAST GERMANY. THERE IS A GROWING AWARENESS IN THE UNITED STATES THAT AMERICA HAS NOT ONLY GAINED 16 MILLION NEW
ALLIES BUT THAT THE DIFFERENT STANCE ADOPTED BY MANY EASTERM ALLIES BUT THAT THE DIFFERENT STANCE ADOPTED BY MANY EASTERM
GERMANS TOWARDS THE NATO ALLIANCE COULD HAVE IMPLICATIONS GERMANS TOWARDS THE NATO ALLIANCE COULD HAVE IMPLICATIONS WHICH EXTEND FAR BEYOND THE GERMAN-AMERICAN RELATIONSHIP. SOME AMERICAN FIRMS HAVE INVESTED IN THE NEW LANDER, BUT THE OVERALL AMOUNT OF INVESTMENT HAS BEEN RELATIVELY INSUBSTANTIAL. SEYERAL FOUNDATIONS HAVE SPONSORED EXCHANGE PROGRAMS, BUT THEY REMAIN LIMITED. THE NEW LANDER CERTAINLY DO NOT EXPECT THE KIND OF MARSHALL PLAN AID WHICH THE WEST GERMANS RECEIVED AFTER THE WAR. BUT THEY HOULD BE EXTREMELY DISAPPOINTED IF THEY WERE LEFT ALONE BY THEIR NEH ALLY ON

THE DIFFICULT ROAD TO DEMOCRACY ANO A MARKET ECONOMY.

01685 BORTFELDT, $H$.

THE GERMAH COMMUNISTS IN DISARRAY 
JOURNAL OF COMMUNIST STUDIES, $7(4)$ (DEC 91), 522-532. THE EARLY 1990S FIND GERMAN COMMUNISM IN THE THROES OF A CRISIS. ONLY THE PARTY OF DEMOCRATIC SOCIALISM IS OF ANY POL ITICAL RELEVANCE AS AN ELECTORAL AND PARLIAMENTARY FORCE. THE GERMAN COMMUNIST PARTY IS AN ALMOST IRRELEVANT POLITICAL FACTOR. OTHER SPLINTER GROUPS AND SECTS ARE ISOLATED AND OF NO POLITICAL INFLUENCE. THE UNSUCCESSFUL COUP IN THE SOVIET UNION, AS WELL AS GORBACHEV'S MOVE TO DISSOLVE THE CPSR, TOOK THE GERMAN COMMUNISTS BY SURPRIZE AND CALLED THEIR OWM EXISTENCE INTO QUESTION.

01686 BOSNIAK, L.

HUMAN RIGHTS, STATE SOVEREIGNTY AND THE PROTECTION OF UNDOCUMENTED MIGRANTS UNDER THE INTERNATIONAL MIGRANT WORKERS CONVENTION

INTERNATIONAL MIGRATION REVIEH, 25(4) (HIN 91), 737-770.

TERNATIONAL MIGRATION REVIEW, 25(4) (HIN 91), 737-770.
THE INTERNATIONAL MIGRANT WORKERS CONVENTION SEEKS TO THE INTERNATIONAL MIGRANT WORKERS CONVENTION SEEKS TO
ACCOMMODATE COMPETING CONCERHS BY PROVIDING HUMAN RIGHTS ACCOMMODATE COMPETING CONCERHS BY PROVIDING HUMAN RIGHTS
PROTECTIONS TO UNDOCUMENTED MIGRANTS HHICH ARE SUBSTANTIAL PROTECTIONS TO UNDOCUMENTED MIGRANTS WHICH ARE SUBSTANT
BUT LESS EXTENSIVE THAN THOSE PROVIDED TO DOCUMENTED MIGRANTS, AND THROUGH ENSURING STATES' CONTINUING AUTHORITY IN THE SPHERES OF IMMIIGRATION CONTROL AND NATIONAL

MEMBERSHIP POLICY. IT REPRESENTS AN IMPORTANT ADVANCE FOR THE RIGHTS OF UNDOCUMENTED MIGRANTS NOTHITHSTANDING ITS TWOTIERED STRUCTURE OF PROTECTIONS. HOWEVER, AN EXAMINATION OF THE CONVENTIONS LEADS TO THE CONCLUSION THAT DESPITE THE UNMISTABLE NORMATIVE VALUE OF MANY OF THE CONVENTION'S PROTECTIVE PROVISIONS, THE CONVENTION'S ABILITY TO SUBSTANTIALLY AMELIORATE THE HUMAN RIGHTS SITUATION OF IRREGULAR MIGRANTS IS SIGNIFICANTLY CONSTRAINED BY ITS OVERRIDING COMMITMENT TO THE NORMS AND STRUCTURES OF SOVERIGH STATEHOOD.

01687 BOSQUE-MAUREL, J.; BOSQUE-SENDRA, J.; GARCIA-BALLESTEROS, A. POLITICAL GEOGRAPHY AROUND THE WORLD IX: ACADEMIC GEOGRAPHY IN SPAIN AND FRANCD'S REGIME, 1935-1955 POLITICAL GEOGRAPHY, 11(6) (NOV 92), 550-562. CONTEMPORARY ACADEMIC GEOGRAPHY IN SPAIN BEGAN IN THE 1940 'S WITH THE EDUCATIONAL REFORMS CARRIED OUT BY GENERAL FRANCD'S REGIME. HOWEVER, SPANISH ACADEMIC GEOGRAPHY DID NOT FRANCD'S REGIME. HOHEVER, SPANISH ACADEMIC GEOGRAPHY DID NOT REFLECT ANY FASCIST TREND; FOR EXAMPLE, GERMAN GEOPOLITICS

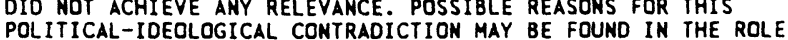
POLITICAL-IDEOLOGICAL CONTRADICTION MAY BE FOUND IN THE ROLE PLAYED BY THE STAFF WHO MANHED THE UNIVERSITY GEOGRAPHY ISOLATED FROM ANY FASCIST POLITICAL APPROACH.

01688 BOSTDORFF, D.

THE PRESIDENCY AND PROMOTED CRISIS: REAGAN, GRENADA, AND ISSUE MANAGEMENT

PRESIDENTIAL STUDIES QUARTERLY, XXI(4) (FAL 91), 737-750. ONLY DAYS AFTER OVER TWO HUNDRED AMERICANS WERE KILLED BY A TERRORIST BOMB IN BEIRUT, THE UNITED STATES LAUNCHED "OPERATION URGENT FURY," AN INVASION OF GRENADA. PRESIDENT RONALD REAGAN USED GRENADA TO TURN ATTENTION AWAY FROM THE FAILURE AT BEIRUT. THIS ESSAY ARGUES THAT REAGAN'S RHETORIC ON GRENADA IS AN EXEMPLAR OF CRISIS PROMOTION AND MANAGEMENT. TO "PROMOTE" A CRISIS, COMmANDERS IN CHIEF ADVANCE A CLAIM OF CRISIS OR ASSERT THAT A CRISIS EXISTS. THE "MANAGEMENT" OF CRISIS OCCURS WHEN PRESIDENTS ATTEMPT TO PERSUADE PUBLICS TO ATTACH DESIRED MEANINGS TO AN EVENT AND TO ACCEPT THEIR RESOLUTION OF THE CRISIS EVENT AS THE MOST APPROPRIATE ONE.

01689 BOSTON J.

ASSESSING THE PERFORMANCE OF DEPARTMENTAL CHIEF EXECUTIVES: PERSPECTIVES FROM NEW ZEALAND

PUBLIC ADMINISTRATION (LONDON), 70(3) (FAL 92), 405-428.

THE AUTHOR EVALUATES THE NEW APPROACH TO SPECIFYING AND

ASSESSING THE PERFORMANCE OF DEPARTMENTAL CHIEF EXECUTIVES

IN NEW ZEALAND. DRAWING ON A SERIES OF INTERVIEWS WITH

MINISTERS, CHIEF EXECUTIVES, AND OTHER SENIDR PUBLIC
SERVANTS CONDUCTED BY A NUMBER OF RESEARCHERS, HE OUTLINES

SERVANTS CONDUCTED BY A NUMBER OF RESEARCHERS, HE OUTLINES
THE ORIGINS AND IMPLEMENTATION OF THE NEW POLICY FRAMEWORK

THE ORIGINS AND IMPLEMENTATION OF THE NEN POLICY FRAMEH
AND EVALUATES ITS STRENGTHS AND HEAKNESSES. FROM THE AND EVALUATES ITS STRENGTHS AND HEAKNESSES. FROM THE EVIDENCE AVAILABLE TO DATE, IT APPEARS THAT THE NEW MODEL
HAS HON THE SUPPORT OF MOST OF THE PARTIES DIRECTLY AFFECTED HAS WON THE SUPPORT OF MOST OF THE PARTIES DIRECTLY AFF
AND THAT IT HAS ENHANCED THE ACCOUNTABILITY OF CHIEF AND THAT IT HAS ENHANCED THE ACCOUNTABILITY OF CHIEF
EXECUTIVES TO THEIR PORTFOLIO MINISTERS. HOWEYER, THE IMPLEMENTATION OF THE NEH REGIME HAS HIGHLIGHTED THE INHERENT PROBLEMS OF ASSESSING THE PERFORMANCE OF SENIOR
PERSONNEL IN THE PUBLIC SECTOR AND OF IMPOSING SANCTIONS IN PERSONNEL IN THE PUBLIC SECTOR AND OF IMPOSING SANCTIONS IN THE EVENT OF SUBSTANDARD PERFORMANCE. IN ADDI I ION, VARIOUS ISSUES OF A CONSTITUTIONAL NATURE HAVE ARISEN CONCERNING THE
ROLES AND RESPONSIBILITIES OF CHIEF EXECUTIVES, THE BALANCE ROLES AND RESPONSIBILITIES OF CHIEF EXECUTIVES, THE BALA
OF POWER BETWEEN CHIEF EXECUTIVES AND THEIR PORTFOLIO OF POWER BETWEEN CHIEF EXECUTIVES AND THEIR PORTFOLLIO
MINISTER(S), AND THE PROPER ROLE OF THE PRIME MINISTER AND CABINET IN THE NEW ACCOUNTABILITY FRAMEWORK.

01690 BOSTON, J.

THE PROBLEMS OF POLICY COORDINATION: THE NEW ZEALAND EXPERIENCE

GOVERNANCE, 5(1) (JAN 92), 88-103.

THE PROBLEMS OF COORDINATING THE OEVELOPMENT AND IMPLEMENTATION OF PUBLIC POLICY ARE LEGION. WHILE SUCH
PROBLEMS ARE MOST COMMONLY ASSOCIATED WITH LARGE FEDERAL SYSTEMS, THEY CAN ARISE HITH EQUAL FORCE AND COMPLEXITY IN SMALL, HIGHLY CENTRALIZED, UNITARY STATES SUCH AS NEW ZEALAND. THIS ARTICLE HAS FOUR MAIN PURPOSES. FIRST, IT BRIEFLY SURVEYS SOME OF THE RECENT LITERATURE ON THE NATURE OF COORDINATION AND THE MECHANISMS FOR ENHANCING POLICY COORDINATION IN GOVERNMENT. SECOND, IT OUTLINES THE NATURE AND CAUSES OF THE COORDINATION DIFFICULTIES THAT HAVE BEEN ENCOUNTERED IN RECENT YEARS IN NEW ZEALAND. THIRD, IT EXPLORES THE VARIOUS ATTEMPTS WHICH THE LABOUR GOVERMMENT (1984-90) AND THE NATIONAL GOVERMMENT (1990-PRESENT) HAVE MADE TO OVERCOME THESE DIFFICULTIES. FINALLY, THE ARTICLE CONSIDERS SOME OF THE LESSONS WHICH EMERGE FROM NEW CONSIDERS SOME OF THE LESSONS
ZEALAND'S RECENT EXPERIENCE.

01691 BOSTON, R.

AMERICAN PUBLIC SCHOOLS: MISSION FIELD USA? CHURCH AND STATE, 45(1) (JAN 92), 8-12

IN THE WAKE OF THE 1990 U.S. SUPREME COURT RULING UPHOLDING THE EQUAL ACCESS ACT, SOME EVANGELICAL CHRISTIAN GROUPS ARE EXPANDING THEIR CAMPAIGN TO HIN INFLUENCE IN THE PUBLIC SCHOOLS, AND THEY ARE INCREASINGLY USING THE STUDENTS THEMSELVES TO DO IT. GENERALLY SPEAKING, THEY ARE CREATING PROBLEMS IN FOUR BROAD CATEGORIES: DISTRIBUTION OF RELIGIOUS LITERATURE IN PUBLIC SCHOOLS, SCHOOL ASSEMBLIES HITH RELIGIOUS OVERTONES, STUDENT-INITIATED RELIGIOUS ACTIVITIES NOT COVERED BY THE EQUAL ACCESS ACT, AND ATTEMPTS BY OUTSIDE GROUPS TO INFILTRATE PUBLIC SCHOOLS TO PROSELYTIZE.

01692 8OSTON, $R$.

CAMPAIGN 92: CHURCH, STATE, AND THE RACE FOR THE WHITE HOUSE

CHURCH AND STATE, 45(2) (FEB 92), 7(31)-11(35).

THE AUTHOR PROFILES THE FIVE DEMOCRATS AND THREE

REPUBLICANS CONSIDERED SERIOUS CANDIDATES FOR THE U.S. PRESIDENCY IN 1992, FOCUSING ON THEIR RELIGIOUS BACKGROUNDS AND THEIR POSITIONS ON CHURCH-STATE ISSUES.

01693 BOSTON, R.

CAMPAIGN 92

CHURCH AND STATE, 45(9) (OCT 92), 7(199)-13(205).

BASED ON THEIR PUBLIC STATEMENTS, THE AUTHOR SUMMARIZES THE VIEWS OF THE 1992 REPUBLICAN AND DEMOCRATIC PRESIDENTIAL AND VICE-PRESIDENTIAL CANDIDATES REGARDING THE SEPARATION OF CHURCH AND STATE. HE ALSO DISCUSSES THE DEMOCRATIC AND REPUBLICAN PARTY PLATFORMS AND THE VIEHS OF H. ROSS PEROT, A POTENTIAL THIRD-PARTY CANDIDATE.

01694 BOSTON, R.

JERRY'S KIDS AND THE CONSTITUTION

CHURCH AND STATE, 45(8) (SEP 92), 4(172)-6(174).

IN HABEL $V$. I INDUSTRIAL DEVELOPMENT AUTHORITY, THE VIRGINIA SUPREME COURT RULED THAT LIBERTY UNIVERSITY, AS A "PERVASIVELY SECTARIAN" INSTITUTION, DOES NOT QUALIFY FOR GOVERNMENT-ISSUED BONDS. NOW THE VIRGINIA COUNCIL OF HIGHER EDUCATION IS DEBATING WHETHER THE UNIVERSITY MAY RECEIVE PUBLIC ASSISTANCE THROUGH THO STATE FINANCIAL AID PROGRAMS FOR STUDENTS, THE TUITION ASSISTANCE GRANT PROGRAM AND THE COLLEGE SCHOL ARSHIP ASSISTANCE PROGRAM.

01695 BOSTON, $R$.

PUBLIC FORUM OR PUBLIC NUISANCE?

CHURCH AND STATE, 45(4) (APR 92), 4(76)-6(78).

THE SUPREME COURT HILL SOON DECIDE HHETHER RELIGIOUS GROUPS HAVE THE RIGHT TO DISTRIBUTE LITERATURE AND SOLICIT FUNDS IN AIRPORTS. SOME RELIGIOUS GROUPS FEAR THAT A RULING AGAINST THE HARE KRISHNAS IN INTERNATIONAL SOCIETY FOR KRISHNA CONSCIOUSNESS (ISKCON) VS. LEE COULD ESTABLISH A PRECEDENT FOR NEW, RESTRICTIVE GUIDELINES FOR GOVERNMENT REGULATION OF FREE SPEECH IN A VARIETY OF PLACES.

01696 BOSTON, R.

RELIGION AT THE POLLS 1992

CHURCH AND STATE, 45(11) (DEC 92$), 4(244)-8(248)$.

THE DEFEAT OF, GEORGE BUSH IN THE 1992 PRESIDENTIAL

ELECTION HAS RAISED QUESTIONS ABOUT THE IMPACT OF THE

RELIGIOUS RIGHT IN THAT CAMPAIGN AND ABOUT ITS FUTURE ROLE

IN THE REPUBLICAN PARTY.

01697 BOSTON, R.

SHOOT-DUT' IN COLORADO

CHURCH AND IN COLORADO (OCT 92), $4(196)-6(198)$

IN NOVEMBER 1992 , COLORADO CITIZENS WILL VOTE ON A PROPOSED CONSTITUTIONAL AMENDMENT THAT WOULD ESTABLISH A FARREACHING VOUCHER PLAN FOR FUNOING SCHOOLS. UNDER THE PLAN, THE TRADITIONAL MECHANISMS FOR FUNDING PUBLIC EDUCATION IN COLORADO WOULD BE REPLACED WITH VOUCHERS THAT COULO BE USED FOR PUBLIC OR PRIVATE SCHOOLS OR HOME EDUCATION. IF ADOPTED, THE NEW LANGUAGE WOULD DRAMATICALLY ALTER THE CHURCH-STATE SEPARATION PROVISIONS OF THE COLORADO CONSTITUTION, GUTTING WHOLE SECTIONS THAT PRESENTLY BAR ANY APPROPRIATION OF PUBLIC FUNDS FOR SECTARIAN SCHOOLS OR INSTITUTIONS. 
01698 BOSTON, R.

WHITHER ZION?

CHURCH AND STATE, 45(11) (DEC 92), 9(249)-13(253). AL THOUGH THE UTAH CONSTITUTION CONTAINS STROMG PROVISIONS GUARANTEEING CHURCH-STATE SEPARATION, THE STATE'S PREDOMINANTLY MORMON POLITICAL ESTABLISHMENT HAS OFTEN INCORPORATED ITS RELIGION INTO PUBLIC LIFE. WHEN THE SOCIETY OF SEPARATIONISTS CHALLENGED THE PRACTICE OF OFFICIALLYSANCTIONED PRAYERS BEFORE MEETINGS OF THE SALT LAKE CITY COUNCIL, IT WON A SURPRISING COURTROOM VICTORY, WHICH SPARKED AN EFFORT BY STATE LEGISLATORS TO REWRITE THE CONSTITUTION'S SEPARATION PROVISIONS. AS A RESULT, UTAH IS NOW LOCKED IN A HEATED DEBATE THAT COULD BRING BIG CHANGES IN RELIGIOUS LIBERTY FOR ITS RESIDENTS.

01699 BOSTWICK, J.

TAKING THE LEAD: THE UPWARD MOBILITY OF BAHAMIAN WOMEN

PARLIAMENTARIAN, LXXIII(3) (JUL 92), 192-193, 195.

BAHAMIAN WOMEN DID NOT WIN THE RIGHT TO VOTE UNTIL 1962,

AND ONLY ONE HOMAN HAS EVER HELD A CABINET POST IN THE

GOVERNMENT OF THE BAHAMAS. NEVERTHELESS, WOMEN ARE MAKING

GAINS. THE BAHAMAS NOW BOASTS OF WOMEN IN THE HIGHEST

ECHELONS OF THE DIPLOMATIC CORPS, THE PUBLIC SERVICE, AND

THE PROFESSIONS, AND THE PACE OF WOMEN'S ADVANCEMENT' SEEMS

THE PROFESSIONS, AND THE

01700 BOSWORTH, S.W.

THE UNITED STATES AND ASIA

FOREIGN AFFAIRS, 71(1) (1992), 113-129.

BECAUSE BOTH ASIANS AND AMERICANS RECOGNIZE THEIR OWN INTERESTS IN HEALTHY TRANS-PACIFIC RELATIONS, THEY FEAR THE UNCERTAINTY THAT WOULD ACCOMPANY ANY SUBSTANTIAL WEAKENING OF THE UNITED STATES' REGIONAL ENGAGEMENT. BUT THE USA'S ABILITY AND WILLINGNESS TO MAINTAIN A SIGNIFICANT REGIONAL MILITARY PRESENCE IS BEING CALLED INTO QUESTION. A STRONG AMERICAN PRESENCE IN THE ASIAN-PACIFIC REGION WILL REQUIRE NEW STRUCTURES OF COOPERATION AND FRESH ATTITUDES ON BOTH SIDES OF THE PACIFIC.

01701 BOTSAS, E.

TRADE AND THE COLLAPSE OF CENTRAL PLANNING IN EUROPE

EAST EUROPEAN QUARTERLY, XXVI (2) (SUM 92), 239-259.

ALTHOUGH EASTERN EUROPE'S COMMUNIST REGIMES ARE GONE,

THE PROBLEMS THEY LEFT BEHIND ARE FAR FROM BEING SOLVED

TRADE REGIMES DO NOT FALL WITH THE FALL OF POLITICAL REGIMES,

AND THERE HAS BEEN A LONG INTERDEPENDENCE BETHEEN PLANNING

AND THERE HAS BEEN A LONG INTERDEPENDENCE BETHEEN PLANH
AND TRADE THAT CANHOT BE REFORMED OVERNIGHT. THIS PAPER

AND TRADE THAT CANNOT BE REFORMED OVERNIGHT. THIS PAPER

CENTRALLY-PLANNED ECONOMIES IN THEIR EFFORTS TO MODERNIZE
THEIR ECONOMIC STRUCTURES. IT CONSIDERS THEIR TRADE BEHAYIOR

THEIR ECONOMIC STRUCTURES. IT CONSIDERS THEIR TRADE BEHAYIOR

THE INTERMAL ADJUSTMENTS NECESSITATED BY THE EXTERNAL SECTOR,

AND THE IMPLICATIONS FOR FUTURE ECONOMIC GROWTH.

01702 BOUCHER, D.

INTER-COMMUNITY AND INTERNATIONAL RELATIONS IN THE POLITICAL PHILOSOPHY OF HOBBES

OLITY, XXIII (2) (HIN 90), 207-232.

RELATIONS AMONG COMMUNITIES, WHETHER AMONG SMALL GROUPS

OR EVEN AMONG STATES, ARE NOT ANALOGOUS, THIS ARTICLE ARGUES, TO THE RELATIONS AMONG INDIVIDUALS IN THE STATE OF NATURE. HOBBES'S SCATTERED REFERENCE TO SUCH MATTERS, THE AUTHOR CONTEMDS, CAN BE NOTIOMALLY DISTINGUISHED INTO THREE CATEGORIES: FIRST, RELATIONS IN THE HYPOTHETICAL STATE OF NATURE; SECOND, RELATIONS IN THE HISTORICAL STATE OF NATURE: AND THIRD, RELATIONS AMONG CIVIL SOCIETIES, IN ALL THREE CATEGORIES, CERTAIN CONSTRAINTS SERVE TO REGULATE THE MANNER AND MODE OF CONDUCT AMONG NON-SOCIAL COMMUNITIES IN THE STATE OF MATURE AND AMONG STATES IN THE CIVIL CONDITION. THE AUTHOR INSISTS THAT NONE OF THESE CAN BE FRUITFULLY COMPARED TO THE UNMITIGATED WAR OF ALL AGAINST ALL WITHOUT SEVER QUALIFICATIONS.

01703 BOUCHEY, L.F.

DON'T CRY FOR ARGENTINA

NATIONAL REVIEW, XLIV(10) (MAY 92), 18-20.

WHEN CARLOS SAUL MENEM, THE STANDARD BEARER OF THE PERONIST PARTY, BECAME THE PRESIDENT OF ARGENTINA IN 1989 , THE COUNTRY BRACED FOR ANOTHER ROUND OF PERONIST STATISM AND EXCESS. INSTEAD, MENEM SUCCEEDED IN EXORCISING HALF A EXCESS. INSTEAD, MENEM SUCCEEDED IN EXORCISING HALF A CENTURY OF POLITICAL INSTABILITY AND ECONOMIC RUIN, THE POR HIS COUNTRY WAS THE EMBRACE OF THE FREE MARKET PARADIGH, FOR HIS COUNTRY WAS THE EMBRACE OF THE FREE MARKET PARA HE LAUNCHED A PROGRAM OF ECONDMIC LIBERALIZATION AND PRIVATIZATION. NOW, INFLATION IS DOWN FROM 1,396 PERCENT
1989 TO UNDER 24 PERCENT FOR 1991 AND MAY SLIP TO SINGLE 1989 TO UNDER 24 PERCENT FOR 1991 AMD MAY SLIP TO SIMGLE DIGITS IN 1992. THE MOST EUROPEAN NATION IN THE AMERICAS, ARGENTINA WILL MORE THAN EMULATE THE MEXICAN TURMAROUND AND
COULD RIVAL THE CHILEAN ECONOMIC MIRACLE THAT NOW PROMISES 5 PERCENT ANNUAL GROWTH FOR THE REST OF THE DECADE. ABUNDANT MATURAL RESOURCES ARE AN OBVIOUS PLUS FOR ARGENTINA, BUT HUMAN RESORUCES GIVE IT THE VITALLY IMPORTANT COMPETITIVE EDGE IN A POST-INDUSTRIAL AGE.
01704 BOUDREAU D.

BEYOND TIAMAMEN SQUARE: CHINA AND THE MFN DEBATE WORLD AFFAIRS, 153 (1) (SPR 91), 140-147.

THIS ARTICLE EXAMINES HOW PRIMARY POLICY ISSUES SURROUNDING CHINA'S HUMAN RIGHTS, TRADE, AND ARMS PROLIFERATION POLICIES HAVE IMPACTED ON THE DEBATE AS TO WHETHER TO RENEW CHINA'S MOST FAVORED NATION (MFN) STATUS WITH THE UNITED STATES. THE WRITER ARGUES THAT THE CONGRESS WOULD BE ILL ADVISED TO ATTEMPT TO OVERBURDEN CHINA'S MFN STATUS WITH UNREASONABLE CONDITIONS, PARTICULARLY IN LIGHT OF THE HISTORY OF MFN STATUS HITH THE SOVIET UNION. FINALLY, HE CONCLUDES BY SUGGESTING THAT THE OPTIMAL MANNER IN WHICH CHINA POLICYMAKERS IN THE UNITED STATES AND OTHER HESTERN GOVERMMENTS CAN ATTAIN THE DESIRED POLICY OBJECTIVES BY ENGAGING THE CHINESE GOVERNMENT IN NEGOTIATIONS, THUS ASSISTING IN MAXIMIZING THE REFORMIST FORCES CURRENTLY PRESENT IN CHINA.

01705 BOUDREAU, $F$.

PARTNERSHIP AS A NEW STRATEGY IN MENTAL HEALTH POLICY: THE PARTE OF QUEBEC

JOURNAL OF HEALTH POLITICS, POLICY AND LAK, 16(2) (SUM 91), $307-330$.

THE MOTION OF "PARTNERSHIP" IS INCREASINGLY ADOPTED AS A SINE OUA NON OF THE SUCCESSFUL RESOLUTION OF STRATEGIC PROBLEMS IN THE FIELD OF HUMAN SERVICES. IN THIS PAPER, THE AUTHOR EXAMINES OUEBEC'S RECENT MENTAL HEALTH POLICY AKD ITS OPERATIONAL DEFINITION OF THE CONCEPT. THE AUTHOR THEN SUGGESTS SOME OF THE ROOTS AND REASONS BEHIND THE PROVINCE'S ADOPTION OF PARTNERSHIP AS THE BASIS FOR POLICY. THE AUTHOR SUGGESTS THAT IT IS A RESPONSE TO FOUR KEY STRATEGIC PROBLEMS: THE EXHAUSTION OF RESOURCES AND ALLOCATION OF LOSSES; THE LOSS OF FAITH IN GOVERNMENT AND THE CONSEQUENT NEED TO REDEFINE THE ROLE OF THE STATE; THE LOSS OF FAITH IN PROFESSIONAL KNOWLEDGE AND THE INCREASINGLY FORCEFUL VOICE OF ALTERNATIVE AND "PSYCHIATRIC SURVIVOR" GROUPS; AND THE PROBLEM OF OVERLOAD IN PLURALIST AND COMPETITIVE DEMOCRACY.

01706 BOUDRIA, D.

MEMBER'S INTERESTS: NEH CONFLICT OF INTEREST RULES FOR CANADIAN PARLIAMENTARIANS

PARLIAMENTARIAN, LXXIIII(4) (OCT 92), 247-248. CANADIAN MEMBERS OF PARLIAMENT ARE GRAPPLING WITH THE ISSUES SURROUNDING THE DISCLOSURE OF PERSONAL INTERESTS IN A CONCERTED EFFORT TO IMPROVE BOTH THE APPEARANCE AND THE REALITY OF PUBLIC PROBITY. THIS ARTICLE EXPLORES THE FINE REALITY OF PUBLIC PROBITY. THIS ARTICLE EXPLORES THE FINE
LINE BETWEEN THE LEGISLATOR'S PRIVATE INTERESTS AND HIS OR LINE BETWEEN THE LEGISLATOR'S PRIVATE INTERESTS AND HIS OR
HER PUBLIC DUTIES. IT EXPLORES THE RESULTS OF STUDY OF THE HER PUBLIC DUTIES. IT EXPLORES THE RESULTS OF A STUDY OF THE
JOINT HOUSES AND ITS CONCLUSION THAT A MINISTER HAD BREACHED THE CANADIAN CONFLICT OF INTEREST RULES ON 14 DIFFERENT THE CANADIAN CONFLICT OF INTEREST RULES ON 14 DIFFERENT 1986 .

01707 BOULDING, E. (ED.) NEH AGENDAS FOR PEACE RESEARCH: CONFLICT AND SECURITY REEXAMINED

LYNME RIENNER PUBLISHERS, 1992, 250

CONFRONTING A CHANGING POST-COLD WAR ENVIRONMENT--IN WHICH NORTH-SOUTH CONFLICTS HAVE SUPERCEDED THOSE BETHEEN EAST AND WEST, AND THE BOUNDARIES BETWEEN INTERNAL AND INTERSTATE CONFLICTS HAVE ALL BUT DISAPPEARED--PEACE RESEARCHERS REEXAMINE IN THIS BOOK THE CONCEPTS OF CONFLICT AND SECURITY. THE AUTHORS EXPLORE THE OLD AND NEW CONFLICTS FROM EUROPEAN, THIRD WORLD, AND FEMINIST PERSPECTIVES; EXAMINE RECONCEPTUALIZATIONS OF SECURITY, CRITICALLY ANALYZING THE APPROPRIATENESS OF USING ENVIRONMENTAL AND DEVELOPMENTAL CONCEPTS TO EXPAND EARLIER FORMULATIONS OF STRATEGIC SECURITY; OFFER INSIGHTS INTO CREATIVE NEH APPROACHES TO CONFLICT AND VIOLENCE, CONCLUDING WITH A LOOK AT THE PROCESS OF REPLACING CULTURES OF MILITARISM WITH PEACE CULTURES; AND HIGHLIGHT THE CHALLENGES FACING PEACE RESEARCH NOH AND IN THE DECADES TO COME.

01708 BOULEGUE, J.

"FEMINIZATION" AND THE FRENCH MILITARY: AN ANTHROPOLOGICAL APPROACH

ARMED FORCES AND SOCIETY, 17(3) (SPR 91), 343-362. THIS STUDY EXPLORES COMSEOUENCES OF RECENT MEASURES OF "FEMINIZATION" IN THE FRENCH ARMED FORCES, WHERE CONSCRIPTION REMAINS LIMITED TO MALES. THE CURRENT SITUATION CONSCRIPTION REMAINS LIMITED TO MALES. THE CURRENT SITUATION
IS NOT FULLY EGALITARIAN, BUT ONE OF MINORITY PARTICIPATION IS NOT FULLY EGALITARIAN, BUT ONE OF MINORITY PART CONSEOUENCE AFFECTS RELATIONS BETWEEN THE ARMED FORCES AND CONSEQUENCE AFFECTS RELATIONS BETWEEN THE ARMED FORCES THE NATION: THE MASCULINITY OF CONSCRIPTION, WHICH HAS ALREADY LOST LEGITIMACY DUE TO GLOBAL CHANGES, IS BECOMING LESS AND LESS JUSTIFIED BECAUSE OF NEW MILITARY FUNCTIONS ASSIGNED TO WOMEN. IN A PARALLEL FASHION, THE IMAGE OF DISUSE. ANOTHER CONSEQUENCE, INTERNAL TO THE ARMED FORCES, IS THE SUCCESS OF CERTAIN FEMALES IN THE RANKS DUE TO A CHARISMATIC TYPE OF AUTHORITY. THE MILITARY INSTITUTION, HHOSE MODEL STILL APPLIES TO MALE ENLISTEES, HAS DIFFICULTY RECOGNIZING THIS PHENOMENON. 
01709 BOURNE, R.

COMMONWEALTH AT UNCED

ROUND TABLE, 324(324) (OCT 92), 457-564.

THE BRIEF HISTORY OF NORTH-SOUTH NEGOTIATION HAS NOT BEEN A HAPPY ONE, BUT THE UNITED NATIONS CONFERENCE ON ENVIRONMENT AND DEVELOPMENT (UNCED) AT RIO OE JANEIRO IN JUNE 1992 GAVE A GLIMMER OF HOPE. FOR THE COMMONWEALTH THIS COULD TURN OUT TO BE A CRITICALLY IMPORTANT OPENING BECUASE MANY MEMBERS HAVE SAID THAT THEY SEE THE MAIN CONTEMPORARY VALLE OF THE COMMONWEALTH AS AN ASSOCIATION WHICH LINKS VALUE OF THE COMMONWEALTH AS AN ASSOCIATION WHICH LINKS NORTH AND SOUTH. AN IMPORTANT ASPECT OF THE COMMONKEALTH AT RIO LAY IN THE CONTRIBUTION OF THE COMMONWEALTH SECRETARI PRESENTED.

01710 BOURNE, $R$.

THE COMMONHEALTH AND HUMAN RIGHTS

OUND TABLE, (320) (OCT 91), 411-416.

TWO MAJOR ISSUES FOR THE 1990S ON THE INTERNATIONAL STAGE HILL BE, IT IS ALREADY CLEAR, THE STRENGTHENIMG OF BASIC HUMAN RIGHTS AND OF DEMOCRACY. THE THO GO TOGETHER, BUT THEY ARE NOT IDENTICAL. IT IS DIFFICULT TO PRESERVE HUMAN RIGHTS WHERE THERE IS NO DEMOCRACY, BUT THE EXISTENCE
OF A DEMOCRATIC SYSTEM WHICH ENABLES THE PEOPLE TO CHANGE THEIR RULERS DOES NOT, OF ITSELF, GUARANTEE THAT FUNDAMENTAL
RIGHTS WILL BE RESPECTED. THIS ARTICLE CONSIDERS WHETHER THE COMMONWEALTH HAS ANYTHING TO CONTRIBUTE TO THESE MOVEMENTS IT ANALYZES WHY THE COMMONWEALTH HAS DONE SO LITTLE HITHERTO, EXAMINES THE ISSUES THAT IT NOW FACES, AND CONSIDERS FUTURE PROSPECTS.

01711 BOURNE, $S$.

THE AFRICAN AMERICAN IMAGE IN AMERICAN CINEMA

BLACK SCHOLAR, 21 (2) (MAR 90), 12-19.

THIS ARTICLE EXAMINES THE TRADITIONAL IMAGE OF AFRICAN

AMERICANS IN THE AMERICAN CINEMA AND THE EFFECTS ON SOCIETY.

IT ALSO EXPLORES THE ATTEMPTS, SUCH AS THE "LA REBELLION,"

OF BLACK ACTORS AND FILMMAKERS TO BREAK OUT OF THE

TRADITIONAL. RACIST, MDOE AND PORTRAY THEIR ACTUAL

TRADITIONAL, RACIST, MOOE AND PORTRAY THEIR ACTUAL

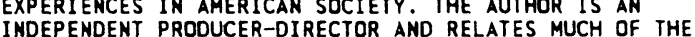

INDEPENDENT PRODUCER-DIRECTOR AND
MATERIAL FROM PERSONAL EXPERIENCE.

01712 BOUTROS-GHALI, B.

THE MARGIMALIZATION OF AFRICA

THE MARGIHALIZATION OF AFRICA
MEDITERRANEAN QUARTERLY: A JOURNAL OF GLOBAL ISSUES, 3(1)

(WIN 92 ), $1-14$.

SIX RECENT INTERNATIONAL DEVELOPMENTS HAVE A DIRECT

BEARING ON NORTH AFRICA AND THE POTENTIAL FOR THE FURTHER

MARGINALIZAITON OF AFRICA. THEY ARE: THE RISE OF

EUROCENTRICISH; THE REVIVIAL OF THE "PRODIGAL SON"

PHENOMENON, REPRESENTED BY THE RETURN OF COUNTRIES OF

THE EROSION OF AID TO AFRICA, WHOSE COUNTRIES HAVE GROWN

INCREASINGLY POOR SINCE THE INCEPTION OF THE INDEPENDENCE

PROCESS: THE LIBERALIZATION OF THE INTERMATIONAL ECONOMY

THE SUDDEN AVAILABILITY OF EASTERN EUROPEAN MANPOWER; AND

THE NEW CONDITIONS IMPOSED ON AID TO AFRICAN COUNTRIES BY

THE WEST. IN GENERAL TERMS, WHILE THE INTERNATIONAL

SITUATION HAS EVOLVED FROM A CLIMATE OF CONFRONTATION TO ONE OF COOPERATION BETWEEN EAST AND WEST, AFRICA HAS NOT BEEN ABLE TO ACHIEVE SUFFICIENT PROGRESS IN ITS QUEST FOR ECONOMIC DEVELOPMENT. THE ONLY SOLUTION TO AFRICA'S DEVELOPMENTAL PROBLEMS IS AN ACCEPTANCE BY THE RICH OF THE WORLD THAT BY BEING LESS RICH, THEY CAN MAKE THE POOR LESS POOR.

01713 BOVA, R.

TOHARDS A CIVIL SOCIETY? INFORMAL ACTIVITY AND THE SOVIET WORKING CLASS

NATIONALITIES PAPERS, 18(2) (FAL 90), 42-49.

THIS ARTICLE EXAMINES UNOFFICIAL OR INFORMAL SOCIAL-

POLITICAL ACTIVITIES THAT SOVIET WORKERS HAVE BEEN ENGAGED

IN OVER THE COURSE OF THE LAST SEVERAL YEARS. TO INTRODUCE

THE DISCUSSION, THE AUTHOR LOOKS BACK TO 1987 AT ATTEMPTS BY

THE DISCUSSION, THE AUTHOR LOOKS BACK TO 1987 AT ATTEMPTS BY
THE GORBACHEV REGIME TO PREEMPT UNOFFICIAL ACTIVITY ON THE

THE GORBACHEV REGIME TO PREEMPT UNOFFICIAL ACTIVITY ON THE
PART OF WORKERS, WHICH, THE AUTHOR ARGUES, WAS DONE IN ORDER PART OF WORKERS, WHICH, THE AUTHOR ARGUES, WAS DONE
TO CONTROL THOSE ACTIVITIES AND TO USE THEM FOR HIS

POL CONTROL THOSE ACTIVITIES AND TO USE THEM FOR HIS

THOSE ATTEMPTS HAS LED TO THE GROWTH OF UNOFFICIAL ACTIVITY

THOSE ATTEMPTS HAS LED
AMONG SOVIET HORKERS.

01714 BOVAIRD, T.; GREGORY, D. : MARTIN, S.

IMPROVED PERFORMANCE IN LOCAL ECONOMIC DEVELOPMENT: A WARM IMPROVED PERFORMANCE IN LOCAL

PUBLIC ADMINISTRATION, 69(1) (SPR 91), 103-120.

THIS ARTICLE EXAMINES THE EXTENT TO WHICH CHANGING

APPRDACHES TO PERFORMANCE MANAGEMENT HAVE HAD AN IMPACT ON A RANGE OF AGENCIES RESPONSIBLE FOR LOCAL ECONOMIC DEVELOPMENT PROGRAMHES IN BRITAIN. IT EXPLORES THE POSSIBILITY THAT THE EFFECTIYENESS OF PUBLIC PROGRAMMES COULD BE MORE SHARPLY HIGHLIGHTED AND INCORPORATED IN THE PERFORMANCE REVIEH OF ORGANIZATIONS. IT DEMONSTRATES THAT MAJOR IMPROVEMENTS HAVE OCCURRED BY THAT OVERALL THE PLANNING AND MANAGEMENT OF
LOCAL ECONOMIC DEVELOPMENT REMAINS LARGELY INCREMENTAL. WHILE THE FMI (FINANCIAL MANAGEMENT INITIATIVE) HAD LED TO GREATER UNDERSTANDING OF THE EXTENT TO WHICH CORPORATE ANO PROGRAMME ACCOUNTABILITY CAN BE ACHIEVED IN PUBLIC AGENCIES, IT IS NOT CLEAR THAT SUFFICIENT MOMENTUM HAS BEEN ACHIEVED FOR FUTURE CHANGES TO BE SELFGENERATING. FURTHER PROGRESS IN PERFORMANCE MANAGEMENT CONTINUES TO BE DEPENDENT ON STRONG EXTERMAL PRESSURES TO PUBLICIZE, PROBE AND REWARD DEMONSTRABLE IMPROVEMENTS IN PUBLIC SECTOR PERFORMANCE.

01715 BOVAIRD, T.

LOCAL ECONOMIC DEVELOPMENT AND THE CITY

URBAN STUDIES, 29(2) (APR 92), 343-368.

THIS ARTICLE FOCUSES ON THE ECONOMIC DEVELOPMENT PROCESS AT THE LOCAL LEVEL, ESPECIALLY THE INTER-RELATIONSHIP OF ECONOMIC DEVELOPMENT AND SPATIAL PROCESSES. KEY QUESTIONS INCLUDE THE FOLLOWING: HOW CAN LOCAL ECONOMIES BE DEFINED AND ANALYZED? IS IT POSSIBLE TO ISOLATE THE KEY ECONOMIC POLITICAL AND SOCIAL FORCES FOR CHANGE AT THE LOCAL LEVEL? WHAT ARE THE MAIN PERSPECTIVES WITHIN WHICH LOCAL ECONOMIC DEVELOPMENT POLICY IS BEING DEVELOPED AND IMPLEMENTED? IS THERE ANY EVIDENCE THAT CERTAIN APPROACHES TO
DEVELOPMENT ARE MORE LIKELY TO BE SUCCESSFUL?

01716 BOVARD, J.

BUSH PROTECTION

NEW REPUBLIC, 206 (3) (JAN 92), 9.

GEORGE BUSH, WHO HAS CEDED TO THE DEMANDS OF ONE

DOMESTIC LOBBY AFTER ANOTHER, MAY BE THE MOST PROTECTIONIST U.S. PRESIDENT SINCE HERBERT HOOVER. THE DUMPING LAW IS THE BUSH ADMINISTRATION'S FAVORITE PROTECTIONIST TOOL, WITH COMMERCE DEPARTMENT OFFICIALS URGING AMERICAN COMPANIES TO BRING ANTI-DUMPING SUITS. IN ADDITION, THE ADMINISTRATION HAS TAKEN SOME HIGHLY PROTECTIONIST POSITIONS IN THE CURRENT GATT ROUND.

01717 BOVARD, J.

FAIR TRADE FOLLIES

NEW REPUBLIC, 206 (19) (MAY 92), 12-13.

"FAIR TRADE" HAS LONG BEEN A MANTRA IN CONGRESS, BUT THERE'S NOTHING FAIR ABOUT THE LATEST ROUND OF PROTECTIONIST PLANS BEING LAID ON CAPITOL HILL. NO IMPORT IS TOO TRIVIAL, NO RESTRICTION TOO DRACONIAN, NO ARGUMENT TOO SHAME-FACED FOR SOME MEMBER OF CONGRESS TO SEIZE UPON
FOR A NEH CRUSADE AGAINST FOREIGN IMPORTS.

01718 BOVARD, J.

MISMANAGED TRADE

WATIONAL REVIEW, XLIII(14) (AUG 91), 40-42.

THE MULTIFIBER AGREEMENT (MFA), HHICH SOUGHT "THE REDUCTION OF TEXTILE TRADE BARRIERS AND THE LIBERALIZATION OF HORLD TRADE, WAS SUPPOSED TO BE A TRANSITIONAL ARRANGEMENT TO HELP RICHER COUNTRIES PHASE OUT OF AN INDUSTRY IN WHICH THEY WERE UNCOMPETITIVE. INSTEAD, THE MFA PROVIDED A BLANK CHECK FOR WEALTHY IMPORTING NATIONS TO SHACKLE POORER EXPORTING NATIONS. IN THE END, THE MFA PROTECTS AMERICANS ONLY FROM LOW-PRICED CLOTHING.

01719 BOWEN, D.; DRAKE, L.

THE SYRIAN-ISRAELI BORDER CONFLICT, 1949-1967

MIDDLE EAST POLICY, 1(4) (1992), 17-28.

THE ORIGINS OF THE 1967 WAR IN THE MIDDLE EAST LIE JUST BELOW THE GOLAN HEIGHTS. THIS ARTICLE OFFERS AN EXAMINATION OF THREE SMALL PATCHES OF LAND ALONG THE SYRIAN-ISRAELI BORDER, THE ONLY TERRITORY IN WHAT WOULD HAVE BEEN ISRAEL UNDER THE U.S. PARTITION PLAN THAT THE ISRAELIS DID NOT SUCCEED IN OCCUPYING AT THE TIME OF THE ARMISTICE. IT CONCLUDES THAT IN THE FINAL ANALYSIS, THE ARAB-ISRAELI CONFLICT IS NOT ABOUT THE GOLAN HEIGHTS. IT IS ABOUT PALESTINE.

01720 BOWEN, $M$

BEYOND REFORM: ADJUSTMENT AND POLITICAL POWER IN CONTEMPORARY MOZAMBIQUE

JOURNAL OF MODERN AFRICAN STUDIES, 30(2) (JUN 92), 225-279. FACED WITH GLOBAL DEPRESSION ANO POLITICAL READJUSTMENTS IN THE LATE 1980S, ALL STATES IN AFRICA HAVE BEEN TRYING TO IMPLEMENT MAJOR REFORMS. THE MOVE TO CAPITALIST MARKETS IN PRIVATE RELATIONS AND STRUCTURAL ADJUSTMENT PROGRAMS IN THE PUBLIC SPHERE WERE NOT SHIFTS UNDERTAKEN HILLINGLY IN EVERY CASE. THIS STUDY SEEKS TO ANALYZE THE RANGE OF
INYOL VED IN A SHIFT TO A FREE MARKET, ECONOMY.

01721 BOWEN, $R$

JAPAN'S FOREIGN POLICY

PS: POLITICAL SCIENCE AND POLITICS, XXV(1) (MAR 92), 57-73.

JAPAN IS AN EXCELLENT EXAMPLE OF THE ANOMALY OF THE ECONOMIC GIANT-POLITICAL PYGMY WHOSE ABILITY TO INFLUENCE INTERNATIONAL EVENTS IS SEVERELY LIMITED DESPITE A MANIFEST DESIRE TO PLAY A LARGER ROLE IN WORLD AFFAIRS. WHILE MUCH OF JAPAN'S FOREIGN POLICY CAN PROPERLY BE TERMED "ECONOMIC DIPLOMACY," JAPAN HAS NOT ALWAYS BEEN SUCCESSFUL IN SEPARATING ECONOMIC RELATIONS FROM POLITICAL AND STRATEGIC CONSIDERATIONS IN ITS RELATIONS WITH THE USA AND WITH ITS 
ASIAN NEIGHBORS.

01722 BOWERS, S.R. PRAGMATISM AND SOVIET FOREIGN POLICY: USSR-SOUTH KOREAN RELATIONS

ASIAN AFFAIRS, AN AMERICAN REVIEW, 19(1) (SPR 92), 19-34. UNDER MIKHAIL GORBACHEV, SOVIET FOREIGN POLICY TOWARD SOUTH KOREA ENTERED A NEW ERA WHEN THE THO COUNTRIES ESTABLISHED FULL DIPLOMATIC RELATIONS IN 1990. IN THIS PAPER, THE AUTHOR OUTLINES THE FACTORS THAT MOTIVATED THE FORMER USSR TO SEEK DETENTE WITH THE REPUBLIC OF KOREA AND DISCUSSES THE RELEVANCE FOR THE COMMONWEALTH OF INDEPENDENT STATES AND FOR RUSSIAN POLICY IN THE FAR EAST.

01723 BOWLER, S.; DONOVAN, T.; HAPP, T.

BALLOT PROPOSITIONS AND INFORMATION COSTS: DIRECT DEMOCRACY AND THE FATIGUED YOTER

WESTERN POLITICAL QUARTERLY, 45(2) (JUN 92), 559-568. BALLOT PROPOSITIONS HAVE ATTRACTED A GREAT DEAL OF ATTENTION IN RECENT YEARS, BECAUSE THEY HAVE BECOME AN INCREASINGLY IMPORTANT PART OF THE DEMOCRATIC PROCESS IN THE UNITED STATES, ESPECIALLY IN CALIFORNIA. YET VOTERS SEEY INCREASINGLY DISENCHANTED WITH THIS PROCESS. ONE WAY OF UNDERSTANDING VOTER REACTION TO PROPOSITIONS IS TO CONCEIVE OF THEM AS PRESENTING VOTERS WITH A SET OF DECISION-MAKING COSTS THAT THEY SEEK TO MINIMIZE. DEVELOPING HYPOTHESES FROM THIS SIMPLE BASIS ALLOWS THE AUTHORS TO MAKE A SERIES OF PREDICTIONS OF LIKELY VOTER TURNOUT ON BALLOT PROPOSITIONS THEY FIND THAT BALLOT POSITION, PROPOSITION TYPE, AND SPENOING PATTERNS HAVE STATISTICALLY SIGNIFICANT IMPACTS UPON THE DECISION OF VOTERS TO EXPRESS A PREFERENCE ON A GIVEN PROPOSITION.

01724 BOWLER, S.

CONTEXTUAL MODELS OF POLITICS: THE POLITICAL IMPACT OF FRIENDS AND NEIGHBORS

POLITICAL GEOGRAPHY QUARTERLY, 1012) (APR 91), 91-96. WHILE THE IMPACT OF SOCIAL NETHORKS OF FRIENDS AND NEIGHBORS ON VIEHS OF THE POLITICAL WORLD IS GENERALLY ACCEPTED, EMPIRICAL SUBSTANTIATION OF THIS PROCESS HAS BEEN HARD TO FIND. THIS ARTICLE DISCUSSES OBJECTIONS TO THE CONTEXTUAL APPROACH AND WAYS IN WHICH THOSE CRITICISMS CAN BE ADDRESSED.

01725 BOWLER, S.; LANOUE, D.J. STRATEGIC AND PROTEST VOTING FOR THIRD PARTIES: THE CASE OF THE CANADIAN NDP

WESTERN POLITICAL QUARTERLY, 45(2) (JUN 92), 485-500. DUYERGER'S LAW ARG TER TY 45(2) ( JUN 92), $485-500$. DISAPPEAR UNDER THE "FIRST PAST THE POST" SYSTEM. THUS, THE EXISTENCE OF LONG-LIVED THIRD PARTIES IS AN ANOMALY THAT NEEDS EXPLANATION. IN THIS PAPER, THE AUTHORS ARGUE THAT THE "WINNER TAKE ALL" ELECTORAL SYSTEM CAN PROVIDE CIRCUMSTANCES "WHAT CAN SUSTAIN MINOR PARTIES. TAKING CANADA'S NEH THAT CAN SUSTAIN MINOR PART IES. TAKIHG CANADA THAT BOTH DEMACRATIC PARTY AS A CASE ST OOY, BENE IT MINOR PARTIES. BOTH TYPES OF VOTING MODIFY THE TRADITIONAL CONCEPTIONS OF DUVERGER'S LAH AND REJECTION VOTING.

01726 BOWLES, S. ; GINTIS, H.

POWER AND WEALTH IN A COMPETITIVE CAPITALIST ECONOMY PHILOSOPHY AND PUBLIC AFFAIRS, 21(4) (FAL 92), 324-353. IT IS ARGUED THAT THE HALRASIAN MODEL IS A LIMITING CASE BASED ON AN ARBITRARY TRUNCATION OF THE CONCEPT OF RATIONAL ACTION. THIS ARTICLE EXAMINES THE ROLE OF THIRD-PARTY ENFORCEMENT IN THE WALRASIAN MODEL, AND DEVELOPS AN ALTERNATIVE MODEL. IT PROVIDES A CONTESTED EXCHANGE MODEL OF A COMPETITIVE LABOR MARKET AND DEMONSTRATES THAT EMPLOYERS HAVE POWER OVER WORKERS IN EOUILIBRIUM. IT EXPLORES THE TYPE OF POWER ACCRUING TO AGENTS WHO OCCUPY ADVANTAGEOUS POSITIONS ON SUCH NONCLEARING MARKETS AND ADDRESSES THE RELATIONSHIP BETWEEN PONER AND WEALTH.

01727 BOWMAN, A.O.; PAGANO, M.A.

CITY INTERVENTION: AN ANALYSIS OF THE PUBLIC CAPITAL MOBILIZATION PROCESS

URBAN AFFAIRS QUARTERLY, 27(3) (MAR 92), 356-374.

THE AUTHORS CONSTRUCT A CONCEPTUAL FRAMEHORK AROUND THO FACTORS THAT TRIGGER THE MOBILIZATION OF PUBLIC CAPITAL: (1) A PERCEPTION OF IMBALANCE BETHEEN A CITY'S COMPETITIVE TAX BURDEN AND SERVICE-DELIVERY LEVELS AMD (2) CITY OFFICIALS' BURDEN AND SERVICE-DELIVERY LEVELS AND (2) CITY OFFICIALS
VISION OF THE APPROPRIATE PLACE FOR THEIR CITY AMID WHAT VISION OF THE APPROPRIATE PLACE FOR THEIR CITY AMID WHAT
THEY CONSIDER TO BE RELEVANT CITIES. TRIGGER MECHANISMS THEY CONSIDER TO BE RELEVANT CITIES. TRIGGER MECHANISMS
PRODUCE FOUR CITY-LEVEL ORIENTATIONS TO DEVELDPMENT THAT THE PROOUCE FOUR CITY-LEVEL ORI ENTATIONS TO DEVELOPMENT THAT THE
AUTHORS LABEL "SURVIVALIST," "MARKET, "EXPANSIONIST," AND AUTHORS LABEL "SURYIVALIST," "MARKET," "EXPANSIONIST," AND "MAINTENANCE." IN AN APPLICATIDN OF THE CONCEP

01728 BOHMAN, A.O.; PAGANO, M.A. THE STATE OF AMERICAN FEDERALISH, 1991-92 PUBLIUS: THE JOURNAL OF FEDERALISM, 22(3) (SUM 92), 1-20. IN 1991-92, WHILE SYSTEMIC QUESTIONS OF INTERGOVERNMENTAL RELATIONS DOMINATED PUBLIC DEBATE IN MANY COUNTRIES, MOST SUBSTANTIVE DEBATE IN THE UNITED STATES
REMAINED IN A PRE-ELECTION HOLDING PATTERN. CONSTRAINED BY GROWING DEBT AND A RECESSION, FEH NEW FEDERAL INITIATIVES MADE THEIR WAY THROUGH THE POLICYMAKIMG THICKET. IN TERMS OF POWER AND AUTHORITY, THE FEDERAL GOVERNMENT OFTEN PULLED IN ONE DIRECTION WHILE THE STATES TUGGED IN ANOTHER. IN THE STATES, FISCAL STRESS DOMINATED THE AGENDA AS STATE GOVERNMENTS TRIED TO DELIVER SERVICES AND BALANCE THEIR BUDGETS THROUGH A COMBIMATION OF TAX INCREASES AND CUTBACKS. IN THE JUDICIAL BRANCH, MATTERS OF INTERGOVERNMENTAL RELATIONS RECEIVED EXTENSIVE TREATMENT.

01729 BOWMAN, J.C.

IMPROVING THE QUALITY OF OUR WATER: THE ROLE OF REGULATION BY THE NATIONAL RIVERS AUTHORITY

PUBLIC ADMINISTRATION (LONDON), 70(4) (WIN 92), 565-575.

THE AUTHOR TRACES THE EVOLUTION OF THE NATIONAL RIVERS AUTHORITY IN THE UNITED KINGDOM AND DISCUSSES THE ROLE OF REGULATION IN IMPROVING THE QUALITY OF HATER.

01730 BOWMAN, J.H.; MACMANUS, S.; MIKESELL, J.L. MOBILIZING RESOURCES FOR PÜLIC SERVICES: FINANCING URBAN GOVERMMENTS

JOURNAL OF URBAN AFFAIRS, 14(3-4) (1992), 311-335.

URBAN LOCAL GOVERMMENTS MUST LOOK FOR' NEW FINANCIAL RESOURCES BECAUSE PROSPECTS FOR MAJOR ASSISTANCE FROM THE FEDERAL GOVERMMENT ARE DIM. POLITICAL CANDIDATES MUST ASSESS THE COST OF PUBLIC SERVICES AND AVOID BLANKET PROMISES OF NO NEW, OR NO INCREASED, TAXES. URBAN LOCAL GOVERMMENTS MUST HAVE ACCESS TO THE FISCAL RESOURCES OF THE FULL URBAN AREA
FOR WHICH THEY ARE RESPONSIBLE FOR PROVIDING PUBLIC SERVICES. FOR WHICH GOVERNMENTS MUST COORDINATE AND COOPERATE: FISCAL MERCANTILISM IS NOT PRODUCTIVE PUBLIC POLICY. URBAN LOCAL GOVERNMENTS MUST GIVE GREATER PRIORITY TO IMFRASTRUCTURE MAINTENANCE AND OEVELOPMENT IN THEIR FINANCIAL PLANS. IN ADOITION, THEY MUST IMPROVE PROPERTY TAX STRUCTURE AND ADMINISTRATION, WITH APPROPRIATE ASSISTANCE FROM STATE GOVERNMENTS. FINALLY, URBAN LOCAL GOVERNMENTS MUST MAKE BETTER USE OF CHARGE FINANCING AND MUST EXPAND USE OF BROADBASED SALES AND INCOME TAXES IN COOPERATION WITH THEIR STATE GOVERMMENTS.

01731 BOWRING, P.; MOSHER, S.

LORD HITHOUT MANOR

FAR EASTERN ECONOMIC REVIEW, 155(2) (JAN 92), 10-12. HONG KONG'S GOVERNOR SIR DAVID WILSON WAS ALWAYS

EXPECTED TO LEAVE BEFORE THE END OF 1992 BUT THE PREMATURE ANNOUNCEMENT OF HIS RETIREMENT, FOLLOWING HIS ELEVATION TO A PEERAGE IN BRITAIN'S NEW YEAR HONORS LIST, HAS PUZZLED MANY. NO DECISION HAS BEEN MADE ABOUT WILSON'S SUCCESSOR. THE MANMER OF HIS GOING SEEMS TO HAVE DESTABILIZED THE COLONY AS MANNER OF HIS GOING SEEMS TO HAVE DESTABILIZED THE COLO
WELL AS CREATING FRESH MISUNDERSTANDINGS WITH CHINA. WELL AS CREATING FRESH MISUNDERSTANDINGS WITH CHINA.
WILSON'S POOR PERFROMANCE ON A HOST OF ISSUES INCLUDING THE WILSON'S POOR PERFROMANCE ON A HOST OF ISSUES INCLUDING THE
PROPOSED CONSTRUCTION OF A NEW AIRPORT, REACTION TO THE PROPOSED CONSTRUCTION OF A NEW AIRPORT, REACTION TO THE BRITISH CITIZENSHIP TO HONG KONG NATIONALS, DIMINISHED HIS BRITISH CITIIZENSHIP TO HONG KONG NATIONALS, DIMINISHEE

01732 BOWRING, P.; AHANOHARA, S.; CHEUNG, T.; SHIM, J. PLAYING FROM STRENGTH

FAR EASTERN ECONOMIC REVIEN, 151(19) (MAY 91), 14-15. SOUTH KOREA IS IN THE PROCESS OF PARLAYIMG SUPERPOHER DETENTE AND ITS OWN ECONOMIC STRENGTH INTO ENDING ITS NEUTERED INTERNATIONAL STATUS. IN THE PROCESS IT MAY BE
LAYING THE GROUNDWORK FOR EVENTUAL, PHASED REUNIFICATION. IN THE SPACE OF A FEH DAYS IN APRIL, PRESIDENT ROH TAE WOO RECEIVED SOVIET PRESIDENT MIKHAIL GORBACHEV; THE SOUTH FORMALLY ANNOUNCED ITS INTENTION TO APPLY FOR MEMBERSHIP IN THE UN; AND SOUTH KOREAN LEGISLATORS VISITED PYONGYANG (THE NORTH KOREAN CAPITAL) FOR THE FIRST TIME TO ATTEND A MEETING OF THE INTERPARLIAMENTARY UNION. FOR THE SOUTH, THE UN MEMBERSHIP WOULD NOT JUST BE A VICTORY FOR ITS NORTHERN DIPLOMACY--THE OPENING OF THE SOVIETS AND CHINA--BUT WOULD UNDERLINE ITS EFFORT TO PLAY THE ROLE IN INTERHATIONAL AFFAIRS THAT IT BELIEVES ITS ECONOMIC STRENGTH ENTITLES IT TO.

01733 BOWRING, P.; AHHAR, D.

THE ANHAR DOCTRIME

FAR EASTERN ECONOMIC REVIEW, 151(23) (JUN 91), 55-56. FINANCE MINISTER DATUK SERI ANHAR IBRAHIM ANSWERS QUESTIONS ABOUT MALAYSIA'S NEW ECONOMIC BLUEPRINT, TRADE BLOCS, AND FREEDOH OF EXPRESSION. HE DISCUSSES THE NEW BLOCS, AND FREEDOH OF EXPRESSIDN. HE DISCUSSES THE NEW
OUTLINE PERSPECTIVE PLAN AND HOW IT FITS INTD THE GENERAL OUTLINE PERSPECTIVE PLAN AND HOW IT FITS INTO THE GENERAL
TREND TOWARDS LIBERALIZATION, DEREGULATION AND PRIVATIZATION. TREND TOWARDS LIBERALIZATION, DEREGULATION AND PRIVATIZAT
HE ALSO OUTLINE FUTURE PROBLEMS FACING THE MALAYSIAN HE ALSO OUTLINE FUTURE PROBLEMS FACING THE MALAYSIAN
ECONOMY INCLUDING DHINDLING FOREIGN INVESTMENT, GROHING ECONOMY INCLUDING DHINDLING FOREIGN INVESTMENT, GRONING
INFLATIDN. AHD THE FUTURE OF MALAYSIAN HEAVY INDUSTRY. HE INFLATIDN, AND THE FUTURE OF MALAYSIAN HEAVY INDUSTRY
DEFENDS THE EAST ASIAN ECONOMIC GROUPING (EAEG) AS A RESPONSE TO GROWING TRADE BLOCS IN OTHER REGIONS.

01734 BOWSHER, C.A.

MEETING THE NEH AMERICAN MANAGEMENT CHALLENGE IN A FEDERAL AGENCY: LESSONS FROM THE GENERAL ACCOUNTING OFFICE PUBLIC ADMINISTRATION REVIEN, 52(1) (JAN 92), 3-7. 
WITH ITS FOCUS ON HUMAN RESOURCES, CUSTOMER SERVICE, AND HIGH QUALITY PRODUCTIVITY, THE GENERAL ACCOUNTING OFFICE HAS DEMONSTRATED THAT PUBLIC SECTOR AGENCIES CAN LIVE UP TO HIGH THE FUTURE.

01735 BOX-STEFFENSMEIER, J.M.; DOW, J.K.

CAMPAIGN CONTRIBUTIONS IN AN UNREGULATED SETTING: AM ANALYSIS OF THE 1984 AND 1986 CALIFORNIA ASSEMBLY ELECTIONS HESTERM POLITICAL OUARTERLY 45(3) (SEP 92) 609-628. THE STUDY OF CAMPAIGN FIMANCE HAS BEEN GREATLY INFORMED BY THE USE OF ECONOMIC MODELS OF THE CONTRIBUTOR-LEGISLATOR BY THE USE OF ECONOMIC MODELS OF THE CONTRIBUTOR-LEGISLATO
RELATIONSHIP. PREDOMINANT AMONG THESE IS THE INVESTMENT RELATIONSHIP. PREDOMINANT AMONG THESE IS THE INVESTMENT
THEORY OF RESOURCE ALLOCATION, WHICH PREDICTS THAT INTEREST THEORY OF RESOURCE ALLOCATION, WHICH PREDICTS THAT INTEREST GROUPS EQUATE THE MARGINAL VALUE OF THE LAST DOLLAR PROVID
ACROSS RECIPIENTS. SINCE THE MODEL IS PREDICATED ON THE ACROSS RECIPIENTS. SINCE THE MODEL IS PREDICATED ON THE
EXISTENCE OF AN UNREGULATED CAMPAIGN FINANCE ENVIRONMENT, EXISTENCE OF AN UNREGULATED CAMPAIGN FINANCE ENVIRONMENT, ANE AUTH CAL IFORNIT ASSEMBLY ELECTIONS. THE RESULTS INDICATE AND 1986 CALIFORNIA ASSEMBLY ELECTIONS. THE RESULTS INDICATE THE ACCEPTANCE AFFORDED THE MODEL IS JUSTIFIED. FURTHER, EMPIRICAL FINDINGS SUGGEST THAT RESTRICTIONS ON CAMPAIGN AT THE EXPENSE OF CHALLENGERS AND MEMBERS OF MINOR PARTIES.

01736 BOX, R.

THE ADMINISTRATOR AS TRUSTEE OF OF THE PUBLIC INTEREST: NORMATIVE IDEALS AND DAILY PRACTICE ADMINISTRATION AND SOCIETY, 24(3) (NOY 92), 323-345. THIS ARTICLE ARGUES THAT CALLS FOR GREATER ADMINISTRATIVE OISCRETION ARE USEFUL FROM A NORMATIVE VIEWPOINT, BUT THAT ADMINISTRATIVE PRACTICE IS CONSTRAINED BY THE RELATIONSHIP BETHEEN THE ADMINISTRATOR AND THE GOVERNING BODY. A TYPOLOGY OF DISCRETION IS OFFERED WHICH DISTINGUISHES BETHEEN NORMATIVE THEORY AHD DESCRIPTIVE THEORY, OR THEORY-IN-USE. AN EXAMINATION IS MADE OF THE LITERATURE AND PRACTICE OF LOCAL ADMINISTRATION AS A LOCUS FOR EYALUATING HOW ADMINISTRATORS DETERMINE THEIR SPHERE OF DISCRETION IN DAILY PRACTICE.

01737 BOX, R.C.

AN EXAMINATION OF THE DEBATE OVER RESEARCH IN PUBLIC ADMINISTRATION

PUBLIC ADMINISTRATION REVIEN, 52(1) (JAN 92), 62-69.

THE AUTHOR DISAGREES WITH THE PESSIMISTIC ASSESSMENT OF PUBLIC ADMINISTRATION RESEARCH OFFERED BY ROBERT E. CLEARY PUBLIC ADMINISTRATION RESEARCH OFFERED BY ROBERT E. CLEARY AND HOWARD MCCURDY. HE CHALLENGES THEIR ASSUMPTIONS ABOUT THE KIND OF RESEARCH DONE IN THE MAINSTREAM SOCIAL SCIENCI AS WELL AS THEIR LACK OF REFERENCE TO RESEARCH IN MORE PRACTITIONER-ORIENTED FIELDS, SUCH AS LAN AND PLANNING. HE CHALLENGES THEIR NARROW VIEH OF SCIENTIFIC WRITING STYLE AS WELL AS THEIR CONTENTION THAT PUBLIC ADMINISTRATION RES
IS NOT REALLY ADDRESSING THE CORE ISSUES IN THE FIELD.

01738 BOYCE, J.K

THE REVOLVING DOOR? EXTERNAL DEBT AND CAPITAL FLIGHT: A PHILIPPINE CASE STUDY

WORLD DEVELOPMENT, 20(3) (MAR 92), 335-349.

IN RECENT DECADES, THE PRIVATE CITIZENS OF A NUMBER OF THIRD HORLD COUNTRIES ACCUMULATED SUBSTANTIAL EXTERNAL ASSETS VIA "CAPITAL FLIGHT" AT THE SAME TIME THAT THEIR GOVERNMENTS INCURRED LARGE EXTERNAL DEBTS. THIS PAPER PROPOSES A CLASSIFICATION OF HYPOTHETICAL LINKAGES BETWEEN CAPITAL FLIGHT AND EXTERNAL DEBT DISBURSEMENTS AND EXAMINES THE STRENGTH OF THESE LINKAGES IN THE PHILIPPINES DURING 1962-1986. ECONOMETRIC ANALYSIS AND ANECDOTAL EVIDENCE INDICATE THAT LARGE SUMS OF CAPITAL FLOWED TO AMD FROM THE PHILLIPINES THROUGH A FINANCIAL REVOLVING DOOR. THUS, THERE IS SCOPE FOR POLITICAL AND LEGAL CHALLENGES TO THE

LEGITIMACY OF A SUBSTANTIAL FRACTION OF THE COUNTRY'S

EXTERNAL DEBT.

01739 BOYER, A.

AN EXEMPLARY TRANSITION

AFRICA REPORT, 37 (4) (JUL 92), 40-42.

AFTER TWO DOZEN YEARS OF DICTATORSHIP, MALI FINALLY HAS

A DEMOCRATICALLY ELECTED PRESIDENT, ALPHÁ OUMAR KONARE, WHO A DEMOCRATICALLY ELECTED PRESIDENT, ALPHA OUMAR KONARE, WHO DEMOCRACY WAS SMOOTHED BY LT. - COL. AMADOU TOUMANI TOURE, THE YOUNG SOLDIER WHO OVERTHREW MOUSSA TRAORE, AND KEPT HIS YOUNG SOLDIER WHO OVERTHREH MOUSSA TRAORE, AND KEPT HIS PROMISE TO RETURN POWER TO THE CIVILIANS. ALTHOUGH THE CHARISMATIC KONARE INSPIRES CONFIDENCE,
MAY PROVE TO BE A TOUGH ACT TO FOLLOH.

01740 BOYER, A.

UNITY' AT' LAST?

AFRICA REPORT, 37(2) (MAR 92), 37-40.

PRESIDENT PIERRE BUYOYA'S NATIONAL UNITY REFORMS ARE DESIGNED TO END DECADES OF BITTER ENMITY AND SOMETIMES HORRIFIC VIOLENCE BETHEEN BURUNDI'S THO MAJOR ETHNIC GROUPS, HUTU AND TUTSI. ONCE ENTIRELY TUTSI-DOMINATED, THE GOVERMHENT NOW HAS A HUTU MAJORITY; THE EDUCATIONAL SYSTEM HAS BEEN RID OF ITS PRO-TUTSI BIAS; AND A PROGRAM OF MULTIPARTY REFORM HAS BEEN LAUNCHED IN WHICH ALL ETHNIC GROUPS MUST BE REPRESENTED.
01741 BOYER, M.A.

INTERNATIONAL COOPERATION AND PUBLIC GOODS--OPPORTUNITIES FOR THE WESTERN ALLIANCE

JOHNS HOPKINS UNIVERSITY PRESS, 1992, 208

IN CONTEMPORARY INTERNATIONAL AFFAIRS, SECURITY IS NOT A ONE-DIMENSIONAL CONCEPT. NATIONS DEFINE SECURITY ACROSS ECONOMIC, MILITARY, POLITICAL, AND EVEN SOCIAL BOUNDARIES. THIS BOOK BROADENS THE UNDERSTANDNG OF SECURITY BEYOND MILITARY CAPABILITY AND SHOWS HOW ECONOMIC AND POLITICAL POWER ENTER INTO THE BALANCE, ESPECIALLY IN THE CASE OF ADVANCED INDUSTRIALIZED NATIONS. IN CONTRAST TO THE THEORISTS WHO INSIST U.S. MILITARY EFFORTS ARE PROVIDING THE WESTERN ALLIES WITH A "FREE RIDE," THE AUTHOR REACHES WESTERN ALLIES WITH A "FREE RIDE," THE AUTHOR REACHES
DRAMATICALLY DIFFERENT CONCLUSIONS REGARDING THE NATURE OF ORAMATICALLY DIFFERENT CONCLUSIONS REGARDING THE NA
ALLIANCE BURDEN SHARING, THE EFFICIENCY OF SECURITY ALLIANCE BURDEN SHARING, THE EFFICIENCY OF SECURITY
PROVISION, AND THE FUTURE OF ALLIED COOPERATION AS AMERICAN PROYISION, AND THE FUTURE OF ALLIED COOPERATION AS AMERICAN
HEGEMONY DECLINES. FOCUSING ON "TRADE" IN PUBLIC GOODS AND HEGEMONY DECLINES. FOCUSING ON "TRADE" IN PUBLIC GOODS AND DEMONSTRATES THAT NATIONS SPECIALIIE IN THE PRODUCTION OF DEMONSTRATES THAT NATIONS SPECIALIZE IN THE PRODUCTION OF ALLIANCE GOODS--ECONOMIC, POLITICAL, OR MIL
THEY POSSESS ADVANTAGES OVER OTHER NATIONS.

01742 BOYER, W.W.

REFLECTIIONS ON DEMOCRATIZATION

PS: POLITICAL SCIENCE AND POLITICS, XXV(3) (SEP 92),

517-522

THE AUTHOR OFFERS SOME REFLECTIONS ON THE WORLDWIDE TREND THAT HAS MANY COUNTRIES MOVING AWAY FROM AUTHORITARIANISM TO MORE PARTICIPATORY SYSTEMS OF GOVERNMENT.

01743 BOYLAN, J.

CAMPAIGN ISSUES: HHY

COLUMBIA JOURNALISM REVIEN, $31(4)$ (NOV 92 ), 56

THE AUTHOR LOOKS AT HOW' PUBLIC OPINION POLLS ARE INFLUENCING THE MEDIA'S COVERAGE OF ELECTIONS. HE ALSO EXPLAINS HOW ELECTORAL "HOT SPOTS" ARE IDENTIFIED AND HOW THEY ARE REFLECTED IN ELECTION RETURNS.

01744 BOYLE, L.

REFORMING CIVIL SERVICE REFORM: SHOULD THE FEDERAL GOVERMMENT CONTINUE TO REGULATE STATE AND LOCAL GOVERMMENT EMPLOYEES?

JOURNAL OF LAW \& POLITICS, VII(2) (WIN 91), 243-288.

OURNAL OF LAW \& POLITICS, VII (2) (WIN 91), 243-288.
THIS PAPER EXAMINES AN AREA OF LEGISLATIVE REFORM: THE REGULATION OF THE POLITICAL ACTIVITY OF STATE AND LOCAL GOVERNMENT EMPLOYEES BY THE FEDERAL GOVERMMENT. ALTHOUGH INDIVIDUALS COMMONLY ASSOCIATE THE REGULATION OF FEDERAL EMPLOYEES HITH THE HATCH ACT, MANY STATE AND LOCAL GOVERNMENT EMPLOYEES MAY NOT REALIZE THAT THE HATCH ACT ALSO REGULATES THEIR POLITICAL ACTIVITY AS WELL. AFTER REVIEHING THE HISTORICAL ORIGINS OF THE REGULATIDN OF GOVERNMENT EMPLOYEE POLITICAL ACTIVITY, THIS PAPER SUMMARIZES THE CURRENT FEDERAL LAW AND THE REGULATION OF THE POLITICAL ACTIVITIES OF STATE AND LOCAL GOVERNMENT EMPLOYEES. LOOPHOLES IN THE LAW AS WELL AS DEFENSES ARE ANALYZED ALONG WITH CONSTITUTIONAL CHALLENGES AND POTENTIAL CHILLING EFFECTS RESULTING FROM ZEALOUS ENFORCEMENT POLICIES. FINALLY, THE NEED FOR FURTHER REFORMS WILL BE DISCUSSES IN LIGHT OF THE CURRENT EFFORTS TO REFORM THE HATCH ACT.

01745 BOYLE, M.

AFFIRMATIVE ACTION IN THE DEMOCRATIC PARTY: AN ANALYSIS OF THE EQUAL DIVISION RULE

JOURNAL OF LAW \& POLITICS, VII(3) (SPR 91), 559-590.

THE DEMOCRATIC PARTY ENTERED THE AFFIRMATIVE ACTION

DEBATE WITH THE ENACTION OF AN "EQUAL DIVISION RULE" WHICH REQUIRED THAT VOTES FOR DELEGATES TO THE DEMOCRATIC NATIONAL CONVENTION BE DIVIDED EVENLY BETWEEN MEN AND HOMEN. THIS NOTE EXAMINES BACHUR $\checkmark$. NATIONAL DEMOCRATIC PARTY. FOCUSING ON THE CONSTITUTIONALITY OF THE EQUAL DIVISION RULE AND THE ROLE OF AFFIRMATIVE ACTION IN INCREASING THE NUMBER OF WOM ELECTED OFFICIALS. THE BACHUR CASE AND THE EQUAL DIVISION
RULE ARE LIKELY TO ASSUME GREATER IMPORTANCE IN LIGHT OF RULE ARE LIKELY TO ASSUME GREATER IMPORTANCE IN LIGHT OF RECENT SUPREME COURT DECISIONS LIMITING THE CIRCUMSTANCES UNDER WHICH NUMERICAL QUOTAS CAN BE USED TO REMEDY PAST
DISCRIMINATION. THE PURPOSE OF THE NOTE IS TO ILLUSTRATE THE DISCRIMINATION. THE PURPOSE OF THE NOTE IS TO IILUSTRAT
SHORTCOMINGS OF THE EQUAL DIVISION RULE ANO TO SUGGEST SHORTCOMINGS OF THE EQUAL DIVISION RULE ANO TO SUGGEST
ALTERHATIVE APPROACHES TO EXPAND THE NUMBER OF WOMEN IN THE ALTERHATIVE APPROACH
POLITICAL PROCESS

01746 BOYNE, G.

LOCAL GOVERMMENT STRUCTURE AND PERFORMANCE: LESSONS FROM AMERICA?

PUBLIC ADMINISTRATION, 70(3) (FAL 92), 333-358.

THE DEBATE IN THE UK ON THE REFORM OF LOCAL GOVERMMENT STRUCTURE IS POORLY INFORMED BY EMPIRICAL EVIDENCE. THIS ARTICLE BRIDGES PART OF THE EMPIRICAL GAP ABY DRAWING UPON ANALYSES OF STRUCTURAL EFFECTS IN THE USA. THE EMPIRICAL EVIDENCE SUGGESTS THAT FRAGMENTATION IS ASSOCIATED WITH LOWER SPENDING AND CONCENTRATION IS ASSOCIATED HITH HIGHER SPENDING. IT IS CONCLUDED THAT THE CREATION OF A SINGLE-
SYSTEM MAY NOT LEAD TO GREATER EFFICIENCY, AND THAT THE ADVANTAGES OF A TWO-TIER SYSTEM HAVE BEEN UNDERESTIMATED. 
01747 BOYNE, G.A.

IS THERE A RELATIONSHIP BETWEEN FRAGMENTATION AND LOCAL GOVERNMENT COSTS? A COMMENT ON DREW DOLAN

URBAN AFFAIRS QUARTERLY, 28 (2) (DEC 92), 317-322.

DREW DOLAN HAS CONCLUDED THAT LOCAL GOVERNMEN FRAGMENTATION APPEARS "TO HAVE A STRONG POSITIVE RELATIONSHIP WITH THE COST OF GOVERMMENT." IN THIS COMMENT, THE AUTHOR CHALLENGES THE VALIDITY OF DOLAN'S EVIDENCE. FIRST, HE OUTLINES THE POLICY DEBATE ON THE REFORM OF LOCAL GOVERNMENT STRUCTURE. NEXT, HE ANALYZES THEORETICAL

PERSPECTIVES AND RECENT EMPIRICAL EVIDENCE ON FRAGMENTATION. FINALLY, HE EVALUATES DOLAN'S EMPIRICAL TEST AND ARGUES THAT DOLAN'S CONCLUSIONS ARE INCORRECT.

01748 BOZDAG, A.

CRISIS AND DEMOCRACY IN KIRGIZIA

AUSSEN POLITIK, 43(3) (JUL 92), 277-286.

MOST INTEREST SHOWN IN DEVELOPMENTS IN FORMER SOVIET UNION CONCENTRATES, FOR GOOD REASON, ON EVENTS IN THE

RUSSIAN FEDERATION. ATTENTION SHOULD ALSO TURN, HOWEVER, TO

THE DEVELOPMENTS IN OTHER SUCCESSOR STATES, ESPECIALLY IN THE DEVELOPMENTS IN OTHER SUCCESSOR STATES, ESPECIALLY IN
THE PREVIOUSLY COLONIALIZED CENTRAL ASIAN REGION, TO ENSURE THE PREVIOUSLY COLONIALIZED CENTRAL ASIAN REGION, TO ENSURE THAT SUBSTANTIAL DETERMINANT FACTORS FOR THE FUTURE ARE NOT
NEGLECTED. KIRGIZIA CAN CLAIM PARTICULAR INTEREST, SINCE NEGLECTED. KIRGIZIA CAN CLAIM PARTICULAR INTEREST, SINCE
THERE ARE TENDENCIES THER TOWARDS DEMOCRACY AND A MARKET THERE ARE TENDENCI IES THER TOHARDS DEMOCRACY AND A MARKET
ECONOMY. HOW CAN SUCH AN ORIENTATION ASSERT ITSELL AGAINST ECONOMY. HOW CAN SUCH AN ORIENTATION ASSERT ITSELF AGAIN
THE BACKGROUND OF A RESURGENT ISLAMIC LEGACY, SERIOUS THE BACKGROUND OF A RESURGENT ISLAMIC LEGACY, SERIOUS
UNDERDEVOPMENT AND NUMEROUS CONFLICTS? THIS QUESTION IS UNDERDEVOPMENT AND NUMEROUS
ADDRESSED IN THIS ARTICLE.

01749 BOZDAG, A.

REGION OF CONFLICT: KIRGIZIA. DYNAMICS AND ESCALATION OF THE BLOODY UNREST IN 1990

ORIENT, 25(3) (1991), 365-395

THE INTER-ETHNIC CONFLICTS IN THE SUMMER OF 1990 IN KIRGIZIA CULMINATED INTO AN ALL-OUT CIVIL WAR BETWEEN KIRGIZ AND UZBEKS. ETHNIC BOUNDARIES BETWEEN BOTH ISLAMIC TURKISH PEOPLES IN ORIGIN, LANGUAGE, TRADITION AND RELIGIOUS PRACTICE WERE REINFORCED IN THE PAST BY POLICY AND ARBITRARY DRAWING OF BORDERS. THIS TRIGGERED OFF SEPARATE PROCESSES OF NATIONALIZATION. THE INTER-ETHNIC BOUDARIES WERE INTENSIFIED BY ABOVE-AVERAGE INCREASES IN POPULATION, ONE-SIDED AND RAPID INDUSTRIALIZATION, MIGRATION FROM THE COUNTRY TO THE CITIES AND AGGRAVATION OF THE CULTURAL-ECOLOGICAL CRISIS THROUGH MIGRATION. ALSO THERE IS A STRONG ETHMO-

NATIONALISITS MOVEMENT HHICH IS IN FAVOR OF FULL SOVEREIGHTY, DEMOCRATIZATION AND THE INTRODUCTION OF A MARKET ECONOMY.

01750 BOZEMAN, B.: REED, P.: SCOTT, P.

RED TAPE AND TASK DELAYYS IN PUBLIC AND PRIVATE RED TAPE AND
ORGANIZATIONS

ADMINISTRATION AND SOCIETY, 24(3) (NOV 92), 290-322.

USING A MEASURE OF RED TAPE BASED ON THE AMOUNT OF TIME REOUIRED FOR THE PERFORMANCE OF CORE ORGANIZATIONAL TASKS, HYPOSTHESE ARE TESTED AS TO WHY SOME ORGANIZATIONS HAVE MORE RED TAPE THAN OTHERS. THE DATA FOR THE STUDY COMES FROM A NATIONAL STUDY OF MORE THAN 900 RESEARCH-INTENSIVE ORGANIZATIONS. RESULTS INDICATE THAT IT IS USEFUL TO THINK OF RED TAPE IN TERMS OF DIVERSE DIMENSIONS RELATED TO KEY ORGANIZATIONAL TASKS. CONTRARY TO PREVIOUS STUDIES, ORGANIZATIONAL SIZE SEEMS TO HAVE LITTLE BEARING OH DIFFERENCES IN RED TAPE.

01751 BOZYK, $P$

THE TRANSFORMATION OF EAST CENTRAL EUROPEAN ECONOMIES: A CRITICAL ASSESSMENT

STUDIES IN COMPARATIVE COMMUNISM, XXV(3) (SEP 92), 257-273.

IN 1991 THE COUNTRIES OF EAST CENTRAL EUROPE MADE SOME PROGRESS BUT ALSO SUFFERED SOME SETBACKS. THERE HAS A CONTINUATION OF THE PROFOUND POLITICAL, SOCIAL, AND ECONOMIC REFORMS THAT ARE BRINGING ABOUT THE DISMANTLING OF REAL SOCIALISM AND REPLACING IT WITH MEW STRUCTURES IN VARYING STAGES OF ADVANCEMENT. THE COMMON DENOMINATOR WAS THE MOVEMENT TOWARD DEMOCRACY AND A MARKET ECONOHY. ALL THE COUNTRIES OF EAST CENTRAL EUROPE WERE AFFLICTED WITH SYMPTOMS OF CRISIS IN THEIR ECDNOMIES THAT WERE WITHOUT PRECEDENT IN THE POSTWAR PERIOD. THESE PRODUCED DECLINES IN NATIONAL INCOME, IN INDUSTRIAL AND AGRICULTURAL OUTPUT, IN CONSUMPTION, IN INVESTMENT, AND IN LIVING STANDARDS AMD WERE CONSUMPTION, IN INVESTMENT, AND IN LIVING STANDARDS AMD ACCOMPANIED BY HIGH UNEMPLOYMENT. FUMDAMENTAL CHANGES OCCURRED IN THE EXTERNAL RELATIONS AMONG THE COUNTRIES.
THESE HERE MANIFESTED IN BOTH THE VOLUME AND THE STRUCTURE THESE HERE MANIFESTED IN BOTH THE VOLUME AND THE STRUCTUR OF FOREIGN TRADE AND IN THE INSTITUTIDNAL FRAMEWORK OF ECONOMIC RELATIONS. ALTHOUGH THE MAJORITY OF EAST CENTRAL
EUROPEAN COUNTRIES INITIATED REFORMS IN RESPONSE TO POPULAR EUROPEAN COUNTRIES INITIATED REFORMS IN RESPONSE TO POPULAR PRESS
1991.

01752 BRABAND, J.; BRIE, A.; KLEIN, T.

THE EAST GERMAN LEFT AND THE SOCIAL DEMOCRATS: AN EXCHANGE OF LETTERS

SOCIALISM AND DEMOCRACY, (12) (JAN 91), 33-42.

THIS ARTICLE CONSISTS OF AN "OPEN LETTER" FROM EAST
GERMAN LEFTIST GROUPS TO THE SOCIAL DEMOCRATS AND A RESPONSE TO IT. THE LEFTIST GROUPS ARGUE THAT THE DEMISE OF STALIMIST REGIMES IN EASTERN EUROPE DOES NOT NECESSARILY SIGNAL THE EVENTUAL DEMISE OF SOCIALISH AS A THEORY. IT CALLS FOR RESISTANCE TO THE ABSORPTION OF EAST GERMANY AND THE GOOD FACETS OF SOCIALISM INTO THE CAPITALIST WEST. THE RESPONSE LETTER ARGUES THAT THE "PEOPLE HAVE SPOKEN" THEIR WISHES AND UNIFICATION INTO A CAPITALIST SYSTEM WILL CONTINUE.

01753 BRACHET-MARQUEZ, $V$.

EXPLAINING SOCIOPOLIITICAL CHANGE IN LATIN AMERICA: THE CASE OF MEXICD

LATIN AMERICAN RESEARCH REVIEW, $27(3)$ (1992), $91-122$.
RATHER THAN ATTEMPT TO FIRST-GUESS WHAT MEXICO'S

POLITICAL FUTURE MIGHT BE, THIS ARTICLE PROPOSES FIRST TO REASSESS THE POTENTIAL FOR ANALYZING POLITICAL CHANGE OF THE MOOELS THAT WERE AVAILABLE TO ANALYSTS HHEN THEY BEGAN TO TURN TO THIS PROBLEM. THE DISCUSSION NEXT EXAMINES THE WAYS IN WHICH THESE MODELS HAVE INFLUENCED CURRENT DEBATES ON POLITICAL CHANGE AND THEN SHOWS WHAT BENEFITS COULD BE DERIVED FROM THEIR MORE SYSTEMATIC USE. THIS EXERCISE IS TO HELP TO PLACE THE VARIOUS CONCEPTIONS OF POLITICAL CHANGE HELP TO PLACE THE VARIOUS CONCEPTIONS OF POLITICAL CHA
FOUND IN THE LITERATURE IN THEIR PROPER THEORETICAL FOUND IN THE LITERATURE IN THEIR PROPER THEORETICAL
PERSPECTIVES, THEREBY CLARIFYING THE CURRENT DEBATE OVER PERSPECTIVES,
THAT PROCESS.

01754 BRADA, J.C.

THE MECHANICS OF THE YOUCHER PLAK IN CZECHOSLOVAKIA

RFE/RL RESEARCH REPORT, $1(17)$ (APR 92 ), $42-45$.
THE CZECHOSLOVAK GOVERNMENT HAS TAKEN AN AMBITIOUS, THE CZECHOSLOVAK GOVERNMENT HAS TAKEN AN AMBITIOUS INNOVATIVE APPROACH TO OWNERSHIP TRANSFORMATION. AN
IMPORTANT PART IS THE ISSUING OF VOUCHER BOOKLETS TO THE IMPORTANT PART IS THE ISSUING OF VOUCHER BOOKLETS TO THE
POPULATION, WHO CAN USE THE VOUCHERS TO BID FOR STOCK IN FIRMS SCHEDULED FOR PRIVATIZATION. ON THE WHOLE, THE PROGRAM SEEMS RELATIVELY WELL THOUGHT OUT AND MANAGEABLE, DESPITE THE INTRICACY OF SOME OF THE ADMINISTRATIVE DETAILS. HOWEVER, QUESTIONS REMAIN ABOUT WHETHER THE PROCESS WILL PRODUCE EQUILBRIUM AND STABILITY.

01755 BRADY, D.; MO, J.

ELECTORAL SYSTEMS AND INSTITUTIONAL CHOICE--A CASE STUDY OF THE 1988 KOREAN ELECTIONS

COMPARATIVE POLITICAL STUDIES, 24 (4) (JAN 92), 405-429.

THIS ARTICLE SHOWS HOW THE RULING PARTY OF' KOREA, THE DEMOCRATIC JUSTICE PARTY (DJP), CHOSE AND IMPLEMENTED A STRATEGY TO WIN THE 13TH NATIONAL ASSEMBLY ELECTION OF 1988 AND EXPLAINS WHY THAT STRATEGY FAILED. IN ADDITION, THIS AND EXPLAINS WHY THAT STRATEGY FAILED. IN ADDITION, THIS ELECTION IS ANALYZED IN A MORE GENERAL CONTEXT. THE AUTHO FIND, FOR EXAMPLE, THAT THE PREFERENCE OF A PARTY OVER
ELECTORAL SYSTEMS IS DETERMINED BY THE SPATIAL DISTRIBUTION ELECTORAL SYSTEMS IS DETERMINED BY THE SPATIAL DISTRIBUTION
OF ITS VOTES AND THAT THE CHOICE OF AN ELECTORAL SYSTEM IS OF ITS VOTES AND THAT THE CHOICE OF AN ELECTORAL SYSTEM IS THE OUTCOME OF A BARGAINING PROCESS AMONG THE PARTIES. IN THE CONTEXT OF DEMOCRATIZATION, THE KOREAN EXPERIENCE SHOWS THAT THE DEMOCRATIC REFORH POLICIES OF AN AUTHORITARIAN
GOVERMMENT ARE SHAPED BY THE INTERPLAY BETWEEN THE RULING GOVERNMENT ARE SHAPED BY THE INTERPLAY BETWEEN THE RULING MAINTAIN POWER AND THE CONSTRAINTS TO CREATE A SYSTEM THAT WOUL CHAMNEL THE OPPOSITION'S ACTIVITIES INTO ELECTORAL OR WOULD CHANHEL THE OPPOSI

01756 BRAHM, H

THE DISINTEGRATING SOVIET UNION AND EUROPE AUSSEN POLITIK, 43(1) (1992), 43-53

IN AN AGE OF GROWING INTERDEPENDENCE, DOMESTIC POLICY CONDITIONS AND DEVELOPMENTS HAVE BECOME DECISIVE FACTORS IN INTERNATIONAL POLITICS. TO NO COUNTRY DOES THIS APPLY MORE THAN TO THE SOVIET UNION, WHICH FIRST THREATENED THE WEST ON ACCOUNT OF A PREMISE OF IDEOLOGICAL ANTAGONISM, THEN SOUGHT COOPERATION WITH THE WEST AS A POWER KEEN ON DISPENSING WITH IDEOLOGY, AND HAS IN THE MEANTIME BECOME A RENEWED PROBLEM FOR SECURITY IN EUROPE AS A MULTINATIONAL STATE WHICH IS FALLING APART AT THE SEAMS. THIS ARTICLE OUTLINES EVENTS AND INTERRELATIONSHIPS IN THIS CONTEXT.

01757 BRAITHWAITE, R.

THE END OF THE RUSSIAN EMPIRE

RUSI JOURNAL, $137(2)$ (APR 92), 29

THE COLLAPSE OF THE SOVIET UNION FACES THE WEST WITH A CHALLENGE FOR WHICH THERE IS NO PRECEDENT IN HISTORY: HOW TO HELP A FORMER ENEMY, A SOPHISTICATED EUROPEAN MATION A MILITARY SUPERPOHER, SUSTAIM DEMDCRACY AMD OYERCOME THE CONSEQUENCES OF DECADES OF TYRANNY, DECEIT, POLITICAL

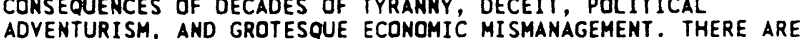
ADVENTURISM, AND GROTESQUE ECONOMIC MISMANAGEMENT. THERE NO SIMPLE SOLUTIONS, BUT IT IS CLEAR THAT THE RUSSIANS CANNOT DO IT ALONE. THEIR SUCCESS WILL REQUIRE AN
EXPENDITURE BY THE WEST OF IMAGINATION, AS WELL AS MONEY AND HUMAN EFFORT, ON A MASSIVE SCALE.

01758 BRAMS, S.J.

A GENERIC NEGOTIATION GAME

JOURNAL OF THEORETICAL POLITICS, (1) (JAN 92), 53-66.

THE AUTHOR USES A GENERIC NEGOTIATION GAME (NG) TO MODEL A CONFLICT BETWEEN TWO PARTIES SEEKING TO RESOLVE THEIR DIFFERENCES AND REACH A SETTLEMENT. HG IS A $2 \times 2$ NON-CONSTANT- 
SUM SYMMETRIC GAME THAT IS GENERIC IN THE SENSE THAT ITS PAYOFFS HHICH ARE ASSUMED TO BE CARDINAL, ARE ONLY INCOMPLETELY SPECIFIED. CONSEQUENTLY, CONCLUSIONS DRAWM ABOUT IT ARE APPL ICABLE TO ALL GAMES WITH WHICH IT IS CONSISTENT, INCLUDING SUCH HELL-KNOWN GAMES AS PRISONERS DILEMMA, CHICKEN, DEADLOCK, AND STAG HUNT. NG MAY BE IN EXACTLY ONE OF FOUR MUTUALLY-EXCLUSIVE STATES, WITH DIFFERENT PURE-STRATEGY NASH EQUILIBRIA ASSOCIATED WITH EACH STATE: (1) CONFLICT ALONE; (2) COOPERATION ALONE; (3) A COMBINATION OF CONFLICT AND COOPERATION; AND (4) TWO WINCOMBINATION OF CONFLICT AND COOPERATION; AND (4) THO WINLOSE OUTCOMES, EACH FAVORING A OIFFERENT PLAYER. THE MOS POTENT FORCE DRIVING NG TOHARD STATE (2) IS REDUCING THE DIFFERENCE BETWEEN WINNING AND LOSING; INCREASING THE REWARDS OF COOPERATION AND THE PENALTIES OF CONFLICT ARE NOT AS HELPFUL UNLESS THEY OCCUR IN TANDEM. THE AUTHOR DISCUSSES THE NORMATIVE IMPLICATIONS
NEGOTIATED SETTLEMENTS.

01759 BRAMDES, A.

SOCIAL DEMOCRATS MOVE TOWARDS CHANGE OF MIND ON ASYLUM GERMAN TRIBUNE, (1533) (SEP 92), 3

GERMANY'S SOCIAL DEMOCRATIC LEADER, BJORN ENGHOLM, HAS INDICATED THAT HE WOULD BE PREPARED UNDER CERTAIN CIRCUMSTANCES TO AGREE TO A CHANGE IN THAT SECTION OF THE CONSTITUTION THAT ALLOWS POLITICAL ASYLUM TO PERSECUTED PEOPLE. IN ANNOUNCING THIS DEPARTURE FROM PARTY POLICY, ENGHOLM MOVED THE SPD TOWARDS THE CDU LINE AND TOWARDS' THE MIDDLE OF THE POLITICAL SPECTRUM. BUT ENGHOLM'S CHANGE MUST STILL WIN APPROVAL FROM THE PARTY MEMBERSHIP.

01760 BRANDT, $H$.

EAST AND WEST: NOT QUITE ACCORDING TO PLAN

GERMAN TRIBUNE, (1505) (FEB 92), 4.

WEST GERMANS WERE ABSOLUTELY CERTAIN WHEN THE THO GERMAN STATES WERE UNIFIED THAT, AT BEST, A FEW MINOR EAST GERMAN CUSTOMS COULD REMAIN. THEY BELIEVED THAT THE POLITICAL, CUSTOMS COULD REMAIN. THEY BELIEVED THAT THE POLITICAL, ECONOMIC AND SOCIAL STRUCTURES IN THE WEST WERE MUCH BETTER
ORGANIZED AND THAT LIFE IN EASTERN GERMANY WOULD RAPIDLY AND ORGANIZED AND THAT LIFE IN EASTERN GERMANY WOULD RAPIDLY AND
SMOOTHLY ADAPT TO THE ATTRATCIVE HESTERN NORMS. THINGS HAVE SMOOTHLY ADAPT TO THE ATTRATCIVE WESTERN NORMS. THINGS HAVE
NOT DEVELOPED THIS WAY. IN VIEW OF THE DRAMATIC UNEMPLOYMENT NOT DEVELOPED THIS WAY. IN VIEW OF THE DRAMATIC UNEMPLOYMENT
FIGURES IN EASTERN GERMANY, THE TREMENDOUS UNCERTAINTY ABOUT FIGURES IN EASTERN GERMANY, THE TREMENDOUS UNCERTAINTY THE LEGAL SITUATION, AND THE STILL CONFUSING CHANGES
EVERYDAY LIFE, THE OEMOCRATIC STATE AND SOCIAL MARKET EVERYDAY LIFE, THE DEMOCRATIC STATE AND SOCIAL MARKET ECONOMY HAY

01761 BRANKOVIC, S.

HOW BOLSHEVIK IS SERBIA?

EAST EUROPEAN REPORTER, 5 (1) (JAN 92), 8-11.

THE PURPOSE OF THIS ARTICLE IS TO "MEASURE" THE EXTENT TO WHICH THE CITIZENS OF SERBIA ACCEPT COMMUNIST VALUES AND OUTLOOKS CONCERNING SEVERAL MAJOR AREAS OF LIFE SUCH AS PRODUCTION AND DISTRIBUTION, POWER, AND POLITICAL FREEDOMS. THE DATA PRESENTED SHOWS THAT SERBIA HAS "SOBERED UP FROM THE INTOXICATION OF COMMUNIST VALUES." AN IMPORTANT CONCLUSION IS THAT THE ELIMINATION OF THE COMMUNIST CHOICE AMONG THE CITIZENS OF SERBIA HAS NOT RESULTED IN THE GROWTH OF ANTI-COMMUNISM. THE FORMER COMMITMENT TO COMMUNISM HAS GIVEN WAY INSTEAD TO WHAT MIGHT BE CALLED "TOLERANT NONCOMMUNISM": THE PERCENTAGE OF THOSE TAKING AN ANTI-COMMUNIST POSITION HAS ACTUALLY DECREASED 4 PERCENT IN THE LAST YEAR. THIS CONCLUSION CAN AID THE INTERPRETATION OF THE MEANING OF THE OUTCOME OF LAST YEAR'S ELECTION IN SERBIA.

01762 BRAMHAN, G.; HAMLIN, A.

BICAMERALISM AND MAJORITARIAN EQUILBRIUM

PUBLIC CHOICE, 74(2) (1992), 169-180.

RECENT PAPERS HAVE ESTABLISHED THAT BICAMERALISM CAN

SUPPORT A NON-EMPTY CORE IN MAJORITY VOTING GAMES IN TWO SUPPORT A NON-EMPTY CORE IN MAJORITY VOTING GAMES IN TWO RESULT TO THE N-DIMENSIONAL CASE, AND PROVIDE A DISCUSSION OF MULTI-CAMERALISM. BICAMERALISM GENERATES A CORE OF POTENTIALLY STABLE EOUILBIRIA BY INSTITUIONALIZING POTENTIALLY STABLE EOUILBIRIA BY INST ITUIONALIZING OPPOSITION BETWEEN MUTUALLY ORIENTED MEDIAN VOTERS, THIS PROVIDES A CLEAR LINK WITH THE STANDARD MEDIAN VOTER

01763 BRANS, $M$

THEORIES OF LOCAL GOVERNMENT REORGANIZATION: AN EMPIRICAL EVALUATION

PUBLIC ADMINISTRATION (LONDON), 70(3) (FAL 92), 429-451.

LOCAL GOVERNMENT REORGANIZATION HAS BEEN WIDESPREAD THROUGHOUT EUROPE IN THE POSTHAR ERA. THREE BROAD TYPES OF THEORY HAVE BEEN OFFERED TO EXPLAIN THIS PHENOMENON IN A CROSS-NATIONAL CONTEXT: A WELFARE STATE PERSPECTIVE, A FUNCTIONAL REVOLUTION PERSPECTIVE, AND A POLITICAL PERSPECTIVE. IN THIS PAPER, THE AUTHOR ASSESSES THE VALIDITY OF THESE THEORIES IN THE SPECIFIC CONTEXT OF BELGIUH. THE EVIDENCE SUGGESTS THAT NONE OF THE PREVAILING THEORIES CAN ADEQUATELY EXPLAIN THE TIMING AND FORM OF REORGANIZATION. MORE PROMISING EXPLANATIONS ARE TO BE FOUND BY EXAMINING BROADER VALUES AND BELIEFS AND SPECIFIC POLITICAL CONSTELLATIONS. THE CLAIM OR IMPLICATION THAT THE MAJOR LOCAL GOVERMMENT REORGANIZATIONS OF THE POSTHAR ERA HERE
INDEPENDENT EVENTS PRODUCED BY A COMMON PATTERN OF DOMESTIC SOCIAL. ECONOMIC, OR POLITICAL DEVELOPMENT HAS THE TRAPPINGS OF SCIENTIFIC THEORY HITHOUT ITS TRUE SUBSTANCE--THE ABILITY TO EXPLAIN.

01764 BRANT, R.

POLITICAL ECOLOGY: AN EMERGING RESEARCH AGENDA IN THIRDWORLD STUDIES

POLITICAL GEOGRAPHY OUARTERLY, 11(1) (JAN 92), 12-36. A PRELIMINARY EXPLORATION OF THIRD-WORLD POLI TCAL FOR UNDERSTANDING THE EMERGIMG RESEARCH AGENDA HHICH INCLUDES THREE CRITICAL AREAS OF INQUIRY. THESE ARE: THE INCLUDES THREE CRITICAL AREAS OF INQUIRY. THESE ARE: THE CONTEXTUAL SOURCES OF ENVIRONMENTAL CHANGE: CONFLICT OVER ACCESS: AND THE POLITICAL RAMIFICATIONS OF ENVIRDNMENTAL
CHANGE. EACH OF THESE AREAS IS ADORESSED BY WAY OF A TWOCHANGE. EACH OF THESE AREAS IS ADDRESSED BY WAY OF A TWO-
FOLD STRATEGY-THE RELEVANT LITERATURE IS FIRST REVIEWED, FOLD STRATEGY-OTHE RELEVANT LITERATURE IS FIRST REVIEWED,
AND THEN CENTRAL ANALYTICAL ISSUES ARE DISCUSSED. THROUGHOUT, AND THEN CENTRAL ANALYTICAL ISSUES ARE DISCUSSED. THROUG IT IS SUGGESTED THAT THIRD-HORLD POLITICAL ECONOLOGY
REPRESENTS AN ATTEMPT TO DEVELOP AN INTEGRATED UNDERSTANDING REPRESENTS AN ATTEMPT TO DEVELOP AN INTEGRATED UNDERSTAN
OF HOW ENYIRONMENTAL AND POLITICAL FORCES INTERACT TO MEDIATE SOCIAL AND ENVIRONMENTAL CHANGE.

01765 BRASS, $P$

ETHNICITY AND NATIONALISM: THEORY AND COMPARISON SAGE PUBLICATIONS, $1991,358$.

PAUL BRASS PRESENTS A DISTINCTIVE THEORY CONCERNING THE ORIGINS OF ETHNIC IDENTITY AND MODERN NATIONALISM. HE BASES HIS THEORY ON TWO ARGUMENTS; ONE, THAT ETHNICTY AND NATIONALISM ARE NOT GIVENS BUT ARE SOCIAL AND POLITICAL CONSTRUCTION; AND THO, THAT ETHNICTY AND NATIONALISM ARE MODERN PHENOMENA INSEPARABLY CONNECTED WITH THE ACTIVITIES OF THE MODERN CENTRALIZING STATE. THE THEORY OF ELITE COMPETITION IS PRESENTED TO SHOW HOW BOTH EHTNICITY AND NATIONALISM ARISE OUT OF SPECIFIC TYPES OF INTERACTIONS BETHEEN THE LEADERSHIP OF CENTRALIZING STATES AND ELITES FROM NON-DOMINANT ETHNIC GROUPS, ESPECIALLY IN THE PERIPHERIES OF THOSE STATES. THE AUTHOR TESTS HIS THEORY AND DISCUSSES THE VARIOUS PATTERNS OF EHTNIC MOBILIZATION AND NATION-FORMATION THROUGH CASE STUDIES.

01766 BRASS, T.

MORAL ECONOMISTS, SUBALTERNS, NEW SOCIAL MOVEMENTS, AND THE (RE-) EMERGENCE OF A (POST-) MODERNIZED (MIDOLE) PEASANT

JOURNAL OF PEASANT STUDIES, 18(2) (JAN 91), 173-205.

THIS ARTICLE EXAMINES THE WAY IN HHICH PEASANT MOVEMENTS IN BOTH INDIA AND LATIN AMERICA HAVE BEEN REINTERPRETED BY THE POST-MODERN AND POLITICALLY REVISIONIST PROJECT OF THE SUBALTERN STUDIES SERIES ON INDIA AND THE NEW SOCIAL MOVEMENTS THEORY ON LATIN AMERICA. IT IS SUGGESTED THAT MUCH OF THE CONCEPTUAL ANALYSIS EMBODI ED IN BOTH THESE FRAMEWORKS IS PREFIGURED IN THE EARLIER 'MORAL ECONOMY' APPROACH, INCORPORATING THE MIDOLES PEASANT THESIS OF WOLF AND ALAVI, AN EPISTEMOLOGICAL LINEAGE IN WHICH THE WORK OF J.C. SCOTT DISCHARGES A PIVOTAL ROLE. AN ADDITIONAL CLAIM MADE HERE IS THAT SUCH FRAMEWORKS IMPLICITLY PROVIDE CHAYANOVIAN NEOPOPULIST ECONOMIC THEORY WITH ITS MISSING POLITICOIOEOLOGICAL DIMENSION.

01767 BRATERSKY, M.; LUNYOV, S.

INDIA AT THE END OF THE CENTURY: TRANSFORMATION INTO AN ASIAN REGIONAL POHER

ASIAN SURVEY, $X X X(10)$ (OCT 90), 927-942.

IN THE 1970 , INDIA BECAME A CENTER OF FORCE IN THE SOUTH ASIAN SUBCONTINENT; IN THE 1980S IT BECAME A REGIONAL NAVAL POWER. THIS ARTICLE ARGUES THAT THE 1990S WILL BE THE DECADE IN WHICH INDIA EMERGES AS A MAJOR REGIONAL POWER IN ASIA. IT CONSIDERS INDIA'S GROWING POLITICAL AND MILITARY DOMINANCE IN SOUTH ASIA; CHANGES IN SUPERPOWER APPROACHES TO DOMINANCE IN SOUTH ASIA; CHANGES IN SUPERPOWER APPROACHES
THE REGION AS THE COLD WAR FADES; POLITICAL, CULTURAL, AND PSYCHOLOGICAL FACTORS SHAPING INDIA'S STRATEGY; INDIA'S NORTHERN POLICY; AND ECONOMIC MEASUREMENTS OF INDIA'S FOREIGN POLICY STRATEGY. ALL OF THESE FACTORS POINT TO A GROHING DOMINANCE OF THE REGION BY INDIA.

01768 BRATT, R.G.

FEDERAL CONSTRAINTS AND RETRENCHMENT IN HOUSING: THE OPPORTUNITIES AND LIMITS OF STATE AND LOCAL GOVERNMENTS JOURNAL OF LAH \& POLITICS, VIII(4) (SUM 92), 651-702. THE AUTHOR EXPLORES THE ROLE OF FEDERAL, STATE, ANO OCAL GOVERNMENTS IN HOUSING. SHE PRESENTS AN HISTORICAL LOCAL GOVERNMENTS IN HOUSING. SHE PRESENTS AN HISTORICAL OVERVIEW OF THE FEDERAL GOVERMMENT'S ROLE IN HOUSING, DIVIDING II INTO FIVE TIME PERIOOS THAT ILLUSTRATE THE DISTINCT ROLES PLAYED BY THE FEDERAL GOVERNMENT DURING DIFFERENT ERAS. THE MAJOR IDEOLOGICAL AND PHILOSOPHICAL
THEMES THAT HAVE PERMEATED U.S. HOUSING POLICIES ARE

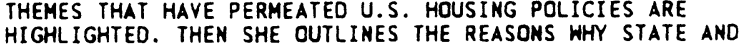
HIGHLIGHTED. THEN SHE OUTLINES THE REASONS WHY STATE AND
LOCAL GOVERNMENTS HAVE BECOME INVOLVED IN HOUSING. SHE PRESENTS A CASE STUDY OF THE NONPROFIT HOUSING SYSTEM IN BOSTON, MASSACHUSETTS, AND EXPLORES THE GAPS IN BOSTON'S PROGRAM. SHE CONCLUDES WITH RECOMMENDATIONS THAT HOULD ENABLE FEDERAL-STATE-LOCAL PUBLIC PARTNERSHIPS TO OPERATE MORE EFFECTIVELY. 
01769 BRATTON, M.; VANDEWALLE, N. REFORM IN AFRICA THATTIYE POLITIS 24)(4) (JUL 92) 419-442. THE AUTHORS EXAMINE THE GOVERMMENTAL RESPONSES TO THE POL ITICAL PROTESTS THAT ERUPTED THROUGHOUT SUB-SAHARAN AFRICA IN THE 18 MONTHS FOLLOWING THE COLLAPSE OF THE BERLIN WALL IN 1989. THEY USE A SAMPLE OF 30 REGIMES, OF WHICH ABOUT ONE-HALF EXPERIENCED POPULAR UNREST AND TWO-THIRDS UNDERTOOK PEACEFUL POLITICAL REFORM BY MAY 1991. WITHOUT REJECTING STANDARD STRUCTURAL AND OIFFUSIONIST EXPLANATIONS OF PROTEST AND REFORM. THE AUTHORS FAVOR A CONTINGENT APPROACH THAT EMPHASIZES THE RESOURCES AVAILABLE TO GOVERMMENT AND OPPOSITION POLITICAL ACTORS AS THEY JOCKEY FOR POHER AND LEGITIMACY. THE AUTHORS CONCLUDE THAT RECENT POLITICAL LIBERALIZATION MEASURES IN AFRICA, THOUGH

SIGNIFICANT, FALL SHORT OF A FULL TRANSITION TO DEMOCRACY.

01770 BRATTON, $M$.

ZAMBIA STARTS OVER

JOURNAL OF DEMOCRACY, 3(2) (APR 92), 81-94.

AFTER 17 YEARS OF' SINGLE-PARTY RULE, ZAMBIA RETURNED TO MULTIPARTY COMPET ITION IN LATE 1991. IT IS THE FIRST ENGLISHSPEAKING COUNTRY IN AFRICA TO COMPLETE SUCH A TRANSITION SPEAKING COUNTRY IN AFRICA TO COMPLETE SUCH A TRANSITION PEACEFULLY. THE ZAMBIAN CASE RAISES GENERAL QUESTIONS ABOUT PRECISELY HOW ARE ONE-PARTY REGIMES DISASSEMBLED AND PRECISELY HOW ARE ONE-PARTY REGIMES DISASSEMBLED AND REPLACED BY MORE OPEN, COMPETITIVE ONES? WHICH IDEOLOGICAL AND INSTITUATIONAL INNOVATIONS MARK THE ROUTE OF POLITICAL LIBERALIZATION? WHAT POLITICAL TENSIONS ARISE AS PLURAL
AFFILIATIONS AND COMPETITIVE ELECTIONS ARE REINTRODUCED? HOH STABLE ARE THE NEW REGIMES? THESE QUESTIONS ARE EXPLORED THROUGH A REVIEW OF THE ZAMBIAN EXPERIENCE.

01771 BRAUN, A.

A SHORTAGE OF ANSHERS TO THE TURMOIL IN THE BALKANS GERMAN TRIBUNE, (1526) (JUL 92), 3

THE CONTINUED VIOLENCE IN BOSNIA-HERCEGOVINA HAS IMCREASED THE NUMBER OF REFUGEES HEADING FOR EUROPE. HHILE HUMANITARIAN IDEALS REQUIRE THE RECEPIION AND AID OF THESE REFUGEES, THERE IS A DANGER THAT YUGOSLAVIA COULD SET AN EXAMPLE THAT OTHERS MIGHT FOLLOH. CONOUERERS MIGHT BE ENCOURAGED IF THEY FELT THEY COULD RELY ON THEIR VICTIMS FINDING REFUGE OR POSSIBLY A NEW HOME ELSEWHERE. IT IS, THEREFORE, OF CRITICAL IMPORTANCE THAT THE CONFLICT IN YUGOSLAVIA IS ENDED AND THE FLOW OF REFUGEES HALTED. THIS WILL PROBABLY REQUIRE THE ESTABLISHMENT OF UNITED NATIONS WROTECTED ZONES FOR REFUGEES ON THE BORDER WITH BOSNIA, AS PROTECTED ZONES FOR REFUGEES ON THE BORDER HITH BOS
WAS DONE IN NORTHERN IRAO FOLLOHING DESERT STORM.

01772 BRAUN, G.

THE SOMALI DEVELOPMENT CONCEPT IN CRISIS

ORIENT, 31 (3) (SEP 90$)$ T $403-414$

SOMLIA IS THE ONLY COUNTRY IN THE WORLD WITH A NOMAD MAJORITY, IN WHICH PASTORALISM AND A NOMADIC WAY OF LIFE STILL PREDOMINATE. BASIC THESIS OF THE ARTICLE IS THAT NOMADS BEHAVE LIKE THE IDEAL "HOMO ECONOMICUS", PRACTISING A RATIONAL STRATEGY OF SURVIVAL, I.E. "SAFETY FIRST" AND "RISK AVERSION". THIS LOGIC OF SURVIVAL IS SYSTEMATICALLY IGNORED BY THE MODERNIZATION CONCEPT OF THE SOMALI GOVERNMENT AND INTERNATIONAL DONORS, A CONCEPT WHICH EQUATES DEVELOPMENT WITH ECONOMIC GROWTH AND SOLID BUREAUCRATIZATION. THIS FAILURE IS DEMONSTRATED IN VARIOUS CRISIS AREAS: (1) THE CRISIS IN THE STATE'S PHILOSOPHY OF DEVELOPMENT (DIRIGISTE BUREAUCRATIC BIAS, URBAN BIAS, INDUSTRIAL BIAS), (2) THE CRISIS IN THE STATE'S EDUCATIONAL CONCEPT AND (3) THE CRISIS IN SEDENTARIZATION PROGRAMMES. THE CRISIS AREAS REFLECT A CRISIS OF ACCEPTANCE BY THE NOMADIC POPULATION. THEREFORE, NON-INTERVENTION SHOULD BE PREFERRED TO INTERVENTION. UNAVOIDABLE INTERVENTIONS SHOULD BE "GENTLE", THAT IS, ADJUSTED TO SOCIO-CULTURAL CONDITIONS AND ORIENTED BY THE NEEDS OF THE POPULATION. IN OTHER WORDS: THE FUTURE OF PASTORALISM IS PRIMARILY A MATTER FOR THE NOMADS THEMSELVES.

01773 BRAUN, U.

YEMEN: ANOTHER CASE OF UNIFICATION

AUSSEN POLITIK, 43(2) (1992), 174-184

THE YEAR OF' 1990 WAS NOT ONLY THE YEAR OF GERMAN UNIFICATION. MUCH LESS A FOCUS OF INTERNATIONAL ATTENTION, A DIVIDED COUNTRY WAS ALSO UNITED IN THE MIDOLE EAST-THE TWO YEMENS. SIMILAR TO THE SITUATION IN DIVIDED GERMANY THE CLASSIFICATION TO THE TWO OPPOSING INTERNATIONAL POWER BLOCS CLASSIFICATION TO THE THO OPPOSING INTERNATIONAL POHER BLOCS PLAYED A DECISIVE ROLE DURING THE FINAL PHASE. NEY
UNIFICATION TOOK PLACE UNDER COMPLETELY CIFFERENT UNIFICATION TOOK PLACE UNDER COMPLETELY CIFFERENT CIRCUMSTANCES TO THOSE IN CENTRAL EUROPE, WITH COMPLETELY
DIFFERENT RESULTANT PROBLEMS. THIS ARTICLE TAKES STOCK OF DIFFERENT RESULTANT PROBLEMS. THIS
THIS SITUATION IN THIS CONTEXT.

01774 BRAVEBOY-WAGNER, J.; GAYLE, D.J.; GRIFFITH, I.L.; WILL, H.M. THE CARIBBEAN IN THE PACIFIC CENTURY--PROSPECTS FOR CARIBBEAN-PACIFIC COOPERATION

LYNNE RIENNER PUBLISHERS, 1993,216

IN THE 1970S, THERE WAS LITTLE INTEREST IN THE ASIA-
PACIFIC REGION ON THE PART OF CARIBBEAN POLICYMAKERS. BUT DURING THE LATE 1980S AND EARLY 1990S, IT HAS BEEN IMPOSSIBLE TO IGNORE THE GROWING TREK OF CARIBBEAN FOCUS ATTRIBUTABLE TO THE DYNAMISM OF THE ASIA-PACIFIC FOCUS ATTRIBUTABLE TO THE DYNAMISM OF THE ASIA-PACIFIC REGION AND TO THE SEARCH FOR DIVERSIFIED SOURCES OF AID AND
TRADE. THE AUTHORS OF THIS BOOK EXPLORE THE COMMONALITIES TRADE. THE AUTHORS OF THIS BOOK EXPLORE THE COMMONALITIES AND CURRENT LINKS BETHEEN THE ASIA-PACIFIC AND CARIBBEAN
STATES AND EXAMINE WAYS IN WHICH TIES BETWEEN THE TWO GROUPS CAN BE DEEPENED TO THEIR MUTUAL BENEFIT. TOPICS EXAMINED INCLUDE: INTRA-REGIONAL RELATIONS, ECONOMIC LINKAGES, APPLICATION OF THE EAST ASIA DEVELOPMENT MODEL TO THE CARIBBEAN, SECURITY ISSUES, AND THE FUTURE OF RELATIONS BETHEEN THE THO REGIONS.

01775 BRAY, J.

ETHNIC MINORITIES AND THE FUTURE OF BURMA

WORLD TODAY, 48(8-9) (AUG 92), 144-147.

SINCE 1948, BURMA'S CENTRAL GOVERMMENT HAS BEEN CONTINUOUSLY AT WAR WITH AT LEAST ONE--AND FREQUENTLY SEVERAL-OOF THE COUNTRY'S MINORITY GROUPS. IN 1962, GENERAL NE WIN CLAIMED THAT THE PRIME OBJECTIVE OF HIS COUP WAS TO PRESERVE NATIONAL UNITY. BUT HE HAS BEEN CONSPICUOUSLY UNSUCCESSFUL. IN 1992, BURMA IS MORE DIVIDED THAN EVER, WITH UNSUCCESSFUL. IN 1992 , BURMA IS MORE DIVIDED THAN EV THE ARMY FIGHTING KAREN, KACHIN, NAGA, AND ROHINGYA
INSURGENTS. IN THIS ARTICLE. THE AUTHOR ASSESSES THE

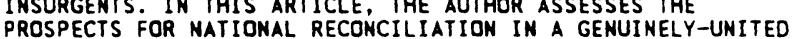
BURMA.

01776 BRAY, J.

NEW DIRECTIONS IN PAKISTAN'S FOREIGN POLICY WORLD TODAY, 48(4) (APR 92), 65-68

THE NEH INTERMATIONAL ENVIRONMENT DEMANDS A REASSESSMENT OF ISLAMABAD'S FOREIGN POLICY OPTIONS. THIS ARTICLE ANALYZES THE COMPETING INFLUENCES THAT WILL DETERMINE PAKISTAN'S NEH FOREIGN POLICY. TOPICS INCLUDE THE FUTURE OF PAKISTAN'S NUCLEAR WEAPONS PROGRAM, THE SUSPENSION OF U.S. FOREIGN AID, AND PAKISTAN'S REACTION' TO THE GULF CRISIS.

01777 BRECHON, P.; MITRA, S.K.

THE NATIONAL FRONT' IN FRANCE: THE EMERGENCE OF AN EXTREME RIGHT PROTEST MOVEMENT

COMPARATIVE POLITICS, 25(1) (OCT 92), 63-82.

IN FRANCE, THE NATIONAL FRONT HAS RISEN TO PROMINENCE BECAUSE IT HAS SUCCEEDED IN GIVING CONCRETE POLITICAL EXPRESSION TO A LATENT XENOPHOBIA, REINFORCED BY THE PROBLEM OF IMMIGRATION, AND HAS PLACED THIS LATENT XENOPHOBIA IN THE CONTEXT OF A GENERAL IDEOLOGY OF THE EXTREME RIGHT, BASED ON A REJECTION OF ESTABLISHED POLITICAL PARTIES AND DISTRUST OF DEMOCRACY. THIS PAPER LOOKS AT THE RISE OF THE NATIONAL FRONT, DRANING ON PUBLIC OPINION ON SIGNIFICANT POLITICAL FRONT, DRANING ON PUBLIC OPINION ON SIGNIFICANT POLITICAL
ISSUES, AGGREGATE DATA, AND INFORMATION ON ITS REGIONAL ISSUES, AGGREGATE DATA, AND INFORMATION ON ITS REGIONAL
GRONTH, SUPPLEMENTED BY AN ANALYSIS OF THE CONTROVERSY OVER GROWTH, SUPPLEMENTED BY AN ANALYSIS OF THE CONTROVERSY WEARING THE ISLAMIC HEADSCARF IN PUBLIC SCHOOLS AND A DETAILED CASE STUDY OF THE CONSTITUENCY OF DREUX, HHERE THE A RELATIVELY SHORT TIME.

01778 BRECKMAN, $H$.

LUDWIG FEUERBACH AND THE POLITICAL THEOLOGY OF RESTORATION HISTORY OF POLITICAL THOUGHT, 13(3) (FAL 92), 437-462.

TO ACCOMPANY HIS CRITIQUE OF THE PERSONAL GOD AND GODMAN, FEUERBACH MOUNTED AN ATTACK ON THE IDEA OF PERSONALITY AS IT WAS USED TO SUPPORT RESTORATIONIST THEORIES OF SOCIAL AND POLITICAL ORDER. CONTROVERSY OVER HEGEL'S THOUGHT WAS AN IMPORTANT CATALYST FOR THE ARTICULATION OF THE IMPLICATIONS OF THE IDEA OF PERSONAL ITY. IN ORDER TO EXPLORE THE ISSUES, THIS ESSAY DISCUSSES THE RESTORATION CRITIQUE OF HEGEL. WITHIN THE CONTEXT DF THE POLITICO-THEOLOGICAL DEBATE OVER PERSONALITY, THE ARTICLE EXAMINES FEUERBACH'S EVOLVING CRITOUE OF CHRISTIAN CIVIL SOCIETY.

01779 BREDOH, $W$

CONSCRIPTION, CONSCIENTIOUS OBJECTION, AND CIVIC SERVICE:

THE MILITARY INSTITUTIONS AND POLITICAL CULTURE OF GERMANY, 1945 TO THE PRESENT

JOURNAL OF POLITICAL AND MILITARY SOCIOLOGY, 2O(2) (WIN 92), 289-304.

THE EAST-WEST CONFLICT AND THE UNIFICATION OF GERMANY CAME AS A SUDDEN CHALLEMGE TO THE POLITICAL SELFUMDERSTANDING OF THE GERMANS. AMONG THOSE INSTITUTIONS WHICH HAYE TO BE FUNDAMENTALLY RESHAPED ARE THE ARMED FORCES. THE POSSIBLE END OF CONSCRIPTION WILL, HOWEVER, NOT ONLY POSSIBLE END OF CONSCRIPTION WILL, HOWEVER, NOT ONLY INFLUENCE THE MILITARY INSTITUTIONS BUT ALSO THE POLITICAL
CULTURE OF GERMANY. THE INTERNATIONAL SITUATION DEMANDS MORE CULTIVE POLITICAL AND MILITARY INVOL VEMENT OF GERMANY, E.G. ACTIVE POLITICAL AND MILITARY INVOL VEMENT OF GERMANY, E.G. IN THE FRAME WORK OF THE UNITED NATIONS. HOWEVER, PUBL
SUPPORT FOR THE MILITARY AS AN INSTITUTION AND AS AN SUPPORT FOR THE MILITARY AS AN INSTITUTION AND AS AN
INSTRUMENT OF POLITICAL ACTION IS DECREASING. THIS INSTRUMENT OF POLITICAL ACTION IS DECREASING. THIS
CONTRADICTION HILL BECOME A FEATURE OF GERMANY'S POLICY IN CONTRADICTION
THE FUTURE.

01780 BREINDEL, E. MOSCON GOLD 
COMMENTARY, 94(6) (DEC 92), 46-48.

THE END OF THE COLD WAR AND THE ACCESSION TO PONER IN RUSSIA OF A DEMOCRATICALLY ELECTED GOVERMMENT HAVE FORCED THE OPENING OF THE COMMUNIST PARTY CENTRAL COMMITTEE'S ARCHIVE IN MOSCOW. THANKS TO THIS DEVELOPMENT, DOCUMENTARY EVIDENCE CONCERNING THE DISTRIBUTION IN AMERICA OF WHAT USED TO BE CALLED 'MOSCOW GOLD' IS ENTERING THE PUBLIC DOMAIN. BEYOND THESE ARCHIVAL REVEALATIONS, FORMER KGB OFFICALS ARE BEYOND THESE ARCHIVAL REVEALATIONS, FORMER KGB OFFICALS ARE BEGINNING TO TELL THEIR STORIES. ALSO INFORMATIOSN LONG
CLOSELY BY THE U.S. INTELLIGENCE COMMUNITY IS LIKEWISE CLOSELY BY THE U.S. INTELLIGENCE COMMUNITY IS LIKEHISE
BECCMING ACCESSIBLE. THIS ARTICLE ARGUES THAT THERE IS NOW NO DOUBT THAT THE AMERICAN COMWUNIST MOVEMENT WAS FINANCED THE SOVIET ROLE IN FINANCING AN IMPORTANT COMMUNIST FRONT: THE NATIONAL COUNCIL OF AMERICAN-SOVIET FRIENDSHIP. THE
CONCLUSION DRAWN IS THAT THE COMMUNIST PARTY AND A HANDFUL OF FRONT ORGANIZATIONS DID REPRESENT A CONSPIRACY.

01781 BREN, $P$.

CONVERSION SLOWS DOWN AS CZECHS AND SLOVAKS PART

RFE/RL RESEARCH REPORT, 1 (32) (AUG 92), 38-43.

WITHIN 18 MONTHS OF THE VELVET REVOLUTION

CZECHOSLOVAKIA'S ARMS TRADE POLICY TRAVELED FULL CIRCLE,

BEGINNING WITH A 1990 ANNOUNCEMENT THAT THE COUNTRY WOULD

CEASE ALL ARMS TRADING AND ENDING WITH A 1991 TANK SALE TO SYRIA, WHICH WAS STRONGLY OPPOSED BY THE UNITED STATES AND ISRAEL. THIS SHIFT REFLECTS CZECHOSLOVAKIA'S PROBLEMS HITH THE CONVERSION OF ITS ARMS INDUSTRY, WHICH HAS BECOME A VOLATILE POLITICAL AND ECONOMIC ISSUE. AT THE MOMENT, THERE IS LITTLE EVIDENCE OF A COHERENT CONVERSION PROGRAM, AND THE ISSUE IS HIDENING THE CZECH-SLOVAK RIFT.

01782 BRENNAN, $M$

A STEP IN THE "RIGHT" DIRECTION: CONSERVATIVE REPUBLICANS AND THE ELECTION OF 1960

PRESIDENTIAL STUDIES QUARTERLY, 22(1) (WIN 92), 73-88.

PRESIDENTIAL ELECTION YEARS FREQUENTLY SERVE AS

CONVENIENT BENCHMARKS FOR CHARTING CHANGES IN PARTISAN,

POLITICAL OR SOCIETAL BEHAVIOR. BECAUSE OF THE INTERPLAY OF

POLITICAL OR SOCIETAL BEHAVIOR. BECAUSE OF THE INT
IDEOLOGY AND PERSONALITY SURROUNDING ANY CAMPAIGN,

IDEOLOGY AND PERSONALITY SURROUNDING ANY CAMPAIGN,

PRESIDENTIAL ELECTIONS REVEAL MUCH ABOUT THE EVOLUTION OF
POLITICAL PARTIES. THE RACE FOR THE REPUBLICAN PRESIDENTIAL

POLITICAL PARTIES. THE RACE FOR THE REPUBLICAN PRESIDENT

NOMINATION IN 1960 OFFERS A GOOD EXAMPLE OF MOW SUCH A

CAMPAIGN SHAPES THE DEVELOPMENT OF POLITICAL PARTIES. THE

ELECTION ITSELF DID NOT CAUSE A SHIFT WITHIN THE PARTY, BUT

WITHOUT THE FORUM OF THE ELECTION, THE DEVELOPMENTS HITHIM STERILE.

01783 BRENHAN, T.

NATURAL RIGHTS AND THE CONSTITUTION: THE ORIGINAL ORIGINAL INTENT

HARVARD JOURNAL OF LAW AND PUBLIC POLICY, 15(3) (SUM 92),

965-1029.

THE AUTHOR PROBES MODERN OBJECTIONS TO THE ASSERTION OF UNENUMERATED NATURAL RIGHTS IN LIGHT OF REL EVANT EVIDENCE FROM THE CONSTITUTIONAL RATIFICATION DEBATES. HE SHOWS THAT IF CONSTITUTIONAL INTERPRETATION WERE EVER TRULY INFORMED BY THE ORIGINAL UNDERSTANDING OF THE RATIFIERS. THESE MODERN

OBJECTIONS WOULD BE REFUTED BY THE ORIGINAL "ORIGINAL INTENT.

" He oIsCusSes natural RIGHTS aNo positive LaW, CREATED RIGHTS, VINDICATED RIGHTS, PRIVACY, IMPLAUSIBLE RIGHTS, RETAINED RIGHTS, AND ENUMERATED RIGHTS.

01784 BRENNER, $M$.

GAUGING A DECLINE? A NORMATIVE QUEST?

POLITY, 29(1) (FAL 91), 107-128.

INTERNATIONAL POLITICS HAS BEEN DRAMATICALLY RECAST BY RECENT CHANGES IN THE COMMUNIST WORLD. THIS HAS RAISED QUESTIONS OF HOW BEST TO UNDERSTAND THE PLACE OF THE U.S. IN THE WORLD ORDER. ONE SCHOOL OF THOUGHT, WHICH IS THE FOCUS OF THIS ARTICLE, STRESSES THE LOSS OF AMERICAN HEGEMONY--THE DECLINE OF THE U.S. IN WORLD AFFAIRS. THE AUTHOR EXPLORES SEVERAL RECENT WORKS DEALING WITH THE "DECLINE" THESIS AND CONCLUDES THAT IT IS THE PRACTICE OF AMERICAN FOREIGN POL
NOT ITS RESOURCE BASE, WHICH IS BEING FORCED TO CHANGE.

01785 BRENNER, M.

NEW TERMS OF ENGAGEMENT

SAIS REVIEH, 11(1) (WIN 91), 11-26

HITH THE COLLAPSE OF COMHUNISM IN EASTERN EUROPE AND THE DISSOLUTION OF THE SOYIET MILITARY THREAT NEW PERSPECTIVES ARE DEVELOPING ABOUT THE UNITED STATES' EMGAGEMENT IM THE INTERNATIONAL ARENA. THIS ARTICLE ASSESSES THE U.S. ROLE AND FOCUSES ON SEVERAL BASIC QUESTIONS: WHAT THE U.S. STAKES ARE IN A WORLD WITH A DECLINING SOVIET CHALLENGE; WHETHER U.S. POHER CORRESPONDS TO RESIDUAL U.S. INTERESTS AND RESPONSIBILITIES; THE OPERATIONAL SIGNIFICANCE OF CONVENTIONAL INDICES OF MILITARY AND ECONOMIC POWER; THE CIRCUMSTANCES IN WHICH TASKS OF COLLECTIVE POLITICAL MANAGEMENT HAVE COME TO THE FORE, AND THE REQUIREMENTS OF MULTILATERAL DIPLOMACY WITH ALLIES ANO ECONOMIC PARTNERS; BE ADAPTED TO CONDITIONS UNDER WHICH THE UNITED STATES NO
LONGER HAS THE FULL PREROGATIVES OF ITS FORMER PREDOMINANCE.

01786 BRENNER, S.; DORFF, R.H.

THE ATTITUDINAL MODEL AND FLUIDITY VOTING ON THE UNITED STATES SUPREME COURT

JOURNAL OF THEORETICAL POLITICS, 4(2) (APR 92), 195-205. THE ATTITUDINAL MODEL, AS APPLIED TO THE UNITED STATES SUPREME COURT, POSITS THAT VOTING BY A JUSTICE IS DETERMINED BY HIS OR HER POL ICY ATTITUDES AND BY THE LOCATION ALONG THE POLICY DIMENSION OF THE STIMULUS PROVIDED BY THE CASE. IT HAS BEEN ARGUED THAT THERE IS EXTENSIVE FLUIDITY IN VOTING BETHEEN THE ORIGINAL VOTE ON THE MERITS OF A CASE AND THE FINAL VOTE, THAT THIS FLUIDITY DEFLATES THE IDEOLOGICAL FINAL VOTE, THAT THIS FLUIDITY DEFLATES THE IDEOLOGICAL MOOEL, IS AN UNRELIABLE INOICATOR OF JUDICIAL ATTITUDES. THE MODEL, IS AN UNREL IABLE INDICATOR OF JUDICIAL ATTITUDES,
AUTHORS QUESTION WHETHER THERE IS EXTENSIVE FLUIDITY IN AUTHORS QUESTION WHETHER THERE IS EXTENSIVE FLUIDITY IN VOTING USUALLY MOVES IN THE EXPECTED IDEOLOGICAL DIRECTION. NEVERTHELESS, THE GENERAL ARGUMENT THAT THE ATTITUDINAL NEVERTHELESS, THE GENERAL ARGUHENT THAT THE ATTITUDINAL MODEL DOES NOT CAPTURE THE REALITY OF SUPREME COURT DECISION MAKING SEEMS TO BE VALID BECAUSE NOT ALL FLUIDITY VOT
IN THE EXPECTED DIRECTION AND THE MOST FREQUENT TYPE IN THE EXPECTED DIRECTION AND THE MOST FREQUENT TYPE
(MINORITY-MAJORITY VOTES) IS ALSO DRIVEN BY SMALL-GROUP VARIABLES.

01787 BRESHEETH, H. (ED.); YUVAL-DAVIS, N. (ED.) THE GULF HAR AND THE NEW WORLD ORDER ZED BOOKS, 1991, 272.

THE GULF WAR WAS A MAJOR TURNING POINT IN INTERNATIONAL AFFIARS. IN THIS COLLECTION, EXPERTS ANALYZE THE FACTORS BEHIND THE WAR AND ITS IMPACT ON THE REGION. CHAPTERS COVER THE SUPERPOWERS' CHANGING ROLE, THE POSITION OF VARIOUS MIDOLE EASTERN PROTAGONISTS- FROM IRAN TO MOROCCO--THE ECONOMIC AND STRATEGIC CONTEXT OF THE WAR AND THE RESULTING DEBATE. OVERALL, THE WAR IS SHOWN TO HAVE SHATTERED THE CONSENSUS ON FOREIGN AFFAIRS, AND TO HAVE RAISED THE ISSUE OF DEMOCRACY IN THE ARAB WORLD TO A NEW PROMINENCE.

01788 BRESLAU, D.

BHE SCIENTIFIC APPROPRIATION OF SOCIAL RESEARCH: ROBERT PARK'S HUMAN ECOLOGY AND AMERICAN SOCIOLOGY

PARK'S RUMAN ECOLOGY AND AMERICAN SOCIOLOGY
THEORY AND SOCIETY, 19 (4) (AUG 90), 417-446.

THIS ARTICLE DESCRIBES THE APPROPRIATION OF SOCIAL RESEARCH-DHE BRINGING OF EMPIRICAL SOCIAL RESEARCH INTO AN ACADEMIC SETTING--THAT BEGAN WITH THE RESEARCH PROGRAM THAT HAS PROPOSED BY ROBERT PART IN 1915 AND CARRIED OUT OVER THE NEXT 20 YEARS. IN THAT CONTEXT THE FOCUS IS ON THE CHICAGO SCHOOL OF SOCIOLOGY IN THE INTER-WAR PERIOD.

01789 BRESLIN, S.

CHINA'S INTERRUPTED EVOLUTION

JOURNAL OF COMHUNIST STUDIES, 8(1) (MAR 92), 63-83.

VIRTUALLY THE ONLY CONSISTENT FACTOR IN CHINESE POLITICS SINCE 1949 HAS BEEN INCONSISTENCY. LEADERSHIP CONFLICTS HAVE PROOUCED RADICAL POLICY SHIFTS THAT HAVE AFFECTED THE ENTIRE CHINESE POPULATION AT ALARMINGLY REGULAR INTERVALS. WHEN DENG XIAOPING TOOK OVER IN 1978, THERE WAS GREAT HOPE THAT CHINA WAS ENTERING A PERIOD OF CERTAINTY AND STABILITY THAT HOULD FACILITATE THE LONG MARCH TO ACHIEVING THE FOUR MODERNIZATIONS, A POLICY OF DELIBERATELY-INDUCED EVOLUTION. BUT THIS HAS NOT BEEN THE CASE BECAUSE THE REFORMS IMPLEMENTED IN THE $1980^{\prime}$ 'S HAVE GIVEN RISE TO A PLETHORA OF SOCIAL AND ECONOMIC PROBLEMS. UNABLE TO DOMINATE EVENTS, THE PARTY AND STATE ELITES HAVE SQUABBLED OVER THE CAUSES AND POTENTIAL REMEDIES, WHILE INTELLECTUALS AND STUDENTS HAVE LOST FAITH IN THEIR LEADERS. THE ECONOMIC RETRENCHMENT POLICIES OF 1988 AND THE REPRESSION OF THE DEMOCRACY MOVEMENT IN 1989 MAY HAVE STABILIZED THE SITUATION IN THE SHORT RUN, BUT MUCH REMAINS TO BE RESOL VED BEFORE CHINA'S COMMUNIST'PARTY CAN FACE THE 21ST CENTURY WITH CERTAINTY AND CONFIDENCE.

01790 BRETT, J.

THE END OF THE PARTIES

ARENA MAGAZINE, (1) (OCT 92), 10-13.

JUDY BRETT LOOKS AT THE MALAISE AFFECTING AUSTRALIA'S MAJOR POLIIICAL PARTIES IN THIS ARTICLE. NON-LABOR HAS FACED THE DISAPPEARANCE OF ITS MASS BASE BEFORE, BUT IT IS A NEW EXPERIENCE FOR THE ALP. MS. BRETT OFFERS A HAY TO UNDERSTAND THE PUBLIC'S WIDESPREAD DISAFFECTION AND PONDERS WHETHER ONE OR OTHER OF THE PARTIES WILL BE ABLE TO RENEW ITSELF
SUFFICIENTLY TO FORM A CREDIBLE GOVERNMENT WITH WHICH LARGE SUFFICIENTLY TO FORM A CREDIBLE

01791 BREYTENBACH, $W$.

RIGHT-WING RESISTANCE--RHETORIC OR REVOLUTION? SOUTH AFRICA FOUNDATION REYIEW I $(6)$ RIJH 92 ) THIS AFRICA FOUNDATION REVIEW, 19(6) (JUN 92), 6 .
THIS ARTICLE ASSESSES THE THREAT TO THE NEGOTIATION PROCESS FROM RADICAL RIGHT-WING GROUPS IN SOUTH AFRICA. IT STATES THAT RIGHT-WING RESISTANCE TO TRANSITION HAS MANIFESTED ITSELF IN AT LEAST THREE HAYS: ATTACXS ON THE WHITE LEFT; ANTI-STATE VIOLENCE; AND THE SPECTER OF A RIGHTWING TAKEOVER FROM HITHIN THE SECURITY APPARATUS. HOWEVER,
THE DANGER OF A RIGHT-WING COUP IN THE SECURITY FORCES HAS 
PROBABLY RECEDED SINCE A REFERENDUM ESTABLISHED WIDESPREAD SUPPORT FOR CHANGE. WHILE FRUSTRATIONS WILL LINGER AND THERE IS SOME EVIDENCE OF RIGHT-WING-SUPPORTED VIOLENCE, THE WING THREAT MAY OIMINISH OVER THE NEXT FIVE YEARS. THE LIKELIHOOD OF THIS OUTCOME IS INCREASED BY STABILITY, "SELECONOMIC GROWTH AND A
DETERMINATION" ISSUE.

01792 BRIAN, H.

THE EVOLUTION OF HUMAN RIGHTS POLICY IN ONTARIO

CANADIAN JOURMAL OF POLITICAL SCIENCE, 29(4) (DEC 91), 783-802.

CANADIAN HUMAN RIGHTS POLICY HAS CHANGED OVER TIME, INCORPORATING ELEMENTS BOTH OF EXPANSION IN HUMAN RIGHTS PROTECTIONS AMD OF RESTRAINT IN THE EMFORCEMENT OF THE LEGISLATION. THIS STUDY SEEKS TO EXPLAIN THIS CHANGE BY EXAMINING THE EVOLUTION OF THE POLICY IN THE PROVINCE OF ONTARIO. THE CONCLUSION DRAHN IS THAT THE EVOLUTION HAS BEEM SHAPED LARGELY BY CONFLICTING PRESSURES FOR REFORM AND RESTRAINT, REFLECTING AN UNDERLYING CONFLICT BETWEEN RIVAL

LIBERAL ETHICS WHICH COMES INTO PLAY AS CONSCIOUSNESS GROWS

OF GAPS BETWEEN THE PRINCIPLES AND PRACTICE OF RIGHTS.

01793 BRIANCON, $P$.

OUTSIDERS GET ON THE INSIDE TRACK

WORLD PRESS REVIEW, 39(5) (MAY 92) 12-13.

IN 1992 EVERY ASPIRANT TO THE WHITE HOUSE MUST CAMPAIGN AGAINST THE WASHINGTON POLITICAL-MEDIA ESTABLISHMENT ON BEHALF OF THE PEOPLE. THE TASK OF ANY CANDIDATE WHO WISHES TO SUCCEED IS TO CONVINCE THE VOTERS THAT HE IS THE REAL
"QUTSIDER"--A STRANGER TO THE BYZANTINE WAYS OF WASHINGTON.

01794 BRICE, $K$

MISLEADING IMPRESSIONS

WEST AFRICA, (3903) (JUL 92), 1122-1123.

SEVERAL YEARS AGO. AFRICAN JOURNALISTS COULD ONLY DREAM OF EXPOSING CORRUPTION AT THE HIGHEST LEVELS OF GOVERMMENT. TODAY, A REVOLUTION IS TAKING PLACE ON THE PAGES OF AFRICA'S NEWSPAPERS. AFRICAN LEADERS, ONCE SACROSANCT, ARE NOW BEING CRITICIZED; STORIES ABOUT HIGHLLEVEL CORRUPTION ARE COMMOMPLACE. BUT THIS MEW OUTSPOKEMMESS CAM GIVE A MISLEADING IMPRESSION ABOUT THE STATUS OF PRESS FREEDOM IN AFRICA. JOURNALISTS ARE STILL SUBJECT TO RESTRICTIONS, AND SOME ARE STILL IN PRISON.

01795 BRICE, $K$.

MUZZLING THE MEDIA

AFRICA REPORT, 37 (4) ( JUL 92) 49-51.

AS MANY AFRICAN COUNTRIES HAVE BECOME MORE DEMOCRATIC, MUCH OF THE PRESS HAS BEEN RELEASED FROM STATE CONTROL AND MUCH OF THE PRESS HAS BEEN RELEASED FROM STATE CONTROL AND
THUS FREED TO CRIIICI ZE THE GOVERMMENT, WHICH IRONICALLY HAS THUS FREED TO CRIICI ZE THE GOVERMMENT, WHICH IRONICALLY HAS
LED TO LESS DEMOCACY FOR THE PRESS. THE COMMITEE TO PROTECT JOURMALISTS HAS DOCUMENTED A RISE IN THE REPRESSION OF AFRICAN REPORTERS, WHO CAN NOW WRITE ABOUT ONCE-TABOD SUBJECTS BUT

01796 BRICK, D.

THE GOOD, THE BAD AND THE UNLUCKY: CASE STUDIES IN AMERICAN HEAPONS PROCUREMEN

ARMS CONTROL, 13(2) (SEP 92), 285-303.

THIS ARTICLE OFFERS THREE CASE STUDIES TO EXAMINE AMERICAN ARMS PROCUREMENT. THE FIRST CONSIDERS THE LIGHTWEIGHT FIGHTER PROGRAM. THE SECOND LOOKS AT THE ARMY'S DIVISION AIR DEFENSE GUN SYSTEM. BESIDES THE PREFORMANCE CRITERION, OTHER CRITERIA TO BE CONSIDERED INCLUDE THE EFFICIENCIES OF THE PROCUREMENT STRATEGIES, GROWTH POTENTIAL, COSTS, AND THE SYSTEMS' APPROPRIATENESS IN TERMS OF HOW THEY WERE TO FIT INTO CURRENT DOCTRINE. THE THIRD CASE STUDY EXAMINES THE TACTICAL FIGHTER EXPERIMENTAL PROGRAM

RESPONSIBLE FOR THE AIR FORCES'S F-111 AS AN EXAMPLE OF A SYSTEM THAT SEEMED DESTINED FOR FAILURE AND YET AND PROYIDED REMARKABLE SERVICE.

01797 BRIDGES, A.

WINNING THE WEST TO MUNICIPAL REFORM

URBAN AFFAIRS QUARTERLY, 27 (4) (JUN 92), 494-518.

THE AUTHOR RECOUNTS HOW THE WEST WAS WON TO MUNICIPAL REFORM IN THE EARLY $20 T H$ CENTURY. SHE ARGUES THAT THE ADOPTION OF REFORM CHARTERS WAS NOT THE PRODUCT OF CONDUCIVE LOCAL POLITICAL CUL TURE BUT THE RESULT OF FACTORS THAT ADVANTAGED ADVOCATES OF CHARTER REVISION.

01798 BRIDGES, $B$.

JAPAN AND EUROPE: REBALANCING A RELATIONSHIP

ASIAN SURVEY, XXXII(3) (MAR 92), 230-245.

JAPANESE, THE UNITED STATES AND EUROPEAN RELATIONS ARE DISCUSSED IN THIS ARTICLE. UP TO NOW. IT HAS PROVED TO BE "SKEWED TRIANGLE," WITH BOTH THE JAPANESE AND THE EUROPEANS FAR MORE INTERESTED IN THEIR SEPARATE BILATERAL RELATIONS WITH THE AMERICANS THAN WITH EACH OTHER. FOR JAPAN, THE DEVELOPMENT OF A MORE "TOTAL" RELATIONSHIP WITH EUROPE WILL BE AN IMPORTANT TEST CASE OF HOW FAR IT CAN REFORMULATE ITS CLOSE INTERLOCKING RELATIONSHIP WITH THE UNITED STATES AND
CHART A MORE INDEPENDENT PATH IN INTERMATIONAL AFFAIRS.

01799 BRIDGES, B.

JAPAN: BACK TO THE FUTURE

NORLD TODAY, 48(8-9) (AUG 92), 135-136.

DESPITE KIICHI MIYAZAWA'S CAMPAIGN PROMISES TO REFORM JAPANESE POLITICS, HE HAS DONE LITTLE TO CHANGE THE SYSTEM. ALTHOUGH THE 1992 UPPER HOUSE ELECTIONS ARE LIKELY TO SEE ANOTHER SLIGHT EROSION OF THE LIBERAL DEMOCRATIC PARTY'S (LDP) STRENGTH, IT WILL NOT BE SUFFICIENT TO PRODUCE GENUINE REFORM OR A RESTRUCTURING OF JAPANESE POLITICS. FOR THE FORESEEABLE FUTURE, THE LDP WILL CONTINUE TO BE INYOLVED IN CONVOLUTED BARGAINING WITH THE SMALLER OPPOSITION PARTIES TO PUSH LEGISLATION THROUGH THE DIET. THE JAPANESE PUBLIC WILL REGISTER THE OCCASIONAL PROTEST VOTE AGAINST LOP CORRUPTION BUT WILL MOT OVERTURN A SYSTEM THAT, ON BALANCE, HAS BROUGHT THEM A CONSIDERABLE MEASURE OF ECONOMIC BENEFIT.

UNFORTUNATELY, THE PROBLEMS OF JAPAN'S POLITICAL AMD

ECONOMIC SYSTEMS ARE NOT HELPING THE COUNTRY PURSUE ITS GOAL

TO BE A SUPERPOWER IN THE NEW HORLD ORDER.

01800 BRIDGES, 8.

JAPAN'S RELATIONS WITH NORTH KOREA: TOWARDS MORMALIZATION KOREAN JOURNAL OF DEFENSE ANALYSIS, 3(2) (WIN 91), 187-206. MOT UNTIL 1965 WERE RELATIONS BETWEEN JAPAN AND SOUTH KOREA MORMALIZED, WHILE NEGOTIATIONS TO NORMAL IZE RELATIONS FINALLY BETWEEN JAPAN AND NORTH KOREA HAVE ONLY JUST BEGUN. THIS ARTICLE EXAMTNES THE PROGRESS AND PROSPECTS OF THESE JAPAN-NORTH KOREAN NEGOTIATIONS, HHICH CONSITUTE ONE OF THE ELEMENTS OF THE EMERGING "NEW ORDER" IN NORTHEAST ASIA. THE FOCUS WILL BE PRIMARILY ON THE JAPANESE SIDE: ON THE FUMDAMENTALS OF JAPAN'S PAST POLITICAL AND ECONOMIC INTERACTIONS WITH NORTH KOREA, THE VARIOUS DOMESTIC INPUTS TO THE POL ICY-MAKING PROCESS, THE INFLUENCE OF THE UNITED
STATES, AND THE CHARACERISTICS OF THE NEGOTATIONS SO FAR.

01801 BRIDGLAND, $F$.

ANC CRACK-UP

NATIONAL REVIEN, XLIV(19) (OCT 92), 24, 26.

A NEW DIVISIOM HAS BECOME EVIDENT HITHIN THE AFRICAN NATIONAL CONGRESS--ONE BETHEEN "INSURRECTIONISTS" AND "MEGOTIATIONISTS." THE INSURRECTIONISTS BELIEVE THAT THE CONSTITUTIOMAL NEGOTIATIONS WITH PRESIDENT F.W. DEKLERK ARE a TRAP AND THAT THE ANC CAN NEVER WIN ABSOLUTE POLIIICAL POWER THROUGH THE BALLOT BOX. THE MEGOOIATIONISTS ARGUE THAT IT IS POSSIBLE TD CUT A FAIR DEAL WITH DEKLERK AND TO START TAKING ESSENTIAL STEPS TO GET SOUTH AFRICANS, PARTICULARLY

BLACKS, BACK ON THEIR FEET ECONOHICALLY.

01802 BRIGGS, $P$.

GENERAL MACARTHUR AND THE PRESIDENTIAL ELECTION OF 1944 PRESIDENTIAL STUDIES QUARTERLY, 22 (1) (HIN 92), 31-46. IT IS NOT CLEAR HOW COMMANDERS BECOME AVAILABLE FOR POLITICAL OFFICE. THIS STUDY EXAMINES THE ROLE OF GENERAL DOUGLAS A. MACARTHUR IN THE PRESIDENTIAL ELECTION OF 1944. RELATED EVENTS, POLICIES AND LEADING PERSOHALITIES, INCLUDING SENATOR ARTHUR VANDENBERG AND PRESIDENT FRANKLIN 0. ROOSEVELT ARE ALSO EXAMINED. THE STUOY'S CONCLUSIONS ARE THEN BRIEFLY EVALUATED AGAINST CONCLUSIONS DRAHM BY MAJOR SCHOLARS ON CIVIL-MILITARY RELATIONS INCLUDING HUNTINGTON, JANOWITZ AND MILLS.

01803 BRIGHTBILL, $T$.

POLITICAL ACTION COMMITTEES: HOW MUCH INFLUENCE WILL $\$ 7.7$ MILLION BUY

INTERNATIONAL JOURNAL OF HEALTH SERVICES, 21(2) (1991), 285-290.

THE INFLUENCE OF HEALTH-RELATED POLITICAL ACTION COMHITTEES (PACS) CONTINUED TO GROH DURING THE 1990 ELECTION CAMPAIGN. DURING THE FIRST 18 MONTHS OF THE ELECTION CYCLE, CONTRIBUTIONS FROM MEDICAL AND HEALTH CARE PACS TO CONGRESSIONAL CANDIDATES REACHED A TOTAL OF $\$ 7.7$ MILLION. AMONG THE LEADING PACS WERE THE AMERICAN MEDICAL ASJOCIATION, AMERICAN DENTAL ASSOCIATION, AMD AMERICAM MOSPITAL ASSOCIATION, WHICH CONTRIBUTED A TOTAL OF $\$ 3.3$ MILLION TO CONGRESSIONAL RACES THROUGH SEPTEMBER 1990. FOR ITS STUDY, HEALTHHEEK MONITORED THE CONTRIBUTIONS AND FEDERAL ELECT! JN COMMISSION REPORTS OF 52 LEADING HEALTH CARE PACS, INCLU: : NG PROFESSIONAL AND TRADE ASSOCIATIONS, DRUG COMPANIES

PRSURS A AND OTHER GROUPS. TRADE GROUPS MADE UP ABOUT TWO-
INSURERS, AND INSURERS, AND OTHER GROUPS. TRADE GROUPS MADE UP ABOUT TWOTHIRDS OF ALL PAC DOLLARS SPENT, AAD SEVERAL OF THESE GROUPS
HEALTH-RELATED CONGRESSIONAL COMMITTEES RECEIVED NEARLY $\$ 1.5$ HEALTH-RELATED CONGRESSIONAL COMMITTEES RECEIVED NEARLY \$1.5 MILLION FROM MEALTH CARE PACS, THE STUDY FOUND. IN ALL, 16 FROM HEAL TH CARE PACS. SEEATOR JOHM D. ROCKEEELLER IV

FREMOCRAT. WEST VIRGINIA) AND REPRESENTATIVE THOMAS TAUKE (DEMOCRAT, WEST VIRGINIA) AND REPRESENTATIVE THOMAS TAUKE (REPUBLICAN, IOHA) LED TH

01804 BRILLANTES, A.

THE PHILIPPINES IN 1991: DISASTERS AND DECISIONS

ASIAN SURVEY, XXXII (2) (FEB 92), 140-145.

AMIDST FRENZIED PREPARATIONS FOR THE 1992 NATIONAL AND LOCAL ELECTIONS AND HITH AN ECONOMY IN STAGFLATION, 1991 WAS 
A YEAR OF DISASTERS AND DECISIONS FOR THE PHILIPPINES. TWO MAJOR NATURAL OISASTERS, THE ERUPTION OF MOUNT PINATUBO ANO THE FLOODS IN LEYTE, STRUCK THE COUNTRY, RESULTING IN THE LOSS OF THOUSAMDS OF LIVES AMO THE DISPLACEMENT OF MILLIONS OF PEOPLE. THO MAJOR POL ITICAL DECISIONS MADE DURING THE YEAR--THE REJECTION OF THE CONTINUED U.S. PRESENCE OF U.S BASES IN THE COUNTRY AND THE ENACTMENT OF THE LOCAL GOVERMMENT CODE--WILL HAVE SIGNIFICANT AND FAR-REACHING EFFECTS ON THE DIRECTIONS OF THE COUNTRY'S INTERNATIONAL RELATIONS AND ITS POLITO-ADMINISTRATIVE SYSTEM IN THE COMING YEARS. THESE WATERSHED DECISIONS MANIFEST THE PRESENCE OF A YEARS. THESE WATERSHED DECISIONS MANIFEST THE PRESENCE OF NASCENT POLITICAL WILL TO CONFRONT THO OF THE COUNTRY FUNDAMENTAL PROBLEMS--INTERNATIONALLY, THE INORDINATE GOVERNMENTAL CENTRALIZATION.

01805 BRIMELOW, $P$

TIME TO RETHINK IMMIGRATION?

NATIONAL REVIEW, XLIV (12) (JUN 92), 30-46.

IN THIS ARTICLE, PETER BRIMELOH REOPENS THE IMMIGRATION DEBATE. AMERICANS HAVE COME TO FEEL THAT DISCUSSION OF IMMIGRATION IS FUTILE AT BEST, ANO POSSIBLY UN-AMERICAN SINCE WE ARE A NATION OF IMMIGRANTS. HOWEVER, IMMIGRATION IS NOT AN IRRESISTABLE NATURE FORCE, IT IS A MATTER OF PUBLIC POLICY, AND PUBLIC POLICIES CAN BE CHANGED. AMONG THE
OUESTIONS THAT SHOULD SHAPE THE DEBATE: IS IMMIGRATION REALLY NECESSARY TO THE ECONOMY? IS THE U.S. STILL CULTURALLY CAPABLE OF ABSORBING IMMIGRANTS? THE QUESTION IS WHETHER WE HAVE GIVEN UP ON TURNING OUR IMMIGRANTS INTO AMERICANS.

01806 BRINIG, M.

POLITICS, ECONOMICS AND THE MCCARRAN-FERGUSON ACT PUBLIC CHOICE, 73(4) (1992), 383-384

THE AMERICAM IMSURANCE COMPAHY UMLIKE AMY OTHER FINANCIAL INSTITUTION, IS REGULATED ALMOST EXCLUSIVELY BY STATE AGENCIES. THE SOURCE OF THIS UNIQUE STATUS, ITS CONSEQUENCES FOR THE INDUSTRY, AND THE RECENT REACTION CONSEQUENCES FOR THE INDUSTRY, AND THE RECENT REACTION AGAINST THE POHER OF INSURERS IN STATE LEGISLATURES ARE SUBJECTS OF THIS PAPER. SECTION 2 EXAMINES THE HISTORY
THE INSURANCE INDUSTRY IN THE UNITED STATES. SECTION 3 THE INSURANCE INDUSTRY IN THE UNITED STATES. SECTION 3
CONTAINS A DESCRIPTION OF LITERATURE INVOLVING THE BEHAVIOR OF LEGISLATORS AND REGULATORS. SECTION 4 EVALUTES RECENT OF LEGISLATORS AND REGULATORS. SECTION 4 EVALUTES RECENT
OATA CONCERNING A COURT ATTACK ON THE MCCARRAN-FERGUSON ACT, DATA CONCERNING A COURT ATTACK ON THE MCCARRAN-FERGUSON ACT, ACTIVITIES. THAT INSURERS ARE BEING CHALLENGED IN THE STATES WHERE THEY HAVE HISTORICALLY BEEN THE STRONGEST IS NOTED.

01807 BRINKERHOFF, D.W.; GOLDSMITH, A.A.

PROMOTING THE SUSTAINABILITY OF DEVELOPMENT INSTITUTIONS: A FRAMEHORK FOR STRATEG

HORLD DEVELOPMENT, 20(3) (MAR 92), 369-383.

THIS PAPER PRESENTS A GENERIC FRAMEHORK FOR

UNDERSTANDING INSTITUTIONAL SUSTAINABILITY IN DEVELOPMENT. DRAHING LESSONS FROM THE HEALTH AND AGRICULTURAL SECTORS, THE FRAMEWORK TREATS INSTITUTIONS AS FOLLOWS: (A) SYSTEMS THAT FUNCTION IN RELATIONSHIP TO THEIR ENVIRONMENTS; (B) ORGANIZED AND MANAGED ENTITIES WHOSE ORGANIZATIONAL STRUCTURES ANO PROCEDURES MUST MATCH THE TASKS, PRODUCTS, PEOPLE, RESOURCES, AND CONTEXTS THEY DEAL WITH; AND (C) SETTINGS INTIMATELYY CONCERNED WITH THE EXCHANGE OF RESOURCES WHERE ECONOMIC AND POLITICAL RELATIONSHIPS INTERTWINE TO CREATE VARYING PATTERNS OF POHER AND INCENTIVE. APPLICATION OF THE ANALYTIC FRAMEWORK SHOWS THAT INSTITUTIONAL SUSTAINABILITY DEPENDS UPON MAINTAINING RESPONSIVE OUTPUT FLOHS (HIGH QUALITY AND VALUED GOODS AND SERVICES); COSTEFFECTIVE GOOOS AND SERVICES DELIVERY MECHANISHS

(ORGANIZATION AND MANAGEMENT): AND RESOURCE FLOWS (RECURRENT COSTS, CAPITAL INVESTMENTS, HUMAN RESOURCES).

01808 BRINKLEY, A.

ROOTS

NEW REPUBLIC, 207 (5) ( JUL 92), 44-45

THERE ARE DOZENS OF THEORIÉS FLOATIING AROUND TO EXPLAIN "THE PEROT PHENOMENON," BUT NO SINGLE ONE CAN ACCOUNT FOR THE STRIKING ECLECTICISM OF THE MOVEMENT. THE PEROT CAMPAIGN MARKS THE UNLIKELY, AND PROBABLY TEMPORARY, COALESCENCE OF SEYERAL VERY DIFFERENT POLITICAL LANGUAGES AND IMPULSES-SEVERAL VERY DIFFERENT POLITICAL LANGUAGES AND IMPULSES--
MOST OF THEM DEEPLY ROOTED IN THE AMERICAN EXPERIENCE. HE MOST OF THEM DEEPLY ROOTED IN THE AMERICAN EXPERIENCE
DERIVES HIS STRENGTH LESS FROM NEWHESS THAN FROM THE DERIVES HIS STRENGTH LESS FROH
FAMILIARITY OF HIS MESSAGE.

01809 BRISBIN, R.A. JR.

THE REHMOUIST COURT AHD THE FREE EXERCISE OF RELIGIOM JOURNAL OF CHURCH \& STATE, 34(1) (WIN 92), 57-76.

IN LITTLE MORE THAN FOUR TERMS UNDER CHIEF JUSTICE HILLIAM REHNQUIST (1986-1991), THE SUPREME COURT HAS RESTRUCTURED THE BOUNDARIES OF THE FREE EXERCISE CLAUSE OF THE FIRST AMENDMENT. ALTHOUGH AN ABSOLUTE BAN ON COERCION OF RELIGIOUS BELIEF REMAINS IN PLACE, ALTERATION OF THE FREE EXERCISE CLAUSE DOCTRINE HAS OCCURRED ALONG THO DIMENSIONS RELATED TO GOVERMMENTAL COERCION OF RELIGIOUS CONDUCT. FIRST, THE REHMQUIST COURT ESTABLISHED LIMITATIONS ON THE APPLICABILITY OF STRICT SCRUTINY ANALYSIS IN FREE EXERCISE
CASES, A MODE OF ANALYSIS CENTRAL TO THE TREATMENT OF RELIGIOUS CONDUCT AS A FUNDAMENTAL RIGHT. SECONDLY, THE REHNQUIST COURT JUSTICES ADOPTED A LESS GENERAL READING OF THE MEANING OF FREE EXERCISE THAT EFFECTIVELY LIMITED THE SCOPE OF CONDUCT OF EXPRESSION COVERED BY THE CLAUSE.

01810 BRITTON, A.

ECONOMIC POLICY IN THE 1990S: THE NEH AGENDA

POLITICAL QUARTERLY (THE), 62(2) (APR 91), 151-166. THIS ARTICLE PROPOSES THAT TO LOOK AHEAD AT ECONOMIC POLICY IN THE 1990 S REQUIRES ASSESSING WHAT HAS BEEN ACHI EVED IN THE 1980 S BECAUSE THAT IS THE FOUNDATION ON
WHICH THE NEXT STAGE WILL BE BUILT. THE ARTICLE REVIENS AND EXPLAINS VARIOUS ASPECTS OF 1980 S ECONOMIC POLICY AND
IDENTIFIES 1980 S TRENDS THAT WILL DETERMINE WHAT HAPPENS IN IDENTIFIES 1980 S

01811 BROCATO, D.

STEPPING FORWARD

FREEDOM REVIEW, 23(2) (MAR 92), 22-23.

SINCE THE SINGLE EUROPEAN ACT HENT INTO EFFECT IN 1987 , THE EUROPEAN PARLIAMENT (EP) HAS BROADENED ITS INSTITUTIONAL MANDATE. THE ENLARGEMENT OF EP RESPONSIBILITIIES IS OCCURRING AT THE EXPENSE OF THE PROCESS KNOWN AS "INTERGOVERNMENTAL DECISION MAKING," WHICH THUS FAR HAS SET THE PACE OF EUROPEAN INTEGRATION. CRITIICS OF THIS PROCESS CLAIM THAT IT HAS SUBORDINATED BROADER EUROPEAN INTERESTS TO NATIONAL ONES, LEADING TO FREQUENT DEADLOCKS.

01812 BROCK, D.

NOT LOSING AT ALL COST: SMOOTH JIM BAKER'S ROCKY REIGN AT STATE

AMERICAN SPECTATOR, 24 (8) (AUG 91), 17-21.

AN ANALYSIS OF THE PERFORMANCE OF JAMES BAKER AND HIS CRONIES AT THE U.S. DEPARTMENT OF STATE REVEALS A HISTORY OF INEPTITUDE AND FAILURE. BAKER'S VAUNTED POLITICAL SAVYY AND DEAL-MAKING SKILLS HAVE DONE LITTLE BUT APPEASE DICTATORS (WHO LATER MUST BE DEALT HITH BY THE MILITARY AS IN PANAMA AND IRAQ) AND SELL OUT TO DEMOCRATS. HE HAS MANAGED TO DIMINISH THE INFLUENCE OF THE FOREIGN SERVICE ON THE

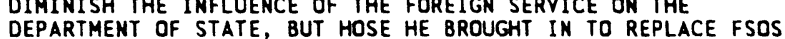
HAVE LITTLE OR NOTHING TO DO. IN THE MEAN TIME, SMALL HAVE LITTLE OR NOTHING TO DO. IN THE MEAN TIME, SMALL
PROBLEMS BREW AND THREATEN TO BECOME THE CRISIS OF TOMORROW.

01813 BROCKETT, C.D.

MEASURING POLITICAL VIOLENCE AND LAND INEQUALITY IN

AMERICAN POLITICAL SCIENCE REVIEW, 86(1) (MAR 92), 169-178. THE AUTHOR CHALLENGES THE VALUE OF CROSS-NATIONAL QUANTITATIVE STUDIES OF THE RELATIONSHIP BETHEEN MASS
POLITICAL VIOLENCE AND LAND INEQUALITY ALONG THREE LINES. FIRST, GROSS AND SYSTEMATIC ERRORS IN THE POLITICAL VIOLENCE DATA OF THE "WORLD HANDBOOK OF POLITICAL AND SOCIAL

INDICATORS" RENDER THEM WORTHLESS FOR CENTRAL AMERICA AT LEAST AND PROBABLY MUCH OF THE THIRD WORLD AS WELL. SECONDLY, CONCEPTUALIZATIONS OF LAND INEQUALITY HAVE BEEN TOO SIMPLISTIC TO BE OF MUCH THEORETICAL VALUE. THIRDLY, THE TEMPORAL NATURE OF THIS RELATIONSHIP HAS BEEN INADEQUATELY CONSIDERED. RESPONDING TO SUCH DEFICIENCIES, THE AUTHOR ELABORATES A BROADER UNDERSTANDING OF LAND INEOUALITY AND PROVIDES A FULLER DISCUSSION OF THE TEMPORAL NATURE OF ITS RELATIONSHIP TO POLITICAL VIOLENCE. HE USES APPROPRIATE CASE MATERIAL FROM THE FIVE CENTRAL AMERICAN NATIONS.

01814 BROCKWAY, G.

A ROAD EASTERN EUROPE COULD TAKE

NEW LEADER, LXXIV (15) (NOV 91), 17-18.

THIS ARTICLE ARGUES THAT THE COUNTRIES OF EASTERN EUROPE HAVE A UNIQUE OPPORTUNITY TO COMBINE THE VIRTUES OF CAPITALISM AND SOCIALISM. IF THEY DO NOT SEIZE THE
OPPORTUNITY--AND POLAND SEEMS INTENT ON KICKING IT AWAY-THEY WILL BE IN DANGER OF COMBINING THE VICES OF BOTH SYSTEMS. THE PROMISE OF "THE BETTER ROAD" OFFERS FREEDOM AND SYSTEMS. THE PROMISE OF "THE BETTER ROAD" OFFERS FREEDOM AND IDEAL OF CLASSLESSNESS AND THE PRACTICAL ABOLITION OF IDEAL OF CLASSLESSNESS AND THE PRACTICAL ABOLITION OF
UNEMPLOYMENT. FAILURE TO TRAVEL THIS ROAD (IRONICALLY BY UNEMPLOYMENT. FAILURE TO TRAYEL THIS ROAD (IRONICALLY
FOLLOWING MODELS IN THE WEST), WILL RESULT IN DEBT, FOLLOWING MODELS IN THE WEST), WILL
UNEMPLOYMENT AND CLASS CONFLICT.

01815 BROCKWAY, G.

MISTER BUSH, MEET MISTER HOOVER
NEW LEADER, LXXV(1) (JAN 92), 14-15.

THIS ARTICLE ARGUES THAT GEORGE BUSH'S ECONOMIC POLICIES HAVE A LOT IN COMMON WITH HERBERT HOOVER'S. THAT IS TO SAY, HE HAS PRACTICALLY NO POLICIES AT ALL. NOT ONLY ARE PRESIDENT HOOVER'S AND PRESIDENT BUSH'S POLICIES SIMILAR, BUT SO ARE THEIR DEPRESSIONS (AND OURS). THE AUTHOR EXAMINES THE CURRENT STATE OF THE ECONOMY AND CONCLUDES THAT THE UNITED STATES ECONOMY IS CURRENTLY IN A STATE OF "CONTAINED DEPRESSION." CAUSED BY A CAPITAL GOODS GLUT, IT WILL LIKELY LAST FOR SOME TIME TO COME. HOWEVER, DUE TO A LARGE GOVERNMENT SAFETY NET (I.E. FOIC) AND TO THE GOVERNMENT'S GUARANTEED PARTICIPATION IN ACTIVITES THAT ACCOUNT FOR 25 

DROP INTO THE LOWEST DEPTHS THAT CHARACTERIZED THE GREAT
DEPRESSION.

01816 BROCKWAY, G.

OUR AUSTERITY RECESSION

NEW LEADER, LXXIV (1) (JAN 91), 14-15

THIS ARTICLE TAKES TO TASK' THOSE WHO ARGUE THAT AMERICAN CITIZENS SHOULD REDUCE CONSUMPTION. HE REFUTES THE CLASSICAL NOTION THAT CONSUMPTION IS A DRAG ON INVESTMENT, AND ARGUES INSTEAD THAT CONSUMPTION IS THE ONLY WAY TO IMPROVE ECONOMIC CONDITIONS. THEREFORE, THE GRAMM-RUDMAN-HOLLINGS DEFICIT REDUCTION ACT WILL HARM THE ECONOMY BY FORCING THE FEDERAL GOVERNMENT TO DECREASE CONSUMPTION AND DIMINISH ITS DEMAND FOR PRIVATE ENTERPRISE. IN SHORT, GRAMM-RUDMAN-HOLLINGS WILL MAKE THE RECESSION BOTH DEEPER AND HARDER TO CLIMB OUT OF.

01817 BROCKWAY, G.

TAXING OUR CREDULITY

NEH LEADER, LXXIY (13) (DEC 91), 7-8.

THIS ARTICLE EXAMINES SEVERAL OF THE VARIOUS TAX REFORM

PROPORALS WHICH ARE CIRCULATING AROUND WASHINGTON. THEY

INCLUDE JACK KEMP'S ACROSS THE BOARD TAX CUTS, PRESIDENT

INCLUDE JACK KEMP'S ACROSS THE BOARD TAX CUTS, PRESIDENT
BUSH'S CAPITAL GAINS TAX CUTS, THE RETURN OF INDIVIDUAL

BUSH'S CAPITAL GAINS TAX CUTS, THE RETURN OF INDIVIDUAL

RETIREMENT ACCDUNTS (IRA), AND THE TAX REFORM PROPOSALS OF
ALBERT GORE AND THOMAS DOWNEY AND OF DAN ROSTENKOWSKI. THE ALBERT GORE AND THOMAS DOWNEY AND OF DAN ROSTENKOWSKI. THE
ARTICLE CONCLUDES THAT EVEN IF ANY ONE OF THESE PROPOSALS ARTICLE CONCLUDES THAT EVEN IF ANY ONE OF THESE PROPOSALS
PASSES THROUGH CONGRESS AND AVOIDS THE PRESIDENTIAL VETO, THE EFFECT ON THE SLUGGISH ECONOMY WILL BE MINIMAL.

01818 BROCKHAY, G.

THE ILLOGIC OF LEANESS AND MEANNESS

NEW LEADER, LXXV(14) (NOV 92), 15-16.

THE LEAN-AND-MEAN LOGIC'S MAJOR PREMISE: THE AMERICAN

STANDARD OF LIVING WILL BE RAVAGED BY FOREIGN COMPETITION.

MINOR PREMISE: SELF PROTECTION IS UNACCEPTABLE BECAUSE IT

INTERFERES WITH THE FREE MARKET. THIS PREMISE CONCLUDES THAT WE SHOULD MAKE CORPORATIONS LEAN BY FIRING PEOPLE, MAKE THEM MEAN BY WORKING THE SURVIVING EMPLOYEES HARDER FOR LESS PAY, AND THEREBY MAKE OURSELVES MISERABLE WITHOUT HELP FROM ANYONE ELSE. THE AUTHOR FINDS IT ODO THAT STANDARD ECONOMICS, BASED AS IT IS ON SELF-INTEREST, SHOULD FIND SELF-

PROTECTION INVARIABLY REPREHENSIBLE.

01819 BRODIE, J.; GAVIGAN, S.A.M.; JENSON, J.

THE POLITICS OF ABORTION

OXFORD UNIVERSITY PRESS, 1992, 204.

ABORTION POLITICS IN CANADA RESONATES WITH DEEPER DISCORDS OVER REPRESENTATIONS OF GENDER, SEX AND SOCIAL EQUALITY. THE THREE SEPARATELY AUTHORED ESSAYS IN THIS BOOK EQUALITY. THE THREE SEPARATELY AUTHORED ESSAYS IN THIS BOOK
ARE LDOSELY ORGANIZED AROUND THIS METHODOLOGICAL PRINCIPLE,
AS WELL AS THE IMPORTANCE OF THE MEDICALIZED DISCOURSE ON AS WELL AS THE IMPORTANCE OF THE MEDICALIZED DISCOURSE ON
ABORTION AND RECENT CHALLENGES FROM THE PRO-LIFE AND PROABORTION AND RECENT CHALLENGES FROM THE PRO-LIFE AND PRO-
CHOICE PERSPECTIVES. ONE ESSAY ON POST-WAR ABORTION POLITICS CHOICE PERSPECTIVES. ONE ESSAY ON POST-WAR ABORTION POLITICS TO THE 1988 MORGENTALER DECISION EXAMINES THE 1969 CHANGES TO THE CRIMINAL CODE IN TERMS OF THE COALITIONS FAVORING LIBERALIZATION AND THE ARGUMENTS THEY USED. THE AUTHOR
ARGUES THAT BOTH WOMEN AND PRO-LIFE GROUPS WERE MARGINALIIED IN THE 1960 S IN FAVOR OF A MEDICALIZED DEFINITION OF THE ABDRTION ISSUE. ANOTHER ESSAY DETAILS THE PARLIAMENTARY MANEUVERS FROM THE SUPREME COURT DECISION IN 1988 TO THE DEFEAT OF BILL C-43 IN 1991. A THIRD ESSAY EXAMINES LEGAL AND EXTRA-LEGAL DISCOURSES SURROUNDING A HOST OF REPRODUCTIVE ISSUES INCLUDING ABORTION, FETAL RIGHTS, FATHERS' RIGHTS, AND PROVINCIAL REGULATION OF ABORTION AS A HEALTH MATTER.

01820 BRODSGAARD, $K$

CHINA'S POLITICAL ECONOMY IN THE NINETIES

CHINA REPORT, 27 (3) (JUL 91), 117-196.

THIS PAPER ARGUES THAT CHINA HAS NOT YET SUCCEEDED IN BREAKING AWAY FROM THE SOVIET DEVELOPMENT STRATEGY WHICH WAS ADOPTED AND IMPLEMENTED SINCE THE EARLY FIFTIES. IT SPECULATES ON WHETHER THE CHINESE ECONOMIC DEVELOPMENT PROCESS IS LIKELLY TO EXPERIENCE ANY BASIC CHANGE DURING THE NEXT DECADE. IT DISCUSSES A FEW THEORET ICAL OBSERVATIONS IN ORDER TO PLACE THE DISCUSSION IN A PROPER PERSPECTIVE. IT OBSERVES THAT OF LATE, THE CHINESE REFORM DISCUSSION HAS 1978.

01821 BRODY, $H$.

OF BYTES AND RIGHTS
TECHNOLOGY REVIEW, 95 (8) (NOV 92), 22-29.

THE PROLIFERATION OF COMPUTER NETHORKS IS RAISING

QUESTIONS ABOUT PROTECTING INDIVIDUAL PRIVACY, ABOUT FREEDOM OF SPEECH, AND ABOUT WHAT KINDS OF LANS OR REGULATIONS GOVERMMENTS SHOULD ADOPT TO PROTECT INDIVIDUAL RIGHTS.

01822 BRONNER, E.

UNVEILED

NEW REPUBLIC, 206 (23) (JUM 92), 17-18, 20

THIS APPEARS TO BE A TRANSITION PERIOD FOR IRAN'S

ISLAMIC REVOLUTION. THE IRAN-IRAQ WAR IS OVER. ELIMINATING

THE RATIONALE FOR TIGHT SOCIAL STRICTURES AND MATERIAL
SHORTAGES. YET POWER OUTAGES ARE COMMON; HOUSING IS LIMITED AND EXPENSIVE; CRIME IS ON THE RISE. PRESIDENT RAFSANJAH SEEMS TO UNDERSTAND IRAN'S PROBLEMS BETTER THAN ALMOST ANYONE ELSE IN GOVERNMENT. HIS BACKERS WON A MAJORITY IN THE 1992 ELECTIONS TO THE MAJLIS, INSURING THAT THE HARDLINERS WON'T CONTROL THE PARLIAMENT, FOR THE FIRST TIME SINCE THE 1979 REVOLUTION.

01823 BRONNER, S.

CONFRONTING NATIONALISM

NEW POLITICS, 13(1) (SUM 92), 60-65.

THIS ARTICLE STATES THAT NATIONALISM REMAINS THE ISSUE

FOR OUR TIME. THE ALLURE OF IMPERIALISM AND CONCERN WITH THE NATIONAL INTEREST BY THE "GREAT POHERS," NO LESS THAN THE VISION OF SOVEREIGNTY AND THE RIGHT TO SELF-DETERMINATION BY THE COLONIZED, HAS DOMINATED THE POLITIICS OF MODERNITY. BY THE SAME TOKEN, BENEATH THE SURFACE, AN OPPOSING VISIOM WAS ALSO TAKING ROOT. AND SO, EVEN HHILE RECENT EVENTS CENTER ON THE ROLE OF NATIONALISM, A NEW INTERNATIONALISM IS BECOMING ANCHORED IN A HOST OF TRANSWATIONAL POLITICAL INSTITUTIONS AND THE INCREASING ECONOMIC INTERDEPENDENCE AMONG NATIONS. AND THE INCREASING ECONOMIC INTERDEPENDENCE AMONG NATIONS. THIS ARTICLE SEEKS TO JUDGE THESE DEVELOPMENTS FROM THE
PERSPECTIVE OF GENERAL STRATEGIES CONSONANT WITH THE PERSPECTIVE OF GENERAL STRATEGIES CONSONANT WITH THE
EXPANSION OF GLOBAL JUSTICE, REPUBLICANISM AND ECONOMIC EXPANSION

01824 BRONNER, S. TRANSFORMING THE STATE: CAPITALIST DEMOCRACY, SOCIALIST POLITICS, AND THE LABOR MOVEMENT

NEW POL ITICAL SCIENCE, (20) (SUM 91), 17-40.

A THEORY OF THE STATE UNDERPINS EVERY NOTION OF

POLITICAL PRACTICE. A SOCIALIST THEORY SEEKING CHANGE WILL THUS DEMAND MORE THAN MERE ANALYTIC ATTEMPTS TO ESTABLISH SOME DIRECT CAUSAL RELATION BETHEEN ECONOMICS AND POLITICS. THIS ARTICLE EXAMINES THE RELATIONSHIP BETWEEN CAPITALISM AND SOCIALISM, LIBERALISM, AND DEMOCRACY. IT CONSIDERS THE GROWING PHENOMENON OF "INTERNATIONALIZATION." IT CONCLUDES THAT A TIME IS APPROACHING IN WHICH THE STATE WILL NO LONGER SERVE AS THE AUTONOMOUS UNIT FOR MAKING POLITICAL JUDGMENTS. CONFLICTS OF SOVEREIGNTY AND IDEOLOGY WILL INCREASINGLY ENTRAP EVEN THE MOST POWERFUL STATES.

01825 BROOKE, $P$.

POLITICIANS, SOLDIERS AND THE PLACE OF THE SECURITY FORCES RUSI JOURNAL, $137(2)$ (APR 92), 1-6.

THIS ARTICLE, WRITTEN BY THE SECRETARY OF STATE FOR NORTHERN IRELAND, DISCUSSES THE THREAT OF TERRORISM IN THE PROVINCE. THE AUTHOR EXPLAINS THE PRINCIPLES UNDERLINING THE GOVERMMENT'S APPROACH TO THE PROBLEMS OF TERRORISH AND SETS THE SECURITY POLICY IN THE HIDER CONTEXT OF ITS POLICIES FOR THE SECURITY POLICY IN THE WIDER CONTEXT OF ITS POLICI POLITICAL, SOCIAL AND ECONOMIC ISSUES TO THE DEFEAT OF POLITICAL, SOCIAL AND ECONOMIC ISSUES TO THE DEFEAT OF TERRORISM. HE CONCLUDES THAT TO DEFEAT TERRORISM, THE
SUPPORT OF THE ENTIRE NORTHERN IRELAND COMMUNITY IS REQUIRED SUPPORT OF THE ENTIRE NORTHERN IRELAND COMMUNITY IS REQUIRED TO ISOLATE THE TERRORISTS. FURTHERMORE, THE UNREMITTIMG AND WHO OPERATE THE MECHANISMS OF CRIMINAL JUSTICE IS REQUIRED.

01826 BROOKES, S.

A NEW POWER STRUGGLE

INSIGHT, 6(52) (JAN 91), 14-17

DEMOCRATIZATION IN EASTERN EUROPE AND THE END OF THE COLD WAR ARE THREATENING TO MAKE POSTHAR SECURITY ALLIANCES OBSOLETE. IN ADOITION, CHAOS IN THE SOVIET UNION, TOGETHER WITH THE THREAT OF WAR IN THE MIDOLE EAST AND THE POSSIBILITY OF A GLOBAL TRADE HAR FOLLOWING THE BREAKDOWM OF THE GENERAL AGREEMENT ON TARIFFS AND TRADE TALKS ARE ALL BRINGING THE FRAGILE SYSTEM OF COALITIONS AN DALLIANCES AND INTERNATIONAL ORGANIZATIONS THAT GOVERN WORLD AFFAIRS TO THE BREAKING POINT. WESTERN EUROPE AND JAPAN ARE YEARNING TO BE MORE INDEPENDENT AND AGGRESSIVE IN THEIR FOREIGN POLICIES WHICH HAVE BEEN DRIVEN BY THE UNITED STATES SINCE WORLD WAR II. WASHINGTON IS TRYING TO MAKE SURE THAT IT WILL BE SHUT OUT FROM THE GAME IN WHATEVER "NEW WORLD ORDER" THAT WILL EMERGE.

01827 BROOKES, S.

THE NEXT WAR IN VIETMAM

INSIGHT, 8(5) (FEB 92), 6-11; 30-33.

NOT A POLITICAL WAR' THIS TIME, BUT AN ECONOMIC WAR,

VIETMAM'S SHIFT TO A FREE MARKET HAS ORAWH INVESTORS FROM 31 NATIONS. INVESTORS FROM AROUND THE HORLD HAVE BEEN STREAMING INTO VIETMAM TO GET IN ON THE GROUND FLOOR OF THE COMMUNIST INTO VIETNAM TO GET IN ON THE GROUND FLOOR OF THE COMMUNIS NATION'S BURGEONING FREE MARKET. EVEN THE U.S. MAY OPEN BENEFIT AMERICAN BUSINESS. JAPAN MAY HAVE THE PLACE SEWH UP.

01828 BROOKES, S.

THE WEST LENDS A HAND

INSIGHT, 6(52) (JAN 91), 12-13.

FEARING A COLLAPSE OF THE SOVIET UNION, THE HEST IS

TRYING TO HELP MOSCOW BUILD A MARKET ECDNOHY. BUT TURMOIL IN THE NATION HAS LED TO QUESTIONS OF HOW MUCH AID TO GIVE AND 
INTO TROUBLED EASTERN EUROPEAN NATIONS TO FORESTALL A FLOOD OF IMMIGRANTS FROM THOSE LANDS

01829 BROOKHISER, R.

ALL THE DEMOCRATS' WOMEN

NATIONAL REYIEH, XLIV (16) (AUG 92), 20-22.

THE AUTHOR DISSECTS THE THEMES AND PERSONALITIES OF THE 1992 DEMOCRATIC NATIONAL CONYENTION.

01830 BROOKHISER, $R$.

CLINTON: THE ROADSIDE VIEW

NATIONAL REVIEH, XLIV(4) (MAR 92), 17-18.

IT IS EASY TO SEE WHY BILL CLINTON HAS IMPRESSED SO MANY DEMOCRATIC POLITICIANS, SO MANY REPORTERS, AND MANY VOTERS. HIS MOST OBVIOUS ADVANTAGE IS HIS ENERGY. HE ALSO SEEMS TO TRULY LIKE THE PEOPLE HE MEETS. BUT IT ALSO EASY TO SEE WHY CLINTON HAS HAD SUCH TROUBLE SWEEPING ALL BEFORE HIM. HE HAS IDEAS IN ABUNDANCE; WHAT HE DOES NOT HAVE IS A COMPELLING IDEAS IN ABUNDANCE; WHAT HE DOES NOT HAVE IS A COMPELLING EXPLANATION OF HOW THEY ALL FIT TOGETHER. HIS COUNTLESS POSITIONS ON COUNTLESS ISSUES ARE ONLY LOOSELY GATHERED SHORT, CLINTON HAS AS BIG A VISION PROBLEM AS GEORGE BUSH.

01831 BROOKHISER, R.

PARTY IN SEARCH OF A THEME

NATIONAL REVIEW, XLIV(18) (SEP 92) 32-34.

THE AUTHOR DESCRIBES THE 1992 REPUBLICAN CONVENTION IN HOUSTON, FINDING FOUR MAJOR THEMES SCATTERED THROUGHOUT THE WEEK'S ORATORY.

01832 BROOKHISER, R

SENATOR POTHOLE V. MR. LIBERAL

NATIONAL REVIEW, XLIV(21) (NOV 92), 20-21.

THE AUTHOR LOOKS AT NEW YORK'S 1992 SENATORIAL CONTEST BETWEEN REPUBLICAN INCUMBENT ALFONSE D'AMATO AND DEMOCRATIC CHALLENGER ROBERT ABRAMS.

01833 BROOKHISER, R.

WAITING FOR RIGHTY

NATIONAL REVIEW, XLIV(1) (JAN 92), 40-42.

WHAT EXACTLY DOES PAT BUCHANAN MEAN TO DO? RICHARD BROOKHISER REPORTS WHAT THE CANDIDATE IS ACTUALLY SAYING IN NEW HAMPSHIRE, AND MUSES ON HIS HISTORY, CHARACTER, AND CHANCES. THE AUTHOR SUGGESTS THAT BUCHANAN IS ON THE PROWL FOR SPARRING PARTNERS AND IS FINDING THEM, LEFT AND RIGHT: ACT-UP DEMONSTATORS, IMMIGRANTS, FELLOW CONSERVATIVES, JAPANESE MANUFACTURERS--AND ABOVE ALL, GEORGE BUSH. THE JAPANESE MANUFACTURERS--AND ABOVE ALL, GEORGE BUSH. THE
AUTHOR CONCLUDES THAT THE GATEWAY TO THE FUTURE IS NEW HAMPSHIRE AND THAT PAT BUCHANAN IS NOT GOING TO QUIT AFTER ONE WARM-UP BOUT.

01834 BROOKMILLER, K.; BROOKMILLER, R.

PALESTINIAN' RADID AND THE UPRISING

PALESTINIAN RADIO AND THE UPRISING
JOURNAL OF PALESTINE STUDIES, XIX(76) (SUM 90), 96-105.

LITTLE HAS BEEN WRITTEN ABOUT THE ROLE OF RADIO WITHIM THE PALESTINIAN MOVEMENT SINCE THE OUTBREAK OF THE INTIFADA, PARTICULARLY THOSE BROADCASTS EMANATING FROM THE AL-QUDS PALESTINIAN ARAB RADIO STATION AND THE VOICE OF THE PLOBAGHDAD. THIS ARTICLE CONDUCTS A BRIEF EXAMINATION OF THESE BROADCASTS, BOTH OF WHICH ARE CLEARLY HEARD AND HIDELY LISTENED TO IN THE OCCUPIED TERRITORIES, AND REFLECT THE LARGER POLITICAL CONFLICT WITHIN THE PALESTINIAN COMMUNITY OVER STRATEGY AND MEANS IN PURSING THE INTIFADA.

01835 BROOKS, 0 .

YES, MINISTER

AMERICAN SPECTATOR, 25(11) (NOV 92), 52-53

THE AUTHOR PROFILES BRITISH PRIME MINISTER JOHN MAJOR,

WHO SCORED AN UNEXPECTED VICTORY OVER NEIL KINHOCK IN

BRITAIN'S 1992 ELECTIONS.

01836 BROOKS, J.

ABORTION POLICY IN WESTERN DEMOCRACIES: A CROSS-NATIONAL ANALYSIS

GOVERNANCE, 5(3) ( JUL 92), 342-357.

THIS ARTICLE PROVIDES A COMPARATIVE ANALYSIS OF ABORTION POLICIES FOR 21 COUNTRIES IN WESTERN EUROPE AND NORTH AMERICA. FIRST A TYPOLOGY OF CURRENT ABORTION LAHS IS PRESENTED. SECOND, THE MODE OF DETERMINING ABORTION POLICY IS COMPARED--JUDICIAL LEGISLATIVE, AMD DIPECT DEMOCRACY. THIRD, THE QUESTION OF ABORTION POLICY IMPLEMENTATION IS CONSIDERED. FOURTH, POTENTI IAL EXPLANATORY VARIABLES REGARDING THE CONTENT AND PROCESS OF ABORTION POLICIES IS EVALUATED.

01837 BROUGH, R.K.

THE EIGHT RULES FOR PRODUCING RESULTS

THE EIGHT RULES FOR PRODUCING RESULTS

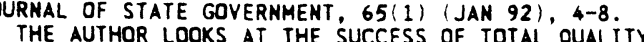

MANAGEMENT (TOM) IN JAPAN AND HOW IT MAY BE APPLIED TO

IMPROVE STATE GOVERNMENT SERVICES IN THE UNITED STATES.

01838 BROUN, J.A.

ANTI-CATHOL ICISM IN ROMANIA
FREEDOM REVIEW, 23(5) (SEP 92), 26-27

EASTERN RITE CATHOLICISM IS NOW LEGAL IN ROMANIA, BUT FEW OF THE CONGREGATIONS THAT MET IN HIDING FOR 40 YEARS HAVE BEEN ABLE TO GET INTO THEIR CHURCHES. OF MORE THAN 2000 CATHOLIC CHURCH BUILDINGS THAT THE COMMUNISTS COMFISCATED AND TURNED OVER TO THE ORTHODOX CHURCH IN 1948, ONLY 17 HAVE BEEN RETURNED. ROMANIAN PRESIDENT ION ILIESCU HAS SHOWN NO INTEREST IN RELIGIOUS AFFAIRS, REDUCING THE CHANCES OF STATE INTERYENTION TO RIGHT THE WRONG.

01839 BROWN, A.

THE MAJUR EFFECT: CHANGES IN PARTY LEADERSHIP AND PARTY POPULARITY

PARLIAMENTARY AFFAIRS, 45(4) (OCT 92), 545-564 THIS ARTICLE AIMS TO RE-EXAMINE THE EFFECTS OF

LEADERSHIP IN THE LIGHT OF THE 1992 ELECTION. IT FALLS INTO THREE MAIN SECTIONS. THE FIRST EXAMINES THE LEADERSHIP

IMAGES OF MAJOR AND KINNOCK DURING THE LONG CAMPAIGN. THE

SECOND LOOKS AT LEADERSHIP PERFORMANCE IN THE SHORT OFFICIAL CAMPAIGH. THE LAST ASSESSES THE EFFECTS OF CHANGES IN CAMPAIGN. THE LAST ASSESSES THE EFFECTS OF CHANGES IN LEADERSHIP ON ELECTORAL SUPPORT BY COMPARING THE POPULARITY OF PRIME MINISTERS AND LEADERS OF THE OPPOSITION IN THE POST WAR PERIOD. IN CONCLUSION, THE ARTICLE ARGUES THAT THERE
STRONG EVIDENCE BEARING OUT THE CONVENTIONAL WISDOM THAT STRONG EVIDENCE BEARING OUT THE CONVENTIONAL WISDOM MAJOR WAS FAR MORE POPULAR THAN KINNOCX. IT ALSO
DEMONSTRATES THAT THE CHANGE IN LEADERSHIP IN NOVEMBER 1990 DEMONSTRATES THAT THE CHANGE IN LEADERSHIP IN NOVEMBER
PRODEUCED A SIGNIFICANT SHORT-TERM HONEYMOON EFFECT.

01840 BROWN, B

CENTRAL ASIA

RFE/RL RESEARCH REPORT, 1(39) (OCT 92), 22-25.

SINCE THE SOVIET REPUBLICS OF CENTRAL ASIA WON THEIR

INDEPENDENCE, THE STATUS OF THE MEDIA IN THE REGION HAS

VARIED ACCORDING TO THE DEGREE OF POLITICAL LIBERALIZATION

THAT HAS OCCURRED IN EACH COUNTRY. TURKMENISTAN HAS SEEN MO

REAL CHANGE FROM THE SOVIET ERA; UZBEKISTAN HAS EXPERIENCED LITTLE LIBERALIZATION; KAZAKHSTAN HAS DEVELOPED A LIVELY, VARIED NEWS SCENE; KYRGYZSTAN'S MEDIA HAVE BEEN AFFECTED'BY

THE ECONOMIC PROBLEMS PLAGUING THE COUNTRY AS A WHOLE.

01841 BROWN, B.

CENTRAL ASIA

RFE/RL RESEARCH REPORT, 1(7) (FEB 92), 17-21

THUS FAR, THE MEMBERSHIP OF KAZAKHSTAN, UZBEEKISTAN,

KYRGYZSTAN, TAJIKISTAN, AND TURKMENISTAN IN THE COMMONHEALTH OF INDEPENDENT STATES HAS BROUGHT FEH BENEFITS TO CENTRAL

ASIA. PRICE LIBERALIZATION, UNOERTAKEN BY THE FIVE CENTRAL ASIAN STATES IN RESPONSE TO RUSSIA'S ACTION, HAS CAUSED INCREASED HARDSHIP FOR THE POPULATION, LEADING TO STRIKES IN KAZAKHSTAN AND VIOLENCE IN PZBEKISTAN. ON THE OTHER HAND, KAZAKHSTAN HAS DERIVED SOME BENEFITS FROM ITS NEW STATUS AS A NUCLEAR POWER AND HAS THE COMMONWEALTH TO THANK FOR ITS
INDEPENDENCE.

01842 BROWN, B.

CENTRAL ASIA EMERGES ON THE HORLD STAGE

RFE/RL RESEARCH REPORT, 1(1) (JAN 92), 51-56.

IN THE WAKE OF THE FAILED COUP OF AUGUST 1991, FOUR OF THE CENTRAL ASIA REPUBLICS--UZBEKISTAN, KYRGYZSTAN,

TAJIKISTAN, ANO TURKMENISTAN--DECLARED INDEPENDENCE. BECAUSE OF ITS ETHNIC STRUCTURE, KAZAKHSTAN COULD NOT JOIN THE RUSH TO INDEPENDENCE BUT HAD TO CONTENT ITSELF WITH RECONFIRMING IIS EARLIER DECLARATION OF REPUBLICAN SOVEREIGNTY. AT THE END OF 1991, IT WAS STILL UNCLEAR WHAT INDEPENDENCE HOULD MEAN TO THE CENTRAL ASIANS. THE FOUR REPUBLICS THAT HAD DECLARED INDEPENDENCE APPEARED TO BE THREATENED BY BOTH THE HARDLINERS WHO HAD STAGED THE COUP AND BY THE OUTBURST OF RUSSIAN NATIONALISM THAT FOLLOWED IT. SINCE THE CENTRAL ASIAN REPUBLICS ARE ECONOMICALLY DEPENDENT ON THE OTHER FORMER SOVIET REPUBLICS, ALL FIVE ARE EAGER TO JOIN A LOOSE CONFEDERATION, AND THE CREATION OF A "GREATER TURKESTAN" IMMEDIATE FUTURE.

01843 BROWN, B.

CENTRÁ ASIA'S DIPLOMATIC DEBUT

RFE/RL RESEARCH REPORT, 1 (10) (MAR 92), 20-25.

SINCE THEIR APPEARANCE ON THE GLOBAL SCENE AS

INDEPENDENT STATES, THE NEW COUNTRIES OF CENTRAL ASIA HAVE BEEN PLUNGED INTO A LIVELY ROUND OF EXCHANGES WITH FOREIGN COUNTRIES. THE NEW STATES ARE VISIBLY REJOICING IN THE RECOGNITION BEING ACCORDED THEM BY BOTH THEIR MUSLIM NEIGHBDRS AND THE WEST AND ARE EAGER TO JOIN INTERNATIONAL ORGANIZATIONS THAT MAY ENHANCE THEIR STATUS AND BRING ORGANIZATIONS THAT MAY ENHANCE THEIR STATUS AND BRING
ECDNOMIC BENEFITS. MEANHHILE, THE HEST IS FEARFUL THAT THE ECONOMIC BENEFITS. MEANHHILE, THE HEST IS FEARFUL THAT THE FOLLOW A RADICAL ANTI-WESTERN COURSE.

01844 BROMN, B.: TEDSTROM, J.

KAZAKHSTAN AND KYRGYSTAN: CENTRAL ASIA'S LEADERS RFE/RL RESEARCH REPORT, 1(17) (APR 92), 58-63. OF THE FIVE CENTRAL ASIAN STATES, KAZAKHSTAN AND KYRGYZSTAN HAVE ADVANCED THE FARTHEST WITH MARKET-ORIENTED REFORM. IN BOTH COUNTRIES, THE CENTERPIECE OF THE REFORM 
PROGRAM IS PRIVATIZATION, ALTHOUGH EACH IS FOLLOHING A SLIGHTLY DIFFERENT SCHEME SO FAR, KAZAKHSTAN HAS

CONCENTRATED MAINLY ON HOUSING. KYRGYZSTAN DID NOT LAUNCH

ITS PROGRAM UNTIL JANUARY 1992 AND HAS YET TO SHOW RESULTS

01845 BROWN, B.

KAZAKHSTAN AND KYRGYZSTAN ON THE ROAD TO OEMOCRACY

RFE/RL RESEARCH REPORT, 1(48) (DEC 92), 20-22.

WHEN THE USSR DISINTEGRATED, KAZAKHSTAN AND KYRGYZSTAN APPEARED TO BE THE MOST LIKELY OF THE CENTRAL ASIAN

REPUBLICS TO DEVELOP WESTERN-STYLE DEMOCRACIES. ALTHOUGH

KAZAKHSTAN PRESIDENT NURSULTAN NAZARBAEV HAS DESCRIBED

HIMSELF AS A RADICAL ONLY AS FAR AS ECONOMIC REFORM IS

CONCERNED, HE PERMITTED THE DEVELOPMENT OF A FAIRLY BROAD

SPECTRUM OF POLITICAL GROUPS EYEN PRIOR TO INDEPENDENCE.

KAZAKHSTAN'S GOVERMMENT RESTRICTS OR PROHIBITS THE

ACTIVITIES ONLY OF THOSE PARTIES AND POLITICAL ASSOCIATIONS

THAT ESPOUSE EXTREME NATIONALIST POSITIONS, INCLUDING THE

TINY KAZAKH NATIONALIST PARTY ALASH, WHICH ADVOCATES THE

EXPULSION OF ALL RUSSIANS FROM KAZAKHSTAR, AND THE COSSACK

SOCIETIES IN THE HEAVILY SLAVIC NORTHERN OBLASTS, WICH

SOCIETIES IN THE HEAVILY SLAVIC NORTHERN OBLASTS, WHICH

SUPPORT RUSSIAN NATIONALIST DEMANDS THAT THE NORTHERN
REGIONS OF KAZAKHSTAN BE ANMEXED BY THE RUSSIAN FEDERATION.

01846 BROWN, B.

KAZAKHSTAN SINCE INDEPENDENCE

RFE/RL RESEARCH REPORT, 1(14) (APR 92), 5-6.

SINCE IT BECAME AN INDEPENDENT STATE, KAZAKHSTAN HAS

ATTRACTED WORLD ATTENTION LARGELY BECAUSE OF ITS RELUCTANCE TO GIVE UP ITS STRATEGIC MISSILES. UNDER THE LEADERSHIP OF
PRESIDENT NAZARBAEY. ITS ECONOMIC REFORM IS CONTINUING AND A PRESIDENT NAZARBAEV, ITS ECONOMIC REFORM IS CONTINUING AND
REFORM OF ITS GOVERNMENTAL STRUCTURE HAS BEGUN. THUS FAR, INTER-ETHNIC PEACE HAS BEEN MAINTAINED.

01847 BROWN, B.

TAJIKISTAN: THE FALL OF NABIEY

RFE/RL RESEARCH REPORT, 1(38) (SEP 92), 12-18.

AFTER A WEEK OF INCREASING TENSION IN DUSHANBE AND FIGHTING BETHEEN RIVAL FACTIONS IN KURGAN-TYUBE, THE OPPOSITION AND CONCERNED MEMBERS OF THE GOVERNMENT AND THE SUPREME SOVIET SUCCEEDED IN FORCING TAJIKISTAN'S PRESIDENT RAKHMON NABIEY TO RESIGN. DURING NABIEV'S TIME IN OFFICE, A SERIES OF MEASURES WERE UNDERTAKEN THAT EXACERBATED TENSION AMONG ETHNIC GROUPS. MOREOVER. THE PRESIDENT FAILED TO ADVANCE THE EFFORTS TO MAKE PEACE AMONG THE FACTIONS THAT

HAVE REDUCED SOUTHERN TAJIKISTAN TO A STATE OF VIRTUAL CIVIL

WAR. HOHEVER, HABIEY'S DEPARTURE IS NO GUARANTEE OF PEACE.

01848 BROWN, B.

THE PRESIDENTIAL ELECTION IN UZBEKISTAM

THE PRESIDENTIAL ELECTION IN UZBEKISTAN

SOME POLITICAL OBSERVERS SAY THAT THE RESULTS OF

UZBEKISTAN'S PRESIDENTIAL ELECTION ON DECEMBER 29, 1991,

CONFIRMED THE WIDELY Y HELD BELIEF THAT THE REPUBLIC IS FIRMLY IN THE GRIP OF COMMUNIST CONSERVATIVES WHO HAVE LITTLE INTEREST IN GENUINE REFORM. HOWEVER. THE RESOUNDING VICTORY OF INCUMBENT PRESIDENT ISLAM KARIMOV MAY ALSO BE ATTRIBUTED TO THE RELATIVE WEAKNESS OF THE DEMOCRATIC INTELLIGENTSIA AND THE FACT THAT KARIMOV HAS KEPT A TIGHT REIN ON EMERGING ISLAMIC FORCES IN THE REPUBLIC.

01849 BROWN, B

TRANSFORMING POSTCOMMUNIST LABOR MARKETS: THE POLISH CASE RFE/RL RESEARCH REPORT, I(32) (AUG 92), 50-56.

POSTCOMMUNIST COUNTRIES MUST LIBERALIZE BOTH RESOURCE AND PRODUCT MARKETS IN THEIR TRANSITION TO A MARKET ECONOMY. LABOR MARKETS IN POLAND ANO OTHER REFORMING COUNTRIES HAVE CHARACTERISTICS AND INCENTIVE MECHANISMS THAT INHIBIT EFFICIENT RESOURCE ALLOCATION. THE PRESENCE OF A "REAL" OHNER WOULD BE A GREAT IMPROVEMENT, BUT PRIVATIZATION TAKES TIME. IN THE INTERIM, REFORMING COUNTRIES MUST DEVELOP EFFECTIVE POLICIES FOR THE LABOR MARKET AND INSTITUTIONS FOR COLLECTIVE BARGAINING BEFORE THE POPULATION BECOMES REFORMWEARY, UNCOOPERATIVE, AND HOSTILE TO MARKETIZATION.

01850 BROWN, B.

TURKMENISTAN ASSERTS ITSELF

RFE/RL RESEARCH REPORT, 1(43) (OCT 92), 27-31.

TURKMENISTAN WAS LONG REGARDED BY OBSERVERS BOTH INSIDE AND QUTSIDE THE USSR AS ONE OF THE MOST BACKWARD REPUBLICS OF THE UNION. HOWEVER, SINCE IT BECAME AN INDEPENDENT STATE, IT HAS ESTABLISHED ITSELF AS ONE OF THE TWO CENTRAL ASIAN COUNTRIES, ALONG WITH KAZAKHSTAN, WITH THE MOST PROMISING COUNTRIES, ALONG WITH KAZAKHSTAN, WITH THE MOST PROMISING FUTURE. THE NEW STATE OWES ITS INTERMATIONAL PROMINENCE ITS READILY EXPLOITABLE GAS AND OIL DEPOSITS ANO TO THE PROMOTION OF ITS INTERESTS BY PRESIDENT SAPARMUT
THE ARCHITECT OF TURKMENISTAN'S INDEPENDENCE.

01851 BROWN, B. (ED.); CROW, S. (ED.); KOSIBA, H. (ED.) WEEKLY REVIEW: $16-29$ SEPTEMBER 1992 RFE/RL RESEARCH REPORT, 1(40) (OCT 92), 65-75.

THE EDITORS SUMMARIZZE MAJOR NEWS EVENTS IN YUGOSLAVIA, RUSSIA, GEORGIA, KAZAKHSTAN, MOLDOVA, ROMANIA, ESTONIA, LATVIA, LITHUANIA, ARMENIA, AZERBAIJAN, BULGARIA,
CZECHOSLOVAKIA, HUNGARY, KYRgYZSTAN, POLAND, TAJIKISTAN, AND UKRAINE DURING SEPTEMBER 16-29, 1992.

01852 BROWN, B.A.

THE KUURDS TAKE A BOLD STEP

FREEDOM REVIEW, 23(4) (JUL 92), 3.

ON MAY 19, 1992, THE KURDS HELD FREE ELECTIONS FOR PRESIDENT AND PARLIAMENT. THE CHOICE WAS ESSENTIALLY BETWEEM THE KURDISTAN DEMOCRATIC PARTY, WHICH HANTS TO PURSUE GREATER AUTONOMY THROUGH DIRECT NEGOTIATIONS WITH SADDAM HUSSEIN, AND THE PATRIOTIC UNION OF KURDISTAN, WHICH FAVORS SELF-DETERMINATION WITHIN IRAQ WHILE OPPOSING DIRECT NEGOTIATIONS WITH BAGHOAD. ONLY A HANDFUL OF AMERICAM OBSERVERS WERE PRESENT BECAUSE THE STATE DEPARTMENT THREATENED TO PROSECUTE AMERICANS TRAVELING TO KURDISTAN MAKING THE USA AN UNLIKELY ALLY OF SADDAM, WHO HAD DECLARED THE ELECTIONS ILLEGAL.

01853 BROWN, C.

REALLY EXISTING LIBERALISM AND INTERNATIONAL ORDER MILLENNIUM, 21(1) (SPR 92 ), 313-328.

EVEN IF "THE END OF HISTORY" IS NOT IN SIGHT, LIBERALISM IN ONE FORM OR ANOTHER IS LIKELY TO BE THE DOMINANT POLITICAL IDEOLOGY FOR THE FORESEEABLE FUTURE, RAISING PUESTIONS ABOUT WHAT KIND OF INTERNATIONAL RELATIONS THIS QUESTIONS ABOUT WHAT KIND OF INTERNATIONAL RELATIONS WILL PROOUCE. KANTIAN ACCOUNTS OF THE INTERNATIONAL
RELATIONS OF "LIBERAL" STATES FAIL TO TAKE INTO ACCOUNT THE RELATIONS OF "LIBERAL" STATES FAIL TO TAKE INTO ACCOUNT THE
GAP BETWEEN THE MODELS AND "REALLY EXISTING" LIBERALISM. GAP BETWEEN THE MODELS AND "REALLY EXISTING" LIBERALISM. IMPORTANT NON-LIBERAL ENEMIES OF LIBERAL STATES IN THE PAST. IMPORTANT NON-LIBERAL ENEMIES OF LIBERAL STATES IN THE BUT SIMPLE, COST BENEFIT ANALYSIS MAY INCLINE LIBERAL REGIMES
FUTURE.

01854 BROWN, C. ; LONGWORTH, J.

RECONCILING NATIONAL, ECONOMIC REFORMS AND LOCAL INVESTMENT DECISIONS IN CHINA: FISCAL DECENTRALIZATION AND FIRSTSTAGE HOOL PROCESSING

DEVELOPMENT POLICY REVIEW, 10(4) (DEC 92), 389-402.

CAREFUL EVALUATION OF THE IMPACT OF REFORMS IN CHINA IN THE EARLY 1980S MAY PROVIDE SOME INSIGHTS INTO THE DIFFICULTIES WHICH MAY BE ENCOUNTERED BY THE PREVIOUSLY HIGHLY PLANMED ECONOMIES OF CENTRAL EUROPE AND THE COMMONWEALTH OF INDEPENDENT STATES. THIS ARTICLE PRESENTS ONE SUCH CASE STUDY. IT STUDIES THE SO-CALLED 'WOOL-WARS' IN WHICH NEIGHBORING PROVINCES COMPETED DESTRUCTIVELY AGAINST EACH OTHER FOLLOWING THE LIBERALIZATION OF THE WOOL MARKET. THE ARTICLE INVESTIGATES THE DEVELOPMNET OF LOCAL FIRSTSTAGE WOOL PROCESSING. ALTHOUGH THIS IS A SPECIFIC CASE, PREFECTURES IN THE PASTORAL REGION AND FOR A NUMBER OF ANIMAL HUSBANDRY-RELATED INVESTMENTS.

01855 BROWN, C.

THE ELECTORAL RISK OF REDISTRICTING: EVIDENCE FROM THE UNITED STATES

ELECTORAL STUDIES, 11(2) (JUN 92), 122-137.

THIS ARTICLE INVESTIGATES WHETHER REDISTRICTING POSES AN ELECTORAL RISK TO THE RE-ELECTION OF INCUMBENT US REPRESENTATIVES. ANALYSIS OF COUNTY ELECTION RETURNS FOR SIX AMERICAN STATES FROM 1972 TO 1984 INDICATE THAT INCUMBENTS INITIALLY RECEIVE MARGINALLY LESS SUPPORT IN THE NEW TERRITORY WEN COMPARED WITH THE OLD BUT THAT INCUMBENTS ARE ABLE TO QUICKLY ELIMINATE THE DIFFERENCE BETHEEN THE TWO KINDS OF TERRITORY. THE ANALYSIS CONCLUDES THAT REDISTRICTING DOES NOT POSE A SERIOUS THREAT TO INCUMBENT REELECTION.

01856 BROWN, C.G.; L LONGWORTH, J.H. MULTILATERAi ASSISTANCE AND SUSTAINABLE DEVELOPMENT: THE CASE OF AN IFAD PROJECT IN THE PASTORAL REGION OF CHINA HORLD DEVELOPMENT, 20(11) (NOV 92), 1663-1674.

THE PASTORAL AREAS OF CHINA PRESENT MAJOR CHALLENGES IN RELATION TO SUSTAINABLE DEVELOPMENT. THIS PAPER DESCRIBES AND EVALUATES A MAJOR MULTILATERAL AID EFFORT DESIGNED TO MEET THESE CHALLENGES, THE IFAD NORTH CHINA PASTURE AND ANIMAL DEVELOPMENT PROJECT. THE ANALYSIS SUPPORTS THE ARGUMENT THAT MULTILATERAL AID AGENCIES SHOULD PLACE MORE EMPHASIS ON PROJECTS THAT FACILITATE THE DEVELOPMENT OF NEH INSTITUTIONS AND POLICY REFORMS THAN ON PROJECTS THAT CONCENTRATE ON INVESTMENT IN NEW TECHNOLOGY. THE CASE STUDY ALSO ILLUSTRATES THE POINT THAT FINANCIAL ARRANGEMENTS ALSO ILLUSTRATES THE POINT SHAT FINAMCIAL ARRANGEMENTS ADOPIOUS UNINTENDED BURDENS ON THE RECIPIENT COUNTRY.

01857 BROWN, C.J. KEEPING IT SAFE FOR SERBIA

KEEPING IT SAFE FOR SERBIA

KOSOVO IS AN OVERWHELMINGLY ALBANIAN ETHNIC ENCLAVE IN SOUTHERN SERBIA. IN THIS ARTICLE, THE AUTHOR REPORTS ON THE ALBANIANS' EFFORTS TO ESCAPE SERBIAN OPPRESSION AND OBTAIN SELF-RULE. 
01858 BROWN, C.W.

THE GULF CRISIS

RIPON FORUM, (DEC 90), 18-19.

IN THIS ARTICLE THE AUTHOR ANALYZES PRESIDENT GEORGE BUSH'S HANDLING OF THE GULF CRISIS. BUSH IS SEEN AS PERFORMING CORRECTLY IN THE SITUATION. THE REASONS WHY IT IS IMPORTANT TO REMOVE HUSSEIN FROM KUWAIT ARE EXAMINED, WITH EMPHASIS ON OIL. BUSH'S METHODS IN ACHIEVING HIS AIMS IN THE GULF, AS WELL AS CONSTITUTIONAL QUESTIONS OF WAR AND PEACE, ARE EXPLORED.

01859 BROWN, D. INSTITUTIONALISM AND THE POSTMODERN POLITICS OF SOCIAL

JOURNAL OF ECONOMIC ISSUES, 26(2) (JUN 92), 545-552.

PEOPLE HAVE BEEN RETHINKING CLASS SINCE' AT LEAST MARX'S TIME. WHEN WE RETHINK CLASS, WHAT WE ARE CONCERNED WITH IS HOW PEOPLE WHO ARE VICTIMS OF SOCIAL INJUSTICE IDENTIFY THEMSELVES AND THEIR PROBLEMS. THE ISSUE OF CLASS IS AN
ISSUE OF IDENTITY. IN THIS PAPER, THE AUTHOR ORAHS UPON THO SETS OF OVERLAPPING LITERATURE: POST-MARXISM AND POSTMODERNISM. THE CONCLUSION FROM BOTH ARE COMPATIBLE WITH INSTITUTIONALISM. WHAT HE TAKES FORM BOTH SETS OF LITERATURE IS THE CONCLUSION THAT WE HAVE EXPERIENCED AN IDENTITY CRISIS REGARDING CLASS, BOTH IN THE REAL WORLD AND IN THE THEORIES THAT WE USE TO EXPLAIN IT. HE SUGGESTS THAT THIS CRISIS SHOULD ALTER BUT NOT NEUTRALIZE THE STRUGGLE FOR A FULLY DEMOCRATIC, SOCIALLY JUST SOCIETY IN WHICH CLASS IS NO LONGER A TERM IDENTIFYING THE ABUSE OF ONE GROUP BY ANOTHER.

01860 BROWN, E.

CONTENDING PARADIGMS OF JAPAN'S INTERMATIONAL ROLE: ELITE VIEWS OF THE PERSIAN GULF CRISIS

JOURNAL OF NORTHEAST ASIAN STUDIES, 10(1) (SPR 91), 3-18. IN THIS STUDY THE AUTHOR EXAMINES JAPAN'S RECENT DEBATE OVER ITS POLICY IN THE PERSIAN GULF CRISIS. PARTICULAR
ATTENTION IS GIVEN TO FIVE COMPETING SCHOOLS OF THOUGHT THAT SHAPED THE NATIONAL DEBATE AMONG JAPANESE OPINION LEADERS. SHAPED THE NATIONAL DEBATE AMONG JAPANESE OPINION LEADERS.
ALTHOUGH JAPAN'S RESPONSE TO THE GULF CRISIS WAS MARKED BY A ALTHOUGH JAPAN'S RESPONSE TO THE GULF CRISIS WAS MARKED BY
SERIES OF FALSE STARTS AND CONFUSION, IT LIKELY THAT A NEH SERIES OF FALSE STARTS AND CONFUSION, IT LIKELY THAT A
FOREIGN POLICY PARADIGM WILL EVENTALIY EMERGE FROM THE FOREIGN POLICY PARADIGM WILL EVENTALLY EMERGE FROM THE
ONGOING DEBATE AMONG THE CDNTENDING SCHOOLS OF THOUGHT ONGOING DEBATE AMONG THE
IDENTIFIED BY THE AUTHOR.

01861 BROWN, $F$

CAMBODIA IN 1991: AN UNCERTAIN PEACE

ASIAY SURYEY XXXI I AN UNCERTAIN PEACE

ASIAN SURVEY, XXXII(1) (JAN 92), 88-96. AFTER DECADES OF WAR, CIVIL STRIFE, AND MULTITIERED DIPLOMACY, A COMPROMISE POL ITICAL SETTLEMENT HAS FINALLY
COME TO CAMBODIA. THE GENESIS OF THE PEACE SETTLEMENT COULD COME TO CAMBODIA. THE GENESIS OF THE PEACE SETTLEMENT COULD
BE FOUND IN THE DECISION OF THE "EXTERNAL FACTORS" IN THE BE FOUND IN THE DECISION OF THE "EXTERNAL FACTORS IN THE REMOVE CAMBODIA AS A CENTRAL IRRITANT IN THEIR BILATERAL RELATIONS. THE COLLAPSE OF EUROCOMMUNISM HAS ALSO CONTRIBUTED TO THE UNCERTAIN PEACE IN CAMBODIA.

01862 BROWN, G.; CAVAMAGH, J.; GOOLD, $W$. MAKING TRADE FAIR: A SOCIAL ANO ENVIRONMENTAL CHARTER FOR NORTH AMERICA

HORLD POLICY JOURNAL, IX(2) (SPR 92), 309-328.

SINCE 1991. THE BUSH ADMINISTRATION HAS PLACED ITS GREATEST TRADE NEGOTIATING ENERGIES BEHIND FORGING A NORTH AMERICAN FREE-TRADE AGREEMENT THAT HOULD STRIKE DOWH BARRIERS TO ECONOMIC INTEGRATION BETHEEN THE UNITED STATES, MEXICD, AND CANADA. PRESIDENT BUSH SPEAKS OF THIS PROPOSED AGREEMENT AS A STEPPING STONE TOWARD THE ESTABLISHMENT OF A FREE-TRADE AREA FOR THE ENTIRE WESTERN HEMISPHERE WITH BENEFITS FOR EVERYONE. BUS INESSES ARE TO REAP THE ADVANTAGES
OF A LARGER MARKET, INCREASED TRADE WILL GENERATE MORE JOBS, AND CONSUMERS CAN LOOK FORHARD TO MANY PRODUCT CHOICES.

01863 BROWN, G.

THE SERVANT STATE: TOWARDS A NEW CONSTITUTIONAL SETTLEMENT POLITICAL OUARTERLY (THE), 63(4) (OCT 93), 394-403.

THIS ARTICLE ARGUES THAT SCOTLAND REQUIRES AN ENTIRELY NEW SETTLEMENT BETHEEN INDIVIDUAL, COMMUNITY AND GOVERMMENT; NEW SETTLEMENT BETWEEN INDIVIDUAL, COMMUNITY AND GOVERMMENT; THAT A MODERN VIEW OF SOCIALISM MUST RETRIEVE THE BROAD IDEA
OF COMIUNITY FROM THE NARROW NOTION OF THE STATE; AND THAT OF COMMUNITY FROM THE NARROH NOTION OF THE STATE; AND THA
IT MUST BE ENSURED THAT THE COMMUNITY BECOMES A MEANS BY WHICH INDIVIDUALS CAN REALIZE THEIR POTENTIAL, NOT AT THE WHICH INDIVIDUALS CAN REALIZE THEIR POTENTIAL, NOT AT THE
EXPENSE OF LIBERTY BUT IN ADVANCING IT. THE ARTICLE MAKES EXPENSE OF LIBERTY BUT IN ADVANCING IT. THE ARTICLE MAKES THE CASE FOR CONSTITUTIONAL CHANGE FROM LABOR VALUES AND
ARGUES FOR THE PROPOSITION THAT CITIZENS MUST NOW TAKE ARGUES FOR THE PROPOSIIION THAT CITIZENS MUST NOW TAKE SERIOUSLY THE CASE FOR A EUROPEAN BILL OF RIGHTS SO THAT
THEY CAN BE PROTECTED FROM ABUSE OF POWER BY ANY MAJOR THEY CAN BE PROTECTED FROM ABUSE OF POWER BY
PUBLIC INSITUTION THAT TOUCHES THEIR LIVES.

01864 BROWN, H.; DOMENICI, P.V.; HATCH, O.G.; LIEBERMAN, J.I.; ROTH, W.V. JR.

THE \$25-BILLION QUESTION

POLICY REVIEH, (61) (SUM 92), 70-73.

FIVE INCUMBENT U.S. SENATORS EXPLAIN THEIR OWM PRIORITIES IN REDUCING GOVERNMENT SPENDING AND BALANCING THE BUDGET.
01865 BROWN, J.

IS MACEDONIA NEXT?

COMMONHEAL, CXIX(14) (AUG 92), 7-8

AS THE CONFLAGRATION OF CIVIL STRIFE SPREADS INEXORABLY SOUTHWARD THROUGH THE FORMER YUGOSLAVIA, THE TINDER BOX LOOKS SET TO BE LIT NEXT IN MACEDONIA. IN THIS ARTICLE, THE AUTHOR LOOKS AT MACEDONIA'S ETHNIC COMPOSITION, ITS RELATIONS WITH ITS NEIGHBORS, AND THE PROSPECTS FOR ITS FUTURE.

01866 BROWN, J.

THE NEXT EXPLOSION

THE NEXT EXPLOSION

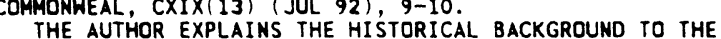
THE AUTHOR EXPLAINS THE HISTORICAL BACKGROUND TO THE
GROWING TENSION IN KOSOVO, WHERE THE PROVINCE'S ETHNIC

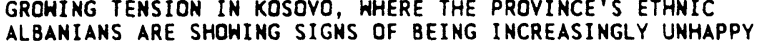
WITH SERBIAN DOMINATION.

01867 BROWN, J.F

A CHALLENGE TO POLITICAL VALUES

RFE/RL RESEARCH REPORT, 1(40) (OCT 92), 23-25.

A MANIFESTO BY ISTVAN CSURKA, A LEADER OF THE RULING HUNGARIAN DEMOCRATIC FORUM, ARGUES THAT A COMMUNIST-JEWISHLIBERAL CONSPIRACY HAS HAUNTED HUNGARIAN LIFE FOR NEARLY A HALF-CENTURY. CSURKA'S TRACT HAS CAUSED MUCH CONTROVERSY, BUT THE QUESTION IS HOW MUCH INFLUENCE HIS MESSAGE WILL HAVE. PRIME MINISTER JOZSEF ANTALL, WHOM CSURKA ATTACKS, HAS SOUGHT TO DOWNPLAY THE SIGNIFICANCE OF THIS EPISODE, BUT HIS "DAMAGE-CONTROL" TACTICS COULO BACKFIRE. CSURKA'S INTERVENTION WILL UNDOUBTEDLY AFFECT THE FUTURE OF THE HUMGARIAN DEMOCRATIC FORUM, BUT THE MORE IMPORTANT QUESTION IS HOW THE HUNGARIAN PEOPLE WILL RESPONO TO IT.

01868 BROWN, J.F.

DEMOCRACY IN THE MEDIA

RFE/RL RESEARCH REPORT, 1(39) (OCT 92), 1-3.

FREE MEDIA IS AS ESSENTIAL TO DEMOCRACY AS CENSORSHIP IS TO DICTATORSHIP. IN SOME PARTS OF THE FORMER SOVIET UNION AND EASTERN EUROPE. THE EMERGING FREE MEDIA PLAYED AN

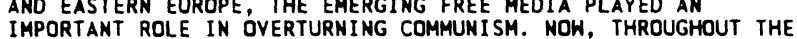
IMPORTANT ROLE IN OVERTURNING COMMUNISM. NOW, THROUGHOU
ENTIRE REGION, FREE MEDIA ARE NEEDED TO CUT AHAY THE ENTIRE REGION, FREE MEDIA ARE NEEDED TO CUT AHAY THE
BARNACLES OF THE OLD SYSTEM THAT STILL CLING TO THE NEH BARNACLES OF THE OLD SYSTEM THAT STILL CLING TO THE NEN
SHIPS OF STATE AND TO HELP CONSTRUCT AND CONSOLIDATE THE NEW DHIPS OF STATE AND

01869 BROWN, J.F.

INTRODUCTION: TOWARD THE RULE OF LAW

RFE/RL RESEARCH REPORT I(27) (JUL 92), 1-3.

THE NEWLY-INDEPENDENT AND NEWLY-FOUNDED STATES OF EASTERN EUROPE AND THE COMMONWEALTH OF INDEPENDENT STATES INTEND TO REPLACE THE COMMUNIST PERVERSION OF THE LAW WITH THE RULE OF LAW--LAW THAT PROTECTS THE CITIZENS RATHER THAN CONTROLS THEM, THAT REGULATES THEIR RELATIONS WITH ONE ANOTHER AND WITH THE AUTHORITIES THEY ELECT. THEIR EFFORTS ARE ENCOUNTERING BOTH HOPE AND SKEPTICISM.

01870 BROWN, J.F.

PRESENT HOPES AND PAST SHADOWS

RFE/RL RESEARCH REPORT, 1(1) (JAN 92), 1-4.

THE AUTHOR REVIEWS THE DRAMATIC POLIIICAL EVENTS IN EASTERN EUROPE AND THE SOVIET UNION OVER THE PAST THREE YEARS, FOCUSING ON THE CAUSES AND EFFECTS OF THE DEATH OF COMMUNISM.

01871 BROWN, J.F.

RELIEF HITHOUT RELAXATION: EASTEN EUROPE PONOERS THE CIS RFE/RL RESEARCH REPORT, 1(8) (FEB 92), 17-20.

WHILE RELIEVED AT THE COLLAPSE OF COMMUNISM IN THE SOVIET UNION AND AT THE DISINTEGRATION OF THE POWER THAT HAD DOMINATED THEM, THE EAST EUROPEAN STATES REALIZE THAT THE NEW COMMONHEALTH OF INDEPENDENT STATES WILL PRESENT SERIOUS PROBLEMS. BUT THESE PROBLEMS WILL BE QUITE DIFFERENT FROM THOSE THAT CONFRONTED THEM IN RELATIONS WITH THE OLD SOVIET VARIOUS KINDS.

01872 BROWN, J.F. SURGE TO FREEDOM: THE END OF COMMUNIST RULE IN EASTERN

DUKE UNIVERSITY PRESS, $1991,338$.

THIS HORK EXAMINES THE REVOLUTIONARY EVENTS OF 1989 IN EASTER EUROPE. THE AUTHOR DEYOTES A CHAPTER TO EACH OF THE COUNTRIES IN TURMOIL: POLAND, HUNGARY, THE GERMAN DEMOCRATIC REPUBLIC, CZECHOSLOYAKIA, BUIGARIA, ROMANIA YUGOSLAVIA, AND ALBANIA. THE AUTHOR ALSO' DISCUSSES, THE HISTORICAL FRAMEHORK FROM BOTH THE SOYIET AND EAST EUROPEAN PERSPECTIVES, HHICH LAID THE GROUNDWORK FOR THE ENSUING RADICAL CHANGES IN EACH COUNTRY. THE IMPACT OF VARIOUS SOVIET LEADERS--STALIN, KHRUSCHCHEV, BREZHNEV, AND GORBACHEV--ON EAST EUROPE IS ASSESSED. WHILE GORBACHEV'S ROLE IN FACILITATING THE CHANGES IN EAST EUROPE IS MOST OBVIOUS, THE AUTHOR ARGUES THAT GORBACHEV'S EXAMPLE AND NEGLECT WERE MORE IMPORTANT THAT HIS EXERTIONS. THE AUTHOR CATEGORIZES THE SOVIET ROLE AS ONE OF 
A POLICY ORIENTATION THAT CREATED THE EMYIRONMENT, AND, IN FACT, NECESSITATED THE EAST EUROPEAN REVOLUTIONARY RESPONSE.

01873 BROWH, J.W.

ROAD MAP TO RIO: AN AGENDA FOR ECO 192

HEMISPHERE, 4(2) (WIN 92), 2-4.

IN THE NORTH, ENYIRONMENTALISTS AND A GROWING NUMBER OF

POLITICIANS HAVE MADE SAVING TROPICAL FORESTS AND

STABILIZING POPULATION THE PRIMARY ENVIRONMENTAL OBJECTIVES-

WITHOUT OFFERING ANY NEW MONEY TO HELP MEET THESE GOALS. IN

THE SOUTH, THE CHARGE OF "ECOLOGICAL DEBT" IS COUPLED WITH

FEARS THAT THE NORTH IS TRYING TO "INTERNATIONALIZE THE

AMAZON." THE MOST STRIDENT VOICES IN THIS DEBATE ARE RAISING

HACKLES WITHOUT PROOUCING ANY CONSTRUCTIVE RESULTS. WORSE

YET, THE UNITED STATES IS BLOCKING PROGRESS ON SUCH CRITICAL

ISSUES AS CLIMATE CHANGE AND CONSERVATION FINANCING.

01874 BROWN, $K$.

KHABAROYSK: RESURRECTIHG THE NOMENKLATURA

RFE/RL RESEARCH REPORT, 1(38) (SEP 92), 26-32.

REPORTS FROM KHABAROVSK PORTRAY A LOCAL GOVERMMENT IN A

CHAOTIC STATE BETWEEN COLLAPSE AND REGENERATION. LOCAL

CHAOTIC STATE BETWEEN COLLAPSE AND REGENERATION. LOCAL
LEGISLATIVE AND EXECUTIVE BRANCHES ARE CLASHING AS THEY

LEGISLATIVE AND EXECUTIVE BRANCHES ARE CLASHING AS THEY
ATTEMPT TO DEFINE THEIR RESPECTIVE SPHERES OF AUTHORITY,

WHILE THE JUDICIARY HAS YET TO ESTABLISH ITS INDEPENDENCE

WHILE THE JUDICIARY HAS YET TO ESTABLISH ITS INDEPENDENCE

PROM THE OTHER BRANCHES OF GOVERMMENT. THE RESULT HAS BEEN PARALYSIS IN THE DECISION-MAKING APPARATUS, HHICH HAS L REPEATED BREAKDOWNS AND SHORTAGES. MANY LEADERS OF THE
GOVERNMENT-IN-TRANSITION ARE FORMER COMMUNIST OFFICIALS, AND MANY OF THEM HAVE USED THEIR POSITIONS TO COLLECT THE SPOILS TO BE FOUND IN THE DISMANTLING OF THE SOVIET STATE. THIS ATMOSPHERE HAS INSPIRED SEVERAL KHABAROVSK JOURNALISTS TO WRITE HITH NOSTALGIA
OF THE SOVIET ERA.

01875 BRONN, $K$

SAKHALIN'S VALENTIN FEDEROV MAKES NATIONALIST ALLIES RFE/RL RESEARCH REPORT, 1(38) (SEP 92), 33-38.

VALENTIN FEDOROV. THE AUTHOR OF A DARING ECONOMIC EXPERIMENT LAUNCHED IN SAKHALIN OBLAST IN 1990, HAS BEEN HAILED AS A LIBERAL REFORMER. BUT HIS MORE RECENT STRUGGLE WITH PRESIDENT BORIS YELTSIN OVER ECONOMIC POLICY AND THE POSSIBLE TRANSFER OF FOUR OF THE KURIL ISLANDS TO JAPAN HAS WON FEDOROV ALLIES AMONG THE ANTI-YELTSIN NATIONALIST MOVEMENT. IN ESSENCE, FEDOROV IS A LOCAL LEADER WHOSE VIEWS EMBRACE $A$ H ECLECTIC MIXTURE OF WESTERM ECONOMIC THEOPY AMD EMBRACE AN ECLECTIC MIXTURE OF WESTERN ECONOMIC THEORY AND HARD-LINE COMMUNIST ADMINISTRATIVE TECHNIQUES. AS A RESUL OF HIS UNORTHOOOX METHODS TO KEEP HIS ECONOMIC EXPERIMEN AFLOAT, FEDOROV HAS MADE ENEMIES IN SAKHALIN OBLAST. HIS CHANGE OF POLITICAL OUTLOOK IS PART OF A TREND: OVER THE PAST YEAR, SEVERAL POLITICAL LEADERS HAVE MADE A SIMILAR
SHIFT FROM LIBERAL DEMOCRATIC TO NATIONALIST ALLEGIANCES. AS A REGIONAL LEADER EMGAGED IN TO NATIONALIST ALLEGIANCES. A BATTLE WITH MOSCOW OVER SCARCE RESOURCES, FEDOROV IS LIKELY BO OPPOSE ANY CENTRAL GOYERNMENT, HHATEVER ITS POLITICAL TO OPPOSE ANY
COLORATION.

01876 BROWN, $K$.

THE RUSSIAN MEDIA DEFEND THEIR INDEPENDENCE

FFE/RL RESEARCH REPORT 1 (35) (SEP 92) 45-51

ON JULY 17, 1992, THE RUSSIAN SUPREME SOVIET PASSED A

LAH MAKING "IZVESTIYA," THE COUNTRY'S MOST PRESTIGIOUS

INDEPENDENT NEWSPAPER, SUBORDINATE TO THE LEGISLATURE.

HOWEVER, THE RUSSIAN MINISTRY OF THE PRESS AND INFORMATION

REFUSED' TO COMPLY WITH THE DEMAND TO REREGISTER "IZVESTIYA"

AS AN OFFICIAL NEWSPAPER OF THE PARLIAMENT, AND RUSSIAN

JOURNAL ISTS LABELED THE LEGISLATURE'S ACTIONS "A QUIET

PUTSCH." DURING THE SAME PARLIAMENTARY SESSION, THE

LAWMAKERS DECIDED TO POSTPONE YOTING ON A DRAFT RESOLUTION

REQUIRING ALL RUSSIAN RADIO AND TV STATIONS TO ACCEPT

CENSORSHIP FROM AN OVERSIGHT COMMITTEE APPOINTED BY THE

GOVERMMENT. NEVERTHELESS, EVENTS IN PARLIAMENT SIGMAL A

TIGHTENING OF PRESS CONTROLS, REFLECTING AN INCREASINGLY

FIERCE POLITICAL STRUGGLE BETHEEN BORIS YELTSIN AND THE

OPPOSITION, WHICH CONTROLS PARLIAMENT. THE AUTONOMY OF

RUSSIA'S MASS MEDIA IS ALSO THREATENED BY FINANCIAL PROBLEMS.

01877 BROWM, L.D.

THE POLITICS OF HEALTH-CARE REFORM

CURRENT HISTORY, 91(564) (APR 92), 173-175.

A SIZABLE BODY OF EVIDENCE SUGGESTS THAT THE AMERICAN PUBLIC IS DISSATISFIED WITH THE CURRENT HEALTH-CARE SYSTEM AND IS READY TO EMBRACE SIGNIFICANT, PERHAPS EVEN

FUNDAMENTAL. CHANGE. THROUGH HALTING PERAPS EVEN FND DECISIVE STEPS, THE U.S. HEALTH CARE SYSTEM MAY END UP "TRD DECISIVE STEPS, THE U.S. HEALTH CARE SYSTEM MAY END UP "TRANSFORMED" IN A DECADE OR TWO. HOWEVER, EACH STEP WILL BE A BATTLEGROUND FOR REFORMERS, PURCHASERS, AND SPECIAL INTERESTS WHO MUST SACRIFICE SOME BENEFIT OR PRIVILEGE. NOTHING GUARANTEES WISE DECISIONS OR A BETTER WORLD AFTER THE SMOKE CLEARS. WOULD-BE REFORMERS SHDULD BE FOREWA MANY TROUBLESOME ISSUES THAT MAY BE OVERLOOKED IN THE
EUPHORIA OVER THE BEGINNING OF THE END OF THE TRADITIONAL AMERICAN HEALTH-CARE SYSTEM.
01878 BROWN, M.C.; WARNER, B.D.

IMMIGRANTS, URBAN POLITICS, AND POLICING IN 1900 AMERICAN SOCIOLOGICAL REVIEH, 57 (3) (JUN 92), 293-305.

IN 1900 THE LARGEST U.S. CITIES WERE STRUGGLING WITH THE EFFECTS OF INDUSTRIALIZATION, URBANIZATION, AND IMMIGRATION. THE INCREASING NUMBERS OF IMMIGRANTS PRESENTED POLITICAL, ECONOMIC, AND CULTURAL THREATS TO THE HEGEMONY OF NATIVEBORN MIDDLE- AND UPPER-CLASS AMERICANS. AS A RESULT, NONIMMIGRANT AMERICANS PRESSURED THE POL ICE TO CLAMP DOWN ON URBAN CRIME, ESPECIALLY CRIME RELATED TO UNDESIRABLE ASPECTS OF THE "FOREIGN" COMMUNITY'S LIFESTYLE, SUCH AS THE CONSUMPTION OF ALCOHOL. IN THIS PAPER, THE AUTHORS TEST THE THREAT HYPOTHESIS OF CONFLICT THEORY IN LARGE AMERICAN CITIES IN 1900 BY RELATING THE PERCENT OF FOREIGN-BORN AND THE ARREST RATE FOR DRUNKENNESS UNDER CONTROLS SUGGESTED BY CRIMINOLOGICAL RESEARCH. BECAUSE THE URBAN POLITICS OF THE PERIOD REVOLVED AROUND BATTLES BETHEEN CITY BOSSES AND REFORMERS, THEY INCORPORATE POLITICAL VARIABLES INTO THE ANALYSIS. THE RESULTS SUPPORT A POLITICAL INTERPRETATION OF THE AGGRESSIVENESS HITH WHICH URBAN POL ICE MADE ARRESTS FOR DRUNKENAESS.

01879 BROWN, M.E. (ED.); MARTIN, R. (ED.); ROSENGARTEN, F. (ED.); SNEDEKER, G. (ED.) SNEDEKER, G. (ED.) ' POLITICS AND CULTURE OF U.S. COMMUNISM MONTHLY REVIEW PRESS, $1992,384$.

THIS COLLECTION OF ESSAYS SEEKS TO RECAST PREYAILING CONCEPTIONS OF THE U.S. COMMUNIST PARTY AND ITS SOCIAL MILEU AND THEREFORE TO RECLAIM THE HISTORICAL ROOTS OF THE PARTY IN THE UNITED STATES. RATHER THAN VIEAING THE HISTORY OF THE PARTY FROM THE VANTAGE POINT OF ITS ADMINSTRATIVE HIERARCHY AND ITS ACTIVITIES, THE CONTRIBUTORS EXAMINE THE SOCIAL MOVEMENT THAT FORMED AROUND IT AND THE POPULAR CULTURE THAT IT EXPRESSED. THEY ALSO INVESTIGATE THE WAYS IN WHICH THE PARTY WAS AN INDIGENOUS PHENOMENON THAT RESPONDED TO NATIONAL CIRCUMSTANCES. THEY LOOK AT THE IMPACT OF THE PARTY ON ITS MEMBERS IN THE AREAS OF EDUCATION, LITERATURE, THE ARTS, IN THE AFRICAN-AMERICAN COMMUNITY, AND ON THE WOMEN'S AND LABOR MOVEMENTS. IN THEIR TOTALITY, THEY PRESENT A PICTURE OF AN ORGANIZATION WHOSE INFLUENCE EXTENDED FAR BEYOND ITS MEMBERSHIP INTO MAINSTREAM U.S. CULTURE AND POLITICS.

01880 BROWN, $N$.

A WAR AGAINST WARMING?

ROUND TABLE, (320) (OCT 91), 445-454.

THE COLD WAR IS OFFICIALLY OVER. IN ITS STEAD THERE HAS ARISEN A WARM WAR IN WHICH THE HEAVY AND DIVERSE PRESSURES BEING EXERTED BY MANKIND ON THE GLOBAL MARKET ARE BEING BEING EXERTED BY MANKIND ON THE GLOBAL MARKET ARE BEING CLIMATE CONFERENCE IN GENEVA IN NOVEMBER 1990, IT WAS AGREED CLIMATE CONFERENCE IN GENEVA IN NOVEMBER 1990, IT WAS AGREED
THAT A DRAFT TREATY ON EMISSION CONTROL AND OTHER REMEDIAL THAT A DRAFT TREATY ON EMISSION CONTROL AND OTHER REMEDIAL ACTION SHOULD BE PREPARED IN TIME FOR THE EARTH SUMMIT: THE BE HELD IN RID DE JANERIO IN JUME 1992. THAT GENEVA BE HELD IN RID DE JANERIO IN JUNE 1992. THAT GENEVA AGREEMENT HAS TO BE REGARDED AS A MINIMAL ONE, THE ONLY ACCORD POSSIBLE BETHEEN 137 COUNTRIES MUCH AT VARIANCE HITH ONE ANOTHER. THIS ARTICLE EXAMINES THE PROBLEM WITH EMPY ON THE FINDINGS OF THE MOST REC
HARMING AND POSSIBLE SOLUTIONS.

01881 BROWH, $N$.

ECOLOGY AND WORLD SECURITY

WORLD TODAY, $48(3)$ (MAR 92), 51-54.

THE AUTHOR DISCUSSES THE INTERRELATIONSHIP BETWEEN THE USE OF NUCLEAR POWER AS AN INTERNATIONAL ECOLOGICAL ISSUE AND AS AN INTERNATIONAL SECURITY ISSUE.

01882 BROWN, R.; WRIGHT, G.

ELECTIONS AND STATE PARTY POLARIZATION

AMERICAN POLITICS QUARTERLY, 20(4) (OCT 92), 411-426.

THIS ARTICLE EXAMINES THE EFFECT OF IDEOLOGICAL

POLARIZATION IN STATE PARTY SYSTEMS ON THE BROAD CONTOURS OF STATE ELECTORAL OUTCOMES. MEASURING IDEOLOGICAL POLARIZATION THE AUTHORS FIND THAT INCREASED IDEOLOGICAL POLARIZATION AMONG STATE PARTY COALITIONS HAS A SIGNIFICANT DAMPENING EFFECT ON SPILT-TICKET VOTING, PARTY DEFECTION, VOTE SHING, AND ELECTORAL VOLATILITY. THEIR COMPARISION SUGGESTS THAT THE GENERAL DECLINE OF PARTY IN STRUCTURING ELECTORAL OUTCOMES HAS NOT BEEN UNIFORM ACROSS THE STATES, AMD THAT THE IDEOLOGICAL DISTINCTIVENESS OF STAT

01883 BROWN, $S$.

BREAKING HABITS OF THE HEART

CRITICAL REYIEW, 5(3) (SUM 92), 379-398.

THE AUTHORS OF "HABITS OF THE HEART" BELIEVE THAT AMERICAN INDIVIDUALISM MAY BE DESTROYING THOSE SOCIAL INTEGUMENTS BELIEVED TO BE MODERATING ITS MORE DESTRUCTIVE POTENTIALITIES. HOWEVER, BECAUSE THEY COME TO THEIR RESEARCH WITH AN ANTI-INDIVIDUALISTIC BIAS IN PLACE, THE AUTHORS FAIL TO ACKNOWLEDGE THE ROLE OF EITHER RECENT HISTORICAL EVENTS OR INFLUENCES OTHER THAN INDIVIDUALISTIC IDEAS IN SHAPING AMERICAN CULTURE. AN ALTERNATIVE EXPLAMATION FOR THE 
EMERGENCE OF THE ISOLATED SELF AND THE INCOHERENCE OF MORAL DISCOURSE IN AMERICAN LIFE IS PRESENTED. BOTH OF THESE PHENOMENA ARE VIEWED AS TEMPRORARY RESPONSES TO A SHIFT IN AMERICAN CHARACTER.

01884 BROWN, H.

SOVEREIGNTY AND HUMAN RIGHTS: 500 YEARS OF THE NEW WORLD ORDER

BEIJING REVIEW, 35(22) (JUN 92), 12-16.

THIS ARTICLE EXPOSES ATROCITIIES OF WESTERN COLONIALISM. THE AUTHOR NOTES THAT UNDER THE NEW HORLD ORDER, WHICH BEGAN WITH COLUMBUS' VOYAGE TO THE NEW WORLD IN 1492, ONLY WESTERN NATIONS MAY ENJOY SOVEREIGNY WHILE NON-WESTERN NATIONS MAY NATIONS MAY ENJOY SOVEREIGNY WHILE NON-WESTERN NATIONS MAY NOT AND THAT THE LOSS OF NATIONAL SOVEREIGNTY MEANS SLAVE TRACES THE HISTORICAL DEVELOPMENT OF THE NEH WORLD ORDER.

01885 BROWN, W.L.

THE 1992 EUROPEAN COMMUNITY AND AFRICA

TRANSAFRICA FORUM, $9(3)$ (FAL 92), 3-13.

THE AUTHOR IS NOT VERY OPTIMISTIC ABOUT THE FUTURE OF AFRICA IN THE POST-COLD WAR WORLD. SHE PREDICTS THAT EUROPE 1992 WILL MEAN THAT TIES BETWEEN AFRICA AND ITS FORMER COLONISTS WILL BE BENEFICIAL ONLY TO THE DEGREE THAT THE FORMER COLONIAL NATIONS ARE ABLE TO OBTAIN INFLUENTIAL POSITIONS IN THE EUROPEAN COMMUNITY. EVEN HIGH COMMODITY PRICES WILL NOT HELP AFRICA BRIDGE THE TECHNOLOGY GAP, CASHPOOR EASTERN EUROPE MAY FLOOD AFRICA WITH ARMS, AND THE LACK OF FAITH EXHIBITED BY THE REST OF THE WORLD TOWARD AFRICA IS UNL. IKELY TO CHANGE.

01886 BROXUP, M.B.

COMRADE MUSLIMS

WILSON QUARTERLY, XVI(3) (SUM 92), 39-47.

THOSE FAMILIAR WITH CENTRAL ASIA'S ANCIENT HISTORY MIGHT ASSUME THAT THE SOVIET ERA COULD HAVE LEFT FEH SCARS ON PEOPLE WHO SINCE TIME IMMEMORIAL HAD WITHSTOOD AND ADAPTED TO FOREIGN CONQUERORS. BUT THEY WOULD BE WRONG. MORE ZEALOUSLY THAN ANY PREVIOUS INVADER, THE SOVIET OVERLORDS SET OUT TO DESTROY THE FOUNDATION AND FABRIC OF CENTRAL SET OUT TO DESTRYY THE FOUNDATION AND FABRIC OF CENTRAL THAT COMMUNISM HAD TRANSFORMED THE CENTRAL ASIAN REPUBLICS THAT COMMUNISM HAD TRANSFORMED THE CENTRAL ASIAN REPUBLICS DEVELOPED INDUSTRIALIZED COUNTRIES AND A STANDARD OF LIVING MUCH SUPERIOR TO THEIR NONCOMMUNIST MUSLIM NEIGHBORS. SUCH MUCH SUPERIOR TO THEIR NONCOMMUNIST MUSLIM NEIGHBORS. SUCH TALES OF SOVIET ACHIEVEMENTS WERE CASTLES OF SAND HIDING THE REAL POVERTY.

01887 BROYLES, W. JR.

COLUMBIA JOURMALISY REYIEH, 31(4) (MOY 92) 42-43.

THE AUTHOR LOOKS RE THE, 31(4) (NOV 92), 42-43. RECORD IN THE 1992 U.S. PRESIDENTIAL ELECTION CAMPAIGN AND HOW THE BUSH FORCES SOUGHT TO CAPITLIZE ON IT.

01888 BRUBAKER, W.R

CITIZENSHIP STRUGGLES IN THE SOVIET SUCCESSOR STATES INTERNATIONAL MIGRATION REVIEH, XXVI (2) (SUM 92), 269-291. THE BREAKUP OF THE SOVIET UNION HAS TRANSFORMED YESTERDAY'S INTERNAL MIGRANTS, SECURE IN THEIR SOVIET CITIZENSHIP, INTO TOOAY'S INTERNATIONAL MIGRANTS OF CONTESTED LEGITIMACY AND UNCERTAIN MEMBERSHIP. THIS TRANSFORMATION HAS TOUCHED RUSSIANS IN PARTICULAR, OF WHOM SOME 25 MILLION LIVE IN NON-RUSSIAN SUCCESSOR STATES. THIS ARTICLE EXAMINES THE POLITICS OF CITIZENSHIP VIS-A-VIS RUSSIAN IMMIGRANTS IN THE SUCCESSOR STATES, FOCUSING ON THE BALTIC STATES, HHERE CITIZENSHIP HAS BEEN A MATTER OF SUSTAINED AND HEATED CONTROVERSY. 01889 BRUCE, J.M.; CLARK, J.A.; KESSEL, J.H. AMERICAN POLITICAL SCIENCE REVIEH, 85(4) (DEC 91), 1089-1106.

ANALYSIS OF DATA FROM A 1988 SURVEY OF PRESIDENTIAL PARTIES DEMONSTRATES THAT CAMPAIGN LEADERS ARE BETTER UNDERSTOOD AS "TRUE BELIEVERS" THAN AS EITHER REPRESENTATIVES OR VOTE-MAXIMIZERS. ANALYSIS OF LEADERS' REPRESENTATIVES OR VOTE-MAXIMIZERS. ANALYSIS OF LEADERS ATTITUDES REVEALS FOUR ISSUE GROUPS IN BOTH THE REPUBL
AND DEMOCRTAIC PARTIES. THE DOMINANT COALITION IN THE AND DEMOCRTAIC PARTIES. THE DOMINANT CDALITION IN THE REPUBLICAN PARTY IS SLIGHTLY MORE CONSERVATIVE, AND THAT IN THE DEMOCRATIC PARTY IS SLIGHTLY MORE LIBERAL, THAN THE PARTY MEDIAN. COMPARISON WITH SIMILAR 1972 DATA SHOWS STABLE TIME PERIOD BUT SOMEWHAT INCREASED ISSUE DISTANCE BETWEEN TIME PERIOD BUT SOMEHHA
THE PARTIES IN 1988 .

01890 BRUCE, $S$.

THE PROBLEM OF "PRO-STATE" TERRORISM: LOYALIST

PARAMILITARIES IN NORTHERN IRELAND

TERRORISM AND POL ITICAL VIOLENCE, 4(1) (SPR 92), 67-88.

THIS ESSAY BRIEFLY OUTLINES THE CAREERS OF THE THO LARGEST PROTESTANT, UNIONIST AND LOYALIST PARAMILITTARY ORGANIZATIONS IN NORTHERN IRELAND. IT ARGUES THAT A RANGE OF
APPARENTLY UNCONNECTED CHARACTERISTICS OF THESE GROUPS CAN BE EXPLAINED BY REFERENCE TO THE NOTION OF "PRO-STATE TERRORISM" WHEN THE STATE IS PERCEIVED TO BE UMABLE OR UNHILLING TO DEFEND ITSELF AGAINST ITS ENEMIES, THERE IS SPACE FOR "PRO-STATE" GROUP IS COMPETING WITH THE STATE ITSELF.

01891 BRUDNEY, J.L.; DUNCOMBE, W.D. AN ECONOMIC EVALUATION OF PAID, VOLUNTEER, AND MIXED STAFFING OPTIONS FOR PUBLIC SERVICES

PUBLIC ADMINISTRATION REYIEH, 52(5) (SEP 92), 474-481. USING MUNICIPAL FIRE DEPARTMENTS IN FIVE NEH YORK STATE COMMUNITIES, THE AUTHORS COMPARE THE COSTS OF PAID, COMMUNITIES, THE AUTHORS COMPARE THE COSTS OF PAID,
VOLUNTEER, AND MIXED STAFFING. THEY TAKE SPECIAL NOTE OF VOLUNTEER, AND MIXED STAFFING. THEY TAKE SPECIAL NOTE
COSTS ASSOCIATED HITH THE RECRUITMENT, TRAINING, AND COSTS ASSOCIATED HITH THE RECRUITMENT, TRAINING, AND
MANAGEMENT OF YOLUNTEERS--FACTORS THAT OFFSET ASSUMED SALARY MANAGEMENT OF YOLUNTEERS- AT A CERTAIN LEVEL OF COSTS (MORE THAN S800 PER SAVINGS. AT A CERTAIN LEVEL OF COSTS (MORE THAN $\$ 800$ PER
VOLUNTEER IN THE CASE OF MUNICIPAL FIRE DEPARTMENTS), THE USE OF VOLUNTEERS SHOULD BE RECONSIDERED.

01892 BRUEGGEMAN, J.A.

WHERE IS THE FIRST AMENDMENT WHEN YOU REALLY NEED IT? LOWERING THE CONSTITUTIONAL BARRIERS TO SUITS AGAINST THE PRESS

JOURNAL OF LAW \& POLITICS, IX(1) (FAL 92), 147-184.

THE U.S. SUPREME COURT RECENTLY DECIDED COHEN $\checkmark$. COWLES MEDIA COMPANY, A CASE THAT DEMONSTRATES THE TENSION BETHEEN GENERALLY APPLIICABLE LAWS AND CONTENT REGULATION OF THE PRESS. COHEN $V$. COWLES CENTERED AROUND A PROMISSORY ESTOPPEL CLAIM BROUGHT BY A POLITICAL CAMPAIGN WORKER AGAINST THO NEWSPAPERS FOR BREAKING THEIR PROMISE NOT TO DISCLOSE HIS IDENTITY AS THE SOURCE OF DAMAGING INFORMATION ABOUT A CANDIDATE. IT INVOLVED A STATE COMMON LAH CLAIM THAT HAS APPLICABLE TO EVERYONE, BUT IT ALSO INVOLVED THE IMPOSITION OF LIABILITY BASED ON THE SPECIFIC INFORMATION THE NEWSPAPERS CHOSE TO PUBLISH. SURPRISINGLY, THE COURT DECLINED TO BALANCE THE FIRST AMENDMENT INTERESTS OF THE PRESS AND THE PUBLIC WITH THE SOURCE'S INTEREST IN ENFORCING THE AGREEMENT. INSTEAD, THE COURT HELD THAT BECAUSE PROMISSORY ESTOPPEL IS A CONTENT-NEUTRAL CLAIM THAT HAS ONLY AN INDIRECT EFFECT ON WHAT IS PUBLISHED, THE FIRST AMENDMENT SHOULD NOT EVEN BE A FACTOR IN DECIDING WHETHER OR NOT TO SHOULD NOT EVEN BE A FACTOR IN DECIDING WHETHER OR
ENFORCE AGREEMENTS BETHEEN REPORTERS AND SOURCES.

01893 BRUMBAUGH, R.D. JR.; SCOTT, K.E.

A POLITICAL LOGJAM STILL BLOCKS BANKING REFORM CHALLENGE, 35(2) (MAR 92), 35-41.

CHALLENGE, $35(2)$ (MAR 92 ), $35-41$.
CONGRESS AND THE PRESIDENT BEGAN WITH SWEEPING PLANS TO RECAPITALIZE THE FDIC, TO OVERHAUL MAJOR PARTS OF THE RECAPITALIZE THE FDIC, TO OVERHAUL MAJOR PARTS OF THE DEPOSIT INSURANCE SYSTEM, AND TO IMPROVE THE CONDITION OF DEPOSITORY INSTITUTIONS BY TEARING DOWN BARRIERS TO BANK OWNERSHIP, PROHIBITIONS ON BANK AFFILIATIONS WITH SEC AND INSURANCE COMPANIES, AND RESTRICTIONS LIMITING OPERATIONS ACROSS STATE LINES. AFTER OFTEN-BRUISING DE
IN SIX DIFFERENT SENATE AND HOUSE COMMITTEES, ENDLESS SORTIES BY LEGIONS OF FINANCIAL-INOUSTRY LOBBYISTS, AND SEVERAL FLOOR FIGHTS, CONGRESS APPROVED ONLY EMERGENCY BORROWING FOR THE FDIC AND MODEST DEPOSIT-INSURANCE REFORM.

01894 BRUNET, E.

DEBUNKING WHOLESALE PRIVATE ENFORCEMENT OF ENVIRONMENTAL RIGHTS

HARVARD JOURNAL OF LAW AND PUBLIC POLICY, 15(2) (SPR 92), 311-324

In "Free market environmentalism," terRy anderson and DONALO LEAL ARGUE FOR A PRIVATIZED MODEL OF ENVIRONMENTAL PROTECTION. A LEGAL SCHEME OF CONTRACT AND PROPERTY RIGHTS-COMBINED WITH TORT LIABILITY FOR THE INEVITABLE INTRUSIONS UPON THOSE RIGHTS--WOULD FORCE PARTIES TO INTERNALIZE THE COSTS OF THEIR ACTIONS AND AVOID MISALLOCATIVE EXTERNAL COSTS. IN THIS ESSAY, THE AUTHOR FOCUSES ON THE PROCEDURAL COSTS. IN THIS ESSAY, THE AUTHOR FOCUSES ON THE PROCEDURAL
IMPLICATIONS OF ANDERSON AND LEAL'S PROPOSAL, BY ANALYZING IME WORKABILITY OF ENVIRONMENTAL PROTECTION THROUGH RELIANCE ON PRIVATE JUDICIAL ENFORCEMENT OF COMMON LAW RIGHTS. THE AUTHOR CONCLUDES THAT THE COURTS ARE UNL IKELY TO ENFORCE ENVIRONMENTAL RIGHTS IN THE EFFECTIVE MANNER ESSENTIAL FOR ANDERSON AND LEAL'S PROPOSAL. "FREE MARKET ENVIRONH
RELIES TOO HEAVILY ON THE IDEALISTIC AND SOMEWHAT RELIES TOO HEAVILY ON THE IDEALISTIC AND SOMEWHAT
UNREALISTIC EXPECTATION THAT THE PROCEDURAL SYSTEM OF UNREALISTIC EXPECTATION THAT THE PROCEDURAL SYSTEM OF
DISPUTE RESOLUTION CAN EFFICIENTLY APPLY THE COMMON LAH DISPUTE RESOLUTION CAN EFFICIENTLY APPLY THE COMMON LAH
RIGHTS NECESSARY FOR A SYSTEM OF PRIVATE ENFORCEMENT.

01895 BRUNOLD, G.

ERITREA AND THE CHALLENGES OF PEACE
SHISS REVIEW OF WORLD AFFAIRS, 42(4) (JUL 92), 21-23.

SINCE ITS LIBERATION, ERITREA HAS HAD THE STATUS OF A COUNTRY-IN-THE-MAKING, WITHOUT DIPLOMATIC RECOGNITION AND, THUS, WITHOUT ACCESS TO MULTINATIONAL ORGANIZATIONS AND BILATERAL AID. THIS SMALL NATION IS NOW FACED WITH THE TASK OF BUILDING PEACE ON THE RUINS OF 30 YEARS OF WAR, AN UNDERTAKING OISPROPORTIONATE TO ITS POWERS AND MEANS. STILL, TODAY ERITREA IS THE ONLY COUNTRY ON THE HORN OF AFRICA WHERE NO ARMED CONFLICT IS TAKING PLACE--A VIRTUAL CITADEL OF STABILITY. 
01896 BRUNOLD, G

PLURALISM HITHOUT SOCIAAISM IN ZAMBIA

SISS REVIEH OF WORLD AFFAIRS, $42(8)$ (NOY 92), 23-24. PLURALISM IS THE CURRENT SLOGAN OF ZAMBIA'S GOVERNING MOVEMENT FOR MULTI-PARTY DEMOCRACY, WHICH WON MORE THAN 80 PERCENT OF THE PARLIAMENTARY SEATS IN THE 1991 ELECTIONS. FREDERICK CHILUBA'S MOVEMENT HAS BEEN GOVERNING WITHOUT ANY SIGNIFICANT OPPOSITION, BUT THE TRANSITION FROM SOCIALISM TO CAPITALISM, WHICH IS LIKELY TO INVOLVE SUBSTANTIAL ECONOMIC TURMOIL AND PROBLEMS, WILL SEVERELY TEST THE PATIENCE OF ZAMBIANS.

01897 BRUNOLD, G.

SUDAN'S JUNTA UNDER SADDAM'S THUMB

SHISS REVIEW OF WORLD AFFAIRS, $40(8)$ (NOV 90), 10. THE AUTHOR ARGUES THAT SUDAN'S FUNDAMENTALIST MILITARY JUNTA STANDS CLOSEST TO IRAQ'S BAATH REGIME. THE REPRESSIVE NATURE OF SUDAN'S CURRENT REGIME IS DISCUSSED. THE ATTEMPT GY EGYPT'S MUBARAK TO MEDIATE IN THE SUDANESE CIVIL WAR WITH U.S. SUPPORT IS DESCRIBED. IRAQI ARMS SALES TO KHARTOUM ARE
REVIEWED, AND IRAQI-SUDANESE MILITARY CDOPERATION EXAMINED.

01898 BRUNOLD, G.

UGANDA'S LABORIOUS RECOVERY

SWISS REVIEW DF WORLD AFFAIRS, 42(7) (OCY 92), 21-23.

UGANDA'S NORMALIZATION IS PROGRESSING VERY' SLOWLY. THE COUNTRY IS STILL A LONG HAY FROM THE RELATIVE PROSPERITY IT ENJOYED IN THE 1960'S, AND THE LEADERSHIP OF PRESIDEN YOWERI MUSEVENI CONTINUES TO MANIFEST CERTAIN WEAKNESSES. HOWEVER, THERE IS A SENSE OF ENERGY IN THE CITIES AND UNLIKE MUCH OF THE REST OF AFRICA, THE OVERALL MOOD IS ONE OF IMPROVEMENT RATHER THAN DECLINE.

01899 BRUNOLD, G

YEMEN AND THE GULF CRISIS

SWISS REVIEW OF WORLD AFFAIRS, 40(8) (NOV 90), 9-10. THIS ARTICLE PROVIDES AN OVERVIEW OF YEMEN'S

RELATIONSHIP WITH THE OTHER ARAB STATES. THIS RELATIONSHIP IS THEN EXAMINED IN LIGHT OF THE GULF CRISIS. YEMEN'S POL ITICAL CHARACTER AND THE NATURE OF ITS PRESIDENCY ARE DISCUSSED.

01900 BRYAK, D

INTERMATIONAL ACCUMULATION AND THE CONTRADICTIONS OF MONETARY POLICY

SCIENCE AND SOCIETY, 56(3) (FAL 92), 324-352. THE ROLE OF NATION STATES IN SECURING THE MONEY SYSTEM HAS BECOME AMBIGUOUS. THE EFFECT IS THAT NATIONAL MONETARY POL ICY COMES TO REFLECT THE CONTRADICTIONS BETWEEN DIFFERENT SECTIONS OF CAPITAL WHICH ARE THEMSELVES INTEGRATED INTO INTERNATIONAL ACCUMULATION IN DIFFERENT WAYS. THE SHIFTING EMPHASIS IN MONETARY POLICY BETWEEN THE EXCHANGE RATE, THE INTEREST RATE, THE INLATIONS RATE, ECT., IS TO BE READ AS CHANGING RELATIONS BETWEEN DIFFERENT SECTIONS OF CAPITAL IN INTERNATIONAL ACCUMULATION. INCREASINGLY, NATIONAL MONETARY POLICY IS DRAWING ON POLICIES WHICH SECURE WAGE REDUCTIONS,
SO AS TO SECURE THE MONETARY SYSTEM WITHOUT DIVIDING CAPITAL.

01901 BRYM, R.J.

SOME ADVANTAGES OF CANADIAN DISUNITY: HOW QUEBEC SOVEREIGNTY MIGHT AID ECONOMIC DEVELOPMENT IN ENGLISHSPEAKING CANADA

CANADIAN REVIEW OF SOCIOLOGY AND ANTHROPOLOGY, 29(2) (MAY 92), 210-226.

JURISDICTIONAL DISPUTES BETHEEM LARGE, INSTITUTIONALLY COMPLETE ETHNIC COMMUNITIES IN A SINGLE SOCIETY MAY PROMOTE SO MUCH DECENTRALIZATION OF AUTHORITY THAT THE STATE BECOMES INEFFECTIVE AS AN ECONOMIC PLANNER. ECONOMIC DECLINE MAY RESULT. THE CANADA/QUEBEC CASE ILLUSTRATES THIS PROCESS AND SUGGESTS THAT QUEBEC'S INDEPENDENCE MIGHT IMPROVE CANADA'S ECONOMIC PROSPECTS.

01902 BRYNEN, R.

ECONOMIC CRISIS AND POST-RENTIER DEMOCRATIZATION IN THE ARAB HORLD: THE CASE OF JORDAN

CANADIAN JOURMAL OF POLITICAL SCIENCE, 35(1) (MAR 92), 69-98.

IN MANY ARAB COUNTRIES. THE POLITICAL ECONOMY OF REGIONAL PETROLEUM WEALTH HAS SERVED TO INHIBIT DEMOCRATIZATION. IN THE PART ICULAR CASE OF JORDAN, PETRODOLLAR FOREIGN AID AND WORKER'S REMITTANCES LONG SERVED AS A CRITICAL ASPECT OF PARTICIPATION. EQUALLY. THE DECLINE AS A CRITICAL ASPECT OF PARTICIPATION. EQUALLY, THE DECLIN COLLAPSE OF THE FOUNDATILATE 1980 S SPURRED THE EVENTUAL COLLAPSE OF THE FOUNDATIONS UPON WHICH THE OLD ECONOMIC AND PEGOTIATE A NEH SOCIAL CONTRACT, RESULTING IN A FAR-REACHING PROCESS OF POLITICAL LIBERALIZATION AND PARTIAL DEMOCRATIZATION AFTER APRIL 1989

01903 BRZEZINSKI, I

THE GEOPOLITICAL DIMENSION

NATIONAL INTEREST, 27 (SPR 92 ), 48-52.

EUROPEAN SECURITY IS IN A STATE OF FLUX. ONE OF THE MORE
IMPORTANT NEW PLAYERS AND ONE HHOSE BEHAYIOR IS, IN THE NATURE OF THINGS, DIFFICULT TO PREDICT IS UKRAINE, A NEWLY INDEPDENDENT NATION LARGER THAN FRANCE, WITH A POPULATION OF FIFTY-TWO MILLION, A STRONG SCIENTIFIC-INDUSTRIAL BASE, A ROBUST AGRICULTURE, AND INTENSIFYING NATIONAL IDENTITY, AND MOST IMPORTANT, A HISTORY THAT INTERLOCKS WITH THAT OF RUSSIA. HOW UKRINE AFFECTS EUROPE WILL LARGELY BE DETERMINED BY HOH IT CONSOL IDATES ITS SOVEREIGNTY. CRITICAL CHALLENGES INCLUDE ECONOMIC REFORM, THE INSTITUTIONALIZATION OF DEMOCRATIC GOVERNANCE, AND THE ESTABLISHMENT OF NATIONAL SECURITY STRUCTURES, INCLUDING DEFENSE FORCES. EQUALLY, IF NOT MORE IMPORTANT, WILL BE THE EVOLUTION OF UKRAINIAN NAT IONAL ISM.

01904 BRZEZINSKI, Z.

THE COLD WAR ANO ITS AFTERMATH

FOREIGN AFFAIRS, 71(4) (FAL 92), 31-49.

IN THE COLD WAR, THE GEOPOLITICAL STRUGGLE WAS, FIRSTLY, FOR CONTROL OVER THE EURASIAN LAND MASS AND EVENTUALLY FOR GLOBAL PREPONDERANCE. EACH SIDE UNDERSTOOD THAT EITHER THE SUCCESSFUL EJECTION OF THE ONE FROM THE WESTERN AND EASTERN SUCCESSFUL EJECTION OF THE ONE FROM THE WESTERN AND EASTERN
FRINGES OF EURASIA OR THE EFFECTIVE CONTAINMENT OF THE OTHER FRINGES OF EURASIA OR THE EFFECTIVE CONTAINMENT OF THE OTHER WOULD ULTIMATELY DETERMINE THE GEOSTRATEGIC OUTCOME OF THE
CONTEST. ALSO FUELING THE COLD WAR WERE SHARPLY CONFLICTING, CONTEST. ALSO FUELING THE COLD WAR WERE SHARPLY CONFLICTING, EVEN OF THE HUMAN BEING ITSELF. AFTER SOME 45 YEARS OF EVEN OF THE HUMAN BEING ITSELF. AFTER SOME 45 YEARS OF POL ITICAL COMBAT AND A FEW SECONDARY MILITARY SKIRMISHES, THE COLD WAR OID INDEED COME TO A
SIDE AND DEFEAT FOR THE OTHER.

01905 BRZEZNIEW, B.

ORDER, OISORDER, AND U.S. LEADERSHI

WASHINGTON QUARTERLY, $15 i 2$ ) (SPR 92), 5-14.

THE PHRASE "NEW WORLD ORDER" HAS BECOME A SUBJECT OF WIDESPREAD DEBATE AND A TARGET OF INTELLECTUAL CRITIQUE. THIS ARTICLE STATES THAT A NEW HORLD ORDER IS NOT UPON US. A GENUINELY NEW WORLD ORDER MAY TAKE DECADES TO EVOLVE. IN THE INTERIM IT REOUIRES NOT JUST U.S. ENGAGEMENT BUT ALSO U.S. LEADERSHIP. WITHIN EACH OF THE REGIONS OF THE GLOBE WHERE ISSUES OF ORDER REMAIN UNRESOLVED, U.S. INFLUENCE, PATIENCE, POWER, AND RELATIVE WEALTH WILL BE CRITICAL FACTORS IN THE PROGRESS TOWARD ORDER OR THE DESCENT INTO DISORDER.

01906 BRZOSKA, $M$

ARMING SOUTH AFRICA IN THE SHADOW OF THE UN ARMS EMBARGO DEFENSE ANALYSIS, 7 (1) (MAR 91), 21-38.

THIS PAPER DISCUSSES THE MAIN FEATURES OF SOUTH AFRICAN

HEAPONS PROCUREMENT IN THE SHADOW OF THE MANDATORY ARMS

WEAPONS PROCUREMENT IN THE SHADOW OF THE MANDATORY ARMS EMBARGO. THE FIRST SECTION SETS OUT SOME PRACTICALITIES SURROUNDING THE EMBARGO. IN THE SECOND SECTION, THE EFFECT
OF THE EMBARGO ON SOUTH AFRICAN PROCUREMENT IS ASSESSED. THE OF THE EMBARGO ON SOUTH AFRICAN PROCUREMENT IS ASSESSED. THE NEXT SECTION IS ON SOUTH AFRICAN ACTION IN PREPARATION FOR
THE EMBARGO. THEN FOLLOWS A SECTION ON THE DOMESTIC ARMS INDUSTRY, THE MAIN ELEMENT IN EMBARGO EVASION. THE AR INDUSTRY, THE MAIN ELEMENT IN EMBARGO EVASION. THE ANOTHER SECTION. THE VARIOUS SUPPLY ROUTES ARE DISCUSSED IN ANOTHER SECTION.

01907 BUAM, J.

REFUSING THE BAI

FAR EASTERN ECONOMIC REVIEW, 155(3) (JAN 92), 29. WHILE TAIWAN HAS AGREED TO COMPLY WITH A RECENT UN RESOLUTION BANNING ENVIRONMENTALLY DESTRUCTIVE DRIFTNET FISHING, IT APPEARS THAT THIS IS EASIER SAID THAN DONE. THE U.S.-SPONSORED BAN, PASSED BY THE UN GENERAL ASSEMBLY ON 20 DECEMBER, REQUIRES THAT DRIFTNET FISHING ON THE HIGH SEAS BE REDUCED BY HALF BY JULY AND CEASE ENTIRELY BY DECEMBER. THE MAJOR DRIFTHETTING FLEETS ARE FROM JAPAN, SOUTH KOREA, AND TAIWAN. BUT THE TAIWAN FISHING INDUSTRY IS THE LEAST REGULATED OF THE THREE AND FISHING BOATS FROM TAIWAN HAVE CONSISTENTLY EVADED RULES ON DRIFTNETTING IN RECENT YEARS. ANALYSTS SAY THAT EVEN A PARTIAL IMPLEMENTATION OF THE BAN HILL BE A BLOW TO TAIHAN'S FISHING COMPANIES, WHICH ARE ALREADY FACING RECESSION.

01908 BUCHAN, D.

THE CONSTRAINTS OF THE EUROPEAN COMMUNITY POL ITICAL QUARTERLY (THE), 62(2) (APR 91), 186-192. THE AUTHOR ARGUES THAT' THE NEXT BRITISH GOVERNMENT HILL BE MORE CONSTRAINED IN ITS ACTIONS BY UK MEMBERSHIP IN THE EUROPEAN COMMUNITY (EC) THAN WERE ANY OF ITS PREDECESSORS. EUROPEAN COMAUNITY (EC) THAN WERE ANY OF ITS PREDECESSORS THE ROLE OF MARGARET THATCHER, BY HER ADVOCACY OF THE
SINGLE MARKET, IN UNLEASHING INTEGRATIONIST FORCES IS SINGLE MARKET, IN UNLEASHING INTEGRATIONIST FORCES IS DESCRIBED. ONE ECONOMIC CONSTRAINT ON A NEW BRITISH GOVERNMENT WHICH IS DESCRIBED IS BRITAIN'S INHERITED

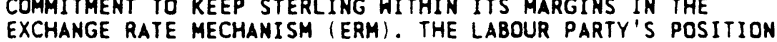
ON INCLUDING THE STERLING INTO THE ERM IS DISCUSSED.

01909 BUCHLOVSKY, S.

DEFENSE AND EUROPEAN INTERESTS

RUSI JOURNAL, $137(3)$ ( JUN 92), 6-10

THIS ARTICLE CONSIDERS, FROM A CENTRAL EUROPEAN

PERSPECTIVE, THE CHALLENGES CURRENTLY CONFRONTING EUROPEAN 
SECURITY AND DEFENSE COOPERATION. IT ARGUES THAT EUROPEAN SECURITY DEPENDS ON THE COOPERATION OF KEY EUROPEAN AND TRANSATLANTIC ORGANIZATIONS. NO SINGLE ORGANIZATION, SUCH AS NATO, IS SUFFICIENT TO GUARANTEE THE SECURITY OF THE EASTERN EUROPEAN STATES--AND THEREBY THE SECURITY OF ALL OF EUROPE. INSTEAD, EUROPEAN SECURITY SHOULD BE BASED ON A HARMONIOUS COOPERATION OF THE CONFERENCE ON SECURITY AND COOPERATION IN
EUROPE (CSCE). NATO, THE EUROPEAN COMMUNITY, THE WESTERN EUROPEAN UNION (WEU) AND THE COUNCIL OF EUROPE.

01910 BUCKLEY, W.F.

TOWARD A DEFINITION OF CONSERVATISM

TOWARD A DEFINITION OF CONSERVATISM
MATIONAL REYIEN, XLIV (16) (AUG 92), 17-18

NATIONAL REYIEH, XLIV(16) (AUG 92), 17-18.
THE DIFFICULTY IN DEFINING "CONSERVATISM" DERIVES

PRIMARILY FROM ITS FREDUENT USE AS THE DEFENSE EITHER OF THE

STATUS QUD OR THE STATUS QUO ANTE. IT WAS IN THE UNITED

STATES THAT CONSERVATISM CRYSTALLIZED WITH A MEANING THAT

PRETTY WELL OVERTOOK COMPETING MEANINGS. WHAT CAUSED THIS

TRANSFORMATION WAS THE HEAVY EMPHASIS OF LIBERTARIANISH,

INSTANTLY DISTINGUISHING CONSERVATISM FROM ITS ASSOCIATION

WITH THE 19TH-CENTURY SOCIAL AND ECONOMIC STANDPATTISM OF THE BRITISH.

01911 BUCKLEY, H.F. JR.

CONVENTION NOTES

NATIONAL REVIEW, XLIV(18) (SEP 92), 34-36, 37.

THE AUTHOR REPORTS ON THE 1992 REPUBLICAN CONVENTION IN HOUSTON. HE DISCUSSES THE ROLE SUCH ISSUES AS CHARACTER AND FAMILY VALUES ARE LIKELY TO PLAY IN THE REPUBLICAN PRESIDENTIAL CAMPAIGN.

01912 BUDRIN, R.

ENDLESS HAR

FAR EASTERN ECONOMIC REVIEW, 153(31) (AUG 91), 21-22.

TWO-AND-A-HALF YEARS AFTER THE HITHDRAHAL OF SOYIE

TROOPS FROM AFGHANISTAN, AN END TO THE WAR IS STILL NOT IN

SIGHT. THE WAR HAS, IN FACT, GATHERED STRENGTH WHILE THE

SIGHT. THE WAR HAS, IN FACT, GATHERED STRENGTH WHILE THE
FOREIGN BACKERS OF THE VARIOUS AFGHAN PARTIES HOVER BETWEEN

FOREIGN BACCERS OF THE VARIOUS AFGHAN PARTIES HOVER 8ET

THE DESIRE TO END THE CONFLICT AND THE URGE TO CONTINUE
SUPPORTING THEIR FAVORITE FACTIONS. THE MAIN TASK FACING ALL

SUPPORTING THEIR FAVORITE FACTIONS. THE MAIN TASK FACING ALL
THE PARTIES TO THE CONFLICT--FIRST AND FOREMOST, THE SOVIET

THE PARTIES TO THE CONFLICT--FIRST AND FOREMOST, THE SOVIET
UNION--IS TO FIND A SOLUTION WHICH WOULD ALLOW A LEADER TO

UNION-IS TO FIND A SOLUTION WHICH WOULD ALLOW A LEADER TO COME TO POWER WHO WOULD BE ACCEPTED BY THE AFGHAN

OTHER WORDS, WHAT IS NEEDED IS NOT A GAME OF "NON-
INTERFERENCE" AFTER A DECADE-LONG MILITARY PRESENCE BUT AN

INTERFERENCE" AFTER A DECADE-LONG MILITARY PRESENCE BUT INTERNATIONAL INVOLVEMENT.

01913 BUDRIN, R.

THE TURKESTAN CARD

FAR EASTERN ECONOMIC REVIEW, 155(2) (JAN 92), 21-22.

THE SIGNING IN SEPTEMBER 1991 OF THE LONG-AWAITED SOVIETU.S. DECLARATION ON AFGHANISTAN, WHICH SET A 1 JANUARY DEADLINE FOR ENDING ARMS DELIVERIES TO OPPOSING SIDES FORCED THE AFGHAN GROUPS TO TAKE CERTAIN MILITARY AND POLITICAL DECISIONS. UNFORTUNATELY, THE SUBSEQUENT DISINTEGRATION OF THE USSR HAS INCREASED THE DISORDER IN THE REGION, AND HAS GIVEN RISE TO GROWING NUMBERS OF CENTRAL ASIAN ETHNIC GROUPS CLAMORING FOR AUTONOMY. THESE CHANGES DO NOT BODE WELL FOR A PEACEFUL SETTLEMENT OF THE CONFLICT IN AFGHANISTAN. PRESIDENT NAJIBULLAH, INCREASIMGLY ON THE DEFENSIVE AS REBEL MUJAHIDEEN CONTROL SIZABLE PORTIONS OF THE COUNTRY, MAY BE TEMPTED TO FORM A BLOC WITH THE KHAZARIS, UZBEKS AND TAJIKS IN ORDER TO STAY IN POWER, THUS REYIVING THE OLD IDEA OF AN INDEPENDENT TURKESTAN--A STATE WHICH WOULD COMPRISE WHAT IS NOW NORTHERN AFGHANISTAN AND SOUTHERM CENTRAL ASIA. SUCH A MOVE WOULD EXACERBATE ETHMIC TENSION IN THE REGION AND COULD LEAD TO THE "LEBANONIZATION" OF AFGHANISTAN.

01914 BUERGENTHAL, T.

COPENHAGEN: A DEMOCRATIC MANIFESTO

WORLO AFFAIRS, 153 (1) (SUM 91), 5-8

TODAY IT IS CLEAR THAT FOR THE SOVIET UNION AND ITS THEN ALLIES THE ADOPTION OF THE HELSINKI FINAL ACT OF THE CONFERENCE ON SECURITY AND COOPERATION IN EUROPE (CSCE) WAS CONFERENCE ON SECURITY AND COOPERATION IN EUROPE (CSCE) WAS
A MAJOR POLITICAL BLUNDER. THE RESULTANT CSCE PROCESS

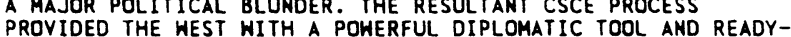
PROVIDED THE WEST WITH A POWERFUL DIPLOMATIC TOOL AND READY-
MADE PLATFORM FOR EXPOSING THE BRUTALITY OF THE COMMUNIST SYSTEM AND FOR CHALLENGING THE SOVIETS TO IMPLEMENT THE HUMAN RIGHTS COMMITMENTS ESTABLISHED BY THE FINAL ACT. ALTHOUGH IT DID NOT BRING ABOUT THE DEMISE OF THE SOVIET EMPIRE, IT SPARKED THE HUMAN RIGHTS MOVEMENTS IN THE USSR AND IN THE STATES ALLIED WITH IT. THESE MOVEMENTS, IN TURN CONTRIBUTED SIGNIFICANTLY TO THE CHANGES THAT TRANSFORMED EASTERN ANO CENTRAL EUROPE. A CROHING ACHIEVEMENT IN THIS PROCESS WAS THE COPENHAGEN MEETING ON THE HUMAN DIMENSION 15 JUNE TO 29 JUNE 1990 ). THE CONFERENCE PROCLAIMED A NEW PAN-

01915 BUHL, D.

CHOICE OF CLINTON MARKS a CHOICE FOR BOTH CHANGE AND A NEH GENERATION

GERMAN TRIBUNE, 1540 (NOV 92), 2.
AMERICA HAS OPTED FOR CHANGE. BILL CLINTON'S ELECTION AS PRESIDENT DOES NOT JUST MARK THE END OF 12 YEARS OF REPUBLICAN RULE IN THE WHITE HOUSE. IT ALSO SIGNIfIES A CHANGE OF GENERATION ANO THE HANDING OVER OF POWER FROM AN EXPERIENCED WORLD STATESMAN TO A PROVINCIAL GOVERNOR. THIS ARTICLE DISCUSSES THE EXPECTATIONS FOR THE CLINTON PRESIDENCY FROM AN INTERNATIONAL VIEWPOINT, FOCUSING OF RELATIONS WITH GERMANY, EUROPE, AND NATO.

01916 BUHL, E.; GSTEIGER, F.

THE NEW BOSS WILL WORK FOR THE THIRD HORLD

HORLD PRESS REVIEW, 39(2) (FEB 92), 22-23.

UNITED NATIONS SECRETARY-GENERAL BOUTROS BOUTROS GHALI WARNS THAT THE COLD WAR COULD BE REPLACED WITH ACCELERATING STRUGGLES BETWEEN THE NORTH AND THE SOUTH. HE BELIEVES THA THE UNITED NATIONS IS AN IMPORTANT FORUM FOR DEBATES ABOUT LAWS TO REGULATE RELATIONS BETHEEN COUNTRIES.

01917 BULATAO, R.A.

FAMILY PLANNING: THE UNFINISHED REVOLUTION

FINANCE AND DEVELOPMENT, $29(4)$ (DEC 92), 5-8

VOLUNTARY FAMILY PLANNING PROGRAMS IN THE DEVELOPING WORLD HELP REDUCE POPULATION GROWTH, CONTRIBUTE TO BETTER MATERNAL AND CHILO HEALTH, AND AIO IN POVERTY ALLEVIATION. DESPITE THE NOTABLE SUCCESS DF FAMILY PLANNING PROGRAMS IN A NUMBER OF REGIONS, POPULATION GROWTH REMAINS HIGH IN MANY AREAS. THE CHALLENGE LIES IN IMPROVING THE DESIGH AND IMPLEMENTATION OF PROGRAMS TO ENSURE MORE SUCCESSFUL POPULATION POLICY.

01918 BULGER, $P$.

CODESA FOR BEGINNERS

SOUTH AFRICA FOUNDATION REVIEW, 18(5) (MAY 92), 1-3. THE CONVENTION FOR A DEMOCRATIC SOUTH AFRICA (CODESA) WAS ESTABLISHED AT THE END OF 1991 AS A FORUM IN WHICH TO PREPARE FOR A NEW POLITICAL DISPENSATION FOR SOUTH AFRICA. IT FOLLOWED CALLS FROM THE AFRICAN NATIONAL CONGRESS (ANC) AND THE RULING NATIONAL PARTY (NP) GOVERMMENT FOR TALKS AND THE RULING NATIONAL PARTY (NP) GOVERMMENT FOR TALKS
INYOLYING ALL POLITICAL PARTIES ABOUT SOUTH AFRICA'S FUTURE. IHIS ARTICLE OUTLINES THE ORGANIZATION OF CODESA AND LISTS THIS ARTICLE OUTLINES THE ORGANIZATION OF CODESA AND THE POLITICAL PARTIES WHICH ARE PARTICIPATING IN THE
NEGOTIATIONS. CODESA ITSELF IS NOT INTENDED TO NEGOTIATE A NEGOTIATIONS. CODESA ITSELF IS NOT INTENDED TO NEGOTIATE
NEW CONSTITUTION BUT RATHER TO OFFER SUGGESTIONS AND TO DEVISE AN INTERIM GOVERMMENT.

01919 BULL, M.

DISTANT THUNDER AT A PICNIC: THE SICILIAN REGIONAL ELECTIONS OF JUNE 1991

REGIONAL POLITICS \& POLICY 2(3) (FAL 92) 76-86,

THE SICILIAN ELECTIONS OF JUNE 1991 WERE OF SIGNAL IMPORTANCE BOTH REGIONALLY AND NATIONALLY. THEY CONFIRMED THAT A NEW PHASE HAS ON THE HORIZON IN SICILIAN POL ITICS, AND ONE WHICH COULD MARK A SEA CHANGE IN SICILIANS' PERCEPTIONS OF THE POSSIBILITY OF CHANGING A SYSTEM CORRUPTED BY MACHINE POLITICS AND THE MAFIA. THE SUCCESS OF SUBSTANTIAL PERCENTAGE OF THE POPULATION WHICH OPPOSES THE TRADITIONAL SYSTEM BUT ALSO IS PREPARED TO VOTE AGAINST IT.

01920 BULL, M.

THE CORPORATIST IDEAL-TYPE AND POLITICAL EXCHANGE

POLITICAL STUDIES, XL(2) (JUN 92), 255-272.

THE FUMDAMENTAL REASON FOR CORPORATISM'S PERSISTENCE IN POLITICAL SCIENCE DEBATES IS ITS FAILURE TO RESPOND TO THE DEMANDS OF POLITICAL THEORY AND PRESENT A CONVINCING IDEALTYPE TO CAPTURE THE RELATIONSHIP BETWEEN INTEREST GROUPS AND THE STATE. CORPORATIST WRITERS HAVE MISUSED IDEAL-TYPE IS STRUCTURALLY FLAWED. THERE ARE MORE PROFOUND PROBLEMS THAN THIS, HOWEVER, IN THE CONSTRUCTION OF A CORPORATIST IDEALTHE CORPORATIST PROCESS: POLITICAL EXCHANGE.

01921 BULL, M.

WHATEVER HAPPENED TO ITALIAN COMMUNISM? EXPLAINING THE WHATEVER HAPPENED TO ITALIAN COMMUNISM? EXPLAINING THE
DISSOLUTION OF THE LARGEST COMMUNIST PARTY IN THE WEST DISSOLUTION OF THE LARGEST COMMUNIST PARTY IN
WEST EUROPEAN POLITICS, 14(4) (OCT 91), 996-120.

WHY THE LARGEST AND MOST SUCCESSFUL' COMMUNIST PARTY IN WHY THE LARGEST AND MOST SUCCESSFUL COMMUNIST PARTY IN
THE WEST, THE ITALIAN COMAUNIST PARTY, HAS BEEN THE FIRST TO THE WEST, THE ITALIAN COMMUNIST PARTY, HAS BEEN THE FIRST TO
OISSOLVE ITSELF UNDER THE APPARENT IMPACT OF THE REVOLUTIONS DISSOLVE ITSELF UNDER THE APPARENT IMPACT OF THE REVDLUTIONS IN EASTERN EUROPE IS EXPLAINED. THE ARTICLE UTILIZES AND
CDMPARES FOUR POSSIBLE APPROACHES TO THE STUDY OF HEST COMPARES FOUR POSSIBLE APPROACHES TO THE STUDY OF STRATEGIC AND INTERHAL-EXTERNAL APPROACHES. THE FIRST THREE APPROACHES ARE OUTLINED AND THEIR LIMITATIONS INDICATED APPROACHES ARE OUTLINED AND THEIR LIMITATIONS INDICATED BEFORE A MORE DETAILED EXPOSITION AND APPLICATION OF THE FOURTH APPROACH IS MADE AS OFFERING THE MOST ADEQUA
FRAMEWORK TO EXPLAIN ONE OF THE MOST SIGNIFICANT

DEVELOPMENTS IN ITALIAN POLITICS AND WEST EUROPEAN COMMUNISM.

01922 BULLOCK, C.; MACMANUS, S.

MUNICIPAL ELECTORAL STRUCTURE AND THE ELECTION OF

COUNCILHOMEN
THE JOURMAL OF POLITICS, 53(1) (FEB 91), 75-89. 
A SURYEY OF THE 946 AMERICAN CITIES HAVING POPULATIONS IN EXCESS OF 25,000 IN 1980 REVEALS YERY LITTLE RELATIONSHIP IN EXCESS OF 25,000 IN 1980 REVEALS VERY LITTLE RELATIONSHIP
BETWEEN ELECTION STRUCTURES AND THE PRESENCE OF WOMEN ON THEIR COUMCILS. THESE RESULTS HOLD FOR THE FULL DATA SET AS THEIR COUNCILS. THESE RESULTS HOLD FOR THE FULL DATA SET A
WELL AS FOR FOUR REGIONAL SUBSTS. THE EVIDENCE DOES NOT WELL AS FOR FOUR REGIONAL SUBSTS. THE EVIDENCE DOES NOT
SUSTAIN THE DESIRABILITY HYPOTHESIS THAT SUGGESTS WOMEN WILL SUSTAIN THE DESIRABILITY HYPOTHESIS THAT SUGGESTS WOMEN WILL LESS OFTEN BE ELECTED IN CITIES WHERE THE POSITION IS MORE VALUED. WOMEN SERVE SOMEWHAT MORE FREQUENTLY IN THE HEST, AS EXPECTED, HOWEVER, THE PROPOSITION THAT THE SOUTH HILL HAVE

01923 BULPITT, J.

CONSERVATIVE LEADERS AND THE 'EURO-RATCHET': FIVE DOSES OF SCEPTICISM

POLITICAL OUARTERLY (THE), 6313) (JUL 93), 258-275.

THIS ARTICLE EXPLORES HHAT HAPPENS HEN THE

PROCCUPATIONS AND BEHAVIOR OF CONSERVATIVE LEADERS ARE

SUBJECT TO ASSESSMENT FROM A EURO-SCEPTIC'S STANDPOINT. IT

OFFERS FIVE POINTS WHICH REPRESENT ONE CRITIQUE OF THOSE

LEADERS AND ONE CONTRIBUTION TO THE WIDER 'BRITAIN IN

EUROPE' DEBATE. THESE FIVE DOSES OF SCEPTICISM, EVEN IN

EUROPE DEBATE. THESE FIVE DOSES OF SCEPTICISM, EVEN IN

OUTLINE FORM, REPRESENT A PLAUSIBLE CRITIQUE OF PAST AND
PRESENT CONSERVATIVE LEADERS, AND IN DEBATING TERMS, ARE AS

GOOD AS THE ALTERNATIVES PRESENTLY OFFERED BY THE EURO-

GOOD AS THE
ENTHUSIASTS.

01924 BUMILLER, $K$.

THE CIVIL RIGHTS SOCIETY--THE SOCIAL CONSTRUCTION OF VICTIMS

JOHNS HOPKINS UNIVERSITY PRESS, 1992, 172

IN AN EXAMINATION OF THE ROLE OF LAN IN PROMOTING SOCIAL CHANGE, THE AUTHOR OF THIS BOOK CONTENDS THAT ONE EFFECT OF ANTI-DISCRIMINATION LAWS HAS BEEN TO PERPETUATE THE VICTIMIZATION OF THE PEOPLE THEY WERE INTENDED TO BENEFIT. PROBING THE ROLE OF LEGAL IDEOLOGY IN "THE SOCIAL CONSTRUCTION OF EVERYDAY LIFE," THE BOOK DESCRIBES THE WAYS IN WHICH THE SOCIAL IDENTITY OF VICTIMS CONSTRAINS THEIR CHOICES AND REINFORCES THEIR SENSE OF POWERLESSNESS.

01925 BUNBONGKARN, S.

THAILAND IN 1991: COPING WITH MILITARY GUARDIANSHIP ASIAN SURVEY, XXXII(2) (FEB 92), 131-139.

THIS ARTICLE EXAMINES POLITICAL. ECONOMIC AND SOCIAL EVENTS IN THAILAND DURING 1991. POLITICS IN THAILAND WERE CHANGED IN EARLY 1991 WHEN THE ARMED FORCES TOOK POWER FROM THE ELECTED GOVERMMENT OF GENERAL CHATICHAI CHOONHAVAN ON FEBRUARY 23. THE COUP, WHICH ENDED A DECADE-LONG FEBRUARY 23. THE CDUP, WHICH ENDED A DECADE-LONG
PARLIAMENTARY DEMOCRACY, CAME AS A SURPRISE TO MOST PARLIAMENTARY DEMOCRACY, CAME AS A SURPRISE TO MOST
OBSERVERS. FURTHERMORE, MANY BELIEVED THAT THE MILITARY OBSERVERS. FURTHERMORE, MANY BELIEVED THAT THE MILITARY
HOULD NOT RELENOUISH POWER AS PROMISED, BUT A GROHING WOULD NOT RELENQUISH POWER AS PROMISED, BUT A GROHING LIBERAL EFFORT TO RAISE THE PEOPLE'S POLITICAL CONSCI GUARDIANSHIP. IN ADDITION, ANNAND PUNYARACHUN, THE NEWLYGUARDIANSHIP. IN ADDITION, ANNAND PUNYARACHUN, THE NEWLYSELECTED PRIME MINISTER WAS SUCCESSFUL IN MAKING HIMSELF INDISPENSABLE AND INDEPENDENT ENOUGH TO PURSUE SOME WHICH RAN AGAINST THE INTERESTS OF THE MILITARY. A CONSTITUTIONAL DRAFTING COMMMITTEE WAS ALSO ABLE TO ACT WITH UNPRECEDENTED INDEPENDENCE. ON THE ECONOMIC FRONT THE GOVERNMENT WAS ABLE TO MAINTAIN ECONOMIC STABILITY WITH A MILD INCREASE OF THE INFLATION RATE. ASEAN AND THE INDOCHINESE STATES CONTINUED TO OCCUPY THE CENTER OF ATTENTION IN THAILAND'S FOREIGN POLICY THROUGHOUT 1991, BUT THE MILITARY GOVERNMENT DID LITTLE TO CHANGE FOREIGN POLICY FROM THAT OF PREVIOUS YEARS.

01926 BUNCH, B.S.; STRAUSS, R.P

MUNICIPAL CONSOLIDATION: AN ANALYSIS OF THE FINANCIAL BENEFITS FOR FISCALLY DISTRESSED SMALL MUNICIPALITIES URBAN AFFAIRS QUARTERLY, 27(4) (JUN 92), 615-629.

THE AUTHORS ANALYZE THE EXPENDITURES AHD REVENUES ASSOCIATED WITH THE POTENTIAL CONSOL IDATION OF NINE SHALL, FISCALLY-DISTRESSED MUNICIPALITIES IN WESTERN PENNSYLVANIA THAT HAVE LOST SUBSTANTIAL PORTIONS OF THEIR TAX BASE DUE TO THE CLOSING OF STEEL MILLS AND RELATED HEAVY INDUSTRY. THE ANALYSIS INCLUDES THE COLLECTION OF CONSISTENT FINANCIAL INFORMATION, THE CREATION OF FORECASTED BASE-CASE 1989 REVENUE-AND-EXPENDITURE SCENARIOS, AND THEIR JUXTAPOSITION FOR THE NINE JURISDICTIONS AGAINST CONSOLIDATION SCENARIOS THAT MIGHT PROVIDE COST SAVINGS WHILE MAINTAINING CRITICAL SERVICE LEVELS. FINDINGS INDICATE THAT CONSOLIDATION MAY PROVIDE A METHOD FOR ELIMINATING CHRONIC OPERATING DEFICITS PRO FOR REALIZING ECONOHIES OF SCALE.

01927 BUNGS, D.: GIRNIUS, S.; KIONKA, R.

CITIZENSHIP LEGISLATION KIN THE BAITIC STATES RFE/RL RESEARCH REPORT, 1(50) (DEC 92) 38-40.

BOTH ESTONIA AND LITHUANIA HAVE PASSED CITIZENSHIP AND NATURALIZATION LAHS. IN ESTONIA, ALL PERMANENT RESIDENTS REGARDLESS OF CITIZENSHIP, ARE ELIGIBLE TO VOTE IN LOCAL AND MUNICIPAL ELECTIONS, BUT ONLY CITIZENS MAY VOTE IN NATIONAL ELECTIONS. IN LITHUANIA, A LARGE NUMBER OF MON-LITHUANIAN RESIDENTS, INCLUDING ETHNIC RUSSIANS AND POLES, HAVE CHOSEN TO BECOME NATURALIZED CITIZENS. LATVIA HAS ADOPTED

GUIDELINES FOR CITIZENSHIP AND NAUTRALIZATION LAWS, AND ITS
LEGISLATURE IS CONSIDERING A DRAFT LAW ON CITIZENSHIP.

01928 BUNGS, $D$.

DE-SOVIETIZING THE PRESS: THE LATVIAN EXPERIENCE

RFE/RL RESEARCH REPORT, 1 (14) (APR 92), 29-35.

IN FEBRUARY 1992 NEWSPAPER EDITORS AND PUBLISHERS IN LATVIA STAGED A PROTEST ACTION, CALLED "A WEEK HITHOUT THE PRESS," TO DRAW ATTENTION TO THE PLIGHT OF THE LATVIAN NEWSPAPER INDUSTRY. THE IMHEDIATE CAUSE OF THE ACTION WAS THE CATASTROPHIC SHORTAGE OF NEWSPRINT THAT THREATENED WIDESPREAD SHUTDOWNS OF NEWSPAPERS THROUGHOUT THE COUNTRY. THE STAGING OF THE ACTION ALSO REFLECTED THE SITUATION OF THE PRESS IN THE LATVIAN SSR AND THE EFFORTS TO CHANGE IT NOW THAT LATVIA IS INDEPENDENT. "A WEEK HITHOUT THE PRESS" SUCCEEDED IN ENLISTING GOVERNMENT HELP TO FIND ALTERMATE SOURCES OF NEWSPRINT AND IN PRODDING LEGISLATORS TO REMEMBER THE DIFFICULT SITUATION OF LATVIA'S NEWSPAPERS AND

PERIODICALS.

01929 BUNGS, $D$.

LATVIA
RFE/RL RESEARCH REPORT, 1(39) (OCT 92), 66-69.

ONE YEAR AFTER LATVIA REGAINED ITS INDEPENDENCE, THE LATVIAN MEDIA ARE STILL IN TRANSITION. ALTHOUGH FREEDOM OF THE PRESS IS RESPECTED AND CENSORSHIP HAS BEEN ABOLISHED, THE ROLE OF THE MEDIA HAS NOT BEEN CLEARLY DEFINED. A RECENT THE ROLE OF THE MEDIA HAS NOT BEEN CLEARLY DEFINED. A RECENT
SURVEY REVEALED THAT THE LATVIAN MEDIA EXERCISE CONSIDERABLE SURVEY REVEALED THAT THE LATVIAN MEDIA EXERCISE CONSIDERA INFLUENCE OVER ETHNIC LATVIANS BUT HAVE LITTLE INFLUENCE OVER THE REMAINDER OF THE POPULATION, WHICH IS LARGELY SLAVIC AND DEPENDS ON RUSSIAN TELEVISION FOR NEWS AND ENTERTAINMENT. THIS STATE OF AFFAIRS, WITH ITS POLITICAL
IMPLICATIONS, CHALLENGES THE LATVIAN MEDIA TO FOCUS MORE ON RUSSIANS AND THE OTHER NATIONALITIES LIVING IN LATVIA.

01930 BUNGS, D.

LATVIA

RFE/RL RESEARCH REPORT, 1(27) (JUL 92), 62-66.

SINCE THE RESTORATION OF THE INDEPENDENT REPUBLIC OF LATVIA IN 1991, LATVIA'S LEGAL FOUNDATIONS HAVE BEEN PROVIDED IN PRINCIPLE BY THE 1922 CONSTITUTION OF THE INTERWAR REPUBLIC, ALTHOUGH IN PRACTICE THEY HAVE BEEN LIMITED TO ONLY A FEH ARTICLES OF THAT CONSTITUTION. THIS SITUATION IS LARGELY DUE TO THE INCOMPLETE TRANSITION TO INDEPENDENCE. IN ORDER TO ACHIEVE A SOLID LEGAL BASE, LATVIA NEEDS TO COMPLETE THE TRANSITION PROCESS AND ELECT A NEW PARLIAMENT HITH THE AUTHORITY TO ADOPT A NEW CONSTITUTION. CONSIDERING THE MULTI-ETHNIC NATURE OF LATVIA'S POPULATION, THESE TASKS HILL NOT BE EASY.

01931 BUNGS, D.

LATVIA: LAYING NEW FOUNDATIONS
RFE/RL RESEARCH REPORT, 1(1) (JAN 92), 61-64.

RFE/RL RESEARCH REPORT, 1 (1) (JAN 92), 61-64. SOVIET SOCIALIST REPUBLICS. THE DECLARATION OF INDEPENDENCE WAS DISSEMINATED JUST AS NEWS WAS BREAKING THAT THE

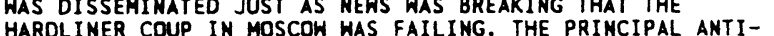
INDEPENDENCE FORCES WERE THE LATVIAN COMMUNIST PARTY, OMON, AND THE LEADERSHIP OF THE SOVIET BALTIC MILITARY DISTRICT.

01932 BUNGS, D.

LATVIA: NEH LEGISLATION OPENS DOOR TO REFORM RFE/RL RESEARCH REPORT, 1(17) (APR 92), 73-79.

PRIVATIZATION OF STATE AND LOCAL GOVERMMENT ENTERPRISES IN LATVIA RECEIVED THE GREEN LIGHT IN MARCH 1992 WHEN THE LATVIAN SUPREME COUNCIL PASSED TWO LEGISLATIVE MEASURES: A DECREE OUTLINING THE CONCEPTS UNDERLYING PRIVATIZATION AND A LAW ON PRIVATIZATION COMMISSIONS. BUT IT IS UNLIKELY THAT PRIVATIZATION WILL BE EITHER SPEEDY OR SMODTH, DUE TO THE AMOUNT OF LEGISLATION STILL NEEDED, THE CONTROVERSIES SURROUMOING VARIOUS ASPECTS OF PRIVATIZATION, AND THE LACK OF VALID LEGAL ACCORDS TO DEFINE LATVIA'S RELATIONS WITH RUSSIA.

01933 BUNGS, D.

RUSSIAN TROOP HITHDRAWAL FROM LATVIA: AN UPDATE

RFE/RL RESEARCH REPORT, 1(49) (DEC 92), 28-32

LATVIA'S HOPE THAT RUSSIAN TROOPS WOULD BE WITHDRAWM FROM ITS TERRITORY BY 1993 HAS BEEN DASHED BY PRESIDENT YELTSIN'S SUSPENSION OF THE HITHORAHAL PROCESS. RECENT STATEMENTS AND POLITICAL DEVELOPMENTS IN MOSCOW SUGGEST THAT LATVIA WILL HAVE TO WORK HARD TO MAINTAIN STABILITY IN VIEW OF THE PRESENCE OF FOREIGN TROOPS ON ITS SOIL FOR AN INDEFINITE PERIOD AND THE PRESSURE FROM MOSCOW TO LINK THE PRESENCE OF TROOPS HITH THE RIGHTS OF RUSSIANS AND RUSSIANSPEAKERS, WHO MAKE UP ABOUT 44\% OF LATVIA'S POPULATION.

01934 BUNGS, D.

SOYIET TROOPS IN LATVIA

RFE/RL RESEARCH REPORT, I(34) (AUG 92), 18-28.

DESPITE MOMIMALY GAINING ITS INDEPENDENCE IN 1991 LATVIA IS NOT IN PRACTICE FULLY INDEPENDENT BECAUSE ABOUT 60 , OOO RUSSIAN (FORMERLY SOVIET) TROOPS ARE STILL STATIONED THERE. LATVIANS CONSIDER THEIR PRESENCE DETRIMENTAL TO THE POLITICAL, ECONOMIC, AND DEMOGRAPHIC DEVELOPMENT OF THEIR 
COUNTRY AND WANT THE "OCCUPYING FORCES" TO LEAVE AS QUICKLY AS POSSIBLE. RUSSIA, HOWEVER, WOULD LIKE TO RETAIN SOME OF ITS FORCES AND MILITARY INSTALLATIONS THERE AND HAS FORMULATED TOUGH CONDITIONS FOR WITHDRAWAL. THESE CONDITIONS SEEM TO SUGGEST THAT RUSSIA WOULD LIKE TO KEEP LATVIA IN ITS SPHERE OF INFLUENCE AND MAINTAIN ITS MILITARY PRESENCE THERE, FOR STRATEGIC REASONS.

01935 BUNGS, $D$.

THE LATVIAN-RUSSIAN TREATY OR THE VICISSITUDES OF THE LATVIAN-RUSSIAN

RFE/RL RESEARCH REPORT, 1(9) (FEB 92), 28-33 ALTHOUGH THE LATVIAN-RUSSIAN TREATY ON INTERSTATE RELATIONS HAS BEEN RATIFIED BY THE LATVIAN SUPREME COUNCIL RELATIONS HAS BEEN RATIFIED BY THE LATVIAN SUPREME COUNCIL AND SIGNED BY BOTH PARTIES, IT HAS NOT GONE INTO EFFEC RATIFICATION. THE RUSSIAN LEGISLATORS' DELAY IS NOT CAUSED RATIFICATION. THE RUSSIAN LEGISLATORS' DELAY IS NOT CAUSED
BY ANYTHING PARTICULARLY CONTROYERSIAL IN THE TREATY BUT BY ANYTHING PART ICULARLY CONTROVERSIAL IN THE TREATY BUT
RATHER BY THEIR MIXED FEELINGS ABOUT AN INDEPENDENT LATVIA RATHER BY THEIR MIXED FEELINGS ABOUT AN INDEPENDENT LATVIA,
THEIR DIFFERENCES WITH BORIS YELTSIN, AND OPPOSITION TO THE TREATY HITHIN LATVIA FROM ANTI-INDEPENDENCE GROUPS WHO CLAIM IT IS ANTI-RUSSIAN.

01936 BUNGS, D.; TEAGUE, E.; TOLZ, V.

WEEKLY REVIEW: 25-31 MARCH 1992

RFE/RL RESEARCH REPORT, 1 (15) (APR 92), 56-68.

MAJOR DEYELOPMENTS IN EASTERM EUROPE AND THE

COMMONWEALTH OF INDEPENDENT STATES DURING THE WEEK OF MARCH

25-31, 1992, INCLUDED THE COMPLETION OF A BALTIC-SWEDISH

ENVIRONMENTAL ACCORD, THE NATIONAL SALVATION FRONT

CONVENTION IN ROMANIA, AN AGREEMENT TO HOLD TRIPARTITE TALKS

ON THE NAGORND-KARABAKH DISPUTE, AMD THE ARRIVAL OF A CSCE

MISSION IN BAKU. IN THIS ARTICLE, THE EDITORS SUMMARIZE

THESE NEWS STORIES AND OTHERS.

01937 BUNGS, D. (ED.); CROW, S. (ED.); MIHALISKO, K. (ED.); TOLZ

WEEKLY (ED.)

RFE/RL RESEARCH REPORT, 1(16) (APR 92), 61-72.

E/RL RESEARCH REPORT, $1(16)$ (APR 92), 61-72.
BASED ON NEWS REPORTS IN THE FOREIGH PRESS, THE EDITORS

BASED ON NEWS REPORTS IN THE FOREIGN PRESS, THE
SUMMARIZE MAJOR EVENTS IN EASTERN EUROPE AND THE

SUMMARIZE MAJOR EVENTS IN EASTERN EUROPE AND THE

COMHONHEALTH OF INDEPENDENT STATES DURING THE FIRST WEEK OF

APRIL 1992. SUBJECTS INCLUDE POLISH PRESIDENT LECH WALESA'S

VISIT TO GERMANY, THE SIGNING OF A CZECH-RUSSIAN TREATY OF

FRIENDSHIP, FIGHTING IN WESTERN GEORGIA, THE OPENING OF THE
RUSSIAN CONGRESS OF PEOPLE'S DEPUTIES, AND THE CONCLUSION OF

RUSSIAN CONGRESS OF PEDPLE'S DEPUTIES,
A HUNGARIAN-GREEK TREATY OF FRIENDSHIP.

01938 BUNGS, D. (ED.); CROW, S. (ED.); KOSIBA, H. (ED.);

SABBAT-SWIDLICKA, A. (ED.)

WEEKLY REVIEW: 14-20 OCTOBER 1992

RFE/RL RESEARCH REPORT, 1 (43) (OCT 92), 70-77

THE EDITORS SUMMARIZZE MAJOR NEWS STORIES DURING THE WEEK

OF OCTOBER 14-20, 1992, IN THE BALTIC STATES, EASTERN EUROPE,

AND THE COMMONHEALTH OF INDEPENDENT STATES. THESE INCLUDE

THE CONTINUING PROBLEMS IN YUGOSLAVIA, FIGHTING IN

TAJIKISTAN, THE ADOPTION OF THE "LITTLE CONSTITUTION" BY

POLAND'S SEJM, AND THE PROSPECTS FOR FORMING A NEW

GOVERNMENT IN UKRAINE.

01939 BURANT, S.R.

POLISH-BELARUSIAN RELATIONS

RFE/RL RESEARCH REPORT, 1 (37) (SEP 92 ), 41-45.
POLAND'S RELATIONS HITH BELARUS CONSTITUTE A SUCCESS FOR

ITS FOREIGN POLICY MAKERS, WHO ARE ATTEMPTING TO EFFECT

RAPPROCHEMENT WITH ITS NEIGHBORS TO THE EAST. POLISH-

BELARUSIAN RELATIONS ARE CONTRIBUTING TO THE STABILIZATION

OF EAST CENTRAL EUROPE, AND THE OUTLOOK FOR THEM IS QUITE

OF EAST CENTRAL EUROPE, AND THE OUTLOOK FOR THEM IS QUI
FAVORABLE, PARTICULARLY SINCE BOTH COUNTRIES HAVE MADE

FAVORABLE, PARTICULARLY SINCE BOTH COUNTRIES HAVE MADE
PROGRESS IN THE TREATMENT OF THEIR NATIONAL MINORITIES. THE

PROGRESS IN THE TREATMENT OF THEIR NATIONAL MINORITIES. THE
TWO COUNTRIES HAVE ESTABLISHED DIPLOMATIC RELATIONS AND HAVE

TWO COUNTRIES HAVE ESTABLISHED DIPLOMATIC RELATIONS AND HAVE
SIGNED A NUMBER OF AGREEMENTS. HOWEVER, SOME OF THE ECONOMIC

SIGNED A NUMBER OF AGREEMENTS. HOWEVER, SOME OF THE ECONOMIO
AGREEMENTS MAY HAVE LIMITED VALUE, BECAUSE BOTH SIDES ARE

AGREEMENTS MAY HAVE LIMITED VALL
PLAGUED BY A LACK OF CAPITAL.

01940 BURAHOY, M.: KROTOY, P.

THE SOVIET TRANSITION FROM SOCIALISM TO CAPITALISM: WORKER

THE SOVIET TRANSITION FROM SOCIALISM TO CAPITALISM:

CONTROL AND ECONOMIC BARGAINING IN THE WOOD INDUSTRY
AMERICAN SOCIOLOGICAL REVIEH, 57 (1) (FEB 92), 16-38.

ANALYSES OF THE TRANSITION FROM STATE SOCIALISM TO

CAPITALISH TYPICALLY FOCUS ON POLITICAL IMPEDIMENTS AND

UNDERESTIMATE THE ECONOMIC OBSTACLES AL IMPEDIMENTS AND

BASED ON A CASE STUOY OF THE SOVIET HOOD INDUSTRY. THE

AUTHORS ARGUE THAT THERE WILL BE NO ECONOMIC TRANSITION SO

LONG AS ENTERPRISES RETAIN THO HISTORIC FEATURES- NAMELY

ANARCHY IN PRODUCTION AND BARGAINING IN EXTERNAL RELATIONS

FAR FROM CONSTITUTING A REVOLUTION, THE WITHERING AWAY OF

THE PARTY STATE HAS EXAGGERATED THE PATHOLOGIES OF THE OLD

ECONOMIC ORDER. BARTER HAS BECOME MORE IMPORTANT,

CONGLOMERATES HAVE STRENGTHENED THEIR MONOPOLY, AND WORKERS HAVE GREATER CONTROL OF THE SHOP FLOOR. IF THERE IS A

MOVEMENT TOWARD A MARKET ECONOMY AT ALL. IT IS TOHARD A FORM

OF MERCHANT CAPITALISM THAT DEEPENS ECONOMIC

UNDERDEVELOPMENT AND THWARTS THE RISE OF MODERN BOURGEOIS
CAPITALISH.

01941 BURCH, M.; HOLLIDAY, I.

THE CONSERVATIVE PARTY AND CONSTITUTIOMAL REFORM: THE CASE OF DEVOLUTION

PARLIAMENTARY AFFAIRS, 45(3) (JUL 92), 386-398

A MAJOR PUBLIC OPINION SURVEY HAS REVEALED THAT NEARLY TWICE AS MANY BRITISH VOTERS SUPPORT AS OPPOSE PROPOSALS TO DEVOLVE POWER TO GOVERNMENTS IN SCOTLAND, WALES, AND THE ENGLISH REGIONS. IF CONSTITUTIONAL REFORM IS TO SUCCEED IN BRITAIN, ATTENTION MUST BE PAID NOT SIMPLY TO THE CONTENT OF
REFORM PROPOSALS BUT ALSO TO THE MANHER IN WHICH THEY CAN BE REFORM PROPOSALS BUT ALSO TO THE MANNER IN WHICH THEY CAN
IMPLEMENTED. PROPOSED CHANGES ARE OF SUCH MAGNITUDE THAT IMPLEMENTED. PROPOSED CHANGES ARE OF SUCH MAGNITUDE THAT
THEY WILL REQUIRE BROAD-BASED SUPPORT ACROSS THE POLITICAL THEY WILL REQUIRE BROAD-BASED SUPPORT ACROSS THE POLITI
SPECTRUM. A MAJOR STUMBLING BLOCK TO PROGRESS IS THE SPECTRUM. A MAJOR STUMBLING BLOCK TO PROGRESS IS THE
CONSERYATIVE PARTY. WHICH IS NEITHER ENGAGED IN THE DEBATE CONSERVATIVE PARTY, WHICH IS NEITHER ENGAGED IN THE DEBATE NOR SUPPORTIVE OF IT. THIS IS A SUBSTANTIAL PROBLEM, AND REFORM CANNOT BE SENSIBLY DEBATED UNLESS SOME CONSIDERATION
IS GIVEN TO THE POSITION AND POTENTIAL OF THE CONSERVATIVE IS GIVEN TO THE POSITION AND POTENTIAL OF THE CONSERVAT
PARTY. AS AN INITIAL CONTRIBUTION TO DEBATE, THIS ESSAY REVIEWS THE CONSERVATIVE CONSTITUTIONALIST TRADITION, FOCUSING ON THE PRINCIPLES INVOLVED, PAST PRACTICE AND POLICY POSITIONS, AND STRATEGIC CONSIDERATIONS RELATING TO THE PARTY'S PURSUIT OF POHER.

01942 BURDICK, J.

THE MYTH OF RACIAL DEMOCRACY

REPORT ON THE AMERICAS, 25(4) (FEB 92), 40-44.

ALTHOUGH RACIAL DISCRIMINATION IS RIFE, THE TREATMENT OF PEOPLE OF VISIBLY MIXED ANCESTRY VARIES WIDELY. BLACKMULATTO RELATIONS IN BRAZIL AND CUBA, THE LAST THO COUNTRIES TO ABOLISH SLAVERY, ARE A STUDY IN CONTRASTS. ACCORDING TO RACIAL DEMOCRATS, THE PRESENCE OF THE MANY MIXED-BLOOOS PROMOTES MILD, FRATERHAL RACE RELATIONS. THIS IS NOT TRUE IN ACTUALITY. PEOPLE ON THE LIGHTER END OF THE COLOR-RACE CONTINUUM, ANXIOUS TO MAXIMIZE THEIR DISTANCE FROM PEDPLE DARKER THAN THEMSELVES, CAN BE AS RACIST, IF NOT MORE SO, DARKER THAN THEMSELVES, CAN BE AS RACIST, IF NOT MORE SO, CUBA AND COLOMIBIA IS ANALYZED IN THIS ARTICLE.

01943 BURGER, A.S.

CHANGING CIVIL-MILITARY RELATIONS IN SRI LAMKA ASIAN SURVEY, XXXII (8) (AUG 92), 744-756.

A NEW STAGE IN CIVIL-MILITARY RELATIONS IN SRI LANKA BEGAN IN SEPTEMBER 1991 WHEN CIYILIAN POLITICIANS INVITED THE MILITARY TO STEP INTO, AND SETTLE A FACTIONAL FIGHT BETWEEN SOME OF THE POLITICAL GROUPINGS. PRIOR TO THIS, THREE ATTEMPTS AT COUPS BY THE SECURITY FORCES HAD BEEN THWARTED BECAUSE THE PLOT HAD BEEN REVEALED TO A FAMILY
MEMBER OR CLOSE FRIEND IN THE PARLIAMENT. IN EACH CASE, THE MEMBER OR CLOSE FRIEND IN THE PARLIAMENT. IN EACH CAS

MEMBER OF PARLIAMENT HAD INFORMED THE PRIME MINISTER,
DEMONSTRATING A DEVOTION TO CIVILIAN RULE AND DISREGARD FOR DEMONSTRATING A DEVOTION TO CIVILIAN RULE AND DISREGARD FOR
THE PROBABLE ADVERSE CONSEQUENCES TO FRIENDS OR FAMILY. THIS ARTICLE CONSIDERS SEVERAL OF THE PUZZLING QUESTIONS THAT ARISE DUE TO THIS EVENT. THEY INCLUDE: WHAT WAS THE NATURE OF THE CONFLICT AMONG SOME OF THE POLITICOS OF THE UNITED NATIONAL PARTY (UNP) THAT LED TO THEIR INVITATION TO THE MILITARY; WHAT EXPLAINS THE DECISION BY THE MILITARY HIGH COMMAND TO THROW ITS SUPPORT TO ONE FACTION; AND HOW HAVE CIVIL-MILITARY RELATIONS CHANGED AND WHY?

01944 BURGER, $H$.

WAIGEL BRIEFS SOVIET LEADERS ON WHERE LIMITS TO AID LIE GERMAN TRIBUNE, 1487 (OCT 91), 1-2.

THIS ARTICLE DISCUSSES THE GERMAN FINANCE MINISTER, THEO WAIGEL'S FACT-FINDING MISSION TO THE SOVIET UNION. HE' WANTED TO GAIN A FIRST-HAND IMPRESSION OF THE POST-COUP SITUATION IN THE USSR. HIS TASK, IN PARTICULAR, WAS TO SOUND OUT WHAT NEW STRUCTURES APPEARED TO BE IN THE MAKING, WHO SEEMED LIKELY TO REMAIN A MEMBER OF THE NEH-LOOK SOVIET UNION, WHO WOULD BE GUARANTEEING INTERNATIONAL TREATIES AND OTHER' COMMITMENTS AND WHO WOULD BE EMPOWERED TO SPEAK FOR WHOM ON WHAT ISSUES.

01945 BURGER, J.

POLITICS OF RESTITUTION IN CZECHOSLOVAKIA

POLITICS OF RESTITUTION IN CZECHOSLOVAKIA
EAST EUROPEAN QUARTERLY, XXVI (4) (WIN 92), 485-498. CZECHOSLOVAKIA HAS PASSED LAWS INTENDED TO PROVIDE REMEDIES FOR TORTS AND OTHER INJUSTICES SUFFERED BY REMEDIES FOR TORTS AND OTHER INJUSTICES SUFFERED BY INDIVIDUALS AND ASSOCIATIONS DURING THE MARXIST ERA. THE
LAWS PROVIDE NOT ONLY FOR RESTITUTION OF PHYSICAL PROPERTY LAWS PROVIDE NOT ONLY FOR RESTITUTION OF PHYSICAL PROPERTY BUT ALSO COMPENSATION FOR INVOLUNTARY SERVITUDE AND FOR LOSS OF LIFE, LIBERTY, JOBS, INCOMES, OR PENSIONS. THROUGH THESE LANS, THE GOVERNMENT IN THUSTICE AMONG THE ELDERLY AND MIDDLE-AGED. SENSE OF INJUSTICE AMONG THE ELDERLY AND MIDOLE-AGED.
HOWEVER. THE DETAILS OF THE POLICY REVEAL COMPETING GOALS. HOWEVER, THE DETAILS OF THE POLICY REVEAL COMPETING GOALS. THEY FEAR THAT COMPENSATION MIGHT BANKRUPT THE STATE OR LIMIT ECONOMIC DEVELOPMENT. IN THIS PAPER, THE AUTHOR ANALYZES THE RESTITUTION POL ICIES TO DEMONSTRATE HOH THE ELITE TRIED TO RESOLVE COMPETING OR INCOMPATIBLE POLITICAL AND ECONOMIC GOALS; TO SHOW HOW THE IMPLEMENTATION OF THE RESTITUTION STATUTES AFFECTS THE ECONOMIC INTERESTS ANO ATTITUDES OF DIFFERENT CATEGORIES OF INDIVIDUALS; AND TO 
AHALYZE THE CONSEQUENCES OF ADOPTING THESE POLICIES WITHOUT SIMULTANEOUSLY BUILDING AN INSTITUTIONALIZED POLITICAL SUPPORT BASE FOR THEIR IMPLEMENTATION.

01946 BURGER, W.E.

BICENTENMIAL CONSIDERATIONS ON AMERICA'S BILL OF RIGHTS PRESIDENTIAL STUDIES QUARTERLY, XXII (4) (FAL 92), 663-666. THE MOST IMPORTANT WORDS IN THE U.S. CONSTITUTION ARE "WE THE PEOPLE." THE SECOND MOST IMPORTANT ARE THE WORDS OF THE FIRST AMENDMENT GUARANTEEING FREEDOM OF SPEECH, PRESS, RELIGION, AND ASSEMBLY.

01947 BURGERS, J.

THE ROAD TO SAN FRANCISCD: THE REVIVIAL OF THE HUMAN RIGHTS IDEA IN THE TWENTIETH CENTURY

HUMAN RIGHTS QUARTERLY, 14(4) (NOV 92), 447-477.

THE ORIGIN OF THE REVIVAL OF THE HUMAN RIGHTS IDEA AMD WHEN AND HOW IT CAME ABOUT ARE EACH EXPLORED. THIS ARTICLE EXAMINES: THE LEAGUE OF NATIONS AND THE MINORITY CLAUSES; THE PIONEER ROLE OF ANDRE MANDELSTAM AND THE INVOLVEMENT' OF NONGOVERMMENTAL ORGANIZATION: THE EMERGENCE OF NAZI GERMANY, NONGOVERMMENTAL ORGANIZATION; THE EMERGENCE OF NAZI
THE RIGHTS OF MAN CAMPAIGN OF H.G. WELLS: PRESIDENT THE RIGHTS OF MAN CAMPAIGN OF H.G. HELLS; PRESIDENT
ROOSEVELT AND THE FOUR FREEDOMS; THE HUMAN RIGHTS MOVEMENT ROOSEVELT AND THE FOUR FREEDOMS; THE HUMAN RIGHTS MOVEME DURING WORLD WAR II;
FRANCISCO CONFERENCE.

01948 BURGESS, S.R.; DAVISON, D.L.; REAGAN, D.J. RECLAIMING A DEMOCRATIC CONSTITUTIONAL POLITICS: SURVEY CONSTRUCTION AND PUBLIC KNOWLEDE

REVIEH OF POLITICS, 54(3) (SUM 92), 399-415.

IT HAS BEEN ARGUED THAT PUBLIC OPINION RESEARCH TENDS TO FAVOR THE EXPERT AUTHORITY OF ELITE INSTUTITIONS, SUCH AS COURTS, OVER THE DEMOCRATIC AUTHORITY OF THE PEOPLE AS A SOURCE OF LAW OR CONSTITUTIONAL INTERPRETATION. IN THIS PAPER, THE AUTHORS INTRODUCE AN ALTERNATIVE SURVEY CONSTRUCTION THAT ALLOWS THE PUBLIC TO BE CONSIDERED AS A POSSIBLE SOURCE OF CONSTITUTIONAL KNOWLEDGE. USING THIS SURVEY, THEY FIND THAT MOST RESPONDENTS CAN CLEARLY ARTICULATE THEIR POSITION ON THE CONSTITUTIONALITY OF ABORTION AND OFFER AND RECOGNIZE REASONS BOTH TO SUPPORT AND TO REFUTE THEIR POSITION. THESE FINDINGS SUGGEST THAT FURTHER WORK WITH ALTERNATIVE SURVEY CONSTRUCTIONS MAY MORE FIRMLY ESTABLISH PUBLIC KNOWLEDGE IN CONSTITUTIONAL DEBATES, THEREBY FORMING THE BASIS TO RECLAIM A DEMOCRATIC

CONSTITUTIONAL POLITICS.

01949 BURGIN, E.

CONGRESS, THE hAR POWERS RESOLUTION, AND THE INVASION OF CONGRESS,

POLITY, $X X V(2)$ (WIN 92), 217-242

IN SIGNIFICANT MILITARY INITIATIVES FROM 1973 TO THE 1989 PANAMA INVASION, PRESIDENTIAL DISREGARD OF THE WAR POWERS RESOLUTION DREW CONGRESSIONAL CRITICISM. DESPITE THE POWERS RESOLUTION DREW CONGRESSIONAL CRITICISM. DESPITE THE PANAMA, CONGRESS REMAINED VIRTUALLY SILENT ABOUT THE RESOLUTION. THIS ESSAY EXPLORES THE REASONS FOR, AND THE IMPLICATIONS OF, CONGRESSIONAL SILENCE IN THE CASE OF PANAMA.

01950 BURGOON, M.; BAILEY, M. PC AT LASTi' PC aT LASTi THANK GOD ALMIGHTY, he ARE PC AT LAST!

JOURHAL OF COMHUNICATION, 42(2) (SPR 92), 95-104.

ONE OF THE CONTINUING PROBLEMS OF HOLDING PROGESSIONAL MEMBERSHIP IN THE DISCIPLINE OF COMMUNICATION IS A LACX OF IDENTITY. IT IS THE AUTHOR'S CONTENTION THAT THE PRESENT
ACADEMIC/SOCIAL CONCERH HITH POLITICAL CORRECTNESS (PC) IS THE FORCE THAT MARKS THE END TO OUR PAST FISSIPAROUS ACTIVITIES. THE AUTHORS EXPLORE THE CHALLENGE TO SECULAR HUMANISM AND THE CHARACTERISTICS OF PC. WITH REFERENCE TO ORHELL'S 1984, THEY CONCLUDE THAT UNDER "BIG SISTER'S" GUIDANCE, HOW MUCH EASIER HAS BEEN OUR PATH TO PCI THEY HOPE SHE COMES TO US SOON WHILE OUR MINDS ARE CLEAN.

01951 BURKE, J.P.

THE INSTITUTIONAL PRESIDENCY

JOHNS HOPKINS UNIVERSITY PRESS, 1992, 288

THIS BOOK EXAMINES HOW THE HHITE HOUSE STAFF SYSTEM INTERACTS WITH A PARTICULAR PRESIDENT'S MANAGEMENT ABILITY AND STYLE. IT BEGINS BY DESCRIBING THE INSTITUTIONAL PRESIDENCY THAT EMERGED DURING THE ROOSEVELT ADMINISTRATION AND THAT EVERY MODERM PRESIDENT INHERITS. THE CENTRAL ARGUMENT IS THAT ANALYSTS AND ADVISERS MUST EXAMINE BOTH THE ARGUMENT IS THAT ANALYSTS AND ADVISERS MUST EXXMIME MANAGEMENT STYLE OF INDIVIDUAL PRESIDENTS AND THE PART ITUIORAL FEATURES OF THE PRESIDENCY THAT TRANSCEND PARTICULAR ADMINSTRATIONS. THE SUCCESS OF AN ADMINISTRATION LIES IN THE DEGREE TO WHICH THE THO MODELS CAN BE DRAHM IN THE DAY-TO-DAY WORK OF DEFINING AND FURTHERING THE PRESIDENT'S AGENDA. THE BOOK CONCLUDES HITH A DETAILED
COMPARISON OF THE CARTER AND REAGAN ADMINISTRATIONS. IT ALSO MAKES SOME PRELIMINARY OBSERVATIONS ABOUT GEORGE BUSH--WHO COMBINES "EISENHOWER'S MORE FORMAL PROCEDURES WITH KENNEDY'S INFORMAL COLLEGIAL STYLE."
01952 BURKE, L.

REPRESSION AND RESTITUITON: HONG KONG AND THE PRC JOUPAL JORNAL OF CONTEMPORARY ASIA, $22(2)$ (1992), 234-248.

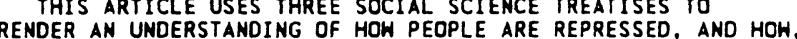
RENDER AN UNDERSTANDING OF HOW PEOPLE ARE REPRESSED, AND HOH,
CONYERSELY, THOSE PEOPLE CAN GAIN RESTITUTION. THE THREE WORKS PROVIDE INSIGHT INTO THE PROCESS BY HHICH GOVERNMENTS REPRESS CITIZENS. THEY ALSO OFFER ADVICE AS TO HOW PEOPLE CAN USE COUNTERVAILING ORGANIZATIONS TO ESCAPE, OR AT LEAST AMELIORATE, THE REPRESSION. IT DEMONSTRATES THAT POWER GRAVITATES TO "FICTITIOUS" ACTORS. THESE ACTORS ARE RULED BY AN OLIGARCHY. THE FEH PEOPLE WHO MAKE UP THAT OLIGARCHY SUBVERT THE GOALS OF THE ORGANIZATION AND REPLACE THEM WITH THE GOAL OF THE OLIGARCHY'S SURVIVAL. FOR THE OLIGARCHY TO SURVIVE, REPRESSION MAY BE NECESSARY. THE EXAMPLES OF THE IMPENDING CHANGE IN SOVEREIGNTY OF HONG KONG WHEN IT REVERTS TO THE PEOPLE'S REPUBLIC OF CHINA (PRC) AND THE MASSACRE IN TIANANMEN SQUARE ON 4 JUNE 1989 ARE USED TO INVESTIGATE SEVERAL CONCEPTS ADOUCED BY THE THREE THEORIES.

01953 BURKHALTER, H.

MOVING HUMAN RIGHTS TO CENTER STAGE

WORLD POLICY JOURNAL, IX(3) (SUM 92), 417-428.

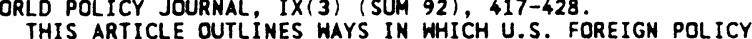

CAN GIVE GREATER WEIGHT TO HUMAN RIGHTS CONCERNS. THESE WAYS CANCLUDE: INITIATE AND VIGOROUSLY SUPPORT COOPERATIVE INCLUDE: INITIATE AND VIGOROUSLY SUPPORT COOPERATIVE CONFLICTS: MAKE GOOD ON FINANCIAL OBLIGATIONS TO THE UNITED NATIOUS AND ITS SPECIALIZED AGENCIES; USE AMERICAM AID AND NATIONS AND ITS SPECIALIZED AGENCIES; USE AMERICAN AID
TRADE AS A LEVER TO ENCOURAGE RESPECT FOR MUMAN RIGHTS; LIMIT THE SALE OF WEAPONS ABROAD, NORK FOR AN INTERNATIONAL BAN ON PARTICULARLY EGREGIOUS WEAPONS SUCH AS LAND MINES, AND DENOUNCE FOREIGN GOVERMMENTS THAT SELL ARMS TO ABUSIVE REGIMES; HONOR INTERNATIONAL OBLIGATIONS TO REFUGEES FL UNITED STATES AND LEAD INTERNATIONAL EFFORTS TO ASSIST THE WORLD'S 67 MILLION REFUGEES; LINK TRADE PRIVILEGES TO BENEFICIARY COUNTRIES' RESPECT FOR LABOR RIGHTS AND BUILD A LABOR RIGHTS "SOCIAL CONTRACT" INTO NEW TRADE ARRANGEMENTS; ISOLATE AND OSTRACIZE REPRESSIVE REGIMES, SHORE UP CIVILIAN AUTHORITY WHERE IT IS ENDANGERED BY THE MILITARY, AND SUPPORT HUMAN RIGHTS ACTIVISTS AND POLITICAL REFORMERS EVERYWHERE.

01954 BURKHALTER, $H$

THE BUSH ADMINISTRATION'S HUMAN RIGHTS RECORD

PEACE \& DEMOCRACY NEWS, 6(1) (WIN 92), 26-27.

IT HAS BEEN SUGGESTED BY U.S. MILITARY OFFICERS THAT THE UNITED STATE'S MILITARY ROLE IN LATIN AMERICA SHOULD BE,

GIVEN THE END OF THE COLO WAR TO ASSIST GOVERNMENTS IN GIVEN THE END OF THE COLD WAR TO ASSIST GOVERNMENTS IN IN DEFENSE AGAINST SUBVERSION. THIS ARTICLE ALSO EXPLORES IN DEFENSE AGAINST SUBVERSION. THIS ARTICLE ALSO EXPLORE THE MIXED RECORD IN KENYA AND ZAIRE, AND CHINA'S OUTLAW MEANT AN END TO THE UNITED STATES' INYOLVEMENT WITH WHOLLY MEANT AN END TO THE UNITED STATES INVOLYEM

01955 BURKI, S.J.

PAKISTAN'S CAUTIOUS DEMOCRATIC COURS

CURRENT HISTORY, 91(563) (MAR 92), 117-122.

PAKISTAN'S PRIME MINISTER MIAN' NAWAZ SHARIF HAS SHOWN HIMSELF ADEPT AT ALLAYING THE FEARS OF THE MILITARY AND AT REJUVENATING THE ECONOMY. BUT THE MILITARY REMAINS CONFIDEN OF ITS ABILITY TO SOLVE PAKISTAN'S PROBLEMS AND HAS CHOSEN TO STAY IN THE BACKGROUND FOR THE TIME BEING LARGELY DUE TO WESTERN IMPATIENCE WITH THE MILITARY LEADERSHIP.

01956 BURNELL, B.

THE EFFECT OF SCHOOL DISTRICT STRUCTURE ON EDUCATION SPENDING

PUBLIC CHOICE, 69(3) (MAR 91), 253-264.

THIS PAPER OEVELOPS A THEORETICAL AND EMPIRICAL MODEL OF LOCAL SPENDING ON EDUCATION THAT ANALYZES THE EFFECT OF INSTITUTIONAL STRUCTURE ON EDUCATION SPENDING. IT ATTEMPTS CONSISTENT WITH SCHOOL DISTRICT SPENDING DECISIONS BY TESTING THE HYPOTHESIS THAT THE NUMBER OF SCHOOL DISTRICTS IN A COUNTY HAS A NEGATIVE EFFECT ON PER PUPIL EXPENDITURES. THE RESULTS ARE NOT CONSISTENT WITH THE THEORY, BUT INDICATE THAT A FRAGMENTED SCHOOL DISTRICT STRUCTURE SERVES TO INCREASE EXPENDITURES.

01957 BURNELL, P.J.

THE STATUS OF POLITICS IN ST. AUGUSTINE'S CITY OF GOD HISTORY OF POLITICAL THOUGHT, XIII(1) (SPR 92), 13-30. THE TEXT OF "DE CIVITATE DEI" YIELDS A SUBTLE BUT CONSISTENT TREATMENT OF THE RELATIONSHIP BETWEEN POLITICS AND THE CHRISTIAN FAITH THE THO MAJOR QUESTIONS AT ISSUE ARE WHETHER CIVIL LIFE IS NATURAL AND WHAT ITS FUNCTION IS IN THIS WORLD (OR, TO PUT IT MORE THEOLOGICALLY--TO WHAT EXTENT THE POLITICAL ASPECT OF MAN'S NATURE. IF THERE IS ANY, HAS BEEN VITIATED BY THE FALL). IN APPROACHING AUGUSTINE'S POSITION ON THESE QUESTIONS, IT IS IMPORTANT TO BEAR TWO 
POLITICS TO CHRISTIANITY AND THE RELEVANCE OF CHRISTIANITY TO POLITICS; THE SECOND DISTINCTION IS BETWEEN SAYING THAT SOMETHING IS TRUE IN PRINCIPLE AND SAYING THAT IT IS

UNIVERSAL (EVEN NECESSARILY SO) IN PRACTICE.

01958 BURNHAM, P.

RE-EVALUATING THE WASHINGTON LOAN AGREEMENT: A REVISIONIST VIEW OF THE LIMITS OF POSTWAR AMERICAN POWER

REVIEW OF INTERNATIONAL STUDIES, 18(3) (JUL 92), 241-260. THE FINANCIAL AGREEMENT SIGNED BETWEEN THE GOVERNMENTS OF THE UNITED STATES AND THE UNITED KINGDOM ON THE GTH DECEMBER 1945 IS WIDELY INTERPRETED AS AN AGREEMENT WHICH IMPOSED FUNDAMENTAL CONSTRAINTS ON BRITISH EXTERNAL ECONOMIC IMPOSED FUNDAMENTAL CONSTRAINTS ON BRITISH EXTERNAL INTERNATIONAL RELATIONS SIGNALLING THE SUBORDINATION OF INTERNATIONAL RELATIONS SIGNALLING THE SUBORDINATION OF
BRITAIN TO THE LEVEL ALMOST OF A CLIENT STATE OF THE UNITED BRITAIN TO THE LEVEL ALMOST OF A CLIENT STATE OF THE UNITED
STATES. THIS ARTICLE OFFERS THE DETAILS OF THE AGREEMENT AND STATES. THIS ARTICLE OFFERS THE DETAILS OF THE AGREEMENT AND
ANALYZES ITS HISTORY. BY HIGHLIGHTING THE GAPS IN ORTHODOX ANALYZES ITS HISTORY. BY HIGHLIGHTING THE GAPS IN ORTH SUGGESTS THAT THERE IS A NEED FOR THE HISTORY OF THE POSTWAR INTERNATIONAL POLITICAL ECONOMY TO BE REWRITTEN.

01959 BURNIAUX, J.M.; WAELBROECK, J.

PRELIMINARY RESULTS OF THO EXPERIMENTAL MODELS OF GENERAL

EQUILIBRIUM WITH IMPERFECT COMPETITION

JOURNAL OF POLICY MODELING, 14(1) (FEB 92), 65-92.

TO ASSESS THE IMPACT OF THE EURDPEAN COMMUNITY'S 1992 INTEGRATION PROGRAM ON THE WORLD ECONOMY, THIS PAPER DESCRIBES EXPERIMENTS WITH TWO MODELS OF' GENERAL EQUILIBRIUM UNDER IMPERFECT COMPETITION. THE MODELS' DISTINGUISHING CHARACTERISTIC IS THAT THE 1992 PROGRAM IS NOT THOUGHT OF AS ELIMINATING MYSTERIOUS BARRIERS TO TRADE (ANALOGOUS TO TARIFFS) BUT AS MAKING COMPETITION MORE INTENSE (RAISING THE ELASTICITY OF DEMAND PERCEIVED BY PRODUCERS). THE MODEL PREDICTS THAT THE 1992 PROGRAM WILL CAUSE A LARGE REDISTRIBUTION OF INDUSTRIAL ACTIVITIES AMONG COUNTRIES. THE CALCULATED WELFARE GAINS, WHILE SUBSTANTIAL, ARE MUCH SMALLER THAN THOSE PRESENTED IN A WELL-KNOWM PAPER BY SMITH AND VENABLES.

01960 BURNS, N.E.

INSTITUTIONS AND SOCIAL MOVEMENTS: THE CASE OF COMPARABLE HORTH

INTERNATIONAL JOURNAL OF PUBLIC ADMINISTRATION, 14(5) 1991), 773-798.

EMPLOYING EVIDENCE FROM THE HISTORY OF THE COMPARABLE WORTH MOVEMENT, THE AUTHOR OF THIS ARTICLE ARGUES THAT: THE STATE-CIYIZEN SHAPING PROCESS IS ONE IN WHICH STATES SHAPE CITIZENS AND MOVEMENTS AND CITIZENS AND MOVEMENTS SHAPE STATES; STATES ARE NOT ALWAYS SUCCESSFUL IN SHAPING MOVEMENTS BECAUSE MOVEMENTS REQUIRE A CERTAIN LEVEL OF BOTH STAKES AND CONSCIOUSNESS ON THE PART OF POTENTIAL MEMBERS; STATES ARE MORE EFFECTIVE AT INFLUENCING WHETHER A MOVEMENT WILL WIN THAN THEY ARE AT ACTUALLY PRODUCING SOCIAL MOVEMENTS: AND THE COSTS AND BENEFITS ASSOCIATED HITH THE VARIOUS INSTITUTIONAL CHANNELS IMPACT HEAVILY UPON A MOVEMENT, PARTICULARLY UPON ITS ORGANIZATION AND ITS ALLIANCES. THESE THEORETICAL PROPOSITIONS PROVIDE CLUES AS TO WHY THE COMPARABLE WORTH MOVEMENT HAS BEEN ABLE TO PERSIST AT THE STATE AND LOCAL LEVEL DESPITE FEDERAL OPPOSITION.

01961 BURNS, W.F.

ARMS CONTROL CHALLENGES TO DEFENSE PLAMHING ANNALS OF THE AMERICAN ACADEMY OF POLITICAL AND SOCIAL SCIENCE, (517) (SEP 91), 135-145.

MILITARY PLANNERS AND STRATEGISTS REQUIRE NEH AND REFINED GUIDANCE TO MOVE INTO THE UNCHARTED POST-COLD WAR WATERS. THEY SHOULD CALL UPON THE RESOURCES PROVIDED BY ARMS
CONTROL INITIATIVES. ARMS CONTROL OFFERS THE OPPORTUNITY TO NEGOTIATE PARITY AT THE LOWEST PRACTICAL LEVELS ANO TO DEVELOP STRATEGIES AND FORCE STRUCTURES WITH A RELATIVELY HIGH ASSURANCE OF SUCCESS AGAINST POTENTIAL ENEMIES. THE STRATEGICANE OF SUCCESS AGAINST POTENTIAL ENEMIES. THE STRATEGIC ARMS REDUCTION TALKS, CONVENTIONAL FORCES IN
EUROPE, AND INTERMEDIATE-RANGE NUCLEAR FORCES TREATIES OFFER
UNIOUE, OPPORTUNITIES TO APPLY ARMS CONTROL AGREEMENTS TO UNIQUE OPPORTUNITIES TO APPLY ARMS CONTROL AGREEMENTS TO ENHANCE DEFENSE PLANNERS ' EFFORTS. FUTURE TREATIES SHOULD BE
SHAPED BY DEFENSE NEEDS AS HELL AS BY ARMS CONTROL THEORIES SHAPED BY DEFENSE NEEDS AS WELL AS BY
AND BROADER FOREIGN POLICY CONCERNS.

01962 BURRELL, B.

WOMEN CANDIDATES IN OPEN-SEAT PRIMARIES FOR THE U.S. HOUSE:

LEGISLATIVE STUDIES QUARTERLY, XVII(4) (NOV 92), 493-508.

THIS STUDY COMPARES THE PERFORMAMCE OF MALE AND FEMALE CANDIDATES IN OPEN-SEAT PRIMARY ELECTIONS FOR THE U.S. HOUSE OF REPRESENTATIVES FROM 1968 THROUGH 1990. FEMALE CANDIDATES THROUGHOUT THIS PERIOD TENDED TO DO AS HELL AS THEIR MALE COUNTERPARTS IN ACQUIRING VOTES AND WINNING OPEN-SEAT PRIMARIES. THEY WERE NOT APPRECIATIVELY OLDER THAN THEIR MALE CHALLENGERS, AND THEY HAD HAD EQUAL PRIOR EXPERIENCE IN PUBLIC OFFICE. THE FACT THAT HOMEN HOLD FEW SEATS IN THE HOUSE IS PRIMARILY DUE TO THE SCARCITY OF THEIR NUMBERS IN THESE RACES.
01963 BURRIS, V.; DIAMOND, $S$. ACADEMIC FREEDOM, CONSPICUOUS BENEVOLENCE, AND THE NATIONAL ASSOCIATION OF SCHOLARS

CRITICAL SOCIOLOGY, 18(3) (FAL 92), 125-142.

ASA PRESIDENT JAMES COLMAN HAS JOINED THE NATIONAL ASSOCIATION OF SCHOLARS (NAS) IN ITS CAMPAIGN AGAINST "POLITICAL CORRECTHESS" IN ACADEMIA. IN THIS ARTICLE THE AUTHORS EXAMINE THE ORIGINS OF THE NAS, ITS SOURCES OF THE NAS, IS PART OF A BROADER "NEOCONSERVATIVE" NETWORK AND ARGUE THAT THE ORGANIZATION, DESPITE ITS DECEPTIVE RHETORIC, POSES A SERIOUS THREAT TO ACADEMIC FREEDOM.

01964 BURT-WAY, B.J.; KELLY, R.M.

GENDER AND SUSTAINING POLITICAL AMBITION: A STUDY OF ARIZONA ELECTED OFFICIALS

WESTERN POLITICAL QUARTERLY, 45(1) (MAR 92), 11-26.

THIS STUDY OF LOCAL AND STATE ELECTED OFFICIALS IN ARIZONA EXAMINES HOW GENDER RELATES TO SOCIOPOLITICAL STATUS AND POLITICAL OPPORTUNITY EXPLANATIONS OF POLITICAL AMBITION. IT ALSO IDENTIFIES GENDER DIFFERENCES IN BELIEFS ABOUT BARRIERS TO POLITICAL OPPORTUNITY AND ABOUT HOW ELECTORAL SUCCESS OCCURS. THE DATA SUGGEST THAT THE FEMALE BELIEF STRUCTURE ABOUT ELECTORAL SUCCESS SUSTAINS FEMALE AMBITION FOR ELECTIVE OFFICE IN A MANNER DIFFERENT FROM MEN. THE AUTHORS PROPOSE AN EXPLANATION FOR WHY WOMEN SUSTAIN POLITICAL AMBITION EVEN THOUGH THE PREVAILING MALE-BASED MODEL OF POL ITICAL AMBITION SUGGESTS THAT WOMEN WILL NOT BE AMBITIOUS OR SUCCESSFUL.

01965 BURT, J.

FACADE OF DEMOCRACY CRUMBLES

REPORT ON THE AMERICAS, 26 (1) ( JUL 92), 3-6.

GIVEN SHINING PATH'S ADVANCE IN THE CITIES

DISINTEGRATING STATE INSTITUTIONS AND A PROSTRATE ECONOMY,

IF ANY COUNTRY IN SOUTH AMERICA SEEMED RIPE FOR A COUP, IT WAS PERU. AFTER CONGRESS THHARTED HIS ATTEMPTS TO LEGISLATE AUTHORITARIANISM WITH A FACADE OF DEMOCRATIC RULE, PRESIDENT FUJIMORI CLOSED CONGRESS AND THE JUDICAIRY IN A SELF INFLICTED PRESIOENTIAL COUP. WITH THE LINES CLEARLY DRAWN, INFLICTED PRESIDENTIAL COUP. WITH THE LINES CLEARLY DRAWN,
AND DEMOCRATIC ALTERNATIVES SUFFOCATED BY THE COUP, SHINING AND DEMOCRATIC ALTERNATIVES SUFFOCATED
PATH'S BRUTAL LOGIC CAN ONLY FLOURISH.

01966 BURTLESS, G.

WHEN WORK DOESN'T HORK: EMPLOYMENT PROGRAMS FOR WELFARE RHEN WORK

BROOKINGS REVIEW, 10(2) (SPR 92), 26-29.

THE FAMILY SUPPORT ACT OF 1988 OBLIGATES STATE

GOVERMMENTS TO TRANSFORM AFDC FROM AN INCOME-MAINTENANCE PROGRAM INTO A JOBS PROGRAM. SINGLE PARENTS ON WELFARE WHOSE CHILDREN ARE AT LEAST FOUR-YEARS-OLD MUST FIND REGULAR WORK. IF THEY CANNOT, THEY MUST ENROLL IN EDUCATIONAL OR JOB TRAINING PROGRAMS AND EVENTUALLY IN A STATE-ORGANIZED EMPLOYMENT PROGRAM. UNFORTUNATELY, THE LAW AUTHORIZES ONLY \$3.3 BILLION IN NEW SPENDING OVER A FIVE-YEAR PERIOD, AND THIS IS NOT ENOUGH MONEY TO DO THE JOB. MOREOVER, THE SEDUCTIVE DOUBLE PROMISE BEHIND HORK AND TRAINING PROGRAMS IS BASED ON AN ILLUSION. IT IS NEARLY IMPOSSIBLE FOR A WORK PROGRAM TO SIMULTANEOUSLY RAISE THE LIVING STANDARDS OF FAMILIES HHO DEPEND ON PUBLIC TRANSFERS AND BOOST THE NET INCOMES OF TAXPAYERS WHO PAY THE DIRECT COSTS OF THE PROGRAM AS WELL AS THE BILL FOR AFDC BENEFITS. PROGRAMS THAT DRAMATICALLY RAISE THE WELL-BEING OF DISADVANTAGED SINGLE MOTHERS ARE NOT CHEAP: THEY COST TAXPAYERS MONEY. PROGRAMS THAT TANGIBLY REDUCE WELFARE OUTLAYS, AND THUS LOWER PUBLIC SPENDING, OFTEN REDUCE THE NET INCOMES AND WELL-BEING OF THE POOR.

01967 BUSCH, A.

IN DEFENSE OF THE "MIXED" SYSTEM: THE GOLDWATER CAMPAIGN \& IN DEFENSE OF THE "MIXED" SYSTEM: THE GOLDWATER CAMPAIGN \&
THE ROLE OF POPULAR MOVEMENTS IN THE PRE-REFORM NOMINATION PROCESS

POLITY, 24(4) (SUM 92), 527-550.

THIS ARTICLE EXAMINES WHETHER THE MIXED SYSTEM HELPED OR HINDERED THE GOLDHATER CANDIDACY. THE AUTHOR CONCLUDES THAT THE MIXED SYSTEM WAS MORE OPEN TO POPULAR MOVEMENTS THAN HAS THE MIXED SYSTEM WAS MORE OPEN TO POPULAR MOVEMENTS THAN HAS
OFTEN BEEN ASSUMED AND, IRONICALLY, THAT THE REFORMED SYSTEM, OFTEN BEEN ASSUMED AND, IRONICALLY, THAT THE REFORMED SYSTEM,
BY DISTANCING THE PARTY FROM THE NOMINATING PROCESS, MAY BY DISTANCING THE PARTY FROM THE NOMINATING PROCESS,
HAYE MADE IT MORE DIFFICULT FOR MOVEMENTS TO WIN AND HAYE MADE IT MORE DIFFICULT
CONSOLIDATE THEIR POSITION.

01968 BUSCHE, J.

ABORTION LAW REFORM: AGREEMENT AT LAST

GERMAN TRIBUNE, (1522) (JUL 92), 3

IN AN ALL-DAY AND LATE-NIGHT' SESSION THE BUNDESTAG (GERMANY'S PARL AMENT) REACHED AGREEMENT ON ABORTION LAH REFORM. AGREEMENT WAS NEEDED BECAUSE ABORTION LAW DIFFERED IN THE TWO HALVES OF GERMANY AND A COMPROMISE HAS NEEDED. 355 MPS. INCLUDING 32 CHRISTIAN DEMOCRATS, VOTED FOR THE WOMAN'S RIGHT TO DECIDE (HITHIN 12 WEEKS OF CONCEPTION), WHILE 283 MPS VOTED AGAINST AND 126 ABSTAINED. VIEWS DIFFERED IN ALL PARTIES, BUT ALL SEEMED PLEASED WITH THE OUTCOME. ONE REASON FOR THE GENERAL SATISFACTION IS THAT THE 
LAW REFORM WILL ACTUALLY CHANGE VERY LITTLE IN GERMAN PRACTICE. THEREFORE NEARLY EVERYONE FELT CONVINCED THAT THEY DID THEIR BEST--EITHER TO ACHIEVE THE SOLU
OR TO PREVENT EVEN WORSE FROM HAPPENING.

01969 BUSCHE, J.

CLAMPDOWN ON NEO-NAZIS FOLLOWS DEATHS IN FIRE-BOMB ATTACK GERMAN TRIBUNE, 31(1543) (DEC 92), 1-2.

THE GERMAN INTERIOR MINISTER HAS BANNED ONE NEO-NAZI

GROUP. THE NATIONALISTIC FRONT AND SAYS THAT MORE EXTREMERIGHT HING GROUPS ARE TO FOLLOH. THE DECISION COMES AFTER NEO-NAZI ATTACKS IN WHICH THREE TURKS, THO OF THEM CHILDREN, WERE BURNED TO DEATH. THE INTERIOR MINISTER ALSO INTENDS WI THDRAWING FREE-SPEECH RIGHTS FOR NEO-NAZI GROUPS.

01970 BUSH, $D$.

WOMEN'S MOVEMENTS AND STATE POLICY REFORM AIMED AT DOMESTIC VIOLENCE AGAINST WOMEN: A COMPARISON OF THE CONSEQUENCES OF MOVEMENT MOBILIZATION IN THE U.S. AND INDIA CONSEQUENCES OF MOVEMENT MOBIL)
GENDER AND SOCIETY, 6(4) (DEC 92 ), 587-608.

THIS ARTICLE COMPARES THE SOCIAL MOVEMENT MOBILIZATION THAT LED TO REFORMS IN POLICE AMD JUDICIAL HAMDLING OF THAT LED TO REFORMS IN POLICE AMD JUDICIAL HANDLING OF BATTERING IN THE UNITED STATES TO THE MOVEMENT IDEOLOGY,
ORGANIZATION, AND TACTICS THAT RESULTED IN ANALOGOUS POLICY REFORM IN THE PROCESSING OF DOWRY BURNINGS AND BEATING IN REFORM IN THE PROCESSING OF DOWRY BURNINGS AND BEATING IN INDIA. USING FIELD NOTES AND SECONDARY SOURCES FROM BOTH COUNTRIES, THE ARTICLE EXAMINES HOW BOTH MOVLMENTS REDEFIC ISSUE, THEN VIOLENCE AGAINST WOMEN IN FAMILIES AS A PUBLIC ISSUE, THEN LOOKS AT HOW MOVEMENT DEMANDS AFFECTED POLICY

CONCEPTUALIZATION OF SOCIAL MOVEMENT SUCCESS. SOCIAL MOVEMENTS THEORY ASSUMES THAT ENTRY INTO THE POLITY OF LIBERAL, DEMOCRATIC STATES CONSTITUTES SUCCESS IN THE SENSE OF SOCIAL CHANGE. YET THE CASES ANALYZED SUGGEST THAT ASSUMPTIONS ABOUT THE GENDER NEUTRALITY OF STATE RESPONSE TO MOVEMENTS PREVENTS RESEARCHERS FROM CRITICALLY EXAMINING THE OUTCOMES OF SOCIAL MOVEMENT MOBILIZATION. MOREOVER, INSTITUTIONALIZATION OF HOMEN'S MOVEMENT DEMANDS AND ORGANIZATION MAY DIMINISH THE CAPACITY OF SUCH MOVEMENTS TO CONTROL THE SOCIAL CONSTRUCTION OF DOMESTIC VIOLENCE AGAINST HOMEN BY PROVIDING PROTECTION WITHOUT EMPOWERMENT.

01971 BUSH, G.

CONVENTION MOMINATION ACCEPTANCE SPEECHES: GEORGE BUSH CONGRESSIONAL DIGEST, $71(10)$ (OCT 92), 213,233 THIS ARTICLE CONTAINS EXCERPTS FROM THE SPEECH DELIVERED BY GEORGE BUSH ON AUGUST 22, 1992, WHEN HE ACCEPTED THE REPUBLICAN PARTY'S NOMINATION FOR' PRESIDENT.

01972 BUSH, G.

THE STATE OF THE UNION ADDRESS

CONGRESSIONAL DIGEST 71(3) (MAR 92), 65-66.

ON JANUARY 28,1992 , PRESIDENT GEORGE BUSH DELIVERED HIS ON JANUARY 28, 1992 , PRESIDENT GEORGE BUSH DELIVERED STATE OF THE UNION ADORESS TO CONGRESS AND THE AMERICAN
PEOPLE. THIS ARTICLE CONTAINS EXCERPTS FROM THE SPEECH, PEOPLE. THIS ARTICLE CONTAINS EXCERPTS FROM THE SPEECH,
INCLUDING BUSH'S STATEMENTS ON DEFENSE SPENDING, THE ECONOMY, AND TAXES

01973 BUSH, K.

COMMONWEALTH OF INDEPENDENT STATES: FOREIGN INDEBTEDNESS

RFE/RL RESEARCH REPORT, 1 (2) (JAN 92), 20-22.

THE COMMONWEALTH OF INDEPENDENT STATES IS EXPECTED TO ATTEMPT TO REPAY IN FULL THE CONVERTIBLE-CURRENCY DEBT INCURRED BY THE FORMER SOVIET UNION. IN FACT, RECEIVING FURTHER CREDITS FROM THE WEST IS LIKELY TO BE CONDITIONAL UPON SUCH A COMMITMENT. BUT THE EXTENT OF THIS INDEBTNESS IS NOT CLEAR. THIS ARTICLE OFFERS AN ESTIMATE OF THE OUTSTANDING DEBT. AS WELL AS SOME OBSERVATIONS ON THE ABILITY OF THE COMMONWEALTH TO SERVICE THIS DEBT IN THE SHORT-TERM.

01974 BUSH, K.

LITTLE PROGRESS REGISTERED TOWARD ECONOMIC INTEGRATION RFE/RL RESEARCH REPORT, 1(8) (FEB 92), 14-16.

THE RESULTS OF THE TWO SUMIT MEETIMGS OF THE COMMONWEALTH OF INDEPENDENT STATES IN FEBRUARY 1992 REFLECTED MODEST AND FALTERING PROGRESS IN ESTABLISHING A VIABLE ECONOMIC FRAMEHORK FOR THE CIS. HOWEVER, THE PARTIES DID REACH FORMAL AGREEMENTS ON ECONOMIC COORDINATION, DID REACH FORMAL AGREEMENTS ON ECONOMIC COORDINATION, COOPERATION, ECOLOGY, GOODS TRAFFIC, AND TRANSPORTATION COOPERATION, ECOLOGY, GOODS TRAFFIC, AND TRANSPORTATION TARIFFS. ON THE OTHER HAND, THERE HAVE BEEN SOME STEPS BACKWARD, IN PARTICULAR THE ERECTION OF INTERNAL TRAOE BARRIERS. GIVEN THE DISSIMILARITY OF THE STATES INVOLVED, MORE RAPID
IMPOSSIBLE.

01975 BUSH, K.

RUSSIA: GAIDAR'S GUIDELINES

RFE/RL RESEARCH REPORT, 1(15) (APR 92), 22-25

THE EXECUTIVE BOARD OF THE INTERNATIONAL MONETARY FUND HAS GIVEN A QUALIFIED ENDORSEMENT TO THE ECONOMIC REFORM PRDGRAM DRAHN UP BY THE RUSSIAN FIRST DEPUTY PRIME MINISTER, EGOR GAIDAR. ITS PRIMARY AIMS ARE TO BALANCE THE BUDGET,
REDUCE INFLATION, HALT THE FREE FALL IN OUTPUT, AND IMPROVE THE COUNTRY'S FOREIGN TRADE POSTURE. BUT SOME OF THE PROGRAM'S PROVISIONS ARE UNREALISTIC.

01976 BUSH, K.

RUSSIA'S LATEST PROGRAM FOR MILITARY CONVERSION RFE/RL RESEARCH REPORT, 1(35) (SEP 92), 32-35.

IN JULY 1992, ACTIMG PRIME MINISTER' EGOR GAIDAR PRESENTED THE DRAFT OF THE PROGRAM FOR THE SECOND STAGE OF ECONOMIC REFORM TO THE RUSSIAN SUPREME SOVIET. THE SECTION DEALING WITH THE CONVERSION OF RUSSIA'S DEFENSE INDUSTRY FAILS TO ADDRESS THE PRINCIPAL HEAKNESSES OF PREVIOUS CONVERSION PROGRAMS.

01977 BUSH, K.

RUSSIAN PRIVATIZATION PROGRAM ACCELERATEO

RFE/RL RESEARCH REPORT, $1(30)$ (JUL 92), 43-45.

ALTHOUGH THE PROVISIONS OF THE DECEMBER 1991

PRIVATIZATION PROGRAM HAVE NOT BEEN FULLY ELABORATED OR

ENACTED, MUCH LESS IMPLEMENTED, THE RUSSIAN GOVERMMENT HAS

UNVEILED A NEW AND EVEN MORE AMBITIOUS PLAN FOR SMALL- AND

LARGE-SCALE PRIVATIZATION.

01978 BUSH, K.

THE DISASTROUS LAST YEAR OF THE USSR

RFE/RL RESEARCH REPORT, 1(12) (MAR 92), 39-41.

THE USSR STATE COMMITTEE FOR STATISTICS' REPORT ON ECONOMIC PERFORMAMCE DURING THE LAST YEAR OF THE SOVIET UNION'S EXISTENCE PORTRAYS A DISINTEGRATING ECONOMY ENTERING A MAJOR RECESSION AND PERHAPS EVEN A DEPRESSION. THIS ART HAR RECESI COMPARABLE SALIENT IMDICATORS FOR THE PRECEDING DEBATE AND OBSERVATIONS ON THE IMMEDIATE PROSPECTS FOR THE CIS ECONOMY.

01979 BUSH, K

THE RUSSIAN BUDGET DEFICIT

RFE/RL RESEARCH REPORT, 1(40) (OCT 92), 30-32

ACHIEVING A BALANCED OR NEARLY-BALANCED BUDGET HAS BEEN A KEY GOAL FOR FIRST DEPUTY PRIME MINISTER EGOR GAIDAR'S ECONOMIC STABILIZATION PROGRAM, BUT THIS GOAL NOW APPEARS TO HAVE BEEN ABANDONED.

01980 BUSH, M.

CONFLICT OF INTEREST: THE CASE FOR A WRITTEN CODE OF ETHICAL CONDUCT IN THE CAYMAN ISLANDS

PARLIAMENTARIAN, LXXIII(2) (APR 92), 119-120.

THE AUTHOR EXPLAINS THE SPECIAL PROBLEMS INHERENT IN

DRAWING UP A WRITTEN CODE OF ETHICAL CONDUCT FOR

PARLIAMENTARIANS IN A SMALL COMMUNITY, SUCH AS THE CAYMAN

ISLANDS.

01981 BUSIA, N.K.A.

IMPROYIMG HUMAN RIGHTS

HEST AFRICA, (3917) (OCT 92), 1713-1714.

ALTHOUGH' THE PROTECTION OF HUMAN RIGHTS IS AN ISSUE OF INTERNATIONAL CONCERM, IT IS BECOMING INCREASINGLY CLEAR THAT THE MOST EFFECTIVE WAY OF IMPIEMENTING HUMAN RIGHTS

NORMS IS ON A REGIONAL BASIS. THE CENTRALITY OF THE REGIONAL

SYSTEM IN THE PROTECTION OF HUMAN RIGHTS IS EVIDENCED BY THE ADOPTION OF THE AFRICAN CHA
BY THE OAU MEMBER STATES.

01982 BUSTAMANTE, F.

ECUADOR: PUTTTING AN END TO THE GHOSTS OF THE PAST?

JOURNAL OF INTERAMERICAN STUDIES AND WORLD AFFAIRS, $34(4)$ (WIN 92), 195-224.

THE MAJOR ISSUES OF THE FOREIGN POLICY AGENDA OF EDUADOR IN 1991 ARE DETAILED IN THIS ARTICLE. MULTILATERALISM, REGIONAL PEACEKEEPING ANO CONTROL OF NATIONAL CONFLICT SHARPENED BY THE FALL OF THE SOCIALIST BLOC, DEMOCRACY AND HUMAN RIGHTS, PEACE AND RECONCILIATION IN CENTRAL AMERICA, PROMOTION OF A NEW INTERNATIONAL ORDER BASED ON ETHICS, ENVIRONMENT, ILLEGAL DRUG TRAFFIC AND INTEGRATIONISM ARE EACH EXPLORED. THE NEW STAGE IN THE ECUADOR-PERU AMAZON CONFLICT AND OTHER ISSUES ON ECUADOR'S FOREIGN POLICY AGENDA ROUND OUT THIS DISCUSSION OF THE POLITICAL CLIMATE IN ECUADOR.

01983 BUSZYNSKI, L. SOUTHEAST ASIA IN THE POST-COLD HAR ERA: REGIONALISM AND SECURITY

ASIAN SURYEY, XXXII(9) (SEP 92), 830-847

THE ASSOCIATION OF SOUTHEAST ASIAN MATIONS (ASEAM) HAS BEEN A SUCCESSFUL EXAMPLE OF REGIONALISM. HOWEVER, THE FUTURE DIRECTION OF REGIONAL ORGANIZATION IN SOUTHEAST ASIA FUTURE DIRECTION OF REGIONAL ORGANIZATION IN SOUTHEAST ASI HAS BEEN STRONGLY DEBATED SINCE THE TERMINATION OF THE CAMBODIAN CONFLICT AND THE COLD WAR. THE ASEAN COUNTRIES REALIZE THAT THEIR ORGANIZATION IS AN INADEQUATE INSTRUMENT TO MEET THE NEW DEMANDS THAT ARE A PRODUC OF REG TONAL AND GLOBAL CHANGE. THE CHALLENGE THAT ASEAN FACES IS TO BECOME RELEVANT TO CHANGING CONDITIONS AND YO PROVIDE ITS MEMBERS WITH THE ENHANCED BENEFITS OF COLLECTIVE POLITICAL SECURITY
AND SUPPORT. THIS ARTICLE EXAMINES THE PRESENT STRUCTURE OF ASEAN AND THE FUTURE CHALLENGES POSED BY QUESTIONS OF 
EXPANSION OF MEMBERSHIP AND NEW SECURITY FUNCTIONS. IT CONSIDERS THE FUTURE OF ASEAN'S RELATIONS WITH CHINA, JAPAN, AND THE UNITED STATES. IT CONCLUDES THAT AN EXTENSIVE REGIONAL STRUCTURE THAT INVOLVES CHINA, JAPAN, AND THE REGIONAL STRUCTURE THAT INVOLVES CHINA, JAPAN, AND THE UNITED STATES WOULD REDUCE THE DILEMHAS THAT THE ASEAN CONSEQUENCES OF GREAT POWER ACTIONS.

01984 BUTENSCHON, N.A. THE FRONTIER STATE AT WORK: MODELS OF CONTEMPORARY ISRAELI THE FRONTIER STA STATE-BUILDING

JOURNAL OF THEORETICAL POLITICS, 4(4) (OCT 92), 413-433.

THE CURRENT CONFLICT OVER THE ISRAELI-OCCUPIED TERRITORIES IS INTIMATELY RELATED TO THE CHARACTER OF ISRAEL AS A STATE FORMATION. THE AUTHOR DISCUSSES THE SIGNIFICANCE OF THE OCCUPATION FOR ALTERNATIVE INTERPRETATIONS OF ISRAELI STATE-BUILOING PATTERNS. HE CONCLUDES THAT THESE PATTERNS ARE BEST UNDERSTOOD IF STUDIED WITHIN "THE FRONTIER PERSPECTIVE."

01985 BUTLER, D.; MORTIMER, R.

A LEVEL PLAYING FIELD FOR BRITISH ELECTIONS?

PARL IAMENTARY AFFAIRS, 45(2) (APR 92) 164-172

BRITISH ELECTIONS HAVE BEEN TRANSFORMED IN THE LAST

FORTY YEARS. HOWEYER, THE REVOLUTION IN THE NATURE OF

CAMPAIGNING HAS NOT BEEN MATCHED BY AN SIGNIFICANT CHANGE IN THE LAHS GOVERHING ELECTIONS. ALTHOUGH STUDIES OF PARTICULAR ASPECTS OF THE ELECTORAL PROCESS HAVE BEEN PLENTIFUL, ASPECTS OF THE ELECTORAL PROCESS HAVE BEEN PLENTIFUL, ADMINISTRATIVE REFORM HAVE BEEN SCARCE. A RECOGNITION OF THIS LED THE HANSARD SOCIETY TO SPONSOR A COMMISSION THAT WOULD EXAMINE HOW FAR CONTEMPORARY BRITISH ELECTIONS ARE CONDUCTED ON LEVEL PLAYING FIELDS AND TO EXPLORE WHETHER ANY FUNDAMENTAL REFORMS IN LAW OR PRACTICE WERE CALLED FOR. THE
CONCLUSION IS DRAWN THAT THE WHOLE PROCESS WOULD BENEFIT CONSIDERABLY FROM THE EXISTENCE OF AN ELECTORAL COMMISSION LEVEL OF CENTRALLY-CONTROLLED FUNDING.

01986 BUTLER, D.

THE CHATAHAY COMMISSION

ELECTORAL STUDIES, 11(1) (MAR 92), 70-71.

IN GREAT BRITAIN, THE LAWS CONCERNING ADMINISTRATION AND FAIR PLAY IN ELECTIONS HAVE CHANGED LITTLE SINCE 1918. THIS ARTICLE BRIEFLY DISCUSSES THE FINDINGS OF THE CHATAHAY COMMISSION, AN INVESTIGATION WHICH SUGGESTS MUCH-NEEDED REFORMS OF' THE BRITISH ELECTORAL SYSTEM. THE RECOMMENDATIONS OF THE COMMISSION INCLUDE: THE RIGHT TO VOTE SHOULD BE EXTENDED TO ALL NON-BRITISH EUROPEAN COMMUNITY CITIZENS SUBJECT TO FOUR YEARS' RESIDENCE IN THE UNITED KINGDOM; THE PERIOO DURING HICH A BRITISH CITIZEN ABROAD CAN VOTE SHOULO BE REDUCED FROM THENTY YEARS TO SEVEN; PARLIAMENTARY CONSTITUENCIES SHOULD BE BASED ON A UNIFORM ELECTORAL QUOTA, ENDING THE OVER-REPRESENTATION OF SCOTLAND AND HALES: AN ELECTORAL COMMISSION SHOULD TAKE OVER FROM THE FOUR CURRENT BOUNDARY COMMISSIONS. FIXED TERM PARLIAMENTS SHOULD BE THE NORM; AND POSTAL VOTING SHOULD BE GREATLY EXTENDED.

01987 BUTLER, H.

EUROPEAN UNION WITH A QUESTION MARK

SWISS REVIEH OF WORLD AFFAIRS, $42(4)$ ( JUL 92), 4-5.

SHISS REVIEH OF WORLD AFFAIRS, 42 (4) (JUL 92 ), $4-5$. CONSTERMATION HAVE BEEN CREATED BY DENMARK'S "NO" VOTE ON

CONSTERNATION HAVE BEEN CREATED BY DENMARK'S "NO" VOTE ON FUTURE OF EUROPEAN UNION SOMEWHAT LESS CLEAR AND MORE QUESTIONABLE THAN IT HAS BEFORE.

01988 BUTLER, J.S.

AFFIRMATIVE ACTION IN THE MILITARY

AMMALS OF THE AMERICAH ACADEMY OFAROLITICAL AMD SOCIAL SCIENCE, (523) (SEP 92), 196-206.

AFRICAN AMERICANS HAYE FOUGHT IN U.S. CONFLICTS SINCE COLONIAL DAYS, BUT THE SEGREGATION PRACTICED IN THE MILITARY DURING THE CIVIL WAR ENDURED UNTIL 1948. SINCE THE ALLVOLUNTEER FORCE WAS ESTABLISHED IN 1973, THE NUMBER OF HAS RISEN. DESEGREGATION AND AFFIRMATIVE ACTION IN THE MILITARY HAVE BEEN YEARS AHEAD OF THAT IN CIVILIAN SOCIETY. CURRENT POLICY SEEKS TO INCREASE THE ENLISTMENT OF HHITES AND TO ENSURE EQUAL TREATMENT AND OPPORTUNITY AS WELL AS GOOD RACE RELATIONS.

01989 BUTLER, M.

DEMOCRATIC LEGACY: THE MARCH TO NATIONHOOD ALONG A PARL I AMENTARY PATH

PARLIAMENTARIAN, LXXIII(3) ( JUL 92), 171-173.

THE AUTHOR BRIEFLY REVIEHS THREE CENTURIES OF BAHAMIAN PARLIAMENTARY HISTORY AND DISCUSSES THE CONTINUING EVOLUTION OF THE BAHAMIAN PARLIAMENT TODAY.

01990 BUTLER, H.E.

BUTLER, W.E. USE DRAFT USSR FUNDAMENTAL PRINCIPLES OF CRIMINAL LEGISLATION

COEXISTENCE, 28(1) (MAR 91), 159-196.

THIS ARTICLE EXPLORES HOH THE DEVELOPMENT OF A SOCIALIST
RULE-OF-LAW STATE IS LINED WITH THE STRENGTHENING OF THE LEGAL BASIS OF STATE AND SOCIAL LIFE IN THE USSR. THE AUTHOR ARGUES THAT THE CRIMINAL LEGISLATION OF THE USSR AND THE REPUBLICS FURTHERS THE IMPLEMENTATION OF THE PRINCIPLES OF SOCIAL JUSTICE.

01991 BUTORA, M.; BUTOROVA, Z.; ROSOVA, T. THE HARD BIRTH OF DEMOCRACY IN SLOVAKIA: THE EIGHTEEN MONTHS FOLLOWING THE \$TENDER' REVOLUTION

JOURNAL OF COMMUNIST STUDIES, $7(4)$ (DEC 91), 453-476. THE EIGHTEEN MONTHS SINCE THE COLLAPSE OF COMMUNIST RULE THE EIGHTEEN MONTHS SINCE THE COLLAPSE OF COMMUNIST RUL IN SLOVAKIA SAN SWINGS IN PUETS LIBERAL, CHRISTIAN AND EMERGENT PARTIES AND MOVEMENTS, LIBERAL, CHRISTIAN AND NATIONALIST. SINCE THE JUNE 1990 ELECTION A MORE INWARDLOOKING AND DEFENSIVE NATIONAL MT THE EXPENSE OF THE MORE OUTHARD-LOOKING, STRENGTH AT THE EXPENSE OF THE MORE OUTHARD-LOCKING, PLURALISTIC TRADITION REPRESENTED BY THE PUBLIC AGAINST VIOLENCE WHICH REMAINS THE ONE MOVEMENT IN SLOVAKIA UNEQUI YOCALLY COMMITTED TO THE MIND OF FEDERAL

CONSTITUTIONAL SETTLEMENT PREFERRED BY THE CZECHS AND TO RADICAL ECONOMIC REFORM. THE CONSTRUCTION OF A NEN ORDER IN SLOVAKIA DEPENDS ON CREATION OF A BALANCE BETWEEN VARIOUS FORCES FAVORABLE TO REFORM.

01992 BUTORA, M.; BUTOROVA, Z.

THE UNWANTED DIVORCE

FREEDOM REVIEH, 23(6) (NOV 92), 20-23.

THE AUTHORS ARGUE THAT THE BREAKUP OF CZECHOSLOVAKIA IS BOTH UNCONSTITUTIONAL AND CONTRARY TO THE WISHES OF THE PEOPLE. DESPITE POPULAR SENTIMENT AGAINST THE DISSOLUTION OF CZECHOSLOVAKIA, THE LEADERS REFUSE TO HOLO A REFERENDUM ON THE QUESTION, GIVING ORDINARY CITIZENS NO VOICE IN THE MATTER.

01993 BUTOROVA, Z.

THE HARD BIRTH OF OEMOCRACY IN SLOVAKIA

THE HARD BIRT EUROPEAN REPORTER, 5(1) (JAN 92), 62-66.

THT EUROPEAN REPORTER, SI 1) INAN 92 1 , 62-66.' CONSTITUTIONAL FUTURE GREW MORE INTENSE. BY THE END OF THE YEAR, WITH NUMEROUS TALKS AMONG FEDERAL AND REPUBLICAN YEAR, WITH NUMEROUS TALKS AMONG FEDERAL AND REPUBLICAM
LEADERS FAILING TO DECIDE THE BASIC ISSUE OF WHETHER LEADERS FAILING TO DECIDE THE BASIC ISSUE OF WHETHER CZECHOSLOVAKIA SHOULD BE A FEDERAL OR COFEDERAL STATE, AND WITH PRESIDENT HAVEL S INITIATIVE TO RESOLVE THE DEADLOCK THROUGH A REFERENDUM ALSO UNSUCCESSFUL, A STALEMATE HAD BEEN REACHED AND THE ONLY WAY OUT APPEARED TO BE THE COUNTRY'S BREAK-UP. IF THIS HAPPENS, IT WILL BE AGAINST THE HIS MOST CZECHS AND SLOVAKS, WHO HAVE IN OPINION POLLS REPEATEDLY AFFIRMED THEIR SUPPORT FOR THE COMMON STAT SLOVAKIA ITSELF, HOWEVER, MAJORITY BACKING FOR THE CONTINUATION OF CZECHOSLOVAKIA HAS NOT PREVENTED THE NATIONAL UNION FROM BECOMING THE MOST POPULAR IN THE REPUBLIC. MANY COMMENTATORS HAVE CONCLUDED THAT THE CRISIS FACING THE COUNTRY IS THE RESULT LESS OF DISAGREEMENTS BETWEEN CZECHS AND SLOVAKS THAN OF A CRISIS IN SLOVAK POLITICS. NONETHELESS, GROUNDS FOR RESENTMENT AMONG SLOVAKS AND CZECHS ARE UNDOUBTEDLY BASED PARTLY ON HISTORICAL GRIEVANCES AND PARTLY ON MORE RECENT CONCERNS ABOUT THE IMPACT OF A UNION ON SLOVAKIA'S ECONONY. THE REAL QUESTION WOULD ALLOW THESE MISGIVINGS TO BE ARTICULATED IN A DEMOCRATIC WAY.

01994 BUTSCHER, M.

HARD ROAD TO DEMOCRACY

WEST AFRICA, (3885) (MAR 92), 373-374.

SIERRA LEONEANS ARE AHAITING THE PUBLICATION OF THE TIMETABLE FOR THE PRESIDENTIAL ANO GENERAL ELECTIONS, WHICH

WILL BE HELD BEFORE THE END OF 1992. SEVEN POLITICAL PARTIES,

WILL BE HELD BEFORE THE END OF 1992. SEVEN POLITICAL PARTIES,
INCLUDING THE RULING ALL PEOPLES CONGRESS (APC), HAVE BEEN

INCLUDING THE RULING ALL PEOPLES CONGRESS (APC), HAVE
REGISTERED FOR THE UPCOMING ELECTIONS. SOME OBSERVERS

REGISTERED FOR THE UPCOMING ELECTIONS. SOME OBSERVERS
PREDICT THAT THE APC WILL WIN THE ELECTIONS SIMPLY BECAUSE

OF OPPOSITION WEAKNESS.

01995 BUTSCHER, M

HERCULEAM TASKS AHEAD

WEST AFRICA, (3878) (JAN 92), 66

THE AUTHOR REYIEWS THE DRAMATIC POLITICAL CHANGES THAT

OCCURRED IN SIERRA LEONE IN 1991.

01996 BUTSCHER, M.

PEACE BEFORE ELECTIONS?

PEACE BEFORE ELECTIONS? 92), 241.

THE WASHINGTON-BASED INTERNATIONAL FOUNDATION FOR

ELECTORAL SYSTEMS HAS PUBLISHED ITS RECOMMENDATIONS FOR

REFORMING THE SIERRA LEONE ELECTORAL PROCESS. ITS MAIN

RECOMMENDATIONS INCLUDE RE-REGISTERING VOTERS BECAUSE THE

CURRENT ROLLS ARE INFLATED WITH FICTITIDUS NAMES, SEPARATING

THE ELECTORAL COMMISSION FROM THE MINISTRY OF INTERNAL

AFFAIRS, AND EDUCATING THE MASSES ON THE DEMOCRATIZATION

PROCESS AND ITS SIGNIFICANCE.

01997 BUTSCHER, M.

TEST FOR DEMOCRACY 
WEST AFRICA, (3892) (APR 92), 676-677.

ON APRIL 2,1992, GUINEA'S MILITARY PRESIDENT LANSANA CONTE ANNOUNCED THAT CONSTITUTIONAL RULE WOULD TAKE EFFECT THE FOLLOWING DAY. WITH THE UPCOMING GENERAL ELECTIONS POSING A MAJOR CHALLENGE FOR GUINEANS, CONTE APPEALED FOR PATIENCE, FORGIVENESS, PEACE, AND A SENSE OF REASON IN THE EXERCISE OF SOCIETY'S "RECOVERED FREEDOM." ALTHOUGH SOME OBSERVERS EXPRESSED CONCERN ABOUT THE HIGH SPEED OF THE TRANSITION IN A COUNTRY WHERE DEMOCRACY IS A NEN CONCEPT THE RESPONSE FROM POLITICIANS HAS BEEN RESOUNDINGLY POSITIVE.

01998 BUTSCHER, M.

THE DIPLOMATIC OPTION

WEST AFRICA, (3880) (JAN 92), 146.

THE REBEL WAR CONTINUES TO EXERT INTENSE ECONOMIC AND POLITICAL PRESSURE ON THE SIERRA LEONE GOVERNMENT, WHICH HAS LAUNCHED A DIPLOMATIC OFFENSIVE TO END THE FIGHTING. ON JANUARY 4, 1992, AN OFFICIAL DELEGRATION FROM SIERRA LEONE MET WITH LIBERIAN LEADERS, INCLUDING THE MINISTERS OF DEFENSE, JUSTICE, TRANSPORT, AND COMMUNICATIONS. THE TALKS DEFENSE, JUSTICE, TRANSPORT, AND COMMUNICATIONS. THE TALKS
ENABLED THE PARTIES TO EXPRESS THEIR GRIEVANCES, AND THEY ENABLED THE PARTIES TO EXPRESS THEIR GRIEVANCES, AND THEY
AGREED TO MEET REGULARLY AT THREE-WEEK INTERVALS AS A HAY OF AGREED TO MEET REGULARLY AT THREE-HEE
ESTABLISHING TRUST AND CONFIDENCE.

01999 BUTSCHER, M.

THINGS FALLING APART

IT IS ESTIMATED THAT REBEL TERRORISTS ARE ACTIVE IN MORE THAN 20\% OF SIERRA LEONE. HOWEVER, OFFICIAL GOVERNMENT INFORMATION ABOUT THE FIGHTING IS SCARCE. OPPOSITION POLITICIANS AND LOCAL JOURMALISTS HAVE REPEATEDLY COMPLAINED THAT THE GOVERNMENT IS TRYING TO PROSECUTE THE WAR IN TOTAL SECRECY. INFORMATION THAT SHOULD BE PUBLIC IS BEING SUPPRESSED, GIVING RISE TO MUCH SPECULATION. ARGUABLY, THE FIGHTING IS A OY-PROOUCT OF THE LIBERIAN CIVIL WAR BECAUSE SIERRA LEONE HAS SERYED AS A LAUNCHING PAD FOR LIBERIAN REBELS SIMCE 1986

02000 BUTSCHER, M.

WE'LL WIN THE WAR

WEST AFRICA, (3888) (MAR 92), 496-497.

IN THIS INTERVIEH, ABDULAI CONTEH, SIERRA LEONE'S FIRST VICE PRESIDENT AND MINISTER OF INTERNAL AFFAIRS AND JUSTICE, REBEL TERRORISTS AND THE SITUATION OF SIERRA LEONE'S MANY REFUGEES.

02001 BUTT, G.

EIGHT PAIRS OF EYES ON IRAO

MIDOLE EAST INTERNATIONAL, (396) (MAR 91), 9-11.
THE FOREIGN MINISTERS OF THE ARAB PARTNERS IN THE ANTIIRAQ COALITION-DHE SIX STATES OF THE GULF COOPERATION IRAQ COALITION--THE SIX STATES OF THE GULF COOPERATION MARCH AND ISSUED A STATEMENT OF PRINCIPLES. KNOWN AS THE MARCH AND ISSUED A STATEMENT OF PRINCIPLES. KNOWN AS THE DAMASCUS DECLARATION. IT DEALT 8OTH WITH SECURITY IN THE GULF AND THE ARAB-ISRAEL CONFLICT. THE DECLARATION CALLED
FOR THE CREATION OF AN ARAB PEACEKEEPING FORCE AND FOR THE MAINTENANCE OF IRAQ'S TERRITORIAL INTEGRITY. THE DECLARATION'S LACK OF ANY REFERENCE TO IRAN LED TO ANGRY DENUNCIATIONS FROM TTEHRAN. MOST OBSERVERS NOTE THAT THE MEETING AND THE DECLARATION WILL HAVE LITTLE IMPACT UNTIL AFTER THE DOMESTIC CONFLICT IN IRAQ IS SETTLED.

02002 BUTT, G.

FLAGGING ARAB SPIRITS

MIDOLE EAST INTERNATIONAL, (418) (FEB 92), 4-5

THE OPENING OF THE MULTILATERAL MIDDLE EAST PEACE TALKS IN MOSCOH HAS DONE LITTLE TO RAISE THE FLAGGING SPIRITS OF THE ARAB PARTIES TO THE PEACE PROCESS. ISRAEL, ON THE OTHER HAND, HAS MUCH TO PLEASED ABOUT: ISRAEL WON DIPLOMATIC RECOGNITION FROM CHINA. IT HAS NOT FORCED TO ABANDON ITS PRINCIPLES ON WICH PALESTINIANS SHOULD TAKE PART IN THE TALKS, AND ITS OBJECTION TO THE UNITED NATIONS PLAYING A ROLE IN THE REGIONAL DISCUSSIONS WENT UNOPPOSED. DISARRAY AMOMG THE ARAB RANKS INCREASED WITH SYRIA'S REFUSAL TO ATIEND TO TALKS. SOME FEAR THAT THE PEACE TALKS--WHICH SEEM TO BE APPROACHING NO NEARER TO REAL SOLUTIONS--WILL SOON FALTER AND STOP COMPLETELY.

02003 BUTT, G.

LEBANON--DISARRAY AND DESPAIR

MIDDLE EAST INTERNATIONAL, (433) (SEP 92), 12-16.

THAT LEBANON'S GENERAL ELECTIONS WERE HELD WITHOUT MAJOR VIOLENCE IS THE ONLY POSITIVE THING THAT CAN BE SAID ABOUT THE COUNTRY'S ATTEMPT TO REHABILITATE PARLIAMENTARY THE COUNTRY'S ATTEMPT TO REHABILITATE PARL IAMENTARY AB BLOW DEMOCRACY. ON THE NEGATIVE SIDE, THE ELECTION DEALT A BLOW
TO INTERCOMMUNAL RECONCILIATION, LEFT THE MARONITE CHRISTIAN COMNUNITY EMBITTERED IN THE POLITICAL WILDERNESS, DISCREDITED THE SYRIAN-BACKED GOVERMMENT, AND ESTABLISHED A PARL IAMENT WITH LITTLE CREDIBILITY IN THE EYES EITHER OF THE LEBANESE PEOPLE OR FOREIGN GOVERMMENTS. NOW THE GOVERNMENT MUST FIND A WAY OF WOOING THE CHRISTIANS BACK INTO THE POLITICAL PROCESS IF THE DISINTEGRATION OF LEBANON IS TO BE AVOIDED. THE UNCERTAINTIES SPRINGING FROM THE POLL HILL HAYE
DONE NOTHING TO ENCOURAGE LEBANESE EXILES TO RETURM AND INVEST IN THE COUNTRY.

02004 BUTT, G.

LEBANON--ISRAEL'S ONSLAUGHT

MIODLE EAST INTERNATIONAL, (412) (NOV 91), 7-8.

HILE MIDEAST DELEGATES WERE TALKING ABOUT PEACE IN MADRID. IT WAS BUSINESS AS USUAL IN SOUTH LEBANON. FOR FIVE DAYS, BEGINNING ON THE EVE OF THE OPENING OF THE PEACE CONFERENCE, THE ISRAEL IS AND THEIR CLIENT MILITIA POUNDED VILLAGES IN THE AREA. THE ACTION WAS THE CLEAREST POSSIBLE SIGNAL THAT ISRAEL HAS NO INTENTION OF ENDING ITS OCCUPATION OF SOUTH LEBANON IN THE FORESEEABLE FUTURE AND HILL GO ON IGNORING UN SECURITY COUNCIL RESOLUTION 425, NO MATTER HOW STRENUOUSLY LEBANON DEMANDS ITS IMPLEMENTATION. MANY MILITARY ANALYSTS BELIEVE THAT THE CONTINUED BOMBARDMENT OF VILLAGES IN THE REGION IS A PART OF AN ISRAELI PLAN TO DENY BASES TO ITS ENEMIES BY FORCING THE GENERAL POPULATION TO LEAVE TO AN AREA BEYOND THE CURRENT ZONE OF ISRAELI OCCUPATION.

02005 BUTT, G.

LEBANON-THE MARONITE BOYCOTT

MIDOLE EAST INTERNATIONAL, (432) (AUG 92), 9-10.

FIVE DAYS BEFORE THE OPENING ROUND OF VOTING IN

LEBANON'S GENERAL ELECTION, MARONITE CHRISTIAN LEADERS WERE STILL TRYING TO SEEK A POSTPONEMENT THE CONTROVERSY SURROUNDING THE TIMING OF THE ELECTION HAS PLUNGED THE COUNTRY INTO AN INCREASINGLY SERIOUS POLITICAL CRISIS. MARONITE CHRISTIAN OPPOSITION TO ELECTIONS WHILE SYRIAN TROOPS REMAIN DEPLOYED IN AND AROUND BEIRUT HARDENED WITH A DECISION BY THE PHALANGE PARTY, LED BY GEORGE SADEH, TO JOIN THE BOYCOTT ANNOUNCED PREVIOUSLY BY OTHER GROUPS. UP TO THAT POINT THE PHALANGE HAD PREVARICATED, HOPING THAT POPULAR OPPOSITION TO THE TIMING OF THE POLLING WOULD PERSUADE THE GOVERNMENT TO POSTPONE IT. BUT SADEH'S HAND WAS FORCED BY THO FACTORS: THE REALIZATION THAT THE SYRIANS HAD NO INTENTION OF ALLOWING THE BEIRUT GOVERNMENT TO POSTPONE THE VOTING; AND A GROWING CALL AMONG THE MARONITE CHRISTIAN COMMUNITY AND SENIOR PARTY OFFICIALS FOR THE PHALANGE TO FALL INTO LINE WITH OTHER GROUPS OPPOSED TO THE ELECTIONS. THE CHRISTIANS BELIEVE THAT THE ELECTION--WHETHER THEY TAKE PART OR NOT--WILL LEAD TO A PARLIAMENT WHICH WILL SEEK LEBANON'S GRADUAL INTEGRATION WITH SYRIA. THIS IN TURN, THEY SAY, HILL ERODE FURTHER THE STATUS OF LEBANESE CHRISTIANS WITHIN THE POLITICAL SYSTEM.

02006 BUTT, G.

RUTHLESS REVENGE

MIDDLE EAST INTERMATIONAL, (379) (APR 91), 4-5.

BY 4 APRIL, IRAQ'S REPUBLICAN GUARD HAD APPARENTLY

CRUSHED THE REBELLION IN SOUTHERN IRAQ, AND, IN THE SPACE OF CRUE

KURDISTAY FROM KURDISH ALREGULAR FORCES. DESPITE PLEAS FROM THE KURDS FOR INTERNATIONAL HELP AGAINST SADDAM'S ADVANCING FORCES, THE ANTI-IRAQ COALITION REMAINED SILENT AND STAGNANT AS MANY AS TWO MILLION PEOPLE WERE REPORTED TO BE FLEEING THEIR HOMES, WITH MANY THOUSANDS STRANDED IN COLD WEATHER ON THE TURKISH FRONTIER.

02007 BUTT, G.

THE KURDS--INTERNAL DISPUTES

MIDDLE EAST INTERNATIONAL, (421) (AUG 92), 11

THE AMBITIONS OF THE KURDISH PEOPLE HAVE BEEN FRUSTRATED FURTHER, BOTH BY RENEWED INTERNAL DISSENT AND A FRESH PLEDGE BY SYRIA TO CURB ACTIVITIES OF ANTI - TURKISH GUERRILLAS.
KURDS IN NORTHERN IRAO HAVE ACCUSED THE KURDISH WORKERS PARTY (PKK)--WHICH IS FIGHTING FOR INDEPENDENCE IN SOUTHEASTERN TURKEY-COF SIDING WITH THE BAGHDAD GOVERNMENT BY HELPING TO ENFORCE AN ECONOMIC BLOCKADE OF THE AREA. THE DISPUTE BETHEEN THE PKK AND THE GROUPS IN NORTHERN IRAQ IS BEING PLAYED OUT AGAINST THE BACKGROUND OF A RENEHED COMMITMENT ON THE PART OF THE DAMASCUS GOVERMMENT TO CURB THE ACTIVITIES OF KURDISH FIGHTERS UNDER ITS CONTROL. TURKEY, WITH ITS CONTROL OVER THE VITAL WATERS OF THE EUPHRATES RIVER, HAS INCREASED ITS PRESSURE ON SYRIA TO CLAMP DOWN ON KURDISH ACTIVITES. THIS IS NOT THE FIRST TIME THAT THE DESIRES OF KURDISH GROUPS HAVE BEEN SUBORDINATED TO THE INTEREST OF THE GOVERNMENTS SHARING CONTROL OF WHAT ONCE MIGHT HAVE BEEN THE STATE OF KURDISTAN.

02008 BUTT, G.

U.S. AND IRAQ--NOT AO COVERT ACTIVITY

MIDOLE EAST INTERHATIONAL (419) (FEB 92), 10-11.

A NEW YORK TIMES REPORT INDICATES THAT U.S. PRESIDENT GEORGE BUSH HAD DISPATCHED ROBERT GATES, THE DIRECTOR OF THE CIA, TO EGYPT, SAUDI ARABIA AND ISRAEL TO COORDINATE EFFORTS TO OVERTHROW THE IRAQI REGIME. PRESIDENT BUSH REFUSED TO COMMENT DIRECTLY ON THE STORY ABOUT GATES' MISSION TO THE MIDDLE EAST, BUT THE ADMINSTRATION MADE NO ATTEMPT TO DENY THIS OR OTHER REPORTS IN A SIMILAR VEIN WHICH APPEARED IN
SUBSEOUENT DAYS. SOME SEE THIS OVERT "COVERT ACTION" AS A MEANS TO EXERT PSYCHOLOGICAL PRESSURE ON THE IRAQI REGIME. IN BAGHDAD, MEANWHILE, SADDAM HUSSEIN IS TAKING FURTHER 
STEPS TO SHORE UP THE CIRCLE OF FAMILY MEMBERS AND TRUSTED CONFIDANTS AROUND HIM.

02009 BUTT, G.

WARY ARAB EYES ON IRAQ IN DEFEAT

MIDOLE EAST INTERNATIONAL, (395) (MAR 91), 3-4.

NEARLY A WEEK AFTER THE DECLARATION BY' PRESIDENT BUSH OF A CEASE-FIRE IN THE GULF WAR, COUNTRIES IN THE REGION WERE STILL WATCHING ANXIOUSLY TO SEE WHAT KIND OF REGIME WOULD BE IN CONTROL IN BAGHDAD WHEN THE DUST FINALLY SETTLED. IN SOUTHERN IRAQ, SHI-ITE FUNDAMENTALISTS ROSE UP AGAINST SADDAM HUSSEIN. KURDS IN THE NORTH SOON FOLLOWED SUIT. WHILE MANY OF THE ARAB MEMBERS OF THE ANTI-IRAQ COALITION WOULD BE MORE THAN HAPPY TO SEE THE FALL OF SADOAM HUSSEIN, SOME MORE THAN HAPPY TO SEE THE FALL OF SADOAM HUSSEIN, SOME
HORRY ABOUT THE ETHNIC, RELIGIOUS, AND NATIONALIST TENSIONS WORRY ABOUT THE ETHNIC, RELIGIOUS, AND NATIONALIST TENSIONS
THAT MIGHT ARISE IN THE RESULTING CHAOS AND SPREAD TO THEIR OWN NATIONS.

02010 BUTT, G.

WESTERN HESITATION LEAVES KURDS AND SHI'ITES TO DIE

MIDDLE EAST INTERNATIONAL, (398) (APR 91) 3-4.

THE OELAY IN GETTING HUMANITARIAN HELP' TO IRAQI KURDISH AND SHI'ITE REFUGEES HAS BEEN ACCOMPANIED BY FURTHER DEBATE AND UNCERTAINTY WITHIN THE INTERNATIONAL COMMUNITY ABOUT WHAT ITS POLITICAL AND MILITARY RESPONSE SHOULD BE. THE COLLECTIVE HESITATION AND CONFUSION ON THE PART OF WESTERN AND OTHER GOVERNMENTS HAD THO IMMEDIATE AND OBVIOUS EFFECTS : IT COMPOUNDED THE SUFFERING OF THE HOMELESS IRAQIS AND IT ALLONED THE BAGHDAD AUTHORITIES MORE TIME TO REASSERT THEIR GRIP ON THE COUNTRY.

02011 BUTTARI, J.

ECONOMIC REFORM IN FOUR CENTRAL AMERICAN COUNTRIES:

PATTERNS AND LESSONS LEARNED

JOURNAL OF INTERAMERICAN STUDIES AND WORLD AFFAIRS, 34(1)

(SPR 92), 179-214.

THIS ARTICLE SURVEYS THE EXPERIENCES OF FOUR CENTRAL AMERICAN COUNTRIES--COSTA RICA, EL SALVADOR, GUATEMALA, AND HONDURAS--IN IMPLEMENTING ECONOMIC POLICY REFORM; IT ANALYZES THE FACTORS WHICH LED TO THE INTRODUCTION OF NEW POLICIES, EXPLORES THE VARIDUS ASPECTS IN THEIR

IMPLEMENTATION, ASSESSES LESSONS LEARNED IN THE PROCESS, AND IMPLEMENTATION, ASSESSES LESSONS LEA
DISCUSSES PROSPECTS FOR THE FUTURE.

02012 BUTTERWORTH, C.E.

POLITICAL ISLAM: THE ORIGINS

ANNALS OF THE AMERICAN ACADEMY OF POLITICAL AND SOCIAL

SCIENCE, (526) (MOY 92 ) 26-37.

TO UNDERSTAND WHY ISLAMICISTS PRIZE THE NONDEMOCRATIC AND EVEN NONLIBERAL POLITICAL RULE FOUND IN REVELATION-BASED POLITICS, THE AUTHOR CONSIDERS THE OLDER ARABIC AND ISLAMIC ANALYSIS OF POLITICAL REGIMES AND THEIR GOALS. THEN HE INVESTIGATES WHY, IN THE MORE RECENT PAST, SERIOUS THINKERS WITHIN THAT SAME CULTURAL MILIEU CALLED FOR INDEPENDENC WHILE ENDORSING NONDEMOCRATIC AND NONL IBERAL REGIMES. FINALLY, HE SUGGESTS WHY THINKERS TODAY CONTINUE TO DO THE SAME. HIS GOAL IS NOT TO APOLOGIZE FOR ISLAMICIST DOCTRINES BUT TO ILLUMINATE THE PROBLEMS WITH CURRENT WESTERN ANALYSES AND CRITIQUES OF POLITICAL ISLAM.

02013 BUTTY, J.

CLARIFYING A POLITICAL FUTURE

WEST AFRICA, (3884) (FEB 92), 316-317.

IN THIS INTERVIEW, LIBERIA'S FORMER VICE PRESIDENT HARRY MONIBA DISCUSSES HIS PLANS TO RUN FOR THE PRESIDENCY AND HOH HE WILL ATTEMPT TO HEAL THE COUNTRY'S HOUNDS.

02014 BUTTY, J.

GATHERING GLOOM

ST AFRICA, (3919) (OCT 92), 1822.

FIGHTING WAS RENEWED IN LIBERIA ON OCTOBER 15,1992 WHEN THE NPFL LAUNCHED AN ARTILLERY ATTACK ON THE OUTSKIRTS OF MONROVIA. IN A COUNTER-ATTACK, ECOMOG WAR PLANES BOMBED NPFL-CONTROLLED TERRITORIES, INCLUDING HARBEL AND KAKATA. THE FIGHTING CAME AS WEST AFRICAN LEADERS PREPARED FOR A SUMMIT MEETING ON LIBERIA.

02015 BUTTY, J.

GOVERNMENT DEFENDS RESULTS

WEST AFRICA, 75(3923) (NOV 92), 2014.

FOLLOWING CHARGES THAT THE RESULTS OF OCTOBER 11 FOLLOWING CHARGES THAT THE RESULTS OF OCTOBER 11 PRESIDENTIAL ELECTIONS HERE MARKED BY "WIDESPREAD IRREGULARITIES" THE GOVERMMENT OF CAMEROON HAS BEEN
EXPLAINING TO THE OUTSIDE WORLD HOW IT CONDUCTED AND WON THE EXPLAINING TO THE OUTSIDE WORLD HOW IT CONDUCTED AND WON THE ELECTIONS. AT A NEHS CONFERENCE IN WASHINGTON DC, ANGRY CAHEROONIANS WERE TOLD THAT THE ELECTIONS WERE FAIR AND THAT
STORIES OF TORTURE AT THE UNIVERSITY OF YOUNDE WERE UNTRUE. STORIES OF TORTURE AT THE UNIVERSITY OF YOUNDE WERE THE STATEMENT SAID THE NDI SHOULD UNDERSTAND THAT AN ELECTORAL LAH
CONSITUTION.

02016 BUTTY, J.

I HAS LIKE AN OUTCAST

WEST AFRICA, (3879) (JAN 92), 102-103.
THE LACK OF TRUST IS THE NUMBER ONE PROBLEM IN THE LIBERIAN CRISIS, ACCORDING TO PETER NAIGOW, FORMER VICE PRESIDENT OF THE INTERIM GOVERNMENT OF NATIONAL UNITY. NAIGOW SAYS THAT HE RESIGNED BECAUSE HE WAS TREATED LIKE AN OUTSIDER BY OTHER MEMBERS OF THE GOVERNMENT, ESPECIALLY AFTER HE BEGAN TO PROMOTE THE IDEA OF DIALOGUE AND COMPROMISE AMONG COMPETING FACTIONS.

02017 BUTTY, J.

LITTLE PROMISE FOR AFRICA

WEST AFRICA, (3920) (NOV 92), 1874.

THE UNITED STATES' NOVEMBER 1992 PRESIDENTIAL ELECTION PROMISES LITTLE FOR AFRICA, REGARDLESS OF HHICH CANDIDATE WINS. NEI THER REPUBLICAN GEORGE BUSH NOR DEMOCRAT BILL CLINTON HAS EXPRESSED MUCH CONCERN ABOUT AFRICA DURING THE CAMPAIGN.

02018 BUTTY, J.

NPFL RESPONDS TO EMGARGO

WEST AFRICA, 75(3925) (DEC 92), 2093.

THE CHARLES TAYLOR-LED NPFL' HAS, IN A STATEMENT WHICH APPEARS CONCILIATORY, EXPRESSED GRATITUDE TO THE UN FOR "HEEDING THE CRIES OF LIBERIANS TO STOP THE GENOCIDE IN LIBERIA". THE STATEMENT PUT FORHARD FIVE STEPS TO

DEMONSTRATE NPFL SINCERITY AND ITS DESIRE FOR PEACE. SOME SAY THAT MR. TAYLOR'S CONCILIATORY RESPONSE TO THE UN EMBARGO COULD BE A SINCERE ONE, KNOWING THAT ANY REBUFF OF A 15 TO O SECURITY COUNCIL VOTE MAY LEAVE THE NPFL IN A LONELY POSITION.

02019 BUTTY, J.

QUESTIONS REMAIM

WEST AFRICA, (3888) (MAR 92), 504.

LIBERIA'S ELECTIONS COMMISSION HAS ANNOUNCED THAT IT PLANS TO HOLD GENERAL ELECTIONS BEFORE SEPTEMBER 1,1992 BUT THERE IS INCREASING DOUBT THAT THE ELECTIONS CAN BE HELD UNOER THE PREVAILING CIRCUMSTANCES IN WAR-TORN LIBERIA.

02020 BUTTY, J.

TAKE THE FIRST STEP

WEST AFRICA, (3882) (FEB 92 ), 240.

IT APPEARS THAT THE ON-AGAIN, OFF-AGAIN ELECTION PROCESS IN LIBERIA MAY BE BACK ON TRACK. REBEL LEADER CHARLES TAYLOR HAS FINALLY AGREED TO OPEN SOME ROADS LEADING INTO THE TERRITORIES UNDER HIS CONTROL. MORE IMPORTANTLY, ON JANUARY 3, 1992, THE INTERIM ELECTIONS COMMISSION WAS SWORN IN, OPENING THE WAY FOR IT TO BEGIN THE MONUMENTAL TASK OF PREPARING LIBERIA FOR FREE AND FAIR ELECTIONS.

02021 BUTTY, J.

UN STEPS IN

HEST AFRICA, 75(3924) (NOV 92), 2052-2053.

EVER SINCE THE MURDER IN OCTOBER 1992 OF FIVE AMERICAN ROMAN CATHOL IC NUNS ALLEGEDLY BY THE NAT IONAL PATRIOTIC FRONT OF LIBERIA, IT HAS SEEMED THAT A SOLUTION TO THE NEARLY THREE YEAR-OLD CIVIL HAR IN LIBERIA IS FINALLY FAST
APPROACHING. IN THE US. THE INTERNATIONAL REACTION TO THE MURDER OF THE NUNS AND TO THE PROTRACTED NATURE OF THE WAR ITSELF WENT INTO HIGH GEAR ON THREE FRONTS--AT THE UN, IN THE US CONGRESS, AND LIBERIANS' REJECTION OF THE WAR.' THE UNITED NATIONS SECURITY COUNCIL VOTED UNANIMOUSLY ON

NOVEMBER 19 TO IMPOSE AN ARMS EMBARGO ON LIBERIA IN A EFFORT TO RESTORE PEACE AND STABILTIY TO THE COUNTRY.

02022 BUTTY, J.

WHAT DOES ULIMO WANT?

WEST AFRICA, (3912) (SEP 92), 1519

IN 1990, A GROUP CALLING ITSELF THE UNITED LIBERATION MOVEMENT FOR DEMOCRACY IN LIBERIA (ULIMO) BECAME THE THIRD FIGHTING FACTION IN THE LIBERIAN CIVIL WAR. ALTHOUGH ULIMO WAS NOT TAKEN SERIOUSLY AT FIRST, IT HAS BECDME A FORCE TO BE RECKONED WITH BY THOSE SEEKING TO FURTHER THE PEACE

PROCESS IN LIBERIA.

02023 BUTTY, J.

YEAR OF POLITICAL WRANGLING

WEST AFRICA, (3877) (JAN 92 ), 13.

AT THE BEGINNING OF 1991, THE LIBERIAN CIVIL WAR HAD

PROGRESSED FROM FLYING BULLETS AND CARNAGE TO POLITICAL

NEGOTIATIONS. FOR THE WAR-WEARY LIBERIANS AND THEIR

NEIGHBORS, HOPES WERE VERY HIGH THAT AN END TO THE CONFLICT

WAS IN SIGHT. BUT BY THE END OF THE YEAR, IT SEEMED THAT FOR EVERY POSITIVE STEP THE COUNTRY HAD TAKEN, IT HAD TAKEN TWO NEGATIVE ONES.

02024 BUYS, J.

SOUTH AFRICA'S ECONOMIC PROSPECTS 1992-1995

SOUTH AFRICA INTERNATIONAL, 22 (4) (APR 92), 161-168.

ALTHOUGH SOUTH AFRICA'S ECONOMIC PERFORMANCE OVER THE PAST DECADE HAS BEEN POOR. AND THE CURRENT RECESSION IS DEEPER THAN FORECAST, THERE ARE GROUNDS FOR HOPE. OUTWARD MANIFESTATIONS OF THIS INCLUDE THE SIGNIFICANT REVIVAL OF PRIVATE SECTOR FIXED INVESTMENT, AND THE GROWTH IN MANUFACTURED EXPORTS OF RECENT YEARS. SUBSTANTIAL ECONOMIC 
RECOVERY IN THE PERIOD TO 1995 IS LIKELY FOR A RANGE OF REASONS. THESE INCLUDE THE RECOVERY OF THE HORLD ECONOMY AMO THE IMPACT OF POLITICAL REFORMS IN SOUTH AFRICA. THERE ARE PROSPECTS OF GROWTH RATES OF 4 TO 5 PERCENT OVER THE NEXT FOUR YEARS. OF CRITICAL IMPORTANCE, MOWEVER, WILL BE WHETHER OR NOT THIS GROWTH BECOMES SUSTAINABLE. IF POPULIST EXCESSES CAN BE AVOIDED, AND THE NECESSARY CONDITIONS FOR FOREIGN AND DOMESTIC PRIVATE SECTOR FIXED INVESTMENT GROWTH ARE CREATED, THERE IS REAL REASON FOR HOPE.

02025 BUZO, A.

THE PYONGYANG MYTH

FAR EASTERN ECONOMIC REVIEN, 48(155) (DEC 92), 21.

DESPITE SPECULATION THROUGHOUT 1992 THAT NORTH KOREA WAS SEEKING OUT A CAUTIOUS PATH TO LIBERALIZATION, THE YEAR IS DRAHING TO CLOSE WITH LITTLE OR NOTHING CHANGED IN PYONGYANG. THE FATHER-AND-SON LEADERSHIP OF KIM IL-SUNG ANO KIM JONGIL IS BACKED UP BY AN UNCHANGING POLITBURO CONFIGURATION, AND IS STILL PUBLICLY PROCLAIMING THE POLITICAL VIRTUES AND ECONOMIC ACCOMPLISHMENTS OF ITS STALINIST SYSTEM. THE POSSIBILITY THAT LOOMS LARGE IS NOT ONE OF IMMINENT CHANGE POSSIBILITY THAT LOOMS LARGE IS NOT ONE OF IMMINENT CHANGE
IN NORTH KOREA, BUT THAT OF A NATION PERSISTING IN ITS IN NORTH KOREA, BUT THAT OF A NATION PERSISTING IN ITS
CURRENT POLICIES FOR MUCH, IF NOT ALL, OF THE 1990S. IN CURRENT POLICIES FOR MUCH, IF NOT ALL, OF THE $1990 S$.
LEADERSHIP TERMS, THERE IS NO PARTICULAR REASON TO

LEADERSHIP TERMS, THERE IS NO PARTICULAR REASON TO
ANTICIPATE THE DEPARTURE OF KIM IL-SUNG IN THE NEAR FUTURE, ANTICIPATE THE DEPARTURE OF KIM IL-SUNG IN THE NEAR FUTURE, AND THERE IS NOTHING TO SUGGEST THAT THE KIM FAMILY'S HOLD ON POWER WOULD BE IMMEDIATELY LOOSENED BY HIS DEATH. EVEN IF STATE, A RESILIENT, HIGHLY ORGANIZED BODY, HOULD NOT NECESSARILY COLLAPSE AS HELL.

02026 BYERS, B.

ECOREGIONS, STATE SOVEREIGNTY AND CONFLICT

BULLETIN OF PEACE PROPOSALS, 22 (1) (MAR 91), 65-76.
THIS PAPER EXPLORES SOME OF THE CONSEQUENCES OF INCONGRUITIES BETHEEN THE NATURAL BOUNDARIES OF ECOSYSTEMS AND THE POLITICAL BORDERS OF STATES. IT ARGUES THAT THIS MISMATCHIMG HAS THE POTENTIAL TO STIMULATE CONFLICT, AND THAT MAPPING SUCH INCONGRUITIES CAN BE A TOOL FOR PREDICTING CONFLICTS IN TIME FOR PREVENTIVE ACTION. IT ALSO ARGUES THAT PREVENTING ECOLOGICALLY ROOTED CONFLICTS REQUIRES SOME MODIFICATION OF STATE SOVEREIGNTY. IT CONCLUDES THAT MORE EFFORTS ARE NEEDED IN THE DIRECTION OF DECENTRALIZING STATE SOVEREIGNTY IN ORDER TO RESOLVE ECOLOGICALLY ROOTED CONFLICTS.

02027 BYRD, $R$

SENATOR BYRD ON LOAN GUARANTEES AND U.S. -ISRAELI RELATIONS JOURNAL OF PALESTINE STUDIES, XXI(4) (SUM 92), 130-139. IN THIS ADORESS DELIVERED ON THE FIOOR OF THE U.S.
IN

SENATE, SENATOR ROBERT BYRD OF WEST VIRGINIA EXPLAINS WHY HE BELIEVES THAT THE PROPOSED U.S. LOAN GUARANTEES FOR ISRAEL WOULD NOT SERVE THE BEST INTEREST OF EITHER COUNTRY.

02028 BYRNE, EL

ALGERIA: THE DEBATE ON THE FIS

MIDDLE EAST INTERNATIONAL, 436 (OCT 92), 9-10.

IS THERE SUCH A THING AS A MODERATE ISLAMIC MOVEMENT? THIS QUESTION IS AT THE CENTER OF DEBATE ON ALGERIA'S POLITICAL FUTURE BETHEEN THOSE WHO BELIEVE THE COUNTRY HAS ONLY NARROWLY ESCAPED COMING UNDER THE CONTROL OF A TOTALITARIAN "FUNDAMENTALIST INTERNATIONAL" AND THOSE WHO ARGUE THAT A PROCESS OF NATIONAL "RECONCILIATION" AND "DIALOGUE" SHOULD INCLUDE AT LEAST SOME CURRENTS FROM WITHIN THE BANNED ISLAMIC SALVATION FRONT. THERE IS A PROPOSAL FOR A NATIONAL CONFERENCE TO OVERSEE THE TRANSITION TO A MULTIPARTY SYSTEM BASED ON THE ACCEPTANCE BY ALL PARTIES OF THE ALTERNATION OF POWER, PLURALISM AND THE REJECTION OF ALL FORMS OF TERRORISM.

02029 BYRON, W.J.

RENEWING COMMUNITY: WHEN CONGRESS DOES IT RIGHT

COMMONWEAL, CXIX(8) (APR 92), 6-8.

BY ENACTING THE NATIONAL AND COMMUNITY SERVICE ACT OF 1990, CONGRESS HAS SAID THAT IT WANTS TO ENHANCE COMMUNITY SERVICE AND RENEH THE ETHIC OF CIVIC RESPONSIBILITY IN THE UNITED STATES. THE ACT ESTABLISHES A NEW COMMISSION ON NATIONAL AND COMMUNITY SERYICE. HENCEFORTH, COMMUNITY

SERVICE WILL BE ENCOURAGED AS A MATTER OF PUBLIC POLICY.

02030 BZDERA, A.

THE COURT OF JUSTICE OF THE EUROPEAN COMMUNITY AND THE PHE COURT OF JUSTICE OF THE EUROPEA

WEST EUROPEAN POLITICS, 15) (3) (JUL 92), 122-136.

TWO PROMINENT JURISTS RECENTLY PROPOSED A REFORM OF THE EUROPEAN COURT OF JUSTICE THAT AIMS AT ADAPTING IT TO THE GRADUAL FEDERALIZATION OF THE COMAUNITY AND PARTICULARLY TO THE EXTENSION OF MAJORITY VOTING IN THE COMMUNITY COUNCIL. THEIR PROPOSAL KOULD GENERALLY REINFORCE THE CONTEMPORARY TENDENCY OF THE COURT TO DEFEND ALL LEGISLATIVE INITIATIVES
OF THE COMUNITY. THIS PAPER PRESENTS SEVERAL ALTERNATIVE REFORMS THAT COULO BETTER RESPOND TO THE POLITICAL NEED FOR AN IMPARTIAL ARBITER FOR CONFLICTING INTERPRETATIONS OF COMMUNITY COMPETENCES. DEBATE ON THE POLITICAL ROLE OF THE
EUROPEAN COURT OF JUSTICE AND ON ITS REFORM MUST $8 E$ CONSIDERABLY BROADENED.

02031 CAIN, B.E.

VOTING RIGHTS AND DEMOCRATIC THEORY: TOWARD A COLOR-BLIND SOCIETY?

BRDOKINGS REVIEW, 10(1) (WIN 92), 46-50.

SINCE THE MID-1970'S, THE THRUST OF THE VOTING RIGHTS ACT, AS AMENDED BY CONGRESS AND INTERPRETED BY THE COURTS, HAS BEEN TO PREVENT DISCRIMINATORY ELECTION PRACTICES FROM MUFFLING THE VOICE OF MINORITIES. THIS HAS RAISED A SERIOUS ISSUE REGARDING REPRESENTATION: TO WHAT DEGREE SHOULD A DEMOCRACY GIVE SPECIAL RECOGNITION IN ANY FORM TO THE RIGHTS OF MINORITIES? AT ITS HEART, THE VOTING RIGHTS CONTROVERSY IS REALLY ANOTHER VARIANT OF A LOMGSTANOING DILEMMA IN DEMOCRATIC THEORY: HOW SHOULD MINORITY RIGHTS BE BALANCED AGAINST THE MAJORITY WILL IN A SYSTEM OF GOVERMMENT THAT DERIVES ITS LEGITIMACY FROM THE CONSENT OF THE GOVERNED? IN DERIVES ITS LEGITIMACY FROM THE CONSENT OF THE GOVERMED? IN THIS ARTICLE, THE AUTHOR ARGUES THAT DEMOCRATIC FORMS OF
GOVERNMENT ARE CONSISTENT WITH MANY DIFFERENT KINDS OF TRADEGOVERMMENT ARE CONSISTENT WITH MANY DIFFERENT KINDS OF TRAD
OFFS BETHEEN MAJORITY AND MINORITY RIGHTS, INCLUDING THE OFFS BETWEEN MAJORITY AND MINORITY RIGHTS, INCLUDING THE
PARTICULAR TRADE-OFF IMPLICIT IN THE VOTING RIGHTS ACT. A PARTICULAR TRADE-OFF IMPLICIT IN THE VOTING RIGHTS ACT. A STRONG CUI TURAL PREDISPOSITION AGAINST TRADING-OFF IN FAVOR STRONG CULTURAL PREDISPOSITION AGAINST TRADING-OFF IN FAVOR
OF MINORITY RIGHTS. THIS CULTURAL BIAS IS SO PERVASIVE THAT IT MAY ULTIMATELY FRUSTRATE LEGAL STRATEGIES AIMED AT
SOFTEMING THE HARD MAJORITARIAN EDGE OF U.S. POLITICS.

02032 CAIN, F.

SOME ASPECTS OF AUSTRALIAN-SOVIET RELATIONS FROM 1800 TO 1960

JOURNAL OF COMMUNIST STUDIES, 7(4) (DEC 91), 501-521.

IF THE 150 YEARS OF CONTACT BETWEEN AUSTRALIA AND RUSSIA TO 1960 ARE ANALYZED, THE DEVELOPMENT OF RUSSOPHOBIA DURING THE NINETEENTH CENTURY CAN BE SEEN TO RELECT A MOOD SIMILAR TO THAT OF BRITAIN. THIS ARTICLE ANALYZES THE WAY IN WHICH THIS LARGE NORTHERM NATION, HAVING LITTLE TRADE OR CULTURAL OR POPULATION CONTACT HITH ASUTRIALIA, CAME TO BE VIEWED WITH SUCH TREPIDATION. IT ALSO EXPLORES WHY THE EARLIER RUSSOPHOBIC MOOO HAD SO SWIFTLY GRAFTED ONTO IT THE STRONGER AND MORE EMOTIONAL ANTI-COMMUNIST FEELINGS THAT PREVAILED IN THE DECADES FOLLOWING THE BOLSHEVIK REVOLUTION.

02033 CAIRNS, A.C.

CHARTER VERSUS FEDERALISM: THE DILEMMAS OF CONSTITUTIONAL REFORM

MCGILL-OUEEN'S UNIVERSITY PRESS, 1991, 160

THIS BOOK PROVIDES AN ANALYSIS OF THE CONSEQUENCES--FOR

CITIZEN AND GOVERMMENT ALIKE--OF THE CHANGES UNDERGONE BY THE CANADIAN CONSTITUTION, ESPECIALLY SINCE 1982. IT ALSO ILLUMINATES THE DIFFICULTIES OF RESOLVING THE CONSTITUTIONAL TENSIONS BETWEEN QUEBEC AND THE REST OF CANADA. THE 1982 CONSTITUTION ACT AMENDED THE BRITISH NORTH AMERICA ACT AND INTRODUCED THE CHARTER OF RIGHTS AND FREEDOMS, GIVING NEH POWERS TO HETEROGENOUS GROUPS WITHIN THE CANADIAN POLITY. THESE CHANGES DISTURBED THE EQUILIBRIUM OF AN OLDER,

FEDERALIST CANADA HHOSE CONSTITUTIONAL CONCERNS WERE LIMITED TO THE RELATIVE POWERS OF THE FEDERAL AND PROVINCIAL

GOVERNMENTS AND TO FRENCH-ENGLISH ETHNIC/LINGUISTIC

QUESTIONS. CANADA IS NOW POPULATED BY "CHARTER CANADIANS,"

WHO SEE THEMSELVES AS RIGHTS-BEARERS AND TEND TO LOOK TO' THE FEDERAL GOVERMMENT AS THE EFFECTIVE FOCUS OF POLITICAL COMMUNITY. DURING THE MEECH LAKE AFFAIR, THE DEMANDS OF CHARTER CANADIANS AND POLITICIZED ABORIGINAL PEOPLES CLASHED HITH QUEBEC'S CONSTITUTIONAL ASPIRATIONS AS WELL AS OLDER ELITE ACCOMMODATION POLITICS. MEECH LAKE ALSO INDICATES THAT CANADA'S FUTURE CONSTITUTIONAL HEALTH DEPENDS NOT ONLY ON THE RECONCILIATION OF QUEBEC WITH THE REST OF CANADA BUT ON A SIMULTANEOUS CONSTITUTIONAL RAPPROCHEMENT BETWEEN CITIZENS AND GOVERNMENTS IN THE PROCESS OF CONSTITUTIONAL REFORM.

02034 CAIRNS, $R$

NATURAL RESOURCES AND CANADIAN FEDERALISM: DECENTRALIZATION, RECURRENT CONFLICT, AMD RESOLUTION PUBLIUS: THE JOURNAL OF FEDERALISM, 22 (1) (WIN 92), 55-70. A RECURRING CHALLENGE OF RESOURCE POLICY IN CANADA HAS BEEN TO BALANCE INTERRELATED POHER WHEN THERE IS DIVERGENCE IN THE GOALS OF PROVINCIAL AND FEDERAL GOVERNMENTS. CONSTITUTIONAL AMENDEMENTS IN 1982 AND FEDERAL - PROVINCIAL CONSTITUTIONAL AMENDEMENTS IN 1982 AND FEDERAL PROVINCIAL
NEGOTIATIONS IN THE 1970 S AHD THE 1980 S CONFIRMED THE NEED NEGOTIATIONS IN THE 1970 S AND THE 1980 S CONFIRMED THE
FOR ACCOMMODATION. THE RESULT WAS TO STRENGTHEN THE FOR ACCOMMODATION. THE RESULT WAS TO STRENGTHEN THE LEGITIMACY OF THE INTERESTS OF BOTH OROERS OF GOVERNMENT. ESPECIALLY WITH THE EMERGENCE OF NEW TYPES OF INTERESTS IN ESPECIALLY WITH THE EMERGENCE OF NEW TYPES OF INTERESTS IN THE RESDURCE SECTOR, OCCASIONAL FRICTIONS MAY
BECAUSE OF THE INTERRELATEDNESS OF POWERS.

02035 CALABRESI, M.

MIKHAIL GORBACHEV'S UNINTENDED CONSEQUENCES

NATIONAL REVIEH, XLIV(1) (JAN 92), 44-45.

THIS REFLECTION ON THE RECENT COUP IN THE USSR SUGGESTS THAT FROM THE MOMENT HE WAS LIBERATED AFTER THE AUGUST COUP, MIKHAIL GORBACHEV'S EVERY POLITICAL STATEMENT, HIS EVERY 
THE CENTRAL STURUCTURE. THAT FREEDOM FROM THE CENTRAL BUREAUCRACY WAS WHAT THE REPUBLICS MEANT BY THE INDEPENDENCE THEY HERE DEMANDING SEEMED TO ELUDE HIM. THE ARTICLE CONCLUDES THAT THOSE WHO HAD SOUGHT TO SHORE UP GORBACHEV FOR THE SAKE OF STABILITY HAD IN FACT BEEN HASTENING DISINTEGRATION. ALSO, THAT THE SITUATION IS NOW FAR MORE PROMISING THAN IT HAS IN OCTOBER.

02036 CALAMITA, F.P.

SOLVING THE VOTERS' DILEMMA: THE CASE FOR LEGISLATIVE TERMLIMITATION

JOURNAL OF LAH \& POLITICS, VIII(3) (SPR 92), 559-608.

THIS ESSAY ARGUES THAT LIMITING LEGISLATIVE TENURE WOULD FURTHER THE GOALS OF REPRESENTATIVE DEMOCRACY AS ENVISIONED BY THE FRAMERS OF THE U.S. CONSTITUTION. WHILE IT FOCUSES PRIMARILY ON THE MERITS AND METHODS OF LIMITING

CONGRESSIONAL TENURE, THE DISCUSSION ALSO ADDRESSES RECENT CONGRESSIONAL TENURE, THE DISCUSSION ALSO ADDRESSES RECENT
EFFORTS TO LIMIT STATE LEGISLATIVE TERHS. PART I ANALYZES EFFORTS TO LIMIT STATE LEGISLATIVE TERMS. PART I ANALYZES BICAMERAL CONGRESS. PART II DISCUSSES THE MERITS OF TERM BICAMERAL CONGRESS. PART II DISCUSSES THE MERITS OF TERM LIMITATION BY IDENTIFYING THE MAJOR PROBLEMS ATTRIBUTED COMBAT THOSE PROBLEMS. IT COVERS ISSUES OF INCUMBENCY VERSUS COMBAT THOSE PROBLEMS. IT COVERS ISSUES OF INCUMBENCY VERSUS
CITIZEN-LEGISLATORS, QUESTIONS ABOUT THE SENIORITY SYSTEM CITIZEN-LEGISLATORS, QUESTIONS ABOUT THE SENIORITY SYST
AND THE VALUE OF CONGRESSIONAL EXPERIENCE, THE DILEMMA AND THE VALUE OF CONGRESSIONAL EXPERIENCE, THE DILEMMA
VOTERS FACE ON ELECTION DAY, THE IMPACT OF SPECIAL INTEREST GROUPS, AND WHAT THE AUTHOR CALLS "POTOMAC FEVER." PART II TRACES THE RISE OF THE CURRENT NATIONAL MOVEMENT TO LIMIT CONGRESSIONAL TENURE, HIGHLIGHTING THE RECENT EFFORTS OF PROPONENTS OF TERM LIMITS ON BOTH THE STATE AND CONGRESSIONAL LEVELS. PART IV EXPLORES THE MECHANISMS THROUGH WHICH CONGRESSIONAL TENURE MAY BE CONSTITUTIONALLY LIMITED. PART Y ARGUES THAT LIMITING CONGRESSIONAL TENURE IS NOT ONLY CONSTITUTIONAL BUT ESSENTIAL TO RESTORING U.S. DEMOCRACY.

02037 CALAVITA, $N$.

GROWTH MÁCHINES AND BALLOT BOX PLANNING: THE SAN DIEGO CASE JOURNAL OF URBAM AFFAIRS, 14(1) (1992), 1-24.

GROWTH MACHINE THEORY IS AMBIGUOUS ABDUT THE CHANGES OF SUCCESS OF CITIZEN GROUPS FIGHTING LAND-BASED ELITES, AN AMBIGUITY REFLECTED IN CONTRASTING THEORETICAL ASSUMPIIONS AND EMPIRICAL RESEARCH. THIS PAPER SUGGESTS THAT A LONGITUDINAL FRAME OF REFERENCE IS NECESSARY TO UNDERSTAND IMPORTANCE OF BALLOT BOX PLANING IN CONTESTING GROWTH IMPORTANCE OF BALLOT BOX PLANNING IN CONTESIING GROWTH
MACHINES NEEDS TO BE ASSESSED. GROWTH CONFLICTS IN SAN DIEGO MACHINES NEEDS TO BE ASSESSED. GROWTH CONFLICTS IN SA
DURING 1970--1990 HERE STUDIED. THE FINDINGS OF THESE DURING 1970--1990 WERE STUDIED. THE FI
STUDIES ARE PRESENTED IN THIS ARTICLE.

02038 CALDEIRA, G.; GIBSON, J.

THE ETIOLOGY OF PUBLIC SUPPORT FOR THE SUPREME COURT AMERICAN JOURNAL OF POLITICAL SCIENCE, 36(3) (AUG 92), 635-664

THE SUPREME COURT, LIKE ALL POLITICAL INSTITUTIONS, REQUIRES SOME MINIMAL LEVEL OF SUPPORT BECAUSE, AS THE HIGH BENCH PERFORMS ITS POLITICAL AND CONSTITUTIONAL ROLES, THE JUSTICES MUST ON OCCASION STAND AGAINST THE WINDS OF PUBLIC OPINION. WITH DATA FROM A RECENT NATIONAL SURVEY, THIS ART ICLE REEXAMINES THE LEVELS, SOURCES, AND EXPLANATIONS OF PUBLIC SUPPORT FOR THE SUPREME COURT. IT CLOSES WITH SPECULATIONS ABOUT THE PROCESS BY WHICH DIFFUSE SUPPORT FOR THE COURT CHANGES OVER TIME AND, MORE GENERALLY, THE IMPLICATIONS OF ATTITUDES AMONG THE MASS PUBLIC AND OPNION LEADERS FOR THE FUNCTIONING OF THE SUPREME COURT.

02039 CALDER, C.

AN ORANGE SHEEP: THE PORTUGUESE GENERAL ELECTIONS OF 1991 WEST EUROPEAN POLITICS, $15(2)$ (APR 92), 167-170.

IN SECURING ITS SECOND CONSECUTIVE OVERALL PARLIAMENTARY MA JORITY THE SOCIAL DEMOCRATIC PARTY (PSD) IN PORTUGAL ESTABL ISHED A NEW RECORD BY BECOMING THE FIRST PARTY TO ACHIEVE SUCH A RESULT SINCE THE REPUBLIC'S FOUNDATION 80 YEARS AGO. IT WAS EVIDENT THAT THE PREDOMINANT MOOD OF THE RELATIYELY UNKMOWN IN PORTUGAL HAS HEL USED IN THE PSD'S ELECTORAL STRATEGY. THE ELECTION HAS ASSURED CAVACO SILVA OF A PREDOMINANT ROLE IN PORTUGUESE POLITICS WELL INTO THE DECADE, WHILE IT HAS THROWN THE OPPOSITION PARTIES INTO A SEVERE' IDENTITY CRISIS.

02040 CALDER, $K$.

JAPAN IN 1991: UNCERTAIN OUEST FOR A GLOBAL ROLE ASIAN SURVEY, XXXII (1) (JAN 92), 32-41.

AS THE SECOND LARGEST ECONOMY IN THE WORLD, WITH HIGH PROOUCTIVITY, A POWERFUL CURRENCY, AND STATE OF THE ART TECHNOLOGY ACROSS A BROADENING RANGE OF INDUSTRIES, JAPAN TECHNOLOG ACROSS A BROADENING RANGE OF INDUSTRIES, JAPAN THERE WAS REMARKABLY LITTLE CONSIDERATION OF JUST WHERE JAPAN'S OWN INTEREST IN INTERNATIONAL AFFAIRS TRULY LAY. AS 1991 DAWNED, THE ISSUE OF JAPAN'S GLOBAL ROLE HAS AT LAST THRUST TO THE HEART OF JAPANESE POLITICAL AND SOCIAL DIALOGUE, DRIVEN BY THE DEEPENING U.S.-IRAQI CONFRONTATION IN THE PERSIAN GULF AND THE FORMAL OISSOLUTION OF THE SOVIET
UNION.

02041 CALDERON, J

"HISPANIC" AND "LATINO": THE VIABILITY OF CATEgories fOR PANETHINIC UNITY

LATIN AMERICAN PERSPECTIVES, 19(75) (FAL 92), 37-44.

THE QUESTION HAS BEEN RAISED WHETHER THERE IS A HISPANIC OR LATINO ETHNICITY THAT SUPERSECES INDIVIDUAL GROUP IDENTITIES. FELIX PADILLA DEPARTS FROM THE PRIMORDIAL INTERPRETATION OF ETHNICITY TO PROPOSE THE VIABILITY OF A PANETHNIC IDENTITY BASED ON SITUATIONAL AND COLLECTIVE ACTION THAT TRANSCENDS DISTINCTIVE NATIONAL AND CULTURAL IDENTITIES. THIS ARTICLE OISCUSSES THE VIABILITY OF A PANETHNIC IDENTITY AMONG LATINO GROUPS IN RELATION TO THE TERMS THAT ARE USED TO IDENTIFY THEM AS COLLECTIVE TERMS THAT
FORMATIONS

02042 CALDWELL, C

A QUEBECER HAYES A FLAG FOR ENGLISH

A QUEBECER HAVES A FLAG FOR ENGLISH
INSIGHT, $8(25)$ (JUN 92 ), 6-11; 34-36.

INSIGHT, 8(25) ( JUN 92), 6-11; 34-36.
MONTREAL NATIVE MORDECAI RICHLER, BEST-KNOWN IN THE U.S FOR HIS NOVELS, HAS MADE OUITE A NAME FOR HIMSELF IN HIS HOME PROVINCE OF QUEBEC WITH A BOOK CHALLENGING THE SEPARATIST NATURE OF HIS FRANCOPHONE SOCIETY, WHICH, HE BELIVES, DISCRIMINATES AGAINST THE NON-FRENCH. HE WANTS ENGLISH TO ONCE AGAIN BE A FREE-FLOWING TONGUE IN QUEBEC, ALONGSIDE FRENCH.

02043 CALDHELL, C

MEXICAN-AMERICANS FIND AN L.A. NICHE

INSIGHT, 8(39) (SEP 92), 14-16;38.

WHEN BOXER OSCAR DE LA HOYA WAVED THE U.S. AND MEXICAN

FLAGS AFTER HIS OLYMPIC VICTORY, IT HAS SYMBOLIC TO BOTH SIDES IN THE IMMIGRATION DEBATE. TO THE MEXICAN-AMERICAN POPULATION, PRIDE IN HERITAGE IS IMPORTANT, BUT SOME CRITICS SAY IMMIGRANTS WILL NEVER LET GO OF THEIR CULTURAL PAST. ONE THING IS IRREFUTABLE THOUGH: THE MEXICAN-AMERICAN COMMUNITY IS FIRMLY IN PLACE AND GAINING POLITICAL AND ECONOMIC STRENGTH.

02044 CALDWELL, D.

THE DYNAMICS OF DOMESTIC POLITICS AND ARMS CONTROL: THE SALT II TREATY RATIFICATION DEBATE

UNIVERSITY OF SOUTH CAROLINA PRESS, 1991, 234.

THIS BOOK CHRONICLES THE FAILURE OF THE STRATEGIC ARMS LIMITATION TALKS II (SALT II) TREATY. THE AUTHOR EMPHASIZES THE IMPACT OF PUBLIC OPINION AND DOMESTIC POLITICS ON THE OUTCOME OF THE TREATY. HE CONCLUDES THAT SALT II HAS NOT RATIFIED FOR SEVERAL REASONS: THE CARTER ADMINSTRATION'S STRATEGY, THE ACTION OF PUBLIC OPINION AND INTEREST GROUPS, THE CHARACTER AND BEHAVIOR OF THE SENATE, AND THE EVENTS OF FALL 1979. THE AUTHOR QUESTIONS THE HISDOM OF A SYSTEM IN WHICH 34 SENATORS REPRESENTING 7.1\% OF THE POPULATION CAN BLOCK A TREATY, AND REVIEWS SEVERAL SCHEMES WHICH MIGHT DIMINISH GRIDLOCK. HE THEN DRAWS ON THE ERRORS OF THE CARTER ADMINISTRATION TO FORM SENSIBLE LESSONS ABOUT NEGOTIATING AND RATIFYING TREATIES.

02045 CALHOON, J.

PROJECT VOTE SMART: OBJECTIVE GUIDANCE FOR THE CONSCIENTIOUS VOTER

NATIONAL CIVIC REVIEW, 81(3) (SUM 92) 385-387.

THE CENTER FOR NATIONAL INDEPENDENCE IN POL ITICS (CNIP) IS UNDERTAKING A MAJOR EFFORT, CALLED "PROJECT VOTE SHART," TO CENTRALIZE SUBSTANTIVE BUT OFTEN INACCESSIBLE INFORMATION ON CANDIDATES. CNIP HOPES TO ENCOURAGE INFORMED VOTING BY MAKING ITS DATA AVAILABLE TO ANYONE THROUGH A TOLL-FREE TELEPHONE NUMBER.

02046 CALINGAERT, D.

SOVIET NUCLEAR POLICY UNDER GORBACHEY--A POLICY OF DISARMAMENT

GREENHOOD PRESS, 1991, 192

THIS HORK EXPLORES THE PROFOUND CHANGES IN SOVIET NUCLEAR ARMS CONTROL POLICY THAT HAVE OCCURRED UNDER MIKHAIL GORBACHEV. THE AUTHOR ARGUES THAT THE GORBACHEV LEADERSHIP HAS EMBARKED ON A NEH POLICY OF NUCLEAR DISARMAMENT, ONE THAT ALLOHS THE SOVIETS TO DIVERT RESOURCES TO INDUSTRIAL THAT ALLOHS THE SOVIETS TO DIVERT RESOURCES TO INDUSTRIAL
MODERNIZATION, RESTRUCTURE THE ARMED FORCES, AND JOIN THE GLOBAL ECONOMY. THEREBY REVITALIZING THEIR ECONOMIC STRENGTH GLOBAL ECONOMY, THEREBY REVITALIZING THEIR ECONOMIC STRENGT
AND EXERTING A RENEHED INFLUENCE ON INTERNATIONAL AFFAIRS. AND EXERTING A RENEHED INFLUENCE ON INTERNATIONAL AFFAIRS.
AMONG THE TOPICS ANALYZED ARE INNOVATION IN POLICY FORMATION, AMONG THE TOPICS ANALYZED ARE INNOVATION IN POLICY FORMATION,
ECONOMIC INDUCEMENTS FOR OISARMAMENT. CHANGES IN NATIONAL ECONOMIC INDUCEMENTS FOR OISARMAMENT, CHANGES IN NATIONAL
SECURITY AIMS AND NUCLEAR STRATEGY, AND THE DIPLOMACY OF SECURITY AIMS
ARMS CONTROL

02047 CALINGAERT, M.

THE EUROPEAN COMMUNITY'S EMERGING POLITICAL DIMENSION SAIS REVIEH, 12(1) (WIN 92), 69-84.

THE LEADERS OF THE EUROPEAN COMHUNITY (EC) HAVE AGREED THAT THE EC SHOULD ASSERT ITS IDENTITY ON THE INTERNATIONAL SCENE. AT THE SUMMIT MEETING IN 1991 IT WAS REALIZED THAT THE EC BUILDS ON DEVELOPMENTS IN THE COMMUNITY'S RELATIONSHIPS WITH ITS NEIGHBORS AND COOPERATION OR 
COORDINATION AMONG THE MEMBER STATES ON FOREIGN POLICY ISSUES. THIS ARTICLE EXPLORES FOUR SIGNIFICANT SHOCKS WHICH HAVE COMBINED TO ALTER THE SITUATION SIGNIFICANTLY. THE DISSOLUTION OF THE SOVIET BLOC, GERMAN UNIFICATION. THE GULF WAR, AND THE CIVIL WAR IN YUGOSLAVIA HAVE ALL FORCED THE EC TO TURN ITS ATTENTION
FOREIGN POLICY ISSUES.

02048 CALLAGHAN, J.

SPANISH LESSONS FOR MILITANT AND THE LABOUR PARTY JOURNAL OF COMMUNIST STUDIES, 8(2) (JUN 92), 172-180. THE AUTHOR LOOKS AT THE "MILITANT TENDENCY" FACTION WITHIN MARXISM AND ITS RELATIONSHIP WITH GREAT BRITAIN'S LABOUR PARTY. HE ALSO DISCUSSES HOW THE EXPERIENCE OF THE SPANISH MILITANT TENDENCY HAS INFLUENCED THE MILITANT'S TACTICS IN GREAT BRITAIN.

02049 CALLAHAN, W.J.

CHURCH AND STATE IN SPAIN, 1976-1991

JOURNAL OF CHURCH \& STATE, 34(3) (SUM 92), 503-520.

THE AUTHOR EXPLORES THE CHURCH-STATE RELATIONSHIP IN SPAIN SINCE THE DEATH OF FRANCISCD FRANCO AND THE ACCESSION OF KING JUAN CARLO I TO THE THRONE.

02050 CALLAHAN, D

BUSH'S AMBIVALENCE: SOVEREIGNTY OR COOPERATION?

COMMONWEAL, CXIX(5) (MAR 92), 9-10.

IN A WORLD ORDER GOVERNED BY THE UN CHARTER, NO SINGLE NATION WOULD HAVE TO KEEP THE PEACE ALONE. IT GOES HITHOUT SAYING THAT UNILATERAL MILITARY OPERATIONS STAND AT ODDS WITH THE CHARTER. THIS ARTICLE EXPLORES WHETHER THE BUSH
ADMINISTRATION IS REALLY PREPARED TO LIVE BY THE STRICTURES ADMINISTRATION IS REALLY PREPARED TO LIVE BY THE STRICT
IMPOSED BY THE CHARTER OR WILL CONTIMUE IN ITS IMPULSE IMPOSED BY THE CHARTER OR
TOWARDS UNILATERAL ACTION.

02051 CALLEO, D.

CAN THE UNITED STATES AFFORD THE NEW WORLD ORDER? SAIS REVIEW, 12(2) (SUM 92), 23-33

TO ANSWER THE QUESTION, "CAN THE UNITED STATES AFFORD THE NEW WORLD ORDER?" DEPENDS BOTH ON THE NATURE OF THE NEW WORLD ORDER AND ON WHAT IS MEANT BY "AFFORD." THE LATTER CONSIDERATION SHOULD COME FIRST, SINCE IT HELPS CLARIFY THE REAL ISSUE--THE DISTINCTION BETWEEN AMERICA'S CAPABILITIES ANO PRIORITIES. THIS ARTICLE DETERMINES WHAT AMERICA CAN AFFORD AND EXPLORES THE FISCAL CRISIS AND WHY U.S. DEFICITS ARE SO INTRACTABLE. IT CONCLUDES THAT OVER TIME, THE UNITED STATES MAY BE ABLE TO MAKE HAY FOR A MORE SELF-ASSERTIVE EUROPE IN A MORE RATIONAL FORM OF BURDEN-SHARING.

02052 CALLICK, R.

LAND OF' THE BUNGEE-JUMPERS

LAND OF THE BUNGEE-JUMPERS

NEH ZEALAND HAS ALWAYS PRIDED ITSELF IN BEING APART FROM THE PACK-CHILE AT THE SAME TIME REMAINING ALMOST OBSESSIVELY CONCERNED ABOUT HOW IT IS VIEWED BY ITS PEERS. SUCH A DICHOTOMY BOTH REFLECTS AND SPAWNS INSECURITY. MANY NEW ZEALANDERS HAVE FOUND A SOURCE OF DISTRACTING PRIDE IN FORGING A NEW SENSE OF IDENTITY AS THE TINY NATION THAT SAID
NO TO THE YANKS. AT THIS TIME NEW ZEALND IS OUT ON A BUNGEENO TO THE YANKS. AT THIS TIME NEW ZEALND IS OUT ON A BUNGEE JUMPING BRIDGE, SCANNING THE ABYSS WITH INCREASING ANXI WISHING IT COULD FEEL MORE ASSURED OF REBOUNDI
EXHILARATING ECONOMIC AND STRATEGIC SUCCESS.

02053 CALLINICOS, A.

REFORM AND REVOLUTION IN SOUTH AFRICA: A REPLY TO JOHN SAUL NEW LEFT REYIEW, (195) (SEP 92), 111-117.

JOHW SAUL HAS OFFERED WHAT IS IN MANY RESPECTS A CONVINCING ANALYSIS OF THE CONTRADICTORY CHARACTER OF THE CURRENT SITUATION IN SOUTH AFRICA, AND HE HAS EXTENDED HIS ARGUMENT FROM APPRAISAL TO ADVDCACY. HE BELIEVES THAT THE ALTERNATIVE TO THE COUNTER-REVOLUT IONARY VIOLENCE OF THE INKATHA AND THE STATE IS A STRATEGY OF STRUCTURAL REFORM DESIGNED GRADUALLY TO MOVE SOUTH AFRICA ONTO A SOCIALIST PATH. IN THIS ESSAY, THE AUTHOR CRITIQUES SAUL'S ARGUMENTS

02054 CALLOVI, G.

REGULATION OF IMMIGRATION IN 1993: PIECES OF THE EUROPEAN COMMUNITY JIG-SAH PUZZLE

INTERNATIONAL MIGRATION REVIEW, XXVI(2) (SUM 92), 353-372. MIGRATION AND IMMIGRATION ISSUES ILLUSTRATE BETTER THAN MOST OTHER SUBJECTS THE CHALLENGE THE EUROPEAN COMMUNITY IS FACING, BOTH IN TERMS OF DOCTRINE AMD PRACTICE. THIS ARTICLE FACING, BOTH IN TERMS OF DOCTRINE AND PRACTICE. THIS ARTICLE TAKES STOCK OF PAST EC POLICY ON MIGRATION, AMD COVERS SOME
BASIC ELEMENTS WHICH ARE SHAPING A FUTURE COMMON POLICY, BASIC ELEMENTS WHICH ARE SHAPING A FUTURE COMMON POLICY,
CARR IED OUT EITHER THROUGH INTER-GOVERMMENTAL COOPERATION OR CARRIED OUT EITHER THROUGH INTER-GOVERNMENTAL COOPERATION OR IN 1993 IS STILL AT A CROSSROADS WITH MULTIPLE POSSIBLE OUTCOMES. HOWEVER, THE MOST RECENT FEATURES AND THE VITAL IMPETUS SET UP BY THE INTER-GOVERNMENTAL CONFERENCE ON POLITICAL UNION PROVIDES SOME NEW INSTITUTIONAL CAPACITY FOR THE EC TO ACT IN A STRENGTHENED JURIDICIAL AND POLITICAL FRAMENORK.
02055 CALVERT, R.

LEADERSHIP AND ITS BASIS IN PROBLEMS OF SOCIAL COORDINATION INTERNATIONAL POLITICAL SCIENCE REVIEN, 13(1) (JAN 92), 14 .

LEADERSHIP IS A MEANS BY WHICH SOCIAL GROUPS ATTEMPT TO REALIZE GAINS FROM COOPERATION, COORDINATION, AND EFFICIENT ALLOCATION. THE STABILITY OF LEADERSHIP IS BASED ON THE GROUP'S NEED TO SOLVE COORDINATION PROBLEMS. AS A RESULT, A LEADER HAS DISCRETION OR "POWER," AND CAN GET AWAY WITH LESS-
THAN-MAXIMAL SERVICE OF GROUP GOALS. THIS APPROACH TO UNDERSTANDING LEADERSHIP SUGGESTS SEVERAL USEFUL TECHNIQUES FOR THE STUOY OF POLITICAL LEADERSHIP IN PARTICULAR SETTINGS. THE COORDINATION MODEL ESTABLISHES THAT RESTRAINT IS PROBLEMATIC, AND THUS LOCATES THE POWER OF A LEADER IN THE GOALS OF FOLLOWERS.

02056 CAMERON, D.

A TASTE DEMOCRACY

CANADIAN FORUM, LXX(807) (MAR 92), 3.

WHILE OPEN, FREE ELECTIONS ARE' OFTEN THOUGHT TO BE THE TEST OF DEMOCRATIC GOVERMMENT. THE TRUE BASIS OF DEMOCRACY IS OPEN DISCUSSION AND WIDE DEBATE. THE GREATEST ACHIEVEMENT OF THE CONSTITUTIONAL CONFERENCES OF HALIFAX, CALGARY, OF THE CONSTITUTIONAL CONFERENCES OF HALIFAX, CALGARY,
MONTREAL, TORONTO AND VANCOUVER MAY HAVE BEEN TO GIVE MONTREAL, TORONTO AND VANCOUVER MAY HAVE BEEN TO GIVE CANADIANS A TASTE FOR MORE DEMOCRACY. WHILE NO ONE WOULD
TAKE THESE GATHERINGS TO BE CONSTITUTED IN A DEMOCRATIC TAKE THESE GATHERINGS TO BE CONSTITUTED IN A DEMOCRATIC
FASHION, THEY DID ADVANCE DEBATE IN CANADA OUTSIDE QUEBEC FASHION, THEY DID ADVANCE DEBATE IN CANADA OUTSIDE QUEBEC. THIS ARTICLE SUGGESTS THAT RAISING THE LEVEL OF DEMOCRATIC DEBATE AND BROADENING THE RANGE OF PARTICIPATION WOULD
SUPERIOR TO THE LIMITED PERSPECTIVE OF INTEREST-GROUP SUPERIOR

02057 CAMERON, D

THOUGHT' CONTROL

CANADIAN FORUM, LXXI(809) (MAY 92), 4

BY SHUTTING DOWN CANADA'S FEDERALL 'Y FUNDED RESEARCH INSTITUTES THE CONSERVATIVES HAVE SHOWN WHAT LITTLE VALUE THEY PLACE ON INDEPENDENT THOUGHT, CLAIMS THIS ARTICLE. IT STATES THAT GOOD RESEARCH SETS THE AGENDA FOR PUBLIC LIFE, INTELLIGENT POLICY FORMULATION NEEDS RESEARCH, AND CONCLUDES THAT RESEACH NEEDS TO BE DONE BY MANY GROUPS. IT REQUIRES PUBLIC SUPPORT.

02058 CAMERON, $K$

CLASS STRUGGLE IN THE SOVIET UNION

POLITICAL AFFAIRS, 71(4) (JUN 92), 30-32.

THIS ARTICLE ARGUES THAT CLASS' STRUGGLE WAS BEHIND THE FALL OF THE COMMUNIST PARTY IN THE SOVIET UNION. IT ARGUES THAT AN ELITE CLASS, AN "INTELLIGENTSIA," TEMPORARILY SIDETRACKED THE REVOLUTIONARY SPIRIT OF' THE SOVIET WORKERS SIDETRACKED THE REVOLUTIONARY SPIRIT OF THE SOVIET WORKERS AND THEIR ALLIES. THE ARTICLE SEEKS TO DETERMINE THE ORIGINS
AND HISTORY OF THIS CAPITALIST-ORIENTED CLASS. IT CONCLUDES AND HISTORY OF THIS CAPITALIST-ORIENTED CLASS. IT COMC THAT THE ESSENT IALLY BOURGEOIS-ORIENTED CORE OF THE INTELLIGENTSIA HAS EXISTED EVER SINCE THE REVOLUTION. THIS CLASS HAS MANAGED TO PASS ON ITS HOPES AND HATES FROM

GENERATION TO GENERATION. IT WAS MERELY LYING IN WAIT FOR AN
OPPORTUNITY TO REALIZE THE DREAM OF RESTORING CAPITALISM.

02059 CAMERON, M.

RATIONAL RESIGNATIONS: COALITION BUILDING IN PERU AND THE PHILIPPINES

COMPARATIVE POLITICAL STUDIES, 25(2) (JUL 92), 229-250. UNDER WHAT CONDITIONS IS THE THREAT OF RESIGNATION A POWERFUL BARGAINING INSTRUMENT? THIS ARTICLE DRAWS ON THE THEORY OF GAMES TO SHOW HOW THE RANKING OF ACTOR PREFERENCES AND THE ASSIGNMENT OF RULES CONCERNING THE DECISION-MAKING PROCESS TO STRATEGIC INTERACTION CAN GENERATE GAMES THAT ALLOH US TO EXPLAIN BARGAINING OUTCOMES. A MAJOR LIMITATION OF GAME THEORY, HOWEVER, IS THAT IT ASSUMES ALL ACTORS ARE EQUALLY MOTIVATED TO PLAY. A MODEL IS OEVELOPED TO SHOW HOW ACTORS MAY TRY TO INFLUENCE OTHER ACTORS' PERCEPTIONS OF THEIR WILLINGNESS TO PLAY IN ORDER TO EXTRACT CONCESSIONS THE MODEL IS APPLIED IN TWO DISTINCT NATIONAL SETTING: THE RESIGNATION OF MARIO VARGAS LLOSA FROM THE PERUVIAN DEMOCRATIC FRONT IN AN EFFORT TO FORCE HIS COALITION PARTNERS TO BOW TO HIS DEMANDS OR ACCEPT THE DIVISION OF THE COALITION AND THE RESIGNATION OF PHILIPPINE POLITICIAN SALVADOR LAUREL FROM THE AOUINNO COALITION IN ORDER OVERCOME THE RESISTANCE OF AOUINO'S ALLIES TO THE PREDOMINANCE OF HIS PARTY WITHIN THE ANTI-MARCOS COALITION. THESE EVENTS, AND THE BARGAINING THAT FOLLOWED THEM, SHARED A COMMON STRATEGIC LOGIC. IN BOTH CASES CAREFULLYY REASONED RESIGNATIONS WERE HITHDRAHN AND THE RESPECTIVE COALITIONS RESIGNATIONS WERE WITHDRAWN, AND THE RESPEC

02060 CAMERON, $S$.

HOUSING, GENTRIFICATION, AND URBAN REGENERATION POLICIES URBAN STUDIES, 29 (1)

THE AUTHOR EXAMINES THE ROLE OF HOUSING IN RECENT URBAN REGENERATION POLICIES IN GREAT BRITAIN AND THE QUESTION OF WHETHER THIS INVOLVES A PROCESS OF GENTRIFICATION. USING EXAMPLES FROM TYNESIDE, HE NOTES THE EMPHASIS ON RIVERSIDE AND CENTRAL-CITY LOCATIONS, AWAY FROM ESTABLISHED RESIDENTIAL AREAS, AND ON HIGH-COST HOUSING. BUT THIS IS NOT 
GENTRIFICATION IN THE MOST DIRECT SENSE, BECAUSE IT DOES NOT DISPLACE OR REDUCE HOUSING OPPORTUNITIES FOR LOH-INCOME RESIDENTS. EVALUATION MUST TAKE ACCOUNT OF NON-HOUSING ISSUES, SUCH AS THE EMPLOYMENT EFFECTS AND THE POLITICAL AND IDEOLOGICAL IMPLICATIONS OF THESE HOUSING POLICIES.

02061 CAMPBELL, J.

FORECASTING THE PRESIDENTIAL VOTE IN THE STATES AMERICAN JOURNAL OF POLITICAL SCIENCE, 36(2) (MAY 92), 386-407.

THIS RESEARCH EXAMINES AN EQUATION DEVELOPED TO FORECAST THE TWO-PARTY PRESIDENTIAL VOTE IN THE STATES. THE EQUATION IS COMPOSED OF 16 INDEPENDENT VARIABLES MEASURED AT THE NATIONAL, REGIONAL AND STATE LEVELS. IT INCLUDES NATIONAL NAT IONAL, REGIONAL AND STATE LEVELS. IT INCLUDES NATIONAL
TRIAL-HEAT POLLS FROM EARLY IN THE CAMPIAGN. THE GROWTH IN TRIAL-HEAT POLLS FROM EARLY IN THE CAMPIAGN, THE GROWTH IN THE NATIONAL ECONOMY, PRESIDENTIAL INCUMBENCY, THE STATE'S HOME STATE AND REGI HOME STATE AND REGIONAL ADVANTAGES FOR THE CANDIDATES, THE
PARTISAN DIVISION OF THE STATE LEGISLATURE FOLLOWING THE PARTISAN OIVISION OF THE STATE LEGISLATURE FOLLOWING THE LAST MIDTERM ELECTION, AN INDEX OF STATE IDEOLOGY BASED ON THE ROLL CALL VOTING OF THE ITS HOUSE DELEGATION, AND FIVE REGIONAL TREND VARIABLES TO TAKE INTO ACCOUNT PARTISAN SHIFTS OVER TIME. THE EQUATION IS ESTIMATED OVER 531 STATE ELECTIONS FROM 1948 TO 1988. THE OVERALL FIT OF THE EQUATION IS QUITE GOOD. IT ACCOUNTS FOR NEARLY $85 \%$ OF THE VARIANCE AND LEAVES A STANDARD ERROR OF LESS THAN FOUR PERCENTAGE POINTS.

02062 CAMPBELL, J.

LAND OR PEASANTS?: THE DILEMMA CONFRONTING ETHIOPIAN RESOURCE CONSERYATION

AFRICAN AFFAIRS, 90(358) (JAN 91), 5-22.

THE AUTHOR ARGUES AGAINST THE ASSUMPTION THAT RURAL PEOPLE HAVE ONLY A PASSIVE ROLE TO PLAY IN CONSERVATION AND, AS ULTIMATE BENEFACTORS OF LONG-TERM IMPROVEMENT, CAN ONLY GAIN BY CONSERYATION PROJECTS. THE PAPER IS DIVIDED INTO THREE PARTS: (1) A LOOK AT THE PRESENT STATE OF LAND DEGRADATION TOGETHER WITH AN ANALYSIS OF ITS CAUSES; (2) A LOOK AT EVIDENCE CONCERNING GROHING IMPOVERISHMENT OF THE RURAL PEASANTRY AS THEY ARE CAUGHT BETHEEN GOVERNMENT POLICY RURAL CONSERVATION EFFORTS: AND (3) AN EXAMINATION OF POLICY AND CONSERVATION EFFORTS; AND (3) AN EXAMINATION OF POLICY
OPTIONS WHICH DO NOT REQUIRE SAVING LAND AT THE EXPENSE OF OPTIONS WHIO
PEASANTS.

02063 CAMPBELL, J.; CHERRY, L.; WINK, K.

THE CONVENTION BUMP

AMERICAN POLITICS QUARTERLY, 20(3) (JUL 92), 287-307. THIS STUOY INVESTIGATES WHETHER POLL STANDINGS ARE BUMPED UPWARDS FOLLOWING THE PARTY CONVENTIONS. THE CONVENTION BUMP IS EXAMINED THROUGH THE COURSE OF SEVEN CAMPAIGNS FROM 1964-TO 1988. THE AUTHORS FIMD THAT (1) WITH FEW EXCEPTIONS, THERE IS A CONVENTION BUMP; (2) THE BUMP TYPICALLY ADDS ABOUT 5 TO 7 PERCENTAGE POINTS TO THE NOMINEE'S POSTCONVENTION POLL STANDING; (3) THE EFFECTS OF CONVENTIONS CARRY WELL INTO THE GENERAL ELECTION CAMPAIGN; (4) THE FIRST CONVENTION IN THE CAMPAIGN SEQUENCE, HELD BY THE OUT-PARTY, GENERATES AN ADDITIONAL BUT TEMPORARY INCREASE IN THE NOMINEE'S SUPPORT: AND (5) CONYENTION BUMPS MAY BE GREATER FOR HARMONIOUS CONVENTIONS FOLLOWING DIVISIVE NOMINATION CONTESTS.

02064 CAMPBELL, J.E.; MANN, T.E. FORECASTING THE 1992 PRESIDENTIAL ELECTION: A USER'S GUIDE TO THE MODELS

BROOKINGS REVIEW, 10(4) (FAL 92), 22-27.

THE AUTHORS EXPLAIN SEVERAL MÓDELS DEVELOPED BY ECONOMISTS AND POLITICAL SCIENTISTS TO DISCOVER THE UNDERLYING STRUCTURE OF PRESIDENTIAL ELECTIONS ANO DISCUSS HOW THEY MAY APPLY TO THE 1992 PRESIDENTIAL RACE.

02065 CAMPBELL, $K$.

ALL RISE FOR CHAIRMAN POWELL

NATIONAL INTEREST, (23) (SPR 91), 51-60

THE PERSIAN GULF CRISIS SAW THE CHAIRMAN OF THE JOINT CHIEFS OF STAFF, GENERAL COLIN L. POWELL, PLAYING A VERY PUBLIC ROLE AS MILITARY STRATEGIST, PRESIDENTIAL CONFIDANT, AND ADMINISTRATIVE SPOKESMAN. YET THE CHAIRMAN'S NEW POWER AND ACCESS BOTH PRECEDE AND TRANSCEND THE WAR IN THE GULF. AS A RESULT OF A QUIET EVOLUTION IN THE WAY THE AMERICAN MILITARY ESTABLISHMENT IS ORGANIZED AND OPERATES, THE
CHAIRMAN AND THE MILITARY CULTURE OF "JOINTNESS" ARE NOW IN CHAIRMAN AND THE MILITARY CULTURE OF "JOINTNESS" ARE ASCENDANCE. ALTHOUGH THE RISE OF THE CHAIRMAN IN THE BUREAUCRATIC ARENA OF WASHINGTON HAS BEEN HELPED BY INTERNATIONAL EVENTS, STRONG PERSONAL TIES, AND GOOD
PROFESSIONAL PREPARATION, IT OWES JUST AS MUCH TO AN OBSCURE PROFESSIONAL PREPARATION, IT OWES JUST AS MUCH TO AN MILITARY REFORM ACT. THE GOLDWATER-NICHOLS DEFENSE
REORGANIZATION ACT OF 1986 STANDS AS ONE OF THE MOST REORGANIZATION ACT OF 1986 STANDS AS ONE OF THE MOST
IMPORTANT, YET UNHERALDED, MILITARY REFORMS IN U.S. HISTORY.

02066 CAMPBELL, $K$.

LATIN AMERICA AND SOUTH AFRICA

SOUTH AFRICA FOUNDATION REVIEW, 17 (12) (DEC 91), 7 . UNIVERSITY OF SOUTH AFRICA'S CENTRE FOR LATIN AMERICAM
STUDIES ARE SUMMARIZED IN THIS ARTICLE. MAXI VAN AARDT FOCUSED ON THE POLITICAL ASPECTS OF REGIONAL CO-OPERATION, ARGUING THAT THE SOUTH AMERICAN EXPERIENCE WAS A VALID MODEL FOR SOUTHERN AFRICA. ANTHONY LEYSENS WAS CONCERNED WITH SOUTH AFRICA'S ECONOMIC RELATIONS WITH SOUTH AMERICA, POINTING OUT THAT SOUTH AFRICAN INTEREST IN SUCH RELATIONS REALLY BEGAN IN THE LATE 1960S. MIKE MULLER5 GAVE HIS ATTENTION TO THE PHYSICAL ASPECTS OF REGIONAL INTEGRATION, EMPHASISING THE NEED TO AVOID EUROCENTRIC MODELS AS INAPPROPRIATE TO SOUTHERN AFRICA. AND GAVIN MAASOORP LOOKED AT LATIN AMERICAN AND SOUTHERN AFRICAN EXPERIENCES OF ECONOMIC INTEGRATION.

02067 CAMPBELL, M.L.

AOMINISTERING CHILD PROTECTION: A FEMINIST ANALYSIS OF THE AOMINISTERING CHILD PROTECTION: A FEMINIST ANAL

CANADIAN PUBLIC ADMINISTRATION, 35(4) (WIN 92), 501-518. THE AUTHOR EXAMINES TEXTUALLY-MEDIATED ADMINISTRATIVE TECHNOLOGY, SUCH AS THAT BEING IMPLEMENTED BY ONTARIO'S MINISTRY OF COMMUNITY AND SOCIAL SERVICES TO ORGANIZE MORE EFFECTIVE CONTROL OVER THE DELIVERY OF CONTRACTED SERVICES TO CHILDREN AND FAMILIES UNDER CHILD WELFARE LEGISLATION. A
CASE STUDY OF THE DEVELOPMENT AND TESTING OF CASE-WEIGHTING, CASE STUDY OF THE DEVELOPMENT AMD TESTING OF CASE-WEIG
A RELATED TECHNOLOGY INITIATED BY THE METRD TORONTO CHILOREN'S AID SOCIETY, OFFERS THE OPPORTUNITY FOR AN INDEPTH ANALYSIS OF CONCEPTUAL PRACTICES FOR EXERCISING ORGANIZATIONAL POWER. THE USE OF CONCEPTUAL PRACTICES, MADE PRACTICABLE BY IMPROVEMENTS IN COMPUTER FACILITIES REPRESENTS A MAJOR DEVELOPMENT IN MANAGERIAL METHOD THAT RESTRUCTURES ORGANIZATIONAL MEANINGS, RESULTS, AND RELATIONS AMONG PARTICIPANTS IN HUMAN SERVICE ORGANIZATIONS. FEMINIST SCHOLARSHIP CONTRIBUTES BOTH A CRITICAL STANCE ON THE APPROACH BEING TAKEN TO CHILD PROTECTION SERVICES AND APPROPRIATE METHODOLOGY FOR THE ANALYSIS.

02068 CANAN, P.; HENNESSY, M.; KRETZMANN, M.; PRING, G.H. USING LAW IDEOLOGICALLY: THE CONFLICT BETWEEN ECONOMIC AND POLITICAL LIBERTY

JOURNAL OF LAH \& POLITICS, VIII(3) (SPR 92), 539-558.

THE TYPICAL "SLAPP" (STRATEGIC LAWSUIT AGAINST PUBLIC PARTICIPATION) INVOLVES A CITIZEN OR GROUP WHOSE POLITICAL EXPRESSION TO A PUBLIC OFFICIAL, POLITICAL REPRESENTATIVE, EXPRESSION TO A PUBLLIC OFFICIAL, POLITICAL REPRESENTA
OR THE ELECTORATE THREATENS THE ECONOMIC INTERESTS OF OR THE ELECTORATE THREATENS THE ECONOMIC INTERESTS OF
ANOTHER PARTY. IF THE LATTER CLAIMS LEGAL INJURY FROM THE ANOTHER PARTY. IF THE LATTER CLAIMS LEGAL INJURY FROM THE
EXPRESSIONS OR CLAIMS MADE BY OPPONENTS IN THE POLITICAL EXPRESSIONS OR CLAIMS MADE BY OPPONENTS IN THE POLITICAL
ARENA. THE FILING OF A LAWSUIT IS AN ATTEMPT TO SANCTION ARENA, THE FILING OF A LAWSUIT IS AN ATTEMPT TO SANCTION
THAT POLITICAL SPEECH. IN SLAPP'S, FILERS ASSERT THAT THAT POLITICAL SPEECH. IN SLAPP'S, FILERS ASSERT THAT CONSTITUTIONALLY-PROTECTED POLITICAL ACTS INJURED THEM. IMPORTANT WAYS: (1) THEY ARE NOT TYPICAL COUNTER-MOVES IN THE TRANSFORMATION OF LEGAL DISPUTES; THEY TURN THE TABLES ON CLAIMANTS IN A POLITICAL FORUM, FORCING THEM INTO A JUDICIAL FORUM WHERE THEY ARE CAST IN THE ROLE OF DEFENDANT ; (2) THE NEW JUDICIAL CLAIM MASKS OR DEFLECTS THE ORIGINAL ISSUE IN CONTENTION; (3) AS A TACTIC TO UNDERMINE THE RESOURCES, COMMITMENT, AND VOCABULARY OF POLITICAL OPPOSITION, SLAPP'S ARE A CREATIVE MEANS FOR IDEOLOGICALLY HARRING AGAINST EGALITARIAN PRINCIPLES OF CITIZEN PARTICIPATION. IN THIS PAPER, THE AUTHORS LOOK AT SLAPP'S, FOCUSING ON (1) WHY DISPUTANTS BECOME INVOLVED IN PUBLIC DISPUTES AND RESORT TO LAWSUITS TO STIFLE OPPOSITION AND (2) WHAT THESE SUITS REVEAL ABOUT THE TENSION BETWEEN CAPITALISM AND DEMOCRACY IN THE USA.

02069 CANEPA, E.

BORIS KAGARLITSKY ON NEO-LIBERALISM AND SOCIALISM IN THE SOVIET UNION

SOCIALISM AND DEMOCRACY, (12) (JAN 91), 11-18.

THIS ARTICLE REPORTS ON A SPEECH BY' BORIS KAGARLITSKY, A

LEADER OF THE MOSCOW POPULAR FRONT FOR PERESTROIKA AND OF

THE RUSSIAN SOCIALIST PARTY (RSP). KAGARLIISKY ADDRESSED THO

MAJOR PROBLEMS: WHAT IS THE SIGNIFICANCE OF THE COMMUNIST

PARTY STILL BEING IN POWER WHILE CAPITALIST TRANSFORMATIOM

IS OCCURRING; AND WHAT KIND OF

02070 CANEY, S

LIBERALISM AND COMMUNITARIANISM: A MISCONCEIVED DEBATE POLITICAL STUDIES, XL(2) (JUN 92), 273-289.

THIS ARTICLE CONSIDERS THE CRITICISMS MADE OF LIBERAL POLITICL THOUGHT BY COMMUNITARIANS IN THE 1980S. IT AIMS TO CLARIFY THE COMHUTITARIAN CRITIOUE AND EVALUATE THE FORCE COMMUNITARIAN CRITICISMS OF LIBERALISM. IT ARGUES THAT

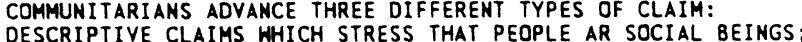
DESCRIPTIVE CLAIMS WHICH STRESS THAT PEOPLE AR SOCIAL BEINGS; NORMATIVE CLAIMS WHICH CELEBRATE THE VALUE OF COMAUN ITY
SOLIDARITY AND A META-ETHICAL CLAIM EMPHASIZING THAT SOLIDARITY, AND A META-ETHICAL CLAIM EMPHASIZING THAT POLIITICAL PRINCIPLES SHOULD MIRROR "SHARED UNDERSTANDINGS" THIS ARTICLE ARGUES THAT THE DESCRIPTIVE AND NORMATIVE
CLAIMS ESPOUSED BY COMHUNITARIANS ARE JUDGED TO BE PLAUSIBLE BUT ARE ACCEPTED BY LIBERALS, AND THAT THE META-ETHICAL THESIS IS UNTENABLE AND LIBERALS ARE RIGHT TO ESCHEW IT. 
02071 CANFIELD, R.L.

IM GREATER CENTRAL ASIA: CHANGING POLITICAL CONFIGURATIONS

ASIAN SURVEY, XXXII(10) (OCT 92), 875-887

THIS ARTICLE ARGUES THAT CERTAIN TECHNOLOGICAL CHANGES ARE BEING INTRODUCED INTO GREATER CENTRAL ASIA WHICH WILL TRANSFORM THE POSSIBILITIES FOR SOCIAL AND POLITICAL ACTIOM IN THE REGION. THE ARTICLE PARTICULARLY EMPHASIZES TRANSPORTATION AND COMMUNICATIONS TECHMOLOGIES. IT FIRST CONSIDERS THE POLITICAL EFFECTS OF TRANSPORT AND COMMUNICATIONS TECHNOLOGIES IN THE PAST. IT THEN EXAMINES THE EMERGING PATTERNS OF CURRENT POLITICAL RELATIONS WITH REGARDS TO THE TECHNOLOGICAL ADVANCES AND CHANGES IN THE REGION. IT THEN CONSIDERS POSSIBLE FUTURE DIRECTIONS. THE AUTHOR ARGUES THAT THE LONG-ESTABLISHED YET RECENTLY COLLAPSED GEOPOL ITICAL CONFIGURATION IN THIS REGION WAS AFFECTED BY CHANGES IN TRANSPORT FACILITIES AND COMMUNICATIONS DEVICES, AND THAT THE NEW GEOPOL ITICAL CONFIGURATION WILL TAKE FORM IN RESPECT TO OTHER CHANGES IN THESE FACILITIES AND DEVICES.

02072 CANNON, M.

THE DEVELOPMENT OF THE AMERICAN THEORY OF LIMITED WAR, THE DEV $1945-63$

ARMED FORCES AND SOCIETY, 19(1) (FAL 92), 71-104.

THIS ARTICE CHALLENGES THE IDEA THAT THE THINKERS WHO DEYELOPED THE AMERICAN THEORY OF LIMITED WAR PRIOR TO VIETNAM WERE GROSSLY IN ERROR. A FRAMEWORK FOR THE ELEMENTS OF THE THEORY IS CONSTRUCTED THROUGH A DISCUSSION OF THE HISTORICAL AMERICAN WAY OF WAR, THE DEVELOPMENTS DURING THE LATE 1940S AND EARLY 1950S THAT BROUGHT ABOUT CHANGES IN THESE TRADITIONS, POLICIES, AND STRATEGIES ADOPTED BY THREE ADMINISTRATIONS, AND AN EXAMINATION OF THE WRITINGS OF THE LIMITED WAR THEORISTS THROUGH THE EARLY 1960S. AN ANALY THEDRISTS AS A BASIS. THE ARITCLE CLOSES WITH A DISCUSSION OF THE IMPLICATIONS OF THE THEORY OF LIMITED WAR FOR TODAY.

02073 CANON, D.T.; SOUSA, D.J.

PARTY SYSTEM CHANGE AND POLITICAL CAREER STRUCTURES IN THE U.S. CONGRESS

LEGISLATIVE STUDIES QUARTERLY, XVII(3) (AUG 92), 347-364. THE AUTHORS EXPLORE THE LINKAGE BETHEEN PARTISAN REALIGHMENTS AND THE CAREER PATTERNS OF POLITICIANS. THEY HYPOTHESIZE THAT WHEN A REALIGNMENT OCCURS QUICKLY, THE EMERGING MAJORITY PARTY WILL RELY HEAVILY ON INEXPERIENCED "POLITICAL AMATEURS" 8ECAUSE IT LACKS A POOL OF "POLITICAL AMATEURS" 8ECAUSE IT LACKS A POOL OF
PROFESSIOMALS. WHEN THE CHANGE IN THE PARTIES IS MORE PROFESSIONALS. WHEN THE CHANGE IN THE PARTIES IS MORE
GRADUAL. THE EMERGING PARTY WILL HAVE THE OPPORTUNITY TO GRADUAL, THE EMERGING PARTY WILL HAVE THE OPPORTUNI
DEVELOP ITS OWN PROFESSIONALS AND WILL ALSO ATTRACT DEVELOP ITS OWN PROFESSIONALS AND WILL ALSO ATTRACT EXPERIENCED POLITICIANS FROM THE OTHER PARTY. THE AUTHORS CAREER PATTERNS OF MEMBERS OF THE U.S. HOUSE OF CAREER PATTERNS OF MEMBERS OF THE U.S. HOUSE OF REPUBLICAN PARTY OF THE MODERN SOUTH.

02074 CANTOR, J.

EXPANDING HEALTH INSURANCE COVERAGE: WHO HILL PAY? JOURNAL OF HEALTH POLITICS, POLICY AND LAW, 15(4) (WIN 90), 755-778.

RECENT DISCUSSIONS ON EXTENDING HEALTH INSURANCE TO THE MORE THAN THIRTY MILLION UNINSURED AMERICANS HAVE FOCUSED ON THO STRATEGIES: EXPANDING THE MEDICAID PROGRAM AND MANDATING THAT EMPLOYERS SPONSOR COVERAGE FOR THEIR EMPLOYEES. THIS ANALYSIS, USING A MICROSIMULATION MODEL OF THE U.S. HEALTH CARE FINANCING SYSTEM, SUGGESTS THAT THESE TWO OPTIONS WOULD
RESULT IN VERY DIFFERENT DISTRIBUTIONS OF FINANCIAL BURDEN. EMPLOYER-SPONSORED COVERAGE IS FINANCED IN A HIGHLY REGRESSIVE FASHION, IN CONTRAST TO THE MEDICAID PROGRAM, WHICH IS PROPORTIONAL TO INCOME. FURTHERMORE. THE BURDEN OF PAYING FOR HEALTH CARE UNDER MEDICAID VARIES LITTLE AMONG GENERATIONS, WHEREAS THE COST OF EMPLOYER-SPONSORED CARE IS LOWEST IN HOUSEHOLDS HEADED BY PERSONS OVER SIXTY-FIVE YEARS OLD. LOW HEALTH STATUS POPULATIONS DO NOT PAY DISPROPORTIONATELY HIGHER TAXES OR PREMIUMS TO FINANCE EITHER THE MEDICAID PROGRAM OR EMPLOYER-SPONSORED COVERAGE. THEIR INCOMES, HOWEYER, ARE MORE EFFECTIVELY PROTECTED BY MEDICAID, BECAUSE IF OFFERS MORE COMPREHENSIYE BENEFITS.

02075 CANTRELL, P.

OPINION POLLING AMO AMERICAN DEMOCRATIC CULTURE INTERNATIONAL JOURMAL OF POLITICS, CULTURE AMD SOCIETY, 5(3) (SPR 92), 405-438.

POLLS ARE AN INTEGRAL PART OF AMERICAN POLITICAL STRUCTURE BECAUSE OF THEIR LONGEVITY, THEIR RELATIVE SUCCESS, STRUCTURE BECAUSE OF THEIR LONGEVITY, THEIR RELATIVE SUCCESS, BEEN CDNDUCTED FOR ALMOST SIXTY YEARS AND HAVE BEEN INSTITUTITIONALIZED IN AMERICAN POLICIS. THE FOUR SECTIONS INSTITUTITIONALIZED IN AMERICAN POLICIS. THE FOUR SECTIONS OF THIS PAPER INCLUDE DISCUSSIONS OF VARIETIES OF POLLING,
OF HOW IT IS USED IN POLITICAL CAMPAIGNS. OF ITS IMPACT ON REPRESENTATION, AKD OF CURRENT ISSUES IN POLITICAL COMMUN ICATION.
02076 CAPEK, S.M.

ENVIRONMENTAL JUSTICE, REGULATION, AND THE LOCAL COMMUNITY INTERNATIONAL JOURNAL OF HEALTH SERVICES, $22(4)(1992)$ $729-746$.

THE AUTHOR EXAMINES THE SOCIOLOGICAL SIGNIFICANCE OF THE CONCEPT OF "ENYIRONMENTAL JUSTICE" FOR GRASSROOTS GROUPS RESPONDING TO TOXIC CONTAMINATION IN THEIR LOCAL COMMUNITIES. SHE DOCUMENTS A PRECEDENT-SETTING EPISOOE IN THE TOWN OF JACKSONVILLE, ARKANSAS, WHERE CITIZEN PROTESTS AND SUPPOR FROM NATIONAL ENVIRONMENTAL GROUPS LED THE ENVIRONMENTAL PROTECTION AGENCY TO WITHDRAW THREE TECHNICAL ASSISTANCE GRANTS INAPPROPRIATELY AWARDED TO A GROUP HITH LINKS TO A POLLUTING INDUSTRY AND SUBSEQUENTLY TO REWRITE THE RULES FOR PARTICIPATION IN SUCH GRANTS. AS THE FIRST SUCH CHALLENGE, THE JACKSONVILLE SCENARIO IS AN IMPORTANT TEST CASE AND PERMITS A THEORETICAL AND PRACTICAL EVALUATION OF THE RELATIONSHIP BETWEEN SOCIAL GROUPS, TECHNOLOGY, AND THE GOVERNMENTAL REGULATORY PROCESS. IT ALSO GIVES INSIGHT INTO THE TECHNICAL ASSISTANCE GRANTS PROGRAM, WHICH HAS BEEN UNDERCUT BY A WEAK EPA AND COOPTATION EFFORTS BY INDUSTRIES.

02077 CAPELIK, A.

YELTSIN'S ECONOMIC REFORM: A PESSIMISTIC APPRAISAL

RFE/RL RESEARCH REPORT, 1(4) (JAN 92), 26-32.

THE PRICE INCREASES LEVIED IN EARLY JANUARY 1992 ARE

ONLY OME ELEMENT OF THE RUSSIAH ECONOMIC REFORM PROGRAM ONLY ONE ELEMENT OF THE RUSSIAN ECONOMIC REFIST PR THE BRAINCHILD OF DEPUTY PRIME MINISTER EGOR GAIDAR. WHICH IS THE BRAINCHILD OF DEPUTY PRIME MINISTER EGOR GAIDAR.
OTHER IMPORTANT ASPECTS ARE DEMONOPOLIZATION, FOREIGN TRADE OTHER IMPORTANT ASPECTS ARE DEMONOPOLIZATION, FOREIGN TRADE
REFORM, INCREASING RUSSIAN SOVEREIGNTY, AND THE CREATION OF REFORM, INCREASING RUSSIAN SOVEREIGNTY, AND THE CREATION OF A SAF MARKETIZATION. THE CHAOTIC ECONOMIC CONDITIONS SURROUNDING THE INTRODUCTION OF REFORMS DO NOT BODE WELL FOR SURROUNDING THE

02078 CAPELIK, V.

THE DEVELOPMENT OF ANTIMONOPOLY POLICY IN RUSSIA RFE/RL RESEARCH REPORT, 1(34) (AUG 92), 66-70 DEMONOPOL IZATION IS WIDELY PERCEIVED AS A CRUCIAL ELEMENT IN RUSSIA'S ECONOMIC TRANSFORMATION. ALTHOUGH ANTIMONOPOLY LEGISLATION WAS PASSED IN 1991, IT HAS BEEN RELATIVELY INEFFECTIVE TO DATE, BECAUSE IT HAS NOT BEEN VIGOROUSLY APPLIED. ON THE OTHER HAND, SPONTANEOUS OEMONOPOLIZATION PROCESSES HAVE ALREADY SUCCEEDED IN INCREASING THE DEGREE OF COMPETITION IN MANY MARKETS.

02079 CAPLAN, L.

FROM TRIBE TO PEASANT? THE LIMBUS AND THE NEPALESE STATE JOURNAL OF PEASANT STUDIES, 18(2) (JAN 91), 305-321. THIS ARTICLE'S CONTEXT IS THE DISTINCTION IN FORM AND MEANING OF LAND TENURE SYSTEMS AS BETWEEN TRIBES AND

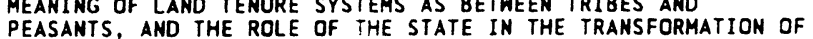
PEASANTS, AND THE ROLE OF THE STATE IN THE TRANSFORMA TRADITIONALLY INALIENABLE TRIBAL LANDS INTO ALIENABLE
PRIVATE PROPERTY. THE HISTORICAL CIRCUMSTANCES WHICH HAVE PRIVATE PROPERTY. THE HISTORICAL CIRCUMSTANCES WHICH
SHAPED AND TRANSFORMED THE ECONOMY AND CULTURE OF A SHAPED AND TRANSFORMED THE ECONOMY AND CULTURE OF A
PARTICULAR TRIBAL POPULATION - THE LIMBUS OF EAST NEPAL PARTICULAR TRIBAL POPULATION - THE LIMBUS OF EAST NEPAL
ARE EXAMINED. THESE IS ANALYSIS OF THE PROGRAMME OF LAND ARE EXAMINED. THESE IS ANALYSIS OF THE PROGRAMME OF LAND
REFORM INTRODUCED BY THE NEPALESE STATE, WHOSE CHIEF OUTCOME REFORM INTRODUCED BY THE NEPALESE STATE, WHOSE CHIEF OUTCOME
FOR THE LIMBUS WAS THE ABOLITION OF THEIR KIPAT TENURES AND FOR THE LIMBUS WAS THE ABOLITION OF THEIR KIPAT TENURES AMD THE CONVERSION OF THEIR LANDS INTO PRIVATE PROPERTY. THE IMPLICATIONS IN TERMS OF LAND AND IDENTITY ARE CONSIDERED,
AND THE OUTCOME OF HEAVY DEPENDENCE ON A SMALL CLASS OF HIGH AND THE OUTCOME OF HEAVY DEPENDENCE ON A SMALL CLASS OF
CASTE HIMDUS WHO ARE NOW THEIR LANDLORDS, CREDITORS AND CASTE HINDUS WHO ARE NOH

02080 CAPORASO, J.

INTERNAL RELATIONS THEORY AND MULTILATERALISM: THE SEARCH FOR FOUNDATIONS

INTERNATIONAL ORGANIZATION, 46(3) (SUM 92), 633-680. INTERMATIONAL RELATIONS' SCHOLARS HAVE PAID LITTLE ATTENTION TO MULTILATERALISM AS AN ORGANIZING PRINCIPLE OF INTERNATIONAL POL ITICAL ECONOMY. A HORKING HYPOTHESIS IS THAT PART OF THIS INATTENTION IS DUE TO THE STRUCTURE OF INTERNATIONAL RELATIONS THEORY. THIS ARTICLE EXAMINES THREE BROAD CATEGORIES OF THEORIES--INDIVIDUALIST, SOCIALCOMMUNICATIVE, AMD INSTITUTIONAL THEORIES--AND ASSESSES THEIR IMPLICATIONS FOR INTERNATIONAL RELATIONS THEORIZING.

02081 CAPPER, D.

JUDGING THE UNITED STATES SUPREME COURT: AN OUTSIDER'S VIEH OF THE RIGHT OF PRIVACY

UNIVERSITY OF DETROIT MERCY LAW REVIEW, 69(4) (SUM 92), 545-580.

THE UMITED STATES SUPREME COURT HAS ADDRESSED THE CONSTITIONALITY OF LEGISLATION INFRINGING UPON AM INDIVIDUAL'S PRIVACY ON SEVERAL OCCASIONS. THIS PAPER INDIVIDUAL'S PRIVACY ON SEVERAL OCCASIONS. THIS PAPER EXAMINES THE SUPREME COURT'S JUDICIAL REVIEW OF LEGISLAT
AFFECTING AN INDIVIDUAL'S PRIVACY. THE OBJECTIVE IS TO AFFECTING AN INDIVIDUAL'S PRIVACY. THE OBJECTIVE IS TO HOW FAR THEY ARE RATIONALLY RELATED TO THE TEXT OF THE HOW FAR THEY ARE RATIONALLY
UNITED STATES CONSTITUTION.

02082 CARALEY, D.

WASHINGTON ABANDONS THE CITIES

POLITICAL SCIENCE QUARTERLY, 1(107) (SPR 92), 1-30. 
DURING THE REAGAN-BUSH ERA, THE PROBLEMS OF AMERICA'S DECLINING CITIES GREW EVEN WORSE, LARGELY DUE TO NEGLECT AT THE FEDERAL LEVEL. IN THIS ESSAY, THE AUTHOR EXAMINES THE MYTHS ON WHICH THE REAGAN-BUSH NEW FEDERALISM IDEOLOGY WAS BASED, THE EXTENT AND IMPACT OF CUTS IN GRANT PROGRAMS TO CITY GOVERMMENT AND POOR PEOPLE, AND THE PROSPECTS FOR A DRAMATIC TURNAROUND IN FEDERAL GOVERNMENT POLICY--FROM SIMPLY ABANDONING THE LARGE CITIES TO RESUMING THE ROLE OF "THE RESCUER-OF-LAST-RESORT."

02083 CARAPICD, S.

WOMEN AND PUBLIC PARTICIPATION IN YEMEN

MIDDLE EAST REPORT, $21(6)$ (NOV 91), 15.

AL THOUGH STILL OLD-FASHIONED WHEN COMPARED WITH THEIR

LEVANTINE OR NORTH AFRICAN SISTERS, CONSTRAINED BY

PATRIARCHAL SOCIAL STRUCTURES, AND' LIMITED IN THEIR EARNING CAPACITIES, YEMENI WOMEN PLAY AT LEAST A TOKEN ROLE IN CAPACITIES, YEMENI WOMEN PLAY AT LEAST A TOKEN ROLE IN THE MOST "LIBERATED," THOUGH NOT THE MOST PRIVILEGED WOMEN IN THE ARABIAN PENINSULA.

02084 CARDINALE, G.J.

THROUGH THE JAPANESE LOOKING GLAS

ASIAN SURVEY, XXXII ( 7 ) (JUL 92), 635-648.

THIS ARTICLE EXAMINES JAPANESE PUBLIC OPINION WITH REGARDS TO AMERICA. SPECIAL ATTENTION IS PLACED ON THE EMERGENCE OF "KENBEI": A NATIONALIST BRAND OF FUNDAMENTAL DISLIKE OF AMERICA. THE ARTICLE CONCLUDES THAT FOR ALL ITS REFERENCES TO HISTORICAL PARALLELS AND CONFRONTATION, THE NATIONALIST SENTIMENT REMAINS MORE OF A FRINGE PHENOMENON WHOSE MARKETING BOTH AT HOME AND ABROAD IS DISPROPORTIONATE TO ITS FOLLOWING. YET, DESPITE ITS MISAPPLICATION, THE "KENBEI" PHENOMENON STILL PROVIDES THE BEST INSIGHT INTO THE PRESENT STATE OF RELATIONS BETHEEN THE UNITED STATES AND JAPAN, BOTH BECAUSE OF THE FEELINGS IT EXPRESSES AND THE SENTIMENTS IT NEGLECTS. INTERVIEWS OF A WIDE-RANGING CROSSSECTION OF JAPANESE SOCIETY HAVE INDICATED A DICHOTOMY BETHEEN THE JAPANESE PEOPLE AND JAPANESE ELITE REGARDING THEIR ATTITUDES TOWARD THE UNITED STATES. FOR THE MOST PART ORDINARY JAPANESE EXPRESS NO HATRED WHATSOEVER TOWARD THE UNITED STATES OR AMERICANS. HOWEVER, AMONG JAPAN'S

POLICYMAKERS, GOVERMMENT OFFICIALS, AND BUSINESS LEADER, POL ICYMAKERS, GOVERNMENT OFFICIALS, AND BUSINESS LEADER,
REMNANTS OF "KENBEI" HAVE SURVIVED AND WERE RESURRECTED BY THE BUSH TRADE MISSION.

02085 CARDOSO, E.; HELWEGE, A.

BELOW THE LINE: POVERTY IM LAIIM AMERICA

HORLD DEVELOPMEMT $20(1)$ (JAN 92 ) 19-37.

THE AUTHOR SURV́EYS EXISTING DATA ON POVERTY IN LATIN AMERICA AND DISCUSSES THE RELATIONSHIP BETWEEN GROWTH, INEQUALITY, AND POVERTY. GIVEN THE INEQUALITY OF INCOME DISTRIBUTION IN LATIN AMERICA AND THE SLOW GROWTH OF OUTPUT, POLICIES TO OVERCOME POVERTY MUST INVOLVE MORE EFFICIENT ALLOCATION OF GOVERNMENT RESOURCES, REDISTRIBUTION, AND FOREIGN AID.

02086 CARDOSO, E.; FISHLOW, A.

LATIN AMERICAN ECONOMIC DEVELOPMENT: 1950-1980

JOURNAL OF LATIN AMERICAN STUDIES, 24 (1992), 197-218.

IN THE DECADES BETHEEN 1950 AND 1980, LATIN AMERICA EXPERIENCED RAPID ECONOMIC GRONTH. IN THIS PAPER, THE AUTHORS ANALYZE THE SOURCES OF THAT GROWTH, STRESSING THE REGION'S EVOLUTIONARY AND ADAPTIVE EXPERIENCE OVER THE THREE DECADES. THEN THEY LOOK AT THE INFLATIONARY PROCESS AND ITS DETERMINANTS. THEY ALSO CALL ATTENTION TO THE GRAVE AND PERSISTENT PROBLEMS OF INCOME DISTRIBUTION AND POVERTY THAT THE YEARS OF GROWTH FAILED TO ELIMINATE.

02087 CAREY, J.

POLITICAL CORRECTNESS AND CULTURAL STUDIES

JOURNAL OF COMMUNICATION, 42(2) (SPR 92), 56-72.

THIS AUTHOR SUGGESTS THAT CULTURAL STUDIES IS A CONSTRUCTED AND POROUS TRADITION, AND THAT IT IS IN A STATE ON CONSTANT MODIFICATION AND REINVENTION AND OUGHT TO BE ASSESSED IN TERMS OF ITS POLITICAL USES AND CONSEQUENCES. HE EXAMINES CULTURAL STUDIES AND THE LEFT, AND THE CONSERVATIVE ASSAULT ON CULTURAL STUDIES FROM THE RIGHT. IN THE CONTEXT AF POLITICAL CORRECTNESS IN THE UNIVERSITY, HE CONCLUDES THAT THE BIG LORERS IN THIS GREAT DEBATE ARE THE STUDENTS AND THROUGH THEM THE COUNTRY AT LARGE.

02088 CAREY, $N$.

PUBLIC FINANCE: HEALTH CARE SPENDING

MATIONAL CIYIC REYIEW, 81(2) (SPR 91) 179-180.

ANALYSIS REYEALS THAT CONOITIONS CONTRIBUTING TO DIFFERENCES IN PER-CAPITA HEALTH SPENDING AMONG STATES RESULT LARGELY FROM FACTORS BEYOHO THE DIRECT CONTROL OF STATE GOVERMMENTS; THESE INCLUDE PERSONAL INCOME; THE NUMBER OF PHYSICIANS, HOSPITALS, AND NURSING HOME BEDS; AND THE DISTRIBUTION OF HEALTH SERVICES IN URBAN AND RURAL AREAS STATES WITH HIGHER PERSONAL INCOMES AND/OR GREATER INTENSITY OF HOSPITAL BEDS AND PHYSICIANS TEND TO SPEND MORE ON HEALTH CARE. INTERESTINGLY, THE MARKET FORCES OF SUPPLY AND DEMAND
STATES WITH MORE HEALTH CARE RESOURCES HAVE HIGHER COSTS, PARTIALLY BECAUSE THEY ATTRACT MANY OUT-OF-STATE PATIENTS'

02089 CARGILL, J.

ANC ECONOMIC POLICY

SOUTH AFRICA FOUNDATION REVIEW, 18(7) (JUL 92), 8.

THE AFRICAN NATIONAL CONGRESS' RECENTLY ADOPTED POLICY GUIDELINES, PARTICULARLY THE ECONOMIC COMPONENT, DEMONSTRATE THE FINE LINE THE ORGANIZATION IS WALKING BETWEEN BALANCING THE MANY AND VARIED INTERESTS IN SOUTH AFRICA AND MEETING

THE DEMANDS OF ITS OWN LARGELY DEPRIVED CONSTITUENCY.

02090 CARGILL, T.F.; MAYER, T.

U.S. DEPOSIT INSURANCE REFORM

CONTEMPORARY POLICY ISSUES, X(3) (JUL 92), 95-103

IN 1991, CONGRESS ENACTED A BANKING REFORM MEASURE THAT (I) AUTHORIZES $\$ 70$ BILLION OF ADDITIONAL FDIC FUNDING, (II) ENHANCES BANK REGULATION AND SUPERVISION, AND (III) ADOPTS A "TRIP HIRE" SYSTEM FOR INCREASINGLY SEVERE REGULATION BASED ON A BANK'S CAPITAL. BUT CONGRESS REJECTED A NUMBER OF KEY ELEMENTS PROPOSED BY THE TREASURY DEPARTMENT, INCLUDING INTERSTATE BANKING AND EXPANDED BANK PONERS. IN DUE TIME, OTHER ATTEMPTS WILL PROBABLY BE MADE TO RESTRUCTURE THE
BANKING SYSTEM ALONG THE LINES OF THE TREASURY PROPOSAL. THE CONGRESSIONAL ACTION FELL SHORT OF COMPLETE DEPOSIT INSURANCE REFORM, AND THE TREASURY PROPOSAL FAILED TO MARKET DISCIPLINE IN THE CURRENT FINANCIAL ENVIRONMENT.

02091 CARLIN, A.; GARNER, D.; SCODARI, $P$.

ENVIRONMENTAL INVESTMENTS: THE COST OF CLEANING UP ENVIRONMENT, 34(2) (MAR 92), 12-20; 38-44.

THE U.S. ENVIRONMENTAL PROTECTION AGENCY HAS ASSESSED THE NATION'S COSTS, BOTH PUBLIC AND PRIVATE, FOR CONTROLLING POLLUTION THROUGH THE YEAR 2000. IN THIS SUMMARY OF THE AGENCY'S REPORT TO CONGRESS, THE COSTS ARE BROKEN DOWN BY FUNDING SOURCE AND BY ENVIRONMENTAL MEDIUM AND ARE COMPARED TO OTHER EXPENDITURE CATEGORIES-- SUCH AS MEDIAL CARE AND DEFENSE--AND TO OTHER COUNTRIES' COSTS. WHETHER PAYING HIGHER TAXES TO COVER THE COSTS OF ENFORCING THE CLEAN AIR ACT OR SPENDING MORE FOR TRASH COLLECTION, THE U.S. PUBLIC ACT SHELLING OUT HUNDREDS OF BILLIONS OF DOLLARS EACH YEAR TO IS SHELLING OUT HUNDREDS OF BILLI

02092 CARLIN, D.P.

PRESIDENTIAL DEBATES AS FOCAL POINTS FOR CAMPAIGN ARGUMENTS POLITICAL COMMUNICATION, $(4)$ (1992), 251-265.

THE AUTHOR ANALYZES THE 1988 BUSH-DUKAKIS PRESIDENTIAL CAMPAIGN BASED ON THE PREMISE THAT POLITICAL DEBATES CAN PROVIDE A FRAMENORK FOR EXAMINING THE ARGUMENTS AND ISSUES THAT HELP SHAPE VOTERS' PERCEPTIONS ABOUT EACH CANDIDATE'S
CHARACTER AND FITNESS FOR OFFICE. SHE EXAMINES THE ARGUMENTS CHARACTER AND FITNESS FOR OFFICE. SHE EXAMINES THE ARGUMENTS
PRESENTED IN THE DEBATES TO DETERMINE THE DOMINANT THEMES PRESENTED IN THE DEBATES TO DETERMINE THE DOMINANT THEMES EACH CANDIDATE DEVELOPED AS A WAY OF DESCRIBING HIMS
HIS OPPONENT. ANALYSIS OF NEWS REPORTS OF SUBSEQUENT CAMPAIGN SPEECHES AND POLLING INFORMATION SUGGESTS WHICH THEMES WERE ACCEPTED BY THE MAJORITY OF VOTERS.

02093 CARLIN, D.R. JR.

BLAME THE MESSAGE

COMMONHEAL, CXIX(9) (MAY 92), 9-10

FOR THE PAST TWO DECADES, THE DEMOCRATIC PARTY HAS EXPLAINED ITS REPEATED FAILURES TO WIN PRESIDENTIAL

ELECTIONS BY RATIONALIZING THAT IT CHOSE THE WRONG CANDIDATE. THUS, IT HAS BECOME AN ARTICLE OF FATIH IN THE DEMOCRATIC RELIGION THAT PRESIDENTIAL ELECTION DEFEATS ARE TO BE EXPLAIMED ENTIRELY IN TERMS OF CANDIDATES AND CAMPAIGM STRATEGIES, NEVER IN TERMS OF THE MESSAGE DELIVERED BY THE CANDIDATE OR PARTY.

02094 CARLIN, D.R. JR. LESSONS FROM MOVEMBER COMMONHEAL, CXIX(22) (DEC 92 ), 7-8.
ROSS PEROT'S STRONG SHOWING IN THE 1992 PRESIDENTIAL ELECTION ANO GEORGE BUSH'S DRAMATIC DECLINE IN POPULARITY ARE BOTH SIGNS OF THE DISSOLUTION OF AMERICAN POLITICAL PARTIES, RAISING QUESTIONS ABOUT THE IMPORTANCE OF PARTIES PART WHETHER THEY ARE STILL NEEDED.

02095 CARLIN, D.R. JR. QUAYLE SAYS IT RIGHT: BUT DOES IT WRONG COMMONHEAL, CXIX(13) (JUL 92), 12 .

IN HIS CRUSADE FOR "FAMILY' VALUES" AND AGAINST THE CULTURAL ELITE, VICE PRESIDENT DAN QUAYLE IS RIGHT. BUT HE'S CULTURAL ELITE, VICE PRESIDENT DAN QUAYLE IS RIGHT. BUT HE ALSO A HYPOCRITE. IF A LEADER BELIEVES IN FAMILY VALUES, THAT SUPPORT AND ENCOURAGE THOSE VALUES. BUT THE REAGAN-BUSH-
QUAYLE REGIME. WHILE TALKING A GOOD GAME ABOUT FAMILY VALUES, QUAYLE REGIME, WHILE TALKING A GOOD GAME ABOUT FAMILY VALUES,
HAS DONE LITTLE OR NOTHING TO PROTECT THEM. FOR THE PAST 12 YEARS. THIS REGIME HAS BEEN ALL TALK AND NO ACTION WHEN IT COMES TO FAMILIES.

02096 CARLIN, D.R. JR.

SIT DOWN AND SHUT UP: THE DEMOCRATS' GAG RULE 
COMMOHWEAL, CXIX(14) (AUG 92), 10.

THE 1992 DEMOCRATIC NOMINATING CONVENTION IN NEN YORK CITY EMPHASIZED THAT THE PARTY IS NOW STRIDENTLY PRO-CHOICE

02097 CARLIN, D.R. JR.

THE BUSINESS OF BEING PEROT

COMMONWEAL, CXIX(11) (JUN 92), 11-12.

H. ROSS PEROT'S CANDIDACY FOR PRESIDENT IS A GOOD THING IF YOU'RE LOOKING FOR ENTERTAINMENT, BECAUSE IT PROMISES TO BE FUN TO WATCH. BUT IT IS OF DOUBTFUL MERIT IF YOU'RE LOOKING FOR SIGNS OF HEALTH IN AMERICAN SOCIETY IN GENERAL AND THE AMERICAN POLITICAL SYSTEM IN PARTICULAR.

02098 CARLIN, JR., D.

WHERE'S THE' PARTY? POLITICIANS WITHOUT POLTICS

COMMONHEAL, CXIX(3) (FEB 92), 6-7.

DAVID CARLIN, JR. SUGGESTS THAT THERE IS A SEMI -

ANARCHIST STRAIN THAT RUNS THROUGH THE AMERICAN SOUL. AFTER

GIVING SOME HISTORICAL EXAMPLES OF FEDERAL POWERS SURGING

AND SUBSIDING HE CLAIMS THAT IT MANIFESTS ITSELF IN

POLITICAL CAMPAIGNS IN WHICH CANDIDATES DENOUNCE THE

EXISTENCE OF BIG GOVERNMENT, AND IN THE TERM LIMITATION

MOVEMENT. THE MOST STRIKING SYMPTOM OF OUR ABIDING SEMI-

ANARCHISM IS THE MOVEMENT TOWARD THE ABOL ISHMENT OF

POLITICAL PARTIES IN AMERICA. WITH THE DECLINE OF POLITICAL PARTIES, THE ELECTORATE BECOMES INCREASINGLY UNSTABLE,
UNINFORMED, AND APATHETIC.

02099 CARLISLE, D.S.

UZBEKISTAN AND THE UZBEKS

PROBLEMS OF COMMUNISH, XL (5) (SEP 91), 23-44.

THE SOVIET REPUBLIC OF UZBEKISTAN WAS AN ARTIFACT OF KREMLIN POLICY: IN 1924-1925, MOSCOW CARVED OUT STATE FORMATIONS NAMED FOR HISTORICALLY WELL-KNOWN ETHNIC GROUPS THAT WERE NOT YET CONSOLIDATED AS DISTINCT PEOPLES, LET ALONE MODERN NATIONS. AN UZBEK NATIONAL IDENTITY REMAINED LARGELY LATENT, UNCONSOLIDATED, AND UNFOCUSED UNTIL THE STIGMA OF CORRUPTION. MOSCOW'S INEPT HANDLING OF THIS SITUATION APPEARS TO HAVE TRIGGERED A REACTIVE NATIONALISM THAT JUST MIGHT TURN THE REPUBLIC'S DIVERSE GROUPS INTO AN UZBEK NATION. ANOTHER POSSIBLE DEVELOPMENT IS UZBEK PARTICIPATION IN SOME SORT OF TURKIC LEAGUE OR CONFEDERATION. HOWEVER, THE INTENTIONS AND ALLEGIANCES OF UZBEKISTAN'S MASSES--URBAN AND RURAL--ARE STILL UNANNOUNCED.

02100 CARLSHAES, $W$.

THE AGENCY-STRUCTURE PROBLEM IN FOREIGN POLICY ANALYSIS INTERNATIONAL STUDIES QUARTERLY, 36(3) (SEP 92) 245-270. INTERNATIONAL STUDIES QUARTERLY, 36 (3) (SEP 92), 245 PREMISED ON A CONCEPTION OF THE CONTEXTUALLY BOUND NATURE OF THE FOREIGN POLICY BEHAVIOR OF STATES, ARGUING THAT THIS RECONCEPTUALIZATION CAM INCORPORATE MOT ONLY (1) CERTAIN RECONCEPTUALIZATION CAN INCORPORATE NOT ONLY (1) CERTAIN COGNITIVE EXPLANATORY APPROACHES, AND (3) THE ROLE, BROADLY SPEAKING, OF SITUATIONAL-STRUCTURAL FACTORS, BUT ALSO (4) AN SPEAKING, OF SITUATIONAL-STRUCTURAL FACTORS, BUT ALSO (4) AN
INSTITUTIONAL PERSPECTIVE COMBINED WITH (5) COMPARATIVE CASE STUDY ANALYSIS.

02101 CARLSSON, I.

A NEH INTERNATIONAL ORDER THROUGH THE UNITED NATIONS SECURITY DIALOGUE, 23 (4) (DEC 92 ), 7-12

THE END OF THE COLD WAR HAS CREATED A VACUUM, WHICH CAN BE FILLED EITHER BY THE UN OR BY SELF-APPOINTED GREAT POWERS THIS MEANS THAT THE UN CAN NOW BECOME THE ORGANIZATION IT WAS ORIGINALLY MEANT TO BE--BUT RE-STRUCTURING IS NEEDED. A NEW INDEPENDENT COMMISSION WILL PREPARE A REPORT ON HOW TO STRENGTHEN INTERHATIONAL INSTITUIONS, TO BE PRESENTED IN 1994. THIS ARTICLE ENUMERATES A VARIETY OF ISSUES WHICH ARE TO BE CONSIDERED BY THE COMMISSION.

02102 CARMENT, D.

THE INTERNAL DIMENTIONS OF CRISIS BEHAVIOUR--A CASE STUDY OF THE INDO-SRI LANKAN CRISIS 1983-1990

ETUDES INTERNATIONALES, 23(2) (JUN 92), 253-278.

THIS PAPER TRACES THE EVENTS AND DECISIONAL FLOW OF SRI LANKA'S ELITES FROM THE PRE-CRISIS PERIOD OF 1983 TO CRISIS ABATEMENT IN 1990 IN AN ATTEMPT TO UNDERSTAND THE EVENTS AND PATTERNS OF BEHAVIOR THAT LED TO AN INTERNATIONAL CRISIS BETWEEN SRI LANKA AND INDIA AND MORE GENERALLY TO ELUCIDATE THE RELATIONSHIP BETWEEN DOMESTIC ETHNIC CONFLICT AND THE RELATIONSHIP BETWEEN DOMESTIC ETHNIC CONFLICT AND INTERNATIONAL CRISIS. THE PAPER ARGUES THAT SRI LANKA INTERNAL THREATS TO ITS POL ITICAL INTEGRITY ENGENDERED BY ITS DOMESTIC ETHNIC CONFLICT. FIRST. THE THEORETICAL ITS DOMESTIC ETHNIC CONFL ICT. FIRST, THE THEORETICAL LANKA'S DECISIONLDRED. SECOND, THE PERCEPIIONS OF SRILANKA'S DECISION-MAKERS IN RESPONSE TO INCREASING INDIAN INVOLVEMENT DURING THE PRE-CRISIS AND CRISIS PERIOD ARE
ASSESSED. THIRD AN ANALYSIS OF SRI LANKAN DECISION-MAKING ASSESSED. THIRD AN ANALYSIS OF SRI LANKAN DECISION-MAKING
PROCESS IS WEIGHED AGAINST PATTERNS OF COPING FOUND IN THE THEORETICAL LITERATURE. FOURTH, IMPL ICATIONS FOR FURTHER RESEARCH ARE EXPLORED, SPECIFICALLY THE ROLE THAT ETHNIC CONFLICTS PLAY IN TRIGGERING INTERMATIONAL CRISES AND THE
IMPLICATIONS THAT HAS FOR THE MANAGEMENT OF ETHNIC CONFLICTS BY REGIONAL HEGEMONS.

02103 CARMINES, E.G.; STAMLEY, H.H.

THE TRANSFORMATION OF THE NEH DEAL PARTY SYSTEM: SOCIAL GROUPS, POLITICAL IDEOLOGY, AND CHANGING PARTISANSHIP AMONG MORTHERN WHITES, 1972-1988

POLITICAL BEHAVIOR, 14 (3) (SEP 92), 213-238.

THE AUTHORS STUDY THE PARTISANSHIP OF A NEGLECTED

SEGMENT OF THE U.S. ELECTORATE- WHITE NORTHERNERS. LIKE THEIR SOUTHERN COUNTERPARTS, NORTHERN WHITES HAVE MOVED TOWARD THE GOP AND AWAY FROM THE DEMOCRATIC PARTY DURING THE LAST TWO DECADES, UNTIL A SUBSTANTIAL PLURALITY OF NORTHERN WHITES NOW IDENTIFY WITH THE REPUBLICAN PARTY. DEMOCRATIC LOSSES AND REPUBLICAN GAINS HAVE NOT BEEN CONFINED TO PARTICULAR CATEGORIES OF SOCIAL GROUPS BUT HAVE CUT ACROSS GROUPS TRADITIONALLY IDENTIFIED WITH ONE PARTY OR THE OTHER. HOWEVER, POL ITICAL IDEOLOGY IS CLOSELY RELATED TO THE CHANGING PARTISANSHIP OF NORTHERN WHITES. LIBERALS HAVE BECOME MORE DEMOCRATIC AND CONSERVATIVES HAVE BECOME SUBSTANTIALLY MORE REPUBLICAN SINCE 1972. MOREOVER, THE RELATIONSHIP BETWEEN IDEOLOGY AND CHANGING PARTISANSHIP SUGGESTING THAT IDEOLOGICAL ORIENTATIONS NOW OVERRIDE SOCIAL SUGGESTING THAT IDEOLOGICAL ORIENTATIONS NOW OVERRIDE SOCIA
GROUP TIES IN THE FORMATION OF PARTISANSHIP. IN SUM, THE GROUP TIES IN THE FORMATION OF PARTISANSHIP. IN SUM, THE TRANSFORMATION THAT IS RESHAPING THE CDNTOURS OF AMERICAN TRANSFORMATI
POLITICS.

02104 CARNAHAN, B.M.

PROTECTING NUCLEAR FACILITIES FROM MILITARY ATTACK: PROSPECTS AFTER THE GULF WAR

AMERICAN JOURMAL OF INTERNATIONAL LAH, 86(3) (JUL 92), 524-541

THE AUTHOR DISCUSSES THE IMPACT OF ATTACKS AGAINST IRAQ'S NUCLEAR WEAPONS FACILITIES DURING DESERT STORM AND THE NEED FOR A NEH INTERNATIONAL CONVENTION ON NUCLEAR FACILITIES.

02105 CARMEVALE, 0.

THE LEARNING SUPPORT MODEL: PERSONNEL POLICY BEYOND THE TRADITIONAL MODEL

AMERICAN REVIEW OF PUBLIC ADMINISTRATION, 22(1) (MAR 92), 19-36.

THERE IS INCREASING INTEREST IN ACHIEVING QUALITY THROUGH EFFECTIVE MANAGEMENT ANO USE OF HUMAN RESOURCES IN PUBLIC ADMINISTRATION. THIS ESSAY COMPARES TWO HUMAN

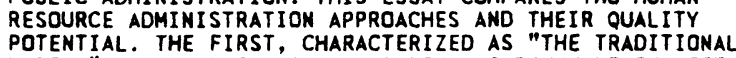
POTENTIAL. THE FIRST, CHARACTERIZED AS "THE TRADITIONAL PUBLIC ORGANIZATIONS. BUT IT IS ANTIQUATED, MORE SUITED FOR THE MASS PROOUCTION REOUIREMENTS OF AMERICA'S EARLY THE MASS PROOUCTION REQUIREMENTS OF AMERICA S EARLY INDUSTRIALIZATION PERIOD. THE SECOND, CALLED "THE LEARNING SUPPORT MODEL, RESPONDS TO THE CHALLENGES OF POSTINDUSTRIAL WORKERS BY DEVELOPING THEIR PROBLEM-SOLVING CAPACITIES. THIS
ESSAY FOCUSES ON THE FEDERAL GOVERNMENT AND ARGUES THAT THE TRADITIONAL MODEL IS GIVING WAY TO THE NEW DESIGN.

02106 CARNEY, C.P.

HUMAN RIGHTS, CHINA, AND U.S. FOREIGN POLICY: IS A NEW STANDARD NEEDED?

ASIAN AFFAIRS, AN AMERICAN REVIEH, 19(3) (FAL 92), 123-132.

BY MAKING HUMAN RIGHTS AN ISSUE OF HIGH SALIENCE, U.S.

POLICY MAKERS HAVE PLACED THEMSELVES IN A PARADOXICAL

SITUATION. DEFINING RELATIONS WITH STATES BASED ON THEIR

HUMAN RIGHTS RECORD IS FLAWED FOR AT LEAST THREE REASONS.

FIRST, THE UNITED STATES FAILS TO EVENLY APPLY THE SAME STANDARDS TO EVERY STATE. SOME NATIONS ARE PUNISHED FOR NOT MEETING U.S. STANDARDS WHILE OTHER ABUSIVE STATES FACE NO SANCTIONS WHATSOEVER. SECONDLY, THE MEASURES USED TO DETERMINE HUMAN RIGHTS CONDITIONS ARE INCONSISTENT AND SUBJECT TO DEBATE. MOREOVER, THEY TEND TO BE VALUE-LADEN WITH WESTERH IDEALS AND PAY LITTLE ATTENTION TO A NATION'S UNIQUE CULTURAL EXPERIENCE. FINALLY, IT MAY REASONABLY BE ARGUED THAT THE UNITED STATES FOCUSES ON THE WRONG KIND OF HUMAN RIGHTS, RATHER THAN CONCENTRATING SOLELY ON CIVIL AND POLITICAL FREEDOM, U.S. POLICY SHOULD ALSO CONSIDER HOW HELL A NATION PROVIDES FUNDAMENTAL HUMAN NECESSITIES, INCLUDING NUTRITION, WATER, HOUSING, HEALTH CARE, AND EDUCATION.

BECAUSE OF ITS TENACIOUS ADHERENCE TO A NARROH HUMAN RIGHTS

CAMOH THE USA IS MISSING MANY OPPORTUNITIES TO EXPAND ITS

CANON, THE USA IS MISSING MANY OPPORTUNITIES TO
INFLUENCE WITHIN THE PEOPLE'S REPUBLIC OF CHINA.

02107 CARPENTER, C.

SECURITY COUNCIL RESOLUTION 688 (1991): WHAT DUTY TO INTERFERE?

ETUDES INTERNATIONALES, 23(2) (JUN 92), 279-318.

RESOLUTION 688 (1991) DOES NOT ESTABLISH THE RIGHT TO INTERFERE FOR HUMANITARIAN REASONS. ALTHOUGH THE SECURITY COUNCIL RECOGNIZED ITSELF AS BEING COMPETENT TO INTERVENE, IT DID SO BECAUSE IT HAD SUCCEEDED IN IDENTIFYING A THREA TO PEACE. ALTHOUGH THE UNITED STATES, FRANCE, AND GREAT BRITAIN INTERVENED, THEY WERE ABLE TO DO SO BECAUSE THEY HAD BREATHED NEW LIFE INTO HUMANITARIAN-MOTIVATED INTERVENTION 
BY GIVING IT THE FORM OF A SANCTION-INTERVENTION.

02108 CARPENTER, T.

A NEW PROLIFERATION POLICY

NATIONAL INTEREST, 28 (SUM 92), 63-72

U.S. OFFICIALS SEEM TO BE IN A STATE OF DENIAL ABOUT THE MOUNTING EVIDENCE OF PROLIFERATION, AND THEY CLING REFLXIVELY TO A NON-PROLIFERATION SYSTEM THAT IS BECOMING LESS AND LESS VIABLE. THIS PAPER ARGUES THAT THERE IS AN URGENT NEED FOR A COMPREHENSIVE REASSESSMENT OF U.S. POLICY. ALSO, THAT POLICYMAKERS MAY HAVE TO ACCEPT THE POSSIBILITY THAT THERE ARE NO GOOD SOLUTIONS TO THE PROBLEM-ONLY A DIFFICULT CHOICE AMONG UNPLEASANT ALTERNATIVES. IT EXPLORES DIFFICULT CHOICE AMONG UNPLEASANT ALTERNATIVES. IT EXPLORES
THREE OPTIONS THAT APPEAR TO BE AVAILABLE TO THE UNITED THREE OPTIONS THAT APPEAR TO BE AVAILABLE TO THE
STATES: A "STATUS QUO PLUS" POLICY, COERCIVE NON-

PROLIFERATION, AND ADJUSTMENT TO PROLIFERATION.

02109 CARPENTER, T.G.; CODEVILLA, A.; FRIEDBERG, A.; HAWKINS, W.R.; WEIDENBAUM, M.; ZAKHEIM, D.S. FIGHTING TRIM: HOW TÓ CUT THE DEFENSE BUDGET BY $\$ 100$ BILLION

POLICY REVIEN, (60) (SPR 92), 50-55

IN THIS SYMPOSIUM, THE AUTHORS ADORESS THREE QUESTIONS: (1) HHAT ARE THE MOST IMPORTANT SECURITY THREATS THE UNITED STATES IS LIKELY TO FACE IN THE NEXT FIVE TO 15 YEARS? (2) TO GUARD AGAINST THESE THREATS, WHAT MISSIONS MUST U.S. ARMED FORCES BE PREPARED FOR AND WHAT KINDS OF WEAPONS, FORCES, AND DEPLOYMENTS WILL BE REQUIRED? (3) HOW CAN U.S. MILITARY EXPENDITURES BE CUT BY $\$ 100$ BILLION ANNUALLY AND STILL GUARANTEE THE RESOURCES FOR THESE PRIORITIES?

02110 CARPENTER, $H$.

LABOR AND POLIITICAL INDEPENDENCE

POLITICAL AFFAIRS, 71(10) (OCT 92), 9-10.

THE PROCESS OF' DISCUSSING, DEBATING, AND ORGANIZING IN THE DIRECTION OF INDEPENDENT POLITICAL ACTION, CAN, SHOULD, AND IS TAKING PLACE WITHIN THE FRAMEWORK OF THE NOVEMBER ELECTION. FOR 20 YEARS OR MORE, ORGANIZED LABOR HAS BEEN DEVELOPING AN INDEPENDENT POLITICAL APPARATUS. THIS ARTICLE REPORTS ON THE ACTIVITIES OF LOCAL STRUCTURE. IT SUGGESTS THAT COMMUNIST PARTY CANDIDATES ARE MAKING IMPORTANT AND FUNDAMENTAL CONTRIBUTIONS TO BUILDING A MASS BASE FOR THIRD PARTY MOVEMENTS AND THAT THE LESSONS OF THESE CAMPAIGNS NEED THROUGHOUT THE COUNTRY.

02111 CARPINI, M.X.D.; KEETER, S.

STABILITY AND CHANGE IN THE U.S. PUBLIC'S KNOWLEDGE OF POLITICS

PUBLIC OPINION QUARTERLY (CHICAGO), 55(4) (WIN 91),

583-612.

THE AUTHORS COMPARED THE U.S. PUBLIC'S KNOWLEDGE ABOUT POLITICS IN 1989 WITH LEVELS OF KNOWLEDGE IN THE $1940^{\prime} S$ AND 1950 ' $\mathrm{S}$. THEY INCLUDED 14 QUESTIONS ASKED BY GALLUP ON VARIOUS SURVEYS FROM 1945 TO 1957 ON A LARGER SURVEY OF POL I TICAL KNOWLEDGE CONDUCTED BY TELEPHONE IN 1989 WITH A RANDOMLY-SELECTED SAMPLE OF 610 ADULTS. ON 8 OF THE 14 ITEMS, THE PERCENTAGE ANSHERING CORRECTLY IN 1989 WAS HIGHER THAN IN THE EARLIER SURYEYS. HOWEVER, WHEN THE LEVEL OF EDUCATION WAS CONTROLLED, LEYELS OF KNOWLEDGE APPEARED TO HAVE DECLINED FOR MOST OF THE ITEMS. THE AUTHORS RE-ANALYZED SOME OF THE ORIGINAL GALLUP DATA TO ESTIMATE THE EFFECTIVENESS OF SCHOOLS IN TRANSMITTING POLITICAL INFORMATION IN THE 1940's, $1950^{\prime} S$, AND 1989.

02112 CARRINGTON, L.

TURMOIL IN THE BALKANS: DEVELOPMENTS AND PROSPECTS RUSI JOURNAL, $137(5)$ (OCT 92), 1-4.

LORD CARRINGTON ELUCIDATES THE PROBLEMS FACING A PEACE

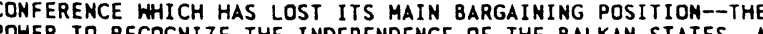
SHORT EXAMINATION OF EACH OF THE MAIM PHE BALKAN STATES. A SHORT EXAMINATION OF EACH OF THE MAIN PROBLEM AREAS PUTS OVERALL SITUATION INTO PERSPECTIVE, AND ABOVE ALL, LORD CARRINGTON STRESSES THE NEED TO CONTINUE NEGOTIATIONS IF EVENT IN MODERN EUROPEAN HISTORY.

02113 CARROLL, J.

JAMES A. SHITH'S THE IDEA BROKERS: THINK TANKS AND THE

RISE OF THE NEW POLICY ELITE

PERSPECTIVES ON POLITICAL SCIENCE, 21(3) (SUM 92), 152-156.

THE BOOK THAT IS REVIEHED IS A THEMATIC HISTORY OF THINK
THEC THE BOOK THAT IS REVIEHED IS A THEMATIC HISTORY OF TH
TANKS IN THE UNITED STATES. JAMES A. SMITH DESCRIBES THE TANKS IN THE UNITED STATES. JAMES A. SMITH DESCRIBES THE
EVOLUTION OF THINK TANKS AS AN ORGANIZATIONAL FORM AND DEVELOPS SEVERAL THEMES ABDUT THE RELATIONSHIP OF KNOWLEDGE TO POLITICAL POWER. THE BOOK DRAHS ON SMITH'S EXPERIENCE AS A PROGRAM OFFICER AT THE THENTIETH CENTURY FUND, INTERVIEWS, AND ARCHIVAL AND PUBLISHED MATERIALS. THIS BOOK HAS A USEFUL APPENDIX DESCRIBING TWENTY-NINE THINK TANKS AND A VALUABLE BIBLIOGRAPHIC ESSAY.

02114 CARROLL, J.; ENGLISH, A

TRADITIONS OF STATE CONSTITUION MAKING

STATE AND LOCAL GOVERNMENT REVIEH, 23(3) (FAL 91), 103-109.
TWO TRADITIONS OF CONSTITUTION MAKING HAVE EMERGED IN THE STATES - A HIGHER-LAW TRADITION BASED ON THE FEDERAL MODEL AND A POSITIVE-LAW ALTERNATIVE WHICH ORIGINATED IN THE SOUTHERN AND WESTERN STATES. CONTEMPORARY STATE CONSTITUTION MAKERS ARE CROSS-PRESSURED BY THESE THO TRADITIONS, ALTHOUGH EVIDENCE SUPPORTS THE PROPOSITION THAT THE HIGHER-LAH TRADITION HAS BECOME ASCENDANT DURING THE SECOND HALF OF THIS CENTURY. COMPETING TRADITIONS OF CONSTITUTION MAKING HAVE MADE THE PROCESS OF REVISION INCREMENTAL RATHER THAN COMPREHENSIVE AND ONE IN WHICH CONSTITUION-MAKING ELITES CHOOSE BETWEEN ABSTRACT PRINCIPLES AND CONCRETE APPLICATIONS.

02115 CARROLL, J.D.

THE PUBLIC ADMINISTRATION OF INVESTMENT: GRAPPLING WITH THE PUBLIC ADMINISTRATION OF INY

PUBLIC ADMINISTRATION REVIEW, 52(3) (MAY 92), 223-239. WHAT ROLE SHOULD PUBLIC ADMINISTRATION PLAY IN

GOVERNMENT EFFORTS TO ADDRESS THE CONSUMPTION-INVESTMENT GOVERNMENT EFFORTS TO ADORESS THE CONSUMPTION-INVESTMENT IMBALANCE PLAGUING THE UNITED STATES TODAY? THE AUTHDR OFFERS SUGGESTIONS CENTERED ON THE NEED TO REINVENT THE HAMILTONIAN SYSTEM AND APPLY IT TO THE GLOBAL ORDER OF THE 21ST CENTURY. REVIENING THE TRENDS THAT HAVE SHAPED THE
CURRENT IMBALANCE CRISIS, HE EXAMINES THEIR IMPLICATIONS AND CONSIDERS HOW PUBLIC ADMINISTRATION CAN DEAL WITH THEM THROUGH ANALYTIC, MANAGERIAL, AND STRATEGIC EFFORTS THAT GIVE DIRECTION TO PUBLIC POLICY AND INFLUENCE PRIVATE SECTOR BEHAVIOR. ESTABLISHING REINVESTMENT IS A CENTRAL PRIORITY, AS ARE DEVELOPING INNOVATIVE INVESTMENT STRATEGIES AND ACCOUNTS AS ALTERHATIVES TO CURRENT SERVICE DELIVERY APPROACHES, EXTENDING THE TIME HORIZON OF DECISION MAKING, AND KEEPING PUBLIC ADMINISTRATION AS A FIELD OF STUDY OPEN AND RESPONSIVE TO THESE AND OTHER CHALLENGES.

02116 CARRUTHERS, J.

OUTSIDE ACADEMIA: BERNAL'S CRITIQUE OF BLACK CHAMPIONS OF ANCIENT EGYPT

JOURNAL OF BLACK STUDIES, 22(4) (JUN 92), 459-476.

ALTHOUGH THE THESIS OF MARTIN BERNAL HAS BEEN EXPLORED BY AFRICAN AMERICAN THINKERS AND WRITERS OF THE 19TH CENTURY, HIS PRESENTATION WITHIN THE BOUNDS OF ACADEMIA AND USING
ITS METHODOLOGY IS RELEVANT TO THE CONTINUING STRUGGLE ITS METHODOLOGY IS RELEVANT TO THE CONTINUING STRUGGLE
AGAINST THE INTELLECTUAL TYRANKY OF THE WESTERN WORLD. THIS AGAINST THE INTELLECTUAL TYRANNY OF THE WESTERN WORLD. THIS
ARTICLE OFFERS A CRITIOUE OF BERNAL'S MODELS AND CONCLUDES ARTICLE OFFERS A CRITIOUE OF BERNAL'S MODELS AND CONCLUDES
THAT WHILE BENAL WAS ATTEMPTING TO DESTROY THE ARYAN MODEL THAT WHILE BENAL WAS ATTEMPTING TO DESTROY THE ARYAN MODEL
AND RESTORING THE ANCIENT MODEL, HE INTRUDES INTO A TWOAND RESTORING THE ANCIENT MODEL, HE INTRUDES INTO A THOEXTENDED WORLD AFRICAN COMMUNITY.

02117 CARTER, I.

THE MEASUREMENT OF PURE NEGATIVE FREEDOM

POLITICAL STUDIES, XL(1) (MAR 92), 38-50

EXAMINING THE QUESTION OF HHETHER FREEDOM IS MEASURABLE CONTRIBUTES TO THE ANALYIS OF THE CONCEPT OF FREEDOM IN TWO WAYS. IT INVOLVES ATTEMPTING TO ESTABLISH CRITERIA FOR ANSWERING QUESTIONS ABOUT HOW FREE INDIVIDUALS OR SOCIETIES ARE AND IT HELPS TO SHOW HOW FAR DIFFERENT DEFINITIONS OF FREEDOM REALLY CONFLICT. CRITICS OF PURE NEGATIVE CONCEPTION OF FREEDOM HAVE ARGUED EITHER THAT FREEDOM IS UNMEASURABLE ON SUCH A CONCEPTION, OR THAT SUCH A CONCEPTION IS COUNTERINTUITIVE BECAUSE THE MEASUREMENTS OF FREEDOM IMPLIED BY IT CONFL ICT WITH THE INTUTITIVE COMPARISONS WHICH WE NORMALLY MAKE. CLOSER EXAMINATIONS OF THE NATURE OF MEASUREMENT AND OF THE NATURE OF ACT INDIVIDUATION SHOW BOTH OF THESE CRITICISMS TO BE ILL FOUNDED.

02118 CARTER, J.; GUERETTE, S.

AN EXPERIMENTAL STUDY OF EXPRESSIVE VOTING

PUBLIC CHOICE, 73(3) (APR 92), 251-260.

THIS PAPER' REPORTS RESULTS OF AN INITIAL ATTEMPT TO THE THEORY OF EXPRESSIVE VOTING. THE EXPERIMENT INVOLVES REOUIRING SUBJECTS TO YDTE BETHEEN RECEIVING SA IN CASH OR SB DONATED TO CHARITY ON THEIR BEHALF. ACROSS SUBJECTS IT YARIES THE PROBABILITY THAT THEIR VOTE WILL DECIDE WHICH DISBURSEMENT IS MADE. AS THE PROBABILITY OF BEING DECISIVE IS LOWERED, THE OPPORTUNITY COST OF GIVING EXPRESSION TO IS LOWERED, THE OPPORTUNITY COST OF GIVING EXPRESSION TO CHARITABLE SENTIMENT DECREASES; HENCE, THE LIKELIHOOD OF
VOTING IN ACCORDANCE WITH SUCH SENTIMENT IS EXPECTED TO VOTING IN ACCORDANCE WITH SUCH SENTIMENT IS EXPECTED TO
INCREASE. IT FINDS WEAK SUPPORT FOR THE HYPOTHESIS, BUT THE
RESULTS DO NOT REPLICATE WHEN THE PARAMETER SETTIMGS ARE RESULTS DO NOT REPLICATE WHEN THE PARAMETER SETTI
ALTERED. LIMITATIONS OF THE DESIGN ARE DISCUSSED.

02119 CARTER, J.

COMMUNITY AND CONFLICT: THE ALEXANDRA REBELLION OF 1986 JOURNAL OF SOUTHERN AFRICAN STUDIES, 18(1) (MAR 92). $115-142$

THIS PAPER EXAMINES A SHORT-LIVED TOWNSHIP IMSURRECTION. IT IS SHOWN THAT IT WAS AMID THE VIOLENT ENCOUNTERS BETWEEN THE POLICE AND THE PEOPLE IN ALEXANDRA DURING THE FIRST SIX MONTHS OF 1986 THAT COLLECTIVE INITIATIVES OCCURRED. WHILE THE INTENTION OF MANY ACTIVISTS MAY WELL HAVE BEEN THE DESIRE TO CONSTRUCT AN ALTERNATIVE HEGEMONY, THE PROCESS BY WHICH ANC RHETORIC AND STRATEGY RESONATED THROUGH THE ALEXANDRA COMMUNITY WAS MORE COMPLEX THAN THE NEATLY DELINEATED CONSPIRACY PROPOUNDED BY BOTH SECURITY POLICEMEN 
AND ANC COMMENTATORS ALIKE. IN THE CONTEXT OF A LIBERATION MOYEMEMT LACKING NATIOMAL COHEREMCE THE IMAGE OF A COMMUNITY IN REBELLION CAN BE SEEN TO PROVIDE A POWERFUL POLITICAL SYMBOL.

02120 CARTER, J.; MAKASONE, Y.

ENSURING ALLIANCE IN AN UNSURE WORLD: THE STRENGTHENING OF U.S. -JAPAN PARTNERSHIP IN THE 1990

WASHINGTON QUARTERLY, 15(1) (WIN 92), 43-56.

THE UNITED STATES AND JAPAN TOGETHER HOLD THE IMMENSE POTENTIAL TO SHAPE THE COURSE OF GLOBAL AFFAIRS. THE PURPOSE OF THIS ARTICLE IS TO UNDERSTAND THE POTENTIAL INHERENT IN THE U.S. - JAPAN PARTNERSHIP AND TO SUGGEST WAYS IN WHICH OUR RESPECTIVE PEOPLES CAN BUILD UPON IT FOR THEIR COMMON GOOD AS WELL AS GLOBAL BENEFIT. AFTER EXAMINING MAJOR CHALLENGES AND KEY IMPENOING ISSUES IN U.S. - JAPAN RELATIONS FROM A GLOBAL PERSPECTIVE, THE AUTHORS PROPOSE POLICY OPTIONS, TOGETHER WITH INSTITIUTIONAL INITIATIVES, THAT BEAR UPON THE FUTURE POTENTIAL OF THE U.S.-JAPAN GLOBAL PARTNERSHIP.

02121 CARTER, J.

HUMAN RIGHTS: THE REAL COST OF WAR

MEDITERRANEAN QUARTERLY: A JOURNAL OF GLOBAL ISSUES, $3(2)$

MEDITERRANEAM
(SPR 92), 1-7.

WAR VIOLATES BASIC HUMAN VALUES AND IGNORES LAW DESIGNED OVER CENTURES, EVEN MILLENHIA, THAT PROTECT THE RIGHTS OF ONE PERSON LIVING ADJACENT TO ANOTHER. IN THE 1980S, THE TRILLION U.S. DOLLARS, WHICH IS A THOUSAND BILLION DOLLARS-TRILLION U.S. DOLLARS, WHICH IS A THOUSAND BILLION DOLLARS-THO MILLION DOLLARS EVERY MINUTE. JIMAY CARTER SUGGESTS THAT CYCLE OF DEATH AND DESTRUCTION AND DEPRIVATION. HE ADVOCATES CYCLE OF DEATH AND DESTRUCTION AND DEPRIVATION. HE ADVOCATE THE LEARMING OF GENERIC PRINCIPLES ON WHICH HUMANITY CAN
MOVE FORHARD TO A TIME WHEN WARS ARE NOT TREATED AS LITTLE NUISANCES OR, WORSE, IGNORED, BUT ARE ELEVATED TO THEIR PROPER PLACE AS MATTERS OF PRESSING INTERNATIONAL CONCERN.

02122 CARTON, E.

THE SELF-BESIEGED: AMERICAN IDENTITY ON CAMPUS AMD IN THE GULF

TIKKUN, 6(4) (JUL 91), 40-47.

THIS ARTICLE ARGUES THAT THE WAR ON MULTICULTURALISM AMD THE WAR IN THE GULF BOTH EXPRESS THE SAME COMPLEX OF DOMINANT--YET INCREASINGLY UNSETTLED--AMERICAN ASSUMPTIONS ABOUT THE NATURE OF PERSONAL AND NATIONAL IDENTITY. WHILE THEY OBYIOUSLY DIFFER IN IMMUMERABLE RESPECTS OPERATIOM DESERT STORM AMD "OPERATIOM CAMPUS STORM" BOTH RESPOHD TO DESERT STORM AMD "OPERATION CAMPUS STORM" BOTH RESPOND TO INTERNAL CHALLENGES TO THE TRADITIONAL CHARACTER OF THE
AMERICAN UNION AND THE OSTENSIBLE UNITY OF THE AMERICAN SELF AMERICAN UNION AND THE OSTENSIBLE UNITY OF THE AMERICAN SEL
IN THE 1990S. BOTH ENACT AND REFLECT AN AMERICAN "POLITICS IN THE 1990S, BOTH ENACT AND REFLECT AN AMERICAN "POL ITICS IMCL INES AMERICA TO AN ABSTRACT AND MATIONALIZED IMAGE OF THE AUTONOMOUS SELF AND TO A PERSONIFIED AND DESOCIALIZED IMAGE OF THE NATION.

02123 CARTY, R.K.

CANADÁ

EUROPEAN JOURNAL OF POLITICAL RESEARCH, 22(4) (DEC 92), 373-377

THE AUTHOR DESCRIBES PRIME MINISTER MULRONEY'S 1991 CABINET SHUFFLES AND OUTLINES SOME OF CANADA'S MAJOR DOMESTIC POLITICAL ISSUES.

02124 CASAMOYA, J.

PRIVATE AND PUBLIC RELIGIONS

SOCIAL RESEARCH, 59(1) (SPR 92), 17-58

THE WALLS OF SEPARATION BETWEEN CHURCH AND STATE KEEP DEVELOPING CRACKS. RELIGIOUS INSTITUTIONS OFTEN REFUSE TO ACCEPT THEIR ASSIGNED MARGINAL PLACE IN THE PRIVATE SPHERE, MANAGING TO ASSUME PROMINENT PUBLIC ROLES. RELIGION AND POLITICS KEEP MIXING UP IN ALL KINDS OF SYMBIOTIC RELATIONS, TO SUCH AN EXTENT THAT IT IS NOT EASY TO ASCERTAIN WHETHER ONE IS HITMESSIMG POLITICAL MOVEMENTS THAT HAVE DONMED RELIGIOUS GARBS OR RELIGIOUS MOVEMENTS THAT HAVE ASSUMED POLITICAL FORMS. PARADOXICALLY, HHILE RELIGION IN THE MOOERN WORLD CONTINUES TO BECOME AN EVER MORE PRIVATE AFFAIR, A SIMULTANEOUS DE-PRIVATIZATION OF RELIGION SEEMS TO BE OCCURRING. TO UNDERSTAMD THIS PARADOX. THIS PAPER REEXAMINES THE VARIOUS MEANINGS OF THE OISTINCTION BETHEEN PRIVATE AND PUBLIC RELGIONS. THE RESULTING CONCEPTUAL CLARIFICATION IS INTENDED TO: (1) SERVE AS A CONCEPTUAL TOOL IN THE INTERPRETATION OF WHAT COULD BE CALLED THE "VARIETIES OF PUBLIC RELIGION" IN THE MODERN WORLD; (2) REVEAL THE
EXTENT TO WHICH THEORIES OF SECULARIZATION DOUBLE AS EXTENT TO WHICH THEORIES OF SECULARIZATION DOUBLE AS EMPIRICALLY DESCRIPTIVE THEORIES OF MODERM SOCIAL PROCESSES
AND AS NORMATIVELY PRESCRIPTIVE THEORIES OF MODERN SOCIETIES; AND AS NORMATIVELY PRESCRIPTIVE THEORIES OF MODERN SOCIETIES AND (3) TO EXAMINE WHETHER PUBLIC RELIGIONS MAY NOT PLAY
ROLE IN REDRAWING THE CONTESTED BOUNDARIES BETWEEN THE PRIVATE AND PUBLIC SPHERES IN THE MODERN WORLD.

02125 CASEY, L.A.

PIRATE CONSTITUTIONALISM: AN ESSAY IN SELF-GOVERMMENT JOURNAL OF LAW \& POLITICS, VIII (3) (SPR 92), 477-538.

ALTHOUGH PIRATES OPERATED OUTSIDE THE BOUNDS OF NORMAL
SOCIETY AND LAW. THEY ESTABLISHED A DIRECT DEMOCRACY WHERE EACH MAN HAD AN EQUAL VOTE, THE MAJORITY RULED, AND MOST RECEIVED AN EQUAL SHARE OF THE PROCEEDS FROH THE COMPANY' ACTIVITIES. ADJUDICATION PLAYED THE MAJOR ROLE IN PIRATE
DISPUTE RESOLUTION, ALTHOUGH THEY OID DEVELOP RULES AIMED AT AVOIDING SOURCES OF CONFLICT AND SOME OF THEIR OISPUTING MECHANISMS WERE DIRECTED AT RECONCILIATION. PIRATE NORMS WERE NOT MERELY INFORMAL RULES OF BEHAYIOR DEFINED THROUGH INDIVIDUAL INTERACTION. THEY WERE CLEARLY ARTICULATED AND AUTHORITATIVE RULES OF CONDUCT, FORMALLY AGREED TO BY THE GROUP AND ENFORCED BY COERCION' IF NECESSARY.

02126 CASIMIR, J.

HAITI AFTER THE COUP

WORLD POLICY JOURNAL, IX (2) (SPR 92), 349-364.

AFTER SEVERAL MONTHS OF INTERMITTENT NEGOTIATIONS, EXILED HAITIAN PRESIDENT JEAN-BERTRAND ARISTIDE AND A GROUP OF HAITIAN PARLIAMENTARIANS ANNOUNCED AN AGREEMENT OM FEBRUARY 23 DESIGNED TO RESOLVE THE CURRENT CRISIS IN THE CARIBBEAN ISLAND NATION. THE RECENT COMPROMISE NAMES A NEW PRIME MININSTER, SUBJECT TO THE APPROVAL OF THE HAITIAN PARL IAMENT AND' PROVIDES FOR ARISTIDE'S RETURM TO HAITI PARLIAMENT, AND PROVIDES FOR ARISTIDE'S RETURN TO HAITI AT SOME INDEFINITE POINT IN THE FUTURE. THE EXILED PRESIDENT NOW FINOS HIMSELF, HALF A YEAR AFTER BEING OUSTED IN A MILITARY COUP, IN THE AHKWARD POSITION OF NEGOTIATING HIS WAY BACK TO A COUNTRY STILL OUITE FIRMLY UNDER

02127 CASSIDY, D.C.

HEISENBERG GERMAN SCIEMCE AMD THE THIRD REICH SOCIAL RESEARCH, 59(3) (FAL 92), 643-662.

THE CONNECTION 8ETWEEN KNOHLEDGE AND POWER HAS BEEN RECOGNIZED AND EXPLOITED SINCE THE BEGINNING OF CIVILIZATION. PROBLEMATIC AND OF GREATEST URGENCY DUE TO THE EXISTENCE OF NUCLEAR WEAPONS, CHEMICAL WARFARE, TECHNOLOGY-DEPENDENT ECDNOMIC GROWTH, AND OTHER REALITIES OF THE 2OTH CENTURY. THE CASE OF GERMAN ACADEMIC PHYSICS DURING HITLER'S THIRD REICH AND PHYSICS PROFESSOR WERNER HEISENBERG PROVIDES A CASE STUDY OF HOW SEEMINGLY APOL ITICAL RESEARCH CAN BECOME A PROMINENT PLAYER IN THE PRACTICAL AIMS OF A POLITICAL SYSTEM.

02128 CASTIEL, C.

BATTLING HITH BALLOTS

WEST AFRICA, (3910) (AUG 92), 1440-1441.

MARGARET ANSTEE, THE U.N. SPECIAL REPRESENTATIVE TO

ANGOLA, HAS BEEN LOBBYING THE UNITED STATES FOR MORE AIO TO

HELP ENSURE THAT THE ANGOLAN ELECTIONS ARE HELD AS SCHEDULED

IN SEPTEMBER 1992 .

02129 CASTIEL, C.

DESIRE FOR CHANGE

DESIRE FOR CHANGE
WEST AFRICA, (3908) (AUG 92), 1353.

MORE THAN 100 AFRICAN GOVERMMENT AND PARTY LEADERS WERE INVITED TO ATTEND THE 1992 U.S. DEMOCRATIC PARTY CONVENTION INVITED TO ATTEND THE 1992 U.S. DEMOCRATIC PARTY CONVENTION AFRICANS' RESPONSE TO THE CONVENTION.

02130 CASTIEL, C.S.

THE STRUGGLE CONTINUES

WEST AFRICA, (3889) (MAR 92), 536-537.

IN 1992 GUINEA-BISSAU WILL HOLD ITS FIRST FREE

PRESIDENTIAL AND LEGISLATIVE ELECTIONS. ARISTIDES DE MENEZES, LEADER OF THE DEMOCRATIC FRONT, PREDICTS THAT THE RULING

PAIGC (INDEPENDENCE PARTY OF CAPE VERDE AND GUINEA-BISSAU)

WILL BE DEFEATED BY ONE OF THE NEW POLITICAL MOVEMENTS.

02131 CASTIEL, C.S.

WE NEED SOCIAL PEACE

WEST AFRICA, (3889) (MAR 92), 538-539.

THE AUTHOR INTERYIEWS ARISSTIDES DE MENEZES, LEADER OF

THE OPPOSITION DEMOCRATIC FRONT OF GUINEA-BISSAU. MENEZES

DISCUSSES THE FORMATION OF HIS PARTY IN 1991, THE

POSSIBILITY OF THE DEMOCRATIC FRONT JOINING A COALITION TO

DEFEAT THE RULING PAIGC, AND THE STATUS OF THE BUREAUCRACY

IN GUINEA-BISSAU.

02132 CASTLES, F.; MITCHELL, D. REGIMES: THE LINKS BETHEEN POLITICS, INSTRUMENTS AND OUTCOMES

GOVERNANCE, 5(1) (JAN 92), 1-26.

WITH NEH SOURCES OF CROSS-MATIONAL OATA APPEARING ON INCOME DISTRIBUTION AND THE CHARACTERISTICS OF

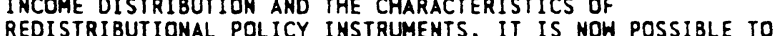

REDISTRIBUTIONAL POLICY INSTRUMENTS, IT IS NOW POSSIBLE TO

TAKE THE COMPARATIVE ANALYSIS OF HELFARE STATES WELL BEYOM

THE CONVENTIONAL FOCUS ON GOVERNMENT EXPENDITURES. THIS
STUDY OF 18 OECD NATIONS EXAMINES THE LINKAGES BETHEEN

STUDY OF 18 OECD NATIONS EXAMINES THE LINKAGES BETHEEN

VARIOUS ASPECTS OF THE INCOME REDISTRIBUTION PROCESS,
ELABORATES A TYPOL OGY OF WELFARE STATE REGIMES AND LOCATES

THE POLITICAL ORIGINS OF EACH OF THESE REGIMES.

02133 CASTLES, S.

THE AUSTRALIAN MOOEL OF IMMIGRATION AND MULTICULTURALISM:

IS IT APPLICABLE TO EUROPE? 
INTERNATIONAL MIGRATION REVIEW, XXVI (2) (SUM 92), 549-567. IMMIGRATION HAS PLAYED A CENTRAL ROLE IN NATION-BUIDLING IN AUSTRALIA. SINCE 1945, OVER 5 MILLION SETTLERS HAVE COME FROM MANY DIFFERENT COUNTRIES, LEADING TO A SITUATION OF GREAT CULTURAL DIVERSITY. STATE INVOL VEMENT IN THE MANAGEMENT OF SETTLEMENT AND ETHNIC RELATIONS HAS ALWAYS BEEN PRONOUNCED. OVER THE LAST TWENTY YEARS, A POLICY OF MULTICULTURALISM HAS EMERGED, GIVING RISE TO SEVERAL SPECIAL INSTITUTIONS. THIS HAS HAD PROFOUND EFFECTS BOTH ON SOCIAL POLICY AND ON CONCEPTS OF NATIONAL IDENTITY. THE RELEVANCE ARTICLE CONCLUDES THAT IT CAN PROVIDE USEFUL IMPULSES,

THOUGH NOT READY-MADE ANSWERS.

02134 CASTRO, F.

IN DEFENSE OF SOCIALISM

PATHFINDER PRESS, $1989,142$.

THIS $800 K$ CONSISTS OF FOUR SPEECHES BY CUBAN LEADER

FIDEL CASTRO IN THE WEEKS SURROUNDING THE THIRTIETH

ANMIVERSARY OF THE CUBAN REVOLUTION CELEBRATED ON JANUARY 1

ANNIVERSARY OF THE CUBAN REVOLUTION CELEBRATED ON JANUARY 1 ,
1989. HE CONCLUDES THAT SOCIALISM IS AND WILL CONTINUE TO $8 E$,

THE ONLY ROAD FOR THE PEOPLES. THE OPPRESSED, THE EXPLOITED,

THE ONLY ROAD FOR THE PEOPLES, THE OPPRESSED, THE EXPLOITED,
AND THE PLUNDERED. IN THE SPEECHES CASTRO CONSIDERS WHETHER

AND THE PLUNDERED. IN THE SPEECHES CASTRO CONSIDERS
ECONOMIC ANO SOCIAL PROGRESS WITHOUT THE DOG-EAT-DOG

ECONOMIC AND SOCIAL PROGRESS WITHOUT THE DOG-EAT-DOG

COMPETITION OF CAPITALISH; WHETHER MEN AND WOMEN CAN

ORGANIZE TO CONSCIOUSLY TAKE CONTROL OF THEIR OHN DESTI IMPERIALIST SOLIDARITY DECISIVE TO DEFENDING AND ADVANCING IMPERIALIST SOLIDARITY DECISIVE
CUBA'S OWN SOCIALIST REVOLUTION.

02135 CASTRO, F.

THE MEANING OF OUR STRUGGLE

POLITICAL AFFAIRS, LXX(12) (DEC 91) 7-14.

FIDEL CASTRO SPEAKS OF THE PROBLEMS FACING THE SOCIALIST MOVEMENT IN GENERAL ANO THOSE FACING CUBA IN PARTICULAR. HE CANDIDLY ADMITS THAT SOCIALISM HAS COLLAPSED IN THE SOVIET UNION AND EASTERN EUROPE AND THAT "THE PREVAILING VOICES ARE IN FAVOR OF CLASSICAL CAPITALISH." NOTING THAT HE WARNED THE SOVIET UNION OF ITS IMPENDING DANGER, HE SPEAKS OF WAYS IN WHICH CUBA CAN AVOID THE SAME FATE. HE ALSO DISCUSSES THE POSSIBILITY OF ECONOMIC INTEGRATION HITH THE REST OF LATIN AMERICA.

02136 CASTRO, V.; PREVOST, G.

THE 1990 ELECTIONS IN NICARAGUA AND THEIR AFTERMATH

ROWMAN \& LITTLEFILED PUBLISHERS, INC., 1992, 240.

THE AUTHORS HAVE INTEGRATED FOUR IN-DEPTH ANALYSES OF

THE SANDINISTA DEFEAT INTD ONE VOLUME. VIEWING THE ELECTION

FROM DIFFERENT VANTAGE POINTS, THEY HAVE COMPILED A

FROM DIFFERENT VANTAGE POINTS, THEY HAVE COMP ILED A
COLLECTION OF ESSAYS THAT ATTEMPT TO EXPLAIN THE OUTCOME OF

COLLECTION OF ESSAYS THAT ATTEMPT TO EXPLAIN THE OUTCOME OF
THE 1990 NICARAGUAN ELECTION. THE BOOK INCLUDES DOCUMENTS

THE 1990 NICARAGUAN ELECTION. THE BOOK INCLUDES DOCUMENTS
FROM THE 1991 FSLN PARTY CONGRESS, DRAWS CONTRIBUTIONS BY

FROM THE 1991 FSLN PARTY CDNGRESS, DRAWS CONTRIBUTIONS BY
TWO PARTICIPANTS IN THE FSLN'S 1990 ELECTION CAMPAIGN AND

TWO PARTICIPANTS IN THE FSLN'S 1990 ELECTION CAMPAIGN AND

TWO NORTH AMERICAN ACADEMIC OBSERVERS OF THAT PROCESS. THE
ESSAYS OFFER AN ANALYSIS OF THE FORCES BEHIND THE FSLN'S

ESSAYS OFFER AN ANALYSIS OF THE FORCES BEHIND THE FSLN'S
ELECTORAL DEFEAT AND THE IMPACT OF THE LOSS ON THE POLITICAL

ELECTORAL DEFEAT AND THE

02137 CATER, N

AT WAR WITH ITS PEOPLE

AFRICA REPORT, 37(6) (NOV 92), 65-67

HUMAN RIGHTS ORGANIZATIONS REPORT THAT ARBITRARY

KILLINGS, METHODICAL TORTURE, AND "ETHNIC CLEANSING"-

CHARACTERISTICS OF THE FUMDAMENTALIST ISLAMIC MILITARY

REGIME IN KHARTOUM--ARE INCREASINGLY BEING USED TO

OBLITERATE SUDAN'S MANY MINORITIES. UNFORTUNATELY, THERE HAS

BEEN LITTLE SUSTAINED PROTEST FROM THE OUTSIDE WORLD, WHILE

THE COUNTRY'S OWN OPPOSITION, BOTH POLITICAL AND MILITARY,

IS OISORGANIZED AND SEEMINGLY UNABLE TO MAKE ANY REAL HEADWAY AGAINST THE JUNTA.

02138 CaVANaUgh, $C$.

CONFLICT IN MOLDOVA: THE GaGaUz FACTOR

RFE/RL RESEARCH REPORT, 1(32) (AUG 92), 11-17.

SINCE THE DECLARATION OF A GAGAUZ SOVIET SOCIALIST

REPUBLIC IN AUGUST 1990, THE REPUBLIC OF MOLDOVA AND THE

GAGAUZ, A TURKIC-SPEAKING CHRISTIAN MINORITY IN SOUTHERN

MOLDOVA, HAVE BEEN UNABLE TO FIND AM ENDURING POLITICAL COMPROMISE. HITHIN THE GAGAUZ MOVEMENT ITSELF, A SPLIT HAS DEVELOPED BETWEEN RADICALS AND MODERATES, WITH THE LATTER GROUP GAINING MORE SUPPORTERS AND POWER IN THE PAST YEAR. AT THE SAME TIME, THE ESCALATING TRANSDNIESTER CONFLICT HAS THREATENED TO SPILL OVER INTO THE GAGAUZ REGION. RUSSIAN AND GAGAUZ SEPARATISTS HAVE RECOGNIZED ONE ANOTHER'S SOVEREIGNTY AND PLEDGED MUTUAL SUPPORT. SOME REPORTS INDICATE THAT THE GAGAUZ PARAMILITARY FORCES ARE RECEIVING ARMS, PRESUMABLY GAGAUZ PARAMILITARY FORCES ARE RECEIVING ARMS, PRESUMABLY
FROM RUSSIAN SYMPATHIZERS, WHICH IS SURE TO HEIGHTEN THE FROM RUSSIAN SYMPATHIZERS, WHICH IS SURE TO HEIGHTEN
TENSION BETHEEN THE GAGAUZ MOVEMENT AND THE MOLDOVAN TENSION BET
GOVERNMENT.

02139 CAVANAUGH, $C$

CRACKDOWN ON THE OPPOSITION IN UZBEKISTAN

RFE/RL RESEARCH REPORT, 1 (31) (JUL 92) 20-24.

BECAUSE THE POPULAR MOVEMENT BIRLIK IS GROWING IN
STRENGTH AND GAINING NEH ALLIES, THE NEOCOMMUNIST GOVERNMENT OF PRESIDENT ISLAM KARIMOV HAS INTENSIFIED ITS ATTACKS, USING A VARIETY OF STRATEGIES TO INTIMIDATE THE OPPOSITION. ITS USE OF BRUTE FORCE BACKFIRED, HOWEVER, BECAUSE IT HELPED TO REPAIR THE RIFT BETWEEN BIRLIK AND ITS SPLINTER GROUP, ERK.

02140 CAVANAUGH, C.

UZBEKISTAN LOOKS SOUTH AND EAST FOR ROLE MODELS

RFE/RL RESEARCH REPORT, 1(40) (OCT 92 ), 11-14.

WHILE THE WEST HAS ENDORSED TURKEY AS THE ECONOMIC MODEL FOR THE FORMER SOVIET CENTRAL ASIAN REPUBLICS, THE NEW STATES HAVE BEEN CONSIDERING A NUMBER OF MODELS OF ECDNOMIC AND POLITICAL DEVELOPMENT. HHILE PROFESSING ADMIRATION FOR THE DEMOCRATIC AND SECULAR SYSTEM IN TURKEY, UZBEKISTAN HAS ALSO SHOWN INTEREST IN THE ECONOMIC DEVELOPMENT STRATEGIES ALSO SHOWN INTEREST IN TH

02141 CaVAMAUGH, C.

UZBEKISTAN REEXAMINES THE COTTON AFFAIR

RFE/RL RESEARCH REPORT, 1 (37) (SEP 92), 7-11.

UZBEKISTAN'S CURRENT LEADERSHIP IS ENGAGED IN AN EFFORT TO REASSIGN THE BLAME FOR THE CRIMES KNOWN AS THE "COTTON AFFAIR" TO THE COMMUNIST PARTY OF THE SOVIET UNION. SHARAF RASHIDOV, THE UZBEK COMYUNIST PARTY FIRST SECRETARY WHO WAS FORMERLY DISCREDITED FOR HIS ROLE IN THE CORRUPTION, IS ENJOYING A RENAISSANCE AND HAS BEEN ELEVATED TO A UZBEK NATIONAL HERO. THIS SELECTIVE INTERPRETATION OF HISTORY SERVES THE GOAL OF THE PRESENT REGIME, WHICH WANTS TO TRANSFORH ITS IMAGE FROM COMMUNIST TO NATIONALIST EVEN THOUGH THIS MAY COMPLICATE RELATIONS BETWEEN UZBEKS AND THE LARGE RUSSIAN MINORITY.

02142 CaVANAUGH, C.

UZBEKISTAN'S LONG ROAD TO THE MARKET

RFE/RL RESEARCH REPORT, 1(29) (JUL 92), 33-38.

SINCE UZBEKISTAN HAS BECOME AN INDEPENDENT POLITICAL ENTITY, ITS LEADERSHIP HAS VOICED SUPPORT FOR THE INTRODUCTION OF MARKET MECHANISHS BUT HAS DECLARED THAT UZBEKISTAN WILL FOLLOW ITS OWN PATH AND NOT BE PRESSURED INTO ORASTIC MEASURES BY OUTSIDE FORCES. ALTHOUGH RUSSIA'S RAPID ADOPTION OF MARKET REFORMS HAS FORCED UZBEKISTAN TO MOVE TOWARD THE MARKET WITH GREATER SPEED, ITS CONSERVATIVE MARKETIZATION, SUCH AS PRIVATIZATION AND THE ELIMINATION OF MARKETIZATION,
STATE ORDERS.

02143 CAVAROZZI, M.

BEYOND TRANSITIONS TO DEMOCRACY IN LATIN AMERICA JOURNAL OF LATIN AMERICAN STUDIES, 24(3) (OCT 92), 665-684. THE POLITICAL TRENDS OF THE LATE 1970 's AND 1980's IN LATIN AMERICA INSPIRED THE PRIMARY GENERALIZATIONS AND HYPOTHESES OF A NEW ANALYTICAL PARADIGM THAT EYOLVED ALONGSIDE DEMOCRATIZATION. THE TRANSITION PARADIGM--OR THE "INTERACTIONIST" MODEL - - HAS CONTRIBUTED SIGNIFICANTLY TO THE UNDERSTANDING OF THE PROCESSES OF REGIME CHANGE IN LATIN AMERICA AND ELSEWHERE. HOWEVER, THE TRANSITION FRAMEHORK TENDS TO NEGLECT LONG-TERM HISTORIC PROCESSES. THIS PAPER ARGUES THAT THESE PROCESSES HAVE A MORE DECISIVE INFLUENCE ON THE POLITICS OF DEMOCRATIC CONSOL IDATION. MOREOVER, THE POST-TRANSITION DILEMMAS AND THE DIFFICULTIES OF CONSTRUCTING A STABLE DEMOCRATIC POLITICAL ORDER ARE BETTER UNDERSTOOD IN TERMS OF THE EXHAUSTION OF THE STATE-CENTERED MATRIX PRESENTED IN THIS PAPER.

02144 CAVAROZZI, M.

REMAKING THE LEFT

HEMISPHERE, 4(2) (HIN 92), 23-25.

TODAY THE LATIN AMERICAN LEFT ENCOMPASSES VARIED

COMPONENTS, FRDM GRASSROOTS MOVEMENTS AND PARLIAMENTARY

OPTIONS TO MILLENARIAN VIOLENCE AND GUERRILLA ARMIES.

HOWEVER, A CLEAR TREND HAS EMERGED. WITH A FEW EXCEPTIONS,

LEFTIST MILITARISM HAS GIVEN WAY TO A POSTURE OF POL ITICAL

LEFT AND RIGHT IS THE RECOGNITION THAT, IN A CHANGING REGION AND HORLD, THE THO SIDES FACE A COMMON ENEMY: A POTENTIALLY UNGOVERNABLE ECONOMY THAT THREATENS TO UNDERMINE SOCIALIST AND CAPITALIST REGIMES ALIKE. HOHEVER SALUTARY THIS CONVERGENCE MAY BE, ITS COST HAS BEEN THE EROSION OF CREDIBLE POLITICAL VISION AND ORGANIZATION FOR THE REGION'S POOR.

02145 CAVAZZA, F.L.

THE ITALIAN PARADOX: AN EXIT FROM COMMUNISH

DAEDALUS, $121(2)$ (SPR 92 ), 217-249.

THE AUTHOR BRIEFLY REVIEWS THE HISTORY OF ITALIAN

COMMUNISM AND DISCUSSES THE PRESENT STATE OF THE ITALIAN COMMUNIST PARTY.

02146 CAWTHRA, G.; NAVIAS, M.

AFRICA'S HOMELAND FORCES

RUSI JOURNAL, $137(6)$ (DEC 92), 15-20.

WITH NEWS OF RECURRING CONFLICT BETWEEN OPPOSING FORCES

IN SOUTH AFRICA, VERY LITTLE HAS BEEN SAID ABOUT THE ROLE OF 
THE HOMELAND ARMIES OF THE "INDEPENDENT" AND "SELFGOVERMING" TERRITORIES SET UP DURING THE HEIGHT OF THE APARTHEID ERA. THE AUTHORS HERE FOCUS ON THESE DISPARATE FORCES IN THE CONTEXT OF THE HOMELAND SYSTEM AND DISCUSS THEIR POTENTIALLY DISRUPTIVE INFLUENCES IN THE LIGHT OF THE EVOLVING PEACE PROCESS IN SOUTH AFRICA.

02147 CAYTON, A.R.L.

SEPARATE INTERESTS AND THE NATION-STATE: THE WASHINGTON ADMINISTRATION AND THE ORIGINS OF REGIONALISM IN THE TRANSAPPALACHIAN WEST

JOURNAL OF AMERICAN HISTORY, 79(1) (JUN 92), 39-67.

THE AUTHOR ARGUES THAT THE AHARENESS OF DISTINCTIVE REGIONAL IDENTITIES IN THE TRANS-APPALACHIAN WEST ORIGINATED IN RESPONSE TO THE FRONTIER POLICY OF THE WASHINGTON ADMINISTRATION. COMPETITION FOR THE RESOURCES OF THE NATIONSTATE--PARTICULARLY THE ARMY--LAID THE FOUNDATION FOR HHAT BECAME THE WIDESPREAD SENSE THAT THE OHIO RIVER WAS FAR MORE THAN WATER; IT WAS A FRONTIER BETWEEN TWO DIFFERENT WORLDS.

02148 CAZES, B.

TRUE LIKENESS OR DISTORTED IMAGE? PROBING THE EXPLANATORY POWER OF VALUE CHANGES

FUTURES, 26(4) (MAY 92 ) 291-300.

THIS ARTICLE CONSIDERS THE EMERGENCE OF VALUES AS A KEY ELEMENT OF SOCIETAL ISSUES. SPECIFICALLY, THE ALLEGED AUTONOMY OF THE DYNAMICS OF VALUE CHAMGES, AND ITS ON BOTH ASPECTS THE DISCUSSION FOCUSES ON VALUES AND VALUE CHANGE IN EUROPE.

02149 CEFKIN, J.L.

AFRICA: A TRULY HISTORIC YEAR

FREEDOM REVIEW, 23(1) (JAN 92), 40-43.

THE YEAR 1991 WAS A TRUE WATERSHED IN AFRICA, AS ONE-

PARTY REGIMES CONTINUED TO FALL AND MULTI-PARTY DEMOCRACY BECAME THE ORDER OF THE DAY IN MORE AFRICAN COUNTRIES. MULTIPARTY DEMOCRACY OFFERS AN OPPORTUNITY FOR AFRICAN STATE- AND NATION-BUILDING. PERIODIC FREE AND FAIR ELECTIONS PROMISE STABILITY. BUT THERE IS CONCERN THAT THE UNITED STATES AND THE COUNTRIES OF WESTERN EUROPE WILL NEGLECT AFRICA NOW THAT THE COLD WAR HAS ENDED. SUCH A PROSPECT IS UNFORTUNATE AT A TIME WHEN AFRICANS ARE IN NEED OF ENCOURAGEMENT TO DEVELOPMENT THEIR POTENTIALLY PROSPEROUS DEMOCRACIES.

02150 CEKA, $N$.

THE NATION'S FUTURE IN DANGER

EAST EUROPEAN REPORTER 5(1) (JAN 92), 50-52.

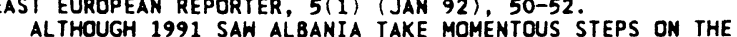
PATH TO TRANSFORMATION--IN MARCH IT HELD THE FIRST FREE ELECTION IN ITS MODERN HISTORY AND IN JUNE IT WAS ADMITTED AS A FULL MEMBER OF THE CONFERENCE ON SECURITY AND AS A FULL MEMBER OF THE CONFERENCE ON SECURITY AND COOPERATION IN EUROPE-THE LATTER PART OF THE YEAR WAS SURYIVAL. AMONG OTHER SIGNS OF SOCIAL (THO MASS EXODUSES BY SURVIVAL. AMONG OTHER SIGNS OF SOCIAL (THO MASS EXODUSES BY BOAT OF OVER 20,000 PEOPLE TO ITALY), ECONOMIC (INDUSTRIAL ANO AGRICULTURAL PRODUCTION DOWN BY 55 PERCENT FROM 1990) AND POLITICAL (THE POST-ELECTION GOVERNMENT OF FATOS NAM LASTING JUST ONE MONTH BEFORE BEING BROUGHT DOWN BY A GENERAL STRIKE) COLLAPSE, PERHAPS THE MOST STRIKING IN A SOCIETY ACCUSTOMED TO FORTY-FIVE YEARS OF RIGID ONE-PARTY RULE HAS BEEN THE DRAMATIC RISE IN CRIME AND DISORDER, WITH
A NUMBER OF ALBANIAN TOWNS IN A VIRTUAL STATE OF ANARCHY. TO MANY IN THE DEMOCRATIC PARTY (NARROW LOSERS IN THE ELECTIONS), SUCH PROBLEMS ARE MORE THAN SYMPTOMATIC OF THE DIFFICULT TRANSITION FACING ALBANIA, THEY ARE EVIDENCE OF AM ATTEMPT BY THE RENAMED SOCIALIST PARTY TO DESTABILIZE THE COUNTRY IN ORDER TO DISCREDIT DEMOCRACY AND HALT REFORMS

02151 CENTENO, M.; MAXFIELD, S.

THE MARRIAGE OF FINANCE AND ORDER: CHANGES IN THE MEXICAN POLITICAL ELITE

JOURNAL OF LATIN AMERICAN STUDIES, 24(1) (FEB 92), 57-86.

RECENT LITERATURE ON LATIN AMERICAN POLITICAL ECONOMY

EMPHASIZES TECHNICAL EXPERTISE IN GOVERMMENT. THIS ARTICLE

EXPLORES ITS FAILURE TO ADORESS ONE OF THE MAIN ISSUES

DEBATED EARLIER; THE POLITICAL CONSEQUENCES OF INCREASINGLY TECHMOCRATIC GOVERNMENT. IT ALSO EXAMINES THAT FACT THAT WHEN IT DOES AOORESS CAUSAL ISSUES, IT TENDS TO FOLLOW THE FUNCTIONALIST LOGIC OF EARLIER LITERATURE. USING DATA ON MEXICAN POLITICAL ELITES. THIS ARTICLE DEVELOPS A NEH TYPOLOGY HICH CAREFULLY DIFFERENTIATES THE NEH TECHNOBUREAUCRATIC ELITES FROM OTHER ELITE GROUPS. THE AIM IS TO SHED NEW LIGHT ON THE DEBATE OVER THE IMPLICATIONS OF IS TO SHED NEH LIGHT ON THE DEBATE OVER THE IMPLICATIONS OF INCREASING TECHNOCRATIZATION. ALSO, THIS STUDY OF THE

CHANGES WITHIN THE GOVERMMENT BUREAUCRACY IN ADOITION TO THE STATE'S FUNCTIONAL RESPONSE TO CHANGES IN ITS POLITICOSTATE'S FUNCTIONAL RESP
ECONOMIC ENVIRONMENT.

02152 CHA, Y.; KIM, T

PROSPECTS FOR POLITICAL CHANGE AND LEADERSHIP SUCCESSIOM IN NORTH KOREA

KOREAN JOURNAL OF DEFENSE ANALYSIS, 3(2) (HIN 91), 207-238. PROSPECTS FOR POLITICAL CHANGE IN NORTH KOREA ARE
EXAMINED AND THE POSSIBLE DIRECTIONS NORTH KOREA MIGHT TAKE IN THE COMING YEARS ARE ASSESSED. THIS ARTICLE ANALYZES THE PATTERNS OF CHANGE IN COMMUNIST REGIMES, IDENTIFIES SOME INTERNAL AND EXTERNAL FACTORS THAT WILL CAUSE CHANGE IN NORTH KOREA, EVALUATES THE BALANCE OF FORCES SUPPORTING OR OPPOSING THE LEADERSHIP SUCCESSION, AND SPECULATES ON VARIOUS ALTERNATIVES FOR LEADERSHIP SUCCESSION IN NORTH
KOREA. IT CONCLUDES THAT NORTH KOREA WILL INITIATE NEW AND KOREA. IT CONCLUDES THAT NORTH KOREA WILL INIT
SIGHIFICANT POLICY CHANGES IN THE NEAR FUTURE.

02153 CHABAT, $J$.

MEXICO'S FOREIGN POLICY IN 1990: ELECTORAL SOVEREIGNTY AND INTEGRATION WITH THE UNITED STATES

JOURNAL OF INTERAMERICAN STUDIES AND WORLD AFFAIRS, $33(4)$

(WIN 92), 1-26.

MEXICD'S FOREIGN POLICY OF 1990 WAS MARKED BY AN ACCELERATION OF TRENDS THAT PRODUCED A PATTERM OF RELATIONSHIPS THAT WOULD HAVE BEEN ALMOST INIMAGINABLE ONLY A DECADE AGO. ECONOMIC RECOVERY AND THE MOVEMENT TOWARDS INTEGRATION WITH THE UNITED STATES HEADS THE LIST. SECONDLY, MEXICO'S FOREIGN POLICY HAS BECOME INCREASINGLY ENTWINED WITH ITS DOMESTIC POL ICY AS THE ISSUE OF IT'S DEMOCRACY CAME UNDER CHALLENGE BY THE INTERNATIONAL PRESS. ALSO, THE UNDER CHALLENGE BY THE INTERNATIONAL PRESS. ALSO, THE SALINAS ADMINISTRATION MANIFESTED UNEXPECTED SUCCESS IN THE VISIBLE IMPROVEMENT IN ITS RELATIONS WITH THE VATICAN. THIS ARTICLE TAKES A CLOSER LOOK AT THESE DEVELOPMENTS, DRAWS COURSE OF FUTURE EVENTS IN THE NEAR TERM.

02154 CHAHIN, R.

MRS. SMITH GOES TO WASHINGTON

NATIONAL REVIEW, XLIIII(7) (APR 91), 41.

WASHINGTON'S RESPONSE TO NICARAGUA AND EL SALYADOR

ILLUSTRATES THE MIXED SIGNALS AMERICAN CONTINUES TO SEND TO

THAT PART OF THE WORLD. EL SALVADOR'S PRESIDENT ALFREDO

CRISTIANI HAS EMBARKED ON AN AMBITIOUS POLITICAL AND

ECONOMIC REFORM PROGRAM AND HAS BEGUN TO REASSERT CIVILIAN

CONTROL OVER THE MILITARY. HIS REHARD FROM HASHINGTON HAS

BEEN A FREEZE ON PROMISED MILITARY AID. DESPITE THE GROWING

EVIDENCE OF CORRUPTION, NEPOTISM, EXTORTION, FRAUD, AND

COOPERATION WITH THE SANDINISTAS BY VIOLETA CHAMORRO, SHE WILL RECEIVE A RED CARPET TREATMENT UPON HER STATE VISIT TO HASHINGTON.

02155 CHAKRAYARTY, S.

IMPACT OF SOVIET TRANSFORMATION ON SOUTH ASIA

SOUTH ASIA JOURNAL, 5(2) (OCT 91), 143-160.

THIS ARTICLE EXAMINES THE IMPACT OF THE BREAK-UP OF THE

SOVIET UNION ON VARIOUS AREAS OF SOUTH ASIA. IT OUTLINES THE

IMPLICATIONS OF THESE CHANGES FOR THE CONFLICT IN

IMPLICATIONS OF THESE CHANGES FOR THE CONFLICT IN

AFGHANISTAN, THE LONG-SIMMERING DISPUTE BETHEEN PAKISTAN AND

INDIA OVER THE KASHMIR REGION, AHD THE FUTURE OF INDO-S

TIES. IT ALSO EXAMINES THE FUTURE ROLE OF THE NEWLY-
INDEPENDENT CENTRAL ASIAN REPUBLICS IN SOUTH ASIA. ITS MAJOR CONCLUSION IS THAT THE PROCESS UNLEASHED IN THE FORMER CONCLUSION IS THAT THE PROCESS UNLEASHED IN THE FORMER SOVIET EMPIRE WILL INEXORABLY DRAW THE ENTIRE INDIAN SUBCONTINENT TONARDS A CONFEDERATIONAL SET-UP THEREBY ENSURING A GENUINELY DEMOCRATIC DECENTRALIZED POLITY, AN
OUTCOME VITAL FOR THE BALANCED GROWTH OF THE DEVELOPING OUTCOME VITAL FOR THE BALANCED GROHTH
WORLD WHICH SOUTH ASIA REPRESENTS.

02156 CHALK, P.

CLINTÓN: POLITICS' NEW BREED

INSIGHT, 8(39) (SEP 92), 14-16; 38.

BILL CLINTON REPRESENTS A BREED OF POLITICAL

ENTREPRENEURS WHO ROSE UP FROM THE ANTIWAR PROTESTS OF THE

19605 AND POLITICAL ACTIVITISM OF THE SEVENTIES. THIS NEW

CROP SAW POLITICS AS A FULL-TIME PROFESSION. THE CAREER PATH LED THEM THROUGH CITY COUNCILS TO STATE LEGISLATURES AND ON TO WASHINGTON. ENTIRE SCHOOLS OF GOVERNMENT AND THINK TANKS HAVE GROWM TO SUPPORT THEM.

02157 CHAMORRO, A.; DELLA BUONO, R.

THE POLITICAL ECONOMY OF THE SANDINISTA ELECTORAL DEFEAT

CRITICAL SOCIOLOGY, 17(2) (SUM 90), 93-102.

THIS ARTICLE SEEKS TO OUTLINE WHY THE UNO ALLIANCE IN

NICARAGUA, IN CONJUNCTION WITH THEIR ALLIES IN THE U.S.

ADMINISTRATION. WERE ABLE TO ACHIEVE THE IMPORTANT SUCCESS

IN THEIR CONTINUING EFFORT TO DERAIL THE SANDINISTA

REVOLUTION. IT FOCUSES ON THE UNDERLYING DYNAMICS WHICH THE

AUTHORS BELIEVE CONTRIBUTED TO THE ELECTORAL DEFEAT OF

FEBRUARY 1990 . THEIR ANALYSIS IS BASES IN THE UNDERLYING

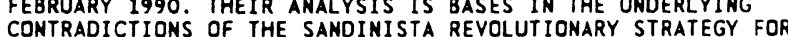

CONTRADICTIONS
DEVELOPMENT.

02158 CHAN, A.L.

THE CAMPAIGN FOR AGRICULTURAL DEVELOPMENT IN THE GREAT LEAP FORHARD: A STUDY OF POLICY-MAKING AND IMPLEMENTATION IN LIAONING

CHINA QUARTERLY, (129) (MAR 92), 52-71.
THE GREAT LEAP FORHARD OF 1958-59 WAS THE MOST INTENSE MOBILIZATIONAL PHASE IN THE HISTORY OF THE PEOPLE'S REPUBLIC OF CHINA AND THE MOST CONCENTRATED EXPRESSION OF THE UTOPIAN MAOIST DEVELOPMENTAL MODEL. BUT THE ADOPTION OF A NEW 
DEVELOPMENT STRATEGY AND DECENTRALIZATION DID NOT BRING ABOUT MATERIAL ABUNDANCE; IN FACT, IT LED DIRECTLY TO AN ECONOMIC DEPRESSION THAT LASTED UNTIL 1965. IN ANALYZING THE GREAT LEAP FORWARD. THE ROLE PLAYED BY THE PROVINCES IN THE POLICY-MAKING PROCESS, THE BUREAUCRATIC BEHAVIOR OF THE PROVINCIAL AUTHORITIES, THE WAY POLICIES WERE IMPLEMENTED, PROVINCIAL AUTHORITIES, THE WAY POL ICIES WERE IMPLEMENTED, AND THE ENVIRONMENTAL CONSTRAINTS AND HOW . IN THIS ESSAY, POLICY-MAKING ARE PARTICULARLY INTERESTING. IN THIS ESSAY, THE AUTHOR FOCUSES ON A SINGLE PROVINCE, LIAONING, AND ITS

02159 CHAN, J.

DOES ARISTOTLE'S POLITICAL THEORY REST ON A 'BLUNDER'? HISTORY OF POLITICAL THOUGHT, 13(2) (SUM 92), 189-202.

ONE OF THE MOST IMPORTANT ISSUES CONCERNING ARISTOTLE' POLITICAL THEORY IS WHETHER HIS NATURALISTIC APPROACH TO POLITICS IS CONSISTENT WITH HIS GENERAL POLITICAL THEORY. THE QUESTION HAS ARISEN: HOW CAN IT BE POSSIBLE THAT A POLIS IS BOTH A NATURAL THING AND A RESULT OF HUMAN CONSCIOUS CONSTRUCTION? THIS ARTICLE ATTEMPTS TO PROVIDE A COHERENT AND THEORETICALLY PLAUSIBLE INTERPRETATION OF ARISTOTLE'S THEORY OF THE NATURALNESS OF THE POLIS. IT ALSO ATTEMPTS TO TO OFFER AN INTERPRETATION THAT IS NOT SO WEAK THAT IT WOULD DEGENERATE INTO THE 'NATURAL TO MAN' VERSION, BUT IS NOT SO STRONG THAT IT WOULD EXCLUDE ANY NOTION OF HUMAN INVOVEMENT IN THE EXISTENCE AND MAINTENANCE OF THE POLIS. AFTER HIS EXAMINATION. THE AUTHOR CONCLUDES THAT THE THEORY IS NOT THE BLUNDERED DOCTRINE ITS CRITICS SUPPOSE IT TO BE.

02160 CHAN, S.; DAYIS, D.

DEFENSE ALLOCATION, INFLATION, AND UNEMPLOYMENT IN SOUTH KOREA

KOREAN JOURNAL OF DEFENSE ANALYSIS, 3(2) (WIM 91), 239-258.

THIS PAPER OFFERS PRELIMINARY ATTEMPT AT DECIPHERING THE DEFENSE MANPOHER AND DOLLAR COMMITMENTS ON THE ONE HAND, AND UMEMPLOYMENT AND INFLATION RATES ON THE OTHER. THE IMMEDIATE CONCERN IS TO TEST FOR GRANGER CAUSALITY AMONG THE PERTINENT TIME SERIES FROM SOUTH KOREA AND TAIWAN. THE REST OF THIS PAPER OEALS WITH THE RATIONALE FOR CHOOSING THESE CASES, THE EXPECTATIONS FOR ALTERNATIVE CAUSAL POSSIBILITIES AMONG THE VARIABLES, THE GRANGER APPROACH TO CAUSAL ANALYSIS AND THE DISCUSSION OF THE ANALYSIS RESULTS.

02161 CHAN, S.

DEMOCRACY IN SOUTHERN AFRICA: THE 1990 ELECTIONS IN ZIMBABHE AND 1991 ELECTIONS IN ZAMBIA

ROUND TABLE, 322(322) (APR 92) 183-203.

IN SOUTH AFRICA, DEMOCRACY IS NOT SO MUCH GROWING OUT OF THE PRINCIPLE OF MAJORITY RULE AS SUBJECTED TO THE

NEGOTIATED CONDITIONS UNDER WHICH MAJORITY RULE MIGHT BE POSSIBLE. IN 1990, THE GOVERNMENT OF ZIMBABWE DREW BACK FROM THE INTRODUCTION OF A ONE-PARTY STATE. IN 1991 THE ZAMBIA VOTED OUT OF OFFICE THE UNIP PARTY THAT HAD 1990 THIS ARTICLE LOOKS AT THE BACKGROUND TO MUTI-PARTY DEMOCRACY IN BOTH COUNTRIES.

02162 CHAN, $S$.

HUMANITARIAN, MERCANTILISM, OR COMPREHENSIVE SECURITY? DISBURSEMENT' PATTERNS OF JAPANESE FOREIGN AID

ASIAN AFFAIRS, AN AMERICAN REVIEW, 19(1) (SPR 92), 3-17. THE AUTHOR FOCUSES ON TOKYO'S BILATERAL FOREIGN AID AGREEMENTS AS A HINDOH OFFERING A BROADER VIEW INTO THE NATURE OF JAPAN'S ECONOMIC AND POLITICAL STATECRAFT. HE NATURE OF JAPAN'S ECONOMIC AND POLITICAL STATECRAFT. HE ANALYZES THE DISTRIBUTION PATTERN OF TAPAN S FOREYGN IN AN ATTEMPT TO INFER THE CONCERNS THAT PREOCCUPY ITS LEADERS AND THE GOALS THAT MOTIVATE THEM. HE CONCLUOES FOREIGH AID: THE MAINTENANCE OF THE CAPITALIST WORLO ORDER FOREIGN AID: THE MAINTENANCE OF THE CAPITALIST WORLO ORDER AND THE ENHANCEMENT OF JAPAN'S POSITION IN IT. THIS DUAL EMPHASIS ON INTERNATIONAL STABILIZATION AND SECTARIAN ADVANTAGE HAS L
FOREIGN POLICY.

02163 CHAN, S.; ALNER, J.

THE NATURE OF REGIONAL CONFLICT: A REVIEW OF 1990--PART

THREE: THE LEGACY OF SUPERPOWER COMPETITION

CDNTEMPORARY REVIEW, 259(1506) (JUL 91), 14-18.

THIS ARTICLE EXAMINES THE LEGACY OF SUPERPOWER

COMPETITION IN TWO ARENAS: KOREA AND CAMBODIA. ALTHOUGH THE UNITED NATIONS IS MOVING TOHARDS RESOLVING THE CONFLICT IN CAMBODIA, THERE IS NO ASSURANCE THAT A LASTING PEACE CAN BE GUARANTEED. THE DECADES-LONG LEGACY OF SUSPICION AND DISTRUST BETWEEN THE TWO KOREAS WILL BE DIFFICULT TO ELIMINATE. THE ARTICLE GIVES A DETAILED CHRONOLOGY OF EVENTS WHICH TOOK PLACE DURING 1990 IN BOTH ARENAS, WITH EMPHASIS ON THE SLOW PROGRESS TOWARDS PEACE AND THE CONTINUED CONFLICT THAT STANOS IN THE WAY.

02164 CHAND, G.

THE UNITED STATES AND SOUTH PACIFIC REGIONALISM:

PARTICIPATION OR SUBVERSION

BULLETIN OF CONCERNED ASIAN SCHOLARS, 24(3) (JUL 92),
26-42.

INCREASING POLITICAL AWARENESS IN THE PACIFIC ISLAND NATIONS DURING THE 1970 S LED THEM TO ADOPT FOREIGN AND DOMESTIC POLICIES THAT THE METROPOLITAN NATIONS CONSIDERED PACIFIC FORUM (SPF) STOOD AT THE CENTER OF MUCH OF THE DECISION MAKING. FOR THE UNITED STATES IN PARTICULAR IT BECAME IMPERATIVE THAT IT CHECK THE SPF'S DECISION MAKING PROCESS. THIS LED THE UNITED STATES TO SEEK AVENUES THROUGH HHICH IT COULD EFFECTIVELY INFLUENCE THE DECISIONS OF THE SOUTH PACIFIC'S REGIONAL ORGANIZATIONS. SUCH ATTEMPTS WERE SOUTH PACIFIC'S REGIONAL ORGANIZATIONS. SUCH ATTEMPTS INTENDED PRIMARILY TO UNDERMINE THE SOVEREIGNTY AND INDEPENDENCE OF THE SOUTH PACIFIC FORUM ANO AFFILIAT ORGA RATIONS. THIS ARTICLE DISCUSSES THE RATIONALE REGIONAL ORGANIZAT IONS. THIS ARTICLE UNITED STATES HAS BEEN FOR AND PROCESSES THROUGH WHICH THE UNITED STATES HAS BEEM TRYING TO MANIPULATE SOUTH PACIFIC REGIONAL

02165 CHANDA, $N$.

ATMOIC AMBIVALENCE

FAR EASTERN ECONOMIC REVIEH, 155(39) (OCT 92), 8-10.

IN RECENT TALKS WITH THE UNITED STATES, NORTH KOREA HAS BEEN PUSHING HARD TO NORMALIZE BILATERAL TIES. WHILE THIS MAY BE NATURAL FOR A BANKRUPT AND INTERNATIONALLY ISOLATED REGIME, PYONGYANG'S EAGERNESS, PERSISTENCE AND WILLINGNESS TO PERMIT INTERNATIONAL INSPECTION OF ITS NUCLEAR FACILITIES HAVE INTENSIFIED A DEBATE IN WASHINGTON ABDUT PRESIDENT KIM IL-SUNG'S QUEST FOR NUCLEAR WEAPONS. WHILE THE SOUTH KOREAN GOVERNMENT AND THE U.S. STATE DEPARTMENT SEEM INCL INED TO BELIEVE THAT NORTH KOREA HAS ABANDONED ITS WEAPONS PROGRAM, THE PENTAGON AND THE CIA HARBOR DEEP SUSPICIONS THAT PYONGYANG IS STILL PURSUING ITS NUCLEAR AMBITION. THE NUCLEAR ISSUE HAS ACOUIRED GREATER URGENCY WITH NORTH KOREA STEPPING UP ITS EFFORTS TO ESTABLISH DIPLOMATIC TIES WITH THE U.S. AND SOUTH KOREAN PRESIDENT ROH TAE WOO PRESSING TO BUIL ECONOMIC TIES WITH NORTH KOREA. BOTH MOVES COULD BE FACI FACILITATED IF NORTH KOREA WAS FOUND TO HAVE GIVEN UP ITS NUCLEAR PROGRAM. HOWEVER, NORTH KOREA'S RELUCTANCE TO GIVE INTERNATIONAL ATOMIC ENERGY AGENCY (IAEA) INSPECTORS FREE ACCESS TO CORE SAMPLES FUELS THE SUSPICION THAT

02166 CHANDA, $N$.

DISTANT THUNDER

FAR EASTERN ECONOMIC REVIEW, 155(46) (NOV 92), 15-18.

AMERICAN PRESIDENT BILL CLINTON SAYS HIS FIRST PRIORITY AFTER HE TAKES OFFICE IN JANUARY WILL BE THE U.S. ECONOMY. HOWEVER, ASIA MAY CLAIM HIS ATTENTION EARLIER THAN HE EXPECTS, IF ONLY BECAUSE OF THE NEED TO DO SOMETHING ABOUT BIG U.S. TRADE DEFICITS IN THE REGIDN. ASIA WILL ALSO BE THE TESTING GROUND FOR CLINTON'S POLICIES ON HUMAN RIGHTS, WITH CHINA AS THE MOST DIFFICULT AREA DF DECISIDN. ALTHOUGH THE ASIAN REGION AS A WHOLE IS NOW MORE PEACEFUL THAN IT WAS FOUR YEARS AGO, NATIONAL AND ETHNIC STRUGGLES COULD STILL CREATE PROBLEMS FOR U.S. POLICY.

02167 CHANDA, $N$.

GHOST AT THE FEAST

FAR EASTERN ECONOMIC REYIEW, 155(23) (JUL 92), 8-9. AS THE CAMBODIAN PEACE PROCESS LURCHES AHEAD, THE KHMER ROUGE IS FINDING ITSELF INCREASINGLY ISOLATED AND UNDER CRITICISM FROM MANY FRONTS. THE LATEST CRITICISM DIRECTED TOWARDS THE ERSTHHILE RULERS OF CAMBODIA WAS SPARKED BY THE REFUSAL OF THE KHMER ROUGE, STILL THE MOST POHERFUL FACTION IN THE WATI THE KHAR RORM ITS FORCES. WITHOUT THE DISARMING AND DE RATION, AND DEFOBILIZATION OF TROOPS OF ALL THE FOUR CONTENDING FACTIONS, CAMBODIA CANNOT HOLD A NATIONAL ELECT ION ANO CREATE A STABLE SITUATION--AS ENVISAGED BY THE PARIS PEACE ACCORD. THE FOUR CAMBOOIAN FACTIONS--THE PHNOM PENH REGIME LED BY PRIME MINISTER HUN SEN, THE KHMER PEOPLE'S NATIONAL I THE FOLLOWERS OF PRINCE NORODOH SIHANOUK, AND THE KHMER ROUGE--PLAN TO MEET AGAIN IN PHNOM PENH ON 2 JULY TO TRY TO RESOLVE THE PROBLEM. BUT OBSERVERS FROM THE UNITED NATIONS AND ELSEHHERE HOLD OUT LITTLE HOP ROUGE COOPERATION. THE KHMER ROUGE JUSTIFIES ITS INTRANSIGENCE WITH CLAIMS THAT VIETNAMESE TROOPS ARE STILL IN CAMBODIA--IN VIOLATION OF THE PEACE AGREEMENT-O-AND BY ARGUING THAT FOREIGN DONDRS

02168 CHANDA, $N$

FAR EASTERM ECONOMIC REVIEW, 155(25) (JUN 92), 18.

THE PASSAGE ON 15 JUNE OF A BILL THAT ALLOWS JAPANESE SOLDIERS TO BE DEPLOYED ABROAD--ALBEIT ONLY UNDER THE BLUE UN FLAG--EMDED OEPL-YEAR OID TABDO EMSHRINED IN JAPAN'S POSTWAR "PEACE CONSTITUTION." WHILE ASIAN PUBLIC REACTION TO THE MOVE WAS LIMITED TO MEASURED OFFICIAL STATEMENTS, OFFICIALS OF SOME COUNTRIES HAVE BEEN BLUNT IN PRIVATE IN EXPRESSING THEIR CONCERN. THE LEVEL OF ANXIETY DISPLAYED AS A RESULT OF THE CHANGE DEPENDED LARGELY ON EACH COUNTRY'S HISTORICAL EXPERIENCE WITH JAPAN, AND ON PRACTICAL CONCERNS SUCH AS THE EXTENT OF JAPANESE AID, INVESTMENT AND TRADE. THAILAND, 
PROPOSED JOINT MILITARY EXERCISES WITH TOKYO, HELCOMED THE MOVE. AT THE OPPOSITE EXTREME, SOUTH KOREA POINTEDLY VOICED CONCERNS ABOUT THE FUTURE. SINGAPORE WAS ALSO FAIRLY OPEN IN EXPRESSING ITS UNEASINESS. HOPING TO SECURE FURTHER JAPANESE TRADE AND AID, OTHER NATIONS-CHINA, NORTH KOREA, YIETNAM AND MALAYSIA--GENERALLY MUTED THEIR CONCERNS

02169 CHANDA, $N$.

WOUNDS OF HISTORY

FAR EASTERN ECONOMIC REYIEW, 155(30) (JUL 92), 14-16.

THE UNITED MATIONS' BOLD PLAM TO RESTORE PEACE AND REBUILD CAMBODIA HAS RUN INTO AN INTRACTABLE OBSTACLE LEFT OVER BY HISTORY: HATRED BETWEEN CAMBODIANS AND VIETNAMESE. AS THE UN POURS IN FUNDS TO RESETTLE CAMBODIAN REFUGEES, RUN THE INTERIM ADMINISTRATION AND REYIVE THE ECONOHY, A CONSTRUCTION BOOM HAS BEGUN IN PHNOM PENH ATTRACTING SKILLED VIETNAMESE WORKERS. IN TURN, THIS HAS REKINDLED THE CAMBODIAN FEAR AND LOATHING OF VIETNAMESE DOMINATION, WHICH HAS BEEN EXPLOITED BY ALL THE CAMBODIAN POLITICAL FACTIONS EXCEPT THE PHNOM PENH REGIME. HOWEVER, THESE ANTI-VIETHAMESE SENTIMENTS ARE NOT SIMPLY THE PRODUCT OF RECENT EVENTS; THEY SENTIMENTS ARE NOT SIMPLY THE PRODUCT OF RECENT EVENTS; T
RUN DEEP AND ARE ROOTED IN HUNDREDS OF YEARS OF SOUTHEAST RUN DEEP AND ARE ROOTED IN HUNDREDS OF YEARS OF SOUTHEAST ASIA'S HISTORY. THE KHMER ROUGE HAS TURNED ITS ANTI-HANOI TIRADE INTO A LARGER XENOPHOB IC CAMPAIGN TARGETING
AND ITS WESTERN BACKERS. WHILE PRINCE SIHANOUK, THE

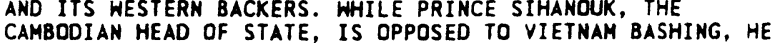
CAMBDDIAN HEAD OF STATE, IS OPPOSED TO VIETNAM BASHING, HE HAS FOUND LITTLE SUPPORT FOR HIS VIENS. MANY OBSERVERS FEAR POGROM COULO DESTABILIZE THE REGION.

02170 CHANDLER, A.

ETHNICITY, EMIGRATION AND THE STATE: THE REVIVAL OF SOVIET JEWISH NATIONALISM AFTER KHRUSHCHEV

CANADIAN REVIEW OF STUDIES IN NATIONALISM, XIX(1) (1992), 93-108.

THIS CASE STUDY EXPLORES THE RELATIONSHIP THAT GUIDED JEHISH ETHNICITY, EMIGRATION, AND THE SOVIET STATE IN THE POST-KHRUSHCHEV ERA, USING EVIDENCE DERIVED FROM JEHISH UNDERGROUND SAMIZDAT WRITINGS, SOVIET OFFICIAL SOURCES, AND THE SOVIET PRESS. IT ARGUES THAT THE JEWISH MOVEMENT, ACTING ON ITS POLITICAL GRIEVANCES, PUT PRESSURE ON THE STATE FOR THE RIGHT TO EMIGRATE. INSOFAR AS INDEPENDENT POL ITICAL ACTIVITY WAS POSSIBLE UNDER THE AUTHORITARIAN BREZHNEVITE SYSTEM. THE SOVIET STATE, WHICH UNTIL RECENTLY SEVERELY RESTRICTED EMIGRATION, CAN BE SEEN AS, IN EFFECT, RESTRICTED EMIGRATION, CAN BE SEEN AS, IN EFFECT,
COMPROMISING WITH SOVIET JEWS BY ALLOHING LIMITED EMIGRATION AS PREFERABLE TO IMPROVING SOCIOPOL ITICAL CONDITIONS FOR AEWS WITHIN THE SOVIET STATE. THEREFORE, THIS ARGUNENT SEES JEWS WITHIN THE SOVIET STATE. THEREFORE, THIS ARGUHENT SEES
BOTH SOVIET JEWS AND THE STATE AS PLAYING ACTIVE ROLES IN BOTH SOVIET JEWS AND THE STATE AS PLAYING ACTIVE ROLES IN
THE PHENOMENON OF MASS JEWISH EMIGRATION, RESULTING IN AN THE PHENOMENON OF MASS JEHISH EMIGRATION, RESULTING
OUTCOME ACCEPTABLE THOUGH NOT IDEAL TO BOTH SIDES.

02171 CHANDRA, $M$

BUKHARIM'S ALTERMATIVE TO STALIN: INDUSTRIALISATION WITHOUT FORCED COLLECTIVISATION

JOURKAL OF PEASANT STUDIES, 20(1) (OCT 92), 97-159.

WAS THE BUKHARIN ALTERNATIVE FEASIBLE? THIS ARTICLE FOCUSES ON HIS CONCRETE PROPOSAL. ESCHEWING FORCED COLLECTIVIZATION, TO OVERCOME THE CRUCIAL GRAIN PROCUREMENT CRISIS OF 1927-29. THEN IT FOLLOWS COUNTER-FACTUAL EXERCISES, DRAWING ON THE EXPERIENCES OF CONTEMPORARY DEVELOPIMG COUNTRIES ON THE PROSPECTS OF SOVIET INDUSTRIALIZATION IN THE 1930S: THE PACE OF OEVELOPMENT NEEDS HAS SLACKENED. FINALLY, THE CONTEMPORARY RELEVANCE OF SOME OF BUKHARIN'S IDEAS IS ALSO UNDERLINED.

02172 CHAMG, D

THE END OF COLD HAR AND THE FUTURE OF SOUTH KOREA-JAPAN RELATIONS

KOREA \& WORLD AFFAIRS, 16(3) (FAL 92), 503-524,

BOTH JAPAN AND SOUTH KOREA HAVE RECENTLY BEGUN TO SHOH SIGNS OF STRAIN REGAROING ALMOST EVERY ASPECT OF THEIR BILATERAL RELATIONS, INCLUDING DISPUTES OVER TRADE, TECHNOLOGY TRAMSFER, KOREAN MINORITIES IN JAPAN, "COMFORT WOMEN," JAPAN'S TWO-KOREA POLICY, AMD THE RESURGENCE OF JAPAN'S DOMINANCE. THIS MUTUAL SUSPICION INDICATES THAT THERE IS SOMETHING OF A NEW DIMENSIONAL CRISIS OF CONFIDENCE BETWEEN THE TWO COUNTRIES. THIS NEH CRISIS HAS MUCH TO DO WITH THE LOGIC OF INTERMATIOMAL RELATIONS STEMMING FROM THE END OF THE COLD WAR.

02173 CHANG, M.H.

CHINA'S FUTURE: REGIONALISM, FEDERATION, OR OISINTEGRATION STUDIES IN COMPARATIVE COMMUNISM, XXV(3) (SEP 92), 211-227.

THE IMPLOSION OF COMHUNIST REGIMES IN THE SOVIET BLOC HAS MADE POSSIBLE WHAT WAS ONCE UNTHINKABLE: CHINA, TOO, HILL SEE THE PASSING OF CDMMUNIST RULE. WHAT REMAINS IN QUESTION IS HOH COMMUNIST RULE HILL END IN CHINA. SOME EXPERTS HAVE PREDICTED THAT THE GROWING PHENOMENON OF REGIONAL AUTONOMY IN THE PEOPLE'S REPUBLIC WILL CULMINATE IN THE COLLAPSE OF CENTRAL CONTROL OVER CHINA'S CONSTITUENT REGIONS. THEY CITE THE IMPACT OF POST-MAO ECONOMIC REFORMS, REGIONAL ECONOMIC INDEPENDENCE, INCREASING REGIONAL ASSERTIVENESS, REGIONAL ECONOMIC DISPARITIES, AND REGIONAL
PROTECTIONISM.

02174 CHANG, M.H.

THE PHENOMENON OF REGIONALISM IN THE PRC; ASSOCIATION FOR ASIAN STUDIES 1992 ANNUAL MEETING

ASSOCIATION FOR ASIAN STUDIES, $1992,53$.

THIS PAPER SEEKS TO DESCRIBE, ANALYZE, AND EXPLAIN THE RISING PHENOMENON OF REGIONALISM ("DIFANG ZHUYI") IN THE PEOPLE'S REPUBLIC OF CHINA. THE PAPER ASSESSES THE EXTENT OF THE PHENOMENON, THE EFFORTS OF THE BEI JING AUTHORITIES TO PREVENT ITS FURTHER DEVELOPMENT, AND CONCLUDES BY PROVIDING THE CONTINGENT CONDITIONS THAT WOULD BE NEEDED FOR REGIONALISM TO DEVOLVE INTO THE FRAGMENTATION OF THE POLITICAL SYSTEM OF CHINA.

02175 CHANG, P.

DENG'S LAST STAND ON CHINA'S REFORM MOYEMENT KOREAN JOURNAL OF DEFENSE ANALYSIS, IV(1) (SUM 92), 105-128.

A CAMPAIGN IS UNDER WAY BY DENG XIAOPING AND HIS SUPPORTERS TO REVIVE THE OPEN DOOR AND REFORM PROGRAMS THAT THE HARDLINERS IN THE CHINESE COMMUNIST PARTY (CCP) HAVE ROLLED BACK AFTER TIANANMEN. LEADERSHIP DIFFERENCES ARE EXTENSIVE, AND THE ISSUES OF CONTENTION COVER ECONOMIC AND POLITICAL MEASURES, AND EXTERNAL AFFAIRS SUCH AS CHINA'S POL ITICAL MEASURES, AND EXTERNAL AFFAIRS SUCH AS CHINA'S
POLICY TOWARD THE SOVIET UNION. THE U.S. AND THE KOREAN POLICY TOWARD THE SOVIET UNION, THE U.S. AND THE KOREAN THE CCP LEADERSHIP STILL ATTACH GREAT IMPORTANCE TO NORTH THE CCP LEADERSHIP STILL ATTACH GREAT IMPORTANCE TO NOR

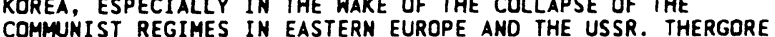
COMWNIST REGIMES IN EASTERN EUROPE AND THE USSR. THERGORE THEY OPPOSE NORMALIZATION OF DIPLOMATIC RELATIONS WITH SOUTH KOREA, LEST SUCH A MOVE MAY
OF THE MORTH KOREAN REGIME.

02176 CHANG, P.; DENG, 2

THE CHINESE BRAIN DRAIN AND POLICY OPTIONS STUDIES IN COMPARATIVE INTERNATIONAL DEVELOPMENT, $27(1)$ (SPR 92), 44-60.

BRAIN DRAIN HAS BECOME A GROHING PROBLEM IN CHINA'S OVERSEAS EDUCATION, ESPECIALLY SINCE THE TIANANMEN INCIDENT OF JUNE 1989. MANY STUDENTS HAVE FOUND IT MORE DIFFICULT TO ADJUST TO THE HOME ENVIRONMENT. SOME ARE AFRAID THEY WOULD BE PUNISHED FOR POLITICAL REASONS IF THEY WENT HOME. SOME USE THE ISSUE AS AN OPPORTUNITY TO SEEK PERMANENT RESIDENCE. BEIJING IS FACING VARIOUS DIFFICULTIES IN COPING WITH THE BRAIN DRAIN PROBLEM. RESTRICTIONS ALWAYS ANGER STUDENTS ABROAD. FAMILY MEMBERS OFTEN DISCOURAGE STUDENTS FROM RETURNING. INCENTIVES TO ATTRACT STUDENTS TO RETURN ARE INADEQUATE. MOST IMPORTANTLY, AFTER TIANANMEN, WESTERN GOVERNMENTS REFUSED TO COOPERATE WITH BEI JING AND ALLOWED GOVERMMENTS REFUSED TO COOPERATE WITH BEI JING AND ALLOWED CHINESE STUDENTS TO STAY. CONCERNED WITH THE BRAIN DRAIN,
BEIJING IS RECONSIDERING ITS POLICY ON FOREIGN STUDY. OF THE BEIJING IS RECONSIDERING ITS POLICY ON FOREIGN STUDY.
POLICY ALTERNATIVES, A CONTINUATION OF THE OPEN POLICY
APPEARS TO REMAIN OPTIMAL. THOUGH SOME ADJUSTMENTS ARE APCEASSARY. IN ADDITION, SEVERAL TECHNICAL SOLUTIONS TO THE NECESSARY. IN ADDITION, SEVERAL TECHNICAL SOL
PROBLEM OF BRAIN DRAIN ARE WORTH CONSIDERING.

02177 CHANG, P.H.

CHIMA'S RELATIONS HITH HONG KONG AND TAIHAM

ANNALS OF THE AMERICAN ACADEMY OF POLITICAL AND SOCIAL SCIENCE, 519 ( JAN 92 ), 127-139.

NATIONAL REUNIFICATION IS A TOPMOST PRIORITY FOR THE PEOPLE'S REPUBLIC OF CHINA (PRC). IN RECENT YEARS, THE PRC HAS BLOCKED HONG KONG'S DEMOCRATIC REFORM AND INCREASINGLY MEDDLED IN THE COLONY'S INTERNAL AFFAIRS. THESE ACTIONS HAVE EXACERBATED HONG KONG'S CRISIS OF CONFIDENCE, CAUSING A SEVERE BRAIN DRAIN AND CAPITAL FLIGHT FROM THE COLONY. BEIJING IS ALSO WORRIED ABOUT DEVELOPMENTS IN TAIWAN DUE TO THE ACCESSION TO THE PRESIDENCY BY LEE TENG-HUI, A NATIVE TAIWANESE, AND THE GROWING DEMOCRATIZATION OF TAIWAN'S POLITICS AND POWER STRUCTURE ALONG WITH CALLS FOR GREATER INDEPENDENCE. THEREFORE, THE PRC AUTHORITIES ARE PULLING OUT ALL THE STOPS, INCLUDING A LOW-KEYED THREAT OF FORCE, TO FORESTALL SEPARATISM AND PRESS THE GOVERNMENT IN TAIPEI TO COME TO THE NEGOTIATING TABLE. BEIJING SEEMS LIKELY TO INTENSIFY ITS CAMPAIGN FOR REUNIFICATION WITH TAIWAN, EVEN BEFORE HONG KONG'S REVERSION TO CHINESE SOVEREIGNTY IN 1997. SHOULD THE PRC USE COERCION AGAINST TAIPEI, BEI JING AND WASHINGTON WOULD BE ON A COLLISION COURSE BECAUSE THE USA HAS A STRONG INTEREST IN TAIWAN'S STABILITY, SECURITY, AND PROSPERITY.

02178 CHAMG S.L.

CAUSES OF BRAIN DRAIN AND SOLUTIONS: THE TAIHAN EXPERIENCE STADIES IN COMPARATIVE INTERMATIONAL DEYELOPMENT, 27 (1) (SPR 92 ) $27-43$.

OVER THE YEARS, TAIHAN HAS EXPERIENCED "BRAIN DRAIN," AS MORE THAN 80 PERCENT OF ITS STUDENTS WHO COMPLETED THEIR GRADUATE STUDY IN THE UNITED STATES HAVE FAILED TO RETURN. INSTEAD, THEY HAVE FOUND THEIR WAYS INTO THE FACULTIES OF AMERICAN COLLEGES AND UNIVERSITIES OR EMPLOYMENT OPPORTUNITIES IN VARIOUS RESEARCH ORGANIZATIONS AND INDUSTRIES. THIS ARTICLE EXAMINES BRAIN DRAIN, ITS ORIGIN IN TAIHAN, AND GOVERMMENT RESPONSE. ONE OF THE MAJOR FINDINGS 
OF THIS STUDY IS THAT THE ELITE EMIGRATION IN TAIWAN HAS BEEN CAUSED BY A HOST OF COMPLEX ACADEMIC, SOCIAL, ECONOMIC AND PERSONAL FACTORS. SECOND, TAIWAN'S BRAIN DRAIN INTO THE UNITED STATES IS PRIMARILY A CASE OF "EDUCATION AND MIGRATION." IT IS AN OUTFLOW OF COLLEGE GRADUATES, NOT AN EXODUS OF TRAINED SCIENTISTS AND ENGINEERS; THEREFORE, TAIWAN'S MANPOWER LOSS IN THE SHORT RUN IS NOT AS SERIOUS AS THE CASE WHERE MATURE AND EXPERIENCED SCIENTISTS AND PROFESS IONALS LEAVE. FURTHERMORE, WHEREAS A LARGE NUMBER OF COLLEGE GRADUATES LEAVE EACH YEAR TO STUDY ABROAD, A MUCH LARGER NUMBER OF THE GRADUATING CLASS DOES REMAIN IN TAIWAN. TO REVERSE TAIWAN'S BRAIN DRAIN, THE GOVERMMENT OF THE TO REVERSE TAIWAN'S BRAIN DRAIN, THE GOVERNMENT OF THE
REPUBLIC OF CHINA (ROC) HAS ALREADY IMPLEMENTED AN AMBITIOUS
PROGRAM TO RECRUI TAIWAN'S HIGHLY TRANED TALENTS FROM PROGRAM TO RECRUIT TAIWAN'S HIGHLY TRAINED TALENTS FROM
OVERSEAS. TAIWAN'S SUCCESSFUL EXPERIENCE COULD BE EMULATED OVERSEAS. TAIWAN'S SUCCESSFUL
BY OTHER DEYELOPING COUNTRIES.

02179 CHANG, $Y$.

PHOTOS OF AIR RAID ILLUSTRATE CRUELTY OF WAR

JAPAN TIMES (WEEKLY INTERMATIONAL EDITION), 32(14) (APR 92), $12-13$.

THE GREAT TOKYO AIR RAID ON MARCH 10, 1945, KILLED OR WOUNDED ABOUT 120,000 PEOPLE AND DESTROYED MORE THAN 230,000 HOMES. BUT PHOTOS OF THE EVENT AND ITS AFTERMATH ARE EXTREMELY RARE BECAUSE CARRYING A CAMERA OFTEN LED TO CHARGES OF ESPIONAGE AND BECAUSE THE EXIENT OF THE DAMAGE A POLICEMAN WORKING IN THE PHOTOGRAPHY DIVISION OF THE NATIONAL POLICE AGENCY RECORDED THE GREAT TOKYO AIR RAID AS PART OF HIS DUTIES, AND HIS PHOTOS HAVE RECENTLY BEEN

PRESENTED IN A ONE-MAN SHOW AT MEGURO MUSEUM OF ART IN TOKYO. THE PHOTOGRAPHS OFFER A RARE INSIGHT INTO THE CRUELTY OF WAR.

02180 CHANMON, J.

FROM MUZIIK TO KOLKHOZNIK: SOME RECENT WESTERN AND SOVIET STUDIES OF PEASANTS IN LATE IMPERIAL AND EARLY SOVIET RUSSIA

SLAVONIC AND EAST EUROPEAN REVIEW, 70(1) (JAN 92), 127-139. THE AUTHOR REVIEHS SEVERAL MAJOR HORKS ON THE RUSSIAN PEASANT ECOMOMY CUL TURE, POLITICS, AND HISTORY IN THE IOTH AND 2OTH CENTURIES.

02181 CHAPIN, J.

BUSH FALTERING: IS TSONGAS A REPUBL ICAN?

COMMONWEAL CXIX) (5) (MAR 92) 6-7.

GEORGE BUSH HAS JUST THO CHANCES OF GETTING REELECTED AN ECDNOMIC UPSHING OR A NONCREDIBLE OPPONENT. THE NATION FACES THE BAD FORTUNE OF HAVING BEEN LEFT HITH AN EXCELLENT MANAGER OF THINGS-AS-THEY-ARE IN CHARGE OF A SITUATION IN
WHICH NOTHING IS AS IT WAS. OTHER CONTENDERS, INCLUDING PAUL WHICH NOTHING IS AS IT WAS. OTHER CONT
TSONGAS ARE EVALUATED IN THIS ARTICLE.

02182 CHAPMAN, G.

PUSH COMES TO SHOVE ON TECHNOLOGY POLICY

TECHNOLOGY REVIEW, 95(8) (NOV 92), 42-49.

THE AUTHOR LOOKS AT THE POSITIONS BILL CLINTON AND

GEORGE BUSH HAVE MARKED OUT ON U.S. TECHNOLOGY POLICY DURING THE 1992 PRESIDENTIAL ELECTION CAMPAIGN. HE ALSO DISCUSSES BUSH'S RECORD AS A TECHNOLOGY POLICY-MAKER DURING HIS FIRST TERM.

02183 CHAPMAN, J.W.M.

TRICYCLE RECYCLED: COLLABORATION AMONG THE SECRET INTELLIGENCE SERVICES OF THE AXIS STATES, 1940-41

INTELLIGENCE AND NATIONAL SECURITY, 7 (3) (JUL 92), 268-299. THIS ARTICLE RE-EXAMINES CHARGES THAT BRITISH

INTELLIGENCE HAD PRIOR KNOWLEDGE OF JAPAN'S INTENTION TO ATIACK PEARL HARBOR. AND THAT BRITAIN DID NOT SHARE THIS KNOHLEDGE WITH THE UNITED STATES. IT EXAMINES IN SOME DETAIL THE INTELLIGENCE COOPERATION THAT TOOK PLACE BETHEEN THE THREE AXIS POWERS: JAPAN, ITALY AND GERMANY. IT CONCLUDES THAT THE BRITISH PROBABLY DID KNOW MORE THAN HAS BEEN ADMITTED IN THE PAST SIMPLY BECAUSE ALL THE SOURCES OF KNOWLEDGE WERE NOT FULLY SHARED WITH THE UNITED STATES. HOWEVER, THE ARGUMENT THAT MUCH EVIDENCE WAS SUPPRESSED SHOULD NOT

02184 CHAREST, H.J.J.

THE FUTURE OF FEDERALISH

CANADIAN PARL IAMENTARY REVIEW (WIN 91) 5-6.

THE DEMISE OF THE MEECH LAKE CONSTITUTIOUAL ACCORD IN CANADA MARKED A TURNING POINT IN THE DEVELOPMENT OF FEDERALISM IN THAT COUTRY FO OUEBEC IT IMDICATES THAT FEDERALTSM IN THAT COUNRRY. FOR QUEBEC, IT IMDICATES THAT THE RELATIVELY STRONG CONSENSUS IN THAT PROVINCE IS FREE TO PURSUE A MORE AUTONOMOUS GOVERMMENT, HITH TOTAL INDEPENDENCE BEING THE EXTREME LIMIT. FOR THE REST OF CAMADA, NO CLEAR CONSENSUS ON FUTURE DIRECTIONS EXIST. CANADA REMAINS UNIP BY GEOGRAPHY, HISTORY, A TRADITIONAL ACCOMMODATION OF HOWEVER, THERE IS LITTLE AGREEMENT ABOVE AND BEYOND THESE ISSUES.
02185 CHARLIER, M.

A CHANGE OF UNDERSTANDING ABOUT THE STATE AND POLITICS GERMAN TRIBUNE, (1513) (MAY 92 ), $1,3$.

THE OUTBURSTS OF "EURO-SKEPTICISM" FOLLOWING THE MAASTRICHT RESOLUTIONS ARE NOT A PHENOMENON PECULIAR TO GERMANY; IN OTHER COUNTRIES, THE PUBLIC HAS ALSO SUDDENLY GRASPED THE PRINCIPLE OF HOW EURO-GOVERMMENTS HORK-GOVERNMENT LEADERS NEGOTIATE FAR-REACHING COMMITMENTS IN LOFTY HEIGHTS, WHICH CAN THEN NO LONGER BE CONTROLLED OR RESHAPED BY NATIONAL PARLIAMENTS. THIS ARTICLE ARGUES THAT EUROPE COULD LEARN A LESSON FROM THE EXCESSES OF GERMAN STATE CENTRALIZATION IN THE PAST. IT POINTS TO THE INCREASING DEMAND FOR REGIONAL AUTONOMY AND SELFDETERMINATION ALL OVER EUROPE AS EVIDENCE THAT A EURODETERMINATION ALL OVER EUROPE AS EVID
GOVERNMENT IS NOT WANTED, NOR NEEDED.

02186 CHARLTON, R.

BUREAUCRATS AND POLITICIANS IN BOTSWANA'S POLICY-MAKING PROCESS: A RE-INTERPRETATION

JOURNAL OF COMMONWEALTH AND COMPARATIVE POLITICS, 29(3) MOV 92 ), 265-282.

BOTSWAMA'S ACHIEVEMENT IN MOVING FROM A POSITION AS ONE OF THE WORLD'S POOREST STATES IN 1966 TO ITS CURRENT STATUS AS ONE OF SUB-AFRICA'S MIDDLE-INCDME ECDNOMIES RAISES THE PROBLEM OF FITTING THE BOTSWANA CASE INTO COMPARATIVE ANALYSES OF CASES OF RECENT ECONOMIC SUCCESS. BOTSHANA'S UNUSUAL POLICY-MAKING SYSTEM OPERATES IN AN OVERALL CONTEXT OF APPARENT HARMONY AND CREATIVE CO-OPERATION BETWEEN BUREAUCRATS AND POLITICIANS. THIS ARTICLE SEEKS TO PURSUE THE ANALYSIS OF THIS GROWTH WITH PART ICULAR REFERENCE TO THE QUESTION OF THE RELATIONSHIP BETWEEN POLITICIANS AND BUREAUCRATS WITHIN BOTSWANA'S POLICY-MAKING PROCESS. THE ESSAY'S PRINCIPLE AIMS ARE TO REVIEW AND THEN TO REINTERPRET CURRENTLY AVAILABLE ASSUMPTIONS AND FIMDINGS ON THIS SUBJECT.

02187 CHARTERS, D.

BRITISH INTELLIGENCE IN THE PALESTINE CAMPAIGN, 1945-47 INTELLIGENCE AND NATIONAL SECURITY, 6(1) (JAN 91), 115-140. THIS ARTICLE SEEKS TO ILLUMINATE THE OPERATIONS OF THE BRITISH INTELLIGENCE SERVICES IN PALESTINE, 1945-47. AND TO DETERMINE THE EXTENT TO WHICH THOSE OPERATIONS CONTRIBUTED DETERMINE THE EXTENT TO WHICH THOSE OPERATIONS CONTRIBUTED TO THE OUTCOME OF THE BRITISH COUNTER-INSURGENCY CAMPAIGN:
DEFEAT AND BRITISH WITHDRAWAL IN 1948. IT CONCLUOES THAT THE DEFEAT AND BRITISH WITHDRAWAL IN 1948. IT CONCLUOES THAT
INTELLIGENCE FAILURE WAS A DIRECT CAUSE OF THE BRITISH INTELLIGENCE FAILURE HAS A DIRECT CAUSE OF THE BRITISH DEFEAT. THE SOURCE OF THE FAILURE LAY PRINCIPALLY IN THE COMPLEX OF PROBLEMS WHICH BESET THE POLITICAL BRANCH OF THE PALESTINE POLICE CID. SOME WERE INDIGENOUS TO THE FORCE AND WORKLOADS; PRIORITIES IN TASKS AND TRAINING. OTHER PROBLEMS WORKLOADS; PRIORITIES IN TASKS ANO TRAINING. OTHER PROBLEMS WERE EXOGENOUS: THE RUTHLESS SKILL OF THE INSURGENTS AND THEIR SECURE BASE OF SUPPORT WITHIN THE JEWISH POPULATION, WHICH ENSURED

02188 CHATTERJEE, A.

SMALL INDUSTRYY AND ECONOMIC COOPERATION BETWEEN INDIA AND NEPAL

SOUTH ASIA JOURNAL, 5(3) (JAN 92), 299-312.

ALTHOUGH BANGLADESH, INDIA, NEPAL, PAKISTAN AND SRI LANKA ARE STILL AT DIFFERENT STAGES OF DEVELOPMENT, THE GROWTH OF SMALL-SCALE INDUSTRIES IN THESE COUNTRIES IS CONSIDERED TO BE IMPORTANT FOR THE MORE RAPID SPREAD OF INDUSTRIALIZATION, EMPLOYMENT GENERATION, OUICKER TURNOVER OF ASSETS AND GOODS, AND DISPERSIBILITY OF INDUSTRY ACROSS THE COUNTRY AT RELATIVELY LOWER CAPITAL COSTS PER UMIT ACTIVITIES FOR INDIAXPORES POSSIBLE JOINT ECONOMIC SO AS TO FRAME A MODEL OF REGIONAL ECONOMIC COOPERATION OF SMALL-SCALE INDUSTRIES SECTORS IN THE SOUTH ASIAN REGION AS A WHOLE.

02189 CHATTERJEE, P.

HISTORY AND THE NATIONALIZATION OF HINOUISM

SOCIAL RESEARCH, 59(1) (SPR 92), 111-150.

IN THE MOST EXPLICIT WAY POSSIBLE, HISTORY IS THE PRETEXT FOR TODAY'S VIOLENT POLITICAL CONFLICT IN INDIA, PRETEXT FOR TODAY'S VIOLENT POLIIICAL CONFLICT IN INDIA, WHICH THREATENS TO TEAR APART THE CONSENSUS ABOUT THE
FUNDAMENTAL CHARACTER OF THE INDIAN NATION-STATE. FOR NEARLY FUNDAMENTAL CHARACTER OF THE INDIAN NATION-STATE. FOR NEA
THREE YEARS, THE CONFLICT OVER THE AYODHYA MOSQUE HAS THREE YEARS, THE CONFLICT OVER THE AYODHYA MOSQUE HAS
PREOCCUPIED THE YERY CENTER OF ORGANIZED POLITICAL LIFE, PREOCCUPIED THE YERY CENTER OF ORGANIZED POLITICAL LIFE,
PRODUCING SHATTERING REVERBERATIONS IN THE CENTRAL CORRIDORS PRODUCING SHATTERING REVERBERATIONS IN THE CENTRAL CORRID
OF POWER BECAUSE IT REFLECTS THE INCREASINGLY STRIDENT OF POWER BECAUSE IT REFLECTS THE INCREASINGLY STRIDENT CLAIMS BEING MADE BY THE PROPONENTS OF POLITICAL HIMDUISM. THE CENTRAL DEMAND OF THIS POLITICAL CAMPAIGN, SPEARHEADED BY THE BHARATIYA JANATA PARTY AND THE VISWA HINDU PARISHAD, IS THAT THE PAST, PRESENT, AND FUTURE OF THE INDIAN NATION" REVOLVES AROUND A CONCEPT OF "HINDUTVA," OR "HINDU-NESS." THE HISTORICAL CLAIMS OF HINDUTVA ARE POSSIBLE ONLY HITHIM THE MODERN FORMS OF HISTORIOGRAPHY, WHICH IS NECESSARILY CONSTRUCTED AROUMD THE COMPLEX IDENTITY OF A PEOP STATE. TO THE EXTENT THAT THE GENEALOGY OF MODERM
HISTORIOGRAPHY IN INDIA IS DEEPLY INVOLVED WITH THE HISTORIDGRAPHY IN INDIA IS DEEPLY INVOLVED WITH THE OF POLIIIICAL HINDUISM ARE ALSO A PROOUCT OF THE 
CONFRONTATIONS WITH THE FORMS OF COLONIAL KNOWLEDGE. MANY OF THE THEMES IN THE CONTEMPORARY RHETORIC OF HINDU EXTREMIST POLITICS WERE PART AND PARCEL OF THE HISTORICAL IMAGINING IN THE IOTH CENTURY OF INDIA AS A NATION.

02190 CHAUVIN, L.

PERU DE-CONSTRUCTS

COMMONWEAL, CXIX(15) (SEP 92), 6-7

LIMA HAS BECOME THE NEHEST' TARGET IN PERU'S BLOODY $12-$ YEAR WAR AGAINST THE MAOIST SHINING PATH. IN JULY 1992, THE GUERRILLAS LAUNCHED AN OFFENSIVE AGAINST THE CITY THAT KILLED 50, HOUNDED HUNDREDS, AND CAUSED MILLIONS OF DOLLARS IN DAMAGES. MUNICIPAL ELECTIONS ARE SCHEDULED FOR NOVEMBER, BUT MANY OBSERVERS DOUBT THAT THE ARMY WILL RELIMQUISH ITS POWER TO CIVILIAN OFFICIALS. PRESIDENT ALBERTO FUJIMORI, WHO SUSPENDED PERU'S CONSTITUTIONAL DEHOCRACY IN APRIL, SAYS THAT HE WILL CONTINUE TO SERVE AS PRESIDENT UNTIL HIS TERM EXPIRES IN 1995. MEANWHILE, THE SHINING PATH'S INSURGENCY THREATENS TO CAUSE CHAOS.

02191 CHAVEZ, L.

BEYOND THE WATER'S EDGE: FOREIGN POLICY AS AN ELECTION ISSUE

POLICY REV

CY REVIEW, (62) (FAL 92), 68-71.

IN ALMOST EVERY PRESIDENTIAL ELECTION SINCE WORLD WAR II, FOREIGN POLICY ISSUES HAVE PLAYED AN IMPORTANT, ALTHOUGH NOT DECISIVE, ROLE IN DETERMINING THE RESULT. IN THE 1992
CAMPAIGN, MOST AMERICANS HAVE SEEMED UNINTERESTED IN SERIOUS CAMPAIGN, MOST AMERICANS HAVE SEEMED UNINTERESTED IN PROBLEMS AT HOME AND THE VIRTUAL ELIMINATION OF THE SOVIET MILITARY THREAT HAVE DIVERTED ATTENTION FROM FOREIGN AFFAIRS MILITARY THREAT HAVE DIVERTED ATTENT ION FROM FOREIGN AFFAIRS
AND TOWARD SOLVING DOMESTIC PROBLEMS. HOWEVER, IT HOULD BE A TREMENDOUS MISTAKE FOR AMERICANS TO BECOME SO SELF-ABSORBED THAT THEY FAIL TO CONSIDER THE SECURITY ISSUES THAT STILL CONFRONT THE UNITED STATES AS WELL AS THE CHALLENGES ENTAILED IN THE USA'S ROLE AS THE ONLY MILITARY SUPERPOWER.

02192 CHAVEZ, L.

HISPANICS, AFFIRMATIVE ACTION, AND YOTING

ANNALS OF THE AMERICAN ACADEMY OF POLITICAL AND SOCIAL SCIENCE, (523) (SEP 92), 75-87.

THE VOTING RIGHTS ACT OF 1965 HAS ORIGINALLY INTENDED TO PROTECT THE RIGHTS OF BLACKS LIVING IN THE DEEP SOUTH. IN 1975, THE ACT WAS AMENDED TO INCLUDE JURISDICTIONS WITH LARGE NUMBERS OF MEXICAN AMERICANS, DESPITE LITTLE EVIDENCE THAT MEXICAN AMERICANS HAD BEEN SYSTEMATICALLY EXCLUDED FROM VOTING. IN 1982. THE ACT WAS AGAIN AMENDED. THIS TIME TO BROADEN THE DEFINITION OF VOTING DISCRIMINATION TO APPLY AN E

02193 CHAZAN, $N$.

AFRICA'S DEMOCRATIC CHALLENGE: STRENGTHENING CIVIL SOCIETY AND THE STATE

WORLD POLICY JOURNAL, IX(2) (SPR 92), 279-308.

AFRICA IS CURRENTIY UNDERGOING A PERIOD OF MAJOR SOCIAL ECONOMIC, AND POLITICAL FERMENT. DURING THE PAST FIVE YEARS ALMOST EVERY AFRICAN COUNTRY HAS INTRODUCED SUBSTANTIAL ALMOST EVERY AFRICAN COUNTRY HAS INTRODUCED SUBSTANTIAL ECONOMIC LIBERALIZATION MEASURES AND ACCEPTED A RIGOROUS STRUCTURAL ADJUSTMENT PROGRAM. IN THE COURSE OF 1990 AND
1991 . THE LEADERS OF ALL BUT FIVE AFRICAN STATES BEGAN TO 1991. THE LEADERS OF ALL BUT FIVE AFRICAN STATES BEGAN
ADOPT THE TRAPPINGS OF MULTIPARTY POLITICS AND MOST SCHEDULED COMPETITIVE ELECTIONS. IN MANY RESPECTS, THE POSTCOLONIAL ORDER IS UNRAVELING AS THE CONTINENT ENTERS ITS SECOND PHASE OF DECOLONIZATION.

02194 CHAZAN, N.; MORTIMER, R.; RAVENHILL, J.; ROTHCHILD, D. POLITICS AND SOCIETY' IN CONTEMPORARY AFRICA

LYNNE RIENNER PUBLISHERS, $1992,482$.

IN THIS TEXTBOOK, UNLIKE OTHERS ON AFRICAN POLITICS, THE AUTHORS CONCENTRATE ON THE PERIOD SINCE INDEPENDENCE IN ORDER TO EXPOSE EXISTING PROBLEMS IN GREATER DETAIL AND TO EXPLORE THE POSSIBILITIES THAT EMANATE FROM THE NEED TO CONFRONT THESE DIFFICULT REALITIES. EACH CHAPTER PRESENTS THE HISTORICAL BACKGROUND, GIVES AN OVERVIEW OF DEVELOPMENT SINCE INDEPENDENCE, AND DEPICTS THE DIFFERING MANIFESTATIONS ON EACH TOPIC AND ISSUE. THE BOOK CONDUCTS A COMPARATIVE ANALYSIS OF PROCESSES THAT EXEMPLIFY EMERGING PATTERNS ON THE CONTINENT. EACH CHAPTER CONCLUDES BY EXTRACTING THE MAJOR PATTERNS THAT EMERGE FROM THE DATA AND VARIOUS EXPLANATIONS ARE DISCUSSED.

02195 CHEE, C.

SOUTH KOREA'S SECURITY IN THE AGE OF THE MEH WORLD ORDER

KOREA \& WORLD AFFAIRS, 16(1) (SPR 92), 82-99.

THE AUTHOR DISCUSSES HOW RECENT CHANGES IN THE INTERNATIONAL SITUATION THAT COULD AFFECT SOUTH KOREA'S INTERNATIONAL SITUATION THAT COULD AFFECT SOUTH KOREA'S
SECURITY POLICY. THESE INCLUDE THE DISSOLUTION OF THE SOVIET UNION, CHINA'S INCREASING COIMERCIAL CONTACTS WITH SOUTH KOREA, AND NORTH KOREA'S GRADUAL ACCEPTANCE OF PEACEFUL KOREA, AND NORTH KOREA' S GRADUA
COEXISTENCE HITH SOUTH KOREA.

02196 CHEGE, M. REMEMBERING AFRICA

FOREIGN AFFAIRS, 71(1) (1992), 146-163

THE AUTHOR LOOKS AT THE ORIGINS OF MANY OF AFRICA'S MOST
INTRACTABLE PROBLEMS AND AT THE PROSPECTS FOR ORDERLY CHANGE TO MORE DEMOCRATIC RULE. HE ALSO DISCUSSES THE ROLE OF U.S. FOREIGN POLICY IN AFRICA.

02197 CHELALA, C.A.

a PATH TO DEMOCRACY

SWISS REVIEW OF WORLD AFFAIRS, 41(12) (MAR 92), 15.

THE FEBRUARY 1992 ATTEMPTED COUP D'ETAT IN VENEZUELA,

THE OUSTER OF HAITI'S PRESIDENT JEAN-BERTRAND ARISTIDE, AND

THE CRISIS IN BURMA ILLUMINATE A MAJOR WEAKNESS IN WORLDWIDE EFFORTS TO PROMOTE DEMOCRACY. THEY UNDERSCORE AN URGENT NEED TO ESTABLISH BINDING INTERNATIONAL LEGAL PRINCIPLES BANNING THE RECOGNITION OF DE FACTO MILITARY REGIMES. THE

ESTABLISHMENT OF SUCH PRINCIPLES AND THE CREATION OF

MECHANISMS TO IMPLEMENT THEM AS A NORMAL RESPONSE TO ANY KIND OF MILITARY UPRISING WOULD DO MUCH TO FOSTER DEMOCRACY THROUGHOUT THE NORLD.

02198 CHELALA, C.A.

CENTRAL AMERICA'S HEALTH PROBLEMS

SWISS REVIEW OF WORLD AFFAIRS, 40(8) (NOV 90), 29-30.

THIS ARTICLE INVESTIGATES THE DETERIORATION OF HEALTH

CONDITIONS IN CENTRAL AMERICA. DETAILS AND EXAMPLES OF THIS
DETERIORATION ARE GIVEN, AND ITS CAUSES EXAMINED. EFFORTS

UNDERWAY TO IMPROVE HEALTH CONDITIONS IN CENTRAL AMERICA ARE

DESCRIBED. THE HEALTH SITUATION IN NICARAGUA RECEIVES

DESCRIBED. THE HEALTH

02199 CHELF, C.P.

CONTROVERSIAL ISSUES IN SOCIAL WELFARE POLICY--GOVERMMENT AND THE PURSUIT OF HAPPINESS

SAGE PUBLICATIONS, 1992,200

WHILE THE SOCIAL SECURITY ACT OF 1935 AND THE WAR ON

POVERTY IN 1964 ACHIEVED SUBSTANTIAL SUCCESS IN THE SOCIAL

WELFARE FIELD, THEY FAILED TO PROVIDE ULTIMATE SOLUTIONS TO

SOME OF AMERICA'S MOST PERPLEXING SOCIAL AND ECONOMIC

PROBLEMS. THIS BOOK EXPLORES THE ROLE OF GOVERMMENT (FEDERAL,

STATE AND LOCAL) IN FUTURE PROGRAMS TO ALLEVIATE POVERTY,

HUNGER, HOMELESSNESS, AND UNEMPLOYMENT.

02200 CHEN, C.V.; BIH-JAH, L.; CHUN-SHAN, C.; KAIHUANG, Y.; TE-SHENG, C.; YING-MING, L.; YU-SHAN, $H$.

TROUBLESHOOTER OR TROUBLE MAKER?

FREE CHINA REVIEW, 42(3) (MAR 92), 52-61.

IN DECEMBER 1991 MAINLAND CHINA ESTABLISHED THE

ASSOCIATION FOR RELATIONS ACROSS THE TAIWAN STRAITS,

COUNTERPART TO TAIWAN'S STRAITS EXCHANGE FOUNDATION' THE

FORMATION OF THE CHINESE COMMUNIST ASSOCIATION REFLECTS THE

SUCCESS OF TAIWAN'S MAINLAND POLICY AND ITS "GUIDELINES FOR

NATIONAL UNIFICATION" AS HELL AS THE MAINLAND'S FLEXIBILITY

AND READINESS TO WORK WITH TAIWAN. THE ESTABLISHMENT OF
NEW ASSOCIATION MEANS THAT CROSS-STRAITS RELATIONS HAVE

NEH ASSOCIATION MEANS THAT CROSS-STRAITS RELATIONS HAVE

ENTERED A NEW PHASE. POLICY MAKERS CAN NOH CONSIDER THE

FUTURE DIRECTION OF RELATIONS, WHAT INTERACTIONS ARE

APPROPRIATE IN THIS NEN ENVIRONMENT

02201 CHEN, J.

THE SIND-SOVIET ALLIANCE AND CHINA'S ENTRY INTO THE KOREAN WAR; ASSOCIATION FOR ASIAN STUDIES 1992 ANNUAL MEETING ASSOCIATION FOR ASIAN STUDIES, 1992, 32

COMMUNIST CHINA AND THE SOVIET UNION SIGNED A STRATEGIC ALLIANCE IN FEBRUARY 1950. ONLY EIGHT MONTHS LATER, CHINA ENTERED THE KOREAN WAR. WITH THE SUPPORT OF RECENTLY AVAILABLE SOURCES, THIS PAPER ARGUES THAT THE SINO-SOVIET ALLIANCE SERVED AS THE CORNERSTONE OF COMMUNIST CHINA'S FOREIGN POLICY IN ITS EARLY YEARS. NEITHER CHINA NOR THE SOVIET UNION OPPOSED KIM IL-SUNG'S PLAN OF UNIFYING THE KOREAN PENINSULA THROUGH MILITARY MEANS. CHINA'S DECISION TO ENTER THE KOREAN WAR, THOUGH BASICALLY A CHINESE DECISION (OR, MORE ACCURATELY' SPEAKING, MAO'S DECISION), WAS IN ONE WAY' OR ANOTHER BACKED BY THE PERCEIVED SUPPORT OF THE SINOSOVIET ALLIANCE. THE RELATIONSHIP BETWEEN CHINA AND THE SOVIET UNION, HOWEVER, WAS NOT WITHOUT PROBLEMS. THE SOVIET BREAKING OFF OF ITS PROMISE TO OFFER TO THE CHINESE AN AIR UMBRELLA IN KOREA, FOR INSTANCE, SOHED A SEED FOR THE FUTURE CHINESE-SOVIET SPLIT.

02202 CHEN, L.

U.S. VISUALIZES A PACIFIC COMMUNITY

BEIJING REVIEH, 35(24) (JUN 92), 15-17.

WASHINGTON INTENDS TO BUILD A NEW ASIA-PACIFIC ORDER AND TO MAINTAIN AMERICAN POLITICAL, ECONOMIC, AND MILITARY ANO LEADERSHIP IN THE REGION. THE BUSH ADMINISTRATION ENVISIONS A PACIFIC COMMUNITY WITH THE USA AT ITS CORE AND THE JAPANESE-AMERICAN ALLIANCE AS ITS CENTRAL AXIS. THE EVENTUALLY BRINGING THOSE THO COUNTRIES INTO THE STRUCTURE.

02203 CHEN, Y

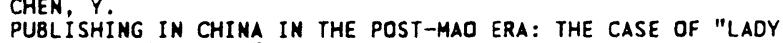
CHATTERLEY'S LOVER"

ASIAN SURYEY, 22(6) (JUN 92) 568-582. THIS ARTICLE ATTEMPTS TO DELINEATE THE VICISSITUDES OF 
CHINESE PUBLISHING AT A TIME WHEN STATE CONTROL ANO CENSORSHIP BEGAN TO RECEDE, AND THROUGH CONSTANTLY THREATENING RETALIATION, LEFT UNPRECEDENTED SPACE SINCE 1949 FOR THE PUBLISHING SECTOR TO TAKE INITIATIVES AS WELL AS RISKS. THE CASE STUDY PRESENTED HERE, PUBLICATION OF "LADY CHATTERLEY'S LOVER", ADDS SIGNIFICANCE TO THIS RESEARCH. THE BANNINGS AND PIRATINGS, ALSO HELPS DEFINE THE HISTORY OF POST-MAO CHINESE PUBLISHING, AS IT BRINGS TO LIGHT TO A PIGNIFICANT EXTENT MOST OF THE KEY ISSUES OF CONTROVERSIES THAT HAVE CAUSED RETALIATION BY CENSORSHIP. THE OFFICIAL BAN THAT HAVE CAUSED RETALIATION BY CENSORSHIP. THE OFFION OF THE ON THE BOOK CONTINUES TO ATTRACT SERIOUS SPECULATION OF
YALIDITY OF THE NEW ACT AND ITS POSSIBLE DISTANCE FROM VALIDITY OF THE
ACTUAL PRACTICE.

02204 CHENG, C.Y

NEH TRENDS IN ECONOMIC REFORM AND OPEN-DOOR POLICY IM NEW TRENDS IN ECONOMIC REFORM AND OPEN-DOOR POLICY IN CHINA; ASSOCIATION FOR ASIAN STUDIES 199

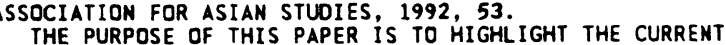
THE PURPOSE OF THIS PAPER IS TO HIGHLIGH POL CY IN CHINA. STATUS OF ECONOMIC REFORM AND THE OPEN-DOOR POL ICY IN CHIMA IT ALSO CONSIDERS THE PATH WHICH CHINA MAY FOLLOW IN THE
YEARS AHEAD. THE TIANANMEN SOUARE INCIDENT HAS UNDERMINED CHINA'S ECONOMIC RESTRUCTURING PROGRAM. THE MOST FARREACHING EFFECT HAS BEEN THE DESTRUCTION OF THE REFORH LEADERSHIP. NOT ONLY HAVE THE REFORM LEADERS BEEN PURGED, THE BRAIN-TRUST OF THE REFORM CAMP HAS ALSO BEEN LOST. THE ENTIRE PROGRAM HAS BEEN GRADUALLY DISMANTLED. MAJOR SETBACKS CAN BE DISCERNED IN PRICE REFORM, LOCAL AUTONOMY, PRIVATE BUSINESS, AND INCOME DISTRIBUTION. PIECEMEAL REFORM HAS TAKEN PLACE BUT WITHOUT A THOROUGH REFORM OF THE EXISTING PRICE SYSTEM THERE IS LITTLE MOPE OF IMPROVING EFFICIENCY AND PRODUCTIVITY. IRONICALLY, DENG XIAOPING'S OPEN-DOOR POLICY HAS RECEIVED ENDORSEMENT FROM THE HARDLINERS AS THE MEANS TO ALLEVIATE THE COUNTRY'S CAPITAL SHORTAGE. HOWEVER, THE NEW OPEN-DOOR POLICY DIFFERS FROM THE PREVIOUS ONE DUE TO ITS STRONG EMPHASIS ON ATTRACTING TAINANESE CAPITAL.

02205 CHENG, E.; MOSHER, S.

DENG'S DIS'TANT VISION

FAR EASTERN ECONOMIC REVIEW, 156(19) (MAY 92), 23-24. ELEVEN YEARS OF STUNMING ECONOMIC GROWTH IN CHINA'S SHENZHEN SPECIAL ECONOMIC ZONE (SEZ) HAVE VASTLY IMPROVED THE OUALITY OF LIFE IN CHINA'S FOREMOST LABORATORY FOR THE QUALITY OF LIFE IN CHINA'S FOREMOST LABORATORY FOR ECONOMIC REFORMS. EVEN AMONG CHINA'S OTHER SEZS IT PROVIOES A REFRESHING ALTERNATIVE TO THE FOSSILIZED SYSTEM IN THE AND ITS PROXIMITY TO HONG KONG CONTINUE TO BE ITS STRONGEST ATTRACTIONS. SINCE THE BEGINNING OF 1992, THE SHENZHEN ALTERNATIVE HAS BEEN THRUST EVEN MORE INTO THE LIMELIGHT. ON A VISIT IN JANUARY, PARAMOUNT LEADER DENG XIAPOING ENDORSED THE CITY AS A MODEL FOR THE FUTURE DEVELOPMENT OF CHINA, AND A VINDICATION OF HIS ECONDMIC REFORMS. HOWEVER, MANY ARE STILL UNCERTAIN AS TO THE FUTURE OF SHENZHEN, AND SOME ARE OPENLY WONDERING ABOUT THE COMPATIBILITY OF A LIBERALIZED SEZ AND A SOCIALIST ECONOMY.

02206 CHENG, T.; KRAUSE, L.

DEMOCRACY AND DEVELOPMENT: WITH SPECIAL ATTENTION TO KOREA JOURNAL OF NORTHEAST ASIAN STUDIES, 10(2) (SUM 92), 3-25.

THE CASE OF KOREA SHOWS THAT DEMOCRATIC CHANGES MAVE RESULTED IN HIGHER CONSUMPTION, HAVE INDUCED INFLATIONARY POLICY, AND HAVE LED TO WAGE INCREASES IN EXCESS OF PRDOUCTIVITY GAINS, HOWEYER, THESE MIGHT WELL BE TRANSISTIONAL RATHER THAN STEADY-STATE PHENOMENA. THIS

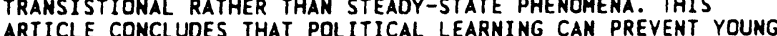
DEMOCRACIES FROM BECOMING CAPTIVES TO DISTRIBUTIONAL COALITIONS.

02207 CHENG, T.; HARRARD, S.

POLITICAL ' CHANGE IN TAIWAN

LYNNE RIENNER PUBLISHERS, 1991, 269

DURING THE PAST THO DECADES, THO MAJOR TRENDS HAVE OCURRED IN THE GLOBAL POL ITICAL-ECONOMIC ENVIRONMENT. THE OCCURRED IN THE GLOBAL POL ITICAL-ECONOMIC ENVIRONMENT S THE ECONOMIC RISE OF EAST ASIA IS ONE MAJOR TREND AND A SECOND HAS BEEN THE TRANSITION TO DEMOCRACY IN A LARGE NUMBER OF COMNRIES THR TAIHAN THIS BOOK STUDIES: THE BASIC PROCESSES DEMOCRACY IN TAIWAN THIS BOOK STUDIES: THE BASIC PROCESSES OF SOCIAL CHANGE--LIBERALIZATION AND DEMOCRATIZATION; THE TRANSFORMATION OF THE KMT AND THE PARTY SYSTEM; THE ELECTORAL SYSTEM AND ELECTORAL BEHAVIOR; AND PROSPECTS FOR THE FUTURE. IT EXPLORES THE QUESTION OF HOW DEMOCRACY HILL DEVELOP AND SURVIVE IN TAIWAN OR OTHER SOCIETIES THAT EMPHASIS ON AUTHORITY AS AGAINST LIBERTY, STRESS THE
IMPORTANCE OF HIERARCHY, AND THAT ELEVATE THE ROLE OF THE IMPORTANCE OF HIERARCHY, AND THAT ELEVATE THE ROLE OF THE THAT AS TAIHAN MOVES FORHARD ON THE DEMOCRATIC PATH, ONE SHOULD NOT BE SURPRISED TO SEE THE POSSIBLE EMERGENCE OF NEH INSTITUTIONAL FORMS OF DEMOCRACY.

02208 CHENG, T.; CHOU, T.

POLITICAL DECONTROL AND THE EMERGENT PATTERN OF INFORMAL POLITICS IN TAIHAN; ASSOCIATION FOR ASIAN STUDIES 1992 ANNUAL MEETING
ASSOCIATION FOR ASIAN STUDIES, 1992, 170.

POLITICAL DECONTROL UNDERWAY IN TAIWAN SINCE 1986 HAS BROUGHT ABOUT A RADICAL CHANGE IN THE PATTERN OF INFORMAL POLITICS. AS SEVERAL RIVAL FACTIONS BEGAN TO FORM HITHIN THE KUOMINTANG, POL ITICAL MONEY HAS BECOME A KEY FACTOR IN POLITICAL COMPETIIION FOR THE FIRST TIME, A VARIETY OF BECOME ACTIVE AND INFLUENTIAL POLITICAL ACTORS, AND A NEW SET OF LEADERSHIP RECRUITMENT RULES HAS EMERGED. UNDER THE CIRCUMSTANCES, THE SEARCH FOR A NEW ORDER IN THE RESULTING HOBBESIAN STATE DF ANARCHY HAS BECOME A PRESSING ISSUE AND A PREOCCUPATION OF CONTEMPORARY TAIWAN POLITICS. THIS PAPER AMALYZES THE EMERGENT PAITERM OF INFORMAL POLITICS IM TAIHAN WITH SPECIAL ATTENTION TO THE ROLE AND STRUCTURE OF FACTION POL ITCS IN THE KMT MONEY POO ITICS AND POL ITICAL SCANDALS. POLITICS IN THE KMT, MONEY POLITICS, AND POLITICAL SCANDAL

IT COMPARES SALIENT ASPECTS OF INFORMAL POLITICS IN POST

02209 CHENGCAI, $W$.

HARD LIFE BUT NO SERIOUS CHAOS

BEIJING REVIEW, 35 (42) (OCT 92), 15-17.

THE YELTSIN GOVERNMENT HAS SURVIVED THE INITIAL STAGE OF REFORM SINCE TEN MONTHS AGO. ALTHOUGH DEMONSTRATIONS ANO PROTEST RALLIES HAVE BEEN HELD SEVERAL TIMES DURING THIS PERIOD, NO DISASTROUS SOCIAL UPHEAVALS HAVE OCCURRED. NEVERTHELESS,
RUSSIA'S ECONOMIC SITUATION REMAINS A MAJOR PROBLEM FOR THE YELTSIN GOVERNMENT.

02210 CHERIET, B.

THE RESILIENCE OF ALGERIAN POPULISM

MIDDLE EAST REPORT, 22(1) (JAN 92), 9-14.

IN THE LAST FOUR YEARS, ALGERIAN POPULISM HAS UNDERGONE A PERIOD OF SHOCK THERAPY AND THE OUTCOMES REMAIN UNCERTAIN. THIS ARTICLE SUGGESTS THAT ALGERIA'S DESCENT INTO ECONOMIC AND IDEOLOGICAL BANKRUPTCY IN THE 1980 S STEADILY

DELEGITIMIZED THE OFFICIAL EGALITARIAN IDEOLOGY OF SPECIFIC SOCIALISM. THE OCTOBER 1988 DEMONSTRATIONS COMPRIZED MOSTLY OF YOUNGSTERS BETHEEN 12 AND 18 SOUGHT THE DEPARTURE OF THE PRESIDENT AND ALL NATIONAL LIBERATION FRONT OFFICIALS WHO HAD BETRAYED THE EGALITARIAN PROMISES CONTAINED IN THE OFFICIAL DISCOURSE OF SOCIALISM. THE APPEAL FOR

OFFICIAL DISCOURSE OF SOCIALISM. THE APPEAL FOR EGALITARIANISM WAS THE MOST TELL WG OBSESSION OF ALGERIAN SOCIETY. WHETHER OR NOT ALGERIA WILL SUCCEED IN INSTALLING A
PARLIAMENTARY DEMOCRACY IN A PIECEMEAL ENGINEERING MANNER IS PARLIAMENT
DEBATED.

02211 CHERTOK, $H$

DESERT SCORN: BEDOUIN LIFE UNDER ISRAELI RULE TIKKUN 7 (4) (JUL 92 ), 48-55.

ISRAEL IS PURSUING AN AGGRESSIVE CAMPAIGN OF DISPLACEMENT AND RESETTLEMENT APART FROM THE OCCUPATION -AGAINST ITS OWN BEDOUIN CITIZENS IN THE NEGEV.

02212 CHERU, $F$

STRUCTURAL ADJUSTMENT, PRIMARY RESOURCE TRADE, AND

SUSTAINABLE DEVELOPMENT IN SUB-SAHARAN AFRICA

WORLD DEVELOPMENT, 20(4) (APR 92), 497-512.

THE FOOD SHORTAGES, INDEBTEDNESS, AND ENVIRONMENTAL CRISIS IN SUB-SAHARAN AFRICA CANNOT BE UNDERSTOOD IN ISOLATION FROM THE DEVELOPMENT STRATEGIES FOLLOWED SINCE INDEPENDENCE. WHILE ADJUSTMENT POLICIES IN PRICING, EXCHANGE RATES, PUBLIC SECTOR REFORM, AND LIBERALIZATION OF MARKETS ARE SOME OF THE ESSENTIAL INGREDIENTS OF A BALANCED NATIONAL STRATEGY, CONVENTIONAL IMF/HORLD BANK PRESCRIPTIONS HAVE OFTEN PRODUCED ADVERSE SOCIAL AND ECOLOGICAL EFFECTS. SHORTTERM POLICIES, DESIGNED TO IMPROVE COMMODITY EXPORTS TO GENERATE FOREIGN EXCHANGE, OFTEN CONFLICT HITH LONG-TERM DEVELOPMENT MEEDS SCARCE LAND, HATER, CREDIT AMD DEVELOPMENT NEEDS. SCARCE LAND, WATER, CREDIT, AND
TECHNOLOGY ARE BEING PREEMPTED BY THE EXPORT SECTOR WHILE THE NEEDS OF SMALL FARMERS ARE IGNORED. FOR SUSTAINABLE DEVELOPMENT THERE MUST BE A FUNDAMENTAL REORIENTATION OF GOVERNMENT POLICIES AND RESOURCES TOWARD SOLVING RURAL PROBLEMS. LAND REFORM, CREDIT, IMPROVED EXTENSION, GREATER PROBLEMS. LAND REFORM, CREDIT, IMPROVED EXTENSION, GREAT
GOVERNMENT ACCOUNTABILITY, AND PUBLIC PARTICIPATION ARE GOVERNMENT ACCOUNTABILITY, AND PUBLIC PART ICIPATION ARE
IMPORTANT IF POOR FARMERS ARE TO SUCCEED. FURTHER, POLICY IMPORTANT IF POOR FARMERS ARE TO SUCCEED. FURTHER, POLICY REFORM IN SUB-SAHARAN AFRICA NEEDS TO BE BACKED BY MEASURES TO COMPENSATE FOR UNEXPECTED, UNCONTROLLABLE SHORTFALLS IN
COMMODITY EXPORT EARNINGS. FINALLY, SIGNIFICANT DEBT HRITECOMMODITY EXPORT EARNINGS. FINALLY, SIGNIFICANT DEBT WRI OFFS BY BILATERAL AND MULTILATERAL AGENCIES ARE A SINE OUA NON IF SUB-SAH

02213 CHEUNG, T.

BOMB AND BOMBAST

FAR EASTERN ECONOMIC REVIEW, 156(22) (JUN 92), 24.

FAR EASTERN ECONOMIC REVIEW, $156(22)$ JOKYN MOSCOW AND MANY OTHER CAPITALS, NORTH KOREA IS TOTALLY UNJUSTIFIED IN SEEKING TO ACQUIRE NUCLEAR WEAPONS. BUT THE RESPONSE FROM THE THIRD WORLD IS EQUIVOCAL. INDEED, THERE ARE PROBABLY QUITE A FEH THIRD WORLD LEADERS WHO ARE OUIETLY APPLAUDING NORTH KOREA'S DEFIANT STANCE AGAINST THE SUPERPOWERS' NUCLEAR HEGEMONY. THERE ARE COMPELLING REASONS FOR PYONGYANG TO HAVE NUCLEAR WEAPONS. MOST OBVIOUSLY, IT IS STILL IN A 
STATE OF UNDECLARED WAR WITH SOUTH KOREA, WHICH IS BACKED BY A SIZABLE U.S. PRESENCE. THE SECURITY IMPERATIVE WILL ONLY GROW STRONGER AS THE MILITARY BALANCE ON THE PENINSULA SHINGS STEADILY IN FAVOR OF SOUTH KOREA. THERE ARE ALSO DIPLOMATIC BENEFITS TO THE BOMB. THEY INCLUDE GIVING PYONGYANG A MAJOR BARGAINING LEVER IN ITS NEGOTIATIONS ON REUNIFICATION WITH SOUTH KOREA AND THE NORMALIZATION OF RELATIONS WITH JAPAN AND THE UNITED STATES. ANOTHER FACTOR IS THE PRESTIGE A NUCLEAR WEAPONS CAPABILITY HOULD CONFER ON NORTH KOREA.

02214 CHEUNG, T.

CHANMEIS OF SUPPORT

FAR EASTERN ECONOMIC REVIEW, 151(24) (JUN 91), 15

NEARLY TWO YEARS AFTER BEING PLUCKED FROM PROVINCIAL OBSCURITY TO BECOME CHINA'S PARAMOUNT LEADER, COMMUNIST PARTY GENERAL SECRETARY JIANG ZEMIN HAS BEEN DISMISSED BY PARTY GENERAL SECRETARY JIANG ZEMIN HAS BEEN DISMISSED BY
SOME AS A LIGHTWEIGHT WHO WILL NOT SURVIVE THE EXPECTED SOME AS A LIGHTWEIGHT WHO WILL NOT SURVIVE THE EXPECTED UPHEAVALS WHEN THE OCTOGENARIAN LEADERS STEP ASIDE OR DIE.
BUT OTHERS BELIEVE HE IS QUIETLY FORGING POLITICAL ALLIANCES BUT OTHERS BELIEVE HE IS QUIETLY FORGING POLITICAL ALLIANCES
BEHIND THE SCENES, IN PARTICULAR IN HIS CAPACITY AS MILITARY COMMANDER-IN-CHIEF, THAT COULD ALLOW HIM TO ASSUME A MORE COMMANDER-IN-CHIEF, THAT COULD ALLOW HIM TO ASSUHE A MC INFLUENTIAL AND LONG-TERM DECISION-MAKING ROLE. SOME
ANALYSTS BELIEVE THAT JIANG'S POLITICAL BASHFULNESS MAY MASK A CAREFUL STRATEGY THAT AIMS TO AVOID ATTRACTING TOO MUCH ATTENTION, AND CONSEQUENTLY POLITICAL OPPOSITION. HOWEVER, HIS LONG-TERM PROSPECTS AT REMAINING IN POHER STILL APPEAR SLIM.

02215 CHEUNG, T.; ALI, S.

NUCLEAR AMBITIONS

FAR EASTERN ECONOMIC REVIEW, 155(3) (JAN 92), 12.

AN AGREEMENT FOR CHINA TO BUILD A NUCLEAR-POWER STATION IN PAKISTAN IS A MAJOR STEP FORWARD IN THE TWO COUNTRIES' CIVILIAN NUCLEAR AMBITIONS. IT MEANS THAT PAKISTAN'S NUCLEARPOWER PROGRAM IS FINALLY ON THE MOVE AGAIN AFTER BEING STALLED FOR TWO DECADES BY INTERNATIONAL CONCERNS OYER ISLAMABAD'S EFFORTS TO DEVELOP NUCLEAR WEAPONS. THE DEAL IS ALSO A SIGNIFICANT BOOST TO CHINA'S ATTEMPTS TO DIVERSIFY THE EXPORTS OF ITS DEFENSE INDUSTRY FROM PRIMARILY ARMS TO CIVILIAN PRODUCTS. PEKING'S DECISION TO SUPPLY THE NUCLEAR REACTOR UNDERMINES THE U.S. -LED MOVES TO ISOLATE PAKISTAN FROM THE INTERNATIONAL MUCLEAR COMMUNITY.

02216 CHEUNG, T.

PUSHING THE PENDULUM

FAR EASTERN ECONOMIC REVIEW, 155(14) (APR 92), 46-47.

AS CONSERVATIVES AND LIBERALS WRESTLE FOR CONTROL OF CHINA'S ECONOMIC FUTURE, A DIVERSE RANGE OF REFORMS PERCOLATING THROUGH THE' SYSTEM COULD DECISIVELY SHIFT THE ECONOMY TO A MORE MARKET ORIENTED PATH. BUT WHETHER THE CHANGES WILL STICK DEPENDS ON THE OUTCOME OF AN INTENS POWER STRUGGLE UNDER WAY IN BEIJING. THE IMMEDIATE FLASHPOINT HAS BEEN AN ARGUMENT OVER THE ECONOMY'S OPTIMAL RATE OF GROWTH. CONSERVATIVE PRIME MINISTER LI PENG REASSERTED AT THE NATIONAL PEOPLE'S CONGRESS IN LATE MARCH THAT THE GROWTH TARGET FOR 1992 IS 6\%, BUT REFORMISTS- LED BY DENG XIAOPING--ARE URGING THAT THE ECONOMY BE ALLOWED TO EXPAND BY AT LEAST 10\%. HOWEVER, THE REFORMISTS APPEAR TO HAVE NO COORDINATED PLAN OF ACTION, WITH MINISTRIES PROVINCES, OTHER ORGANIZATIONS AND INDIVIDUALS PROMOIING DIFFERENT AGENDAS. THE RESULT IS A DISPARATE RANGE OF REFORM MEASURES ON A VARIETY OF ISSUES INCLUDING STOCKMARKETS,

02217 CHEUNG, T.

SHORT ON SOLUTIONS

FAR EASTERN ECONOMIC REVIEW, 151(14) (APR 91), 8-9.

THE LACK OF DIRECTION IN THE CHINESE GOVERMMENT'

CURRENT POLICIES WAS AMPLY UNDERLINED WHEN PREMIER LI PENG PRESENTED A BLUEPRINT FOR THE COUNTRY'S DEVELOPMENT OVER THE NEXT DECADE AT THE ANNUAL SESSION OF THE NATIONAL PEOPLE'S CONGRESS (NPC). LI OFFERED ONLY VAGUE SUGGESTIONS ON HOW TO ACHIEVE THE PREDICTED HIGH LEVELS OF GROWTH AND DEVELOPMENT, AND INDICATED THAT TOP LEADERS WERE STILL DIVIDED OVER THE, DIRECTION AND PACE OF REFORMS. FOR THE SAKE OF PUBLIC UNITY, THEREFORE, THE CONTENDING FACTIONS IN THE LEADERSHIP HAVE PAPERED OYER THEIR DIFEREMCE BY ISSUING LEADERHIP HAVE COMMITTAL STATEMENT THAT DEFIES IMPLEMENTATION INTO CONCRETE POLICIES.

02218 CHEUNG, T.

THE OPENING SALVO

FAR EASTERN ECONOMIC REVIEW, 155(11) (MAR 92), 10

CHINESE PARAMOUNT LEADER DENG XIAOPING HAS' IN RECENT MONTHS TAKEN A HIGH PROFILE IN THE NATIONAL POLITICAL DEBATE, SETTING THE STAGE FOR A MAJOR POWER STRUGGLE IN THE CENTRAL LEADERSHIP. ALTHOUGH DENG'S PRONOUNCEMENTS ON THE NEED FOR BOLDER ECONOMIC REFORMS AND A MORE OPEN-MINDED LEADERSHIP HAVE SO FAR GONE LARGELY UNCHALLENGED BY CONSERVATIVES, THE RUN-UP TO THE 14TH PARTY CONGRESS, WHICH IS SCHEDULED FOR THE END OF 1992, IS LIKELY TO NITHESS INTENSIFIED POLITICAL IN-FIGHTING. THE 14TH PARTY CONGRESS IS SEEN AS DENG'S LAST
DOWN BY HIM IN THE LATE 1970 S ARE CONTINUED WELL AFTER HIS OWN DEMISE. CONCERNS THAT CONSERVATIVE POLICY MAKERS WERE DRAGGING THEIR FEET OVER THE PACE AND DIRECTION OF REFORMS, IN PARTICULAR IN THE LATTER PART OF 1991, MAY HAVE FINALLY WORN DENG'S PATIENCE, PUSHING HIM TO RE-ENTER THE POLITICAL FRAY.

02219 CHEUNG, T.

THE HIND CHANGES

FAR EASTERN ECONOMIC REVIEH, 151(16) (APR 91), 12-13.

IN CHINA THE PROMOTIONS OF SHANGHAI MAYOR ZHU RONGJI AND STATE PLANNING COMMISSION HEAD ZOU JIAHUA AS VICE-PREMIERS COULD MARK THE BEGINNING OF A SIGNIFICANT SHIFT IN FAVOR OF MODERATE ELEMENTS WITHIN THE CENTRAL LEADERSHIP. THE ELECTION OF GUANGDONG GOVERNOR YE XUANPING, 67, AS VICEPOLITICAL CONSULTATIVE CONFERENCE MAY POINT IN THE SAME DIRECTION. UT ALL THREE WILL CERTAINLY HAVE PROBLEMS OIRECTION. UT ALL THREE WILL CERTAINLY HAVE PROBLEMS
OVERCOMING THE ENTRENCED CONSERVATISM OF THEIR PEERS. THE OVERCOMING THE ENTRENCED CONSERVATISM OF THEIR PEERS. THE
TRANSFERS OF YE AND ZHU, AGRUABLY THO OF THE COUNTRY'S MOST TRANSFERS OF YE AND ZHU, AGRUABLY THO OF THE COUNTRY'S MOST FAVOR IN THE BALANCE OF POWER BETWEEN CENTER AND PROVINCES.

02220 CHEUNG, $T$.

UNCERTAIN LOYALTIES

FAR EASTERN ECONOMIC REVIEW, 151(16) (APR 91), 29-30.

OF ALL THE STRANDS IN THE CENTER-PROVINCE RELATIONSHIP, PEKIMG GUARDS ITS GRIP ON THE MILITARY MOST JEALOUSLY. A TIGHTLY MANAGED SYSTEM OF CHECKS AND BALANCES, TO PREVENT LOCAL MILITARY CHIEFS FROM AMASSING POHER OR ABUSING THEIR POSITIONS, HAS BEEN IMPOSED SINCE THE COMMUNISTS CAME TO POWER IN 1949. WHILE LOCAL MILITARY COMMANDS ARE IN GENERAL LOYAL TO PEKING IN MILITARY AND POLITICAL TERMS, THEY ARE NOT IMMUNE TO THE IMPACT OF THE GROWING DECENTRALIIZATION OF ECONOMIC AUTHORITY TO THE PROVINCES. AN INCREASE OF MILITARY INVOL VEMENT IN ECONOMIC VENTURES NEEDED TO MAINTAIN REVENUE HAS INEVITABLY BEEN TRANSLATED INTO WEAKER LINES OF COMMAND, AS WELL AS LESS ADHERENCE TO MILITARY REGULATIONS.

02221 CHEUNG, $T$.

UNGUIDED MISSILE

FAR EASTERM ECONOMIC REVIEH, 155(5) (FEB 92), 42-43.

CHINA'S DEFENSE INDUSTRY' HAS CARVED A LUCRATIVE NICHE IN THE INTERNATIONAL ARMS BAZAAR SINCE THE EARLY 1980S, SELLING MILITARY WARES TO THE THIRD HORLD. PEKING RECENTLY CONFIRMED THE TRANSFER OF MII TACTICAL-RANGE MISSILES TO PAKISTAN. THE TRANSFER OF MII TACTICAL-RANGE MISSILES TO PAKISTA
FOREIGN INTELLIIGENCE AGENCIES ALSO BELIEVE CHINA IS FOREIGN INTELLIGENCE AGENCIES ALSO BELIEVE CHINA IS
SUPPLYING M9 TACTICAL MISSILES TO SYRIA THAT COULD BE WORTH SUPPLYING M9 TACTICAL MISSILES TO SYRIA THAT COULD BE WORTH HUNDREDS OF MILLIONS OF U.S. DOLLARS. CHINA'S NUCLEAR
EXPORTS INCLUDE A SMALL RESEARCH REACTOR TO ALGERIA, NUCLEAR EXPORTS INCLUDE A SMALL RESEARCH REACTOR TO ALGERIA, NUCLEAR 300 MEGAWATT NUCLEAR POWER PLANT IN PAKISTAN. CHINA'S TOTAL ARMS INCOME DURING THE 1980S HAS MORE THAN USS10 BILLION, BUT EARNING FROM ARMS SALES COULD FALL IN THE COMING DECADE. THE END OF THE IRAN-IRAQ WAR IN 1989 LEFT IRAQ OWING HUNDREDS OF MILLIONS OF U.S. DOLLARS TO CHINESE ARMS FIRMS. CHINA HAS MANAGED TO FIND SOME NEH CLIENTS TO COMPENSATE FOR LOST TRADE, INCLUDING BURMA AND SRI LANKA. THESE NEH BUSINESS RELATIONSHIPS, HOWEVER, ARE INSUFFICIENT TO FILL THE YACUUM LEFT BY SHALLER SALES TO THE MIDDLE EAST.

02222 CHEUNG, T.M.

FAR EASTERN ECONOMIC REVIEW, 155(8) (FEB 92), 15.

CHINA IS BELIEVED TO HAVE BEGUN TO CUT BACK THE PEOPLE'S LIBERATION ARMY (PLA) BY NEARLY 10 PERCENT TO BOOST A MILITARY MODERNIZATION PROGRAM FLOUNDERING BECAUSE OF LACK OF FUNDS. EVEN BIGGER REDUCTIONS MAY BE ON THE WAY FOLLOWING THE COLLAPSE OF THE SOVIET UNION AND THE RELAXATION OF TENSIONS ALONG CHINA'S OTHER BORDERS. SOME 260,000 DUT OF THE PLA'S 3.2 MILLION TROOPS WILL BE DEMOBILIZED OVER THE NEXT FEN YEARS, WITH THE BULK OF REDUCTIONS LIKELY TO COME FROM THE 2.3 MILLION-STRONG GROUND FORCES, ACCORDING TO MILITARY ANALYSTS. THE CUTS ARE PART OF THE 1991-95 FIVEYEAR DEFENSE PLAN, AND ARE BELIEVED TO HAVE BEEN ENDORSED AT AN ENLARGED SESSION OF THE COMMUNIST PARTY'S CENTRAL POLICYMAKING ORGAN--CONVENED IN DECEMBER 1991.

02223 CHEUNG, T.M.

EMBATTLED GOVERNOR IN THE STAMD-OFF BETHEEN BRITAIN AND CHINA OVER HONG KONG GOVERNOR CHRIS PATTEN'S PLANS FOR GREATER DEMOCRACY, PEKING HAS BEGUN TO HARN THAT PAST AGREEMENTS OVER THE COLONY'S RETURN TO CHINESE SOVEREIGNTY IN 1997 MAY NO LONGER BE VALID. DURING A VISIT TO LONDON ON 16 NOVEMBER, CHINES VICE-PREMIER ZHU RONGJI IMPLICITLY WARNED THAT PEKING MAY NOT HONOR THE 1984 JOINT DECLARATION IF PATTEN DID NOT
OFF FROM HIS REFORM PLANS. CHINESE OFFICIALS QUICKLY FOLLOWED UP THIS STATEMENT BY WARNING THE HONG KONG AUTHORITIES NOT TO GO AHEAD WITH BUILDING THE TERRITORY'S CONTROVERSIAL AIRPORT WITHOUT GAINING THE MAINLAND'S APPROVAL. ACUTELY SENSITIVE TO THE POTENTIALLY SERIOUS 
RAMIFICATIONS THIS WOULD HAVE ON HONG KONG'S ECONOMIC VIABILITY, THE COLONY'S CONSERVATIVE BUSINESS ELITE HAS COME DUT SOUARELY BEHIND CHINA. THE MOVE APPEARS TO BE PART OF A BROADER EFFORT BY CONSERVATIVE GROUPS TO COUNTER NOT ONLY PATTEN BUT ALSO THE GRONING INFLUENCE OF THE LIBERAL ESTABLISHMENT IN HONG KONG POLITICS.

02224 CHEUMG, T.M.

LOADED WEAPONS

FAR EASTERN ECONOMIC REVIEW, 155(35) (SEP 92), 21.

LURED BY THE OFFER OF CHEAP ARMS FROM THE FORMER SOVIET UNION, CHINA-TO THE CONSTERNATION OF MANY OF ITS REGIONAL NEIGHBORS--IS MOVING RAPIDLY TO ACOUIRE ADVANCED WEAPONS TO REPLACE ITS OUTDATED ARSENAL. RUSSIA'S WILLINGNESS TO ACCEPT A SUBSTANTIAL PART OF THE PAYMENT IN BARTER IS AN ADDED ATTRACTION. CHINA'S SHOPPING LIST INCLUDES SEVERAL TYPES OF AIRCRAFT, AN AIRCRAFT CARRIER, LONG-RANGE RADAR SYSTEMS AND ARMORED VEHICLES. OF GREATER STRATEGIC SIGNIFICANCE IS THE POSSIBILITY THAT RUSSIA MAY HELP UPGRADE CHINA'S DEFENSE INDUSTRIES BY TRANSFERRING TECHNOLOGY AND PRODUCTION INDUSTRIES BY TRANSFERRING TECHNOLOGY AND PRODUCTION
FACILIITIES. CHINA HAS ALREADY SIGNED SEVERAL ARMS CONTRACTS, INCLUDING ONE WORTH MORE THAN USS1 BILLION FOR 24 SU-27
FIGHTERS. SEVERAL ITEMS ON OFFER OR UNDER DISCUSSION HAVE AN FIGHTERS. SEVERAL ITEMS ON OFFER OR UNDER DISCUSSION
OFFENSIVE ROLE, A FACT WHICH WORRIES SOME OF CHINA'S OFFENSIVE

02225 CHEUNG, T.M.

NUKE BEGETS NUKE

FAR EASTERN ECONOMIC REVIEN, 156(22) (JUN 92), 22-23.

THE POIENTIAL SPREAD OF NUCLEAR ARMS, SPURRED BY A NORTH KOREAN ACQUSITION OF NUCLEAR BOMBS, IS ONE OF THE MOST SERIOUS THREATS TO ASIA'S SECURITY. THE MAIN CONCERN AT PRESENT COMES FROM NORTH KOREA'S--AND OTHER DEVELOPING COUNTRIES'--APPARENT EASE IN CIRCUMVENTING EXISTING ARRANGEMENTS FOR CHECKING PROL IFERATION. IF PYONGYANG DOES GO NUCLEAR, THE PRESSURE FOR SEOUL TO FOLLOW WILL BE INTENSE. SUCH A MOVE WOULD LIKELY PROMPT JAPAN TO RECONSIDER ITS BAN ON NUCLEAR WEAPONS, THUS TRIGGERING A SCRAMBLE FOR NUCLEAR CAPABILITY AMONG ALL THE NATIONS OF THE REGION. IN ORDER TO PRE-EMPT THESE MILITARY DEVELOPMENTS DIPLOMATIC MOVES ARE NOW UNDERWAY TO STRENGTHEN THE INTERNATIONAL ATOMIC ENERGY AGENCY (IAEA)'S POWERS BY ALLOWING IT TO CARRY OUT SURPRISE INSPECTIONS OF SUSPECTED FACILITIES. BUT THE IAEA CAN DO NOTHING TO COMBAT THE SPREAD OF INDIGENOUS TECHNOLOGY WHICH HAS PUT A NUMBER OF ASIAN STATES, INCLUDING JAPAN, SOUTH KOREA AND TAIWAN, WITHIN EASY REACH OF MAKING A BOMB.

02226 CHEUNG, T.M.

PRESSURE TACTICS

FAR EASTERN ECONOMIC REVIEN, 155(44) (NOV 92), 8-9 HONG KONG GOVERNOR CHRIS' PATTEN'S PROPOSALS FOR GREATER DEMOCRACY IN THE COLONY HAVE RUN UP AGAINST SEVERE AND SEEMINGLY INTRACTABLE OPPOSITION FROM CHINA. A CHINESE OFFICIAL ACCUSED PATTEN OF HAVING VIOLATED THE BASIC LAW--

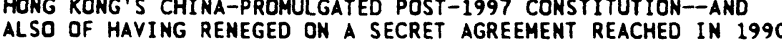
ALSO OF HAVING RENEGED ON A SECRET AGREEMENT REACHED IN 19 BETHEEN LONDON AND PEKING. THE OFFICIAL ALSO SAID THA
PATTEN PRESSED AHEAD HITH PLANS TO WIDEN THE COLONY'S PATTEN PRESSED AHEAD HITH PLANS TO WIDEN THE COLONY'S
FRANCHISE BEFORE LEGISLATIYE ELECTIONS IN 1995, PEKING WAS PREPARED TO SACK HONG KONG'S EXECUTIVE AND JUDICIARY-AS HELL AS ITS LEGISLATURE--WHEN THE COLONY REVERTS TO CHINESE CONTROL IN 1997. AS FOR HONG KONG'S PROPOSED AIRPORT, IF
HONG KONG CONSTRUCTS IT WITHOUT CHINA'S APPROVAL. PEKING PROMISED RETALIATION--INCLUDING THE CLOSING OF CHINESE AIRSPACE TO ANY AIRCRAFT OPERATING THROUGH THE AIRPORT. ALTHOUGH CHINA HAS OSTENSIBLY AGREED TO RELEASE THE RECORDS DOCUMENTING THE SECRET NEGOTIATIONS, SOME OBSERVERS ARGUE THAT CHINA IS MERELY BLUFFING IN ORDER TO MAINTAIN A STRONG NEGOTIATING STANCE.

02227 CHEUNG, T.M.

PUSH CAME TO SHOVE

FAR EASTERN ECONOMIC REVIEW, $155(49$ ) (DEC 92), 8-9.

CHINA HAS SERYED FORMAL NOTICE THAT ITS HORKING

RELATIONSHIP WITH HONG KONG GOVERNOR CHRIS PATTEN HAS COME TO AN END BY DECLARING ITS REFUSAL TO HONOR ANY CONTRACTS, LEASES OR AGREEMENTS UNDERTAKEN BY THE COLONIAL GOVERNMENT AFTER HONG KDNG REVERTS TO CHINESE SOVEREIGNTY IN 1997. WITH BUSINESS CONFIDENCE IN HONG KONG ALREADY VISIBLY WILTING UNDER PEKING'S RELENTLESS BARRAGE OF THREATS AND CRITICISMS, THE LOCAL STOCKMARKET REACTED IMMEDIATELY WITH A MASSIVE FALL AS INYESTOR NERYOUSNESS TURNED INTO PANIC. THE CHINESE STATEMENT HAS HEIGHTENED FEARS THAT PEKING IS NOW ATTEMPTING TO SERIOUSLY ERODE THE HONG KONG GOVERNMENT'S AUTHORITY SO TO SERIOUSLY ERODE THE HONG KONG GOVERMMENT'S AUTHORITY
THAT IT BECOMES VIRTUALLY POHERLESS FOR THE REST OF THE THAT IT BECOMES VIRTUALLY POHERLESS FOR THE REST OF THE
TRANSITION. WHILE THE STATEMENT CAME FROM THE HONG KONG AND TRANSITION. WHILE THE STATEMENT CAME FROM THE HONG KONG AND MORE SENIOR LEADERS, INCLUDING PATRIARCH DENG XIAOPING.

02228 CHHIBBER, P.K.; MISRA, S.; SISSON, R. ORDER ANO THE INDIAN ELECTORATE: FOR WHOM DOES SHIVA DANCE? ASIAN SURVEY, XXXIII7) (JUL 92), 606-616.

IN THE PAST DECADE MUCH ATTENTION HAS BEEN FOCUSED ON INDIA'S "PROBLEM OF ORDER." WHILE NOT DENYING THAT THERE IS
A "PROBLEM OF ORDER," THIS ARTICLE QUESTIONS BOTH THE EXTENT OF THE PROBLEM AND ALSO THE ASSUMPTION THAT IT CARRIES SIMILAR SALIENCE FOR ALL THE VARIOUS SEGMENTS--TERRITORIAL AND SOCIAL--MAKING UP INOIAN SOCIETY. THE AUTHORS ARGUE THAT
AT THE LOCAL LEVEL THE PROBLEM OF ORDER AND THE EXTENT OF CASTE AND/OR RELIGIOUS VIOLENCE ARE LESS WIDESPREAD THAN IS COMMONLY ASSUMED. THEY SUPPORT THEIR CLAIMS WITH DATA DRAWN FROM A POST-ELECTION SURVEY CONDUCTED IMMEDIATELY AFTER THE 1991 GENERAL ELECTIONS AND COVERING SIX STATES. THEY ARGUE THAT ORDER IS MORE LIKELY TO BE PERCEIVED AS A MAJOR PROBLEM BY A SPECIFIC SUBSET OF THE POPULATION: THE URBAN, UPPERCLASS, FORHARD CASTE HINDUS.

02229 CHI, K.S.

TRENDS IN EXECUTIVE REORGANIZATION

JOURNAL OF STATE GOVERNMENT, 65(2) (APR 92), 33-40.

"REORGANIZATION" IS A TERM OFTEN HEARD IN THE HALLS OF STATE CAPITOLS. BUT MEANINGFUL REORGANIZATION OF THE STATE EXECUTIVE BRANCH CAN BE DIFFICULT TO IMPLEMENT AND, IN THE RECENT PAST, THE RESULTS OF REORGANIZATION EFFORTS HAVE BEEN MIXED. NEVERTHELESS, STATES CONTINUE TO EXPLORE WAYS TO RECONFIGURE AGENCIES AND OFFICES AS THEY SEARCH FOR OPTIMAL EFFICIENCY AT MINIMAL COST.

$02230 \mathrm{CHI}, \mathrm{Z}$.

MARKET INCOMPLETENESS, INNOVATION, AND REFORM: COMMENTARY ON ADAM PRZEHORSKI'S ARTICLE

POLITICS AND SOCIETY, 19(1) (MAR 91), 59-70.

THIS ARTICLE COMMENTS ON ADAM PRZEWORKSI'S PAPER ON THE "IRRATIONALITY OF CAPITALISM AND INFEASIBILITY OF SOCIALISM.

" the author seEks to further elaborate on, and give more SUBSTANCE TO, THE CONCLUSION ABOUT "THE IRRATIONALITY OF CAPITALISM AND THE INFEASIBILITY OF SOCIALISM." HE TRIES TO DEFINE PRECISELY WHERE THE SOURCES OF THESE CHARACTERISTICS LIE. HE ALSO MAKES SOME COMMENTS ON THE DIFFERENT STRATEGIES FOR REFORMING SOCIALISM. THESE COMMENTS FOR A THEME THAT FOLLOWS MATURALLY FROM PRZEWORSKI'S CONCLUSION ABOUT

SOCIALISM'S INFEASIBILITY.

02231 CHIBBER, A.

TACKLING INFLATION DURING REFORMS IN AFRICA

FINANCE AND DEVELOPMENT, 28(1) (MAR 91), 28-30.

THE RAPID INCREASE IN THE RATE OF INFLATION IN A LARGE

NUMBER OF ECONOMIES IN SUB-SAHARAN AFRICA HAS BEEN A CAUSE

OF MUCH CONCERN, NOT LEAST BECAUSE OF ITS DAMAGING SOCIAL

AND ECONOMIC CONSEQUENCES, AND FEH AFRICAN COUNTRIES HAVE

AND ECONOMIC CONSEQUENCES, AND FEH AFRICAN COUNTRIES

THE INSTITUTIONS TO MANAGE INFLATION, EITHER THROUGH
INDEXATION OR THROUGH SAFETY NET PROGRAMS. THIS ARTICLE

INDEXATION OR THROUGH SAFETY NET PROGRAMS. THIS ARTICLE
PRESENTS THE MAJOR LESSONS FOR AN ANTI-INFLATIONARY POLICY.

PRESENTS THE MAJOR LESSONS FOR AN ANTI-INFLATIONARY POLI
IT IS BASED ON A WORLD BANK RESEARCH PROJECT COVERING

IT IS BASED ON A WORLD BANK RESEARCH PROJECT COVERING
ALGERIA, COTE D'IVORIE, GHANA, AND ZIMBABWE. THE ARTICLE

FOCUSES ON THE IMPACT ON INFLATION OF A REALIGNMENT OF

EXCHANGE RATES, MONETARY AND FISCAL POLICIES, AND PRICE
LIBERALIZATION.

02232 CHIH-LIEN, H.

CHINA'S FOREIGN POLICY: ONTO THE TWENTY-FIRST CENTURY CHINA REPORT, 27 (4) (OCT 91), 299-308.

THE NINETIES WILL MARK THE BEGINNING OF A NEW ERA IN CHINA'S FOREIGH POLICY. CHINA, BEING A DEVELOPING COUNTRY WITH A SOCIALIST SYSTEM, MUST HAVE A FOREIGN POLICY FIRMLY BASED ON RELATIONS WITH THE THIRD WORLD. THIS ARTICLE SUGGESTS THAT CHINA SHOULD STAGE A BREAKTHROUGH IN BOTH INTERNAL POLITICS AND EXTERNAL AFFAIRS, IF IT IS TO STRIVE FOR THE ESTABLISHMENT OF A SOCIALIST SOCIETY WITH CHINESE CHARACTERISTICS AND A BRAND NEW CHINESE CIVILIZATION, IN THE INTERNATIONAL ORDER. IT STUDIES FIVE PRINCIPLES OF PEACEFUL COEXISTENCE AND SOUTH-SOUTH COOPERATION AND SOUTH-NORTH COOPERATION. IT ALSO SUGGESTS THAT CHINA WILL HAVE TO TACKLE THE LINKED PROBLEMS OF HUMAN RIGHTS AND DEMOCRACY ACCORDING TO THE DIRECTION OF HISTORICAL DEVELOPMENT, CHINA'S OWN CONDITIONS, AND CURRENT INTERNATIONAL PRACTICE IN THE NEH CONTEXT OF DE-COLD-WAR AND DE-HESTERNISM.

02233 CHILD, J.

THE CENTRAL AMERICAN PEACE PROCESS, 1983-1991: SHEATHING SWORDS, BUILDING CONFIDENCE

LYNNE RIENNER PUBLISHERS, 1992, 200.

THE AUTHOR ANALYZES THE PROCESSES OF VERIFYING THE CENTRAL AMERICAN PEACE ACCORDS AND OF BUILDING CONFIDENCE AMONG THE VARIOUS PARTIES. BECAUSE OF THE PROMINENT ROLES THEY PLAYED, CONSIDERABLE ATTENTION IS GIVEN TO THE UNITED NATIONS, THE OAS, AND CANADA. THE LONG, PAINFUL PROCESS OF SEARCHING FOR PEACE IN CENTRAL AMERICAN HAS EMPHASIZED THO CONCEPTS--PEACE VERIFICATION AND ZONES OF PEACE--WITH A
DISTINCTLY LATIN AMERICAN FLAVOR. THE AUTHOR ARGUES THAT THE DISTINCTLY LATIN AMERICAN FLAVOR. THE AUTHOR ARGUES THAT
SPECIAL USE OF THESE TWO CONCEPTS IN THE CONTEXT OF THE SPECIAL USE OF THESE TWO CONCEPTS IN THE CONTEXT OF THE CENTRAL AMERICAN PEACE PROCESS IS AN IMPORTANT ADOITION TO
THE FIELD OF CONFLICT RESOLUTION AND CAN BE EXTENDED BEYOND CENTRAL AMERICA TO INFLUENCE THE SEARCH FOR PEACE IN OTHER REGIONS.

02234 CHILDERS, E.

GULF CRISIS LESSONS FOR THE UNITED NATIONS 
BULLETIN OF PEACE PROPOSALS, 23(2) (1992), 129-138.

THIS ARTICLE OFFERS A RECONSTRUCTION WHICH SEEKS OUT KEY LESSONS FOR THE UN FROM A CRISIS WHICH HAS NOT STRENGTHENED IT--AS MANY WESTERNERS HAVE BEEN LED TO BEL IEVE--BUT HAS IN FACT GRAVELY WEAKENED THE UNIVERSAL TRUST THAT IS ITS SINGLE
MOST VITAL ASSET. IT EXAMINES NON-ENDOGENOUS BORDERS, NATURAL RESOURCE DISPUTES, UN EARLY WARNING AND INITIIATIVE, THE UN AS THE GUARDIAN OF THE CHARTER, STRENGTHENING UN CAPACITIES, AND PUTTING AN END TO DOUBLE STANDAROS.

02235 CHILDERS, E.

THE USE AND ABUSE OF THE UN IN THE GULF CRISIS

MIDOLE EAST REPORT, 21(2) (MAR 91), 5-7.

WHILE THE ACTIONS OF THE UN FOLLOWING SADDAM HUSSEIN'S AUGUST INVASION OF KUHAIT REVEAL A HIGHER DEGREE OF HARMONY AMONG MEMBERS THAN IN PREVIOUS CRISIS, THE GULF CRISIS ALSO REVEALED SOME SIGNIFICANT FLAWS TO THE UN SYSTEM. CHIEF AMONG THESE IS THE LACK OF A MECHANISM TO DEAL WITH THE NONENDOGENOUS MATURE OF BOROERS IN THE MIDDLE EAST AND

ELSEHERE. IN THE FUTURE. THE UN MUST BE EOUIPPED WITH A FAR ELSEWHERE. IN THE FUTURE, THE UN MUST BE EQUIPPED WITH A FAR RE-EMERGING ETHNIC DISPUTES IN EASTERN EUROPE) AND TO HELP THE PEOPLES ON ALL SIDES OF SUCH BOUNDARIES TO FIND THE THE PEOPLES ON ALL SIDES OF SUCH BOUNDARIES TO FIND THE ACCEPTABLE TO THEM, AND ECONOMIES THAT ARE VIABLE FOR THEM.

02236 CHILMAN, C.

WELFARE REFORM OR REVISION? THE FAMILY SUPPORT ACT OF 1988 SOCIAL SERVICE REVIEH, 66(3) (SEP 92), 349-377.

THE CHIEF PROVISIONS OF THE 1988 FAMILY SUPPORT ACT ARE OUTLINED. ITS BACKGROUND AND IMPLEMENTATION ARE DISCUSSED. IN ADDITION, THE CHILD-CARE EARNED INCOME TAX CREDIT AND EXPANDED MEDICAID ASSISTANCE PROVISIONS OF THE 1990 BUDGET RECONCILIATION ACT ARE BRIFLY SUMMARIZED. A CRITIQUE OF MANY ASPECTS OF THE FAMILY SUPPORT ACT PLUS AN ESTIMATE OF THE PROBABLE SUCCESS OF THE JOB OPPORTUNITIES AND BASIC SKILLS TRAINING PROGRAM COMPONENTS ARE PRESENTED, TOGETHER WITH SUGGESTIONS FOR FURTHER EXPERIMENTATION AND RESEARCH.

02237 CHIMELLI, R.

GERMANY AND FRANCE ADJUST TO A NEH RELATIONSHIP

GERMAN TRIBUNE, (1517) (MAY 92), 1.

PLANS FOR A JOINT GERMAN-FREMCH ARMY CORPS WERE REVEALED DURING A TWO-DAY SUMAIT BETWEEN GERMAN CHANCELLOR KOHL AND DURING A TWO-DAY SUMHIT BETHEEN GERMAN CHANCELLOR KOHL AND
PRESIDENT MITTERAND AT THE FRENCH ATLANTIC COAST CENTER OF PRESIDENT MITTERAND AT THE FRENCH ATLANTIC COAST CENTER OF
LA ROCHELLE. THE CORPS IS BEING PRESENTED AS THE BASIS FOR A LA ROCHELLE. THE CDRPS IS BEING PRESENTED AS THE BASIS FOR
EUROPEAN DEFENCE FORCE. KOHL HOPES THE FORCE WILL BRING EUROPEAN DEFENCE FORCE. KOHL HOPES THE FORCE WILL BRING
FRANCE CLOSER TO NATO. MITTERAND HOPES IT WILL BRING GERMANY FRANCE CLOSER TO NATO. MITTERAND HOPES IT WILL BRING GERMANY
CLOSER TO AN INDEPENDENT EUROPEAN COMMUNITY DEFENSE SYSTEM. CLOSER TO AN INDEPENDENT EUROPEAN COMMUNITY DEFENSE SYSTEH. SPEED RAIL SYSTEM LINKING PARIS HITH MUNICH AND BERLIN.

02238 CHING, F.

\section{BOXED IM A CORMER}

FAR EASTERN ECONOMIC REVIEN, 155(50) (DEC 92), $16-18$

CHINA'S THREATS TO DISMANTLE ALL HONG KONG GOVERMMENT STRUCTURES IN 1997 AND TO REPUDIATE GOVERMMENT CONTRACTS HIGHLIGHT A BASIC CONFLICT: WHO IS TO RUN HONG KONG IN THE NEXT FEW YEARS, BEFORE SOVEREIGNTY OVER THE COLONY PASSES FROM LONDON TO PEKING? THE IMMEDIATE CHINESE OBJECTIVE IS TO DISCREDIT GOVERNOR CHRIS PATTEN, AND. IF POSSIBLE, GET RID
OF HIM. HOWEVER, CHINA'S MOVES ARE CAUSING SERIOUS CONCERN AMONG THE GENERAL POPULACE AS IS INDICATED BY EARLY DECEMBER'S PLUNGE IN THE STOCK MARKET. POLITICAL ANALYSTS NOTE THAT PEKING IS EVEN WILLING TO DAMAGE INVESTOR CONFIDENCE AS A PART OF ITS CAMPAIGN TO UNDERMINE THE AUTHORITY OF THE HONG KONG ADMINSITRATION. THERE IS A GENERAL AGREEMENT THAT THE PROSPECTS FOR COOPERATION BETWEEN CHINA AND HONG KONG OVER CONSTITUTIONAL REFORM AND ECONOMIC POLICY ARE SLIM.

02239 CHING, F.

CLEARED FOR ACTION

FAR EASTERN ECONOMIC REVIEH, 155(41) (OCT 92), 20-21. GOVERMOR CHRIS PATTEN'S PROPOSALS OF HOW HONG KOMG SHOULD BE RULED READ MORE LIKE AN ELECTION MANIFESTO THAN A BLUEPRINT FOR THE REMAINING YEARS OF BRITAIN'S COLONIAL TENURE. DISPLAYING SKILLS LEARNED AS A PROFESSIONAL

POLITICIAN, PATTEN SOUGHT TO REGAIN THE POLITICAL INITIATIVE FROM CHINA THAT HAD BEEN LARGELY FORFEITED BY PREYIOUS BRITISH POLICY. IN DOING SO, HOWEVER, HE MAY HAVE

BRITISH POLICY. IN DOING SO, HOWEVER, HE MAY HAVE
DELIBERATELY PROVOKED PEKING BY BOTH THE SUBSTANCE AND STYLE DELIBERATELY PROVOKED PEKING BY BOTH THE SUBSTANCE AND
OF HIS FIRST GUBERNATORIAL ADDRESS. ATTENTION HAS NOW

SWITCHED TD CHINA, AND HOW THE PEKING LEADERSHIP WILL REACT

TO WHAT THEY CAN ONLY YIEW AS A CHALLENGE TO THEIR AUTHORITY.

02240 CHING, F.

HIT WHERE IT HURTS

FAR EASTERN ECONOMIC REVIEH, 151(28) (JUL 91), 26

OPPOSITION TO THE MOVEMENT TO DENY MOST-FAVORED NATION (MFN) STATUS TO THE PEOPLE'S REPUBLIC OF CHINA IS COMING FROM AN UNFORESEEN SOURCE: HONG KONG. THE HONG KONG GOVERMMENT'S CONTENTION IS THAT UP TO 1.8 PERCENTAGE POINTS WOULD BE SHAVED OFF THE COLONY'S ECONOMIC GROWTH SHOULD MFN
STATUS BE DENIED TO CHINA. FURTHERMORE, HONG KONG--ITS SUCCESS DEPENDENT ON FREE INTERNATIONAL TRADE--HAS CONSISTENTLY LOBBIED FOR FREE TRADE. WHILE IT MAY GO AGAINST THE GRAIN FOR LIBERALS WHO ARE APPALLED BY CHINA'S HUMAN RIGHTS RECORD TO ACCEPT THAT MFN SHOULD BE UNCONDITIONALLY CONTINUED, THIS COURSE HOULD ACTUALLY BEST SERVE THE INTERESTS OF CHINA, HONG KONG, AND THE UNITED STATES. DENIAL OF MFN STATUS IS UNLIKELY TO IMPROVE CHINA'S HUMAN RIGHTS RECORD AND WILL ULTIMATELY HURT THE COMMON PEOPLE AND THE PROGRESSIVE PROVINCES SUCH AS GUANGDONG AND FUJIAN MORE THAN IT WILL HURT THE CENTRAL GOVERMMENT.

02241 CHING, F.

PAST IMPERFECT

FAR EASTERN ECONOMIC REVIEH, 155(43) (OCT 92), 23. HONG KONG'S GOVERNOR CHRIS PATTEN HAS DEMONSTRATED CONSIDERABLE AMBIVALENCE TOWARD HIS PREDECESSOR, LORD WILSON. WHILE PATTEN FREQUENTLY PRAISES WILSON'S FIVE YEARS OF SERVICE, THE NEW GOVERNOR HAS MADE GREAT EFFORTS TO UNDO SOME OF HILSON'S MAIN HANDIHORK. CONDEMNING THE PRACTICE OF PLACING APPOINTED LEGISLATIVE COUNCIL (LEGCO) MEMBERS IN TH EXECUTIVE COUNCIL (EXCO), PATTEN THREW OUT ALL OF WILSON'S APPOINTEES FROM LEGCD. HE HAS ALSO ABOLISHED ALL APPOINTED
MEMBERS TO THE LOCAL COUNCILS KNOWN AS DISTRICT BOARDS, AND MEMBERS TO THE LOCAL COUNCILS KNOWN AS DISTRICT BOARDS, AND
HAS PROPOSED THE CREATION OF FUNCTIONAL CONSTITUENCIES HHERE HAS PROPOSED THE CREATION OF FUNCT IONAL CONSTI IUENCIES HHERE
EVERY WORKING PERSON WOULD HAVE A VOTE. HOWEVER, PATTEN'S EVERY WORKING PERSON WOULD HAVE A VOTE. HOWEVER, PATTEN'S
FREEDOM TO ACT IS CONSTRAINED BY DECISIONS MADE BY PREVIOUS BRI IISH AND HONG KONG OFFICIALS. THEREFDRE, IF HE IS TO GAIN THE NECESSARY SUPPORT FOR HIS REFORMS, HE MAY HAVE BE MORE OPENLY CRITICAL OF PAST LEADERS AND THEIR POLICIES.

02242 CHINWORTH, M.; CHENG, D.

THE UNITED STATES AND ASIA IN THE POST-COLD WAR WORLD SAIS REVIEW, 11(1) (WIN 91), 73-92.

THE U.S. DECLARATION OF VICTORY IN THE COLD WAR RAISES THE DANGEROUS POSSIBILITY THAT EVENTS IN ONE PART OF THE GLOBE--EUROPE--WILL BE ALLOWED TO DICTATE POLICY IN ANOTHER-ASIA--WITHOUT A FULL UNDERSTANDING OF THE DIFFERENCES AND CDMPLEXITIES INVOLVED. A PRECIPITOUS U.S. WITHDRAWAL FROM ASIA WOULD ONLY SERVE TO EXACERBATE REGIONAL FEARS AND INSTABILITIES THAT HAVE NOT YET BEEN SURMOUNTED. THIS WOULD UNDO THE MOST IMPORTANT CONTRIBUTION OF THE U.S. MILITARY PRESENCE IN THE REGION: THE PROVISION OF POLITICAL AND ECONOMIC STABILITY, WHICH HAS FACILITATED TREMENDOUS GROWTH. ECONOMIC STABILITY, WHICH HAS FACILITATED TREMENDOUS GROWTH
THEREFORE, THE U.S. SHOULD CONTINUE TO BALANCE COMPETING INTERESTS AND AVOID POTENTIAL FRICTION, THUS PROVIDING THE INTERESTS AND AVOID POTENTIAL
BASIS FOR CONTINUED GROWTH.

02243 CHIPMAN, J.

THE FUTURE OF STRATEGIC STUDIES: EVEN GRAND STRATEGY ROUND TABLE $322(322)$ (APR 92) 135-152

TRUE STRATEGIC THINKING REQUIRES AN APPRECIATION OF THE FORCES AT PLAY, BOTH LOCALLY AND GENERALLY, WHICH MAY RESULT IN PEOPLES, NATIONS OR STATES USING MILITARY FORCE TO ACHIEVE THEIR AMBITIONS OR TO REVERSE A PERCEIVED WRONG. THIS MAKES NECESSARY AN ANALYSIS OF THE QUALITY OF SOCIAL ORGANIZATION, ECONOMIC PROWESS, POL ITICAL UNITY AND MILITA
PREPAREDNESS THAT MAKES THE USE OF FORCE BY ANY GROUP A REALISTIC OPTION, OR ITS RENUNCIATION AN IMPERATIVE. THIS ARTICLE SUGGESTS THAT TO THOSE WHO ARGUE THAT DEFINITIONS OF STRATEGIC STUDIES NEED TO BE WIDENED, IT IS RIGHT TO ANSWER THAT, HAVING BEEN ARTIFICIALLY SHRUNK IN THE PAST 40 YEARS, THEY ARE NOW RETURNING TO THEIR NATURAL AND NECESSARY PROPORTIONS. FEATURES OF THE INTERNATIONAL SYSTEM

CONSEQUENCES FOR INTERNATIONAL STRATEGY; AND THE

STRATEGIST'S INTELLECTUAL POLICY AGENDA ARE EACH EXPLORED.

IT CONCLUDES THAT THE MORAL ELEMENT FOR THE GENERAL IN WAR,

OR THE ANALYST IN PEACE, MUST NEVER BE FAR AHAY.

02244 CHIPOSA, S

ZAMBIA--PARTIES PROLIFERATE

NEW AFRICAN, (282) (MAR 91), 18.

EXACTLY EIGHTEEN YEARS AFTER THE BIRTH OF ONE-PARTY RULE IN ZAMBIA, THE COUNTY RESUMED MULTI-PARTY POLITICS FOLLOWING THE REPEAL OF ARTICLE FOUR OF THE CONSTITUTION WHICH MADE THE UNITED NATIONAL INDEPENDENCE PARTY (UNIP) THE SOLE LEGAL PARTY. SINCE THEM, A HOST OF STRANGE SPLINTER GROUPS HAVE PRESENTED THEIR PAPERS SO THAT THEY CAN CAMPAIGN IN THE FORTHCOMING ELECTIONS. MANY OF THEM ARE LITTLE BUT EMPTY SHELLS, BUT THE MOVEMENT FOR MULTI-PARTY DEMOCRACY IS POSING A SERIOUS CHALLENGE.

02245 CHIRIYANKANDATH, J.

CDEMOCRACY' UNDER THE RAJ: ELECTIONS AND SEPARATE

COEMOCRACY UNDER THE RAJ: ELECTIC

JOURNAL OF COMMONHEALTH AND COMPARATIVE POLITICS, 30(1) (MAR 92), 39-63

THE PROCESS THROUGH WHICH ELECTED INSTITUIONS DEVELOPED AND DEMOCRATIC POLITICS SPREAD IN THE 60 YEARS BEFORE INDIA'S INDEPENDENCE IS EXAMINED. ON THE BASIS OF THIS ANALYSIS OF THE CHANGES SET IN MOTION IN 1892. THE REFORMS OF 1909, \$DYDARCHY' AND THE EXPANSION OF ELECTORAL POLITICS, AND THE 1935 ACT AND THE EMERGENCE OF SEPARATIST POL ITICS, 
HAVE HELPED DETERMINE THE FORMATION OF MOBILIZABLE POLITICAL CATEGORIES WITH SOCIETY PRIOR TO INDEPENDENCE AND THE INTRODUCTION OF UNIVERAL ADULT FRANCHISE. DURING THE LONG PROCESS LEADING UP TO INDEPENDENCE, ELECTORAL POLITICS ALONG WITH THE POL ITICS OF MOVEMENT, WAS AN IMPORTANT CHANNEL OF POLITICAL SOCIALIZATION. THE CONTINUATION OF THE LINKS BETWEEN POLITICAL ELITES AND SOCIAL FORMATIONS PRIOR TO INDEPENDENCE IN POST-INDEPENDENCE INDIA GAVE HER AN IMPORTANT ADVANTAGE IN BUILDING A STABLE, REPRESENTATIVE POLTICAL SYSTEM.

02246 CHLOPECKI, M.

THE PROPERTY RIGHTS ORIGINS OF PRIVACY RIGHTS

FREEMAN, 42(8) (AUG 92), 306-309.

PRIVACY AND PROPERTY RIGHTS ARE INTIMATELY LINKED. MOREOVER, THE INTEGRITY OF PRIVACY RIGHTS DEPENDS LARGELY UPON THE PROTECTION OF PRIVATE PROPERTY RIGHTS.

02247 CHOATE, P.

THE FUTURE OF AMERICAN-JAPANESE TRADE

ANNALS OF THE AMERICAN ACADEMY OF POLITICAL AND SOCIAL SCIENCE, 522 ( JUL 92 ), 36-44.

DUE TO THE END OF THE COLD WAR AND THE DISSOLUTION OF THE SOVIET UNION, THE CONFLICTS BETWEEN NATIONS HILL INCREASINGLY BE ECONOMIC RATHER THAN MILITARY. BUT THE EXISTING INTERNATIONAL INSTRUMENTS FOR DEALING WITH TRADE CONFLICTS ARE ANTIQUATED AND INADEQUATE. THE GENERAL AGREEHENT ON TARIFFS AND TRADE (GATT), AS A FOUNDATION FOR GLOBAL TRADE, IS FUNDAMENTALLY FLAWED. JAPAN HAS IGNORED ITS GATT OBLIGATIONS, TAKING ADVANTAGE OF OPEN MARKETS HHEREVER IT CAN WHILE KEEPING ITS OWN MARKETS CLOSED THROUGH A VARIETY OF FORMAL AND INFORMAL BARRIERS. IN CONTRAST TO EUROPE, THE UNITED STATES' RESPONSE HAS BEEN PASSIVE, RESULTING IN A LONG HISTORY OF FAILED PROCESS-ORIENTED BILATERAL NEGOTIATIONS HITH JAPAN. IN THE FINAL ANALYSIS, THE DIFFICULTY LIES NOT WITH JAPAN BUT WITH THE USA. THE SOLUTION IS A RESULTS-ORIENTED AGREEMENT WITH JAPAN: ONE THAT CONCENTRATES ON OUTCOMES, TIMETABLES AND MUTUAL RESPONSIBILITIES, LEVELS OF PERMISSIBLE TRADE IMBALANCES, THE COMPOSITION OF TRADE, ALLOWABLE MARKET SHARES, INVESTMENT IN BOTH COUNTRIES, AND SUCH PRACTICES AS DUMPING IN THIRD MARKETS.

02248 CHOI K.S.

KOREA IN THE POST-COLD WAR ERA

JOURNAL OF NORTHEAST ASIAN STUDIES, $X(4)$ (WIN 92), 24-34. IN RECENT YEARS, THERE HAVE BEEN IMPORTANT CHANGES IN THE FOREIGN POLICIES OF THE TWO KOREAN STATES AND IN INTERKOREAN RELATIONS. IN THIS PAPER, THE AUTHOR ANALYZES AND ASSESSES THE IMPACT AND THE IMPLICATIONS OF THESE CHANGES; DESCRIBES THE EFFORT THAT KOREANS ARE MAKING TO TURN THESE CHANGES INTO OPPORTUNITIES FOR THE TWO STATES TO MOVE FROM CONFRONTATION TOWARD RECONCILIATION AND, ULTIMATELY UNIFICATION; AND DISCUSSES THE TRANSITIONAL AND PROBABLE UNIFICATION; AND DISCUSSES THE TRANSITIONAL AND PRO
FUTURE FOREIGN POLICIES OF THE REPUBLIC OF KOREA.

02249 CHOMSKY, $N$.

NEH HORLD ORDER

SCANDINAVIAN JOURNAL OF DEVELOPMENT ALTERNATIVES, $11(3)$

SEP 92$), 217-234$

THE NEW WORLD ORDER IS THE OLD WORLD ORDER ADAPTED TO NEW CONTINGENCIES. THE TENDENCIES TOWARDS THE NEW IMPERIAL AGE ARE OBVIOUS AND UNDERSTANDABLE. PARALLEL TENDENCIES ARE INCREASINGLY GIVING A THIRD WORLD CAST TO THE WEALTHY SOCIETIES THEMSELVES WITH SECTORS OF EXTREME WEALTH AND PRIVILEGE IN THE MIOST OF A POPULATION THAT IS SUPERFL FUNCTIONS RECOGNIZED IN THE DOMINANT' INSTITUTIONS AND THEIR IDEOLOGY. THE PROCESS OF DEMOCRATIZATION AND CONCERN FOR SOCIAL JUSTICE HAS LARGE SIGNIFICANCE AND OFFERS THE ONLY REAL HOPE FOR THE GREAT MASS OF PEOPLE IN THE WORLD.

02250 CHON, $S$.

REGIONAL BASES AND PATTERNS OF INFORMAL POLITICS IN SOUTH KOREA; ASSOCIATION FOR ASIAN STUDIES 1992 ANNUAL MEETING

ASSOCIATION FOR ASIAN STUDIES, 1992, 169.

DESPITE THE APPARENT PENETRATION OF LOCAL POLITICS BY THE SEOUL-CENTERED NATIONAL POWER STRUCTURE, REGIONAL AND LOCAL POLITICS REMAIN ALIVE AND WELL IN SOUTH KOREA. IN THE 1988 NAT IONAL ASSEMBLY ELECTION, A NUMBER OF PROMINENT DEMOCRATIC JUSTICE PARTY CANDIDATES LOST DUE TO LACK OF LOCAL SUPPORT. THE RESULTS OF THE ELECTION SUGGEST THE IMPORTANCE OF REGIONAL AND LOCAL CONNECTIONS FOR SEOUL-BASED POLITICIANS AND OF DISTINCTIONS BETWEEN NOMINAL AND REAL LEADERS IN LOCAL POLITICS. THIS PAPER DISCUSSES AND COMPARES ASPECTS OF INFORMAL POLITICS IN CHOLLA AND KYONGSANG ASPECTS OF INFORMAL POLITICS IN CHOLLA AND KYONGSANG PROVINCES, INCLUDING THE INTERACTION BETHEEN LOCAL LEADERS CHARACTER AND CENTER-PROVINCIALLOCAL POLITICAL-ECONOMIC CHARACTER
LINKAGES.

02251 CHONG, D.

SOCIAL INCENTIVES AND THE PRESERVATION OF REPUTATION IN PUBLIC-SPIRITED COLLECTIVE ACTION
INTERNATIONAL POLITICAL SCIENCE REVIEN, 13(2) (APR 92), 171-198.

THE FOLLOWING ARGUMENTS ARE ILLUSTRATED HITH A SERIES OF EXAMPLES FROM THE CIVIL RIGHTS MOVEMENT IN THE UNITED STATES AND OTHER INSTANCES OF COLLECTIVE ACTION: LARGE-SCALE COOPERATION CAN OFTEN BE MANUFACTURED OUT OF SMALL-SCALE RELATIONSHIPS; PEOPLE FREQUENTLY COOPERATE IN LARGE-SCALE VENTURES IN ORDER TO PROTECT THEIR REPUTATIONS IN EVERYDAY RELATIONSHIPS, SINCE AN ESTEEMED REPUTATION HAS CONSIDERABLE INSTRUMENTAL VALUE IN A COMMUNITY; REGULAR SOCIAL

INTERACTIONS IS CONDUCIVE NOT ONLY TO THE DEVELOPMENT OF OBLIGATIONS ANO COMMITMENTS, BUT ALSO TO THE FORMATION OF OTHER REGARDING INTERESTS.

02252 CHONGYUAN, H.

ALGERIA ROCKED BY POLITICAL UNREST

BEIJING REVIEW, $35(9)$ (MAR 92), 14-15

ON FEBRUARY' 9, 1992, ALGERIA'S RULING HIGH STATE COUNCIL (HSC) DECLARED A YEAR-LONG, NATIONWIDE STATE OF EMERGENCY AND BANNED THE ISLAMIC SALVATION FRONT (FIS). BUT TENSIONS REMAIN HIGH BECAUSE THE FIS HAS CALLED ON THE PEOPLE NOT TO YIELD TO THE HSC.

02253 CHONGYUAN, $\mathrm{H}$.

DIPLOMATIC INITIATIVES PAY OFF

BEI JING REVIEH, 35(43) (OCT 92)

IN RECENT YEARS, EGYPT HAS ENERGETICALLY PURSUED A FOREIGN POL ICY OF PEACE, NEUTRALITY, AND NON-ALIGNMENT. ALTHOUGH EGYPT'S MAIN FOCUS IS TO IMPROVE AND DEVELOP ITS RELATIONS WITH OTHER ARAB COUNTRIES, IT ALSO MAINTAINS GOOD RELATIONS WITH THE WEST, ISRAEL, CHINA, AND MANY OF THE FORMER SOVIET REPUBLICS.

02254 CHOPER, J.H.

SEPARATION OF CHURCH AND STATE: "NEW" DIRECTIONS BY THE "NEW" SUPREME COURT

JOURNAL OF CHURCH \& STATE, 34(2) (SPR 92), 363-375.

ISSUES OF SEPARATION OF CHURCH AND STATE AND FREEDOM OF RELIGION WERE AMONG THE MOST ACTIVE AREAS OF CONSTITUTIONAL ADJUDICATION IN THE UNITED STATES SUPREME COURT DURING THE 1970 'S AND 1980'S. INDEED, IN THE PAST SEVERAL YEARS, THE COURT HAS MADE MAJOR CHANGES IN ITS APPROACH TO EVERY IMPORTANT ASPECT OF THE SUBJECT. THIS ESSAY EXPLORES FOUR GENERAL THEMES REVEALED IN RECENT DECISIONS AND DISCUSSES THOSE THEMES IN THE CONTEXT OF THE FOUR MAJOR AREAS OF CONSTITUTIONAL ADJUDICATION UNOER THE RELIGION CLAUSES OF THE FIRST AMENDMENT.

02255 CHOUCRI, N.; NORTH, R.C.; YAMAKAGE, S.

THE CHALLENGE OF JAPAN BEFORE WORLD HAR II AND AFTER ROUTLEDGE, 1992,383 .

THIS BOOK IS THE LATEST IN A SERIES OF WORKS WHICH EXAMINE THE DYNAMICS OF INTERNATIONAL CONFLICT AND INTEGRATION. AT THE CORE OF THESE STUDIES IS LATERAL PRESSURE, THE AUTHORS' THEORY OF NATIONAL EXPANSION. THIS WORK IS A SYSTEMATIC ANALYSIS OF JAPAN OVER 100 YEARS. IT CONSIDERS THE EXTENT TO HHICH TERITORIAL EXPANSION IS LESS AN INEVITABLE CONSEQUENCE OF GROWTH THAN AN OUTCOME OF THE DEMANDS AND REQUIREMENTS OF STATES AND THEIR ECONOMIC, POLITICAL, STRATEGIC, AND SECURITY NEEDS. IT OFFERS AN HISTORICAL ANALYSIS OF MODERN JAPAN'S EARLY GROWTH AND EXPANSION THROUGH WORLD WAR I AND A MODEL OF THE COUNTRY'S LATERAL PRESSURE DURING THAT PERIOD. IT ALSO COVERS MANY IMPORTANT INTER-WAR EVENTS AND COMPARES PATTERNS OF PREWORLD WAR I AND PRE-WORLD WAR II PRESSURE. IT ALSO EXAMINES JAPAN'S POST-HAR GROWTH ANO EXPANSION AS WELL AS MAJOR TRENDS INTO THE EARLY TWENTY-FIRST CENTURY.

02256 CHOWDHURY, G.R.

UNHATURAL DISASTERS

CULTURAL SURVIVAL QUARTERLY, 16(1) (WIN 92), 14-17 BANGLADESH'S MINORITIES ARE WAGING ONE OF THE WORLD'S MOST DIFFICULT STRUGGLES FOR SURVIVAL. SUCCESSIVE MILITARYAND GOVERNMENT-SPONSORED POGROMS HAVE KILLLED THOUSANDS OF BANGLADESHIS WHILE COUNTLESS OTHERS HAVE ESCAPED INTO INDIA. BANGLADESH'S MINORITIES SUFFER POLICE, MILITARY, AND JUDICIAL INACTION IN THE FACE OF INDIVIDUAL AND ORGANIZED TERROR, DISCRIMINATION, AND REPRESSION. A PARTICULARLY HARSH LAW IS THE ENEMY PROPERTY ACT, WHICH ALLOWS THE GOVERNMENT TO CONFISCATE MINORITY PROPERTY AND BUSINESSES WITHOUT NOTICE OR COMPENSATION, SIMPLY BY DECLARING A PERSON TO BE AN ENEMY OF THE STATE.

02257 CHRISOPHER, I

GUYANA: THE WESTERN HEMISPHERE'S POOREST COUNTRY GUYANA: THE WESTERN HEMISPHERE S POOREST COUNTRY
CONTEMPORARY REVIEW, 260(1517) (JUM 92) 303-304

FOR GUYANA TO BE AN ASSET TO THE REGION, THE PEOPLE MUST HAVE A GOVERNMENT THAT IS ACCOUNTABLE TO THEM, A GOVERNMENT THEY CAN ELECT AND RECALL. THIS FACT HAS BEEN RECOGNIZED AND HENCE SUPPORT IS BEING GIVEN TO THE REALIZATION OF DEMOCRACY. HOWEVER, THERE IS A BODY OF OPINION THAT DISAGREES WITH THE OPTIMISTS. MANY ARE OF THE OPINION THAT, EVEN IN THE FACE OF EXTERNAL PRESSURES AND INTERNAL AGITATION FOR POLITICAL CHANGE, THE PNC WILL NOT BE REMOVED FROM POLITICAL OFFICE BY 
THE UPCOMING ELECTION. THIS ARTICLE OUTLINES CERTAIN RATIONAL ARGUMENTS WHICH PREMISE THIS PESSIMISTIC VIEW.

02258 CHRISTENSEN, J.G.

HIERARCHICAL AND CONTRACTUAL APPROACHES TO BUDGETARY REFORM JOURNAL OF THEORETICAL POLITICS, 4(1) (JAN 92), 67-91.

BASED ON A REVIEN OF RECENT REFORMS OF THE BUDGETARY SYSTEMS USED IN THE DANISH PUBLIC SECTOR, THE AUTHOR ARGUES THAT SUCH REFORMS HAVE NOT BEEN EFFECTIVE INSTRUMENTS FOR PUBLIC SECTOR RESOURCE MANAGEMENT. THE REASON FOR THIS LACK OF EFFECTIVENESS IS FOUND IN THE PRINCIPLES OF HIERARCHICAL GOVERNANCE ON WHICH THESE REFORMS ARE BASED. THE SYSTEMS PROVIDE ONLY WEAK INCENTIVES FOR RESPECTING SPENDING TARGETS DECIDED AT SUPERIOR LEVELS WHILE, SIMULTANEOUSLY, BUDGET HOLDERS ARE TEMPTED TO EXCEED THESE TARGETS. AN ALTERNATIVE HOLDERS ARE TEMPTED TO EXCEED THESE TARGETS. AN ALTERNATIVE
IS A CONTRACTUCAL APPROACH TO BUDGETARY REFORM, WHICH BRINGS IS A CONTRACTUCAL APPROACH TO BUDGETARY
MICRO-LEVEL INCENTIVES INTO OPERATION.

02259 CHRISTENSEN, S.

THAILAND IN' 1990: POLITICAL TANGLES

ASIAN SURYEY, XXXI (2) (FEB 91), 196-204.

THE SENSE OF PROGRESS IN THÁILAND CREATED IN 1988 BY PRIME MINISTER CHATICHAI CHOONHAVAN'S STATED INTENTIONS TO CARRY OUT DEMOCRATIC AND ADMINISTRATIVE REFORMS ANO TO DISTRIBUTE WEALTH TO THE RURAL MAJORITY WAS ALMOST LOST IN 1990. AMID REPEATED CORRUPTION SCANDALS IN HIS ADMINISTRATION, CHATICHAI WAS UNABLE TO PREVENT FEUDS AMONG POLITICAL PARTIES FROM FRACTURING THE RULING COALITION. AND HE RESHUFFLED HIS CABINET ON FOUR OCCASIONS. AT THE SAME TIME. THE PREMIER MANEUVERED CONSTANTLY TO FEND OFF APPARENT CHALLENGES FROM MILITARY LEADERS, MANY OF WHOM ALLEGE THAT CORRUPTION IS A PERMANENT AILMENT IN THE POLITICAL PROCESS. THE YEAR WAS A GREAT TEST OF THE COALITION'S ABILITY TO GOVERN, AND THE RECORD WAS MIXED AS PUBLIC CONFIDENCE IN THE GOVERMMENT DIMINISHED SIGNIFICANTLY AND THE PARTIES STROVE TO MANAGE THEIR DISPUTES ACCORDING TO EXISTING CONSTITUTIONAL PROCEDURES.

02260 CHRISTENSON, L.

WASHINGTON STATE COMMISSION ON EFFICIENCY AND ACCOUNTABILTIY IN GOVERMMENT

PUBLIC PRODUCTIVITY \& MANAGEMENT REVIEW, 15(2) (WIN 91), 159-162.

SIGNIFICANT IMPROVEMENTS IN THE EFFICIENCY AND EFFECTIVENESS OF WASHINGTON STATE GOVERNMENT PROGRAMS WERE ATTAINED BY COMBINGING THE PRAGMATIC EXPERIENCE AND KNOWLEDGE OF STATE MANAGERS WITH THE BOTTOM-LINE, ENTREPRENEURIAL. TECHNICALLY ADVANCED PRIVATE SECTOR. ENTREPRENEURIAL, TECHNICALLY ADVANCED PRIVATE SECTOR.
IMPLEMENTING CHANGE HAS SUCCESSFUL BECAUSE OF CAREFUL IMPLEMENTING CHANGE WAS SUCCESSFUL BECAUSE OF CAREFUL PLANNING AND CONSIDERABLE ANALYSIS OF PREVIOUSLY
UNSUCCESSFUL EFFORTS. THE COMMISSION STRUCTURE AND PROCESS UNSUCCESSFUL EFFORTS. THE CDMMISSION STRUCTURE AND PROCESS WERE DESIGNED TO INCORPORATE A MEANS FOR SUCCESS. THE AUTHOR
CONCLUDES THAT ALTHOUGH STATE GOVERNMENT IS BIG BUSINESS AND THAT PROBLEMS WILL ALWAYS EXIST, SIGNIFICANT IMPROVEMENT CAN BE MADE.

02261 CHRISTIANSEN, N.F.

THE DANISH NO TO MAASTRICHT

NEW LEFT REVIEW, (195) (SEP 92), 97-101

THE AUTHOR IDENTIFIES THE MOTIVES BEHIND THE OANISH REJECTION DF THE MAASTRICHT TREATY AND EXPLAINS THE ROLE PLAYED BY DEMOCRATIC OBJECTIONS AND FEAR OF THE DEFLATIONARY DOGMA OF THE EUROPEAN MONETARISTS.

02262 CHRISTIE, M.

ISOLATIONISM AND SOUTH AFRICA

SOUTH AFRICA INTERNATIONAL, 22 (3) (JAN 92), 143-144.

IT IS WIDELY RECOGNIZED THAT SUCCESSFUL POLITICA

TRANSITIONS TO DEMOCRACY DEPEND ON SUSTAINED ECONOMIC GROHTH. THE CURRENT TRIBULATIONS OF THE SOVIET UNION UNDERLINE THIS FACT; BUT IT IS NOT CLEAR THAT ALL SOUTH AFRICANS ARE SUFFICIENTLY AWARE OF IT. AFTER YEARS OF ISOLATION, SOUTH AFRICANS ARE STILL BESET BY A DANGEROUS PAROCHIALISM WHICH OVERLOOKS THE EXPERIENCE OF THE REST OF THE WORLD. WHAT IS URGENTLY MEEDED IS INTERNATIONAL SUPPORT, NOT JUST FOR THE ENDING OF APARTHEID, BUT TO REMIND SOUTH AFRICANS OF THE LESSONS LEARNED IN OTHER SOCIETIES TO ASSIST THEM TO BREAK OUT OF THEIR ISOLATIONISM.

02263 CHRISTIE, M.

SOUTH AFRICA ANO THE US--DANGERS OF INDIFFERENCE SOUTH AFRICA INTERNATIONAL, $22(2)$ (OCT 91 ) $98-99$ IT IS INCREASINGLY WIDEL LY ACCEPTED THAT' A KEY ELEMENT IN DEMOCRACY IN SOUTH AFRICA IS A GROWING ECONOMY. YET U.S. POLICY TOWARDS SOUTH AFRICA AT PRESENT PURSUES MUTUALLY CONTRADICTORY GOALS: TO USE REMAINING SANCTIONS TO PUSH SOUTH AFRICA TOWARDS DEMOCRACY, WHILE THESE SAME MEASURES (BY DAMAGING THE ALREADY HARD-HIT ECONOMY) MAKE THE ATTAINMENT OF ANY KIND OF DEMOCRACY LESS LIKELY. AS ATTITUDES ABOUT SOUTH AFRICA ABROAD SLIP FROM OSTRACISM TO INDIFFERENCE, U.S. FORIEGN POLICYMAKING IS TRANSFORMED MORE AND MORE INTO A BY-PRODUCT OF DOMESTIC POLITICS.
02264 CHRISTIE, M.

THE US AND CHANGE IN SOUTH AFRICA

SOUTH AFRICA INTERNATIONAL, 23(2) (OCT 92), 91-92.

THERE IS A ROLE FOR THE INTERNATIONAL COMMUNITY TO PLAY IN SOUTH AFRICA. THE UNITED STATES COULD PLAY A CRUCIAL PART IN THIS REGARD. THERE IS A REAL DANGER THAT THE U.S. COULD ALLOW POLICY TOWARDS SOUTH AFRICA TO FALL INTO THE HANDS OF PARTISAN SPECIAL INTEREST GROUPS. IN THIS REPECT THE U.S. HAS THE CAPACITY TO PROVIDE VITAL ASSISTANCE WHERE IT IS NEEDED OR TO DO CONSIDERABLE DAMAGE.

02265 CHRISTIE, M.

US PERCEPTION

SOUTH AFRICA INTERNATIONAL, 23(1) (JUL 92), 50-52.

IN THE UNITED STATES, THERE IS GROWING CONCERN AT PRESIDENT DE KLERK'S APPARENT INABILITY TO CONTROL THE STATE APPARATUS AND THE SECURITY FORCES. ALSO, CONCERN IN THE UNITED STATES BUSINESS CIRCLES IS GROWING AT POSSIBLE ANC SUPPORT FOR CONTINUED FOREIGN MONITORING OF THEIR PRESENCE IN SOUTH AFRICA. FOR BOTH THE ANC AND THE NATIONAL PARTY THE INYOL VEMENT OF THE UNITED STATES COULD BE OF SUBSTANTIAL BENEFIT. BOTH PARTIES WILL NEED TO REDEFINE THEIR APPRDACHES AND POLICIES IF THEY ARE TO SECURE THIS INVOLVEMENT.

02266 CHRISTIE, M.

USA SANCTIONS--A THREAT TO THE NEW SOUTH AFRICA SOUTH AFRICA FOUNDATION REVIEW, 18 (3) (MAR 92), 4-5. THIS ARTICLE ARGUES THAT SOUTH AFRICANS HAVE THE OPPORTUNITY TO ACHIEVE A NON-RACIAL DEMOCRACY. BUT THIS DEMOCRACY HILL HAYE TO PROVIDE JOBS AND SOCIAL SERVICES IF IT IS TO SURVIVE. THE FIRST TASK IS TO RESTORE CONFIDENCE OF INVESTORS, BOTH LOCAL AND FOREIGN. A KEY PART OF THIS RESTORATION PROCESS IS THE LIFTING OF ECONOMIC SANCTIONS AGAINST SOUTH AFRICA BY THE UNITED STATES. IF THE PEOPLE OF THE UNITED STATES WISH TO ENCOURAGE THE EMERGENCE OF A DEMOCRACY IN SOUTH AFRICA, THEY SHOULD RECOGNIZE THAT THIS GOAL IS AT RISK IF CURRENT TRENDS IN THE SOUTH AFRICAN ECONOMY CONTINUE MUCH LONGER.

02267 CHRISTIE, M.

WHY SA CANNOT IGNORE THE USA

SOUTH AFRICA FOUNDATION REVIEW, 18(4) (APR 92), 7-8. SOUTH AFRICA FOUNDATION REVIEW, 18(4) (APR 92), 7-8.
RELATIONS BETWEEN SOUTH AFRICA AND THE UNITED STATES ARE CURRENTLY IN A MORE COOPERATIVE PHASE THAN AT ANY TIME SINCE THE XOREAN WAR. NOW THAT AN OVERWHELMING MAJORITY OF WHITE THE KOREAN WAR. NOW THAT AN OVERWHELMING MAJORITY OF CREATING A DEMOCRACY, SOUTH AFRICA CAN LOOK FORWARD TO CREATING A DEMOCRACY, SOUTH AFRICA CAN LOOK FORWARD TO
SUPPORT FROM THE WORLD'S MOST POWERFUL COUNTRY. IT IS, THEREFORE, OF PARTICULAR IMPORTANCE THAT THE U.S. HAS MADE THEREFORE, OF PARTICULAR IMPORTANCE THAT THE U.S. HAS MADE IT CLEAR THAT IT REGARDS ECONOMIC GROHTH AS AN ESSENTIAL SOUTH AFRICA. IN ADDITION. THE IMPORTANCE OF THE INFLUENCE, ADVICE, PRESSURE, AND COMMITMENT OF CDUNTRIES SUCH AS THE UNITED STATES CANNOT BE OVERSTATED: IT WILL ENSURE THAT ANY FUTURE GOVERMMENT DOES NOT REPEAT THE COSTLY MISTAKES OF THE PAST. IT IS ALSO IMPORTANT TO SEE THAT THE ISSUE OF SOUTH AFRICA IS NOT RELEGATED TO THE PERIPHERY OF U.S. CONCERNS, THUS GUARANTEEING THAT U.S. POL ICY WILL NOT BE SHAPED BY
SPECIAL INTEREST GROUPS RATHER THAN THE MODERATE CENTER.

02268 CHRISTISON, $K$.

THE "FULLER REPORT"

JOURNAL OF PALESTINE STUDIES, XIX(4) (SUM 90), 106-111. THIS ARTICLE EXAMINES THE 1989 RAND CORPORATION REPORT ENTITLED THE WEST BANK OF ISRAEL: POINT OF NO RETURN, WRITTEN BY FORMER CIA OFFICIAL GRAHAM FULLER. THE ARTICLE ASSESSES THE CONTENT OF THE REPORT AS WELL AS ITS IMPACT ON U.S. POLICY MAKERS. IT CONCLUDES THAT FULLER'S PORTRAYAL OF THE PLO LEADERSHIP AS LARGELY UNRESPONSIVE AND INDECISIVE, STILL HAMSTRUNG BY RADICAL INFLUENCES, IS MISLEADING, BUT THE BULK OF THE REPORT IS ON THE MARK IN STRONGLY EMPHASIZING THE GENERAL PALESTINIAN DESIRE FOR PEACE, AS WELL AS THE PALESTINIAN DETERMINATION TO SETTLE FOR NOTHING LESS THAN INDEPENDENCE AND TO CONTINUE THE INTIFADA UNTIL THIS IS ACHIEYED.

02269 CHRISTOFILOPOULOU, $P$

PROFESSIONALISM AND PUBLIC POLICY MAKING IN GREECE: THE INFLUENCE OF ENGIMEERS IN THE LOCAL GDVERMMENT REFORMS PUBLIC ADMINISTRATION (LONDON), 70(1) (SPR 92), 99-118. PUBLIC ADMINISTRATION (LONDON), 70 (1) (SPR 92 ), 99-118.
THE AUTHOR ASSESSES PROFESSIONAL INFLUENCE IN THE THE AUTHOR ASSESSES PROFESSIONAL INFLUENCE IN THE CENTRALIZED ADMINISTRATION IS DOMINATED BY THE DEMANDS OF CENTRALIZED ADMINISTRATION IS DOMINATED BY THE DEMANDS OF POLITICAL CLIENTELISM. FOCUSING ON THE INFLUENCE OF ENGINEERS IN LOCAL GOVERNMENT REFORM BETWEEN 1974 AND 1989, HE STUDIES THE ROLE OF PROFESSIONALISM IN THE HESITANT DECENTRALIZATION OF FUNCTIONS AND RESOURCES TO LOCAL AUTHORITIES AND THE INITIATION OF INSTITUTIONS THAT HAVE ALLOWED THE BIRTH AND DEVELOPMENT OF NEW ORGANIZATIONS AT THE CENTRAL AND THE LOCAL LEVELS. GIVEN THE SHIFT TOWARDS PARTY-DIRECTED PATRONAGE AND THE INTENSE PARTY POLITICIZATION OF PROFESSIONAL AND TRADE ORGANIZATIONS, THE CENTRAL STATE APPARATUS, AND LOCAL GOVERHMENT IN POST- 
POLICIES APPEARS TO BE CLOSELY RELATED TO THE RISE OF PROFESSIONALS IN PARTY HIERARCHIES. THE CATALYTIC ROLE OF PROFESSIONALS IN THE PROMOTION OF REFORM POLICIES PRODUCING ORGANIZATIONAL DIVERSITY AND FRAGMENTATION CAN BE UNDERSTOOD WITHIN THE CONTEXT OF THE CONTRADICTION BETWEEN THE NEED TO ADAPT STATE STRUCTURES AND PRACTICES IN A RAPIDLY-CHANGING INTERNATIONAL ENVIRONMENT AND THE PRESERVATION OF TRADITIONAL POLITICAL AND ADMINISTRATIVE FORCES IN KEY POSITIONS OF THE POWER STRUCTURE.

02270 CHRISTOFILOPOULOU, $P$.

PROGESSIONALISM AND PUBLIC POLICY MAKING IN GREECE: THE INFLUENCE OF ENGINEERS IN THE LOCAL GOVERMMENT REFORMS PUBLIC ADMINISTRATION, 70(1) (SPR 92), 99-118.

PROFESSIONAL INFLUENCE IS ANALYZED' IN THE CONTEXT OF PROFESSIONAL INFLUENCE IS ANALYZED IN THE CONTEXT OF
GREEK PUBLIC POL ICY, WHERE THE INTENSELY CENTRALIZED
ADMINISTRATION IS DOMINATED BY THE DEMANDS OF POLITICAL ADMINISTRATION IS DOMINATED BY THE DEMANDS OF POL ITICAL ENGINEERS IN LOCAL GOVERMMENT REFORM BETWEEN 1974 AND 1989 THE ARTICLE REVEALS THE ROLE OF PROFESSIONALISM IN THE HESITANT DECENTRALIZATION OF FUNCTIONS AND RESOURCES TO LOCAL AUTHORITIES AND THE INITIATION OF INSTITUIONS THAT HAVE ALLOWED THE BIRTH AND DEVELOPMENT OF NEW ORGANIZATIONS AT THE CENTRAL AND THE LOCAL LEVEL. PROFESSIONAL INFLUENCE OF PROFESSIONALS IN PARTY HIERARCHIES.

02271 CHRISTOPH, J.B.

THE REMAKING OF BRITISH ADMINISTRATIVE CULTURE: WHY WHITEHALL CAN'T GO HOME AGAIN

ADMINISTRATION AND SOCIETY, 24(2) (AUG 92), 163-181.

THE AUTHOR EVALUATES MARGARET THATCHER'S ATTEMPTS TO SHAPE THE SENIOR BRITISH CIVIL SERVICE INTO A RESPONSIVE INSTRUMENT OF POLICY IMPLEMENTATION FROM THE STANDPOINT OF HER OWH POLITICAL VALUES. HE ALSO CONSIDERS SOME KEY QUESTIONS AFFECTING THE ROLES OF CIVIL SERVANTS IN THE POSTTHATCHER PERIOD. EMPHASIS IS GIVEN TO EFFORTS TO ALTER ROLES AND ATTITUDES IN FOUR CENTRAL AREAS: DEPRIVILEGING, REORGANIZATION, MANAGERIALISM, AND POLITICIZATION. ALTHOUGH REORGANIZATION, MANAGERIALISM, AND POL ITICIZATION. ALTHOUGH
GRANTING THAT THATCHERISM HAS NOT SUCCEEDED IN TRANSFORMING GRANTING THAT THATCHERISM HAS NOT SUCCEEDED IN TRANSFORMING ALL ELEMENTS OF TRADITIONAL WHITEHALL CUL TURE, HE ARGUES THAT THATCHER'S ACTIONS HAVE ERECTED FORMIDABLE BARRIERS TO
ANY HOPED-FOR RETURN TO THE HEYDAY OF THE BRITISH MANDARIN OR TO THE ATTITUDES ASSOCIATED WITH IT.

$02272 \mathrm{CHU}, \mathrm{L}$.

NAM IS FULL OF VIGOR

BEIJING REVIEW, 35(23) (JUN 92), 16-17

THE DRAMATIC CHANGES IN THE INTERNATIONAL SITUATION HAVE AROUSED DOUBTS AMONG SOME PEOPLE AS TO WHETHER THE NONALIGNED MOVEMENT (NAM) SHOULD CONTINUE TO EXIST. BUT NAM IS STILL AN IMPORTANT INDEPENDENT POLITICAL FORCE IN THE INTERNATIONAL ARENA; ITS FUNDAMENTAL PRINCIPLES AND PURPOSES STILL HAVE POWERFUL' VITALITY.

$02273 \mathrm{CHU}, \mathrm{S}$

F-16 FIGHTERS DEAL AND THE MEETING OF FIVE

BEIJING REVIEW, 35(41) (OCT 92), 33-34

ON SEPTEMBER 2, 1992 . THE U.S. GOVERNMENT CONFIRMED THAT IT WILL SELL $150 \mathrm{~F}-16$ FIGHTER PLANES TO TAIWAN, DESPITE STRONG PROTESTS FROM CHINA. THE CHINESE GOVERNMENT HAS WARNED THAT IT WILL BE DIFFICULT FOR CHINA TO CONTINUE MEETING WITH RUSSIA, THE UNITED STATES, THE UNITED KINGDOM, AND FRANCE ON ARMS CONTROL ISSUES UNLESS THE U.S. GOVERNMENT REVERSES ITS DECISION ON THE AIRPLANE SALE.

02274 CHUAN, $X$.

GERMANY BOOTS ITS FOREIGN RELATIONS

GEIJING REVIEW

SINCE ITS UNIFICATION IN 1990, GERMANY HAS TRIED HARD TO CHANGE ITS IMAGE OF "AN ECONOMIC GIANT BUT A POL ITICAL PYGMY. IT HAS GIVEN UP ITS PAST LOW-PROFILE DIPLOMACY IN A BID TO DEME BOTH AN ECONOMIC AND POLITICAL POWER. EASTERN EUROPE IS A KEY TARGET IM GERMANY'S FOREIGN POLICY WHICH HAS ATTRACTED WORLD ATTENTION.

02275 CHUFRIN, G.

THE USSR AMD ASIA IN 1991: DOMESTIFC PRIORITIES PREVAIL ASIAN SURVEY, XXXIII(1) (JAN 92), 11-18.

THE FOREIGN POLICY BETWEEN THE USSR AND ASIA IN 1991 IS

THE SUBJECT OF THIS ARTICLE. THE INTERACTION BETWEEN THE SOVIET UNION AND THE ASIAN COUNTRIES WAS MINIMAL, WITH DOMESTIC POLICY BEING THE CHEIF CONCERN. AS SOVIET FOREIGN POLICY BECAME INFLUENCED EVER MORE HEAVILY BY DOMESTIC INTERESTS AND CONCERNS, EDUARD SHEVARDNADZE WAS SUMMONED BACK TO THE OFFICE HE LEFT IN 1990 AND WAS REINSTATE
SOVIET FOREIGN MINISTER IN THE MIDDLE OF NOVEMBER.

02276 CHUNG, J.M.; NAGLE, J.D. GENERATIONAL DYNAMICS AND THE POLITICS OF GERMAN AND XOREAN UNIFICATION

WESTERN POLITICAL QUARTERLY, 45(4) (DEC 92), 851-868.

THE AUTHORS COMPARE LONG-TERM TRENDS IN PUBLIC ATTITTUDS TOWARD UNIFICATION IN WEST GERMANY AND SOUTH KOREA, USIMG
GENERATIONAL THEORY PERSPECTIVE. THEY DEMONSTRATE THAT A LONG-TERM TREND OF ATTITUDINAL EVOLUTION COULD BE QUICKLY CHANGED OR DISRUPTED BY CIRCUMSTANTIAL FACTORS THAT HAD RATHER SIMILAR EFFECTS ON ATTITUDES IN THE THO CASES. A MORE SALIENT AND ENDURING FACTOR WAS THAT OF GENERATION, WHICH ACCOUNTED FOR SIGNIFICANT ATTITUDINAL DIFFERENCES IN BOTH COUNTRIES. A MAJOR FINDING FRDM THE THO CASES IS THE FUNDAMENTALLY DIFFERENT DYNAMIC BETWEEN POPULAR ATTITUDES AND ELITE POLICIES ON UNIFICATION. COMPARED TO THE WEST GERMAN CASE, IN SOUTH KOREA, THERE WAS MORE OFTEN CONFLICT THAN CONSENSUS BETHEEN GOVERMMENT POLICIES AND POPULAR ATTITUDES, ESPECIALLY THE ATTITUDES OF YOUNG PROGRESSIVES OF THE GENERATION BORN AFTER THE KOREAN WAR.

02277 CHUNJIAN, Z.; NYIMA, $X$.

HUMAN RIGHTS' IN TIBET: PAST AND PRESENT BEIJING REVIEW, $35(8)$ (FEB 92), 24-27.

IN RECENT YEARS, THE DALAI LAMA, THE LARGEST ESTATEHOL DER AND THE TOP RANKING PERSON IN OLD TIBET, AND ALSO CERTAIN FOREIGN FORCES, HAVE ACCUSED THE CHINESE GOVERMMENT OF VIOLATING TIBETAN HUMAN RIGHTS AND HAVE CALLED FOR THEIR RESTORATION. THIS ARTICLE EXPLORES THE PAST AND PRESENT STATE OF TIBETAN HUMAN RIGHTS. FROM THE CHANGES IN THE LEGAL RELATIONSHIP AND POSITION OF TIBETANS IN OLD AND NEH TIBET, THIS ARTICLE PROVIDES A FACTUAL EVALUATION OF HUMAN RIGHTS IN THAT COUNTRY.

02278 CIGAR, $N$. CHEMICAL WEAPONS AND THE GULF WAR: THE DOG THAT DID NOT BARK

STUDIES IN CONFLICT AND TERRORISM, 15(2) (APR 92), 145-156.

DESPITE A REALISTIC THREAT THAT IRAQ WOULD USE' CHEMICAL WEAPONS (CH) DURING THE GULF WAR, IT DID NOT DO SO. FEAR OF RETALIATION WAS PROBABLY A KEY FACTOR, BUT BATTLEFIELD CONDITIONS--INCLUOING THE RAPID TEMPO OF OPERATIONS, THE DESTRUCTION OF IRAQ'S OELIVERY SYSTEMS, AND THE WEATHER-ALSO MAY HAVE PLAYED A SIGNIFICANT PART IN BAGHDAD'S DECISIONMAKING. THERE IS GREATER IMPETUS FOR CONTROLS ON CWS NOW. HOWEVER, THIRD HORLD STATES MAY CONCLUDE THAT IT WAS ASSUMED RETALIATION THAT PREVENTED IRAQ'S CW USE, THUS VALIDATING THE NEED TO FIELD THEIR OWN CW AS A DETERRENT.

02279 CIGAR $M$

IRAQ'S STRATEGIC MINDSET AND THE GULF WAR: BLUEPRINT FOR DEFEAT

JOURNAL OF STRATEGIC STUDIES, 15(1) (MAR 92), 1-29.

THE MAGNITUDE OF IRAQ'S DEFEAT DURING THE' 1991 GULF WAR HAS SELDOM BEEN MATCHED IN THE ANNALS OF MILITARY HISTORY. ALTHOUGH AMPLE CREDIT MUST BE GIVEN TO THE PROFESSIONALISM AND COURAGE OF THE COALITION'S ARMED FORCES AND POLITICAL LEADERSHIP, IRAQ'S OHN STRATEGY MUST BEAR A GREAT DEAL OF THE BLAME FOR THE SPEED AND THOROUGHNESS OF ITS DEFEAT. IN RETROSPECT, IT IS OBVIOUS THAT IRAQ'S BASIC POLITICAL AND MILITARY MINDSET HAD A PREDICTABLE AND DECISIVE IMPACT ON THE OUTCOME OF THE CRISIS: FIRST, BY PREDISPOSING BAGHDAD RISK THE POSSIBILITY OF GOING TO HAR AND, SECONDLY, BY DETERMINING TO A LARGE EXTEND HOW IT PREPARED FOR AND FOUGHT
THE WAR. IRAQ'S KEY STRATEGIC ASSUMPTIONS UNDERESTIMATED U.S NATIONAL HILL, MISREAD THE MILITARY BALANCE AND LIKELY NATURE OF WAR IN THE GULF, UNDERESTIMATED THE COHESION OF THE UNITED NATIONS COALITION, AND MISINTERPRETED THE SOVIET UNION'S POSITION.

02280 CIMBALA, S.

BEHAVIOUR MODIFICATION AND THE CUBAN MISSILE CRISIS: FROM BRINKMANSHIP TO DISASTER AVOIDANCE

ARMS CONTROL, 13(2) (SEP 92), 252-284.

THE CUBAN' MISSILE CRISIS PROVIDED A REAL WORLD TEST OF THE LOGIC OF BEHAVIOR MODIFICACTION UNDERLYING NUCLEAR DETERRENCE THEORY AMD COERCIVE DIPLOMACY BASED ON NUCLEAR THREAT-MAKING. THIS ARTICLE EXAMINES THREE STAGES OF

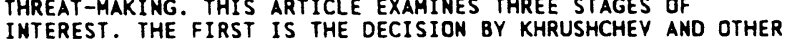
INTEREST. THE FIRST IS THE OECISISN BY KHRUSHCHEV AND OTHER SOVIET LEADERS TO DEPLOY THE MISSILES IN CUBA, THE SECOND
THE U.S. DECISION TO IMPOSE A BLOCKADE AGAINST CUBA AFTER THE U.S. DECISION TO IMPOSE A BLOCKADE AGAINST CUBA AFTER DECISION BY KHRUSHCHEV TO WITHDRAH THE MISSILES.

02281 CIMBALA, S

STRATEGY AFTER DETERRENCE

GREATTEGY AFTER DETERRENCE

THIS VOLUME CONSIDERS THE WAYS IN WHICH AMERICAN AND NATO MILITARY PRIORITIES WILL HAVE TO CHANGE NOW THAT THE TANGIBLE THREAT TO EUROPE HAS BEEN REMOVED BY THE PROFOUND POLITICAL CHANGES IN EASTERN EUROPE AND THE USSR DURING 1989. DRAHIMG UPOH A RICH UITERATURE OF SOVIET AND AMERICAN DEFEMSE STRATEGY

EFFECTIVENESS OF DETERRENCE AS A MILITARY STRATEGY, EXPLORES THE OPTIONS AVAILABLE TO AMERICA AND NATO GIVEN THE NEW POLITICAL AND ECONOMIC REALITIES IN EUROPE AND THE SOVIET UNION, ANALYZES THE RELATIONSHIP BETHEEN CONVENTIONAL AND NUCLEAR WEAPONS, AND REVIEWS BOTH THE LIKELY COURSE OF FUTURE CONFLICTS AND ALTERNATIVES TO DETERRENCE AS A MILITARY STRATEGY. 
02282 CISSE, A.

CALLS FOR REFORM

WEST AFRICA, 75(3924) (NOV 39), 2057

THE "SUMMIT LEVEL GROUP FOR SOUTH-SOUTH CONSULTATION AND COOPERATION" KNOWN AS THE GROUP OF 15 OR G-15, WOUND UP A THREE-DAY MEETING IN DAKAR, SENEGAL WITH AN 18-PAGE JOINT COMMUNIQUE REVIEWING NEARLY TO ITEMIZED PREDCCUPATIONS. THI TRI-CONTINENTAL THINK TANK, WITH MEMBERSHIP SPREAD OVER WITH FINDING THE PATH TO SUSTAINABLE DEVELPMENT. THIS ARTICLE INCLUDES SOME EXCERPTS FROM THE JOINT COMMUNIQUE. THE G-15'S COMMITMENT TO PROMOTING DEMOCRACY, TO HUMAN RIGHTS, AND TO SHAPING A NEW INTERNATIONAL DRDER, IS STRESSED IN THE COMMUNIOUE ALONG WITH THE GROUP'S COMMITMENT TO A DIALOGUE WITH THE DEVELOPED COUNTRIES.

02283 CIZRE-SAKALLIOGLU, U.

LABOUR AMD STATE IN TURKEY: 1960-80

MIDOLE EASTERN STUDIES, 28(4) (OCT 92), 712-729.

FROM 1923 UNTIL 1946 TURKEY WAS ORGANIZED ON

AUTHORITARIAN LINES. IN 1946 THE DEMOCRATIC PARTY ENTERED

INTO PARLIAMENT AS THE VOICE OF THE OPPOSITION. HOWEVER, CORPORATE PROVISIONS WERE NOT UTILIZED TO WIN AND MOBILIZE THE SUPPORT OF THE ALREADY EXISTING LABOR ORGANIZATIONS FOR STATE POLICIES BY OFFERING POPULIST INDUCEMENT. THEY WERE USED FOR APPLYING STRONG CONTROL OVER THE DEVELOPMENT POTENTIAL OF LABOR THROUGH ANTI-LABOR POLICIES. THUS, THE STRENGTH AND AUTONOMY OF THE LABOR MOVEMENT WAS NIPPED IN THE BUD TO AVOID A FUTURE LABOR QUESTION. THIS ARTICLE EXPLORES DEMOCRATIC PARTY RULE FROM 1950-60, AND CONTINUES ON TO THE 1960-1980 ERA.

02284 CLAD, J.

INDIA: CRISIS AND TRANSITION

WASHINGTON QUARTERLY, 15(1) (WIN 92), 91-104.

RAJIY GAHDHI'S MURDER IN 1991 SEEMS ONE MORE CALAMITY IN A COUNTRY WHOSE COMPOUNDING PROBLEMS WEAR MANY GUISES. CASTE CONFLICT, VIOLENT ETHNIC SEPARATISM, RELIGIOUS INTOLERANCE, AND UNPRECEDENTED CONSUMER PRICE INFLATION ALL BEAR HEAVILY ON THE WORLD'S SECOND MOST POPULOUS COUNTRY. MANY INDIANS ARE CONVINCED THAT THE QUICKENING PACE OF POLITICS IN THEIR COUNTRY AFTER 1989 POINTS TO TRANSFORMATIONAL CHANGE EVERY BIT AS SIGNIFICANT AS THE FLUX IN OTHER PARTS OF THE WORLD. THIS ARTICLE EXPLORES THE VACUUM AT THE CENTER, THE GATHERING CRISIS, AND INDIA'S INTERNATIONAL CONTEXT. IT GATHERING CRISIS, AND INDIA'S INTERNATIONAL CONTEXT.
CONCLUDES WITH A STUDY OF THE TRANSFORMATION OF THE POSTCOLONIAL ORDER AND OFFERS A CASE FOR AN ENLIGHTENED CONDITIONALITY.

02285 CLAD, J.

OLD WORLD DISORDERS

WASHINGTOM OUARTERIY 15(4) (FAL 92), 141-148.

THIS ARTICLE LOOKS BEYOND THE FADING OF GLOBAL

CONFRONTATION TO ANOTHER, AND FAR MORE COMPELLING, REASON FOR THE LENGTHENING OF THE ROLL CALL OF "NATIONAL" FAILURES. THE DISAPPEARANCE OF THE OUTSIDE BUTTRESSING OCCURS AT A MOMENT WHEN DECAY WITHIN THESE FLIMSY SOVEREIGNTIES DOOMS MANY TO DISMEMBERMENT OR CHAOS. FAILURE HAS PREDOMINATED THROUGHOUT THE THIRD WORLD DURING THE LAST 30 YEARS. THE REASON FOR THIS STATE OF AFFAIRS GOES WELL BEYOND THE PRESENCE, OR ABSENCE, OF DEMOCRACY OR EVEN GOOD GOVERNMENT, REACHING INSTEAD RIGHT DOWN TO THE CORE OF IDENTITY ITSELF. POOR GOVERNANCE, RELENTLESS DEMOGRAPHICS, AND ANTAGONISTIC ETHNICITY ARE THE MAIN CULPRITS FOR THE EMERGING WORLD DISORDER. OF THESE, ETHHICITY PRESENTS THE MOST IMMEDIATE THREAT. THE KEY QUESTION IS: WITHOUT THE FORCED DISCIPLINE OF GREAT POWER COMPETITION, WILL SCORES OF IMPROBABLE NATIONSTATES LOSE WHATEVER REMAINING COHESION THEY NOH HAVE?

02286 CLAD, J.C.

THE HALF-EMPTY BASIN

WILSON QUARTERLY, XVI (1) (WIN 92), 76-86.

THE AUTHOR LOOKS AT THE FUTURE OF THE ASIA-PACIFIC

REGION. HE CONSIDERS SUCH FACTORS AS THS REGION'S RAPID

ECONOMIC GROWTH, INTERHATIONAL TRADE, THE NEED FOR

COHESIVENESS, AND U.S. ATTITUDES TOWARD ASIA.

02287 CLAIRMONTE, F.

THE HORLD'S TOP ARMS MERCHANT

HORLO PRESS REYIEN, 39(9) (SEP 92), 13-14.

THE EXIT OF THE FORMER SOVIET UNION FROM THE GLOBAL ARMS MARKET HAS BROUGHT A TEMPORARY DECLIME IN INTERNATIOMAL WEAPONS TRADE, BUT ITS PLACE WILL BE TAKEN BY OTHERS, HITH WEAPONS TRADE, BUT ITS PLACE HILL BE TAKEN BY OTHERS, WITH SHARE OF THE SHRINKING MARKET.

02288 CLAPHAM, C

THE SOCIALIST EXPERIENCE IN ETHIOPIA AND ITS DEMISE JOURNAL OF COMMUNIST STUDIES, 8(2) (JUN 92), 105-125. MARXISM-LENINISH HAD AN INDIGENOUS APPEAL IN ETHIOPIA. FOR THE MILITARY GOVERHMENT, IT COMBINED RUTHLESS CENTRALIZATION WITH RADICAL SOCIAL CHANGE. FOR REGIONAL OPPOSITION GROUPS, IT WAS A DOCTRINE OF INSURGENT WARFARE. BOTH THE CENTRAL GOVERNMENT AND THE ERITREAN EPLF SAH IT AS
AN AID TO MULTI-ETHNIC NATION-BUILDING. AT THE CENTRE, IT FAILED BOTH ECONOMICALLY AND POLITICALLY. THE INSURGENTS, WHO SEIZED POWER IN 1991, ABANDONED IT IN THEIR SEARCH FOR WESTERN SUPPORT. NONETHELESS, SOME MARXIST ELEMENTS REMAIN, ESPECIALLY IN ERITREA.

02289 CLAPHAM, D.; SATSANGI, M. PERFORMANCE ASSESSMENT AND ACCOUNTABILITY IN BRITISH HOUSING MANAGEMENT

POLICY AND POLITICS, 20(1) (JAN 92), 63-74.

THE AUTHORS DISCUSS PERFORMANCE ASSESSMENT IN THE MANAGEMENT OF PUBLIC HOUSING IN BRITAIN WITHIN THE CONTEXT OF THE LIBERALIZATION OF HOUSING POLICY UNDERTAKEN IN THE LAST DECADE. THEY FOCUS ON THE IMPACT OF APPRAISAL SYSTEMS ON THE ACCOUNTABILITY OF HOUSING MANAGEMENT. THEY CONCLUDE THAT APPRAISAL SYSTEMS HAVE ENHANCED ACCOUNTABILITY TO GOVERNMENT BUT HAVE DONE LITTLE TO ENHANCE THE LEGITIMATE ACCOUNTABILITY OF THE MANAGEMENT SERVICE TO THE CONSUMER.

02290 CLARK, C. ; CLARK, J.

FEDERAL AID TO LOCAL GOVERNMENTS IN THE WEST: AN IRONY OF THE REAGAN REYOLUTION

POL ICY STUDIES REYIEH, 11(1) (SPR 92), 91-99.

ALTHOUGH RONALD REAGAN'S ELECTION WAS VIEWED AS A POWER SHIFT TOWARD THE WESTERN UNITED STATES, THE DECADE OF THE 1980 'S WAS A CRUEL DISAPPOINTMENT FOR THE REGION, WHICH WAS GENERALLY LEFT OUT OF THE ECONOMIC RECOVERY DUE TO THE POOR PERFORMANCE OF ITS AGRICULTURAL AND MINING INDUSTRIES. THE WESTERN STATE AND LOCAL GOVERNMENTS, WHICH SUFFER FROM HIGH COSTS AND LOW RESOURCES, WERE PARTICULARLY DEPENDENT ON THE NATIONAL GOVERNMENT AT THE VERY TIME WHEN THE REAGAN ADMINISTRATION WAS REDUCING FEDERAL AID AND TRANSFERRING POWER TO THE STATES. UNLIKE NIXON'S NEH FEDERALISM, WHICH HAD HELPED THE STATE AND LOCAL GOVERNMENTS OF THE WEST, REAGAN'S POLICIES CAUSED THEIR RELATIVE POSITION IN FEDERAL AID FLOWS TO DETERIORATE. ALTHOUGH THE REAGAN POLICY OF CUTTING DOMESTIC PROGRAMS WAS VIEHED AS THE EMBODIMENT OF WESTERN RUGGED INDIVIDUALISM. THE REGION LOST IN TERMS OF FEDERAL AID TO SMALL RURAL LOCAL GOVERMMENTS.

02291 CLARK, C.; AKAHA T.; CHAN, S.

JAPAN'S POST-COLD WAR CHALLENGES AND OPPORTUNITIES IN ASIA PACIFIC; THE EVOLVING PACIFIC BASIN IN THE GLOBAL POLITICAL ECONOMY

LYNNE RIENNER PUBLISHERS, 1992, 49-66.

THE LONG-AWAITED EFFECTS OF THE THAH IN THE EAST-WEST COLD WAR HAVE FINALLY REACHED THE SHORES OF THE ASIA PACIFIC. THIS CHAPTER EXAMINES THE KEY DIMENSIONS OF POSTHAR THIS CHAPTER EXAMINES THE KEY DIMENSIONS OF POSTHAR
JAPANESE FOREIGN POLICY AND RECENT CHANGES IN IT. THE JAPANESE FOREIGN POLICY AND RECENT CHANGES IN IT. THE RELATIONS, RELATIONS WITH NORTH AND SOUTH KOREA, CHINA, AND RELATIONS, RELATIONS WITH NORTH AND SOUTH KOREA, CHINA, AND FACES DAUNTING POST-COLD WAR CHALLENGES AS WELL AS EXPANDED FACES DAUNTING POST-COLD WAR CHALLENGES AS WELL AS EXPANDED OPPORTUNITIES
HORLD ORDER.

02292 CLARK, C.; CHAN, S

THE CHANGING PERSPECTIVES ON THE EVOLVING PACIFIC BASIN: INTERNATIONAL STRUCTURE AND DOMESTIC PROCESSES; THE EVOLVING PACIFIC BASIN IN THE GLOBAL POLITICAL ECONOMY LYNNE RIENNER PUBLISHERS, $1992,1-26$.

THIS OVERVIEH OF THE EVOLVING PACIFIC BASIN IS ORGANIZED AROUND CHALLENGES TO THEORETICAL PERSPECTIVES. THE FIRST SECTION EXAMINES THE CHANGING ROLE OF THE STATE WITHIN THE REGION TO INOICATE SOME SERIOUS SHORTCOMINGS IN THE STATIST MODEL. THE SECOND SECTION SHOWS HOW THE WORKINGS OF THE INTERNATIONAL PRODUCT CYCLE HAVE NEGATED MOST OF THE DISMAL "DEPENDENCIA" PREDICTIONS ABOUT THIRD WORLD ECONOMIES. THE THIRD SECTION PRESENTS FOUR MODELS OF THE DIFFERENT

POLITICAL ECONOMICES IN THE REGION. THE FINAL SECTION SUMMARIZES THE PRINCIPAL ARGUMENTS OF THE CHAPTER IN THE BOOK AND ASKS WHAT THEY TELL US ABOUT INTERNATIONAL STRUCTURE AND DOMESTIC PROCESSES IN THE PACIFIC BASIN.

02293 CLARK, C. ; CHAN, S.

THE EVOL VING PACIFIC BASIN IN THE GLOBAL POLITICAL ECONOMY: DOMESTIC AND INTERNATIONAL LINKAGES

LYNNE RIENNER PUBL ISHERS, $1992,225$.

THIS COLLLCTION ADORESSES THE NEW INTERNATIONAL ROLE OF THE PACIFIC BASIN NATIONS AND THE POLITICAL AND ECONOMIC FORCES THAT ARE INFLUENCING THEIR GROWTH AND STABILITY. THE FORCES THAT ARE INFLUENCING THEIR GROWTH AND STABILITY.
BOOK IS ORGANIZED AROUND TWO DOMINANT THEMES. THE FIRST BOOK IS ORGANIZED AROUND TWO DOMINANT THEMES. THE FIRST EXAMINES THE GENERAL NATURE OF THE PACIFIC BASIN'S REGIONAL
SYSTEM AND LOOKS AT HOW THE EVOLYING INTERNATIONAL CONTEXT OF INCREASING INTERDEPENDENCE IS IMPINGING ON NATIONAL OF INCREASING INTERDEPENDENCE IS IMPINGING ON NATIONAL POLICY CONDUCT. THE SECOND EVALUATES THE DOMESTIC CONTEXTS OF SELECTED COUNTRIES, COMPARING POLICY CONDUCT AND OUTCOMES EITHER ACROSS COUNTRIES OR ACROSS TIME FOR A SINGLE COUNTRY.
AMONG THE CONTRIBUTIONS OF THE BOOK IS A REEVALUATION OF THE DOMINANT IMAGE OF THE FACTORS UNDERLYING THE ECONOMIC MIRACLES IN THE EAST ASIAN NICS.

02294 CLARK, C. ; CHAN, S.

THE RISE OF THE EAST ASIAN NICS: CONFUCIAN CAPITALISM, 
STATUS MOBILITY AND DEVELOPMENTAL LEGACY; THE EVOLVING PACIFIC BASIN IN THE GLOBAL POLITICAL ECONOMY LYNME RIENMER PUBLISHERS, $1992,27-48$

THIS CHAPTER EXAMINES THE ROLE OF THE EAST ASIAN NICS IN THE GLOBAL ECONOMY. IT ASKS WHETHER THERE HAS BEEN ANY MAJOR RECENT CHANGE IN THE INTERNATIONAL DIVISION OF LABOR, WHETHER THE EXTERNAL CONSTRAINTS PINPOINTED BY DEPENDENCY THEORY MAY WORK IN WAYS THAT HAVE NOT BEEN GENERALLY RECOGNIZED, AND WHETHER THE EAST ASIAN NICS CONSTITUTE A SPECIAL CASE OF CONFUCIAN CAPITALISM. THE FIRST SECTION DISCUSSES HOW THE RISE OF THE NICS HAS AFFECTED PERSPECTIVES ON THE POLITICAL ECONOMY OF DEVELOPMENT; THE SECOND USES CLUSTER ANALYSIS TO DEPICT THE STRUCTURE OF THE WORLD ECONOYY IH SIMILARITIES AND DIFFERENCES AMONG THE PACIFIC BASIN SIMILARITIES AND DIFFER

02295 CLARK, D.

WHY SO MANY LAWYERS? ARE THEY GOOD OR BAD?

FORDHAM LAH REYIEH L XI(2) (NOY 92) 275-302.

THE POPULAR NOTION THAT THE USA HAS TOO MANY LAHYERS AND THAT THIS ABUNDANCE BURDENS THE NATION IS EXAMINED IN THIS ESSAY. THE AUTHOR ARGUES THAT BEFORE DENOUNCING THIS TREND, WE SHOULD FIRST SEEK TO DEVELOP A FULLER EXPLANATION OF ITS CAUSES ANO CONSEQUENCES. AFTER DISCUSSING JUST HHAT IT IS THAT LAWYERS DO, HE CRITIQUES THREE CURRENT CANCEROUS GROWTH THEORIES THAT ATTEMPT TO EXPLAIN WHY THERE HAS BEEN SUCH A GREAT AND UNHEALTHY INCREASE IN THE NUMBER OF LAWYERS. HE THEN OFFERS AND ANALYZES FOUR BENIGN GROHTH THEORIES. HE INDICATES AREAS HHERE ADOITIONAL RESEARCH MAY YIELD A DEEPER UNDERSTANDING OF THE FORCES THAT SHAPE THE ROLES THAT LAWYERS ASSUME IN SOCIETY AND THE DEMAND FOR LEGAL SERVICES.

02296 CLARK, G.; HARRIS, C. APPROACHING CONSTITUTIONAL REFORM: A BRITISH COLUMBIA PERSPECTIVE

CANADIAN PARLIAMENTARY REVIEW, 14(1) (SPR 91), 18-20. THIS ARTICLE ADORESSES THE ISSUE OF CONSTITUTIONAL REFORM BY EXAMINING THE FAILURE OF THE MEECH LAKE ACCORO IN BRITISH COLUMBIA. THE AUTHOR ARGUES THAT MUCH OF THE MISUNDERSTANDING WHICH ENVELOPED THE MEECH LAKE DEBATE COULD HAVE BEEN AVOIDED IF CANADA'S LEADERS HAD RECDGNIZED EARLIER HAVE BEEN AVOIDED IF CANADA'S LEADERS HAD RECDGNI ZED EARL IER
THAT THE OLD PROCESSES OF ELITE ACCOMMODATION WERE NO LONGER THAT THE OLD PROCESSES OF ELITE ACCOMMODATION WERE NO LONG INTO THE PROCESS OF CONSTITUTIONAL REFORM ARE PROPOSED.

02297 CLARK, H.C.

CONYERSATION AND MODERATE VIRTUE IN ADAM SMITH'S "THEORY OF MORAL SENTIMENTS"

REVIEW OF POLITICS, 54(2) (SPR 92), 185-210.

ADAM SMITH'S ADAPTATION OF THE CLASSICAL TRADITION OF MORAL PHILOSOPHY CONSTITUTES AN IMPORTANT ATTEMPT TO SHAPE THE LANGUAGE OF THE VIRTUES TO THE CONDITIONS OF COMMERCIAL SOCIETY. AN OVERLOOKED AVENUE TO UNDERSTANDING HIS ENTERPRISE IS HIS ANALYSIS OF THE PRACTICE OF DAILY CONVERSATION, BOTH AS A MEDIUM OF MORAL KNOWLEDGE AND AS A SOURCE OF THE SORTS OF VIRTUES POSSIBLE IN COMMERCIAL SOCIETY. IN HIS ATTEMPT TO ANSWER THE CHALLENGE OF EGOISTIC, LICENTIOUS PHILOSOPHERS SUCH AS BERNARD MANDEVILLE--WHOSE NOTION OF PRIVATE VICES, PUBLIC BENEFITS TYPIFIED THE THENFASHIONABLE ARGUMENT THAT MODERN SOCIETY IS HELD TOGETHER NOT BY VIRTUES BUT BY THE MUTUAL SATISFACTION OF INTERESTS-SMITH DREW ON A COMBINATION OF NATURAL LAW THEORY AND SCOTTISH SOCIOLOGY TO FASHION A CONCEPTION OF MODERATE VIRTUE THAT COULD HARMONIZE PRUDENCE AND BENEVOLENCE, AS HELL AS THE "MASCULINE" VIRTUES OF SELF-COMMAND AND THE "FEMININE" VIRTUES OF HUMANITY, IN WAYS CONSONANT WITH THE CHARACTER OF DAILY INTERACTIONS IN A MODERN SOCIETY.

02298 CLARK, J.

GETIING THERE: WOMEN IN POLITICAL OFFICE

ANNALS OF THE AMERICAN ACADEMY OF POLITICAL AND SOCIAL SCIENCE, (514) (MAR 91), 63-76.

IN THE UNITED STATES, HOMEN ARE STILL GREATLY UNDERREPRESENTED IN MOST STATES AND IN THE NATIONAL UNDERREPRESENTED IN MOST STATES AND IN THE NATIONAL
GOVERNMENT. THE PROPORTION OF WOMEN IN THE U.S. CONGRESS IS GOVERNMENT. THE PROPORTION OF WOMEN IN THE U.S. CONGRESS
ABOUT HALF THE AVERAGE FOR NATIONAL LEGISLATIVE BODIES ABOUT HALF THE AVERAGE FOR NATIONAL LEGISLATIVE BODIES
THROUGHOUT THE WORLD. MANY THEORIES HAVE BEEN DEVELOPED TO THROUGHOUT THE WORLD. MANY THEORIES HAVE BEEN DEVELOPED
EXPLAIN THIS UWDERREPRESENTATION OF WOMEN IN AMERICAN EXPLAIN THIS UNDERREPRESENTATION OF WOMEN IN AMERICAN
POLITICS. POLITICAL CULTURE, SOCIALIZATION, AND ROLE POL ITICS. POLITICAL CULTURE, SOCIALIZATION, AND ROLE
CONFLICT HAVE ALL HAD AN IMPACT ON WOMEN'S REPRESENTATION, CONFLICT HAVE ALL HAD AN IMPACT ON WOMEN'S REPRESENTATION,
AS HAS DISCRIMINATION AGAINST WOMEN BY POLITICAL ELITES AND AS HAS OISCRIMINATION AGAINST WOMEN BY POLITICAL ELITES BARRIERS TO THE ELECTION OF HOMEN. HOWEVER, CURRENT TRENDS ARE FAVORABLE TO THE CONTINUED GRADUAL INCREASE IN THE ARE FAVORABLE TO THE CONTINUED GR
NUMBER OF WOMEN IN PUBLIC OFFICE.

02299 CLARK, J.; BRUCE, J.; JACOBY, W.; KESSEL, J. I'D RÁTHER SWITCH THÁN FIGHT: LIFELONG DEMOCRATS AND CONVERTS TO REPUBLICANS AMONG CAMPAIGN ACTIVISTS AMERICAN JOURNAL OF POLITICAL SCIENCE, 35(3) (AUG 91), 577-597.

ANALYSIS OF A SURVEY OF 1988 PRESIDENTIAL CAMPAIGN ACTIVISTS REVEALED THAT ONE-THIRD OF THE REPUBLICAN
ACTIVISTS AT ONE TIME THOUGHT OF THEMSELVES AS DEMOCRATS. DRAWING ON THE MASS REALIGNMENT LITERATURE, THE DURATION, MOVEMENT, AND MOTIVATIONS OF THIS ELITE REALIGNMENT WERE EXAMINED'. A MULTIVARIATE PROBIT MODEL WAS DEVELOPED TO ANALYZE PARTY SHITCHING THAT COMBINES DEMOGRAPHICS, POLITICAL AND ATTITUDINAL MOTIVATIONS. IDEOLOGY, PARENTS' POLITICAL ACTIVITY, AND AGE WERE FOUND TO BE STATISTICALLY SIGNIFICANT INFLUENCES ON THE DECISION TO SWITCH PARTIES. WE THAN EXPLORED PATTERNS OF REPUBLICAN-TO-DEMOCRAT SHITCHING USING BIVARIATE ANALYSIS. THE ARTICLE CONCLUDES BY DISCUSSING SOME IMPLICATIONS OF PARTY SWITCHING FOR THE AMERICAN PARTY SYSTEM.

02300 CLARK, J.A.; SANCTUARY, C.J. ANTI-DRUG SMUGGLING OPERATIONAL RESEARCH IN H.M. CUSTOMS AND EXCISE

PUBLIC ADMINISTRATION (LONDON), 70(4) (WIN 92), 577-589.

IN THE LAST DECADE, THE BRITISH GOVERNMENT HAS

ENDEAVORED TO DEVELOP' AND APPLY METHODS TO MEASURE AND

IMPROVE THE LEVEL OF EFFECTIVENESS AND FINANCIAL

ACCOUNTABILITY. THIS PAPER DISCUSSES SUCH DEVELOPMENTS IN THE OPERATIONAL RESEARCH GROUP OF H.M. CUSTOMS AND EXCISE IN THE AREA OF DRUGS ENFORCEMENT, WHICH IS ONE OF THE TOP OPERATIONAL PRIORITIES OF THE DEPARTMENT. IT INCLUDES BRIEF DESCRIPTION OF THE DEPARTMENT'S ANTI-SMUGGLING RESOURCES AND OPERATIONS, OUTLINES THE KEY CONCEPTS IN PERFDRMANCE MEASUREMENT, AND ARGUES THAT THE INTERCEPTION RATE IS NOT FEASIBLE AS AN ACCOUNTABLE MEASURE OF PERFORMANCE.

02301 CLARK, M.A.

COSTA RICA'S EXPORT STRATEGY

HEMISPHERE, 4(3) (SUM 92), 10-13.

COSTA RICA IS WIDELY REGARDED AS THE SUCCESS STORY OF THE CARIBBEAN BASIN BECAUSE IT HAS REBOUNDED FROM ECONOMIC CRISIS IN THE EARLY 1980'S TO BECOME A REGIONAL LEADER IN EXPORT-LED GROWTH STRATEGIES. DESPITE ITS CURRENT SUCCESS, COSTA RICA'S NONTRADITIONAL EXPORT STRATEGY.

02302 CLARK, $P$

THE SOVIET MANNED LUNAR PROGRAM AND ITS LEGACY

SPACE POLICY, 73 (AUG 91), 221-232.

SINCE 1989 THE USSR HAS NOT ONLY ACKNOWLEDGED PUBLICLY FOR THE FIRST TIME THAT IT WAS TRYING TO "RACE" THE USA TO PUT THE FIRST MAN ON THE MOON, BUT THEY HAVE FINALLY GIVEN SOME DETAILS OF THE PROGRAM, THE EQUIPMENT AND THE POLITICAL IN-FIGHTING WHICH ENSURED THAT THE PROGRAM WAS A FAILURE. THIS ARTICLE TRACES THE HISTORY OF THE SOVIET MANNED LUNAR PROGRAM AND ALSO DISCUSSES THE IMPLICATIONS FOR THE FUTURE DEVELOPMENT OF THE SOVIET MANNE

02303 CLARK, R.

NEGOTIATING WITH INSURGENTS: OBSTACLES TO PEACE IN THE BASQUE COUNTRY

TERRORISM AND POLITICAL VIOLENCE, 2(4) (WIN 90), 489-507.

BETHEEN 1975 AND 1988, THERE WERE AT LEAST 20 IDENTIFIABLE ATTEMPTS TO NEGOTIATE AN END TO THE VIOLENCE OF THE BASOUE INSURGENT GROUP EUZKADI TA ASKATASUNA (ETA), AN ORGANIZATION THAT HAS BEEN WAGING ARMED STRUGGLE AGAINST THE SPANISH STATE SINCE THE 1960S. DESPITE CLEAR EVIDENCE THAT BOTH ETA AND THE SPANISH GOVERNMENT HANT THE VIOLENCE TO END, THESE ATTEMPTED NEGOTIATIONS HAVE ALL ENDED IN FAILURE. THIS STUDY ANALYSES THREE GENERAL SET OF REASONS FOR THESE FAILURES. ONE SET OF REASONS IS CONTAINED IN THE POLITICAL AND SOCIAL SETTING WITHIN WHICH NEGOTIATIONS TAKE PLACE, AND IN THE WAYS IN WHICH THAT SETTING INTRUDES INTO AND SHAPES THE NEGOTIATIONS. A SECOND SET HAS TO DO WITH THE LINKAGES BETWEEN THE CESSATION OF VIOLENCE AND THE CONDUCT OF NEGOTIATIONS. A THIRD CLUSTER OF OBSTACLES INVOLVES THE NATURE OF THE NEGOTIATION ITSELF, PART ICULARLY THE TOPICS THAT ARE ALLOWED ON THE AGENDA. THIS STUDY IS FOUNDED ON ARMED INSURGENCY TO A CLOSE; BUT UNLESS FUNDAMENTAL CHANGES ARMED INSURGENCY TO A CLOSE; BUT UNLESS FUNDAMENTAL CHANGES
ARE MADE IN THE APPROACH TO NEGOTIATIONS, THEY ARE LIKELY TO ALWAYS END IN FAILURE.

02304 CLARK, H.A.

CRIME AND PUNISHMENT IN SOVIET OFFICIALDOM--COMBATING CORRUPTION IN THE SOVIET ELITE, $1965-1990$

M. E. SHARPE, 1993, 288

THIS STUDY OF OFFICIAL CORRUPTION AND THE POLITICS OF ANTI-CORRUPTION CAMPAIGNS OFFERS AN EMPIRICAL, COMPARATIVE AHD THEORETICAL ANALYSIS OF THIS PHENOMENON AS BOTH SYSTEM AND SYMPTOM. IT COVERS THE 25-YEAR PERIOD BEGINHING WITH THE OUSTER OF NIKITA KHRUSHCHEV AND ENDING WITH THE FINAL YEARS OF THE GORBACHEV PERIOD. IT HIGHLIGHTS THE STRUCTURE, IMPACT AND FUNCTION OF POLITICAL ELITE CORRUPTION DURING THIS PERIOD AS REFLECTIVE OF AN OVERALL SOCIETAL MALAISE EXACERBATED BY THE BREZHNEV LEADERSHIP'S UNIQUE APPROACH TO PROBLEM SOLVING AND REFORM. ASSESSING BOTH THE POSITIVE AND NEGATIVE CONSEOUENCES OF SOCIETAL AND OFFICIAL CORRUPTION 
AUTHOR PROVIDES EVIDENCE OF THE POLITICAL LEADERSHIP'S AMBIGUOUS POSITION ON CERTAIN TYPES OF ILLEGAL BEHAVIOR, ITS ARBITRARINESS IN COMBATING CORRUPTION, AND ITS PROPENSITY AT TIMES TO SEE CORRUPTION AS AN ALTERNATIVE TO REAL FORMAL INSTITUTIONAL REFORM. THE AUTHOR EXAMINES THE SOVIET CASE IN COMPARATIVE PERSPECTIVE, LINKING THE CORRUPTION OF THE SOCALLED PERIOD OF STAGNATION WITH NOT ONLY THE RUSSIAN AND SOVIET HISTORICAL RECORD BUT ALSO THE GENERAL THEORETICAL LITERATURE ON CORRUPTION IN OTHER POLITICAL SETTINGS.

02305 CLARKE, D.L.

ARMS CONTROL AND SECURITY: AFTER THE WARSAH PACT

RFE/RL RESEARCH REPORT, 1 (1) (JAN 92), 105-108.

THE YEAR 1991 SAH THE FORMAL DISSOLUTION OF THE WARSAH

PACT, THE COMPLETION OF SOVIET TROOP WITHDRAWALS FROM

CZECHOSLOVAKIA AND HUNGARY, AND HISTORIC ARMS CONTROL

AGREEMENTS AFFECTING EUROPE, THE UNITED STATES, AND THE

SOVIET UNION. THIS PRODUCED A GENERALLY POSITIVE PICTURE FOR

EAST EUROPEAN SECURITY, WITH THE EXCEPTION OF YUGOSLAVIA,

WHERE THE CIVIL WAR IS PERSISTING DESPITE EFFORTS TO

NEGOTIATE A LASTING CEASEFIRE.

02306 CLARKE, D.L.

CENTRAL EUROPE: MILITARY COOPERATION IN THE TRIANGL RFE/RL RESEARCH REPORT, 1 (2) (JAN 92), 42-45.

CZECHOSLOVAKIA, HUMGARY, AND POLAND ARE DEVELOPING STRONG TIES IN POST-WARSAW PACT CENTRAL EUROPE. EACH COUNTRY HAS SIGNED BILATERAL MILITARY COOPERATION AGREEMENTS WITH THE OTHER THO. THEY STRESS THAT THESE AGREEMENTS ARE NOT THE BEGINNING OF A NEW MILITARY ALLIANCE BUT ARE DESIGNED TO HELP THEM DEAL WITH THEIR COMMON MILITARY PROBLEMS, SUCH AS THE DEPOLITICIZATION OF THEIR ARMED FORCES AMD THE RATIONALIZATION OF THEIR ARMS PRODUCTION AND PROCUREMENT IN THE FACE OF LIMITED FUNOS. DESPITE THE PUBLIC DISCLAIMERS, THERE ARE SOME INDICATIONS THAT THERE IS A GROHING MUTUAL SECURITY DIMENSION TO THIS TRILATERAL COOPERATION.

02307 CLARKE, D.L.; FLOHR, E.

CHRISTIAN CHURCHES AMD THE PALESTINE OUESTIOH JOURNAL OF PALESTINE STUDIES, XXI(4) (SUM 92), 67-79.

THE NATIONAL ASSEMBLIES OF MOST MAINLINE CHRISTIAN CHURCHES IN THE UNITED STATES HAVE TAKEN VIGOROUS, WELLPUBLICIZED POLICY STANCES REGARDING U.S. POLICY IN THE MIDOLE EAST. IN THIS ARTICLE, THE AUTHORS FOCUS ON LESS MIDOLE EAST. IN THIS ARTICLE, THE AUTHORS FOCUS ON LESS VISIBLE ASPECTS OF THE CHURCHES' ROLE: THE MAINLINE
CHURCHES' ADVOCACY ACTIVITIES IN WASHINGTON AND THEIR CHURCHES ADVOCACY ACTIVITIES IN WASHINGTON AND THEIR EDCA EXAMINE THE ACTIVITIES OF TRADITIONAL PEACE CHURCHES, THEY EXAMINE THE ACTIVITIES OF TRADITIONAL PEACE CHURCHES,
DENOMINATIONS OF LIMITED ADVOCACY, ACTIVIST CHURCHES, AND VARIOUS ECUMENICAL AND INTERRELIGIOUS UNDERTAKINGS.

02308 CLARKE, D.L.

EUROPEAN MUL TILATERAL ORGANIZATIONS: AM UPDATE RE

THE END OF THE COLD WAR AND THE DISINTEGRATION OF THE SOVIET UNION HAVE SPURRED THE SEARCH FOR NEH SECURITY STRUCTURES AND ORGANIZATIONS TO REPLACE THE OLD ONES IN EUROPE. BOTH PAN-EUROPEAN AND REGIONAL AFFILIATIONS ARE BEING EXPLORED. THIS ARTICLE LOOKS AT SOME OF THE RECENT DEVELOPMENTS IN EUROPEAN INTERNATIDNAL ORGANIZATIONS, INCLUDING THE CSCE, NATO, THE EUROPEAN COMMUNITY, AND THE WESTERN EUROPEAN UNION.

02309 CLARKE, D.L

FORMER SOVIET ARMED FORCES IN THE BALTIC STATES

RFE/RL RESEARCH REPORT, 1(16) (APR 92), 43-49.

THE LEADERS OF THE THREE BALTIC COUNTRIES VIEW THE

SIZABLE NUMBER OF FORMER SOVIET SOLDIERS, SAILORS, AND AIRMEN ON THEIR TERRITORIES AS A THREAT TO THEIR INDEPENDENCE. LITTLE PROGRESS HAS BEEN MADE TOWARD NEGOTIATING THEIR REMOVAL, AND ONLY TOKEN WITHDRAWALS HAVE TAKEN PLACE. IN VIEH OF THE DRASTIC POLITICAL CHANGES SINCE 1989, THESE FORCES HAVE LOST MUCH OF THEIR STRATEGIC SIGNIFICANCE, BUT THEIR WITHORAWAL IS LOW ON THE RUSSIAN PRIORITY LIST AND THEY ARE LIKELY TO REMAIN A SOURCE OF IRRITATION, TENSION, AND INSTABILITY FOR YEARS TO COME.

02310 CLARKE, D.L.; VINTON, L.

MILITARY AND SECURITY NOTES: CIS, LITTLE PROGRESS AT MINSK SUMMIT

RFE/RL RESEARCH REPORT, 1(9) (FEB 92), 48-53.

THIS SUMMARY OF EVENTS RELATED TO MILITARY MATTERS IN EASTERN EUROPE AND THE COMMONHEALTH OF INDEPENDENT STATES INCLUDES REPORTS ON THE COMPLEXITY OF ESTABI ISHING A COMMON MILITARY FOR THE CIS, THE CONTINUING DISPUTE BETHEEN RUSSIA MIL UARY FOR THE CIS, THE CONTINUING DISPUTE BETWEEN RUSSIA AMD UKRAINE OVER THE BLACK

02311 CLARKE, D.L.

THE BATTLE FOR THE BLACK SEA FLEE RFE/RL RESEARCH REPORT, 1(5) (JAN 92), 53-57.

UKRAINE'S DEMAND THAT IT BE ALLONED TO CONTROL SOME, IF NOT ALL, OF THE FORMER SOVIET BLACK SEA FLEET HAS THREATENED
IT HAS haD a CHANCE TO GATHER MUCH STEAM. ALTHOUGH THE CONTROVERSY OVER THE FLEET IS BECOMING LESS HEATED, IT IS STILL FAR FROM RESOLVED. IN THE ABSENCE OF AN AMICAB
SOLUTION, THE FUTURE OF THE COMMONWEALTH LOOKS DIM.

02312 CLARKE, D.L

THE SAGA OF THE BLACK SEA FLEET

RFE/RL RESEARCH REPORT, 1(4) (JAN 92), 45-49.

UKRAINE'S DEMAND THAT IT BE GIVEN CONTROL OF SOME, IF

NOT ALL, OF THE FORMER SOVIET BLACK SEA FLEET IS THREATENING TO DERAIL THE NEW COMMONWEALTH OF INDEPENDENT STATES. THIS ARTICLE DESCRIBES THE BLACK SEA FLEET AND BRIEFLY TRACES ITS HISTORY.

02313 CLARKE, D.L. (ED.); REISCH, A.A. (ED.)

MILITARY AND SECURITY NOTES

RFE/RL RESEARCH REPORT, 1(36) (SEP 92), 70-73.

THE EDITORS REPORT ON MAJOR DEVELOPMENTS INVOLVING

SECURITY AND DEFENSE IN THE COMMONWEALTH OF INDEPENDENT

STATES, THE BALTIC STATES, HUNGARY, AND POLAND DURING LATE AUGUST' 1992.

02314 CLARKE, D.L. (ED.)

MILITARY AND SECURITY NOTES, CIS: THE KIEV SUMMIT

RFE/RL RESEARCH REPORT, 1(14) (APR 92), 48-54.

THE EDITOR SUMMARIZES MAJOR DEVELOPMENTS INVOLVING SECURITY AND THE ARMED FORCES IN THE COMMONWEALTH OF INDEPENDENT STATES, BULGARIA, THE BALTICS, CZECHOSLOVAKIA, HUNGARY, POLAND, AND ROMANIA DURING MARCH 1992. HE REPORTS ON THE SIGNING OF AN AGREEMENT DEFINING THE POWER OF THE VARIOUS CIS BODIES IN DEFENSE MATTERS, THE CONTINUED WRANGL ING AND SOME CONCESSIONS ON THE DISPUTED BLACK SEA FLEET, QUESTIONS OVER HOW TO DIVIDE CFE QUOTAS BETHEEN THE FORMER SOVIET REPUBLICS, AND THE SALE DF CZECHOSLOVAK JETS TO THAILAND.

02315 CLARKE, D.L. (ED.)

MILITARY AND SECURITY NOTES: CIS, EAST-HEST SECURITY

RFE/RL RESEARCH REPORT, 1(13) (MAR 92), 50-54.

THE EDITOR REPORTS ON IMPORTANT MILITARY AND SECURITY DEVELOPMENTS IN THE COMMONWEALTH OF INDEPENDENT STATES, THE BALTIC STATES, BULGARIA, POLAND, AND CZECHOSLOVAKIA DURING MARCH 1992. SUBJECTS INCLUDE A RUSSIAN PROPOSAL FOR A GLOBAL BAN ON TACTICAL NUCLEAR WEAPONS, UKRAINE'S HALTING ITS BRANSFER OF TACTICAL NUCLEAR HEAPONS TO RUSSIA, AND THE TRANSFER OF TACTICAL NUCLEAR WEAPONS TO RUSSIA,
ESTABLISHMENT OF THE RUSSIAN DEFENSE MINISTRY.

02316 CLARKE, D.L. (ED.)

MILITARY AND SECURITY NOTES: CIS, PREPARING FOR THE NEXT SUMMIT

RFE/RL RESEARCH REPORT, 1(12) (MAR 92), 46-50

THE EDITOR SUMMARIZES IMPORTANT DEVELOPMENTS REGARDING MILITARY AND SECURITY ISSUES IN THE BALTIC STATES, BULGARIA, CZECHOSLOVAKIA, HUNGARY, POLAND, YUGOSLAVIA, AND THE

COMMONHEALTH OF INDEPENDENT STATES IN EARLY MARCH 1992.

02317 CLARKE, H.; KORMBERG, A.

DO NATIONAL ELECTIONS AFFECT PERCEPTIONS OF MP RESPONSIVENESS? A NOTE ON THE CANADIAN CASE

LEGISLATIVE STUDIES QUARTERLY, 27(2) (MAY 92), 183-204. 1979-90 NATIONAL CROSS-SECTIONAL AND PANEL DATA IS USED TO INVESTIGATE HOW THE PUBLIC PERCEIVES CANADIAN MP'S REPRESENTATIONAL ACTIVITIES AND HOW THESE PERCEPTIONS ARE INFLUENCED BY THE OCCURRENCE AND OUTCOMES OF NATIONAL ELECTIONS. ALTHOUGH THE OCCURRENCE OF ELECTIONS AND IDENTIFICATION HITH THE WINNING NATIONAL PARTY POSITIVELY INFLUENCE THESE PERCEPTIONS, THE EFFECTS ARE MODEST AND, IN THE AGGREGATE, LARGE MAJORITIES OF CANADIANS EXPRESS RESERVATIONS ABOUT THE RESPONSIVENESS OF MPS. THAT STRUCTURAL FEATURES OF THE CANADIAN POLITICAL SYSTEM AND THE BREVITY OF PARLIMENTARY CAREERS MAKE IT DIFFICULT FOR MPS TO DEVELOP IMAGES AS RESPONSIVE PUBLIC SERVANTS WHILE LEAVING THEM EXPOSED TO THE FREE-FLOATING DISCONTENT THAT CHARACTERIZES CANADIANS' FEELINGS ABOUT POLITICS AND POLITICIANS IS ARGUED.

02318 CLARKE, H.; KORNBERG, A. RISKY BUSIMESS: PARTISAM VOLATILITY AND ELECTORAL CHOICE IN CANADA, 1988

ELECTORAL STUDIES, 11(2) (JUN 92) 138-156. THIS PAPER INVESTIGATES THE EFFECTS OF PARTISANSHIP ISSUE CONCERNS AND PARTY LEADER IMAGES ON VOTING BEHAVIOR IH THE NOVEMBER 1988 CANADIAN FEDERAL ELECTION. ANALYSIS OF THE NOVEMBER 1988 CANADIAN FEDERAL ELECTION. ANALYSIS OF NATIONAL CROSS-SECTIONAL AND PANEL SURVEY DATA GATHERED THROUGHOUT THE 1980S DEMONSTARTE CONCLUSI VELY THAT THERE HAS BEEN NO REALIGNMENT AND THAT, SIMILAR TO EARLIER ELECTIONS, VOTING IN 1988 WAS STRONGLY AFFECTED BY HIGHLY VOLATILE SHORT-TERM FORCES. POST-1988 SURVEYS SHOW THAT PARTISANSHIP REMAINS WEAK AND UNSTABLE, AND IT IS VERY LIKELY THAT SUCH
FORCES WILL REMAIN ASCENDANT IN THE FORESEEABLE FUTURE.

02319 CLARKE, H.; KORNBERG, A.

SUPPORT FOR THE CANADIAN FEDERAL PROGRESSIVE CONSERVATIVE PARTY SINCE 1988: THE IMPACT OF ECONOMIC EVALUATIONS AND 
ECONOMIC ISSUES CANADIAN JOURNAL OF POLITICAL SCIENCE, 35(1) (MAR 92),
29-54.

SINCE THEIR VICTORY IN THE 1988 CANADIAN ELECTION, THE GOVERNING PROGRESSIVE CONSERVATIVES HAVE SUFFERED A DECLINE IN PUBLIC SUPPORT. THIS ARTICLE CONTENDS THAT MANY CANADIANS BLAME THE FEDERAL GOVERNMENT FOR THE POOR STATE OF THE NATIONAL ECONOMY AND ADVERSE PERSONAL ECONOMIC CIRCUMSTANCES. NEGATIVE REACTIONS TO FREE TRADE AND THE GOODS AND SERVICES TAX ARE PRODUCTS OF PUBLIC DISAPPROVAL OF THE GOVERMMENT'S ECONOHIC PERFORMANCE. THE ANALYSES ARE BASED ON DATA GATHERED IN NATIONAL CROSS-SECTIONAL AND PANEL SURVEYS CONDUCTED OVER THE 1983-1990 PERIOD.

02320 CLARKE, $S$.

FEAR OF A BLACK PLANET

SOCIALIST REVIEW, 3(4) (1991), 37-60.

IT IS IMPORTANT TO DEVELOP A POLITICALLY EFFECTIVE, CRITICAL PERSPECTIVE ON IDENTITY POLITICS. COMMON SENSE
SUGGESTS THAT IDENTITY POLITICS, MOST CLEARLY EVIDENCED IN SUGGESTS THAT IDENTITY POLITICS, MOST CLEARLY EVIDENC POLITICAL MOBILIZATIONS AROUND RACE, ARE PART OF A FUNDAMENTAL ATTACK ON THE CORE VALUES OF OUR POLITICAL
CUTURE. THIS ARTICLE SUGGESTS THAT OUR SOCIAL APPETITE FOR CUTURE. THIS ARTICLE SUGGESTS THAT OUR SOCIAL APPETITE FOR
IMAGES OF BLACK MEN MISBEHAVING SKEHS OUR PERCEPTIONS OF ALL IMAGES OF BLACK MEN MISBEHAVING SKEHS OUR PERCEPTIONS OF ALL
INOENTITY POLITICS--AND PLAYS INTO THE HANDS OF THE RIGHT.

02321 CLARKE, S

PRIVATIZATION AND THE DEVELOPMENT OF CAPITALISM IN RUSSIA NEW LEFT REVIEH, (196) (NOV 92), 3-28

THE RUSSIAN GOVERNMENT HAS NOT ABANDONED THE GOAL OF PRIVATIZATION, BUT ITS SOCIAL MEANING COULD CHANGE GREATLY AS IT BECOMES A CENTRAL STAKE IN A NEH FORM OF CLASS STRUGGLE. THE INTRODUCTION OF VARIOUS FORMS OF PRIVATIZATION SHOULD NOT, UNDER RUSSIAN CONDITIONS, BE EQUATED HITH CAPITALISM, SINCE IT HAS OFTEN TENDED TO REPRODUCE A VARIANT OF THE SOCIAL RELATIONS OF PRODUCTION OF THE OLD SOVIET UNION MUTUAL Y-SUPPORT ING CARTELS ANO MONOPOL SOVIE PREVENTED ANY ENCROACHMENT BY CAPITALIST-STYLE COMPETITION AS DIFFERENT ENTERPRISES EXTEND CREDIT TO ONE ANOTHER. BUT, IN CONJUNCTION WITH WIDER POLITICAL AND TRADE-UNION IN CONJUNCTION WITH WIDER POLITICAL AND TRADE-UNION
STRUGGLES, PRIVATIZATION IS ALREADY OBLIGING RUSSIAN WORKERS TO DEFINE THEIR ROLE IN THE MAKING OF THE NEN ORDER. THE
COLLAPSE OF THE SOYIET SYSTEM HAS INAUGURATED A TRANSITION COLLAPSE OF THE SOVIET SYSTEM HAS INAUGURATED A TRAM
THAT IS HIGHLY PROBLEMATICAL AND KEENLY CONTESTED.

02322 CLARKSON, F.

INSIDE THE COVERT COALITION

CHURCH AND STATE, 45(10) (NOV 92), 4(220)-7(223). PRESIDENT GEORGE BUSH ADORESSED THE CHRISTIAN COALITION'S 1992 "ROAD TO VICTORY II" CONFERENCE. BUT THE COALITION LEADERS, WHO HAD EXPECTED THE PRESIDENT TO MAKE A MAJOR ADORESS ON SOCIAL ISSUES, WERE DISAPPOINTED WHEN BUSH DELIVERED HIS STANDARD CAMPAIGN SPEECH. HE FAILED TO MENTION EITHER SCHOOL PRAYER OR GAY RIGHTS AND GAVE ONLY ONE SENTENCE TO ABORTION RESTRICTIONS.

02323 CLARKSON, F

THE CHRISTIIAN COALITION: ON THE ROAD TO VICTORY? CHURCH AND STATE, 45(1) (JAN 92), 4-7.

THE CHRISTIAN COALITION IS A RAPIDLY-GROWING,

TECHNOLOGICALLY SOPHISTICATED RELIGIO-POLITICAL ORGANIZATION 8UILT LARGELY UPON THE APPARATUS OF PAT ROBERTSON'S 1988 PRESIDENTIAL CAMPAIGN. CHRISTIAN COALITION ACTIVISTS ARE WORKING TO TAKE OVER THE REPUBLICAN PARTY FROM THE GRASSROOTS UP, WHILE ELECTING RIGHT-TO-LIFE CONSERVATIVE CHRISTIAN REPUBLICANS TO PUBLIC OFFICE AT ALL LEVELS. THEY VIEW GEORGE BUSH AND "ESTABLISHMENT" REPUBLICANS AS THEIR PRINCIPAL OPPONENTS AND BELIEVE THEMSELVES DIVINELY

APPOINTED TO TAKE POWER AND RULE THE UNITED STATES.

02324 CLARY, B.B.

THE ENACTMENT OF THE NUCLEAR WASTE POLICY ACT OF 1982: A MULTIPLE PERSPECTIVES EXPLANATION

POLICY STUDIES REVIEH, 10(4) (WIN 92), 90-102. THE NUCLEAR WASTE POLICY ACT (NHPA) IS GENERALLY ANALYZED FROM THE DISTINCT PERSPECTIVE OF A GIVEN ACTOR ANALYZED FROM THE DISTINCT PERSPECTIVE OF A GIVEN ACTOR
INYOLVED IN THE NUCLEAR WASTE POLICY-MAKING PROCESS. INVOLVED IN THE NUCLEAR WASTE POLICY-MAKING PROCESS.
COMPETING PERSPECTIVES OFTEN RELY ON TOTALLY DIFFERENT COMPETING PERSPECTIVES OFTEN RELY ON TOTALLY DIFFERENT
MODELS OF POLICY MAKING. THIS ESSAY APPLIES A MULTIPLE MODELS OF POLICY MAKING. THIS ESSAY APPLIES A MULTIPLE
PERSPECTIVE EXPLANATION TO THE NHPA AND EXPLAINS POLICY PERSPECTIVE EXPLANATION TO THE NHPA AND EXPLAINS POLICY RESULTS BY REFERENCE TO THREE MODELS OF DECISION-MAKING: RATIONAL ACTOR, ORGANIZATIONAL PROCESSES, AND GOVERNMENTAL THREE MODELS ARE HIGHLIGHTED AND PROSPECTS FOR FUTURE NUCLEAR WASTE DISPOSAL POLICY DEVELOPMENT ARE ASSESSED, NUCLEAR WASTE DISPOSAL POLICY DEVELOPMENT ARE
USING AN INTEGRATED DECISION-MAKING FRAMEWORK.

02325 CLAUSEN, C.

A CAVEAT FOR THE DEMOCRATS

NEW LEADER, LXXY(14) (NOV 92), 5-6

EVEN THOUGH FEWER PEOPLE VOTED FOR CLINTON THAN HAD VOTED FOR DUKAKIS IN HIS DISASTROUS DEFEAT FOUR YEARS EARLIER, CLINTON'S POPULAR YOTE WAS REMARKABLY CONSISTENT WITH THAT OF OTHER RECENT DEMOCRATIC STANDARD BEARERS. THIS
ARTICLE SUGGESTS THAT THE POPULAR VOTE THAT A DEMOCRAT CAN EXPECT SEEEMS TO BE LARGELY UNAFFECTED BY THE IDENTITY OF THE NOMINEE, THE QUALITY OF THE CAMPAIGN, THE STATE OF THE ECONOMY, OR THE NUMBER OF SIGNIFICANT ALTERNATIVES APPEARING ON THE BALLOT. WHETHER OR NOT CLINTON WILL BE RETURNED TO OFFICE DEPENDS ON WHETHER HIS GOVERNS LIKE FDR OR LIKE JIMMY CARTER. CLINTON MUST SHIFTLY CREATE CONFIDENCE IN THE FEDERAL GOVERMMENT'S ABILITY TO HAVE A POSITIVE INFLUENCE ON THE ECONOMY AND THE BIGGEST OUESTION IN HIS POLITICAL FUTURE MAY BE HOW FAR HE CAN GO IN KEEPING HIS PROMISES WITHOUT ALIENATING THE WHITE SUBURBAN VOTERS WHO ARE DEMOGRAPHICALLY CENTRAL TO ANY SUCCESSFUL PRESIDENTIAL CAMPAIGN.

02326 CLAVERT, $P$.

THE UN INTERVENTION IN PANAMA
SMALL WARS \& INSURGENCIES, 1(3) (DEC 90), 307-314.

THE DECISION TO ORDER U.S. INTERVENTION IN PANAMA HAD FOUR OBJECTIVES: TO SAFEGUARD THE LIVES OF AMERICANS; TO DEFEND DEMOCRACY IN PANAMA; TO COMBAT DRUG TRAFFICKING; AND TO PROTECT THE INTEGRITY OF THE PANAMA CANAL TREATY. AFTER THE SURRENDER OF NORIEGA TO U.S. FORCES, PRESIDENT BUSH AMENDED THE LIST OF OBJECTIVES: TO COMBAT DRUG TRAFFICKING BECAME TO BRING GENERAL MANUEL NORIEGA TO JUSTICE. THIS ARTICLE REVIEHS THE BACKGROUND OF THE CONFLICT AND DESCRIBES
OPERATION JUST CAUSE. IT CONCLUDES WITH A TECHNICAL ASSESSMENT AND THE POL ITICAL AND DIPLOMATIC CONSEQUENCES.

02327 CLEARY, R.E.

REVISITING THE DOCTORAL DISSERTATION IN PUBLIC

ADMINISTRATION: AN EXAMINATION OF THE DISSERTATIONS OF 1990

PUBLIC ADMINISTRATION REVIEW, 52(1) (JAN 92), 55-61.

BASED ON A STUDY OF ABSTRACTS OF 165 PUBLIC

ADMINISTRATION DISSERTATIONS FOR 1990, THE AUTHOR FINDS THAT THE QUALITY OF DOCTORAL DISSERTAIION RESEARCH HAS IMPROVED OVER THE PAST DECADE. APPLYING THE METHODS AND CRITERIA USED IN AN EARLIER STUDY OF DISSERTATIONS COMPLETED IN 1981, HE CONCLUDES THAT THE 1990 GROUP REFLECTS "SUPERIOR RESEARCH PROJECTS " HOHEVER HE SEES A NEED FOR IMPROYEMENT IN THE SELECTION OF TOPICS.

02328 CLEAVER, C.

HAITI TAKES A NEH TURN

HAITI TAKES A NEW TURN
NEW LEADER, LXXIV(1) (JAN 91), 9-11.

FROM THE DESTABILIZATION OF THE GOVERNMENT OF JEANCLAUDE DUVALIER IN 1985, THROUGH FIVE UNELECTED AND UNPOPULAR REGIMES, THE HAITIAN PEOPLE IN A CLIMATE OF CONSTANT CHAOS AND ECONOMIC STAGNATION. THE FACT THAT HAITIANS WERE ABLE TO HOLD THEIR FIRST FREE AND FAIR ELECTIONS IN 33 YEARS HITH LITTLE OR NO BLOODSHED WAS PROMISING TO MANY OBSERVERS. FURTHERMORE, THE FACT THAT THE ARMY HAS COME DOWN IN FAYOR OF THE PRESIDENT-ELECT, JEANBERTRAND ARSTIDE, GIVES HOPE FOR STABILITY IN THE FUTURE. HOHEVER, THE REMNANTS OF SUPPORTERS OF THE OLD REGIMES REMAIN ENTRENCHED AND WELL ARMED. THE FUTURE OFFERS A MIXTURE OF HOPE AND TREPIDATION.

02329 CLEMENT, $R$.

NORTH ATLANTIC COOPERATION COUNCIL CONFRONTS EASTERN EUROPEAN PROBLEMS

GERMAN TRIBUNE, (1508) (MAR 92), 2.

THE NORTH ATLANTIC COOPERATION COUNCIL IS A CONSULTATIVE BODY SET UP IN THE SUMMER OF 1991. ITS PURPOSE IS TO MEET THE DEMANDS MADE BY EASTERN AND CENTRAL EUROPEAN COUNTRIES, ESPECIALLY POLAND, HUNGARY, AND CZECHOSLOVAKIA, FOR CLOSER TIES WITH THE NORTH ATLANTIC PACT, ESPECIALLY AS NATO IS NOT YET PREPARED TO GRANT THE WOULD-BE NEW MEMBERS FROM THE FORMER WARSAW PACT FULL MEMBERSHIP. THE COUNCIL'S TASK IS TO MANEUVER ON THE BORDERLINE BETWEEN MEMBERSHIP AND REJECTION, ITS AIM IS TO PROMOTE MUTUAL UNDERSTANDING FOR EACH OTHER'S
SECURITY NEEDS AND TO SUPPORT DEMOCRATIC RECONSTRUCTION IN SECURITY NEEDS AND TO SUPPORT DEMOCRATIC RECONSTRUCTION
THE FORMER WARSAH PACT STATES, BUT NOT TO GIVE SECURITY THE FORMER WARSAH PAC STATES, THERE IS SOME DISAGREEMENT AMONG NATO STATES AS TO THE ROLE OF THE COUNCIL: SOME HOULD LIKE TO EVENTUALLY EXPAND IT TO INCLUDE SECURITY ISSUES; OTHERS WOULD LIKE TO COOPERATION IN EUROPE (CSCE).

02330 CLEMENTS, $K$.

PEACE AND SECURITY IN THE ASIA PACIFIC REGION--POST COLD PEACE AND SECURITY IN THE
WAR PROBLEMS AND PROSPECTS

BULLETIN OF PEACE PROPOSALS, 23(2) (1992), 173-184.

THE HORLD AND REGIOMAL, 23 (2) 1992$)$, 173-184.

REPRESENTS DANGERS AND OPPORTUNITIES FOR NATION-STATES AND

PEOPLES. THE DANGERS LIE IN THE REASSERTION OF OUTMODED AND INAPPROPRIATE PARADIGMS. THE OPPORTUNITIES ARISE FROM THE CONSCIOUS NEGOTIATION OF MORE APPROPRIATE PARDIGMS WHICH MIGHT ENABLE PEOPLE COMMUNITIES AND NATIONS TO LIVE IN PEACE, AND TURN THEIR COMBINED ATTENTION TO PROBLEM-SOLVING RATHER THAN THE BLIND PROMOTION OF NATIONAL OR SECTIONAL INTEREST. SINCE THE ASIA PACIFIC REGION CAN BE SEEN AS A MICROCOSM OF THE HORLD AS A WHOLE, AN EVALUATION OF THE PROCESSES AT WORK HERE MAY HELP US UNDERSTAND WHAT IS OR NOT LIKELY TO GENERATE STABLE REGIONAL AND GLOBAL PEACE. THIS ARTICLE EXPLORES POSITIVE PROCESSES, ECONOMIC IMPERATIVES 
WHICH OVERRIDE CULTURAL PREFERENCE, AND OTHER FACTORS WHICH REIMFORCE THE DESIRE OF THE MOST POWERFUL NATIONS TO ENHANCE TRADITIONAL OEFENSE AND SECURITY ARRANGMENTS.

02331 CLEWLOW, $H$.

BUSINESS AND GOVERNMENT--TIME FOR A NEW RELATIONSHIP SOUTH AFRICA FOUNDATION REVIEW, 18(4) (APR 92), 3-4. WHILE THE POLITICAL REFORMS IN SOUTH AFRICA HAVE BEEN ENCOURAGING TO NEARLY ALL OBSERVERS, IT IS CLEAR THAT DEMOCRACY AND EQUALITY WILL LOSE ITS TENUOUS FOOTHOLD IF POLITICAL CHANGE IS NOT ACCOMPANIED BY ECONOMIC GROWTH. SOUTH AFRICA'S ECONOMIC PROGRESS REQUIRES A OUAL STRATEGY ON THE ONE HAND, LARGE BUSINESSES MUST BE ENCOURAGED TO BE AS EFFICIENT AS POSSIBLE, TO STAY ABREAST OF TECHNOLOGY, AND TO MAKE SOUTH AFRICA A LEADING NATION IN WORLD TERMS. ON THE OTHER HAND, AN INTENSE DOMESTIC PROGRAM OF JOB CREATION-WHICH CAN ALSO MEET SOME OF THE HOUSING AND INFRASTRUCTURAL NEEDS OF THE NATION--IS REQUIRED. SUCH AN AMBITIOUS ECONOMIC PROGRAM CAN BE ACCOMPLISHED ONLY IF THE GOVERMMENT AND THE PRIVATE SECTOR ACHIEVE AN UNPRECEDENTED OEGREE OF

COOPERATION.

02332 CLIFFORD, $M$.

BATTERED BUT NOT BEATEN

FAR EASTERN ECONOMIC REVIEW, 155(5) (FEB 92), 32-33.

MANY CONSCRIPTS IN THE SOUTH KOREAN ARMED FORCES ARE FORCED TO TRAVEL A PATH OF VIOLENCE BY A MILITARY SYSTEM IN WHICH CASUAL BRUTALITY IS COMMONPLACE. EYEWITHESS ACCOUNTS POINT TO A GRIM RECORD OF DEATH, DISABILITY AND INJURIES SUFFERED BY CONSCRIPTS. THE SOUTH KOREAH ARMED FORCES HAVE ALHAYS BEEN KNOWN FOR FIERCE DISCIPLINE, BUT A YOUNGER, MORE RADICAL GENERATION OF CONSCRIPTS ARE BEGINNING TO ATTACK A SYSTEM THAT TOLERATES BRUTALITY. A RECENT REPORT POINTS TO A STAGGERING DEATH COUNT: A TOTAL OF 9,060 SOLDIERS DIED IN SERVICE BETWEEN 1980 AND 1988, AN AVERAGE OF OVER 1,000 YEAR. FORMER SOLDIERS ARE TEAMING UP WITH HUMAN RIGHTS CRUSADERS TO CHANGE THE SYSTEM, BUT THE CAMPAIGN HAS ENJOYED LITTLE SUCCESS

02333 CLIFFORD, $M$.

BATTLE OF THE GIANTS

FAR EASTERN ECONOMIC REVIEW, 155(16) (APR 92), 10-11.

THE CLASH BETHEEN THE SOUTH KOREAN GOVERNMENT AND THE HYUNDAI GROUP OVER TAXES HAS GROWN MORE BITTER AND ASSUMED IMPLICATIONS BEYOND THE IMWEDIATE HEALTH OF THE GIANT CONGLOMERATE. IT IS A LEADERSHIP FACE-OFF BETHEEN $8 I G$ BUSINESS AND THE GOVERMMENT. IN EARLY APRIL, SOUTH KOREAN AUTHORITIES ARRESTED MORE THAN HALF A DOZEN HYUNDAI AUTHORI IES ARRESTED MORE THAN HALF A DOZEN HYUNDAI EXECUTI IVS FOR ALLEGED TAX EVASION, EMBEZZLEMENT AND
POLLUTION VIOLATIONS. THE ESCALATING GOVERMMENT OFFENSIVE POLLUTION VIOLATIONS. THE ESCALATING GOVERMMENT OFFENSIVE
RAISES THE COST OF HYUNDAI FOUNDER CHUNG JU YUNG'S APPARENT PRESIDENTIAL BID AND COULD PLACE HYUNDAI IN A DEBILITATING CASH SQUEEZE, FORCING IT TO SHED ASSETS AT FIRE-SALE PRICES. CASH SQUEEZE, FORCING IT TO SHED ASSETS AT FIRE-SALE PRICES. OTHER POHERFUI COMPAYIES THAT REGARD GOYERMMENT INYOLYEMENT OTHER POWERFUL COMPANIES THAT REGARD GOVERMMENT INVOLVEM IN THE ECONOMY AS TOO INTRUSIVE. MOST OF THE COUNTRY'S
BUSINESS EXECUTIVES ARE SIMPLY HOPING NOT TO GET CAUGHT IN THE FALLOUT, BUT THAT MAY NOT BE POSSIBLE.

02334 CLIFFORD, $M$

BRIGHT LIGHTS, DIM CITIES

FAR EASTERN ECONOMIC REVIEW, 153(31) (AUG 91), 50-52.

ASIA IS IN THE MIST OF AN ELECTRICITY CRISIS BROUGHT ON BY BOOMING GROWTH AND THE PROFLIGATE USE OF ENERGY. VIRTUALLY EVERY COUNTRY IN THE REGION IS FACING A POTENTIAL CAPACITY CRUNCH. CHEAP, DEPENDABLE ELECTRICITY IS VITAL FOR CONTINUED ECONOMIC EXPANSION, YET THE COSTS OF NEW PONER STATIONS IS STAGGERING. THE AMOUNT OF INVESTMENT NEEDED FOR NEH ELECTRICITY PRODUCTION IS HUGE. THE WORLD BANK EXPECTS 14 ASIAN COUNTRIES--EXCLUDING JAPAN--WILL SPEND US\$456 BILLION ON GENERATION, TRANSMISSION, AND DISTRIBUTION IN THIS DECADE. A TECHNOLOGICAL REVOLUTION IN ENERGY EFFICIENCY MAKES IT CHEAPER TO SAVE ENERGY THAN TO BUILD NEH POWER PLANTS. USING MORE EFFICIENT LIGHTS, MOTORS AND WINDOHS CAM SHARPLY REDUCE THE GROWTH RATE OF DEMAND AND IMPROVE ENERGYINTENSITY LEVELS. INCREASINGLY, ENERGY PLANNERS WILL BE FORCED TO USE THESE TECHNOLOGIES.

02335 CLIFFORD, $M$.

DEADLY DEMONSTRATIOM

FAR EASTERN ECONOMIC REVIEW, 151(18) (MAY 91), 18-19.

ALTHOUGH THE THREE ROUMDS OF PRIME MINISTERIAL TALKS BETHEEN NORTH AMD SOUTH KOREA HAVE CONVINCED SOME THAT BETHEEN NORTH ANO SOUTH KOREA HAVE CONVINCED SOME THAT TENSIONS ON THE PENINSULA ARE DECLINING. MILITARY OFFICIALS INDICATE OTHER WISE. THEY POINT TO NORTH KOREA'S CONTINUING BHE AMBITIOUS FORCE MODERNIZATION PROGRAH OF THE NORTH. IN ADDITIOH NUCLEAR ACTIVITIES AT MORTH KOREA'S YONG BYON ADDITION NUCLEAR ACTIVITIES AT MORTH KOREA'S YONG BYON RESEARCH REACTOR HAVE CONVINCED SOME ANALYSTS OF THE POSSIBILITY OF A NUCLEAR WEAPON BY THE MID 1990S. SOUTH KORAN GOVERNMENT LEADERS HAVE HINTED AT A POSSIBL PREEMPTIVE ATTACK IF THE NORTH DOES NOT AGREE TO LET THE FACILITY BE INSPECTED BY THE INTERNATIONAL ATOMIC ENERGY AGENCY. DESPITE THIS CONTINUED MILITARY TENSION, THE UNITED
STATES IS CONTINUING THEIR PLANNED REDUCTION OF AMERICAN TROOPS IN THE SOUTH.

02336 CLIFFORD, $M$

EXPEMSIYE EMBRACES

FAR EASTERN ECONOMIC REVIEW, 155(12) (MAR 92), 54-55. WHENEVER AND HOWEVER UNIFICATION COMES, IT' WILL BE A MAJOR DRAIN ON THE SOUTH KOREAN ECONOMY, AT LEAST IN THE INITIAL STAGES. GERMANY'S ROCKY ROAD TO UNIFICATION HIGHLIGHTS SOME OF THE PROBLEMS KOREA IS LIKELY TO FACE. WESTERN GERMANY HAS STAGGERED UNDER THE FINANCIAL BURDEN OF ABSORBING THE EAST; SOUTH KOREA'S CAPITAL POSITION IS MUCH MORE TENUOUS. THE EXPERIENCED GERMAN CENTRAL BANK, THE BUNDESBANK, WAS ABLE TO KEEP INFLATION RELATIVELY LOW. SOUTH KDREA, HOWEVER, HAS A POOR RECORD ON INFLATION AND ITS CENTRAL BANK IS POL ITICALLY WEAK. GERMANY HAS CONTINUED TO FACE A SIGMIFICANT GAP BETWEEN EAST AND WEST IN BOTH WAGES AND WORKER PRODUCTIVITY. KOREA WILL FACE MUCH OF THE SAME PROBLEM. THE PER-CAPITA BURDEN OF UNIFICATION IN SOUTH KOREA WILL BE PROPORTIONATELY MUCH HIGHER THAN THAT OF GERMANY.

02337 CLIFFORD, M.

WHEELS OFF THE WAGON

FAR EASTERM ECONOMIC REVIEH, 155(3) (JAN 92), $44-45$. U.S. CAR BEHEMOTH GENERAL MOTORS (GM) AND SOUTH KOREA'S DAEWOO GROUP ARE NEGOTIATING AN END TO A 15-YEAR JOINT VENTURE TO PRODUCE CARS FOR DOMESTIC AND FOREIGN CONSUMPTION. ACCORDING TO A SOURCE FAMILLIAR WITH THE NEGOTIATIONS, THE TWO SIDES ARE EXPECTED TO ANNOUNCE WITHIN HEEKS THE OISSOLUTION OF THE PARTNERSHIP BEHIND DAEWOO MOTOR, THE SECOND-LARGEST FOREIGN INVESTMENT IN SOUTH KOREA. THE DISHARMONY BETWEEN DAEWOO AND GM WAS THE RESULT OF FUNDAMENTAL DIFFERENCES IN INDUSTRIAL STRATEGY. DAEWOO'S INSISTENCE THAT DOMESTIC MARKET SHARE TAKE PRECEDENCE OVER BOTTOM LINE RESULTS WAS ANATHEMA TO GM, DOGGED BY ITS OWN FINANCIAL PROBLEMS. THE SPLIT IS LIKELY TO UNDERSCORE THE OIFFICULTIES OF DOING BUSINESS WITH MANY SOUTH KOREAN COMPANIES, WHERE AUTOCRATIC MANAGEMENT STYLES ARE INCREASINGLY ILL-SUITED TO RUNNING SPRAHL ING ENTERPRISES.

02338 CLINE, M.

POLITICAL PARTIES AND PUBLIC OPINION IN POLAND RFE/RL RESEARCH REPORT, 1(43) (OCT 92), 66-69.

A SERIES OF PUBLIC OPINION POLLS INDICATE THAT BETWEEN POLAND'S OCTOBER 1991 ELECTIONS AND THE FALL OF JAN OLSZEWSKI'S GOVERNMENT IN JUNE 1992 THERE HAS AN INCREASE IN POPULAR OISSATISFACTION WITH THE POLITICAL AND ECONOMIC POPULAR OISATISACION IN POLAND. ACCORDING TO THE POLLS, THIS TREND
COINCIDED WITH A GROWING TENDENCY TO BLAME THE BATTLING

COINCIDED WITH A GROWING TENDENCY TO BLAME THE BATTLING
POLITICAL PARTIES FOR THE POLITICAL AND ECONOMIC INSTABILITY.

02339 CLINTON, B.

CLINTON: IF I EVER LET ISRAEL DOWH, GOD WOULD NEVER FORGIVE ME

WASHINGTON REPORT ON MIDOLE EAST AFFAIRS, XI(3) (AUG 92), 36 .

THIS ARTICLE CONTAINS EXCERPTS FROM AN ADDRESS BY PRESIDENTIAL CANDIDATE BILL CLINTON TO THE JEWISH LEADERSHIP COUNCIL ON JUNE 30, 1992. IN THE SPEECH, CLINTON SPOKE OF IMPROVING BOTH POLITICAL AND ECONOMIC TIES BETHEEN ISRAEL AND THE UNITED STATES.

02340 CLINTON, B.

CONVENTION NOMINATION ACCEPTANCE SPEECHES: BILL CLINTON CONGRESSIONAL DIGEST, $71(10)$ (OCT 92), 230, 232

THIS ARTICLE GIVES EXCERPTS FROM THE SPEECH DELIVERED BY GOVERNOR BILL CLINTON WHEN HE ACCEPTED THE DEMOCRATIC PARTY'S NOMINATION FOR PRESIDENT IN 1992.

02341 CLOETE, F.

FEDERALISM FOR MINORITY PROTECTION IN SOUTH AFRICA? SOUTH AFRICA FOUNDATION REVIEW, 16(11) (NOV 90), 1-3. THE LATEST SOLUTION THAT IS SUPPOSED TO BRING POLITICAL SALVATION TO SOUTH AFRICA IS FEDERALISM. THIS ARTICLE EXAMINES FEDERAL PROPOSALS IN SOUTH AFRICAN HISTORY AND OUTLINES SOME OF THE PROBLEMS AND CHALLENGES THAT AN ATTEMPT TO CREATE A FEDERAL SYSTEM WOULD HAVE TO CONFRONT. IT ALSO CONSIDERS SOME ALTERNATE OPTIONS INCLUDING: UNITARISM; AND AUTONOMOUS AFRICKANER STATE; AND ETHNIC AUTONOMY.

02342 CLOGG, R.

WAR IN THE CAUCASUS?

WAR IN THE CAUCASUS?
WORLD TOOAY, 48(12) (DEC 92), 214-215

THE GRANTING OF SOVEREIGNTY HAS BEEN SEEN AS A UNIVERSAL PANACEA FOR THE PROBLEMS CAUSED BY THE BREAKUP OF THE SOVIET EMPIRE. BUT THIS CAN HAVE DIRE CONSEOUENCES FOR MINORITIES, AS THE CURRENT CRISIS IN ABKHAZIA DEMONSTRATES, GEORGIAN MILITARY LEADERS HAVE VOWED TO WIPE OUT "THE ENTIRE ABKHAZ NATION" IF NECESSARY TO KEEP ABKHAZIA UNDER GEORGIAN RULE.

$02343 \mathrm{CLOUGH}, \mathrm{M}$.

THE UNITED STATES AND AFRICA: THE POLICY OF CYNICAL DISENGAGEMENT

CURRENT HISTORY, 91(565) (MAY 92), 193-198. 
WITH THE DISSOLUTION OF THE SOVIET UNION, THE UNITED STATES HAS BECOME THE ONLY SUPERPOWER. THIS HAS CAUSED AFRICANS TO LOOK TO WASHINGTON FOR DIRECTION, ENCOURAGEMENT, AND SUPPORT. UNFORTUNATELY, THESE HAVE NOT BEEN FORTHCOMING. PRESIDENT GEORGE BUSH'S POLICY TOWARD AFRICA SEEMINGLY OPERATES ACCORDING TO THREE GUIDELINES: DO NOT SPEND MUCH MONEY UNLESS CONGRESS MAKES YOU; DO NOT LET AFRICAN ISSUES COMPLICATE POLICY TOWARD OTHER, MORE IMPORTANT PARTS OF THE WORLD; DO NOT TAKE STANDS THAT MIGHT CREATE POLITICAL CONTROVERY IN THE USA. THIS HAS LED TO A WAVERING, HYPOCRITICAL AFRICAN POLICY BEST DESCRIBED AS "CYNICAL DISENGAGEMENT."

02344 CLOWES, E.W.

IDEDLOGY AND UTOPIA IN RECENT SOYIET LITERATURE

RUSSIAN REVIEW, 51(3) (JUL 92), 378-395

IN THE LAST FIVE YEARS, SOVIET RUSSIANS HAVE

INCREASINGLY CONFRONTED THE INADEQUACIES OF MARXIST-LENINIST IDEOLOGY. THIS RE-EVALUATION OF VALUES HAS OCCURRED IN A NUMBER OF ARENAS, FROM HISTORICAL REASSESSMENTS OF LENIN'S ACHIEVEMENTS TO PHILOSOPHICAL DEBATES TO THE RESTRUCTURING OF PUBLIC RITUALS, SUCH AS THOSE ON MAY DAY. THE LITERARYINTELLECTUAL DEBATE HAS CONTRIBUTED SIGNIFICANTLY TO DISCREDITING BOTH MARXIST-LENINIST THINKING AND STALINIST PRACTICE. NOWHERE HAS THIS NEW THINKING BEEN EXPRESSED MORE STRONGLY THAN IN THE POWERFUL BACKLASH AGAINST THE UTOPIAN PREMISES INFORMING SOVIET IDEOLOGY. A LARGE NUMBER OF EARLY AND MID-2OTH CENTURY DYSTOPIAN NOVELS HAVE BEEN REPRINTED, ELICITING A TREMENDOUS RESPONSE FROM READERS. THESE PUBLICATIONS HAVE TRIGGERED A SHOCK WAVE OF NATIONAL SELFRECOGNITION AND BECOME AN IMPORTANT FOCAL POINT FOR BROAD IDEOLOGICAL RE-EVALUATION.

02345 CLUCAS, $R$.

LEGISLATIVE LEADERSHIP AND CAMPAIGN SUPPORT IN CALIFORNIA

LEGISLATIVE STUDIES QUARTERLY, 27 (2) (MAY 92), 265-284.

THAT LEGISLATIVE LEADERS ARE MOTIVATED PREEMINENTLY BY

THE DESIRE TO RETAIN POWER, IS ARGUED. THIS ARTICLE EXAMINES

THE STRATEGY USED BY CALIFORNIA ASSEMBLY SPEAKER WILLIE

BROWN IN DISTRIBUTING CAMPAIGN SUPPORT FROM 1982-TO 1986.

THE FINDINGS INDICATE THAT BROWN HAS FOLLOWED A STRATEGY

DIFFERENT FROM THE ONE TRADITIONALLY ASSOCIATED WITH

CONGRESSIONAL LEADERS BUT THAT BOTH ACT RATIONALLY TO RETAIN

CONGRESSIONAL LEADERS BUT THAT BOTH ACT RATIONALLY TO RET
POHER. THE DIFFERENCE IN STRATEGY IS ATTRIBUTED TO THE

POHER, THE DIFFERENCE IN STRATEGY IS ATTRIBUTED TO THE

THE SPEAKER TO MAXIMIZE HIS PARTY'S POSITION IN THE ASSEMBLY.

02346 CDAKLEY, J

POLITICAL SCIENCE IN IRELAND: DEVELOPMENT AND DIFFUSION IN A EUROPEAM PERIPHERY

EUROPEAN JOURMAL OF POLITICAL RESEARCH, 20(3-4) (DEC 91),

THE AUTHOR DISCUSSES THE STATUS OF IRISH POLITICAL SCIENCE, FOCUSING ON THE RECENT DEVELOPMENT OF THE DISCIPLINE IN THE TWO PARTS OF THE ISLAND. THIS IS FOLLOWED BY A MORE SYSTEMATIC EXAMINATION OF THE CONTEMPORARY STRUCTURE OF THE DISCIPLINE, BY A REVIEW OF ITS GENERAL INTELLECTUAL ORIENTATION, AND BY AN ASSESSMENT OF ITS RELATIONSHIP WITH THE WORLD OF PUBLIC POLICY.

02347 COAKLEY, J.

THE RESOLUTIION OF ETHNIC CONFLICT: TOWARDS A TYPOLOGY INTERNATIONAL POLITICAL SCIENCE REVIEW, $13(4)$ (OCT 92), 343-358.

THE POLICIES ADOPTED BY STATES TO DEAL WITH THEIR ETHNIC MINORITIES--RANGING FROM GENOCIDE, POPULATION TRANSFER, AND BOUNDARY ALTERATION TO ASSIMILATION AND ACCOMMODATION--IS PRESENTED IN A TYPOLOGY. THE NATURE OF THE POLICIES ADOPTED DEPENDS ON SUCH CHARACTERISTICS AS THE SOURCE OF
DIFFERENTIATION OF THE MINORITY, ITS RELATIONSHIP TO OTHER GROPS IN TM OF THE MINORITY, ITS RELATIONSHIP TO OTHE DIVISION OF LABOR, THE TRADITION OF THE STATE IN TERMS OF ITS RECOGNITION OF INDIVIDUAL AND GROUP RIGHTS, AND THE STATE'S AUTONOMY IN THE INTERNATIONAL DOMAIN. THE ISSUE OF WHICH STRATEGIES ARE APPROPRIATE IN DEALING WITH ETHNIC QUESTIONS IS ULTIMATELY A POLITICAL ONE.

02348 COAKLEY, J. (ED.)

THE SOCIAL ORIGINS OF NATIONALIST MOVEMENTS--THE CONTEMPORARY WEST EUROPEAN EXPERIENCE

SAGE PUBLICATIONS, 1992, 288.

THROUGHOUT WESTERN EUROPE, INTERNAL NATIONALIST CONFLICTS ARE THREATENING THE STABILITY OF DOZENS

COMHUNITIES, STATES, AND IN SOME CASES, ENTIRE NATIONS. THIS COLLECTION OF ESSAYS EXAMINES THE CORRE, ENTIRE NATIONS. THIS NATIONALIST TRENDS AND THE SOCIAL FACTORS THAT FUEL THEM. IN NATIONALIST TRENDS AND THE SOCIAL FACTORS THAT FUEL THEM. IN
PARTICULAR, CONTRIBUTORS EXPLORE THE CONFLICT ING PRESSURES PARTICULAR, CONTRIBUTORS EXPLORE THE CONFLICTING PRESSURES OF CLASS AND ETHNICITY AS
POLITICAL MOBILIZATION.

02349 COATS, R.M.; DALTON, T. R.

A NOTE ON THE COST OF STANDING FOR THE BRITISH PARLIAMENT: $1852-1880$

LEGISLATIVE STUDIES QUARTERLY, XVII(4) (NOV 92), 585-593.
THE COST OF RUNMING FOR A COUNTY PARLIAMENTARY SEAT IN 19TH-CENTURY BRITAIN WAS ABOUT TWICE THE COST OF RUNNING FOR A BOROUGH SEAT. SINCE THERE WERE NO RESIDENCY REQUIREMENTS AND NO DIFFERENCE IN POLITICAL POWER BETWEEN THE BOROUGH AND COUNTY MP'S, THIS PERSISTENT PRICE DISCREPANCY NEEDS EXPLANATION. HIGHER INFORMATIONAL COSTS IN THE COUNTIES MAY HAVE LED TO FEHER CONTESTED ELECTIONS.

02350 COBB, J.

NEW GLUE NEEDED TO STRENGTHEN U.S. - JAPAN RELATIONSHIP JAPAN TIMES (WEEKLY INTERNATIONAL EDITION), $32(17)$ (APR $92), 9$.

AMERICANS AND JAPANESE HAVE BECOME SO NARROWLY FOCUSED ON BILATERAL TRADE ISSUES THAT THEY ARE PAYING LITTLE ATTENTION TO LARGER INTERNATIONAL CONCERNS, ACCORDING TO THE CONSENSUS OF A DISTINGUISHED PANEL AT A RECENT CONFERENCE ON CONSENSUS OF A DISTINGUISHED PANEL AT A RECENT CONFERENCE ON "U.S. -JAPAN RELATIONS: ARE THEY REALLY THAT BAD?" CONFEREM

VANCE AND FORMER JAPANESE FOREIGN MINISTER TARO NAKAYAMA.

02351 COBBAN, $H$.

THE SUPERPOWERS AND THE SYRIAN-ISRAELI CONFLICT PRAEGER PUBLISHERS, 1991,208

SINCE THE DEFANGING OF IRAQ'S MILITARY MACHINE IN THE PERSIAN GULF WAR, THE TWO PREEMINENT MILITARY POWERS OF THE MIDDLE EAST ARE ONCE AGAIN ISRAEL AND SYRIA. THIS VOLUME EXAMINES THE EVOLUTION OF THE MILITARY BALANCE BETWEEN ISRAEL AND SYRIA FROM 1978 TO 1989 AND THE EFFECTS OF THE CLOSE STRATEGIC TIES THAT DEVELOPED IN THIS PERIOD BETWEEN THESE STATES AND THEIR RESPECTIVE SUPERPOWER PARTNERS. THE AUTHOR ANALYZES THE FIGHTING IN LEBANON IN 1982, PROVIDING IMPORTANT LESSONS CONCERNING THE INTERACTION OF THE THO SUPERPOWERS IN THE MIDDLE EAST. THE STUDY ALSO EXPLORES THE IMMUNITY OF THE AREA TO DIPLOMATIC SOLUTIONS AND ITS SURPRISING OVERALL STABILITY.

02352 COBBE, J.

LESOTHO: WHAT WILL HAPPEN AFTER APARTHEID GOES?

AFRICA TODAY, 38(1) (WIN 91), 18-32.

THIS ARTICLE CONSIDERS THREE POSSIBLE SCENARIOS FOR THE FUTURE OF LESOTHO IN TERMS OF ITS RELATIONSHIP WITH THE NEW SOUTH AFRICA. IN EACH CASE SOME OF THE FACTORS THAT MAY SOUTH AFRICA. IN EACH CASE SOME OF THE FACTORS THAT MAY
INFLUUENCE THE LIKEL IHOOD THAT THE PARTICULAR SCENARIO HILL INFLUENCE THE LIKELIHOOD THAT THE PARTICULAR SCENARIO HILL
ACTUALLY OCCUR ARE PRESENTED; AND THE POSSIBLE CONSEQUENCES ACTUALLY OCCUR ARE PRESENTED; AND THE POSSIBLE CONSEQUE OF THE SCENARIO FOR THE ECONOMY, POLITY, AND PEOPLE OF THE SECOND SPECULATES THAT ONCE SOUTH AFRICA IS LIBERATED THE SECOND SPECULATES THAT ONCE SOUTH AFRICA IS LIBERATED
LESOTHO'S REASON FOR EXISTING VANISHES ANO LESOTHO WILL LESOTHO'S REASON FOR EXISTING VANISHES ANO LESOTHO WILL BECOME PART OF SOUTH AFRICA; AND THE THIRD SCENARIO IS
MIOWAY BETWEEN THE FIRST TWO. SALIENT FACTS CONCERNING THE ECONOMY OF LESOTHO, ITS RECENT HISTORY, AND ITS DEPENDENCE ECONOMY OF LESOTHO, ITS RECE
ON SOUTH AFRICA ARE GIVEN.

02353 COBLEY, A.

\$FAR FROM HOME': THE ORIGINS AND SIGNIFICANCE OF THE AFRDCARIBBEAN COMMUNITY IN SOUTH AFRICA TO 1930 INTERNATIONAL JOURNAL OF PUBLIC ADMINISTRATION, 15(7) (1992), 349-371.

THIS PAPER TRACES THE ORIGINS OF THE AFRO-CARIBBEAN COMMUNITY IN SOUTH AFRICA, WHICH ARE TO BE FOUND PREDOMINANTLY AMONG ECONOMIC MIGRANTS SUCH AS SEAFARERS. IT THEN CONSIDERS THE NATURE OF THE AFRO-CARIBBEAN COMMUNITY IN SOUTH AFRICA AND DISCUSSES ITS IMPACT ON BLACK POLITICAL. CONSCIOUSHESS AND ORGANIZATION, BOTH BEFORE AND AFTER THE FIRST WORLD WAR。

02354 COCHRAN, A. III; SCOTT, C.

CLASS, STATE AND POPULAR ORGANIZATIONS IN MOZAMBIQUE AND NICARAGUA

LATIN AMERICAN PERSPECTIVES, 19 (2) (SPR 92), 105-124.

THO CASES, MOZAMB IQUE AND NICARAGUA, WHERE STATE POWER WAS ACTIVELY ENGAGED IN A PROCESS OF DEMOCRATIZATION OF THE STATE, PROMOTING RATHER THAN COUNTERING POPULAR ORGANIZATION, ARE EXAMINED. THE AUTHORS ARGUE THAT EACH OF THESE EFFORTS HERE QUALIFIED SUCCESSES AND FOCUS THEIR ANALYSIS ON THE MASS ORGANIZATIONS IN EACH COUNTRY AND PARTICULAR ON THE ORGANIZATIONS OF WOMEN AND WORKERS. THE IMPORTANCE OF MASS ORGANIZATIONS IN BOTH THE TRANSITION TO THE NEW STATE AND IN THE IMMEDIATE POSTREVOLUT IONARY SOCIETY ARE CONSOLIDATION OF THE POPULAR ORGANIZATION IN THE ROLE OF FORMENTER OF POPOULAR DEMOCRACY ARE IDENTIFIED. THE AUTHORS
POINT TO EXAMPLES IN BOTH COUNTRIES WHERE MASS ORGANIZATIONS POINT TO EXAMPLES IN BOTH COUNTRIES WHERE MASS ORGANIZATIONS
ASSUMED RESPONSIBLITY FOR CONCRETE TASKS AND PROMOTED THE ASSUMED RESPONSIBLITY FOR CONCRETE TASKS AND PROMC
DEVELOPMENT OF NEH POLITICAL FORMS OF POLITICAL DEVELOPMENT OF
PARTICIPATION.

02355 COCHRAN, T.B.; NORRIS, R.S.

A FIRST LOOK AT THE SOVIET BOMB COMPLEX

BULLETIN OF THE ATOMIC SCIENTISTS, $47(4)$ (MAY 91), 25-31.

THIS ARTICLE EXAMINES THE SOVIET NUCLEAR WEAPONS COMPLEX AS WELL AS THE ENVIRONMENTAL PROBLEMS IT HAS CAUSED. FOREIGN VISITORS WERE FIRST ALLOWED TO VISIT ONE OF THE SITES IN 1989. THE PLUTONIUM AND TRITIUM PRODUCTION SITES ARE 
DISCUSSED.

02356 COCORAN, T.

CANADIAN MEDICARE: DOOMED FROM THE START

FREEMAN, 42(2) (FEB 92), 182-183.

CANADIAN MEDICARE IS EXPECTED TO OELIVER HEALTH CARE TO 25 MILLION PEOPLE WITHOUT THE THREE ESSENTIAL INGREDIENTS OF A MORKABLE ECONOMIC SYSTEM: PRICES, MARKETS AND PROFITS. THE SYSTEM IS NOH LUMBERING TOHARD DISINTEGRATION. UNLESS ACTION IS SOON TAKEN, MEDICARE'S MASSIVE BEAUCRATIC AND POLITICAL STRUCTURE WILL FALL APART. THIS ARTICLE EXPLORES THE MEDICARE DEBATE, WHICH IT SUGGESTS IS ONLY BUILDING AROUND THE SALVAGE OPERATION.

02357 CODEVILLA, A.

A SECOND ITALIAN REPUBLIC?

FOREIGN AFFAIRS, 71(3) (SUM 92), 146-164.

MAJOR CHANGES, IF NOT A BRAND NEW CONSTITUTIONAL ORDER, ARE IN THE OFFING IN ITALY. ON JUNE 10, 1991, ITALIAN VOTERS OVERWHELMINGLY APPROVED A MINOR CHANGE' IN THE COUNTRY'S ELECTORAL LAW THAT PROMISES TO HAVE MAJOR CONSEQUENCES. AFTER THE VOTE, ITALY'S POWERFUL PARTIES TRIED TO PREEMPT AFTER THE VOTE, ITALY'S POWERFUL PARTIES TRIED TO PREEMPT
SERIOUS INSTITUTIONAL CHANGES BY PROPOSING REFORMS TO SERIOUS INSTITUTIONAL CHANGES BY PROPOSING REFORMS TO STRENGTHEN THE PRESENT SYSTEM. BUT THE ISSUE OF REFORM
ESCAPED THE PARTIES' CONTROL AND DOMINATED THE 1992 GENERAL ESCAPED THE PARTIES CONTROL AND DOMINATED THE 1992 GEME
ELECTION CAMPAIGNS. THE ELECTION RESULTS WEAKENED THE ELECTION CAMPAIGNS. THE ELECTION RESULTS WEAKENED THE PARTIES, AND THE PRESENT SYSTEM IS NOT LIKELY TO SURVIVE THE
MASSIVE, OPEN ICONOCLASM THAT HAS SPREAD FROM THE GENERAL POPULATION TO THE POLITICAL CLASS ITSELF.

02358 CODEVILLA, A.

MAGNIFICENT, BUT WAS IT WAR?

COMMENTARY, $93(4)$ (APR 92), 15-20.

THERE IS A RULE THAT NO ONE OUGHT TO START A WAR WITHOUT FIRST BEING CLEAR IN HIS MIND WHAT HE INTENDS TO ACHIEVE BY THAT WAR AND HOH HE INTENDS TO CONDUCT IT. THIS ARTICLE SUGGESTS THAT IT WAS GOOD THAT THE U.S. WENT TO WAR AGAINST IRAQ, BUT BECAUSE PRESIDENT BUSH AND HIS TEAM VIOLATED THAT BASIC RULE THEY CANNOT FULLY ENJOY THE FRUITS OF PEACE. THE RULE OF THUMB THAT ENEMIES ARE EITHER TO BE CARESSED OR EXIEINGUISHED HAS SO DEMANDING THAT THE BUSH ADMINISTRATION PREFERRED NOT TO LOOK AT EITHER, BUT TO IMAGINE THAT THERE EXISTED EASIER DIAGNOSES AND PRESCRIPTIONS SOMEHWERE IN THE MIDDLE. THIS ARTICLE CONCLUDES THAT AT THIS POINT, NO ONE CAN ENJOY THE FRUITS OF PEACE.

02359 CODEVILLA, A.

THE COMING EUROMESS

NATIONAL REVIEW, XLIV(11) (JUN 92), 44-46.

THE BRIGHT PROMISES OF PEACE, FREEDOM AND PROSPERITY IN A UNIFIED EUROPE ARE OVERSHADOWED BY FEARS OF A GROWING BUREAUCRACY AND A TREND TOWARDS CENTRALIZATION IN AN AGE OF BUREAUCRACY AND A TREND TOWARDS CENTRALIZATIDN I

"GROWING FREEDOM FOR LOCALITIES. THE APPROACHING

FORTUNATELY. THE NATIONS OF EUROPE ARE MUCH FARTHER FROM THE GORTUNATELY, THE NATIONS OF EUROPE ARE MUCH FARTHER FROM GOAL OF ECONOMIC UNION THAN THEIR RHETORIC INDICATES. AS 1992 BEGAN ALL 12 STATES HAD PASSED ONLY 43 OF THE 282 LAWS
WHICH THEY HAD COMMITTED THEMSELVES TO PASSING BY THE END OF 1992. NO STATE HAD PASSED MORE THAN 190. THIS SNAIL'S PACE TOWAROS PROGRESS COMBINES WITH A LACK OF EFFECTIVE LEADERSHIP TO ENSURE THAT ECONOMIC (LET ALONE POLITICAL) UNION IS A THING OF THE FAR FUTURE.

02360 CODY, $H$.

SOME IMPLICATIONS OF COMMONS REFORM FOR "OUTER" CANADA CANADIAN PARLIAMENTARY REVIEH, (WIN 91), 21-24

THIS ESSAY EXAMINES THE PROCESS OF PARLIAMENTARY REFORH IN CANADA. IT SUMMARIZES THE MAJOR RECOMMENDATIONS OF THE MCGRATH COMMITTEE WITH REGARDS TO THE POSITION OF "PRIVATE MEMBERS." IT ALSO CONSIDERS THE ASSESSMENTS OF "OUTER" CANADIAN MEMBERS OF PARLIAMENT OF CHANGES WHICH REFORMS HAVE (OR HAVE NOT) BROUGHT TO THE COMMONS. IT ALSO SPECULATES ABOUT CHANGES WHICH FURTHER REFORM MIGHT PRDDUCE, AND ABOUT HOW MUCH "CONGRESSIONALISM" WOULD RESULT FROM LESS CENTRALIZED PARTIES. IT CONCLUDES THAT CONTINUATION OF THE COMMONS REFORM PROCESS COULD ENHANCE THE PARTICIPATION OF ATLANTIC AND HESTERN CANADIANS IN NATIONAL POL ICYMAKING.

02361 CODY, H.

SOME IMPLICATIONS OF PARLIAMENTARY REFORM FOR WESTERM CANADA

AMERICAN REVIEW OF CANADIAN STUDIES, 22(1) (SPR 92), 11-22.

ALIENATION FROM THE FEDERAL GOVERNMENT IN THE

ALIENATION FROM THE FEDERAL GOVERNMENT IN THE
PERIPHERIES OF THE EAST AND HEST REPRESENTS A FAMILIAR THEME PERIPHERIES OF THE EAST AND HEST REPRESENTS A FAMILIAR THEME AND A POTENTIAL THREAT TO CAMADIAN PARLIAMENTARY DEMOCRACY. THIS ARTICLE STATES THAT CANADA'S POLITICAL INSTITUTIONS AT THE CENTER -- PARLIAMENT AND THE POLICY-INITIATING FEDERAL CABINET - - FAITHFULLY FOLLOW THE WESTMINSTER MODEL WHICH PROVIDES AUTHORITATIVE CONTROL FOR MAJORITIES AND MINIMAL
LEVERAGE FOR MINORITES. THIS ARTICLE DISCUSSES PARLIAMENTARY REFORM AND ITS IMPLICATIONS ON WESTERN CAMADA.

02362 COE, B.P.

TUG HILL, NEW YORK: PROGRESS THROUGH COOPERATION IN A
RURAL REGION

MATIONAL CIVIC REVIEW, 81(4) (FAL 92), 449-465.

THE KEY TO PROGRESS IN RURAL REGIONS IS COOPERATION

BETHEEN LOCAL AND STATE GOVERMMENTS AND RESOURCE POOL ING AMONG LOCAL GOVERMMENTS TO RAISE INDIGENOUS PROBLEM-SOLVING CAPACITY.

02363 COFFIN, F.M. JUDICIAL GRIDLOCK: THE CASE FOR ABOLISHING DIVERSITY JURISDICTION

BROOKINGS REVIEH, 10(1) (WIN 92), 34-39

THE U.S. FEDERAL COURTS, ALREADY UNDER INTENSE STRAIN, WILL BE INCREASINGLY OVERBURDENED IN THE COHING YEARS. ONE REASON IS DIVERSITY JURISDICTION, WHICH GIVES FEDERAL COURTS JURISDICTION OVER CASES INVOLVING STATE LAN ISSUES SOLELY BECAUSE THE PARTIES ARE CITIZENS OF DIFFERENT STATES. WHILE FEDERAL COURTS FACE EVER INCREASING DEMANDS TO HEAR AND DECIDE FEDERAL STATUTORY AND CONSTITUT IONAL CASES, THEY MUST CASES INVOLVING STATE LAW.

02364 COGAN, C.

SHAWL OF LEAD: FROM HOLY WAR TO CIVIL HAR IN AFGHANISTAM CONFLICT, 10(3) (1990), 189-204.

A YEAR AND A HALF FOLLOWING THE DEPARTURE OF THE LAST SOVIET SOLDIER FROM AFGHANISTAN, THE NAJIBULLAH GOVERMMENT, SOVIET SOLDIER FROM AFGHANISTAN, THE RAJIBULLAH GOVERMMENT, IN PLACE IN KABUL. THIS UMPREDICTED OUTCOME CAN BE

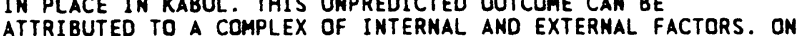
ATTRIBUTED TO A COMPLEX OF INTERNAL AND EXTERNAL FACTORS. OM THE INTERNAL PLANE, THE RESISTANCE, DOMINATED BY ISLAMIST
COMING LARGELY FROM NEWLY EDUCATED RURAL ELITES, AND
COMPOSED A STRONG TADJIK ELEMENT IN ADDITION TO PUSHTUNS, COMPOSED A STRONG TADJIK ELEMENT IN ADDITION TO PUSHTUNS,
DID NOT REPRESENT A POLITICAL ALTERMATIVE FOR THE ENTRENCHED DID NOT REPRESENT A POL ITICAL ALTERNATIVE FOR THE ENTRENCHED
PUSHTUN ELITES, PARTICULARLY THE DETRIBALIZED ELITES IN THE TOWNS. IN THE EXTERNAL CONTEXT, WITH THE DEPARTURE OF THE SOVIET TROOPS, A NEW "SHAWL OF' LEAD" DESCENDED OVER THE COUNTRY: THE TRADITIONAL AFGHAN ANTAGONISM TOWARD FOREIGNERS HAS NOW FOCUSED ON PAKISTAN, AND BEHIND PAKISTAN, THE UNITED STATES AND SAUDI ARABIA.

02365 COHEN-ALMAGOR, R.

THE INTIFADA: CAUSES, CONSEQUENCES AND FUTURE TRENDS

SMALL WARS \& INSURGENCIES, 2(1) (APR 91), 12-40.

THE INTIFADA OPENED A NEW CHAPTER IN THE HISTORY OF THE ISRAELI-PALESTINIAN CONFLICT. THE AUTHOR CLAIMS THAT DURING THE MID-1970S THE PALESTINIANS WERE ON THE ROAD TOWARDS AN UPRISING, BUT SADAT'S PEACE INITIATIVE SHUFFLED THE CARDS. ALSO THAT THE LEBANON WAR CAUSED A CHANGE IN THE PALESTINIANS' FRAMEWORK OF MIND, AND INDUCED THEM TO OPEN A CIVIL REBELLION. ALSO, OF SIGNIFICANCE HERE THE SOCIOECONOMIC CONDITIONS OF THE REFUGEES, WHICH PUT THEM IN A ECONOMIC CONDITIONS OF THE REFUGEES, WHICH PUT THEM IN A
POSITION WHERE THEY SIMPLY HAD NOTHING TO LOSE. PART OF IHIS POSITION WHERE THEY SIMPLY HAD NOTHING TO LOSE. PARI
ESSAY ANALYSES THE EFFECTS OF THE UPRISING ON THE ESSAY ANALYSES THE EFFECTS OF THE UPRISING ON THE
PALESTINIANS, ISRAEL, AND THE PLO. IT CLOSES BY DRAWING PALESTINIANS, ISRAEL, AND THE PLO. IT CLOSES BY DRAWING ATIENTION TO THREE PARTIES WHOSE POSITIONS ARE OF GROWING IMPORTANCE IN THE ISRAELI P PALESTINIAN CONFLICT. THESE ARE THE ISLAMIC FUMD
PALESTINIANS.

02366 COHEN-ALMAGOR, $R$.

VIGILANT JEHISH FUNDAMENTALISM: FROM JDL TO KACH TERRORISM AND POLITICAL VIOLENCE, 4(1) (SPR 92), 44-66. THE ESSAY AIMS TO EXPLAIN THE EMERGENCE OF KAHANISM IN ISRAEL AND WHY ISRAEL I DEMOCRACY SAW IT NECESSARY TO DEFEND ITSELF AGAINST MEIR KAHANE'S QUASI-FASCIST IDEAS AND TO CURTAIL HIS LEGITIMACY. THE AUTHOR REFLECTS ON THE KAHANIST PHENOMENON, ITS IDEOLOGY AND POLITICAL PROGRAM WHICH BROUGT RABBI KAHANE TO THE KNESSET. THE READING OF KACH'S RACIST PROPOSALS EXPLAINS WHY EXTRAORDINARY MEASURES HERE TAKEN AGAINST KAHANE BY POLITICAL SYSTEM AS WELL AS BY THE MEDIA AND THE EDUCATIONAL SYSTEM.

02367 COHEN, B.

ISRAEL'S EXPANSION THROUGH IMMIGRATION

MIDOLE EAST POLICY, 1(2) (1992), 120-135.

THE STRUGGLE OVER LAND HAS ALWAYS BEEN THE MOST TANGIBLE FEATURE OF THE ISRAELI/PALESTINIAN/ARAB CONFLICT. SINCE ITS CREATION IN 1948, THE STATE OF ISRAEL HAS CONSISTENTENTLY EXPANDED EASTHARD AT THE PRIMARY EXPENSE OF THE PALESTINIAN ARAB PEOPLE. THE ARRIYAL OF HUGE NUMBERS OF IMMIGRANTS IN ARAB PEOPLE. THE ASR HAS PROYIDED THE BOOST FOR A FRESH ROUND OF LAND EXPROPRIATIONS AND RENEWED SETTLEMENT. THIS ROUND OF LAND EXPROPRIATIONS AND RENEWED SETTLEMENT. THIS PAPER ATTEMPTS TO ANALYZE THE CAUSES AND CONSEQUENCES OF THAT IMMIGRATION. IN PARTICULAR, II WILL FOCUS ON THE CONDITIONS WHICH ENCOURAGE JEWISH CITIZENS TO EMIGRATE TO ISRAEL, THE SITUATION THEY FACE ON ARRIVAL, THE ROLE OF ISRAEL AND THE WORLD ZIONIST ORGANIZATION IN ORGANIZING THE IMIGRATION AND THE EFFECTS OF THE IMMIGRATION ON BOTH THE
PALESTINIANS IN THE OCCUPIED TERITORIES AND THOSE HHO REMAIN PALESTINIANS IN THE OCCUPIED TERI
WITHIN ISRAEL'S PRE-1967 BORDERS.

02368 COHEN, C.; HART, S.; KOSLOSKE, S.

THE UN CONVENTION ON THE RIGHTS OF THE CHILD: DEVELOPING AN "INFORMATION MODEL" TO COMPUTERIZE THE MONITORING OF 
TREATY COMPLIANCE

HUMAN RIGHTS QUARTERLY, 14(2) (MAY 92), 216-231.

DUE TO OVERWHELMING WORLD SUPPORT, THE CONVENTION ON THE RIGHTS OF THE CHILD DEMANDS THE CREATION OF INTEGRATED COMPUTER SYSTEMS AND DATABASES DEVELOPED FROM AN INFORMATION MODEL THAT WILL GO BEYOND EXISTING METHODS OF CATALOGUING TEXT INFORMATION. SUCH A MODEL WILL GLOBALLY USE COMPUTER CAPABILITIES IN EVALUATING THE EXTENT TO WHICH A COUNTRY IS COMPLYING WITH THE STANDARDS OF THE CONVENTION. THIS ARTICLE REVIEWS THE ESTABLI SHMENT OF A HUMAN RIGHTS INFORMATION MODEL FOR THE CONVENTION ON THE RIGHTS OF THE CHILD (HURIIMMODEL FOR THE CONVENTION ON THE RIGHTS OF THE CHILD (HURIIM-
CRC) AND THEN EXAMINES THE PURPOSE AND FUNCTIONS OF HURIIMCRC) AND THEN EXAMINES THE PURPOSE AND FUNCTIONS OF
CRC. IT CONCLUDES THAT NOW IS THE TIME TO BUILD THE CRC. IT CONCLUDES THAT NOW IS THE TIME TO BUILD THE
FRAMEWORK AND THAT HURIIM-CRC WILL PROVIDE THE HIGH-LEVEL FRAMEWORK ANO THAT HURIIM-CRC WILL PROVIDE THE HIGH-LEVEL INTERPRETATION OF THE CONVENTION NECESSARY TO DEVELOP
INTEGRATED DATABASES REQUIRED TO COMPUTERIZE REPORTING.

02369 COHEN, D.

THE NEW APARTHEID

CANADIAN FORUM, LXX(806) (JAN 92), 9-16.

A FORMER SOUTH AFRICAN ACTIVIST FINDS THAT THE NEW SOUTH AFRICA DOESN'T LIVE UP TO ITS INTERNATIONAL BILLING. THE ARTICLE STATES THAT RACISM AND RACE ARE NATIONAL OBSESSIONS. IN SOUTH AFRICA, FROM INFANCY, THE IDEOLOGY OF RACE PERMEATES EVERY' CORNER OF EXPERIENCE. POVERTY IS THE MOST NORMAL FEATURE OF BLACK LIFE, AND KEEPS THE RACIAL DIVISION AS FIRMLY AS THE FORMER APARTHIED LAWS DID.

02370 COHEN, J.

MASIMIZING SOCIAL WELFARE OR INSTITUTIONALIZING DEMOCRATIC IDEALS? COMMENTARY ON ADAM PRZEWORSKI'S ARTICLE

POLITICS AND SOCIETY, 19(1) (MAR 91), 39-58.

THE AUTHOR COMMENTS ON ADAM PRZEWORSKI'S ARTICLE "COULD

WE FEED EVERYONE" THE IRRATIONALITY OF CAPITAL ISM AND THE

INFEASIBILITY OF SOCIALISM." HE CONCENTRATES ON POINTS OF

DISAGREEMENT SUCH AS PRZEWORSKI'S CONFINING OF OISCUSSION TO

A COMPARISON OF THE WELFARE CONSEQUENCES OF ALTERNATIVE

POLITICAL-ECONOMIC CONSTITUTION WHERE "WELLARE" IS

UNDERSTOOD SUBJECTIVELY AS THE SATISFACTION OF OE FACTO

UNDERSTOOD SUBJECTIVELY AS THE SATISFACTION OF DE FAC
PREFERENCES; AND PRZEWORSKI'S ATTEMPT TO DISTINGUISH

PREFERENCES; AND PRZEHORSKI'S ATTEMPT TO DISTINGUISH
RATIONALITY AND FEASIBILITY OF SYSTEMS. THE AUTHOR OF THIS

RATIONALITY AND FEASIBILITY OF SYSTEMS. THE AUTHOR OF THIS
ARTICLE CONCLUDES THAT ARGUMENTS ABOUT THE VICES OF MARKETS

ARTICLE CONCLUDES THAT ARGUMENTS ABOUT THE VICES OF MAR

MOTIVATIONS THAT WOULD DEFEAT ALL SUCH SPECULATIONS. IN THE

MOTIVATIONS THAT WOULD DEFEAT ALL SUCH SPECULATIONS. IN THE ABSENCE OF A MORE COMPELLING CASE FOR THOSE CONTENTIONS, AND IN THE ABSENCE OF A PLAUSIBLE AND WELL-DEFINED ALTERNATIVE TO MARKET COORDINATION, THERE ARE NO COMPELLING GROUNDS FOR CONDEMNING MARKETS AS IRRATIONAL AND AS ESSEM
TO THE IDEAL OF A FREE COMMUNITY OF EQUALS.

02371 COHEN, J.; ROGERS, J.

SECONDARY ASSOCIATIONS AND DEMOCRATIC GOVERNANCE

POLITICS AND SOCIETY, 20(4) (DEC 92), 393-472.

THE ARGUMENT IS MAOE FOR ASSOCIATIVE DEMOCRACY. THE FIRST SECIION OF THIS ARTICLE PROVIDES A CRITICAL ASSESSMENT OF NEOL IBERAL CONSTITUTIONALIST, CIVIC REPUBLICAN, AND EGALITARIAN PLURALIST APPROACHES TO THE PROBLEM OF FACTION, TO WHICH ASSOCIATIVE DEMOCRACY STANDS IN CONTRAST. SECTION 2 GIVES A POSITIVE CHARACTERIZATION OF THE ASSOCIATIVE VIEW. SECTION 3 ILLUSTRATES A STRATEGY BY SHOHING HOW IT MIGHT BE APPLIED TO A WIDE RANGE OF PRACTICAL PROBLEMS OF DEMOCRATIC GOVERNANCE AND HHAT EFFECT SUCH APPLICATION WOULD HAVE ON THE VARIOUS NORMS OF DEMOCRATIC ASSOCIATION IDENTIFIED EARLIER. SECTION 4 ROUNDS OUT THE DISCUSSION WITH SOME SUGGESTIONS FOR ASSOCIATIVE REFORM IN THE UNITED STATES, OFFERED IN LIGHT OF THE PREVIOUS ANALYSIS.

02372 COHEN, L.

POST-FEDERALISM AND JUDICIAL CHANGE IN YUGOSLAYIA: THE RISE OF ETHNO-POLITICAL JUSTICE

INTERNATIONAL POL ITICAL SCIENCE REVIEW, 13(3) (JUL 92), INTERNA

THE YUGOSLAV CASE IS A VIVID ILLUSTRATION OF JUST HOW CONTINGENT JUDICIAL AUTHORITY IS UPON REGIME LEGITIMATION. AS THE STRUGGLE TO MAINTAINN YUGOSLAY STATE UNITY ENTERED A CRITICAL STAGE IN 1990-91. THE COUNTRY'S "CONSTITUTIONAL CRITICAL STAGE IN 1990-91, THE COUNTRY'S "CONSTITUTIONAL WITHIN THE TITOIST AND SELF-MANAGEMENT LEGAL ORDER, PROVED HELPLESS TO PREVENT THE COLLAPSE OF THE FEDERAL SYSTEM. MOREOVER. THE ADMINISTRATIONM OF JUSTICE WAS INCREASINGLY MOREOVER, THE ADMINISTRATIONN OF JUSTICE WAS INCREASING NATIONALIST POLITICAL PARTIES WHICH, ALTHOUGH PROGRAMMATICALLY COMMITIED TO THE "RULE-OF-LAW" AND ALSO TO THE "DEPOL ICALLY COMMITTED TO THE "RULE-OF-LAW" AND ALSO TO THE "DEPOL ITICIZATION" OF THE JUDICIARY, WERE, NEVERTHELESS, PREPARED TO UTILIZE THE JUOICIAL SECTOR AND LEGAL SYSTEM FOR THEIR OWN POL ITICAL GOALS. COMMUNIST POL ITICAL CONTROL OVER
THE COURTS HAD LARGELY BEEN ELIMINATED, BUT YUGOLAVIA AS A THE COURTS HAD LARGELY BEEN ELIMINATED, BUT YUGOLAYIA WHOLE WAS STILL A LONG WAY FROM THE CREATION OF AN
INDEPENDENT JUDICIARY, LET ALONE A POST-COMMUNIST RECHSSTAAT.

02373 COHEN, L.J.

THE DISINTEGRATION OF YUGOSLAVIA

CURRENT HISTORY, 91(568) (NOY 92), 369-375

THO FACTORS ARE PARTICULARLY SIGNIFICANT FOR
UNDERSTANDING THE VIOLENT DISSOLUTION OF THE YUGOSLAV FEDERATION. ONE IS THE PERSISTENCE AND INTENSIFICATION OF DEEP ANTAGONISMS AMONG THE COUNTRY'S DIVERSE ETHMIC AND RELIGIOUS GROUPS. THE SECOND IS THE FAILURE OF THE POLITICAL LEADERS WHO CAME TO POWER IN 1990 TO AGREE ON A NEW MODEL OF
POLITICAL AND ECONOMIC COEXISTENCE THAT WOULD HAVE PRESERVED SOME FORM OF YUGOSLAY STATE UNITY BUT WOULD ALSO HAVE TERRITORIAL UNITS AND ETHNIC GROUPS.

02374 COHEN, $M$.

A FORUM ON ECONOMIC OPTIONS FOR SOCIAL DEMOCRACY STUDIES IN POLITICAL ECONOHY: A SOCIALIST REVIEW, 37(1) (SPR 92) 147-150.

SINCE NEW CONDITIONS MUST BE UNDERSTOOD AND SUCH UNDERSTANDIMGS MUST GENERATE NEH POLICY PRESCRIPTIONS THIS FORUM DISCUSSES TWO BOOKS--"PUTTING PEOPLE FIRST" AND "SOCIAL DEMOCRACY WITHOUT ILLUSIONS." THREE SHORT ESSAYS REPRESENT EFFORTS TO ASSESS THESE TWO WORKS. THE HOPE OF "STUDIES IN POLITICAL ECONOMY" IS THAT THIS FORUM WILL GENERATE A DEBATE ABOUT SUCH MATTERS, BECAUSE IT IS ONLY IN GENUINE DEBATE THAT THE WAYS FORWARD MAY BE IDENTIFIED.

02375 COHEN, M.; KUMAR, N.; MCGUIRE, T.; WALLACX, S.

FINANCING UNIVERSAL HEALTH INSURANCE: TAXES, PREMIUMS, AND THE LESSONS OF SOCIAL INSURANCE

JOURNAL OF HEALTH POLITICS, POLICY AND LAH, 17(3) (FAL 92), 439-462.

CONGRESS IS CONSIDERING PROPOSALS TO IMPROVE ITS FINANCING OF LONG-TERM CARE. THIS ARTICLE SUGGESTS THAT CONGRESS SHOULD CONSIDER A PROGRAM THAT ENHANCES MEDICAID; IMPROVES CONSUMER EDUCATION; ASSISTS STATES IN REGULATING LONG-TERM CARE POLICIES, SO AS TO ENHANCE CONSUMER PROTECTION AND CONFIDENCE; AND CLARIFIES TAXES ON LONG-TERM CARE INSURANCE TO ENCOURAGE WORKERS AND THE ELDERLY TO PROTECT THEMSELVES AGAINST CATASTROPHIC EXPENSES.

02376 COHEN, $M$

MARCHIMG TO A CROSSROADS

FAR EASTERN ECONOMIC REVIEW, 155(35) (SEP 92), 28-30. THE INDONESIAN ARMED FORCES HAVE LONG ARGUED THAT THEY SERVE A "DUAL FUNCTION." IN OTHER WORDS, THE MILITARY IS A SOCIOPOLITICAL FORCE AS WELL AS THE DEFENDER OF THE NATION. SOCIOPOLITICAL FORCE AS WELL AS THE DEFENDER OF THE IN CONCRETE TERMS, "DUAL FUNCTION" TRANSLATES INTO INFLUENTIAL AND POTENTIALLY LUCRATIVE POSTS AS MINISTERS,
GOVERNORS, VILLAGE HEADS, AMBASSADORS, AND MANAGERS OF STATE GOVERNORS, VILLAGE HEADS, AMBASSADORS, AND MANAGERS OF APPROACHES THE END OF HIS FIFTH FIVE-YEAR TERH, CIVILIANAPPROACHES THE END OF HIS FIFTH FIVE-YEAR TERM, CIVILIANMILITARY RELATIONS APPEAR TO BE NORSENING. WHIE NO MTHER
NATIONWIDE POL ITICAL FORCE HAS EMERGED TO PUSH THE MILITARY
OUT OF THE RULING CIRCLE. MANY INDONESIANS ARE PROMPTED BY OUT OF THE RULING CIRCLE, MANY INDONESIANS ARE PROMPTED BY THE GLOBAL SPREAD OF DEMOCRACY TO CALL FOR MORE OPENNESS IN
THEIR OWM GOVERNMENT. TO COMBAT THIS GROWING TREND AND TO THEIR OWN GOVERHMENT. TO COMBAT THIS GROWING TREND AND TO
RENEW THE HISTORICAL BONDS BETWEEN CIVILAN AND MILITARY, THE ARMED FORCES HAVE EMBARKED ON A PROGRAM OF COMAUNITY LABOR AND EDUCATION FOR YOUNG CADETS, A PROGRAM WHICH OFTEN SENDS CADETS AND CIVILIANS OUT TO RURAL AREAS TOGETHER TO IMPLEMENT PUBLIC WORKS PROJECTS. THE ARMED FORCES HOPE THAT SUCH A COURSE WILL MANIFEST THEIR INTEREST IN SOCIAL IMPROVEMENT AND DEMONSTRATE THE IMPORTANT ROLE OF THE ARMED FORCES IN FOSTERING NATIONAL UNITY.

02377 COHEN, M.

SOCIAL DEMOCRACY- ILLUSION OR VISION?

STUDIES IN POLITICAL ECONOMY: A SOCIALIST REVIEW, 37(1)

(SPR 92) 151-160.

SOCIAL DEMOCRACY SHOULD BIND TOGETHER THE CONCEPTS OF FREEDOM, DEMOCRACY, AND EQUALITY IN WAYS WHICH GENERATE AN ALTERMATIVE KIND OF POLITICS. IN SUCH POLITICS PEOPLE ARE NOT MERELY CONFRONTED WITH CHOICES BUT CAN ACTUALLY
DETERMINE WHAT THE CHOICES WILL BE. IN LIGHT OF THIS DESCRIPTION OF SOCIAL DEMOCRACY, THE AUTHOR ASSESSES TWO WORKS, "SOCIAL DEMOCRACY WITHOUT ILLUSIONS" AND "PUTTING
PEOPLE FIRST." SHE FINOS THEM LACKING A SENSE OF PROCESS OF ECONOMIC RESTRUCTURING, AND ALSO FINDS FAULT WITH THE SPECIFICS OF THEIR ECONOMIC ANALYSIS.

02378 COHEN, R.

EAST-WEST AND EUROPEAN MIGRATION IN A GLOBAL CONTEXT NEW COMMUNITY, 18(1) (OCT 91), 9-26.

THERE IS CURRENTLY A GREAT DEAL OF CONCERN ABOUT THE CHARACTER AND DIMENSIONS OF EAST-WEST MIGRATION TO EUROPE. CHARACTER ANO DIMENSIONS OF EAST-WEST MIGRATION TO EUROPE.
IN ORDER TO GAIN SOME UNDERSTANDING OF THE CURRENT MIGRATORY IN ORDER TO GAIN SOME UNDERSTANDING OF THE CURRENT MIGRATORY 2000. HE IDENTIFIES KEY WORLD-WIDE MIGRATORY MOVEMENTS, 2000. HE IDENTIFIES KEY WORLD-WIOE MIGRATORY MOVEMENTS, FOCUSING ON MIGRATION FROM EUROPE TO THE COLONIES AND THE UNITED STATES, SUCCESSIVE PERIODS OF MIGRATION TO EUROPE, AND THE CONTEMPORARY AND PROJECTED MOVEMENT TO EUROPE FROM
THE EAST AND THE SOUTH. HE ALSO DISCUSSES THE POLITICAL AND SOCIAL STATUS OF THE MIGRANTS IN EUROPE.

02379 COHEN, $S$.

GAZA NOHI PROSPECTS FOR A GAZA MICROSTATE

MEDITERRANEAN QUARTERLY: A JOURNAL OF GLOBAL ISSUES, $3(2)$ 
(SPR 92), 60-80

SINCE THE GULF WAR'S END, THE UNITED STATES HAS MOUNTED A VIGOROUS INTERMATTOMAL EFFORT TO BRING ISRAEL AND THE ARABS TO THE NEGOTIATING TABLE. THIS INITIATIVE DIFFERS FROH OTHERS THAT HAVE SOUGHT RESOLUTION OF THE CONFLICT BECAUSE IT IS BASED ON A BROAD INTERNATIONAL CONSENSUS AND ITS EMPHASIS IS ON THE PROCESS OF NEGOTIATION INSTEAD OF THE END RESULT. PRESENT CIRCUMSTANCES FAVOR PEACE PROSPECTS. ISRAEL ALSO MAY BE MORE AMENABLE TO COMPROMISE. THIS ARTICLE REVIEWS THE NEGOTIATING AGENDA, THE RATIONALE FOR FOCUSING PEACE NEGOTIATIONS ON GAZA, THE ISSUES OF BOUNDARIES AND LAND, WATER AND ENERGY REOUIREMENTS, AND THE PROSPECTS FOR A GAZA SOLUTION.

02380 COHEN, $S$

JUSTICE UNDER FIRE

TIKKUN, 6(1) (MAR 91), 23-25.

THE STRIDENT PALESTINIAN SUPPORT FOR SADDAM HUSSEIN HAS BITTERLY SPLIT THE ISRAELI PEACE MOVEMENT. THE LEFT PART HAS STAYED FAITHFUL TO THE TRADITIONAL TWO-STATE POSITION AND ITS CRITIOUE OF THE INTERESTS BEHIND THE WAR. BUT THE LOUDEST VOICES COME FROM THOSE WHO ARGUE THAT AS LONG AS THE MISSILES FALL AND AS LONG AS THE PALESTINIANS APPLAUD THEM, MISSILES FALL, AND AS LONG AS THE PALESTINIANS APPLAUD THEM, THE WAR AGAINST IRAQ IS JUSTIFIED, AND THE PALESTINIANS HAVE UMDERSTANDING OF A FEW TRUTHS: FIRST THE "BETRAYED" RELATIONSHIP BETWEEN THE ISRAEL I LEFT AND THE PALESTINIANS RELATIONSHIP BETWEEN THE ISRAELI LEFT AND THE PALESTINIANS WAS NEVER AS DEEP OR INTENSE AS IT IS NOW BEING POR

SECOND, TOO MUCH OF THE "SYMPATHY, UNDERSTANDING,
COLLABDRATION AND FRIENDSHIP: HAS BEEN BASED ON FRAGILE AND COLLABORATION AND FRIENDSHIP: HAS BEEN BASED ON FRAGILE A
ASYMMETRICAL MOTIVATIONS; AND THIRD, THE ISRAELI PEACE MOVEMENT IS THE ONLY ONE IN THE WORLD THAT IS PRO-AMERICAN. THE AUTHOR OF THIS ARTICLE CALLS FOR THE CREATION OF A "JUSTICE NOH" MOVEMENT TO REPLACE THE PEACE MOVEMENT IN ISRAEL.

02381 COHEN, S.; INBAR, E.

VARIETIES OF COUNTER-INSURGENCY ACTIVITIES: ISRAEL'S MILITARY OPERATIONS AGAINST THE PALESTINIANS, 1948-90

SMALL WARS \& INSURGENCIES, 2(1) (APR 91), 41-60.

DRAHING ON EXAMPLES TAKEN FROM THE EXTENDED HISTORY OF ISRAELI OPERATIONS AGAINST ARAB INSURGENCY, THIS ARTICLE AIMS TO DEMONSTRATE THE VARIETY OF MILTARY OPTIONS AVAILABLE TO GOVERMMENTS WHICH CONFRONT A CHALLENGE OF YIOLENT REVOLUT IONARY INSURGENCY. IT ARGUES THAT EVEN WHEN THE DATA BASE IS LIMITED TO INSTANCES IN HHICH YIOLENCE IS ACTUALIY EMPL OYED THE CHOICES AYAILABLE TO GOYERMMENTS ARE MORE NUMEROUS THAN IS COMMONLY SUGGESTED. THEY ARE ALSO AMENABLE TO SYNOPTIC ANALYSIS AND EXAMINATION. THIS PAPER BRIEFY SUMMARIZES THREE VARIABLES WHICH HAVE EXERTED THE MOST SALIENT INFLUENCES ON ISRAEL'S CHOICES OF CDUNTER-INSURGE MILITARY ACTIONS. MORE EXTENSIVELY, IT
RESULTANT TAXONOMY OF THOSE OPERATIONS.

02382 CDHEN, S.A.

CHANGIMG EMPHASES IN ISRAEL'S MILITARY COMMITMENTS, 19811991: CAUSES AND CONSEQUENCES

JOURNAL OF STRATEGIC STUDIES, 15(3) (SEP 92), 330-350.

THROUGHOUT ISRAEL'S EXISTENCE, HER SOCIETY AND ECONOMY HAVE HAD TO SUSTAIN EXCEPTIONALLY HIGH RATES OF DEFENSE EXPENDITURES AND OBLIGATIONS, AS WELL AS FREQUENT INTERRUPTIONS OF NORMAL CIVILIAN LIFE. THIS IS USUALLY ATTRIBUTED TO TWO CIRCUMSTANCES: (1) THE PROTRACTED NATURE AND ESCALATING COSTS OF THE ARAB-ISRAELI CONFLICT IN ITS VARIOUS FORMS AND (2) ISRAEL'S NEED TO MOBILIZE AN INORDIMATE PROPORTION OF ITS AVAILABLE HUMAN AND MATERIAL RESOURCES IN ORDER TO OFFSET THE QUANTITATIVE SUPERIORITY OF ITS POTENTIAL ADVERSARIES. WITHOUT DENYING THE SALIENCE OF EITHER FACTOR, THE AUTHOR OF THIS ARTICLE SUGGESTS A THIRD. SPECIFICALLY, HE ARGUES THAT THE MAGNITUDE OF ISRAEL'S DEFENSE EXPENDITURES MUST ALSO BE ATTRIBUTED TO THE DISTINCTIVE VARIETY OF ISRAEL'S MILITARY COMMITMENTS. HE OUTLINES AND CATEGORIZES THOSE COMMITMENTS AND DEMONSTRATES HOW THEIR COMPOSITION HAS BEEN TRANSFORMED IN RECENT YEARS. SUCH CHANGES POSSESS VARIED IMPLICATIONS BOTH FOR ISRAEL'S OVERALL STRATEGIC DOCTRINE AND FOR THE FORCE DISPOSITIONS OF THE ISRAEL DEFENSE FORCES.

02383 COHEN, S.P

U.S. SECURITY IN A SEPARATIST SEASON

BULLETIN DF THE ATOMIC SCIENTISTS, 48(6) (JUL 92), 28-32.

THIS ARTICLE ARGUES THAT THE INCREASE IN ETHNIC SEPARATIST MOVEMENTS SIGNALS A SERIOUS THREAT TO THE CURRENT SEPARATIST MOVEMENTS SIGHALS A SERIOUS THREAT TO THE CURREN SYSTEM OF NATION STATES. IT EXAMINES THE FACTORS THAT HAVE STATE. THEY ARE: THE STATE HAS LOST ITS MONOPOLY ON STATE. THEY ARE: THE STATE HAS LOST ITS MONOPOLY ON INFRMATION; THE STATE CANNOT PROTECT ITS CITIZENS IN WARTIME; THE STATE NO LONGER INSURES ECONOMIC PROSPERITY; THE STATE HAS LOST ITS MONOPOLY ON JUSTICE; AND THE STATE IS BEING ATTACKED FROM HITHIN. HOWEVER. THE ARTICLE ARGUES THAT REPLACED BY EITHER GLOBAL OR REGIONAL POLITICAL INSTITUTIONS IN THE NEAR FUTURE. THEREFORE, A POLICY OF INTERNATIONAL ISOLATIONISM IS NOT JUSTIFIED. THE UNITED STATES MUST REMAIN
ENGAGED IN HORLD AFFAIRS IN ORDER TO DEAL WITH THE SPREAD OF WEAPONS OF MASS DESTRUCTION.

02384 COHEN, T

COVERING THE PEACE MOVEMENT

NUCLEAR TIMES, $9(2)$ (SUM 91), 24-26.

THE COVERAGE OF THE 1990-91 CONFLICT AND RESULTIING WAR IN THE PERSIAN GULF BY NEWS MEDIA IS ASSESSED. THE FOCUS IS ON THE FAILURE OF THE PRESS TO ADEQUATELY PRESENT THE ARGUMENTS OF THOSE WHO OPPOSED OFFICIAL GOVERMMENT POLICY.

02385 COHLER, L.

RETHINKING SYRIA

TIKKUN, 7(5) (SEP 92), 29-34

SYRIA SEEKS A ROLE FOR ITSELF IN THE NEW WORLD ORDER.

THE REALPOLITIK IMPLICATIONS OF THIS, IF IGNORED, WILL COST

THE WEST--AND ISRAEL--ONE OF THE BEST OPPORTUNITIES THEY

HAVE HAD IN SOME TIME TO ADVANCE THEIR INTERESTS IN THE REGION, INCLUDING INTERESTS CERTAIN TO BE REGARED AS LEGITIMATE BY ADVOCATES OF PEACE IN THE MIDDLE EAST. THIS ARTICLE SUGES SHOULD FOR MAXIMUM BENEFIT, ISRAEL AND THE UNITED STATES-WHILE CONTINUING TO ENGAGE ASSAD--IS LIKELY UNITED STATES--WHILE CONTINUING TO ENGAGE ASSAD--IS LIKELY TO OFFER NEH OPPORTUNITIES IN THE PEACE PROCESS FOR ISRAEL-IF ISRAEL OPENS ITSEL

02386 COHN, A.

FROM' A POLICY OF INEQUALITY TO A PROPOSAL OF EOUITY: FROM A POLICY OF INEQUALITY TO A PROPOSAL OF EQUITY: POLITICAL

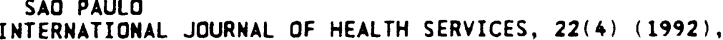
767-781.

THE AUTHOR OFFERS A TENTATIVE ANALYSIS OF THE RECENT SAO PAULO EXPERIENCE IN HEALTH CARE MANAGEMENT, IN WHICH THE CHIEF GUIDELINE HAS BEEN TO CREATE INSTITUTIONAL SPACE FOR GRASSROOTS AND HEALTH WORKER PARTICIPATION WITHIN THE STATE APPARATUS. HER ANALYSIS TAKES BRAZIL'S RECENT HEALTH POLICIES AMD THE SO-CALLED "SANITARY REFORM MOVEMENT" AS REFERENCE POINTS. SHE APPROACHES THE ISSUE FROM THE ANGLE OF DEMOCRACY AND DEMOCRACY'S POSSIBILITIES IN THE CONTEXT OF A SOCIETY CHARACTERIZED BY TREMENDOUS SOCIAL INEQUALITIES AND IN THE CONTEXT OF THE CURRENT INTERNATIONAL AND NATIONAL NEOLIBERAL OFFENSIVE.

02387 COKER, C.

BRITAIN AND THE NEW WORLD ORDER: THE SPECIAL RELATIONSHIP IN THE 1990'S

INTERNATIONAL AFFAIRS, 68(3) (JUL 92), 407-422.

IN THE POST-COLD WAR ERA, THE UNITED STATES HAS EMERGED AS A NATION NEEDING ALLIES MORE THAN EVER BEFORE. THE AUTHOR SUGGESTS THAT A CONTINUATION OF THE SPECIAL RELATIONSHIP BETHEEN THE USA AND BRITAIN COULD BE SEEN AS A CONSOLATION FOR A COUNTRY THAT HAS LOST ITS HAY, OR IN BRITAIN'S CASE, FOR A COUNTRY THAT HAS LOST ITS NAY, OR IN BRITAIN'S CASE, COULD LEGITIMIZE ITS DETACHMENT FROM EUROPE ANO JUSTIFY ITS EUROPE.

02388 COKER, $C$

BRITAIN'S DEFENCE OPTIONS

HORLD TODAY $48(4)$ (APR 92), 72-75.

BRITAIN'S TWO MAJOR PARTIES--LABOR AND TORY--WERE

ALREADY MOVING TOWARDS THE CENTRE ON DEFENSE POLICY BEFORE ALREADY MOVING TOWARDS THE CENTRE ON DEFENSE POLICY BEFORE ECONOMIC DECLINE WAS PUSHING THEM TOWARD MAJOR DEFENSE CUTS EVEN BEFORE THE COLLAPSE OF COMMUNISM IN EASTERN EUROPE AND THE DISINTEGRATION OF THE SOVIET UNION LEGITIMIZED THEIR POSITION. EVEN BEFORE THE COLD WAR CAME TO AN END, COSTACCOUNTANCY HAD BECOME THE PREVAILING POLITICAL PASSION.

02389 COKER, C.

POST-MODERNITY AND THE END OF THE COLD WAR: HAS WAR BEEN DISINVENTED?

REVIEW OF INTERNATIONAL STUDIES, 18(3) (JUL 92), 189-198. THIS ARTICLE EXPLORES THE MEANING OF POST-MODERNITY AND THE REASONS WHY POST-MODERNISTS HAVE CONCLUDED THAT WAR HAS BEEN DISINVENTED. IT ANALYSES A HORLD WITHOUT THE BOMB AND PONDERS WHETHER THE FIRST WORLD WILL CONFRONT THE THIRD. IT CONCLUDES THAT THE POST-MODERN CULTURE IS \&AFTER WHAT WE HAVE KNOHN BEFORE', AND THAT IT IS POSSIBLE THAT ONE OF THINGS IT MAY BE WELL BE SAFTER' IS THE TWENTIETH-CENTURY EXPERIENCE OF HAR.

02390 COLBORNE, D.

SOUTH AFRICA--THE LINK BETWEEN NORTH AND SOUTH

SOUTH AFRICA FOUNOATION REVIEW, 18(4) (APR 92), 6-7.

IN THE CURRENT ATMOSPHERE OF FAST-PACED CHANGE, SOUTH AFRICA'S FUTURE IS MORE THAN EVER IN THE BALANCE. ITS SUCCESS OR FAILURE DEPENDS TO NO SMALL EXTENT ON ITS RELATIONS WITH THE REST OF THE HORLD. FOREIGN INVESTMENT AND FOREIGN TRADE ARE THE ENGINES OF GROWTH THAT WILL MAKE THE DIFFERENCE. HOWEVER, SOME ARE LOOKING BEYOND THE IMMDEDIATE FUTURE TO VIEN SOUTH AFRICA AS A POTENTIAL DEVELOPMENT
BRIDGE BETWEEN THE NORTH AND SOUTH. THE CONCEPT OF TRI- 
LATERAL COOPERATION BETWEEN EUROPE, SOUTH AFRICA, AND OTHER DEVELOPING NATIONS IS AN IDEA THAT IS RECEIVING INCREASING ATTENTION THROUGHOUT THE WORLD.

02391 COLBORNE, $D$.

THE YEAR OF PORTUGAL AND SPAIN

SOUTH AFRICA INTERNATIONAL, 22(3) (JAN 92), 145-146.

WITH THE OLYMPIC GAMES TO BE HELD IN SPAIN IN 1992, AND THE COLUMBUS COMMEMORATIONS AND PORTUGAL'S ACCESSION TO THE PRESIDENCY OF THE EUROPEAN COMMUNITY, HORLD ATTENTION WILL PRESIDENCY OF THE EUROPEAN COMMUNITY, HORLD ATTENTION WILL BE INCREASINGLY FOCUED ON THESE TWO COUNTRIES. AFTER YEAR OF DICTATORSHIPS, BOTH COUNTRIES HAVE SUCCEEDED IN THE
TRANSITION TO DEMOCRACY AND IN A MARKET-DRIVEN REYIVAL OF TRANSITION TO DEMOCRACY AND IN A MARKET-DRIVEN REVIVAL OF
THIS HITHERTO RELATIVELY ECONOMICALLY BACKWARD REGION. FOR THIS HITHERTO RELATIVELY ECONOMICALLY BACKWARO REGION. FOR
THESE REASONS, BOTH SPAIN AND PORTUGAL WILL MERIT SOUTH AFRICA'S CLOSER ATTENTION, NOT LEAST BECAUSE OF THE CLOSE AFRICA'S CLOSER ATTENTION, NOT LEAST BECAUSE OF THE CLOSE AND SOUTH AFRICA.

02392 COLBORNE, D.

TRILATERAL CO-OPERATION IN AFRICA

SOUTH AFRICA INTERNATIONAL, 22(4) (APR 92), 192-194.

HISTORIC OPPORTUNITIES EXIST FOR TRANSFORMING SOUTH

AFRICA AND MAKING IT THE WEST'S DEVELOPMENT BRIDGE IN AFRICA.

THE AUTHOR OF THIS ARTICLE, WHO FOR MANY YEARS HAS PROMOTED THE IDEA OF TRILATERAL COOPERATION BETWEEN EUROPE, SOUTH AFRICA, AND THE DEVELOPING CDUNTRIES IN AFRICA, URGES
RAPID IMPLEMENTATION OF AN IDEA WHOSE TIME HAS COME.

02393 COLBORNE, D.

WRITING OFF AFRICA

SOUTH AFRICA INTERNATIONAL, 23(2) (OCT 92), 95-96.

AFRICA IS SEEN IN FRANCE AS A PROBLEM CONTINENT, AND SOUTH AFRICA IS IN DANGER OF BEING ADVERSELY AFFECTED BY THIS. THE FOCUS ON AFRICA IN A RECENT CONFERENCE IN THE FRENCH SENATE HAS AN UNUSUAL EVENT. THE DEBATE STRESSED THE NEED FOR ECONOMIC RESTRUCTURING ON AFRICAN MARKET LINES AND URGED GREATER REGIONAL COOPERATION. IT STRESSED THE KEY ROLE SOUTH AFRICA COULD PLAY AS PART OF THE REVITALIZATION OF SUB SOUTH AFRICA COULD PLAY AS PART OF THE REVITALIZATION OF
SAHARAN AFTRICA. FRANCO-SOUTH AFRICAN COOPERATION COULD SAHARAN AFTRICA. FRANCO

02394 COLBURN, F.D.

THE FADING OF THE REVOLUTIONARY ERA IN CENTRAL AMERICA CURRENT HISTORY, 91 (562) (FEB 92), 70-73.

SOCIETY, ECONOMY, AND THE STATE HERE TRANSFORMED IN CENTRAL AMERICA IN THE $1980^{\circ} \mathrm{S}$. IN A SURREAL FASHION, THE ISTHMUS HAS BECOME STRANGELY MODERN, WITH SOME CHARACTERISTICS OF POSTINDUSTRIAL STATES AMID THE REGION'S TRADITIONAL POVERTY; CITIZENS ARE POLITICALLY INFORMED, ACTIVE, AND ORGANIZED; THERE IS A CONSTANT INTERNATIONAL FLOW OF PEOPLE, GOODS, AND CAPITAL; ECONOMIES ARE INCREASINGLY DEPENDENT ON SERVICES RATHER THAN AGRICULTURE AND INDUSTRY. AUTHORITY MAY BE AS CENTRALIZED AS EVER IN CENTRAL AMERICA, BUT POWER IS NOW DISPERSED AND LOCALIZED. THE INSURRECTIONS IN CENTRAL AMERICA HAVE NOT LED TO A DESIRE FOR POLITICAL ACCOMMODATION. THE NET POL ITICAL RESULT IS THAT THE REGION IS MORE POLITICIZED AND FACTIONALIZED AND, THEREFORE, MORE DIFFICULT TO GOVERN.

02395 COLBY, D. ; COOK, T.

EPIDEMICS AND AGENDAS: THE POLITICS OF NIGHTLY NEWS COVERAGE OF AIDS

JOURNAL OF HEALTH POLITICS, POLICY AND LAW, 16(2) (SUM 91),

215-250.

THE AUTHORS OF THIS ARTICLE EXAMINE WHY THE EXPONENTIAL GROWTH OF AIDS CASES OR THE WIDESPREAD PROFESSIONAL PERCEPTION OF A HEALTH CRISIS DID NOT MOVE THE EPIDEMIC MORE QUICKLY ONTO THE AGENDA OF PUBLIC PROBLEMS. ONE POSSIBLE EXPLANATION FOCUSES ON HOW THE NATIONAL NEWS MEDIA'S CONSTRUCTION OF AIDS SHAPED THE MEANING OF THE EPIDEMIC FOR CONSTRUCTION OF AIDS SHAPED THE MEANING OF THE EPIDEMIC
MASS ELITE AUDIENCES. AN EXAMINATION OF NIGHTLY NEWS
COVERAGE COVERAGE BY THE THREE MAJOR NETWORKS FROM 1982 TO 1989 REVEALS CONSIDERABLE VARIABILITY AND VOLATILITY IN THEIR COVERAGE. TOPIC-DRIVEN SATURATION COVERAGE OCCURRED ONLY
DURING THREE SHORT PERIODS IN 1983, 1985, AND 1987, WHEN THE DURING THREE SHORT PERIODS IN 1983, 1985, AND 1987, WHEN THE EPIDEMIC SEEMED LIKELY TO AFFECT THE "GENERAL POPULATI THE AUTHORS CONCLUDE BY CONSIDERING THE PROSPECTS AND PITFALLS
AGENDA.

02396 COLE, B.

RECIPE FOR RECOVERY

WEST AFRICA, (3878) (JAN 92), 66-67

ACCORDING

OF COMMERCE, INDUSTRY, AND AGRICULTURE, THE COUNTRY NEEDS TO STOP RELYING ON ECONOMIC "CRISIS MANAGEMENT" AND ESTABLISH A TASK FORCE TO TAKE AN OVERALL YIEH OF THE ECONOMY AND WORK OUT SHORT-, MEDIUM-, AND LONG-TERM PLANS FOR ECONOMIC REVITALIZATION.

02397 COLEMAN, D.A.

DOES EUROPE NEED IMMIGRANTS? POPULATION AND WORK FORCE PRDJECTIONS
INTERNATIONAL MIGRATION REVIEW, XXVI (2) (SUM 92), 413-461. IT HAS BEEN ARGUED THAT EUROPE NEEDS MORE IMMIGRANTS TO RESTORE ITS AGE STRUCTURE AND ITS HORK FORCE. EVEN IF LOW EUROPEAN FERTILITY CONTINUES, DECLINE IN THE WORK FORCE IS RELATIVELY MODEST IN THE MEOIUM TERM AND IS CONSIDERABLY LOWER THAN THE POTENTIAL RESERVE LABOR FORCE IN EUROPE. IT SEEMS ECCENTRIC TO PROPOSE THE RESUMPTION OF IMMIGRATION FOR LOW-GRADE LABOR WHEN THERE ARE 15 MILLION UNEMPLOYED IN EUROPE, MOST UNDER AGE 25 AND MANY THEMSELVES IMMIGRANTS, ESPECIALLY SINCE FUTURE DEMAND FOR LABOR EMPHASIZES HIGH SKILLS. A RESUMPTION OF GENERAL IMMIGRATION TO ENSURE

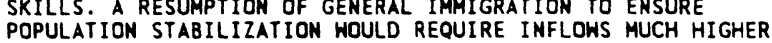
POPULATION STABILIZATION WOULD REQUIRE INFLOWS MUCH HIGHER
EVEN THAN THOSE PREVIOUSLY CONI SDERED UNACCEPTABLE. INSTEAD,
ATTENTION SHOULD BE GIVEN TO MAKING IT EASIER FOR WOMEN TO ATTENTION SHOULD BE GIVEN TO MAKING IT EASIER FOR WOMEN
COMBINE THEIR DESIRES FOR CHILDREN WITH THOSE FOR WORK.

02398 COLEMAN, $H$.

FINANCIAL SERVICES REFORM IN CANADA: THE EVOLUTION OF POLICY DISSENSION

CANADIAN PUBLIC POLICY--ANALYSE DE POLITIQUES, XVIIII(2)

JUN 92), 139-152.

THIS ARTICLE EXAMINES THE EVOLUTION OF FINANCIAL SERVICES REGULATION IN CANADA, FOCUSING ON DEVELOPMENTS IN THE 1980 S. DESPITE MARKET AND INTERNATIONAL PRESSURES TOWARD INCREASED REGULATORY HARMONIZATION WITHIN NATION-STATES, FINANCIAL SERVICES REGULATION IN CANADA EMERGED LESS HARMONIZED THAN ANY TIME IN THE POST-WAR PERIOD. IT ARGUES THAT REGULATORY REFORM WAS ORAWN INTO THE VORTEX OF FEDERALPROVINCIAL CONFLICT. INTEREST ASSOCIATIONS REPRESENTING VARIOUS MARKET GROUPS LACKED A CONSENSUS ON THE CHANGES
NEEDED. IN ADOITION, DIFFERENT LEVELS OF GOVERNMENT WERE ATTACHED TO PARTICULAR TYPES OF FINANCIAL FIRMS.

CONSEOUENTLY, REGULATION AND SUPERVISION OF FINANCIAL

SERVICES BECAME MORE FRAGMENTED IN CANADA. THE ARTICLE CONCLUDES WITH SOME SUGGESTIONS FOR CHANGES BASED ON THE EUROPEAN COMHUNITY MODEL.

02399 COLGAN, C.

INTERNATIONALIZATION OF THE GOVERNOR'S ROLE: NEH ENGLAND GOVERNORS AND EASTERN CANADIAN ENERGY, 1973-1989 GOVERNORS AND EASTERN CANADIAN ENERGY, $1973-1989$
STATE AND LOCAL GOVERMMENT REVIEW, $23(3)$ (FAL 91 ), 119-126.
WHEN NEW ENGLAND GOVERNORS ARRANGED TO PURCHASE SIGNIFICANT QUANTITIES OF ELECTRICTY FROM QUEBEC, THEY SIGNIFICANT QUANTITIES OF ELECTRICTY FROM QUEBEC, THEY
EXPANDED THEIR INTERNATIONAL ROLE TO A LEVEL OF DIRECT EXPANDED THEIR INTERNATIONAL ROLE TO A LEVEL OF DIRECT
GOVERMMENT-TO-GOVERMMENT NEGOTIATION. THE EXPERIENCE IN GOVERMMENT-TO-GOVERNMENT NEGOTIATION. THE EXPERIENCE
THESE NEGOTIATIONS PROVIOES LESSONS IN THE NATURE OF THESE NEGOTIATIONS PROVIDES LESSONS IN THE NATURE OF GUBERNATORIAL-LEVEL FOREIGN RELATIONS, INCLUDING THE

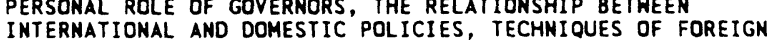
INTERNATIONAL AND DOMESTIC POL ICIES, TECHNIQUES OF FOREIGN RELATIONS SUCH AS REGULAR ANHUAL MEETINGS WITH FOREIGN
COUNTERPARTS, AND THE EVOLVING RELATIONS BETWEEN THE FEDERAL AND STATE GOVERMMENTS IN INTERNATIONAL AFFAIRS.

$02400 \mathrm{COLL}, \mathrm{A}$.

AMERICA AS THE GRAND FACILITATOR

FOREIGN POLICY, (87) (SUM 92), 47-66.

THIS ARTICLE ARGUES THAT AMERICAN FOREIGN AND DEFENSE

POLICY IN THE 1990 S MUST RECOGNIZE THE ACCELERATING

FRAGMENTATION AND DIFFUSION OF POWER AND THE PROSPECTS FOR CONSIDERABLE INTERNATIONAL OISORDER THROUGHOUT THE HORLD.

AMERICA'S POLICY OBJECTIVES SHOULD BE: MAINTAIN A GLOBAL

BALANCE OF POWER ANO FAVORABLE REGIONAL BALANCES; PROMOTE AN INTERNATIONAL TRADING AND MONETARY SYSTEM CONDUCIVE TO AMERICAN ECONOMIC PROSPERITY; SUPPORT THE GRADUAL SPREAD OF OPEN AND AND DEMOCRATIC POLITICAL SYSTEMS; STRENGTHEN THE FRAMEHORK OF INTERNATIONAL NORMS AND PRACTICES TO PROTECT ELEMENTAL STANDARDS OF ORDER, JUSTICE AND HUMAN RIGHTS; AND MANAGE CHANGE AND INSTABILITY IN SUCH A WAY THAT CORE AMERICAN VALUES AND INTERESTS ARE NOT UNDERMINED EVEN WHILE DIFFERENT SOCIETIES AND THE INTERNATIONAL SYSTEM ITSELF ARE DIFFERENT SOCIETIES AND THE INTERNATIONAL SYSTEM ITSELF ARE
ALLOWED TO EVOLVE IN NEH DIRECTIONS. IN SHORT, THE UNITED
STATES SHOULD STRIVE TO PLAY A ROLE OF "HOLDER OF THE STATES SHOULD STRIVE TO PLAY A ROLE OF "HOLOER OF THE
BALANCE," SIMILAR TO THE ROLE PLAYED BY GREAT BRITAIN DURING MUCH OF, THE EIGHTEENTH AND NINETEENTH CENTURIES.

02401 COLLEY, L.

WOMEN AND POLITICAL POWER

WILSON OUARTERLY XYI (2) (SPR 92), 50-58,

ACCORDING TO MOST HISTORY TEXTBOOKS, WOMEN CAME INTO ACCOROING TO MOST HISTORY TEXTBOOKS, WOMEN CAME INTO
REAL POLITICAL POHER ONLY AFTER THEY OBTAINED THE VOTE.

HOWEYER, A CLOSER LOOK REVEALS THAT FEMALES EXERCISED

HOWEYER, A CLOSER LOOK REVEALS THAT FEMALES EXERCISED
POLITICAL INFLUENCE IN UNCONVENTIONAL, AND OFTEN EFFECTIVE, WAYS BEFORE WOMEN'S SUFFRAGE.

02402 COLLIE, M.: ROBERTS, $B$.

TRADING PLACES: CHOICE AND COMMITTEE CHAIRS IN THE U.S TRADING PLACES: CHOI

SENATE, 1950-1986
THE JOURNAL OF POLITICS, 54 (1) (FEB 92), 231-245

WHY MEMBERS OF CONGRESS CHAIR THE COMMITTEES THEY DO IS ASKED IN THIS PAPER, WHICH ARGUES THAT THE ANSWER INVOLVES STRATEGIC CONSIDERATIONS. THE ANALYSIS EXAMINES THE CHOICES OF SENATORS 1950-1986 WHO HAVE HAD THE OPPORTUNITY TO CHAIR THO OR MORE COMMITTEES. BECAUSE SENATORS ARE ALLOWED TO CHAIR ONLY ONE COMMITTEE IN ANY GIVEN CONGRESS, THESE 
LEGISLATORS MUST DECIDE WHICH COMMITTEE TO CHAIR. EMPIRICAL AKALYSIS INDICATES THAT THE CHOICE OF COMMITTEE CHAIRS INVOLVES A STRATEGY THAT EXTENDS THE INFLUENCE OF SENATORS IN A POSIIIION TO MAKE SUCH DECISIONS AND EFFECTIVELY REDUCES THE VARIANCE OF POLICY PREFERENCES IN THE SET OF COMHITTEE LEADERSHIP POSITIONS.

02403 COLLIER, D.; NORDEN, D.L. STRATEGIC CHOICE MODELS OF POLITICAL CHANGE IN LATIN AMERICA

COMPARATIVE POLITICS, 24(2) (JAN 92), 229-243.

STRATEGIC CHOICE MODELS EXPLORE HOW GIVEN ACTORS PURSUE GOALS BY SHAPING THE CONTEXT IN WHICH OTHER ACTORS MAKE CHOICES. THE DISCUSSION IN THIS PAPER CENTERS ON HIRSCHMAN'S ANALYSIS OF REFORM-MONGERING, PRZEWORSKI'S THRESHOLD MODEL OF TRANSITIONS TO DEMOCRACY, AND O'DONNELL'S MODEL OF DEMOCRATIC CONSOLIDATION. THE AUTHORS EXAMINE THE MODELS' BASIC COMPONENTS, INCLLOING THE DEFINITION OF ACTORS, PREFERENCE DISTRIBUTIONS, COALITIONAL THRESHOLDS, PERCEPTIONS OF THE LIKELIHOOD OF GIVEN OUTCOMES, AND EFFORTS PERCEPTIONS OF THE LIKELIHOOD OF GIVEN OUTCOMES, AND EFFORTS
TO CHANGE THE ACTUAL AND PERCEIVED COSTS OF THESE OUTCOMES. TO CHANGE THE ACTUAL AND PERCEIVED COSTS OF THESE OUTCOMES THEN THEY EXPLORE THE RELATIONSHIP BETWEEN SUCH MOOELS AND
MORE FAMILIAR PERSPECTIVES IN THE LATIN AMERICAN FIELD. THE MORE FAMILIAR PERSPECTIVES IN THE LATIN AMERICAN FIELD. THE
MODELS DISPLAY A DISTINCTIVE EMPHASIS ON UNCERTAINTY AND THE MODELLS DISPLAY A DISTINCTIVE EMPHASIS ON UNCERTAINTY AND THE
CREATIVE USE OF UNCERTAINTY BY POLITICAL LEADERS, BUT THEY CREATIVE USE OF UNCERTAINTY BY POLITICAL LEADERS, BUT THEY
ALSO HAVE MUCH IN COMMON WITH OTHER RESEARCH TRADITIONS.

02404 COLLIER, $K$

THE 1990 GUBERNATORIAL ELECTIONS: THE MYTHICAL REVOLT SOCIAL SCIENCE QUARTERLY, 73(1) (MAR 92), 188-193.

SOME ANALYSTS EXPECTED THAT THE ELECTION OF 1990 WOULD TURN INTO A REVOLT AGAINST INCUMBENTS. AFTER CONGRESS RETURNED 97 PERCENT OF ITS MEMBERS, INCUMBENT GOVERNORS WERE SEEN BY SOME AS THE PRIMARY VICTIMS OF VOTER DISCONTENT. THIS PAPER EXAMINES THE HISTORY OF GUBERNATORIAL ELECTIONS IN ORDER TO PLACE THE 1990 ELECTION IN A BROADER PERSPECTIVE. THE RESULTS OF THIS ANALYSIS SUGGEST THAT BY HISTORICAL STANDARDS THE "REVOLT OF 1990" ACTUALLY DID LITTLE TO THREATEN INCUMBENT GOVERNORS.

02405 COLLIER, P.

FROM CRITIC TO SECULAR GOD: THE WORLD BANK AND AFRICA: A COMMENTARY UPON SUB-SAHARAN AFRICA: FROM CRISIS TO SUSTAINABLE GROWTH

AFRICAN AFFAIRS, 90(358) (JAN 91), 111-118.

THIS ARTICLE DISCUSSES THE WORLD BANK'S REPORT ON AFRICA,

THIS ARTICLE DISCUSSES THE WORLD BANK'S REPORT ON AFRICA,
"AFRICA, FROM CRISIS TO SUSTAINABLE GROWTH.: THE AUTHOR

"AFRICA, FROM CRISIS TO SUSTAINABLE GROWTH.: THE AUTHOR
DESCRIBES IT AS A COMPREHENSIVE AND GENERALLY SOUND STUDY.

DESCRIBES IT AS A COMPREHENSIVE AND GENERALLY SOUND STUDY.
HE DISCUSSES THE ROLE OF THE WORLD BANK IN THE PROCESS OF

HE DISCUSSES THE ROLE OF THE WORLD BANK IN THE PROCESS OF
POL ICY CHANGE. THE ARTICLE PROPOSES THAT EASTERN EUROPE WILL

PROVIDE LESSONS FOR AFRICA, THO OF WHICH ARE REVIEWED.

02406 COLLIER, R.B.; COLLIER, D.

SHAPING THE POLITICAL ARENA: CRITICAL JUNCTURES, THE LABOR MOVEMENT, AND REGIME DYNAMICS IN LATIN AMERICA

PRINCETON UNIVERSITY PRESS, $1991,300$.

THE AUTHORS EXPLAIN THE SHAPE AND EVOLUTION OF THE POLITICAL SYSTEMS OF EIGHT LATIN AMERICAN COUNTRIES UTILIZING THO STRATEGIES OF COMPARISON: THE MOST SIMILAR AND MOST DIFFERENT SYSTEMS DESIGN. DURING A GIVEN PERIDD OF TIME, AN HISTORIC CHANGE--FROH REPRESSION TO INCORPORATION-OCCURRED IN THE RELATIONSHIP BETHEEN THE STATE AND ORGANIZED LABOR. THE ALTERNATIVE STRATEGIES OF CONTROL AND MOBILIZATION DURING THE INCORPORATION PERIOD GENERATED DIFFERENT PATTERNS OF CONFLICT AND ACCOMMODATION THAT LAUNCHED THE CONTRASTING POLITICAL LEGACIES FOR DECADES TO COME.

02407 COLLINGE, $C$.

THE OYNAMICS OF LOCAL INTERVENTION: ECONOMIC DEVELOPMENT

AND THE THEORY OF LOCAL GOVERMMENT
URBAN STUDIES, 29(1) (FEB 92), 57-75.

THE AUTHOR PRESENTS A THEORETICAL APPROACH TO THE LARGESCALE DYNAMICS OF LOCAL GOVERMMENT DERIVED FROM MARXIAN POLITICAL ECONOMY. HE EXPLORES AND DEVELOPS IT BY REFERENCE TO THE HISTORY OF LOCAL AUTHORITY INTERVENTION IN THE SPHERE OF PRDOUCTION OVER THE LAST 100 YEARS IN THE UNITED KINGDOM. THE HISTORICAL EVIDENCE REVEALS A PATTERN OF PERIODIC CHANGE IN THE STANCE OF LOCAL GOVERNMENT TOWARDS THE LOCAL ECONOMY-A PATTERN THAT CAN BE BROADLY CORRELATED WITH THE MAIN A PATTERN THAT CAN BE BROADLY CORRELATED WITH THE MAIN
PHASES OF ECONOMIC CHANGE THAT HAYE OCCURRED SINCE 1880. PHASES OF ECONOMIC CHANGE THAT HAVE OCCURRED SINCE 1880.
THIS IS CONSISTENT WITH THE AUTHOR'S THEORETICAL POSITION THIS IS CONSISTENT WITH THE AUTHOR'S THEORETICAL POSITION AND SUPPORTS THE VIEN THAT PROGRESS TOWARDS A MACROSCOPIC INVESTIGATION OF THE LONG MARCH OF LOCAL HISTORY.

02408 COLLINS, F.

HOUSE SUBCOMITTEE PROTESTS STONEWALLING OF U.S. INVESTIGATIOH

WASHINGTON REPORT ON MIDOLE EAST AFFAIRS, XI(3) (AUG 92),

DESPITE EVIDENCE OF WIDESPREAD CORRUPTION INVOLVING U.S. MILITARY AID TO ISRAEL, LITTLE PROGRESS HAS BEEN MADE IN INVESTIGATING THE MATTER. CONGRESSMAN JOHN D. DINGELL, WHO
IS CHAIRING A COMMITTEE INVESTIGATING THE PROBLEMS, HAS COMPLAINED THAT HIS COMMITTEE IS UNABLE TO DO A THOROUGH JOB BECAUSE THE ISRAELI GOVERMMENT HAS FAILED TO CDOPERATE.

02409 COLLINS, F.

IF SOVIET JEWS HAVE STOPPED COMING, DOES ISRAEL NEED LOAN GUARANTEES?

WASHINGTON REPORT ON MIDDLE EAST AFFAIRS, XI(3) (AUG 92),

$15,92$.

ONE OF THE FIRST PRIORITIES OF ISRAEL'S NEW LEADERS WILL BE TO BREAK THE LINK BETWEEN ISRAELI SETTLEMENTS AND U.S. LOAN GUARANTEES AND REPLACE IT WITH A LINK BETHEEN THE LOAN GUARANTEES AND IMMIGRATION TO ISRAEL FROM THE FORMER SOVIET UNION. BUT THIS WILL BE DIFFICULT BECAUSE THE FLOW OF JEWISH REYERSED, HITH MORE JEWS LEAYING THAN ENTERIMG ISRAEL.

02410 COLLINS, F.

WHAT DOES ISRAEL COST U.S. TAXPAYERS?

WASHINGTON REPORT ON MIDDLE EAST AFFAIRS, XI(1) (JUN 92),

$27,87$.

THE AUTHOR LOOKS AT THE COST OF U.S. AID TO ISRAEL,

WHICH INCLUDES OUTRIGHT GRANTS, FORGIVEN LOANS, INTEREST

COSTS, ARMS AND TECHNOLOGY TRANSFERS, AND LOAN GUARANTEES.

02411 COLLINS, $H$.

PC AND THE PRESS

CHANGE, 34(1) (JAN 92), 12-16.

THE BIG NEWS ON COLLEGE CAMPUSES IS A LEFT-HING

CONSPIRACY BY COLLEGE ADMINISTRATORS AND $1960 S-E R A$

PROFESSORS TO STIFLE DISSENT AND IMPOSE A LIBERAL ORTHODOXY ABOUT RACE AND GENDER. THE GOAL: TO CAPTURE THE HEARTS AND MINDS OF THE NATION'S 13 MILLION COLLEGE STUDENTS. SUCH IS THE ALARMIST PICTURE THAT HAS EMERGED FROM A SIGNIFICANT SEGMENT OF THE POPULAR PRESS OVER THE PAST YEAR. THE AUTHOR SUGGESTS THAT THE DISTORTED COVERAGE OF PC IS PART OF A LONG TRADITION OF ANTI-INTELLECTUALISM IN THE POPULAR PRESS,

02412 COLLINS, $J$.

THE JURY'S STILL OUT ON JURORS CASHING IN

INS IGHT, 8(18) (MAY 92), 12-13, 38

THE RIGHT OF JURORS TO WRITE OR TALK ABOUT A TRIAL AFTER A YEROICT MAY BE CONSIITUTIONALLY PROTECTED, BUT THAT HASN'T STOPPED QUESTIONS FROM BEING RAISED ABOUT ETHICS OF PROF ITING FROM SUCH TALES AND HHETHER THEY COUID UPSET THE JUDICIAL PROCESS. SOME EXPERTS FEAR THAT VERDICTS COULD BE JUDICIAL PROCESS. SOME EXPERTS FEAR THAT VERDICTS COULD BE BOOKS AND ARTICLES BY EX-JURORS.

02413 COLLINS, R.

THE RISE AND FALL OF MODERMISM IN POLITICS AND RELIGION ACTA SOCIOLOGICA, 35(3) (1992), 171-186.

IN MODERNISM.' THE STRUCTURAL BASES OF CONFLICT ARE TRIANGULAR: IN POLITICS, MOVING AMONG THE POLES OF CENTRALIZATION, MASS PARTICIPATION, AND A DECENTRALIZED BALANCE OF POWERS; IN RELIGION, THE CORRESPONDING POLES ARE CHURCH HIERARCHY, SECT ENTHUSIASM, AND SPIRITUAL ELITES. THE PERIOD OF STRUGGLE FOR SECULARIZATION AND RELIGIOUS TOLERATION CRYSTALIZED IN THE LIBERAL/CONSERVATIVE POLARIZATION OF THE ENLIGHTENMENT AND THE FRENCH REVOLUTION. THIS BINARY DIMENSION HAS BROKEN DOHN AGAIN IN THE LATE 2OTH CENTURY, GIVING RISE TO THE SELF-DOUBTS MANIFESTED IN THE IDEOLOGY OF POSTMODERNISM.

02414 COLMO, C.

THEORY AND PRACTICE: ALFARABI'S "PLATO" REVISITED AMERICAN POLITICAL SCIENCE REVIEW, 86(4) (DEC 92), 966-976. ACCOROING TO LEO STRAUSS, KNOWLEDGE OF THE BEST WAY OF LIFE IS CRUCIAL TO POLITICAL PHILOSOPHY. IN "FARABI'S PLATO, "STRAUSS ASKS, ASSUMING THAT THE THEORETICAL LIFE CAN BE, KNOWN TO BE THE BEST WAY OF LIFE, WHAT IS THE STATUS OF THIS KNOWLEDGE? IS THE KNOWLEDGE OF THE BEST WAY OF LIFE ITSELF THEORETICAL KNOWLEDGE OR PRACTICAL KNOWLEDGE? WITHOUT A COHERENT ANSWER TO THIS OUESTION, PHILOSOPHERS CANMOT BE CERTAIN THAT THEY KNOW WHAT THEY' MEAN HHEN THEY CLAIM TO KMOH THAT PHILOSOPHY IS THE BEST HAY OF LIFE. STRAUSS ANSWERS THE QUESTION ABOUT THE STATUS OF THE KNOWLEDGE OF ANSWERS THE QUESTION ABOUT THE STATUS OF THE KNOWLEDGE OF THE BEST WAY OF LIFE BY AFFIRMING THAT IT IS PRACTICAL, NOT ANSWER IS NOT PERSUASIVE IN THE FORM IN WHICH STRAUSS GIVES ANS

02415 COLOMER, J.

BENEFITS AND COSTS OF VOTING

ELECTORAL STUDIES, 10(4) (DEC 91), 313-325

THE MODEL OF THE RATIONAL VOTER ASSUMES THAT THE CHOICE BETWEEN VOTING AND ABSTAINING BASICALLY DEPENDS ON EXPECTED BENEFITS AND COSTS. THIS ARTICLE OFFERS A TEST OF THESE ASSUMPTIONS, CONCEIVING BENEFITS OF VOTING AS DERIVING FROM THE IMPORTANCE OF POLITICS AND FROM DIFFERENTIAL DEMOCRATIC SYSTEM, AND COSTS OF VOTING COMING FROM YOLUNTARY VOTE AND VOLUMTARY REGISTRATION OF ELECTORS. THE ANALYSIS COMPARES AVERAGE TURNOUT HITH OTHER RESPECTIVE DATA. THE RESULTS OF 
REGRESSIONS STRONGLY SUPPORT THE RATIONAL CHOICE THEORY.

02416 COLOMER, J.M.

RATIONAL CHOICE POLITICAL THEORY IN SPAIN EUROPEAN JOURNAL OF POLITICAL RESEARCH, 21(4) (JUN 92), 409-421.

THE AUTHOR SURVEYS THE DEVELOPMENT OF THE LITERATURE ON RATIONAL CHOICE POLITICAL THEORY IN SPAIN. THE SURVEY IS DIVIDED INTO TWO PARTS. THE FIRST DEALS WITH CONTRIBUTIONS AT A THEORETICAL LEVEL, DISTINGUISHING THOSE PLACED IN THE RANKS OF NARROWLY-DEFINED SOCIAL CHOICE THEORY, THOSE RELATED TO THE PUBLIC CHOICE SCHOOL, AND THOSE' ORIENTED TO RELATED TO THE PUBLIC CHOICE SCHOOL, AND THOSE ORIENTED
THE INTRODUCTION OF NEH APPROACHES IN MORE CONVENTIONAL THE INTRODUCTION OF NEW APPROACHES IN MORE CONYNTIONAL POL ITICAL SCIENCE. THE SECOND PART PRESENTS APPLIED ANALYSES
OF THE CONSTITUTION, INSTITUTIONS, POLITICAL-ECONOMIC CYCLES, AND COLLECTIVE ACTION.

02417 COLOMER, J.M.

TRANSITIONS BY AGREEMENT: MODELING THE SPANISH WAY AMERICAN POLITICAL SCIENCE REVIEH, 85(4) (DEC 91), 1283-1302.

THE AUTHOR MOOELS SEVERAL CASES OF NONREVOLUTIONARY TRANSITION TO DEMOCRACY. DIFFERENT PREFERENCES AND STRATEGIC CHOICES AMONG THE ALTERNATIVES OF CONTINUITY, REFORM, AND RUPTURE OF THE AUTHORITARIAN REGIME ARE USED TO MORE PRECISELY OEFINE CONVENTIONAL DISTINCTIONS AMONG HARD-LINERS, SOFT-LINERS, AND OPPOSITION. SIX GROUPS OF ACTORS EMERGE. USING GAME THEORY, THE AUTHOR ANALYZES THE INTERACTIONS AMONG THESE ACTORS. THE POSSIBILITY OF POLITICAL PACT IN THE FIRST PHASE OF CHANGE IS IDENTIFIED WITH THE POSSIBILITY OF COOPERATION BETWEEN PLAYERS IN GAMES IN WHICH THE EQUILIBRIUM IS A DEFICIENT OUTCOME. THREE MODELS OF TRANSITION BY AGREEMENT ARE ESTABLI ISHED: AGREED REFORM WITHIN THE RULING BLOC, CONTROLLED OPENING TO THE OPPOSITION, AND SUDDEN COLLAPSE OF THE AUTHORITARIAN REGIME. EACH OF THESE MODELS ENTAILS DIFFERENCES IN THE PACE OF CHANGE ANO THESE MODELS ENTAILS DIFFERENCES IN THE PACE OF CHANGE
IN THE LIMITS OF THE PACT AND CAN BE ASSOCIATED WITH IN THE LIMITS OF THE PACT AND CAN BE ASSOCIATED WITH
DIFFERENT CASES OF TRANSITION IN SOUTHERN EUROPE, LATIN DIFFERENT CASES OF TRANSITION
AMERICA, AND EASTERN EUROPE.

02418 COMMONER, $B$.

THE FAILURE OF THE ENYIRONMENTAL EFFORT

CURRENT HISTORY, 11 (564) (APR 92) 176-181.

THERE IS A CRISIS IN THE DEVELOPMENT OF THE UNITED STATES' ENVIRONMENTAL PROGRAM. NONE OF US IS READY TO PRESCRIBE WHAT SHOULD BE DONE TO REMEDY THE ENVIRONMENTAL FAILURE, BUT WE KNOW HOW TO BEGIN--WITH AN OPEN PUBLIC DISCUSSION OF WHAT HAS GONE WRONG AND WHY. THAT IS THE
NECESSARY FIRST STEP ON THE PATH TOWARD REALIZING THE GOAL OF RESTORING THE QUALITY OF THE ENVIRONMENT.

02419 CONO, J.

CHINOCHET?

NATIONAL REVIEW, XLIV(18) (SEP 92), 29-30.

INSTEAD OF WAITING FOR THE PERUVIAN ARMY TO LAUNCH A STAMDARD LATIN AMERICAN COUP, PRESIDENT ALBERTO FUJIMORI LAUNCHED A SELF-COUP ("AUTOGOLPE"), SUSPENDED THE CONGRESS, REVOKED PARTS OF THE CONSTITUTION, AND FIRED MOST OF THE JUDICIARY. EIGHTY PERCENT OF PERUVIANS APPROYED OF FUJIMORI'S ACTIONS, BECAUSE THEY DESPISED THE TIMOROUS JUDGES AND THE DO-NOTHING, OLD-LINE LEGISLATORS. YET MOST DOUBT THAT FUJIMORI'S COUP WILL CURE PERU'S WOES.

02420 COMO, J.

DEBATES, \DEBATES, AND SHOWBIZ

NATIONAL REVIEH, XLIV(22) (NOV 92), 37.

JAMES COMO SUGGESTS THAT TO A DEGREE EVERY DEBATE IS A RORSCHACH TEST AND THAT HINNING THE PRESIDENTIAL DEBATES MEANS GAINING THE MOST VOTES, MAKING THE BEST IMPRESSION, OR MAKING THE BEST CASE. HE ANALYZES THE RECENT ROUND OF PRESIDENTIAL DEBATES AND DECLARES THE WINMER OF EACH OF THEM. THIS YEAR A SUBSTANTIAL PERCENTAGE OF VOTERS HAD NOT YET THIS YEAR A SUBSTANTIAL PERCENTAGE OF VOTERS HAD NOT YET
DECIDED, AHD PRESIDENTIAL III HAS WATCHED BY 88 MILLION DECIDED, AND PRESIDENTIAL III WAS WATCHED BY 88 MILLION
PEOPLE; ITS 44.6 RATING WAS THE HIGHEST OF ALL THE DEBATES.

02421 CONANT, $J$.

EXECUTIVE BRANCH REORGANIZATION: CAN IT BE AN ANTIDOTE FOR EXECUTIVE BRANCH REORGANIZAT

STATE AND LOCAL GOVERMMENT REVIEW, 24(1) (WIN 92), 3-11.

TATE AND LOCAL GOVERMMENT REVIEW, 24 (1) (WIN 92), 3-11. THE PRINCIPAL QUESTION EXAMINED IN THIS ARTICLE IS
WHETHER EXECUTIVE BRANCH REORGAMIZATION CAN BE AN ANTIDOTE TO A STATE'S FISCAL PROBLEMS. AS PART OF THE ANALYSIS, CAUSES OF FISCAL STRESS IN THE STATES ARE DEFINED, SOME OF CAUSES OF FISCAL STRESS IN THE STATES ARE DEFINED, SOME THE CONSTRAINTS THE STATE'S CHIEF EXECUTIVES FACE IN RESPONDING TO FISCAL STRESS ARE OUTLINED, THE TWO PRINCIPAL SCHOLARLY PERSPECTIVES ON EXECUTIVE BRANCH REORGANIZATION
ARE DESCRIBED. AND THE RHETORIC AND OUTCOMES OF EXECUTIVE BRANCH REORGANIZATIONS IN 22 STATES ARE EXAMINED. ON THE BASIS OF THIS ANALYSIS, THE AUTHOR CONCLUDES THAT EXECUTIVE BRANCH REORGANIZATION DOES NOT CURE A STATE'S FISCAL ILLS. HE ALSO CONCLUDES THAT IN TIMES OF FISCAL STRESS, EXECUTIVE BRANCH REORGANIZATION MAY BE USEFUL FOR A VARITY' OF OTHER PURPOSES.
02422 CONANT, J.K.

ENROLLMENT TRENDS IN SCHOOLS OF PUBLIC AFFAIRS AND ADMINSTRATION: A SEARCH FOR WINNERS AND LOSERS PUBLIC ADMINISTRATION REVIEN, 52(3) (MAY 92), 288-297. THE AUTHOR STUDIES ENROLLMENT PATTERNS AT PUBLIC AFFAIRS/ADMINISTRATION SCHOOLS OVER THE PAST 15 YEARS. DATA FROM THE NATIONAL ASSOCIATION OF SCHOOLS OF PUBLIC AFFAIRS AND ADMINISTRATION INDICATE THAT ENROLLMENTS EXPERIENCED PERIODS OF RAPID GROWTH (1972-79), SHARP DECLINE (1979-83), AND RELATIVE STABILITY (1983-89). USING ADJUSTED ENROLLMENT DATA, THE AUTHOR EXAMINES SEVERAL FACTORS: TYPE OF UNIVERSITY (PUBLIC OR PRIVATE), GEOGRAPHIC REGION, TYPE OF PROGRAM, AND SIZE. HE FINDS MIXED RESULTS, WITH DIFFERENT PROGRAM, AND SIZE. HE FINDS MIXED RESULTS, WITH DIFFERENT
PATTERNS EMERGING FOR DIFFERENT SCHOOLS DEPENDING ON THE PATTERNS EMERGING FOR DIFFERENT SCHOOLS DEPENDING ON THE
PERIOD AND VARIABLE UNDER CONSIDERATION. THE SEARCH POINTS PERIOD AND VARIABLE UNDER CONSIDERATION. THE SEARCH POINTS
TO SPECIAL PROBLEMS FOR PROGRAMS AT PRIVATE UNIVERSITIES, AS TO SPECIAL PROBLEMS FOR PROGRAMS AT PRIVATE UNIVERSITIES, AS ADDRESSED BY ALL PUBLIC AFFAIRS AND ADMINISTRATION PROGRAMS.

02423 CONANT, M.

ISLAM AND THE THREAT TO THE HEST'S OIL SUPPLIES

MIDOLE EAST INTERNATIONAL, (396) (MAR 91), 22-23.

THERE IS INCREASING SPECULATION AMONG INDUSTRIAL NATIONS DEPENDENT ON OIL IMPORTS AS TO HOW THE ISLAMIC REVIVAL MAY COME TO AFFECT OIL SUPPLIES. ALTHOUGH NONE OF THE OIL-RICH COUNTRIES HAS ASPIRED AS YET TO ISLAMIC LEADERSHIP, WITH THE NOTABLE EXCEPTION OF IRAN. THEIR CONCERN FOCUSES ON WHAT MAY COME TO BE A MIX OF ISLAMIC FERVOR PLUS OIL AND HOW REGIONAL POLITICS MAY BE AFFECTED. THE FUTURE MOST BENEFICIAL TO THE OIL INTERESTS OF THE INDUSTRIALIZED NATIONS IS ONE IN WHICH TWO FLASHPOINTS OF ISLAMIC FERVOR AND ANTI-WESTERN FEELING: THE ARAB-ISRAELI CONFLICT AND THE CONFLICT BETWEEN RICH AND POOR ISLAMIC NATIONS IS PEACEABLY RESOLVED.

02424 CONCA, $K$.

TECHNOLOGY, THE MILITARY, AND DEMOCRACY IN BRAZIL JOURNAL OF INTERAMERICAN STUDIES AND WORLD AFFAIRS, 34(1) (SPR 92), 141-178.

BRAZIL ENTERED THE 1990 S WITH ITS TRANSITION FROM AUTHORITARIAN RULE INCOMPLETE. THIS DISCUSSION BEGINS WITH A BRIEF DESCRIPTION OF THE MILITARY INDUSTRIES AND PROGRAMS THAT EMERGED DURING THE PERIOD OF MILITARY RULE. NEXT, IT THAT EMERGED OURING THE PERIDD OF MILITARY RULE. NEXT, IT
SCRUTINIZES THE PROCESS BY WHICH THE ARMED FORCES ' CONROL OF SCRUTINIZES THE PROCESS BY WHICH THE ARMED FORCES CONRO
THE DEFENSE SECTOR WAS RESTRUCTURED. AND IN MANY WAYS PRESERVED, DURING THE TRANSITION TO CIVILIAN RULE. FOLLOWING PRESERVED, DURING THE TRANSITION TO CIVILIAN RULE. FOLLOHI A REVIEW OF THE RESULTING EFFECTS OF ENDURING MILITARY
CONTROL ON A RANGE OF PUBLIC POLICY ISSUES, THE CONCLUSION WILL DISCUSS THE PROBLEMS AND PROSPECTS FOR EFFECTIVE

02425 CONDREY, S.; BUDNEY, J. PERFORMÁMCE-BASED MÁNAGERIAL PAY IN THE FEDERAL GOVERMMENT: DOES AGENCY MATTER? JOURNAL OF PUBLIC ADMINISTRATION RESEARCH AND THEORY, 2(2) APR 92 ), 157-174.

DO FACTORS UNIQUE TO PARTICULAR AGENCIES AFFECT THE DESIGN, IMPLEMENTATION, AND RESULTS OF PERFORMANCE-BASED
COMPENSATION SYSTEMS? THE RESEARCH PRESENTED ADORESSES THIS QUESTION, USING THE FEDERAL PERFORMANCE MANAGEMENT AND RECONGITION SYSTEM (PMRS) AS THE FOCUS OF ANALYSIS. THE FINDINGS SHOW THAT AGENCY DOES IMPACT THE DESIGN, IMPLEMENTATION, AND PERCEIVED OUTCOMES OF AN EXPECTANCYBASED COMPENSATION SYSTEM. THE RESEARCH SUGGESTS THAT AGENCY BASED DIFFERENCES SHOULD BE EXPLORED BEFORE IMPLEMENTING A PAY-FOR-PERFORMANCE COMPENSATION SYSTEM. THIS RESEARCH TAKES ON PARTICULAR SIGNIFICANCE SINCE RECENT FEDERAL LEGISLATION REOUIRES A FEASIBILILTY STUDY OF EXTENDING A PMRS-LIKE PAY SYSTEM TO THE ENTIRE FEDERAL WORKFORCE.

02426 CONGLETON, R.D.; SWEETSER, H.

POLITICAL DEADLOCCKS AND DISTRIBUTIONAL INFORMATION: THE VALUE OF THE VEIL

PUBLIC CHOICE, 73(1) (JAN 92), 1-20.

CONTRACTARIAN NORMATIVE THEORY RELIES ON THE "VEIL OF CONTRACTARIAN NORMATIVE THEORY RELIES ON THE "VEIL OF
IGNORANCE" CONSTRUCT TO GENERATE THE POL ITICAL CONSENSUS IGNORANCE" CONSTRUCT TO GENERATE THE POL ITICAL CONSEN REQUIRED FOR ITS THEORIES OF JUSTICE. BY EL IMINATING
DISTRIBUTIONAL INFORMATION, THE VEIL IS PRESUMED TO DISTRIBUTIONAL INFORMATION, THE VEIL IS PRESUMED TO
FACILITATE CONSENSUS BUILDING BY REDUCING CONFLICT OVER FACILITATE CONSENSUS BUILDING BY REDUCING CONFLICT OVER
DISTRIBUTIONAL EFFECTS OF PROPOSED CONSTITUTIONAL RULES OR OISTRIBUTIONAL EFFECTS OF PROPOSED CONSTITUTIONAL RULES OR

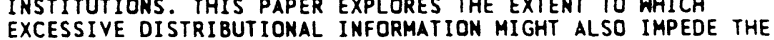
EXCESSIVE DISTRIBUT IONAL INFORMATION MIGHT ALSO IMP
ORDINARY DAY-TO-DAY DECISIONMAKING OF DEMOCRATIC ORDINARY DAY-TO-DAY DECISIONMAKING OF DEMOCRATIC INSTITUTIONS. THE AUTHORS ANALYSIS SUGGESTS THAT
DISTRIBUTIVE INFORMATION MAKES POLITICAL DEADLOCKS UNDER DISTRIBUTIVE INFORMATION MAKES POLITICAL DEADLOCKS UNDER MAJORITY RULE MORE LIKELY. STATISTICAL EVIDENCE SUGGESTS THAT THE EFFICACY OF THE U.S. CONGRESS HAS BEEN REDUCED BY
THE DRAMATIC INCREASE IN DISTRIBUTIONAL INFORMATION MADE AVAILABLE TO IT OVER THE PAST THENTY-FIVE YEARS.

02427 CONLAN, T. INTERGOVERMMENTAL MANDATES AND PREEMPTION IN AN ERA OF DEREGULATION

PUBLIUS: THE JOURMAL OF FEDERALISM, 21(3) (SUM 91), 43-58. FOR STATE AND LOCAL GOVERNMENTS, THE 1OIST CONGRESS 
(1989-1990) COMPILED A MIXED RECORD OF INTERGOVERMMENTAL REGULATION AND PREEMPTION. COSTLY AND INTRUSIVE MANDATES HERE ENACTED TO COMBAT AIR POLLUTION, PROTECT THE RIGHTS OF DISABLED PERSONS, AND PROVIDE MEDICAL ASSISTANCE TO THE POOR. AT THE SAME TIME, NEW RESTRICTIONS WERE DEFEATED IN LEGISLATION AFFECTING OIL-SPILL LIABILITY AND CHILD CARE THIS ARTICLE REVIEWS THE ISSUES AND POLITICS SURROUNDING THESE ENACTMENTS, AND PLACES THEM WITHIN THE BROADER CONTEXT OF INTERGOVERNMENTAL REGULATORY TRENDS DURING THE 1980S. THE PAST DECADE WAS CHARACTERIZED BY INCREASING REGULATORY BURDENS IMPOSED ON STATES AND LOCALITIES, PUNCTUATED BY OCCASIONAL EXAMPLES OF REGULATORY RELIEF AND DEFERRAL.

02428 CONN, J.L.

ROBERTSON ROULETTE

CHURCH AND STATE, 45(9) (OCT 92), 14(206)-16(208).

ALTHOUGH PRESIDENT BUSH NEEDS THE SUPPORT OF THE RELIGIOUS RIGHT IN HIS 1992 RE-ELECTION BID, SOME OF PAT ROBERSON'S RADICAL RHETORIC IS MAKING BUSH CAMPAIGN AIDES NERVOUS. THE VERY CONSERVATIVE CHRISTIAN COALITION IS FIGHTING THE TRADITIONAL GOP LEADERSHIP FOR CONTROL OF THE FIGHTING THE TRADITIONAL GOP LEADERSHIP FOR CONTROL OF THE WASHINGTON, VIRGINIA, IONA, COLORADO, LOUISIANA, SOUTH WASHINGTON, VIRGINIA,
CAROLINA, AND ALASKA.

02429 CONNELL, R.H. THE STATE, GENDER, AND SEXUAL POLITICS: THEORY AND APPRAISAL

THEORY AND SOCIETY, 19(5) (OCT 90), 507-544.

IN THIS ARTICLE SEXUAL POLITICS AND FEMINISM IN THE 1980 S IN THE U.S. AND EUROPE ARE EXAMINED. IT IS ARGUED THAT ALTHOUGH PROGRESS HAS BEEN MADE ON SOME SPECIFIC POINTS, OVERALL THE 1980 S HAVE NOT YIELDED SUBSTANTIAL STRIDES IN FAIRNESS OR FREEDOM ON THESE ISSUES. THE LACK OF AN ESTABLI SHED THEORETICAL FRAMEWORK FOR APPRAISAL OF THE SITUATION IS DISCUSSED.

02430 CONMER, A.; POIRIER, R.

THE INSTITUUTES OF THE USSR ACADEMY OF SCIENCE: AN EXAMINATION OF THEIR ROLES IN SOVIET DOCTRINE AND STRATEGY JOURNAL OF SOVIET MILITARY STUDIES, 4(1) (MAR 91), 62-86. A PARTICULARLY SIGNIFICANT DEVELOPMENT IN SOVIET POLITICAL-MILITARY AFFAIRS IS THE APPARENT RISE TO PROMINENCE OF SEVERAL OF THE RESEARCH INSTITUTIONS OF THE USSR ACADEMY OF SCIENCES. THIS ARTICLE EXAMINES THE

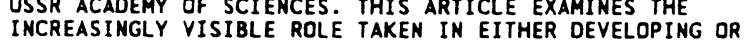
INCREASINGLY VISIBLE ROLE TAKEN IN EITHER DEVELOPING OR
ARTICULATING SOVIET NATIONAL SECURITY POSITIONS BY CERTAIN CURRENT AND FORMER MEMBERS OF TWO OF THE INSTITUTES: THE INSTITUTE OF THE USA AND CANADA, AND THE INSTITUTE OF WORLD ECONOMICS AND INTERNATIONAL RELATIONS. THE ARTICLE EXAMINES THE PERSONALITIES INVOLVED AND THE RECENT CHANGES HAVE PLACE. IT CONCLUDES THAT IT IS NOW POSSIBLE FOR THE INSTITUTES TO ENGAGE THE SOVIET MILITARY IN SIGNIFICANT DEBATE. WHILE THE MILITARY IS STILL FULLY CAPABLE OF HOLDIM
ITS OWN IN SUCH A DEBATE, THE POSSIBILITY NOW EXISTS FOR COMPROMISE WITHIN THE OVERARCHING GUIDELINES OF THE MILITARY DOCTRINE.

02431 CONNER, $W$.

THE POLISH ROAD FROM SOCIALISM: THE ECONOMICS, SOCIOLOGY, AND POL ITICS OF TRANSITION

M. E. SHARPE, INC., 1992,400

THE CONTRIBUTORS TO THIS VOLUME FOCUS ON POLAND'S MOVEMENT TOWARD AN INTERMATIONALLY COMPETITIVE MARKET ECONOMY, A POLITICAL DEMOCRACY IN WHICH PLURAL INTERESTS COMPETE, AND THE CONSTITUTION OF A CIVIL SOCIETY THAT BOTH TOLERATES AND AMELIORATES CONFLICT. THIS IS NEITHER A ROMANTIC VERSION OF THE COURSE OF POL ISH HISTORY NOR A JUBILANT ACCOUNT OF THE RECOVERY OF NATIONAL INDEPDENDENCE AND POLITICAL CHOICE. RATHER, THEY OFFER A VARIETY OF TOUGHMINDED ANALYIIC PERSPECTIVES ON WHAT COMES WHEN THE PARTY'S OVER--NOT JUST THE PZPR BUT THE CELEVRATION MARKING ITS DOWWFALL.

02432 CONNOLLY, M.E.H.; STARK, A.H.

POLICY MAKING AND THE DEMONSTRATION EFFECT: PRIVATIZATION IN A DEPRIVED REGION

PUBLIC ADMINISTRATION (LONDON), 70(3) (FAL 92), 369-385. THE GOALS OF PUBLIC POLICIES ARE NOT ALWAYS CLEARLY ARTICULATED BY MINISTERS. MOREOVER, THE AIMS THAT ARE STATED MAY NOT REFLECT ALL, OR EVEN THE MOST IMPORTANT, GOALS. IN SOME CASES, DECLARED POLICY AIMS BEAR LITTLE RELATION TO THE REAL INTENTIONS OF MINISTERS IN UNDERTAKING AN INITIATIVE. REAL INTENTIONS OF MINISTERS IN UNDERTAKING AN INITIATIVE. IN OTHER CASES, POL ICY DECISIONS ARE INTENDED AS SYMBOLIC STATEMENTS, DEMONSTRATING GOVERMMENT ATTITUDES ON A RANGE OF ISSUES BEYOND THE SPECIFIC MATTER UNDER CONSIDERATION. IN THIS ESSAY, THESE IDEAS ARE EXPLORED IN THE CONTEXT OF THE PRIVATIZATIONS OF TWO MAJOR INDUSTRIAL GOVERNMENT-OWNED
COMPANIES IN NORTHERN IRELAND, WHERE THE GOVERNMENT SOUGHT COMPANIES IN NORTHERN IRELAND, WHERE THE GOVERNMENT SOUGHT
TO USE THE PRIVATIZATIONS AS S SYMBOL IC STATEMENT--NAMELY, TO USE THE PRIVATIZATIONS AS A SYMBOLIC STATEMENT--NAMELY SECTOR WITHIN NORTHERN IRELAND HAD TO BE REDUCED.
02433 CONNOR, J.D

UNGREEN MACHINE

NEW REPUBLIC, $207(3-4)$ ( JUL 92), 24, 26.

THE RECENT BLOSSOMING OF BRAZIL'S GREEN IMAGE IS BASED ON THREE MYTHS: DEFORESTATION IS DOWN; POPULATION GROWTH IS UNDER CONTROL; AND PROTECTIVE STEPS--INCLUDING THE CREATION OF PARKS AND RESERVES--ARE UNDERWAY. IN THIS ARTICLE, THE AUTHOR SCRUTINIZES THESE THREE CLAIMS.

02434 CONQUEST, $R$

THE IMPORTANCE OF HISTORICAL TRUTH

FREEDOM REVIEH, 23(6) (NOV 92), 7-8

THE ECONOMIC AND ECOLOGICAL DISASTERS OF THE SOVIET ERA ARE WELL KNOWN. WHAT HAS PERHAPS NOT BEEN STRESSED ENOUGH IS THE MORAL AND INTELLECTUAL VACUUM OF THE COMMUNIST REGIME. FOR MORE THAN HALF A CENTURY, FALSIFICATION ON AN ENORMOUS SCALE WAS A MAINSTAY OF THE SYSTEM. HISTORY, PRODUCTION FIGURES, AND CENSUS RESULTS WERE ALL FAKED. BUT EVEN MORE DEMORALIZING, THE WHOLE SPHERE OF THOUGHT WAS CONTROLLED AND DEMORALIZING, THE WHOLE SPHERE OF THOUGHT WAS CONTROLLED AND
DISTORTED. THE INHUMAN AND CONTINUOUS PRESSURES OF THE STATE DISTORTED. THE INHUMAN AND CONTINUOUS PRESSURES OF THE STATE
DEMANDED THAT ALL MINDS ACCEPT A FANTASY OF HAPPINESS AND DEMANDED

02435 CONQUEST, $R$

THE MOSCOH COUP

NATIONAL REVIEH, XLIII(16) (SEP 91), 19-20

THIS ARTICLE IS AN INTERVIEW WITH SOVIETOLOGIST ROBERT CONQUEST. HE DISCUSSES THE HARD-LINE COUP IN THE SOVIET UNION AND ITS IMPLICATIONS. TOPICS DISCUSSED INCLUDE: THE TIMING OF THE COUP; THE "PROGRAM" OF THE HARD-LINERS; THE SHORT AND LONG TERM PROSPECTS; POTENTIAL RESISTANCE TO THE COUP; THE ROLE OF BORIS YELTSIN, THE KGB, AND THE ARMED FORCES; SIMILARITIES TO THE 1981 CRACKDOWN IN POLAND; THE POTENTIAL INFLUENCE OF THE WEST; THE FUTURE OF ARMS-CONTROL AGREEMENTS; PRECEDENTS IN RUSSIAN HISTORY; AND THE ROLE AND FUTURE OF MIKHAIL GORBACHEV.

02436 CONRAD, B.

EYE-TO-EYE ON MAASTRICHT

GERMAN TRIBUNE, 31(1541) (NOV 92), 1.

ONCE JOHN MAJOR TOLD HELMUT KOHL WHAT PARTY-POLITICAL CONSTRAINTS HE FACES, THE CHANCELLOR REALIZED THAT THE MAASTRICHT TREATY TIMETABLE WAS A WRITE-OFF. IT COULD NO LONGER BE MORE THAN A MATTER OF SALVAGING WHAT WAS LEFT TO BE SALVAGED. IT WAS CLEAR FROM THE OUTSET THAT KOHL AND MAJOR WOULD AGREE IN REJECTING A TRADE WAR BETWEEN EUROPE AND THE UNITED STATES. LUCKILY, MITTERAMD TOO SEEMS READIER NOW TO ACCEPT THE NEED FOR A SENSIBLE GATT COMPROMISE.

02437 CONRAD, B.

GERMANY RETAINS RESPONSIBILITY FOR ISRAEL AND THE JEWS GERMAN TRIBUNE, (1516) (MAY 92), 2.

THE POLITICAL INTEREST OF THE EUROPEANS IN GENERAL AND THE GERMANS IN PARTICULAR HAS RECENTLY BEEN REDIRECTED TOWARD EASTERN AND SOUTH-EASTERN EUROPE AND THE NEW GERMAN LANDER (PROVINCES) AND AHAY FROM THE MIDDLE EAST. AS GERMANY HEADS INCREASINGLY TOWARD EUROPEAN UNION AND INCORPORATES ITS FOREIGN AND MIDDLE EAST POLICY IN THE COMMON APPROACH ADOPTED BY THE EUROPEAN CDMMUNITY, THE SPECIFIC NATURE OF GERMAN-ISRAELI TIES IS DECLINING IN IMPORTANCE. IT USED TO BE A SPECIAL RELATIONSHIP BASED ON GERMANY'S HISTORIC RESPONSIBILITY TOWARD THE JEWS AND THE JEWISH STATE. THE PRESENT TENDENCY IS FOR ISRAEL TO BE VIEWED AS A STATE LIKE ANY OTHER. THIS SHIFT IN FOREIGN POLICY EMPHASIS HAS STRAINED RELATIONS BETHEEN ISRAEL AND GERMANY, BUT SEEMS UNAVOIDABLE.

02438 CONROY, M. ; GLASMEIER, A.

UNPRECEDENTED DISPARITIES, UNPARALLELED ADJUSTMENT NEEDS: WINNERS AND LOSERS ON THE NAFTA FAST TRACK

JOURNAL OF INTERAMERICAN STUDIES AND WORLD AFFAIRS, 34(4)

(WIN 92 ), 1-38.

THE SCOPE AND SCALE OF ADJUSTMENT PROGRAMS NEEDED UNDER THE PROPOSED NORTH AMERICAN FREE TRADE AGREEMENT (NAFTA) IS GAUGED THROUGH AN EXAMINATION OF HISTORICAL EUROPEAN ADJUSTMENT PROGRAMS. THIS PAPER EXPLORES DISTRIBUTIVE ISSUES AND BEGINS BY COMPARING THE RELATIVE DISPARITIES BETWEEN MEXICO AND THE UNITED STATES WITH THE DISPARITIES BETWEEN PORTUGAL AND SPAIN AND THE REST OF THE EUROPEAN ECONOMIC COMHUNITY ON THE EVE OF THEIR INTEGRATION INTO THE EEC. THE COMMUNITY ON THE EVE OF THEIR INTEGRATION INTO THE EEC. THE RECENT EXPERIENCE OF THE US-CANADIAN FREE TRADE AGREEMENT AND LOSERS UNDER THE TRADE AGREEMENT. THE ARTICLE CONCLUDES AND LOSERS UNDER THE TRADE AGREEMENT. THE ARTICLE CONCL STRATEGIES TO MITIGATE IMPACTS ON THE PENDING NAFTA.

02439 CONSTABLE, M.

FOUCAULT AND WALZER: SOVEREIGNTY, STRATEGY AND THE STATE POLITY, XXIV(2) (HIN 91), 269-294

MICHAEL WALZER FAULTS THE POLITICAL THEORY OF MICHEL FOUCAULT FOR FAILING TO PROVIDE AN ACCOUNT OF THE LIBERAL STATE AND THE RULE OF LAN OR TO PROVIDE THE KIND OF KNOWLEDGE THAT REGULATES DISCIPLINARY ARRANGEMENTS IN SOCIETY. THIS ARTICLE ASSESSES WALZER'S CRITICISM IN LIGHT 
OF FOUCAULT'S ANALYSIS OF LIBERAL POLITICAL THEORY. IT CONCLUDES THAT WALZER'S THEORY, COUCHED IN THE DISCOURSE OF SOVEREIGNTY, EMPLOYS OISCIPLINARY STRATEGIES OF POHER, AKIN TO THOSE FOUCAULT DESCRIBES TO COMBAT THE TYRANMICAL STATE.

02440 CONSTABLE, P.

DATELINE HAITI: CARIBBEAN STALEMATE

FOREIGN POLICY, (89) (WIN 93), 175-190.

THO OPPOSING FORCES ARE CHOKING HAITI: AN OPPRESSIVE MILITARY REGIME THAT HAS SYSTEMATICALLY CRUSHED POLITICAL RESISTANCE WHILE OPERATING BEHIND A THIN VENEER OF CIVILIAN AUTHORITY AND A WELL-INTENTIONED BUT HALF-HEARTED EMBARGO BY THE ORGANIZATION OF AMERICAN STATES THAT HAS DRIVEN HAITI'S SUBSISTENCE-LEVEL ECONOMY EYEN FURTHER INTO THE GROUND. ALTHOUGH THE CRISIS HAS BECOME A STAL EMATE FOREIGN DEMOCRACIES MUST REMAIN ENGAGED AND HELP HAITI EVOLVE TOHARD A POLIIIICAL SYSTEM THAT ENSURES THE PEACEFUL RESOLUTION OF DISAGREEMENTS. IT IS CLEAR THAT THE PRESENT POLICY OF A POORLY ENFORCED, HALF-HEARTED EMBARGO IS NOT SUFFICIEN FOSTERING COMPROMISE WILL REQUIRE STRONG AND PERHAPS UNPALATABLE MEASURES, BUT EVENTUALLY THE CONFLICT UNLEASHED BY THE DUVALIERS' DEPARTURE AND ARISTIDE'S ELECTION MUST BE PLAYED OUT. THE ONLY REAL QUESTION FOR THE WESTERN HEMISPHERE' S POWERS IS WHETHER THEY, LED BY THE USA, WILL HELP HAITI CHART A PEACEFUL PATH TO DEMOCRATIC COMPROMISE OR ABANOON IT TO AN INEYITABLE, BLDODY CLASH BETWEEN THE FORCES OF RADICAL CHANGE AND REACTIONARY RESISTANCE.

02441 CONSTABLE, P.

HAITI'S SHATTERED HOPES

JOURNAL OF DEMOCRACY, 3(1) (JAN 92), 41-51.

AFTER A BRIEF, DEEPLY FLAHED BUT UNPRECEDENTED

EXPERIMENT IN POPULAR DEMOCRACY, HAITI HAS ABRUPTLY RETURNED TO THE POLITICS OF GREED AND TERROR THAT HAVE DOMINATED ITS HISTORY FOR MOST OF THE 200 YEARS SINCE SLAVE REVOLTS OVERTHREW FRENCH COLONIAL RULE AND LED TO THE CREATION OF THE FIRST BLACK REPUBLIC IN THE HESTERN HEMISPHERE. ON 30 SEPTEMEBER, 1991, PRESIDENT JEAN-BERTRAND ARISTIDE, THE FIRST FREELY ELECTED CHIEF EXECUTIVE IN HAITI'S HISTORY, WAS OVERTHROWN BY THE ARMY LESS AFTER LESS THAN EIGHT MONTHS IN POWER. HUNDREDS OF PROTESTERS WERE GUNNED DOWN IN THE STREETS, AND ARISTIDE HAS FORCED INTO EXILE. THE ORGANIZATION OF AMERICAN STATES HAS STRONGLY CALLED FOR ARISTIDE'S RETURN TO HAITI ; BUT EVEN IF HE IS EVENTUALLY ALLOHED BACK, HAITI SEEMS HEADED FOR ANOTHER BOUT OF CONFLICT AND INSTABILITY BEFOR DEMOCRACY CAN EMERGE AGAIN.

02442 CONYERSE, P.E.; PIERCE, R.

PARTISANSHIP AND THE PARTY SYSTEM

POLITICAL BEHAVIOR, 14(3) (SEP 92), 239-260.

THE TRADITIONAL DEFINING PROPERTIES OF PARTY IDENTIFICATION IN THE UNITED STATES OFTEN FAIL TO BE REPLICATED IN ELECTORAL SYSTEMS ABROAD. A NUMBER OF PLAUSIBLE SUGGESTIONS HAVE BEEN OFFERED TO ACCOUNT FOR THIS SYSTEM-LEVEL VARIABILITY: MOST OF THESE HAVE SOME MERIT, BUT NONE TAKEN ALONE IS ADEQUATE TO PROVIDE A FULL CROSS-SYSTEM EXPLANATION. VARIATION IN PARTY SYSTEM SIZE OR FRACTIONALIZATION HAS RECENTLY BEEN DISCUSSED AS ANOTHER SOURCE OF DIFFERENTIAL DYNAMICS OF PARTY LOYALTIES. UNFORTUNATELY, THE CONVENTIONAL MEANS OF ASSESSING PARTY IDENTIFICATION PROPERTIES ARE SUBJECT TO RATHER SEYERE ARTIFACTS, TYPICALLY IGNORED, WHEN COMPARISONS ARE MADE ACROSS SYSTEMS OF VERY DIFFERENT PARTY SIZE. THE CONCEPTUAL STAKES UNDERLYING KEY METHODS OPTIONS FOR SUCH COMPARISONS-MOST NOTABLY, BETHEEN CONTINUOUS AND OISCRETE STATISTICAL TOOLS--ARE EXAMINED. THE USE OF CONTINUOUS STATISTICS FOR SYSTEMS WITH MULTIPLE PARTIES RESTS ON AN ASSUMPTION THAT IMBEDDED IN A CONTINUDUS SPACE. A SIMPLE TEST FOR THIS ASSUMPTION IS MOUTINUOUS SPACE. A SIMPLE TEST FOR THIS ASSUMPIION IS MOUNTED AND CLEAR SUPPORT IS SHOWN FOR IT. ANALYSIS OF RESIDUALS BEYOND THIS OBVIOUS RESULT ADD SEVERAL
POINTS OF LESS OBVIOUS INFORMATION ABOUT THE DISTRIBUTION OF PARTY AFFECT IN SUCH SYSTEMS.

02443 CONWAY, J.S.

THE POLITICAL ROLE OF GERMAN PROTESTANTISM, 1870-1990

JOURMAL OF CHURCH \& STATE, 34(4) (FAL 92), 819-842.

THE AUTHOR STUDIES THE POLITICAL ROLE PLAYED BY

GERMANY'S EVANGELICAL (I.E., PROTESTANT) CHURCHES SINCE

SUNIFICATION OF GERMANY IN 1870-71.

02444 CONYBEARE, J.

WEAK CYCLES, LENGTH AND MAGNITUDE OF WAR: DURATION

DEPENDENCE IN INTERNATIONAL CONFI ICT

CONFLICT MANAGEMENT AND PEACE SCIENCE, 12(1) (WIN 92), 99-116.

STANDARD STATISTICAL TESTS HAVE PROVIDED LITTLE EVIDENCE FOR THE EXISTENCE OF WAR CYCLES. TESTS ARE PERFORMED ON A 500-YEAR DATA SET. TURNING POINTS IN LONG CYCLES OF WAR INTENSITY DO MANIFEST A WEAK CYCLES OF 50 YEARS. THE LENGTH AND MAGNITUDE OF INDIVIDUAL HARS EXHIBIT NO COMMON DURATIONS ANO APPEAR PRONE TO AN ANTI-CYCLICAL PROCESS OF NEGATIVE DURATION DEPENDENCE, WHEREBY THE PROBABILITY OF WAR
TERMINATION DECLINES WITH THE TIME AND MAGNITUDE DURATION OF THE WAR.

02445 CONZE, H.

TIME'S RUNNING OUT FOR TRANSATLANTIC DIALOGUE ABOUT DUALUSE TECHNOLOGIES

ARMED FORCES JOURNAL INTERNATIONAL, (APR 91), 38. DUE TO A REDUCED THREAT FROM THE SOVIETS, WESTERN EUROPE SECURITY PROBLEMS, FOCUSING INSTEAD ON "OUT OF AREA" ISSUES. SIGNIFICANTLY THIS NEW THRUST NOT ONLY THREATENS WESTERN INDUSTRIES , ECONOMIC AND INDUSTRIAL STAKES IN COOPERATIVE EFFORTS, BUT OPENS THE DOOR FOR NON-NATO NATIONS' INDUSTRIES EFFORTS, BUT OPENS THE DOOR FOR NON-NATO NATIONS' INDUSTRIES
(I.E. JAPAN) TO FORGE NEW RELATIONSHIPS. FAILURE OF THE U.S. (I.E. JAPAN) TO FORGE NEW RELATIONSHIPS. FAILURE OF THE U.S.
AND WESTERN EUROPE TO INSTIGATE A TRANSATLANTIC DIALOGUE ON AND WESTERN EUROPE TO INSTIGATE A TRANSATLANTIC DIALOGUE
SUCH ISSUES AS HDIV, ELECTRONIC COMPONENTS, SPACE, AND SUCH ISSUES AS HDTV, ELECTRONIC COMPONENTS, SPACE, AND AERONAUTICS WILL LIKELY RESULT IN JAPAN TAKING OVER

02446 COOK, B.J.; EMEL, J.L.; KASPERSON, R.E. A PROBLEM OF POLITICS OF TECHNIQUE? INSIGHTS FROM WASTEMANAGEMENT STRATEGIES IN SHEDEN AND FRANCE POLICY STUDIES REVIEH, 10(4) (HIN 92), 103-113.

IN MANY RESPECTS, FRANCE AND SWEDEN ARE IN THE VANGUARD OF HIGH-LEVEL RADIOACTIVE WASTE DISPOSAL EFFORTS, BUT THEIR BASIC STRATEGIES AND UNDERLYING PHILOSOPHIES OF HASTE MANAGEMENT CONTRAST SHARPLY. THE AUTHORS COMPARE THE FRENCH AND SWEDISH WASTE DISPOSAL PROGRAMS FOR INSIGHT INTO THE PROBLEM OF SITING AND DEVELOPING A PERMANENT HASTE REPOSITORY. TECHNICAL DECISIONS, AS WELL AS THE MORE OBVIOUS SOCIO-POLITICAL DECISIONS ABOUT REPOSITORY DEVELOPMENT, ARE SHAPED BY DEEP-SEATED SOCIAL AND POLITICAL FORCES IN EACH NATION.

02447 COOK, B.J. SUBORDINATION OR INDEPENDENCE FOR ADMINISTRATORS? THE DECISION OF 1789 REEXAMINED

PUBLIC ADMINISTRATION REVIEH, 52(5) (SEP 92), 497

THE AUTHOR STUDIES THE CONGRESSIONAL DEBATES SURROUNDING THE ESTABLISHMENT OF THE FIRST FEDERAL EXECUTIVE DEPARTMENTS TWO VIEWS EMERGED DURING THOSE DEBATES: AN INSTRUMENTAL THO VIEWS EMERGED OURING THOSE DEBATES: AN INSTRUMENTAL
PERSPECTIVE VIEWING PUBLIC ADMINISTRATION AS A SERVANT OF THE MAJOR POLITICAL BRANCHES (THE PRESIDENT AND CONGRESS) AND A CONSTITUTIVE VIEW THAT WOULD GIVE PUBLIC AND A CONSTISTRATORS CONSTITUTIONAL RESPONSIBILITIES AND ADMINISTRATORS CONSTITUTIONAL RESPONSIBILITIES AND PRORSPECTIVE ULTIMATELY PREVAILED, THOSE SUPPORTING THE PERSPECTIVE ULTIMATELY PREVAILED, THOSE SUPPORTING THE CONSTITUTIVE POSITION HELPED SHAPE THE OUTCOME AS WELL AS THE ONGOING DEBATE OVE
FEDERAL BUREAUCRACY.

02448 COOK, E.A.

A ROSE BY ANY OTHER NAME: MEASURING SUPPORT FOR ORGANIZED FEMINISM USING A.N.E.S. FEELING THERMOMETERS WOMEN AND POLITICS, 12 (1) (1992), 35-51.

BETWEEN 1972 AND 1984. THE AMERICAN NATIONAL ELECTION STUDIES (A.N.E.S.) INCLUDED A "FEELING THERMOMETER" THAT MEASURED ATTITUDES TOWARD THE "WOMEN'S LIBERATION MOVEMENT." IN 1988 THE SURVEY SUBSTITUTED A NEW ITEM THAT ASKED RESPONDENTS TO RATE "FEMINISTS," ANO IN 1990 THE QUESTIONNAIRE CHANGED THE WORDING TO "THE WOMEN'S MOVEMENT." USING DATA FROM THE 1985 PILOT STUDY, THE AUTHORS COMPARE RESPONSES TO THESE TWO ITEMS FOR BOTH MEN AND WOMEN. THEY CONCLUDE THAT THE NEW MEASURE IS "HARDER," ELICITING MORE NEGATIVE RESPONSES. MOREOVER, THE CORRELATES OF THE NEW MEASURE DIFFER FROM THE ORIGINAL FEELING THERMOMETER. WHEN THE FEELING THERMOMETER IS INCORPORATED INTO A MULTI-ITEM MEASURE OF FEMINIST CONSCIOUSNESS, HOWEVER, THE PATTERN OF MEASURE OF FEMINIST CONSCIOUSNESS, HOWEVER, THE PATTERN OF OF LONGITUDINAL ANALYSIS MAY STILL BE POSSIBLE.

02449 COOK, M.

THE THIRD WORLD: LIVING WITH DEBT?

CONTEMPORARY REVIEN, 260(1516) (MAY 92), 233-238.

RECENTLY, ONE AREA OF CONCERN HAS TAKEN A BACK SEAT-THIRD WORLD DEBT. HOWEVER, IGNORING THE PROBLEM WILL NOT
MAKE IT GO AWAY. EXTERNAL DEBT PROBLEMS IMPOSE RESTRUCTURING MAKE IT GO AWAY. EXTERNAL DEBT PROBLEMS IMPOSE RESTRUCTURI
CDSTS, LOWER STANDARDS OF LIVING AND DEVELOPMENT PROBLEMS FOR MANY THIRD WORLD COUNTRIES. THIS ARTICLE INVESTIGATES FOR MANY THIRD WORLD COUNTRIES. THIS ARTICLE INVESTIGATES
THE REASONS FOR THIS MORE LOW KEY APPROACH TO THE DEBT THE REASONS FOR THIS MORE LOW KEY APPROACH TO THE DEB
CRISIS AND WHETHER THERE CAN BE ANY PAINLESS WAY OF CRISIS AND WHETHER THERE CAN BE ANY PAINLESS WAY OF
RESOLVING THESE DEBT PROBLEMS. IT EXAMINES HOW THE DEBT RESOLVING THESE DEBT PROBLEMS. IT EXAMINES HOW THE
CRISIS AROSE AND THE METHODS BY WHICH THE DEVELOPED

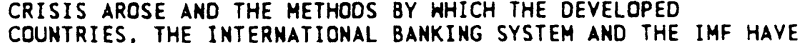
COUNTRIES, THE INTERNATIONAL BANKING SYSTEM
ATTEMPTED TO COME TO TERMS WITH THE PROBLEMS.

02450 COOK, P.; STEVENS, J.

AN END-USER APPROACH TO THE MEASUREMENT OF PERFORMANCE OF CAPITAL IN AN ENYIRONMENTAL CONTEXT IN ASI WORLD DEVELOPMENT, 20(4) (APR 92), 541-555.

FOCUSING ON ASIA, THE AUTHORS DESCRIBE A USER-BASED SERVICE LEVEL (SL) APPROACH TO VALUING NATURAL AND CONSTRUCTED ASSETS IN ORDER TO MAKE BETTER PROJECT AND POLICY DECISIONS. USING THE SL APPROACH IMPROVES THE ABILITY 
OF LOCAL DECISION MAKERS TO MONITOR ASSET PERFORMANCE, CALCULATE REAL RATES OF ASSET DEGRADATION, MAKE SOUMD MANAGERIAL DECISIONS, AND PERFORM MORE COST-EFFECTIVE ENYIRONMENTAL IMPACT ASSESSMENTS. ON A NATIONAL SCALE, SL PERFORMANCE INDICATORS WILL ENABLE POLICYMAKERS TO BETTER UNDERSTAND AND QUANTIFY THE LINKAGES AMONG ECONOMIC GRONTH, ITFRASTRUCTURE BLT HAS THE POTENTIAL TO IMPROVE SOCIAL AND ENVIRONMENTAL ACCOUNTING.

02451 COOLEY, J.

MIDDLE' EAST WATER: POWER FOR PEACE

MIDOLE EAST POLICY, 1(2) (1992) $1-15$

WATER, FROM 1947 TO THE PRESENT, LIES AT THE VERY HEART

OF THE ISRAEL-PALESTINE-ARAB DILEMMA. SINCE THE ILL-FATED U. N. EFFORTS TO SOLVE THE DILEMMA BEGAN, ATTEMPT AFTER ATTEMPT TO DRAW VIABLE ARMISTICE LINES OR WRITE PEACE AGREEMENTS THAT NOULD LAST HAVE BEEN BLOCKED BY THE WATER QUESTION. THIS ARTICLE DISCUSSES THE NEED FOR RATIONAL INTERNATIONAL THIS ARTICLE DISCUSSES THE NEED FOR RATIONAL INTERNATIONAL WATER-SHARING SCHEMES. IT STATES THAT AN ORGANIZATION IN
CHARGE OF WATER AUTHORITY HOULD HAVE MASSIVE POLITICAL CLOUT CHARGE OF WATER AUTHORITY WOULD HAVE MASSIVE POLITICAL CLOUT
AND REAL ENFORCEMENT POWER. AS WELL AS CONCLUDING THAT THE AND REAL ENFORCEMENT POWER. AS WELL AS CONCLUDING THAT THE
SOONER THE UNITED STATES TAKES THE LEAD IN SEEKING GLOBAL SOLUTIONS TO THESE PROBLEMS. THE CLOSER THE MIDOLE EAST WILL DRAH TO A PEACE WHICH SECURES ENOUGH LAND AND WATER FOR ALL ITS INHABITANTS.

02452 COOMARASHAMY, $R$

DEMOCRATIC MEANS AND ENDS

FAR EASTERN ECONOMIC REVIEW, 154(52) (JAN 92), 14.

SEVERAL LEADING POLITICIANS HAVE BEGUN TO CALL FOR THE IMPEACHMENT OF SRI LANKA'S PRESIDENT, RANASINGHE PREMADASA. ACCUSING HIM OF HAVING A "BONAPARTIST" STYLE OF LEADERSHIP AND OF VIOLATING THE SRI LANKAN CONSTITUTION, THEY HAVE SHIFTLY MOVED TO OUST PREMADASA. HOWEVER JUSTIFIED THEIR MOTIVES ARE, THE METHODS OF THESE "REBELS" ARE DANGEROUS TO DEMOCRACY IN SRI LANKA. THE REBELS JUSTIFIED THE MOVE TO IMPEACH BY CLAIMING THAT THE PRESIDENT HAS THINKING OF DISSOLVING THE PARLIAMENT. IF THIS WERE TRUE, A VOTE OF NOCONFIDENCE, NOT IMPEACHWENT, WOULD BE THE PROPER COURSE. THE REBELS AND THE OPPOSITION CALLED FOR A SECRET BALLOT ON THE IMPEACHMENT MOTION. THUS OEMONSTRATING A MISUNDERSTANDING OF THE ROLE OF ELECTED REPRESENTATIVES ACTING IN THE PUBLIC INTEREST. THE OPPOSITION WOULD BE WELL ADVISED TO ENSURE THAT IMPEACHMENT IS A FAIR, DELIBERATE AND OPEN PROCESS. IF THE OPPOSITION IS SUCCESSFUL IN REACHING THEIR GOAL DEMOCRACY IN SRI LANKA HILL HAVE SUFFERED A SIGNIFICANT DEMOCRACY

02453 COOPER, A.

LIKE MINDED NATIONS AND CONTRASTIMG DIPLOMATIC STYLES: AUSTRALIAN AND CANADIAN APPRDACHES TO ARGRICULTURAL TRADE CANADIAN JOURNAL OF POLITICAL SCIENCE, XXV(2) (JUN 92), 349-380.

THE PAIRING of AUSTRALIA AND CANADA HAS BECOME A RICH SOURCE OF COMPARATIVE STUDIES WITH RESPECT TO FOREIGN ECONOMIC POLICY. THIS MATCHING HAS BEEN LARGELY INSPIRED BY THE LIKE-MINDEDNESS OF THE THO COUNTRIES. USING INTERMATIONAL-LEVEL STYLE IN THE CASE OF AGRICULTURAL TRADE. IT IS DEMONSTRATED THAT A NUMBER OF MUTUALLY REINFORCING FACTORS COMBINE TO GIVE A TOUGH-MINDED QUALITY TO

AUSTRALIA'S APPROACH. IN THE RANGE OF FOREIGN POLICY OPTIONS, CANADA'S STYLE IN THE AGRICULTURE TRADE ISSUE HAS BECOME INCREASINGLY NUANCED.

02454 COOPER, JR., J.

ENTHUSIASTS' OR DEMOCRATS? SEPARATISM, CHURCH GOVERMMENT, AND THE GREAT AWAKENING IN MASSACHUSETTS

NEW ENGLAND QUARTERLY, LXV(2) (JUN 92), 265-283.

HISTORIANS HAVE TRADITIONALIY REGARDED THE GREAT

AWAKENING IN NEW ENGLAND AS A TURNING POINT IN POPULAR CONCEPTION OF AUTHORITY, WHICH PAVED THE WAY FOR A MORE DEMOCRATIC CULTURE AMD THE AMERICAN REVOLUTION. HISTORIANS - hAVE RELIED hEAVILY UPON THE RISE AND DEVELOPMENT OF THE SEPARATE MOVEMENT. AN EXAMINATION THAT FOCUSES SPECIFICALLY UPON THE MASSACHUSETTS SEPARATES IS OFFERED IN THIS ARTICLE IN THE HOPE THAT IT WILL HELP HISTORIANS REFINE THEIR UNDERSTANDING OF THE GOALS, PROCESS, AND LASTING DEMOCRATIZING INFLUENCE OF THE SEPARATE MOVEMENT AND THE GREAT AHAKENING.

02455 COOPER, $R$.

WILL AN EC CURRENCY HARM OUTSIDERS?

WILL AN EC CURRENCY HARM OUTSID
ORBIS, 36(4) (FAL 92) 517-530.

FORMATION OF A EUROPEAM ECONOMIC AND MONETARY UNION (EMU) WILL BE A MOMENTOUS OCCASION IN THE HISTORY OF MONETARY AFFAIRS. THIS PAPER DISCUSSES THE EMU'S IMPACT ON THE REST OF THE WORLD DURING THE LONG PATH OF GETTING FROM PRESENT ARRANGEMENTS TO AN EFFECTIVELY FUNCTIONING MONETARY UNION. ALSO IT DISCUSSES THE IMPACT ON THE REST OF THE HORLD OF AN EMU IN BEING. PRIOR TO THESE DISCUSSIONS, IT DESCRIBES THE EUROPEAN POSITION ON THE CONTENT OF THE MONETARY UNION,
02456 COOPER, $S$

THE PATRIOTIC FRONT

SOUTH AFRICA FOUNDATION REVIEN, 17(11) (NOV 91), 8. AT THE PATRIOTIC FRONT CONFERENCE, HELD IN SOUTH AFRICA IN OCTOBER 1991, THE AFRICAN NATIONAL CONGRESS AND PANAFRICANIST CONGRESS DEMONSTRATED THE ABILITY TO OVERCOME PAST ANIMOSITIES AND DIFFERENCES. IN FORMING A UNITED FRONT THESE THO MAJOR BLACK POLITICAL ORGANIZATIONS HAVE RETAINED A LEADERSHIP HOLD ON THE REPRESENTATION OF PERHAPS THE MAJORITY OF SOUTH AFRICANS. FOR ALMOST THREE DECADES, THESE TWO ORGANIZATIONS HAVE PUBLICLY SCRAPPED IN THE CAPITALS AND FORUMS OF THE WORLD, EACH CLAIMING TO BE THE LEGITIMATE REPRESENTATIVE OF THE OPPRESSED MAJORITY IN SOUTH AFRICA.
THIS ARTICLE DISCUSSES THE NEW COOPERATION BETHEEEN THE THO GROUPS.

02457 COPE, G

WALKIMG THE FISCAL TIGHTROPE: LOCAL GOVERMMENT BUDGETING AND FISCAL STRESS

INTERNATIONAL JOURNAL OF PUBLIC ADMINISTRATION, 15(5)

(1992), 1097-1120.

MOST LOCAL GOVERMMENTS ARE REQUIRED BY THEIR CHARTERS STATE LAHS, OR BOTH TO BALANCE THEIR OPERATING BUDGETS. THIS PAPER DISCUSSES THE COMPONENTS OF LOCAL GOVERNMENT BUDGE PROCESSES AND THEIR RELATIONSHIP TO FISCAL STRESS. USING HOW LOCAL GOVERNMENTS HAVE DEVELOPED BUDGET PROCESSES WHICH HOW LOCAL GOVERMMENTS HAVE DEVEL SD BUDGET PROCESSES RESPOND TO THESE CHANGING FISCAL SITUATIONS. BUDGET
PROCESSES ARE PROVIDING GOOD IMFORMATION TO LOCAL GOYERMMENT PROCESSES ARE PROVIDING GOOD INFORMATION TO LOCAL GOVERMMENT
DECISION MAKERS WHICH IS HELPING THEM RESPOND CONSTRUCTIVELY DECISION MAKERS WHICH IS HELPING THE
TO THE FISCAL CRISES OF THE $1990 \mathrm{~S}$.

02458 COPELAND, E.

GLOBAL REFUGEE POLICY: AN AGENDA FOR THE 1990S INTERNATIONAL MIGRATION REVIEW, 26(3) (FAL 92), 992-999. THE CONFERENCE ON GLOBAL REFUGEE POLICY (1992) WAS HELD TO REVIEW DEVELOPMENTS CONCERNING REFUGEES AND OTHER FORCED MIGRANTS OVER THE LAST DECADE, TAKE STOCK OF THE CURRENT WORLOWIDE REFUGEE SITUATION, CONSIDER THE POLICY CHALLENGES OF THE 1990S, AND FORMULATE POLICY OPTIONS TO MEET THE NEH DEMANDS ON THE INTERNATIONAL SYSTEM. FOUR TOPICS ARE DISCUSSED IN THIS ARTICLE: PARTIES HO SHOULD BE OF CONCERN TO THE INTERNATIONAL REFUGEE REGIME IN THE 1990S; INTERNALLY DISPLACED PERSONS; GOVERNMENTAL RESPONSIBILITIES; AND THE

ADEOUACY OF THE INSTITUTIONAL FRAMEWORK FOR MEETING THE

CHALLENGES POSED BY FORCED MIGRATIONS IN THE $1990 \mathrm{~S}$.

02459 COPPEDGE, $M$.

VENEZUELA'S VULNERABLE DEMOCRACY

VENEZUELA'S VULNERABLE DEMOCRACY
JOURNAL OF DEMOCRACY, 3(4) (OCT 92), 32-44.

JOURNAL OF DEMOCRACY, 3(4) (OCT 92), 32-44.
VENEZUELA'S RECENT POLITICAL TURMOIL CHALLENGES THE CONYENTIONAL SISDCM CONCERMING THREATS TO DEMOCRATIC STABILITY. THE CENTRAL IRONY IS THAT CERTAIN CHARACTERISTICS UNIQUE TO VENEZUELA-OIL HEALTH, CONSENSUAL LEADERSHIP, AND STRONG POLITICAL PARTIES--THAT FOR DECADES HELPED DEMOCRACY TO SURVIVE THERE ULTIMATELY UNDERMIMED THE LEGITIMACY OF THE POLITICAL CLASS THAT RAN THE COUNTRY. AS A RESULT, WHEN VENEZUELA'S LEADERS FINALLY RECOGNIZED THE NEED FOR STRUCTURAL ADJUSTMENT OF THE ECONOMY, THEY LACKED THE MORAL AUTHORITY MECESSARY TO DEMAND SACRIFICES FROM THE POPULATION. SINCE THE FUNDAMENTAL CAUSE OF THE PROBLEM IS PECULIARLY VENEZUELAN, THERE IS NO REASON TO EXPECT AN EXACT REPLICATION OF THIS KIND OF CRISIS IN OTHER COUNTRIES. YET SOME ELEMENTS OF VENEZUELA'S CRISIS--ESPECIALLY THE NEED FOR STRUCTURAL ADJUSTMENT AND THE IMPACT OF PRESIDENTIALISM-ARE COMMON TO MOST OF LATIN AMERICA, RAISING THE POSSIBILITY OF SIMILAR DIFFICULTIES. MOREOVER, THE SUDOEN OUTBREAK OF INSTABILITY IN ONE OF THE STRONGER OEMOCRACIES HAS GREAT SYMBOLIC IMPORTANCE FOR THE ENTIRE REGION, ALARMING THE FRIENDS OF DEMOCRACY WHILE EMBOLDENING ITS FOES.

02460 COPPIETERS, 8

CONSCIENTIOUS OBJECTION POLICIES AND THE SOVIET NATIONAL ETHOS

JOURNAL OF COMMUNIST STUDIES, 8(4) (DEC 92), 186-209. THE REFORM PROCESS IN EAST-CENTRAL EUROPE IN THE LATE 1980'S LED TO THE INTRODUCTION OF ALTERHATIVE CIVILIAN SERVICE IN SEVERAL COUNTRIES BUT NOT IN THE SOVIET UNION OR RUSSIA. THIS HAS BEEN CITED AS EVIDENCE OF THE STRENGTH OF THE CIVIC CULTURE IN EAST-CENTRAL EUROPEAN COUNTRIES AND OF THE CIVIC CULTURE IN EAST-CENTRAL EUROPEAN COUNTRIES AND
ITS WEAKNESS IN RUSSIA. BUT RUSSIA HAS A LONG HISTORICAL ITS WEAKNESS IN RUSSIA. BUT RUSSIA HAS A LONG HISTORICAL TRADITION OF CONSCIENTIOUS OBJECTION, AND OTHER
BE THE REASON FOR THE DIFFERENCE IN THIS AREA.

02461 CORAK, $M$.

ELIGIBILITY RULES IN THE CANADIAN JOBS STRATEGY: SHIFTING THE BURDEN OR TARGETING THE ASSISTANCE?

CANADIAN PUBLIC POLICY--ANALYSE DE POLITIQUES, XVII(1)

(MAR 91), 64-76

THIS PAPER IS CONCERNED WITH THE APPROPRIATE SETTING OF THE ELIGIBILITY CRITERIA FOR ENTRANCE INTO A GOVERNMENT SPONSORED PROGRAM OF TRAINING OR WAGE SUBSIDY. THE FOCUS OF THE DISCUSSION IS UPON THE 'SORTING' ROLE PLAYED BY SUCH RULES, AND AN EXPLICIT ATTEMPT IS MADE TO EVALUATE THE SIX 
MONTH WAITING RULE IMPOSED BY THE JOB DEVELOPMENT PROGRAM OF THE CANADIAN JOBS STRATEGY. THIS RULE HAS BEEN THE SUBJECT OF SOME DEBATE IN THE RECENT PAST AND USE IS MADE OF EMPIRICALLY DETERMINED HAZARD RATES TO SUGGEST THAT IT IS TOO LONG. THE RESULTS OF AN ANALYSIS OF UNEMPLOYMENT SPELL DATA DERIVED FROM THE ANNUAL WORK PATTERNS SURVEY SUGGEST THAT A WAITING PERIOD OF THREE TO FOUR MONTHS HOULD BE JUST AS EFFECTIVE A SORTING DEVICE AND WOULD REDUCE THE DEADWEIGHT COSTS PLACED UPON THE UNEMPLOYED. IT IS ALSO FOUND THAT IF THE EXISTING RULE WERE REDUCED TO THREE MONTHS THE NUMBER OF INDIVIDUALS ELIGIBLE FOR PROGRAM PARTICIPATION HOULD INCREASE BY ONLY ABOUT 12 PERCENT. IN THIS LIGHT THE HOULD INCREASE BY ONLY ABOUT 12 PERCENT. IN THIS LIGHT THE
SIX MONTH RULE DOES MORE TO SHIFT THE BURDEN OF UNEMPLOYMENT SIX MONTH RULE DOES MORE TO SHIFT THE BURDEN OF UNEMPLOYM
ONTO THE UNEMPLOYED THAN IT DOES TO TARGET PROGRAM FUNDS ONTO THE UNEMPLOYED THAN
UPON THOSE MOST IN NEED.

02462 CORAM, B.

WHY POLITICAL PARTIES SHOULD MAKE UNBELIEVABLE PROMISES: A THEORETICAL NOTE

PUBLIC CHOICE, 69(1) (JAN 91), 101-106.

SOCIAL SCIENTISTS USUALLY ASSUME THAT IT IS IN THE INTERESTS OF POLITICAL PARTIES TO TRY TO EXPAND THEIR CREDIBILITY AS MUCH AS POSSIBLE, AND TO SEEK THE OPTIMUM POINT OF THEIR CREDIBILITY FUNCTION. AN ASSUMPTION OF THIS TYPE UNDERLIES MUCH O F THE DISCUSSION OF LEGITIMATION CRISES AND THE MANNER IN WHICH PARTIES SUPPLY INFORMATION TO THE ELECTORATE. THE PURPOSE OF THIS PAPER IS TO CHALLENGE THE SECOND PART OF THIS ASSUMPTION. WHILE IT IS OBVIOUS THAT THE RETURNS TO A PARTY WILL INCREASE AS MORE OF ITS PROGRAM IS BELIEVED, IT DOES NOT FOLLOW THAT A PARTY SHOULD SEEK THE MAXIMUM CREDIBILITY FOR ALL PROMISES. THE AUTHORS ARGUMENT IS THAT THERE ARE GOOD REASONS FOR PARTIES TO PROMISE MORE THAN IT IS BELIEVED THEY CAN DELIVER.

02463 CORCORAN, P.; KENDALL, K.

COMHUNICATION IN THE FIRST PRIMARIES: THE VOICE OF THE PEOPLE IN 1912

PRESIDENTIAL STUDIES QUARTERLY, 22(1) (WIN 92), 15-30. PRIMARIES, ONCE A SOLUTION TO REMOTE AND UNRESPONSIVE PARTY GOVERNMENT, ARE NOW VIEWED AS A PROBLEM DEMANDING REPAIR AND REVISION. THIS STUDY FOCUSES ON THE STRUCTURES AND PROCEDURES OF THE PARTY NOMINATING PROCESS AND THE CRITICAL ROLE OF THE NEWSPAPERS IN THE FIRST PRIMARIES IN 1912. IT WAS A DEBUT FOR A PROCESS THAT FASCINATED AND DISAPPOINTED THEN AS IT DOES TODAY. THE AUTHORS EXAMINE HOW CAMPAIGN STRATEGIES EVOLVED IN 1912. THE PROCESS BY WHICH THE PRIMARY EMERGED FROM THE OUTSET AS A CAMPAIGM ISSUE ITSELF, AND THE ROLE OF THE MEDIA IN PRESENTING THE CAMPAIGN. SIMILARITIES IN STYLE AND IN PERCEIVED DEFECTS BETWEEN 1912 AND CONTEMPORARY PRESIDENTIAL PRIMARIES CAST OLD LIGHT ON WHAT ARE CONVENTIONALLY DEEMED TO BE PECULIAR FEATURES
CAMPAIGN STRATEGIES AND MEDIA PRACTICES OF THE $1990 \mathrm{~S}$.

02464 CORD, R.L.

CHURCH, STATE, AND THE REHNQUIST COURT

NATIOHAL REVIEW, XLIV(16) (AUG 92), 35-37.

THE AUTHOR SUMMARIZES THE U.S. SUPREME COURT'S RULING IN LEE $V$. WEISMAN. HE ALSO DISCUSSES SOME OF THE LEGAL PRECEDENTS FOR THE DECISION AND THE VIEWS OF JAMES MADISON AND THOMAS JEFFERSON ON THE MEANING OF THE ESTABLISHMENT CLAUSE OF THE FIRST AMENDMENT.

02465 CORDAHI, C.

CENTRAL ASIA EMERGES INTO THE MUSLIM WORLD

MIDDLE EAST INTERNATIONAL, (422) (APR 92), 16-17.

AROUND 50 MILLION PEOPLE LIVE IN THE FIVE MUSIIM

REPUBLICS OF WHAT USED TO BE SOVIET CENTRAL ASIA: KAZAKHSTAN, KYRGYZSTAN, TAJIKISTAN, TURKMENISTAN, AND UZBEKISTAN. JUST OVER 35 MILLION OF THOSE ARE MUSLIM. SAUDI ARABIA HAS TAKEN A KEEN INTEREST IN FUNDING ISLAMIC REVIVAL IN THE REGION. ITS CHIEF COMPETITION FOR THE ROLE OF LEADER OF THE CENTRAL ASIAN STATES INTO THE MUSLIM WORLD IS IRAN, SO FAR, SAUOI ARABIA, WHICH IS ABLE TO BACK ITS PLEDGES HITH HARD CURRENCY, IS WELL AHEAD. RIYADH HAS THE ADVANTAGE OF BEING ABLE TO OFFER WHAT TEHRAN CAN NEVER OFFER, THE HAJJ (MUSLIM PILGRIMAGE TO MECCA). HOWEVER, BOTH COUNTRIES HAVE TO RECKON WITH A DEEP SEAM OF SECULARISH AMONG THE REGION'S SUNNI MUSLIMS. SOME CENTRAL ASIAN STATES, MOST NOTABLY UZBEKISTAN, ARE TRYING TO BALANCE ISLAMIC REVIVAL BY FORGING CLOSE TIES WITH SECULAR TURKEY. WHATVER THE CASE, THE POTENTIAL FOR WITH SECULAR TURKEY. WHATVER THE CASE, THE POTENTIAL FOR
CONFLICT IN THIS METLING POT OF ETHNIC GROUPS IS HIGH. IF LAW AND ORDER BREAKS DOWN UNDER ECONOMIC HARDSHIP, GRASSRODTS ISLAMIC FUNDAMENTALISM IN THE FERGHANA VALLEY, THE RODTS ISLAMIC FUNDAMENTALISM IN THE FERGHANA VALLEY, THE LEAST RUSSIFIED AREA OF THE REGION, MAY GROW. OBSERVERS FEAR MUSLIM ESTABLISHMENT BACKED BY SAUDI ARABIA AND IRAN.

02466 CORDAHI, $C$

CLAIMS AND DENIALS

MIDDLE EAST INTERNATIONAL, (395) (MAR 91), 4-5

THE MILITARY DEFEAT OF IRAO HAS GIVEN RISE TO SEVERAL GROUPS CLAIMING TO SPEAK FOR THE IRAQI PEOPLE IN OPPOSITION TO SADDAM HUSSEIN. THESE INCLUDE THE JOINT ACTION OF THE IRAQI OPPOSITION, A LONDON BASED GROUP, AND THE SAUDI-BASED
FREE IRAQ COUNCIL--WHICH IS ACCUSED BY SOME AS BEING A SAUDI MINION AND UNREPRESENTATIVE OF THE IRAQI PEOPLE. RUMORS OF PARTICIPATION OF THE SUPREME ASSEMBLY FOR THE ISLAMIC REVOLUTION, ONE OF THE MAIN ISLAMIC PARTIES IN THE JOINT ACTION, IN UPRISINGS IN SOUTHERN IRAQ HAVE BEEN FLOATING. BUT ARE DIFFICULT TO CONFIRM.

02467 CORDAHI, C.

G7 BACKS BAKER

MIDDLE EAST INTERNATIONAL, (405) (JUL 91), 7

THE GROUP OF SEVEN LEADING INDUSTRIAL COUNTRIES MEETING IN LONDON ON 15-17 JULY FULLY ENDORSED SYRIA'S POSITIVE REPLY TO PRESIDENT BUSH AND JAMES BAKER'S HURRIEDLY ARRANGED TRIP TO THE MIDDLE EAST, HIS FIFTH SINCE THE END OF THE GULF WAR. IN THEIR POLITICAL DECLARATION THE G? BACKED THE IDEA WAR. IN THEIR POLITICAL DECLARATION THE G? BACKED THE IDEA
OF A "THIN TRACK SOLUTION," STATING THAT THERE SHOULD BE OF A "THIN TRACK SOLUTION," STATING THAT THERE SHOULD PARALLEL AND DIRECT NEGOTIATIONS BETWEEN ISRAEL AND
REPRESENTATIVE PALESTINIANS ON THE ONE HAND AND ISRAEL AND REPRESENTATIVE PALESTINIANS ON THE ONE HAND AND ISRAEL AND
THE ARAB STATES ON THE OTHER." THE GROUP OF SEVEN ALSO MADE STATEMENTS ON LIMITING AND OVERSEEING THE INTERNATIONAL ARMS STATEMENTS ON LIMITING AND OVERSEEING THE INTERNATIONAL ARMS
TRADE, THE IMPLEMENTATION OF THE TAIF PROCESS IN LEBANON, AND THE RELEASE OF A BRITISH HOSTAGE HELD IN IRAQ.

02468 CORDAHI, C.

STICKING TO ITS PRINCIPLES

MIDDLE EAST INTERNATIONAL, (398) (APR 91), 16.

AFTER TALKS WITH U.S. SECRETARY OF STATE JAMES BAKER,

SYRIA'S FOREIGN MINISTER CALLED FOR THE UN TO PLAY A

SIGNIFICANT ROLE IN ACHIEVING PEACE BETWEEN ISRAEL AND THE ARABS, AND FOR A PEACE CONFERENCE TO BE HELD TO ACHIEVE THIS GOAL. SYRIA'S NEGOTIATION POSITION IS FAR FROM STROMG. IT NO LONGER HAS THE BACKING OF A POHERFUL USSR, NOT CAN IRAQ'S DIMINISHED ARMED FORCES POSE AS A SERIOUS ARAB MILITARY THREAT TO ISRAEL. SYRIA IS HOPING THE U.S., WHOSE MIDDLE EAST POL ICIES IT NOW BELIEVES ARE NO LONGER WHOLLY GOVERNED BY ITS CLOSE RELATIONSHIP WITH ISRAEL, HILL PLAY THE ROLE OF UMPIRE BETWEEN THE COMPETING PLAYERS.

02469 CORDAHI, C.

TAJIKISTAN: RUSSIA GETS SUCKED IN

MIDDLE EAST INTERNATIONAL, 436 (OCT 92), 13

THE ESCALATING WAR IN THE FORMER SOVIET REPUBLIC OF TAJIKISTAN IS TAKING A TURN FOR THE WORSE, WITH ATTACKS NOW BEING DIRECTED AGAINST COMMONWEALTH OF INDEPENDENT STATE TROOPS WHO UNTIL RECENTLY HAVE MANAGED TO REMAIN LARGELY NEUTRAL IN THE CONFLICT BETWEEN SUPPORTERS AND OPPONENTS OF THE FORMER COMMUNIST GOVERNMENT. RUSSIA IS CAUGHT SOMEWHER IN THE MIDOLE OF THE CONFLICT. ITS PRINCIPLE CONCERNS ARE THE PROTECTION OF ALMOST HALF A MILLION ETHNIC RUSSIANS
OF A POPULATION OF FIVE MILLION AND TO SEAL THE POROUS AFGHAN BORDER TO CUT OFF THE SUPPLY OF WEAPONS.

02470 CORDAHI, $C$

TAJIKISTAN:ISLAMIST REVERSAL

MIDOLE EAST INTERNATIONAL, 439 (DEC 92), 14.

THE PROSPECT OF THE ISLAMISTS IN THE TROUBLED CENTRAL ASIAN REPUBLIC OF TAJIKISTAN CONSOLIDATING GAINS MADE EARLIER THIS YEAR ARE RECEDING. IN A REVERSAL OF FORTUNES FORCES OF THE ISLAMIC RENAISSANCE PARTY, WHICH ESPOUSED AN ISLAMIC STATE NOW FIND THEMSELVES BOXED IN IN THE CAPITAL BY SUPPORTERS OF THE OLD COMMUNIST REGIME. WHILE THE RUSSIANS HAVE MADE CLEAR THAT, IF IT CAME TO THE CRUNCH, THEY WOULD SUPPORT THE NEW GOVERNMENT, THE FACTION CONTINUES TO DEMAND THE ARMY UNITS WITHDRAWAL.

02471 CORDAHI C.J.

AZERBAIJAN AND TAJIKISTAN--CHANGES AT THE TOP MIDOLE EAST INTERNATIONAL, (426) (MAY 92), 14. AZERBAI JAN'S INTERNAL POLITICAL STRIFE' HAS PLAYED AN IMPORTANT ROLE IN WEAKENING THE FORMER SOVIET REPUBLIC IN ITS FOUR-YEAR WAR WITH NEIGHBORING ARMENIA. LACK OF FIRM LEADERSHIP ANO DEEP OIVISIONS IN AZERI POLITICS HAVE HELPED UNDERMINE TROOP MORALE ULTIMATELY LEADING TO A RECENT SERIES OF ARMENIAN VICTORIES. AZERBIAJAN'S EX-COMMUNIST PRESIDENT, AYAZ MUTAKIBOV. RETURNED TO POWER IN MID-MAY AFTER BEING OUSTED FOR THO MONTHS, ONLY TO BE OUSTED AGAIN BY FORCES LOYAL TO AZERBAI JAN'S POPULAR FRONT. MEANWHILE, ONE OF THE UNION, TAJIKISTAN, TOOK A STEP CLOSER IN MAY TO BECOMING WHAT THE HEST FEARS MOST-AAN IRANIAN-STYLE ISLAMIC STATE. IN WHAT THE WEST FEARS MOST--AN IRANIAN-STYLE ISLAMIC STATE. IN
A SERIES OF EVENTS SIMILAR TO THOSE IN AZERBAIJAN, THE TAJIK A SERIES OF EVENTS SIMILAR TO THOSE IN AZERBAIJAN, THE TAJIK
PRESIDENT. RAKHMON MABIYEY FLED FROM POWER ONLY TO RETURN A PRESIDENT, RAKHMON NABIYEV, FLED FROM POWER ONLY TO RETURN A
FEH DAYS LATER. NABIYEY FINALLY RETURNED AS PRESIDENT AFTER FEH DAYS LATER. NABIYEY FINALLY RETURNED AS PRESIDENT AFTER A POHER-SHARING DEAL BETHEEN HIS COMMUNIST GOVERNM THE OPPOSITION, WHIC

02472 CORDAHI, C.J.

RUSSIA--REASSESSING POLICIES

MIDOLE EAST INTERNATIONAL, (435) (OCT 92), 8

DESPITE ITS AVIDLY PRO-WESTERN FOREIGN POLICY, RUSSIA HAS DECIDED TO RISK ANGERING THE WORLD'S REMAINING SUPERPOWER BY GOING AHEAD WITH THE DELIVERY OF THE FIRST OF THREE SUBMARINES TO IRAN, ALLOWING THE ISLAMIC STATE TO BE 
THE FIRST COUNTRY IN THE GULF TO HAVE A SUBMARINE CAPABILITY. OBSERVERS NOTE THAT RUSSIA'S CHOICE WAS PROMPTED BY A DESPARATE NEED FOR HARD CURRENCY. RUSSIA'S WILLINGNESS TO DISPLEASE A WEST ALARMED AT GROWING IRANIAN POWER AND INFLUENCE IS BUT ONE INDICATION THAT ITS FOREIGN POLICY IS IN FLUX. THIS CHANGE OF POLICY IS PARTICULARLY NOTICEABLE IN THE GULF WHERE RUSSIA IS BRAZENLY LOOKING FOR NEW MARKETS FOR ITS MIDDLE-OF-THE-RANGE MILITARY HARDWARE. THERE HAVE BEEN RECENT REPORTS OF A DEAL FOR GROUND ATTACK AIRCRAFT WITH THE UNITED ARAB EMIRATES AND A DEAL WITH IRAN FOR 110 WARPLANES. OBSERVERS HAVE ALSO NOTED A PRO-ISRAEL SWING IN RUSSIA'S POLICY. RUSSIA HOPES THAT THE LARGE NUMBER OF RUSSIAN EMIGRANTS IN ISRAEL WILL ACT AS A BRIDGE BETHEEN THE THO COUNTRIES AND WILL PROMOTE LUCRATIVE TRADE RELATIONS BETWEEN THE TWO.

02473 CORDESMAN, A.H.

U.S. STRATEGY IN THE 1990'S: REQUIREMENTS VERSUS RESOURCES ANNALS OF THE AMERICAN ACADEMY OF POLITICAL AND SOCIAL SCIENCE, (517) (SEP 91), 39-65.

IN THIS DECADE OF HEIGHTENED BUDGETARY RESTRAINTS, THE UNITED STATES WILL CONTINUE TO CONFRONT THE PRACTICAL UNITED STATES WILL CONTINUE TO CONFRONT THE PRACTICAL PROBLEM OF HOW TO REDUCE STRATEGIC COMMITMENTS AND FORCE LEYELS IN KEEPING WITH FUTURE MILITARY ROLES AND MISSIONS. THE UNITED STATES FORMULATED STRATEGIES AND REOUIREMENTS THE UNITED STATES FORMULATED STRATEGIES AND REQUIREMENTS THAT COULD NOT BE MET AND THEN PROCURED FORCES BASED ON THE
AVAILABLE FUNDS, SIMPLY BY CUTTING THE SHARE OF THE PIE FOR AVAILABLE FUNDS
EACH SERVICE.

02474 CORDOVA, E.

THE INFORMAL CHALLENGE

HEMI SPHERE, 4(2) (WIN 92), 32-33.

THROUGHOUT LATIN AMERICA, ORGANIZED LABOR IS LOSING SUBSTANTIAL GROUND TO THE ACCELERATED GROWTH OF EMPLOYMENT IN THE INFORMAL SECTOR. IT SEEMS REASONABLE TO ASSUME THAT, THROUGH SOME FORM OF POLITICAL CONVERGENCE BETHEEN HORKERS IN THE THO SECTORS, ORGANIZED LABOR WILL EVENTUALLYY REPRESENT MUCH OF THE INFORMAL SECTOR. HOHEVER, FORMIDABLE OBSTACLES MUST BE OVERCOME BEFORE THIS OCCURS.

02475 CORKILL, D.

THE PORTUGUESE PRESIDENTIAL ELECTION OF 13 JANUARY 1991 WEST EUROPEAN POLITICS, 14(4) (OCT 91), 185-192.

ALTHOUGH THE OUTCOME OF THE 1991 CONTEST HAS PREDICTABLE IT DID HAVE IMPORTANT CONSEQUENCES FOR THE STABILITY AND FUTURE EVOLUTION OF PORTUGAL'S POLITICAL SYSTEM AND THE PARLIAMENTARY ELECTIONS SCHEDULED FOR LATER IN THE YEAR. TAKEN AT FACE VALUE, THE 13 JANUARY 1991 POLL TO ELECT TAKEN AT FACE VALUE, THE 13 JANUARY 1991 POLL TO ELECT
PORTUGAL'S NEXT PRESIDENT WAS A NONEVENT. BY GENERAL PORTUGAL'S NEXT PRESIDENT HAS A NONEVENT. BY GENERAL
CONSENSUS THE CAMPAIGN HAS LUCKLUSTRE AND DEVOID OF ANY CONSENSUS THE CAMPAIGN HAS LUCKLUSTRE AND DEVOID OF ANY MEANINGFUL DEBATE AND THE RESULT A FORMALITY. THIS REPORT EVALUATES THE SOARES PRESIDENCY, THE CHALLENGE FRO RIGHT AND FROM THE LEFT, THE
PREDICTIONS FOR THE FUTURE.

02476 CORM, G.

THOUGHTS ON THE ROOTS OF THE ARAB-ISRAELI CONFLICT JOURNAL OF PALESTINE STUDIES, XXI(3) (SPR 92), 71-79.

IN ORDER FOR JEHS AND ARABS TO LIVE TOGETHER AND BUILD A FUTURE WHERE WAR, EXPULSION, AND OPPRESSION ARE NO LONGER THE ORDER OF THE DAY, A NEW REGIONAL CONTEXT MUST EMERGE. THIS ARTICLE STATES THAT IN A VERY REAL SENSE, IT IS IN THE HANDS OF THE WEST. THE ARAB-ISRAELI CONFLICT WAS FORGED NOT BY THE MALEVOLENCE AND FANATICISM OF THE ARABS, OR A MODERM NATIONALIST IDEOLOGY. RATHER, IT WAS FORGED IN THE HISTORY OF THE WEST, AND IN THE EUROPEAN AND AMERICAN BORDERS CLOSED TO THE VICTIMS OF ANTI-SEMITISH. IT IS THUS FOR THE WEST TO START DOWN THE ROAD TOWARDS REPAIRING THE RAYAGES THAT IT HAS WROUGHT IN THE NEAR EAST.

02477 CORNFIELD, $M$

HOW TO READ THE CAMPAIG

WILSON QUARTERLY, XVI (2) (SPR 92), 38-46.

THE AUTHOR LOOKS AT THE ROLE OF PROFESSIONAL JOURANLIS: COVERING THE U.S. PRESIDENTIAL CAMPAIGN, THE FUNCTION OF PROFESSIONAL CAMPAIGN CONSULTANTS, AND THE IDEA OF CAMPAIGN "MOMENTUM."

02478 CORNFIELD, M.B.

THE PRESS AMD POLITICAL CONTROVERSY: THE CASE FOR MARRATIVE ANALYSIS

POLITICAL COMMUNICATION, $9(1)$ (1992), 47-59.

THIS PAPER INTRODUCES NARRATIVE ANALYSIS, A METHOD FOR PRESS CRITICISM THAT RELIES ON CONCEPTS DRAWN FROM NONDECONSTRUCTISH THA RELIES ON CONCEPTS DRAWN FROM NONABOUT THE POLITICAL POHER OF THE MEDIA. NARRATIVE AHALYSIS ABDUT THE POLITICAL POWER OF THE MEDIA. NARRATIVE AMAL AVAILABLE TO JOURNALISTS COVERING A PARTICULAR TOPIC AND THE CONVENTIONAL MEANINGS ASSOCIATED WITH EACH OPTION. IN THIS ANALYSIS, THE AUTHOR IDENTIFIES CHOICES MADE BY WRITERS PROFILING JAMES A. BAKER III THAT PLACE THEIR NEWS STORIES IN ONE OF SIX GENRES OF AMERICAN POLITICAL JOURNALISM: CELEBRITY, CONTEST, IMAGE, PASSAGE, INVESTIGATION, OR
CRUSADE. IN THIS CASE, CLASSIFYING NEWS STORIES BY GENRE SHOWS THAT MEDIA PORTRAYALS OF AUTHORITY FIGURES ARE NOT AS UNIFORMLY SUPPORTIVE OR ADVERSARIAL AS, RESPECTIVELY, LEFTLIBERAL AND NEOCONSERVATIVE THEORISTS OF MEDIA POWER HAVE CONTENDED.

02479 CORNUELLE, $R$.

THE POWER AND POVERTY OF LIBERTARIAN THOUGHT

CRITICAL REVIEN, 6(1) (WIN 92), 1-10.

THE COLLAPSE OF THE COMMUNIST ECONOMIES HAS AT LAST PUT

TO REST ONE OF THE UNSETTLED QUESTIONS OF MDDERN TIMES AND

LIBERTARIANS HAD IT RIGHT FROM THE VERY BEGINNING. THE IRONY IS THAT WHILE LIBERTARIANS WAITED NEARLY A CENTURY FOR ACCEPTANCE, THE SUN SHONE ON THEM FOR ONLY A MOMENT. THEIR CENTRAL PROPOSTION WAS PROMPTLY ABSORBED INTO THE

CONVENTIONAL WISDOM AND IS NO LONGER INTERESTING. THIS ARTICLE EXPLORES LIBERTARIAN THOUGHT WHICH IT DESCRIBES AS WONDERFULLY SOUND AS FAR AS IT GOES. IT EXPLORES TWO GAPING HOLES IN IT THAT ARE NOW TAKING ON A DECISIVE IMPORTANCE: THAT THERE IS NO VERY DISTINCT LIBERTARIAN VISION OF THAT THERE IS NO VERY DISTINCT LIBERTARIAN VISION OF
COMMUNITY AND THE HYPOCRISY OF THE CAPITALIST RATIONALE COMMUNITY AND THE HYPOCRISY OF THE CAPITALIST RATIONALE WHICH INSISTS THAT HHILE CAPITALISTS MUST HAVE EXTENSI
FREEDOM OF ACTION, THEIR EMPLOYEES MAY HAVE MUCH LESS.

02480 CORRADI, J.E.

THE ARGENTINA OF CARLOS SAUL MENEM

CURRENT HISTORY, 1 (562) (FEB 92) 80-84

IN ARGENTINA, THE ISSUE IS NO LONGER THE CONSOLIDATION OF DEMOCRACY BUT THE LINKS BETWEEN NORMAL POLITICS AND CONCRETE ECONOHIC POLICIES. THE THO GOVERNMENTS OF THE NEH DEMOCRATIC PERIOD HAVE ADOPTED, HITHOUT SUCCESS, SEYERAL ECONOMIC STABILIZATION AND REFORM PLANS. IN THIS ARTICLE, THE AUTHOR EXAMINES THESE RECENT ATTEMPTS TO "FIX" THE

02481 CORRADI, J.E. (ED.); FAGEN, P.H. (ED.); GARRETON, M.A.

FEAR AT THE EDGE--STATE TERROR AND RESISTANCE IN LATIN AMERICA

UNIVERSITY OF CALIFORHIA PRESS, 1992, 260.

DESPITE THE EMERGENCE OF FRAGILE DEMOCRACIES IN LATIN AMERICA IN THE 1980S, A LEGACY OF FEAR AND REPRESSION HAUNTS THIS REGION. THIS VOLUME CHRONICLES THE EFFECT OF SYSTEMATIC STATE TEROR ON THE SOCIAL FABRIC IN CHILE, ARGENTINA, BRAZIL, AND URUGUAY FROM THE 1960 S TO THE MID-1980S. THE CONTRIBUTORS EXAMINE THE DEEP SENSE OF INSECURITY AND THE COMPLEX SOCIAL PSYCHOLOGY OF PEOPLE HHO LIVE IN COMPLEX SOCIAL PSYCHOLOGY OF PEOPLE WHO LIVE IN AUTHORITARIAN REGIMES. THERE IS ARGENTINA, WHERE THE BRUTAL
REPRESSION OF THE 1976 COUP ALMOST COMPLETELY SHOTHERED REPRESSION OF THE 1976 COUP ALMOST COMPLETELY SHOTHERED
INDIVIDUALS WHO MIGHT ONCE HAVE OPPOSED GOVERMMENT PRACTICES, INDIVIDUALS WHO MIGHT ONCE HAVE OPPOSED GOVERMMENT PRACT
AND URUGUAY, WHERE THE GOVERNMENT FORCED THE POPULATION INTO NEUTRALITY AND ISOLATION AND CAST A SILENT PALL ON EVERYDAY LIFE. ACCOUNTS OF REPRESSION AND RESISTANCE IN CHILE AND BRAZIL ARE ALSO VIVIDLY PRESENTED. THE DENIAL AND RATIONALIZATION BY CITIZENS CAN ONLY BE UNDERSTOOD IN THE CONTEXT OF THE GENERALIZED FEAR AND CONFUSION CREATED
VIOLENT MILITARY CAMPAIGHS, HHICH INCLUDED ABDUCTIONS, VIOLENT MILITARY CAMPAIGNS, HHICH INCLUDED ABDUCT
TORTURE, AND DISAPPEARANCE OF ALLEGED TERRORISTS.

02482 CORREA, H.; NAMKOONG, $K$.

DETERMINANTS AND EFFECTS OF HEALTH POLICY

JOURNAL OF POLICY MODELING, 14(1) (FEB 92), 41-63. THIS PAPER HAS TWO PURPOSES: (A) TO EVALUATE THE RELATIVE IMPORTANCE OF SOCIOECONOMIC DEVELOPMENT AND POL ITICAL CONDITIONS AS DETERMINANTS OF PUBLIC HEALTH POL ICIES AND ( 8 ) TO ASSESS THE INFLUENCE OF THOSE POL ICI ON THE HEALTH CONDITIONS OF THE POPULATION. THE FIRST INDICES CONSTRUCTED FROM THEM. THE FINAL SECTIONS CONTAIN THE RESULTS OF THE STATISTICAL ANALYSES. THEY SHOW THAT POLITICAL CONDITIONS HAVE AS MUCH INFLUENCE AS ECONOMIC CONDITIONS ON HEALTH POLICIES AND THAT SOCIOECONOMIC CONDITIONS ARE THE MAIN DETERMINANT OF THE HEALTH CONDITIONS OF A POPULATION, HITH HEALTH POLICIES--PARTICULARLY NATIONAL HEALTH INSURANCE AND SERVICE--HAVING A SIGNIFICANT SECONDARY ROLE.

02483 CORSUN, A.; ALEXANDER, Y. (ED.); PLUCHINSKY, D.A. (ED.) GROUP PROFILE: THE REVOLUTIOMARY ORGANIZATION 17 NOVEMBER IN GREECE (1975-1991); EUROPEAN TERRORISM: TODAY AND TOMORROH

BRASSEY'S (US), 1992, 93-125

SINCE DECEMBER 1975, THE REVOLUTIONARY ORGANIZATION 17 NOVEMBER HAS CARRIED OUT 46 ATTACKS IN GREECE, INCLUDING SEVERAL AIMED AT U.S. TARGETS IN ATHENS. ALTHOUGH 17

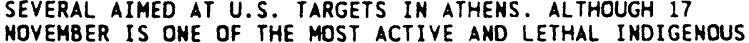
NOVEMBER IS ONE OF THE MOST ACTIVE AND LETHAL INDIGENOUS TERRORIST GROUPS OPERATING IN WESTERN EUROPE, RELATIVELY FAILED TO APPREHEND ANY OF ITS MEMBERS. MOST OF THE INFORMATION ABOUT THE GROUP COMES FROM ITS COMMUNIQUES, WHICH INDICATE THAT IT IS A VIOLENT MARXIST-LENINIST ORGANIZATION THAT IS DOCTRINALLY ANTI-IMPERIALIST, ANTICAPITALIST, ANTI-AMERICAN, AND ANTI-MATO. IN THE PAST, IT HAS REACTED VIOLENTLY TO GREEK DOMESTIC ISSUES, THE 
SITUATION IN CYPRUS, AND OPERATION DESERT STORM.

02484 CORHIN, E.H.

CONGRESSIONAL LIMITS ON AGENCY DISCRETION: A CASE STUDY OF THE HAZARDOUS AND SOLID WASTE AMENDMENTS OF 1984

HARVARD JOURNAL OF LEGISLATION, 29(2) (SUM 92), 517-460. DEFINING THE PROPER SCOPE OF POWER TO BE DELEGATED FROM CONGRESS TO ADMINISTRATIVE AGENCIES HAS LONG BEEN A SUBJECT CONGRESS TO ADMINISTRATIVE AGENCIES HAS LONG BEEN A SUBJECT
OF DEBATE. TWELVE YEARS OF REPUBLICAN AOMINISTRATIONS AND A DEMOCRATIC CONGRESS HAVE INCREASED THE TENSION BETWEEN THE SEEM TO ABUSE BROAD GRANTS OF POWER, CONGRESS HAS TURNED TO LEGISLATING IN NARROW, SPECIFIC TERMS AS ONE APPROACH TO LEGISLATING IN NARROW, SPECIFIC TERMS AS ONE APPROACH TO AMENDMENTS OF 1984 (HSHA) ARE AH EXTREME EXAMPLE OF CONGRESS AMENDMENTS OF 1984 (HSHA) ARE AN EXTREME EXAMPLE OF CONGRESS USING SPECIFIC STATUTORY MANDATES TO CONTROL THE REAGAN EPA. DETAILED MANDATES, SUCH AS HSWA, CAN BE EFFECTIVE POL ITICAL
IOOLS FOR LIMITING AGENCY OISCRETION. HOWEVER, STATUTES LIKE HSWA ARE NOT EFFECTIVE AS A POLICY MATTER BECAUSE THEY PRECLUDE AGENCIES FROM IMPLEMENTING THE BEST SOLUTIONS TO REGULATORY PROBLEMS.

02485 COSGROVE, C.

THE IMPACT OF 1992 ON EC-ACP TRADE AND INVESTMENT; EUROPE AND AFRICA: THE NEW PHASE

LYNNE RIENNER PUBLISHERS, 1992, 63-74.

THE IMPLICATION OF LOME IV IN RESPECT TO TRADE AND AID PROVISIONS, THE SINGLE EUROPEAN MARKET, ITS IMPACT ON NONTRADITIONAL EXPORTS, TAXATION, THE FRANC ZONE AND EUROPEAN MONETARY UNION AID AMD INVESTMENT ARE EACH EXPLORED IN THIS ARTICLE. IT IS SUGGESTED THAT THE DEBATE ON THE SEM AND THE LIBERALIZATION OF EASTERN EUROPE ALREADY HAS POLITICAL REPERCUSSIONS ON EC-ACP RELATIONS. THE EMERGENCE OF MULTIPARTY SYSTEMS AMD DEMOCRACIES IN EASTERN EUROPE HAS PROMPTED MANY WESTERN POLITICIANS TO LOOK FOR THE SAME PROMPTED MANY WESTERH POLITICIANS TO LOOK FOR THE SAME
METAMORPHOSIS FROM THEIR PARTNERS IN AFRICA. THIS WOULD BE METAMORPHOSIS FROM THEIR PARTNERS IN AFRICA. THIS WOULD BE
AN UNCOMFORTABLE PROCESS FOR MOST ACP STATES, WHICH STILL AN UNCDMFORTABLE PROCESS FOR MOST ACP STATES, WHICH STILL POLITICAL FRAMEWORK FOR DEVELOPMENT.

02486 COSSOLOTTO, M.

DEMOCRACY, DIVERSITY, AND "SMART" BALLOTS

NATIONAL CIVIC REVIEW, 81(3) (SUM 92), 347-351.

A DEMOCRACY THAT IS TRULY SAFE FOR DIVERSITY IS ONE THAT ENSURES EFFECTIVE REPRESENTATION OF WOMEN AND MINORITIES ON POLICY-MAKING BODIES. THE CENTRAL ISSUE IS NOT THE RIGHT TO VOTE BUT THE POWER TO CAST A MEANINGFUL VOTE.

02487 COSSOLOTTO, M.

THE 'GRAND CANYON' OF AMERICAN DEMOCRACY

NATIONAL CIVIC REVIEW, 81(1) (WIN 92), 64-68

THE "GRAND CAMYON" OF AMERICAN SOCIETY IS THE HUGE GULF BETWEEN THE NUMBER OF WOMEN AND MINORITIES IN THE GENERAL POPULATION AND THEIR SCANT REPRESENTATION IN CONGRESS. THE SMALL NUMBER OF HOMEN AND MINORITIES IN CONGRESS SAYS LESS ABOUT THE GENDER, RACIAL, OR ETHNIC PREFERENCES OF THE AMERICAN ELECTORATE THAN IT DOES ABOUT THE NATURE OF THE U.S. ELECTORAL SYSTEM.

02488 COSTAIN, A.N.

AFTER REAGAN: NEH PARTY ATTITUDES TOWARD GENDER ANMALS OF THE AMERICAN ACADEMY OF POLITICAL AND SOCIAL SCIENCE, (515) (MAY 91), 114-125.

FROM THE SUFFRAGE PERIOD UNTIL THE 1960'S, THE DEMOCRATIC AND REPUBLICAN PARTIES WERE SPLIT' OVER WOMEN'S ISSUES. THE REPUBLICAN PARTY ADVOCATED EQUAL RIGHTS FOR WOMEN, WHILE THE DEMOCRATS PREFERRED PROTECTIVE LEGISLATION TO SHIELD WOMEN FROM SOCIAL AND ECONOMIC COMPETITION. IN THE TO SHIELD WOMEN FROM SOCIAL AND ECONOMIC COMPETITION. IN THE
$1960^{\circ} \mathrm{S}$, THE PARTIES BEGAN A PROCESS OF CONVERGENCE. BY THE $1960^{\prime} ' S$, THE PARTIES BEGAN A PROCESS OF CONVERGENCE. BY
END OF THE JOHNSON ADMINISTRATION, THERE WAS A VIRTUAL END OF THE JOHNSON ADMINISTRATION, THERE WAS A VIRTUAL CONSENSUS THAT LEGAL EQUALITY SHOULD BE EXTENDED TO WOMEN YET, IN THE EARLY 1970'S, THE REPUBLICAN PARTY BEGAN A HISTORIC ROLE REVERSAL, BACKING AWAY FROM LEGAL EQUALITY AS WELL AS ACCEPTANCE OF THE SUPREME COURT'S STANCE ON ABORTION RIGHTS. ALTHOUGH THESE ISSUES DID NOT CREATE A GENDER GAP IN THE ELECTORATE, THEY, ALONG WITH STATEMENTS BY PARTY LEADERS,
CREATED THE PERCEPTION THAT DEMOCRATS WERE REACHING OUT TO CREATED THE PERCEPTION THAT DEMOCRATS WERE REACHING OUT TO AOMEN AS CONSTITUENTS WHILE REPUBLICANS WERE RETREATING. ADVANCED OR OEFEATED IN EACH PARTISAN ELECTORAL CONTEST.

02489 COSTAIN, A.N.

INVITING HOMEN'S REBELLION--A POLITICAL PROCESS INTERPRETATION OF THE WOMEN'S MOVEMENT

JOHNS HOPKINS UNIVERSITY PRESS, 1992, 208

THIS BOOK EXAMINES THE DEVELOPMENT OF THE WOMEN'S MOVEMENT FROM ITS APPEARANCE IN THE 1960S, THROUGH ITS FORMATIVE YEARS TO ITS PEAK IN THE 1970S, AND INTO ITS RECENT "DECLINE." POLITICAL SCIENTISTS HAVE GENERALLY UNDERSTOOD IT AS A TRADITIONAL SOCIAL MOVEMENT, ONE THAT GATHERED ITS CONSTITUENTS AND MOBILIZED ITS RESOURCES TO FIGHT FOR CHANGE--IN PART, AGAINST A GOVERNMENT THAT WAS HOSTILE OR INDIFFERENT TO WOMEN'S RIGHTS. THIS BOOK ARGUES INSTEAD FOR A "POLITICAL PROCESS" INTERPRETATION THAT INCLUDES THE FEDERAL GOVERNMENT'S ROLE IN FACILITATING THE
MOVEMENT'S SUCCESS. IT ARGUES THAT THE CRUMBLING OF THE NEW DEAL COALITION IN THE LATE SIXTIES CREATED A PERIOD OF POL ITICAL UNCERTAINTY. REALIZING THE POTENTIAL ELECTORAL IMPACT OF A BLOC OF WOMEN VOTERS, POLITICIANS SAW THE VALUE OF MAKING SERIOUS EFFORTS TO ATTRACT WOMEN'S SUPPORT. IN THIS SYMPATHETIC POLITICAL CLIMATE, THE WOMEN'S MOVEMEN EARLY LEGISLATIVE VICTORIES WITHOUT NEEDING TO DEVELOP SIGNIFICANT RESOURCES OR TACTICAL SKILLS. IT ALSO ENCOURAGED
THE MOVEMENT'S EMPHASIS ON LEGISLATION, PARTICULARLY THE PASSAGE OF THE EOUAL RIGHTS AMENDMENT.

02490 COSTAIN, W.D.; COSTAIN, A.N.

THE POLITICAL STRATEGIES OF SOCIAL MOVEMENTS: A COMPARISOM OF THE HOMEN'S AND ENYIRONMENTAL MOVEMENTS

CONGRESS AND THE PRESIDENCY, 19(1) (SPR 92), 1-27.

THE WOMEN'S AND ENVIRONMENTAL MOVEMENTS INITIALLY TOOK ADVANTAGE OF FAVORABLE SOCIAL AND POLITICAL CONDITIONS BUT LATER ADJUSTED TO UNFAVORABLE CIRCUMSTANCES TO BECOME INFLUENTIAL ACTORS IN U.S. POLITICS. THE CASES SUGGEST THAT MOVEMENTS ACHIEVE SUCCESS LARGELY BECAUSE THEIR LOOSE ORGANIZATION AND MEMBERSHIP ALLOW THEM TO ADAPT QUICKLY TO
CERTAIN TYPES OF POLITICAL ENVIRONMENTS. IN PERIODS OF SOCIAL AND POLITICAL FLUX, MOVEMENTS HAVE THE POTENTIAL TO RESPOND TO CHANGING CONDITIONS MORE QUICKLY AND OFTEN MORE EFFECTIVELY THAN STRUCTURED GROUPS, SUCH AS POLITICAL PARTIES. BUT MOVEMENTS ARE SIGNIFICANTLY LIMITED AS DURABLE INSTRUMENTS FOR REPRESENTING THEIR PREYIOUSLY UNDERREPRESENTED INTERESTS. THE INITIAL EMERGENCE OF A NEH MOVEMENT REQUIRES AN INFREQUENT COINCIDENCE OF FAVORABLE SOCIETAL AND POLITICAL CONDITIONS. EVEN AFTER MOVEMENTS INSTITUTIONALIZE AS INTEREST GROUPS, THEY NEED HOSPITABLE POLITICAL EVENTS TO KEEP THEIR AGENDAS BEFORE THE PUBLIC. INSTITUTIONALIZATION COMBINED WITH A PERIODIC MOBILIZATION POL ITICAL INFLUENCE THAT IS GREATER THAN THE SUM OF THEIR SEPARATE INTEREST GROUPS BUT LESS THAN THE SUM OF THEIR SEPARATE INTERE
SYMPATHIZERS.

02491 COSTANTINI, E.; NASH, M.

SLAPP/SLAPPBACK: THE MISUSE OF LIBEL LAW FOR POLITICAL PURPOSES AND A COUNTERSUIT RESPONSE

JOURNAL OF LAH \& POLITICS, VIII(3) (SPR 91), 417-480,

THIS ARTICLE IS CONCERNED WITH A PARTICUL ARLY PERNICIOUS AND POLITICALIY SIGNIFICANT SUBSET OF LIBEL SUITS THAT HAVE RISEN TO PROMINENCE ON THE LITIGATION LANDSCAPE OVER THE PAST THO DECADES. CALLED "STRATEGIC LAWSUITS AGAINST POLITICAL PARTICIPATION" (SLAPP), THEY HAVE BEEN CHARACTERIZED AS THE "MOST SERIOUS CURRENT THREAT TO CITIZEN PARTICIPATION IN GOVERMMENT DECISION-MAKING." SLAPPS ARE LEGALLY MERITLESS SUITS DESIGNED, FROM THEIR INCEPTION, TO INTIMIDATE AND HARASS POLITICAL CRITICS INTO SILENCE AND NOT TO ACHIEVE THE PURPOSES FOR WHICH LIBEL LAW EXISTS, THE RESTORATION OF FALSELY DAMAGED REPUTATIONS AND POSSIBLE WAYS OF COUNTERING THIS TREND. MOST NOTABLE IS A SLAPPBACK, A COUNTERSUIT IN WHICH DAMAGES ARE SOUGHT FROM THE ORIGINAL PLAINTIFF FOR ABUSING THE LEGAL PROCESS.

02492 COSTANZA, R.; CORNWELL, L.

THE 4P APPROACH TO DEALING WITH SCIENTIFIC UNCERNTAINTY ENVIRONMENT, 34(9) (NOV 92), 12-20, 42.

HOULD HALVING TOTAL CARBON EMISSIONS STOP GLOBAL WARMING? POLICYMAKERS ARE EAGER FOR SCIENTISTS TO GIVE THEM DEFINITE ANSHERS TO SUCH QUESTIONS, BUT MANY ENVIRONMENTAL PROBLEMS ARE SO COMPLEX THAT THEY PRECLUDE CLEAR-CUT ANSWERS. ENYIRONMENTALISTS HAYE URGED POLICYMAKERS TO ADHERE TO THE "PRECAUTIONARY PRINCIPLE" WHEN ADDRESSING ENYIRONMENTAL PROBLEMS WITH UNCERTAIN BUT POTENTIALLY DIRE IMPACTS. THEY PAYE ALSO HAVE ALSO LOBBIED FOR POL ICIES THAT MAKE POLLUTERS PAY
ENVIRONMENTAL CLEANUPS. THE "4P" APPROACH PROPOSED HERE ENVIRONMENTAL CLEANUPS. THE "4P" APPROACH PROPOSED HERE SHOWS HOW POLICYMAKERS MIGHT DEAL WITH UNCERTAINTY BY APPLYING BOTH

02493 COTTAM, M.L.

THE CARTER ADMINISTRATION'S POLICY TOWARD NICARAGUA: IME CARTER ADMINISTRATION, GOALS, AND TACTICS

POLITICAL SCIENCE QUARTERLY, 107(1) (SPR 92), 123-146. THE COMPLEXITIES OF THE CARTER ADMINISTRATION'S POLICIES AMD ACTIONS TOWARD NICARAGUA CAN BE CLARIFIED THROUGH AM AMALYSIS OF THE COGNITIVE IMAGES OF THREE DIFFERENT PERCEPTUAL GROUPS: TRADITIONAL COLD WARRIORS, HHO SUPPORTED TRADITIONAL CONTAINMENT TACTICS; MODIFIED COLD WARRIORS, WHO ACCEPTED LONTAIMUET AS ACECESSARY GLOB POLICY BUT FELT SECURE ENOUGH TO ACCEPT THE USE OF NEW TACTICS AND ADDITIONAL FOREIGN POLICY GOALS; AND THE HUMAN RIGHTS GROUP, WHO DID NOT SEE CONTAINMENT AS A NECESSARY OR ADEQUATE GLOBAL POLICY. IN THIS ESSAY, THE AUTHOR EXPLORES THE IMPACT OF THESE PERCEPTIONS ON CARTER'S NICARAGUAN POLICY AND ARGUES THREE BASIC POINTS. FIRST, PSYCHOLOGICAL IMAGES PRODUCE POLICY PREFERENCES IN THE FORM OF GENERAL AND SPECIFIC GOALS AND THE STRATEGIES AND TACTICS DESIGNED TO ACHIEVE THEM. SECONDLY, ONE CANNOT TRACE CHANGES IN U.S. 
POLICY TOWARD NICARAGUA TO SHIFTS IN THE POWER OF COMPETING POLICY ADYOCACY GROUPS. FIMALLY, THE PERCEPTUAL GROUP THAT REALLY DISAGREED WITH THE PREVAILING CONTAINMENT GOALS AND STRATEGY DID NOT ARTICULATE THAT DISAGREEMENT AS AN ALTERNATIVE.

02494 COTTON, J.

CIVIL SOCIETY IN THE POLITICAL TRANSITION OF NORTH KOREA: THE LIMITATIONS OF THE EAST EUROPEAN MODEL

KOREA \& WORLD AFFAIRS, 16(2) (SUM 92), 319-337

AMONG THE MEMBERS OF THE FORMER SOCIALIST BLOC, NORTH KOREA IS OFTEN IDENTIFIED AS THE SYSTEM IN WHICH MARXISM IS MOST DEEPLY ENTRENCHED. NEVERTHELESS, GIVEN THE RAPID DISSOLUTION OF ONCE SOLID POL ITICAL AND SOCIAL ORDERS IN EASTERN EUROPE, IT MAY BE SUPPOSED THAT NORTH KOREA IS LIKELIHOOD OF THIS OCCURRENCE AND SEEKS TO DETERMINE WHETHER THERE WILL BE ANY ASSERTION OF THE POWER OF CIVIL SOCIETY AGAINST THE STATE SIMILAR TO THAT IN POLAND AND

CZECHOSLOVAKIA.

02495 COTTON, J.

UNDERSTANDING THE STATE IN SOUTH KOREA

COMPARATIVE POLITICAL STUDIES, 2414) (JAN 92), 512-531. SOUTH KOREA CANMOT BE SEEN AS AN EXAMPLE OF THE BUREAUCRATIC-AUTHORITARIAN STATE TYPE. NEITHER ITS POSITION IN THE WORLD SYSTEM NOR ITS INDUSTRIALIZATION STRATEGY CAN BE USED TO GIVE A SUFFICIENT EXPLANATION OF ITS POLITICAL AND SOCIAL CHARACTER. ALTHOUGH THESE FACTORS HAVE PLAYED A PART, PARTICULAR HISTORICAL, POLITICAL, AND CULTURAL CIRCUMSTANCES HAVE PERMITTED THE STATE' TO ENJOY A DEGREE OF AUTONOMY DURING THE PERIOD OF RAPID SOCIAL AND ECONOMIC TRANSFORMATION FROM THE 1960 S TO THE 1980S. THE DETERMINANTS AND CHARACTER OF THE TRANSITION TO DEMOCRATIZATION GENERALLY SUPPORT THIS ANALYSIS, BUT ALSO INDICATE THAT LIMITS EXIST TO THE DEGREE OF LIBERALIZATION TO BE EXPECTED IN THE POLITICAL SYSTEM.

02496 COUCH, J.; ATKINSON, K. ; SHUGHART II, $W$.

ETHICS LAWS AND THE OUTSIDE EARNINGS OF POLITICIANS: THE CASE OF ALABAMA'S "LEGISLATOR-EDUCATORS"

PUBLIC CHOICE, 73(2) (MAR 92) 135-146.

THIS PAPER' IS ABOUT THE PRICE OF PORK. IN PARTICLAR, IT EXAMINES THE DISTRIBUTIONAL IMPACT OF A PROVISION OF ALABAMA'S CODE OF ETHICS WHICH ALLOWS SITTING STATE LEGISLATORS TO BE ON THE PAYROLL OF PUBLIC INSTITUTIONS OF HIGHER EDUCATION. THE PAPER FINDS THAT THE 15 JUNIOR AND SENIOR COLLEGES IN ALABAMA THAT PAY EDUCATIONAL SALARIES TO SENIOR COLLEGES IN ALABAMA THAT PAY EDUCATIONAL SALARIES
LEGISLATORS RECEIVE NEARLY \$19 IN EXTRA PUBLIC FUNDING LEGISLATORS RECEIVE NEARLY \$19 IN EXTRA PUBLIC FUMD
ANNUALLY FOR EVERY S1 PAID TO A STATE SENATOR OR ANNUALLY FOR EVERY \$1 PAID TO A STATE SENATOR OR
REPRESENTATIVE. THIS PAPER DISCUSSES THE RELATIONSHIP BETHEEN LEGISLATIVE PAY AND THE OUTSIDE EARNINGS OF BETWEEN LEGISLATIVE PAY AND THE OUTSIDE EARNINGS OF
POLITICANS. IT PRESENTS THE DATA AND EMPIRICAL RESULTS.

02497 COUGHLIN, P.

BALANCED-BUDGET REDISTRIBUTION AS THE OUTCOME OF POLITICAL COMPETITION: A COMMENT

PUBLIC CHOICE, 70(2) (MAY 91), 239-244.

THIS COMMENT IS CONCERNED WITH THE RELATION BETHEEN THE BASIC MODEL OF ELECTIONS AND INCOME REDISTRIBUTION OF LINBECK AND WEIBULL (1987) AND THE MODEL IN COUGHLIN (1986)THE AUTHOR'S MODEL. ITS PURPOSE IS TO ISOLATE THE ASSUMPTIONS THAT SEPARATE THESE CLOSELY RELATED MOOELS AND TO IDENTIFY A SPECIAL CASE OF THE LINDBECK-WEIBULL MODEL WHERE THEIR RESULTS IMMEDIATELY PROVIDE DIRECT EXTENSIONS OF FOUR OF THE RESULTS IN THE AUTHOR'S PAPER. THE COMMENT ALSO RELATES THESE OBSERVATIONS TO LINDBECX AND WEIBULL'S EXAMPLE OF FAMILIAR ASSUMPTIONS THAT SATISFY THEIR SUFFICIENT CONDITIONS FOR THE EXISTENCE OF A POLITICAL EQUILIBRIUM.

02498 COULTER, P.B.

THERE'S A MADNESS IN THE METHOD: REDEFINIMG CITIZEN CONTACTING OF GOVERNMENT OFFICIALS

URBAN AFFAIRS QUARTERLY, 28(2) (DEC 92), 297-316. META-ANALYSIS OF RESEARCH ON CITIZEN-IMITIATED CONTACTS WITH GOVERMMENT OFFICIALS REVEALS THAT THE FINDINGS ARE BASICALLY AN ARTIFACT OF THE METHOD USED. MACRO-ANALYTIC STUDIES USING AGGREGATE DATA FIND A NEGATIVE OR CURVILINEAR RELATIONSHIP BETWEEN CONTACTING AND SOCIOECONOMIC STATUS (SES). WHILE MICRO-ANALYTIC STUDIES USING SURVEY DATA FIND A POSITIVE OR NULL RELATIONSHIP BETHEEN CONTACTING AND SES. ALMOST ALL SURVEY RESEARCHERS HAVE USED AN INVALID ALMOST ALL SURVEY RESEARCHERS HAVE USED AN INVALID
OPERATIONAL MEASURE OF CONTACTING. ANALYSIS OF RESULTS FROM A BIRMINGHAM, ALABAMA, SURVEY THAT DEFINED CONTACT IN A A BIRMINGHAM, ALABAMA, SURVEY THAT DEFINED CONTACT IN A
CONYENTIONAL WAY AND WITH SPECIFIC, BOUNDED- AND AIDDEDCONYENTIONAL WAY AND WITH SPECIFIC, BOUNDED- AND AIDEDRESEARCHERS KNOW OR THINK THEY KNOW ABOUT CONTACTING IS RESEARCHER
SUSPECT.

02499 COULTER, T.

SELF-DETERMINATION AND GROUP RIGHTS

CULTURAL SURVIVAL QUARTERLY, 16(3) (FAL 92), 27-29.

THE CAMPAIGN FOR A DECLARATION OF INDIGENOUS RIGHTS IS CHANGING THE WAY TO THINK ABOUT HUMAN RIGHTS. HUMAN RIGHTS
INVOLVE GROUP RIGHTS, NOT JUST INDIVIDUAL RIGHTS, THE RECOGNITION OF WHICH IS AN HISTDRIC STEP FORWARD IN THE HUMAN-RIGHTS MOVEMENT. THE AUTHOR SUGGESTS THAT WE HILL
S GRADUAL EVOLUTION OF INTERNATIONAL LAW TO PROTECT INDIGENOUS PEOPLES FROM NATION STATES.

02500 COURSEY, D.; ROBERTS, R. COMPETITION IN POLITICAL AND ECONOMIC MARKETS PUBLIC CHOICE, 70(1) (APR 91), 83-88.

THIS ARTICLE CONSIDERS HHETHER ANOMALIES PLAY AN IMPORTANT ROLE IN EXPLAINING ECONOMIC AND POLITICAL CHOICES AND WHETHER POLITICAL DECISIONS ARE MORE PRONE TO ANOMALIES, IRRATIONALITY, AND INEFFICIENCY THAN ECONOMIC DECISIONS. THEY EXAMINE THE WORK OF FREY AND EICHENBERGER (1990) IN LIGHT OF A LARGER BODY OF EXPERIMENTAL DATA WHICH INCLUDES CHOICES MADE IN MARKET SETTINGS. THEY CONCLUDE THAT COMPETITION IN POLITICAL MARKETS WILL TREND TO ELIMINATE AGGREGATE ANOMALIES JUST AS IT DOES IN ECONOMIC MARKETS.

02501 COURTOIS, S.

THE FREMCH COMMUNIST PARTY'S REACTION TO THE COLLAPSE OF THE CPSU

JOURNAL OF COMMUNIST STUDIES, 8(1) (MAR 92), 187-196.

IN AUGUST 1991, THE ATTEMPTED COUP IN THE SOVIET UNION BROUGHT TO A HEAD THE CRISIS THAT HAD BEEN BREWING FOR MONTHS WITHIN THE FRENCH COMMUNIST PARTY. THE LEAST THAT COULD BE SAID IS THAT THE FRENCH COMMUNIST LEADERS ADOPTED AN AMBIGUOUS POSITION REGARDING THE EVENTS IN MOSCOW.

02502 COUTO, $R$

HEROIC BUREAUCRACIES

ADMINISTRATION AND SOCIETY, 23(1) (MAY 91), 123-147.

ACCORDING TO THE SCANT LITERATURE ON THE TOPIC, HEROIC BUREAUCRACIES ADDRESS A SEVERE SOCIAL PROBLEM IN A NEW MANNER. THEY PROVIDE SUBORDINATE GROUPS NEW RESOURCES THAT HAVE IMPACTS LATER FOR POLITICAL CHANGE AND INCREASED EQUALITY. THIS ARTICLE EXAMINES THREE BUREAUCRACIES THAT FULFILL THESE CRITERIA: THE FREEDMEN'S BUREAU, THE FARM SECURITY ADMINISTRATION, AND THE OFFICE OF HEALTH AFFAIRS. THE ANALYSIS IS GROUNDED IN THE WORK THAT THESE

BUREAUCRACIES CONDUCTED IN FOUR RURAL, SOUTHERN, LOW-INCOME , AND PREDOMINATELY AFRICAN-AMERICAN COMMUNITIES OVER THE COURSE OF A CENTURY. THE COMMON CHARACTERISTICS OF THESE BUREAUCRACIES SUGGEST HOW HEROIC BUREAUCRACIES DIFFER FROM NORMAL BUREAUCRACIES. THEIR CHARACTERISTICS INCLUDE AN ORIGIN IN AN EXTRAORDINARY POLITICAL ENVIRONMENTS, AND INTENDED, BUT UNSPECIFIED IMPACTS ON LOCAL LEADERS OF INTENDED, BUT UNSPECIFIED IMPACTS ON LOCAL LEADERS OF
ENSUING CHANGE EFFORTS. IN ADOITION, DISTINGUISHING INTERNAL ENSUING CHANGE EFFORTS. IN ADOITION, DISTINGUISHING INTERNAL CHARACTERISTICS INCLUDE A PREDILECTION FOR EXPERIMENT OVER PRECEDENT AND THE CREATION AND UTILIZATION OF N
CITIZEN-CLIENT PARTICIPATION IN THEIR PROGRAMS.

02503 COUTO, R.A.

WHAT'S POL ITICAL ABOUT SELF-HELP?

SOCIAL POLICY 23(2) (FAL 92 ) 39-43.

THE AUTHOR DISTIMGUISHES BETHEEN TWO TYPES OF SELF-HELP GROUPS: THOSE THAT EMPHASIZE INMER STRENGTH (E.G. SUPPORT GROUPS FOR INOIVIDUALS WITH A COMMON PROBLEM OR ILLNESS) AND ADVOCACY GROUPS (E.G., MOTHERS AGAINST DRUNK DRIVING). THEN HE DISCUSSES HOW GROUPS OF EACH TYPE MAY CROSS OVER FROM BEING SELF-HELP MECHANISMS TO BEING SOCIAL OR POLITICAL MOVEMENTS THAT ENGAGE IN POLITICAL ACTIVISM.

02504 COVINGTON, S.; LOUGH, J. RUSSIA'S POST-REVOLUTION CHALLENGE: REFORM OF THE SOVIET SUPERPOWER PARADIGM

WASHINGTON QUARTERLY, 15(1) (WIN 92), 5-26

THE FATE OF SOVIET MILITARY POWER WITH THE PASSING OF THE UNION OF SOVIET SOCIALIST REPUBLICS IS EXPLORED. WHETHER A NEW, LESS DANGEROUS, STILL POHERFUL RUSSIAN BEAR EMERGES OR A FUMDAMENTAL REORIENTATION IS THE MORE LIKELY IS ALSO STUDIED. THIS ESSAY TRACES THE CONFLICT BETHEEN RUSSIAN REFORM AND SOVIET SUPERPOWER STATUS DURING RECENT YEARS AND OFFERS A NOVEL INTERPRETATION OF THE COUP OF AUGUST 1991, AND SPECULATES ABOUT THE FUTURE OF THE RUSSIAN MILITARY.

02505 COX, G.

IMPLEMENTATION OF THE ROUTINE USE CLAUSE OF THE PRIVACY ACT POLICY STUDIES REVIEH, $10(4)$ (WIN 92), 42-50.

IMFORMATION PRIVACY. THE PRIVACY OF PERSONALLYIDENTIFIABLE DATA HELD BY ORGANIZATIONS, HAS BEEN ON THE FEDERAL POLICY AGENDA SINCE THE 1960's. THE PASSAGE OF SEVERAL LEGISLATIVE ACTS INSURED PROTECTION FOR INFORMATION PRIVACY IN SPECIFIC ENVIRONMENTS AND CIRCUMSTANCES. IN 1974 THE PRIVACY ACT WAS PASSED, PROVIDING CITIZENS LIMITED PROTECTIOM FOR DATA HELD BY AGENCIES OF THE FEDERAL GOVERMMENT. PROTECTION FOR CITIZENS HITH REGARD TO GOVERMMENT-HELD DATA THE LAW HAS BEEN LESS EFFECTIVE THAN ITS ARCHITECTS EXPECTED ONE MAJOR DEFECT IS THE ROUTINE USE CLAUSE, WHICH HAS BEEN SUBJECTED TO BROAD INTERPRETATION AND DISTORTION, TO THE BENEFIT OF THE EXECUTIVE BRANCH AGENCIES THAT HANDLE PERSONALLY-IDENTIFIABLE DATA. IN THIS PAPER, THE AUTHOR 
MISUSE OF THE ROUTINE USE CLAUSE AND SUBSEQUENT IMPLICATIONS FOR CITIZEN PRIVACY.

02506 COX, M.

TROTSKY AND HIS INTERPRETERS: OR, WILL THE REAL LEON TROTSKY PLEASE STAND UP?

RUSSIAN REVIEW, 51(1) (JAN 92), 84-102.

THE HISTORICAL REHABILITATION OF LEDN TROTSKY IN THE SOVIET UNION CLEARLY POSES A NUMBER OF INTRIGUING QUESTIONSINCLUDING HOW MUCH CAN MODERN SOVIET HISTORIANS LEARN FROM WESTERN COMMENTARIES ON TROTSKY AND, IN TURN, HOW MUCH CAN WESTERN SCHOLARS LEARN FROM THE CONTEMPORARY SOVIET DEBATE? IN THIS ESSAY, THE AUTHOR EXPLORES THESE THO QUESTIONS BY PROVIDING A GUIDE TO TRADITIONAL WESTERN INTERPRETATIONS OF TROTSKY AND BY EXAMINING NEW HISTORIOGRAPHICAL DEVELOPMENTS IN THE USSR. HE ALSO ENUMERATES SOME OF THE QUESTIONS THAT

IN THE USSR. HE ALSO ENUMERATES SOME OF THE QUESTIONS THAT
MODERN SCHOLARSHIP IS BEGINNING TO ASK, AND SHOULD BE ASKING, MODERN SCHOLARSHIF
ABOUT TROTSKY.

02507 COX R.

AFTER CORPORATISM: A COMPARISON OF THE ROLE OF MEDICAL PROFESSIONALS AND SOCIAL WORKERS IN THE DUTCH WELFARE STATE COMPARATIVE POLITICAL STUDIES, 24(4) (JAN 92), 532-552. THIS ARTICLE COMPARES THE EMERGING ROLE OF PROFESSIONAL GROUPS IN TWO AREAS OF WELFARE POL ICY IN THE NETHERLANDS. THE FOCUS ON THE ROLE OF MEDICAL PROFESSIONALS IN DUTCH OISABILITY PROGRAMS AND OF SOCIAL WORKERS IN THE AREA OF PUBLIC ASSISTANCE. THE STUDY SHOWS THAT MEDICAL PROFESSIONALS HAVE COME TO REPLACE THE LABOR AND CAPITAL INTERESTS FORMERLY ENGAGED IN OISABILITY POLICYMAKING. IN THE AREA OF SOCIAL WORK. PROFESSIONAL SOCIAL WORK AGENCIES HAVE SUPERCEDED RELIGIOUS CHARITY ORGANIZATIONS THAT FOUND THEIR BASIS FOR POLICY INFLUENCE IN A "PILLARIZED" SOCIETY. THE ARGUMENT PRESENTED IS THAT A POLICY SHIFT ACCOUNTS FOR THIS CHANGE IN WHAT FORMERLY WERE CORPORATIST POLICY INSTITUTIONS. THE POLICY SHIFT RESULTS FROM A CHANGE IN THE NATURE OF WELFARE POLICY DEBATE FROM FUNDAMENTAL DISCUSSIONS OF THE RIGHTS BASIS OF WELFARE PROGRAMS TOWARD TECHNICAL OISCUSSIONS OF HOW TO BEST MAKE THE PROGRAMS OPERATE. AN EXAMINATION OF RETRENCHMENT DEBATES IN THE 1980 S SHOWS THAT PROFESSIONALS REMAIN IMPORTANT ACTORS IN THE POLICY PROCESS. THE IMPLICATIONS FOR CORPORATIST THEORY ARE DISCUSSED.

02508 COX, R.

CAN WELFARE STATES GROW IN LEAPS AND BOUNDS? NONINCREMENTAL POL ICYMAKING IN THE NETHERLANDS

GOVERHANCE, 5(1) (JAN 92), 68-87.

THE RAPID EXPANSION OF THE DUTCH WELFARE STATE IN THE 19605 IS DESCRIBED AS AN EXAMPLE OF NON-INCREMENTAL POLICY $1960 S$ IS DESCRIBED AS AN EXAMPLE OF NON-INCREMENTAL POLICY
GROWTH. THE REASONS FOR THIS INCLUDE: THE LARGENESS OF POLICY CHANGE; THE WILLINGNESS OF POLICYMAKERS TO CONSIDER NEW PROGRAMS THAT MARKED DRAMATIC DEPARTURES FROM OLDER PROGRAMS: THE COMHITMENT OF POL ICYMAKERS TO THE GOAL OF UNIVERSALIZING PROGRAMS RATHER THAN INTRODUCING SATISFYING MEASURES; AND THE DISRUPTION OF THE TRADITIONAL MODE OF CORPORATIST REPRESENTATION IN POLICYMAKING. THE POSSIBILITIES FOR AN EQUALLY RAPID DISMANTLING OF THE WELFARE STATE ARE ALSO DISCUSSED.

02509 COX, R.

MULTILATERALISM AND WORLO ORDER

REVIEW OF INTERNATIONAL STUDIES, 18(2) (APR 92), 161-180 WORLD ORDER HAS BECOME A CURRENT CATCHPHRASE OF POLITICAL DISCOURSE AND JOURNALISH. MULTILATERALISM HAS BECOME SOMETHING OF A GROWTH SECTOR IN ACADEMICS STUDIES. WHAT CURRENT EVENTS HAVE BROUGHT INTO PROMINENCE, SCHOLARSHIP HAS AN OBLIGATION TO SUBJECT TO CRITICAL ANALYSIS. THIS ARTICLE RAISES SOME OF THE QUESTIONS THAT SHOULD BE PROBED IN THIS ANALYSIS. MULTILATERALISM IS EXAMINED FROM THO MAIN STANDPOINTS: ONE, AS THE INSTITUTIONALIZATION AND REGULATION OF ESTABLISHED ORDER; THE OTHER, AS THE LOCUS OF INTERACTIONS FOR THE TRANSFORMATION OF EXISTING ORDER.

02510 COYLE, C.; SINNOTT, R.

REGIONAL ELITES, RÉGIONAL \$POWERLESSNESS' AND EUROPEAN REGIONAL POLICY IN IRELAND

REGIONAL POLITICS \& POLICY, 2(1,2) (SPR 92), 71-108. THIS STUDY BEGINS WITH AN OVERVIEW OF THE SYSTEM OF LOCAL GOVERNMENT IN IRELAND--ITS HISTORICAL DEVELOPMENT, STRUCTURE AND FUNCTIONS AND RECENT REFORMS. THE METHODOLOGICAL PROBLEMS ENCOUNTERED IN ADAPTING THE STUDY TO THE IRISH SETTING AND THE SOLUTIONS ADOPTED ARE OUTLINED. THE ANALYSIS OF THE DATA PROVIDES A COMPREHENSIVE OVERVIEW OF THE ATTITUDES OF REGIONAL ELITES TO REGIONAL PROBLEMS IN OF THE ATTITUDES OF REGIONAL ELITES TO REGIONAL PROBLEMS
THE CONTEXT OF THE INTERNAL MARKET IN 1992. FINALLY, THE THE CONTEXT OF THE INTERNAL MARKET IN 1992 . FINALLY, THE
RESULTS OF THE ANALYSIS ARE EVALUATED IN THE HIDER CONTEXT OF THE CURRENT TRENDS IN REGIONAL POLICY IN BOTH THE NATIONAL AND THE EC ARENAS.

02511 COYNE, J.

VOUCHERS AND THE PHARAOH'S SON

WATIONAL REVIEW, XLIII (7) (APR 91), 25-26.

IN 1985 AND 1987, HAROLD WASHINGTON WON CHICAGO'S
MAYORAL RACE BY ADDING ABOUT 18 PERCENT OF THE WHITE VOTE TO HIS CORE SUPPORT AMONG BLACK VOTERS. IN 1991, ACCORDING TO POLLS, A COMPARABLE PERCENTAGE OF BLACKS FAVOR RICHARD $M$. DALEY, SON OF THE FAMOUS CHICAGO MAYOR RICHARD J. DALEY. WITH A 2 TO 1 APPROVAL RATING AMONG BLACKS, DALEY MIGHT BE IN A POSITION TO BRING THE SORT OF BI-RACIAL COALITION THAT HAS NOT EXISTED IN CHICAGO SINCE HIS FATHER DIED.

02512 COYNE, J.R. JR.

NATIONAL REVIEW, XLIV(18) (SEP 92), $24,26$.

THE AUTHOR DISCUSSES THE 1992 SENATORIAL RACE IN

ILLINOIS, WHERE CAROL MOSELY BRAUN IS THE FRONTRUNNER AND

COULD BECOME THE FIRST BLACK FEMALE SENATOR EVER.

02513 CPUSA

AN ECONOMIC PROGRAM FOR TODAY

POLITICAL AFFAIRS, $71(10)$ (OCT 92), 26-35.

THE COMMUNIST PARTY ECONOMIC PROGRAM FOR TODAY SHOWS

THAT THERE IS A WAY TO DEAL WITH THE LONG-STANDING CRISIS OF THE CAPITALIST SYSTEM. A UNITED PEOPLE'S MOVEMENT TO WIN SUCH REFORMS WOULD PUT THE WORKING CLASS AND OPPRESSED PEOPLES INTO A POSITION OF GREATER STRENGTH IN THE STRUGGLE BETWEEN THE CLASSES. FULL RESOLUTION OF THE CRISES REOUIRES THAT THE CAPITALIST SYSTEM BE REPLACED WITH SOCIALISM. THIS ARTICLE OUTLINES A WAY TO FUND THE PROGRAM. IT ADDRESSES THE MILITARY BUDGET AND CONYERSION ANO OFFERS PROGRAM PROPOSALS.

02514 CRAFTS. N.

INSTITUTIONS AND ECONOMIC GROHTH: RECENT BRITISH EXPERIENCE IN AN INTERNATIONAL CONTEXT

WEST EUROPEAN POLITICS, 15(4) (OCT 92), 16-38.

THE IMPACT OF INSTITUITONS AND POLITIICAL CONSTRAINTS ON ECONOMIC GROWTH IS GREATER THAN MANY ECONOMISTS' MODELS ACKNOWLEDGE. AT THE SAME TIME JUDGMENTS ABOUT GROWTH PERFORMANCE ANO POLICY EFFECTIVENESS NEED TO TAKE ACCOUNT OF DIFFERENTIAL SCOPE FOR GROHTH THROUGH 'CATCH-UP' ACROSS COUNTRIES AND OVER TIME. BRITISH PERFORMANCE, PARTICULARLY THAT OF THE 1980S, SEEN IN THE LIGHT OF THE EARLIER RELATIVE WCONOMIC DECLINE OF THE UK, IS REVIENED AND COMPARISIONS WITH OTHER EUROPEAN COUNTRIES ARE HIGHLIGHTED. THIS EVIDENCE
CONFIRMS THE IMPORTANCE OF AN APPROACH TO GROWTH BASED ON POLITICAL ECONOMY AND PERMITS SOME PREDICTIONS ABOUT PELITICAL ECONOMY AND PERMITS SOME

02515 CRAIG, B. ; GILMOUR, R.

THE CONSTITUTION AND ACCOUNTABILITY FOR PUBLIC FUMCTIONS GOVERHANCE, 5(1) (JAN 92), 46-67.

IN REVIEW OF JUDICIAL INTERPRETATION OF THE UNITED STATES CONSTITUTION SET AGAINST THE CURRENT REALITY OF AMERICAN GOVERNANCE, THE AUTHORS OF THIS ARTICLE CONCLUDE THAT TRADITIONAL SEPARATION OF POWERS DOCTRINES HOLD FEH CONSTRAINTS FOR DELEGATION OF "PUBLIC FUNCTIONS" BEYOND THE BOUNDARIES OF THE THREE BRANCHES. AS THE RESULT OF CONSTITUTIONAL PERMISSIVENESS, THE LEGISLATIVE AND EXECUTIVE DEPARTMENTS HAVE INCREASINGLY LOST OUT (OR ABDICATED) TO PRIVATE AND QUASI-GOVERNMENTAL INSTITUTIONS TO CONDUCT CORE GOVERNMENT FUNCTIONS. PUBLIC ACCDUNTABILITY HAS BEEN LOST IN THE EXCHANGE. AT A TIME OF REVOLUTIONARY CHANGE ACROSS EASTERN EUROPE AND ELSEWHERE, WHEN NEWLY FORMING GOVERNMENTS LOOK TO THE UNITED STATES FOR STRUCTURAL MODELS, THEY ARE UNLIKELYY TO BE INFORMED ABOUT THE FUNCTIONAL REALITY OF AMERICAN GOVERNANCE BY EITHER THE WRITTEN CONSTITUTION OR DOCTRINES ARTICULATING THE CONSTITUTION.

02516 CRAIG, C.

GULF WAR: THE MARITIME CAMPAIGN

RUSI JOURNAL, $137(4)$ (AUG 92), 11-16.

COMMODORE' CRAIG FOCUSES ON THE ORGANIZATION ANO PLANMING BEHIND THE MARITIME WAR IN THE GULF; PREPARING THE MARITIME CAMPAIGN PLAN AND ENSURING THE TASK GROUP WAS READY AND BRIEFED. HE ATTRIBUTES THE SUCCESS OF THE CAMPAIGN TO SUPERIOR LOGISTICS, INTERNATIONAL COOPERATION AND EFFICIENT EXECUTION.

02517 CRAIG, R.H GOVERMMENT-SPONSORED PRAYER: HHY THE SUPREME COURT SHOULDN'T SAY AMEN

CHURCH AND STATE, 45 (2) (FEB 92), 19(43)-20(44).

LEE V. WEISMAN, A CASE CURRENTLY BEFORE THE U.S. SUPREME COURT, RAISES CONSTITUTIONAL QUESTIONS OF WHETHER GOVERNMENT MAY SEEK TO ACTIVELY PROMOTE RELIGION. AT RISK IN THIS CASE MAY SEEK TO ACTIVELY PROMOTE RELIGION. AT RISK IN THIS CASE AND 40 YEARS OF PRECEDENT ON GOVERMMENT-SPONSORED RELIGION AND 40 YEARS OF PRECEDENT

02518 CRAIN, W.M.; MILLER, J.C. III

BLUEPRINT FOR HILLER, J.C. IIT JOURNAL OF LAH \& POLITICS, IX(1) (FAL 92), 127-136. THE AUTHORS HYPOTHESIZE ABOUT INSTITUTIONAL INCENTIVES AND ARRANGEMENTS IN THE STATE GOVERMMENTS THAT ARE LIKELY TO RESULT IN GREATER OR LESS SPENDING. THEY SUGGEST THAT SUCH FACTORS AS SPECIFIC BUDGETARY CONTROL LANGUAGE, GREATER DISCRETIONARY SPENDING, BALANCED BUDGET REQUIREMENTS, AND 
EXECUTIVE LINE-ITEM VETO POWER ARE LIKELY TO PRODUCE RESTRAINED SPENDING. THEY CONCLUDE THAT A FEDERAL LINE-ITEM RESTRAINED SPENDING. THEY CONCLUDE THAT A FEDERAL LINE-ITEM HAVE REDUCED SPENDING BY $\$ 500$ BILLION DURING THE 1980's.

02519 CRANDALL, R.W.

EGULATING COMMUMICATIONS: CREATING MONOPOLY WHILE 'PROTECTING' US FROM IT

BROOKINGS REVIEH, 10(3) (SUM 92), 34-39.

THE UNITED STATES HAS A LONG HISTORY OF GOVERMMENT INTERVENTION IN THE COMMUNICATIONS SECTOR TO ESTABLISH AND PROTECT MONOPOLIES. ALTHOUGH THE PAST TWO DECADES HAVE WITNESSED A GENERAL SHIFT AHAY FROM ECONOMIC REGULATION IN SOME INDUSTRIES, OFFICIAL WASHINGTON IS VERY RELUCTANT TO RELINOUISH ITS CONTROL OVER THE COMMUNICATIONS MEDIA. OFTEN IT JUSTIFIES ITS ACTIONS BY ARGUING THAT THERE ARE BOTH DANGERS TO ALLOWING GOVERNMENT-PROTECTED MONOPOLIES TO EXTEND INTO NEW MARKETS AND COSTS TO ALLOWING NEW

COMPETITORS TO TAKE MARKETS FROM PROTECTED MONOPOLISTS. IN

THIS SETTING, DEFENDERS OF ENTRENCHED MARKET POSITIONS

CANMOT BE BLAMED FOR CONTINUING THEIR TRADITIONAL BATTLE FOR

PROTECTION FROM NEH COMPETITION.

02520 CRANE, G.

ACCELERATED SEZ DEVELOPMENT, 1983-1985; THE POLITICAL ECONOMY OF CHINA'S SPECIAL ECONOMIC ZONES

M.E. SHARPE, 1990,76-107.

THE PACE' OF SEZ DEVELOPMENT QUICKENED MARKEDLY IN 1983. THE HIGH-GROWTH, HIGH-TECH STRATEGY IMPLIED BY THE 982 PLAN WAS EMBRACED BY' CENTRAL LEADERS AS WELL AS LOCAL

ADMINISTRATORS. STRUCTURAL REFORM WAS TAKEN TO GREATER LENGTHS IN ORDER TO ACHIEVE AMBITIOUS GOALS OF INDUSTRIAL EXPANSION AND TECHNOLOGY TRANSFER. A FLUSH OF OPTIMIST ACCOMPANIED THE APPARENT SUCCESS, PROMPTING ADVOCATES TO
HOLD UP THE SEZS AS MODELS OF NATIONAL DEVELOPMENT. IN SHORT 1983 TO EARLY 1985 WAS THE HIGH POINT OF SEZ POLICY.

02521 CRANE, G

EXPLAINING CHINA'S SPECIAL ECONOMIC 2ONES; THE POLITICAL ECONOMY OF CHINA'S SPECIAL ECONOMIC ZONES

M.E. SHARPE, $1990,3-19$.

IN 1979 THE PEOPLE'S REPUBLIC OF CHINA INITIATED A NEH INTERNATIONAL ECONOMIC POLICY UNDER HHICH IT ESTABLISHED FOUR SPECIAL ECONOMIC ZONES (SEZS). THIS CHAPTER OFFERS AN OVERVIEW OF THIS PHENOMENON. IT EXAMINES STUDIES THAT SPECIFICALLY DEAL WITH SEZS AS WELL AS SIMILAR POLICIES (EXPORT PROCESSING ZONES) IN OTHER LESS DEVELOPED COUNTRIES. IN ADDITION, AT A HIGHER LEVEL OF ABSTRACTION, IT OFFERS A MORE GENERAL DISCUSSION OF POLITICAL AND ECONOMIC DEVELOPMENT WHICH IS USEFUL IN FASHIONING AN ACCOUNT OF DEVELOPMENT HHI
CHINA'S SEZS.

02522 CRAME, $G$.

RETRENCHMENT AND REVISION, 1985-1987; THE POLITICAL ECOMOYY OF CHIMA'S ECONOMIC ZOMES

M.E. SHARPE $1990,108-145$.

CHINA'S SPECIAL ECONOMIC ZONE POLICY MET ITS MOST SERIDUS CHALLENGE IN 1985 . MOUNTING ECONOMIC COSTS ESPECIALLY FOREIGN EXCHANGE IMBALANCES AND INFRASTRUCTURAL SPENDING, LED TO A REASSERTION OF CENTRAL CONTROL AND A DIMINUTION OF SEZ PREFERENTIAL STATUS. THE STRATEGY OF ACCELERATED DEVELOPMENT WAS JETTISONED, AFTER WIDE-RANGING DEBATE, IN FAVOR OF MORE MODEST OBJECTIVES. HOWEVER, THE SITUATION CHANGED ABRUPTLY IN THE FALL OF 1986 AS NATIONAL LEADERS REALIZED THAT CONSOLIDATION WAS SCARING OFF FOREIGN CAPITAL, HAMPERING THE MODERNIZATION PROGRAM. IN A LITTLE OVER A YEAR, RETRENCHMENT WAS SWEPT ASIDE BY NEW EFFORTS TO TO THE SEZS DID NOT COMPLETELY DISAPPEAR. THE THREE-YEAR PERIOO 1985-1987 THIS ENDED THE WAY IT HAD BEGUN, WITH SEZS SURVIVING A CRISIS BUT STILL BESET BY UNDERLYING DIFFICULTIES.

02523 CRANE, G

SEZ MANAGEMENT AND PERFORMANCE, 1979-1982; THE POLITICAL ECONOMY OF CHINA'S SPECIAL ECONOMIC ZONES

M.E. SHARPE, , 1990, 50-75.

IN ITS DISCUSSION OF THE EARLY YEARS OF CHINA'S SPECIAL ECONOMIC ZONES (SEZS), THIS CHAPTER EMPHASIZES THE ROLE AND IMPLICATIONS OF THE MOVES TOWARDS DECENTRAL IZATION: THE GIVING OF BROADER DISCRETIDH IN APPROYIMG COMTRACTS, COLLCTIMG DUTIES AMD MOMITORING CUSTOHS COCACTS, COLLECTING DUTIES, AND MONI TORING CUSTOMS, LOCAL ZONE AUTHORITIES HOPED TO FACILITATE THE MOVEMENT OF FOREIGN INVESTMENT INTO THE SEZS. THE CHAPTER ALSO ASSESSES THE ECONOMIC PERFORMANCE OF THE SEZS IN THE EARLY YEARS. IT CONCLUDES THAT, AS OF 1982 , THE INTERNATIONAL CAPITAL
WAS ATTRACTED INTO THE ZONES DID NOT MATCH SUBSTANTIAL INFRASTRUCTURAL COSTS.

02524 CRANE, G.

THE POLITICAL ECONOMY OF CHINA'S SEZS; THE POLITICAL ECONOMY OF CHINA'S SPECIAL ECONOMIC ZONES

M.E. SHARPE, , 1990, 146-166

CHINA'S S'EZS HAVE HAD A SHORT BUT CHECKERED HISTORY.
THEY HAVE BEEN HELD UP AS DEVELOPMENTAL MODELS AND CASTIGATED AS DENS OF INIQUITY. THEY HAVE ATTRACTED HIGHER CONCENTRATIONS OF FOREIGN CAPITAL THAN OTHER LOCATIONS IN CHINA BUT HAVE BEEN HAMPERED BY CHRONIC ECONOMIC PROBLEMS. THIS CONCLUOING CHAPTER SUMMARIZES SEZ POLITICS AND

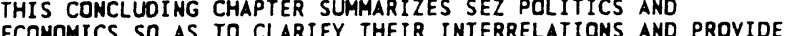
ECONOMICS SO AS TO CLARIFY THEIR INTERRELATIONS AND PROVIDE A RUDIMENTARY UNDERSTANDING OF SEZ DEVELLPMENT. THE CHAPTER ALSO REITERATES THE THEMES OF POL
TO EXPLAIN SEZ POLITICAL ECONOMY.

02525 CRANE, G.

THE POLITICAL ECONOMY OF CHINA'S SPECIAL ECONOMIC ZONES M.E. SHARPE, , 1990, 204.

THIS BOOK' SETS FORTH TO EXPLAIN THE DEVELOPMENT AND PERFORMANCE OF CHINA'S SEZS. THE AMALYTIC FRAMEHORK FOR THIS ENDEAVOR IS DERIVED FROM A GROHING LITERATURE THA INVESTIGATES HOW DOMESTIC POLITICAL STRUCTURES SHAPE, AND ARE CONSTRAINED BY, ECONOMIC OUTCOMES. THIS PERSPECTIVE GROWS OUT OF THE STRENGTHS AND WEAKNESSES OF ARGUMENTS RELEVANT TO CHINA'S ZONE EXPERIENCE. THE BOOK CHRONICLES THE CREATION, DEVELOPMENT AND REFORM OF THE SEZS AND EMPHASIZES THE NEARLY CONSTANT RESISTANCE TO THEIR IMPLEMENTATION BY MANY OF CHINA'S RULING OFFICIALS.

02526 CRANE, G.

THE POLITICS OF SEZ CREATION; THE POLITICAL ECONOMY OF CHINA'S SPECIAL ECONOHIC ZONES

M.E. SHARPE, $1990,20-49$.

SINCE THEIR IMCEPTION IN 1979. THE SEXES HAVE SPARKED CONTROVERSY IN CHINA. FUNDAMENTAL ISSUES-DOBJECTIVES,

STRATEGY, PERFORMANCE CRITERIA-HAVE BEEN POINTEDLY DEBATED AS SUPPORTERS AND ADVERSARIES VIE TO SHAPE THE AGENDA OF ZOME DEVELOPMENT. AT ONE LEVEL. THE SEZS REFLECT THE

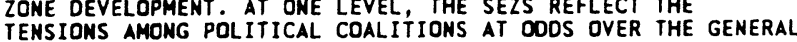
DIRECTION OF THE NATIONAL ECONOMY. ADOITIONALLY, A VARIETY OF OPINION GROUPS, HITH VARYING DEGREES OF POLITICAL POWER, HAVE FORMED AROUND QUESTIONS SPECIFIC TO THE ZONES. THIS CHAPTER OFFERS A CLOSE EXAMINATION OF EARLY ZONE POLICY, FROM HARBINGERS IN NATIONAL ECONOMIC DISPUTES OF THE MID1970S TO THE WIDESP

02527 CRAWLEY, E.; RYMARCSUK, J. US-SOVIET COOPERATION IN SPACE--BENEFITS, OBSTACLES AND OPPORTUNITIES

SPACE POLICY, 8(1) (FEB 92), 29-38.

ONE OF THE GREATEST AREAS OF COMMON INTEREST BETWEEN THE USSR AND THE UNITED STATES IS THE EXPLORATION OF UTILIZATION OF SPACE. THIS ARTICLE HIGHLIGHTS THE MOST SIGNIFICANT BENEFITS THAT COULD BE DERIVED FROM US-SOVIET COOPERATION IN SPACE, LISTS SOME OF THE MOST PROMISING OPPORTUNITIES FOR FURTHER CDOPERATION AND DISCUSSES IN DETAIL THE MAIN

OBSTACLES TO THE EXPIOITATION OF THESE OPPORTUNITIES. IT CONCLUDES WITH RECOMMENDATIONS ADORESSED TO THE US GOVERMMENT AND SPACE INDUSTRY AND TO THEIR COUNTERPARTS IN THE USSR.

02528 CREED, J.

THE IMPACT OF ARAB SUMMITS ON CONLICT MANAGEMENT IN INTERARAB RELATIONS

NEW POLITICAL SCIENCE, 21-22 (SPR 92), 159-184.

SINCE 1964. THE ARABS HAVE DEVELOPED A LONG RECORD OF SUMMIT DIPLOMACY AMD RELIED ON MEETINGS INVOLYING ALL THE REGION'S HEADS OF STATE TO MANAGE DIFFERENCES AMONG THEIR RANKS AND FORGE COMMON APPROACHES TO OUESTIONS THAT CONCERN THEM. FOR A TIME THE SYSTEM WORKED FOR THEM, ALTHOUGH IMPERFECTLY, BUT SINCE 1976 LEADERS IN THE REGION HAVE NOT PROVEN SO ADEPT AT USING SUMMITS FOR THE PURPOSES THEY WERE ONCE DESIGNED. THIS ARTICLE REVIEWS SUMMITY IN THE ARAB WORLD AND SUGGESTS THAT SUMMITRY TODAY PAYS FEW DIVIDENDS TO THE ARABS AND INDEED, MAY PLAY A GREATER ROLE IN EXACERBATING DIFFERENCES THAM BRIDGING THEM.

02529 CRENHA, C

CANADA'S EXPERIENCE OF CONVERSION FOLLOWING HORLD WAR II PEACE AND THE SCIENCES, 1(1) (1992), 39-41.

WHILE MANY CIRCUMSTANCES SURROUNDING CANADA'S CONVERSION PROCESS MERE UNIQUE TO THAT ERA. THERE ARE SOME IMPORTANT PRINCIPLES AND LESSONS WHICH CAN BE DRAWN FROM THE SUCCESSFUL CANADIAN EXPERIENCE DURIMG THE PERIOD 1946-50. THIS ARTICLE EXPLORES THE SCALE OF THE CANADIAN WAR EFFORT, THE DEMOBILIZATION AND CONVERSION PROCESS, AND ORIGINS OF PLANHING FOR POST-WAR CONVERSIONS. IT CONCLUDES BY DETAILING THE LESSONS FROM THE CANADIAN EXPERIENCE OF CONVERSION AFTER WORLD WAR II.

02530 CRENSHAH, M.

CURRENT RESEARCH ON TERRORISM: THE ACADEMIC PERSPECTIVE STUDIES IN CONFLICT AND TERRORISM, 1 (1992), 1-12. MOST DEFINITIONS OF TERRORISM AGREE THAT' IT IS A FORM OF POL ITICAL YIOLENCE. THE PHENOMENON OF TERRORISH MIGHT SERVE AS A USEFUL TEST-CASE FOR GENERAL THEORIES OF VIOLENCE, WHICH ARE RARELY APPLIED TO TERRORISM BY THEIR AUTHORS. THIS ESSAY IDENTIFIES COMMON PROBLEMS FOR RESEARCH. IT THEN TURNS 
TO A DISCUSSION OF THE RELATIONSHIP BETWEEN THE PHENOMENON OF TERRORISM AND OTHER MANIFESTATIONS OF POLITICAL VIOLENCE: OF WHAT MIGHT TERRORISM BE CONSIDERD A CASE? IN ADDITION, WHICH GENERAL THEORIES OF VIOLENCE ARE MOST APPLICABLE TO TERRORISM? THIS ASSESSMENT CONCLUDES WITH A CONSIDERATION OF FUTURE RESEARCH DIRECTIONS FOR THE FIELD OF TERRORISM STUDIES.

02531 CREPAZ, M.

CORPORATISM IN DECLINE? AN EMPIRICAL ANALYSIS OF THE IMPACT OF CORPORATISM ON MACROECONOMIC PERFORMANCE AND INDUSTRIAL DISPUTES IN 18 INDUSTRAILIZED DEMOMOCRACIES

COMPARATIVE POLITICAL STUDIES, 25(2) (JUL 92), 139-169. DURING THE 1970 S AND EARLY' 1980 S MOST STUDIES ON CORPORTATISH INDICATED THAT CORPORTIST POLICIES LED TO LOWER CORPORTATISH INDICATED THAT CORPORTIST POLICIES LED TO LOWER
UNEMPLOYMENT AND INFLATION AND HIGHER ECONOMIC GROWTH RATES. UNEMPLOYMENT AND INFLATION AND HIGHER ECONOMIC GROWTH RATE
IN THE MID- AND LATE 1980 , HOWEVER, VOICES CLAIMING THAT IN THE MID- AND LATE 1980 , HOWEVER, VOICES CLAIMING THAT
CORPORATISM IS IN "DECLINE" BECAME MORE AND MORE FREQUENT ALTHOUGH HARDLY ANY EMPIRICAL EXAMINATIONS WERE UNDERTAKEN. ALTHOUGH HARDLY ANY EMPIRICAL EXAMINATIONS WERE UNDERTAKEN. THE PURPOSE OF THIS STUDY IS TO ESTIMATE EMPIRICALLY THE INFLUENCE OF CORPORATIST ARRANGEMENTS ON MACROECONOMIC
PERFORMANCE AND INDUSTRIAL DISPUTES IN THE 1980 S AS COMPARED WITH THE $1970 S$ AND 1960S. THIS POOLED ANALYSIS PROVIDES EVIDENCE THAT CORPORATIST POLICIES HAVE NOT LOST THEIR CAPACITY TO ACHIEVE THE DESIRED MACROECONOMIC GOALS IN THE 1980 S. THERE IS EVIDENCE THAT ECONOMIC GROWTH IS ADVERSELY AFFECTED BY GOVERNMENT OUTLAYS.

02532 CREWE, I

A NATION OF LIARS? OPINION POLLS AND THE 1992 ELECTION PARLIAMENTARY AFFAIRS, 45(4) (OCT 92), 475-495.

THE PROLIFERATION OF POLLS IN BRITAIN HAS A PROFOUND IMPACT ON THE ELECTORAL PROCESS. THEY BEGAN ON THE BOUNDARY AS SCORERS OF THE PARTY-POLITICAL GAME BUT THEY HAVE MOVED ON THE FIELD AS KEY PLAYERS. THIS ARTICLE EXPLORES THE INFLUENCE OF POLLS ON THREE ASPECTS OF AN ELECTION: (1) THE ELECTION DATE; (2) THE PARTIES' INITIAL CAMPAIGN STRATEGIES; AND (3) THE COURSE OF THE CAMPAIGN.

02533 CRIDDLE, B.

ELECTORAL SYSTEMS IN FRANCE

PARLIAMENTARY AFFAIRS, 45(1) (JAN 92), 108-116.

IN FRANCE, A TRADITION OF TAMPERING WITH THE ELECTORAL

SYSTEM AS A MEANS OF MARGINAL IZING OPPONENTS IN A POLITY

TRADITIONALLY LACKING IN CONSENSUS HAS ENSURED THAT NO

ELECTORAL SYSTEM HAS ENJOYED COMPLETE LEGITIMACY, BUT HAS

ELECTORAL SYSTEM HAS ENJOYED COMPLETE LEGITIMACY, BUT HAS

BEEN SEEN RATHER AS AN INSTRUMENT FOR SECURIMG PARTISAM

POLITICAL INSTITUTIONS, TRADITIONS AND SOCIAL CLEAYAGES THAN TO ANY GIVEN ELECTORAL SYSTEMS AND A SALIENT EXAMPLE IS THE ELECTORAL SYSTEM USED IN FRANCE FOR MOST OF THE PARLIAMENTARY ELECTIONS BEFORE 1940 AND FOR ALL BUT ONE SINCE 1958. THIS ARTICLE EXPLORES ELECTORAL SYSTEM CHANGE AND NATIONAL-LOCAL LINKAGES IN FRANCE. IT CONLCLUDES THAT AS LONG AS PROPORTIONAL REPRESENTATION IS LIMITED TO ELECTIONS AT SUB-NATIONAL LEVEL, ITS IMPACT SHOULD NEITHER BE DISCDUNTED NOR EXAGGERATED.

02534 CRILL, P.

ANCIENT ROLE: THE BAILIFFS OF GUERNSEY AND JERSEY AS SPEAKERS

PARL IAMENTARIAN, LXXIII(2) (APR 92), 101-103.

MANY OF BRITAIN'S PARLIAMENTARY INSTITUTIONS WERE

EXPORTED TO THE ENGLISH COLONIES AND TOOK ROOT IN THE LOCAL LEGISLATURES. THE CHANNEL ISLANDS OF JERSEY AND GUERNSEY, ALTHOUGH HITHIN THE BRITISH ISLES, WERE OUTSIDE THE UNITED KINGDOM AND WERE NEVER COLONIES. FOR MANY YEARS BRITISH PARLIAMENTARY INSTITUTIONS AND PRACTICES WERE LARGELY UNKNOWN TO THE INSULAR LEGISLATURES. THUS, THE ISLANDS' POLITICAL INSTITUTIONS TENDED TO DEVELOP ALONG INDEPENDENT LINES.

02535 CRITCHLOH, J. CARAVANS AND CONQUESTS

WILSON QUARTERLY, XVI(3) (SUM 92), 20-32.

THE AUTHOR LOOKS AT THE HISTORY OF CENTRAL ASIA, A

REGION STRUGGLING TO REVIVE ITS HERITAGE AS IT EMERGES FROM

COMMUNISM RULE.

02536 CRITCHLOH, J.

DEMOCRATIZATION IN KAZAKHSTAN

RFE/RL RESEARCH REPORT, 1 (30) (JUL 92) 12-14.

IT IS TOO EARLY TO ATTEMPT TO ASSESS THE PROGRESS TOWARD DEMOCRATIZATION IN KAZAKHSTAN. THERE ARE SOME ENCDURAGING DEMOCRATIZATION IN KAZAKHSTAN. THERE ARE SOME ENCOURAGING SIGNS, AS WELL AS A FEW TROUBLESOME ONES. ON THE POSITIVE SIDE, THE KAZAKHS ARE HEIRS TO A NOMADIC TRADITION OF TRIBAL DEMOCRACY, AND THEY ARE NOW FREE TO REEXAMINE THEIR HISTORY
WITHOUT THE HUMILIATING IDEOLOGICAL STAMP OF A PEOPLE LIVING IN PRIMITIVE DARKNESS UNTIL CIVILIZED BY A RUSSIAN "ELDER BROTHER." SINCE ACHIEVING INDEPENDENCE, THE REPUBLIC HAS MADE CAUTIOUS PROGRESS IN ASSURING POLITICAL RIGHTS ITS CITIZENS. AT THE SAME TIME, PRESIDENT NURSULTAN
NAZARBAEV, MINDFUL OF THE POTENTIAL FOR EXPLOSIVE ETHNIC CONFLICT, IS RELUCTANT TO GIVE UP THE REINS OF AUTHORITARIAN
POWER TOO QUICKLY.

02537 CRITCHLOW, J.

KAZAKHSTAN AND NAZARBAEV: POLITICAL PROSPECTS

RFE/RL RESEARCH REPORT, 1(3) (JAN 92), 31-34.

BY VIRTUE OF ITS SIZE, RESOURCES, AND STRATEGIC LOCATION, KAZAKHSTAN COULD PLAY A PIVOTAL ROLE IN THE COMMONWEALTH OF INDEPENDENT STATES. ITS POLITICAL STABILITY HILL DEPEND ON THE SOLUTION OF DELICATE ETHNIC, ECONOMIC, AND ENVIRONMENTAL PROBLEMS. PRESIDENT NURSULTAN NAZARBAEV IS A STRONG ADVOCATE OF ETHNIC TOLERANCE, AND HE IS ALSO PRESSING FOR PRIVATIZATION OF THE ECONOMY. BECAUSE POLLS HAVE SHOWN THAT NAZARBAEY'S LEADERSHIP IS RECOGNIZED BY ALL OF KAZAKHSTAN'S MAJOR ETHNIC GROUPS, THE CONCENTRATION OF POWER IN HIS HANDS MAISES QUESTIONS ABOUT THE FATE OF KAZAKHSTAN IF HE WERE REPLACED BY A LEADER OF LESSER STATURE.

02538 CRITCHLOW, J.

KAZAKHSTAN. THE OUTLOOK FOR ETHMIC RELATIONS RFE/RL RESEARCH REPORT, 1(5) (JAN 92), 34-39.

IN KAZAKHSTAN, THE SECOND LARGEST REPUBLIC IN THE COMMONWEALTH OF INDEPENDENT STATES, ETHNIC HARMONY WILL BE A KEY FACTOR IN FUTURE STABILITY. OF PRIMARY CONCERN IS THE RELATIONSHIP BETWEEN THE REPUBLIC'S TWO MOST NUMEROUS GROUPS KAZAKHS AND RUSSIANS, WHO ARE ALMOST EVENLY BALANCED IN SIZE. DESPITE THE TROUBLED HISTORY OF RELATIONS BETWEEN THEM, THERE ARE ENCOURAGING SIGNS THAT IN THE POST-SOVIET AGE THEY HAVE SIMILAR VIEWS ON IMPORTANT ISSUES, INCLUDING THE DELICATE QUESTION OF REVISING REPUBLICAN BORDERS. THIS WAS REVEALED BY A POLL TAKEN IN VARIOUS PARTS OF KAZAKHSTAN IN SEPTEMBER 1991.

02539 CRITCHLOW, J.

UZBEKISTAN: UNDERLYING INSTABILITIES

RFE/RL RESEARCH REPORT, $1(6)$ (FEB 92), 9-10.

THE RECENT STUDENT RIOTS IN TASHKENT WERE A SOMBER REMINDER OF THE SOCIOECONOMIC DIFFICULTIES THAT MAY JEOPARDIZE UZBEKISTAN'S STABILITY AS AN INDEPENDENT NATION. PRESIDENT ISLAM KARIMOV HAS EXPRESSED CONCERN ABOUT THE EXPLOSIVE POTENTIAL OF POPULAR DISSATISFACTION AND HAS BEEN ENERGETIC IN PURSUING FOREIGN TIES THAT COULD IMPROVE HIS COUNTRY'S ECONOMIC SITUATION. AT THE SAME TIME, HE HAS BEEM COUNTRY'S ECONOMIC SITUATION. AT THE SAME TIME, HE HAS BEEN
CAUTIOUS ABOUT DOMESTIC POLITICAL AND ECONOMIC REFORMS. THE CAUTIOUS ABOUT DOMESTIC POLITICAL AND ECONOMIC REFORMS.
PRESENT UNEASY ATMOSPHERE IS CAUSING THE EXODUS OF MANY RUSSIANS AND EUROPEANS. MOSCOH IS NO LONGER AVAILABLE AS A SCAPEGOAT FOR POPULAR GRIEVANCES, AND RELIGIOUS ACTIVISM IS ADDING TO OFFICIAL CONCERN.

02540 CRITCHLOW, J.

WILL THERE BE A TURKESTAN?

RFE/RL RESEARCH REPORT, 1(28) (JUL 92), 47-50.

NOW THAT THE CENTRAL ASIAN REPUBLICS ARE FREE FROM SOVIET CONTROL, SOME OBSERVERS HAVE SUGGESTED THAT THEY MAY WISH TO DISCARD THE BORDERS CREATED BY SOVIET PLANNERS IN THE 1920'S IN FAVOR OF A TERRITORIAL REALIGNMENT. ONE FAVORITE TOPIC OF SPECULATION IS THE POSSIBLE EMERGENCE OF "TURKESTAN" AS A REGIONAL IDENTITY. HOWEVER, AT PRESENT, THERE APPEARS TO BE LITTLE MOVEMENT IN THAT DIRECTION BY OFFICIALS OR THE CITIZENRY.

02541 CROCKETT, A.D.

THE INTERMATIONAL MONETARY FUND IN THE $1990^{\prime}$ ' GOVERNMENT AND OPPOSITION, 27(3) (SUM 92), 267-282.

THE AUTHOR DISCUSSES THE CHANGING FUNCTIONS OF THE INTERNATIONAL MONETARY FUND, FOCUSING ON THREE PROBLEMS: (1) THE CONVERSION OF THE PLANNED ECONOMIES OF EASTERN EUROPE AND THE SOVIET UNION TO A MARKET ORIENTATION; (2) HOW TO DEAL WITH THE INTERNATIONAL INDEBTEDNESS OF LOW AND MIDDLEINCOME DEVELOPING COUNTRIES; AND (3) HOW TO RESTORE AND MAINTAIN STABLE ECONOMIC GROWTH IN THE INDUSTRIAL COUNTRIES AFTER THE RECESSION OF THE EARLY 1990 's.

02542 CROFT, $S$

BRITISH APPROACHES TO THE EUROPEAN SECURITY DEBATE ARMS CONTROL, $12(3)$ (DEC 91), 120-128.

THE SECURITY DEBATE IN GREAT BRITAIN FOCUSES ON QUESTIONS OF POL ITICAL STABILITY AND PEACEKEEPING RATHER QUESTIONS OF POL ITICAL STABILITY AND PEACEKEEPING RATHER
THAN ON NUCLEAR WEAPONS, IN THE CONTEXT OF A NEW DEFENSE THAN ON NUCLEAR WEAPONS, IN THE CONTEXT OF A NEW OEFENSE
CONSENSUS BETWEEN THE CONSERVATIVE GOVERNMENT AND THE LABOR CONSENSUS BETWEEN THE CONSERVATIVE GOVERNMENT AND THE
OPPOSITION. AND IS THE SUBJECT OF PUBLIC INDIFFERENCE OUTSIDE THE COLUMNS OF THE QUALITY PRESS. PART OF THE REASON OUTSIDE THE COLUMNS OF THE QUALITY PRESS. PART OF THE REASOM
FOR THIS CHANGE IS THE ALTERED STRATEGIC ENYIRONMENT, BUT A FOR THIS CHANGE IS THE ALTERED STRATEGIC ENVIRONMENT, BUT A CARGE PROPORTION OF THE EXPLANATION MAY BE FOUND IN THE THATCHER AS PRIME MINISTER. THIS ARTICLE SEEKS TD THATCHER AS PRIME MINISTER. THIS ARTICLE SEEKS TO DEMONSTRATE THIS PROPOSTION, AND THEN TRIES TO EXAMINE THE IMPLICATIONS IN RELATION TO THE DEBATES IN BRITAIN POSSIBILITY FOR PEACEKEEPING IN YUGOSLAVIA.

02543 CROPPER, M.L.; BERARDI, S.J.; DUCLA-SOARES, M.M.; EVANS W.N.; PORTNEY, P.R THE DETERMINANTS OF PESTICIDE REGULATION: A STATISTICAL ANALYSIS OF EPA DECISION-MAKING 
JOURNAL OF POLITICAL ECONOMY, 100(1) (FEB 92), 175-197.

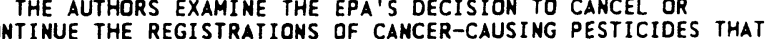
WENT THROUGH THE SPECIAL REVIEW PROCESS BETWEEN 1975 AND WENT THROUGH THE SPECIAL REVIEW PROCESS BETWEEN 1975 AND 1989. THEY CONCLUDE THAT, DESPITE CLAIMS TO THE CONTRARY, THE EPA DID
PESTICIDES.

02544 CROPSEY, S

BARKING UP A FALLEN TREE

NATIONAL INTEREST, 27 (SPR 92), 53-62.

THE IMPORTANCE OF SUCCESS IN LOW-INTENSITY CONFLIC (LIC) HAS LESSENED BECAUSE OF AMERICA'S NEW RELATIONSHIP WITH SUCCESSOR STATES OF THE FORMER USSR. WHERE IT COULD ONCE BE ARGUED THAT LIC OCCUPIED A THIRD CENTER OF ATTENTION, TODAY IT IS BARELY A SIDE SHOW. IF LIC ADVOCATES RECOGNIZE THIS, THEY CAN APPLY THEIR GOOD IDEAS IN THE SERVICE OF FOREIGN POLICY. OTHERHISE, THE PROPONENTS OF LIC WILL END UP DOING EXACTLY WHAT THEY HAVE CHARGED THE CONVENTIONAL

MILTARY WITH SINCE VIETNAM: FIGHTING THE LAST WAR.

02545 CROVITZ, L.

HOH LAH DESTROYS ORDER

HATIOWAL REYIEH, III(2) (FEB 91), 28, 30-33.

THIS ARTICLE ARGUES THAT MOUNTIMG CRIME AND DISORDER IN AMERICA ARE CAUSED BY MORE THAN CRACX, OVERCROHDING, AND POVERTY, THEY RESULT FROM CHANGES IN THE CRIMINAL, CIVIL, AND CONSTITUTIONAL JURISPRUDENCE--AND THE PERPETRATORS ARE JUDGES. THE ARTICLE ARGUES FOR THE "RECAPTURING" OF THE MOST FUNDAMENTAL IDEA IN AMERICAN JURISPRUDENCE-THE RULE OF LAH. IT OUTLINES THE NEED FOR LAWS THAT ARE FAIR, BASED ON COMMON SENSE, EASILY UNDERSTOOD BY THE CITIZENS WHO ARE EXPECTED TO LIVE UNDER THEM, AND THEY MUST PUNISH THE GUILTY AND PROTECT THE INNOCENT. IT CONSIDERS SEVERAL REFORMS IN CRIMINAL,

CIVIL, AND CONSTITUTIONAL LAH THAT WOULD FURTHER THESE ENDS.

02546 CROVITZ, L.G.

PROPERTY AND LIBERTY: CLARENCE THOMAS AND THE COMING CONSERVATIVE-LIBERTARIAN SPLIT ON THE SUPREME COURT PRESIDENTIAL STUDIES QUARTERLY, XXII(4) (FAL 92), 711-719. THE AUTHOR ARGUES THAT PROPERTY RIGHTS WERE ONE OF JAMES MADISON'S BASIC CONCERNS, POINTING TO THE FIFTH AMENDMENT DECLARATION THAT PRIVATE PROPERTY SHALL NOT BE TAKEN FOR PUBLIC USE "WITHOUT JUST COMPENSATION." IN "FEDERALIST \#54" MADISON WROTE THAT GOVERMMENT "IS INSTITUTED NO LESS FOR THE PROTECTION OF PROPERTY THAN OF THE PERSONS OF INDIYIDUALS" PROTECTION OF PROPERTY, THAN OF THE PERSONS OF INDIVIDUAL
THE AUTHOR ARGUES THAT THE U.S. SUPREME COURT, IN RECENT THE AUTHOR ARGUES THAT THE U.S. SUPREME COURT, IN RECENT YEARS, HAS FAILED TO PLACE SUFFICIENT
RIGHTS AND SHOULD CORRECT THAT TREND.

02547 CROVITZ, L.G.

1992 FOR ASIA, IT WAS FOR RICHER, FOR FREER

FAR EASTERM ECONOMIC REYIEW, 155(5i) (DEC 92), 28-30.

THIS ARTICLE BRIEFLY EXAMINES SIGNIFICANT EVENTS AND TRENDS IN ASIA DURING 1992. IN CONTRAST HITH MUCH OF THE REST OF THE WORLD, ASIA WAS AN OASIS OF ECONOMIC DYNAMISM AND POL ITE WORLD, ASIA WAS AN OASIS OF ECONOMIC DYNAMISM SPECIAL ECONOMIC ZONE MADE AT LEAST PART OF THAT COMMUNIST COUNTRY SEEM REMARKABLY CAPITALISTIC. PROPERTY MARKETS SOARED IN HONG KONG, TAIHAN, AND EVEN VIETNAM. GNP GROWTH RATES IN ASIA WERE THE ENVY OF THE WORLD. THIS ECONOMIC PROSPERITY WAS ACCOMPANIED BY POLIIICAL CHANGES INCREASINGLY TOWARDS MORE ACTIVE DEMOCRACY. MIDDLE-CLASS PEOPLE POWER FORCED THE RESIGNATION OF AN UN-ELECTED FORMER GENERAL AS PRIME MINISTER IN THAILAND, FOLLOWED BY OPEN ELECTIONS AN POPULARLY SELECTED GOVERNMENT. CONTRARY TO CONVENTIONAL WISDOM AT THE TIME, NATIONAL ELECTIONS IN THE PHILIPPINES WERE ON THE AGENDA FOR TAIWAN AND SOUTH KOREA. THERE HAS EVEN A PEACE ACCORD FOR CAMBODIA. THERE WAS A SIGNIFICAN EXCEPTION TO THIS GOOD NEWS IN THE REGION: JAPAN, HHERE ECONOMIC TROUBLES WERE MATCHED BY SCANDALS THAT THREATENED THE COLLAPSE OF THE LONG-TIME RULING LIBERAL DEMOCRATIC PARTY (LDP). STILL, FOR MOST ASIANS, 1992 WAS SMOOTH SAILING.

02548 CROW, $S$.

COMPETING BLUEPRINTS FOR RUSSIAN FOREIGN POLICY

RFE/RL RESEARCH REPORT, 1(50) (DEC 92 ), 45-50.

RUSSIA'S PRESENT FOREIGN-POLICY COURSE IS FAR FROM FIXED, AND OPPONENTS ARE PUSHING FOR CHANGE, AS EVIDENCED BY THE FREOUENT ATTACKS ON FOREIGN MINISTER ANDREI KOZYREV AND HIS FOREIGN-POLICY PRIORITIES. AN ALTERHATIVE PROGRAM PROPOSED FOREIGN-POLICY PRIORITIES. AN ALTERNATIVE PROGRAM PROPOSED BY THE INFLUENTIAL COUNCIL FOR FOREIGN AND DEFENSE POLICY
MAY BE GAINING ADHERENTS. THIS IS CAUSING CONCERN BECAUSE MAY BE GAINING ADHERENTS. THIS IS CAUSING CONCERM "THE COUNCIL LEADERS ARE CONVINCED THAT RUSSIA IS "GEOPOLITICALLY ENCIRCLED," ARE PESSIMISTIC ABOUT MOSCOW'S ABILITY TO BE INTEGRATED INTO THE WORLD ECONOMY AND DEVELOP DEMOCRATIC INSTITUTIONS, AND VIEN THE RUSSIAN AND RUSSIANSPEAKING POPULATIONS IN THE DIASPORA AS TRUMP CARDS OF SIGNIFICANT POTENTIAL POHER. UNLESS THERE IS A DRAMATIC STRENGTHENING OF THE MODERATES' INFLUENCE IN MOSCOW, SUCH
VIEWS COULD BECOME RUSSIA'S OFFICIAL FOREIGN-POLICY' LINE.
02549 CROW, S.

PERSOMNEL CHANGES IN THE RUSSIAN FOREIGN MINISTRY RFE/RL RESEARCH REPORT, 1(16) (APR 92), 18-22.

THE COMPOSITION OF THE RUSSIAN FOREIGN MINISTRY HAS CHANGED DRAMATICALLY SINCE THE COLLAPSE OF THE SOVIET UNION HAVING ABSORBED A SIZABLE PORTION OF THE USSR FOREIGN MINISTRY STAFF AND TAKEN OVER THAT INSTITUTION'S HEADQUARTERS AT SMOLENSKAYA SOUARE. THE RUSSIAN FOREIGM MINISTRY HAS BEEN IN A STATE OF UPHEAVAL SINCE DECEMBER 1991. THE PROCESS OF REBUILDING THE FOREIGN-POLICY-MAKING APPARATUS IS STILL UNDERHAY, AND MAJOR CHANGES ARE REPORTEDLY IN THE OFFING.

02550 CROW, S.

READING MOSCOW'S POLICIES TOWARD THE RUMP YUGOSLAVIA

RFE/RL RESEARCH REPORT, 1(44) (NOV 92), 13-19.

RUSSIA'S DIPLOMACY TOWARD THE DISINTEGRATING YUGOSLAVIA REFLECTS A OIVERGENCE OF VIEWS BETWEEN RUSSIAN LEGISLATORS AND THE FOREIGN MINISTRY. WHILE SOME MEMBERS OF THE RUSSIAN PARLIAMENT HAVE ATTEMPTED TO STEER RUSSIA'S POLICY TOWARD UNCONDITIONAL SUPPORT FOR SERBIA AND MONTENEGRO. THE FOREIGN MINISTRY PREFERS TO BACK THE RUMP YUGOSLAVIA DNLY AS LONG AS THIS CAN BE DONE WITHOUT ISOLATING RUSSIA FROM THE THIS CAN BE DONE WITHOUT ISOLATING RUSSIA FROM THE MAINSTREAM OF INTERNATIONAL OPINION. SIMILAR DISAGREEME OVER FOREIGN POL ICY TOWARD THE BALKANS AS A WHOLE IS
DISCERNIBLE IN THE RUSSIAN DEBATE ABOUT HOW THE BALKAN DISCERNIBLE IN THE RUSSIAN DEBATE ABOUT
PENINSULA FITS INTO RUSSIA'S HORLD VIEW.

02551 CROW, S.

RUSSIA AND THE MACEDONIAN QUESTION

RFE/RL RESEARCH REPORT, 1 (45) (NOV 92), 36-38.

RUSSIA'S RECOGNITION OF MACEDONIA HAS ADOED A NEW TWIST TO ITS RELATIONS WITH THE BALKAN STATES. TORN BETHEEN DEFENDING ITS NATIONAL INTERESTS AND AVOIDING INTERNATIONAL CONDEMNATION, RUSSIA HAS GENERALLY STRUCK A BALANCE IN ITS POLICIES TOWARD THE DISINTEGRATING YUGOSLAVIA. HOWEVER, THIS WAS NOT THE CASE WITH DECISION TO RECOGNIZE MACEDONIA, WHICH WAS APPARENTLY A UNILATERAL MOVE BY RUSSIAN PRESIDENT BORIS
YELTSIN AND RAISED EYEBROWS BOTH IN RUSSIA AND ABROAD.

02552 CROW, S.

RUSSIA DEBATES ITS NATIONAL INTERESTS

RFE/RL RESEARCH REPORT, 1(28) (JUL 92), 43-46.

RUSSIA IS FACING THE DAUNTING TASK OF TRYING TO DEFINE ITS NATIONAL INTERESTS. ASKING THE MOST BASIC QUESTIONS ABOUT WHAT RUSSIA'S ROLE IN THE WORLD SHOULD BE, RUSSIAN POLITICIANS, ACADEMICS, AND POLITICAL ANALYSTS ARE TRYING TO PIECE TOGETHER BOTH SPECIFIC AND GENERAL GUIDELINES FOR THE ARE AS BROAD AS THE RUSSIAN POLITICAL SPECTRUM.

02553 CROW, $S$.

RUSSIA PREPARES TO TAKE A HARD LINE ON 'NEAR ABROAD' RFE/RL RESEARCH REPORT, $1(32$ ) (AUG 92 ), 21-24.

THE CREATION OF A NEW MINISTRY FOR THE AFFAIRS OF THE COMMONHEALTH OF INDEPENDENT STATES UNDER THE DIRECTION OF SERGEI STANKEVICH--A PLAN CURRENTLY UNDER DISCUSSION IN MOSCOH--COULD PROYE TO BE A SEVERE SETBACK FOR RUSSIAN MODERATES. SUCH A DEVELOPMENT HOULD PROBABLY MARK THE FORMAL DEFEAT OF THE RUSSIAN FOREIGN MINISTRY'S ATTEMPT TO PURSUE A POLICY OF MODERATION TOWARD THE CIS STATES AND WOULD HERALD A MUCH MORE INTRUSIVE AND PERHAPS COERCIVE POLICY ON THE PART OF RUSSIA. TRANSFERRING COMPETENCE FOR TIES WITH CIS STATES TO A NEW MINISTRY WOULD BE CONSONANT WITH ANOTHER TREND CURRENTLY VISIBLE IN RUSSIA--THE DIFFUSION OF FOREIGN POLICY ACTIVITIES AN
AND INSTITUTIONS

02554 CROW, S.

RUSSIA'S RELATIONS WITH MEMBERS OF THE COMMONWEALTH RFE/RL RESEARCH REPORT, 1(19) (MAY 92), 8-12.

RUSSIA'S POLICY TOWARD ITS NEIGHBORS IN THE COMMONWEALTH OF INDEPENDENT STATES HAS BECOME A MATTER OF INTENSE DEBATE WITHIN RUSSIA. INITIALLY THE RUSSIAN FOREIGN MINISTRY HAS CRITICIZED FOR FAILING TO CONCENTRATE ON IMPROVING BILATERAL RELATIONS WITH THE OTHER FORMER SOVIET REPUBLICS. THEN, WHEN THE MINISTRY DID BEGIN TO FOCUS ITS ATTENTION ON THE OTHER CIS MEMBERS, IT DREW FIRE FOR ITS HANDLING OF RELATIONS. AS THE OISCUSSION DURING THE SIXTH CONGRESS OF PEOPLE'S DEPUTIES DEMONSTRATED. THE QUESTION OF RUSSIA'S BILATERAL TIES WITH OTHER CIS MEMBERS IS PART OF THE LARGER DEBATE ABOUT HHETHER THE COLLAPSE OF THE SOVIET UNION WAS REALLY MECESSARY AND IF IT IS REVERSIBLE.

02555 CROW, $S$.

RUSSIA'S RESPONSE TO THE YUGOSLAV CRISIS

RFE/RL RESEARCH REPORT, $1(30)$ (JUL 92), 31-35.

RUSSIA'S DECISION TO SUPPORT SANCTIONS AGAINST SERBIA AND MONTENEGRO, FOLLONING AN ABORTIVE PEACE MISSION TO YUGOSLAVIA BY THE RUSSIAM FOREIGN MINISTER, PRODUCED A PARL IAMENTARY UPROAR. THE QUESTION OF RUSSIA'S STANCE TOWARD YUGOSLAVIA IS YET THE LATEST ROUND IN THE STRUGGLE BETHEEN MODERATES AND CONSERVATIVES FOR THE CONTROL OF RUSSIAN FOREIGN POLICY. 
02556 CROW, S.

RUSSIAN FEDERATION FACES FOREIGN POLICY DILEMMAS

RFE/RL RESEARCH REPORT, 1(10) (MAR 92), 15-19.

DURING ITS FIRST MONTHS AS AN INDEPÉNDENT STATE, THE RUSSIAN FEDERATION HAS DEMONSTRATED ITS DESIRE TO MAINTAIN AN ACTIVE ROLE IN THE INTERNATIONAL ARENA. LIKE THE FORMER SOVIET UNION, RUSSIA IS DRIVEN BY THE NEED FOR GOOD RELATIONS HITH THE HEST BOTH TO SECURE ECONOMIC AND TECHNICAL ASSISTANCE AND TO ENSURE A SYMPATHETIC

INTERNATIONAL CLIMATE. UNLIKE THE SOVIET UNION, RUSSIA FACES AN ENTIRELY NEW CATEGORY OF FOREIGN POLICY CHALLENGES: HOW TO ARRIVE AT A MODUS VIVENDI WITH ITS NEW NEIGHBORS, THE FORMER CONSTITUENT REPUBLICS OF THE USSR. ON BOTH FRONTS, RUSSIA'S PERFORMANCE HAS BEEN PLODDING.

02557 CROW, $S$.

RUSSIAN PEACEKEEPING: DEFENSE, DIPLOMACY, OR IMPERIALISM? RFE/RL RESEARCH REPORT, 1 (37) (SEP 92), 37-40.

RUSSIAN-DOMINATED PEACEKEEPING FORCES HAVE TAKEN POSITIONS IN TWO "HOT SPOTS" OF THE FORMER SOVIET UNION, AND THERE HAS BEEN TALK OF DEPLOYMENTS IN OTHER AREAS. BUT THERE IS NO CONSENSUS ABOUT THE MATTER. SOME RUSSIANS ARGUE THAT PEACEKEEPING SHOULD BE UNDERTAKEN ONLY WHEN RUSSIA'S SECURITY IS OR COULD BE THREATENED. OTHERS FOCUS ON THE DIPLOMATIC VALUE OF SUCH MISSIONS. ANOTHER VIEH, WHICH MAY BE GAINING INFLUENCE, HOLDS THAT IT IS RUSSIA'S NATURAL AND JUSTIFIED ROLE TO OUELL CONFLICTS IN SOVIET SUCCESSOR STATES, THAT WESTERN COUNTRIES DO NOT WISH TO BECOME INVOLVED IN SUCH CONFLICTS, AND THAT THE WEST SHOULD BE WILLING TO COMPENSATE RUSSIA FOR HANDLING THESE DISPUTES.

02558 CROW, S.

THE THEORY AND PRACTICE OF PEACEKEEPING IN THE FORMER USSR RFE/RL RESEARCH REPORT, 1 (37) (SEP 92), 31-36.

PEACEKEEPING FORCES IN THO "HOT SPOTS"--SOUTH OSSETIA IN GEORGIA AND THE DNIESTER REPUBLIC IN MOLDOVA--ARE HAVING ONLY LIMITED SUCCESS. NOT ONLY HAVE THE PEACEKEEPERS COME UNDER ATTACK AND SUFFERED FATALITIES, IT APPEARS THAT THE NUMBER OF CONFLICT ZONES IN LINE FOR PEACEKEEPING CONTINGENTS IS GROHING. RUSSIA, WHICH HAS THUS FAR DOMINATED THE PEACEKEEPING FORCES, HAS A VESTED INTEREST IN PARTICIPATING IN SUCH MISSIONS IN ORDER TO MAINTAIN ITS PARTICIPATING IN SUCH MISSIONS IN ORDER TO MAINTAIN ITS
INFLUENCE IN THESE REGIONS. HOWEVER. THE INTERESTS OF THE INFLUENCE IN THESE REGIONS. HOWEVER, THE INTERESTS OF QUESTIONS HAVE BEEN RAISED ABOUT THE NEUTRALITY OF RUSSIAN PEACEKEEPING FORCES. FURTHERMORE, HOST STATES MAY HAVE PEACEKEEPING FORCES. FURTHERMORE, HOST STATES MAY HAVE DIFFICULTY IN ARRANGING FOR THE WITHDRAWAL OF RUSSIAN DURING A CRISIS THE GUIDELINES FOR INTRODUCING SUCH A FORCE DURING A CRISIS THE GUIDELINES FOR INTRODUCING SUCH A FORCE MIGHT BE LESS THAN STRICTLY OBSERVED. AS CAN BE SEEN SIGNIFICANT GAP BETHEEN THEORY AND PRACTICE.

02559 CROW, S.

THE TWILIGHT OF ALL-UNION DIPLOMACY

RFE/RL RESEARCH REPORT, 1(1) (JAN 92), 27-28,

THE YEAR 1991 SAH SHEEPING CHANGES IN SOVIET FOREIGN POLICY. DURING EARLY 1991, THE CONSERVATIVES MEDDLED IN FOREIGN POLICY, MINIMIZING GORBACHEV'S "NEW THINKING." THE REFORMIST ELEMENT HAS MORE INFLUENTIAL AFTER THE ATTEMPTED COUP IN AUGUST BECAUSE ITS FAILURE DISCREDITED CONSERVATIVES AND REMOVED THE SPECTRE OF A HARD-LINE TAKEOVER. THE FAILED PUTSCH ALSO GALVANIZED INDEPENDENCE-SEEKING REPUBLICS TO PUSH FOR EITHER GREATER AUTONOMY FROM MOSCOW OR FULL SOVEREIGNTY. AS A RESULT, FUNDAMENTAL REFORM OF THE SOVIET FOREIGN MINISTRY WAS UNDERTAKEN WITH A VIEN TOHARD INCREASING THE REPUBLICS' INFLUENCE OVER FOREIGN POLICYMAKING. BY THE END OF THE YEAR, IT SEEMED UNLIKELY THAT A UNIFIED FOREIGN POLICY WOULD SURVIVE, DUE TO THE SCHEDULED DEMISE OF THE USSR AS A POLITICAL UNIT.

02560 CROH, S.; KIONKA, R.; KOSIBA, H. : SABBAT-SHIDLICKA, A. HEEKLY REVIEW: 4-10 NOVEMBER 1992

RFE/RL RESEARCH REPORT, 1 (46) (NOV 91), 64-72.

THE EDITORS SUMMARIZE MAJOR NEWS STORIES DURING THE WEEK OF NOVEMBER 4-10, 1992, IN EASTERN EUROPE, THE BALTIC STATES, AND THE COMMONWEALTH OF INDEPENDENT STATES. TOPICS INCLUDE RUSSIAN APPEALS FOR HUMAN RIGHTS IN THE BALTIC STATES, REACTIONS TO THE ELECTION OF BILL CLINTON TO THE U.S. REACTIONS TO THE ELECTION OF BILL CLINTON TO THE U.S. PRESIDENCY, CONTINUING PROBLEMS IN YUGOSLAVIA, PLANS FOR A NEW GOVERNHENT IN BULGARIA, FIGHTING BETWEEN ABKHAZ FORCES AND GEORGIANS

02561 CROW, S. (ED.); MIHALISKO, K. (ED.); TOLZ, V. (ED.) WEEKLY REVIEW: MARCH 11-17, 1992

RFE/RL RESEARCH REPORT, 1(13) (MAR 92), 71-83.

THE EDITORS REPORT ON MAJOR NEWS STORIES IN LITHUANIA, MOLDOVA, ROMANIA, YUGOSLAVIA, THE COMMONHEALTH OF INDEPENDENT STATES, BULGARIA, LATVIA, CZECHOSLOVAKIA, ESTONIA, HUNGARY, AND POLAND DURING MID-MARCH 1992. MAJOR EVENTS INCLUDED THE BOSNIAN SERBS' REJECTION OF THE EUROPEAN
MEETING OF THE USSR CONGRESS OF PEOPLE'S DEPUTIES, ANTIGOVERNMENT RALLIES IN RUSSIA, A MEETING OF THE CIS HEADS OF GOVERNMENT, AND UKRAINIAN CONCERN OVER THE CONFLICT IN MOLDOVA.

02562 CROH, S. (ED.); RAHR, A. (ED.); SOCOR, V. (ED.) WEEKLY REVIEW: $1-7$ JULY 1992

RFE/RL RESEARCH REPORT, 1(29) (JUL 92), 73-82.

ON JULY 6, 1992, THE CIS HEADS OF STATE MET IN MOSCOW AND AGREED IN PRINCIPLE TO CREATE JOINT PEACEKEEPING FORCES FOR DEPLOYMENT IN EASTERN MOLDOVA. THE SUMMIT ALSO PRODUCED AGREEMENTS ON A NUMBER OF CIS DEFENSE AND ECONOMIC ISSUES. IN THIS SUMMARY OF MAJOR DEVELOPMENTS DURING THE WEEK OF JULY $1-7,1992$, THE EDITORS REPORT ON THIS SUMMIT MEETING AND OTHER EVENTS IN EASTERN EURDPE AND THE COMMONHEALTH OF ANDEPENDENT STATES.

02563 CROW, S. (ED.); DEWEYDENTHAL, J.B. (ED.); SHEEHY, A. (ED.); HI SHNEVSKY, J. (ED.)

WEEKLY REVIEW: 12-18 AUGUST 1992

FE/RL RESEARCH REPORT, 1(34) (AUG 92), 75-82.

THE EDITORS SUMMARI ZE NEWS REPORTS ON MAJOR EVENTS IN EASTERN EUROPE AND THE COMMONHEALTH OF INDEPENDENT STATES DURING THE WEEK OF AUGUST 12-18, 1992. THE WEEK'S NEWS WAS DOMINATED BY THE CONTINUING PROBLEMS IN THE FORMER YUGOSLAVIAN REPUBLICS.

02564 CROW, S. (ED.); MIHALISKD, K. (ED.); TOLZ, Y. (ED.) WEEKLY REVIEW: $12-18$ FEBRUARY RFE/RL RESEARCH REPORT, 1(9) (FEB 92), 76-86,

THE EDITORS REPORT ON MAJOR POLITICAL DEVELLPMENTS IN EASTERN EUROPE AND THE COMMONWEALTH OF INDEPENDENT STATES DURING THE WEEK OF FEBRUARY 12-18, 1992. TOPICS INCLUDE THE CIS SUMMIT MEETING ON FEBRUARY 14, THE LOCAL ELECTIONS IN ROMANIA, THE INITIALING OF A FRIENDSHIP TREATY BETWEEN
RUSSIA AND CZECHOSLOVAKIA, A VISIT TO ARMENIA BY A CSCE TEAM, AND THE MEMBERSHIP OF THE CENTRAL ASIAN REPUBLICS IN THE ECONOMIC COOPERATION ORGANIZATION.

02565 CROW, S. (ED.); RAHR, A. (ED.)

WEEKLY REVIEW: $15-21$ JULY 1992

RFE/RL RESEARCH REPORT, 1 (31) (JUL 92), 72-79.

THE EDITORS SUMMARIZE NEWS REPORTS OF MAJOR DEVELOPMENTS IN EASTERN EUROPE AND THE COMMONHEALTH OF INDEPENDENT STATES IN EASTERN EUROPE AND THE COMMONAE THE WEEK OF JULY 15-21, 1992. MAJOR EVENTS INCLUDE DURING THE WEEK OF JULY 15-21, 1992. MAJOR EVENTS INCLUDE THE RESIGNATION OF CZECHOSLOVAK PRESIDENT VACLAV HAVEL, ELECTION OF A NEW PRIME MINISTER IN LITHUANIA, AND THE

02566 CROW, S. (ED.); RAHR, A. (ED.); SOLCHANYK, R. (ED.) WEEKLY REVIEW: $17-23$ JUNE 1992

RFE/RL RESEARCH REPORT, 1 (27) (JUL 92), 70-78.

THE EDITORS SUMMARIZE MAJOR POLITICAL DEVELOPMENTS IN RUSSIA, MOLDAVIA, UKRAINE, GEORGIA, BULGARIA, ARMENIA, CZECHOSLOVAKIA, ESTONIA, HUNGARY, KAZAKHSTAN, LATVIA, LITHUANIA, POLAND, ROMANIA, TAJIKISTAN, TURKMENISTAN,

UKRAINE, AND YUGOSLAVIA DURING THE WEEK OF JUNE 17-23, 1992.

02567 CROW, S. (ED.); MIHALISKO, K. (ED.); TOLZ, V. (ED.) WEEKLY REVIEW: $18-24$ MARCH 1992

RFE/RL RESEARCH REPORT, 1(14) (APR 92), 65-77

THE EDITORS SUMMARIZZE IMPORTANT POLITICAL DEVELOPMENTS IN EASTERN EUROPE AND THE COMMONHEALTH OF INDEPENDENT STATES DURING THE WEEK OF MARCH 18-24, 1992. HEADLINES INCLUDE THE CIS SUMMIT MEETING IN KIEV. THE MOLDOVAN CRISIS, THE FIGHTING IN THE YUGOSLAVIAN REPUBLICS OF CROATIA AND BOSNIA AND HERZEGOVINA, AND THE CREATION OF A NATIONAL ARMY IN AZERBAI JAN.

02568 CROW, S. (ED.); FULLER, E. (ED.); SHAFIR, M. (ED.); THORSON, C. (ED.) HEEKLY REVIEH: 19-25 AUGUST 1992

RFE/RL RESEARCH REPORT, 1 (35) (SEP 92), 68-75. THE EDITORS SUMMARIZZE MAJOR POLITICAL DEVELOPMENTS IN EASTERN EUROPE AND THE COMMONWEALTH OF INDEPENDENT STATES DURING THE HEEK OF AUGUST $19-25,1992$.

02569 CROW, S. (ED.); MIHALISKO, K. (ED.); TOLZ, V. (ED.) HEEKLY REVIEH: 19-25 FEBRUARY 1992

RFE/RL RESEARCH REPORT, 1 (10) (MAR 92), 66-77

THE EDITORS SUMMARIZE NEWS REPORTS ON MAJOR DEYELOPMENTS IN THE COMMONWEALTH OF INDEPENDENT STATES AND EASTERN EUROPE DURING THE WEEK OF FEBRUARY 19-25, 1992.

02570 CROW, S. (ED.); GIRNIUS, S. (ED.); THORSON, C. (ED.) WEEKLY REVIEH: $2-8$ SEPTEMBER 1992

RFE/RL RESEARCH REPORT, 1 (37) (SEP 92), 71-78

THE CONTINUING FIGHTING IN YUGOSLAVIA AND THE OUSTER OF PRESIOENT RAKHMON NABIEV IN TAJIKISTAN WERE TOP NEWS STORIES DURING THE WEEK OF SEPTEMBER 2-8, 1992. OTHER MAJOR DEVELOPMENTS INCLUDED A MEETING OF CIS DEFENSE MINISTERS, TALKS BETHEEN THE RUSSIAN AND MOLDOVAN PRESIDENTS, THE SIGNING OF THE SLOVAK CONSTITUTION, THE CEASEFIRE' IN ABKHAZIA, AND A MAJOR LABOR STRIKE IN UKRAINE. THESE AND 
OTHER EVENTS ARE SUMMARIZED IN THIS ROUNDUP OF DEVELOPMENTS IN EASTERN EUROPE AND THE COMMONWEALTH OF INDEPENDENT STATES.

02571 CROW, S. (ED.); RAHR, A. (ED.); SHEEHY, A. (ED.) WEEKLY REVIEH: 22 JULY-4 AUGUST 1992 RFE/RL RESEARCH REPORT, 1 (32) (AUG 92), 70-81. THE EDITORS SUMMARIZE MAJOR POLITICAL DEVELOPMENTS IN EASTERN EUROPE AND THE COMMONWEALTH OF INDEPENDENT STATES DURING THE WEEK OF JULY 22 THROUGH AUGUST 4, 1992. REPORTS COVER THE DIPLOMATIC INITIATIVES TO RESOLVE THE CRISIS IN YUGOSLAVIA, WORK ON A REVISED CIS CHARTER, THE CSCE TALKS ON NAGORNO-KARABAKH. THE SIGNING OF A GERMANY-LITHUANIAN TRANSPORTATION AGREEMENT, NEGOTIATIONS ON THE PEACEFUL DISSOLUTION OF CZECHOSLOVAKIA, AND OTHER EVENTS.

02572 CROW, S. (ED.); MIHALISKO, K. (ED.); TEAGUE, E. (ED.); TOLZ, $V$. (ED.) WEEKLY REVIEH: 22-28 APRIL 1992

RFE/RL RESEARCH REPORT, 1 (19) (MAY 92), 59-69.

THE EDITORS SUMMARIZE NEWS REPORTS OF MAJOR DEVELOPMENTS IN EASTERN EUROPE AND THE COMMONWEALTH OF INDEPENDENT STATES IN EASTERN EUROPE AND THE COMMONHEALTH OF INDEPENDENT STA
DURING THE WEEK OF APRIL 22-28, 1992. TYPICAL TOPICS ARE DURING THE WEEK OF APRIL 22-28, 1992. TYPICAL TOPICS ARE
RELATIONS BETHEEN RUSSIA AND MOLDOVA, UKRAINIAN PRESIDENT RELATIONS BETHEEN RUSSIA AND MOLDOVA, UKRAINIAN PRESIDENT
KRAVCHUK'S OFFICIAL VISIT TO IRAN, AND A SUMMIT MEETING KRAVCHUK'S OFFICIAL VISIT TO IRAN, AND A SUMMIT MEET
INVOLVING THE PRESIDENTS OF KYRGYSTAN, KAZAKHSTAN, TURKMENISTAN, AND UZBEKISTAN.

02573 CROW, S. (ED.); MIHALISKO, K. (ED.); TOLZ, V. (ED.) WEEKLY REVIEW: 24 JANUARY-28 JANUARY RFE/RL RESEARCH REPORT, 1(6) (FEB 92), 63-69.

THE MAJOR NEWS EVENTS OF JANUARY $24-28,1992$, IN EASTERN EUROPE AND THE COMMONWEALTH OF INDEPENDENT STATES ARE SUMAARIZED. HEADLINES IMCLUDE UKRAINE'S REJECTION OF RUSSIA'S CLAIMS TO THE CRIMEA, THE JAPANESE OFFER OF EMERGENCY AID TO RUSSIA, RUSSIA'S AND NORTH KOREA'S AGREEMENT TO REVISE THEIR COOPERATION PACT, AND THE TALKS ON ROMANIAN-MOLDOVAN REUNIFICATION.

02574 CROW, S. (ED.); RAHR, A. (ED.); SHAFIR, M. (ED.); SOLCHANYK, R. (ED.)

WEEKLY REVIEW: 24-30 JUNE 1992

RFE/RL RESEARCH REPORT, $1(28$ ) (JUL 92), 73-81.

THE EDITORS SUMMARIZE MAJOR NEWS STORIES IN EASTERN

EUROPE AND THE COMMONWEALTH OF INDEPENDENT STATES DURING THE WEEK OF JUNE 24-30. AMONG THE TOP STORIES ARE THE SITUATION IN MOLDOVA. A MEETING OF CIS HEADS OF GOVERNMENT, POLITICAL CHANGES IN CZECHOSLOVAKIA, A REFERENDUM ON ESTONIA'S CHANGES IN CZECHOSLOVAKIA, A REFERENDUM ON ESTONIA'S
CONSTITUTION, AND THE NOMINATION OF PRESIDENTIAL CANDIDATES IN ROMANIA.

02575 CROH, S. (ED.); RAHR, A. (ED.)

HEEKLY REVIEW: 26 AUGUST- 1 SEPTEMBER

WEEKLY REVIEW: 26 AUGUST-1 SEPTEMBER
RFE/RL RESEARCH REPORT, $1(36$ ) (SEP 92), 74-81

THE AUTHORS REPORT ON MAJOR POLITICAL DEVELOPMENTS DURING THE WEEK OF AUGUST 26 THROUGH SEPTEMBER 1, 1992, IN YUGOSLAVIA, MOLDAVIA, RUSSIA, UKRAINE, ARMENIA, AZERBAI JAN, BULGARIA, CZECHOSLOVAKIA, GEORGIA, HUNGARY, LITHUANIA, POLAND, ROMANIA, AND TAJIKISTAN.

02576 CROW, S. (ED.); MIHALISKO, K. (ED.); TOLZ, V. (ED.) WEEKLY REVIEH: 26 FEBRUARY -3 MARCH 1992

RFE/RL RESEARCH REPORT, 1(11) (MAR 92), 68-80.

THE EDITORS SUMMARI ZE NEWS REPORTS OF MAJOR EVENTS IN EASTERN EUROPE AND THE COMMONWEALTH OF INDEPENDENT STATES DURING THE WEEK OF FEBRUARY 26-MARCH 3, 1992. THEY REPORT ON A MEETING OF CIS PARLIAMENTARY LEADERS, THE SIGNING OF THE HELSINKI FINAL ACT BY FIVE CIS STATES, AN OFFICIAL CONFERENCE OUTLINING THE GOALS OF RUSSIAN FOREIGN POLICY, AND THE RUSSIAN FOREIGN MINISTER'S TRIP TO AFRICA FOR TALKS WITH LEADERS OF ANGOLA, EGYPT, AND LIBYA.

02577 CROW, S. (ED.); MIHALISKO, K. (ED.); TOLZ, V. (ED.) WEEKLY REVIEW: 29 JANUARY 4 FEBRUARY

RFE/RL RESEARCH REPORT, 1(7) (FEB 92), 70-82

THE EDITORS SUMHARIZE MAJOR NEHS EVENTS IN EASTERM EUROPE AND THE COMMONWEALTH OF INDEPENDENT STATES DURING JANUARY 29 THROUGH FEBRUARY 4, 1992. HEADLINES INCLUDE THE OPENING OF THE CSCE FOREIGN MINISTERS' MEETING, THE START OF BORIS YELTSIN'S INTERNATIONAL TOUR, A MEETING OF UKRAINIAN AND GERMAN LEADERS, AND PROGRESS ON A NEW TREATY BETHEEN HUNGARY AND ROMANIA.

02578 CROW, S. (ED.); MIHALISKO, K. (ED.); TOLZ, V. (ED.) WEEKLY REVIEW: 4-10 MARCH 1992

RFE/RL RESEARCH REPORT I(12) (MAR 92), 62-73.

DURING THE WEEK OF MARCH -10,1992, MAJOR NEWS STORIES IN EASTERN EUROPE AND THE COMMONWEALTH OF INDEPENDENT STATES REPORTED NEH INITIATIVES ON THE MAGORNO-KARABAKH PROBLEM, CSCE TALKS WITH ARMENIA AND AZERBAIJAN, THE LAUNCH OF AN AZERBAI JANI OFFENSIVE AGAINST ASKERAN, THE ESTABLISHMENT OF THE BALTIC SEA COUNCIL, THE BREAK-UP OF THE SLOVAK CHRISTIAN DEMOCRATIC PARTY, PRO-COMMUNIST RALLIES IN MOSCOH, AND MIKHAIL GORBACHEV'S TRIP TO GERMANY.
02579 CROW, S. (ED.) ; SHEEHY, A. (ED.); WISHWEYSKY, J. (ED.) HEEKLY REVIEW: 5-11 AUGUST 1992

RFE/RL RESEARCH REPORT, 1(33) (AUG 92), 73-81. THE EDITORS SUMMARIZE MAJOR NEWS STORIES IN EASTERN EUROPE AND THE COMMONWEALTH OF INDEPENDENT STATES FOR THE WEEK OF AUGUST 5-11, 1992. THEY REPORT ON THE CONTINUING FIGHTING IN YUGOSLAVIA, TALKS BETHEEN RUSSIA AND MOLDOVA, THE FORMATION OF A NEW' CONSERVATIVE COALITION IN BELARUS, EXILED KING MICHAEL'S VISIT TO ROMANIA, AND OTHER NEWSWORTHY EVENTS.

02580 CROW, S. (ED.); MIHALISKO, K. (ED.); TOLZ, V. (ED.) WEEKLY REVIEK: 5-11 FEBRUARY 1992

RFE/RL RESEARCH REPORT, 1(8) (FEB 92), 63-76. THIS COLLECTION OF SHORT REPORTS SUMMARIZES MAJOR MEWS EVENTS IN EASTERN EUROPE AND THE COMMONHEALTH OF INDEPENDENT STATES DURING THE WEEK OF FEBRUARY 5-11, 1992. SUBJECTS INCLUDE THE MEETING OF CIS HEADS-OF-GOVERNMENT ON FEBRUARY 8 IN MOSCOW, TALKS BETWEEN RUSSIA AND JAPAN, THE CONTINUING DISPUTE BÉTHEEN RUSSIA AND UKRAINE OVER CRIMEA, THE DISPUTE BETHEEN RUSSIA AND UKRAINE OVER CRIMEA, THE
POLITICAL SITUATION IN GEORGIA, AND THE ELECTIONS IN ROMANIA.

02581 CROW, S. (ED.); BUNGS, D. (ED.); KOSIBA, H. (ED.); SABBAT-SHIDLICKA, A. (ED.)

WEEKLY REVIEW: 7-13 OCTOBER 1992

RFE/RL RESEARCH REPORT, 1(42) (OCT 92), 61-70. THE EDITORS REPORT ON MAJOR EVENTS DURING THE WEEK OF OCTOBER 7-13, 1992, INCLUDING THE CONTINUED FIGHTING IN BOSNIA AND HERZEGOVINA, SKIRMISHES BETWEEN GEORGIAN AND ABKHAZ FORCES, THE CIS HEADS-OF-STATE AND HEADS-OFGOVERMMENT SUMMIT, THE TRIAL OF FORMER COMMUNIST LEADERS IN BULGARIA. THE ELECTION OF EDUARD SHEVARDNADZE AS GEORGIA'S PARLIAMENTARY CHAIRMAN, AND ROMANIA'S PRESIDENTIAL ELECTION CAMPAIGN.

02582 CROW, S. (ED.); RAHR, A. (ED.); SOCOR, V. (ED.) WEEKLY REVIEW: $8-14$ JULY 1992

RFE/RL RESEARCH REPORT, 1(30) (JUL 92), 72-79.

THE EDITORS REPORT ON THE CSCE SUMMIT IN JULY 1992, THE CONFLICT IN MOLDOVA, PLANS FOR A NEH CZECH CONSTITUTION, THE FORMATION OF A NEW GOVERNMENT IN POLAND, AND OTHER MAJOR DEVELOPMENTS IN EASTERN EUROPE AND THE FORMER SOVIET UNION DURING THE WEEK OF JULY 8-14, 1992.

02583 CROW, S. (ED.); DEWEYDENTHAL, J.B. (ED.); KIONKA, R. (ED.); TOLZ, V. (ED.); WISHNEVSKY, J. (ED.)

HEEKLY REVIEW: 8-21 APRIL 1992

RFE/RL RESEARCH REPORT, 1 (18) (MAY 92), 67-82

THE EDITORS SUMMARIZE IMPORTANT NEWS REPORTS REGARDING MAJOR DOMESTIC AND INTERNATIONAL EVENTS IN EASTERN EUROPE AND THE COMMONHEALTH OF INDEPENDENT STATES DURING THE WEEKS OF APRIL 8-21, 1992.

02584 CROH, S. (ED.); GIRNIUS, S. (ED.); THORSON, C. (ED.) WEEKLY REVIEW: 9-15 SEPTEMBER 1992

RFE/RL RESEARCH REPORT, 1(38) (SEP 92), 71-79,

THE EDITORS REPORT ON MAJOR DEVELOPMENTS IN BOSNIA, RUSSIA, MOLDOVA, ARMENIA, BULGARIA, CZECHOSLOVAKIA, THE BALTIC STATES, GEORGIA, POLAND, ROMANIA, RUSSIA, UKRAINE,
AND YUGOSLAVIA DURING THE WEEK OF SEPTEMBER $9-15,1992$.

02585 CROWE, D.

GERMANY AND THE BALTIC QUESTION IN LATVIA, 1939-1940

EAST EUROPEAN QUARTERLY, XXVI(3) (FAL 92), $371-389$.

THE AUTHOR FOCUSES ON THE STATUS AND FATE OF THE ETHNIC GERMANS IN LATVIA DURING A PERIOD WHEN THE BALTIC STATES WERE INDEPENDENT. THE BALTIC GERMAN COMMUNITIES MANAGED TO REMAIN VIABLE SOCIAL, CULTURAL, AND ECONOMIC FORCES EVEN THOUGH THE GOVERNMENT CONFISCATED MOST OF THEIR LAND.

02586 CRONE, M.

MARCO'S RIGHT-HAND MAN TO BEAT

INSIGHT, 8(19) (MAY 92) 6-13: 34.

DANDLING COJUANGCO, WHO WAS THE TOP CRONY OF PHILIPPINE STRONGMAN FERDINAND MARCOS, HAS RETURNED FROM HUMILIATING EXILE TO BECOME A TOP CONTENDER IN MAY'S PRESIDENTIAL ELECTION. HE IS THE ESTRANGED FIRST COUSIN OF SITTING PRESIDENT CORAZON AQUINO. COJUANGCO, WHO EXUDES EXPERIENCE AND REPRESENTS PROFUSE ECONOMIC SUCCESS IN A DRIFTING, POVERTY PLAGUED COUMTRY, APPEARS TO HAVE MANEUVERED HIS WAY POVERTY-PLAGUED COUNTRY, APPEARS TO HAVE MANEUVERED HIS WAY
TO THE FRONT OF THE PRESIDENTIAL PACK. HE IS ABLE TO REACH TO THE FRONT OF THE PRESIDENTIAL PACK. HE IS ABLE TO REACH
PEOPLE WHO ARE IN NEED OF A LEADER. THIS ARTICLE REPORTS ON PEOPLE WHO ARE IN NEED OF A LEADER.
HIS PROGRESS AND ON HIS COMPETITION.

02587 CROHLEY J.E.

COMMERCE AND THE PHILADELPHIA CONSTITUTION: NEO MERCANTALISH IN FEDERALIST AND ANTI-FEDERALIST POLITICAL ECONOMY

HISTORY OF POLITICAL THOUGHT, XIII(1) (SPR 92), 73-98. ATTENTION TO THE POLITICAL DISCOURSE OF MERCANTILIST THOUGHT PROVIDES A DIRECT UNDERSTANDING OF THE ISSUES OF COMMERCE AND MARKET RELATIONS IN THE FRAMING AND RATIFICATION OF THE CONSTITUTION DRAFTED AT THE PHILADELPHIA CONVENTION IN 1787. MERCANTILIST POLITICAL DISCOURSE WAS 
READILY EMPLOYABLE ALONGSIDE THE REPUBLICAN, LIBERAL, AND OTHER POLITICAL LANGUAGES. IN CONTRAST TO THE VAGUENESS OF CLASSICAL REPUBLICAN REFERENCES TO "COMMERCE," WHICH MADE IT A METAPHOR FOR ENTIRE SOCIAL AND POLITICAL ORDERS, MERCANTILIST THOUGHT ENABLED ANGLO-AMERICANS TO BÉ PRECISE AND ELABORATE IN DISCUSSING ECONOMIC RELATIONS IN POLITICAL CONTEXTS. MERCANTILIST THOUGHT PROVIDED A POSITIVE ANALYSIS OF MARKET ACTIVITIES, BUT IT SIMULTANEOUSLY FORESTALLED A COMPLETE IDENTIFICATION OF LIBERTY WITH ECONOMIC SELFINTEREST. BY ASSUMING THAT ECONOMIC REGULATION MIGHT SERVE A INTEREST. BY ASSUMING THAT ECONOMIC REGULATION MIGH

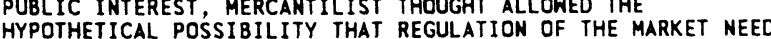
HYPOTHETICAL POSSIBILITY THAT REGULAT
NOT COMRPOMISE FREEDOM IN A REPUBLIC.

02588 CROZIER, 8

AN ATTACK OF PACTITIS

MATIOMAL REYIEW, XLIII (14) (AUG 91), 43-44.

ONE OF THE PERMANENT OBSTACLES TO SENSIBLE FOREIGN POLICIES IS THE COLLECTIVE UNHISDOM OF THE PROFESSIONALS OF FOREIGN POLICY. DESIRING TO MAINTAIN THE STATUS QUO, THEY FALL VICTIM TO "PACTITIS," THE IDEA THAT ANY AGREEMENT IS BETTER THAN NONE. THIS PHENOMENON IS WELL ILLUSTRATED BY THE EAGERNESS WITH WHICH THE WESTERN EUROPEAN STATES HAVE ENTERED INTO AGREEMENTS OF COOPERATION WITH THEIR ERSTWHILE ENEMY, THE SOVIET UNION. SUCH AGREEMENTS MAINTAIN THE STABILITY OF EXISTING BORDERS, BUT DO LITTLE TO FOSTER LONG TERM PEACE AND SECURITY. A MORE PRUDENT COURSE WOULD BE TO CONTINUE THE MUTUALLY BENEFICIAL RELATIONSHIP BETHEEN THE UNITED STATES AND WESTERN EURDPE.

02589 CROZIER, B.

CAN DENG SQUARE THE CIRCLE?

NATIONAL REVIEH, XLIV(13) (JUL 92), 44-46.

ON 3 JULY 1992, PEKING'S MOST FAVORED NATION (MFN)

STATUS EXPIRES. SHOULD THE U.S. CONTINUE IMPORTING CHINESE

SHOES AND SHIRTS ON MFN TERMS? PRESIDENT BUSH'S VIEWS ARE

WELL KNOWN: AN UNCONDITIONAL YES. "NO," SAYS A SMALL AND PLAINTIVE VOICE FROM THE CAMPUSES: HUMAN RIGHTS COME FIRST, AND SO LONG AS THE CHINESE REGIME CONTINUES TO HOLD A AHDUSAND DEMOCRACY PROTESTORS IN INHUMAN CONDITIONS, MFN SHOULD BE WITHHELD.

02590 CROZIER, B.

SADOAH'S SOYIET CONNECTION

NATIOAA REVIEH XLIII (4) (MAR 91) 40.

THIS ARTICLE TRACES THE DEVELOPMENT OF TIES BETHEEN THE SOVIET UNION AND THE IRAO. THIS MILITARY COOPERATION BEGAN WITH THE APRIL 1972 SOVIET FRIENDSHIP TREATY AND CONSISTED OF NUMEROUS SECURITY AND INTELLIGENCE DEALS AS WELL AS LARGE QUANTITIES OF MILITARY AID AND ARMS. THIS LONG RELATIONSHIP HAS MADE LIFE DIFFICULT FOR MIKHAIL GOBACHEV WHO IS TORN BETWEEN HIS DUTY TO A CLIENT STATE AND ALLY AND HIS DESIRE
TO MAINTAIN AN INTERNATIONAL IMAGE OF MODERATION AND REFORM.

02591 CRUSH, J.

POWER AND SURVEILLANCE ON THE SOUTH AFRICAN GOLD MINES JOURNAL OF SOUTHERN AFRICAN STUDIES, $18(4)$ (DEC 92), 825-844.

THIS PAPER ATTEMPTS A PRELIMINARY ANALYSIS OF THE IMPACT OF COMPUTER TECHNOLOGY ON LABOR REGULATION IN THE SOUTH AFRICAN MINING INDUSTRY. ITS MAIN FOCUS IS THE INTRODUCTION OF ELECTRONIC SURYEILLANCE TECHNIQUES ON THE GOLD MINES. THE PAPER ARGUES THAT COMPUTERIZATIOH THEORETICALY PREFIGURES A DRAMATIC EXTENSION OF RULING CLASS CAPABILITY TO

IMPERSONALLY MONITOR THE BEHAVIORS AND BODIES OF THE DOMINATED. FURTHER, BY DEPERSONALIZING SURVEILLANCE, IT HAS DHE POT THE POTENTIAL TO CIRCUMSCRIBE THE CAPACITY OF WORKERS TO AVOIDANCE OF THE AGENTS OF SURVEILLANCE.

02592 CRUZ, A.

NICARAGUA'S FLEDGLING DEMOCRACY

INSIGHT, 7 (8) (FEB 19), 34-38.

A YEAR INTO THE DEMOCRATIC REVOLUTION, VIOLETA CHAMORRO'S GOVERMMENT HAS NOT RESOLYED NICARAGUA'S ECONOMIC PROBLEMS, BUT NEITHER HAVE THE SPLIT AND DEMORALIZED PROBLEMS, BUT NEITHER HAVE THE SPLIT AND DEMORALIZED CHAMORRO'S IS A BEDROOM GOVERMMENT, WITH THE CHAMORRO AMD ORTEGA FAMILIES AS ALLIES AS HELL AS ENEMIES, FULL OF ORTEGA FAMILIES AS ALLIES AS WELL AS ENEMIES, FULL OF HUMBERTO ORTEGA. HHO HAS EMERGED ON GOOD TERMS WITH ALL PARTIES INVOLVED.

02593 CRUZ, A.

THE EUROPEAN COMMUNITY AND CARRIER SANCTIONS

MIGRATION WORLD, 19(1) (1991), 16-20

THE TWELVE EUROPEAN COMMUNITY STATES, UNDER THE PRESSURE OF LIFTING THEIR BORDERS BY THE END OF 1992 HAVE BEEM SCHEDULED TO SIGN THE DRAFT CONVENTION ON ALL ASPECTS OF CHECKS ON PERSONS AT EXTERNAL BORDERS. ONE CONTROVERSIAL ARTICLE IN THIS DRAFT CONVENTION PROVIDES FOR CARRIER SANCTIONS FOR UNDOCUMENTED PASSENGERS. THE AUTHOR THEREFORE SURVEYS CARRIER SANCTIONS IN TRADITIOMAL COUNTRIES OF
IMMIGRATION, I.E., THE UNITED STATES, CANADA, AUSTRALIA, THAILAND, AND BRAZIL. THE AUTHOR THEN EXAMINES CARRIER SANCTIONS IN FOUR EUROPEAN COMMUNITY STATES: BELGIUM, DENMARK, WEST GERMANY, AND THE UNITED KINGDOM. THE QUESTION OF WHETHER CARRIER SANCTIONS ARE UNREASONABLE IS ADORESSED AND THE AUTHOR EXPLAINS WHY SUCH SANCTIONS, AS PRACTICED IN THE EUROPEAN COMMUNITY, ARE INEFFECTIVE IN CONTROLLING IMMIGRATION AND CONSTITUTE AN EXAMPLE OF HOW TRAVEL OPERATIONS ARE PENALIZED DESPITE ALL POSSIBLE PRECAUTIONS AND MEASURES TAKEN TO ABIDE BY THE LAW. WAYS IN WHICH
CARRIER SANCTIONS THREATEN RIGHT OF ASYLUM, HUMAN RIGHTS, AND CIVIL AVIATION OBLIGATIONS ARE THEN DISCUSSED.

02594 CRUZ, A. JR.; SEQUEIRA, C.C.

CLING-ONS

NEW REPUBLIC, 206(20) (MAY 92), 21-22, 24

THE AUTHORS DESCRIBE THE FATE OF MICARAGUA'S SAMDINISTAS AND THE FRAGMENTATION OF THE FSLN SINCE IT WAS VOTED OUT OF POWER IN 1990.

02595 CSAKI, C.

TRANSITION AND TRADE PERSPECTIVES ON EASTERN EUROPEAN AGRICUL TURE

POLICY STUDIES JOURNAL, 20(3) (1992), 447-458,

IN THE ECONOMIC AND POLITICAL RESTRUCTURING OF EASTERN EUROPE, A NEH AGRICULTURAL STRUCTURE IS TAKING SHAPE, BASED UPON PRIVATE OWNERSHIP, GENUINE COOPERATIVES, AND A MARKET ECONOMY. AGRICULTURAL TRADE POLICY IN THE SIX EAST EUROPEAN NATIONS WILL BE CHARACTERIZED BY THE GOAL OF SELFSUFFICIENCY BUT PRIVATIZED AND CENTERED AROUND MARKET METHODS. IMPROVEMENT IN AGRICULTURAL SYSTEMS WILL OCCUR SLOWLY AND, OVER THE LONG TERM, MAY BRING SELF-SUFFICIENCY AND GREATER EXPORTS. MEANHHILE, EAST EUROPEAN AGRICULTURE WILL PROVIDE INYESTMENT AND MARKET OPPORTUNITIES FOR THE COUNTRIES OF THE DEVELOPED WORLD.

02596 CUBERT, $H$.

THE MILITAANT PALESTINIAN ORGANIZATIONS AND THE ARABISRAELI PEACE PROCESS

TERRORISM AND POLITICAL VIOLENCE, 4(1) (SPR 92), 22-43. THE CURRENT ARAB-ISRAELI PEACE NEGOTIATIONS HAVE NORMALIZED FREQUENT AND OPEN CONTACTS BETHEEN ISRAEL AND ITS NEIGHBORS. THIS ARTICLE BEGINS BY EXAMINING THE WAYS IN NEIGHBORS. THIS ARTICLE BEGINS BY EXAMINING THE WAYS
WHICH THESE EVENTS HAVE AFFECTED THOSE CONTRIES AND WHICH THESE EVENTS HAVE AFFECTED THOSE CONTRIES AND
ORGANIZATIONS WHICH CHOSE TO PARTICIPATE IN THE PEACE ORGANIZATIONS WHICH CHOSE TO PARTICIPATE IN THE PEACE PALESTINIAN NATIONAL MOVEMENT -- SPECIFICALLY THE GROUPS PALESTINIAN NATIONAL MOVEMENT -- SPECIFICALLY THE GROUPS
WHICH ARE OPPOSED TO THE NEGOTIATIONS AND HAVE VOWED TO UNDERHINE THEM. IT ARGUES THAT THESE GROUPS SEEK TO SUBVERT ANY PEACE TREATY WHICH THE TALKS MAY PRODUCE AND THAT THE MODERATE PALESTINIAN LEADERSHIP HAS PROVEN INCAPABLE OF CONTROLLING THEM. IT CONCLUDES THAT UNLESS THIS OCCURS, IT WILL BE IMPOSSIBLE TO IMPLEMENT ANY AGREEMENT.

02597 CUENCA, A.; RAMIREZ, S

SANDINISTA' ECONOMICS IN PRACTICE--AN INSIDER'S CRITICAL REFLECTIONS

SOUTH END PRESS, 1991,220

IN LIGHT OF THE SANDINISTA'S 1990 ELECTORAL DEFEAT, THE AUTHOR OF THIS BOOK OFFERS AN ASSESSMENT OF THE SANDINISTA REVOLUTION--AND THE FUTURE OF SOCIALISM IN NICARAGUA. CAPITALIST RESTRUCTURING IN THE INDUSTRIALIZED WORLD, THE BREAKDOWN OF WORLD TRADE ANO PROTECTIONISM, AND THE GROWING LATIN AMERICAN DEBT CRISIS POSED TREMENDOUS OBSTACLES TO THE SANDINISTA PROJECT. YET THE SANDINISTAS BRDUGHT A RAY OF HOPE TO THE PEOPLES OF CENTRAL AND LATIN AMERICA, A REGION CRUSHED BY MILITARY DICTATORSHIPS, POLITICAL REPRESSION, AND HARSH ECONOMIC INEQUITY. AMONG THE THEMES ANALYZED IN THIS BOOK ARE: THE SANDINISTA PROGRAM OF RECONSTRUCTION, CENTRALIZATION AND ECONOMIC POLICY, AND THE RESPONSIBILITIES OF THE GOVERNMENT.

02598 CUKIERMAN, A.

ASYMMETRIC INFORMATION AND THE ELECTORAL MOMENTUM OF PUBLIC OPINION POLLS

PUBLIC CHOICE, 70(2) (MAY 91), 181-214.

UBLIC CHOICE, 70(2) (MAY 91), $181-214$.
THIS PAPER OEMONSTRATES THAT THE EXISTENCE OF PUBLIC OPINION POLLS AMPLIFIES THE EFFECTS OF SHIFTS IN THE DISTRIBUTION OF THE PUBLIC'S PREFERENCES OVER THE ISSUED SPACE ON THE ELECTION'S RESULTS. VOTERS EVALUATE CANDIDATES SPACE ON THE ELECTION'S RESULTS. VOTERS EVALUATE CANDIDATES
BY THEIR POSITIONS ON THE ISSUE SPACE AND BY A VALENCE OR BY THEIR POSITIONS ON THE ISSUE SPACE AND BY A VALENCE OR GENERAL ABILITY OIMENSIONS. SOME INDIVIDUAL'S (THE INFORMED) HAVE MORE PRECISE INFORMATION ABOUT THE RELATIVE ABILITIES OF CANDIDATES THAN OTHERS (THE UNINFORMED). SINCE PUBLIC OPINION POLLS REFLECT THE INFORMATION OF THE INFORMED, APPROVAL FOR A CANDIOATE AT THE POLLS SIGNALS TO THE UNINFORMED THAT HE IS MORE LIKELY TO BE ABLER. HOWEVER, HIGH APPROVAL MAY ALSO REFLECT CHANGES INT HE DISTRIBUTION OF THE PUBLIC ON THE ISSUE SPACE. AS A RESULT THE UNINFORMED PARTLY
CONFUSE THE THO EFFECTS AND PUBLIC OPINION POLLS TEND TO CONFUSE THE TWO EFFECTS AND PUBLIC OPINION POLLS TEND TO
REINFORCE THE EFFECTS OF SHIFTS IN THE PUBLIC'S IDEOLOGICAL PREFERENCES ON ELECTION RESULTS. 
02599 CULHANE, D.

THE QUANDARIES OF SHELTER REFORM: AN APPRAISAL OF EFFORTS TO "MAMAGE" HOMELESSMESS

SOCIAL SERVICE REVIEW, 66(3) (SEP 92), 428-440.

EFFORTS TO MANAGE THE CAPACITY OF HOMELSS SHELTER PROGRAMS IN PHILADELPHIA ARE DESCRIBED AND THE IMPACT OF THOSE EFFORTS ON PROVIDERS ANO CONSUMERS OF HOMELESS SERVICES ARE ASSESSED. ALTERNATE METHOOS OF FINANCING SHELTER (BY REDUCING THE LENGTH OF STAY) ARE DESCRIBED, AS
ARE ATTEMPTS TO CREATE A SYSTEM OF SPECIALTY SHELTER PROVIDERS. THE CONTRADICTIONS OF SHELTER REFORM AND THE NEED FOR A MORE COMPREHENSIVE HOMELESSNESS PREVENTION STRATEGY ARE DISCUSSED.

02600 CULYER, A.; MEADS, A.

THE UNITED KINGDOM: EFFECTIVE, EFFICIENT, EQUITABLE? JOURMAL OF HEALTH POLITICS, POLICY AND LAH, 17(4) (WIN 92 ), 667-688.

THE BRITISH NATIONAL HEALTH SERVICE (NHS) HAS, SINCE ITS INCEPTION, AIMED TO MAKE HEALTH CARE AVAILABLE TÓ ALL REGARDLESS OF INCOME, AMD IT HAS MANAGED TO ACHIEVE THIS GOAL WHILE KEEPING COSTS LOWER AS A PROPORTION OF THE GROS DOMESTIC PRODUCT THAN MANY HESTERH COUNTRIES AND AT THE SAME TIME ASSURING EOUITABLE DISTRIBUTIDN OF RESOURCES REGIONALLY. TIME ASSURING EQUITABLE DISTRIBUTION OF RESOURCES REGIONALLY. MHS HAS CHARACTERIZED BY CENTRALIZED FINANCING AND NHS WAS CHARACTERIZED BY CENTRALIZED FINANCING AND REGULATION; DESPITE SOME PROBLEMS IN THE DELIVERY AND MANAGEMENT OF CARE, THE SYSTEM WAS A POPULAR ONE. THE NEW REFORMS HOPE TO ENHANCE EFFICIENCY IN THE NHS BY STIMULATI COMPETITION AND FURTHER DECENTRALIZING THE MANAGEMENT OF PRACTICE THE REFORMS HILL HAVE THE DESIRED EFFECT. INITIAL COSTS WILL BE HIGH, PEOPLE MAY NOT RESPOND TO INCENTIVES AS PREDICTED, AND THE QUALITY OF CARE AND ACCESS TO IT COULD HELL DETERIORATE. NATIONS PLANHING
A MODEL ARE ADVISED TO USE CAUTION.

02601 CUMINGS, B.

SPRING THAH FOR KOREA'S COLD WAR?

BULLETIN OF THE ATOMIC SCIENTISTS, 48(3) (APR 92), 14-23.

IN DECEMBER 1991, NORTH AND SOUTH KOREA SIGNED A LANDMARK AGREEMENT ON RECONCILIATION. AFTER 40 YEARS, THE BITTER KOREAN HAR SHOULD BE OVER, BUT TROUBLING QUESTIONS ABOUT MUCLEAR AMBITIONS REMAIN. THIS ARTICLE REPORTS ON KOREAN EFFORTS TO REESTABLISH ITSELF AS A NATION WHOSE CONTINUOUS INTEGRITY GOES BACK A MILLENNIUM. IT CONCLUDES THAT THAT UNITED STATES SHOULD HELP THE KOREANS END A 40YEAR CONFLICT AND CREATE GENUINE RECONCILIATION AMONG ALL YEAR CONFL
PARTIES.

02602 CUNHAL, A.

THE OCTOBER REVOLUTION AND "PERESTROIKA"

POLIIICAL AFFAIRS $71(2)$ (FEB

MANY SEE THE COLLAPSE OF THE SOVIET UNION AS THE FINAL INVALIDATION OF THE OCTOBER REVOLUTION AND OF THE GOALS AND AIMS OF THOSE WHD INSPIRED IT. THIS ARTICLE, EXCERPTED FROM A SPEECH DELIVERED TO THE CENTRAL COMMITTEE OF THE PORTUGUESE COMMUNIST PARTY IN JAHUARY OF 1992, DIFFERS FROM THIS VIEH. IT REPUDIATES THOSE HWO USED PERESTROIKA TO DESTROY SOCIALISM. IT REFUSES TO ACKNOWLEDGE THE "DEATH OF SOCIALISM." IT PROCLAIMS THE READINESS OF THE PORTUGUESE COMMUNIST PARTY TO CONTINUE TO HORKERS' STRUGGLE FOR EQUALITY, DEMOCRACY AND JUSTICE.

02603 CUNHINGHAM, S.

THE DEVELOPMENT OF EQUAL OPPORTUNITIES THEORY AND PRACTICE IN THE EUROPEAN COMHUNITY

POLICY AND POLITICS, 2013) (JUL 92), 177-190.

THE AUTHOR TRACES THE DEVELOPMENT OF EQUAL OPPORTUNITIES POLICIES AND PRACTICE WITHIN THE EUROPEAN COMMUNITY SIMCE 1975. SHE COMPARES POLICIES RELATING TO HOMEN, RACE, AND DISABILITY WITHIN THE FRAMEWORK OF A CONCEPT OF EQUALITY OF OPPORTUNITY AS A PRIMARY RIGHT. EOUAL OPPORTUNITIES POLICY HAS DEVELOPED MOST STRONGLY IN RELATION TO WOMEN AND REPRESENTS THE MODEL FOR IMPLEMENTATION. ACTION IN RESPECT TO RACE AND DISABILITY IS LESS ADYANCED. OVERALL CURREMT EOUAL OPPORTUNITIES POL ICY IS NOW MORE RADICAL IN ITS APPROACH BUT ITS IMPLEMENTATION IS HAMPERED BY THE OPERATION OF THE SUBSIDIARITY PRINCIPLE. UNLESS EQUALITY OF OPPORTUNITY IS RECOGNIZED AS A PRIMARY RIGHT, THEN THE POL ICIES HIL NEVER GO FAR ENOUGH TO FULFIL' THE BASIC POLICIES HILL NEVER GO FAR ENDUC
SOCIAL OBJECTIVES OF THE E.

02604 CUNHINGTON, C

APARTHEIO'S FINAL WALK

WEST AFRICA, (3889) (MAR 92), 548

IN THE MARCH 17, 1992, REFERENDUM WHITE SOUTH AFRICANS OVERHHELMINGLY VOTED TO CONTINUE THE NEGOTIATIONS OF THE CONVENTION FOR A DEMOCRATIC SOUTH AFRICA (CODESA). WITH CODESA NOW CLAIMING WIDESPREAD SUPPORT, THE PARTIES THAT HAVE THUS FAR REFUSED TO PARTICIPATE IN THE NEGOTIATION PROCESS MUST RETHINK THEIR POSITIONS.
02605 CUOMO, M.

PRODUCTIVITY INITIATIVES IN NEW YORK STATE GOVERNMENT PUBL IC PRODUCTIVITY \& MAYAGEMENT REYIEH, 15(2) (WIN 91), 109-112.

NEW YORK STATE GOVERNOR, MARIO M. CUOMO, DISCUSSES HIS DESIRE TO MAKE GOVERNMENT MORE RESPONSIVE, EFFICIENT, AND AFFORDABLE. FIRST-HAND EXPERIENCE IN THE PRIVATE SECTOR LED MR. CUOMO TO QUESTION THE DIFFERENCES IN THE PUBLIC AND PRIVATE WORLDS. WHY COULDN'T GOVERNMENT BE MORE EFFICIENT? IN EIGHT YEARS, THE GOVERNOR'S OFFICE OF MANAGEMENT AND PRODUCTIVITY HAS SAVED THE STATE NEARLY 500 MILLION DOLLARS. HE CONCLUDES THAT PRAISE AND RECOGNITION CANMOT AND WILL NOT BE THE REWARD BUT NONETHELESS THE ATTEMPT TO MAKE GOVERNMENT MORE RESPONSIVE, MORE EFFICIENT, AND MORE AFFORDABLE MUST GO ON.

02606 CURRIE, D. ; VINES, D.

A GLOBAL ECONOMIC POLICY AGENDA FOR THE 19905

INTERNATIONAL AFFAIRS, 68 (4) (OCT 92) 585-602

AN IMPERIAL HERITAGE AND THE LEGACY OF INSTITUIONAL

EXPERIMENTATION IN THE 1980 S PUTS BRITAIN IN A UNIQUE

POSITION TO MAKE ITSELF HEARD IN GLOBAL ECONOMIC

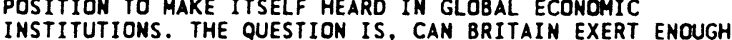

INSTITUTIONS. THE QUESTION IS, CAN BRITAIN EXERT ENOUGH
INFLUENCE TO PROMOTE ITS VISIOM OF A NON-INTERVENTIONIST, OPEN MARKET STRUCTURE? CURRIE AND VINES BELIEVE BRITAIN CAN, IF ONLY IT FIRST BUILDS A CONSENSUS FOR SUCH AN APPROACH IF ONLY IT FIRST BUILDS A CONSENSUS

02607 CURRY, J.L.

THE PUZZLE OF POLAND

CURRENT HISTORY, 91(568) (NOV 92), 385-389

THREE YEARS AFTER POLAND'S COMMUNIST LEADERS ADMITTED DEFEAT, FAITH IN THE GOVERNMENT IS LOWER THAN IT WAS DURING THE LAST DAYS OF COMMUNISM. FEW POLES BELIEVE IN THE SYSTEM OR HOPE THEIR LOT IN LIFE WILL IMPROVE. POLITICS IS NO LONGER A CLEAR-CUT MATTER OF FREEDOM VERSUS COMMUNISM. POLITICIANS OFTEN ENGAGE IN VICIOUS PERSONAL POWER STRUGGLES, AND THE PARLIAMENT IS SO DIVIDED THAT IT IS ABLE TO PASS VERY LITTLE LEGISLATION. ECONOMIC REFORM IS STYMIED.

02608 CURTICE, J.

THE HIDOEN SURPRISE: THE BRITISH ELECTORAL SYSTEM IN 1992 PARL IAMENTARY AFFAIRS, 45(4) (OCT 92), 466-474.

IF THE BRITISH ELECTION RESULT DEMANDS AN INOUEST INTO THE PERFORMANCE OF THE OPINION POLLS, IT ALSO REQUIRES AN THE PERFORMANCE OF THE OPINION POLLS, IT ALSO REQUIRES AN
EXAMINATION OF THE OPERATION OF THE ELECTORAL SYSTEM. THIS EXAMINATION OF THE OPERATION OF THE ELECTORAL SYSTEM.
ARTICLE SETS UPON THAT TASK. IT ASKS WHY THE ELECTORAL ARTICLE SETS UPON THAT TASK. IT ASKS WHY THE ELECTORAL
SYSTEM FAILED TO DELIVER THE CONSERVATIVES THE KIND OF LEAD SYSTEM FAILED TO DELIVER THE CONSERVATIVES THE KIND OF LEAD IMPLICATIONS OF THE 1992 SYSTEM FOR ANY EYALUATIOM OF THE UTILITY OF THE SINGLE MEMBER PLURALITY SYSTEM.

02609 CURTISS, R.H.

RABIN AT KENNEBUNKPORT: BETTING ON THE POLLS OR ON HISTORY? WASHINGTON REPORT ON MIDOLE EAST AFFAIRS, XI(3) (AUG 92),

7, 83

THE COMPETING CANDIDATES IN THE U.S. PRESIDENTIAL ELECTION CONFRONT YITZHAK RABIN WITH THE CHOICE OF BETTING ON THE POLLS OR BETTING ON HISTORY. THE CHOICE FACING THE ISRAELI PRIME MINISTER IS A STARK ONE, AND HE IS A NOTORIOUSLY INDECISIVE MAN. IF HE BETS ON INCUMBEMT PRESIDENT GEORGE BUSH, HE MUST BEGIN MAKING THE SERIOUS COMPROMISES NECESSARY FOR A LASTING PEACE HITH HIS ARAB NEIGHBORS IN RETURN FOR SCALED-DOWN BUT ADEOUATE LONG-TERM U. S. FINANCIAL ASSISTANCE. BUT EMISSARIES FROM GOVERNOR BILL CLINTON, THE DEMOCRATIC CANDIDATE, HAVE REPORTEDLY PROMISED RABIN EVEN MORE AID AND COOPERATIDN. RABIN MAY DECIDE ON A MIDDLE GROUND, SEEMING TO GO ALONG WITH BUSH WHILE STALLING IF POLLS FORECAST A CLINTON VICTORY.

02610 CURTISS, R.H.

WHO STARTED THE SIX-DAY WAR ON JUME 5, 1967? THE RECORD IS CLEAR

WASHINGTON REPORT ON MIDDLE EAST AFFAIRS, XI(1) (JUN 92), $11-13$.

THE SIX-DAY WAR OPENED WITH SHOCKING SUDDENMESS AND ENDED QUICKLY, WITH MUCH OF THE ARAB WORLD'S MILITARY MIGHT AND ALL OF ITS POLITICAL ILLUSIONS IN SMOKING RUINS. BUT THE AND ALL OF ITS POLITICAL ILLUSIONS IN SMOKING RUINS. BUT THE BUILDUP TO THE WAR HAD BEEN SLOW AND AMBIGUOUS. TOOAY, CLEAR THAT THE ISRAELIS WANTED HAR, EGYPT DID NOT, THE
SOVIETS COULD HAVE PREYENTED IT, AND THE AMERICANS SHOULD SOVIETS.

02611 CUSHMAN, 8

A STREAM OF LEGAL CONSCIOUSNESS: THE CURRENT OF COMMERCE DOCTRINE FROM SHIFT TO JONES AND LAUGHLIN FORDHAM LAW REVIEW, LXI(1) (OCT 92), 105-160.

IN THIS PAPER ON CONSTITUTIONAL DEVELOPMENT ANO THE NEW DEAL COURT, THE AUTHOR ARGUES THAT THE CONVENTIONAL STORY OF THE COURT'S RADICAL REVERSING OF ITS JURISPRUDENCE IN THE FACE OF THE COURT-PACKING PLAN IS MISCONCEIVED. HE SEEKS TO DEMONSTRATE THAT JONES AND LAUGHLIN, ONE OF THE CASES COMPRISING THE CONSTITUTIONAL REVOLUTION OF 1937. WAS CONCEPTUALLY, STYLISTICALLY, AND DOCTRINALLY CONGRUENT WITH 
THE COURT'S CONTEMPORARY JURISPRUDENCE. THE PARADIGM SHIFT IN COMMERCE CLAUSE JURISPRUDENCE CAME NOT IN 1937 BUT IN 1941-42, AFTER PRESIDENT ROOSEVELT HAD HAD AN OPPORTUNITY TO REFASHION THE COURT WITH A NEW GENERATION OF LEGAL THINKERS.

02612 CUTLER, A.

THE "GROTIAN TRAOITION" IN INTERNATIONAL RELATIONS

REVIEW OF INTERNATIONAL STUDIES, $17(1)$ (JAN 91), 41-66.

THE WORKS OF HUIG DE GROOT, OR GROTIUS, THE SEVENTEENTHCENTURY DUTCH JURIST, ARE SAID TO EXEMPLIFY A PARTICULAR TRADITION IN INTERNATIONAL LAW AND IN INTERNATIONAL THEORY. THE CONVICTION THAT THE TOTALITY OF INTERNATIONAL RELATIONS IS SUBJECT TO THE RULE OF LAW IS ONE DF THE PRINCIPLE FEATURES OF THE GROTIAN TRADITION, A FEATURE THAT DISTINGUISHES THIS FROM ALTERMATIVE CONCEPTIONS OR TRADITIONS. IN ASSESSING THE CONTRIBUTIONS THAT THE GROTIAM TRADITION HAS MADE TO INTERNATIONAL THEORY AND RESEARCH, TRADITION HAS MADE TO INTERNATIONAL THEORY AND RESEARCH, TRADITION BY CONSIDERING THE THOUGHT OF ALLEGED "GROTIANS" IN THE CONTEXT OF THREE QUESTIONS OF FEATURES: THE RAISON D'ETRE OR PROBLEMATIC OF THE FIELD, THE IDENTIFICATION OF THE MAIN ACTORS OR UNITS OF ANALYSIS, AND THE IMAGE OF THE WORLD.

02613 CUTLER, D.M.; KATZ, L.F. UNTOUCHED BY THE RISING TIDE

BROOKINGS REVIEW, 10(1) (WIN 92), 40-45

ECONOMIC GROWTH HAS TRADITIONALLY BEEN SEEN AS THE MAJOR SOURCE OF GAINS FOR THE POOR. FROM WORLD WAR II THROUGH THE EARLY 1980'S, ECONOMIC DATA SHOWED A POSITIVE AND STEADY CORRELATION BETHEEN OVERALL ECONOMIC GROWTH AND THE WELLBEING OF THE POOR IN THE UNITED STATES. BUT THE ECONOMIC EXPANSION OF THE 1980'S PROVED TO BE AN EXCEPTION AS THE POOR FAILED TO BENEFIT FROM IT. INCOME INEQUALITY BETWEEN THE RICH AND THE POOR INCREASED SUBSTANTIALLY IN THE 1980's, BELYING MORE THAN 30 YEARS OF MACROECONOMIC EXPERIENCE.

02614 CUZAN, A.; BUNDRICK, C.

SELECTED FISCAL AND ECONOMIC EFFECTS ON PRESIDENTIAL ELECTIONS

PRESIDENTIAL STUDIES QUARTERLY, 22(1) (WIN 92), 127-134. THE EFFECTS OF FISCAL EXPANSION AND FISCAL CUT-BACK ON PRESIDENTIAL ELECTIONS HAVE PREVIOUSLY BEEN EXAMINED. THIS ARTICLE CARRIES THE ANALYSIS A STEP FURTHER, CONTROLLING FOR ARTICLE CARRIES THE ANALYSIS A STEP FURTHER, CONTROLLING FOR
CERTAIN ECONOMIC EFFECTS. WHEN INFLATION AND ECONOMIC GROWTH ARE TAKEN INTD ACCOUNT, FISCAL POLICY IS THE SINGLE BEST ARE TAKEN INTO ACCOUNT, FISCAL POLICY IS THE SINGLE BEST PREDICTOR OF WHETHER THE INCUMBENT PARTY ELECTS ITS

CANOIDATE TO THE WHITE HOUSE. HOWEVER, INFLATION DEFLATION IS THE BEST PREDICTOR OF THE SHARE OF THE POPULAR VOTE GOING
TO THE INCUMBENT PARTY.

02615 CYR, A.

NED VERUS NEW ISOLATIONISM

SOCIETY, 29(6) (SEP 92), 18--21.

THE NEW ISOLATIONISM, BE IT IN CONSERVATIVE OR IN LIBERAL FORM MAY STIMULATE SERIOUS FOREIGN POLICY DEBATE OVER THE LONGER TERM. HOWEVER THIS ARTICLE SUGGESTS THAT IT IS MORE LIKELY THAT BUCHANAN'S CAMPAIGN HAS PERMITTED OTHER PRESIDENTIAL CANDIDATES TO AVOID A DISCUSSION OF FOREIGN POLICY. THE RIGHTWING ISOLATIONIST CHALLENGE HIGHLIGHTS THE STARK CHOICE BETWEEN THIS SIMPLISTIC APPROACH AND CONVENTIONAL INTERNATIONALISM. THE REAL TASK, HIDDEN BY THIS SUPERFICIAL DEBATE, IS TO DEFINE THAT INSTITUTIONAL MECHANISMS AND PHILOSOPHICAL BASES OF AMERICAN FOREIG POLICY IN A POST-COLD WAR WORLD, ADDRESSING PROBLEMS THAT HAVE TO BE HANDLED IN SPECIFIC TERMS IN THE VARIOUS REGIONS OF THE HORLD AND IN THE INTERNATIONAL SYSTEM GENERALLY.

02616 CZAPLINSKI, $\mathrm{H}$.

THE NEW POLISH-GERMAN TREATIES AND THE CHANGING POLITICAL STRUCTURE OF EUROPE

AMERICAN JOURNAL OF INTERNATIONAL LAW, 86(1) (JAN 92), 163-173.

THE BILATERAL TREATIES CONCLUDED BY POLAND AND GERMANY ON NOVEMBER 14, 1990, AND JUNE 17, 1991, ILLUSTRATE THE RECENT POL ITICAL AND SOCIAL CHANGES IN CENTRAL EUROPE. THE TREATIES ARE DESIGNED TO CONSTITUTE A TURNING POINT IN THE RELATIONS BETHEEN THE TWO NEIGHBORS--ENEMIES FOR CENTURIES WHO ARE NOW STARTING TO CONSTRUCT A COMMON FUTURE.

02617 D'AQUINO, $\mathrm{N}$.

ITALY
EUROPE, 315 (APR 92), 23; 26-28.

THE MOST RECENT E.C. CLASSIFICATIONS PUT ITALY IN THIRD PLACE BEHIND GERMANY AND FRANCE IN TERMS OF GROSS DOMESTIC PRODUCT. SIXTY-THO ITALIAN COMPANIES ARE IN THE NUMBER ONE POSITIDN WORLDWIDE IN THEIR FIELDS. ITALY PAYS 55.7 PERCENT OF ITS GROSS NATIONAL PRODUCT FOR SCHOOLING, SIXTH PLACE HORLDHIDE, AHEAD OF JAPAN, GERMANY, AND THE U.S. IN ORDER TO UNDERSTAND THESE FACTS, ONE MUST USE DIFERENT PARAMTERS WHEN LOOKING AT ITALY THAN THOSE USUALLY USED HHEN EXAMINING THE STATISTICS OF OTHER INDUSTRIAL POWERS. THE ITALIAN MIRACLE IS COMPOSED NOT ONLY OF BIG NAMES BUT OF A MYRIAD OF SMALL
"MADE IN ITALY". ITALY IS ALSO THE LAND OF DRAMATIC LASTMOMENT RECOVERIES, AS IN THE CASE OF
STAMDARDS INTO NATIONAL LEGISLATION.

02618 D'AQUINO, N.

THE NEW GREEN EUROPE

EUROPE, (317) ( JUN 92), 9-10.

THIS ARTICLE BRIEFLY EXAMINES THE ENVIRONMENTAL POLICY OF THE EUROPEAN COMMUNITY OVER THE PAST TWO DECADES. SINCE 1972. THE COMMUNITY HAS PRODUCED OVER 200 LEGISLATIVE AGREEMENTS CONCERNING THE ENYIRONMENT. THIS LONG-STANDING POLICY OF ENVIRONMENTAL PROTECTION HAS REACHED MATURITY WITH RIGE "EARTH CHARTER," A "DECLARATION OF THE FUNDAMENTAL " WHICH IS TO BE PRESENTED AT THE UNITED NATIONS EARTH

SUMHIT IN RIO DE JANERIO. FUTURE COMMUNITY FOCUS WILL BE OH

FIVE SECTORS: INDUSTRY, ENERGY, TRANSPORTATION, AGRICULTURE, FIVE SECTORS
AND TOURISM.

02619 D'MONTE, D.

MARKET MANIPULATION COMES TO INDIA

NEW LEADER, LXXXV(15) (NOY 92 ) 13-14.

INDIANS WERE SURPRISED WHEN THE MARKET THERE SURGED TO DIZZYING HEIGHTS IN THE FIRST QUARTER OF 1992--AND SHOCKED WHEN THE BUBBLE BURST AT THE END OF APRIL, SETTING OFF A SCANDAL THAT HAS YET TO BE RESOL VED. BROKERS WERE BORROWING MONEY ON SECURITIES THEY NEVER HAD. THE STATE BANK OF INDIA WAS CENTRAL TO THE SCAM. OTHER BANKS WERE INVOLVED AS WELL. THE SCAM IS BELIEVED TO HAVE INVOLVED A STAGGERING $\$ 1.7$ BILLION, YET BROKER, HARSHAD MEHTA, HAS EMERGED AS A SAVIOR RATHER THAN A SWINDLER. THE AUTHOR SUGGESTS THAT THIS REVEALS A GREAT DEAL ABOUT INDIA'S FETTERED ECONOMY AND THE NUMBER OF PEOPLE STRAINING TO BREAK FREE.

02620 DAALDER, $H$.

A CRISIS OF PARTY?

SCANDINAVIAN POLITICAL STUDIES, 15(4) (DEC 92), 269-288.

THE DEBATE ABOUT THE FUTURE ROLE OF POLITICAL PARTIES IN MODERN DEMOCRACIES SUFFERS FROM GENERALLY UNACKNOWLEDGED NORMATIVE PRECONCEPTIONS, AS HELL AS A TENDENCY TO REASON IN NORMATIVE PRECONCEPTIONS, AS HELL AS A TENDENCY TO REASON IN
TERMS OF "INEVITABLE" SOCIAL PROCESSES RATHER THAN PRECISE TERMS OF "INEVITABLE" SOCIAL PROCESSES RATHER THAN PRECISE
THEORETICAL REASONING OR EMPIRICAL ANALYSIS. AT LEAST FOUR THEORETICAL REASONING OR EMPIRICAL ANALYSIS. AT LEAST FOUR
DISTINCT BODIES OF THOUGHT AFFECT THE DISCUSSION ABOUT THE DISTINCT BODIES OF THOUGHT AFFECT THE DISCUSSION ABOUT THE
ASSUMED CRISIS OF PARTY: (1) PARTIES ARE A DANGER TO THE GOOD SOCIETY, LEADING TO THE DENIAL OF PARTIES AS LEGITIMATE GOOD SOCIETY, LEADING TO THE DENIAL OF PARTIES AS LEGITIMATE
ACTORS: (2) SOME TYPES OF PARTIES ARE "GOOD" WHILE OTHERS ACTORS; ( 2) SOME TYPES OF PARTIES ARE "GODD" WHILE OTHERS
ARE "BAD," CAUSING A SELECTIVE REJECTION OF PARTIES: (3) ARE "BAD," CAUSING A SELECTIVE REJECTION OF PARTIES; (3)
CERTAIN PARTY SYSTEMS ARE "GOOD" AND OTHERS "BAD" "PRODUCING CERTAIN PARTY SYSTEMS ARE "GOOD" AND OTHERS "BAD," PRODUCING A SELECTIVE REJECTION OF PARTY SYSTEMS; AND (4) PARTIES ARE BECDMING REDUNDANT. THE LATTER SUGGESTION IS EXPRESSED IN VARIETY OF APPROACHES-TTHE IDEA THAT PARTIES ARE TRANSIENT AGENTS OF DEMOCRATI IATION, THE ANALYSIS OF PARTIES AS MERE
MARKET FORCES, THE ASSUMPTION THAT PARTIES DO NOT MATTER IM MARKET FORCES, THE ASSUMPTION THAT PARTIES DO NOT MATTER IN POLICIES, AND THE VIEH THAT PARTIES INEVITABLY LOSE THEIR
FUMCTIONS TO OTHER POLITICAL ACTORS. THE PERVASIVE PRESENCE FUNCTIONS TO OTHER POLITICAL ACTORS. THE PERVASIVE PRES HOUSE-CLEANING, THE IMPORTANCE OF DISTINGUISHING NORMATIVE FROM EMPIRICAL ARGUMENTS, AND THE NEED FOR MORE DETAILED EMPIRICAL RESEARCH GIVING DUE WEIGHT TO DIFFERENCES AMONG COUNTRIES, PARTY SYSTEMS, PARTIES, AND PERIODS.

02621 DAALDER, H.

POLITICAL SCIENCE IN THE NETHERLANDS

EUROPEAN JOURNAL OF POLITICAL RESEARCH, 20(3-4) (DEC 91), 279-300.

THE AUTHOR DISCUSSES THE DEVELOPMENT OF THE DISCIPLINE OF POLITICAL SCIENCE IN THE NETHERLANDS, FOCUSING ON THE BEGINNINGS OF MODERN POLITICAL SCIENCE, THE INCREASING INTERMATIONALIZATION. THE GROWING SPECIALIZATION, THE
PROBLEMS OF THE WELFARE STATE, AND THE DEBATE ABOUT DEMOCRACY.

02622 DAASE, C.; JOCHUM, M.

"PARTNERS IN LEADERSHIP"? UNITED GERMANY IN THE EYES OF THE USA
AUSSEN POLITIK, 43(3) (JUL 92), 237-245.

GERMAN UNIFICATION HAS ALTERED PERCEPTIONS ABROAD. GERMANY HAS INCREASED IN SIZE, AND IT HAS ACQUIRED AN UNRESTRICTEDLY SOVEREIGN STATUS FOLLOWING A LONG PERIOD UNRESTRICTEDLY SOVEREIGN STATUS FOLLOWING A LONG PERIOD
CONSTRAINED BY FOUR-POWER RIGHTS OF RESERVATION. FALLING CONSTRAINED BY FOUR-POHER RIGHTS OF RESERVATION. FALLING
BACK ON THE INSIGHTS AND STIMULI GAINED DURING A LONG STAY BACK ON THE INSIGHTS AND STIMULI GAINED DURING A LONG STAY
IN THE USA, TWO GERMAN POLITICAL SCIENTISTS, EXAMINE HOW AMERICANS PERCEIVE GERMANY'S NEH ROLE AND ITS INTERNATIONAL AMERICANS PERCEI

02623 DABBAGH, A.

GCC-U.S. RELATIONS: A DECADE OF REDEFINITION MIDOLE EAST POLICY, I (1) (1992), 85-88.

THE GULF IS NOW SEEN AS THE MOST IMPORTANT STRATEGIC ASSET IN THE MIDDLE EAST AND SAUDI ARABIA'S STRATEGIC ROLE HAS ALSO BEEN ENHANCED. ECONOMICALLY THEY ARE AT A WATERSHED IN GLOBAL ECONOMIC RELATIONS. THREE ELEMENTS THAT PROMISE TO REDEFINE COMMERCIAL RELATIONSHIPS HORLEWIDE ARE; THE 
AYAILABILITY OF TECHNOLOGY AND THE NEED FOR TECHNOLOGY TRANSFER; AND THE TRIUMPH OF THE MARKET ECONOMY AND THE RISE OF THE PRIVATE SECTOR. THIS ARTICLE SUGGESTS THAT AMERICANS NEED TO APPRECIATE DIFFERENCES RATHER THAN USE THEM AS WEDGES TO ATTRIBUTE INFERIORITY, LOWER STATUS OR INTELLIGENCE TO PEOPLES WHO WANT TO LIVE THEIR LIVES DIFFERENTLY.

02624 DACOSTA, G FRESH IMPETUS FOR PEACE? WEST AFRICA, (3922) (NOV 92), 1968

THE AUTHOR REPORTS ON A CONFERENCE ON LIBERIA THAT ATTRACTED MANY WEST AFRICAN LEADERS TO ABUJA ON NOVEMBER 7 , 1992. THE LEADERS RULED OUT THE POSSIBILITY OF WITHDRAWING THE ECOMOG FORCES FROM LIBERIA.

02625 DACOSTA, G.

IDENTIFYING THE PITFALLS

WEST AFRICA, (3913) (SEP 92), 1564-1565

NIGERIA'S COMMITMENT TO POLITICAL REFORM AND A NON-

MILITARY REGIME FACES ENORMOUS CHALLENGES. PRESIDENT

BABANGIDA IS NOT OBLIVIOUS TO THE SEEMINGLY ENTRENCHED

BABANGIDA IS NOT OBLIVIOUS TO THE SEEMINGLY ENTRENCHED
INDISCIPLINE THREATENING TO AMBUSH HIS PET PROJECT. HE HAS

INDISCIPLINE THREATENING TO AMBUSH HIS PET PROJECT. HE HAS

COULD THWART PLANS TO KEEP THE MILITARY OUT OF POLITICS IN

THE POST-BABANGIDA ERA.

02626 DACOSTA, G.

LOOKING FOR CLUES

WEST AFRICA, (3898) (JUN 92), 916-917

MANY NIGERIANS HOPE THAT THEIR COUNTRY'S IMPENDING

RETURN TO A DEMOCRATIC GOVERNMENT WILL TRIGGER AN

IMPROVEMENT IN THE ECONOMY. BUT INDICATIONS ARE THAT

DEMOCRATIC RULE WILL NOT AUTOMATICALLY OBLITERATE NIGERIA'S

SEVERE ECONOMIC WOES--THE MOUNTAIN OF EXTERNAL DEBT, THE

INFLATION, AND THE LACK OF PRODUCTION CAPACITY.

02627 DACOSTA, G.

THE RELIGIOUS FACTOR

WEST AFRICA, (3904) (JUL 92), 1165

REPRESENTATIVES OF THE KHARTOUM GOVERMMENT AND THE THO

FACTIONS OF THE REBEL SPLA/M MET RECENTLY IN NIGERIA TO SEEK

A NEGOTIATED END TO THE CONFLICT IN SUDAN. THE TALKS

HIGHLIGHTED THE DEEPLY-ENTRENCHED POSITIONS ON BOTH SIDES OF THE DISPUTE, AS SPEAKERS USED THE OPPORTUNITY TO CAST THE

CONFLICT IN MORAL TERMS.

02628 DACOSTA, P.

AN END TO COHABITATION?

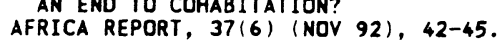

OPPOSITION LEADER ABDOULAYE WADE'S SURPRISE WITHDRAHAL FROM PRESIDENT DIOUF' S "COHABITATION" GOVERMMENT IN OCTOBER 1992 HAS THROWN THE SENEGALESE POI ITICAL SCENE INTO CONFUSION. HITH PRESIDENTIAL ELECTIONS SLATED FOR FEBRUARY 1993, DIOUF HOPES TO PROVE THAT SENEGAL TRULY ESPOUSES POLITICAL PLURALISM BY HOLDING A GENUINELY FREE AND FAIR VOTE. BUT WITH WADE AS HIS MAJOR OPPONENT, THE 1993 ELECTIONS MIGHT BE A REPEAT OF THE CONTROVERSIAL 1988 POLL.

02629 DACOSTA, $P$ CHRISTMAS CHEER WEST AFRICA, (3878) (JAN 92), 68-69.

MANY GAMBIANS WERE RELIEVED WHEN SIR DAWDA, THEIR LEADER FOR NEARLY 30 YEARS, ANMOUNCED THAT HE HAD CHANGED HIS MIND ABOUT RETIRING AND WILL LEAD THE PEOPLE'S PROGRESSIVE PARTY (PPP) IN THE 1992 GENERAL ELECTION BATTLE, WHICH THE PPP IS EXPECTED TO WIN BY A LANDSLIDE.

02630 DACOSTA, $P$

COMBINING AGAINST CONFLIC

AFRICA REPORT, 37 (5) (SEP 92), 21-26

A NEW PROPOSAL FOR THE ORGANIZATION OF AFRICAN UNITY

(OAU) TO TAKE UP THE ROLE OF PEACEKEEPER ON THE CONTINENT HAS BEEN TENTATIVELY ACCEPTED BY MEMBER STATES, ALTHOUGH SOME WORRY THAT THE MECHANISM COULD UNDERMINE NATIONAL SOVEREIGNTY. CONFLICT MANAGEMENT HAS RISEN TO THE TOP OF THE OAU'S AGENDA MAINLY BECAUSE OF AFRICA'S RECENT EXPERIENCES WITH VIOLENT, PROLONGED CIVIL WARS IN LIBERIA AND SOMALIA. MANY AFRICANS NOW BELIEVE THAT A UNIFIED APPROACH TO STOPPING WARS COULD BE THE ANSWER TO ENDING UNNECESSARY HUMAN SUFFERING.

02631 DACOSTA, P.

DAHNING' OF A NEH ERA?

WEST AFRICA, (3893) (APR 92) 710-711.

GAMBIANS WILL GO TO THE POLIS ON APRIL 29, 1992, IN ONE OF THE MOST OPEN ELECTIONS IN THE COUNTRY'S HISTORY. BECAUSE PRESIDENT SIR DAWDA JAWARA IS RETIRING, OTHER PARTIES SEE AN EXCELLENT OPPORTUNITY TO BREAK THE PEOPLE'S PROGRESSIVE PARTY'S HOLD ON POWER.

02632 DACOSTA, $P$.

DEMOCRACY IN DOUBT

AFRICA REPORT, 37(3) (MAY 92), 58-60.
AFTER 28 YEARS OF ONE-PARTY RULE, MILITARY STRONGMAN COL. MAAOUIYA OULD SID AHMED TAYA WON MAURITANIA'S FIRST-EVER DEMOCRATIC PRESIDENTIAL ELECTION. BUT THE OPPOSITION, WHICH SUPPORTS BLACK RIGHTS IN THE COMPLEX ARAB-AFRICAN ETHNIC OIVIDE IN THE DESERT NATION, CHARGED ELECTION FRAUD AND BOYCOTTED THE SUBSEQUENT LEGISLATIVE POLL. IT REMAINS TO SEEN IF PRESIDENT TAYA HILL RECOGNIZE THE NECESSITY OF
RESOLVING THE NATION'S ETHNIC CRISIS BEFORE ITS ECONOMIC PROBLEMS CAN BE ADDRESSED.

02633 DACOSTA, P.

ENDING AN ERA

AFRICA REPORT, 37(2) (MAR 92), 34-36.

THE LEADER OF GAMBIA FOR 30 YEARS, SIR DAWDA JAWARA IS ONE OF THE LAST OF AFRICA'S OLD-GUARD POLITICIANS. AFTER FIRST WITHDRAWING HIMSELF FROM CONTENTION IN THE UPCOMING MAY 1992 ELECTION, HE HAS RELENTED AND DECIDED TO RUN AGAIN. JAWARA AND HIS PARTY HAVE DOMINATED THE NATION'S POLITICS SINCE BEFORE INDEPENDENCE IN 1965, AND HIS EVENTUAL

RETIREMENT COULD USHER IN A NEW ERA OF MULTI-PARTY POLITICS.

02634 DACOSTA, P.

JAHARA'S NEW GOVERMMENT

WEST AFRICA, (3897) (MAY 92), 876-877.

THE AUTHOR REPORTS ON THE INAUGURATION OF SIR DAHDA

JAWARA'S FIFTH TERM AS GAMBIA'S PRESIDENT.

02635 DACOSTA, $P$.

PEACE POSTPONED

AFRICA REPORT 37(3) (MAY 92), 49-54.

LIBERIA IS BOGGED DOWN IN A POLITICAL AND MILITARY STALEMATE. THE CAREFULLY DRAWN ECOWAS BLUEPRINT, WHICH WAS SUPPOSED TO CULMINATE IN ELECTIONS IN APRIL 1992, HAS BROKEM DOWN--PRIMARILY DUE TO THE INTRANSIGENCE OF CHARLES TAYLOR AND HIS NATIONAL PATRIOTIC FRONT REBELS. THE SITUATION HAS FRUSTRATED THE INTERIM GOVERHMENT OF AMOS SAHYER AND TRIED THE PATIENCE OF THE ECOWAS PEACE-BROKERS.

02636 DACOSTA, P.

THE YOUNG GUNS

AFRICA REPORT, 37(4) (JUL 92), 36-39.

A GROUP OF' JUNIOR MILITARY OFFICERS, FED UP WITH LOW PAY AND POOR CONDITIONS, STAGED A SUCCESSFUL COUP AGAINST THE BANKRUPT REGIME OF PRESIDENT JOSEPH MOMOH IN APRIL 1992 TO PROVE THEY MEANT BUSINESS, THE SOLDIERS MOVED TO INSTILL DISE PI TEA THE GOVERMMENT BUREAUERS MOVE TA INSTILL INCLUDING SOME VETERAN OFFICIALS WITH EXPERIENCE IN ECONOMICS AMD FOREIGN AFFAIRS. THE NEW GOVERMMENT HAS ECONOMICS AND FOREI GN AFFAIRS. THE NEW GOVERMMENT HAS
PROMISED TO REPAIR THE COLLAPSED ECONOMY AND RESTORE PROMISED TO REPAIR THE COLLA

02637 DADRIAN, $Y$

THE ROLE OF THE TURKISH MILITARY IN THE DESTRUCTION OF OTTOMAN ARMENIANS: A STUDY IN HISTORICAL CONTIMUITIES JOURNAL OF POLITICAL AND MILITARY SOCIOLOGY, 2012) (WIM 2), 257-288

LARGE SCALE EXTERMINATORY MASSACRES BY A STATE NOT ONLY PRESUPPOSE CONCURRENT DECISION MAKING AT THE HIGHEST LEVEL OF THE STATE AUTHORITY BUT ALSO ARE, TO A LARGE DEGREE, CONTINGENT ON A HIGH LEVEL OF COMPETENCE IN THE

ADMINISTRATION OF THE REQUISITE LETHAL VIOLENCE. IN EXAMINING THE EVOL VING PROCESSES THROUGH WHICH THE ARMENIAN POPULATION OF THE OTTOMAN EMPIRE WAS PROGRESSIVELY DECIMATED AND ULTIMATELY ALL BUT DESTROYED, IHIS ESSAY FOCUSES ON THE INSTRUMENTAL ROLE TO THE TURKISH MILITARY IN THE ATTAINMENT OF THIS GOAL. THE MANIFESTATION OF THE ROLE IN A HISTORICAL CONTINUUM IS SEEN AS A FUNCTION OF A UNIQUE RELATIONSHIP OBTAINING AND PERSISTING BETHEEN THE MILITARY ESTABLISHMENT ON THE ONE HAND AND THE SUCCESSIVE GENERATIONS OF POLITICAL RULES OF THE EMPIRE ON THE OTHER. THE WORLD WAR I GENOCIDAL CLIMAX OF THIS PROCESS OF DESTRUCTION SUGGESTS THAT THE MORE PERVASIVE THIS MILITARY-POLITICAL RELATIONSHIP IS, THE HIGHER THE EFFICIENCY OF THE INSTRUMENTALITY OF THE MILITARY, AND THE MORE OPTIMAL THE RESULTS OF THE DESTRUCTION MAY BE.

02638 DAHL, R.A.

THE PROBLEM OF CIVIC COMPETENCE

JOURNAL OF DEMOCRACY, 3(4) (OCT 92), 45-59.

IF DEMOCRACY IS TO WORK, IT WOULD SEEM TO REQUIRE A CERTAIN LEVEL OF POLITICAL COMPETENCE ON THE PART OF ITS CITIZENS. IN NEWLY-DEMOCRATIC OR DEMOCRATIZING COUNTRIES, WHERE PEDPLE ARE JUST BEGINMING TO LEARN THE ART OF SELFGOVERMMENT THE QUESTION OF CITIZEN COMPETENCE POSSESSES AM GOVERNMENT, THE QUESTION OF CITIZEN COMPETENCE POSSESSES OBVIOUS URGENCY. YET EVEN IN COUNTRIES WHERE DEMOCRATIC
INSTITUTIONS HAVE EXISTED FOR SEVERAL GENERATIONS OR LONGER, INSTITUTIONS HAVE EXISTED FOR SEVERAL GENERATIONS OR LONGER A GROWING BODY OF EVIDENCE REVEALS GRAVE LIMITS TO CITIZEM COMPETENCE. THESE LIMITS ARE SERIOUS ENOUGH TO REQUIRE A
SYSTEMATIC SEARCH FOR NEW WAYS OF ENHANCING CIVIC COMPETENCE.

02639 DAHL, R.A.

WHY FREE MARKETS ARE NOT ENOUGH

JOURNAL OF DEMOCRACY, 3(3) (JUL 92), 82-89.

THIS ARTICLE EXAMINES SEYERAL REASOMS HHY ALL DEMOCRATIC COUNTRIES HAVE REJECTED STRICTLY COMPETITIVE MARKET 
ECONOMIES IN FAVOR OF MIXED ECONOMIES IN WHICH MARKETS ARE SIGNIFICANTLY MOOIFIED BY STATE INTERVENTION. IT ARGUES THAT THE PROCESSES AND INSTITUTIONS OF DEMOCRACY MUST BE INSULATED FROM THE MARKET--FOR EXAMPLE BY MAKING IT ILLEGAL TO SELL ONE'S VOTE WHETHER AS A CITIZEN OR LEGISLATOR. A CONFLICT BETWEEN DEMOCRATIC PROCESSES AND COMPETITIVE MARKETS ARISES BECAUSE PERSONS HHO BELIEVE THEMSEL VES INJURED BY THE MARKET WILL ACCEPT ECONOMICALLY EFFICIENT OUTCOMES AS DESIRABLE ONLY IF THEY ACT NOT FROM RATIONAL SELF-INTEREST BUT RATHER FROM A COMMITMENT TO THE GENERAL GDOD (AN OUT COME WHICH GENERALLY CAN NOT BE EXPECTED). A FURTHER SOURCE OF CONFLICT BETWEEN DEMOCRACY AND STRICTLYY COMPETITIVE MARKETS CAN BE TRACED TO THE OBVIOUS TRUTH THAT IN SOME CASES THE ARGUMENT FOR NON-INTERVENTION IS NECESSARILY TOO ABSTRACT AND RECONDITE TO BE PERSUASIVE TO NECESSARILY TOO ABSTRACT AND RECONDITE TO BE PERSUASIVE TO
THE GENERAL PUBLIC. A FINAL SOURCE OF CONFLICT ARISES FROM THE HIGH COSTS OF IMPOSING COMPETITIVE MARKET OUTCOMES ON PEOPLE IN A DEMOCRATIC COUNTRY. THE GENERAL CONCLUSION IS NOT ALWAYS THE IDEOLOGY, OF UNREGULATED COMPETITIVE MARKETS.

02640 DAHLER, $F$

SIGNS OF DEMOCRATIZATION IN AFRICA

SWISS REVIEW OF WORLD AFFAIRS, 42(8) (NOV 92), 25

IN MAY 1992, LEADERS FROM 46 AFRICAN COUNTRIES MET IN DAKAR AND HORKED OUT A "CODEX OF DEMOCRATIC CULTURE." IN OVER TO GIVE TANGIBLE FORM TO THE WILL TO CHANGE, THE CONFERENCE CREATED THREE PAN-AFRICAN COMMITTEES, WHICH WILL SCRUTINIZE AFRICA'S TRANSITION TO DEMOCRACY, MEDIATE CDNFLICTS, AND CONTINUE THE WORK OF THE CONFERENCE. IT IS EXPECTED THAT AFRICA'S CHURCHES WILL PLAY AN IMPORTANT ROLE IN DEMOCRATIZATION.

02641 DAHMS, $\mathrm{H}$

DEMOCRACY AND THE POST-ENLIGHTENMENT: LYOTARD AND HABERMAS REAPPRAISED

INTERNATIONAL JOURNAL OF POLITICS, CULTURE AND SOCIETY, 5(3) (SPR 92) 473-510.

IN ORDER TO EXAMINE THE PRESENT STATUS OF THE CONCEPT OF DEMOCRACY IN HESTERN SOCIAL AND POLITICAL THOUGHT, THE AUTHOR FOCUSES ON TWO CONTEMPORARY EUROPEAN THINKERS, JEANFRANCOIS LYOTARD AND JURGEN HABERMAS. LYOTARD APPROACHES THE PROBLEM OF POLITICAL LEGITIMACY FROM A POSTMODERNIST PERSPECTIVE, WHILE HABERMAS DOES SO FROM A MODERNIST POINT PERSPECTIVE, WHILE HABERMAS DOES SO FROM A MODERNIST POINT
OF VIEW. THE RELATIONSHIP BETWEEN LYOTARD AND HAVERMAS OF VIEW. THE RELATIONSHIP BETWEEN LYOTARD AND HAVERMAS
PROVIDES THE FOIL FOR AN ATTEMPT TO CLARIFY THE CURRENT PROVIDES THE FOIL FOR AN ATTEMPT TO CLARIFY THE CURR
CONDITION OF DEMOCRATIC THEORY IN THE MOST DEYELOPED CONDITION
SOCIETIES.

02642 DAINOV, E.

BULGARIA: POLITICS AFTER THE OCTOBER 1991 ELECTIONS RFE/RL RESEARCH REPORT, 1(2) (JAN 92), 12-16.

BULGARIA HAS ACQUIRED A RELATIVELY' SIMPLE TWO-PARTY POLITICAL SYSTEM, WITH THE SOCIALISTS AND THE DEPUTIES FROM THE UNION OF DEMOCRATIC FORCES DOMINATING THE PARLIAMENT. IN THE OCTOBER 1991 ELECTIONS, ALMOST 67 PERCENT OF THE ELECTORATE VOTED AGAINST THE SOCIALIST PARTY (FORMERLY THE BULGARIAN COMMUNIST PARTY). IF THE NEW UNION OF DEMOCRATIC FORCES GOVERMMENT UNDER FILIP DIMITROV PROVES TO BE AS DETERMINED AND DYNAMIC AS ITS COMPOSITION SUGGESTS, THE BULGARIA NEEDS CLEAR AND URGENT ACTION RATHER THAN COMPROMISE.

02643 DAJUN, $W$

NEW SPRING IN SINO-JAPANESE TIES HERALDED

BEI JING REVIEW, 35 (14) (APR 92), 7,9

IN 1992, JAPAN AND CHINA WILL MARK THE 20TH ANNIVERSARY OF THE NORMALIZATION OF BILATERAL RELATIONS. CHINESE PREMIER JIANG ZEMIN WILL PAY AN OFFICIAL STATE VISIT TO JAPAN TO EMPHASIZE THAT COOPERATION BETWEEN THE TWO COUNTRIES IS IMPORTANT NOT ONLY TO THEIR NATIONAL INTERESTS BUT ALSO TO PEACE AND STABILITY IN ASIA AND THE WORLD AS A WHOLE.

02644 DALBY, S.

SECURITY, MODERNITY, ECOLOGY: THE DILEMMAS OF POST-COLD WAR SECURITY DISCOURSE

ALTERNATIVES, 17(1) (WIN 92), 95-134.

MANY OF THE CALLS FOR ENHANCING AND ENLARGING THE SCOPE OF THE CONCEPT OF SECURITY ARE MADE WHILE THE AMBIGUITIES, INCONSISTENCIES, AND PERSISTENT LACK OF CLARITY CONCERNING ITS USE REMAIN. THIS CONTRADICTORY SITUATION PROVIDES A POINT OF DEPARTURE FOR THIS ARTICLE. USING INSIGHTS DRAWN POINT OF DEPARTURE FOR THIS ARTICLE. USING INSIGHTS DRANM FROM CONTEMPORARY CRITICAL THEORIZING IN INTERNATIONAL
RELATIONS. THIS ARTICLE EXPLORES THE POLITICAL IMPLICATIONS RELATIONS, THIS ARTICLE EXPLORES THE POLITICAL IMPLICATIONS
OF THE TRADITIONAL DISCOURSE OF SECURITY. IT EXAMINES THE ARGUMENTS FOR EXTENDING THE TERM TO INCLUDE THEMES OF COMMON ARGUMENTS FOR EXTENDING THE TERM TO INCLUDE THEMES OF COMMON SECURITY AND MATTERS OF RESOURCES AND ECOLOGY. THE ANALYSIS LEADS TO THE CONCLUSION THAT UNLESS CONSIDERABLE CARE IS TAKEN THE UNOUESTIONED POLITICAL ASSUMPTIONS OF EARLIER FORMULATIONS OF NATIONAL SECURITY MAY WELL END UP ATTACHED TO THE NEW MEANINGS OF THE TERM HITH UNINTENDED IMPLICATIONS WAYS IN IN NEW CIRCUMSTANCES.
02645 DALE, R. EUROPEAN POLITICS

EUROPE, 322(1) (1992), 19-23.

POLITICS IN EUROPE ARE LOOKED AT IN THIS ARTICLE. IT COMMENTS ON THE POLITICAL SYSTEMS OF EACH OF THE 12 E.C. COUNTRIES AND COMPARES POLITICS IN EUROPE TO POLITICS IN THE UNITED STATES. IT SUGGESTS THAT RARELY HAVE VOTERS ON BOTH SIDES OF THE ATLANTIC HAVE HAD MORE IN COMMON THAN THEY DO TODAY. COMMON GRIEVANCES ARE THE INABILTIY OF POLITICIANS TO SOLVE A NATION'S PROBLEMS, OR RESTART A STALLED ECONOMY AND THE GROWING CREDIBILTIY GAP WHICH HAS OPENED UP BETWEEN MOST POLITICIANS AND THEIR ELECTORATES.

02646 DALEY, T.

CAN THE U.S. STRETCH TO FIT ITS FUTURE?

BULLETIN OF THE ATOMIC SCIENTISTS, 48(3) (APR 92), 38-42.

BHE IDEA THAT THE FIVE GREAT POWERS OF THE WORLD OF 1945
THE SHOULD FOREVER RETAIN THE LEADING ROLE IN THE MAINTENANCE OF INTERNATIONAL PEACE AND SECURITY SIMPLY DOESN'T PLAY WELL ANYMORE WITH THE REST OF THE PLANET. AFTER THE FIRST-EVER SECURITY COUNCIL SUMMIT, QUESTIONS REMAIN. WHO GETS THE
SEATS? WHO KEEPS THE PEACE? WHAT ABOUT HUMAN RIGHTS. AND FOR THAT MATTER, WHAT ABOUT THE PLANET? THIS ARTICLE SUGGESTS THAT THE POST-COLD WAR WORLD HILL REOUIRE GLOBAL INSTITUTIONS WITH THE POWER AND AUTHORITY TO ADDRESS THE INCREASINGLY GLOBAL ISSUES OF THE NEW MILLEUNNIUM, AND THAT A GREAT DEAL MORE IS POSSIBLE TODAY, AS WE EMERGE FROM THE COLD WAR ERA, THAN WAS POSSIBLE HHEN WE ENTERED IT A HALF CENTURY AGO.

02647 DALLIN, A.

AMERICA'S SEARCH FOR A POLICY TOWARD THE FORMER SOYIET UNION

CURRENT HISTORY, 91(567) (OCT 92), 321-326.

THE UNITED STATES CANNOT BEGIN TO SOLVE THE PROBLEMS OF THE SOVIET SUCCESSOR STATES; AT THE SAME TIME. IT CAMMOT AFFORD TO IGNORE THEM. ONCE THE USA DECIDES THAT THE OUTCOME OF THE POLITICAL AND ECONOMIC UPHEAVAL IN THE COMMONHEALTH OF INDEPENDENT STATES MATTERS TO IT--AS INDEED IT DOES IN A GREAT MANY WAYS-IIT MUST BE PREPARED TO DO MORE THAN OFFER PIOUS ADVICE. IT MUST WORK WITH OTHERS, AND IT MUST DO SO WITHOUT DELAY.

02648 DALLMAYR, F.

MODERNIZATION AND POSTMODERNIZATION: WHITHER INDIA? ALTERNATIVES, $17(4)$ (FAL 92), 421-452.

THIS ESSAY EXPLORES THE ISSUE OF DEYELOPMENT AND MODERNIZATION IN A PARTICULAR CONTEXT. THE FOCUS IS ON INDIA AS ONE OF THE MOST PROMINENT DEVELOPING COUNTRIES TODAY. EMPHASIS IS PLACED ON THE THEORETICAL UNDERSTANDING OF THE MEANING OF DEVELOPMENT AND MODERNIZATION AS SUCH. THE ARTICLE REVIEWS THE DEVELOPMENTAL MODEL ARTICULATED BY
THEORISTS DURING THE PERIOD AFTER WORLD WAR II. WHENEVER THEORISTS DURING THE PERIOD AFTER WORLD WAR II. WHENEVER
POSSIBLE, ITS GIVES ROOM TO ARGUMENTS OF INDIAN PHILOSOPHERS POSSIBLE, ITS GIVES ROOM TO ARGUMENTS OF INDIAN PHILOSOPHERS
AND SOCIAL THEORISTS TO COUNTERACT THE CONCEIT OF A WESTERM MONOPOLY OF THE DEVELOPMENT DEBATE.

02649 DALONG, $H$.

BUSH SEEKS REMEOY FOR AILING US ECONONY

BEIJING REVIEW, 35 (3) (JAN 92), 13-14.

U.S. PRESIDENT. GEORGE BUSH, CELEBRATED THE NEW YEAR TOURING AUSTRALIA, SINGAPORE, SOUTH KOREA, AND JAPAN TO SEEK A REMEDY FOR THE U.S. ECONOMY, WHICH IS STRUGGLING TO GET OUT OF A RECESSION. THE ASIA-PACIFIC VISIT WAS PRIMARILY MEANT TO OPEN THE REGION'S MARKETS AND TO BOOST U.S. EXPORTS, SO AS TO CREATE MORE JOBS FOR AMERICANS. THE VISIT TOOK ON AN UNMISTAKABLE APPEARANCE OF A TRADE MISSION BY THE FACT THAT THE PRESIDENT'S CONTINGENT CONTAINED 21 TOP U.S. BUSINESS EXECUTIVES.

02650 DALY, J

DALY EFFECTS OF ANGER ON NEGOTIATIONS OVER MERGERS AND ACQUISITIONS

NEGOTIATION JOURNAL, 7(1) (JAN 91), 31-40.

ALTHOUGH EMOTIONS HAVE BEEN FOUND TO CONSTITUTE A FUNDAMENTAL ASPECT OF CONFLICT AS THE INVOLVED PARTIES PERCEIVE IT, VERY LITTLE RESEARCH HAS BEEN DONE ON THE EFFECT THAT EMOTION HAS ON BEHAVIOR IN CONFLICT SITUATIONS. EFFECT THAT EMOTION HAS ON BEHAVIOR IN CONFLICT SITUATIONS.
THE STUDY THAT FORMS THE BASIS FOR THIS ARTICLE FOCUSES ON A THE STUDY THAT FORMS THE BASIS FOR THIS ARTICLE FOCUSES ON A
SPECIFIC EMOTION, ANGER, IN A SPECIFIC SETTING, NEGOTIATIONS SPECIFIC EMOTION, ANGER, IN A SPECIFIC SETTING, NEGOTIATION
OVER MERGERS AND ACQUISITIONS. THE FOCUS OF THE STUDY OF OVER MERGERS AND ACQUISITIONS. THE FOCUS OF THE STUDY OF ANGER BECAUSE OF ITS POTENTIAL ROLE AS A KEY EMOTION IN
NEGOTIATIONS DUE TO ITS RELATIONSHIP TO "FAIRNESS JUDGMENTS "THE ARTICLE CONSIDERS WHAT TRIGGERS ANGER IN NEGOTIATIONS; WHAT EFFECT ANGER HAS ON NEGOTIATION PROCESS AND OUTCOMES
AND THE IMPLICATIONS FOR NEGOTIATION PRACTICE.

02651 DAMIS, J.

THE U.N. SETTLEMENT PLAN FOR THE WESTERN SAHARA: PROBLEMS AND PROSPECTS

MIDOLE EAST POLICY, 1(2) (1992), 36-46.

EFFORTS TO ACHIEVE A NEGOTIATEO SOLUTION OF THE LONG FESTERING CONFLICT OVER THE WESTERN SAHARA HAVE NOW REACHED 
A CRITICAL TURMING POINT. THE CURRENT U.N. SETTLEMENT PLAN REPRESENTS THE MOST PROMISING OPPORTUNITY SINCE 1975 TO END THE 17-YEAR DISPUTE THAT HAS DIVIDED NORTHWEST AFRICA. CONCERN IS MOUNTING, HOWEVER, OVER DELAYS IN IMPLEMENTING THE PLAN, AND ITS FULL IMPLEMENTATION IS FAR FROM ASSURED. THIS ARTICLE EXAMINES BOTH THE PROBLEMS AND PROSPECTS FOR THE IMPLEMENTATION OF THE U.N. SETTLEMENT PLAN FOR THE WESTERN SAHARA.

02652 DANESHKHU, $S$

ELECTIONS' IN IRAN: RAFSANJANI VS. THE RADICALS

MIDOLE EAST INTERNATIONAL, (422) (APR 92) 17-18

IRAN'S PARLIAMENTARY ELECTIONS, WHICH ARE DUE TO TAKE PLACE ON 10 APRIL, ARE EXPECTED TO REDUCE THE NUMBERS OF RADICALS OPPOSED TO THE POLICIES OF PRESIDENT HASHEMI RAFSANJANI. THE 270 SEAT CHAMBER, THE MAJLIS, IS ONE OF THE LAST BASTIONS OF THOSE WHO DISAGREE WITH THE' IOEOLOGICAL REVISIONISH PROPOUNDED BY RAFSANJANI. THIS REVISIONISM INCLUDES ADVOCATING A FREE MARKET ECONOMY, ACCEPTING FOREIGM LOANS, RELAXING SOME OF THE HARSH SOCIAL ASPECTS OF ISLAMIC LOANS, RELAXING SOME OF THE HARSH SOCIAL ASPECTS OF ISLAMI
RULE, BACKING AHAY FROM THE ISLAMIC REPUBLIC'S FORMALLY RULE, BACKING AHAY FROM THE ISLAMIC REPUBLIC'S FORMALLY
INTERVENTIONIST AND RADICAL FOREIGN POLICY AND INVITING BACK EXILES WHO FLED AT THE TIME OF THE REVOLUTION. RAFSANJANI HAS BEEN PREPARING FOR THE PRESENT ELECTIONS--THE FOURTH IN THE ISLAMIC REPUBLIC'S 13-YEAR HISTORY--FOR WELL OVER A YEAR TO ENSURE THAT THE RADICALS ARE KEPT OUT. THE MEASURES ADOPTED HAVE BEEN A COMBINATION OF TRYING TO HUMILIATE AND DISCREDIT THE RADICALS AND TO MAKE USE OF TECHNICAL INSTRUMENTS TO CLEAR THE HAY FOR THE ELECTION OF DEPUTIES WHO ARE LIKELY TO SHARE HIS OWN IDEAS ABOUT HOW IRAN SHOULD BE GOVERNED.

02653 DANESHKHU, S

OPEC--THE SAUDIS GET THEIR WAY

MIDOLE EAST INTERNATIONAL, (420) (MAR 91), 12-13.

OIL PRICES HAVE WEAKENED FOLLONING THE MID-FEBRUARY OPEC MEETING IN GENEVA AT THE END OF WHICH PRODUCTION CUTS FELL BELOW EXPECTATIONS. THE AGREEMENT SET A PRODUCTION CEILING OF 22.98 MILLION BARRELS PER DAY (MBPD), FROM AN ESTIMATED OPEC PRODUCTIOH LEVEL OF 24 MBPD, BUT IT LEFT MANY MEMBERS DISGRUNTLED. INITIAL SUGGESTIONS FOR A 22 MBPD CEILING WERE REJECTED, PRINCIPALLY BY SAUDI ARABIA, IN FAVOR OF A BARGAINING POSITION OF 22.5 MBPD BY A MAJORITY IN OPEC. HOWEVER, AFTER FOUR DAYS OF NEGOTIATION, IT BECAME CLEAR INDIVIDUAL STATE. WHILE SAUDI ARABIA IS KEEN TO HAVE HIGHER OIL PRICES TO INCREASE ITS FINANCIAL RESERVES, BADLY HIT BY ITS GENEROUS CONTRIBUTIOH TO THE HAR EFFORT , BADLY HIT BY IS NOT PREPARED TO DO SO AT THE COST OF LOSING MARKET SHARE.

02654 DANESHKHU, $S$

SAUDIS IN' THE DRIYING SEAT

MIDDLE EAST INTERNATIOMAL, (396) (MAR 91), 16-17.

THE FIRST OPEC MEETING SINCE THE GULF HAR WAS HELD ON MARCH 11 AND 12 IN GENEVA. BY ALL ACCDUNTS, THE MEETING WAS DOMINATED BY SAUDI ARABIA. THE SAUDIS WERE QUICK TO USE THEIR POST-HAR ENERGY TO IMPLEMENT A "VOLUNTARY" PLAN FOR A FIVE-PERCENT REDUCTION IN OIL OUTPUT AMONG OPEC NATIONS. OTHER OPEC NATIONS WANTED FURTHER REDUCTIONS TO KEEP OIL PRICES FROM FALLING BELOW THE \$21 A BARREL PROCE ESTABLISHED LAST JULY, BUT THE SAUDIS HERE INSISTENT. THE APPARENT SAUDI CONTROL OF THE PROCEEDINGS LED TO ARAB FEARS THAT SAUDI--AND INDIRECTLY OPEC--OIL POLICY WILL NOW BE DETERMINED BY THE UNITED STATES.

02655 DANFORTH, $K$.

THE BREAKUP OF YUGOSLAVIA

EUROPE, (314) (MAR 92), 22-27

THE ILLUSION OF PERPETUAL PEACE IN EUROPE WAS SHATTERED IN 1991 WHEN ETHNIC HATRED AND TERRITORIAL AMBITIONS THAT HAD BEEN SUPPRESSED BY YUGOSLAV COMMUNISM FOR FORTY-SIX YEARS ERUPTED IN VIOLENCE SHOCKINGLY REMINISCENT OF HORLD WAR II. PERHAPS THE MOST HORRIFYING FEATURE OF THE SERBOCROATIAN WAR IS THE DELIBERATE SLAUGHTER OF THOUSAMDS OF CIVILIANS BY ARTILLERY BOMBARDMENT. MORE THAN 10,000 PEOPLE HAYE ALREADY BEEN KILLED IN THE YUGOSLAY WAR. AN ESTIMATED 400,000 CROATIAN HOMES HAYE BEEN LOOTED. THEN DESTROYED OR SEIZED BY SERBS. MORE THAN HALF A MILLION PEOPLE ARE REFUGEES. EUROPEAN COMMUNITY AND UNITED NATIONS ATTEMPTS TO NEGOTIATE A SOLUTION TO THE CONFLICT HAVE BEEN UNSUCCESSFUL.

02656 DANIEL, J.

SCHOOL FOR SCANDALS: JAPAN'S LONG-RUNHING POLITICAL SOAP SCHOOL FOR SCANDALS: JAPAN'S LONG-RUNNING POLITICAL SOAP
JAPAN TIMES (WEEKLY INTERNATIONAL EDITION), 32(12) (MAR JAPAN TIME 3.

92 ), 3 . RECENT POLITICAL SCANDALS IN JAPAN. HE CLAIMS THAT THE BRITISH ELECTORATE IS INCREASINGLY CYNICAL ABOUT THE BUSINESS WORLD BUT STILL EXPECTS HONESTY FROM ITS POLITICIANS. BRITISH POLIIICIANS KNOW THAT CORRUPTION WILL NOT BE TOLERATED, AND THIS ACTS AS A POWERFUL DETERRENT.

02657 DANIELS, C.R.

COMPETING GENDER PARADIGMS: GENDER OIFFERENCE, FETAL
RIGHTS, AND THE CASE OF JOHNSON CONTROLS

POLICY STUDIES REVIEW, 10(4) (WIN 92), 51-68.

POLITICAL DEBATES OVER THE CONCEPT' OF FETAL RIGHTS REVOLVE AROUND QUESTIONS REGARDING THE MEANING OF BIOLOGICAL GENDER OIFFERENCE FOR GENDER EOUALITY. CAN THE STATE'S OBLIGATION TO PROTECT FETAL HEALTH BE USED TO MODIFY OR CONTROL WOMEN'S BEHAVIOR? IF SO, WHAT DOES THIS MEAN FOR WOMEN'S STATUS AS FULL AND EQUAL CITIZENS IN A DEMOCRATIC SOCIETY? IN THIS PAPER, THE AUTHOR ADDRESSES THESE QUESTIONS THROUGH AN ANALYSIS OF THE POLITICAL, LEGAL, MORAL, AND
SCIENTIFIC DEBATES OVER FETAL PROTECTION POLICIES IN HAZARDOUS WORKPLACES. SHE USES THE POLICY OF THE JOHNSON CONTROLS COMPANY AS A CASE STUDY.

02658 DANIELS, P.

THE DEMOCRATIC PARTY OF THE LEFT AND THE 1992 ITALIAN GENERAL ELECTION

URNAL OF COMMUNIST STUDIES, 8(3) (SEP 92), 129-134.

THE ITALIAN GENERAL ELECTION OF APRIL 1992 HAS HELD

AGAINST A BACKGROUND OF POLITICAL CHANGE. ONE OF THE NEW

ELEMENTS ON THE ELECTORAL SCENE WAS THE DEMOCRATIC PARTY OF THE LEFT (PDS). THIS ARTICLE REPORTS ON THE ELECTION AND CONCLUDES THAT THE 1992 ELECTION RESULTS PORTEND A DIFFICULT
FUTURE FOR THE PDS. IN THE FALL-OUT FROM A MILAN CORRUPTION FUTURE FOR THE PDS. IN THE FALL-OUT FROM A MILAN CORR DEVELOPING A MORE STREAML INED PARTY STRUCTURE AND ABOLISHING DEVELOPING A MORE STREAMLINED
THE TRADITIONAL CADRE SYSTEM.

02659 DANIELS, R.

THE LIMITS OF GORBACHEV'S REFORM

NEH LEADER, LXXIV(2) (JAN 91) 7-9

AN ANALYSIS OF THE EVENTS OF THE PAST FIVE YEARS IN THE SOVIET UNION REVEALS THAT MIKHAIL GORBACHEV HAS ACHIEVED TWO EPOCHAL SUCCESSES, AND HAS SUFFERED TWO PAINFUL FAILURES. THE SUCCESSES HERE VIRTUALLY UNPRECEDENTED: HE ALMOST COMPLETELY DISMANTLED THE STALINIST TOTAL ITARIAN SYSTEM, AND HE WITHDREW FROM SUPERPOWER CONFRONTATION AND THE EAST EUROPEAN EMPIRE--IN BOTH CASES WITHOUT THE USE OF FORCE. BUT HIS SUCCESSES CONTAINED THE SEEDS OF FAILURE: THEY PRODUCED THE NEAR-PARALYSIS OF THE SOVIET ECONOMY, AND THEY TRIGGERED THE RAPID DISSOLUTION OF THE SOVIET UNION INTO ITS CONSTITUENT NATIONALITY ELEMENTS--TO THE EMBITTERMENT OF THOSE WHO COMMANDED THE RESIDUAL INSTRUMENTS OF COERCION, THE ARMY AND THE POLICE. WHILE GORBACHEV IS ATTEMPTING TO THE ARMY AND THE POL ICE. WHILE GORBACHEV IS ATTEMPTING TO
PUT THE BRAKES ON REFORM, IT IS UNLIKELY THAT HE HILL BE PUT THE BRAKES ON REFORM, IT IS UNLIKELY THAT HE HIL
SUCCESSFUL: SOVIET SOCIETY IS NOH FAR TOO MODERN,

SOPHISTICATED AND COMPLEX TO BE RUN IN THE OLD MONOLITHIC WAY.

02660 DANIELS, R.S. A MATTER OF FAIRNESS: THE EQUITY OF URBAN GENERAL ASSISTANCE

POLICY STUDIES REVIEW, 11(1) (SPR 92), 165-176.

ALTHOUGH GENERAL ASSISTANCE IS THE "SAFETY NET" OF THE $U$. S. WELFARE SYSTEM, THE GENERAL ASSISTANCE PROGRAMS IN MOST STATES REFLECT THE GOAL OF COST CONTAINMENT MORE CLEARLY THAN THE GOAL OF EQUITY. IN THIS PAPER, THE AUTHOR USES DATA FROM A 1982 SURVEY OF GENERAL ASSISTANCE PROGRAMS AS THE BASIS FOR A CAUSAL ANALYSIS. HE FINDS THAT THE SUBSTANTIAL VARIATIONS ACROSS STATES SEEM TO BE BASED ON THE GOVERNMENT'S WILLINGNESS TO PROVIDE SERVICES RATHER THAN NEED. STATE WELFARE COMMITMENT IS THE MOST INFLUENTIAL EXPLANATION OF GENERAL ASSISTANCE COVERAGE, ALTHOUGH PER CAPITA INCOME, POLITICAL CULTURE, PERCENT METROPOL ITAN, AND UNEMPLOYMENT RATE ALSO HAVE SOME EFFECT. CENTRALIZATION AT THE FEDERAL LEVEL MIGHT PROVIDE EOUITABLE COVERAGE, BUT THE CURRENT POLITICAL ENVIRONMENT MAKES SUCH A STEP UNLIKELY WITHOUT MAJOR CHANGES IN PUBLIC OPINION.

02661 DANIELS, R.Y.

YELTSIN IN TROUBLE AT HOME

NEW LEADER, LXXV(8) (JUN 92), 5-6.

WHILE BORIS YELTSIN STILL ENJOYS INTERNATIONAL ACCLAIM FOR HIS ROLE IN RESISTING THE HARD-LINE COUP IN THE SOVIET UNION, HE IS COMING UNDER INCREASING FIRE AT HOME. IT IS BECOMING MORE APPARENT THAT, ASIDE FROM DISMANTLING THE SOVIET UNION AMD ELIMINATING THE COMMUNIST PARTY'S HOLD ON POWER YELTSIN HAS LITTLE IN THE WAY OF CONCRETE PROPOSALS OR PROGRAMS DESIGNED TO SHORE UP RUSSIA'S AILING ECONOMY. OR PROGRAMS DESIGNED TO SHORE UP RUSSIA'S AILING ECONOMY. INCREASING NUMBERS OF ERSTHHILE SUPPORTERS ARE TURNING AGAINST YELTSIN BECAUSE OF HIS RETICENCE TO ADOPT NEEDED
ECONOMIC REFORMS AND HIS GROHING AUTHORITARIAN TENDENCIES.

02662 DANILOVICH, A.

ON NEH MILITARY DOCTRINES OF THE CIS AND RUSSIA JOURNAL OF SOVIET MILITARY STUDIES, 5(4) (DEC 92), 517-538. THE CIS AND RUSSIA MUST WORK OUT A COMPLETELY NEW DOCTRINE WHICH WILL DIFFER FUNDAMENTALLY FROM PREVIOUS SOVIET MILITARY DOCTRINE BECAUSE OF POLITICAL AND MILITARY CIRCUMSTANCES. THIS ARTICLE STUDIES BASIC SECURITY MODELS, GENERAL PRINCIPLES OF MILITARY DOCTRINES AND ITS MAJOR TENENTS, AND THE NATURE OF MILITARY THREATS--ENEMIES AND ALLIES. IT CONCLUDES HITH BASIC TENENTS OF THE MILITARYTECHNICAL ASPECTS OF MILITARY DOCTRINE. 
02663 DANIN, R.

MOSCOW AND THE MIDDLE EAST PEACE CONFERENCE AFTER THE COUP MIDDLE EAST INSIGHT, 8(2) (SEP 91), 4-8.

IN THE WAKE OF THE AUGUST COUP, MOSCOW'S ATTITUDE TOWARDS THE PROPOSED MIDDLE EAST PEACE CONFERENCE SEEMS PARADOXICAL: DESPITE CONTINUED UPHEAVAL WITHIN THE SOVIET UNION, THE GOVERNMENT OF MIKHAIL GORBACHEV APPEARS MORE INTERESTED NOW THAN BEFORE THE AUGUST PUTSCH IN COSPONSORING THE REGIONAL PEACE TALKS. INDEED, WHILE MOSCOW'S INTEREST IN MANY KEY THIRD WORLD ISSUES HAS WANED, THE SOVIETS DO NOT APPEAR TO BE PREPARING TO DISENGAGE FROM THE SOVIETS DO NOT APPEAR TO BE PREPARING TO DISENGAGE FROM THE
MIDDLE EAST. THIS IS BECAUSE THE SOVIETS VIEW THE MIDOLE MIDDLE EAST. THIS IS BECAUSE THE SOVIETS VIEW THE MIDDLE
EAST IN A MANNER UNLIKE OTHER AREAS OF THE WORLD WHICH HAVE EAST IN A MANNER UNLIKE OTHER AREAS OF THE WORLD WHICH HAV
SERVED AS AN ARENA FOR SUPERPOWER RIVALRY DURING THE COLD SERVED AS AN ARENA FOR SUPERPOWER RIVALRY DURING THE COLD
WAR. THE VAST REGION ON THE SOVIET UNION'S SOUTHERN BORDER WAR. THE VAST REGION ON THE SOVIET UNION'S SOUTHERN
PRESENTS NEW AND VALUABLE OPPORTUNITIES, AS WELL AS PRESENTS NEW AND VALUABLE OPPORTUNITIES, AS WELL AS

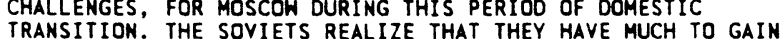
TRANSITION. THE SOVIETS REALIZE THAT THEY HAVE MUCH TO GAIN AND LITTLE TO LOSE BY

02664 DANIN, R.M.

TAJIKISTAN'S TURBULENT SPRING

MIDDLE EAST INSIGHT, VIII (6) (JUL 92), 33-38

POLITICAL DEMONSTRATIONS AND VIOLENCE DOMINATED THE

SPRING OF 1992 IN TAJIKISTAN. BY THE FALL, POLITICAL

PARALYSIS HAD SET IN AND THE COUNTRY WAS BEING GOVERMED

NOMINALLY BY THE LEGISLATIVE SPEAKER. TAJIKISTAN NOW FACES

THE LIKELY PROSPECT OF MORE TURMOIL AND FIGHTING THAT COULD

ESCALATE INTO CIVIL WAR AND THE NATION'S FRAGMENTATION ALONG

REGIONAL LINES. TWO DRAMATIC TRENDS ARE EVIDENT: FIRST,

ISLAM IS PLAYING AN INCREASINGLY PROMINENT ROLE IN THE

TAJIKS' PERSONAL AND POL ITICAL LIVES. SECONDLY, PERSIAN-

02665 DANNHAEUSER, $N$.

FORMAL-SECTOR RETAIL TRADE IN THE URBAN THIRD WORLD:

CONCEPTUAL ISSUES AND THE CASE OF NASIK CITY, INDIA ECONOMIC DEVELOPMENT AND CULTURAL CHANGE, 39(2) (JAN91), $311-330$.

IT IS NOT KNOWN WHETHER THE FORMAL TRADE SECTOR IN THE URBAN THIRD WORLD IS GROWING AT THE EXPENSE OF THE INFORMAL ONE, BUT THERE IS LITTLE DOUBT THAT IN MOST SOCIETIES IT IS EXPANDING IN ABSOLUTE TERMS. THIS DEVELOPMENT WARRANTS STUDY BECAUSE IT IS ESPECIALLY THROUGH THE FORMAL SECTOR THAT INNOVATIONS ARE INTRODUCED THAT CAUSE A TRANSFORMATION THE CHARACTER OF THIRD WORLD URBAN TRADE, CONSUMPTION
PATTERNS, AND CULTURE FROM TRADITIONAL FORMS TO ONES ATTUNED PATTERNS, AND CULTURE FROM TRADITIONAL FORMS TO ONES ATTUNEC
TO A MASS MARKET. THIS ARTICLE SEEKS TO CLARIFY CERTAIN TO A MASS MARKET. THIS ARTICLE SEEKS TO CLARIFY CERTAIN AMBIGUITIES CONCERMING THE CONCEPT OF FORMAL RETAIL TRADE
AND DESCRIBE THE FORMAL RETAIL SECTOR OF A SECONDARY CITY IN AND DESCRIBE THE FORMAL RETAIL SECTOR OF A SECONDARY INTRODUCED MODERN/HESTERN THEMES INTO THE LOCAL TRADE COMMUNITY.

02666 DANOPOULOS, C.

DEMOCRATISING THE MILITARY: LESSONS FROM MEDITERRANEAN EUROPE

WEST EUROPEAN POLITICS, 14(4) (OCT 91), 25-41.

THE FACTORS AND PROCESSES INVOLYED IN DEMOCRATIZING THE

ARMED FORCES OF SPAIN, GREECE AND PORTUGAL IN THE 1970S AND $1980 S$ ARE ANALYZED. AFTER A REVIEW OF THE HISTORY OF CIVILMILITARY RELATIONS IN THE TREE COUNTRIES, THE ARTICLE EXAMINES THE ROLE OF SOCIETAL, INSTITUTIONAL AND INTERNATIONAL FACTORS IN THE DEMOCRATIZATION PROCESS. IT CONCLUDES THAT MILITARY PROFESSIONALISM CAN BE A STIMULANT TO THE INTERVENTION AND DE-INTERVENTION, DEPENDING ON SOCIETAL CONSIDERATIONS AND THE PERCEPTIONS OF THE MILITARY AT A GIVEN TIME.

02667 DANZIGER, J.

INTERGOVERNMENTAL STRUCTURE AMD FISCAL MANAGEMENT STRATEGIES: A CROSSHATIONAL AMALYSIS

GOVERNANCE, 4(2) (APR 91), 168-183.

USING EMPIRICAL DATA FROM MORE THAN 800 LOCAL GOVERNMENTS IN FIVE COUNTRIES, THIS ARTICLE CONCLUDES THAT INTERGOVERMMENTAL STRUCTURE IS ASSOCIATED WITH IMPACT ATTRIBUTED TO VARIOUS FISCAL MANAGEMENT STRATEGIES. SUCH STRATEGIES HAVE GENERALLY HAD GREATER IMPACT IN LOCAL GOVERMMENTS THAN THOSE IN UNITARY STATE SYSTEMS. THESE FINDINGS SUGGEST THAT LOCAL GOVERMMENTS IN MORE DECENTRALIZED SYSTEMS HAVE GREATER FLEXIBILITY TO MANIPULATE DECENTRALIZED SYSTEMS HAVE GREATER FLEXIBILITY TO MANIPULAT
RELATIONS WITH OTHER GOVERNMENTS IN ORDER TO ENHANCE THEIR RELATIONS HITH OTHER GOVERNMENTS IN ORDER TO ENHANCE
OWN FISCAL SITUATION. THE DATA ALSO SUGGEST THAT THE OWN FISCAL SITUATION. THE DATA ALSO SUGGEST THAT THE
GOVERNMENT'S LEVEL OF FISCAL STRESS IS NOT SYSTEMATICALLY GOVERNMENT'S LEVEL OF FISCAL STRESS IS NOT SYSTEMATICAL MANAGEMENT STRATEGIES, ESPECIALLY IN UNITARY STATE SYSTEMS.

02668 DAOYI, $Z$.

THE FOUR CHINESE UNDERSECRETARIES-GENERAL OF THE U.N. BEIJING REVIEH, 35 (34) (AUG 92), 34-36.

THE AUTHOR PROFILES THE FOUR CHINESE DIPLOMATS WHO HAVE HELD THE POSITION OF UNDERSECRETARY-GENERAL OF THE UNITED
NATIONS SINCE OCTOBER 1971 WHEN CHINA RESUMED ITS SEAT IN THE U.N.

02669 DAOYU, $L$

THE RIGHT TO DEVELOPMENT AN INALIENABLE HUMAN RIGHT BEIJING REVIEW, 35(51) (DEC 21), 12-13.

THE AUTHOR, HO IS CHINA'S AMBASSADOR TO THE UNITED NATIONS, EXPLAINS CHINA'S POSITION ON THE AGENDA FOR THE 1993 WORLD CONFERENCE ON HUMAN RIGHTS. HE STATES THAT, FIRST OF ALL. THE HORLD CONFERENCE SHOULD GIVE PRIORITY TO THE ISSUE OF THE GROSS VIOLATIONS OF HUMAN RIGHTS RESULTING FROM RACISM, APARTHEID, COLONIALISM, AND FOREIGN AGGRESSION AND RACISM, APARTHEID, COLONIALISM, AND FOREIGN AGGRESSION AND INTERNATIONAL ECONOMIC ORDER GRAVELY HINDERS THE SOCIAL AND INTERNATIONAL ECONOMIC ORDER GRAVELY HINDERS THE SOCIAL AMD
ECONOMIC DEVELOPMENT OF THE THIRD WORLD, THE CONFERENCE ECONOMIC DEVELOPMENT OF THE THIRD WORLD, THE CONFERENCE
SHOULD NOT ONLY REAFFIRM THAT THE RIGHT TO DEVELOPMENT IS AN SHOULD NOT ONLY REAFFIRM THAT THE RIGHT TO DEVELOPMENT IS AM INALIENABLE RIGHT BUT INTRODUCE EFFECTIVE MEASURES FOR THE
REALIZATION OF THIS RIGHT. THIRDLY, THE CONFERENCE SHOULD EMPHASIZE THE INDIVISIBILITY AND INTERDEPENDENCY OF EMPHASIZE THE INDIVISIBILITY AND INTERDEPENDENCY OF UNIVERSALITY, OBJECTIVITY, IMPARTIALITY, AND NON-SELECTIVITY OF HUMAN RIGHTS. FOURTHLY, THE CONFERENCE SHOULD REITERATE THE PRINCIPLE OF STATE SOVEREIGNTY. FINALLY, IT SHOULD ENHANCE INTERNATIONAL COOPERATION IN THE FIELD OF HUMAN
RIGHTS, BASED STRICTLY ON THE PURPOSES AND PRINCIPLES OF THE U.N. CHARTER AND ON MUTUAL RESPECT AND EQUALITY.

02670 DARDEN, J.T.; DULEEP, H.O.; GALSTER, G.C.

CIVIL RIGHTS' IN METROPOLITAN AMERICA

JOURNAL OF URBAN AFFAIRS, 14(3-4) (1992), 469-496.

THE AUTHORS FOCUS ON THREE AREAS OF CIVIL RIGHTS POLICY: HOUSING, EDUCATION, AND EMPLOYMENT. THEY DESCRIBE THE CURRENT STATE OF DISCRIMINATION AND/OR SEGREGATION IN EACH AREA AND ANALYZE THE COSTS, DIAGNOSE PAST FAILURES OF PUBLIC POLICIES, AND PROPOSE NEW STRATEGIES. THEY RECOMMEND BOTH ANTI-DISCRIMINATION AND PRO-INTEGRATION POLICIES, ARGUIMG THAT ONE CANNOT PROCEED EFFECTIVELY WITHOUT THE OTHER. THEY SHOW HOW LINKS AMONG THE HOUSING, EDUCATION, AND EMPLOYMENT COMPONENTS FORM A RACIST METROPOI ITAN STRUCTURE THAT EXACTS HIGH SOCIAL COSTS AND MUST BE ATTACKED HITH A COMPREHENSIVE CIVIL RIGHTS STRATEGY.

02671 DARILEK, R.E.

CONFIDENCE BUILDING AND ARMS CONTROL IN THE EAST-HEST CONFIDENCE BUILDING AND ARMS CONTROL IN THE EAST-HEST KOREAN JOURNAL OF DEFENSE ANALYSIS, IV (2) (WIN 92),

207-244.

THIS PAPER ATTEMPTS TO DEFINE BROADLY APPLICABLE LESSONS FOR THE FUTURE FROM THE HISTORY OF ARMS CONTROL THAT OEVELOPED DURING THE FORMER EAST-WEST RIVALRY IN EUROPE. IT ALSO EXPLORES THE POSSIBILITY OF APPLYING THESE LESSONS TO OTHER REGIONS OF THE WORLD. IN PARTICULAR, THE PAPER ASKS WHETHER CONFIDENCE-BUILDING MEASURES (CBMS), OTHER SIMILAR MEASURES, AND VERIFICATION PROVISIONS ORIGINALLY DESICHE
ADORESS COLD-WAR CONOITIONS IN EUROPE CAN USEFULLY BE APPLIED TO THE RESOLUTION OF POLITICAL-MILITARY EUROPEAN EXPERIENCE THAT MAY BE APLLIED ELSEWHERE INCLUDE THE FOLLOWING: THE RANGE OF MEASURES THAT IS LIKELY TO PROVE USEFUL AMONG ADVERSARIES IS RATHER LIMITED; THERE IS A RELATIONSHIP BETWEEN POLITICAL AND ARMS CONTROL DEVELOPMENTS ; BREACHING THE WALL OF SECRECY THAT ADVERSARIES TEND TO ERECT AROUND THEIR MILITARY ESTABLISHMENTS IS THE SINGLE MOST IMPORTANT CONTRIBUTION THAT INITIAL CBM AGREEMENTS CAN MAKE; AND, MULTILATERAL ARMS CONTROL NEGOTIATIONS AND AGREEMENTS ARE NOT NECESSARILY INFERIOR TO THEIR BILATERAL COUNTERPARTS.

02672 DARNOVSKY, M.; KAUFFMAN, L.; ROBINSON, B. WARRING STORIES--READING AND CONTESTING THE NEW HORLD ORDER SOCIALIST REVIEW, 21(1) (JAN 91), 11-26. THE GULF WAR SEEMS TO CALL NOT JUST FOR LARGE-SCALE ORGANIZING AND RESISTANCE BUT ALSO FOR A HHOLESALE REASSESSMENT OF OPPOSITIONAL THEORIES AND CRITIQUES. THIS ARTICLE SEEKS TO UNTANGLE THE PERPLEXITIES BY THINKING CAROUGH THE WAYS IN WHICH EXISTING FRAMEHORKS OF ANALYSIS CAN STILL AID UNDERSTANDING AND THE WAYS THEY FALL SHORT. IT POST-COLD WAR, FEMINIST, MEDIA CONTROL, AND LEGACY-OFPOST-COLD WAR, FEMINIST, MEDIA CONTROL, AND LEGACY-OF-
VIETNAM PERSPECTIVE. WHILE NO SINGLE YIEWPOINT SUFFICIENTLY VIETNAM PERSPECTIVE. WHILE NO SINGLE VIEWPOINT SUFFICI
ANSHERS ALL THE QUESTIONS AND CALMS FEARS, THEY ALL ANSHERS ALL THE QUESTIONS AND CALMS
CONTRIBUTE SOMEWHAT TO UNDERSTAMD.

02673 DARTNELL, M.

DARTNELL, M. FRANCE'S ACT

REVOLUTION
TERRORISH AND POLITICAL VIOLENCE, 2(4) (HIN 90), 457-488. THIS ARTICLE FOCUSES ON THE IDEOLOGY OF THE FRENCH TERRORIST GROUP ACTION DIRECTE. ACTIVE FROM 1979 UNTIL 1987, AD WENT THROUGH SEVERAL PHASES OF IDEOLOGICAL CHANGE. IT WAS ORIGINALLY INFLUENCED BY BOTH ANARCHISH AND MAOISM. IN THE EARLY 1980S, THE GROUP SUBSTANTIALLY REVISED ITS IDEOLOGY. FORTH IN A NUMBER OF COUNTRIES DURING THE 1980S. AFTER THIS 
POINT, AD DREW THE INSPIRATION FOR ITS ATTACKS FROM A STRUGGLE AGAINST NATO AND THE 'AMERICANIZATION' OF EUROPE. THESE MOTIVES PRODUCES A SPIRAL OF VIOLENCE AFTER 1984 AND CULMINATED IN A SERIES OF ASSASSINATION ATTEMPTS AGAINS FRENCH BUSINESS AND MILITARY FIGURES. THROUGHOUT, AD ATTEMPTED TO REALIZE THE SAME GOAL: THE ASSEMBLY OF A SOCIAL GROUP WILLING/CAPABLE OF TAKING UP THE BATTLE FOR COMMUNIST REVOLUTION. THIS GOAL WAS AD'S 'SEARCH FOR REVOLUTION'.

02674 DAS, $N$.

CHINA'S QUEST FOR DEMOCRACY

CHINA REPORT, 28(2) (APR 92), 113-124.

THIS ARTICLE BRIEFLY RECOUNTS THE HISTORY OF CHINA'S DECADES-LONG SEARCH FOR DEMOCRACY. IMPORTANT MILESTONES IN THIS SEARCH INCLUDE SUN YAT SEN'S FOUNDING OF THE KUOMINTANG, THE ESTABLISHMENT OF A CONSTITUTION IN 1947, THE CHINESE COMMUNIST PARTY'S INSISTENCE ON CREATING A "SMALL DEMOCRACY" AFTER ITS ASCENSION TO POWER, AND THE PRO-DEMOCRACY PROTESTS AT TIANANMEN SOUARE. THE ARTICLE ARGUES THAT THE CHINESE COMMUNIST PARTY HAS FAILED TO FULFILL ITS TWIN OBJECTIVES OF ERADICATIMG POVERTY AMONG THE MASSES AND ATTAINING THE STATUS OF A MODERN, POHERFUL NATION. THEREFORE, ITS JUSTIFICATION FOR BLOCKING DEMOCRATIC REFORMS IS NOT COMPELLING. FURTHERMORE, DESPITE THE REFORMIST RHETORIC OF HAS NOT YET FOUND THE DEMOCRACY IT HAS BEEN SEARCHING FOR.

02675 DASGUPTA, P. : WEALE, $M$ ON MEASURING THE QUALITY OF LIFE WORLD DEVELOPMENT, 20(1) (JAN 92), 119-131. BECAUSE PER CAPITA INCOME IS NÓT AN ADEQUATE INDICATOR OF AGGREGATE WELL-BEING, IT HAS BECOME CUSTOMARY TO USE A RANGE OF SOCIOECONOMIC INDICES FOR ASSESSING THE OUALITY OF LIFE IN A SOCIETY. IN THIS PAPER, THE AUTHORS EXTEND MEASURES OF GENERAL WELL-BEING IN CURRENT USE BY INCLUDING ORDINAL INDICES OF POLITICAL AND CIVIL LIBERTIES, AND THEY PROVIDE A RANKING OF THE WORLD'S POOREST COUNTRIES ON THE BASIS OF THE BORDA RULE. THEN THEY COMPARE IMPROVEMENTS IN SOCIOECONOMIC PERFORMANCE WITH THE AVAILABILITY OF POLITICAL AND CIVIL LIBERTIES DURING THE DECADE OF THE 1970'S AND OBSERVE THAT IMPROVEMENTS IN PER CAPITA NATIONAL INCOME, LIFE EXPECTANCY AT BIRTH, AND INFANT MORTALITY ARE
POSITIVELY CORRELATED WITH THE EXTENT OF POLITICAL AND CIVIL LIBERTIES ENJOYED BY CITIZENS, WHILE IMPROVEMENTS IN

LITERACY ARE NEGATIVELY CORRELATED WITH THESE LIBERTIES

02676 DATOR, J

LOOKING FOR EUROPE FROM THE OUTSIDE

TURES, $24(5)$ (JUN 92), 507-510.

THIS ESSAY LOOKS AT THE NATURE OF THE NEW EUROPE AND OUTLINES A NUMBER OF FUTURE TRENDS, FOCUSING ON EUROPE'S ROLE IN WORLD POLITICS AS SEEN FROM AN AMERICAN PERSPECTIVE. ISSUES EXAMINED INCLUDE THE TREND TOWARDS EURO-

CENTRALIZATION, THE GRADUAL DISAPPEARANCE OF NATIONAL BORDERS, AND, PARADOXICALLY, THE GROWTH OF NATIONALIST, ETHNIC, AND RACIST TENSIONS.

02677 DAUDELIN, J.

POLITICAL DEPENDENCE AND RELIGIOUS POLICY: PROTESTANTS AND THE STATE IN PRE-REVOLUTIONARY NICARAGUA (1937-1979) JOURNAL OF CHURCH \& STATE, 34(2) (SPR 92), 229-258. THE AUTHOR EXAMINES THE RELATIONSHIPS AMONG U.S. INTERESTS IN NICARAGUA, THE ACTIVITIES OF PROTESTANT MISSIDNARIES IN NICARAGUA, AND THE NICARAGUAN GOVERNMENT'S ATTITUDES TOWARD EVANGEL ICAL CHURCHES IN THE PREREVOLUTIONARY ERA. HE BEGINS HITH A REYIEW OF THE CONSTITUTIONAL AND LEGAL DISPOSITIONS PERTAINING TO THE ACTIVITIES OF THE EVANGELICAL CHURCHES IN NICARAGUA FROM THE BEGINMING OF THE 2OTH CENTURY UNTIL THE END OF THE SOMOZA ERA. THEN HE EXAMINES THE RELATIONSHIP BETHEEN THE STATE AND 1937 TO 1979.

02678 DAUSTER, H.G.

BUDGET PROCESS ISSUES FOR 1993

JOURMAL OF LAW \& POLITICS, IX(1) (FAL 92), 9-38.

THE AUTHOR EXPLAINS HOH THE BUDGET ENFORCEMENT ACT OF 1990 WILL SET THE STAGE FOR BUDGET ACTION IN 1993. HE IDENTIFIES THE MOTIVATIONS THAT WILL UNDERLIE THE CONSIDERATION OF THE BUDGET, AND HE RECOMMENDS THAT THE PRESIDENT AND CONGRESS REJECT THE USE OF FIXED DEFICIT PRESIDENT AND CONGRESS REJECT THE USE OF FIXED DEFICIT
TARGETS AND ENTITLEMENT CAPS. HE DESIRES AND ENDORSES THE TARGETS AND ENTITLEMENT CAPS. HE DESIRES AND ENDORSES
CONGRESSIONAL BUDGET OFFICE'S ALTERHATIVE FOR DEFICIT CONGRESSIOI

02679 DAVID, F

SOPHISTICATION IN CORPORATE PAC CONTRIBUTIONS DEMOBILIZING THE OPPOSITION

AMERICAN POLITICS QUARTERLY, 20(4) (OCT 92), 388-410.

THIS RESEARCH EXAMINES THE EXTENT TO WHICH HIGHLY FUNDED CORPORATE POL ITICAL ACTION COMMITTEES' (PACS) CONTRIBUTIONS REFLECT CONCERNS ASSOCIATED HITH PAC LEADERS. FOUR AIRLINE AND THREE RAIL COMPANY PACS' CONTRIBUTIONS TO HOUSE CANDIDATES IN THE 1980 ELECTION ARE ANALYZED. RESULTS REVEAL
THAT, CONTRARY TO PAST FINDINGS REGARDING HIGHLY FUNDED ASSOCIATION PACS. THE CONTRIBUTIONS OF THESE CORPORATE PACS REFLECT PRIORITIES GENERALLY ASSOCIATED WITH PAC LEADERS. IN PARTICULAR, THESE PACS MADE LARGER CONTRIBUTIONS TO CANDIDATES WHO WERE LIKELY TO OPPOSE THEM THAN THEY OID TO CANDIDATES WHO WERE AMONG THEIR EXPECTED SUPPORTERES IN AN APPARENT ATTEMPT TO DEMOBILIZE OPPOSITION.

02680 DAVID, $J$.

A THO-ROW VIOLATION

CULTURAL SURVIVAL QUARTERLY, 16(3) (FAL 92), 12-13.

ON JULY 11, 1990 , AN ARMED CONFLICT HAS SPARKED WHEN

POLIICE ASSAULTED A MOHAWK BARRICADE ERECTED TO PROTECT A PINE FOREST FROM A GOLF COURSE EXPANSION IN KANEHSATAKE, QUEBEC, WHICH ADJOINS THE WHITE COMMUNITY OF OKA. FOR THREE MONTHS, OKA WAS AN ISSUE TALKED ABOUT AROUND THE WORLD AS CANADA LAID SIEGE TO THO MOHAWK COMMUNITIES AND MOBILIZED THE ENTIRE FIFTH BRIGADE - 3,400 TRDOPS - OF THE CANADIAN OVER 100 MOHAWKS AND THEIR SUPPORTERS, CHARGING THEM WITH OBSTRUCTING PEACE OFFICERS, RIOTING, A ND POSSESSION OF HEAPONS DANGEROUS TO THE PUBLIC PEACE. MOST PLED GUILTY, AND WEAPONS DANGEROUS TO THE PUBLIC PEACE. MOST PLED GUILTY, AND
MANY CASES WERE DROPPED. BUT IN THE CASE OF THOSE PROTESTERS MANY CASES WERE DROPPED. BUT IN THE CASE OF THOSE PROTESTERS TRAPPED AT A TREATMENT CENTER DURING SEPTEMBER 1990, NO PLEA
WAS ENTERED, AND NEARLY THO YEARS LATER THE LARGEST TRIAL IN WAS ENTERED, AND NEARLY THO YEARS LATER THE LARGEST TRIAL IN CANADIAN HISTORY TOOK PLACE. IN HIS CLOSING ARGUMEMTS

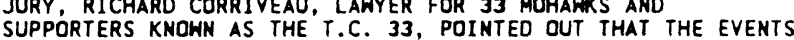
SUPPORTERS KNOWN AS THE Y.C. 33, POINTED OUT THAT THE EVENTS OF 1990 HERE A MANIFESTATION OF DEEPLY FELT BELIEFS ON THE PART OF THE MOHAHK PEOPLE AND THAT CERTAIN THINGS IN THIS
COUNTRY WOULD HAVE TO STOP. NAMELY THE OPPRESSION OF NATIVE NATIONS. A NOT-GUILTY VERDICT, HE SAID, WOULD DEMONSTRATE THAT THE JUSTICE SYSTEM HAS BEGUN TO UNDERSTAND. A BLANKET ACQUITTAL WAS ANNOUNCED ON JULY 3, 1992.

02681 DAVID, S

WHY THE THIRD HORLD STILL MATTERS

INTERNATIONAL SECURITY, 17 (3) (WIN 92), 127-159.

THE END OF THE COLD WAR AND THE DISINTEGRATION OF THE SOVIET UNION HAVE NOT ENDED THE IMPORTANCE OF THE THIRD WORLD TO AMERICAN INTERESTS AND WORLDWIDE STABILTIY, NOR HAVE THEY USHERED IN A NEW ERA OF PEACE. THIS ARTICLE CONSIDERS THE IMPACT OF THE SUPERPOWER CONPETITION AND ITS DEMISE IN DEFINING THE IMPORTANCE OF THE THIRD WORLD TO THE UNITED STATES. IT THEN EXAMINES WHY THE CHARACTERISTICS OF MANY THIRD WORLD COUNTRIES MAKE THEM MORE LIKELY TO BE BESET BY INSTABILTY AND WAR THAN OTHER STATES. IT DISCUSSES THE INCREASING CAPABILITY OF THIRD WORLD STATES TO THREATEN AMERICAN INTERESTS AND WORLD PEACE. IT CONSIDERS SPECIFIC WAYS THAT THE INSTABILTIY OF THIRD WORLD STATES COMBINED WITH THEIR GROHING STRENGTH POSES A THREAT TO AMERICAN INTERESTS. IT CONCLUDES WITH SOME BROAD SUGGESTIONS FOR AMERICAN POLICY.

02682 DAVIDHEISER, E.B.

STRONG STATES, WEAK STATES: THE ROLE OF THE STATE IN REVOLUTION

COMPARATIVE POLITICS, 24(4) (JUL 92), 463-475.

PAST STUDIES ADDRESSING THE ROLE OF THE STATE IN REVOLUTION HAVE ARGUED THAT WEAK STATES ARE MOST OFTEN ASSOCIATED WITH REVOLUTION. THIS ESSAY ARGUES THE CONVERSE-THAT STRONG STATES ARE MORE LIKELY TO BE ASSOCIATED WITH REVOLUTION. THE ARGUMENT IS FOUNDED ON A DEFINITION OF STATE STRENGTH BASED ON THREE CRITERIA: THE DEPTH OF PENETRATION OF SOCIETY BY POLICY INSTITUTIONS, THE BREADTH OF PENETRATION OF SOCIETY BY POLICY INSTITUTIONS, AND THE PENETRATION OF THE STATE BY SOCIETY, OR PERMEABILITY. THE ARGUMENT IS BUTTRESSED BY CASE STUDIES OF RUSSIA (1870-1917), GERMANY (1871-1933), AND SWEDEN $(1870-1932)$.

02683 DAVIDOFF, $N$.

BIG SU

NEH REPUBLIC, 206 (23) (JUN 92), 10-11.

THE AUTHOR OISCUSSES DEVELOPMENTS IN THAILAND'S

POLITICAL SITUATION SINCE THE COUP OF FEBRUARY 23, 1991.

02684 DAVIDOW, M.

SOVIET TRADE UNIONS

POLITICAL AFFAIRS, 71(4) (MAY 92), 28-30.

THIS ARTICLE ARGUES THAT THE OUTSTANDING WEAKNESS TODAY IN THE STRUGGLE FOR THE RESTORATION OF A RENOVATED USSR IS IHE FAILURE OF THE WORKING CLASS TO PLAY ITS DECISIVE ROLE. THE FAILURE OF THE WORKING CLASS TO PLAY ITS DECISIVE ROLE. THIS FAILURE IS LINKED TO THE COLLABORATIONIST ROLE PLA
BY THE TOP LEADERS OF THE THO MAIN TRADE UNIONS: THE BY THE TOP LEADERS OF THE THO MAIN TRADE UNIONS: THE FEDERATION OF UNIONS AND THE INDEPENDENT TRADE UNION FEDERATION. IN ADDITION, SEVERAL FACTORS ASSOCIATED WITH UNIONS, OR HITH THE COMHUNIST PARTY OF THE SOVIET UNIOH

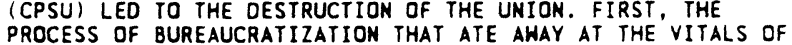
PROCESS OF BUREAUCRATIZATION THAT ATE AHAY AT THE VITA
THE CPSU ALSO GNAWED AT THE BODY OF THE TRADE UNIONS.

THE CPSU ALSO GNAWED AT THE BODY OF THE TRADE UNIONS.
SECONDLY, THE UNIONS DID NOT SUCCESSFULLY DEMOCRATIZE. THIRD, BORIS YELTSIN ISSUED A DECREE BANNING PARTY ANO TRADE UNION ORGANIZATION. AS YELTSIN CONSOL IDATED POWER, HE FURTHER CURTAILED THE POWER AND INFLUENCE OF THE TRADE UNIONS. 
02685 DAVIDOW, M.

STRENGTHENING THE PARTY: THE KEY TO SOVIET STABILITY

POLITICAL AFFAIRS, LXX(4) (APR 91), 21-27.

THIS ARTICLE EXAMINES THE EVENTS AND CHANGES THAT HAVE

LED TO THE DRAMATIC STATE OF AFFAIRS IN THE SOVIET UNION TODAY. II FOCUSES ON THE IDEOLOGICAL CHANGES THAT HAVE CHANGED THE PERCEPTION OF THE SOVIET COMMUNIST PARTY FROM THE VANGUARD OF WORLD SOCIALISM TO A BLOODTHIRSTY ANACHRONISM. THE ARTICLE ARGUES THAT THE UNPRECEDENTED OPENMESS IN THE SOVIET UNION LED TO THIS SORRY STATE. FURTHERMORE, ONLY THROUGH A STRENGTHENED COMMUNIST PARTY CAN STABILITY BE ACHIEVED IN THE SOVIET UNION.

02686 DAVIDOW, $M$.

YELTSIN'S ASSAULT ON SOCIALISM

POLITICAL AFFAIRS, 71 (3) (APR 92), 10-13.

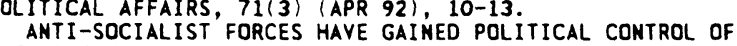
ANTI-SOCIALIST FORCES HAVE GAINED POLITICAL CONTROL OF THE SOVIET UNION. HOWEVER, THOUGH GREATLY UNDERMINED, THE
SOCIALIST ECONOMIC STRUCTURE STANDS IN THE WAY OF THE FULL SOCIALIST ECONOMIC STRUCTURE STANDS IN THE WAY OF THE FULL RESTORATION OF CAPITALISM. THUS, THE ESSENCE OF THE YELSTINGAIDER "ECONOMIC REFORM' IS POL ITICAL: THE FINAL DESTRUCTION
OF SOCIALISM'S ECONOMIC FOUNDATIONS. THIS ARTICLE DISCUSSES WHAT HAS BEEN AND IS BEING DESTROYED BY THE COUNTERWHAT HAS BEEN
REVOLUTION.

02687 DAVIDSON, B

FOR A POLITICS OF RESTITUTION

WEST AFRICA, 75(3924) (NOY 92), 2059

THE STRUCTURES OF GENUINE PARTICIPATION AND HOW TO ACHIEVE AND SAFEGUARD THEM AND MAKE THEM GROW IN AFRICA IS THE THEME OF THIS ARTICLE. BASIL DAVIDSON ARGUES THAT IF AFRICA NEEDS TO RE-STRUCTURE ITS INSTITUIONS, THAN AFRICA NEEDS TO RE-INVENT ITSELF. HE SUGGESTS THAT THE ESSENTIAL SOLUTIDN IS TO ABOLISH THAT ACUTE DISJUNCTION BETHEEN THE HISTORY OF THE PAST AND THE HISTORY OF THE PRESENT, WHICH WAS IMPOSED BY THE DISPOSSESSIONS AND THEIR CONSEQUENCES. HE CONCLUDES THAT THE NATION-STATE HAS REACHED THE END OF ITS USEFUL LIFE.

02688 DAVIDSON, B.

\section{PIRATES IN POHER}

WEST AFRICA, (3912) (SEP 92), 1514-1518

THE AUTHOR DESCRIBES THE SITUATION IN MONROVIA IN OCTOBER 1990, FOLLOWING THE EXECUTION OF PRESIDENT SAMUEL

DOE. HE STATES THAT IN DOE'S BRIEF AND VIOLENT LIFE ONE MAY SEE. HE STATES THAT IN DOE'S BRIEF AND VIOLENT LIFE ONE COLONIAL AND POSTCOLONIAL DRAMAS PLAYED OUT BY MEN WHO POSSESS THE STRENGTH AND CHARACTER TO SEIZE POHER BUT LACK THE WISDOM TO CONTROL IT.

02689 DAVIDSON, L.S.; FRATIANNI, M.; VON HAGEN, J. TESTING THE SATISFICING VERSION OF THE POL ITICAL BUSINESS CYCLE 1905-198

PUBLIC CHOICE, 73(1) (JAN 92), 21-36.

THIS PAPER DEVELOPS A TEST OF THE SATISFICING VERSION OF THE BUSINESS CYCLE. PREVIOUS TESTS HAVE FOCUSED ON MAXIMIZING MODELS OF POLITICAL BEHAVIOR AND ARE NOT SUFFICIENTLY GENERAL TO TEST FOR SATISFICING BEHAVIOR. USING ANNUAL U.S. DATA FOR THE PERIOD 1905-1984. THE AUTHORS FIND EVIDENCE SUPPORTING THE SATISFICING VERSION OF THE POLITICAL BUSINESS CYCLE MODEL, BUT THEY REJECT THE MAXIMIZING VERSION. IN ACCORDANCE WITH THE SATISFICING HYPOTHESIS, THEY FIND THAT INCREASING INFLATION OR UNEMPLOYHENT AND DECREASING MONETARY BASE GROWTH IN THE THIRD YEAR OF A PRESIDENTIAL TERM ARE FOLLOWED TYPICALLY BY REVERSALS DURING THE ELECTION YEAR.

02690 DAVIDSON, $P$

HOW TO AVOID ANOTHER GREAT DEPRESSIOM

NEW LEADER, LXXY(2) (FEB 92), 8-12,

THIS ARTICLE CONSIDERS WHETHER THE BUSH ECONOMIC REFORM PROGRAM WILL SIGNIFICANTLY IMPROVE AMERICA'S ECONOMY. IT OUTLINES THE CLAIMS AND PROGNOSTICATIONS OF FIVE GROUPS OF "ECONOMIC EXPERTS": THE FISCALLY RESPONSIBLE DO-NOTHING NEOL IBERALS. THE DO-SOMETHING TEMPORARIY PERMANENTLY ; THE DO-SOMETHING TEMPORARILY, DO-NOTHING SOMETHING LIBERALS; THE; SUPPLY-SIDE CONSERYATIVES; AND THE SINGLE UNABASHED "KEYNESIAN." THE ART ICLE CDNCLUDES THAT THE SINGLE UNABASHED "KEYNESIAN." THE ART ICLE CDNCLUDES THAT KEYNSIAN IS CORRECT: RE-ESTABLISHING A FULL EMPLOYMENT
ENYIRONMENT WOULD ENABLE MIDOLE CLASS AMERICA TO EARN ENOUGH ENVIRONMENT WOULD ENABLE MIDOLE CLASS AMERICA TO EARN ENOUGH TO PAY FOR WHAT THE ECONOMY IS CAPABLE OF PRODUCING. IT IS,
THEREFORE, THE RESPONSIBILITY OF THE GOVERNMENT TO SPENO AS THEREFORE, THE RESPONSIBILITY OF THE GOVERNMENT TO SPEND AS MUCH AS NECESSARY TO GUARANTEE A LEVEL OF AGGREGATE DEMA
THAT ENSURES EVERY AMERICAN WHO WISHES TO WORK A JOB.

02691 DAVIES, C.

A SYMPOSIUM ON FUTURISM

INTERNATIONAL SOCIAL SCIENCE REVIEW, 67(4) (FAL 92), 147-158.

THE UNITED STATES HAS BEEN THE HORLD'S LEADING ECONOMIC POWER FOR MUCH OF THE 2OTH CENTURY BUT IS NOW AT THE BEGINNING OF AN ECONOMIC DECLINE. IN THE PAST, AMERICA'S CRITICS HAVE FALLACIOUSLY DEPICTED HER ECONOMIC SYSTEM, HER
PREPONDERANT SHARE OF THE HORLD'S HEALTH, AND HER DEMAND FOR RAW MATERIALS AS CAUSES OF WORLD POVERTY, BUT THIS IS NONSENSE. THE RECENT HISTORY OF COMMUNIST CHINA'S AUTARCHIC ECONONY CLEARLY SHOWS THAT THE CENTRAL PROBLEM IS POPULATION GROWTH AND THAT THE SOLUTION LIES IN GIVING WOMEN IN POOR COUNTRIES CONTROL OVER THEIR FERTILITY EVEN IF IT OFFENDS POLITICAL AND RELIGIOUS LEADERS. IRONICALLY, GLOBAL BIRTH RATES WILL PROBABLY FALL FOR ANOTHER REASON: THE DEVELOPMENT OF CHEAP WAYS TO DETERMINE THE SEX OF CHILDREN IN ADVANCE. THUS, THE FEMALE POPULATION WILL DECLINE DRAMATICALLY. ALTHOUGH AMERICA HAS NOT EXPLOITED THE REST OF THE WORLD IN THE PAST, IT WILL DO SO IN THE FUTURE. THE DEVELOPMENT OF SOPHISTICATED HIGH-TECH INDUSTRY IN AMERICA HIL REQUIRE LARGE NUMBERS OF EDUCATED AND SKILLED WORKERS WHOM THE UNITED STATES' COLLAPSING SCHOOL SYSTEM WILL BE UNABLE TO UNITED STATES' COLLAPSING SCHOOL SYSTEM WILL BE UNABLE TO
PROVIDE. THEY WILL BE RECRUITED FROM THE THIRD WORLD, THUS PROVIDE. THEY WILL BE RECRUITED FROM THE THIRD WORLD,
PREVENTING THOSE COUNTRIES FROM PARTICIPATING IN THE PREVENTING THOSE COUNTRIES FROM PARTICIPATING IN
SCIENTIFIC TRANSFORMATIONS OF THE NEXT 50 YEARS.

02692 DAVIES, C.

SAFELY EXECUTED

NATIONAL REVIEW, XLIII (14) (AUG 91), 44-45.

THE OVERTURN OF THE CONVICTION OF THE FAMED "BIRMINGHAM SIX" IN GREAT BRITAIN HAS RENEWED THE DEBATE OVER THE USE (OR LACK OF) OF THE DEATH PENALTY IN BRITAIN AND THE UNITED STATES. THIS ARTICLE EXAMINES THE ISSUE WITH EMPHASIS ON THE TRIPLE REQUIREMENTS OF INFALLIBILITY, RETRIBUTION, AND DETERRENCE THAT ARE NECESSARY FOR A JUST AND EFFECTIVE SYSTEM OF CAPITAL PUNISHMENT. THE AUTHOR ARGUES THAT JUSTICE WOULD BE SERVED BY THE PASSAGE OF A LAW TO THE EFFECT THAT
MURDERERS WITH A LONG STRING OF PERVIOUS CONVICTIONS FOR ACTS OF HEINOUS VIOLENCE (ANO ONLY THOSE WITH SUCH

CONYICTIONS) SHOULD BE EXECUTED. SUCH A LAW OUGHT TO SATISFY BOTH THE BRITISH SENSE OF FAIRNESS AND THE STRICT RULES LAID DOWN BY THE U.S. SUPREME COURT.

02693 DAVIES, $G$.

CONGO: LISSOUBA'S WORRIES

WEST AFRICA, 75(3925) (DEC 92$), 2100-2101$

ETHNICITY, TRIBALISM, REGIONALISM, FOREIGN SUPPORT AND

OIL COMPANIES' INFLUENCE ALL POSE CONGO'S BIGGEST POLITICAL, ECONOMICAL AND SOCIAL MALAISE. AT FACE VALUE, CONGO'S

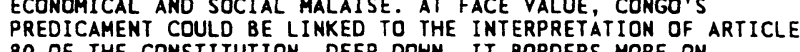
80 OF THE CONSTITUTION. DEEP DOWN, IT BOROERS MORE ON
ETHNICITY, TRIBALISM, DEEP ROOTED LETHARGY AND AN INABILTIY ETHNICITY, TRIBALISM, DEEP ROOTED LETHARGY AND AN INABILT,
TO CHANGE FROM A SYSTEM WHICH LOATHES HARD WORK. WHAT, TO CHANGE FROM A SYSTEM WHICH LOATHES HARD WORK. WHAT, ETHNIC DIVIDE, IS THE THINKING IN THE ARMY.

02694 DAVIES, G.0.

DIOUF IN PARIS

WEST AFRICA, (3899) ( JUN 92), 957.

IN JUNE 1992, SENEGAL'S PRESIDENT ABDOU DIOUF PAID AN OFFICIAL VISIT TO FRANCE, WHERE HE WAS WARMLY RECEIVED. IMMEDIATELY PRIOR TO THE VISIT, FRENCH PRESIDENT FRANCDIS MITTERAND HAD ANNOUNCED THAT HIS COUNTRY WOULD INCREASE ITS DEVELOPMENT AID TO AFRICA IN 1992 AND 1993.

02695 DAVIES, I.

BRITISH CUL TURAL MARXISM

INTERNATIONAL JOURNAL OF POLITICS, CULTURE AND SOCIETY,

4(3) (SPR 91), 323-344.

BRITISH CULTURAL MARXISM WAS BORN IN THE LATE NINETEENFIFTIES, BY BEING LIBERATED FROM BOTH STALINISM AND A REGIMENTAL BASE- SUPERSTRUCTURE MODEL. THIS REQUIRED NOT ONLY A RETHINKING OF MARXIST THEORY BUT ALSO OF THE WAYS THAT THE STORY OF BRITISH SOCIETY, POLITICS AND CULTURE HAD BEEN TOLD. THIS ARTICLE ARGUES THAT THROUGHOUT THE LATE 1960 S AND THE 1970S, BRITISH CULTURAL STUDIES WERE FIRMLY ANCHORED IN A STRATEGY OF POLITICAL STRUGGL, ITS PRIORITIES WERE THOSE OF AN ELABORATION OF THE CULTURAL PROBLEMS FACING THE LEFT AT THE TIME. BY THE 1980S, HOWEVER, BRITISH CULTURAL MARXISM BECAME MORE CULTURIST AND LESS MARXIST, CARRIED ALONG BY ITS OWN ACADEMIC INSTITUTIONALIZATION.' IN THE END, IT BECAME CAUGHT UP IN THE PROCESS WHICH IT HAD SET OUT TO CRITICIZE.

02696 DAVIS, A.

THE SOUTH AFRICAN COMMUNIST PARTY: A PERSONAL VIEW

POLITICAL AFFAIRS, LXX(12) (DEC 91 ), $1-6$. A CONTEMPORARY EXPLANATION OF THE POPULARITY OF THE
SOUTH AFRICAN COMMUNIST PARTY IS THAT THE POPULARITY IS A SOUTH AFRICAN COMMUNIST PARTY IS THAT THE POPULARITY IS A
BYPRODUCT OF THE UNRELENTING ANTI-COMMUNISM OF THE SOUTH AFRICAN GOVERNMENTS OF THE LAST FOUR DECADES. THE AUTHOR OF AFRICAN GOVERNMENTS OF THE LAST FOUR DECADES. THE AUTHOR THIS ARTICLE, CITING PERSONAL EXPERIENCE, ARGUES THAT GROWING NUMBERS OF SOUTH AFRICANS HAVE DECIDED TO AFFILIATE WITH THE COMMUNIST PARTY BECAUSE THEY SEEK TO FURTHER DEFINE THE PRESENT BATTLE FOR DEMOCRACY IN SOUTH AFRICA IN TERMS
THAT INCLUDE THE POSSIBILITY OF A SOCIALIST ALTERNATIVE IN A POST-APARTHEID FUTURE.

02697 DAVIS, C.

STATE ENYIRONMENTAL REGULATION AND ECONOMIC DEVELOPMENT: ARE THEY COMPATIBLE? 
POLICY STUDIES REVIEW, 11(1) (SPR 92), 149-157. DURING THE 1970 'S SEYERAL POLLUTION CONTROL POLICIES HERE ENACTED BY CONGRESS TO PROTECT U.S. CITIZENS FROM EXPOSURE TO AIR, LAND, AND WATER-BASED POLLUTANTS. UNDER AN APPROACH TERMED "PARTIAL PREEMPTION," THE U.S. ENVIRONMENTAL PROTECTION AGENCY AND THE DEPARTMENT OF THE INTERIOR SET MINIMUM ENVIRONMENTAL QUALITY STANDARDS DESIGNED TO FILL THE POLICY VACUUM IN STATES LACKING STATUTORY COVERAGE OR, IN SOME CASES, TO SUPPLANT STATE ACTS OR REGULATIONS INCOMPATIBLE WITH FEDERAL LAW. AN UNDERLYING ASSUMPTION OF THE PARTIAL PREEMPTION APPROACH IS THE BELIEF THAT MINIMUM FEDERAL STANDARDS CONTRIBUTE TO THE PROSPECTIVE

DECENTRALIZATION OF ENYIRONMENTAL PROTECTION PROGRAMS $8 Y$ REMOVING OR REDUCING INDUSTRY INCENTIVES TO SHOP AROUND FOR STATES WITH A MORE LENIENT REGULATORY STANCE. THIS PAPER EXAMINES THIS ASSUMPTION THROUGH A SURVEY OF CHIEF EXECUTIVE OFFICERS OF POLLUTION-GENERATING FIRMS. THE DATA SUGGEST THAT CORPORATE OFFICIALS SEE REGULATORY CLIMATE AS AN IMPORTANT COMPONENT OF OVERHEAD COSTS. THE AUTHOR CONCLUDES THAT THE DESIRE TO RETAIN INDUSTRIES WITHIN STATE BOUNDARIES DOES INHIBIT THE PROMULGATION OF STRICT ENVIRONMENTAL REGULATIONS BY PUBLIC OFFICIALS.

02698 DAVIS, C.; FEIOCK, R.

TESTING THEORIES OF STATE HAZARDOUS WASTE REGULATION: A TESTING THEORIES OF STATE HAZARDOUS WASTE REGULA REASSESSMENT OF THE WILLIAMS AND MATHENY STUDY
AMERICAN POLITICS OUARTERLY, 20(4) (OCT 92), 501-511.

THIS RESEARCH REASSESSES THE CONCLUSIONS REACHED BY WILLIAMS AND MATHENY IN THEIR ANALYSIS OF STATE AND INDUSTRY SPENDING FOR HAZARDOUS WASTE REGULATION. USING UPDATED AND IN SOME CASES RECONFIGURED INDICATORS FOR HAZARDOUS WASTE EXPENDITURES, THE AUTHORS AFFIRMED EARLIER FINDINGS PERTAINING TO THE LINK BETHEEN INDUSTRY INFLUENCE AND REGULATORY SPENDING DECISIONS. HOWEVER, THEY ALSO CONCLUDED THAT THE MARKET FAILURE THESIS PROVIDED A BETTER EXPLANATION OF STATE HAZARDOUS WASTE DECISION MAKING THAN THE ORIGINAL RESEARCH AND THAT THE SOCIALIZATION OF COST THESIS WAS LESS USEFUL IN ACCOUNTING FOR INTERSTATE VARIATION IN POLLUTION CONTROL EXPENDITURES.

02699 DAVIS, C.L.

RELIGION AND PARTISAN LOYALTY: THE CASE OF CATHOLIC WORKERS IN MEXICO

WESTERN POLITICAL QUARTERLY, 45(1) (MAR 92), 275-297.

THE AUTHOR EVALUATES THO EXPLANATIONS FOR WORKING-CLASS CATHOLIC SUPPORT FOR MEXICO'S RULING PRI. HE FINDS LITTLE OR NO EMPIRICAL SUPPORT FOR A RELIGIOUS SOCIALIZATION

EXPLANATION, ACCORDING TO WHICH THE MEXICAN CATHOLIC CHURCH

EXPLANATION, ACCORDING TO WHICH THE MEXICAN CATHOLIC CHURCH
SHAPES A CONSERVATIVE, ACQUIESCENT POL ITICAL CONSCIOUSNESS SHAPES A CONSERVATIVE, ACQUIESCENT POL ITICAL CONSCIOUSNESS
AMONG LOWER-CLASS CATHOL ICS. HE THEN EXAMINES AN ALTERNATIVE AMONG LOWER-CLASS CATHOLICS. HE THEN EXAMINES AN ALTERNATIVE EXPLAHATION: MEXICAN CATHOLICS TEND TO SUPPORT THE PRI IN ORDER YO PROTECT THE POLITICAL INTERESTS OF THE CHURCH. HE AN INTEREST-BASED, AS OPPOSED TO A SOCIALIZATION-BASED, TYPE AN INTEREST-BASED, AS OPPOSE
OF RELIGIOUS PARTISANSHIP.

02700 DAYIS, J.A.; CONYERSE, P.E.; ZUKIN, C.

CHANGEABLE WEATHER IN A COOL ING CLIMATE ATOP THE LIBERAL PLATEAU: CONVERSION AND REPLACEMENT IN 42 GENERAL SOCIAL SURVEY ITEMS, 1972-1989

PUBLIC OPINION QUARTERLY (CHICAGO), 56(3) (FAL 92),

261-314.

JAMES A. DAVIS TRACKS TRENDS FROM THE EARLY 1970'S TO THE LATE 1980'S IN AMERICAN PUBLIC OPINION FOR 42 "GENERAL SOCIAL SURVEY" ITEMS WITH LIBERAL/CONSERVATIVE OVERTONES. THE BROAD QUESTION IS WHETHER THE GREAT "LIBERAL" SHIFT SINCE WORLD WAR II HAS ENDED; THE NARROW ISSUE IS THE SHIFTS. DESPITE COMMON IMPRESSIONS, THE OVERALL TREND IS MORE LIBERAL THAN CONSERVATIVE, BUT IT CONCEALS OPPOSING "WEATHER" AND "CLIMATE" PROCESSES. WITHIN COHORTS (HEATHER), DAVIS FINDS A CONSERVATIVE TREND BETWEEN THE EARLY AND LATE 1970'S AHD A LIBERAL REBOUND IN THE 1980'S. BETHEEN COHORTS VIRTUALLY ALL ITEMS SHOW SMALL BUT CUMULATIVE LIBERALIZING PRODUCED BY COHORT SUCCESSION. THESE COHORT EFFECTS ARE DECLINING IN MAGNITUDE BECAUSE THE ASSOCIATION BETWEEN YEAR OF BIRTH AND LIBERALISM IS NONLINEAR. DAVIS FINDS A CURVILINEARITY SUCH THAT AMERICANS BORN AFTER WORLD WAR II ARE NOT CONSISTENTLY MORE LIBERAL THAN THEIR PREDECESSORS. THIS SHIFT IS NOT EXPLAINED BY THE LESSER SCHOOLING OF THE YOUNGEST ADULTS OR BY CEILING EFFECTS. CONSEOUENTLY, DAVIS YOUNGEST ADULTS OR BY CEILING EFFECTS. CONSEOUENTLY, DAVIS PREDICTS LESSENING OF THE LIBERALIZING CLIMATE PRODUCED BY
COHORT SUCCESSION. CLIFF ZUKIN AND P.E. CONYERSE COMMENT ON COHORT SUCCESSION.
DAYIS' FINDINGS.

02701 DAVIS, $R$.

ANTI-RACIST ORGANIZING, THEN AND NOH

SOCIALIST REVIEW, 20(4) (OCT 90), 29-36.

THIS ARTICLE ADDRESSES THE ISSUES OF MOVEMENT DRGANIZING BOTH PAST AND PRESENT. THE PURPOSE OF THE ARTICLE IS THREEFOLD: FIRST, TO POINT OUT THE EXTENT OF THE MYTHOLOGIZING OF THE PERIOD SOMETIMES CALLED "THE SIXTIES," AND SHOH THE HAYS THAT MYTHOLOGIZING TENDS TO DISTORT AND EYEN MIX-REPRESENT AFRICAN-AMERICAN HISTORY; SECOND, TO LOOK
AT THE WAYS IN WHICH THE CONCEPT OF THE SIXTIES HAS HELPED OR HINDERED STUDENT AND YOUTH ACTIVISTS TODAY; AND LASTLY, TO SHOW THE IMPORTANCE OF A HISTORICAL UNDERSTANDING OF THE DEVELOPMENT OF THE MOVEMENT TO PROGRESSIVE ANTI-RACIST ORGANIZING TODAY.

02702 DAVIS, R

SPYING ON THE GOVERMMENT: THE MEDIA, REMOTE-SENSING

SATELLITES, AND U.S. NATIONAL SECURITY POLICY

POLITICAL COMMUNICATION, 9 (3) (1992), 191-206

THE AUTHOR DESCRIBES THE EMERGENCE OF REMOTE-SENSING TECHNOLOGY AND ITS EFFECT ON NEWS MEDIA COVERAGE OF NATIONAL SECURITY ISSUES. HE DISCUSSES GOVERMMENT ATTEMPTS TO
RESTRICT MASS MEDIA USAGE OF REMOTE SENSING FOR NEWSGATHERING PURPOSES AND GOVERMMENT EFFORTS TO RESTRICT MEDIA OISSEMINATION OF NATIONAL-SECURITY-RELATED INFORMATION OBTAINED THROUGH REMOTE SENSING. NONGOVERNMENTAL USE OF REMOTE SENSING TO SCRUTINIZE GOVERNMENTAL ACTIVITY, PARTICULARLY BY THE NEWS MEDIA, IS AN ISSUE THAT WILL PRESENT COMPLEX QUESTIONS FOR U.S. POLICY MAKERS IN THE FUTURE.

02703 DAYIS, $R$.

THE FOREIGN POLICY MAKING ROLE OF CONGRESS IN THE 1990'S: REMOTE SENSING TECHNOLOGY AND THE FUTURE OF CONGRESSIONAL PONER

CONGRESS AND THE PRESIDENCY, 19(2) (FAL 92), 175-192.

A NEW TECHNOLOGY HAS EMERGED FOR COMMERCI IL USE WHICH COULD ENHANCE CONGRESS' INFORMATION-GATHERING PROCESSES AND AGENDA-SETTING ROLE, POSSIBLY ALTERING THE BALANCE OF POWER IN THE RELATIONSHIP BETHEEN CONGRESS AND THE PRESIDENT IM THE AREA OF FOREIGN POLICY. CONGRESSIONAL ACCESS TO NEWS MEDIA STORIES OF IMAGERY MAY PROVIDE AN INDEPENDENT INFORMATION SOURCE ON U.S. OR FOREIGN MILITARY INSTALLATIONS AND ACTIVITIES. SUCH A SOURCE COULD BE UTILIZED TO ASSESS ISSUES SUCH AS PENTAGON APPROPRIATIONS, TREATY COMPLIANCE, AND FOREIGN AID FUNDING. WHEN INTEREST GROUPS AND THE NEWS MEDIA USE REMOTE SENSING IMAGERY ON FOREIGN POLICY ISSUES, THE FOREIGN AND NATIONAL SECURITY POLICY-MAKING PROCESS WILL BE TRANSFORMED BY ENHANCING THE INFORMATION STATUS AND THE PUBLIC AGENDA-SETTING ROLE OF PREVIOUSLY EXCLUDED SEGMENTS, SUCH AS INTEREST GROUPS, THE MEDIA, AND THE GENERAL PUBLIC. THE EXPANDED ROLE OF THESE GROUPS WILL DECENTRALIZE DECISION MAKING BY FRAGMENTING POWER AND WILL PROBABLY RESTRUCTURE BRANCH DURING THE 1990'S.

02704 DAVIS, $S$.

REHNOUIST AND STATE COURTS: FEDERALISM REVISITED

WESTERN POL ITICAL OUARTERLY, 45(3) (SEP 92), 773-782.

WESTERN POLITICAL QUARTERLY, 45(3) (SEP 92), 773-782. REHMOUIST DURING HIS TENURE AS AN ASSOCIATE JUSTICE OF THE $U$. S. SUPREME COURT. IF REHNQUIST'S DECISION-MAKING WERE BASED ON A COHERENT JUDICIAL PHILOSOPHY RATHER THAN RESULTORIENTED ATTEMPTS TO ACHIEVE THE GOALS OF A CONSERVATIVE POLITICAL AGENDA. HE WOULD HAVE VOTED CONSISTENTLY TO SUPPORT STATE AUTONOMY EVEN WHEN IT LED TO A LIBERAL RESULT. ANALYZING REHNOUIST'S VOTING IN CASES IN WHICH THE SUPREME COURT REVIEWED A DECISION OF A STATE COURT OF LAST RESORT, THE AUTHOR FINDS THAT ALTHOUGH THE JUSTICE WAS MORE DEFERENTIAL TO THE DECISIONS OF STATE COURTS THAN ANY OTHER MEMBER OF THE BURGER COURT, HE CLEARLY FAYORED DECISIONS THAT HAD A CONSERVATIVE OUTCOME. THE RESULTS SUGGEST THAT REHNOUIST VALUED FEDERALISM AS A MEANS TO A CONSERVATIVE END.

02705 DAVIS, $V$.

DEFENSE REORGANIZATION AND NATIONAL SECURITY ANMALS OF THE AMERICAN ACADEMY OF POLITICAL AND SOCIAL SCIENCE, (517) (SEP 91), 157-173

THE GOLDHATER-NICHOLS DEPARTMENT OF DEFENSE REORGANIZATION ACT OF 1986 DRAMATICALLY PUNCTUATED ALMOST A CENTURY OF EFFORTS TO MAKE THE LEADERSHIP, MANAGEMENT, AND USE OF AMERICAN ARMED FORCES MORE COHESIVE AND EFFICIENT. THE GOLOWATER-NICHOLS ACT SOUGHT TO CENTRALIZE THE UNIFORMED SIDE OF THE PENTAGON IN PARALLEL WITH THE CIVILIAN SIDE, RUNMING THE RISK THAT THIS COULD LEAD TO CIVIL-MILITARY CONFLICT INSTEAD OF A SMOOTH PARTNERSHIP BETWEEN THE DEFENSE SECRETARY AND THE JOINT CHIEFS-OF-STAFF CHAIRMAN. THIS PAPER ANALYZES THE MAIN CONSEQUENCES OF THE GOLDWATER-NICHOLS ACT SINCE IT BECAME LAN.

02706 DAYY, $R$.

EASTERM EUROPE III PRAGMATISM IN BULGARIA

WORLD TODAY, 48(5) (MAY 92), 85-87.

BULGARIA' IS FINDING ITS WAY TO DEMOCRACY AND MARKET ECONOMICS MORE SLOHLY THAN CENTRAL EUROPE BUT MUCH FASTER AND MORE EFFECTIVELY THAN ROMANIA. BULGARIA'S PACE HAS BEEN SLOW BECAUSE THE CONTEXT IS VERY DIFFERENT FROM THAT OF CENTRAL EUROPE. BULGARIA HAS THE POTENTIAL FOR TROUBLE DUE TO ECONOMIC HARDSHIP, WAGE PRESSURES, DISPUTES OVER THE HASTILY-DRAFTED CONSTITUTION, UNFAMILIARITY WITH DEMOCRACY, AND THE POSITION OF THE TURKISH MINORITY. BUT THE COUNTRY CONVEYS THE FEELING THAT IT POSSESSES ENOUGH COMMON SENSE, REALISM, AND DETERMINATION TO HAVE A GOOD CHANCE FOR 
SURVIVAL.

02707 DAYY, R.

EUROPEAN DETENTE: A REAPPRAISAL

SAGE PUBLICATIONS, 1992, 277

THIS BOOK PRESENTS A BALANCED ASSESSMENT OF THE REALITY OF DETENTE, AND OF THE DIFFERENT INTERESTS INVOLVED, LOOKING BACK THROUGH THE EYES OF CONTRIBUTORS FROM BRITAIN, GERMANY, FRANCE, ITALY, POLAND, HUNGARY AND AUSTRIA. IT TAKES A PARTICULARLY CLOSE LOOK AT THE CONFERENCE ON SECURITY AND COOPERATION IN EUROPE WHICH PRODUCED THE HELSINKI FINAL ACT AND A SERIES OF FOLLOW-UP MEASURES THAT CONTINUE TO EVOL VE TO THE PRESENT DAY. IT ARGUES THAT THE WEST WON A VICTORY THAT WAS INSUFFICIENTLY RECOGNIZED AT THE TIME AMD CONCLUDES THAT DETENTE WAS AMBIGUOUS, CONFERRING SHORT-TERM POLITICAL AND ECONOMIC BENEFITS ON EAST EUROPEAN REGIMES WILE AT THE SAME TIME WEAKENING THEIR FOUNDATIONS AND CONTRIBUTING TO THEIR COLLAPSE.

02708 DAYYDOY, V.

NYET TO FULL BATTLE DRESS

BULLETIN OF THE ATOMIC SCIENTISTS, 48(6) (JUL 92), 33-37.

THE U.S. APPROACH TO SOVIET DISINTEGRATION WAS BASED ON A SIMPLE THREE-PART PREMISE: THAT THERE HAS BEEN A SINGLE NUCLEAR STATE; THAT A SINGLE NUCLEAR STATE SHOULD EMERGE; AND THAT ONLY RUSSIA COULD BE THE HEIR. WASHINGTON DID NOT WANT TO FACE THE POSSIBILITY THAT RUSSIA MIGHT DECLINE THE ROLE OF SUPERPOWER. NOW, THE U.S. MUST CONSIDER THE POSSIBILITY OF THE REPUBLICS RETATNING AND DISTRIBUTING NUCLEAR WEAPONS. THEREFORE, NEW AGREEMENTS SHOULD BE SOUGHT TO REDUCE THE RISK OF NUCLEAR WEAPONS TRANSFER. THE FACT THAT RUSSIA HAS AGREED TO ASSUME CONTROL OF ALL NUCLEAR WEAPONS IN THE FORMER SOVIET UNION, AND THAT UKRAINE AND BELARUS HAVE DECLARED THEIR INTENTION TO JOIN THE NONPROLIFERATION TREATY (NPT), ARE BOTH ENCOURAGING. YET, THE U. S. AND RUSSIA FACE SERIOUS DIPLOMATIC TASKS AHEAD AS THEY SEEK TO FORMULATE A CIS MUCLEAR POLICY.

02709 DAHISHA, A.

THE UNITED STATES IN THE MIDDLE EAST: THE GULF WAR AND ITS AFTERMATH

CURRENT HISTORY, 91(561) (JAN 92), 1-5.

IN THE AFTERMATH OF THE GULF WAR, THE BUSH

ADMINISTRATION WAS TROUBLED BY SADDAM HUSSEIN'S CONTINUED

RULE IN IRAQ BUT BOUYED BY ITS SUCCESS IN CONVENING A MIDOLE

EAST PEACE CONFERENCE IN OCTOBER 1991.

02710 DAY, P.; KLEIN, R.

CONSTITUTIONAL AND DISTRIBUTIONAL CONFLICT IN BRITISH MEDICAL POLITICS: THE CASE OF GENERAL PRACTICE, 1911-1991 POLITICAL STUDIES, XL(3) (SEP 92), 462-478.

OLITICAL STUDIES, XL(3) (SEP 92), 462-478.

EXPLANATIONS OF HEALTH POLICIES BY DISTINGUISHING BETWEEN

THE POLITICS OF CONSTITUTIONAL CONFLICT AND THE POLITICS OF DISTRIBUTIONAL CONFLICT. THE FIRST TYPE IS EPITOMIZED BY THE COLLISIONS BETWEEN THE BRITISH STATE AND THE MEDICAL PROFESSION IN 1911, 1945, AND 1989 ON THE ISSUE OF GENERAL PRACTICE. THE SECOND IS CHARACTERIZED BY A CORPORATIST-STYLE, INSTI ITUTIONALIZED RELATIONSHIP BETWEEN THE STATE AND THE PROFESSION BETHEEN AND SUBSEQUENT TO THESE EVENTS. THE AUTHORS DRAH CONCLUSIONS ABOUT THE LIMITATIONS OF

CORPORATIST AND OTHER THEORIES AND ABOUT THE METHODOLOGY OF POLICY ANALYSIS.

02711 DAYNES, B.H.; TATALOVICH, R.

PRESIDENTIAL' POLITICS AND ABORTION, 1972-198

PRESIDENTIAL STUDIES QUARTERLY, XXII(3) (SUM 92), 545-562. ABORTION HAS PERSISTED AS A CONTROYERSIAL ISSUE IN THE

UNITED STATES SINCE 1973. TO DISCOVER HOW ABORTION HAS AFFECTED THE PRESIDENCY AND PARTY POLITICS. THIS STUDY EXAMINES ABORTION POLICY IN PARTY PLATFORMS ABORTION DEBATES DURING PRESIDENTIAL CAMPAIGNS, AMD PRESIDENTIAL VOTING BEHAVIOR REGARDING ABORTION. ALTHOUGH PRESIDENTIAL CANDIDATES HAVE MADE THEIR VIEWS ON ABORTION KNOWN SINCE THE EARLY 1970'S. NATIONAL ELECTION SURVEY DATA AND POLLING DATA SUGGEST THAT PRESIDENTIAL CANDIDATES HAVE NOT BEEN SELECTED ON THE BASIS OF THEIR STANCE ON ABORTION.

02712 DE ALTERIIS, M.

POLITICAL SCIENCE TRAINING AND POLICY RESEARCH IN PUBLIC SETTINGS

PS: POLITICAL SCIENCE AND POLITICS, 25(4) (DEC 92),

724-727.

THE MAJORITY OF POLITICAL SCIENTISTS NOULD PROBABLY CONSIDER A CAREER AS AN APPLIED PUBL IC POLICY RESEARCHER ONLY IF ACADEMIC DISASTER LOOMED OR EXTRAORDINARY

ONLY IF ACADEMIC DISASTER LOOMED OR EXTRAORDINARY

DOCTORAL PROGRAMS IN POLITICAL SCIENCE HAS THE SKILLS NEEDED OOCTORAL PROGRAMS IN POLITICAL SCIENCE HAS THE SKILLS NEEDED
FOR THESE POSITIONS. THIS ARTICLE EXPIORES THE REOUIREMENTS FOR THESE POSITIONS. THIS ARTICLE EXPLORES THE REQUIREMENTS
FOR A CAREER IN APPLIED POLICY RESEARCH AND ALSO THE TOOLS FOR A CAREER IN APPLIE
OF APPLIED RESEARCH.

02713 DE BEER, $Z$.

CODESA II PLENARY SESSION
SOUTH AFRICA FOUNDATION REVIEH, 19(6) (JUN 92), 3.

ZACH DE BEER, LEADER OF SOUTH AFRICA'S DEMOCRATIC PARTY ASSESSES THE SECOND PLENARY SESSION OF THE CONVENTION FOR OEMOCRATIC SOUTH AFRICA (CODESA) WITH EMPHASIS ON THE DEADLOCK BETWEEN THE NATIONAL PARTY AND THE AFRICAN NATIONAL CONGRESS OVER THE PERCENTAGE VOTE REQUIRED TO ESTABLISH A NEW CONSTITUTION. DE BEER CRITICIZES BOTH GROUPS FOR BEING OVERLY CONCERNED WITH FUTURE ELECTORAL BATTLES AND NOT CONCERNED ENOUGH WITH THE PROCESS NECESSARY TO CREATE A SOUTH AFRICA IN WHICH FREE ELECTIONS CAN BE HELD. HOWEVER, HE CONCLUDES THAT, IF THE CODESA PROCESS HAS NOT MADE MUCH PROGRESS, IT IS STILL MOVING FORWARD AND WILL EYENTUALLY SUCCEED.

02714 DE GRAAFF, $B$.

WHAT HAPPENED TO THE CENTRAL PERSONALITY INDEX?

INTELLIGENCE AND NATIONAL SECURITY, $7(3)$ (JUL 92), 317-326. THE CENTRAL PERSONALITY (SOMETIMES CALLED PERSONALITIES) INDEX (CPI) WAS THE BACKBONE OF ALLIED COUNTER-INTELLIGENCE AT THE END OF THE SECOND WORLD WAR. THIS ARTICLE EXAMINES THE CREATION OF THIS RECORD OF NAZI WAR CRIMINALS, ITS USE AND ITS APPARENT DISAPPEARANCE. IT CONCLUDES THAT THE FILES HAVE NOT BEEN DESTROYED, BUT ARE KEPT SECRET BECAUSE IN
ORDER NOT TO GIVE SUPPORT TO CLAIMS THAT THE ALLIES USED NAZIS IN INTELLIGENCE OPERATIONS AFTER THE END OF THE SECONO NAZIS IN INTI
WORLD WAR.

02715 DE GRAZIA, V.

HOW FASCISM RULED WOMEN--ITALY 1922-1945

UNIVERSITY OF CALIFORNIA PRESS, 1992, 384.

"ITALY HAS BEEN MADE; NOW HE NEED" TO MAKE THE ITALIANS," GOES A FAMILIAR ITALIAN SAYING. MUSSOLINI WAS THE FIRST HEAD OF STATE TO INCLUDE WOMEN IN THIS MANDATE. HOW THE FASCIST DICTATORSHIP DEFINED THE PLACE OF HOMEN IN MODERN ITALY AND HOW WOMEN EXPERIENCED THE DUCE'S RULE ARE THE SUBJECTS OF THIS BOOK. THE AUTHOR DRAHS ON AN ARRAY OF SOURCES- MEMOIRS AND NOVELS, THE IMAGES, SONGS, AND EVENTS OF MASS CULTURE, AS WELL AS GOVERNMENT STATISTICS AND ARCHIVAL REPORTS. SHE OFFERS A BROAD YET DETAILED CHARACTERIZATION OF ITALIAN WOMEN'S AMBIGUOUS AND AMBIVALENT EXPERIENCE OF A REGIME THAT PROMISED MODERNITY, YET DENIED WOMEN EMANCIPATION.

02716 DE KLERK, W.

THE POLITICAL PROCESS IN SOUTH AFRICA

SOUTH AFRICA INTERNATIONAL, 23(2) (OCT 92), 65-70.

IN SOUTH AFRICA THE ELEMENTS OF A COMPROMISE BETHEEN THE MAIN ACTORS IS EMERGING: A UNITARY STATE, BUT WITH A REGIONAL DEVOLUTION OF POHERS, A MULTIPARTY DEMOCRACY BASED ON PROPORTIONAL REPRESENTATION AND A BILL OF RIGHTS AND MAJORITY RULE WITH PROTECTION FOR MINORITIES. A NEW FORUM
WILL REPLACE CODESE. THERE WILL BE RELAPSES AND CLASHES OF WILL REPLACE CODESE. THERE WILL BE RELAPSES AND CLASHES OF
POWER. HOHEYER, WHILE A SUCCESSFUL DUTCOME IS NOT INEVITABLE, POWER. HOWEVER, WHILE A SUCCESSFUL DUTCOME IS NOT INEVITA
THERE ARE GROUNDS FOR HOPE THAT, ALONG WITH AN ECONOMIC THERE ARE GROUNDS FOR HOPE THAT, ALONG WITH AN
RECOVERY, SOUTH AFRICAN'S TRANSITION CAN SUCCEED.

02717 DE MELO, J.; PANAGARIYA, A.

THE NEW REGIONALISM

FINANCE AND DEVELOPMENT, 29(4) (DEC 92), 37-40.

WITH A NEW WAVE OF REGIONAL TRADING ARRANGEMENTS IN THE OFFING, THE WORLD BANK AND THE CENTER FOR ECONOMIC AND POLICY RESEARCH HELD A CONFERENCE IN APRIL 1992 ON THE NEW REGIONALISM AND ITS LIKELY EFFECTS ON THE MULTILATERAL TRADING SYSTEM. PARTICIPANTS DISAGREED ON WHETHER REGIONALISM WILL HELP OR HINDER MULTILATERALISM. BUT THEY AGREED THAT REGIONALISM IS HERE TO STAY, SO STEPS MUST BE TAKEN TO ENSURE THAT THE WORLD DOES NOT DIVIDE UP INTO INWARD-LOOKING TRADING BLOCS.

02718 DE MESQUITA, B.; ORGANSKI, A.

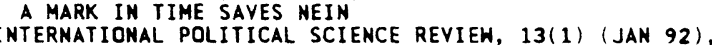
81-100.

A METHOD FOR PREDICTING POLITICAL INTERACTIONS AND POLICY OUTCOMES BASED ON TWO POL ITICAL THEDREMS IS PRESENTED AND ILLUSTRATED WITH AN EXAMINATION OF THE DECISION TO MERGE THE THO GERMAN CURRENCIES. THE PROPOSED MODEL HAS PROVEN ACCURATE ABOUT 90 PERCENT OF THE TIME. THIS METHOD IDENTIFIES A SEQUENTIAL STRATEGY THAT MAY HAVE BEEN FOLLOHED BY CHANCELLOR KOHL IN FORGING THE COALITION NEEDED TO MERGE SUCCESSFULLY THE TWO GERMAN CURRENCIES. USING COMPARATIVE STATICS, THE ANALYSIS SUGGESTS HOW SUBTLE AND SOPHISTICATED CHANCELLOR KOHL HAD TO BE TO SUCCEED IN GETTING THE POLICY CHANCELLOR KOHL HAD TO BE TO SUCCEED IN GETT

02719 DE MESOUITA, B.; KIM, CHAE-HAN

PROSPECTS FOR A NEH REGIOHAL DRDER IN NORTHEAST ASIA KOREAN JOURNAL OF DEFENSE ANALYSIS, 3(2) (WIN 91), 65-82. KOREAN JOURNAL OF DEFENSE ANALYSIS, 3(2) (WIN 91), 65-82. FEASIBLE NEW REGIONAL ORDER THAT WILL REDUCE COSTS WITHOUT FEASIBLE NEW REGIONAL ORDER THAT WILL REDUCE COSTS WITHOUT UNDERMINING STABILITY IN THE NORTHEAST ASIAN REGION. THERE
HAS BEEN SUCCESSFUL RESEARCH IN FORECASTING THE RESULTS OF MULTILATERAL NEGOTIATIONS THROUGH THE APPLICATION OF AN EXPECTED-UTILTIY APPROACH. THE AUTHORS USE THE EXPECTED
UTILITY FRAMEWORK IN CONJUNCTION WITH THE MEDIAN VOTER 
THEOREM AND THE MONOTONICITY THEOREM. THEY FOCUS ON TWO ISSUES OF CENTRAL IMPORTANCE TO THE PROSPECTS FOR A NORTHEAST ASIAN REGIONAL ORDER AND APPLY THE EXPECTED
UTILITY MODEL TO DATA ON THE PROPOSED RESOLUTION OF THE SETTING WITHIN WHICH NORTHEAST ASIAN REGOTIATIONS CAN TAKE PLACE.

02720 DE SILVA, M.

SINHALESE BACKLASH

FAR EASTERN ECONOMIC REVIEW, 155(7) (FEB 92), 26

ALTHOUGH SRI LANKA'S PRESIDENT RANASINGHE PREMADASA REMAINS COMMITTED TO ENDING THE 10-YEAR CIVIL WAR HITH THE SEPARATIST LIBERATION TIGERS OF TAMIL EELAM (LTTE). RIGHTWING SINHALESE OPPOSITION IS BLOCKING ANY REAL PROGRESS TOWARDS PEACE. THE FAINT POSSIBILITY OF A PEACE SOLUTION SURFACED AT THE END OF 1991 WHEN S. THONDAMAN, TOURISM AND RURAL INDUSTRIAL DEVELOPMENT MINISTER IN PREMADASA'S GOVERMMENT, ANNOUNCED HE INTENDED TO NEGOTIATE WITH THE GOVERMMENT, ANNOUNCED HE INTENDED TO NEGOT IATE WITH THE SINHALESE, WITH GAMANI JAYASURIYA, AN INFLUENTIAL CABINET MEMBER, TAKING THE LEAD. THONDAMAN'S ABORTED INITIATIVE COINCIDED WITH ATTEMPTS BY THE TIGERS TO EXPLORE ALTERNATIVE CHANNELS. THIS HAS BECOME A MATTER OF SOME URGENCY SINCE THE MILITARY IS REPORTEDIY URGING A FRESH ONSLAUGHT ON TIGER THE MILITARY IS REPORTEDLY URGING A FRESH ONSLAUGHT

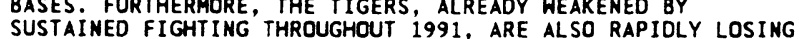
THE MATERIAL AND MORAL SUPPORT OF NEW DELHI, WHICH HAS BEEN THE MATERIAL AND MORAL SUPPORT OF
PATCHING RELATIONS WITH COLOMBO.

02721 DE SILVA, M.

TIGERS BARE TEETH

FAR EASTERN ECONOMIC REVIEW, $151(28$ ) (JUL 91), 15.
THE 21 JUNE BOMB WHICH WRECKED THE OPERATIONAL

HEADQUARTERS OF SRI LANKA'S DEFENSE MINISTRY, KILLING ELEVEN SOLDIERS AND AS MANY CIVILIANS, HAS LED TO AN ANGRY EXCHANGE BETWEEN THE GOVERNMENT AND OPPOSITION OVER ALLEGED SECURITY NEGLIGENCE. THE GOVERMMENT HAS BEEN SHARPLY CRITICIZED FOR LOCATIMG THE VIRTUAL NERVE CENTER OF ITS OPERATIONS AGAINST THE SEPARATIST LIBERATION TIGERS OF TAMIL EELAM (LTTE) IN A RESIDENTIAL AREA. SOME SPECULATE THAT THE LTTE, SUFFERING DRAMATIC LOSSES OF SUPPORT DUE TO ITS ALLEGED RESPONSIBILITY FOR THE ASSASSINATION OF IMDIA'S RAJIV GANDHI, WISHED TO DEMONSTRATE ITS STRENGTH, AND THEREFORE INCREASE ITS DEMONSTRATE ITS STRENGTH, AND THEREFORE INCREASE ITS
BARGAINING POSITION IN THE WIDELY EXPECTED RESUMPTION OF BEGOTIATIONS WITH THE GOVERNMENT.

02722 DE HECK, $R$.

DOHWHARD TREND IN THE WEST IS BEGINNING TO AGGRAVATE DOWWHARD TREND IN THE WEST

DIFFICULTIES IN THE EAST
GERMAN TRIBUNE, (1505) (FEB 92), 6.

DESPITE THE LACK OF PREDICTIONS FROM GOVERMMENT EXPERTS, THERE ARE MANY PEOPLE IN GERMANY WHO BELIEVE THAT THE NATION IS GOING INTO RECESSION. UNEMPLOYMENT IS ON THE RISE; PROFITS ARE DECLINING; AND SAVINGS AND INVESTMENT ARE DOWM. MANY HESTERN GERMANS HAVE FOREBODINGS THAT TIMES WILL GET TOUGHER. BUT THIS CANNOT BE COMPARED TO THE CRISIS WHICH
EAST GERHANS ARE FACING. IN THE NEW LANDER (PROVINCES) IT IS NOT THE ECONOMY THAT IS SICK BUT THE HHOLE ECONOMIC STRUCTURE, AND THERE IS NO DOUBT THAT A DOWNWARD TREND IN WESTERN GERMANY IS AGGRAVATING THE SITUATION IN EASTERN GERMANY. THE ECONOMIC DOWNTURN WILL HURT ON BOTH SIDES OF THE ELBE.

02723 DE WECK, R.

THE DECISIONS haVe BEEN TAKEN, BUT THE DEBATE IS ONLY BEGINHING

GERMAN TRIBUNE, (1496) (DEC 91), 3

THE MAASTRICHT SUMMIT IS OVER BUT THE EUROPEAN DEBATE HAS YET TO BEGIN. WHAT THE TWELVE HEADS OF STATE AND GOVERNMENT AGREED ON AT THE SUMMIT MUST FIRST BE RATIFIED BY THEIR NATIONAL GOVERMMENTS. GERMANS ARE RATHER RELUCTANT TO ADOPT THE MEASURES FOR A COMMON CURRENCY BECAUSE IT MEANS SURRENDERING THEIR DEUTSCHMARK. THE GERMAN CURRENCY HAS LONG STOOD FOR ECONOMIC STABILITY, GERMAN INDUSTRIOUSNESS AND THE MARKED NEED FOR SECURITY THAT GERMANS FEEL. THE PROPONENTS OF EUROPEAN UNITY COUNTER HITH THE ARGUMENT THAT POWER IS MORE BEARABLE WHEN IT IS SHARED. INTERESTS THAT ARE INTERLINKED AND COINCIDE WILL, IN THE LONG TERM, ENSURE MORE SECURITY, STABILITY AND DISCIPL INE THAN NATIONAL HEGEMONY AS NOW PRACTICED BY THE GERMANS WITH THEIR CURRENCY. ANY SERIOUS DEBATE ON EUROPEAN POLICY MUST TRY TO HARHESS THIS SERIOUS DEBATE ON EUROPEAN POLICY MUST TRY TO HARNES
REALIZATION RATHER THAN INSIST ON RETENTION OF THE REALIZATION RAT
DEUT SCHMARK.

02724 DEACON, $B$.

EAST EUROPEAN WELFARE: PAST PRESENT AND FUTURE IN COMPARATIVE CONTEXT; THE NEW EASTERN EUROPE: SOCIAL POLICY PAST, PRESENT AND FUTURE

SAGE PUBLICATIONS, $1992,1-30$.

THE MAIN CHARACTERISTICS OF THE PRE-1989 SYSTEM OF WELFARE THAT EXISTED IN A FAIRLY STANDARD FORM ACROSS EASTERN EUROPE AND THE SOVIET UNION ARE SET OUT IN THE BEGINMING OF THIS CHAPTER. IT THEN DESCRIBES THE IMMEDIATE SOCIAL POLICY PROBLEMS THAT THE SUCCESSOR REGIMES ARE
CONFRONTED WITH. THE TWIN EMERGENT ISSUES OF FACILITATING BOTH AN ACTIVE CIVIL SOCIETY AND A NEW AND ACCEPTABLE CONCEPTION OF SOCIAL JUSTICE IN THE PERIOD OF TRANSITION IS FOCUSSED UPON. THE LATER PART OF THE CHAPTER SITUATES THE STUDY OF THE NEWLY EMERGING AND OIVERSE POST-COMMUNIST WELFARE REGIMES IN THE BROADER COMPARATIVE AND CROSSNATIONAL SOCIAL POLICY LITERATURE.

02725 DEACON, B. : CASTLE-KANEROVA, M.

SOCIAL POLICY IN BULGARIA; THE NEW EQASTERN EUROPE: SOCIAL POLICY PAST, PRESENT AMD FUTURE

SAGE PUBLICATIONS, 1992, 67-90.

THE CURRENT DEBATE ABOUT SOCIAL POLICY IN CZECHOSLOVAKIA REFLECTS THE FORTY-YEAR-OLD CONUNDRUM FACING THE COUNTRIES OF EASTERN EUROPE--WAS THE STATE'S INVOLVEMENT IN SOCIAL WELFARE BENEFICIAL OR NOT? WHAT DISTINGUISHES CZECHOSLOVAKIA IS THAT A DISCUSSION ABOUT POLICY ISSUES CONSTITUTES A FIERCELY POL ITICAL BATTLE BETWEEN EMERGENT RIVAL GOVERNMENTAL FACTIONS. WHAT IS ARGUED IN THIS CHAPTER IS GOVERNMENTAL FACTIONS. WHAT IS ARGUED IN THIS CHAPTER IS THAT NEITHER 1968 NOR 1989 BROUGHT A FULL-SCALE DEMOCRATIC
REVOLUTION. AS A RESULT THERE ARE A NUMBER OF CONTRADICTIONS REVOLUTION. AS A RESULT THERE ARE A NUMBER OF CONTRADICTIONS IN CURRENT SOCIAL POLICIES. HOWEVER, FOR THE FIRST TIME IN FORTY YEARS SOCIAL AND ECONOMIC ISSUES ARE NOT BEING DEALT WITH IN ISOLATION FROM EACH OTHER. CZECHOSLOVAKIA IS AT CONCEPTUALIZATION OF THE ROLE OF SOCIAL POLICY IN THE CONCEPTUALI ZATION
BROADEST SENSE.

02726 DEACON, B.; OROSZ, E.; SZALAI, J. SOCIAL POLICY IN HUNGARY; THE NEW EASTERN EUROPE: SOCIAL POLICY PAST, PRESENT AND FUTURE

SAGE PUBLICATIONS, $1992,144-166$.

THIS CHAPTER ON HUNGARIAN SOCIAL POLIYC FOCUSES ON SOCIAL SECURITY POLICY AND MEDICAL CARE POLICY. THE MAJOR PART IS AN ANALYSIS OF THE WAY IN WHICH DEVELOPMENTS IN SOCIAL SECURITY POLICY IN THE YEARS BEFORE 1989 UNDERPINNED THE ORGANIC DEVELOPMENT OF A SECOND ECONOMY WHICH IN TURN FACILITATED THE GROWTH OF A HIDDEN CIVIL SOCIETY IN HUNGARY, THE FINAL SECTION FOCUSES ON THE CURRENT PROPOSALS BY THE MINISTRY OF WELFARE TO OVERCOME THE LEGACY OF MORBIDITY AND MORTALITY PROBLEMS BEQUEATHED TO IT BY THE PREVIOUS

INEFFICIENT AND UNDERFUNDED STATE MEDICAL CARE SERVICE. THE CHAPTER UNDERLINES THE POINT THAT EVEN THO YEARS INTO THE REFROM PROCESS VERY LITTLE HAS YET BEEN SETTLED BY WAY OF THE NEN INSTITUTIONAL MECHANISMS TO IMPLEMENT A NEW SOCIAL POLICY.

02727 DEACON, B.; MILLARD, F.

SOCIAL POLICY IN POLAND; THE NEW EASTERN EUROPE: SOCIAL POLICY PAC

SAGE PUBLICATIONS, $1992,118-143$. EXPLAIN THE MATURE OF COMMUNIST SOCIAL POL ICY IN POLAND AND EXPLAIN THE NATURE OF COMMUNIST SOCIAL POLICY IM POLA
HOW AND WHY IT FAILED. SECOND, IT WILL EXAMINE THE HOW AND WHY IT FAILED. SECOND, IT WILL EXAMINE THE IMPLICATIONS OF THIS FAILURE FOR THE THO SOL IDARITY
GOVERNMENTS OF 1989-91. THIRD, IT AIMS TO EXPLAIN THE SOCIAL POLICY OF THE EARLY POST-COMMUNIST PERIOD, INDICATING THE EXTENT AND REASONS FOR CHANGE. THE PROBLEMS ENCOUNTERED PROVIDE ONE WITH THE BASIS FOR AN ASSESSMENT OF FUTURE PROSPECTS FOR THE SURVIVAL OF A POLISH WELFARE STATE; THESE PROSPECTS ARE NOT ENCOURAGING.

02728 DEACON, B.; MANNING, N.

SOCIAL POLICY IN THE SOVIET UNION AND ITS SUCCESSORS; THE NEW EASTERN EUROPE: SOCIAL POLICY PAST, PRESENT AND FUTURE SAGE PUBLICATIONS, 1992, 31-66.

TO UNDERSTAND SOVIET SOCIAL POLICY, THIS CHAPTER

EXPLAINS THE NATURE OF THE SOVIET UNION, AS IT WAS UNTIL DECEMBER 1991. IT EXPLORES THE PROBLEMS OF SOCIAL POLICY, PRE-PERESTROIKA AND THE COLLAPSE OF THE OLD REGIME. IT CONTINUES WITH AN ANALYSIS OF THE NEW CRISES OF SOCIAL POLICY AND THE EMERGING STRATEGIES FOR WELFARE. IT CONCLUDES THAT IN THE IMMEDIATE FUTURE THERE WILL BE LITTLE SUBSTANTIAL CHANGE IN SOCIAL POLICY, UNLESS EITHER THERE IS A SPECTABULAR COLLAPSE IN THE ECONOMY, OR YELTSIN'S POPULARITY BEGINS TO SLIP AWAY.

02729 DEACON, B.

THE FUTURE OF SOCIAL POLICY IN EASTERN EUROPE; THE NEH EASTERN EUROPE. SOCIAL POL ICY PAST, PRESENT AND FUTURE SAGE PUBLICATIONS, 1992, 167-191.

THE MAIN TRENDS IN THE DEVELOPOMENT OF SOCIAL POLICY IN EASTERN EUROPE AT THE BEGINNING OF THE TRANSITION TO MARKET ECONOMIES ARE SUMMARIZED. THE DIVERSIIY OF DEVELOPMENTS AS WELL AS THE COMHONALITIES ARE NOTED AND HOW THE ISSUES OF SOCIAL POLICY IN TRANSITION ARE BEING HANDLED IN PRACTICE IS REFLECTED UPON. THIS CHAPTER ALSO ADDRESSES THE QUESTION THAT WILL BE OF INTEREST TO THOSE WHO WONDER WHAT THE IMPLICATIONS OF THE COLLAPSE OF COMMUNISM IN EASTERN EUROPE AND SOVIET UNION ARE FOR ANY FUTURE ATTEMPT TO IMAGINE AND CONSTRUCT A SOCIALIST SOCIAL POLICY.

02730 DEACON, B.; CASTLE-KANEROVA, M.; MANNing, N.: MILlaRd, F. OROSZ, E.; SZALAL, J.; VIDIMOVA, A. 
THE NEW EASTERN EUROPE--SOCIAL POLICY PAST, PRESENT, AND FUTURE

SAGE PUBLICATIONS, 1992, 208

BRINGING TOGETHER LEADING SPECIALISTS ON THE SOCIAL POLICY OF THE FORMER SOVIET UNION, HUNGARY, CZECHOSLOVAKIA, BULGARIA AND POLAND, THIS BOOK SYSTEMATICALLY OUTLINES THE, SHORTCOMINGS OF THE OLD BUREAUCRATIC COLLECTIVIST BRAND OF WELFARE. THE AUTHORS EXPLAIN WHY THE EMERGING SYSTEM IS--A LEAST INITIALLY--OFTEN INADEQUATE. EMPHASIZING THIS UNIQUE THE DIFFICULTY OF BALANCING SOCIAL JUSTICE AND ECONOMIC

THE DIFFICULTY OF BALANCING
EFFICIENCY IN SOCIAL POLICY.

02731 DEBARDELEBEN, J. (ED.)

TO BREATHE FREE

JOHN HOPKINS UNIVERSITY PRESS, 1991, 272

THIS BOOK DESCRIBES ENYIRONMENTAL PROBLEMS, GOVERHMENTAL RESPONSES, AND THE ENVIRONMENTAL MOVEMENTS (BOTH OFFICIAL AND UNOFFICIAL) OF EAST EUROPEAN COUNTRIES. ISSUES DISCUSSED INCLUDE: ENVIRONMENTAL PROTECTION ISSUES AS THEY AFFECT SOVIET-EAST EUROPEAN RELATIONS; LEGAL ASPECTS OF POLLUTION ACROSS NATIONAL BOUNDARIES; ENVIRONMENTAL DAMAGE IN THE GERMAN DEMOCRATIC REPUBLIC; ROMANIA'S ENVIRONMENTAL CRISIS AND RECENT HUNGARIAN APPROACHES TO AGRICULTURAL POLLUTION.

02732 DEBO, R.K.

SURVIVAL AND CONSOLIDATION: THE FOREIGN POLICY OF SOVIET RUSSIA, 1918-1921

MCGILL-OUEEN'S UNIVERSITY PRESS, 1992, 532.

THIS BOOK PROVIDES A DETAILED EXAMINATION OF THE NEW POLITICAL REALITIES THAT SLOWLY EMERGED IN EASTERN EUROPE AFTER THE FIRST WORLD WAR. THE AUTHOR ARGUES THAT THE SUPERIOR POLITICAL AND DIPLOMATIC SKILLS OF THE BOL SHEVIKS ENABLED THEM TO WIN THE RUSSIAN CIVIL HAR. THEIR ABILITY TO FIND ALLIES AND DIVIDE OPPONENTS WAS CRITICAL IN THEIR VICTORY. THE BOOK DESCRIBES THE BOLSHEVIKS' DIPLOMATIC SUCCESSES WITH BRITAIN, POLAND, AND GERMANY, THE CONTINUING DIFFICULTUES WITH ROMANIA, FRANCE AND THE UNITED STATES, AND THE THREAT FROM THE FAR EAST. IT CONCLUDES THAT THE DIPLOMATIC SUCCESS HAS THE RESULT OF SOVIET VICTORY IN THE DIPLOMATIC SUCCESS HAS THE RESULT OF SOVIET VICTORY IN THE
CIVIL WAR AND THE PATIENT PURSUIT OF REALIZABLE OBJECTIVES.

02733 DECARVALHO, J.M.

BRAZIL 1870-1914: THE FORCE OF TRADITION

JOURMAL OF LATIN AMERICAN STUDIES, 24 (1992), 145-162

ALTHOUGH THERE HAS AN ADVANCE OF MODERMITY IN BRAZIL AFTER 1870 TRADITION AN ADVANCE OF MODERNITY IN BRAZIL THE VALUES OF A RURAL, PATRIARCHAL, AND HIERARCHICAL SOCIETY. THIS BRAZILIAN MODERNITY ASSUMED CHARACTERISTICS THAT DIST INGUISHED IT FROM THE CLASSIC MODEL REPRESENTED BY THE ANGLO-SAXON EXPERIENCE. IN THE PERIOD FROM 1870 TO 1914 IN BRAZIL, THE GROUND HAS CLEARED FOR THE CONSERVATIVE MODERNIZATION OF THE 1930'S.

02734 DECK, G.

REFORM IS NOT POLITICALLY NEUTRAL

PUBLIC ADMINISTRATION REVIEH, 52(6) (NOV 92), 600

THE AUTHOR COMMENTS ON AARON HILDAVSKY'S "POLITICAL IMPLICATIONS OF BUDGETARY REFORM" AND "THE POLITICS OF THE BUDGETARY PROCESS" FROM A PRACTICTIONER'S PERSPECTIVE.

02735 DECTER, $M$.

HOW THE RIOTERS WON

COMMENTARY, $94(1)$ (JUL 92), 17-22.

AFTER REVIEWING THE WATTS RIOTS AND THE MORE RECENT CARNAGE IN LOS ANGLES, THIS AUTHOR SUGGESTS THAT THERE HAS EMERGED A NEW CADRE OF JOURNALISTS WHO SEEM POSITIVELY BLOWN AWAY BY THE DISCOVERY THAT ALL IS NOT WELL AMONG AMERICA'S INNER-CITY-BLACKS. ADD THIS TO THE FACT THAT WE ARE IN A PRESIDENTIAL YEAR AND YOU HAVE THE INGREDIENTS OF AN EVEN PRESE VOLUBLE ROUND OF THE RITUALISTIC POSITION-TAKING WHICH HAS COME TO CONSTITUTE THE NATION'S NORMAL DISCUSSION OF RACE POLICY. IT IS SUGGESTED THAT THE PROBLEM OF THE BLACK UNDERCLASS IS A PROBLEM THAT WILL ONLY BE SOLVED ONE BY ONE AND FROM THE INSIDE OUT.

02736 DEDE, C.J.

EDUCATION IN THE THENTY-FIRST CENTURY

ANNALS OF THE AMERICAN ACADEMY OF POLITICAL AND SOCIAL SCIENCE, 522 (JUL 92), 104-115.

THE UNITED STATES' 'MULTIPLE EDUCATIONAL SYSTEMS ARE ITS MAJOR LONG-TERM MECHANISM FOR SHAPING THE FUTURE, BUT THIS MAJOR LONG-TERM MECHANISM FOR SHAPING THE FUTURE, BUT THIS STATIC WHILE SOCIETY HAS CHANGED. THE EMERGENCE OF A GLOBAL STATIC WHILE SOCIETY HAS CHANGED. THE EMERGENCE OF A GLOBAL INTELLIGENT TOOLS AND THE GROWING CHALLENGE OF DIVERSITY INTELLIGENT TOOLS AND THE GROWING CHALLENGE OF DIVERS WHEN EXCELLENCE AND QUALITY DEPEND ON A PLURALISTIC
UNDERSTANDING OF A WORLDWIDE MARKET ARE UNDERSCORING THE DECLINE IN THE EFFECTIVENESS OF AMERICA'S INSTRUCTIONAL ENVIRONMENTS. BUILDING ON SOCIETAL DISCONTENT WITH TRADITIONAL EDUCATIONAL MODELS, THE EVOLUTION OF ADVANCED TECHMOLOGIES FOR TEACHING, LEARNING, AND MANAGEMENT AND THE INITIATION OF A RESTRUCTURING MOVEMENT FOR EDUCATIONAL REFORM PROVIDE CONTEXTS FOR INMOVATION THAT COULD FOSTER THE
IMPLEMENTATION OF NEW PARADIGMS FOR EDUCATION. NONETHELESS, A FUTURE OF LITTLE OR NO CHANGE IN AMERICAN EDUCATION IS ALL TOO PROBABLE; SIMILAR OPPORTUNITIES FOR INMOVATION HAVE SLIPPED AWAY IN THE PAST.

02737 DEDERICHS, R.

A SIGN OF HOPE SURFACES FOR BOGGED-DOWN EFFORTS TO BRING PEACE TO MIDDLE EAST

GERMAN TRIBUNE, (1526) ( JUL 92), 2.

ISRAEL'S NEH GOVERNMENT, LED BY YITZHAK RABIN, HAS BREATHED NEW LIFE INTO THE STALLED EFFORTS TO SETTLE THE MIDOLE EAST CONFLICT. THE LIMITED DISCONTINUATION OF THE MIDOLE EAST CONFLICT. THE LIMITED DISCONTINUATION OF THE
ESTABLISHMENT OF NEW SETTLEMENTS IN THE OCCUPIED TERRITORIES ESTABLISHMENT OF NEN SETTLEMENTS IN THE OCCUPIED TERR CAN AT LEAST BE VIEWED AS A SIGN OF GOOOWILL AND A
CONFIDENCE-BUILDING MEASURE, EVEN THOUGH THE PROJECTS UNDER CONFIDENCE-BUILDING MEASURE, EVEN THOUGH THE PROJECTS UNDER
CONSTRUCTION ARE TO BE COMPLETED. RABIN'S COMPROMISE WAS CONSTRUCTION ARE TO BE COMPLETED. RABIN'S COMPROMISE WAS
HIGHLY PRAISED BY THE UNITED STATES. HOWEVER, SIGNIFICANT OBSTACLES TO PEACE--FROM RADICAL ISRAELI SETTLERS TO FUNDAMENTALIST PALESTINIAN GROUPS--REMAIN.

02738 DEDIAL, J.

MOUNTING SOCIAL PRESSURES IN SOUTH AFRICA

SWISS REVIEW OF WORLD AFFAIRS, 42(2) (MAY 92), 12-13.

CHANGES ARE COMING SWIFTLY' IN SOUTH AFRICA: NEGOTIATIONS ON A NEW CONSTITUTION PROMISE THE RAPID DISMANTLING OF APARTHEID. BUT, WITH EACH PASSING DAY, THE REAL PROBLEMS ARE BECDMING MORE VISIBLE AGAINST A BACXGROUND OF SERIOUS ECONOMIC TROUBLES; MASSES OF IMPOVERISHED BLACKS ARE STREAMING FROM THE COUNTRYSIDE INTO THE CITIES, WHERE SOCIAL CONDITIONS ARE DETERIORATING RAPIDLY.

02739 DEEB, M.

MILITANT ISLAM AND THE POLITICS OF REDEMPTION ANNALS OF THE AMERICAN ACADEMY OF POLITICAL AND SOCIAL SCIENCE, (524) (NOV 92), 52-65.

IN THE LAST DECADE, MILITANT ISLAM HAS EMERGED AS A MAJOR POLITICAL FORCE IN THE MIDDLE EAST. IT IS CHARACTERIZED BY THE READINESS TO USE VIOLENCE AND BY THE CHALLENGE IT POSES TO EXISTING POLITICAL INSTITUTIONS. IN THIS PAPER, THE AUTHOR DESCRIBES THE CONDITIONS UNDER WHICH MILITANT ISLAMIC MOVEMENTS HAVE EMERGED AS A POLITICAL FORCE MILITANT ISLAMIC MOVEMENTS HAVE EMERGED AS A POLITICAL FORCE
IN ALGERIA, TUNISIA, LIBYA, LEBANON, THE GAZA STRIP, AND THE IN ALGERIA, TUNISIA, LIBYA, LEBANON, THE GAZA STRIP, AND THE
WEST BANK. SHE ALSO EXPLAINS THE CONCEPTS THEY HAVE USED TO WEST BANK. SHE ALSO EXPLAINS THE CONCEPTS THEY HAVE
MOBILIZE PUBLIC SUPPORT AND CREATE A MASS BASE FOR MOBILIZE PUBLIC SUPPORT AND CREATE A MASS BASE FOR THEMSELVES IN ORDER TO CHALLENGE INCUMBENT LEADERS OR
GOVERNMENTS. THE CONDITIONS INCLUDE POLITICAL STAGNATION AND GOVERMMENTS. THE CONDITIONS INCLUDE POLITICAL STAGNATION LEADING TO A DECLINE IN LIVING STANDARDS, DETERIORATING LEADING TO A DECLINE IN LIVING STANDARDS, DETERIORATING SECURITY CONDITIONS, THE PERVASIVENESS OF HESTERN CULTURE,
AND SECULAR STATES AND LEADERS PERCEIVED AS ANTAGONISTIC TO AND SECULAR STATES AND LEADERS MOVEMENTS. THE LEADERS OF THESE MOVEMENTS DO NOT PORTRAY THEMSELVES AS REVOLUTIONARIES TRYING TO CREATE A NEW SOCIETY BUT RATHER AS SAYIORS TRYING TO RESCUE THE OLD SOCIETY FROM SELF-DESTRUCTION. THEIRS IS AN IDEOLOGY OF REDEMPTION.

02740 DEEB, M. ; DEEB, M.K.

REGIONAL CONFLICT AND REGIONAL SOLUTIONS: LEBANON ANNALS OF THE AMERICAN ACADEMY OF POLITICAL AND SOCIAL SCIENCE, (518) (NOV 91), 82-94.

THE LEBANESE CONFLICT WENT THROUGH A NUMBER OF PHASES, EACH WITH ITS OWN RATIONALE, INCORPORATING DIFFERENT ISSUES AND AT TIMES DIFFERENT PLAYERS. THROUGHOUT, THERE WERE ATTEMPTS ON BOTH THE INTERNAL AND EXTERNAL LEVELS TO FIND A SOLUTION TO WHAT WAS PLAGUING THE COUNTRY AND EROOING ITS POLITICAL AND SOCIAL INSTITUTIONS. THIS ARTICLE STUDIES THREE MAJOR ATTEMPTS AT RESOLVING THE LEBANESE CONFLICT WHEN THE REPRESENTATIVES OF THE DOMESTIC FACTIONS MET AND CAME UP WITH FORMULAE THAT APPEARED TO ADDRESS EVERYONE'S CONCERNS. THE PROCESS OF MULAPEARE TEGOTIATIONS THE ASYMMETRICAL STRUCTURES OF THOSE NEGOTIATIONS, THE RIPE MOMENT FOR NEGOTIATING, THE ROLE OF EXTERNAL MEDIATORS, AND THE ISSUE OF THE VALID SPOKESMAN ARE ANALYZED WITHIN A THEORETICAL FRAMEHORK BASED ON I. WILLIAM ZARTMAN'S MODEL OF GOVERNMENTINSURGENCY NEGOTIATIONS.

02741 DEERE, C.D.; MEURS, M.

MARKETS, MARKETS EVERYWHERE? UNDERSTANDING THE CUBAN

ANOMALY
HORLD DEYELOPMENT, 20(6) (JUN 92), 825-839.

COMPARED WITH OTHER CENTRALLY-PLANNED ECONOMIES, CUBA HAS MADE EXCEPTIONALLY LITTLE USE OF MARKETS. HOWEVER, IN THE 1970'S THE CUBANS DID BEGIN TO EXPERIMENT WITH A STATECONTROLLED, PARALLEL MARKET AND IN 1980 WITH A FREE PEASANT MARKET. AFTER SIX YEARS, THIS MARKET WAS CLOSED BECAUSE IT PRODUCED TENSIONS COMMON TO OTHER SOCIALIST EXPERIMENTS WITH MARKET MECHANISMS: HIGH PRICES, INCOME AND CONSUMPTION INEQUALITY, AND THE ILLEGAL REDIRECTION OF RESOURCES FROM
THE PLANNED TO THE MARKET SPHERE. THE FREE PEASANT MARKET THE PLANMED TO THE MARKET SPHERE. THE FREE PEASANT MARKET WAS REPLACED WITH A MORE LIMITED MARKET MECHANISM--AN
EXPANDED PARALLEL MARKET IN BOTH AGRICULTURAL PROCUREMENT AND FOOD OISTRIBUTION--CONSIDERED MORE COMPATIBLE WITH THE CUBAN COMMITMENT TO EGALITARIANISM. 
02742 DEFRANCISCIS, M.E.; ZANNINI, R. JUDICIAL POLICY-MAKING IN ITALY: THE CONSTITUTIONAL COURT HEST EUROPEAN POLITICS, 15(3) (JUL 92), 68-79

THIS STUDY FOCUSES ON THE ITALIAN CONSTITUTIONAL COURT, THE NEWEST AND MOST PRESTIGIOUS ADDITION TO A JUDICIAL TRADITION THAT CAN BE TRACED BACK TO THE ROMAN EMPIRE. THIS COURT HAS BEEN AN EFFECTIVE POLICY-MAKING BODY, PARTICULARLY IN MATTERS OF CIVIL LIBERTIES AND CHURCH-STATE RELATIONS, AS WELL AS IN COMPELLING THE LEGISLATIVE BRANCH, WHERE IT HAS BEEN SO CHARGED, TO COMPLETE THE DRAFTING OF THE CONSTITUTION. HOWEVER, THE COURT HAS FALTERED AT TIMES IN DEFENOING ITS INDEPENDENCE, AND LIFE APPOINTMENTS MIGHT BE A VIABLE MEANS OF ACHIEVING THE GOAL OF A CONSTITUTIONAL BODY THAT SERVES "NEC SPE MEC METU."

02743 DEGRAAF, N.; HEATH, A.

HUSBANDS' ANO WIVES' VOTING BEHAVIOR IN BRITAIN: CLASSDEPENDENT MUTUAL INFLUENCE OF SPOUSES

ACTA SOCIOLOGICA, 35(4) (1992), 311-322

THE AUTHORS INVESTIGATE THE' RELATIVE IMPACT OF

RESPONDENT'S AND SPOUSE'S CLASS ON VOTING BEHAVIOR USING LOGISTIC DIAGONAL REFERENCE MODELS. THEY TEST SEVERAL LOGISTIC DIAGONAL REFERENCE MODELS. THEY TEST SEVERAL 1974, 1979, 1983 AND 1987. THEY FIMD THAT THERE ARE STILL $1974,1979,1983$ AND 1987 . THEY FIND THAT THERE ARE SIILL THEIR OWN CLASS POSITIONS ACCOUNT FOR THE WAY THEY VOTE, THEIR OWN CLASS POSITIONS ACCOUNT FOR THE WAY THEY VOTE,
WOMEN BEING MORE INFLUENCED BY THEIR PARTHER;S CLASS WOMEN BEING MORE INFLUENCED BY THEIR PARTHER;S CLASS POSITION, A "CLASS DOMINANCE" MODEL CANNOT ACCOUNT FOR THE
GREATER INFLUENCE OF HUSBANDS THAN OF WIVES. THE RESULTS DO HOWEVER MODIFY THE CONVENTIONAL APPROACH TO CLASS IN IMPORTANT RESPECTS. THEY FIND SIGNIFICANT INTERACTION EFFECTS, WOMEN IN THE HIGHER AND LOWER SERVICE CLASS AND WOMEN IN BLUE-COLLAR OCCUPATIONS BEHAVING MUCH LIKE MEN: THEIR PARTNER'S. CONVERSELY, WOMEN IN THE PETTY BOURGEOISIE AND IN THE ROUTINE NONMANUAL CLASS TAKE RELATIVELY LITTLE ACCOUNT OF THEIR OWN CLASS POSITIONS: THEIR BEHAVIOR IS MORE IN LINE WITH THE CONVENTIONAL ASSUMPTION OF MALE DOMINANCE. FINALLY, NO TRENDS OVER TIME, WHETHER TOWARDS "INDIVIDUALISM,

" "FEMINISM" OR "SHARING," COULD BE DETECTED.

02744 DEGRAFT-JOHNSON, J.H.S

QUESTIONS OF HONESTY

WEST AFRICA, (3889) (MAR 92), 544

FLT. LT. JERRY RAWL INGS HAS ANMOUNCED A PROGRAM TO RETURN CONSTITUTIONAL. CIVILIIAN GOVERMMENT TO GHANA. THE TIMETABLE CALLS FOR THE COMPLETION OF A CONSTITUTION BY APRIL 28, 1992; LIFTING OF THE BAN ON POLITICS ON MAY 18; APRIL 28, 1992; LIFTING OF THE BAN ON POLITICS ON MAY 18; ELECTIONS ON DECEMBER 8; AND THE INAUGURATION OF THE ELECTED ELECTIONS ON DECEMBER 8; AND THE INAUGURATION OF THE ELECTED
GOVERNMENT IN JANUARY 1993. SOME OBSERVERS ARE OUESTIONING RAWLINGS' INTENTIONS AND FEAR THAT HE WILL ABANDON THESE PLANS WHEN IT IS CONYENIENT FOR HIM TO DO SO.

02745 DEGREGORIO, C

LEADERSHIP' APPROACHES IN CONGRESSIONAL COMMITTEE HEARINGS WESTERN POLITICAL QUARTERLY, 45(4) (DEC 92), 971-984.

THE PUBLIC HEARING OFFERS A CRITICAL OPPORTUNITY FOR CONGRESSIONAL COMMITTEE LEADERS TO AFFECT WHICH ISSUES WILL BE GRANTED TIME FOR PUBLIC SCRUTINY AND WHICH BILLS WILL BE ADVANCED TO THE FLOOR WITH A FAVORABLE RECORD. BASED ON THE PERSONAL REFLECTIONS OF 43 STAFF DIRECTORS AND A SMALL COMPLEMENT OF COMMITTEE CHAIRS, THIS PAPER PRESENTS NEW EVIDENCE ON THE LEADERS, ROLE IN AGEMDA FORMATION AMD WITNESS SELECTION. THE FINDING THAT BEHAVIORAL DIFFERENCES IN MANAGING AGENDAS ANO TESTIMONY DO NOT CLUSTER AROUND ACKNOWLEDGED DIFFERENCES AMONG COMMITTEES OFFERS AN INTERESTING PUZZLE SUGGESTING LINES FOR FURTHER INQUIRY.

02746 DEIBEL, T.

STRATEGIES BEFORE CONTAIMMENT: PATTERNS FOR THE FUTURE INTERNATIONAL SECURITY, 16(4) (SPR 92), 79-108.

THE END OF THE COLD WAR AND THE DISINTEGRATION OF THE SOVIET UNION DEMAND THAT AMERICAN FOREIGN POLICY ANALYSTS RETHINK THEIR MOST BASIC ASSUMPTIONS. THIS ARTICLE IS INTENDED TO CONTRIBUTE TO THAT EFFORT BY COMPARING PAST STRATEGIC PATTERNS WITH FUTURE STRATEGIC POSSIBILITIES. SPECIFICALLY, IT EXAMINES U.S. FOREIGN AFFAIRS STRATEGIES BEFORE THE COLD WAR, IN THREE AREAS OF THE NATIONAL INTEREST, FOR CLUES ABOUT THE LIKELY CONTOURS OF THE AMERICAN STRATEGY IN THE POST-COLD WAR ERA. ITS PURPOSE IS TO BROADEN STRATEGY IN THE POST-COLD WAR ERA. ITS PURPOSE IS TO BROA THE RANGE OF POSSIBILITIES UNDER CONSIDERATION, ON THE
PREMISE THAT STRATEGIES DESIGNED TO SERVE U.S. INTERESTS PREMISE THAT STRATEGIES DESIGNED TO SERVE U.S. INTERESTS BEFORE THE SOVIET THREAT DOMINATED AMERICAN STATECRAFT MAY THOSE INTERESTS AFTER THE SOVIET THREAT HAS DISAPPEARED.

02747 DEIS, M.J.

A STUDY OF NATIONALISM IN CZECHOSLOVAKIA

RFE/RL RESEARCH REPORT, 1(5) (JAN 92), 8-13.

THE PHENOMENON OF NATIONALISM IN CZECHOSLOVAKIA IS OF GROWING INTEREST AND IMPORTANCE. A STUDY CONDUCTED IN LATE 1991 BY THE MEDIA AND OPINION RESEARCH DEPARTMENT OF THE RFE/RL RESEARCH INSTITUTE INDICATED THAT NEITHER CZECHS NOR
SLOYAKS FAYOR THE DISINTEGRATION OF CZECHOSLOYAKIA AT PRESENT FAVR THE OTSINTEGRATION OF CZECHOSLOVAKIA AT SIGNIFICANTLY AND IN MANY CASES ARE AT ODDS WITH EACH OTHER. THE SITUATION IS RIPE FOR MISUNDERSTANDING, AKD THE ISSUE OF NATIONALISM HILL NOT BE EASLIY RESOLVED IN CZECHOSLOVAKIA.

02748 DEJONG, W.; VERKUYTEN, M.

POSITIVE ACTION POLICY FOR ETHNIC MINORITIES IN THE NETHERLANDS

NEH COMMUNITY, 18(4) (JUL 92), 591-602.

IN CONTRAST TO THE UNITED KINGDOM AND THE UNITED STATES, POSITIVE ACTION FOR ETHNIC MINORITIES IS A RELATIVELY NEH ISSUE IN THE NETHERLANDS. CURRENTLY, THERE IS MUCH DEBATE ABOUT SOCIAL POLICY AND THE LEGAL FORMS THAT POSITIVE ACTION PROGRAMS SHOULD TAKE. TWO SURVEYS HAVE BEEN CONDUCTED TO ASCERTAIN THE OPINIONS OF THE DUTCH POPULATION AND OF MANAGERS IN PUBLIC SECTOR COMPANIES. BOTH STUDIES REVEAL THAT, IN GENERAL, THERE IS AGREEMENT WITH POSITIVE ACTION POLICIES BUT PEOPLE OBJECT TO THEM WHEN THEY IMPLY

PREFERENTIAL TREATMENT.

02749 DELAGRAN, L.

CONFLICT' IN TRADE POLICY: THE ROLE OF CONGRESS AND THE PROVINCES IN NEGOTIATING AND IMPLEMENTING THE CANADA-U.S. FREE TRADE AGREEMENT

PUBLIUS: THE JOURNAL OF FEDERALISM, 22(4) (FAL 92), 15-30.

UNTIL RECENTLY THE PROVINCIAL ROLE IN CANADIAN TRADE

POL ICY HAS BEEN LIMITED BUT THE INCREASING IMPACT OF

INTERNATIONAL TRADE NEGOTIATIONS ON DOMESTIC POLICY ISSUES HAS COME INTO DIRECT CONFLICT WITH PROVINCIAL JURISDICTION. AT THE SAME TIME, CONGRESS HAS CEDED SOME OF ITS

CONSTITUTIONAL AUTHORITY OVER TRADE MATTERS TO THE EXECUTIVE BRANCH BY GRANTING "FAST TRACK" NEGOTIATING AUTHORITY. THIS PAPER ARGUES THAT, AS A RESULT OF THESE DEVELOPMENTS, THE FUNCTIONAL ROLES THAT CONGRESS AND THE PROVINCES PLAYED IN THE NEGOTIATION OF THE FTA WERE NOT SIGNIFICANTLY OIFFERENT IN THE TWO COUNTRIES. HOWEVER, IN THE IMPLEMENTATION OF THE TRADE AGREEMENT, ROLES AGAIN BECAME CLEARLY DEFINED BY CONSTITUT IONAL JURISDICTION.

02750 DELATORRE, C.

THE AMBIGUOUS MEANINGS OF LATIN AMERICAN POPULISMS SOCIAL RESEARCH, 59(2) (SUM 92), 385-414.

THROUGH A DISCUSSION OF RECENT CASE STUDIES, THE AUTHOR PRESENTS A NEH APPROACH TO THE STUDY OF LATIN AMERICAN POPULISMS, EMPHASIZING THE ANALYSIS OF THOSE MECHANISMS THAT, ON ONE HAND, EXPLAIN THE APPEAL OF POPULIST LEADERS AND, ON THE OTHER, ILLUMINATE THE AUTONOMOUS EXPECTATIONS AND ACTIONS OF THEIR FOLLOWERS.

02751 DELCASTILLO, P.; LOPEZ-NIETO, L. SPAIN

EUROPEAN JOURNAL OF POLITICAL RESEARCH, 22(4) (DEC 92),

IN SPAIN'S 1991 LEGISLATIVE ELECTIONS, 128 SOCIALIST PARTY CANDIDATES WERE ELECTED TO THE SENADO (UPPER HOUSE), GIVING THAT PARTY THE LARGEST REPRESENTATION. AS OF JANUARY 1, 1991, ALL MEMBERS OF PRESIDENT GONZALEZ'S CABINET
BELONGED TO THE SOCIALIST PARTY.

02752 DELEON, $P$.

THE DEMOCRATIZATION OF THE POLICY SCIENCES

PUBLIC ADMINISTRATION REVIEW, 52(2) (MAR 92), 125-129.

THE AUTHOR BELIEVES IT IS POSSIBLE TO REDUCE THE ISOLATION OF POLICY ANALYSTS AND PROGRAM EVALUATORS, WHO OFTEN PRODUCE ASSESSMENTS AND RECOMMENDATIONS THAT SEEM TO BE OUT OF TOUCH WITH THE PUBLIC'S NEEDS AND WANTS. HE CALLS FOR A PARTICIPATORY POLICY ANALYSIS THAT WOULD OPEN THE PROCESS TO GREATER INPUT AND INVOLVEMENT IN SITUATIONS WHERE SUCH AN APPROACH IS FEASIBLE. WHILE ADMITIING THAT SUCH DEMOCRATIZATION IS MORE DIFFICULT IN PRACTICE THAN IN CONCEPT, HE NOTES THAT THE LEGITIMACY OF THE POLICY ANALYST'S ENDEAVOR IS AT STAKE.

02753 DELEON, $P$

THINKING ABOUT CORRUPTION

M. E. SHARPE, 1993, 192.

THIS BOOK PROPOSES A MODEL OF CORRUPTION THAT ANALYZES THE PHENOMENON FOR THE MOST PART AS A HIDDEN BUT INTEGRAL FEATURE OF THE AMERICAN POLITICAL SYSTEM, A RECOURSE DESIGNED NOT TO UNDERMINE THE HORKINGS OF GOVERNMENT BUT ACTUALLY TO EXPEDITE THEM. WHILE IT IS INDIVIDUALS WHO ACTUALLY TO EXPEDITE THEM. WHILE IT IS INOIVIDUALS WHO ACTUALLY ENGAGE IN CORRUPTION, THEIR MOTIVES ARE OFTEN
BEYOND SIMPLE AVARICE; MOREOVER, IT IS THE POLITICAL SYSTEM BEYOND SIMPLE AVARICE; MOREOVER, IT IS THE POLITICAL SYSTEM THAT CONDONES AND EVEN ENCOURAGES SUCH ACTIONS. ONCE PERSPECTIVE IS RECOGNIZED, ONE MIGHT EVEN BEGIN TO UNDERSTAND WAYS IN WHICH THE COSTS OF CORRUPTION MIGHT BE ALLEVIATED. THE BOOK OFFERS A THEORY OF POLITICAL CORRUPTION, DRAHING LARGELY ON THE WORK OF SOCIOLOGIST ROBERT K. MERTON. IT THEN PROVIDES FIVE CASE STUDIES OF CONTEMPORARY AMERICAN POLITICAL CORRUPTION ON THE FEDERAL LEVEL-OTHE HUD SCANDALS, WEDTECH, IRAN-CONTRA, PROCUREMENT IRREGULARITIES IN THE ARGUMENT. THE FIMAL CHAPTER SUGGESTS SOME WAYS IN WHICH 
POLITICAL CORRUPTION ANO ITS EFFECTS MIGHT BE REDUCED.

02754 DELEON, R.E.

THE URBAN ANTI-REGIME: PROGRESSIVE POLITICS IN SAN FRANCISCO

URBAN AFFAIRS QUARTERLY, 27(4) (JUN 92), 555-579.

SAN FRANCISCO IS IN TRANSITIION BETWEEN TWO URBAN REGIMES, A CUMBLING BUSINESS-DOMINATED PRO-GROWTH REGIME AND AN EMERGING PROGRESSIVE SLOW-GROWTH REGIME, WHICH IS BEST DESCRIBED AS AN "ANTI-REGIME" BECAUSE IT FUMCTIONS MAINLY TO INTO A REGIME, THE CITY'S PROGRESSIVE LEADERS MUST RECONCILE INTO A REGIME, THE CITY'S PROGRESSIVE LEADERS MUST RECONC
THE DIVERGENT POLITICAL INTERESTS OF CDALITION ELEMENTS,
RENEGOTIATE A PARTNERSHIP WITH THE PRIVATE SECTOR THAT IS RENEGOTIATE A PARTNERSHIP WITH THE PRIVATE SECTOR THAT IS
CONSISTENT WITH SLOW-GROWTH OBJECTIVES, AND SETTLE DISPUTES CONSISTENT WITH SLOW-GROWTH OBJECT IVES, AND SETTLE D
SURROUNDING MAYOR AGNOS'S TENURE. THE PROGRESSIVE

COALITION'S EXCLUSIVE RELIANCE UPON A SMALL-BUSINESS ECONOMY COALITION'S EXCLUSIVE RELIANCE UPON A SMALL-BUSINESS
IS NOT SUFFICIENT TO RESOLVE CONTRADICTIONS BETWEEN MATERIALIST AND POST-MATERIALIST GOALS IN THE PROGRESSIVE MATERIALIS
AGENDA.

02755 DELFS, R

ADVANCE TO THE REAR

FAR EASTERN ECONOMIC REVIEN, 151(23) (JUN 91), 12-13.

STUNG BY CRITICISM OYER ITS FAILURE TO CONTRIBUTE. PERSONNEL AS WELL AS MONEY DURING THE GULF CRISIS, THE JAPANESE GOVERNMENT HAS PROPOSED THAT SELF-DEFENSE FORCE (SDF) MEMBERS MAY PARTICIPATE IN UN PEACEKEEPING OPERATIONS (PKO). THE NEW PLAN WOULD IN EFFECT ABROGATE A FORMER AGREEMENT SIGNED IN NOVEMBER 1990 AMONG THE RULING LIBERAL DEMOCRATIC PARTY (LDP) AND THO OPPOSITION PARTIES THAT CALLED FOR THE CREATION OF A SEPARATE ORGANIZATION FOR PKO PARTICIPATION COMPOSED OF CIVILIANS AND DISTINCT FROM THE SOF. HOWEVER, OPPOSITION TO THE PLAN IS LESS THAN THAT WHICH FACED THE EARL IER GOVERNMENT PROPOSAL INITIATED DURING THE GULF CRISIS. ONE REASON FOR THE CHANGE IS GROWING AWARENESS OF FOREIGN, NOTABLY AMERICAN, CRITICISM OF JAPAN'S PREVIOUS "UNCOOPERATIVE" POSITION.

02756 DELFS, R.

BACK ON TRACK

FAR EASTERN ECONOMIC REVIEW, 155(31) (AUG 92), 17.

JAPAN'S RULING LIBERAL DEMOCRATIC PARTY (LOP) WON SWEEPING VICTORY IN THE REGULAR UPPER HOUSE ELECTION ON 26 JULY, TAKING 69 OF 127 SEATS. THE RESULT IS A PERSONAL YICTORY FOR KIICHI MIYAZAHA HHICH MAY ENABLE HIM TO ACT MORE ASSERTIVELY IN THE SECOND YEAR OF HIS TERM AS PRIME MINISTER. IT ALSO SUGGESTS THAT THE LDP IS WELL ON TRACK TO RESTORING ITS LOST UPPER HOUSE MAJORITY AT THE NEXT ELECTION IN 1995. IN THE LAST UPPER HOUSE ELECTION, HELD IN 1989, VOTER ANGER
OVER THE RECRUIT BRIBERY SCANDAL, THE UNPOPULAR CONSUMPTION TAX, AND LIBERALIZATION OF FARM IMPORTS LED TO THE LDP WINNING ONLY 36 SEATS. THE 1992 OUTCOME IS ALL THE MORE SURPRISING BECAUSE ONLY FIVE MONTHS BEFORE THE VOTERS WENT TO THE POLLS THE LDP APPEARED HEADED FOR ELECTORAL DISASTER. POLITICAL ANALYSTS HAD FORECASTED THAT MIYAZAWA WOULD BE FORCED TO STEP DOWN TO TAKE RESPONSIBILITY FOR WHAT EVEN LDP SUPPORTERS THOUGHT WOULD BE A REPEAT OF THE 1989 DEBACLE. INSTEAD, IT IS THE OPPOSITION, ESPECIALLY THE RENGO-NO-KAI LABOR UNION, THAT IS REELING IN DEFEAT.

02757 DELFS, $R$.

CARRYING THE CAN

FAR EASTERN ECONOMIC REVIEW, 151(29) (JUL 91), 18-20.

TOKYO'S HESITANT RESPONSE TO U.S. REQUESTS FOR A DIRECT CONTRIBUTION TO THE GULF HAR HAS SPARKED CRITICISM OF THE "GAIMUSHO," AS JAPAN CALLS ITS FOREIGN MINISTRY. RELATIONS BETWEEN THE RULING LIBERAL DEMOCRATIC PARTY (LDP) LEADERSHIP AND THE FOREIGN MINISTRY HAVE DEGENERATED INTO WHAT SOME DESCRIBE AS A "COLD WAR." BUT THE MINISTRY APPEARS ONLY PARTLY TO BLAME FOR THE CHRONIC FAILURE OF JAPANESE FOREIGN POLICY TO MATCH THE COUNTRY'S STATUS AS A MAJOR ECONOMIC POWER. FOREIGN MINISTRY OFFICIALS LACK THE POLITICAL PULL ENJOYED BY THEIR COLLEAGUES IN OTHER MINISTRIES AND THE
MINISTRY IS OFTEN SEEN AS NOTHING MORE THAN A CHANNEL FOR THE TRANSMISSION OF FOREIGN PRESSURES.

02758 DELFS, R.

DOI CALLS IT A DAY

FAR EASTERN ECONOMIC REVIEN, 151(27) (JUL 91), 18.

THE FUTURE OF THE SOCIAL DEMOCRATIC PARTY OF JAPAN

(SDPJ) REMAINS UNCERTAIN FOLLOHING THE RESIGNATION OF TAKAKO DOI AS PARTY CHAIRMAN, OSTENSIBLY TO TAKE RESPONSIBILITY FOR THE PARTY'S DISASTROUS PERFORMANCE IN APRIL'S LOCAL ELECTIONS. DOI WAS THE FIRST HOMAN TO HEAD A MAJOR POLITICAL PARTY IN JAPAN. THE WAVE OF "DOI FEYER" WHICH SWEPT THE COUNTRY IN 1989 PROMPTED MANY PREDICTIONS THAT THE ELECTORAL GAINS UNDER HER LEADERSHIP COULD LEAD TO THE ESTABLISHMENT OF A TRUE THO-PARTY SYSTEM IN JAPAN. HOWEVER, THE SDPJ FAILED TO CAPITALIZE ON THE WEAKNESS OF THE RULING LIBERAL DEMOCRATIC PARTY, AND A SCHISM BETWEEN RIGHT-WING REFORMERS FAILUE MARXIST LEFT AND THE CURRENT SPECULATIONS OF FURTHER DECLINE.
02759 DELFS, R.

FALLING APART

FAR EASTERN ECONOMIC REVIEN, 154(52) (JAN 92), 13.

IT WAS A SHORT HONEYMOON BY ANY MEASURE. KIICHI

MIYAZAWA'S SELECTION AS PRIME MINISTER WAS BASED ON

EXPECTATIONS THAT HE WOULD BE A STRONGER LEADER THAN HIS HAPLESS PREDECESSOR, TOSHIKI KAIFU. BUT MIYAZAWA HAS PROVED FAR MORE VULNERABLE OVER HIS PAST INVOLVEMENT IN THE RECRUIT CORPORATE SCAMDAL THAN ANYONE ANTICIPATED. NOW IT IS DOUBTFUL THAT HE WILL EVEN BE ABLE TO SERVE OUT HIS THD-YEAR TERM. TWO SIGNIFICANT ISSUES WHICH HAVE DAMAGED MIYAZAWA ARE THE FAILURE OF THE BADLY MISHANDLED BILL TO AUTHORIZE JAPANESE SELF-DEFENSE FORCE (SDF) PARTICIPATION IN UN

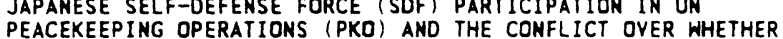
PEACEKEEPING OPERATIONS (PKO) AND THE CONFLICT OVER WHETHER

TO LIBERALIZE JAPAN'S DOMESTIC RICE MARKET AS PART OF
FINAL NEGOTIATIONS OF THE URUGUAY ROUND OF THE GATT.

02760 DELFS, $R$

HISTORY STIRS LEGACY OF FEAR

FAR EASTERN ECONOMIC REVIEW, 151(25) (JUN 91), 57-58.

THE PRESENT MISUNDERSTANDING AND CONFLICTS BETWEEN JAPAN AND THE UNITED STATES EXIST FIRMLY IN THE PRESENT TENSE AND THE U.S. SIDE SEEMS AT TIME TOTALLY LACKING IN HISTORICAL MEMORY. NOT SO FOR THE NATIONS OF ASIA WHO SUFFERED UNDER JAPANESE COLONIZATION AND DOMINATION, SOME FOR DECADES. THERE IS NO QUESTION THAT RESENTMENTS AND TENSIONS ULTIMATELY ROOTED IN WAR AND COLONIAL ERA MAY LIMIT THE PROSPECTS FOR A GREATER DEGREE OF POLITICAL AND MILITARY INTEGRATION IN NORTHEAST ASIA. THIS IS ONE OF THE MAIN REASONS WHY A NATO-STYLE MILITARY ALLIANCE IN THE REGION REMAINS UNTHINKABLE. FURTHERMORE, ECONOMIC COOPERATION-INCONCEIVABLE IN ANY OTHER FORM BUT A "VERTICAL" GROUPING HITH JAPAN AT THE TOP--MAY ALSO BE IMPEDED BY THESE HISTORICAL FACTORS.

02761 DELFS, $R$.

LOOKING FOR A ROLE

FAR EASTERN ECONOMIC REVIEW, $155(24)$ (JUN 92), 41-44. UNITED STATES AND EUROPE IS COMPLICATING JAPAN'S SEARCH FOR A NEW GLOBAL AND REGIONAL ROLE IN THE POST-COLD WAR ERA IN KEEPING WITH ITS ENORMOUS WEALTH AND ECONOMIC POWER. DESPITE PRESSURE FROM TRADING PARTNERS TO REDUCE THE COUNTRY'S

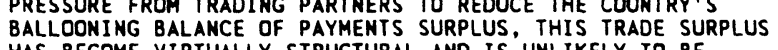
REDUCED IN THE NEAR FUTURE. TENDENCIES TOWARD THE FORMATION REDUCED IN THE NEAR FUTURE. TENDENCIES TOWARD THE FORMATION
OF EXCLUSIVE ECONOMIC GROUPS IN EUROPE AND NORTH AMERICA OF EXCLUSIVE ECONOMIC GROUPS IN EUROPE AND NORTH AMERICA ASIAN ECONOMIES WHICH EXPERIENCED DYNAMIC ECONOMIC GROWTH IN ASIAN ECONOMIES WHICH EXPERIENCED DYNAMIC ECONOMIC GROWTH
THE $1980 S$. IRONICALLY, THIS HAS DRIVEN JAPAN, SO OFTEN THE 1980 S. IRONICALLY, THIS HAS DRIVEN JAPAN, SO OFTEN
ACCUSED OF PROTECTIONISM, TO EMERGE AS A LEADING ADVOCATE OF ACCUSED OF PROTECTIONISM, TO EMERGE AS A LEADING ADVC
GLOBAL FREE TRADE, WHILE AT THE SAME TIME BECOMING

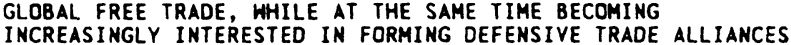
IN ASIA AS A FALL-BACK POSITION. HEIGHTENING TRADE TENSIONS HITH THE UNITED STATES IN PARTICULAR ARE UNNERVING FOR TOKYO BECAUSE OF THEIR LONGSTANDING "SPECIAL RELATIONSHIP." NOT ONLY ARE JAPAN'S OVERALL FOREIGN AND TRADE POLICIES BASED ON THE PREMISE OF COOPERATION WITH THE U.S., BUT THE U.S. -JAPAN SECURITY ALLIANCE IS VITAL TO ASSURE NEIGHBORING COUNTRIES THAT JAPAN WILL NOT FEEL COMPELLED TO ADOPT A MORE ASSERTIVE POLITICAL AND MILITARY PRESENCE IN THE REGION.

02762 DELFS, R.; ROWLEY, A.

NO DEAL, MO MONEY

FAR EASTERN ECONOMIC REVIEH, 151(18) (MAY 91), 11-13. SOVIET PRESIDENT MIKHAIL GORBACHEY LEFT TOKYO IN APRIL AT THE END OF THE FIRST VISIT TO JAPAN BY A TOP SOVIET LEADER IN THE SAME WAY HE ARRIVED: EMPTY-HANDED. HOPES THAT HE SUMMIT BETHEEN GORBACHEV AND JAPAN'S PRIME MINISTER TOSHIKI KAIFU WOULD YIELD SIGNIFICANT PROGRESS TOWARDS RESOLUTION OF THE KURILE ISLANDS DISPUTE PERHAPS IN RETURN FOR GUARANTEES OF JAPANESE FOREIGN AID TO THE USSR WERE PROVEN EMPTY. GORBACHEV'S PRESENT WEAKNESS VIS-A-VIS THE ABILITY TO CUT ANY SIGNIFICANT DEAL WITH REGARD TO THE ABILITY TO CUT ANY SIGNIFICANT DEAL WITH REGARD TO THE
ISLANDS. KAIFU WAS SIMILARLY LIMITED BY POWERFUL POL ITICAL FORCES WHICH DEMANDED NOTHING SHORT OF THE UNCONDITIONAL RETURN OF ALL FOUR DISPUTED ISLANDS.

02763 DELFS, R.

FAR EASTERN ECONOMIC REVIEW, 155(51) (DEC 92), 18. JAPANESE CABINET RESHUFFLES TYPICALLY OCCUR WITH CLOCKHORK REGULARITY, REFLECTING THEIR ROLE IN DISTRIBUTING THE SPOILS OF OFFICE AMONG THE FACTIONS OF THE RULING LIBERAL DEMOCRATIC PARTY (LDP). BUT THE RESHUFFLE ANHOUNCED ON 11 DECEMBER BY PRIME MINISTER KIICHI MIYAZAWA WAS NOT TYPICAL. THE COMPOSITION OF THE NEH CABINET FORMALIZES MIYAZAWA'S BREAK WITH THE POWERFUL TAKESHITA FACTION, WHICH HAS DOMINATED JAPANESE POLITICS FOR NEARLY TWO DECADES. THE BREAK-UP OF THE TAKESHITA FACTION, CAUSED BY THE INVOLVEMENT OF THO KEY LEADERS IN CORRUPTION SCANDALS, MAY HAVE FREED MIYAZAHA'S HANDS WHERE CABINET APPOINTMENTS ARE CONCERNED, 
POLITICAL ACCOMPLISHMENTS DURING HIS FIRST YEAR HERE PRIMARILY DUE TO THE FACTION'S INFLUENCE AND POWER. INSTEAD OF RELYING ON A SINGLE DOMINANT GROUP TO ENFORCE A POLICY CONSENSUS, MIYAZAWA NOW MUST TRY TO BALANCE ON HIS OWN THE
INTERESTS OF FIVE DIFFERENT FACTIONS OF ROUGHLY EQUAL SIZE.

02764 DELFS, R

OFFSHORE SAMURA

FAR EASTERN ECONOMIC REVIEW, 155(24) (JUN 92), 10-11.

A RECENT PARLIAMENTARY BATTLE OVER A BILL WHICH WOULD ALLOW JAPANESE FORCES TO PARTICIPATE IN UNITED NATIONS PEACEKEEPING OPERATIONS PLAYED INTO THE HANDS OF PRIME MINISTER KIICHI MIYAZAHA. THE RULING PARTY MIGHT NOW FARE MUCH BETTER THAN ORIGINALLY EXPECTED IN THE UPPER HOUSE ELECTION SCHEDULED FOR JULY. OPINION POLLS TAKEN AS THE PARLIAMENTARY STRUGGLE HAS GETTING UNDER WAY ALREADY SHOWED A SHARP RISE IN THE MIYAZAWA CABINET'S SUPPORT RATINGS. RESPONSIBLE FOR THE SHIFT IN PUBLIC OPINION HERE THE DELAYING TACTICS OF THE OPPOSITION SOCIAL DEMOCRATIC PARTY OF JAPAN AND THE JAPAN COMMUNIST PARTY. THE OPPOSITION'S USE OF CENSURE MOTIONS AND "OX-HALKING" MERELY SERVED TO DELAY THE INEVITABLE OUTCOME AND, DUE TO THE WIDESPREAD MEDIA THE INEVITABLE OUTCOME AND, DUE TO THE WIDESPREAD MEDIA
COVERAGE, MADE THE OPPOSITION PARTIES LOOK RATHER SILLY.

02765 DELFS, $R$

OPPOSITION GLUE

FAR EASTERN ECONOMIC REVIEW, 155(15) (APR 92), 20-22.

Y YET IIL-DEFINED POL ITICAL GROUPIMG BACKED BY THE JAPANESE TRADE UNION CONFEDERATION (RENGO) APPEARS LIKELY TO WREST CONTROL OF THE DECIDING VOTE IN THE UPPER HOUSE OF THE JAPANESE PARLIAMENT AFTER THE REGULAR UPPER HOUSE ELECTIONS IN JULY. RENGO'S RISE HILL FURTHER COMPLICATE THE PROBLEMS OF PRIME MINISTER KIICHI MIYAZAWA AND THE RULING LIBERAL DEMOCRATIC PARTY (LDP) IN PUSHING LEGISLATION THROUGH AN OPPOSITION-CONTROLLED UPPER HOUSE. RENGO CANDIDATES HAVE ALREADY WON THO BY-ELECTIONS IN 1992 AGAINST THE LDP BOOSTING THEIR PRESENCE IN THE 252-MEMBER UPPER HOUSÉ FROM ELEVEN TO THIRTEEN. POLITICAL OBSERVERS BELIEVE RENGO IS LIKELY TO HOLD TWENTY-EIGHT OR MORE SEATS AFTER THE JULY ELECTION, MAKING IT THE SECOND LARGEST OPPOSITION GROUPING IN THE UPPER HOUSE AFTER THE JAPAN SOCIALIST PARTY (JSP). AS A POLITICAL ORGANIZATION, RENGO MAY BE BEST VIEWED AS A KIND OF CONCRETE HORKING PROPOSAL FOR REUNITING THE JSP AND THE SMALIER OEMOCRATIC SOCIALIST PARTY (DSP), JAPAN'S TWO MAJOR LABOR-BACKED SOCIAL DEMOCRATIC PARTIES.

02766 DELFS, R.

POISONED FRIENDSHIP

FAR EASTERN ECONOMIC REVIEW, 155(3) (JAN 92), 11. THE EMBATTLED CABINET OF' JAPAN'S PRIME MINISTER KIICHI MIYAZAWA SUFFERED YET ANOTHER SERIOUS BLOW ON 13 JAMUARY MIYAZAWA SUFFERED YET ANOTHER SERIOUS BLOW ON 13 JANUARY WHEN FUMIO ABE, A FORMER MINISTER WHO IS ALSO A CLOSE MIYAZAWA ASS CCIATE, WAS ARRESTED ON SUSPICION OF TAKIM BRIBES FROM KYOWA CORP. I A NOH BANKRUPT STEEL-FRAME MANUFACTURER. ABE, 69, IS THE FIRST INCUMBENT MP TO BE ARRESTED SINCE 1976. ALTHOUGH THERE IS SO FAR LITTLE EVIDENCE THAT MIYAZAWA IS PERSONALLY INVOL VED, THE ARREST OF A CLOSE POLITICAL ASSOCIATE IS CERTAIN TO FURTHER WEAKE AUTHORITY AS PRIME MINISTER AND MAY WELL PROYIDE THE

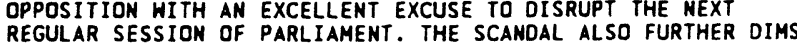
REGULAR SESSION OF PARLIAMENT. THE SCANDAL ALSO FURTHER DIMS REGAINING ITS UPPER HOUSE MAJORITY IN THE ELECTIONS SCHEDULED FOR JULY.

02767 DELFS, R.

QUESTION OF SURVIVAL

FAR EASTERN ECONOMIC REVIEH, 155(10) (MAR 92), 11. FACING INTENSE POLITICAL' PRESSURE OVER THE' KYOWA AMD TOKYO SAGAHA KYUBIN POLITICAL FUNDS SCANDALS, JAPAN'S RULING LIBERAL DEMOCRATIC PARTY (LDP) HAS FORCED THE GOVERNMENT TO HARDEN ITS PUBLIC STANCE ON LIBERALIZATION OF RICE IMPORTS, AT LEAST FOR ITS DOMESTIC AUDIENCE. THE TOUGHER POSITION MAY NOT PRECLUDE EVENTUAL ACCEPTANCE BY JAPAN OF A GATT PROPOSAL UNDER WICH THE EXISTING DE FACTO IMPORT BAN HOULD BE REPLACED BY TARIFFS. BUT THE LDP APPARENTLY HOPES TO BE ABLE TO DODGE THE RICE ISSUE, AT LEAST UNTIL AFTER THO CRUCIAL BYELECTIONS IN RURAL AREAS WHICH ARE SCHEDULED TO BE HELD IN MARCH AND POSSIBLY UNTIL AFTER THE JULY ELECTIONS TO THE UPPER HOUSE OF PARLIAMENT.

02768 DELFS, R.

RURAL RETREAT

FAR EASTERN ECONOMIC REVIEN, 155(11) (MAR 92), 11.

THE NARROW DEFEAT OF THE LIBERAL DEMOCRATIC PARTY (LDP) CANDIDATE IN THE MIYAGI PREFECTURE BY-ELECTION TO THE UPPER HOUSE OF PARL IAMENT ON 8 MARCH IS SENDING CHILLS DOWN THE SPINES OF MANY OF JAPAN'S RULING PARTY MEMBERS. HAVING ALREADY LOST AY-ELECTIO RUL THE LDP SAW THE MIYAGI CONTEST AS A FURTHER TEST OF HOW MUCH PUBLIC SUPPORT HAD BEEN ERODED BY TWO MESSY POLITICAL FUNDS SCANDALS--THE ABE-KYOWA BRIBERY CASE AND THE COMPLEX SAGAHA KYUBIN AFFAIR. THE MIYAGI LOSS COULD ALSO BE THE DEATH KNELL FOR PRIME MINISTER KIICHI MIYAZAWA'S CABINET. HOWEVER, WHILE
LDP UPPER HOUSE MEMBERS ARE EXPECTED TO PUSH FOR MIYAZAWA TO STEP DOWN BEFORE THE REGULAR UPPER-HOUSE ELECTION IN JULY, THERE IS NO OBVIOUS CANDIDATE NOW WILLING TO REPLACE HIM AND THERE IS NO OBVIOUS CANDIDATE NOW WILLING YO REPLACE HIM ANO TAKE RESPONSIBILITY FOR H

02769 DELFS, $R$

SAYING NO TO PEKING

FAR EASTERN ECONOMIC REVIEW, 151(14) (APR 91), 21-24. THE EMERGENCE OF THE PROVINCES AS INCREASINGLY AUTONOMOUS ENTITIES HAS BECOME A CRUCIAL THEME IN CHINA'S NATIONAL DEVELOPMENT. PROVINCIAL POWER HAS BEEN DEMONSTRATED UN VETOES DN A SERIES OF ATTEMPTS TO ROLL BACK ECONOMIC REFORMS INTRODUCED IN THE PRE-1989 LIBERALIZING ERA. AT A MORE BASIC LEVEL THE PROVINCES HAVE SUCCEEDED IN BLOCKING EFFORTS BY THE CENTER TO REWRITE THE COUNTRY'S FISCAL CODE TO GIVE THE CENTER A LARGER SHARE OF TAX REVENUE. ALTHOUGH OFFICIALS IN THE CENTER HAVE DISPLAYED THEIR UNEASINESS AT THIS CHANGE. THERE IS STILL NO SIGN THAT THE LEADERSHIP IS IN ANY POSITION TO LAUNCH A COUNTER-ATTACK ON PROVINCES THAT INSIST ON GOING THEIR OWN HAY. THE AMOUNT OF FREEDOM ENJOYED BY AMBITIOUS OR CUNHING LOCAL LEADERS MAY DECLINE IN THE COMING YEARS AS SOME LEADING PRACTITIONERS OF ELUDING PEKING'S DIRECTIVES LEAVE THE SCENE. BUT THE PROVINCES THEMSELVES AS INSTITUTIONS WILL PROBABLY BE ABLE TO HANG ON TO MUCH OF THE AUTONOMY THEY WON DURING THE LAST DECADE OF TURBULENT CHANGE.

02770 DELFS, R.

SCAMDAL TACTICS

FAR EASTERN ECONOMIC REVIEH, 155(6) (FEB 92), 11-12.

LEATER OF THE FOUR MAIN JAPAMESE OPPOSITION PARTIES HAVE LAUNCHED A NEW ATTACK ON PRIME MINISTER KIICHI MIAZAWA OVER THE INVOL VEMENT OF A CLOSE POLITICAL ASSOCIATE IN A BRIBERY SCANDAL. BUT THE OPPOSITION'S STRATEGY SEEMS TO B TO DISCREDIT THE GOVERMMENT, RATHER THAN TO ATTEMPT TO PARALYZE IT BY USING THE SCAMDAL TO DISRUPT OTHER PARLIAMENTARY BUSINESS AS HAD BEEN DONE ON SIMILAR OCCASIONS IN THE PAST. ONE REASON FOR THIS MAY BE THAT ALL FOUR PARTIES NOW HAVE THEIR SIGHTS ON THE JULY ELECTIONS TO THE UPPER HOUSE WHEN THE RULING LIBERAL DEMOCRATIC PARTY (LDP) IS ALMOST CERTAIN TO SUFFER A SERIOUS SETBACK. ALL FOUR OPPOSITION PARTIES HAVE SET UP INTERNAL COMMITTEES TO INVESTIGATE THE SCANDALS, AND ARE EXPECTED TO PUSH FOR THE OFFICIAL ESTABLISHMENT OF A SPECIAL INVESTIGATIVE COMMITTEE IN PARLIAMENT AS WELL.

02771 DELFS, R.

SENSE OR SENSIBILITY

FAR EASTERN ECONOMIC REVIEH, 151(17) (APR 91), 52-55. THE SHAPE OF ASIA IN THE NEXT CENTURY WILL BE LARGELY DETERMINED BY SINO-JAPANESE RELATIONS. IF THE RELATIONSHIP IS COOPERATIVE--AS IT IS PROVING TO BE IN THE NORTHERN AREAS IS CDOPERATIVE--AS IT IS PROVING TO BE IN THE NORTHERM OF CHINA ONCE COLONI ZED BY JAPAN--THESE COUN IS ANTAGONISTS, DOMINATE THE ASIA-PACIFIC REGION. BUT IF IT IS ANTAGONISTS,
EVERY COUNTRY IN THE REGION WILL BE FORCED TO TAKE A STAND. EVERY COUNTRY IN THE REGION WILL BE FORCED TO TAKE A STAND. CURRENTLY THE CONTRASTS BETWEEN THE TWO ARE FAR GREATER THE SIMILARITIES, A FACT WHIC

02772 DELFS, $R$.

SMOKING GUN
FAR EASTERN ECONOMIC REVIEN, 155(48) (DEC 92), 18-20.

THE JAPANESE PUBLIC HAS BEEN BUFFETED BY REPORTS OF ILLICIT DEALINGS BETHEEN SENIOR PARTY POLITICIANS AND AN INDICTED BUSINESSMAN WITH CLOSE LINKS TO ORGANIZED CRIME. NOW NEW INFORMATION RELEASED BY THE TOKYO DISTRIC

PROSECUTORS OFFICE IN CONNECTION WITH THE SAGAWA KYUBIN

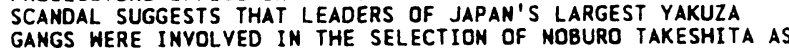
PRIME MINISTER IN 1987. EVIDENCE INDICATES THAT TAKESHITA WAS FORCED TO DEPEND ON UNDERWORLD SUPPORT IN HIS BID FOR THE POST OF PRIME MINISTER AND THUS BECAME INDEBTED TO SUSUMU ISHII, A YAKUZA GANG LEADER. THE GROHING REVELATIONS OF CORRUPTION AND UNDERHORLD CONNECTIONS IN JAPANESE POLITICS HAVE GREATLY INCREASED PUBLIC ALIENATION AND DISMAY.

02773 DELFS, R.; AWAMOHARA, S.

STRATEGIC ERROR

FAR EASTERN ECONOMIC REVIEN, 155(3) (JAN 92), 16-17. A SOUR TASTE LINGERED ON AFTER U.S. PRESIDENT GEORGE BUSH'S DEPARTURE FROM TOKYO ON THE LAST LEG OF AN ASIAN TOUR THAT ALSO TOOK IN AUSTRALIA, SINGAPORE AND SOUTH KOREA. THE TRIP WAS ORIGINALLY INTENDED TO REINFORCE THE IMPORTANCE AND STABILITY OF THE U.S. -JAPAN RELATIONSHIP. WHEN IT FINALLY TOOK PLACE, HOWEVER, THE VISIT ONLY UNDERL INED THE GROWING TOOK PLACE, HOWEYER, THE VISIT ONLY UNDERLINED THE GROWING
DIFFERENCES OF PERCEPTION AMONG MAINSTREAM OPINION IN THE DIFFERENCES OF PERCEPTION AMONG MAINSTREAM OPINION IN THE THO COUNTRIES. THE DISAPPOINTING SUMMIT DEMONSTRATED HOW QUICXLY THE END OF THE COLD WAR AND THE DISSOLUTION OF THE SOVIET EMPIRE IS ERODING THE GLUE THAT HAS BOUND JAPAN AND THE U.S. TOGETHER IN THE DECADES SINCE WORLD WAR II. IN WASHINGTON THE EFFECT OF THE TRIP WAS TO FURTHER DAMAGE THE AMMUNITION FOR HIS ELECTION CHALLENGERS, WHO ARE ALL MORE 
PROTECTIONIST THAN HE IS.

02774 DELFS, R.

THE GODFATHER STUMBLES

FAR EASTERN ECONOMIC REVIEW, 155(36) (SEP 92), 10-11.

SHIN KANEMARU, JAPAN'S MOST POWERFUL POLITICIAN,

CONTROLS THE KEY' STRINGS IN AN INTRICATE WEB OF FACTIONAL

ALLIANCES IN JAPANESE POLITICS. THEREFORE, IT CAME AS NO

SMALL SURPRISE WHEN KANEMARU ADMITTED, AT A PRESS CONFERENCE

ON 27 AUGUST, THAT HIS SECRETARY HAD ACCEPTED 500-MILLION

YEN (USS4 MILLION) IN 1990 FROM HIROYASU WATANABE, FORMER

PRESIDENT OF THE SCANDAL-RIDDEN TOKYO SAGAWA KYUBIN TRUCKING

PRESIDENT OF THE SCANDAL-RIDDEN TOKYO SAGAWA KYUBIN TRUCKING
COMPANY. IN A BRIEF STATEMENT, KANEMARU SAID HE WOULD TAKE

COMPANY. IN A BRIEF STATEMENT, KANEMARU SAID HE WOULD TAKE
RESPONSIBILITY BY RESIGNING AS VICE-PRESIDENT OF THE RULING

RESPONSIBILITY BY RESIGNING AS VICE-PRESIDENT OF THE

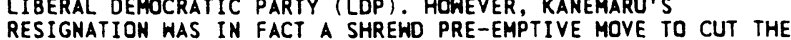

RESIGNATION WAS IN FACT A SHREWD PRE-EMPTIVE MOVE TO CUT THE

GROUHD FROM BENEATH HIS CRITICS, WHILE PRESERVING THE REAL

BASE OF HIS POWER AS LEADER OF THE TAKESHITA FACTION, THE
RULING PARTY'S LARGEST SUB-GROUP. THE LATEST DEVELOPMENT IM

RULING PARTY'S LARGEST SUB-GROUP. THE LATEST DEVELOPMENT IN

THE YEAR-LONG INVESTIGATION INTO POLITICAL PAYOFFS BY SAG
EXECUTIVES MAY CLAIM MORE CASUALTIES. WATANABE'S MONEY
CONMECTIONS ALLEGEDLY EXTEND TO SOME MEMBERS OF PRIME

MINISTER KIICHI MIYAZAWA'S GOVERNMENT AND A CABINET SHUFFLE

IS EXPECTED AS PART OF MIYAZAHA'S DAMAGE CONTROL.

02775 DELFS, $R$

THE UNTOUCHABLE

FAR EASTERN ECONOMIC REVIEW, 155(41) (OCT 92), 10-11.

INVESTIGATIONS INTO WHAT' HAD BEEN BILLED AS JAPAN'S

BIGGEST EVER POLITICAL FUNDING SCANDAL EFFECTIVELY CAME TO AN END IN EARLY OCTOBER AFTER THE TOKYO PUBLIC PROSECUTOR' OFFICE HAD IMPOSED A NOMINAL FINE ON LIBERAL DEMOCRATIC PARTY (LDP) BOSS SHIN KANEMARU FOR BREACHING THE POLITICAL
FUNDS CONTROL LAN. KANEMARU HAD PLEADED GUILTY TO ACCEPTING 500-MILLION YEN (USS4 MILLION) FROM SAGAWA KYUBIN, A
TRUCKING COMPANY WHICH IS KNOWN TO HAVE GANGSTER CONNECTIONS, WITHOUT DECLARING THE MONEY TO THE AUTHORITIES. HOWEVER KANEMARU'S INDICTMENT CERTAINLY DOES NOT END THE POLITICAL PART OF THE PROCEEDINGS. WHILE THE SAGAHA KYUBIN AFFAIR IS PART OF THE PROCEEDINGS. WHILE THE SAGAHA KYUBIN AFFAIR
UNLIKELY TO BRING DOWN THE GOVERNMENT, THE SCANDAL HAS
EXPOSED A HIDENING GAP BETHEEN THE ETHICAL STANDARDS OF EXPOSED A HIDENING GAP BETWEEN THE ETHICAL STANDARDS OF
PROFESSIONAL POLITICIANS AND WHAT THE PUBLIC SEEMS TO EXPECT PROFESSIONAL POLITICIANS AND WHAT THE PUBLIC SEEMS TO EXPECT
FROM THEM. POPULAR ANGER WITH KANEMARU IS UNLIKELY TO BE FROM THEM. POPULAR ANGER WITH KANEMARU IS UNL IKELY TO BE
TRANSLATED INTO CALLS FOR RESIGNATION OF THE CABINET AND MAY TRANSLATED INTO CALLS FOR RESIGNATION OF THE CABINET AND NOT EVEN AFFECT SUPPORT FOR THE LDP AT THE NEXT GENERAL ELECTION DUE IN 1994. BUT THE PERCEIVED FAILURE OF THE AUTHORITIES TO METE OUT ADEQUATE PUNISHMENT IN THE SAGA KYUBIN CASE CERTAINLY ADDED TO PRIME MINISTER KIICHI
MIYAZAHA'S IMAGE AS A WEAK LEADER, MORE CONCERNED WITH MIYAZAWA'S IMAGE AS A WEAK LEADER, MORE CONCERNED WITH SAVING HIS
COLLEAGUES.

02776 DELFS, R.

THE VANISHING THREAT

FAR EASTERN ECONOMIC REVIEW, 155(7) (FEB 92), 10-11. JAPAN'S DEFENSE ESTABLISHMENT, THE THIRD LARGEST IN THE WORLD AND LONG BOLSTERED BY THE SUPPOSED EXISTENCE OF $A$ SOVIET THREAT, HAS BEEN ABRUPTLY CONFRONTED BY THE BLDGET REALITIES OF THE POST-COLD WAR ERA. IN THE WAKE OF THE SOVIET UNION'S COLLAPSE, DEFENSE OFFICIALS MUST REDEFINE THEIR ROLE. JAPAN'S TWO MAJOR OPPOSITION PARTIES, THE DEMOCRATIC SOCIALIST PARTY (DSP) AND THE KOMEI PARTY, HAVE BEEN CALLING FOR A REDUCTION IN THE DFEENSE BUDGET AND THE REYISION OF THE CURRENT FIVE-YEAR BUILD-UP PLAN. THIS MEANS THAT THERE IS NOW A CONSENSUS TO CUT DEFENSE SPENDING AMONG ALL FOUR MAJOR OPPOSITION PARTIES. PARTIALLY IN RESPONSE TO THESE CHANGING CONDITIONS, PRIME MINISTER KIICHI MIYAZAWA ANNOUNCED ON 4 FEBRUARY REVISIONS AND CUTS IN JAPAN'S DEFENSE BUDGET.

02777 DELFS, $R$.

UNEXPLODED BOMB

FAR EASTERN ECONOMIC REVIEH, 155(4) (JAN 92), 8-9.

WHILE THE SCANDAL SURROUNDING LIBERAL DEMOCRATIC PARTY (LDP) MP FUMIO ABE CONTINUES TO DEEPEN, WITH REPORTED LINKS TO VARIOUS MEMBERS OF THE PARLIAMENTARY FACTION HEADED BY TO VARIOUS MEMBERS OF THE PARL IAMENTARY FACTION HEADED
PRIME MINISTER KIICHI MIYAZAWA, YET ANOTHER POLITICAL PRIME MINISTER KIICHI MIYAZAWA, YET ANOTHER POL ITICAL
SCANDAL IS SIMMERING NEAR THE SURFACE. THE SO-CALLED SAGAWA SCANDAL IS SIMMERING NEAR THE SURFACE. THE SO-CALLED SAGAWA
KYUBIN SCANDAL. INVOLVING MASSIVE POL ITICAL CONTRIBUTIONS BY KYUBIN SCANDAL, INVOLVING MASSIVE POL ITICAL CONTRIBUTIONS BY
A TRANSPORT FIRM HITH LINKS TO ORGANIZED CRIME, COULD TOPPLE A TRANSPORT FIRM HITH LINKS TO ORGANIZED CRIME, COULD TOPPLE EVEN BIGGER HEADS THAN THE ABE CASE. ONE VERSIDN OF THE LIST
OF POLITICIANS IMPLICATED INCLUDES NO FEWER THAN FIVE FORMER OF POLITICIANS IMPLICATED INCLUDES NO FEWER THAN FIVE FORMER PRIME MINISTERS AS HELL AS THO OTHER LEADERS OF LDP FACTIONS AND A FORMER SECRETARY-GENERAL OF THE PARTY. THE MEMO LISTS
SUMS RANGING FROM 800 MILLION TO 10.8 BILLION YEN AS HAVING SUMS RANGING FROM 800 MILLIDN TO 10.8 BILLION YEN AS BEEN HANDED
POLITICIANS.

02778 DELL, E.

A WORLD OF CARE

POLITICAL OUARTERLY (THE), 63(4) (OCT 93), 372-383.

IN BRITAIN, DESPITE A CHANGE IN LEADERSHIP, ONLY THE

EXTRAORDINARY INCAPACITY OF THE LABOR PARTY TO COMMAND

PUBLIC CONFIDENCE PROTECTED THE CONSERVATIVE PARTY FROM THE
EXPECTED ELECTORAL CONSEQUENCES OF RECESSION AND MOUNTING UNEMPLOYMENT. MRS. THATCHER CLAIMS THAT SHE IMPLEMENTED A PHILOSOPHY OF GOVERMMENT WHICH RESTORED THE 'GREAT' TO GREAT BRITAIN. OTHERS MIGHT SAY THAT SHE RAN THE MOST DELIBERATELY UNCARING GOVERNMENT SINCE THE WAR. THIS ARTICLE EXPLORES WHETHER THE CRITICISM IS ANY MORE JUSTIFIED THAN THE SELFCONGRATULATIONS. IT ALSO EXAMINES, IF THE POLICY WAS MEAN AND UNCARING, HOW FAR THAT WAS A DELIBERATE CHOICE AND HOW FAR IS WAS THE EFFECT OF EXTERNALLY IMPOSED CONSTRAINTS.

02779 DELLACAVA, R.

VATICAN POLICY, 1978-1990: AN UPDATED OVERYIEH

SOCIAL RESEARCH, 59(1) (SPR 92), 169-200.

SOCIAL RESEARCH, 59(1) (SPR 92), 169-200. "DEFEAT" OF LIBERATION THEOLOGY AND ITS LEADING EXPONENTS AND COUNTLESS PRACTITIONERS IN BRAZIL. BUT IT IS TIME TO ADMIT THAT A STRATEGY DESIGNED, AT THE VERY LEAST, TO CHECKMATE THAT HIGHLY ORIGINAL, INTERPRETATION OF FAITH AND SOCIETY HAS BEEN IN EFFECT FOR MORE THAN A DECADE. MOREOVER, ITS AUTHORS ARE TO BE FOUND AMONG THE POLICY MAKERS WITHIN THE WALLS OF VATICAN CITY AND IN CHANCERY OFFICES AROUND THE HORLD.

02780 DELLER, S.; RUDNICKI, E. MANAGERIAL EFFICIENCY IN LOCAL GOVERMMENT: IMPLICATIONS ON JURISDICTIONAL CONSOL IDATION

PUBLIC CHOICE, $74(2)(1992), 221-233$

USING DATA FROM MAINE, ESTIMATES OF SIZE ECONOMIES IN THE PRDDUCTION OF PUBLIC EDUCATION SERVICES ARE PROVIDED UNDER THE ALTERNATIVE ASSUMPTIONS OF MANAGERIAL EFFICIENCY AND INEFFICIENCY. WHILE SIZE ECONOMIES WERE IDENTIFIED UNDER THE TRADITIONAL ASSUMPTION OF MANAGERIAL EFFICIENCY, LIMITED OR NO ECONOMIES WERE IDENTIFIED UNDER THE MORE GENERAL ASSUMPTION OF MANAGERIAL INEFFICIENCY. THESE RESULTS QUESTION THE VALIDITY OF THE TRADITIONAL ECONOMIES OF SIZE LITERATURE AND THE JURISDICTIONAL CONSOLIDATION POLICY WHICH FOLLOWS FROM THE TRADITIONAL LITERATURE.

02781 DELLER, S.; NELSON, C.; HALZER, N.

MEASURING MANAGERIAL EFFICIENCY IN RURAL GOVERNMENT PUBLIC PRODUCTIVITY \& MANAGEMENT REVIEW, 15(3) (SPR 92) 355-370.

STRUCTURAL LIMITATION AND NARROW MANAGERIAL CAPACITY HAVE CONSISTENTLY HAMPERED BOTH EFFECTIVE AND EFFICIENT DECISION-MAKING PRDCESSES IN SMALL RURAL GOVERNMENTS. THIS ARTICLE EXAMINES THE MANAGERIAL EFFICIENCY OF SMALL MIDWESTERN TOWHSHIP OFFICIALS HITH RESPECT TO THE PRODUCTION OF RURAL ROAD SERVICES. AN OBJECTIVE MEASURE OF LOCAL GOVERNMENT EFFICIENCY IS DEVELOPED. THE EMPIRICAL RESULTS SUGGEST THAT MANAGERIAL INEFFICIENCES SHOULD BE SYSTEMATICALLY ADDRESSED.

02782 DELLINGER, $W$.

GAG ME WITH A RULE

NEH REPUBLIC, 206(1-2) (JAN 92), 14-16.

THE ABORTION COUNSELING POLICY BECAME NATIONAL LAW OVER THE STRONG OPPOSITION OF SUBSTANTIAL MAJORITIES IN BOTH HOUSES OF CONGRESS. IT IS AN EXAMPLE OF A GOVERNING STRUCTURE IN WHICH A PRESIDENT WHO DEFERS ON SOCIAL ISSUES TO AN EXTREME WING OF THE REPUBLICAN PARTY AND IS SUPPORTED BY A CDMPLAISANT SUPREME COURT CAN SIMPLY BYPASS THE
NATIONAL LEGISLATURE AND ADOPT FEDERAL POLICIES THAT OVERRIDE STATE LAW AND IMPAIR IMPORTANT CONSTITUTIONAL VALUES. IT IS ALSO AN EXAMPLE OF CONSERVATIVE JUDICIAL ACTIVISM AND CONSERVATIVE BIG GOVERMMENT.

02783 DELORME, C. JR.; KAMERSCHEN, D.; THOMPSON, H. JR. PRICING IN THE NUCLEAR POWER INDUSTRY: PUBLIC OR PRIVATE INTEREST?

PUBLIC CHOICE, 73(4) (1992), 385-396

THE RAMSEY VERSION OF THE PUBLIC-INTEREST THEORY OF REGULATION IS TESTED EMPIRICALLY BY EXAMINING THE PRICING PRACTICES IN THE NUCLEAR POHER INDUSTRY USING A 1985 CROSSSECTIONAL SAMPLE OF 40 ELECTRIC UTILITIES. OTHER RESEARCHERS HAVE AVOIDED THIS SEGMENT OF THE INDUSTRY BECAUSE OF HAVE AVOIDED THIS SEGMENT OF THE INDUSTRY BECAUSE
DIFFICULTIES WITH NUCLEAR FUEL DATA, OR PERCEIVED DIFFERENCES IN THE UNDERLYING PRODUCTION FUNCTION. THE DIFFERENCES IN THE UNDERLYING PRODUCTION FUNCTION. THE
AUTHORS SHOW THAT REGULATORS RESPOND TO POLITICAL INFLUENCES AUTHORS SHOW THAT REGULATORS RESPOND TO POLITICAL INFLUENCES
ACCORDING TO THE STIGLER-PELTZMAN VERSION OF REGULATION AND ACCORDING TO THE STIGLER-PELTZMAN VERSION OF REGULATION AND
THAT RAMSEY PRICING CANHOT BE VALIDATED, AT LEAST FOR THE THAT RAMSEY PRICING CANNOT BE VALIDATED, AT LEAST
NUCLEAR SEGMENT OF THE ELECTRIC POWER INDUSTRY.

02784 DELVOIE, L.A.

PROCLAIMING THE END OF THE COLD haR: THE DECLARATION OF TWENTY-THO STATES

CANADIAN DEFENCE QUARTERLY, 20(4) (FEB 91), 7-10.

THIS ARTICLE EXAMINES THE JOINT DECLARATION OF THENTYTWO STATES, SIGNED AT THE 1990 PARIS SUMMIT BY THE LEADERS OF THE MEMBER STATES OF NATO AND THE HARSAH PACT ORGANIZATION. THE DECLARATION IS ESSENTIALLY A STATEMENT OF INTENTIONS GEARED TO SIGNALING AN END TO AN ERA OF EAST-WEST CONFLICT. THE GENESIS AND LANGUAGE OF THE DECLARATION ARE DESCRIBED. SEVERAL OF ITS ARTICLES ARE DETAILED. 
02785 DEMCHAK, C.C.

COMPLEXITY, ROGUE OUTCOMES, AMD WEAPON SYSTEMS PUBLIC ADMINISTRATION REYIEW', 52(4) (JUL 92), 347-355. IN THIS STUDY OF THE U.S. ARMY'S MI ABRAMS TANK. THE AUTHOR DETAILS THE ORGANIZATIONAL CONSEQUENCES OF CONTENDING WITH THE COMPLICATIONS CREATED BY THIS NEW WEAPON SYSTEM. SHE FOCUSES ON HOW THE ARMY HANDLED "ROUGE SET" OUTCOMES-THAT IS, THOSE PROBLEMS THAT ARE UNKNOWABLE WHEN A NEW TECHMOLOGY IS ADOPTED. EFFORTS TO DEAL WITH THE MI'S ROUGE SET PRODUCED MORE COMPLEX ORGANIZATIONAL ARRANGEMENTS. THE ULTIMATE TEST PROVIDED BY THE PERSIAN GULF WAR DEMONSTRATED THAT SOLUTIONS WERE POSSIBLE UNDER THE RIGHT CIRCUMSTANCES. OVERALL, THE LESSONS OF THE MI CASE REVEAL THE NEED FOR GREATER ATTENTION TO THE ORGANIZATIONAL IMPLICATIONS OF ADOPTING HIGH-TECH SYSTEMS.

02786 DEMESQUITA, B.B.; SIVERSON, R.M.; WOLLER, G. WAR AND THE FATE OF REGIMES: A COMPARATIVE ANALYSIS AMERICAN POLITICAL SCIENCE REVIEN, B6(3) (SEP 92), 638-646. GOVERMMENTS ARE LIKELY TO BE HELD ACCOUNTABLE FOR THE SUCCESS OR FAILURE OF THEIR FOREIGN POLICIES. CONSEQUENTLY, INTERNATIONAL WARS CAN, UNDER SPECIFIED CONDITIONS,

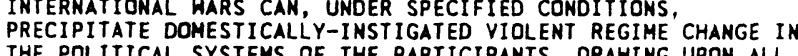
THE POLITICAL SYSTEMS OF THE PARTICIPANTS. DRAWING UPON ALL
INTERNATIONAL WAR PARTICIPATION BETHEEN 1816 AND 1975. THE INTERNATIONAL WAR PARTICIPATION BETHEEN 1816 AND 1975 , VIOLENT CHANGES OF REGIME AND, IF SO, UNDER WHAT CONDITIONS? VIOLENT CHANGES OF REGIME AND, IF SO, UNDER WHAT CONDITIONS?
THREE HYPOTHESES DESCRIBE THE EXPECTED ASSOCIATIONS OF A THREE HYPOTHESES DESCRIBE THE EXPECTED ASSOCIATIONS OF
NATION'S INITIATOR OR TARGET ROLE IN A HAR, THE WAR'S OUTCOME, AND THE COSTS OF THE WAR WITH DOMESTICALLY INSTIGATED VIOLENT CHANGES OF REGIME. DIRECT RELATIONSHIPS ARE FOUND FOR ALL THREE AND HOLD EVEN AGAINST POSSIBLE THREATS TO THEIR VALIDITY AND ROBUSTHESS. THE RESULTS SUGGEST THAT DOMESTIC POLITICS PLAY A LARGER ROLE IN NATIONAL SECURITY POLICY THAN IS GENERALLY BELIEVED BY REALIST OR NONREALIST THEORISTS.

02787 DENEV, $P$

GETTING BULGARIA HRONG

EAST EUROPEAN REPORTER, 5(1) (JAN 92), 72-73.

THIS ARTICLE ARGUES THAT THE OCTOBER 13 ELECTIONS PROVIDE YET MORE REASONS TO BE UNHAPPY ABDUT BULGARIA'S PLACE IN THE HORLD AS SEEN BY FOREIGN POLITICIANS AND THE MASS MEDIA. THE FACT THAT FEW HESTERNERS UNDERSTAND BULGARIA WAS EXEMPLIFIED BY THE EUROPEAN AND AMERICAN REPORTS ABOUT THE "SPLIT IN THE OPPOSITION" AND THE RESULTING CONFUSION IN THE ELECTORATE. THIS ARTICLE ARGUES THAT THE ELECTION RESULTS DO NOT POINT TO CONFUSION, BUT TO CONSENSUS: THE RESULTS DO NOT POINT TO CONFUSION, BUT TO CONSENSUS: MAJORITY OF PEOPLE IN BULGARIA DO NOT WANT COMMUNISM.
SIMILAR MISPERCEPTIONS ARE EVIDENT IN WESTERN REPORTING ABOUT BULGARIAN POLITICAL PARTIES, AND THE CURRENT SITUATION ABOUT BULGARIAN PHE COUNTRY

02788 DENG, F.M.

AN AFRICAN RESPONSE TO A NEH U.S. POLICY

TRANSAFRICA FORUM, 9 (2) (SUM 92), 47-51)

THE BASIS OF U.S. -AFRICAN RELATIONS HAS UNDERGONE MAJOR CHANGES SINCE THE END OF THE COLD WAR, BRINGING APPREHENSIONS OF FURTHER ISOLATION AND MARGINALIZATION FOR AFRICA. AFRICANS HAVE RESPONDED BY ACCEPTING PRIMARY RESPONSIBILITY FOR THEIR SITUATION AS WELL AS BY RESISTING FURTHER MARGINALIZATION THROUGH MOVEMENTS TOWARD GREATER RESPECT FOR HUMAN RIGHTS, DEMANDS FOR DEMOCRACY, AND IMPROVED ECONOMIC PERFORMANCE. MORAL RESPONSIBILTY, COMBINED WITH THE ADVANCEMENTS MADE BY AFRICANS THEMSELVES, WILL OBLIGE THE INTERNATIONAL COMMUNITY TO CONSIDER NOT ONLY HUMANITARIAN ASSISTANCE FOR AFRICA BUT ALSO PRACTICAL CDOPERATION IN THE PURSUIT OF SUCH IDEALS AS DEMOCRACY, LIBERTY, AND HUMAN DIGNITY.

02789 DENG, S.; WANG, Y

MANAGEMENT EDUCATION IN CHINA: PAST, PRESENT, AND FUTURE WORLD DEYELOPMENT, 20(6) (JUN 92), 873-880.

DUE TO CHINA'S AMBITIOUS ECONOMIC REFORM, MANAGEMENT EDUCATION HAS GAINED PROMINENCE, AND RELATED FIELDS HAVE DEVELDPED CONCURRENTLY BECAUSE THE REFORM EFFORT REQUIRES A LARGE CONTINGENT OF ENTREPRENEURIAL-TYPE MANAGERIAL PERSONNEL. NEVERTHELESS, CHINA'S MANAGEMENT SCHOOLS FACE SERIOUS PROBLEMS, INCLUDING A SHORTAGE OF QUALIFIED FACULTY, AN UNBALANCED CURRICULUM, DEFICIENT FACILITIES, AND AN ANDIVERSIFIED STUDENT BODY. ALL THESE PROBLEMS POSE AN SERIOUS THREAT TO CHINA'S ECONOMIC REFORM, BECAUSE BETTERSERIOUS THREAT TO CHINA'S ECONOMIC REFORM, BECAUSE

02790 DENITCH, B.

A FOREIGN POLICY FOR RADICAL DEMOCRATS

SOCIAL POLICY, 23(2) (FAL 92), 23-26.

THE AUTHOR LOOKS AT RECENT U.S. FOREIGN POLICY AND SPECULATES ABOUT THE SHAPE OF U.S. FOREIGN INVOLVEMENTS UNDER PRESIDENT BILL CLINTON.

02791 DENNIS, E.

FREEDOM OF EXPRESSION, THE UHIVERSITY, AND THE MEDIA JOURNAL OF COMMUNICATION, $42(2)$ (SPR 92), 83-94.
IT IS IMPORTANT THAN ANY BROAD EXAMINATION OF HIGHER EDUCATION'S HIGHLY PUBLICIZED DILEMHA BE CONSIDERED AGAINST THE BACKDROP OF A GIVEN UNIVERSITY'S OWN POLICIES AND PRACTICES REGARDING ACADEMIC FREEDOM AND FREE SPEECH. THIS AUTHOR EXPLORES THE FREEDOM OF SPEECH CONTROVERSY, PC--A CAMPUS CONDITION, AND RESOLUTION THROUGH DISCUSSION. HE SUGGESTS THAT THE WAR OF WORDS IN HIGHER EDUCATION MUST SLOW JUST LONG ENOUGH FOR SOME TRUE UNDERSTANDING TO OCCUR BETWEEN THE UNIVERSITY AND THE SOCIETY IT SERVES.

02792 DENMIS, $J$.

POL ITICAL INDEPENDENCE IN AMERICA III: IN SEARCH OF CLOSET PARTISANS

POLITICAL BEHAYIOR, 14(3) (SEP 92), 261-296.

THE AUTHOR RELIES ON THE 1980 NES QUESTIONS OH

PARTISANSHIP TO IDENTIFY THE ATTRIBUTES OF "CLOSET PARTISANS, " USING A TYPOLOGY OF PARTISANS AND INDEPENDENTS DEVELOPED FROM AN ALTERNATIVE (PST) SET OF SURVEY ITEMS TO THE USUAL FROM AN ALTERNATIVE (PST) SET OF SURVEY ITEMS TO THE USUA ONES. HE APPLIES FOUR CRITERIA TO THOSE "LEANERS" MOST
SUSPECTED OF BEING UNDERCOVER PARTISANS. HE FINDS THAT THOSE SUSPECTED OF BEING UNDERCOVER PARTISANS. HE FINDS THAT THOSE
LEANERS WHO MOST CLOSELY RESEMBLE STRONG PARTISANS ON THE LEANERS WHO MOST CLOSELY RESEMBLE STRONG PARTISANS ON THE CRITERIA OF POLITICAL INVOLVEMENT AND PARTISAN COMMITMEN ARE NONETHELLSS LEAST INE ITITUDE AND AFFECTIVE RESPONSE TO CRITERIA: INDEPENDENCE ATTITUDES AND AFFECTIVE RESPONSE TO THE SUBSTANTIVE CONTENT OF ELECTIONS. THUS, "THE AMERICAN
VOTER" ANALYSIS, HHICH ASSUMES LEANERS ARE INDEPENDENTS, AND THE WOLFINGER CRITIOUE OF "THE AMERICAN VOTER," WHICH CONCLUDES THAT LEANERS ARE PARTISANS, ARE BOTH OVERSIMPLIFICATIONS OF POLITICAL REALITY.

02793 DENNIS, R.

LIFE AFTER LEGALIZATION

REASON, $23(9)$ (FEB 92), 34-39

THIS ARTICLE PRESENTS A POTENTIAL FUTURE SCENARIO OF AN AMERICA IN WHICH DRUG USE IS LEGAL. IT SEEKS TO BE CONSERVATIVE IN DESCRIBING THE BENEFITS OF LEGALIZATION AND REALISTIC IN ACKNOWLEDGING BOTH ITS COSTS AND PROBLEMS IT WOULD NOT SOLVE. IT EXAMINES THE EFFECTS OF SUCH A CHANGE ON SEVERAL REPRESENTATIVE STEREOTYPES: THE CDLLEGE STUDENT, THE WELFARE MOTHER, THE JUDGE, THE GANG LEADER, THE POLICE

OFFICER, THE ADOICT, THE PRIEST, AND THE YUPPIES.

02794 DENNIS, R.; RYAN, P.

STATE CORPORATE AND FEDERAL SECURITIES LAW: DUEL REGULATION IN A FEDERAL SYSTEM

PUBLIUS: THE JOURNAL OF FEDERALISM, 22(1) (WIN 92), 21-38. CORPORATE LAW IN THE UNITED STAYTES INYOLVES DUAL REGULATION. ALTHOUGH STATE AND FEDERAL CORPORATE LAH REGULATION. ALTHOUGH STATE AND FEDERAL CORPORATE LAW THIRTY YEARS HAVE REVEALED POTENTIAL CONFLICTS CHIEFLY IN THO SITUATIONS. ONE INYLLVES CIVIL REMEDIES FOR INYESTORS THO SI TUATIONS. ONE INVOLVES CIVIL REMEDIES FOR INVESTORS TARER FEDERAL SECURITIES STATUTES; THE OTHER IS STATE ANTI WILLIAMS ACT. THE AUTHORS ARGUE THAT THE CORE INTERPRETIVE TASK IN FEDERAL SECURITIES LAW IS PRESERVATIN OF BOTH REGIMES TO MAXIMUM EFFECT, BECAUSE THE CONGRESS HAS EXPRESSLY DECLARED THAT STATE AUTHORITY SHOULD CONTINUE ADJACENT TO FEDERAL REGULATION.

02795 DENHIS, T.; MONTEIRO, T. THE PERVASIVE MENACE' OF INSTITUTIONALIZED RACISM POLITICAL AFFAIRS, LXX(2) (FEB 91), 5-12

IN THE UNITED STATES, THE MOST SOPHISTICATED AND DEVELOPED PRACTICES OF RACISM INFLUUENCE EVERY ASPECT OF LIFE AND CUL TURE. THIS ARTICLE CONSIDERS THIS PHENOMENON, ITS ROOTS IN AMERICAN SLAVE PRACTICES, AND ITS FORMS. THESE INCLUDE: NATIONALITY, CLASS EXPLOITATION, GENDER OPPRESSION, DIVISION OF LABOR, GHETTOIZATION, CRIMINALIZATION, DRUGS, AND PUBLIC EDUCATION.

02796 DENYER, D. ; HANDS, H.

CONSTITUENCY CAMPAIGNING

PARL IAMENTARY AFFAIRS, 4514) (OCT 92), 528-544.

LOCAL CONSTITUENCY CAMPAIGNING IN GENERAL ELECTIONS IS A TRADITIONAL ASPECT OF THE BRITISH ELECTORAL PROCESS. IN ORDER TO PROVIDE SOME EVIDENCE ABOUT HOW LOCAL CAMPAIGNS ARE FOUGHT, THE AUTHORS CONDUCTED A NATIONAL SURYEY OF ELECTION AGENTS IMMEDIATELY FOLLOWING THE 1992 ELECTION. HITHERTO, INFORMATION RELATING TO CONSTITUTENCY CAMPAIGNS HAS BEEN LARGELY IMPRESSIONISTIC OR CONFINED TO PARTICULAR LOCALITIES. LARGELY IMPRESSIONISTIC OR CONFINED TO PARTICULAR LOCALITIES THIS STUDY ENABLES ONE TO DESCRIBE IN A SYSTEMATIC WAY
LEVEL AND NATURE OF LOCAL CAMPAIGNING ACROSS THE WHOLE LEVEL AND NATURE OF LOCAL CAMPAIGNING ACROSS THE WHOLE
COUNTRY, AND TO ASSESS WHETHER PARTIES HAVE RESPONDED TO THE DEALIGHMENT OF THE ELECTORATE AND HAVE TAKEN AOVANTAGE OF DEALIGHMENT OF THE ELECTORAT
TECHNOLOGICAL INNOVATIONS

02797 DENVER, D.; HALFACREE, K.

INTER-CONSIITUENCY MIGRATION AND PARTY SUPPORT IN BRITAIN POLITICAL STUDIES, XL(3) (SEP 92), 571-580.

OVER THE PAST 30 YEARS OR SO, THE ELECTORAL GEOGRAPHY OF BRITAIN HAS ALTERED IN TWO MAIN WAYS. FIRST, THERE HAS BEEN A GROWING POLARIZATION OF PARTY SUPPORT BETWEEN, BROADLY SPEAKING, THE NORTH AND THE SOUTH. SECONDLY, RURAL AREAS 
ESPECIALLY LARGE CITIES, HAVE BECOME RELATIVELY MORE PROLABOUR. USING DATA DERIVED FROM A RECENT SERIES OF GALLUP POLLS, THE AUTHORS INVESTIGATE THE PARTY CHOICE OF RECENT CAN ACCOUNT FOR THIS POLARIZATION OF PARTY CHOICE.

02798 DENVER, D.; HALFACREE, K.

INTER-CONSTIITUENCY MIGRATION AND TURNOUT AT THE BRITISH GENERAL ELECTION OF 1983

BRITISH JOURNAL OF POLITICAL SCIENCE, 22(2) (APR 92),

248-254.

ONE OF THE MOST STRIKING FEATURES OF BRITISH GENERAL ELECTIONS IS THE LARGE VARIATION IN TURNOUT ACROSS CONSTITUENCIES. IN 1983, TURNOUT RANGED FROM 82.1 PERCENT IN CARMARTHEN TO 51.8 PERCENT IN THE CITY OF LONDON AND WESTMINSTER. MOREOVER, THESE VARIATIONS TEND TO BE REPRODUCED IN SUCCESSIVE ELECTIONS. IN THIS ESSAY, THE AUTHORS INVESTIGATE THE EXTENT TO WHICH TURNOUT VARIATION OF ELECTORAL ROLLS ARE COMPILED ANHUALLY IN OCTOBER, GO INTO FORCE THE FOLLOWING FEBRUARY, AND REMAIN IN FORCE FOR TWELVE MONTHS. CLEARLY, PEOPLE WHO MOVE DURING THAT PERIOD HILL HAVE GREATER DIFFICULTY VOTING BECAUSE THEY MUST TRAVEL BACK TO THE POLLING STATION WHERE THEY REGISTERED OR APPLY FOR A MAIL-IN BALLOT.

02799 DERLIEN, H.

OBSERVATIONS ON THE STATE OF COMPARATIVE ADMINISTRATION

RESEARCH IN EUROPE--RATHER COMPARABLE THAN COMPARATIVE

GOVERNANCE, 5(3) (JUL 92), 279-311.

THIS ARTICLE TRIES TO REVIEW PUBLIC ADMINISTRATIOM RESEARCH UNDERTAKEN IN EUROPE SINCE ABOUT 1980. AN ATTEMPT IS MADE TO SYSTEMATIZE COMPARABLE RESEARCH ALONG THREE OIMENSIONS; ORGANIZATION STRUCTURES (MACRO AND MICRO), METAPOL ICYMAKING AS IT REFERS TO BUDGETING AND PLANNING PROCEDURES AND RESEARCH ABOUT PERSOMNEL AMD PERSOMMEL POLICY. IT' IS ARGUED IN FAVOR OF MORE BASIC RESEARCH AND THE INSTITUTIONALIZATION OF ADMINISTRATIVE MONITORING ON THE NATIONAL LEVEL AS WELL AS STRONGER COOPERATION ON THE NATIONAL LEVEL AS WELL AS STRONGER COOPERATION ON THE INTERNATIONAL LEVEL TO ADVANCE COMPARATIVE RESEARCH
SECONDARY ANALYSIS OF THE INCIDENTALLY COMPARABLE.

02800 DERRYCK, V.L.

PREMISES, PROMISES, AND PARADOXES: U.S. POLICY TOWARD THE PREMISES, PROY

TRANSAFRICA FORUM, $9(2)$ (SUM 92), 11-24.

THE AUTHOR DISCUSSES U.S. POLICY IN AFRICA AND THE CARIBBEAN. FIRST, SHE EXAMINES THE CHARACTERISTICS OF THE POST-COLD WAR WORLD. THEN SHE SUGGESTS SPECIFIC STEPS THAT BLACK AMERICANS COULD TAKE TO INFLUENCE U.S. POLICY TOWARD THOSE TWO REGIONS.

02801 DERTHICK, M

FEDERAL GOVERNMENT MANDATES: WHY THE STATES ARE COMPLAINING BROOKINGS REVIEW, 10(4) (FAL 92), 50-53.

THE FEDERAL GOVERNMENT INFLUENCES STATE GOVERMMENTS IN FOUR MAIN HAYS: COURT DECREES, LEGISLATIVE REGULATIONS PREEMPTIONS, AND CONDITIONAL GRANTS-IN-AID. THE USE OF ALL FOUR METHODS HAS GROWN SIGNIFICANTLY MORE COERCIVE IN THE PAST HALF-CENTURY. ALTHOUGH THE MAJOR CONCERN OF STATE GOVERNMENTS IS THE COST OF FEDERAL MANDATES, CONSTITUTIONAL ISSUES ARE ALSO INVOLVED BECAUSE THE CONSTITUTION PROTECTS THE STATES IN YARIOUS WAYS.

02802 OERTHICK, M.

UP-TO-DATE IN KANSAS CITY: REFLECTIONS ON AMERICAN FEDERALISM

PS: POLITICAL SCIENCE AND POLITICS, 25(4) (DEC 92), $671-675$.

THE AUTHOR'S PURPOSE FOR THIS PAPER IS TO ASK, "WHAT DIFFERENCE DOES AMERICAN FEDERALISM MAKE?" BY AMERICAM FEDERALISM, SHE REFERS TO AN ARRANGEMENT WHEREBY THE FUNCTIONS OF GOVERMMENT ARE DIVIDED BETWEEN ONE NATIONAL GOVERNMENT AND NUMEROUS SUB-NATIONAL ONES, ALL RESTING ON GOVERNMENT AND NUMERDUS SUB-NATIONAL ONES, ALL RESTING ON
POPULAR CONSENT ANO ON WRITTEN CONSTITUTIONS. SHE SUGGESTS POPUL AR CONSENT ANO ON WRITTEN CONSTITUTIONS. SHE SUGGEST THAT AMERICAN STATES ARE NOT CREATURES OF THE NATIONAL
GOVERNMENT, BUT THAT STATE GOVERNMENTS DERIVE AUTHORITY FROM THEIR RESPECTIVE CONSTITUENT COMMUNITIES. SHE ALSO SUGGESTS THAT FEDERALISH AFFECTS THE SETTING WITHIN WHICH AMERICAN PUBLIC ADMINISTRATORS
DEFENSE OF FEDERALISM.

02803 DERUETTE, S.; LOEB-MAYER, N.

BELGIUM

EUROPEAN JOURNAL OF POLITICAL RESEARCH, 22(4) (DEC 92),

THE AUTHOR SUMMARIZES THE RESULTS OF BELGIUM'S NOVEMBER 1991 LEGISLATIVE ELECTIONS. HE ALSO DISCUSSES RECENT INSTITUTIONAL CHANGES AND THE MAJOR ISSUES DRIVING NATIONAL POLITICS IN $1991-92$.

02804 DERVAI, K.; GREgOROHICZ, P.; HEGJI, C.E.

FEDERAL BUDGET DEFICITS, MONEY, AND EXCHANGE RATES

CONTEMPORARY POLICY ISSUES, $X(1)$ (JAN 92), 81-90.
THE DOLLAR'S STRENGTH DURING THE 1980'S APPEARS TO MANY TO HAVE BEEN LINKED TO THE DECADE'S LARGE BUDGET DEFICITS ANO THE SUBSEQUENT INCREASE IN THE STOCK OF FEDERAL DEBT OUTSTANDING. THE POPULAR ARGUMENT IS THAT THE BUDGET DEFICIT AND THE GROWTH OF FEDERAL GOVERNMENT CREDIT MARKET DEMAND CAUSED U.S. INTEREST RATES TO RISE OVER THAT PERIOD, INDUCING LARGE CAPITAL INFLOHS FROM ABROAD TO FINANCE THE DEFICIT. ACCORDING TO THE ARGUMENT, THE CAPITAL INFLOHS CAUSED THE DOLLAR TO APPRECIATE. DESPITE THE ARGUMENT'S POPULARITY THE EMPIRICAL LITERATURE DOES NOT STROMGLY SUPPORT IT' AND EYIDENCE ON THE RELATIONSHIP BETWEEN THE SUPPORT IT, AND EVIDENCE ON THE RELATIONSHIP BETWEEN THE FEDERAL DEFICIT AND THE DOLLAR IS AT BEST MIXED. IN THIS
PAPER, THE AUTHORS RECONSIDER THE EFFECTS OF FEDERAL BUDGET PAPER, THE AUTHORS RECONSIDER
DEFICITS ON THE EXCHANGE RATE.

02805 DERVIN, D.

THE DYNAMICS OF THE DELEGATE IN BUSH'S PRESIDENCY IOURMAL OF PSYCHOHISTORY 20(2) (FAL 92 ) $167-184$

THIS EVALUATION OF THE PRESIDENTIAL CAMPAIGN IS THAT IN THE POLITICAL SEASON OF 1992, THE ELECTORATE RAGES AROUND BALLOTS OR BULLETS, PITCHES DIZZILY BETWEEN ELECTION OR ASSASSINATION, YEARNS FOR A PURE LEADER YET LUSTS FOR A
POISON CONTAINER. IT CONCLUDES THAT IF NOTHING ELSE IS CLEAR, AT LEAST IN THE DYNAMICS OF THE DELEGATE, ONE IS MOS UNLIKELY TO FIND DEFINING MOMENTS, FOR THE DELEGATE IS ORIGNIALLY AND ULTIMATELY HE WHO IS DEFINED.

02806 DESAI, A.V.

ALTERNATIVE ENERGY IN THE THIRD HORLD: A REAPPRAISAL OF SUBSIDIES

WORLD DEVELOPMENT, 20(7) (JUL 92), 959-965.

HEAVY SUBSIDIES GIVEN TO SELECTED ALTERNATIVE ENERGY SOURCES IN DEVELOPING COUNTRIES HAVE LED EITHER TO LITTLE ENERGY MARKET PENETRATION OR HAVE BEEN OF DOUBTFUL ECONOMIC VALUE. SUBSIDIES TO PRODUCERS HAVE CREATED INEFFICIENT AND FRAGILE INDUSTRIES WHILE SUBSIDIES TO PRODUCTS HAVE FROZEN TECHNOLOGY. THE COSTS OF CONVENTIONAL ENERGY SOURCES INCREASE WITH THE DISTANCE FROM THE POINTS OF PRODUCTION; THEIR HIGH COSTS IN REMOTE AREAS CREATE A NICHE THAT COULD BE EXPLOITED BY DECENTRALIZED SOURCES OF ALTERNATIVE ENERGY BE EXPLOITED BY DECENTRALIZED
TO CREATE DEPENDABLE MARKETS.

02807 DESANTIS, Y.S.; GLASS, J.J.; NEHELL, C.

CITY MANAGERS, JOB SATISFACTION, AND COMMUNITY PROBLEM CITY MANAGERS,

PUBLIC ADMINISTRATION REVIEW, 52(5) (SEP 92), 447-481.

USING 1990 SURVEY DATA GATHERED BY THE INTERNATIONAL CITY/COUNTY MANAGEMENT ASSOCIATION, THE AUTHORS IDENTIFY THE FACTORS THAT HELP TO SHAPE THE LEVEL OF JOB SATISFACTION AMONG CITY MANAGERS AND THEIR PERCEPTIONS OF COMMUNITY PROBLEMS. THE AUTHORS FOCUS ON THE IMPACT OF MANAGERIAL VALUES, JOB CHARACTERISTICS, AND CITY SIZE. AMONG THE SURVEYED MANAGERS, THE WORKING CONDITIONS--ESPECIALLY SUPPORTIVE RELATIONSHIPS WITH CITY COUNCIL MEMBERS-WERE POSITIVELY CORRELATED WITH A SENSE OF JOB SATISFACTION WHILE THEIR VIEW OF COMMUNITY PROBLEMS WAS MORE CLOSELY RELATED TO CITY SIZE. IN NEITHER CASE DID MANAGERIAL VALUES SEEM TO PLAY A SIGNIFICANT ROLE.

02808 DESHALIT, A.

ENVIROMMENTAL POLICIES AND JUSTICE BETWEEN GENERATIONS EUROPEAN JOURNAL OF POLITICAL RESEARCH, 21(3) (APR 92), 307-316

VARIED MORAL DILEMMAS ARISE FROM ENYIRONMENTAL POLICIES. OVER AND ABOVE RELATIONS BETWEEN HUMAN BEINGS AND EITHER ANIMALS OR NATURE, THESE INCLUDE RELATIONS BETWEEN CONTEMPORARIES ANO FUTURE INHABITANTS OF THE EARTH. IN THAT SENSE MANY ENYIRONMENTAL POLICIES CAN BE SEEN AS A MATTER OF OISTRIBUTION OF ACCESS TO GOOOS BETWEEN CONTEMPORARIES AND FUTURE GENERATIONS. IM LIGHT OF THIS COMPRERMSIY AND FUTURE GENERATIONS. IN LIGHT OF THIS, A COMPREHENSIVE POERY OF THTORISTS TD EYALUIE ENYIRONMENTAL PROBLEMS AND DISCUSS ECOLOGICAL OUESTIONS WITH A NEH APPROACH.

02809 DESHINGKAR, G.

THE DENG XIAOPING "WHIRLWIND"

THE DENG XIAOPING "WHIRLWIND"
CHINA REPORT, 28(2) (APR 92), 153-158.

CHINA'S PREMIER LEADER DENG XIAOPING MADE A TOUR OF VARIOUS PARTS OF THE COUNTRY IN EARLY 1992 DURING WHICH HE STRONGLY ADVOCATED ECONOMIC LIBERALIZATION FOR CHINA. DENG'S STRONGLY ADVOCATED ECONOMIC LIBERALIZATION FOR CHINA. DENG' TOUR WAS UNEXPECTED BY CHINESE GOVERNMENT OFFICIALS; IT SIGNALS A POWER STRUGGLE BETWEEN THE CONSERVATIVE AND

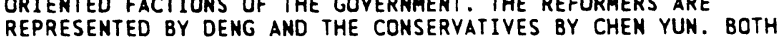
REPRESENTED BY DENG AND THE CONSERVATIVES BY CHEN YUN. BOTH ARE VERY OLD AND OBVIOUSLY NOT AFTER PERSONAL POHER. IT IS STRUGGLE OVER SHAPING THE FUTURE OF CHINA. WHILE IT IS IMPOSSIBLE TO DETERMINE THE OUTCOME OF THIS STRUGGLE, IT
APPEARS THAT DENG AND THE REFORMERS ARE GAINING THE UPPER APPEARS
HAND.

02810 DESHPANDE, $G$.

THE CHINESE POLITICAL SYSTEM IN THE WAKE OF TIANANMEN

CHINA REPORT, 27(4) (OCT 91) 267-274.

WITHOUT UMDERRATING WHAT HAPPENED AT THE TIANANMEN 
SOUARE IN THE SUMMER OF 1989 , ONE HAS TO SAY THAT IT WOULD BE PREMATURE TO READ INTO THE WHOLE BUSINESS, A CERTAIN ALIENATION OF THE MASSES FROM THE CHINESE STATE AND THE
PARTY. IN ORDER TO DETERMINE THE NATURE OF THE CHINESE STATE OVER THE NEXT FEW YEARS, THIS ARTICLE PRESENTS SOME BASIC FORMULATIONS, INTEGRATING ECONOMICS, THE ROLE OF THE PARTY
AND THE INTERNATIONAL FACTOR. THE MESSAGE THAT THE COMMUNIST AND THE INTERNATIONAL FACTOR. THE MESSAGE THAT THE COMMUHI
PARTY OF CHINA SEEMS TO BE BROADCASTING IS THAT IT IS A DICTATORSHIP AND PLANS TO REMAIN ONE.

02811 DESJARLAIS, D.C.; FRIEDMAN, S.R.

AIDS AND LEGAL ACCESS TO STERILE DRUG INJECTION EQUIPMENT ANNALS OF THE AMERICAN ACADEMY OF POLITICAL AND SOCIAL SCIENCE, 521 (MAY 92), 42-65.

LEGAL ACCESS TO STERILE INJECTION EOUIPMENT HAS BEEN A PRIMARY STRATEGY FOR PREVENTIMG THE SPREAD OF ACOUIRED IMMUNE DEFICIENCY SYNDROME (AIDS) AMONG INTRAVENOUS DRUG USERS IN ALMOST ALL DEVELOPED COUNTRIES. BUT THIS STRATEGY HAS REMAINED HIGHLY CONTROVERSIAL IN THE UNITED STATES, WITH ONLY A SMALL NUMBER OF LOCALITIES ADOPTING IT. IN THIS ONLY A SMALL NUMBER OF LOCALITIES ADOPTING IT. IN THIS ARTICLE, THE AUTHORS REVIEH DIFFERENT TECHNIQUES FOR
PROVIDING LEGAL ACCESS (OVER-THE-COUNTER SALES AND SYRINGE PROVIDING LEGAL ACCESS (OVER-THE-COUNTER SALES AND SYRINGE
EXCHANGES), RESEARCH DESIGN ISSUES RELEVANT TO EVALUATING LEGAL-ACCESS PROGRAMS, AND THE FINDINGS FROM THE STUDIES DECREASES IN AIDS RISK BEHAVIOR AND NO INCREASE IN ILLICIT DECREASES IN AIDS RISK BEHAVIOR AND NO INCREASE IN ILLICI DRUG USE RELATED TO LEGAL-ACCESS PROGRAMS. THE DESIGN OF LEGAL-ACCESS PROGRAMS FOR HAXIMAL IMPACT AND THE ULTIMATE EFFECT OF THE DECREASES IN AIDS RISK BEHAVIOR ON TRANSMISSION OF THE HUMAN IMMUNODEFICIENCY VIRUS REMAIN TO BE DETERMINED.

02812 DESOTO, $H$.

A NEW PARADIGM FOR DEVELOPMENT

SWISS REVIEW OF WORLD AFFAIRS, 42(3) (JUN 92), 6-8.

IN THE DEVELOPING COUNTRIES, BOTH SOCIALIST AND OSTENSIBLY CAPITALIST SYSTEMS HAVE FAILED. THIS ESSAY ABANDONS THE USUAL PERSPECTIVES ON ECONOMIC DEVELOPMENT AND, PARTLY VIA THE EXAMPLE OF PERU, ASSESSES THE ROLE PLAYED BY'
BASIC DEMOCRATIC INSTITUTIONS, RELIABLE PROPERTY RIGHT, AND MARKETS IN A COUNTRY'S CHANCES FOR ECONOMIC GROWTH.

02813 DESOUZA, $P$

EXECUTIVE DISCRETION TO REGULATE FOREIGN INYESTMENT IN THE UNITED STATES

JOURNAL OF LAH \& POLITICS, VII(2) (WIN 91), 289-324.

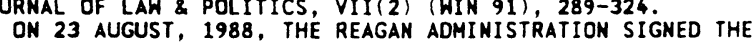
OMNIBUS TRADE AND COMPETITIVENESS ACT OF 1988 PART OF WICH AMENDED THE DEFENSE PRODUCTION ACT OF 1950. THIS AMENDMENT AMENDED THE DEFENSE PRODUCTION ACT OF 1950. THIS AMENDMENT
PROVIDES THAT THE PRESIDENT MAY SUSPEND OR PROHIBIT ANY PROVIDES THAT THE PRESIDENT MAY SUSPEND OR PROHIBIT ANY
MERGER, ACQUISITION, OR TAKEOVER BY PERSONS WHICH WOULD MERGER, ACQUISITION, OR TAKEOVER BY PERSONS WHICH WOULD
RESULT IN FOREIGN CONTROL, WHERE SUCH CONTROL THREATENS TO RESULT IN FOREIGN CONTROL, WHERE SUCH CONTROL THREATENS TO
IMPAIR NATIONAL SECURITY. THIS ARTICLE EXAMINES THIS CHANGE IMPAIR NATIONAL SECURITY. THIS ARTICLE EXAMINES THIS CHANGE
AND ARGUES THAT THIS GRANT OF POWER MUST BE MORE CAREFULLY AND ARGUES THAT THIS GRANT OF POWER MUST BE MORE CAREFULL TAILORED BY THE PROPOSED IMPLEMENTING REGULATIONS TO MEET THE SPECIFIC NEEDS OF NATIONAL SECURITY WHILE AVOIDING
BECOMING A BLANKET GRANT OF POWER TO THE PRESIDENT WHICH BECOMING A BLANKET GRANT OF POHER TO THE PRESIDENT WHICH COULD LEAD TO ABUSES OF DISCRETION BY
BROADLY REGULATING FOREIGN INVESTMENT.

02814 DESSOUKI, A.E.H.

EGYPT'S RESPONSE TO THE PERSIAN GULF CRISIS CURRENT HISTORY, 91 (561) (JAN 92), 34-36.

THE AUTHOR REVIEWS EGYPT'S DIPLOMATIC MANEUVERING IMMEDIATELY PRIOR TO THE IRAQI INVASION OF KUHAIT, DURING THE GULF CRISIS, AND FOLLOWING THE IRAQI DEFEAT. HE CONCLUDES THAT THE GULF CRISIS DEMONSTRATED THE STABILIZING ROLE EGYPT NOW PLAYS IN THE MIDDLE EAST AND THAT CAIRO HAS BECOME THE FOCUS OF POSTHAR DIPLOMACY IN THE REGION.

02815 DESHAAN, A.

PERSPECTIIVES FOR TRANSHATIONAL SOCIAL POLICY GOVERNMENT AND OPPOSITION, 27 (1) (WIN 92), 33-51.

A TRANSHATIONAL WELFARE SCHEME WOULD IMPLY THA PROSPEROUS NATIONS WOULD CONTRIBUTE TO PAYMENTS MADE TO THE CITIZENS OF OTHER NATIONS IN A SYSTEMATIC MANNER UNDER BINDING ARRANGEMENTS. THE OBJECTIVE OF THIS PAPER IS NOT TO ADVOCATE SUCH A POLICY OR ARGUE AGAINST IT, NOR TO PRESENT BLUEPRINTS OR CRITIQUES, BUT TO EXPLORE THE CONDITIONS THAT MIGHT ONE DAY GIVE RISE TO TRANSNATIONAL WELFARE POLICIES.

02816 DETKEN, C. : GARTNER, M.

GOVERNMENTS, TRADE UNIONS AND THE MACRO-ECONOMY: AN GOVERNMENTS, TRADE UNIONS AND THE MACRO-ECONONY: AN EXPOSITORY ANALYSIS OF THE POLITICAL
PUBLIC CHOICE. $73(1)$ (JAN 92 ) $37-54$.

PUBLIC CHOICE THEORISTS HAVE INTRODUCED THE IDEA THAT PART OF THE UPS AND DOWNS IN MACROECONOMIC DEVELOPMENT MAY BE DUE TO DELIBERATE GOVERNMENT ACTION. ANOTHER LINE OF REASONING ARGUES THAT TRADE UNIONS WHO POSSESS SOME DEGREE OF MONOPOLY POWER AND WHO ARE INTERESTED IN BOTH ECONOHIC AND POL ITICAL TARGETS MAY AL SO CAUSE AN ECONOMY TO FLUCTUATE WITH THE RHYTHM OF ELECTION DATES. THIS PAPER ELABORATES ON
THESE IDEAS AND ATTEMPTS TO INTEGRATE THEM INTO A COHERENT THESE IDEAS AND ATTEMPTS TO INTEGRATE THEM
MACROECONOMIC AND MACROPOL ITICAL FRAMEWORK.
02817 DEUDNEY, D.: IKENBERRY I.

SOYIET REFORM AMD THE END OF THE COLD WAR: EXPLAINING LARGE-SCALE HISTORICAL CHANGE

REVIEW OF INTERNATIONAL STUDIES, 17(3) (JUL 91), 225-250. THE RAPID AND FUNDAMENTAL CHANGES THAT HAVE SWEPT THROUGH THE SOVIET UNION AND EASTERN EUROPE HAVE CAUSED ACADEMICS TO RE-EXAMINE LONG-HELD THEORIES AND EXPLANATIONS OF SOVIET BEHAVIOR. THIS PAPER SURVEYS AND DEVELOPS A RANGE OF THEORIES RELEVANT TO THE RECENT EVENTS IN EASTERN EUROPE AND THE SOVIET UNION. THREE BROAD THEORETICAL FAMILIES-REALISM, GLOBALISM, AND SOCIOECONONIC THEORIES OF DEMOCRACY, CAPITALISM AND INDUSTRIALISM--ARE EXAMINED FOR THE CLAIMS THAT THEY MAKE ABOUT THE CHARACTER OF WORLD POLITICS, THE SOURCES OF HISTORICAL CHANGE, AND THEIR RELEVANCE TO THE RECENT EVENTS IN QUESTION. DRAHING ON THESE THEORIES, THE OF THE SOVIET CRISIS IS A MISMATCH BETWEEN SOVIET COMMAND POLITICAL AND ECONOMIC STRUCTURES AND THE IMPERATIVES OF ADVANCED INDUSTRIAL PRODUCTION.

02818 DEUDNEY, D.; IKENBERRY, G.

WHO WON THE COLD WAR?

FOREIGN POLICY, (87) (SUM 92), 123-138.

THE FALL OF THE SOVIET UNION AND THE ENSUING END OF THE COLD WAR WAS A SURPRISE TO MOST (IF NOT ALL) OBSERVERS. HOWEVER, A NUMBER OF PEOPLE AND GROUPS, MOST NOTABLY THE REAGAN RIGHT, WERE OUICK TO TAKE CREDIT FOR THIS DRAMATIC TURN OF EVENTS. FORMER ADMINISTRATION OFFICIALS DECLARE THAT THEY "WON" THE COLD WAR THROUGH A COMBINATION OF MILITARY BUILDUP AND INTENSE IDEOLOGICAL WARFARE WITH THE USSR. THIS ARTICLE ARGUES THAT REAGAN AND HIS ADMINISTRATION'S MILITARY INITIATIVE PLAYED A FAR DIFFERENT AND MORE COMPLICATED ROLE IN INOUCING SOVIET CHANGE THAN THE REAGAN VICTORY SCHOOL ASSERTS. FOR EVERY "HARDENING" THERE HAS A "SOFTENING": REAGAN'S RHETORIC OF THE "EVIL EMPIRE" WAS MATCHED BY HIS VIGOROUS ANTI-NUCLEARISM; THE MILITARY BUILDUP IN THE HEST WAS MATCHED BY THE RESURGENCE OF A LARGE POPULAR PEACE MOVEMENT; AND THE REAGAN DOCTRINE'S TOUGHENING OF CONTAINMENT WAS MATCHED BY MAJOR DEVIATIONS FROM CONTAINMENT IN EAST-WEST ECONOMIC RELATIONS. MOREOVER, OVER THE LONGER TERM, THE STRENGTH MARSHALED IN CONTAINMENT WAS MATCHED BY MUTUAL WEAKNESS IN THE FACE OF NUCLEAR WEAPONS, AND EFFORTS TO ENGAGE THE USSR WERE AS IMPORTANT AS EFFORTS TO CONTAIN

02819 DEUTCH, J.

CONTAINING HEAPONS PROLIFERATION

TECHNOLOGY REVIEW, $94(6)$ (AUG 91 ), 73

THE PACE OF MILITARY TECHNOLOGY TRANSFER AND ARMS SALES APPEARS TO BE INCREASING. U.S. AND WESTERN EUROPEAH

INDUSTRIES FACE DECLINING DEFENSE BUDGETS AND ARE VIGOROUSLY PURSUING INTERNATIONAL MARKETS. THE SOVIET UNION, EASTERN EUROPEAN COUNTRIES, AND CHINA SEE ARMS SALES AS IN IMPORTANT SOURCE OF HARD CURRENCY. INDEED, THE VERY EXISTENCE OF EXCESS CAPACITY FOR WEAPONS PRODUCTION ENCOURAGES PROLIFERATION. THIS COMBINATION OF DEMANO AND SUPPLY FOR MILITARY TECHNOLOGY WEIGHS AGAINST THE PROSPECTS FOR CONTROLLING PROL IFERATION BUT THE UNITED STATES CAN COMBINE SEVERAL INSTRUMENTS OF FOREIGN POLICY--ARMS LIMITATION AGREEMENTS, EXPORT CONTROLS, DIPLOMACY, AND MILITARY AND ECONOMIC AID--TO SLOW THE PROCESS AND
DESTRUCTIVE CONFLICTS IN THE FUTURE.

02820 DEUTCH, J.

NUCLEAR WEAPONS IN THE NEH WORLD ORDER

TECHNOLOGY REVIEW, 95(2) (FEB 92), 68.

DRAMATIC CHANGES IN THE FORMER' SOVIET UNION SHOULD ALLOW THE U.S. TO CUT BACK ITS NUCLEAR ARSENAL AND REAPPRAISE ITS STRATEGY. THIS PAPER SUGGESTS THAT THE U.S. NUCLEAR ACTIVITIES CANNOT ABRUPTLY CEASE. THAT IT HILL REMAIM IMPORTANT TO MAINTAIN THE WEAPONS COMPLEX THAT IS RESPONSIBLE FOR THE DESIGN, MANUFACTURE, AND TESTING OF NUCLEAR ARMAMENTS. IT WILL NEED THESE FACILITIES FOR THE TASK OF GETTING RID OF UNNEEDED WEAPONS. THE AUTHOR ADVOCATES A SYSTEM OF PLANS WHICH WOULD ADD GREATER FLEXIBILITY TO LAUNCH LIMITED STRIKES, THUS IMPROVIMG THE CAPACITY TO CONTROL ESCALATION.

02821 DEUTCH, J.M.

THE NEW MUCLEAR THREAT

FOREIGN AFFAIRS, 71(4) (FAL 92), 120-134.

ON THE INTERHATIONAL AGENDA, THE THREAT OF NUCLEAR WEAPONS SPREAD AROUND THE WORLD HAS DISPLACED THE FEAR OF SUPERPOHER NUCLEAR WAR. SEVERAL COUNTRIES ARE DETERMINED TO PURSUE NUCLEAR WEAPONS CAPABILITY, AND SOME MAY EVENTUALLY PURSUE NUCLEAR WEAPONS CAPABILITY, AND SOME MAY EVENTUAL INFLUENCING POLITICAL AND MILITARY EVENTS IN UNPREDICTABLE AND DANGEROUS HAYS

02822 DEUTCHMAN, I

UNGENDERED BUT EQUAL: MALE ATTITUDES TOWARD WOMEN IN STATE LEGISLATURES

POLITY, 24(3) (SPR 92), 417-132. 
DRAWING UPON SURVEY DATA FROM SIX NORTHEASTERN STATES, THIS ARTICLE EXPLORES THE ATTITUDES OF MALE LEGISLATORS TOWARD THEIR FEMALE COUNTERPARTS AND ALSO THE ATTITUDE OF WOMEN LEGISLATORS TOWARD THEIR STILL MINORITY STATUS IN THE SEVERAL LEGISLATIVE BODIES. THE AUTHOR FINDS A RANGE OF VIEWS AND CONCLUDES THAT WOMEN ARE ACCEPTED LARGELY TO THE EXTENT THAT THEY BECOME UNGENDERED BUT EQUAL.

02823 DEVIC, A.

THE LIMITS OF ETHMO-NATIONAL ANALYSIS

INTERNATIONAL JOURNAL OF POLITICS, CULTURE AND SOCIETY, 6(1) (FAL 92), 133-138.

ANA DEVIC CONTENDS THAT IN YUGOSLAVIA "HISTORY IS REPEATING ITSELF NOT THROUGH ITS EVENTS BUT THROUGH THE PATTERNS OF WRITING ABOUT IT." SHE CHALLENGES THE WIDESPREAD ASSUMPTION THAT THE CURRENT VIOLENCE HAS ETHNO-HISTORICAL CAUSES. SHE CONCLUDES THAT THE PREVAILING INTERPRETATIONS OF THE "NEW AGE OF NATIONALISM" WILL SEAL THE STORY OF THE "WILD BALKAN TRIBES": THEY WILL REMAIN THE DEEPEST WELLS OF SOME FUTURE EXERCISE IN AWAKENING THEIR "COLLECTIVE MEMORY."

02824 DEVINS, $N$.

A SYMBOLIC BALANCED BUDGET AMENDMENT

JOURNAL OF LAW \& POLITICS, IX(1) (FAL 92), 61-88.

THE AUTHOR ADVOCATES A SYMBOLIC BALANCED BUDGE AMENDMENT TO THE CONSTITUTION TO BE SUPPLEMENTED HITH A STATUTORY REALIGNMENT OF BUDGETARY RESPONSIBILITIES. HE PARTICULARLY OBJECTS TO THE PROCEDURAL ARRANGEMENTS ESTABLISHED BY THE BUDGETARY REFORMS OF 1974 , GRAMM-RUDMANHOLLINGS, AND THE BUDGET ENFORCEMENT ACT OF 1990, BECAUSE THEY DEFLECT INSTITUTIONAL ACCOUNTABILITY. HE SUPPORTS REVISIONS IN THE PROCESS THAT RE-EMPHASIZE THE PRESIDENT'S CONTROL OVER BUDGET AGGREGATES AND CONGRESSIONAL CONTROL OVER DETAILS AND PRIORITIES.

02825 DEWAAL, A.

PREVENTING FAMINE AT ITS SOURCE

TECHNOLOGY REVIEW, 95(8) (NOV 92), 70-71.

NO COUNTRY HAS MOVED FROM BEING FAMINE-STRICKEN TO BEING FAMINE-FREE BY RECEIVING FOOD AID. AND NO GOVERNMENT IS SO POOR THAT IT CANNOT AFFORD A FAMINE-PREVENTION SYSTEM. ONLY BY MAKING EMERGENCY FOOD SHIPMENTS AS WELL AS DEVELOPMENTAL AID CONDITIONAL ON FUNDAMENTAL CHANGES IN RECIPIENT AID CONDIIIONAL ON FUNDAMENTAL CHANGES IN RECIPIENT COUNTRIES CAN THE WORLD ELIMINATE FAMINE

02826 DEWAAL, A.; OMAAR, R.

THE LESSONS OF FAMIME

AFRICA REPORT, 37(6) (NOV 92), 62-64.

SOMALIA IS SUFFERING A SEVÉRE FAMINE, BUT BY RELYING ON THE EXISTING SOCIAL STRUCTURE AND AN UNDERSTANDING OF SOMALI CULTURE, INTERNATIONAL RELIEF ORGANIZATIONS CAN MANAGE TO SUCCESSFULLY DISTRIBUTE FOOD. IN ADOITION, THE SYSTEM USED FOR FOOD DISTRIBUTION CAN HELP TO REBUILD POLITICAL STRUCTURES THAT WERE TORN APART BY THE OUSTER OF MOHAMED SIAD BARRE AND THE ENSUING CIVIL WAR.

02827 DEHAR, M.E.

LOANS TO BUSINESS TO ENCOURAGE RURAL ECONOMIC DEVELOPMENT POLICY STUDIES JOURNAL, 20(2) (1992), 230-240.

PROGRAMS THAT SUBSIDIZE BUSINESSES TO STIMULATE ECONOMIC DEVELOPMENT IN NONMETROPOLITAN AREAS FACE FORMIDABLE ODOS AGAINST SUCCESS; YET THEY CONTINUE TO BE POPULAR HITH STATE AND LOCAL GOVERNMENTS. IN THIS PAPER, THE AUTHOR ANALYZES MINNESOTA'S BUSINESS LOAN PROGRAM IN DETAIL IN ORDER TO UNDERSTAND WHY SUCH PROGRAMS SUCCEED OR FAIL.

02828 DEWEES, $D$.

THE ROLE OF TORT LAW IN CONTROLLING ENVIRONMENTAL POLLUTION CANADIAN PUBLIC POLICY--ANALYSE DE POLITIOUES, 18(4) (DEC 92) $425-442$

THE REDUCTION IN POLLUTION EMISSIONS IN CANADA AND IN THE US SINCE 1970 APPEARS TO BE ATTRIBUTABLE PREDOMINANTLY TO GOVERNMENT REGULATION, ALTHOUGH TORT LAH HAD CONTRIBUTED TO THE REDUCTION OF SOME POLLUTANTS. TORT HAS PLAYED A SMALL ROLE FOR SEVERAL REASONS. THE LIMITED EFFECTIVENESS OF TORT LAW HAS SPAWNED A NUMBER OF PROPOSED REFORMS, SOME OF HIICH HAVE BEEN INCORPORATED IN AN ENVIRONMENTAL BILL OF RIGHTS. SOME CHANGES TO THE REQUIREMENTS FOR PROVING CAUSATION MAY BE HELPFUL, BT GENUINE SCIENTIC UNCERTAINTY WILL CONTINUE TO PREVENT TORT LIGIGATION IN MANY CASES.

02829 DEWEYDENTHAL, J.B.

CROSS-BORDER DIPLOMACY IN EAST CENTRAL EUROPE

RFE/RL RESEARCH REPORT, 1(42) (OCT 92)

ALTHOUGH CZECHOSLOVAKIA, POLAND, AND HUNGARY ABANDONED COMMUNIST RULE ALMOST THREE YEARS AGO THEY ARE STILL STRUGGLING TO UNDO THE ECONOMIC AND POLITICAL DAMAGE IT INFLICTED ON THEIR MUTUAL RELATIONS AND FOREIGN POLICIES. THE NEED TO DEVELOP INTERNATIONAL TIES IS WIDELY RECOGNIZED THROUGHOUT THE REGION AS BOTH A MEANS OF LESSENING TENSIONS BETWEEN NATIONAL GROUPS AND AS A HAY TO FACILITATE RAPPROCHEMENT AMONG GOVERNMENTS.
02830 DEWEYDENTHAL, J.B.

CZECHOSLOVAKIA, HUNGARY, AND POLAND GAIN ASSOCIATE MEMBERSHIP IN THE EC

RFE/RL RESEARCH REPORT, 1(6) (FEB 92), 24-26.

THE AGREEMENTS OF ASSOCIATION BETWEEN THE EUROPEAN COMMUNITY AND CZECHOSLOVAKIA, HUNGARY, AND POLAND ARE OF MAJOR SIGNIFICANCE, BECAUSE THEY CREATE A FRAMEWORK FOR THE POLITICAL INTEGRATION OF EASTERN EUROPEAN CDUNTRIES INTO WESTERN POLITICAL AND ECONOMIC SYSTEMS. ONCE IMPLEMENTED, THE AGREEMENTS MAY LEAD TO MAJOR ECONOMIC CHANGES IN EUROPE AS A WHOLE. HOWEVER, THEIR IMPLEMENTATION WILL NOT BE EASY, BECAUSE POTENTIAL ECONOMIC BENEFITS WILL BE RELATIVELY SLOW IN COMING AND THE CONTINUING DIFFICULTIES MAY PROMPT PROTESTS AND PUBLIC DISSATISFACTION IN THE CENTRAL EUROPEAN COUNTRIES.

02831 DEWEYDENTHAL, J.B.

GERMAN PLAN FOR BORDER REGION STIRS INTREST IN POLAND RFE/RL RESEARCH REPORT, $1(7)$ (FEB 92), 39-42.

A GERMAN PLAN TO DEVELOP THE POLISH-GERMAN BORDER REGION HAS AROUSED CONSIDERABLE INTEREST IN POLAND. CRITICIZED BY SOME AS AN ATTEMPT TO IMPOSE FOREIGN CONTROL OVER PART OF POLAND, THE PLAN HAS HELPED TO FOCUS ATTENTION ON THE NEED TO DEVELOP POLICIES TO DEAL WITH THE PROBLEMS OF POLISH BORDER REGIONS IN GENERAL. THE DISCUSSION ABOUT THE PLAN HAS ALSO REVEALED THE WEAKNESS OF THE POLISH SYSTEM OF DECISIONMAKING AT LOCAL LEVELS. ALTHOUGH SOME FEATURES OF THE PLAN ARE CERTAIN TO BE REJECTED BY THE POLES, ITS LONG-TERM EFFECT ON POLISH POLICIES MAY FACILITATE DEALING WITH SIMILAR SITUATIONS IN THE FUTURE.

02832 DEWEYDENTHAL, J.B.

POLAND FREE OF RUSSIAN COMBAT TROOPS

RFE/RL RESEARCH REPORT, 1(45) (NOV 92), 32-35.

FOLLOWING PROTRACTED AND DIFFICULT NEGOTIATIONS BETWEEN THE RUSSIAN AND POLISH GOVERNMENTS, THE LAST COMBAT UNIT OF THE FORMER SOVIET ARMY LEFT POLAND ON OCTOBER 28, 1992. THE DEPARTURE MARKED A FURTHER RECOGNITION OF POLISH SOVEREIGNTY AND LAID THE FOUNDATION FOR BETTER RELATIONS BETHEEN THE TWO COUNTRIES. A NON-COMBAT RUSSIAN MILITARY CONTINGENT REMAINS IN POLAND TO ASSIST RUSSIAN TROOPS RETURNING HOME FROM GERMANY.

02833 DEWEYDENTHAL, J.B.

POLAND PREPARES A NEH MILITARY DOCTRINE

RFE/RL RESEARCH REPORT, 1 (33) (AUG 92), 45-48.

THE POLISH AUTHORITIES HAVE BEGUN TO FORMULATE A NEW DEFENSE DOCTRINE AND TO REORGANIZE THE MILITARY ESTABLISHMENT. THE PROGRAM IS A CONTINUATION OF EARLIER EFFORTS TO BUILD A NATIONAL SECURITY SYSTEM, WHICH WERE DELAYED BY INTERHAL POLITICAL CONFLICTS. THE NEW DOCTRINE RELIES ON COOPERATION WITH WESTERN MILITARY AND SECURITY ORGANIZATIONS AND EMPHASIZES THE NEED FOR CLOSE LINKS WITH POLAND'S NEIGHBORS.

02834 DEWEYDENTHAL, J.B.

POLISH-RUSSIAN RELATIONS OISTURBED BY TROOP DISPUTE RFE/RL RESEARCH REPORT, 1(11) (MAR 92), 32-34.

POLAND AND RUSSIA ARE LOCKED IN A DISPUTE ABOUT THE WITHORAWAL OF SOVIET TROOPS FROM POLAND. THE QUARREL FOCUSES ON FINANCIAL COUNTERCLAIMS FOR SERVICES REMDERED AND DAMAGE INCURRED. THE IMPASSE IN NEGOTIATIONS THREATENS TO STALL THE WITHORAWAL AND MAY AFFECT POLISH-RUSSIAN RELATIONS IN OTHER AREAS. THERE IS AN URGENT NEED FOR DECISIVE ACTION BY POLITICAL LEADERS TO OVERCOME THE DEADLOCK.

02835 DEWEYDENTHAL, J.B. POLISH-UKRAINIAN RAPPROCHEMENT RFE/RL RESEARCH REPORT, 1(9) (FEB 92), 25-27, POLAND AND UKRAINE ARE ON THE VERGE OF SIGNING A

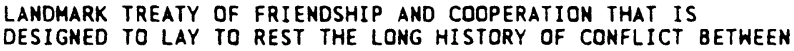
DESIGNED TO LAY TO REST THE LONG HISTORY OF CONFLICT BETWEEN FUTURE. BILATERAL RELATIONS BETWEEN UKRAINE AND POLAND ARE ALSO LIKELY TO BE AFFECTED BY THEIR RELATIONSHIPS WITH RUSSIA, THE DOMINANT POWER IN THE REGION.

02836 DEWEYDENTHAL, J.B.

POLITICAL PROBLEMS AFFECT SECURITY HORK IN POLAND RFE/RL RESEARCH REPORT, 1(16) (APR 92), 39-42.

EFFORTS TO BUILD A COMPREHENSIVE SYSTEM OF MILITARY SECURITY IN POLAND ARE DEADLOCKED OVER WHO SHOULD DIRECT AND COORDINATE THE WORK OF THE VARIOUS AGENCIES. PLANS TO PROVIDE A FRAMEWORK FOR THE SYSTEM HAVE RECENTLY BEEN

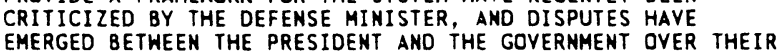
EMERGED BETWEEN THE PRESIDENT AND THE GOVERNMENT OVER THEI RESPECTIVE PREROGATIVES. THERE IS AN URGENT NEED FOR A COMPROMISE; OTHERWISE, THE SITUATION MAY DETERIORATE EVEN
FURTHER, WITH MAJOR CONSEQUENCES FOR NATIONAL SECURITY AND FURTHER, WITH MAJOR
POLITICAL STABILITY.

02837 DEWEYDENTHAL, J.B.

THE REALIGNMENT OF POLISH FOREIGN AND MILITARY POLICIES RFE/RL RESEARCH REPORT, $1(30)$ (JUL 92), 40-42. 
A WIDE-RANGING REALIGNMENT OF POLAND'S FOREIGN AND MILITARY POLICIES, PARTICULARLY WITH REGARD TO THE STYLE OF EXECUTION AND COORDINATION OF ACTIVITIES, OCCURRED IN MID1992. THIS DEVELOPMENT FOLLOWED A MAJOR CONFLICT WITHIN THE POLISH POLITICAL ESTABLISHAENT ABOUT WHO, OR WHICH INSTITUTION, SHOULD CONTROL THE COUNTRY'S MILITARY. THE REAL IGNMENT SUGGEST THAT THE DISPUTE HAS BEEN EFFECTIVELY RESOL VED.

02838 DEZELL, M. BUNDY'S REVENGE

NEH REPUBLIC, 206(10) (MAR 92), 15-16.

KENTUCKY SENATOR MITCHELL MCCONHELL HAS INTRODUCED A SWEEPING ANTI-PORNDGRAPHY BILL CALLED THE "PORNOGRAPHY VICTIMS' COMPENSATION ACT," WHICH IS BEING CONSIDERED BY THE SENATE JUDICIARY COMMITTEE. THE PROPOSAL HAS THE SUPPORT OF FUNDAMENTAL IST CHRISTIAN ORGANIZATIONS, PRO-FAMILY LOBBYS, AND MANY FEMINISTS. ALTHOUGH MCCONNELL CAREFULLY CRAFTED HIS LEGISLATION TO AVOID FREE SPEECH ISSUES, SOME OBSERVERS FEAR THAT IT WOULD INFRINGE ON FIRST AMENDMENT RIGHTS.

02839 DEZHEN, $Z$.

WESTERN AID PACKAGE STALLED

BEI JING REVIEW, $35(33$ ) (AUG 92), 45.

AT THE 1992 G-7 SUMMIT MEETING, THE WORLD'S LEADING INDUSTRIALIZED NATIONS APPROVED AN AID PACKAGE TO EASE RUSSIA'S ECONOMIC TROUBLES. UNDER THE PLAN, US\$2 24 BILLION WILL BE DISBURSED TO RUSSIA IN STAGES. BUT, IN THE RECENT PAST, THE WEST HAS PROMISED MORE ECONOMIC AID TO RUSSIA THAN IT HAS DELIVERED. RUSSIAN OFFICIALS ARE BEGINNING TO COMPLAIN THAT THEY CANNOT COUNT ON THE WEST TO EASE THEIR ECONOMIC TROUBLES

02840 DHAKAL, D.; GRABOWSKI, R.; SHIELDS, M.

THE ROLE OF SAVINGS IN ECONOMIC DEVELOPMENT: THE U.S. AND JAPANESE EXPERIENCES

JAPAN AND THE HORLD ECONOMY, 3(4) (APR 92), 331-340.

THIS PAPER EXPLORES THE RELATIONSHIP BETHEEN SAVINGS AND GROWTH IN THE UNITED STATES AND IN JAPAN WITHIN A SIMPLE GRANGER CAUSALITY FRAMEHORK. FOR JAPAN, GROWTH CAUSED SAVINGS BEFORE WORLD WAR II WHILE AFTER WORLD WAR II SAVINGS CAUSED GROWTH, FOR THE UNITED STATES, GROHTH CAUSED SAYIMGS AFTER WORLD WAR II. THESE RESULTS SUGGEST THAT THE SAVINGS GROWTH RELATIONSHIP MAY DEPEND UPON THE STAGE OF DEVELOPMENT.

02841 DHLOMO, O.

LIBERAL DEMOCRACY--VALUES WORTH KEEPING
SOUTH AFRICA FOUNDATION REVIEW, 18(12) (DEC 92), 8

ALTHOUGH MANY BLACK POLITICAL LEADERS CLAIM TO SUBSCRIBE TO LIBERAL DEMOCRATIC PRINCIPLES, THEY ARE NEVERTHELESS TO LIBERAL DEMOCRATIC PRINCIPLES, THEY ARE NEVERTHELESS UNHILLING TO DESCRIBE THEMSELVES AS LIBERAL DEMOCRATS. DR. ARE TIME-HONORED LIBERAL DEMOCRATIC VALUES. LIBERAL

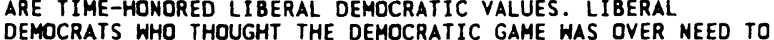
QUICKLY GET BACK ONTO THE PLAYING-FIELD. APPARENTLY THE GAME QUICKLY GET BACK ONTO THE P
HAS NOT YET EVEN STARTED.

02842 DIAKOSAVYAS, D.; SCANDIZZO, P.Z.

TRENDS IN THE TERMS OF TRADE OF PRIMARY COMMODITIES, 19001982: THE CONTROVERSY AND ITS ORIGINS

ECONOMIC DEVELOPMENT AND CULTURAL CHANGE, 39(2) (JAN 91), $231-264$

PRIMARY COMMODITY MARKETS HAVE OFFERED AN OPPORTUNITY FOR MUCH ECONOMIC DEBATE ON A NUMBER OF KEY ISSUES INCLUDING DECLINING TERMS OF TRADE, DOMINATION OF THE PERIPHERY BY THE CORE, AND THE CAUSES OF INSTABILITY. THE OBJECTIVE OF THIS ARTICLE IS TO SHED LIGHT UPON THESE ISSUES BY EXAMINING, IN SOME DETAIL, THE ISSUES OF SECULAR TRENDS OF TERMS OF TRADE OF 14 INDIVIDUAL PRIMARY COMMODITIES AND FIVE COMMODITY AGGREGATES BETHEEN 1900 AND 1982. THE MAIN CONTRIBUTION OF THIS ARTICLE OYER PREVIOUS STUDIES IS THE BROAD RANGE OF COMMODITIES AND SUBSTANTIAL DISAGGREGATION OVER A LONG TIME PERIOD.

02843 DIALLO, I.B.Y.

RECOVERY AHEAD?

WEST AFRICA, (3877) (JAN 92), 10-11.

THE AUTHOR SUMMARIZES GENERAL ECONOMIC TRENDS IN AFRICA IN 1991. HE LOOKS AT AFRICAN DEBT, STRUCTURAL ADJUSTMENT PRDGRAMS, AND BUDGETS. HE ALSO DISCUSSES THE ECONOMIC PROSPECTS FOR AFRICA IN 1992.

02844 DIAMAMDOUROS, F.N.; SPOURDALAKIS, M. POLITICAL SCIENCE IN GREECE POLITICAL SCIENCE IN GREECE
EUROPEAN JOURNAL OF POLITICAL RESEARCH, 20(3-4) (DEC 91), EUROPEAN

THE EVOLUTION AND DEVELOPMENT OF POLITICAL SCIENCE IN GREECE CAN BE UNDERSTOOD ON TWO ANALYTICALLY-SEPARATE BUT CLOSELY-CONNECTED LEVELS. THE FIRST CONFORMS TO THE GENERAL TREND OBSERVABLE IN EUROPEAN AND WESTERN MATIONS SINCE THE LATE 19TH CENTURY AND INVOLVES THE GRADUAL EMANCIPATION OF SYSTEMIC SOCIAL AND POL ITICAL INOUIRY FROM THE TUTELAGE OF THE LEGAL SCIENCES AND THE GRADUAL TRANSFORMATION INTO DISCRETE SOCIAL SCIENCE DISIPLINES--POLITICAL SCIENCE BEING
ONE OF THE LAST TO CLAIM ITS INDEPENDENCE. THE SECOND LEVEL RELATES TO THE GREEK HISTORICAL EXPERIENCE AND TO THE WAYS IN WHICH DELAYED SOCIAL AND POLITICAL DEVELOPMENT COMBINED WITH THE DYNAMICS OF NATION- AND STATE-BUILDING IN GREECE TO DETERMINE THE TRAJECTORIES TRAVELLED BY THE SOCIAL SCIENCES
AND POLITICAL SCIENCE ON THEIR WAY TO EVENTUAL EMANCIPATION.

02845 DIAMOND, E.; NEWMAN, J.

THE CANDIDATES AND THE ISSUES

TECHNOLOGY REVIEH, 95(4) (MAY 92), 26-33.

UNLIKE 1988, THIS YEAR'S PRESIDENTIAL RACE HAS DEALT

LARGELY WITH SUBSTANTIVE QUESTIONS--SO FAR. DEMOCRATS AND REPUBLICANS ALIKE HAVE MADE SERIOUS PROPOSALS IN AREAS SUCH AS HEALTH CARE, THE ENVIRONMENT, INDUSTRIAL COMPETITIVNESS, AND DEFENSE. THIS ARTICLE DETAILS THE NEW IDEAS ON NATIONAL HEALTH CARE, ATTEMPTS TO RECONCILE GREEN AND GROWTH, AND CONSIDERS EDUCATION FOR THE NEXT CENTURY. A REDIRECTION OF DEFENSE DOLLARS IS SUGGESTED. IT CONCLUDES THAT AS LONG AS THE CANDIDATES CONTINUE TO DEBATE POL ICY RATHER THAM PORN, THERE IS REASOM TO CONCENTRATING ON THE URGENT NATIONAL BUSINESS OF THE 19905 CONCENTRATIMG
AND BEYOND.

02846 DIAMOND,

A CONSTITUTION THAT HORKS--SOME OPTIONS

A CONSTITUTION TRAT HORAL, 23(1) (JUL 92), 45-49. SOUTH AFRICA INTERNATIONAL, 23(1) (JUL 92), 45-49.
A PARLIMENTARY SYSTEM OF GOVERNMENT AVOIDS PROBLEMS SSOCIATED WITH AN OVER-CONCENTRATION OF POWER, AND ENCOURAGES COALITION-BUILOING. THE SPECIFIC TYPE OF PROPORTIONAL RESPRESENTATION CHOSEN FOR ELECTING THE PARLIAMENT IS IMPORTANT. THE CREATION OF SPECIAL INDEPENDENT INSTI ITUTIONS TO PREVENT THE ABUSE OF STATE POWER CAN ALSO BE CRITICAL. THIS ARTICLE ILLUSTRATES HOW SUCH TECHNICAL DETAILS MAY WELL PROVE TO BE AS IMPORTANT AS THE BROADER GENERALIZATIONS ABOUT SOUTH AFRICA'S NEW CONSITUTION.

02847 DIAMOND, L.

PROMOTING DEMOCRACY

FOREIGN POLICY, (87) (SUM 92), 25-46.

THIS ARTICLE ARGUES THAT NOT SINCE THE END OF WORLD WAR ONE HAVE THE WESTERN DEMOCRACIES HAD SUCH AN OPPORTUNITY TO SHAPE THE POLITICAL NATURE OF THE WORLD. BY PROMOTING DEMOCRACY ABROAD, THE UNITED STATES CAN HELP BRING INTO BEING FOR THE FIRST TIME IN HISTORY A HORLD COMPOSED MAINLY OF STABLE DEMOCRACIES. HOWEVER, "PROMOTING" DEMOCRACY DOES NOT MEAN "EXPORTING" IT. RATHER, IT MEANS OFFERING MORAL, POLITICAL, DIPLOMATIC, AND FINANCIAL SUPPORT TO INDIVIDUALS POLITICAL, DIPLOMATIC, AND FINANCIAL SUPPORT TO AND ORGANIZATIONS THAT ARE STRUGGLING TO OPEN UP
AUTHORITARIAN REGIMES. IN ADOITION, COUNTRIES THAT ARE AUTHORITARIAN REGIMES. IN ADOITION, COUNTRIES THAT ARE
TRYING TO INSTITUTIONALIZE DEMOCRATIC GOVERNMENT MUST

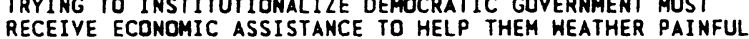
RECEIVE ECONOMIC ASSISTANCE TO HELP THEM HEATHER PAINFUL ECONOMIC REFORM AND THE TRAINING AND TECHNICAL SUPPORT TO
MAKE DEMOCRACY FUNCTION EFFECTIVELY. ASSISTANCE MUST ALSO BE MAKE DEMOCRACY FUNCTION EFFECTIVELY. ASSISTANCE MUST ALSO BE PROVIDED TO NONGOVERMENTL PILLARS OF DEMOCRACY: PART MES, CIVIC GROUPS, TRADE UNIONS, THINK TANKS, AND THE MASS MEDIA. THE ARTICLE EXAMINES THE VARIOUS AVENUES OPEN TO THE U.
ITS QUEST TO PROMOTE DEMOCRACY. THESE INCLUDE THE U.S. INFORMATION AGENCY (USIA), THE AGENCY FOR INTERNATIONAL DEVELOPMENT (AID), AND THE NATIONAL ENDOWMENT FOR DEMOCRACY (NED).

02848 DIAMOND, L.

THE SECOND LIBERATION

AFRICA REPORT, 37(6) (NOV 92), 38-41.

AFRICA IS UNDERGOING A DRAMATIC TRANSFORMATION FROM AUTOCRACY TO DEMOCRACY HITH FREE AND FAIR ELECTIONS. BUT ELECTIONS ARE ONLY THE START OF BUILDING VIABLE DEMOCRATIC STRUCTURES. STRENGTHENING DEMOCRATIC INSTITUTIONS--SUCH AS THE PRESS AND THE JUDICIARY, STAMPING OUT CORRUPTION, MANAGING ETHNIC DIVERSITY, AND ACHIEVING ECONOMIC GRONTH ARE IMPERATIVES FOR THE SURVIVAL OF GOOD GOVERNANCE.

02849 DIANI, M. ; EYERMAN, R.

STUDYING COLLECTIVE ACTION

SAGE PUBLICATIONS, 1992,263

THIS ORIGINAL BOOK IS THE FIRST TO CONCENTRATE ON THE METHODOLOGICAL PROBLEMS OF STUDYING COLLECTIVE ACTION. HOW DO SOCIAL MOVEMENTS SUCH AS ENVIRONMENTAL CONCERN, POLITICAL PROTEST OR FEMINISM EMERGE AND OPERATE? HOW CAN THE RESEARCHER CHART AND ANALYSE THE PROCESS? THE TUTHORS EMPHASIZE THE LINK BETHEEN THEORIZATION AND DATA ANALYSIS. THE BDOK ILLUSTRATES THE DIFFERENT RESEARCH STRATEGIES THAT THE BDOK ILLUSTRATES THE DIFFERENT RESEARCH STRATEGIES
HAVE DEVELOPED TO FIT THE THEORETICAL AND EMPIRICAL HAVE DEVELOPED TO FIT THE THEORETICAL AND EMPIRICAL

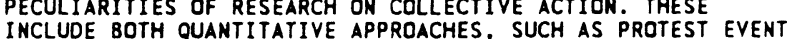
INCLUDE 8OTH QUANTITATIVE APPROACHES, SUCH AS PROTEST EVENT ANALYSIS AND NETHORK ANALYSIS, AND QUALITATIVE APPROACHES, SUCH AS POLITICAL DISCOURSE ANALYSIS AND LIFE HISTORIES. THE IMPACT ON THE RESEARCH PROCESS OF THE RELATI

02850 DIBBA, E.

JAHARA'S MISSION AND CONVICTIONS

WEST AFRICA, (3883) (FEB 92) 284-285.

IN THIS INTERVIEN, GAMBIA'S PRESIDENT SIR DAWDA JAWARA 
TALKS ABOUT HIS OWN POLITICAL CAREER AND ABOUT THE PROGRESS OF DEMOCRACY IN HIS COUNTRY.

02851 DICK, C.

INITIAL THOUGHTS ON RUSSIA'S DRAFT MILITARY DOCTRINE JOURNAL OF SOVIET MILITARY STUDIES, $5(4)$ (DEC 92$), 552-566$.
THIS ARTICLE PARAPHRASES THE RUSSIAN DRAFT MILITARY DOCTRINE, PUBLISHED IN MAY 1992. IN SUBSEQUENT SECTIONS, THE BRIEF COMPARES THIS WITH THE SOVIET DRAFT MILTARY DOCTRINE LIMITATIONS AND IMPLICATIONS OF RUSSIAN MILITARY THINKING.

02852 DICK, C.

SOVIET OPERATIONAL LEVEL DEFENCE: AN OVERVIEW
JOURMAL OF SOVIET MILIITARY STUDIES, 5(2) (JUN 92), 220-241.

SOVIET MILITARY WRITING IS GENERALLY FORWARD LOOKING.

THE CONCEPTS DESCRIBED ARE USUALLY BASED ON HISTORICAL

EXPERIENCE, BUT SHOW AN AHARENESS OF FUTURE WAR DEMANDS.

HOWEVER, THIS OFTEN SEEMS TO BE LESS TRUE FOR DEFENSE THAN FOR THE OFFENSIVE. THE SOLUTIONS FOUND SEEM TO BE A MIXTURE OF THE BARELY ADEQUATE AND THE CONTRADICTORY. BEFORE SOVIET THEORY OF OPERATIONAL DEFNSE CAN BE CONSIDERED FULLY OEVELOPED, A LOT MORE WORK MUST BE DONE ON SEVERAL AREAS. WHEN THESE SUBJECTS HAVE BEEN EXPLORED, THE SOVIET ARMY CAN START TO CONSIDER EQUIPMENT PROCURMENT AND ORGANIZATIONAL CHANGES APPROPRIATE TO AN ARMY WHICH IS DEFENSIVELY ORIENTATED.

\section{DICKERSON, $M$}

WHOSE NORM? POLITICAL CHANGE, POLITICAL DEVELOPMENT, AND SELF-GOVERNMENT IN THE NORTHWEST TERRITORIES

UBC PRESS, APR 92, 200

"WHOSE NORTH?" PROVIDES THE CONTEXT FOR A BETTER UNDERSTANDING OF THE POLIIIICAL ISSUES IN THE NORTHWEST TERRITORIES, A DISTINCT REGION WHICH COMPRISES ONE-THIRD OF CANADA'S LAND MASS. HITHIN THIS AREA A MAJORITY OF THE RESIDENTS ARE NATIVE PEOPLE. THEIR NON-PARTISAN CONSENSUS STYLE OF GOVERNMENT IS A UNIQUE POLITICAL JURISOICTION IN CANADA. THIS BDOK DISCUSSES SUCH ISSUES AS LAND CLAIMS, DIVISION, CONSTITUTIONAL DEVELOPMENT, SELF-GOVERNMENT, AND ECONOMIC DEVELOPMENT AND TRACES THE EVOLUTION OF THE ECONOMIC DEVELOPMENT AND TRACES THE EVOLUTION OF THE TERR ITORIAL GOVERNMENT FROM BEING COMPLET
OTTAWA TO INVOLVING NATIVE ORGANIZATIONS.

02854 DICKSON, B.J.

WHAT EXPLAINS CHINESE POLITICAL BEHAVIOR? THE DEBATE OVER WHAT EXPLAINS CHINESE

COMPARATIVE POLITICS, 25(1) (OCT 92), 103-118.

RECENT PUBLICATIONS TAKE CONTRASTING STANCES IN THE DEBATE OVER WHETHER POLITICAL BEHAVIOR IN CHINA IS A DEBATE OVER WHETHER POLITICAL BEHAVIOR IN CHINA IS A
RESPONSE TO INSTITUTIONAL OR TO CUL TURAL SIGNALS. PRIVATE CITIZENS AND PUBLIC OFFICIALS ENGAGE IN CLIENTELISTIC BEHAVIOR APPROPRIATE TO THE HIERARCHICAL STRUCTURE OF THE COMMUNIST POLITICAL SYSTEM; YET BEHAVIORAL PATTERNS IN CHINA HAVE REMAINED REMARKABLY CONSTANT DESPITE THE INSTITUTIONAL CHANGES ASSOCIATED WITH THE COMMUNIST REVOLUTION IN 1949 AND LATER WITH THE REFORMS OF THE 1980's. THIS SUGGESTS THAT SCHOLARS OUGHT TO INTEGRATE THE CONCEPTS OF CULTURE AND STRUCTURE BY SHOWING HOW TRADITIONAL CULTURAL VALUES SURVIVE DESPITE THE EFFORTS OF POLITICAL INSTITUTIONS TO CHANGE THEM AND HOW THE POLITICAL STRUCTURE ITSELF IS SHAPED BY THE TRADITIONAL CULTURE.

02855 DIEHL, P.; GOERTZ, G.

ENTERING INTERHATIONAL SOCIETY: MILITARY CONFLICT AND NATIONAL INDEPENDENCE, 1816-1980

COMPARATIVE POLITICAL STUDIES, 23(4) (JAN 91) 497-518.

THIS ARTICLE SEEKS TO PREDICT AND EXPLAIN WHEN THE PROCESS OF NATIONAL INDEPENDENCE IS ACCOMPANIED BY MILITARY CONFLICT, IN ORDER TO ACCOUNT FOR MILITARY CONFLICT IN 121 CASES OF NATIONAL INDEPENDENCE FROM 1816-1980, A LISREL MODEL (WITH MULTIPLE INDICATORS) WITH THE FOL IOWING VARIABLES IS EMPLOYED: (A) THE INTRINSIC IMPORTANCE OF THE TERRITORY GAINING INDEPENDENCE, (B) THE SPECIFIC IMPORTANCE OF THE TERRITORY TO THE FORMER SOVEREIGN, (C) THE RELATIVE OF THE TERR ITORY TO THE FORMER SOVEREIGN, (C) THE RELATIVE
POWER DECLINE OF THE FORMER SOVEREIGN, AND (D) INTERNATIONAL POWER DECLINE OF THE FORMER SOVEREIGN, AND (D) INTERMATIONAL
NORMS AT THE TIME OF THE INDEPENDENCE. ALL VARIABLES BUT THE NORMS AT THE TIME OF THE INDEPENDENCE. ALL VARIABLES BUT THE
FIRST ARE STATISTICALLY SIGNIFICANT, AND THE MODEL ACCOUNTS FIRST ARE STATISTICALLY SIGNIFICANT, AND THE MODEL ACCOUA
FOR HALF OF THE VARIATION IN THE INCIDENCE OF MILITARY FOR HALF OF THE VARIATION IN THE INCIDENCE OF MILITARY
CONFLICT. THE INTERMATIONAL NORMS VARIABLE WAS FOUND TO BE CONFLICT. THE INTERNATIONAL NORMS VARIABLE WAS FOUND TO BE
THE STRONGEST PREDICTOR OF MILITARY CONFLICT. IMPLICATIONS THE STRONGEST PREDICTOR OF MILITARY
FOR THEORY AND POLICY ARE DISCUSSED.

02856 DIEHL, P.; KUMAR, C.

MUTUAL BENEFITS FROM INTERNATIONAL INTERVENTION: NEW ROLES FOR UNITED NATIONS PEACE-KEEPING FORCES

BULLETIN OF PEACE PROPOSALS, 22(4) (DEC 91), 369-376.

THE PASSING AWAY OF THE COLD WAR HAS, ON THE ONE HAND. REDUCED TENSION IN THE INTERNATIONAL SYSTEM. ON THE OTHER HAND, IT ALSO ENTAILS AN INCREASED POSSIBILITY OF SHALLSCALE, SUB-SYSTEMIC CONFLICTS ARISING OUT OF ETHNIC, BORDER, AND REGIONAL DISPUTES. FORTUNATELY, THESE CONCERNS HAVE BEEN ACCOMPANIED BY AN INCREASE IN THE ABILITIES OF INTERNATIONAL
ORGANIZATIONS TO INTERVENE CONSTRUCTIVELY IN THOSE CONFLICTS.
THIS ARTICLE EXPLORES SOME WAYS IN WHICH THE SCOPE OF UN PEACE-KEEPING OPERATIONS CAN BE EXPANDED BEYOND THEIR TRADITIONAL ROLE AS AN INTERPOSITION FORCE FOLLOHING A CEASEFIRE. A UNIQUE FEATURE OF THE ANALYSIS IS THAT IT CASTS THESE NEW ROLES IN THE FORM OF "WIN-WIN" SOLUTIONS, THEREBY INCREASING THEIR APPEAL TO POLICY-MAXERS. IN THE CONTEXT OF UN PEACE-KEEPING OPERATIONS, THE ARTICLE LOOKS FOR USES OF PEACE-KEEPING TROOPS THAT ARE BENEFICIAL TO ALL SIDES IN A DISPUTE. SUPERIOR TO STATUS QUD ARRANGEMENTS AND IN SOME CASES SUPERIOR TO ALL OTHER LIKELY ARRANGEMENTS.

02857 DIEHL, P.F.

WHAT ARE THEY FIGHTING FOR? THE IMPORTANCE OF ISSUES IN INTERNATIONAL CONFLICT RESEARCH

JOURNAL OF PEACE RESEARCH, 29(3) (AUG 92), 333-344.

MOST EMPIRICAL RESEARCH ON INTERNATIONAL CONFLICT HAS FOCUSED ON NATIONAL, OYADIC, AND SYSTEMIC ATTRIBUTES TO UNDERSTAND STATE BEHAVIOR. FOLLOWING THE IDEAS OF VASOUEZ AND MANSBACH, THIS STUDY ARGUES THAT SCHOLARS MUST CONSIDER THE DISPUTED ISSUES AND THEIR SALIENCE IN ORDER TO EXPLAIN THE ONSET AND ESCALATION OF CONFLICT. THE AUTHOR BEGINS WITH A REVIEW OF THE MOST PROMINENT DATA SETS AND MODELS IN
SUBFIELD. MOST OF THE PROMINENT THEORETICAL APPROACHES SUBFIELD. MOST OF THE PROMINENT THEORETICAL APPROACHES
EXPLICITLY OR IMPLICITLY IGNORE THE ISSUES IN DISPUTE. FURTHERMORE, ONLY A FEN OF THE AVAILABLE CONFLICT DATA SETS INCLUDE ISSUE COMPONENTS AND EVEN THEN ONLY IN A LIMITED FASHION. THE AUTHOR REVIEWS SEVERAL REASONS FOR THIS, INCLUDING THOSE RELATED TO REALPOLITIK, IGNORING THE' DECISION-MAKING LEVEL OF ANALYSIS, AND METHODOLOGICAL DIFFICULTIES. THERE ARE SOME STUDIES THAT DO LOOK AT ISSUES AND THEIR SALIENCE WHEN TRYING TO EXPLAIN THE INCIDENCE AND ESCALATION OF INTERNATIONAL CONFLICT. ALMOST UNIFORMLY, THESE DEMONSTRATE THAT FOREIGN POLICY BEHAVIOR VARIES BY ISSUE AREA AND THAT STATES ARE MORE WILLING TO FIGHT FOR ISSUES THAT THEY REGARD AS IMPORTANT. THE REMAINDER OF THE STUDY IS DEVOTED TO HOW THESE CONCERNS MIGHT BE INTEGRATED INTO INTERNATIONAL CONFLICT RESEARCH. SPECIFIC SUGGESTIONS DESIGN, IDENTIFYING ISSUES, AND MEASURING THEIR SALIENCE.

02858 DIETERICH, $\mathrm{H}$.

FIVE CENTURIES OF THE NEW WORLD ORDER

FIVE CENTURIES OF THE NEW WORLD ORDER
LATIN AMERICAN PERSPECTIVES, $19(74)$ (SUM 92), 48-52. ATIN AMERICAN PERSPECTIVES, 19(74) (SUM 92), 48-52.
OCTOBER 12, 1492 DIVIDED MANKIND INTO WHAT ARE KNOWN TODAY AS THE FIRST WORLD AND THE THIRD WORLD. THIS ARTICLE TODAY AS THE FIRST WORLD AND THE THIRD WORLD. THIS ARTICLE
SUGGESTS THAT THE FIRST WORLD-VS. -THIRD WORLD SYSTEM OF 1492 SUGGESTS THAT THE FIRST WORLD-VS. -THIRD WORLD SYSTEM OF 1492 HAS FOR 500 YEARS BEEN IN THE HANDS OF AN ATLANTIC SYNDICATE (NOW JOINED BY JAPAN) BRUTAL, POWERFUL, AND FLEXIBLE TO KEEP THE MAJORITY OF MANKIND WITHIN THE SYSTEM OF EXPLOITATION WITHOUT CONCEDING ANY DEMOCRATIC CONTROL TO THE MASSES. IT ADDRESSES THE QUESTION WHETHER THIS SYSTEM WILL
ENDURE FOR ANOTHER HALF-MILLENNIUM-IN OTHER WORDS, WHETHER DEMOCRATIZATION OF THE 1492 SYSTEM IS POSSIBLE.

02859 DIETRICH, D.J.

CATHOLIC EUGENICS IN GERMANY 1920-1945: HERMANN MUCKERMANN,

S.J. AND JOSEPH MAYER

JOURNAL OF CHURCH \& STATE, 34(3) (SUM 92), 575-600

AFTER WORLD WAR I, GERMAN CATHOLICS FACED ACUTE

POLITICAL PROBLEMS. NOT ONLY DIO THEY HAVE TO FUNCTION IN WHAT SOME FELT HAS A DETESTABLE LIBERAL, DEMOCRATIC ORDER, BUT THEY ALSO HAD TO ANALYZE AND CRITIQUE THE EUGENICS MOVEMENT THAT HAD BEEN GAINING STRENGTH AND IN WEIMAR GERMANY REPRESENTED AN ATTRACTIVE BIOLOGICAL SOLUTION FOR SOCIOECONOMIC AND POLITICAL PROBLEMS. MAKING THE THEOLOGICAL AND POLITICAL SITUATION PARTICULARLY INVOLVED WAS THE FACT THAT THE NAZI NATIONALIST AND ANTI-MARXIST ASSAULT ON WEIMAR COULD BE SUPPORTED BY VARIED INDIVIDUALS AND GROUPS ACROSS A BROAD SPECTRUM. THIS WAS TRUE EVEN THOUGH THE NAZI RADICAL RACIST EUGENIC THEORIES MIGHT BE ANATHEMA TO MOST CATHOLIC
LEADERS, SINCE SUCH APPROACHES THREATENED THE INTEGRITY OF THE HUMAN PERSON. HOWEVER, TWO CATHOL IC INTELLECTUALS-HERMANN MUCKERMANN $S$.J. AND JOSEPH MAYER--OFFERED THEORIES THAT WOULD HAVE ALLOHED CATHOLICS TO ADAPT TO THE MORE PROBLEMATIC NEGATIVE EUGENIC POLICIES OF THE NAZI REPRESENTED THE VIEW THAT SCIENTIFICALLY - GUIDED STERILIZATION, FOR EXAMPLE, COULD MORALLY BE EMBEDDED IN AN
ALL-INCLUSIVE PROGRAM OF POSITIVE EUGENICS UNOER THE CORRECT ALL-INCLUSIVE
CONDITIIONS.

02860 DIETRICH, M.

FIRMS, MARKETS AND TRANSACTION COST ECONOMICS FIRMS, MARKETS AND TRANSACTION COST ECONOMICS
SCOTIISH JOURNAL OF POLITICAL ECONOMY, $38(1)$ (FEB 91), 41-57.

WITHIN ECONOMICS THERE HAS OEVELOPED A FAIRLY COHESIVE BODY OF THEORY THAT IS FREQUENTLY REFERRED TO AS "TRANSACTION COST ECONOMICS." THIS ARTICLE EXAMINES THE LITERATURE ON THE SUBJECT AND SUGGESTS THAT MUCH OF THIS BODY OF THOUGHT IS BASED ON INCOMPLETE REASONING. UNDERLYING THIS SUGGESTION IS THE OBSERVATION THAT ANY ECONOMIC ACTIVITY, BE IT PRODUCTION OR CONSUMPTION, IS MADE UP OF TWO PARTS: A CONTROL ASPECT AND A USE ASPECT.' IT ARGUES THAT A SHORTCOMING OF TRANSACTION COST ECONOMICS IS THE SOLE 
ALLOCATION.

02861 DIETZ, J.

OVERCOMING UNDERDEVELOPMENT: WHAT HAS BEEN LEARNED FROM THE EAST ASIAN AND LATIN AMERICAN EXPERIENCES? JOURNAL OF ECONOMIC ISSUES, $26(2)$ ( JUN 92), 373-384. IN ORDER NOT TO OVER OR UNDERESTIMATE THE RANGE OF DETERMINANTS THAT HAVE CONTRIBUTED TO DEVELOPMENT IN EAST ASIA, IT IS MECESSARY TO TAKE NOTE OF HOW THEIR EXPERIENCE
HAS DIFFERED FROM THE LESS SUCCESSFUL CASES IN LATIN AMERICA. THIS ARTICLE SUGGESTS THAT IN THEIR EXPLANATIONS, NEOL IBERALS HAVE ASSIGNED FAR TOO MUCH WEIGHT TO THE MARKET. THE EAST ASIAN EXPERIENCE CONFIRMS THAT IT IS POSSIBLE TO OUTDO THE MARKET THROUGH APPROPRIATE POL ICIES THAT CHEAT ON THE MARKET-DIRECTED OUTCOME. ON THESE COUNTS EAST ASIA HAS SUCCEEDED AMD LATIN AMERICAN HAS FAILED.

02862 DIGESER, $P$.

THE FOURTH FACE OF POWER

THE JDURNAL OF POLITICS, 54(4) (NOV 92), 977-1007

MICHEL FOUCAULT'S WRITINGS HAVE GIVEN THE DEBATE OVER POWER YET ANOTHER TWIST. BUT HOW USEFUL IS THIS NOVEL POWER YET ANOTHER TWIST. BUT HOW USEFUL IS THIS NOVEL
CONCEPTION OF POWER TO THE STUDY OF POLITICS? WE CAN BETTER UNDERSTAND FOUCAULT'S MEANING OF "POWER" BY PLACING IT UNDERSTAND FOUCAULT'S MEANING OF "POWER" BY PLACING I POLITICAL SCIENTISTS FOR 30 YEARS. THIS JUXTAPOSITION REVEALS A CONCEPTION OF POWER THAT CLAIMS TO BE BOTH REVEALS A CONCEPTION OF POWER THAT CLAIMS TO BE BOTH DESCRIPTIVE AND CRITICAL OF THE NORMS GOVERNING OUR SELF-
UNDERSTANDING AND POLITICAL PRACTICES. THE ESSAY CONCLUDES UNDERSTANDING AND POLITICAL PRACTICES. THE ESSAY CONCLUDES BY CONSIDERING A POLITICAL RESPO
NOTION OF DISCIPLINARY POWER.

02863 DIGGELEN, M.

COMMUNIST PARTY EDUCATION IN FINLAND: FROM RED FLAGS TO WINE TASTING

JOURNAL OF COMMUNIST STUDIES, 7(4) (DEC 91), 477-500.

THE FINNISH COMMUNIST PARTY HAS ALWAYS TAKEN IDEOLOGICAL WORK IN THE PARTY VERY SERIOUSLY, HITH A VIEH TO INSTILLING THE PARTY'S VALUES IN A MEMBERSHIP WHICH WOULD THEN BE EQUIPPED TO BE ACTIVE IN THE PLACE OF WORK AND IN SOCIETY AS A HHOLE. THE RESULT WAS THE CREATION OF A PARTY CULTURE IN WHICH COMMUMIST FAMILIES LIVED. CENTRAL TO THIS EMPHASIS WAS THE SYSTEM OF PARTY SCHOOLS AMD CORRESPONDENCE COURSES. THIS ARTICLE EXPLORES THE CURRICULUM OF A PERMANT RESIDENTIAL SCHOOL--SIROLA COLLEGE.

02864 DIIULIO, J.J. JR.

A LIMITED WAR ON CRIME THAT WE CAN WIN

A LIMITED WAR ON CRIME THAT WE CAN WIN
BRDOKINGS REVIEN, 10(4) (FAL 92), 6-11.

SINCE 1967 THE U.S. FEDERAL GOVERMMENT HAS HAGED THO ALLQUT WARS ON CRIME AND, IN THE VIEW OF MOST OBSERVERS, LOST BOTH. THE EVIDENCE IS MOST OBVIOUS IN THE NATION'S INNER CITIES. BUT THERE IS NO GOOD PRACTICAL REASON TO CONCEDE THE FUTURE TO THE BLEAK PAST. EXISTING LIMITS--POL ITICAL, ADMINISTRATIVE, BUDGETARY, AND INTELLECTUAL--ON FEDERAL CRIME POLICY MAY PRECLUDE A NEH ALL-OUT OFFENSIVE. BUT
WASHINGTON CAN PUSH AHEAD BOLDLY ON THO FRONTS. FIRST, THE FEDERAL GOVERNMENT CAN EXPAND ITS DRUG TREATMENT PROGRAMS FOR OFFENDERS AND EXTEND THEM TO THE STATES. SECONDLY, I CAN HELP BIG CITIES DEVELOP COMMUNITY POLICING PROGRAMS.

02865 DIJKINK, G.; VAN DER WUSTEN, H.

POLITICAL GEOGRAPHY OF CONTEMPORARY EVENTS XII : GREEM POLITICS IN EUROPE: THE ISSUES AND THE VOTERS

POLITICAL GEOGRAPHY QUARTERLY, 11(1) (JAN 92), 7-11. THE FATE OF THE GREENS IN GERMANY DEMONSTRATES THE VOLATILITY OF POLITICAL PREOCCUPATIONS. THIS DECREASE IN ENVIRONMENTAL CONCERN WAS THE EXPRESSION OF AN INTERNATIONAL TREND. DIFFERENCES IN ECONOMIC PROSPERITY OFFER A MORE PROMISING EXPLANATION FOR THE VARYING LEVEL OF ENVIRONMENTAL CONCERN. THIS ARTICLE EXPLORES WHAT WILL HAPPEN ON THE EASTERN FRINGE OF EUROPE. IT CONCLUDES THAT A HIGH LEVEL OF ATTEMTION OVER A LONGER PERIOD OF TIME MAY BE A NECESSARY CONDITION FOR POSITIVE RESULTS IN THIS FIELD.

02866 DIKKENBERG, J.

SUPERMARKET IN THE PACIFIC

WORLD PRESS REVIEW, 39(9) (SEP 92), 14-16.

ASIA IS ON AN ARMS-BUYING SPREE. WHILE THE REST OF THE

WORLD IS SCALING DOWN DUE TO THE END OF THE COLD WAR, ASIA IS EXPERIENCING A MILITARY BUILD-UP OF UNPRECEDENTED PROPORTIONS. THE WITHDRAHAL OF THE SOVIET UNION FROM VIETNAM PROPORTIONS. THE WITHDRAHAL OF THE SOVIET UNION FROM VIET
AND THE CLOSURE OF U.S. MILITARY BASES IN THE PHILIPPINES AND THE CLOSURE OF U.S. MILITARY BASES IN THE PHILIPP COUNTRIES TO RECONSIDER THEIR INTERNAL AND EXTERNAL SECURITY COUNTRIES TO
ARRANGEMENTS.

02867 DILGER, R.J.

ISTEA: A NEH DIRECTION FOR TRANSPORTATION POLICY PUBLIUS: THE JOURNAL OF FEDERALISH, 22(3) (SUM 92), 67-78.

THE INTERMODAL SURFACE TRANSPORTATION EFFICIENCY ACT

(ISTEA) OF 1991 IS LIKELY TO BE REMEMBERED AS ONE OF

PRESIDENT BUSH'S MOST SIGNIFICANT CONTRIBUTIONS TO

GOVERNHENT DECENTRALIZATION AND THE IDEALS OF NEW FEDERALISM.
IT IS A LANDMARK PIECE OF LEGISLATION THAT MAKES WHOLESALE REVISIONS IN THE FEDERAL GOVERNMENT'S ROLE IN TRANSPORTATION POLICY, GIVING STATE AND LOCAL POLICYMAKERS AN UNPRECEDENTED OPPORTUNITY TO DETERMINE THE FUTURE DIRECTION OF THE

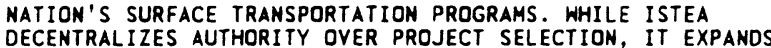
DECENTRALI IES AUTHORITY OVER PROJECT SELECTION, IT EXPAND
THE NUMBER OF CROSSOVER SANCTIONS ATTACHED TO FEDERAL THE NUMBER OF CROSSOVER SANCTIONS ATTACHED TO FEDERAL
TRANSPORTATION FUNDING AND PREEMPTS STATE AUTHORITY OVER TRUCK WEIGHTS AND LENGTHS. THIS UNDERSCORES RECENT RESEARCH FINDINGS SUGGESTING THAT FEDERALIST PRINCIPLES ARE IMPORTANT TO FEDERAL POLICYMAKERS BUT NOT NECESSARILY MORE IMPORTANT THAN OTHER COMPETING VALUES THAT EMANATE FROM DIFFERENT POLITICAL, SOCIAL, AND ECONOMIC VIEWS.

02868 DILLON, G.; EVERARD, J.

STAT(E)ING AUSTRALIA: SOUID JIGGING AND THE MASQUE OF STATE ALTERNATIVES, 17 (3) (SUM 92), 281-312.

THERE COULD HARDLY BE A TIME MORE EVIDENTLY CONCERNED WITH THE FUNDAMENTAL CHALLENGE OF POLITICAL MODERNITY -SELF RULE - THAN IN WHICH WE CURRENTLY LIVE. THE GREAT
EVENTS OF THE PAST SEVERAL YEARS, FOLLOWING THE DISSOLUTION EVENTS OF THE PAST SEVERAL YEARS, FOLLOWING THE DISSOLUTION
OF THE SOVIET EMPIRE, HAVE ALL CONCERNED THIS BASIC QUESTION. OF THE SOVIET EMPIRE, HAVE ALL CONCERNED THIS BASIC QUESTION.
AND THEY HAVE WITHESSED A GREAT BURGEONING OF ATTEMPTS -AND THEY HAVE WITNESSED A GREAT BURGEONING OF ATTEMPTS --
LOCALLY, NATIONALLY, AND REGIONALLY, PARTICULARLY IN EUROPE LOCALLY, NATIONALLY, AND REGIONALLY, PARTICULARLY IN EUROPE WELLL AS TO RECONSTITUTE OLD ONES. THIS ARTICLE DISCUSSES THELL AS TO RECONSTITUTE OLD ONES. THIS AF

02869 DILORENZO, T.J.

WHY SOCIALISH CAUSES POLLUTION

FREEMAN, 42(3) (MAR 92), 107-112.

ALTHOUGH FREE ENTEPRISE IS SUPPOSEDLY INCOMPATIBLE WITH ENVIRONMENTAL PRESERVATION, THE SOCIALIST WORLD SUFFERS FROM THE WORST POLLUTION ON EARTH.

02870 DING, L.

NORHAY AT THE CROSSROADS

BEI JING REVIEW, 35(50) (DEC 92), 14-15.

ON NOVEMBER 19, 1992, THE NORWEGIAN PARLIAMENT PASSED A MOTION IN FAVOR OF SEEKING MEMBERSHIP IN THE EUROPEAN COMMUNITY. HOWEVER, THE NORHEGIAN PUBLIC IS SHARPLY DIVIDED OVER THIS ISSUE, HITH OPINION POLLS SHOWING AN EVEN SPLIT.

02871 DION, D.

THE ROBUSTNESS OF THE STRUCTURE-INDUCED EQUILIBRIUM AMERICAN JOURNAL OF POLITICAL SCIENCE, 36(2) (MAY 92), 462-482.

THIS PAPER ANALYZES THE QUESTION OF THE EXISTENCE OF A STRUCTURE-I NDUCED EOUILIBRIUM (SIE) UNDER ASSUMPTIONS WEAKER THAN THOSE CONSIDERED BY KENNETH SHEPSLE (1979). ACCORDING TO THE ORIGIMAL THEORY A POLICY POSITION IS IN SIE UNDER A GIVEN INSTITUTIONAL STRUCTURE IF THERE IS NO OTHER ALTERNATIVE ADMISSIBLE UNDER THAT STRUCTURE THAT CAN DEFEAT THE GIVEN POLICY POSITION. IT TURNS OUT THAT THE EXISTENCE RESULT IS EXTREMELY FRAGILE: COUNTEREXAMPLES SHOW THAT WEAKENING ALMOST ANY OF THE ASSUMPTIONS OF THE ORIGIMAL THEOREM CAN RESULT IN THE NOHEXISTENCE OF AN SIE. THE AUT THEN UTILIZES THE INSIGHTS OF THESE CDUNTEREXAMPLES TO CONSTRUCT NEW MODELS IN WHICH SIE WILL EXIST AND DERIVE
IMPLICATIONS FROM THESE MODELS FOR QUESTIONS OF LEGISLATIVE POLITICS.

02872 DIONHE, E.J. JR. HEY, THE $80^{\circ}$ 'S ARE OVER COMMONWEAL, CXIX(14) (AUG 92), 5-7,

THE AUTHOR EXPLAINS WHY DEMOCRATIC CANDIDATE 8ILL CLINTON HAS A LEAD IN THE POLLS AND WHY GEORGE BUSH IS LIKELY TO LOSE THE 1992 PRESIDENTIAL ELECTION.

02873 DIOP, A.

PLUS CA CHANGE

AFRICA REPORT, 37(2) (MAR 92), 25-27.

THE NEW REGIME OF IDRISS DEBY, HICH PROMISED TO RESTORE DEMOCRACY IN CHAD AFTER OUSTING HISSENE HABRE, HAS RESORTED TO ARBITRARY ARRESTS AND SUMMARY EXECUTIONS AGAINST SUSPECTED OPPONENTS IN RETALIATION FOR RAIDS BY REBELS LOYAL TO THE FORMER PRESIDENT. FRANCE, WHICH SUPPORTS THE DEBY GOVERNMENT AND PROVIDES MILITARY AID, HAS BEGUN TO CRITICIZE ITS METHODS, WHICH ARE REMINISCENT OF THOSE USED BY HABRE HIMSELF.

02874 DISEKO, $N$

THE ORIGINS AND DEVELOPMENT OF THE SOUTH AFRICAN STUDENT'S MOVEMENT (SASM): $1968-1976$

JOURMAL OF SOUTHERN AFRICAN STUDIES, 18(1) (MAR 92) 40-63.

TO UNDERSTAND WHY THE SOUTH AFRICAN STUDENTS' MOVEMENT

(SASM) WAS ABLE TO PLAY SUCH AN IMPORTANT ROLE IN THE SOWETO STUDENT UPRISING OF 1976, IT IS IMPORTANT TO UNDERSTAND THE ORIGINS OF THE ORGANIZATION, ITS IDEOLOGICAL DEVELOPMENT, ORGANIZATIONAL STRUCTURES AND MOBILIZATION TACTICS. THIS' PAPER DEALS WITH ALL THESE ISSUES, FOCUSING PRIMARILY ON ITS TRANSVAAL REGIONAL BRANCH, AND IN PARTICULAR ITS SOWETO LOCAL BRANCH, AS THIS IS WHERE THE ORGANIZATION WAS BORN AND WHERE IT BUILT ITS STRONGEST STUCTURES. THE HISTORY OF THE 
ORGANIZATION IS ANALYZED IN TWO PHASES HHICH MARK DIFFERENT STAGES IN ITS STRUCTURAL AND IDEOLOGICAL DEVELOPMENT. IN CONCLUSION THE IMPACT OF CLOSER TIES WITH THE ANC IS CONCLUSIOM
EXAMINED.

02875 DISKIN, A.

ISRAEL

EUROPEAN JOURNAL OF POLITICAL RESEARCH, 22(4) (DEC 92 ),

443-447.

THE AUTHOR SUMMARIZES THE PARTY COMPOSITION OF THE

ISRAELI PARLIAMENT AND PRIME MINISTER SHAMIR'S CABINET AS OF JANUARY $1,1991$.

02876 DISKIN, A.

THE ISRAELI GENERAL ELECTION OF 1992

ELECTORAL STUDIES, 11 (4) (DEC 92), 356-361.

IN ISRAEL'S JUNE 1992 ELECTIONS, THE LABOR PARTY

RECAPTURED ITS PIVOTAL POSITION IN THE KNESSET. TOGETHER

LABOR AND THE MORE "DOVISH" PARTIES CLAIMED 61 SEATS WHILE

THE LIKUD AND THE MORE "HANKISH" PARTIES CAPTURED 59.

02877 DITELLA, T.S.

LETTER FROM ARGENTINA

GOVERMMENT AND OPPOSITION, 27(1) (WIN 92), 27-32.

THE AUTHOR DISCUSSES RECENT POL ITICAL AND ECONOMIC

CHANGES IN ARGENTINA, WHERE THE POPULACE IS SLOWLY BECOMING CHANGES IN ARGENTINA, WHERE THE POPULACE IS SLVWY GUARDE ACCUSTOMED TO STABILITY AND IS BEGINMI
OPTIMISM ABOUT THE COUNTRY'S FUTURE.

02878 OITTMER, L.: LEE, P.; HU, Y.S.

INFORMAL POI ITICS AND LEADERSHIP CHANGE IN THE PEOPLE'S INFORMAL POLITICS AND LEADERSHIP CHANGE IN STUDIES 1992 REPUBLIC OF CHIN

ANNUAL MEETING

ASSOCIATION FOR ASIAN STUDIES, 1992,169 . THE RULES OF FORMAL POLITICS IN THE PEOPLE'S REPUBLIC OF CHINA LEAVE A NUMBER OF GAPS TO BE FILLED BY THE PRACTICES OF INFORMAL POLITICS. SUCH GAPS ARE PARTICULARLY NOTEWORTHY IN THO AREAS: LEADERSHIP RECRUITMENT, AND CONFLICT CONTROL
AND RESOLUTION. THIS PAPER FOCUSES ON POLITICS DURING RECENT AND RESOLUTION. THIS PAPER FOCUSES ON POLITICS DURING RECENT CRISIS PERIODS, SUCH AS THE 1986-87 DEMOCRACY MOVEMENT AND THE 1989 TI INANMEN SOUARE MASSACRE, WHICH TEND TO HIGHLIGHT THE ROLE OF INFORMAL POL ITICS. IT ATTEMPTS TO RELATE THE CHANGING TEMPER OF POLITICS, BOTH FORMAL AND INFORMAL, TO PHASES OF THE BUSINESS CYCLE, ON THE ASSUMPTION THAT THE EXPANSION AND RETRENCHMENT OF THE ECONOMY OFFER CONTENDING PARTY FACTIONS DIFFERENT OPPORTUNITIES AND ADVANTAGES. IT ALSO ASKS SPECIFIC OUESTIONS SUCH AS WHO BELONGS TONEY FOR WHAT PURPOSES, ETC.

02879 DIX, R.

DEMOCRATIZATION AND THE INSTITUTIONALIZATION OF LATIN AMERICAN POLITICAL PARTIES

COMPARATIVE POLITICAL STUDIES, 24(4) (JAN 92) 488-511. IN THIS ARTICLE, THE AUTHOR ASSESSES THE PROSPECTS FOR THE CONSOLIDATION OF DEMOCRACY IN LATIN AMERICA IN THE 1990S, THE CONSOL IDATION OF DEMOCRACY IN LATIN AMERICA IN THE 1960S, COMPARED WITH THE FAILURE TO ACHIEVE THAT GOAL IN THE 19605 ,
BY EXAMINING THE INSTITUTIONALIZATION OF POLITICAL PARTIES BY EXAMINING THE INSTITUTIONALI IATION OF POLITICAL PARTI
IN THE THO TIME PERIOOS. SAMUEL HUNTINGTON'S CRITERIA OF IN THE THO TIME PERIOOS. SAMUEL HUNTINGTON'S CRITERIA OF
INSTI ITUTIONALIZATION (ADAPTABILITY, COMPLEXITY, AUTONOMY, AND COHERENCE) ARE USED AND EMPLOY A VARIETY OF INDICATORS (SOME EMPIRICAL, SOME MORE JUDGMENTAL) TO ASSESS THE DEGREE
OF CHANGE BETHEEN THE 1960 S AND THE 1980S. HE CONCLUDES THAT, OF CHANGE BETHEEN THE 1960S AND THE 1980S. HE CONCLUOES THAT, ALTHOUGH THERE IS A SIGNIFICANT VARIATION AMONG COUNTRIES, FOR THE MAJORITY OF THEM, AND FOR THE LATIN AMERICAN REGION AS A WHOLE, POLITICAL PARTIES HAVE INDEED BECOME SOMEWHAT MORE INSTITUTIONAL IZED OVER TIME, THEREBY MOCEST YN THE THE PROSI
1990 S.

02880 DIX, R.

EASTERN EUROPE'S IMPLICATIONS FOR REVOLUTIONARY THEORY POLITY, XXIV(2) (HIN 91 ), 227-242.

SHEEPING CHANGES IN EASTERN EUROPE POSE A VARIETY OF CHALLENGES TO THEORIES OF REVOLUTION WHICH ARE ROOTED LARGELY IN THE EXPERIENCES OF SUCH AGRARIAN-BASED AUTOCRACIES AS THE FRENCH, RUSSIAN AND CHINESE. THIS ARTICLE ADDRESSES QUESTIONS OF THE CAUSES, PROCESSES, AND OUTCOMES OF THESE REVOLUTIONS, AS WELL AS THEIR IMPLICATIONS FOR THE VERY TERM "REVOLUTION" ITSELF. THE AUTHOR ARGUES THAT A NEH GENERATION OF REVOLUTIONARY THEORY IS NEEDED TO INCORPORATE THE EXPERIENCES OF EASTERN EUROPE.

02881 OIXON, H.; SMITH, D.

ARMS CONTROL AND THE EVOLUTION OF SUPERPOWER RELATIONS SCIENCE AND SOCIETY, 56(4) (HIN 92), 876-889.

THIS STUDY INYESTIGATES WHETHER OR NOT THE EMACTMENT OF BILATERAL ARMS CONTROL AGREEMENTS SYSTEMATICALLY INFLUENCED THE FOREIGN POLICIES AND BEHAVIOR OF THE UNITED STATES AND THE SOVIET UNION TOWARD ONE ANOTHER. THE RESULTS INDICATE THAT FORMAL BILATERAL SECURITY ARRANGEMENTS DID CARRY A DISCERMABLE INFLUENCE ON SUBSEQUENT SUPERPOWER BEHAVIOR DURING THE COLD WAR ERA. THE IMPACT CLEARLY CONTRIBUTED TO DURING THE COLD WAR ERA. THE IMPACT CLEARLY CONTRIBUTED
REVERSE, AND THESE IMPROVMENTS WERE SUFFICIENTLY ROBUST TO RISE ABOVE THE POWERFUL EFFECTS OF ACTION-REACTION DYNANMICS.

02882 DIXON, W.; GAARDER, S

PRESIDENTIAL SUCCESSION AND THE COLD WAR: AN ANALYSIS OF SOVIET-AMERICAN RELATIONS, 1948-1988

THE JDURNAL OF POLITICS, 54(1) (FEB 92), 156-178.

THE EFFECTS OF PRESIDENTIAL SUCCESSION ON SELECTED

THE EFFECTS OF PRESIDENTIAL SUCCESSTAVIOR IS EXAMINED.

PATTERNS OF AMERICAN FOREIGN POLICY BEHAVIOR IS EXAMINED.

THE AUTHOR'S EMPIRICAL TEST CASE CONSISTS OF THE

PRESIDENCIES--DIPLOMATIC RELATIONS WITH THE SOYIET UNION.

THE CENTRAL RESULTS SUGGEST THAT U.S. FOREIGN POLICY

THE CENTRAL RESULTS SUGGEST THAT . S. FOREIGN POLICY

BEHAVIOR EXHIBITS A CHARACTERISTIC PERSISTENCE THAT SEEMS

RELATIVELY IMMUNE FROM THE POTENTIALLY DISRUPTIVE EFFECT

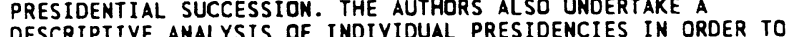

DESCRIPTIVE ANALYSIS OF INDIVIDUAL PRESIDENCIES IN ORDER TO WAR PATTERN.

02883 DJAKSAM, T. CONFLICTING INTERESTS? WEST AFRICA, 75(3925) (DEC 92), 2101-2102

THE LATEST IN A SERIES OF LÉCTURES AT THE AFRICA CENTER NEAR COVENT GARDEN IN LONDON FOCUSED ON RELATIONS BETWEEN THE AFRICANS OF SUB-SAHARA AND THEIR ARAB COUNTERPARTS OF THE NORTHERN PART. TWO SPEAKERS PRESENTED VIEWS ON THE RELATIONS FROM THEIR OWN PERSPECTIVES. THE ESSENCE OF THE AFRICAN ARGUMENT WAS THAT THE RELATIONS BETWEEN AFRICANS AND ARABS EFFECTIVELY BEGAN TO TAKE A SOUR TURN FROM THE TIM THE OIL CRISIS OF THE EARLY SEVENTIES WHEN THE AFRICAN OIL EMBARGO INTENDED TO HARM ISRAEL AND ITS WESTERN ALLIES.

02884 DJAKSAM, T DEMOCRACY IN JEOPARDY DEMOCRACY IN JEOPARDY WEST AFRICA, ( 3920 ) (NOV 92), 1870 . FOR MORE THAN A YEAR, NO REAL PROGRESS HAS BEEN MADE. FOR MORE THAN A YEAR, NO REAL PROGRESS HAS BEEN MADE. THE GENERAL GNASSINGBE
REAL POWERS IN TOGO.

02885 DJILAS, A.

THE NATION THAT WASN'T

NEW REPUBLIC, 207 (13) (SEP 92), 25, 28-31.

IT IS A COMMON BELIEF THAT BOSNIAN SOVEREIGNTY AND INDIVISIBILITY IS A PREREQUISITE FOR PEACE. SUCH THINKING REPRESENTS A MISUNDERSTANDING ABOUT THE NATURE OF THE REGION'S LONG HISTORY OF INTERETHNIC STRIFE. WHILE THE
WEST'S REFUSAL TO ACCEPT SERBIA'S AND CROATIA'S LAND GRAB IN BOSNIA IS COMMENDABLE, ITS RECOGNITION OF BOSNIA WILL BE REMEMBERED AS ONE OF THE MOST IRRESPONSIBLE WESTERN DECISIONS IN POSTWAR HISTORY BECAUSE IT PLUNGED BOSHIA INTO CIVIL HAR.

02886 DJIHANDONO, J.S PROBLEMS OF FOREIGN TRADE AND THE GULF CRISIS INDONESIAN QUARTERLY, 19(1) (WIN 91), 74-81.

THIS ARTICLE VIEWS THE PROSPECTS FOR INDONESIAN INTERNATIONAL TRADE IN THE 1990S BY OBSERVING THE DEVELOPMENT OF WORLD ECONOMY AND TRADE UP TO THE PRESENT. IT CONCLUDES WITH SOME PREDICTIONS CONCERNING THE FUTURE.

02887 DLAKHA, $W$.

SALIENT FEATURES OF THE 1988 CIVIL SERVICE REFORMS IN SALIENT

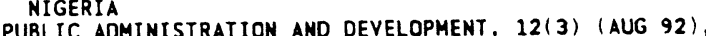
297-312.

THE MAIN PROVISIONS OF THE 1988 CIVIL SERVICE REFORM IN MIGERIA ARE DISCUSSED INCLUDING STRUCTURAL REORGANIZATION, PROFESSIONALIZATION AND THE ENFORCEMENT OF PUBLIC ACCOUNTABILITY. DEFECTS ASSOCIATED WITH THE CIVIL SERVICE AS ACCOUNTABILITY. DEFECTS ASSOCIATED WITH THE CIVIL SERVICE AS WELL AS MEASURES TAKEN TO RECTIFY THESE DEFECTS ARE OUTL TNED. THESE PROVISIONS ARE LITTLE MORE THAN THE REHASHING OF PAS
LEGISLATIONS, WHICH FAILED TO ACHIEVE POSITIVE RESULTS, NOT LEGISLATIONS, WHICH FAILED TO ACHIEVE POSITIVE RESULTS, NOT BECAUSE THEY WERE FAULTY IN PRECEPT BUT BECAUSE THEY NERE SACRIFICED TO SLOPPY IMPLEMENTATION. THEREFORE, THE 1988 , REFORM MAY SUFFER FROM THE SAME FATE BECAUSE IT WAS SIMPLY PAST REFORMS BEFORE IT.

02888 DO ROSARIO, L.; FAIRCLOUGH, G.

TOILERS OF' THE' EAST

FAR EASTERH ECONOMIC REVIEN, 155(13) (APR 92), 20-21.

FROM THE MID-1970S ONWARDS THE OIL-RICH COUNTRIES OF THE MIDDLE EAST ATTRACTED HUGE NUMBERS OF MIGRANT WORKERS FROM SOUTH AND SOUTHEAST ASIA ACT AS A MAGNET FOR MIGRANT LABOR. SLOW POPULATION GROWTH IN COUNTRIES LIKE JAPAN, TAIWAN AND SOUTH KOREA, COUPLED WITH THE INCREASING RELUCTANCE OF LOCAL PEOPLE TO DO DIRTY OR OANGEROUS JOBS, HAS CREATED A MEED FOR IMPORTED LABOR WHICH IS BEING MET BY MIGRANTS FROM PAKISTAN, BANGLADESH AND THE PHILIPPINES. IN SOUTHEAST ASIA, INDONESIANS ARE FLOCKING TO WORK ON MALAYSIAN PLANTATIONS WHILE HIGHLY SKILLED 
MALAYSIANS TAKE JOBS IN SINGAPORE. HOWEVER, OPINION IS SHARPLY DIVIDED ABOUT THE BENEFITS OF LABOR MIGRATION TO THE ECONOMIES OF EXPORTING NATIONS.

02889 DO ROSARIO, L.

WINNING BOTH WAYS

FAR EASTERN ECONOMIC REVIEH, 153(31) (AUG 91), 57

DESPITE THE FACT THAT ASIA IS EXPORTING MORE

MANUFACTURES TO JAPAN, THERE IS NO SIGN THAT THE REGION'S TRADE DEFICIT WITH THAT COUNTRY IS NARROWING. IN THE DAYS WHEN OIL PRICES WERE HIGH AND ASEAN'S EXPORTS TO JAPAN WERE ALMOST ALL COMMODITIES, THE GROUPING ENJOYED A BIG TRADE SURPLUS WITH JAPAN. BUT THIS IS DISAPPEARING, WHILE THE DEFICIT OF THE NIC'S (SOUTH KDREA, TAIWAN, HONG KONG AND SIMGAPORE) IS STEADILY GROWING. LAST YEAR, JAPAN EXPORTED US\$102 BILLION-HORTH OF GOODS TO ASIA AND AUSTRALIA AND IMPORTED US\$83 BILLION, GIVING IT A TRADE SURPLUS OF US $\$ 19$ BILLION, 37\% MORE THAN' THE SURPLUS A YEAR EARLIER. THIS TREND IS DUE TO THE INDUSTRIALIZATION OF ASIA WHICH RELIES TREND IS DUE TO THE INDUSTRIALIZATION OF ASIA WHICH RELIES INCREASINGLY ON JAPAN FOR CAPITAL EQUIPMENT AND COMPONENTS AND THE RISE IN CONSUMER DEMAND FOR ITEMS SUCH AS JAPANESE CARS AND ELECTRICAL GOODS. JAPAN'S TRADE SURPLUS WITH THE REST OF ASIA WILL BECOME AN INCREASINGLY SORE POINT THE LONGER IT CONTINUES TO GROH. ASIA'S CLOUT MAY BE WEAKER THAN THE U.S. OR THE EC, BUT IT MAY MAKE ITS POINT FEL
NONETHELESS.

02890 DOBEL, J.P.

THE MORAL REALITIES OF PUBLIC LIFE: SOME INSIGHTS OF FICTION

AMERICAN REVIEH OF PUBLIC ADMINISTRATION, 22(2) (JUN 92), $127-143$

FICTION PROVIDES THE BEST WAY UNDERSTAND SOME ASPECTS OF THE MORAL REALITIES OF PUBLIC LIFE AND TO SUPPLEMENT A PRINCIPLED OR THEORETICAL CONCEPTION OF ETHICS. IN THIS PAPER, THE AUTHOR ADDRESSES FOUR ASPECTS OF MORALITY HIGHLIGHTED BY FICTION: THE MORAL ECOLOGY OF SELFHOOD, THE ROLE OF DECISION AND REDEMPTION, THE REALITY OF THE OTHER, AND THE IRONIES OF RECTITUDE.

02891 DOCKBILL, S.

HIROHITO, THE EMPEROR'S ARMY AND PEARL HARBOR

REVIEW OF INTERNATIONAL STUDIES, 18(4) (OCT 92), 319-334. HIROHITO'S DEATH HAS ENCOURAGED THE PUBLICATION OF A LARGE NUMBER OF BOOKS ABOUT THE PACIFIC WAR. THIS ARTICLE DEALS WITH THE EMPEROR'S RELATIONS WITH THE JAPANESE DEALS WITH THE EMPEROR'S RELATIONS WITH THE JAPANESE
MILITARY ESTABLISHMENT. IT THEN TRIES TO DEMONSTRATE THAT MILITARY ESTABLISHMENT. IT THEN TRIES TO DEMONSTRATE THAT
HIROHITO WAS NOT ABSOLUTE SOVEREIGN AS WAS DEFINED UNDER THE HIROHITO WAS NOT ABSOLUTE SOVEREIGN AS WAS DEFINED UNDER THE MEIJI CONSTITUION NOR DID HE MERELY LISTEN TO AND ACCEPT THE ADVICE OF HIS OFFICIALS, CIVILIAN AND MILITARY, AS HAS BEEN GENERALLY ACCEPTED BY HISTORIANS. A FINAL THEME EXAMINES HOW
HE TRIED TO EXERT SOME INFLUENCE ON POLICY AND WHY HE FAILED HE TRIED TO EXERT SOME INFLUENCE
TO AVERT WAR IN DECEMBER 1941 .

02892 DODGE, W.R.

STRATEGIC INTERCOMMUNITY GOVERMANCE NETHORKS /"SIGNETS" OF ECONOMIC COMPETITIVENESS IN THE 1990'

MATIONAL CIVIC REVIEW, 81(4) (FAL 92), 403-417.

DEVELOPING NEW MODELS AND PURSUING EFFECTIVE STRATEGIES FOR STRENGTHENING INTER-COMHUNITY/REGIONAL GOVERNANCE ARE CRITICAL TO FOSTERING ECONOMIC COMPETITIVENESS IN THE 1990's.

02893 DOEPFNER, A.

KIRGIZSTAN MOVES TOWARD DEMOCRACY

SHISS REVIEW OF WORLD AFFAIRS, 42(7) (OCT 92), 9-11.

KIRGIZSTAN'S PRESIDENT ASKAR AKAYEV WAS THE FIRST LEADER

OF A UNION REPUBLIC TO OPENLY CONDEMN THE ATTEMPTED MOSCOW COUP OF AUGUST 1991 AND TO SUPPORT BORIS YELTSIN'S REFORM PROGRAM. IN HIS NOW-I NDEPENDENT CENTRAL ASIAN HOMELAND, HE IS TRYING TO ESTABLISH A MODERN, WESTERN-ORIENTED SYSTEM WITH A CONSTITUTION GUARANTEEING PRIVATE PROPERTY, FREE ENTERPRISE, INDIVIDUAL RIGHTS, AND A CLEAR SEPARATION OF GOVERNMENT POWERS. AKAYEV PRAISES THE TURKISH MODEL OF DEMOCRACY IN A SECULAR SOCIETY WITH ISLAMIC CULTURAL TRADITIONS.

02894 DOERN, G.B.

EUROPE UNITING: THE EC MODEL AND CANADA'S CONSTITUTIONAL DEBATE

C.D. HOWE INSTITUTE, $1991,52$.

ARGUING THAT THE EUROPEAN COMMUNITY (EC) DYMAMIC IS NOW MOVING IN A CENTRAL IED AMD INTEGRATING DIRECTION THIS BDOK SEEKS TO PROVIDE A CLEAR UNDERSTANDING OF THE EC MOOEL AND SEEKS TO PROVIDE A CLEAR UNDERSTANDING OF THE EC MODEL AKD THREE PHASES OF EC DEVELOPMENT: UNANIMITY RULE (1957-1980S), QUALIFIED-MAJORITY VOTING (1986-92), AND THE NASCENT MOVE TOWARDS POLITICAL AKD MONETARY UNION (MID-199OS). HE ALSO PROVIDES A CLEAR OVERVIEW OF THE EC'S MAJOR INSTITUTIONAL AND POLICY CHANGES. HE THEN DISCUSSES THE USEFULNESS OF THE EC MODEL FOR THE CANADIAN DEBATE--AND ITS OBVIOUS LIMITS-WITH REGARD TO A NUMBER OF IMPORTANT QUESTIONS SUCH AS CENTRALIZATION AND DECENTRALIZATION, SOVEREIGNTY, ALLOCATION OF POWERS ("SUBSIDIARITY"), POLICY CAPACITY, ECONOMIC UNION, AND STABILITY.
02895 DOHNANYI, K.

PROSPECTS FOR EUROPEAN ECONOMIC INTEGRATION

PEACE AND THE SCIENCES, 3 (SEP 91), 1-3.

THE MARSHALL PLAN WAS OF IMPORTANCE FOR EUROPEAN

COOPERATION. BUT THE DIFFERENCE BETWEEN THE SITUATION IN

EASTERN EUROPE TODAY AND THE SITUATION IN EUROPE AFTER THE

WAR, AT THE TIME OF THE MARSHALL PLAN, IS OBVIOUS: WESTERN

EUROPE, INCLUDING WESTERN GERMANY, WAS ONLY PHYSICALLY

DESTROYED; THE GERMAN INDUSTRY HAD ITS PEAK OF PRODUCTION IN

1944. THEREFORE THE MARSHALL PLAN WAS BY NO MEANS THE REAL ORGIN OF THE EUROPEAN RECOVERY. THIS ARTICLE STATES THAT DRASTIC CHANGES ARE NEEDED THROUGH EASTERN EUROPE IF

ECONOMIC INTEGRATION IS TO TAKE PLACE.

02896 DOKULIL, M.

ETHNIC UNITY AND DIVERSITY IN CZECHOSLOVAKIA

INTERNATIONAL SOCIAL SCIENCE REVIEH, 67(2) (SPR 92), 76-86. WHATEVER A GOOD DEFINITION OF "NATION" OR "NATIONALITY" MAY BE AND WHETHER IT REFERS TO THE CHARACTERISTICS OF LANGUAGE OR ECONOMIC CONDITIONS, THERE ARE GROWING DEMANDS THAT NATIONAL SOVEREIGNTY BE REFLECTED IN POLITICAL POWER OWING TO ITS EMOTIONAL CONTENT, ANALYSIS OF NATIONAL UNITY CAN HARDLY BE MATTER-OF-FACT AND INCONTESTABLE.

CZECHOSLOVAKIA, AS A STATE HITH ETHNIC MINORITIES, IS EXPERIENCING THE PROBLEMS OF NATIONAL ISM. THROUGH POLITICAL TRANSFORMATION, THE LANGUAGE AND ECONOMIC STATUS OF ITS BEARERS HAVE, AGAIN AND AGAIN, BEEN A SOURCE OF POTENTIAL UNREST AND CRISIS IN CZECHOSLOVAKIA.

02897 DOLAN, F

HOBEES AND/OR NORTH: THE RHETORIC OF AMERICAN NATIONAL SECURITY

CANADIAN JOURNAL OF POLITICAL AND SOCIAL THEORY, 15(1-3) (1991), 191-209.

"UNDECIDABILITY" IS CENTRAL TO THE YOCABULARY OF "CONTAINMENT," WHICH HAS DOMINATED AMERICAN DISCUSSION OF FOREIGN AFFAIRS SINCE WORLD WAR II. ALTHOUGH SAID TO BE A LOCKEAN SOCIETY DEVOTED TO MAXIMIZING INDIVIDUAL FREEDOM, AMERICAN PUBLIC AND QUASI -PUBLIC FIGURES HAVE PROMULGATED A DISCOURSE THAT TACITLY SPECIFIES THE CONDITIONS UNDER WHICH THE UNITED STATES MUST PUT ASIDE ITS LOCKEAN COMMITMENTS. THE UNITED STATES MUST PUT ASIDE ITS LOCKEAN COMMITMENTS THE IRAN-CONTRA SCANDAL DEMONSTRATES THAT RONALD REAGAM,
OLIVER L. NORTH AND HIS CABAL. AND ANONYMOUS PENTAGON

OLIVER L. NORTH AND HIS CABAL, AND ANONYMOUS PENTAGON
PLANHERS HAVE BUILT A DISCURSIVE BRIDGE LEADING BACK BEHIND

PLANNERS HAVE BUIL
LOCKE TO HOBBES

02898 DOLAN, M.

WAR, RELIGION, AND GENDER IDEOLOGY: THE POLITICS OF PEACE SYMBOLS IN THE 1990 NICARAGUAN ELECTIONS

CRITICAL SOCIOLOGY, 17(2) (SUM 90), 103-110.

THIS PAPER EXAMINES HOW THE COMPLEX PERSONAL AND POL ITICAL COMPONENT OF THE LIVED EXPERIENCE OF PROLONGED WARFARE BECAME ARTICULATED IN THE GENDER POLITICS OF NICARAGUA'S 1990 ELECTORAL CAMPAIGN. THE AUTHOR ARGUES THAT THE INTERNATIONAL PROCESS OF MILITARIZATION THAT CHARACTERIZED THE CONTRA WAR SHAPED THE CONTEST FOR THE CONSTRUCTION OF GENDER POL ITICS IN THE CAMPAIGN. FURTHERMORE, THE GENDER METAPHORS OF THE POLITICAL DISCOURSE, AS UTILIZED IN THE IDEOLOGICAL CONSTRUCTION OF THE PRESIDENTIAL CANDIDATES AS PEACE CANDIDATES, CONSTITUTE A KEY SITE IN WHICH THE ELECTORAL CAMPAIGNS OF THE SANDINISTAS AND THE UNO CDALITION DEFINED THEIR STRATEGY.

02899 DOLINSKY, G.

DEBT AND STRUCTURAL ADJUSTMENT IN CENTRAL AMERICA

LATIN AMERICAN PERSPECTIVES, 17(4) (FAL 90), 76-90.

AN IN-DEPTH TREATMENT OF FOREIGN DEBT IN CENTRAL AMERICA REQUIRES CONSIDERATION OF THE STRUCTURAL CHARACTERISTICS OF THE ECONOMIES OF THESE SOCIETIES. CONTRARY TO WHAT IS OFTEN THOUGHT, THE PROBLEM OF FOREIGN DEBT IN THE REGION HAS BEEN DEVELOPING OVER SEVERAL DECADES AND IS NOT IN ANY WAY THE EXCLUSIVE RESULT OF INAPPROPRIATE MACROECONOMIC POLICIES. THIS ARTICLE ARGUES THAT THE PROCESS OF INDEBTEDNESS IN THE REGION HAS BEEN HISTORICALLY ASSOCIATED WITH THE NEEDS AND CONTRADICTIONS WHICH MARKED THE PROCESS OF MODERNIZATION OF DEPENDENT CAPITALISM IN CENTRAL AMERICA.

02900 DOLLAH, S.R.

ASEAN LOOKS FOR ECONOMIC BLUEPRINT

JAPAN TIMES (WEEKLY INTERNATIONAL EDITION), 32(4) (JAN 92), 3 .

THE ASEAN HEADS OF GOVERMMENT HILL HOLD THEIR FOURTH SUMMIT JANUARY 27-28, 1992. THEY ARE EXPECTED TO SIGN TWO MAJOR ECONOMIC AGREEMENTS--A FRAMEWORK ACCORD TO ENHANCE ASEAN ECONOMIC COOPERATION AND A PACT TO REDUCE TARIFF AND NON-TARIFF BARRIERS IN ORDER TO GRADUALLY TRAKSFORM THE REGION INTO A FREE-TRADE AREA.

02901 DOMAHIDY, M.R.; GILSINAN, J.F.

THE BACKSTAGE IS NOT THE BACK ROOM: HOW SPATIAL

ARRANGEMENTS AFFECT THE ADMINISTRATION OF PUBLIC AFFAIRS

PUBLIC ADMINISTRATION REVIEH, 52(6) (NOV 92), 588-593.

TO STUDY HOW THE ARRANGEMENT OF CIVIC SPACE INFLUENCES 
THE CONDUCT OF PUBLIC BUSINESS, THE AUTHORS INSPECT THE SPATIAL ARRANGEMENTS SURROUNDING THE HORK OF A MIDHESTERN CITY PLANHING COMMISSION. THEY FOCUS ON THREE SPATIAL AREAS: A FRONT STAGE WHERE THE COMMISSION HOLDS PUBLIC HEARINGS AND FORMAL BUSINESS MEETINGS; A BACKSTAGE SPACE WHERE PLANNING COMMISSIONERS MEET AROUND A CONFERENCE TABLE IN A LESS FORMAL, LESS STRUCTURED ATMOSPHERE; AND A DEEPER BACKSTAGE AREA (THE PLANNER'S OFFICE) WHERE BUSINESS IS CONDUCTED IN PRIVATE MEETINGS. THEY PROVIDE AN OVERVIEW OF THE POLICY-
MAKING DYNAMICS IN EACH SPACE AND DISCUSS THE IMPLICATIONS MAKING DYNAMICS IN EACH SPACE AND DISCUSS THE IMPLICATIONS
OF EACH AREA ON DECISION-MAKING. THE ANALYSIS ALSO TOUCHES OF EACH AREA ON DECISION-MAKING. THE ANALYSIS ALSO TOUCHES
ON THE INCREASING IMPORTANCE OF SOCIAL SPACE (E.G., MEETINGS ON THE INCREASING IMPORTANCE OF SOCIAL SPACE (E.G., MEETI SPACE (E.G. EXCHANGES IN THE MEDIA OR THROUGH SPACE (E.G., EXCHANGES IN THE
TELECOMMUNICATIONS TECHNOLOGY)

02902 DOMES, J.

TAIWAN IN 1991: SEARCHING FOR POLITICAL CONSENSUS ASIAN SURVEY, XXXII(1) ( JAN 92), 42-49.

FOR THE REPUBLIC OF CHINA (ROC) ON TAIHAN, 1991 BROUGHT CONSIDERABLE SUCCESS AND REMARKABLE POLITICAL CHANGE BUT ALSO ELEMENTS OF CRISIS, MAINLY CONNECTED WITH THE INCREASED SPEED OF POLITICAL REFORM. THIS ARTICLE DISCUSSES TAIWAN'S ECONOMIC RECOVERY; IT FOREIGN RELATIONS WITH EFFORTS TO END INTERNATIONAL ISOLATION: AND DOMESTIC POLITICS WHICH ARE ADVANCING REFORMS AND INCREASING CONFRONTATION.

02903 DOMHOFF, G.

AMERICAN STATE AUTOMOMY VIA THE MILITARY? ANOTHER COUNTERATTACK ON A THERORETICAL DELUSION

CRITICAL SOCIOLOGY, 18(3) (FAL 91), 9-56.

THIS PAPER PRESENTS A CRITIOUE OF THE CLAIM IN GREGORY

HOOK"S "FORGING THE MILITARY-INDUSTRIAL COMPLEX" (1991) THAT

THE INDUSTRIAL MOBILIZATION FOR WORLD WAR II LED TO AUTOMONY

FOR THE PENTAGON. IT ARGUES INSTEAD THAT A COALITION OF

CORPORATE LEADERS AND MILTARY OFFICERS DOMINATED DECISION-

MAKING ON INDUSTRIAL MOBILIZATION, DESPITE OPPOSITION FROM A MAKING ON INDUSTRIAL MOBILIZATION, DESPITE OPPOSITIOH
NEW DEAL, LIBERAL/LABOR COALITION ROOTED IN UNIONS,

NEW DEAL, LIBERAL/LABOR COALITION ROOTED IN UNIONS,
UNIVERSITIES, GOVERNMENT APPOINTMENTS, AND THE MASS MEDIA.

UNIVERSITIES, GOVERNMENT APPOINTMENTS, AND THE MASS MEDIA. IT CRITICIZES THE STATE AUTONOMY THEORY GROUP FOR ADOPTI
STYLE OF THEORIZING THAT RELIES ALMOST EXCLUSIVELY ON STYLE OF THEORIZING THAT RELIES ALMOST EXCLUSIVELY ON
SECONDARY SOURCES IN MAKING NEW AND CONTROVERSIAL CLAIMS.

02904 DOMINGUEZ, J.; MCCANH, J. WITHER THE PRI? EXPLAINING VOTER DEFECTION IN THE 1988 MEXICAN PRESIDENTIAL ELECTIONS

ELECTORAL STUDIES, 11 (3) (SEP 92), 207-220.

BASED ON A NATIONWIDE GALLUP POLL CONDUCTED IN MEXICO IN MAY 1988, THE AUTHORS STUDY VOTERS WHO SAID THAT THEY HAD VOTED FOR MEXICD'S RULING PARTY (THE INSTITUTIONAL REVOLUTIONARY PARTY--PRI) IN 1982 BUT WOULD NOT IN THE JULY 1988 PRESIDENTIAL ELECTION. BY MEANS OF LOGISTIC REGRESSION, THEY ARGUE THAT THE INTENDED BEHAVIOUR OF THESE SELFIDENTIFIED PRI DEFECTORS IS BEST EXPLAINED BY THEIR JUDGEMENTS ABOUT THE PROSPECTS FOR THE POLITICAL REGIME'S INSTITUTIONS AND BY THEIR VIEW OF CANDIDATE CARLOS SALINAS'S PERSONAL QUALITIES. DEFECTION WAS NOT EXPLAINED.

02905 DOMMEL, $P$.

INTERGOVERNMENTAL RELATIONS; MANAGING LOCAL GOVERMMENT-PUBLIC ADMINISTRATION IN PRACTICE

SAGE PUBLICATIONS, $1991,135-155$.

THE CENTRAL FACT OF LOCAL ADMINISTRATION IS THAT GOVERNING AUTHORITY IS HIGHLY FRAGMENTED AMONG A NUMBER OF ACTORS BOTH VERTICALLY AND HORI ZONTALLY (IN 1987, THERE WAS A TOTAL OF 83,136 LOCAL GOVERMMENTS IN THE UNITED STATES). THE PURPOSE OF THIS CHAPTER IS TO MAP THE BASIC MOVING PARTS THE PURPOSE OF THIS CHAPTER IS TO MAP THE BASIC MOVING PARTS
OF THIS COMPLEX NETHORK AND TO ILLUSTRATE WAYS, SOME VERY OF THIS COMPLEX NETHORK AND TO ILLUSTRATE WAYS, SOME VERY VISIBLE AND SOME NOT SO VISIBLE. IN WHICH LOCAL GOVERNMEE
ADMINISTRATORS OPERATE WITHIN THE GOVERNMENTAL SYSTEM.

02906 DOMMEN, A.J.; DALLEY, G.W.

THE OSS IN LAOS: THE 1945 RAVEN MISSION AND AMERICAN POLICY JOURHAL OF SOUTHEAST ASIAN STUDIES, 22(2) (SEP 91), $327-346$.

IN SEPTEMBER 1945, THE U.S. OFFICE OF STRATEGIC SERVICES (OSS) HEADOUARTERS IN KUNMING DISPATCHED A MISSION TO LAOS TO HELP WITH PRISONER-OF-WAR RELIEF WORK. THE SO-CALLED "RAVEN MISSION" WAS AN UNSETTLING ELEMENT IN THE LAOTIAN POLIITICAL SITUATION. THROUGH THEIR TALKS WITH LAOTIAN AND VIETHAMESE OFFICIALS, THE AMERICANS RAISED EXPECTATIONS AND HOPES AMONG THE LAOTIANS WHO ADVOCATED INDEPENDENCE FROM
FRANCE AND WOULD SOON FORM THE LAO ISSARA PROVISIONAL FRANCE AND WOULD SOON FORM
GOVERNMENT IN VIENTIANE.

02907 DONALD, J.

DEWEY-EYED OPTIMISM: THE POSSIBILITY OF DEMOCRATIC EDUCATION

NEW LEFT REVIEW, (192) (MAR 92), 133-144.

EDUCATIONAL REFORMS SHOULD BE ACCOMPANIED BY A PROPER RECOGNITION OF THE NEED FOR ADEQUATE NORMS OF CULTURAL AUTHORITY AND SHOULD REJECT THE HALF-HEDONISTIC, HALFPURITAN NOTION OF THE TEACHER AS THERAPIST. THE AUTHOR FINDS MERIT IN GRAMSCI'S ACCOUNT OF THE NECESSARY DISCIPLINES THAT
ARE TRANSMITTED BY A DEMOCRATIC AND PLURALIST EDUCATIONAL SYSTEM. HE ALSO DRAWS ATTENTION TO THE WAYS IN WHICH JOHN DEWEY'S WRITINGS FURNISH INDISPENSABLE INSIGHT INTO THE EDUCATIONAL CONTENT OF ANY DEMOCRATIC PROJECT OF MODERNIZATION. HE OUTLINES THE CHARACTERISTIC WEAKNESSES OF A SOCIALIST CASE FOR THE TRANSFORMATION OF EDUCATION THAT IS COUCHED IN NARROWLY UTILITARIAN TERMS.

02908 DONATELLI, F.J.

REGULATING THE POLITICAL MARKETPLACE

JOURNAL OF LAW \& POLITICS, VIII (2) (WIN 92), 249-252.

THE SIMILARITIES BETWEEN THE POLITICAL ARENA AND THE ECONOMIC MARKETPLACE ARE RELEVANT IN DECIDING WHEN

ECONOMIC MARKETPLACE ARE RELEVANT IN DECIDING WHEN
GOVERNMENT REGULATION IS APPROPRIATE IN POLITICAL CAMPAIGNS. GOVERMMENT REGULATION IS APPROPRIATE IN POLITICAL CAMPA IN TME ECO GOODS AND SERVICES OFFERED BY PRODUCERS. IN POLITICS, VOTERS ARE ASKED TO CHOOSE AMONG COMPETING POLITICS, VOTERS ARE ASKED TO CHOOSE AMONG COMPETING CANDIDATES OFFERED BY CAMPAIGNS AND POLITICAL PARTIES. IN THE POLITICAL REALM, LAHS HAVE BEEN ENACTED THAT DEFINE
GENERAL RULES OF THE POLITICAL GAME, PROVIDE VOTERS WITH IMPORTANT INFORMATION, AND STRENGTHEN COMPETITION. THESE LAWS ARE DESIGNED TO ENHANCE THE POLITICAL MARKETPLACE AND FACILITATE VOTER DECISIONS. DESPITE MUCH DEBATE ABOUT SOME OF THESE PROVISIONS. THEY HAVE BEEN ENACTED AS MARKETPERFECTING MEASURES. BUT REGULATIONS THAT INTERFERE WITH OR DISTORT THE POLITICAL MARKETPLACE BY REGULATING THE CONTEXT AND CHARACTER OF CAMPAIGNS OR THAT INVOLVE GOVERNMENT TOO DEEPLY IN MATTERS OF CAMPAIGN TIMING, STRATEGY, AND CONTENT, WILL PROBABLY DO MORE HARM THAN GOOD. THESE POLITICAL
CONTROLS CAN DISTORT RATHER THAN ENHANCE VOTER OPTIONS.

02909 DONER, $R$.

APPROACHES TO THE POLITICS OF ECONOMIC GROWTH IN SOUTHEAST ASIA

JOURNAL OF ASIAN STUDIES, 50(4) (NOV 91), 811-849.

RICHARD F. DONER, IN REFERENCE TO SOUTHEAST ASIA,

ASSERTS THE NEED TO BROADEN THE DISCUSSION OF ECONOMIC

GROWTH TO INCLUDE POLITICAL ECONOMY, WHICH HE DEFINES AS

"THE WAYS POLITICS INFLUENCES ASPECTS OF ECONOMIC

POL ICYMAKING," AND, IN TURN, HOW ECONOMIC ACTIVITY
INFLUENCES THE POLITICAL PROCESS. HE POINTS OUT THAT

INFLUENCES THE POLITICAL PROCESS. HE POINTS OUT THAT

DEPENDENCY THEORY HAS THE VALUE OF SHOWING HOH EXTERNAL

PARTICIPATING IN A REGIONAL OR WORLD ECONOMY, WHILE

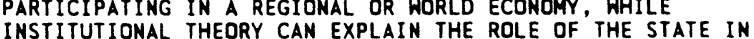

INSTITUTIONAL THEDRY CAN EXPLAIN THE ROLE OF THE STA
CREATING LIMITS TO THE FUNCTIONING OF MARKET FORCES.

02910 DONER, R.F.

LIMITS OF STATE STRENGTH: TOWARD AN INSTITUTIONALIST VIEW

OF ECONOMIC DEVELOPMENT

HORLD POLITICS, 44(3) (APR 92), 398-431.

WITHIN AN EXPLICIT COLLECTIVE ACTION AND PUBLIC GOOOS FRAMEWORK, THE AUTHOR ARGUES FOR AN INSTITUTIONALIST APPROACH TO ECONOMIC DEVELOPMENT THAT INCORPORATES, BUT ALSO GOES BEYOND, STATISM. THROUGH AN EXAMINATION OF AUTO MANUFACTURING IN FIVE COUNTRIES IN SOUTHEAST AND NORTHEAST ASIA, HE IDENTIFIES SPECIFIC COLLECTIVE ACTION PROBLEMS CENTRAL TO THE DEVELOPMENT PROCESS AND EXPLORES LIMITS TO THE CAPACITIES OF EVEN STRONG STATES TO RESOLVE SUCH PROBLEMS. HE STRESSES THE ROLE OF THE PRIVATE SECTOR AND JOINT PUBLIC-PRIVATE SECTOR INSTITUTIONS, IDENTIFIES SYSTEMATIC DIFFERENCES WITHIN AND AMONG LOCAL ENTREPRENEURS WITH REGARD TO DEVELOPMENT ISSUES, EMPHASIZES THE NEED FOR RESEARCH ON FACTORS INFLUENCING THE SUPPLY OF INSTITUTIONS, COOPERATION AMONG DOMESTIC INTERESTS

02911 DONHOFF, M.G.

NEED FOR STATESMEN AS THE WORLD SLIDES INTO A NEW EPOCH GERMAN TRIBUNE, (1513) (MAY 92), 3.

A SERIES OF PROBLEMS CONFRONT THE LEADERS OF THE NATIONS OF EUROPE. ONE IS THE ISSUE OF HOW, GIVEN THE DEMISE OF COMMUNISM, ARE NEW BARRIERS AND ENEMY IMAGES TO BE KEPT FROM REPLACING OLD ONES. WHILE THE LEADERS OF HESTERH EUROPEAN STATES ARE QUICK TO POINT TO THE SOLUTION OFFERED BY ECONOMIC REFORM AND LIBERALIZATION, MOST ARE ADOPTING A POLICY OF WITHOLDING THE MEDICINE--FOREIGN AID--UNTIL THE PATIENT HAS PROVEN THAT HE OR SHE CAN GET WELL. SUCH A MISGUIDED POLICY MAY DELAY OR EVEN HALT THE TRANSITION TO PEACEFUL, DEMOCRATIC, MARKET-ORIENTED POLITY IN EASTERN EUROPE. ANOTHER PROBLEM VEXING EUROPE IS THE RESURGENCE OF
NATIONALIST AND ETHNIC SEPARATISM. AS THE PROBLEMS FACING NATIONALIST AND ETHNIC SEPARATISM. AS THE PROBLEMS FACINC THE WORLD-DEVELOPMENTAL, ENVIRONMENTAL, POLITICAL--ARE REQUIRING INCREASINGLY GLOBAL SOLUTIONS, ANY MOVEMENT TO FURTHER SUBDIVIDE EUROPE WILL BE COUNTERPRODUCTIVE. THESE
AND OTHER PROBLEMS REOUIRE FIRM LEADERSHIP FROM VISIONARY AND OTHER PROBLEMS REQUIRE FIRM LEADERSHIP FROM VISIONARY
STATESMEN. UNFORTUNATELY, FEH SEEM TO BE STEPPING TO THE FORE.

02912 DONNELLY, J.

HUMAN RIGHTS IN THE NEW HORLD ORDER

WORLD POLICY JOURNAL IX(2) (SPR 92), 249-278.

IN THE POST-COLD WAR WORLD, THE UNITED STATES FACES THE 
CHALLENGE OF DEVELOPING A REALISTIC, COMMITTED, MORALLY SOUND INTERNATIONAL HUMAN RIGHTS POLICY THAT IS TRULY INTEGRATED WITH THE REST U.S. FOREIGN POL ICY. PRESIDEN BUSH'S SELF-SATIFACTION OVER "WINNING" THE COLD WAR REPRESENTS A TRAGIC FAILURE TO RISE TO THAT CHALLENGE. AS A RESULT, THE UNITED STATES RISKS MISSING A HISTORIC OPPORTUNITY FOR PROGRESSIVE CHANGE IN INTERNATIONAL HUMAN RIGHTS POLICIES.

\section{DONNEUR, A.}

THE END OF THE COLD WAR--CANADA AND EUROPEAN SECURITY ETUDES INTERNATIONALES, 23(1) (MAR 92), 121-168.

CANADA'S INTERNATIONAL COMMITMENTS HERE DICTATED BY ITS ATTITUDE VIS-A-VIS THE USSR. IT WAS NECESSARY TO WAIT UNTIL MAY 1989 FOR CANADA TO DECLARE ITS SUPPORT FOR THE REFORMS UNDERTAKEN BY GORBACHEV. FROM 1990 ON, CANADA DREH NEAR TO
THE USSR. THE LARGE-SCALE PULLOUT OF CANADIAN TROOPS FROM EUROPE DOES NOT CALL INTO QUESTION CANADA'S PARTICIPATION IN NATO, COOPERATION AMONG MEMEBERS OF THE ATLANTIC ALLIANCE NATO, COOPERATION AMONG MEMEBERS OF THE ATLANTI
BEING OF CARDINAL IMPORTANCE TO THIS COUNTRY.

02914 DONNINI, $F$.

FOUNDATION CRACKS IN ANZUS: DAMAGE ASSESSMENT, CONTROL, AND REPAIR

COMPARATIVE STRATEGY, 11(1) (JAN 92), 99-114.

AFTER ALMOST 35 YEARS OF EFFECTIVE DEFENSE COOPERATION AMONG ALLIES, THE WESTERN WORLD'S COLLECTIVE SECURITY ARRANGEMENT INVOLVING AUSTRALIA, NEW ZEALAND, AND THE UNITED STATES, BETTER KNOWN AS ANZUS, STARTED TO CRUMBLE. THIS SURPRISED AND FRUSTRATED MANY IN ALL THREE NATIONS, SINCE ANZUS WAS CONSIDERED A "SHOWCASE" ALLIANCE BECAUSE' OF ITS STRONG FOUNDATION AND SPECIAL TRILATERAL PARTNERSHIP, DESPITE AN ASYMMETRICAL ARRANGEMENT THAT GAVE DISPROPORTIONATE INFLUENCE TO SMALLER PLAYERS. FROM THE MID$1980 S$ ONHARD, OLD AND NEW DILEMMAS CAUSED THE ALLIANCE STRUCTURE TO UNDERGO GREAT WEAKENING AND STRESS AND MADE PROBLEM FIXING DIFFICULT. AS CRACKS IN THE ALLIANCE APPEARED, SERIOUS SECURITY ISSUES BECAME INTERTWINED WITH ECONOMIC AND SOCIAL ONES, THE NO-NUCLEAR POLICY OF NEW ZEALAND BEING ONE OF THE MOST VISIBLE. THIS ARTICLE EXAMINES PERTINENT FEATURES SURROUNDING ANZUS CHANGES, ASSESSES THEIR IMPACTS AND ADORESSES WAYS FOR SHORING UP ANZUS FOUNDATIONS IN THE FUTURE.

02915 DONOVAN, M.

A PARTY SYSTEM IN TRANSFORMATION: THE APRIL 1992 ITALIAN ELECTION

WEST EUROPEAN POLITICS, 15(4) (OCT 92), 170-177

THE PROCESS OF TRANSITION IN ITALY, INITIATED IN THE 1980 S HAS CONTINUED WITH THE 1992 ELECTION. THIS CAN BE SEEN ABOVE ALL IN THE TRANSFORMATION OF THE ITALIAN LEFT AND IN THE CHALLENGE TO THE GROVERNING PARTIES. THIS ELECTION REPORT EXAMINES THE GOVERNING BLOCK--THE QUADRIPARTITO, AND THE ANTI-PARTITOCRAZIA MOBILZATION PRESENT IN ITALIAN POLITICS. IT CONCLUDES THAT THE DC HOULD BE DRAMATICALLY CHANGED BY MAJOR ELECTORAL REFORM.

02916 DONOVAN, R.; SCHERER, R.

UNSILENT REVOLUTION-TELEVISION NEWS AND AMERICAN PUBLIC LIFE, 1948-1991

CAMBRIDGE UNIVERSITY PRESS, 1992, 369

THIS BOOK CONSIDERS THE IMPACT TELEVISION NEWS HAS HAD

ON POLITICS, CURRENT EVENTS AND THE PRINT MEDIA. THROUGH AM EXAMINATION OF MAJOR EVENTS, THE BOOK PROVIDES AN EPISOOIC HISTORY OF THE RISE AND ASCENDENCY OF TELEVISION NEWS EVENTS AND ISSUES COVERED INCLUDE: THE CIVIL RIGHTS STRUGGLE IN THE SOUTH, THE RED SCARE AND JOE MACCARTHY, THE KENNEDY ASSASSINATION, SPACE EXPLORATION, THE VIETNAM AND PERSIAN

02917 DONOVAN, R.J.; SCHERER, R.

POLITICS TRANSFORMED

WILSON QUARTERLY, XYI (2) (SPR 92), 19-37.

THE AUTHORS REVIEW THE HISTORY OF THE TELEVISION NETHORKS' COYERAGE OF THE DEMOCRATIC AND REPUBL ICAN NOMINATING CONVENTIONS FROM 1952 TO 1988. THEY ALSO DISCUSS THE EVOLUTION OF TELEVISION COMMERCIALS FOR PRESIDENTIAL CANDIDATES.

02918 DONOVAN, T. NEIMAM, M.

CITIZEN MOBILIZATION AND THE ADOPTION OF SUBURBAN GROWTH CONTROLS

WESTERN POLITICAL QUARTERLY 45(3) (SEP 92), 651-676.

THE AUTHORS EXPLORE HOW DIFFERENCES IN THE LOCAL POLICY PROCESS MAY AFFECT LOCAL GROWTH-CONTROL POL ICIES ACROSS JURISDICTIONS. THE RELATIONSHIP BETWEEN LEVELS OF CITIZEN MOBILIZATION AGAINST GROWTH AND THE CONTENT OF LOCAL LAND USE POLICY IS EVALUATED. USING CENSUS DATA AND THE RESULTS OF A DETAILED SURVEY OF CITY PLANNING OFFICIALS, THE MOBILIZATION AGAINST GROWTH AND LOCAL CONFLICT OVER GROWTH. THEN THEY EXAMINE THE HYPOTHESIS THAT HIGHER LEVELS OF LOCAL CONFLICT AND ANTI-GROWTH MOBILIZATION LEAD TO OUALITATIVE AND QUANTITATIVE DIFFERENCES IN LOCAL GROWTH-CONTROL POLICY
CONTENT. THE FINDINGS INDICATE THAT LOCAL POLICY IS CONDITIONED BY LEVELS OF CITIZEN MOBILIZATION.

02919 DONOVAN, T.; NEIMAN, M.

COMMUNITY SOCIAL STATUS, SUBURBAN GRONTH, AND LOCAL

GOVERNMENT RESTRICTIONS ON RESIDENTIAL DEVELOPMENT

URBAN AFFAIRS QUARTERLY, 28(2) (DEC 92), 323-336.

THE AUTHORS EXAMINE RESIDENTIAL DEVELOPMENT RESTRICTIONS

IN SUBURBAN JURISIDCTIONS IN SOUTHERN CALIFORNIA. THEY

ATTEMPT TO ASSESS THE RELATIVE IMPORTANCE OF VARIOUS

MEASURES OF COMMUNITY STATUS, PARTISANSHIP, AND GROWTH AS

PREDICTORS OF LOCAL POLICY TO REGULATE RESIDENTIAL

DEVELOPMENT. SOCIAL STATUS AND GROWTH RATES APPEAR TO

ACCOUNT FOR SOME OF THE INTERJURISOICTIONAL VARIATIONS IM

POLICY ALTHOUGH IT IS CLEAR THAT OTHER FACTORS ARE ALSO

IMPORTANT.

02920 DOOGAN, $K$.

THE SOCIAL CHARTER AND THE EUROPEANISATION OF EMPLOYMENT AND SOCIAL POLICY

POLICY AND POLITICS, 20(3) (JUL 92), 167-176.

IN DISCUSSING THE SOCIAL DIMENSION OF EUROPEAN

INTEGRATION. THERE HAS BEEN A NOTICEABLE PREOCCUPATION WITH THE LEGAL IMPLICATIONS OF SUPRANATIONAL POLICY MAKING. IN A COUNTRY LIKE BRITAIN, WHERE LABOR MARKET REGULATION RELIES LESS ON THE DIRECT INVOLVEMENT OF THE STATE, SUCH DEBATE CAN ONLY OFFER PARTIAL INSIGHTS INTO THE EUROPEAN DIMENSIONS OF DOMESTIC EMPLOYMENT AND SOCIAL POLICY. THIS PAPER ARGUES THAT THE PRINCIPLE OF SUBSIDIARITY REFERS NOT ONLY TO THE COMPETENCE OF DIFFERENT LEVELS OF GOVERNMENT BUT ALSO ATTRIBUTES A CRITICAL ROLE TO EMPLOYERS AND UNIONS IN EMPLOYMENT AND SOCIAL POLICY. IT IS SUGGESTED THAT THE INSTITUTIONAL FRAMEWORK WITHIN WHICH POLICY IS FORMULATED WILL REMAIN ESSENTIALLY NATIONAL IN CHARACTER ALTHOUGH IT WILL BE INCREASINGLY INFORMED BY PRACTICE IN OTHER MEMBER STATES.

02921 DORAN, C.F.

CONFLICT AND COOPERATION: BETWEEN THE COLD WAR AND THE GULF ANNALS OF THE AMERICAN ACADEMY OF POLITICAL AND SOCIAL

SCIENCE, (518) (NOV 91), 153-164.

THE AUTHOR EXAMINES THE HISTORICAL AND STRUCTURAL

SETTING THAT HAS CREATED A PROPER CLIMATE FOR PARALLEL U.S. AND SOVIET INITIATIVES AND JOINT DIPLOMATIC EFFORTS

REGARDING THIRD WORLD DISPUTES. CONFLICTS THAT MAY LEND REGARDING THIRO WORLD DISPUTES. CONFLICTS THAT MAY LEND
THEMSELVES MOST TO JOINT U.S. -SOVIET INVOLVEMENT ON BEHALF OF CONFLICT REGULATION OR RESOLUTION ARE (1) CONFLICTS OUTSIDE LOCAL SPHERES OF INFLUENCE, (2) CONFLICTS WERE WHERE DUTSIDE LOCAL SPHERES OF INFLUENCE, ( 2 ) CONFLICTS WERE WHERE THE LEVERAGE AVAILABLE TO HASHINGTON AND MOSCOW HITH RESPECT TO ONE OR BOTH DISPUTANTS IS GREATEST, (3) DISPUTES THAT CAN BE PAIRED AND ARE SUBJECT TO WORKABLE QUID PRO QUOS, AND ( 4 CONFLICT SITUATIONS THAT CAN BE SUBMITTED TO INTERNATIONAL ORGANIZATIONS WITHIN HHICH THE SUPERPOWERS HOLD SIGNI MEMBERSHIP. PRAGMATISM AND FLEXIBILITY WILL SERVE THE
SUPERPOWERS WELL IN THEIR QUEST TO GENERATE A MORE STABLE, SUPERPOWERS WELL IN THEIR QUEST TO GENERA
SECURE THIRD WORLD POLITICAL ENVIRONMENT.

02922 DORE, E.; HEEKS. J.

UP FROM FEUDALISH

REPORT ON THE AMERICAS, 36(3) (DEC 92), 38-44,

THIS INTERPRETATION' OF EVENTS SUGGESTS THAT DESPITE THEIR MARXIST IDEOLOGY, THE REVOLUTIONS IN NICARAGUA AND (PERHAPS) EL SLAVADOR COMPLETED A LONG TRANSITION FROM DESPOTIC FEUDALISM TO LIBERAL CAPITALISM. WHILE THE SOCIAL CHARACTERISTICS OF INDIVDUAL COUNTRIES MAKE EACH CASE DISTINCT, OVERALL THERE HAS BEEN A PROCESS OF SOCIAL TRANSFORMATION OF AN EXTREMELY VIOLENT NATURE. THIS ARTICLE DETAILS THE MAJOR CHALLENGES FACED BY THE REACTIONARY REGIMES OF CENTRAL AMERICA DURING THIS CENTURY. THE REVOLUTIONS OF NICARAGUA AND EL SALVADOR ARE EXPLORED AND THE ARTICLE CONCLUDES THAT THE TRAGIC DILEMMA OF CENTRAL AMERICAN DERIVES FROM THE POSTPONEMENT OF THE REGION'S MODERNIZATION.

02923 DORFF, R.; BRENNER, S CONFORMITY VOTING ON THE UNITED STATES SUPREME COURT THE JOURNAL OF POLITICS, 54(3) (AUG 92), 762-775.

THIS PAPER EXAMINES CONFORMITY YOTIMG ON THE US. SUPREME COURT FROM 1946 TO 1975 . IT COMPARES PAIRS OF VOTES IN WHICH A JUSTICE SHITCHES FROM THE MINORITY AT THE IN WHICH A JUSTICE SHITCHES FROM THE MINORITY AT THE ORIGINAL VOTES ON THE MERITS TO THE MAJORITY AT THE FINAL VOTE (CONFORMITY VOTING) WITH PAIRS OF VOTES IN WHICH A
JUSTICE VOTES WITH THE MINORITY AT BOTH VOTES. USING PROBIT, IT IDENTIFIES EIGHT VARIABLES ASSOCIATED WITH SWITCHING. PARTICULARLY IMPORTANT ARE CASE SALIENCE AND THE SIZE OF THE MAJORITY AT THE ORIGINAL VOTE.

02924 DORING, H.

HIGHER EDUCATION AND CONFIDENCE IN INSTITUTIONS: A

SECONDARY ANALYSIS OF THE SEUROPEAN YALUES SURVEY', 1981-83

WEST EUROPEAN POLITICS, 15(2) (APR 92), 1226-146.

A SECONDARY ANALYSIS OF THE GEUROPEAN VALUES SURYEY

TESTS SOME OF THE THEORETICAL CONCLUSIONS REGARDING THE RATIONALITY OF TRUST AND DISTRUST IN ESTABLISHED 
INSTITUTIONS. A REANALYSIS OF THE DATA SET'S QUESTION RELATING TO CONFIDENCE IN TEN PARTICULAR INSTITUTIONS SHOWS THAT THE EXPECTED IMPACT OF HIGHER EDUCATION ON CONFIENCE IN INSTITUTIONS TO PUNISH GOYERMMENTS FOR BREACH OF TRUS T APPLIES ONLY TO THOSE COUNTRIES WITH A LONG, UNINTERRUPTED TRADITION OF UPHOLDING CIVIL LIBERTIES. IN THESE COUNTRIES MULTIVARIATE ANALYSES REVEAL A LATENT PATTERN OF \$CIVIL SOCIETY' WHICH IS THE MOST IMPORTANT DIMENSION OF HOW SOCIETY WHICH IS THE MOST IMPORTANT DIMENSI
INSTITUTIONS ARE PERCEIVED BY RESPONDENTS.

02925 DORLAKD, M.

RESSENTIMENT AND POSTMODERN POLITICS

CANADIAN JOURNAL OF POLITICAL AND SOCIAL THEORY, 15(1-3) (1991), 225-259.

THE THEME OF RESSENTIMENT HAS BEEN NEGLECTED IN THE CRITICAL LITERATURE ON CANADIAN CULTURE. NOT BECAUSE THE THEME IS NOT A MAJOR ONE IN THE CANADIAN DISCOURSE, BUT ON THE CONTRARY PERHAPS BECAUSE IT IS SO MASSIVELY PERVASIVE BY ITS ABSENCE. FOR IN THIS NEGATIVE FORM, RESENTIMENT PRESENTS PROFOUND PROBLEMS IN THE DEYELOPMENT OF CULTURAL EXPRESSION AND THE FORMATION AND APPLICATION OF A CULTURAL POLITICS THAT WOULD INCLUDE ARTISTIC PRACTICES, THEIR INSTITUT IONAL ORIENTATION AND CRITICAL INTERPRETATION--IN SHORT, FOR THE PROBLEMS OF CANADIAN CULTURE. THIS ARTICLE ARGUES THAT RESSENTIMENT CONSTITUTES A DOMINANT THEME EXPLICITLY IN THE ADMINISTRATIVE PRACTICES OF THEIR INSTITUTIONAL ORIENTATION.

02926 DORNER, J.

RUSSIA TURNS ITS ATTENTION BACK TO THE UNITED STATES GERMAN TRIBUNE, (1510) (APR 92), 1, 3

GERMANY BASKED IN THE

YEARS. UNDER GORBACHEY. THE NUMBER DF SOYIET DIPLORATS

SKYRDCKETED AND THE SOVIET LEADER SELDOM MADE A TRIP ABROAD

SKYRDCKETED AND THE SOVIET LEADER SELDOM MADE A TRIP AB

HOWEVER, AFTER THE SOVIET FOREIGN MINISTRY BECAME THE
RUSSIAN FOREIGN AFFAIRS MINISTRY, THE EMPHASIS ON GERMANY

RUSSIAN FOREIGN AFFAIRS MINISTRY, THE EMPHASIS ON GERMANY
DECLINED. BORIS YELTSIN ENCOURAGED INCREASED TIES WITH (AND

DECLINED. BORIS YELTSIN ENCDURAGED INCREASED TIES WITH (AND

DIPLOMATS IN) THE UNITED STATES. SUCH A TREND DISMAYS SOME
GERMANS WHO FEAR THAT THE RUSSIANS ARE IGNORING A STRONG

GERMANS WHO FEAR THAT THE RUSSIANS ARE IGNORING A

SOURCE OF ECONOMIC AID IN RETURN FOR A SUPERFICIAL
"SUPERPOWER" RELATIONSHIP WITH THE UNITED STATES

02927 DORSEY, J.

THE GROHING ENTENTE BETWEEN ARMENIA AND IRAN

MIDDLE EAST INTERNATIONAL, 439 (DEC 92), 17-18.

FEW NATIONS HAVE LESS IN COMMON AT FIRST GLANCE THAN ARMENIA AND IRAN. DESPITE IRAN'S UNCOMPROMISING ISLAMIC COURSE, A CONVERGENCE OF MUTUAL INTERESTS IS DRIVING ARMENIA INTO A REGIONAL ALLIANCE WITH IRAN WHICH COULD RESHAPE THE POLITICAL MAP OF THE MIDDLE EAST. THIS ARTICLE EXPLORES THE IMPACT THAT AN ALLIANCE WOULO HAVE ON TURKEY, AND ALSO THE KURDISH SITUATION.

02928 DORSEY, R.

THE VOLUNTARY CONTRIBUTIONS MECHANISM WITH REAL TIME REVISIONS

PUBLIC CHOICE, 73(3) (APR 92), 261-282.

EXPERIMENTAL RESULTS ARE PRESENTED SHOWING THE EFFECTS OF ALLOWING REAL TIME REVISIONS OF VOLUTARY CONTRIBUTIONS FOR THE PROVISION OF A PUBLIC GOOD. FOR PUBLIC GOOD PAYOFF FUMCTIONS ARE EXAMINED EACH OF HHICH GENERATES SPECIFIC EOUIL IBRIA. EYIDENCE OF INCREASED PROYISION OF THE PUBL GOOD IS DEMOYSTRATED OF. THE CASE IH WHICH REVISIONS ARE GOOD IS DEMONSTRATED OFO THE CASE IN WHICH REVISIONS ARE WHEN THER IS A HIGH ANITIAL MARGINAL RETURN FROM THE PUBLIC GOOD.

02929 DOSTAL, R.

FRIENDSHIP AND POLITICS: HEIDEGGER'S FAILING

POLITICAL THEORY, 20 (AUG 92), 399-423.

HEIDEGGER'S POLITICS HAVE COME ONCE AGAIN UNDER SCRUTINY. HIS PHILOSOPHICAL ACHIEVEMENTS STAND ALHAYS IN THE SHADOW
OF HIS ENTHUSIASTIC INYOLVEMENT WITH THE NAZI PARTY IN THE 19305 . THIS ESSAY CONTRIBUTES TO THE DISCUSSION OF

HEIDEGGER'S POLITICS AND THE POLITICS OF HEIDEGGER'S

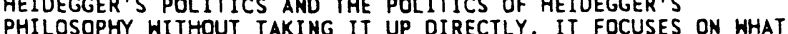
MIGHT BE CALLED THE "ETHICAL" BACKGROUND FOR HIS POL ITICAL MIGHT BE CALLED THE "ETHICAL" BACKGROUND FOR HIS POL

THOUGHT, NAMELY, THE TREATMENT OF FRIENDSHIP, WHOSE RELEVANCE TO HEIDEGGER'S VIEW OF POLITICS IN THE 1930 S. THE FIRST TWO PARTS OF THE ESSAY DISCUSS THE DIFFICULTIES THAT BESET ANY DISCUSSION OF THE "ETHICS" AND "POL ITICS" OF
HEIDEGGER'S THOUGHT. THE THIRD PART EXAMINES THE THEME OF FRIENDSHIP AND HUMAN RELATIONSHIP IN HIS LECTURES AND PUBLICATIONS THROUGH 1930; IN THE CONCLUDING PART, THE RELIGIOUS AND MONSTROUS CHARACTER OF HEIDEGGER'S POLITICAL THOUGHT IS DISCUSSED.

02930 DOUGLAS J.M.

STATE CIVIL SERVICE AND COLLECTIVE BARGAINING: SYSTEMS IN CONFLICT

PUBLIC ADMINISTRATION REVIEH, 52(2) (MAR 92), 162-172.

THE AUTHOR ASSESSES THE IMPACT OF THE EMERGENCE OF
PUBLIC-SECTOR LABOR RELATION SYSTEMS ON THE LEGAL STRUCTURE AND DESIGN OF STATE CIVIL SERVICE MERIT SYSTEMS. HE EXPLORES THE ISSUE THROUGH A CONTENT ANALYSIS OF STATE LAWS RELATED TO BOTH SYSTEMS. HIS ANALYSIS SUGGESTS THE DEVELOPMENT OF DUAL PERSONNEL SYSTEMS IN MANY JURISDICTIONS AND THE LACK OF EFFORTS TO INTEGRATE THE TWO CONTRADICTORY SYSTEMS. IN MOST CASES, LABOR RELATION SYSTEMS HAVE BECOME THE PRIMARY FORCE IN PUBLIC-SECTOR HUMAN RESOURCE MANAGEMENT POLICIES; BUT CIVIL SERVICE SYSTEMS REMAIN A FACTOR OFTEN TIMES GENERATING PROBLEMS BECAUSE THE THO DO NOT FIT TOGETHER WELL.

02931 DOUGLAS, W.A.

FREE TRADE AND FREE SOCIETY: POLITICAL AND ECONOMIC PLURALISM

FREEDOM REVIEH, 23(4) (JUL 92), 28-31.

THE AUTHOR DISCUSSES THE RELATIONSHIP BETWEEN POLITICAL SYSTEMS AND ECONOMIC SYSTEMS. HE CONSIDERS THE QUESTION OF WHETHER VIRTUALLY ANY ECONOMIC SYSTEM CAN BE COMBINED WITH ALMOST ANY KIND OF POLITICAL SYSTEM. OR, ARE ONLY CERTAIN POLITICAL AND ECONOMIC PAIRINGS VIABLE?

02932 DOVEY, H.O.

SECURITY IN SYRIA, 1941-45

INTELLIGENCE AND NATIONAL SECURITY, 6(2) (APR 91), 418-444. DURING WORLD WAR THO, SYRIA WAS DESCRIBED AS THE MOST IMPORTANT LINK IN THE BRITISH CHAIN OF MIDOLE EAST INTELLIGENCE AND SECURITY. THIS ARTICLE CHRONICLES THE BRITISH EFFORTS TO GATHER INTELLIGENCE AND MAINTAIN SECURITY IN SYRIA OVER THE PERIOD 1941-45. IT EXAMINES THE COOPERATION (AND SOMETIMES CONFLICT) WITH THE FREE FRENCH FORCES IN THE AREA, THE ATTEMPTS TO COUNTER AXIS ESPIONAGE AND PROPAGANDA EFFORTS IN THE REGION, AND PROTECT BRITISH SECURITY INTERESTS.

02933 DOWDING, $K$.

CHOICE: ITS INCREASE AND ITS VALUE

BRITISH JOURNAL OF POLITICAL SCIENCE, 22(3) (JUL 92),

8RITISH $301-314$.

IN RECENT YEARS MUCH VALUE HAS BEEN PLACED ON INCREASING THE CHOICE OF THE CITIZEN-CONSUMER. BUT THE CONCEPT OF INCREASING CHOICE IS FAR MORE PROBLEMATIC THAN IT AT FIRST APPEARS AND HAS LITTLE INTRINSIC VALUE IN ITSELF. CHOICE IS APPEARS AND HAS LITTLE INTRINSIC VALUE IN ITSELF. CHOICE IS CHOI OR DALUE IN ITSELF IN THE SENSE THAT 'S DISCOVERY OF ONE'S OHN PREFERENCES. TO JUSTIFY THE INTRODUCTION OF THE MARKET PROCESS ON THE GROUNDS OF INCREASING CHOICE IS MARKET PROCESS ON THE GROUNDS OF INCREASING CHOICE IS DOUBTLY WRONG; FIRST, INCREASING CHOICE IS NOT IN ITSELF
VALUABLE AND, SECONDLY, WHAT IS VALUABLE ABOUT THE MARKET VALUABLE AND, SECONDLY, WHAT
HAS LITTLE TO DO WITH CHOICE.

02934 DOWIE, M. AMERICAN ENVIRONMENTALISM: A MOVEMENT COURTING IRRELEVANCE WORLD POLICY JOURNAL, 9 (1) (WIN 91), 67-92.

IF THE ROLE OF MAINSTREAM ORGANIZATIONS REMAINS CENTRAL AND THE ENVIRONMENTAL MOVEMENT HOPES TO ACHIEVE ITS PREDICTED SIGNIFICANCE BEFORE THE END OF THE CENTURY, SOME RAPID AND RADICAL CHANGES MUST BE MADE IN THE PRIORITIES, STRUCTURE, AND TACTICS OF THE NATIONALS. LESS RELIANCE ON REGULATORY LEGISLATION AND MORE DIRECT CONFRONTATION WITH POLLUTERS IS NEEDED. THIS ARTICLE SUGGESTS THAT THE MAINSTREAM NEEDS TO ABANDON ITS FAITH IN THE ABILITY TO CONTAIN POLLUTION AND ADOPT, INSTEAD, AN APPROACH THAT FAVORS POLUTION PREVENTION. MAINSTREAM LEADERS MUST FURTHER QUESTION THE COMPATIBILITY OF EFFECTIVE ENVIROMMENTALISM WITH THE WORLD'S PREVAILING ECONOMIC ORTHOOOXIES. IT CONCLUDES THAT TIME IS RUNMING OUT FOR A MOVEMENT COURTING IRRELEVANCE.

02935 DOWNIE, R.

LOW-INTENSITY CONFLICT DOCTRINE AND POLICY: OLD WINE IN A TOTLE?

STUDIES IN CONFLICT AND TERRORISM, 1 (1992), 53-68. CONTEMPORARY LOW-INTENSITY CONFLICT (LIC) POLICY AND DOCTRINE HAVE BEEN CRITICIZED AS CARRYING FORWARD THE SAME CONCEPTS AND ASSUMPTIONS THAT SERVED AS THE FOUNDATION FOR THE FAILED VIETHAM-WAR ERA U.S. COUNTERINSURGENCY POLICY. THIS ARTICLE REVIEWS AND ORGANIZES THE BODY OF LITERATURE ON LIC, THEN ANALYZES LIC DOCTRINE AND LITERATURE ACROSS FOUR DIMENSIONS TO DETERMINE IF CURRENT LIC POLICY AND DOCTRINE FAILURE OF THE UNITED STATES, VIETMAM-WAR ERA FAILURE OF THE UNITED STATES VIETNAM-WAR ERA COUNTERINSURGENCY DOCTRINE. THE ANALYSIS REVEALS THAT THERE BEEN SUFFICIENTLY ADDRESSED OR RESOLVED.

02936 DOWNING, B

THE MILITARY REVOLUTION AND POLITICAL CHANGE PRINCETON UNIVERSITY PRESS, 1992, 314

TO EXAMINE THE LONG-RUN ORIGINS OF DEMOCRACY AND DICTATORSHIP, THIS BOOK FOCUSES ON THE IMPORTANCE OF MEDIEVAL POLIITICAL CONFIGURATIONS AND OF MILITARY MODERNIZATION IN THE EARLY MOOERN PERIOD. THE AUTHOR MAINTAINS THAT IN LATE MEDIEVAL TIMES AN ARRAY OF CONSTITUTIONAL ARRANGEMENTS (PARLIAMENTS, LOCAL AUTONOMY, 
RULE OF LAH, AND PERSONAL FREEDOMS) DISTINGUISHED WESTERM EUROPE FROM OTHER PARTS OF THE WORLD AND PREDISPOSED IT TOWARD LIBERAL DEMOCRACY. HE THEN LOOKS AT HOW MEDIEVAL
CONSTITUTIONALISM WAS AFFECTED BY THE "MILITARY REVOLUTION" CONSTITUTIONALISM WAS AFFECTED BY THE "MILITARY REVOLUTION" FEUDAL LEVIES TO LARGE STANDING ARMIES. HE ARGUES THAT THE "MILITARY REVOLUTION" ENTAILED THE DESTRUCTION OF CONSTITUTIONAL GOVERMMENT AND THE RISE OF MILITARY-CENTERED AUTOCRACY. WHERE WAR WAS LIGHT, HOWEVER, OR WHERE MILITARY MODERNIZATION WAS ACCOMPLISHED WITHOUT RELYING ON SUBSTANTIAL AMOUNTS OF DOMESTIC RESOURCES, CONSTITUTIONAL GOVERNMENT SURVIVED AND BECAME THE FOUNDATION OF MODERM DEMOCRACY

02937 DOWNS, A.

CITIZEN-SPONSORED INITIATIVES: FILLING THE LEGISLATIVE VACUUM ON DISCRIMINATION ISSUES

NATIONAL CIVIC REVIEW, 80(4) (FAL 91), 413-416. QUESTIONS CONCERNIHG ANTI-DISCRIMINATION LEGISLATION ARE TOO CONTROVERSIAL TO SIMMER FOR YEARS ON THE POLITICAL BAOCONTROVERSIAL TO SIMMER FOR YEARS ON THE POLITICAL BACKBURNER. CONSEQUENTLY, RATHER THAN WAITING FOR THEI
LEGISLATURES TO PASS MEN CIVIL RIGHTS LAWS, CITIZEN LEGISLATURES TO PASS NEW CIVIL RIGHTS LAWS, CITIZEN TO FORCE THE ISSUE. WHILE VOTERS MAY NOT ALWAYS FAVOR PROPOSED CIVIS RIGHTS INITIATIVES, THE FACT THAT SUCH ISSUES ARE NOT SIMPLY IDLING ON THE LEGISLATIVE DOCKET IS A VICTORY ARE NOT SIMPLY IDLING ON THE

02938 DOWNS, C.

A SHORT HISTORY OF THE PORTUGUESE REVOLUTION: THE DIALECTIC OF POPULAR MOBILIZATION; REVOLUTION AT THE GRASSROOTS:

STATE UNIVERSITY OF NEH YORK PRESS, 1989, 15-33.

ON 25 APRIL 1974, IN A MATTER OF' HOURS, THE OLDEST AND LONGEST LASTING FASCIST REGIME IN EUROPE WAS BROUGHT TO AN END IN PORTUGAL. ONCE THE OLD REGIME WAS OVERTHROWN BY THE MILITARY, MUCH MORE DIFFICULT SOCIAL AND POLITICAL QUESTIONS CAME TO THE FORE. THE QUESTIONS OF WHO WAS TO RULE AND WHAT CHANGES HERE TO BE MADE WERE DISPUTES DURING SIX PROVISIONAL GOVERMMENTS, AND IN FACTORIES, FARMS, BARRACKS NEIGHBORHOOOS, AND IN THE STREETS OVER THE NEXT THO YEARS. THIS CHAPTER CHRONICLES THIS TIME AND DIVIDES IT INTO FOUR MAJOR PERIODS: APRIL TO SEPTEMBER 1974; OCTOBER 1874 TO MARCH 975: MARCH TO NOVEMBER 1975; AND NOVEMBER 1975 TO JUNE 1976. THE MAIN ISSUES OF CONCERN FOR POLITICAL DEBATE, MASS STRUGGLES AND GOVERNMENT POLICIES WERE DIFFERENT IN EACH PERIOD, AS WERE THE RELATIONSHIPS AMONG THE MASS MOVEMENTS, PERIOD, AS HERE THE RELATIONSHIPS AMONG THE
THE MILITARY, THE PARTIES, AND THE STATE.

02939 DOWNS, C.

NEITHER SPONTANEITY NOR MANIPULATION: ROOTS OF URBAN SOCIAL MOVEMENTS; REVOLUTION AT THE GRASSROOTS: COMMUNITY ORGAMIZATIONS IN THE PORTUGUESE REVOLUTION

STATE UNIYERSITY OF NEH YORK PRESS, $1989,66-86$.

MASS MOVEMENTS FOCUSING ON THE CONDITIONS AND CONTROL OF THE WORKPLACE AND NEIGHBORHOODS WERE VERY IMPRTANT DURING THE PORTUGUESE REVOLUTION, BUT THEIR GENESIS AND ROLE WERE OFTEN DISPUTED. THIS CHAPTER PROVIDES AND EMPIRICAL RESPO TO THE QUESTIONS UMDERLYING THE POL.EMICS REGARDING THE MOVEMENT DURING THE PORTUGUESE REVOLUTION. IT ASKS: WAS IT ESSENTIALLY ORGANIZED AND OIRECTED BY OUTSIDE POLITICAL FORCES, OR DID IT ESSENTIALLY DEVELOP ACCORDING TO A LOGIC SPECIFIC TO THE MOVEMENT AND OUTSIDE THE CONTROL OF ANY POLITICAL ORGANIZATIONS? IF IT IS THE LATTER, DOES THIS RESULT IN RELATIVELY RANDOM AND UNPREDICTABLE BEHAVIOR AS A SIMPLE VIEW OF SPONTANEITY MIGHT SUGGEST. OR IN A CONSISTENT BEHAVIOR THAT IS LARGELY DETERMINED BY IDENTIFIABLE
STRUCTURAL FACTORS?

02940 DOWNS, $C$.

REVOLUTION AT THE GRASSROOTS: COMMUNITY ORGANIZATIONS IN THE PORTUGUESE REVOLUTION

STATE UNIVERSITY OF NEH YORK PRESS, 1989, 215.

THE PORTUGUESE REVOLUTION PROVIDES A UNIOUE WINDOH

THROUGH WHICH TO EXAMINE, NOT ONLY THE ROLE OF COMMUNITY

ORGANIZATIONS IN A TIME OF REVOLUTIONARY CHANGE, BUT ALSO THE DYNAMICS, POTENTIAL, AND LIMITATIONS OF MAJORITY PARTICIPATION. OVER A PERIOD OF NINETEEN MONTHS THE PORTUGUESE SOCIETY AND POLITICAL DEBATE WERE SIGNIFICANTLY TRANSFORMED, LARGELY BY THE UNANT ICIPATED DEVELOPMENT OF TRANSFORMED, LARGELY BY THE UNANT ICIPATED DEVELOPMENT
MASS MOVEMENTS ADVOCATING DIRECT DEMOCRACY AND SOCIAL, MASS MOVEMENTS ADVOCATING DIRECT DEMOCRACY AND SOCIAL, HISTORY OF THE REVOLUTIONARY PROCESS AT THE NATIONAL LEVEL AND AS IT WAS EXPERIENCED IN ONE MAJOR PORTUGUESE CITY. AND AS IT WAS EXPERIENCED IN ONE MAJOR PORTUGUESE CITY. WHILE GENERALLY LITTLE KNOWN, THE ACHIEVEMENTS OF GRASS ORGANIZATIONS IN PORTUGAL FAR EXCEEDED THOSE OF OTHER
DEVELOPED COUNTRIES, AND THEIR EXAMINATION PROVIDES INSIGHTS, POSES IMPORTANT QUESTIONS, AND SUGGESTS UNEXPECTED ANSHERS RELEVANT FAR BEYOND PORTUGAL.

02941 DOWNS, C

THEORY AND PRACTICE OF URBAN SOCIAL MOVEMENTS;
IMPLICATIONS OF THE PORTUGUESE REVOLUTION; REVOLUTION AT THE GRASSROOTS: COMMUNITY ORGAMIZATIONS IN THE PORTUGUESE REVOLUTION

STATE UNIVERSITY OF NEW YORK PRESS, 1989, 108-137.

THE GRASSROOTS ORGANIZATIONS AND URBAN SOCIAL MOVEMENTS THAT DEVELOPED FOLLOWING THE OVERTHROW OF PORTUGUESE FASCISM PROVIDES AN EXTREME BUT TYPICAL CASE UPON WHICH TO BASE CONSIDERATION OF THE FUNDAMENTAL DYNAMICS AND POSSIBILITIES FOR SUCH MOVEMENTS GENERALLY. THIS CHAPTER SUMMARIZES THE BASIC THEORETICAL APPROACH AND CONCLUSIONS DEVELOPED IN THE AUTHOR'S STUDY, AND THEN POSES THE RELEVANCE OF THE PRESENT STUDY FOR OTHER CONTEXTS BY SPECIFIC DISCUSSION OF THE EMPIRICAL AND THEORETICAL ARGUMENTS OTHERS HAVE MADE REGARDING THE ORIGIN OF URBAN SOCIAL MOVEMENTS, THEIR POLITICAL ORIENTATIONS, THE DEVELOPMENT OF COORDINATION AMONG MOVEMENT ORGANIZATIONS, THEIR RELATIONSHIP TO THE STATE, AND THE SIGNIFICANCE OF "POPULAR POWER" AS A ALTERNATIVE MODEL FOR SOCIETY.

02942 DOWNS, D.

PORNOGRAPHY AND HARM: TOHARD A NEW CLASSIFICATION OF UNPROIECTED SPEECH?: THE NEH POLITICS OF PORNOGRAPHY

UNIVERSITY OF CHICAGO PRESS, $1989,144-198$.

THIS CHAPTER ADORESSES THE LEGAL ISSUE OF WHAT TO DO ABOUT PORNOGRAPHY. IT IS DEVOTED TO LEGAL ANALYSIS OF THE ANTI-PORNOGRAPHY ORDINANCE IN RELATION TO DEVELOPING OBSCENITY DOCTRINE. IT CONSIDERS THE FEASIBILITY OF NEH RESTRICTIONS ON THE AVAILABILITY OF PORNOGRAPHIC (AS DISTINCT FROM OBSCENE) MATERIAL AND DISCUSSES THE DESIRABILITY OF MAINTAINING LIBERAL PRINCIPLES AS THE BASIS OF GENERAL FIRST AMENDMENT DOCTRINE. THE AUTHOR CONCLUDES BY REJECTING THE SEARCH FOR A SINGLE PERSPECTIVE ON THE LEGAL TREATMENT OF SEXUAL MATERIALS. THE AUTHOR ADVOCATES LEGAL TOLERANCE AND ENDORSES PRESERVING THE LIBERAL CORE OF GENERAL FIRST AMENDMENT LAH FOR EXPRESSIOH THAT MAY POSSESS INTELLECTUAL VALUE.

02943 DOWHS, D.

THE NEW POLITICS OF PORNOGRAPHY

UNIVERSITY OF CHICAGO PRESS, 1989, 266.

FRESH EMPIRICAL EVIDENCE OF PORNOGRAPHY'S NEGATIVE EFFECTS AND THE RESURGENCE OF FEMINIST AND CONSERVATIVE CRITIQUES HAVE CAUSED LOCAL, STATE, AND FEDERAL OFFICIALS TO REASSESS THE PORNOGRAPHY ISSUE. THIS BOOK EXPLORES THE CONTEMPORARY ANTI-PORNOGRAPHY MOVEMENT AND ADDRESSES DIFFICULT QUESTIONS ABOUT THE LIMITS OF FREE SPEECH. THE DIFFICULT QUESTIONS ABOUT THE LIMITS OF FREE SPEECH. THE
AUTHOR ARGUES THAT BOTH CONSERVATIVE AND LIBERAL CAMPS ARE OFTEN CHARACTERIZED BY EXTREME INTOLERANCE WHICH HAMPERS OPEN POLICY DEBATE AND MAY ULTIMATELY THREATEN THE MODERN
DOCTRINE OF FREE SPEECH. THE BOOK CONCLUDES WITH A BALANCED DOCTRINE OF FREE SPEECH. THE BOOK CONCLUDES WITH A BALANCED DISCUSSION OF WHAT

02944 DOWNS, D.

THE NEW POLITICS OF PORNOGRAPHY AND THE CHALLENGE TO THE MODERN DOCTRINE OF FREE SPEECH AND OBSCENITY; THE NEH POLITICS OF PORNOGRAPHY

UNIVERSITY OF CHICAGO PRESS, 1989, 1-33,

THIS CHAPTER EXAMINES THE LEGAL AND POLITICAL CONTEXT OF THE NEW POLITICS OF PORNOGRAPHY AND DEMONSTRATES HOW IT CHALLENGES THE LIBERAL DOCTRINE OF FREEDOM OF SPEECH. THE AUTHOR ALSO DISCUSSES OBSCENITY DOCTRINE--THE TRADITIONAL, ESSENTIALLY CONSERVATIVE APPROACH TO THE CONTROL OF SEXUAL MATERIAL--AND HOW IT HAS BEEN MODIFIED IN THE MODERN ERA BY IBERAL PRINCIPLES. THE AUTHOR CONCLUDES THAT THE NEH DEBATE OVER PORNOGRAPHY IS PART OF A BROADER CONTROVERSY CONCERNING THE NATURE OF LIBERTY AMD FREEDOM IN SOCIETY. THE LIBERAL CORE OF THE FIRST AMENDMENT HAS BEEN AFFIRMED IN THE COURT DECISIONS OF THE LAST TWENTY YEARS, EVEN IN THE ERSTWHILE CONSERVATIVE DOMAIN OF OBSCENITY LAH. BUT MANY CRITICS NOW QUESTION WHETHER THE FIRST AMENDMENT, IN ITS APPLICATION TO SEXUAL MATERIALS (OR EVEN BEYOND), SHOULD BE REINTERPRETED IN A MANNER MORE CONSISTENT WITH OTHER, LESS LIBERAL, AREAS OF LAW AND WITH NON-LIBERAL SOCIAL VALUES, WHETHER PROGRESSIVE OR TRADITIONAL.

02945 DOYLE, $R$.

RECONCILIATION AND THE BUDGET PROCESS

POLICY STUDIES JOURMAL, 20(3) (1992), 489-498.

THE GRAMM-RUDMAN-HOLLINGS BILLS ARE THE BEST-KNOWN REFORMS OF THE CONGRESSIONAL BUDGET PROCESS, BUT THE DECADE REFORMS OF THE CONGRESSIONAL BUDGET PROCESS, BUT THE DECADE
OF THE 1980'S WAS BRACKETED BY THE PASSAGE OF TWO MASSIVE OF THE 1980'S WAS BRACKETED BY THE PASSAGE OF TWO MASSIVE RECONCILIATION BILLS, BUDGET LEGISLATION THAT RELIED UPON FIRST EMPLOYED IN 1980 TO EFFECT MINOR SPENDING CUTS AT THE FIRST EMPLOYED IN 1980 TO EFFECT MINOR SPENDING BEGINNING OF THE CONGRESSIONAL BUDGET PROCESS, RECONCILIATION GAINED NOTORIETY THE NEXT YEAR WHEN IT WAS
COMMANDEERED BY THE NEWLY-ELECTED REAGAN ADMINISTRATION TO COMMANDEERED BY THE NEWLY YELECTED REAGAN ADMINISTRATI
IMPLEMENT ITS BUDGET POLICY MANDATE. THE PRODUCT OF INNOVATION AND EVOLUTION, RECONCILIATION WAS THE FIRST MAJOR REFORM OF THE CONTEMPORARY BUDGET PROCESS.

02946 DRACHE, D. (ED.)

GETTING ON TRACK: SOCIAL DEMOCRATIC STRATEGIES FOR ONTARIO 
MCGILL-QUEEN'S UNIVERSITY PRESS, 1991, 264.

THIS COLLECTION CONSIDERS THE TASKS FACING BOB RAE'S ONTARIO NEW DEMOCRATIC PARTY GOVERNMENT. IT DEMONSTRATES THAT IF A MODERN SOCIAL DEMOCRATIC ADMINISTRATION EXPECTS TO BE DYNAMIC AND SOCIALLY EFFECTIVE IT HAS TO HAVE AN ECONOMIC STRATEGY TO RESTRUCTURE THE ECONOMY WHILE UPHOLDING ITS TRADITIONAL COMMITMENT TO SOCIAL EQUALITY. THE CONTRIBUTORS TO THE COLLECTION ARGUE THAT THE SOCIAL DETERMINANTS OF PRODUCTIVITY ARE KEY TO A DIFFERENT FUTURE--ESPECIALLY IM LIGHT OF THE HIDE RANGE OF ISSUES EXPOSED BY FEMINIZATION OF LABOR MARKETS, THE RISE OF THE SERVICE INDUSTRY, AND THE DECLINE OF THE WELFARE STATE. THE AUTHORS EMPHASIZE THE CONTINUING IMPORTANCE OF A FULL EMPLOYMENT STRATEGY AND THE URGENT NEED FOR INCOME SECURITY FOR WORKERS IN HIGHLY FRAGMENTED LABOR MARKETS, AND OUTLINE TOUGH NEN MEASURES FRAGMENTED LABOR MARKETS, AND OUTLINE TOUGH NEN MEASURES
DESIGNED TO CLOSE THE WAGE GAP BETWEEN MEN AND WOMEN. THEY DESIGNED TO CLOSE THE WAGE GAP BETWEEN MEN AND WOMEN. THEY
DELINEATE A FRESH PERSPECTIVE ON DEALING WITH DEFICITS, MAKE DELINEATE A FRESH PERSPECTIVE ON DEALING WITH DEFICITS, MAKE
A STRONG CASE FOR WIDE-REACHING SOCIAL WELFARE REFORM, AND A STRONG CASE FOR WIDE-REACHING SOCIAL WELFARE REFORM,
PROPOSE A FRAMEWORK BY WHICH ONTARIO CAN REBUILD ITS PROPOSE A FRAMEHORK BY
SHATTERED INDUSTRIES

02947 DRACHE, D. (ED.); GERTLER, M. (ED.)

THE NEH ERA OF GLOBAL COMPETITION

PRESS, 1991

THE INCREASING GLOBALIZATION OF PRODUCTION AND THE

CONSERVATIVE AGENDA FOR MARKET - LED GROHTH ARE DRAMATICALLY AFFECTING THE LIFE OF THE AVERAGE CANADIAN AND THE CHOICES MADE BY SOCIAL AND ECONOMIC POLICYMAKERS. THE WORLDHIDE REORGANIZATION OF MARKETS POSES NEW CHALLENGES FOR DOMESTIC INDUSTRY WHILE CONTINENTAL TRADE INITIATIVES THREATEN THE LIVELIHOOD OF CANADIAN WORKERS AND THE STABILITY OF COMMUNITIES ACROSS ALL REGIONS OF THE COUNTRY. ENVIRONMENTAL QUALITY IS SIMILARLY AT RISK FROM DEVELOPMENT STRATEGIES DRIVEN MORE BY POSSIBILITIES OF SHORT-TERM GAIN FROM EXPORT SALES THAK BY ATTEMPTS TO PROMOTE LONG-TERM SUSTAINABILITY.

02948 DRAGNICH, A.

YUGOSLAVIA IN HISTORICAL PERSPECTIVE

MEDITERRANEAN QUARTERLY: A JOURNAL OF GLOBAL ISSUES, $3(3)$

( SUM 92 ), 5-19.

THIS ARTICLE OFFERS A BRIEF OVERVIEW OF THE HISTORY OF THE STATE OF YUGOSLAVIA. IT BEGINS WITH AN ASSESSMENT OF THE IMPACT OF KEY EVENTS ON YUGOSLAVIA'S FOUNDING: THE DISSOLUTION OF THE HAPSBURG EMPIRE, THE DECAY OF THE OTTOMAN EMPIRE, THE GROWING DESIRE OF THE SOUTH SLAVS TO UNITE, AND EMPIRE, THE GROWING DESIRE OF THE SOUTH SLAVS TO UNITE, AND YUGOSLAVIA (1918-1941). IT ALSO EXAMINES THE CREATION OF A "SECOND" YUGOSLAVIA UNDER MARSHALL TITO. FINALLY, IT "SECOND" YUGOSLAVIA UNDER MARSHALL TITO. FINALLY, IT CHRONICLES THE GROWING ETHNIC TENSION AND ECONOMIC TURMOIL THAT CHARACTERIZED YUGOSLAVIA FOLLOWING TITO'S DEATH IN 1980 THESE PROBLEMS LED TO THE DISSO
THE RENEHAL OF ETHNIC WARFARE.

02949 DRAGSDAHL, J.

THE GULF WAR: NEW CHALLENGES FOR JOURNALISH

BULLETIN OF PEACE PROPOSALS, 23(2) (1992), 139-146.

THERE ARE FUNDAMENTAL NEW QUESTIONS CONCERNING THE ROLE OF MODERN MASS MEDIA DURING INTERNATIONAL CONFLICT. THE TERM MEDIALISM IS USED FOR THE MEDIA'S NOVEL INFLUENCE IN INTERNATIONAL POLITICS. FOR TRADITIONAL POL ICY-MAKERS MEDIALISM IS A CHALLENGE AGAINST THEIR POWER. US MEDIA CORPORATIONS, AND ANGLO-SAXON VALUES ON JOURNALISM, ARE DOMINANT IN MEDIALISM. THIS STUDY IS BASED LARGELY ON RESEARCH ON THE US MEDIA DURING THE GULF CONFLICT. THE STUDY EXPLORES THE ROLE OF THE MEDIA EVEN BEFORE THE ACTUAL COMBAT OPERATIONS, NEWS MANAGEMENT, AND NEW CHALLENGES FACING THE MEDIA SINCE THE GULF CRISIS.

02950 DRAKE, $R$.

IDEOLOGY AND TERRORISM IN ITALY: AUTOBIOGRAPHY AS A HISTORICAL SOURCE

TERRORISM AND POLITICAL VIOLENCE, 4(2) (SUM 92) 47-61. ANY ATTEMPT TO UNDERSTAMD THE PROBLEM OF CONTEMPORARY ITALIAN TERRORISM MUST BEGIN WITH A HISTORICAL EXAMINATION OF THE IDEAS AND VALUES THAT HAVE MOTIVATED THE TERRORISTS COMPRISING THE CULTURE OF ANTI-DEMOCRATIC VIOLENCE AT BOTH POLITICAL EXTREMES. IN THIS PAPER, THE AUTHOR ANALYZES REPRESENTATIVE SAMPLES OF THE AUTOBIOGRAPHICAL HRITINGS OF ITALIAN TERRORISTS ON BOTH THE LEFT AND THE RIGHT.

02951 DRAKE, W.; NICOLAIDIS, K.

IDEAS, INTERESTS, AND' INSTITUTIONALIZATION: "TRADE IN SERVICES" AND THE URUGUAY ROUND

INTERNATIONAL ORGANIZATION, 46(1) (WIN 92), 37-100,

INTERNATIONAL ORGANIZATION, 46 (1) (WIN 92), 37-100.
MEMBER GOVERMMENTS OF THE GENERAL AGREEMENT ON TARIFFS AND TRADE (GATT) HAVE AGREED TO PURSUE A NEW REGIME FOR INTERNATIONAL TRADE IN SERVICES AS PART OF THE URUGUAY ROUND NEOTIATIONS BEGUN IN 1986. THIS ARTICLE ARGUES THAT AN EPISTEMIC COMMUNITY OF SERVICES EXPERTS PLAYEO A CRUCIAL ROLE IN CLARIFYING AND FRAMING THE COMPLEX ISSUE OF TRADE IN SERVICES AND PLACING IT ON THE GLOBAL AGENDA. THROUGH THEIR ANALYSES OF THE SERVICES ISSUES, THE EPISTEMIC COMMUNITY MEMBERS WERE ABLE TO CONVINCE GOVERNMENTS THAT INTERNATIONAL
SERVICES TRANSACTIONS HAD COMMON TRADE PROPERTIES AND THAT
THE LIBERALIZATION OF SERVICES THROUGH REMOVAL OF NONTARIFF BARRIERS WAS POTENTIALLY ADVANTAGEOUS TO DEVELOPING AS WELL AS DEVELOPED COUNTRIES. THE COMMUNITY MEMBERS WERE INSTRUMENTAL IN SPECIFYING A RANGE OF POLICY OPTIONS TO BE CONSIOERED. HOWEVER, ONCE GOVERNMENTS UNDERSTOOD THEIR INTERESTS AND DOMESTIC CONSTITUENCIES WERE MOBILIZED. THEIR POLICY CHOICES WERE INFLUENCED MORE BY POWER AND BARGAINING DYNAMICS THAN BY CONTINUING, DIRECT EPISTEMIC COMMUNITY INFLUENCE.

02952 DRAVIS, $M$.

STORMING FORTRESS ALBANIA: AMERICAN COVERT OPERATIONS IN MICROCOSM, 1949-54

INTELLIGENCE AND NATIONAL SECURITY, 7(4) (OCT 92), 425-442.

SINCE THE SECOND WORLD WAR, CDVERT ACTION HAS BEEN AN ENDURING FEATURE OF US FOREIGN POLICY. THE PRONOUNCED IDEOLOGICAL SCHISM BETWEEN THE SUPERPOWERS CONTRIBUTED GREATLY TO THE RATIONALE FOR SECRET SERVICES AND THEIR UNSAVORY MISSIONS. THIS ARTICLE EXPLORES JOINT ANGLOAMERICAN COVERT ACTION AND OTHER COVERT OPERATIONS IN EASTERN EUROPE. IT EXPLORES WHY THE ALBANIAN OPERATION FAILED AND CONCLUDES THAT THE TRUE BENEFIT OF EXAMINING THE ALBANIAN PROJECT LIES IN IDENTIFYING KEY ISSUES WHICH STILL AFFECT THE US INTELLIGENCE COMMUNITY AS WELL AS DECISIONMAKING IN AMERICAN FOREIGN POLICY.

02953 DREANO, B.

RACISM AND ANTI-RACISM IN FRANCE

NEW POLITICS, 3(4) (WIN 92), 61-70

THE PRINCIPAL SOCIAL MOVEMENT IN FRANCE DURING THE 1980 S WAS THE ANTI-RACIST MOVEMENT, WITH THE ABILITY TO MOBILIZE HUNDREDS OF THOUSANOS OF YOUNG PEOPLE AND EXERCISE REAL PRESSURE ON THE POLITICAL LEADERS OF THE LEFT AND CENTER. THE CONFRONTATION BETWEEN RACISM AND ANTI-RACISM, AND THE DIALECTIC BETWEEN COMMUNALISM AND UNIVERSALISM, CONSTITUTE THE MAJOR AXES AROUND WHICH POLITICAL FORCES AND IDEOLOGICAL CURRENTS ARE NOW IN THE PROCESS OF REDEFINING THEMSELVES. FRANCE IS A PLACE WHERE PRINCIPLES ARE BEING DEFINED, A PROVING GROUND FOR CONCEPTS AND PROTOTYPES. THE ANTI-RACIST RACISM THROUGHOUT THE WORLD.

02954 DREIER, P.; BERNARD, E.

CANADA: A KINDER, GENTLER NATION
SOCIAL POLICY, 23(1) (SUM 92), 6-19.

WHEN CANADA AND THE UNITED STATES ARE COMPARED, CANADA HAS LESS POVERTY, LESS CRIME AND FEWER MURDERS, FEWER INFANT DEATHS, LESS HAZARDOUS WASTE, HIGHER VOTER TURNOUT, AND BETTER UNEMPLOYMENT INSURANCE. ON MOST INDICATORS OF SOCIAL WELL-BEING, CANADA OUTPERFORMS THE UNITED STATES, OFTEN BY A WIDE MARGIN. THE CANADIAN EXPERIENCE SUGGESTS THAT ACTIVIST GOVERNMENT DOES NOT INEVITABLY LEAD TO BUREAUCRATIC RED TAPE, EROSION OF THE WORK ETHIC, A DECLINE IN PERSONAL FREEDOM,
OR A WEAKER ECONOMY.

02955 DREISZIGER, $N$.

BETWEEN NATIONALISM AND INTERNATIONALISM: OSCAR JASZI'S PATH TO DANUBIAN FEDERALISM, 1905-1918

CANADIAN REVIEW OF STUDIES IN NATIONALISM, XIX(1) (1992), 19-29.

OSCAR JASZI'S HUNGARIAN COMPATRIOTS KNOW HIM FOR HIS

PLAN FOR A CONFEDERATION OF THE DANUBIAN NATIONS, A

BLUEPRINT OF WHICH HE PUBLISHED IN 1918. HIS FEDERALIST

PLANS HAVE BEEN OUTLINED IN ENGLISH, BUT UNTIL RECENTLY EVEN READERS IN HUNGARY HAD NO ACCESS TO SOME LATER VERSIONS OF THESE PLANS, IN PARTICULAR TO THE PROPOSAL FOR THE REORGANIZATION OF THE KINGDOM OF HUNGARY. THIS ARTICLE EXPLORES THESE PLANS.

02956 DREW, A.

PROFILE OF THE SOUTH AFRICAN COMMUNIST PARTY JOURNAL OF COMMUNIST STUDIES, 8(2) (JUN 92), 160-165. THE AUTHOR DISCUSSES THE HISTORY OF THE SOUTH AFRICAN COMMUNIST PARTY AND SUMMARIZES THE WORK OF

02957 DREW, A.; BINNS, D.

PROSPECTS FOR SOCIALISM IN SOUTH AFRICA: AN INTERYIEW WITH NEVILLE ALEXANDER

JOURNAL OF COMMUNIST STUDIES, 8(4) (DEC 92), 251-274.

THE AUTHORS SUMMARIZE THE CAREER OF NEVILLE ALEXANDER,

CHAIRMAN OF THE WORKERS' ORGANIZATION FOR SOCIALIST ACTION, CHAIRMAN OF THE WORKERS ORGANIZATION FOR SOCIALIST ACTI FOCUSING ON HIS POLITICAL IDEAS. THEN THEY RECORD HIS
ANSWERS TO OUESTIONS ABOUT THE WORKING CLASS STRUGGLE IN ANSWERS TO QUESTIONS ABOUT THE WORKING CLASS STRUGGLE IN
SOUTH AFRICA. THE CONCEPT OF "RACIAL CAPITALISM," THE STATUS SOUTH AFRICA, THE CONCEPT OF "RACIAL CAPITALISM," THE STATUS OF THE LIBERATION MOVEMENT IN SOUTH AFRICA, THE INFLUENCE OF
TROTSKYISM ON SOUTH AFRICAN MARXISTS, AND HOW THE COLLAPSE TROTSKYISM ON SOUTH AFRICAN MARXISTS, AND HOW THE COLLAPSE
OF THE SOVIET UNION HAS AFFECTED THE SOCIALIST CAUSE IN OF THE SOVIET
SOUTH AFRICA.

02958 DREWRY, G. JUDICIAL POLITICS IN BRITAIN: PATROLLING THE BOUNDARIES WEST EUROPEAN POLITICS, $15(3)$ ( JUL 92), 9-28.

THE AUTHOR CONSIDERS JUDICIAL POLICY-MAKING IN GREAT 
BRITAIN, NOTING THE PECUL IARLY BRITISH INSTI TUT IONAL RESTRAINTS ON JUDICIAL ACTION, INCLUDING PARLIAMENTARY SOVEREIGNTY, THE RESULTING SUBORDINATION OF ALL COURTS TO THE LEGISLATIVE BRANCH, AND THE ABSENCE OF A CONSTITUTION OR CODIFIED CHARTER OF RIGHTS. THOUGH THERE IS NO JUDICIAL POWER TO ANNUL LEGISLATIVE OR EXECUTIVE ACTIONS, BRITISH COURTS AND JUDGES STILL PLAY A SMALL, BUT SIGNIFICANT, ROLE IN POLICY-MAKING THROUGH THE COMMON LAN AND, IN PARTICULAR, THROUGH JUDICIAL REVIEW OF ADMINISTRATIVE ACTIONS. A WRITTEN BILL OF RIGHTS WOULD LIKELY DRAW COURTS FURTHER INTO THE

02959 DREYER, J.T.

THE ANTI-PEACEFUL TRANSFORMATION MOVEMENT; ASSOCIATION FOR ASIAN STUDES 1992 ANNUAL MEETING

ASSOCIATION FOR ASIAN STUDIES, 1992, 53.

ONE OF THE ALLEGATIONS MADE BY PRC CONSERVATIVES IN THE WAKE OF THE TIANANMEN INCIDENT OF JUNE 1989 WAS THAT WESTERN NATIONS IN GENERAL, AND THE UNITED STATES IN PARTICULAR, HAD
FOR SOME TIME BEEN ENGAGED IN A SUBVERSIVE PLOT AGAINST THEIR COUNTRY BASED ON SPREADING THE IDEA OF CHINA'S NONTHEIR COUNTRY BASED ON SPREADING THE IDEA OF CHINA'S NON-
VIOLENT EVOLUTION TOWARD CAPITALISH. THIS PLOT, THEY ALLEGED, VIOLENT EVOLUTION TOWARD CAPITALISM. THIS PLOT, THEY ALLEGED
AIMED AT MAKING THE PRC A VASSAL STATE OF THE CAPITALIST WORLD HEADED BY THE UNITED STATES SPECIAL EFFORTS HAD BEEN WORLD HEADED BY THE UNITED STATES. SPECIAL EFFORTS HAD
MADE TO INFILTRATE THE PEOPLE'S LIBERATION ARMY. THESE ALLEGATIONS BECAME MORE STRIDENT AFTER AMERICA'S STUNNING ALLEGATIONS SUCCESSES IN THE PERSIAN GULF IN EARLY 1991, AND THE USSR'S CONCOMITANT DECLINE AS A WORLD POWER. MANY WESTERN ANALYSTS HAVE ASSUMED THAT, AFTER THE DEATH OF THE PRC'S OCTOGENARIAN LEADERSHIP, LIBERAL IDEAS WILL AGAIN COME TO THE FORE. THE CAMPAIGN AGAINST PEACEFUL TRANSFORMATION IS INTERESTING, AMONG OTHER REASONS. IN THAT IT DRAHS HEAVILY ON THE HORK OF A YOUNG (42 AT PRESENT) CONSERVATIVE IDEOLOGUE NAMED HE XIN. THIS PAPER ANALYZES THE INTELLECTUAL UNDERPINNINGS OF THE CAMPAIGN, ITS DEVELOPMENT, AND ITS
IMPLICATIONS FOR THE PRC'S FUTURE DOMESTIC AND' FOREIGN POLICY.

02960 DREZE, J.; GAZDAR, $H$.

HUNGER AND POVERTY IN IRAQ, 1991

WORLD DEVELOPMENT, 20(7) (JUL 92), 921-945

THE AUTHORS ASSESS THE IMPACT OF ECONOMIC SANCTIONS, WAR,

AND INTERNAL CONFLICTS ON THE WELL-BEING OF IRAQ'S CIVILIAN POPULATION DURING AND AFTER THE GULF WAR. PARTICULAR POPULATION DURING AND AFTER THE GULF WAR. PARTICULAR ATTENTION IS PAID TO THE ISSUE OF FOOD ENTITLEMENTS AND
NUTRITIONAL DEPRIVATION. THE AUTHORS UTILIZE DATA COLLECTED NUTRITIONAL DEPRIVATION. THE AUTHORS UTILIIE DATA COLLECT
THROUGH HOUSEHOLD SURVEYS AND RELATED INVESTIGATIONS IN THROUGH HOUSEHOLD SURVEYS AND RELATED INVESTIGATIONS IN
DIFFERENT PARTS OF IRAQ. ECONOMIC REASONING AND EMPIRICAL DIFFERENT PARTS OF IRAQ. ECONOM BOTH POINT TO VERY HIGH LEVELS OF POVERTY ANALYSIS BOTH POINT TO VERY HIGH LEVELS OF POVERTY,
MORTALITY, AND NUTRITIONAL DEPRIVATION IN 1991. THE SHARP DECLINE IN LIVING STANDARDS IN THIS PERIOD CLEARLY DECLINE IN LIVING STANDARDS IN THIS PERIOD CLEARLY
CORRESPONDS TO THE COLLAPSE OF ECONOMIC ACTIVITY DUE TO WAR CORRESPONDS TO THE COLLAP
AND ECONOMIC SANCTIONS.

02961 DRINAN, R. : KUD, T.

THE 1991 BATTLE FOR HUMAN RIGHTS IN CHINA HUMAN RIGHTS QUARTERLY, 14(1) (FEB 92), 21

IN THE TWO-AN-A-HALF YEARS SINCE THE TIANANMEN MASSACRE, THE EXTENSION OF MOST-FAVORED-NATION (MFN) TRADE STATUS TO CHINA HAS BECOME THE FOCAL ISSUE IN SINO-US RELATIONS. THIS ARTICLE TRACES THE MFN BATTLE OF 1991, OFFERING THE VIEWPOINTS OF BOTH SIDES AND EXAMINING THE ISSUES INVOL VED IN THE DEBATE. IT ARGUES IN FAVOR OF EXTENDING MFN TO CHINA WITH A REASONABLE SET OF CONDITIONS AND ANALYZES THE REASONS FOR THE SENATE'S FAILURE TO PASS SUCH A MEASURE. THE ARTICLE CONCLUDES WITH SOME SUGGESTIONS FOR ACHIEVING GREATER RESPECT FOR HUMAN RIGHTS IN CHINA.

02962 DROPKIN, $N$

ISRAEL'S DIPLOMATIC OFFENSIVE IN AFRICA: THE CASE OF ZAIRE TRANSAFRICA FORUM, $9(1)$ (SPR 92), 15-26.

MOST AFRICAN COUNTRIES SEVERED DIPLOMATIC RELATIONS WITH ISRAEL FOLLOWING THE ARAB-ISRAELI WAR OF 1973. IN 1982 ZAIRE BROKE RANK AND RESTORED TIES WITH ISRAEL. THIS ESSAY EXPLORES THE REASONS UMDERLYING ZAIRE'S MOVE AND ASSERTS THAT THE PRIMARY MOTIVATION WAS PRESIOENT MOBUTU'S DESIRE TO STAY IN POWER DESPITE THE SERIOUS ARMED CHALLENGES TO HIS TOTALITARIAN RULE. FACED WITH GROWING ISOLATION FROM THE INTERNATIONAL COMMUNITY--ESPECIALLY FROM FRANCE, BELGIUM, AMD THE USA--MOBUTU TURNED TO ISRAEL TO OBTAIN MILITARY TRAINING FOR HIS SECURITY FORCES.

02963 DROR, Y.

ISRAEL WILL GO IN TRAUMAS
JERUSALEM JOURNAL OF INTERNATIONAL RELATIONS, 14(4) (DEC 92), 60-84

ISRAEL'S SITUATION AS A FORMATIVE SOCIETY, LOCATED IN AN UNSTABLE REGION AND SUBJECTED TO MANY STRESSES AND SURPRISES, ENSURES THAT THE CHAIN OF TRAUMAS IT HAS UNDERGONE WILL CONTINUE INTO THE FORESEEABLE FUTURE. THERE IS AN URGENT NEED FOR BETTER UNDERSTANDING OF THIS SITUATION AND FOR FORIULATION OF POLICIES AIMED AT IMPROVED COPING WITH TRAUMAS AND, WHERE POSSIBLE, EXPLOITATION OF THEIR POSITIVE POTENTIALITIES.
02964 DROWER, G

THE UK LABOUR PARTY'S DEPENDENT TERRITORIES POLICY ROUND TABLE, (320) (OCT 91), 477-482.

BRITAIN'S POLICY OF BENIGNLY ACCEPTING THE STATUS QUD IN ITS DEPENDENT TERRITORIES HAS REMAINED UNALTERED SINCE THE FALKLANDS CONFLICT--BUT COULD CHANGE IF THE LABOUR PARTY WINS THE FORTHCOMING UK GENERAL ELECTION. IN THE THATCHER YEARS. THE PERSONAL ANIMOSITY BETWEEN NEIL KINNOCK AND THE PRIME MINISTER MADE IT INSTINCTIVE FOR THE LABOUR LEADER TO TAKE A DIFFERENT STANCE TO THE GOVERMMENT ON THE PRINCIPAL ISSUES. KINHOCK'S PROCLIVITY BECAME TO MAKE OPPOSITION GESTURES JUST FOR THE SAKE OF OPPOSITION. THIS ARTICLE EXAMINES LABOUR'S POLICY TOWARDS THE FALKLANDS, HONG KONG, GIBRALTAR, AND OTHER "SMALLER TERRITORIES."

02965 DRYZEK, J

THE GOOD SOCIETY VERSUS THE STATE: FREEDOM AND NECESSITY IN POLITICAL INNOVATION

THE JOURMAL OF POLITICS, 54(2) (MAY 92), 518-542.

AS A PRACTICAL ENTERPRISE, POLITICAL INQUIRY HAS
A $918-542$.

HISTORICALLY TRIED TO ADDRESS AS WELL AS TO UMDERSTAND THE HISTORICALLY TRIED TO ADDRESS AS WELL AS TO UNDERSTAND THE
WORLD. THE RECENT EFFORTS OF POLITICAL THEORISTS IN THIS WERLD. THE RECENT EFFORTS OF POLITICAL THEORISTS IN THIS OF THE GOOD SOCIETY WHICH ARE INATTENTIVE TO REAL-WORLD CONSTRAINTS. ON THE OTHER HAND, EMPIRICAL WORK WHICH HAS CONSTRAINTS. ON THE OTHER HAND, EMPIRICAL WORK WHICH HAS

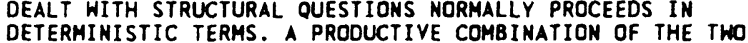
DETERMINISTIC TERMS. A PRODUCTIVE COMBINATION OF THE TWO TRADITIONS WOULD HAVE POLITICAL THEORY SUPPLY THE CONCEP EMPIRICAL WORK. THE LATTER IN ITS TURN WOULD SUPPLY EMPIRICAL RESOURCES TO COUNTERACT THE IDEALISH OF POLITICAL ENUMERATE SPACES FOR FREEDOM IN POLITICAL INMOVATION AMID STRUCTURAL NECESSITY.

02966 DRYZEK, J.S.

HOW FAR IS IT FROM VIRGINIA AND ROCHESTER TO FRANKFURT? PUBLIC CHOICE AS CRITICAL THEORY

BRITISH JOURNAL OF POLITICAL SCIENCE, 22(4) (OCT 92), 397-417.

PUBLIC CHOICE AND CRITICAL THEORY CONSTITUTE TWO VERY DIFFERENT AND OFTEN MUTUALLY-HOSTILE RESEARCH TRADITIONS. BUT THERE IS AN OPPORTUNITY FOR DIALOGUE ACROSS THE TWO TRADITIONS INASMUCH AS PUBLIC CHOICE HAS DEMONSTRATED THE INCOHERENCE OF A POLITICS--IN PARTICULAR, A DEMOCRATIC INCOHERENCE OF A POLITICS--IN PARTICULAR, A DEMOCRATIC
POLITICS-DF UNCONSTRAINED RATIONAL EGOISH. BY DEPLOYING AN POLITICS-DF UNCONSTRAINED RATIONAL EGOISM. BY DEPLOYING AN
EXPANDED, COMHUNICATIVE CONCEPTION OF RATIONALITY, CRITICAL EXPANDED, COMMUNICATIVE CONCEPTION OF RATIONALITY, CRITICAL
THEORY COULD HELP MOVE PUBLIC CHOICE BEYOND SEVERAL RELATED THEORY COULD HELP MOVE PUBLIC CHOICE BEYOND SEVERAL RELATED
IMPASSES. CRITICAL THEORY WOULD BENEFIT FROM THIS ENCOUNTER IMPASSES. CRITICAL THEORY WOULD BENEFIT FROM THIS ENCOUNTER
BY GAINING CONTENT FOR ITS CURRENTLY RATHER ABSTRACT

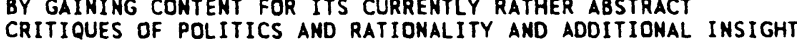
CRITIQUES OF POLITICS AND RATIONALITY AND ADDITIONAL INSIGHT INTO THE FORCES CONDUCIVE TO DIFFERENT KINDS OF RATIONAL

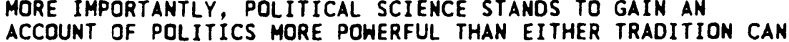
ACCOUNT OF POLITICS
MUSTER BY ITSELF.

02967 DUANY, J.

CARRIBEAN MIGRATION TO PUERTO RICO: A COMPARISON OF CUBANS AND DOMINICANS

INTERNATIONAL MIGRATION REVIEN, 29(1) (SPR 92), 46-66.

CUBAN AND DOMINICAN MIGRATION TO PUERTO RICO IS A RECENT EXAMPLE OF THE INTRA-CARIBBEAN MOVEMENTS INITIATED OVER 200 YEARS AGO. THIS ARTICLE ARGUES THAT MIGRATION WITHIN THE CARIBBEAN IS AS IMPORTANT AS MIGRATION OUTSIDE THE REGION AS IT EXAMINES THE SIMILARITIES AND DIFFERENCES BETWEEN CUBANS AND DOMINICANS IN PUERTO RICO. ITS OBJECTIVES ARE TO DETERMINE THE MAGNITUDE OF THE FLOWS, DESCRIBE THE MIGRANTS RESIDENTIAL PATTERNS, ANALYZE THEIR MODE OF INCORPORTATION INTO THE LABOR MARKET, ASSESS THEIR SOCIOECONOMIC ORIGINS AND EVALUATE THEIR REASONS FOR MIGRATING. THE ARTICLE CONCLUDES THAT INTRA-CARIBBEAN MIGRATION CONTIUES TO PROVIDE A SIGNIFICANT AVENUE FOR SOCIAL MOBILITY WITHIN THE REGION.

02968 DUANY, $H$.

THE NUER CONCEPT OF COVENANT AND COVENANTAL WAY OF LIFE PUBLIUS: THE JOURNAL OF FEDERALISM, 22(4) (FAL 92), 67-90. THE NUER OF SOUTHERN SUDAN HAVE A STRONG COYENANTAL TRADITION WITHOUT THE FEDERAL POLITICAL APPARATUS ASSOCIATED WITH THO OR MORE LEVELS OF GOVERMMENT IN A FEDERAL GOVERNMENTAL SYSTEM. THERE ARE IMPORTANT FEATURES OF NUER SOCIETY PERTAINING TO THE IDEAS OF COVENANT, BREACH OF SOCIETY PERTAINING TO THE IDEAS OF COVENANT, BREACH OF
COVENANT, AND REESTABLISHING THE BONDS OF COVENANTAL COVENANT, AND REESTABLISHING THE BOMDS OF COVENANTAL RELATIONSHIPS THAT HAVE IMPORTANT IMPLICATIONS FOR ALL
COVENANTING SOCIETIES. HOW THE NUER THINK ABOUT THEMSELVES, COVENANTING SOCIETIES. HOW THE NUER THINK ABOUT THEMSELVES, WITH THE LARGER WORLD ARE ESSENTIAL ELEMENTS IN THEIR WAY OF LIFE.

02969 DUBE, $S$

BALANCE OF POWER AT THE UN

WORLD PRESS REVIEN, 39(12) (DEC 92), 56.

DESPITE IDEALISM ABOUT WORLD PEACE AND INTERMATIONAL COOPERATION, THE UNITED NATIONS IS NOT A PLAYGROUND FOR THE 
WEAK. POHER AND MONEY DOMINATE THE UN SYSTEM. BOTH ARE NEEDED TO CORNER TOP-MANAGEMENT POSITIONS. SO IT IS NOT SURPRISING THAT MEN FROM RICH, INDUSTRIALIZED COUNTRIES OCCUPY AN OVERWHELMING SHARE OF THE KEY POSTS IN THE UN SECRETARIAT AND THE UN'S SPECIALIZED AGENCIES. THE MAJOR LOSERS ARE WOMEN AND NATIONALS OF DEVELOPING COUNTRIES.

02970 DUCATEL, K.; MILES, I

INTERMATIONÁLIZATION OF INFORMATION TECHNOLOGY SERVICES AND PUBLIC POLICY IMPLICATIONS

WORLD DEVELOPMENT, 20(12) (DEC 92), 1843-1857.

WORLD TELECOMMUNICATIONS TRAFFIC GREW AT A RATE OF MORE THAN 15\% PER YEAR IN THE 1980 'S, SUBSTANTIALLY FASTER THAN MERCHANDISE OR SERVICE TRADE. THE GROWTH OF SUCH TRAFFIC IS LINKED CLOSELY TO THE INTERMATIONAL FLOW OF SERVICES AND INVESTMENT. ECONOMIZING ON TIME, INVENTORIES, AND FINANCIAL BALANCES ARE IMPORTANT IN THE USE DF INTERNATIONAL TELECOMMUNICATIONS NETWORKS. AT THE SAME TIME, NETWORK PROVIDERS ARE ENGAGING IN INTERNATIONAL ALLIANCES TO SUPPLY A VARIETY OF TELECOMMUNICATION SERVICES ACROSS BORDERS. THESE ALLIANCES WILL STRONGLY INFLUENCE THE FURTHER EVOLUTION OF NATIONAL AND INTERNATIONAL REGULATORY REGIMES AN INTERNATIONAL REGIME MORE OPEN IN THE TRADE OF SERVICES AND MOVEMENT OF INVESTMENT IS NEEDED.

02971 DUCH, R.M.; GIBSON, J.L.

"PUTTING UP WITH" FASCISTS IN WESTERN EUROPE:

COMPARATIVE, CROSS-LEVEL ANALYSIS OF POLITICAL TOLERANCE

WESTERN POLITICAL QUARTERLY, 45(1) (MAR 92), 237-274.

THE AUTHORS EXAMINE POLITICAL INTOLERANCE IN THE MEMBER COUNTRIES OF THE EUROPEAN COMMUNITY. BASED ON PUBLIC OPINION SURVEYS CONDUCTED IN 1988, THEY TEST SEVERAL HYPOTHESES DERIVED FROM THEORIES OF CITIZEN SOCIALIZATION TO SYSTEM NORMS. THE DATA REVEAL STARTLINGLY LOW LEVELS OF POLITICAL TOLERANCE IN WESTERN EUROPE. NOT SURPRISINGLY, THOSE WHO ARE MORE THREATENED BY THEIR POLITICAL ENEMIES ARE LESS LIKELY TO TOLERATE THEM, AND THE MORE HIGHLY-EDUCATED TEND TO BE MORE TOL ERANT TOLERANCE IS MORE HIDESPREAD IM THE MEH DEMOCRACIES (SPAIN, PORTUGAL, GREECE), WHILE THOSE WHO HAVE EN JOYED DEMOCRACY FOR A LONG TIME SEEM TO TAKE IT FOR GRANTED. WITHIN MATURE OEMOCRACIES, IDEOLOGICAL DIVERSI AND STRONG PARTY-GROUP LINKAGES CONTRIBUTE TO POLITICAL TOLERANCE. THE GREATER POL ITICAL TOLERANCE IN THE NEW
DEMOCRACIES REFLECTS THE RESIDUE OF EXPERIENCES FROM THE DEMOCRATIZATION ERA.

02972 DUDLEY, L.

PUNISHMENT, REWARD, AND THE FORTUNES OF STATES PUBLIC CHOICE, 74(3) (OCT 92), 293-315.

EXISTING THEORIES EXPLAIN THE RISE AND FALL OF STATES EITHER BY RANDOM FACTORS SPECIFIC TO EACH STATE OR BY A LIFECYCLE TO WHICH ANY STATE EVENTUALLY SUCCUMBS. BUT NEITHER APPROACH CAN EXPLAIN SYSTEMATIC PATTERNS, SUCH AS THE TENDENCY TOWARD SMALLER POLITICAL UNITS DURING THE MILLENNIUM FROM 400-1400 A.D. AND THE MOVEMENT IN THE OPPOSITE DIRECTION OVER THE LAST SIX CENTURIES. IN THIS PAPER, THE AUTHOR ARGUES THAT SUCH CHANGES ARE DUE TO INNOVATIONS IN THE TECHNOLOGY OF INFORMATION PROCESSING AND MILITARY CONTROL THAT ALTER THE COST OF GENERATING REWARDS AND IMPOSING PUNISHMENT.

02973 DUDHICK, N.

THE QUEST FOR IDENTITY

CULTURAL SURVIVAL QUARTERLY, 16(1) (WIN 92), 26-29.

THE NATIONAL MOVEMENTS IN ARMENIA AND AZERBAIDZHAN THAT HAVE EMERGED IN RESPONSE TO THE STRUGGLE IN NAGORNO KARABAGH HAVE TRANSFORMED POLITICAL LIFE IN THE REPUBLICS AND BROUGHT THE REGION TO THE BRINK OF ALL-OUT WAR. THE ROOTS OF THIS COMPLEX SITUATION LIE IN AZERBAIDZHAN'S CONTROL OF NAGORNO KARABAGH. TO UNDERSTAND HOW NAGORNO KARABAGH, WITH A LARGELY ARMENIAN POPULATION AND SEPARATED FROM ARMENIA BY ONLY A FEH MILES, CAME TO BE PART OF AZERBAIDZHAN, IT IS NECESSARY TO GO BACK TO THE EARLY NINETEENTH CENTURY WHEN RUSSIA ANNEXED GO BACK TO THE EARLY NINE

02974 DUEDNEY, D.; IKENBERRY, G.

THE INTERMATIONAL SOURCES OF SOVIET CHANGE

THE INTERNATIONAL SOURCES OF SOVIET CHANGE
INTERNATIONAL SECURITY, 16 (3) (HIN 91 ), $74--118$.

NTERNATIONAL SECURITY, 16 ( 3 ) (WIN 91), 74--118.
THE AUTHORS EXAMINE THE CAUSES THAT ULTIMATELY PERSUADED THE AUTHORS EXAMINE THE CAUSES THAT ULTIMATELY PERSUADED
THE SOVIET UNION TO ABANDON ITS POLICIES OF CONFRONTATION THE SOVIET UNION TO ABANDON ITS POLICIES OF CONFRONTATION AND INTEGRATE ITSELF INTO WESTERN-DOMINATED INTERNATIONAL NUCLEAR WEAPONS, THE SPREAD OF LIBERAL CAPITALIST STATES, NUCLEAR WEAPONS, THE SPREAD OF LIBERAL CAPITALIST STATES, THE ECONOMIC DYNAMISH OF THE HEST, THE DIMINISHING APPEAL OF MARXISM-LENINISM, THE GROWTH OF TRANSNATIONAL NETWORKS, AND THE ATTRACTIVENESS OF WESTERN CULTURE, CREATED AN INTERNATIONAL ENVIRONMENT THAT THWARTED SOVIET EXPANSIONISM WHILE PRESENTING AN APPEALING ALTERMATIVE.

02975 DUFFIELD, J.

INTERNATIONAL REGIMES AND ALLIANCE BEHAVIOR: EXPLAINING NATO CONVENTIONAL FORCE LEVELS

INTERNATIONAL ORGANIZATION, 46(4) (FAL 92), 857-898.

THIS ARTICLE SEEKS TO EXPLAIN NATO'S RECORD OF STABILTIY
IN TERMS OF THREE WIDELY USED THEORIES OF INTERNATIONAL RELATIONS. IT ARGUES THAT BALANCE-OF-POWER THEORY AND PUBLIC GOOD THEORY CANNOT ALONE PROVIDE A SATISFACTORY ACCOUNT. THEY MUST BE SUPPLEMENTED BY REGIME THEORY. IT SHOWS HOW AN INTERNATIONAL REGIME HAS INFLUENCED THE PROVISION OF CONVENTIONAL FORCES IN THE CENTRAL REGION BY ALLIANCE MEMBERS. THE MODEL STRESSES BOTH THE WAYS IN WHICH REGIMES EFFECTIVELY MODIFY THE INTERNATIONAL ENVIRONMENT WITHIN WHICH STATES OPERATE ALTERING THE COSTS AND BENFITS ASICH STATES OPERATE, ALTERING THE COSTS AND BENFITS ASSOCIATED WITH OIFFERENT COURSES OF ACTIONS, AND THE WAYS IN WHICH PAR

02976 DUFFIELD, J.S.

THE SOVIET MILITARY THREAT TO WESTERN EUROPE: U.S.

ESTIMATES IN THE 1950'S AND 1960'S

JOURNAL OF STRATEGIC STUDIES, 15(2) (JUN 92), 208-227.

THE AUTHOR INVESTIGATES THE FORMULATION AND USE OF U.S. ESTIMATES OF SOVIET GROUND FORCE CAPABILITIES FROM THE FOUNDING OF NATO THROUGH THE MID-1960'S. HE SUMMARIZES HOW THE SOVIET THREAT IN EUROPE HAS PUBLICLY CHARACTERIZED IN THE EARLY 1950'S AND THE CONVENTIONAL WISDOM ABOUT THE REASSESSMENT THAT OCCURRED ROUGHLY 10 YEARS LATER. NEXT, HE DETAILS THE CONSIDERATIONS THAT WENT INTO THE PENTAGON ANALYSES OF THE EARLY $1960^{\prime}$ 'S AND DISCUSSES THE INTELL

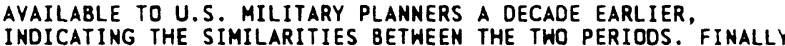
INDICATING THE SIMILARITIES BETWEEN THE THO PERIODS. FINALLY, 1960'S AND CONSIDERS THE DISCREPANCY BETWEEN WHAT THE U.S. MILITARY KNEW ABOUT THE THREAT AND HOW IT WAS PORTRAYED IN PUBLIC IN THE EARLY $1950^{\prime} \mathrm{S}$.

02977 DUFFIELD, M.

THE EMERGENCE OF TWO-TIER WELFARE IN AFRICA:

MARGINALIZATIOM OR AN OPPORTUMITY FOR REFORM?

PUBLIC ADMINISTRATION AND DEVELOPMENT, 12(2) (MAY 92),

139-154. DEFINED BY TWO INTERCONNECTED DEVELOPMENTS. FIRSTLY, A GROWING UNDERSTANDING THAT AFRICAN FAMINE IS A COMPLEX AND DEEP SEATED PROBLEM COMBINING POLITICAL, ENVIRONMENTALECONOMIC AND CONFLICT FACTORS. SECONDLY, IN RESPONSE TO THIS SITUATION A WORLD HISTORIC INTERNATIONALI ZATION OF PUBLIC WELFARE HAS OCCURRED. THIS PAPER, OY FIRST SKETCHING THE NATURE OF THE CRISIS, SEEKS TO CONTRIBUTE TO THE DEBATE BY WITHIN THE EMERGING SAFETY NET SYSTEM.

02978 DUGGAN, L.

MAKING IT PERFECTLY QUEER

SOCIALIST REVIEW, 22(1) (JAN 92), 11-32

THOUGH LIBERAL ASSIMILATIONISH AND MILITANT NATIONALISM HAVE DOMINATED LESBIAN AND GAY MOVEMENTS, "QUEERNESS" IS RECONFIGURING POLITICAL IDENTITIES ON THE MARGINS. IN THIS ESSAY THE AUTHOR STRIVES TO ELUCIDATE AND ADVOCATE A NEW POTENTIAL FOR NEWLY DEFINED QUEERNESS WITHIN POLITICS AND THEORY. FROM AN ACCOUNT OF CONCRETE EVENTS SHE CONSTRUCTS A CERTAIN POLITICAL HISTORY, AND FROM THAT HISTORY RAISES CERTAIN THEORETICAL QUESTIONS. SHE TAKES UP THE POSITON OF QUEER LARGELY IN ORDER TO CRITICIZE THE LIBERAL AMD NATIONALIST STRATEGIES IN GAY POLITICS AND TO ADVOCATE THE CONSTRUCTIONIST TURN IN LESBIAN AND GAY THEORIES AND PRACTICES.

02979 DUMAS, L.

ECONOMIC CONVERSION: FROM VISION TO REALITY

PEACE AND THE SCIENCES, O(O) (DEC 91) 13-19. THE WORLD IS CHANGING IN WAYS THAT REACH FROM THE GLOBAL AND PANHISTORICAL RIGHT DOWN INTO THE ORDINARY BUSINESS OF DAY-TO-DAY LIFE IN LARGE AND SMALL COMMUNITIES OVER MUCH OF DAY-TO-DAY LIFE IN LARGE AND SMALL COMMUNITIES OVER MUCH OF
THIS PLANET. AFTER THE COLD WAR, THE QUESTION OF HOW TO BEST THIS PLANET A AFTER THE COLD WAR, THE QUESTION OF HOW TO UTILIZE MILITARY ASSETS BECOMES A PROBLEM OF ECONOMIC
TRANSITION. THIS ARTICLE STATES THAT ECONOMIC CONVERSION IN TRANSITION. THIS ARTICLE STATES THAT ECONOMIC CONVERSION IN
THE MOST THOROUGH-GOING APPROACH. IT INVOLVES THE RETRAINING THE MOST THOROUGH-GOING APPROACH. IT INVOLVES THE RETRAINING
AND REDRIENTATION OF WORKFORCES, AND THE RESTRUCTURING OF AND REDRIENTATION OF WORKFORCES, AND THE RESTRUCTURING
ORGANIZATIONS AND FACILITIES THAT HAVE BEEN SERVING THE
MILITARY SECTOR SO THAT THEY CAN EFFICIENTLY PRODUCE MILITARY SECTOR SO THAT THEY

02980 DUMMETT, $M$.

TOWARD A MORE REPRESENTATIVE VOTING SYSTEM: THE PLANT REPORT

NEW LEFT REYIEW, (194) (JUL 92), 98-113.

THE AUTHOR ASSESSES THE INTERIM REPORT OF THE PLANT COMMITTEE, A GROUP APPOINTED BY THE LABOUR PARTY TO ADVISE IT ON ITS' POLICY TOWARD ELECTORAL REFORM IN THE UNITED KINGDOM.

02981 DUMPER, M.

ISRAELI SETTLEMENT IN THE OLD CITY OF JERUSALEM JOURALL OF PALESTINE STUDIES, XXI(4) (SUM 92), 32-53.

THERE HAVE BEEN FOUR PHASES OF ISRAELI SETTLEMENT IN THE OLD CITY. THE FIRST, IN THE IMMEDIATE AFTERMATH OF THE JUNE
1967 WAR, INVOLVED THE DEMOLITION OF THE ENTIRE MAGHARIB 
QUARTER AND THE EVICTION OF ITS PALESTINIAN RESIDENTS. DURING THE SECOND PHASE, FROM 1968 TO THE LATE 1970's, THE ISRAELI GOVERNMENT EXPANDED THE JENISH QUARTER BY EXPROPRIATING PALESTINIAN AND ISLAMIC PROPERTIES BETWEEN THE ARMENIAN AND MAGHARIB QUARTERS, EVICTING THE PALESTINIAN TENANTS, AND REPLACING THEM WITH ISRAELIS. BEGINNING IN THE EARLY 1980'S, MILITANT ISRAELI SETTLER GROUPS INITIATED THE THIRD PHASE AIMED AT ESTABLISHING AN ISRAELI PRESENCE IN THE HEART OF THE MUSLIM QUARTERS OF THE OLD CITY AND NEAR THE HARAM AL-SHARIF. THE FOURTH PHASE BEGAN IN 1987 WHEN MINISTER OF HOUSING ARIEL SHARON OCCUPIED A PROPERTY IN ONE OF THE MUSLIM QUARTERS. THE THIRD PHASE HAS CHARACTERIZED BY COVERT SETTLER PENETRATION, AS OPPOSED TO THE MORE OVERT OFFICIAL ACTION IN THE FOURTH PHASE.

02982 DUNAY, $P$.

STABILITY IN EAST CENTRAL EUROPE

JOURHAL OF PEACE RESEARCH, 29(1) (FEB 92), 1-6.

MANY ARGUE THAT THE TERMINATION OF FAMILIAR, PREDICTABLE, COLD WAR STRUCTURES UNAVOIDABLY LEADS TO INSTABILITY AND THAT THE EUROPEAN SECURITY STRUCTURE HAS WITHIN THE SPAN OF THAT THE EUROPEAN SECURITY STRUCTURE HAS WITHIN THE SPAN OF LESS THAN A YEAR MOVED FROM WHAT WAS PERCEIVED AS A STABLE TO A HIGHLY UNSTABLE OR EVEN VOLATILE ENTITY. THIS ARTICLE ARGUES THAT THE UNCERTAINTIES OF THE EAST-CENTRAL EUROPEAN REGION ARE ROOTED IN CONCERNS OF INTERNATIONAL POL ITICS AND SECURITY. IT CLOSELY EXAMINES THREE ISSUE AREAS: THE CHANGE IN THE TERRITORIAL STATUS QUD; THE NEH GEOSTRATEGIC ROLE
ATTRIBUTED TO THE COUNTRIES OF CENTRAL EUROPE; AND THE NEW INSTITUTIONAL ARRANGEMENTS AFTER THE DISSOLUTION OF THE INSTITUTIONAL ARRANGEMENTS AFTER
WARSAH TREATY ORGANIZATION (WTO).

02983 DUNBAR-ORTIZ, R

THE FUTURE OF THE MISKITO PEOPLE IN A TROUBLED BORDERLAND NICARAGUAN PERSPECTIVES, (19) (FAL 90), 15-19.

THIS ARTICLE INVESTIGATES THE PROSPECTS FOR THE MISKITO

PEOPLE IN LIGHT OF THE RECENT NICARAGUAN ELECTION. THE AUTHOR VIEHS THE ELECTION AS AN EXPRESSION OF MISKITO DEMOCRATIC RIGHTS AMD A STRIDE TOWARD THEIR AUTONOMOUS GOVERNMENT. THE ANIMOSITY BETHEEN THE INDIAN MISKITOS AND THE MESTIZOS, SPANISH-SPEAKING SETTLERS, IS DESCRIBED. DEVELOPMENTS AFTER THE ELECTION ORIGINATING WITH THE CHAMORRO GOVERMMENT THAT ARE UNFAVORABLE TO THE MISKITOS, PARTICULARLY THE CREATION OF A NEW MINISTRY FOR THE DEVELOPMENT OF THE ATLANTIC COAST, ARE EXAMINED.

02984 DUNCAN, C.; EPPS, $W$.

THE DEMISE OF \&COUNTRYMINDEDNESS': NEH PLAYERS OR CHANGING VALUES IN AUSTRALIAN RURAL POLITICS

POLIIICAL GEOGRAPHY QUARTERLY 11 (5) (SEP 92), $430-448$ AITKIN'S ANALYSIS OF THE NATIONAL PARTY DEPICTS IT AS AN IDEOLOGICALLY BASED PARTY, BORN OF A PAST POLITICAL CULTURE IDEOLOGICALLY BASED PARTY, BORN OF A PAST POLITICAL CULLTUR THAT THE PARTY'S ELECTORAL FORTUMES WERE LIKELY TO DECLINE THAT THE PARTY'S ELECTORAL FORTUNES WERE LIKELY TO DECLINE AS A RESUL TF THE IMPACT THAT DEMOGRAPHIC AND HENCE SOCIS CHANGE WAS HAVING ON THE COUNTRYMINDEDNESS ETHOS THAT HAS
UNPERPINNED THE PARTY'S ELECTORAL SUCCESS SINCE THE 1920. UNPERPINNED THE PARTY'S ELECTORAL SUCCESS SINCE THE 192 THIS PAPER EXAMINES AITKIN'S THESIS BY ANALYSING THE NATIONAL PARTY'S PERFORMANCE IN SIX NORTHERN NEW SOUTH WALES
ELECTORATES IN RECENT FEDERAL ELECTIONS, AND CONSIDERS THE ELECTORATES IN RECENT FEDERAL ELECTIONS, AND CONSIDERS THE
IMPACT THAT DEMOGRAPHIC AND SOCIAL CHANGE HAS HAD ON THE PARTY'S ELECTORAL FORTUMES.

02985 DUNCOMBE, S.; DUNCOMBE, W.: KINNEY, R. FACTORS INFLUENCING THE POLITICS AND PROCESS OF COUNTY GOVERNMENT BUDGETING

STATE AND LOCAL GOVERNMENT REVIEH, 24(1) (WIN 92), 19-27. THE RESULTS OF A NATIONAL SURVEY ON THE POLITICS AND PROCESS OF BUDGETING IN NEARLY 200 COUNTIES ARE REPORTED. THE AUTHORS FIND THAT REVENUE AVAILABILITY IS THE SINGLE MOST IMPORTANT DETERMINANT OF THE TOTAL COUNTY BUDGET. OTHER KEY FACTORS THAT GREATLY INFLUENCE COUNTY BUDGETS ARE FEDERAL AND STATE MANDATES, TAX AND DEBT LIMITATIONS, AND THE PRIORITIES OF COUNTY OFFICIALS. THIS ARTICLE ALSO EXAMINES THE PROCESS OF COUNTY BUDGETING, PARTICULARLY WHO HAS THE PRIMARY REPSONSIBILITY FOR PREPARING COUNTY BUDGETS THE AUTHORS FDUND THAT FENER THAN 10 PERCENT DF THE SAMPLE COUNTIES HAD AN EXECUTIVE BUDGET OF THE TYPE FOUND IN STATE OR NATIOHAL GOVERNMENTS.

02986 DUNKEL, T.

ANOTHER WAR

INSIGHT, 7 (7) (FEB 91), 15-17.

THE PRINT MEDIA, UNABLE TO COMBAT THE IMMEDIACY OF TELEVISION WAR COVERAGE, HAVE FOUGHT BACK WITH HUMAN INTEREST STORIES AND IN -DEPTH ASSESSMENTS. HOWEVER, THE INTEREST STORIES AND IN -DEPTH ASSESSMENTS. HOWEVER, THE STORIES OFTEN SEEM LACKLUSTER HHEN COMPARED HITH THE SPARKLE OF HAR FOOTAGE. THE COMPETITION WITH TELEVISION IS COMPOUNDED BY THE PENTAGON'S TIGHTENED REINS ON THE OVERSEAS PRESS CORPS. NEVERTHELESS, NEWSPAPER CIRCULATION HAS INCREASED ALMOST UNIVERSALLY SINCE THE HAR BEGAN.

02987 DUNLAP, $R$. PUBLIC' OPINION IN THE 1980S: CLEAR CONSENSUS, AMBIGUOUS COMMI TMENT
ENVIRONMENT, 33(8) (OCT 91), 10-15, 32-37

IS PROTECTING THE ENVIRONMENT SO IMPORTANT THAT ENVIRONMENTAL STANDARDS CANNDT BE TOO HIGH AND IMPROVEMENTS MUST BE MADE REGARDLESS OF COST? DURING THE 1980S. THE PROPORTION OF THE U.S. PUBLIC THAT RESPONDED POSITIVELY TO THIS QUESTION INCREASED FROM LESS THAN HALF TO NEARLY THREEQUARTERS. TRANSFORMING THIS SENTIMENT INTO EFFECTIVE POLITICAL ACTION, HOWEVER, WILL BE THE CHALLENGE FOR THE DECADE AHEAD.

02988 DUNLEAVY, P.; MARGETTS, H.; WEIR, S. HOW BRITAIN WOULD HAVE VOTED UNDER ALTERNATIVE ELECTORAL SYSTEMS

PARLIAMENTARY AFFAIRS, 45(4) (OCT 92), 640-655.

IN 1992, THE CONTINUATION OF PLURALITY RULE ELECTIONS BECAME A SERIOUS GENERAL ELECTION ISSUE. THIS PAPER PROVIDES A SUMMARY OF THE AUTHOR'S RESULTS FOR THREE AREAS OF ENGLAND, LONDON, SCOTLAND AND WALES. IT DISCUSSES THE LEVEL OF PUBLIC SUPPORT FOR THE ELECTORAL REFORM AND THE HAYS IN WHICH THE PLURALITY RULE ELECTORAL SYSTEM ALLOCATED SEATS IN RELATION TO VOTES ACROSS THE DIFFERENT PARTS OF THE COUNTRY IT DESCRIBES THE DIFFERENT ELECTORAL SYSTEMS AND DISCUSSES IT DESCRIBES THE DIFFERENT ELECTORAL SYSTEMS AND DISCUSSES IN TURN WHAT KIND OF HOUSE OF COMMONS WOULD HAVE RESULTED AT THE 1992 ELECTION UNDER THE ALTERNATIVE VOTE, THE ADOITIOMA
MEMBER SYSTEM, THE SINGLE TRANSFERABLE VOTE AND THE LIST MEMBER SYSTEM, THE SINGLE TRANSFERABLE
SYSTEM OF PROPORTIONAL REPRESENTATION.

02989 DUNLOP, J.

NATIONAL INTEREST, (23) (SPR 91), 24-32.

WHILE AMERICAN ATTENTION WAS FOCUSED ON THE PERSIAN GULF THE SOVIET UNION APPEARS TO BE BEGINNING AN AMBITIOUS ROLLING COUP, WHICH THREATENS TO SPREAD FROM THE BALTIC TO THE REMAINING TWELVE SOVIET REPUBLICS. THE GORBACHEV "CENTER" SEEMS TO HAVE LAUNCHED A SLOH-MOTION CIVIL WAR AGAINST THE CONSTITUENT REPUBLICS AND SUCH PRO-DEMOCRACY ELECTED BODIES AS THE MOSCOW CITY COUNCIL. IN THE ECONOMIC SPHERE, THE SOVIET LEADERSHIP HAS TAKEN A DECISIVE STEP AWAY FROM MARKET REFORM BACK TOWARD BREZHNEV-ERA CENTRAL PLANNING. THIS ARTICLE EXAMINES THIS PHENOMENON, ITS CAUSES, AND IMPLICATIONS FOR THE FUTURE OF EAST-WEST RELATIONS IN THE 1990 S.

02990 DUNLOP, J.B.

KGB SUBVERSION OF RUSSIAN ORTHODOX CHURCH

RFE/RL RESEARCH REPORT, 1(12) (MAR 92), 51-53.

THE RUSSIAN ORTHODOX CHURCH HAS RECENTLY BEEN SHAKEN BY REVELATIONS THAT TWO PERMANENT MEMBERS OF ITS RUL ING HOLY SYNOD AS WELL AS THE HEAD OF ITS PUBLICATIONS DEPARTMENT ARE SYNOD AS WELL AS THE HEAD OF ITS PUBLICATIONS DEPARTMENT
VETERAN KGB AGENTS. IT IS EXPECTED THAT, IN THE LONG RUN, VETERAN KGB AGENTS. IT IS EXPECTED THAT, IN THE LONG RUN,
THE SCANDAL WILL STRENGTHEN THE HAND OF TWO COMPETING ECCLESIASTICAL ORGANIZATIONS: THE RUSSIAN ORTHODOX CHURCH ECCLESIASTICAL ORGANIZATIONS: THE RUSSIAN ORTHOD

02991 DUNA, C

CHANGING THE DESIGN: CABINET DECISION-MAKING IN THREE PROYIMCIAL GOVERMMENTS

CANADIAN PUBLIC ADMINISTRATION, 34(4) (WIN 91), 621-640. THE AUTHOR INVESTIGATES CABINET DECISION-MAKING IN THE PROVINCIAL GOVERNMENTS OF SASKATCHENAN, MANITOBA, AND BRITISH COLUMBIA, FOCUSING ON THE FORCES THAT UNDERGIRD THE INITIATION AND PERSISTENCE OF CABINET INSTI IUT IONALI ZATION UNCOORDINATED CENTRAL EXECUTIVES HAVE GIVEN WAY TO THOSE THAT ARE MORE STRUCTURED, MORE COLLEGIAL, AND MORE PRONE TO EMPHASIZE PLANNING AND COORDINATION. THE' FACTORS PROMOTING INITIAL CABINET INSTITUTIONALIZATION IN THE THREE PROVINCES WERE A MIXTURE OF IDEOLOGY, PRAGMATISM, AND HISTORICAL PRECEDENT UNIQUE TO EACH PROVINCE. NOT SURPRISINGLY, THE INSTITUTIONALIZATION OF PROVINCIAL CABINETS HAS HAD MAJOR EFFECTS ON POLITICAL ACTORS AND FUNCTIONS IN THE THREE PROVINCES.

02992 DUNA, J.F.

HARD TIMES IN RUSSIA FOSTER CONSPIRACY THEORIES

RFE/RL RESEARCH REPORT, 1(46) (NOV 91), 24-29.

CONSPIRACY THEORIES ARE NOT NEW IN RUSSIA, BUT TODAY THEY ARE MORE PREVALENT THAN EVER. SOME CONSERVATIVES ACCUSE PAST AND PRESENT GOVERNMENTS OF CONSPIRING HITH THE WEST TO DESTROY THE COUNTRY. LIBERALS AND RADICALS, ON THE OTHER HAND, FEAR THAT NEO-BOL SHEVIKS ARE AGAIN PLOTTING A RETURN TO POWER. THE CIRCULATION OF SUCH THEORIES BOTH REFLECTS THE DEPTH OF THE SYSTEMIC CRISIS THE COUNTRY NOW FACES AND DEPTH OF THE SYSTEMIC CRISIS THE COUNTRY NOW FACES AND
INCREASES THE SENSE OF INSECURITY AMONG THE POPULATION, INCREASES THE SENSE OF INSECURITY AMONG THE POPULATION, CREDENCE BY MASS-CIRCULATION NEWSPAPERS. THUS, CONSPIRACY CREDENCE BY MASS-CIRCULATION NEWSPAPERS. THUS, CONSPIRACY NEH PLOTTERS TO INTERVENE POLITICALIY IN THE NAME OF NEW PLOTTERS TY

02993 DUMY, K.

PAKISTAAN'S ENERGY POSITION: PROBLEMS AND PROSPECTS

ASIAN SURVEY, 31(12) (DEC 91), 1186-1199.

PAKISTAN HAS ONE OF THE WORLD'S FASTEST GROWING 
ECONOMIES, AND ENERGY RESOURCE DEVELLPMENT WILL BE ESSENTIAL IN ITS ABILITY TO SUSTAIN HIGH GROWTH RATES THROUGH THE 1990S. THIS ARTICLE REVIEWS PAKISTAN'S ENERGY POSITION, PROBLEMS, AND PROSPECTS. THE FIRST SECTION EXAMINES THE SUPPLIES OF CONVENTIONAL RESOURCES, IDENTIFIES INEFFICIENCIES IN ENERGY PROVISION AND CONSUMPTION, AND ASSESSES SECTORAL TRENDS. NEXT, THE OIL, NATURAL GAS, COAL, AND ELECTICITY SECTORS ARE OISCUSSED, FOLLOWED BY A LOOK AT ALTERNATIVE AND TRADITIONAL SOURCES OF ENERGY--HOOD, BIOGAS, ALTERNATIVE AND TRADITIONAL SOURCES OF ENERGY--HOOD, BIOGAS, SMALL HYDROELECTRIC PLANTS, SOLAR, AND WIND ENERGY,
ENERGY-CAUSED BURDENS ON PAKISTAN'S ENVIRONMENT ARE ENERGY-CAUSED
CONSIDERED.

02994 DUNA, M.

OMAN: DEFENDING THE STRAIT

INSIGHT $9(1)$ (1992) 48-53.

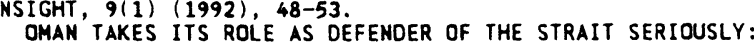
OMAN TAKES ITS ROLE AS DEFENDER OF THE STRAIT SERIOUS
DESPITE ITS SERIOUS COMMITMENT TO ECONOMIC DEVELPMENT EDUCATION, AND MODERNIZATION, IT SPENDS A SIGNIFICANT' PART OF WHAT FUNDS IT HAS ON DEFENSE, AUGUMENTED BY PAYMENTS BY ITS RICHER GULF COOPERATION COUNCIL PARTNERS. THIS ARTICLE EXPLORES THE THREAT, THE PRESSURE FOR A GULF FORCE, THE SULTAN'S ARMED FORCES, THE ROYAL ARMY, NAVY AND AIR FORCE OF OMAN AND OMAN'S LINKS' WITH THE WORLD. IT CONCLUDES THAT OMAN CONTINUES TO STRONGLY FAVOR A MORE CREDIBLE GCC DETERRENT, THOUGH ITS PROPOSAL OF A 100,000 MAN JOINT GULF FORCE HAS' LONG WAY TO GO.

02995 DUNN, M.

REVIVALIST ISLAM AND DEMOCRACY: THINKING ABOUT THE ALGERIAN QUANDARY

MIDDLE EAST POLICY, 1(2) (1992), 16-22.

DUE TO RECENT CHANGES IN ALGERIA. THE QUESTION IS BEING ASKED WHETHER MODERN POLITICALLY ACTIVIST ISLAMIC REVIVAL MOVEMENTS -- WHAT ARE USUALLY CALLED "FUNDAMENTALIST" MOVEMENTS -- CAN COEXIST HITH DEMOCRACY. THIS ARTICLE STATES THAT ALGERIA'S EXPERIMENT WITH DEMOCRACY APPEARS AT STATES THAT ALGERIA'S EXPERIMENT WITH DEMOCRACY APPEARS AT
BEST AMBIGUOUS. THE GREATEST OBSTACLE TO DEMOCRACY DOES NOT BEST AMBIGUOUS. THE GREATEST OBSTACLE TO DEMOCRACY DOES POLITICAL ORIENTATION OF THE STATE.

02996 DUNN, M.C.

AT THE END OF HISTORY, THE ARMS BAZAAR BECOMES A YARD SALE WASHINGTON REPORT ON MIDDLE EAST AFFAIRS, XI(3) (AUG 92), 20, 91

THE COLLAPSE OF THE SOVIET UNION HAS SPURRED NOT JUST THE CLASSIC MIDEAST ARMS BAZAAR BUT AN ARMS YARD SALE. SOVIET EOUIPMENT IS BEING OFFERED BY RUSSIA AND OTHER FORMER SOVIET REPUBLICS AT BARGAIN BASEMENT PRICES. EVEN ARAB STATES THAT HAVE TRADITIONALLY PURCHASED WEAPONS FROM THE WEST ARE BUYING BARGAINS FROM THE FORMER SOVIET BLOC.

02997 DUNM, M.C.

AZERBAIJAN: STRATEGIC PRIZE IN A VOLATILE REGION

WASHINGTON REPORT ON MIDDLE EAST AFFAIRS, XI(1) (JUN 92),

43, 88 .

THE AUTHOR REPORTS ON THE RECENT FIGHTING IN AZERBAIJAN

AND THE MISTORICAL BACKGROUND TO THE PRESENT CONFLICT.

02998 DUNN, $R$.

TOKYO OPENS ASIAN DOOR FOR PRETORIA

JAPAN TIMES (WEEKLY INTERMATIONAL EDITION), 32(7) (FEB 92), 3.

ON FEBRUARY 1, 1992, JAPAN FORMALLY ESTABLISHED FULL DIPLOMATIC TIES WITH SOUTH AFRICA. THIS WILL ALLOW JAPAN TO HAVE HIGH-LEVEL DISCUSSIONS WITH SOUTH AFRICA'S REPRESENTATIVES AND OFFICIALLY YOICE ITS CONCERNS TO PRESIDENT F.W. DEKLERK AND FOREIGN MINISTER PIK BOTHA. THIS SHOULD ALSO GIVE JAPAN A GREATER
OTHER SOUTHERN AFRICAN COUNTRIES.

02999 DUNAE, J.R.

PROTECTION OF MINORITY VOTING RIGHTS

PRESIDENTIAL STUDIES QUARTERLY, XXII(4) (FAL 92), 697-702.

MORE THAN 30 YEARS AFTER THE PASSAGE OF THE FIRST

FEDERAL CIVIL RIGHTS ACT SINCE RECONSTRUCTION. THE VOTING

FEDERAL CIVIL RIGHTS ACT SINCE RECONSTRUCTION, THE VOIING

RIGHTS OF MINORITY GROUPS ARE STILL BEING SUBVERTED. YET

THERE HAS BEEN GREAT PROGRESS AND GAINS IN THE NUMBERS

MINORITIIES, ESPECIALLY BLACKS AND HISPANICS, ELECTED TO

BECAUSE OF THE PROTECTIONS AGAINST DISCRIMINATING ELECTION

SYSTEMS AND DISTRICTING PLANS.

03000 DUNPHY, R, HOPKINS, S.

THE ORGANIZATIONAL AND POLITICAL EVOLUTION THE WORKERS PARTY OF IRELAND

JOURNAL OF COMMUNIST STUDIES, 8(3) (SEP 92), 91-118.

THE WORKERS' PARTY OF IRELAND (WP) WAS ALMOST ALONE AMONGST WEST EUROPEAN COMMUNIST AND WORKERS' PARTIES IN HAVING EXPERIENCED STEADY, IF MODEST, ELECTORAL GROWTH THROUGHOUT THE 1980S. THE PARTY IS A RECENT CONVERT TO MARXISM-LENINISM, AND A NEH GENERATION OF HP LEADERS SOUGHT BY THE LATE 1980 S TO TRANSCEND THAT IDEOLOGY'S PERCEIVED LIMITATIONS. THEIR EFFORTS WERE RESISTED BY AN OLDER
LEADERSHIP GENERATION WHICH HAD ZEALOUSLY ADOPTED MARXISMLENINISM AS A MOOEL FOR PARTY-BUILDING DURING THE 1970S. THE ENSUING CONFLICT LED TO A SPLIT IN THE WP ANO THE CREATION OF A NEW PARTY--DEMOCRATIC LEFT--BY THE REFORM-ORIENTED MAJORITY IN MARCH 1992.

03001 DUNPHY, R.; HOPKINS, S.

THE 1992 ALBANIAN ELECTIONS

JOURNAL OF COMMUNIST STUDIES, 8(3) (SEP 92), 119-128.

IN MARCH 1992, FOR THE SECOND TIME IN A YEAR, ALBANIA HELD PARL IAMENTARY ELECTIONS. THE ELECTIONS WERE

PRECIPITATED BY THE WITHDRAHAL OF SOME OPPOSITION MINISTERS FROM THE 'GOVERNMENT OF EXPERTS'--A COALITION OF SOCIALIST AND OPPOSITION PARTIES IN WHICH THE FORMER COMMUNISTS HAD MA JORITY. THIS ARTICLE REPORTS ON THE ELECTORAL LAN, THE CANDIDATES AND THE RESULTS.

03002 DUNTON, $C$.

DIAGNOSING THE ILLS

WEST AFRICA, (3885) (MAR 92), 370-371.

WITH NIGERIA ON THE THRESHOLD OF ITS THIRD REPUBLIC, THE LAST FEW YEARS HAVE SEEN A STEADY FLOH OF BOOKS AND PAMPHLETS DIAGNOSING THE NATION'S POLITICAL AND ECONOMIC ILLS. THESE ACCOUNTS ARE FREQUENTLY STIMULATING, BUT TOO OFTEN THEY OFFER ONLY ERSATZ EXPLANATIONS AND FAIL TO IDENTIFY THE STRUCTURAL PRINCIPLES THAT HAVE SUSTAINED POLITICAL AND ECONOMIC INJUSTICE FOR SO LONG, UNDER BOTH MILITARY AND CIVILIAN REGIMES. IN EXTREME CASES, ONE CAN ARGUE THAT IN FAILING TO ADDRESS THE STRUCTURAL PROBLEMS OF THE NIGERIAN STATE, THESE ACCOUNTS SERVE TO BUTTRESS THE STATUS QUD.

03003 DUPONT, P.

TIGERS BY THE TAIL

AMERICAN SPECTATOR, $25(9)$ (SEP 92), 41-42.

IF THERE IS A COMMON THREAD LINKING SOUTH KOREA, TAIWAN, AND HONG KONG IN THE 1990'S, IT IS COMMUNISH-AS A PRACTICAL ISSUE, AS A DEFINING IDEOLOGY, AND AS AN IMMINENT THREAT. NEW WORLD ORDER WISDOM HOLDS THAT CHINA IS GOING CAPITALIST NEW WORLD ORDER WISDOM HOLDS THAT CHINA IS GOING CAPITALIST AND THAT NORTH KOREA WILL TEMPER ITS WAYS WHEN KIM IL-SUNG FINALLY DIES. BUT A TOUR OF THE DEMILITARIZED ZONE NORTH SEDUL LEAVES LITTLE DOUBT THAT NORTH KOREAN COMMUNISM IS STILL FIRMLY IN PLACE AND AGGRESIVELY FOCUSED ON SOUTH KOR NORTH KOREA, VIETNAM, AND COMMUNIST CHINA DEFY THE NEH
HORLD ORDER. TO ANYONE LOOKING NORTH FROM HONG KONG, CHINA'S WORLD ORDER. TO ANYONE LDOKING NORTH FROM HONG KONG, CHINA'S DANGER.

03004 DUPONT, R.L.; HISH, E.D.

OPERATION TRIPWIRE REVISITED

ANNALS OF THE AMERICAN ACADEMY OF POLITICAL AND SOCIAL SCIENCE, 521 (MAY 92), 91-111.

A MAJOR PROPOSAL TO REFOCUS NATIONAL EFFORTS PERTAINING TO HEROIN ADDICTS IN THE CRIMINAL JUSTICE SYSTEM, CALLED "OPERATION TRIPHIRE," WAS ANHOUNCED IN OCTOBER 1977. THE PROPOSAL CALLED FOR UNIVERSAL DRUG TESTING OF OFFENDERS IN THE CRIMINAL JUSTICE SYSTEM AND FOR SUSTAINED DRUG-FREE STATUS, CONFIRMED BY REPEATED DRUG TESTIMG, AS A CONDITION FOR RELEASE. DESPITE BEING BASED ON A LARGE BODY OF SOLID RESEARCH EVIDENCE AND MEETING VITAL SOCIAL NEEDS, TRIPWIRE HAS NEVER IMPLEMENTED. TODAY, HITH THE INTRODUCTION OF THE DRUG USE FORECASTING PROGRAM, THERE IS A MORE CONVINCING INDICATION OF THE ENORMOUS ORUG ABUSE PROBLEMS IN THE CRIMINAL POPULATION. IT MAY BE TIME TO DUST OFF AND UPDATE THE ORIGINAL TRIPWIRE IDEA. IF THAT IS TO HAPPEN, IT WILL REQUIRE THE CONYERGENCE OF MANY POL ITICAL MEDIA, AND FISCAL FORCES. THE POTENTIAL BENEFICIARIES ARE MANY, BUT THE DDOS AGAINST OPERATION TRIPWIRE REMAIN LONG.

03005 DUPUY, T.

HOW THE WAR WAS WON

NATIONAL REVIEW, XLIII(5) (APR 91), 20-31.

A PRELIMINARY ANALYSIS OF THE KUWAIT WAR SUGGESTS THAT OF THE COMPONENTS OF THE REMARKABLE OUTCOME, SEVEN WERE PARTICULARLY SIGNIFICANT. THIS ARTICLE CONSIDERS ALL SEVEN
IN ORDER OF IMPORTANCE: AIR-POWER SUPERIORITY OF THE UN IN ORDER OF IMPORTANCE: AIR-POWER SUPERIORITY OF THE UN
FORCES: RELATIVE COMBAT EFFECTIVENESS OF UN AND IRAQI FORCES ; FORCES; RELATIVE COMBAT EFFECTIVENESS OF UN AND IRAQI FORCES
LEADERSHIP AND PLANNING (OR PROFESSIONALISM); LOGISTICAL LEADERSHIP ANO PLANNING (OR PROFESSIONALISM); LOGISTI
VIRTUOSITY; TECHNOLOGICAL SUPERIORITY; INTELLIGENCE VIRTUOSITY; TECHNOLOGICAL SUPERIORITY:

03006 DURAN, $K$

RIVALRIES OYER THE NEH MUSLIM COUNTRIES AUSSEN POLITIK, 43(4) (1992), 373-380.

THERE ARE FUMDAMENTALIY NEW PATTERNS OF RELATIONSHIP BOTH AMONG SUCCESSOR COUNTRIES AND OUTSIDE THE FORMER SOVIET UNION. PARTICULARLY IN CENTRAL AISA, FOREIGN COUNTRIES COMPETE FOR INFLUENCE AND BECOME INCREASINGLY ENGAGED IN CONFLICTING EFFORTS TO SHAPE FUTURE DEVELOPMENTS. THIS ARTICLE ANALYZES THE PROBLEMS HHICH RESULT.

03007 DURANT, $R$, ; KLUESHER, T.; LEGGE, JR , J. DOMESTIC PROGRAMS, BUDGET OUTLAYS, AND THE REAGAN 
REVOLUTION: A TEST OF COMPETING THEORIES IN FOUR POLICY ARENAS

JOURNAL OF PUBLIC ADMINISTRATION RESEARCH AND THEORY, $2(4)$ (OCT 92), 369-386

THIS STUDY INVESTIGATES THE IMPACT OF THE REAGAN ADMINISTRATION ON FOUR DOMESTIC BUDGET OUTLAYS TRANSPORTATION, HEALTH, COMMUNITY AND REGIONAL DEVELOPMENT, AND EDUCATION. USING AN INTERRUPTED TIME SERIES MODEL, THE AUTHORS TEST THE VALIDITY OF COMPETING HYPOTHESES REGARDING THE REAGAN REVOLUTION: THE SECULAR TREND, THE IMPRINT, AND THE REALIGMMENT THESES. THESE FINDINGS THEN ARE ASSESSED FOR THEIR IMPLICATIONS FOR THREE PERSPECTIVES ON PRESIDENTIAL LEADERSHIP.

03008 DURANT, $R$.

FIRE ALARMS, GARBAGE CANS, AND THE ADMINISTRATIVE PRESIDENCY

ADMINISTRATION AND SOCIETY, 23(1) (MAY 91), 94-122.

THIS EXPLORATORY ESSAY OFFERS AN ANALYTICAL FRAMEWORK FOR ASSESSING THE IMPLICATIONS OF THE ADMINISTRATIVE PRESIDENCY FOR WHAT HECLO TERMED THE "LARGER ORGANIZATIOM PRESIDENCY FOR WHAT HECLO TERMED THE "LARGER ORGANIZATION
LIFE OF GOVERNMENT." IT BEGINS BY OFFERING A FOUR-CELL LIFE OF GOVERNMENT." II BEGINS BY OFFERING A FOUR-CEL TYPOLOGY OF POLICY INITIATIVES ASSOCIATED WITH THE
ADMINISTRATIVE PRESIDENCY. THE ESSAY THEN LINKS DISPARATE ADMINISTRATIVE PRESIDENCY. THE ESSAY THEN LINKS DISPARATE TYPES OF POLITICAL DYMAMICS TO THESE FOUR TYPES. A THREEFOLD ARGUMENT IS PRESENTED. FIRST, PRESIDENTIAL APPOINTEES USING ADMINISTRATIVE STRATEGIES TO ALTER AGENCY AGENDAS ROUTINELY FIND THEMSELVES TRYING TO COPE WITH "FIRE ALARM" OVERSIGHT SECOND, THE TYPE OF POLICY INITIATIVE PURSUED (QUANTUM,
EMERGENT, CONVERGENT, AND GRADUALIST) WILL AFFECT THE NATURE, SCOPE, AND INTENSITY OF CONFLICT SPAWNED BY THIS TYPE OF OVERSIGHT (DISINTEGRATIVE, ADVERSARIAL, MANIPULATED AGREEMENT, AND MUTUAL ACCOMMODATION). FINALLY, THE DYNAMICS ILLUSTRATED INDICATE THAT THE ADMINISTRATIVE PRESIDENCY IS MORE PERMEABLE TO BOTH MICRO- AND MACROPOL ITICAL INTERVENTION THAN COMMONLY PORTRAYED BY EITHER ITS SUPPORTERS OR DETRACTORS. THE ESSAY CONCLUDES BY SUGGESTING AREAS OF RESEARCH THAT SCHOLARS INTERESTED IN THE

03009 DURENBERGER, D.; BRADLEY, B.; BYRD, R.C.; DECONCINI, D.; HARKIN, T.; LIEBERMAN, J.I.; MIKULSKI, B.A.; SEYMOUR, J. SHOULD THE FREEDOM SUPPORT ACT OF 1992 BE APPROVED? CONGRESSIONAL DIGEST, 71(8-9) (AUG 92), 206-223. THIS ARTICLE CONTAINS EXCERPTS FROM THE SENATE DEBATE OVER THE FREEDOM FOR RUSSIA AND EMERGING EURASIAN
DEMOCRACIES AND OPEN MARKETS SUPPORT ACT OF 1992.

03010 DUTT, A.K.

THE NIC'S, GLobal ACCUMULATION, AND UNEVEN DEVELOPMENT: IMPLICATIONS OF A SIMPLE THREE-REGION MODEL

WORLD DEVELOPMENT, $20(8)$ (AUG 92) $1159-1171$

AFTER DIVIDING THE WORLD INTO THREE REGIONS (THE NORTH, NEW-INDUSTRIALIZING COUNTRIES, AND THE REST OF THE SOUTH), THIS PAPER DEVELOPS A SIMPLE REGIOMAL MODEL OF THE GLOBAL' ECONOMY ALONG STRUCTURALIST LINES. THE MORTH PRODUCES AN INVESTMENT-CUM-CONSUMPTION GOOD WHILE THE NIC'S AND THE SOUTH PRODUCE TWO DIFFERENT CONSUAPTION GOOOS. THE NORTH GROWS WITH EXCESS CAPACITY ALONG KALECKI-KEYNES LINES; THE NIC'S ARE MODELED ALONG MARXIAN LINES WITH A GIVEN RATE OF EXPLOITATION; AND THE SOUTH IS MODELED ALONG LEWIS LINES WITH A GIVEN SUBSISTENCE WAGE. THE SHORT-RUN AND LONG-RUN DYNAMICS AND EQUILIBRIUM PROPERTIES OF THE MODEL ARE ANALYZED. IT IS SHOWN THAT PARAMETRIC SHIFTS THAT RESULT IN A NEGATIVE GROWTH OF NIC CAPITAL (AS COMPARED TO THE NORTH AND THE SOUTH) IN THE LONG RUN USUALLY RESULT IN UNEVEN NORTH-SOUTH DEVELOPMENT.

03011 DUTTA, D.K

PLANNING AND THE REgUlatoRy ROLE OF THE INDIAN STATE JOURNAL OF CONTEMPORARY ASIA, 22 (1) (1992), 82-93. IN THE COURSE OF TIME. THE STATE AS A POL ITICAL INSTITUTION HAS EXTENDED ITS AUTHORITY FROM THE POLITICAL SPHERE TO THE ECONOMIC ONE. IN THE CASE OF INDIA, DEVELOPMENT PLANS ARE BASED ON THE PRINCIPLE OF A MIXED ECONOMY IN WHICH BOTH THE PUBLIC AND PRIVATE SECTORS OPERATE SIDE BY SIDE. HITHIN THE APPROPRIATE LEGISLAIIVE FRAMEWORK THE STATE DESIGNS SHORT-TERM POLICIES IN LINE HITH ITS LONGTERM PLANS FOR THE COUNTRY'S ECONOMIC GROWTH AND DEVELOPMENT. THIS ARTICLE EXAMINES THE INTERRELATIONSHIP BETHEEN PLANS AND POLICIES UNDER DIFFERENT DEVELOPMENT STRATEGIES DURING AND POLICIES UNDER DIFFERENT DEVELOPMENT STRATEGIES DURING THE NEHRU ERA OF 1947-64, DURING THE PERIOD OF $1965-79$, AND
DURING THE EIGHTIES. THE AUTHOR CONCLUDES WITH A FEN GENERAL DURING THE EIGHTIES. THE AUTHOR CONCLUDES WITH A FEH

03012 DWIVEDI, O.P.

AN ETHICAL APPROACH TO ENVIRONMENTAL PROTECTION: A CODE OF CONDUCT AND GUIDING PRINCIPLES

CANADIAN PUBLIC ADMINISTRATION, 35(3) (FAL 92), 363-380.

THE WORLD COMMISSION ON ENVIRONMENT AND DEVELOPMENT HAS RECOMMENDED A SET OF ETHICAL PRINCIPLES CONCERNING

ENVIRONMENTAL PROTECTION AND SUSTAINABLE DEVELOPMENT. IN ITS "GREEN PLAN," CANADA HAS CONCEDED THE NEED FOR DEVELOPING
AUTHOR DISCUSSES THE ATTITUDES TOWARD NATURE THAT HAVE PRODUCED THE PRESENT ENVIRONMENTAL CRISIS; HOW HORLD CULTURES AND RELIGIONS COULD ASSIST HUMANITY TO CHANGE ITS PERSPECTIVES TOWARD NATURE: THE NEED FOR AN ENVIRONMENTAL CODE OF CONDUCT AND ITS BASIC PRINCIPLES AND TENETS; GUIDINC PRINCIPLES FOR ENVIRONMENTAL MANAGEMENT TO PUT GOVERNMENTAL COMMITMENT TO ENVIRONMENTAL STEWARDSHIP ON FIRMER GROUND; AND THE ROLE OF THE MEDIA, NONGOVERNMENTAL ORGANIZATIONS, AND INDIVIDUAL CITIZENS IN RAISING THE CONSCIOUSNESS ABOUT THE ENVIRONMENT THROUGH THE USE OF THE PROPOSED CODE.

03013 DWYRE, D.; STONECASH, J.

WHERE'S THE PARTY? CHANGING STATE PARTY ORGANIZATIONS AMERICAN POLITICS QUARTERLY, 20(3) (JUL 92), 326-344. THIS ARTICLE PRESENTS A COMPREHENSIVE CASE STUDY OF CHANGES IN STATE PARTY ORGAMIZATIONS. IT EXAMINES THE CONDITION AND GROWTH OF ALL STATE PARTY ORGANIZATION IN NEW YORK ACROSS THREE ELECTION CYCLES. THE LEGISLATIVE PARTY COMMITTEES ARE BETTER FINANCED THAN THE TRADITIONAL STATE PARTY COMMITTESS, AND THEY PLAY A MAJOR ROLE IN FINANCING STATE LEGISLATIVE CANDIDATES. THE FOCUS SHOULD BE AS MUCH ON STATE LEGISLATIVE CANDIDATES. THE FOCUS SHOULD BE AS M THE LEGISLATIVE PARTY CAMPAIGN COMMITTEES AS ON THE
TRADITIONAL STATE PARTY COMMITTEES WHEN TRYING TO UNDERSTAND TRADITIONAL STATE PARTY COMMITTEES WHEN TRYIM

03014 DZISAH, M.

COTE D'IVOIRE: DISCOURAGEMENT SETS IN

WEST AFRICA, 75(3925) (DEC 92), 2090-2099

AT PRESENT, UNLIKE WHEN COTE D'IVOIRE POLITICIANS COULD MOUNT PUBLIC PLATFORMS AND SHEET-TALK THEIR WILLING LISTENERS AND GET AWAY WITH IT, THEY ARE BEING MET BY A HOSTILE POPULACE, DEMANDING THEIR SHARE OF THE NATIONAL CAKE. THIS REPORT DESCRIBES CURRENT REACTIONS OF CITIZENS STUDENTS, WORKERS AND ESPECIALLY OF THE FARHING SECTOR. FARMERS ARE ANGRY BECAUSE AS PRODUCERS OF THE NATION'S WEALTH, THEY HAVE BEEN DENIED THEIR DUE SHARE OF THAT WEALTH.

03015 DZISAH, M.

THE HARD TIMES ARE HERE

WEST AFRICA, (3916) (OCT 92), 1667-1668

NOT LONG AGO FELIX HOUPHOUET BOIGHY'S COTE D'IVOIRE WAS BEING TOUTED AS AN ECONOMIC MIRACLE. THE PEOPLE BASKED IN THE COUNTRY'S ECONOMIC HELL-BEING AND POLITICAL STABILITY. TODAY, HARDSHIP HAS BECOME THE LOT OF NEARLY EVERYONE. POLITICAL UNCERTAINTIES CONTINUE TO PULL THE TIDE IN ONE DIRECTION, WHILE ECONOMIC RECESSION PULLS IT THE OTHER WAY. THE RESULT IS CHAOS.

03016 DZISAH, M.

THE POLITICS OF DEMOCRACY

HEST AFRICA, (3903) (JUL 92), 1131

HUMAN RIGHTS ORGANIZATIONS ARE CONCERNED ABOUT THE THREATS TO THE DEMOCRATIC PROCESS IN COTE D' IVOIRE, ESPECIALLY THE ARRESTS OF OPPOSITION LEADERS BY THE RULING PARTY. THE GOYERMMENT, BY ITS ACTIONS THUS FAR, HAS SHOWH PARTY THE GOVERMMENT, BY ITS ACTIONS THUS FAR, HAS SHOWN WILL ALLOW CITIZENS AT ANY GIVEN TIME.

03017 EAGLES, $M$

SOURCES OF VARIATION IN WORKING CLASS FORMATION EUROPEAN JOURNAL OF POLITICAL RESEARCH, 21(3) (APR 92), 225-243.

EMPIRICAL RESEARCH INTO THE VARIABILITY OF WORKING-CLASS POLITICS HAS TENDED TO CENTER ON THREE PERSPECTIVES: THE ECOLOGICAL, THE SECTORAL AND THE SOCIALIZATION. FOR AT LEAST A DECADE, PROPONENTS OF THESE RIVAL VIEWPOINTS ON THE POLITICIZATION OF CLASS HAVE ENGAGED IN A LIVELY BUT INCDNCLUSIVE DEBATE. THIS PAPER REPORTS A STUDY DESIGNED TO COMPARE THE RELATIVE PLAUSIBILITY AND EXPLANATORY POHER OF THESE RIVAL PERSPECTIVES. THE AUTHOR CONTENDS THAT SUCH COMPARATIVE TESTING IN A CAREFULLY-CHOSEN LOCALE (OR SET OF MICRO-LOCALES) CONSTITUTES A SUITABLE STRATEGY FOR EVALUATING THE RELATIVE PLAUSIBILITY OF THESE BROAD PERSPECTIVES. HE USES DATA FROM THE RESIDENTS OF THREE DIFFERENTIATED WORKING-CLASS NEIGHBORHOODS IN SHEFFIELD, ENGLAND.

03018 EAGLES, $M$

THE POLITICAL ECOLOGY OF CAMPAIGN CONTRIBUTIONS IN CANADA: A CONSTITUENCY-LEYEL AMALYSIS

CANADIAN JOURNAL OF POLITICAL SCIENCE, XXY(3) (SEP 92), 535-555.

THE AUTHOR EXPLORES THE CONSTITUENCY DIMENSION OF CAMPAIGH FIMANCING IN CAMADA'S 1984 AMD 1988 FEDERAL ELECTIONS. THE ANALYSIS UNCOVERS CONSIDERABLE VARIATIONS IN THE CAPACITY OF CONSTITUENCY PARTIES TO ATTRACT CAMPAIGM DONATIONS. THESE VARIATIONS APPEAR TO BE RELATED TO THE PAST LOCAL AND REGIONAL STRENGTH OF PARTIES, TO THE EXPECTED
CLOSENESS OF THE CURRENT CONTEST, AND TO WHETHER INCUMBENTS ARE RUNHING FOR RE-ELECTION. MULIIVARIATE ANALYSES SUGGES THAT THESE POLITICAL VARIABLES HAVE A BROADLY CONSISTENT IMPACT ON FUNDRAISING AFTER OTHER FEATURES OF THE SOCIO- 
03019 EAGLETON, T.

THE CRISIS OF CONTEMPORARY CULTURE

NEW LEFT REVIEW, (196) (NOV 92), 29-42.

THE AUTHOR REFLECTS ON THE VICISSITUDES OF ENGLISH STUDIES AND ON THE CONTEMPORARY STATUS OF CULTURE AS A HIGHER SPHERE, REMOVED FROM THE CRASS PRESSURES OF POLITICS. HE SHOWS THAT SOME OF THE TRADITIONAL EXPONENTS OF ENGLISH AS A FIELD OF STUDY FREELY ACKNOWLEDGED ITS POLITICAL PURPOSES. AND THOSE WHO TOOAY MOST INDIGNANTLY SEEK TO REPEL THE SUPPOSED INTRUSIONS OF THE POLITICAL ARE THEMSELVES HUMAN CHARACTERI ZED BY EXCLUSIONS OF THE MOST IN JURIOUS AND OFFENSIVE SORT.

03020 EARLY, S.; HILSON, R.

HEALTH CARE REFORY FROM THE BOTTOM UP

NEH POLITICS, 3(4) (WIN 92) 109-114.

THE CHALLENGE OF ORGANIZING AN EFFECTIVE HEALTH CARE REFORM MOVEMENT IS ONE THAT PROGRESSIVE TRADE UNIONISTS ARE GRAPPLING WITH THROUGHOUT THE NATION. CREATING A CANADIANSTYLE SYSTEM WOULD BE THE FIRST MAJOR EXPANSION OF THE SOCIAL WAGE IN THE U.S. IN MANY DECADES. THE AUTHORS DESCRIBE THE CRISIS, AND RANK-AND-FILE-BASED STRUGGLES ON THE ISSUE ORGANIZED BY JOBS WITH JUSTICE (JWJ). EVEN AS JWJ CONTINUES TO MOBILIZE NATIONALLY FOR HEALTH CARE REFORM, IT ALSO SEEKS NEW WAYS TO BUILD THE LOCAL LABOR-COMMUNITY COALITIONS THAT ARE THE BASIS FOR ALL ITS WORK.

03021 EASTERBROOK, F.H.

BILLS OF RIGHTS AND REGRESSION TO THE MEAN

HARVARD JOURNAL OF LAH AND PUBLIC POLICY, 15(1) (WIN 92), $71-84$

ONE MUST EXERCISE CAUTION IN EVALUATING CLAIMS THAT BILLS OF RIGHTS ARE IMPORTANT IN THEMSELVES. THE FRAMERS OF THE U.S. CONSTITUTION WERE RIGHT TO CALL THEM "PARCHMENT BARRIERS." IT TAKES A TOLERANT POLITICAL AND ECONOMIC CULTURE TO NURTURE INDIVIDUAL LIBERTIES AND SUPPORT CLAIMS OF PERSONAL FREEDOM. THE UNITED STATES HAS USED THE JUDICIARY AND THE CONSTITUTION AS ONE EMBODIMENT OF THIS TOLERANT SPIRIT, BUT ALTERATE INSTITUTIONS ARE CONCEIVABLE AND ARE USED EFFECTIVELY IN OTHER NATIONS.

03022 EASTERBROOK, G.

BLACK THUMBS

NEW REPUBLIC, 207 (21) (NOY 92), 26-27.

ALTHOUGH THE ECONOMY WAS DEFINITELY A MORE IMPORTANT ISSUE THAN THE ENVIRONMENT IN THE 1992 PRESIDENTIAL ELECTION, GEORGE BUSH'S FAILURE TO SENSE THE SIGNIFICANCE OF ENVIRONMENTAL ISSUES WAS ONE CAUSE OF HIS DECLINING POPULARITY. BUSH'S REVERSAL FROM DECLARING HIMSELF TO BE "THE ENVIRONMENTAL PRESIDENT" TO CRITICIZING LEGISLATION DESIGNED TO PROTECT THE ECOLOGY SEEMS TO HAVE CONFIRMED ONE OF THE VOTERS' WORST FEARS-THAT THE PRESIDENT WAS OUT OF TOUCH WITH COMMON AMERICAN CONCERNS.

03023 EASTLAND, T

ANONYMOUS CHICKENS

AMERICAN SPECTATOR, 24(12) (DEC 91), 31-32.

DURING THE AMAZING WEEK OF THE "SPECIAL HEARING ON A CHARGE OF SEXUAL HARASSMENT" AGAINST CLARENCE THOMAS, THE PRESS, FOR THE MOST PART, PROVED UNINTERESTED IN HRITING ABOUT THE LEAK THAT LED TO THE HEARING, EXCEPT DISHISSIVELY, EVEN CONDESCENDINGLY. THIS ARTICLE EXAMINES THE PHENOMENON OF THE LEAK AND ITS IMPLICATIONS FOR JOURNALISTIC INTEGRITY AND FOR THE INTEGRITY OF THE SENATE JUDICIARY COMMITTEE.

03024 EASTLAND, T.

BUSH'S FATAL ATTRACTION: ANATOMY OF THE BUDGET FIASCO POLICY REVIEH, (60) (SPR 92), 20-24.

IT IS NOW WIDELY RECDGNIZED THAT THE 1990 BUDGET AGREEMENT WAS THE GREATEST MISTAKE OF THE BUSH PRESIDENCY. BY ITS OWN CRITERIA, THE AGREEMENT FAILED TO REDUCE EITHER FEDERAL SPENDING OR, THE BUDGET DEFICIT. BY RAISING TAXES FEDERAL SPENDING OR THE BUDGET DEFICIT. BY RAISING TAXE
WITHOUT SOLVING ANY LONG-TERM STRUCTURAL PROBLEMS IN

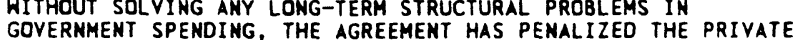
GOVERNMENT SPENDING, THE AGREEMENT HAS PENALIZED THE PRIVATE
SECTOR IN THE SHORT TERM AND REDUCED LONG-TERM CONFIDENCE IN SECTOR IN THE SHORT TERM AND REDUCED LONG-TERM CONF
THE HEALTH OF THE ECONOMY. THUS, THE AGREEMENT HAS THE HEALTH OF THE ECONOMY. THUS, THE AGREEMENT HAS
CONTRIBUTED TO BOTH THE DEPTH AND THE LENGTH OF THE RECESSION. MOREOVER, THE POLITICAL MISTAKES OF THE BUDGET RECESSION. MOREOVER, THE POLITICAL MISTAKES OF THE BUDGE
AGREEMENT WERE AS SERIDUS AS THE ECONOMIC MISTAKES. THE AGREEMENT WERE AS SERIOUS AS THE ECONOMIC MISTAKES. THE POLITICAL DAMAGE TO THE BUSH ADMINISTRAT
PRESIDENT EVEN IF HE WINS RE-ELECTION.

03025 EASTLAND, T.

GAG RULERS

AMERICAN SPECTATOR, 24(9) (SEP 91), 27-28

THIS ARTICLE ARGUES THAT THERE IS A COMPELLING REASOM FOR THE PRESS TO AVOID POLITICS AND STICK TO THE LAH IN REPORTING ON THE SUPREME COURT (AND OTHER COURTS, FOR THAT
MATTER). IN THEIR INTELLECTUAL COMPLEXITY, JUDICIAL DECISIONS DEMAND A READER'S CLOSE ATTENTION. INTRODUCING POLITICAL IMPLICATIONS, ESPECIALLY IN LEAD PARAGRAPHS AND HEAOLINES, IS HARDLY A WAY TO BRING ABOUT A WELL-INFORMED CITIZENRY. A BETTER COURSE FOR THE PRESS WOULD BE TO RUN TWO
STORIES: ONE ON THE LAH IN A CASE, THE OTHER ON THE DECISION'S POLITICAL IMPACT.

03026 EASTLAND, T

RUSH LIMBAUGH: TALKING BACK

AMERICAN SPECTATOR, 25(9) (SEP 92), 22-27.

RADIO TALK SHOW HOST RUSH LIMBAUGH HAS BECOME ONE OF THE MOST VOCAL AND BEST-KNOWN ADVOCATES OF THE CONSERVATIVE LINE IN THE UNITED STATES. WHEN HE UNAPOLOGETICALLY AND FANATICALLY CHAMPIONS CONSERVATISM, LIMBAUGH FILLS THE POLITICAL-CULTURAL VOID CREATED BY THE DEPARTURE OF RONALD REAGAN.

03027 EASTLAND, T.

THE POWER EXECUTIVE

AMERICAN SPECTATOR, 24(5) (MAY 91), 35-37.

VERY FEW NEWS ANALYSES POINTED OUT THAT ONE OF THE WINNERS OF THE GULF CONFLICT WAS THE PRESIDENCY AS AN INSTITUTION. ONE OF THE FEW THAT TREATED THIS SUB JECT CONCLUDED THAT "THERE WILL BE FEWER QUESTIONS ABOUT THE POHER OF THE COMMANDER-IN-CHIEF IN THE FUTURE, AND LESS TALK OF THE WAR POWERS ACT." OVER THE SEVEN MONTHS OF THE CRISIS, THE PRESIDENT--WHETHER DISPATCHING DIPLOMATS OR TROOPS OR BULLETS--TOOK ACTION PURSUANT TO HIS FORMAL POWERS. ONLY ONCE DID HE PROPOSE TO INVOLVE CONGRESS-WHEN HE SOUGHT THE RESOLUTION AUTHORIZING FORCE--AND EVEN THEN HE DENIED THAT ITS PARTICIPATION WAS NECESSARY. CONGRESS WAS NOT THE ONLY INSTITUTION THAT HAS FALLEN A NOTCH SINCE THE REMARKABLE DISPLAY OF PRESIDENTIAL POWER. THE MEDIA ALSO FOUND ITSELF LESS FAVORED, IF NOT LESS MONIED.

03028 EATON, J.; ENGERS, M.

SANCTIONS

JOURNAL OF POLITICAL ECONOMY, 100(5) (OCT 92), 899-928.

SANCTIONS ARE MEASURES THAT ONE PARTY (THE SENDER) USES

TO INFLUENCE ANOTHER (THE TARGET). SANCTIONS, OR THE THREAT

OF SANCTIONS, HAVE BEEN USED BY GOVERNMENTS TO ALTER THE

HUMAN RIGHTS, TRADE, AND FOREIGN POLICIES OF OTHER

GOVERMMENTS. THE AUTHORS DEVELOP NOTIONS OF THE SENDER'S AND

TARGET'S TOUGHNESS THAT DEPEND ON PATIENCE AND ON THE EXTENT

OF SUFFERING FROM SANCTIONS. HOW MUCH A SENDER CAN EXACT

FROM THE TARGET DEPENDS ON THE RELATIVE TOUGHWESS OF THE TWO.

PARADOXICALLY, SANCTIONS THAT IMPOSE LESS HARM ON THE

PARADOXICALLY, SANCTIONS THAT IMPOSE LESS HARM ON THE
TARGET CAN SOMETIMES BE MORE EFFECTIVE THAN THOSE THAT

TARGET CAN SOMETIMES

03029 EATWELL, R.

TOWARD A NEW MODEL OF GENERIC FASCISM

JOURMAL OF THEORETICAL POLITICS, 4(2) (APR 92), 161-194.

THE AUTHOR PROPOSES A CONCEPTUAL APPROACH TO FASCISM

CALLED THE "SPECTRAL-SYNCRETIC," WHICH SEES THE ESSENCE OF FASCISM AS A SERIES OF SYNTHESES AROUND FOUR MAIN THEMES. THE IMPORT OF THIS APPROACH IS TO UNDERMINE THE VIEW THAT FASCISM WAS ESSENTIALLY A FEATURE OF INTER-WAR EUROPE WITHOUT ALLOWING THE TERM TO DEGENERATE SO THAT IT CAN BE
APPLIED TO LARGE NUMBERS OF SIGNIFICANT NON-EUROPEAN MOVEMENTS/REGIMES. DIFFERENCES OF INTERPRETATION OVER THE SYNTHESES, ESPECIALLY NATIONAL CONTEXTUAL FACTORS, MAKE IT DIFFICULT' TO PLACE FASCISM ON THE LEFT-RIGHT SPECTRUM.

03030 EBANKS, B.0.

TEAM POLITICS: MAKING A TRUSTED PARLIAMENTARY SYSTEM HORK PARLIAMENTARIAN, LXXIII(2) (APR 92), 121.

THE AUTHOR DISCUSSES THE ELECTORAL SYSTEM IN THE CAYMAN ISLANDS, WHERE THERE ARE NO POLITICAL PARTIES BUT CANDIDATES IN MULTI-MEMBER OISTRICTS ARE GROUPED INTO "TEAMS." EACH CANDIDATE OR TEAM PRODUCES AN ELECTION MANIFESTO THAT USUALLY HAS A NATIONAL THEME REFLECTING THE CANDIDATE'S OR TEAM'S GOALS AND POLITICAL PHILOSOPHY.

03031 EBERLE, J.

INTERNATIONAL BOUNDARIES: THE SECURITY ANGLE

WORLD TOOAY, 48(4) (APR 92), 68-71.

THE CHANGES IN THE INTERNATIONAL ENVIRONMENT AND THE INCREASING GLOBALI ZATION OF THE ECONOMY ARE RAISING NEW QUESTIONS ABOUT THE IMPORTANCE OF NATIONAL BOUNDARIES AND HOW THEY SHOULD BE DEFENDED.

03032 EBERLE, J.

NATO REBORN

ARMS CONTROL, 12(3) (DEC 91), 17-26.

IF NATO HAS ACHIEVED ITS PRIMARY PURPOSE, THEN THE QUESTION HAS TO ASKED "IS THIS THE END OF NATO?" IF IT IS NOT AND THERE IS A NEW NATO WAITING TO BE BORN, THEN WHAT IS ITS NEH PURPOSE AND HOH CAN IT BEST BE FULFILLED? THERE ARE EVEN MORE FUMDAMENTAL GUESTIONS ABOUT THE EFFECTIVENESS OF EVEN MORE FUNOAMENTAL QUESTIONS ABOUT THE EFFECTIVENESS OF MILITARY POWER, AND THE ROLE OF ALLIANCES IN THE NEH WORLD
ORDER. THIS ARTICLE EXPLORES THE UTILITY OF MILITARY POWER, ORDER. THIS ARTICLE EXPLORES THE UTILITY OF MILITARY POWER, GLOBAL SECURITY, THE SECURITY OF EURO
EUROPEAN COMMUNITY, AND A NEH NATO.

03033 EBERLE, J.

RUSSIA AND UKRAINE: WHAT TO DO WITH THE BLACK SEA FLEET? WORLD TODAY, 48(8-9) (AUG 92), 158-160. 
THE FATE OF THE SOVIET UNION'S BLACK SEA FLEET REMAINS A SERIOUS PROBLEM BETHEEN RUSSIA AND UKRAINE. IN THE UKRAINIAN VIEW, ALL THE FLEET'S SHORE FACILITIES ARE NOW THE PROPERTY OF THE UKRAINIAN GOVERNMENT BECAUSE THEY ARE ON UKRAINIAN TERRITORY. UKRAINE ALSO CLAIMS A LARGE AIRCRAFT CARRIER UNDER CONSTRUCTION IN THE NIKOLAYEV SHIPYARD.

03034 EBERSTADT, $N$

NO AID TO RUSSIA

NATIONAL INTEREST, 29(29) (FAL 92), 62-67.

THE PRINCIPLE FOCUS FOR INTERMATIONAL DEVELOPMENT ASSISTANCE IN THE 1990 S PROMISES TO BE THE FORMER SOVIET UNION. APART FROM THE IMMEDIATE SYMBOLISM OF THE GESTURE, THIS ARTICLE ASKS WHAT WESTERN DEVELOPMENT ASSISTANCE TO THE FORMER SOVIET UNION IS SUPPOSED TO ACCOMPLISH, AND EXACTLY HOW IT IS EXPECTED TO ACHIVE THESE RESULTS. IT PONDERS WHY THE DONOR COMHUUITY SHOULD BE EXPECTED TO SUCCEED IN THIS CHA DONR COMHUNITY SHOULO BE EXPECTED TO SUCCEEO IN THIS TESTS. IT SUGGESTS THAT THE ECONOMIC ASS ISTANCE PROGRAMS NOH UNDER CONSIDERATION IN THE WEST MAY NOT ONLY PROVE TO BE UASTEFUL. BUT MAY EVEN ULTIMATELY RETARD REFORM WORTHY OF WASTEFUL,

03035 EBERT, B.

THE GULF WAR AND ITS AFTERMATH: AN ASSESSMENT OF EVOLVING ARAB RESPONSES

MIDDLE EAST POLICY, 1(4) (1992), 77-95.

THE OUTSET OF THE GULF CRISIS SAW THE DIVISION OF THE ARAB WORLD INTO TWO ROUGH COALITIONS, ONE STAUNCHLY ANTISADOAM, IN WHICH EQYPT, SYRIA AMD THE GCC WERE UNITED IN A COMMON FRONT, AND THE OTHER A GROUP OF STATES THAT CHOSE TO REMAIN OUTSIDE THE ANTI-SADDAM COALITION. THIS ARTICLE EXPLORES THESE CONTRASTING REACTIONS. IT ALSO EXPLORES STATE INTERESTS AND EVOLVING ARABS ATTITUDES AS WELL. THE IMPACTS OF WESTERN MILITARY INTERVENTION, U.S. SANCTIONS AND INSPECTION REGIMES AND OF NUCLEAR WEAPONS AND

NONPROLIFERATION ARE EACH EXAMINED.

03036 ECHEVERRI-GENT, J.

BETWEEN AUTONOMY AND CAPTURE: EMBEDDING GOVERMMENT AGENCIES IN THEIR SOCIETAL ENVIRONMENT

POLICY STUDIES JOURNAL, 20(3) (1992), 342-364.

THE AUTHOR USES ORGANIZATION THEORY AND POLITICAL ECONOMY TO DEVELOP A CONCEPTUAL FRAMENORK FOR ANALYZING FACTORS THAT SHAPE RELATIONS BETWEEN GOVERNMENT AGENCIES AND THEIR SOCIAL ENVIRONMENT. THE FRAMEWORK CONCEPTUALIZES THESE RELATIONS AS SOCIAL NETWORKS COMPOSED OF ACTORS ENGAGED IN THE EXCHANGE OF RESOURCES. THEN IT DEVELOPS AN UNDERSTANDING THE EXCHANGE OF RESOURCES. THEN IT DEVELOPS AN UNDERSTANDI OF HOW CULTURAL NORMS SHAPE THESE EXCHANGES. THE
CONCLUDES BY EXAMINING THE FRAMEWORK'S NORMATIYE CONCLUDES BY EXAMINING THE FRAMEWORK'S NORMATIVE AUTOMOMY PROMOTES EFFECTIVE POLICY IMPLEMENTATION AND WHEM AUTONOMY PROMOTES EFFECTIVE POLICY IMPLEMENTATION AND WHEN IN MANY WAYS, AN AGENCY'S DEPENDENCE ON ACTORS IN ITS ENVIRONMENT MAY
IMPLEMENTATION.

03037 ECHEVERRI-GENT, J

PUBLIC PARTICIPATION AND POVERTY ALLEVIATION: THE EXPERIENCE OF REFORM COMMUNISTS IN INDIA'S WEST BENGAL HORLD DEVELOPMENT, 20(10) (OCT 92 ), 1401-1422.

PUBLIC PARTICIPATION IS ESSENTIAL TO MAKING POVERTYALLEVIATION PROGRAMS RESPONSIVE TO THE NEEDS OF THE POOR, BUT IT REQUIRES A POL ITICAL PROCESS THAT ADEQUATELY REPRESENTS THE POOR'S INTEREST. THIS LEADS TO A PARADOX OF PARTICIPATION: AS LONG AS THE POOR REMAIN POOR. THEY ARE DISDAVANTAGED IN SECURING EOUITABLE REPRESENTATION. THIS ESSAY SHOWS HOW IMPLEMENTING POVERTY-ALLEVIATION PROGRAMS THROUGH ELECTED GOVERNING COUNCILS HAS SIMULTANEOUSLY MADE POLICY MORE RESPONSIVE TO THE POOR WHILE PERMITTING THE ORGANIZATIONAL INTERESTS OF THE RULING COMMUNIST PARTY TO DISTORT IMPLEMENTATION IN WEST BENGAL. IT HIGHLIGHTS THE IMPORTANCE OF POLITICAL COMPETITION AMONG PARTIES AND NONGOVERNMENT ORGANIZATIONS FOR MAXIMIZING RESPONSIVENESS TO THE POOR.

03038 ECHOLS, A.

WE GOTTA GET OUT OF THIS PLACE: NOTES TOWARD A REMAPPING OF THE SIXTIES

SOCIALIST REVIEW, 22 (2) (APR 92), 9-34.

ALICE ECHOLS ASKS WHY MOST HISTORIES OF THE 19605 MARGINALIZE FEMINISM AND ASSUME AM ESSENTIAL ANTAGONISM BETHEEN IT AND THE NEW LEFT. SHE SUGGESTS THAT ANY REMAPPING OF THE SIXTIES MUST NECESSARILY INYOLVE A GREATER EFFORT TO LOCATE SIXTIES RADICALISM SPECIFICALLY WITHIN THE SOCIAL AND LOCATE SIXTIES RADICALISM SPECIFICALLY WITHIN THE SOCIAL AND CULTURAL TERRAIN OF THE POSTHAR UNITED STATES. MORE HORK NEEDED ON OFFICIAL AND OPPOSITIONAL DISCOURSES AND THE POPULAR CULTURE OF THE POSTHAR PERIOD WHICH WILL OFFER
BETTER UNDERSTANDING OF THE WHITE WOMAN'S SIDE OF THE BETTER UNDERSTANDING OF THE WHITE WOMAN'S SIDE OF THE -WHICH IS SO VITAL A PART OF THE SIXTIES STORY.

03039 ECKERSLEY, R.

GREEN VERSUS ECOSOCIALIST ECONOMIC PROGRAMS: THE MARKET
RULES OK?

POL ITICAL STUDIES, XL (2) (JUN 92), 315-333.

SOCIALIST THOUGHT IS UNDERGOING A PROFOUND SHAKE-UP IN RESPONSE TO THE ECONOMIC AND ECOLOGICAL CHALLENGES OF THE LATE TWENTIETH CENTURY. WHETHER A NEW SOCIALISM WILL WITHSTAND THESE MOMENTOUS CHALLENGES AND EMERGE TRIUMPHANT IS AN OPEN QUESTION. THIS PAPER IS CONCERNED TO REVIEW THE ARGUMENTS FOR AND AGAINST THE MARKET ECONOMY VERSUS THE PLANNED ECONOMY IN THE LIGHT OF THE SOCIAL AND ECOLOGICAL PROBLEMS OF THE LATE THENTIETH CENTURY AND TO COMPARE AND EVALUATE THE ALTERNATIVE ECONOMIC PROGRAMS DEFENDED BY ECOSOCIALISTS AND GREEN ECONOMISTS IN RESPONSE TO THESE PROBLEMS.

03040 ECKERSLEY, R.

HABERMAS AND GREEN POLITICAL THOUGHT: TWO ROADS DIVERGING THEORY AND SOCIETY, $19(6)$ (DEC 90), 739-776.

THIS ARTICLE EXPLORES THE CONTRIBUTION TO GREEN

POLITICAL THOUGHT OF CONTEMPORARY CURRENTS OF HESTERN

MARXISM, MOST OF WHICH REJECT ORTHODOX MARXISM AND MANY OF

WHICH HAVE FORESHADOWED IMPORTANT ASPECTS OF THE GREEN

CRITIOUE OF SCIENTISH, INDUSTRIALISM, AND MODERNITY. THE COMPATIBIL ITY BETWEEN' GREEN POL ITICAL PHILOSOPHY AND THE CRITICAL THEORY OF JURGEN HABERMAS IS EXAMINED. THE CRITIQUE IS CONDUCTED FROM THE PERSPECTIVE OF THE MORE RADICAL. THE RADICAL, ECOCENTRIC WING OF THE EMERGENT GREEN POLITICAL RADICAL,
SPECTRUM

03041 ECKES, A.E.

TRADING AMERICAN INTERESTS

FOREIGN AFFAIRS, 71(4) (FAL 92), 135-154.

FOR 45 YEARS, U.S. PRESIDENTS HAVE CONSCIOUSLY

SUBORDINATED DOMESTIC ECONOMIC INTERESTS TO FOREIGN POLICY

OBJECTIVES. IN THE AFTERMATH OF THE COLD WAR, THE UNITED STATES HAS THE OPPORTUNITY TO STOP TRADING ACCESS TO THE AMERICAN MARKET FOR FOREIGN POLICY FAVORS. IMPORT CONCESSIONS SHOULD BE USED TO GENERATE RECIPROCAL EXPORT OPPORTUNITIES FOR AMERICAN GOODS AND SERVICES IN FOREIGN MARKETS, NOT VOTES IN THE UNITED NATIONS OR GOOD WILL IN DIPLDMATIC NEGOTIATIONS. FOR THE UNITED STATES, TRADE POLICY MUST INCREASINGLY BECOME AN INSTRUMENT OF DOMESTIC POLICY, AS IT IS FOR THE COUNTRY'S MAJOR COMPETITORS.

03042 ECKHARDT, $W$

MAKING AND BREAKING ENEMY IMAGES

BULLETIN OF PEACE PROPOSALS, 22 (1) (MAR 91), 87-96.

A WAR ECONOMY NEEDS ENEMIES IN ORDER TO JUSTIFY ITS

MILITARY EXPRENDITURES. THIS ARTICLE EXPLORES THE MAKING AND BREAKING ENEMY IMAGES. IT SUGGESTS THAT ENEMY IMAGES ARE USED TO JUSTIFY WAR PREOPARATIONS IN THE FORM OF MILITARY EXPENOITURES. IN GENERAL, THESE IMAGES ARE WASTFUL, IF NOT NEEDS THEM IS NOT DOING ANYONE A FAVOR--INCLUDING ONESELF IN NEEDS THEM IS NOT DOING ANYONE A FAVOR--INCLUDING ONESELF IN THE LONG RUN. IT ALSO

03043 ECONOMIDES, S

THE BALKANS AND THE SEARCH FOR SECURITY: FROM INTER-WAR TO POST-COLD HAR

ARMS CONTROL, 13(1) (APR 92), 121-139.

SINCE WORLD WAR I, THE QUEST FOR BALKAN REGIONAL SECURITY HAS UNDERGONE TWO BASIC PHASES, NEITHER OF WHICH HAS RECEIVED HIDESPREAD ATTENTION FROM THE OUTSIDE HORLD. THE THO BASIC PHASES WERE THE ATTEMPTS TO CREATE A BALKAN UNION IN THE 1930'S AND THE MORE RECENT PROCESS OF BALKAN COOPERATION AND SECURITY. THIS ESSAY EXPLORES THE SIMILARITIES BETWEEN THE THO PHASES, ALONG WITH THE NATURE OF THE ATTEMPTED PROCESS OF REGIONAL COOPERATION ANO INTEGRATION AND THE PROSPECTS FOR SUCCESS. IT ALSO FINDS A RANGE OF DISSIMILARITIES, BOTH CONTEXTUAL AND PROCEDURAL, WHICH ARE EXAMINED TO DISCERN WHETHER THERE CAN BE A DIRECT COMPARISON BETWEEN THE BALKANS OF TODAY AND THAT OF THE 1930 's.

03044 EDELMAN, M.W.

VANISHING DREAMS OF AMERICA'S YOUNG FAMILIES

CHALLENGE, 35(3) (MAY 92), 13-27.

AMERICANS FROM ALL WALKS OF LIFE ARE PROFOUNDLY ANXIOUS-TROUBLED BY WHAT THEY SEE AROUND THEM TODAY AND EYEN MORE BY WHAT THEY SEE AHEAD. THIS ANXIETY IS MANIFESTED IN COUNTLESS WHAT THEY SEE AHEAD. THIS ANXIETY IS MANIFESTED IN COUNTLE
WAYS--IN PARALYZING ECONOMIC INSECURITY; IN AN EMERGING WAYS--IN PARALYZING ECONOMIC INSECURITY; IN AN EMERGING
POLITICS OF REJECTION, FRUSTRATION, AND RAGE; IN A GROWING POLITICS OF REJECTION, FRUSTRATION, AND RAGE; IN A GROWING
POLARIZATION OF U.S. SOCIETY BY RACE AND BY CLASS; AND IN AN POLARIZATION OF U.S. SOCIETY BY RACE AND BY CLASS; AND IN AN EROSION OF THE SENSE OF RESPONSIBILITY TO HELP THE WEAKEST SMALL CHILDREN IS NOW IN GREAT JEOPARDY. CONGRESS AND THE SHALL CHILDREN IS NOW IN GREAT JEOPARDY. CONGRESS AND THE CHILD HAS A FAIR START, A HEALTHY START, AND A HEAD START.

03045 EDGELL, S.; DUKE, S.

A MEASURE OF THATCHERISM

HARPER AND COLL

THIS BOOK SEEKS TO ASSESS THE NATURE AND IMPACT OF 
THATCHERISM IN SOCIOLOGICAL TERMS. IT USES NEO-MARXIST CLASS ANALYSIS AND THE NOTION OF PRODUCTION AND CONSUMPTION CLEAVAGES TO ILLUMINATE THE SOCIOLOGY OF THATCHERISM. THE AUTHORS SUGGEST THAT PREVIOUS CLASS ANALYSES OF THATCHERISM ARE OFTEN INADEQUATE ON THREE MAIN GROUNDS: THEY TEND TO FOCUS ON OCCUPATIONAL RATHER THAN SOCIAL CLASS DISTINCTIONS; THEIR COVERAGE IS LIMITED IN SO FAR AS THEY TEND TO EXCLUDE WOMEN AND THE UNEMPLOYED; AND IT IS DIFFICULT TO COMBINE THESE ANALYSES HITH SECTORAL ANALYSIS. THE AUTHORS DEFEND A SOCIAL CLASS ANALYSIS OF THE ECONOMICALLY ACTIVE THAT IS OREINTED TO THEIR ROLE IN THE OWNERSHIP AND CONTROL OF PRODUCTION AND ITS EXTENSION TO HOUSEHOLD UNITS WHERE CONSUMPTION ISSUES ARE BEING EXPLORED. FURTHERMORE, THEY DEMONSTRATE THAT THE ELECTORAL BASIS OF THATCHERISM HAS DARROW AND BECOME NARROWER, ANCHORED PRINCIPALLY IN THE EMPLOYER AND PETTY BOURGEOIS SOCIAL CLASSES.

03046 EDMONDS, R.L.

AGAINST' THE FLOH

FAR EASTERN ECONOMIC REVIEH, 156(20) (MAY 92), 24.

ALTHOUGH CONSTRUCTION OF LARGE DAMS AS A SOLUTTION TO DEVELOPMENT PROBLEMS IS INCREASINGLY QUESTIONED, ON 3 APRIL, CHINA'S NATIONAL PEOPLE'S CONGRESS APPROVED THE' THREE GORGES DAM PROJECT ON THE YANGTZE RIVER BY 1,767 VOTES TO 177 WITH 664 ABSTENTIONS. HHILE OVER THO-THIRDS OF THE DELEGATES VOTED FOR THE PROJECT, THE RECORD NUMBER VOTING AGAINST OR ABSTAINING MAY REPRESENT FAR GREATER OPPOSITION THAN THE FIGURES SUGGEST. MANY OPPOSE THE PROJECT FOR REASONS OF COSTEFFECTIVENESS AND EFFICIENCY. SOME SUSPECT AN ULTERIOR MOTIVE TO THE PROJECT: PEKING CAN USE THE THREE GORGES PROJECT TO HELP KEEP WEALTHY PROVINCES SUCH AS GUANGDONG IN LINE, SINCE THEY WILL HAVE TO PAY MORE THAN OTHERS FOR THIS PROJECT TO DEVELOP CENTRAL CHINA. FURTHERMORE, ONCE CONSTRUCTION HAS BEGUN IT HILL ALSO ENHANCE THE POHER OF CENTRAL AUTHORITY AT THE EXPENSE OF LOCAL AUTONOMY.

03047 EDNEY, L.

MARITIME ROLES BEYOND BLOC POLITICS

RUS I JOURMAL $137(1)$ (FEB 22 ) $10-1$

THIS ARTICLE SUGGESTS THAT NATO'S FUTURE ROLE IS TO CONTINUE TO FOSTER COOPERATION BETWEEN MEMBERS OF THE ALLIANCE IN ORDER TO PROMOTE GROWTH AND STABILITY, WHILE PROVIDING A DEFENSIVE SECURITY ALLIANCE. STRESSING PROVIDING A DEFENSIVE SECURITY ALLIANCE. STRESSING
FLEXIBILITY, IT PROPOSES A STRUCTURE OF FORCES FOR PEACE FLEXIBILITY, IT PROPOSES A STRUCTURE OF FORCES FOR PEACE TIME WHICH WOULD ALSO BE ABLE TO OPERATE EFFICIENTLY IN CONFLICT. THE ARTICLE EXAMINES A NUMBER OF FACTORS HHIC STRUCTURES AND THEIR EVENTUAL IMPLEMENTION. IT CONCLUDES STRUCTURES AND THEIR EVENTUAL IMPLEMENTION. IT CONCLUDES THAT NAVAL FORCES MAXIMISE OPTIONS WHILE CONTRIBUTING TD
STABILTIY OF THE WHOLE SPECTRUM OF SECURITY INTERESTS.

03048 EDWARDS, D.

WHAT HAPPENED TO THE GREEM MOVEMENT?

CONTEMPORARY REVIEW, 260(1516) (MAY 92), 252-255.

CURRENT ENVIRONMENTAL CONCERN HAS NOT LESSENED BECAUSE THE PROBLEMS HAVE GONE AWAY. THE PROBLEMS ARE STILL HERE. OZONE DEPLETION AND GLOBAL WARMING ARE ALIVE AND WELL. HHILE THESE CRISES ALMOST SEEM TO BE WORSENING IN DIRECT PROPORTION TO THE GOWTH OF INDIFFERENCE, SO TOO MANY OTHER SERIOUS PROBLEMS HAVE BEGUN TO ASSAIL THE WORLD WITH ALMOST NO GENERAL PUBLIC AWARENESS. THIS ARTICLE SUGGESTS THAT APPROACHING CATASTROPHE HAS COME TO BE TURHED INTO A PASSING FASHION, A WAY TO WIN VOTES AND SELL PRODUCTS. THE ONLY HOPE FOR THE GREEN MOVEMENT AND FOR THE ENVIRONMENT, LIES IN THE ABILTIY TO SEE THAT THE \&NORMAL' IS NOT NORMAL ANY MORE.

03049 EDWARDS, J.; DEAKIN, $N$

PRIVATISH AMD PARTNERSHIP IM URBAN REGENERATION

PUBLIC ADMINISTRATION, 70(3) (FAL 92), 359-368.

IN 1988, INNER CITY POL ICY TOOK ON A NEW STYLE. THE RATIONALE OF PRIVATISM AS A MEANS OF ABOLISHING URBAN DEPRIVATION HOHEVER, RESTS ON UNTESTED LOGIC. THERE ARE FUNDAMENTAL ASSUMPTIONS, THE CONTESTABLE NATURE OF WHICH THROWS DOUBT ON THE POSSIBILITY OF THE PRIVATISM STRATEGY EVER HORKING. PRINCIPLE AMONG THESE ARE THAT THERE ARE DISCRETE AND INSULATED INNER CITY ECONOMIES THAT CAN BE
REGENERATED; THAT IT IS EVEN NOH POSSIBLE TO REVERSE HISTORY
IN THE INMER CITIES AND THAT TO BE OF BENEFIT IO INMER CITY IN THE INNER CITIES, AND THAT TO BE OF BENEFIT TO INHER CITY
RESIDENTS, INVESTMENT MUST BE IN THE INNER CITIES THEMSELVES.

03050 EDHARDS, P.R.

CHOICES THAT INCREASE COMPLIANCE

POLICY STUDIES REVIEH, 10(4) (WIN 92), 6-27

POLICY STUDIES REVIEH, 10(4) (WIN 92), 6-27.

THEIR ABILITY TO MANIPULATE FACTORS THAT INCREASE COMPLIANCE.

PRIMARILY, POLICY MAKERS ARE ABLE TO ADJUST INVESTIGATORY

PRACTICES TO ALTER THE PROBABLE LEVEL OF SANCTIONS AND

PROBABILITY OF DETECTION. EXTERMAL FACTORS LIMITING MOST

CASE LAH, AND BUDGETS. TO OPTIMIZE AN AGENCY'S EFFECTIVENESS, THE PROGRAM ADMINISTRATOR NEEDS TO RECOGNIZE THE LIMITATIONS AND STRUCTURE INYESTIGATIONS TO PROPERLY BALANCE DETECTION AND SANCTIONS. COMPLIANCE DECISION MODELS PROVIDE THE THEORETICAL UNDERPINNING AND METHOD FOR DETERMINING HOH
TO OPTIMIZE REGULATORY IMPACT BY BALANCING SANCTIONS AND DETECTION. THIS ESSAY INTRODUCES A COMPLIANCE DECISION MODEL, BASED ON EQUAL EMPLOYMENT OPPORTUNITY REQUIREMENTS, THAT CAN BE USED TO GUIDE AN ADMINISTRATOR'S ADJUSTMENTS TO THE PROBABILITIES OF DETECTION AND SANCTIONS. THE AUTHOR PRESENTS EMPIRICAL EVIDENCE TO INDICATE HOW TO BALANCE THESE PROBABILITIES.

03051 EFRON, E.

NATIVE SON

REASON, $23(9)$ (FEB 92 ), 22-32.

THIS ARTICLE ARGUES THAT THE SENATE JUDICIARY COMMITTEE HEARINGS ON THE NOMINATION OF JUDGE CLARENCE THOMAS TO THE SUPREME COURT WERE A RACIST PHENOMENON. THE PROCESS

SUPREME COURT WERE A RACIST PHENOMENON. THE PROCESS

CEASELESSLY GENERATED NEGATIVE STEREOTYPES ABOUT THOMAS.
THESE ARE SEEN IN YARIOUS STAGES AND ASPECTS OF THE PROCESS:

THESE ARE SEEN IN VARIOUS STAGES AND ASPECTS OF THE
THE NOMINATION. THE STRATEGY OF EVASION, SENATORIAL

ETIQUETTE, THE "CHARACTER ISSUE," THE ABORTION ISSUE, AND,

MOST SIGNIFICANTLY. THE "SEX CRIMES" ISSUE.

03052 EHRENGERG, J.

THE DICTATORSHIP OF THE PROLETARIAT: MARXISH'S THEORY OF SOCIALIST DEMOCRAC

ROUTLEDGE, 1992, 203.

MARXISM TOOK SHAPE AS PART OF THE NIMETEENTH-CENTURY EFFORT TO UNDERSTAND HOW CAPITALISM WORKED AND IT CAME TO MATURITY AS THE GUIDING THEORY OF THE HORLD'S FIRST SUCCESSFUL PROLETARIAN REVOLUTION. IT NOH STANDS AT THE SAME CROSSROADS AS DOES THE POLITICAL MOVEMENT TO WHICH IT HAS PROVIDED THEORETICAL LEADERSHIP FOR MOST OF THIS CENTURY. THIS BOOK ATTEMPTS TO BE CLEAR ABOUT THE CONTENT OF MARXISM'S DEHOCRATIC CLAIMS. THE ACCOUNT TREATS THE THEORY OF THE DICTATORSHIP OF THE PROLETARIAT AS AN ACCOUNT OF THE POLITICAL CONTENT OF AN HISTORICALLY UNPRECEDENTED REVOLUTIONARY TRANSTION WHOSE MEANING IS TO BE FOUND IN ITS MOTION TOWARD A CLASSLESS SOCIETY. IT BEGINS AT THE BEGINMING: WITH THE EYOLUTION OF MARX AMD EMGEL'S UNDERSTANDING OF THE PROLETARIAN REVOLUTION'S ULTIMATE RESULT AND IMMEDIATE AIM BEFORE 1848, AFTER WHICH IT IS THEN IN A POSTION TO APPROACH THE ROLE OF POLITICS AND THE NATURE OF A DEMOCRACY WHOSE FRANKLY REVOLUTIONARY AND DICTATORIAL CHARACTER MAKES IT VERY DIFFERENT FROM THE DEMOCRACY WITH CHARACTER MAKES IT VERY
WHICH WE ARE FAMILIAR.

03053 EISENBERG, L.Z.

PASSIVE BELLIGERENCY: ISRAEL AHD THE 1991 GULF WAR JOURNAL OF STRATEGIC STUDIES, 15(3) (SEP 92), 304-329.

REPEATED IRAQI MISSILE ATTACKS DURING THE' 1991 GULF WAR MARKED BOTH THE FIRST TIME AN ARAB COUNTRY HAD SUCCEEDED IN STRIKING ISRAELI POPULATION CENTERS SINCE 1948 AND THE FIRST TIME ISRAEL HAD PERMITTED AN ARAB ATTACK TO GO UNPUNISHED. IN THIS ARTICLE, THE AUTHOR DISCUSSES HOW THE ISRAELI GOVERNMENT DEFINED ITS INTERESTS AND OBJECTIVES DURING THE CRISIS, THE PAY-OFF ISRAEL EXPECTED TO RECEIVE, AND WHAT ISRAEL ACTUALLY ACHIEVED.

03054 EISENHOWER, $D$ CORPORATE "DOWNSIZING"

POLITICAL AFFAIRS, 71(4) (JUN 92), 6-9.

THE NEWS HAS RECENTLY BEEN FULL OF ACCOUNTS OF LARGE COMPANIES DISMISSING THOUSANDS OF WORKERS IN AN EFFORT TO "SLIM DOWN." HOWEVER, MEDIA AND ACADEMIC ANALYSES OF THE FORCES BEHIND THESE HEADLINES ARE VERY MISLEADING. RATHER THAN TREATING ECONOMIC CASUALTIES AS THE LATEST VICTIMS OF THE PROCESS OF CAPITAL ACCUMULATION UNDER THE DIRECTION OF A FINANCIAL OLIGARCHY, THEY ARE REMOVED FROM A CLASS CONTEXT AND TREATED AS A NATURAL PHENOMENON. CORPORATE "DOWNSIZING" IS THE LATEST BUZZWORD USED TO EXPLAIN THE CURRENT HAVE OF ECONOMIC RESTRUCTURING DESIGNED TO INCREASE THE RATE OF

EXPLOITATION AND THE CONCENTRATION OF WEALTH.

03055 EISENSTADT, $S$

FRAMEWORKS OF THE GREAT REYOLUTIONS: CULTURE, SOCIAL STRUCTURE, HISTORY AND HUMAN AGENCY

INTERNATIONAL SOCIAL SCIENCE JOURNAL, (133) (AUG 92),

385-402.

THERE IS A GREAT DEBATE WHETHER HUMAN ACTIVITIES AND THE COURSE OF HUMAN HISTORY ARE SHAPED BY "DEEP" RULES WHICH REGULATE HUMAN ACTIVITY, EITHER THOSE OF THE HUMAN MIND OR REGULATE HUMAN ACTIVITY, EITHER THOSE OF THE HUMAN MIND OR
THOSE GOVERNING SOCIAL RELATIONS AND THE MODES OF PRODUCTION. THIS ARTICLE QUERIES WHAT ABOUT HUMAN ACTIVITY? WHAT ABOUT THE INDIVIDUAL AS AN AUTONOMOUS AGENTS? IT STUDIES WHETHER LAWS OR PATTERNS OF CHANGE COMMON TO ALL HUMAN SOCIETIES EXIST, OR WHETHER DIFFERENT SOCIETIES OR CIVILIZATIONS DEYELOP IN THEIR OWN WAYS.

03056 EISENSTADT, S.N.

THE BREAKDOWN OF COMMUNIST REGIMES AND THE VICISSITUDES OF MODERNITY

OAEDALUS, 121(2) (SPR 92), 21-41.

THE AUTHOR EXPLAINS THE SIMILARITIES AND DIFFERENCES BETWEEN CLASSICAL REVOLUTIONS AND THE RECENT REVOLUTIONS IN EASTERN EUROPE. HE PAYS CLOSE ATTENTION TO THE ORIGINS OF THE EAST EUROPEAN REVOLUTIONS AND THEIR SIGNIFICANCE. 
03057 EISLER, R. HOMEN, MEM AMD MAMAGEMENT: REDESIGNING OUR FUTURE

FUTURES, 23(i) (JAN 91), 3-18. FUNDAMENTAL POLITICAL AND ECONOMIC CHANGES THAT ARE UNDER WAY ARE EXAMINED, TOGETHER WITH IMPLICATIONS FOR THE WORKPLACE AND SOCIETY AT LARGE, FROM THE PERSPECTIVE OF THO UNDERLYING SOCIAL ORGANIZATION TYPES--THE DOMINATOR AND PARTNERSHIP MODELS. CONTEMPORARY ECONOMIC TRENDS AND GENDER ISSUES ARE PLACED IN BOTH THE CONTEXT OF FUNDAMENTAL SOCIAL ANO IDEOLOGICAL CHANGE, AND THE BROADER CONTEXT OF SOCIOCULTURAL EVOLUTION. PARTICULAR EMPHASIS IS PLACED ON THE ISSUE OF WOMEN AS MANAGERS OR LEADERS.

03058 EISNER, M.A.

ANTITRUST AND THE TRIUMPH OF ECONOMICS: INSTITUTIONS, EXPERTISE AND POLICY CHANGE

UNIVERSITY OF NORTH CAROLINA PRESS, 1991, 302

THIS BOOK PROVIDES AN ANALYSIS OF THE RISE OF ECONOMICS

IN ANTITRUST LAW. THE AUTHOR ARGUES THAT THE REASONS FOR THE

PASSAGE OF THE SHERMAN ANTI-TRUST ACT ARE ABTRUSE, AND ITS

PASSAGE OF THE SHERMAN ANTI-TRUST ACT ARE ABTRUSE, AND ITS
LANGUAGE IS TOO GENERAL TO FURNISH A COHERENT BASIS FOR

LANGUAGE IS TOO GENERAL TO FURNISH A COHERENT BASIS FOR
REGULATION. THEREFORE, THERE AROSE AN ANTI-TRUST "POL ICY

COMMUNITY" OF JUDGES, BUREAUCRATS, LAWYERS, POLITICIANS AND

COMMUNITY" OF JUDGES, BUREAUCRATS, LAWYERS, POLI

SIGNIFICANCE ARE THE ECONOMISTS. PARTICULARLY WITH THE

SIGNIFICANCE ARE THE ECONOMISTS. PARTICULARLY WITH THE
ASSENT OF THE CHICAGO SCHDOL OF INDUSTRIAL ORGANIZATION ASSENT OF THE CHICAGO SCHDOL OF INDUSTRIAL ORGANIZATION, ECONOMISTS' EXPERTISE IN ANTITRUST HAS INCREASINGLY
RECOGNIZED TO THE POINT THAT THEY COMPLETELY DOMINATE ANTITRUST LAW AND SCHOLARSHIP TODAY. FURTHERMORE, THIS TRANSFORMATION TOOK PLACE WELL IN ADVANCE OF THE' "REAGAN REVOLUTION." THEREFORE, CONTRARY TO THE POPULAR NOTION, THE
EIGHTIES SAH LITTLE CHANGE IN ANTITRUST THOUGHT AND PRACTICE.

03059 EKELUND, JR., R. ; THORNTON, M.

THE UNION BLOCKADE AND DEMORALIZATION OF THE SOUTH: RELATIVE PRICES IN THE CONFEDERACY

SCIENCE AND SOCIETY, 56(4) (WIN 92), 890-902.

THE UNION BLOCKADE ENCOURAGED BLOCKADE RUNNERS TO SUPPLY LUXURY ITEMS TO THE CIVIL WAR SOUTH. EVIDENCE FROM THE CONFEDERACY INDICATES THAT THIS EFFECT HAD A STRONG INFLUENCE ON THE COMPOSITION OF IMPORTS. THE BLOCKADE THEREFORE CONTRIBUTED TO THE DEMISE OF THE CONFEDERACY THROUGH BOTH GENERAL ECONOMIC DEGRADATION AND THE UNTOHARD IMPACT THAT IT HAD ON MORALE DUE TO THE LUXURY-BIASED COMPOSITION OF IMPORTS IT HELPED CREATE.

03060 EKEUS, $R$.

THE IRAOI EXPERIENCE AND THE FUTURE OF NUCLEAR THE IRAQI EXPERIEN

WASHINGTON OUARTERLY, 15(4) (FAL 92), 67-74,

ONE LESSON TO BE, DPA 4 ONE LESSON TO BE DRAWN FROM THE IRAQI EXPERIENCE IS THE NEED TO TAKE INTO ACCOUNT THE COMPREHENSIVE CHARACTER OF ANY MUCLEAR WEAPONS PROGRAM AND THE NEED FOR CORRESPONDING CONTROL AND MONPROL IFERATION MEASURES OF AN EQUALLY COMPREHENSIVE NATURE. THIS ARTICLE EXPLORES NUCLEAR NONPROL IFERATIONS EFFORTS ; INSTITUTIONALIZING THE CEASE-FIRE AND PROJECTS FUTURE UN RESPONSES TO NUCLEAR PROLIFERATION. IT CONCLUDES THERE MUST BE IMPROVED COORDINATION OF THE MANY
EXISTING AND INTERRELATED INTERNATIONAL ACTIVITIES IN THIS DOMAIN.

03061 EKIERT, G.

PECULIARITIES OF POST-COMAUNIST POLITICS: THE CASE OF POLAND

STUDIES IN COMPARATIVE COMMUNISM, 25(4) (DEC 92), 341-362.

THIS PAPER EXPLORES SOME PECULIARITIES OF THE POLITICA

TRANSITION PROCESS IN POLAND, ARGUING THAT THE ESTABLISHMENT OF A DEMOCRATIC POLTIICAL SYSTEM IS AS CHALLENGING A TASK AS THE CREATION OF A MARKET ECONOMY. HE PREDICTS THAT IT HILL TAKE MANY YEARS AND HILL REQUIRE AN EXTENSIYE PROCESS OF EXPERIMENTATION AND LEARNING INVOLVING ALL POLITICAL FORCES AND GROUPS OF SOCIETY. HE SUGGESTS THAT THE CONTINUATION OF ECONOMIC TRANSFORMATIONS HINGES ON THE SUCCESS OF THE DEMOCRATIC CONSOLIDATION.

03062 EKONG, E.

OPENING UP NIGERIA

WEST AFRICA, (3896) (MAY 92), 838-839.

IN THIS INTERVIEH, THE CHAIRMAN OF THE NATIONAL

REPUBLICAN CONVENTION DISCUSSES HIS PARTY'S GOALS FOR

REPUBLICAN CONVENTION DISCUSSES HIS PARTY'S GOALS FOR
NIGERIA, FOCUSING ON ECONOMIC DEVELOPMENT POLICIES.

03063 EKONG, E.

SOUTHERN DISCOMFORT

WEST AFRICA, (3903) ( JUL 92), 1134.

AT A SUMMIT MEETING IN JUNE 1992, THE OAU MINISTERS PASSED A RESOLLUTION SUPPORTING THE ANC'S DEMANDS FOR A FULL INVESTIGATION INTO THE MASSACRE AT BIOPATONG. IN ADOITION TO ASKING PRESIDENT F.W. DEKLERK TO EXPLAIN THE ROLE OF THE SECURITY FORCES IN THE VIOLENCE, THE RESOLUTION REAFFIRMED THE NEED FOR A NEGOTIATED SETTLEMENT IN SOUTH AFRICA.
03064 EKONG, E.

TAYLOR'S FAMFARE

WEST AFRICA, (3894) (MAY 92), 755

THE AUTHOR REPORTS ON THE' NATIONAL PATRIOTIC FRONT'S ALLLIBERIA CONFERENCE HELD IN APRIL 1992 IN GBARNGA.

03065 EKONG, E THEIR' SISTERS' KEEPERS?

NEST AFRICA, (3886) (MAR 92), 412-413

THE AUTHOR DESCRIBES A SUMMIT MEETING OF 64 FIRST LADIES DEVOTED TO THE ECONOMIC ADVANCEMENT OF RURAL WOMEN. THE FIRST LADIES DESCRIBED THE PROBLEMS OF RURAL WOMEN IN THEIR COUNTRIES AND SHARED IDEAS ABOUT IMPROVING THE LIVES OF THIS SEGMENT DF SOCIETY.

03066 EKONG, E. VEERED NAM?

WEST AFRICA, (3913) (SEP 92), 1571.

THE CONTINUED FIGHTING IN BOSNIA WAS A SOURCE OF MUCH CONTROVERSY AT THE TENTH SUMMIT OF THE NONAL IGNED NATIONS IN SEPTEMBER 1992. ISLAMIC NATIONS, RESPONDING TO DOMESTIC PRESSURES TO DO SOMETHING ABOUT THE PLIGHT OF BOSNIAN PRESSURES TO DO SOMETHING ABOUT THE PLIGHT OF BOSNIAN
MUSLIMS, DEMANDED THAT THE SUMMIT ADOPT A STRONG STATEMENT MUSLIMS, DEMANDED THAT THE SUMMIT ADOPT A STRONG STATEMENT
NAMING SERBIA AS THE AGGRESSOR. THE SUMMIT'S CONCLUDING DAMING SERBIA AS THE AGGRESSOR. THE SUMMIT'S CONCLUDING DOCUMENT URGED NAM TO PLAY A STRONG ROLE IN THE CONSTRUCTION OF THE NEH

03067 EKONG, E. WHICH WAY OUT? WEST AFRICA, (3901) (JUN 92), 1043

THE ETHNIC FIGHTING IN SOMALIA IS JUST ONE OF SEVERAL INTRA- AND INTER-STATE CONFLICTS RAGING ACROSS AFRICA. THESE CONFLICTS DRAW ATTENTION TO THE URGENT NEED FOR THE OAU TO ASSUME A MORE PURPOSEFUL ROLE IN THE SETTLEMENT OF THE CONTINENT'S POLITICAL PROBLEMS.

03068 ELAZAR, D.

CHANGING CONCEPTIONS OF RIGHTS IN THE UNITED STATES AND THE WEST

PUBLIUS: THE JOURNAL OF FEDERALISH, 22(2) (SPR 92), 5-18. AMONG THE MOST PRONOUNCED FEATURES OF THE AMERICAN REVOLUTIONARY GENERATION, WICH CULMINATED IN THE WRITING AND ADOPTION OF THE CONSTITUTION OF THE UNITED STATES, WERE THE INTRODUCTION OF THE IDEA OF INDIVIDUAL RIGHTS AS THE BASIS FOR POLITICAL ORGANIZATION AND THE PROTECTION OF THOSE RIGHTS AS A MAJOR TASK OF GOVERNMENT. THIS IDEA IN ITSELF REPRESENTS ONLY ONE CONCEPTION OF RIGHTS AND MUST BE UNDERSTOOD AS SUCH. THIS ARTICLE EXAMINES WHAT IS A UNDERSTOOD AS SUCH. THIS ARTICLE EXAMINES WHAT IS A
CONCEPTION OF RIGHTS AND HOW RIGHTS ARE JUSTIFIED. IN THIS CONCEPTION OF RIGHTS AND HOW RIGHTS ARE JUSTIFIED. IN THIS
EXPLORATION, ONE MUST UNDERSTAND HOW EACH CONCEPTION OF EXPLORATION, ONE MUST UNDERSTAND HOW EACH CONCEPTION OF RIGHTS IS SHAPED BY A PARTICULAR VIEW OF THE NATURE OF MAN, A PARTICULAR UNDERSTANDING OF THE SOURCES OF RIGHTS,

03069 ELAZAR, D.

CONSTITUTIONAL RIGHTS IN THE FEDERAL SYSTEM PUBLIUS: THE JLURMAL PUBLIUS: THE JOURNAL OF FEDERALISH, 22(2) (SPR 92), 1-4.
THE THEME OF THIS ISSUE IS CHANGE. ITS THIN OBJECTIVE IS TO SHOW THAT RIGHTS WERE TAKEN SERIOUSLY IN THE AMERICAN SYSTEM FROM THE VERY FIRST, AND AT THE SAME TIME THAT TODAY'S UNDERSTANDING OF RIGHTS WAS NOT BROUGHT DOWN FROM HEAVEN AND NEED NOT BE TREATED AS SUCH. ANOTHER PURPOSE OF THIS ISSUE IS TO RAISE CONSCIOUSNESS OF THE EXISTENCE OF RIGHTS DOCTRINES SO THAT AMERICANS MAY STRENGTHEN THE DIALOGUE BETHEEN THEM.

03070 ELDAR, A.

LIKUD'S LOANS LOST: ISRAEL AT THE POLLS

TIKKUN, 7 ( 3 ) (MAY 92), 15-18; 80

THE LOAN GUARANTEE DILEMMA HAS BECOME A SOCIAL AND ECONOMIC DISPUTE, WHICH PRESENTS ISRAEL WITH THE CHOICE BETWEEN STRENGTHENING SETTLEMENTS IN THE OCCUPIED TERRITORIES AND STRENGTHENING ITS NEH IMMIGRANT POPULATION AND DOMESTIC ECONOMY--IN OTHER WORDS, OF WHETHER ISRAEL CAN STILL REALIZE THE CENTRAL ZIONIST GOAL OF EXTENDING SHELTER TO EVERY JEH IN DISTRESS. THIS ARTICLE SUGGESTS THAT BY LINKING U.S. LOAN GUARANTEES TO A SETTLEMENT FREEZE IN THE TERRITORIES, GEORGE BUSH HAS REALIGNED THE ISRAELI POLITICAL MAP IN A CRITICAL ELECTION YEAR. IT CONCLUDES THAT IF THE U. S. KNOWS HOW TO REWARD THE ISRAELI PUBLIC FOR ELECTING A PRAGMATIC GOVERMMENT WITH A COMPREHENSIVE PACKAGE OF PCDNOAIC, POLITICAL, AND SECURITY INCENTIVES, THEN THERE IS A REASONABLE CHANCE THAT THE VAST MAJORITY OF VOTERS WHO MINORITY TO STAND IH THE WAY OF A REALISTIC ARRANGEMENT WITH MINORITY TO STAND I

03071 ELEGANT, R.

EDUCATE JAPAN, DON'T ATTACK HER

ORBIS, 36(4) (FAL 92), 511-516.

EDWARD A. OLSEN'S PROPOSALS DO NOT MESH EITHER WITH EACH OTHER OR HITH THE DEMANDS OF THE REAL HORLD, AMD WOULD NOT 
ROBERT ELEGANT IN HIS RESPONSE TO OLSEN'S ANALYSIS OF RELATIONS BETWEEN THE UNITED STATES AND JAPAN. ELEGANT
EXPLORES SECURITY ARRANGEMENTS, BUREAUCRATIC REFORMS, COOPERATION, AND DEALINGS WITH JAPAN. ELEGANT CONCLUDES THAT HOSTILITIES ARE NOT NECESSARY TO CHANGE JAPAN. THE USA NEEDS THE CARROT AND THE STICK, NOT BLLDGEONS AND RANTING.

03072 ELEGANT, R.

YEARS OF LIVING PROSPEROUSLY

NATIONAL REVIEW, XLIV(12) (JUN 92), 22-24.

LIKE MUCH OF SOUTHEAST ASIA, INDONESIA HAS GROWN FAT UNDER AUTHORITARIAN CAPITALISM AND AMERICAN-LED STABILITY. THIS ARTICLE DESCRIBES PRESENT DAY INDONESIA AND PROJECTS WHAT MAY HAPPEN WHEN THE USA PULLS OUT. IT SUGGESTS THAT AMERICANS ARE NAIVE IN TALKING OF AN ELECTORAL CONTEST. THE MILITARY HOLDS ALL THE LEVERS OF PONER. CORRUPTION IS MILITARY HOLDS ALL THE LEVERS OF POWER. CORRUPTION IS
GETTING WORSE AS THINGS GET BETTER AND THE PICKINGS GET GETTING
FATTER.

03073 ELGIE, R.; MAOR, M.

ACCOUNTING FOR THE SURVIVAL OF MINORITY GOVERNMENTS: AN EXAMINATION OF THE FRENCH CASE, 1988-1991

WEST EUROPEAN POLITICS, 15(4) (OCT 92), 57-74.

THIS ARTICLE EXAMINES THE POST-ELECTORL CONDITIONS UNDER WHICH MINORITY GOVERNMENTS OPERATE. IT IS ARGUED THAT A MINORITY GOVERMMENT WILL REMAIN IN OFFICE FOR SO LONG AS IT ENJOYS THE SUPPORT OF EITHER A COMMITMENT TO RELATIONS, TO BEHAVIOUR, OR TO OUTCOMES. IF NO SUCH COMMITMENTS ARE FORTHCOHING, THEN IT WILL ONLY CONTIUE TO SURVIVE IF THERE IS A SPECIFIC CONSTITUTIONAL DEVICE UPON WHICH IT CAN RELY. THIS HYPOTHESIS IS TESTED UPON THE SITUATION IN FRANCE DURING 1988-91. HERE, MICHEL ROCARD'S MINORITY GOVERNMENT SURYIVED BECAUSE IT ENJOYED A COMMITMENT TO OUTCOMES.

03074 ELGIE, R.

THE PRIME MINISTER'S OFFICE IN FRANCE: A CHANGING ROLE IN A SEMI-PRESIDENTIAL SYSTEM GOVERNANCE, 5(1) (JAN 92), 104-121.

IN FRANCE SINCE 1958, IT IS POSSIBLE TO IDENTIFY THREE DIFFERENT TYPES OF POLITICAL LEADERSHIP: PURE PRESIDENTIAL GOVERNMENT, LIMITED PRESIDENTIAL GOVERNMENT, AND PRIME MINISTERIAL GOVERMMENT. THESE THREE LEADERSHIP TYPES ARE THE RESULT OF THE SEMI-PRESIDENTIAL NATURE OF THE FIFTH REPUBLIC. RENDER EACH OF THE THREE DIFFERENT FORMS OF LEADERSHIP. THE UNDER EACH OF THE THREE DIFFERENT FORMS OF LEADERSHIP, THE
ROLE OF THE PRIME MINISTER'S OFFICE HAS CHANGED. FOLLOWING A ROLE OF THE PRIME MINISTER'S OFFICE HAS CHANGED. FOLLOWING A
BRIEF PRESENTATION OF THE FUNCTIONS OF THE TWO COMPONENTS OF BRIEF PRESENTATION OF THE FUNCTIONS OF THE TWO COMPONENTS
THE PRIME MINISTER'S OFFICE, HIS CABINET AND THE GENERAL THE PRIME MINISTER'S OFFICE, HIS CABINET AND THE GENERAL
SECRETARIAT OF THE GOVERMMENT, THE CHANGES WHICH THE OFFICE HAS UNDERGONE ARE IDENTIFIED. WHILE THE ROLE OF BOTH OF THE HAS UNDERGONE ARE IDENTIFIED. WHILE THE ROLE OF BOTH OF THE COMPONENTS OF THE OFFICE VARIED ACCORDING TO THE DIFFERENT OF ITS DISTINCTIVE STRUCTURE AND FUNCTIONS, THE ROLE OF PRIME MINISTER'S CABINET HAS BEEN SUBJECT TO THE GREATEST PRIME MINISTER'S CABIME
AMOUNT OF VARIATION.

03075 ELIAS, C.

SIDELINING SEIDMAN

INSIGHT, $7(9)$ (MAR 91), 34-35.

THE BUSH ADMINISTRATION PROPOSAL TO BRING ORDER TO THE TROUBLED BANKING SYSTEM WOULD CUT RIGHT INTO THE FEDERAL DEPOSIT INSURANCE CORPORATION'S REGULATORY AUTHORITY. THE PROPOSAL. WHICH WOULD CREATE A NEW FEDERAL BANKING AGENCY INSIDE THE TREASURY DEPARTMENT TO REGULATE THRIFTS AND NATIONAL BANKS AND GIVE THE FEDERAL RESERVE BOARD JURISDICTION OVER STATE BANKS, UNDERSCORES THE DEBATE OVER THE FDIC'S ABILITY TO COVER DEPOSIT INSURANCE LOSSES. L. WILLIAM SEIDMAN, THE AGENCY'S CHIEF, IS YOCAL IN OPPOSING THE PLAN, A MOVE THAT HILL NOT IMPROVE HIS ALREADY SHAKY RELATIONS WITH THE WHITE HOUSE.

03076 ELIAS, C

WHOSE RECESSION?

INSIGHT, 7(7) (FEB 91) 40-41.

NOW THAT THE LONG-FEARED IF OFT-IGMORED RECESSION IS EVIDENT, MANY ECONOMIC ANALYSTS ARE REFLECTING ON HOW IT STARTED AND WHEN IT WILL END. BLAME IS BEING PLACED ON EVERYONE FROM ALAN GREENSPAN TO SADDAM HUSSEIN. WHAT SEEMS CERTAIN IS THAT IT WAS BROUGHT ON PARTLY BY FEDERAL RESERVE BOARD POLICIES AND BY THE FIXATION OF DEFICITS IN THE WHITE HOUSE AND CONGRESS THAT RESULTED IN TAX INCREASED. FORTUNATELY, SOME ECONOMISTS PREDICT THAT A RECOVERY WILL BE UNDERWAY BY' THE SUMMER.

03077 ELIAS, $R$.

ORUG HARS AS VICTIMIZATION AND SOCIAL CONTROL

NEW POLITICAL SCIENCE, (20) (SUM 91), 41-62.

THE CURRENT WAR ON DRUGS EMPHASIZES A

MILITARY/ENFORCEMENT MODEL. IT USES CRIMINALIZATION, FIREPOHER INTERYENTIOM AND PUMISHMEMT RATHER THAN DECRIMINALIZATION, TREATMENT, EDUCATION AND SOCIAL CHANGE. THIS ARTICLE EXAMINES HOH OFFICIALS PROMOTE DRUG WARS AS SYMBOLIC CRUSADES, THROUGH GOVERNMENT AND MEDIA PROPAGANDA. IT ALSO EXAMINES HOW DRUG WARS PRODUCE MORE VICTIMIZATION
ON DRUGS MIGHT BE TRANSFORMED INTO A PEACE MOVEMENT AGAINST THE PROBLEM'S REAL SOURCES.

03078 ELIOT, T

AFGHANISTAN IN 1990: GROPING FOR PEACE

ASIAN SURYEY, XXXI(2) (FEB 91), 125-133.

IN AFGHANISTAN, THE FIGHTING BETWEEN THE SOVIET-

SUPPORTED KABUL REGIME AND ITS OPPONENTS AS WELL AS BETWEEN OPPOSITION FACTIONS CONTINUED IN MANY PARTS OF THE COUNTRY DURING 1990. HITH NO ASSURANCES OF SECURITY, THE ECONOMIC INFRASTRUCTURE SEYERELY DAMAGED, AND LAND MINES SCATTERED EVERYWHERE, FEW OF THE MORE THAN FIVE MILLION AFGHAN REFUGEES IN PAKISTAN AND IRAN RETURNED TO THEIR HOMES. NEVERTHELESS, AS THE YEAR DREW TO A CLOSE THERE HERE A FEW RAYS OF HOPE. AFGHANS FROM MANY DIFFERENT FACTIONS WERE TALKING TO EACH OTHER, IN SOME CASES FOR THE FIRST TIME. TALKING TO EACH OTHER, IN SOME CASES FOR THE FIRST TIME. OPTIMISTIC OBSERVERS HOPE THAT THE PEACE PROCESS--STILL
LONG AND DAUNTING PROCESS--IS STARTING TO GET UNDERHAY.

03079 ELKLIT, J.

THE BEST OF BOTH WORLDS? THE DANISH ELECTORAL SYSTEM 191520 IN A COMPARATIVE PERSPECTIY

ELECTORAL STUDIES, 11(3) (SEP 92), 189-205

THE DANISH 1915-20 LOWER HOUSE' ELECTORAL SYSTEM COMBINED A TRADITIONAL PLURALITY SYSTEM AND A PR SYSTEM WITH MULTISTAGE COMPENSATORY SEATS IN TWO PROVINCIAL REGIONS, AND CLOSED PARTY LIST PR IN THE THIRD, METROPOLITAN, REGION. THIS COMPLEX SYSTEM IS PRESENTED AND ITS EFFECTS ON THE DISTRIBUTION OF SEATS IN THE "FOLKETING" ARE ANALYZED. IT WAS AN EARLY CASE OF PERSONALIZED PR WHICH CALLS FOR COMPARISONS WITH LATER CASES OF THIS KIND OF ELECTORAL SYSTEM. IN ORDER TO ASSESS IF SUCH COMPARISONS ARE APPROPRIATE, THE PAPER ALSO ASKS IF THESE FOUR ELECTORAL SYSTEMS ARE GENUINE MIXED SYSTEMS OR PR SYSTEMS IN DISGUISE.

03080 ELLICKSON, M.

PATHWAYS TO LEGISLATIVE SUCCESS: A PATH ANALYTIC STUDY OF THE MISSOURI HOUSE OF REPRESENTATIVES

LEGISLATIVE STUDIES QUARTERLY, 27(2) (MAY 92), 285-302.

A CAUSUAL MODEL DEPICTING PERSONAL, ENVIRONMENTAL, AND INSTITUTIONAL PATHWAYS TO LEGISLATIVE SUCCESS IS DEVELOPED AND TESTED WITH DATA DRAWN FROM THE $1987-88$ MISSOURI HOUSE OF REPPRESENTATIVES. WITH LEGISLATIVE SUCCESS CONCEPTUALIZED OF REPPRESENTATIVES. WITH LEGISLATIVE SUCCESS CONCEPTUALIZED AS A MULTISTEP PROCESS ENDING IN 8 ILL PASSAGE, DIRECT PATHS
TO SUCCESS INCLUDE POLITICAL PARTY, SENIORITY, FORMAL OFFICE, TO SUCCESS INCLUDE POLITICAL PARTY, SENIORITY, FORMAL OFFICE AGE, RACE AND EDUCATIONAL LEVEL. THE RESULTS OF THE PATH
ANALYSIS PROVIDE STRONG SUPPORT FOR THE PROPOSED MODEL.

03081 ELLICKSON, R.C.

THE UNTENABLE CASE FOR AN UNCONDITIONAL RIGHT TO SHELTER HARVARD JOURNAL OF LAW AND PUBLIC POLICY, 15(1) (WIN 92), $17-34$

AS HOMELESSNESS HAS BECOME A PROMINENT DOMESTIC ISSUE, SOME ADVOCATES HAVE CALLED FOR CONSTITUTIONAL RECOGNITION OF AN INDIVIDUAL'S UNCONDITIONAL RIGHT TO A MINIMUM LEVEL OF SHELTER. BUT THESE ADVOCATES HAVE FAILED TO DEAL HITH THE FUNDAMENTAL FACT THAT A SOCIETY MUST MAINTAIN IMCENTIVES TO WORK. BOTH THEORY AND DATA INDICATE THAT AN UNCONDITIONAL SHELTER RIGHT, PRESUMABLY COUPLED WITH IRONCLAD RIGHTS TO ENJOY OTHER MATERIAL BENEFITS, WOULD BE COUNTERPRODUCTIVE IN GENERAL, THERE ARE THREE OVERARCHING ISSUES IN THE DESIGN OF A CONSTITUTION'S BILL OF RIGHTS: (1) SHOULD A BILL OF RIGHTS PROTECT ONLY NEGATIVE LIBERTIES--THAT IS, RIGHTS AGAINST GOVERNMENT INTRUSIONS--OR SHOULD IT ALSO AFFIRM SPECIFIED POSITIVE LIBERTIES, SUCH AS ENTITLEMENTS TO A MINIMUM LEVEL OF MATERIAL WELFARE? (2) SHOULD A

CONSTITUTION'S BILL OF RIGHTS BE COMPLEMENTED WITH A BILL OF DUTIES THAT SPECIFIES EACH CITIZEN'S CIVIC RESPONSIBILITIES? (3) WHAT RIGHTS IN A FEDERAL SYSTEM ARE APPROPRIATELY PLACED ONLY IN A STATE CONSTITUTION'S BILL OF RIGHTS?

03082 ELLIG, J.; HIGH, J.

SOCIAL CONTRACTS AND PIPE DREAMS

CONTEMPORARY POLICY ISSUES, $X(1)$ (JAN 92 ), 39-51.

DEBATE OVER THE PUBLIC UTILITY "REGULATORY CONTRACT" HAS INCREASINGLY FOCUSED ON THREE ISSUES CREATED BY SUHK COSTS: (I) PROTECTION OF SUNK CAPITAL, (II) DIVISION OF WINDFALLS IN A HORLD OF UNCERTAINTY, AND (III) MECHANISMS TO CONTROL THE REGULLATOR WHO ADMINISTERS LONG-TERM AGREEMENTS. IN THIS ESSAY, THE AUTHORS USE THREE CRITERIA TO EVALUATE REGULATORY ALTERNATIVES IN THE NATURAL GAS INDUSTRY. THEY OISCUSS GOVERNMENT REGULATION OF PIPELINES AS INTEGRATED GAS MERCHANTS, GOVERNMENT REGULATION OF PIPELINES AS GAS TRANSPORTERS, AND PRIVATE REGULATION THROUGH COMPETITIVE CONTRACTING. THEY ARGUE THAT PRIVATE CONTRACTING OFFERS SUPERIOR CONTROL OVER THE CONTRACT ADMINISTRATOR BECAUSE IT REMOVES THE FEDERAL ENERGY REGULATORY COMMISSION'S MONOPOLY ON CONTRACT ADMINISTRATION.

03083 ELLINGS, R.J.: OLSEN, E.A.

A NEH PACIFIC PROFIL

FOREIGN POLICY, (89) (WIN 93), 116-136

THE UNITED STATES IS ATTEMPTING TO ADJUST ITS FOREIGN POLICY TO FIT THE NEW CIRCUMSTANCES IN ASIA, BUT IT IS 
PROCRUSTEAN EFFORT. AMERICAN STRATEGY IN THE REGION REMAINS A CAUTIOUS ADAPTATION OF EUROCENTRIC COLD WAR POLICIES TO THE NEW DYNAMICS OF THE POST-COLD WAR WORLD. IT IS OVERLY TENTATIVE AND INCREASINGLY INEFFECTIVE. THE UNITED STATES MUST RECOGNIZE ITS ENORMOUS STAKE IN ASIA AND TREAT THE REGION ON ITS OWN TERMS, FORMULATING A NEW STRATEGY THAT ASSERTIVELY PURSUES U.S. ECONOMIC COMPETITIVENESS AS WELL AS A FLEXIBLE COALITION APPROACH TO REGIONAL SECURITY.

03084 ELLIOT, E.; GRYSKI, G.; REED, B.

MINOR PARTY SUPPORT IN STATE LEGISLATIVE ELECTIONS STATE AND LOCAL GOVERMMENT REVIEN, 22(3) (FAL 90), 123-131.

THIS STUDY FOCUSES ON THE PHENOMENON OF MINOR PARTY VOTING IN THE UNITED STATES. THE AUTHORS ANALZYE ELECTION STATISTICS FOR ALL RACES TO THE LOWER HOUSES OF STATE LEGISLATURES DURING THE PERIOD 1976-1984. THEY FIND THAT SUPPORT FOR MINOR PARTIES IS STRONGEST IN THE WESTERN STATES AND WEAKEST IN THE SOUTH.

03085 ELLIOTT, D.

VIETNAM'S 1991 PARTY ELECTIONS

ASIAN AFFAIRS. AN AMERICAN REVIEW, 19(3) (FAL 92), 159-168.

THE ELECTION OF THE CENTRAL COMMITTEE OF THE VIETHAMESE COMMUNIST PARTY AT ITS SEVENTH CONGRESS REVEALED THO IMPORTANT DEVELOPMENTS IN VIETNAMESE POLITICS. THE FIRST IS THE INCREASING FRAGMENTATION OF POHER AND BALKANIZATION OF THE POLITICAL SYSTEM. SECONDLY, ALTHOUGH THE LEADERSHIP GROUP IS A TRANSITIONAL ONE BETHEEN THE OLD AND NEW GENERATIONS, IT IS MORE LIKE THE OLD GUARD THAN DIFFERENT FROM IT, INDICATING THAT VIETNAM HAS NOT YET DISCOVERED ITS
POLITICAL FUTURE.

03086 ELLIOTT, K.A.

UNITED STATES TRADE POLICY AFTER THE COLD WAR

CURRENT HISTORY, 91 (564) (APR 92), 162-167.

THE END OF THE COLD WAR PRESENTS THE UNITED STATES WITH OPPORTUNITIES AND DANGERS AS IT DEVELOPS ITS TRADE AND COMPETITIVENESS STRATEGY FOR THE REST OF THE DECADE. IT MUST WORK OUT TRADE PROBLEMS AND NEW TERMS OF COOPERATION WITH THE REST OF THE WORLD, INCLUDING THE EUROPEAN COMMUNITY, JAPAN, AND MEXICO. BUT TRADE POLICY IS FAR LESS IMPORTANT TO COMPETITIVENESS THAN OTHER ISSUES THAT THE USA NEEDS DESPERATELY TO ADDRESS. MISMANAGEMENT OF MACROECOMOMIC POL ICY IN THE ARDY 1980 'S SEYERELY IMPAIRED AMERICAM COMPETITIVENESS IN THE SHORT RUN BY LEADING TO AN OVERVALUED DOLLAR, WHICH PRICED U.S. EXPORTS OUT OF INTERMATIONAL MARKETS, ALLOHED FOREIGN EXPORTERS TO UNDERPRICE AMERICAM MARKETS, ALLOWED FOREIGN EXPORTERS TO UNDERPRICE AMERICAM PRODUCERS I
DEFICITS.

03087 ELLIOTT, L.A.; HARRINGTON, L.; JACKSON, B.; LOWELL, F.K.; MCCONHELL, M.; SWILLINGER, D.j.

CAMPAIGH FIMAMCE

JOURNAL OF LAH \& POLITICS, VIII(2) (WIN 92), 291-310.

THIS REPORT INCLUDES THE TRANSCRIPT OF A PANE

DISCUSSION ON PUBLIC FINANCING OF PRESIDENTIAL CAMPAIGNS THE PANELISTS CONSIDER THE METHOD OF COLLECTING PUBLIC MONEY FOR PRESIDENTIAL CAMPAIGNS, THE LIMITS ON CAMPAIGN EXPENDITURES, THE FUNDING OF MINOR CANDIDATES, AND SIMILAR I SSUES.

03088 ELLIOTT, L.A.

THE FACTS AND FIGURES ABOUT CAMPAIGN FINANCE: A VIEW FROM INSIDE THE FEDERAL ELECTION COMMISSION

JOURNAL OF LAW \& POLITICS, VIII(2) (WIN 92), 311-320.

THE AUTHOR EXPLAINS THE CURRENT SYSTEM OF FINANCING PRESIDENTIAL ELECTION CAMPAIGNS AND DISCUSSES THE ROLE OF POLITICAL ACTION COMMITTEES AND THE FEDERAL ELECTION COMMISSIOH.

03089 ELLIS, M.

CLOSING RAMKS' AND 'SEEKING HONORS : H.E.B. DUBOIS IN HORLD HAR I

JOURMAL OF AMERICAN HISTORY, 79(1) (JUN 92), 96-124.

IN JULY 1918, AT THE HEIGHT OF AMERICAN MOBILIZATION FOR WORLD WAR I, H.E.B. DUBOIS WROTE "CLOSE RANKS," CALLING ON AFRICAN AMERICANS TO FORGET THEIR GRIEVANCES AND CLOSE RANKS WITH THE ALLIES FOR THE DURATION OF THE WAR. DUBOIS' EXHORTATIOY HAS A CONTROYERSIAL OME BECAUSE IT HAS ACOMAT COMMISSION AS A CAPTAIN IN THE MILITARY INTELLIGENCE BRANCH (MIB) OF THE U.S. ARMED SERVICES AT THE TIME. THE CDNTROVERSY DAMAGED DUBOIS'S REPUTATION AS AN UHBENDING OPPONENT OF RACIAL DISCRIMINATION AND DEEPENED THE DIVISIONS

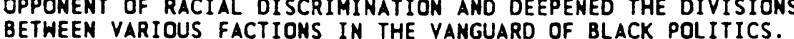

03090 ELLIS, M.

ENDING AUSCHWITZ AND RENEWING PALIESTINE IN THE JEWISH IMAGINATION MIDOLE EAST POLICY, 1(4) (1992), 55-76.

THE JEWISH AUTHOR OF THIS ARTICLE PONDERES THESE QUESTIONS: IF HE DWELL ONLY IN AUSCHWITZ, IN OUR PAST SUFFERINGS, HOW CAN WE UNDERSTAND SUFFERING IN THE CONTEMPORARY HORLD? AND IF AUSCHWITZ AS AN ANCHOR OF MEMORY
IS USED AS A BLUNT INSTRUMENT OF OPPRESSION, HOW CAN HE UNDERSTAMD THE SUFFERING OF THE PALESTINIAN PEOPLE AT OUR HANDS? HE EXPLORES HOW THE HEALING OF THE PALESTINIAN TRAUMA IS ABSOLUTELY ESSENTIAL FOR THE HEALING OF THE JEWISH TRAUMA, AND THAT THE REINTEGRATION OF PALESTINE IS AS ESSENTIAL TO JEWISH HISTORY AS IT IS TO PALESTINIAN HISTORY. HE SUGGESTS THAT THE ONLY WAY TO FINALLY END AUSCHWITZ IS TO REIMAGINE A PALESTINE WHERE FOR JEWS ONLY AN INNOCENT AND YET IN REALITY AN IMPERIAL ISRAEL EXISTS TODAY.

03091 ELLIS, R.

PLURALIST POLITICAL SCIENCE \& "THE STATE": DISTINGUISHING BETWEEN AUTONOMY \& COHERENCE

POLITY, 24(4) (SUM 92), 569-590.

THE DEBATE OVER "BRINGING THE STATE BACK IN" TO

POLITICAL ANALYSIS COMBINES TWO ISSUES: STATE AUTONOMY AND STATE COHERENCE. THIS ARTICLE CONTENDS THAT PLURALIST POLIIICAL SCIENTISTS ARE RELUCTANT TO SPEAK OF "THE STATE" BECAUSE THEY DOUBT THAT GOVERMMENTAL ACTORS ARE COHERENT BECAUSE THEY DOUBT THAT GOVERTMENTAL ACTORS ARE COHERENT ENOUGH TO WARRENT A LOCUTION THAT ENCOURAGES THE TREATMENT THE LITERATURE HAS ASSUMED AND DEMONSTRATED SUBSTANTIAL THE LITERATURE HAS ASSUMED AND DEMONSTRATED

03092 ELLIS, R.J.

RADICAL LOCKEANISM IN AMERICAN POLITICAL CULTURE WESTERN POLITICAL

THE AUTHOR ARGUES THAT EVEN IF ALL AMERICANS ARE LOCKEAM, AS LOUIS HARTZ HAS CLAIMED, THEY NEVERTHELESS INTERPRET LOCKE IN VERY DIFFERENT WAYS. THROUGH AN EXAMINATION OF 19THCENTURY RADICAL AMERICAN POLITICAL THOUGHT AND CULTURE, FROM TOM PAINE TO HENRY GEORGE. THE AUTHOR SHOWS THAT THERE' IS A HORLD OF DIFFERENCE BETHEEN THE INDIVIDUALIST READING OF LOCKE, WHICH IS USED TO JUSTIFY UNL IMITED ACCUMULATION, AND THE EGALITARIAN READING OF LOCKE, WHICH INSISTS THAT EACH PERSON HAS A NATURAL RIGHT TO PROPERTY. THE IDEOLOGICAL OISTANCE BETWEEN THESE TWO INTERPRETATIONS OF LOCKE CALLS
INTO OUESTION THE HARTZIAN VIEW THAT A SHARED COMMITMENT TO LOCKEAN PRECEPTS SIGNIFIES A CONSENSUS ON COMPETITIVE INDIVIDUALISM.

03093 ELLIS, R.J.

RIVAL VISIONS OF EQUALITY IN AMERICAN POLITICAL CULTURE REVIEW OF POLITICS, $54(2)$ (SPR 92), 253-280.

THE AUTHOR DISTINGUISHES BETHEEN A COMPETITIVE INDIVIDUALIST PROCESS-ORIENTED VISION OF EQUALITY AND AN EGALITARIAN RESULTS-ORIENTED VISION OF EQUALITY AND EXAMINES THE CHANGING RELATIONSHIP BETHEEN THESE VISIONS IN THE THE CHANGING RELATIONSHIP BETHEEN THESE VISIONS IN THE
AMERICAN PAST. WHAT IS EXCEPTIONAL ABDUT THE UNITED STATES AMERICAN PAST. WHAT IS EXCEPTIONAL ABDUT THE UNITED STATES
IS NOT THAT IT LACKED A TRADITION OF EQUAL RESULTS BUT THAT IS NOT THAT IT LACKED A TRADITION OF EQUAL RESULTS BUT THAT
THOSE WHO FAVORED EQUALIZING RESULTS BELIEVED THAT EOUAL THOSE WHO FAVORED EQUALIZING RESULTS BELIEVED THAT EQUAL RESULTS. THESE RIVAL VISIONS OF EQUALITY, ONCE BELIEVED TO RESULTS. THESE RIVAL VISIONS OF EQUALITY, ONCE BELIEVED TO BE MUTUALLY SUPPORTIVE,
2OTH CENTURY AMERICA.

03094 ELLIS, S

THE SOUTH AFRICAN COMMUNIST PARTY AND THE COLLAPSE OF THE SOVIET UNION

JOURNAL OF COMMUNIST STUDIES, 8(2) (JUN 92), 145-159.

FROM 1950 TO 1990, THE SOUTH AFRICAN COMMUNIST PARTY (SACP) WAS BANNED BY A GOVERNMENT THAT PORTRAYED

INTERNATIONAL COMMUNISM AS THE SOURCE OF ALL POLITICAL EVIL. THE CONDITIONS OF EXILE PARTIALLY EXPLAIN THE SACP'S CONTINUING ADHERENCE TO MARXIST-LENINIST ORTHODOXY. THE PRACTICAL CONSEQUENCES OF THE QUASI-STALINIST REGIME THAT THE SACP INTRODUCED IN ANC CAMPS IN ANGOLA HERE UNKNOWN TO PEOPLE BACK HOME IN SOUTH AFRICA. THE FACT THAT THE SACP IS SUCH A MILITANT FOE OF APARTHEID, BUT DOES NOT HAVE A RECORD IN GOVERNMENT TO DEFEND, HAS CONTRIBUTED TO ITS POPULARITY AMONG BLACK SOUTH AFRICANS TODAY. IT IS ARGUABLY THE ONLY COMMUNIST PARTY IN THE WORLD WHOSE POPULARITY IS INCREASING

03095 ELLISON, C.

MILITARY BACKGROUND, RACIAL ORIENTATIONS, AND POLITICAL PARTICIPATION AMONG BLACK ADULT MALES

SOCIAL SCIENCE QUARTERLY, 73(2) (JUN 92), 360-378.

ANALYZING DATA ON A NATIONAL SAMPLE OF BLACK ADULT MALES, THIS STUDY SHOWS THAT BLACKS WITH MILITARY BACKGROUNDS -PARTICULARLY COMBAT VETRANS - EXPRESS LOWER LEVELS OF RACIAL IDENTIFICATION AND SEPARATIST SENTIMENT THAN DO NONVETERANS. VETERANS, ESPECIALLY COMBAT VETERANS, ARE ALSO MORE LIKELY THAN NONVETERANS TO ENGAGE IN HIGH-INITIATIVE POLITICAL THAN NONVETERANS TO ENGAGE IN HIGH-INITIATIVE POL ITICAL ACTIUITY, BUT NOT LOW-INITIATIVE ACTIVITY. THE POSSIBLE SEYERAL DIRECTIONS FOR FUTURE RESEARCH.

03096 ELLMAN, M.

RUSSIA II: IS CORPORATISM THE ANSWER? WORLD TODAY, 48(7) ( JUL 92), 125-126.

AN IMPORTANT ASPECT OF THE RUSSIAN TRANSITION FROM STATE SOCIALISM THAT HAS RECEIVED LITTLE PUBLICITY IN THE WEST IS THE ATTEMPT TO INTRODUCE THE INSTITUTIONS OF WHAT WESTERN EUROPE CALLS "THE SOCIAL MARKET ECONOMY" ("SOZIALE 
MARKWIRTSCHAFT"). THE RUSSIAN AUTHORITIES ARE TRYING TO AVOID BITTER SOCIAL CONFLICTS BY EMULATING THE WEST EUROPEAN EXPERIENCE WITH THE HARMONY MOOEL. IN ORDER TO GIYE SOME FLESH TO THIS ASPIRATION, THE RUSSIAN TRILATERAL COMMISSION FOR LABOR RELATIONS--REPRESENT ING EMPLOYERS, TRADE UNIONS, AND THE GOVERNMENT--WAS ESTABLISHED ON JANUARY 24, 1992. ONE OF ITS FIRST ACHIEVEMENTS WAS THE GENERAL AGREEMENT FOR 1992 , WHICH ESTABLISHED A FRAMEHORK FOR LABOR RELATIONS.

03097 ELLMAN, M.

SHOCK THERAPY IN RUSSIA: FAILURE OR PARTIAL SUCCESS?

RFE/RL RESEARCH REPORT, 1 (34) (AUG 92), 48-61.

THE GENERAL VIEW IS THAT ACTING PRIME MINISTER EGOR

GAIDAR'S ECONOMIC POLICIES HAVE BEEN A FAILURE. INFLATION IS

VERY HIGH; SHORTAGES ARE COMMON; AND LARGE-SCALE MONETARY

FINANCING OF THE DEFICIT ON THE BUDGET PERSISTS. THE

POLICIES SEEM TO HAVE TRIGGER HYPERINFLATION RATHER THAN

MONETARY STABILIZATION, AS INTENDED. THE OEPRESSION HAS

DEEPENED AND IS MUCH WORSE WITH RESPECT TO OUTPUT REDUCTION THAN THE GREAT DEPRESSION IN THE HEST; LIVING STANDARDS HAVE FALLEN SHARPLY; OFFICIALLY-REGISTERED FOREIGN TRADE HAS BEEN
GREATLY REDUCED; THE FOREIGN DEBT IS INCREASING; AND INCOME DISTRIBUTION IS VERY UNEQUAL. NEVERTHELESS, THE SITUATION IS NOT ENTIRELY BLACK. AS A LIBERALIZATION PROGRAM, GAIDAR'S POLICIES HAVE ACHIEYED SOME RESULTS. AS A DEMILITARIZATION PROGRAM, THEY HAVE ALSO MADE SOME PROGRESS, ALTHOUGH THEY HAVE GIVEN RISE TO NEW PROBLEMS. EVEN AS MONETARY STABILIZATION POLICIES, THEY HAVE BEEN PARTIALLY SUCCESSFUL. THE FAILURE OF RUSSIA'S STABILIZATION PROGRAM TO BE AS SUCCESSFUL AS POLAND'S IS DUE TO SOME IMPORTANT DIFFERENCES BETHEEN THE THO PROGRAMS AND BETWEEN THE ECONOMIC

ENYIRONMENTS. IT SEEMS LIKELY THAT THE FAILURE OF GAIDAR'S PROGRAM WILL HAVE MAJOR POLIIICAL CONSEQUENCES IN THE NOT

TOO DISTANT FUTURE.

03098 ELLSBERG, $D$.

NUCLEAR SECURITY AND THE SOCIET COLLAPSE

WORLD POLICY JOURNAL, $Q$ (1) (WIN 91), 135-156

DANIEL ELLSBERG EXPLAINS THE URGENCY OF BREAKING WITH PAST HABITS AT THIS PARTICULARLY CRITICAL MOMENT IN MODERN HISTORY AND WARNS OF THE DANGERS OF NUCLEAR PROLIFERATION IF HISTORY AND WARNS OF THE DANGERS OF NUCLEAR PROLIFERATION IF
"INSTITUTIONAL INERTIA" IS ALLOWED TO PREVAIL IN THE POST"INSTITUTIONAL INERTIA" IS ALLOWED TO PREVAIL IN THE POST-
COLD WAR ERA. IN THE VOLATILE POST-COUP CLIMATE THE NEED FOR COLD WAR ERA. IN THE VOLATILE POST-COUP CLIMATE THE NEED
RAPID AND DRAMATIC REDUCTIONS IN NUCLEAR WEAPONS BECOME RAPID AND DRAMATIC REDUCTIONS IN NUCLEAR WEAPONS BECOME DOUBLY URGENT. DESPITE HAVING STRUCK THE RIGHT NOTE WITH HIS BYPASS OF PONDEROUS NEGOTATIONS, ONE MUST ASK WHETHER BUSH'S INITIATIVES HERE NOT ALREADY TOO LITTLE AND TOO LATE, GIVEN
THE SPLINTERING OF THE UNION AND EVER MORE TENUOUS AUTHORITY THE SPLINTERING OF THE UNION AND EVER MORE TENUDUS AUTHOR OF THE CENTRAL GOVERNMENT. ELLSBERG CONCLLDES THAT THE HEAPONS IS A SERIOUS POSSIBILITY.

03099 ELLWOOD, S.M.

THE EXTREME RIGHT IN POST-FRANCOIST SPAIN

PARLIAMENTARY AFFAIRS, 45(3) (JUL 92), 373-385.

ONE OF THE MOST NOTABLE FEATURES OF THE POST-FRANCO ERA HAS BEEN THE VIRTUAL DISAPPEARANCE OF THE SPANISH RIGHT AS IT HAD EXISTED UP TO 1975. AS SUCCESSIVE ELECTIONS HAVE SHOWN, THE INHABITANTS OF THE FRANCOIST BUNKER HAVE ONLY VERY LIMITED APPEAL FOR CONTEMPORARY SPANISH VOTERS. BUT IT WOULD BE WRONG TO CONCLUDE THAT RIGHT-WING EXTREMISM IS DEAD IN SPAIN. IN THIS ESSAY, THE AUTHOR SURVEYS THE ACTIVITIES OF EXTREME RIGHT-WING GROUPS IN SPAIN FROM 1989 TO 1939, DURING THE FRANCD REGIME, AND SINCE FRANCO. HE ALSO LOOKS AT THE CURRENT STATUS OF THE SPANISH RIGHT-WING AND ITS PROSPECTS FOR THE FUTURE.

03100 ELM, M.

OIL, POHER, AND PRINCIPLE

IEMPORARY ISSUES IN THE MIDDLE EAST, 1992, 400

IRAN'S REVOLT AGAINST BRITISH IMPERIALISM CULMINATED IN THE NATIONALIZATION OF BRITISH OIL INTEREST IN IRAN IN 1951. THIS BOOK EXAMINES TH NATIONALISTS AND THE ANGLO-IRANIAN OIL COMPANY, WHICH WAS THE PILLAR OF BRITAIN'S ECONOMIC AND STRATEGIC POWER IN THE REGION. DRAWING ON RECENTLY DECLASSIFIED DOCUMENTS AND INTERVIEWS, THE AUTHOR OFFERS EVIDENCE THAT THE BRITISH
FOREIGN INTELLIGENCE AND THE AMERICAN CIA ORGANIZED THE COUP FOREIGN INTELLIGENCE AND THE AMERICAN CIA ORGANIZED THE
IN 1953 THAT CRUSHED THE DEFIANT ATTEMPT OF MOSADEQ'S IN 1953 THAT CRUSHED THE DEFIANT ATTEMPT OF MOSADEQ'S
NATIONALIST GOVERNMENT TO RUN ITS OIL INDUSTY WITHOUT NATIONALIST GOVERNMENT TO RUN ITS OIL INDUSTY WITHOUT WESTERN HELP. HE ALSO ARGUES THAT ALTHOUGH THE COUP RESULTED IN AN AMERICAN-DOMINATED OIL CONSORTIUM, FAR FROM PROVIDING
ENERGY SECURITY FOR THE WEST IT ACTUALLY CONTRIBUTED TO FURTHER INSTABILTIY IN THE MIDOLE EAST, BEGINING CHAIN OF EVENTS THAT ULTIMATELY CONTRIBUTED TO THE GULF WAR.

03101 ELMAN, B.

POLITICAL, SOCIAL, AND CULTURAL REPRODUCTION VIA CIVIL SERVICE EXAMINATIONS IN LATE IMPERIAL CHINA

JOURAAL OF ASIAN STUDIES, 50(1) (FEB 91) 7-28.

MANY HISTORIANS HAVE EVALUATED THE EXAMINATION PROCESS IN LATE IMPERIAL CHINA FROH THE PERSEPCTIVE OF THE MODERNIZATION PROCESS IN MODERN EUROPE AND THE UNITED STATES. THEY HAVE THEREBY SUCCESSFULLY EXPOSED THE FAILURE OF THE
CONFUCIAN SYSTEM TO ADVANCE THE SPECIALIZATION AND TRAINING IN SCIENCE THAT ARE DEEMED ESSENTIAL FOR NATION-STATES TO POLITICAL TRADITIONS. IN THIS ARTICLE. THE AUTHOR CAUTIONS AGAINST SUCH CONTEMPORARY, A HISTORICAL STANDARDS FOR POLITICAL, CULTURAL, AND SOCIAL FORMATION. THESE A PRIORI JUDGEMETNS ARE OFTEN EXPRESSED TELEOLOGICALLY WHEN TIED TO THE "MODERNIZATION NARRATIVE" THAT STILL PERVADES THE HISTORIOGRAPHY OF MING AND CH'ING DYNASTY CHINA.

03102 ELOVITZ, P.

CHARACTER, CANCER AND ECONOMIC REGENERATION IN THE 1992

PRESIDENTIAL COMPAIGN OF SENATOR PAUL E. TSONGAS

PRESIDENTIAL COMPAIGN OF SENATOR PAUL E. TSONGAS
JOURNAL OF PSYCHOHISTORY, 20(2) (FAL 92), 217-228.

THIS ARTICLE WILL PROBE THE CHILDHODD, CAMPAIGN AND ECONOMIC IDEAS OF PAUL TSONGAS RELATING THEM TO THE DUAL ECONOMIC IDEAS OF PAUL TSONGAS RELATING THEM TO THE DUAL TRAUMAS OF THE LOSS OF HIS MOTHER AS A YOUNG CHILD AND
CANCER. SINCE CHARACTER IS DEVELOPED IN CHILDHOOD THE FIRST CANCER. SINCE CHARACTER IS DEVELOPED IN CHILDHOOD THE FIRST HALF DEVELOPMENT OF HIS PERSONALITY. THE REST OF THE ARTICLE THE DEVELOPMENT OF HIS PERSONALITY. THE REST OF THE ARTICLE SHOWS HOW THE ECONOMIC DECLINE OF LOWELL AND THE CANCER IN
HIS BODY, WHICH WAS HELPED BY DRASTIC TREATMENT, INTENSIFIED HIS FOCUS ON THE NEED FOR STRONG ACTION TO SAVE THE AMERICAN ECONOMY.

\section{ELSENHANS, H.}

DEVELOPMENT AND UNDERDEVELOPMENT--THE HISTORY, ECONOMICS, AND POLITICS OF NORTH-SOUTH RELATIONS

SAGE PUBLICATIONS, $1991,176$.

THIS VOLUME EXPLORES AND ANALYZES THE COMPLEX POLITICAL AND ECONOMIC RELATIONS BETHEEN THE ADVANCED INDUSTRIAL COUNTRIES OF THE NORTH AND THE DEVELOPING COUNTRIES OF THE SOUTH. PROVIDING A DYNAMIC VIEH OF NORTH-SOUTH RELATIONS, THE BOOK DISCUSSES SUCH CRITICAL ISSUES AS THE CAUSES OF UNDERDEVELOPMENT, THE IMPACT OF SOCIAL STRUCTURES, AND THE POLITICAL-ECONOMIC ASPECTS OF NORTH-SOUTH RELATIONS. IN ADDITION, IT OFFERS A POSSIBLE REFORM STRATEGY FOR THE WEST, ONE WHICH COMBINES COMMITMENT TO SOCIAL REFORM IN THE SOUTH AND INCREASED RESOURCE FLOWS FROM THE NORTH TO SOUTH IN THE FRAMEWORK OF A NEW INTERNATIONAL ECONOMIC ORDER.

03104 ELSENHANS, H.

EUROPE 89-92 AND THE THIRD WORLD

INTERNATIONAL SOCIAL SCIENCE JOURNAL, 131(131) (FEB 92), 125-140.

FUNDAMENTAL CHANGES IN EASTERN EUROPE ARE EXPLORED WHICH ARE DUE TO THE ATTRACTIVENESS OF THE LIBERAL WELFARE STATE, IMPOSED BY THE REFORMIST LABOR MOVEMENT OF THE WEST ON ITS
OWN CAPITALIST CLASSES. THIS VICTORY OF THE REFORMIST LABOR OWN CAPITALIST CLASSES. THIS VICTORY OF THE REFORMIST LABOR MOVEMENT WILL NOT RESULT, THIS ARTICLE PROJECTS, IN THE TRANSFER OF THE MAJOR MECHANISMS OF SOCIAL AND POLITICAL REGULATION OF THE WEST TO THE SOUTH I.E. EXPANDING MASS
MARKETS DUE TO POLITICAL PRESSURES FROM THE UNDERPRIVILEGED CLASSES WHICH ALLOW FOR LOCAL TECHNOLOGY PRODUCTION WHICH IN TURN LEADS TO NET INVESTMENT AND POSITIVE PROFIT RATES.

03105 ELSHTAIN, J.B.

ETHICS IN THE HOMEN'S MOVEMENT

ANNALS OF THE AMERICAN ACADEMY OF POLITICAL AND SOCIAL SCIENCE, (515) (MAY 91), 126-139.

FEMINISM WITHOUT ETHICS IS INCONCEIVABLE. EACH FEMINIST POSITION MAKES CONTACT HITH EXISTING POLITICD-ETHICAL SYSTEMS, SOMETIMES EXTENDING, SOMETIMES REPUDIATING FEATURES OF THOSE SYSTEMS. IN THIS ESSAY, THE AUTHOR ELABORATES THE RELATIONSHIP BETWEEN FEMINISH IN ITS RADICAL, LIBERAL, MARXIST OR SOCIALIST, AND ECOLOGICAL VARIETIES AND VARIOUS POLITICAL AND ETHICAL POSITIONS ON SOME OF THE MOST HIGHLYCHARGED ISSUES OF THE DAY. HER AIM IS TO SHOW THAT FEMINISM CANMOT ESCAPE EXUDING ETHICAL ASSUMPIIONS AND IMPLICATIONS AND THAT FEMINISTS CAN AND SHOULD BE HELD ACCOUNTABLE FOR AND THAT FEMINISTS CAN AND SHOULD BE HELD ACCOUNTAE
THE STANCES THEY EITHER UNDERHRITE OR REPUDIATE.

03106 ELY, J.W. JR.

PROPERTY RIGHTS AND LIBERTY: ALLIES OR ENEMIES?

PRESIDENTIAL STUDIES QUARTERLY, XXIII (4) (FAL 92), 703-710. THE AUTHOR LAMENTS THAT CERTAIN OF THE ORIGINAL CONCERNS THAT INSPIRED THE U.S. CONSTITUTION AND BILL OF RIGHTS HAVE RECENTLY BEEN PUSHED ASIDE--E.G., PROPERTY RIGHTS. THE RECENTLY BEEN PUSHED ASIDE--E.G. PROPERTY RIGHTS. THE
CONSTITUTIONAL CONVENTION OF 1787 WAS, IN PART, TRIGGERED BY CONSTITUTIDNAL CONVENTION OF 1787 WAS, IN PART, TRIGGERED
SHAY'S REBELLION, WHICH CHALLENGED PROPERTY RIGHTS. EARLY SHAY'S REBELLION, WHICH CHALLENGED PROPERTY RIGHTS. EARLY
EMINENT JURISTS, INCLUDING CHIEF JUSTICE MARSHALL AND DANIEL EMINENT JURISTS, INCLUDING CHIEF JUSTICE MARSHALL AND
WEBSTER, EMPHASIZED PROPERTY RIGHTS AS BASIC TO THE WEBSTER, EMPHASIZED PROPERTY RIGHTS AS BASIC TO THE
REPUBLICAN SYSTEM. THE ANTI-PROPERTY TREND CAME DURING AND REPUBLICAN SYSTEM. THE ANTI-PROPERTY TREND CAME DURING AND AFTER THE 1937 SUPREME COURT. THE AUTHOR ARGUES THAT RECENT
EVENTS IN EASTERN EUROPE VIVIDLY UNDERSCORE THE LINK BETHEEN EVENTS IN EASTERN EUROPE VIVIDLY UNDERSCD
PROPERTY RIGHTS AND POLITICAL LIBERTY.

03107 EMADI, H.

CONFLICTS IN THE MIDDLE EAST: THE KURDISH NATIONAL QUESTION CONTEMPORARY REVIEW, 261(1519) (AUG 92), 62-71.

THE KURDS ARE THE LARGEST MINORITY IN THE MIDOLE EAST WHICH HAVE BEEN SUBJECTED TO NATIONAL OPPRESSION IN COUNTRIES WHERE THEY RESIDE. THIS ARTICLE CHRONICLES THE KURDS' LONG STRUGGLE FOR AUTONOMY IN TURKEY, IRAQ, IRAN, 
SYRIA, AND OTHER MIDDLE EASTERN STATES. IT OUTLINES KURDISH MOVEMENTS FOR INDEPENDENCE BEGINHING WITH THE FIRST WORLD WAR AND FOLLOWS THEIR EXPLOITS AND ADVERSITIES THROUGH TO THE GULF WAR. IT EXAMINES THE UNIQUE PROBLEMS FACED BY KURDS IN EACH OF THEIR "HOST" COUNTRIES. IT CONCLUDES THAT THE KURDS' MORE RECENT FAILURES TO ACHIEVE ANY SUBSTANTIAL DEGREE OF INDEPENDENCE IS DUE LARGELY TO THEIR TRIBAL LEADERS' NARROW INTERESTS AND POLITICAL PERSPECTIVES. IRAN, IRAQ, AND TURKEY WERE ABLE TO EXPLOIT DIFFERENCES WITHIN THE TRADITIONAL KURDISH LEADERSHIP AND MANEUVERED TO GRANT "PARTIAL AUTONOMY," "CULTURAL AUTONOMY," ETC., IN ORDER TO SPLIT THE KURDISH MOVEMENT. DESPITE RECENT SETBACKS, THE KURDS REMAIN A POWERFUL FORCE IN THE REGION AND WILL LIKELY CONTINUE TO AFFECT EVENTS IN THE FUTURE.

03108 EMANUEL, E.J.

\section{THE PRESCR}

NEW REPUBLIC, 206(22) (JUN 92), 21-22, 24, 26

A COMPREHENSIVE SYSTEM OF HEALTH CARE BUILT AROUND THE MODEL OF COMMUNITY HEALTH PLANS--AND THE ELIMINATION OF PRIVATE INSURANCE--MAY BE THE BEST WAY TO BRING MARKET FORCES TO BEAR, COMBINING VOUCHERS, GROUP BUYING POWER, AND A MEASURE OF DEVOLVED DEMOCRATIC DECISION MAKING. THIS SYSTEM WOULD DEPEND ON A CENTRAL BOARD TO SET THE NATIONAL LEYEL OF HEALTH CARE SPENOING AND DETERMINE THE VALUE OF VOUCHERS. THIS HOULD CIRCUHVENT THE POLITICAL PRESSURES THAT PUSH GOVERNMENT SPENDING EVER UPWARD WITHIN ANY KIND OF NATIONAL SYSTEM, AS THEY DO IN THE CASE OF MEDICARE AND MEDICAID.

03109 EMBER, C.; EMBER, M.

RESOURCE UNPREDICTABILITY, MISTRUST, AND WAR: A CROSSCULTURAL STUDY

OURNAL OF CONFLICT RESOLUTION, 36(2) (JUN 92), 242-262. THE RESULTS OF THIS CROSS-CULTURAL STUDY SUGGEST THAT WAR MAY BE CAUSED MOSTLY BY A FEAR OF NATURE AND A PARTIALLY RESULTANT FEAR OF OTHERS. A HISTORY OF UNPREDICTABLE NATURAL DISASTERS STRONGLY PREDICTS MORE HAR, AS DOES SOCIALIZATION FOR MISTRUST. IT SEEMS THAT PEOPLE, PARTICULARLY IN NONSTATE SOCIETIES MAY TRY TO PROTECT THEMSELVES AGAINST FUTURE

DISASTERS BY GOING TO WAR TO TAKE RESOURCES FROM ENEMIES.

03110 EMBER, C.R.; EMBER, M.; RUSSETT, B.

PEACE BETHEEN PARTICIPATORY POLITIES: A CROSS-CULTURAL TEST OF THE DEMOCRATS-RARELY-FIGHT-EACH-OTHER HYPOTHESIS

WORLD POLITICS, 44(4) (JUL 92 ), 573-599.

IN THE MOOERN INTERNATIONAL SYSTEM, DEMOCRACIES RARELY FIGHT EACH OTHER, BUT THE REASONS FOR THIS PHENOMENON ARE FIGHT EACH OTHER, BUT THE REASONS FOR THIS PHENOMENOH
NOT WELL UNDERSTOOD. THIS PAPER EXPLORES A SIMILAR NOT WELL UNDERSTOOD. THIS PAPER EXPLORES A SIMILAR
PHENOMENON IN OTHER SOCIIETIES, USING CROSS-CULTURAL PHENOMENON IN OTHER SOCIETIES, USING CROSS-CULTURAL
ETHNOGRAPHIC EVIDENCE. IT FINDS THAT POLITIES ORGANIZED ETHMOGRAPHIC EVIDENCE. IT FINDS THAT POLITIES ORGANIZED ACCORDING TO MORE PARTICIPATORY (DEMOCRATIC) PRINCIPLES FIGHT EACH OTHER LESS OFTEN THAN DO POL ITIES ORGANIZED ACCORDING TO HIERARCHICAL PRINCIPLES. STABLE PARTICIPATORY INSTITUTIONS SEEM TO PROMOTE PEACEFUL RELATIONS, ESPECIALLY
IF PEOPLE PERCEIVE THAT OTHERS ALSO HAVE SOME CONTROL OVER POLITICS.

03111 EMERY, G.

GETTING THE NEWS DUT

INSIGHT, 7(7) (FEB 91), 11-14

THE REPORTING COUP IN BAGHDAD DISTINGUISHES CNN FROM THE OTHER NETWORKS. ITS REPORTING FROM AN ENEMY CAPITAL MAKES HISTORY. BUT SUCH ACCOMPLISHMENTS DON'T COME EASY. SINCE ITS BIRTH IN 1980, CNN HAS BEEN CHARACTERIZED BY ROUND-THE-CLOCK COVERAGE, TOUGH TECHNICAL WORK BEHIND-THE-SCENES, A LOT OF MONEY, AND CAREFUL NEGOTIATION WITH FOREIGN GOVERMMENTS.

03112 EMERY, $N$

\section{RACE, LIES AND DEMOCRATS}

THE ARY, $92(6)$ (DEC 91), 33-37.

THE WILLIE HORTON ISSUE WAS THE KEY IN THE SHITCH THAT IN THE 1988 PRESIDENTIAL CAMPAIGN TURMED A 19-POINT DUKAKIS LEAD IN MAY INTO AN 8-POINT LEAD FOR BUSH IN NOVEMBER. DEMOCRATS CALL THE ISSUE RACE-BAITING, PLAYING ON PREJUDICE. REPUBLICANS, FROM THE PRESIDENT DOWN, SAY THE ISSUE IS NOT WHAT HORTON LOOKED LIKE, BUT WHAT DUKAKIS OID. ALONG HITH THE QUOTA WARS, THE STRUGGLE OVER BUSING, RACIAL TENSIONS IN CITIES AND ON UNIVERSITY CAMPUSES, THE HORTON CASE DCCUPIES THE GROUND WHERE RACE CROSSES CRIME AND OTHER ISSUES, A TERRAIN OF DANGER AND IMMENSE COMPLEXITY, WHERE FEELINGS ARE TERRAIN OF DANGER AND IMMENSE COMPLEXITY, WHERE FEEL INGS
HIGH, MOTIVES SUSPECT, AND MEANINGS EVERYWHERE UNCLEAR. HIGH, MOTIVES SUSPECT, AND MEANINGS EVERYWHERE UNCLEAR.
THESE PROBLEMS WHICH CENTER ON THE SO-CALLED SOCIAL ISSUE THESE PROBLEMS WHICH CENTER ON THE SO-CALLED SOCIAL ISSUE
HAVE BITTERLY DIVIDED WHITES THROUGH THO DECADES AND ARE NOH HAVE BITTERLY DIVIDED WHITES THROUGH THO DECADES AMD ARE NOH
DIVIDING BLACKS AS WELL. THEY HAVE SHATTERED THE DEMOCRATS DIVIDING BLACKS AS WELL. THEY HAVE SHATTERED THE DEMOCRATS CONTEST AND ACCOUNTABILITY.

03113 EMMERSON, $D$.

INDONESIA IN 1990: A FORESHADOW PLAY

ASIAN SURVEY, XXXI(2) (FEB 91), 179-187

NEARLY A QUARTER-CENTURY OF' SUSTAINED ECONOMIC GROWTH AT HOME HADE ENABLED INDONESIA'S PRESIDENT, GENERAL SUHARTO, IN
TURN HIS ATTENTION MORE TOWARD FOREIGN AFFAIRS. IN 1990 THE PRESIDENT AND HIS ADVISERS INTENSIFIED THEIR EFFORTS TO REDUCE THE DISCREPANCY BETWEEN INDONESIA'S PREVIOUSLY LOW-
KEY DIPLOMACY AND ITS GEOPOLITICAL POTENTIAL AS THE WORLD'S KEY DIPLOMACY AND ITS GEOPOLITICAL POTENTIAL AS THE
BIGGEST ARCHIPELAGIC AND FIFTH MOST POPULATED STATE. MEANWHILE, THE RECORD COMMITMENT OF THE INTERGOVERMMENTAL GROUP ON INDONESIA (IGGI) TO AID INDONESIA'S ECONOMY AND THE RUN-UP IN OIL AND GAS PRICES FOLLOWING THE IRAQIFICATION OF KUWAIT REMINDED OBSERVERS HOW MUCH INDONESIA'S DEVELOPMENT AT HOME HAD BEEN ASSISTED BY REVENUES FROM ABROAD.

03114 EMMERT, C.

AN INTEGRATED CASE-RELATED MODEL OF JUDICIAL DECISION MAKING: EXPLAINING STATE SUPREME COURT DECISIONS IN JUDICIAL REVIEW CASES

THE JOURNAL OF POLITICS, 54(2) (MAY 92), 543-552. EMPLOYING DATA FROM MORE THAN THREE THOUSAND STATE SUPREME COURT JUDICIAL REVIEW CASES, THE AUTHOR CONSTRUCTS AND TESTS AN INTEGRATED CASE-RELATED MODEL OF JUDICIAL
DECISION MAKING. LOGIT ANALYSIS REVEALS THAT THE TYPE OF DECISION MAKING. LOGIT ANALYSIS REVEALS THAT THE TYPE OF
ISSUE RAISED. THE IDENTIFTY OF THE CHALLENGING PARTY, THE ISSUE RAISED, THE IDENTIFTY OF THE CHALLENGING PARTY, THE
CONSTITUTIONAL ARGUMENTS ADVANCED, THE CENTRALITY OF THE CONSTITUTIONAL CHALLENGE, AND THE LOWER COURT RULING ON CONSTITUTIONALITY ALL HAVE AN INDEPENDENT IMPACT ON STATE SUPREME COURT DECISIONS IN JUDICIAL REVIEW CASES. THE FINDINGS CLEARLY PROVIDE SUPPORT FOR THE NOTION THAT MORE COMPLEX THEORETICAL ANO METHODOLOGICAL APPROACHES PROVIDE A MORE COMPLETE EXPLANATION OF JUDICIAL DECISION MAKING.

03115 EMMERT, M.A.; TAHER, W.A.

PUBLIC SECTOR PROFESSIONALS: THE EFFECTS OF PUBLIC SECTOR JOBS ON MOTIVATION, JOB SATISFACTION, AND HORK INVOLVEMENT AMERICAN REVIEW OF PÚBLIC ADMINISTRATION, 22 (1) (MAR 92), 37-48

THE AUTHORS COLLECTED DATA FROM A RANDOM SAMPLE OF PROFESSIONAL AND BLUE-COLLAR WORKERS IN STATE GOVERNMENT. THEN THEY STUDIED THE JOB CHARACTERISTICS OF PUBLIC-SECTOR PROFESSIONALS AND THE IMPACT OF THESE CHARACTERISTICS ON MOTIVATION, JOB SATISFACTION, AND WORK INVOLVEMENT. THEIR FINDINGS INCLUDE THE FOLLOWING: (1) ALTHOUGH PUBLIC-SECTOR PROFESSIOMAL JOB CHARACTERISTICS ARE CONSISTENT WITH THE NORMATIVE DATA FROM THE JOB DIAGNOSTIC SURVEY, JOB SATISFACTION AND WORK INVOLVEMENT ARE LOWER THAN THOSE OF BLUE-COLLAR WORKERS AND WORK MOTIVATION IS NO HIGHER THAN THAT OF BLUE-COLLAR WORKERS; (2) JOB CHARACTERISTICS DO NOT EXPLAIN VARIATIONS IN PROFESSIONALS' SATISFACTION, EXPLAIN VARIATIONS IN PROFESSIONALS SATISFACTION,
MOTIVATION, AND INYOLVEMENT: RATHER THEY ARE EXPLAINED BY MOTIVATION, AND INVOLVEMENT : RATHER THEY ARE EXPLAINED BY
SOCIAL SATISFACTION, FULFILLMENT OF EMPLOYEES ' INTRINSIC SOCIAL SATISFACTION, FULFILLMENT OF EMPLOYEES' INTRINSIC
NEEDS (ESPECIALLY GROWTH NEEDS), AND INFORMATION FROM OTHERS NEEDS (ESPECIALLY GROWTH NEEDS), AND INFORMATION FROM OTHERS ON JOB PERFORMANCE. THESE FINDINGS CONTRADICT SOME STUDIES ABOUT THE NATURE OF PUBLIC-SECTOR WORK.

03116 ENDRES, A.

ADAM SMITH'S RHETORIC OF ECONOMICS: AN ILLUSTRATION USING "SMITHIAN" COMPOSITIONAL RULES

SCOTTISH JOURNAL OF POLITICAL ECONOWY, 38(1) (FEB 91), 76-95.

LEADING COMMENTARIES ON THE WEALTH OF NATIONS (ESPECIALLY BOOK FOUR) HAVE VARIOUSLY AND LOOSELY DESCRIBED PRESENTATION OF ADAM SMITH'S ARGUMENT OR HIS STYLE OF DISCOURSE AS PROPAGANDIST, AS A TRACT, AS RHETORICAL, OR AS POLEMICAL. IN THIS PAPER, THE AUTHOR INVESTIGATES WHETHER SMITH'S AVOWED, PASSIONATELY HELD INTENTION TO "ATTACK" THE MERCANTILE SYSTEM LED HIM TO CRAFT A COMPOSITIONAL STYLE IN BOOK FOUR WHICH WAS DESIGNED ACTIVELY TO PERSUADE ITS READERS AND HAD A PERVASIVE IMPACT ON THE FORM OF THAT SECTION OF THE WEALTH OF NATIONS. IN ORDER TO EFFECT THIS TASK, DETAILED REFERENCE IS MADE TO THE CHAPTER ON BOUNTIES: TO ASSESS COMPOSITIONAL STYLE AND TO ENDEAVOR TO GAUGE THE WAYS IN WHICH SHITH'S CHOICE OF STYLE AFFECTED BOTH SELECTIVITY IN HIS ARGUMENT AND HIS USE OF HISTORICAL EVIDENCE.

03117 ENELOW, J.

AN EXPANDED APPROACH TO ANALYZING POLICY-MINDED CANDIDATES PUBLIC CHOICE, 74(4) (1992), 425-446.

A RANDOM PIVOT MODEL IS USED TO EXPAND THE THEORY OF POLICY-MINDED CANDIDATES. PREVIOUS RESULTS ARE DERIVED UNDER WEAKER ASSUMPTIONS. NEW RESULTS ABOUT CANDIDATE STRATEGIES IN MULTIPLE ELECTIONS ARE ALSD OBTAINED. THE THRUST OF THESE IN MULTIPLE ELECTIONS ARE ALSD OBTAINED. THE THRUST OF THESE RESULTS SUPPORTS CALVERT'S FINDINGS THAT OFFICE-SEEKING
POLICY-MINDEDNESS ARE COUNTERVAILING FORCES IN ELECTION POL ICY MI
CONTESTS.

03118 ENGELBREKT, $K$

BULGARIA
RFE/RL RESEARCH REPORT, 1(39) (OCT 92), 30-33.

SINCE BULGARIA ENTERED ITS NEH DEMOCRATIC ERA, MEDIA DEVELOPMENTS HAVE OCCURRED IN FOUR MAIN AREAS. (1) DUE TO A COMBINATION OF RISING PROOUCTION COSTS AND GROHING COMPETITION, BULGARIAN MEDIA VENTURES ARE INCREASINGLY BEING RUN AS ORDINARY PROFIT-MAKING BUSINESSES. (2) WHEREAS MOST PUBLICATIONS FORMERLY SERVED AS MOUTHPIECES OF THE COMMUNIST 
PARTY OR OTHER ORGANIZED INTERESTS, TODAY THE PREFERENCES AND HABITS OF MEDIA CONSUMERS HAVE BECOME MORE IMPORTANT. (3) JOURNALISM IS RAPIDLY DEVELOPING AS A CRAFT AND A PROFESSION. (4) HOWEVER, TO THE FRUSTRATION OF JOURNALISTS SEEKING EDITORIAL INDEPENDENCE, STRONG POLITICAL AND ECONOMIC INTERESTS STILL TEND TO INTERFERE IN SETTING BOTH THE AGENDA AND THE TONE.

03119 ENGELBREKT, K.

BULGARIA
RFE/RL RESEARCH REPORT, 1(27) (JUL 92), 4-9.

BULGARIA'S JUDICIAL INSTITUTIONS, HAUNTED BY THEIR INGLORIOUS PAST AS PART OF THE REPRESSIVE COMMUNIST SYSTEM, ARE OF INCREASING CONCERN TO THE COUNTRY'S LAWMAKERS. THE UNION OF DEMOCRATIC FORCES GOVERNMENT HAS PLEDGED ITS DETERMINATION TO INTRODUCE MOOERN JUDICIAL PRACTICES AND LIMIT THE INFLUENCE OF POLITICIANS OVER LEGAL INSTITUTIONS. ALTHOUGH THO NEH, KEY LEGAL BOOIES--THE CONSTITUTIONAL COURT AND THE SUPREME JUDICIAL COUNCIL--ARE ALREADY FUNCTIONING, OTHER MAJOR IMPROVEMENTS ARE UNLIKELY TO BE MADE SOON. HORK
IS PROCEEDING ON FORMULATING A NEW ORGANIZATIONAL FRAMEWORK, IS PROCEEDING ON FORMULATING A NEW ORGANIZATIONAL FRAMEWORK
WHILE THE EXISTING LEGAL SYSTEM IS STRUGGLING TO COME TO

TERMS WITH A CHANGING SOCIETY AND THE RAPID RISE IN CRIME.

03120 ENGELBREKT, K.; NIKOLAEV, R

BULGARIA: SOCIALIST PARTY ELECTS NEW LEADER

RFE/RL RESEARCH REPORT, 1 (3) (JAN 92), 27-30.

IN DECEMBER 1991, THE FORTIETH CONGRESS OF THE BULGARIAN SOCIALIST PARTY ELECTED JEAN VIDENOY, A 32 YEAR-OLD

ECONOMIST, TO BE ITS NEH CHAIRMAN. VIDENOV APPEARED TO BE A COMPROMISE CANDIDATE, ACCEPTABLE TO BOTH THOSE WHO STROMGLY OPPOSED ANOTHER TERM FOR ALEKSANDAR LILOV AND TO THOSE WHO ADVOCATED CONTINUITY OF LEADERSHIP. THE CONGRESS WAS MARKED BY A CONFRONTATION BETWEEN CONSERVATIVES FAVORING A "MODERM LEFT PARTY" AND RADICALS CALLING FOR A SOCIAL-DEMOCRATIC PLATFORM. A FEW DAYS AFTER THE CONGRESS IT BECAME EVIDEMT THAT THE FORMER GROUP HAD PREVAILED IN APPOINTING THE LEADER. BUT NO AGREEMENT HAS BEEN REACHED ON FUTURE PARTY POLICY, AND A STRONG SOCIAL-DEMOCRATIC ALTERNATIVE TO THE OLD LINE HAS BEEN MAKING ITS VOICE HEARD.

03121 ENGELBREKT, $K$.

BULGARIA'S CABINET SHAKE-UP: A LASTING COMPROMISE? RFE/RL RESEARCH REPORT, 1(28) (JUL 92 ), 1-5.

ON MAY 20, 1992, THE NATIONAL ASSEMBLY APPROVED SLIGHT CHANGES IN THE CABINET, SENDING SHOCK WAVES THROUGH BULGARIA'S POLITICAL SPECTRUM. THE FACT THAT A

STRAIGHTFORWARD CABINET REORGANIZATION COULD SHAKE BULGARIA'S POLITICAL ESTABLISHMENT TO ITS FOUNDATIONS IS AN INDICATION OF CONSIDERABLE TENSION WITHIN THE RULING COALITION. THE UNION OF DEMOCRATIC FORCES. THE CHANGES SEEM TO HAVE STRENGTHENED THE PARTY DOMINATED BY BULGARIA'S ETHNIC TURKS AND WEAKENED THE POSITION OF PRESIDENT ZHELYU ZHELEV; THE TRADE UNION PODKREPA IS LESS AFFECTED BY THE CHANGES.

03122 ENGELBREKT, $K$

BULGARIA'S COMMUNIST LEGACY: SETTLING OLD SCORES

RFE/RL RESEARCH REPORT, 1(28) (JUL 92), 6-10.

FOLLOWING TWO YEARS OF FOOT-DRAGGING BY THE JUDICIARY, LEGAL MEASURES SUPPORTED BY THE GOVERNING UNION OF DEMOCRATIC FORCES ARE LEADING TO THE SCREENIMG OF MORE FORMER TOP-RANKING COMMUNIST OFFICIALS FOR MISDEEDS. ALTHOUGH SOME LEGAL QUESTIONS REMAIN TO BE RESOLVED, THE NEW PROSECUTOR-GENERAL HAS BEEN SUCCESSFUL IN MANY INSTANCES. OVER THE LAST FEN MONTHS, MANY ONGOING INVESTIGATIONS AND TRIALS HAVE GAINED MOMENTUM WHILE NEH ONES HAVE BEEN INITIATED.

03123 ENGELBREKT, $K$.

BULGARIA'S FOREIGN DEBT PREDICAMENT

RFE/RL RESEARCH REPORT, 1(8) (FEB 92), 37-40.

THE QUESTION OF BULGARIA'S HUGE FOREIGN DEBT, LARGELY OWED TO COMMERCIAL BANKS, HAS NOT YET BEEN SETTLED. HOWEVER, NEARLY THO YEARS AFTER BULGARIA UNILATERALLY SUSPENDED THE REPAYMENT OF ITS DEBT, A COMPREHENSIVE AGREEMENT WITH ITS CREDITORS NOW SEEMS FEASIBLE.

03124 ENGELBREKT, $K$.

GRONING POVERTY AMONG BULGARIA'S PENSIONERS
RFE/RL RESEARCH REPORT, 1(9) (FEB 92), 64-66.

BULGARIA'S PENSIONERS ARE AMONG THOSE HARDEST HIT BY THE CURRENT ECONOMIC CRISIS. BECAUSE HIGH INFLATION IS EATING UP CURRENT ECONOMIC CRISIS. BECAUSE HIGH INFLATION IS EATING THEIR SAVINGS AND REDUCING THE VALUE OF THEIR PENSIONS IN REAL TERMS, THE ELDERLY FEEL INCREASINGLY UNSURE ABOUT THEIR FUTURE. THE GOVERNMENT HAS DECLARED THAT IT IS UNABLE COMPENSATE PEOPLE IN FULL FOR THE SHRINKAGE OF THEIR PENSIONS, AND THERE ARE INDICATIONS THAT PENSIONERS ARE BEGINNING TO ORGANIZ
SPECIAL INTERESTS.

03125 ENGELBREKT, $K$.

NEW BULGARIAN GOVERNMENT HOPES TO END DELAYS

RFE/RL RESEARCH REPORT, $1(17)$ (APR 92), 80-84.
IN BULGARIA, THE PUBLIC SECTOR HAS REMAINED LARGELY UNTOUCHED. IN 1991 A NUMBER OF LARGE-SCALE STATE COMPANIES WERE RESTRUCTURED, AND RECENTLY THE PARLIAMENT PASSED LAWS RETURNING STATE PROPERTY TO ITS FORMER OWHERS. AFTER MANY DELAYS AND REVISIONS OF ITS PLANS, BULGARIA IS NOW PREPARING TO LAUNCH A PRIVATIZATION PROGRAM. THE GOVERNMENT IS PRESSING FOR QUICK ACTION, AND LEGISLATION IS BEING DRAFTED.

03126 ENGELBREKT, $K$.

REFORMS REACH THE BULGARIAN ARMED FORCES

RFE/RL RESEARCH REPORT, 1(4) (JAN 92), 54-58

IN 1991. BULGARIA ACQUIRED ITS FIRST CIVILIAN MINISTER OF DEFENSE SINCE THE $1930^{\prime} \mathrm{S}$. HE MUST TAKE THE LEADERSHIP IN REFORMING THE MINISTRY, INTRODUCING RADICAL ORGANIZATIONAL REFORMING THE MINISTRY, INTRODUCING RADICAL ORGANIZATIOMAL FORCES, AND REDUCING AND MODERNIZING BOTH THE TRDOPS AND THE MILITARY INDUSTRY.

03127 ENGELBREKT, K.; PERRY, D.M.

THE CONVICTION OF BULGARIA'S FORMER LEADER RFE/RL RESEARCH REPORT, $1(42)$ (OCT 92) 6-9

IN SEPTEMBER 1992, TODOR ZHIVKOV, BULLARIA'S FORMER HEAD OF STATE AND COMMUNIST PARTY LEADER, HAS FOUND GUILTY OF EMBEZZLEMENT AND SENTENCED TO SEVEN YEARS IN PRISON. HE IS THE FIRST EAST EUROPEAN COMMUNIST LEADER TO BE TRIED AND SENTENCED IN A COURT OF LAH. THE PUBLIC RESPONSE TO ZHIVKOV'S TRIAL HAS BEEN MUTED BECAUSE MOST PEOPLE ARE MORE CONCERNED WITH THEIR PERILOUS ECONOMIC CONDITIONS. IT APPEARS THAT THE AUTHORITIES ARE MORE INTERESTED IN PROSECUTING THE OLD GUARD THAN IS THE PUBLIC-AT-LARGE.

03128 ENGELBREKT, $K$

THE FALL OF BULGARIA'S FIRST NONCOMMUNIST GOVERNMENT RFE/RL RESEARCH REPORT, 1(45) (NOV 92), 1-6.

ON NOVEMBER 28, 1992, FOLLOHING THE BREAKDOWN OF THE INFORMAL COALITION BETWEEN THE RULING UNION OF DEMOCRATIC FORCES AND THE MOVEMENT FOR RIGHTS AND FREEDOMS, BULGARIA'S FIRST NONCOMMUNIST CABINET RESIGNED. THE GOVERNMENT HAD BEEN FACING MOUNTING CRITICISH FOR SEVERAL MONTHS OVER ITS TOUGH ANTI-COMMUNIST STANCE AND STRICT ADHERENCE TO ECONOMIC AUSTERITY POLICIES. THE CABINET'S POSITION RAPIDLY WEAKENED AUSTERITY POLICIES. THE CABINET'S POSITION RAPIDLY
AFTER PRESIDENT ZHELYU ZHELEV JOINED ITS CRITICS.

03129 ENGLUND, $S$.

CHURCH AND STATE IN FRANCE SINCE THE REVOLUTION JOURAAL OF CHURCH \& STATE, 34(2) (SPR 92), 325-36). JOURNAL OF CHURCH \& STATE, 34 2) (SPR 92), $325-361$. RELATIONS IN FRANCE FROM THE REVOLUTION TO THE MODERN ERA.

03130 ENTELIS, J.; ARONE,L. ALGERIA IN TURHOIL: ISLAM DEMOCRACY AMD STATE MIDDLE EAST POLICY, I (2) (1992), 23-35.

THE CURRENT WAVE OF POLITICAL LIBERALIZATION SWEEPING THROUGH EASTERN EUROPE, EAST ASIA AND LATIN AMERICA HAS ALSO AFFECTED THE MIDDLE EAST AND AFRICA. YET IN AFRICA AND THE ARAB WORLD POLITICAL CHANGE HAS BEEN FAR LESS SUBSTANTIAL. REFORMS HAVE BEEN LARGELY UNSUCCESSFUL. IN ALGERIA, HOWEVER, THE GOVERNMENT APPEARED TO HAVE BEEN ATTEMPTING A DIFFERENT KIND OF EXPERIMENT. FOLLOWING THE MOST VIOLENT PUBLIC DEMONSTRATIONS SINCE INDEPENDENCE, THE LEADERS ARE PURSUIMG A PATH OF POLITICAL REFORM WHICH CAME TO CONSTITUTE ONE OF THE AFRO-ARAB WORLD'S BOLDEST EXPERIMENTS IN POLITICAL PLURALISM, LIBERALISM AND DEMOCRATIZATION.

03131 ENTELIS, J.

U.S.-MAGHREB RELATIONS IN A DEMOCRATIC AGE: THE PRIORITY OF ALGERIA

MIDOLE EAST INSIGHT, 8(3) (1992), 31-35.

THE WORLD OF THE 1990 S FINDS THE UNITED STATES AT A CRITICAL CROSSROADS IN ITS FOREIGN POL ICY HISTORY. THE STATES BECAUSE OF GEOPOLITICS, NATURAL RESOURCES, PROXIMITY STATES BECAUSE OF GEOPOLITICS, NATURAL RESOURCES, PROXIMIT
TO EUROPE, TIES TO AFRICA AND THE MIDDLE EAST, AND THE TO EUROPE, TIES TO AFRICA AND THE MIDDLE EAST, AND THE
DEVELPMENT POTENTIAL IT REPRESENTS. THE STRUGGLE IN THE DEVELPMENT POTENTIAL IT REPRESENTS. THE STRUGGLE IN THE MAGHREB TODAY IS THE STRUGGLE IN THE WORLD AT LARGE: TO
OVERCOME THE AUTHORITARIANISM OF THE MUKHABARAT STATE AND TO RERCACE IT BY A FUNCTIONING POLITICAL DEMOCRACY. THIS REPLACE IT BY A FUNCTIONING POLITICAL DEMOCRACY. THIS
ARTICLE EXPLORES DEMOCRATIZATION IN THE MAGHREB, ISLAMIC ARTICLE EXPLORES DEMOCRATIZATION IN THE MAGHREB, ISLAMIC
DEMOCRACY, THE PRIORITY OF ALGERIA, POLICIES OF AN ISLAMIST DEMOCRACY, THE PRIORITY OF ALGERIA, POLICIES OF AN ISLAMIST
GOVERNMENT AMD ALTERNATE REGIMES. IT CONCLUDES WITH A NOTE GOVERNMENT AND ALTERNATE REGIMES. IT CONCLUDES WITH A NOT OF CAUTION THAT ALGERIA APPE
INVOKING ITS DREADED PAST.

03132 ENTIN, S

SEE HOW THEY RUN

NATIONAL REVIEW, XLIV(10) (MAY 92), 29-31.

THIS ARTICLE ARGUES THAT THE SUMMIT OF THE FINANCE MINISTERS OF THE GROUP OF SEVEN (THE LEADING INDUSTRIAL NATIONS--THE U.S., JAPAN, GERMANY, FRANCE, ITALY, THE UNITED KINGDOM, AND CANADA) ILLUSTRATES HOH LITTLE FINANCE MINISTERS KNOW ABOUT ECONOMICS. THE U.S. WAS QUICK TO CRITICIZE THE GERMANS FOR RUNNING UP A LARGE DEFICIT AND IMPLIED THAT FURTHER TAX HIKES WOULD BE NECESSARY TO REDUCE IT. THE GERMANS RESPONDED BY POINTING OUT THE IRONY THAT THE 
BUSH ADMINISTRATION OPPOSES TAX INCREASES AT HOME BECAUSE THEY ARE ANTI-GROWTH, BUT FAVORS THEM IN GERMANY TO PROMOTE GROWTH. CRITICISM OF JAPAN LED JAPANESE REPRESENTATIVES TO WONDER WHY FISCAL STIMULUS IS PRO-GROWTH IN ASIA AND ANTIGROWTH IN EUROPE. IN SHORT, THE SUMAIT HAS A CASE OF THE BLIND LEADING THE BLIND.

03133 ENTMAN, R.

FRAMING U.S. CONVERAGE OF INTERNATIONAL NEWS: CONTRASTS IN NARRATIVES OF THE KAL AND IRAN AIR INCIDENTS

JOURNAL OF COMMUNICATION, 41(4) (FAL 91), 6-27.

BY DE-EMPHASIZING THE AGENCY AND THE VICTIMS AND BY THE CHOICE OF GRAPHICS AND ADJECTIVES, THE NEWS STORIES ABOUT THE U.S. DOWNING OF AN IRANIAN PLANE CALLED IT A TECHNICAL PROBLEM WILE THE SOVIET DOWNING OF A KOREAN JET WAS PORTRAYED AS A MORAL OUTRAGE. BY DEMONSTRATING THAT DIFFERENT WORDS AND IMAGES WERE CONSISTENTLY CHOSEN IN THE TWO STORIES TO DEPICT SIMILAR PHENOMENA, THIS ARTICLE SUGGESTS EXACTLY WHICH DIMENSIONS OF THE KAL AND IRAN AIR SUGGESTS EXACTLY WHICH DIMENSIONS OF THE KAL AND IRAN AIR COVERAGE CARRIED THE INFORMATION THAT COMPRISED THE FRAME. IN THIS WAY, IT AIMS TO ILLUMINATE IN SOME DETAIL THE NATURE OF THE FRAME IN THE FOREIGN NEWS TEXT. IT ALSO SPECULATES THINKING OF JOURNALISTS, AUDIENCES, AND POLITICAL ELITES.

03134 ENYEDI, G.

SOCIAL SCIENCES AND THE POLITICAL TRANSITION IN HUNGARY INTERNATIONAL SOCIAL SCIENCE JOURNAL, 131(131) (FEB 92), 147-152.

THE DEMOCRATIZATION MOVEMENT WHICH HAS BEEN TRANSFORHIMG THE CENTRAL AND EASTERN EUROPEAN COUNTRIES HAD IMPORTANT REPERCUSSIONS OF THE ROLE AND STATUS OF THE SOCIAL SCIENCES IN THESE SOCIETIES. THIS ARTICLE ARGUES THAT THE POL ITICAL CHANGES HAD A GREAT IMPACT ON SOCIAL SCIENCES, JUST AS THE LATTER ALSO STRONGELY INFLUENCE TRANSTIONS. IT SUGGESTS THAT DID NOT FORECAST THE EVENTS. MANY SOCIAL SCIENTISTS, HOPED, MANY OF THEM WORKED FOR IT--BUT NOBODY EXPECTED THE IMMINENCE AND SPEED OF THE CHANGES. THE ARTICLE DESCRIBES THE CHANGES IN HUNGARY.

03135 ENYEDI, G.

URBANIZATION IN EAST CENTRAL EUROPE: SOCIAL PROCESSES AND SOCIETAL RESPONSES IN STATE SOCIALIST SYSTEMS

URBAN STUDIES, $29(6)$ (AUG 92), 869-880.

THE AUTHOR EXAMINES THE PRESENT STATE OF URBAN AND

THE AUTHOR EXAMINES THE PRESENT STATE OF URBAN AND
REGIONAL STRUCTURES IN EAST CENTRAL EUROPE. HE ALSO ANALYZES REGIONAL STRUCTURES IN EAST CENTRAL EUROPE. HE ALSO ANALY
THE CHANGES IN THE PRODUCTION SYSTEM AND THEIR EFFECTS THE CHANGES IN THE PRODUCTIDN SYSTEM AND THEIR EFFECTS
DURING THE SOCIALIST ERA, FOCUSING ON THREE AREAS: (1) THE DURING THE SOCIALIST ERA, FOCUSING ON THREE AREAS: (1) THE
MOST IMPORTANT CHARACTERISTICS OF CHANGES IN THE PRODUCTION MOST IMPORTANT CHARACTERISTICS OF CHANGES IN THE PRODUCTION (2) HOW URBANIZATION IN A SPATIAL SENSE DEVELOPED DURING THE 12) HOW URBANIZATION IN A SPATIAL SENSE DEVELOPED DUR LAST 40 YEARS AND HHETHER THE LONG-TERM PROCESSES OF EUROPEAN URBANIZATION CONTINUED EVEN WITHIN STATE SOCIALISM; AND (3) HOW SOCIETAL RESPONS
IN SOCIALIST URBANIZATION.

03136 EPHSON, B.

AN ELUSIVE UNITY

WEST AFRICA, (3914) (SEP 92), 1598-1599.

GHANA'S NKRUMAHISTS HAVE TRADITIONALLY BEEN DIVIDED IN FACTIONS, BOASTING THAT THEY ALWAYS MANAGE TO GET TOGETHER AT ELECTION TIME. BUT NOT THIS TIME. THE VARIOUS FACTIONS OF THE NKRUMAH TRADITION HAVE NOT ONLY TRANSFORMED THEMSELVES INTO POLITICAL PARTIES, THESE PARTIES ARE DIGGING IN AND CREATING THEIR OWN IDENTITIES.

03137 EPHSON, B.

AND NOW THE REFERENDUM

WEST AFRICA, (3890) (APR 92), 586-587.

ON MARCH 27, 1992, THE CONSULTATIVE ASSEMBLY ADOPTED THE FINAL TEXT OF THE DRAFT CONSTITUTION FOR GHANA'S FOURTH REPUBLIC. THE PROVISIONS WERE TAILORED TO ENSURE STABILITY, PEACE, AND NATIONAL RECONCILIATION.

03138 EPHSON, $B$.

BUDGET' OF RELIEF?

WEST AFRICA, (3882) (FEB 92), 239.

GHANA'S 1992 BUDGET HAS THREE MAJOR MACROECONOMIC

OBJECTIVES: TO ACHIEVE REAL GDP GROHTH OF FIVE PERCENT; TO

LOWER THE INFLATION RATE TO EIGHT PERCENT ON AN ANNUAL'

LOWER THE INFLATION RATE TO EIGHT PERCENT ON AN ANNUAL

AVERAGE BASIS AND FIVE PERCENT ON AN END-PERIOD BASIS, AND
TO GENERATE AN OVERALL BALANCE OF PAYMENTS SURPLUS OF' 140

TO GENERAT

03139 EPHSON, 8.

COUNTDOWN TO MAY 18

WEST AFRICA, (3895) (MAY 92), 794-795

IN GHANA' FEVERISH PREPARATIONS ARE UNDERWAY FOR THE LIFTING OF THE FREEZE ON POLITICAL PARTIES IMPOSED BY THE GOVERMMENT OF FLT-LT. JERRY RAWLINGS. VARIOUS SOCIAL GROUPS ARE PLANHING TO TRANSFORM THEMSELVES INTO FULL-FLEDGED POLITICAL PARTIES. CAPT. (RTD,) FELIX NII OKAI, THE FOUMDER OF THE EAGLE CLUB, haS INDICATED THAT HIS CLUB WILL FORM A
POLITICAL PARTY AND ASK RAHLINGS TO BE ITS PRESIDENTIAL NOMINEE.

03140 EPHSON, B. CRACKS IN UNITED FRONT? WEST AFRICA, ( 3899 ) (JUN 92 ), 956

THE AUTHOR REPORTS ON DEVELOPMENTS IN GHANA'S PROGRESS TOWARD FORMING POLITICAL PARTIES, HOLDING FREE ELECTIONS ADOPTING A NEW CONSTITUTION, AND OTHER STEPS ALONG THE ROAD TO GREATER DEMOCRATIZATION.

03141 EPHSON, $B$.

DISAPPOINTING AND EVASIVE?

WEST AFRICA, (3878) ( JAN 92), 62-63.

THE NEW YEAR'S DAY ADDRESS OF GHANA'S HEAD OF STATE, FLT.

LT. JERRY RAWLINGS, FAILED TO MEET THE EXPECTATIONS OF THOSE WHO HAD WANTED TO HEAR CLEAR AND UNEQUIYOCAL

STATEMENTS ABOUT THE PROGRESS OF THE POLITICAL TRANSITION PROGRAM. RAHLINGS' MESSAGE FOCUSED ON THE GAINS OF THE REVOLUTION, BUT BARELY TOUCHED ON THE ISSUES THAT EXCITE MOST GHANAIANS: A REVISED TIMETABLE FOR THE RETURN TO WHETHER THE PNDC WIL TRANSFORM ITSELF INTO AMOIIIONS, PARTY, AND CLEAR GUIDELINES ON THE CONSTITUTIONAL REFERENDUM.

03142 EPHSON, $B$.

GOING INTO POLITICS

NEST AFRICA, 75(3887) (MAR 92), 451

GHANA'S 35TH INDEPENDENCE ANHIVERSARY CELEBRATION ON MARCH 6 WAS PRECEDED BY A 15-MINUTE NATIONHIDE RADIO AND TELEVISION BROADCAST THE PREVIOUS NIGHT BY THE CHAIRMAN OF THE PNDC, JERRY RAHLINGS, IN WHICH HE UNVEILED MORE DETAILS OF THE TRANSITION PROGRAM. HE SAID 35 YEARS MAY NOT BE A LONG TIME FOR A NATION BUT IT MUST BE A SOURCE OF PRIDE TO GHANAIANS THAT GHANA HAS TRAVELED TOGETHER AS A UNITED COUNTRY OVER THESE YEARS. HE HOPED THAT GHANA WILL SEE MANY MORE YEARS OF PEACE, STABILITY AND DEYELOPMENT.

03143 EPHSON, B. JERRY JOINS THE RACE

WEST AFRICA, (3915) (SEP 92), 1604.

FLT-LT. JERRY JOHN RAHLINGS WAS SELECTED AS THE NATIONAL DEMOCRATIC CONGRESS'S (NDC) PRESIDENTIAL CANDIDATE AT THE PARTY CONVENTION IN SEPTEMBER 1992. RAHLINGS CAUTIONED THE MEMBERS OF HIS PARTY THAT HIS ENEMIES ARE BENT ON MAKING AN NDC GOVERNMENT'S CONSTITUTIONAL RULE UNTENABLE AND URGED THEM TO BE VIGILANT.

03144 EPHSON, B.

JOURNEYING INTO MULTIPARTYISH

HEST AFRICA, (3902) (JUN 92), 1087

IN GHANA, SEVEN POLITICAL PARTIES ARE IN THE PROCESS OF SUBMITTING OR HAVE ALREADY SUBMITTED THEIR REGISTRATION DOCUMENTS TO THE INTERIM NATIONAL ELECTORAL COMMISSION. THE PARTIES AND SOME POTENTIAL CANDIDATES ARE INVOLVED IN ORGANIZING AND CAMPAIGNING ACTIVITIES.

03145 EPHSON, 8. LATENT TENSIONS? WEST AFRICA, (3916) (OCT 92), 1661-1662

IN A SEPTEMBER 25, 1992, MEETING BETWEEN THE INTERIM NATIONAL ELECTORAL COMMISSION (INEC) AND REPRESENTATIVES OF GHANA'S POL ITICAL PARTIES, THE INEC'S EXECUTIVE CHAIRMAN ASKED FOR BROADER POWERS. HE POINTED OUT THAT THE POWERS OF ARREST, INVESTIGATION, AND PROSECUTION OF OFFENDERS IN THE COURSE OF PREPARING FOR AND DURING PUBLIC ELECTIONS REST WITH THE GOVERNMENT OF GHANA, NOT INEC.

03146 EPHSON, $B$.

POL ITICAL CONFUSION

WEST AFRICA, (3906) (JUL 92), 1247-1248.

ON JULY 13, 1992, THE EGLE PARTY FORMALLY SUBMITTED ITS REGISTRATION PAPERS TO THE INTERIM NATIONAL ELECTORAL COMMISSION. ON JULY 16, TEAMS OF POLICEMEN WENT TO THE HOUSES OF FOUR PARTY LEADERS, SEARCHED THEIR HOMES, AND ARRESTED THREE OF THE LEADERS.

03147 EPHSON, B.

POL ITICAL HEAT IS ON

WEST AFRICA, (3898) (JUN 92), 917-919.

THE AUTHOR EXPLAIMS GHAMA'S NEH LAH THAT LIFTS THE BAH

ON POLITICAL PARTIES AS OF MAY 18, 1992.

03148 EPHSON, 8.

POL ITICAL HORSETRADING

WEST AFRICA

ON JULY 6, 1992, THE EXECUTIIVES AND MEMBERS OF THE

NATIONAL INDEPENOENCE PARTY IN THE NORTHERN, UPPER HEST, AND

UPPER EAST REGIONS MERGED INTO THE PEOPLE'S HERITAGE PARTY.

03149 EPHSON, $B$.

POL ITICAL WARM-UPS

WEST AFRICA, (3886) (MAR 92), 408-409.

GHANA'S GOVERMMENT IS INVOLVED IN PREPARATIONS FOR THE 
UPCOMING MULTI-PARTY ELECTIONS. THE GOVERNMENT HAS APPOINTED THE EXECUTIVE CHAIRMAN AND MEMBERS OF THE NATIONAL ELECTORAL COMMISSION, WHICH WILL CONDUCT AND SUPERVISE THE

CONSTITUTIONAL REFERENDUM AS WELL AS THE PRESIDENTIAL AND PARL I AMENTARY ELECTIONS.

03150 EPHSON, B.

RACE TO THE CASTLE

WEST AFRICA, (3910) (AUG 92), 1436-1437.

ON AUGUST 14, 1992, TWO THOUSAND REPRESENTATIVES

ATTENDED THE NATIONAL DELEGATES CONFERENCE OF THE NEW

PATRIOTIC PARTY IN ACCRA. THE CONFERENCE HAD THREE MAIN

OBJECTIVES: ADOPTING A PARTY CONSTITUTION, ENDORSING THE

PARTY MANIFESTO, AND ELECTING PARTY OFFICIALS AND A

PRESIDENTIAL CANDIDATE. ADU BOAHEN WAS CHOSEN AS THE PARTY'S

PRESIDENTIAL CONTENDER.

03151 EPHSON, 8.

RAHLINGS TO RUN ON N.D.C. TICKET

WEST AFRICA, (3911) (AUG 92 ) 1491

THE NATIONAL DEMOCRATIC CONGRESS HAS OPENLY EMBRACED FLT. -LT. JERRY RAWLINGS AS ITS CANDIDATE FOR PRESIDENT OF GHANA, BUT THERE IS STILL A POSSIBILITY THAT RAWLINGS MIGHT DENOUNCE THE PARTY AND DECIDE TO RUN AS AN INDEPENDENT CANDIDATE.

03152 EPHSON, $B$.

SET FOR REFERENDUM

WEST AFRICA, (3893) (APR 92), 713

ON APRIL' 28, 1992, GHANA'S REGISTERED VOTERS WILL ACCEPT OR REJECT THE DRAFT CONSTITUTION FOR THE FOURTH REPUBLIC. THE INTERIM NATIONAL ELECTORAL COMMISSION WILL CONDUCT THE REFERENDUM, AND THE RESULT WILL BE DETERMINED BY A SIMPLE MAJORITY OF THE VOTES CAST.

03153 EPHSON, $B$

THE EXCITEMENT MOUNTS

WEST AFRICA, (3901) (JUN 92), 1049

THE AUTHOR REPORTS ON THE FOUNDING OF THE NATIONAL DEMOCRATIC CONGRESS, A POLITICAL PARTY FORMED BY THE PNDC TO PARTICIPATE IN GHANA'S 1992 PRESIDENTIAL ELECTIONS.

03154 EPHSON, B.

WHO IS WHO?

WEST AFRICA, (3919) (OCT 92), 1815-1817

THE AUTHOR PROFILES GHANA'S 1992 PRESIDENTIAL ASPIRANTS, INCLUDING ALBERT ADU BOAHEN, HILLA LIMANN, KWABENA DARKO,

AND FLT-LT. JERRY JOHN RAHLINGS.

03155 EPPEL, M.

IRAOI POLITICS AND REGIONAL POLICIES, 1945-49

IRAQI POLITICS AND REGIONAL POLICIES, 1945-49

TWO MAIN APPRACHES AMONG IRAOI POLITICIANS REGARDING THE INTEREST, AIMS, AND PRIORITIES OF THEIR COUNTRY'S REGIONAL FOREIGN POLICY ARE EXAMINED. IRAQI POLITICIANS, WHEN FORCED TO REACH DECISIONS AND TAKE MEASURES RELATED TO FOREIGN POLICY, COULD NOT IGNORE ALTERNATIVES FACING IRAQ IN THE REGIONAL ARENA. THIS PAPER STUDIES NURI AL-SAID'S MOVES TOWARD STRENGTHENIMG RELATIONS BETWEEN IRAO AND TURKEY AND CONCLUDES THAT NURI'S SKILL AT MANEUVERING HITHIN THE INTERNAL IRAQI ARENA EXCEEDED THAT OF OTHER POLITICIANS. HE WAS ABLE TO FRUSTRATE POLICIES IN OPPOSITION TO HIS OWN AND TO PREVENT OTHER POLITICIANS FROM ASSUMING POSITIONS OF STRENGTH.

03156 EPSTEIN, B.

"POL ITICAL CORRECTNESS" AND COLLECTIVE POHERLESSNESS SOCIALIST REVIEH, 3(4) (1991), 13-36

THE TERM "POL ITICAL CORRECINESS" HAS TO DO WITH THE INTERSECTION OF IDENTITY POLITICS AND MORALISM. THIS ARTICLE SUGGESTS THAT THERE IS A DIFFERENCE BETHEEN MAINTAINING A CRITICAL AWARENESS OF THE ASSUMPTIONS BEHIND OUR LANGUAGE AND CREATING A SUBCULTURE IN WHICH EVERYONE IS ON EDGE, HAITING TO BE CHARGED WITH BIAS OR LOOKING FOR

OPPORTUNITITES TO ACCUSE OTHERS OF IT. THE ARTICLE CONCLUDES THAT THOUGH VICIOUS AND DISHONEST, THE NEOCONSERVATIVE ATTACK ON PC USEFULLY HIGHLIGHTS A TROUBLING RESURGENCE OF LEFT MORALISM.

03157 EPSTEIN, L.G.; SEGAL, U.

QUADRATIC SOCI SEGAL, UELFARE FUNCTIONS

JOURNAL OF POLITICAL ECONOMY, 100(4) (AUG 92), 691-712. JOHN HARSANYI HAS ARGUED THAT SOCIAL WELFARE CAN BE EXPRESSED AS A WEIGHTED SUM OF INDIVIDUAL UTILITIES. HIS THEOREM HAS BEEN CRITICIZED ON THE GROUNDS THAT A CENTRAL AXIOM, THAT SOCIAL PREFERENCE SATISFIES THE INDEPENDENCE AXIOM, THAT SOCIAL PREFERENCE SATISFIES THE INDEPENDENCE
AXIOM, HAS THE MORALLY UNACCEPTABLE IMPLICATION THAT THE AXIOM, HAS THE MORALLY UNACCEPTABLE IMPLICATION THAT THE
PROCESS OF CHOICE AND CONSIDERATIONS OF EX ANTE FAIRNESS ARE PROCESS OF CHOICE AND CONSIDERATIONS OF EX ANTE FAIR TE OF NO IMPORTANCE. THIS PAPER PRESENTS A VARIATION OF
HARSANYI'S THEOREM IN WHICH THE AXIOMS ARE COMPATIBLE WITH A HARSANYI'S THEOREM IN WHICH THE AXIOMS ARE COMPATIBLE HITH
CONCERN FOR EX ANTE FAIRNESS. THE IMPLIED MATHEMATICAL FORM CONCERN FOR EX ANTE FAIRNESS. THE IMPLIED MATHEMATICAL FORM
FOR SOCIAL WELLARE IS A STRICTLY QUASI-CONCAVE AND OUADRATIC FOR SOCIAL WELFARE IS A STRICTLY
FUNCTION OF INOIVIDUAL UTILITIES.
03158 EPSTEIN, R.A.

THE INDIVISIBILITY OF LIBERTY UNDER THE BILL OF RIGHTS HARVARD JOURNAL OF LAW AND PUBLIC POLICY, 15(1) (WIN 92), 35-42

THERE IS A VERY DANGEROUS SENTIMENT ABROAD IN THE LAND THAT WE CAN IDENTIFY TWO CLASSES OF RIGHTS--THOSE THAT ARE FUNDAMENTAL AND THOSE THAT ARE NOT. THE FIRST CLASS OF RIGHTS IS REGARDED AS ROBUST AGAINST LEGISLATIYE INTERFERENCE, WHILE THE SECOND IS FAR MORE FRAIL AND LESS WORTHY OF CONSTITUTIONAL PROTECTION. ANY APPROACH TO FUNDAMENTAL RIGHTS REQUIRES THAT THE LIST BE SHORT BUT THAT IT BE CAPABLE OF UNIFORM AND COMPREHENSIVE APPLICATION ACROSS A WIDE RANGE OF PHENOMENA THAT INITIALLY APPEAR SEPARATE AND DISTINCT FROM EACH OTHER. IT IS NECESSARY TO WORK HITH POWERFUL GENERALIZATIONS CAPABLE OF CONCRETE APPLICATION. NOTHING IS MORE DANGEROUS TO INTELLECTUAL DISCOURSE THAN THE RAPID PROLIFERATION OF PARTICULARISTIC INDIVIDUALS, GROUPS, OR POLITICAL CAUSES.

03159 EPSTEIN, H.

NUCLEAR' SECURITY FOR THE KOREAN PENINSULA

KOREAN JOURNAL OF DEFENSE ANALYSIS, IV (2) (WIN 92), 55-70. WITH GERMANY NOW REUNITED THE STILL-DIVIDED KOREAN PENINSULA IS THE MOST IMPORTANT REMAINING VESTIGE OF THE COLD WAR. BOTH NORTH AND SOUTH HAVE FOR YEARS PROCLAIMED THEIR DESIRE TO BRING ABOUT THE UNIFICATION OF KOREA, BUT IT WAS NOT UNTIL THE SERIES OF HIGH-LEVEL BILATERAL TALKS BETWEEN THE TWO PRIME MINISTERS IN 1990 THAT ANY SIGNIFICANT PROGRESS WAS MAOE TOWARDS SOLVING THEIR MANY PROBLEMS. THE PROBLEMS RELATING TO ANY EARLY UNIFICATION ARE MANY ANY DEEP BUT THE CENTRAL AND BASIC PROBLEM IS THAT OF SECURITY, MORE SPECIFICALLY, NUCLEAR SECURITY. THIS ARTICLE ARGUES THAT THE PROBLEM OF NUCLEAR SECURITY IS NOT ONLY CAPABLE OF SOLUTION BUT IS INDEED RIPE FOR SOLUTION. TRULY REMARKABLE PROGRESS HAS BEEN MADE IN THE LAST YEAR. THE AUTHOR ARGUES THAT A MAJOR STEP TOWARDS UNIFICATION CAN BE TAKEN BY UNITING THE KOREAN PENINSULA THROUGH A FORMAL NUCLEAR-HEAPON FREE ZONE TREATY. HE OUTLINES THE RECENT CHANGES IN RELATIONS THAT MAKE SUCH A TREATY POSSIBLE AND CONCLUDES THAT IF SUCH A TREATY CAN BE ACHIEVED, THE

03160 ERICKSON, L.: CARTY, R.K.

PARTIES AND CANDIDATE SELECTION IN THE 1988 CANADIAN GARTIES AND CANOID

CANADIAN JOURNAL OF POLITICAL SCIENCE, XXIV(2) (JUN 91),

331-350.

THIS ARTICLE EXPLORES CANDIDATE SELECTION IN CANADIAN POLITICAL PARTIES WITH A PARTICULAR FOCUS ON THE BASIC PROCESSES INVOLVED AND THE CHARACTER OF THE CANDIDATES THEY PRODUCE. AFTER A REVIEW OF THE POPULAR CONVENTIONAL WISDOM THE ARTICLE REPORTS THE RESULTS OF THE FIRST SYSTEMATIC NATION-WIDE STUDY OF NOMINATION PROCESSES IN LOCAL CONSTITUENCY PARTY ASSOCIATIONS (CARRIED OUT AT THE TIME OF THE 1988 GENERAL ELECTION). DESPITE DEMOCRATIC FORMS,
COMPETITION FOR PARTY NOMINATIONS CONTINUES TO BE THE COMPETITION FOR PARTY NOMINATIONS CONTINUES TO BE THE
EXCEPTION RATHER THAN THE NORM AND NATIONAL PARTY INTERESTS ARE ONLY WEAKLY ARTICULATED.

03161 ERICKSON, P.G.

RECENT TRENDS IN CANADIAN DRUG POLICY: THE DECLINE AND RESURGENCE OF PROHIBITIONISM

DAEDALUS, $121(3)$ (SUM 92), 239-268

IN 1986-87, WHILE THE UNITED STATES LAUNCHED A NEWLYINVIGORATED DRUG WAR, CANADA ENUNCIATED A VERY DIFFEREMT NATIONAL DRUG STRATEGY. SINCE REPRESSIVE RESPONSES TO ILLICIT DRUG USE HAD BEEN THE HALLMARK OF DRUG POLICIES IN BOTH COUNTRIES FROM THE EARLY 1900'S, THIS APPARENT DIVERGENCE COULD BE SEEN AS AN EFFORT BY CANADA TO DISTANCE ITSELF FROM THE LEGACY OF ITS PAST POLICIES, TO FORGE NEW DIRECTION. IN THIS PAPER, THE AUTHOR LOOKS AT CANADA'S NEW DRUG CONTROL POLICY AND COMPARES IT TO THE MORE

UNEQUIVOCALLY AGGRESSIVE U.S. APPROACH TO THE PROBLEM.

03162 ERIE, S.P.

HOW THE URBAN WEST WAS WON: THE LOCAL STATE AND ECONOMIC GROWTH IN LOS ANGELES, 1880-1932

URBAN AFFAIRS QUARTERLY, 27 (4) (JUN 92), 519-554.

THE AUTHOR STUDIES LOS ANGELES' TRANSITION FROM AN ESSENTIALLY ENTREPRENEURIAL GROWTH REGIME (1880-1906) TO A MORE STATE-CENTERED GRONTH REGIME (1906-1932). THE ANALYSIS HIGHLIGHTS THE ROLE OF PUBLIC INFRASTRUCTURE PROJECTS (WATER, HIGHLIGHTS THE ROLE OF PUBLIC INFRASTRUCTURE PROJECTS (WATER,
POWER, AND THE HARBOR) AND OF POWERFUL LOCAL BUREAUCRACIES POWER, AND THE HARBOR) AND OF POWERFUL LOCAL BUREAUCRACI
(I.E. THE DEPARTHENT OF HATER AND POWER) IN SHAPING THE (I.E.' THE DEPARTMENT OF WATER AND POWER) IN SHAPING THE
REGION'S PROGRESSIVE ERA DEVELOPMENT. LOS ANGELES' RELIIANCE REGION'S PROGRESSIVE ERA DEVELOPMENT. LOS ANGELES' RELIANCE
UPON A PUBLIC STRATEGY OF ECONOMIC DEVELOPMENT IS PLACED IN UPON A PUBLIC STRATEGY OF ECONOMIC DEVELOPMENT IS PLACED IN COMPARATIVE REGIONAL PERSPECTIVE. IN THE EARLY TWENTIETH
CENTURY. THE LOCAL GOVERNMENT SERVED AS A KEY INSTRUMENT OF CENTURY, THE LOCAL GOVERNMENT SERVED AS A KEY I
ECONOHIC DEVELOPMENT THROUGHOUT THE URBAN WEST.

03163 ERIKSEN, T. ETHNICITY AND NATIONALISM: DEFINITIONS AND CRITICAL REFLECTIONS 
BULLETIN OF PEACE PROPOSALS, 23(2) (1992), 219-224 RATHER THAN VANISHING OR LOSING ITS SIGNIFICANCE IN MODERN SOCIETIES, ETHNICITY HAS BECOME AN EVER MORE IMPORTANT PRINCIPLE FOR POLITICAL ORGANIZATION, AND A FOCUS FOR INDIVIDUAL IDENTITY. THIS ARTICLE EXPLORES ETHNIC GROUPS NATIONS, TENSIONS BETHEEN NATIONS AND MINORITIES MAJORITIES AND MINORITIES, AND ALTERNATIVES TO NATIONALISM. IT CONCLUDES THAT ETHNIC IDENTITIES WILL PREVAIL IN THE FORESEEABLE FUTURE, AS HILL THE SYSTEM OF STATES BUT THAT THERE IS A REAL POSSIBILITY OF KEEPING THE THO APART.

03164 ERIKSEN, T.H.

LINGUISTIC HEGEMONY ANO MINORITY RESISTANCE

JOURNAL OF PEACE RESEARCH, 29(3) (AUG 92), 313-332.

THE PROCESSES OF INTEGRATION INTO NATION-STATES PUTS STRONG PRESSURES ON MINORITIES TO ASSIMILATE. FOR THIS REASON, MANY MINORITY LANGUAGES ARE THREATENED. THIS ESSAY COMPARES THE STATUS OF SEVERAL LINGUISTIC MINORITIES, FOCUSING ON THEIR RELATIONSHIPS WITH THE NATION-STATES TO WHICH THEY ARE SUBJECTED THEIR STRATEGIES OF RESISTAMCE, AND PROA AND PROBLY ARE SUB IN CHALLENGING LINGUISTIC HEGEMONY. PERHAPS PARADOXICALLY. CULTURAL MINORITIES MAY HAVE TO ASSIMILATE CULTURALLY IN IMPORTANT RESPECTS IN ORDER TO PRESENT THEIR CASE EFFECTIVELY AND THEREBY RETAIN THEIR MINORITY IDENTITY. A MAJOR CONCLUSION EMERGING FROM THE COMPARI SONS IS THAT STATES NEED NOT BE NATION-STATES RELYING ON NATIONALIST IDEOLOGIES PROCLAIMING THE VIRTUES OF ABSOLUTE CULTURAL HOMOGENEITY. ALTHOUGH THEY MAY BE UNSPECTACULAR, FORMS OF LINGUISTIC OPPRESSION ARE FORMS OF OPPRESSION NO LESS, AND

03165 ERISMAN, $H$

PURSUING POSTDEPENDENCY POLITICS: SOUTH-SOUTH RELATIONS IN THE CARIBBEAN

LYNNE RIENNER PUBLISHERS, 1992,163

THIS BOOK SEEKS TO EXAMINE THE GENERALLY UNEXPLORED WATERS OF POSTDEPENDENCY POLITICS. THE AUTHOR ARGUES THAT THE OPTION OF SOUTH-SOUTH RELATIONS CAN BE A VIABLE WAY FOR A DEVELOPING COUNTRY TO MOVE BEYOND DEPENDENCY BY ACQUIRING EITHER ENOUGH BARGAINING POWER TO EXERT SOME CONTROL OVER THE TERMS OF ITS DEPENDENT NORTH-SOUTH RELATIONS OR THE MANEUVERING SPACE NECESSARY TO MINIMIZE ITS EXPOSURE TO ANY SINGLE FOREIGN SOURCE OF INFLUENCE. HE SHEDS LIGHT ON THE EVOLVING ROLE OF SMALL STATES IN GENERAL IN THE CONTEMPORARY INTERNATIONAL SYSTEM.

03166 ERLER, E.J.

JAMES MADISON AND THE FRAMING OF THE BILL OF RIGHTS REAL ITY AND RHETORIC IN THE NEH CONSTITUTIONALISM

POLITICAL COMMUNICATION, $9(4)$ (1992), 213-229.

JAMES MADISON'S LEADERSHIP IN FRAMING THE BILL OF RIGHTS EXEMPL IFIES THE ROLE OF DEMOCRATIC STATESMANSHIP. ALTHOUGH EXEMPLIFIES THE ROLE OF DEMOCRATIC STATESMANSHIP. ALTHOUGH NEVER WAIVERING IN HIS PRINCIPLED OPPOSI ION TO A BILL PIGHSS MADISON AMENDMENTS TO FORESTALL MORE RADICAL REVISIONS TO PROPOSING AMENDMENTS TO FORESTALL MORE RADICAL REVISIONS THE CONSTITUTION. HIS TASK WAS TO APPEASE PUBLIC OPINION WONSTITUTION: IN THIS TASK, HE ONLY PARTIALLY SUCCEEDED.

03167 ERNST, A.

FROM LIBERAL CONTINENTALISM TO NEOCONSERVATISM: NORTH AMERICAN FREE TRADE AND THE POLITICS OF THE C.D. HOWE

STUDIES IN POLITICAL ECONOMY: A SOCIALIST REVIEW, 39(39) FAL 92), $109-140$

A GROWING BODY OF LITERATURE HAS FOCUSED ON THE NEW BUSINESS AGENDA AND ITS RISE TO PREEMINENCE WITHIN CANADA. IT IS THE CONTENTION OF THIS PAPER THAT, ALTHOUGH SOME SECTIONS OF CANADIAN CAPITAL HAVE ALWAYS BEEN SYMPATHETIC TO CONTINENTAL FREE TRADE AND FREE MARKET POLICIES, THE CHANGES IN THE INTERNATIONAL AND CANADIAN POLITICAL ECONOMIES IN THE EARLY 1980 S GAVE ADDED SUPPORT TO THESE VIEWS. THIS ARTICLE TRACES THE CHANGES IN THE C.D. HOWE INSTITUTE ECONOMIC POLICY AFTER OFFERING A BRIEF DISCUSSION OF THE ROLE OF INSTITUTE.

03168 ERNST, R.J. III

CLEAN AIR'S DIRTY POLITICS

AMERICAN SPECTATOR, 25(10) (OCT 92), 46-47

FEH CALIFORMIANS RELIZE THAT THEIR TWO-TIERED SYSTEM OF STATE AND LOCAL GOVERNMENT NO LONGER REALLY EXISTS. THE AIR POLLUTION CONTROL DISTRICTS AND OTHER SUPER-REGIONAL AGENCIES--ALL EXEMPT FROM PROPOSITION 13-- HAVE QUIETLY SUPPLANTED SACRAMENTO AND LOCAL GOVERMMENT, DECIDING THE UNIFIED AIR POLLUTION CONTROL DISTRICT OFFERS A GOOD EXAMPLE UNIFIED AIR POLLUTION CONTROL
OF HOW THESE AGENCIES OPERATE.

03169 ERSOY, M.

RELATIONS BETWEEN CENTRAL AND LOCAL GOVERNMENTS IN TURKEY AM HISTORICAL PERSPECTIVE

PUBLIC ADMINISTRATION AND DEVELOPMENT, $12(4)$ (OCT 92), 325-341.
THE AUTHOR ANALYZES TRENDS IN CENTRAL-LOCAL GOVERNMENT RELATIONS IN TURKEY OVER THE PAST 150 YEARS IN THREE AREAS: (1) THE POL ITICAL AND ADMINISTRATIVE LEVEL; (2) FINANCIAL POLICIES; (3) HISTORICAL DEVELOPMENT OF THE RELATIONSHIP WITH RESPECT TO THE LEGAL AND INSTITUTIONAL FRAMEWORK OF URBAN PLANNING. THE RELATIONSHIP HAS BEEN FUNDAMENTALLY PATERNALISTIC AND AUTHORITARIAN. THE AUTHOR ASSESSES THE AUTHENTICITY OF THE PROCLAIMED LIBERAL POLICIES AND THE SUBSEQUENT IMPLEMENTATION MECHANISMS DEVISED BY THE PRESENT ADMINISTRATION OVER THE PAST EIGHT YEARS. ALTHOUGH A CHANGE OF GOVERNMENT SEEMS IMMINENT, MOST OF THE POLICIES ALREADY IMPLEMENTED ARE CONSIDERED TO BE IRREVERSIBLE. EMPHASIS IS GIVEN TO AN ASSESSMENT OF THE CLAIM THAT LIBERAL GOVERNMENTS HAVE INTRODUCED POSITIVE CHANGES IN THIS STRUCTURAL MECHANISM, RATHER THAN A NORMATIVE EVALUATION OF THIS STRUCTURAL RELATIONSHIP.

03170 ESCOBAR, A.

REFLECTIONS ON "DEVELOPMENT"--GRASSROOTS APPROACHES AND ALTERNATIVE POLITICS IN THE THIRD HORLD

FUTURES, $24(5)$ ( JUN 92 ), 411-436.

THIS ARTICLE ANALYZES A RADICAL CRITIQUE OF THE DISCOURSE OF "DEVELOPMENT" AS A HEGEMONIC FORM OF REPRESENTATION OF THE THIRD HORLD THAT HAS BEEN ADVANCED REPRESENTATION OF THE THIRD WORLD THAT HAS BEEN ADVANCED RECENTLY BY A NUMBER OF THIRD IN VARIOUS GEOGRAPHIC AREAS, THE AUTHORS OF THIS ORIGINATING IN VARIOUS GEOGRAPHIC AREAS, THE AUTHORS OF THIS PROMINENT AMONG THESE ARE THE INTEREST IN LOCAL KNOWLEDGE AND CULTURE AS THE BASIS FOR REDEFNING REPRESENTATIONS; A AND CULTURE AS THE BASIS FOR REDEFNING REPRESENTATIONS; CRITICAL STANCE WITH RESPECT TO ESTABLISHED SCIENTIFIC KNOWLEDGE; AND THE DEFENSE AND PROMOTION OF LOCALIZED,
PLURALISTIC GRASSROOTS MOVEMENTS. THE CALL OF THESE AUTHORS FOR THE DISMANTLING OF "DEVELOPMENT" IS DISCUSSED IN THE CONTEXT OF BROADER QUESTIONS POSED BY THE EMERGENCE OF 1980S' AND 1990S' SOCIAL MOVEMENTS GENERALLY.

03171 ESHET, G.

ISRAEL'S ECONOMY

MIDDLE EAST INSIGHT, VIII(6) (JUL 92), 62-63

THERE ARE THO MAJOR CAUSES FOR ISRAEL'S ECONOMIC

AILMENTS: WAR AND PEACE. DURING PERIODS OF WAR, MANY

COUNTRIES MAINTAIN HIGH MILITARY EXPENDITURES OVER SHORT

PERIODS OF TIME. ISRAEL'S UNIQUE SITUATION IS A RESULT OF MAINTAINING HIGH MILITARY EXPENDITURES OVER A LONG PERIOD OF TIME.

03172 ESMAN, M.J.

THE STATE AMD LANGUAGE POLICY

INTERNATIONAL POL ITICAL SCIENCE REVIEH, 13(4) (OCT 92), 381-396.

LANGUAGE IS A CRITICAL ISSUE IN MANY ETHNICALLY-DIVIDED STATES, AND LANGUAGE POLICY IS ONE METHOD BY WHICH GOVERNMENTS ATTEMPT TO MANAGE ETHNIC CONFLICT. WHILE SUCH POLICY IS CONSTRAINED BY SOCIETAL PRESSURES, IT TENOS TO BE POLICY IS CONSTRAINED BY SOCIETAL PRESSURES, IT TENOS TO BE INSTRUMENTAL TO ELITE PREFERENCES FOR ASSIMILATIONIST OR THE AUTHOR EVALUATES A VARIETY OF SPECIFIC LANGUAGE POLICIES IN TERMS OF THEIR CONTRIBUTION TO THIS GOAL. WHILE THEIR IN TERMS OF THEIR CONTRIBUTION YO THIS GOAL. WHILE THEIR EFFECTIVENESS TENDS TO BE HIGHLY CONTINGEN, ORE LIKELY THAN MUILINGUALISM, WHERE PRACTICABLE, SEEMS MORE LIKELY THAN

03173 ESPINAL, $R$.

LATIN AMERICA'S NEW RIGHT

HEMISPHERE, 4(2) (WIN 92), 20-22.

DURING THE 1980'S THO MAJOR CHANGES HAD FAR-REACHING IMPLICATIONS FOR THE RIGHT AS A POLITICAL FORCE IN LATIN AMERICA: THE TRANSITION TO DEMOCRACY AND THE WORLDWIDE IDEOLOGICAL ASCENDANCY OF NEOL IBERALISM. THE TRANSITION TO DEMOCRACY HAS FORCED LATIN AMERICA'S RIGHT TO COMPETE ELECTORALLY, WHILE THE ASCENDANCY OF NEOL IBERALISM HAS PROVIDED NEW IDEOLOGICAL POINTS OF REFERENCE. THESE REGIONAL AND GLOBAL SHIFTS HAVE SPURRED ANALYSTS TO DIFFERENTIATE AMONG LATIN AMERICAN POLITICAL FORCES USING A HIDER, MORE NUANCED SPECTRUM OF IOEOLOGICAL ISSUES, IN ADDITION TO THOSE FORCES' TRADITIONAL STANCES ON SUCH MATTERS AS CIVILIAN VERSUS MILITARY GOVERNANCE.

03174 ESQUITH, S.

LIBERAL EDUCATION AND CITIZENSHIP

PERSPECTIVES ON POLITICAL SCIENCE, 20(2) (SPR 91), 69-72. OVER THE PAST CENTURY IN THE UNITED STATES AND GREAT BRITAIN, A LIBERAL OR LIBERAL ARTS EDUCATION IDEALLY HAS MEANT A BROAD AND HUMANISTIC UNDERGRADUATE PROGRAM OF STUDY DESIGNED TO PREPARE STUDENTS TO THINK FOR THEMSELVES AND THEN PURSUE THEIR OWN CAREERS RESPONSIBLY AND HITH TOLERANCE FOR OTHERS. THERE ARE THO IMPORTANT ASSUMPTIONS THAT

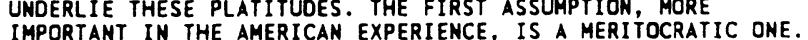
IMPORTANT IN THE AMERICAN EXPERIENCE, IS A MERITOCRATIC ONE.
THE SECOND, HHOSE ORIGINS CAN BE TRACED TO THE EDUCTION OF THE SECOND, WHOSE ORIGINS CAN BE TRACED TO THE EDUCTION ARISTOCRATIC. ALTHOUGH THESE ASSUMPTIONS SEEM TO POINT IN OPPOSITE DIRECTIONS. THE AUTHOR OF THIS ARTICLE ARGUES THA
THEY HAVE FAVORED A COHERENT BUT INADEQUATELY DEMOCRATIC 
CONCEPTION OF CITIZENSHIP IN THE CURRENT CONTEXT OF NEOCORPORATIST PLANNING AND POLICY MAKING.

03175 ESQUITH, S.

POLITICAL THEORY AND POLITICAL EDUCATION

POL ITICAL THEORY, 20(2) (MAY 92) 247-273.

PHILOSOPHERS AND POLITICAL THEORISTS HAVE BECOME INCREASINGLY INVOLVED IN PUBLIC POLICYMAKING OVER THE PAST THO DECADES IN LIBERAL DEMOCRATIC SOCIETIES. HOWEVER, THE CONSEQUENCES OF THEIR WORK ARE STILL HARD TO GAUGE. INSTEAD OF TRYING TO DETERMINE HOW PARTICULAR POLICY CHOICES HAVE BEEN INFLUENCED BY ARGUMENTS, THIS ARTICLE SUGGESTS ANOTHER BEEN INFLUENCED BY ARGUMENTS, THIS ARTICLE SUGGESTS ANOTHER
WAY OF THINKING ABDUT THE PRACTICAL IMPORTANCE OF THIS WORK USING THE CONCEPT OF POLITICAL EDUCATION. IT ARGUES THAT WE USING THE CONCEPT OF POLITICAL EDUCATION. IT ARGUES THAT WE THAT MEDIATE TRUST IN EXPERT AUTHORITY. MORE SPECIFICALLY, THAT MEDIATE TRUST IN EXPERT AUTHORITY. MORE SPECIFICALLY, DHESE THEORETICAL INTERVENTIONS CAN BE CRITICIZED FOR DOMESTICATING THE ANGRY VOICES OF CITIZENS IN THESE NEOCORPORATIST DEMOCRACIES WHO HAVE OCCUPIED THE POSITION OF OTHER IN A POLITICS OF EXPERT POLICY-MAKING. LIBERAL DEMOCRATIC THEORY HAS MADE IT POSSIBLE FOR THE OTHER TO BE SEEN BUT BARELY HEARD.

03176 ESTES, C.L.; ALFORD, R.R.

SYSTEMIC CRISIS AND THE NONPROFIT SECTOR: TOWARD A POLITICAL ECONOMY OF THE NONPROFIT HEALTH AND SOCIAL SERVICES SECTOR

THEORY AND SOCIETY, 19(2) (APR 90), 173-198.

THIS ARTICLE EXPLORES THE RELATION OF SYSTEMIC CRISIS TENDENCIES TO THE NONPROFIT SECTOR. THE CRISIS LITERATURE IS USED TO EXPLAIN HOW THE NONPROFIT-SECTOR HEALTH AND SOCIAL SERVICES MAY BE EMPLOYED AS A BUFFER AND A RESOURCE FOR CAPITAL AND THE STATE IN RESPONDING TO CRISIS TENDENCIES. ISSUES ADORESSED INCLUDE THE USE OF STATE INTERVENTION IN PERIODS OF CRISIS; THE ENSUING SOCIAL STRUGGLES; AND THE CONSEQUENCES OF THE PROCESSES OF CRISIS PRODUCTION AND CRISIS RESOLUTION FOR NONPROFIT HEALTH AND SOCIAL SERVICES. EMPHASIS IS GIVEN TO UNDERSTANDING THE LINKS BETWEEN CRISIS AND CRISIS TENDENCIES OF CAPITAL AND THE STATE, AND WHAT IS AND CRISIS TENDENCIES OF CAPITAL AND THE STATE, AND WHAT IS THE NONPROFIT SECTOR.

03177 ETCHESON, C.

\section{THE PEACE IN CAMBODIA}

CURRENT HISTORY, 91(569) (DEC 92), 413-417

CAMBODIA'S GEMOCIDAL MISERY UNDER POL POT'S KHMER ROUGE ENDED WITH THE YIETMAMESE INYASION OF 1979 BUT THE COUNTRY HAS CONTINUED TO EXPERIENCE GUERRILLA WARFARE ANO TO SUFFER ECONOMIC DEPRIVATIONS. SINCE A PEACE AGREEMENT HAS SIGNED IN OCTOBER 1991, THE UNITED NATIONS HAS ATTEMPTED TO IMPLEMENT PEACE, WITH LIMITED SUCCESS.

03178 ETHEREDGE, L.

WISDOM AND GOOD JUDGMENT IN POLITICS

POLITICAL PSYCHOLOGY, 13(3) (SEP 92), 497-516.

THE JOB OF POLITICAL LEADER REQUIRES UNIQUE SENSIBILITES TO ASSURE GOOD POLITICAL JUDGMENT AND WISDOM. CLASSIC POLITICAL THEORISTS HAVE OFTEN RECOMMENDED ANTITHETICAL DECISION ALGORITHMS AS A BASIS FOR GOOD POLITICAL JUDGMENT. TWO MAJOR DISAGREEMENTS CONCERN THE ALLEGED DARHINIAN ADVANTAGE OF AMORAL MACHIAVELLIAN DECISION ALGORITHMS AND STRUCTURAL REALIST PERCEPTIONS OF INTERNATIONAL POLITICS. CURRENT RESEARCH SUGGESTS MACHIAVELLIAN AND STRUCTURAL REALIST THEORIES ARE MISLEADING AND RATIONALIZE BEHAVIOR THAT IS BOTH MORE DANGEROUS AND IRRATIONAL, AND MORE HOPEFUL. THAN THEY PORTRAY.

03179 ETHESHAMI, A.

IRAN RIDES OUT THE STORM IN THE GULF

MIDDLE EAST INTERNATIONAL, (395) (MAR 91), 23-24.

IRAN'S STANCE ON THE GULF WAR SURPRISED MANY OBSERYERS. HOWEVER, AS TEHRAN SEES IT, ITS DECLARED NEUTRALITY IN THE CURRENT CRISIS DOES NOT IN ANY WAY AMOUNT TO AN ABROGATION OF ITS "ISLAMIC" AND REGIONAL RESPONSIBILITIES. MANY OBSERYERS INDICATE THAT IRAN HAS GENUINELY TURNED THE CORNER IN ITS FOREIGN RELATIONS AND IS NOW SINCERE ABOUT IT DESIRE IN ITS FOREIGN RELATIONS AND IS NOW SINCERE ABOUT IT DESIRE THE ISLAMIC REPUBLIC AND THE REIGN OF KHOMEINI. ITS IMAGE AS THE ISLAMIC REPUBLIC AND THE REIGN OF KHOMEINI. ITS IMAGE AS

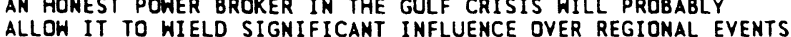
ALLOW IT TO WIELD SIGNIFICANT INFLU
IN THE MONTHS AND YEARS TO COME.

03180 ETZIONI, A.

CAUTION: IMDUSTRIAL POLICY IS COMING

CHALLENGE, 35 (5) (SEP 92 ) 58-61.

THE AUTHOR ARGUES THAT, WHETHER GEORGE BUSH OR BILL

CLINTON IS ELECTED PRESIDENT IN 1992, INDUSTRIAL POLICY IS INEVITABLE FOR THE UNITED STATES. HE EXAMINES THE NEOCLASSICAL ECONOMIC ARGUMENTS AGAINST INDUSTRIAL POLICY AND SUGGESTS SOME MEASURES THAT CAN BE UNDERTAKEN TO SAFEGUARD THE UNITED STATES FROM THE PITFALLS OF INDUSTRIAL POLICY.
03181 ETZIONI, A.

COMMUNITARIAN SOLUTIONS/WHAT COMMUNITARIANS THINK JOURMAL OF STAIE GOVERMMENT 65(1) (JAN 92) 9-11.

THUS FAR, THE NEW COMMUNITARIAN MOVEMENT' IN THE UNITED STATES HAS FOCUSED LARGELY ON DEVELOPING ITS BASIC PHILOSOPHY--THAT PUBLIC POLICIES MUST BE RESTRUCTURED TO INCLUDE SOCIAL RESPONSIBILITY. IN THIS ARTICLE, THE AUTHOR CONSIDERS THE POLICY IMPLICATIONS OF THE COMMUNITARIAN PHILOSOPHY IN A NUMBER OF AREAS, INCLUDING FAMILY POLICY.

03182 ETZIONI, A.

HOW IS RUSSIA BEARING UP?

CHALLENGE, 35 (3) (MAY 92 ), 40-43.

MAJOR SOCIETAL CHANGE IS A SLOW AND GRADUAL PROCESS THAT CANHOT BE HURRIED. IN THE FORMER SOVIET UNION THERE ARE NO DEMOCRATIC, CAPITALISTIC SOCIETIES THAT ANY GOVERNMENT,

HOWEVER WELL-MEANING AND AFFLUENT, COULD STABILIZE. THE BEST WAY THE WEST CAN HELP IS BY REDUCING, RATHER THAN FANNING, EXPECTATIONS.

03183 ETZIONI, A.

THE EVILS OF SELF-DETERMINATION FOREIGN POLICY, (89) (WIN 93), 21-35

SELF-DETERMINATION MOVEMENTS HAVE LARGELY EXHAUSTED THEIR LEGITIMACY AS A MEANS TO CREATE MORE STRONGLY DEMOCRATIC STATES. HHILE SUCH MOVEMENTS FORMERLY SERVED TO DESTROY EMPIRES AND FORCE GOVERNMENTS TO BE MORE RESPONSIVE TO THE GOVERNED, HITH RARE EXCEPTIONS, THEY NOW UNDERMINE THE POTENTIAL FOR DEMOCRATIC DEVELOPMENT IN NONDEMOCRATIC COUNTRIES AND THREATEN THE FOUNDATIONS OF DEMOCRACY IN DEMOCRATIC ONES. IT IS TIME TO WITHDRAH MORAL APPROVAL FROM MOST OF THESE MOVEMENTS AND SEE THEM FOR WHAT THEY MAINLY ARE--DESTRUCTIVE.

03184 EVANS-PRITCHARD, A. NICARAGUA'S KILLIING FIELDS

NATIONAL REVIEW, XLIII (7) (APR 91), 38, 40-44.

THE ELECTION OF VIOLETA CHAMORRO'S OPPOSITION COALITION TO POWER IN NICARAGUA LED TO A LIBERALIZATION OF PRESS RESTRICTIONS. ONE RESULT HAS BEEN SEVERAL GRISLY STORIES OF SANDINISTA REPRESSION DATING BACK TO 1981. MANY OF THOSE ACCUSED WITH THE ATROCITIES STILL HOLD POSITIONS OF POWER ACCUSED WITH THE ATROCITIES STILL HOLD POSITIONS OF POWER
AND THE KILLING CONTINUES IN SOME AREAS. CHAMORRO, WHO HAS AND THE KILLING CONTINUES IN SOME AREAS. CHAMORRO, WHO HAS
SURROUNDED HERSELF WITH CLOSE FAMILY AND FRIENDS, SEEMS TO BE GIVING AT LEAST TACIT APPROVAL TO THE CONTINUED POWER AND INFLUENCE OF THE SANDINISTAS.

03185 EVANS, C.A.

LIMITATIONS OF THE VOTING RIGHTS ACT OF 1965: PRESLEY $V$. ETOWAH COUNTY COMMISSION HARVARD JOURNAL OF LAW AND PUBLIC POLICY, 15(3) (SUM 92), 1031-1040

THE VOTING RIGHTS ACT OF 1965 REQUIRES JURISOICTIONS WITH A HISTORY OF DENYING BLACK CITIZENS THE RIGHT TO VOTE TO SUBMIT ALL CHANGES IN THEIR VOTING PRACTICES TO THE U.S. ATTORNEY GENERAL FOR APPROVAL BEFORE IMPLEMENTATION. PRIOR TO PRESLEY $Y$. ETOWAH COUNTY COMMISSION, THE SUPREME COURT HAD HELD THAT PRE-CLEARANCE WAS REQUIRED FOR NEH PRACTICES THAT MIGHT CAUSE MINORITY VOTE DILUTION, AS WELL AS FOR THOSE THAT DIRECTLY AFFECTED THE RIGHT TO CAST A BALLOT. IN PRESLEY, THE COURT ABANDONED ITS PRIOR COMMITMENT TO ANALYZING A PRACTICE'S POTENTIAL FOR VOTE DILUTION AND INSTEAD FOCUSED NARROWLY ON WHETHER A PROPOSED PRACTICE WAS A CHANGE "WITH RESPECT TO VOTING."

03186 EVANS, C.L.

LEADERSHIP IN COMMITTEE: A COMPARATIVE ANALYSIS OF LEADERSHIP BEHAVIOR IN THE UNITED STATES SEMATE

UNIVERSITY OF MICHAGAN PRESS, 1991,210

THIS BOOK OFFERS A CAREFULLY DRAWN PORTRAIT OF THE DISTINCTIVE LEGISLATIVE POLITICS OF THE MODERN SENATE. THE AUTHOR FOCUSES ON "LEADERSHIP BEHAVIOR" ON FOUR COMMITTEES ( COMMERCE, ENVIRONMENT AND PUBLIC WORKS, JUDICIARY, AND LABOR AND HUMAN RESOURCES) IN THE REPUBLI ICAN-CONTROLLED SENATE OF THE NINETY-NINTH CONGRESS $(1985-1986)$. HIS OBJECTIVE IS TO EXPLAIN THE PATTERNS HE FINDS IN THE ACTIVITY OF THE CHAIRS OF THESE COMMITTEES (DANFORTH, STAFFORD, THURMOND, HATCH) AND THEIR RESPECTIVE RANKING MINORITY MEMBERS (HOLLINGS, BENTSEN, BIDEN, KENNEDY) IN FOUR
"ASPECTS OF LEADERSHIP BEHAVIOR": AGENDA-SETTING FOR THE FULL COMMITTEE; DELEGATION OF LEGISLATIVE RESPONSIBILITIES TO SUBCOMYITTEE LEADERS; INTERACTION BETWEEN COMHITTEE TO SUBCOMAITTEE LEADERS; INTERACTION BETHEEN COMHITTEE CHAIRS AND RANKING MINORITY MEMBERS; AND EFFORTS TO TAILOR BILLS IN ANTICIPATION OF REACTIONS BY THE FULL SENATE. HE DRAWS ON BOTH "NEW INSTITUT IONAL" AND INFORMATIONAL THEORIES TO ARGUE THAT LEGISLATIVE LEADERS CAN AND DO EXERCISE POWER ACCESS TO INFORMATION TO FRAME FAVORABLE ALTERMATIVES ON COMPLEX POLICY ISSUES.

03187 EVANS, E.

THE CATHOLIC CHURCH AND POLITICAL CONFLICT CONFLICT, 11(4) (1991), 225-236.

THE INTRODUCTION TO A SPECIAL ISSUE OF "CONFLICT" NOTES 
THAT BEGINMING WITH THE PONTIFICATE OF JOHN XXIII AND VATICAN II, POLITICAL SCIENTISTS HAVE PAID INCREASED ATTENTION TO THE POL ITICAL ROLE OF THE CATHOL IC CHURCH. THE ARTICLES SEEKS TO ANSHER TWO KEY OUESTIONS ABOUT THE ROLE OF THE CATHOLIC CHURCH IN POLITICS: FIRST WHY IS THE CHURCH IN GENERAL SO RELUCTANT TO GET INVOLVED IN POLITICAL CONFLICT; AND SECOND, WHAT ARE THOSE SPECIAL CONDITIONS THAT LEAD TO IT BECOMING INYOLVED IN CERTAIN POLITICAL CONFLICTS, DESPITE ITS NATURAL TENDENCY TO AVOID THEM?

03188 EVANS, E.

THE IRISH CATHOLIC CHURCH AND THE NORTHERN IRELAND CONFLICT CONFLICT, 11(4) (1991), 267-278.

THIS ARTICLE ARGUES THAT THE IRISH CATHOLIC CHURCH HAS MIXED AND AMBIGUOUS FEELINGS ABOUT THE NORTHERN IRELAND CRISIS. AS A RESULT OF THESE MIXED FEELINGS, THE IRISH CATHOL IC CHURCH HAS PURSUED A CAUTIOUS AND PRUDENT POLICY ON THE NORTHERN IRELAND CONFLICT. IT CONCLUDES THAT IT MUST BE THE NORTHERN IRELAND CONFLICT. IT CONCLUDES THAT IT MUST
REMEMBERED THAT THE IRISH CATHOL IC CHURCH IS A RELIGIOUS INSTITUION AND THAT A POLICY OF MODERNATION, PRUDENCE, AND

INSTITUION AND THAT A POLICY OF MODERNATION, PRUDENCE,
CAUTION IS MOST IN KEEPING WITH ITS RELIGIOUS GOALS.

03189 EVANS, G.

NAMIBIA-SOUTH AFRICA: RELATIONS SINCE INDEPENDENCE ROUND TABLE, 323(323) (JUL 92), 293-302.

THE PURPOSE OF THIS ARTICLE IS TO OFFER A PROGRESS REPORT ON KEY ASPECTS OF THE POST-INDEPENDENCE RELATIONSHIP BETWEEN NAMIBIA AND SOUTH AFRICA AND TO ASSESS THE LIKELY FUTURE SIGNIFICANCE OF THIS CRUCIAL BILATERAL TIE IN THE OVERALL CONTEXT OF REGIONAL SECURITY, DEVELOPMENT AND COOPERATION. IT EXPLORES THE OUTSTAMDING ISSUES AT INDEPENDENCE AND JOINT ADMINISTRATION OF THE BAY AND ISLANDS IT CONCLUDES THAT NAMIBIA'S DIPLOMACY HAS HELPED TO CREATE A MORE RELAXED ATTITUDE IN PRETORIA AND MIGHT HELL PROVIDE THE CATALYST FOR FURTHER REGIONAL DISPENSATIONS.

03190 EVANS, G.

THE STRUGGLE FOR POWER IN SOUTH AFRICA: THE EXTERMAL CONSTITUENCY

MORLD TODAY, 48(12) (DEC 92), 221-224.

WHILE THE FUTURE CHARACTER AND SHAPE OF THE SOUTH AFRICAN POL ITY HILL BE DETERMINED BY THE SOUTH AFRICANS THEMSELVES, THE OUTSIDE WORLD WILL NOT BE ENTIRELY EXCLUDED FROM THE PROCESS. THE INTERNAL PROTAGONISTS WILL CONTINUE, WITH VARYING DEGREES OF SUCCESS, TO APPEAL TO EXTERNAL SYMPATHI ZERS AND PATRONS FOR SUPPORT. MOREOVER. THE INTERNATIONAL COMMUNITY WILL OF ITS OWM VOLITION SEEK TO INTERNATIONAL COMMUNITY WILL OF ITS OWM VOLITION SEEK TO INFLUENCE THE CONSTRUCTION PHASE OF THE "NEH SOUTH AFRICA."
THE ROLE PLAYED BY THE INTERHATIONAL COMMUNITY, ASSUMING THAT SOUTH AFRICA'S PROBLEMS DO NOT ESCALATE INTD A CIVIL WAR, WILL ALMOST CERTAINLY NOT INVOL VE HIGH-PROFILE

WAR, WILL ALMOST CERTAINLY NOT INVOLVE HIGH-PROFILE NEVERTHELESS, ITS INFLUENCE WILL BE FELT IN VIRTUALLY ALL NEVERTHELESS, ITS INFLUEMC
ASPECTS OF THE STRUGGLE.

03191 EVANS, $M$

REPEATING MISTAKES IN THE MIDOLE EAST

WORLD PRESS REVIEW, 39(9) (SEP 92), 17-18.

BECAUSE THE RUSSIANS ARE DESPERÁTE FOR HARD CURRENCY THEY ARE SELLING CONVENTIONAL WEAPONS AT AN ALARMING RATE. SOME OBSERVERS ARE CONCERNED ABOUT THE RISK OF RUSSIAN TACT ICAL NUCLEAR WARHEADS BEING SMUGGLED OUT OF THE COUNTRY INTO THE HANDS OF HOULD-BE NUCLEAR POWERS, SUCH AS THE IRANIANS, THE IRAQIS, AND THE LIBYANS.

03192 EVANS, P.B.

INDIAN INFORMATICS IN THE 1980'S: THE CHANGING CHARACTER OF STATE INYOL VEMENT

WORLD DEVELOPMENT, 20(1) (JAN 92), 1-18.

IN THE $1980^{\prime} \mathrm{S}$, LIBERALIZATION OF THE INDIAN INFORMATICS INDUSTRY OCCURRED IN THE CONTEXT OF CONTINUED HIGH LEVELS OF STATE INVOLVEMENT, BUT THERE WAS EVIDENCE THAT THE CHARACTER OF THAT INVOL VEMENT HAS CHAMGING. IN THE 1960'S AND 1970'S, THE INDIAN STATE COMBINED RESTRICTIVE REGULATION WITH ATTEMPTS TO SUBSTITUTE STATE-OWNED FOR PRIVATE PRODUCTION. EXAMINING THE CHANGING ROLE OF CENTRAL GOVERNMENT REGULATORY AGENCIES AND STATE-OWNED ENTERPRISES IN THE INFORMATICS INDUSTRY DURING THE 1980'S REYEALS TENTATIVE ATTEMPTS TO INCREASE STATE ACTIONS AIMED AT COMPLEMENTING AND PROMOTING PRIVATE ENTREPRENEURSHIP. ILLUSTRATIVE COMPARISONS WITH STATE INVOLVEMENT IN INFORMATICS IN SOUTH KOREA AND BRAZIL SUGGEST THAT THIS TRAJECTORY OF CHANGE MAY HAVE RELEYANCE SUGGEST THAT
BEYOND INDIA.

03193 EVANS, $R$

CANADA: THE REAL ISSUES

JOURNAL OF HEALTH POLITICS, POLICY AND LAW, 17(4) (WIN 92),

CANADIANS ARE, BY AND LARGE, SATISFIED HITH THEIR HEALTH CARE SYSTEM. IT IS FOR THEM A SYMBOL OF THEIR COMMUNITY AND DISTINGUISHES THEM FROM THE UNITED STATES. UNLIKE THE HEALTH SYSTEM OF THAT COUNTRY, IT IS UNIVERSAL, COMPREHENSIVE, AND ACCESSIBLE, AND IT COSTS LESS AS A PERCENTAGE OF GNP TO RUN. THE DIFFERENCE BETWEEN THE TWO SYSTEMS IS ROOTED IN
DIFFERENCES IN FUNDING. BY PROVIOING COVERAGE OF MEDICALLY NECESSARY CARE UNDER A SINGLE NONPROFIT PAYER (THE PROVINCIAL GOVERMMENTS, HITH GUIDANCE AND SOME FUNDS FROM THE FEDERAL GOVERNMENT), THE CANADIAN SYSTEM AVOIDS THE LARGE OVERHEADS AND PROFIT INCENTIVES THAT MAKE A FRAGMENTED PRIVATE INSURANCE INDUSTRY SO EXPENSIVE AND INEOUITABLE. WHEREAS HEALTH INSURANCE IN CANADA IS SOCIALIZED, CARE IS NOT: PATIENTS ARE FREE TO CHOOSE AMONG PROVIDERS, PHYSICIANS ARE PRIMARILY IN PRIVATE PRACTICE, AND HOSPITALS ARE INDEPENDENT, NONPRDFIT INSTITUTIONS OVERSEEN BY BOARDS OF TRUSTEES. CANADA AND THE UNITED STATES VIEW THE CHALLENGES CONFRONTING THE CANADIAN SYSTEM DIFFERENTLY. TO CANADIANS, THE REAL ISSUE IS HOH TO IMPROVE THE MANAGEMENT OF A POPULAR, EFFECTIVE, AND HERETOFORE AFFORDABLE SYSTEM, SO AS TO PRESERVE IT IN A MORE HOSTILE ECONOMIC ENVIRONMENT. THE SPECIFIC AREAS OF CONCERN ARE COMMON TO ALL HEALTH CARE SYSTEMS IN THE DEVELOPED WORLD BUT BEAR LITTLE RESEMBLANCE SYSTEMS IN THE DEVELOPED WORLD BUT BEAR LITTLE RESEMBLANCE
TO THE MISLEADING IMAGES OF CANADA FABRICATED IN THE UNITED STATES FOR INTERMAL POL ITICAL PURPOSES. FOR CANADIANS, THE STATES FOR INTERMAL POL ITICAL PURPOSES. FOR CANADIANS, THE
PROOF OF THEIR SYSTEM IS THAT IT WORKS, WHILE MILLIONS IN PROOF DF THEIR SYSTEM IS THAT

03194 EVANS, T.; WILSON, P.

REGIME THÉORY AND THE ENGLISH SCHOOL OF INTERNATIONAL RELATIONS: A COMPARISON

MILLENNIUM, 21(1) (SPR 92), 329-352.

IN RECENT YEARS A NUMBER OF AUTHORS HAVE DRAWN ATTENTION TO THE SIMILARITIES BETWEEN REGIME THEORY AND THE ENGLISH SCHOOL. IT HAS BEEN SUGGESTED THAT SOME KIND OF SYNTHESIS BETHEEN THE TWO SCHOOLS MAY BE BOTH POSSIBLE AND DESIRABLE. THIS ESSAY OUTLINES THE SIMILARITIES AND DIFFERENCES BETWEEN THEM WITH AN EYE TOWARDS IDENTIFYING WHAT SUCH A SYNTHESIS MIGHT INVOLVE.

03195 EVENSON, B.

TRUMAN, PALESTINE AND THE COLD WAR

MIDDLE EASTERN STUDIES, 28(1) (JAN 92), 120-156.

A CONSIDERABLE LITERATURE HAS DEVELOPED OVER THE PAST FORTY YEARS PURPORTING TO EXPLAIN PRESIDENT TRUMEN'S SUPPORT FOR A JEWISH STATE IN PALESTINE DURING THE FALL OF 1947 AND HIS PROMPT RECOGNITION OF THAT STATE WITHIN MINUTES OF ITS DECLARATION. THE PUPOSE OF THIS PAPER IS TO SUGGEST THAT FAR MORE THAN JEHISH VOTERS WERE ON TRUMAN'S MIND AS HE STRUGGLED TO CONSTRUCT A POST-WAR POLICY IN PALESTINE. PRIMARY DOCUMENTS OF THE PERIOD SHOW THE DEGREE TO WHICH TRUMAN'S CALCULATIONS ON THE MIDDLE EAST WERE LINKED TO COLD TRUMAN'S CALCULATIONS ON THE MIDOLE EAST WERE LINKED TO COLD
WAR CONSIDRATIONS AS WELL AS THE PUBLIC PERCEPTION OF EASTWAR CONSIDRATIONS AS WELL AS THE PUBLIC PERCEPTION OF EAST
WEST RELATIONS. HOW THE PREVALING INTERPRETATION DEVELOPED WEST RELATIONS. HOW THE PREVALING INTERPRETATION DEVELOPED THE TRUMAN POLICY ON PALESTINE IS THE SUBJECT OF THIS STUDY.

03196 EVERATT, D.

ALLIANCE POLITICS OF A SPECIAL TYPE: THE ROOTS OF THE ANC/SACP ALLIANCE, 1950-1954

JOURNAL OF SOUTHERN AFRICAN STUDIES, 18(1) (MAR 92), 40-63.

THE RELATIONSHIP BETHEEN THE AFRICAN NATIONAL CONGRESS AND THE SOUTH AFRICAN COMMUNIST PARTY HAS LONG BEEN A SUBJECT OF CONTROVERSY AND LITTLE ANALYSIS. THIS PAPER SEEKS TO REDRESS THE IMBALANCE BY RETURNING TO THE POINT AT WHICH THE ALLIANCE HAS FORGED, IN THE EARLY 1950S, AND STUDIES THE IDEOLOGICAL BASIS OF THE ALLIANCE. THE ROOTS OF THE MODERM ANC LIE IN THE CHANGES IT UNDERHENT IN THE LATE $1940 S$ AND EARLY 1950S, WHEN THE PRESENT ANC LEADERSHIP MERGED AS MILITANT YOUNG AFRICAN NATIONALISTS, COMMITTED TO MASS ACTION AND OPPOSED TO ALL ORGANIZATIONS WHICH IMPEDED THE GROWTH OF AFRICAN NATIONALISM--INCLUDING THE COMMUNIST PARTY. THE COMMUNISTS WERE TO REASSESS THEIR RELATIDNSHIP WITH THE ANC AND AS THE STRUGGLE AGAINST APARTHEID INTENSIFIED, A NEW THEORY WAS EVOLVED TO FIT SOUTH AFRICA'S UNIQUE CONDITIONS. THAT THEORY HELD THE AFRICAN NATIONAL CONGRESS/SOUTH AFRICAM COMMUNIST PARTY ALLIANCE TOGETHER FOR THE NEXT FOUR DECADES.

03197 FABER, D.

IMPERIALISM, REVOLUTION, AND THE ECOLOGICAL CRISIS OF CENTRAL AMERICA

LATIN AMERICAN PERSPECTIVES, $19(72)$ (WIN 92) 17-44. THE ECOLOGICAL CRISIS CREATED BY CAPITALIST DEVELOPMENT IN CENTRAL AMERICA IS SYSTEMATICALLY EXAMINED FROM A MARXIST OR SOCIALIST PERSPECTIVE. THIS ARTICLE EXPLORES THE THESIS OR SOCIALIST PERSPECTIVE. THIS ARTICLE EXPLORES THE THES
THAT THE SURVIVAL STRATEGIES ADOPTED BY THE PEASANTY IN THAT THE SURVIVAL STRATEGIES ADOPTED BY THE PEASANTY
RESPONSE TO ITS IMPOVERISHMENT HAVE RESULTED IN THE RESPONSE TO ITS IMPOVERISHMENT HAVE RESULTED IN THE WIDESPREAD DEGRADATION AND COLLAPSE OF THE ECOLOGICAL
CONDITIONS NECESSARY FOR THE REPRODUCTION OF SEMIPROLETARIAN CONDITIONS NECESSARY FOR THE REPRODUCTION OF SEMIPROLETARIAN CRISIS TO THE DEVELOPMENT OF POHERFUL REFORMIST AND CRISIS TO THE DEVELOPMENT OF POHERFUL REFORMIST AND REVOLUTIONARY MOVEMENTS FOR SOCIAL AND ECOLOGICAL JUSTICE
AND CONCLUDES THAT MARXIST AND SOCIAIST THEORY SHOULD PLACE AND CONCLUDES THAT MARXIST AND SOCIAIST THEORY SHOULD REVOLUTION AND IMPERIALISM IN CENTRAL AMERICA.

03198 FAIR, E.; ASTROFF, R.

CONSTRUCTIING RACE AND VIOLENCE: U.S. NEHS COVERAGE AND THE SIGNIFYING PRACTICES OF APARTHEID

JOURNAL OF COMMUNICATION, 41(4) (FAL 91), 58-103. 
THE REIFICATION OF THE DESCRIPTION OF VIOLENCE AS "BLACKON-BLACK" INVOKES STEREOTYPED IMAGES OF TRIBALISM, WHICH UNDERCUTS THE POLITICAL AND ECONOMIC SOURCES OF VIOLENCE AND SUPPORTS AN IMAGE OF THE HITE GOVERMMENT AS BRINGERS OF LAW AND ORDER. THIS ARTICLE ASKS IN WHAT SENSE IS THE CATEGORY BLACK-ON-BLACK VIOLENCE PART OF A DISCURSIVE STUGGLE? AND SUGGESTS THAT INITIALLY NOT ALL U.S. REPORTERS UNCRITICALLY ACCEPTED THE CATEGORY OF BLACK-ON-BLACK VIOLENCE. IT OFFERS AN ANALYSIS OF THE LANGUAGE USED TO DESCRIBE THE ALLEGED PERPETRATORS OF THE VIOLENCE WHICH HIGHLIGHTS THE

SIGNIFICANCE OF LABELS. IT ALSO SUGGESTS THAT THIS CASE STUDY OF MEDIA PRESENTATIONS OF BLACK-ON-BLACK VIOLENCE IN STUDY OF MEDIA PRESENTATIONS OF BLACK-ON-BLACK VIOLENCE IN
SOUTH AFRICA HAS ANALYZED THE INTERPLAY OF RACE AND NEWS AS SOUTH AFRICA HAS ANALYZED
THO DISCURSIVE FORMATIONS.

03199 FAIRBANKS, J.; BURKE, J.

RELIGIOUS PERIODICALS AND PRESIDENTIAL ELECTIONS, 1960-1988 PRESIDENTIAL STUDIES QUARTERLY, 22(1) (WIN 92), 89-106.

THE PURPOSE OF THIS PAPER IS TO EXAMINE THE WAY IN WHICH FOUR OF THE NATION'S LEADING RELIGIOUS PERIOOICALS HAVE COVERED NATIONAL PRESIDENTIAL ELECTIONS SINCE 1960. THE PAPER EXPLORES THE QUESTIONS: HOW EXTENSIVE IS EACH JOURNAL'S COVERAGE OF ELECTION; DOES EACH JOURNAL SUGGEST THAT ITS READERS HAVE THEIR OWN PUBLIC POLICY AGENDA; AND, HOW DOES THE EVIDENCE REGARDING WHAT THE CONCERNS ARE OF THOSE CHRISTIANS TARGETED BY THE JOURNAL COMPARE WITH OTHER TYPES OF EVIDENCE? IT CONCLUDES THAT THE JOURNALS ARE POL ITICALLY SIGNIFICANT IN AT LEAST FOUR WAYS, WHICH ARE EACH DISCUSSED.

03200 FAIRCLOUGH, G.

PICTURE OF CONTENTION

FAR EASTERN ECONOMIC REVIEW, 153131) (AUG 91),

A RECENTLY PUBLICIZED SHAPSHOT THAT PURPORTS TO SHOW AMERICAN PILOTS HELD CAPTIVE IN INDOCHINA HAS GIVEN NEW LIFE TO THE NAGGING SUSPICIONS THAT THERE ARE STILL U.S. PRISONERS OF WAR (POWS) IN SOUTHEAST ASIA. AND DESPITE DOUBTS ABOUT THE PHOTDGRAPH'S AUTHENTICITY, SOME EXPERTS EASING OF TRADE SANCTIONS AGAINST VIETNAM. SAID ONE EXPERT : "AS LONG AS THE PUBLIC PERCEPTION IS THAT THERE ARE LIVE

"AS LONG AS THE PUBLIC PERCEPTION IS THAT THERE ARE LIVE

03201 FAKLYA, C.

POWER STRUGGLE: POLITICAL CHANGES AND PECULIARITIES IN HUMGARY

PARL IAMENTARIAN, LXXIII 3) (JUL 92), 158-160.

THE AUTHOR DISCUSSES THE RETURN TO POLITICAL PLURALISH

IN HUNGARY AND EXPLAINS HOW HUNGARY'S NEW PARLIAMENTARY SYSTEM WORKS.

03202 FAKSH, M.

SYRIA'S ROLE ANO OBJECTIVES IN LEBANON

MEDITERRANEAN QUARTERLY: A JOURNAL OF GLOBAL ISSUES, 3(2)

SPR 92 ), 81-95

AN INTERESTING ASPECT OF THE LEBANESE CIVIL WAR IS THE NATURE OF THE INTERVENTION OF OUTSIDE ELEMENTS. SYRIA HAS BEEN THE MOST DETERMINED INTERLOPER AND IS STILL THERE. THE REASONS BEHIND SYRIA'S PERSISTENCE ARE EXAMINED AND THREE CONCERNS ARE IDENTIFIED IN THIS ARTICLE: LEBANON'S UNITY AND INDEPENDENCE, THE SPECIAL RELATIONSHIP BETHEEN THE THO COUNTRIES, AND SYRIAN NATIONAL SECURITY NEEDS. THE CONCLUSION IS DRAWN THAT LEBANON WILL REMAIN PART OF A PAX SYRIANA SO LONG AS NO UNIFYING NATIONAL WILL EXISTS AMONG ITS COMMUNITIES, SO LONG AS NO OUTSIDE POWER IS WILLING TO CHALLENGE SYRIA'S POSTION, AND SO LONG AS THERE IS NO SOLUTION TO THE MIDDLE EAST PROBLEM.

03203 FALCO, M.

FOREIGN DRUGS, FOREIGN WARS

DAEDALUS, $121(3$ ) (SUM 92 ), 1-14.

FOR MUCH OF THIS CENTURY, THE UNITED STATES HAS BELIEVED THAT FOREIGNERS ARE CHIEFLY TO BLAME FOR THE NATION'S DRUG PROBLEMS. SINCE THE HARRISON NARCOTIC ACT OF 1914, U.S. DRUG POLICY HAS CONCENTRATED PRIMARILY ON REDUCING SUPPLIES OF ILLICIT DRUGS THROUGH LAW ENFORCEMENT, INTERDICTION, AND ERADICATION IN DRUG-PRODUCING COUNTRIES. THIS SUPPLY-SIDE APPROACH ASSUMES THAT CURTAILING DRUG AVAILABILITY WILL DRIVE UP PRICES, FORCING AMERICAN DRUG USERS TO STOP OR SEEK DRIVE UP PRICES, FORCING AMERICAN DRUG USERS TO STOP OR SEE
TREATMENT. IN THIS VIEW, INCREASED PRICES ALSO DETER NEH
USERS FROM TRYING DRUGS. USERS FROM TRYING DRUGS. UNFORTUNATELY, SUPPLY-CONTROL INITIATIVES HAVE FAILED TO REDUCE DRUG ADOICTION AND DRUG
CRIME IN THE UNITED STATES, WHILE COSTING AMERICAN TAXPAYERS CRIME IN THE UNITED STATES, WHILE COSTING AMERICAN TAXPAY
MORE THAN $\$ 100$ BILLION IN THE PAST DECADE ALONE. IT IS MORE THAN $\$ 100$ BILLION IN THE PAST DECAD
FINALLY TIME TO HAGE THE BATTLE AT HOME.

03204 FALCOFF, M.

CASTRO BOMBS IN MADRID

NATIONAL REVIEW, XLIV(19) (OCT 92), 49-50, 52.

AT THE 1992 SUMMIT OF LATIN AMERICAN PRESIDENTS AND THE PRIME MINISTERS OF SPAIN AND PORTUGAL, FIDEL CASTRO SEEMED OUT-OF-STEP WITH THE OTHER LEADERS. HIS SPEECHES HERE STRANGELY OUT OF TUNE-- HORN CLICHES ABOUT IMPERIALISM AND

EXPLOITATION. MOREOVER, HE FAILED IN HIS TWO MAJOR
OBJECTIVES--TO HAVE THE FINAL DOCUMENT CONDEMN THE U.S. ECONOMIC EMBARGO ON CUBA AND TO PREVENT THE LATIN AMERICAN LEADERS FROM ADVOCATING REPRESENTATIVE DEMOCRACY FOR THE REGION.

03205 FALCOFF, M.

IS CUBA' NEXT?

COMMENTARY, 94(5) (NOV 92), 42-46.

SINCE THE COLLAPSE OF COMMUNIST POWER, FIDEL CASIRO'S

CUBA HAS ENTERED INTO THE DEEPEST CRISIS' OF ITS HISTORY.

THIS ARTICLE EXPLORES THE POSSIBILITY THAT COMMUNISM HAS

SUCCEEDED IN CUBA AND IF SO, WHAT CASTRO'S SURVIVAL MEANS IN

TERMS OF THE BROADER POLITICAL VALUES WHICH HAVE INSPIRED
MOVEMENTS TOWARD FREEDOM THROUGHOUT THE WORLD? IT WONDERS IF

THERE ARE SPECIAL RULES AND NEEDS FOR POOR, AGRARIAN

COUNTRIES THAT SUPERSCEDE THE ASPIRATIONS OF PEOPLE IN MORE

COUNTRIES THAT SUPERSCEDE THE ASPIRATIONS OF PEOPLE IN MORE ADVANCED SOCIETIES? I SUGGESTS THAT THE ONGOING DEBATE OVER ENBA'S FUTURE IS COMING TO RESEMBLE SOMETHING LIKE THE FINAL OR WHAT REMAINS OF IT.

03206 FALCOFF, M.

THE STRANGE CASE OF ERICH HONECKER

FREEDOM REVIEW, 23(4) (JUL 92), 12-15

ON DECEMBER 11, 1991, FORMER EAST GERMAN PRESIDENT ERICH HONECKER SET UP HOUSEKEEPING IN THE CHILEAN EMBASSY IN MOSCOW TO AVOID EXTRADITION TO THE GERMAN FEDERAL REPUBLIC ON CHARGES OF POLITICAL REPRESSION AND HUMAN RIGHTS ABUSES. THE HONECKER CASE SHEDS SOME FASCINATING LIGHT ON THE WAY THE LINES OF DOMESTIC AND FOREIGN POLICY HAVE BECOME CONFUSED AS RELATIONS BETWEEN SMALL COUNTRIES AND LARGE ONES HAVE BECOME INTERNATIONALIZED OVER THE PAST GENERATION OR SO. IT ALSO SHOWS HOW CERTAIN COLD WAR THEMES CONTINUE TO
RESONATE AND DISRUPT THE LINES OF COMMUNICATION BETWEEN DEMOCRACIES.

03207 FALCON, A.

TIME TO RETHINK THE VOTING RIGHTS ACT?

SOCIAL POL.ICY, 23(2) (FAL 92), 17-22

THE AUTHOR DISCUSSES THE PRACTICE OF DRAHING UP CONGRESSIONAL DISTRICTS TO VIRTUALLY ASSURE THE ELECTION OF A MINORITY REPRESENTATIVE, AS IN THE CASE OF NEW YORK CITY'S A MINORITY REPRESENTATIVE, AS IN THE CASE OF NEW YORK CITY'
$12 T H$ DISTRICT WHERE A LATINO RECENTLY DEFEATED A 12-TERM $12 T H$ DISTR
INCUMBENT.

03208 FALKE, J.

WHERE MORALITY, NATURAL JUSTICE, THE LAW AND PRACTICAL POLITICS COME INTO COLLISION

GERMAN TRIBUNE, (1476) (JUL 91), 15.

RECENT PROPOSALS FOR CHANGES IN GERMAN IMMIGRATION POLICY HAVE BEEN HIDELY CRITICIZED BY HUMAN RIGHTS AND REFUGEE GROUPS. AMNESTY INTERNATIONAL LAMENTS THE

OEPORTATION PROPOSALS INVOLVING THOUSANDS OF ETHIOPIANS,

SOMALIS, SUDANESE, PALESTINIANS, IRAOIS, IRANIANS, AND

TAMILS, A SPOKESWOMAN FOR AMNESTY INTERNATIONAL SPOKE OF

"QUALITATIVE AND QUANTITATIVE NEW STEPS IN AN INHUMAN POLICY TOHARDS REFUGEES." THE DEPORTATION AND IMMIGRATION RESTRICTION PROPOSALS COME AT A TIME WHEN WAVES OF EASTERN EUROPEAN, SOVIET, AND THIRD HORLD IMMIGRANTS ARE POISED TO CRASH ON' THE "GOLDEN WEST."

03209 FALLENBUCHL, A.; FALLENBUCHL, $Z$

PRIVATIZATION AND MARKETIZATION IN POLAND

STUDIES IN COMPARATIVE COMMUNISM, XXIIII(3-4) (FAL 90), 349-354.

THIS ARTICLE EXAMINES THE PROCESS OF ECONOMIC REFORM AND LIBERALIZATION IN POLAND. IT BEGINS WITH THE FIRST, PREPARATORY STAGES OF "STABILIZATION" OF 1989 AND FOLLONS THE PROGRESS OF THE REFORMS THROUGH THE MID-1990. GOVERMMENTSPONSORED REFORMS INCLUDE: PRICE LIBERALIZATION,

PRIVATIZATION OF GOVERNMENT INDUSTRY, AND THE ELIMINATION OF SUBSIDIES ON FODD AND AGRICULTURAL PRODUCTS. THE MARKETIZATION AND PRIVATIZATION OF THE POLISH ECONOMY HILL HAVE TO DEPEND ON LARGE SCALE PARTICIPATION OF HESTERN CAPITAL. THEREFORE, THE GOVERNMENT SHOULD ENCOURAGE THAT PARTICIPATION BY LIBERALIZATION OF REGULATIONS AND, AT THE SAME TIME, SHOULD EDUCATE THE PUBLIC ON THE ROLE OF FOREIGM CAPITAL IN THE MODERN ECONOHY.

03210 FALLESEN, L.

MEMBER COUNTRY REPORT: DENMARK

EUROPE. 322 (1) (1992) 13-15.

AS DENMARK TAKES OVER THE ROTATING PRESIDENCY OF THE EUROPEAY COMMUNITY IN JANUARY ITS LEADERS WIUL HAYE TO REPRESENT TO THE WORLD. THE E.C. AND ITS GOALS OF A CLOSER UNION, EYEN THOUGH THE DANES NARROWLY VOTED THIS SUMMER AGAINST THE MAASTRICHT TREATY AND ITS GOALS OF CIOSER POL ITI RECEIVE THE UNDIVIDED ATTENTION OF THE DANISH PRESIDENCY-THE SINGLE MARKET. OTHER PRIORITIES HILL BE THE ENVIRONMENT AND SOCIAL ISSUES. IT IS A POLITICAL FACT THAT THE DANES ARE DEFINING A POSITION AT THE VERY REAR OF EUROPEAN INTEGRATION AND ONE THAT CONTAINS FOUR SIGNIFICANT "NO'S," WHICH ARE DETAILED IN THIS ARTICLE. 
03211 FANGER, U.

CUBA CONFRONTED WITH THE CHALLENGE OF SOCIALIST CRISIS AUSSEN POLITIK, 42(4) (1991), 344-352

THE COLLAPSE OF THE SOCIALIST SYSTEM IN EASTERN EUROPE HAS INEVITABLY AFFECTED FIDEL CASTRO'S CUBA, WHICH CLINGS TO ITS BRAND OF SOCIALISH. THE CUBAN REGIME CAN NO LONGER COUNT ON MOSCOW'S SUPPORT AND AUTHORITY; THE PREVIOUS SOVIETBACKED POLICY OF REVOLUTIONARY EXPANSION AND INTERVENTION HAS BEEN DEPRIVED OF ITS BASIS; VITAL MATERIAL SUPPORT FROM THE USSR HAS BEEN CUT BACK AND HOULD APPEAR TO BE GENERALLY JEOPARDIZED BY THE ECONOMIC PLIGHT IN THE SOVIET UNION AND THE GROWING NORTH AMERICAN INFLUENCE ON THE KREMLIN. THIS ARTICLE OUTLINES THE HISTORICAL BACKGROUND AND EXAMINES THE CHALLENGES WITH WHICH CASTRO AND HIS TEAM NOW FIND THEMSELVES CONFRONTED.

03212 FARAMAZYN, $R$.

CONVERSION AND SECURITY

PEACE AND THE SCIENCES, 1(1) (SEP 92), 45-47.

AN ESSENTIALLY NEW MILITARY-POLITICAL AND ECONOMIC

SITUATION IS TAKING SHAPE IN THE HORLD. IT HAS BECOME OBVIOUS THAT TO CONTINUE AN ARMS RACE IS IRRATIONAL AND THAT IT IS NECESSARY TO CURTAIL THE SCOPE OF MILITARY PREPARATIONS AND TO ESTABLISH A NEW SYSTEM OF SAFEGUARDING IMTERMATIONAL STABILITY AND MILITARY SECURITY. THIS ARTICLE EXPLORES "CONVERSION" WHICH IS A GOAL-ORIENTED PROCESS OF TRANSFERRING MATERIAL AND HUMAN RESOURCES FROM THE SPHERE OF DEFENSE-RELATED ACTIVITIES TO CIVILIAN PRODUCTION.

03213 FARBER, $S$.

CASTRO UNDER SIEGE

WORLD POLICY JOURMAL, IX(2) (SPR 92), 329-348.

IN THE AFTERMATH OF THE DISINTEGRATION OF THE SOVIET UNION, CUBA IS FACING ONE OF THE MOST SERIOUS CRISES IN ITS HISTORY. THE COUNTRY THAT WAS THE MAJOR SOURCE OF POLITICAL AND ECONOMIC SUPPORT FOR THE CASTRO REGIME HAS VANISHED. MEANHHILE, THE BUSH ADMINISTRATION HAS BEEN TIGHTENING THE 32-YEAR-OLD U.S. ECONOMIC BLOCKADE OF THE ISLAND REPUBLIC. THIS ARTICLE DISCUSSES THE CHALLENGES CUBA IS FACED WITH, DOMESTICALLY AND INTERNATIONALLY.

03214 FARBER, S.

THE U.S. . CUBA, AND ALTERNATIVES TO CASTRO

PEACE \& DEMOCRACY NEWS, 6(1) (WIN 92), 28-30.

CUBA IS ONE OF THE LAST HOLDOUTS OF WORLD COMMUNISM. HOWEVER, THE DRASTIC REDUCTIONS IN SOVIET AND EAST EUROPEAK AID AND TRADE WITH CUBA HAVE BROUGHT ABOUT THE MOST SEVERE AID AND TRADE WITH CUBA HAVE BROUGHT ABOUT THE MOST SEV
ECONOMIC CRISIS IN THE HISTORY OF CUBAN COMINUNISM. THE ECONOMIC CRISIS IN THE HISTORY OF CUBAN COMINUNISM. THE
VICTORY OF THE U.S. IN THE COLD WAR PROVIDES THE RIGHT-WING AND RELATIVELY AFFLUENT CUBAN COMMUNITY IN FLORIDA HITH AN AND RELATIVELY AFFLUENT CUBAN COMAUNITY IN FLORIDA WITH AN INCREASINLY IMPOYERISHED CUBA. THIS ARTICLE CONCLUDES THAT INCREASINLY IMPOVERISHED CUBA. THIS ARTICLE CONCLUDES THAT BREAKDOWN OF CUBAN COMMUNISM WITHIN THE RELATIVELY NEAR BREAKDOWN
FUTURE.

03215 FARDMANESH, $M$

CONOMIC GROWTH AND ALTERNATIVE DEFICIT-REDUCING TAX INCREASES AND EXPENDITURE CUTS: A CROSS-SECTIONAL STUDY PUBLIC CHOICE, 69(2) (FEB 91), 223-232.

THIS PAPER ASSESSES EMPIRICALLY THE RELATIVE DESIRABILITY OF ALTERNATIVE DEFICIT-REDUCING TAX INCREASES AND EXPENDITURE CUTS IN TERMS OF THEIR INDIVIDUAL IMPACT ON ECONOMIC GROWTH, USING CROSS-SECTIONAL DATA FROM A SAMPL OF 21 DEVELOPED COUNTRIES FOR THE PERIOD 1972-81. PROPERTY TAXES ARE BY FAR SUPERIOR TO DEFICIT FINANCING, AND ARE THE BEST CHOICE FOR IMPLEMENTING DEFICIT-REDUCING TAX INCREASES INCOME TAXES AND DOMESTIC TAXES ON GOODS AND SERVICES, WHICH ARE AS BAD FOR GROWTH AS ARE DEFICITS, RANK SECOND HITH NO DIFFERENCE BETHEEN THEM. FOREIGN TRADE TAXES ARE EVEN HORSE FOR GROWTH THAN ARE DEFICITS, AND ARE THE WORST CHOICE FOR REDUCING DEFICITS. CLASSIFYING GOVERMMENT EXPENDITURES INTO CAPITAL AND CURRENT EXPENDITURES RENDERS THE LATTER AS THE BEST TYPE FOR IMPLEMENTING A REDUCTION IN EXPENDITURES. DEFICIT-REDUCING CUTS IN CAPITAL EXPENDITURES ARE CONCOMITANT HITH LOWER GROWTH, WHILE SUCH CUTS IN CURRENT EXPENDITURES HAVE NO NET IMPACT ON GROWTH.

03216 FARER, T.

HUMAN RIGHTS AND FOREIGN POLICY: WHAT THE KURDS LEARNED (A DRAMA IN ONE ACT )

HUMAN RIGHTS QUARTERLY, 14(1) (FEB 92), 62-77.

THIS DRAMA ABDUT HUMAN RIGHTS AND FOREIGM POLICY THINKS

THROUGH THE PARAMENTERS OF A HUMAN RIGHTS PROGRAM THAT WILL GO RIGHT INTO THE PRESIDENT'S STATE-OF-THE-UNION SPEECH AND EMERGE AS PRESIDENTIAL POLICY. IT TALKS ABOUT OPERATIONAL GUIDELINES, TRADE-OFFS AND BUILDING HUMAN RIGHTS INTO STANDARD OPERATING PROCEDURES. IT CONCLUDES THAT US POLICY MAKERS SEE THE WORLD AS IT IS--A WORLD OF STATES AND THAT THE UNITED STATES IS AND WILL REMAIN ISOLATIONIST.

03217 FARER, T

HUMAN RIGHTS INVESTMENT IN HISPANIC SOUTH AMERICA:
RETROSPECT AND PROSPECT

HUMAN RIGHTS QUARTERLY, 13(1) (FEB 91), 99-122.

PRIVATE AND GOVERNMENT-SUPPORTED FOUNDATIONS IN THE UNITED STATES AND EUROPE HAVE INVESTED MILLIONS OF DOLLARS OVER THE PAST FIFTEEN YEARS IN AN EFFORT TO ENHANCE THE PROTECTION OF HUMAN RIGHTS IN LATIN AMERICA. THIS ARTICLE EXAMINES THIS PRACTICE WITH EMPHASIS ON THE PROBLEMS OF LETTING ADMINISTRATIVE CONVENIENCE DETERMINE WHICH PROJECTS SHOULD BE INVESTED IN. IT ALSO EXAMINES CHALLENGES TO ANY ATTEMPT TO IMPROVE THE HUMAN RIGHTS SITUATION IN LATIN AMERICA AND OUTLINES SOME NON-TRADITIONAL METHODS OF INVESTMENT THAT MAY BE MORE PRODUCTIVE.

03218 FARER, T.

ISRAEL'S UNLAWFUL OCCUPATION

FOREIGN POLICY, (82) (SPR 91), 37-58,

IN ORDER TO REALIZE THE GULF CRISIS'S POSITIVE POTENTIAL AND TO LIMIT ITS RISKS, THE UNITED STATES MUST ACT IN DEFENSE OF BROAD PRINCIPLES BENEFICIAL TO MOST PEOPLES AND MUST AVOID THE PERCEPTION THAT THE PRIMARY REASON FOR CRUSHING IRAQ IS TO KEEP THE ARAB WORLD DIVIDED AND WEAK. A KEY FACTOR IN THIS PERCEPTION IS THE ONGOING ARAB-ISRAELI KEY FACTOR IN THIS PERCEPTION IS THE ONGOING ARAB-ISRAELI
CONFLICT. IF THE UNITED STATES AND THE OTHER MEMBERS OF THE INTERMATIONAL COALITION ARRAYED AGAINST IRAQ REFUSE TO ACKNOWLEDGE ISRAEL'S DELINQUENCIES AND FAIL TO INITIATE MEASURES COMPELLING ISRAELI COMPLIANCE WITH THE NORMS THAT IRAO HAS SO RUTHLESSLY AND FLAGRANTLY VIOLATED, THEN IRAQI LEADER SADDAM HUSSEIN COULD END UP APPEARING TÓ A CONSEQUENTIAL PART OF THE ARAB WORLD AS THE VICTIM OF A DOUBLE STANDARD.

03219 FAROUK-SLUGLETT, M.: SLUGGET, P. SADDAM HUSSEIN'S IRAQ

MIDDLE EAST INTERNATIONAL, (395) (MAR 91), 20-21.

THIS ARTICLE EXAMINES THE PRINCIPAL FIGURES OF SADDAM HUSSEIN'S REGIME. IT CONCENTRATES ON SIX: IZZAT AL-DURI, LATIF NUSAYYIF JASIM, TAHA TASIN RAMADAN, HUSAIN KAMIL MAJID, TARIQ AZIZ, AND SA'DUN HAMMADI. IT IS MOST UNLIKELY THAT SINCE THEIR PERSONAL INVOLVEMENT WITH HIM AND WITH THE ATROCITIES HE COMMITTED IS SO CLOSE.

03220 FAROUK-SLUGLETT, M.; SLUGLETT, $P$. SADDAM HUSSEIN'S IRAQ--ITS FUTURE IN THE BALANCE MIDDLE EAST INTERMATIONAL (397) (APR 91) 18-19. THE FEARFUL DEVASTATION TO WHICH IRAQ WAS SUBJECTED IN THE AIR AND LAND WAR BY THE UNITED STATES AND ITS ALLIES HAS NOW GIVEN WAY TO A DESPERATE AND ALMOST UNBELIEVINGLY NOW GIVEN WAY TO A DESPERATE AND ALMOST UNBELIEVINGLY
DESTRUCTIVE STRUGGLE FOR SURVIVAL ON THE PART OF SADDAM DESTRUCTIVE STRUGGLE FOR SURVIVAL ON THE PART OF
HUSSEIN AND HIS ENTOURAGE. ALTHOUGH THE REGIME'S HUSSEIN AND HIS ENTOURAGE. ALTHOUGH THE REGIME'S
MONOPOLIZATION OF THE POLITICAL ARENA HAS HAD THE EFFECT OF MONOPOLIZATION OF THE POLITICAL ARENA HAS HAD THE EFFECT OF
STUNTING AND DISTOP -ING PROCESSES OF NATIONAL INTEGRATION STUNTING AND DISTOF -ING PROCESSES OF NATIONAL INTEGRATION
AND FORCING INDIVIC.ALS BACK TO FORMS OF ASSOCIATION BASED AND FORCING INDIVIC-ALS BACK TO FORMS OF ASSOCIATION BASED ON "PRIMORDIAL LOYALTIES, "THE FUTURE OF SADDAM HUSSEIM LDOKS GRIM. THE POSSIBILITY OF A MILITARY COUP OR THE
INSTALLMENT OF A PRO-SAUDI REGIME TO REPLACE SADDAM SEEMS INSTALLMENT OF A PRO-SAUDI REGIME TO REPLACE SADDAM SEEMS
MORE LIKELY THAN EITHER THE "LEBANONIZATION" OF IRAQ INTO VARIOUS SPHERES OF INFLUENCE OR A TOTAL TAKE-OVER BY SHI'ITE VARIOUS SPHERES OF
FUNDAMENTALISTS.

03221 FARRENKOPF, J.

THE CHALLENGE OF SPENGLERIAN PESSIMISM TO RANKE AND POL ITICAL REALISM

REVIEW OF INTERNATIONAL STUDIES, 17(3) (JUL 91), 267-284.

AT THIS JUNCTURE IN HISTORY, WHEN ETERNAL HOPE ONCE AGAIN COLLIDES WITH RECURRENT DESPAIR, IT IS TIMELY TO CONSIDER THE INTERNATIONAL RELATIONS THOUGHT OF OSWALD SPENGER, THE AUTHOR OF THE DECLINE OF THE WEST AMD "PESSIMIST EXTRAORDINARY." THIS ARTICLE REFLECTS UPON SPENGLER'S PROVOCATIVE IDEAS ABOUT INTERNATIONAL POLITICS AND THE CIVILIZATIONAL CRISIS IN MODERN HISTORY. THE ARTICLE BEGINS, HOWEVER, BY EXAMINING THE WORK OF LEOPOLD VON RANKE. HE AND HIS FOLLOWERS REPRESENT A DOMINANT FORCE IN GERMAN HISTORICAL AND INTERMATIONAL POLITICAL THOUGHT AMD ARE PRECURSORS OF MODERN REALISM. THIS PROVIDES THE BACKGROUND FOR A DISCUSSION OF MODERN POLITICAL REALISM AND ITS RELATIONSHIP TO SPENGLER'S THOROUGHGOING PESSIMISM. THE CENTRAL THESIS OF THE PAPER IS THAT THE FAILURE TO BUILD UPON THE FOUNDATION PROVIDED BY SPENGLER HAS IMPOVERISHED CONTEMPORARY THEORIZING ABOUT INTERNATIONAL RELATIONS.

03222 FARRENKOPF, J.

THE EARLY PHASE IN SPENGLER'S POLITICAL PHILOSOPHY HISTORY OF POLITICAL THOUGHT, 13(2) (SUM 92), $319-338$. ANTIDEMOCRATIC THINKER. THIS INVESTIVATION OF SPENGLER'S ANTIDEMOCRATIC THINKER. THIS INVESTIVATION OF SPENGLER'S
EARLY PERIOD OF THOUGHT REVEALS THAT HE WAS NOT VEHEMENTLY EARLY PERIOD OF THOUGHT REVEALS THAT HE WAS NOT VEHEMENTLY ANTIDEMOCRATIC DURING THIS TIME AND WAS, IN FACT, A CYNICAL AND OPPORTUNISTIC CONSERVATIVE ADVOCATE OF THE IDEA OF THE THIS CLAIM RESTS PRIMARILY UPON CAREFUL EXAMINATION OF TWO UNFINISHED, UNSOL ICITED MEMORANDA DRAFTED BY SPENGLER, ALONG WITH SEVERAL RELATED NOTES ON POLITICAL MATTERS. THIS INQUIRY INTO THIS RATHER OBSCURE BUT IMPORTANT EARLY PHASE 
IN SPENGLER'S POL ITICAL THROUGHT PROVIDES A CASE STUDY IN THE CRUCIAL ROLE THE LOSS OF THE FIRST WORLD WAR PLAYED IN FUELING HOSTILITY AMONG EMBITTERED CONSERVATIVES TOWARDS

GERMANY'S FIRST DEMOCRACY.

03223 FATAH, A.A.

THE REMAKING OF THE SOMALI NATION

WASHINGTON REPORT ON MIDDLE EAST AFFAIRS, XI(1) (JUN 92),

46,61 .

SOMALIA IS CURRENTLY IN A STATE OF CIVIL WAR AS RIVAL MILITIAS STRUGGLE FOR POWER. DESPITE THE INDISCRIMINATE VIOLENCE AND WANTON DESTRUCTION, SOME LOCALITIES HAVE THROWH DFF THE YOKE OF THE HARLORDS AND ARE RETURNING TO

TRADITIONAL GOVERNMENTAL SYSTEMS. OUT OF THE DESTRUCTIVE

CIVIL WAR, A NEW PATTERN IN WHICH COMMUNITY-BASED DEMOCRATIC INSTITUTIONS WILL CONTROL POWER SEEMS TO BE EMERGING.

03224 FATTON, R. JR.

PREDATORY RULE: STATE AND CIVIL SOCIETY IN AFRICA LYNME RIENNER PUBLISHERS, 1992, 164

"PREDATORY RULE" ARGUES THAT STATE AND CIVIL SOCIETY ARE TWO ASPECTS OF AN ORGANIC TOTALITY. THE AUTHOR'S ALTERNATIVE CONCEPTUALIZATION OF THE AFRICAN SOCIAL ORDER IS BASED ON THE DIALECTIAL INTERDEPENDENCE OF STATE AND CIVIL SOCIETY. EXAMINING HOW THE STATE FUNCTIONS AS THE GOVERNING CLASSES STRUCTURE OF DOMINANCE AND AS THE PRINCIPAL INSTRUMENT OF THEIR PREDATORY RULE, HE EXPLORES HOW CIVIL SOCIETY OFFERS AUTONOMOUS VENUES FOR THE COLLECTIVE EXPRESSION OF SUBORDINATE CLASS GRIEVANCES, WHILE PARADOXICALLY FORTIFYING THE GOVERNING CLASSES' DOMINANCE.

03225 FAUCHER, P.; FITZGIBBONS, $K$

THE POLITICAL ECONOMY OF' ELECTRICAL POWER GENERATION: PROCUREMENT POLICY AND TECHNOLDGICAL DEVELOPMENT IN QUEBEC, ONTARIO, AND BRITISH COLUMBIA

POLICY STUDIES JOURNAL, 20(4) (WIN 92), 552-573.

THE AUTHORS EVALUATE THE PROCUREMENT PRACTICES OF

CANADA'S THREE LARGEST ELECTRIC POWER UTILITIES--ONTARIO

HYDRO, HYDRO QUEBEC, AND B.C. HYDRO--IN TERMS OF THEIR

IMPACT ON THE TECHNOLOGICAL DEYELOPMENT OF THE ELECTRIC

POWER EQUIPMENT INDUSTRY IN CANADA. UNDER CERTAIN ECONOMIC,

TECHNICAL, AND INSTITUTIONAL CONDITIONS, PROCUREMENT AS

MANAGED BY LARGE PUBLICLY-OWNED CORPORATIONS WITH A HIGH

LEVEL OF TECHNICAL CAPACITY CAN BE A POWERFUL INSTRUMENT OF

INDUSTRIAL INMOVATION. IN THE FACE OF WEAKENING MARKET POWER

FOLLOWING A 20-YEAR EXPANSION PHASE IN THE INDUSTRY (19601980) AND GLOBAL RESTRUCTURING AMONG ELECTRICAL POHER EQUIPMENT SUPPLIERS, THE THREE UTILIES HAVE BEEN FORCED TO REASSESS CONFLICTING COMARCIAL AND TECHNOLOGICAL OBJECTIVES AS AN EXAMPLE OF A NEW APPROACH TO PROCUREMENT THROUGH CONCENTRATED USE OF LIMITED MARKET POHER IN CRITICAL PRODUCT AREAS, HYDRO OUEBEC RECENTLY SIGNED A SERIES OF STRATEGIC PRODUCTION AGREEMENTS WITH KEY SUPPLIERS. THE DISTRIBUTION OF RISKS INVOLVED IN TECHNOLOGY DEVELOPMENT BETWEEN BUYERS AND SELLERS IS DEPENDENT ON MARKET STRUCTURES. THE NATURE OF THESE CLIENT-SUPPLIER INTERACTIONS IN MANAGEMENT OF RISK WILL REFLECT THE INTERNAL COHERENCE OF AN ORGANIZATION'S COMMERCIAL AND TECHNOLOGICAL STRATEGIES.

03226 FEAGIN, J.

THE CONTINUING SIGNIFICANCE OF RACISM: DISCRIMINATION AGAINST BLACK STUDENTS IN HHITE COLLEGES

JOURNAL OF BLACK STUDIES, 22(4) (JUN 92), 546-578.

A NUMBER OF SURVEY STUDIES HAVE FOUND' THAT COLLEGE ENROLLMENT AND GRADUATION RATES FOR BLACK AMERICANS HAVE DECLINED IN MANY PROGRAMS. THE PURPOSE OF THIS PAPER IS: TO PROVIDE A DETAILED DESCRITIION OF THE BARRIERS FACED BY BLACK COLLEGE STUDENTS IN PREDOMINANTLY WHITE COLLEGES AND UNIVERSITIES; TO SUGGEST A TYPOLOGY OF KINDS OF CUMULATIVE DISCRIMINATION. THE STUDY DRAWS ON INTERVIENS HITH COLLEGE STUDENTS, ADMINISTRATORS, AND FACULTY MEMBERS IN A LARGE SAMPLE OF MIDDLE-CLASS BLACK AMERICAN INTERVIEWS IN 14 CITIES. THE CONCLUSION IS DRAWN THAT THE COLLEGE IN 14 CITIES. THE CONCLUSION IS DRAWN THAT THE COLLEGE
SUBCULTURE IS WHITE-NORMED; DISCRIMINATION IS REINFORCED BY SUBCULTURE IS WHITE-NORMED; DISCRIMINATION IS REINFORCED
THE EVERYDAY, UNSTATED ASSUMPTIONS ABOUT THE PRIORITY OF THE EVERYDAY, UNSTATED ASSUMPTIONS ABOUT THE PRIORITY OF
WHITENESS. THE ARRAY OF BARRIERS DAILY CONFRONT THOSE BLACK STUDENTS COURAGEOUS ENOUGH TO ENTER THE PREDOMINANTLY WHITE COLLEGES.

03227 FEAVER, P.

COMMAND AND CONTROL IN EMERGING NUCLEAR NATIONS

COMMAND AND CONTROL IN EMERGING NUCLEAR NATIONS

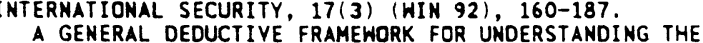
FACTORS THAT HILL SHAPE NEW COMMAND AND CONTROL SYSTEMS TO AID IN ASSESSING THE DETAILS OF EACH NEW NUCLEAR NATION'S POLICIES AS THEY BECOME KNOWN IS PROPOSED IN THIS ARTICLE. IT BUILDS UPON RECENT ANALYSES OF U.S. NUCLEAR OPERATIONS TO CONSTRUCT A FRAMEWORK FOR ASSESSING COMMAND AND CONTROL IN AN EMERGING NUCLEAR STATE. CENTRAL TO THE FRAMEHORK IS AN ASSERTIVE/DELEGATIVE TYPOLOGY THAT IDENTIFIES KEY PERFORMANCE FEATURES OF NUCLEAR COMMAND AND CONTROL SYSTEMS. THE FRAMEWORK IS ALSO USED TO EVALUATE PROPOSALS FOR MANAGING NUCLEAR PROLIFERATION AND CAUTIONS AGAINST ANY
POLICY THAT IGNORES THE NEED FOR BALANCE IN NEW NUCLEAR COMMAND AND CONTROL SYSTEMS.

03228 FEDDERSEN, T.

A VOTING MODEL IMPLYING DUYERGER'S LAW AND POSITIVE TURNOUT AMERICAN JOURNAL OF POLITICAL SCIENCE, 36(4) (NOY 92), 938-962.

THIS PAPER PRESENTS A MODEL OF COSTLY VOTING UNDER PLURALITY RULE THAT OMITS PARTIES AS STRATEGIC ACTORS AND IMPLIES DUVERGER'S LAN AND POSITIVE TURNOUT. THE MODEL DEMONSTRATES THAT STRATEGIC VOTING REDUCES THE NUMBER OF PARTIES THAT RECEIVE VOTES UNDER PLURALITY RULE TO TWO OR PARTIES THAT RECEIVE VOTES UNDER PLURALITY RULE TO TWO OR
LESS WHILE POSITIVE COSTS TO VOTE INCREASES THE NUMBER TO LESS WHILE POSITIVE COSTS TO VOTE INCREASES THE NUMBER TO
MORE THAN ONE. THE TWO ASSUMPTIONS TAKEN TOGETHER LEAD TO EXACTLY TWO PARTIES RECEIVING VOTES.

03229 FEFFER, J.

POLAND AFTER SOLIDARITY

PEACE \& DEMOCRACY NEWS, 11(2) (WIN 92), 1; 43-46.

IN POLAND, THE SOLIDARITY UNION IS PAYING TODAY WITH ITS NAME BECAUSE UNDER THE BANNER OF SOL IDARITY THE ENTIRE ECONOMIC REFORM WAS UNDERTAKEN. SUPPORTING A SHOCK THERAPY THAT PRIMARILY HURT ITS OWN CORE SUPPORTERS, SOLIDARITY HAS EXPENDED MUCH OF ITS ONCE CONSIDERABLE MORAL CAPITAL. THIS ARTICLE EXAMINES POLAND AFTER SOLIDARITY AND THE CONFUSION OF LEFT AND RIGHT. IT EXPLORES THE POSSIBILITY OF A THEOCRACY. IT ALSO EXAMINES ECONOMIC PROSPERITY-ECONOMIC SHOCK AS WELL AS THE STRUGGLING WOMEN'S MOVEMENT AND THE ROLE OF YOUTH IN THE POLISH LEFT.

03230 FEGELER, F.

EC LEADERS SPEAK OF FEARS FOR FATEFUL SUMMIT

GERMAN TRIBUNE, (1494) (NOV 91), 1

GERMAN CHANCELLOR KOHL AND FRENCH PRESIDENT MITTERAND WARNED THAT FAILURE AT THE EUROPEAN SUMMIT IN THE DUTCH TOWN OF MAASTRICHT IN DECEMBER WOULD BE A CATASTROPHE FOR THE EUROPEAN COMMUNITY. THEY HAD BEEN DISCUSSING IN BONN VARIOUS SUMMIT ISSUES INCLUDING OBJECTIONS BY BRITAIN IN THE FIELDS OF POLITICAL AND MONETARY UNION. WHILE BRITISH PEOPLE FROM ALL CAMPS VIEW THE CALLS FOR CLOSER INTEGRATION WITH ALL CAMPS VIEW THE CALLS FOR CLOSER INTEGRATION HITH
SUSPICION, IT IS OBVIOUS THAT THE BRITISH GOVERNMENT IS

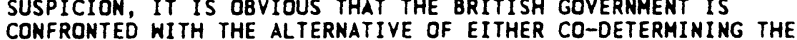
CONFRONTED WITH THE ALTERNATIVE OF EITHER CO-DETERMINING THE EUROPEAN COMMUNITY'S FUTURE DEVELOPMENT FROM THE START OR OF
BEING ECONOMICALLY AND POLITICALLY PUSHED TO THE PERIPHERY.

03231 FEGUSON, A.

LESBIANISM. FEMINISM, AND EMPOWERMENT IN NICARAGUA SOCIALIST REVIEW, 3(4), (1991), 75-98

THE AUTHOR IS CONCERNED WITH THE QUESTION OF HOW NORTH AMERICAN ANTI-IMPERIALIST FEMINISTS LIKE HERSELF CAN SUPPORT CENTRAL AMERICAN GROUPS WITHOUT EITHER UNDERMINING THEIR OWN VALUES OR MAKING THE CULTURALLY IMPERIALISTIC ASSUMPTION THAT OUR OWH STRATEGIES FOR LIBERATION WILL AUTOMATICALLY SUIT THEM. SHE OUTLINES A FEMINIST MATERIALIST THEORY AND EXAMINES HOW IT CAN BE APPLIED TO NICARAGUA. THEN SHE PRESENTS SOME OBSERVATIONS ABOUT NICARAGUAN LESBIAN AND GAY MALE CULTURE. FINALLY, SHE CONSIDERS WHAT LIGHT THE EXPERIENCE OF NICARAGUAN FEMINIST AND LESBIANS CAN SHED ON SEVERAL PHILOSOPHICAL AND POLITICAL QUESTIONS, INCLUDING A POSTMODERN CONCEPTION OF THE SELF. THE ROLE OF SEPARATISM AND IDENTITY POLITICS, AND THE ISSUE OF SOLIDARITY AMONG FEMINISTS IN DIFFERENT PARTS OF THE WORLD.

03232 FEIN, B.

THE OIC HAS GOT TO GO

INSIGHT, $8(27)$ (SEP 92 ), 23-24.

STATUTORY AUTHORIZATION FOR THE OFFICE OF INDEPENDENT COUNSEL LAPSES ON DECEMBER 15, 1992. ESTABLISHED IN 1978, THE OFFICE HAS TURNED THE POWER OF CRIMINAL PROSECUTION INTO AN INSTRUMENT OF POLITICAL PROSECUTION AGAINST HIGH-LEVEL EXECUTIVE OFFICIALS. PRESIDENT BUSH SHOULD VETO ANY CONGRESSIONAL ATTEMPT TO EXTEND THE LIFE OF THE OIC TO VINDICATE LEGAL AND POLITICAL FAIRNESS AND ENLIGHTENED BUT RISKY FOREIGN POLICY GAMBITS.

03233 FEINBERG, R.; BOYLAN, D.

MODULAR MULTILATERALISM: NORTH-SOUTH ECONOMIC RELATIONS IN THE 1990 S

WASHINGTON QUARTERLY, 15(1) (WIN 92), 1870-202.

THAT 8 IPOLARITY'S' DEMISE WILL ALLOH THE LONG-DORMANT SEED OF NORTH-SOUTH COOPERATION TO GERMINATE AS PREVIOUSLY STYMIED NORTH-SOUTH ALLAINCES EMERGE TO FORGE SOLUTIONS TO STYMIED NORTH-SOUTH ALLAINCES EMERGE TO FORGE SOLUTIOYS COMMON PROBLEMS IS ARGUED IN THIS PAPER. GERMINATION REQUIRES THAT THE NORTH CULTIVATE SUCH COOPERATIVE
ARRANGEMENTS AND THE ALTERNATIVE IS THE RISK OF COMMERCIAL. ARRANGEMENTS AND THE ALTERNATIVE IS THE RISK OF COMMERCIAL, ENVIRONMENTAL, AND SECURITY SETBACKS. THE PAPER SUGGESTS THAT WHAT IS NEEDED IS A FRAMEHORK, BOTH THEORETICAL AND APPLIED, THROUGH WHICH TO VIEW NORTH-SOUTH RELATIONS, ONE THAT CAPITALIZES ON COOPERATION WHERE COMMON GROUND CAN ACHEIVED BUT THAT DOES NOT IGNORE THE COMPLEXITIES. IT CONCLUDES THAT THE MODULAR MULTILATERAL FRMEWORK SEEMS WELL
SUITED BOTH TO THE PRESENT STATE OF THE INTERNATIONAL SYSTEM AS HELL AS TO THE WAYS IN WHICH IT WILL MOST LIKELY EVOLYE OVER THE NEXT DECADE. 
03234 FEINBERG, R.E.

PALTRY AID TO CENTRAL EUROPE

CHALLENGE, 35(1) (JAN 92), 36-43.

THE SUCCESSFUL REFORM OF POL ITICAL AND ECONOMIC

STRUCTURES IN THE NEHLY IMDEPENDENT CENTRAL EUROPEAN STATES

WILL REQUIRE FINANCING. VARIOUS SOURCES OF EXTERNAL CAPITALOFFICIAL AND PRIVATE--COULD CONTRIBUTE TO THIS HISTORIC ENTERPRISE. EACH OF THESE SOURCES IS BEHAVING DIFFERENTLY, AS IS EVIDENT IN AN ANALYSIS OF FINANCIAL FLOWS TO THREE COUNTRIES AT THE VANGUARD OF REFORM: CZECHOSLOVAKIA, POLAND, AND HUNGARY. THUS FAR, THE UNITED STATES' CONTRIBUTION TO THE REFORM PROCESS IN CENTRAL EUROPE HAS BEEN LIMITED. OBSERVERS QUESTION WHETHER THE REASON IS THE SHORTSIGHTEDNESS OF U.S. LEADERSHIP OR PRIVATE MARKETS' AVERSION TO RISK.

03235 FEINERMAN, J.V.

ECONOMIC AND LEGAL REFORM IN CHINA, 1978-91

PROBLEMS OF COMAUNISM, XL(5) (SEP 91), 62-75.

FOLLOHING THE DEATH OF MAO ZEDONG AND THE FALL OF THE GANG OF FOUR IN THE LATE 1970'S, CHINA'S LEADERSHIP ATTEMPTED TO INSTITUTE ASPECTS OF A MARKET ECONOMY PRIMARILY ATTEMPTED TO INSTITUTE ASPECTS OF A MARKET ECONOHY PRIMA THROUGH CHANGES IN LAW. THIS POLICY CONTRASTS WITH THE
EXPERIENCE OF WESTERN MARKET ECONOMIES, WHERE LAW EVOLVES IN RESPONSE TO CHANGES IN OTHER REALMS THAT CREATE CONDITIONS RESPONSE TO CHANGES IN OTHER REALMS THAT CREATE CONDITIONS
FOR ECDNOMIC DEVELOPMENT. AS LONG AS THE CHINESE TAKE AN FOR ECONOMIC DEVELOPMENT. AS LONG AS THE CHINESE
INSTRUMENTALIST VIEW OF LAH AS PROMOTING ECONOMIC INSTRUMENTALIST VIEW OF LAH AS PROMOTING ECONOMIC
DEVELOPMENT, RATHER THAN PROMOTING THE RULE OF LAH AS AN END IN ITSELF, SOCIETY WILL FACE NUMEROUS PROBLEMS ASSOCIATED WITH REFORM--SUCH AS CORRUPTION, BRIBERY, AND OTHER FORMS OF "ECONOMIC CRIME." NEVERTHELESS, DEVELOPMENTS IN THE PAST DECADE GIVE GROUNDS FOR OPTIMISM. A VIBRANT ECONOMY GUIDED
BY LAH COULD ENHANCE THE "RULE OF LAH" CONSCIOUSNESS OF THE CHINESE PEOPLE, AS THE BENEFITS OF LEGAL GUIDANCE (RATHER THAN AN ADMINISTRATIVE FIAT) LEAD TO THE KIND OF ECONOMIC DEVELOPMENT THAT IS UNACHIEVABLE IN A COMMAND ECONOMY.

03236 FEINERMAN, J.V.

LEGAL FORMALISM AND ECONOMIC CHANGE IN POST-MAO CHINA; ASSOCIATION FOR ASIAN STUDIES 1992 ANNUAL MEETING ASSOCIAITON FOR ASIAN STUDIES, 1992, 33-34.

SINCE THE ASCENDANCY OF DENG XIAOPING AND HIS PRAGMATIC ECONOMIC POLICIES IN THE LATE 1970S, LEGAL REFORM HAS BEEN INEXTRICABLY LINKED WITH ECONOMIC CHANGE IN THE PRC. IN THE LEGAL SPHERE. THIS HAS INCLUDED THE ENACTMENT OF NUMEROUS LAWS, REGULATIONS AND OFFICIAL DECREES IN AN ATTEMPT TO PROVIDE LONG-TERM PUBLIC GUIDANCE AS TO NEW GOVERNMENT POLICY. THIS PAPER CONSIDERS THE EXTENT TO WHICH LEGAL POL ICY. THIS PAPER CONSIDERS THE EXTENT TO WHICH LEGAL
CHANGE HAS SUPPORTED CORRESPONDING ECONOMIC POLICIES TO CHANGE HAS SUPPORTED CORRESPONDING ECONOMIC POLICI ENCOURAGE MARKET FORCES, TO FOSTER THE HOUSEHOLD PRC IT SCRUT PRC. IT SCRUTINIZES THE FUNCTION OF LAH IN AREAS WHERE ECONOMIC REFORMS HAVE FAILED TO ACHIEVE FULL SUCCESS. I ALSO ASSESSES THE VALIDITY OF INSTRUMENTALIST ATTITUDES TOWARDS LEGALIZATION AND THEIR CONTRIBUTION TO MODERNIZATION. THE PAPER ALSO CONSIDERS WHETHER LEGALIZATION IS BETTER SERVED BY DECENTRALIZATION OR CENTRALIZATION OF GOVERNMENT POWER, WHETHER SIGNIFICANT LEGAL CHANGE CAN OCCUR IN A SOCIETY WITH AN HISTORICAL ANTIPATHY TOWARD LEGALISM, AND FAILURE TO ACHIEVE MODERNIZATION AS RAPIDLY AS INITIALLY PROMISED.

03237 FEINSTEIN, L. ARMS $R$ US

BULLETIN OF THE ATOMIC SCIENTISTS, 48(9) (NOV 92), 8-10. IN THE AFTERMATH OF THE GULF WAR, U.S. PRESIDENT BUSH LAUNCHED THE "BIG 5" TALKS ON ARMS SALES. AFTER MORE THAN A YEAR OF TALKS, THE MAJOR ACCOMPLISHMENT OF THE WORLD'S LARGEST WEAPONS DEALERS--THE UNITED STATES, RUSSIA, GREAT BRITAIN, FRANCE, AND CHINA--REMAINS TWO PAGES OF VAGUE, UNENFORCEABLE GUIDELINES FOR ARMS EXPORTS.

03238 FEIOCK, R.; CABLE, G. NEED, INSTITUTIONAL ARRANGEMENTS, AND ECONOMIC DEVELOPMENT POLICY

JOURMAL OF PUBLIC ADMINISTRATION RESEARCH AND THEORY, 2(4) (OCT 92 ), 387-398.

BY EMPLOYING MORE-APPROPRIATE ANALYIS TECHNIQUES THIS RESEARCH BUILDS ON ELAINE SHARP'S HORK INVESTIGATING THE RELATIONSHIP BETHEEN ECONOMIC NEED AMD LOCAL ECONOMIC DEVELOPMENT POLICY ADOPTIONS. THE AUTHORS FOUND THE LINKAGE DEVELOPMENT POLICY ADOPTIONS. THE AUTHORS FOUND THE LINKAGE
BETWEEN ECONOMIC NEED AND DEVELOPMENT POLICY IS STRONGEST IN BETWEEN ECONOMIC NEED AND DEVELOPMENT POLICY IS STRONGEST CLOSED RATHER THAN IN OPEN DECISIONMAKING CONTEXTS. THESE
RESULTS ALSO PROVIDE CLEARER SUPPORT FOR THE HYPOTHESIS THAT RESULTS ALSO PROVIDE CLEARER SUPPORT FOR THE HYPOTHESI ECONOMIC NEED POSITIVELY AFFECTS DEVELOPMENT POLICY ADOPTIONS IN UNREFORMED CITIES. THE RESULTS REVEAL
CONTINGENT PREDICTIVE POWER OF THE ORIGINAL VARIABLES ACROSS CONTINGENT PREDICTIVE PONER
DEVELOPMENT-POLICY TYPES.

03239 FEIOCK, R.

THE EFFORTS OF ECONOMIC DEVELOPMENT POLICY ON LOCAL ECONOMIC GROWTH
AMERICAN JOURNAL OF POLITICAL SCIENCE, 35(3) (AUG 91), 643-655.

THIS ARTICLE, AFTER EXAMINING THE EVIDENCE FOR THE CONVENTIONAL WISDOM THAT DEVELOPMENT POLICIES ARE INEFFECTIVE, REPORTS THE RESULTS OF AN EMPIRICAL ANALYSIS OF THE EFFECTS OF LOCAL POLICIES ON MANUFACTURING GROWTH IN U.S. CITIES. IN RESPONSE TO OESIGN DIFFICULTIES IN PREVIOUS STUDIES, THE EFFECTS OF LOCAL ECONOMIC DEVELOPMENT POLICY ON MANUFACTURING ACTIVITY FOR 212 CITIES WERE ESTIMATED WITH A DISEQUILIBRIUM ADJUSTMENT MODEL. THE RESULTS PROVIDE EVIDENCE THAT LOCAL POLICIES HAVE POSITIVE EFFECTS ON

CAPITAL INVESTMENT BUT LITTLE EFFECT ON EMPLOYMENT.

03240 FEIOCK, R.C.; CLIMGERMAYER, J.C. DEVELOPMENT POLICY CHOICE: FOUR EXPLANATIONS FOR CITY IMPLEMENTATION OF ECONOMIC DEVELOPMENT POLICIES AMERICAN REVIEH OF PUBLIC ADMINISTRATION, 22(1) (MAR 92), 49-64.

THE AUTHORS ENDEAVOR TO ACCOUNT FOR THE MUMBER OF ADOPTIONS OF FOUR ECONOMIC DEVELOPMENT POLICIES IN LARGE U.S. CITIES. THEY EXAMINE FOUR EXPLANATIONS FOCUSING ON FISCAL STRESS, GROWTH COALITIONS, GOVERNMENT INSTITUTIONS, AND COMPETITION AMONG CITIES IN LIGHT OF A TYPOLOGY THAT CLASSIFIES THE POLICIES ON THE BASIS OF THEIR VISIBILITY AND DISTRIBUTIONAL IMPACT. THEY HYPOTHESIZE THE APPLICABILITY OF THE FOUR EXPLANATIONS TO BE CONTINGENT UPON THE PARTICULAR POLICY BEING EXPLAINED AND ITS VISIBILITY AND DISTRIBUTIONAL CONSEQUENCES. POISSON REGRESSION ANALYSES OF DATA DRAWN FROM LARGE U.S. CITIES REVEAL INCONSISTENT SUPPORT FOR THESE EXPECTATIONS. THE AUTHORS DISCUSS THE IMPORTANCE OF POLICY CHARACTERISTICS IN THE PREDICTION OF POLICY ADOPTION.

03241 FEIOCK, R.C.; HALEY, M.M.

THE POLITICAL ECONOMY OF STATE ENVIRONMENTAL REGULATION: THE DISTRIBUTION OF REGULATORY BURDENS

POLICY STUDIES REVIEH, 11(1) (SPR 92), 158-164.

DISTRIBUTION OF COSTS FOR HAZARDOUS HASTE REGULATION IN THE AMERICAN STATES. THEIR ANALYSIS IDENTIFIES THE DISTRIBUTION OF REGULATORY COSTS FOR TECHNICAL EXTERMALITIES AND ANSWERS SPECIFIC QUESTIONS ABOUT THE REGULATORY STRATEGIES OF STATE GOVERNMENTS COMPETING IN A FEDERAL SYSTEM.

03242 FEIVESON, H.; VON HIPPEL, F.

DISMANTL ING THE DOOMSDAY MACHINE

TECHMOLOGY REVIEW, 95(4) (MAY 92), 61-69.

THE UNITED STATES AND THE FORMER SOVIET UNION CLAIM TO

BE FOMENTING A LANDSLIDE DISARMAMENT. IT DOESN'T GO FAR ENOUGH SUGGEST THE AUTHORS WHO OFFER A PLAN FOR CUTTING NUCLEAR ARSENALS EVEN DEEPER. AS THE COLD WAR RECEDES INTO HISTORY, THE FORMER RIVALS HAVE AN UNPRECEDENTED OPPORTUNITY TO DISARM. EACH SIDE COULD CUT ITS NUCLEAR ARSEMAL TO 1,000 WARHEADS WITHOUT SACRIFICING SECURITY. A 1,000-WARHEAD ARSENAL WOULD BE DESTRUCTIVE ENOUGH TO HOLD THE OTHER SIDE
HOSTAGE BUT FAR TOO SMALL TO MOUNT A PRE-EMPTIVE STRIKE. THE POSSIBIL TY OF T MUCLEAR-WEAPONS-FREE HORLD IS JUST POSSIBILITY OF A NUCLEAR-WEAPONS-FREE
BEGINNING TO BE TAKEN SERIOUSLY AGAIN.

03243 FELD, $S$.

VOICE OF THE RAINFOREST: IMPERIALIST NOSTALGIA AND THE POLITICS OF MUSIC

ARENA, 9 (100) (1992), 164-178.

THIS ARTICLE IS A CRITIQUE OF PROFESSIONAL INNOCENCE, SPECIFICALLY OF THE DOCUMENTATION PRACTICES OF ETHMOMUSICOLOGISTS THAT IMPLICATES THEM IN THE COMPLEX POL ITICS OF MUSICAL COMMODIFICATION. THE AUTHOR SITUATES IT AROUND THE RESPRESENTATION POLITICS OF "VOICE OF THE RAINFOREST" HIS RECORDING OF MUSIC AND ENVIROMMENTAL SOUNDS FROM BOSAVI, PAPUA NEH GUINEA. HIS CONCERN IS TO SITUATE HOH THE LOCAL AND GLOBAL INTERSECT IN NEH FORMS OF CULTURAL PRODUCTION AND TO INDICATE HOW SUCH PROJECTS CAN SIMULTANEOUSLY ENCODE MESSAGES THAT MIGHT BE READ AS REPRESENTING BOTH ENDS OF A MORAL AND POLITICAL SPECTRUM.

03244 FELD, S.L.; GROFMAN, B.

WHO'S AFRAID OF THE BIG BAD CYCLE? EVIDENCE FROM 36 ELECTIONS

JOURNAL OF THEORETICAL POLITICS, 4(2) (APR 92), 231-327. THE AUTHORS ANALYZE 36 ELECTIONS HELD BY UNIONS, PROFESSIONAL ASSOCIATIONS, AND NONPROFIT ORGANIZATIONS IN ENGLAND AND IRELAND. THEY'SHOW THAT THESE ELECTIONS MANIFEST A REMARKABLY HIGH DEGREE OF TRANSITIVITY, WITH A CONDORCET A REMARKABLY HIGH DEGREE OF TRANSITIVITY, WITH A COND
(MAJORITY) WINNER ALNAYS FOUND. MOREOVER, ORDERING (MAJORITY) WINNER ALWAYS FOUND. MOREDVER, ORDERING ALTERNATIVES ACCORDING TO THEIR BORDA SCORE PROVIDES
TRANSITIVE MAJORITY ORDERING IN NEARLY ALL INSTANCES.

03245 FELDMAN, $H$.

THE BALKAN DIMENSIONS OF THE YUGOSLAV CRISIS

MEDITERRANEAN QUARTERLY: A JOURNAL OF GLOBAL ISSUES, 3(3) (SUM 92), 20-25.

THIS ARTICLE EXAMINES THE ETHMIC TENSIONS THAT HAVE SPARKED CIVIL HAR IN YUGOSLAVIA AND THREATEN TO DO SO IN OTHER AREAS OF EASTERN EUROPE. IT ARGUES THAT THE CHAUVINISMS THAT HAVE TORN YUGOSLAVIA APART EXIST ALSO IN 
MOST OF ITS NEIGHBORS IN CENTRAL AND EASTERN EUROPE. A POGROM AGAINST HUNGARIANS IN ROMANIA OR TURKS IN BULGARIA COULD SPARK A CONFLAGARATION THAT WOULD ENVELOPE MUCH OF THE REGION. ONLY A DEDICATED, MULTI-YEAR PROGRAM THAT TEACHES SKILLS IN THE MANAGEMENT AND RESOLUTION OF ETHNIC CONFLICT THROUGHOUT CENTRAL AND EASTERN EUROPE AND AN ACCOMPANYING PROGRAM OF ECONOMIC AID MIGHT AVERT FULL-SCALE WAR.

03246 FELDMAN, J.

LONGING' FOR THE "GOOD TSAR"

NEW LEADER, LXXY(5) (APR 92), 9-10.

THIS ARTICLE RECOUNTS THE RESUL TS OF A CROSS-SECTIONAL SURVEY OF CITIZENS OF RUSSIA AND UKRAINE. THE STUDY PROVIDES A FAIRLY COMPREHENSIVE PICTURE OF THE CURRENT MILIEU. ASSUMING THAT THE FOUNDATION OF DEMOCRACY AND A LAWFUL, LIMITED GOVERNMENT IS A CITIZENRY IMBUED WITH A SENSE OF PUBLIC EFFICACY, TOLERANCE OF DISSENT, AND RESPECT FOR MINORITY RIGHTS, IT WOULD BE HARD TO CHARACTERIZE CONTEMPORARY UKRAIMAIAN AND RUSSIAN POLITICAL CULTURE AS CONTEMPORARY UKRAINAIAN AND RUSSIAN POLITICAL CULTURE AS
DEMOCRATIC. THERE IS ALSO EVIDENCE OF A LONGING FOR A "GOOD DEMOCRATIC. THERE IS ALSO EVIDENCE OF A LONGING FOR A "GOOD
TSAR," A STRONG, POWERFUL LEADER WHO WOULD BRING ORDER TO TSAR," A STRONG, POWERFUL LEADER WHO WOULD BRING ORDER
THE CURRENT CHAOS. SUCH A TENDENCY INDICATES A NEED, A THE CURRENT CHAOS. SUCH A TENDENCI
LONGING, FOR AN ABSOLUTE RULER.

03247 FELDMAN, O.; KAWAKAMI, K. MEDIA USE ÁS PREDICTORS OF POLITICAL BEHAVIOR: THE CASE OF

POLITICAL PSYCHOLOGY, 12(1) (MAR 91), 65-80.

THIS PAPER ATTEMPTS TO OBSERVE MEDIA EFFECTS ON THE POLITICAL KNOWLEDGE, BEHAVIOR, AND INTEREST OF THE JAPANESE YOUNGER GENERATION. EMPLOYING A SAMPLE COLLECTED FROM MORE THAN 1100 STUDENTS IN FOUR UNIVERSITIES IN JAPAN, THE DISCUSSION FOCUSES ON MEASURING EXPOSURE, ATTENTION TO AND RELIANCE ON NEWSPAPER AND TELEVISION SEPARATELY; THIS ENABLES ANALYSIS OF CERTAIN ASSOCIATIONS RELATED TO SPECIFIC MEDIA IN COMPARISON TO OTHERS REGARDING POLITICAL COGNITION AND INTEREST. THE FINDINGS SHOW THAT, MORE THAN TELEVISION VARIABLES, ATTENTION AND EXPOSURE TO PRINT MEDIA ARE THE STRONGEST PREDICTORS OF KNOWLEDGE, BEHAVIOR, AND INTEREST AMONG JAPANESE STUDENTS.

03248 FELDMAN S. ZALLER

THE POLITICAL CULTURE OF AMBIVALENCE: IDEOLOGICAL RESPONSES TO THE WELFARE STATE

AMERICAN JOURMAL OF POLITICAL SCIENCE, 36(1) (FEB 92), 268-307.

THE PRINCIPLES THAT PEOPLE DRAH UPON TO JUSTIFY THEIR SUPPORT FOR SOCIAL WELFARE POLICY IN THE UNITED STATES IS EXPLDRED. THE DATA HERE PRODUCED BY OPEN-ENDED QUESTIONS ASKED OF A RESPRESENTATIVE SAMPLE OF THE U.S. PUBLIC. THE RESULTS SHOW THAT MOST PEOPLE READILY USE VALUES AND RESUNCIS SHOW THAT MOST PEOPLE READILY USE VALUES AND PRINCIPLES CENTRAL TO THE POLITICAL CULTURE WHEN DISCUSSIMG VALUES--INDIVIDUALISM, HUMANITARIANISM, AND OPPOSITION TO BIG GOVERMMENT--LEADS TO SIGNIFICANT AMBIVALENCE IN PEOPLE'S BIG GOVERMMENT--LEADS TO SIGNIFICANT AMBIVALENCE IN PEOPLE'
DICUSSIONS OF THEIR ISSUE POSITIONS. THE IMPLICATIONS OF THESE PATTERNS OF BELIEF FOR POPULAR SUPPORT OF THE WELFARE THESE PATTERNS OF BELIE
STATE ARE DISCUSSED.

03249 FELDMAN, T.

AN INTERVIEW WITH PRESIDENT GEORGE BUSH MIDDLE EAST INSIGHT VIIII(4) (MAR 92)

IN THIS INTERVIEN PRESIDENT GEORGE BUSH REFLECTS ON HIS ROLE IN THE GULF CRISIS AND OPERATION DESERT STORM. HE EXPRESSES CONCERM THAT SADOAM HUSSEIN IS STILL IN POWER, BUT NEITHER DENIES NOR CONFIRMS REPORTS OF A U.S. "WAR OF NERVES" DESIGNED TO OUST THE IRAOI LEADER. HE REJECTS CRITICISM THAT HE DIMINISHED HIS OHN VICTORY BY ENDING THE WAR TOO SOON. HE ALSO REFLECTS ON THE CONSEQUENCES OF HIS
DECISIONS AS SEEN ONE YEAR LATER. HE IS CONVINCED THAT THE POSSIBLE EXISTENCE OF BIOLOGICAL, CHEMICAL, AND ATOMIC WEAPONS, AS WELL AS THE USE OF TERRORISM, ARE THREATS THAT STILL NEED TO BE ERADICATED IN THE REGION. HE TELLS OF HIS VISION FOR THE MIDDLE EAST AND HOW IT MIGHT FIT INTO HIS NEH WORLD ORDER. HE BELIEVES THAT AMERICA'S STRENGTHENED CREDIBILITY IN THE AFTERMATH OF THE GULF HAR HAS MADE IT POSSIBLE TO FINALLY LAUNCH OIRECT ARAB-ISRAELI NEGOTIATIONS. AND HE PRAISES SECRETARY OF STATE JAMES BAKER FOR "SUPERB EFFORTS" IN BRINGING THE PARTIES TOGETHER FOR THEIR FIRST FACE-TO-FACE PEACE TALKS.

03250 FELDMAN, T

INTERVIEW: BILL CLINTON PLEDGES TO MAINTAIN THE MOMENTUM INSIGHT, 9 (1) (1992), 10-15.

BILL CLINTON SAYS THAT WHEN HE SUCCEEDS GEORGE BUSH IN THE OVAL OFFICE, HE WILL WORK TO MAKE SURE THAT THE MOMENTUM OF THE PEACE NEGOTIATIONS IS MAINTAINED. DURING AN EXCLUSIVE INTERVIEW HE SHOWED AN IMPRESSIVE KNOWLEDGE OF RECENT INTERVIEW HE SHOWED AN IMPRESSIVE KNOWLEDGE OF RECENT SITUATION IN THE MIDDLE EAST. THIS ARTICLE OFFER EXCEPTS OF SITUATION IN THE MIDDLE EAST. THIS ART

03251 FELDMEYER, $K$

DISCONTENTED CDU GRASS ROOTS IN SEARCH OF A MISSING MISSION
GERMAN TRIBUNE, (1476) (JUL 91), 4.

GERMANY'S CHRISTIAN DEMOCRATS (CDU) ARE IN THE THROES OF A CRISIS. FROM ITS LEADERSHIP TO ITS MUCH-VAUNTED GRASS ROOTS THE PARTY IS AGREED ON THE REALITY OF THE CRISIS. EVIDENCE OF THE DECLINE OF THE PARTY'S FORTUNES ARE FOUND IN THE ELECTORAL DEFEATS SINCE THE DECEMBER 1990 GENERAL ELECTION, AND THE OVERALL DECLINE IN PARTY SUPPORT SINCE 1983. THERE IS LITTLE DOUBT THAT THE CDU OWES ITS DECEMBER VICTORY TO GERMAN UNIFICATION. IT WILL ONLY BE ABLE TO WIN THE NEXT GENERAL ELECTION IF IT FOLLOWS UP POLITICAL REUNIFICATION WITH SUBSTANTIAL PROGRESS ON ECONOMIC, HUMAN AND, ABOVE ALL, EMOTIONAL REUNIFICATION.

03252 FELDMEYER, $K$.

NATO MEETING: REALITY BEHIND THE WORDS

GERMAN TRIBUNE, (1518) (JUN 92), 1-2.

GERMAN TRIBUNE, (1518) (JUN 92), 1-2.
THE NATO CONFERENCE, HELD IN BRUSSELS IN MAY,

THE NATO CONFERENCE, HELD IN BRUSSELS IN MAY,
ILLUUSTRATED THE GROWING CONFLICT AND DISUMITY THAT IS

IRLUSTRATED THE GROWING CONFLICT AND DISUNITY THAT IS GAVE LITTLE INDICATION OF DISAGREEMENT, THERE IS GROWING EVIDENCE OF A ROW BETWEEN THE UNITED STATES AND FRANCE OVER EVIDENCE OF A ROW BETHEEN THE UNITED STATES AND FRANCE OVER
A PROPOSED FRANCD-GERMAN ARMY CORPS. THE UNITED STATES FEARS A PROPOSED FRANCO-GERMAN ARMY CORPS. THE UNITED STATES FEARS THAT SUCH A DEVELOPMENT WILL SIGNAL THE BEGINMING OF THE END FOR U.S. INFLUENCE IN WESTERN EUROPE. FRANCE HOPES THAT THE
CORPS WILL DIMINISH SUPPORT FOR U.S. ATTEMPTS TO STRENGTHEN NATO AND GIVE THE ORGANIZATION A POL ITICAL AS WELL AS SECURITY DIMENSION. A SPLIT BETWEEN THOSE WHO SUPPORT THE FRANCO-GERMAN CORPS AND THOSE (UNDER CONSIDERABLE U.S. PRESSURE) WHO OPPOSE IT SEEMS LIKELY.

03253 FELDSTEIN, $M$.

THE BUDGET AND TRADE DEFICITS AREN'T REALLY TWINS CHALLENGE, 35(2) (MAR 92), 60-63.

IN THE 1980'S THE LINK BETHEEN THE U.S. BUDGET AMD TRADE DEFICITS SEEMED SO CLEAR THAT THE THO WERE POPULARLY LABELED "THE TWIN DEFICITS." IN THE PUBLIC'S MIND, THE TWO APPEARED AS SIAMESE TWINS THAT COULD NOT BE SEPARATED. ATLHOUGH THERE IS SOME TRUTH IN THIS OVERSIMPLIFIED PICTURE, IT IS WRONG TO GENERALIZE FROM THE AMERICAN EXPERIENCE OF THE 1980'S TO THE CONCLUSION THAT BUDGET AND TRADE DEFICITS ARE TWO SIDES OF THE SAME COIN. WHILE THE PARABLE OF THE THINS MAY PREVENT HARMFUL PROTECTIONIST POLICIES AND POTENTIAL TRADE WARS, IT MAY ALSO LEAD TO COMPLACENCY ABOUT BOTH THE BUDGET DEFICIT AND U.S. TRADE PERFORMANCE. THE SAVINGS GAP THAT DRIVES THE UNITED STATES' ENLARGED TRADE DEFICIT AT THE PRESENT TIME IS UNITED STATES ENLARGED TRADE DEFICIT AT THE PRESENT TIME IS
THE LNGER DUE TO THE INCREASED BUDGET DEFICIT BUT RATHER TO
THE SHARP DECLINE IN PRIVATE SAVINGS DURING THE PAST DECADE.

03254 FELSENTHAL, D.S.

PROPORTIONAL REPRESENTATION UNDER THREE VOTING PROCEDURES: AN ISRAELI STUDY

POLITICAL BEHAVIOR, 14(2) (JUN 92), 159-192.

THIS PAPER ATTEMPTS TO EVALUATE, BY MEANS OF A PUBLIC OPINION SURVEY, THE LIKELY EFFECTS ON THE ISRAELI POL ITICAL SYSTEM OF REPLACING THE EXTANT ELECTORAL PROCEDURE OF PROPORT IONAL SV (WHERE EVERY VOTER CAN VOTE JUST FOR ONE PARTY) WITH EITHER PROPORTIONAL AV (WHERE VOTERS CAN VOTE I
FAVOR OF AS MANY PARTIES AS THEY LIKE) OR PROPORTIONAL CAD (WHERE VOTERS CAN VOTE IN FAVOR OF OR AGAINST AS MANY PARTIES AS THEY WISH). IT ALSO SHOWS HOW THE RESULTS OF PROPORTIONAL AV AND CAD ENABLES ONE TO MEASURE THE EXTENT OF AFFINITY OR RIVALRY EXISTING BETWEEN INDIVIDUAL PARTIES OR PARTY BLOCS. THE MAIN FINDINGS ARE AS FOLLOWS: (1) THESE THREE ALTERNATIVE PROPORTIONAL REPRESENTATION SCHEMES WOULD HAVE CONSIDERABLY DIFFERENT EFFECTS IN TERMS OF THE NUMBER AND TYPE OF PARTIES GAINING REPRESENTATION, AS WELL AS IN TERMS OF GOVERNMENTAL COALITIONS. (2) THE EXTENT OF AFFINITY (OR RIVALRY) EXISTING BETHEEN BLOCS OF PARTIES IS USUALLY NOT SYMMETRICAL--ONE BLOC CAN APPROVE OR DISAPPROYE OF ANOTHER BLOC SIGNIFICANTLY MORE THAN YICE VERSA. (3) VOTERS TEND TO VOTE SINCERELY (RATHER THAN STRATEGICALLY) UNDER THE PROPORTIONAL SV PROCEDURE. THE AUTHOR DISCUSSES THEDRETICAL ISSUES AND PRACTICAL IMPLICATIONS OF THESE PROCEDURES.

03255 FELTEN, E.

A FAREWELL TO RED ARMS

INSIGHT, $7(36$ ) (SEP 91), 23-24.

WHEN SOVIET FIELD COMMANDERS BALKED AT JUMPING ABOARD THE COUP LEADERS' WOULD-BE BANDWAGON. THEY MAY HAVE MARKETED THE BEGINHING OF THE END OF A NATIONAL MILITARY AND HASTENED THE DISINTEGRATION OF THE UNION. THE WORLD'S LARGEST MILITARY, HITH NEARLY FOUR MILLION MEN UNDER ARMS AND SOME 30,000 NUCLEAR HARHEADS AT ITS DISPOSAL. REFUSED TO SUPPORT THE HARD-LINE COUP AND HAS ENSURED THE ACCELERATION OF THE HARD-LINE COUP AND HAS ENSURED THE ACCELERATION OF
RADICAL REFORMS IN THE SOVIET UNION AND ITS OWN EVENTUAL RADICAL REFORMS IN THE SOVIET UNION AND ITS OWH EVENTUAL
DESTRUCTION. ITS HESITATION ALSO SHOWS THAT DEMOCRATIC DESTRUCTION. ITS HESITATION ALSO SHOWS THAT DEMOCRATIC
REFORMS HAVE LOOSENED THE CONTROL THE COMMUNIST PARTY LONG REFORMS HAVE LOOSENED THE CONTROL THE COMMUNIST PARTY LONG
ENJOYED OVER THE MILITARY, AND SUGGESTS THAT THE MILITARY ENJOYED OVER THE MILITARY, AND SUGGESTS THAT THE MILITARY
WILL NOT POSE A SERIOUS THREAT OF A FUTURE COUP. ONE OF THE MOST DIFFICULT MILITARY QUESTIONS THAT REMAINS IS WHAT TO DO MOST DIFFICULT MILITARY QUESTIONS
WITH THE SOVIET NUCLEAR ARSENAL.

03256 FELTEN, E.

AIMING TO PLEASE THE FOLKS AT hOME 
INSIGHT, 8(42) (DCT 92), 6-11, 34-39.

DESPITE THE HEAYY TURNOYER EXPECTED IN CONGRESS IN NOVEMBER, THIS WILL NOT BE A REGULAR OCCURENCE, HARNS THIS ARTICLE. IT ARGUES THAT IMCUMBENCY HAS ADYANTAGES THAT HELP MEMBERS STAY IN OFFICE. ALSO, HOUSE AND SENATE MEMBERS SOON LEARN THAT THE BEST WAY TO KEEP THE VOTERS BACK HOME IN THEIR CAMPS IS TO USE THIER OFFICES TO KEEP THEM HAPPY.

03257 FELTEN, E.

ARI ZONA UNDER INDICTMENT

INSIGHT, $7(9)$ (MAR 91), 20-21.

WHAT STARTED AS AN INVESTIGATION OF ILLEGAL GAMBLING IN

PHOENIX LED CITY POLICE TO THE ARIZONA CAPITAL, HHERE THEY FOUND LEGISLATORS EAGER TO PROMISE THEIR VOTES IN RETURN FOR CAMPAIGN CONTRIBUTIONS. SEVEN LAWMAKERS AND ELEVEN NON-

LEGISLATORS WERE INDICTED IN A STING OPERATION IN WHICH THE POLICE HANDED OUT MEARLY $\$ 400,000$ IN OUESTIONABLE CAMPAIGN CONTRIBUTIONS AND OUTRIGHT BRIBES. BEFORE THIS, MANY VOTERS HAD THOUGHT THAT THE REPUTATION OF THE STATE'S' POLITICAL

LEADERS COULD NOT SINK AKY LOWER.

03258 FELTEN, E.

BUDGETING FOR WAR

INSIGHT, 7 (8) (FEB 91), 8-12

ESTIMATES OF THE COST OF THE PERSIAN GULF WAR HAVE BEEN

DAUNTING, SOME OF THEM RANGING AS HIGH AS A BILLION DOLLARS A DAY OR A TOTAL COST OF $\$ 268$ BILLION. THESE ESTIMATES HAVE SPARKED FEARS OF ECONOMIC DECLINE IN THE U.S. AND THE NECESSITY OF O SAY THAT THESE ASSESSMENTS ARE INFLLATED: AIR LOSSES HAVE BEEN FAR LESS THAN EXPECTED, AMD EOUIPMENT AND MUNITIONS WILL NOT NECESSARILY BE REPLACE AS THE ADMINISTRATION HOLDS TO ITS COMMITMENT TO REDUCE THE SIZE OF THE MILITARY. IN ADDITION, SEVERAL OTHER NATIONS ARE PICKING UP A SUBSTANTIAL PORTION OF THE TAB.

03259 FELTEN, E.

CLINTON AND CONGRESS

INSIGHT, 8(47) (NOV 92), 4-7; 34

BILL CLINTON'S ELECTION VICTORY MEANS THAT FOR THE FIRST TIME IN 12 YEARS, ONE PARTY HILL HAVE A HOLD ON BOTH THE WHITE HOUSE AND CONGRESS. HOPES ARE HIGH FOR ENDING GRIDLOCK, BUT THE LAST TIME SUCH A SITUATION EXISTED--IN THE CARTER YEARS-THE OPPOSITE HAPPENED. CLINTON, HOWEVER, LEARNED FROM CARTER'S MISTAKES, AND QUIETLY POSITIONED HIMSELF DURING THE CAMPAIGN NOT TO REPEAT THEM. THIS ARTICLE SUGGESTS THAT WHAT CANNDT BE GAINED IN THE LEGISLATIVE ARENA CAN OFTEN BE WON IN THE CAREFUL WRITING OF REGULATIONS, WHICH ARE DRAFTED FROM FROM THE LIMELIGHT. TO STIFFEN ANTIPOLLUTION LAHS, FOR FROM FROM THE LIMELIGHT, TO STIFFEN ANTIPOLLUTION LAWS, FOR EXAMPLE, DEMOCRATES WON'T NEED TO PASS A NEW CLEAN AIR

03260 FELTEN, E.

DRAWIMG A NEW CONGRESS

INSIGHT, 6(52) (JAN 91), 20-21.

MAPPING OUT MEW 9ISTRICTS WIL BE ONE OF THE MOST CONTENTIOUS AND CONSUMING POLITICAL BRAWLS IN THE COMING YEAR. HOH THE POPUILATION IS CARVED UP HIS DETERMINE WHOSE SEATS ARE SAFE. WHOSE ARE AT RISK AND WHOSE HIL BE GONE ALTOGETHER. THE PROSPECT OF GERRYMANDERING CAN DILUTE THE POWER OF MINORITIES WHO VOTE IN BLOCS, SO THE NAACP PLANS COURT CHALLENGES UNDER THE VOTING RIGHTS ACT TO ANT REDISTRICTING PLANS THAT SPLIT UP MINORITY STRONGHOLDS.

03261 FELTEN, E.

HANDS DFF

INSIGHT, 7 (5) (FEB 91), 26-27

CRITICS OF THE FBI SAY IT SHOULD INVESTIGATE MEMBERS OF CONGRESS MORE AGGRESSIVELY, BUT THE AGENCY HAS BEEN UNWILLING TO DO SO. TOP FBI OFFICIALS DECLARE THAT THEY HAVE 作 THE BUREAU FOUND ITSELF ON THE DEFENSIVE. ACKNOWLEDGING THAT CONGRESS HAS THE POHER TO MAKE LIFE FOR THE BUREAU EXTREMELY DIFFICULT. THE BUREAU IS RELUCTANT TO MAKE THE SAME MISTAKE AGAIN. HOWEVER, THE OUTCOME OF THE KEATING FIVE HEARINGS MAY SAY MUCH $\rightarrow$ ZOUT THE FUTURE OF SUCH PROBES.

03262 FELTEN, E.

PUBLIC NORKERS PLEDGE SOLIDARITY WITH CLINTON INSIGHT, 8(46) (NOV 92), 10-13;36;38-39.

BILL CLINTON HAS FOUMD A AROENT ALLY IN THE AMERICAN FEDERATION OF STATE, COUNTY AND MUNICIPAL EMPLOYEES (AFSCME). THE UNION HAS DONATED MONEY AND VOLUNTEERS TO THE DEMECRAT'S CAMPAIGN IN THE HOPES THAT ITS 1.3 MILLION DEMOCRAT'S CAMPAIGN IN THE HOPES THAT ITS 1.3 MILLION MEMBERS WILL REAP BIG REWARDS IN THE AREAS OF HEALTH CARE SUSTAIN ITS DRAMATIC GROWTH. MORE GOVERMMENT MEANS MORE GOVERMMENT WORKERS--AND MORE UNION MEMBERS.

03263 FELTEN, E.

THE BELTHAY'S THO-PARTY SCANDAL

INSIGHT, 7 (36) (SEP 91), 28-31.

SENATOR JOHN KERRY AND HIS CHIEF INVESTIGATOR, JACK BLUM.

HAVE MADE HEADLINES BY EXPOSING THE BANK OF CREDIT AND
COMMERCE INTERNATIONAL'S MONEY LAUNDERING AND ILLEGAL OHNERSHIP OF FIRST AMERICAN BANK SHARES. THEY LAMBASTED THE JUSTICE DEPARTMENT, THE CIA, THE FEDERAL RESERVE, THE U.S CUSTOMS SERVICE AND OTHERS FOR "NOT DOING THEIR JOBS" BY ALLOWING THE ILLEGAL ACTIVITIES OF BCCI TO CONTINUE. HOWEVER
SOME QUESTION WHETHER KERRY AND BLUM BLUNTED THEIR OWN INVESTIGATION INTO BCCI YEARS AGO TO SPARE POWERFUL FRIENDS EMBARRASSMENT OR RUIN. SOME ALSO CHARGE THAT THE ONLY REVELATIONS IMPORTANT TO THE KERRY INVESTIGATION WERE ONES THAT MIGHT EMBARRASS GOP POLITICIANS, PARTICULARLY THENPRESIDENTIAL CANDIDATE GEORGE BUSH.

03264 FELTEN, E.

THE NEW IRAO

INSIGHT, ?(10) (MAR 91), 16-17

AFTER THE HAR, THE UNITED STATES WILL FACE A CHOICE ON WHAT TO DO WITH A CONOUERED IRAQ. EXPERTS SAY THE YICTOR COULD SUCCEED IN A BENIGN RECONSTRUCTION OF IRAD'S INFRASTRUCTURE, AS IT DID WITH JAPAN AND GERMANY AFTER WORLD WAR II, BUT THAT FORMING A GOVERMMENT IN ITS IMAGE WILL BE SOMETHING ELSE AGAIN. THE BEST AMERICANS CAN HOPE FOR COULD SIMPLY BE KEEPING THEIR ALLIES FROM TRYING TO CARVE UP TERRITORY. THE BATTLES FOR IRAQI LAND BETWEEN ERSTHHILE TERRITORY. THE BATTLES FOR IRAQI LAND BETWEEN ERSTHHILE ALLIES, NOT TO MENTION

03265 FELTEN, E.

THE SLOE TRACK

INSIGHT, 7(14) (APR 91), 38-40.

MEXICO'S PRESIDENT CARLOS SALINAS DE GORTARI IS EAGER TO ESTABLISH A FREE TRADE AGREEMENT HITH THE UNTIED STATES THAT WOULD ELIMINATE TARIFFS. A U.S. MEXICD AGREEMENT HOULD GO A LONG WAY TOWARDS THE CREATION OF A NORTH AMERICAN FREE TRADE ZONE, AND HAS MANY ADHERENTS ON BOTH SIDES OF THE BORDER. THE ALF-CIO, HOWEVER, SAYS U.S. HORKERS WOULD LOSE THEIR JOBS, MEXICAN WORKERS HOULD BE EXPLOITED AND THE ENVIRONMENT WOULD SUFFER. THE UNION ALSO OBJECTS TO PRESIDENT BUSH'S USE OF FAST TRACK POWERS IN TRADE TALKS SUCH AS THE GENERAL AGREEMENT ON TARIFFS AND TRADE (GATT). THE DECISION TO LET BUSH HAVE SUCH POWERS HILL BE MADE BY CONGRESS ON JUNE 1.

03266 FELTEN, E.

THE TIMES BEACH FIASCO

INSIGHT, $7(32)$ (AUG 91), 12-19.

THE FEDERAL GOVERMMENT EVACUATED TIMES BEACH, MO., IN

1982 WHEN IT WAS DISCOVERED THAT THE TOWN HAD BEEN

CONTAMINATED WITH THE CHEMICAL DIOXIN. AT THE TIME, MANY APPLAUDED THE SHIFT AND SHEEPING GOVERMMENT RESPONSE. BUT NOW, NEARLY A DECADE LATER, IT APPEARS THAT THE GOVERNMENT MAY HAVE OVERREACTED. RESEARCH INDICATES THAT DIOXIN POSES LITTLE OR NO TH

03267 FENECH, $D$

MALTA

EUROPEAN JOURMAL OF POLITICAL RESEARCH, 22(4) (DEC 92),

THE AUTHOR SUMMARIZES THE MAJOR ISSUES IN MALTESE DOMESTIC POLITICS AND LISTS THE MEMBERS OF PRIME MINISTER EDDIE FENECH ADAMI'S CABINET AS OF JANUARY $1,1991$.

03268 FENECH, D.

THE 1992 MALTESE ELECTION

WEST EUROPEAN POLITICS, 15(4) (OCT 92), 189-195.

MALTESE ELECTIONS ARE TRADITIONALLY CHARACTERIZED BY

THREE FEATURES: A HIGH TURNOUT; A TWO-PARTY CONTEST; AND A

CLOSE RESULT. THE MALTESE HAVE ONCE AGAIN RETURMED TO POWER

THE CONSERVATIVE NATIONALIST PARY (PN) IN EARLY GENERAL

ELECTIONS HELD ON 22 FEBRUARY, 1992. WITH A FIVE PER CENT

ADVANTAGE OVER THE OPPOS ITION MALTA LABOUR PARTY (MLP), THE
SUCCESS OF THE PN EXCEEDED BOTH ITS OWN EXPECTATIONS AHD THE

SUCCESS OF THE PN EXCEEDED BOTH ITS OWN EXPECTATIONS

MLP'S FEARS. THIS ARTICLE EXPLORES THE FACTORS WHICH

AFTER FIVE YEARS, AND THAT ITS TIMING WILL BE CRUCIAL IN

DETERMINING WHICH PARTY HINS IT.

03269 FENG, $G$.

SHANGHAI COMUNIOUE: TONE SETTER FOR SIMO-U.S. RELATIONS

BEIJING REVIEW, 35(9) (MAR 92), 30-33.

FOR 20 YEARS, THE SHAMGHAI COMMUNIOUE HAS BEEN REGARDED

AS THE CORNERSTONE OF SINO-U.S. RELATIONS. THE COMHUNIQUE IS

SIGNIFICANT IN THREE RESPECTS: (1) IT REITERATES THE

IMPORTANCE OF PEACEFUL COEXISTENCE AND MUTUAL RESPECT; (2)

IT OPPOSES HEGEMONY. (3) IT AFFIRMS THAT THERE IS ONLY ONE

CHIMA AND THAT TAIHAN IS A PROYINCE OF CHINA.

03270 FENSTERMACHER, $D$.

ARMS RACE: THE MEXT GENERATION

BULLETIN OF THE ATOMIC SCIENTISTS, 47(2) (MAR 91), 29-33.

THIS ARTICLE DISCUSSES THE DEVELOPMENT OF THIRD-

GENERATION (OR DIRECTED-ENERGY) NUCLEAR WEAPONS, WHICH

CONTINUES TO BE INVESTIGATED IN US WEAPONS LABORATORIES. THE

RESEARCH PROGRAM IN NUCLEAR DIRECTED-ENERGY WEAPONS IS

DESCRIBED. VARIOUS TYPES OF SUCH WEAPONS THAT COULD BE 
CREATED ARE CONSIDERED.

03271 FEROINAND, $P$

RUSSIA AND RUSSIANS AFTER COMAUNISM: WESTERN OR EURASIAN? WORLD TODAY, 48(12) (DEC 92), 225-229.

DUE TO THE FALL OF COMMUNISH, THE RUSSIAN PEOPLE ARE ONCE AGAIN FACED WITH A QUESTION THAT HAS PUZZLED THEM FOR CENTURIES: SHOULD THE RUSSIANS BE HESTERN-ORIENTED OR DO THEY HAVE A UNIQUE CIVILIZATION THAT IS (OR SHOULD BE) AN AMALGAM OF WESTERN AND ASIAN CHARACTERISTICS--I.E. EURASIAN? ULTIMATELY, THE OUTCOME OF THIS DEBATE WILL HAVE A MAJOR IMPACT UPON THE FUNDAMENTAL ATTITUDES OF THE RUSSIAN STATE TOWARDS THE OUTSIDE HORLD.

03272 FERDINAMD, $P$.

RUSSIA AND SOVIET SHADOWS OVER CHINA'S FUTURE?
INTERNATIONAL AFFAIRS, $68(2)$ (APR 92), 279-292.

INTERNATIONAL AFFAIRS, $68(2)$ (APR 92 ), 279-292.
THE MAJOR DIFFERENCES BETWEEN THE APPARENTLY SIMILIAR REGIMES OF THE FORMER SOVIET UNION AND THE PEOPLES REPUBLIC OF CHINA (PRC), BOTH BEFORE AND AFTER THE INTRODUCTION OF POL CHINA (PRC), BOTH BEFORE AND AFTER THE INTRODUCTION OF PHE AUTHOR SUGGESTS FURTHER THAT THE PRC IS UNLIKELY TO THE AUTHOR SUGGESTS FURTHER THAT THE PRC IS UNLIKELY TO
SUFFER THE SAME FATE OR DEGREE OF ETHNIC DISINTEGRATION THAT HAS BEEN IN THE FORMER USSR. HE ALSO ARGUES, HOWEVER, THAT THE PRC IS STILL CONFRONTED BY MANY OF THE SAME PROBLEMS THAT CONFRONTED AND DEFEATED GORBACHEY. THESE REQUIRE DECISIVE ACTION, BUT THE CHINESE LEADERSHIP STILL PRIZE STABILITY AT ALL COSTS. THEY MAY LEARN FROM THE SOVIET EXPERIENCE. BUT DO THEY HAVE THE VISION, THE VIGOUR AND THE DECISIVENESS TO DEVISE AND OVERALL STRATEGY WHICH WOULD PREVENT A SIMILIAR FATE?

03273 FERGUSON, B.G.B.; KENNEDY, T.

NORTH AFRICA AT RISK AS HESTERN SAHARA PEACE PLAN STALLS WASHINGTON REPORT ON MIDOLE EAST AFFAIRS, XI(3) (AUG 92), 50 .

THE SAHRAWI REFERENDUM WAS SCHEDULED FOR JANUARY 1992 BUT WAS DELAYED WHEN MOROCCO AND THE POLISARIO COULD NOT AGREE ON VOTER ELIGIBILITY RULES. THE UNITED NATIONS SECRETARY-GENERAL IS WORKING ON NEW CRITERIA THAT HE MOPES WECRETARY-GENERAL IS WORKING ON NEW CRITERIA THAT HE HOPES WILL BE ACCEPTABLE FOR ALL PARTICIPANTS IN THE PEACE PROC BUT THE U.N. PLAN HAS BEEN SLOWED BY REDUCED FUNDING,
REDUCED PEACEKEEPING DEPLOYMENTS, AND STALLED PRISONER REDUCED PEACEKEEPING DEPLOYMENTS, AND STALLED PRISONER
TRANSFERS. THE RESULTS OF THE U.N.-SUPERVISED VOTE COULD TRANSFERS. THE RESULTS OF THE U.N. - SUPERVISED VOTE COULD DISTURB THE STABILITY OF EITHER THE TROUBLED REGIME IN GROWING DEMAND FOR MULTI-PARTY RULE.

03274 FERGUSON, $N$.

MAASTRICKEN

NEW REPUBLIC, 207(15) (OCT 92), 11-13

THE PEOPLE OF EUROPE ARE REVOLTING AGAINST THE

MAASTRICHT TREATY, AN ENORMOUS AND OFTEN UNINTELLIGIBLE DOCUMENT, WITH TWO MAIN OBJECTIVES: (1) THE CREATION OF A SINGLE EUROPEAN CURRENCY, MANAGED BY A CENTRAL EUROPEAN BANK, BY THE END OF THIS DECADE AND (2) THE DEVELOPMENT OF COMMON SECURITY AND FOREIGN POLICIES. THE WIDESPREAD DISDAIN FOR THIS TREATY AMONG THE EUROPEAN PUBLIC IS GOOD NEWS FOR DEMOCRATS EVERYWHERE.

\section{FERGUSON, $N$.}

RERUN SEASON

NEW REPUBLIC, 206 (3) (JAN 92), 18, 20.

THE AUTHOR LOOKS AT THE RECENT'DRAMATIC POLITICAL CHANGES IN EASTERN EUROPE AND COMPARES THEM TO EARLIER EPOCHS OF HISTORIC CHANGE THAT THEY SEEM TO RESEMBLE, INCLUDING 1848.

03276 FERGUSON, $N$.

THE TRIAL

NEW REPUBLIC, 206 (20) (MAY 92), 20-21.

THE OPENING OF THE CONFIDENTIAL FILES OF STASI THE EAST GERMAN SECRET POLICE, HAS REVEALED THAT SEVERAL LEADERS PROMINENT IN POSTCOMHUNIST POLITICS WERE STASI AGENTS DURING THE COMMUNIST ERA. THIS HAS LED TO THE RESIGNATION OF THE COMMUNIST ERA. THIS HAS LED TO THE RESIGNATION OF EXACTLY HOW MANY SPIES WORKED FOR STASI, BUT THERE WERE LEAST 300,000 . THEY WERE THE EYES AND EARS OF A SECRET
POLICE SYSTEM WHOSE PARANOID APPETIITE FOR INFORMATION GREW STEADILY AND WHOSE PUNCTILIOUS ATTENTION TO THE PETTY
DETAILS OF HOUNDING AND HARASSING ALL THOSE IDENTIFIED AS DETAILS OF HOUNDING AND HARASSING ALL THOS

03277 FERGUSSON, J.

THE CHANGING ARMS CONTROL AGENDA: NEW MEANINGS, NEW PLAYERS ARMS CONTROL, $12(2)$ (SEP 91), 191-210.

IN THE CASE OF ARMS CONTROL, THE END OF THE COLD WAR IS A WATERSHED. THE PURPOSE OF THIS PAPER IS TO EXAMINE THE CHANGES HHICH HAVE OCCURRED IN THE THEORETICAL MEANING AND PRACTICAL APPLICATION OF ARMS CONTROL. ITS CONCLUSION IS THAT ARMS CONTROL HAS BECOME DIVORCED FROM ITS TRADITIONAL THERORETICAL FOUNDATION. AS A RESULT, ARMS CONTROL MEANS DIFFERENT THINGS TO DIFFERENT PEOIPLE. IT HAS BECOME BOTH AN END IN ITSELF AND A POLITICAL SYMBOL WHICH MAY BE
MANIPULATED TO ADVANCE THE POLITICAL INTERESTS OF STATES. ARMS CONTROL HAS BECOME A SIMPLE MANIFESTATION OF STATECRAFT-THE DIPLOMACY OF WEAPONS.

03278 FERGUSSON, J.

THE SIGNIFICANCE OF EUROPE FOR CANADA'S DEFENCE INDUSTRIES CANADIAN DEFENCE QUARTERLY, 20(4) (FEB 91), 28-32.

THIS ARTICLE EXAMINES THE PROSPECTS FOR CANADA'S DEFENSE INDUSTRIES IN LIGHT OF THE HINDING DOWN OF THE EAST-WEST CONFLICT AND THE COLD WAR. THE AUTHOR ARGUES THAT THE SIGNIFICANCE IS THOFOLD: (1) THE AMBITIOUS FUTURE PAINTED BY THE 1987 DEFENCE WHITE PAPER IN THE AREA OF EXPENDITURES HAS BEEN REPLACED BY A GLOONY FUTURE OF LITTLE, IF ANY, GROWTH. (2) CANADA'S DEFENSE INDUSTRIES WILL FACE INCREASED COMPETITION FOR MARKETS AS COMPETITORS CHASE THE SHRINKING COMPETITION FOR MARKETS AS COMPETITORS CHASE THE SHRINKING DEFENSE DOLLAR WORLDHIDE. SPECIFICALLY DISCUSSED ARE:
EVOLUTION OF TRADE SINCE THE 1960S; EUROPE AND ITS EVOLUTION OF TRADE SINCE THE 1960S; EUROPE AND ITS
MACRO/MICRD-SIGNIFICANCE; THE NICHE ISSUE; THE OWNERSHIP MACRO/MICRO-SIGNIFICANCE; THE NICHE ISSU
DIMENSION; AND THE AMERICAN COMPONENT.

03279 FERHADI, A.; ELTURAN, B.; HASSAMPOUR, A.

THE KURDS I' IRAQ, IRAN, AND TURKEY: THREE KURDISH PERSPECTIVES

WASHINGTON REPORT ON MIDDLE EAST AFFAIRS, XI(1) (JUN 92), 40-42.

THE AUTHORS DISCUSS THE PRESENT STATUS OF THE KURDS AND THEIR TREATMENT BY THE GOVERMMENTS OF IRAQ, IRAN, AND TURKEY.

03280 FERLEGER, L.; MANDLE, J.

FOUR RULES OF A GOOD' SOCIETY

SOCIALIST REVIEH, 21(1) (JAN 91), 177-180.

THIS ARTICLE PROPOSES FOUR "RULES" OF A GOOD SOCIETY, TO MAKE EXPLICIT THE STANDARDS FOR EYALUATING AND ANALYZING COUNTRIES. THE AUTHORS EMPLOY THESE STANDARDS TO ASSESS THE UNITED STATES, CUBA, AND THE TRANSITIONAL SOCIETIES OF CENTRAL AND EASTERN EUROPE. THE RULES ARE: POLITICS MUST BE RIGOROUSLY DEMOCRATIC; DEMOCRATIC POLITICS SHOULD APPLY TO THE STRUCTURE OF THE ECONOMY, PARTICULARLY TO DECIDING THE DEGREE TO WHICH EITHER PLANMING OR THE MARKET MECHANISM IS USED IN DIRECTING THE ECONDMY: A MINIMUM INCOME MUST BE USED IN DIRECTING THE ECONOMY; A MINIMUM INCOME MUST BE GUARANTEED TO ALL INDIVIDUALS, INCLUDING ADEQUATE HOUSING EQUAL OPPORTUNITY FOR ALL CITIZENS, LIMITATIONS ON EQUAL OPPORTUN
INHERITANCE.

03281 FERRARO, J.

FREEDOM AND OETERMINATION IN HISTORY ACCORDING TO MARX AND ENGELS

MONTLY REVIEH PRESS, 1992, 256.

OVER THE PAST ONE HUNDRED YEARS, NUMEROUS INTERPRETERS OF MARX AND ENGELS HAVE PROVIDED ONE-SIDED ANALYSES OF HISTORICAL MATERIALISM THAT EMPHASIZED EITHER FREEDOM OR DETERMINISM, HUMANISM OR STRUCTURAL ISM, UTOP IANISM OR POSITIVISM. IN THIS STUDY, THE AUTHOR TAKES ONE OF THESE DICHOTOMIES, FREEDOM VERSUS DETERMINISM, AND ARGUES THAT
EACH MUST BE GIVEN EQUAL STANDING IF WE ARE TO RECAPTURE THE DIALECTICAL SUBTLETY OF MARX AND ENGELS' THOUGHT. RECONSTRUCTING MARX AND ENGELS' METHOD THROUGH AN ANALYSIS OF THE FORMS OF ABSTRACTION THAT THEY EMPLOYED, TOGETHER WITH THE NATURE OF THE SOCIAL "LAWS" THAT THEY UNCOVERED, THE AUTHOR HAS PROOUCED A NECESSARY CORRECTIVE TO THE NUMEROUS LOPSIDED INTERPRETATIONS OF CLASSICAL MARXIST THOUGHT. BASING HIS DISCUSSION ON A WIDE RANGE OF MARXIST LITERATURE, THE AUTHOR SHOWS HOW THOSE WHO HAVE EMPHASIZED FREEDOM BUT NEGLECTED DETERMINISM HAVE LOST ANY SENSE OF HISTORICAL NECESSITY OR OF THE INNER LOGIC OF HISTORY; HHILE THOSE WHO HAVE EMPHASIZED DETERMINISM AND MEGLECTED FREEDOM HAVE LOST SIGHT OF HUMAN BEINGS THEMSELVES. HE THEN ARGUES THAT BOTH FREEDOM AND DETERMINISM ARE A PART OF ALL OF MARX AND ENGELS' OBSERVATIONS OF SOCIETY AND THAT BOTH CONSTITUTE THE CORE OF THE MARXIST DIALECTIC.

03282 FERRAROTTI, F.

CIVIL SOCIETY AS A POLYARCHIC FORM: THE CITY INTERNATIONAL JOURNAL OF POLITICS, CULTURE AND SOCIETY, 6(1) (FAL 92), 23-38.

USING ROME AS HIS EXEMPLAR OF THE MODERN CITY, FRANCO FERRAROTTI ARGUES THAT THE MODERN URBAN PHENOMENON REMAINS A PROBLEMATIC TANGLE, A THEATER FOR THE STRUGGLE AMONG COUNTERPOSED MATERIAL, MORAL, ETHICAL AND CREEDAL INTERESTS. HE SUGGESTS THAT THE CITY MAY BE VIEWED AS A MULTIPLICITY OF SYSTEMS: A) AN ECONOMICO-ECOLOGICAL OR PRODUCTIVE STYSTEM B) A POL ITICAL SYSTEM; C) A CULTURAL SYSTEM; D) A FAMILY
SYSTEM, REPRODUCTIVE AND RELATIVELY EDUCATIONAL: E) A SYSTEM, REPRODUCTIVE AND RELATIVELY EDUCATIONAL:
SYMBOLIC SYSTEM. DETERMINED BY RELIGIOUS FAITHS.

03283 FERRERA, M. ITALIAN POLIITICAL SCIENCE AND PUBLIC POLICIES: A LATE BUT PROMISING ENCOUNTER

EUROPEAN JOURNAL OF POLITICAL RESEARCH, 21(4) (JUN 92), 469-482.

THE AUTHOR REVIEWS THE PROGRESS OF THE PUBLIC POLICY DEBATE IN ITALY FROM ITS INCEPTION IN THE EARLY $1960^{\prime} \mathrm{S}$ TO THE PRESENT, IN AN EFFORT TO HIGHLIGHT THE OISTINCTIVE 
CONTRIBUTIONS OFFERED BY POLITICAL SCIENTISTS AND THE PROMISING PROSPECTS OF A FURTHER MUTUAL FERTILIZATION BETWEEN THE POLITOLOGICAL APPROACH AND THE THEME OF "L'INTERVENTO PUBLICO."

03284 FETT, P.J. TRUTH IN ADVERTISIMG: THE REVELATION OF PRESIDENTIAL LEGISLATIVE PRIORITIES

WESTERN POLITICAL QUARTERLY, 45(4) (DEC 92), 895-920. THE PRESIDENT'S REVEALED LEGISLATIVE PRIORITY RANKINGS FOR THE FIRST YEAR OF THE CARTER AND REAGAN ADMINISTRATIONS ARE IDENTIFIED AND TESTED FOR THREE TYPES OF STRATEGIC BEHAVIOR: (1) CLEANSING THEIR AGENDAS OF CONTENTIOUS PROPOSALS; (2) PUBLICLY INFLATING THE PRIORITY THEY PLACE ON LESS CONTENTIOUS PROPOSALS WITH THE HOPE OF APPEARING LEGISLATIVELY SUCCESSFUL; AND (3) OVER-ADVERTISING PROPOSALS WOSE FATE IN CONGRESS IS IN DOUBT, HOPING THAT THE ADOITIONAL PROMOTION MAY TURN A MARGINAL LOSER INTO AN ULTIMATE HINNER. THE RESULTS INDICATE THAT PRESIDENTS CARTER AND REAGAH DID NOT USE AMY OF THESE STRATEGIC TACTICS DURING THEIR FIRST YEARS IN OFFICE. THUS SUPPORTING THE HYPOTHESIS THAT A PRESIDENT'S REVEALED LEGISLATIVE PRIORITIES ARE HIS TRUE PRIORITIES.

03285 FEUILHEARDE, $P$

$$
\text { COUP PILOT IN DJIBOUTI }
$$

HEW AFRICAN, (282) (MAR 91), 17

SOMALIAN' PRESIDENT SIYAD BARRE'S FLIGHT FROM SOMALIA IN LATE JANUARY COINCIDED WITH UNREST IN NEIGHBORING DJIBOUTI, WHERE GOVERMMENT AUTHORITIES HAVE CHARGED A COUP LED BY VETERAN AFAR POLITICIAN ALI AREF BOURHAN HITH PLOTTING TO SEIZE POWER IN AN ARMED COUP ATTEMPT AIMED AT KILLING SEVERAL OF THE COUNTRY'S POLITICAL AND MILITARY LEADERS, INCLUDING PRESIDENT HASSAN GOULED APTIDON. GOVERNMENT FORCES CLAIM THAT HAD THE COUP BEEN SUCCESSFUL, A CIVIL WAR WOULD HAVE BECOME INEVITABLE BETHEEN THE TWO LARGEST ETHNIC GROUPS, THE AFARS AND THE ISSAS.

03286 FEURWERGER, $M$

DEFENSE AGÁINST MISSILES: PATRIOT LESSONS

ORBIS, 36(4) (FAL 92), 581-588.

ANTI-TACTICAL BALLISTIC MISSILE (ATBM) PROGRAMS ARE ONE OF THE FEH AREAS OF GROWTH IN THE DEFENSE DEPARTMENT BUDGET. POLICY MAKERS JUSTIFY THIS GROWTH ON THE BASIS OF EXPANDING REGIONAL THREATS AND THE CONCOMITANT NEED FOR U.S. FORCES TO COPE WITH THESE THREATS. THE MOST SPIRITED DEBATE LIES IN THE AREA OF ACTIVE MISSILE DEFENSE--WITH PARTICULAR EMPHASIS ON THE PERFORMANCE OF THE PATRIOT DURING THE GULF WAR. THIS ON THE PERFORMANCE OF THE PATRIOT DURING THE GULF WAR ARTICLE ATTEMPTS TO TAKE A HARD LOOK AT THE AREAS OF
AGREEMENT AND DISAGREEMNT IN THE DEBATE OVER THE PARTIOT AND AGREEMENT AND DISAGREEMNT IN THE DEBATE OVER THE PAR
OTHER PROJECTED ATBM SYSTEMS. IT ARGUES THAT SUCH AN OTHER PROJECTED ATBM SYSTEMS. IT ARGUES THAT SUCH AN
EXAMINATION PROVIDES THE BEST HOPE FOR REASONABLE POLICY EXAMINATION PROVIDES THE BEST HOPE
FORMULATION IN THIS IMPORTANT AREA.

03287 FIELD, R.M.

CHINA'S INDUSTRIAL PERFORMANCE SINCE 1978

CHINA OUARTERTY

IN 1978 AND AGAIN IN $1983-84$, CHINESE LEADERS INITIATED MAJOR REFORMS IN THE COUNTRY'S INDUSTRIAL SECTOR. ANALYSIS OF RELEVANT STATISTICS AND SOURCES REVEALS AN IMPRESSIVE. BUT ERRATIC. PATTERN OF INDUSTRIAL GROWTH DURING THE 1980's. ANNUAL INDUSTRIAL GROWTH RATES FLUCTUATED WILDLY, AND THE EXPANSIONARY TREND WORKED MORE CONSISTENTLY TO THE ADVANTAGE OF CONSUMER GOODS PRODUCTION, WITH THE KEY EXCEPTIONS OF MACHINERY, BUILDING MATERIALS, AND CHEMICALS. THE BENEFITS OF GROWTH WERE SPREAD UNEVENLY AMONG ENTERPRISES, THE MAIN BENEFICIARIES BEING UNITS AT AND BELOH TOWNSHIP LEVEL. THE RAPID INDUSTRIAL GROWTH WAS NOT REFLECTED IN MAJOR IMPROVEMENTS IN PRODUCTIVITY OR EFFICIENCY. IN STATE AND COLLECTIVE SECTORS, INCREASED PROVISION OF CAPITAL DURING THE SECOND HALF OF THE $1980^{\prime}$ 'S WAS ACCOMPANIED BY SIGNIFICANT DECLINES IN THE EFFICIENCY WITH WHICH IT WAS USED. BY 1990 BOTH THE NUMBER OF LOSS-MAKING ENTERPRISES AND THE LEVEL OF THEIR LOSSES WERE GREATER THAN IN THE EARLY 1980'S--A SITUATION THAT WAS PARTICULARLY SERIOUS IN THE KEY STATE SECTOR. TODAY THE CHINESE INDUSTRIAL SECTOR HAS PROBLEMS THAT HILL BE DIFFICULT TO SOLVE WITHOUT FURTHER, FUNDAMENTAL ECONOMIC REFORM.

03288 FIELDHOUSE, R.

CHINA'S MIXED SIGNALS ON MUCLEAR WEAPONS

BULLETIN OF THE ATOMIC SCIENTISTS, 47(4) (MAY 91), 37-42.

THIS ARTICLE DISCUSSES CHINA'S NUCLEAR WEAPONS' POTENTIAL.

THIS ARTICLE DISCUSSES CHINA'S NUCLEAR WEAPONS POTENTIAL. THE AUTHOR ARGUES IT IS UNCLEAR WHETHER THE CHINESE
TACTICAL NUCLEAR WEAPONS OR NEUTRON BOMBS. SIMULATED TACTICAL NUCLEAR WEAPONS OR NEUTRON BOMBS. SIMULATED TACTICAL NUCLEAR SKIRMISHES ARE DESCRIBED; THEY ARE SEEN AS EVIDENCE OF CHINA'S INTEREST IN TACTICAL NUCLEAR HEAPONS. A SPREAD OF NUCLEAR-CAPABLE WEAPONS TO OTHER COUNTRIES.

03289 FIELDS, G.

THE MARKET: SOUL OF RUSSIAN REDEMPTION?

NEW POLITICS, 3(4) (HIN 92), 50-60.

THE ESTABLISMENT OF MARKET RELATIONS IS VIEWED ALMOST
UNIVERSALLY AS THE BRIDGE RUSSIA MUST CROSS IN ORDER TO TRAVERSE THE ABYSS CREATED BY THE COMMUNIST EXPERIMENT. THE FUNDAMENTAL POLITICAL QUESTION IN RUSSIA AT THE MOMENT IS HOW THE ECONOMIC INSTITUTIONS AND PROOUCTION RELATIONS OF CENTRAL PLANNING AND STATE OWNERSHIP, WHICH HAVE BROUGHT THE COUNTRY TO THE VERGE OF RUIN ARE TO BE DISMANTLED AND REPLACED BY NEW FORMS OF OHNERSHIP ASSOCIATED WITH THE WESTERN MARKET ECONOMICS. WHILE THE OBJECTIVE APPEARS STRAIGHTFORWARD, THE PRACTICAL STEPS TOWARD THIS GOAL,
ESPECIALLY IN THE AFTERMATH OF THE POWER VACUUM CREATED BY THE FAILED COUP IN AUGUST, REPRESENT UNCHARTED TERRAIN.

03290 FIELDS, $K$.

PUblic finance, PRIVATE COMPLIANCE: the finanCING OF the SOUTH KOREAN "CHAEBOL"; ASSOCIATION FOR ASIAN STUDIES 1992 ANNUAL MEETING

ASSOCIATION FOR ASIAN STUDIES, 1992, 121

THIS PAPER WEIGHS THE RELATIVE IMPORTANCE OF MARKET, SOCIAL AND POLITICAL FACTORS IN THE DEVELOPMENT OF THE SOUTH KOREAN "CHAEBOL" THROUGH AN ANALYSIS OF THESE INDUSTRIAL COMBINES' SOURCES OF FINANCE. THE PAPER EXAMINES THE FINANCIAL GOALS AND STRATEGIES OF PUBLIC POLICY-MAKERS AND PRIVATE ENTREPRENEURS AND EXPLAINS THE RELATIVE CONVERGENCE OF THEIR MUTUAL OBJECTIVES. IT ALSO INTRODUCES THE KOREAN FINANCIAL SYSTEM THAT HAS SUPPLIED MASSIVE AMOUNTS OF FINANCIAL SYSTEM THAT HAS SUPPLIED MASSIVE AMOUNTS OF

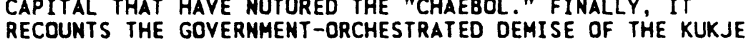
RECOUNTS THE GOVERMMENT-ORCHESTRATED DEMISE OF THE KUKJE
"CHAEBOL" IN 1985 AS AN ILLUSTRATION OF THE OYNAMIC OF STATE"CHAEBOL" IN 1985 AS AN ILLUST

03291 FIELDS, S.

A TALE OF THREE CANDIDATES, THREE DECADES INSIGHT, 8(45) (NOV 92), 21.

THE AUTHOR PROFILES THE THREE 1992 PRESIDENTIAL CANDIDATES. SHE DESCRIBES GEORGE BUSH AS THE QUINTESSENTIAL MAN OF THE 1940'S, WHEN AMERICANS EXPRESSED A PRIDE IN THEIR COUNTRY, NURTURED BY HUMILITY RATHER THAN ARROGANCE. ROSS PEROT INHERITED THE VALUES OF THE FORTIES BUT IS A FIFTIES MYTH, A MAN WHO GREW RICH AS AMERICA GREW GREATER. BILL CLINTON, THE 1960'S GRADUATE STUDENT, IS THE REBEL HITH A CAUSE.

03292 FIELDS, $S$

THE WOMEN'S VOTE DEFIES BLOC LOGIC

INSIGHT, 8(27) (SEP 92), 17-18

'S ISSUES" ARE BUZZWORDS 作

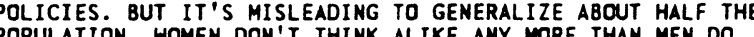
POPULAT'S. WOMEN DON T THINK ALIKE ANY MORE THAN MEN DO AND IT'S DANGEROUS AND DEMEANING TO SUGGEST THAT THEY DO THE REPUBLICAN PEMOCRATS.

03293 FIGUERAS, M.

STRUCTURAL CHANGES IN THE CUBAN ECONOMY

LATIN AMERICAN PERSPECTIVES, 18 (2) (SPR 91), 69-85.

THE REVOLUTIONARY REGIME' IN CUBA INITIALLY FACED AN THE REVOLUTIONARY REGIME IN CUBA INITIALLY FACED AN UNEMPLOYMENT AND UNDEREMPLOYMENT. THIS ARTICLE OUTLINES THE ATTEMPTS OF THE REGIME TO RESTRUCTURE THE ECONOAY WITH EMPHASIS ON FOUR AREAS OR ASPECTS: TRANSFORMING A BACKHARD AGRICULTURE; THE PROCESS OF INDUSTRIALIZATION; CHANGES IN INVESTMENT AND THE CONSTRUCTION INDUSTRY; AND A DEGREE OF DIVERSIFICATION OF EXTERMAL TRADE.

03294 FIGUERAS, M

TRANSFORMATION OF THE CUBAN SUGAR COMPLEX

LATIN AMERICAN PERSPECTIVES, 18(2) (SPR 91), 86-94.

THE PRODUCTION OF SUGAR CONTINUES TO BE A SUBJECT OF MAJOR RELEVANCE IN ANY ANALYSIS OF THE CUBAN ECONOMY, BOTH BECAUSE OF ITS INFLUENCE IN THE PAST DEVELOPMENT OF THE COUNTRY AND BECAUSE OF ITS PRESENT IMPORTANCE. THIS ANALYSIS SEEKS TO REFLECT THE QUALITATIVE CHANGES THAT HIS TRADITIONALLY STAGNANT SUBSECTOR HAS UNDERGONE. AFTER A PRESENTATION OF A BRIEF HISTORICAL OVERVIEH, IT EXAMINES THE CHANGES THAT HAVE OCCURRED IN SUGAR PRODUCTION IN CUBA OVER THE LAST THIRTY YEARS.

03295 FILATOV, S.: FURMAN, D.

RELIGION AND POLITICS IN MASS CONSCIOUSNESS IN RUSSIA PEACE AND THE SCIENCES, 1(1) (SEP 92), 26-32.

A PRELIMINARY ANALYSIS OF THO SURVEYS CONDUCTED IN 1990 AND 1991 GAVE RISE TO MANY QUESTIONS. THE AUTHOR'S GOAL WAS TO STUDY THE CONTEMPORARY MASS RELIGIOUS CONSCIOUSHESS, PRIMARIIY OF THE RUSSIAN POPULATION IN THE FORMER USSR AND INTERLATED CHANGES IN THE RELIGIOUS AND POLITICAL MENTALITY. INTERLATED CHANGES IN THE RELIGIOUS AND POLITICAL MENTALITY
THEY PRESENT SOME RESULTS OF THIS WORK. THEY CONCLUDE THAT THEY PRESENT SOME RESULTS OF THIS WORK. THEY CONCLUDE THAT THE CURRENT POHERFUL DRIVE TOWARD WESTSERN DEMOCRACY IS NOT

03296 FINDLEY, P. A FUNDAMENTAL CHANGE IN U.S. -ISRAELI RELATIONS WASHINGTON REPORT ON MIDDLE EAST AFFAIRS, XI(1) (JUN 92), 18 . 
PRESIDENT GEORGE BUSH IS PLACING CONDITIONS ON U.S. AID TO ISRAEL AMD CONGRESS IS COOPERATING. THIS IS A FUNDAMENTAL TO ISRAEL AND CONGRESS IS COOPERATING. THIS IS A FUNDAMENT CHANGE FROM PAST U.S. POLICY TOWARD ISRAEL, BUT IT MAY DEMOCRATIC PRESIDENT IN NOVEMBER 1992 OR BY UNPREDICTABLE DEMOCRATIC PRESIDENT IN NOVE
EVENTS IN THE MIDOLE EAST.

03297 FINE, J.

THE HUMANITARIAN IMPERATIVE IN IRAQ

MIDDLE EAST INSIGHT, 8(2) (SEP 91), 44-45.

MORE THAN SEVEN MONTHS AFTER THE END OF THE GULF WAR, IRAO'S 18 MILLION PEOPLE CONTINUE TO FACE A LETHAL PUBLIC HEALTH CRISIS. THIS CRISIS INCLUDES A SHARP RISE IN INFANT MORTALITY, GROWING MALNUTRITION, INSUFFICIENT WATER AND SANITATIOM SERYICES, AND THE NEAR COLLAPSE OF THE HEALTH CARE SYSTEM UNDER THE WEIGHT OF MULTIPLE SHORTAGES OF DRUGS AND SUPPLIES. WHILE INDUCED IN PART BY U.S. AND COALITION ANO SUPPLIES. WHILE INDUCED IN PART BY U.S. AND COALITION THE RESULT OF THE CONTINUED IMPOSITION OF ECONOMIC SANCTIONS THE RESULT OF THE CONTINUED IMPOS ITION OF ECONOMIC SANCTIONS AGAINST IRAQ IN A WAY THAT HAS BLOCKED ADEQUATE AMOUNTS OF
FOOD AND MEDICINE FROM REACHING THE COUNTRY AND PREVENTED FOOD AND MEDICINE FROM REACHING THE COUNTRY AND PREVENTED THE REBUILDING OF VITAL ELECTRIC POHER, WATER TREATMENT
SEWAGE PLANTS. UNITED NATIONS AGENCIES AND OTHER RELIEF SEWAGE PLANTS. UNITED NATIONS AGENCIES AND OTHER RELIEF
GROUPS HAVE BEEN ABLE TO PROVIDE AID TO ONLY A FRACTION OF GROUPS HAVE BEEN ABLE TO PROVIDE AID TO ONLY A FRACTION THOSE IN NEED. THIS DISASTROUS CONDITION IS LIKELY TO CONTINUE

03298 FINE, J.

THE IRAO SANCTIONS CATASTROPHE

MIDDLE EAST REPORT, 22(1) (JAN 92), 36; 39

THE CONTINUING PUBLIC HEALTH EMERGENCY IN IRAQ IS TAKING A HIGHER TOLL IN CIVILIAN LIVES THAN THE COALITION BOMBING LAST JANUARY AND FEBRUARY. THE EMERGENCY COULD HAVE BEEN OVER BY NOH IF THE BUSH ADMINISTRATION AND ITS ALLIES AT THE UNITED NATIONS HAD ACCEPTED RECOMMENDATIONS ON HUMANITARIAN NEEDS AND MONITORING SAFEGUARDS MADE BY UN RELIEF OFFICIALS LAST JULY. AFTER AN EXAMINATION OF THIS SITUATION, THIS ARTICLE CONCLLDES THAT THE DEADLOCK ON HUMANITARIAN AID CAN BE BROKEN BY A NEW OFFER FROM THE US AND ITS COALITION PARTNERS AT THE UN OF A ONE-TIME SALE OF IRAOI OIL EXCLUSIVELY FOR HUMANITARIAN PURPOSES. THE SAME CONTROLS AND EXCLUSIVELY FOR HUMANITARIAN PURPOSES. THE SAME CONTROLS AND
SAFEGUARDS RECOMMENDED BY UN RELIEF OFFICIALS IN JULY CAN BE
EMPLOYED TO PREYENT MISUSE AND THE AMOUNT HOULD HELP EMPLOYED TO PREVENT MISUSE AND THE AMOUNT HOULD HELP CIVILIANS SURVIVE THE WINTER AND BEGIN TO ALL

03299 FINE, T.S.

IMDIVIDUALISM AND LIBERALISM/CONSERVATISM: BROADENING DIMENSIONS OF POLICY SUPPOR

POLITY, XXV(2) (HIN 92), 315-327.

SINCE THE LATE $1960^{\prime}$ 'S, SCHOLARS HAVE EXPLORED PUBLIC OPINION AND THE IDEOLOGY OF INDIVIDUALISM--A BELIEF SYSTEM THAT RESTS ON THE NOTION THAT THE INDIVIDUAL, NOT SOCIETY, IS ULTIMATELY RESPONSIBLE FOR HIS OWH SUCCESS OR FAILURE. THIS SYSTEM ADVOCATES ONLY LIMITED GOVERMMENT AND GOVERNMENT INTERVENTION. THIS PAPER EXPLORES THE COMPARATIVE IMPACT THAT BELIEF IN SELF-RELIANCE, HARD WORK, AND A COMMITMENT TO EQUAL OPPORTUNITY HAS ON REDISTRIBUTIVE AND COMPENSATORY POLICY SUPPORT. THE INFLUENCE OF CAUSAL FACTORS IS COMPARED WITH IDEOLOGICAL IDENTIFICATION, A WIDELY APPLIED COMPONENT OF PUBLIC OPINION RESEARCH.

03300 FINEMAN, M.A. (ED.); THOMADSEN, N. (ED.) AT THE BOUNDARIES OF LAH: FEMINISM AND LEGAL THEORY ROUTLEDGE, $1991,368$.

THIS BOOK IS A BROAD INTERDISCIPLINARY COLELCTIOH OF PAPERS ON FEMINISM AND LEGAL THEORY. THE AUTHORS HAIL FROM VARIOUS BACKGROUNDS AND VIEWPOINTS INCLUDING SOCIOLOGY, ANTHROPOLOGY AS WELL AS LEGAL THEORY. TAKEN TOGETHER, THEIR ANTHROPOLOGY AS WELL AS LEGAL THEORY. TAKEN TOGETHER,
PAPERS FORM A PASTICHE OF ETHNOGRAPHIC PERSPECTIVE AKD PERSONAL EXPERIENCE LOCATED IN THE LEGAL FABRIC OF PERSONAL EXPERIENCE LOCATED IN THE LEGAL FABRIC OF
THEORIZING AND THE LAH ITSELF. SEVERAL OF THE PAPERS ARE
INFORMED BY AND DRAH ON POST-STRUCTURALIST THEORY AND INFORMED BY AND DRAW ON POST-STRUCTURALIST THEORY AND FEMINIST JURISPRUDENCE CONCERNIMG PRIMARILY THE MEANIMG OF
LEGAL LANGUAGE. THE MESSAGE OF THE COLLECTION IS CRITICAL LEGAL LANGUAGE. THE MESSAGE OF THE COLLECTION IS CRI
AND PRESCRIPTIVE: CONFRONTING THE BARRIERS AND THE AND PRESCRIPTIVE: CONFRONTING THE BARRIERS AND THE
CONCEPTUAL FRAMENORK AND AVOIDING FALSE CONSCIOUSNESS OF CONCEPTUAL FRAMEHORK AND AVOIDING FALSE CONSCIOUSNES BEING DUPED INTO BELIEIVING THE LAW IN ITSELF CAN BE
TRANSFORMED INTO A LAN FOR ITSELF, AND FOR HOMEN IS PART OF TRANSFORMED INTO

03301 FINGER, M.; HUG, S.

GREEM POL ITICS IN SHITZERLAND

EUROPEAN JOURNAL OF POLITICAL RESEARCH, 21(3) (APR 92), 289-306.

THE AUTHORS IDENTIFY THE MAJOR SHORTCOMINGS OF THE CURRENT DOMINANT THEORIES OF GREEN POLITICS AND GREEN PARTIES. USING SHITZERLAND AS A CRITICAL CASE, THEY EXPLORE A DIFFERENT APPROACH TO GREEN POLITICS, SEEING IT AS A RESULT OF DIFFERENT ABOUT WAYS AND MEANS TO SOLVE ENYIRONMENTAL PROBLEMS. THEY CONCLUDE WITH SOME IDEAS THAT WOULD LEND THEMSELVES TO A MORE COMPREHENSIVE THEORY OF GREEN POLITICS.
03302 FINIFTER, A.W.; MICKIEWICZ, E. DEFINING THE POLITICAL SYSTEM OF THE USSR: MASS SUPPORT FOR POL ITICAL CHANGE

AMERICAN POLITICAL SCIENCE REVIEW, 86(4) (DEC 92), 857-874 USING DATA FROM A NATIONAL PUBLIC OPINION SURYEY CONDUCTED IN THE SOVIET UNION DURING NOVEMBER AND DECEMBER 1989, THE AUTHORS EXPLORE THO ATTITUDES RELEVANT TO THE REVOLUTIONARY CHANGES THERE: (1) ATTITUDES TOWARD CHANGE AND POLITICAL DEMOCRACY AND (2) ATTITUDES TOWARD A CORE COMPONENT OF SOCIALIST IDEOLOGY, THE LOCUS OF RESPONSIBILITY FOR SOCIAL WELL-BEING (THE STATE OR INDIVIDUALS?). THESE VARIABLES ARE UNRELATED, WITH THE SAMPLE RELATIVELY EVENLY DIVIDED AMONG THE INTERSECTING CELLS OF A CROSS-TABULATION. WHILE SOCIAL CONFLICT MAY BE MITIGATED BY THE SHALL SIZES OF ABSOLUTELY OPPOSING GROUPS, CONSENSUS MAY ALSO BE HARD TO REACH. ETHNICITY, EDUCATION, INCOME, AGE, PARTY MEMBERSHIP, AND LIFE SATISFACTION HAVE IMPORTANT EFFECTS ON THESE ATTITUDES. THE AUTHORS DISCUSS HOW ATTITUDE PATTERNS IN THE ATTITUDES. THE AUTHORS DISCUSS HOW ATTITUDE PATTERNS IN THE
DATA MAY BE RELATED TO THE DISINTEGRATION OF THE USSR AND TO DATA MAY BE RELATED TO THE DISINTEGRATION OF THE USSR AND TO
PROBLEMS FACED BY THE INDEPENDENT SUCCESSOR STATES AS THEY DEVELOP NEW INSTITUTIONS AND FOSTER NEW VALUES.

03303 FINKEL, V.R.

BROTHERS IN ARMS

AFRICA REPORT, 37 (2) (MAR 92), 60-64

WITH THE WAR OVER, ANGOLA IS FORGING A NEW NATIONAL ARMY OF 40,000 MEN FROM THE MPLA ARMED FORCES AND THE UNITA GUERRILAS, WHO WERE ENEMIES FOR 16 YEARS. ANGOLANS IN ALL WALKS OF LIFE ARE VERY WAR-WEARY, AND PEACE HAS ENERGIZED THE REBUILDING PROCESS AS THE TWO FORMERLY-WARRING SIDES FIGHT IT OUT IN THE POLITICAL ARENA, RATHER THAN ON THE BATTLEFIELD.

03304 FINKEL, V.R.

VIOLENCE AND THE VOTE

AFRICA REPORT, 37(4) (JUL 92), 52-54.

LUANDAN RESIDENTS ARE BEING TERRORIZED BY GROUPS OF ARMED BANDITS, INCLUDING DEMOBILIZED SOLDIERS AND DIAMOND SMUGGLERS. THE SECURITY SITUATION HAS RAISED DOUBTS ABOUT THE SAFETY OF CANDIDATES AND CITIZENS DURING ANGOLA'S UPCOMING CAMPAIGN AND VOTER REGISTRATION FOR THE SEPTEMBER 1992 ELECTIONS. NEVERTHELESS, ALL PARTIES SEEM TO AGREE THAT 1992 ELECTIONS. NEVERTHELESS, ALL PARTIES SEEM TO AGRE IMPERFECT THE PROCESS OR THE RESULTS.

03305 FINKLESTEIN, H.

WHY PALESTINIANS CHEERED THE SCUD MISSILES WHY PALESTINIANS CHEERED THE SCUD MISSILES SCANDINAVIAN JOURNAL
(SEP 92) 235-258.

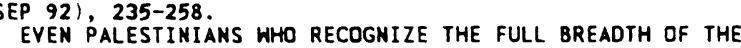
POLITICAL AND MILITARY DEFEAT INFLICTED BY THE U.S. WILL NOT OPENLY DENOUNCE SADOAM HUSSEIN. THIS ARTICLE EXPLORES WHY PALESTINIANS CHEERED THE SCUD MISSILES AND CONCLUDES THAT THE ANSHER IS AS SIMPLE AS THE FACT THAT THE PALESTINIANS WANTED THE ISRAELIS TO FEEL THE SAME PANIC AS THEY HAVE CAUSED THEM.

03306 FINN, J,

THE UNITED STATES: THE SOLE BUT UNEASY SUPERPOWER

FREEDOM REVIEW, 23(1) (JAN 92), 25-28.

DURING 1991, THE UNITED STATES BEGAN TO EXPERIENCE SEVERAL GREAT SHIFTS IN SELF-UNDERSTANDING, BUT THESE SHIFTS HAVE YET TO REACH A FULL RESOLUTION. THEY REFLECT BOTH THE NEW ROLE THE USA HAS ASSUMED IN WORLD AFFAIRS AS THE ONLY REMAINING SUPERPOWER AND A RENEWED FOCUS ON DOMESTIC AFFAIRS, WHICH THIS NEW INTERNATIONAL STATUS ALLOWS AND WHICH IS BEING DEMANDED BY AN UNEASY, DISCONTENTED ELECTORATE.

03307 FIORINA, M.

AN ERA OF DIVIDED GOVERNMENT

POLITICAL SCIENCE, 107(3) (FAL 92), 387-410.

WHY DO WE HAVE DIVIDED GOVERMMENT, AND WHAT ARE ITS CONSEQUENCES? THIS ARTICLE ADORESSES THESE QUESTIONS, ALTHOUGH THE DISCUSSION IS ONLY SUGGESTIVE. IT BEGINS BY PLACING THE CONTEMPORARY PERIOD IN HISTORICAL CONTEXT, THEN PROCEEDS HITH A SURVEY OF THE OUESTIONS OFFERED FOR THE CONTEMPORARY CONDITION AND CONCLUDES WITH QUESTIONS ABOUT ITS LIKELY CONSEOUENCES.

03308 FIRSTIN, J. FIRSTIN, J. SCANDAL
SHIFFING OUT SCANDL

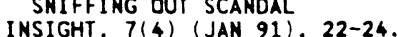

INSIGHT, $7(4)$ ( JAN 91), 22-24. DEVELOPMENT DURING SAMUEL PIERCE'S REIGN ALSO REVEALS A DEVELOPMENT DURING SAMUEL PIERCE'S REIGN ALSO REVEALS A LESSER-KNOWN FACT: THE CONGRESSIONAL COMMITTEES OVERSEEING
THE DEPARTMENT ADOPTED A HANDS-OFF POLICY DESPITE NUMERDUS THE DEPARTMENT ADOPTED A HANDS-OFF POLICY DESPITE NUMERDUS
WARNINGS FROM HUD'S INSPECTOR GENERAL'S OFFICE AND
CONGRESS'S OWN INVESTIGATIVE REPORTS. RECENT PROPOSALS WHICH CONGRESS'S OWN INVESTIGATIVE REPORTS. RECENT PROPOSALS ARGUE FOR EXPANDING CONGRESS'S ABILITY TO OVERSEE HUD
OPERATIONS WILL BE ON GUARANTEE AGAINST A REPEAT PERFORMANCE.

03309 FISCHER, A.

SWINGS AND GERRYMANDERS 
ELECTORAL STUDIES, 10 (4) (DEC 91), 299-312.

IT IS USUAL FOR ELECTORAL ANALYSTS TO CALCULATE THE SHING NECESSARY AT THE NEXT ELECTION TO UNSEAT A GOVERNMENT ASSUMING THAT THE SWING IS A UNIFORM ONE. HOWEVER, SHINGS ARE NOT UNIFORM. THE NON-UNIFORM SHING WHICH WOULD, ON AVERAGE, UNSEAT A GOVERMMENT IS SHOWN TO BE DIFFERENT FROM THE UNIFORM SHING. IMPLICATIONS OF VARIABILITY FOR THE SIZE OF THE MAJORITY, THE POSSIBIITIES OF A PARL IAMENT HITH AN
EVEN NUMBER OF SEATS BEING EQUALLY-DIVIDED, AND THE USE OF THIS ANALYSIS TO DETECT GERRYMANDERING AND TO CORRECT FOR IT, ARE CONSIDERED.

03310 FISCHER, B.J.

LARGE PRIVATIZATION IN POLAND, HUNGARY, AND CZECHOSLOVAKIA RFE/RL RESEARCH REPORT, 1(44) (NOV 92), 34-39.

THE PRIVATIZATION OF LARGE ANO MEDIUM-SIZED STATE-OWNED ENTERPRISES IN POLAND, HUNGARY, AND CZECHOSLOVAKIA HAS BEEN CHARACTERIZED BY DIFFERENT APPROACHES AND RESULTS. HHILE HUNGARY HAS SOUGHT DIRECT FOREIGN INVESTMENT ON A CASE-BYCASE BASIS, CZECHOSLOVAKIA HAS EMPHASIZED VOUCHER PRIVATIZATION TO PROVIDE A MEASURE OF "PEOPLE'S CAPITALISM." POLAND HAS HAD THE GREATEST SUCCESS WITH SO-CALLED POLAND HAS HAD THE GREATEST SUCCESS WITH SO-CALLED
"LIQUIDATION PRIVATIZATION," BASED UPON THE SALE OR RENTAL "LIQUIDATION PRIVATIZATION," BASED UPON THE SALE OR RENTAL OF THE REAL ASSETS OF STATE-OWNED ENTERPRISES. ALL THREE
APPROACHES POSE QUESTIONS THAT HAVE NOT YET BEEN ANSWERED.

03311 FISCHER, D.A.V.

IMPLEMENT ING A NUCLEAR-WEAPON-FREE-ZONE IN AFRICA DISARMAMENT, XIV (3) (1991), 112-130

THE AUTHOR DISCUSSES THE PROSPECTS FOR ESTABLISHING A NWFZ IN AFRICA. HE MAKES SUGGESTIONS REGARDING THE GEOGRAPHICAL SCOPE OF AN AFRICAN NHFZ, THE BASIC OBLIGATIONS OF THE PARTIES, SPECIAL REQUIREMENTS THAT WOULD BE APPROPRIATE TO' THE REGION, ARRANGEMENTS THAT WOULD BE NEEDED FOR VERIFICATION OF COMPLIANCE, THE STEPS THAT WOULD PRECEDE IMPLEMENTATION, AND THE POSSIBILITY OF LINKING AN AFRICAN NWFZ WITH OTHER NWFZ'S.

03312 FISH, S.

THE EMERGENCE OF INDEPENDENT ASSOCIATIONS AND THE TRANSFORMATION OF RUSSIAN POLITICAL SOCIETY

JOURNAL OF COMMUNIST STUDIES, 7 (3) (SEP 91), 299-334. THE EMERGENCE OF INDEPENDENT ASSOCIATIONS DURING THE $1980 S$ ILLUSTRATES THE INADEQUACY OF TRADITIONAL APPROACHES TO THE STUDY OF STATE-SOCIETY RELATIONS IN RUSSIA. RUSSIAN POLITICAL SOCIETY TODAY RESEMBLES LESS A CIVIL SOCIETY--WITH POLITICAL PARTIES, UNIONS, PROFESSIONAL GROUPS AND OTHER POLITICAL PARTIES, UNIONS, PROFESSIONAL GROUPS AND OTHER
INTEREST ASSOCIATIONS--THAM A MOVEMENT SOCIETY--A MYRIAD OF INTEREST ASSOCIATIONS--THAN A MOVEMENT SOCIETY--A MYRIAD
COMPLEX, INTERACTING POLITICAL CAMPAIGNS. THIS MOVEMENT COMPLEX, INTERACTING POL ITICAL CAMPAIGNS. THIS MOVEMENT SOCIETY WILL BE MORE THAN A TRANSIENT PHENOMENON, NOT LEAST BECAUSE OF MAJOR OBSTACLES, BOTH STRUCTURAL AND ATTITUDINAL, TH THE DEVELOPMENT OF CIVIL SOCIETY. THIS ARTICLE CONCLUDES THAT INITIATIVE FOR THE FORMULATION OF ALTERNATIVES TO THE CURRENT POLITICAL SYSTEM HAS ALREADY SHIFTED FROM THE PARTY TO THE INDEPENDENT ORGANIZATION
SEEN WHETHER POWER WILL FOLLOW.

03313 FISHEL, J.

THE MURKY WORLD OF CONFLICT TERMINATION: PLANNING AND EXECUTING THE 1989-90 RESTORATION OF PANAMA SMALL WARS \& INSURGENCIES, 3(1) (SPR 92), 58-71.

IT SEEMS AS IF THERE IS AS MUCH FOG IN ESTABLISHING PEACE AT THE END OF A CONFLICT AS THERE IS ON THE BATTLEFIELD. THIS ARTICLE ADDRESSES THE TERMINATION OF OPERATION \$JUST CAUSE' IN PANAMA IN 1990. IT FOCUSES ON THE PLANNING PROCESS THAT BEGAN IN FEBRUARY 1988 AND CARRIES THE STORY THROUGH THE ACTIVITIES OF THE US MILITARY SUPPORT GROUP UNTIL ITS DEACTIVATION IN JANUARY 1991. IT IS A STUDY OF HOW THE US FORCES IN PANAMA ATTEMPTED TO DEAL WITH THE EFFECTS OF MILITARY INTERVENTION. IT DISCUSSES BOTH SUCCESS AND FAILURE IN PLANMING AND EXECUTION AND SUGGESTS APPROACHES THAT WILL MAXIMIZE SUCCESS AND AVOID THE SAME ERRORS IN THE FUTURE.

03314 FISHER, L.

THE EFFECTS OF A BALANCED BUDGET AMENDMENT ON POLITICAL INSTITUTIONS

JOURNAL OF LAH \& POLITICS, IX(1) (FAL 92), 89-104.

THE AUTHOR WARNS THAT REVISIONS IN THE BUDGETARY PROCESS ESPECIALLY A BALANCED BUDGET AMENDMENT, WOULD UPSET THE ESPECIALLY A BALANCED BUOGET AMENDMENT, HOULD UPSET THE
EXISTING BALANCE BETHEEN THE EXECUTIVE, LEGISLATIVE, AND EXISTING BALANCE BETHEEN THE EXECUTIVE, LEGISLATIVE, AND
JUDICIAL BRANCHES OF GOVERNMENT. A BALANCED BUDGET AMENDMENT WOULD TRANSFER POWER FROM THE LEGISLATIYE TO THE EXECUTIVE AND THE JUDICIAL BRANCHES, SUCH AN AMENDMENT HOULD PRESSURE AND THE JUDICIAL BRANCHES. SUCH AN AMENOMENT WOULD PRES ENHANCED IMPOUNDMENT PONERS, AND EVEN SOME AUTHORITY TO TAX.

03315 FISHER, R.

RIGHT AND WRONG

FAR EASTERN ECONOMIC REVIEN, 155(7) (FEB 92), 15. THE CONSERVATIVE NEH COMMENTATOR TURNED POPULIST

REPUBLICAN PRESIDENTUAL CANDIDATE, PATRICK BUCHANAN,

DESERVES SPECIAL ATTENTION FROM ASIANS. THE SUCCESS OR

FAILURE OF HIS CAMPAIGN WILL HELP DETERMINE IF ANTI-ASIAN
ECONOMIC NATIONALISM MAY SOON REPLACE ANTI-COMMUNISM AS THE BI-PARTISAN CEMENT OF U.S. FOREIGN POLICY. BUCHANAN'S MIX OF "AMERITA CESSATION OF FOREIGM AID AND THE HITHDRAWAL OF U.S. IROOPS CESSATION OF FOREIGN AID AND THE WITHDRAWAL OF U.S. TROOPS FROM KOREA AND JAPAN HAVE WORRIED SOME ASIANS. ALTHOUGH MOST ACKNOWLEDGE THAT BUCHANAN STANDS LITTLE CHANCE OF DEFEATING PRESIDENT GEORGE BUSH IN THE NOVEMBER PRESIOENTIAL ELECT
MANY FEAR THAT BUCHANAN WILL DO WELL ENOUGH TO CLAIM MANY FEAR THAT BUCHANAN WILL DO WELL ENOUGH TO CLAIM
LEADERSHIP OF U.S. CONSERVATIVES WHO WILL SIGNIFICANTLY DEFINE THE REPUBLICAN PARTY IN THE 1996 PRESIDENTIAL ELECTION.

03316 FISHER, $R$

THE NORTH AMERICA FREE TRADE AGREEMENT: A U.S. PERSPECTIVE SAIS REVIEW, 12(1) (WIN 92), 43-56.

PROPONENTS FOR THE NORTH AMERICAN FREE TRADE AGREEMENT (NAFTA) ARGUE THAT IT REPRESENTS THE FIRST MAJOR STEP TOWARD HEMISPHERIC FREE TRADE, AS ENVISIONED IN THE PRESIDENT'S ENTERPRISE FOR THE AMERICAS INITIATIVE. THE NAFTA'S OPPONENTS IN THE UNITED STATES SEE IT AS ANOTHER THREAT TO $U$. S. JOBS, PARTICULARLY IN MANUFACTURING. THIS ARTICLES EXAMINES SOME OF THE FACTORS AFFECTING THE U.S. DECISION TO PUASUE THE NAFTA, THE BENEFITS THE NAFTA SHOULD PRESENT TO PURSUE THE NAFTA, THE BENEFITS THE NAFTA SHOULD PRESENT TO TAKING TO LIMIT THE POTENTIAL ADJUSTMENTS COSTS, AMD THE RELATIONSHIP OF THE NAFTA TO OVERALL U.S. TRADE POLICY.

03317 FISHER, $S$.

IRAQI MISSILE ATTACKS SPUR BACKING FOR ISRAELI MILITARY SATELLITES

ARMED FORCES JOURMAL INTERMATIONAL, (APR 91), 29 ONE OF THE STRATEGIC SHORTCOMINGS ALREADY APPARENT TO ISRAELI PLANNERS IN THE AFTERMATH OF THE PERSIAN GULF WAR IS THE PRESSING NEED FOR LONG-RANGE INTELLIGENCE-GATHERING CAPABILITIES, INCLUDING SATELLITES. DEVELOPMENT OF ISRAELI "SPY" SATELLITES IS NOW ON THE NATIONAL AGENDA, ACCORDING TO ISRAELI MINISTER OF DEFENSE MOSHE ARENS. THE UTILITY OF REALTIME SATELLITE INFORMATION FOR ISRAEL HAS STIMULATED STRONG BACKING FOR INDIGENOUS SPY SATELLITES. SOME ANALYSTS POINT OUT THAT HAD SUCH SATELLITES BEEN DEPLOYED PRIOR TO THE OUTBREAK OF THE PERSIAN GULF CRISIS, ISRAEL WOULD HAVE HAD AN INDEPENDENT MEANS OF ASSESSING IRAQ'S INTENTION OF INVADING KUWAIT, IN ADDITION TO A DOMESTIC CHANNEL FOR WARNING THE POPULATION OF INCOMING MISSILES.

03318 FISHMAN, J.

TAX THE R

POLITICAL AFFAIRS, 71(10) (OCT 92), 11-18.

JOELLE FISHMAN ARGUES THAT THE DEVASTATING RESULTS OF TRICKLE DOWN ECONOMICS HAS LEFT NO QUESTION IN THE MINDS OF THOSE WHO ARE SUFFERING THAT THERE MUST BE A BIG CHANGE, FAST. SHE SUGGESTS THAT IN TODAY'S POLITICAL ENVIRONMENT, INDEPENDENT POL ITICAL FORMS ARE NOT ONLY MORE POSSIBLE THAN EVER BEFORE--THEY ARE INCREASINGLY NECESSARY TO PROVIDE THE OPPORTUNITY FOR ADVANCED DEMANDS TO BE EXPRESSED AND WON. THIS ART ICLE EXPLORES THE CONNECTICUT BUDGET CRISIS, ULTRARIGHT DEMAGOGY, AND THE IDEA OF TAXING THE RICH. IT CONCLUDES THAT THE CHALLENGE IN THE POST-ELECTION PERIOD WILL BE HOW TO MAINTAIN THE MOMENTUM AND GENERATE THE FEVER INTO A WINNING MULTI-RACIAL, GRASS ROOTS MOVEMENT AS PART OF THE BROADER DEVELOPMENTS TOWARD LABOR AND PEOPLE INDEPENDENT POLITICS IN CONNECTICUT AS IN THE NATION AS A WHOLE.

03319 FITZMAURICE, J.

BELGIAN PARADOXES: THE NOVEMEBER 1991 ELECTIDN

WEST EUROPEAN POL ITICS, 15(4) (OCT 92), 178-183.

THE ELCTION OF 24 NOVMEBER 1991 BY BELGIAN STANDARDS WAS AN UPSET OF ALMOST SEISMIC PROPORTIONS, WHICH SURPRISED MOST OBERVERS AND POLITICAL LEADRS, YET IT HAS A RESULT FULL OF PARADOXES. THIS ARTICLE EXAMINES THESE PARADOXES AND EVALUATES THE RESULTS AND CAMPAIGN ISSUES. A MEN FEATURE OF THE CAPAIGN WAS THE FIRST OUTING OF THE NEW CAPAIGN FINANCE LAW, BELGIUM'S FIRST.

03320 FITZMAURICE, J.

THE BELGIAN ELECTION OF 1991

ELECTORAL STUDIES, 11(2) (JUN 92), 162-165.

AT THE RECENT BELGIAN ELECTIONS THERE WAS A STRONG VOTER TENDENCY TO PUNISH ALL THE SO-CALLED TRADITIONAL PARTIES. TENDENCY TO PUNISH ALL THE SO-CALLED TRADITIONAL PARTIES. THE ELECTION ILLUSTRATED THE FACT THAT THERE ARE THO QUITE DISTINCT REGIONAL POL ITICAL SYSTEMS IN BELGIUM. THE IS THAT THE VOTERS HAVING POINTED TO NO REALISTIC

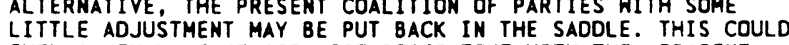
FUEL A NEW WAVE OF POPULIST DISCONTENT HITH THE APPARENT LOSERS REMAINING IN POHER, BUT THERE IS NO ALTERNATIVE.

03321 FITZMAURICE, J.

THE EXTREME RIGHT IN BELGIUM: RECENT DEVELOPMENTS PARLIAMENTARY AFFAIRS, 45(3) (JUL 92), 300-308.

THE EXTREME RIGHT IS ENJOYING A RESURGENCE IN MANY EUROPEAN COUNTRIES. BELGIUM IS NOT IMMUNE FROM THIS DEVELOPMENT, AS WAS EYIDENT IN THE MOVEMBER 1991 GEMERAL ELECTION. WHILE BELGIUM HAS BEEN PART OF A GENERALIZED TREND, 
IT HAS SHOWN SOME OUITE DISTINCT BELGIAN CHARACTERISTICS.

03322 FITZPATRICK, C.

HOW THE AUGUST COUP FAILED

NEW POLITICS, 3(4) (HIN 92), 42-29.

WHO WERE THE PEDPLE WHO MADE THE AUGUST REVOLUTION, WHAT KIND OF REVOLUTION WAS IT, AND HOW MANY OF THEM WERE THERE REALLY, ARE QUESTIONS THAT ARE ADDRESSED IN THIS ARTICLE. IT OBSERVES THAT RUSSIA'S PATH TO DEMOCRACY WILL BE A TORTUOU ONE, BUT THAT THE NATURE OF THE CROWD OUTSIDE THE RUSSIAN WHITE HOUSE SHOWS THAT MANY IMPORTANT FORCES ARE MORE THAN READY FOR IT. THE AUGUST COUP DECISIVELY SUNDERED WHAT WAS THE SOVIET UNION AND UNDERMINED ITS COMMUNIST CENTER. HHAT WILL REPLACE THEM IS NOT YET CLEAR. SUPPORT FOR YELTSIN'S RESISTANCE TO THE COUP PLOTTERS IS AN INDICATION THAT RUSSIA IS NOT ABOUT ABOUT TO MOVE BACKWARDS, EVEN THOUGH ITS MANY PEOPLES HAVE DIFFERENT, SOMETIMES CONFLICTING, IDEAS ABOUT HOW TO GO FORHARD.

03323 FITZPATRICK, J.

THE COLD WAR AND THE GEOPOLITICS OF EMBEDOED LIBERALISM INTERNATIONAL JOURNAL OF GROUP TENSIONS, 21(1) (SPR 91), $17-56$

THIS PAPER EXAMINES THE RELEVANCE OF THE GEOPOLITICAL AND IDEOLOGICAL DIVISIONS OF THE COLD WAR ERA FOR THE SOCIAL AND POLITICAL "EMBEDDING" OF THE LIBERAL INTERNATIONAL ECONOMY ESTABLISHED IN THE FIRST TWO DECADES AFTER WORLD WAR II. THE CONCEPT OF "EMBEDDED LIBERALISM" IS DERIVED IN THE FIRST INSTANCE FROM JOHN RUGGIE'S SEMINAL ARTICLE ON THIS THEME AND THE FORMAL AGENDA OF THIS PAPER IS DEFINED LARGELY BY THE AGENDA IDENTIFIED BY RUGGIE IN PARTICULAR AND THE BROADER NED-REALIST DEBATE ON "HEGEMONIC STABILITY," "INTERMATIONAL REGIMES," AND "COOPERATION AFTER HEGEMONY" IN GENERAL. THE AUTHOR FOLLOWS THIS DEBATE IN SEEKING TO THROUGH A COMPARISON WITH THE CONDITIONS UNDERPINNING THE MUCH MORE RESTRICTED LIBERAL ORDER ESTABLISHED UNDER THE 19IH CENTURY "PAX BRITANIICA."

03324 FITZROY, F.; ACS, Z.

THE NEW INSTIITUTIONAL ECONOMICS OF THE FIRM AND LESSONS FROM JAPAN

FROM JAPAN
JAPAN AND THE WORLO ECONOMY, 4(2) (SEP 92), 129-144.

THE PERVASIVE ROLE OF INFORMATION COSTS IN CONTRACTING FORMS THE BASIS OF THE NEW INSTITUTIONAL ECONOMICS OF THE FIRM. HILLIIAMSON, WHO PRESENTS THE MOST FULLY ARTICULATED DEFENSE OF THE EFFICIENCY OF CAPITALIST INSITUTIONS, QUICKLY DISMISSES JAPANESE FIRM ORGANIZATION AS CULTURALLY DETERMINED, AND HENCE WITHOUT LESSONS FOR THE WEST. IN FACT THERE IS MUCH EVIDENCE SUPPORTING IMPORTANT AND PRACTICAL LESSONS FROM JAPAN FOR AMERICAN AND OTHER WESTERN FIRMS.

03325 FLAHERTY, D.H.

PRIVACY, CONFIDENTIALITY, AND THE USE OF CANADIAN HEALTH INFORMATION FOR RESEARCH AND STATISTICS

CANADIAN PUBLIC ADMINISTRATION, 35(1) (SPR 92), 75-93.

CONCERN FOR PRIVACY AND CONFIDENTIALITY IS A STRATEGIC BARRIER TO THE USE OF PERSONAL INFORMATION FOR EXPANDED HEALTH RESEARCH AND STATISTICS, MORE EFFECTIVE SERVICES, AND BETTER USE OF RESOURCES IN CANADA. IN THIS PAPER, THE AUTHOR OUTLINES THE PRIVACY CONCERNS AND CONSIDERS VARIOUS RESPONSES. HE ARGUES THAT IT IS ESSENTIAL THAT LEGISLATION, POLICIES, AND PRACTICES GOYERNING A NATIONAL HEALTH INFORMATION SYSTEM INSURE A CLEAR, FUNCT IONAL SEPARATION BETWEEN RESEARCH AND/OR STATISTICAL AND ADMINISTRATIVE USES OF PERSOMAL DATA. THE NATIOMAL COUMCIL ON HEALTH INFORMATION SHOULD ACTIVELY PROMOTE THE ENACTMENT OF GENERAL DATA PROTECTION LEGISLATION FOR THE PUBLIC SECTOR IN THE CANADIAN PROVINCES WITHOUT SUCH LAWS, SINCE THE EXISTENCE OF SOUND DATA PROTECTION WILL FACILITATE THE DEVELOPMENT OF AN ADVANCED HEALTH INFORMATION SYSTEM UNDER CONTROLLED CONDITIONS.

03326 FLAMMANG, $R$.

BILATERAL BEGINS: BLESSING, BURDEN, OR BOTH? SCANDINAVIAN JOURNAL OF DEVELOPMENT ALTERNATIVES, $11(3)$ (SEP 92), 291-308.

THE INDIVIDUAL (THE SOCIO-CULTURAL PERSON) AND HIS OR HER REFERENCE GROUP IS TAKEN AS THE BASIC UNIT OF THIS

ANALYSIS. THIS PAPER EXPLORES: THE INDIVIDUAL, EXPERIMENTATION, AND CHANGE; THE GROUP, CONFORMITY, AND SECURITY; THE SURVIVAL VALUE OF INOIVIDUAL AND SOCIAL BEHAVIOR; HUMAN ROLES AND STRUCTURAL CHANGE; ECONOMIC
DEVELOPMENT; STATIC EFFICIENCY AND DYNAMIC EFFECIENCY; AND DEVELOPMENT; STATIC EFFICIENCY AND DYNAMIC EFFECIENCY; AND THE MEANING OF FREEDOM. II CONCLUDES THAT BILATERAL BEINGS CHANGE) AND BURDENED (WE NEVER KNOW WITH CERTAINTY HHEN TO CHANGE) AND BURDENED (WE NEVER KNOW WITH CERTAINTY WHEN TO
FAYOR ONE TYPE OF FREEDOM OVER THE OTHER). THE BOTTOM LINE FAYOR ONE TYPE
IS: IT WORKS.

03327 FLANAGAN, $S$.

NATO AND ' CENTRAL AND EASTERN EUROPE: FROM LIASON TO SECURITY PARTNERSHIP

WASHINGTON QUARTERLY, 15(2) (SPR 92), 141-152.
PEACE AND STABILITY IN THE EUROPE OF THE 1990S REMAIN VERY MUCH AT ISSUE, WITH THE YUGOSLAV CIVIL WAR STANDING AS A VIVID EXAMPLE OF THE POTENTIAL CONFLICTS TO COME. IN THE WAKE OF THE COLD WAR, QUESTIONS HAVE EMERGED ABOUT HOW TRADITIONAL INSTRUMENTS OF COLLECTIVE SECURITY CAND BE MODIFIED AND COMBINED WITH NEW POLITICAL AND ECONDMIC FACTORS. THIS ARTICLE QUESTIONS, IS THERE A CONTINUING ROLE FOR NATO? WHAT KIND OF RELATIONSHIP CAN OR SHOULD NATO ESTABLISH WITH NEWLY INDEPENDENT STATES IN CENTRAL AND EASTERN EUROPE? IT ALSO DISCUSSES THE POSSIBILITY OF EASTERN EUROPE? IT ALSO DISCUSSES THE POSSIBILITY OF
INTEGRATING THE NEWLY REFORMED USSR INTO THE ALLIANCE.

03328 FLEISCHMAN, J.

THE JOHNSON FACTOR

THE JOHNSON FACTOR
WEST AFRICA, (3884) (FEB 92), 315.

WHILE LIBERIA'S DIFFICULT' PEACE PROCESS IS COMMANDING THE ATTENTION OF INTERIM PRESIDENT AMOS SAWYER AMD MPFL LEADER CHARLES TAYLOR, INPFL LEADER PRINCE JOHNSON HAS REFUSED TO SUBMIT TO THE JURISDICTION OF THE INTERIM GOVERNMENT AND IS CONTINUING TO STIR UP TROUBLE. IN AN APPARENT EFFORT TO PROVE THAT THERE CAN BE NO PEACE WITHOUT HIM, JOHNSON IS INSERTING HIMSELF INTO THE PROCESS THE ONLY WAY HE KNOWS--BY KILLING, ARRESTING, AND ABUSING THOSE WHO ENTER THE TERRITORY HE CONTROLS.

03329 FLEISCHMANN, A.; GREEN, G.P.; KWONG, T.M. WHAT'S A CITY TÓ DO? EXPLAINING DIFFERENCES IN LOCAL ECONOMIC DEVELOPMENT POLICIES

WESTERN POL ITICAL QUARTERLY, 45(3) (SEP 92), 677-700.

THE AUTHORS RELY ON TWO THEORETICAL PERSPECTIVES AND A NATIONAL SAMPLE OF CITIES TO ANALYZE THE VARIATION IN LOCAL ECONOMIC DEVELOPMENT POLICIES. THE EVIDENCE SUGGESTS THAT BOTH BROADER ECONOMIC OR SOCIAL FORCES ("STRUCTURE") AND THE ACTIONS OF LOCAL POLITICAL AND ECONOMIC ACTORS ("AGENCY") INFLUENCE LOCAL ECONOMIC DEVELOPMENT EFFORTS. AMONG THE BEST PREDICTORS OF THE ECONOMIC DEVELOPMENT POLICIES ADOPTED BY A CITY ARE ITS TOTAL POPULATION, METROPOL ITAN STATUS, POVERTY LEVEL, PROPERTY TAX BURDEN, THE TYPE OF LOCAL ORGANIZATION LEVEL, PROPERTY TAX BURDEN, THE TYPE OF LOCAL ORGANIZATION
SERVING AS LEAD ACTOR IN PROMOTING ECONOMIC DEVELOPMENT, THE SERVING AS LEAD ACTOR IN PROMOTING ECONOMIC DEVELOPMENT, THE
ADOPTION OF AN ECONOMIC DEVELOPMENT PLAN, AND THE PRESENCE ADOPTION OF AN ECONOMIC DEVELOPMENT PLAN, AND THE PRES
OF A SPECIALIZED CITY AGENCY FOR ECONOMIC DEVELOPMENT.

03330 FLEISHER, R. BOND, J.

ASSESSING PRÉSIDENTIAL SUPPORT IN THE HOUSE II: LESSONS FROM GEORGE BUSH

AMERICAN JOURNAL OF POLITICAL SCIENCE, 36(2) (MAY 92), 525-541.

THIS PAPER USES PARAMETER ESTIMATES OF A REGRESSION MODEL OF CONGRESSIONAL SUPPORT OF PREVIOUS ADMINISTRATIONS TO FORECAST INDIVIDUAL MEMBERS' SUPPORT FOR BUSH IN 1989. THE FORECAST ERRORS REVEAL WHETHER A MEMBER'S ACTUAL LEVEL
OF SUPPORT IS HIGHER OR LOWER THAN SHOULD BE EXPECTED GIVEN OF SUPPORT IS HIGHER OR LOHER THAN SHOULD BE EXPECTED GIVEN
THE EFFECTS OF PARTY, IDEOLOGY, AND PUBLIC APPROYAL OF THE PRESIDENT. THE AUTHORS FIND THAT BUSH RECEIVED LESS SUPPORT FROM HOUSE MEMBERS THAN PREDICTED BY THE BASELINE MODEL. THE MEAN FORECAST ERROR IN 1989 WAS -1.77 . SUPPORT FROM REPUBLICANS WAS CONSIDERABLY LOWER THAN EXPECTED. LIBERAL DEMOCRATS WERE SLIGHTLY MORE SUPPORTIVE THAN PREDICTED, AND CONSERVATIVE DEMOCRATS AVERAGED NEARLY 10 POINTS HIGHER THAN EXPECTED. FURTHERMORE, FRIENDSHIP DID NOT PAY OFF IN ABNORMALLY HIGH SUPPORT SCORES.

03331 FLETCHER, C. ; WALSH, W.

REFORM OF INTERGOVERMMENTAL RELATIONS IN AUSTRALIA: THE POLITICS OF FEDERALISM AND THE NON-POLITICS OF MANAGERIALISM

PUBLIC ADMINISTRATION, 70(4) (WIN 92), 591-616.

A REMARKABLE PROCESS OF REFORM OF INTERGOVERMMEMTAL

ARRANGEMENTS WAS INITIATED IN AUSTRALIA IN 1990, DESIGNED TO IMPROVE NATIONAL EFFICIENCY AND INTERMAIIONAL IMPROVE NATIONAL EFFICIENCY AND INTERNATIONAL
COMPETITIVENESS AND TO IMPROVE THE DELIVERY AND QUALITY OF SERVICES GOVERNMENTS PROVIDE. THE PROCESS INTENTIONALLY WAS SERVICES GOVERNMENTS PROVIDE. THE PROCESS INTENTIONALLY WAS
CDOPERATIVE, INCORPORATING ALL STATE ADMINISTRATIVE CAPACITY, AND INCLUDING REPRESENTATIVES OF LOCAL GOVERNMENT. THIS ARTICLE POINTS BOTH TO THE VALUABLE INNOVATIONS EMBODI ED IN ITS PROCESSES, AND TO THE RISKS OF REDUCED POL ITICAL ACCESS ITS PROCESSES, AND TO THE RISKS OF REDUCED POLITICAL ACCES AND CITIZEN PARTICIPATION CREATED BY ITS ATTEMPTS TOSATS APP SINGLE-GOVERNMENT MANAGERIALIST PRINCIPLES TO THE RED
OF INTERGOVERMMENTAL ARRANGEMENTS IN FEDERAL SYSTEMS.

03332 FLICKINGER, R.; STUDLAR, D.

THE DISAPPEARING VOTERS? EXPLORING DECLINING TURNOUT IN THE DISAPPEARING VOTERS? EXPL
WESTERN EUROPEAN ELECTIONS

WEST EUROPEAN POL ELCS, 15(2) (APR 92), 1-16.

IN THE $1980 S$ VOTING TURNOUT HAS HELD STEADY OR DECLINED IN MOST COUNTRIES FOR NATIONAL AND WESTERM EUROPEAN ELECTIONS. A SERIES OF FACTORS BELIEVED TO AFFECT TURNOUT ARE IDENTIFIED FROM RECENT STUDIES OF POLITICAL PARTICIPATION. THEIR UTILITY FOR EXPLAINING THE RECENT EUROPEAN TURNOUT PATTERNS IS ASSESSED THROUGH REFERENCE TO JUDGEMENTS OFFERED BY ANALYSTS OF RECENT ELECTIONS, AND A SELECTIVE ANALYSIS OF EUROBAROMETER DATA. NONE OF THE PROPOSITIONS PURPORTING TO EXPLAIN THE PARADOX IS SUFFICIENT. 
03333 FLOOD, $8 . P$.

WHAT IS POLICY SHITCHING?

FINANCE AND DEVELOPMENT, 29 (3) (SEP 92), 33-35.

CHANGES IN ECONOMIC CONDITIONS AND POLICIES CREATE CHALLENGES FOR POLICY MAKERS IMPLEMENTING THE CHANGES, FOR ORDINARY CITIZENS AND BUSINESSES THAT MUST COPE WITH THE CHANGES, AND FOR RESEARCHERS ATTEMPTING TO MODEL AND EXPLAIN BEHAVIOR AFTER-THE-FACT. THIS ARTICLE EXAMINES PRIVATE RESPONSES TO POLICY SWITCHING BY THE GOVERNMENT, WITH A BRIEF LOOK AT SHITCHING IN THE PRIVATE SECTOR.

03334 FLORKOWSKI, W.J.; MCNAMARA, K.T. POLICY IMPLICATIONS OF ALCOHOL AND TOBACCO DEMAND IN POLAND JOURNAL OF POL ICY MODELING, 14(1) (FEB 92), 93-98.

THIS STUDY USES A CONSUMER DEMAND FRAMEWORK TO EXAMINE THE IMPLICATIONS OF ALCOHOL AND TOBACCO CONSUMPTION IN POLAND. IT INCLUDES A DISCUSSION OF POTENTIAL CONFLICTS BETWEEN POLICIES AIMED AT REDUCING ALCOHOL AND TOBACCO CONSUMPTION AND THE IMPORTANCE OF REVENUE FROM ALCOHOL AND TOBACCO SALES TO THE NATIONAL BUDGET. THE LONG-TERM POLICY SHOULD LEAD TO INCREASED ECONOMIC ACTIVITY THAT LESSENS THE IMPORTANCE OF ALCOHOL AND TOBACCO SALES AS A SOURCE OF GOVERMMENT REVENUE.

03335 FOGARTY, M.

THE CHURCHES AND PUBLIC POLICY IN BRITAIN POLITICAL QUARTERLY (THE), 63(3) (JUL 93), 301-316. THIS PAPER TAKES UP THE CHALLENGE IMPLIED IN THE CONCLUSIONS OF JOHN WHYTE'S "CATHOL ICS IN WESTERN DEMOCRACIES." THE PAPER EXAMIMES CLOSE ORDER IN THE CLASSIC COUNTRIES OF CHRISTIAN DEMOCRACY AND DETERMINES THAT THERE ARE THREE MAIN AND CONNECTED REASONS WHY 'CLOSE ORDER' DEVELOPED AND PERSISTED MORE STRONGLY IN THE CLASSIC COUNTRIES OF CHRISTIAN DEHOCRACY THAN IN BRITAIN: DEFENSE IN THE FACE OF CONFLICT BETHEEN CHURCH AND STATE; THE DEVELOPMENT OF A DISTINCTIVE POLITICAL AND SOCIAL IDEOLOGY AND EDUCATION OF THE AUDIENCE TO RECEIVE AND AMPLIFY THE MESSAGE WHICH THE IDEOLOGY CONVEYED.

03336 FOLEY, $P$.

LOCAL ECONOMIC POLICY AND JOB CREATION: A REVIEW OF EVALUATION STUDIES

URBAN STUDIES, 29(2) (APR 92), 557-598.

THIS PAPER FOCUSES ON A NUMBER OF LEADING EVALUATION STUDIES THAT EXAMINE MAJOR BRITISH ECONOMIC POLICY INITIATIVES, SUCH AS THE URBAN PROGRAM, ENTERPRISE ZONES, AND THE REGIONAL ENTERPRISE GRANTS. THE TYPES OF SCHEMES EVALUATED IN THESE STUDIES RANGE FROM LARGE INFRASTRUCTURE PROJECTS TO SMALL TRAINING PRDJECTS COSTING ONLY A FEW THOUSA S O SMALL TRAINING PRDSECTS COSTING ONLY A FEH THOUSAMD POUNDS. THATMING PRDJECTS COSTHNG ONEY EVALUATION STUDIES COMPLETED IN THIS FIELD, THE EMPHASIS IS PRIMARILY ON EMPLOYMENT GROWTH AND JOB CREATION. THIS PAPER IS DIVIDED INTO TWO PARTS. PART I CONSIDERS THE BACKGROUND

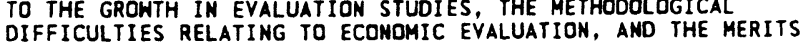
DIFFICULTIES RELATING TO ECOMOMIC EVALUATION, AND THE MERITS OF USING JOB CREATION AS A MEASURE OF SUCCESS IN EVALUATION COMPLETED IN THE LAST EIGHT YEARS.

03337 FOLEY, T

YUGOSLAVIA

POLITICAL AFFAIRS, 71(12) (DEC 92), 32-37.

IN ORDER TO UNDERSTAND WHAT IS GOING ON IN YUGOSLAVIA IT IS NECESSARY TO LOOK NOT ONLY AT YUGOSLAVIA ITSELF, BLT

BEYOND ITS BORDERS AS HELL. THE AUTHOR SUGGESTS THAT

YUGOSLAVIA IS LIKE A PIECE IN A GIANT PUZZLE AND IT TRIES TO EXPOSE THE MAIN PIECES OF THE PUZZLE AND SUGGESTS HOH THEY MIGHT FIT TOGETHER. IT EXPLORES OLD PATTERNS WHICH ARE REEMERGING AND THE GERMAN LURCH TO THE RIGHT. THE DIVIDING OF YUGOSLAYIA, THE FEAR OF GENOCIDE, AND U.S. POLICY ARE EACH ANALYZED, AS WELL AS THE INFLUENCE OF THE WEST. IT CONCLUDES THAT THERE IS A THREAT OF MILITARY INTERYENTION FROM THE OUTSIDE.

03338 FONOAHL, G.A.

AFTER THE BREAKUP: ROOTS OF SOVIET DIS-UNION

CULTURAL SURVIVAL QUARTERLY, 16(1) (WIN 92), 18-20.

THE AUTHOR LOOKS AT THE PERSISTENCE OF NATIONALISM AS A

FORCE WITHIN THE SOVIET UNION AND AS AN IMPETUS FOR

INDEPENDENCE AS THE SOVIET UNION BEGAN TO DISINTEGRATE.

03339 FONG, L.Y.

THE IMPACT OF THE COLD WAR ON THE OEVELOPMENT OF TRADE THE IMPACT OF THE COLD WAR ON

JOURMAL OF SOUTHEAST ASIAN STUDIES, 23(1) (MAR 92) 60-73.

IN THE AFTERMATH OF WORLD WAR II, MALAYA EXPERIENCED THE EMERGENCE OF THE MALAYAN COMMUNIST PARTY (MCP) AND AN ATTEMPT TO MOBILIZE LABOR SUPPORT AGAINST THE RETURHING BRITISH COLONIAL GOVERMMENT. THE PAN MALAYAN GENERAL LABOR UNION (PMGLU) WAS ESTABLISHED AS A FRONT ORGANIZATION TO HARNESS MULTI-RACIAL LABOR SUPPORT AND TO WORK IN CLOSE LIAISON WITH OTHER LEFT-WING POLITICAL GROUPS. IN 1948, THE MCP TURNED TO ARMED REVOLUTION, FOLLOHING WHICH A STATE OF
WERE SUPPRESSED. THIS PAPER EXAMINES THE PROCESS OF REBUILDING THE TRADE UNION MOVEMENT DURING THE EMERGENCY AND THE CIRCUMSTANCES AND CONDITIONS THAT SURROUNDED THE PROCESS THE "NEW TRADE UNIONISM" THAT EVOLYED DURING THE EMERGENCY WAS DESIGNED TO COMBAT COMMUNISM BOTH INSIDE AND OUTSIDE MALAYA, AND TRADE UNION DEVELOPMENTS WERE SUBORDINATED TO THE POI ITICAL INTERESTS OF THE COLONIAL GOVERNMENT. TRADE UNIONISM DURING THE EMERGENCY WAS, IN FACT, RELATED TO THE OYERAL STRATEGY OF CONTAINING THE ROLE OF THE MCP AMD THE INFLUENCE OF THE WORLD FEDERATION OF TRADE UNIONS.

03340 FONTAINE, R.W.

THE PHILIPPINES: AFTER AQUINO

ASIAN AFFAIRS, AN AMERICAN REVIEH, 19(3) (FAL 92), 170-190.

THE AUTHOR EXAMINES THE LEGACY OF PRESIDENT CORAZON

AQUINO'S ADMINISTRATION AND SPECULATES ABOUT THE PROSPECTS

FOR THE FUTURE OF THE PHILIPPINES.

03341 FOOT, $R$.

NEW LIGHT ON THE SINO-SOVIET ALLIANCE: CHINESE AND AMERICAN PERSPECTIVES

JOURNAL OF NORTHEAST ASIAN STUDIES, X(3) (FAL 91), 16-29. HITH THE PARTIAL OPENING OF DOCUMENTARY RECORD IN THE UNITED STATES AND A WILLINGNESS ON THE PART OF CHINESE OFFICIALS AND RESEARCHERS TO GIVE A MORE CONSIDERED ASSESSMENT OF THEIR COUNTRY'S RELATIONSHIP WITH THE SOVIET UNION IN THE 1950S, THE VALUE OF THE SINO-SOVIET ALLIANCE TO BEIJING CAN NOW BE BETTER DETERMINED. THIS ARTICLE DISCUSSES BEIJING CAN NOW BE BETTER DETERMINED. THIS ARTICLE DISCUSSES RECENT CHINESE ANALYSIS WHICH DEMONSTRATES THAT THE BEIJIM ECONOMIC BENEFIT FROM THE ALLIANCE UNTIL 1958-59.

03342 FORBES, $J$.

THE HISPANIC SPIN: PARTY POLITICS AND GOVERMMENTAL MANIPULATION OF THE ETHNIC IDENTITY

LATIN AMERICAN PERSPECTIVES, 19(75) (FAL 92), 59-78. HISPANIC AND REPUBLICAN STRATEGIES HAVE PROVEN

DISASTROUS FOR CHICANO-MEXICANOS, PUERTO RICANS, AND LATIM AMERICANS IN GENERAL. THIS ARTICLE SUGGESTS THAT THE REPUBLICAN PLAN FOR FREE TRADE WITH MEXICO AND CENTRAL AMERICAN PROMISES TO LITERALLY WIPE OUT THE JOBS REMAINING FOR MOST LOW-INCOME "RAZA" IN THE UNITED STATES. IT CONCLUDES THAT THE USE OF THE REPUBLICAN'S SPANISH EMPIRE CATEGORY HAS BLUNTED ACTIVISM AND ALLOHED THE PARTY TO HELP THE RICH AND POWERFUL AT THE EXPENSE OF THE COMMON PEOPLE.

03343 FORD, J.

JAPAN-U.5. RELATIONS: AFTER THE LOVE HAS GONE JAPAN TIMES (WEEKLY INTERNATIONAL EDITION), 32(11) (MAR $92), 3$.

RECENT CRITICISM BY JAPANESE LEADERS OF TRENDS IN U.S. SOCIETY HAS PROMPTED SOME AMERICANS TO ACCUSE JAPAN OF FEELING SUPERIOR TO ITS POSTWAR ROLE MODEL. HOWEVER, CRITICISM FROM JAPAN MAY SIMPLY REFLECT THE NATION'S

EMERGENCE FROM A LONG-STANDING INFERIORITY COMPLEX TOWARD

03344 FORD, $J$

PM'S YISIT UMDERSCORES ANIMOSITY

PM'S VISIT UNDERSCORES ANIMOSITY 1,6 .

JAPANESE PRIME MINISTER'S KIICHI MIYAZAWA'S JANUARY 1992 VISIT TO SEOUL UNDERSCORED THE OIFFICULTY JAPAN FACES IN OVERCOMING OLD ANIMOSITIES AS IT SEEKS A LEADERSHIP POSITION IN WORLD AFFAIRS. MIYAZAWA AND SOUTH KOREAN PRESIDENT ROH TAE WOO MADE PROGRESS ON SOME ISSUES, INCLUDING THE TRADE IMBALANCE AND JAPAN'S WARTIME PRACTICE OF FORCING KOREAN WOMEN TO PROVIDE SEXUAL SERVICES FOR THE IMPERIAL ARMY. B THE DAY OF REAL POLITICAL COOPER

03345 FORDE, $S$.

BENJAMIN FRANKLIN'S "AUTOBIOGRAPHY" AND THE EDUCATION OF AMERICA

AMERICAN POLITICAL SCIENCE REVIEW, 86(2) (JUN 92), 357-368.

BEN JAMIN FRANKLIN'S "AUTOBIOGRAPHY" WAS HRITTEN, IN PART, TO PROVIDE A MODEL FOR THE EMERGING DEMOCRATIC INDIVIDUAL AND FOR THE DEMOCRATIC CULTURE OF AMERICA. IN THIS ESSAY, THE AUTHOR STUDIES FRANKLIN'S PRESENTATION OF THE RELATIONSHIP BETWEEN HEALTH AND VIRTUE, HIS UTILITARIANISM, AND HIS VISIDN OF DEMOCRATIC SOCIETY. THE AUTHOR FINDS A SUBTLE YET ROBUST IDEAL DEFTLY CALCULATED TO EDUCATE AND ELEVATE AMERICAN CULTURE.

03346 FORDE, $S$.

VARIETIES OF REALISM: THYCYDIDES AND MACHIAVELLI

THE JOURMAL OF POLITICS, 54(2) (MAY 92), 372-394.

THE AUTHOR EXPLORES THE THOUGHT OF THUCYDIOES AND MACHIAVELLI HITH SPECIAL ATTENTION TO THEIR VIEWS OF THE RELATION OF INTERNATIDNAL REALISM TO GENERAL ETHICAL RELATION OF INTERNATIDNAL REALISM TO GENERAL ETHICAL
SKEPTICISM AND TO DOMESTIC POLITICS IN PARTICULAR. EXAMINING SKEPTICISM AND TO DOHESTIC POLITICS IN PARTICULAR. EXAMINI THEIR RESPECTIVE VIENS OF INTERNATIONAL REALISH, OF THE AND AMORAL NECESSITY, HE CONCLUDES THAT WHILE FOR 
MACHIAVELLI INTERNATIONAL REALISM IS ONLY A PART OF A MORE GENERAL ETHICAL SKEPTICISM. THYCYDIDES TRIES TO MANAGE A DIFFICULT OF NOT TRAGIC TENSION BETWEEN THE REQUIREMENTS OF INTERNATIONAL REALISM AND DOMEWTIC MORALITY.

03347 FOREMAN, A.

ROMANIA: THE ABILITY TO SURPRISE

HORLD TODAY, 48(8-9) (AUG 92), 166-168.

ROMANIA HAS AGAIN BEEN DEMONSTRATING WHAT SEEMS TO BE A LACK OF ENTHUSIASM FOR DEMOCRACY. THE DOMINANT POSITIONS RETAINED BY FORMER COMMUNISTS, THE SNAIL'S PACE OF ECONOMIC PRIVATIZATION, AND THE LOGJAM OF REFORM LEGISLATION DELAYED BY PARL IAMENT HAVE LED TO A CONVENTION VIEW OF ROMANIA AS A BASKET CASE AMONG EMERGING DEMOCRACIES. BUT ROMANIA IS A COUNTRY KNOWN FOR THE UNEXPECTED, AND ITS UNDERLYING POSITION ITS HEALTHIER THAN ITS STUNTED ACHIEYEMENTS INDICATE.

03348 FORGUS, $S$

SOVIET SUBVERSIVE ACTIVITIES IN INDEPENDENT ESTONIA (19181940

JOURMAL OF BALTIC STUDIES, 23(1) (SPR 92), 29-46.

EVEN THOUGH THE DECLARATION OF ESTONIAN INDEPENDENCE OCCURRED IN 1918, LENIN HAD BY NO MEANS GIVEN UP ON PLANS TO SOVIETIZE ESTONIA LATER, OVER A PERIOD OF 22 YEARS THE SOYIET GOVERMMENT EXPLORED EVERY AVENUE OF SUBVERSION. THEY USED PROPAGANDA, ORGANIZED STRIKES \& DEMONSTRATIONS INFILTRATED LEGITIMATE ORGANIZATIONS AND ASSOCIATIONS, USED ESPIONAGE, BRIBERY, EXTORTION AND BLACKMAIL. FINALLY THEY USED INTIMIDATION AND MILITARY FORCE. 1939 MARKED THE END OF
ESTONIAN INDEPENDENCE.

03349 FORJE, J.

THE ROLE AND EFFECTIVENESS OF NATIONAL SCIENCE AND TECHNOLOGY POL ICY-MAKING BODIES IN AFRICA JOURNAL OF ASIAN AND AFRICAN STUDIES, XXVII(I) (JAN 92), $12-30$

THIS PAPER PRESENTS AN OVERVIEH OF SCIENCE AND TECHNOLOGY POLICY IN AFRICA AS IT HAS DEYELOPED FROM THE LAGOS PLAN FOR SCIENTIFIC RESEARCH AND TRAINING IN 1964 THROUGH THE ARUSHA PLAN OF ACTION IN 1987. THE ANALYSIS USES THE RECOMMENDATIONS OF THESE AND OTHER INTERVENING CONFERENCES AS THE STARTING POINT FOR DISCUSSING THE SHIFTS IN NATIONAL SCIENCE AND TECHNOLOGY POLICIES, THEIR IMPACTS ON AFRICAN SOCIETY AMD ECONOMY AND THE REOUIRED CHANGES IN POLICY STRUCTURES AND PROCESSES.

03350 FORMAN, $M$

ON SOCIALISM AND THE MULTICULTURAL SOCIETY

NEW POLITICS, IV (1) (SUM 92), 41-48,

DRAWING ON THE HORKS OF OTTO BAUER AND OTHERS, THIS ARTICLE ARGUES THAT ALTHOUGH CAPITALISM IS INTERNATIONALLY TRIUMPHANT, SOCIALISM IS MORE NECESSARY THAN EVER. THE NEH SOCIAL MOVEMENTS HAVE REMAINED TRUER TO THE OLD PRINCIPLES (DEMOCRACY, SOCIALLY RESPONSIBLE DEVELOPMENT, HUMAN DIGNITY, THE FREE DEVELOPMENT OF EACH AS THE PRECONDITION FOR THE DEVELOPMENT OF ALL) THAN SIGNIFICANT PORTIONS OF THE OLD LEFT. YET, THEIR EFFECTIVENESS AS PROGRESSIVE MOVEMENTS IS LIMITED BY THE VERY CONDITIONS THAT MAKE THEM POSSIBLE. ON THE OTHER HAND, A NEH SOCIALIST MOVEMENT HOULD HAVE TO PROMOTE INTERNATIONALISM BY BUILDING AND EDUCATING IN MULTICULTURAL SOCIETIES. THIS ENTAILS TAPPING INTO THE VERY COMMUNITIES OF FATE THAT UNDERLIE THE POLITICS OF IDENTITY.

03351 FORRESTER, J.P.; MULLINS, D.R. REBUDGETING: THE SERIAL NATURE OF MUNICIPAL BUDGETARY PROCESSES

PUBLIC ADMINISTRATION REVIEW, 52(5) (SEP 92), 467-473. "REBUDGETING" IS A COMMON AND SIGNIFICANT' FACTOR IN THE BUDGETING PROCESSES OF MANY CITIES. WHILE OFTEN REGARDED BY OFFICIALS AS MERELY AN EXTENSION OF THE NORMAL BUDGETARY PROCESS, THE REBUDGETING PROCESS IS LESS VISIBLE AND MORE TECHMICALLY-DRIVEN, GIVING A GREATER ROLE TO ADMINISTRATORS THAN TO THE PUBLIC OR THE LEGISLATORS. THE PROCESS IMPACTS DIFFERENTLY ON DIFFERENT SERYICES.

03352 FORSBERG, $R$.

A NEW HORLD ORDER? FROM ABOYE OR FROM BELOH PEACE \& DEMOCRACY NEWS, 11(2) (WIN 92), 6-8. A NEW KIND OF PEACE MOVEMENT HAS BEEN BORN WHICH SUGGESTS THAT ONE CAN NOT RELY ON EXISTING GOVERMENTS OR POWER STRUCTURES TO ACHIEVE A LASTING PEACE. THIS AUTHOR SUGGESTS THAT TODAY'S POLITICIANS AND PUNDITS DEFEND A HIGHLY UNDEMOCRATIC, INEOUITABLE, AND MILITARIZED GLOBAL ORDER. THE ISSUE OF HHO MAKES SECURITY AND ECONOHIC ORDER. THE ISSUE OF HHO MAKES SECURITY AND ECONOHIC
DECISIONS IS AT THE HEART OF THE QUESTION OF ACHIEVING A DECISIONS IS AT THE HEART OF THE QUESTION OF ACHIEVING A
JUST AND DURABLE PEACE. THE ERUPTION OF CONFLICTS AROUND THE HORLD SINCE 1989 HAS PROMPTED PEOPLE CONCERNED HITH PEACE HORLD SINCE 1989 HAS PROMPTED PEOPLE CONCERNED HITH PEACE AND JUSTICE TO CONSIDER THE NEED FOR ACTION BY THE NATIONS AND REGIONAL BODIES. DEMOCRATIC CONTROL OF
TRANSNATIONAL INSITITUTIONS IS VITAL IN THE AREA OF POLITICS AND SECURITY; IT IS EQUALLY URGENT IN THE ECONOMIC SPHERE.
03353 FORSBERG, R

WHY COOPERATIVE SECURITY? WHY MOH?

PEACE \& DEMOCRACY NEWS $11(2)$ (WIM 92 ), 9-14.

THE END OF THE COLD WAR OFFERS AN HISTORIC OPPORTUNITY TO MOVE FROM A MILITARIZED, UINILATERAL APPROACH TO SECURITY TO A DEMILITARIZED, COOPERATIVE APPROACH. THIS ARTICLE MAKES A CASE FOR A SUSTAINED INTERNATIONAL EFFORT, LASTING 10-20 YEARS, TO DEVELOP A FULL-FLEDGED COOPERATIVE SECURITY SYSTEM. IT SKETCHES OUT THE CHARACTER OF SUCH A SYSTEM, AND IDENTIFIES KEY PHASES IN MOVING FROM EXISTING MILITARY AND ARMS CONTROL ARRANGMENTS TO MORE COOPERATIVE ARRANGEMENT. THE FINAL SECTIONS CONTRAST THE BENEFITS OF MOVING TOWARO COOPERATIVE SECURITY WITH THE COSTS AND RISKS OF

PERPETUATING THE CURRENT MILITARY SYSTEM.

03354 FORSTER, N.R. PROTECTING FRAGILE LANDS: NEW REASONS TO TACKLE OLD PROBLEMS

WORLD DEVELOPMENT, 20(4) (APR 92), 571-585.

PAST EFFORTS TÓ EXPAND THE PEASAMTRY'S IAND BASE THROUGH REDISTRIBUTIVE LAND REFORM AND COLONIZATION GENERALLY LACKED AN ENVIRONMENTAL DIMENSION AND OFTEN INTENSIFIED RESOURCE DEGRADATION. MOST AGRARIAN REFORM INTERVENTIONS WERE LIMITED DEGRADATION. MOST AGRARIAN REFORM INTERVENTIONS WERE LIMITED TO PROPERTIES WITH MARGIMAL AGRICULTURAL POTENTIAL, WHILE COLONIZATION (OIRECTED AND SPONTANEOUS) TRIGGERED EXTENSIVE DEFORESTATION AND RESOURCE DEGRADATION. BUT INCREASING PEASANT ACCESS TO ARABLE LAND CAN HAVE A POSITIVE ENVIRONMENTAL IMPACT. PROGRAMS TO INCREASE SUCH ACCESS CAN BE TARGETED TO DRAH PEASANT FARMERS AWAY FROM STEEP SLOPES IN CRITICAL WATERSHEDS AND TO REDUCE THEIR MIGRATION TO SPECIFIED LOWLAND FORESTS. THE PROGRAMS REVIEWED IN THIS PAPER DEPEND ON STRATEGIC INTERVENTIONS TO SUPERSEDE CURRENT MARKET IMPERFECTIONS LIMITING PEASANT ACCESS TO LARGE ARABLE PROPERTIES.

03355 FORSYTHE, D.

DEMOCRACY, WAR, AND COVERT ACTIOH

JOURNAL OF PEACE RESEARCH, 29(4) (NOV 92), 385-396.

IT IS WELL ESTABLISHED THAT STABLE INDUSTRIALIZED DEMOCRACIES DO NOT USE OVERT FORCE AGAINST EACH OTHER. BUT DO DEMOCRACIES EVER USE COVERT FORCE AGAINST OTHER ELECTED GOVERNMENTS? THIS ARTICLE CONFIRMS THE U.S. THREAT OR USE OF FORCIBLE COVERT ACTION AGAINST A SERIES OF ELECTED NONEUROPEN GOVERMMENTS DURING THE COLD WAR: IRAN, GUATEMALA, INDONESIA, BRAZIL, CHILE, AND NICARAGUA. THREE TYPES OF
ANALYSIS ARE OFFERED FOR THIS PATTERN. ONE EXPLANATION IS ANALYSIS ARE OFFERED FOR THIS PATTERN. ONE EXPLANATION IS
THAT THE TARGETED REGIMES DID NOT QUALIFY AS MATURE LIBERAL THAT THE TARGETED REGIMES DID NOT OUALIFY AS MATURE LIBERAL
REGIMES SHOWIMG THE CHARACTERISTIC OF NEO-KANTIAN LIBERALSM.

03356 FORSYTHE, D. HUMAN RIGHTS, THE UNITED STATES AND THE ORGANIZATION OF AMERICAN STATES

HUMAN RIGHTS QUARTERLY, 13(1) (FEB 91), 66-98.

THIS ARTICLE EXAMINES A PARADOX IN THE WESTER

HEMISPHERE: THE DEVELOPMENT OF HUMAN RIGHTS NORMS AND PRACTICES IN THE ORGANIZATION OF AMERICAN STATES (OAS) AND THE WIDESPREAD ABUSE OF HUMAN RIGHTS AMONG OAS MEMBER STATES, IT EXAMINES THE CREATION AND DEVELOPMENT OF THE OAS AND THE CONCURRENT EVOLUTION OF A HUMAN RIGHTS REGIME SECDND ONLY TO THE COUNCIL OF EUROPE. IT THEN SEEKS TO DETERMINE WHY THERE LACKS THE UNDERLYING COMMITMENT TO IMPLEMENTING RIGHTS.

03357 FOSSEDAL, G.

THE LEHRMAN-MUELLER HYPOTHESIS: A NEW THEORY OF DEFICITS, STAGFLATION, AND MONETARY DISORDER

POLICY REVIEW, (59) (WIN 92), 71-81.

THE AUTHOR DISCUSSES THE ÉCONOMIC RECESSION OF THE BUSH PRESIDENCY AND LOOKS FOR AN EXPLANATION OF WHY THE ECONOMY FAILED TO PERFORM UP TO EXPECTATIONS.

03358 FOSTER, C.

IS THE TRIANGLE STILL GOLDEN? THE POLITICS OF OPIUM AND THE NEW REGIME IN THAILAND

CONTEMPORARY REVIEW, 260(1516) (MAY 92), 244-248.

OPIUM CULTIVATION IN THE GOLDEN TRIANGLE IS A RELATIVELY NEW INDUSTRY. CHIEF AMONST ITS ARCHITECTS WAS KHUN SA, THE GREAT OPIUM WARLORD OF SOUTH EAST ASIA WHO HAS BEEN A MASTER BUSINESS MAN. AFTER REVIEWING THE HISTORY OF THE OPIUM INDUSTRY, THIS ARTICLE EXPLORES THE INYOLVEMENT OF THE UNITED STATES, BOTH AS A SUPPORTER OF OPIUM GROWING AND LATER, AS A SUPPRESSOR OF THE INDUSTRY. THE THAI GOVERNMEN IS IN AN IMPOSSIBLE POSITION. IF IT DOES NOT STAMP ON
NARCOTICS TRADE THE WEST WILL NOT SMILE AS BROADLY AS NARCOTICS TRADE THE WEST WILL NOT SMILE AS BROADLY AS
THAILAND WANTS IT TO. IF IT DOES CUT DOWN KHUN SA IT WILL THAILAND WANTS IT TO. IF IT DOES CUT DOWN KHUN SA IT WILL
FORCE NORTHERN THAILAND INTO ENVIRONMENTALLY DISTASTEFUL FORCE NORTHERN THAILAND INTO ENVIRONMEMTA
POLICIES WHICH WILL ALIENATE THE WEST.

03359 FOSTER, C.

WHO WON THE WAR? GREED, SCHISM AND THE PARTY FAITHFUL IN VIETNAM

CONTEMPORARY REVIEW, 261(1522) (NOV 92), 240-241

THE HANOI REGIME COULD SOON BE IN SERIOUS TROUBLE. THE

DANGER IS OF A NATIONS SPLIT ALONG THE OLD NORTH-SOUTH

DIVIDE, WITH HEDONISTIC SAIGON AS THE CAPITAL OF THE SOUTH, 
OR ONE SPLIT INTO A THOUSAND PETTY FEUDAL BARONIES. THE COUNTRY IS ONE OF THE POOREST NATIONS ON EARTH. THIS ARTICLE EXPLORES THE CHOICES WHICH HANOI FACES IN THE SITUTIOH. THE AUTHOR SUGGESTS THAT PRESENT GREED AND FUTURE RICHES SPEAK AUTHOR SUGGESTS THAT PRESENT GREED AND FUTURE RICHES SPEAK SMALL, CHAUVINISTIC NATION STATES.

03360 FOSTER, G.

WARRIORS IN THE "NEW WORLD ORDER"

SOCIETY, 29(6) (SEP 92 ), 28-33.

WITH THE PASSAGE OF TIME AND THE ADVANCE OF TECHNOLOGY THE TERM WARRIOR HAS BECOME PROGRESSIVELY MORE OBSCURE IN MEANING, AND THE CORPOREAL WARRIOR MORE SYMBOL THAN REALITY. THIS ARTICLE SUGGESTS THAT THERE CAN BE LITTLE DOUBT THAT THE WARRIOR REFLECTS TRAITS THAT ARE HIGHLY DESIRABLE FOR HIM, BUT MAY HAVE LITTLE OR NO REDEEMING VALUE OUTSIDE THE PROFESSION OF ARMS. HE ATTEMPTS TO EXPLAIN WHY THE WARRIOR IMAGE HAS SUCH ALLURE FOR AMERICANS, EVEN THOUGH WE ARE NOT KNOWN AS A PARTULARLY MILITARISTIC PEOPLE. THE WARIOR IDEAL IS ATTRACTIVE AND RESILIENT BECAUSE IT IS A PHYSICAL CONCEPTION THAT PLAYS ON THE EMOTIONS. RECOURSE TO VIOLENCE BECOMES EVER MORE PALATABLE AS TIME AND TECHMOLOGY INCREASE THE DISTANCE BETWEEN KILLER AND KILLED. UNTIL SUCH TIME AS THE PHILOSOPHE-THE PERSON OF IDEALS COMMITTED TO APPLYING THOSE IDEALS TO THE REALM OF HUMAN AFFAIRS--DISPLACES THE THOSE IDEALS TO THE REALM OF HUMAN AFFAIRS-DISPLACES THE
WARRIOR AS OUR ROLE MOOEL, WE WILL NEVER RISE ABOVE OUR WARRIOR AS OUR ROLE MOOEL, WE WILL NEVER RISE ABOVE OUR LOVELY STATION IN LIFE NOR ESCAPE THE BARBAR
EXISTENCE WE HAVE INHERITED AND SUSTAINED.

03361 FOSTER, J.E. WOMEN AS A CLASS UNDER SECTION 1985(3): A REALISTIC APPROACH

OURNAL OF LAW \& POLITICS, VIII(4) (SUM 92), 781-812.

THE AUTHOR STUDIES THE ISSUE OF WHETHER WOMEN SEEKING ABORTIONS SHOULD BE PROTECTED UNDER SECTION 1985 (3) FROM GROUPS, SUCH AS OPERATION RESCUE, THAT BLOCKADE ABORTION CLINICS. THE ESSAY BEGINS WITH A SHORT HISTORY OF OPERATION RESCUE AND EXPLAINS WHY IT REMAINS A THREAT DESPITE $A$ DECLINE IN THE POWER OF THE NATIONAL ORGANIZATION. PART II SKETCHES THE ORIGIMAL INTENT OF THE RECONSTRUCTION CONGRESS THAT PASSED SECTION 1985(3) AND SHOWS THAT IT DID NOT INTEND TO LIMIT APPLICATION TO BLACKS AND WHITE REPUBLICANS. PART III DISCUSSES THE SUPREME COURT'S NARROW INTERPRETATION OF THE SECTION AND THE CONCERNS ABOUT UNLEASHING A FLOOD OF LITIGAT:ON. PART IV EXPLAINS WHY WOMEN ARE ENTITLED TO THE PROTECTION OF SECTION 1985(3). PART $V$ ARGUES THAT THE COURT SHOULD ADOPT A STANDARD EXTENDING SECTION 1985(3) PROTECTION TO GROUPS LIKE WOMEN THAT POSSESS AN IMMUTABLE

CHARACTERISTIC AND HAVE BEEN THE SUBJECTS OF HISTORICALLY-

CHARACTERISTIC AND HAVE BEEN THE SUBJECTS OF HISTORICALLY-
PERVASIVE DISCRIMINATION. SUCH A STANDARD WOULD REMOVE THE

PERVASIVE DISCRIMINATION. SUCH A STANDARD WOULD REMOVE THE UNCERTAINTY FROM THE CURRENT CLASS-BASED ANIMUS STANDARD AMD WOULT SUBSTANTI

03362 FOSTER, S.A.; GORR, W.L.

FEDERAL HEALTH CARE POLICY AND THE GEOGRAPHIC DIFFUSION OF PHYSICIANS: A MACRO-SCALE ANALYSIS

POLICY SCIENCES, 25(2) (MAY 92), 117-134.

IN THE 1960'S AND 1970'S, THE FEDERAL GOVERMMENT PASSED LEGISLATION TO INCREASE THE NUMBER OF PHYSICIANS AND REDUCE SPATIAL INEQUALITIES IN ACCESS TO PHYSICIANS. A MAJOR GOAL WAS TO AGGRESSIVELY INCREASE THE OVERALL SUPPLY OF PHYSICIANS ON THE ASSUMPTION THAT MARKET FORCES WOULD EVENTUALLY DIVERT PHYSICIANS FROM AREAS OF HIGH-PHYSICIAN DENSITY TO THOSE OF LOW DENSITY. USING STATE-LEVEL, ANHUAL DATA COLLECTED OVER A 21-YEAR PERIOD, THIS PAPER INVESTIGATES THE MACRO-SCALE SPATIAL' DIFFUSION OF PHYSICIANS AS AN ESSENTIAL ELEMENT IN EVALUATING THIS POLICY. THE RESULTS PROVIDE EVIDENCE THAT THE POLICY IMPACTED LOCATIONAL TRENDS RELATIMG TO PRIMARY CARE PHYSICIANS BUT NOT SPECIALISTS. THEY ALSO INDICATE THAT THE MEDICAID AMD MEDICARE PROGRAMS MAY HAVE ADVERSELY AFFECTED THE MALDISTRIBUTION PROBLEM.

03363 FOSU, A.

EFFECT OF EXPORT INSTABILITY ON ECONOMIC GROWTH IN AFRICA JOURNAL OF DEVELOPING AREAS, 26(3) (APR 92), 301-322.

THIS STUDY CONCENTRATES ON AFRICAN (AND SUB-SAHARAN AFRICAN) LDCS AS A GROUP AND EXAMINES THE EFFECT, IF ANY, THAT EXPORT INSTABILITY MAY HAVE HAD ON THEIR ECONOMIC GROWTH. IT ANALYZES THE INFLUENCE OF EXPORT INSTABILTIY (EI) WITHIN THE FRAMEWORK OF THE AUGMENTED PRODUCTION FUNCTION, THE ARGUMENT OF WHICH COMPRISE EI AS HELL AS GROWTHS OF CAPITAL LABOR, AND EXPORTS. IT DISTINGUISHES BETHEEN THE CAPITAL, LABOR, ANO EXPORTS. IT DISTINGUISHES BETHEEN THE OVERALL IMPACT OF EI WHEN OTHER FUNCTIONAL ARGUMENTS AR ALLOHED TO VARY AND ITS DIRECT EFFECT INDEPENDENT OF PRODUCTION INPUT LEVELS. IT SUGGESTS THAT FUTURE RESEARCH SHOULD INVESTIGATE THE POTENTIAL ROLE OF
FORMATION ITSELF IN THE GROWTH PROCESS.

03364 FOUAD, M.

CAIRO THINS AGAIN

THE MIDOLE EAST, (201) (JUL 91), 23-24.

THIS PAPER EXAMINES EGYPT'S ROLE IN ARAB AFFAIRS IN THE
POST-GULF WAR PERIOD. THE FACTORS WHICH LED TO EGYPT'S DECISION TO WITHDRAH TROOPS FROM THE PERSIAN GULF ARE ANALYZED, ALONG WITH THE DETERIORATION IN INTERNATIONAL RELATIONS AMONG THE ARAB STATES WHICH RESULTED FROM THAT RECISION.

03365 FOUAD, $M$

TIME TO GET THEIR HOUSE IN ORDER

THE MIDDLE EAST, (201) (JUL 91), 19-20.

THE RAMIFICATIONS OF THE PERSIAN GULF CRISIS FOR EGYPT'S POLITICAL PARTIES ARE REVIEWED. THE AUTHOR OBSERVES THAT THE GULF CRISIS EXPOSED THE PARTIES' WEAKNESS (THEIR EXCESSIVE CENTRALIZATION, LACK OF POPULAR SUPPORT, AND INABILITY TO RESPOND COHERENTLY IN A CRISIS), THAT EGYPTIAN POLITICS HAS BEEN ALTERED BY THE DISSOLUTION OF THE MUSLIM ALLIANCE, AND THAT IT IS UNCERTAIN WHETHER THE TAGAMU PARTY WILL SURVIVE INTERNAL DISSENSION AND WHETHER NDP CAN UNDERGO REFORM TO BECOME FUNCTIONAL AS A POLITICAL BODY. IT IS CONCLUDED THAT THE PARTIES MUST MODIFY THEMSELVES IN ORDER TO BECDME GENUINELY EFFECTIVE IN EGYPTIAN POLITICS.

03366 FOHLER, $H$

MARKETING ENERGY CONSERVATION IN AN ENVIRONMENT OF ABUNDANCE

POLICY STUDIES JOURNAL, 20(1) (1992), 76-86.

MANY APPROACHES HAVE BEEN TRIED TO OVERCOME CUSTOMER RELUCTANCE TO CONSERVE IN AN ENVIRONMENT OF APPARENT ENERGY ABUNDANCE. THIS PAPER EXPLORES SOME OF THE APPROACHES AND TECHNIOUES USED IN THE SACRAMENTO, CALIFORNIA, AREA. THE RELATIVE ADVANTAGES AND DISADVANTAGES OF THESE TECHNIQUES ARE DISCUSSED AND SOME TENTATIVE CONCLUSIONS DRAWN REGARDING ARE DISCUSSED AND SOME TENTATIVE CONCLUSIONS DRAWN REGARDING THEIR POSSIBLE APPLICATION TO OTHER SITUATIONS. THE PAPER ALSO PRESENTS THE PRIMARY ASSUMPIIONS AND SOME PRELIMINARY UTILITY'S ENERGY CONSERVATION PRODUCT SALES PROGRAM.

03367 FOHLER, J.

DEMOCRATS IN DISARRAY

NATIONAL REVIEH, XLIII(1) (JAN 91), 27-28. THE DEMOCRATIC PARTY HAS YET TO ESTABLISH A CLEAR

POSITION ON THE GULF CRISIS. EMERGING IN THE FIVE MONTHS SINCE SADDAM HUSSEIN'S LAND GRAB ARE THREE DEMDCRATIC BLOCS: THO COMPARATIVELY SMALL ONES, ONE OPPOSED TO THE PRESIDENT, THE OTHER SUPPORTING HIM, AND A LARGE ONE IN THE MIDOLE, UNHILLING TO COME DOWN ON EITHER SIDE. THE BULK OF HILL DEMOCRATS IS INCREASINGLY CONCERNED ONLY WITH LAYING THE CRISIS BLOW UP IN THE PRESIDENT'S FACE.

03368 FOX-GENOVESE, E.; HEWITT, $N$. RETHINKING FEMINISH

TIKKUN, 7 (3) (MAY 92), 29-36; 84-87

THE TENSION BETWEEN LIBERAL AND COMMUNITARIAN VIEWS HAS INCREASINGLY DOMINATED DEBATE IN THE PROGRESSIVE SOCIALINCREASINGLY DOMINATED DEBATE IN THE PROGRESSIVE SOCIAL-

CHANGE MOVEMENTS. ELIZABETH FOX-GENOVESE'S RECENT BOOK, "FASIMG FEMINISM ON A IBERAL PARADIGM FOR WHICH THE HIGHEST BASING FEMINISM ON A LIBERAL PARADIGM FOR WHICH THE H GOOD IS TO SECURE FOR EACH WOMAN THE FREEDOM TO ACT ACCORDING TO HER INDIVIDUAL CHOICE. SHE ARGUES FOR A MORE CORPORATIST CONCEPTION OF THE FEMINIST MOVEMENT. THE LEFT AND FEMINIST PRESS HAS FIERCELY CRITIZED HER POSITION AMT SOME HAVE EVEN CALLED INTO QUESTION HER RIGHT TO CALL HERSELF A FEMINIST. HERE, FOX-GENOVESE DISCUSSES HER
POSITIOM IN LIGHT OF THOSE CRITIQUES AND FEMINIST HISTORIAN, POSITION IN LIGHT OF THOSE
NANCY HERWITT, RESPONDS.

03369 FOX, C.J.

WHAT do WE MEAN WHEN WE SAY 'PROFESSIONALISM'? a LANGUAGE USAGE ANALYSIS FOR PUBLIC ADMINISTRATION

AMERICAN REVIEH OF PUBLIC ADMINISTRATION, 22(1) (MAR 92), $1-18$.

THE AUTHOR STUDIES THE USE OF THE TERM "PROFESSIONALISM" IN PUBLIC ADMINISTRATION BY LANGUAGE USAGE ANALYSIS- AN INTERPRETIVE METHODOLOGY. HE BEGINS BY ARGUING AGAINST THE STATIC INTERPRETATION OF PROFESSIONAL ISM IMPLIED BY THE
SOCIOLOGICAL MODEL. THEN HE EXPLORES VARIOUS MEANINGS OF PROFESSIONALISM BY USING A SERIES OF ANTIMOMIES:

PROFESSIONAL-LAITY, PROFESSIONAL-AMATEUR, ACHI EYEMENT-

ASCRIPTION, AND PROFESSIONALS AS A NEW CLASS IN OPPOSITION TO OTHER CLASSES. EACH ANTINOMY REVEALS MEANINGS OF PROFESSIONALISH THAT PUBLIC ADMINISTRATORS SHOULD AVOID OR EMBRACE IN THEIR QUEST TO MAKE PUBLIC ADMINISTRATION A WIDELY RECOGNIZED PROFESSION. THE AUTHOR SUGGESTS A DEFINITION OF "PROFESSIONALISM" APPROPRIATE TO PUBLIC DEFINITIST OF

03370 FOX, D.; SCHAFFER, D.

TAX ADMINISTRATION AS HEALTH POLICY: HOSPITALS, THE INTERMAL REVENUE SERVICE, AND THE COURTS

JOURNAL OF HEALTH POLITICS, POLICY AND LAW, 16(2) (SUM 91), 251-279.

SINCE 1969 FEDERAL TAX POLICY HAS PERMITTED NONPROFIT HOSPITALS TO TURN AWAY INDIGENT PATIENTS TO TRANSFER THEM TO PUBLIC HOSPITALS. THE INTERNAL REVENUE SERVICE MADE HEALTH 
POLICY, BUT ITS OFFICIALS REMAINED CONVINCED THAT THEY WERE NOT MAKING POLICY AT ALL. CONVINCED THAT IT WAS REASONING FROM LEGAL PRINCIPLES, THE REVENUE SERVICE ACCEPTED THE HOSPITAL INDUSTRY'S YIEH OF THE HISTORY AND PURPOSE OF HOSPITALS. THE FEDERAL COURTS FURTHER OBSCURED THE PROBLEM.
THE AUTHORS OF THIS ARTICLE EXAMINE THESE EVENTS AND SEEK TO THE AUTHORS OF THIS ARTICLE EXAMINE THESE EVENTS AND SEEK TO
EXPLAIN THEM BY LINKING THE RECENT HISTORY OF HEALTH POLICY EXPLAIN THEM BY LINKING THE RECENT HISTORY OF HEALTH POL ICY
TO ASSUMPTIONS THAT GOVERN THE MAKING OF TAX POLICY. THEY TONCLUDE THAT THE MAKING OF HEALTH POLICY BY TAX OFFICIALS CONCLUDE THAT THE MAKING OF HEALTH POLICY BY TAX OFFICIALS NOT MAKING POLICY AT ALL IS NOT IN THE PUBLIC INTEREST.

03371 FOX, J.; HERNANDEZ, L. MEXICO'S DIFFICULT DEMOCRACY: GRASSROOTS MOVEMENTS, NGOS, AND LOCAL GOVERNMENT

ALTERHATIVES, 17 (2) (SPR 92), 165-208

IN SPITE OF MEXICO'S LONG ELECTORAL HISTORY, THE IMAGE OF POLITICAL OPENING HAS BEEN DECEPTIVE FOR SOME CANDIDATES. CONFLICTS BETHEEN NATIONAL POLITICAL PARTIES AND LEADERS AS WELL AS A BROADER RANGE OF ACTORS TELL THE STORY. THIS ARTICLE WILL ANALYZE THE INTERACTION BETWEEN GRASSROOTS SOCIAL MOVEMENTS, LOCAL GOVERMMENTS, AND NONGOVERNMENTAL DEVELOPMENT ORGANIZATIONS (NGOS). A GENERAL OVERVIEH OF STATE-SOCIETY RELATIONS AND THE FORMAL STRUCTURES OF MUNICIPAL AUTHORITY PROVIDES THE BACKGROUND FOR ANALYSIS OF THE KEY TRENDS IN SOCIAL MOVEMENTS, ESPECIALLY THEIR INCREASING INVOLVEMENT IN EFFORTS TO DEMOCRATIZE LOCAL GOVERNEMENT. THIS DISCUSSION THEN TURNS TO THE ROLE OF NGOS
IN THIS PROCESS, AS ONE OF A VARIETY OF LINKAGES BETHEEN INTELLECTUALS AND GRASSROOTS MOVEMENTS IN MEXICO.

03372 FOX, J.

NEW' TERRAIN FOR RURAL POLITICS

REPORT ON THE AMERICAS, 25 (5) (MAY 92), 38-42.

SINCE THE DRAMATIC POLITICAL AND ECONOMIC CHANGES OF THE LATE 1980 S, THE LEFT AND BROADER SOCIAL SOCIAL MOVEMENTS HAVE BEGUN, TO RETHINK THEIR RELATIONSHIPS WITH ONE ANOTHER. PAVE BEGUN TO RETHINK THEIR RELATIONSHIPS WITH ONE ANOT PEASANT MOVEMENTS ARE NO EXCEPTION. AFTER DECADES OF FRUSTRATING SUBORDINATION TO THE URBAN LEFT, AUTONOMOUS PEASANT MOVEMENTS NOW HELP SHAPE THE TERHS OF POLICY DEBATE
AND PROYIDE REAL VEHICLES FOR CHANGE. REGIONAL NETWORKS HAVE AND PROVIDE REAL VEHICLES FOR CHANGE. REGIONAL NETHORKS HAVE TO ADVANCE PEASANT'S STRUGGLE FOR POLITICAL FREEDOM AND TO ADVANCE PEASANT'S
ECONOMIC DEVELOPMENT.

03373 FOX, J.

THE STATE, THE MONOPOLY CAPITALIST CLASS AND THE FORMATION OF THE SOUTH KOREAN "CHAEBOL"; ASSOCIATION FOR ASIAN STUDIES 1992 ANHUAL MEETING

ASSOCIATION FOR ASIAN STUDIES, 1992, 120-121.

THE RELATIONSHIP BETWEEN THE SOUTH KOREAN STATE AND THE "CHAEBOL" HAS RECENTLY COME TO THE FOREFRONT IN ANALYSES OF ECONOMIC DEVELOPMENT IN THE NEWLY INDUSTRIALIZING COUNTRIES. THE PURPOSE OF THIS PAPER IS TWOFOLD: TO CLARIFY THE CONCEPTUAL AMBIGUITY OF THE NOTION OF STATE AUTONOMY IN SOUTH KDREA BY DISTINGUISHING BETWEEN "STATE-CENTERED" AND "CLASS-CENTERED" AUTONOMY AND IDENTIFYING THE CLASS NATURE OF THE "CHAEBOL" AS THE ORGANIZATIONAL BASIS OF THE MONOPOLY CAPITALIST CLASS; AND TO SPECIFICALLY ANALYZE THE EBBS AND FLOWS OF STATE AUTONOMY AND "CHAEBOL" DOMINATION WIHTIN A CLASS-CENTERED FRAMEWORK. THE SPECIFIC CONDITIONS UNDER WHICH STATE AUTONOMY HAS BEEN ACHIEVED AND THE SPECIFIC STRUCTURAL AND INSTRUMENTAL MECHANISMS OF CLASS DOMINATION ARE EXAMINED IN THE SOUTH KOREAN CONTEXT.

03374 FOYE, $S$.

ARMED FORCES CONFRONT LEGACY OF SOVIET PAST

RFE/RL RESEARCH REPORT, 1 (8) (FEB 92), 9-13.

THE FATE OF THE ARMED FORCES IS AMÓNG THE MOST EXPLOSIVE ISSUES FACING THE LEADERS OF THE COMMONWEALTH OF INDEPENDENT STATES. THE PROCESS OF DISAGGREGATING MILITARY ASSETS AND REASSIGNING MILITARY PERSONMEL IS COMPLICATED BY THE FACT THAT THE SOVIET MILITARY MACHINE HAS THE MOST CLOSELY INTEGRATED INSTITUTION IN THE OLD EMPIRE. RESOLVING KEY DIFFERENCES ON RESTRUCTURING THE ARMY IS ALSO MADE DIFFICULT
BY THE WIDE DIVERGENCE OF VIEWS AMONG POLITICAL AND MILITARY LEADERS.

03375 FOYE, $S$.

CIS: KIEV AND MOSCOW CLASH OVER ARMED FORCES

RFE/RL RESEARCH REPORT 1(3) (JAN 92), 1-3.

IN THE HAKE OF THE MEETING OF THE COMMONWEALTH OF INDEPENDENT STATES ON DECEMBER 30,1991, UKRAINE MOVED TO CREATE ITS OWM INDEPENDENT ARMED FORCES' BY CLAIMING THE BLACK SEA FLEET AND GENERAL-PURPOSE FORCES ALREADY STATIONED IN THE REPUBLIC. KIEV'S ACTIONS, UNDERTAKEN IN THE HOPE OF SAFEGUARDING UKRAINIAN SOVEREIGNTY, BROUGHT IT INTO SERIOUS CONFLICT WITH ELEMENTS WITHIN THE ARMED FORCES AND THE RUSSIAN FEDERATION GOVERMMENT.

03376 FOYE, $S$.

POST-SOVIET RUSSIA: POLITICS AND THE NEW RUSSIAN ARMY RFE/RL RESEARCH REPORT 1(33) (AUG 92) 5-12. THUS FAR, THE CREATION OF AN INDEPENDENT RUSSIAN ARMY
AND MINISTRY OF DEFENSE HAS BEEN A DISAPPOINTMENT TO THOSE WHO THOUGHT THAT THE MOVE WOULD REMEDY THE TENSE AND UNCERTAIN RELATIONS BETWEEN CIVILIAN LEADERS AND THE FORMER SOVIET ARMY. THIS FAILURE CAN BE ATTRIBUTED IN LARGE PART TO THE NEW RUSSIIAN DEFENSE MINISTRY'S PERSONNEL AND POLICIES, WHICH APPEAR TO REFLECT NOT THE PROGRESSIVE WING OF THE WHICH APPEAR TO REFLECT NOT THE PROGRESSIVE WING OF THE RUSSIAN GOVERHMENT BUT AN ALLIANCE BETWEEN THE CONSERVAT
INDUSTRIALIST LOBBY AND REACTIONARY NATIONAL-PATRIOTIC INDUSTRIALIST LOBBY AND REACTIONARY NAT IONALLPATRIOTIC
FORCES. THE READINESS OF THE NEW RUSSIAN MILITARY LEADERSHIP FORCES. THE READINESS OF THE NEW RUSSIAN MILITARY LEADERS
TO GET INVOLVED IN POLITICS AND TO INTERVENE IN ETHNIC TO GET INVOLVED IN POLITICS AND TO INTERVENE IN ETHNIC
DISPUTES ON THE PERIPHERY OF THE FORMER SOVIET UNION THREATENS REFORM IN RUSSIA AND STABILITY THROUGHOUT THE THREATENS
REGION.

03377 FOYE, S.

REBUILDING THE RUSSIAN MILITARY: SOME PROBLEMS AND PROSPECT

RFE/RL RESEARCH REPORT, 1(44) (NOV 92), 51-56.

SINCE THE RUSSIAN MILITARY LEADERSHIP WAS INSTALLED TO COMMAND THE COUNTRY'S NEWLY-ESTABLISHED ARMED FORCES IN THE SPRING OF 1992, IT HAS FACED THE DAUNTING TASK OF TRYING TO REBUILD AN ARMY RAVAGED BY REYOLUTIONARY SOCIAL CHANGES ENORMOUS MORALE AND ORGANIZATIONAL PROBLEMS AFFLICTING BOTH THE CONSCRIPT ARMY AND THE OFFICER CORPS MAKE QUICK PROGRESS UNLIKELY, AS DOES THE GENERAL ENVIRONMENT OF ECONOMIC AND POLITICAL INSTABILITY. MILITARY LEADERS ARE ATTEMPTING TO USE RUSSIAN NATIONALISM AS A MEANS OF BUILDING ESPRIT DE CORPS, A POLICY THAT IS LIKELY TO BRING POSITIVE RESULTS BUT COULD ALSO HAVE UNSAVORY EFFECTS.

03378 FOYE, $S$.

RUSSIAN POLITICS COMPLICATES BALTIC TROOP WITHDRAWAL

RFE/RL RESEARCH REPORT, 1(46) (NOV 91), 30-35.

SINCE EARLY 1992 RUSSIAN PRESIDENT BORIS YELTSIN AND HIS PRO-REFORM ADVISERS HAVE MADE A NUMBER OF POLICY CONCESSIONS TO SATISFY INCREASINGLY ASSERTIVE CONSERVATIVE FORCES. A TO SATISFY INCREASINGLY ASSERTIVE CONSERVATIVE FORCES
RECENT DIRECTIVE FROM YELTSIN SUSPENDING THE RUSSIAN RECENT DIRECTIVE FROM YELTSIN SUSPENDING THE RUSSIAN
MILITARY WITHORAHAL FROM THE BALTIC STATES APPEARS TO MILITARY WITHORAHAL FROM THE BALTIC STATES APPEARS TO
CONFIRM THAT RUSSIAN FOREIGN POLICY-MAKING IS NOT IMMUNE TO THESE PRESSURES. AMID THE INCREASINGLY HARSH RHETORIC

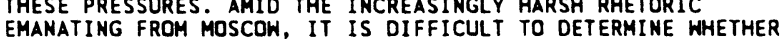
EMANATING FROM MOSCOW, IT IS DIFFICULT TO DETERMINE WHETHER YELTSIN'S DECREE REPRESENTS A FUNDAMENTAL CHANGE IN RUSSIAN A RISING TIDE OF RUSSIAN NATIONALISM.

03379 FOYE, $S$.

RUSSIAN TROOPS ABROAD: VESTIGES OF EMPIRE

RFE/RL RESEARCH REPORT, 1(34) (AUG 92), 15-17.

IRONICALLY, THE LATEST EFFORTS TO MÁINTAIN MOSCOW'S INFLUENCE IN SEVERAL OF THE SMALLER STATES ON THE PERIPHERY OF THE FORMER SOVIET UNION HAVE BEEN LAUNCHED UNDER A PSEUDODEMOCRATIC GUISE--NAMELY, DEFENDING THE RIGHTS OF RUSSIAN MINORITIES IN THOSE AREAS.

03380 FOYE, $S$.

THE SOVIET ARMED FORCES: THINGS FALL APART

RFE/RL RESEARCH REPORT, 1(1) (JAN 92), 15-18.

THE YEAR 1991 WAS A WATERSHED FOR THE USSR'S ARMED

FORCES. IT BEGAN WITH A RESURGENT MILITARY LEADERSHIP MARCHING CONFIDENTLY IN LOCKSTEP WITH SOVIET PRESIDENT GORBACHEV IN AN INCREASINGLY BOLD CAMPAIGN BY THE CENTRAL AUTHORITIES TO INTIMIDATE PRO-INDEPENDENCE FORCES ON THE PERIPHERY. BUT BY THE END OF 1991, GORBACHEV HIMSELF HAD BECOME A FIGUREHEAD AND THE SOVIET "RED" ARMY HAD CEASED TO BE SOVIET, RED, OR, IN MANY RESPECTS, EVEN AN ARMY. THE IN AUGUST 1991.

03381 FOYE, $S$.

THE STRUGGLE OVER RUSSIA'S KURIL ISLANDS POLICY

RFE/RL RESEARCH REPORT, $1(36)$ (SEP 92), 34-40

AMID INCREASING PRESSURE FROM TOKYO FOR A FAVORABLE

SETAIOMET ON THE ISSUE OF THE KURI ISLANDS RUSSIAN

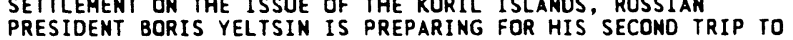
JAPAN. RUSSIAN CONSERVATIVES ARE DENOUNCING WHAT THEY ALLEGE JAPAN. RUSSIAN CONSERVATIVES ARE DENOUNCING WHAT THEY ALLEGE
ARE PLANS TO GIVE AWAY THE SOUTHERN KURIL ISLANDS AND HAVE ARE PLANS TO GIVE AWAY THE SOUTHERN KURIL ISLANDS AND HAV
USED THE ISSUE TO LAUNCH A BITTER AND DIVISIVE CAMPAIGN USED THE ISSUE TO LAUNCH A BITTER AND DIVISIVE CAMPAIGN
AGAINST THE LIBERALLY-ORIENTED RUSSIAN MINISTRY OF FOREIGN AGAINST THE LIBERALLY-ORIENTED RUSSIAN MINISTRY OF FOREIGN
AFFAIRS. THE RUSSIAN DEFENSE MINISTRY, HHICH IS CONTROLLED AFFAIRS. THE RUSSIAN DEFENSE MINISTRY, HHICH IS CONTROLLED
BY CONSERVATIVE RUSSIAN NATIONALISTS, HAS WEIGHED IN ON THE BY CONSERVATIVE RUSSIAN NATIONALISTS, HAS WEIGHED IN ON THE SIDE OPPOSED TO A FLEXIBLE POLICY. THE BATTLE APPEARS TO
HAVE ELIMINATED ANY ROOM FOR MANEUVERING THAT YELTSIN MIGHT HAVE ELIMINATED ANY ROOM FOR MANEUVERING THAT YELT
HAVE HAD AND SUGGESTS THAT THERE WILL BE NO MAJOR HAVE HAD AND SUGGESTS THAT THERE WILL BE NO MAJOR BREAKTHROUGH REGARDING
SEPTEMBER 1992 VISIT.

03382 FOYE, S. (ED.); CLARKE, D.L. (ED.) MILITARY AND SECURITY BRIEFS--USSR AND COMMONWEALTH OF INDEPENDENT STATES: CONTROL OVER NUCLEAR WEAPONS RFE/RL RESEARCH REPORT, 1(2) (JAN 92), 46-49.

THE AUTHORS REPORT ON DEVELOPMENTS REGARDING SECURITY AND WEAPONS IN THE COMMONWEALTH OF INDEPENDENT STATES FOCUSING ON THE CONTROVERSY OYER CONTROL OF THE NUCLEAR ARMS THAT BELONGED TO THE SOVIET UNION. THEY ALSO DISCUSS 
MILITARY DEVELOPMENTS IN THE BALTICS, BULGARIA, HUNGARY, POLAND, AND ROMANIA.

03383 FOYE, S. (ED.)

MILITARY AND SECURITY NOTES

RFE/RL RESEARCH REPORT, 1(34) (AUG 92), 44-47.

THE EDITOR SUMMARIZES MAJOR DEVELOPMENTS INVOLVING THE MILITARY IN THE COMMONWEALTH OF INDEPENDENT STATES, THE BALTIC STATES, POLAND, AND HUNGARY DURING MID-AUGUST 1992. HE REPORTS ON RUSSIAN PRESIDENT YELTSIN'S PLEDGE TO WITHDRAH RUSSIAN TROOPS FROM THE SOUTHERN KURIL ISLANDS BY MID-1995 UKRAINIAN COMPLIANCE WITH THE CONVENTIONAL FORCES IN EUROPE TREATY, AMD PROBLEMS WITH BORDER FORCES IN SEVERAL FORMER

SOVIET REPUBLICS.

03384 FOYE, S. (ED.)

MILITARY AND SECURITY NOTES

RFE/RL RESEARCH REPORT, 1(35) (SEP 92), 41-44.

THE EDITOR REPORTS ON EAST-WEST SECURITY ISSUES

INTERREPUBLICAN SECURITY ISSUES WITHIN THE COMMONWEALTH OF INDEPENDENT STATES, AND MILITARY DEVELOPMENTS IN THE BALTIC STATES, BULGARIA, CZECHOSLOVAKIA, AND YUGOSLAVIA DURING LATE
AUGUST 1992.

03385 FOYE, S. (ED.); REISCH, A.A. (ED.)

MILITARY AND SECURITY NOTES

RFE/RL RESEARCH REPORT, 1(38) (SEP 92), 56-59.

THE EDITORS SUMMARIZE MAJOR MILITARY AND SECURITY

DEVELOPMENTS IN THE COMMONHEALTH OF INDEPENDENT STATES, THE

BALTIC STATES, CZECHOSLOVAKIA, HUNGARY, POLAND, AND ROMANIA DURING SEPTEMBER 1992.

03386 FOYE, S. (ED.); REISCH, A.A. (ED.)

MILITARY AND SECURITY NOTES

RFE/RL RESEARCH REPORT, 1(37) (SEP 92), 65-68.

THE EDITORS REPORT ON EAST-HEST SECURITY ISSUES AND MILITARY DEVELOPMENTS IN THE COMHONWEALTH OF INDEPENDENT STATES, THE BALTIC STATES, BULGARIA, CZECHOSLOVAKIA, HUNGARY, AND ROMANIA DURING EARIY' SEPTEMBER 1992. THEY AL SO' HIST THE NEH COMMANDERS APPOINTED ON SEPTEMBER 4, 1992, TO HEAD POLAND'S FOUR MILITARY DISTRICTS.

03387 FOYE, S. (ED.); REISCH, A.A. (ED.)

MILITARY AMD SECURITY NOTES

RFE/RL RESEARCH REPORT, 1(43) (OCT 92), 60-65.

THE EDITORS SUMMARIZZE MAJOR DEVELOPMENTS INVOLVING SECURITY AND DEFENSE IN THE COMMONHEALTH OF INDOLPENDENT STATES, THE BALTIC STATES, BULGARIA, CZECHOSLOVAKIA, HUNGARY, AMD POLAMD DURING MID-OCTOBER 1992 .

03388 FOYE, S. (ED.); REISCH, A.A. (ED.)

MILITARY AND SECURITY NOTES

FE/RL RESEARCH REPORT, 1(45) (NOV 92), 58-63.

THE EDITORS REPORT ON EAST-WEST SECURITY ISSUES INTERREPUBL ICAN SECURITY ISSUES WITHIN THE COMMONHEALTH OF INDEPENDENT STATES, AND MILITARY DEVELOPMENTS IN THE CIS THE BALTIC STATES, CZECHOSLOVAKIA, HUNGARY, POLAND, AND ROMANIA DURING EARLY NOVEMBER 1992.

03389 FOYE, S. (ED.)

MILITARY AND SECURITY NOTES

RFE/RL RESEARCH REPORT, 1(32) (AUG 92), 44-49.

THE EDITOR REPORTS ON MILITARY AND SECURITY DEVELOPMENTS

IN RUSSIA, UKRAINE, BELARUS, ESTONIA, LITHUANIA, LATVIA,

03390 FOYE, S. (ED.); REISCH, A.A. (ED.)

MILITARY AND SECURITY NOTES

RFE/RL RESEARCH REPORT, 1(31) (JUL 92), 59-64.

THE EDITORS REPORT ON EAST-WEST SECURITY ISSUES, CIS

INTERREPUBLICAN SECURITY ISSUES, AND DEFENSE DEVELOPMENTS IN THE BALTIC STATES, BULGARIA, HUNGARY, POLAND, AND ROMANIA IN JULY 1992.

03391 FOYE, S. (ED.)

MILITARY AND SECURITY NOTES

RFE/RL RESEARCH REPORT, 1(33) (AUG 92), 57-61.

THE EDITOR DISCUSSES DEVELOPMENTS CONCERNING SECURITY

AND THE ARMED FORCES IN THE BALTIC STATES, BULGARIA, HUNGARY,

POLAND, AND THE COMMONWEALTH OF INDEPENDENT STATES DURING

EARLY AUGUST 1992. HE REPORTS OM NEGOTIATIONS ON THE

WARLY AUGUST 1992. HE REPORTS ON NEGOTIATIONS ON THE

POSSIBILITY THAT RUSSIA HILL JOIN SDI RESEARCH, AND THE SALE OF RUSSIAN MISSILES TO CHINA.

03392 FOYE, S. (ED.); REISCH, A.A. (ED.)

MILITARY AND SECURITY NOTES

RE/RL RESEARCH REPORT, 1(47) (NOV 92), 55-59.

THE EDITORS REPORT ON IMPORTANT DEVELOPMENTS INVOLVING SECURITY AND DEFENSE IN THE COMHONHEALTH OF INDEPENDENT STATES, ESTONIA, CZECHOSLOVAKIA, HUNGARY, AND POLAND DURING MID-NOVEMBER 1992.
03393 FOYE, S. (ED.); CLARKE, D.L. (ED.) MILITARY AND SECURITY NOTES

RFE/RL RESEARCH REPORT, 1(19) (MAY 92), 48-53

THE EDITORS SUMMARIZE MAJOR DEVELOPMENTS INVOLVING DEFENSE AND THE MILITARY FORCES IN EASTERN EUROPE AND THE COMMONWEALTH OF INDEPENDENT STATES DURING LATE APRIL 1992. TOPICS INCLUDE THE FORMER SOVIET STATES' PARTICIPATION IN THE START TREATY, THE UKRAINIAN SPACE PROGRAM, AND KAZAKHSTAN'S OVERTURES TO WASHINGTON REGARDING A STRATEGIC ALLIANCE WITH THE USA.

03394 FOYE, S. (ED.); CLARKE, D.L. (ED.) MILITARY AND SECURITY NOTES

RFE/RL RESEARCH REPORT, 1(16) (APR 92), 50-56 THE EDITORS SUMMARIZE MAJOR DEVELOPMENTS CONCERNING SECURITY ISSUES AND THE ARMED FORCES IN EASTERN EUROPE AND THE COMMONHEALTH OF INDEPENDENT STATES DURING EARLY APRIL 1992. THEY REPORT ON THE CONTINUING CLASH BETWEEN RUSSIA AND UKRAINE OVER THE BLACK SEA FLEET, RUSSIA'S PLANS TD UKRAINE OVER THE BLACK SEA FLEET, RUSSIA'S PLANS TO
STREAMLINE ITS ARMY, JAPAN'S DEMAND THAT RUSSIA UNDERTAKE DEFENSE CUTS IN RETURN FOR FOREIGN AID. THE CIS-CZECH AGREEMENT ON DISPOSAL OF SOVIET MILITARY PROPERTY IN CZECHOSLOVAKIA, AND HUNGARY'S COMPLIANCE WITH CFE LIMITS AND CZECHOSLOVAKIA, AND HUNGARY'S
ITS HOPES FOR NATO MEMBERSHIP.

03395 FOYE, S. (ED.)

MILITARY AND SECURITY NOTES

RFE/RL RESEARCH REPORT, 1(28) (JUL 92), 63-69.

THE EDITOR SUMMARIZÉS MAJOR DEVELOPMENTS INVOLVING THE

MILITARY AND SECURITY ARRANGEMENTS IN THE COMMONWEALTH OF

INDEPENDENT STATES, THE BALTIC STATES, BULGARIA,

CZECHOSLOVAKIA, POLAND, ROMANIA, AND YUGOSLAVIA IN LATE JUNE 1992.

03396 FOYE, S. (ED.)

MILITARY AND SECURITY NOTES

RFE/RL RESEARCH REPORT, 1(29) (JUL 92), 56-60.

THE EDITOR SUMMARIZES MAJOR DEVELOPMENTS INVOLVING TROOPS AND SECURITY ISSUES IN THE COMMONHEALTH OF INDEPENDENT STATES, THE BALTIC STATES, BULGARIA, HUNGARY, AND POLAND DURING EARLY JULY 1992.

03397 FOYE, S. (ED.): REISCH, A.A. (ED.)

MILITARY AND SECURITY NOTES

RFE/RL RESEARCH REPORT, 1(30) (JUL 92), 57-61.

THE EDITORS REPORT ON MAJOR DEVELOPMENTS INVOLVING

MILITARY AND DEFENSE ISSUES IN EASTERN EUROPE AND THE

COMMONHEALTH OF INDEPENDENT STATES DURIMG JULY 1992. TOPICS

INCLUDE U.S.-RUSSIAN TALKS ON MISSILE DEFENSES, THE RUSSIAN

RATIFICATION OF THE CFE TREATY, THE CONTINUING CONFLICT OVER THE BLACK SEA FLEET, AND THE PULLOUT OF RUSSIAN TROOPS FROM
THE BALTIC STATES.

03398 FOYE, S. (ED.); CLARKE, D.L. (ED.) MILITARY AND SECURITY NOTES--CIS: CONTINUING DISCORD OVER ARMED FORCE

RFE/RL RESEARCH REPORT, 1(4) (JAN 92), 59-65.

THE AUTHORS REPORT ON MILITARY AND SECURITY ISSUES IN

THE COMMONWEALTH OF INDEPENDENT STATES. THE BALTIC STATES,

ALBANIA, BULGARIA, AND POLAND. THEY SUMMARIZE THE DISPUTE

WITHIN THE CIS OVER THE FATE OF THE BLACK SEA FLEET.

03399 FOYE, S. (ED.); CLARKE, D.L. (ED.)

MILITARY AND SECURITY NOTES--CIS: DISAGREEMENT OVER

MILITARY ISSUES THREATENS TO DERAIL COMMONWEALTH PROCESS

RFE/RL RESEARCH REPORT, 1(3) (JAN 92), 49-55.

THE AUTHORS SUMMARIZE ISSUES CONCERNING MILITARY POLICY

IN THE COMMONWEALTH OF INDEPENDENT STATES IN LATE DECEMBER

1991 AND EARLY JANUARY 1992. THEY REPORT ON THE DISAGREEMENT

OVER THE CONTROL OF THE FORMER SOVIET UNION'S NUCLEAR

WEAPONS AND UKRAINE'S MOVES TO TAKE CONTROL OF THE BLACK SEA FLEET AND SOME OTHER FORCES.

03400 FOYE, S. (ED.); CLARKE, D.L. (ED.)

MILITARY AND SECURITY NOTES, CIS: KIEY AND MOSCOW CONTINUE TO CLASH

RFE/RL RESEARCH REPORT, 1(18) (MAY 92), 60-66.

THE EDITORS SUMMARIZE IMPORTANT DEVELOPMENTS INVOLVING

MILITARY POLICY AND FORCES IN EASTERN EUROPE AND THE

COMMONHEALTH OF INDEPENDENT STATES IN EARLY APRIL 1992.

03401 FOYE, S. (ED.); CLARKE, D.L. (ED.)

MILITARY AND SÉCURITY NOTES: CIS, EAST-WEST SECURITY RFE RL RESEARCH REPORT, 1(11) (MAR' 92), 51-56.

IHE EDITORS REPORT ON MAJOR DEVELOPMENTS CONCERNING SECURITY IN EASTERN EUROPE AND THE COMMONWEALTH OF INDEPENDENT STATES IN FEBRUARY AND MARCH 1992. TOPICS INCLUDE THE NATO-CIS TALKS, TALXS BETHEEN CIS COLONEL GENERAL VIKTOR SAMSONOV AND MILITARY LEADERS IN CHINA AND NORTH KOREA, AND RUSSIAN PRESIDENT BORIS YELTSIN'S VISIT TO ARZAMAS-16. A FORMERLY SECRET SOVIET NUCLEAR WEAPONS PRODUCTION SITE. 
03402 FOYE, S. (ED.)

MILITARY AND SECURITY NOTES: CIS, NO EASING OF TENSION

RFE/RL RESEARCH REPORT, 1(8) (FEB 92), 53-57,

THIS COLLECTION OF SHORT REPORTS SUMMARIZES DEVELOPMENTS INYOLVING DEFENSE ISSUES AND MILITARY MATTERS IN EASTERN EUROPE AND THE COMMONWEALTH OF INDEPENDENT STATES IN EARLY TO MID-FEBRUARY 1992.

03403 FOYE, S. (ED.); CLARKE, D.L. (ED.) MILITARY AND SECURITY ROTES: CIS, RUSSIA MOVES TO CREATE DEFENSE MINISTRY

RFE/RL RESEARCH REPORT, 1(15) (APR 92), 43-46, THE EDITORS REPORT ON IMPORTANT DEVELOPMENTS INVOLVING SECURITY AND MILITARY POLICY IN THE BALTIC STATES, BULGARIA, CZECHOSLOVAKIA, POLAND, AND THE COMMONWEALTH OF INDEPENDENT STATES IN LATE MARCH 1992.

03404 FOYE, S. (ED.); CLARKE, D.L. (ED.) MILITARY AND SECURITY NOTES: CIS, TENSION OVER DEFENSE ISSUES CONTINUES TO SHOLDER

RFE/RL RESEARCH REPORT, 1(5) (JAN 92), 58-64.

THE EDITORS REPORT ON MILITARY DEVELOPMENTS IN CZECHOSLOVAKIA, THE BALTICS, BULGARIA, HUNGARY, POLAND, AND THE COMMONHEALTH OF INDEPENDENT STATES IN JANUARY 1992. MAJOR EVENTS INCLUDED THE WITHDRAWAL OF TACTICAL NUCLEAR WEAPONS FROM UKRAINE, A MISSILE TEST LAUNCH IN KAZAKHSTAN, AND THE CONTINUING DISPUTE BETWEEN UKRAINE AND RUSSIA OVER THE CONTROL OF THE BLACK SEA FLEET.

03405 FOYE $S$. (ED.) MILITARY AND SECURITY NOTES: CIS, THE EVOLVING SECURITY ENYIRONMENT

RFE/RL RESEARCH REPORT, 1(6) (FEB 92), 55-58,

THE EDITOR SUMMARIZES MAJOR NEWS REPORTS CONCERNING DEFEMSE AND SECURITY ISSUES IN EASTERM EUROPE AND THE COMMONHEALTH OF INDEPENDENT STATES IN LATE JANUARY 1992. COMMONHEALTH OF INDEPENDENT STATES IN LATE JANUARY 1992. TOPICS INCLUDE BORIS YELTSIN'S VISIT TO NOVOROSSIIK TO ASSURE SEAMEN THAT THE BLACK SEA FLEET WOULD NOT FALL UNDER UKRAINIAN CONTROL, BELARUS OECLARATION THAT IT WANTS TO BE NUCLEAR-FREE, THE TROOP WITHDRAWALS FROM THE BALTICS,
BULGARIAN MILITARY RELATIONS WITH THE UNITED STATES.

03406 FOYE, S. (ED.); CLARKE, D.L. (ED.) MILITARY AND SECURITY NOTES: CIS, YELTSIN'S STRATEGIC ARMS CONTROL PROPOSALS

RFE/RL RESEARCH REPORT, 1(7) (FEB 92), 64-69

THE EDITORS REPORT ON DEVELOPMENTS INVOLVING SECURITY AND DEFENSE ISSUES IN EASTERN EUROPE AND THE COMMONHEALTH OF INDEPENDENT STATES. TOPICS INCLUDE BORIS YELTSIN'S ARMS REDUCTION PROPOSALS, THE SIGNING OF A U.S. -RUSSIAN PLEDGE TO REDUCE THEIR NUCLEAR ARSENALS, THE STATUS OF LATVIA'S ARMED FORCES, AND THE REORGANIZATION OF THE BULGARIAN ARMY.

03407 FOYE, S. (ED.); CLARKE, D.L. (ED.) MILITARY AND SECURITY NOTES: EVOLVING EAST-WEST SECURITY RFE/RL RESEARCH REPORT, 1(10) (MAR 92), 51-57.

THE EDITORS REPORT ON DEVELOPMENTS INVOLVING THE

MILITARY FORCES OF THE FORMER SOVIET REPUBLICS ANO ON

SECURITY ISSUES INVOLVING THE MEMBERS OF THE COMMONWEALTH OF INDEPENDENT STATES.

03408 FRANCIS, J.G. THE EVOLVING

JORNAL OF CHURCH \& STATE, 34(4) (FAL 92), 775-804.

THE AUTHOR EXPLORES THE CONSEQUENCES OF THE REGULATORY PATTERNS THAT HAVE EMERGED IN EAST AND WEST EUROPEAN CHURCHSTATE RELATIONS SINCE THE END OF WORLD WAR II. HE BELIEVES AN UNDERSTANDING OF THESE REGULATORY REGIMES CAN HELP IN UNDERSTANDING THE APPARENT PARADOXES IN EUROPEAN CHURCHSTATE RELATIONSHIPS. HE ARGUES THAT THE REGULATORY REGIMES STATE RELAT IONSHIPS. HE ARGUES THAT THE REGULATORY RAVE DEVELOPED IN EUROPE HAVE CREATED INCENTIVES FOR EUROPEAN CHURCHES TO PLAY ROLES IN SOCIETY OTHER THAN THAT OF MOBILIZING PARTICIPATION IN INSTITUTIONALIZED RELIGION. TRADITIONAL EUROPEAN CHURCHES HAVE RESPONDED TO THE REGULATORY ENVIRONMENT BY BECOMING MORE INVOL YED IN EDUCATION, CHARITY AND POITICAL COMMENTARY, RATHER THAN IN EDUCATION, CHARITY, AND POLITICAL COMMENTARY,

03409 FRANCK. T.M.

JUDICIAL QUESTIONS JUDICIAL ANSWERS: DOES THE RULE OF LAW APPLY TO FOREIGN AFFA.

PRINCETON UNIVERSITY PRESS, 1992, 216

ALMOST SINCE THE BEGINNING OF' THE REPUBLIC, AMERICA'S RIGOROUS SEPARATION OF POWERS AMONG EXECUTIVE, LEGISLATIVE, AND JUDICIAL BRANCHES HAS BEEN UMPIRED BY THE FEDERAL JUDICIARY. IT MAY SEEM SURPRISING, THEN, THAT MANY OTHERWISE ORDINARY CASES ARE NOT DECIDED IN COURT EVEN WHEN THEY INCLUDE ALLEGATIONS THAT THE PRESIDENT, OR CONGRESS, HAS VIOLATED A LAW OF THE CONSTITUTION ITSELF. MOST OF THESE ORPHAN CASES ARE SHUNNED BY THE JUDICIARY SIMPLY BECAUSE THEY HAVE FOREIGN POLICY ASPECTS. THE AUTHOR OF THIS BOOK, MAINTAINS THAT WHEN COURTS IMVOKE THE "POLITICAL QUESTION" DOCTRINE TO JUSTIFY SUCH RETICENCE, THEY EVADE A
CONSTITUTIONAL DUTY. IN HIS VIEW, WHETHER THE GOYERNMENT HAS ACTED CONSTITUTIONALLY IN SENDING MEN AND WOMEN TO DIE IN FOREIGN BATTLES IS JUST AS APPROPRIATE AN ISSUE FOR A COURT TO DECIDE AS WHETHER PROPERTY HAS BEEN TAKEN WITHOUT DUE TO DECIDE AS WHETHER PROPERTY HAS BEEN TAKEN WITHOUT DUE
PROCESS. THE AUTHOR PROPOSES WAYS TO SUBJECT THE CONOUCT OF PROCESS. THE AUTHOR PROPOSES WAYS TO SUBJECT THE CONOUCT
FOREIGN POLICY TO THE RULE OF LAW WITHOUT COMPROMISING FOREIGN POLICY TO THE RULE OF LAW WITHOUT COMPROMISING
EITHER JUDICIAL INTEGRITY OR THE NATIONAL INTEREST.

03410 FRANCK, T.M.

THE POHERS OF APPRECIATION: WHO IS THE ULTIMATE GUAROIAN OF U.N. LEGALITY?

AMERICAN JOURNAL OF INTERNATIONAL LAW, 86(3) (JUL 92), 519-523.

THE INTERNATIONAL COURT OF JUSTICE'S RECENT DECISIONS IN THE CASE CONCERNING INTERIM MEASURES BROUGHT BY LIBYA AGAINST THE UNITED STATES AND THE UNITED KINGDOM MAY BE THE MOST IMPORTANT AND JURISPRUDENTIALLY RICH OF ANY HANDED DOWN BY THIS COURT SINCE THE END OF THE COLD WAR. THE JUDGES MADE PRELIMINARY DECISIONS ABOUT A NUMBER OF PRICKLY ISSUES, INCLUDING WHETHER THE COURT COULD REVIEH THE LEGALITY OF A SECURITY COUNCIL DECISION.

03411 FRANK, A.

ECONOMIC IRONIES IN EUROPE: A WORLD ECONOMIC

INTERPRETATION OF EAST-HEST EUROPEAN POLITICS

INTERNATIONAL SOCIAL SCIENCE JOURNAL, 131(131) (FEB 92), 41-56.

THIS ARTICLE BRINGS A WORLD ECONOMIC INTERPRETATION TO BEAR ON SELECTED FACETS OF EUROPEAN POLITICS AND POLICY AS WELL AS CULTURE AND ETHNICITY. IT ARGUES THAT MOST OF THE FAVORABLE AND UNFAVORABLE CHANGES--AND INDEED THE IDEOLOGICAL AND POPULAR RESPONSES THEMSELVES--ARE ROOTED IN WORLD-WIDE ECONOMIC DEVELOPMENTS WHICH EXISTING OR PROSPECTIVE POLITICS, IDEOLOGY OR CULTURE, IRONICALLY, HAVE PROSPECTIIVE POLITICS, IDEOLOGY OR CULTURE, IRONICALLY, HAVE LITTLE OR NO POWER TO CHANGE. IT SUGGESTS THAT IF DELIBERATE
POLICY ACCOMPLISHES ANYTHING AT ALL, IT USUALLY REINFORCES POL ICY ACCOMPLISHES ANYTHING AT ALL, IT USUALLY REINFORCES THE ECONOMICALLY UNDERLYING TREND AND ACHIEVES AT BEST THE
OPPOSITE OF WHAT WAS INTENDED. THE THESIS THAT POLITICAL OPPOSITE OF WHAT WAS INTENDED. THE THESIS THAT POL
POWER AND POLICY IS LOCALLY, NATIONALLY OR AT MOST POWER AND POLICY IS LOCALLY, NATIONALLY OR AT MOST
IMPERIALLY CONFINED BUT THAT IT IS UP AGAINST WORLD-WIDE IMPERIALLY CONFINED BUT THAT IT IS UP AGAINST WORLD-WIDE
ECONOMIC FORCES WHICH ARE BEYOND ANYONE'S CONTROL IS ARGUED.

03412 FRANK, A.G.

THE CENTRALITY OF CENTRAL ASIA BULLETIN OF CONCERNED ASIAN SCHOLARS, 24(2) (APR 92), 50-74.

THIS PAPER POSES SOME QUESTIONS ABOUT HOW CENTRAL ASIA FITS INTO WORLD HISTORY. THE AUTHOR SEEKS TO CLARIFY THE ROLE OF CENTRAL ASIANS IN THE HISTORY OF THEIR NEIGHBORS BEYOND CENTRAL ASIA AND THUS THEIR PLACE IN WORLD-SYSTEM HISTORY AS A HOLE. IT CONSIDERS SEVEN ISSUES RELATING TO CENTRAL ASIA: THE DEFINITION OR LOCATION OF CENTRAL ASIA; FORMATION; SPECIAL NEXUSES; INTERNATIONAL TRADE; AND INTERNATIONAL POLITICAL-ECONOMIC RELATIONS IN THE HORLD SYSTEM. THE AUTHOR THEN CONSIDERS FOUR SYSTEMIC STRUCTURES AND PROCESSES DERIVED FROM THE STUDY OF THE CONTEMPORARY WORLD SYSTEM THAT MAY BE USEFUL IN THE STUDY OF THE PLACE AND ROLE OF CENTRAL ASIA IN WORLD HISTORY. THESE ARE THE PROCESS OF ACCUMULATION, CORE-PERIPHERY STRUCTURE, HEGEMONYRIVALRY ALTERNATION, AND POLITICAL-ECONOMIC CYCLES. THE ARTICLE OFFERS THO CONCLUSIONS: THAT IT IS TIME TO ABANDON THE HISTORICAL AND STILL. POPULAR IMAGE OF CENTRAL ASIA AS THE HOME OF NOMAD BARBARIANS OR BARBARIAN NOMADS; AND THAT THE IMAGE OF PASTROAL NOMADISM AS A STAGE OF DEVELOPMENT BETHEEN HUNTING-GATHERING AND AGRICULTURAL URBANIZATION IS INACCURATE AND SHOULD BE DONE AWAY WITH.

03413 FRANK, H.A.; MCCOLLOUGH, J.

MUNICI IPAL FÓRECASTING PRACTIICE: DEMAND- AND SUPPIY-SIDE PERSPECTIVES

INTERNATIONAL JOURNAL OF PUBLIC ADMINISTRATION, $15(9)$

(1992), 1669-1695.

FINDINGS FROM A NATIONAL SURVEY OF MEMBERS OF THE GOVERNMENT FINANCE OFFICERS ASSOCIATION CONFIRM PREVIOUS RESEARCH INDICATING AN OVER-RELIANCE ON JUDGMENTAL, AS OPPOSED TO QUANTITATIVE FORECAST METHODS, FOR BOTH REVENUE AND EXPENDITURES. WHILE INCUMBENTS IN LARGER CITIES AND WITH ADVANCED DEGREES HAVE MORE FORECAST TRAINING THAN THEIR SMALL-CITY, BACCALAUREATE-ONLY COUNTERPARTS, THIS DIFFERENTIATION FAILS TO MATERIALIZE IN FORECAST PRACTICE. MPA'S ARE AT A OISADVANTAGE RELATIVE TO MBA'S IN REGRESSION AND ECONOMETRICS. CONTENT ANALYSIS OF LEADING PUBLIC ADMINISTRATION TEXTS SUGGESTS WHY UTILIZATION MAY BE RETARDED IN PRACTICE: FORECASTING, LIKE MANY OTHER "NUTS AND BOLTS" AREAS IN PUBLIC FINANCIAL MANAGEMENT, IS DISPLACED CONTINUED TREATMENT OF BUDGET FORMAT, BUDGET THEORY, AND PUBLIC FINANCE. THIS LENDS CREDENCE TO RECENT REPORTS OF INCREASING PRACTITIONER OISSATISFACTION WITH ACADEMIC-BASED CONSULTING AND TRAINING IN THE FIELD AND RAISES OUESTIONS REGARD TO THE PUBLIC FINANCIAL MANAGEMENT CURRICULUM. 
03414 FRANK, H.A.

PUBLIC FIMANCIAL MANAGEMENT IN THE 1990'S: NEW DIRECTIONS FOR RESEARCH AND PEDAGOGY

AMERICAN REVIEW OF PUBLIC ADMINISTRATION, 22(3) (SEP 92), 189-206.

THE AUTHOR PROPOSES NEW DIRECTIONS FOR PUBLIC FINANCIAL MANAGEMENT IN THE 1990'S. HE CALLS FOR LESS RESEARCH AND PEDAGOGY DEVOTED TO BUDGET THEORY AND FORMAT WORK AND GREATER ATTENTION TO "NUTS-AND-BOLTS" TOPICS, SUCH AS CASH MANAGEMENT FORECASTING, AND BUDGET EXECUTION, AS WELL AS BROADER SOCIAL ISSUES RELATED TO U.S. COMPETITIVENESS. ANOTHER MAJOR AREA FOR COMSIDERATIOM IS BUPEAUCRATIC INCENTIVE STRUCTURE A TOPIC GENERALLY THOUGHT OF AS FALLING WITHIN THE PURVIEW OF PUBLIC PERSONNEL. PUBLIC FINANCIAL MANAGEMENT SHOULD ESCHEW PUBLIC ADMINISTRATION'S TRADITIONAL HOSTILITY TOWARD "ECONOMIC MAN" AND ITS CONCERM FOR CAPITAL FORMATION, SAVINGS, AND GROWTH.

03415 FRANK, $P$

PONER STRUGGLE IN POST-SOVIET RUSSIA

WORLD TOOAY $48(8-9)$ (AUG 92$)$ 155-158

AS PRESIDENT BORIS YELTSIN AND HIS SUPPORTERS STRUGGLE TO CREATE A NEW POST-SOYIET RUSSIA. THEY MUST OVERCOME MANY OBSTACLES AND DEAL WITH OPPOSITION FROM MANY QUARTERS, INCLUDING THE MILITARY-INDUSTRIAL LOBBY.

03416 FRANK, R.L.

PRELUDE TO COLD WAR: AMERICAN CATHOLICS AND COMMUNISM JOURMAL OF CHURCH \& STATE, 34(1) (WIN 92), 39-56.

THE APPEAL OF CATHOLIC ANTI-COMMUNIST RHETORIC IN THE INTERWAR ERA DERIVED FROM A CAREFUL AND THOROUGH FUSION OF IDEOLOGY AND RELIGION IN A RHETORIC THAT OFFERED AN ULTIMATE ORDERING OF TERMS THAT ENABLED AMERICAN CATHOLICS TO TRANSCEND THE LIMITATIONS OF BEING BOTH ROMAN CATHOLIC AND AMERICAN. RELIGIOUSLY, THE CRUSADE AGAINST COMMUNISM WAS A RHETORICAL MEANS OF REKINDLING COMMITMENT TO CATHOLIC DOCTRINE. POLITICALLY, THE MOVEMENT AFFIRMED THE PATRIOTISH OF EVERY CATHOLIC AMERICAN IN A PASSIONATE CAMPAIGN AGAINST THE ARCHENEMY OF DEMOCRACY. AMERICAN CATHOL ICS MIMED THE THEMES AND STRATEGIES OF POPE PIUS XI'S ENCYCLICAL ON COMMUNISM IN AN EFFORT TO PROVE THEIR LOYALTY TO BOTH THEIR CHURCH AND THEIR COUNTRY.

03417 FRANKEL, B.

THE SOCIAL MOVEMENTS AND THE POLITICAL CRISIS IN AUSTRALIA ARENA MAGAZINE, 2 (DEC 92), 11-14.

BORIS FRANKEL EXAMINES THE PROBLEMS FACING THE SOCIAL MOVEMENTS IN THE NEW POLITICAL CLIMATE IN AUSTRALIA AND THEIR PROSPECTS FOR RENEWAL. HE CONCLUDES THAT THE UNPLEASAMT REALITY FOR SOCIAL MOVEMENT ACTIVISTS IS THAT NO ADEOUATE SUBSTITUTE HAS BEEN FOUMO FOR THE POLT IICAL PARTY. YET WITHOUT NEH POL ITICAL FORMATIONS, PONERFUL RIGHT-WING POL ITICAL FORCES WII BRUSH ASIDE ISOLATED SOCIAL MOVEMENT. HE SUGGESTS THAT IT IS IMPERATIVE THAT NEW FORMS OF COOPERATION AND UNITED ACTION BE EXPLORED.

03418 FRANKEL, $N$. WATER AND TURKISH FOREIGN POLICY POLITICAL COMMUNICATION AND PERSUASION, 8(4) (1991), 257-311.

TURKEY AND IRAN ARE THE ONLY MIDDLE EASTERN COUNTRIES WITH ABUNDANT WATER SUPPLIES. TURKEY HAS DEVELOPED AN AMBITIOUS PROGRAM TO MANAGE THE HATERS OF THE TIGRIS AND EUPHRATES RIVERS AND HAS PLANS FOR OTHER WATER PROJECTS, WHICH HAVE THE POTENTIAL TO BENEFIT THE WATER-STARVED MIDOLE EAST. THIS ESSAY EXAMINES TURKISH PERSPECTIVES ON WATER MANAGEMENT AND THE INFLUENCE OF WATER ON TURKISH DOMESTIC AND FOREIGN AFFAIRS. IT DISCUSSES THE PURPOSE OF TURKEY'S WATER MANAGEMENT PROJECTS, THE EFFECT OF WATER ON TURKEY'S POSITION IN THE ARAB-ISRAELI CONFLICT, KURDISH SEPARATISM, AND OTHER IMPORTANT ISSUES.

03419 FRANKENBERGER, $K$

GULF STATES 'MEED TO DO MORE FOR OWN SECURITY'

GERMAN TRIBUNE, 31(1499) (JAN 92), 2

THE WAR WITH IRAQ HAS IMPOSED A LIMIT ON THE BAGHDAD REGIME'S FAR-REACHIMG AMBITIONS. NOH THAT THE HAR IS OVER, INTERNATIONAL AGENCIES RESPONSIBLE FOR INSPECTION MUST CONTIMUE TO EXERCISE YIGILANCE AMD TO ENSURE THAT SADOAM DOES MOT GAIN ACCESS TO WEAPONS OF MASS DESTRUCTION FROM THE FORMER SOVIET UNION'S BANKRUPT STOCK. PRESENTLY PRESIDENT BUSH HAS ADVISED HIS ARAB ALLIES IN THE GULF TO DRAW UP A SYSTEM OF COLLECTIVE SECURITY OF THER OWN THAT COULD BE SYSTEM OF COLLECTIVE SECURITY OF THER OWN THAT COULD ASSISTANCE PACTS WITH THE UNITED STATES, ARAB STATES IN THE GULF MUST FOR THE MOST PART LOOK AFTER THEIR OWN SECURITY, GULF MUST FOR THE MOST PART
PREFERABLY ON A JOINT BASIS.

03420 FRANKLIN, C.H.

ESCHEWING OBFUSCATION? CAMPAIGNS AND THE PERCEPTION OF U.S. SENATE INCUMBENTS

AMERICAN POLITICAL SCIENCE REVIEW, 85(4) (DEC 91),

1193-1214.

THE AUTHOR EXAMINES THE EFFECT OF CAMPAIGNS ON THE
VOTERS' PERCEPTION OF THE IDEOLOGICAL POSITIONS OF INCUMBENT SENATORS. THE RESULTS DEMONSTRATE THAT INCUMBENTS AFFECT VOTER PERCEPTION THROUGH THEIR ACTIONS BOTH IN OFFICE AHD ON THE CAMPAIGN TRAIL. USING THE 1988 SENATE ELECTION STUDY, THE AUTHOR FINDS THAT THE PERCEIVED LOCATION OF AN INCUMBENT DEPENDS ON HIS ROLL CALL VOTING RECORD, THE PERCEIVED POSITION OF HIS PARTY, AND THE VOTER'S OWN POSITION. CANDIDATES CAN AFFECT THE CLARITY OF THESE PERCEPTIONS THROUGH THEIR CAMPAIGN STRATEGIES. INCUMBENTS WHO STRESS ISSUES INCREASE THE CLARITY OF VOTER PERCEPTIONS, WHILE THE CHALLENGERS' ATTACKS ON INCUMBENTS REDUCE CLARITY. WHILE ELECTIONS ALONE INCREASE CLARITY, THESE EFFECTS ARE SMALL IN COMPARISON TO THE EFFECT DUE TO CANDIDATE CAMPAIGN STRATEGIES. THEREFORE, IN ORDER TO UNDERSTAND THE POLITICS OF ELECTIONS, SCHOLARS MUST INCORPORATE CANDIDATE STRATEGY INTO THEIR MODELS.

03421 FRANKLIN, C.H.

MEASUREMENT AND THE DYNAMICS OF PARTY IDENTIFICATION POLITICAL BEHAVIOR, 14(3) (SEP 92), 297-310.

RECENT SCHOLARSHIP HAS QUESTIONED THE REVISIONIST MODEL OF PARTY IDENTIFICATION, INCLUDING THE MEASUREMENT OF PARTY I.D. ACCORDING TO CRITICS, THE RESEARCH SHOWING THAT PARTISANSHIP IS RESPONSIVE TO OTHER POLITICAL EVALUATIONS IS ERRONEOUS DUE TO PECULIARITIES OF MEASUREMENT. THE AUTHOR TESTS THIS ASSERTION BY CONSIDERING THE EFFECTS THAT CHANGES IN MEASUREMENT HAVE ON ESTIMATES DF THE DYNAMICS OF PARTY IDENTIFICATION. THE RESULTS STRONGLY SUPPORT THE REVISIONIST CONCLUSIONS. THE FINDINGS OF RESPONSIVENESS OF PARTY IDENTIFICATION TO EVALUATIONS OF PARTY ISSUE POSITIONS ARE QUITE ROBUST IN THE FACE OF ALTERNATIVE MEASURES OF PARTY IDENTIFICATION.

03422 FRANKLIN, D.

INTERNATIONAL BOUNDARIES: EX-SOVIET UNION AND EASTERN EUROPE

WORLD TODAY, 48(3) (MAR 92), 38-40.

THE QUESTION OF INTERMATIONAL BOUMDARIES IS DOMINATING POLITICS THROUGHOUT EUROPE. IN THE EAST, NEW FRONTIER POSTS AND BARBED-WIRE BORDERS ARE BUSILY BEING ERECTED AS YUGOSLAVIA AND THE SOVIET UNION BREAK UP. FOR EXAMPLE, OF THE 23 BORDERS BETWEEN THE REPUBLICS OF THE FORMER SOVIET UNION, ONLY THREE ARE NOT BEING CONTESTED. THIS CREATES A FRIGHTENING POTENTIAL FOR CONFLICT--AND A GREAT CHALLENGE FOR DIPLOMACY.

03423 FRANKLIN, D.P.

EXTRAORDINARY MEASURES: THE EXERCISE OF PREROGATIVE POWERS EXTRAORDINARY MEASURES

UNIVERSITY OF PITTSBURGH PRESS, 1991, 172.

THIS BOOK PROPOSES A THEORY OF PRERDGATIVE POWER, BASED

ON THE CONTENTION THAT AMERICAN PREROGATIVES "ARE A' SET OF POHERS EMANATING FROM THE STATE. "THE AUTHOR ARGUES THAT STUDENTS OF PUBLIC LAN HAVE DEVOTED TOO MUCH ATTENTION TO THE PRESIDENTIAL PREROGATIVES AND NOT ENOUGH TO LEGISLATIVE AND JUDICIAL PREROGATIVES. BASED ON HIS READING OF THE INTENTIONS OF THE FOUNDERS AND FRAMERS, HE BELIVES THAT AN AMERICAN "SOCIAL CONTRACT" CREATED A CONSTIIUTION OF SOVEREIGN POWERS WHICH GOES WELL BEYOND THE FORMAL INSTI TUT IONAL ARRANGEMENTS OF THE CONSTI TUTION OF 1787. THIS LARGER CONSTITUTION CAN BE DISCOVERED BY HISTORICAL AND INSTITUTIONAL ANALYSIS, BY A FUNCTIONAL READING OF THE NECESSITY FOR CRISIS DECISION-MAKING, AND BY AN UNDERSTANOING OF THE LARGER PHILOSOPHICAL AND CONSTITUTIONAL PRINCIPLES WHICH INFORMED THE FRAMERS. THIS SECOND AND LARGER CONSTI TUTION PROVIDES THE CRITERIA BY WHICH TO JUDGE THE EXERCISE OF PREROGATIVE.

03424 FRANKOVIC, K.; GELB, J.

PUBLIC OPINION AND THE THOMAS NOMINATION

PS: POLITICAL SCIENCE AND POLITICS, XXV(3) (SEP 92 ),

$481-484$

UNTIL RECENTLY, THE NOMINATION OF A JUSTICE TO THE U.S. SUPREME COURT HAD' LITTLE PUBLIC OPINION RELEVANCE. ALTHOUGH QUESTIONS MIGHT BE RAISED ABOUT THE NOMINEE'S QUALIFICATIONS, THE AMERICAN PEOPLE TENDED TO ACQUIESCE IN COURT APPOINTMENTS. THAT CHANGED DURING THE REAGAN ADMINISTRATION, WHEN OPPONENTS OF ROBERT BORK EFFECTIVELY CAMPAIGMED TO TURM PUBLIC OPINION AGAINST HIM. CLARENCE THOMAS' NOMINATION RAISED EVEN MORE OUESTIONS ABOUT PUBLIC OPINION AS THE ISSUES OF RACE, HIS LEGAL OPINIONS, AND SEXUAL HARASSMENT CAME TO THE FOREFRONT.

03425 FRASER, N.; GORDON, L.

CONTRACT VERSUS CHARITY" WHY IS THERE NO SOCIAL CONTRACT VERSUS CHARITY" WHY IS THER
CITIZENSHIP IN THE UNITED STATES?

SOCIALIST REYIEH, 22(3) (JUL 92), 45-68.

THE AUTHORS ARGUE THAT THE IDEA OF SOCIAL CITIZENSHIP IN A WELFARE STATE IS OUT OF PHASE WITH POWERFUL CURRENTS IN CONTEMPORARY U.S. POLITICAL CULTURE. NEITHER THE PHRASE NOR THE IDEA OF SOCIAL CITIZENSHIP FIGURED IN THE 1992

PRESIDENTAL ELECTION. THEIR DISCUSSION PROCEEDS LARGELY FROM ENGLISH SOCIOLOGICAL THEORY TO CRITIQUE U.S. POLITICAL

CULTURE, HHILE AT THE SAME TIME, THEY USE ASPECTS OF U.S. 
HISTORY AND CULTURE TO REVEAL SOME LIMITATIONS OF THE ENGLISH CONCEPT. THEY EXPLORES WHAT IT WOULD TAKE TO REVIVIFY SOCIAL CITIZENSHIP IN THE FACE OF THE CONTRACTARIANISM.

03426 FRASER, $S$.

WHEN ALL THE FISH WERE GONE

CANADIAN FORUM, LXXI(809) (MAY 92), 14-17.

WHEN BIG BUSINESS AND GOVERMMENT OVERHAULED THE ATLANTIC FISHING INDUSTRY IT WAS THE BEGINING OF THE END FOR COD STOCKS AND A 500-YEAR-OLD WAY OF LIFE, STATES THIS ARTICLE ABOUT THE CANADIAN FISHING INDUSTRY. IT STATES THAT THERE IS MORE TO THE DISAPPEARANCE OF ATLANTIC COD STOCKS THAN SEALS MORE TO THE DISAPPEARANC

03427 FREDENBURG, $M$

CLEANING HOUSE

NATIONAL REVIEW, XLIV(20) (OCT 92), 44-46; 48

AS OF SEPTEMBER 15,88 MEMBERS OF THE HOUSE HAD RETIRED, LOST PRIMARIES, RUN FOR HIGHER OFFICE, OR DIED. NO MATTER WHAT HAPPENS IN NOVEMBER TO THE INCUMBENTS STILL ON THE BALLOT, THE 1993 FRESHMAN CLASS IS GUARANTEED TO BE THE HIGHEST SINCE WORLD WAR II. GENDER POLITICS AND ABORTION HAVE BOTH PLAYED A PART, BUT THE BIGGEST FACTORS HAVE BEEN REDISTRICTING AND ANTI-INCUMBENT SENTIMENT, FUELED BY THE HOUSE BANK AND POST OFFICE SCANDALS. THIS ARTICLE PREDICTS THAT THE FRESHMAN CLASS IS LIKELY TO HAVE A RECORD NUMBER OF WOMEN AND THAT IT APPREARS THAT THERE WILL BE NO SIGNIFICANT ADVANTAGE FOR ABORTION-RIGHTS CANDIDATES. IT OBSERVES THAT PEOPLE ARE VOTING FOR CHANGE.

03428 FREDENBURG, $M$.

PARTY WITHOUT A CAUSE

NATIONAL REVIEH, XLIV(3) (FEB 92), 36-39.

THE NATIONAL REPUBLICAN LEADERSHIP PRIDES ITSELF ON PUTTING WINNING ABOVE "IDEOLOGY". AS A RESULT, THIS ARTICLE STATES, THAT IT SUPPORTS CANDIDATES WHO ARE NEITHER LACKS SOLID PRINCIPLES, THEREFORE, IS ITS OWH BEST ENEMY.

03429 FREEDMAN, L.; KARSH, E.

HOW KUWAIT WAS WON: STRATEGY IN THE GULF WAR

INTERNAT IONAL SECURITY, $16(2)$ (FAL 91) 5-41

INTERNATIONAL SECURITY, $16(2)$ (FAL 91), 5-41.
THIS ARTICLE COMPARES THE STRATEGIES EMPLOYED BY IRAO AND THE U.S. -LED COALITION. THE MILITARY STRATEGIES USED BY EACH SIDE HERE ANTICIPATED BEFDRE THE WAR: THE COALITION RELIED ON AIR POWER TO PREPARE FOR AN EVENTUAL LAND CAMPAIGN, WHILE IRAO HOPED TO WEATHER THE STORM OF THE AERIAL OFFENSIVE AND THEN GET THE UNITED STATES INTO A VIETNAMSTYLE QUAGMIRE. BOTH STRATEGIES WERE SHAPED BY THE POLITICAL CONTEXT, BUT THE ALLIES SUCCEEDED IN MINIMIZING THEIR CASUALTIES AND HOLDING THE COALITION TOGETHER, WHEREAS COALITION, OR STIR UP DOMESTIC OPPOSITION IN THE WEST.

03430 FREEDMAN, L.

ORDER AND DISORDER IN THE NEW HORLD

FOREIGN AFFAIRS, 71 (1) (1992), 20-37.

THE UNITED STATES HAS ATTAINED AM INTERMATIONAL

PREEMINENCE BEYOND CHALLENGE AND IS WELL PLACED TO DEFINE BOTH THE CHARACTER OF THE EMERGING NEH STAGE IN

INTERNATIONAL HISTORY AND THE WEST'S ROLE WITHIN IT. YET THE

TASK IS PROVING TO BE EXTREMELY DIFFICULT AMD PERPLEXING.

EVENTS SINCE THE CONCLUSION OF THE GULF WAR HAVE QUALIFIED
CONFIDENCE IN THE ABILITY OF THE USA AND ITS ALLIES TO SHAPE

THE FUTURE ACCORDING TO THEIR VALUES AND INTERESTS.

03431 FREEDMAN, L.; KARSH, E.

THE GULF' CONFLICT 1990-1991--DIPLOMACY AND WAR IN THE NEW HORLD ORDER

PRINCETON UNIVERSITY PRESS, 1993,400

THIS BOOK PROVIDES A COMPREHENSIVE ACCOUNT OF IRAQ'S OCCUPATION OF KUHAIT, ITS EXPULSION BY A COALITION OF WESTERN AND ARAB FORCES SEVEN MONTHS LATER, AND THE AFTERMATH OF THE WAR. BLENDING NARRATIVE HISTORY WITH OBJECTIVE ANALYSIS, THE AUTHORS INQUIRE INTO THE FUNDAMENTAL ISSUES UNDERLYING THE DISPUTE AND PROBE THE STRATEGIC CALCULATIONS OF ALL THE PARTICIPANTS. THE CONFLICT OFFERS A "SNAPSHOT" OF THE INTERNATIONAL SYSTEM AT THE START OF THE 19905 AND AN OPPORTUNITY TO EXPLORE THE GLOBAL IMPACT OF THE BREAKUP OF THE THE SOVIET EMPIRE IN EUROPE. THE AUTHORS CONSIDER ISSUES SUCH AS WHY SADDAM HUSSEIN INVADED KUWAIT, THE PRESENCE OF ALTERNATIVES TO WAR FOLLOWING IRAQ'S INVASION OF KUWAIT, THE USE OF MILITARY POWER, AND THE REASONS WHY SADDAM HAS BEEN ABLE TO REMAIN IN POWER.

03432 FREEDMAN, $R$.

SOVIET POLICY TOHARD ISRAEL UNDER GORBACHEY

PRAEGER PUBLISHERS, 1991,141

THIS BOOK DISCUSSES THE CHANGES THAT HAVE TAKEN PLACE IN SOVIET-ISRAELI RELATIONS SINCE MIKHAIL GORBACHEV ASSUMED POHER IN 1985. IT MAKES THO MAJOR CONCLUSIONS. THE FIRST IS THAT SOVIET POLICY TOHARDS THE MIDDLE EAST CONTINUES, AS IN THE PAST, TO BE REACTIVE TO A SERIES OF REGIONAL
DEVELOPMENTS, AND THAT SUCCESSIVE SOVIET LEADERS HAVE BEEN ESSENTIALLY UNABLE TO STRENGTHEN THIS POLICY TO FIT SOVIET GOALS IN THE AREA. THE SECOND CONCLUSION IS THAT "THERE HOULD APPEAR TO BE MORE CONTINUITY THAN CHANGE IN SOVIET POLICY TOWARDS THE MIDDLE EAST."

03433 FREEDOMAN, R.O. (ED.) THE INTIFADA: ITS IMPACT ON ISRAEL, THE ARAB WORLD, AND THE SUPERPOWERS

INTERNATIONAL UNIVERSITY PRESS, 1991, 417. THIS COLLECTION OF ESSAYS EXPLORES THE INTIFADA'S ORIGINS AND CONSIDERS ITS CONSEQUENCES FOR MIDOLE EASTERN DIPLOMATIC EFFORTS. ESSAYS DEAL WITH SUCH SPECIFIC ISSUES AS THE ROLE OF THE PLO IN THE UPRISING AND THE UPRISING'S RECIPROCAL EFECTS ON THE PLO; U.S. RESPONSE TO THE INTIFADA; AMERICAN JEWISH REACTIONS; SYRIA, JORDAN, AND EGYPT'S FOREIGN POLICY FOLLOWING THE UPRISING; THE RESPONSE IN ISRAEL INCLUDING THE EFFECTS OF THE UPRISING ON BOTH MAJOR POLITICAL PARTIES IN ISRAEL; AND SOVIET POLICY TOWARDS THE
PALESTINIAN MOVEMENT.

03434 FREEMAN, G.

MIGRATION POLICY AND POLITICS IN THE RECEIVING STATES INTERNATIONAL MIGRATION REVIEW, 26(4) (WIN 92), 1144-1167. A SURVEY OF THE POLITICS OF IMMIGRATION IN THE MAJOR RECEIVING STATES SHOWS A STRONG PATTERN OF RESTRICTIONISM IN THE FACE OF UNPRECEDENTED PRESSURES OF ENTRY. BUT ALSO AMNESTIES, EXCEPTIONS ON HUMANITARIAN GROUNDS, AND HESITATION TO ENFORCE THE LAW. AS INDIVIDUAL STATES FOUNDER, MULTILATERAL STRATEGIES ABOUND, BUT WITH SCANT SUCCESS. THE IMMIGRATION CRISIS IMPEDES EC PROGRESS TOWARD THE SINGLE MARKET AND CONTRIBUTES TO OPPOSITION TO THE MAASTRICHT TREATY. IRONICALLY, THE FAILURE OF STATES TO DEAL WITH THE CRISIS MAY REINFORCE NATIONAL PREROGATIVES AND CAPACITIES WITH RESPECT TO IMMIGRATION AND STRENGTHEN RATHER THAN ERODE THE DISTINCTION BETWEEN ECONOMIC MIGRANTS AND REFUGEES.

03435 FREEMAN, $N$.

ECONOMIC AND POLITICAL REFORM IN VIETNAM

JOURMAL OF COMMUNIST STUDIES, 8(4) (DEC 92), 275-279.

THE AUTHOR DISAGREES HITH PER RONNAS AND ORJAN SJOBERG'S ANALYSIS OF THE PROSPECTS FOR CONTINUED REFORM IN VIETMAM. RONNAS AND SJOBERG HAVE STATED THAT VIETHAM'S ECONOMIC

REFORMS CANMOT CONTINUE TO BE SUCCESSFUL HITHOUT MEANINGFUL POL ITICAL CHANGE. HOWEVER, IN THIS ESSAY, THE AUTHOR ARGUE THAT VIETMAMESE POLITICAL REFORM IS CURREMTLY UMDESIRABLE.

03436 FREEMAN, N.J.

INTERNATINAL ECONOMIC RESPONSES TO REFORM IN VIETHAM: AN OVERVIEW OF OBSTACLES AND PROGRESS

STUDIES IN COMPARATIVE COMMUNISM, XXV(3) (SEP 92), 287-302. THE AUTHOR SURVEYS THE INTERNATIONAL ECONOMIC

COMMUNITY'S RESPONSE TO VIETNAM'S RECENT DOMESTIC REFORMS AND ITS BID FOR GRATER INTEGRATION INTO THE WORLD ECONOMY. MUCH HAS BEEN WRITTEN ABOUT THE GEOSTRATEGIC STANCES AND INITIATIVES THAT SURROUND INDOCHINA, BUT THERE HAS BEEN LESS ATTENTION PAID TO THE ECONOMIC SUBSTRUCTURE THAT LIES BEHIND THIS POLITICAL FRAMEWORK. AFTER OUTLINING THE ECONOMIC REFORMS IN VIETNAM, THE AUTHOR SUMAARIZED THE RESPONSES OF THE EASTERN BLOC STATES AND CHINA, THE USA, THE INTERNATIONAL LENDING INSTITUTIONS, JAPAN, THE EUROPEAN STATES, AND THE ASIAN COUNTRIES.

03437 FREEMAN, S

ORIGINAL MEANING, DEMOCRATIC INTERPRETATION, AND THE CONSTITUTION

PHILOSOPHY AND PUBLIC AFFAIRS, 21(1) (WIN 91), 3-42. THE SUPREME COURT'S ROLE IN THE U.S. CONSTITUTION HAS ALWYS BEEN IN DISPUTE. THIS ARTICLE ARGUES THAT ORIGINALISM IS INCOMPATIBLE WITH A DEMOCRATIC CONSTITUTION THE YIEW THAT DEMOCRACY IS NOT JUST A FORM OF GOVERMMENT; MORE ELEMENTALLY IT IS A KIND OF SOVEREIGNTY BASED IN THE EQUAL FREEDOM AND INDEPENDENCE OF ALL CITIZENS PROVIDES THE AIM OF THE ARTICLE WHICH IS TO TRACE THE CONSEQUENCES OF DEMOCRATIC CONTRACT THEORY FOR CONSTITUTIONAL INTERPRETATION AND THE ROLE OF THE COURTS IN JUDICIAL REVIEH. THE ARTICLE CONCLUDES ROLE OF THE COURTS IN JUDICIAL REVIEH. THE ARTICLE CONCLUDES
THAT ON THIS CONCEPTION OF DEMOCRACY, ORIGINALISM TURNS OUT

TO BE A PROFOUNDLY UNDEMOCRATIC VIEH.

03438 FREIE, J.F.

THE INDIVIDUAL LEARNING CONTRACT

PS: POLITICAL SCIENCE AND POLITICS, $X X V(2)$ (JUN 92),

230-234.

THE INDEPENDENT LEARNING CONTRACT (ILC) IS A

NONDIRECTIVE APPROACH TO TEACHING HHICH MOVES IN THE

DIRECTION OF CIVIC EDUCATION FOR DEMOCRACY WHILE OPERATING WITHIN THE PARAMETERS OF TRADITIOMAL EDUCATION. THE ILC IS BUILT UPON THE EVOLVING INTERESTS AND ASPIRATIONS OF EACH STUDENT. WORKING TOGETHER, THE STUDENT AND PROFESSOR SHAPE A PROGRAM OF STUDY THAT IS FOUNDED UPON THE STUDENT'S COMPELLING INTERESTS.

03439 FREITAS, C.R.D.

THE GREENHOUSE CRISIS: MYTHS AND MISCONCEPTIONS 
AREA, 23(1) (MAR 91), 11-18.

THIS PAPER HIGHLIGHTS AREAS OF UNCERTAINLY AND CONFUSION REGARDING THE GREENHOUSE CRISIS, AND IT EVALUATES COMPLICATIONS THAT ARISE FOR POLICY FORMULATION. THE PAPER OUTLINES THE DIFFICULTIES CREATED BY (A) THE

INTERDISCIPLINARY NATURE OF THE SUBJECT OF CLIMATE CONTROL, (B) THE GREAT RANGE OF RESEARCHERS INVOLVED, (C) THE EXPECTATION BY POLITICIANS OF UNCOMPLICATED ANSWERS FROM SCIENTISTS, (D) THAT POSSIBILITY THAT SCIENTISTS HAVE VESTED INTERESTS, AND (E) THE REALITY THAT SCIENTIFIC ADVICE IS WIDE OPEN TO ABUSE BY GOVERNMENTS. PHYSICAL EVIDENCE OF THREATS, INCLUDING THE THREAT TO THE COASTAL ZONE.

03440 FRELICK, B.

HAITIANS AT SEA: ASYLUM DENIED

REPORT ON THE AMERICAS, 26(1) (JUL 92), 34-38.

THE U.S. EMBASSY IN HAITI CONFIRMS "CREDIBLE REPORTS OF INDISCRIMINATE KILLINGS, POLICE HARASSMENT, ILLEGAL SEARCHES. INDISCRIMINATE KILLINGS, POL ICE HARASSMENT, ILLEGAL SEARCHES. .AND DETENTION OF PERSONS HITHOUT CHARGES..." YET HAITIAM
REFUGEES ARE TURNED AHAY. ALTHOUGH PRESIDENT BUSH CLAIMS REFUGEES ARE TURNED AHAY. ALTHOUGH PRESIDENT BUSH CLAIM REFUGEES AND POL ITICAL REFUGEES THIS ARTICLE VOICES CONCER REFUGEES AND POLITICAL REFUGEES THIS ART ICLE VOICES CONCERN ABOUT THE MESSAGE THAT THE UNITED STATES IS SENDING TO THE
REST OF THE WORLD. IT SUGGESTS THAT BUSH IS TRODING ON POOR, BLACK NON-VOTERS TO SUIT HIS POLITICAL INTERESTS AND THAT THIS COULD HELL HAVE WROUGHT THE END OF ASYLUM AS HE HAVE KNOWN IT.

03441 FRELICK, B.

STATE TERROR AND THE DEGRADATION OF POLITICS IN IRAQ MIDOLE EAST REPORT, $22(3)$ (MAY 92), 15-21

THE DEGRADTION OF IRAQI POLITICS AND SOCIETY UNDER THE BA'THI REGIME IS A STORY THAN CAN NOW BE PIECED TOGETHER FROM DOCUMENTS THAT JUST A FEW MONTHS AGO NO ONE HOULD HAVE DREAMED HAVING ACCESS TO. FOR SEVERAL HEEKS A TERRORIZED POPULATION OVERCAME ITS FEAR AND ATTACKED THAT STATE WHICH IT CONSIDERED RESPONSIBLE FOR ITS HUMILIATION AND SUFFERING. IN THE COURSE OF THESE EVENTS THEY CAPTURED TENS OF THOUSANDS OF INVALUABLE DOCUMENTS FROM THE VARIOUS IRAQI INTELLIGENCE ORGANIZATIONS. THESE DOCUMENTS RECOUNT THE FATES OF THOUSANDS OF IRAOIS, AND AL SO ARE AN EXCELLENT SOURCE TO UNDERSTANDING HOW THE BA? TH REGIME EXACERBATED CLEAVAGES IN IRAQI SOCIETY WHILE CLAIMING TO CREATE THE NEW CLEAVAGES IN IRAQI SOCIETY WHILE CLAIMING TO CREATE THE NEW IRAOI. THIS RISKLY AND UNSTABLE EQUILIBRIUM WHICH GUARA
THE REGIME'S SURVIVAL FOR MORE THAN THO DECADES IS NOW THE REGIME' S SURVIVAL FOR MORE THAN THO DECADES IS NOW
CRUMBLING, HITH GRAVE CONSEQUENCES FOR THE FUTURE OF THE CRUMBLING,
COUNTRY.

03442 FRELICK, B.

THE FALSE PROMISE OF OPERATION PROVIDE COMFORT: PROTECTING REFUGEES OR PROTECTING STATE POWER?

MIDOLE EAST REPORT, 22(3) (MAY 92), 22-27.

THE US-LED RESPONSE TO IRAO'S INVASION OF KUWAIT HAS HAD MAMY IMHEDIATE REPERCUSSIONS ON THE INTERNATIONAL

HUMANITARIAN NETHORK SET UP AT THE CLOSE OF WORLD WAR II. THE INTERVENTION FAILED TO ESTABLISH A MORE EOUITABLE AND FAR-REACHING SYSTEM FOR RESPONDING TO HUMANITARIAN NEEDS BASED NOT ON THE POPULARITY OF THE OPPRESSED GROUP OR ITS USEFULMESS IN PROMOTING PARTICULAR IDEOLOGICAL OR GEOPOLITICAL ENDS, BUT RATHER ON ITS VULNERABILITY AND NEED FOR PROTECTION. THIS ARTICLE SUGGESTS THAT THE INTERNATIONAL REGIME ESTABLISHD FOR REFUGGEES HAS BEEN CREATED AND MAINTAINED LESS FOR THEIR PROTECTION THAN TO PRESERVE THE PREROGATIVES OF POWERFUL STATES.

03443 FRENCH, D.

HAVE THE OPTIONS REALLY CHANGED? BRITISH DEFENSE POLICY IN THE TWENTIETH CENTURY

JOURNAL OF STRATEGIC STUDIES, 15(1) (MAR 92), 50-72.

IN THE 20TH CENTURY, THE HILINGNESS OF BRITISH

GOVERNMENTS TO DEVOTE GREATER OR LESSER RESOURCES TO DEFENSE HAS BEEN DETERMINED BY A NUMBER OF STRICTLY POLITICAL FACTORS. THE GOVERMMENTS HAVE TRIED TO BALANCE THE NEED FOR A STRONG DEFENSE AGAINST THE LIMITATIONS OF ECONOMIC SCARCITY. ONLY RARELY DURING PEACETIME HAVE THEY APPROACHED THE ELECTORATE TO PERSUADE THEM TO PAY MORE FOR DEFENSE. INSTEAD THEY HAVE PREFERRED TO STRETCH EXISTING RESOURCES BY ADOPTING THE LATEST HIGH-TECH MILITARY EQUIPMENT IN ORDER TO MULTIPLY THE FORCE AT THEIR DISPOSAL. THEY HAVE PURSUED BURDEN-SHARING STRATEGIES WITH THE DOMINIONS, INDIA, AND BURDEN-SHARING STRATEGIES WITH THE DOMINIONS, INDIA, AND
FOREIGN ALLIES. THEY HAVE SOUGHT ARMS CONTROL AGREEMENTS IN FOREIGN ALLIES. THEY HAVE SOUGHT ARMS CONTROL AGREEMENTS
ORDER TO REDUCE THE NEED TO COMPETE WITH FOREIGN RIVALS. ORDER TO REDUCE THE NEED TO COMPETE WITH FOREIGN RIVALS. THEY HAVE TRIED TO APPEASE POTENTIAL ENEMIES AND, FINALLY, WARS. IN THIS PAPER, THE AUTHOR ASSESSES THE EFFECTIVENESS WARS. IN THIS PAPER, THE AUTHOR ASSESSES THE EFFECTIVENESS OF THESE POLICIES ANO QUESTIONS WHETHER BRITAIN'S CURRENT DEFENSE POLIC
TRADITION.

03444 FRENCH, H.

THE VENEZUELAN COUNTERHEIGHT

HEMISPHERE 4(2) (WIN 92) 15-16.

CAPITALIZING ON VENEZUELA'S VAST OIL RESERVES AND THE
HIDESPREAD DESIRE FOR A COUNTERWEIGHT TO THE UNITED STATES IN THE CARIBBEAN PRESIDENT CARLOS AMDRES PEREZ HAS DEFTLY MOVED HIS COUNTRY INTO THE HEMISPHERE'S SELECT CIRCLE OF OIPLOMATIC POWERS. WITH FEH EXCEPTIONS, EACH OF THE CARIBBEAN ISLANDS RELIES UPON THE SAN JOSE ACCORD, COSPONSORED BY VENEZUELA AND MEXICO, TO IMPORT VITAL OIL. ALTHOUGH OIL IS ITS STRONG CARD, CARACAS' LEVERAGE IS NOT LIMITED TO PETROLEUM SUPPLIES. VENEZUELA HAS ALSO TAKEN THE LEAD IN RESPONDING TO U.S. TRADE POLICIES IN THE REGION AND HAS TAKEN AN ACTIVE ROLE IN HAITI'S PROBLEMS.

03445 FRENCH, H.W.

LEADING THE OPPOSITION--LAURENT GBAGBO

AFRICA REPORT, 37(6) (NOV 92), 49-50.

LAURENT GBAGBO, LEADER OF FRONT POPULAIRE IVORIEN, IS THE OPPOSITION'S MOST POPULAR FIGURE. RECENTLY FREED FROM JAIL, GBAGBO, ALONG WITH OTHER OPPOSITION LEADERS, IS 8 IDING HIS TIME, HORKING TO REFORM THE ELECTORAL LAWS, AND LOOKING AHEAD TO THE 1995 ELECTIONS, WHEN THE PDCI'S TIME MAY FINALLY BE UP.

03446 FRENCH, H.W.

OBSTACLES FOR THE OPPOSITION
AFRICA REPORT, $37(6)$ (NOV 92$), 46-48$.

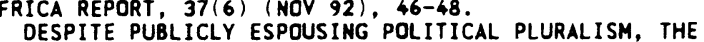
GOVERNMENT OF PRESIDENT FELIX HOUPHOUET-BOIGNY HAS SUBTLY AND SUCCESSFULLY THWARTED OPPOSITION ATTEMPTS TO MAKE HEADHAY AGAINST THE ONE-PARTY STATE. ALTHOUGH WEALTHY AND POWERFUL, THE RULING PARTY ELITE IS STAGNANT, AGING, AND JUDGED VULNERABLE BY THE LAURENT GBAGBO-LED OPPOSITION,
WHICH IS BIDING ITS TIME.

03447 FRENKEL, J.; GOLDSTEIN, M.

EUROPE'S EMERGING ECONOMIC AND MONETARY UNION

FINANCE AND DEVELOPMENT, 28(1) (MAR 91), 2-5.

AFTER MORE THAN A DECADE OF EXPERIENCE WITH THE EUROPEAN MONETARY SYSTEM (EMS), THE MEMBER COUNTRIES OF THE EUROPEAN COMMUNITY ARE NOW ENGAGED IN IMPORTANT DISCUSSIONS AND NEGOTIATIONS ABOUT THE PATH TO ECONOMIC AND MONETARY UNION (EMU). THIS ARTICLE TAKES A LOOK AT KEY ISSUES RELATING TO THE DESIGN AND IMPLEMENTATION OF MONETARY POLICY IN THE EMERGING EMU. THE EMPHASIS IS ON THE INTERRELATIONSHIPS AMONG PRICE STABILITY, CURRENT ACCOUNT EQUILIBRIUM AND EXCHANGE RATE STABILITY, AS WELL AS THE QUESTION OF THE DEGREE OF COORDINATION AND RULES VERSUS DISCRETION. ALSO CONSIDERED ARE THE CRITICAL IMPLICATIONS OF FISCAL POL ICY WAYS OF ENCOURAGING FISCAL DISCIPLINE.

03448 FRENZEL, B.

TERM LIMITS AND THE IMMORTAL CONGRESS

BROOKINGS REVIEW, $10(2)$ (SPR 92), 18-22.

TROKINGS REVIEW, 10(2) (SPR 92), 18-22. THE AUTHOR DISCUSSES THE PROBLEM OF ENTRENCHED
IMCUMBENTS IN THE U.S. CONGRESS. THE MOVEMENT TO LIMIT THE INCUMBENTS IN THE U.S. CONGRESS, THE MOVEMENT TO LIMIT THE NUMBER OF TERMS A REPRESENTATIVE CAN SERVE, AND

03449 FRETZ, G. NEGI, T S. PIKE, P.; SHER, D.T.K. THE ENVIRONMENT: ENVIRONMENTAL PROTECTION IN RELATION TO THE ENVIRONMENT: ENVIRONMENTAL PROTECTION IN RELATION
POPULATION GROWTH, INDUSTRIALIZATION, AND URBANIZATION POPULATION GROWTH, INDUSTRIALIZATION, AND
PARL IAMENTARIAN, LXXIII (1) (JAN 92) 16-18.

PARLIAMENTARIAN, LXXIII (1) (JAN 92), 16-18. POPULATION GROWTH, INDUSTRIALIZATION, AND URBANIZATIOM ARE INTEGRAL PARTS OF THE GRONTH PROCESS THROUGHOUT THE
WORLD. TODAY DEVELOPED COUNTRIES ARE PAYING THE PRICE FOR WORLD. TODAY DEVELOPED COUNTRIES ARE PAYING THE PRICE
NOT ADDRESSING ENVIRONMENTAL ISSUES EARLIER IN THEIR DEVELOPMENT. DEVELOPING COUNTRIES HAVE THE ADVANTAGE OF LEARNING FROM THIS EXPERIENCE AND HAVE THE OPPORTUNITY TO INSTITUTE A BETTER ALLOCATION OF THEIR NATURAL RESOURCES.

03450 FREY, B.; EICHENBERGER, R. ANOMALIES IN POLITICAL ECONOMY PUBLIC CHOICE, 68 (1-3) (JAN 91), 71-90. RESULTS IN' COGNITIVE PSYCHOLOGY AND EXPERIMENTAL ECONOMICS INDICATE THAT UNDER IDENTIFIABLE CONDITIONS INDIVIDUALS DO NOT ACT IN AN ECONOMICALLY RATIONAL WAY. THESE RESULTS ARE IMPORTANT FOR POLITICAL ECONOMY. ANOMALIES APPEAR IN THE BEHAVIOR OF VOTERS, POLITICIANS AND ADMINISTRATORS. ECONOMIC MARKETS DO NOT FULLY ELIMINATE ANOMALIES IN THE AGGREGATION PROCESS. IT IS SHOWN THAT POLITICAL AGGREGATION BY DEMOCRACY, BARGAINING OR BUREAUCRACY MAY WEAKEN OR STRENGTHEN SUCH INDIVIDUAL ANOMALIES. MOREOVER, INSTITUTIONS CAN PARTIALLY BE INTERPRETED AS ENDOGENOUSLY EMERGING AS A RESULT OF IMDIVIDUALS' DEMANDS TO COPE WITH AMOMALIES.

03451 FRICKE K.

THE STATE SECURITY APPARATUS OF THE FORMER GDR AND ITS LEGACY

AUSSEN POLITIK, 43(2) (1992), 153-163.

ONE OF THE MOST OMEROUS GDR LEGACIES IS THE HIDELY RAMIFIED STATE SECURITY SYSTEM (STASI) BECAUSE OF ITS UNDERHAND AND UNSCRUPULOUS METHODS, IT WAS FEARED BY THE POPULATION. HOW CAN A DEMOCRACY, HHICH CAN ONLY EMPLOY DEMOCRATIC MEANS AGAINST ITS OPPONENTS, AND IN THIS 
PARTICULAR CASE, IS ALSO CONFRONTED WITH A SYSTEMATIC COVERING UP OF CRIMINAL TRACES, MEET THIS CHALLENGE? THE AUTHOR A LEADING AUTHORITY ON PROBLEMS RELATING TO THE STASI EXAMINES THIS QUESTION IN DETAIL.

03452 FRIEDAN, $B$.

OUR PARTY

NEW REPUBLIC, 207(15) (OCT 92), 16, 18, 20

THE AUTHOR DISCUSSES HOW WOMEN'S ROLE AND CLOUT HAS CHANGED IN THE U.S. POLITICAL ARENA, PARTICULARLY IN THE CHANGED IN THE U.S. POLITICAL ARENA, PART
DEMOCRATIC PARTY, OVER THE PAST 20 YEARS.

03453 FRIEDBERG, A.; KFIR, A.

THE POLITICAL AGEMDA AMD POLICY-MAKING: THE CASE OF EMIGRATION FROM ISRAEL

INTERNATIONAL JOURNAL OF PUBLIC ADMINISTRATION, 15(7) (1992), 1449-1468

THIS ARTICLE EXAMINES THE PROCESS OF INTRODUCING THE PHENOMENON OF EMIGRATION FROM ISRAEL ON THE ISRAELI POLITICAL AGENDA, THE PLACE OF THIS PHENOMENON ON THE AGENDA, ITS EFFECT ON PUBLIC POLICY MAKING IN THIS SPHERE, AND ITS BEING DELEGATED FROM AN IMPORTANT ITEM TO A PSEUDO ITEM. BASED ON ONE OF THE MODELS OF COBB AND ROSS--AN ANALYSIS IS MADE OF THE TRENDS OF DEVELOPMENT AND STAGES OF THE RISING OF THE TOPIC OF EMIGRATION ON THE POLITICAL AGENDA AND THE STRATEGIES, PROCEDURES AND FRAMEWORKS THAT HAVE LED TO ITS INCLUSION ON THE AGENDA. IT SUGGESTS THAT ALTHOUGH THE PRESUMPIIVE PROCESSES AND FACTORS THAT ARE RAISED MIGHT EXPLAIN THE ALTERATION OF THE PLACE OF THE PHENOMENON OF EMIGRATION ON THE ISRAELI POLITICAL AGENDA, IT SEEMS THAT THEY ARE ALSO CAPABLE OF EXPLAINING THE CONVERSION OF OTHER TOPICS FROM REAL ONES TO PSEUDO ONES.

03454 FRIEDBERG, A.

WHY DIDN'T THE UNITED STATES BECOME A GARRISON STATE? INTERMATIONAL SECURITY, 16(4) (SPR 92), 109-142.

THE INTERIOR DIMENSION OF THE NATIONAL STRATEGY OF THE UNITED STATES AFTER THE CONCLUSION OF THE COLD WAR IS UNITED STATES AFTER THE CONCLUSION OF THE COLD WAR IS EXAMINED. THIS ARTICLE ARGURES THAT THE U.S. APPROACH TO THE SUPERPOWER COMPETITION WAS SHAPED BY FACTORS THAT ARE OFTEN STATES. EVEN IN THE PRESENCE OF A COMPELLING EXIERNAL THREAT STATES. EVEN IN THE PRESENCE OF A COMPELLING EXTERNAL THREAT, GROUP PRESSURES AND THE CONTENT OF AMERICAN IDEOLOGY GROUP PRESSURES AND THE CONTENT OF AMERICAN IDEOLOGY COMBINED TO PLACE VERY REAL LIMITS ON THE POHER OF THE STATE OVER SOCIETY AND THE ECONOMY. THE EXISTENCE OF THESE EASED THE UNITED STATES TOWARDS A PARTICULAR KIND OF MILITARY POSTURE AND AWAY FROM SEVERAL ALTERNATIVES THAT MIGHT HAVE APPEARED EQUALLY PLAUSIBLE ON PURELY STRATEGIC GROUNDS. THE AUTHOR BELIEVES THAT THESE CHOICES ALLOWED THE UNITED STATES TO STAY THE COURSE OF AN EXTENDED COMP
WITHOUT DOING ITSELF IRREPARABLE INTERNAL INJURTY.

03455 FRIEDLAND, J.; DO ROSARIO, L.

FINAMCIAL EARTHOUAKE

FAR EASTERN ECONOMIC REVIEW, 155(47) (NOV 92), 55-58.

AFTER MORE THAN THO YEARS OF DECLINE, JAPAN'S PROPERTY

MARKET STILL DOES NOT SEEM TO HAVE TOUCHED BOTTOM. LAND

PRICES MAY HAVE FALLEN $30 \%$ SINCE THEY PEAKED AT THE END OF 1989, BUT ANALYSTS SAY VALUES WOULD HAVE TO FALL BY ANOTHER 30\% OR SO BEFORE REACHING HHAT THEY REGARD AS A MORE REASONABLE LEVEL. SUCH A PROSPECT IS TDO AHFUL TO CONTEMPLATE FOR BANKS AND DEVELOPERS, NOT TO MENTION THE GOVERNMENT. INDEED, THE ONLY SIZABLE GROUP WITH AN INTEREST IN SEEING THE MARKET FALL FURTHER ARE THE 38\% OF THE POPULATION WHO DO NOT OWN THEIR OHN HOMES. THIS ARTICLE ANALYZES THE CONFLICTING VIEWS OF PLAYERS IN THE JAPANESE PROPERTY MARKET, AND HOW THE IMBALANCE BETWEEN SUPPLY AND DEMAND MIGHT BE WORKED OUT.

03456 FRIEDLAND, J.

HOW TO BE INSCRUTABLE

FAR EASTERN ECONOMIC REYIEW, 155(9) (MAR 92), 29-30.

ASIANS ARE TAKING THEIR PERSONAL INVESTMENTS OFFSHORE BY USING A SWELLING REGIONAL COMMUNITY OF PRIVATE BANKERS AND FUND MANAGERS TO SHIELD THEIR MONEY FROM POLITICAL CURRENTS AND TO AVOID TAXES. THEY ARE DOING THIS ON A CORPORATE AEVEL AS WELL COMPANIES LARGE AND SMALL. FROM NEW DELHI TO MANILAS WELL COMPANIES LARGE AND SMALL, FROM NEW DELHI PLACES LIKE THE BRITISH VIRGIN ISLANDS TO BEAT THE TAXMAN, PLACES LIKE THE BRITISH VIRGIN ISLANDS TO BEAT THE TO FRUSTRATE THE CURIOUS, AND TO ISOLATE POTENTIAL TAXMAM, LIABILITIES. KEY ASIAN OFFSHORE CENTERS INCLUOE HONG KONG, SINGAPORE, LABUAN, THE MARSHALL ISLANDS, NAURU, VANUATU, DOMICILES ARE USED FOR TASKS AS DIVERSE AS SHIELDING MONEY FROM A LITIGIOUS EX-SPOUSE TO AVOIDING THE CONVEYANCING CHARGES ON THE TRANSFER OF A HANDFUL OF PARKING PLACES. THEY ARE USED BY IMMIGRATION ATTORNEYS TO PUT THE AFFAIRS OF THEIR CLIENTS IN ORDER AND BY MERCHANT BANKERS TO CUT THE TAX BILL ON AIRCRAFT LEASING DEALS

03457 FRIEDLAND, J.

TAX CUTS IN DEMAND

FAR EASTERN ECONOMIC REVIEH, 155(44) (NOV 92), 46-47.
JAPAN'S LEADING POLITICIANS ARE CURRENTLY TOO DISTRACTED BY FACTIONAL RIVALRIES TO TAKE THE INITIATIVE ON TAX REFORM. BUT THEY MAY FIND IT HARD TO STAY AHAY FROM THE ISSUE AS EVIDENCE MOUNTS THAT JAPAN'S SPUTTERING ECONOMY IS NOT RESPONDING TO THE HOPED-FOR STIMULUS OF LOWER INTEREST RATES AND HIGHER PUBLIC SPENDING. PRIVATE ECONOMISTS SUGGEST THAT JAPAN'S ECONOMY WILL GROW BY ONLY $1.4-1.6 \%$ IN THE YEAR TO 31 MARCH 1993. A GROWING NUMBER OF JAPANESE BUSINESS

MARCH 1993. A GROWING NUMBER OF JAPANESE BUSINESS ORGANIZATIONS ARE CALLING FOR INCOME TAX CUTS WHICH, THEY
ARGUE, HOULD HAVE ONLY A MINOR EFFECT ON GOVERMMENT REVENUES ARGUE, HOULD HAVE DNLY A MINOR EFFECT ON GOVERMMENT REVE
BUT WOULD INDUCE CDNSUMERS TO SPEND MORE ON GOOOS AND BUT WOULD INDUCE CONSUMERS TO SPEND MORE ON GOODS AND
SERVICES. THE SUCCESS OF THE CAMPAIGN FOR TAX CUTS WILL SERVICES. THE SUCCESS OF THE CAMPAIGN FOR TAX CUTS

HINGE ON A RESUMPTION OF CONSUMER DEMAND. IF THE GOVERNMENT'S FISCAL STIMULUS PACKAGE FAILS TO JUMP-START THE ECONOMY--AND IF MAJOR DEMAND-SIDE INDICATORS SUCH AS RETAIL
SALES AND INVENTORY LEVELS FAIL TO RESPOND--THE DEBATE WILL SALES AND INVENTORY LEVELS FAIL TO RESPOND--THE
TAKE ON AN INCREASINGLY POLITICAL COMPLEXION.

03458 FRIEDLANDER, J.

RELIGIOUS METAPHYSICS AND THE NATION-STATE: THE CASE OF OSKAR GOLDBER

SOCIAL RESEARCH, 59(1) (SPR 92), 151-168.

OSKAR GOLDBERG'S ENEMIES CHARACTERIZED HIM AS A JEWISH FASCIST, BUT HIS SUPPORTERS INCLUDED LEFT-HING POLITICAL ACTIVISTS HHO INCORPORATED HIS THEOLOGICAL ANALYSIS INTO THEIR POLITICAL CRITIQUE OF EUROPEAN NATIONALISM. GOLDBERG'S IDEAS CONFIRMED METAPHYSICALLY THE POLITICAL OPPOSITION HIS DISCIPLES EXPRESSED TO THE FORMATION OF ALL NATION-STATES, INCLUDING THE STATE OF ISRAEL. THE QUESTIONS RAISED BY GOLDBERG AND HIS FOLLOWERS REMAIN BURNING ISSUES FOR JEWISH INTELLECTUALS IN FRANCE AS THEY REVIEW THE OPTIONS OPEN TO THOSE WHO WANT TO LIVE AS JEWS IN THE MODERN WORLD.

03459 FRIEDMAN, A.

BNL HELL

NEW REPUBLIC, 207(20) (NOV 92), 18-20

THE ORIGINS OF "IRAQGATE" CAN BE FOUND IN THE WAY THE

REAGAN ADMINISTRATION'S TILT TOWARD SADDAM HUSSEIN INCREASED

AFTER GEORGE BUSH TOOK OVER THE WHITE HOUSE. APOLOGISTS FOR

THE BUSH ADMINISTRATION ARE EAGER TO DISMISS HIS ACTIONS AS

A "FAILED POLICY," BUT IT WAS FAR MORE THAN A POLICY MISSTEP.

IT MAY YET BE SHOWN THAT SOME OF THE COVERT ASSISTANCE

PROVIDED TO IRAO WAS ILLEGAL, AND THE EVIDENCE SUGGESTS THAT

THERE WAS A COVER-UP THAT ALMOST CERTAINLY BROKE THE LAW.

03460 FRIEDMAN, J.

ACCOUNTING FOR POLITICAL PREFERENCES: CULTURAL THEORY VS CULTURAL HISTORY

CRITICAL REVIEW, 5(3) (SUM 92), 325-352.

A STRIKING NEW ATTEMPT TO GO BEHIND THE LIBERAL AND ATIONAL-CHOICE STARTING POINT IN ORDER TO UNDERSTAND POL ITICAL PREFERENCES IS FOUND IN AARON WILDAVSKY'S CULTURAL THEORY. EVEN WHILE REJECTING METHODOLOGICAL INDIVIDUALISM, CULTURAL THEORY'S MONOCAUSALLY SOCIAL THEORY OF PREFERENCE FORMATION RETAINS IN A NEW GUISE THE LIBERAL PRESERYATION OF PREFERENCES FROM CRITICISM BY REESTABLISHING A DETERMINISTIC VIEW DF THE FORMATION OF VALUES, LEADING IT TO SHARE WITH LIBERALISM AN AHISTORICAL VIEN OF THIER ORIGINS.

03461 FRIEDMAN, $M$.

FRANKLIN D. ROOSEVELT, SILVER, AND CHINA

JOURNAL OF POLITICAL ECONOMY, 100(1) (FEB 92), 62-83.

THE SILYER PURCHASE PROGRAM, INITIATED BY PRESIDENT FRANKLIN D. ROOSEVELT IN 1933 IN RESPONSE TO THE SMALL BUT POLITICALLY-POTENT SILVER BLOC, GAVE A LARGE SHORT-TERM SUBSIDY TO SILVER PROOUCERS BUT DESTROYED ANY LONG-RUM MONETARY ROLE FOR SILVER. MORE IMPORTANTLY, IT IMPOSED SEVERE DEFLATION ON CHINA. THE ONLY MAJOR COUNTRY STILL ON A SILVER STANDARD, AND FORCED IT ONTO A FIAT STANDARD, WHICH ACCELERATED IN TIME AND SEVERITY THE SUBSEQUENT WARTIME INFLATION AND POSTWAR HYPERINFLATION. THUS, THE SILVER PURCHASE PROGRAM CONTRIBUTED, THOUGH PERHAPS ONLY MODESTLY, TO THE ULTIMATE TRIUMPH OF THE COMHUNISTS IN CHINA.

03462 FRIEDMAN, $S$.

NAFTA AS SOCIAL DUMPING

CHALLENGE, 35(5) (SEP 92), 27-32.

THE CONVENTIONAL WISDOM THAT THE NORTH AMERICAN FREE

TRADE AGREEMENT (NAFTA) WILL BE UNAMBIGUDUSLY GOOD FOR U.S

TRADE AGREEMENT (NAFTA) WILL BE UNAMBIGUOUSLY GOOD FOR
INCOMES AND JOBS MAY BE COMFORTING, BUT IT IS ALMOST

INCOMES AND JOBS MAY BE COMFORTING, BUT IT IS ALMOST
CERTAINLY HRONG. THE BUSH-SALINAS BLUEPRINT FOR ECONOMIC

CERTAINLY HRONG. THE BUSH-SALINAS BLUEPRINT FOR ECONOMIC
INTEGRATION IGNORES THE INTERESTS OF WORKERS, FARMERS, AND

INTEGRATION IGNORES THE INTERESTS OF WORKERS, FARMERS, AND
ENYIRONMENTALISTS ON BOTH SIDES OF THE BORDER. THE EUROPEAN

ENVIRONMENTALISTS ON BOTH SIDES OF THE BORDER. THE EUROPEAM

COMMUNITY OFFERS A MORE POSITIVE MODEL, WITH BIG "SOCI
FUNDS" AND A CHARTER FOR UPHARD SOCIAL MOBILIZATION.

03463 FRIEND, J.H.

THE P.S. IN 1992: SOCIAL DEMOCRACY FOR THE LEAN YEARS FRENCH POLITICS AND SOCIETY, 10(1) (WIN 92), 69-73.

ON DECEMBER 13-15, 1991, THE FRENCH SOCIALIST PARTY HELD A SPECIAL CONGRESS TO UNVEIL "NOUVEL HORIZON," A SORT OF PLATFORM DESIGNED TO COME TO TERMS HITH BOTH' THE MISTAKES AND SUCCESSES OF THE PAST AND TO TRACE A FUTURE THAT HILL BE IDENTIFIABLY SOCIALIST. 
03464 FRISCH, H.

BETWEEN DIFFUSION AND TERRITORIAL CONSOLIDATION IN REBELLION: STRIKING AT THE HARD CORE OF THE INTIFADA TERRORISH AND POLITICAL VIOLENCE, 34(4) (WIN 92), 39-62. THE LEADERSHIP OF THE INTIFADA IN THE TERRITORIES TEACH A STRATEGY OF LOH-SCALE VIOLENCE. TO SUSTAIN A REBELLION
OVER A LONG PERIOD, THERE WAS A NEED TO CREATE TERRITORYWIDE ORGANIZATIONS, WHICH ALSO PROVIDED SERVICES TO A PUBLIC WHICH EXPERIENCED GREAT HAROSHIPS. TERRITORIAL CONSOLIDATION WAS NEVER ACHIEVED. A STRATEGY OF ORGANIZATIONAL DIFFUSION INCREASES THE NEED FOR CENTRALIZED CONTROL, A FUNCTION WHICH THE UNC FAILED TO PERFORM. POLITICAL STRIFE WITHIN THE HARD CORE, INCREASING ABUSE OF ITS POWER, AND SOCIAL LAWLESSNESS COMPOUNDED THE PROBLEM OF VULNERABILITY, AND EVENTAULLY TRANSFORMED A POPULAR INTIFADA INTO A MANHUNT.

03465 FRISKEN, F.

LOCAL CONSTRAINTS ON PROVINCIAL INITIATIVE IN A DYNAMIC LOCAL CONSTRAINTS ON PROVINCIAL INITIATIVE IN A DYNAMI CANADIAN JOURNAL OF POLITICAL SCIENCE, XXIV(2) (JUN 91), 351-378.

ONTARIO'S ATTEMPT IN THE 1970 S TO REFORM ITS SYSTEM OF LOCAL PROPERTY TAXATION AIMED TO MAKE THE LOCAL TAX SYSTEM MORE EQUITABLE AND EFFICIENT IN THE INTEREST OF ALLOWING LOCAL GOVERNMENTS GREATER AUTONOMY TO ACT HITHIN THEIR OWN AREAS OF RESPONSIBILITY. IN TRYING TO IMPLEMENT THE PRDGRAMME, THE GOVERNMENT USED A VARIETY OF MEANS TO INFORM LOCAL OFFICIALS ABOUT THE OBJECTIVES OF REFORM AND TO SECURE THEIR CO-OPERATION IN ACHIEVING IT. THESE EFFORTS FAILED AND THE PROVINCE ABANDONED THE FIELD TO LOCAL AND REGIONAL GOVERNMENTS, HAVING CONCLUDED THAT THE ECONOMIC AND POLITICAL COSTS OF PROVINCIALLY IMPOSED REFORM OUTWEIGHED ANY ADVANTAGES TO BE DERIVED FROM IT. THE OUTCOME ATTESTED TO THE INFLUENCE THAT LOCAL INTERESTS AND INSTITUTIONS CAN EXERCISE OVER PROVINCIAL POLICY-MAKING DESPITE THEIR LEGALLY SUBORDINATE POSITION IN THE GOVERNMENTAL HIERARCHY.

03466 FRITSCHER, F.

THE END OF ANGOLA'S PUPPET SHOW

WORLD PRESS REVIEH, 39(9) (SEP 92), 39

THE EMERGENCE OF 30 NEW POLITICAL PARTIES AND THE RETURN OF JONAS SAVIMBI, LEADER OF THE NATIONAL UNION FOR THE TOTAL MDEPNDENCE OF ANGOLA, HAVE GIVEN THE PEOPLE OF ANGOLA HOPE, FUTURE.

03467 FRODEMAN, $R$.

RADICAL ENYIRONMENTALISM AMD THE POLITICAL ROOTS OF RADICAL ENVIRONMENTALISM AND THE POLITICAL ROOTS OF ENVIRONMENTAL ETHICS, 14 (4) (HIN 92), 307-319.

THIS ARTICLE EXAMINES THE CLOSE RELATIONSHIP BETHEEM RADICAL ENYIRONMENTAL ISM AND POSTMODERNISM. IT ARGUES THAT RADICAL ENVIRONMENTALISM AND POSTMODERNI SM. IT ARGUES THAT
THERE IS AN INCOHERENCE WITHIN MOST POSTMODERNIST THOUGHT, BORN OF AN UNWILLINGNESS OR INCAPACITY TO DISTINGUISH BORN OF AN UNWILLINGNESS OR INCAPACITY TO DISTINGUISH
BETHEEN CLAIMS TRUE FROM AN ONTOLOGICAL OR EPISTEMOLOGICAL PERSPECTIVE AND THOSE APPROPRIATE TO THE EXIGENCIES OF POLITICAL LIFE. THE FAILURE TO DISTINGUISH WHICH DIFFERENCES MAKE A DIFFERENCE NOT ONLY VITIATES POSTMODERNIST THOUGHT, BUT ALSO RUNS UP AGAINST SOME OF THE FUNDAMENTAL ASSUMPTIONS OF RADICAL ENVIRONMENTALISM.

03468 FROGNIER, A.P.; DEWINTER, L.

THE STATE OF POLITICAL SĆIENCE IN BELGIUM EUROPEAN JOURNAL OF POLITICAL RESEARCH, 20(3-4) (DEC 91), 389-397.

THE AUTHORS OUTLINE THE FIELDS OF INTEREST WITHIM

BELGIAN POLITICAL SCIENCE AND THEN DESCRIBE THE DISCIPLINE'S INSTIIUTIONAL ARRANGEMENTS. THEY ALSO DISCUSS SOME OF THE STRUCTURAL PROBLEMS OF POLITICAL SCIENCE IN BELGIUM.

03469 FROHLICH, T.

IN SPITE OF CRITICISM, PERHAPS RIO DOES MARK A BEGINNING GERMAN TRIBUNE, (1520) (JUN 92), 1-2.

DESPITE THE WIDESPREAD CRITICISM OF THE UNITED NATIONS EARTH SUMMIT HELD IN RIO DE JANERIO, THE CONFERENCE CAN BE SEEN AS THE STARTING POINT FOR A NEW UNDERSTANDING OF THE RELATIONSHIP BETWEEN THE ENVIRONMENT AND DEVELOPMENT. THE SHORTCOMINGS OF TODAY'S POLITICIANS WERE GLARINGLY APPARENT AT THE SUMMIT WHERE THE GENERAL CONVENTION ON PROTECTION OF THE CLIMATE CONTAIMED NO BINDING GOALS ON THE REDUCTION OF GREENHOUSE GASES. NEVERTHELESS, THE CLIMATE CONVENTION IS NOW A REALITY, AND IT WILL BE INTERNATIONALLY BINDING. THE PROSPECTS OF IT BEING TIGHTENEED IN THE NEXT FEW YEARS IN PROSPECTS OF IT BEING TIGHTENEED IN THE NEXT FEN YEARS IN LINE WITH THE VIENNA CONVENTION ON PROTECTION OF THE OZONE LAYER ARE REASONABLE. PERHAPS THE LARGEST SUCCESS OF THE SUMMIT WAS THAT IT MARKED THE FIRST TIME THAT THE CONNECTION BAS PRESENTED AND DISCUSSED AT A WORLDWIDE FORUM. THIS IS A WAS PRESENTED AND DISCUSSED AT A WORLDWIDE FORUM. THIS PRECONDITION TO THE ATTITUDE CHAN
REACHING ENVIRONMENTAL REFORM.

03470 FROST, $G$.

ADRIFT IN EUROPE
FREEDOM REVIEW, 23(2) (MAR 92), 8-13.

THOSE IN FAVOR OF A SINGLE FEDERAL EUROPEAN STATE HAVE AMPLE REASON TO SUPPOSE THAT THE ESTABLISHMENT OF A EUROPEAN UNION AT MAASTRICHT HAS CREATED, IN EMBRYO FORM, THE CRUCIAL ELEMENTS OF A FEDERAL EUROPE. EUROPEAN FEDERALISTS BELIEVE THAT TIME HILL TAKE CARE OF THE REST AND THAT, WHILE THE AMBIVALENT AND EXCESSIVELY PRAGMATIC BRITISH MAY NOT LIKE IT, THE MOMENTUM BEHIND THE CREATION OF A FEDERAL STATE IS IRRESISTIBLE. IN DEFERENCE TO BRITISH SENSIBILITIES THE WORD "FEDERAL" MAY HAVE BEEN DROPPED FROM THE TEXT OF THE MAASTRICHT TREATY BUT, IN THE FEDERALISTS' VIEH, EUROPE'S DESTINY CANNOT BE DERAILED BY SUCH STRATAGEMS. IN THIS ARTICLE, THE AUTHOR CRITICALLY AMALYZES THIS VIEW AND TAKES ISSUE WITH IT.

03471 FROST, L.

THE EVOLUTION OF THE INTER-AMERICAN COURT OF HUMAN RIGHTS: REFLECTIONS OF PRESENT AND FORMER JUDGES

HUMAN RIGHTS QUARTERLY, 14(2) (MAY 92), 171-205.

THE HISTORY OF THE INTER-AMERICAN COURT OF HUMAN RIGHTS DATES BACK TO 1969, WHEN A SUBCOMMITTEE OF THE ORGANIZATION DF AMERICAN STATES DRAFTED THE AMERICAN CONVENTION ON HUMAN RIGHTS. THE COURT CONSISTS OF SEVEN JUDGES ELECTED IN AN INDIVIDUAL CAPACITY FOR SIX-YEAR TERMS BY THE STATES PARTY TO THE CONVENTION. AT THIS WRITING, THE COURT HAS HEARD SEVEN CONTENTIOUS CASES. AS THE COURT ENTERS ITS SECOND DECADE, ITS CASE LOAD IS INCREASING DRAMATICALLY. IN THIS ARTICLE DISCUSSES ISSUES WITH THOSE MOST DIRECTLY INVOLVED IN THE INSTITUION. TO GAUGE THE CHANGING ROLE OF THE COURT NINE CURRENT AND FORMER JUDGES WERE INTERVIWED FOR THIS ARTICLE. HIGHLIGHTS FROM THOSE INTERVIEWS ARE OFFERED. THE ARTICLE CONCLUDES THAT THE HOPE IS THAT THE SYSTEM CAN COALESCE INTO A MEANINGFUL AND REALISTIC MECHANISM TO PROTECT THE FUNDAMENTAL RIGHTS OF ALL RESIDENTS OF THE AMERICAS.

03472 FROST, R.M.

LOSING ECONOMIC HEGEMONY: U.K. 1850-1891 AND U.S. 1950-1990 CHALLENGE, 35(4) (JUL 92), 30-34.

THE AUTHOR SUMMARIZES THE PARALLELS BETHEEN THE UNITED KINGDOM OF 1850-1891 AND THE UNITED STATES OF 1950-1990. ALTHOUGH THE LOSS OF ECONOMIC MOMENTUM COMMON TO BOTH COUNTRIES IS OFTEN ATTRIBUTED TO NON-ECONOMIC INFLUENCES THE REAL SEEDS OF THEIR DECLINE MAY LIE IN THE FREE TRADE AND FIXED-EXCHANGE RATE PACKAGE.

03473 FROHEIN, J.A.

THE REUNIFICATION OF GERMANY

THE REUNIFICATION OF GERMANY
AMERICAN JOURMAL OF INTERMATIONAL LAW, 86(1) (JAN 92), AMERICAN

THE REUNIFICATION OF GERMANY HAS RAISED A VARIETY OF PUBLIC IMTERMATINAL FAW OUESTIONS THAT HAVE BEEN SUBJECTED PUBLIC INTERMATIONAL LAW QUESTIONS THAT HAVE BEEN SUBJECT TO EXTENSIVE SCHOLARLY REVIEH IN GERMANY. THIS ARTICLE SCHOLARS AND LAWYERS.

03474 FRUM, D.

CAMPUS COUNTERREVOLUTION

AMERICAN SPECTATOR, 24(5) (MAY 91), 12-14,

IN AMERICA'S UNIVERSITIES, THE MEDIA CHALLENGE AND THE ACADEMIC RESPONSE MAKE IT LOOK AS IF, UNDER TREMENDOUS CRITICISM FROM THE PRESS, THE ACADEMIC LEFT IS BEGINNING TO RETREAT. NEW APPOINTMENTS AT HARVARD LAW SCHOOL AND YALE COLLEGE INDICATE THAT THE LEFT'S ASSAULT ON THE UNIVERSITIES MAY BE PETERING OUT.

03475 FRUM, $D$.

THE CONSERVATIVE BULLY BOY

AMERICAN SPECTATOR, 24(7) (JUL 91), 12-14.

NOTED CONSERVATIVE PATRICK BUCHANAN'S CRITIQUE OF

"NEOCONSERVATISM," WHATEVER HE UNDERSTANDS IT TO MEAN, RESTS

ON BITTERNESS, INCONSISTENCY, AND AN OBSESSION WITH

ETHNICITY AND CULTURE. HE CHARGES THAT THE

"NEOCONSERVATIVES" HAVE ABANDONED THE OLD RIGHT AND HAVE

GIVEN IN TO THE ENEMY ON IMPORTANT ISSUES SUCH AS BIG VS. SMALL GOVERNMENT AND GLOBALISM VS. AMERICA FIRST. HOWEVER, AN ANALYSIS OF BUCHANAN'S OWN IDEOLOGY REVEALS THAT HIS POSITION ON THESE ISSUES IS QUITE MIXED. FURTHERMORE, WELL KMOWH COMSERYATIVES NHO ESPOUSE THE IDEAS THAT BUCHANAM ESCHEWS SOMEHOW ESCAPED HIS CENSURE.

03476 FRYE, A.

ZERO BALLISTIC MISSILES

ZERO BALLISTIC MISSILES
FOREIGN POLICY, (88) (FAL 92), 3-20

AN OLD CONCEPT KNOWN AS "ZBM"--2ERO BALLISTIC MISSILES-NOH CHALLENGES ANALYSTS AND POLICY MAKERS TO THINK ANEW ABOUT A RADICAL TRANSFORMATION OF THE STRATEGIC ENVIRONMENT. UNTIL RECENTLY, THE NOTION OF ELIMINATING ALL BALLISTIC MISSILES DESIGNED FOR DEEP STRIKES BEYOND AN IMMEDIATE BATTLEFIELD SEEMED FANCIFUL. BUT THE DRASTIC SHIFT IN THE GEOPOL ITICAL TERRAIN AND THE RISING APPREHENSION ABOUT THE SPREAD OF WEAPONS OF MASS DESTRUCTIDN HAVE MADE THAT AMBitious Goal PLAUSible. 
03477 FUENTES, A.

NEW YORK: ELUSIVE UNITY IN LA GRAN MANZANA

REPORT ON THE AMERICAS, XXVI(2) (SEP 92), 27-33.

ALTHOUGH LATIMOS MAKE UP ABOUT ONE-OUARTER DF MEH YORK CITY'S POPULATION, THEY ACCOUNT FOR ONLY 15\% OF REGISTERED VOTERS. BECAUSE OF THIS DORMAMT POTENTIAL AND BECAUSE NATIONALLY THE LATINO POPULATION IS EXPECTED TO DOUBLE IN NATIONALLY THE LATINO POPULATION IS EXPECTED TO DOUBLE IN THE NEXT 30 YEARS, POL ITICAL ANALYSTS OFTEN REFER TO THE
LATINO VOTE AS A "SLEEPING GIANT." THIS SLEEPING GIANT IMAG LATINO VOTE AS A "SLEEPING GIANT." THIS SLEEPING GIANT IMAGE
IMPLIES THAT LATINOS ARE A UNIFIED GROUP THAT WILL VOTE AS A IMPLIES THAT LATINOS ARE A UNIFIED GROUP THAT WILL VOTE
BLOC, BUT THE DIVERSE CULTURES, CLASS BACKGROUNDS, AND BLOC, BUT THE DIVERSE CULTURES, CLASS BACKGROUNDS, AND
ASPIRATIONS OF LATINOS HEIGH AGAINST UNITY. ANOTHER FACTOR ASPIRATIONS OF LATINOS WEIGH AGAINST UNITY. ANOTHER FACTOR LIMITING THE POTENTIAL IMPACT OF THE LATINO VOTE IS THE OPPORTUNISM OF THE FEW LATINO ELECTED OFFICIALS, MANY DELIVER THEIR ALLEGIANCE TO THE PARTY MACHINERY RATHER THAN THEIR CONSTITUENTS.

03478 FUHR, E.

LOSS OF SUPPORT FOR MAIN PARTIES NOT A RECENT PHENOMENON GERMAN TRIBUNE, (1512) (APR 92), 3 .

THE LOSS OF YOTES SUFFERED BY THE SOCIAL DEMOCRATS (SPD) AND THE CHRISTIAN DEMOCRATS (CDU/CSU) ON THEIR IDEOLOGICAL FRINGES IS A PHENOMENON WHICH DID NOT FIRST APPEAR IN THE 1992 LAND (PROVINCE) ELECTIONS IN BADEN-HURTTEMBERG AND SCHLESWIG-HOLSTEIN. AT THE BEGINNING OF THE 198OS, THE SOCIAL DEMOCRATS EXPERIENCED THE GREENS ESTABLISHING THEMSELVES AS A NEW FORCE ON THE LEFT SIDE OF THE POLITICAL SPECTRUM. DURING THE SECOND HALF OF THE DECADE, THE CDU WAS CONFRONTED WITH RIGHT-WING POPULIST RIVALS. HOWEVER, THE RECENT ELECITON GAINS OF THE RADICAL RIGHT ARE AN INDICATION THAT GERMANY'S MAJOR PARTIES CANNOT AFFORD TO COMPLACENTLY DISMISS GROWING APPREHENSIONS AMONG GERMANS ABOUT IMMIGRATION AND CRIME.

03479 FUHR, E.

OPPOSITION MIGHT BE INTERESTED IN A GRAND COALITION GERMAN TRIBUNE, (1514) (MAY 92), 4

IN VIEH OF THE TURBULENCE THE GERMAN COALITION GOVERNMENT HAS RUN INTO IN THE WAKE OF HANS-DIETRICH GENSCHER'S RESIGNATION FROM THE OFFICE OF FORIEGN MINISTER, THE SOCIAL DEMOCRATIC OPPOSITION MUST NOW DECIDE WHETHER IT WHE SOCIAL DEMOCRATIC OPPOSITION MUST NOH DECIOE WHEN OF THE KOHL GOVERNMENT OR WHETHER IT SHOULD OFFER COOPERATION IM "NATIONAL RESPONSIBILITY." THE SPD HAS RECENTLY BEEN REPEATEDLY SENDING COOPERATION SIGNALS. HOWEVER THESE REPEATEDLY SENDING COOPERATION SIGNALS. HOL CONSIDERATION SIGNALS HAVE NOT BEEN FREE OF THE TACTICAL CONSIOERATI POLITICAL BANKRUPTCY. THE SPD HAS DECIDED TO MAKE AN OFFER OF COOPERATION THE NEXT TIME THE THORHY ISSUE OF ASYLUM IS DISCUSSED. ACCEPTANCE OF THE OFFER WOULD REQUIRE NEW MAJORITIES AND WOULD PUT A TREMENDOUS STRAIN ON LOYALTIES WITHIN THE GOVERNMENT COALITION. MANY WITHIN THE PARTY HOPE THAT A GRAND COALITION HOULD BE ABLE TO RESTORE CONFIDENCE IN THE TWO LARGE PEOPLE'S PARTIES IN GERMANY.

03480 FUKAI, S.N.; FUKUI, $H$.

ELITE RECRUI TMENT ANO POLITICAL LEADERSHIP

PS: POLITICAL SCIENCE AND POLITICS, XXV(1) (MAR 92), 25-36.

"ELITE" AND "LEADERSHIP" ARE TWO CONCEPTS THAT HELP

SCHOLARS IDENTIFY AND ANALYZE THOSE WHO PLAY CENTRAL ROLES IN A NATION'S POL ICYMAKING PROCESS. IN THIS ARTICLE, THE AUTHORS EXAMINE THE ROLE

03481 FUKUI, H.; FUKAI, S.N.

ELECTION CAMPAIGNING IN CONTEMPORARY JAPAN; ASSOCIATION FOR ASIAN STUOIES 1992 ANNUAL MEETING

ASSOCIATION FOR ASIAN STUDIES, 1992, 169-170.

CAMPAIGHS IN NATIONAL, PREFECTURAL, ANO LOCAL ELECTIONS IN CONTEMPORARY JAPAN ARE CONDUCTED FAR MORE IMPORTANTLY ACCORDING TO SETS OF INFORMAL RULES THAN ACCDRDING TO FORMAL PROVISIONS OF LAW. LIBERAL DEMOCRATIC PARTY CANDIDATES CONTINUE TO DEPEND ON THEIR PERSONAL CAMPAIGN ORGANIZATIONS CONTINUE TO DEPEND ON THEIR PERSONAL CAMPAIGN ORGANI ZATIONS
KNOWN AS SUPPORT ORGANIZATIONS (KDENKAI) AND EXTENSIVE USE OF MONEY, WHILE SOCIAL DEMOCRATIC PARTY CANDIDATES CONTINUE TO DEPEND HEAVILY ON LABOR UNIONS BOTH FOR CAMPAIGN FUNDS AND VOTE MOBILIZATION. SUCH RULES OF THE INFORMAL POLITICS AND VOTE MOBILIZATION. SUCH RULES OF THE INFORMAL POLITICS BUT THE CHANGES HAYE COME ONLY VERY SLOWLY AND THEIR IMPACTS REMAIN LIMITED. THIS PAPER PRESENTS A FEW CASE IMPACTS REMAIN LIMITED. THIS PAPER PRESENTS A FEH CASE
STUDIES OF LDP AND SOCIALIST CAMPAIGN ORGANIZATIONS AND STUDIES OF LOP AND SOCIALISI CAMPAIGN ORGANIZATIONS AND THEIR ACTIVITIES IN RECENT NATIONAL AND LOCAL ELECTIONS. IT THEN EXTRACTS AND SUMMARIZES THE IMPLICATIONS OF THESE
STUDIES FOR THE RECRUITMENT AND CHANGE OF POLITICAL STUDIES FOR THE RECRUITMENT AND CHA

03482 FUKURAI, H.; BUTLER, E.; KROOTH,

RACE AND THE JURY: RACIAL DISENFRANCHISEMENT AND THE SEARCH FOR JUSTICE

PLENUM PRESS, 1992, 241.

THE STUDY OF THE JURY AND RACE HAS PREOCCUPIED SOCIAL

PSYCHOLOGISTS WHO HAVE EXAMINED THE INTERTHINING
RELATIONSHIP OF THE ATTITUDES AND PSYCHOLOGICAL

CHARACTERISTICS OF JURORS AND THEIR INCLINATION TO REACH PARTICULAR VERDICTS. THIS BOOK EXAMINES THE INSTITUIONAL AND STRUCTURAL MECHANISMS THAT HAVE MAINTAINED THE UNDERREPRESENTATION OF RACIAL AND ETHNIC MINDRITIES ON JURIES AND PRESENTS A SAMPLE OF SUBSTANTIVE PROBLEMS IN THE METHODOLOGICAL APPLICATION OF VARIOUS STATISTICAL TECHNIQUES TO EVALUATE RACIAL REPRESENTATION ON JURIES. IT EXAMINES THE "VOIR DIRE" JURY SELECTION BY THE DEFENSE IN THE MCMARTIN "VHILD-MOLESTATION TRIAL.

03483 FUKURAI, H.; ALSTON, J.P.

SOURCES OF NED-NATIONAL ISM AND RESISTANCE IN JAPAY

JOURNAL OF CONTEMPORARY ASIA, 22(2) (1992), 207-223.

JOURNAL OF CONTEMPORARY ASIA, 22(2) 1992 ), 207-223. THE GOVERNMENT'S EFFORT TO INDOCTRINATE PEOPLE HITH THE NOTION OF NATIONALISM AND SHINTO PRINCIPLES, FILIAL PIETY AND LOYALTY TO THE GOVERNMENT AND THE EMPEROR. THIS ARTICLE EXAMINES THE EXTENT AND SOURCES OF NON-CONFORMITY TOWARD JAPAN'S MOST SACRED NATIONALISTIC IMAGES, THE NATION AND THE EMPEROR. THE ANALYSIS WAS FORMED BY EXAMINING THE EXTENT TO WHICH THE SCHOOL SYSTEM IN JAPAN PROVIDES THE OPPORTUNITY FOR THEIR STUDENTS TO SING THE NATIONAL ANTHEM AND SALUTE THE NATIONAL FLAG DURING A GRADUATION CEREMONY. THE ANALYSIS SUGGESTS THAT ETHNIC DIVERSITY (I.E. KOREANS AND OTHER FOREIGN NATIONALS IN JAPAN) AFFECTS NEO-NATIONALISTIC BEHAVIOR NEGATIVELY, INOICATING THAT THE GREATER THE DIVERSITY OF ETHNIC COMPOSITION IN A GIVEN PREFECTURE, THE LESS THE CONFORMITY TO STATE AND RELIGION. IT ALSO SUGGESTS THAT POPULATION INFLUX AND INSTABILITY AFFECT POSITIVELY THE EXTENT OF CONFORMITY TO THE STATE. THE ANALYSIS SUBSTANTIATES THE ARGUMENT THAT BOTH ETHNIC AND POPULATION HETEROGENEITIES ARE IMPORTANT DETERMINANTS OF NEONATIONALISTIC MOVEMENTS IN CONTEMPORARY JAPAN. THE FINDINGS SUGGEST THAT HETEROGENEITIES REDUCE CONFORMIST HARMOMY AMD CONSEQUENTLY THE OVERALL LEVEL OF NEO-NATIONALISTIC ACTIVITIES.

03484 FUKUSHIMA, $M$.

ABE AFFAIR FLIES IN FACE OF REFORM RHETORIC JAPAN TIMES (WEEKLY INTERNATIONAL EDITION), 32(5) (FEB 92)

4. DUE TO A CASH-FOR-FAVORS SCANDAL IMPLICATING ONE OF HIS CLOSEST ALLIES, PRIME MINISTER KIICHI MIYAZAWA FACES THE URGENT TASK OF TIGHTENING CONTROLS ON POLITICAL FUNDS. THE LIBERAL DEMOCRATIC PARTY HAS ESTABLISHED A "POLITICAL REFORM OEVELOP PROPOSALS FOR REGULATING POLITICAL DONATIONS.

03485 FUKUYAMA, $F$.

CAPITALISM \& DEMOCRACY: THE MISSING LINK

JOURAAL OF DEMOCRACY, 3(3) (JUL 92), 100-110.

THIS ARTICLE ARGUES THAT THE PAST HALF-CENTURY HAS SEEN A REMARKABLE INVERSION OF THE EXPECTATIONS THAT JOSEPH SCHUMPETER EXPRESSED IN HIS "CAPITALISM, SOCIALISM AND DEMOCRACY." RATHER THAN CAPITALISM LEADING INEVITABLY TO SOCIALISM, AS HE PREDICTED, SOCIALISM HAS INEXORABLY GIVEN WAY TO CAPITALISM. MEANWHILE, CAPITALISM AND DEMOCRACY-WHICH HE BELIEVED TO BE STRONGLY AT ODOS--HAVE FOUND A WAY OF COEXISTING, INDEED, OF REINFORCING ONE ANOTHER. THE AUTHOR EXAMINES THE RELATIONSHIP BETWEEN CAPITALISM AND DEMOCRACY AND CONCLUDES THAT THE CHIEF PSYCHOLOGICAL IMPERATIVE UNDERLYING DEMOCRACY IS THE DESIRE FOR UNIVERSAL AND EQUAL RECOGNITION. THIS DESIRE FOR RECDGNITION CAN PROVIDE THE MISSING LINK BETHEEN ECONOMIC DEVELOPMENT AND DEMOCRACY THAT ECONOMIC OR FUNCTIONAL EXPLANATIONS BY THEMSELVES DO NOT PROVIDE. HOWEVER, THE ASIAN EXPERIENCE PROVIDES AN INTERESTING COUNTERPOINT TO THE INEXORABLE TREND TOWARDS DEMOCRACY, AN INCREASING NUMBER OF ASIANS WOULD
ARGUE THAT "SOFT" AUTHORITARIANISM IS SUPERIOR TO THE INDIVIDUALISM OF WESTERN LIBERAL DEMOCRACY IN PRODUCING THE HIGHLY EDUCATED, MOTIVATED AND DISCIPLINED POPULATIONS NECESSARY TO ACHIEVE AN ADVANCED, TECHNOLOGICAL,

POSTINUDSTRIAL SOCIETY.

03486 FUKUYAMA, F.

THE BEGINMING OF FOREIGN POLICY

NEW REPUBLIC, $207(8-9)$ (AUG 92), 24-25, 28, 30, 32

THE REAL DEBATE OVER U.S. NATIONAL SECURITY STRATEGY IN THE POST-COLD WAR ERA RESURRECTS SOME YERY OLD DICHOTOMIES IN AMERICAN FOREIGN POLICY AND CONCERNS NOT WHETHER TO BE IN AMERICAN FOREIGN POLICY AND CONCERNS NOT WHETHER TO BE ONE POLE ARE THE "HYPER -REALISTS," WHO BELIEVE THAT ONE POLE ARE THE "HYPER-REALISTS, WHO BELIEVE THAT NATIONAL INTERESTS AND THAT THE USA SHOULD BE GUIDED BY MERE BALANCE-OF-POWER CONSIDERATIONS.

03487 FUKUYAMA, F.

THE NEXT' SOUTH AFRICA

SOUTH AFRICA INTERNATIONAL, 22(2) (OCT 91), 71-81.

IN THIS ARTICLE, HELL-KNOWM POLITICAL HRITIER FRANCIS FUKUYAMA PROOUCES AN ANALYSIS OF SOUTH AFRICA'S FUTURE PROSPECTS. DRAHING ON SOME OF THE THEMES RAISED IN HIS EARLIER ARTICLES, HE HIGHLIGHTS THE SIMILARITIES AND 
DIFFERENCES BETHEEN THE CHANGE PROCESS IN EASTERN EUROPE AND SOUTH AFRICA, AND THE INFLUENCE OF ECONOMIC DEVELOPMENT ON DEMOCRATIC EVOLUTIONS. AFTER AN OVERVIEW OF KEY DEVELOPMENTS IN SOUTH AFRICA, HE CONCLLDES WITH A NUMBER OF POSSIBLE
SCENARIOS FOR THE COUNTRY: THE GERMAN OPTION (THE MOST OPTIMISTIC), THE LEBANON OPTION, AND THE LATIN AMERICAN OPTION, WHERE ECONOMIC DECLINE, ACCELERATED BY INTERVENTIONIST ECONOMIC POLICIES, PRODUCES POLITICAL DISINTEGRATION, NOT JUST IN SOUTH AFRICA, BUT IN THE REGION AS A WHOLE. AFTER OUTLINING SOME OF THE PRESCRIPTIONS FOR AVOIDING THE GLOOMY SCENARIOS, FUKUYAMA ENDS WITH

SUGGESTIONS FOR U.S. POLICY.

03488 FULLER, A.; DOW, M.

MILITARY TERROR IN HAITI

NEW POLITICS, IV(1) (SUM 92), 6-13.

THE BUSH ADMINISTRATION HAS JUSTIFIED ITS FORCED

REPATRIATION OF HATIAN REFUGEES BY ARGUING THAT MOST ARE

"ECONOMIC MIGRANTS" AND THAT NONE HAS COME TO ANY HARM BACK

IN HAITI. HOWEVER, FIVE MONTHS AFTER THE MILITARY COUP. THE GRIP OF THE MILITARY IS TIGHTER THAN EVER. AFTER QUELLING ALL OPPOSITION IN THE CAPITAL CITY, THE ARMY IS SPREA

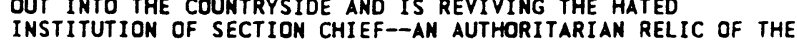
DUVALIER ERA. THE GROWING REPRESSION HAS BEEN CONFIRMED BY PRIESTS LIVING IN HAITI, CHURCH GROUPS, AND HUMAN RIGHTS GROUPS THAT HAVE VISITED THE COUNTRY.

03489 FULLER, B.

RAISING LITERACY UNDER FRAGILE STATE INSTITUTIONS ANNALS OF THE AMERICAN ACADEMY OF POLITICAL AND SOCIAL SCIENCE, (520) (MAR 92), 133-142.

GOVERNMENTS AND EDUCATORS ARE DIGGING MORE DEEPLY INTO THE QUESTION OF HOH TO MAKE THIRD WORLD CLASSROOMS MORE STIMULATING SETTINGS FOR LEARNING. INTERVENTIONS EMPHASIZE MAKING THE SKILLS OF TEACHERS AND THE SOCIAL ORGANIZATIONS OF CLASSROOMS MORE COMPLEX. BUT ARE FRAGILE POLITICAL INSTITUTIONS AND EDUCATION AGENCIES EQUIPPED TO MOVE TEACHERS TOWARD MORE COMPLEX, MDRE INVIGORATING FORMS OF INSTRUCTION?

03490 FULLER, C.

FADE TO BLACK: CULTURE UNDER FREE TRADE

CANADIAN FORUM, LXX(801) (AUG 91), 5-10.

THIS ARTICLE CONSIDERS TWO CAREFULLY CONSTRUCTED MYTHS THAT SURROUND THE U.S. - CAMADA FREE TRADE APPARATUS. ONE IS THAT CANADA SUCCEEDED IN PROTECTING THE CULTURAL SECTOR THAT CANADA SUCCEEDED IN PROTECTING THE CUL TURAL SECTOR DURING FREE TRADE NEGOTIATIONS WITH THE AMERICANS IN THE
$1980 S$. ANOTHER IS THAT OTTAWA IS DETERMINED TO DEFEND 1980S. ANOTHER IS THAT OTTAWA IS DETERMINED TO DEFEND
CULTURE (AND, BY EXTENSION, CANAOIAN SOVERIEGNTY) DURING THE 1990S. THE UNITED STATES HAS MADE IT CLEAR IT WANTS CULTURE 1990S. THE UNITED STATES HAS MADE IT CLEAR IT WANTS CULTURE DN THE CANADA-U.S. - MEXICO FREE TRADE TABLE. WHILE THE CONCERNS OF THE POWERFUL U.S. FILM PRODUCTION AND DISTRIBUTION CONGLOMERATES HAVE BEEN PANDERED TO BY THE CANADIAN GOVERMMENT, THERE ARE STILL, AS GEORGE BUSH PUT IT RECENTLY, "IRRITANTS." AMERICAN CORPORATIONS SEEKING "INVESTMENT OPPORTUNITIES" ARE PARTICULARLY IRRITATED BY OWNERSHIP RESTRICTIONS IN CANADIAN PUBLISHING AND BROADCASTING. THIS ARTICLE ARGUES THAT THE CANADIAN PUBLIC MUST BE ALERTED TO THE CONSEQUENCES OF AN EXTENDED FREE TRADE AGREEMENT AND THE BEST WAY TO DO THAT IS TO SHOW WHAT HAPPENED TO THE SO-CALLED EXEMPTIONS IN THE CANADA-U.S. FREE TRADE PACT.

03491 FULLER, $E$.

ABKHAZIA ON THE BRINK OF CIVIL HAR?

RFE/RL RESEARCH REPORT, I(35) (SEP 92), 1-5.

FIGHTING BETWEEN GEORGIAN TROOPS SENT TO ABKHAZIA TO HUNT FOR ABDUCTED GEORGIAN OFFICIALS AND ABKHAZ INTERIOR MINISTRY FORCES AND A SUBSEQUENT GEORGIAN ATTACK ON THE ABKHAZ SUPREME SOVIET HAVE PRODUCED UP TO 70 DEATHS AND EXACERBATED RELATIONS BETHEEN TBILISI AUTHORITIES AND THE ABKHAZ LEADERSHIP. SINCE THE CONVENING OF A NEH ABKHAZDOMINATED SUPREME SOVIET IN THE AUTONOMOUS REPUBLIC EARLY IN 1992. THE ABKHAZ LEADERSHIP HAS EMBARKED ON A MEW DRIVE TO UPGRADE THE REGION'S STATUS.

03492 FULLER, E.

AZERBAIJAN'S RELATIONS WITH RUSSIA AND THE CIS

RFE/RL RESEARCH REPORT, 1 (43) (OCT 92), 52-55.

PRIOR TO THEIR SEIZURE OF POWER IN MAY 1992, LEADING MEMBERS OF THE AZERBAIJANI POPULAR FRONT TOOK A CONSISTENTLY ANTI-RUSSIAN, ANTI-CIS POSITION. OVER THE PAST FEN MONTHS, HOHEVER, THE LEADERSHIP HAS MODIFIED ITS ORIGINAL STANCE DUE TO ECONOMIC AND GEOPOLITICAL CONSTRAINTS, DESPITE INTERNAL POLITICAL OPPOSITION.

03493 FULLER, E.

EDUARD SHEVARDNADZE AND THE GEORGIAN ELECTIONS RFE/RL RESEARCH REPORT, 1(36) (SEP 92) 32-33.

DESPITE PROTESTS FROM POL ITICAL OBSERVERS IN GEORGIA,

THE STATUTES UNDER WHICH THE OCTOBER 1992 PARLIAMENTARY

ELECTIONS ARE TO BE HELD HAYE BEEN REVISED TWICE--MOST

RECENTLY IN AN APPARENT ATTEMPT TO FACILITATE THE ELECTION
OF STATE COUNCIL CHAIRMAN EDUARD SHEVARDNADZE AS CHAIRMAN OF THE PARL IAMENT. SHEVARDNADZE HAD ORIGINALLY ANNDUNCED HIS ATTENTION TO STAND FOR THE BLOC THAT INCLUDES THE SUCCESSOR PARTY TO THE GEORGIAN COMMUNIST PARTY.

03494 FULLER, E.

GEORGIA, ABKHAZIA, AND CHECHENO-INGUSHETIA

RFE/RL RESEARCH REPORT, 1(6) (FEB 92), 3-7

OYER THE PAST THREE YEARS, THE ABKHAZ AUTONOMOUS SOVIET SOCIALIST REPUBLIC AND THE SOUTH OSSETIAN AUTONOMOUS OBLAST HAVE REACTED TO GEORGIAN ASPIRATIONS FOR INDEPENDENCE BY SEEKING TO JOIM A PROPOSED ALLIANCE OF NORTH CAUCASIAN NATIONS THAT WOULD EXCLUDE GEORGIA. GEORGIA HAS PROTESTED SUCH MOVES AND PROPOSED A "CAUCASIAN COMMONWEALTH" IN WHICH IT WOULD PLAY THE LEADING ROLE. THE IDEA OF A CAUCASIAN IT WOULD PLAY THE LEADING ROLE. THE IDEA OF A CAUCASIAY COMMONHEALTH IS SUPPORTED BY CHECHEN PRESIDENT-GENERAL
DZHAKHAR DUDEAV, AN ALLY OF OUSTED GEDRGIAN PRESIDENT ZVIAD DZHAKHAR DUDEAY
GAMSAKHURDIA.

03495 FULLER, E.

GEORGIAN PRESIDENT FLEES AFTER OPPOSITION SEIZES POWER RFE/RL RESEARCH REPORT, 1(3) (JAN 92), 4-7

GEORGIAN PRESIDENT ZVIAD GAMSAKHURDIA FLED FROM TBILISI TO ARMENIA ON JANUARY 6, 1992, AFTER A MILITARY-CIVILIAN COALITION SEIZED POHER. FOLLOHING HIS OVERWHELMING ELECTION VICTORY IN MAY 1991, GAMSAKHURDIA'S POPULARITY HAD PLUMMETED BECAUSE HE FAILED TO IMPLEMENT REFORMS AND PURSUED INCREASINGLY IRRATIONAL, DICTATORIAL POLICIES.

03496 FULLER, E.

NAGORMO-KARABAKH: CAN TURKEY REMAIN NEUTRAL?

RFE/RL RESEARCH REPORT, 1(14) (APR 92), 36-38.

TO DATE, TURKEY HAS APPEARED TO HAVE THE GREATER CHANCE FOR SUCCESS IN ITS CONTEST WITH IRAN FOR POLITICAL INFLUENCE IN THE MUSLIM STATES OF THE FORMER SOVIET UNION. BUT THE TURKISH GOVERHMENT'S INSISTENCE ON MAINTAINING STRICT NEUTRALITY IN THE CONFLICT BETWEEN ARMENIA AND AZERBAI JAN OVER NAGORNO-KARABAKH MAY UNDERMINE TURKEY'S POSITION. PUBLIC DEMAND FOR TURKISH INTERVENTION ON THE SIDE OF AZERBAIJAN POSES A SERIOUS PROBLEM FOR TURKEY'S COALITION GOVERNMENT, AS DO RISING TERRORISM, KURDISH INSURGENCY, AND ECONOMIC DIFFICULTIES.

03497 FULLER, E.

NAGORNO-KARABAKH: INTERNAL CONFLICT BECOMES INTERNATIONAL RFE/RL RESEARCH REPORT, 1(11) (MAR 92), 1-5.

THE DEMISE OF THE USSR HAS TRANSFORHED THE DISPUTE BETHEEN ARMENIA AND AZERBAIJAN OVER SELF-DETERMINATION FOR THE ARMENIAN POPULATION OF NAGORNO-KARABAKH FROM AN INTERNAL SOVIET MATTER INTO AN INTERNATIONAL POL ITICAL ISSUE. TURKEY, IRAN, RUSSIA, FRANCE, AND THE CONFERENCE ON SECURITY ANO COOPERATION IN EUROPE HAVE ALL EXPRESSED INTEREST IN TRYING TO PRODUCE A PEACEFUL SETTLEMENT. BUT THE EFFECTIVENESS OF SUCH EFFORTS DEPENDS TO A LARGE EXTENT ON THE OUTCOME OF INTERMAL POLITICAL POWER STRUGGLES WITHIN ARMENIA AND AZERBAIJAN AND THE DEGREE OF INVOLVEMENT OF THE CIS MILITARY IN THE REGION.

03498 FULLER, E.

THE GEORGIAN PARLIAMENTARY ELECTIONS

RFE/RL RESEARCH REPORT, 1(47) (NOV 92), 1-4.

ON OCTOBER 11, 1992, ELECTIONS WERE HELD IN GEORGIA FOR A NEW PARLI IMENT AND PARLIAMENTARY CHAIRMAN IN ORDER TO GIVE LEGITIMACY TO THE LEADERSHIP THAT HAD OUSTED PRESIDENT ZVIAD GAMSAKHURDIA IN JANUARY. EDUARD SHEVARDNADZE HAS ELECTED PARL IAMENTARY CHAIRMAN. THE COMMUNIST-DOMINATED DEMOCRATIC UNION EMERGED AS THE LARGEST FACTION WITHIN THE NEH PARL IAMENT BUT HITHOUT AN OVERALL MAJORITY. FUTURE POLICY WILL DEPEND LARGELY ON THE WAR IN ABKHAZIA AND GEORGIA'S RELATIONS WITH RUSSIA.

03499 FULLER, E.

THE ONGOING POLITICAL POWER STRUGGLE IN AZERBAIJAN RFE/RL RESEARCH REPORT, 1(18) (MAY 92), 11-13. IN MARCH 1992 THE AZERBAIJAN POPULAR FRONT FORCED THE RESIGNATION OF PRESIDENT AYAZ MUTALIBOV. PRIME MINISTER HASAN HASANOV, THE FRONT'S CANDIDATE TO SUCCEED MUTALIBOV, WAS THEN FIRED BY ACTING PRESIDENT YAKUB MAMEDOV. A NEW POWER STRUGGLE BETWEEN MAMEDOY AND THE FRONT'S CHAIRMAN, ABULFAZ EL-CHIBEI, IS LIKELY DURING THE PREPARATIONS FOR THE ABULFAZ EL-CHIBEI, IS LIKELY DURI
PRESIDENTIAL ELECTIONS IN JUNE.

03500 FULLER, E.

THE TRANSCAUCASUS REPUBLICS

RFE/RL RESEARCH REPORT 1(7) (FEB 92), 14-16. ARMENIA AND AZERBAI JAN HAVE AGREED TO JOIN THE COMHONHEALTH OF INDEPENDENT STATES DESPITE MISGIVINGS ABOUT SECURITY. NAGORNO-KARABAKH HAS APPLIED FOR MEMBERSHIP INDEPENDENTLY OF AZERBAIJAN. FOLLOWING THE OUSTER OF PRESIDENT ZVIAD GAMSAKHURDIA, THE NEW GEORGIAN PROVISIONAL GOVERMMENT IS CONSIDERING MEMBERSHIP IN THE COMMONWEALTH'S MILITARY STRUCTURE; A DECISION ON FULL MEMBERSHIP WILL BE TAKEN ONLY AFTER NEW PARLIAMENTARY ELECTIONS. 
03501 FULLER, E.

THE TRANSCAUCASUS: REAL INDEPENDENCE REMAINS ELUSIVE RFE/RL RESEARCH REPORT, 1(1) (JAN 92), 46-50.

THE KEY ISSUES IN GEORGIA, ARMENIA, AND AZERBAIJAN IN 1991 WERE THE POSSIBILITY OF A NEW UNION TREATY, DIRECT PRESIDENTIAL ELECTIONS, AND THE FAILED COUP IN MOSCOH. CONTRIBUTING TO ARMENIA'S AND GEORGIA'S DIFFICULTIES WERE THEIR DETERIORATIMG ECOMOMIC PERFORMAMCES HHICH CAST THEIR DETERIORATING ECONOMIC PERFORMANCES, WHICH CAST SOVEREIGN STATES. IN ADDITION, TENSION MOUNTED OWING TO THE SOVEREIGN STATES. IN ADDITION, TENSION MOUNTED OWING TO THE CONTINUED FAILURE OF ALL ATTEMPTS TO SETTLE THE CONFLICT FOR A PEACEFUL SOLUTION TO THE DEADLOCK BETHEEN THE GEORGIAN FORD SOUTH OSSETIAN PARLIAMENTS.

03502 FULLER, G.

GEORGE BUSH AND THE MIDDLE EAST: A NEW DAWN EMERGES FROM THE VIOLENCE?

MIDDLE EAST INSIGHT, VIII(4) (MAR 92), 5-8

THE LAST THO YEARS OF GEORGE BUSH'S ADMINISTRATION IN THE EARLY 1990 S HAS ALREADY HAD GREATER IMPACT ON THE MIDOLE EAST THAN ANY ADMINISTRATION IN THE 1980S, AND MAY YET BRING ABOUT CHANGES IN THE MIDOLE EASTERN ORDER THAT TRANSCEND EVEN THE GROUND-BREAKING CAMP DAVID ACCORDS OF THE CARTER ADMINISTRATION. THE ULTIMATE VERDICT OF HISTORY, HOHEVER, WILL REST NOT ON THE GULF WAR AND OPERATION DESERT STORM, BUT ON WHAT PRESIDENT BUSH WILL HAVE BEEN ABLE TO CREATE OUT OF THE VICTORY OVER IRAQ. BUSH'S ABILITY AND WILLINGNESS TO TAKE ADVANTAGE OF AN UNPRECEDENTED DEGREE OF ARAB COOPERATION TO RESOLVE THE LONG-STANDING ARAB-ISRAEL DISPUTE AND TO FOSTER THE GROWTH OF DEMOCRACY IN THE REGION WILL
DETERMINE HOW HE IS REGARDED BY FUTURE GENERATIONS IN THE MIDDLE EAST AND THROUGHOUT THE WORLD.

03503 FULLER, G.E.

SOVIET MATIONALITIES AND DEMOCRATIC REFORM

GLOBAL AFFAIRS, 6(1) (WIN 91), 23-39.

THE AUTHOR ARGUES THAT AT THIS POINT IN SOVIET HISTORY THE NATIONALITIES ISSUES ECLIPSES VIRTUALLY EVERY OTHER THE NATIONALITIES ISSUES ECLIPSES VIRTUALLY EVERY OTHER
INTERNAL ISSUE IN ITS THREAT TO THE INTEGRITY OF THE SOVIET INTERNAL ISSUE IN ITS THREAT TO THE INTEGRITY OF THE SOVIET
UNION, AND THAT THE MINORITY PEOPLES OF THE USSR ARE ENGAGED UNION, AND THAT THE MINORITY PEOPLES OF THE USSR ARE ENGAGED INTO A NEW FORM OR FORMS. THE ARTICLE DISCUSSES THESE ISSUES AND DESCRIBES A CONFERENCE CONVENED BY THE INTERNATIONAL SECURITY COUNCIL IN WASHINGTON, DC IN THE FALL OF 1990 TO DISCUSS THEIR IMPLICATIONS FOR THE SOVIET UNION AND THE U.S.

03504 FUMENTO, M YOU

THE DYING DUTCHMAN: COMING SOON TO A NURSIMG HOME NEAR

AMERICAN SPECTATOR, 24(10) (OCT 91), 18-22.

FOR EIGHTEEN YEARS, EUTHANASIA HAS BEEN WIDESPREAD IN THE NETHERLANDS. MANY DUTCH CLAIM THAT THE PRACTICE IS OFTEN INVOLUNTARY, THAT THE CONSENT OF THE PERSON TO BE KILLED IS OFTEN NOT RÉQUESTED, AND THAT THE DEFINITION OF WHAT IS PERMISSIBLE AS "EUTHANASIA" IS BROADENING DAILY. THEY ALSO THINK THAT THE UNITED STATES IS PARTICULARLY VUL NERABLE TO WIDESPREAD DUTCH-STYLE KILLING OF THE OLD AND INFIRM.

03505 FUMENTO, M.

FETAL ATTRACTION

AMERICAN SPECTATOR, 25(7) (JUL 92), 30-36.

FETAL TRANSPLANTS COULD HERALD A NEW AGE IN MEDICINE WITH BENEFITS TO VICTIMS OF MANY OISEASES. THEY COULD ALSO USHER IN A BRAVE NEW HORLD. ACCORDING TO SOME ETHICISTS--THE USE OF FETUSES AS ORGAN AND TISSUE DONORS IS A TICKING TIME BOMB OF BIOETHICS. IF FETAL CELLS ARE AS MEDICALLY USEFUL AS SOME DOCTORS THINK, WE COULD SOON HAVE A BULL MARKET IN ABORTION-FOR-PROF IT AMD THAT IS OMLY ONE OF THE ETHICAL PROBLEMS. THIS AUTHOR SUGGESTS THAT HOWEVER EFFECTIVE FETAL CELL TRANSPLANTATION TURNS OUT TO BE, IT COULD WELL BE SURPASSED BY ANOTHER TECHNOLOGY BEFORE IT COMES TO FRUITION.

03506 FUNABASHI, $Y$.

JAPAN AND AMERICA: GLOBAL PARTNERS

FOREIGN POLICY, (86) (SPR 92), 24-39.

JAPANESE-U.'S. RELATIONS NOW FACE THEIR GRAVEST CHALLENGE SINCE 1945. THE END OF THE COLD WAR HAS DRASTICALLY ALTERED THE GLOBAL GEOPOL ITICAL AND GEOECONOMIC CONTEXT THAT SHAPED JAPANESE-U.S. RELATIONS. BOTH COUNTRIES NOW FACE AN URGENT NAPANESE-U.S. RELATIONS. BOTH COUNTRIES NOW FACE AN URGENT THE EFFORT REVOLVES AROUND FIVE BASIC CONCERNS: STATUS, IDEOLOGY, POWER, REGIONAL INFLUENCE, AND RELATIONS WITH THE IDEOLOGY, POWER, REGIONAL INFLUENCE, AND RELATIONS WITH FORMER SOVIET REPUBLICS AND CHINA. ONLY ADHERENCE TO "OBSESSION WITH BEING NUMBER ONE " AND AN INCREASING "OBSESSION WITH BEING NUMBER ONE," AND AN INCREASING AWARENESS OF THEIR JOINT RESPONSIBILITY AS THE MOST DYNAMIC CAPTIALIST COUNTRIES-CHILL ENABLE THE UNITED STATES
JAPAN TO SUCESSFULY COOPERATE IN THE YEARS TO COME.

03507 FUMKE, H.; MEAMAN, E.

GERMAN ROULETTE: THE LOADED GUN OF NATIONALISM

NATIONAL REYIEN, XLIV (1) (JAN 92), 47-48.

GERMANY'S CHRISTIAN DEMOCRATIC GOVERNMENT (CDU) IS
EXPLOITING A DANGEROUS BRAND OF RIGHT-WING EXTREMISM AS IT TRIES TO MAKE A HINDFALL OUT OF REUNIFICATION. THE POLITICS OF THE CDU MUST BEAR THE RESPONSIBLITY FOR MUCH OF THE RADICAL RIGHT'S SUCCESS. THIS ARTICLE SUGGESTS THAT THE EXTENT OF THE RADICAL RIGHT'S ACTIVITY IN EASTERN GERMANY CANNOT BE MEASURED SOLELY AT THE BALLOT BOX. IT CONCLUDES THAT KOHL IS PLAYING A DANGEROUS GAME WITH NATIONALISM FOR SHORT-TERM GAINS, RATHER THAN PROVIDING THE KIND OF SHORT-TERM GAINS, RATHER THAN PROVIDING THE KIND OF LEADERSHIP THAT WILL SOLVE THE LONG-TERM PROBLEMS THAT
CONTINUE TO HAUNT THE NEW GERMANY ON ITS TROUBLED PATH TO CONTINUE TO HAUN

03508 FURLONG, $P$.

GOVERNMENT STABILITY AND ELECTORAL SYSTEMS: THE ITALIAM EXAMPLE

PARLIAMENTARY AFFAIRS, 44(1) (JAN 92), 50-59.

IT IS SOMETIMES CLAIMED THAT PROPORTIONAL REPRESENTATION LEADS TO COALITION GOVERNMENT AND THENCE TO GOVERNMENT

STABILITY. THIS ARTICLE CONSIDERS THE CASE OF ITALY AND ASKS "IS THE ITAL IAN CASE AN EXAMPLE OF THE UNHAPPY CONSEQUENCES OF PROPORTIONAL REPRESENTATION?" AND "IS THE GOVERNMENT INSTABILITY IN SOME SENSE CAUSED BY OR ATTRIBUTABLE TO THE ELECTORAL SYSTEM?:" IT CONCLUDES THAT THERE IS NOT

REPRESENTATION AND INSTABILITY. THEREFORE EXTRAPOLATIONS OF THE ITALIAN EXPERIENCE TO OTHER STATES SHOULD BE CONDUCTED WITH EXTREME CAUTION.

03509 FURLONG, $P$.

THE EXTREME RIGHT IN ITALY: OLD ORDERS AND OANGEROUS NOVELTIES

PARLIAMENTARY AFFAIRS, 45(3) (JUL 92), 345-356.

THE ITALIAN VERSION OF THE RESURGENCE OF THE EXTREME RIGHT IN WESTERN EUROPE CLEARLY SHARES SOME CHARACTERISTICS WITH KINDRED MOVEMENTS IN FRANCE AND GERMANY--PARTICULARLY THE PERCEPTION OF THREAT FROM IMMIGRANTS FROM NORTHERN AFRICA AND THE MIDOLE EAST, THE STREET VIOLENCE, AND THE AFRICA AND THE MIDOLE EAST, THE STREET VIOLENCE, AND THE
AMBIVALENCE OF RIGHT-WING PARTIES. BUT THERE ARE SIGNIFICANT DMBIVALENCE OF RIGHT-WING PARTIES. BUT THERE ARE SIGNIFICANT DIFFERENCES THAT RELATE TO ITALIAM POLITICAL AND ECONOMIC
DEVELOPMENT. IN TERMS OF POLITICAL DEVELOPMENT, THE RACISM DEVELOPMENT. IN TERMS OF POL ITICAL DEVELOPMENT, THE RACISM
OF RECENT YEARS HAS NOT BEEN ASSOCIATED WITH THE EMERGENCE OF RECENT YEARS HAS NOT BEEN ASSOCIATED WITH THE EMERGENCE
OF A NATIONAL EXTREME-RIGHT MOVEMENT BECAUSE SUCH A MOVEMENT ALREADY EXISTED, WITH A LONG TRADITION OF VIOLENCE AND ALREADY EXISTED, WITH A LONG TRADITION OF VIOLENCE AND
FASCIST RHETORIC BEHIND IT; AND POPULAR SUPPORT FOR IT HAS FASCIST RHETORIC BEHIND IT; AND POPULAR SUPPORT FOR IT HAS FEATURE OF THE ITALIAN POLITICAL SCENE OF RECENT YEARS HAS BEEN THE SUCCESS OF THE SEPARATIST PROTEST MOVEMENTS.

03510 FURMAN, J.

BROKEN RECORDS

NEW REPUBLIC, 207(10) (AUG 92), 18

THE AUTHOR ANALYZES SOME OF THE CHARGES BEING MADE AGAINST ARKANSAS GOVERNOR BILL CLINTON BY REPUBLICAN GOVERNORS. HE FOCUSES ON ISSUES RELATED TO THE ENVIRONMENT, EDUCATION, AND TAXES.

03511 FURMAN, $J$.

THE SPEECH THINC

NEW REPUBLIC, 207(8-9) (AUG 92), 14-15.

PRESIDENT GEORGE BUSH'S SPEECH PATTERNS REVEAL A NUMBER OF CHARACTERISTICS ASSOCIATED WITH A BRAIN DISORDER CALLED APHASIA: FREQUENT GRAMMATICAL ERRORS, TALKING AROUND SUBJECTS, GROPING UNSUCCESSFULLY FOR THE RIGHT WORD, AND SUBSTITUTING ONE WORD FOR ANOTHER OF CLOSE MEANING OR SIMILAR SOUND. BUT DOCTORS SAY THAT BUSH'S APHASIC SPEAKING PATTERNS SHOULD NOT BE TAKEN AS AN EARLY SIGN OF ALZHEIMER'S OR THE MANIFESTATION OF AN UNDISCLOSED STROKE. THE MANGLED SPEECH PATIERNS DO NOT NECESSARILY REFLECT CONFUSED THOUGHT OR LACK OF INTELLIGENCE.

03512 FUXIAN, $Z$.

CZECHOSLOYAKIA: DANGER OF BREAKUP LOOMS LARGE BEI JING REVIEW, 35(33) (AUG 92), 43.

THE BREAKUP' OF CZECHOSLOVAKIA INTO TWO SEPARATE STATES APPEARS INCREASINGLY CERTAIN FOLLOWING THE ANNOUNCEMENT OF PRESIDENT VACLAV HAVEL'S RESIGNATION AND THE SLOVAK NATIONAL COUNCIL'S ADOPTION OF A DECLARATION OF INDEPENDENCE.

03513 FUXIAN, $Z$.

1991: A DISAPPOINTING YEAR FOR EASTERH EUROPE

1991: A DISAPPOINTING YEAR FOR EASTERM
BEIJING REVIEW, 35(4) (JAN 92), 15-16.

THE YEAR 1991 WAS CHARACTERIZZED BY POLITICAL INSTABILITY, THE YEAR 1991 WAS CHARACTERIZED BY POLITICAL INSTABILITY,
ECONOMIC RECESSION, A DRASTIC DECLINE IN LIVING STANDARDS, ECONOMIC RECESSION, A DRASTIC DECLINE IN LIVING STANDARDS,
AND HOPELESSNESS AMONG THE POPULACE IN EASTERN EUROPE, HHICH AND HOPELESSNESS AMONG THE POPULACE IN EASTERN EUROPE,

03514 FYLE, H. WE NEED URGENT HELP WEST AFRICA, (3900) (JUN 92), 1002-1003.

THE AUTHOR INTERVIEHS CAPTAIN VALENTINE STRASSER, CHAIRMAN OF THE SIERRE LEONE NATIONAL PROVISIONAL RULING COUNCIL (NPRC) THAT OVERTHREW THE APC GOVERNMENT LED BY JOSEPH MOMOH. CAPTAIN STRASSER DESCRIBES THE PROBLEMS FACED BY SIERRA LEONE'S TROOPS AND CITIZENS ON THE HARFRONT NEAR 
THE BORDER TOWN OF KOINDU.

03515 FYSH, P.; WOLFREYS, J.

LE PEN, THE NATIONAL FRONT, AND THE EXTREME RIGHT IN FRANCE PARL IAMENTARY AFFAIRS, 45(3) (JUL 92), 309-326.

ON ONE LEVEL, IT IS EASY TO EXPLAIN THE FRONT NATIONAL'S (FN) SUCCESS BY REFERENCE TO THE FAVOURABLE CONJUNCTION OF A NUMBER OF SIMPLE FACTORS, SOME OPERATING FAIRLY NEAR THE SURFACE OF FRENCH POLITICS. ON ANOTHER LEVEL, THE STORY HAS A DARKER SIDE AND SHOULD NOT BE READ AS A JOURNEY FROM EXTREMISM TO MODERATION. THE FOUNDING OF AN ALL-EMBRACING FRONT WAS THE DECISION OF AN AVOWEDLY FASCIST ORGANIZATION, THE ORDRE NOUVEAU. HAVING NEITHER RECANTED ITS IDEOLOGY NOR MODIFIED ITS STRATEGY, THE FN HAS SUCCESSFULLY ATTRACTED GROUPS OF FELLOW THINKERS FROM A VARIETY OF ORGANIZATIONS THE FN LEADERSHIP HAS SUCCESSFULLY NEUTRALIZED ONE OF THE CHARACTERISTIC WEAKNESSES OF EXTREME-RIGHT PARTIES WITH STRONG IDEOLOGICAL PROFILE--THE TENDENCY TO SPLINTER--BY
ADROIT USE OF A FEDERAL OR FRONTIST STRUCTURE THAT SERVES TO ADROIT USE OF A FEDERAL OR FRONTIST STRUCTURE THAT SERVES TO HARNESS A MASS MEMBERSHIP AND ALSO EFFECTIVELY ALLOWS DUAL
MEMBERSHIP IN THE FN AND OTHER GROUPS. THE FN LEADERSHIP. WITH A RARE DEGREE OF PROFESSIONALISM. IS BUSILY WITH A RARE DEGREE OF PROFESSIONALISM, IS BUSILY CONSTRUCTING A NETWORK OF ACTIVISTS SKILLED IN PROPAGANDA AND AWARE THAT RESPECT FOR INSTITUTIONS AND LEGALITY IS A TACTIC RATHER THAN AN UNBREAKABLE PRINCIPLE.

03516 GABB, S

CZECHOSLOVAKIA REJOINS THE WEST

FREEMAN, 42(7) ( JUL 92), 266-269.

A ECONOMIC CHANGES IN THE CZECH AND SLOVAK FEDERAL REPUBLIC.

03517 GABB, S

SIR HENRY VANE: AMERICA'S FIRST REVOLUTIONARY

FREEMAN, 42(1) (JAN 92), 16-20.

THE AUTHOR RECOUNTS THE STORY OF SIR HENRY VANE, A

CHAMPION OF RELIGIOUS TOLERANCE WHO WAS BEHEADED AS A

TRAITOR AGAINST THE BRITISH CROWN ON JUNE 14, 1662.

03518 GABEL, P.

CLINTON AND THE ID

TIKKUN, $7(6)$ (NOV 92), 10-12

ONE' OF THE MOST INTERESTING ASPECTS OF THE 1992 PRESIDENTIAL CAMPAIGN WAS THE FAILURE OF ANY OF THE CONVENTIONAL RIGHT-WING ASSAULTS ON BILL CLINTON TO AFFECT HIS RATINGS IN THE POLLS OR, ULTIMATELY, THE ELECTION. THE HIS RATINGS IN THE POLLS OR, ULTIMATELY, THE ELECTION. THE ARTICLE STATES THAT IT WASN'T JUST "THE ECDNOMY." CLINTON SPOKE TO OUR DESIRE FOR CONNECT

03519 GABRIS, G.

STRATEGIC PLANNING IN MUNICIPAL GOVERNMENT: A TOOL FOR EXPANDING COOPERATIVE DECISION MAKING BETWEEN ELECTED AND APPOINTED OFFICIALS

PUBLIC PRODUCTIVITY \& MANAGEMENT REVIEW, XVI(1) (FAL 92),

THIS ARTICLE EXAMINES THE COMMON ASSUMPTION THAT STRATEGIC PLANS NEVER GET IMPLEMENTED. DOES THE STRATEGIC PLANNING PROCESS ACTUALLY PRODUCE RESULTS? THE AUTHOR ARGUES THAT STRATEGIC PLANNING CAN INDEED FACILITATE IMPORTANT OUTCOMES. DRAWING UPON HIS EXTENSIVE EXPERIENCE HITH STRATEGIC PLANNING WORKSHOP SESSIONS, HE POSES QUESTIONS OF PROCESS AND DUTCOME.

03520 GACK, T.

EC DEAL WITH EFTA SETS THE TONE FOR THE NEW EUROPE

GERMAN TRIBUNE, (1491) (NOV 91), 5

EUROPE HAS TAKEN A MAJOR STEP IN THE DIRECTION OF CONTINENTAL UNIFICATION IN A MOVE THAT MANY WOULD HAYE DISMISSED AS NO LONGER POSSIBLE IN THE WEEKS THAT LED UP TO IT. AFTER NEARLY THO YEARS OF HARD BARGAINING AND MANY SETBACKS, THE 12-MEMBER EUROPEAN COMMUNITY AND THE SEVENMEMBER EUROPEAN FREE TRADE ASSOCIATION HAVE AGREED TO SET UP A GREATER EUROPEAN ECONOMIC AREA (EEA). IN 1993. THE SINGLE EUROPEAN MARKET WILL BE EXTENDED TO INCLUDE THE SEVEN NEIGHBORING EFTA COUNTRIES. FREE TRADE IN GOODS, SERYICES, CAPITAL AND MANPOWER WILL THEN EXTEND FROM THE NORTH CAPE TO SICILY AND FROM BREST TO THE HOODS AND LAKES OF FINLAND. THE BREAKTHROUGH TO WHAT WILL BE THE WORLD'S LARGEST MARKET OF 380 MILLION CONSUMERS IS DOUBTLESS A SIGNIFICANT FACT IN ITS OWN RIGHT AND ONE THAT WILL HAVE A PROFOUND EFFECT ON BOTH EUROPEAN BUSINESS AND PEOPLE'S DAILY LIVES.

03521 GACK, T

THE É GETS ITS ACT TOGETHER AT HISTORIC MAASTRICHT SUMMIT GERMAN TRIBUNE, (1496) (DEC 91) 1 )

AT THE END OF THE TOUGH MAASTRICHT SUMMIT SCHEDULE, EUROPEAN COMMUNITY POLITICIANS AGRRED THAT THE MEETING HAD BEEN AN HISTORIC SUCCESS STORY. THE THELVE HEADS OF STATE AND GOVERNMENT SUCCEEDED IN GETTING THEIR ACT TOGETHER, IN SURMOUNTING THEIR MANY DIFFERENCES OF OPINION, AND IN AGREEING ON ECONOMIC AND MONETARY UNION (EMU)' AND EUROPEAN POLITICAL UNION (EPU). THE FAR-REACHING REFORM OF THE EUROPEAN COMMUNITY SET IN MOTION IN ROME LAST YEAR WAS THUS
ENDED IN A SURPRISINGLY SHORT TIME, WHICH IS MORE THAN THE SKEPTICS HAD BELIEVED POSSIBLE. YET THE OUTPUT WAS LESS THAN EUROPEANS MIGHT HAVE HOPED. THE TWELVE MAY HAVE TAKEN THE PLUNGE AND DECIDED TO GO AHEAD WITH EMU, BUT THEY TOOK ONLY SMALL, INITIAL STEPS ON THE ROAD TO POLITICAL UNION. THE LAMENTABLE LACK OF UNITY AND INABILITY TO COORDINATE ACTIVITY THAT THE EC HAS DEMONSTRATED ON YUGOSLAVIA WAS EVIDENTLY NOT ENOUGH TO PERSUADE COMMUNITY LEADERS TO MAKE MORE COURAGEOUS MOVES IN THE DIRECTION OF A COMMON FOREIGN AND SECURITY POLICY.

03522 GADOIS, J.

INTERNATIONAL RELATIONS THEORY AND THE END OF THE COLD WAR INTERNATIONAL SECURITY, 17(3) (WIN 92), 5-58.

HISTORIANS, POLITICAL SCIENTISTS, ECONOMISTS

PSYCHOLOGISTS, AND EVEN MATHEMATICIANS HAVE CLAIMED THE POWER TO DETECT PATTERNS IN THE BEHAYIOR OF NATIONS AND THE INDIVIDUALS WHO LEAD THEM: AN AWARENESS OF THESE, THEY HAVE ASSURED US, WILL BETTER EOUIP STATESMEN--AND THE STATES--TO ASSURED US, WILL BETTER EQUIP STATESMEN--AND THE STATES--TO DEAL WIP PRESENTS AN OPPORTUNITY TO TEST THESE CLAIMS. THE EVENT WAS OF SUCH IMPORTANCE THAT NO APPROACH TO THE STUDY OF INTERNATIONAL RELATIONS CLAIMING BOTH FORESIGHT AND COMPETENCE SHOULD HAVE FAILED TO SEE IT COMING. NONE COMPETENCE SHOULD HAVE FAILED TO SEE IT COMING. NONE ACTUALLY DID SO, THOUGH, AND THAT FACT OUGHT TO RAISE UNDERSTAND WORLD POLITICS. THIS ESSAY SUGGESTS SOME REASONS FOR THIS FAILURE OF MODERN-DAY SOOTHSAYING. IT ALSO ADVANCES A FEH IDEAS ON HOW THE ACCURACY OF THAT INTERPRISE MIGHT HENCEFORTH BE IMPROVED.

03523 GADDIS, J.L.

TECTONICS, HISTORY, AND THE END OF THE COLD WAR

THE MERSHON CENTER, THE OHIO STATE UNIVERSITY, 1992, 20.

THIS ESSAY EXAMINES THE EVENTS WHICH TOOK PLACE IN THE REVOLUTIONARY YEAR 1989. IT ARGUES THAT THE SURPRISING COLLAPSE OF SOCIALISM WAS ONLY THE SURFACE MANIFESTATION OF UNDERLYING TRENDS. IT EXAMINES THREE TRENDS THAT CONVERGED TO PRODUCE THE SHOCKS OF 1989: THE EMERGENCE JF NEW CRITERIA FOR DEFINING GREAT POWERS; THE COLLAPSE OF AUTHORITARIAN ALTERNATIVES TO LIBERALISM; AND THE DECLINE OF BRUTALITY IN BOTH INTERNAL AND INTERNATIONAL AFFAIRS. THESE TRENDS ALONE BOTH INTERNAL AND INTERNATIONAL AFFAIRS. THESE TRENDS ALONE
COULD NOT HAVE BROUGHT ABOUT THE AMAZING CHANGES OF 1989; IT COULD NOT HAVE BROUGHT ABOUT THE AMAZING CHANGES OF 1989;
WAS THEIR INTERACTION THAT WAS THE CRITICAL FACTOR. THE WAS THEIR INTERACTION THAT WAS THE CRITICAL FACTOR. THE
ESSAY CONCLUDES WITH TENTATIVE SPECULATIONS ABOUT THE ESSAY CONCLUDES WITH TENTATIVE
CONSEQUENCES OF THESE TRENDS.

03524 GADZEY, A.

THE STATE AND CAPITALIST TRANSFORMATION IN SUB-SAHARAN AFRICA: A DEVELOPMENT MODEL

COMPARATIVE POLITICAL STUDIES, 24(4) (JAN 92), 455-487

DECLINING PERFORMANCE OF THE POSTCOLONIAL AFRICAN STATES SUGGEST THE INEFFICIENCY OF CENTRALIZATION AND/OR SOCIALIST STRATEGY THAT CURRENTLY DOMINATES THE REGION. THE SOLUTION, HOWEVER, IS NOT A RETURN TO THE LARGELY UNRESTRAINED LIBERAL ECONOMIC MODELS OF THE 1960 S SUCH AS IMPORT SUBSTITUTION, INOUSTRIALIZATION, OR COMMODITY EXPORT SPECIALIZATION. WHETHER FROM THE LEFT OR THE RIGHT, THE INABILITY OF ALL THREE MODELS TO DEFINE PRECISE DEVELOPMENT ROLES FOR AFRICA STATE ELITES SUGGESTS THEIR INSENSITIVITY TO AND INADEQUACY FOR THE NEEDS OF THESE POL ITICALLY DYNAMIC YOUNG STATES OF AFRICA. AN ALTERNATIVE MODEL PRESENTED IN THIS ARTICLE WOULD INVOLVE STATE ELITES IN GRASS ROOTS CAPITALIST DEVELOPMENT. THE MODEL FOSTERS DECENTRALIZATION AND ECONOMIC DEVELOP HI THOUT SACRI FICING RULE LEGITIMIZATION AND NATIONAL INTEGRATION AS EQUAL OB JECTIVES. IN MANY RESPECTS, THE HODE EMBEDOED LIBERALISM THAT PROPERLY DESCRIBE CURRENT WESTERN LIBERALISM.

03525 GAFFNEY, J.

THE POLITICAL THINK-TANKS IN THE UK AND THE MINISTERIAL CABINETS IN FRANCE

WEST EUROPEAN POLITICS, 14(1) (JAN 91), 1-17.

IN THE UNITED KINGDOM, SINCE THE ELECTORAL VICTORY OF THE CONSERVATIVE PARTY IN 1979, THE RIGHT-WING THINK-TANKS, IN PARTICULAR THE CENTRE FOR POL ICY STUDIES, HAVE HAD DIRECT ACCESS TO GOVERNMENT. IN FRANCE, THE MINISTERIAL CABINETS HAVE LONG BEEN A SITE OF INTERACTION BETWEEN POLITICAL REFLECTION AND POLICY INITIATIVES. SINCE 1981, THE FRENCH LEFT, FAR FROM RESTRICTING THE INFLUENCE OF THE CABINETS, LEFT, FAR FROM RESTRICTING THE INFLUENCE OF THE CABINETS,
HAS USED THEM TO ENHANCE ITS CONTROL OVER THE INNOVATION, HAS USED THEM TO ENHANCE ITS CONTROL OVER THE INNOVATION,
PASSAGE AND APPLICATION OF REFORMIST LEGISLATION. THE PASSAGE AND APPLICATION OF REFORMIST LEGISLATION. THE

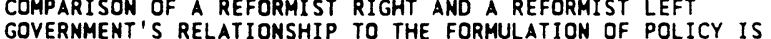
GLLUSTRATIVE OF THE CHANNELS THROUGH WHICH POLITICAL IDEAS ILLUSTRATIVE OF THE CHANNELS THROUGH WHICH
GAIN CURRENCY IN REPRESENTATIVE DEMOCRACY.

03526 GAFFNEY, M.

THE TAXABLE SURPLUS IN WATER RESOURCES

CONTEMPORARY POLICY ISSUES, $X(4)$ (OCT 92), 74-82.

TAXES OR RENTAL CHARGES FOR WATER USE ARE BEARABLE AND LEGAL AND HOULD ENCOURAGE ECONOMICAL USE OF WATER, BUT THE FOLLOWING FALLACIES IMPEDE ACCEPTANCE OF THE CONCEPT: (I) 
WATER RIGHTS ARE REAL PROPERTY; (II) A CHARGE ON WATER WOULD BE PASSED ON TO CONSUMERS; (III) THE COST OF WATER IS ONLY ITS DEVELOPMENT COST; (IV) MARKETS SOLVE MOST PROBLEMS IF PROPERTY RIGHTS ARE FIRM; (V) ONLY CONSUMPTIVE USE IS A SDCIAL COST: AND (VI) COMMON RIGHTS MUST SPELL TRAGEDY. THIS POCIAL COST; AND (VI) COMMON RIGHTS MUST SPELE TRAGEDY THIS RENTAL CHARGES FOR WATER USE.

03527 GAFFNEY, P.D.

POPULAR ISLAM

ANNALS OF THE AMERICAN ACADEMY OF POLITICAL AND SOCIAL

SCIENCE, (524) (NOV 92), 38-51.

THE CURRENT WAVE OF RELIGIOUSLY-MOTIVATED PROTEST

MOVEMENTS THROUGHOUT THE ISLAMIC WORLD HAS FREQUENTLY BEEN

ASSOCIATED WITH POPULAR ISLAM. THIS CONCEPT OF A POPULAR, AS

OPPOSED TO AN OFFICIAL, PRACTICE HAS DEEP ROOTS EXTENDING

BACK TO THE FORMATIVE PERIOD OF THE MUSLIM TRADITION.

CLASSICALLY, THE EMERGENCE OF A CLERICAL ELITE DEFINED IN

TERMS OF THEIR FUNCTIONS IN THE FIELDS OF LAW, EDUCATION AND ADMINISTRATION AS HELL AS RELIGION COINCIDED HITH THE RISE OF A PARALLEL FOLK PIETY INSPIRED BY SUFISM WHICH ADAPTED ISLAM TO LOCAL CIRCUMSTANCES. THE SHEEPING CHANGES OF THE LAST THO CENTURIES HAVE UNDERMINED MANY OF THE OLD RELIGIOUS INSTITUTIONS BELONGING TO BOTH THESE SPHERES. BUT THE OVERALL STRUCTURES OF SOCIAL RELATIONS HAVE LARGELY REMAINED WITHIN THE CONTEXT OF THE NATION-STATE. WITH FEW AND SHORT-LIVED EXCEPTIDNS, RURAL PEASANTS AND URBAN MASSES WHO CONTINUE TO REGARD ISLAM AS THE PRIMARY BASIS FOR THEIR IDENTITY HAYE MOT RESPONDED POSITIVELY TO THE SUMMONS OF THE CURRENT REVIVAL. ON THE OTHER HAND, ISLAMICISTS, DESPITE DIVISIONS AMONG THEMSELVES, HAVE ESTABLISHED THEIR IMPORTANCE. THUS, POPULAR ISLAM PERSISTS AS A VITAL CONCEPT POINTING IN THO DIRECTIONS.

03528 GAGE, R.W.

SECTOR ALIGNMENTS OF REGIONAL CONFLICTS: IMPLICATIONS FOR INTERGOVERMMENTAL RELATIONS IN THE 1990's AMERICAN REVIEW OF PUBLIC ADMINISTRATION, 22(3) (SEP 92), 207-226.

THE RESURGENCE OF INTEREST IN SUB-STATE REGIONALISM HAS IMPLICATIONS FOR INTERGOVERNMENTAL RELATIONS IN THE 1990'S. THIS RESEARCH ANALYZES CHANGES IN THE SECTOR ALIGNMENTS OF REGIONAL COUNCILS FROM 1985 TO 1995 AS ASSESSED BY THEIR EXECUTIVE DIRECTORS. IT EXPLORES THE ALIGNMENTS OF REGIONAL COUNCILS TO FIVE INSTITUTIONAL SECTORS: THE NATIONAL GOVERMMENT, STATE GOVERNMENTS, THE REGIONAL SECTOR, LOCAL GOVERMMENTS, AND THE PRIVATE SECTOR. THE PRIORITIES THE COUNCIL DIRECTORS EXPECT TO PLACE ON RELATIONSHIPS WITH THEIR STATE GOVERNMENTS AND HITH THE PRIVATE SECTOR ARE INCREASING DRAMATICALLY. THE LOWEST SECTOR PRIORITIES ARE PLACED ON RELATIONSHIPS WITH THE NATIONAL GOVERNMENT, EVEN THOUGH IT REMAINS THE COUNCILS' SINGLE LARGEST SOURCE OF FISCAL SUPPORT.

03529 GAHR, E.

ORTHODOX JEWS GET POLITICIAL

INSIGHT, 8(3) ( JAN 92), 14-16; 38.

DEPARTING FROM TRADITION. ORTHODOX JEWS ARE FINDING THEIR VOICE IN WASHINGTON POLITICS, NO LONGER TRUSTING THE OISSEMINATION OF THEIR YIEWS TO SECULAR JEWISH GROUPS, TWO ORTODOX ORGAN MYTH OF A UNIFIED LIBERAL JEWISH STANCE. THIS ARTICLE MYTH OF A UNIFIED LIBERAL JEWISH STANCE. THIS ARTICLE REPORTS THAT THE ORTHODOX COMMUNITY HAS NOT BEEN WELL REPRESENTED BY THE JEWISH ESTABLI IHAENT. AS A GENERALIZATIC
THERE IS A TENDENCY IN CERTAIN SEGMENTS OF THE SECULAR THERE IS A TENDENCY IN CERTAIN SEGMENTS OF THE SECULAR
JEHISH ESTABL ISHMENT TO REGARD RELIGION AS SOMETHING THAT JEHISH ESTABL ISHMENT TO REGARD REL

03530 GAHR, E.

THE LIBERALS' ELDER STATESMAN

INS IGHT, $7(49)$ (DEC 91) $12-13,36-38$

WITH MORE THAN 50 YEARS AS A LIBERAL ACTIVIST, JOE RAUH HAS A LONG LIST OF ACCOMPLISHMENTS TO LOOK BACK ON. THEY INCLUDE: WRITING THE HISTORIC CIVIL RIGHTS PLANK AT THE 1948 DEMOCRATIC NAT IONAL CONVENTION, HELPING TO ESTABLISH THE DMERICANS FOR DEMOCRATIC ACTION AS A LIBERAL ANTI-COMMUNIST GROUP: REPRESENTING PLAYWRIGHTS LILLIAN HELLMAN AND ARTHUR GROUP; REPRESENTING PLAYWRIGHIS LILLIAN HELLMAN AND ARTHU MILLER BEFORE THE HOUSE UN-AMERICAN ACTIVITIES COMMITTEE; AND WORKING AS A KEY LOBBYIST IN THE FIGHT TO PASS NHE CIVIL RIGHTS ACT. HOWEVER, HIS ACCOMPLISHMENTS ARE NOI STILL IS ACTIVE. IN RECENT MONTHS HE HAS TESTIFIED AGAINST STILL IS ACTIVE. IN RECENT MONTHS HE HAS TESTIFIED AGAINS THE CONFIRMATION OF CLARENCE THOMAS TO THE SUPREME COURT, ATTENDED STRATEGY SESSIONS ON THE 1991 CIVIL RIGHTS ACT, AND
WORKED TO OPPOSE A KEY PROVISION IN PRESIDENT BUSH'S CRIME BILL.

03531 GAINSBOROUGH, M.

VIETNAM II: A TURBULENT NORMALISATION WITH CHINA

WORLD TODAY, 48(11) (NOY 92), 205-207.

ON THE SURFACE, RELATIONS BETWEEN CHINA AND VIETNAM HAVE ENTERED A NEW, HARMONIOUS PHASE. HOHEVER, THE TRADITIONAL MISTRUST STILL EXISTS BELOW THE SURFACE AND SIGNIFICANT BILATERAL PROBLEMS REMAIN, DESPITE A SUCCESSION OF OFFICIAL
VISITS AND EXPRESSIONS OF POSITIVE INTENT. NORMALIZATION HAS BEEN ACHIEVED LARGELY AT THE EXPENSE OF A WEAKER HANOI DEFERRING TO BEIJING. ONE CAN WELL IMAGINE A FUTURE TIME WHEN A STRONGER VIETNAM, RENEWING OLD DESIGNS, WILL AGAIN COME INTO CONFLICT WITH CHINA.

03532 GALLAGHER, M.

A NEW AGENDA OF HOPE?

PEACE AND THE SCIENCES, 1(1) (SEP 92), 15-16

IN VIEW OF THE EXTRAORDINARY CHANGES OF RECENT YEARS, A KEY QUESTION CONCERNS THE NEH AGENDA OF HOPE FOR THE ENTIRE CONTINENT OF EUROPE AND ITS PEOPLES. EITHER THIS NEH VISION, AND THE DECISIONS THAT STEM FORM IT, WILL BE EXPLICITLY GROUNDED IN FUNDAMENTAL ETHICAL VALUES, OR ELSE THE PLANNING OF A CHAMGED EUROPE

UTILITARIAN WAY. THIS PAPER SUGGESTS THAT THE SHAPERS OF THE UTILITARIAN WAY. THIS PAPER SUGGESTS THAT THE SHAPERS OF THE THE SAINTS. IT IS BY THIS GROUP THAT EUROPE'S AGENDA OF HOPE CAN BE BEST EXPRESSED WITH GENUINE ELOQUENCE.

03533 GALLAGHER, M.

COMPARING PROPORTIONAL REPRESENTATION ELECTORAL SYSTEMS: QUOTAS, THRESHOLDS, PARADOXES, AND MAJORITIES BRITISH JOURNAL OF POLITICAL SCIENCE, $22(4)$ (OCT 92), 469-496.

THE AUTHOR FOCUSES ON CERTAIN ELEMENTS--THE QUOTA, THRESHOLDS, PARADOXES, AND THE CONDITIONS UNDER WHICH A MAJORITY OF SEATS CAN BE WON--TO COMPARE SEAT ALLOCATION METHODS. CERTAIN SEAT ALLOCATION METHODS CONVENTIONALLY SEEN AS VARIANTS OF PROPORTIONAL REPRESENTATION (PR) CANNOT, IN ACCORDING TO WHETHER, WHEN COMPLETE PROPORTIONAL ITY IS NOT ATTAINABLE. THEY DISPLAY ELECTORAL BIAS TOWARDS LARGER OR SMALLER PARTIES. HOWEVER, A DEFINITIVE ORDERING IS ELUSIVE, SMALLER PARTIES. HOWEVER, A DEFINITIVE ORDERING IS ELUSIVE SINCE SOME METHODS THAT ARE GENERALLY MORE FAVORABL
LARGER PARTIES CAN IN SOME CIRCUMSTANCES SET LOWER LARGER PART IES CAN IN SOME CIRCUMSTANCES SET LOWER THRESHOLDS OF REPRESENTATION THA
FAYORABLE TO SMALLER PARTIES.

03534 GALLAGHER, M.; MARSH, M.

REPUBLIC OF IRELAHD PRESIDENTIAL ELECTION: 7 NOVEMBER 1990 WEST EUROPEAN POLITICS, 14 (4) (OCT 91), 169-173.

THE IRISH PEOPLE EXPERIENCED THEIR FIRST PRESIDENTIAL ELECTION IN OVER 17 YEARS ON 7 NOVEMBER 1990, AND BY ELECTING MARY ROBINSON THEY GAVE THEMSELVES ONLY THE SECOND WOMAN PRESIDENT TO BE ELECTED IN EUROPE. MOREOVER, THE VICTORY OF A WOMAN WHO HAD CAMPAIGNED VIGOROUSLY FOR LIBERAL REFORMS OVER THE PAST THO DECADES, IN A COUNTRY THAT HAD REAFFIRMED TRADITIONAL CATHOLIC VALUES IN TWO REFERENDUMS IN THE 1980S, OCCASIONED BOTH SURPRISE AND SPECULATION AS TO THE IMPLICATIONS OF HER ELECTION FOR IRISH POLITICS IN THE THE END OF HER TERM IN 1997 SHE MANAGES TO REDUCE THE NUMBER OF POLL RESPONDENTS WHO THINK THAT THE OFFICE OF PRESIDENT SHOULD BE ABOL I SHED.

03535 GALLAGHER, T.

ELECTORAL BREAKTHROUGH FOR ROMANIAN NATIONALISTS

RFE/RL RESEARCH REPORT, 1(45) (NOV 92), 15-20.

THE SEPTEMBER 1992 ELECTIONS IN ROMANIA PROVIDED AN OPPORTUNITY FOR RADICAL NATIONALISTS TO ADVANCE A RANGE OF POPULIST ISSUES AND CONSOLIDATE THEIR POSITION IN TRANSYL VANIA, WHERE THE POLITICAL LANDSCAPE IS VERY DIFFERENT FROM THAT IN THE REST OF THE COUNTRY. AN INTERNAL SPLIT IN THE LARGEST NATIONALIST PARTY AND THE ABILITY OF MAINSTREAM DEMOCRATS TO OPPOSE EXTREME NAIIONALISM WITH A MODERATE YARIETY OF THEIR OWH MAY IMPEDE THE PROGRESS OF THE CHAUYINISTIC LOBBY. MEYERTHELESS THAT GROUP NOW HAS EMOUGH STRENGTH IN PARLIAMENT TO EXPLOIT THE FAILINGS OF THE STRENGTH IN PARLIAMENT TO EXPLOIT THE FAILINGS OF THE
POLITICAL SYSTEM AND IS IN A BETTER POSITION TO ADVOCATE AUTHORITARIAN REMEDIES FOR THE COUNTRY'S TROUBLES.

03536 GALLAGHER, T. MASSACHUSÉTTS: MIRACLE TO DEBACLE SOCIALIST REVIEW, 21 (1) (JAN 91), 155-176.

THE OFT-TOUTED "MASSACHUSETTS MIRACLE" OF MICHAEL DUKAKIS HAS CRUMBLED INTO ECONOMIC DECLINE AND DECAY. THIS ARTICLE SEEKS TO DETERMINE THE UNDERLYING CAUSES. THEY ARE: ARTICLE SEEKS TO DETERMINE THE UNDERLYING CAUSES. THEY ARE THE FACT THAT THERE ARE NO MIRACLES IN ECONOMICS, ONLY
NEWSPAPERS AND IN BUSINESS AND POLITICAL PROMOTIONAL MATERIAL: AN INEVITABLE ECONOMIC DOWNSWING SNOWBALLED INTO MATERIAL; AN INEVITABLE ECONOMIC DOWNSWING SNOWBALL FISCAL WIPEOUT DUE TO THE REPUBLICANIZATION OF THE MASSACHUSETTS DEMOCRATIC PARTY; AND MURAEL DCONAKIS DOES SHARE IN THE BLAME FOR THE STAIE'S CURRENT ECONOMIC PLIGHT, ALTHOUGH NOT IN THE WAY HE IS ACCUSED OF, FOR THE COURSE HE NATIONAL PARTY WHOSE STANDARD HE BORE IN 1988.

03537 GALLAGHER, T.

ROMANIA: THE DISPUTED ELECTION OF 1990

PARLIAMENTARY AFFAIRS, 44(1) (JAN 91), 79-93.

THIS ARTICLE CHRONICLES AND EXAMINES ROMANIA'S TROUBLED TRANSITION AWAY FROM TOTALITARIAN RULE. IN CONTRAST TO OTHER POST-COMMUNIST STATES OF EASTERN EUROPE WHICH WENT TO THE 
POLLS IN 1990, ROMANIA'S ELECTIONS WERE HELD IN A POLARIZED ATMOSPHERE IN WHICH SHARP SOCIAL DIVISIONS AND BITTER DISAGREEMENTS ABOUT THOSE WHO HAD TAKEN CHARGE OF THE PROCESS OF DEMOCRACY CAST A DARK SHADOW OVER THE COUNTRY'S IMMEDIATE PROSPECTS. A CLEAR WINNER EMERGED IN THE NATIONAL SALVATION FRONT; HOWEVER, THE COMMUNIST BACKGROUND OF ITS LEADERS, THEIR PRE-ELECTION TACTICS AND CONTROL OF THE STATE APPARATUS, AND THE SUITABILITY OF HOLDING AN ELECTION WHILE MILLIONS OF VOTERS WERE STILL UNFAMILIAR WITH THE MOST RUDIMENTARY DEMOCRATIC PRACTICE, CAUSED A VOCAL SEGMENT OF THE POPULATION TO DENY THE VALIDITY OF THE RESULT.

03538 GALLAGHER, $T$. ROME AT BAY: THE CHALLENGE OF THE NORTHERN LEAGUE TO THE ITALIAN STATE

GOVERNMENT AND OPPOSITION, 27(4) (FAL 92), 470-485. THE NORTHERN LEAGUE, WHICH WON A SURPRISING NUMBER OF VOTES IN ITALY'S APRIL 1992 ELECTIONS, WANTS TO MAKE NORTHERN ITALY SELF-GOVERNING WITHIN A RADICALLY DECENTRALIZED ITALIAN STATE. IT REPRESENTS A SERIOUS DECENTRALIZED ITALIAN STATE. IT REPRESENTS A SERIOUS CHALLENGE TO MORE THAN A CENTURY OF CENTRALIZED RULE IN
WHICH CONSISTENT EFFORTS HAVE BEEN MADE TO CREATE A SINGLE WHICH CONSISTENT EFFORTS HAVE BEEN MADE TO CREATE A SINGLE
NATION, WITH UNIFORM TRADITIONS AND LAWS, UNITING DIVERSE RAGIONS OF THE IFORM TRADITIONS AND LAWS, UNITING DIVERSE REGIONS OF THE ITALIAN PENINSULA. THE LEAGUE S MESSAGE IS ONE THAT APPEALS TO A RANGE OF SOCIAL GROUPS WHO FEEL THAT
THEIR INTERESTS ARE NO LONGER SERVED BY A POL ITICAL SYSTEM UNABLE TO CORRECT SERIOUS ABUSES IN ITALIAN PUBLIC LIFE.

03539 GALLAGHER, T.

ULTRANATIONALISTS TAKE CHARGE OF TRANSYLVANIA'S CAPITAL RFE/RL RESEARCH REPORT, 1(13) (MAR 92), 23-30.

THE DECISIVE VICTORY OF THE ULTRANATIONALIST PARTY OF ROMANIAN NATIONAL UNITY IN CLUJ DURING THE RECENT LOCAL ELECTIONS CASTS A SHADOW OVER THE BREAKTHROUGH ACHIEVED BY THE DEMOCRATIC CONVENTION IN OTHER RONANIAN TOWNS AND CITIES. IN KEY RESPECTS, THE VICTORY WAS DELIVERED TO THE PARTY BY THE RULING NATIONAL SALVATION FRONT, WHOSE LACK OF A POWER BASE IN CLUJ LED IT TO PROMOTE NATIONALISM AS A MEANS OF DISABLING THE MAINSTREAM OPPOSITION--A STRATEGY SPEARHEADED BY PRIME MINISTER PETRE ROMAN. THE ACTIVE INTERVENTION OF THE LOCAL MILITARY COMMANDER IN THE ELECTION CAMPAIGN ALSO RAISED DOUBTS ABOUT THE POLITICAL NEUTRALITY OF THE ROMANIAN ARMED FORCES.

03540 GALLES, $G$.

HALF-TRUTHS OR CONSEQUENCES

FREEMAN, $42(11)$ (NOV 92), 434-436.

THE LEGITIMATE ROLE OF THE AMERICAN GOVERNMENT IS SMALL, AT BEST. GIVEN THAT MUCH OF WHAT OUR GOVERNMENT DOES IS INDEFENSIBLE BY REFERENCE TO EITHER LOGIC OR PRINCIPLE THIS INOEFENSIBLE BY REFERENCE TO EITHER LOGIC OR PRINCIPLE THIS ARTICLE EXPLORES HOW THE GOVERNMENT'S ACTIONS ARE MADE TO APPEAR WORTHWHILE. IT SUGGESTS THAT THEY ARE JUSTIFIED WITH PLAUSIBLE SOUNDING BUT INVALID ARGUMENTS, MANY OF THEM AS OLD AS GOVERNMENT ITSELF. IT REVIEWS SOME OF THE MORE FREQUENT
COURSE.

03541 GALLINER, $P$.

HOW FREE IS THE PRESS? A GLOBAL SAMPLER

WORLD PRESS REVIEW, 39(2) (FEB 92), 10-15.

THE AUTHOR ASSESSES THE LEVELS OF PRESS FREEDOM AND GOVERMMENT CENSORSHIP IN ALGERIA, CAMEROON, CHILE, MAINLAND CHINA, COLOMBIA, ETHIOPIA, GREECE, INDONESIA, TURKEY, ZIMBABWE, AND THE SOVIET UNION IN 1991.

03542 GALLIS, P. IDEALS AND PRACTICALITY: THE REORIENTATION OF US FOREGIGN POLICY

OF DEFENSE ANALYSIS, 3(2) (HIN 91), 123-142. THE RECEDING SOVIET THREAT HAS CREATED NEH OPPORTUNITIES FOR THE UNITED STATES TO RE-ORIENT ITS FOREIGN POLICY AND TO ACHIEVE ENDS THAT PROTECT ITS INTERESTS AND THOSE OF ITS FRIENDS AND ALLIES. THE POST-COLD WAR ERA DEMANDS A MORE OPEN APPROACH TO COALITION-BUILDING AND TO THE MANAGEMENT OF INTERNATIONAL POLITICAL AND ECONOMIC AFFAIRS. THIS ARTICLE EXPLORES: OLD AND NEW OBJECTIVES; THE PRESERVATION OF NATO; AN EMERGENT GERMANY; EUROPEAN INSTITUTION-BUILDING AND U.S. FOREIGN POLICY; WAR AND PEACE IN THE PERSIAN GULF; AND THE REFORMULATION OF U.S. FOREIGN POLICY.

03543 GALLUP, A.

BUSH'S' FOREIGN POLICY RATINGS DECLINE SHARPLY GALLUP POLL MONTHLY, (318) (MAR 92), 43-45.

IN EARLY 1992, PRESIDENT GEORGE BUSH'S FOREIGN POLICY RATINGS DECLINED SHARPLY. THE PERCENTAGE OF AMERICANS HHO APPROVED OF THE WAY BUSH HANDLED FOREIGN POLICY FELL FROM 65 PERCENT IN JANUARY 1992 TO 55 PERCENT IN MARCH.

03544 GALLUP, A.; NEWPORT, F DUKE UNPOPÚLAR ACROSS COUNTRY GALLUP POLL MONTHLY, (314) (NOV 91), 26-29 ACCORDING TO A GALLUP POLL, AMERICANS FEEL STRONG PERSONAL DISAPPROVAL OF THE REPUBLICANS' LOUISIANA GUBERNATORIAL NOMINEE, DAVID DUKE, BUT SUPPORT MANY OF HIS
CAMPAIGN THEMES. A MAJORITY OF AMERICANS FAVOR MANY ELEMENTS OF DUKE'S PLATFORM, INCLUDING ACROSS-THE-BOARD REDUCTIONS IN ALL GOVERMMENT AGENCIES, TAXES, AND FEES; ELIMINATION OF BUSING AND QUOTAS; AND REQUIRING WELFARE RECIPIENTS TO WORK FOR THEIR CHECKS.

03545 GALLUP, G. JR.; NEWPORT, F.

AFTER FIRST WEEK OF HEARINGS, MAJORITY STILL SUPPORT THOMAS NOMINATION

GALLUP POLL MONTHLY, (312) (SEP 91), 42-46.

THE FIRST WEEK OF SENATE HEARINGS ON SUPREME COURT NOMINEE CLARENCE THOMAS HAD LITTLE IMPACT ON PUBLIC SUPPORT FOR HIM. A GALLUP POLL CONDUCTED AFTER A WEEK OF HEARINGS SHOWS THAT AMERICANS FAVOR HIS CONFIRMATION BY A 54\% TO 25\% MARGIN, WHICH IS NOT SIGNIFICANTLY DIFFERENT FROM A POLL CONDUCTED BEFORE THE HEARINGS BEGAN.

03546 GALLUP, G. JR.; NEWPORT, F.

CONFIDENCE IN MAJOR U.S' INSTITUTIONS AT ALL-TIME LOW GALLUP POLL MONTHLY, (313) (OCT 91), 36.

ACCORDING TO A GALLUP POLL, AMERICAN CONFIDENCE IN THE U. S. CONGRESS AND SUPREME COURT IS AT AN ALL-TIME LOW. THE PRESIDENCY ENJOYS THE HIGHEST PUBLIC CONFIDENCE OF THE THREE BRANCHES OF GOVERMMENT, BUT ITS RATING HAS SLIPPED FROM $72 \%$ TO 50\%. THE MIL ITARY EN JOYS THE HIGHEST CONFIDENCE RATING, ALTHOUGH ITS RATING HAS ALSO FALLEN, AND ORGANIZED RELIGION RANKS SECOND.

03547 GALLUP, G. JR. : NEWPORT, F. FAVORABLE ATTI TUDES TOWARD JAPAN DECLINING GALLUP POLL MONTHLY, (315) (DEC 91), 11-18.

A GALLUP POLL SHOWS THAT A MAJORITY OF AMERICANS HAVE FORGIVEN THE JAPANESE FOR PEARL HARBOR, BUT ALMOST HALF SAY IT IS AT LEAST SOMEWHAT LIKELY THAT JAPAN COULD AGAIN BECOME AN AGGRESSOR NATION. OVERALL, U.S. ATTITUDES TOWARDS JAPAN AND THE JAPANESE PEOPLE ARE ONLY MODERATELY FAVORABLE AND ARE ON THE DECLINE. THE ECONOMIC THREAT POSED BY JAPAN APPEARS TO BE THE MAIN CAUSE OF THESE FEELINGS.

03548 GALLUP, G. JR, MEWPORT $F$. PROPOSED NUCLEAR WEAPONS REDUCTION HAS NO IMPACT ON BUSH'S APPROVAL RATINGS

GALLUP POLL MONTHLY, (313) (OCT 91), 15-17. ALTHOUGH PRESIDENT BUSH'S ANNOUNCEMENT OF A UNILATERAL REDUCTION IN NUCLEAR FORCES WAS HAILED AS AN EPOCH-ENDIMG BREAKTHROUGH, IT APPARENTLY HAD LITTLE IMPACT ON OPINIDNS ABOUT HIS PRESIDENCY. ALTHOUGH 71\% OF AMERICANS APPROVE OF ABOUT HIS PRESIDENCY. ALTHOUGH 71\% OF AMERICANS APPROVE
BUSH'S NUCLEAR REDUCTION PLAN, HIS OVERALL JOB APPROVAL BUSH'S NUCLEAR REDUCTION PLAN, HIS OVERALL JOB APPROV
RATING DID NOT SHOW ANY SIGNIFICANT CHANGE AFTER THE RATING DID NOT SHOW ANY SIGNIFICANT CHANGE AFTER THE
ANNOUNCEMENT. MOREOVER, BUSH'S RATING HAS SHOWN A GRADUAL ANNOUNCEMENT. MOREOVER, BUSH'S RATING HAS SHOWN A GRADUAL
DECLINE FROM $89 \%$ IN MARCH 1991 TO $65 \%$ IN THE FALL OF 1991.

03549 GALSTON, W. : ETZIONI, A.

GALSTON, W. ; ETZIONI, A. HOW TO CUT THE DEFICIT AND PUT AMERICA BACK TO WORK AMERICA BACK TO WORK

U.S. PRESIDENT BILL CLINTON INHERITS SEVERE ECONOMIC PROBLEMS ON THO FRONTS--GROHTH AND DEFICITS. DURING HIS CAMPAIGN, HE BUILT A MANDATE FOR PUBLIC EFFORTS TO RESTART THE ENGINE OF ECONOMIC GROWTH AND PUT AMERICANS BACK TO WORK. HE SHOULD BEGIN IMMEDIATELY TO BUILD A PARALLEL MANDATE FOR ELIMINATING THE FEDERAL BUDGET DEFICIT BY THE END OF HIS SECDND TERM. HE SHOULD BUILD THIS MANDATE FOR FISCAL CHANGE BY EXPLAINING TO THE PEOPLE THEIR SHARED STAKE IN DEFICIT REDUCTION AND BY ACKNOWLEDGING TO THEM THAT THE SITUATION IS WORSE THAN MANY REALIZE.

03550 GALTUNG, J.

ON THE WAY TO SUPERPOWER STATUS

FUTURES, $24(9)$ (NOV 92), 917-930.

THE COLD WAR HAD A POOR ROLE REPERTORY TO OFFER MEMBERS

OF THE INTER-STATE SYSTEM: SUPERPOHER, CLIENT AND NON-

ALIGNED. BUT THESE ARE STILL KEY ROLES IN THE SYSTEM, AND WITH THE RAPID DEMISE OF THE SOVIET UNION AS A SUPERPOWER AND THE SLOWER DECLINE OF THE USA THE QUESTION OF MOBILITY IN THE SYSTEM IS RAISED. THE EC COUNTRIES WERE LABORING HARD DURING THE COLD WAR AS CLIENTS, PROVIDING A NEGATIVE MOTIVATION FOR THE DRIVE TO SUPERPOWER STATUS, WHEREAS INDIA DERIVED SOME MORAL STATUS AS NON-ALIGNED, PROVIDING A POSITIVE MOTIVATION AS A COUNTRY BEYOND REPROACH. THE ARTICLE EXAMINES THE CAPABILITIES OF THE THO FOR FILLING THE REOUIREMENTS FOR SUPERPOWER STATUS, CONCLUDING THAT THEY ARE BOTH WELL ON THEIR WAY.

03551 GALVIN, J.

BUILDING ON SUCCESS: ALLIED COMMAND EUROPE LOOKS TO THE FUTURE

RUSI JOURNAL, 137(4) (AUG 92), 1-6.

GENERAL GALYIN PRESENTS HIS VIEH OF THE ROLE OF NATO AFTER THE END OF THE COLD HAR. HE SEEKS TO ALLAY SEVERAL AFTER THE END OF THE COLD WAR. HE SEEKS TO ALLAY SEVERAL ISSUES OF CRISIS MANAGEMENT, THE PEACE DIVIDEND AND AMERICA'S ROLE IN EUROPE, CONCLUDING THAT ALTHOUGH THERE ARE OTHER ORGANIZATIONS CAPABLE OF DEALING WITH POTENTIAL CRISES, 
NATO IS STILL THE BEST QUALIFIED, EQUIPPED AND MANAGED, TO WIN THE PEACE.

03552 GAMBARI, I.A.

AFRICA AT THE CROSSROADS

WEST AFRICA, (3896) (MAY 92), 832-834.

THE AUTHOR DISCUSSES THE ROLE OF AFRICA, THE UNITED NATIONS, AND THE UNITED STATES IN THE EVOLVING NEW HORLD ORDER.

03553 GAMSON, W.A.

TALKING POLITICS

CAMBRIDGE UNIVERSITY PRESS, 1992, 256

THOSE WHO ANALYZE PUBLIC OPINION HAVE LONG CONTENDED THAT THE AVERAGE CITIZEN IS INCAPABLE OF RECOUNTING CONSISTENTLY EVEN THE MOST RUDIMENTARY FACTS ABOUT CURRENT POLITICS: THAT THE LITTLE THE AVERAGE PERSON DOES KNOW IS TAKEN AT FACE VALUE FROM THE MEDIA REPORTS; AND THAT THE CONSEQUENCE IS A POLITY THAT IS ILL-PREPARED FOR DEMOCRATIC GOVERNANCE. YET SOCIAL MOVEMENTS, COMPRISED BY AND LARGE OF AVERAGE CITIZENS WHO HAVE BECOME EXERCISED ABOUT PARTICUL
ISSUES, HAVE BEEN A PROMINENT FEATURE OF THE AMERICAN POLITICAL SCENE THROUGHOUT AMERICAN HISTORY AND THEY ARE EXPERIENCING A RESURGENCE IN RECENT YEARS. THE AUTHOR OF THIS BOOK ASKS THE QUESTION: HOW IS IT THAT SO MANY PEOPLE BECDME ACTIVE IN MOVEMENTS IF PEOPLE ARE SO GENUINELY UNINTERESTED AND BADLY INFORMED ABOUT ISSUES? THE CONCLUSION HE REACHES IS A REFUTATION OF THE COMMON WISDOM ABOUT THE PUBLIC'S ABILITY TO REASON ABOUT POLITICS. THE AUTHOR REPORTS ON HIS ANALYSIS OF OISCUSSIONS AMONG SMALL GROUPS OF WORKING-CLASS PEOPLE ON FOUR CONTROVERSIAL ISSUES:

AFFIRMATIVE ACTION, NUCLEAR POWER, THE ARAB-ISRAELI CONFLICT, AND THE TROUBLES IN AMERICAN INDUSTRY.

03554 GANCHEY, G.; NIKOLOV, C.

MACROECONOMIC STABILIZATION PROGRAMS IN EASTERN EUROPE: A CONCEPTIONAL APPROACH

PEACE AND THE SCIENCES, 1(1) (1992), 14-15.

THE REFORMS IN EASTERN EUROPE PRESENT A TEXT-BOOK

EXAMPLE FOR THE IMPOSSIBILITY OF THE DIRECT IMPLEMENTATION

OF NEOCLASSICAL CONCEPTS AS A POLICY-BACKGROUND FOR

TRANSITION. THE CATASTROPIHIC RESULTS OF THE ECONOMIC

TRANSITION. THE CATASTROPIHIC RESULTS OF THE ECONOMIC
REFORMS IN EASTERN EUROPE EMPHASIZE THE NEED FOR A NEW

REFORMS IN EASTERN EUROPE EMPHASIZE THE NEED FOR A NEH
CONCEPTIONAL APPROACH TO THE TRANSITIONS. THIS ARTICLE

CONCEPTIONAL APPROACH TO THE TRANSITIONS. THIS ARTICLE
SUGGESTS THAT THE EASTERN EUROPEAN COUNTRIES HAVE NO OTHER

SUGGESTS THAT THE EASTERN EUROPEAN COUNTRIES HAVE NO OTHER
CHOICE THAN A PRAGMATIC COMMON-SENSE-BASED POLICY WHICH

WOULD BEGIN HITH AN ERHARD-STYLE MONETARY REFORM.

03555 GANCHEV, G.; NIKOLOV, C.

PRIVATIZATION, MARKET INSTITUTIONALIZATION AND ECONOMIC EFFICIENCY PROMOTION

PEACE AND THE SCIENCES, 1(1) (1992), 13-14.

THE IMPORTANCE OF THE PRIVATIZATION PROCESS IN EASTERN

EUROPE IS CONNECTED FIRST OF ALL WITH THE FACT, THAT IT

LEADS TO REAL TRANSFORMATIDN OF THE SYSTEM. THE PROCESS OF

THE PRIVATIZATION IN EASTERN EUROPE SHOULD NOT BE
CORRECTLY WITHOUT THE USE OF THE BACKGROUND OF THE

"PRINCIPAL-AGENT" THEORY WHICH IS EXPLAINED IN THIS ARTICLE.

THE CONTEMPORARY "POST-SOCIALIST" SOCIETY FROM THE MARKET

POINT OF VIEH IS OFFERED AND THE OISADVANTAGES OF

PRIVATIZATION ARE EXPLORED.

03556 GANESAN, $N$

SINGAPORE'S FOREIGN POLICY TERRAIM

ASIAN AFFAIRS, AN AMERICAN REVIEH, 19(2) (SUM 92), 67-79.

THIS ARTICLE IDENTIFIES AND EXAMINES SINGAPORE'S FOREIGN POLICY TERRAIN, FOUR CONSTRAINTS THAT THE ARTICLE ADDRESSES ARE VULNERABILITY AND THE SOVEREIGNTY PRINCIPLE, DEMOGRAPHY, STRATEGIC LOCATION, AND RESOURCE BASE, OR THE LACK OF IT. THESE CONSTRAINTS CONSTITUTE AN INPUT IN THE FOREIGN POL ICY FORMULATION PROCESS OF THE PRESENT GOVERNMENT. THE ARTICLE ALSO PROVIDES A BRIEF SUMMARY OF SINGAPORE'S FOREIGN POLICY PRIOR TO ITS INDEPENDENCE.

03557 GANG, $D$.

NORDIC CO-OPERATION ON SECURITY

BEI JING REVIEW, 35(36) (SEP 92), 17.

THE HEADS OF FIVE NORDIC NATIONS--DENMARK, FINLAND,

ICELAND, SWEDEN AND NORWAY--RECENTLY MET TO DISCUSS MEASURES

TO STRENGTHEN REGIONAL CO-OPERATION. THE SUMMIT STRESSED

ENHANCED CD-OPERATION WITHIN THE NORDIC COMMUNITY IN THE

FIELDS OF FOREIGN POLICY AND SECURITY. ALTHOUGH THE NORDIC

COUNTRIES CANMOT SET UP A DEFENSE ALLIANCE, THEY CONSIDER IT

COUNTRIES CANNOT SET UP A DEFENSE ALLIANCE, THEY CDNSIDER
NECESSARY TO STRENGTHEN CO-OPERATIOH ON SECURITY CONCERNS.

NECESSARY TO STRENGTHEN CO-OPERATION ON SECURITY CONCERNS
THIS ARTICLE REPORTS OF THE LONG HISTORY OF REGIONAL CO-

THIS ARTICLE REPORTS OF THE LONC
OPERATION IN NORTHERM EUROPE.

03558 GANGULY, S.

JOINT BENEFICIARIES

FAR EASTERN ECONOMIC REVIEW, 155(4) (JAN 92), 24-25

CRITICS OF INOIA'S PERFORMANCE DURING CHINESE PREMIER LI PENG'S STATE VISIT TO INDIA ARGUE THAT INDIA MADE TOO MAMY CONCESSIONS TO THE CHINESE AND FAILED TO SECURE COMMENSURATE GAINS ON ISSUES INCLUDING THE SINO-INDIAN BORDER DISPUTE.
HOHEVER, LI'S PRESENCE IN INDIA REFLECTS THE FUNDAMENTALLY CHANGED INTERNATIONAL CONTEXT WITHIN WHICH BOTH NEW DELH AND PEXING HAVE TO OPERATE FOLLOWING THE COLLAPSE OF THE SOVIET UNION. AGAINST THIS BACKDROP, IT MAKES SENSE FOR INDIA TO SEEK A NEH RELATIONSHIP WITH CHINA. GIVEN THE CONTINUING BORDER DISPUTE WITH ITS LARGEST NEIGHBOR AND RIVAL, THE POSSIBILITIES OF A SINO-PAKISTANI COLLUSION ON KASHMIR AND INDIA'S CONSTRAINED FINANCIAL CIRCUMSTANCESLEADING TO CUTS IN THE DEFENSE BUDGET-A MORE RELAXED

RELATIONSHIP WITH CHINA IS A NECESSITY.

03559 GANGULY, $S$.

SOUTH ASIA AFTER THE COLD WAR

SOUTH ASIA AFTER THE COLD WAR
WASHINGTON QUARTERLY, 15(4) (FAL 92), 173-184.

WITH THE END OF THE COLD WAR, IT MAY BEHOOVE THE UNITED
WHA

STATES TO DEVOTE MORE ATTENTION TO THE REGION OF SOUTH ASIA.

THIS ARTICLE EXAMINES SOUTH ASIA AFTER THE COLO WAR, INDIAN FOREIGN POLICY AFTER THE COLD WAR, ARENAS OF INDO-U,S

COOPERATION, THE U.S. VIEW OF ISLAMABAD, AND THE FUTURE OF $U$. S. POLICY FOR SOUTH ASIA. IT CONCLUDES THAT THE UNITED STATES DOES HAVE INTERESTS AND CONCERNS IN THE REGION.

03560 GANS, $C$.

TURNOUT TRIBULATIONS

JOURNAL OF STATE GOVERMMENT, 65(1) (JAN 92), 12-14.

THE LOW AND DECLINING LEVEL OF VOTER TURNOUT IN THE UNITED STATES IS BOTH A DISEASE AFFLICTING AMERICAN

DEMOCRACY AND A SYMPTOM OF DEEP SYSTEMIC ILLS IN THE

POLITICAL SYSTEM. STIMULATING CITIZEN INVOLVEMENT AT ALL

LEVELS OF THE POLITICAL PROCESS MAY BE THE ONLY CURE.

03561 GAO, M.C.F.

DEMOCRACY, WHAT DEMOCRACY? CHINA'S ROAD TO MODERNIZATION

CHINA REPORT, 28(1) (JAN 92), 13-26.

THIS PAPER ARGUES THAT THE PRESSING PROBLEM FOR CHIMA

TOOAY IS TO MAINTAIN STABILITY IN ORDER TO DEYELOP ITS

ECONOMY. WHILE POLITICAL REFORMS ARE DEFINITELY NEEDED, THEY

MUST BE GRADUAL AND PRAGMATICALLY ORIENTED. THE PAPER

EXAMINES SEVERAL ISSUES CONCERNING THE RELATIONSHIP BETHEEN

EXAMINES SEVERAL ISSUES CONCERNING THE RELATIONSHIP BETHEEN

THE POLITICAL SYSTEM AND ECONOMIC DEVELOPMENT. IT ARGUES

THAT A MARKET ECONOMY AND PRIVATE OWNERSHIP OF THE MEANS OF
PRODUCTION DO NOT NECESSARILY MEAN WESTERN-STYLE DEMOCRACY.

PRODUCTION DO NOT NECESSARILY MEAN WESTERN-STYLE DEMOCRACY.
IT ALSO ARGUES THAT WITHIN THE CHINESE POLITICAL CULTURE THE

IT ALSO ARGUES THAT WITHIN THE CHINESE POL ITICAL CULTURE THE
DOMINANT IDEOLOGY IS ONE WHICH IS OPPOSED TO THE BOURGEOIS

DOLINAS WHICH ARE THE FOUNDATION OF WESTERN-STYLE DEMOCRACY.

VALUES WHICH ARE THE FOUNDATION OF WESTERN-STYLE DEMOCRA

WITHOUT FIRST TRANSFORMING ITSELF INTO A WESTERN-STYLE

WITHOUT FIRST TRANSFORMING ITSELF INTO A WESTERN-STYL

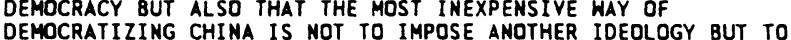

DEMOCRATIZING CHINA IS NOT TO IMPOSE ANOTHER IDEOLOGY BUT TO
FURTHER DEVELOP A MARKET ECONOMY AND PRIVATIZATION ALONG THE

LINES OF ECONOMIC RATIONALISH WHICH HILL EVENTUALLY

ELIMINATE

03562 GARA, O.A.; ARCULLI, R.J.; MARSHALL, M.; MISHRA, M. REFUGEES: CURRENT GLOBAL REFUGEES PROBLEES: PROTECTION OF REFUGEES: HUMAN RIGHTS

PARLIAMENTARIAN, LXXIII (1) (JAN 92), 12-13.

THIS IS A REPORT OF A PANEL DISCUSSION ON INTERHATIONAL

REFUGEE PROBLEMS HELD AT THE 37TH COMMONWEALTH PARLIAMENTARY

CONFERENCE IN SEPTEMBER 1991. THE PARTICIPANTS DISCUSSED THE

GLOBAL REFUGEE SITUATION, THE ROLE OF THE UNITED NATIONS,

AND HOW COMMONWEALTH MEMBERS SHOULD BE INVOLVED IN SOLVING

HUMAN RIGHTS PROBLEMS.

03563 GARAND, J.C.

ARE BUREAUCRATS DIFFEREMT

AND POLITICAL BEHAVIOR

M. E. SHARPE, $1993,256$.

THIS BOOK EXPLORES THE ATTITUDINAL AND BEHAYIORAL

DIFFERENCES BETWEEN GOVERHMENT EMPLOYEES--BUREAUCRATS--AND

OTHER CITIZENS IN THE UNITED STATES. IN PARTICULAR, IT

FOCUSES ON THOSE DIFFERENCES THAT MIGHT HAVE IMPLICATIONS

FOR GOVERNMENT SPENDING AND FOR GROWTH IN THE SIZE OF THE

FROM THE NATIONAL ELECTION STUDIES AND GENERAL SOCIAL SURVEY

SERIES. HENCE, THE BOOK PROVIDES A CDMPREHENSIVE, MICROLEVEL

SERIES. HENCE, THE BOOK PROVIDES A COMPREHENSIVE, MICROLEVEL
TEST OF THE ASSUMPTIONS UNDERLYING THE BUREAU VOTING MODEL

TEST OF THE ASSUMPTIONS UNDERLYING THE BUREAU VOTING MODEL

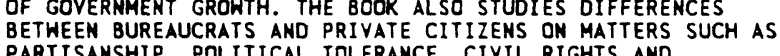

PARTISANSHIP, POLITICAL TOLERANCE, CIVIL RIGHTS AND
LIBERTIES, AND POLITICAL PARTICIPATION, ESPECIALLY VOTING

LIBERTIES, AND POLITICAL PARTICIPATION, ESPECIALLY VOTING

GOVERMMENT EMPLOYEES, ESPECIALLY AT THE FEDERAL LEVEL, ARE

EXTREME LIBERALS.

03564 GARAND, J.C

CHANGING PATTERNS OF RELATIVE STATE ECOMOMIC GROWTH OVER

TIME: LIMITATIONS ON CROSS-SECTIONAL TESTS OF OLSON'S

THESIS

WESTERN POLITICAL QUARTERLY, 45(2) (JUN 92), 469-484

OLSON'S ORGANIZED INTERESTS THEORY SUGGESTS THAT

ECONOMIC GROWTH IS A FUNCTION OF THE DOMINANCE OF THE

POLITICAL SYSTEM BY INTEREST GROUPS THAT SUPPORT EXCLUSIVE- 
BENEFIT POLICIES LIKELY TO CREATE ECONOMIC INEFFICIENCY THUS FAR, MOST TESTS OF THIS MODEL IN U.S. STATES HAVE BEEN CROSS-SECTIONAL. IN THIS PAPER, THE AUTHOR QUESTIONS THE EMPIRICAL VALIDITY OF INFERENCES DRAWN FROM CROSS-SECTIONAL TESTS OF OLSON'S THESIS. SPECIFICALLY, HE FINDS THE FOLLOWING: (1) IN THE POSTWAR ERA, RELATIVE STATE ECONOMIC GROWTH RATES HAVE FLUCTUATED SUBSTANTIALLY FROM YEAR-TO-YEAR (2) THE RELATIONSHIP BETWEEN STATE AGE AND ECONOMIC GROWTH IS HIGHLY TIME-DEPENDENT, WITH STRONG SUPPORT FOR OLSON'S THESIS LIMITED LARGELY TO THE 1970'S; AND (3) PREVIOUS RESEARCH TESTING OLSON'S MODEL HITH DATA FROM THE 1970'S MAY HAVE YIELDED IMFERENCES THAT WOULD BE UNSUPPORTED FOR OTHER TIME PERIODS. THESE RESULTS RAISE SERIOUS QUESTIONS ABOUT PREVIOUS FIMDINGS OF SUPPORT FOR THE ORGANIZED INTERESTS THEORY.

03565 GARCIA, J.Z.

MILITARY QUESTIONS IN EL SALYADOR

HEMISPHERE, 4(3) (SUM 92), 32-35.

ON JANUARY 16, 1992 , THE FMLN GUERRILLAS AND THE

GOYERNMENT OF EL' SALYADOR SIGNED AGREEMENTS ENDING THE

COUNTRY'S LONG CIVIL WAR. THE PEACE ACCORDS OHE MUCH OF THEIR SUCCESS TO INTERNATIONAL PRESSURE. IT IS UNCERTAIN WHETHER THERE EXISTS ENOUGH GOODWILL AMONG THE PARTIES IN EL SALVADOR TO CREATE A VIABLE POLITICAL SYSTEM WHEN THE INTERNATIONAL COMMUNITY IS NO LONGER FOCUSED ON SALVADORAN AFFAIRS.

03566 GARDELLA, R.

SQUARING ACCOUNTS: COMMERCIAL BOOKKEEPING METHODS AND CAPITALIST RATIONALISM IN LATE OING AND REPUBLICAN CHINA JOURNAL OF ASIAN STUDIES, 51(2) (MAY 92), 317-339.

ACCOUNTING HAS BEEN DEFINED AS THE ART OF CLASSIFYING, RECORDING AND REPORTING SIGNIFICANT FINANCIAL EVENTS TO FACILITATE EFFECTIVE ECONOMIC ACTIVITY. THIS ARTICLE BEGINS BY EXAMINING THE ACTUAL ROLE OF ACCOUNTING IN THE EMERGENCE OF WESTERN CAPITALISM FROM THE FOURTEENTH TO THE EARLY NINETEENTH CENTURIES IN LATE QUING AND REPUBLICAN CHINA. IT EXAMINES THE REPERTOIRE OF NATIVE PRIVATE MERCANTILE BOOKKEEPING METHODS DEVELOPED BY THE LATE QING--METHODS THAT HERE ADAPTED TO MEET THE BASIC REOUIREMENT OF SMALL RETAIL SHOPS AMD THE COMPLEX MEEDS OF LARGE COMMERCIAL FIRMS AMD NATIVE BANKS. THO CASE STUDIES ARE PRESENTED AND THE CONCLUSION ADORESSES WHAT AMOUNTS TO A DISCOURSE BETHEEN THE SUBSTANTIVE RATIONALITY OF INDIGENOUS CHINESE BUSINESS AND THE FORMAL RATIONALITY OF MODERN ENTERPRISE.

03567 GARDILL, J.; THIERY, P.

GUIDELINES TO DEVELOPMENT IN SOUTHEAST ASIA AND LATIN AMERICA

AUSSEN POLITIK, 42(4) (1991), 353-362.

DESPITE FOUR DECADES OF INTENSIVE DEVELOPMENT EFFORTS THE GAP BETWEEN NORTH AND SOUTH HAS WIDENED. AT THE SAME TIME, THE PROCESS OF DIFFERENTIATION BETWEEN COUNTRIES AND REGIONS HAS PROGRESSED CONSIDERABLY. HHEREAS QUITE A FEW
COUNTRIES IN EAST AND SOUTHEAST ASIA HAVE BECOME PROTOTYPES COUNTRIES IN EAST AND SOUTHEAST ASIA HAVE BECOME PROTOTYPES OF DYNAMIC DEVELOPMENT ACCOMPANIED BY ACTIVE INTEGRATION INTO THE HORLD ECONOMY, MOST LATIN AMERICAN COUNTRIES HAVE STILL NOT FOUND A WAY OUT OF THEIR DEVELOPMENT CRISIS. THIS
ARTICLE COMPARES THE DEVELOPMENT MODELS AND STRATEGIES OF ARTICLE COMPARES THE DEVELOPMENT MODELS AND STRATEGIES OF BOTH REGIONS AND SEEKS TO DEMONSTRATE WHY SOUTHEAST ASIA
BEEN SO SUCCESSFUL IN FOSTERING DEVELOPMENT WHILE LATIM AMERICA'S EFFORTS HAVE NOT BEEN AS SUCCESSFUL.

03568 GARDINER, L.

SQUARING THE CIRCLE: DEALING HITH INTELLIGENCE-POLICY BREAKDOWNS

INTELLIGENCE AND NATIONAL SECURITY, 6(1) (JAN 91) 141-153. THIS ARTICLE EXAMINES THE GAP THAT EXISTS BETHEEN POLICYMAKERS AND INTELLIGENCE ANALYSTS. IT ANALYZES THE PERSONAL AND INSTITUTIONAL CAUSES OF THE GAP AND OFFERS SOME SUGGESTIONS THAT WOULD AID THE PROCESS OF BRIDGING THE GAP. THE AUTHOR ADVOCATES CREATING NEW OR STRENGTHENED LINKS BETHEEN ANALYSTS AND POLICYMAKERS, MAKING INTELLIIGENCE ANALYSIS ALL BUT INDISPENSABLE TO POLICYMAKERS IN THEIR BUREAUCRATIC BATTLES, AND DEVELOPING NEW MEANS AND FORMS TO CONYEY ANALYSIS TO POLICYMAKERS IN A WAY THAT FITS IN HITH THEIR PERCEIVED METHODS OF PERCEIVING AND THINKING.

03569 GARDNER, J.

LOBBYING, EUROPEAN-STYLE

EUROPE, (311) (NOV 91), 29-30

MANY EUROPEANS WHO HAVE NOT DIRECTLY OBSERVED THE EUROPEAN COMMUNITY'S INSTI IUTIONS IN OPERAT ION WILL DENY
STEADFASTLY THAT LOBBYING OCCURS IN BRUSSELS OR IN THE STEADFASTLY THAT LOBBYING OCCURS IN BRUSSELS OR IN THE NATIONAL CAPITALS OF EC MEMBER STATES. ONLY WHEN ONE DISCUSSES THE TOPIC OF LOBBYING WITH THE EUROCRATS IN BRUSSELS AND THE ELECTED MEMBERS OF THE EUROPEAM
(MEP'S) DOES ONE BEGIN TO HEAR STRAIGHTFORWARD (MEP'S) DOES ONE BEGIN TO HEAR STRAIGHTFORWARD
ACKNOWLEDGMENTS OF THE EXISTENCE, INDEED LEGITIMACY, OF LOBBYING IN THE COMMUNITY. THE EVIDENCE IS BEGINNING TO MOUNT THAT INTENSIVE EUROPEAN LOBBYING CAN HELP REDUCE OR POSSIBLY ELIMINATE NON-TARRIF BARRIERS. THE EC'S WITHDRAWAL OF A PROPOSED BANKING RECIPROCITY RULE AND OF PROPOSED
RESTRICTIONS ON CERTAIN FRANCHISER-FRANCHISEE CONTRACTUAL PROVISIONS ARE GOOD EXAMPLES OF RECENT LOBBYING SUCCESSES BY NON-EC INTERESTS. EXPERIENCE INDICATAES THAT LOW-KEY PRESENTATIONS ARE THE SECRET TO LOBBYING SUCCESS IN THE COMMUNITY.

03570 GARDNER, R.

PRACTICAL INTERNATIONALISM: THE UNITED STATES AND COLLECTIVE SECURITY

SAIS REVIEH, $12(2)$ (SUM 92 ), 35-50.

THE UNITED STATES IS SEEKING TO REDEFINE ITS HORLD ROLE IN THE POST-COLD WAR ERA. AN APPROACH WHICH CAN BEST BE DESCRIBED AS "PRACTICAL INTERNATIONALISM" ANIMATES THIS ESSAY. PRACTICAL INTERNATIONALSM REFLECTS NEW REALITIES AND CALLS FOR THE MAXIMUM USE OF INTERNATIONAL INSTITUTIONS IN THE PURSUIT OF AMERICAN NATIONAL INTERESTS. THIS ARTICLE SUGGESTS THAT THE UNITED STATES NEEDS TO CONSIDER WHERE THE UN FITS INTO ITS SECURITY POLICIES FOR THE 1990 S AND MORE SPECIFICALLY, JUST WHAT KIND OF EVOLUTION IN UN ACTIVITIIES SPECIFICALLY, JUST WHAT KIND OF EVOLUTION IN UN ACTIVITI AND STRUCTURES WOULD SERVE U.S. NATIONAL INTERESTS. IT
OFFERS PROPOSALS WHICH ARE DESIGNED TO PROVIDE A UN AGENDA OFFERS PROPOSALS WHICH ARE DES

03571 GARDY, A.

MEXICO: A GRASSROOTS CHALLENGE

REPORT ON THE AMERICAS, 36(3) (DEC 92), 8-11.

THE ABSOLUTE POWER OF THE PRI IS BEING CHIPPED AWAY AT THE LOCAL LEVEL BY STRONG GRASSROOTS MOVEMENTS LIKE THE HORKER-PEASANT-STUDENT COALITION OF THE ISTHMUS (COCEI) IN OAXACA. UNLIKE MOST OTHER INDO-AMERICAN PEOPLES IN MEXICO, JUCHITECOS HAVE MADE KEEPING ALIVE THEIR INDIGENOUS TRADITIONS, LANGUAGE AND IDENTITY A TOP PRIORITY. THIS ARICLE REPORTS ON THE MOVEMENT'S IDEOLOGY AND DETAILS THE CONCESSIONS GRANTED BY THE PRI. THE QUESTION IS: IS THE COCEI'S STRUGGLE A MICROCOSM OF FUTURE POLITICAL BATTLES ON A NATIONAL SCALE?

03572 GAREEV, M.

ON MILITARY DOCTRINE AND MILTARY REFORM IN RUSSIA JOURNAL OF SOVIET MILITARY STUDIES, 5(4) (DEC 92), 539-551. WITH THE MAJOR CHANGES WHICH HAVE BEEN TAKING PLACE RECENTLY IN THE WORLD ALL NATIONS HAVE TD RETHINK AND REDEVELOP THEIR MILITARY POLICIES AND MILITARY DOCTRINES. REPUBLICS OF THE FORMER USSR. THE AUTHOR ATTEMPTS TO TIE TOGETHER PROBLEMS OF MILTARY REFORM AND MILITARY DOCTRINE AND A REFORMULATION OF IT. HE SUGGESTS THAT THE PROGRAM OF AND A REFORMULATION OF IT. HE SUGGESTS THAT THE PROGRAM OF MILTARY REFORM MUST IMPART A UNIFORM APPROACH TO DEFENSE
ISSUES AND, TO SOME EXTENT, CALM THE PUBLIC'S CONCERN ABOUT ISSUES AND, TO SOME EXTENT, CALM THE PUBLIC'S CONCERN ABOUT
AFFAIRS IN THE ARMY AND NAVY, MOBILIZING ALL ARMED FORCES AFFAIRS IN THE ARMY AND NAVY, MOBILIZIING
PERSONNEL TO WORK UNDER NEW CONDITIONS.

03573 GARFINKLE, A.

PLAYING WASHINGTON'S HAND

NATIONAL REVIEH, XLIII (5) (APR 91), 37-40.

THE SHIFT AND DECISIVE VICTORY OF THE COALITION FORCES IN THE GULF HAVE LED MANY WESTERN LEADERS TO DECLARE THAT THERE IS AN HISTORIC OPPORTUNITY FOR MAJOR DIPLOMATIC CHANGE IN THE MIDDLE EAST-MORE SPECIFICALLY, A RESOLUTION OF THE ARAB-I SRAELI CONFLICT. HOWEVER THREE' FACTORS COMBINE TO CLOUD THIS BRIGHT HORIZON: THE FACT THAT MUCH HINGES ON SYRIA, AND THERE IS NO ASSURANCE OF ITS WILLINGNESS TO MAKE PEACE; SEALING A DEAL WITH THE ISRAELIS WILL REQUIRE JORDANIAN PARTICIPATION, ANOTHER DIFFICULT THING TO ASSESS: AND, FINALLY, THE POSSIBILITY THAT ISRAEL MAY STILL REJECT ANY DIPLOMATIC EFFORTS.

03574 GARNHAM, D.

THE UNITED STATES AND THE EUROPEAN COMMUNITY JERUSALEM JOURNAL OF INTERNATIONAL RELATIONS, 14(2) (JUN 92), 48-67

FOR MORE THAN FOUR DECADES US-HEST EUROPEAN RELATIONS WERE FOUNDED ON TWO PRINCIPLES: THE FORMIDABLE SOVIET MILTARY THREAT AND AMERICAN ECONOMIC DOMINANCE. THIS ARTICLE EXAMINES THE EVOLVING POLITICAL AND MILTARY RELATIONSHIP NOH THAT THESE CORE ASSUMPTIONS HAYE CHANGED. A NEW RELATIONSHIP IS INEVITABLE AND DESIRABLE BUT IT WILL BE EVOLUTIONARY AND MANIFESTED PRINC- PALLY WITHIN WELL-ESTABLISHED INSTITUTIONS SUCH AS NATO, TH: EUROPEAN COMMUNITY, AND THE WESTERN EUROPEAN UNION.

03575 GARRETT, B.

THE "NEW WORLD ORDER," AMERICAN POWER AMD NORTHEAST ASIA KOREAN JOURNAL OF DEFENSE ANALYSIS, $3(2)$ (WIN 91), 9-38. USED BOTH AS AN EMPIRICAL DESCRIPTION OF AN EMERGING WORLD SITUATION AND AS A NORMATIVE VISION OF POSSIBILITIES FOR SHAPING THE INTERNATIONAL ENVIRONMENT IN THE POST-COLD WAR ERA. THIS ARTICLE EXPLORES SOME OF THE TRENDS AND DEVELOPMENTS THAT HAVE LED TO THE END OF THE COLD WAR AND THE TRANSITION TO A NEW WORLD ORDER, THE GLOBAL AND REGIONAL ROLES OF THE UNITED STATES IN THE POST-COLD WAR ERA, BUSH ADMINISTRATION THINKING ABOUT THE NEW WORLD ORDER, AND, 
NORTHEAST ASIA.

03576 GARRETT, B.; GLASER, B.
YELTSIN'S CHINA MISSION

FAR EASTERN ECONOMIC REVIEH, 155(50) (DEC 92), 24. IN HIS SCHEDULED DECEMBER TRIP TO CHINA, RUSSIAN PRESIDENT BORIS YELTSIN WILL NOT CREATE THE DIPLOMATIC SENSATION THAT MARKED HIS MID-NOVEMBER VISIT TO SOUTH KOREA. NEVERTHELESS, THE TRIP WILL LIKELY BUILD ON THE UNEXPECTED RUSSIAN OFFICIALS HAVE BEEN RELIEVED TO FIND THAT, DESPITE RUSSIAN OFFICIALS HAVE BEEN RELIEVED TO FIND THAT, DESPI
ENDURING IDEOLOGICAL DIFFERENCES AND RUSSIAN SECURITY ENDURING IDEDLOGICAL DIFFERENCES AND RUSSIAN SECURITY
CONCERNS ABOUT CHINA, THERE HAS BEEN A POSITIVE SHIFT IN THE TENOR AND DEVELOPMENT OF BILATERAL TIES. RUSSIANS VIEW ECONOMIC TIES WITH CHINA--WHICH ARE EXPANDING WHILE RUSSIA'S TRADE WITH VIRTUALLY ALL OTHER COUNTRIES IS CONTRACTING--AS PROVIDING AN ANCHOR FOR THE RELATIONSHIP. BUT THE FASTES
DEVELOPING ASPECT OF THE SINO-RUSSIAN RELATIONSHIP IS DEVELOPING ASPECT OF THE SINO-RUSSIAN RELATIONSHIP IS MILITARY TIES, ESPECIALLY THE TRANSFER OF ARMS AND MILITARY
TECHNOLOGY TO CHINA. WHILE CONTINUED MILITARY COOPERATION TECHNOLOGY TO CHINA. WHILE CONTINUED MILITARY COOPERATION
POSES SOME FUTURE SECURITY PROBLEMS, RUSSIAN OFFICIALS SEEM POSES SOME FUTURE SECURITY PROBLEMS, RUSSIAN OFFICIALS
TO ARGUE THAT SHORT-TERM STABILITY AND FINANCIAL GAINS OUTWEIGH THE LONG-TERM CONCERNS.

03577 GARRETT, G.

INTERNATIONAL COOPERATION AND INSTITUTIONAL CHOICE: THE EUROPEAN COMMUNITY'S INTERNAL MARKET

INTERNATIONAL ORGANIZATION, 46(2) (SPR 92), 533-560.

THE DECISION OF THE EUROPEAN COMMUNITY (EC) MEMBERS TO COMPLETE THEIR INTERHAL MARKET IS AN IMPORTANT INSTANCE OF INTERNATIONAL COOPERATION. THE ECONOMIC OBJECTIVE IS TO REMOVE A HIDE ARRAY OF NONTARIFF BARRIERS TO TRADE THAT ELSEWHERE HAVE PROYED INTRACTABLE. THE INSTITUTIONAL STRUCTURES ESTABLISHED TO REACH THIS GOAL HEAVILY CONSTRAIM THE AUTONOMY OF SOVEREIGN STATES AND CANMOT BE EXPLAINED BY TRADITIONAL THEORIES OF INTERNATIONAL COOPERATION THAT FOCUS ON THE EFFICIENCY OF SOLUTIONS TO COLLECTIVE ACTION PROBLEMS. THIS ARTICLE DISCUSSES MANY FORMS OF TRADE LIBERALISM AND REFORM.

03578 GARRETT, G.

THE POLITICAL CONSEQUENCES OF THATCHERISM

POLITICAL BEHAVIOR, 14(4) (DEC 92), 361-382.

WHILE THE ECONOMIC CHANGES EFFECTED BY BRITAIN'S

CONSERVATIVE GOVERMMENT IN THE 1980'S ARE TRANSPARENT, THERE IS CONSIDERABLE DEBATE AS TO WHETHER THERE WAS A POL ITI ICAL DIMENSION TO THE "THATCHER REVOLUTION." THIS PAPER ARGUES
THAT THE CONSERVATIVES WERE SUCCESSFUL IN UNDERTAKING SOCIAL STRUCTURAL REFORMS THAT EFFECTIVELY MOVED THE POLITICAL CENTER OF GRAVITY IN BRITAIN TO THE RIGHT AND TOWARD THE GOVERNMENT'S PREFERRED MARKET-ORIENTED POLICY AGENDA. THE GOVERMMENT'S STRATEGY--MANIFEST IN THE SALE OF COUNCIL HOUSES TO TENANTS AND OF SHARES IN PRIVATIZED CORPORATIONS TO INDIVIDUALS AND ITS ATTACK ON ORGANIZED LABOR--HAS NARROWLY TARGETED TO THE SHING ELECTORATE AMONG WEALTHIER MEMBERS OF THE LOWER SOCIOECONOMIC STRATA. THE LABOR PARTY HAS ACKNOWLEDGED THE SUCCESS OF THE CONSERVATIVES

STRUCTURAL REFORMS AND HAS MOVED ITS POLICY PLATFORM TO THE RIGHT IN ORDER TO REGAIN ELECTORAL COMPETITIVENESS.

03579 GARRETT, J.M.

CONFIDENCE-BUILDING MEASURES: FOUNDATIONS FOR STABILITY IN EUROPE

JOURNAL OF STRATEGIC STUDIES, 15(3) (SEP 92), 281-303.

THE AUTHOR DISCUSSES THE PROSPECTS FOR BRINGING A NEW

STABILITY TO EUROPE AND THE VEHICLES BY WHICH EUROPEAN

SECURITY MAY BE ACHIEVED IN THE POST-COLD WAR ERA.

03580 GARRITY, P.; MAARANEN, S.

NUCLEAR WEAPONS IN THE CHANGING WORLD: PERSPECTIVES FROM EUROPE, ASIA AND NORTH AMERICA

PLENUM PRESS, $1992,278$.

IN THIS BOOK, INTERNATIONALLY RECOGNIZED EXPERTS ASSESS THE CHANGING ROLE OF NUCLEAR WEAPONS IN LIGHT OF INCREASINGLY IMPORTANT REGIONAL DEVELOPMENTS THAT ARE
IRANSFORMING THE WORLD. THE CONTRIBUTORS SHOW HOW TODAY'S TRANSFORMING THE WORLD. THE CONTRIBUTORS SHOW HOW TODAY'S
FLUID GLOBAL ENVIRONMENT AND THE PROL IFERATION OF NUCLEAR FLUID GLOBAL ENVIRONMENT AND THE PROL IFERATION OF
ARMS AND TECHNOLOGY RADICALLY TRANSFORM STRATEGIC ARMS AND TECHNOLOGY RADICALLY TRANSFORM STRATEGIC
INTERNATIONAL RELATIONS. THEY PROBE ALTERNATIVE POLICY INTERNATIONAL RELATIONS. THEY PROBE ALTERNATI
RESPONSES BY THE MAJOR NUCLEAR-WEAPON STATES.

03581 GARRITY, P.; WEINER, S

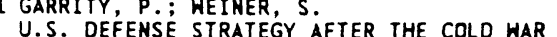

WASHINGTON QUARTERLY, 15(2) (SPR 92), 57-80.

WASHINGTON QUARTERLY, $15(2)$ (SPR 92 ), 57-80. THE SOVIET OF THE COLD WAR MEANS THE PASSING NOT JUST OF THE SOVIET THREAT BUT OF AN ENTIRE WAY OF TH INTERNATIONAL SECURITY AND THE INTERNATIONAL
RESPONSIBILITIES OF THE UNITED STATES. U.S. STRATEGY, SO RESPONSIBILITIES OF THE UNITED STATES. U.S. STRATEGY
LONG BASED ON THE MILITARY AND POLITICAL DICTATES OF LONG BASED ON THE MILITARY AND POLITICAL DICTATES OF
CONTAINMENT, MUST BE RECONCEPTUALIZED IF THE U.S. NATIONAL INTEREST IS TO BE WELL SERVED IN THE YEARS AHEAD. THIS ESSAY EXAMINES THE EMERGING NATIONAL DEBATE OVER THE DIRECTION OF U.S. DEFENSE POLICY.
03582 GARSON, P.

THE GUN CULTURE

AFRICA REPORT, 37 (4) (JUL 92), 58-61.

ANGRY YOUTHS IN SOUTH AFRICA'S BLACK TOWNSHIPS, ENMESHED IN THE CONTINUING VIOLENCE BETHEEN ANC AND INKATHA SUPPORTERS, ARE DEEPLY INVOLVED IN THE GUN CULTURE. WHETHER INTO ORGANIZED MASS POLITICAL ACTION--SUCH AS STRIKES, BOYCOTTS, AND DEMONSTRATIONS--IS AN IMPORTANT QUESTION FOR THE FUTURE OF THE ANC.

03583 GARSON, P.

THE PAC ENTERS THE FRAY

AFRICA REPORT, 37 (6) (NOV 92), 19-22.

THE PAN AFRICANIST CONGRESS (PAC), WHICH FOR YEARS OISTANCED ITSELF FROM THE AFRICAN NAIIONAL CONGRESS, NOH WANTS TO BE A PLAYER IN NEGOTIATIONS WITH THE SOUTH AFRICAM GOVERMMENT. AFTER BOYCOTTING THE FIRST TWO ROUNDS OF CODESA TALKS, PAC IS TALKING WITH THE GOVERNMENT ABOUT ITS ROLE IN CODESA 3 AND IS STRESSING ITS BELIEF IN A QUICK TRANSITION TO A CONSTITUENT ASSEMBLY THAT HOULD TRANSFER POWER TO THE BLACK MAJORITY.

03584 GARSON, $P$. THE THIRD FORCE

AFRICA REPORT, 37 (3) (MAY 92), 68.

IN SOUTH AFRICA, VIOLENCE RAGES IN MANY OF THE TOWNSHIP SLUMS IN THE REEF AND NATAL. SOME OBSERVERS BELIEVE IT IS ETHNIC WARFARE OR A POLITICAL STRUGGLE BETWEEN THE INKATHA FREEDOM PARTY AND THE AFRICAN NATIONAL CONGRESS. OTHERS THINK IT IS THE DOMESTICATION OF LOW-INTENSITY CONFLICT, SIMILAR TO THAT PRETORIA PERPETRATED IN MOZAMBIQUE, ANGDLA, AND NAMIBIA.

03585 GARTHOFF, R.L.

THE SOVIÉT MILITARY

BRDOKINGS REVIEW, 10(1) (WIN 92), 52

THE AUTHOR SPECULATES ABOUT THE FUTURE OF THE SOVIET

ARMED FORCES AFTER THE DISINTEGRATION OF THE USSR.

03586 GARTNER, P.

UNHAPPY EASTERNERS FORM OWN PRESSURE GROUP

GERMAN TRIBUNE, (1524) (JUL 92), 3

A NEW GERMAN EXTRA-PARLIAMENTARY OPPOSITION GROUP HAS BEEN ESTABLISHED WITH THE AIM OF PUTTING PRESSURE ON THE FEDERAL GOVERMMENT IN BONN ON BEHALF OF PEOPLE LIVING IN THE FIVE NEW LANDER (FEDERAL STATES) OF EASTERN GERMANY. THE "COMMITTEES FOR JUSTICE" REFLECT A DEEP-SEATED AND HIDERANGING DISSATISFACTION AMONG EASTERNERS WITH THE WAY THEIR PROBLEMS ARE BEING DEALT WITH BY THE GOVERMMENT IN BONN. THE NEW MOVEMENT CUTS ACROSS PARTY LINES: CHRISTIAN DEMOCRAT PETER-MICHAEL DIESTEL AND PDS (THE EX-COMMUNIST PARTY) LEADER GREGOR GYSI ARE LEADING FIGURES. HOWEVER, THERE ARE SIGNS THAT THE COMMITTEE, FOUNDED OVER-HASTILY ON A WAVE OF POPULISM, MAY END NOT AS A POWERFUL CIVIC MOVEMENT BUT AS A POLITICAL DEAD END.

03587 GARVER, J.W.

CHINA AND SOUTH ASIA

ANNALS OF THE AMERICAN ACADEMY OF POLITICAL AND SOCIAL

SCIENCE, 519 ( JAN 92), 67-85.

SINO-SOVIET RAPPROCHEMENT AND THE REEVALUATION OF INDIA'S CHINA POLICY BY RAJIV GANDHI HAVE PRODUCED THE MOST CORDIAL SINO-INDIAN RELATIONS IN MORE THAN 30 YEARS. BOTH BEIJING AND NEW DELHI DESIRE STILL MORE IMPROVEMENT IN BILATERAL RELATIONS BUT HAVE BEEN STYMIED BY A PAUCITY OF PARALLEL INTERESTS AND BY CONTINUING FUNOAMENTAL CONFLICTS OVER THE TERRITORIAL ISSUE AND CHINA'S ROLE IN SOUTH ASIA. ZHOU ENLAI'S 1960 PROPOSAL THAT CHINA ACCEPT INDIAN CLAIMS IN THE EASTERN HIMALAYAS WHILE INDIA ACCEPT CHINA'S CLAIMS IN THE REGION SOUTHEAST OF THE KARAKDRAM PASS NO LONGER STANDS. BEIJING NOW CALLS FOR INDIAN CONCESSIONS IN THE EAST IN EXCHANGE FOR CHINESE CONCESSIONS IN THE WEST. CHINA VIEWS MILITARY RELATIONS BETWEEN ITSELF AND THE SOUTH ASIAN COUNTRIES AS LEGITIMATE RELATIONS HELL HITHIN THE PURVIEW OF COUNTRIES AS LEGI TIMATE RELATIONS WELL WITHIN THE PURVIEW
THE FIVE PRINCIPLES OF PEACEFUL COEXISTENCE, WHILE TO NEW DELHI, THEY CONSTITUTE UNACCEPTABLE THREATS TO INDIAN

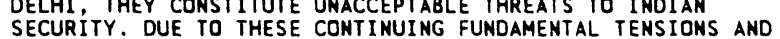
SECURITY. DUE TO THESE CONTINUING FUNDAMENTAL TENSIONS AND RIVALRIES, CHINA'S "ENTI
IMPORTANT TO BEIJING.

03588 GARVER, J.W.

COMMENT: MAO, THE COMINTERN, AND THE SECOND UNITED FRONT COMMENT: MAO, THE COMINTERN, AND THE SECO

BETWEEN MID-1935 AND LATE 1936 REPEATED INTERVENTIONS BY THE COMINTERN INDUCED CHANGES IN THE CHINESE COMMUNIST PARTY'S (CCP) POLICY WHICH BROUGHT IT SUCCESSIVELY CLOSER TO A UNITED ANTI-JAPANESE FRONT HITH CHIANG KAI-SHEK. BUT THERE WERE SIGNIFICANT DISCREPANCIES BETHEEN CCP AND COMINTERN LINES ON THIS ISSUE AT SPECIFIC POINTS. MAO'S POLICY WAS CONSISTENTLY MORE ANTI-CHIANG THAN THE COMINTERN'S WAS.

03589 GARVEY, J.

APPALLING, DEPRESSING, REVOLTING 
COMMONWEAL, CXIX(16) (SEP 92), 9-10.

THE AUTHOR REYIEHS THE STANCES OF BILL CLINTON AND GEORGE BUSH ON A NUMBER OF MAJOR ISSUES AND CONCLUDES THAT BOTH THE DEMOCRATIC AND THE REPUBLICAN CANDIDATES ARE POOR CHOICES FOR PRESIDENT IN 1992.

03590 GARVEY, J.

NONE OF THE ABOVE: HHERE I DRAW THE LINE

COMMONHEAL, CXIX(4) (FEB 92), 9-10

ALLEGATIONS OF GOVERNOR BILL CLINTON'S ALLEGED MARITAL IMFIDELITY HAVE RAISED THE SO-CALLED "CHARACTER ISSUE" IN THE 1992 PRESIDENTIAL ELECTION CAMPAIGN. A CANDIDATE'S PRIVATE LIFE INFLUENCES HIS OR HER SUITABILITY FOR OFFICE IF IT INVOLVES SOMETHING THAT MIGHT COMRPOMISE NATIONAL SECURITY OR LEAD TO MANIPULATION OR BLACKMAIL. BUT BEYOND THIS, THERE IS A DEEPER QUESTION. IF A PERSON IS CAPABLE OF LYING TO HIS OR HER SPOUSE, MIGHT HE OR SHE LIE TO THE PUBLIC AS WELL?

03591 GASIOROWSKI, M.J.

THE FAILURE OF REFORM IN TUNISIA

JOURMAL OF DEMOCRACY, 3(4) (OCT 92), 85-97

IN 1987. PRESIDENT ZINE AL-ABIDINE BEN ALI LAUNCHED

REFORM PROGRAM THAT WENT A LONG WAY TOWARD DEMOCRATIZING

TUNISIA'S POLITICAL SYSTEM. ALTHOUGH IT IS UNCLEAR HHETHER

BEN ALI INTENDED TO ESTABLISH A FULLY DEMOCRATIC REGIME OR A MORE LIMITED, TUTELARY FORM OF DEMOCRACY, THESE REFORMS PRODUCED CONSIDERABLE OPTIMISM ABOUT TUNISIA'S PROSPECTS FOR DEMOCRACY. HOWEVER, THE PACE OF POLITICAL REFORM SLOWED IM 1989. THE MAIN OBSTACLE WAS BEN ALI'S REFUSAL TO EXTEND LEGAL RECOGNITION TO HEZB AL-NAHDA, A RAPIDLY GROWING ISLAMIST MOVEMENT. LIKE MANY OTHER TUNISIANS, BEN ALI FEARED THAT AL-NAHDA HOULD TAKE ADVANTAGE OF THE NEW POLITICAL OPENNESS TO FOMENT UNREST AND TRY TO ESTABLISH A NONDEMOCRATIC ISLAMIC STATE. SINCE THE AUTUMN OF 1990, THE FRICTION BETWEEN AL-NAHDA AND THE BEN ALI GOVERNMENT HAS BECOME INCREASINGLY VIOLENT. THE DEMOCRATIC OPENING THAT BEGAN IN 1987 HAS SUFFERED MAJOR REVERSES, AND TUNISIA'S FUTURE IS CLOUDY.

03592 GASIOROWSKI, M.J.

. S. FOREIGM POLICY AND THE SHAH: BUILDING A CLIENT STATE IN IRAN

CORNELL UNIVERSITY PRESS, 1991, 242.

THIS BOOK IS CONCERNED WITH THE DOMESTIC POLITICAL IMPLICATIONS TO IRAN OF ITS LONG-TERM TIES WITH THE UNITED STATES. BEGINNING WITH THE NINETEENTH CENTURY, THE AUTHOR CONSIDERS THE IMPLICATIONS OF FOREIGN PENETRATION IN AND FOR CONSIDERS THE IMPLICATIONS OF FOREIGN PENETRATION IN AND FOR SURROUNDIMG THE AMERICAN-SPONSORED EXPULSION OF MOHAMHED MOSSADEGH IN 1953. THE SECOND PORTION OF THE BOOK PROVIDES A DETAILED AMALYSIS. OF HOW STATE AUTONOMY GREH TO AM ALMOST DETAILED ANALYSIS OF HON STATE AUTONOMY GREN TO AN ALMOST ANCONTROLLABLE LEVEL, HITH THE SHAH'S EGO AND UNREALISTIC AMBITIONS FOR IRAN GRONING CONCOMITANTLY. THE AUTHOR ARGUES THAT "THE CLIENCY RELATIONSHIP ESTABLISHED IN 1953 8ETH THE UNITED STATES AND IRAN WAS AN EXOGENOUS STRUCTURAL FACTOR THAT GREATLY INCREASED THE AUTONOMY OF THE IRANIAN STATE BY STRENGTHENING ITS AUTONONY ENHANCING CAPABILITIES." HE SUPPORTS THE HYPOTHESIS THAT THE HIGH DEGREE OF AUTONOHY ENJOYED OY THE IRANIAN STATE PERMITTED THE SHAH TO PURSUE DESIRES, AND ASPIRATIONS OF IRANIAN SOCIETY.

03593 GASTER, R.

PROTECTIONISM WITH PURPOSE: GUIDING FOREIGN INVESTMENT FOREIGN POLICY, (88) (FAL 92), 91-106.

AS FOREIGN OIRECT INVESTMENT (FOI) CONTINUES TO GROH IN THE UNITED STATES, AMERICAMS MUST DECIDE WHETHER TO WELCOME IT WITH OPEN ARMS OR TO TREAT IT AS A LONG-RUN THREAT TO U.S ECONOMIC AND MILTIARY SECURITY. EVEN IF FDI IS ACCEPTED IN PRINCIPLE AS BENEFICIAL, NEW PUBLIC POLICIES MAY BE NEEDED TO ENSURE THAT THE UNITED STATES EXTRACTS THE MAXIMUM POSSIBLE BENEFIT FROM ITS NEN GUESTS. FDI COULD BE THE BASIS FOR AN ALTOGETHER NEW SET OF ECONOMIC STRATEGIES THAT COULD BREAK WASHINGTON'S CATASTROPHIC LOGJAM OVER ECONOMIC POLICY.

03594 GASTEYGER, C.

EASTERN EUROPE I: BETHEEN REFORM AMD RESIGHATION WORLD TODAY, 48(5) (MAY 92), 81-83.

THE AUTHOR INVESTIGATES EASTERN EUROPE'S STATE OF HEALTH IN EARLY 1992 AS ITS INDIVIDUAL COUNTRIES STRUGGLE PAINFULLY ALONG THE ROAD TOWARDS GREATER POLITICAL STABILITY AND ALONG THE ROAD TOWARDS
ECONOMIC PROSPERITY.

03595 GASTROW, S.

THE OAU IN DAKAR

SOUTH AFRICA FOUNDATION REVIEH, 18(8) (AUG 92), 4.

EXPECTATIONS THAT THE ORGANIZATION FOR AFRICAN UNITY (OAU) WOULD PRODUCE SOMETHING NEW AND OFFER ENLIGHTENED, DYNAMIC LEADERSHIP WERE NOT MET AT THE 1992 SUMMIT OF AFRICAN HEADS-OF-STATE. THE OAU, WHICH IS INCREASINGLY SEEN AS AN INEFFECTUAL AND DIVIDED ORGANIZATION, NEEDS TO REASSESS ITS PRIORITIES IN ORDER TO MEET THE DEMANDS OF ECONOMIC AND POLITICAL TRANSFORMATION IN AFRICA.
03596 GATES, $R$

INTELLIGENCE, DEMOCRACY AND FREEDOM

PRESIDENTIAL STUDIES OUARTERLY XXII(2) (SPR 92) 231-238. THIS ARTICLE EXAMINES THE ROOTS OF AMERICAN INTELLIGENCE OPERATIONS AND OUTLINES THE CHALLENGES FACED BY SUCH OPERATIONS TODAY. AMERICAN INTELLIGENCE BEGAN WITH GENERAL WASHINGTON, BUT IT TOOK PEARL HARBOR TO CONVINCE THE NATION OF THE NECESSITY OF GOOD INTELLIGENCE. AS A RESULT, IN 1942 THE OFFICE OF STRATEGIC SERVICES (OSS) WAS ESTABLISHED. SUCCESSORS TO THIS ORGANIZATION INCLUDE THE NATIONAL SECURITY COUNCIL (NSC) AND THE CENTRAL INTELLIGENCE AGENCY (CIA). WILE THE CIA'S ORIGINAL RAISON D'ETRE WAS COUNTERING THE SOVIET THREAT, THE DANGERS IN THE POST-COLD WAR WORLD JUSITFY ITS CONTINUED EXISTENCE. WITHIN THE AMERICAN SYSTEM OF CHECKS AND BALANCES, HITH CONGRESSIONAL OVERSIGHT, INTELLIGENCE IS A PROTECTOR OF RATHER THAN A THREAT TO BASIC FREEDOMS.

03597 GATES, W.R.; TERASAHA, K.L.

COMMITMENT, THREAT PERCEPTIONS, AND EXPENDITURES IN A DEFENSE ALL IANCE

INTERNATIONAL STUDIES QUARTERLY, 36(1) (MAR 92), 101-118.

THE ECONOMIC THEORY OF ALLIANCES IS BASED ON PUBLIC

GOODS THEORY. THIS THEORY HAS BEEN MODIFIED TO INCLUDE

DEFENSE RESOURCES HITH MIXED PUBLIC/ PRIVATE BENEFITS. THIS PAPER DEVELOPS A DEFENSE ALLIANCE MODEL THAT DISTINGUISHES PUBLIC FROM PRIVATE BENEFITS BASED ON THE DEGREE TO WHICH DEFENSE RESOURCES ARE COMMITTED TO THE ALLIANCE. RESOURCES FULLY COMMITTED TO THE ALLIANCE (E.G. U.S. TROOPS STATI
ABRDAD) PROVIDE PUBLIC BENEFITS. PARTIALLY COMMITTED ABROAD) PROVIDE PUBLIC BENEFITS. PARTIALLY COMMITTED RESOURCES (E.G. U.S. -BASED NATO REINFORCEMENTS) PROVIDE
MIXED PUBLIC/PRIVATE BENEFITS. FINALLY, RESOURCES COMMITTED TO USES OUTSIDE THE ALLIANCE (E.G. INTERNAL SECURITY AND UNRELATED INTERNATIONAL INTERESTS; PROVIDE MOSTLY PRIVATE BENEFITS. THREAT PERCEPTIONS ARE ALSO USED IN EXPLAINING ALLIANCE DEFENSE EXPENDITURES. THIS MODEL PROVIDES PLAUSIBLE EXPLANATIONS FOR RECENT DEFENSE EXPENDITURE TRENDS. IT ALSO SUGGESTS IMPORTANT POLICY IMPLICATIONS. IN PARTICULAR, FREE RIDING IS AN INHERENT CHARACTERISTIC OF DEFENSE ALLIANCES AND AGGREGATE DEFENSE EXPENDITURE DATA CANNOT MEASURE THE OISTRIBUTION OF THE DEFENSE BURDEN.

03598 GATI, C.

FROM SARAJEVO TO SARAJEVO

FOREIGN AFFAIRS, 71(4) (FAL 92), 64-78.

THE HORRORS OF SARAJEVO 1992 HAVE SCANT RESEMBLANCE TO THE EVENTS THAT FOLLOHED SARAJEVO 1914, BUT THE COLLAPSE OF COMMUNISM HAS REKINOLED ANCIENT POLITICAL FEUDS AS ANTAGONISTIC AND PASSIONATE AS EVER. THEY SPRING FROM THE SUDDENLY-FREED STRESSES AND STRAINS OF THE COMMUNIST ERA, FROM THE MEMORY OF DESTRUCTION AND OISLOCATIONS DURING AND FROM THE MEMORY OF DESTRUCTION AND DISLOCATIONS DURING AND AFTER WORLD WAR II, AND FROM REAL AND PERCEIVED IN JUSTICES COUMTERIMG IF NOT CANCELING THE REGION'S DEMOCRATIC IMPULSE, COUNTERING IF NOT CANCELING THE REGION'S DEMOCRATIC IMPULSE, POSTCOMMUNIST TRANSFORMATION.

03599 GAUCH, S.

OK, JUST A FEN WEAPONS

THE MIDDLE EAST, (201) (JUL 91), 20-21.

THIS PAPER REVIEWS THE PROPOSAL MADE IN MAY 1991 BY PRESIDENT GEORGE BUSH FOR A MIDOLE EAST ARMS CONTROL AGREEMENT. THE AUTHOR FIRST CONSIDERS THE "POSITIVE" FEATURES OF THE PLAN: A) ABOL I SHMENT OF MUCLEAR, CHEMICAL, AND BIOLOGICAL WEAPONS WITH THE OBJECTIVE OF DECREASING SUSPICIOUS FEELINGS AMONG ARABS AND ISRAELIS WHO WOULD BE MORE APT TO RESOLVE DIFFERENCES IN CONFERENCE THAN IN BATTLE,
AND B I DECREASING THE FLOW OF CONVENTIONAL WEAPONS VIA MUTUAL NOTIFICATION OF SALES ON THE PART OF THE 5 PERMANENT MEMBERS OF THE UN SECURITY COUNCIL. THUS CONFORMING TO RECENT FRENCH AND BRITISH ARMS CONTROL PROPOSALS. PROBLEMS ASSOCIATED WITH THE PLAN ARE THEN DISCUSSES. THEY INCLUDE: A) THE POLITICAL MANNER IN WHICH THE PLAN COULD BE IMPLEMENTED, HITH SUPPLIER NATIONS PERSISTING IN THEIR DESIRE TO FIND MARKETS FOR THEIR PRODUCTS WHILE MIDOLE EASTERN STATES STRIVE TO REACH ARMS AGREEMENTS, MAKING AGREEMENT AMONG ALL NATIONS EXTREMELY CHALLENGING; B IDECISIONS BY THE BUSH ADMINISTRATION TO PROVIDE THE UAE WITH APACHE HELICOPTERS AND TO ASSIST IN FINANCING ISRAEL'S ARROW "ANTI-MISSILE MISSILE," AND C) THE UNWILLINGNESS OF THE UNITED STATES TO COHERCE ISRAEL INTO REDUCING HER STOCKPILE OF UNCONYENTIONAL ARMS.

03600 GAUPP, $P$.

CAUSES AND CONSEOUENCES OF THE COLLOR AFFAIR

SWISS REVIEH OF WORLD AFFAIRS $42(8)$ (NOY 92 ), 29 DEPENDING OF WORLD AFFAIRS, $42(8)$ (NOV 92), 29 . PRESIDENT FERNANDO COLOR DE MELLO IS PROOF OF HOH DEEPLY BRAZILIAN POLITICS ARE SUNK IN THE SWAMP OF CORRUPTION OR IT IS A SIGN THAT DEMOCRATIC INSTITUTIONS ARE ABLE TO FULFILL THEIR RESPONSIBILITIES. FROM EITHER POINT OF VIEH, IT IS A SYMPTOM OF THE CORRUPTION WITHOUT ATTACKING ITS DEEPER 
CAUSES.

03601 GAUPP, P.

NICARAGUA: LEARNING DEMOCRACY

SWISS REVIEW OF WORLD AFFAIRS, 42(2) (MAY 92), 25-26. UNRESOLVED CONFLICTS FROM THE ERA OF SAMDINISTA RULE HAVE COMPLICATED THE PACIFICATIOM PROCESS AMD DELAYED ECONOMIC RECOVERY IN NICARAGUA. UNOER THE BANNER OF NATIONAL RECONCILIATION, THE CHAMORRO GOVERNMENT IS INVOLVED IN A RECONCILIATION, THE CHAMORRO GOVERNMENT IS INVOLVED IN A DELICATE TIGHTROPE ACT. IN THE SHADOW OF ITS DICTATORIAL PAST, NICARAGUA IS FINDING THE ESTABLISHMENT OF PLUR
DEMOCRACY AND THE RULE OF LAW A DIFFICULT PROCESS.

03602 GAUPP, P.; BAUER, R.

PROGRESS AMD PAIM IN LATIN AMERICA

SHISS REVIEW OF WORLD AFFAIRS, 42(1) (APR 92), 12-17. DOES THE DEMOBILIZATION OF THE FMLN MARK THE END OF GUERRILLA MOVEMENTS IN LATIN AMERICA? THE DEBACLE OF THE SUBCONTINENT'S MILITARY REGIMES, THE REGIONAL TREND TOWARD DEMOCRACY, THE HEAKENING OF FIDEL CASTRO, AND THE END OF THE COLD WAR HAVE COMBINED TO WEAKEN THE BASIS OF THE "ARMED STRUGGLE." BUT FACTORS SUCH AS THE RICH-POOR GAP, ETHNIC TENSIONS, AND THE DRUG TRADE CONTINUE TO SMOOTH THE PATH FOR POLITICALLY-MOTIVATED VIOLENCE IN SOME COUNTRIES. PERU IS A SPECIAL CASE. EXTERMAL POLITICAL PRESSURE, INTENSIVE CAMPAIGNS BY HUMAN RIGHTS ORGANIZATIONS, AND THE INTERNATIONAL RED CROSS HAVE COMPELLED THE FUJIMORI GOVERMMENT TO INSTITUTE MORE EFFECTIVE MEASURES FOR THE PROTECTION OF HUMAN RIGHTS IN ITS BATTLE AGAINST SUBVERSION. AT THE SAME TIME. THE TERRORIST GUERILLA ORGANIZATION SENDERO LUMINOSO HAS EXPANDED ITS FIELD OF OPERATIONS AND DECLARED THAT IT NOW ENJOYS A "STRATEGIC BALANCE" IN ITS WAR WITH THE PERUVIAN ARMED FORCES.

03603 GAUPP, P.

PUERTO RICO'S IDENTITY PROBLEM

SWISS REVIEW OF WORLD AFFAIRS, 41(10) (JAN 92), 22-23.

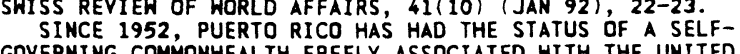
STATES. ITS INHABITANTS HOLD U.S. CITIIENSHIP, WITH LIMITED STATES. ITS INHABITANTS HOLD U.S. CITIZENSHIP, WITH LIMIT

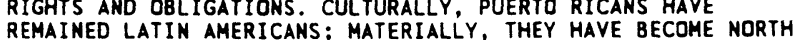
REMAINED LATIN AMERICANS; MATERIALLY, THEY HAVE BECOME NORTH AMERICANS. THE QUESTION OF WHETHER THE ISLAND SHOULD RETAIN ITS COMMONWEALTH STATUS IN ALTERED FORM, REQUEST ACCESSION
AS THE 51ST STATE OF THE UNION, OR PRESS FOR INDEPENDENCE AS THE 5IST STATE OF THE UNION, OR PRESS FOR INDEPENDEN KEEPS PUERT
GUESSING.

03604 GAUPP, P

REPORT FROM CUBA

SHISS REVIEW OF WORLD AFFAIRS, 41(11) (FEB 92), 10-14.

AFTER MORE THAN THREE DECADES, FIDEL CASTRO STILL CLINGS TO POWER, INSISTING THAT HIS ISLAND HILL REMAIN THE LAST BASTION OF TRUE REVOLUTIONARY SOCIALISH. THERE IS A GROWING DEMOCRATIC OPPOSITION, WHICH HAS ARISEN MAINLY FROM THE RANKS OF THE HUMAN RIGHTS MOVEMENT, BUT IT IS KEPT ON A SHORT LEASH BY HAVANA'S REPRESSIVE APPARATUS. SINCE THE COLLAPSE OF THE SOVIET AND EAST EUROPEAN REGIMES, ECONOMIC PRESSURE ON CUBA HAS INCREASED DRAMATICALLY. IF CASTRO CAN SURVIVE THE CURRENT ECONOMIC CRISIS, THE DAYS OF HIS REVOLUTIONARY REGIME MAY NOT YET BE NUMBERED.

03605 GAVIN, N.

TELEVISION NEWS AND THE ECONOMY: THE PRE-CAMPAIGN COVERAGE PARLIAMENTARY AFFAIRS, 45(4) (OCT 92), 596-611.

BETWEEN ELECTIONS THE ECONOMY IS SEEN AS AN IMPORTANT INFLUENCE ON GOVERMMENT POPULARITY. IT HAS BEEN SUGGESTED THAT THE MEDIA HAS A ROLE IN INFORMING THE PUBLIC ABOUT THE THAT THE MEDIA HAS A ROLE IN INFORMING THE PUBLIC ABOUT
NATURE OF GOVERHMENT'S EFFECT ON THEIR PERSONAL LIVES. NATURE OF GOVERMMENT'S EFFECT ON THEIR PERSONAL LIVES. VITAL ELEMENT IN THE EQUATION AND TELEVISION IS OFTEN CITED VITAL ELEMENT IN THE EQUATION AND TELEVISION IS OFTEN CITED
AS AN IMPORTANT SOURCE OF RELIABLE INFORMATION. THIS ARTICLE LOOKS AT MID-WEEK PRIME-TIME TELEVISION NEWS FROM EARLY DECEMBER 1991 TO THE MARCH 1992 BUDGET AND THE CALLING OF DECEMBER 1991 TO THE MARCH 1992 BUDGET AND THE CALLING OF
THE ELECTION. ITS ANALYSIS IS EXPLORATORY AND THEMATIC IN THE ELECTION. ITS ANALYSIS IS EXPLORATORY AND THEMAT
CHARACTER. IT CONCLUDES THAT IF YOTERS WERE USING CHARACTER. IT CONCLUDES THAT IF VOTERS WERE USING WAS ROOM FOR BOTH ENTHUSIASM AND SCEPTICISM.

03606 GAWTHROP, L.

THE ETHICAL FOUNDATIONS OF AMERICAN PUBLIC ADMINISTRATION INTERNATIONAL JOURAAL OF PUBLIC ADMINISTRATION, $16(2)$ INTERNATIONAL JOUR

FROM THE FOUNDING OF THE REPUBLIC TO THE AGE OF JACKSON, FEDERALIST ADMINISTRATORS DOMINATED THE FEDERAL PUBLIC SERVICE, INFUSING IT NOT ONLY WITH A HIGH LEVEL OF ETHICS, BUT ALSO WITH AN ACTIVE RELIGIOUS COVENANT THAT GAVE THE NEW REPUBLIC A FUNDAMENTAL POLITICAL PURPOSE. THAT COVENANT WAS EVENTUALLY LOST, BUT HAS BEEN RESTORED A FEW TIMES IN AMERICAN HISTORY. BY COMPARISON, THE MODERNS RESPECT FOR THE PRIVATENESS OF POLITICAL POWER IS POORLY SUITED TO SUPPORT AN ETHICAL AND COMMITTED PUBLIC SERVICE.
03607 GAY, R.

POPULAR INCORPORATION AND PROSPECTS FOR DEMOCRACY: SOME IMPLICATIONS OF THE BRAZILIAN CASE

THEORY AND SOCIETY, 19(4) (AUG 90), 447-464.

THIS ARTICLE EXPLORES THE PROSPECTS FOR THE SUCCESS OF DEMOCRACY IN BRAZIL. THE AUTHOR ARGUES THAT POSTAUTHORIZATION POLITICS IN BRAZIL SHOWS FEW SIGNS OF CHANGE, AND, FURTHERMORE, THAT ESTABLISHMENT OF TIES BETWEEN CIVIL' AND POLITICAL SOCIETY IS CRITICAL FOR THE LEFT IF THE POWER OF TRADITIONAL ELITES IS TO BE UNDERMINED. THE ROLE POPULAR PROTEST PLAYED IN AUTHORITARIAN BRAZIL IS EXAMINED.

03608 GAZELL, J.A.

PETER F. DRUCKER AND DECENTRALIZED ADMINISTRATION OF THE PETER F. DRUCKER AND

ADMINISTRATION ANO SOCIETY, 24(2) (AUG 92), 182-204.

THE AUTHOR STUDIES PETER F. DRUCKER'S VIEW OF THE NATIONAL GOVERNMENT AND PUBLIC ADMINISTRATION IN THE UNITED STATES. DRUCKER BELIEVES THAT THE FEDERAL GOVERMMENT CAN BECOME MORE EFFECTIVE BY REDUCING ITS ROLE AS A PROBLEM
SOLVER AND ADOPTING A MUCH DIMINISHED ROLE AS THE ARBITER OF NATIONAL PURPOSES, DELEGATING MAMY OF ITS DUTIES TO NONGOVERNMENTAL INSTITUTIONS AND NONPROFIT ORGANIZATIONS. THIS ESSAY COVERS THREE SUBJECTS: DRUCKER'S BACKGROUND, HIS MAJOR ALLEGATIONS OF DEFICIENCIES IN THE FEDERAL GOVERNMENT AND ITS CIVIL SERVANTS, AND HIS VISION OF A GOAL-SETTING,

03609 GAZIT, $S$.

TO SHARE THE SAME CHILD: THE ARAB-ISRAELI COMFLICT-GUIDELINES FOR A SOLUTION

RUSI JOURNAL, $137(5)$ (OCT 92), 55-60.

FUNDAMENTAL TO ANY AGREEMENT OVER THE PALESTINE QUESTION IS THE ISSUE OF 'TERRITORIES FOR PEACE'. ALTHOUGH THE RECENT CHANGE IN THE ISRAELI GOVERNMENT HAS CREATED THE POTENTIAL FOR FAR-REACHING PEACE TALKS, THE AUTHOR HIGHLIGHTS THE ANXIETIES FELT BY MANY ISRAELIS AND SUGGESTS THE CRITERIA FOR VIABLE SOLUTIONS TO THE PROBLEM. HE ARGUES THAT THE IMPLEMENTATION OF THE 'PALESTINIAN RIGHT' OF RETURN WOULD IMPLEMENTATION OF THE 'PALESTINIAN RIGHT' OF RETU
LEAD TO THE COMPLETE DISINTEGRATION OF ISRAEL.

03610 GAZSO, F

CADRE BUREAUCRACY AND THE INTELLIGENTSIA

JOURNAL OF COMMUNIST STUDIES, 8(3) (SEP 92), 76-90

ANALYSIS OF THE COMPOSITION OF THE PARTY-STATE AND THE STATE PARTY IN HUNGARY, BASED ON DATA RELATING TO 6,000 LEADING PERSONALITIES SUGGESTS THAT STATE SOCIALISM NEVER REACHED THE STAGE OF CLASS RULE BY THE INTELLIGENTSIA. THE ENTRY MECHANISM FOR THE SELECTION OF SENIOR PERSONNEL RESTED ON A SYSTEM OF PERSONAL DEPENDENCE, WHICH ALLOWED THE STATE PARTY TO ENSURE IMPLEMENTATION OF CENTRAL DECISIONS LEVELS. THE DATA CLEARLY TESTIFY TO THE PROFESSIONAL PREPONDERANCE OF THE HIGHER ECHELONS
DIRECTED BY THE PARTY LEADERSHIP.

03611 GBANABOME, B. CONFUSION OVER RESOLUTION WEST AFRICA, 75(3923) (NOV 92), 2011-2012.

IN TOGO, MADAM ADOUAYOM'S PARTICIPATION AT CONFERENCE IN LUXEMBOURG HAD BEEN INTERPRETED IN LOME AS THE KEY FACTOR THAT LED TO THE EUROPEAN PARLIAMENT'S ADOPTION OF A NINEPOINT RESOLUTION WHICH CONDEMNED THE REPRESSION AND HUMAN RIGHTS VIOLATION IN THE COUNTRY. THE RESOLUTION ALSO INVITED THE EUROPEAN COUNCIL AND COMMISSION TO PUT EVERY PRESSURE ON GENERAL EYADEMA'S REGIME SO THAT THE TRANSITION PERIOD IS NOT TRANSFORMED INTO A BLOODBATH AND ALSO IT EXPRESSED WORRIES ABOUT THE SERIES OF AGGRESSION AND ACTS OF INTIMIDATION PERPETRATED AGAINST TOGOLESE WOMEN THAT ARE ACTIVE IN THE DEFENSE OF DEHOCRACY IN THE COUNTRY.

03612 GBANABOME, B. MIDOLE-OF-THE-ROAD GESTURE?

WEST AFRICA, (3886) (MAR 92), 410.

AS A COMPROMISE GESTURE, THE GOVERNMENT OF BURKINA FASO CONVENED A NATIONAL FORUM, IN LIEU OF THE NATIONAL

CONFERENCE DEMANDED BY THE OPPOSITION. AT THE OPENING

CONFERENCE DEMANDED BY THE OPPOSITION. AT THE OPENING CEREMONY, PRESIDENT BLAISE COMPAORE ANMOUNCED THAT HEARINGS WOULD NOT BE BROADCAST LIVE, DESPITE THE
OPPOSITION'S DEMAND THAT IT BE ON NATIONAL RADIO AND OPPOSITION'S DEMAND THAT IT BE ON NATIONAL RADIO AND
TELEVISION. AFTER VIGOROUS DISAGREEMENT ON THIS ISSUE, THE TELEVISION. AFTER VIGOROUS DISAGREEMENT ON THIS ISSUE,
PRESIDENT ANNOUNCED THE FORUM'S INDEFINITE SUSPENSION.

03613 GBANANBOME, B.

ENFANT TERRIBLE EXPLAINS

WEST AFRICA, (3894) (MAY 92), 756.

BURKINA FASO'S BLAISE COMPAORE HAS DECLARED THAT HIS COUNTRY NOW HAS LITTLE INTEREST IN LIBERIA AND HAS RATIONALIZED HIS PAST INVOLVEMENT BY DECLARING, "IT WAS A MORAL DUTY TO SAVE LIBERIANS FROM THE WRATH OF A RUTHLESS DICTATOR." CAMPAORE HAS EVADED QUESTIONS ABOUT WHETHER HE IS HARBORING GAMBIAN DISSIDENTS WHO ARE TRAINING IN BURKINA FASO WITH THE ULTIMATE GOAL OF DESTABILIZING THE GOVERNMENT OF SIR DAHOA JAHARA. 
03614 GBESEMETE, K.P.; GERDTHAM, U.

DETERMINANTS OF HEALTH CARE EXPENDITURE IN AFRICA: A CROSSSECTIONAL STUDY

HORLD DEVELOPMENT, 20( 2 ) (FEB 92 ), 303-308.

THIS PAPER PRESENTS SOME QUANTITATIVE EVIDENCE ON THE RELATIONSHIP BETHEEN CERTAIN SOCIOECONOMIC AND DEMOGRAPHIC FACTORS AND PER CAPITA HEALTH CARE EXPENDITURE IN AFRICA. FIRST, GNP PER CAPITA, PERCENTAGE OF BIRTHS ATTENDED BY HEALTH STAFF, AND FOREIGN AID RECEIVED PER CAPITAL TOGETHER
EXPLAIN 78.3\% OF THE VARIANCE IN HEALTH CARE EXPENDITURE. SECONDLY, PER CAPITA GNP IS THE MOST SIGNIFICANT FACTOR EXPLAINING DIFFERENCES IN HEALTH CARE EXPENDITURE. CONTRARY TO WHAT HAS BEEN FOUMD IN COMPARISONS OF HEALTH CARE EXPENDITURE IN THE ORGANIZATION FOR ECONOMIC COOPERATION AND DEVELOPMENT (OECD) COUNTRIES, THE INCOME ELASTICITY IS CLOSE TO UNITY. FURTHERMORE, AID WAS CONSISTENTLY SIGNIFICANT AND POSITIVE IN THE THREE MODELS ESTIMATED. THIRDLY, VARIABLES SUCH AS CRUDE BIRTH RATE AND THE POPULATION UMDER 15 YEARS OF AGE AS PERCENTAGE OF TOTAL POPULATION WERE NOT SIGNIFICANT.

03615 GEEKIE, R.; NOVICKI, M.A.

FIGHTER FOR HUMAN RIGHTS: GITOBU IMANYARA

AFRICA REPORT, 37 (3) (MAY 92) 17-20.

IN THIS INTERVIEW, THE SECRETARY OF INFORMATION FOR THE FORUM FOR THE RESTORATION OF DEMOCRACY (FORD) DISCUSSES THE PROCESS OF INTRODUCING MUL I-PARTY DEMOCRACY TO KENYA. THE OPPOSITION LEADER ALSO OUTLINES FORD'S DEMANDS TO INSURE THAT FREE AND FAIR ELECTIONS ARE HELD AMD DISCUSSES THE WEST'S ROLE IN HELPING TO FOSTER DEMOCRACY IN KENYA.

03616 GEEKIE, R. (ED.) ANC PULLS OUT OF NEGOTIATIONS, BUT FOR HOW LONG? AFRICA REPORT, $37(4)$ (JUL 92), 5, 11

ON JUNE 23, 1992, THE AFRICAN NATIONAL CONGRESS (ANC) ANMOUNCED THAT IT WAS BREAKING OFF NEGOTIATIONS WITH THE DEKLERK GOVERNMENT--BOTH BILATERAL TALKS AND THOSE WITHIN THE FRAMEHORK OF THE CONVENTION ON A DEMOCRATIC SOUTH AFRICA-UNTIL THE REGIME TAKES MEANINGFUL STEPS TO STOP THE VIOLENCE PLAGUING SOUTH AFRICA.

03617 GEEKIE, R. (ED.)

CAN UNITA SURVIVE THE DEMOCRATIZATION PROCESS?

AFRICA REPORT, $37(3)$ (MAY 92), 5-6.

SINCE UNITA AND THE ANGOLAN GOVERNMENT SIGNED PEACE ACCORDS OFFICIALLY ENDING THE CIVIL HAR, THE GUERRILLA GROUP HAS BEEN FORCED TO RE-FOCUS ITS ENERGIES ON THE COUNTRY'S FIRST MULTI-PARTY ELECTIONS, SCHEDULED FOR SEPTEMBER 1992. BUT THE CONFIRMATION OF HUMAN RIGHTS ABUSES AND HIGH-LEVEL BUT THE CONFIRMATION OF HUMAN RIGHTS ABUSES AND HTGH-L DEFECTIONS WITHIN UNITA HAVE SERIOUSLY HINDERED THE MOVEMENT'S EFFORTS TO PRESENT ITSELF AS A VIABLE ALTERNATIVE TO THE POPULAR MOVEMENT FOR THE LIBERATION OF ANGOLA (MPLA), RAISING QUEST
FOR UNITA.

03618 GEEKIE, R. (ED.)

COTE D'IVOIRE

AFRICA REPORT, 37(2) (MAR 92), 7

LAURENT GBAGBO, COTE D'IVOIRE'S MAIN OPPOSITION LEADER, WAS AMONG THE DOZENS ARRESTED ON FEBRUARY 18, 1992, WHEN A MARCH IN ABIDJAN DEGENERATED INTO RIOTING. THE MARCH WAS PART OF A CAMPAIGN ORGANIZED TO PROTEST PRESIDENT FELIX HOUPHOUET-BOIGNY'S DISMISSAL OF A COMMISSION REPORT THAT BLAMED SENIOR MILITARY PERSONNEL FOR A BRUTAL CRACKDOWN ON UNIVERSITY STUDENTS AT YOPOUGON. THE PRESIDENT'S REFUSAL TO ACT ON THE COMMISSION'S FINDINGS HAS BECOME A NEW RALLYING POINT FOR THE OPPOSITION, WHICH HAD LOSTED MOMENTUM AFTER GBAGBO WAS SOUNDLY DEFEATED IN THE 1990 PRESIDENTIAL ELECTION.

03619 GEEKIE, R. (ED.)

EGYPT'S BOUTROS BOUTROS GHALI HEADS UNITED NATIONS

AFRICA REPORT, 37 (1) (JAN 92), $8,11$.

ON JANUARY 1, 1992, EGYPT'S BOUTROS BOUTROS GHALI BECAME THE UNITED NATIONS' FIRST AFRICAN SECRETARY-GENERAL. GHALI'S ELECTION WAS A TRIUMPH FOR THE ORGANIZATION OF AFRICAN UNITY (OAU), WHICH HAD DECLARED THAT IT WAS TIME FOR AN AFRICAN TO HAVE THE JOB.

03620 GEEKIE, R. (ED.)

ELECTION BOYCOTT IN BURKINA FASO

AFRICA REPORT $37(1)$ (JAN 2 ) 6 ,

BURKINA FASO'S PRESIDENT BLAISE COMPAORE, WHO SEIZED

POWER IN A COUP D'ETAT, HAD HOPED TO LEGITIMIZE HIS RULE BY POWER IN A COUP D' ETAT, HAD HOPED TO LEGITIMIZE HIS RULE BY WAS DETERMINED TO DO SO WITHOUT HOLDING A PRE-ELECTION WAS DETERMINED TO DO SO WITHOUT HOLDING A PRE-ELECTION NATIONAL CONFERENCE DEMANDED BY THE OPPOSITION. SO THE BOYCOTT OF THE PRESIDENTIAL ELECTION. FAR FROM LEGITIMIZING BOYCOTT OF THE PRESIDENTIAL ELECTION. FAR FROM LEGITIMIZING CAST SERIOUS DOUBTS ON THE GOVERNMENT'S CREDIBILITY.

03621 GEEKIE, R. (ED, )

EYADEMA'S SHORD IS MIGHTIER THAN THE CONFERENCE
AFRICA REPORT, 37(1) (JAN 92), 5-6.

PRESIDENT GNASSINGBE EYADEMA, TOGO'S AUTHORITARIAM $\angle E A D E R$ FOR THE PAST 24 YEARS, HAS BEEN STRIPPED OF ALL BUT CEREMONIAL PONERS. NEVERTHELESS, HE REMAINS A FORCE TO BE RECKONED WITH AND IS ONE OF THE GREATEST IMPEDIMENTS TO RATIONAL RECONCILIATION. ONE OF THE MAJOR FLAWS IN TOGO'S NATIONAL RECONCILIATION. ONE OF THE MAJOR FLAWS IN TOGO TRANSITIONAL GOVERNMENT TO GAIN CONTROL OVER ALL ELEMENTS OF TRANSITIONAL GO

03622 GEEKIE, R. (ED.)

IN LIBERIA, ELECTIONS ARE A QUESTION OF TRUST

AFRICA REPORT, $37(2)$ (MAR 92), 5-12.

THE LIBERIAN PEACE PROCESS TOOK A STEP FORHARD ON JANUARY 10, 1992, WHEN CHARLES TAYLOR, THE LEADER OF THE NATIONAL PATRIOTIC FRONT OF LIBERIA, ALLOWED THE THO MAIN HIGHWAYS LEADING OUT OF THE CAPITAL' TO BE OPENED AND SECURED BY THE ECOMOG PEACE-KEEPING FORCE. HOWEVER, THE INTERIM GOVERMMENT'S DIFFICULTIES IN CONVINCING TAYLOR TO OPEN THE ROADS DEMONSTRATE THE UPHILL PATH AHEAD OF LIBERIA, AS IT
STRUGGLES AHAY FROM CIVIL WAR AND TOWARD FREE ELECTIONS.

03623 GEEKIE, R. (ED.)

INTERYIEH: PATRICK SEYON, LIBERIAN ELECTORAL COMMISSION COCHAIRMAN

AFRICA REPORT, 37(2) (MAR 92), 6, 10.

IN THIS INTERVIEH, PATRICK SEYON, PRESIDENT OF THE UNIVERSITY OF LIBERIA AND CO-CHAIRMAN OF THE LIBERIAN UNIVERSITY OF LIBERIA ANDCUSSES THE PROSPECTS FOR LIBERIA'S FREE ELECTIONS TO BE HELD AS SCHEDULED IN MID-1992.

03624 GEEKIE, R. (ED.)

MAURITANIA

AFRICA REPORT, 37 (2) (MAR 92), 7

MAAHIYA OULD SID AHMED TAYA SCORED A LANDSLIDE VICTORY IN MAURITANIA'S FIRST MULTI PARTY PRESIDENTIAL ELECTION ON JANUARY 24, 1992. BUT THE ELECTION RETURNS WERE QUICKLY FOLLOWED BY VIOLENCE AND ALLEGATIONS THAT THE VOTING WAS RIGGED. IN ADDITION, THE OPPOSITION THREATENED TO BOYCOTT THE UPCOMING LEGISLATIVE ELECTIONS.

03625 GEEKIE, R. (ED.)

MOZAMBIQUE'S ARCH-ENEMIES AGREE TO CEASEFIRE AFRICA REPORT, 37(5) (SEP 92), 9-10.

MOZAMBICAN PRESIDENT JOAQUIM CHISSANO AND AFONSO DHLAKAMA, THE NATIONAL RESISTANCE LEADER, HAVE SIGNED AN ACCORD WHICH PROMISES TO END THE COUNTRY'S CIVIL WAR BY OCTOBER 1, 1992. THE ACCORD CALLS UPON THE INTERNATIONAL COMMUNITY, ESPECIALLY THE UNITED NATIONS, TO MONITOR THE TERMS OF THE CEASEFIRE AND THE PREPARATIONS FOR ELECTIONS.

03626 GEEKIE, R. (ED.)

RWANDANS TRY TO TRANSFORM WAR INTO DEMOCRACY

AFRICA REPORT, 37(4) (JUL 92), 6, 10

AFRICA REPORT, $37(4)$ (JUL 92), $6,10$.
A PEACE CONFERENCE BETHEEN THE RHANDAN GOVERNMENT AND THE REBEL RWANDAN PATRIOTIC FRONT HAS BEEN SCHEDULED FOR JULY 10-12, 1992. A SETTLEMENT OF THE CIVIL WAR COULD SPEED JULY 10-12, 1992 . A SETTLEMENT OF THE CIVIL HAR COULD SPEED UP THE DEMOCRATIZATION PROCESS, WHICH HAS MOVED ALONG STEADY PACE DESPITE THE WAR. BUT RHANDANS FACE SEVERAL OBSTACLES IN THEIR QUEST TO ENO THE VIOLENCE, WHICH HAS INCLUDED OUTBREAKS OF POLITICAL UNREST ASSOCIATED WITH THE MULTI-PARTY PROC
AND THE ARMY.

03627 GEEKIE, R. (ED.)

SUDANESE TALK PEACE AFTER GOVERMMENT OFFENSIVE AFRICA REPORT, $37(4)$ (JUL 92), 8-9.

IN 1991-92 SUDAN'S CIVIL HAR SEEMED TO FOLLOW THE PATTERN OF FIGHTING ESTABLISHED DURING THE PREYIOUS NINE YEARS OF HOSTILITIES. BUT THE APPEARANCES MAY BE DECEIVING BECAUSE THE ISLAMIC GOVERMMENT, WITH FINANCIAL AID AND ARMS FROM IRAN AND CHINA, MANAGED TO DRIVE DEEPER THAN EVER BEFORE INTO THE PREDOMINANTLY-CHRISTIAN AND ANIMIST TERRITORY OF THE SOUTH. ALTHOUGH THE REBEL MOVEMENT SEEMED TO BE SPLITTING INTO FACTIONS, IT MANAGED TO PRESENT A COMMON FRONT AT THE NEGOTIATING TABLE, WHERE IT DEMANDED SELF-DETERMINATION FOR THE SOUTH.

03628 GEEKIE, R. (ED.)

THE RETURN OF LESOTHO'S KING

AFRICA REPORT, 37 (4) (JUL 92), 9.

AFTER MONTHS OF DEBATE BETWEEN LESOTHO'S GOVERNING

MILITARY COUNCIL AND EXILED KING MOSHOESHOE II, IT APPEARS THAT THE KING WILL RETURN TO HIS HOMELAND, ALTHOUGH IT IS NOT CLEAR WHETHER HE WILL RULE AGAIN. GOVERNMENT OFFICIALS HAVE DECLARED THAT THE FORMER MONARCH WILL RETURN AS A HAVE DECLARED THAT THE FORMER MONARCH HILL RETURN AS A PRIVATE CITIZEN, BUT MOSHOESHOE SAYS THAT THE PEO

03629 GEEKIE, R. (ED.)

U.N. TRUCE IN SOMALIA, BUT WHEN WILL THE FIGHTING END? AFRICA REPORT, $37(2)$ (MAR 92 ), 8-9, 11.

ON FEBRUARY 14, 1992, REPRESENTATIVES OF MOGADISHU'S TWO WARRING FACTIONS MET AT THE UNITED NATIONS AND SIGNED 
SEPARATE PLEDGES TO END HOSTILITIES IMMEDIATELY AND INSTITUTE A FORMAL CEASEFIRE BY THE END OF THE MONTH. NEVERTHELESS, THE FIGHTING CONTINUED.

03630 GEEKIE, R. (ED.)

WHILE U.N. FIGHTS ITSELF, SOMALIS STRUGGLE FOR SURVIVAL AFRICA REPORT, 37 (5) (SEP 92), 5-6, 11.

ON JULY 27, 1992, THE UNITED NATIONS SECURITY COUNCIL ADOPTED A STRONG RESOLUTION ON SOMALIA, CALLING FOR A RELIEF AIRLIFT TO SOMALIA AND BRINGING THE WORLD ORGANIZATION CLOSER TO DEPLOYING TROOPS TO ASSIST AND PROTECT RELIEF WORKERS.

03631 GEEKIE, R. (ED.)

WHITES DECIDE SOUTH AFRICA'S FUTURE

WHITES DECIDE SOUTH AFRICA'S FUTURE

ON MARCH 17, 1992, SOUTH AFRICAN WHITES WILL GO TO THE

POLLS TO DECIDE IF THE NEGOTIATION PROCESS THAT BEGAN IN

1990 SHOULD CONTINUE UNTIL IT REACHES THE STATED GOAL OF A NEW CONSTITUTION.

03632 GEEKIE, R. (ED.) 1992 CALLED THE YEAR OF POPULATION AT THE ADB AFRICA REPORT, 37(6) ( NOV 92), 8-9, 11.

IN LINE WITH THE AFRICAN DEVELOPMENT BANK'S (ADB) GROWING COMMITMENT TO ASSISTING PEOPLE-CENTERED DEVELOPMENT THE ADB IS PREPARIMG TO ADOPT AN OFFICIAL POLICY ON AFRICA'S POPULATION GROWTH. BANK OFFICIALS EXPECT TO APPROVE A POPULATION POLICY PAPER BY THE END OF 1992. A SECTOR POLICY PAPER OUTLINING THE ADB'S CRITERIA FOR FUNDING PROJECTS RELATED TO POPULATION IS ALSO IN THE WORKS.

03633 GEER, J.; SHERE, M.

PARTY COMPETITION AND THE PRISONER'S OILEMMA: AN ARGUMENT FOR THE DIRECT PRIMARY

THE JOURHAL OF POLITICS, 54(3) (AUG 92), 741-761.

RELYING ON THE LOGIC OF THE PRISONER'S DILEMHA, THIS

ARTICLE ARGUES THAT INTRAPARTY COMPETITION IS AN IMPORTANT

INGREDIENT FOR PARTIES TO BE RESPONSIVE TO THE HISHES OF

VOTERS. THIS ARGUMENT IS IMPORTANT IN THAT PRIMARIES

DOMINATE THE NOMINATING PROCESSES IN THE UNITED STATES

DOMINATE THE NOMINATING PROCESSES IN THE UNITED STAT
WHILE THIS ESSAY DOES NOT COMMENT ON THE SPECIFIC

WHILE THIS ESSAY DOES NOT COMMENT ON THE SPECIFIC
ARRANGEMENTS FOR SELECTING NOMINEES, IT DOES PROVIDE

ARRANGEMENTS FOR SELECTING NOMINEES, IT DOES PROVIDE

PRIMARY, THAT PROMOTE INTRAPARTY COMPETITION.

03634 GEER, J.G

NEW DEAL ISSUES AND THE AMERICAN ELECTORATE, 1952-1988

POLITICAL BEHAVIOR, 14(1) (MAR 92), 45-66.

DESPITE THE VAST LITERATURE ON REALIGNMENT, THERE HAVE BEEN FEW EFFORTS TO SEE WHETHER ISSUES ASSOCIATED WITH THE NEW DEAL STILL SHAPE THE POLITICAL ATTITUOES OF THE AMERICAN ELECTORATE. USING THE NES'S OPEN-ENDED LIKE/DISLIKE QUESTIONS ON PARTIES AND CANDIDATES FROM 1952 TO 1988, THE AUTHOR SHOWS THAT NEW DEAL ISSUES REMAIN CENTRAL TO THE PARTISAN ATTITUDES OF THE PUBLIC. HIS FINDINGS REVEAL THAT THE AGENDA OF THE NEW DEAL REMAINS AN INTEGRAL PART OF HOW THE AMERICAN PUBLIC THINKS ABOUT THEIR CANDIDATES AND PARTIES. ALTHOUGH THERE HAS OBVIOUSLY BEEN MUCH CHANGE OVER THE LAST FOUR DECADES, THESE RESULTS SUGGEST THAT AT LEAST PARTS OF THE NEW DEAL PARTY SYSTEM REMAIN INTACT.

03635 GEIFMAN, A.

ASPECTS OF EARLY THENTIETH-CENTURY RUSSIAN TERRORISM: THE SOCIALIST-REVOLUTIONARY COMBAT ORGANIZATION

TERRORISM AND POLITICAL VIOLENCE, 4(2) (SUM 92), 23-46. THE ONLY CONSOL IDATED LEFTIST PARTY IN RUSSIA THAT FORMALLY INCORPORATED TERRORIST TACTICS INTO ITS PROGRAM BETWEEN THE TURN OF THE CENTURY AND 1917 WAS THE PARTY OF SOCIALIST REVOLUTIONARIES (PSR), WHICH CAME INTO EXISTENCE WHEN SEVERAL AUTONOMOUS NEO-POPULIST GROUPS IN RUSSIA AND 1905. THE PSR HAD BECOME THE MOST FORMIDABLE POU ITICAL FOE OF THE TSARIST REGIME. ITS MEMBERS WERE NOT UNIQUE IN PROCL AIMING ASSASSIMAIION AS AM EXPEDIENT REYOIQUE IN METHOD, BUT IT WAS THE PSR THAT CAME TO BE PERCEIVED AS "THE METHOD, BUT IT WAS THE PSR THAT CAME TO BE PERCEIVED AS
PARTY OF TERROR," BECAUSE IT WAS NOTORIOUS FOR ITS WELLPARTY OF TERROR, BECAUSE IT WAS NOTORIOUS FOR ITS WELLREPRESENTATIVES OF THE CENTRAL GOVERNMENT IN MOSCOW AND ST. PETERSBURG.

03636 GEISER, $K$

THE GREENING OF IMDUSTRY--MAKING A TRANSITION TO A THE GREENING OF INDUS

SUSTAINABLE ECONOMY

MANUFACTURERS MUST SHIFT TO SAFER MATERIALS AND CLEANER TECHNOLOGIES INSTEAD OF SIMPLY CONTROLIING TOXIC WASTES. TECHNOLOGIES INSTEAD OF SIMPLY CONTROLLING TOXIC WASTES. WON'T POSE UNDUE RISKS TO THE ENVIRONMENT NOW OR IN THE COMING DECADES. WHILE THE SHAPE OF SUSTAINABLE INDUSTRY IS STILL MERGING, SEVERAL FEATURES WILL BE CRITICAL:

TECHNOLOGIES APPROPRIATE TO THE DESIRED ENDS; SAFE AND ENVIRONMENTALLY COMPATIBLE MATERIALS: PRODUCIS THAT MEET BASIC SOCIAL NEEDS AND SOME INOIVIDUAL WANTS; LOW- AND NO-
WASTE PRODUCTION PROCESSES; SAFE AND SKILL-ENHANCING WORKING CONDITIONS; ENERGY EFFICIENCY; AND RESOURCE CONSERVATION TO MEET THE NEEDS OF FUTURE GENERATIONS

03637 GELB, $N$.

BRITAIN AND THE GULF WAR

NEW LEADER, LXXIV(2) (JAN 91), 5-6.

SINCE THE BEGINNING OF THE GULF WAR, BRITAIN'S JOHN

MAJOR HAS PROVIDED UNHAVERING, INTELLIGENTLY DEFINED

LEADERSHIP FOR HIS COUNTRY IN ITS LARGEST MILITARY

INVOLVEMENT SINCE WORLD WAR II. MAJOR HAS REFUTED THE

PUNDITS WHO HAD PREDICTED HE WOULO BE A LIMP IMITATION OF HIS PREDECESSOR, MARGARET THATCHER. WHILE THE TIES BETWEEN GREAT BRITAIN AND THE UNITED STATES HAVE BEEN SIGNIFICANTLY IMPROVED BY THEIR JOINT OPERATIONS IN THE GULF, RELATIONS BETHEEN THE EUROPEAN COMMUNITY (EC) NATIONS HAVE BECOME INCREASINGLY STRAINED. THE RELUCTANCE OF GERMANY AND FRANCE INCREST DIVISIONS WITHIN THE EC. SOME OBSERVERS ARGUE THAT THE COMMUNITY HAS FAILED ITS FIRST MAJOR TEST OF UNITY AHE THAT WILL HAVE SIGNIFICANT REPERCUSSIONS IN THE MONTHS AND YHAT WILL HAVE

03638 GELB, $N$.

BRITAIN WATCHES THE U.S. PRIMARIES

NEW LEADER, LXXY (4) (MAR 92), 6-7.

BRITONS ARE BEING RELENTLESSLY FED DETAILED COVERAGE OF

THE CURRENT U.S. POLITICAL SCENE. AS A RESULT, THE GENERAL

PUBLIC IN THIS COUNTRY HAS BECOME REMARKABLY HELL-VERSED IN THE COMPETITION FOR THE WHITE HOUSE. ALTHOUGH THE ELECTION IS STILL MANY MONTHS AWAY, TELEVISION, RADIO AND OUALITY NEWSPAPERS IN BRITAIN ARE CLOSELY FOLLOWING THE UPS AND DOWN OF BOTH THE DEMOCRATS AND THE REPUBLICANS. THE COVERAGE HAS BEEN SO EXHAUSTIVE IT SOMETIMES SEEMS LIKE A DOMESTIC EVENT. BRITONS HAVE FORMED RATHER DEFINITE OPINIONS ABOUT THE CANDIDATES. THE INTENSE COVERAGE IS MORE REVEALING OF BRITISH FEELINGS THAN ALL THE CONCERN ABOUT CULTURAL CONTAMINATION. BRITS ARE NOT READY TO BE NUDGED OUT OF THEIR SPECIAL RELATIONSHIP WITH THE UMITED STATES--OR WITH THINGS AMERICAN.

03639 GELB, N.

BRITAIN'S FAMILY QUARREL

NEW LEADER LXXIV(13) (DEC 91) 5-6.

WHILE NATIONALISM FLAUNTS ITS OFTEN UGLY FACE IN MANY PARTS OF THE FORMER SOVIET UNION AND EASTERN AND WESTERN EUROPE, THE PEOPLE OF SCOTLAND ARE EXHIBITING THEIR OWN LESS MILITANT DISCONTENT WITH BEING GOVERNED FROM LONDON. SINCE SCOTLAND WAS MADE PART OF THE UNITED KINGDOM IN 1707 MANY SCOTS HAVE LONG WANTED TO LOOSEN THE POLITICAL TIES THAT BIND THEM TO THE REST OF BRITAIN. THE DESIRE WAS MANIFESTED MOST RECENTLY IN A HOUSE OF COMMONS BY-ELECTION THAT SAH THE GOVERNING CONSERVATIVE PARTY LOSE YET ANOTHER SCOTTISH SEAT TO THE OPPOSITION LABOR PARTY. THE TORIES ARE COMMONLY REGARDED BY THE NORTHERNERS AS LONDON-ORIENTED. THE CHANCES ARE GOOD THAT FOR REASONS OF PARTY POLITICS SCOTLAND WILL EVENTUALLY ACHIEVE A MEASURE OF HOME RULE. YET THE BOTTOM LINE IS THAT THE ENGLISH AND THE SCOTS ARE BOUND INEXTRICABLY BY HISTORY, GEOGRAPHY, ECONOMICS, AND, IN MILLIONS OF CASES, BY PERSONAL RELATIONS.

03640 GELB, $N$

BRITAIN'S MAJOR SHIFT

NEW LEADER, LXXIII(15) (NOV 90), 3-5.

NOW THAT BRITAIN'S MARGARET THATCHER HAS QUIT THE POST OF PRIME MINISTER, THE QUESTION OF HOW ENDURING HER IMPACT WILL BE HAS INEVITABLY RISEN. A CLOSE LOOK AT THE THATCHER REVOLUTION SUGGESTS THAT THE HISTORY BOOKS MAY NOT BE AS ATTENTIVE TO HER ACHIEVEMENTS AS TODAY'S NEWSPAPERS. FOR DESPITE ALL OF HER DRAMATIC ACTIONS AND THE REVIVAL OF BRITAIN'S INTERNATIONAL STANDING, THE COUNTRY HAS THE SAME BASIC PROBLEMS IT HAD WHEN SHE ASSUMED THE PRIME MINISTER'S OFFICE. THESE PROBLEMS MUST BE DEALT HITH BY THATCHER'S SUCCESSOR, JOHN MAJOR. THE NEWLY-INSTALLED PRIME MINISTER WILL HAVE LARGE SHOES TO FILL, BUT HE HAS ALREADY MADE I CLEAR THAT HE IS NOT--AS SOME' OPPOSITION FIGURES HAVE SUGGESTED--"THATCHER'S POODLE."

03641 GELB, $N$.

EUROPE STUMBLING TOWARD UNITY

NEW LEADER, LXXY(2) (FEB 92), 15-16.

IF ALL GOES AS PLANMED, BY THE END OF 1992 EUROPE HILL BE FUNDAMENTALLY TRANSFORMED. THE LAST BARRIERS TO THE ECONOMIC INTEGRATION OF THE EUROPEAN COMMUNITY (EC) ARE SCHEDULED TO BE SWEPT AWAY BEFORE THE STROKE OF MIDNIGHT ON 31 DECEMBER. HOWEVER. THE REALITY OF THE SITUATION DOES NOT MATCH THE PROGNOSTICATIONS. MOST DEVOUT EURO-FANATICS ADMIT THE 1993 DATE AGREED TO YEARS AGO FOR THE CREATION OF A SINGLE MARKET WAS NEVER A FIRM TARGET. IT WAS SET, THEY SAY, MERELY TO STIMULATE THE POLIIICAL ACTION THAT WOULD ULTIMATELY LEAD TO UNITY. AS THINGS NOW STAND, ONLY A FRACTION OF THE ALMOST 300 MEASURES DEVISED BY THE COMHUNITY'S BUREAUCRACY IN BRUSSELS TO PRODUCE THE 320MILLION STRONG MARKET HAVE BEEN IMPLEMENTED BY ALL TWELVE 
MEMBER STATES. IN SUM, 1993 WILL NOT BE THE WONDER YEAR THAT MAYY SUGGESTED IT WOULD BE. MOREOVER, A TRULY EUROPEAN MARKET MAY NDT BE ACHIEVABLE UNTIL THE END OF THE CENTURY, IF BY THEN.

03642 GELB, $M$

LABOR AFTER THE TORY TRIUMPH

NEH LEADER, LXXV(6) (MAY 92), 5-6.

THE SURPRISING OUTCOME OF BRITAIN'S 7 APRIL GENERAL ELECTION PROMISES TO HAVE FAR REACHING RAMIFICATIONS. IN FACT, THE VICTORY GAINED BY PRIME MINISTER JOHN MAJOR'S CONSERVATIVE PARTY MAY SIGNAL A RADICAL CHANGE IN THE PATTERN OF BRITAIN'S POLITICS. THE OPPOSITION LABOR PARTY HAS TUMBLED INTO CONFUSION. IT HAD BEEN CONFIDENT OF AT LAST SCORING A TRIUMPH, AND ITS EXPECTATIONS WERE SOLIDLY REINFORCED BY PUBLIC OPINION POLLS. THE STAKES WERE HIGH: IF ELECTED, LABOR PLANMED TO PROD THE NATION OFF THE PATH IT HAS FOLLOWED DURING 13 YEARS OF FREE-ENTERPRISE THATCHERISM. INSTEAD, AS IT REELS FROM THE SHOCK OF DEFEAT, THE PARTY INSTEA, AS IT REELS FROM THE SHOCK OF DEFEAT' $P$ PECTION. ITS LEADER, MEIL KINNOCK, HAS ANMOUNCED HIS RESIGNATION. LEADER, NEIL KINNOCK, HAS ANNOUNCED HIS RESIGNATION.
EVERYTHING FROM ITS STRUCTURE AND BASIC POLICIES TO THE VERY REASON FOR ITS EXISTENCE WILL COME UNDER REVIEW IN THE MONTHS AHEAD.

03643 GELB, $N$.

MAJOR STUMBLES FORWARD

NEW LEADER, LXXV(14) (NOV 92), 9-11.

PRIME MINISTER JOHN MAJOR IN IN TROUBLE. NO BRITISH LEADER HAS FALLEN SO LOW IN THE PUBLIC'S ESTIMATION SINCE OPINION POLLING BEGAN THERE. THE COUNTRY'S WIDESPREAD AND DEEPROOTED ECONOMIC TRIBUATIONS ACCOUNT IN GREAT PART FOR THE MAJOR GOVERMMENT'S PRECIPITOUS DECLINE. THIS ARTICLE SUGGESTS THAT DESPAIR IS UBIQUITOUS THERE AND THAT THE EFFECT OF THIS ON THE CONSERVATIVE PARTY HAS BEEN DEVASTATING. THE PROBLEM IS THAT NO SUITABLE ALTERNATIVE IS EVIDENT.

03644 GELB, N.

MAJOR'S CRUSADE TO REFORM PUBLIC SERVICE

NEH LEADER, LXXV(10) (AUG 92), 11-12.

A YEAR AFTER TAKING OFFICE, JOHN MAJOR HAS EMBARKED ON A CAMPAIGN TO GUARANTEE THE RIGHTS OF INDIVIDUALS AGAINST THE INEFFICIENCY AND INDIFFERENCE THAT IS WIDELY - AND OFTEN ACCURATELY--SAID TO PLAGUE BRITAIN'S FACELESS BUREAUCRACY. ACCURATE CENTERIECE OF HIS SCHEME IS CALLED THE CIUREN'S THE CENTERPIECE OF HIS SCHEME IS CALLED THE CITIZEN'S CHARTER. MAJOR IS TRYING TO FUNDAMENTALLY TRANSFORM THE
UNCONCERNED ATTITUDES AND LAX STANDARDS LONG PREVALENT IN UNCONCERNED ATTITUDES AND LAX STANDARDS LONG PREVALENT
BRITISH PUBLIC SERVES. HE IS ATTEMPTING, IN EFFECT, A BRITISH PUBLIC SERVES. HE IS ATTEMPIING, IN EFFECT, A
REVOLUTION. THE ARTICLE SUGGESTS THAT THUS FAR THE CITIZEN'S REVOLUTION. THE ARTICLE SUGGESTS THAT THUS FAR THE CITIZER CHARTER HAS NOT GENERATED ANYTHING CLOSE TO THE KIND OF

03645 GELB, $N$.

SHADES OF 1932

MEW LEADER, LXXY(3) (MAR 92), 8-9.

IN MANY CRUCIAL RESPECTS THE ELECTION OF 1992 LOOKS LIKE A RERUN OF THE HATERSHED ELECTION OF 1932. IN OTHER WAYS THIS YEAR'S PRESIDENTIAL CONTEST SEEMS SIGNIFICANTLY UNLIKE THE RACE 60 YEARS AGO. THIS ARTICLE OFFERS AN EXPLORATION OF THIS PHENOMENON WHICH MAY BE A USEFUL STARTING POINT FOR A CITIZENRY EAGER TO RESCUE AN UNEASY AMERICA FROM ITS PRESENT ECONOMIC SLUMP AND POLITICAL CDNFUSION. THE SIMILARITIES ARE ENCOURAGING AND AT THE SAME TIME FRIGHTENING. THE ARTICL CONCLUDES THAT WHAT IS LACKING AMONG THE MOVEMENTS THAT EXIST TODAY IS A SIMILAR UNIFYING THEME, AN IDEOLOGIC COMMON DEMONINATOR THAT WOULD JOIN THEM IN A GRAND COALITION.

\section{GELBER, $Y$.}

ANTECENDENTS OF THE JEWISH-DRUZE ALLIANCE IN PALESTINE MIDDLE EASTERN STUDIES, 28(2) (APR 92), 352-373.

EVER SINCE THE REVIVAL OF THE JEHISH SETTLEMENT IN PALESTINE, CONNECTIONS BETHEEN JEHISH COLONIES AND THE ADJACENT ORUZE VILLAGES HAD DEVELOPED ON THE LOCAL LEVEL. COUNTRY-WIDE AND INSTITUTIONAL IZED JEHISH-DRUZE DIALOGUE COMMENCED, HOWEVER, ONLY IN 1930, FOLLOWING THE ESTABLISHMENT OF THE JOINT BUREAU FOR ARAB AFFAIRS' BY THE JEWISH AGENCY AND THE JEHISH NATIONAL COUNCIL. THIS ARTICLE TRACES THE ANTECEDENTS OF THE JEHISH-DRUZE ALLIANCE AND SUGGESTS THAT AS LONG AS THE CONTEST BETWEEN JEWS AND ARABS IN PALESTINE WAS UNDECIDED, THE MINORITIES WERE APPREHENSIVE OF PUBLICLY COMMITIING THEMSELVES IN FAVOR OF THE JEWS. AN OFFICIAL JEHISH-DRUZE ALEMALE BECAME PRACTICAL ONLY AFTER OFFICIAL JEWISH-DRUZE ALLIANCE BECAME PRACTICAL ONLY AFTER REGULAR ARAB ARMIES IN APRIL-MAY 1948.

03647 GELLER, D.

PWER TRANSITION AND CONFLICT INITIATION

CONFLICT MANAGEMENT AND PEACE SCIENCE, 12(1) (WIN 92), $1-16$.

THIS STUDY DEMONSTRATES THAT AMONG THE STRONGEST STATES AN INTERACTIVE RELATIONSHIP EXISTS BETWEEN THE STATIC POWER BALANCE, DIFFERENTIAL GROWTH RATES IN CAPABILITIES, AND CONFLICT INITIATION: INITIATION PATTERNS ARE ASSOCIATED WITH
CHANGES IN A STATE'S RELATIVE MILITARY/ECONOMIC POWER AND POWER POTENTIAL. THE FINDINGS ARE CONSISTENT WITH THE INHERENT LOGIC OF POWER TRANSITION THEORY AND ARE CONSONANT WITH AN ASSUMPTION OF RATIONAL CALCULATION IN DECISIONS INVOLVING CONFLICT INITIATION. THE RESULTS MAY BE

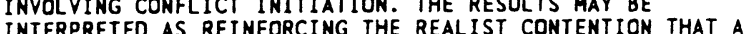

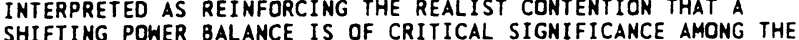
SHIFTING POWER BALANCE

03648 GELLINER, E

ISLAM: DIFFERENT VIEW OF HUMAN RIGHTS

SOCIOLOGICAL PERSPECTIVES, (3) (1990), 17-21.

THIS ARTICLE PRESENTS AN ISLAMIC CONCEPTION OF MUMAN RIGHTS AND COMPARES IT WITH THE WESTERN SECULAR CONCEPTION OF HUMAN RIGHTS. THE ISLAMIC STATE'S VIEW OF ITS ROLE--TO ENCOURAGE VIRTUE AND PUNISH EVIL-OIS EXAMINED. VARIOUS EXAMPLES OF ISLAMIC RULE AND STATEHOOD ARE GIVEN, INCLUDING IRAN AND THE SHI'ITES. THE ROLE OF THE INDIVIDUAL IN A MOSLEM SOCIETY IS DISCUSSED.

03649 GELLNER, E.

NATIONALISM RECONSIDERED AND E.H. CARR

REVIEW OF INTERNAT IONAL STUDIES, 18(4) (OCT 92), 285-294. E.H. CARR'S "NATIONALISM AND AFTER" HAS RECEIVED LITTLE NOTE IN RECENT DISCUSSIONS OF NATIONALISM. THE AUTHOR

CONSIDERS THIS BOOK AND EXAMINES THE PERIODIZATION WHICH

CONSIOERS THIS BODK AND EXAMINES THE PERIODIZATION WHICH CARR PROPOSES. THE STAGES IN THE EVOLUTION OF NATIONALISM ARE EVALUATED AND THE "TIME ZONES" OF EUROPE IN TERMS OF THE ROUNDED OUT BY AN ASSESSMENT OF CARR'S ANALYSIS AND IT RONCLLDES THAT CARR'S UNJUUSTLY NEGLECTED ESSAY REMAINS OF VERY GREAT CONTEMPORARY INTEREST.

03650 GEMMETTE, E.

SELECTIVE PREGNANCY REDUCTION: MEDICAL ATTITUDES, LEGAL IMPLICATIONS, AND A VIABLE ALTERNATIVE

JOURNAL OF MEALTH POLITICS, POLICY AND LAN, 16(2) (SUM 91), 383-395

"SELECTIVE PREGNANCY REDUCTION" IS A MEDICAL PROCEDURE USED TO REDUCE A MULTIPLE PREGNANCY, OFTEN A MULTIPLE PREGNANCY INDUCEO BY IN VITRO FERTILIZATION OR DRUG THERAPY. IN SUCH INSTANCES, HEALTHY EMBRYOS ARE SACRIFICED IN ORDER TO MAXIMIZE THE CHANCES OF SURVIVAL OF THE REMAINING EMBRYOS OR TO ALLOW THE MOTHER TO CHOOSE THE NUMBER OF BABIES SHE WISHES TO DELIVER. PHYSICIANS APPEAR TO RELY ON ROE V. WADE IN ASSUMING THE LEGALITY OF THE PROCEDURE, ALTHOUGH SUCH AN ASSUMPTION MAY BE ERRONEOUS. RATHER THAN CONTINUE TO IMPLANT AN EXCESSIVE NUMBER OF PRE-EMBRYOS, THE AMERICAN MEDICAL ASSOCIATION AND THE ASSOCIATION OF OBSTETRICS AND GYNECOLOGY SHOULD ADOPT GUIDELINES SIMILAR TO THOSE ESTABLISHED BY THE VOLUMTARY LICENSING AUTHORITY IN LONDON, WHICH LIMIT THE NUMBER TO BE INSERTED TO A MAXIMUM OF THREE. CAREFUL ULTRASOUND MONITORING COULD ENSURE THAT NO MORE THAN THREE EMBRYOS IMPLANT WHEN FERTILITY DRUGS ARE USED. SUCH EMBRYOS IMPLANT WHEN FERTILITY DRUGS ARE USED. SUCH PRACTICES WOULD HELP PHYSICIANS AVOID THE MANY MORAL, ETHICAL, LEGAL, AND PHILOSOPHICAL
SELECTIVE PREGNANCY REDUCTION.

03651 GEMPERLE, R.

\section{SWISS FEARS OF EUROPE}

SWISS REVIEW OF WORLD AFFAIRS, 42 (1) (APR 92), 28-29,

THE AUTHOR EXAMINES THE SWISS ATTITUDE REGARDING

ISOIAT

ISORTICIPATION IN THE EUROPEAN COMMUNITY.

03652 GENOUX, J.

THE QUIET REVOLUTIONARIES AT WORK IN BRUSSELS GERMAN TRIBUNE, (1494) (NOV 91), 6, 13.

THE BEST-PAID REVOLUTIONARIES IN THE WORLD ARE AT WORK IN BRUSSELS. WORKING QUIETLY AND RELATIVELY UNNOTICED, EUROCRATS TINKER WITH LAWS, REGULATIONS, AND DECREES HHICH WILL FUNDAMENTALLY ALTER THE LIVES OF MILLIONS. TOURISTS WILL SOON BE ABLE TO GO FROM COPENHAGEN TO LISBON WITHOUT ANY FRONTIER CONTROLS AND COMPANIES HILL SOON BE ABLE TO SELL SPANISH (OR ANY OTHER MEMBER STATE) MERCHANDISE IN ALL 12 MEMBER STATES. THIS QUIET REVOLUTION BEGINS ON 1 JANUARY 1993; MANY OTHER COUNTRIES ARE SO ATTRACTED BY IT THAT THEY HOULD LIKE TO JOIN IN. AS A CONSEQUENCE, THE SEVEN MEMBERS OF THE EUROPEAN FREE TRADE ASSOCIATION (EFTA), FINLAND, ICELAND, LIECHTENSTEIN, NORHAY, AUSTRIA, SWEDEN, AND SHITZERIAND HAVE ESTABLISHED JOINTLY WITH THE EUROPEAN COMMUNITY THE EUROPEAN ECONOMIC AREA (EEA). THERE HILL STILL BE FRONTIER CONTROLS BETHEEN THE EC AND EFTA; CONTROLS WILL BE DISMANTLED WITHIN THE EC FROM 1993 ONWARDS. BUT

EVERYTHING WHICH IS PRODUCED IN THE EFTA COUNTRIES HILL BE ABLE TO BE IMPORTED INTO THE 12 EC-COUNTRIES DUTY-FREE. THE ARLE TITION PHASE WILL NOT BE PAINLESS, BUT MOST OF THE TRANSITION PHASE WILL NOT BE PAINLESS, BUT MOST OF THE MEMBER STATES
INTEGRATION.

03653 GENSCHER, H.

AMERICANS AND EUROPEANS FORGE A REVISED FRIENDSHIP

GERMAN TRIBUNE, (1503) (FEB 92), 5

GERMAN FOREIGN MINISTER, HANS-DIETRICH GENSCHER, 
DISCUSSES THE LONG-STANDING RELATIONSHIP BETWEEN THE UNITED STATES AND EUROPE. HE DECLARES THAT EUROPEANS AND AMERICANS HAVE ESTABLISHED A NEW AND UNINHIBITED RELATIONSHIP. AMERICA WANTS EUROPE AS A PARTNER AND THE EUROPEANS DO NOT VIEH THIS PARTNERSHIP AS DOMINANCE BY AMERICA. THROUGH ITS POLICY OF DETENTE AND RECONCILIATION, GERMANY, WHICH HAD TO BEAR THE MAIN BURDEN OF WESTERN SECURITY AMONG EUROPEAN PARTNERS DURING THE COLD WAR, RESOLUTELY FOSTERED THE CSCE PROCESS, WHICH IS NOW AGAIN REVEALING ITS VITALITY. THE GERMAN
EFFORTS FOR THE UNITY OF THE WHOLE OF EUROPE DO JUSTICE FOR ITS EUROPEAN RESPONSIBILITY FOR PEACE. FOR A EUROPEAN GERMANY, THE UNITED STATES IS AND WILL REMAIN AN INDISPENSABLE PARTNER.

03654 GENT, A.V

REDISCOVERING THE KURDS

SWISS REVIEW OF WORLD AFFAIRS, 40(8) (NOV 90), 8-9

THIS ARTICLE REVIEWS THE HISTORY OF ENMITY' BETWEEN THE DURDS AND IRAQ, PARTICULARLY SADOAM HUSSEIN, IN THE CONTEXT OF THE GULF WAR. IT IS ARGUED THAT THE KURDISH CAUSE HAS BEEN REDISCOVERED BY THE INTERNATIONAL COMMUNITY AS A RESULT OF THE WAR. THE POTENTIAL FOR KURDISH INDEPENDENCE IS DISCUSSED, AND THE CONCERN THAT PROSPECT AROUSES IN TURKEY AND IRAN.

03655 GENTLEMAN, J.; ZUBEK, $V$

INTERNATIONAL INTEGRATION AND DEMOCRATIC DEVELOPMENT: THE CASES OF POLAN

JOURNAL OF INTERAMERICAN STUDIES AND WORLD AFFAIRS, 34(1)

(SPR 92) , 59-110.

THIS ARTICLE EXPLORES THE IMPACT OF FOREIGN INFLUENCE AND THE WEIGHT OF THE INTERNATIONAL FACTOR IN SHAPING CONTEMPORARY POLITICAL DEVELOPMENT IN POLAND AND MEXICO, AS EACH NATION PURSUES INTEGRATION WITH DEMOCRATIC SOCIETIES. FIRST, IT EXAMINES THE PERCEPTIONS OF THE POLITICAL LEADERS OF POLAND AND MEXICO, RESPECTIVELY, OF THEIR PROSPECTS FOR INTEGRATION WITH THE EC AND THE UNITED STATES IN THE WAKE OF EACH NATION'S ECONOMIC COLLAPSE AND THE BANKRUPTCY OF THEIR RESPECTIVE MODELS OF POL ITICAL ECONOMY. THE DISCUSS FOCUSES UPON ELITE PERCEPTIONS OF WESTERN ATTITUDES
CONCERNING PROSPECTS FOR INTEGRATION, BEFORE GOING ON TO CONCERNING PROSPECTS FOR INTEGRATION, BEFORE GOING ON TO
REVIEN THE BACKGROUND OF THE CONTEMPORARY INITIATIVES FOR REVIEW THE BAC
INTEGRATION.

03656 GENYING, $N$.

EIGHT ACCOMPLISHMENTS IN 192

BEIJING REVIEH, 35(44) (NOV 92), 18-19.

IN EARLY 1992. DENG XIAOPING MADE A LANDMARK SPEECH CALLING FOR A NEW COMMITMENT TO REFORM AND OPENING UP TO THE OUTSIDE WORLD. INSPIRED BY DENG'S WORDS, THE CHINESE HAVE MADE SUBSTANTIVE PROGRESS IN EIGHT AREAS, RANGING FROM AN INCREASED PUBLIC UNDERSTANDING OF CHINA'S ECONOMIC POLICIES TO GROWTH IN BOTH DOMESTIC AND INTERNATIONAL TRADE.

03657 GEORGE, B.; ALEXANDER, Y. (ED.); PLUCHINSKY, D.A. (ED.); WATSON, $T$.

COMBATING INTERNATIONAL TERRORISM AFTER 1992; EUROPEAN TERRORISM: TOOAY AND TOMORROH

BRASSEY'S (US), 1992, 181-193.

THE AUTHOR PREDICTS THAT TERRORISM IN ALL ITS FORMS HILL

CONTINUE IN THE 1990'S AND WILL EXPAND TO TAKE ADVANTAGE OF

THE NEW VULNERABILITIES OF MODERN SOCIETY. AT THE SAME TIME,

GOVERMMENTS WILL IMPROVE THEIR COUNTER-TERRORIST STRATEGIES

IN AN EFFORT TO MORE EFFECTIVELY COMBAT THE VIOLENCE.

03658 GEORGE, L.

WAITING FOR THE RAINBOH SIGN

NEW LEFT REVIEH, (193) (MAY 92), 75-79.

THE AUTHOR LOOKS FOR THE CAUSES UNDERLYING THE UPRISING OF THE POOR AND THE INTERCOMMUNAL VIOLENCE IN LOS ANGELES IN MAY 1992, FOLLOHING THE ACOUITTAL OF THE OFFICERS INVOLVED

IN THE RODNEY KING POLICE BRUTALITY TRIAL.

03659 GEORGE, R.

PROPORTIONALISM AND THE CATHOLIC MORAL TRADITION UNIVERSITY OF DETROIT MERCY LAW REVIEH, 70(1) (FAL 92), $1-12$.

THERE IS A SHRINKING CLASS OF MORAL QUESTIONS ON WHICH ONE CAN EXPECT WIDE AGREEMENT AMONG CATHOL IC MORALISTS. THE AUTHOR ARGUES THAT THE APPROACH OF THOSE MORALISTS HHO FOLLOW THE CHURCH'S TRADITIONAL TEACHING IS SUPERIOR TO THAT FOLLOW THE CHURCH'S TRADITIONAL TEACHING IS SUPERIOR TO THAT OF THE PROPORTIONALISTS. HE BOTH EXPLAINS WHAT TRADITIONAL MORALISTS MEAN BY MORAL ABSOLUTES AND INDICATES THE GROUNDS DESCRIPTION AND SUCH PRINCIPLES. HE THEN OFFERS ALTERNATIVE.

03660 GEORGE, T.E.; EPSTEIN, L.

ON THE NATURE OF SUPREME COURT DECISION-MAKING

AMERICAN POLITICAL SCIENCE REVIEN, 86(2) (JUN 92), 323-337.

SINCE THE 1940's, SCHOLARS HAYE FOCUSED ON THO DISTINCT

EXPLANATIONS OF HOW' THE U.S. SUPREME COURT REACHES DECISIONS

THE LEGAL MOOEL SUGGESTS THAT THE RULE OF LAW (STARE

DECISIS) IS THE KEY DETERMINANT; THE EXTRALEGAL MODEL POSITS
THAT AN ARRAY OF SOCIOLOGICAL, PSYCHOLOGICAL, AND POLITICAL FACTORS PRODUCE JUDICIAL OUTCOMES. TO DETERMINE WHICH MODEL BETTER EXPLAINS JUDICIAL DECISIONS, THE AUTHORS STUDY SUPREME COURT CASES INVOLVING THE IMPOSITION OF THE DEATH PENALTY SINCE 1972. ALTHOUGH BOTH MODELS PERFORM SATISFACTORILY, THEY POSSESS DISTURBING NEAKNESSES. THE LEGAL PERSPECTIVE OVERPREDICTS LIBERAL OUTCOMES, WHILE THE EXTRALEGAL OVERPREDICTS CONSERVATIVE ONES. GIVEN THESE RESULTS, THE AUTHORS TEST ANOTHER PROPOSITION--NAMELY, THAT EXTRALEGAL AND LEGAL FRAMEHORKS PRESENT CODEPENDENT, NOT MUTUALLY EXCLUSIVE, EXPLANATIONS OF DECISION-MAKING. THEY OFFER AN INTEGRATED MODEL OF SUPREME COURT DECISION-MAKING THAT CONTEMPLATES A RANGE OF POLITICAL AND ENVIRONMENTAL FORCES AND DOCTRINAL CONSTRAINTS.

03661 GEPP, $C$.

PERU' AWAITS REFORMS AND AN END TO TERROR

INSIGHT, 8(35) (AUG 92), 10-13; 34-37.

PRESIDENT FUJIMORI'S' ORASTIC ACTIONS IN APRIL GAVE SOME PERUVIANS HOPE THAT CHANGE WAS COMING WHICH WOULD LIFT THE COUNTRY'S SAGGING ECONOMY AND BOLD MOVES IN THE WAR WITH SHINING PATH GUERRILLAS. INSTEAD THEY'VE WATCHED THE NATION'S FORTUNE CONTINUE TO NOSE-DIVE AS TERRORISM AND DRUG TRAFFICKING HAVE INCREASED. PERUYIANS ARE STARTING TO WONDER ABOUT THE QUALITY OF THEIR PROTECTION. IF THE SITUATION CONTINUES LIKE THIS, PEOPLE ARE GOING TO THINK THE SHINING
PATH IS STRONGER THAN THE GOVERNMENT. THE SITUATION IN PERU IS BEGINNING TO RESEMBLE WHAT HAS BEEN HAPPENING IN COLOMBIA FOR THE PAST 10 YEARS.

03662 GERACE, $M$.

TRANSFORMING THE PATTERN OF CONFLICT: GEOPLITICS AND POSTCOLD WAR EUROPE

COMPARATIVE STRATEGY, 11(4) (DEC 92), 373-408,

WHAT ROLE WILL WESTERN EUROPE PLAY IN THE POST-COLD-WAR WORLD? MOST ASSESSMENTS OF THE NEH EUROPE SEE IT AS AN EMERGING COMPONENT IN A NEW BALANCE OF POWER FROM A REALIST OR NEOREALIST STANDPOINT. A GEOPOLITICAL APPROACH TO THE NEW EUROPE IS QUITE OIFFERENT FROM A REALISM STANDPOINT. RATHER THAN SEEING WESTERN EUROPE AS SIMPLY A NEW ACTOR, HESTERN EUROPE WILL BE AN AMPHIBIOUS CENTER OF POWER THAT HILL HAVE EUROPE WILL BE AN AMPHIBIOUS CENTER OF POWER THAT HILL HAVE
STRUCTURALLY EXPRESSED INTERESTS ON LAND AND SEA, WHICH WILL STRUCTURALLY EXPRESSED INTERESTS ON LAND AND SEA, WHICH
INTERACT WITH OTHER POWERS WITH STRUCTURALLY EXPRESSED INTERACT WITH
INTERESTS.

03663 GERARD, R.

BUSH'S CARTER PROBLEM

AMERICAN SPECTATOR, $24(12)$ (DEC 91), 28

THE RESEMBLANCE BETWEEN CARTER'S AND BUSH'S POLICIES WITH REGARDS TO THE MIDOLE EAST IS STRIKING. LIKE CARTER, BUSH DESPISES ISRAEL'S LEADERSHIP, IS SURROUNDED BY ANTIISRAELI ADVISORS, IS DETERMINED TO BRING ABOUT A COMPREHENSIVE ARAB-ISRAELI ACCORD, AND IS ALMOST SYCDPHANT ICALLY DEFERENTI IAL TO SAUDI ARABIA. ABOVE ALL, LIKE
CARTER, BUSH IS OBSESSED WITH THE WEST BANK SETTLEMENTS, AND CARTER, BUSH IS OBSESSED WITH THE WEST BANK SETTLEMENTS, AND
CONSIDERS THEM THE PRINCIPAL OBSTACLES TO ARAB-ISRAELI PEACE. FOR ITS PART, THE ISRAELI GOVERNMENT IS COMING TO VIEW GEORGE BUSH WITH UNDISGUISED ALARM, AND SEES HIS WELL -KNOWN OBSESSION HITH THE SETTLEMENTS AS LESS A PERSONAL IDIOSYNCRASY THAN A DEEPLY ROOTED CONVICTION THAT ISRAEL MUST WITHDRAW TO THE 1967 FRONTIERS. WHAT MAKES THE CURRENT IMPASSE ESPECIALLY TRAGIC IS THAT, IF HE ONLY KNEH IT, BUSH COULD EASILY BRING THE SETTLEMENTS POLICY TO THE END. ALL HE HAS TO SAY IS THAT, WHILE THE UNITED STATES MAINTAINS ITS OPPOSITION TO ISRAEL'S ANNEXATION OF THE WEST BANK, THE "LAND FOR PEACE" FORMULA DOES NOT PRECLUDE SUBSTANTIAL TERRITORIAL CHANGES IN ISRAEL'S FAVOR.

03664 GERAS, N.

BRINGING MARX TO JUSTICE: AN ADDENDUM AND REJOINDER NEW LEFT REVIEW, (195) (SEP 92), 37-69.

IN ANOTHER PAPER. THE AUTHOR HAS ARGUED THAT KARL MARX'S CRITIQUE OF CAPITALISM ENTAILED THE VIEW THAT IT WAS UNJUST, EVEN THOUGH MARX HIMSELF WAS UNAWARE OF IT. IN THIS ESSAY, HE DEFENDS HIS ARGUMENT AND EXPANDS UPON IT. HE CONTENDS THAT MARX'S ACCOUNT OF EXPLOITATION AND THE CAPITALIST LABOR PROCESS WAS INFORMED BY DEEP AND UNIVERSALISTIC, ALBEIT UNAYOWED, MORAL COMMITMENTS. BUT MARX'S UNACKNOHLEDGED ETHICAL STANDARO IS NOT THE ONE SOCIALISM NEEDS, SINCE IT ALLOTS AN UNHARRANTED PRIVILEGE TO WORKERS RATHER THAN ALLOTS AN UNWARRANTED PRIVILEGE TO WORKERS RATHER THAN
REGISTERING THE CLAIMS OF ALL THE DISPOSSESSED AND THE REGISTERING THE

03665 GERDES, $P$.

PROGRESS AND PROBLEMS IN MICRONESIA

SWISS REVIEW OF WORLD AFFAIRS, 41(10) (JAN 92), 24-25. PREYIOUSLY AN AMERICAN IRUST TERRITORY THE FEDERATED STATES OF MICRONESIA (FSM) DECLARED ITS INDEPENDENCE FIVE YEARS AGO BUT REMAINS ECONOMICALLY AND POLITICALLY DEPENDENT ON THE UNITED STATES. ON GUAM, NATIVE PROTESTS AGAINST THIS DEPENDENCE HAVE RECENTLY GROWN STRONGER. THE AMERICAN TRUST TERRITORY OF PALAU DECLARED ITSELF A REPUBLIC TEN YEARS AGO AND HAS SINCE PURSUED AN ANTI-NUCLEAR POLICY THAT PREVENTS U. S. HARSHIPS FROM ANCHORING THERE. 
03666 GEREMEK CIVIL SOCIETY THEN AND NOH

JOURNAL OF DEMDCRACY, 3(2) (APR 92), 3-12.

THIS ARTICLE IS A REVISED VERSION OF BRONISLAW GEREMEK'S KEYNOTE ADORESS AT A CONFERENCE ON "THE IDEA OF A CIVIL SOCIETY" HELD IN 1991 IN NORTH CAROLINA. HE TRACES THE CONCEPT OF CIVIL SOCIETY IN OPPOSITION TO THE STATE WHICH HAS IT ROOTS IN THE EIGHTEEN CENTURY. HE THEN ANALYZES THE CONTRONTING OF COMMUNISM AND THE POSTCOMMUNIST LETDOWN. HE CONCLUDES THAT A ROBUST CIVIL SOCIETY OFFERS THE BEST PROSPECTS FOR OVERCOMING THE DIVERGENCE OF STATE AND SOCIETY AND BRINGS CITIZENS INTO ACTIVE ENGAGEMENT WITH PUBLIC LIFE. THAT ONLY UNDER SUCH CONDITIONS CAN DEMOCRACY BE MADE SECURE IS CONCLUDED.

03667 GERGEN, D.

AMERICA'S MISSED OPPORTUNITIES

FOREIGN AFFAIRS, 71(1) (1992), 1-19.

WITH THE END OF THE COLD HAR, IT IS LIKELY THAT U.S.

DOMESTIC POLITICS WILL PLAY A MUCH MORE SIGNIFICANT ROLE IN THE FORMATION OF FOREIGN POLICY AND HILL INCREASINGLY DRIVE THE USA TOHARD A NEH WORLD ROLE SOMEWHERE BETHEEN ISOLATIONISM AND DOMINATION OF A NEW INTERNATIONAL REGIME. ISOLATIONISM AND DOMINATION OF A NEW INTERNATIONAL REGIME. HILL STILL BE CAPABLE OF RALLYING AGAINST AN INTERNATIONAL MENACE LIKE SADOAM HUSSEIN, AND AMERICAN DIPLOMATS WILL MENACE LIKE SADOAM HUSSEIN, AND AMERICAN DIPLOMATS WILL OF DOMESTIC PROBLEMS HILL EXERCISE A RESTRAINING HAND ON THE FOREIGN POLICY ACTIVISM OF EARLIER DAYS.

03668 GERLICH, P

A FAREWELL TO CORPORATISH

WEST EUROPEAN POLITICS, 15(1) (JAN 92), 132-146.

TRADITIONALLY, SOCIAL PARTNERSHIP HAS HELD AN IMPORTANT POSITION WITHIN THE AUSTRIAN POLITICAL SYSTEM, MAKING IT ONE OF THE PRIME EXAMPLES OF CORPORATISM. BUT THE' PERIOD OF CORPORATISM IS NOW DRAWING TO AN END. THE TRADITIONAL PRINCIPLES OF SOCIAL PARTNERSHIP CONCERNING ORGANIZATIONS, POL ITICAL STYLE AND INHERENT STABILITY ARE BEING CALLED INTO QUESTION, INTRODUCING POTENTIALLY SWEEPING CHANGES IN THE COUNTRY THAT WOULD BRING IT IN LINE WITH THE REST OF WESTERN EUROPE. THERE ARE VARIOUS SCENARIOS FOR FUTURE DEVELOPMENT, ALL OF WHICH AGREE THAT SOCIAL PARTNERSHIP WILL BECOME LESS IMPORTANT. BOTH THE POLITICAL AND ECONOMIC SPHERES ARE BECOMING MORE COMPETITION ORIENTED AND HOPEFULLY ALSO MORE COMPETETIVE. IN RETROSPECT CORPORATISM MAY BE VIEWED AS AN INTERMEDIATE STAGE IN THE MODERNIZATION PROCESS OF AUSTRIAN SOCIETY.

03669 GERMANN, R.

SHITZERLAND'S FUTURE IN EUROPE: ISOLATION OR SWITZERLAND'S FUTURE

GOVERNANCE, $5(2)$ (APR 92), 224-234.

IN ORDER TO MOVE CLOSER TO THE EUROPEAN COMMUNITY AND EVENTAULLY TO JOIN IT SHITZERLAND MUST RESHAPE ITS POLITICAL INSTITUTIONS. A MAJOR CONSTITUTIONAL REFORM SHOULD PROVIDE FOR A REAL HEAD OF GOVERMMENT, ADAPT DIRECT DEMOCRACY TO THE CONSTRAINTS OF SUPRA-NATIONALITY, AND SIMPLIFY THE LEGISLATIVE PROCESS. THIS ARTICLE SUGGESTS THAT THE DOMINANT DOCTRINE OF NEGOTIATING FIRST WITH THE EC AND REFORMING LATER IS NOT REALISTIC. THE SO CALLED DOUBLE MA JORITY REFERENDUM IS GIVEN AS AN ILLUSTRATION. THIS RATIFICATION PROCEDURE IS NOT IN ACCORDANCE WITH THE PRINCIPLE OF ONE MAN, ONE VOTE, AND IS CLEARLY BIASED AGAINST EUROPE.

03670 GERMROTH, D.; HUDSON, R.

GERMAN-AMERICAN RELATIONS AND THE POST COLD WAR WORLD AUSSEN POLITIK, 43(1) (1992), 33-42.

GERMAN UNIFICATION HAS NOT ONLY ENDED AN ANOMALY AS THE GERMANS TEND TO SEE IT. AT THE SAME TIME, THE GERMAN POWER POTENTIAL IS GENERALLY PERCEIVED TO HAVE' SUBSTANTIALLY INCREASED, AT LEAST IN THE LONGER RUN WHEN THE WEAKNESSES RESULTING FROM THE NEED TO INTEGRATE A REGION RUINED BY SOCIALISM WILL BE OVERCOME. THIS RAISES BOTH CONCERNS AND DEMANDS IN GERMANY'S INTERNATIONAL ENVIRONMENT. IN THE UNITED STATES, IT IS PRIMARILY THE POSTULATE THAT A GREATER GERMANY MUST LIVE UP TO NEH RESPONSIBILITES WHICH FOCUSSES ATTENTON AND MAKES IMPACT ON RELATIONS BETHEEN THE UMITED STATES AND GERMANY.

03671 GERMROTH, D.; HUDSON, R.

GERMANY'S RESPONSE TO THE GULF CRISIS: THE NEW GERMAN QUESTIOM

MEDITERRANEAN QUARTERLY: A JOURNAL OF GLOBAL ISSUES, 3(1) (WIN 92 ), 78-99

THE COLD WAR'S CURTAILMENT, WHICH BROUGHT ABOUT THE UNIFICATION OF EAST AND HEST GERMANY, INAUGURATED THE RISE OF A NEW "GERMAN QUESTION," A DEBATE OVER THE ISSUE OF WHAT UNITED GERMANY'S ROLE SHOULD BE IN THE FUTURE HORLD ORDER. THE GULF CRISIS PLACED THIS NEW GERMAN QUESTION AT THE FOREFRONT OF FOREIGN POLICY DEBATE IN GERMANY, AS WELL AS IN EUROPE MORE GENERALLY AND IN THE UNITED STATES. WITH GERMANY
MOW A UNITED NATION, ENDOWED FINANCIALLY AND WITH CAPACITY TO PLAY AN ACTIVE ROLE IN WORLD AFFAIRS, THE QUESTION ARISES AS TO WHETHER ITS PEOPLE HAVE THE POLITICAL LEADERSHIP AND AS THIS ARTICLE CONSIDERS THIS QUESTION AND THE CORROLLARY THIS ARTICLE CONSIDERS THIS QUESTION ANO THE CORROLLARY ROLE IN GLOBAL CRISES, PARTICULARLY A MILITARY ROLE?

03672 GERSON, A.

ANATOMY OF A PEACE PROCESS--OR "NEH AGE" DIPLOMACY MIDDLE EAST INSIGHT, 8(2) (SEP 91), 13-14.

THIS ARTICLE SEEKS TO DETERMINE THE CHANGES THAT HAVE TAKEN PLACE IN THE BARGAINING POSITIONS OF THE ISRAELIS, THE ARABS, AND THE AMERICANS HITH REGARDS TO THE ARAB-ISRAELI DISPUTE. IT SEEKS TO DETERMINE WHETHER A "MEETING OF MINDS" BETWEEN ANTAGONISTS IS POSSIBLE. IT CONCLUDES THAT ISRAEL'S POSITION HAS CHANGED SO FAR IS IT IS MORE WILLING THAN EVER TO TURN A BLIND EYE TO PLO BEHIND-THE-SCENES ORCHESTRATION OF PALESTINIAN REPRESENTATION AT A PEACE CONFERENCE. THE ARAB STATES HAVE CHANGED IN COMING TO TERMS WITH THE NECESSITY FOR DIRECT FACE-TO-FACE TALKS BETWEEN ITS REPRESENTATIVES AND THOSE OF ISRAEL. THE UNITED STATES HAS SIGNIFICANTLY MODERATED ITS POSITION TOWARD THE ARAB STATES IN THE REGION (PARTIALLY IN RECOGNITION OF THE VITAL ROLE THEY PLAYED IN THE ANTI-IRAO COALITION). HOWEVER, A "MEETING OF MINDS" IS STILL QUITE UNLIKELY.

BERTRAM L. BAKER, THE UNITED ACTION DEMOCRATIC ASSOCIATION, AND THE FIRST BLACK DEMOCRATIC SUCCESSION IN BROOKLYM 1933-1954 AFRO-AMERICANS IN NEW YORK LIFE AND HISTORY, 16(2) (JUL 92 ) $17-46$

IM AMER BEEN ASSERTED THAT THE CONDITIONS FOR SUCCESS IN AMERICAN CITIES HERE DIFFERENT FOR HHITE ETHNICS THAN FOR NONHHITE MONORITY GROUPS. THE BROOKLYN ILLUSTRATION DEFIES THE PREFAILING VIEH. THIS ARTICLE TAKES INTO ACCOUNT THE CONDITIONS THAT MAKE SUCCESSION LIKELY WHICH HERE PRESENT DURING THE 1930S, 40S, AND $50 S$ IN BROOKLYN'S LARGEST BLACK COMMUNITY. THE ARTICLE RELIES ON IN-DEPTH INTERVIEWS WITH KEY INDIVIDUALS AND COVERS BRDOKLYH DEMOGRAPHY AND THE HISTORY OF BERTRAM L. BAKER AND HIS ELECTION TO THE DISTRICT LEADERSHIP. BY THE LATE 1950S, THE BROOKLYN MACHINE GREW AND GAINED NEW BLACK VOTERS AND LAID THE FOUNDATION FOR WHAT IT HOPED WOULD BE CONTINUED FLUENT SUCCESSIONS.

03674 GERSON, $S$.

POL ITICAL INDEPENDENCE AND THIRD PARTY MOVEMENTS

POLITICAL AFFAIRS, 71(12) (DEC 92), 9-13.

POSITIVE RESULTS ARE ENUMERATED AFTER THE $1992 \mathrm{U} . \mathrm{s}$.

ELECTIONS ARE REVIEWED. THIS ARTICLE REPORTS ON THIRD PARTY

STIRRIMGS AND THE DEBATE ON THE LEFT. STRATEGY IS OFFERED ON HOW THIRD PARTIES CAN MAKE INROADS IN THE POLITICAL SCENE. HOW THIRD PARTIES CAN MAKE INROADS IN THE POLITICAL SCENE. THE COMAHNIST VIEW IS OFFERED. THE ARTICLE CONCLUDES THAT
THE COMMUNIST LINE IS A PRINCIPLED, YET FLEXIBLE POL ICY LINE THE COMMUNIST LINE IS A PRINCIPLED, YET FLEXIBLE POLICY THAT ADVANCES THE STRUGGLE FOR A LABOR-LED, MULTI-RACIAL THIRD PARTY THAT CAN EFFECTIVELY CHALLENG

03675 GERTH, H.

CRISIS MANAGEMENT OF SOCIAL STRUCTURES: PLANNING,

PROPAGANDA, AND SOCIETAL MORALE
INTERNATIOMAL JOURNAL OF POLITICS, CULTURE AND SOCIETY, INTERNATIONAL JOURNAL OF

MATION STATE AND THE RHETORICS OF LIBERALISM ARE EXPLTRD, STATE AND THE RHETTRY OF SOCIAL STRUCTURES AND CRISIS MANAGEMENT IN WARTIME. THE USES OF RACIAL AND ETHMIC DIYERSITY AS WEL IN WARTIME. THE USES OF RACIAL AND ETHNIC DIVISIONS, AS WELL AS THE USES AND MANAGEMENT OF ECONOMIC OF CRISIS ROUND OUT THIS DISCUSSION OF CRISIS MANAGEMENT OF OF CRISIS ROUND OUT THIS DISCUSSION CONCLUSION THAT THE RELATED DECISIONS ARE WEIGHTY AND GRAVE AND AFFECT NOTHING LESS THAN THE FUTURE OF MANKIND.

03676 GERTLER, P.J.; HALDMAN, D.M. QUALITY-ADJUSTIED COST FUNCTIONS AND POLICY EVALUATION IN THE NURSING HOME INDUSTRY

JOURNAL OF POLITICAL ECONOMY, 100(6) (DEC 92), 1232-1256.

PROPER EVALUATION OF COST-QUALITY TRADE-OFFS INHERENT IN REGULATORY POLICY REQUIRES IDENTIFYING THE STRUCTURE OF PRODUCTION FROM THE BEHAVIORAL RESPONSE OF QUALITY TO THE POLICY CHANGE. HOWEVER, ESTIMATING THE STRUCTURE OF PRODUCTION WITH ENDOGENOUS QUALITY IS DIFFICULT BECAUSE OF BOTH MEASUREMENT PROBLEMS AND DATA AYAILABILITY. THE AUTHORS DEVEL OP A SIMPLE METHOD FOR IDENTIFYING AND ESTIMATING COST FUMCTIONS IN THE PRESEMCE OF ENDOGENOUS AND UNOBSERYED FUCCTON IN THE PRESENCE OF ENOY ESTIMATE THAT A OUALTYQUALITY. USING THS METHO, THEY ESTHATE THAT A QUALITYADJUSTED COST FUNCTION FOR NURSING HOMES TREATING QUALITY AS EXOGENOUS YIELDS SERIOUSLY MISLEADING ESTIMATES OF MARGI COST AND ECONOMIES OF SCALE. THE AUTHORS THEN USE THE IN NURSING HOME REGULATORY POLICY. 
03677 GERVASI, S.

BEYOND THE BUSINESS CYCLE: ECONOMIC CRISIS AFTER THE RECESSION

SOCIAL POLICY, 22(4) (SPR 92), 46-50.

THE CURRENT ECONOMIC CRISIS IS A NEW EXPERIENCE FOR THE UNITED STATES. IT IS NOT JUST PART OF THE UPS AND DOWNS OF THE USUAL BUSINESS CYCLE. IT IS NOT THE RESULT OF A RECESSION OR EVEN A SERIES OF RECESSIONS, AND IT DOES NOT FIT THE USUAL DESCRIPTION OF A DEPRESSION. THE PRESENT AMERICAN CRISIS INCREASINGLY RECALLS THE EXPERIENCES OF SPAIN, THE NETHERLANDS, AND GREAT BRITAIN IN THIS AMD PAST CENTURIES. IT IS A LONG-TERM CRISIS ASSOCIATED WITH THE SLOWDOWN OF GROWTH IN THE U.S. ECONOMY DURING THE LAST THO DECADES BUSINESS CYCLE AHALYIS IS OF LITTLE USE IM OECADES. BUSINESS CYCLE ANALYSIS IS OF LITTLE USE IN UNDERSTANDING THE PROBLEM OF LONG-TERM DECLINE. SEEING THE LARGER PICTURE REQUIRES EXAMIN
VARIABLES OVER LONG PERIODS

03678 GESCHKE, $G$

BUNDNIS' 90 GOES FOR PARTY STATUS

GERMAN TRIBUNE 1487 (OCT Q1)

GERMAN TRIBUNE, 1487 (OCT 91 ), 4 .
THIS ARTICLE DISCUSSES A NEW POLITICAL PARTY IN GERMANY: "B 90". IT IS A LOOSE MERGER FOR ELECTION PURPOSES OF THE FIVE CITIZENS' MOVEMENTS WHICH HELPED TOPPLE THE COMMUNIST REGIME AND BRING ABOUT THE DEMOCRATIC REVOLUTION IN THE GDR. ITS THREE MOST SIGNIFICANT MEMBERS ARE: DEMOCRACY NOH; NEH FORUM AND THE INITITIATIVE FOR FREEDOM AND HUMAN RIGHTS. THE ARTICLE DISCUSSES THE NEW PARTY'S BEHAVIOR AND CHANCES IN THE ELECTION.

\section{GEWIRTZ, P.}

HOUSE PARTY

NEW REPUBLIC, 207 (5) (JUL 92), 38, 42-43.

THE AUTHOR EXPLAINS THE HOUSE OF REPRESENTATIVE'S RESPONSIBILITY TO ELECT A PRESIDENT IN CASE NO CANDIDATE WINS IN THE ELECTORAL COLLEGE VOTE.

03680 GEYER, G.A.

YESTERDAY'S CIGAR: FIDEL CASTRO, THE LAST CAUDILLO

POLICY REVIEW, (59) (WIN 92), 66-70.

THE CURTAIN OF HISTORY WILL SOON CLOSE ON FIDEL CASTRO. THE CUBAN DICTATOR LONG PRETENDED TO BE A COMMUNIST

REVOLUTIONARY, BUT IN TRUTH HE ADMIRED FRANCISCO FRANCO MORE

THAN VLADIMIR, LENIN. CASTRO HIL BE REMEMBERED AS THE LAST

THAN VLADIMIR LENIN. CASTRO WILL BE REMEMBERED AS THE LAST

CAUDILLO OF SPANISH CIVILIZATION--A VAIN, MILITARISTIC

ANACHRONISM WHO TOOK CONTROL OF A PROSPEROUS CUBA, REPLACED

RUTHLESS AND MORALISTIC TYRANMY, AND SYSTEMATICALLY

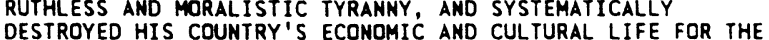
SAFE OF HIS OWN TOTAL POHER.

03681 GEYSER, 0.

A COMMONWEALTH PRIME MINISTER: GENERAL JAN CHRISTAAN SMUTS ROUND TABLE, (320) (OCT 91), 431-436.

IN LIGHT OF THE ANNOUNCEMENT OF THE NEWLY ELECTED SECRETARY-GENERAL OF THE COMMONWEALTH THAT HE WILL SUPPORT SOUTH AFRICA'S READMISSION AS A MEMBER OF THE COMMONHEALTH, IT IS PERTINENT TO CALL TO MIND ONE OF THE COMMONHEALTH'S MAIN ARCHITECTS, GENERAL JAN CHRISTAAN SMUTS, WHOSE INTEREST IN THE COMMONWEALTH LED TO HIS REJECTION BY HIS OWN PEOPLE. THE RISE, DEVELOPMENT AND CONSOL IDATION OF THE BRITISH COMMONHEALTH PROVIDED THE OPPORTUNITY FOR SEVERAL STATESMEN TO PLAY IMPORTANT ROLES IN INTERNATIONAL POLITICS, SOMETHING THAT OTHERHISE THEY WOULD HAVE BEEN UNABLE TO DO. SMUTS WAS ONE OF THESE STATESMEN TO WHOM THE RISE OF THE COMMONWEAL TH OFFERED EXCEPTIONAL OPPORTUNITIES FOR MAKING HIS INFLUENCE CLEARLY FELT. THE ROLE THAT SMUTS PLAYED IN TRANSFORMING THE BRITISH EMPIRE INTO THE BRITISH COMMONWEALTH AND IN THE SUBSEQUENT DEVELOPMENT OF THE COMMONHEALTH AFTER THE FIRST WORLD HAR WAS OF SUCH IMPORTANCE THAT ONE ENGL ISHMAN WROTE THAT THE "IN THE SOUTHERN HEMISPHERE, THE GREATEST ENGL ISHMAN IS AN AFRIKANER."

03682 GHAI, Y

THE PAST AND THE FUTURE OF HONG KONG'S CONSTITUTION CHINA QUARTERLY, (128) (DEC 91), 794-813.

THE AUTHOR EXAMINES THE ROLE OF CONSTITUTIONS IN HONG KONG, FOCUSING ON THE IMPLICATIONS OF THE BASIC LAH THAT GOES INTO EFFECT IN JULY 1997 AS THE CONSTITUTION OF THE HONG KDNG SPECIAL ADMINISTRATIVE REGION (HKSAR). IN ORDER TO ILLUSTRATE THE POWER AND METHOD OF THE BASIC LAH, HE ALSO DISCUSSES THE ROLE OF COLONIAL CONSTITUTIONS IN THE TERRITORY.

03683 GHATE, P.B.

INTERACTION BETWEEN THE FORMAL AND INFORMAL FINANCIAL SECTORS: THE ASIAN EXPERIENCE

WORLD DEYELOPMENT, 20 (6) (JUN 92), 859-872

THE NATURE OF THE INTERACTION BETHEEN THE FORMAL AND INFORMAL FINANCIAL SECTORS IN DEVELOPING COUNTRIES IS A SUBJECT WITH IMPORTANT POLICY IMPLICATIONS. AS THE FORMAL SECTOR EXPANDS IN THE LONG TERM, WILL THE INFORMAL SECTOR WITHER AHAY, AS THE TRADITIONAL VIEW OF FINANCIAL DUALISM ASSUMES, OR WILL IT CONTINUE TO PLAY AN IMPORTANT
COMPLEMENTARY ROLE, PERHAPS EVEN GROWING IN SIZE? THE PATTERN OF INTERACTION BETWEEN THE TWO SECTORS HAS IMPORTANT IMPLICATIONS FOR THE PROSPECTS OF SUCCESS OF THE TWO MAJOR POLICY APPROACHES OFTEN ADVOCATED TOWARD THE INFORMAL SECTOR-OFFERING IT STRONGER COMPETITION SO AS TO INDUCE IT TO IMPROVE ITS TERMS OR PROMOTING LINKAGES WITH IT SO AS TO TAKE ADVANTAGE OF ITS LOWER TRANSACTIONS COSTS IN REACHING SMALLER AND POORER BORROWERS. THE EXISTENCE OF A LARGE INFORMAL SECTOR HAS IMPLICATIONS FOR THE EFFICACY OF MONETARY AND CREDIT POLICY IN ACHIEVING STABILIZATION OBJECTIVES. THE INTERACTION BETHEEN THE FORMAL AND INFORMAL FINANCIAL SECTORS ALSO HAS IMPLICATIONS FOR THE EFFECTS OF FINANCIAL LIBERALIZATION THROUGH REMOVING RESTRICTIONS ON THE DEPOSIT RATE OF INTEREST. THIS PAPER DRAWS ON THE EXPERIENCE OF ASIAN COUNTRIES TO AODRESS THESE ISSUES.

03684 GHILES, F.

ALGERIA'S OLD GUARD HANGS OM

MIDOLE EAST INTERNATIONAL 440(440) (DEC 92), 19-20.

ELEVEN MONTHS AFTER THE BLOODLESS COUP IN ALGIERS,

WESTERN POWERS ARE AS CONFUSED AS EVER AS TO HOW BEST REACT TO THE POSSIBLE ELECTION OF A RADICAL MUSLIM MAJORITY IN A MIDOLE EASTERN COUNTRY. THE FACT THT THE ISLAMIC SALVATION FRONT (FIS) WAS DEPRIVED OF AN ALMOST CERTAIN VICTORY WAS CONSIDERED TO BE OF MUCH GREATER IMPORTANCE THAN THE UNCONST ITUTIONAL MANNER IN WHICH THE DEED WAS DONE. WESTERN GOVERNMENTS ARE GUILTY OF INCONSISTENCY AND DOUBLE STANDARDS IN THEIR BEHAVIOR AND MORAL ATTITUDES. THE GREAT TRAGEDY OF ALGERIA IS THAT THE FRATERNAL VIOLENCE WHICH ITS LEADERS HAVE BEEN PRACTICING ON EACH OTHER SINCE 1954, AND WHICH HAS SERVED THEM WELL IN HOLDING ON TO POWER, HAS MADE THEM UNABLE TO HAND OVER TO A YOUNGER GNERATION.

03685 GHILS, P.

INTERNATIONAL CIVIL SOCIETY: INTERNATIONAL NONGOVERNMENTAL ORGANIZATIONS IN THE INTERMATIONAL SYSTEM INTERNATIONAL SOCIAL SCIENCE JOURNAL, (133) (AUG 92),

$417-432$

THE EMERGENCE IN THE HUMAN SCIENCES OF THE NOTIONS OF COMPLEXITY AND INTERACTION BETHEEN PHENOMENA IS REFLECTED TODAY, IN INTERNATIONAL POLITICAL STUDIES, IN A GROHING INTEREST IN ENTITIES OTHER THAN STATES AND INTERGOVERNMENTAL ORGANIZATIONS AS SUB JECTS OF ANALYSIS. THIS STUDY DEALS WITH THE CATEGORY OF TRANSNATIONAL FORCES WHICH ARE USUALLY KNOWN THE CATEGORY OF TRANSNATIONAL FORCES WHICH ARE USUALLY KNOWN
AS "INTERNATIONAL NONGOVERNMENTAL ORGANIZATIONS" (INGOS) OR "TRANSHATIONAL ASSOCIATIONS." IT ADDRESSES SOME OF THE MORE SIGNIFICANT ISSUED IN INTERNATIONAL RELATIONS TODAY.

03686 GHODS, $M$.

THE IRANIAN COMMUNIST MOYEMENT UNDER REZA SHAH MIDDL EASTERM STUDIES 26(4) (OCT 0 ( $506-513$ MIDOLE EASTERN STUDIES, 26(4) (OCT 90), 506-513.
THE FOUNDING OF THE TUDEH IN 1941 IS OFTEN REGARDED AS THE BEGINNING OF THE MODERN COMMUNIST MOVEMENT IN IRAN. SCHOLARS HAVE GENERALLY REGARDED THE OLD PERSIAN COMMUNIST PARTY (PCP), FOUNDED IN 1920, AS AN ENTIRELY DISCRETE ORGANIZATION WITH FEW, IF ANY, HISTORICAL CONNECTIONS TO THE TUDEH. THE PURPOSE OF THIS ARTICLE IS TO ILLUSTRATE THAT THE PCP, IN FACT, HAD A STRONG ORGANIZATIONAL AS WELL AS IDEOLOGICAL INFLUENCE ON THE FORMATION OF THE TUDEH. REZA SHAH'S REPRESSIVE RULE (1926-41) DID NOT SUCCEED IN ALTOGETHER STOPPING PCP ACTIVITIES. RATHER, IT REMOVED IRANIAN COMMUNIST ACTIVITIES TO EUROPE AND TO TEHRAN'S QASR PRISON. IN BOTH THESE LOCATIONS, THE PCP HELPED SHAPE THE NUCLEUS OF WHAT WAS TO BECOME THE TUDEH.

03687 GIANHAKDS, $S$.

THE MACEDONIAN QUESTION REEXAMINED: IMPLICATIONS FOR BALKAN SECURITY

MEDITERRANEAN QUARTERLY: A JOURNAL OF GLOBAL ISSUES, 3(3)

(SUM 92 ) $26-47$.

THIS ARTICLE SEEKS TO DEFINE THE MACEDONIAN QUESTION,

ESTABL ISH THE DILEMMAS ASSOCIATED WITH IT, AND SUGGEST A VIABLE SOLUTION. IT CONSIDERS GEOGRAPHICAL (IS MACEDONIA A NATURALLY DEFINED REGION? IS IT GEOGRAPHICALLY HOMOGENEOU AND ETHNONATIONAL (IS THERE AN ETHNIC GROUP THAT CAN BE FROM SEVERAL VIEWPOINTS INCLUDEING A GREEK, BULGARIAN,

"MACEDONIAN," SERBIAN, AND ALBIANIAN VIEHS.

03688 GIBBON, P.

A FAILED AGENDA? AFRICAN AGRICULTURE UNDER STRUCTURAL A FAILED AGENDA? AFRICAN AGRICULTURE UNDER STRUCTURAL JOURAAL OF PEASANT STUDIES, 20 (1) (OCT 92), 50-96.

ON THE BASIS OF A CLOSE EXAMINATION OF WORLD BANK AGRICULTURAL REFORM POLICIES IN KENYA AND GHANA IN THE 1980S, THE AUTHOR ARGUES THAT THE STRUCTURAL ADJUSTMENT AGENDA HAS BEEN EITHER ABORTED OR. WHERE IMPLEMENTED, HAS NOT HAD THE RESULTS INTENDED. IN BOTH CASES THIS IS BECAUSE THE ADJUSTMEMT PROBL. INATIC ASSUMES THE PRESEMCE OF STRUCTURES AND CONDITIONS AT VARIANCE TO AFRICAN REALITIES. AS A RESULT, THE MAIN BENEFICIARIES OF ADJUSTMENT TEND TO BE THE FORCES IT OSTENSIBLY SETS OUT TO SUBVERT. 
03689 GIBBOH, P.

THE WORLD BANK AND AFRICAN POVERTY, 1973-91

JOURNAL OF MODERN AFRICAN STUDIES, 30(2) (JUN 92), 193-220. SINCE 1987-8 THE WORLD BANK HAS ENGAGED IN A PROGRAM OF ACTIVITIES KNOWN AS "SOCIAL DIMENSIONS OF ADJUSTMENT." THIS IS THE LATEST IN A LIHE OF "PRO-POOR" INITIATIVES WHICH THE ORGANIZATION HAS SPONSORED OVER THE LAST THO DECADES THIS ARTICLE ANALYZES THE BANK'S SUCCESSION OF POLICIES AGAINST THE BACKGROUND OF THE CHANGING POLITICAL AND ECONOMIC WORLD SITUATION, AS WELL AS ALTERNATIVE POLICY AGENDAS

03690 GIBBONS, G.

THE MISSION THING

AMERICAN SPECTATOR, 24(5) (MAY 91), 15-16.

THOSE WHO DISMISSED GEORGE BUSH'S THREATS OF USING FORCE TO GET SADDAM HUSSEIN OUT OF KUHAIT AS BEING MERE BRAVADO AND BLUFF PAID LITTLE ATTENTION TO THE MAN OR HIS PERFORMANCE. HIS DETRACTORS IGNORED HIS EXPERIENCE AS A WORLD WAR II NAVY PILOT WHO LOST THO FRIENDS AND NARROWLY ESCAPED DEATH HIMSELF. MOREOVER, BUSH'S TWO-YEAR RECORD AS AMERICA'S LEADER SHOWED HIM TO BE A WARRIOR-PRESIDENT. THE AMERICA'S LEADER SHOWED HIM TO BE A WARRIOR-PRESIDENT. THE
INYASION OF PANAMA. THE USE OF U.S. FORCES TO EVACUATE INVASION OF PANAMA, THE USE OF U.S. FORCES TO EVACUATE AMERICAN FOR PHILIPPINE PRESIDENT CORAZON AOUINO ALL DEMONSTRATE HIS WILLINGNESS TO USE FORCE.

03691 GIBNEY, F.B.

THE PROMISE OF THE PACIFIC

WILSON QUARTERLY, XVI(1) (WIN 92), 64-75.

THE HUGE CHANGES, SOCIAL AND ECONOMIC, TAKING PLACE ALONG THE WESTERN SHORES OF THE PACIFIC AMOUNT TO MODERN ASIA'S JET-AGE VERSION OF THE INDUSTRIAL REVOLUTION. SUCH CHANGES ARE HAVING AN IMPACT ON THE UNITED STATES AND EUROPE COMPARABLE TO THE 19TH-CENTURY ASSAULT OF WESTERM COLONIALISM ON ASIA. MANY FORESEE THE COMING OF THE PACIFIC CENTURY, A NEW ERA OF PROSPERITY AND REGIONAL COOPERATION AMONG THE NATIONS BORDERING THE WORLD'S LARGEST BODY OF HATER.

03692 GIBNEY, M.

SUING FOR DEATH, SUFFERING, AND PEACE

HUAN RIGHTS QUARTERLY, 12(3) (AUG 90), 415-425.

IT IS A FACT OF INTERNATIONAL LIFE THAT NATIONS CONDUCT WARS AND PURSUE OTHER MILITARY AND FOREIGN POLICY OBJECTIVES WITHOUT GENERALLY HAVING TO ATTEND TO THE HUMAN CONSEQUENCES OF THEIR ACTIONS. THIS PREMISE HAS BEEN CHALLENGED RECENTLY BY TWO CASES BROUGHT IN U.S. COURTS. IN EACH CASE, CIVILIANS BY TWO CASES BROUGHT IN U.S. COURTS. IN EACH CASE, CIVILIANS
BROUGHT SUIT AGAINST OFFICIALS OF THE U.S. GOVERMMENT FOR BROUGHT SUIT AGAINST OFFICIALS OF THE U.S. GOVERNMENT FOR
THE HARM AND SUFFERING CAUSED BY THE U.S. SPONSORED CONTRA THE HARM AND SUFFERING CAUSED BY THE U.S. SPONSORED
REBEL FORCES. THE PLAINTIFFS IN EACH CASE ASKED WHAT REBEL FORCES. THE PLAINTIFFS IN EACH CASE ASKED WHAT
PREVIOUSLY HAD BEEN UNTHINKABLE: THAT A NATION BE HELD PREVIOUSLY HAD BEEN UNTHINKABLE: THAT A NATION BE HELD LEGALLY RESPONSIBLE FOR THE HUMAN CONSEQUENCES OF ITS
PURSUIT OF FOREIGN POLICY OBJECTIVES. THIS ARTICLE EXAMINES PURSUIT OF FOREIGN POLICY OBJECTIVES. THIS ARTICLE EXAMINES THE RATIONALE FOR THE JUDICIAL DEFERENCE DISPLAYED IN THE
CASES, AND OFFERS AN ALTERMATIVE WAY FOR THE COURTS TO CASES, AND OFFERS AN
ADORESS SUCH ISSUES.

03693 GIBSON, J.; CALDIERA, G

BLACKS AND' THE UNITED STATES SUPREME COURT: MODELS OF DIFFUSE SUPPORT

THE JOURNAL OF POLITICS, 54(4) (NOV 92), 1120-1148.

THE FOCUS OF THIS ARTICLE IS ON DIFFUSE SUPPORT FOR THE SUPREME COURT AND THE ATTENTION IS DIRECTED TOWARD AFRICAN AMERICANS, ONE OF THE MOST IMPORTANT MINORITIES IN AMERICAN POLITICS. THE AUTHORS OESCRIBE THE ATTITUDES OF THIS GROUP TOWARD THE SUPREME COURT AND COMPARE THEM TO THOSE OF WHITES AND ALSO OFFER AND TEST TWO COMPETING THEORETICAL ACCOUNTS OF SUPPORT IN THIS SEGMENT OF THE POPULATION. AN EXPLAINATION IS OFFERD FOR THE SIGNIFICANT PORTION OF THE SUPPORT AMONG BLACKS FOR THE COURT AND SOME SPECULATION ABDUT THE IMPLACTIONS OF WHAT HAS BEEN LEARNED ABOUT BLACKS AND THE COURT FOR THE BROADER QUESTION OF INSTITUTIONAL STABILTIY AND INSTABILTIY IS PRESENTED IN CONCLUSION.

03694 GIBSON, J.; DUCH, R.; TEDIN, K. DEMOCRATIC VALUES AND THE TRANSFORMATION OF THE SOVIET UNION

THE JOURMAL OF POLITICS, 54(2) (MAY 92), 329-371.

THE DEGREE TO HHICH THE CULTURAL PREREOUISITES TO DEMOCRACY ARE PRESENT IN THE COMTEMPORARY POLITICAL CULTURE OF THE USSR IS DETERMINED. THIS ARTICLE FOCUSES ON SUPPORT FOR CORE DEMOCRATIC RIGHTS, LIBERTIES, AND INSTITUTIONS. IT FOR CORE DEMOCRATIC RIGHTS, LIBERTIES, AND INSTITUTIONS.
FINDS SIGNIFICANT LEVELS OF ENDORSEMENT OF COMPETITIVE FINDS SIGNIFICANT LEVELS OF ENDORSEMENT OF COMPETITIVE
ELECTIONS AND FOR MANY DEMOCRATIC RIGHTS AND LIBERTIES. THE ELECTIONS AND FOR MANY DEMOCRATIC RIGHTS AND LIBERTIES. VALUES HERE EDUCATION, GENDER AND AGE. THE BETTER EDUCATED, VALUES WERE EDUCATION, GENDER AND AGE. THE BETTER EDUCA
MALES, AND THE YOUNG TENDED TO BE MORE SUPPORTIVE OF MALES, AND THE YOUNG TENDED TO BE MORE SUPPORTIVE OF
DEMOCRATIC INSTITUTIONS AND PROCESSES. THE AUTHORS TAKE DEMOCRATIC INSTITUTIONS AND PROCESSES. THE AUTHORS DEMOCRATIZE THE SOVIET UNION WILL NOT MEET RESISTANCE FROM SOVIET POLITICAL CULTURE.

03695 GIBSON, J.G.

MEASURING ELECTORAL CHANGE: LOOK BEFORE YOU ABANDON SHING
PS: POLITICAL SCIENCE AND POLITICS, XXY(2) (JUN 92), 195-198.

THE AUTHOR ADVISES POLITICAL SCIENTISTS TO REJECT RICHARD ROSE'S CALL TO ABANDON THE USE OF SWING IN THREE- OR MULTI-PARTY ELECTORAL CONTESTS. HE LOOKS AT THE ACTUAL PERFORMANCE OF SHING AND AT ROSE'S PROPOSED ALTERNATIVE MEASURE OF ELECTORAL CHANGE.

03696 GIBSON, J.G.; STEWART, J.D. POLL TAX, RATES, AND LOCAL ELECTIONS POLITICAL STUDIES, XL(3) (SEP 92), 516-531. THE 1990 LONDON LOCAL ELECTIONS PROVIDED A UNIQUE OPPORTUNITY TO ASSESS THE SENSITIVITY OF VOTERS TO THO LOCAL TAXES: DOMESTIC RATES AND POLL TAX. BOTH TAXES HAD AN IMPORTANT INFLUENCE ON VOTING BUT IN UNEQUAL PROPORTIONS ACCORDING TO PARTY INCUMBENCY PRIOR TO 1990. IN CONSERVATIVE BOROUGHS, SHING WAS SENSITIVE TO POLL-TAX LEVEL, BUT THIS WAS NOT TRUE IN LABOUR BOROUGHS. IN BOTH, SWING WAS SENSITIVE TO THE CHANGE IN AVERAGE LOCAL TAX LEVEL IN THE SWITCH FROM DOMESTIC RATES TO POLL TAX IN 1990. IN ADDITION, RATE INCREASES BETHEEN 1986 AND 1989 HAD A SUBSTANTIAL

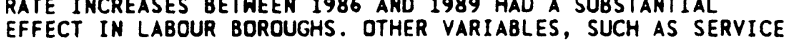
EFFECT IN LABOUR BOROUGHS. OTHER VARIABLES, SUCH AS SERVICE
LEVELS AND SOME BOROUGH-LEVEL ISSUES, ALSO CONTRIBUTED TO LEVELS AND SOME BOROUGH-LEVEL

03697 GIBSON, J.L.; DUCH, R.M.

ANTI-SEMITIC ATTITUDES OF THE MASS PUBLIC: ESTIMATES AND EXPLANATIONS BASED ON A SURVEY OF THE MOSCOW OBLAST PUBLIC OPINION QUARTERLY (CHICAGO), 56(1) (SPR 92), 1-28. THE AUTHORS EXAMINE ANTI-SEMITISM IN THE USSR AS REVEALED BY A SURVEY OF THE RESIDENTS OF THE MOSCOH OBLAST CONDUCTED IN 1990. THEY DISCOVER A SURPRISINGLY LOW LEVEL OF EXPRESSED ANTI-SEMITISM AMONG THE SOVIET RESPONDENTS AND VIRTUALLY NO SUPPORT FOR STATE POLICIES THAT DISCRIMINATE AGAINST JEWS. AT THE SAME TIME, MANY OF THE CONVENTIONAL HYPOTHESES PREDICTING ANTI-SEMITISM ARE SUPPORTED IN THE SOVIET CASE BECAUSE ANTI-SEMITISM IS CONCENTRATED AMONG THOSE WITH LOHER LEVELS OF EDUCATION, THOSE HHOSE PERSONAL FINANCIAL CONDITION IS DETERIORATING, AND THOSE WHO OPPOSE FURTHER DEMOCRATIZATION OF THE SOVIET UNION. WHILE THESE FINDINGS ARE NOT EVIDENCE THAT ANTI-SEMITISM IS A TRIVAL PROBLEM IN THE USSR, THEY SUGGEST THAT EFFORTS TO COMBAT ANTI-JEHISH MOVEMENTS WOULD LIKELY RECEIVE CONSIDERABLE SUPPORT FROM ORDINARY SOVIET PEOPLE.

03698 GIBSON, J.L.

THE POLITICAL CONSEQUENCES OF INTOLERANCE: CULTURAL CONFORMITY AND POL ITICAL FREEDOM

AMERICAN POL ITICAL SCIENCE REVIEW, 86 (2) (JUN 92), 338-356. CITIZENS INFLUENCES REAL POLITICS EVEN IF STRONG LINKAGES TO POLICY OUTPUTS DO NOT EXIST. HE TESTS A MODEL WHICH POSITS POLICY OUTPUTS DO NOT EXIST. HE TESTS A MODEL WHICH THAT CULTURAL INTOLERANCE CONSTRAINS THE LIBERTY OF POLITICAL FREEDOM, HE EXPLORES SEVERAL HYPOTHESES COUPLING POLITICAL FREEDOM, HE EXPLORES SEVERAL HYPOTHESES COUPLING TOLERANCE AND FREEDOM. DATA FROM A NATIONAL SURVEY SHOW THAT TOLERANCE AND FREEDOM ARE CONNECTED. THOSE WHO DO NOT FEEL FREE TO EXPRESS THEMSELVES POLITICALLY ARE MORE LIKELY TO BE INTOLERANT OF OTHERS, TO HAVE LESS HETEROGENEOUS PEER GROUP
AND LESS TOLERANT SPOUSES, AND TO LIVE IN LESS TOLERANT COMMUNITIES. ULTIMATELY, MASS POLITICAL INTOLERANCE IN THE UNITED STATES ESTABLISHES A CUL TURE OF CONFORMITY THAT SEEMS
TO CONSTRAIN INDIVIDUAL POLITICAL LIBERTY IN MANY IMPORTANT WAYS.

03699 GIDENGIL, E.

CANADA YÓTES: A QUARTER CENTURY OF CANADIAN NATIONAL ELECTION STUDIES

CANADIAN JOURNAL OF POLITICAL SCIENCE, XXV(2) (JUN 92), 219-249.

THIS REVIEW ESSAY EXAMINES THE CONTRIBUTION OF THE CANADIAN NATIONAL ELECTION STUDIES TO UNDERSTANDING VOTE CHOICE IN CANADA. ANALYSES USING BOTH THE SOCIOLOGICAL APPROACH AND THE SOCIAL-PSYCHOLOGICAL APPROACH ARE DISCUSSED. THE ESSAY STARTS WITH A REVIEW OF THE DEBATES ABOUT THE ROLE OF CLASS, REGION AND RELIGION IN CANADIAN VOTING AND THEN GOES ON TO DISCUSS THE APPLICABILITY OF THE CONCEPT OF PARTY IDENTIFICATION TO CANADA. AN EVALUATION OF BOTH RECURSIVE AND NON-RECURSIVE MODELS OF VOTE CHOICE FOLLOWS. THE REYIEH CALLS FOR SOCIAL PSYCHOLOGICAL APPROACHES TO TAKE THE SOCIAL CONTEXT OF POLITICAL CHOICE MORE SERIOUSLY AND POINTS TO THE NEED FOR SOCIOLOGICAL APPROACHED TO POINTS TO THE NEED FOR SOCIOLOGICAL APPROACHED TO

03700 GIGLIO, J.

PAST FRUSTRATIONS AND NEW OPPORTUNITIES: RESEARCHING THE KEMHEDY PRESIOENCY AT THE KEMMEDY IBRARY

PRESIDENTIAL STUDIES OUARTERLY, XXII(2) (SPR 92), 371-380. THIS ARTICLE RECOUNTS SOME OF THE INFORMATION FOUND IN NEWLY-AVAILABLE RECORDS AT THE JOHN F. KENNEDY MEMORIAL LIBRARY. WHITE HOUSE GATE LOGS CORROBORATE THE PREVIOUS ALLEGED VISITATIONS OF JUDITH CAMPBELL, MARY PINCHOT MEYER, ALSO CORROBORATE 34 VISITS OF DR. MAX JACOBSON BETWEEN APRIL 
1961 AND MAY 1962; JACOBSON LATER LOST HIS MEDICAL LICENSE FOR "UNPROFESSIONAL CONDUCT." RECENTLY RELEASED MEDICAL FILES REVEAL THE EXISTENCE OF A NUMBER OF SERIOUS MEDICAL PROBLEMS WHICH KENNEDY OVERCAME THROUGH "REMARKABLE HILL AND FORTITUDE." THE AUTHOR OF THE ARTICLE CONCLUDES BY CALLING FOR FULL DISCLOSURE OF ALL INFORMATION IN THE KENNEDY LIBRARY.

03701 GIGOT, P.

A GREAT AMERICAN SCREH-UP--THE U.S. AND IRAQ 1980-1990

NATIONAL INTEREST, (22) (WIN 91), 3-10.

THE U.S. RESPONSE TO ISRAEL' 'BOMBING OF A NUCLEAR FACILITY IN IRAQ IN 1981 WAS THE SYMBOLIC BEGINNING OF A DECADE OF AMERICAN MISJUDGMENT, CLIMAXING IN IRAQ'S INVASION OF KUWAIT ON 2 AUGUST 1990. FROM NUMEROUS INTERVIEWS AND THE AVAILABLE PUBLIC RECORD, THIS ARTICLE MAKES A FEW JUDGMENTS AVAILABLE PUBLIC RECORD, THIS ARTICLE MAKES A FEW JUDGMENTS
ABOUT THE U.S. POLICY TOWARDS IRAQ OVER THE PAST DECADE. IT ABOUT THE U.S. POLICY TOWARDS IRAQ OVER THE PAST DECADE. IT RIVALS DEAN ACHESON'S FAILURE TO INCLUDE KOREA IN THE U.S. RIVALS DEAN ACHESON'S FAILURE
COMTAINMENT PERIMETER IN 1950.

03702 GIL-HAR, Y.

DELIMITATION OF BOUNDARIES: TRANS-JORDAN AND SAUDI ARABIA MIDDLE EASTERN STUDIES, 28 (2) (APR 92), 374-384.

IN 1921, IN ORDER TO PRESERVE BRITISH INTERESTS, BRITISH POLICY-MAKERS WERE INDUCED TO ADOPT A POSITION ON THE DELIMITATION OF BOUNDARIES OF HER MIDOLE EAST MANDATED TERRITORIES. THE BRITISH DREW UP A SCHEME FOR FIXING NEW BOUNDARIES BETWEEN NAJD AND TRANS-JORDAN THAT WOULD REFLECT THE NEW POLITICAL AND MILTARY SITUATION IN THE AREA. THREE POTENTIAL THREATS TO GREAT BRITAIN IN THE MIDDLE EAST ARE DEFINED IN THIS ARTICLE, WHICH DESCRIBES THE NOVELTY CREATED IN THE GEOGRAPHICAL LANOSCAPE OF THE MIDOLE EAST CREATED BY THE SOUTHERN BOUNDARIES OF TRANS-JORDAN. THESE BOUNDARIES WERE CONCEIVED OF UNDER THE PRESSURE OF CURRENT EVENTS AND RELECTED THE CHANGES IN IDEAS ABOUT THE GEO-STRATEGIC IMPORTANCE FOR THE BRITISH OF THE MIDOLE EAST IN THE AFTERMATH OF THE FIRST WORLD WAR.

03703 GIL-HAR, Y.

THE SOUTH-EASTERN LIMITS OF PALESTINE AT THE END OF OTTOMAN RULE

MIDDLE EASTERN STUDIES, 28 (3) (JUL 92), 559-564.

THIS ESSAY IS AT VARIANCE WITH BRITISH SOURCES AND MODERN WRITINGS ON THE SUBJECT OF THE SOUTH-EASTERN LIMITS OF PALESTINE AT THE END OF OTTOMAN RULE. IT MAINTAINS THAT THE LIMITS OF THE OTTOMAN ADMINISTRATIVE DISTRICTS AND THEIR THE LIMITS OF THE OTTOMAN ADMINISTRATIVE DISTRICIS AND IMPACT ON THE MOULDING OF THE CULTURAL LANDSCAPE WERE DIFFERENT FROM THE PREVIOUSLY HELD CONSENSES. IT SUGGESTS
THAT BRITISH GEOGRAPHERS AND SOURCES WERE NOT UP-TO-DATE THAT BRITISH GEOGRAPHERS AND SOURCES WERE NOT UP-TO-DATE MISLED MODERN STUDENTS ABOUT THE HISTORICAL GEOGRAPHY OF PREMISLED MODERN

03704 GILBERT, A.

MUST GLDBAL POLITICS CONSTRAIN DEMOCRACY? REALISM, REGIMES AND DEMOCRATIC INTERNATIONALISM

POL ITICAL THEORY, 20(1) (FEB 92), 8-37.

REALISTS HAVE ENVISIONED INTERNATIONAL POLITICS AS A REALM OF POHER CLASHES, CHARACTERIZED BY STATE INTERESTS, YET IN INTERMATIONAL POLITICAL THEORY, A DEMOCRATIC INTERNATIONALIST CRITIOUE OF REALISM REGISTERS THE LONG-TERM EROSION OF THE JUSTIFICATION OF CONQUEST. THIS ARTICLE OFFERS A BRIEF VIEW OF THE HISTORY, SUBSTANCE, AND MOTIVATIONS OF DEMOCRATIC INTERNATIONALISM. IT SUGGESTS THAT THE SELF-REFUTINGNESS OF OFFICIAL REALISM YIELDS AN IMPORTANT EXPLANATORY ADVANTAGE TO DEMOCRATIC INTERNATIONALIST ALTERNATIVES. THE ARTICLE CONCLUDES THAT REALISTS MAY GRANT THAT GREAT POWER RIVALRY SIGNIFICANTLY CORRUPTS DOMESTIC FREEDOM; NEVERTHELESS, THEY INSIST, THE TESTIMONY OF MODERN HISTORY IS THAT IT MUST DO SO.

03705 GILBERT, C.

RELIGION, NEIGHBORHOOD ENVIRONMENTS AND PARTISAN BEHAVIOR: A CONTEXTUAL ANALYSIS

POLITICAL GEOGRAPHY QUARTERLY, 10(2) (APR 91), 110-131. DRAWING ON A DATA SET COLLECTED IN SOUTH BEND, INDIANA, DURING THE 1984 PRESIDENTIAL CAMPAIGN, THIS PAPER MEASURES AND CONSIDERS THE EFFECTS OF CHURCH CONTEXT AS WELL AS NEIGHBORHOOD CONTESTS, THIS ADDRESSING THO QUESTIONS: HOW DOES THE NEIGHBORHOOD ENVIRONMENT AFFECT MEMBERS OF DIFFERENT DENOMINATIONS AND RELIGIONS; AND TO HHAT EXTENT DIFFERENT DENOMINATIONS AND RELIGIONS; AND TO HHAT EXTENT
ARE INDIVIDUALS INFLUENCED BY CHURCH ENVIRONMENTS AS OPPOSED ARE INDIVIDUALS INFLUENCED BY CHURCH ENVIRONMENTS AS OPPOSED TO NEIGHBORHOOD ENVIRONMENTS? THE RESULTS INDICATE THAT THE
NEIGHBORHOOD ENVIRONMENT DOES HAVE DIFFERENTIAL EFFECTS FOR NEIGHBORHOOD ENVIRONMENT DOES HAVE DIFFERENTIAL EFF DIFFERENT DENOMINATIONS, ESPECIALLY IN REGARD TO
PARTISANSHIP, AND FURTHER SHOWS THAT CHURCH ENVIRONMENTS PARTISANSHIP, AND FURTHER SHOWS THAT CHURCH ENVIRONMENTS
PLAY AN IMPORTANT ROLE IN INFLUENCING INOIVIDUAL POLITICAL PLAY AN IMPORTANT ROLE IN INFLUENCING INOIVIDUAL POL
BEHAVIOR (VOTING), EVEN AFTER CONTROLLING FOR OTHER BEHAVIOR (VOTING), EVEN AFTER
INDIVIDUAL-LEVEL VARIABLES.

03706 GILBERT, G.

QUALITY IMPROVEMENT IN A FEDERAL DEFENSE ORGANIZATION PUBLIC PRODUCTIVITY \& MANAGEMENT REVIEW, XVI(1) (FAL 92),
65-76

THIS ARTICLE EXAMINES ONES OF THE MOST COMPREHENSIVE TOTAL QUALITY MANAGEMENT (TOM) IMPROVEMENT EFFORTS UNDERTAKEN TO DATE AT THE FEDERAL GOVERNMENT LEVEL. THE ORGANIZATION BASED SIGNIFICANT PARTS OF ITS TQM INITIATIVE ON CHANGING PERSONNEL RULES AND POLICIES TIED TO THE FEDERAL CIVIL SERVICE SYSTEM. THE NEED TO CHANGE AND THE ROLE OF THE HUMAN RESOURCES MANAGER IN TOM IN EXAMINED AS A CRITICAL PART OF THE QUALITY IMPROVEMENT PROCESS.

03707 GILDER, G.

STILL SEEKING A GLASS SLIPPER

NATIONAL REVIEW, XLIV(24) (DEC 92), 38-41.

THERE ARE REASONS, GOOD, BAD, AND NEUTRAL, WHY THERE ARE FEWER HOMEN THAN MEN AT THE TOP OF AMERICAN INSTITUTIONS.

THIS ARTICLE SUGGESTS THAT WOMEN WHO WANT TO SHATTER THE 'GLASS CEILING' HAD BETTER DO IT THE OLD FASHIONED WAY. WHEN COMPETING FOR TOP JOBS, WOMEN WILL NOT FACE AVERAGE MEN. WOMEN WILL HAVE TO EXCEL THE MEN WHOSE APTITUDES HAVE LED THEM TO SPECIALIZE IN THE PARTICULAR TASK AT HAND. WHAT WILL
MATTER IS WHETHER THEY ARE WILLING AND ABLE TO COMPETE NEAR MATTER IS WHETHER THEY ARE WILLING
THE TOP MALE LEVEL IN THEIR FIELD.

03708 GILDERBLOOM, J.I.; CAPEK, S.M.

SANTA MONICA A DECADE LATER: URBAN PROGRESSIVES IN OFFICE NATIONAL CIVIC REVIEW, 81(2) (SPR 91), 115-131.

KEY CHARACTERISTICS OF A HEALTHY COMMUNITY ARE THE AVAILABILITY OF DECENT, AFFORDABLE HOUSING; THE MAINTENANCE OF A HUMAN-SCALE URBAN ENVIRONMENT; AND FREEDOM FOR ALL MEMBERS TO PARTICIPATE MEANINGFULLY IN COMMUNITY LIFE. TEN YEARS AFTER LAUNCHING ITS URBAN PROGRESSIVE EXPERIMENT, SANTA MONICA, CALIFORNIA, HAS MADE SUBSTANTIAL PROGRESS TOWARD THESE GOALS.

03709 GILIOMEE, H.

CONFLICTING MODELS OF DEMOCRACY IN SA--COMPROMISE $V$. MAJORITY RULE

SOUTH AFRICA FOUNDATION REVIEH, 17(10) (OCT 91), 7. WITH THE PUBLICATION OF SOUTH AFRICA'S NATIONAL PARTY'S CONSTITUTIONAL PROPOSALS THE CONFLICT IN SOUTH AFRICA HAS FINALLY CRYSTALLIZED INTO TWO CONFLICTING MODELS OF DEMOCRACY CHALLENGING EACH OTHER. IN ESSENCE, THE AFRICAN DEMOCRACY CHALLENGING EACH OTHER. IN ESSENCE, THE AFRICAN
NATIONAL CONGRESS (ANC) IS PROPOSING THE GERMAN MODEL OF NATIONAL CONGRESS (ANC) IS PROPOSING THE GERMAN MODEL OF
MAJORITY RULE. THE NATIONAL PARTY (NP) HAS COUNTERED WITH MAJORITY RULE. THE NATIONAL PARTY (NP) HAS COUNTERED WITH
AN "AMICABLE AGREEMENT" MODEL SIMILAR TO THAT IN SHITZERLAND.
ALTHOUGH THE ANC IS LOATH TO CONSIDER ANYTHING LESS THAN ALTHOUGH THE ANC IS LOATH TO CONSIDER ANYTHING LESS THAM
MAJORITY RULE, IT SEEMS LIKELY THAT THEY WILL EVENTUALLY MAJORITY RULE, IT SEEMS LIKELY THAT THEY WILL EVENTUALLY ACCEPT A MODIFICATION OF THE NP PROPOSALS, ONE THAT WILL WITHOUT ANYONE DOMINATING IT.

03710 GILIOMEE, $H$.

MANDELA'S MES

NEW REPUBLIC, 207 (17) (OCT 92), 16-19.

FOR THOSE SYMPATHETIC TO THÉ AFRICAN MATIONAL CONGRESS IT HAS BECOME EVER MORE DIFFICULT TO UNDERSTAND ITS ZIGZAGGING COURSE AND INFURIATING INABILITY TO DEVELOP A COHERENT STRATEGY TO BECOME THE DOMINANT PARTY IN SOUTH AFRICA'S GOVERNMENT.

03711 GILIOMEE, H.

THE LAST TREK? AFRIKANERS IN TRANSITION TO DEMOCRACY SOUTH AFRICA INTERNATIONAL, 22(3) (JAN 92), 111-120. THE SOUTH AFRICAN NATIONAL PARTY'S (NP) ABANDONMENT OF APARTHEID AND ITS ACCEPTANCE OF NEGOTIAITONS WITH THE LIBERATION MOVEMENTS DID NOT OCCUR AS A FLASH OF NEW INSIGHT. IT WAS INSTEAD A DRAWN OUT PROCESS OF MORE THAN A DECADE WHICH FINALLY CULMINATED IN PRESIDENT DE KLERK'S DECLARATIONS BEFORE PARLIAMENT IN 1990 AND 1991. THE CAUSES UNDERLYING THE TRANSITION ARE THREE. FIRST, THERE WAS THE RECOGNITION OF A POWER BALANCE WHICH IN THE MEDIUM- TO LONGTERM MADE EXCLUSIVE AFRIKANER AND THE LARGER WHITE DOMINATION UNTENABLE. SECOND. THE DE KLERK LEADERSHIP NEITHER HAD THE RESOURCES NOR THE WILL TO PERSEVERE WITH EITHER CO-OPTATION OR REPRESSION IN THE FACE OF UNHAVERIMG RESISTANCE. FINALLY, ECONOMIC STAGNATION MADE IT IMPERATIVE RESISTANCE. FINALLY, ECONOMIC STAGNATION MADE IT IMPERATIVE
TO FIND AN ECONOMIC SOLUTION. THE NP NOW ADVOCATES A POWERTO FIND AN ECONOMIC SOLUTION. THE NP NOW ADVOCATES A POWER-
SHARING PLAN, WITH RESTRICTIONS ON ABSOLUTE MAJORITY RULE SHARING PLAN, WITH RESTRICTIONS ON ABSOLUTE MAJORITY
TOGETHER WITH THE PROTECTION OF MINORITIES, AND THE TOGETHER WITH THE PROTECTION OF MINORITIES, AND THE
PROJECTION OF THE NP AS A MULTI-RACIAL ALLIANCE WITH PROJECTION OF THE NP AS A MULTI-RACIAL ALLI IANCE WITH
SUFFICIENT SUPPORT TO REMAIN A VITAL PART OF THE POWER STRUCTURE. FOR THIS TO SUCCEED, HOWEVER, REQUIRES THE STRUCTURE. FOR THIS TO SUCCEED, HOWEVER, REQUIRES THE
RECONCILIATION OF AFRIKANER AND AFRICAN NATIONALISM.

03712 GILL, E.

MACINTYRE, RATIONALITY, \& THE LIBERAL TRADITION

POLITY, 24(3) (SPR 92) $433-458$

ALASDAIR MACINTYRE ARGUES THAT THE LIBERAL TRADITION LACKS STANDARDS OF RATIONAL JUSTIFICATION AND RELIES INSTEAD ON INTERMINABLE DEBATE. IN CRITIQUING MACINTRYRE'S VIEW, THIS ARTICLE CONTENDS THAT LIBERALISM IS NEITHER MARKED BY
MORE INTERMINABLE DEBATE THAN PREVIOUS TRADITIONS NOR IT IS MORE LACKING IN THE RESOURCES FOR RESOLVING SUCH DEBATE. INDEED, THE AUTHOR ARGUES THAT LIBERALISM MEETS MACINTYRE'S 
DESCRIPTION OF A TRADITION.

$03713 \mathrm{GILL}, \mathrm{R}$.

CURBING BEIJING'S ARMS SALES

ORBIS, 36(3) (SUM 92), 379-396.

AS CHINA EXPANDS ITS WEAPONS TRANSFERS TO INCLUDE A

GROWING HOST OF RECIPIENTS, THE DESIRABILITY OF CURBING

CHINESE ARMS EXPORTS HAS INCREASINGLY BEEN URGED IN

WASHINGTON. THE AUTHOR ARGUES THAT IN ORDER TO ACHIEVE THIS

END, ONE MUST FIRST UNDERSTAND WHAT THE PRC HAS BEEN DOING

IN THE ARMS MARKET AND WHAT IT IS CURRENTLY DOING. THIS

ARTICLE EXPLORES THESE AREAS AND CONCLLOES WITH AN ANALYSIS

OF WHAT MOTIVATES THE PRC TO DO WHAT IT DOES.

03714 GILLESPIE, R.

SPAIN: CENTRIFUGAL FORCES IN THE UNITED LEFT

JOURNAL OF COMMUNIST STUDIES, 8(4) (DEC 92), 306-311.

THE STRUGGLE FOR RENEWAL AMONG SPAIN'S COMMUNISTS AND THEIR ALLIES IS BEING UNDERMINED BY THE CENTRIFUGAL FORCES IN SPANISH POLITICS. RENEWAL EFFORTS IN SPAIN'S COMMUNIST IN SPANISH POLITICS. RENEWAL EFFORTS IN SPAIN'S COMMUNIST
PARTY ARE THREATENED BY REBELLION BY THE PERIPHERY AGAINST PARTY ARE THREATENED BY REBELLION BY THE PERIPHERY AGAINST
THE CENTER, ESPECIALLY IN KEY AREAS OF REGIONALLY BASED THE CENTER, ESPECIALLY IN KEY AREAS OF REGIONALLY-BASED
NATIONALISH, SUCH AS CATALONIA AND THE BASOUE COUNTRY. HERE NATIONALISH, SUCH AS CATALONIA AND THE BASQUE COUNTRY. THE REJECTION OF DEMOCRATIC CENTRALISM REPRESENTS A REPUDIATION NOT JUST OF AUTHORITARIAN CENTRALIZED PARTY MANAGEMENT BUT OF CONTROL FROM MADRID. WHAT HAS BECOME A
DISTINCTIVE FEATURE OF THE PROCESS OF RENEWAL HAS HAD THE DISTINCTIVE FEATURE OF THE PROCESS OF RENEWAL HAS HAD THE
UNFORTUNATE CONSEQUENCE OF UNDERMINING THE OVERALL RENEWAL EFFORT.

03715 GILLESPIE, R.

THIRTEENTH CONGRESS OF THE PCE: THE LONG GOODBYE JOURNAL OF COMMUNIST STUDIES, 8(2) (JUN 92), 165-172.

THE SPANISH COMMUNIST PARTY (PCE) HAS REJECTED CALLS FROM "RENOVADORES" TO DISSOLVE ITSELF INTO "THE UNITED LEFT" AND TRANSFORM THE LATTER INTO A POLITICAL PARTY. AT THE 13TH PARTY CONGRESS IN DECEMBER 1991, THERE WERE SOME MAJOR DEPARTURES FROM TRADITIONAL NORMS, BUT SPAIN'S COMMUNISTS PROVED TO BE IN NO DESPERATE HURRY TO MAKE THE TRANSITION TO POST-COMMUNISM.

03716 GILLESPIE, W.I.

TAX, BORROW AND SPEND: FINANCING FEDERAL SPENDING IN CANADA, 1867-1990

CARLETON UNIVERSITY PRESS, 1991, 347

THE AUTHOR OF THIS 8OOK USES HIS OWN DATABASE OF HISTORICAL REVENUE FIGURES AND PARLIAMENTARY BUDGET DEBATES HISTORICAL REVENUE FIGURES AND PARLIAMENTARY BUDGET DEBATES SINCE CONFEDERATION HITHIN A CAMPREHENSIVE POSITIVE THEORY HIS MODEL IS A VARIANT OF THE CLASSICAL ECONOMIC THEORY OF HIS MODEL IS A VARIANT OF THE CLASSICAL ECONOMIC THEORY OF
COMPETITIVE FIRMS AND UTILITY-MAXIMIZING CONSUMERS. SURVIVAL IN A COMPETITIVE POL ITICAL MARKET CAUSES GOVERNMENTS TO SELECT A SET OF TAXES TO SATISFY TAXPAYERS HUNGRY FOR PUBLIC GOOOS WHO ARE LIKELY TO OPPOSE ANY TAX FALLING ON THEM RATHER THAN THEIR NEIGHBOR. AS EXTERNAL FACTORS AFFECT THE POL ITICAL COST CURVES OF THE COMPONENTS OF THE EXISTING TAX STRUCTURE, GOVERNMENTS RESPOND BY CHAMGING THE MIX OF TAXES AND THE BALANCE BETWEEN TAXING AND BORROWING UNTIL TOTAL COST IS MINIMIZED. WHAT EMERGES FROM HIS THEORY AND ANALYSIS ARE RECURRING REGULARITIES: THE PRIMORDIAL AND PERIODIC RETURN TO DEFICIT FINANCING, THE CONCERN FOR THE NATIONAL CREDIT RATING. THE EVER-PRESENT NEED TO TAKE ACCOUNT OF HORI ZONTAL TAX COMPETITION FROM THE UNITED STATES. THE IMPORTANCE OF "EQUITABLE" TAXES, AND THE EXCHEOUER-SAVING ROLE OF CONSUMPTION TAXES DURING DEPRESSION. FINALLY, HIS ANALYSIS OF THE TAX REFORH ERA OF THE PAST 25 YEARS POINTS TO THE CONCLUSION THAT THE REFORMERS HERE MORE SUCCESSFUL THAN PREYIOUS ANALYSTS WOULD ALLOW.

03717 GILLESSEN, G.

EUROPE CONFRONTED WITH A MORAL DILEMMA IN THE BALKANS GERMAN TRIBUNE, (1528) (AUG 92), 1.

THE AUTHOR LOOKS AT THE RESPONSE OF THE EUROPEAN COMMUNITY AND THE UNITED NATIONS TO THE FIGHTING IN YUGOSLAVIA.

03718 GILLESSEN, G.

THE QUEEN IN GERMANY FOR HER THIRD STATE VISIT

GERMAN TRIBUNE, 31 (1537) (OCT 92), 1-2

THROUGH QUEEN ELIZABETH'S VISIT TO GERMANY, THE GUEST AND HER HOSTS WILL DEMONSTRATE MUTUAL RESPECT. WHAT WILL AND HER HOSTS WILL DEMONSTRATE MUTUAL RESPECT. WHAT WILL BECOME OF EUROPE AND ATLANTIC COHESION DEPENDS ON THE FRANCE, BRITAIN, AND GERMANY. THE CONTRAST HITH THE FRANCDFRANCE, BRITAIN, AND GERMANY. THE CONTRAST HITH THE FRANCDGERMAN RELATIONSHIP UNDERLINES WHAT BRITAIN AND GERMANY
FAILED TO ACHIEVE. GERMAN POLICIES COULD FOSTER BRITISH RELATIONS MORE CONTINUOUSLY, PATIENTLY AND ATTENTIVELY THAN THEY HAVE BEEN DOING.

03719 GILLESSEN, G.

THE QUEEN ON AN HISTORIC MISSION OF RECONCILIATION

GERMAN TRIBUNE, 31(1538) (OCT 92), 1;6

MANY GERMANS FEEL THAT THE POST-WAR ERA OF ANGLO-GERMAN

RELATIONS IS DRAWIMG TO A CLOSE AND THAT THE TIME HAS COME
FOR A COMING TOGETHER. GERMANY FELT THAT IT MUST ARRANGE THE BRITISH QUEEN'S VISIT TO DRESDEN IN SUCH A WAY THAT THERE COULD BE NO WAY OF MISUNDERSTANDING IT IN BRITAIN. SHE MUST AVOID SEEHING TO MAKE PENANCE YET BRING ABOUT A

RECONCILIATION. THIS WAS RESOLVED BY THE FACT THAT QUEEN ELIZABETH WAS SIMPLY THERE IN DRESDEN AND ATTENDED DIVINE SERVICE IN A CHURCH WHICH WAS REBUILT AFTER BEING DESTROYED BY ALLIED BOMBERS DURING THE WAR.

03720 GILLESSEN, G.

1991, A YEAR SHAPED BY A TRIO OF EVENTS

GERMAN TRIBUNE, 1498 (JAN 92), 1, 4.
THIS ARTICLE STATES THAT MEMORIES OF 1991 ARE DOMINATED BY THREE THINGS: THE GULF WAR, THE FAILED COUP D'ETAT IN MOSCOW AND THE BLOODSHED IN CROATIA. SOME WONDER WHETHER THE GULF HAR WAS WORTH THE EFFORT AND THE SACRIFICE. THE BLOOD TOLL WAS HIGH, EVEN THOUGH WESTERN TECHNOLOGY ENSURED THAT MOST OF IT WAS PAID BY THE AGGRESSOR. THE ARTICLE DISCUSSES MOST OF IT WAS PAID BY THE AGGRESSOR. THE ARTICLE DISCUSSES THESE THREE

03721 GILLIOM, J.

RIGHTS \& DISCIPLINE: COMPETING MOOES OF SOCIAL CONTROL IN THE FIGHT OVER EMPLOYEE DRUG TESTING

POLITY, 24(4) (SUM 92), 591-614.

CONFLICTS OVER EMPLOYEE DRUG TESTING PROGRAMS ARE RELATED TO THE COEXISTENCE OF COMPETING DISCOURSES OF SOCIAL CONTROL: (1) A JURIDICAL DISCOURSE OF CRIME AND PUNISHMENT WHICH EMPHASIZES CITIZEN RIGHTS THAT LIMIT STATE SURVEILLANCE, AND (2) A DISCIPLINARY ORIENTATION THAT STRIVES TO PREVENT AND ELIMINATE CRIME THROUGH SUSTAINED SURVEILLANCE AND CONTROL. THE AUTHOR REVIEWS RECENT SUPREME COURT DRUG TESTING DECISIONS AND ARGUES THAT THE COURT ADOPTS THE SECOND PERSPECTIVE.

03722 GILLROY, J.

PUBLIC POLICY AND ENVIRONMENTAL RISK

ENVIRONMENTAL ETHICS, 14(3) (FAL 92), 217-238.

THAT ENVIRONMENTAL RISK IS A STRATEGIC SITUATION THAT

PLACES THE INDIVIDUAL CITIZEN IN THE POSITION OF AN IMPRISIONED RIDER WHO IS BEING EXPLOITED WITHOUT HIS OR HER KNOWLEDGE BY THE PREFERENCES OF OTHERS IS ARGUED. THE AUTHOR CONTENDS THAT WHAT IS AT STAKE IN POLICY DECISIONS REGARDING ENVIRONMENTAL RISK IS RESPECT FOR THE HUMAN AGENCY OF THE ENVIRONMENTAL RISK IS RESPECT FOR THE HUMAN AGENCY OF THE
INDIVIDUAL. HE SUGGESTS THAT THE GUIDELINES FOR EVALUATIOM INDIVIDUAL. HE SUGGESTS THAT THE GUIDELINES FOR EVALUAT AND JUSTIFICATION OF POLICY SHOULD MOVE BEYOND WELFARE
PREFERENCES AND INVOLVE AN ACTIVE STATE PROTECTING HUMAN AGENCY AND EMPOWERING THE IMPRISIONED RIDER. ONLY IN THIS WAY CAN WE FREE ALL CITIZENS FROM FEAR OF EXPLOITATION.

03723 GILLROY, J.M.

THE ETHICAL POVERTY OF COST-BENEFIT METHODS: AUTONOMY, EFFICIENCY, AND PUBLIC POLICY CHOICE

POLICY SCIENCES, 25(2) (MAY 92), 83-102.

THIS ESSAY HAS FOUR BASIC ASSUMPTIONS: (1) EFFICIENCY, OUTSIDE THE MARKET CONTEXT, HAS TWO MANIFESTATIONS (COSTEFFECTIVENESS ANALYSIS AND COST-BENEFIT METHODS) THAT ARE DISTINGUISHED BY CONCENTRATION ON JUDGING THE MOST COSTEFFECTIVE MEANS TO POLICY ENDS OTHERWISE ARRIVED AT OR THE USE OF EFFICIENCY TO JUDGE BOTH THE MEANS AND END OF POLICY CHOICE. (2) ALTHOUGH EFFICIENCY IS A FIT PRIMARY DECISION STANDARD WITHIN A COMPETITIVE MARKET, A PRIMCIPLE WITH MORE DISTINCTLY MORAL WEIGHT IS NEEDED TO JUDGE ENDS IN OTHER CONTEXTS. (3) ONE POSSIBLE SOURCE OF THIS MORAL WEIGHT IS INDIVIDUAL AUTONOMY OR FREEDOM. (4) THE USE OF COST-BENEFIT METHODS RATHER THAN COST-EFFECTIVENESS IMPLIES THAT IT CAN SATISFY THE REQUIREMENTS OF BOTH EFFICIENCY AND AUTONOMY. IF THE EFFICIENT POLICY CHOICE ALSO PROVIDED PROTECTION OF INDIVIDUAL AUTONOMY, THEN COST-BENEFIT METHODS COULD BE USED FOR THE ANALYSIS OF PUBLIC POLICY ENDS; BUT IF IT FAILS TO HAVE A DEEPER MORAL JUSTIFICATION, THEN THE ROLE OF EFFICIENCY IN THE PUBLIC SECTOR MUST BE LIMITED ONLY TO ITS JUDGMENT OF COST-EFFECTIVE MEANS TO POLICY ENDS ARRIVED AT BY A NON-EFFICIENCY STANDARD. THE AUTONOMY OF INDIYIDUAL CHOICE IN A MARKET IS A THIN AND MORALLY IMPOYERISHED ETHICAL STANDARD OF JUDGMENT THAT ADOS NO MORAL WEIGHT TO MARKET EFFICIENCY FOR THE JUDGMENT OF POLICY ENDS.

03724 GILPIN, R.

THE LOST TRIBES

WEST AFRICA, (3908) (AUG 92), 1348

SINCE MARCH 1991 LIBERIA'S CIVIL WAR HAS BEEN SPILLING ACROSS THE BORDER INTO SIERRA LEONE, WITH TROOPS USING IT AS A BASE FOR CROSS-BORDER RAIDS. LIBERIAN REBELS CLAIM THAT THEY ARE OPERATING IN THE NEIGHBORING COUNTRY BECAUSE SIERRA LEONE'S GOVERMMENT HAS SUPPORTED AND HARBORED THEIR ADVERSARIES. THE REBEL INCURSION HAS OISPLACED THOUSANDS OF PERSONS AND PRODUCED CHRONIC FOOO SHORTAGES IN AN AREA WHERE THE FOOD SUPPLY IS OFTEN UNCERTAIN. SIERRA LEONE'S GOVERMMENT MUST TAKE FIRM ACTION TO DEAL WITH BOTH THE LIBERIANS AND THE FOOD SUPPLY PROBLEMS.

03725 GILSON, R.J.

THE POLITICAL ECOLOGY OF TAKEOYERS: THOUGHTS ON 
HARMONIZING THE EUROPEAN CORPORATE GOVERNANCE ENVIRONMENT FORDHAM LAW REVIEW, LXI(1) (OCT 92), 161-192.

PART I OUTLINES A SIMPLE MODEL OF THE ECONOMIC FUNCTION OF CORPORATE TAKEOVERS AS AN EQUILIBRATING MECHANISM THAT TAKES EFFECT WHEN ENVIRONMENTAL CHANGE ALTERS THE EFFICIENT BOUNDARY OF THE FIRM. PART II DESCRIBES THE POLITICAL ECOLOGY OF TAKEOVERS IN THE UNITED STATES DURING THE $1980^{\prime} \mathrm{s}$. RECENT EMPIRICAL STUDIES ARE USED TO DEMONSTRATE HOW THE ECONOMIC, CORPORATE GOYERNANCE AND POL ITICAL ENYIRONMENTS INFLUENCE ACOUISITION TECHNIQUES. PART III DRAWS ON DEVELOPMENTS IN THE ECOLOGY OF NATURAL SYSTEMS TO HIGHLIGHT DEVELOPMENTS IN THE ECOLOGY OF NATURAL SYSTEMS TO HIGHLIGHT THE SINGLE DOMINANT CHARACTERISTIC OF THE POLITICAL OF TAKEOVERS--CONSTANT AND PERVASIVE CHANGE. THIS
CHARACTERISTIC SUGGESTS THE MUTABILITY PRINCIPLE AS AN CHARACTERISTIC SUGGESTS THE MUTABILITY PRINCIPLE AS AN
ORGANIZING PRINCIPLE FOR HARMONIZING EUROPEAN TAKEOVER LAH. ORGANIZING PRINCIPLE FOR HARMONIZING EUROPEAN TAKEO
PART IV UTILIZES AN ECOLOGICAL PERSPECTIVE AND THE PART IV UTILIZES AN ECOLOGICAL PERSPECTIVE AND THE MUTABILITY PRINCIPLE TO COMMENT ON CURRENT EFFORTS TO HARMONIZE EUROPEAN TAKEOVER LAW AND OFFERS A SOMENHAT DIFFERENT, ALBEIT POLITICALLY NAIVE, APPROACH. PART $V$ ANTICIPATES THO OBJECTIONS TO A MUTABILITY-BASED APPROACH TO HARMONIZATION, NAMELY THAT THE MUTABILITY PRINCIPLE IS ONLY THE BRITISH MODEL IN DISGUISE AND THAT IT OPERATES TO RESTRICT BENEFICIAL REGIMES OF IMPLICIT CONTRACTS.

03726 GIMENEZ, M.

U.S. ETHNIC POLITICS: IMPLICATIONS FOR LATIN AMERICANS LATIN AMERICAN PERSPECTIVES, 19(75) (FAL 92), 7-17. THE AUTHOR REVIEWS SOME OF THE THEORETICA

METHODOLOGICAL, AND POLITICAL PROBLEMS ENTAILED BY THE USE OF THE LABELS--ASIANS, BLACKS, AND HISPANICS. THE MAIN FOCUS IS THE OBJECTIVE IMPLICATIONS OF THE HISPANIC LABLE FOR LATIN AMERICANS WHO IMMIGRATE TO OR VISIT THE UNITED STATES, IT IS HER CONTENTION THAT THIS LABEL HAS NEGATIVE SOCIAL AND POLITICAL CONNOTATIONS THAT ARE IMPORTANT FOR AN ASSESSMENT OF THE SOCIAL POL ITICAL. AND SCIENTIFIC USEFULNESS OF THIS AND OTHER RACIAL LABELS FOR CLASSIFYING THE U.S. POPULATION.

03727 GIMSON, A.

A NICE PLACE TO VISIT..

NATIONAL REVIEW, XLIV(5) (MAR 92), 22-24.

TROUBLES HAVE HEATED UP IN NORTHERN IRELAND. THIS

ARTICLE LOOKS AT THE DOWNSIDE OF THE QUEST FOR PEACE.

PROSPECTS OF UNIFICATION BETWEEN THE THO IRELANDS SEEM SLIM, CLAIMS THE ARTICLE. THE NATIONALISTS, UNIONISTS, AND THE IRA ARE ALSO DISCUSSED.

03728 GINTIS, H.

NEH ECONOMIC RULES OF THE GAME

CHALLENGE 35 (5) (SEP 92 ) $47-53$

THROUGHOUT MUCH OF THE 20TH CENTURY, ECONOMIC POLICY HAS SPLIT ALONG POLITICAL LINES, CONSISTING OF A CONSERVATIVE RIGHT FAVORING UNFETTERED MARKET COMPETITION AND A

PROGRESSIVE LEFT FAVORING STATE CONTROL OF ECONOMIC ACTIVITY. THE PAST 12 YEARS HAVE BEEN CRUEL TO THE LEFT, BUT THE COLLAPSE OF THE LEFT IS CAUSING SERIOUS PROBLEMS FOR THE RIGHT AS WELL, SINCE A PRISTINE DEFENSE OF "LAISSEZ FAIRE" HAS ALWAYS BEEN LITTLE MORE THAN A CALL TO ARMS AGAINST THE WELFARE STATE AND THE ENEMIES OF PRIVATE PROPERTY. WITH THE DEFEAT OF THE LEFT AND WITH THE RIGHT IN FULL CONTROL OF ECONOMIC POLICY. THE ONE-SIDEDNESS OF THEIR ECONOMIC ANALYSIS HAS BECOME CLEAR. INDEED, THE TRADITIONAL MARKET VS. STATE OPPOSITION MAY NOT SURVIVE THE 2OTH CENTURY, SINCE MARKET AND STATE ARE, IN FACT, COMPLEMENTARY RATHER THAN ALTERNATIVE POLICY INSTRUMENTS'

03729 GIRMA, M.

MACROPOL ICY AND THE ENYIRONMENT: A FRAMEWORK FOR ANALYSIS WORLD DEVELOPMENT, 20(4) (APR 92), 531-540.

MACROECONOMIC AND PROGRAM POLICYMAKERS ARE NOT WELL EQUIPPED WITH ANALYTICAL METHODS FOR ASSESSING THE ENVIRONMENTAL EFFECTS OF THEIR RECOMMENDATIONS AND ACTIONS. THIS PAPER PROPOSES A FRAMEWORK FOR EXAMINING MACROPOLICY EFFECTS ON INCENTIVES AND CONSTRAINTS IN THE ENVIRONMENTAL SECTOR AND AN APPROACH FOR ADAPTING POL ICY COST-BENEFIT SECTOR AND AN APPROACH FOR ADAPTING POLICY COST-BENEFIT
ANALYSIS TO INCORPORATE SUSTAINABILITY CONCERNS. THE AUTHOR ANALYSIS TO INCORPORATE SUSTAINABILITY CONCERNS. THE AUT
CONSTRUCTS A SIMPLE MODEL AND USES IT TO SHOW HOW THE CONSTRUCTS A SIMPLE MODEL AND USES IT TO SHOW HOW THE
ENVIRONMENT MAY BE INCORPORATED AS A SECTOR OF THE MACROECONOMY. AGGREGATE DEMAND POLICY, SECTORAL POLICY, AND MACROECONOMY. AGGREGATE DEMAND POLICY, SECTORAL POLICY, AND
DISTRIBUTIONAL ISSUES ARE EXAMINED WITHIN THE CONTEXT OF DISTRIBUTIONAL ISSUES
THIS SIMPLE MODEL.

03730 GIRNIUS, $S$.

ARMENIA, AZERBAIJAN, AND GEORGIA

RFE/RL RESEARCH REPORT, 1(39) (OCT 92), 74-76.

OVER THE PAST FEW YEARS, OPPOSITION GROUPS IN ARMENIA AND AZERBAIJAN HAVE BEEN ABLE TO PUBLISH INDEPENDENT NEWSPAPERS WITH LITTLE INTERFERENCE FROM THE STATE, BUT THERE HAS BEEN SYSTEMATIC CENSORSHIP AND HARASSMENT IN GEORGIA. IN ALL THREE STATES, WOULD-BE PUBLISHERS OF INOEPENDENT NEWSPAPERS ARE STRUGGLING DUE TO FINANCIAL CONSTRAINTS.

03731 GIRNIUS, $S$.

LIHTUANIA: A BLOODY STRUGGLE
RFE/RL RESEARCH REPORT, 1(1) (JAN 92), 57-60.

THE SOVIET ARMED FORCES PLAYED A MAJOR ROLE IN SHAPING EVENTS IN LITHUANIA IN 1991. UNTIL THE FAILED HARDLINER COUP IN MOSCOW IN AUGUST, THE PRESENCE OF SOVIET TROOPS WAS A REMINDER THAT THE LITHUANIAN AUTHORITIES DID NOT HAVE CONTROL OF THE TERRITORY AND THAT THE KREMLIN HAD A POWERFUL FORCE AT ITS DISPOSAL. AFTER THE FAILED COUP, LITHUANIA WAS ABLE TO REGAIN ITS INDEPENDENCE.

03732 GIRNIUS, $S$.

LITHUANIA

RFE/RL RESEARCH REPORT, 1(27) (JUL 92), 67-69.

LITHUANIA'S BITTER DEBATE ON A NEW CONSTITUTION HAS SHARPENED DIVISIONS IN THE PARLIAMENT AND CREATED WIDESPREAD POLITICAL DISENCHANTMENT AMONG THE POPULATION. IT WAS HOPED POLIT THE OUESTION OF WHETHER THE COUNTRY SHOULD BE A PARLIAMENTARY OR A PRESIDENTIAL DEMOCRACY WOULD BE SETTLED PARLIAMENTARY OR A PRESIDENTIAL DEMOCRACY WOULD BE SETTLED WHEN APATHY AMONG THE ELECTORATE RENDERED THE VOTE INCONCLUSIVE. IT DOES NOT SEEM LIKELY THAT ANY AGREEMENT CAN INCONCLUSIVE. IT DOES NOT SEEM LIKE
BE REACHED SOON ON THIS QUESTION.

03733 GIRNIUS, $S$.

LITHUANIA FACES GREATER UNEMPLOYMENT

RFE/RL RESEARCH REPORT, $1(9)$ (FEB 92), 38-41.

LITHUANIA IS FACING GREATER UNEMPLOYMENT DUE TO THE PRIVATIZATION OF STATE-OHNED ESTABLISHMENTS AND THE DIFFICULTIES IN OBTAINING FUEL AND OTHER RAN MATERIALS FROM THE FORMER SOVIET REPUBLICS. EMPLOYEES OF SMALL SHOPS HAVE BEGUN A STRIKE TO PROTEST THE SALE OF THEIR BUSINESSES IN PRIVATIZATION AUCTIONS BECAUSE THEY FEAR CLOSURE UNDER NEW OWNERSHIP. THE LITHUANIAN PARLIAMENT HAS PASSED LAWS GRANTING HORKERS LONG VACATIONS AND LARGE COMPENSATION PAYMENTS FOR SEVERANCE, WHICH SEEMS INAPPROPRIATE IN VIEW OF THE PROJECTED RISE IN UNEMPLOYMENT.

03734 GIRNIUS, $S$

LITHUANIA SETS AMBITIOUS GOALS

RFE/RL RESEARCH REPORT, 1(17) (APR 92), 67-72.

ACCORDING TO PRIME MINISTER GEDIMINAS VAGNORIUS, PRIVATIZATION IN LITHUANIA IS PROCEEDING AS PLANNED AND AT A FASTER PACE THAN IN MANY OTHER FORMER SOVIET REPUBLICS. THE GOVERMMENT HAS PROVIDED INVESTMENT VOUCHERS TO BE USED FOR GOVERNMENT HAS PROVIDED INVESTMENT VOUCHERS TO BE USED FOR FOREIGN INVESTMENT IS LAGGING AND IS UNLIKELY TO INCREASE UNTIL THE LANS ARE AMENDED AND THE BANKING SYSTEM IS UNTIL THE LAHS

03735 GIRNIUS, $S$

LITHUANIA'S SAJUDIS DECLINES BUT PARTIES REMAIN WEAK RFE/RL RESEARCH REPORT, 1(15) (APR 92), 8-12.

ALTHOUGH SAJUDIS SOUNDLY DEFEATED THE LITHUANIAN COMMUNIST PARTY IN THE 1990 PARLIAMENTARY ELECTIONS, IT HAS SINCE LOST MUCH OF ITS INFLUENCE AND NO OTHER STRONG PARTY HAS EMERGED TO TAKE ITS PLACE. IN VIEW OF THIS, SOME OF THE PARLIAMENTARY FUNCTIONS NORMALLY PERFORMED BY PARTIES ARE BEING CARRIED OUT BY SMALL FACTIONS. IN ADDITION, THE LACK OF A CLEAR DEMARCATION BETHEEN THE POWERS OF THE PARLIAMENT AND THOSE OF THE GOVERMMENT HAS PRODUCED CONFUSION AND CALLS FOR THE CREATION OF A STRONG PRESIDENCY.

03736 GIRNIUS, $S$

LITHUANIAN SUPREME COUNCIL APPROVES CARETAKER CABIMET RFE/RL RESEARCH REPORT, 1(32) (AUG 92), 7-10.

THE LITHUANIAN SUPREME COUNCIL PASSED A VOTE OF MO CONFIDENCE IN PRIME MINISTER GEDIMINAS VAGNORIUS ON JULY 14 , 1992. AND LATER ELECTED ALEKSANDRAS ABISALA AS HIS REPLACEMENT ON JULY 23 AND 30. THE PARLIAMENT APPROVED THE APPOINTMENTS TO THE NEW PRIME MINISTER'S CABINET. HOWEVER, IT IS UNLIKELY THAT THE CHANGE OF GOVERMMENT WILL HELP BREAK THE DEADLOCK IN THE SUPREME COUNCIL BEFORE THE OCTOBER PARLIAMENTARY ELECTIONS.

03737 GIRNIUS, S.

PROGRESS IN WITHDRAWAL OF TROOPS FROM LITHUANIA?

RFE/RL RESEARCH REPORT, 1(34) (AUG 92), 29-33.

RUSSIAN PRESIDENT BORIS YELTSIN'S OFFER TO HITHDRAW FORMER SOVIET MILITARY PERSONNEL FROM THE BALTIC STATES BY FORMER SOVIET MILITARY PERSONEL FROM THE BALTIC STATES BY
MID-1993 WAS A SHARP CHANGE IN POLICY. FOR MORE THAN NINE
MONTHS, LITHUANIA'S EFFORTS TO SPEED UP THE HITHDRAHAL OF MONTHS, LITHUANIA'S EFFORTS TO SPEED UP THE HITHDRAHAL OF
THE TROOPS FROM ITS TERRITORY HAD BEEN UNSUCCESSFUL. DEMANDS THE TROOPS FROM ITS TERRITORY HAD BEEN UNSUCCESSFUL. DEMAND THAT THEY DEPART BY THE END OF 1992 HAD BEEN REJECTED
RUSSIAN OFFICIALS, WHO ASSERTED THAT EVEN IF SUITABLE

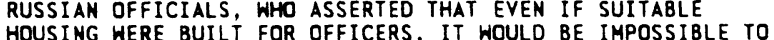
COMPLETE THE PROCESS SO QUICKLY.

03738 GIRNIUS, S.

THE PARLIAMENTARY ELECTIONS IN LITHUANIA

RFE/RL RESEARCH REPORT, $1(48)$ (DEC 92), 6-12.

ON OCTOBER 25 AND NOVEMBER 15, 1992, LITHUANIAN VOTERS WENT TO THE POLLS TO ELECT A NEH PARL IAMENT. THE UNEXPECTED WINNER WAS THE LITHUANIAN OEMOCRATIC LABOR PARTY--THE FORMER COMMUNIST PARTY OF LITHUANIA-WHICH CAPTURED 73 OF 141 SEATS.

LITHUANIA'S DETERIORATING ECONOMIC SITUATION--WHICH HAS 
PRODUCED SHORTAGES OF GAS, HEATING FUELS, AND HOT WATER DURING AN UNSEASONABLY COLD AUTUMN--APPEARS TO HAVE CONVINCED MANY LITHUANIANS TO SUPPORT THE FORMER COMMUNISTS AND THEIR POPULAR LEADER, ALGIRDAS BRAZAUSKAS, IN HOPES THAT HE WILL BE ABLE TO BARGAIN MORE EFFECTIVELY WITH RUSSIA. THE DEFEAT OF THE CENTER-RIGHT PARTIES, MOST NOTABLY THE SAJUDIS COALITION, MAY ALSO HAVE STEMMED FROM HIDESPREAD PUBLIC DISSATISFACTION WITH ECONOMIC REFORM.

03739 GITLIN, T.

A TALE' OF TWO MORAL PRISM

TIKKUN, 6(1) (MAR 91), 31-34,82-83.

THIS ARTICLE EXPLORES THE FIRST FALTERING ATTEMPTS OF THE PRESS IN CZECHOSLOVAKIA TO BALANCE THE DEMANDS OF FREEDOM OF THE PRESS WITH THE NECESSITY OF RESPONSIBILITY. A KEY ISSUE IS A LIST OF SOME 140,000 NAMES OF PEOPLE WHO WERE PAST INFORMERS OR COLLABORATORS FOR THE SECRET POLICE. WHILE MANY (IN NOT MOST) AMERICAN JOURNALISTS HOULD POINT TO THEI TRADITION OF RESISTING PRIOR RESTRAINT AS JUSTIFICATION FOR THE LIST'S PUBLICATION, MANY CZECHOSLOVAK JOURNALISTS FEEL OTHERHISE. EMPHASIZING THE NEED FOR MORAL AS WELL AS LEGAL RESPONSIBILITY, MOST ARGUE THAT THE LIST, WHICH CERTAINLY
CONTAINS THE NAMES OF PEOPLE OF VARYING COMPLICITY AND GUILD, SHOULD BE KEPT SECRET.

03740 GITLIN, T.

THE BUREAUCRACY THAT FAILED: BORIS KAGARLITSKY ON THE SOVIET QUAGMIRE

TIKKUN, 6(4) (JUL 91), 11-15, 84

THIS ARTICLE IS AN INTERVIEH WITH A LEADER OF THE SOVIET DISSIDENT LEFT, BORIS KAGARLITSKY. HE DISCUSSES THE CHANGES THAT HAVE SWEPT ACROSS THE SOVIET UNION, THE SOCIAL BASIS OF BOTH THE FORCES FOR CHANGE AND THE FORCES THAT HAVE REACTED TO IT, AND THE LASTING LEGACY OF GOVERMMENT BUREAUCRATIC STRUCTURE. HE ALSO DISCUESS THE ROLE OF BORIS YELTSIN, ARGUING THAT YELTSIN AND MANY LIKE HIM DERIVE THEIR

LEGITIMACY FROM THEIR POSITIONS WITHIN THE VERY SYSTEM THAT THEY ARE PLANNING TO SUBVERT. KAGARLITSKY ALSO DISCUSSES THE POSITION AND PLIGHT OF SOVIET JEWS.

03741 GLAESER, E.L.; KALLAL, H.D.; SCHEIMKMAN, J.A.; SHLEIFER, A. GROWTH IN CITIES

JOURNAL OF POLITICAL ECONONY, 100(6) (DEC 92), 1126-1152.

RECENT THEORIES OF ECONOMIC GROWTH HAVE STRESSED THE

ROLE OF TECHMOLOGICAL SPILLOVERS IN GENERATING GROWTH.

BECAUSE SUCH KNOWLEDGE SPILLOVERS ARE PARTICULARLY EFFECTIVE BN CITIES, WHERE COMMUNICATIONS AMONG PEOPLE ARE MORE IN CITIES, WERE COMMUNICATIONS AMONG PEOPLE ARE MORE
EXTENSIVE, DATA ON THE GROWTH OF INDUSTRIES IN DIFFERENT EXTENSIVE, DATA ON THE GROWTH OF INDUSTRIES IN DIFFERENT
CITIES ALLOW THE AUTHORS TO TEST SOME OF THESE THEORIES. CITIES ALLOW THE AUTHORS TO TEST SOME OF THESE THEORIES. $170 \mathrm{U}$.S. CITIES BETHEEN 1956 AND 1987, THEY FIND THAT LOCAL 170 U.S. CITIES BETHEEN 1956 AND 1987. THEY FIND SPECIALIZATION. ENCOURAGE EMPLOYMENT GROWTH IN INDUSTRIES. SPECIALIZATION, ENCOURAGE EMPLOYMENT GROWTH IN INDUSTRIES THE EVIDENCE SUGGESTS THAT IMPORTANT KNOWLEDGE SPILLOV
MIGHT OCCUR BETWEEN, RATHER THEN WITHIN, IMDUSTRIES

03742 GLANZ, D.

THE PHILIPPINES: A VOTE OF NO CONFIDENCE AREMA, $9(100)$ (1992), 32-35.

IN THE CLOSING DAYS OF HER PRESIDENCY, AQUINO TOOK CARE TO BIND THE NEXT ADMINISTRATION INTO IMPLEMENTING THE DESIRED ECONDMIC POLICIES BY THE IMF-WB AND OTHER FOREIGN BANKS WHICH RENDERED THE ELECTION AS NOTHING BUT A CONTINUATION OF THE AQUINO ADMINSTRATION AND THE PREVIOUS ADMINISTRATION BEFORE IT. THE ELECTIONS HAVE CHANGED VERY LITTLE, ARGUES THE AUTHOR WHO STATES THAT THE RAMOS VICTORY MAY OR MAY NOT HAVE BEEN A FRAUD BUT THE ELECTION ITSELF CLEARLY WAS.

03743 GLASBERG, D.

RACE, CLASS, AND THE DIFFERENTIAL APPLICATION OF BANK BAILOUTS

CRITICAL SOCIOLOGY, 18(2) (SUM 91), 51-76.

THIS PAPER PRESENTS A COMPARATIVE ANALYSIS OF STATE INTERVENTION IN THO RECENT BANK CRISES AND SUGGESTS THAT FACTORS OTHER THAN THOSE THAT ARE THE FOCUS OF EXISTING THEORIES OF THE STATE MAY BE IMPORTANT IN DEFINING THE MEANING OF "TDO BIG TO FAIL," OR TO UNDERSTAND THE POLITICS OF FINANCE MORE GENERALLY, ONE SHOULD LOOK NOT ONLY AT THE CHARACTERISTICS OF THE BANKS THEMSELVES BUT ALSO AT THE CHARACTERISTICS OF THEIR CUSTOMERS.

03744 GLASBERGEN, $P$

SEVEN STEPS TOWARDS AN INSTRUMENTATION THEORY FOR SEVEN STEPS TOWARDS

EOLVIRONMENTAL POLICY

THE AUTHOR EVALUATES THE TOOLS THAT ARE AVAILABLE FOR ENVIRONMENTAL POLICY IN THE NETHERLANDS. AFTER AN INSPECTION DISADVANTAGES OF VARIOUS CONTROL MODELS. THE LEGAL, THE ECONOMIC, THE COMHUNICATION, AND THE SPATIAL CONTROL MODELS ARE DISTINGUISHED. ON THE BASIS OF THIS DISCUSSION, HE INTROOUCES ELEMENTS OF A PRACTICAL INSTRUMENTATION THEORY FOR THE ENVIRONMENT. THE LESSONS LEARNED PROVIDE THE
PRINCIPLES ON WHICH STRATEGIES TO DEAL WITH COMPLEX ENVIRONMENTAL PROBLEMS MAY BE BASED.

03745 GLASER, C

NUCLEAR POLICY WITHOUT AN ADVERSARY: U.S. PLANMING FOR THE POST-SOVIET ERA

INTERNATIONAL SECURITY, 16(4) (SPR 92), 34-78

THE UNITED STATES HAS NOW PROPOSED THE FIRST BASIC CHANGES IN U.S. STRATEGIC NUCLEAR FORCES, BUT THE STRATEGY THAT THESE FORCES MUST SUPPORT, AND HOW AND WHY IT DIFFERS FROM AMERICA'S COLD WAR STRATEGY, HAVE YET TO BE ARTICULATED. THIS ARTICLE EXPLORES HAT STRATEGY THE UNITED STATES SHOULD ADOPT IN A WORLD OF MUTUAL VULNERABILITY. THE CASE FOR MAINTAINING A COUNTERFORCE STRATEGY BY EYALUATING HOW STRONG THE COLD WAR ARGUMENTS HERE FOR COUNTERFORCE, AND HOW THE END OF THE COLD WAR AFFECTS THESE ARGUMENTS ARE ASSESSED. THIS ARTICLE ARGUES THAT THE UNITED STATES SHOULD REJECT LIMITED BALLISTIC MISSILE DEFENSE DEPLOYMENTS THAT RISK GENERATING RUSSIAN INSECURITY AND STRAINING U.S.-RUSSIAN RELATIONS.

03746 GLASER, C.L.

POLITICAL CONSEQUENCES OF MILITARY STRATEGY: EXPANDING AND REFINING THE SPIRAL AND DETERRENCE MODELS

WORLD POLITICS, 44(4) (JUL 92), 497-538.

ANALYSES OF MILITARY STRATEGY OFTEN OVERLOOK ITS

POL ITICAL CONSEQUENCES-IIS EFFECT ON THE ADVERSARY'S BASIC GOALS AND UNDERSTANDING OF THE DEFENDER'S RESOLVE. AS A RESULT, THEY PRESCRIBE THE WRONG TYPE OF MILITARY POLICY AND THEREBY REDUCE A STATE'S SECURITY. THIS PAPER EXPLORES HOW POLITICAL CONSEOUENCES RESULT FROM THE INTERACTION OF A VARIETY OF FACTORS, INCLUDING THE TYPE OF ADVERSARY (SPECIFICALLY, ITS MOTIVES FOR EXPANSION); THE TYPE OF MILITARY STRATEGY THE DEFENDER ADOPTS (OFFENSIVE OR DEFENSIVE AND UNILATERAL OR BILATERAL); THE SOURCE OF THE ADVERSARY'S MISPERCEPTIONS; AND THE PROCESS THROUGH WHICH POLITICAL CONSEQUENCES ARE GENERATED. THE AUTHOR REFORMULATES JERVIS'S SPIRAL AND DETERRENCE MOOELS AND ARGUES THAT THEY OVERLOOK TYPES OF ADVERSARIES, INCLUDING INSECURE GREEDY STATES; THAT SHIFTS IN THE ADVERSARY'S BALANCE OF DOMESTIC POWER OFFER AN ALTERMATIVE TO INDIVIDUAL LEARNING AS THE BASIC WAY IN WHICH POLITICAL CONSEQUENCES ARE GENERATED; THAT NATIONAL-LEVEL FAILURES OF EVALUATION PROVIDE AN ALTERNATIVE SOURCE OF EXAGGERATED INSECURITY; AND THAT THESE DIFFERENCES CAN REQUIRE THE DEFENDER TO FOLLOW DIFFERENT POLICIES. FINALLY, THE AUTHOR DISCUSSES MILITARY OPTIONS FOR MANAGING POLITICAL CONSEOUENCES AND THE OPTIONS FOR MANAGING POLITICAL CONSEQUEM
IMPLICATIONS FOR U.S. SECURITY POLICY.

03747 GLASER, M.; YEAGER, $S$.

BUSINESS PRIORITIES AND THE RELATIVE IMPORTANCE OF STATE AND LOCAL ECONOMIC-DEVELOPMENT INCENTIVES

INTERMATIONAL JOURNAL OF PUBLIC ADMINISTRATION, 15(8)

(1992), 1527-1552

THIS PAPER PROVIDES STATE AND LOCAL GOVERMMENTS WITH AN IMPROVED UNDERSTANDING OF BUSINESS INVESTMENT MOTIVATION AND THE RELATIVE VALUE OF DIFFERENT INCENTIVES TO EFFECTIVE ECONOMIC DEVELOPMENT POLICY. IT ILLUMINATES DIFFERENCES IN
VALUE ASSIGNED TO INCENTIVES BY DIFFERENT TYPES OF BUSINESS. FINDINGS INDICATE THAT STATE AND LOCAL GOVERMMENTS THAT OFFER INCENTIVES WITHOUT CONSIDERATION OF BUSINESS TYPE ARE IN MANY CASES DELIVERING WINDFALLS TO THE PRIVATE SECTOR.

03748 GLASS, A.

CHANGIMG THE POWER PRECESS

NEW LEADER, LXXV(14) (NOV 92), 3-4.

THIS ASSESSMENT OF THE CHANGING POWER PROCESS PONDERS IF PRESIDENT-ELECT CLINTON WILL BE ABLE TO CURB THE INFLUENCE OF THE LAWYER-LOBBYISTS. THIS MUST BE DONE PRIOR TO ANY MAJOR LERISLATIVE THRUSTS, WHICH HOULD FAIL IF THE OLD SYSTEM REMAINS IN PLACE. CLINTON HAS RAISED THE "NEED TO REFORM THE POLITICAL SYSTEM AND REDUCE THE INFLUENCE OF THE SPECIAL INTERESTS." AND IT MOW APPEARS THAT THE FOLKS HE PICKS TO HELP HIM PICK THE PEOPLE WHO WILL RUN THE SHOH WILL BE BARRED FROM PARTICIPATION FOR A LEAST SIX MONTHS. THEY WILL NOT BE ALLOWED TO LOBBY OFFICIALS FROM THE OUTSIDE FOR THE SAME TIME.

03749 GLASSMAN, J.K.

NO MONEY DOWH

NEW REPUBLIC 206 (6) (FEB 92) 15-17.

THE AUTHOR PROPOSES REFINANCING PART OF THE U.S. DEBT AT LOWER INTEREST RATES AS A WAY TO SIGNIFICANTLY REDUCE THE BUDGET DEFICIT.

03750 GLASSON, J.

THE FALL AND RISE OF REgIONAL PLANHING IN THE ECONOMICALLY ADVANCED NATIONS

URBAN STUDIES, 29(2) (APR 92), 505-532

THIS ARTICLE TAKES A WIDE VIEH OF REGIONAL PLANNING, INCLUDING BOTH THEORY AND PRACTICE, BECAUSE THERE IS CONSIDERABLE INTERACTION BETHEEN THE THO. THE AUTHOR OFFERS A BRIEF OVERVIEH OF RECENT HORKS EXPLAINING REGIONAL GROWTH AND DISCUSSES REGIONAL PLANNING PRACTICE, FOCUSING ON THE 
UNITED KINGDOM AND THE EUROPEAN COMMUNITY.

03751 GLASTRIS, $P$

THE SECRET SOLUTION TO THE DEFICIT

WASHINGTON MONTHLY, 23(1,2) (JAN 91), 25-28.

WHILE DEMOCRATS WERE QUICK TO ATTACK THE REPUBLICAN PLANS FOR TAX BREAKS FOR THE RICH, THEY ALSO WIDENED THE LOOPHOLE FOR THOSE WHO EARN WEALTH THE OLD-FASHIONED WAY: THROUGH INHERITANCE. UNDER THE CURRENT LOOPHOLE. THE S10 BILLION AMERICANS PAY IN ESTATE TAXES ANMUALLY REPRESENTS ONLY 5 PERCENT OF THE ESTIMATED S2O0 BILLION THEY BEOUEATH EACH YEAR. WHILE ANY KIND OF TAX IMCREASE. IF TAKEN TOO FAR, EACH YEAR. WHILE ANY KIND OF TAX INCREASE, IF TAKEN TOO FAR, THE LEAST OISRUPTIVE TO THE ECONOMY'S PRODUCTIVITY. IN FACT, HIGHER ESTATE TAXES MIGHT EVEN BE GOOO FOR THE REDUCING THE FEDERAL DEBT.

03752 GLAUBER, U.

CZECHS AND SLOVAKS MARCH FORWARDS--AND BACKWARDS GERMAN TRIBUNE, (1536) (OCT 92), 2.

THE PROCESS OF SEPARATION IN CZECHOSLOVAKIA IS

CHARACTERIZED BY AN APPROACH THAT COULD BE DESCRIBED AS "THREE STEPS FORWARD, TWO STEPS BACK." FOR EXAMPLE, THE LEADERS OF THE MAJOR CZECH AND SLOVAK PARTIES AGREED TO DISSOLVED THE FEDERATION BY THE END OF 1992, BUT PARLIAMENT FAILED TO PASS THE NECESSARY LAH.

03753 GLAUBITZ, J.

THE SOVIET UNION AND THE KOREAN PENINSULA

AUSSEN POLITIK, 43(1) (1992), 82-91.

AS OPPOSED TO DIVIDED CHIHA, AN INTERIMISTIC DUAL-STATE DEVELOPMENT HAS EVOLVED IN OIVIDED KOREA. FURTHERMORE, THE FACT THAT NORTH KOREA'S PREVIOUS PROTECTING POWER, THE SOVIET UNION, HAS APPRECIABLY MODIFIED ITS STANCE HAS TRIGGERED AS YET UNFORESEEABLE CONSEQUENCES. THIS NEH POLITICAL CONFIGURATION IS ANALYZED IN THIS ARTICLE.

03754 GLAZER, A.; MCMILLAN,H.

AMEND THE OLD OR ADDRESS THE NEW: BROADBASED LEGISLATION AHEN PROPOSING POLICIES IS COSTLY

WHEN PROPOSING POLICIES IS COSTLY
PUBLIC CHOICE, $74(1)$ (1991) $43-38$.

IF EACH LEGISLATOR WISHES TO ENCOURAGE OTHER LEGISLATORS

TO ADDRESS NEW PROBLEMS IN FUTURE PERIOOS. THEN A SUBGAME TO ADDRESS NEH PROBLEMS IN FUTURE PERIOOS, THEN A SUBG
PERFECT NASH EQUILIBRIUM CAN EXIST WITH THE FOLLOWING PERFECT NASH EQUILIBRIUM CAN EXIST WITH THE FOLLOWING PROPERTIES: NO LEGISLATOR FINDS IT HORTHWHILE TO MAKE A
NARROW PROPOSAL THAT APPEALS TO A MINIMUM MAJORITY; INSTEAD, NARROW PROPOSAL THAT APPEALS TO A MINIMUM MAJORITY; INSTEAD,
LEGISLATORS PROPOSE POLICIES THAT APPEAL TO ALL MEMBERS, NOT FOR FEAR OF RETALIATION, BUT RATHER TO ENCOURAGE OTHER MEMBERS TO WORK ON NEW PROBLEMS IN SUCCEEDING PERIODS; IN SUCCEEDING PERIODS NO LEGISLATOR AMENDS THE EXISTING BROAD POLICY. THIS ARTICLE FINDS AN EQUILIBRIUM WITH THESE

PROPERTIES IN FINITE AS WELL AS INFINITE PERIDD GAMES.

03755 GLEASON, G.

ON THE BUREAUCRATIC REINFORCEMENT OF NATIONALISM IN THE USSR

CANADIAN REVIEW OF STUDIES IN NATIONALISM, $X I X(1)$ (1992), 43-58.

THERE IS AN INESCAPABLE CONNECTION BETHEEN GORBACHEY'S GLASTMOST POLICIES AND THE RECENT REVITALIZATION OF NATIONALIST MOVEMENTS IN THE USSR. THE LONGER GLASTNOST WAS SUSTAINED THE MORE VISIBLE NATIONALIST MOVEMENTS BECAME. THIS ARTICLE EXPLORES NATIONALIST ASPIRATIONS BEGINNING WITH ESTONIA AND UKRAINE, WHICH WERE THEIR FIRST STEPS TOWARD INDEPENDENCE.

03756 GLEASON, G

THE FEDERAL FORMULA AND THE COLLAPSE OF THE USSR PUBLIUS:

IN LATE 1988 THE SOVIET PARLIAMENT APPROVED A PLAN FOR THE MOST AMBITIOUS POLITICAL REFORM IN SOVIET HISTORY. AS THE REFORM EVOLVED, A KEY COMPONENT CAME TO BE WHAT MIKHAIL S. GORBACHEY CALLED "A RENEWED FEDERAL STRUCTURE." REFORM S. GORBACHEY CALLED "A RENEWED FEDERAL STRUCTURE."
PROPONENTS ARGUED THAT ONLY A RENEWED FEDERALISM COULD PROPONENTS ARGUED THAT ONLY A RENEWED FEDERALISM COULD
PROVIDE FOR THE CONTINUED INTEGRITY OF THE SOVIET STATE WHILE ASSUR ING GREATER RESPONSIVENESS TO LOCAL DEMANDS.
HOWEVER, THE ATTEMPT TO BREATHE LIFE INTO THE USSR'S PSEUDOFEDERAL STRUCTURE UNLEASED LONG-SUPPRESSED NATIONALIST, TERRITORIAL, AND LOCALIST SENTIMENTS. BEGINNING IN 1990, "REFEDERALIZATION" PASSED FROM MAINLY RHETORICAL DISCUSSION
TO A PLAN FOR A MORE-LOOSELY ORGANIZED FEDERATION UNDER THE TO A PLAN FOR A MORE-LOOSELY ORGANIZED FEDERATION UNDER THE AUSPICES OF A UNION TREATY. FOLLOWING THE ATTEMPTED COUP D'ETAT BY KREMLIN HARD-LINERS IN AUGUST 1991, PRESSURES GREAT SOVIET EXPERIMENT. WITH THE DEMISE OF THE USSR, THE PLAN FOR FEDERAL REDESIGN WAS SUPERSEDED BY THE RAPID EMERGENCE OF INDEPENDENT STATES.

03757 GLEASON, G.

THE POLITICAL ECONOMY OF DEPENDENCY UNDER SOCIALISH: THE ASIAN REPUBLICS IN THE USSR

STUDIES IN COMPARATIVE COMMUNISM, 29(4) (DEC 91), 335-354.
WITH THE ADVENT OF GLASNOST, THE ABILTIY OF LOCALS IN THE CENTRAL ASIAN BORDERLANDS TO MAKE PUBLIC LONG-SUPPRESSED COMPLAINTS ABOUT THE FAILINGS OF THE SOCIALIST SYSTEM HAS INCREASED DRAMATICIALLY. THIS ARTICLE OFFERS A GENERALIZED MODEL OF DEPENDENCY AND EXAMINES CENTRAL ASIAN "REGIONALIZATION". IT CONCLUDES THAT DEPENDENCE DOES NOT DISAPPEAR HITH THE ADVANT OF SOCIALISH. NO MODEL THAT POSITS A SIMPLE LINEAR RELATIONSHIP BETHEEN ACTION IN THE CENTER AND REACTION IN THE PERIPHERY IS APT TO BE SUFFICIENT TO CAPTURE THE INTERACTION BETWEEN CENTRAL AND PERIPHERAL INSTITUTIONS.

03758 GLEDITSCH, N.P.

DEFENSE WITHOUT THREAT? THE FUTURE OF NORHEGIAN MILITARY SPENDING

COOPERATION \& CONFLICT: MORDIC JOURNAL OF INTERMATIONAL POLITICS, $27(4)$ (DEC 92), 397-413.

ALTHOUGH NORHEGIAN MII ITARY SPENDING ROSE DURING THE COLD WAR, IT REPRESENTS A VERY LIMITED PORTION OF NORWAY'S ECONOMY. STUDIES OF THE ECONOMIC CONSEQUENCES OF DISARMAMENT INOICATE THAT THE NATIONAL EFFECTS ARE LIKELY TO BE SMALL AND FAIRLY EASILY COMPENSATED. HOWEVER, ADJUSTMENT IS LIKELY TO BE MORE SERIOUS AT THE LOCAL LEVEL, PARTICULARLY IN NORTHERN NORWAY. HITH THE DEMISE OF THE COLD WAR, IT IS LIKELY THAT NORWEGIAN MILITARY SPENDING WILL DECREASE IN REAL TERMS BECAUSE THE NEW THREAT SCENARIOS--CONFLICTS IN THE BALKANS AND IN THE CAUCASUS OR MOSLEM FUNDAMENTAL ISM IN THE MIDOLE EAST--HAVE LITTLE ESCALATORY POTENTIAL AND ARE UNLIKELY TO AFFECT NORTHERN EUROPE. ALTHOUGH THERE REMAINS AN "UNCERTAINTY SCENARIO" LINKED TO RUSSIA'S UNKNOWN POLITICAL FUTURE, THIS SCENARIO IS UNLIKELY TO SUSTAIN CONTINUED HIGH MILITARY EXPENDITURES AGAINST THE PRESSURE OF COMPETING CIVILIAN PRIORITIES.

03759 GLEDITSCH, N.P.; SMITH, D.; WIBERG, H.

THE NORDIC COUNTRIES: PEACE DIVIDEND OR SECURITY DILEMMA? COOPERATION \& CONFLICT: NORDIC JOURNAL OF INTERMATIONAL POLITICS, $27(4)$ (DEC 92), 323-347.

THE END OF THE COLD WAR RAISES ANEW THE OLD QUESTION OF THE ALTERNATIVE USES OF THE RESOURCES SPENT ON THE ARMS RACE. THE ALTERNATIVE USES OF THE RESOURCES SPENT ON THE ARMS RACE.
AS EUROPE DISARMS, THE SECURITY ENVIRONMENT OF THE NORDIC AS EUROPE DISARMS, THE SECURITY ENVIRONMENT OF THE NORDIC
COUNTRIES IS CHANGING DRAMATICALLY. STUDIES IN THE NORDIC COUNTRIES IS CHANGING DRAMATICALLY. STUDIES IN THE NORDIC
COUNTRIES AND ELSEWHERE INDICATE THAT, ONCE TRANSITION COUNTRIES AND ELSEHHERE INDICATE THAT, ONCE TRANSITION
PROBLEMS HAVE BEEN SURMOUNTED, THE MEDIUM-TO-LONG-TERM EFFECTS OF DISARMAMENT HILL BE POSITIVE FOR EMPLOYMENT AS WELL AS ECONOMIC GROWTH. THE SIZE OF THE "PEACE OIVIDEND" CAN BE ESTIMATED ONLY THROUGH ECONOMETRIC STUDIES BASED ON REALISTIC SCENARIOS OF FUTURE MILITARY SPENDING. SUCH SCENARIOS, IN TURN, MUST BE BASED ON A RECONSIDERATION OF THE FORCE STRUCTURES APPROPRIATE TO THE CHALLENGES FACING THE NORDIC COUNTRIES TODAY. MILITARY SPENDING IN THE NORDIC COUNTRIES ROSE RAPIDLY UNDER THE INFLUENCE OF THE COLD WAR. BEGINNING IN THE MID-1960'S, THE NORDIC COUNTRIES MORE OR LESS PARTED WAYS, WITH CONTINUING ARMIMG IN FINLAND AND NORWAY AND A LEVELLING OFF OF MILITARY SPENDING IN DENMARK AND SWEDEN. THERE IS A PEACE DIVIDEND TO BE COLLECTED IN THE NORDIC COUNTRIES, BUT IT WILL NOT BE
ACCOMPANIED BY GREATER UNCERTAINTY.

03760 GLEES, A.

WAR CRIMES: THE SECURITY AND INTELLIGENCE DIMENSION INTELLIGENCE AND NATIONAL SECURITY, 7(3) (JUL 92), 242-267.

THIS ARTICLE LOOKS AT ONE ASPECT OF THE WAR CRIMES PROBLEM: ITS SECURITY AND INTELLIGENCE DIMENSION. AFTER THE SECOND WORLD WAR GREAT BRITAIN'S SECURITY AND INTELLIGENCE COMMUNITY WAS CHARGED WITH IDENTIFYING WAR CRIMINALS AND KEEPING THEM OUT OF THE UK. THERE ARE FOUR MAJOR ASPECTS OF THIS CHARGE: THE IDENTIFICATION OF WAR CRIMINALS IN GERMANY; THE PREVENTION OF THEIR ENTRY INTO THE UK; THE QUESTION OF POST-ENTRY MONITORING AS A PREREQUISITE OF DEPORTATION WHERE PREVENTION OF ENTRY PROVED IMPOSSIBLE; AND THE CURRENT ROLE OF SECURITY AND INTELLIGENCE AGENCIES IN COLLECTING OF SECURITY AND INTELLIGENCE AGENCIES IN COLLECTING INFORMATION WHICH MIGHT PERMIT PROSECUTION OF INDIVIDUALS RESPECTS THE SECURITY AND INTELLIGENCE COMMUNITY FAILED IN ITS DUTIES.

03761 GLEIBER, D.W.; SHULL, S.A. PRESIDENTIAL INFLUENCE IN THE POLICYMAKING PROCESS WESTERN POLITICAL QUARTERLY, 45(2) (JUN 92), 441-468.

IN ORDER TO ASSESS THE PRESIDENTIAL ROLE' IN POLICYMAKING, THE AUTHORS EXAMINE INFLUENCE AS THE EFFECT OF PREFERENCES AND RESOURCES ON ACTIVITIES. THE FINDINGS SHOW THAT INFLUENCE IS COMPLEX AND VARIABLE ACROSS STAGES OF THE POL ICY PROCESS. THE PRESIDENT'S RESOURCES APPEAR TO AID HIM IN DIFFERENT WAYS, DEPENDING UPON THE SPECIFIC TARGET. PERSUASION AS AN ADDITIONAL MEDIATING FACTOR PROVIDES NO INCREASE IN EXPLANATORY POWER. THE AUTHORS CONCLUDE THAT A VARIETY OF THEORIES OF INFLUENCE ARE CORRECT, EACH LIMITED TO PARTICULAR STAGES OF THE POL ICY PROCESS, SPECIFIC ISSUES, OR BOTH. THEREFORE, FURTHER ANALYSIS IS NECESSARY BEFORE A
MORE GENERAL EMPIRICAL THEORY OF PRESIDENTIAL INFLUENCE IS POSSIBLE. 
03762 GLEIJESES, $P$

THE LIMITS OF SYMPATHY: THE UNITED STATES AND THE INDEPEMDENCE OF SPANISH AMERICA

JOURNAL OF LATIN AMERICAN STUDIES, 24(3) (OCT 92), 481-506. THE AUTHOR ASSESSES THE UNITED STATES' SYMPATHY FOR THE SPANISH AMERICAN REBELS OF THE EARLY 19TH CENTURY AND THE CONTRIBUTION OF THE UNITED STATES TO THE INDEPENDENCE STRUGGLE IN SPANISH AMERICA. HE ALSO CDMPARES THE U.S. CONTRIBUTION WITH THE ASSISTANCE PROVIDED BY GREAT BRITAIN.

03763 GLEISNER, R.F.

ECONOMIC DETERMINANTS OF PRESIDENTIAL ELECTIONS: THE FAIR MODEL

POLITICAL BEHAVIOR, 14(4) (DEC 92), 383-394

RAY FAIR HAS CONSTRUCTED A MODEL EXPLAINING THE INCUMBENT SHARE OF THE TWO-PARTY PRESIDENTIAL POPULAR VOTE FOR THE ELECTIONS OF 1916-1984. THE MODEL SINGLES OUT THE ECDNOMIC MEASURES OF THE GROHTH RATE OF REAL PER CAPITA GNP AND THE ABSOLUTE VALUE OF THE RATE OF INFLATION AS BEING IMPORTANT. ALSO SIGNIFICANT ARE A TIME TREND FAVORING DEMOCRATS AND WHETHER AN INCUMBENT IS SEEKING RE-ELECTION. IN THIS PAPER. THE AUTHOR ARGUES THAT THE FAIR MODEL IS IN THIS PAPER, THE AUTHOR ARGUES THAT THE FAIR MODEL IS
MISSPECIFIED. INCLUOING THE RATE OF GROWTH IN THE DOW JONES MISSPECIFIED. INCLUDING THE RATE OF GROWTH IN THE DOW JONES MODEL, ELIMINATES THE TREND AS SIGNIFICANT, REDUCES THE MODEL, ELIMINATES THE TREND AS SIGNIFICANT, REDUCES THE INCOME PARAMETER, AND STRENGTHENS THE INFLATION PARAMETER 1908 AND 1912 ELECTIONS, AND UPDATING IT TO INCLUDE THE 1988 1908 AND 1912 ELECTIONS, AND UPDATI
ELECTION STRENGTHENS THE RESULTS.

03764 GLENDON, M.A.

RIGHTS TALK

JOURNAL OF STATE GOVERNMENT, 65(1) (JAN 92), 20-24. THE INFLATED DEMANDS OF MANY AMERICANS FOR VARIOUS RIGHTS HAS OBSCURED THE PUBLIC UNDERSTANDING OF WHAT AN AMERICAN'S BASIC CIVIL RIGHTS REALLY ARE AND, JUST AS IMPORTANTLY, THE LIMITATIONS ON THOSE RIGHTS.

03765 GLENMON, M.J.

STATE-SPONSORED ABDUCTION: A COMMENT ON UNITED STATES $V$. AL VAREZ-MACHAIN

AMERICAN JOURNAL OF INTERNATIONAL LAW, 86(4) (OCT 92), 746-756

ON JUNE 15, 1992, THE U.S. SUPREME COURT CONFRONTED WHAT THE PERMANENT COURT OF INTERMATIONAL JUSTICE TERMED "THE FIRST AND FOREMOST RESTRICTION IMPOSED BY INTERNATIONAL LAH UPON A STATE: . . THAT--FAILING THE EXISTENCE OF A PPON A STATE: ${ }_{\text {PERISSIVE RULE TO THE CONTRARY--IT MAY NOT EXERCISE ITS }}$ PERMISSIVE RULE TO THE CONTRARY--IT MAY NOT EXERCISE ITS
POWER IN ANY FORM IN THE TERRITORY OF ANOTHER STATE." WHILE POWER IN ANY FORM IN THE TERRITORY OF ANOTHER STATE." WHIL
THE U.S. COURT DID NOT CHALLENGE THAT PROPOSITION, IT DID THE U.S. COURT DID NOT CHALLENGE THAT PROPOSITION, IT DID APPLY, WITHOUT ADEQUATE ANALYSIS, AN ANTIQUATED DOCTRINE UNALAFUL LESS OF THE SEIZURE. IN DOING SO, IT IGNORED THE UNLAWFULNESS OF THE SEI IURE. IN DOING SO, IT IGNORED THE ISSUE OF PRESIDENTIAL CONSTIIUTIONAL POWER TO CONDUCT SUCH
SEIZES, AND IT PLACED THE ISSUE SQUARELY BEFORE CONGRESS.

03766 GLEWWE, P.; HALL, G.

UNORTHODOX ADJUSTMENT AND POVERTY IN PERI

FINANCE AND DEVELOPMENT, 29 (4) (DEC 92), 10-13.

FACED WITH ECONOMIC STAGNATION OR DECLIINE DURING THE 1980 'S, MANY DEVELOPING COUNTRIES ADOPTED MACROECONOMIC AND STRUCTURAL ADJUSTMENT PROGRAMS THAT WERE RECOMMENDED, AND PARTIALLY FINANCED, BY THE WORLD BANK AND THE IMF. HOWEVER, A FEW COUNTRIES THAT WERE ANXIOUS TO AVOID THE PERCEIVED ECONOMIC AND SOCIAL COSTS OF STRUCTURAL ADJUSTMENT EXPERIMENTED WITH UNORTHODOX, OR HETERODOX, PROGRAMS. WHILE DESIGNED TO ENCOURAGE RAPID GROWTH, ALONG WITH A MORE EQUI TABLE DISTRIBUTION OF WELFARE, SUCH ALTERNATIVE APPROACHES DID NOT ALHAYS SUCCEED AND, IN FACT, MAY HAVE HURT THE POOR MORE THAN THE GENERAL POPULATION. IN PERU, FOR EXAMPLE, THE ECONOMY AS A HHOLE DETERIORATED AND THE POLICIES FAILED TO PROTECT THE POOR.

03767 GLICK, H.R.

JUDICIAL INNOVATION AND POLICY RE-INVENTION: STATE SUPREME COURTS AND THE RIGHT TO DIE

WESTERN POLITICAL QUARTERLY, 45(1) (MAR 92), 71-92.

THE AUTHOR LOOKS AT INHOYATIOM IM STATE JUDICIAL POLICYMAKING, FOCUSING ON THE RIGHT-TO-DIE. IN ADOITION TO THE CHRONOLOGY OF DIFFUSION, HE EXAMINES THE CONTENT OF JUDICIAL POLICY AND POLICY CHANGE (RE-INVENTION) THAT OCCURS JUDICIAL POLICY AND POLICY CHANGE (RE-INVENTION) THAT
DURING THE DIFFUSION PROCESS. HE ALSO ANALYZES COURT DURING THE DIFFUSION PROCESS. HE ALSO ANALYZES COURT
CITATIDN OF PRECEDENTS TO TEST THE UTILITY OF PRECEDENT AS CITATIDN OF PRECEDENTS TO TEST THE UTILITY OF PRECEDENT AS AN INDICATOR OF JUDICIAL POLICY LEADERSHIP. CERTAIN FAMILIAR LEADING COURTS HAVE BEEN PROMINENT IN THE RIGHT-TO-DIE AREA BUT THEY HAVE PRODUCED DIFFERENT POL ICIES THAT HAVE HAD SUBSTANTIALLY DIFFERENT IMPACTS ON LATER ADOPTERS. THERE
A NEED TO BROADEN THE CONCEPT OF INMOVATION TO INCLUDE A NEED TO BROADEN THE CONCEPT OF INMOVAT
ADDITIONAL DIMENSIONS OF POLICYMAKING.

03768 GLICKMAN, T.S.; GOLDING, D.

FOR A FEW DOLLÁRS MORE: PUBLIC TRUST AND THE CASE FOR

TRANSPORTING NUCLEAR WASTE IN DEDICATED TRAINS

POLICY STUDIES REVIEW, 10(4) (WIN 92), 127-138.
SHOULD LARGE SHIPMENTS OF RADIOACTIVE MATERIALS BE TRANSPORTED IN REGULAR FREIGHT TRAINS OR RESTRICTED TO DEDICATED TRAINS? THIS QUESTION HAS BEEN AT THE HEART OF A 15-YEAR DEBATE THAT HAS BEEN TAKEN TO THE SUPREME COURT TWICE AND IS NOW THE SUBJECT OF A STUDY MANDATED BY CONGRESS AS PART OF THE 1990 HAZARDOUS MATERIALS TRANSPORTATION UNIFORM SAFETY ACT (HMTUSA). THE DEBATE OVER DEDICATED TRAINS TO SHIP SPENT FUEL AND OTHER HIGH-LEVEL NUCLEAR HAS PITTED THE RAILROAD INOUSTRY AGAINST THE NUCLEAR UTILITIES, THE NUCLEAR REGULATORY COMMISSION, AND THE DEPARTMENT OF ENERGY. THE HMTUSA GIVES THE RAILROADS AND
OTHER PROPONENTS OF DEDICATED TRAINS ANOTHER OPPORTUNITY TO PRESENT THEIR CASE. THIS PAPER ARGUES THAT EARLIER CONCLUSIONS FAVORING REGULAR TRAINS OVER DEDICATED IRAINS WERE BASED ON INCOMPLETE COST AND RISK INFORMATION AND NEGLECTED OTHER FACTORS THAT WERE NOT TECHNICAL BUT SOCIAL AND INSTITUTIONAL IN NATURE. THE PAPER FINDS THAT THE ADDITIONAL COST OF A DEDICATED SYSTEM IS LOWER THAN PREVIOUSLY PROJECTED AND CONCLUDES THAT IT IS A SMALL PRICE TO PAY FOR REDUCED PUBLIC OPPOSITION AND INCREASED LEVELS OF TRUST.

03769 GLINKIN, A.

AFTER PERESTROIKA

HEMISPHERE, 4(2) (WIN 92), 13-14.

AS THE COMPLEX TRANSFORMATIONS OCCUR IN THE COMMONWEALTH OF INDEPENDENT STATES, THE SIGNIFICANT VOLUME OF ACCUMULATED CAPITAL IN SOVIET RELATIONS WITH LATIN AMERICA SHOULD NOT BE OVERLDOKED. FROM STALIN TO BREZHNEV, SOVIET FOREIGN POLICY TREATED LATIN AMERICA AS A BATTLEGROUMD BETWEEN MOSCOW AND WASHINGTON. THE IDEOLOGY OF PROLETARIAN INTERNATIONALISM GUIDED THE USSR'S RELATIONS WITH ACTUAL AND POTENTIAL ALLIES. THE GLOBAL SHIFTS OF THE 1990'S HAVE REMOVED LATIN AMERICA AS A TURF FOR COLD WAR CONFRONTATION. RELATIONS BETWEEN LATIN AMERICA AND THE COMMONHEALTH OF INDEPENDENT STATES CAN NOW DEVELOP ALONG WIDER, MORE INTRICATE CONFIGURATIONS OF GEOPOL ITICAL INTERESTS.

03770 GLOMM, G.; RAVIKUMAR, B.

PUBLIC VERSUS PRIVATE INVESTMENT IN HUMAN CAPITAL:

ENDOGENOUS GROWTH AND INCOME INEOUALITY

JOURNAL OF POLITICAL ECONOMY, 100(4) (AUG 92), 818-834. THE AUTHORS PRESENT AN OVERLAPPING GENERATIONS MODEL WITH HETEROGENEOUS AGENTS IN WHICH HUMAN CAPITAL INVESTMENT THROUGH FORMAL SCHOOL ING IS THE ENGINE OF GROWTH. THEY USE SIMPLE FUMCTIONAL FORMS FOR PREFERENCES, TECHNOLOGIES, AMD IMCOME DISTRIBUTION TO HIGHLIGHT THE DISTINCTION BETHEEM INCOME DISTRIOUAL FORMS FOR PREFERENCES, TECHNOLOGIES, AM EDUCATION. THEY FIND THAT INCOME INEQUALITY DECLINES MORE EDUCATION. THEY FIND THAT INCOME INEQUALITY DECLINES MORE QDUCATION YIELDS GREATER PER CAPITA INCOMES UNLESS THE EDUCATION YIELDS GREATER PER CAPITA INCOMES UNLESS THE MIND THAT SOCIETIES WILL CHOOSE PUBLIC EDUCATION

03771 GLOSSERMAN, B ECONOMIC DEVELOPMENT OR ENVIRONMENTAL PROTECTION JAPAN TIMES (WEEKLY INTERNATIONAL EDITION), $32(6)$ (FEB 92), $8-9$.

THE THEME OF THE UNITED NATIONS CONFERENCE OM ENVIRONMENT AND DEVELOPMENT, SCHEDULED FOR JUNE 1992, HILL BE "SUSTAINABLE DEVELOPMENT,", REFLECTING THE CHALLENGE OF RECONCILING THE COMPETING DEMANDS OF ECOMOMIC DEVELOPMEN AND ENVIRONMENTAL PROTECTION. BECAUSE OF ITS OWN PAST EXPERIENCE, JAPAN IS WELL PREPARED TO ASSUME A LEADERSHIP ROLE IN TACKLING THIS ISSUE.

03772 GLOSSERMAN, B.

HONG KONG'S MOVE TOWARD 1997 IS NO LEAP IN THE DARK JAPAN TIMES (WEEKLY INTERNATIONAL EDITION), 32 (5) (FEB 92), 3.

3. THE IMPENDING RETURN OF HONG KONG TO CHINESE SOVEREIGNTY IN 1997 IS FORCING HONG KONG TO REAPPRAISE ITS ECONOMIC ORIENTATION AND REEVALUATE ITS TRADE WITH ITS EASTERN NEIGHBORS. THE BIGGEST PLAYER IN HONG KONG'S ECONOMIC FUTURE WILL BE MAINLAND CHINA, BUT HONG KONG IS ALSO COURTING CONTINUED FOREIGN INVESTMENT FROM JAPAN.

03773 GLOSSERMAN, B.

JAPAN AND MEXICO SEARCH FOR COMMON TRADE GROUMD JAPAN TIMES (WEEKLY INTERMATIONAL EDITION), 32 (7) (FEB 92), 17.

RECENT REMARKS BY SENIOR U.S. OFFICIALS HAVE FUELED JAPANESE FEARS THAT OFFSHORE PRODUCERS WILL BE EXCLUDED FROM THE BENEFITS OF THE PROPOSED U.S.-MEXICD FREE TRADE AREA (NAFTA). BUT MEXICAN OFFICIALS HAVE TAKEN PAINS TO ASSURE JAPANESE INVESTORS THAT THIS WILL NOT BE THE CASE.

03774 GLYN, A.

THE COSTS OF STABILITY: THE ADVANCED CAPITALIST COUNTRIES IN THE 1980 's

NEW LEFT REVIEW, (195) (SEP 92), 71-95 THE AUTHOR EXAMINES THE GIDOY ECONOMICS OF THE 1980'sTHE ORGY OF FINANCIAL SPECULATION, BALLOONING BUBBLES OF 
CREDIT, BONFIRE OF CONTROLS, AND UNABASHED CELEBRATION OF INEQUALITY--WHICH HAVE FUELED THE PRESENT RECESSION. DURING THE YEARS OF REAGANOMICS AND THE "THATCHER MIRACLE," INVESTMENT IN SOCIAL AND INDUSTRIAL INFRASTRUCTURE WAS NEGLECTED IN FAVOR OF FINANCIAL SERVICES AND THE NEW "OVERCONSUMPTIONIST" POLITICAL ECONOMY OF EASY CREDIT, FORT IFIED SHOPPING MALLS, AND MILITARY KEYNESIANISM. THERE WAS AN UNEVEN GROWTH OF PROFITABILITY THROUGHOUT THE WAS AN UNEVEN GROHTH OF PROFITABILITY THROUGHOUT THE UNIONS. BUT THESE PROFITS WERE NOT CHANMELED INTO INVESTMENT UNIONS. BUT THESE PROFITS WERE NOT CHANNELED INTO INVESTMENT OR NEH TECHNOLOGIES BUT WERE DIVERTED INTO YUPPY LIFESTYLES
AND REAL ESTATE. IN BRITAIN, INDUSTRIAL PRODUCTIVITY GREH AS AND REAL ESTATE. IN BRITAIN, INDUSTRIAL PRODUCTIVITY GREH AS EXISTING PLANT WAS USED MORE INTENSIVELY, BUT INDUSTRIA CAPACITY REMAINED STAGNANT AND INOUSTRIAL EMPLOYMENT PLUMMETED. THE PRESENT RECESSION LINGERS AND DEEPENDS
BECAUSE OF THE CREDIT TRAP AND THE LOPSIDED INCOME STRUCTURE BECAUSE OF THE CREDIT TRAP AND THE LOPSIDED INCOME STRUCTU THE INTERNATIONAL MONETARY FUND AND THE WORLD BAN
MAKING THEIR OWN DISTINCTIVE CONTRIBUTION TO THE INTERNATIONAL CRISIS BY CLINGING TO NED-LIBERAL NOSTRUMS.

03775 GLYNN, P.

BALKING

NEW REPUBLIC, 207(22) (NOV 92), 20-22.

AMID ALL THE TURMOIL IN THE FORMER YUGOSLAVIA, THE CONSTANT IN WESTERN POLICY HAS BEEN A RELUCTANCE' TO CONFRONT THE MILITARY DIMENSION OF THE CONFLICT, TO IDENTIFY AND RESPOND TO SERBIAN AGGRESSION WITH DIRECT OR INDIRECT MILITARY MEASURES. INSTEAD, WESTERN GOVERNMENTS HAVE PERSISTED IN A COMBINATION OF RELIEF, PEACEKEEPING, ECONOMIC AND ARMS SANCTIONS, AND LARGELY FUT ILE NEGOTIATING EFFORTS-THE CUMULATIVE EFFECT OF WHICH HAS BEEN TO PROLONG THE CONFLICT.

03776 GLYNN, P.

CLOSING THE LOOP

NEW REPUBLIC, 207(10) (AUG 92), 22-23.

THE BUSH ADMINISTRATION COMMITTED A SERIOUS POLITICAL BLUNDER IN ATTACKING BILL CLINTON ON THE ISSUE OF

INTERVENTION IN BOSNIA. INDEED, THE DEBATE OVER BOSNIA HAS INTERVENTION IN BOSNIA. INDEED, THE DEBATE OVER BOSNIA HAS
BROUGHT A REMARKABLE POLITICAL CHANGE. FOR THE FIRST TIME IN BROUGHT A REMARKABLE POLITICAL CHANGE, FOR THE FIRST
20 YEARS, THE DEMOCRATS FIND THEMSELVES, POLITICALLY

SPEAKING, ON THE RIGHT SIDE HHILE MANY REPUBLICANS ARE ON SPEAKING, ON THE RIGHT SIDE WHILE MANY REPUBLICANS INTERNATIONAL AFFAIRS.

03777 GLYNA, P.

NUKRAINE

NEH REPUBLIC, 207(3-4) (JUL 92), 20, 22, 24.

THE AUTHOR DISCUSSES UKRAINE'S EVOLYING MILITARY POL ICY AND THE RESPONSE BY FOREIGN POLICY MAKERS IN RUSSIA AND THE UNITED STATES.

03778 GLYNN, P.

WHY AFRICA?

NEW REPUBLIC, 207(27) (DEC 92), 20-22.

SINCE THE END OF THE COLD WAR THE CENTRAL CHALLENGE OF $U$.

S. FOREIGN POLICY HAS BEEN TO DEVISE A STRATEGY THAT FUSES U.

S. DEMOCRATIC PRINCIPLES WITH GEOPOLITICAL INTERESTS IN CONSTRUCTING A GENUINE NEW WORLD ORDER. THE BUSH

ADMINISTRATION HAS BEEN CAUGHT BETWEEN TWO OPPOSING PUBLIC CURRENTS: AN ISOLATIONIST CONSERVATISM THAT ESCHEWS FOREIG ENTANGLEMENTS UNLESS VITAL INTERESTS ARE SELF-EVIDENTLY AT STAKE AND A VOCAL LIBERAL HUMANITARIANISM RELUCTANT TO SET LIMITS ON U.S. INTERVENTION. THE CHALLENGE HAS BEEN TO FIND A MIDDLE GROUNO, A PRINCIPLE OF SELECTION THAT LEADS THE USA A MIDOLE GROUNO, A PRINCIPLE OF SELECTION URAT LEADS THE USA TO APPLY ITS DIPLOMATIC AND HILITARY RESOURCES TO PROBLEMS CENTRAL TO THE MAINTENANCE OF WHERL ORDER WHILE AVOIDING
ENDLESS ENTANGLEMENTS AROUND THE GLOBE. THE EFFORT TO SAVE
LIVES IN SOMALIA IS DEFINITELY LAUDABLE. BUT IN CHOOSING TO LIVES IN SOMAL IA IS DEFINITELY LAUDABLE. BUT IN CHOOSING TO
INTERVENE IN SOMALIA WHILE ESCHEWING FURTHER INVOLVEMENT IN THE BALKANS, THE BUSH ADMINISTRATION HAS SETTLED ON THE THE BALLANS, THE BUSH ADMINISTRATION HAS SETTLED ON THE
WORST OF BOTH WORLDS--AN ISOLATIONIST-TENDING FOREIGN POLICY WORST OF BOTH WORLDS--AN ISOLATIONIST-TENDING FOREIGN POLICY WHERE INTERVENTION IS GENERALLY SHUNNED BUT THEN SUDOENLY
EMBRACED ON THE CRITERIA OF MILITARY EASE AND SENTIMENT.

03779 GLYNA, P.

YUGOBLUNDER

NEW REPUBLIC, $206(8)$ (FEB 92), 15-17.

THE AUTHOR OUESTIONS THE COURSE OF U.S. FOREIGN POL ICY IY YUGOSLAVIA AND ARGUES THAT IT EPITOMIZES THE ESSENTIAL IN YUGOSLAVIA AND ARGUES THAT IT EPITOMIZES THE ESSENTIAL FOREIGN AFFAIRS.

03780 GNESOTTO, N.

EUROPEAN UNIOH AFTER MINSK AM MAASTRICHT

INTERMATIOHAL AFFAIRS 68(2) APR 92) 233-232.

THE GULF HAR AND THE POLITICAL UPHEAVALS IN THE FORMER

SOVIET UNION BLOC HAVE LED TO A COMPLETE POLITICAL

REVOLUTION IN STRATEGIC THINKING AND IN THE EUROPEAN SECURITY INSTITUTIONS. THE PROSPECT OF A EUROPEAN UNION ENCOMPASSING BOTH SECURITY AND DEFENSE POLICIES HAS BEEN ENHANCED BY THESE EVENTS AND HAS GAINED CREDENCE WITHIN THE NEW STRATEGIC CONTEXT. THE AUTHOR CONFRONTS THE ISSUE OF A
THE MINSK AGREEMENT AND THE MAASTRICHT TREATY, AND EXAMINES HOW RELATIONSHIPS MAY BE DEVELOPED BETWEEN A EUROPEAN UNION, NATO AND THE CSCE.

03781 GOBETTI, D.

GOODS OF THE MIND, GOODS OF THE BODY, AND EXTERNAL GOODS: SOURCES OF CONFLICT AND POLITICAL REGULATION IN

SEVENTEENTH-CENTURY NATURAL LAW THEORY

HISTORY OF POL ITICAL THOUGHT, XIII(1) (SPR 92), 31-50.

THE AUTHOR TESTS THE PLAUSIBILITY OF INTERHEAVING A CONCEPTION OF POLITICS WITH THE NATURE OF THE CONFLICT THAT POLITICS IS SUPPOSED TO REGULATE BY STUDYING A SPECIFIC CASE IN THE HISTORY OF WESTERN POLITICAL THOUGHT. HE CONSIDERS IN THE HISTORY OF WESTERN POLITICAL THOUGHT. HE CONSIDERS THE INTERPRETATION OF MODERN SOCIAL RELATIONS THAT SE
CONFLICT AS ARISING FROM THE UNEQUAL DISTRIBUTION OF CONFLICT AS ARISING FROM THE
RELATIVELY SCARCE RESOURCES.

03782 GOBLE, P.

FORGET THE SOVIET UNION

FOREIGN POLICY, (86) (SPR 92), 56-65

AMERICAN POLICYMAKERS ARE IN PRACTIICE UNWILLING TO ACKNOWLEDGE THAT THE USSR NO LONGER EXISTS, THAT IT HAS BEEN REPLACED BY 15 INDEPENDENT STATES, AND THAT THIS CHANGE PROFOUNDLY AFFECTS THE GLOBAL STANDING OF THE UNITED STATES. WITHOUT AN INTELLECTUAL AND EMOTIONAL SHIFT AMONG BOTH THE AMERICAN PUBLIC AND POLICYMAKERS, THE UNITED STATES WILL NOT BE IN A GOOD POSITION TO PROMOTE AMERICAN VALUES, ENCOURAGE STABILITY ON ONE-SEVENTH OF THE EARTH'S LAND SURFACE, AND GAIN ACESS TO WHAT IS SURELY THE LARGEST NEW MARKET AND SOURCE OF RAW MATERIALS OPEN TO THE WEST IN THIS GENERATION. MAKING THIS INTELLECTUAL LEAP REQUIRES A MORE THOROUGH UNDERSTANDING OF THREE CRUCIAL ISSUES: THE REAL MEANING OF THE COMMONWEALTH OF INDEPENDENT STATES (CIS), WHICH MANY PEOPLE CONTINUE TO VIEH AS THE SUCCESSOR STATE TO THE SOVIET UNION; THE NATURE OF THE INDIVIDUAL AND COLLECTIVE PROBLEMS OF THE FIFTEEN NEW STATES; AND THE AMERICAN ROLE IN DEALING WITH THIS NEW REALITY.

03783 GODWIN, P.H.B.

CHINESE MILITARY STRATEGY REVISED: LOCAL AND LIMITED WAR ANNALS OF THE AMERICAN ACADEMY OF POLITICAL AND SOCIAL SCIENCE, 519 ( JAN 92), 191-201.

IN 1985, THE CHINESE PEOPLE'S LIBERATION ARMY (PLA) BEGAN TO REDIRECT ITS MILITARY STRATEGY FROM A FOCUS ON GENERAL WAR WITH THE USSR TO THE MORE PROBABLE SOURCE OF MILITARY CONFLICT: SMALL-SCALE AND POTENTIALLY INTENSE WARS AROUND CHINA'S PERIPHERY. THE KINDS OF CONFLICTS THAT COULD ARISE WOULD REQUIRE A REVISED DEFENSE POLICY AND MILITARY STRATEGY. THE NEW EMPHASES MADE THE PLA EVEN MORE CONSCIOUS OF ITS TECHNOLOGICAL OBSOLESCENCE. DEVELOPING CONCEPTS OF MILITARY OPERATIONS IN WHICH SPEED AND LETHALITY WOULD THE PRINCIPAL CHARACTERISTICS OF COMBAT, RATHER THAN
DEFENSIVE OPERATIONS BASED UPON ATTRITION WARFARE AND A SOCIETY MOBILIZED FOR WAR, SERVED ONLY TO HIGHLIGHT THE PLA'S TECHNOLOGICAL WEAKNESSES. THE RECOGNITION OF THESE FLAWS HAS LED THE ARMEO FORCES TO DEMAND SWIFTER MODERNIZATION OF ARMS AND OTHER EQUIPMENT.

03784 GODWIN, R.K.

POLICY FORMATION AND IMPLEMENTATION IN LESS INDUSTRIALIZED COUNTRIES: A COMPARATIVE ANALYSIS OF INSTITUTIONAL EFFECTS WESTERN POLITICAL QUARTERLY, 45(2) (JUN 92), 419-440.

DO ALTERNATIVE POLITICAL INSTITUTIONS MAKE A DIFFERENCE IN POLICY OUTCOMES? THIS STUDY ANSHERS THAT QUESTION REGARDING POPULATION POLICIES IN LESS INDUSTRIALIZED COUNTRIES, USING MULTIPLE REGRESSION TO EXPLORE RELATIONSHIPS AMONG REGIME TYPE, POLICY AND PROGRAM CHARACTERISTICS, AND POLICY RESULTS IN 93 LDC'S. THE AUTHOR ANALYZES WHETHER DEMOCRATIC OR AUTHORITARIAN REGIMES ARE MORE SUCCESSFUL IN IMPLEMENTING BIRTH-RATE REDUCTION POLICIES AND INVESTIGATES THE EXTENT TO WHICH POLICY AND PROGRAM ATTRIBUTES--SUCH AS STATED INTENT, EFFECTIVE EVALUATION, AND UTILIZATION OF THE PRIVATE SECTOR--INFLUENCE PROGRAM SUCCESS.

03785 GOEBEL, P.R. : ROSENBERG, S.B.

ECONOMIC ANALYSIS OF THE IMPACT OF ANTI-DISCRIMINATION ECONOMIC ANALYSIS OF THE IMPACT OF ANTI LEGISLATION BASED ON FAMILIAL STATUS
POLICY SCIENCES, 25(2) (MAY 92), 161-174.

FOR YEARS, THERE HAVE BEEN COMPLAINTS THAT LANDLORDS DISCRIMINATE AGAINST FAMILIES WITH CHILDREN BY CHARGING THEM OISCRIMINATE AGAINST FAMILIES WITH CHILDREN BY CHARGING THEM
HIGHER RENTS AND/OR HIGHER SECURITY DEPOSITS TO COMPENSATE HIGHER RENTS AND/OR HIGHER SECURITY DEPOSITS TO COMPEN
FOR THE PERCEIVED INCREASED LIABILITY THAT CHILDREN FOR THE PERCEIVED INCREASED LIABIL ITY THAT CHILDREN
REPRESENT. IN ADDITION, LANDLORDS HAVE ALLEGED THAT RENTAL REPRESENT. IN ADOITION, LANDLORDS HAVE ALLEGED THAT RENTAL PROPERTIES WHICH ALLOW CHILDREN INCUR HIGHER OPERATING
EXPENSES. THE FAIR HOUSING AMENDMENTS ACT OF 1988 WAS PASSED EXPENSES. THE FAIR HOUSING AMENDMENTS ACT OF 1988 WAS PASS TO CORRECT PERCEIVED DISCRIMINATION AGAINST FAMILIES WITH
CHILDREN. YET NO CONCLUSIVE RESEARCH HAS BEEN CONDUCTED TO CHILDREN. YET NO CONCLUSIVE RESEARCH HAS BEEN CONDUCTED TO
DETERMINE WHAT IMPACT THIS CORRECTIVE LEGISLATION MIGHT HAVE ON THE COST OF HOUSING AND ULTIMATELY ON THE FAMILIES THAT THE LEGISLATION IS SUPPOSED TO PROTECT. THIS PAPER LOOKS AT THE EFFECT OF THIS LEGISLATION ON RENTAL COSTS, OPERATING COSTS, AND PROFITS. FOLLOWING A REVIEW OF THE LEGAL BACKGROUND AND LEGISLATION IN THE FIELD, THE ARGUMENTS FOR 
SUCH LEGISLATION ARE OUTLINED. THEN THE AUTHORS PRESENT THE DATA AND MODEL USED FOR THE ANALYSIS, FOLLOWED BY THE RESULTS AND CONCLUSIONS.

03786 GOERING, J.

RACE AND PUBLIC HOUSING IN BRITAIN AND THE UNITED STATES NOTES FOR A POLICY-RELEVANT RESEARCH AGENDA

NEW COMMUNITY, 18 (3) (APR 92), 457-462.

THE AUTHOR' BRIEFLY IDENTIFIES SOME OF THE COMMON AND DISTINCTIVE RACIAL HOUSING ISSUES IN THE UNITED STATES AND THE UNITED KINGDOM. THEN HE DISCUSSES THE NEED FOR COMPARATIVE RESEARCH ON U.S. AND BRITISH PUBLIC HOUSING POLICIES.

03787 GOERTZEN, D.

AGENTS FOR CHANGE

FAR EASTERN ECONOMIC REVIEW, 153(32) (AUG 91), 20-21. WHILE TRAILING MOST OF ITS NEIGHBORS IN TERMS OF ECONOMIC GROWTH, THE PHILIPPINES MAY HAVE HIT ON THE KEY TO INVOLVING LOCAL' COMMUNITIES ANO INTEREST GROUPS IN THE DEVELOPMENT PROCESS. TO A GREATER EXTENT THAN ANYWHERE ELSE IN THE REGION, SO-CALLED NON-GOVERNMENTAL ORGANIZATIONS IN THE REGION, SO-CALLED NON-GOVERNMENTAL ORGANIZATIONS IMPROVING THE LOT OF THE POOR MAJORITY, THROUGH POLITICAL CULTURAL AND ECONOMIC PROGRAMS. THE IRONY OF THEIR SUCCESS IF THAT EVEN THE GOVERNMENT SEEMS HAPPY TO SEE NGOS ASSUME PART OF ITS FUNCTIONS. THERE ARE SOME 18,000 NGOS IN THE PHILIPPINES TODAY, OF WHICH ABOUT 2,000 ARE ENGAGED IN DEVELOPMENT WORK. THEY PROVIDE ASSISTANCE TO COMMUNITIES STRUCK BY NATURAL DISASTERS AND DEVELOP INFRASTRUCTURE FROM THE VILLAGE TO PROVINCIAL LEVEL. THE SUCCESS DF THE NGO MOVEMENT SEEMS TO PROVE THE POINT THAT IT IS OFTEN AT THE LEVEL OF THE COMMUNITY THAT RESOURCES ARE MANAGED MOST EFFICIENTLY.

03788 GOETZ, E.G.

LOCAL GOVERNMENT SUPPORT FOR NONPROFIT HOUSING: A SURVEY OF U.S. CITIES

URBAN AFFAIRS OUARTERLY, 27(3) (MAR 92), 420-435.

NONPROFIT HOUSING DEVELOPERS ARE ACTIVE IN ALL LARGER U. S. CIIIIES, AND LOCAL GOVERMMENTS PROVIDE FINANCIAL AND TECHNICAL RESOURCES TO THEM. THIS STUDY REPORTS ON A SURVEY OF HOW LOCAL GOVERNMENTS PROVIDE SUPPORT FOR NONPROFIT DEVELOPERS AND OFFERS A TYPOLOGY OF POLITICAL AND PROGRAMMATIC ARRANGEMENTS REACHED BY MOMPROFIT HOUSING PROVIDERS AND LOCAL GOVERMMENTS THE FIMDINGS SUGGEST THAT PROVIDERS AND LOCAL GOVERNMENTS. THE FINDINGS SUGGEST THAT THE POLITICAL ORGANIZATION OF THE COMMUNITY-BASED HOUSING SECTOR IS AN IMPORTANT FACTOR IN DETERM
SUPPORT PROVIDED BY LOCAL GOVERNMENT.

03789 GOETZ, R.

IELTSIN'S ECONOMIC REFORM COURSE AND ITS CRITICS AUSSEN POLITIK, 43(3) (JUL 92), 267-276

THE POLITICAL DEVELOPHEMT IM THE FORMER USSR AND THE SECURITY SITUATION IN EUROPE DEPEND TO A SUBSTANTIAL EXTENT ON WHETHER THE RUIN CAUSED BY THE SOCIALIST SYSTEM CAN $B$ OVERCOME AND THE SUPPLY OF THE POPULATION AND ECONOMIC DEVELOPMENT GUARANTEED IN A TRANSITION TO A MARKET ECONOMY. AT THE END OF 1991, THE RUSSIAN PRESIDENT B. IELTSIN INITIATED A PROGRAM OF ECONOMIC REFORM FOR RUSSIA WHICH WAS DRIENTATED TOWARDS THE MODEL OF POLISH "SHOCK THERAPY" AND THE IDEAS OF THE INTERNATIONAL MONETARY FUND. THE REFORM PROGRAM TRIGGERED FIERCE CONTROVERSY IN RUSSIAN ECONOMIST CIRCLES.

03790 GOFFIN, A.

NATIONALISM AND MEXICAN INTERPRETATIONS ON THE WAR OF THE NORTH AMERICAN INVASION, 1846-1848

CANADIAN REVIEW OF STUDIES IN NATIONALISM, XIX(1) (1992),

129-138.

MEXICAN NATIONALISTIC SENTIMENTS HERE STRONG WHEN THE WAR BETWEEN THE UNITED STATES AND MEXICO BEGAN IN 1846. AFTER INDEPENDENCE, THE TEXAS TERRITORY WAS PASSES SON TO MEXICO. MEXICAN NATIONAL I SM WAS THEREFOR CONCERMED WITH TEXAS. HOLDING ON TO THAT TERRITORY IN DEFIANCE OF NORTH AMERICAN INTENTIONS WAS SYMBOLIC OF THE MEXICAN DESIRE FOR INDEPENDENCE ON THE NORTH AMERICAN CONTINENT. MEXICANS VIEWED ANY NORTH AMERICAN ATTEMPT TO TAKE TEXAS AS AN ACT OF WAR. THIS ESSAY INVESTIGATES THE NATURE AND TENOR OF MEXICAN INTERPRETATIONS OF THIS CONFLICT OVER THE PAST CENTURY AND A HALF.

03791 GOHMANN, S.; OHSFELDT, $R$.

THE ECONOMICS OF AIDS-RELATED HEALTH INSURANCE REGULATIONS: THE ECONOMICS OF AIDS-RELATED HEALTH IMSU

PUBLIC CHOICE, 74 (1) (1991), 105-126.

THE PROJECTED IN THE U.S. IN THE NUMBER OF PERSONS WITH AIDS HAS CREATED CONCERN ABOUT SOURCES OF FINANCING THE COSTS OF HEALTH CARE SERVICES FOR THESE PEOPLE. PRIVAT HEALTH INSURERS HAVE MODIFIED OR CONSIDERED MODIFYING UNDERHRITING PRACTICES IN RESPONSE TO THE AIDS EPIDEMIC, BUT SEVERAL STATE GOVERNMENTS HAVE DEVELOPED SIGNIFICANT

REGULATORY CONSTRAINTS ON AIDS-RELATED UNDERNRITING PRATICES.

DISCUSSED IN THIS ARTICLE ARE THE ECONOMICS OF AIDS-RELATED
HEALTH INSURANCE REGULATIONS AS WELL AS INTEREST GROUP INFLUENCE AND IDEDLOGY.

03792 GOLAN, G.

GORBACHEV'S DIFFICULT TIME IN THE GULF

POL ITICAL SCIENCE QUARTERLY, $107(2)$ (SUM 92), 213-230.

MIKHAIL GORBACHEV'S "NEW' POL ITICAL THINKING" IN FOREIGN

POLICY WAS TESTED AND STRETCHED TO, IF NOT BEYOND, ITS

LIMITS IN THE 1990-91 PERSIAN GULF CRISIS. NEW THINKING

POSITED A WORLD OF INTERDEPENDENT STATES AND INTERNATIONAL

RELATIONS DEVOID OF IDEOLOGY, EAST-WEST COMPETITION, AND THE ZERO-SUM GAME APPROACH CHARACTERISTIC OF THE COLD WAR. THESE IDEAS DICTATED SOVIET BEHAVIOR IN THE FIRST STAGE OF THE GULF CRISIS, WHICH BEGAN WITH THE IRAQI INVASION OF KUWAIT. AS THE CRISIS PROGRESSED, A SECOND STAGE COULD BE DISCERNED AS A RESULT OF THE SINGULAR INCREASE IN THE INFLUENCE OF CONSERVATIYES FROM THE SOVIET MILITARY, KGB, AND COMAUNIST PARTY IN MOSCOW. THE POWER OF THESE GROUPS WAS FELT PRIMARILY IN DOMESTIC AFFAIRS, BUT IT WAS ALSO A FACTOR IN FOREIGN POI ICY AS DEMONSTRATED BY THE DIFFICUL T JUGGL ING ACT UNDERTAKEN BY GORBACHEY AS THE GULF WAR PROGRESSED.

03793 GOLD, P.

ARCTIC STRUGGLE

INSIGHT, 7(4) (JAN 91), 20-21.

THE BATTLE OVER DRILLING IN THE ARCTIC NATIONAL WILDLIFE REFUGE MIGHT SET THE TONE FOR THE FIGHTS OVER THE ENYIROMMENT IN THE IO9OS. ENVIRONMENTAL ISTS CLAIM DEYELOPMENT COULD DESTROY THE 19-MILLION ACRE REFUGE AND ENDANGER HI OULE. THE OIL INDUSTRY DOWNPLAYS THE SERIOUSNESS OF THE IMPACT. IN THE END, THE DECISION HILL NOT BE MADE IN ALASKA, BUT IN WASHINGTON.

03794 GOLD, P.

STALLED ASSEMBLY LINE

INSIGHT, $7(8)$ (FEB 91), 16-17.

THE FANTASTIC PERFORMANCE OF U.S. MILITARY HARDHARE IN THE OPENING DAYS OF OPERATION DESERT STORM HAS LAID TO REST MANY FEARS ABOUT THE REAGAN-LED U.S. MILITARY BUILDUP. HOWEVER, ONE GLARING HOLE REMAINS: THE U.S. LACKS THE ABILITY TO ACCELERATE PRODUCTION OF CRITICAL ITEMS AT THE OUTBREAK OF WAR. THE PROBLEM WAS PREDICTED SOME THENTY YEARS AGO, BUT BUDGETARY CONSTRAINTS PREVENTED ANY REAL ACTION.

03795 GOLD, S.D.

THE FEDERAL ROLE IN STATE FISCAL STRESS

UBLIUS: THE JOURNAL OF FEDERALISM, 22(3) (SUM 92), 33-48.

F RECENT AIO REDUCTIONS HAVE NOT BEEN AN IMPORTANT SOURC OF RECENT STATE FISCAL STRESS. HOWEVER, FEDERAL POLICIES
HAVE CONTRIBUTED CONSIDERABLY TO RECENT STATE FISCAL STRESS, HAVE CONTRIBUTED CONSIDERABLY TO RECENT STATE FISCAL STRESS,
PARTICULARLY BECAUSE OF MEDICAID AND THE RECESSION, WHICH PARTICULARLY BECAUSE OF MEDICAID AND THE RECESSION, WHICH
HAS DEPRESSED REVENUE AND INCREASED WELFARE AND MEDICAID HAS DEPRESSED REVENUE AND INCREASED WELFARE AND MEDICAID SPENDING. THE REAL VALUE OF PER CAPITAL FEDERAL AID OTHER
THAM FOR WELFARE PROGRAMS FELL CONSIDERABLY IN THE 1980'S THAN FOR WELFARE PROGRAMS FELL CONSIDERABLY IN THE 1980'S, BUT THE REDUCTIONS WERE MUCH GREATER FOR LOCAL GOVERNHEN

THAN FOR STATES. FEDERAL POL ICIES HAVE AFFECTED STATE
FINANCES IN SEVERAL OTHER WAYS-THROUGH TAX POLICY, UNFUNDED FINANCES IN SEVERAL OTHER WAYS-THROUGH TAX POLICY, UNFUNDED MANDATES, AND THE FEDERAL FAILURE TO COPE EFFECTIVELY HITH PROBLEMS LIKE HEALTH CARE AND POVERTY. FEDERAL AND STATE COURT RULINGS HAVE ALSO CAUSED BUDGET PROBLEMS. RISING SCHOOL ENROLLMENTS, NEW CORRECTIONS POL ICIES, AND INELASTI
TAX SYSTEMS HAVE CREATED FISCAL STRESS FOR MANY STATES. CONTRIBUTED TO RECENT FISCAL PROBLEMS IN SOME STATES, THIS IS NOT GENERALLY THE CASE.

03796 GOLD, $V$

THE CONASS KING AND THE GURU

AMERICAN SPECTATOR, 24(10) (OCT 91), 14-15

THE 1991 GUBERNATORIAL RACE HEATS UP IN LOUISIANA.

FLASHY EX-GOVERNOR EDHIN EDWARDS, AN OLD-STYLE BAYOU

POLITICIAN, SOUARES OFF AGAINST NEW AGE INCUMBENT BUDDY ROEMER, HOSE CONVERSION TO THE REPUBLICAN PARTY IS BY NO MEANS HIS STRANGEST MOVE OF LATE. THIS ARTICLE DISCUSSES THE UPCOMING ELECTION AND ROEMER'S REASONS FOR SWITCHING TO THE REPUBLICAN PARTY.

03797 GOLDBERG,

SELEC 19905

HASHINGTON OUARTERLY, 15(3) (SUM 92), 15-24.

THE END OF THE COID WAR HAS STOOD TRADITIONAL NOTIONS ON THEIR HEADS AND INTRODUCED A GREAT AMOUNT OF UNCERTAINTY INTO U.S. FORIEGN POLICY DECISIONMAKING. THIS ARTICLE ARGUES THAT MANY OF THE COLLECTIVE NOTIONS CURRENT IN HASHINGTON DURING THE LATE 1970 S ANO 1980 S HERE ALREADY DUT OF TOUCH WITH FUNDAMENTAL SHIFTS IN GEOPOLITICS AND ECONOMICS THAT PRECEDED THE DEMISE OF COMHUNISM FOR QUITE SOME TIME. IT PRESENTS A "MIDOLE PATH" BETWEEN THE POLES OF COLLECTIVE ENGAGEMENT AND UNILATERAL ACTION IN TODAY'S TRANSITIONAL GLOBAL ENVIRONMENT: SELECTIVE ENGAGEMENT. SUCH A POLICY
WOULD INVOLVE THREE ELEMENTS. FIRST, U.S. FOREIGN POLICY WOULD INVOLVE THREE ELEMENTS. FIRST, U.S. FOREIGN POLICY
SHOULD SEEK TO NURTURE A RELATIVE EQUILIBRIUM OF POWER AMONG THE MAJOR STATES IN EUROPE AND ASIA. SECOND, HHILE HORKING 
THROUGH INTERNATIONAL ORGANIZATIONS AND COALITIONS WHEREVER POSSIBLE TO RESOLVE SECURITY PROBLEMS, THE UNITED STATES SHOULD ESCHEW MOST PERMANENT MILITARY COMMITMENTS AND TAKE A MORE FLEXIBLE, CASE-BY-CASE APPROACH TO SITUATIONS WHERE THERE IS NO IMMEDIATE THREAT TO ITS SAFETY. FINALLY, INSTEAD PREPONDERANCE AS AN ALTERNATIVE TO EXPANSION OF INDIGENOUS MILTTARY CAPABILITIES THE UNITED STATES SHOUID ACCEPT THE REALITY OF EMERGING NEW MILITARY POWERS.

03798 GOLDBERG, E. THE FOUNDATIONS OF STATE-LABOR RELATIONS IN CONTEMPORARY THE FOUM COMPARAT

ARATIVE POLITICS, 24(2) (JAN 92), 147-161.

THE LOSS OF IRADE UNION INDEPENDENCE AND NASSERIST CORPORATISM WERE DESIRABLE GOALS FOR SOME EGYPTIAN TRADE UNION LEADERS AND MEMBERS IN THE 1950's. FOR APPROXIMATLEY 20 YEARS AFTER NASSER CAME TO POWER, IT WOULD HAVE BEEN IRRATIONAL FOR MANY EGYPTIAN WORKERS TO HAVE SUPPORTED INDEPENDENT TRADE UNION ORGANIZATIONS. THE PRESENT STRUCTURE OF URBAN LABOR MARKETS IN EGYPT MAY BE MORE ADVANTAGEOUS FOR HORKERS LIKELY TO FORM SUCCESSFUL UNIONS THAN THE FORMATION OF NEW INDEPENDENT UNIONS THEMSELVES.

03799 GOLDBERG, J.

UNDERSTANDING THE DIMENSIONS OF TERRORISM

PERSPECTIVES ON POLITICAL SCIENCE, 20(2) (SPR 91), 78-88.

THIS ARTICLE CRITIOUES A RECENT PUBLICATION OF KENNETH J. LONG ENTITLED: "UNDERSTANDING AND TEACHING THE SEMANTICS OF TERRORISH: AN ALTERNATIVE PERSPECTIVE." THE AUTHOR OF THIS ARTICLE CONCLUDES THAT "WHETHER LONG'S INTENTION IS TO BLUNT OUR SENSITIVITIES TO THE NATURE OF TERRORISM OR WHETHER THIS IS THE UNINTENDED RESULT, HIS ASSERTIONS AND FAILURE TO IS THE UNINTENDED RESULT, HIS ASSERTIONS AND FAILURE ATTEND TO THE REALITIES OF POLITICAL LIFE HAVE THAT
CONSEQUENCES." THE ARTICLE INTENDS TO ADDRESS LONG'S

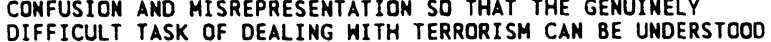
DIFFICULT TASK OF DEALING WITH TERRORISM CAN BE UNDERSTOOD
BY ALL. IN ADDITION, THE AUTHOR SEEXS TO EXAMINE ASPECTS TO BY ALL. IN ADDITION, THE AUTHOR SEEXS TO EXAMINE ASPECTS THE CHARACTER OF TERRORISM THAT ARE NOT OBSCURE AND ONLY WITH DISTINCT POLITICAL AGENDAS TO DELIBERATELY CONFUSE THE ISSUES.

03800 GOLDBERGER, $S$

THE POLITICS OF UNIVERSAL ACCESS: THE MASSACHUSETTS HEALTH SECURITY ACTO OF 1988

JOURNAL OF HEALTH POLITICS, POLICY AND LAW, 15(4) (WIN 90),

857-886.

THIS ARTICLE ANALYZES THE PASSAGE OF AN UNPRECEDENTED STATE LAW, PROMISING EVERY RESIDENT ACCESS TO AFFORDABLE HEALTH INSURANCE. THE MASSACHUSETTS HEALTH SECURITY ACT OF 1988 WAS THE PRODUCT OF A SET OF POLITICAL AND FINANCIAL PRESSURES THAT HAD BEEN DEVELOPING FOR NEARLY A DECADE. CONSUMER ACTIYISM HAS THE KEY FACTOR THAT FORCED THE TRADITIONAL POWERS IN HEALTH POLICY TO ADDRESS THE INTERESTS OF THE UNIMSURED. WHILE THE SOLUTION FOUND IN MASSACHUSETTS IS UNSTABLE AT BEST, THE SAME PRESSURES WHICH LED TO PASSAGE OF THE MASSACHUSETTS LAH ARE WHICH ARE NOW CAUSING OTHER STATES TO ACT WILL CONTINUE TO EXERT THEIR EFFECT UNTIL A MORE DURABLE SOLUTION IS FOUND.

03801 GOLDBLAT, J.

DENUCLEARIZATION OF AFRICA

BULLETIN OF PEACE PRDPOSALS, 23(2) (1992), 169-172. ONCE SOUTH AFRICA HAD ACCEDED TO THE TREATY ON THE NONPROLIFERATION OF MUCLEAR WEAPONS (NPT) IN 1991, REAL

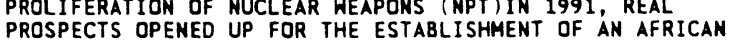
PROSPECTS OPENED UP FOR THE ESTABLISHMENT OF AN AFRICAN
NUCLEAR WEAPON-FREE ZONE. IN DRAFTING A TREATY ON THE NUCLEAR WEAPON-FREE ZONE. IN DRAFTING A TREATY ON THE
DENUCLEARIZATION OF AFRICA, LESSONS COULD BE DRAWN FROM THE
EXISTING INTERHATIONAL AGREEMENTS INTENDED TO ENSURE THE EXISTING INTERNATIONAL AGREEMENTS INTENDED TO ENSURE THE
ABSENCE OF NUCLEAR HEAPONS IN LARGE AND POPULOUS AREAS OF ABSENCE OF NUCLEAR WEAPONS IN LARGE AND POPULOUS AREAS OF THE GLOBE. THESE TREATIES SUFFER FROM CERTAIN WEAKNESSES.

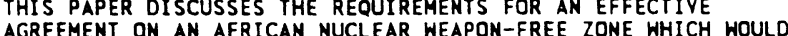
AGREEMENT ON AN AFRICAN NUCLEAR

03802 GOLDBLAT, J.

ISSUES FACING THE 1995 NPT EXTENSION CONFERENCE SECURITY DIALOGUE, 23(4) (DEC 92), 25-32.

TWO ISSUES MAY COMPLICATE THE 1995 NPT EXTENSION CONFERENCE: THE CESSATION OF NUCLEAR WEAPON TESTING, AND THE PROVISION OF SECURITY ASSURANCES TO NON-NUCLEAR-HEAPON STATES. VARIOUS STEPS MAY LEAD TO A COMPREHENSIVE TEST BAN: A FORMAL MORATORIUM; A PHASEOUT OF NUCLEAR TESTING WITHOUT A FORMAL AGREEMENT; A FORMAL AGREEMENT ON EVEN MORE STRINGENT RESTRICTIONS WITH A VIEW TO ULTIMATELY STOPPING THEM. ASSURANCES OF NO FIRST USE OF NUCLEAR WEAPONS, GIVEN TO ALL COUNTRIES WOULO CARRY WEIGHT. MAKING THE EXTENSION OF THE NPT DEPENDENT UPON THE SOLUTION OF SECURITY ASSURANCES COULD BE COUNTER-PRODUCTIVE.

03803 GOLDBLAT, J.

LEGAL PROTECTION OF THE ENVIRONMENT AGAINST THE EFFECTS OF MILITARY ACTIVITIES
BULLETIN OF PEACE PROPOSALS, 22(4) (DEC 91), 399-406. ALL MILITARY ACTIVITIES MAY HAVE DAMAGING EFFECTS FOR THE ENVIRONMENT. THERE ARE, HOWEVER, INTERNATIONAL LEGAL NORMS INTENDED TO MITIGATE SUCH EFFECTS. THOSE NORMS WHICH ARE MEANT TO BE OBSERVED CHIEFLY IN TIME OF PEACE BELONG TO THE LAW OF ARMS CONTROL. THOSE IMPOSING RESTRICTIONS IN TIME OF WAR BELONG TO THE LAW OF ARMED CONFLICT, BUT THERE IS A STRONG BODY OF OPINION WHICH HOLDS THAT PEACETIME RULES ON THE PROTECTION OF THE ENVIROMMENT ARE NEITHER SUSPENDED NOR THE PROTECTION OF THE ENVIRONMENT ARE NEITHER SUSPENDED NOR THE INSUFFICIENCY AND THE WEAKNESSES OF EXISTING CONSTRAINTS THE INSUFFICIENCY AND THE WEAKNESS
AND THE NEED TO STRENGTHEN THEM.

03804 GOLDBLAT, J.; BERNAUER, T.

TOWARDS A MORE EFFECTIVE BAN ON BIOLOGICAL WEAPONS BULLETIN OF PEACE PROPOSALS, 23 (1) (MAR 92), 35-42. BULLETIN OF PEACE PROPOSALS, 23 (1) (MAR 92) 35-42. THE 1972 BIOLOGICAL WEAPONS (BW) CONVENTION TOOK PLACE IN GENEVA. THIS ARTICLE SURVEYS THE RESULTS OF THE CONFERENCE AND POINTS OUT WHAT REMAINS TO BE DONE TO UPHOLD AND ENHANCE THE AUTHORITY OF THE INTERNATIONAL NORM OUTLAHING BIOLOGICAL AND TOXIN WEAPONS. ISSUES EXAMINED INCLUDE: THE IMPORTANCE OF ADHERENCE TO THE CONVENTION; THE SCOPE OF THE CONVENTION; ITS RELATIONSHIP WITH THE 1925 GENEVA PROTOCOL; NATIONAL IMPLEMENTATION; VERIFICATION AND COMPLIANCE; CONFIDENCEBUILDING MEASURES; AND ECDNOMIC AND TECHNOLOGICAL COOPERATION.

03805 GOLDEN, M.

EXIT, VOICE, LOYALTY, AND NEGLECT: BUREAUCRATIC RESPONSES TO PRESIDENTIAL CONTROL DURING THE REAGAN ADMINISTRATION JOURNAL OF PUBLIC ADMINISTRATION RESEARCH AND THEORY, 2(1) ( JAN 92), 29-62.

FORTH IS THAT BUREAUCRATIC BEHAYIOR IS NOT AS EASILY CHARACTERIZED AS THESE THO MODELS--THE RESISTANT AND THE COOPERATIVE--SUGGEST. INSTEAD, THE EXTENT OF RESISTANCE VARIES. THIS ARTICLE PRESENTS FIVE ORGANIZATIONAL FEATURES THAT APPEAR TO BE SIGNIFICANT IN PROMOTING OR INHIBITING RESISTANCE; IDEOLOGY, DOMINANT PROMOTING OR INHIBITING RESISTANCE; IDEOLOGY, DOMINANT

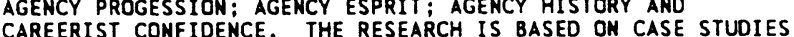
CAREERIST CONFIDENCE. THE RESEARCH IS BASED ON CASE STUDIES ANALYSIS EMPLOYS A MODIFIED VERSION OF HIRCHMAN'S CONCEPTS ANALYSIS EMPLOYS A MODIFIED VERSION OF HIRCHMAN'S CONCEPTS OF EXIT, VOICE, AND LOYALTY, AND AN ADOITIONAL CONCEPT OF ADMINISTRATION'S AGENDA OF POLICY CHANGE.

03806 GOLDEN, M.

THE POLITICS OF JOB LOSS

AMERICAN JOURNAL OF POLITICAL SCIENCE, 36(2) (MAY 92), 408-430.

THIS PAPER UNDERTAKES A RATIONAL CHOICE ANALYSIS OF A PROBLEM IN POLITICAL ECONOMY: NAMELY, WHY TRADE UNIONS, CONFRONTED WITH FIRMS EQUALLY INTRANSIGENT IN THEIR COMMITMENTS TO WORK-FORCE REDUCTIONS, SOMETIMES ACTIVELY RESIST JOB LOSS AND AT OTHER TIMES PASSIVELY ACQUIESCE. CASES INVESTIGATED ARE BRITISH LEYLAND AND FIAT. UNIONS AT BRITISH LEYLAND ACOUIESCED, HHEREAS THOSE AT FIAT RESISTED MASS WORK-FORCE REDUCTIONS IN 1980. THE LITERATURES ON CORPORATISM AND ON CONTEMPORARY INDUSTRIAL RELATIONS BOTH CLASS ITALIAN AND BRITISH LABOR RELATIONS AS ANTAGONISTIC. THEY THEREBY FAIL TO ANTICIPATE THE DIFFERENT OUTCOMES FOR THESE THO CASES. THE OUTCOMES MAY BE UNDERSTOOD AS PRODUCTS OF THE RATIONAL CALCULATIONS THAT UNION LEADERS MAKE WITHIM THE CONSTRAINTS OF LABOR-MARKET INSTITUTIONS. SPECIFICALLY, THE AUTHOR SHOWS THAT UNION RESPONSES TO THE THREAT OR SCALE WORK-FORCE REDUCTIONS VARY WITH THE PRESENCE OR
ABSENCE OF SENIORITY-BASED MECHANISMS FOR ALLOCATING JOB LOSS. WHERE SENIORITY IS USED, THE UNION ACQUIESCES TO JOB LOSS. HHERE SENIORITY IS USED, THE UNION ACQUIESCES TO JOB LOSS, SIMCE SEMI
SHOP STEWARDS

03807 GOLDEY, D.

THE PORTUGUESE ELECTIONS 1987 AND 1991

ELECTORAL STUDIES, $11(2)$ ( ) JUN 92 ), $171-176$.

DESPITE THE REVOLUTIONARY RHETORIC OF THE EARLIER PERIOD PORTUGUESE POLITICS SINCE 1976 HAVE BEEN DOMINATED BY THE
COMPETITION BETHEEN THE SOCIALISTS AND THE SOCIAL DEMOCRATS COMPETITION BETHEEN THE SOCIALISTS AND THE SOCIAL DEMOCRATS
FOR THE FLOATING VOTER AND, THUS, POLITICAL CONTROL. THIS FOR THE FLOATING VOTER AND, THUS, POLITICAL CONTROL. THIS ITS PRESIDENTIAL AND PARTY STRATEGIES, AND COMPARES THEM TO ITS PRESIDENTIAL AND PARTY STRATEGIES, AND COMPARES THEM TO THE 1991 PRESIDENTIAL CAMPAIGN AND RESULTS ALONG WITH ITS CHANGED RAPIDLY SINCE 1974. CACACO AND SOARES HAS EACH CHANGED RAPIDLY SINCE 1974 . CACACO AND SOARES HAS
SUCCEEDED IN MAKING SOMEWHAT DIFFERING VISIONS OF SUCCEEDED IN MAKING SOMEWHAT DIFFERING

03808 GOLDFORD, D.

REPLY TO HOLFE AND MORGAN

POLITY, XXIII (2) (HIN 90), 295-302.

DENNIS GOLDFORD RESPONOS TO THE CRITIQUES OF HIS ARTICLE "THE POLITICAL CHARACTER OF CONSTITUTIONAL INTERPRETATION." HE CLARIFIES THAT THE QUESTION HE ADDRESSES IS NOT WHETHER 
WE BEST UNDERSTAND ITS POLITICAL CHARACTER. HIS DISAGREEMENT WITH HIS CRITICS IS IN UNDERSTANDING OF THE CAPACITY OF LANGUAGE AND TEXTS TO STRUCTURE HUMAN ACTION. HE CONCLUDES THAT THE PARADOX OF ORIGINALISM IS THAT THE POSITIVIS THEORY OF CONSTITUTIONAL TEXTUALITY IT PRESUPPOSES TO EXPLAIN THE CONSTITUTION CANMOT ALSO EXPLAIN THE BINDING CAPACITY OF THE CONSTITUTION ON WHICH IT STAKES ITS CLAIM TO THEORETICAL VALIDITY.

03809 GOLDFORD, D.

THE POLITICAL CHARACTER OF CONSTITUTIONAL INTERPRETATION POLITY, XXIII(2) (WIN 90), 255-282.

CONSTIITUTIONAL INTERPRÉTATION MAY BE SEEN AS A POLITICAL PROCESS WHEREIN DELIBERATION CENTERS ON OUESTIONS OF THE COMMON GOOD FRAMED WITHIN THE TERMS OF A WRITTEN CONSTITUTION. THIS VIEW CONTRASTS WITH "ORIGINALISH," WHICH INTERPRETATION IS BOUMD SUBSTANTIVELY BY THE INTENT OF THE INTERPRETATION IS BOUMD SUBSTANTIVELY BY THE INTENT OF THE
FRAMERS. THE AUTHOR ARGUES THAT THE LOGIC OF ORIGINALISM FRAMERS. THE AUTHOR ARGUES THAT THE LOGIC OF ORIGIMA
UNDERMINES THE CLASSICALLY POLITICAL CHARACTER OF UNDERMINES THE CLASSICALLY POL ITICAL CHARACTER OF
CONSTITUTIONAL INTERPRETATION. BECAUSE ORIGINALISM CONSTITUTIONAL INTERPRETATION. BECAUSE ORIGINALISM
PRIVILEGES THE FRAMERS' INTERPRETATION OF THE TEXT AND NOT PRIVILEGES THE FRAMERS' INTERPRETATION OF THE TEXT AND NOT
JUST THE TEXT ITSELF, IT IS INCOMPATIBLE WITH POLITICS AND JUST THE TEXT ITSELF, IT IS INCOMPATIBLE WITH POLITICS POLITICAL ARGUMENTATION. DRAHING UPON RONDAL DWORKIN'S
DISTINCTION BETHEEN PLAIN-FACT AND INTERPRETIVE THEORIES OF DISTINCTION BETHEEN PLAIN-FACT AND INTERPRETIVE THEOR
LAH, THE AUTHOR CONCLUDES THAT IT IS THE LATTER WHICH SUPPORTS THE CLASSICALLY POLITICAL CHARACTER OF SUPPORTS THE CLASSICALLY POLIT
CONSTITUTIONAL INTERPRETATION.

03810 GOLDGEIER, J.; MCFAUL, M.

A TALE OF' TWO WORLDS: CORE AND PERIPHERY IN THE POST-COLD WAR ERA

INTERNATIONAL ORGANIZATION, 46(2) (SPR 92), 467-492. MANY STRUCTURAL REALISTS HAVE ARGUED THATT A FUTURE MULTIPOLAR INTERMATIONAL SYSTEM WILL BE LESS STABLE THAN THE BIPOLAR SYSTEM OF THE COLD HAR ERA. THIS ARTICLE SUGGESTS THAT ARGUMENTS BASED ON THE STABILITY OF A BIPOLAR OR MULTI POLAR SYSTEM ARE MISPLACED. FOCUSING INSTEAD ON DEMOCRACY, ECONOMIC INTERDEPENDENCE, AND TECHNOLOGY AS FACTORS MAKING WAR OR PEACE MORE LIKELY, THE ARTICLE ARGUES THAT THE FUTURE HILL BEST BE DESCRIBED AS A TALE OF TWO WORLDS. IN THE CORE STATES, THE GROWTH OF SHARED NORMS CONCERNING DEMOCRACY AND MARKETS WILL NOT ONLY MAKE BALANCEOF-POWER POLITICS AMONG THE GREAT POWERS A THING OF THE PAST BUT WILL ALSO MAKE NUCLEAR WEAPONS LESS IMPORTANT FOR MAINTAINING STABILITY THAN THEY WERE DURING THE COLD WAR. IN MAINTAINING STABILITY THAN THEY WERE DURING THE COLD WAR
THE PERIPHERAL STATES, HOWEVER, THE ABSENCE OF ABSOLUTE
DETERRENTS TO WAR AS WELL AS AN ABSENCE OF SHARED NORMS ABOUT DEMOCRACY AND MARKETS WILL MAKE OLD-STYLE BALANCE-OFABOUT DEMOCRACY AND MARKET
POWER POLITICS THE NORM.

03811 GOLDMAN, M.

PRESIDENT BUSH AND AFGHANISTAN: A TURNING POINT IN AMERICAN POLICY

COMPARATIVE STRATEGY, 11(2) (1992), 177-194.

ALTHOUGH THE UNITED STATES WELCOMED THE SOVIET MILITARY WITHDRAHAL FROM AFGHANISTAN IN EARLY FEBRUARY 1989, THE BUSH ADMINISTRATION DID NOT THINK THE KREMLIN HAD GONE FAR ENOUGH IN DIMINISHING ITS INFLUENCE OVER INTERNAL AFGHAN POLITICS BECAUSE A PRO-SOVIET COMMUNIST REGIME WELL ARMED BY THE KREMLIN CONTINUED IN POWER IN KABUL. PRESIDENT BUSH, THEREFORE, DECIDED IN EARLY 1989 TO CONTINUE AMERICAN SUPPORT OF THE ANTI COMMUNIST INSURGENCY, AND THEIR GOAL OF DEFEATING AND REPLACING THE SOVIET-INSTALLED COMHUNIST REGIME IN KABUL. BUT ALTERIN U.S. POLICY IN RESPONSE TO CHANGING CIRCUMSTANCES HAS NOT EASY, ESPECIALLY WHEN COMPROMISE WITH THE USSR WAS INVOLVED. THIS ARTICLE GIVE DETAILS OF THE STRUGGLE.

03812 GOLDMAN, M.I.

NEEDED: A RUSSIAN ECONOMIC REVOLUTION CURRENT HISTORY, 91(567) (OCT 92), 314-320.

THE HIGH HOPES THAT SURROUMDED THE INITIAL STAGES OF MARKET REFORM IN RUSSIA ARE TURNING TO PESSIMISM AS THE REAL ITIES OF ECONOMIC "SHOCK THERAPY" TAKE THEIR TOLL. AT THIS POINT PRESIDENT YELTSIN DOES NOT SEEM TO HAVE THE DETERMINATION TO PUSH THROUGH THE NECESSARY CHANGES OR TO BE WILLING TO TAKE ON THOSE IN POWERFUL PLACES WHO ARE STILL IDEOLOGICALLY OPPOSED TO PRIVATIZATION. UNLESS THE PRODUCTION OF FOOD AND CONSUMER GOODS GREATLY INCREASES SOON, THE WHOLE REFORM PROCESS AND YELTSIN'S PRESIDENCY COULD BE IN JEOPARDY.

03813 GOLDMAN, M.I.

YELTSIN'S REFORMS: GORBACHEY II?

FOREIGH POLICY (88; (FAL 92 ) 76-90.

RUSSIAN PRESIDENT YELTSIN MUST COME TO A NEH UNDERSTANDING OF THE PURPOSE OF ECONOMIC REFORM LEST THE LATEST ROUND OF CHANGES FOUNDER AS GORBACHEY'S DID. AS GORBACHEY CAME TO UNDERSTAND, YELTSIN KNOWS THAT SOVIET CENTRAL PLANMING THWARTED THE RATIONAL USE OF THE COUNTRY'S ECONOMIC RESOURCES BECAUSE OF ITS OBSESSION WITH HEAVY INDUSTRY AND MILITARY PRODUCTION. BUT NEITHER YELTSIN NOR GORBACHEY SEEMS TO APPRECIATE THAT INCREASING ECONOMIC
EFFICIENCY IS MERELY A MEANS TO AN END--AN IMPROVED STANDARD OF LIVING FOR THE AVERAGE RUSSIAN CITIZEN. SUCCESSFUL ECONOMIC REFORM REQUIRES MORE THAN CLOSING UNPRODUCTIVE FACTORIES. REFORMS, IF THEY ARE TO BE SUCCESSFUL, MUST PROVIDE RUSSIAN CONSUMERS WITH THE PRODUCTS THEY WANT AND NEED.

03814 GOLDMAN, N.C.

SPACE POLICY: AN INTROOUCTION

IOWA STATE UNIVERSITY PRESS, 1992, 332.

THIS BOOK IS A "POLITICAL SCIENCE CASE STUDY ON SPACE POLICY." TOPICS EXAMINED INCLUDE: THE HISTORY OF SPACE DEVELOPMENT; CURRENT SPACE POLICY DEVELOPMENT; THE DOMESTIC AND INTERNATIONAL FACTORS AFFECTING POLICYMAKING; SPECIFIC $U$. S. INSTITUTIONS THAT AFFECT POLICYMAKING; OVERALL ECONOMIC AND POLITICAL IMPACTS AS WELL AS CORE TECHNOLOGIES AND OTHER DEVELOPMENTS RESULTING FROM SPACE PROGRAMS; CIVILIAN APPLICATIONS OF SPACE; AND THE MILITARIZATION OF SPACE. THE BOOK IS ORGANIZED AROUND A SYSTEMS MODEL THAT SHOWS THE TRANSLATION OF PUBLIC NEED AND INTEREST, THROUGH INSTITUTIONS, INTO FORMAL SPACE DEVELOPMENT PROGRAMS-INSTITUTIONS, INTO FORMAL SPACE DEVELOPMENT PROGRAMS--
DEMONSTRATING THE INTERRELATIONSHIP OF SOCIETY, TECHNOLOGY DEMONSTRATING
AND POLITICS.

03815 GOLDRICH, D.; CARRUTHERS, D.

SUSTAINABLE DEVELOPMENT IN MEXICO? THE INTERNATIONAL SUSTAINABLE DEVELOPMENT IN MEXICO?

POLITICS OF CRISIS OR OPPORTUNITY
LATIN AMERICAN PERSPECTIVES, 19(72) (WIN 92), 97-122.

THE CHANGE FOR SUSTAINABLE INTERHATIONAL DEVELOPMENT DEPENDS ON THE OPTIONS THAT EMERGE IN MEXICAN ANI? IN U.S POL ITICS. THE MEXICAN CASE PROVIDES A CRUCIAL EXAMPLE OF THE OBSTACLES THAT MUST BE CONFRONTED ON THE ROAD TO INTERNATIONAL ENVIRONMENTAL SECURITY. THIS ARTICLE ARGUES THAT SO LONG AS MEXICO'S INTEGRATION INTO THE WORLD ECONOMY PROCEEDS ALONG ITS PRESENT PATH, EROSION OF THE HUMAN-AND NATURAL-RESOURCE FOUNDATION ON HHICH THE ECONOMY ULTIMATELY DEPENDS WILL ACCELERATE. ITS ATTEMPTS TO SHOW THAT THE REVITALIZATION OF PEASANT COMMUNITIES AND THE SOCIAL AND ECOLOGICIAL RECONSTRUCTION OF THE COUNTRYSIDE OFFER THE MOST PROMISING STRATEGY FOR REVERSING THE CYCLE OF POVERTY AND ECOLOGICAL DESTRUCTION, THUS TRANSFORMING CRISIS INTO OPORTUNITY.

03816 GOLDSMITH, A.A.

INSTITUTIONS AND PLANMED SOCIOECONOMIC CHANGE: FOUR APPROACHES

PUBLIC ADMINISTRATION REVIEH, 52(6) (NOV 92), 582-587. INSTITUTIONS ARE CENTRAL IO THE SUCCESS OF THIRD WORLD DEVELOPMENT EFFORTS, AND OVER THE YEARS DIFFERENT APPROACHES DAVE BEEN USED TO DEAL WITH THAT NEED. EARLY EFFORTS AT HAVE BEEN USED TO DEAL WITH THAT NEED. EARLY EFFORTS AT
SPECIFIC INSTITUTION-BUILDING WERE FOLLOWED BY A BROADER SPECIFIC INSTITUTION-BUILDING WERE FOLLLOHED BY A BROAC
STRATEGY OF INSTITUTION DEVELOPMENT. MORE RECENTLY, STRATEGY OF INSTITUTION DEVELOPMENT. MORE RECENTLY, ATTENTION HAS TURNED TO THE NEW INSTITUTIONALIST APPROACH, WHICH STRESSES (1) THE NEED TO WORK ON PROVIDING INDIVIDUALS WEED TO CREATE SUSTAINABLE INSTITUTIONS THAT LINK NEED TO CREATE SUSTAINABLE INSTITUTIONS THAT LINK
DEVELOPMENT PROGRAMS AND THEIR CONSTITUENTS OVER THE LONG TERM.

03817 GOLDSMITH, C.

A NEW ORDER: THE VIEW FROM EUROPE

EUROPE, (304) (MAR 91), 9-11.

IN THE OLD WORLD ORDER, EUROPE ALWAYS HAD SOMEBDOY ELSE TO BLAME, WHILE FEN PEOPLE BLAMED EUROPE. THE RUSSIAN BEAR WAS THE OBVIOUS CULPRIT FOR POVERTY, MISERY, AND ENVIRONMENTAL NIGHTMARES IN EASTERN' EUROPE.' RISING SAFETY CONCERNS FROM NATO'S MASSIVE ARMS BUILD-UP IN WESTERN EUROPE WERE AMERICA'S FAULT, AND THE EUROPEAN ALLIES HERE ONLY BEING GOOD SOLDIERS BY FOLLOWING ORDERS. HOWEVER, THE ADVENT OF THE "NEW" WORLD ORDER HAS PUT MUCH MORE PRESSURE ON EUROPE TO STAND UP AND ACT LIKE A SUPERPOWER-IN BOTH ECONOMIC AND MILITARY SPHERES. A RESULT OF THIS SHIFT WILL BE THAT EUROPE'S PROBLEMS AND SOLUTIONS HILL BEGIN AT HOME.

03818 GOLDSMITH, C.

BRUSSELS: WHO WILL BE EUROPE'S POLICEMAN? EUROPE, (311) (NOV 91), 10-11.

THE SHEEPING NUCLEAR DISARMAMENT PROPOSALS OF HASHINGTON AND MOSCOW HAVE BEEN WELCOMED IN THE EUROPEAN COMMUNITY HEADQUARTERS, BRUSSELS, AS A HISTORIC STEP TOWARD WORLD PEACE. BUT, THEY ALSO SERVE AS A NAGGING REMINDER THAT

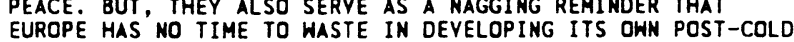
EUROPE HAS NO TIME TO WASTE IN DEVELOPING ITS OWN POST-COLD D TIN
WAR SECURITY STRUCTURE. WITHIN DAYS OF THE AMERICAN AND WAR SECURITY STRUCTURE. WITHIN DAYS OF THE AMERICAN AND
SOVIET PROPOSALS, SENIOR NATO OFFICIALS INDICATED THAT THE ALLIANCE WOULD CUT ITS STOCKPILE OF ABOUT 1,400 NUCLEAR ALLIANCE WOULD CUT ITS STOCKPILE OF ABOUT 1,400 NUCLEAR
AIRCRAFT BOMBS IN EUROPE BY UP TO HALF, YET ANOTHER SIGN AIRCRAFT BOMBS IN EUROPE BY UP TO HALF, YET ANOTHER SIGN THAT THE CONTINENT HAS ENTERED A NEH ERA OF STABILITY IN WHICH MASSIVE AMOUNTS OF NUCLEAR FIREPOHER ARE NO LONGER
EITHER NECESSARY OR DESIRABLE. THE CELEBRATIONS WERE QUICKLY TEMPERED, HOHEVER, BY THE REALIZATION THAT THE END OF THE COLD HAR IS BY NO MEANS THE CLOSING CHAPTER OF THE SECURITY DEBATE IN WESTERN EUROPE. IN FACT, THE LATEST DEVELOPMENT IN NUCLEAR DISARMAMENT HAS FORCED THE PACE IN A CRUCIAL BUT OFTEN LEISURELY DISCUSSION ON JUST WHO HOULD SERVE AS 
EUROPE'S POLICEMAN IN THE YEARS AHEAD.

03819 GOLDSMITH, M.

LOCAL GOVERNMENT

URBAN STUDIES, $29(2)$ (APR 92), 393-410.

THE AUTHOR COMPARES THE RECENT EXPERIENCE OF LOCAL GOVERNMENT IN SEVERAL COUNTRIES, EMPHASIZING THE BRITISH EXPERIENCE. HE CONTRASTS THE EFFECTS ON LOCAL GOVERNMENTS IN THE 1980'S OF CENTRALIZATION (THE BRITISH CASE) AND DECENTRALIZATION (MOST OTHER WESTERN COUNTRIES). THESE EXPERIENCES ARE SET IN THE CONTEXT OF INTERNATIONAL TRENDS, WITH EMPHASIS ON WESTERN EUROPE.

03820 GOLDSTEIN, C.

\section{BACK TO BUSINESS}

FAR EASTERN ECONOMIC REVIEH, 155(5) (FEB 92), 24.

HITH THE ENDING OF INTERNATIONAL SANCTIONS AGAINST SOUTH AFRICA, ASIAN COUNTRIES ARE MOVING RAPIDLY TO ESTABLISH AFRICA, ASIAN COUNTRIES ARE MOVING RAPIDLY TO ESTABLISH
TRADE AND INVESTMENT LINKS OR, IN SOME CASES, TO CONSOLIDATE TRADE AND INVESTMENT LINKS OR, IN SOME CASES, TO CONSOLIDATE EXISTING RELATIONSHIPS. INTEREST FOCUSES ON THREE MAIN AREAS-THE CHANCE TO DIVERSIFY RAW MATERIALS IMPORTS BY STEPPING
UP PURCHASES OF SOUTH AFRICAN IRON ORE AND COAL; CONSUMER UP PURCHASES OF SOUTH AFRICAN IRON ORE AND COAL; CONSUMER
GOODS EXPORTS, AND, IN THE LONGER RUN, THE EMERGENCE OF GOODS EXPORTS, AND, IN THE LONGER RUN, THE EMERGENCE OF SOUTH AFRICA AS A LOW-COST EXPORT-ORIENTED MANUFACTURING BASE. JAPAN, SOUTH AFRICA'S LARGEST TRAOING PARTNER, IS SHOWING STRONG INTEREST IN STEPPING UP IMPORTS OF UNPROCESSED OR SEMI-PROCESSED RAW MATERIALS, ESPECIALLY STEAMING COAL AND STEEL-MAKING RAW MATERIALS. HONG KONG FIRMS PLAYED A KEY ROLE IN SOUTH AFRICA'S PARTIALLY SUCCESSFUL ATTEMPTS TO EVADE INTERNATIONAL SANCTIONS HELPING IMPORT CRUDE OIL AND EXPORT COAL. NOW LOCAL TRADERS AND OFFICIALS HOPE THE TERRITORY CAN PROFIT AS SOUTH AFRICA REBUILDS ITS TRADE LINKS WITH EAST ASIA. UNLIKE MOST OTHER COUNTRIES, TAIWAN MAINTAINED FULL DIPLOMATIC RELATIONS WITH SOUTH AFRICA THROUGHOUT THE SANCTIONS PERIOD AND ALLOWED ITS COMPANIES TO TRADE AND INVEST FREELY. BUT MOST OF THE 200300 PRO JECTS STARTED TO DATE HAVE BEEN IN SMALL SCALE, LOH

TECH SECTORS SUCH AS FOOTWEAR AND TEXTILES.

03821 GOLDSTEIN, C.

CHINA'S OIL SHOCK

FAR EASTERN ECONOMIC REVIEW, 155(45) (NOV 92), 52-54. CHINA'S ECONOMIC REFORMERS, IN THE ASCENDANCY AT THE RECENTLY CONCLUDED 14TH COMMUNIST PARTY CONGRESS, ARE AUMCHING AM AMBITIDUS EFFORT IO OVERHAUL THE COUNTRY'S HIDEBOUND ENERGY SECTOR. AFTER YEARS OF TENTATIVE EFFORTS TO REFORM THIS HIGHLY SUBSIDIZED SECTOR. THE PRICE OF CRUDE OIL WILL TRIPLE IN JANUARY, BRINGING IT MORE INTO LINE WITH INTERNATIONAL RATES. CHINESE PLANNERS HOPE THAT SHOCK TREATMENT ON OIL PRICING WILL ACHIEVE A NUMBER OF POLICY GOALS. ONE IS TO REDUCE THE WASTE OF ENERGY RESOURCES. ANOTHER IS TO GIVE GREATER WEIGHT IN THE SECTOR TO MARKET FORCES RATHER THAN ADMINISTRATIVE POWERS. HOWEVER, CHINESE OFFICIALS NOW MUST FIGURE OUT HOW TO COPE WITH THE CONSEQUENCES OF MUCH HIGHER OIL PRICES. INFLATIONARY PRESSURES WILL BE FELT IN THE ECONOMY AS A WHOLE, WHILE LOSS MAKING STATE INDUSTRIES WILL BECOME EVEN LESS VIABLE.

03822 GOLDSTEIN, C.

THE NEW OIL SHEIKS

FAR EASTERN ECONOMIC REVIEW, 155(3) (JAN 92), 50-51.

DESPITE THE KATION'S LACK OF INDIGENOUS OIL, SOUTH

KOREA'S REFINERS HAVE BECOME EXPORTERS OF OIL PRODUCTS. THIS ARTICLE REPORTS THAT AGGRESIVE SOUTH KOREAN EXPANSIOH--WHERE OUTPUT SEEMS TO MATTER MORE THAN PROFITS--IS ALREADY PUTTING PRESSURE ON JAPANESE AND HESTERN COMPANIES. IN RESPONSE TO A RAPID GROWTH IN OIL DEMAND--THE FASTEST IN THE HORLD-SOUTH KOREAY PEFINERS HAVE LIFTED CAPACITY TO ALMOST 1.6 MILLION BARRELS PER DAY FROM 850,000 IN 1988, AT A COST OF US\$S BILLION.

03823 GOLDSTEIN, J.; RAPKIN, D. HEGEMONY AND THE FUTURE WORLD ORDER FUTURES, $23(9)$ (NOV 91), 935-959.

GEOSTRATEGIC INSULARITY--HISTORICALLY BASED ON HATER AS A MEDIUM OF LONG-DISTANCE COMMERCE AND A BARRIER TO LAND ARMIES--HELPED HEGEMONIC COUNTRIES TO EMERGE FROM GLOBAL WARS WITH WORLDWIDE PREDOMINANCE IN MILITARY CAPABILITY AND ECONOMIC STRENGTH (IN PRODUCTION, TRADE AND FINANCE). THE ROLE OF INSULARITY IN HEGEMONY IS DISCUSSED IN THIS ARTICLE ROLE OF INSULARITY IN HEGEMONY IS DISCUSSED IN THIS ARTICLE
AND TWO PRE-MODERN PROTOTYPES (ATHENS AND VENICE) AND FIVE AND THO PRE-MODERN PROTOTYPES (ATHENS AND VENICE) AND FIVE
MODERN CASES OF INSULARITY (PORTUGAL. THE NETHERLANOS, 18 TH MODERN CASES OF INSULARITY (PORTUGAL, THE NETHERLANDS, 18TH AND 19TH CENTURY BRITAIN, AND THE USA) ARE EXAMINED. THE UNDERMINING OF INSULARITY BY AIR POHER AND MISSILES IS THEN CONSIDERED, AND FOUR SCENARIOS FOR FUTURE HORLO OROER IN A PEST-INSULAR ERA ARE EXPLORED: U.S. HEGEMONIC REVIVAL; HEGEMONIC DECLINE LEADING TO ANARCHY OR HEGEMONIC WAR;
PEACEFUL TRANSITION TO JAPANESE HEGEMONY; AND SLOW HEGEMONIC PEACEFUL TRANSITION TO JAPANESE HEGEMONY; AND SLOW HEGEMONI
OECLINE WITH GREAT POWER COOPERATION UNDER LINGERING U.S. DECLINE WITH GREAT POWER COOPERATION UNDER LINGERING U.S.
LEADERSHIP. NEITHER RESURGENT HEGEMONY NOR RAPID DECLINE APPEARS LIKELY. RATHER, SHARED RESPONSIBILITY FOR HORLD ORDER UNDER CONTINUING U.S. LEADERSHIP IS FORESEEN.
03824 GOLDSTEIN, J.

THE POSSIBILITY OF CYCLES IN INTERNATIONAL RELATIONS INTERNATIONAL STUDIES QUARTERLY, 35(4) (DEC 91), 477-480. IT HAS BEEN ARGUED THAT SOCIAL CYCLES SHOULD BE DEFINED IN TERMS OF FIXED PERIODICY. IT IS ALSO ARGUED THAT RESEARCHERS SHOULD APPLY TIGHT STANDARDS OF EPISTEMOLOGY WHEN SEEKING KNOWLEDGE ABOUT PHENOMENA SUCH AS LONG CYCLES. THE AUTHOR OF THIS ARTICLE DISAGREES AND RESPONDS TO THESE THO PHILOSOPHICAL POINTS.

03825 GOLDSTEIN, L.

IN DEFENSE OF THE TEXT; DEMOCRACY AND CONSTITUTIONAL THEORY ROWMAN AND LITTLEFIELD, 1991, 288.

SINCE THE DEFEAT OF THE BORK NOMINATION TO THE U.S.

SINCE THE DEFEAT OF THE BORK NOMINATION TO THE U.S.
SUPREME COURT, CONSTITUTIONAL PHILOSOPHY HAS BECOME A

SUPREME COURT, CONSTITUTIONAL PHILOSOPHY HAS BECOME A
PROMINENT ISSUE IN NATIONAL POLITICS. THIS BOOK PROVIDES A PROMINENT ISSUE IN NATIONAL POLITICS. THIS BDOX

GUIDE TO THE VARIOUS THEORIES OF CONSTITUIONAL CONTEMPORARY JURISTS. THE AUTHOR INTRODUCES AND CRITIQUES THE PHILOSOPHIES OF IEADING CONSTITUTIONAL THEORISTS. IN THE PHILOSOPHIES OF LEADING CONSTITUTIONAL THEORISTS. IN
RESPONSE SHE ADVOCATES A MODERN VERSION OF THE TEXTUALIST TRADITION. SHE BELIEVES THAT IN THE REALM OF CONSTITUTIONAL LAW THE BEST PRECEDENTS AND THE WISEST JURISTIC NORMS ARE THOSE THAT TAKE THE TEXT SERIOUSLY AS A GUIDE TO JUDICAL DISCRETION, WHILE ALLOWING JUDGES TO ADAPT THE CONSTITUIONAL PRINCIPLE TO CHANGES THAT ARISE IN SOCIETY.

03826 GOLDSTEIN, R.

HATE SPEECH, FREE SPEECH, AND THE UNSPOKEN

TIKKUN, 7(3) (MAY 92), 53-56.

THE POLITICS OF THE EPITHET HAS DRIVEN A WEDGE INTO LONGSTANDING LEFT COALITIONS. THE SURPREME COURT HAS NEVER UPHELD A CONVICTION FOR "FIGHTING WORDS." THIS IS THE MURKY LEGAL LANDSCAPE THE JUSTICES ARE NOW REVISTING. THIS ARTICLE SUGGESTS THAT WE ARE ENTERING AN ERA OF CONSERVATIVE JUDICIAL ACTIVISM UNKNOWN IN THE UNITED STATES SINCE THE DAYS OF JIM CROW. IT WONDERS IF THE STRATEGY OF TODAY'S MAJORITY MAY WELL BE TO FREE UP HATE SPEECH WHILE MAJORITY MAY WELL BE TO FREE UP HATE SPEECH WHILE
SUPPRESSING EXPRESSION OF DISSENT. TO IGNORE THE CONTEXT OF SUPPRESSING EXPRESSION OF DISSENT. TO IGNORE THE CONTEXT OF
SPEECH ENTIRELY IS TO OISCARD THE TIME-HONORED ADVICE THAT THE UNINTENDED CONSEQUENCES OF ANY SOCIAL POLICY ARE ALWAYS THE UNINTENDED CONSEQUENCES OF ANY SOC
MDRE IMPORTANT THAN THE INTENDED ONES.

03827 GOLDTHORPE, J.

INTOXICATED CULTURE: PUNK SYMBOLISM AND PUNK PROTEST INTOXICATED CULTURE: PUNK SYMBOLISM AND
SOCIALIST REVIEW, 22(2) (APR 92), 35-64.

SOCIALIST REVIEW, $22(2$ ) (APR 92), 35-64. POSSIBILITIES OF SOLIDARITY AND TRANSFORMATION IN CULTURAL ARENAS RATHER THAN IN POLITICAL ORGANIZATIONS. THIS ARTICLE REVIEWS THE RISE OF PUNK COUNTERCULTURE AND DECIDES THAT THOUGH THE 19895 HARDCORE SCENE HAS LONG SINCE FRAGMENTED IN PART A VICTIM OF TENSIONS BETWEEN PUNK NEGATION AND "POSITIVE" POLITICS--ELEMENTS OF PUNK STYLE CONTINUE TO PERMEATE RADICAL PROTEST FROM QUEER NATION TO THE GULF WAR. SOCIETY WHICH SOCIALISTS SEEK CAN ONLY EMERGE FROM WIDESPREAD ALLIANCES, AND FROM MAJOR CULTURAL SHIFTS EXTENDING FAR BEYOND THE FIELD OF RADICAL CULTURAL POLITICS.

03828 GOLDTHORPE, J.H.; MARSHALL, G.

THE PROMISING FUTURE OF CLASS ANALYSIS: A RESPONSE TO RECENT CRITIQUES

SOCIOLOGY, 26(3) (AUG 92), 381-400.

CLASS ANALYSIS HAS RECENTLY BEEN CRITICIZED FRDM A VARIETY OF STANDPOINTS. IN THIS PAPER, THE AUTHORS ARGUE THAT MUCH OF THIS CRITICISM IS MISPLACED AND THAT, AS A RESEARCH PROGRAM, THE PROMISE OF CLASS ANALYSIS IS FAR FROM EXHAUSTED. THEY CLARIFY THE NATURE AND PURPOSE OF CLASS ANALYSIS AND DISTINGUISH THEIR VERSION FROM MARXIST CLASS ANALYSIS. THEY ARGUE FOR THE CONTINUING RELEVANCE OF CLASS OF CURRENT RESEARCH.

03829 GOLEMBIEWSKI, R.T.; DENHARDT, R.B.; SCOTT, J.D. EXCERPTS FROM 'ORGÁNIZATION AS A MÓRAL PRÓBLEM' PUBLIC ADMINISTRATION REVIEH, 52(2) (MAR 92), 95-107. IN A 1962 PAPER, ROBERT T. GOLEMBIEHSKI ARGUED THAT IN A 1962 PAPER, ROBERT T. GOLEMBI ENSKI ARGUED THAT
UDAEO-CHRISTIAN VALUES CAN PLAY AN EFFECTIVE ROLE IN THE JUDAEO-CHRISTIAN VALUES CAN PLAY AN EFFECTIVE ROLE IN THE
MANAGEMENT OF PUBLIC ORGANIZATIONS AND OFFERED EVIDENCE THAT MANAGEMENT OF PUBL IC ORGANIZATIONS AND OFFERED EVIDENCE THAT
ORGANIZATIONS OPERATING WITH THOSE FUNDAMENTAL VALUES CAN ORGANIZATIONS OPERATING WITH THOSE FUNDAMENTAL VALUES CAN
ACHIEVE HIGHER SATISFACTION AND PROOUCTIVITY. THIS ARTICLE ACHIEVE HIGHER SATISFACTION AND PRODUCTIVITY. THIS ARTICLE
PRESENTS EXCERPTS FROM THAT ORIGINAL ESSAY, SOME RECENT PRESENTS EXCERPTS FROM THAT ORIGINAL ESSAY, SOME RECENT
REFLECTIONS BY GOLEMBIEWSKI, AND COMMENTS ON HIS WORK BY TWO REFLECTIONS BY GOL
OTHER SCHOLARS.

03830 GOLRIZ, H.

IRAN: AN ECONOMY IN TRANSITION

MIDDLE EAST INSIGHT, VIII(4) (MAR 92), 63-66.

THIS ARTICLE EXAMINES THE FLUCTUATIONS OF THE IRANIAN ECONOMY IN THE YEARS FOLLOWING THE ISLAMIC REVOLUTION. IT PAYS SPECIAL ATTENTION TO THE EFFECTS OF THE PRAGMATIC REFORMS OF PRESIDENT RAFSANJANI. THESE REFORMS INCLUDE DEVALUATION OF THE CURRENCY, NEW MONETARY AND CREDIT POLICIES, MORE AGGRESSIVE SEEKING OF FORIEGN INVESTMENT, AND 
PRIVATIZATION MEASURES. THESE MOVES AHAY FROM REYOLUTIONARY IDEOLOGY HAYE SPURRED AN EMCOURAGIMG REBOUMD IN THE IRANIAN ECONOMY.

03831 GOMEZ, L.

THE BIRTH of the "hISPANIC" generation: atTItUdes of MEXICAN-AMERICAN POLITICAL ELITES TOHARD THE HISPANIC LABEL LATIN AMERICAN PERSPECTIVES, 19(75) (FAL 92), 45-58.

THE EVOLUTION OF ETHNIC LABELS IN THE MEXICAN-AMERICAN GROUP IS TRACED AND THE THEORETICAL FRAMEWORK THAT GUIDES THIS EXPLORATORY STUDY IS PRESENTED. THE AUTHOR EXPLORES THE ROLE OF ONE POTENTIAL SOURCE OF INTERMAL SUPPORT FOR THE TERM: ETHNIC POLITICAL ELITES. HIS FINDINGS FROM INTERVIENS RAISE QUESTIONS ABOUT THE IN-GROUP SOURCES OF POPULARIZATION OF THE HISPANIC LABEL. THE RELATIONSHIP BETWEEN ELITES' WITHIN IDENTITY AND THAT OF THE LARGER GROUP THAT THEY PRESUME TO REPRESENT, AND THE ROLE OF ETHNIC ELITES VIS-AVIS THE ORGANIZATION AND INSTITUTIONS OF THE DOMINANT SOCIETY.

03832 GONCE, R.

F.H. KNIGHT ON CAPITALISM AND FREEDOM

JOURMAL OF ECONOMIC ISSUES, 26(3) (SEP 92), 813-844.

F.H. KNIGHT DEVELOPED HIS OWN FINISHED ANALYSIS OF THE MEANING OF ECONOMIC FREEDOM AND CRITICIZED OTHERS VIEWS. THIS PAPER HAS THO MAJOR OBJECTIVES. ONE IS TO FOCUS ON KNIGHT'S IDEA OF ECONOMIC FREEDOM AS AN EMPIRICAL TERM AND TO CRITICALLY REVIEW HIS ANALYSIS OF ITS MEANING TO SHOW THAT IT EMANATES FROM CERTAIN PRINCIPLES IN HIS SOCIAL PHILOSOPHY AND REPRESENTS A VERSION OF THE POSITIVE CONCEPTION OF FREEDOM. THE SECOND OBJECTIVE IS TO PROVE THAT IN KNIGHT'S HANDS, MICROECONOMIC THEORY EXPLAINS THAT THE NORMAL OPERATIONS OF THE MARKET WILL BRING ABOUT A SIGNIFICANTLY LIMITED CONDITION OF ECONOMIC FREEDOM, CHIEFLY DUE TO TRADE-OFFS MADE IN THE FACE OF COMFLICTS amONG THE VARIOUS KINDS OF ECONOMIC FREEDOM AND BETWEEN ECONOMIC FREEDOM AND EFFICIENCY.

03833 GONCHAROV, S.N.

STALIN'S DIALOGUE WITH MAO ZEDONG

JOURNAL OF NORTHEAST ASIAN STUDIES, $X(4)$ (WIN 92), 45-76.

IVAN VLADIMIROVICH KOVALEV SERVED AS THE PERSONAL REPRESENTATIVE OF JOSEPH STALIN TO MAO ZEDONG IN THE LATE $1940^{\prime}$ 'S AND HANDLED SECRET NEGOTIATIONS BETHEEN THE TWO COMMUNIST LEADERS. IN THIS INTERVIEN, KOVALEV DISCUSSES SINOSOVIET RELATIONS DURING THIS PERIOD AND HIS ROLE IN THE SOVIET RELATIONS DURING THIS PERIOD AND HIS ROLE IN THE
EVENTS SURROUNDING THE BIRTH OF THE PEOPLE'S REPUBLIC OF CHINA.

03834 GONEN, J.; COLEMAN, M.

THE ERA OF INFOTAINMENT: VOTING IN 1992

THE ERA OF INFOTAINMENT: VOTING IN 1992
JOURMAL OF PSYCHOHISTORY, $20(2)$ (FAL 92 ), 135-148.

CAMPAIGNING IN THE AGE OF TELEVISION HAS CHANGED THE CHARACTER OF AMERICAN POLITICS. THE USE, BY THE MEDIA, OF A CAMPAIGN AS ENTERTAINMENT, OR WHAT HAS BEEN CALLED INFORMATION AS ENTERTAINMENT OR INFOTAIMMENT IS WHAT EXISTS TODAY. THIS ARTICLE SUGGESTS THAT WHEN NEWS BECOMES ENTERTAINMENT IT CAN BE A SIGN OF A DECLINING CULTURE. WHEN GRATIFICATION TAKES THE PLACE OF ANALYSIS, THE CULTURE TILTS AWAY FROM THE REALITY NEEDED TO SOLVE PROBLEMS AND MOVES FORWARD INTO THE WISH FULLING PHASE OF THE DECLINING BREAD AND CIRCUS CULTURE AT THE END OF THE ROMAN EMPIRE.

03835 GONG, D.

ON THE CHANGING PATTERN OF INTERMATIONAL RELATIONS CHINA REPORT, 28(1) (JAN 92), 27-38.

THIS ARTICLE BRIEFLY SURVEYS THE SHEEPING CHANGES THAT HAVE TRANSFORMED THE HORLD POL ITICAL AND ECONOMIC SCENE. THE DISINTEGRATION OF THE SOVIET EMPIRE, THE LIBERATION OF
EASTERN EUROPE, THE RELATIVE DECLINE OF UNITED STATES' POWER, THE SPREAD OF POWER TO MULTIPLE POLES, AND THE CONTRADICTORY TRENDS TOHAROS REGIONAL IZATION AMD INTERNATIONALIZATION OF ECONOMIES ARE ALL EXAMIMED. THE ARTICLE CONCLUDES WITH SOME SUGGESTIONS FOR CHINA'S DOMESTIC AND FORIEGN POLICY IN THE YEARS TO COME. IT ARGUES THAT CHINA SHOULD TAKE ADVANTAGE OF WORLD-WIDE DETENTE TO PURSUE ECDNOMIC DEVELOPMENT. FURTHERMORE, CHINA SHOULD AVOID REGIONAL ECONOMIC GROUPINGS WHICH, AS A RULE, WOULD BE DISADVANTAGEOUS TO CHINA.

03836 GONG, G.W.

KOREAN UNIFICATION: IMPLICATIONS FOR THE U.S. AND NORTHEAST ASIA

KOREA \& WORLD AFFAIRS, 16(4) (WIN 92), 654-669.

THE AUTHOR REVIEWS U.S. PERSPECTIVES ON THE DOMESTIC INTER-KOREAN, AND NORTHEAST ASIAN CONDITIONS THAT FORM THE CONTEXT FOR PLANNING EVENTUAL KOREAN UNIFICATIOH. HE ALSO CONSIDERS THE IMPLICATIONS OF KOREAN UNIFICATION FOR U.S. INTERESTS. HE SUGGESTS ANALYTICAL GUIDELINES FOR ASSESSING UNIFICATION, NOTES SOME ASPECTS OF THE CURRENT KOREAN SITUATION AND THE PROCESS OF UNIFICATION AS VIEWED FROM WASHINGTON, ANO CONSIDERS SOME LONGER-TERM ISSUES AND INTERESTS IN TERMS OF POSSIBLE U.S. OBJECTIVES FOR KOREAN UNIFICATION.
03837 GONZALES, E.

SWORDS INTO PLOWSHARES--ECONOMIC CONVERSION AND THE U.S. BASES IN THE PHILIPPINES

AMERICAN FRIENDS SERVICE COMMITTEE, 1990, 24

MANY OPPONENTS OF U.S. MILITARY BASES IN THE PHILIPPINES ARGUE THAT THEY CONTRIBUTE TO THE SECURITY OF NEITHER THE UNITED STATES NOR THE PHILIPPINES. THIS REPORT ADOS TO THIS CHALLENGE BY FOCUSING ON ECONOMIC ISSUES AND QUESTIONING WHETHER FOREIGN BASING CONTRIBUTES TO THE ECONOMIC HEALTH OF THE HOST COUNTRY. SPECIFICALLY, THE REPORT: TAKES STOCK OF THE IMPACT OF THE U.S. BASES ON THE PHILIPPINE NATIONAL ECONOMY AND ON LOCAL HOST COMMUNITIES: ACQUAINTS THE READER WITH CURRENT PHILIPPINE CONVERSION PROPOSALS; PRESENTS BASIC GUIDELINES FOR ASSESSING THE ECONOMIC JUSTICE OF CONVERSIOM PROPOSALS; LOOKS AT THE TASKS AHEAD FOR CONVERSION COALITIONS: AND SUGGESTS WHAT U.S. GROUPS CAN DO TO ASSIST THE CONVERSION MOVEMENT IN THE PHILIPPINES.

03838 GONZALEZ, H.8.

THE REL INQUISHMENT OF CO-EQUALITY BY CONGRESS HARYARD JOURNAL OF LEGISLATION, 29(2) (SUM 92), 331-356. THE UNITED STATES GOVERMMENTAL STRUCTURE IS BASED UPON THE SEPARATION OF THE JUDICIAL, LEGISLATIVE, AND EXECUTIVE POHERS. IN THIS ESSAY, THE AUTHOR ARGUES THAT THE HISTORICAL EQUILIBRIUM AMONG THESE THREE POWERS HAS BEEN DISRUPTED BECAUSE THE LEGISLATIVE BRANCH HAS RELINQUISHED PONERS TO THE EXECUTIVE BRANCH. HE POINTS TO THREE AREAS TO HIS THESIS. FIRST, HE DESCRIBES HOW CONGRESS HAS RELINQUISHED ITS POWER OVER WAR. SECONDLY, HE EXAMINES THE FINALLY, HE EXPLORES THE RELINOUISHMENT OF THE POWERS RELATING TO PRESIDENTIAL SUCCESSION AND THE GENERAL OPERATION OF THE GOVERNMENT.

03839 GONZALEZ, R.; MEHAY, S.

BURDEN SHARING IN THE NATO ALLIANCES: AN EMPIRICAL TEST OF ALTERNATIVE VIEWS

PUBLIC CHOICE, 68(1-3) (JAN 91), 107-136.

THIS PAPER UNDERTAKES AN EMPIRICAL TEST OF TWO OPPOSING VIEWS OF INTERDEPENDENCIES AMONG MEMBERS OF MILITARY ALLIANCES. THE FIRST VIEW, ASSOCIATED WITH OLSON AND ZECKHAUSER, ARGUES THAT THE PUBLIC GOOD ASPECT OF DEFENSE INDUCES FREE RIDING BEHAVIOR BY SMALLER ALLIANCE MEMBERS, WHICH IMPOSES A DISPROPORTIONATE BURDEN OF SUPPORTING THE ALLIANCE ON THE LARGER MEMBERS. A SECOND VIEH ARGUES THAT ALLIANCE ON THE LARGER MEMBERS. A SECOND VIEH ARGUES THAT
NATO DEFENSE ACTIVITIES PRODUCE A MIX OF OUTPUTS, SOME OF NATO DEFENSE ACTIVITIES PRODUCE A MIX OF OUTPUTS, SOME
WHICH ARE NOT PURELY PUBLIC, AND SOME OF WHICH MAY BE WHICH ARE NOT PURELY PUBLIC, AND SOME OF WHICH MAY BE
COMPLEMENTARY ACROSS NATIONS. FURTHERMORE, THE NATURE OF THE COMPLEMENTARY ACROSS NATIONS. FURTHERMORE, THE NATURE OF THE
WEAPONS SYSTEMS AND THEIR RELATIVE USE BY ALLIANCE MEMBERS MAY INDUCE SUBSTANTIAL COOPERATION BY ALLIES. THE TEST PROPOSED HERE ANALYZES THE RELATIONSHIP BETHEEN DEFENSE SPENDING SHARES OF NATO MEMBERS AND THEIR POPULATION AND RELATIVE WEALTH SHARES. A SIMPLE MODEL IS SPECIFIED AND TESTED USING POOLED TIME SERIES CROSS SECTIONAL DATA. THE EMPIRICAL RESULTS INDICATE MORE SUPPORT FOR THE COOPERATIVE $\checkmark I E W$ OF ALLY RELATIONSHIPS THAN THE OLSON-ZECKHAUSER NONCOOPERATIVE MODEL.

$03840 \mathrm{GOOCH}, A$

THE FOREIGN RELATIONS AND FOREIGN POLICY OF SPAIN. PART THREE: SPAIN, THE UNITED STATES AND NATO

CONTEMPORARY REVIEH, 260(1516) (MAY 92), 239-243.

IN 1945 THE ATTITUDE OF THE UNITED STATES AND OTHER WESTERN DEMOCRACIES WAS TO OSTRACIZE SPAIN BUT AS THE COLD WAR BETWEEN EAST AND WEST DEVELOPED, THE AMERICANS GRADUALLY CAME TO THE REALIZATION THAT IT WAS IN THEIR INTEREST TO DROP THEIR HOSTILE, NEGATIVE ATTITUDE AND TAKE ADVANTAGE OF A VIEW OF SPAIN AS A HIGHLY DESIRABLE BASTION IN THE GLOBAL STRUGGLE AGAINST COMMUNISM. IN 1953 THIS POSITION CAUSED SPAIN TO BE IN A POSITION OF CURTAILMENT OF SPANISH SOVEREIGNTY AND EXPOSURE TO RUSSIAN MISSILES. IN 1982 THE SPANISH POLICY TOWARDS NATO WAS ONE OF CALCULATED AMBIGUITY, WHICH COULD BE INTERPRETED IN DIFFERENT WAYS. THE SOCIALIST GOVERNMENT HAS DONE EVERYTHING POSSIBLE TO MAXIMISE SPAIN'S IMPORTANCE AS A NATO MEMBER. THE POLITICAL VALUE OF NATO TO SPAIN IS FAR GREATER THAN THE MILITARY VALUE OF SPAIN TO NATO AT THIS TIME.

$03841 \mathrm{GOOCH}, \mathrm{A}$.

THE FOREIGN RELATIONS AND FOREIGN POLICY OF SPAIN--PART TWO: SPAIM AND LATIM AMERICA CONTEMPORARY REVIEW, 260(1514) (MAR 92), 129-134.

THE HISTORY OF SOUTH, CENTRAL, AND ALSO MUCH OF NORTH AMERICA IS INTIMATELY BOUND UP WITH SPAIN UP TO THE PRESENT DAY. CERTAINLY SINCE 1975 THERE HAS BEEN A GROWING SPANISH INTEREST IN FOSTERING THE SPIRIT OF DEMOCRACY ACROSS THE OCEAN. A ROYAL VISIT TO MEXICD, PERU, AND ARGENTINA IN 1978 HAVING THIS OBJECT SPECIFICALLY IN VIEN AND BEING FOLLOWED BY A STRING OF FURTHER ENDEAVOURS OVER THE YEARS. THE FRUITS OF THESE ENDEAVORS CAN BEEN SEEN TODAY IN MANY PART OF LATIN AMERICA. THIS ARTICLE STUDIES ARGENTINA, CHILE, CUBA, RELATIONSHIP OF SPAIN, LATIN AMERICA AND THE EUROPEAN 
COMMUNITY IS ANALYZED.

$03842 \mathrm{GOOCH}, \mathrm{A}$.

THE FOREIGN RELATIONS AND FOREIGN POLICY OF SPAIN: A SURVEY FOR 1992. PART FIVE: SPAIN, EASTERN EUROPE AND THE SOVIET UNION, AND CONCLUSION

CONTEMPORARY REVIEW, 261(1522) (NOV 92), 229-231.

IN VIEW OF THE EXTREME POSITIONS AND SAVAGE HATREDS ENGENDERED WITH WARS, THE STORY OF THE DEVELOPMENT OF THE RELATIONS BETWEEN SPAIN AND THE EASTERN BLOC IS A LITTLE SHORT OF MIRACULOUS. THIS ARTICLE EXPLORES: SPAIN; THE SOVIET UNION; THE EEC; NATO; AND, OIL; AS HELL AS SPANISH MODELS AND THE EASTERH BLOC. THE AUTHOR CONCLUDES THAT SPAIN IS AT LAST IN HER RIGHTFUL PLACE AMONG THE NATIONS.

$03843 \mathrm{GOOCH}, A$.

THE FOREIGN RELATIONS AND FOREIGN POLICY OF SPAIN: A THE FOREIGN RELATIONS AND FOREIGN POLICY OF SPAIN: A SURVEY FOR 1992 . PAR

CONTEMPORARY REVIEW, 261 (1519) (AUG 92), 57-61.

THIS ARTICLE EXAMINES SPAIN'S ONGOING EFFORTS TO BE ACCEPTED AS A EUROPEAN STATE. THE ESTABLISHMENT OF DEMOCRACY IN SPAIN--AFTER DECADES OF ISOLATION IN THE FRANCO REGIME-LED TO SPAIN'S FOREIGN POLICY BEING BASED ON A "HOLY TRINITY": GIBRALTAR, THE EUROPEAN ECONOMIC COMMUNITY (EEC) AND THE NORTH ATLANTIC TREATY ORGANIZATION (NATO). 1986 MARKED THE CULMINATION OF A LONG PROCESS OF GRADUAL INTEGRATION INTO EUROPE. WHILE LONG-STANDING HISTORIC ACRIMONY CONTINUES TO TROUBLE SPAIN'S RELATIONS WITH FRANCE, THE UNITED KINGDOM, GERMANY AND PORTUGAL. THE OVERALL TREND IN INTERNATIONAL RELATIONS BETWEEN THESE WESTERN EUROPEAN STATES IS TOWARDS FRIENDSHIP AND COOPERATION.

03844 GOOD, K.

INTERPRETING THE EXCEPTIONALITY OF BOTSWANA

JOURNAL OF MODERN AFRICAN STUDIES, 30(1) (MAR 92), 69-95. SINCE INDEPENDENCE IN 1966, BOTSWANA HAS ACHIEVED RAPID GROWTH ALONG WITH STABILITY, LARGELY THROUGH THE SUPPORTIVE INTERRELATIONS BETWEEN AN OPEN MARKET ECONOMY AND A SYSTEM OF ELITE DEMOCRACY, WHICH SUCCESSFULLY BLENDS TRADITIONAL AND MOOERN ELEMENTS TO OFFER A RANGE OF FAIRLY FREE AND MEANINGFUL POLITICAL CHOICES. NEVERTHELESS, GROWTH AND
POLICIES OF A SELECTIVELY-INTERVENTIONIST STATE HAVE POLICIES OF A SELECTIVELY-INTERVENTIONIST STATE HAVE
PRODUCED INCREASINGLY DEEP INEQUALITIES OF PROPERTY AND PRODUCED INCREASINGLY DEEP INEQUALITIES OF PROPERTY AND
INCOMES, POSING PROBLEMS FOR THE STABILITY OF THE POLITICAL INCOMES, POSING PROBLEMS
ECONOMY IN THE FUTURE.

03845 GOODBY, J

PEACEKEEPING IN THE NEH EUROPE

WASHINGTON QUARTERLY, 15(2) (SPR 92), 153-174.

SOME OF THE DIFFICULT ISSUES POSED BY INTRASTATE

CONFLICT ARE POINTED OUT IN THIS ESSAY. TO ILLUSTRATE THE PROBLEMS IN CONCRETE TERMS IT DESCRIBES THE EXPERIENCES OF EUROPEAN AND UNITED NATIONS MEDIATORS IN YUGOSLAVIA DURING THE LATTER HALF OF 1991. THESE EXPERIENCES ADO UP TO A VALUABLE CASE STUDY IN PEACEKEEPING IN THE NEW EUROPE. THE ESSAY CONCLUDES BY OUTLINING SOME STEPS THAT MIGHT BE TAKEN TO BEGIN CONTINGENCY PLANNING FOR THE USE OF PEACEKEEPING FORCES IN EUROPE.

03846 GOODBY, J.

PEACEKEEPINTG IN THE NEW EUROPE

ARMS CONTROL, 12 (3) (DEC 91), 44-50.

EVENTS IN EASTERN EUROPE SIINCE 1989 HAVE PROVED THAT THE USE OF MILITARY FORCE IS NO LESS UNTHINKABLE IN THE NEH EUROPE THAN IT WAS DURING THE DEPTHS OF THE COLD WAR. THIS ARTICLE DEALS WITH THE FOLLOWING QUESTIONS: IS THERE A ROLE FOR THE COLLECTIVE AUTHORIZATION AND USE OF MILITARY FORCE IN DEALING WITH INCIDENTS IN EUROPE? AND, SHOULD THE UNITED STATES BECOME INVOLVED? IT EXPLORES POSSIBLE ANSHERS TO THESE QUESTIONS AND CONCLUDES THAT THE INVOLVEMENT OF THE UNITED STATES IN MAINTAINING PEACE NOT ONLY IN WESTERN EUORPE BUT ALSO IN CENTRAL AND EASTERN EUROPE IS PROBABLY ESSENTIAL TO LONG-TERM STABILITY IN EUROPE.

03847 GOOOE, S.

A MATTER OF DEFINITION

INSIGHT, $7(9)$ (MAR 91), 13-15

SADDAM HUSSEIN CALLED ON MUSLIMS TO HAGE A HOLD HAR, OR JIHAD. THEN OTHER MUSLIMS BEGAN A HOLY WAR AGAINST HIM. ONE MAN'S JIHAD IS NOT NECESSARILY ANOTHER MAN'S IDEA OF HOLY WAR, EVEN AMONG ISLAM;S MOST FAITHFUL. INTERPRETATIONS OF THE PROPER TIME AND THE RIGHT WAY TO HAGE JIHAD ARE THE PROPER TIME AND THE RIGHT WAY TO HAGE JIHAD ARE OIVERGENT. EVEN THOUGH MUHAMMAD SPOKE TO THE MATTER, HIS
PRONOUNCEMENTS LEAVE ROOM FOR MANEUVERING. THE PERSIAN GULF WAR IS PROVING A PERFECT VEHICLE FOR TAKING JIHAD TO ITS LIMITS, BOTH IN PRACTICE AND AS PROPAGANDA.

03848 GOODE, $S$.

THE SPIRIT CAN STILL MOVE THE ELECTORATE

INSIGHT, 8(27) (SEP 92), 12-13, 34-35.

OVER THE YEARS, RELIGION HAS PLAYED AN IMPORTANT ROLE IN AMERICAN POLITICS. THE EXTENT TO WHICH BELIEFS WILL HAVE AN
IMPACT ON THE 1992 ELECTION IS UNCLEAR, ALTHOUGH ISSUES SUCH
AS ABORTION ANO CHARACTER ARE KEY TO MANY VOTERS.

03849 GOODING, J.

PERESTROIKA AS REVOLUTION FROM HITHIN: AN INTERPRETATION RUSSIAN REVIEH, 51(1) (JAN 92), 36-57.

MOST WESTERN OBSERVERS INITIALLY SAW MIKHAIL GORBACHEY AS NO MORE THAN A COSMETIC REFORMER. WHEN THIS VIEW BECAME UNTENABLE, THEY PLACED HIM IN ANOTHER FAMILIAR CATEGORY OF RUSSIAN RULER: THE REVOLUTIONARY-FROM-ABOVE. IN THIS YIEW, GORBACHEY WAS MERELY PUSHING HIS COUNTRY INTO THE NEXT PHASE OF THE REVOLUTION-STAGNATION-REVOLUTION CYCLE WHICH IT SEEMED UNABLE TO ESCAPE. THIS, HOWEVER, WAS AS WIDE OF THE SEEMED UNABLE TO ESCAPE. THIS, HOWEVER, WAS AS WIDE OF THE ANOTHER TYPE OF CHANGE--A REVOLUTION FROM WITHIN.

03850 GDODMAN, A.; BOGART, $S$.

MAKING PEACE: THE UNITED STATES AND CONFLICT RESOLUTION WESTVIEW PRESS, 1992,132

AS RECENT CONFLICTS DEMONSTRATE, WE KNOW MORE ABOUT MAKING WAR THAN WE DO ABOUT MAKING PEACE. SUCH CONFLICTS ARE NOT LIKELY TO DISAPPEAR. THIS VOLUME REVIEHS WHAT HAS AND HASN'T WORKED IN NEGOTIATING AN END TO WAR. SIX CASE STUDIES ILLUSTRATE A VARITY OF ACTORS, STAKES AND STRATEGIES INVOLVED IN THE PEACEMAKING PROCESS. KEY TURNING POINTS TOWARD PEACE OR DEADLOCK ARE IDENTIF IED ALONG THE WAY. "MAKING PEACE" ALSO PROVIDES DISCUSSION QUESTIONS, HISTORICAL BACKGROUNDS, AND THEORETICAL INTRODUCTIONS TO SHOW DIFFERENT AVENUES TO PEACE.

03851 GOODMAN, J.B.

MONETARY POLICY AND FINANCIAL DEREGULATION IN FRANCE FRENCH POLITICS AND SOCIETY, 10(4) (FAL 92), 31-40.

THIS REVIEW OF FRANCE'S INTERNATIONAL FINANCIAL POLICIES UNDERLINES THE MITTERAND REGIME'S ACCOMPLISHMENTS BUT QUESTIONS THEIR LONGEVITY GIVEN THE UNCERTAINTIES OF THE $1990^{\circ} \mathrm{S}$. THE AUTHOR ANALYZES THE CAUSES AND CONSEQUENCES OF FRANCE'S SHIFT IN MONETARY POLICY FOR THE COUNTRY ITSELF AND FOR THE EUROPEAN COMMUNITY. HE BRIEFLY EXAMINES HOW THE COUNTRY'S POSTWAR GOALS AND EXPERIENCES GAVE RISE TO ITS HIGHLY-ADMINISTERED MONETARY SYSTEM. THEN HE DISCUSSES THE REFORMS OF THE 1980 'S. FINALLY, HE EXPLORES
FOR FRANCE'S ROLE IN THE EUROPEAN COMMUNITY.

03852 GOODMAN, $R$.

THINK TWICE ABOUT TRYING SADDAM

THINK TWICE ABOUT TRYING SADDAM
ARMED FORCES JOURNAL INTERNATIONAL, (APR 91), 28.

ARMED FORCES JOURNAL INTERNATIONAL, (APR 91), 28.
MOST AMERICANS AGREE SADDAM HUSSEIN DESERVES TO STAND

TRIAL FOR THE ATROCITIES COMMITTED DURING THE PERSIAN GULF WAR. THE GENEVA CONVENTIONS AND THE 1977 PROTOCOL TO THE CONYENTIONS ADDRESS A HIDE RANGE OF HAR CRIMES WHICH COULO BE USED TO PROSECUTE SADDAM AND THE IRAQI LEADERS. HOWEVER, BY FORCING SUCH A TRIAL, COALITION LEADERS WOULD LIKELY TRAMPLE THE SENSIBILITIES OF THE PEOPLE OF THE MIDDLE EAST. A U.S. - LED PROSECUTION OF SADOAM HUSSEIN WOULD ONLY SERVE TO REINFORCE THE WIDELY-HELD IDEA THAT THE U.S. WAS OUT TO GET HUSSEIN BECAUSE HE REPRESENTED A SIGNIFICANT OBSTACLE TO AMERICAN IMPERIAL AMBITIONS. A POSSIBLE ALTERNATIVE WOULD BE A TRIBUNAL COMPOSED OF THE PRINCIPAL VICTIMS OF IRAQ'S AGGRESSION IN THE MIDOLE EAST.

03853 GOODSELL, C.T.

THE PUBLIC ADMINISTRATION AS ARTISAN

PUBLIC ADMINISTRATION REVIEH, 52(3) (MAY 92), 246-253.

THE AUTHOR LOOKS FOR A THEORY THAT CAN EXPLAIN THE

WORKADAY VALUES OF PUBLIC ADMINISTRATION PRACTITIONERS. HE OFFERS THE FOUNDATIONS OF AN APPROACH THAT FOCUSES ATTENTION ON THE MICROCOSMIC LEVEL OF GOVERNMENT ACTION. BORROWING FROM THE FIELD OF AESTHETICS AND THE THEORY OF ART, HE HIGHLIGHTS THE CRAFT, STYLE, FORM, MATERIAL, AND
CREATIVITY OF PUBLIC ADMINISTRATORS. HE POSITS THIS

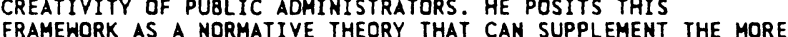
BROADLY-BASED CONCERNS WITH EFFICIENCY, ECONOMY, AND ACCOUNTABILITY.

03854 GOONATILAKE, $S$.

RECONCEPTUALIZING THE CULTURAL DYNAMICS OF THE FUTURE FUTURES, 24(10) (DEC 92 ), $977-986$.

FORHAL CONCEPTUALIZATION ABOUT THE FUTURE IS A PARTIAL OUTCOME OF CORE THEORIES FROM THE SOCIAL SCIENCES AND IS, THEREFORE, SUBJECT TO THE YICISSITUDES AND PARTICULARITIES THEREFORE, SUBJECT TO THE VICISSITUDES AND PARTICULARITIES OF THAT CONCEPTUALIZING. THE PARTICULAR HISTORICALLY-INDUCED SUBJECTIVITIES OF THE EUROPEAN-DERIVED SOCIAL SCIENCES OFTEN GOVERN THE DESCRIPTIONS OF THE PAST, PRESENT, AND POSSI FUTURES OF NON-EUROPEAN CULTURES. THUS, MANY FUTURES APPROACHES ARE BASED ON ETHNO-CENTRIC FACTORS THAT DO NOT
APPLY OUTSIDE THEIR WESTERH CONTEXTS. THIS PAPER SUMMARIZES APPLY OUTSIDE THEIR WESTERN CONTEXTS. THIS PAPER SUMMARIZES CRITIQUES OF CURRENT CORE THEORIES OF THE SOCIAL SCIENCES, TAKING INTO ACCOUNT SOME OF THEIR ETHNO-CENTRICITY. IT ALSO
PRESENTS AN ALTERNATIVE VIEH OF THE DYNAMICS OF THE FUTURE BASED ON CULTURE AS A VARIABLE.
BAR ALLRNATV VIEH OF TH

03855 GOOS, $D$.

SOVIET PULLOUT IS SLOWER THAN EXPECTED 
GERMAN TRIBUNE, 1479 (AUG 91), 5-6.

CONTRARY TO THE GERMAM GOYERMMENT'S EXPECTATIONS, THE SOVIET FORCES STATIONED IN EASTERN GERMANY ARE TAKING LONGER TO VACATE THE GERMANY STATES THEN HAD BEEN EXPECTED. GERMANY HAD CALLED ON THE SOVIET UNION TO GIVE PRIORITY TO WITHDRAWING ITS FORCES FROM CAPITALS, BUT ITS FAILURE TO DO SO IS NOT THE ONLY POINT THAT COMES IN FOR CRITICISM. THE SOVIET SUPREME COMMAND HAS YET TO MEET GERMANY'S PRIORITITY DEMAND FOR THE DISCLOSURE OF ITS WITHDRAHAL PLANS FROM THE 38 AIRFIELDS IN THE FORMER EAST GERMANY THAT ARE USED BY SOVIET ARMY AMD AIR FORCE UNITS.

03856 GORALCZYK, B.

CENTRAL AND EASTERH EUROPE IN TRANSITION: DEMOCRACY HALF DONE

BULLETIN OF PEACE PROPOSALS, 23(2) (1992), 197-204.

FROM THE PERSPECTIVE OF 1991--WHICH IS LIMITED AND NOT YET HISTORICAL--THE AUTHOR PUTS FORWARD EIGHT CLAIMS: (1) TODAY'S CEMTRAL 'EASTERM EUROPE IS A REGION OF SYSTEMATIC TRANSION AND TRANSFORMATION; (2) DEMOCRACY IN CENTRAL AND EASTERN EUROPE HAS BEEN ESTABLISHED ONLY HALF-WAY, AND MAINLY IN THE POLITICAL SPHERE; (3) ESTABLISHING A BASIS FOR STABLE DEMOCRACY HITH A MARKET ECONOMY AND A SOLID MIDDLE STABLE DEMOCRACY HITH A MARKET ECOMOMY AND A SOLID MIDDLE CLASS WILL BE NEITHER OUICK NOR EASY; (4) IF POPULAR DISCOATENT AND PASSIVE OPPOSITION YO AUSTERITY PROGRAMS PREVAIL OVER WEAK DEMOCRACY IN ITS INITIAL STAGE, ANARCY CAN TAKE OVER; (5) THE EAST CAN BECOME A DEN OF REFUGEES, SOCIAL CHASMS AND CIVIL WARS, ESPECIALLY WHEN THE WESTERN GATE IS NOT OPENED; (6) THE SITUATION IS NOT HOPELESS, BUT FLUID, SOMETIMES EVEN BIZARRE; (7) THE MAJOR PROSITIVE SIDE OF CURRENT CHANGES LIES IN THE FACT THAT DAY-BY-DAY MORE AND MORE PEOPLE ARE BECOMING INVOLVED IN THE CREATION OF NEH INSTITUTIONS, PROJECTS AND VENTURES: (8) THE AUGUST 1991 COUP ATTEMPT IN MOSCOW PARTIALLY CHANGED THE GEOSTRATEGIC POSITION OF SOME CENTRAL EUROPEAN COUNTRIES WHO HAVE NOW FOUND THEMSELVES IN THE EPICENTER OF CHANGE. EACH OF THESE CLAIMS IS ANALYZED IN DETAIL.

03857 GORBACHEV, M.

THE RIVER OF TIME

BULLETIN OF THE ATOMIC SCIENTISTS, 48(6) (JUL 92), 22-27. THIS ARTICLE CONTAINS A SPEECH (DELIVERED AT THE SITE OF WINSTON CHURHILL'S "IRON CURTAIN" SPEECH) BY MIKHAIL GORBACHEY. THE FORMER SOVIET LEADER ARGUES THAT NEITHER THE SOVIETS MOR THE WEST WERE PREPARED TO DEAL WITH POST-SECONDWORLD WAR INTERHATIONAL RELATIONS. THEREFORE, THE POTENTIAL FOR MUTUALLY BENEFICIAL COOPERATION WAS LOST, IN THE FOR MUTUALLY BENEFICIAL COOPERATION WAS LOST IN THE
BEGINNING OF THE COLD WAR. HE ALSO OUTLINES THE CHALLENGES BEGINNING OF THE COLD WAR. HE ALSO OUTLINES THE CHALLENGES
FACING THE POLICYMAKERS OF TODAY, WITH EMPHASIS ON THE

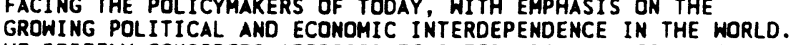
GR BRIEFLY CONSIDERS APPROPRIATE INTERNATIONAL RESPONSE TO VARIOUS PROBLEMS INCLUDING NUCLEAR AND CHEMICAL HEAPONS, THE PARIOUS PROBLEMS INCLUDING NUCLEAR AND CHEMICAL WEAPONS, THE PEACEFUL USE OF NUCLEAR ENERGY, THE EXPORT OF CONVENTIONAL
WEAPONS, REGIONAL CONFLICTS, HUMAN RIGHTS, FOOD, DEMOGRAPHY, AND ECONOMIC ASSISTANCE. HE CONCLUDES HITH THE HOPEFUL ASSERTION THAT THE MEMBERS OF THE UNITED NATIONS WILL BE ABLE TO COOPERATE IN COPING WITH THESE PROBLEMS.

03858 GORDON, A. (ED. ); GORDON, D. (ED.) UNDERSTANDING CONTEMPORARY AFRICA

LYNNE RIENNER PUBLISHERS, $1992,350$.

THIS MULTIDISCIPLINARY COLLECTION CONCENTRATES ON THE CRUCIAL ISSUES FACING AFRICA IN THE 1990S. TOPICS EXAMINED INCLUDE: THE HISTORICAL CONTEXT; AFRICAN POLITICS; SOUTH AFRICA; THE ECONOMIES OF AFRICA; THE GEOGRAPHY OF AFRICA; GROWTH AND URBANIZATION; ENVIRONMENTAL PROBLEMS; FAMILY AND KINSHIP; WOMEN AND DEVELOPMENT: AFRICAN RELIGIONS; THE

03859 GORDON, $L$.

WORKERS OF FREE RUSSIA UNITE

FREEDOM REVIEW, 23(4) (JUL 92), 31-34.

THE AUTHOR DISCUSSES THE POTENTIAL ROLE OF ORGANIZED

LABOR IN SHAPING RUSSIA'S FUTURE.

03860 GORDON, M.J.

CHINA'S PATH TO MARKET SOCIALISM

CHALLENGE, 35(1) (JAN 92), 53-56.

CHINA HAS EMBARKED ON A PROGRAM OF REFORM TO MAINTAIN A SOCIALIST ECONOMIC SYSTEM WILE ENLARGING THE ROLE OF MARKETS IN THE ECONOMY. THE RESULT HAS BEEN CONSIDERABLE DECENTRALIZATION IN ECONOMIC DECISION MAKING, INCREASED DECENTRALIZATION IN ECONOMIC DECISION MAKING, INCREASED RELIANCE ON MARKETS, AND IMPROVEMENTS IN THE PRICE SYSTEM, WITH LITTLE DEPARTURE FROM STATE OR COLLECTIVE OWNERSHIP OF THE MEANS OF PRODUCTION AND WITH LITTLE RELAXATION OF STATE CONTROL OVER FOREIGN ECONOMIC RELATIONS. THESE REFORMS HAYE PRODUCED EXTRAORDINARY GROWTH RATES IN BOTH OUTPUT AND CONSUMPTION WITH COMPARATIVELY LITTLE INCREASE
INEQUALITY OF INCOMES AMONG THE CHINESE PEOPLE.

03861 GORDON, $P$.

RICE POLICY OF JAPAN'S LDP: DOMESTIC TRENDS TOWARD AGREEMENT

ASIAN SURVEY, $X X X(10)$ (OCT 90), 943-958.
THE PRIMARY ISSUE BETHEEN JAPAN AND THE UNTIED STATES AT THE URUGUAY ROUND OF THE GENERAL AGREEMENT OF TARIFFS AND TRADE INVOLVES AGRICULTURE--I.E. JAPAN'S RICE POLICY. THE CONFLICT DURING THE GATT NEGOTIATIONS WILL LIKELY SPARK ARGUMENTS ON HOW TOUGH THE U.S. SHOULD BE DURING

NEGOT IATIONS. SOME IN THE U.S. CONGRESS HAVE HINTED AT INTRODUCING TOUGH MEASURES AIMED AT "UNFAIR TRADING" PRACTICES IN THE AREA OF AGRICULTURE SIMILAR IN FASHION TO THE "SUPER 301" PROVISION OF THE 1988 OMNIBUS TRADE ACT. HOWEVER, THIS ARTICLE ARGUES THAT DOMESTIC RENDS IN JAPAN IMDICATE THAT LIBERALIZATION OF JAPAN'S RICE MARKET IS ONLY A MATTER OF TIME. TOO MUCH PRESSURE FROM THE UNITED STATES MAY ALLOW JAPAN'S RICE LOBBY TO MAKE THE ISSUE A QUESTION OF NATIONALISM, THEREBY INHIBITING FAVORABLE CHANGES THAT WOULD OTHERHISE OCCUR. ON THE OTHER HAND, TOO LITTLE PRESSURE WILL ENCOURAGE JAPAN'S RULING LIBERAL DEMOCRATIC PARTY (LDP) TO FORESTALL AGREEMENTS ON RICE AT THE URUGUAY ROUHD OR,

FLTERMATIVELY, DELAY IMPLEMENTATION OF ANY AGREEMENT.

03862 GORDON, $S$.

INOIAN DEFENSE SPEMDING: TREADING WATER IN THE FISCAL DEEP ASIAN SURVEY, XXXIII(10) (OCT 92 ) 934-950

SEVERAL YEARS AGO SOME CONCERN WAS EXPRESSED IN THE ASIAPACIFIC REGION ABOUT THE RAPID RISE IN INDIAN DEFENSE EXPENDITURE. MANY ASSESSED THAT INDIA HAS ON AN UPWARD TRAJECTORY THAT WOULD LEAVE IT POSITIONED TO EXERCISE A 1995. HOWEVER, IN RECENT YEARS, INDIAN DEFENSE SPENDING HAS PLATEAUED AND EVEN FALLEN IN REAL TERMS. THIS ARTICLE EXAMINES RECENT INDIAN DEFENSE SPENDING IN ORDER TO ASCERTAIN HOW THE IMDIAN GOVERNMENT IS APPROACHING THE PROBLEM OF MODERNIZATION IN THE CONTEXT OF DIFFICULT ECONOMIC CIRCUMSTANCES AND TIGHT BUDGETS. THE AUTHOR ARGUES THAT THIS ANALYSIS WILL PROVIDE USEFUL INSIGHTS INTO ATTITUDES AMONG THE GOVERNING ELITES TOWARD ANY FUTURE ROLE FOR THE MILITARY IN INDIA'S EMERGENCE AS AN ASIA-PACIFIC POWER, ONCE THE CURRENT PERIOD OF ECONOMIC DIFFICULTY HAS PASSED.

03863 GORE-BOOTH, D.

THE MIDDLE EAST: SEEDS OF CONFLICT AND PROSPECTS FOR PEACE RUSI JOURNAL, 137 (5) (OCT 92), 49.

IHE IRAQI INVASION OF KUWAIT BROUGHT THE ARAB WORLD--AND THE WORLD AS A WHOLE--UP AGAINST A NUMBER OF TRUTHS THAT HAD EITHER BEEN CONCEALED UNDER THE PERMAFROST OF THE COLD WAR, EITHER BEEN CONCEALED UNDER THE PERMAFROST OF THE COLD
OR HIDDEN UNDER A BLANKET OF SELF-DELUSION, WHETHER OR HIDDEN UNDER A BLANKET OF SELF-DELUSION, WHETHER
EXTRINSIC OR INTRINSIC TO THE REGION. THEY BOIL DOWN TO AN EXTRINSIC OR INTRINSIC TO THE REGION. THEY BOIL DOWN TO AN
INEFFICIENCY OF POLITICAL AND ECONOMIC SYSTEMS COMPOUNDED BY INEFFICIENCY OF POL ITI ICAL AND ECONOMIC SYSTEMS COMPOUNDED BY
AN OVER-EXPENDITURE ON ARMAMENTS. DAVID GORE-BOOTH SUGGESTS AN OVER-EXPENDITURE ON ARMAMENTS. DAVID GORE-BOOTH SUGGESTS THAT THE NEEO FOR SYSTEMS OF GOVERMMENT THAT ALLOH FOR A GREATER DEGREE OF ACCOUNTABILTIY OF GOVERNMENT YO PEOPLE IS NOH WIDELY RECOGNIZED, NOT LEAST BY ALL OPPONENTS OF SADDAM
HUSSEIN'S BARBARIC BUT BRITTLE REGIME.

03864 GORMLEY, $W$.

THE BUREAUCRACY AND ITS MASTERS: THE NEW MADISONIAN SYSTEM IN THE U.S.

GOVERMANCE, 4(1) (JAN 91), 1-18.

THE BUREAUCRACY'S MASTERS HAVE REDESIGNED THE AMERICAN POLITICAL SYSTEM OVER THE PAST 20 YEARS. AS BEFORE, CHECKS AND BALANCES PLAY A CRITICAL ROLES. THIS TIME, HOWEVER,

RELATIONS BETWEEN ONE BRANCH OF GOVERMMENT (THE BUREAUCRACY) AND THE REST ARE DECIDEDLY AND DELIBERATELY ASYMMETRICAL. WHILE ACKNOWLEDGING THE NEED FOR BUREAUCRATIC ACCOUNTABILITY, THE AUTHOR RAISES QUESTIONS ABOUT A GROWING EMPHASIS ON HIGHLY COERCIVE CONTROLS FROM ABOVE. INSTEAD HE RECOMMENDS GREATER RELIANCE ON CATALYTIC CONTROLS FROM BELOW, WHICH ENERGIZE THE BUREAUCRACY WITHOUT STIFLING BUREAUCRATIC CREATIVITY AND ERODING BUREAUCRATIC INTEGRITY.

03865 GORRITI, G.

MOUSE TRAP

NEW REPUBLIC, 206 (18) (MAY 92), 14-15.

PERUVIAN PRESIDENT ALBERTO FUJIMORI IS A MAN HITH STRONG AUTHORITARIAN LEANINGS AND NO REAL POLITICAL PARTY ON HIS SIDE, SO HE HAS TRIED TO USE THE ARMY AS HIS PARTY AND THE INTELLI IGENCE SERVICE AS HIS POLITBURO. HE HAS RADICALLY CHANGED HIS PROGRAMS, KICKED OUT FORMER ASSOCIATES, AND GOITEN AWAY WITH IT. FUJIMORI'S COUP AGAIHST HIS OWM GOVERMMENT WILL EVENTUALLY FAIL AND HIS DICTATORSHIP WILL GOVERMMENT HILL EVENTUALLY FAIL AND HIS DICTATORSHIP WILL EVENTUALLY CRUMBLE, BUT IN THE MEANTIME IT CAN DO A LOT
HARM, BOTH TO PERU AND TO OTHER FRAGILE LATIN AMERICAN HARM, BOTH TO
DEMOCRACIES

03866 GORTON, S.; LAUTENBERG, F.R.; LIBERMAN, J.I.; MOSBACHER, R.A.; SANFORD, T.

PRO: SHOULD CONGRESS DEBATE THE PROOUCT LIABILITY FAIRNESS ACT

CONGRESSIONAL DIGEST, 71(11) (NOV 92), 270,272,274,276,278,

THESE EXCERPTS FROM THE SENATE FLOOR DEBATE ON 5.640 , THE PRODUCT LIABILITY FAIRNESS ACT, INCLUDE ARGUMENTS FOR THE PASSAGE OF LEGISLATION REFORMING THE PRESENT SYSTEM OF LITIGATING PRODUCT LIABILITY DISPUTES IN THE UNITED STATES. 
03867 GOTLIEB, Y.

RETRIEVING LIFE-PLACE FROM COLONIZED SPACE: TRANSCENDING THE ENCUMBRANCES OF THE POST-COLONIAL STATE

POLITICAL GEOGRAPHY QUARTERLY, 11(5) (SEP 92), 461-474. THE THESIS ADVANCED IN THIS PAPER IS THAT THE PHENOMENA OF IMPEDED DEVELOPMENT AND ETHNO-NATIONAL UNREST IN THE THIRD WORLD ARE INEXTRICABLE FROM ONE ANOTHER. THE POSTCOLONIAL STATE TODAY IS ESSENTIALLY INDIGENIZED SPACE. POL ICES PERPETUATE THE FRAGMENTARY ETHNIC AND ECOLOGICAL TERRITORIES PIECED TOGETHER AS PART OF THE IMPERIAL ENTERPRISE. THE TERRITORIAL COMPOSITION OF THE POST-COLONIAL FRAGMENTATION OF THE KURDISH SUSTAINABLE DEVELDPMENT. THE ESTABLISHMENT OF THE POST-COLONIAL STATES INTO HHICH IT IS DIVIDED SERVES AS THE ILLUSTRATIVE CASE OF THIS STUDY.

03868 GOTTFRIED, P.

SOVEREIGN STATE AT BAY

SOCIETY, 29(6) (SEP 92), 22-27.

THE CURRENT JUSTIFICATION FOR DEMOCRATIC IMPERIALISM IS THAT HORLD PEACE CAN ONLY BE ATTAINED IF OUR CORE VALUES AND SOCIAL PRACTICES ARE UNIVERSALLY HONDRED. WE ARE URGED TO GUARD AGAINST THOSE NATIONS FOUND DEFICIENT IN WHATEVER OUR INTELLECTUALS THEMSELVES ENDORSE AND WHOSE NATIONAL DISASTERS CAN ALL BE LAID AT THE DOORSTEP OF ILLEBERALISM, ANT I-DEMOCRACY, OR DISLIKE FOR MULTICULTURAL I SM. THE AUTHOR SUGGESTS THAT SCHMITT'S REMARKS ON THE TYRANMY OF VALUES AND BABBITT'S PICTURE OF EXPANSIVE HUMANITARIAN DEMOCRACIES STILL HAVE MUCH TO TEACH US AS WE GROPE OUR WAY BEYOND THE COLD WAR.

03869 GOTISCHALK, M.

OPERATION DESERT CLOUD: THE MEDIA AND THE GULF HAR

WORLD POLICY JOURNAL, IX(3) (SUM 92), 449-486.

THIS PAPER ARGUES THAT AMERICANS WERE NOT INFORMED OF THE GULF WAR'S MAJOR OCCURRENCES IN A TIMELY FASHION; THAT THE PENTAGON CONSCIOUSLY MISLED THE MEDIA AND THE PUBLIC; AND THAT MUCH OF THE MEDIA FAILED TO COVER A NUMBER OF CRITICAL ISSUES BEFORE, DURING AND AFTER THE HAR. THE PAPER EXAMINES THE REASONS BEHIND THIS FAILURE. IT ARGUES THAT THE FAILURE OF THE MEDIA IN THE GULF WAR WAS NOT AN ABERRATION PRECIPITATED BY A UNIQUE SET OF POLITICAL CIRCUMSTANCES, BUT PRECIPITATED BY A UNIQUE SET OF POLITICAL CIRCUMSTANCES, BUT RATHER THE PRODUCT OF OISTURBING TRENDS THAT HAVE AFFECTED
BOTH THE MEDIA AND AMERICAN SOCIETY IN GENERAL OVER THE PAST BOTH THE MEDIA AND
10 TO 15 YEARS.

03870 GOTTSCHANG, T.R.

THE ECDNOMY'S CONTINUED GROWTH

CURRENT HISTORY 91(566) (SEP 92), 268-272

WHILE CHINA APPEARS FAR MORE STABLE THAN IT DID ONLY ONE YEAR AGO, THE QUESTIONS OF WHEN DENG XIAOPING WILL DIE, WHO WILL SUCCEED HIM, AND HOW REMAIN THE CENTRAL MYSTERY CASTIMG A SHADOW ON THE COUNTRY'S IMMEDIATE FUTURE. WHAT DENG'S DISAPPEARANCE FROM THE TOP LEADERSHIP WILL MEAN FOR CHINESE ECONOMIC POLICY IS ALSO A LARGE QUESTION MARK.

03871 GOULBOURNE, $\mathrm{H}$.

VARIETIES OF PLURALISM: THE NOTION OF A PLURALIST POSTIMPERIAL BRITAIM

NEW COMMUNITY, 17(2) (JAN 91), 211-228.

PLURALISM IS HIDELY AND OFTEN UNOUESTIONINGLY PRESUMED TO CONSTITUTE THE MOST DESIRABLE SOCIO-POLITICAL ARRANGEMENT FOR A MULTI-CULTURAL POST-IMPERIAL BRITAIN. IT IS THEREFORE PARADOXICAL THAT THE CONCEPT HAS NOT BEEN SUBJECTED TO THE ACADEMIC ANALYSIS WHICH IT MERTIS. THIS ARTICLE SEEKS TO REDRESS THIS IMBALANCE. AFTER DELINEATING THE CURRENT USAGE OF THE TERM, THE HISTORICAL TRADITIONS OF RESPECTIVELY POL ITICAL AND SOCIAL AND CULTURAL PLURALISM ARE EXPLORED. THE DISCUSSION THEN TURHS TO THE LIMITATIONS OF PLURALISM, BOTH OLD AND NEW. THE POINT IS MADE THAT BY CHAMPIONING GROUP RIGHTS OVER INDIVIDUAL RIGHTS, THE NEH PLURALISM IN EFFECT UNDERMINES FREEDOMS FOR THE INDIVIDUAL WHICH HAVE TAKEN CENTURIES TO SECURE. IT IS CONCLUDED THAT PLURALISM, IN ITS CURRENT FORM, HAS LITTLE TO OFFER A POST-IMPERIAL BRITISH SOCIETY ATTEMPTING TO CREATE A SOCIAL ORDER WHICH IS

CAPABLE OF ABSORBING THE BEST FROM ALL CULTURAL TRADITIONS.

03872 GOULET, D.

DEVELOPMENT: CREATOR AND DESTROYER OF VALUES

WORLD DEVELOPMENT, 20(3) (MAR 92), 467-475.

DEVELOPMENT HAS LONG CONSIDERED AN UMALLOYED GOOD.

HOWEVER, AS ATTENDANT SOCIAL, CULTURAL, ECOLOGICAL, AND
HUMAN COSTS BECOME MORE EVIDENT, IT IS INCREASINGLY VIEWED

HUMAN COSTS BECOME MORE EVIDENT, IT IS INCREASINGLY VIEWED

AS A TWO-EDGED SHORD, SIMULTANEOUSLY CREATING AND DESTROYING
VALUES. IT BRINGS MATERIAL AND TECHNOLOGICAL GAINS AND NEH VALUES. IT BRINGS MATERIAL AND TECHNOLOGICAL GAINS AND
FREEDOMS BUT ALSO BREEDS INJUSTICE, DESTROYS CULTURES FREEDOMS BUT ALSO BREEDS INJUSTICE, DESTROYS CULTURES, DAMAGES ENVIRONMENTS, AND GENERALIZES ANOMIE. MORE IMPORTANTLY, DEVELOPMENT ENGENDERS VALUE CONFLICTS OVER THE
MEANING AND CONTENT OF THE GOOD LIFE. THE BASIS OF JUSTICE IN SOCIETY, AND THE CRITERIA GOVERNING THE STANCE OF HUMAN SOCIETIES TOWARO NATURE.
03873 GOULET, D.

INTERNATIONAL ETHICS AND HUMAN RIGHTS

ALTERNATIVES, $17(2)$ (SPR 92), 231-246

A GRONING CONSENSUS ABOUT' THE CENTRALITY OF ETHICS IN INTERNATIONAL POLITICS, THE COMINANT ROLE PLAYED BY HUMAN RIGHTS WITHIN ETHICAL DISCOURSE, AND THE WIDENING SCOPE OF HUMAN RIGHTS--SERVE AS BACKGROUND FOR THE ANALYSIS CONDUCTED IN THIS PAPER. THE AUTHOR FIRST ANALYZES THE MAIN COMPONENT OF SOCIOECONOMIC RIGHTS. THEN HE EXAMINES HOW THE RIGHT TO DEVELOPMENT CONFLICTS HITH NEWLY FORMULATED RIGHTS

CONCERNING ENVIRONMENTAL INTEGRITY AND BIOLOGICAL DIVERSITY. THE THIRD POINT HE ARGUES IS THAT ECOLOGICAL WISDOM AND

AUTHENTIC DEVELOPMENT MUST GO TOGETHER.

03874 GOULET, $K$.

SELF-GOVERMMENT: PART OF A NEW VISION FOR CANADA

CANADIAN PARLIAMENTARY REVIEW, (WIN 91), 16-20.

ONE OF THE OUTSTANDING ISSUES CONFRONIING CANADIANS

TOOAY IS THE RIGHT OF SELF-GOVERNMENT BY THE INDIAN, METIS AND INUIT. THIS ARTICLE EXAMINES THE HISTORY OF RELATIONS BETWEEN COLONISTS AND ABORIGINES FROM THE EARLY COLONIAL PERIOD THROUG TO RECENT SUPREME COURT DECISIONS. IT CONCLUDES THAT CANADA HAS NOT DEALT JUSTLY WITH THE NATIVE POPULATION. WHILE STEPS HAVE BEEN TAKEN TOWARDS GIVING SOME RESPONSIBILITY TO ABORIGINAL PEOPLES, THE SUBSTANCE AND PROCESSES OF RECENT GOVERNMENT POLICY AND PRACTICE STILL LIE IN THE REALM OF OUTDATED COLONIAL CONCEPTS.

03875 GOVIER, T.

A JUST WAR?

CANADIAN FORUM, LXIXX(797) (MAR 91), 11-14.

THIS ARTICLE EXAMINES THE ORIGINS AND RAMIFICATIONS OF

THE SO-CALLED JUST WAR THEORY AND APPLIES IT TO THE CURRENT WAR IN THE GULF. ACCORDING TO THE AUTHOR'S VERSION OF JUST WAR THEORY, A WAR MUST SATISFY THE FOLLOWING CONDITIONS TO BE JUST: JUST CAUSE, LEGITIMATE AUTHORITY, EXHAUSTION OF ALTERNATIVES, RIGHTFUL INTENTIONS, PROPORTIONATE HARM, DISCRIMINATION (BETWEEN COMBATANTS AND CIVILIANS) PROPORTIONATE MEANS, AND THE LIKELIHOOD OF EMERGENT PEACE. THE ARTICLE CONCLUDES THAT WHILE ANY MODERN WAR WOULD HAVE DIFFICULTY FITTING ALL OF THESE CRITERIA, THE GULF WAR MEETS ONLY TWO OF THE EIGHT REOUIREMENTS.

03876 GOW, J.

THE USE OF COERCION IN THE YUGOSLAV CRISIS

WORLD TOOAY, 48(11) (NOV 92), 198-202.

EXPERIENCE THROUGHOUT THE YUGOSLAY WARS OF DISSOLUTION

INDICATES THAT THE SERBIAN CAMP HAS DONE WHAT WAS NECESSARY IHEY IT HAS COERCED. UNTIL THE SERBS IN BOSNIA HAVE TO GIYE UP THEIR CAMPAIGN, IT IS UNLIKELY THAT THEY WILL SEE VALUE IN NEGOTIATING. IT IS PROBABLE THAT IT WILL TAKE AT LEAST A LIMITED USE OF COERCIVE VIOLENCE TO STOP THE SERBIAN MILITARY MACHINE.

03877 GOWAN, $P$

OLD MEDICINE, NEW BOTTLES: WESTERN POLICY TOWARD EAST CENTRAL EUROPE

WORLD POLICY JOURNAL, 9 (1) (WIN 91), 1-34.

THE BITTER TRUTH IS THAT THE DOMESTIC CRISES IN EASTERH EUROPE RESULT IN A LARGE PART FROM A DOUBLE-SIDED WESTERN POLICY TOWARD THE REGION. IN ASSESSING THE NATURE AND IMPACT OF WESTERN ECONOMIC POLICIES, THIS ARTICLE WILL FOCUS ON THE THREE COUNTRIES OF EAST CENTRAL EUROPE, POLAMD, CZECHOSLOVAKIA AND HUNGARY--DRAWING UPON EXPERIENCES ELSEWHERE IN THE REGION ONLY INSOFAR AS THEY ARE RELEYANT TO EAST CENTRAL EUROPE ITSELF. IT CONCLUDES THAT THERE ARE OTHER OPTIONS FOR THESE COUNTRIES, ALTERMATIVES THAT NOULD NOT LEAVE THEM SO ECONOMICALLY VULNERABLE, SO POLITICALLY CHAOTIC, AND SO DANGEROUSLY DEPENDENT ON THE WEST.

03878 GOWON, G.

TALKING POINTS

WEST AFRICA, ( 3908 ) (AUG 92), 1340-1341.

THE AUTHOR REPORTS ON THE WORK OF A COMMITTEE APPOINTED TO REVIEW THE 1975 ECOWAS TREATY AND MAKE RECOMMENDATIONS REGARDING WAYS TO ENERGIZE AND ACCELERATE THE INTEGRATION PROCESS IN WEST AFRICA.

03879 GOYTISOLO, J.

CONSTRUCTING BERLIN'S NEW WALL: FROM BERLIN TO THE STRAIT MIDDLE EAST REPORT, 22 (5) (SEP 91), 17-19.

WHILE FREE EUROPE YESTERDAY FIXED ITS EYES ON THE WALL TO WELCOME IN SOLIDARITY ALL THOSE WHO CROSSED IT, TODAY IT CONTEMPTUOUSLY TURNS ITS BACK ON THE DRAMA OF THE FUGITIVES. EFFICACY OF PRESS ARTICLLS, CONFERENCES AND ROUND TABLES TO EFFICACY OF PRESS ARTICLES, CONFERENCES AND ROUND TABLES REGULATE MIGRATION. HE SUGGESTS THAT FURTHER STEPS ARE
NECESSARY. WE MUST RESORT TO ALL KINDS OF CIVIC ACTION ANO NECESSARY; WE MUST RESORT TO ALL KINDS OF CIVIC ACTION ANO LEGAL MEANS
IMMIGRANTS.

03880 GRABER, M.A.

TRANSFORMING FREE SPEECH: THE AMBITIOUS LEGACY OF CIVIL LIBERTARIANISM 
UNIVERSITY OF CALIFORNIA PRESS, $1991,336$.

THIS BOOK CHALLENGES WIDELY' HELD ASSUMPTIONS ABOUT FREE THIS BOOK CHALLENGES WIDELY HELD ASSUMPTIONS ABOUT FREE FREE SPEECH CHANGED DURING THE LATE NINETEENTH AND EARLY THENTIETH CENTURIES AND THAT IT IS POSED FOR ANOTHER CHANGE. TWENTIETH CENTURIES AND THAT IT IS POSED FOR ANOTHER CHANGE. IT CONTRASTS JUDICIAL APPROACHES TO PROPERTY RIGHTS SPEECH UNDER WHICH THE AUTHOR CALLS THE LIBERTARIAN CONSERVATIVE JUSTICES OF THE LATE NINETEENTH CENTURY AND THE APPROACH GIVEN TO PROPERTY AND SPEECH BY PROGRESSIVES SUCH AS JOHN DEWEY, JANE ADDAMS, ROSCOE POUND, AND THE SCHOOL SOCIOLOGICAL JURISPRUDENCE. THE AUTHOR CONTENDS THAT THE EXIST FOR THE NINETEENTH CENTURY CONSERVATIVES. HOWEVER, THIS POSITION WAS CHALLENGED WHEN PROGRESSIVE REFORMERS ATTACKED JUDICIAL ACTIVISM IN BEHALF OF LIBERTY OF CONTRACT. THE TREND TO DISTINGUISH PROPERTY FROM SPEECH CONTINUED THROUGH THE BURGER COURT. HOWEVER, THE TIME IS RIPE FOR ANOTHER TRANSFORMATION THAT WILL SEEK A NEW SPEECH/PROPERTY ACCOMMODATION.

03881 GRACHEV, $P$.

THE DEFEMCE POLICY OF THE RUSSIAH FEDERATIOM

RUSI JOURNAL, 137 (5) (OCT 92), 5-7.

RUSSIA SEEKS TO PLAY AN ACTIVE PART AS A MEMBER OF THE INTERNATIONAL COMMUNITY IN DEALING WITH ISSUES EXISTING AFTER THE COLD WAR. ARMY GENERAL GRACHEV SETS DUT RUSSIA'S AFTER THE COLD WAR. ARMY GENERAL GRACHEV SETS DUT RUSSIA'S IN THE WORLD, HIGHLIGHTING THE SEARCH FOR STRATEGIC IN THE WORLD, HIGHLIGHTING THE SEARCH FOR STRATEGIC
STABILITY, THE ROLE OF THE ARMED FORCES FOR RUSSIA AND THE STABILITY, THE ROLE OF THE ARMED FORCES FOR RUSSIA AND THE
CIS, AND THE FUNDAMENTAL NEED FOR POLITICAL, RATHER THAN MILITARY SOLUTIONS TO BE THE OVERRIDING GOAL OF INTERNATIONAL POLICY.

03882 GRADSTEIN, $M$

TIME DYNAMICS AND INCOMPLETE INFORMATION IN THE PRIVATE PROVISION OF PUBLIC GOODS

JOURNAL OF POLITICAL ECONOMY, 100(31) (JUN 92), 581-597.

THE AUTHOR DEVELOPS A DYMAMIC MODEL OF THE PROVISION OF A PUBLIC GOOD WITH INCOMPLETE INFORMATION. FOR A FINITE POPULATION, IN ADDITION TO THE STANDARD UNDERPROVISION TYPE OF RESULTS, INEFFICIENCY OCCURS BECAUSE OF A DELAY IN CONTRIBUTIONS. FOR AN INFINITE POPULATION, ALTHOUGH DELAY MAY DISAPPEAR, UNDERPROVISION REMAINS SO THAT EQUILIBRIUM IS STILL INEFFICIENT. THE AUTHOR DESCRIBES THE POLICY RESULTS, EMPHASIZING POSSIBLE

03883 GRADY, $D$.

BUSINESS GROUP INFLUENCE IN STATE DEVELOPMENT POLICYMAKING STASE AND GRAP INFLUENCE IN STATE DEVELOPMENT POLICYMAKING STATE AND LOCAL GOVERMMENT REVIEW, 23(3) (FAL 91), 110-118.
THE INFLUENCE OF A STATE'S BUSINESS COMHUNITY HAS BECOME INCREASINGLY IMPORTANT AS STATES CONTINUE TO EXPEND INCREASINGLY IMPORTANT AS STATES CONTINUE TO EXPEND RESOURCES AND DEVELOP PROGRAMS TO ENHANCE ECONOMIC
DEVELOPMENT POTENTIALS. THIS HORK EXAMINES THE DIRECT EFFECT DEVELOPMENT POTENTIALS. THIS HORK EXAMINES THE DIRECT EFFECT OF BUSINESS LOBBIES ON DECISIONS OF THE STATE DEVELOPMENT
AGENCY. RELYING ON DATA FROM 40 STATE DEVELOPMENT AGENCIES, THE ANALYSIS FINDS THAT BUSINESS GROUPS DO MAVE MARGINAL IMPACT ON STATE DEVELOPMENT DECISION. HHILE INDIVIDUAL FIRMS MAY HIELD DISPROPORTIONATE POWER HITHIN PARTICULAR STATES, THE GENERAL ABILITY OF BUSINESS LOBBIES TO MANIPULATE THE PROCESS TO THE ADVANTAGE OF THE MORE POWERFUL ACTORS IN

03884 GRADY, D.O

THE PÉOPLE FACTOR

JOURNAL OF STATE GOVERMMENT, 65(4) (FAL 92), 16-26,

THE MANAGEMENT OF ARMIES OF STATE GOVERMMENT EMPLOYEES

HAS BECOME A MAJOR ECONOMIC AND POLITICAL CONSIDERATION IN

THE UNITED STATES. USING NEW SURVEY DATA, THE AUTHOR

ANALYZES THE HISTORICAL DEVELOPMENT OF THIS GOVERMMENT
FUNCTION AND LOOKS AT ITS CURRENT POLITICAL CONTEXT.

03885 GRAGLIA, L.

OF RIGHTS AND CHOICES

NATIONAL REVIEW, XLIV(3) (FEB 92), 39-41.

THE BILL OF RIGHTS CAN BE READ EXPANSIVELY. THIS ARTICLE EXPLAINS THAT RIGHTS ARE NOT PERFECT GOODS, BUT LIMITS ON POPULAR SELF-GOVERMMENT, TO CHECK MOMENTARY PASSIONS, NOT ENFORCE IDEOLOGICAL ONES. PEOPLE DEVOTED TO BRINGING ABOUT BASIC SOCIAL CHANGE, WIL THIS ARTICLE STAIES, INTERPRET THE BILL OF RIGHTS AMENDMENTS EXPANSIVELY.

03886 GRAHAM, $C$.

PERU'S APRA: PARTIES, POLITICS, AND THE ELUSIVE QUEST FOR DEMOCRACY

LYNNE RIENNER PUBLISHERS, 1991, 267.

ALIANZA POPULAR REVOLUCIONARIA AMERICANA (APRA) IN PERU IS ONE OF THE OL.DEST MASS-BASED REFORM-ORIENTED PARTIES IN LATIN AMERICA, WHERE THE RECORD OF BOTH DEMOCRACY AND REFORM IS CHECKERED. IN THIS STUDY OF APRA IN POWER THE AUTHOR STUDIES THE PARTY'S ROLE IN THE CONTEXT OF ITS OWN HISTORY, OF ITS DOMINANCE BY THE AUTOCRATIC AND ERRATIC ALAN GARCIA, AND OF THE SUBSTANTIAL EXISTING CONSTRAINTS TO REFORM WHEN
SOCIOECONOMIC AND POLITICAL CONTENTS AND THE PARTY'S ORIGINS AND EVOLUTION UP UNTIL 1985 . THE APRA'S DEVELOPMENT FROM THE $1920 S$ IS EXAMINED. THE ANALYSIS OF APRA'S EVOLUTION FROM 1968 TO THE PRESENT HELPS TO DETERMINE WHAT SORT OF PARTY APRA IS AND PROVIDES INSIGHTS INTO HHY IT WAS NOT ABLE TO MAINTAIN THE CONSENSUS THAT IT INITIALLY CONSTRUCTED, AND THAT WAS SO NECESSARY TO REFORM IN PERU.

03887 GRAHAM, C.

THE POLITICS OF PROTECTING THE POOR DURING ADJUSTMENT:

BOLIVIA'S EMERGENCY SOCIAL FUND

WORLD DEVELOPMENT, $20(9)$ (SEP 92), 1233-1251.

THE EMERGENCY SOCIAL FUND (ESF), A COMPENSATORY SCHEME IMPLEMENTED AS A COMPLEMENT TO BOLIVIA'S DRAMATIC STRUCTURAL REFORM PLAN, HAS ATTRACTED A GREAT DEAL OF ATTENTION. ADVOCATES OF THE ESF CITE ITS DEMAND-BASED APPROACH, ITS EFFICIENCY AND TRANSPARENCY, AND ITS RAPID RESULTS. CRITICS QUESTION THE PROGRAM'S ABILITY TO PROVIDE PERMANENT POVERTY ALLEVIATION OR TO TARGET THE POOREST SECTORS AND ITS INSTITUTIONAL POSITION OUTSIDE THE PUBLIC SECTOR. THIS STUDY ANALYZES THE IMPACT OF THE ESF ON POLITICS AND ON THE SUSTAINABILITY OF THE ADJUSTMENT PROCESS. IT ALSO EVALUATES THE ESF'S EFFECTS ON CENTRAL AND LOCAL INSTITUTIONS, THE ESF'S EFFECTS ON CENTRAL AND LOCAL INSTITUTIONS,
NONGOVERMMENTAL ACTORS, AND THE POOR. IT SEEKS TO ENHANCE
EFFORTS TO PROTECT THE POOR DURING ADJUSTMENT AND TO IDENTIFY THE CONTRIBUTIONS SUCH EFFORTS CAN MAKE TO THE POLITICAL SUSTAINABILITY OF THE PROCESS

03888 GRAHAM, C.

ZAMBIA'S DEMOCRATIC TRANSITION: THE BEGINNING OF THE END OF THE ONE-PARTY STATE IN AFRICA?

BROOKINGS REVIEW, 10(2) (SPR 92), 40-41.

IN 1991 , ZAMBIA MADE A DRAMATIC AHD SURPRISINGLY

PEACEFUL TRANSITION FROM ONE-PARTY RULE TO DEMOCRACY. IN THE FIRST FREE ELECTIONS IN ALMOST THREE DECADES, FREDERICK CHILUBA AND THE MOVEMENT FOR MULTIPARTY DEMOCRACY DEFEATED KENNETH KAUNDA, WHO HAD RULED SINCE 1964. PRESIDENT CHILUBA'S PROMISES TO IMPROVE ECONOMIC PERFORMANCE AND CURB GOVERNMENT CORRUPTION AND MISMANAGEMENT ARE MUSIC TO THE EARS OF ZAMBIANS. BUT HE FACES MANY OBSTACLES AND SUCCESS WILL NOT COME EASILY.

03889 GRAHAM, H.D.

THE ORIGINS OF AFFIRMATIVE ACTION: CIVIL RIGHTS AND THE REGULATORY STATE

ANMALS OF THE AMERICAN ACADEMY OF POLITICAL AND SOCIAL SCIENCE, (523) (SEP 92), 50-62. IENCE, (523) (SEP 92), 50-62.
AFFIRMATIVE ACTION POLICY DEYELOPED DURING THE 1960's AFFIRMATIVE ACTION POLICY DEVELOPED DURING THE 1960
AND $1970^{\prime} S$ IN THO PHASES THAT EMBODIED CONFLICTING

AND 1970'S IN TWO PHASES THAT EMBODIED CONFLICTING
TRADITIONS OF GOVERNMENT REGULATION. THE FIRST PHASE,

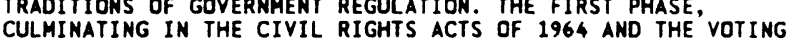
CULMINATING IN THE CIVIL RIGHTS ACTS OF 1964 AND THE VOTING
RIGHTS ACT OF 1965 , WAS SHAPED BY THE PRESIDENT AND CONGRESS RIGHTS ACT OF 1965, WAS SHAPED BY THE PRESIDENT AND AND EMPHASIZED NONDISCRIMINATION UNDER A RACE-BLIND
CONSTITUTION. THE SECOND PHASE, SHAPED PRIMARILY BY FEDERAL CONSTITUTION. THE SECOND PHASE, SHAPED PRIMARILY BY FEDER AGENCIES AND COURTS, WITNESSED A SHIFT TOWARD MINORITY
PREFERENCES DURING THE NIXON ADMINISTRATION. THE DEVELOPMENT PREFERENCES DURING THE NIXON ADMINISTRATION. THE DEVELOPMEM
OF TWO NEW AGENCIES TO ENFORCE THE CIVIL RIGHTS ACT--THE EQUAL EMPLOYMENT OPPORTUNITY COMMISSION UNDER TITLE VII AND THE OFFICE OF FEDERAL CONTRACT COMPLIANCE UNDER TITLE VI-DEMONSTRATES THE TENSIONS BETHEEN THE THO REGULATORY TRADITIONS AND THE EVOLUTION OF FEDERAL POLICY FROM NONDISCRIMINATION TO MINORITY PREFERENCES UNDER THE RUBRIC OF AFFIRMATIVE ACTION. THE RESULT HAS STRENGTHENED THE ECONOMIC AND POLITICAL BASE OF THE CIVIL RIGHTS COALITION WHILE HEAKENING ITS MORAL CLAIMS IN PUBLIC OPINION.

03890 GRAHAM, M.; HYDE, A.C.

COMPARABLE WORTH IN THE UNITED STATES: LEGAL AND ADMINISTRATIVE DEVELOPMENTS IN THE 1980S

INTERNATIONAL JOURNAL OF PUBLIC ADMINISTRATION, $14(5)$

(1991), 799-822.

DURING THE 1980 S THE CONCEPT OF COMPARABLE HORTH HAS BECOME CLOSELY IDENTIFIED WITH HOMEN'S RIGHTS AND SEX DISCRIMINATION CONCERNS, AND IS NOH RECOGNIZED BY ADVOCATES AND CRITICS ALIKE AS ONE OF THE MAJOR AFFIRMATIVE ACTION ISSUES OF THE DECADE. ACCORDING TO COMPARABLE NORTH PROPONENTS, JOBS TRADITIONALLY ASSOCIATED WITH WOMEN HAVE BEEN SYSTEMATICALLY UNDERYALUED IN THE MARKETPLACE. CRITICS OF COMPARABLE HORTH ARGUE THAT THE HAGE DIFFEREMTIAL BETHEEM OF COMPARABLE WORTH ARGUE THAT THE WAGE DIFFERENT IAL BETHEEM MEN AND WOMEN IS MORE THE RESULT OF CAREER CHOICE AND MARKET FORCES THAN SEX DISCRIMINATION. THIS ARTICLE ASSESSES SOME OF THE DUTCOMES AND TRENDS WITH REGARDS TO THE DEBATE OVER
COMPARABLE WORTH. THE AUTHOR EXAMINES THE ISSUE FROM LEGAL, COMPARABLE WORTH. THE AUTHOR EXAMINES THE IS
LEGISLATIVE AND ADMINISTRATIVE PERSPECTIVES.

03891 GRAHAM, S.D.N.

ELECTRONIC INFRASTRUCTURES AND THE CITY: SOME EMERGING IUNICIPAL POLICY ROLES IN THE U.K

URBAN STUDIES, 29 (5) (JUN 92), 755-781.

THE AUTHOR OUTLINES THE PROBLEMS AND OPPORTUNITIES THAT ARE MOTIVATING URBAN LOCAL GOVERNMENTS IN THE UNITED KINGDOM TO BEGIN INTERVENTION IN THE DEVELOPMENT OF STRATEGIC URBAN INFORMATION AND COMMUNICATIONS TECHNOLOGY (ELECTRONIC INFRASTRUCTURES OR ICT'S). THIS INTERVENTION, ALTHOUGH JUST 
COMMENCING, IS LIKELY TO HAVE IMPORTANT LONG-TERM IMPLICATIONS FOR URBAN POL ICY AND GOVERMANCE AS ICT'S BECOME INCREASINGLY CENTRAL STRATEGIC URBAN INFRASTRUCTURES. THE AUTHORS PRESENT SURVEY EYIDENCE OF THE PERCEPTIONS OF THE AUTHORS PRESENT SURVEY EVIDENCE OF THE PERCEPTIONS OF THE IMPACTS OF ELECTRONIC INFRASTRUCTURES AMONG LOCAL POLICY
MAKERS. THEY ALSO DISCUSS A SPECTRUM OF LOCAL POLICY ROLES MAKERS. THEY ALSO OISCUSS A SPECTRUM OF LOCAL POLICY ROLES
IN ICT'S PRESENTLY UNDER DEVELOPMENT IN THE UNITED KINGDOM IN ICT'S PRESENTLY UNDER DEVELOPMENT IN THE UNITED KINGDOH AMONG LEADING-EDGE LOCAL AUTHORITIES AND EXAMINE THESE
WITHIN THE WIDER CONTEXT OF CONTEMPORARY URBAN STRATEGYWITHIN

03892 GRAHAM, $Y$.

CONTINUITY OR CHANGE?

WEST AFRICA, (3919) (OCT 92), 1818

GHANA'S 1992 ELECTIONS ARE NOT SIMPLY A REFERENDUM ON THE PNDC'S ECONOMIC POLICIES BUT RATHER THE TOTALITY OF WHAT THE PNDC'S RULE, SYMBOLIZED BY FLT-LT. JERRY RAWLINGS LEADERSHIP, HAS PRODUCED.

03893 GRAMATSTEIN, J.L.; HILLMER, N. FOR BETTER OR FOR WORSE--CANADA AND THE UNITED STATES TO THE 1990S

COPP CLARK PITMAN, 1991, 352

THIS SURVEY HISTORY OF CANADIAN-AMERICAN RELATIONS IS WRITTEN BY TWO OF CANADA'S LEADING HISTORIANS OF FOREIGN POLICY. BEGINNING IN 1860 WITH THE CIVIL WAR ANO CONFEDERATION, IT TRACES THE COMPLEX COURSE OF CANADA-U.S. RELATIONS THROUGH RECIPROCITY, TWO WORLD WARS, THE COLD WAR, THE RENEWED MATIONALISM OF THE 1960S AND 1970S, CONCLUDING WITH AN UP-TO-DATE ASSESSMENT OF FREE TRADE AND THE PERSIAN GULF CRISIS. IT ARGUES A NATIONALIST LINE AND WARNS OF THE DANGERS OF A QUEBEC-CANADA SPLIT.

03894 GRANBERG, D.; BROWN, T.A.

THE PERCEPTION OF IDEOLOGICAL DISTANCE

WESTERN POLITICAL QUARTERLY, 45(3) (SEP 92), 727-750.

DATA FROM NATIONAL ELECTION STUDIES IN BRITAIN, THE

NETHERLANDS, SHEDEN, AND THE USA ARE ANALYZED TO TEST

NETHERLANDS, SHEDEN, AND THE USA ARE ANALYZED TO TEST

BETHEEN PARTIES AND CAMD PERCETION OFALYZED TDEOLOGICAL DIS

DERIVED FROM SHERIF'S SOCIAL JUDGMENT THEORY AND HEIDER'S

DERIVED FROM SHERIF'S SOCIAL JUDGMENT THEORY AND HEIDER'S

PLACEMENT AND THE PERCEPTION OF IDEOLOGICAL DISTANCE. THIS PLACEMENT AND THE PERCEPTION OF IDEOLOGICAL DISTANCE. HYPOTHESIS-T-THAT EXTREMISTS WOULD PERCEIVE RELAIIVELY GREATER DISTANCE THAN MODERATES, WHO IN TURN WOULD PERCEIVE MORE DISTANCE THAN CENTRISTS--IS SUPPORTED IN DATA FROM EACH OF THE FOUR COUNTRIES. MOREOVER, THIS RELATIONSHIP REMAINS SIGNIFICANT IN THE REGRESSION ANALYSES OF U.S. DATA WHEN A THE SECOND HYPOTHESIS--THAT VOTERS WOULD PERCEIVE MORE THE SECOND HYPOTHESIS--THAT VOTERS WOULD PERCEIVE MORE DISTANCE THAN NONVOTERS-IS SUPPORTED IN BIVARIATE ANALYSES
OF U.S. DATA, BUT THE RELATIONSHIP IS NOT SIGNIFICANT IN THE OF U.S. DATA, BUT THE RELATIONSHIP IS NOT SIGNIFICANT IN
REGRESSION ANALYSES. THE THIRD HYPOTHESIS--THAT PEOPLE VOTING FOR A CANDIDATE OUTSIDE THE POLITICAL MAINSTREAM HOULD PERCEIVE LESS DISTANCE BETHEEN THE MAINSTREAM CANDIDATES THAN PEOPLE WHO VOTED FOR THE MAINSTREAM CANDIDATES--IS NOT SUPPORTED BY DATA FROM THE $1968 \mathrm{U}$.S. ELECTION.

\section{GRANT, $W$}

MODELS OF INTEREST INTERMEDIATION AND POLICY FORMATION APPLIED TO AN INTERNATIONALLY COMPARATIVE STUDY OF THE DAIRY INDUSTRY

EUROPEAN JOURNAL OF POLITICAL RESEARCH, 21(1-2) (FEB 92), 53-68

THE AUTHOR REVIEWS THEORETICAL PERSPECTIVES ON THE RELATIONSHIP BETWEEN GOVERNMENT AND ORGANIZED INTERESTS, UTILIZING AN INTERNATIONAL COMPARATIVE STUDY OF GOVERNMENTINDUSTRY RELATIONS IN THE DAIRY INDUSTRY. FOUR ANALYTICAL MODELS ARE CONSIDERED: MESO CORPORATISM, POLICY COMMUNITY, PRIVATE INTEREST GOVERNMENT, AND THE NEGOTIATED ECONOMY. THE MESO CORPORATIST AND POL ICY' COMMUNITY MODELS PROVIDE USEFUI INSIGHTS BUT ARE LESS HELPFUL IN EXPLAINING RAPID AND FUNDAMENTAL CHANGE AS OPPOSED TO STABILITY AND INCREMENTAL CHANGE. IN SUCH CIRCUMSTANCES. THE NEGOTIATED ECONOMY MODEL CAN BE USEFULLY BE APPLIED.

03896 GRAY, A.; J JENKINS, $W$.

PUBLIC ADMINISTRATION AND GOVERMMENT 1989-90

PARLI IAMENTARY AFFAIRS, 44(1) (JAN 92), 1-19.

IN GREAT BRITAIN, THERE HAS ARISEN A "NEW LANGUAGE" OF PUBLIC ADMINISTRATION AND GOVERNMENT: CORE BUSINESSES, MARKETING, CLOSENESS TO THE CUSTOMER, UNIT COSTS, AND ADDED VALUE HAVE ALL BECOME ESTABLISHED JARGON IN WHITEHALL AND WESTMINSTER. IN A WORLD DOMINATED BY MARKET SOLUTIONS TO SOCIAL PROBL EMS STATE INTERVENTION IS TO BE KEPT TO A MINIMUM, ITS ORGANIZATIONS DECENTRAL IZED WITHIN A CENTRAL REGIME OF SYSTEMIC CONTROLS, AND OPERATION MANAGES GIVEN MORE ACCOUNTABLE FREEDOMS AND REWARDS AND MADE MORE RESPONSIVE TO CUSTOMERS. THIS ARTICLE ARGUES THAT IT IS TIME TO TAKE A HARD AND CRITICAL LOOK AT WHAT THE NEH MANAGEMENT REALLY IMPLIES FOR THE POLITICAL SYSTEM AS A WHOLE, AND IT ATTEMPTS TO CONTRIBUTE TO SUCH AND EXAMINATION.
03897 GRAY, A.; FLYNN, A.; JENKINS, B.; RUTHERFORD, B THE MANAGEMENT OF CHANGE IN WHITEHALL: THE EXPERIENCE OF THE FMI

PUBLIC ADMINISTRATION, 69(1) (SPR 91), 41-60.

THE CONSERVATIVE GOVERMMENT ANMOUNCED THE FINANCIAL MAMAGEMENT INITIATIVE IN 1982. THIS ARTICLE IS BASED ON RESEARCH INTO THE GENESIS, DEVELOPMENT AND IMPACT OF THE FMI. RESEARCH INTO THE GENESIS, DEVELOPMENT AND IMPACT SIGNIFICANTLY TO THE INSTITUTIONALIZATION OF RESOURCE MANAGEMENT IN GENERAL AND COST AWARENESS IN PARTICULAR. MANAGEMENT IN GENERAL AND COST AWARENESS IN PARTICULAR, IMPLEMENTATION HAS BEEN INFLUENCED, HOWEVER, BY THE INEVITABLE TENSION BETHEEN MANAGEMENT AND POLITICS, AND THE DIFFICULTY OF MEETING THE CONDITIONS FOR THE SUCCESSFUL ENGINEERING OF CULTURAL CHANGE.

03898 GRAY, C.

STRATEGIC SENSE, STRATEGIC NONSENSE

NATIONAL INTEREST, 29 (FAL 92), 11-20

THAT THE U.S. COMMITMENT TO A HEALTHY BALANCE, OR

PREFERABLY IMBALANCE, OF POWER IS A DEEPLY MORAL PURPOSE AND CAN BE PRESENTED VERY SUITABLY AS SUCH, IS ARGUED BY COLIN GRAY. HE EXPLORES WHAT U.S. NATIONAL SECURITY POLICY SHOULD BE TEN YEARS FROM AND WHAT KINDS OF FORCES WOULD SUPPORT THAT POLICY. HE ALSO EXAMINES WHETHER THERE IS A SUPERIOR METHOD BY WHICH TO ANALYZE THE BROAD CHARACTER AND STRATEGIC PURPOSES OF THE U.S. MILITARY IN THE EARLY TWENTY-FIRST CENTURY. STRATEGY IS DEFINED AS A CASUALTY OF PEACE AND THE PRESENT DANGERS AND TRENDS IN SECURITY POLKCY ARE EXPLORED.

03899 GRAY, C.S.

DETERRENCE IN THE NEW STRATEGIC ENVIRONMENT

COMPARATIVE STRATEGY, 11(3) (JUL 92), 247-268.

THE NEW STRATEGIC ENVIRONMENT IS BEING SHAPED BY THE SOLO STATUS OF THE UNITED STATES AS A SUPERPOWER, BY AN INCREASING REGIONAL DISORDER AND CULTURAL-POLITICAL INCREASING REGIONAL DISORDER AND CULTURAL-POLITICAL
DISHARMONY, BY THE EROSIOH OF THE RESIDUAL ALLIANCES OF THE DISHARMONY, BY THE EROSION OF THE RESIDUAL ALLIANCES OF THE
COLD WAR ERA, BY A PROCESS OF U.S. GEOSTRATEGIC WITHDRAWAL COLD WAR ERA, BY A PROCESS OF U.S. GEOSTRATEGIC WITHORAWAL
FROM EURASIA, BY AN ABSENCE OF CHANGE IN THE BASIC TERMS OF FROM EURASIA, BY AN ABSENCE OF CHANGE IN THE BASIC TERMS STATECRAFT AND STATEGY, AND BY INFORMATION-AGE MILITARY
CAPABILITIES IN THE HANDS OF THE USA. THE U.S. POLICY DEMAND FOR DETERRENT EFFECTIVENESS WILL BE HIGH IN THE NEW ERA, THOUGH SUCH EFFECTIVENESS WILL BE MORE DIFFICULT TO ACHIEVE YIS-A-YIS REGIONAL ROGUE STATES THAN IT WAS IN THE VIS-A-VIS REGIONAL ROGUE STATES THAN IT WAS IN THE RELATIONSHIP WITH YESTEROAY'S USSR. THE VALUE OF DETERRENCE BY DENIAL RATHER THAN PUNISHMENT WILL BE BOTH MORE
AND MORE CREDIBLE THAN BEFORE. NOT ONLY MUST U.S. AND MORE CREDIBLE THAN BEFORE. NOT ONLY MUST U.S. POLICYMAKERS REMEMBER THAT DETERRENCE REQUIRES THE
COOPERATION OF THE INTENDED DETERREE, BUT THEY SHOULD NOT BE COOPERATION OF THE INTENDED DETERREE, BUT THEY SHOULD
OVERCONFIDENT THAT SUCCESS IN THE COLD WAR VALIOATES TRADI TIONAL IDEAS ON, AND PRACTICES OF, DETERRENCE. IT IS NOT SELF-EVIDENT JUST HOW MUCH DETERRING THE SOVIET UNION NEEDED. OVERALL, AS A NEW AGE IS HERALDED, IT IS IMPORTANT TO CONDUCT POLICY AND FORCE PLANNING IN LIGHT OF THE PRUDENT ASSUMPTION THAT SUPERPOWER THREATS HILL RETURN.

03900 GRAY, J.

THE VIRTUES OF TOLERATION

NATIONAL REVIEH, XLIV(19) (OCT 92), 28, 30, 32, 34-35, 3.

TOLERATION AS A POL ITICAL IDEAL IS OFFENSIVE TO THE NEH LIBERALISM BECAUSE IT IS DECIDEDLY NON-NEUTRAL IN RESPECT OF THE GOOD. FOR THE NEW LIBERALS, JUSTICE DEMANDS THAT GOVERNMENT, IN ITS INSTITUTIONS AND POLICIES, PRACTICE NEUTRALITY, NOT TOLERATION, IN REGARD TO RIVAL CONCEPTIONS OF THE GOOD LIFE. ALTHOUGH IN THE END THIS IDEA OF NEUTRALITY MAY NOT PROVE TO BE FULLY COHERENT, ITS ROUGH SENSE SEEMS TO BE THAT IT IS WRONG FOR GOVERNMENT TO DISCRIMINATE IN FAVOR OF, OR AGAINST, ANY FORM OF LIFE ANIMATED BY A DEFINITE CONCEPTION OF THE GOOD.

03901 GRAY, P.

KICKING THE OIL HABIT

WASHINGTON MONTHLY, 23(3) (MAR 91), 32-35.

ANY SERIOUS DISCUSSION OF BREAKING U.S. PETROLEUM ADOICTION HAS TO FOCUS ON TRANSPORTATION. VEHICLES DRINK NEARLY 12 MILLION OF THE 18 MILLION BARRELS OF OIL USED A DAY. OF THE CONTENDERS TO REPLACE OIL COMPRESSED NATURAL GAS ANO ELECTRICITY ARE THE MOST IMMEDIATELY PROMISING. BOTH ARE
CLEANER THAN GASOLINE. BOTH ARE AVAILABLE NOW, WITHOUT PIECLEANER THAN GASOLINE. BOTH ARE AVAILABLE NOW, WITHOUT
IN-THE-SKY TECHNOLOGICAL ADVANCES. NEITHER POSES THE IN-THE-SKY TECHNOLOGICAL ADVANCES. NEITHER POSES THE NATIONAL SECURITY PROBLEMS OF PETROLEUM. AND WHEN
ENVIRONMENTAL EFFECTS ARE COUNTED, BOTH COST LESS. THIS ENVIRONMENTAL EFFECTS ARE COUNTED, BOTH COST LESS. THIS
ARTICLE ARGUES FOR THE INITIAL TRANSITION TO NATURAL GAS TO ARTICLE ARGUES FOR THE INITIAL TRANSITION TO NATURAL GAS TO
TAKE PLACE IN FLEET VEHICLES. ELECTRIC VEHICLES' FIRST NICHE TAKE PLACE IN FLEET VEHICLES. ELECTRIC VEHICLES' FIRST
MIGHT BE THE "LOCAL CAR" OF A TYPICAL FAMILY'S THO-CAR MIGHT BE THE "LOCAL CAR" OF A TYPICAL FAMILY'S THO-CA
ARSENAL (THE ONE THAT MAKES THE TRIPS AROUND TOWN).

03902 GRAZ, L.

GROSS HUMAN RIGHTS VIOLATIONS

MIDDLE EAST INTERNATIONAL, (421) (MAR 92), 11.

IN GENEVA TWO EXTREMELY SEVERE REPORTS OF IRAQI HUMAN RIGHTS ABUSES--ONE ON VIOLATIONS IN KUWAIT DURING THE OCCUPATION AND THE SECDND ON IRAQ ITSELF--WERE PRESENTED TO THE UNITED NATIONS HUMAN RIGHTS COMMISSION. ACCORDING TO THE 
REPORT ON VIOLATIONS IN KUWAIT, "SUMMARY EXECUTIONS OF CIVILIANS WHO HAD BEEN ARRESTED AND DETAINED IN KUWAIT BY THE IRAQI OCCUPYING FORCES BECAME WIDESPREAD AND SYSTEMATIC AFTER THE INITIAL PHASE OF THE INVASION" AND "HUNDREDS OF
PEOPLE LOST THEIR LIVES AS A CONSEQUENCE OF EXECUTIONS." THE SECOND REPORT ON HUMAN RIGHTS VIOLATIONS IN IRAQ ITSELF WAS EYEN HARSHER. DETAILS OF MASSACRES IN KURDISTAN AND SOUTHERN IRAQ AND SYSTEMATIC USE OF TORTURE ARE ACCOMPANIED BY REVEALING BITS OF IRAQI BA'THIST DOCTRINE IN ACTION. THE UN HUMAN RIGHTS COMMISSION'S PRESTIGE HAS GROWN ENORMOUSLY WI THEREFORE, THE DOUBLE CONDEMNATION OF IRAQ CARRIED CONSIDERABLE DIPLOMATIC CLOUT.

03903 GRAZ, 1

HUMANI TARIAN SURREALISH

MIDDLE EAST INTERMATIONAL (423) (APR 92), 6-7.

THE STALEMATE BETWEEN IHE UMITED NATIONS AGENCIES TRYIMG TO BRING HUMANITARIAN RLEIEF TO IRAO AND THE IRAOI GOVERMMENT. WHICH COMTIMUES TO REFUSE THE BASIC TERMS NEEDED FOR SUCH COOPERATION, CONTINUES. ON THE ONE HAND, THE UN HAS PUT TOGETHER AN ELABORATE PACKAGE CALLED THE PLAN OF ACTION FOR THE CONTIMUATION OF THE HUMANITARIAN ASSISTANCE PROGRAH IN IRAQ. THE PROGRAM IS SUPPOSED TO HELP "THE MOST

VULMERABLE GROUPS AND DISPLACED PERSONS" IN IRAQ MEET THEIR BASIC NEEDS; IT CLEARLY REFERS TO THE KURDS IN THE NORTH AND THE SHI'ITES IN THE SOUTH. ON THE OTHER HAND. MONEY IS A PROBLEM, BECAUSE MOST DONOR COUNTRIES REFUSE TO PAY MORE FOR IRAQI RELIEF AS LONG AS IRAQ REFUSES TO SELL ITS OIL TO PAY FOR ITS OWN BASIC NEEDS, AS PROVIDED FOR IN SECURITY COUNCIL RESOLUTIONS 706 AND 712. MEANHHILE, THE PRICES OF FOOD AND FUEL ARE SKYROCKETING IN THE KURDISH AND SHI'ITE REGIONS OF IRAQ.

03904 GRAZ, L.

KUWAIT: OPPOSTION WINS AT THE POLL

MIDDLE EAST INTERNATIONAL, 436 (OCT 92) 7-8.

FOR MANY KUHAITIS, THE' SMOOTH ELECTIONS WERE A SIGN THAT THE PERIOD OF SOCIAL RECONSTRUCTION AFTER THE DIFFICULT, ACRIMONIOUS PERIOD JUST AFTER THE LIBERATION FROM THE ARAOI OCCUPTION WAS WELL UNDER WAY. WHEN THE RESULTS WERE IN. WITH OVER HALF THE SEATS GOING TO PEOPLE KNOWN TO HAVE SYMPATHIES WITH ONE OR OTHER OPPOSITION GROUP, SATISFACTION WAS GENERAL FROM THE FIRMEST ESTABLISHWENT FIGURES TO THE CANDIDATES OF THE FRINGE GROUPS. BESIDES WOMEN'S SUFFRAGE, THE ABOLITION THE FRINGE GROUPS. BESIDES WOMEN'S SUFFRAGE, THE ABOLITION
OF THE CLASSES OF KUWAIT CITIIZENSHIP SEEMED TO BE FAVORED BY OF THE CLASSES OF KUHAIT CITIZENSHIP SEEMED TO BE MOST CANDIDATES. MANY ALSO CALLED FOR SOME SERIOUS INVESTIGATION INTO FINANCIA
QUESTIONS ABOUT SECURITY.

03905 GRAZ, L.

MOUNT ING WAVES

MIDDLE EAST INTERNATIONAL, (379) (APR 91), 6-7

THE WAYE OF REFUGEES FROM IRAO IS SHEL LING AND MOVING OUT IN ALL DIRECTIONS. AT THE BEGINMING OF APRIL. THE LARGEST NUMBER WAS IN IRAN WHERE OVER 50,000 PEOPLE HAD BEEN OFFICIALLY COUNTED BY REPRESENTATIVES OF THE UNITED NATIONS HIGH COMMISSIONER FOR REFUGEES (UNHCR) AND AT LEAST AS MANY MORE WERE EXPECTED TO ARRIVE IN THE NEAR FUTURE. WESTERN JOURNAL ISTS REPORT THAT UP TO THREE MILLION PEOPLE ARE ON THE MOVE IN NORTHERN IRAQ AND 100,000 ARE PINNED DOWN ON THE TURKISH BORDER. REFUGEES WERE ALSO MOVING IN SMALLER NUMBERS TO JORDAN, SYRIA, AND KUWAIT. IN KUHAIT AND ON THE BORDER WITH IRAQ THERE ARE THREE MAIN PROBLEMS: GETTING THE KUWAITS HOME; SORTING OUT THE FOREIGNERS HANTING TO

03906 GRAZ, L.

PANIC ON THE BORDERS

MIDDLE EAST INTERMATIONAL, (398) (APR 91), 6-7.

THE POLITICAL DISORDER' IN IRAQ HAS LED TO A MASS EXODUS OF REFUGEES TO THE IRANIAN AND TURKISH BORDERS. THE 800,000 REFUGEES THAT CROSSED THE BORDER INTO IRAN STAINED THE FACILITIES OF THE IRANIAN RED CRESCENT AND LED TO THE FIRST INSTANCE OF COOPERATION BETWEEN IRANIAN AMD AMERICAN RELIEF AGENCIES IN 12 YEARS. ON THE TURKISH BORDER, SOME 300,000 REFUGEES LANGUISH IN HARSH MOUNTAIN COMDITIONS AS INTERNATIONAL AID TRICKLES IN. OFTEN FORGOTTEN ARE THE TENS OF THOUSANDS WHO FLED TO THE ZONE OCCUPIED BY THE COALITION IN SOUTHERN IRAO.

SECURITY FORCES FOLLOWING THE WITHDRAWAL OF COALITION FORCES.

03907 GRAZ, L.

YEMEN AND SAUDI ARABIA--A START TO RECOMCILIATIOM?

MIDDLE EAST INTERNATIONAL, (431) (AUG 92) 14-15.

AFTER DECADES OF COOL RELATIONS, A FIRST STEP TOWARDS

RECONCILIATION BENTEEN SAUDI ARABIA AND YEMEN MAY HAVE BEEN TAKEN IN GENEVA ON 20 JULY WHEN YEMENI AND SAUDI MINISTERS MET TO CRACK THE ICE BETWEEN THE TWO NATIONS. HOWEVER, THREE NEW FACTORS HAVE ADDED TO THE LONG-STANDING DIFFICULTIES THAT PLAGUE THE TWO STATES' RELATIONS. THE FIRST IS THE UNIFICATION OF THE TWO YEMENS AND THE ENSUING POLITICAL LIBERALIZATION OF THE COUNTRY. SAUDI ARABIA, HHICH LOOKED ASKANCE AT EVEN THE MILD DEMOCRACY PRACTICED IN KUWAIT
BEFORE THE IRAOI INYASION IS APPALLED BY THIS "BAD EXAMPLE." THE SECOND IS THE DISCOVERY OF SIZABLE OIL RESERVES IN YEMEN, OFTEN ALONG THE UNMARKED BORDER BETWEEN THE FORMER SOUTH YEMEN AND SAUDI ARABIA. THE THIRD RECENT AREA OF DISAGREEMENT IS RELATED TO YEMEN'S ATTITUDE DURING THE GULF CRISIS, OR AT LEAST THE SAUDI PERCEPTION OF THAT ATTITUDE. DESPITE THESE PROBLEMS, OBSERVERS ON BOTH SIDES PREDICT A GRADUAL IMPROVING OF RELATIONS BETWEEN THE THO STATES.

03908 GRAZ, L.

YEMEN WEATHERS THE STORM

MIDOLE EAST INTERNATIONAL, (398) (APR 91), 24-25.

YEMEN HAS NEITHER COLLAPSED NOR SPLIT APART UNDER THE BLOWS IT HAS SUFFERED AS A RESULT OF THE GULF WAR. AS IT PREPARES FOR THE CONSTITUTIONAL REFERENDUM TO RATIFY THE
UNITY PROCLAIMED IN MAY 1990 , IT SEEMS TO BE WEATHERING THE UNITY PROCLAIMED IN MAY 1990, IT SEEMS TO BE WEATHERING THE STORM SURPRISINGLY WELL, WHILE ITS INTERNATIONAL POLICIES--
OF UNUSUALLY HIGH VISIBILITY AS THE ONLY ARAB MEMBER OF THE UN SECURITY COUNCIL AND AN APPARENT SUPPORTER OF SADDAM

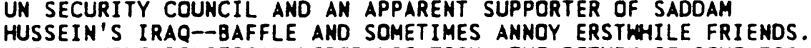
HUSSEIN'S IRAO-DAFFE AND SOMETIMES ANNOY ERSTWHILE FRIENDS. OOO EXILES, AND RELATIONS WITH OTHER STATES ON THE ARABIAN PENINSULA HAVE KEPT YEMENIS BUSY.

03909 GREBENSHCHIKOV, E.

PLACE IN THE SUM

FAR EASTERN ECONOMIC REVIEW, 155(6) (FEB 92), 24.

THE CONTINUATION OF THE ASIA-PACIFIC STRATEGY PROCLAIMED BY MIKHAIL GORBACHEV IN VLADI VOSTOK IN THE SUMMER OF 1986 WILL DEVOLVE MAINLY ON RUSSIA--THE ONLY FORMER SOVIE REPUBLIC WITH A PACIFIC COAST, AND HENCE A DIRECT INTEREST IN MAINTAINING A MAJOR ROLE IN REGIONAL POLITICS. THERE IS REASON TO EXPECT A LARGE DEGREE OF CONTINUITY ON MOSCOW'S POLICY TOWARDS THE ASIA-PACIFIC REGION. HOWEVER, THERE WILL LIKELY BE A SHIFT TOWARDS INCREASED EMPHASIS ON' ECONOMIC RATHER THAN GEOPOL ITICAL INTERESTS. WHILE MOSCOW'S RELATIONS WITH SOUTHEAST ASIAN COUNTRIES HILL BE LARGELY DE-

IDEOLOGIZED AND COMMERCIALIZED, IT IS NOT REALISTIC TO

EXPECT RUSSIA --ALONE OR IN COMBINATION WITH OTHER FORMER

SOVIET REPUBLICS-- TO FIND A PLACE AMONG ASEAN'S MAIN

TRADING PARTNERS.

03910 GREEK, C. ; THOMPSON, $W$

ANTIPORNOGRAPHY CAMPAIGNS: SAVING THE FAMILY IN AMERICA AND ENGLAND

INTERNATIONAL JOURNAL OF POLITICS, CULTURE AND SOCIETY, 5(4) (SUM 92), 601-616.

RELIGIOUS FUNDAMENTALISTS HAVE MOUNTED A SOCIAL MOVEMENT AND A CRUSADE THAT FOCUSES ON THE CLAIM THAT THE TRADITIONAL AND A CRUSADE THAT FOCUSES ON THE CLAIM THAT THE TRADITIOMA NUCLEAR FAMILY IS UNDER ATTACK FROM EROTICA. IN SO DOING THEY HAVE ESTABLISHED THEMSELVES AS THE MORAL ENTREPRENEURS OF MODERN ANGLO-AMERICAN CIVILIZATION. THIS ARTICLE EXPLC THE CAMPAIGN AGAINST PORMOGRAPHY, THE SEXUAL THEORY OF AND CIVIL UIVERTIES YERSUS MORAL ENTREPRENEURSHIP. IT

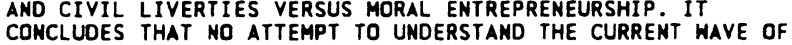
OPPOSITION TO FREEDOM OF SEXUAL EXPRESSION CAN AFFORD TO IGNORE MAX WEBER'S GENERAL MAXIM TO THE EFFECT THAT IDEAS HAVE CONSEOUENCES, OR TO UNDERRATE THE BELIEF SYSTEMS THAT
INSPIRE THE ACTORS ON ALL SIDES OF THESE SOCIAL MOVEMENTS.

03911 GREEN, B.B.

TEACHING AMERICAN GOVERMMENT IN A COMPARATIVE CONTEXT PS: POLITICAL SCIENCE AND POLITICS, XXV(1) (MAR 92), 81-82.

FOR A UNIVERSITY PROFESSOR, ONE OF THE ADVANTAGES OF TEACHING AMERICAN GOVERMMENT IS THAT THE STUDENTS KNOW A GREAT DEAL ABOUT THE SYSTEM IN WHICH THEY LIVE. HOHEVER, BEING PART OF THAT SYSTEM MAKES IT HARDER FOR THEM TO ASSESS ITS STRENGTHS AND WEAKNESSES. TEACHING AMERICAN GOVERNMENT IN A COMPARATIVE FRAMEHORK CAN LEAD THEM TO A MORE CRITICAL, BALANCED APPRAISAL.

03912 GREEN, D.; COHDEN, J.

WHO PROTESTS: SELF-INTEREST AND WHITE OPPOSITION TO BUSING THE JOURNAL OF POLITICS, 54(2) (MAY 92), 471-496.

THE MOST FIRMLY ENTRENCHED EXAMPLE OF THE EMPIRICAL

OISJUNCTURE BETWEEN SELF-INTEREST AND POLITICAL ATTITUDES CONCERNS BUSING AS A MEANS OF INTEGRATING SCHOOLS SURYEY DATA DEMONSTATE THAT WHITES WHO ARE DIRECTLY AFFECTED BY BUSING ARE NO MORE LIKELY THAN OTHER WHITES TO OPPOSE IT. THIS PAPER FINDS THAT, WHILE PERSONAL CONCERNS MAY NOT THIS PAPER FINDS THAT, WHILE PERSONAL CONCERNS MAY NOT
INFLLUENCE WHAT WHITES THINK, THEY DO DETERMINE WHETHER INFLUENCE WHAT WHITES THINK, THEY DO DETERMINE WHETHER
WHITES ACT. THE RESULTS UNDERSCORE THE DISTINCTION BETWEEN WHITES ACT. THE RESULTS UNDERSCORE THE DISTINCTION BETHE
THE BEHAYIORAL AND THE ATTITUDINAL DIMENSIONS OF MASS THE BEHAVIOR
POLITICS.

03913 GREEN, D.P.

THE PRICE ELASTICITY OF MASS PREFERENCES

AMERICAN POLITICAL SCIENCE REVIEH, 86(1) (MAR 92), 112-127. THE AUTHOR COMPARES THE PRICE ELASTICITY OF ECONOMIC AND POLITICAL PREFERENCES. HIS CENTRAL HYPOTHESIS IS THAT WILLINGNESS TO PAY, HHETHER EXPRESSED VERBALLY OR THROUGH CASH TRANSACTIONS, IS MORE PRICE-ELASTIC FOR ECONOMIC CONSUMPTION GOOOS THAN FOR PUBLIC GOODS. HE FINDS THAT 
INCREASES IN PRICE GREATLY DIMINISH THE PROPORTION OF PEOPLE WILLING TO PAY FOR CONSUMER GOODS, SUCH AS HOUSING OR HARDBACK BOOKS, WHEREAS THE PROPORTION WILLING TO PAY MORE IN TAXES TO SUPPORT A PUBLIC GOOD--SUCH AS ENVIRONMENTAL PROTECTION OR SHELTER FOR THE HOMELESS--IS MUCH LESS RESPONSIVE TO CHANGES IN PRICE. HE CONCLUDES BY DISCUSSING THE THEORETICAL AND POLITICAL IMP
PAY FOR PUBLIC AND PRIVATE GOOOS.

03914 GREEN, P.L.

GATT: THE RIGHT TO LIFE FORMS

HEMISPHERE, 4(3) (SUM 92), 14-15.

PATENTS HAVE BECOME A CONTENTIOUS ISSUE IN THE CURRENT ROUND OF GATT NEGOTIATIONS. DEVELOPING NATIONS ACCUSE MULTINATIONAL CORPORATIONS OF STEALING THIRD WORLD PLANTS AND CROP VARIETIES ALONG WITH THE KNOHLEDGE REQUIRED TO USE THEM. THESE NATIONS CONTEND THAT THE MULTINATIONALS LATER RETURN THE PILFERED GOODS TO THE DEVELOPING COUNTRIES AFTER THEY HAVE BEEN PATENTED AND EXPECT THE THIRD WORLD TO PAY A HUGE PRICE FOR WHAT RIGHTFULLY BELONGS TO THEM.

03915 GREEN, $R$.

CONSTITUTIONAL JURISPRUDENCE: REVIVING PRAXIS IN PUBLIC ADMINISTRATION

ADMINISTRATION AND SOCIETY, 24(1) (MAY 92), 3-21. THAT AMERICAN PUBLIC ADMINISTRATIVE THOUGHT RESTS ON PHILOSOPHICALLY PRAGHATIC PREMISES THAT TREAT PRAXIS AS AN EXERCISE IN RELATING EXPLANATORY THEORIES TO EMPIRICALLY DERIVED FACES IS ARGUED. THIS METHODOCENTRIC KNOWLEDGE PRODUCTION APPROACH DIRECTS ATTENTION AHAY FROM A RHETORICAL NORMATIVE JUDGMENT APPROACH THAT UNDERGIRDS AND LEGITIMIZES BOTH LEGAL AND ADMINISTRATIVE PRACTICES. THE LATTER APPROACH EXPOSES BOTH THE RHETORICAL FOUNDATIONS AND THE CENTRALITY OF LAW AS A FOCAL POINT FOR ADMINISTRATIVE WISDOM. THIS OF LAN AS A FOCAL POINT FOR ADMINISTRATIVE WISDOM

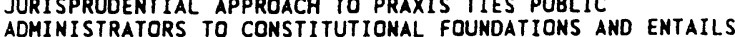
ADMINISTRATORS TO CONSTITUTIONAL FOUNDATIONS AND ENTAILS DRAMATICALLY

03916 GREEN, R.

PRUDENT CONSTITUTIONALISM: HAMILTONIAN LESSONS FOR RESPONSIBLE PUBLIC ADMINISTRATION

INTERNATIONAL JOURNAL OF PUBLIC ADMINISTRATION, 16(2) (1992), 165-186

ALEXANDER HAMILTON'S CAREER PROVIDES MUCH INSIGHT ABOUT RESPONSIBLE PUBLIC ADMINISTRATION. THIS ARTICLE EMPHASIZES HIS LINKING OF CHARACTER AND COMPETENCE IN PUBLIC ADMINISTRATION TO OUR AMERICAN CONSTITUTIONAL FORM AND VALUES. HIS "PRUDENT CONSTITUTIONALISM" YIELDED A NORMATIVE THEORY OF ACTION THAT REMAINS RELEVANT THOUGH LARGELY UNEXAMINED.

03917 GREENACRE, $R$.

SUBSIDIARITY IN STATE AND CHURCH

CONTEMPORARY REYIEN, 260(1517) (JUN 92) 287-290.

THE WORD SUBSIDIARITY IS OF GROWING IMPORTANCE IN BOTH THE POLITICAL AND ECCLESIASTICAL WORLDS BUT IS STILL UNKNOWN PERHAPS TO MOST PEOPLE. IT IS HELD TO BE A PRINCIPLE OF NATURAL LAW AND HAS FIRST CALLED INTO SERVICE TO DEFEND THE RIGHTS OF THE INDIVIDUAL IN THE FACE OF THE ABSOLUTE CLAIMS OF TOTALITARIAN STATES. THIS ARTICLE EXPLORES THE IMPORTANCE OF THIS PRINCIPLE TO THE DISTRIBUTION OF COMPETENCIES BETWEEN INDIVIDUALS AND COMMUNITIES AND BETWEEN SMALLER AND LARGER COMMUNITIES IN THE POLITICAL SPHERE. IT SUGGESTS THAT IN GREAT BRITAIN THE ANGLICANS HAVE AN IMPRESSIVE RECORD IN HONORING THE PRINCIPLE, AND THAT IF \$PROVINCIAL AUTONOMY' MEANS NOT RECDGNIZING ANY AUTHORITY AT ALL OUTSIDE THE REALM MEANS NOT RECOGNIZING ANY AUTHORITY AT ALL OUTSIDE THE REALM
OF ENGLAND. THEN THE ENGLISH SHOULD RELINQUISH THE CLAIM TO OF ENGLAND,

03918 GREENAWAY, J.

BRITISH CONSERVATISM AND BUREAUCRACY

BRITISH CONSERVATISM AND BUREAUCRACY
HISTORY OF POLITICAL THOUGHT, XIII(1) (SPR 92), 129-160.

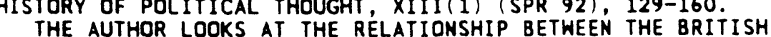

CONSERVATIVE TRADITION AND THE CIVIL SERVICE. HE DISCUSSES

CONSER CONSERVATIVE ATTITUDES TOWARD THE BUREAUCRACY. THE

EARLY CONSERVATIVE ATTITUDES TOWARD THE BUREAUCRACY, THE

APPROACH TO BUREAUCRACY, AND THE CRITICISMS OF THE NEW RIGHT.

03919 GREENBERG, D.H.

DE TELFE-TOWORK PROGRAMS

CONTEMPORARY POLICY ISSUES, X(4) (OCT 92), 51-64.

DURING THE 1980'S, A NUMBER OF STATES OPERATED WELFARETO-WORK PROGRAMS ON A DEMONSTRATION BASIS AND SUBJECTED THESE DEMONSTRATIONS TO FORMAL COST/BENEFIT EVALUATIONS. THIS PAPER EXAMINES THE EVALUATORS' METHODS AND SUMMARIZZS AND INTERPRETS THEIR FINOINGS. COST/BENEFIT ANALYSIS OF WELFARE-TO-WORK PROGRAMS CAN PROVIDE A ROUGH BUT USEFUL CASELOADS. HOWEVER, THE EVALUATION RESULTS ARE MORE DIFFICULT TO INTERPRET THAN THEY MAY APPEAR TO BE. FOR EXAMPLE. THE RESULTS TYPICALLY IMPLY THAT SUCH PROGRAMS PRODUCE SMALL NET GAINS TO SOCIETY WHEN GAINS AND LOSSES ARE
MEASURED IN TERMS OF NET INCOME. HOWEVER, A SENSITIVITY ANALYSIS MEASURING NET GAINS AND LOSSES TO WELFARE RECIPIENTS IN TERMS OF CHANGES IN NET UTILITY SUGGESTS THAT AN IMPORTANT MODIFICATION TO THE EVALUATORS' METHODOLOGY MIGHT WELL REVERSE THE FINDING IN MANY INSTANCES.

03920 GREENBERG, M.; POPPER, F.; SCHNEIDER, D.; WEST, $B$. TOADS GO TO NEW JERSEY: IMPLICATIONS FOR LAND USE AND PUBLIC HEALTH IN MID-SIZED AND LARGE U.S. CITIES URBAN STUDIES, 29(1) (FEB 92), 117-125.

TEMPORARILY OBSOLETE ABANDONED DERELICT SITES (TOADS) ARE DESERTED COMMERCIAL, INDUSTRIAL, OR HOUSING PROPERTIES AND UNDEVELOPED LAND THAT HAVE BECOME HASTE DUMPS, MAKESHIFT HOUSING FOR THE HOMELESS, AND CRACK HOUSES FOR DRUG USERS. USING A SAMPLE OF 21 MID-SIZED CITIES IN NEW JERSEY, THE AUTHORS SHOW THAT COMHUNITIES WITH A SLOW REAL ESTATE MARKET; MANY POOR, MINORITY RESIDENTS; AND A WEAK ECONOMIC BASE ARE LIKELY TO HAVE SERIOUS TOADS-RELATED PROBLEMS. TOADS AND THEIR ASSOCIATED PROBLEMS OFTEN SPREAD TO ADJACENT NEIGHBORHOODS. APPROPRIATE RESEARCH AND CIVIC RESPONSES ARE SUGGESTED.

03921 GREENFELD, L.

KITCHEN DEBATE

NEW REPUBLIC, 207(13) (SEP 92), 22-25.

THE WEST DOES NOT YET UNDERSTAND HOW WEAKLY THE RUSSIAN

"DEMOCRATS" ARE ATTACHED TO DEMOCRATIC IDEALS. THE

DEMOCRATIC INTELLIGENTSIA, WHICH TOOK SHAPE IN OPPOSITION TO

THE COMMUNIST STATE, IS MUCH MORE MOTIVATED BY NATIONALIST

THAN BY DEMOCRATIC CONCERNS. FAR FROM EXTINGUISHING

THAN BY DEMOCRATIC CONCERMS. FAR FROM EXT INGUISHING
NATIONALISM, COMMUNISM PERPETUATED AND REINFORCED THE OLD

NATIONALISM, COMMUNISM PERPETUATED AND RE INFORCED THE OLD
NATIONALIST VALUES. AND THE INTELLIGENTSIA COMMITTED TO

THESE VALUES IS NOW TURNING ON THE DEMOCRATIC REGIME IT

THESE VALUES IS NOW TURNING

03922 GREENFIELD, R.

SOMALIA: REBUILDING A SHATTERED COUNTRY

MEN AFRICAN, (287) (AUG 91), 35

RECENT MEETINGS OF REPRESENTATIVES OF SOMALIA TRIBES AND FACTIONS IN THE CAPITAL OF MOGADISHU AND THE NEIGHBORING STATE OF DJIOUT I HAVE WITNESSED NEGOTIATION AND PROPOSALS STATE OF DJIOUT I HAVE WITNESSED NEGOTIATION AND PROPOSALS REPRESENTED. THE MEETINGS WERE GREETED AS AN IMPORTANT FIRST REPRESENTED, THE MEETINGS WERE GREETED AS AN IMPORTANT FIRS THE NATION FORWARD TO PEACE AND STABILITY.

03923 GREENSTEIN, F.I.; IMMERMAN, R.H. WHAT DID EISENHOWER TELL KENNEDY ABOUT INDOCHINA? THE POLITICS OF MISPERCEPTION

JOURNAL OF AMERICAN HISTORY, 79(2) (SEP 92), 568-587.

THE AUTHORS ATTEMPT TO CLARIFY PRESIDENT' EISENHOWER'S STANCE ON U.S. MILITARY INTERVENTION IN SOUTHEAST ASIA IN THE PERIOD BEFORE THE U.S. ADVISORY PRESENCE IN VIETNAM WAS TRANSFORMED INTO A MILITARY INTERVENTION. THEY RECOUNT AN EPISODE IN WHICH EISENHOWER, ON THE LAST DAY OF HIS PRESIDENCY, MET WITH HIS DEMOCRATIC SUCCESSOR AND SEVERAL OF THEIR ADVISERS IN A RASHOMONESOUE MEETING THAT LEFT THE PARTICIPANTS WITH DIAMETRICALLY-OPPOSED INTERPRETATIONS OF WHAT EISENHOWER HAD SAID. THEY DISCUSS THE CONTROVERSY IN THE SUMMER OF 1965 ABOUT HHETHER PRESIDENT EISENHOHER HAD COMMITTED THE UNITED STATES TO DEFEND SOUTH VIETNAM, AND THEN THEY CONSIDER THE MEETING BETWEEN THE TWO PRESIDENTS AND THE REASONS FOR ITS BLIND-MEN-AND-THE-ELEPHANT CHARACTER. THEY REFLECT ON THE LARGER IMPLICATIONS OF THE EPISODE, PARTICULARLY THOSE THAT PERTAIN TO THE QUESTION OF WHETHER THE CONYICTIONS OF AMERICAN DECISION-MAKERS IN THE PERIOD BEFORE THE UNITED STATES BECAME A PARTY TO THE VIETNAM WAR MADE INTERVENTION INEVITABLE.

03924 GREER, $P$.

THE NEXT STEPS INITIATIVE: AN EXAMINATION OF THE AGENCY FRAMEWORK DOCUMENTS

PUBLIC ADMINISTRATION (LONDON), 70(1) (SPR 92), 89-98. IN 1988 THE PRIME MINISTER'S EFFICIENCY UNIT PRODUCED A REPORT, "IMPROVING MANAGEMENT IN GOVERNMENT: THE NEXT STEPS, "WHICH HAS BECOME THE MANIFESTO FOR CHANGE IN WHITEHALL. THE MAIN GOALS OF THE INITIATIVE ARE TO IMPROVE MANAGEM

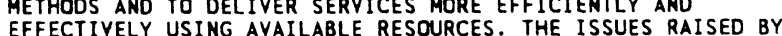
EFFECTIVELY USING AVAILABLE RESOURCES. THE ISSUES RAISED THE INITIATIVE ARE FUNDAMENTAL, QUESTIONING EXISTING
PERCEPTIONS OF THE FUNCTIONS AND NATURE OF THE BRITISH PERCEPTIONS OF THE FUNCTIONS AND NATURE OF THE BRITISH EXECUTIVE AND OF THE EXECUT IVE BRANCH'S RELATIONS WITH
PARLIAMENT. THE FIRST CLUES TO THE LIKELY SOLUTIONS TO THE PARLIAMENT. THE FIRST CLUES TO THE LIKELY SOLUTIONS TO THE ISSUES ARE AVAILABLE IN THE FRAMEWORK DOCUMENTS THAT, ALONG WITH THE ANNUAL BUSINESS PLANS AND THE FIVE YEARLY CORPORATE PLANS, DEFINE THE FRAMEWORK IN WHICH AGENCIES ARE TO OPERATE. THIS ESSAY EXAMINES THE FIRST 34 FRAMEWORK DOCUMENTS
AGENCIES ESTABLISHED THROUGH MARCH 1991. THE AUTHOR AGENCIES ESTABLISHED THROUGH MARCH 1991 . THE AUTHOR
CONSIDERS THE SIMILARITIES BETWEEN THE DOCUMENTS AND THE UNRESOLVED DILEMMAS APPARENT THEREIN. THEN SHE EXAMINES THE DIFFERENCES AND CONSIDERS THE REASONS FOR THESE VARIATIONS AND THEIR IMPLICATIONS. 
03925 GREFFENIUS, S.; GILL, J. PURE COERCION VS. CARROT-AND-STICK OFFERS IN CRISIS BARGAINING

JOURMAL OF PEACE RESEARCH, 29(1) (FEB 92), 39-52.

IN THE CRISIS PRECEDING THE GULF WAR, THE UNITED STATES FAVORED PURE COERCION OVER CARROT-AND-STICK OFFERS. THIS ARTICLE, WHICH REPLICATES AND EXTENDS THE RESEARCH REPORTED BY LENG (1984), SUPPORTS THE HYPOTHESIS THAT CARROT-ANDSTICK OFFERS HORK BETTER THAN PURE COERCION IF AN ACTOR HAS ALREADY DEMONSTRATED RESOLVE. BEGINNING WITH JERVIS'S (1976) ALREADY DEMONSTRATED RESOLVE. BEGINNING HITH JERVIS'S INTERACTION, THE ARTICLE ASSESSES THE EFFECTS OF VARIOUS INTERACTION, THE ARTICLE ASSESSES THE EFFECTS OF VARIOUS
TYPES OF FORCEFUL MOVES IN CRISIS BARGAINING. INTERRUPTED TYPES OF FORCEFUL MOVES IN CRISIS BARGAINING. INTERRUPT TIME-SERIES TECHNIQUES ARE USED WITH DATA ON HOSTILITY
LEVELS IN THO CONFRONTATIONS TO TEST THE HYPOTHESIS THAT PURE COERCION TENDS TO ELICIT A RESPONSE IN KIND, NHEREAS CARROT-AND-STICK OFFERS TEND TO ELICIT ACCOMODATION. CARROT-AND-STICK OFFERS TEND TO ELICIT ACCOMODATION. ANALYSIS OF BEHAVIOR CORRELATES OF WAR OATA ON ACTORS'
RESPONSE IN THE CUBAN MISSILE CRISIS AND IN THE EGYPTIANRESPONSE IN THE CUBAN MISSILE CRISIS AND IN THE EGYPIIANISRAELI CONFRONTATION IN 1967 CORROBORATE LENG'S ORIGINAL
FINDINGS. IRAO'S RESPONSES TO THE UNITED STATES' THREATS IN THE GUS. IRAO'S RESPONSES TO THE UNITED STATES THREATS IN THE GULF CONFLICT SUGGEST THAT PURE COERC
OPPONENT TO FIGHT EVEN WHEN IT IS WEAKER.

03926 GREGOR, A.J.

"LinKS" and "EXChanges": the mainLand policy of the roc GLOBAL AFFAIRS, 6(1) (WIN 91), 54-73.

THIS ARTICLE EXAMINES THE CHANGES IN THE RELATIONSHIP BETHEEN MAINLAND CHINA AND THE REPUBLIC OF CHINA ON TAIWAN (ROC). IT EXPLAINS WHY THE ALTERED RELATIONSHIP HAS AN IMPACT ON THE ECONOMIC, POLITICAL, AND STRATEGIC INTERESTS OF THE U.S., THE REGION, AND THE INTERNATIONAL COMMUNITY. THE HISTORY OF THE RELATIONSHIP IS REVI EWED BACK TO 1979 WHEM THE PRC OPEMED TRADE RELATIONS WITH THE OUTSIDE hORLD AND THE BUSINESS COMMUNITY OF TAIHAN BEGAN UNOFFICIAL EXCHANGES WITH THE ROC. THE NEH MAINLAND POLICY ON THE ROC IS DESCRIBED.

03927 GREGORY, F.

CAN MILITARY FORCE DEFEAT DRUGS TRAFFICKING?

SMALL WARS \& INSURGENCIES, 291(1) (APR 91), 1-7.

GIVEN THAT THE U.S. HAS BEEN THE LEADING MAJOR POWER ADVOCATING MILITARY-STYLE SOLUTIONS TO THE ILLICIT DRUGS SUPPLY PROBLEM, AN IMPORTANT SHIFT OF STANCE HAS TAKEN PLACE IN THE BUSH ADMINISTRATION. THE TRIP BY PRESIDENT BUSH IN FEBRUARY 1990 TO CARTAGENA WENT FAR BEYOND A DIPLOMATIC GESTURE. IT IMPLIED AN ACCEPTANCE OF EOUALITY AND THE GESTRE. IT IMPLIED AN ACCEPTANCE OF EQUALITY AND THE RECOGNITION THAT THE PROBLEM OF DRUG TRAFFICKING IS TOO PRODUCING COUNTRIES AS VILLAINS AND BY DYNAMIIING GUERILLA PRODUCING COUNTRIES AS VILLAINS AND BY DYNAMITING GUERILLA HEADQUARTERS OR COCO PLANTATIONS. DOMESTICALLY, THE NATIONAL DRUG CONTROL STRATEGY RECOGNIZE THE COMPLEXITY OF THE DRUG FOR SIMPLISITIC SOLUTIONS LIKE \&CALL OUT THE TROOPS'.

03928 GREGORY, R.; PEARSON, J.

THE PARLIAMENTARY OMBUDSMAN AFTER TWENTY-FIVE YEARS PUBLIC ADMINISTRATION, 70(4) (WIN 92), 469-498.

THE PARL IAMENTARY COMMISSIONER SCHEME COULD BE USED WITH ADVANTAGE A GOOO DEAL MORE EXTENSIVLY THAN IT IS. THIS ARTICLE SUGGESTS THAT GREATER AHARENESS OF THE FUNCTIONS OF THE OFFICE BY BOTH THE GENERAL PUBLIC AND AMONG MPS; AN EXTENSION OF THE COMMISSIONER'S JURIDICTIOMAL REMIT; A FAST AVERAGE 'THROUGHPUT' TIME FOR INVESTIGATIONS; AND POSSIBLY THE INTRODUCTION OF A 'THO-TRACK' PROCEDURE FOR IMQUIRIES ARE ALL ARGUABLY REQUIRED IF THE FULL POTENTIAL OF THE PARLIAMENTARY COMMISS IONER SCHEME IS TO BE REALIZED.

03929 GREGORY, R.; PEARSON, J.

THE PARL I AMENTARY OMBUDSMAN AFTER 25 YEARS

PUBLIC ADMINISTRATION (LONDON), 70(4) (WIN 92), 469-498.

THENTY-FIVE YEARS AFTER IT HAS ESTABLISHED THE

PARL IAMENTARY COMMISSIONER SCHEME IS BEING CRITICIZED NOT SO WUCH BECAUSE IT LACKS TEETH BUT BECAUSE THE SYSTEM COULD BE USED A GOOD DEAL MORE EXTENSIVELY AND ADVANTAGEOUSLY. THE PARL IAMENTARY OMBUDSMAN HAS BEEN UNDER-UTILIZED LARGELY BECAUSE IT HAS GENERATED ONLY BOUNDED ENTHUSIASM AMONG MP'S, THE GATEKEEPERS, AMD POTENTIAL MAGMETS FOR THE OFFICE. SURVEY EVIDENCE SUGGESTS THAT THE MPS' ATTITUDES ARE RELATED MAINLY TO THEIR DISSATISFACTION WITH THE LIMITATIONS ON THE OMBUDSMAN'S SPATIAL JURISDICTION AND THE LENGTH OF TIME TAKEN BY THE OFFICE TO INYESTIGATE COMPLAINTS. DISAPPROVAL TAKEN BY THE OFFICE TO INVESTIGATE COMPLAINTS. DISAPPROYAL OF THESE ASPECTS OF THE SCHEME MAY BE SYMPTOMATIC OF A
DIVERGENCE BETWEEN MEMBERS' DESIRE FOR OUICK-FIX SOLUTIONS DIVERGENCE BETWEEN MEMBERS' DESIRE FOR OUICX-FIX SOLUTIONS
TO CONSTITUENTS' PROBLEMS AND THE EMPHASIS PLACED ON THE TO CONSTITUENTS PROBLEMS AND THE EMPHASIS PLACED ON AUOIT ROLE OF THE OFFICE BY SUCCESSIVE COMMISSIONERS. GREATER AWARENESS OF THE FUNCTIONS OF THE OFFICE BY GENERAL PUBLIC AND AMONG MP'S, AN EXTENSION OF THE COMMISSIONER'S JURISDICTIONAL REMIT, FASTER INVESTIGATIONS, INQUIRIES COULD HELP THE PARLIAMENTARY COMMISSIONER SCHEME OPERATE MORE EFFECTIVELY.
03930 GREIMEL, $K$.

THE ROLE OF SELF-MASTERY IN PRESERVING NEGATIVE LIBERTY: AN EXAMINATION OF JOHN STUART MILL'S RESPONSE TO THE TYRAMNY OF THE MAJORITY

MICHIGAN JOURNAL OF POLITICAL SCIENCE, 15(15) (FAL 92), $1-36$

THE AUTHOR FOCUSES ON THE WRITINGS OF JOHN STUART MILL AND OTHER PHILOSPHERS IN ORDER TO DETERMINE HOW INDIVIDUAL FREEDOM CAN BE MAINTAINED IN THE FACE OF A TYRANNICAL MAJORITY. AFTER DISCUSSING THE DIFFERENCES BETHEEN POSITIVE AND NEGATIVE LIBERTY, HE TURNS TO AN EXAMINATION OF THE MACHIAVELLAIN FORM OF DEMOCRATIC GOVERMMENT. ULTIMATELY, HE ARGUES THAT A COMBINATION OF SELF-LEGISLATION AND SELFMASTERY IS THE MOST RELIABLE MEANS OF CREA
WHERE NEGATIVE LIBERTY CAN BE PRESERVED.

03931 GRELL, J.M.; GAPPERT, G.

THE FÚTURE ÓF GOVERNANCE IN THE UNITED STATES: 1992-2002 ANNALS OF THE AMERICAN ACADEMY OF POLITICAL AND SOCIAL SCIENCE, 522 (JUL 92), 67-78.

THE UNITED STATES IS ENTERING A NEW ERA OF REDEFINING THE PURPOSE OF LEADERS AND INSTITUTIONS, RESTRUCTURING OLD IDEOLOGIES, AND REDIRECTING THE FOCUS OF RESPONSIBILITIES IN ORDER TO MEET THE GLOBAL CHALLENGES AHEAD. IN THIS ARTICLE, THE AUTHORS OFFER A TEN-YEAR PERSPECTIVE ON THE NECESSITY
FOR MORE GOVERNANCE AND LESS GOVERMMENT. THEY ARGUE THAT THE 8ARRIERS TO THIS CONVERSION ARE POLITICAL BUT NOT INSURMOUNTABLE. INDIVIDUAL, POLITICAL, AND INSTITUTIONAL TRANSFORMATIONS ARE REQUIRED. THE AUTHORS BELIEVE THAT THE KEY ELEMENTS NECESSARY FOR SUCCESSFUL GOVERNANCE INCLUDE A NEW DEMOCRACY, STRATEGIC COOPERATION, A NEW FEDERALISH, DECENTRALIZATION, A NEW MORAL INFRASTRUCTURE, INDIVIDUAL RESPONSIBILITY AND NEH LEADERS, COLLABORATIVE PARTNERSHIPS AND STABILITY, INCREASED COMPETITION, AND TECHNOLOGICAL GROWTH .

03932 GREWLICH, $K$.

THE TECHNOLOGY RACE

AUSSEN POLITIK, 42(4) (1991), 383-389.

TECHNOLOGICAL DEVELOPMENT IS INCREASINGLY BECOMING THE DOMINANT FEATURE OF INTERNATIONAL POWER STRUCTURES AND

RELATIONS. THIS MAKES INTERNATIONAL AND REGIONAL COMPETITION FOR ADVANCES IN THE FIELD OF HIGH TECHNOLOGY HIGHLY

SIGNIFICANT. THIS ARTICLE CONTENDS THAT THERE IS A RISK THAT INTERNATIONAL ANTAGONISMS AND CRISES COULD RESULT FROM TECHNOLOGICAL COMPETITION. IT ARGUES THAT MOVES MADE BY THE TECHOPEAN COMMUNITY IN THIS CONTEXT PROVIDE A PROMISING MODEL EUROPEAN COMMUNITY IN THIS CONTEXT PROVIDE

03933 GREY, T

CIVIL RIGHTS VS CIVIL LIBERTIES: THE CASE OF

DISCRIMIMATORY YERBAL HARASSMEMT

JOURNAL OF HIGHER EDUCATIDN, 63(5) (SEP 92), 485-516. THE AUTHOR PROPOSES AN INTERPRETATION OF THE CONFLICT BETWEEN CIVIL RIGHTS AND CIVIL LIBERTIES IN ITS LATEST MANIFESTATION: THE CONTROVERSY OVER HOW TO TREAT

DISCRIMINATORY HARASSMENT ON CAMPUS. THE HARASSMENT PROBLEM ILLUSTRATES THE ELEMENT OF PARADOX IN THE CONFLICT OF CIVIL RIGHTS AND CIVIL LIBERTIES PERSPECTIVES OR MENTALITIES

03934 GRIER, P.

POKING AND PRYING FOR PEACE

BULLETIN OF THE ATOMIC SCIENTISTS, 47(10) (DEC 91), 25-29. THE ON-SITE INSPECTION AGENCY IS THE MOST VISIBLE SYMBOL OF WHAT MIGHT BE CALLED THE "VERIFICATION REVOLUTION." DECADE AGO IT WAS UNTHINKABLE THAT U.S. INSPECTORS WOULD LIVE NEAR A SOVIET MISSILE FACTORY OR THAT SOVIET INSPECTORS MIGHT BE FETED AT A BACKYARD BARBECUE IN UTAH, OR THAT A NEW TREATY WOULD LIST THE SPECIFIC STEPS IN DESTROYING AN ARMORED VEHICLE. THIS ARTICLE EXAMINES THE EVOLUTION AND DEVELOPMENT OF VERIFICATION MEASURES. IT CONSIDERS THE EXAMPLES OF THE INF TREATY, START, CFE, AND THE CAPABILITIES OF SPY SATELLITES.

03935 GRIFFIN, C.J.G.

NEH LIGHT ON EISENHOWER'S FAREWELL ADDRESS

PRESIDENTIAL STUDIES QUARTERLY, XXII(3) (SUM 92), 469-480. THE AUTHOR SHEDS LIGHT ON THE MEANING OF THE EISENHOHER PRESIDENCY THROUGH AN EXPLICATION OF THE CHIEF EXECUTIVE'S

FAREHEL ADORESS, WHICH INCLUDED THE FAMOUS HARNING AGAINST

THE INFLUENCE OF THE MILITARY-INDUSTRIAL COMPLEX.

03936 GRIFFIN, R.

POLITICAL OPPORTUNITY, RESOURCE MOBILIZATION, AND SOCIAL MOVEMENTS: THE CASE OF THE SOUTH TEXAS FARM WORKERS SOCIAL SCIENCE JOURNAL, $29(2)$ (1992), 129-152.

THE FARM HORKERS MOVEMENT OF SOUTH TEXAS BEGAN WITH THE STARR COUNTY STRIKE IN 1966. WHILE THE MOVEMENT MET POWERFUL INSTITUTIONAL RESISTANCE FROM STATE AND LOCAL POL ITICAL FORCES, DEBILITATING ECONOMIC SANCTIONS AND LEGAL AND POLICE REPRESSION, IT SUCCEEDED IN SECURING A STATE MINIMUM WAGE BILL AND IMPROVED HORKING CONDITONS IN THE FIELDS. THE PURPOSE OF THIS ARTICLE IS TO ANALYZE THE ORGANIZATIONAL, RELIGIOUS, AND POLITICAL EVENTS AND PATTERNS WHICH LED TO 
MANY SUCCESSES FOR THIS LARGELY UNATICIPATED MOVEMENT.

03937 GRIFFITH, I

THE RSS- -A DECADE OF COLLECTIVE SECURITY IN THE CARIBBEAN ROUND TABLE, 324(324) (OCT 92) 465-476.

INDIVIDUAL CARIBBEAN COUNTRIES ARE UNABLE TO RELY ONLY ON THEMSELVES FOR MATIONAL AND REGIONAL SECURITY.

POTENTIALLY, THE MOST FAR-REACHING COLLECTIVE SECURITY VENTURE IS THE REGIONAL SECURITY SYSTEM (RSS). WHICH CELEBRATES A DECADE OF ESTABLISHMENT IN OCTOBER 1992. THIS ARTICLE EXAMINES THE RSS, ITS STRUCTURE AND OPERATIONS, AND THE GRENADA DEPLOYMENT. THE EVENTS IN GRENADA CAST DOUBT ON ITS ABILITY TO DIFFUSE MILITARY TENSIONS OF ANY SIGNIFICANCE WITHOUT THE INVOLVEMENT OF THE

03938 GRIFFITH, I. (ED.)

STRATEGY AND SECURITY IN THE CARIBBEAN

PRAEGER PUBLISHERS, 1991,224

THIS CONTRIBUTION TO THE DEBATE ON SECURITY IN THE CARIBBEAN HIGHLIGHTS THE SECURITY PROBLEMS OF SMALL STATES. THE AUTHORS DRAW FROM REALIST THEORY, CONFLICT THEORY, AND POLITICAL ECONOMY ANALYSES TO EXAMINE THE INDIGENOUS REGIONAL AND EXTRA-REGIONAL DYNAMICS SHAPING THE CARIBBEAN SECURITY ENVIRONMENT. FOUR CASE STUDIES ARE PRESENTED: BARBADOS, GUYAHA. THE YIRGIN ISLANDS, AND THE BELIZEGUATEMALA TERRITORIAL DISPUTE.

03939 GRIFFITH, P.

SMALL WARS AND HOW THEY GROW IN THE TELLING

SMALL WARS \& INSURGENCIES, 2 (2) (AUG 91), 216-231.

IT HAS BEEN SAID THAT THE STUDY OF SMALL WARS CAM INTERFERE WITH THE STUDY OF LARGE ONES, AND IT IS CERTAINLY TRUE THAT MOST ARMIES FIND IT DIFFICULT TO SWITCH FROM ONE TYPE TOAT MOST ARMIES FIND IT DIFFICULT TO SWITCH FROM ONE MIL ITARY OR POL ITICAL DOCTRINES HAVE AN IMPORTANT PART TO PIAY IN DIFFERENCES OF PERCEPTION AS DD MATERIAL FACTORS PLAY IN DIFFERENCES OF PERCEPIION AS DD MATERIAL FACTORS SUCH AS NATIONAL ECONOMIC RESOURCES. THIS ARTICLE ART

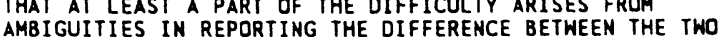
AMBIGUITIES IN REPORTING THE DIFFERENCE BETWEEN THE TWO TYPES OF WAR IN THE PRESS AND THROUGH OTHER FORMS OF THE PRINTED WORD. THE GENERAL READER CAN FIND IT DIFFICUT TO DISTINGUISH BETHEEN DIFFERENT LEVELS OF VIOLENCE. HE TENDS TO SEE ALL WARS AS BIG WARS. THE ARTICLE CONCLUDES THAT THE PROBLEM IS THAT ONE MAN'S SMALL WAR MAY BE ANOTHER MAN'S APOCALYPSE.

03940 GRIFFITHS, I. ; FUNMELL, D.C. THE ABORTIVE SHAZI LAND DEAL

AFRICAN AFFAIRS, $90(358$ ) (JAN 91), 51-64.

THE AUTHOR ARGUES THAT THE ABORTIVE SHAZI LAND DEAL OF THE EARLY 1980 S IS REMARKABLE BECAUSE IT WOULD HAVE INVOLVED A MAJOR CHANGE OF INTERNATIONAL BOUNDARIES, ALLEGEDLY WITH THE APPROVAL OF THE ORGANIZATION OF AFRICAN UNITY (OAU); IT WOULD HAVE GIVEN A LAND-LOCKED STATE, SHAZILAND, A SEABOARD; IRREDENTISM WAS A SWAZI MOTIVE FOR THE DEAL; AND, DESPITE SOUTH AFRICAN INVOL VEMENT, THE DEAL WAS APPARENTLY GIVEN THE BLESSING OF BLACK AFRICA. THE PROPOSED LAND DEAL AND OPPOSITION TO IT ARE EXAMINED.

03941 GRIFFITHS, $M$.

ORDER AND INTERNATIONAL SOCIETY: THE REAL REALISM REVIEN OF INTERNATIONAL STUDIES, 18(3) (JUL 92), 217-240. REALISH IS A SCHOOL HHOSE MEMBERS HARBOR SHARED ASSUMPTIONS ABOUT THE PRIMACY OF STATES AS INTERNATIONAL ACTORS, THE SEPARATION OF DOMESTIC AND INTERNATIONAL ACTORS, THE SEPARATION OF DOMESTIC AND INTERNAT IONAL POLITICS, AND WHO DESCRIBE THE LATTER IN TERMS OF ANARCHY THE PURPOSE OF THIS ARTICLE IS TWO-FOLD. FIRST, THE AUTHD
PRESENTS R. N. BERKI'S INTERPRETATION OF THE MEANING OF PRESENTS R. N. BERKI'S INTERPRETATION OF THE MEANING OF
REALISM AS AN ATTRIBUTE OF THOUGHT RATHER THAN A STIPULATED REAL ISM AS AN ATTRIBUTE OF THOUGHT RATHER THAN A STIPULATED
SCHOOL OF THOUGHT. SECOND, HE ARGUES AGAINST THE ATTRIBUTE SCHOOL OF THOUGHT. SECOND, HE ARGUES AGAINST THE ATT

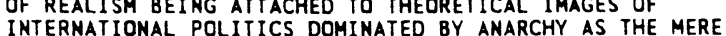
INTERNATIONAL POLITICS DOMINATED BY ANARCHY AS THE MERE
ABSENCE OF SOVEREIGN PRESENCE. HE SUGGESTS THAT POLITICAL ABSENCE OF SOVEREIGN PRESENCE. HE SUGGESTS THAT POLITICAL REALISH OUGHT NOT TO BE UNDERSTOOD AS ONE POLE OF A FALSE DICHOTOMY, BUT AS THE "VIA MEDIA" BETWEEN

03942 GRINEVALD, J.

EUROPE

BUILETIN OF PEACE PROPOSALS, 22(1) (MAR 91), 41-48.

THIS ARTICLE PRESENTS AL, 22(1) (MAR 91) 41-48. OPPOSING SOCIOPOLITICAL AND CIVILIZATIONAL TRENDS THAT CHARACTERIZE THE CULTURAL DYNAMISM OF EUROPE. IT EMPHASIZES A PARADIGMATIC DICHOTOMY ON THE METAPSYCHOLOGY OF EROS AND THANATOS. IN THIS ANTHROPOLOGICAL AND EPISTEMOLOGICAL PERSPECTIVE, BASIC SPIRITUAL, CULTURAL AND POLITICAL OPTIONS ARE SEEN AS A NECESSARY CONDITION TO DEFINING COLLECTIVE SECURITY. IT CONCLUDES THAT THE REAL END OF THE COLD WAR BE REPLACED BY A NEW GREEN POLITICAL PARADIGM.
03943 GRISWOLD, D.

MAN ON A MISSION

NATIONAL REVIEW, XLIV(19) (OCT 92), 26-27

THE AUTHOR LOOKS AT THE 1992 SENATORIAL CONTEST BETWEEN REPUBLICAN TERRY CONSIDINE AND DEMOCRAT BEN NIGHTHORSE
CAMPBELL.

03944 GRIZOLD, A.

MILITARY INTERVENTION IN SLOVENIA

INTERNATIONAL SOCIAL SCIENCE REYIEH, 67(1) (WIN 92), 8-12. THE YUGOSLAV FEDERAL ARMY'S MILITARY INTERVENTION IN SLOVENIA AND THE BRUTAL ARMED COMBAT IN CROATIA REPRESENT THE CULMINATION OF THE YUGOSLAV CRISIS. THE AUTHOR SUMMARIZES THE SOCIAL CHANGES IN YUGOSLAVIA, WHICH OVER THE LAST DECADE LED TO THE ENTROPY OF ITS SOCIOPOLITICAL SYSTEM AND TO ARMED VIOLENCE. HE ARGUES THAT THE YUGOSLAV CRISIS CAN BE SOL VED ONLY BY RADICAL ACTION BY THE INTERNATIONAL COMMUNITY.

03945 GROFMAN, B.; HANDLEY, L. IDENTIFYING AND REMEDYING RACIAL GERRYMANDERING JOURNAL OF LAW \& POLITICS, VIII(2) (WIN 92), 345-404. THE AUTHORS EXAMINE RECENT COURT RULINGS AND THE LAW THAT APPLIES TO RACIAL GERRYMANDERING. THEY SHOW HOW COURTS HAVE ATTEMPTED TO SPECIFY LEGAL STANDARDS FOR RACIAL GERRYMANDERING IN LIGHT OF THE THORNBURG DECISION AND DISCUSS SOME OF THE UNRESOLVED ISSUES. THEN THEY ILLUSTRATE APPROPRIATE USES OF SOCIAL SCIENCE METHODOLOGY IN EVALUATING THE RACIAL CONSEQUENCES OF SINGLE-MEMBER DISTRICT PLANS. THIRDLY, THEY OUTLINE A LEGAL APPROACH TO RACIAL GERRYMANDERING IN SINGLE-MEMBER DISTRICTS BECAUSE CASES INVOLVING SINGLE-MEMBER DISTRICTS WILL PROBABLY BE THE MOST COMHON TYPE OF VOTING RIGHTS LITIGATION IN THE 1990's.

03946 GROFMAN, B.; GLAZER, A.; GRIFFIN, R. THE EFFECT OF BLACK POPULATION ON ELECTING DEMOCRATS AND LIBERALS TO THE HOUSE OF REPRESENTATIVES

LEGISLATIVE STUDIES OUARTERLY XVII (3) (AUG 92), 365-380. LEISLATIVE STUDIES QUARTERLY, XVII(3) (AUG 92), 365
THE AUTHORS STUDY THE RELATIONSHIP BETWEEN BLACK POPULATION AND CONGRESSIONAL LIBERALISM IN RECENT DECADES DISAGGREGATED BY REGION. THEY SHOH THAT DIFFERENT TYPES OF DISAGGREGATED BY REGION. THEY SHOH THAT DIFFERENT TYPES OF IN DIFFEREMT REGIONS OF THE UNITED STATES. THEY LOOK AT THE IN DIFFERENT REGIONS OF THE UNITED STATES. THEY LODK AT THE POTENTIAL POLITICAL IMPLICATIONS OF DISTRICTING SCHEMES EITHER CONCENTRATE OR DISPERSE BLACK POPULATION ACROSS CONGRESSIONAL DISTRICTS. THEY SHOW HOW SUCH REDISTRICTI

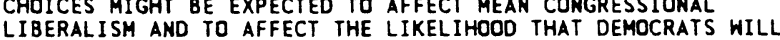
LIBERALISM AND TO AFFECT THE LIKEL IHOOD THAT DEMOCRATS WILL
BE ELECTED TO THE HOUSE OF REPRESENTATIVES IN THE 1990'S. THEY ALSO EXPLORE THE CLAIM THAT CREATING BLACK-MAJORITY DISTRICTS REDUCES THE MEAN POLICY LIBERALISH OF CONGRESS BY LEADING TO REPUBLICAN AND CONSERVATIVE GAINS IN DISTRICTS THAT HAVE BEEN STRIPPED OF BLACK VOTERS.

03947 GROMLEY, W.T. JR.

FOOD FIGHTS: REGULATORY ENFORCEMENT IN A FEDERAL SYSTEM PUBLIC ADMINISTRATION REVIEW, 52(3) (MAY 92), 271-280.

THE AUTHOR ASKS WHICH APPROACHES USED BY FEDERAL AGENCIES TO GAIN COMPLIANCE FROM STATE OFFICIALS IN PROGRAMMATIC AREAS ARE MOST EFFECTIVE. HE POSITS THREE TYPES OF FEDERAL GOVERNMENT APPROACHES: THOSE PROVIDING STATE OFFICIALS WITH CONSIDERABLE DISCRETION (CATALYTIC CONTROLS); THOSE BACKED BY MORE EXPLICIT OVERSIGHT FROM FEDERAL AGENCIES (COERCIVE CONTROLS); AND THOSE RELYING ON POLITICAL AND OTHER INCENTIVES TO GENERATE STATE-LEVEL COMPLIANCE (HORTATORY CONTROLS). USING THE RELATIONS BETWEEN THREE SOUTHERN STATES (MISSISSIPPI, SOUTH CAROLINA, AND GEORGIA) AND THE DEPARTMENT OF AGRICULTURE'S REGIONAL' OFFICE IN ATLANTA, THE AUTHOR STUDIES THE INTERGOVERNMENTAL RELATIONS WITHIN THE USDA'S CHILD CARE FOOD PROGRAM. HE FINDS THAT HORTATORY CONTROLS WORKED HELL IN SOUTH CAROLINA. THE APPLICATION OF CDERCIVE CONTROLS HAD MIXED RESUL TS IN MISSISSIPPI, WHERE THE POLITICAL AND BUREAUCRATIC CONTEXTS MISSISSIPPI, WHERE THE POLITICAL AND BUREAUCRATIC CONTEXTS WERE MORE OPEN TO THE ATLANTA OFFICE'S DEMANDS THAN WERE CONDITIONS IN GEORGIA, WHERE THE COERCIVE APPROACH FAILED HE CONCLUDES BY NOTING THE MORE PROBLEMATIC NATURE OF COERCIVE APPROACH AND THE CARE THAT MUST BE TAKEN IN
DESIGNING AN INTERGOVERMMENTAL IMPLEMENTATION STRATEGY.

03948 GROOM, A.

GIBRALTAR: NO END TO \$EMPIRE'?

GIBRALTAR: NO END TO \$EMPIRE'?
ROUND TABLE, 323(323) (JUL 92), 273-292

NO ONE EXPECTS THE GIBRALTAR CONFLICT TO FLARE UP INTO A CRISIS OR EVEN WORSE, INTO VIOLENCE, YET IT REMAINS A REAL CONFLICT HITH LATENT PROPENSITIES FOR ESCALATION. THIS ARTICE EUROPE SUGGEST THAT WE NEGLECT SUCH CONFLICTS AT OUR PERIL. IT EXPLORES GIBRALTAR: AS \$THE ROCK'; POLITICAL PARAMETERS

THE 8O'S AS A DECADE OF POLITICAL EVOLUTION AND ECONOMIC
CHANGE; SPANISH PERCEPTIONS AND POLICY; AND POSSIBLE OPTIONS

03949 GROSE, A.P.

HOW DO YOU KNOW YOU GET WHAT YOU PAY FOR?

JOURNAL OF STATE GOVERNMENT, 65(3) (SUM 92), 21-28. 
THE AUTHOR EXPLAINS SOME OF THE ADVANTAGES AND DISADVANTAGES OF STATE INCENTIVE PACKAGES FOR ECONOMIC DEVELOPMENT. HE NOTES THAT GOOD INCENTIVE PROGRAMS ARE DIRECTLY CORRELATED WITH OVERALL ECDNOMIC DEVELOPMENT STRATEGY, THAT STATES MUST DO A BETTER JOB OF CORRELATING
THE COST OF BENEFIT PACKAGES WITH LONG-TERM BENEFITS, AND THAT GOOD INCENTIVE PROGRAMS ULTIMATELY SERVE SOCIAL GOALS

03950 GROSS, J.

MAASTRICHT AND THE COMMUNITY: DILEMMAS AND REALITIES GERMAN TRIBUNE, (1528) (AUG 92), 4

TO UNDERSTAND THE MAASTRICHT TREATIES, ONE MUST STUDY THE TREATY ON EUROPEAN UNION, THE MAASTRICHT SUMMIT FINAL ACT, THE STATEMENTS MADE AT THE SUMMIT, THE TREATY OF ROME, THE SINGLE EUROPEAN ACT, THE TREATY ON COMMON ORGANS, THE TREATY ESTABLISHING THE COUNCIL AND THE COMMISSION, AND THE TREATY ESTABLISHING THE COUNCIL AND THE COMMISSION, AND THE ACT ON ELECTIONS TO THE EUROPEAN PARLIAMENT. THEY MAK
MORE THAN 200 PAGES OF SMALL PRINT THAT EXPOSE THE MORE THAN 200 PAGES OF SMALL PRINT THAT EXPOSE THE DIPLOMATIC AND BUREAUCRATIC ACTIVITY AND THE KIND OF
POLITICAL FORMULA THAT HAVE DONE LASTING DAMAGE TO THE POLITICAL FORMULA THAT HAVE DONE LASTING
POPULAR ENTHUSIASM FOR THE EUROPEAN IDEA.

03951 GROSS, $M$.

THE MIDOLE EAST STATE SYSTEM AND NEW SOVIET THINKING MIDDLE EAST INSIGHT, 8(2) (SEP 91), 24-30

CONSIDERABLE INTEREST HAS BEEN DEMONSTRATED IN RECENT YEARS ABOUT THE POTENTIAL IMPACT OF SOVIET "NEW THINKING," AS DEVELOPED BY SOVIET PRESIDENT MIKHAIL GORBACHEV, ON THE PROBABLE COURSE OF SOVIET FOREIGN POLICY IN THE MIDOLE EAST. IN THIS PAPER, RELYING GENERALLY ON A SYSTEMS APPROACH, THE AUTHOR ATTEMPTS TO ASSESS SOME POSSIBLE CONSEQUENCES, MOSTLY UNINTENDED, OF SOVIET "NEN THINKING" IN THE MIDDLE EAST. OF PARTICULAR INTEREST IS THE IMPACT OF SOVIET FOREIGN POLICY

03952 GROTE, J.

DISECONOMIES IN SPACE: TRADITIONAL SECTORAL POLICIES OF THE EC, THE EUROPEAN TECHNOLOGY COMMUNITY AND THEIR EFFECTS ON REGIONAL DISPARTIES

REGIONAL POLITICS \& POLICY, 2(1,2) (SPR 92), 14-46.

THIS ARTICLE TRIES TO ASSESS THE EFFECTS AND CONSEQUENCES OF TRADITIONAL AND MORE RECENT SECTORAL EC POLICIES FOR THE PERFORMANCE OF REGIONAL ECONOMIES AND ARGUES THAT CLASSIC REDISTRIBUTIVE MEASURES WILL NO LONGER ARGUES THAT CLASSIC REDISTRIBUTIVE MEASURES WILL NO
SUFFICE TO NEUTRALIZE AND CANCEL OUT THE NEGATIVE SUFFICE TO NEUTRALIZE AND CANCEL OUT THE NEGATIVE
TERRITORIAL EXTERNALITIES OF THE FORMER. THE INTEREST IS ON TERRITORIAL EXTERNALITIES OF THE FORMER. THE INTEREST IS
THOSE POLICIES UNDERTAKEN BY THE COMMUNITY WHICH ARE COTHOSE POLICIES UNDERTAKEN BY THE COMMUNITY WHICH ARE CO-
RESPONSIBLE FOR AND AMPLIFY PERIPHERALITY. THE REGIONAL RESPONSIBLE FOR AND AMPLIFY PERIPHERALITY. THE REGIO
IMPACT OF A WIDE RANGE OF INTERSECTORAL COMMUNITY IMPACT OF A WIDE RANGE OF INTERSECTORAL COMMUNITY INITIATIVES IN THE FIELDS OF TECHNOLOGICAL INNOVATION,
TELECOMMUNICATIONS AND R\&D ARE MADE THE SUBJECTS OF MORE TELECOMHUNICATIONS
DETAILED ANALYSIS.

03953 GROTH, A.J.

LINCOLN AND THE STANDARDS OF PRESIDENTIAL CONDUCT PRESIDENTIAL STUDIES OUARTERLY, XXII(4) (FAL 92), 765-778. ABRAHAM LINCOLN, WHATEVER HIS CLAIMS TO GREATNESS, MUST BE COUNTED AMONG THOSE PRESIDENTS WHO FROM TIME TO TIME RESORTED TO EXPEDIENTS THAT WERE NOT ONLY DUBIOUS BUT ILLEGAL. YET, THE PARADOX OF HIS CAREER IS THAT HE IS GENERALLY REGARDED AS ONE OF THE MOST, IF NOT THE MOST, PRINCIPLED OF ALL MEN WHO HAVE SERVED AS PRESIDENT OF THE UNITED STATES. IN THIS ESSAY, THE AUTHOR EVALUATES LINCOLN'S MORAL CONDUCT AS PRESIDENT AND COMPARES IT TO THAT OF SOME RECENT PRESIDENTS.

03954 GROTH, A.J.: DANNEHL, C.R. HOMEN IN HIGHER EDUCATION: ECONOMIC, POLITICAL, AND CUL TURAL INFLUENCES

WOMEN AND POLITICS, 12 (1) (1992), 53-71.

THE AUTHORS TEST A MULTICAUSAL HYPOTHESIS: IS THERE CROSSNATIONAL EVIDENCE THAT THE PROPORTION OF UNIVERSITY STUDENTS OHO ARE FEMALE IS INFLUENCED BY LEVELS OF ECONOMIC AND CULTURAL DEVELOPMENT AND BY TYPES OF POLITICAL SYSTEMS? ECONOMIC AND CULTURAL DEVELOPMENT ARE MEASURED BY ENERGY CONSUMPTION AND LIBRARY VOLUMES PER CAPITA, RESPECTIVELY. INDIVIDUAL STATES ARE CATEGORIZED AS MARXIST-LENINIST, NONMARXIST AUTHORITARIAN, OR POLYARCHIC SYSTEMS. MULTIPLE REGRESSION RESULTS FOR TWO INTERVALS $(1975,1985)$ REVEAL SUBSTANTIAL IMPACTS OF BOTH ECONOMICS AND POLITICS STATISTICS ALSO REVEAL GREAT VARIABILITY OF OUTCOMES AMONG STATISTICS ALSO REVEAL
AUTHORITARIAN REGIMES.

03955 GRUBEN, W.C.

NORTH AMERICAN FREE TRADE: OPPORTUNITIES AND PITFALLS CONTEMPORARY POLICY ISSUES, $X(4)$ (OCT 92), 1-10. MOST STUDIES OF THE IMPACT OF THE NORTH AMERICAN FREE TRADE AGREEMENT (NAFTA) ASSUME THAT ONCE NAFTA IS IN PLACE, IT WILL REMAIN IN PLACE. BUT SOME COMMON THEORIES OF TRADE AND OF SPECIAL INTEREST GROUP INFLUENCE ON GOVERNMENT POLICY CALL THESE ASSUMPTIONS INTO QUESTION. IF RATIFICATION OF NAFTA REPRESENTS A LOSS FOR SOME IMPORT-COMPETING SPECIAL INTEREST GROUPS, IT IS LIKELY TO BE ONLY ONE BATTLE IN
AGREEMENT MAY SUCCEED EVEN IF NAFTA ITSELF IS NOT ABRIDGED. U.S. SPECIAL INTEREST GROUPS, RATHER THAN THEIR MEXICAN

03956 GRUBER, R.

CRACKS IN ANC'S SUPPORT BASE IN GERMANY

SOUTH AFRICA FOUNDATION REVIEW, 18(8) (AUG 92) 5 ALTHOUGH NELSON MANDELA STILL COMMANDS GREAT RESPECT AMONG GERMANS, THE MOVEMENT HE LEADS IS IN DANGER OF DISSIPATING THE CAPITAL OF SYMPATHY AND GOODWILL THAT IT HAS ACCUMULATED IN GERMANY OVER THE YEARS.

03957 GRUBER, R.

SA'S ECONOMIC PROSPECTS--SOME ASSESSMENTS
SOUTH AFRICA INTERNATIONAL, 22 (3) (JAN 92$), 140-142$.

SOUTH AFRICA INTERNATIONAL, 22 (3) (JAN 92 ), 140-142.
THO RECENT INTERNATIONAL CONFERENCES FOCUSED ON SOUTH AFRICA'S ECONOMIC PROSPECTS. DESPITE THE POOR PERFORMANCE OF AFRICA'S ECONOMIC PROSPECTS. DESPITE THE POOR PERFORMANCE OF RECESSION, THERE ARE A NUMBER OF FUNDAMENTALS STILL IN PLACE RECESSION, THERE ARE A NUMBER OF FUNDAMENTALS STILL IN PLACE
THAT GIVE GROUNOS FOR OPTIMISM, BOTH IN TERMS OF ECONOMIC GROWTH AND INVESTOR CONFIDENCE. FACTORS SUCH AS A HORLDCLASS PHYSICAL AND FINANCIAL INFRASTRUCTURE, A FUNCTIONI IF FLANED MARKET ECONOMY, A PROVEN BUSINESS COMMUNITY,
HEAVILY UNDEREXPLOITED TOURISH POTENTIAL, AND SOUTH AFRICA'S POSITION IN THE REGION, ALL GIVE GROUND FOR HOPE. AGAINST THESE HAVE TO BE BALANCED NEGATIVES, SUCH AS PODR PRODUCTIVITY, POLITICAL UNCERTAINTY AND OTHERS; BUT THE REAL POTENTIAL FOR GROWTH DOES EXIST.

03958 GRUBER, R.

THE DANGERS OF REGIONAL HEGEMONY

SOUTH AFRICA INTERNATIONAL, 22(4) (APR 92), 190-191.

SEVERAL OBSERVERS OF SOUTH AFRICA'S POSITION WITHIN THE SOUTHERN AFRICAN REGION HAVE LIKENED IT TO JAPAN'S ROLE WITHIN THE FAR EAST OR TO GERMANY'S ROLE WITHIN CENTRAL AND EASTERN EUROPE. SUCH COMPARISONS SOMETIMES FOCUS ON THE ROLE OF THESE DOMINANT REGIONAL ECONOMIES AS THE "ENGINE" DR "DYNAMO" FOR THE REST. OTHERS, INCREASINGLY HEARD, URGE CAUTION. A REUNITED GERMANY, CARRYING WITH IT ALL THE CANSIDERABLE BAGGAGE OF THE PAST HAS MET HITH GREAT CONSIDERABLE BAGGAGE OF THE PAST, HAS MET WITH GREAT
AMBIVALENCE EVEN AMONG ITS EUROPEAN PARTNERS WITHIN THE EC. AMBIVALENCE EVEN AMONG ITS EUROPEAN PARTNERS WITHIN THE EC.

"NEW" SOUTH AFRICA, PARTICULARLY WHEN IT COMES TO HIGH

"NEW" SOUTH AFRICA, PARTICULARLY WHEN IT COMES

03959 GRUENBAUM, E.

THE ISLAMIST STATE AHD SUDANESE WOMEN
MIDDLE EAST REPORT, $22(6)$ (NOV 92 ), 29-32

THE ISLAMICI ZATION OF THE STATE AND CULITURE IN SUDAN ENTAILS POLITICAL REPRESSION AND ECONOMIC MISMANAGEMENT WHICH HAS HURT ALMOST EVERYOME EXCEPT THOSE IN POHER. CULTURAL SHIFTS ARE HAVING A PARTICULARLY PRONOUNCED EFFECT ON WOMEN. ORGANIZED PROTEST HAS BEEN PREVENTED BY STRONG REPRESSION, INCLUDING THE EFFECTIVE SUPPRESSION OF TRADE UNIONS AND WOMEN'S ORGANIZATIONS NOT SANCTIONED BY THE REGIME. CRITICS HOPE THAT THE EDUCATIONAL SYSTEM WILL KEEP CRITICAL THINKING ALIVE, DESPITE THE IMPACT OF WELL-FINANCED IDEOLOGICAL WORK BY ISLAMIST ORGANIZATIONS.

03960 GRUHN, I.V. EURAFRICA RECONSIDERED: THE ROAD BEYOND LOME

MEDITERRANEAN QUARTERLY: A JOURNAL OF GLOBAL ISSUES, 3(3) (SUM 92 ), 55-76.

SINCE' 1975, EUROPE'S VIEWS ON THE RICH-POOR STATE ISSUE HAVE BEEN REFLECTED IN THE NEGOTIATIONS OVER THE CONTENT OF THE LOME CONYENTIONS. AS EUROPE GOES THROUGH A TRANSFORMATION TOWARDS INCREASING ECONOMIC AND POLITICAL INTEGRATION, IT NEEDS TO REEXAMINE LOME AND THE ROAD TO A MUCH NEEDED AND DESIRABLE CHANGE IN RELATIONS WITH THE AFRICAN, CARIBBEAN AND PACIFIC (ACP) COUNTRIES. TH $\$$ ARTICLE EXAMINES THE FOUR LOME CONVENTIONS (NAMED FOR THE APITAL OF TOGO, WHERE THE FIRST CONVENTION WAS SIGNED) AND THEIR DEVELOPMENT OVER TIME. IT CONCENTRATES ON THE NEH POSSIBILITIES AND POTENTIAL OBSTACLES CREATED BY THE EMERGING EUROPE AND ITS RELATIONSHIP TO THE INCREASING IMPOVERISHMENT AND MARGINALIZATION OF MANY POOR COUNTRIES IN THE WORLD--ESPECIALLY ON THE AFRICAN CONTINENT. IT CONCLUDES THAT LOME IV (THE AGREEMENT COVERING THE YEARS 1990-2000) SHOULD BE SEEN AS A HOLDING OPERATION FOR BOTH THE EUROPEAN COMMUNITY AND THE ACP COUNTRIES. FOR THE NEXT FIVE YEARS, COMMUNITY AND THE ACP COUNTRIES. FOR THE NEXT FIVE YEARS, WHILE LDME IV PROVISIONS FAIL TO REDRESS ASYMMETRIES, THEY
CAN SUSTAIN LINKAGES AND OBLIGATIONS THAT CAN FURTHER

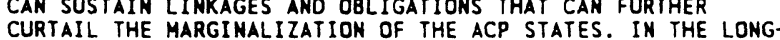
CURTAIL THE MARGINALIZATION OF THE ACP STATES. IN THE LONGLINKS AND NEWLY STRUCTURED RELATIONSHIPS EVOLVE TO ADORESS LINKS AND NEWLY STRUCTURED RELATIONSHIPS EVOLVE TO ADDRESS THE REALISTIC INTERDEPENDENCY PROBLEMS
STATES IN THE THENTY-FIRST CENTURY.

03961 GRUZINSKI, S.

COLONIZATION AND THE WAR OF IMAGES IN COLONIAL AND MODERN MEXICD

INTERNATIONAL SOCIAL SCIENCE JOURNAL, 143(143) (NOV 92),

503-518.

THIS ARTICLE DRAWS ATTENTION TO IMAGERY IN COLONIAL 
MEXICO AND EXAMINES THOSE PROGRAMS, POLICIES, AND NUMEROUS INTERVENT IONS WHICH SUCH IMAGERY REOUIRED OR INDEED PREFIGURED ALONG WITH THE VARIOUS ROLES IT HAS BEEN CALLED TO FILL IN A MULTI-ETHNIC SOCIETY. IT CONSIDERS TO HHAT EXTENT THE OLDER CIYILIZATION OF COLONIAL MEXICO, BASED ON A EXIENT THE OLDER CIYILIZATION OF COLONIAL MEXICD, BASED ON A TO THE MAJOR ROLE PLAYED BY TODAY'S MEXICO IN THE FIELD OF MASS ELECTRONIC IMAGERY, THAT IS, TO TELEVISION. WHAT IS MASS ELECTRONIC IMAGERY, THAT IS, TO TELEVISION. WHAT IS RELIGIOUS DOMINATION AND CULTURAL CROSS-BREEDING BUT ALSO AS A RESPONSE TO THIS VERY POLICY.

03962 GRYSKI, G. THE INFLUENCE OF COMMITTEE POSITION ON FEDERAL PROGRAM SPENDING

POLITY, XXIII(3) (SPR 91), 443-460

IT IS WIDELY BELIEVED THAT MEMBERS OF CONGRESS SEEK COMMITTEE ASSIGNMENTS CONGENIAL TO THE INTERESTS OF THEIR DISTRICTS. BUT IS THERE A REAL RETURN IN FEDERAL DOLLARS TO STATES WHOSE REPRESENTATIVES SIT ON COMMITTEES WITH JURISOICTIONS OVER IMPORTANT HOME-STATE INTERESTS? USING REGRESSION ANALYSIS ON FEDERAL DATA, THIS ARTICLE EXAMINES THE RELATIONSHIP BETWEEN CONGRESSIONAL COMMITTEE ASSIGNMENTS AND PROGRAM FUNDING FOR THE MEMBER'S STATES. THE AUTHOR FINDS A "POLITICAL CONNECTION" IN THE CASE OF SOME COMMITTEES BUT NOT OTHERS, AND HE EXPLORES REASONS FOR THESE DIFFERENCES

\section{GUBITZ, M.B.}

FEAR AND THE POLITICS OF HOPE

SWISS REVIEW OF WORLD AFFAIRS, $42(9)$ (DEC 92), 3

THE SINGLE MOST IMPORTANT FACTOR IN THE 1992

PRESIDENTIAL ELECTION WAS FEAR: THE AMERICAN PEOPLE WERE

BESET BY PROFOUND FEARS AND FINALLY REALIZED THAT THEY COULD

EXPECT NOT EVEN AN ADMISSION FROM GEORGE BUSH THAT THERE WAS

ANYTHING TO FEAR, MUCH LESS SUBSTANTIVE ACTION TO MELP

REMOVE THE CAUSES OF THEIR ANXIETIES.

03964 GUBMAN, B.L.

BEFORE AND AFTER THE ABORTIVE COUP IN THE USSR

INTERNATIONAL SOCIAL SCIENCE REVIEW, 67(1) (HIN 92), 3-7.

AT TVER STATE UNIYERSITY THE ABORTIVE COUP AGAINST MIKHAIL GORBACHEY IN AUGUST 1991. HE ALSO SPECULATES ABOUT THE COUNTRY'S FUTURE.

03965 GUELKE, A.

ETHMIC RIGHTS AND MAJORITY RULE: THE CASE OF SOUTH AFRICA INTERNATIONAL POLITICAL SCIENCE REVIEW, 13(4) (OCT 92), 415-432.

A STRIKING LEGACY OF THE SOUTH AFRICAN GOVERMMENT'S ATTEMPT TO USE IMPOSED ETHNIC CATEGORIES AS A BASIS FOR APARTHEID HAS BEEN AN OVERHHELMING REJECTION BY THE SUBORDINATE CDMPUNITIES OF THE USE OF ETHNICITY AS THE BASIS FOR POLITICAL RIGHTS. THIS IS IN SHARP CONTRAST TO THE DEMANDS FOR THE POLITICAL RECOGNITION OF ETHNIC RIGHTS BEING MADE ELSEWHERE IN THE WORLD. SCHOLARLY ATTEMPTS TO APPLY CONSOCIATIONALISM OR OTHER MODELS OF POWER-SHARING TO SOUTH AFRICA HAVE FAILED TO FULLY COME TO TERMS HITH THE STRENGTH OF HOSTILITY TO THE USE OF ETHNIC CATEGORIES BY THE SUBORDINATE COMMUNITIES, REFLECTED IN THE DOMINANT INFLUENCE OF THE AFRICAN NATIONAL CONGRESS'S IDEOLOGY OF NONRACISM. (BUT THIS IS NOT TO DENY THAT ETHNICITY HAS PLAYED A ROLE IN POLITICAL DIVISIONS AMONG BLACKS.) THE AUTHOR ARGUES THAT SOUTH AFRICA SHOWS THAT PLACING AN EXCLUSIVELY ETHNIC INTERPRETATION ON POL ITICAL EYENTS CAN BE JUST AS MISLEADING AS IGNORING THE POTENTIAL POLITICAL IMFLUENCE OF ETHNICITY.

03966 GUELKE, A.; SHYTH, J.

THE BALLOT BOMB: TERRORISM AND THE ELECTORAL PROCESS IN NORTHERN IRELAND

TERRORISM AND POLITICAL VIOLENCE, 4(2) (SUM 92), 103-124. THE AUTHORS EXPLAIN WHY REPUBLICAN AND LOYALIST

PARAMILITARIES INTERVENED IN ELECTIONS IN NORTHERN IRELAND IN THE 1980'S AND EXAMINE THE IMPACT OF THOSE INTERVENTIONS. THEY CONTRAST THE FAILURE OF LOYALIST CANDIDATES TO ATTRACT VOTES HITH THE SUCCESS ACHIEVED BY REPUBLICAN CANDIDATES AS VOTES WITH THE SUCCESS ACHIEVED BY REPUBLICAN CANDIOATES AS A RESULT OF THE 1981 HUNGER STRIKE CRISIS. THEY ARGUE THAT THE BRITISH PUBLIC'S STEREOTYPE OF TERRORISM IN NORTH TH IRELAND AMPLIFIED THE POLITICAL IMPACT OF SINN FEIN'S ELECTORAL BREAKTHROUGH IN 1982 AND 1983. THE ALARM IN BOTH BRITAIN AND THE IRISH REPUBLIC AT SINA FEIN'S RISE LED TO THE ANGLO-IRISH AGREEMENT OF 1985. A DECLINE IN SUPPORT FOR SINN FEIN FOLLOWED, AND THE PARTY WAS HARGINALIZED IN THE REPUBLIC. WHILE IT CONTINUED YO ATTRACT SIGNIFICANT SUPPORT IN CATHOLIC WORKING-CLASS NEIGHBORHOOOS IN NORTHERN IRELAND IT LOST GROUND IN THE CATHOLIC COMMUNITY AS A WHOLE TO THE CONSTITUTIONAL NATIONALIST PARTY, THE SOCIAL DEMOCRATS, AND LABOUR. THE LOYALIST PARAMILITARIES WERE UNABLE TO TRANSLATE SUPPORT FOR THEIR ACTIVITIES AS PARAMILITARIES INTO ELECTORAL SUPPORT FOR THE POLITICAL IDEAS THEY ESPOUSED, IN PART DUE TO THEIR ADVOCACY OF INDEPENDENCE, AN UNPOPULAR OPTION AMONG PROTESTANTS.
03967 GUELKE, L.; SHELL, R. LANDSCAPE OF CONQUEST: FRONTIER WATER ALIENATION AND KHOIKHOI STPATEGIES OF SURYIVAL 1652-1780 JOURMAL OF SOUTHERN AFRICAN STUDIES, $18(4)$ (DEC 92), 803-824.

IN THE SEVENTEENTH AND EIGHTEENTH CENTURIES EUROPEAM SETTLERS OUSTED THE KHOIKHOI AND SAN FROM MUCH OF THE LAND THEY INHABITED IN SOUTH-WESTERN AFRICA USING A STRATEGIC THEY INHABITED IN SOUTH-HESTERN AFRICA USING A STRATEGIC RESOURCES, AND PASTURE THE EUROPEANS OBTAINED WERE DENIED TO THE KHOIKHOI PASTORALISTS WHO FOUND IT INCREASINGLY THE KHOIKHOI PASTORALISTS WHO FOUND IT INCREASINGLY DIFFICULT TO SUSTAIN THEMSELVES IN A LAND IN WHICH ACCESS LIMITED WATER RESOURCES WAS NECESSARY FOR SUVIVAL. THE
SURVIVORS OF THIS PROCESS OFTEN BECAME CLIENTS OF EUROPEAN SETTLERS AND APPLIED THEIR SKILLS IN ANIMAL HUSBANDY TO THE INYADERS' LIVESTOCK INSTEAD OF THEIR OWN.

03968 GUHA, A.

ALTERNATIVE FOR THE 21ST CENTURY WORLD: MARKET ECONOMY OR SOCIAL WELFARE ECONOMY?

SCANDINAVIAN JOURNAL OF DEVELOPMENT ALTERNATIVES, 11(3)

(SEP 92), 277-290.

THIS PAST DECADE HAS HITMESSED THE COLLAPSE OF ENFORCED, CENTRALIZED, HOMOGENEOUS ECONOMY AND THE TRIUMPH OF FREEMARKET ECONOMY. THERE HAS ALWAYS BEEN A CONFLICT BETWEEN TOTALITARIAN WELFARE AND INDIVIDUAL WELL-BEING, IN BOTH POLITICAL IDEOLOGY AND ECONOMIC CONCEPT AS WELL AS IN BEHAVIOR. THIS STUDY RESTRICTS ITS SCOPE TO ONLY MONETARILY COUNTABLE PRODUCTS AND SERVICES. IT COMPARES THE THO ECONOMIES IN TERMS OF INVESTMENT POLICY, USE OF CAPITAL AND TECHNOLOGY, LABOR, RAN MATERIALS AND SUBSTITUTES, AND ENTREPRENEURSHIP AND MANAGEMENT. THE PAPER ATTEMPTS TO THROW SOME LIGHT ON CERTAIN EMERGING PREMISES FOR CONSIDERATION.

03969 GUHA, A.

HUMAN RIGHTS, STRUCTURAL RACISM AND THIRD HORLD IMMIGRANTS IN NORWAY: SOME FUNDAMENTAL ASPECTS INTERNATIONAL JOURNAL OF GROUP TENSIONS, 21(4) (WIN 91), 287-314.

THIS STUDY DEALS WITH THE INTER-ACTIVE AND COUNTERACTIVE THEORETICAL AND PRACTICAL BEHAVIORAL ASPECTS, WITH EMPIRICAL EVIDENCES, OF THE HUMAN RIGHTS, STRUCTURAL AND STATE RACISM AND THE COLORED IMMIGRANTS OF NORWAY. THE RESULTS OF THIS STUDY LEADS TO THE CONCLUSION THAT THE BEST POSSIBLE REALIZATION OF HUMAN RIGHTS IS POSSIBLE ONLY WHEN THERE TAKES PLACE DESTRUCTURALIZATION OF THE FUNCTIONAL DEVICES AND APPARATUS, AND THAT THIS WILL NOT BE POSSIBLE UNLESS AND UNTIL THE ATTITUDES AND APPRACHES OF THE LEGAL, POLITICAL, SOCIAL, ECONOMIC

03970 GUIDOTTI, P.; KUMAR, M.S MANAGING DOMESTIC PUBLIC DEBT FINANCE AND DEVELOPMENT, $29(3)$ (SEP 92), 9-12.

THE AUTHORS STUDY THE EXTENT TO WHICH DOMESTIC PUBLIC DEBT HAS GROWN IN THE PAST FEW YEARS, THE REASONS BEHIND ITS SUDDEN GROWTH, HOW DOMESTIC AND EXTERNAL DEBT INTERACT WITH A COUNTRY'S CURRENT AND ANTICIPATED FISCAL STANCE, AND HOH DOMESTIC DEBT CAN BE BETTER MANAGED.

03971 GUILLOREL, H.; LEVY, J.

SPACE AND ELECTORAL SYSTEM

POLITICAL GEOGRAPHY OUARTERLY, 11(2) (MAR 92), 205-224.

THE RECENT CHANGES IN THE ELECTORAL LAW IN FRANCE HAVE REVIVED OLD DEBATES ABOUT THE MERITS OF DIFFERENT ELECTORAL SYSTEMS. THIS ART ICLE EXAMINES THE WAYS IN WHICH TERRITORY AND SPACE HAVE FIGURED IN THESE DEBATES. THEY ARE FOUND TO BE CENTRAL, MOT JUST TO THE TECHNICAL ISSUES, BUT TO THE FUNDAMENTAL PROBLEMS OF REPRESENTATION, POWER AND LEGITIMACY. TERRITORY IS THE MOST UNIVERSAL OF ORGANIZING PRINCIPLES
FOR ELECTIONS AND WAYS OF IMPROVING ITS USE ARE PROPOSED. THE ARTICLE DEMONSTRATES THAT SPACE IS BOTH AN INSTUMENT AND AN OBJECT.

03972 GUJER, E.

XENOPHOBIA IN A UNITED GERMANY

SHISS REVIEW OF WORLD AFFAIRS, 41(12) (MAR 92), 10-11. SINCE REUNIFICATION, THE FORMER EAST GERMANY HAS BEEN PLAGUED BY THREATS AND VIOLENCE DIRECTED AGAINST MINORITY GROUPS. SINCE WELFARE PAYMENTS AND JOB PROGRAMS ARE HELPING ALLEVIATE THE CONSEQUENCES OF LARGE-SCALE UNEMPLOYMENT, THE DEPRESSION AND EXISTENTIAL ANGST OF THE EAST GERMANS WHO FIND THEMSELVES THREATENED BY ECONOMIC ADJUSTMENT CAN ONLY BE A PARTIAL EXPLANATION FOR THE ATTACXS AGAINST FOREIGNERS PERHAPS MORE IMPORTANT IS THE DISORIENTATION CAUSED BY THE CHANGE OF IDEOLOGY AND SYSTEMS. AN AUTHORITARIAN CANON OF VALUES OFFERING SECURITY ANO SUPPORT HAS BEEN REPLACED BY THE APPARENTLY OPEN-ENDED FREEDOM OF DEMOCRACY. THE ABRUPT CHANGE HAS GENERATED HEAVY PRESSURE TO ADJUST, FOR WHICH THE SMOOTH POLITICAL PROCESS OF UNIFICATION DID NOT PREPARE EAST
GERMANS.

03973 GUNDELACH, P

RECENT VALUE CHANGES IN WESTERN EUROPE 
FUTURES, 24(4) (MAY 92), 301-319.

THIS ARTICLE ANALYZES YALUE CHANGES IN WESTERN EUROPE IN RELATION TO CHANGES IN SOCIAL INSTITUTIONS. IMPORTANT INSTITUTIONAL CHANGES HAVE BEEN THAT FAMILIES HAVE BECOME SMALLER AND MORE FRAGILE AND THE LABOR MARKET HAS BECOME LARGER AND MORE HETEROGENEOUS. GLOBALIZATION HAS RESULTED IN A DOUBLE TREND OF HETEROGENIZATION AND LOCALISM. THESE CHANGES HAYE INFLUENCED THE VALUES OF THE POPULATION IN WESTERH EUROPE. THE OVERALL CHANGE IS AN INCREASE IN INDIYIDUAL IZATION AND A MORE FRAGMENTED VALUE SYSTEM WHICH MEANS THAT THERE ARE NO CLEAR POLITICAL CLEAVAGES. THE VALUE CHANGES CAN BE SUMMARIZED IN THREE PROCESSES: FROM INDUSTRIAL TO GREEN VALUES; FROM AUTHORITARNIAN VALUES TO INDUSTIAL TO GREEN VALUES; RELIGIOUS VALUES. THESE TRENDS SUGGEST THAT WE ARE APPROACHING A SOCIETY WITH A DIVERSITY OF LIFESTYLES WHERE APPROACHING A SOCIETY WITH A DIVERS
MANY VALUE STRUCTURE ARE COMPETING.

03974 GUNDERSON, M.; RIDDELL, W.C.

COMPARABLE WORTH: CANADA'S EXPERIENCE

COMPARABLE WORTH: CANADA'S EXPERIENCE $21,85-94$

THIS PAPER DISCUSSES THE DESIGN, IMPLEMENTATION, AND ADMINISTRATION OF COMPARABLE WORTH LEGISLATION IN CANADA, FOCUSING ON THE POTENTIAL OF COMPARABLE WORTH TO CLOSE THE MALE-FEMALE EARNINGS GAP. THE AUTHORS SUMMARIZE THE CANADIAN LEGISLATIVE INITIATIVES, PROVIDE EVIDENCE ON THE IMPACT OF COMPARABLE WORTH, AND IDENT IFY THE MAIN
LEARNED FROM THE CANADIAN EXPERIENCE.

03975 GUNN, B

COMPETRUISM: IDEOLOGY HITH A SUSTAINABLE FUTURE FUTURES, 2416 ) (JUL 92 ), 559-578.

UNLESS THE ADVANCED NATIONS ADOPT A NEW SOCIOECONOMIC ORDER COMPATIBLE WITH THE TECHNOLOGICAL MILIEU OF THE INFORMATION AGE, THEY COULD FACE CATASTROPHE IN THE YEARS JUST AHEAD. FREE SOCIETIES SHOULD CONSIDER SHIFTING FROM CAPITALISM, WITH ITS PERILOUS OBSESSION HITH CONSUMPTION, TO THE COMPETRUISTIC IDEOLOGY WICH PROVIDES A SUSTAINABLE FUTURE THROUGH ITS FOCUS ON CONSERVATION. THIS EMERGING IDEOLOGY EMPLOYS \$PROOUCTIVE EFFICIENCY' AS THE CRITERION OF SUCCESS IN ITS MISSION TO MAXIMIZE THE VALUE ITS FREE SOCIETIES ADD TO THE GLOBAL ECONOMY.

03976 GUNN, G.

CUBA'S SEARCH FOR ALTERNATIVES

CURRENT HISTORY, 91 (562) (FEB 92), 59-64.

UNLIKE HIS FALLEN COLLEAGUES IN THE COMMUNIST WORLD, FIDEL CASTRD HAS SHOWN THAT HE IS AN INTELLIGENT LEADER WHO FIDEL CASTRO HAS SHOWN THAT HE IS AN INTELLIGENT LEADER WHO
IS FULLY IN TOUCH WITH REALITY AND WHO KNOWS THAT HE MUST IS FULLY IN TOUCH WITH REALITY AND WHO KNOWS THAT HE MU REFORM SOME OF CUBA S ECONOMIC STRUCTURES. WHILE THE FIDELISTA SYSTEM IS CLEARLY MORE FRAGILE THAN EVER BEFORE, ITS OVERTHROW IS NOT A FOREGONE CONCLUSION. CASTRO MAY PROVE MAY YET AGAIN LAND ON HIS FEET.

03977 GUNA, G.

PEOPLE'S WAR IN LAOS: A NEW GUERRILLA MODEL?

JOURNAL OF CONTEMPORARY ASIA 21(4) (1991), 529-535.

AS THE LAOS CASE DIFFERENT FORMS. HOWEVER. THE LAOS REVOLUTION WAS ALSO PART OF THE INDOCHINA-WIDE REVOLUTION. THE PEOPLES HAR IN LAOS WAS MIRRORED BY THE COUNTER-REVOLUTION, NAMELY THE US COUNTER-INSURGENCY PROGRAMS OF THE SIXTIES AND SEVENTIES. THIS ARTICLE SUGGESTS THAT COUNTER-INSURGENCY IN LAOS WAS THE WRONG ANTIDOTE SUPPLIED TO A PATHOLOGICAL SOCIAL SYSTEM. THE ARTICLE CONCLUDES THAT COUNTER-INSURGENCY IN LAOS HAS O DUAL HISTORICAL SIGNIFICANCE. FIRST, THE REVOLUTION IN THE THE SECRET WAR IN LAOS CONTRIBUTED TO THE NATIONAL AGONIZING OVER THE ABUSE OF EXECUTIVE POWER, AND, SECOND, ITS INVERTED ROLE AS REVOLUTIONARY PROPHYLACTIC HAD THE DISASTROUS CONSEQUENCES FOR THE WEST OF CREATING PATRIOTS OUT OF VICTIMS.

03978 GUOHONG, $Z$.

A HISTORICAL DEMOGRAPHY OF CHINESE MIGRATIOM SOCIAL SCIENCES IN CHINA, XII(4) (NOV 91), 57-84. RESTRICTING HIS INVESTIGATION TO "EMIGRANTS" AND "PERMANENT INTERNATIONAL EMIGRANTS," THE AUTHOR DIVIDES THE DEMOGRAPHY OF CHINESE MIGRATION INTO FIVE STAGES WITH GREAT HISTORICAL SIGNIFICANCE. EMIGRATION IN THE OIN AND HAH PERIODS MOSTLY INVOLVED EXPLORATION, POLITICAL EXILE, THE PERIODS MOSTLY INVOLVED EXPLORATION, POLITICAL EXILE, THE SENDING OF TRIBUTE, AND JOURNEYS UNDERTAKEN BY MONKS IN SEARCH OF RELIGIOUS TRUTHS. FROM THE SUI AND TANG ONWARDS IT ENCOMPASSED TRADE IN SKILLED LABOR, NAVIGATION, AND REFUGEE MIGRATION. AFTER A TRANSITIONAL PERIOD, FROM THE MIDMING TO THE MID-QING, THE COOLIE TRADE BECAME DOMINANT. WAS LATER REPLACED BY VOLUNTARY MIGRATION, A FORM THA

03979 GUOQIANG, $W$

THE UNITED STATES PLAGUED BY DOMESTIC PROBLEMS BEI JING REVIEW, 35(4) (JAN 92), 13-14.

AT THE BEGINNING OF 1992, VARIOUS PROBLEMS, INCLUDING THE SAGGING ECONOMY AND THE DETERIORATING EDUCATIONAL SYSTEM,
WERE THE FOCUS OF PUBLIC ATTENTION IN THE UNITED STATES. THE U S ECOMOMY WAS PLAGUED BY HIGH UNEMPLOYMENT, HEAVY DEBT. AND A DISPARITY BETWEEN IMPORTS AND EXPORTS. THE EDUCATIONAL QUALITY OF PUBLIC SCHOOLS HAD DETERIORATED DUE TO LOW SALARIES FOR TEACHERS, HIGH DROPOUT RATES, AND THE

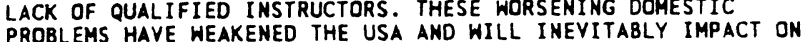
PROBLEMS HAVE WEAKENED THE USA AND WILL INEVITABLY IMPACT ITS FOREIGN POL ICY IN THE FUTURE. SINCE THE U.S. DOMES

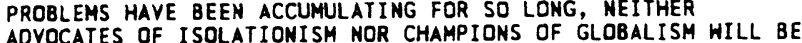
ABLE TO SOLVE THEM EASILY.

03980 GUPTA, D.

PEASANT "UNIONISM" IN UTTAR PRADESH: AGAINST THE RURAL MENTALITY THESIS

JOURNAL OF CONTEMPORARY ASIA, 22(2) (1992), 155-168.

THIS ARTICLE ARGUES THAT THE ORIGIN OF MOST ERRORS IN URBAN VISIONS OF RURAL INDIA IS THE ASSUMPTION THAT THE RURAL PEOPLE ARE DIFFERENT, NOT JUST IN TERMS OF CLOTHING, OCCUPATION, AND RESIDENTIAL PATTERNS, BUT IN A MORE FUNDAMENTAL WAY. THE AUTHOR CHALLENGES THE ASSUMPTION THAT RURAL PEOPLE'S LIVES ARE ORDERED BY A DIFFERENT KIND OF RATIONALITY. EVIDENCE WHICH DISPROVES THIS CONCEPT OF "PATIONALITY. EVIDENCE WHICH DISTALIT" IS FOUND IN THE ACTIVITIES OF THE "PEASANT MENTALI BHARATIYA KISAN UNION (BKU) WHICH LEADS THE FARMERS MOVEMENT IN WEST UTTAR PRADESH. WHILE THE ACT TONS OF THE SEEM, AT FIRST GLANCE, TO BE IN KEEPING WITH TRADITIONAL NOT IONS OF "PEASANT MENTALITY," A CLOSER EXAMINATION REV TRADE UNIONS.

03981 GUSEINOV, G.; DRAGUNSKY, D. ; TSYBURSKY, V. CRISIS OF THE UNION OR OF THE UNION REPUBLICS? SOCIOLOGICAL PERSPECTIVES, (4) (1990), 11-17

IN THIS ARTICLE THE AUTHORS ARGUE THAT WHAT IS GENERALLY SEEN AS A CRISIS OF THE UNION IS, IN FACT, A CRISIS OF THE UNION REPUBLICS AS A SPECIFIC INSTITUTION OF THE SOVIET SYSTEM. THE ARMENIAN-AZERBAI JANIAN CONFLICT IS DESCRIBED AS AN EXAMPLE. THE CONNECTION BETHEEN THE UPRISING OF ETHNIC GROUPS OF THE UNION REPUBLICS AGAINST THE CENTRAL AUTHORITIES AND THE SHARPENING OF THEIR CONFRONTATION WITH THEIR OWN MINORITIES IS ANALYZED. THE RELATION OF THE HISTORICAL RUSSIAN EMPIRE TO THE CURRENT SITUATION IS DISCUSSED.

03982 GUTHRIE, K.K.; DUTTON, W.H.

THE POLITICS OF CITIZEN ACCESS TECHMOLOGY: THE DEVELOPMENT OF PUBLIC INFORMATION UTILITIES IN FOUR CITIES

POLICY STUDIES JOURNAL, 20(4) (WIN 92), 574-59?

DURING THE LATE 1980'S, AMERICAN LOCAL GOVERNMENTS BEGAN TO APPLY INFORMATION TECHMOLOGY NOT ONLY TO SPEED UP DATA PROCESSING BUT ALSO TO IMPROVE DELIVERY OF SERVICES, AID CITIZEN INTERACTIONS WITH LOCAL GOVERNMENT AND POTENTIALLY INCREASE POI ITICAL PARTICIPATION. THIS PAPER USES INCREASE POL TASE STUDIES TO EXAMINE THE POLITICAL SHAPING OF PUBL PUBLIC INFORMATION UTTL TO EXAMINE THE POLITICAL SHAPING OF CITIES-SANTA MONICA, PASADENA, AND GLENDALE. IT ALSO LOOKS AT ONE CITY THAT CHOSE NOT TO ADOPT THE TECHNOLOGY, IRVINE. IN THIS CONTEXT, TECHNOLOGY DESIGN IS VIEHED AS ANALOGOUS TO DEVELOPING PUBLIC POLICY ON CITIZEN PARTICIPATION WHERE THE "LEGISLATION" IS IMBEDOED IN THE TECHNOLOGICAL DESIGN. ANALYSIS CONSIDERS THE ROLE OF TECHNOLOGICAL PARADIGMS, LOCAL POLITICAL CUL TURES, AND ORGANIZATIONAL ARRANGEMENT CHAICES.

03983 GUTTENPLAN, D.D.

COYERIMG A RUMAHAY CAMPAIG

COVERING A RUNAHAY CAMPAIGN

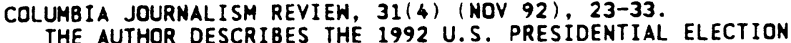
CAMPAIGN AND LOOKS AT THE ROLE OF THE MEDIA.

03984 GUTTERIDGE, $H$.

PROSPECTS FOR REGIONAL SECURITY IN SOUTH AFRICA SOUTH AFRICA INTERNATIONAL, 22(3) (JAN 92), 128-132.

A KEY TO SECURING FOREIGN AID AND INVESTMENT IS THE GUARANTEE OF PEACE AND SECURITY. THIS ARTICLE ASSESSES THE PROSPECTS FOR REGIONAL SECURITY IN SOUTHERN AFRICA. IT EXAMINES SEVERAL INTERRELATED ISSUES: THE POTENTIAL FOR REGIONAL INTEGRATION, DEFENSE POLICIES OF NATIONS IN THE REGION, AND THREATS TO REGIONAL STABILITY. IT ALSO OUTLINES SOME "MECHANICS OF REGIONAL SECURITY" SUCH AS ARMS CONTROL AGREEMENTS, NON-AGGRESSION PACTS, STANDING COMMISSIDNS AND A THE TRANSITION UMDERHAY IN SOUTH AFRICA OFFERS A UNIQUE THE TRANSIY FOR TRANSFORMING RELATIONS IN THE REGION AS WHOLE, TO THE BENEFIT OF ALL.

03985 GUTTMAN, $R$

FINLAND'S PRIME MINISTER, ESKO AHO

EUROPE, 319 (SEP 92 ) 28-29.

THE PRIME MINISTER OF FINLAND, ESKO AHO, SPEAKS OUT OH HIS COUNTRY'S IMTEREST IM JOINIMG THE EUROPEAM COMMUMITY THE FUTURE OF RUSSIA, AND FINNISH-U.S. RELATIONS. AHO STATES 
THAT FINLAND WILL GIVE UP SOME OF ITS SOVEREIGNTY TO BE ABLE TO HAVE AN INFLUENCE IN THE RUROPEAN COMMUNITY; THAT HE BELIEYES THAT RUSSIA HILU SUCCEED; AND THAT IT IS VERY BELIEVES THAT RUSSIA WILL SUCCEED
REASONABLE TO INVEST IN FINLAND.

03986 GUTTMAN, $R$.

SHEDEN'S PRIME MINISTER, CARL BILDT

EUROPE, 315 (APR 92), 20-21.

THE PRIME MINISTER OF SHEDEN, CARL BILDT, WAS INTERVIEWED DURING A VISIT TO WASHINTON, D.C. BILOT CHAIRMAN OF THE MODERATE PARTY, IS TURNING SWEDEN AWAY FROM MANY OF ITS SOCIALIST POLICIES OF THE PAST DECADE. THE SWEDISH PRIME MINISTER DISCUSSES SWEDISH FOREIGN POLICY AND HIS EFFORTS AT PRIVATIZING THE ECONOMY. NEUTRALITY, THE EUROPEAN COMMUNITY, UNITED NATIONS, THE FORMER SOVIET UNION, SOCIALISM, AND THE FREE MARKET ARE EACH DISCUSSED.

03987 GUYER, J.I

REPRESENTATION WITHOUT TAXATION: AN ESSAY ON DEMOCRACY IN RURAL NIGERIA, 1952-1990

AFRICAN STUDIES REVIEW, 35(1) (APR 92), 41-79.

THE THEME OF DEMOCRATIZATION IN AFRICA IS BEING RAISED THEM OF DEMOCRATIZATION IM AFRICA IS BEIMG RAISED MAIN THRUST OF RECENT LITERATURE IMPLIES THAT, WHEREAS THE ANTI-COLONIAL STRUGGLES UNITED THE PEOPLE, THE ORGANIZATIONS OF CIVIL SOCIETY AND THE LEADERSHIP UNDER A BANNER OF FREEDOM AT THE TIME OF INDEPENDENCE, THESE SAME SEGMENTS OF THE BODY POLITIC ARE NOW IN A PRECARIOUS BALANCE WITH ONE ANOTHER EITHER BECAUSE SOCIAL DYMAMICS HAYE PENETRATED THE STATE, BECAUSE THEY ESCAPE THE STATE'S CONTROL ALTOGETHER, STATE, BECAUSE THEY ESCAPE THE STATE'S CONTROL ALTOGETHER, ANASS BECAUSE THERE IS ACTIVE ANTAGONISH BETWEEN SOCI

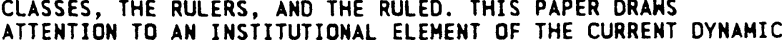
ATTENTION TO AN INSIITUTIONAL ELEMENT OF THE CURRENT DYNAM THAT APPEARS VERY RARELY IN THE CURRENT ANALYSES BUT WHOSE RELATIVE ABSENCE FROM BOTH THE SOCIAL PROCESSES AND THE INTELLECTUAL DEBATES FORMS, WHEN SEEN FROM A COMPARATIVE PERSPECTIVE, THE NEGATIVE SPACE THAT ALONE MAKES THESE OTHER DYNAMICS INTELLIGIBLE--NAMELY, PUBLIC REVENUE. CONTRARY THE HISTORICAL SEQUENCE IN EUROPE AND DIFFERING OUITE PROFOUNDLY FROM THE PROCESSES IN PLACE AT THE TIME OF INDEPENDENCE IN AFRICA, THE PRESENT AFRICAN LEADERSHIP MUST SEEK CONSENT FIRST AND ENFORCE TAXATION AFTERHARDS. THE

CONJUNCTURE IN RURAL NIGERIA ARE THE SUBJECT OF THIS PAPER.

03988 GUYOMARCH, A.; MACHIN, H.

A HISTORY OF HESITATIONS ON THE ROAD TO MAASTRICHT

FRENCH POLITICS AND SOCIETY, 10(4) (FAL 92), 60-80.

THE AUTHORS REVIEW RECENT FRENCH HISTORY AND ATTITUDES

TOWARD EUROPEAN INTEGRATION FROM THE TREATY OF ROME TO THE MAASTRICHT AGREEMENT.

03989 GUYOT, J.

MYANMAR IN 1990: THE UNCONSUMMATED ELECTION

ASIAN SURVEY, XXXI(2) (FEB 91), 205-211.

1990 IN MYAMMAR (BURMA) SAW THE OPPOSITION WIN AN

OVERWHELMING VICTORY IN THE 27 MAY ELECTIONS. HOWEVER, THE

RULING STATE LAW AND ORDER RESTORATION COUNCIL (SLORC)

REFUSED TO HAND OVER POHER AND CONTINUES TO PURSUE ITS OWN

AGENDA. KEY CDMPONENTS OF THE SLORC PLAN INCLUDE THE

PACIFICATION OF THE REBEL KAREN AND OTHER ETHNIC GROUPS: THE

IMPROVEMENT OF TRANSPORTATION INFRASTRUCTURE; THE RAISING OF

STANDARD OF LIVING FOR THE GENERAL POPULACE; AMD

LEGITIMATION OF ITS OWN POWER.

03990 GYAN-APENTENG, $K$.

ACCOUNTABILITY IN THE ARENA

WEST AFRICA, (3894) (MAY 92), 754.

ACCOUNTABILITY IS BECOMING A MAJOR POLITICAL ISSUE IN GHANA DUE TO THE INCLUSION OF SHEEPING INDEMNITY CLAUSES IN THE CONSTITUTION OF THE FUTURE FOURTH REPUBLIC. TO MANY, IT LOOKS LIKE HEAD-OF-STATE JERRY JOHN RAWLINGS IS GOING BACK LOOKS LIKE HEAD-OF-STATE JERRY JOHN RAWLINGS IS GOING BACK AND HIS ASSOCIATES ARE NO LONGER IN POWER.

03991 GYAN-APENTENG, $K$.

ANMUAL REYIEH' OF HOES

WEST AFRICA, (3904) (JUL 92), 1162.

EYERY SUMMIT OF THE ORGANIZITION OF AFRICAM UNITY (OAU)

IS, IN EFFECT, A GRAND ANNUAL REVIEW OF THE HOES AND

IS, IN EFFECT, A GRAND ANNUAL REVIEW OF THE HOES AND

PRESSING ITEMS ON THE 1992 SUMMIT AGENDA WERE SOUTH AFRICA,

PRESSING ITEMS ON THE 1992 SUMMIT AGENDA WERE SOUTH AFRICA, OF AIDS.

03992 GYAN-APENTENG, $K$.

BONN WELCOME

WEST AFRICA, 75(3885) (MAR 92), 371.

NIGERIAN PRESIDENT IBRAHIM BABANGIDA UNDERSCORED THE IMPORTANCE OF ECONOMIC RELATIONS BETHEEN HIS COUNTRY AND GERMANY WHEN HE MET GERMAN PRESIDENT RICHARD VON WEISACKER SHORTLY AFTER HIS ARRIVAL THERE FOR A FOUR-DAY STATE VISIT PRESIDENT BABANGIDA NOTED AN IMPROVEMENT IN GERMAN NIGERIAN RELATIONS AND HE INFORMED GERMANY THAT NIGERIA HAS IMPROVED
INVESTMENT CONDITIONS FOR INDUSTRALIZED COUNTRIES. THE VISIT WAS A MIX OF BUSINESS AND CEREMONIAL DUTIES IN ALMOST-EOUAL MEASURE. MANY DETAILS EMPHASIZED THE SERIOUSNESS OF THE TALKS.

03993 GYAN-APENTENG, $K$.

ELUSIVE UNITY

WEST AFRICA, (3911) (AUG 92), 1481

THE NKRUMAISTS' CAMP IS STILL DIVIDED INTO FACTIONS. BUT AMID CONSIDERABLE MUTUAL OISTRUST, THERE ARE THOSE WHO STILL CHERISH THE HOPE THAT SOMEHOW UNITY CAN BE ACHIEVED KOJO BOTSIO, ONE OF NKRUMAH'S CLOSEST ASSOCIATES AND CHAIRMAN OF THE NATIONAL INDEPENDENT PARTY, HAS SAID THAT HE EXPECTS "THE ENTIRE FAMILY" TO UNITE AND SHOW A COMMON PURPOSE IN THE UPCOMING ELECTIONS.

03994 GYAN-APENTENG, K. MANUAL FOR DEMOCRACY WEST AFRICA, (3890) (APR 92), 584.

THE FIRST CASUALTY OF WAR' IS TRUTH, AND THIS IS NO LESS TRUE OF POLITICAL CAMPAIGNS. THIS IS THE AGE OF THE "SPIN DOCTOR," HHERE THE WORST POSSIBLE SET OF STATISTICS CAN BE GLEEFULLY REINTERPRETED, HHERE DISASTER BECOMES SUCCESS, WHERE THE POLLS ARE ALHAYS RIGHT.

03995 GYAN-APENTENG, $K$. MORE QUESTIONS THAN ANSHERS

WEST AFRICA, (3888) (MAR 92), 503.

ON MARCH 5, 1992, FLT-LT. JERRY RAWLINGS ANMOUNCED DATES FOR THE REFERENDUM ON THE FOURTH REPUBLIC CONSTITUTION AND THE ELECTIONS FOR PARLIAMENT AND PRESIDENT. HE CLEARLY WISHED TO SHOW THE NATION, AND ESPECIALLY THE OPPOSITION FORCES, THAT HE INTENDS TO COMPLETE THE TRANSITION TO CONSTI TUTIONAL RULE. HOWEVER, IF HE EXPECTED HIS CRITICS TO THANK HIM, HE CLEARLY MISCALCULATED. THE HAY HIS FOES SEE IT, RAHLING'S ANNOUNCEMENT RAISED MORE QUESTIONS THAN IT RAWLING

03996 GYAN-APENTENG, $K$. PUTTING AFRICA'S CASE WEST AFRICA, (3886) (MAR 92), 404-405.

IN FEBRUARY 1992, NIGERIAN PRESIDENT IBRAHIM BABANGIDA PAID A HIGH-PROFILE STAIE VISIT TO GERMANY. FOR NIGERIA, GERMANY COULD BE THE LINCHPIN OF A POLITICAL AND ECONOMIC STRATEGY THAT INCLUDES ENHANCING THE COUNTRY'S PRESTIGE ABROAD AND MOBILIZING PRIVATE INVESTMENT FOR AN INCREASINGLY LIBERALISED ECONOMY. THE GERMANS SEEM TO UNDERSTAND THE ROLE BABANGIDA WANTS THEM TO PLAY AND TO BE WILLING PARTNERS, ON THEIR OWN TERMS.

03997 GYAN-APENTENG, $K$

QUESTIONS ON A RAWLINGS CANDIDACY

WEST AFRICA, (3912) (SEP 92 ), 1523

THERE IS ALMOST NO DOUBT THAT THE CHAIRMAN OF THE PNDC,

FLT. LT. JERRY JOHN RAWLINGS WILL RUN FOR THE PRESIDENCY IN GHANA'S NOVEMBER 1992 ELECTION. ALTHOUGH HE HAS NOT FORMALLY DECLARED HIS CANDIDACY, HE HAS NOT MOVED TO QUELL RLMORS OF IT OR TO CURB THE ENTHUSIASM OF HIS SUPPORTERS.

03998 GYAN-APENTENG, $K$.

RAWL INGS HOLDS THE CARDS

WEST AFRICA, (3878) (JAN 92), 60-61.

IF ALL GOES AS PLANNED, GHANA'S NEW GOVERNMENT WILL BE IN PLACE BY DECEMBER 31, 1992. BUT IT IS CLEAR THAT IT WILL BE DIFFICULT TO ACHIEVE THE TARGET DATE BECAUSE THE

CONSTITUENT ASSEMBLY IS FAR BEHIND SCHEDULE.

03999 GYAN-APENTENG, $K$.

RUMOURS FOR PRESIDENT

WEST AFRICA, (3884) (FEB 92), 324-325

THE AUTHOR DISCUSSES THE SPECULATION ABOUT WHO WILL RUM

FOR GHANA'S PRESIDENCY IN THE UPCOMING ELECTION.

04000 GYAN-APENTENG, $K$.

THE BANK AS A BAROMETER

WEST AFRICA, (3901) (JUN 92 ), 1045

THE AFRICAN DEVELOPMENT BANK (ADB) IS ONE OF THE MAJOR

PLAYERS IN THE CONTINENT'S DRIVE TOWARD ECONOMIC AND SOCIAL

DEVELOPMENT. A RECENT ADB REPORT RECOMMENDS THAT THE BANK

DEVELOPMENT. A RECENT ADB REPORT RECOMMENDS THAT THE BANK

ARTICULATE A COHERENT POPULATION POLICY AND GIVE PRE

04001 GYAN-APENTENG, $K$

TRANSITION AND ITS MEANIMG

WEST AFRICA (3920) (NOY 92), 1864-1865.

ON NOVEMBER 3 , 1992 GHAMAIANS WILL GO TO THE POLLS TO

ELECT A PRESIDENT FOR THE FOURTH REPUBLIC. IN THIS ARTICLE, THE AUTHOR PUTS THE TRANSITION PROCESS AND THE RAHLINGS' PHENOMENON IN HISTORICAL PERSPECTIVE AND ASKS WHETHER THE RETIRED FLIGHT LIEUTENANT IS THE MAN TO LEAD GHANA INTO A NEW ERA.

04002 GYAN-APENTENG, K. WAKING A NEW GENERATION 
WEST AFRICA, (3892) (APR 92), 673.

THE GHANA DEMOCRATIC REPUBLICAN PARTY (GDRP), WHICH WAS ESTABLISHED BY POLITICAL EXILES IN THE UNITED STATES, IS POISED TO MOVE ITS HEADQUARTERS TO GHANA WHEN THE BAN ON PARTY POLITICS IS LIFTED ON MAY 18, 1992. THE GDRP'S OBJECTIVES ARE TO CAPTURE THE IMAGINATION OF THE YOUTH OF GHANA, TO INSPIRE THEM TOWARDS HIGHER GOALS AND A NEW PROSPERITY, AND TO GUARANTEE THAT THEIR FREEDOM WILL NEVER AGAIN BE USURPED BY A TOTALITARIAN GOVERNMENT.

04003 GYAN-APENTENG, $K$.

WHAT WENT WRONG?

WEST AFRICA, (3885) (MAR 92), 365-366

MARCH 6, 1957, LIVES IN THE COLLECTIVE MEMORY OF GHANAIANS AS THE BIRTH OF THEIR FREEDOM. THE INDEPENDENCE DAY STORY IS RETOLD EVERY YEAR WITH ALMOST RELIGIOUS FASCINATION, WITH A CONSCIOUS WILL TO PASS IT DOWN TO THE FASCINATION, WITH A CONSCIOUS WILL TO PASS IT DOWN TO THE
COMING GENERATIONS. ON INDEPENDENCE DAY EVERY YEAR, THE COMING GENERATIONS. ON INDEPENDENCE DAY EVERY YEAR,
COUNTRY UNDERGOES A POL ITICAL RITE OF PASSAGE: THE

COUNTRY UNDERGOES A POLITICAL RITE OF PASSAGE: THE
REENACTMENT OF THE STORY IS A MASS REBIRTH AT THE INDIVIDUAL REENAC
LEVEL.

04004 GYAN-APENTENG, K.; YEBOAH-AFARI, A. WINNERS AND LOSERS

WEST AFRICA, (3922) (NOV 92), 1962-1965.

THE AUTHORS SUMMARIZE THE RESULTS OF GHANA'S 1992 ELECTIONS, WHICH WERE MARRED BY VOTING IRREGULARITIES

04005 HAAS, $P$.

INTRODUCTION: EPISTEMIC COMMUNITIES AND INTERMATIONAL POLICY COORDINATION

INTERNATIONAL ORGANIZATION, 46(1) (WIN 92), 1-36.

HOW DECISION MAKERS DEFINE STATE INTERESTS AND FORMULATE POLICIES TO DEAL WITH COMPLEX AND TECHNICAL ISSUES CAN BE A FUNCTION OF THE MANNER IN WHICH THE ISSUES ARE REPRESENTED BY SPECIALISTS TO WHOM THEY TURM FOR ADVICE IN THE FACE OF UNCERTAINTY. THE CONTRIBUTORS TO THIS ISSUE EXAMINE THE ROLE THAT NETHORKS OF KNOHLEDGE-BASED EXPERTS PLAY IN ART ICULATING THE CAUSE-AND-EFFECT RELATIONSHIPS OF PROBLEMS, HELPING STATES IDENTIFY THEIR INTERESTS, FRAMING THE ISSUES FOR COLLECTIVE DEBATE, PROPOSING SPECIFIC POLICIES, AND CONCLUDED THAT CONTROL OVER KNOWLEDGE AND INFORMATION IS AN IMPORTANT DIMENSION OF POWER AND THAT THE DIFFUSION OF NEW IDPORTANT DIMENSION OF POWER AND THAT THE DIFFUSION OF PROVE TO BE AN IMPORTANT DETERMINANT OF INTERNATIONAL POLICY COORDINATION.

04006 HABERMEIER, K.; UNGERER, H.

A SINGLE CURRENCY FOR THE EUROPEAN COMMUNITY

FINANCE AND DEVELOPMENT 29 (3) (SEP 92) 26-29.

UNDER THE MASTRICHT' AGREEMENT, EUROPEAN MONETARY UNIOM

(EMU) WOUID BE REACHED IN THREE STAGES DURING THE FIRST THO STAGES, MEMBER GOVERMMENTS HOUI ENDEAVOR TO ACHIEVE GREATER CONVERGENCE OF THEIR ECONDMIES AS MEASURED BY FOUR CRITERIA: INFLATION, INTEREST RATES, EXCHANGE RATE STABILITY, ANO THE SUSTAINABILITY OF THE FISCAL POSITION. IN THE THIRD STAGE, MEMBER STATES THAT MEET THE ECONOMIC CRITERIA WOULD IRREVOCABLY FIX THEIR EXCHANGE RATES AND ISSUE A SINGLE CURRENCY.

04007 HACKER, A.

TWO NATIONS: BLACK AND WHITE, SEPARATE, HOSTILE, UNEQUAL SCRIBNER'S, 1992, 257.

USING AN EXTENSIVE ARRAY OF STATISTICAL DATA, THIS BOOK EXAMINES THE CHARACTER OF RACE IN AMERICA. THE AUTHOR FIRST EXAMINES THE HISTORICAL BASIS FOR THE CONDITIONS OF SEPARATION AND HOSTILITY IN AMERICAN SOCIETY WHICH FORMS THE BACKDROP FOR LATER DISCUSSIONS. HE THEN TACKLES SPECIFIC ISSUES IN HHICH RACE HAS BEEN A VARIABLE: FAMILIES, INCOME, EQUALITY IN EMPLOYMENT, EDUCATION, CRIME AND POLITICS. FINALLY, HE PRESENTS A REFERENCE ESSAY HITH EXPLANATIONS FOR THE METHOD OF STATISTICAL ANALYSIS AND THE USE OF SUPPLEMENTARY DATA. THE AUTHOR'S INTENT IS TO PROVIDE A NEH BASIS FOR DISCOURSE IN THE AREA OF RACE AND HUMAN RELATIONS IN AMERICA.

04008 HACKETT, S.C.

HETEROGENEITY AND THE PROVISION OF GOVERNANCE FOR COMMONPOOL RESOURCES

JOURNAL OF THEORETICAL POLITICS, 4(3) (JUL 92), 325-342.

THIS PAPER PROVIDES AN INITIAL ANALYSIS OF THE GOVERNANCE PROVISION PROBLEM FOR COMMON-POOL RESOURCES (CPR) CHARACTERIZED BY APPROPRIATE COST HETEROGENETIES. PROVISION CHARACTERIZED BY APPROPRIATE COST HETEROGENETIES. PROVISION FIRST REQUIRES THE SELECTION OF A GOVERNANCE STRUCTURE LOWERS OVERALL APPROPRIATION AND ALLOCATES INDIVIDUAL APPROPRIATION RIGHTS. THE LIKELIHOOD OF SUCCESSFUL IMPLEMENTATION IS THEN INCREASED WHEN APPROPRIATORS MAKE CPRSPECIFIC INVESTMENTS IN MONITORING AND ENFORCEMENT. HETEROGENEITY COMPLICATES EFFICIENT GOVERNANCE STRUCTURES; APPROPRIATION RIGHTS ALLOCATIONS CANNOT MINIMIZE BOTH IMPLEMENTATION COSTS AND HETEROGENEOUS APPROPRIATION COSTS. SOME ADDITIONAL INSTRUMENT, SUCH AS MARKETABLE APPROPRIATION
BOTH FORMS OF PROVISION COST. THE ANALYSIS IDENTIFIES A VOTING RULE TRADE-OFF IN WHICH THE FORM OF PROVISION COS DEPENDS ON THE FORM OF VOTING RULE USED BY APPROPRIATE GROUPS ATTEMPIING SELF-GOVERNANCE.

04009 HACKEY, R.

COMPETING EXPLANATIONS OF VOTER TURNOUT AMONG AMERICAN BLACKS

SOCIAL SCIENCE QUARTERLY, 73(1) (MAR 92), 71-89.

DATA FROM THE 1977-88 NORC GENERAL SOCIAL SURVEYS ARE USED TO MODEL BLACK TURNOUT IN PRESIDENTIAL ELECTIONS FROM 1976 TO 1984. SOCIO-ECONOMIC STATUS (SES), PARTY

IDENTIFICATION, AND POLITICAL RESOURCES SUCH AS EDUCATION AND AGE ARE SIGNIFICANT PREDICTORS OF BLACK ELECTORAL TURNOUT, BUT SHINGLES'S (1981) FINDING THAT THE COMBINATION OF MISTRUST AND EFFICACY AMONG BLACKS STIMULATES POLITICAL INVOLVEMENT IS NOT SUPPORTED. IN ADDITION, CITIZEN INVOLVEMENT IS NOT SUPPORTED. IN ADDITION, CITIZEN CONTRACTING OF LOCAL PUBLIC OFFICIALS EME
SIGNIFICANT PREDICTOR OF BLACK TURNOUT.

04010 HACKMAN, $S$.

AFTER RIO: OUR FORESTS, OURSELVES

TECHNOLOGY REVIEH, 95 (7) (OCT 92 ), 32-41.

A GROWING INTERNATIONAL NETWORK OF PUBLIC-INTEREST GROUPS IS HELPING RESIDENTS OF DEVELOPING COUNTRIES THINK GLOBALLY (ABOUT THE ENVIRONMENT) AND ACT LOCALLY (IN PURSUIT OF SOCIAL AND ECONOMIC HEALTH). BRAZIL, HOST OF THE RECENT EARTH SUMMIT, PROVIDES EXAMPLES BOTH URBAN AND RURAL.

04011 HADAR, L.

HIGH NOON IN WASHINGTON: THE SHOOTOUT OVER THE LOAN GUARANTEES

JOURNAL OF PALESTINE STUDIES, 21(2) (WIN 92), 72-87.

WASHINGTON'S PUNDITS LIKE TO EXPLAIN THE CURRENT ISRAELIAMERICAN RELATIONSHIP IN TERMS OF PERSONALITIES: THE IMAGE OF THE LONE SHERIFF BUSH MEETING SHAMIR AND HIS AIPAC CRONIES FOR A GREAT SHOOTOUT IN THEIR DIPLOMATIC O.K. CORRAL. HOHEVER, BUSH HAS ONLY BROUGHT TO A HEAD PROCESSES THAT WERE ALREADY BOILING UNDER THE SURFACE. THIS ARTICLE SUGGESTS THAT REGARDLESS OF WHAT LEADERS WOULD BE IN POWER IN THE UNITED STATES AND ISRAEL, THERE IS LITTLE DOUBT THAT OBJECTIVE CIRCUMSTANCES, SUCH AS THE END OF THE COLD WAR AND THE GULF WAR, WOULD HAVE LED AT ONE POINT OR ANOTHER TO MAJOR CHANGES IN THE AMERICAN-ISRALI AXIS.

04012 HADAR, L.

ISRAEL'S FUTURE: A TALE OF THO CITIES

WORLD POL ICY JOURNAL, 9 (1) (WIN 91), 111-134.

AS ISRAEL'S POLITICAL WAR WITH WASHINGTON INTENSIFIES, THE STRUGGLE BETWEEN THE MILITANT ZIONIST GOVERNMENT IN JERUSALEM AND THE PROPONENTS OF "BEAUTIFUL ISRAEL" IN TEL AVIV IS LIKEHISE HEATING UP. SHAMIR SUSPECTS THAT THE LONGTERM GOAL OF THE UNITED STATES IS TO REPLACE HIS GOVERNMENT WITH A HORE MODERATE ONE HEADED BY LABOR. IN ORDER TO FORSTALL THIS, THE LIKUD GOVERMMENT HAS STEPPED UP ITS ATTEMPTS TO SILENCE OR BUY OFF DISSENTING VOICES AT HOME. THIS ARTICLE EXPLORES THE IDEOLOGICAL DIFFERENCES EXISTING IN THE TWO CITIES OF TEL AVIV AND JERUSALEM. IT CONCLUDES THAT ULTIMATELY, THE OUTCOME OF THE STUGGLE FOR ISRAEL'S SOUL MAY DECIDE NOT ONLY THE FATE OF THE THIRD JEWISH COMMONHEALTH BUT THE FUTURE OF THE ENTIRE MIDDLE EAST.

04013 HADAR, L.

THE ISRAELI LABOR PARTY: PEACEMAKER OR LIKUD II? JOURNAL OF PALESTINE STUDIES, XXI(3) (SPR 92), 80-94.

THIS ARTICLE OISCUSSES THE FEBRUARY 1992 AMERICAN-STYLE PRIMARY IN ISRAEL, THIS WAS THE FIRST PRIMARY EVER HELD IN THE COUNTRY. THIS COULD LEAD, IN TURN, TO THE FORMATION OF NEW POLITICAL PARTIES AND TO THE RISE OF NEW PUBLIC FIGURES THAT WILL START MOVING ISRAEL TOWARD A NEW ERA IN WHICH THE IDEOLOGICAL BAGGAGE OF BOTH LABOR AND LIKUD, IMPORTED FROM EASTERN EUROPE AT THE BEGINNING OF THE CENTURY WOULD BE REPLACED BY A NEW POLITICAL AND IDEOLOGICAL VISION.

04014 HADAR, 1 .

THE UNITED STATES, EUROPE, AND THE MIDDLE EAST

WORLD POLICY JOURMAL VIII (3) (SUM 91) $421-450$.

FOR THE MOMENT, THE GULF WAR SEEMS TO HAVE DASHED HOPES FOR A EUROPEAN CHALLENGE TO U.S. FOREIGN POLICY IN THE MIDDLE EAST. HOWEVER, A LONG-TERM U.S. POLICY OF EXCLUDING EUROPE FROM A MEANINGFUL ROLE IN THE MIDOLE EAST WILL MOT EUROPE FROM A MEANINGFUL ROLE IN THE MIDOLE EAST HILL NOT
ONLY BE VERY COSTLY, BUT IMPOSSIBLE TO SUSTAIN. THE BUSH ONLY BE VERY COSTLY, BUT IMPOSSIBLE TO SUSTAIN. THE BUSH
ADMINISTRATION WILL SOON DISCOVER THAT THE MORE IT TRIES TO ADMINISTRATION WILL SOON DISCOVER THAT THE MORE IT TRIES TO ITSELF ENTANGLED IN ISSUES THAT HAVE NOTHING TO DO WITH REAL ITSELF ENTANGLED IN ISSUES THAT HAVE NOTHING TO DO WITH REAL ACTORS RANGING FROM KURDISH REBELS IN IRAQ TO THE MILITAN GOVERNMENT IN JERUSALEM. A WISE LONG-TERM POLICY FOR THE UNITED STATES WOULD INCLUDE COOPERATION HITH EUROPE NOW TO FORMULATE A MORE CONSTRUCTIVE AND REALISTIC POLICY IN THE MIDDLE EAST.

04015 HADAR, L.T.

NEW DEMOCRATIC ISRAEL PARTY COULD FORM PEACE COALITION 
HITH LABOR

HASHINGTON REPORT ON MIDDLE EAST AFFAIRS, XI(1) (JUN 92), 9-10.

THE UPCOMING KNESSET ELECTIONS AND THE MIDDLE EAST PEACE PROCESS HAVE PRODUCED ONE OF THE STRANGEST POLITICAL ALLIANCES IN ISRAEL'S HISTORY. A COLLECTION OF FORMER MARXIST ACTIVISTS, A GROUP OF MILTON FRIEDMAN'S FOLLOWERS, AND OPPONENTS OF THE RABBINICAL AUTHORITIES OF THE JEHISH STATE HAVE FORMED THE NEH DEMOCRATIC ISRAEL PARTY, WHICH HOPES TO BECOME THE KING MAKER FOLLONING THE JUNE 1992 ELECTIONS. DEMOCRATIC ISRAEL'S LONG-TERM GOAL IS TO REPLACE THE RELIGIOUS-ORTHODOX PARTIES AS THE THIRD LARGEST POLITICAL FORCE IN ISRAEL AND BECOME THE CRITICAL FACTOR IN
THE FORMATION OF ANY FUTURE GOVERNMENT COALITION.

04016 HADAR, L.T.

THE LAST DAYS OF LIKUD: THE AMERICAN-ISRAELI BIG CHILL JOURNAL OF PALESTINE STUDIES, XXI (4) (SUM 92), 80-94. THE AUTHOR DISCUSSES THE STATUS OF U.S. -ISRAELI RELATIONS IN THE SPRING OF 1992 AS WASHINGTON DEMANDED A FREEZE ON ISRAELI SETTLEMENTS IN THE OCCUPIED TERRITORIES IN
RETURN FOR LOAN GUARANTEES. HE AL SO LOOKS AT HOW JEWISH ISSUES AFFECTED THE 1992 U.S. PRESIDENTIAL PRIMARY ELECTIONS.

04017 HADAR, L.T.

WILL YITZHAK RABIN PROVIDE GEORGE BUSH'S OCTOBER 1992 SURPRISE?

WASHINGTON REPORT ON MIDDLE EAST AFFAIRS, XI(3) (AUG 92), $11-12,38$.

THE AUTHOR EXPLAINS WHY THE LIKUD PARTY LOST THE 1992 KNESSET ELECTIONS AND WHAT THE ELECTION OF YITZHAK RABIN AS

PRIME MINISTER WILL MEAN FOR THE MIDDLE EAST PEACE PROCESS.

04018 HADJIPAVLOU-TRIGEORGIS, M.; TRIGEORGIS, L.

A GAME THEORETIC EXPLANATION OF THE US CONGRESS'S ARMS EMBARGO ON TURKEY

JERUSALEM JOURNAL OF INTERNATIONAL RELATIONS, 1414) (DEC

92), 85-109.

THIS ARTICLE USES A GAME THEORETIC MODEL TO DESCRIBE THE

US CONGRESS'S DECISION TO IMPOSE AN ARMS EMBARGO ON TURKEY

IN DECEMBER 1974 IN AN ATTEMPT TO INDUCE TURKEY TO MAKE

CONCESSIONS OVER CYPRUS, AND SUBSEQUENTLY TO LIFT THE

EMBARGO IN AUGUST 1978. SPECIFICALLY, THE PAPER ANALYZES THE

DYNAMICS OF THREE "GAMES" IN A DYNAMIC EQUILIBRIUM FRAMEHORK.

THIS GAME THEORETIC APPROACH INTRODUCES A DYMAMIC DIMENSIOM

TO THE PROBLEM BY INCORPORATING LONG-TERM CONSIDERATIONS.

04019 HADWIGER, D.

MONEY, TURNOUT, AND BALLOT MEASURE SUCCESS IN CALIFORNIA

CITIES

WESTERN POLITICAL QUARTERLY, 45(2) (JUN 92), 539-548.

THIS STUDY USES A DATA BASE OF CITIZEN-SPONSORED BALLOT

MEASURES IN CALIFORNIA CITIES TO ANALYZE THE EFFECT OF TWO

FACTORS--VOTER TURNOUT AND CAMPAIGN SPENDING--ON BALLOT

MEASURE OUTCOMES. THE RESULTS ARE EXAMINED IN LIGHT OF

EFFORTS TO REFORM THE INITIATIVE PROCESS.

04020 HAERI, $S$.

AHMAD' IS OUT

MIDDLE EAST INTERNATIONAL, (398) (APR 91), 18.

THE RESIGNATION OF HOJÁTOLESLAM AHMAD KHOMEINI, THE 43YEAR OLD SON OF THE LATE AYATOLLAH KHOMEINI, AS THE LEADER OF THE IRANIAN HAJJ CONTINGENT IS A RESOUNDING VICTORY FOR PRESIDENT HASHEMI RAFSANJANI OVER AYATOLLAH KHAMENEI, THE SPIRITUAL LEADER OF THE REPUBLIC. THE MOVE IMPROVED RELATIONS BETHEEN IRAN AND SAUDI ARABIA, THE SAUDI'S REPETITION OF THE VIOLENCE INITIATED BY IRANIAN PILGRIMS IN 1988

04021 HAERI, S.

ANGRY' IRANIANS

MIDDLE EAST INTERNATIONAL, (405) (JUL 91), 7.

IRAN REACTED ANGRILY TO SYRIAN PRESIDENT ASAD'S DECISION

TO BACK U.S. PLANS FOR A MIDDLE EAST PEACE CONFERENCE,

DESCRIBING IT AS A "MOVE DICTATED BY SELF-INTEREST AMD

DESCRIBING IT AS A "MOVE DICTATED BY SELF-INTEREST AND
SACRIFICING THE PALESTINIAN CAUSE. "WHILE IRANIAN LEADERS

SAID NOTHING PUBLICLY CONDEMNING PRESIDENT ASAD'S
WILLINGNESS TO ATTEND U.S,-SPONSORED PEACE NEGOTIATIONS, THE

WILLINGNESS TO ATTEND U.S. -SPONSORED PEACE NEGOTIATIO
OFFICIAL TEHRAN RADIO AND POWERFUL CLERICS SHARPLY

OFFICIAL TEHRAN RADIO AND POWERFUL CLERICS SHARPLY
CRITICIZED THE MOVE. TEHRAN RADIO ALSO CRITICIZED IRAN'S

CRITICIZED THE MOVE. TEHRAN RADIO ALSO CRITICIZED IRAN'S

EXCLSION FROM NEGOTIATIONS ABOUT GULF SECURITY AND

04022 HAERI, S.

CLOSE EYE ON IRAO

MIDDLE EAST INTERNATIONAL, (395) (MAR 91), 18-19.

TO THE DELIGHT OF THE IRANIANS, IRAO HAS BEEN ROUNDLY

DEFEATED AND ITS ARMY DECIMATED AND HUMILIATED. BUT WITH THE

END OF THE FIGHTING THE IRANIAN LEADERSHIP IS BRACING ITSELF

FOR THE ROLE IT WILL HAVE TO PLAY IN ANY POST-WAR REGIONAL

ARRANGEMENT, A POSITION THAT NONE OF ITS FRIENDS OR FOES CAN

DENY IT ANY LONGER. HOWEVER, AS IRAN IS POISED TO REAP THE

BENEFITS OF ITS STRICT NEUTRALITY DURING THE CONFLICT, IT
MAY BE TORN BY INTERNAL FIGHTING BETWEEN ISLAMIC FUNDAMENTALISTS AND THE ADMINISTRATION OF PRESIDENT SOUTHERM IRAQ AND FUTURE SECURITY ARRANGEMENTS IN THE REGION.

04023 HAERI, S.

COURTING CLINTON'S CENSURE

MIDDLE EAST INTERNATIONAL $438(438$ ) (NOY 92 ), 9.

IRAN HAS DASHED ALL HOPES OF A POSSIBLE NORMALIZATION OF ITS RELATIONS WITH WASHINGTON BY DELIBERATELY HARDENING ITS ITS RELATIONS WITH WASHINGTON BY DELIBERATELY HARDENING ITS
ANTI-U.S. STANCE. THIS ARTICLE EXPLORES HOW, SINCE THE U.S ANTI-U.S. STANCE. THIS ARTICLE EXPLORES HON, SINCE THE U.S ELECTIONS, SENIOR HARD-LINE CLERICS CLOSE TO AYATOLLAH ALI AND THE U.S. IN PARTICULAR, MAKING SURE THAT THE NEW AND THE U.S. IN PARTICULAR, MAKING SURE THAT THE NEW PRESIDENT WILL HAVE

04024 HAERI, $S$.

IRAN AND CHINA--NUCLEAR COOPERATION

MIDDLE EAST INTERNATIONAL, (412) (NOV 91), 14.

ACCORDING TO THE UNITED STATES AND EUROPEAN PRESS, IRAN, IN ITS QUEST FOR NUCLEAR WEAPONS, IS GETTING HELP FROM BOTH CHINA AND NORTH KOREA. THE SIGNALS COMING FROM IRAN AND CHINA ON THE SUBJECT ARE CERTAINLY MIXED. HASSAN HABIBI. IRAN'S FIRST VICE-PRESIDENT HAS STRONGLY DENIED HIS COUNTRY WAS ENGAGED IN DEVELOPING NUCLEAR ARMS. HOWEVER, CHINA HAS RECENTLY DISCLOSED DETAILS OF ITS NUCLEAR COOPERATION WITH IRAN, CONFIRMING ITS INVOLVEMENT IN PEACEFUL USE OF NUCLEAR ENERGY, WHICH HABIBI DID NOT MENTION. FURTHERMORE, IRAN'S PRESIDENT RAFSANJANI RECENTLY WAS QUOTED AS TELLING CHINA'S PRESIDENT YANG SHANGKUN THAT IRAN REJECTS THE NEW U.S.DOMINATED WORLD ORDER AND U.S. INTERFERENCE IN IRAN'S

INTERNAL AFFAIRS.

04025 HAERI, $S$.

IRAN CALLS FOR HELP

MIDDLE EAST INTERNATIONAL, (398) (APR 91), 7

AFTER DAYS OF HESITATION IRAN FINALLY DECIDED TO OPEN

ITS DOORS TO INTERNATIONAL RELIEF FOR IRAQI KURDISH REFUGEES AND TO GRANT SPECIAL VISAS TO THE FOREIGN JOURNALISTS TO COVER THE HUMAN TRAGEDY. PRESIDENT RAFSANJANI WAS QUICK TO COVER THE HUMAN TRAGEDY. PRESIDENT RAFSAN JANI WAS QUICK TO REALIZE THAT IRAN COULD NOT COPE ALONE WITH AN INFLUX OF A BETWEEN TEHRAN AND BAGHDAD CONTINUED TO WORSEN, IRAN JOINED BETWEEN TEHRAN AND BAGHDAD CONTINUED TO WORSEN, IRAN JOINED AM "ENCLAVE" FOR IRAQI KURDS, PROVIDED THE SAME THING WAS DONE FOR IRAOI SHI'ITES SUFFERING THE WRATH OF SADDAM DONE FOR

04026 HAERI, S.

IRAN--ATTACK ON WESTERN INFLUENCE

MIDDLE EAST INTERNATIONAL, (430) (JUL 92 ), 13-14.

HUNDREDS OF IRANIANS, MOSTLY WOMEN AND TEENAGERS, HAVE BEEN ARRESTED IN RECENT WEEKS IN A NEW WAVE OF REPRESSION ORCHESTRATED BY AYATOLLAH ALI KHAMENEI AND AIMED AT THE "MERCILESS ERADICATION OF CORRUPT WESTERN CULTURE AND ATITTUDES." IN SEVERAL RECENT SPEECHES, AYATOLLAH KHAMENEI, THE "SUPREME GUIDE AND LEADER OF THE ISLAMIC REVOLUTION," HAS URGED THE COUNTRY'S REVOLUTIONARY GUAROS TO IMPLEMENT A PRINCIPLE OF "APPLY THE RIGHT, REJECT THE BAD." HIS ADMONITIONS STARTED A NEW HAVE OF REPRESSION AGAINST WOMEN AND, PARTICULARLY TEENAGERS, HHO ARE MORE INTERESTED IN WESTERN CLOTHES AND POP MUSIC THAN IN ISLAMIC TEACHINGS. THE SUDDEN LAUNCH OF NEW REPRESSIVE MEASURES, COMING AT A TIME WHEN IRAN IS UNDER HEAVY PRESSURE FROM ABROAD TO REDUCE ITS VIOLATIONS OF HUMAN RIGHTS, IS SEEN AS THE START OF A NEW ROUND OF CLASHES BETWEEN PRESIDENT RAFSANJANI AND KHAMENEI, HIS MAIN RIVAL.

04027 HAERI, $S$.

IRAN--DIFFICULTIES AHEAD

MIDDLE EAST INTERNATIONAL, (425) (MAY 92), 15. PRESIDENT HASHEMI RAFSANJANI'S "LANDSLIDE" VICTORY IN THE IRANIAN GENERAL ELECTIONS WAS CONFIRMED ON 8 MAY AS ALL THE CAPITAL'S 30 SEATS HERE TAKEN BY PRO-PRESIDENTIAL CANDIDATES. WITH THE PARL IAMENT THUS TAMED, PRESIDENT
RAFSANJANI HAS SIX MONTHS TO "MAKE OR BREAK, " ACCORDING TO RAFSANJANI HAS SIX MONTHS TO "MAKE OR BREAK, ACCORDING TO
IRANIAN OBSERVERS. TO STOP THE ECONOMIC DOWNTURN, IRAN NEEDS BILLIONS IN FOREIGN INVESTMENT. THEREFORE, THE GOVERNMENT'S DECISION ON 8 MAY TO DROP THE LIMIT ON FOREIGN OWNERSHIP IN IRANIAN COMPANIES AND BUSINESSES IS SEEN BY ECONOMIC
AS ONE OF ITS FIRST SERIOUS STEPS TO ATTRACT FOREIGN INVESTMENTS. BUT MANY EXPERTS STILL DOUBT THE SITUATION WILL INVESTMENTS. BUT MANY EXPERTS STILL DOUBT THE SITUATION WILL
IMPROVE, ARGUING THAT TO ATTRACT MUCH-NEEDED INVESTMENTS, IMPROVE, ARGUING THAT TO ATTRACT MUCH-NEEDED INVESTMENTS
RAFSANJANI NEEDS A 180 -DEGREE CHANGE IN HIS ECONOMIC, POLITICAL AND SOCIAL POLICIES.

04028 HAERI, $S$.

IRAN--KHAMENEI ON THE WAR PATH

MIDDLE EAST INTERNATIONAL, (431) (AUG 92), 13.

BY CALLING ON "RADICAL HIZBULLAHI ELEMENTS TO TAKE OVER ALL KEY JOBS IN THE ADMINISTRATION AND THE ARMED FORCES," IRAN'S AYATOLLAH ALI KHAMENEI, THE LEADER OF THE ISLAMIC
REVOLUTION, HAS DEALT A NEH AND SEVERE BLOW TO THE AUTHORITY 
AND POLICIES OF PRESIDENT RAFSAMJANI. UNDER KHAMENEI'S "GUIDANCE" AND "INSPIRATION," A NEH, NATIONWIDE CAMPAIGN has BEEN LAUNCHED to REVITALIZE' "I SLAMIC VALUES." ONE OF THE MORE VISIBLE RESULTS OF THIS CONSERVATIVE CAMPAIGN HAS BEEN THE INCREASE OF IRAN'S INTERNATIONAL ISOLATION, WITH A NUMBER OF FOREIGN NATIONAL BANKING AND FINANCIAL INSTITUTIONS REFUSING NEW CREDITS TO THE CRIPPLED IRANIAN ECONOMY. KHAMENEI HAS BECOME INCREASINGY BOLD IN HIS CAMPAIGN TO ERODE THE AUTHORITY AND CREDIBILITY OF RAFSANJANI, WHO IS GENERALLY REgARDED AS A "PRAGMATIC POLITICIAN' WHO ADVOCATES A CLOSER RELATIONSHIP WITH THE WEST, INCLUDING THE UNITED STATES.

04029 HAERI, S.

IRAN--RAFSANJANI CHANGES TACK

IRAN--RAFSANJANI CHANGES TACK
MIDDLE EAST INTERNATIONAL, (432) (AUG 92), 11.

AFTER SEVERAL MONTHS OF AN UPHILL STRUGGLE AGAINST THE HARD-LINE "LEADER," AYATOLLAH ALI KHAMENEI, IRAN'S PRESIDENT HARD-LINE "LEADER," AYATOLLAH ALI KHAMENEI, IRAN'S PRE
RAFSANJANI FINALLY GAVE UP AND JOINED THE VICTORIOUS RAFSANJANI FINALLY GAVE UP AND JOINED THE VICTORIOUS
RADICALS BY CALLING ON THE HIZBULLAH ELEMENTS TO "HELP" THE RADICALS BY CALLING ON THE HIZBULLAH ELEMENTS TO "HELP" THE ISLAMIC REPUBLIC "CROSS ITS PRESENT DIFFICULT TIMES" AND CREATE A JOYFUL, BEAUTIFUL, INDEPENDENT, FREE AND GLORIOUS ISLAMIC STATE. AS A RESULT OF THE RECENT INTERMAL TURMOIL, IRANIAN RELATIONS WITH THE OUTSIDE WORLD, PARTICULARLY WITH LEADING WESTERN EUROPEAN COUNTRIES, HAVE DETERIORATED, WITH
THE GOVERNMENT DEFAULTING FOR THE FIRST TIME ON TWO OF ITS THE GOVERMMENT DEFAULTING FOR THE FIRST TIME ON THO OF ITS
FOREIGN DEBTS, NOW ESTIMATED AT AROUND \$20 BILLION. THE FOREIGN DEBTS, NOW ESTIMATED AT AROUND \$20 BILLION. THE
EUROPEAN COMMISSION HAS RECOMMENDED THAT EC MEMBERS WITHHOLD EUROPEAN COMMISSION HAS RECOMMEND
FURTHER INVESTMENT AND CREDITS.

04030 HAERI, $S$.

IRAN-THWARTED NUCLEAR DEALS

MIDDLE EAST INTERNATIONAL, (413) (NOV 91), 13.

IRAN HAS REACTED ANGRILY TO A UNITED STATES REQUEST TO INDIA TO NOT GO AHEAD WITH ITS DECISION TO SELL IT A REPORTED 10 MEGAWATT ATOMIC REACTOR. IRAN HAS ALREADY RECEIVED A "MINI REACTOR" FROM CHINA AND IS REPORTED TO HAVE "QUI IE ADVANCED" NUCLEAR COOPERATION WITH NORTH KOREA. IN PEKING, U.S. SECRETARY OF STATE JAMES BAKER URGED BOTH CHINA AND INDIA TO END THEIR ATOMIC COOPERATION WITH IRAN, WHICH PROGRAM FOR MILITARY USE. CHINA AND INDIA'S APPARENT WILLINGNESS TO ABIDE BY THE UNITED STATES DEMANDS HAS ANGERED IRAN AND HAS CAUSED IRANIAN LEADERS TO BITTERLY DENOUNCE THE AMERICAN INTERVENTION INTO IRAN'S INTERNAL DEFOUNCE

04031 HAERI, $S$.

IRAN: LOUD PROTESTS

MIDDLE EAST INTERNATIONAL, 17 (JAN 92) 8

IN ITS FIRST PUBLIC REACTION TO IRAN'S CONTINUOUS DENUNCIATION OF THE POSTPONEMENT OF THE ALGERIAM PARL IAMENTARY ELECTIONS AND OPEN SUPPORT FOR THE FIS, THE NEWLY FORMED ALGERIAN JUNTA CALLED ON TEHRAN TO STOP MEDOLING IN ALGERIA'S INTERNAL AFFAIRS. AS IRAN CONTINUED, THE ALGERIAN GOVERNMENT DECIDED TO RECALL ITS AMBASSADO FROM TEHRAN AND TO EXPELL THE IRANIAN AMBASSODOR FROM ALGIERS. OIPLOMATS SAY THAT THE ALGERIAN DECISION IS LIKELY TO I SOLATE FURTHER IRAN'S ALREADY UNPOPULAR REGIME IN THE THIRD HORLD.

04032 HAERI, $S$

SOMALIA: CONDEMNATION

MIDOLE EAST INTERNATIONAL, 440(440) (DEC 92), 7-8.

IRAN BECAME THE FIRST IUSLIM COUNTRY TO OPENLY QUESTION THEN CONDEMN THE REAL AIMS OF THE US INTERVENTION IN SOMALIA AND HONDERED IF THE UN'S PROMPT APPROVAL OF WASHINGTON'S PROPOSAL TO INTERVENE WOULD NOT OPEN THE WAY FOR THE CREATION OF A PUPPET REGIME THERE. FROM THE IRANIAN REGIME'S POINT DF VIEW, THE WHOLE SCHEME IS DESIGNED TO CREATE AN ANTI-ISLAMIC, ANTI-IRANIAN AXIS FROM THE GULF TO THE RED SEA. IRAN HAD EARLIER PROPOSED THAT ANY FOREIGN INVOLVEMENT IN SOMALIA SHOULD BE UNDER THE DUAL OBSERVATION OF THE UN AND MUSLIM STATES.

04033 HAERI, S.

TENSION MOUNTS

MIDDLE EAST INTERMATIONAL, (397) (APR 91), 16.

AS TENSION BETWEEN TEHRAN AND BAGDHAD INCREASED, HITH IRAQ PUBLICLY AND OFFICIALLY ACCUSING IRAN OF BEING BEHIND THE REBELLIONS IN THE SOUTH AND NORTH AND THE WAR-TORN COUNTRY, IRAN SOUARELY BLAMED WASHINGTON FOR THE "GENOCIDE: BEING PERPETRATED BY SADOAM HUSSEIN'S ARMY AGAINST BOTH THE SHI'ITES AND THE KURDS. LIKE THE U.S. IRAN IS OFFICIALLY SHI'ITES AND THE KURDS. LIKE THE U.S., IRAN IS OFFICIALLY BASIS THAT IT CATEGORICALLY AND VEHEMENTLY DENIES ALL IRAQI BASIS THAT IT CATEGORICALLY AND VEHEMENTLY DENIES ALL IRAOI ALLEGATIONS OF "INVOL VEMENT IN IRAQI INTERNAL AFFAIRS." IRANIAN PRESIDENT RAFSANJANI SEES THE GULF HAR AND ITS AFTERMATH AS AN OPPORTUNITY TO ASK THE AMERICANS FOR OFFICIAL RECOGNITION OF THE PREDOMINANT ROLE IRAN PLAYS IN
THE GULF REGION. THE EUROPEAN COMMUNITY FOR A FIRM PLEDGE TO ASSIST IRANIAN ECONOMIC RECONSTRUCTION AND THE RICH ARABS FOR FINANCIAL HELP.
04034 HAFNER, D.F

POL ITICAL MODERNIZATION IN SLOVENIA IN THE 1980'S AND THE EARLY $1990^{\circ} \mathrm{S}$

JOURNAL OF COMMUNIST STUDIES, 8(4) (DEC 92), 210-226. SLOVENIA'S HISTORY AND GEOGRAPHICAL POSITION HAVE MADE ITS EMERGENCE FROM "REAL SOCIALISM" IDIOSYNCRATIC. THE GLOBAL POL IT ICAL CHANGE THAT MARKED THE END OF MARXISTLENINIST RULE WAS USHERED IN BY A NUMBER OF GRADUAL CHANGES CONCERHING BOTH MODIFICATIONS TO SLOVENIA'S POLITICAL CULTURE AND THE DEVELOPMENT OF SOCIAL FACTORS. THE NEW SOCIAL MOVEMENTS PLAYED A KEY TRANSFORMATIVE ROLE IN THE PROCESS OF REGIME CHANGE, BUT IT COULD NOT HAVE BEEN DECISIVE WITHOUT AN EVOLUTION WITHIN THE EXISTING POHER STRUCTURE ITSELF. HOLDING FREE ELECTIONS IN 1990 CONFIRMED THE MOVE TO PLURALISM; HOWEVER, SINCE THE INSTITUTIONAL FRAMEWORK REMAINS SUBSTANTIALLY UNCHANGED, THERE IS A RISK, FRAMEWORK REMAINS SUBSTANTI ALLY UNCHAMGED, THERE IS A RISK,
DURING THE TRANSITION PERIOD, THAT A WEAK OPPOSITION WILL BE OVERPOWERED BY THE STRONG EXECUTIVE EMERGING FROM THE OVERPOWERED BY THE

04035 HAFNER, G.

NEUTRAL AND NON-ALIGNED COUNTRIES IN THE PROCESSES OF PANNEUTRAL AND NON-ALIGNED COUNTRIE

PEACE AND THE SCIENCES, 3 (SEP 91), 31-37.

ANY POLITICAL STATUS CHOSEN FREELY BY A PARTICULAR STATE IS NOT AN AIM IN ITSELF BY ONLY A MEANS TO SECURE THE HELLBEING, PROSPERITY AND SURVIVAL OF THE STATE AND ITS PEOPLE. THE STATUS AS A NN COUNTRY IS THEREFORE ALSO DESIGNED AS ITS MAIN FUNCTION TO SERVE THIS PURPOSE. IN ADDITION, THIS POLITICAL STATUS TO A GREAT EXTENT DEPENDS ON THE POLITICAL SURROUNDING OR ENVIRONMENT AS FOREIGN POLICY ITSELF IS ONLY THE REACTION OF ONE STATE TO THE CHALLENGES STEMMING FROM ITS POLITICAL ENVIRONMENT MAINLY PRODUCED BY THE SURROUNDING STATES. THIS ARTICLE IS AN ANALYSIS OF THE POSITION DF THE NN UNDER THESE CIRCUMSTANCES.

04036 HAGAR, M.

WHAT'S THE LAH GOT TO DO HITH IT?

NEW POLITICS, 13(1) (SUM 92 ), 115-121.

THIS ARTICLE REFLECTS ON THE LABOR MOVEMENT' 's

RELATIONSHIP TO LAW AND TO VARIOUS LEGAL STRATEGIES FOR IMPROVING WORKERS' LIVES AND EXPANDING WORKER POWER. SOME ARGUE THAT JUDGE-MADE LAH WAS SUCCESSFUL FOR DECADES IM DRASTICALLY HINDERING LABOR'S ADVANCEMENT. THIS ARTICLE CONCLUDES THAT SUCH AN ARGUMENT, ALTHOUGH COMPELLING IN MANY RESPECTS, DOES NOT FULLY EXPLAIN WHY U.S. LABOR DID NOT MUSTER AN AGGRESSIVE WELFARE STATE AGENDA. THE AUTHOR MUSTER AN AGGRESSIVE WELFARE STATE AGENDA. THE AUTHOR
CONCLUDES THAT THE ISSUE WARRANTS FURTHER INVESTIGATION.

04037 HAGE, G.

RACISM MULTICUL TURALISM AND THE GULF WAR

RACISM, MULTICUL TURALISM

WHILE PEOPLE ARE VAGUELY AWARE THAT THE GULF WAR LED TO AN INCREASE IN THE INCIDENCE OF RACISM IN AUSTRALIA, NOT MANY ARE AHARE OF THE MAGNITUDE OF WHAT HAPPENED. THE FACT IS, THAT IN SYDNEY AND MELBOURNE IN 1990, A GROUP OF AUSTRALIAN CITIZENS--ARAB-AUSTRAL IANS--WERE SUBJECTED TO ENOUGH HARASSMENT TO FORCE THEM INTO HIDING. IT IS PROBABLE THAT ONLY THE ABORIGINES AND THOSE WORKING WITH THEM CAN APPRECI ATE THE ENORMITY OF THE HAPPENING. AFTER ALMOST THENTY YEARS OF MULTICUL TURALISM, RACISM CAN STILL BE DEPLOYED WITH GREAT INTENSITY IN AUSTRALIA, AND EFFECTIVELY ENOUGH TO FORCE THOSE SUBJECTED TO IT INTO HIDING. THIS NECESSARILY PUTS A QUESTION MARK OVER THE EFFICACY OF MULTICULTURALISM AS AN ANTI-RACIST STRATEGY.

04038 HAGEL, T.; SPAETH, H.

THE EMERGENCE OF A NEW IDEOLOGY: THE BUSINESS DECISIONS OF THE BURGER COURT

THE JOURNAL OF POLITICS, 54(1) (FEB 92), 120-134. THROUGH THE USE OF PROBIT, THE AUTHORS FIND THAT DISTINCT PATTERNS EXIST AMONG THE INDEPENDENT VARIABLES IN RELATION TO THE DIRECTION OF THE COURT'S DECISION. BASED ON THE EXPLANATORY POWER OF THEIR MODEL, IT IS EVIDENT THAT A NEH IDEOLOGY HAS EMERGED: "INSTRUMENTAL LIBERTARIANSIM," IN WHICH THE COURT EFFECTUATES ITS LIBERTARIANISM THROUGH THE EXERCISE OF JUDICIAL POWER AGENCY ACTION, AND CONSIDERATIONS OF FEDERALISH.

04039 HAGELIN, B.; HALLENSTEEN, P. UNDERSTANDING SWEDISH MILIITARY EXPENDITURES COOPERATION \& CONFLICT. MORDIC JOURMAL OF INTERMATIONAL COOPERATION \& CONFLICT: NORDIC JOUR

THE AUTHORS PRESENT INFORMATION ON SHEDISH MILITARY EXPENDITURES SIMCE 1913, USING OFFICIAL AND COMPARABLE EXPENDITURES SINCE 1913, USING OFFICIAL AND COMPARABLE
INDICATORS FOR DIFFERENT HISTORICAL PERIODS. THEY DISCOVER A INDICATORS FOR DIFFERENT HISTORICAL PERIODS. THEY DISCOVER AND FLUCTATIONS IN INTERNATIONAL TENSIONS. THEY DISCUSS THE IMPACT OF THE CREATION OF AN OFFICIALLY-ENCOURAGED SHEDISH MILITARY INDUSTRY, WHICH BEGAN IN THE LATE 1930'S DURING A PERIOD OF INCREASING INTERNATIONAL TENSION. INDUSTRIAL CONSIDERATIONS WERE IMPORTANT DURING THE COLD WAR AND EXPENDITURES HERE INFLUENCED BY THE EXISTENCE OF MAJOR ARMS PRODUCTION PROJECTS, EVEN WHEN REDUCTIONS IN INTERNATIONAL 
TENSIONS MIGHT HAVE BEEN EXPECTED TO LEAD TO LOWER MILITARY SPENDING. THE AUTHORS EXPLAIN THE LOCAL AND REGIONAL ECONOMIC IMPACT OF MILITARY-INDUSTRIAL PRODUCTION, WHICH IS A SIGNIFICANT CONSIDERATION HHEN DEBATING POSSIBLE FUTURE REDUCTIONS.

04040 HAGEMEIER, $H$.

A RECOMMENDED NATIONAL SECURITY STRATEGY FOR A CERTAIN CLASS OF SPACE WEAPONS OR WHAT DO WE DO ABOUT BOMBS IN SPACE?

COMPARATIVE STRATEGY, 11(1) (JAN 92), 49-64.

SPACE WEAPONS HAVE BEEN OF INTEREST TO THE U.S GOVERMMENT, THE MILITARY, AND THE GENERAL PUBLIC FOR MANY YEARS. THE GOVERMMENT HAS OFTEN BEEN CAUGHT BETHEEN THE MILITARY'S DESIRE FOR EXPANDED USE OF SPACE AND THE GENERAL PUBLIC'S DESIRE FOR CONTROLLED USE OF SPACE. THIS ARTICLE EXAMINES SPACE WEAPONS; THEIR POTENTIAL MILITARY UTILITY THEIR IMPLICATIONS, AND THE POSSIBILITIES OF CONTROLLING THEIR PROLIFERATION. IT CONCLUDES WITH RECOMMENDATIONS FOR NATIONAL SECURITY STRATEGY IN THE AREAS OF STUDIES, TECHNOLOGY RESEARCH, INFORMED DISCUSSION AND DECISIONS.

04041 HAGER, $C$

DEMOCRATIZING TECHNOLOGY: CITIZEN \& STATE IN WEST GERMAN ENERGY POLITICS, $1974-1990$

POLITY, 25(1) (FAL 92), 45-70.

IN WEST GERMANY, MASS ENERGY PROTESTS OF THE PAST THO DECADES REOPENED THE QUESTION OF THE CITIZEN'S PROPER ROLE IN TECHNOLOGICAL DECISION MAKING. THIS CASE STUDY ANALYZES THE POLITICS OF ENERGY POLICY, WHERE GRASSROOTS ACTIVISTS CHALLENGED NOT ONLY POLICY DECISIONS THEMSELVES BUT ALSO THE LEGITIMACY OF THE BUREAUCRATIC INSTITUTIONS THAT PRODUCED THEM. THE AUTHOR FIMDS THAT CITIZEN ACTIVISM RAISED THE TECHNICAL COMPETENCE OF THE BUREAUCRACY IN THE MAKING OF ENERGY POL ICY, BUT AL SO ERODED THE LEGITIMACY OF THE TRADITIONAL POLICY-MAKING INSTITUTIONS.

04042 HAGGARD, S. (ED.); KAUFMAN, R.R. (ED.)

THE POLITICS OF ECONOMIC ADJUSTMENT-INTERNATIONAL CONSTRAINTS OF ECRIBUTIVE CONFLICTS, AND THE STATE PRINCETON UNIVERSITY PRESS, 1992, 352.

IN THE 1980 S SOME DEVELOPING COUNTRIES ADOPTED ORTHODOX MARKET-ORIENTED POLICIES IN RESPONSE TO INTERNATIONAL MARKET-ORIENTED POLICIES IN RESPONSE TO INTERNATIONAL
ECONOMIC CRISES, OTHERS EXPERIMENTED WITH ALTERNATIVE ECONOMIC CRISES, OTHERS EXPERIMENTED WITH ALTERNATIVE PROGRAMS, AND STILL OTHERS FAILED TO DEVELOP COHERENT ADJUSTMENT STRATEGIES OF ANY SORT. THESE ESSAYS OFFER COMPARATIVE ANALYSIS OF THESE OIVERGENT EXPERIENCES WITH ISSUES EXAMINED INCLUDE: EXTERNAL PRESSURES ON GOVERNMENTS; THE ROLE OF THE STATE IN THE ADJUSTMENT PROCESS; THE POLITICS OF INCOME DISTRIBUTION IN THE ADJUSTMENT PROCESS; AND, THE POLITICAL CORRELATES OF INFLATION AND STABILIZATION.

04043 HAHM, S.D.; KAMLET, M.S.; MOWERY, D.C.

U.S. DEFENSE SPENDING UNDER THE GRAMM-RUDMAN-HOLLINGS ACT, 1986-1989

PUBLIC ADMINISTRATION REVIEH, $52(1)$ (JAN 92), 8-15.

FOCUSING ON $1986-89$, THE AUTHORS FIND DEFENSE SPENDING

TO HAVE BEEN LOWER UNDER THE GRAMM-RUDMAN-HOLLINGS ACT (GRH) THAN IT WOULD OTHERHISE HAVE BEEN. GRH PARTIALLY, BUT NOT COMPLETELY, RETURNED DEFENSE SPENDING PRIORITIES AND DEFENSEFISCAL POLICY LINKAGES TO THEIR PRE-REAGAN STATUS. GRH RESTRAINED EXPENDITURES BY A SIMILAR PERCENTAGE IN ALL OF THE FUNCTIONAL DEFENSE CATEGORIES EXCEPT ONE--THE POLTICALLY SENSITIVE AREA OF RESEARCH, DEVELOPMENT, TEST, AND EVALUATION. THIS FINDING CONTRASTS WITH' PREVIOUS STUDIES THAT FOUND THE IMPACTS TO BE UNEVEN ACROSS FUNCTIONAL SPENDING CATEGORIES.

04044 HAIBO, L.

GOVERMMENT REPORT ACCENTS ON THE ECONOMY 9-10

BEIJING REVIEW, 35(12) (MAR 92), 9-10.

THIS ARTICLE REPORTS ON THE FIFTH SESSION OF THE SEVENTH NATIONAL PEOPLE'S CONGRESS WHICH OPENED ON MARCH 20 IN BEI JING AND WAS SCHEDULED TO CONCLUDE ON APRIL 3 . IN HIS REPORT LI PENG SAID THAT IN 1991 THE GROSS NATIONAL PRODUC INCREASED BY 7 PERCENT OVER THE PREVIOUS YEAR AND THAT THE DOMESTIC MARKET WAS BRISK. HE STRESSED THAT ORDER LEADS TO PROSPERITY AND CHAOS TO DECLINE AND THAT MAINTAINING SOCIAL AND POLITICAL STABILITY IS THE PREREOUISITE FOR REFORM AND AND POL ITICAL STABILITY IS THE PREREQUISITE FOR REFORM AND
OPENING TO THE OUTSIDE WORLD AND FOR ECONOMIC DEVELOPMENT.

04045 HAIBO, L.

JIANG ON DOMESTIC AND GLOBAL ISSUES

BEI JING REVIEW, 35(14) (APR 92), 10

ON APRIL 1, 1992 , CPC GENERAL SECRETARY JIANG ZEMIN DECLARED THAT' THE CPC IS UNITED IN SUPPORT OF DENG XIAOPING'S POLICIES OF REFORM AND OPENING TO THE OUTSIDE HORLD AND IS COMMITTED TO DENG'S THEORY OF BUILDING SOCIALISM WITH CHINESE CHARACTERISTICS.

04046 HAIBO, L.

PARTY CONGRESS INTRODUCED MARKET ECONOMY

BEI JING REVIEW, 35(42) (OCT 92), 9-10.
THE COMMUNIST PARTY OF CHINA HELD ITS 14TH NATIONAL CONGRESS ON OCTOBER 12-18, 1992. ADDRESSING THE OPENING SESSION, GENERAL SECRETARY JIANG ZEMIN SAID THAT THE OBJECTIVE OF CHINA'S ECONOMIC REFORM IS TO ESTABLISH A SOCIALIST MARKET ECONOMY THAT WILL FURTHER LIBERATE AND EXPAND THE COUNTRY'S PRODUCTIVE FORCES.

04047 HAIBO, L.

THE MAN WHO MAKES HISTORY

BEI JING REVIEW, 35(41) (OCT 92), 12-22.

ALTHOUGH DENG XIAOPING HOLDS NO OFFICIAL POST IN THE GOVERNMENT OR THE COMMUNIST PARTY STRUCTURE, HE IS STILL THE HELMSMAN OF HIS COUNTRY. THE PARTY'S 14TH CONGRESS HILL LEA

POL ITICAL THEORY.

04048 HAIMIN, H.

A FORMULA FOR POLITICAL STABILITY

BEIJING REVIEN, 35(27) (JUL 92), 16-17.

ON JUNE 10, 1992, KING BHUMIBOL ADJULYADEJ APPOINTED

ANAND PAYARACHUN TO SERVE AS PREMIER, BREAKING THE DEADLOCK

BETWEEN THE FORMER RULING FIVE-PARTY COALITION AND THE

OPPOSITION. THE APPOINTMENT OF A PREMIER AND A CABINET PAVES

THE WAY FOR THE DISSOLUTION OF PARLIAMENT AND THE SCHEDULING

OF NEN GENERAL ELECTIONS.

04049 HAINSHORTH, $P$.

1992 REgIONAL ELECTIONS IN FRANCE: A VOTE AGAINST THE ESTABLI SHMENT

REGIONAL POLITICS \& POLICY, 2(3) (FAL 92), 87-93.

THE 1992 REGIONAL ELECTION IN FRANCE WERE A CLEAR DEFEAT FOR THE PS. ALTHOUGH REGIONAL ELECTIONS, THEY REPRESENTED THE FIRST NATIONAL POLL SINCE THE 1989 EUROPEAN ELECTIONS AND ACCENTUATED THE LESSONS OF THE LATTER. CONTROVERSY SURROUNDED THE POSSIBILITY OF ELECTORAL REFORM PRIOR TO THE IMPORTANT 1993 LEGISLATIVE ELECTIONS. THE REGIONAL ELECTIONS

TESTIFIED TO ELECTORAL YOLATITILITY AND THE DISENCHANTMENT

WITH MAINSTREAM POLITIFCAL PARTIES.

04050 HAKIM, $P$

PRESIDENT BUSH'S SOUTHERN STRATEGY: THE ENTERPRISE FOR THE AMERICAS INITIATIVE

WASHINGTON QUARTERLY, 15(2) (SPR 92), 93-106

IN THE THIRTY YEARS SINCE THE ALLIANCE FOR PROGRESS WAS LAUMCHED, NO U.S. POLICY INITIATIVE TOWARD LATIN AMERICA HAS LAUNCHED, NO U.S. POLICY INITIATIVE TOWARD LATIN AMERICA BUSH'S ENTERPRISE FOR THE AMERICAS INITIATIVE OF JUNE 1990. VIRTUALLY EVERY LATIN AMERICAN AND CARIBBEAN LEADER APPLAUDED THE ENTERPRISE INITIATIVE AND ITS CALL FOR CLOSER U.S. ECONOMIC TIES WITH LATIN AMERICA. THE TIMING OF THE INITIATIVE WAS, IN FACT, AS IMPORTANT AS ITS SUBSTANCE. THE WANING OF THE COLD WAR AND THE CRUMBLING OF COMMUNISM IN EASTERN EUROPE A YEAR EARLIER HAD PRODUCED NEW ANXIETIES IN LATIN AMERICA. THIS ARTICLE STATES THAT THE U.S. WAS RIGHT IN LAUNCHING THE INITIATIVE.

04051 HAKIM, $P$.

THE ENTERPRISE FOR THE AMERICAS INITIATIVE: WHAT WASHINGTON WANTS

BROOKINGS REVIEH, 10(4) (FAL 92), 42-45.

PRESIDENT GEORGE BUSH'S ENTERPRISE FOR THE AMERICAS INITIATIVE WAS NOT LAUNCHED UNDER DURESS, NOR HAS IT INTENDED TO SET A NEW COURSE FOR U.S. TRADE POLICY. IT WAS INSTEAD A FRESH STATEMENT OF U.S. POLICY TOHARD LATIN AMERICA. AND SINCE ITS LAUNCHING IN JUNE 1990, IT HAS BECOME THE CENTERPIECE OF U.S. RELATIONS WITH LATIN AMERICA.

04052 HAKIM, $P$

THE UNITED STATES AND LATIN AMERICA: GOOD NEIGHBORS AGAIN? CURRENT HISTORY, $91(562)$ (FEB 92), 49-53.

WITH THE CONFLICTS OF THE 1980'S MOSTLY RESOLVED OR MUTED, THE UNITED STATES AND LATIN AMERICA HAVE BEGUN TO ENJOY' AN "ERA OF GOOD FEELING." THE IMPROVED RELATIONS MAY CONTINUE IF LATIN AMERICA REMAINS LARGELY DEMOCRATIC, CAN BEGIN TO DEMONSTRATE REAL ECONOMIC PROGRESS, AND MAINTAINS ITS OWN INTEREST IN CLOSER RELATIONS WITH THE USA. BUT THE POSITIVE TURN IN U.S. - LATIN AMERICAN RELATIONS SHOULD NOT BE EXAGGERATED OR OVERGENERALIZED BECAUSE THERE ARE SUBSTANTIAL WITH THE MORE THAN 30 LATIN AMERICAN AND CARIBBEAN COUNTRIES.

04053 HALBACH, $U$.

WORLD POLITICS AND INDIGENOUS DEVELOPMENT IN CENTRAL ASIA AUSSEN POLITIK 43(4) (1992) 381-391.

UNTIL RECENTLY, THE FORMER SOVIET COUNTRIES IN CENTRAL ASIA HERE BY AND LARGE TERRA INCOGNITA. SINCE THEIR INDEPENDENCE THEY HAVE BEEN A FREOUENT FOCUS OF INTERNATIONAL ATTENTION. THE REGION IS ONLY RARELY PRECEIVED WITH ITS INDIGENOUS CHARACTER AND WITH STATES WHICH HAVE RIGHTS AS COUNTRIES OF THEIR OWN. THIS IS ESSENTIAL IF THESE STATES ARE TO BE INTEGRATED INTO THE SYSTEM OF INTERNATIONAL RELATIONS AS STABLE PARTNERS. THIS ARICLE OUTLINES THE INTERNAL CONTEXT WITHIN WHICH THE CENTRAL ASIAN COUNTRIES 
EMBARKED UPON THEIR JOURNEY TOWARDS INDEPENDENCE AND THUS AT THE SAME TIME INTO WORLD POLITICS.

04054 HALBERSTAM, $D$. COMING IN FROM THE COLD WAR

WASHINGTON MONTHLY, 23(1,2) (JAN 91), 30-37.

THIS ARTICLE ARGUES THAT TO MAKE THE AMERICAN ECONOMY COMPETITIVE, AMERICANS NEED TO SHAKE OFF LONGSTANDING POLITICAL, EDUCATIONAL, AND PSYCHOLOGICAL HANG-UPS. ON THE POL ITICAL SIDE, AMERICA'S OBSESSION WITH THE COLD WAR HAS
MADE NATIONAL SECURITY THE PRE-EMINENT FOREIGN POL ICY OBJECTIVE. JAPAN, ON THE OTHER HAND, HAS EMPHASIZED ECONOMIC INTEREST HITH OBVIOUS RESULTS. JAPAN'S EMPHASIS ON EDUCATION, AND ON MAKING QUALITY PRODUCTS, NOT MERELY MAKING MONEY, ARE ALSO KEY FACTORS IN THEIR RISE AND THE CORRESPONDING ARE ALSO KEY FACTORS
AMERICAN DECLINE.

04055 HALE, $S$.

REINVENTING GOVERNMENT THE MINMESOTA WAY

REINVENTING GOVERNMENT THE MINNESOTA WAY
PUBLIC PRODUCTIVITY \& MANAGEMENT REVIEW, 15(2) (WIN 91), PUBLIC PROC
$123-132$.

IN MINMESOTA'S STRIVE TOWARD EXCELLENCE IN PERFoRMANCE PROGRAM (STEP) EMPLOYEES ARE INSTRUMENTAL IN INTRODUCING AND MANAGING CHANGE AT THE STATE LEVEL. PARTNERSHIPS BETHEEN LABOR AND MANAGEMENT AND BETWEEN STATE AND LOCAL GOVERMMENTS ARE ESSENTIAL TO THE SUCCESS OF THE PROGRAM. TRADITIONAL

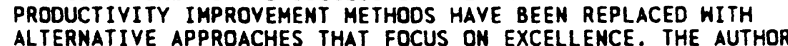
ALTERNATIVE APPROACHES THAT FOCUS ON EXCELLENCE. THE AUTHOR
CONCLUDES THAT INMOVATIVE GOVERMMENT IS NOT A CONTRAOICTION CONCLUDES THAT INMOVATIVE GOVERNMENT IS NOT A CONTRADICT IOH
IN TERMS. THAT THE SHIFT TOWARD ENTERPRISE WITH STEP HAS BEGUN AND THE SHIFT AWAY FROM BUREAUCRACY WITH ENTERPRISE MANAGEMENT IS CONTINUING. BOTH APPROACHES PROVIDE FRESH INSIGHTS INTO GOVERMMENT SERVICE.

04056 HALE, $H$.

TURKEY, THE MIDOLE EAST AND THE GULF CRISIS

INTERNATIONAL AFFAIRS, 68(4) (OCT 92), 679-692

CAN TURKEY ACT OUT A NEW ROLE CENTER STAGE IN THE MIDOLE EAST? THE AUTHOR LOOKS AT TURKEY'S ATTITUDE TO FOREIGN POLICY-MAKING IN THE PAST AND ITS PRESENT RELATIONS HITH NATO AND THE WEST. HE ASKS HHETHER THE GULF CRISIS AND THE KURISH QUESTION HAVE GIVEN FRESH IMPETUS TO TURKEY TO BECOME MORE ACTIVLY INVOLVED IN THE MIDDLE EAST.

04057 HALFACREE, $K$.

WHITHER THE UNIVERSAL FRANCHISE? THE POLITICAL COST OF RESIDENTIAL MIGRATIOM

PARLIAMENTARY AFFAIRS, 45(2) (APR 92), 164--172.

PARLIAMENTARY AFFAIRS, 45(2) (APR 92), 164--172. MOVING HOUSE IS A COMMON OCCURRENCE THROUGHOUT MOST
PEOPLE'S LIVES. THIS SUBSTANTIAL AMNUAL MOVEMENT OF PEOPLE PEOPLE'S LIVES. THIS SUBSTANTIAL ANNUAL MOVEMENT OF PEOPLE
HAS A NUMBER OF POTENTIALLY IMPORTANT POLITICAL IMPLICATIONS HAS A NUMBER OF POTENTIALLY IMPORTANT POLITICAL IMPLICATIONS THIS ARTICLE ILLUSTRATES HOH THE VERY ACT OF MIGRATION HAS THE EFFECT OF DISENFRANCHISING THE MIGRANTS THEMSELVES. THIS
OCCURS DIRECTLY--WITH MIGRANTS SHOWING HIGH LEVELS OF NONREGISTRATION ON THE ELECTORAL ROLL--AND INDIRECTLY--WITH REGISTERED MIGRANTS SHOHING HIGH LEVELS OF NON-VOTING. THE
ARTICLE CONCLUOES THAT THERE IS LITTLE EVIDENCE TO SUGGEST ARTICLE CONCLUDES THAT THERE IS LITTLE EVIDENCE TO SUGGEST
THAT THIS PROBLEM OF MIGRANT NON-VOTING IS BEING ALLEVIATED THAT THIS PROBLEM OF MIGRANT NON-VOTING IS BEING ALLEVIATED THROUGH THE POSTAL VOTING SYSTEM. IT
THE ELECTORAL REGISTRATION SYSTEM.

04058 HALL, A.

CONSTRUCTING DEMOCRACY: PROGRESS AND PROSPECTS IN NEPAL JOURNAL OF COMMONHEALTH AND COMPARATIVE POLITICS, $30(1)$ (MAR 92), 85-95.

NEPAL'S NEH CONSTITUTION AND THE RESULTS OF THE ELECTION WHICH FOLLOWED ITS PROMULGATION IN THE CONTEXT OF THE INTERNATIONAL ENVIRONMENT IN WHICH NEPALESE POLITICS OPERATES, ARE EXAMINED IN THIS ARTICLE WHICH CONSIDERS THE CHALLENGES HHICH LIE AHEAD FOR THE NEH POLITICAL SYSTEM. DESPITE THE CONTIMUING IMPORTANCE OF FAMILY AND XINSHIP LINKS IN POLITICS, PATRONAGE RELATIONSHIPS, LOOSE PARTY STRUCTURES AND FLUID CROSS-PARTY ALIGNMENTS, THE WILLINGNESS BY MOST SIGNIFICANT ELITE GROUPS TO ACCEPT A PLURALIST SYSTEM GIVES DEMOCRACY A FAIR CHANGE OF PUTTING DOWN ROOTS IN NEPAL.

04059 HALL, B.

LABOR LAH AND WORKERS' RIGHTS

NEW POLITICS, $13(1)$ (SUM 92), 122-133.

THE UNITED STATES IS THE ONLY COUNTRY WHICH CONTINUES TO CLING TO "EMPLOYMENT AT WILL" LEGAL PRINCIPLES. IN SHORT, CLING TO "EMPLOYMENT AT WILL" LEGAL PRINCIPLES. IN SHORT, EMPLOYERS MAY DISMISS THEIR EMPLOYEES "FOR GOOD CAUSE, FOR NO CAUSE, OR EVEN FOR CAUSE MORALLY HRONG, WITHOUT BEING THEREBY GUILTY OF LEGAL WRONG." THERE IS AN EXCEPTION. EVEN IN THE UNITED STATES, EMPLOYEES MAY BE PROTECTED IF THEY HAVE A UNION AND ARE COVERED BY A COLLECTIVE BARGAINING
AGREEMENT. HOWEVER, FEWER AND FEHER WORKERS ARE PROTECTED IN AGREEMENT. HOWEVER, FEWER AND FEHER WORKERS ARE PROTECTED IN
SUCH A MANNER. BECAUSE, AS A PRACTICAL MATTER, IN THE UNITED STATES, THEY ARE NOT FREE TO JOIN LABOR UNIONS. DE JURE THERE ARE; DE FACTO THEY'RE NOT.

04060 HALL, G.

BLACK-WHITE UNITY AND THE WORKING CLASS
POLITICAL AFFAIRS, LXX(2) (FEB 91), 2-4.

THIS ARTICLE EXAMINES THE "HISTORIC ROLE" AND NATURE OF THE AFRICAN AMERICAN-LABOR ALLIANCE IN THE UNITED STATES. IT HAS ROOTS IN HISTORY, AND IS FED BY PRESENT-DAY OBJECTIVE FACTORS. IN THE VERY CENTER OF THE COMMUNITY IS THE DEVELOPING UNITED, INTEGRATED BLACK AND WHITE WORKING CLASS, EVER MORE CONSCIOUS OF ITS CLASS NATURE AND ITS ASSIGNED ROLE IN PRESENT AND FUTURE HISTORY. BLACK WORKERS, WHO ARE PART OF BOTH THE U.S. WORKING CLASS AND THE OPPRESSED AFRICAN AMERICAN PEOPLE, ARE OF CARDINAL IMPORTANCE TO INHERENT IN CAPITALISM.

04061 HALL, G.

CHARTING A RENEWED WORKINGCLASS COURSE

POLITICAL AFFAIRS, LXX(B) (AUG 91), 1-9.

THIS ARTICLE IS A SPEECH BY GUS HALL, NATIONAL CHAIRMAN OF THE COMMUNIST PARTY, USA. HE ARGUES THAT THIS IS A MOMENT WHEN WORKINGCLASS FORCES ARE ON THE MOVE, WHEN THE ANTIMONOPOLY AND ANTI-CORPORATE SENTIMENT IS HEIGHTENING, WHEN MONOPOLY AND ANTI CCORPORATE SENTIMENT IS HEI HHTENING, WHEN
HORKINGCLASS FORCES ARE MOVING WITH RENEWED VIGOR INTO THE HORKINGCLASS FORCES ARE MOVING WITH RENEWED VIGOR INTO THE
ARENA OF MASS ACTION, INDEPENDENT POLITICAL ACTION AND UNITY ARENA OF MASS ACTION, INDEPENDENT POLITICAL ACTION AND UNITY
THE COMMUNIST PARTY (USA) HAS A BIG ROLE TO PLAY IN THE THE COMNUNIST PARTY (USA) HAS A BIG ROLE TO PLAY IN THE COMING PERIOD. WHE EFFECTS ONES INDUSTRIAL CDNCENTRATION DEPEND ON HOW WORKINGCLASS AND INDU
POLICY IS DEVELOPED AND APPLIED.

04062 HALL, G.

COMMUNISTS FACE THE FUTURE

POLITICAL AFFAIRS, $71(12)$ (DEC 92), 20-22; 37.

THESE THO PIECES BY GUS HALL, NATIONAL CHAIRMAN OF THE COMMUNIST PARTY, USA, HERE ORIGINALLY PRESENTED TO AUDIENCES ABROAD. HALL DISCUSSES THE DISSOLUTION OF THE USSR AND THE COLLAPSE OF THE COMHUNIST PARTY OF THE SOVIET UNION AND THEIR CAUSES. HE ALSO ESTIMATES THE ROLE PLAYED BY GORGBACHEV AND YELTSIN AND THE NEED FOR A HORLD CONFERENCE OF COMMUNIST PARTIES.

04063 HALL, G.; WHEELER, T.

ON CPUSA ELECTORAL AND LEGISLATIVE POLICY

POL ITICAL AFFAIRS, LXX(9-10) (SEP 91), 9-15, 29.

THE 1992 ELECTIONS HILL TAKE PLACE WHILE THE POLITICS OF THE UNITED STATES ARE MOVING TO THE RIGHT. THIS ARTICLE EXAMINES WAYS IN WHICH THE ULTRA-RIGHT STRANGLEHOLD ON THE EXECUTIVE BRANCH CAN BE BROKEN, HOH THE THO-PARTY SYSTEM CAN BE REFORMED, ANO HOW POLITICAL PARTICIPATION CAN BE FOSTERED. THE COMMUNIST PARTY (USA) SUGGESTS THE FOLLOHING GOALS: THE COMMUNIST PARTY (USA) SUGGESTS THE FOLLOHING GOALS:
BUILD A NETHORK OF INDEPENDENT FORMS OF POLITICAL ACTION; BUILD A NETHORK OF INDEPENDENT FORMS OF POLITICAL ACTION;
HELP IN THE ORGANIZATION OF POLITICAL ACTION COMMITTEES IN HELP IN THE ORGANIZATION OF POLITICAL ACTION COMMITTEES IN ALL THE TRADE UNION LOCALS AND CENTRAL LABOR BODIES; HELP THE ORGANIZATION OF RAINBOH COALITION ORGANIZATIONS; BUILD ELECTORAL WORK IN ALL LEFT ORGANI ZATIONS; HELP ERGATIZ THE STRUGGLE FOR PROPORT PONAL REPRESENTATION

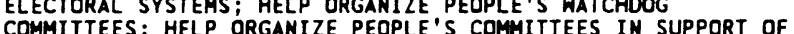
PEOPLE'S CANDIDATES: AND HELP SET UP COMMITTEES IN SUPPORT PEOPLE'S CANDIDATES; AND
OF COMMUNIST CANDIDATES.

04064 HALL, G.

PETTY BOURGEOIS IDEOLOGY

POLITICAL AFFAIRS, LXX(4) (APR 91), 1-3.

THIS ARTICLE EXAMINES THE EXISTENCE AND ROLE OF THE PETTY BOURGEOIS IN BOTH CAPITALIST AND SOCIALIST SOCIETIES. THE RELATIVE SIZE OF THE PETTY-BOURGEOIS SECTORS HAS INCREASED THROUGHOUT THE WORLD. THIS INCREASE HAS BEEN RESPONSIBLE FOR MANY OF THE SETBACKS THAT SOCIALISH HAS SUFFERED, ESPECIALLY IN EASTERN EUROPE. THEIR IDEOLOGY IS MARKED BY WAVERING AND SHIFTING DISGUISED AS NEUTRALITY. THE ARTICLE CONCLUDES THAT WINNING THIS LARGE AND RELATIVELY INFLUENTIAL CLASS OVER TO THE SIDE OF THE WORKING CLASS IS AN IMPORTANT PRECURSOR TO THE SOCIALIST TRANSFORMATION OF THE WORLD.

$04065 \mathrm{HALL}, \mathrm{G}$.

THE REVOLUTIONARY PROCESS AND THE NEW WORLD BALANCE OF FORCES

POLITICAL AFFAIRS, 71(4) (MAY 92), 1-12.

THIS ARTICLE CONSIDERS RECENT CHAMGES IN THE SOVIET UNION, EASTERN EUROPE AND ELSEWHERE, AND SEEKS TO DETERMINE THE CAUSES OF THESE CHANGES AND THEIR IMPLICATIONS FOR SOCIALISH. IT ARGUES THAT GORBACHEV'S "NEW THINKING" IN THE SOVIET UNION ALLOWED THE "AGE-OLD VIRUS OF OPPORTUNISM" TO SOVIET UNION ALLOWED THE "AGE-OLD VIRUS OF OPPORTUNISM" TO GERMINATE. COMMUNIST PARTIES THE WORLD OVER WERE AFFLICTED WITH GROWING NUMBERS OF SO-CALLED ADHERENTS WHO NEGLECT
THE CLASS BASIS OF SOCIALISM AND WHO SOUGHT TO MERGE THE CLASS BASIS OF SOCIALISM AND HHO SOUGHT TO MERGE SOCIALISH WITH CAPITALISM. THE SHORT-TERM RESULT OF THIS OPPORTUNISH WAS THE COLLAPSE OF SOCIALISM IN THE USSR AND
EAST EUROPE AND THE DISARRAY OF MANY WESTERN COMMUNIST EAST EUROPE AND THE DISARRAY OF MANY WESTERN COMMUNIST MOVEMENTS. HOHEVER, THE DEMISE OF SOCIALISM IS ONLY TEMPORARY. THE ARTICLE ARGUES THAT THERE IS NO BASIC FLAN IN THE THEORIES OF MARXIST-LENINSIM AND DIALECTICAL MATERIAL
CAPITALISM, ON THE OTHER HAND, IS PLAGUED HITH SYSTEMIC FLAWS AND WILL SOON BE SUBJECT TO POWERFUL FORCES OF CHANGE. 
04066 HALL, G. U.S. CAPITALISM: NEW STAGE OF THE GENERAL CRISIS POL ITICAL AFFAIRS, 71(11) (NOV 92), 2-3;15 1992 VOTING PATTERNS SHOW THAT AMERICANS FEEL THAT THE ECONOMY IS IN A MESS. TO HAVE AN IMPACT ON THE ECONOMIC "BLACK HOLE" THERE WILL HAVE TO BE A MAJOR SHIFT IN POLICY "BLACK HOLE" THERE WILL HAVE TO BE A MAJOR SHIFT IN POLICY BY THE GOVERNMENT AND THE CORPORATIONS. GUS HALL DISCUSSE
DOWNSIZING THE ECONOHY AND IMPERIALIST TRADE PACTS AND ARGUES THAT WHETHER OR NOT THE CORPORATE RULING CLASS AND THE NEW ADMINISTRATION WILL RESPOND IN A WAY THAT IMPROVES THE LOT OF THE HORKING CLASS DEPENDS ON THE ABILITY OF TRADE UNIONS TO ORGANIZE THE PEOPLE AROUND DEMANDS THAT REFLECT THE PERMANENT CRISIS DIMENSIONS AND THE SUFFERING OF THE THE PERMANENT CRISIS DIMENS
MAJORITY OF THE U.S. PEOPLE.

04067 HALL, I.

SUMURAI LEGACIES, AMERICAN ILLUSIONS

NATIONAL INTEREST, 28 (SUM 92), 14-25.

A MAJOR WATERSHED IN THE HISTORY IN THE HISTORY OF JAPANU.S. RELATIONS IS THE ADVENT OF "REVISIONISM," A FRESH AND UNVARNISHED LOOK AT THE STRUCTURE AND EXERCISE OF JAPANESE ECONOMIC AND POLITICAL POHER. REVISIONISTS CHALLENGE THE NOTION THAT JAPANESE INSTITUTIONAL ARRANGEMENT, PROCEDURES MOTIVATIONS, AMD PURPOSES ARE FUNDAMENTALLY SIMILAR TO THOSE OF THE UNITED STATES. EVIDENCE THAT REVISIONIST PERSPECTIVES WERE BEGINNING TO INFECT THE AMERICAN ESTABLISMENT ITSELF, BROUGHT ON A PREDICTABLE PANICKY JAPANESE ATTEMPT TO DERAIL THE ARGUMENT. THIS PAPER SUGGESTS THAT AMERICA'S RESPONSIBLITY IS TO SEE THAT A TRUE DIALOGUE DEVELOPS AND THAT IT MUST GUARANTEE THAT STRAIGHTFORWARD DISCUSSION OF JAPAN DOES NOT BECOME A POLITICAL AND CULTURAL TABOD IN THE UNITED STATES.

$04068 \mathrm{HALL}$, II, A.

8REATHE DEEP, AMERICA, WHILE LIBERTY IS STILL IN THE AIR

FREEMAN, 42(4) (APR 92),

THE STATE OF LIBERTY IN AMERICA TODAY IS NOT THE BEST

EXAMPLE THE SOVIETS COULD FOLLOW - THE FOUNDER'S LIBERTY IS.

RATHER THAN USE THE SOVIET PEOPLE'S ECONOMIC PLIGHT TO ENACT SOME GRAND BARGAIN. THE U.S. SHOULD BE FLATTERED BY ITS CLAIM TO MORAL AUTHORITY, AND USE THE OPPORTUNITY TO REFLECT SOVIET PEOPLE ARE STARTING OUT MUCH AS AMERICAN'S DID AFTER THE REVOLUTIONARY WAR.

04069 HALL, J.

THE PEACE ACCORD--QUD VADIS?

SOUTH AFRICA FDUNDATION REYIEW, 18(5) (MAY 92), 3

NINE MONTHS AFTER THE SIGNING OF THE NATIONAL PEACE ACCORD, VIOLENCE IS FAST BECOMING A WAY OF LIFE IN MANY AREAS OF SOUTH AFRICA. HOWEVER, THE PEACE ACCORO MECHANISM OF REGIONAL AND LOCAL OISPUTE RESOLUTION COMMITTEES IS HARNESSING THE RESPONSIBLE PEOPLE WITHIN THE COMMUNITIES TO COMBAT VIOLENCE. BUSINESS, CHURCHES, AND POLITICAL LEADERS ARE THROWING THEIR WEIGHT BEHIND THE PROCESS. BUT THE HATRED AND MISTRUST IS SO DEEPLY ROOTED THAT THE MOVES TOWARD PEACE ARE GUARANTEED TO BE SLOW AND GRADUAL AT BEST. WHAT SOUTH AFRICA NEEDS NOW IS AN INTERIM GOVERNMENT TO BOTH CONTROL AND GIVE CREDIBILITY TO THE POLICE. THE ELECTION OF TOWM COUNCILS FOR AREAS HICH COMPRISE ALL ETHNIC GROUPS IS A MATTER OF UTMOST URGENCY AND WILL LEAD TO THE HARNESSING OF SKILLS WHICH ALREADY EXIST IN THE SO-CALLED WHITE COMMUNITIES. IF NECESSARY A STATE OF EMERGENCY SHOULD BE DECLARED IN UNREST AREAS UNTIL LAN AND ORDER HAS BEEN RESTORED.

$04070 \mathrm{HALL}, \mathrm{J}$.

WHEN POLITICAL CAMPAIGMS TURN TO SLIME: ESTABLISHING A VIRGINIA FAIR CAMPAIGN PRACTICES COMMITTEE

JOURNAL OF LAW \& POLITICS, VIII(2) (WIN 91), 353-378. MEGATIVE CAMPAIGNING AND UNFAIR CAMPAIGN TACTICS HAVE EXISTED AS LONG AS POLITICAL CAMPAIGNS. HOWEVER, WITH THE INCREASE IN THE USE OF TELEVISION AS THE PRINCIPLE MEDIUM FOR POLITICAL COMMUNICATION, THE NEGATIVE ATTACK HAS BECOME FOR POLITICAL COMMUN STANDARD TACTIC OF MANY CAMPAIGNS. THE 1990 MIDTERM A STANDARD TACTIC OF MANY CAMPAIGNS. THE 1990 MIDTERM ELECTIONS OFFERED A NUMBER OF CAMPAIGNS THAT DEGENERATED TO LOW LEVELS EARLY IN THE GENERAL ELECTION CONTESTS AMD
PRIMARY CAMPAIGNS. THIS NOTE EXPLORES THE LEGAL AND PRIMARY CAMPAIGNS. THIS NOTE EXPLORES THE LEGAL AND POLITICAL ISSUES THAT ARE INVOLVED IN ANY ATTEMPT TO CURTAIL NEGATIVE CAMPAIGN TACTICS. IT ADVOCATES THE ESTABLISHMENT A CITIZEN COMMITTEE ENTITLED THE VIRGINIA FAIR CAMPAIGH PRACTICES COMMITTEE, WITH THE PURPOSE OF ELEVATING THE COMMONWEALTH OF VIRGINIA.

04071 HALL, M.

ELECTORAL POLITICS AND STRATEGIC VOTING IN STATE SUPREME COURTS

THE JOURNAL OF POLITICS, 54(2) (MAY 92), 427-446.

THAT STATE SUPREME COURT JUSTICES ACT STRATEGICALLY TO

MINIMIZE ELECTORAL OPPOSITION IS SUGGESTED. IN ORDER TO

APPEASE THEIR CONSTITUENCIES, JUSTICES HHO HAVE VIEHS

CONTRARY TO THOSE OF THE YOTERS AND THE COURT MAJORITY, AND WHO FACE COMPETITIVE ELECTORAL CONDITIONS WILL VOTE WITH THE
COURT MAJORITY INSTEAD OF CASTING UNPOPULAR DISSENTS ON POLITICALLY VOLATILE ISSUES. USING PROBIT, MODELS WERE ESTIMATED OF THE EFFECTS OF SEVERAL TYPES OF ELECTORAL SOURCES ON DEATH PENALTY VOTES FROM 1983 THROUGH 1988 IN
FOUR SOUTHERN STATE SUPREME COURTS. IN ESSENSE, CONSTITUENCY FNFLUENCE IN STATE SUPREME COURTS IS ENHANCED BY COMPETITIVE ELECTORAL CONDITIONS AND EXPERIENCE WITH ELECTORAL POLITICS.

$04072 \mathrm{HALL}, \mathrm{M.}$; BRACE. P.

TOWARD AN INTEGRATED MODEL OF JUDICIAL VOTING BEHAVIOR AMERICAN POLITICS QUARTERLY, 20(2) (APR 92), 147-168. AN INITIAL STEP TOWARD THE DEVELOPMENT OF AN INTEGRATED MODEL OF JUDICIAL DECISION MAKING IS MADE BY THE AUTHORS. THEIR STUDY SYNTHESIZES ELEMENTS DERIVED FROM CONTEXTUAL AND ATTITUDINAL PERSPECTIVES BY APPLICATION OF A NEOINSTITUTIONAL PERSPECTIVE. THE NEO-INSTITUTIONAL APPROACH EMPHASIZES THE INTERACTION OF ENVIRONMENTAL FORCES ANO INDIVIDUAL PREFERENCES WITH INSTITUTIONAL RULES AND STRUCTURES. JUDICAL VOTING ON DEATH PENALTY CASES FROM 1980 TO 1988 IN FOUR STATES ARE EXAMINED EMPLOYING POOLED PROBIT ANALYSIS. THE RESULTS INDICATE THAT INSTITUTIONAL RULES ARE IMPORTANT INFLUENCES ON JUDICIAL CHOICE.

04073 HALL, M.A.

FROM MARX TO MUHAMMAD

CULTURAL SURYIVAL QUARTERLY, 16(1) (WIN 92), 41-44.

IN MANY WAYS, THE CURRENT SITUATION IN UZBEKISTAN IS

TYPICAL OF WHAT IS HAPPENING THROUGHOUT THE FORMER SOVIET UNION. THE COLLAPSE OF COMMUNISM HAS ENGENDERED A DEEP POLITICAL CRISIS. IN MANY CASES, NATIONALISM IS RUSHING IN TO FILL THE IDEOLOGICAL VOID, AND THIS IS CERTAINLY TRUE IN CENTRAL ASIA. AS NATIONALIST SENTIMENT SUPPLANTS MARXISMLENINISM IN THE HEARTS AND MINDS OF THE PEOPLE. IT LIKEWISE ERODES THE IDEOLOGICAL BASE FROM WHICH THE CONSERVATIVE LEADERSHIP DERIVES ITS LEGITIMACY. IN CENTRAL ASIA, THE FLEDGLING NATIONAL IDEOLOGY MANIFESTS ITSELF MOST

PROMINENTLY IN A RENEWED INTEREST IN THE PAST.

$04074 \mathrm{HALL}, \mathrm{R}$.

MEASURING LEGISLATIVE INFLUENCE

LEGISLATIVE STUDIES QUARTERLY, 27 (2) (MAY 92), 205-233.

A TECHNIQUE FOR MEASURING LEGISLATIVE INFLUENCE BASED ON A SURVEY INSTRUMENT ADMINISTERED TO CONGRESSIONAL STAFFERS IS PRESENTED. THE INSTRUMENT ELICITS INFORMATIONS ABOUT THE EFFECT OF INDIVIDUAL MEMBERS' PREFERENCES ON THE SUBSTANCE OF SPECIFIC PIECES OF LEGISLATION. THE MEASURE STANDS UP WELL UNDER SYSTEMATIC TESTS OF RELIABILITY AND VALIDITTY, AND IS APPLICABLE TO A WIDE RANGE OF BILLS FOR WHICH PLAUSIBLE ASSUMPTIONS OR REASONABLE INFERENCES ABOUT MEMBER PREFERENCES ARE NOT EASILY MADE.

04075 HALL, S.

BRAVE NEW WORLD

SOCIALIST REVIEW, 21(1) (JAN 91), 57-64.

THIS ARTICLE EXAMINES THE STRUCTURE AND COMPOSITION OF

THESE "NEW TIMES." KNOWN BY SEVERAL TERMS INCLUDING

"POSTINDUSTRIAL," "POST-FORDIST," "REVOLUTION OF THE SUBJECT,

" AND POSTMODERN," THIS TRANSFORMED SOCIETY HAS MANY

IMPLICATIONS FOR' POLITICS ON THE LEFT. THE "PROMISE" OF

MODERNITY HAS BECOME, AT THE END OF THE 2OTH CENTURY,

CONSIDERABLY MORE AMBIGUOUS, ITS LINKS WITH SOCIALISM AND THE LEFT MUCH MORE TENUOUS. THE SHEEPING CHANGES HAS ALSO MADE IT DIFFICULT TO CONCEIVE OF "THE INDIVIDUAL" IN TERMS OF A HHOLE AND COMPLETED EGO OR AUTONOMOUS "SELF." THE "SELF" IS EXPERIENCED AS MORE FRAGMENTED AND INCOMPLETE, COMPOSED OF MULTIPLE "SELVES" OR IDENTITIES IN RELATION TO THE DIFFERENT SOCIAL WORLDS INHABITED.

04076 HALL, T.

THE HUMANITARIAN AGEMDA IN THE NEW WORLD ORDER MEDITERRANEAN QUARTERLY: A JOURNAL OF GLOBAL ISSUES, $3(4)$

( FAL 92), 1-9

PORLD CONTEXT HAS MADE SOME ISSUES,

PASISTANCE, MORE CHALLENGING THAN EVER BEFORE. WHILE THE ASSISTANCE, MORE CHALLENGING THAN EVER BEFORE. WHILE THE EMERGENCE OF A NUMBER OF PRESENT CONFLICTS IN THE WORLD IS RELATL TS THEMSELYES HAVE MUCH DEEPER ROOTS. THIS ARTICLE EXPLORES THE TRAGEDY OF SOMALIA, REGIONAL INITIATIVES, THE HUMANITARIAN DEBATE, LESSONS FROM IRAQ, THE UNITED NATION'S HUMANITARIAN DEBATE, LESSONS FROM IRAQ, THE UNITED NATION
ROLE AND FINALLY, THE ROLE OF THE UNITED STATES. IT
CONCLUDES THE RECENT EVENTS HAVE BEGUN TO POINT TO A NEW CONCLUDES THE RECENT EVENTS HAVE BEGUN TO POINT TO A NEW INTERNATIONAL FRAMEWORK FOR HUMANITARIAN ASSISTANCE THAT CALLS ON THE UN TO ELEVATE THE RIGHT
PAR WITH THAT OF ITS MEMBER STATES.

04077 HALLAJ, M. ALTHOUGH YITZHAK RABIN IS NO DE GAULLE, he MAY Yet BeCOME ONE WASHINGTON REPORT ON MIDOLE EAST AFFAIRS, XI(3) (AUG 92), 10.

THE AUTHOR DISCUSSES THE SIGNIFICANCE OF THE ELECTION OF YITZHAK RABIN TO THE ISRAELI PRIME MINISTERSHIP AND WHAT IT MAY MEAN FOR THE MIDOLE EAST PEACE NEGOTIATIONS. 
04078 HALLAJ, M.

PALESTINE: ARABS DISCOURAGED

MIDOLE EAST INTERNATIONAL, 440(440) (DEC 92), 5-6

THE CURRENT ROUND OF PEACE TALKS IS NOT OVER, BUT NO BREAKTHROUGHS LOOM OVER THE HORIZON. THE PALESTINIANS ALMOST STAYED AWAY THIS TIME. THEY ARE DISCOURAGED BY A LACK OF MEANINGFUL PROGRESS IN PREVIOUS ROUNDS AND ALSO BY A LACK OF SIGNS OF POSSIBLE FUTURE PROGRESS. THE SMALL GAINS MADE IN PREVIOUS ROUNDS WILL REMAIN THE PLATEAU UNTIL THE CLINTON ADMINISTRATION MAKES ITS INTENTIONS CLEAR. THIS ARTICLE REPORTS ON WHAT CLINTON COULD BUILD ON.

04079 HALLAJ, M.

PEACE TALKS ON HOLD

MIDOLE EAST INTERNATIONAL, 438(438) (NOV 92), 5-6.

IT IS ALREADY BEING SAID THAT THE GREATEST ACHIEVEMENT OF THE SEVENTH ROUND OF ARAB-ISRAELI PEACE TALKS IS THAT IT WILL NOT BE THE LAST. IT IS OBVIOUS THAT THE TALKS ARE STALLED. THE ARAB DELEGATIONS ARE STILL UNABLE TO EXTRACT STALLED. THE ARAB DELEGATIONS ARE STILL UNABLE TO EXTRACT FROM ISRAEL RECOGNITION THAT THE LAND FOR PEACE FORMULA
GOVERNS THE NEGOTIATING PROCESS. THE LEBANESE ARE STILL UNABLE TO CONVINCE ISRAEL THAT PEACE REQUIRES ITS WITHNITHDRANL FROM SOUTH LEBANON. THIS ARTICLE EXPLORES THE PASSIVE CO-SPONSORS AND THE MULTILATERAL TALKS WHICH ENDED
WITH NOTHING MORE THAN AN AGREEMENT TO TRY TALKING AGAINS.

04080 HALLAJ, M.

PEACE TALKS: THE ILLUSION OF OPTIMISM EXPOSED MIDDLE EAST INTERNATIOMAL, (434) (SEP 92), 3-4.

WHEN THE SIXTH ROUND OF ARAB-ISRAELI PEACE TALKS--WHICH BEGAN ON 24 AUGUST-WENT INTO RECESS ON 3 SEPTEMBER, IT WAS HIDELY BELIEVED THAT THE SECOND HALF WOULD FINALLY JUSTIFY THE EXPECTATIONS UNLEASHED BY THE RETURN OF LABOR TO POWER IN ISRAEL. BEFORE THE RECESS, THERE WAS A UNANIMOUS OPINION THAT THE TONE OF THE TALKS WAS MUCH IMPROVED, AND THAT THE PARTIES WERE SHOWING GREATER SENSITIVITY TO EACH OTHER'S CONCERNS. HOWEVER, IT IS NOW APPARENT THAT ISRAEL'S OVERTURES TO SYRIA FALL FAR SHORT OF THE SYRIANS' DEMANDS, YET THREATEN TO DIVIDE THE ARAB RAHKS ON OTHER ISSUES. THE PALESTINIANS CONTINUE TO ARGUE THAT THE ISRAELIS ARE ATTEMPTING TO VIOLATE THE TERMS OF REFERENCE OF THE PEACE TALKS AND REDEFINE THEM IN A HAY THAT WOULD FAVOR ISRAEL. THEY INSIST THAT ISRAEL'S POLICIES AND POSITIONS ARE THEY INSIST THAT ISRAEL'S POL ICIES AND POSITIONS ARE
ATTEMPTS TO PRE-EMPT THE LAND-FOR-PEACE FORMULA. AS THE SIXTH ROUND NEARS COMPLETION, HOPES FOR PROGRESS ARE FADING AND EXPECTATIONS ARE ALREADY SHIFTING TO A FUTURE ROUND.

04081 HALLAJ, M.

ROUND SIX: HOPE THEN DISAPPOINTMENT

MIDDLE EAST INTERNATIONAL, (433) (SEP 92), 3-4.

THE SIXTH ROUND OF ARAB-ISRAELI PEACE TALKS OPENED ON 24 AUGUST ON AN UPBEAT NOTE (INITIALLY MARRED BY A ONE-DAY THE PALESTINIAN DELEGATION DUE TO ISRAELI TRAVEL RESTRICTIONS), AND WENT INTO RECESS AMI ISRAEL'S NEW LABOR-LED GOVERNMENT TO WORK FOR PEACE HITH A COMMITMENT THAT ITS PREDECESSOR, THE LIKUD GOVERNMENT OF YITZHAK SHAMIR, WAS NEVER WILLING TO TAKE. BUT, WHILE THE TONE OF THE NEGOTIATIONS HAS CERTAINLY BEEN MORE UPBEAT, ISRAELI PROPOSALS DN MOST OF THE MAJOR ISSUES REMAINS UNCHANGED. THE ISRAELI-JORDANIAN TRACK BROKE UP ON A SOUR NOTE, WITH THE JORDANIANS ACCUSING THE ISRAELIS OF REFUSING TO CONCEDE TO THEIR CONCERNS. THE SYRIANS, HOWEVER, HOPE THAT THE ISRAEL IS HAVE DEPARTED TO THINK SERIOUSLY ABOUT THEIR LATEST PROPOSAL FOR A SETTLEMENT (LAND FOR PEACE IM THE GOLAN HEIGHTS), BUT NO MAJOR PROGRESS WAS ANNOUNCED BEFORE THE RECESS. PALESTINIAN NEGOTIATIORS HAVE SPOKEN WITH GUARDED CONFIDENCE ABOUT THE FUTURE OF THE PROCESS. IN SHORT, THE SIXTH ROUND OF NEGOTIATIONS HAS NOT SEEN ANY CONCRETE PROGRESS TOWARDS PEACE, BUT THE PARTIES INVOLVED REMAIN HOPEFUL ABOUT THE FUTURE.

04082 HALLAJ, M.

THE SEVENTH ROUND OF THE BILATERAL PEACE TALKS

MIDOLE EAST INTERMATIOMAL, (437) (NOY 92) TA

THE SEVENTH ROUND OF ARAB-ISRAELI PEACE TALKS BEGAN IN WASHINGTON UNDER THE SHADOH OF COMPLEX ANO UNPREDICTABLE CIRCUMSTANCES. IT IS TESTIMONY TO HOW LITTLE HAS BEEN ACCOMPLISHED THAT THE GREATEST ACHIEVEMENT THUS FAR IS THE FACT THAT THE MEGOTIATIDHS HAVE MOT BROKEN DOWH THE MOST MEANINGFUL ADVANCE HAS BEEN IN THE ISRAELI-JORDANIAN SEGHENT, MEANINGFUL ADVANCE HAS BEEN IN THE ISRAELI-JORDANIAN SEGHENT,
WHERE THE PARTIES HAVE AGREED ON AN AGENDA. THE PALESTINIANWHERE THE PARTIES HAVE AGREED ON AN AGENDA. THE PALESTIMTA
ISRAELI TRACK CONTINUES TO BE PLAGUED BY ARGUMENTS ABOUT "FRAME OF REFERENCE," A DISPUTE FUELED BY ISRAEL'S REFUSAL "FRAME OF REFERENCE," A DISPUTE FUELED BY ISRAEL'S REFUSAL
TO CONCEDE THAT SECURITY COUNCIL RESOLUTION 242 APPLIES TO THE INTERIM AS WELL AS THE ULTIMATE STATUS NEGOTIATIONS.

04083 HALLIDAY, F.; MILIBAMD, R.; RUSTIN, M.

AN ENCOUNTER WITH FUKYAMA

89-113

THE AUTHORS RESPOND TO FRANCIS FUKUYAMA'S THESIS THAT THE COLLAPSE OF COMMUNISM PROVES THAT HISTORY HAS ENDED, SINCE THERE IS NOW NO ALTERNATIVE TO LIBERAL CAPITALISM.
THOUGH FUKUYAMA GREATLY OVERESTIMATES THE ACHIEVEMENTS AND POTENTIAL OF LIBERAL CAPITALISM AND TAKES NO ACCOUNT OF THE CASE FOR DEMOCRATIC SOCIALISM, HIS WORK, WHICH DEVELOPS THE TRADITION OF HEGEL'S PHILOSOPHY OF HISTORY, HAS A SCOPE ANO THOUGHTFULNESS THAT SETS IT APART FROM SIMPLE WESTERN TRIUMPHALISM.

04084 HALLIDAY, F.

INTERNATIONAL SOCIETY AS HOMOGENEITY: BURKE, MARX, AND FUKUYAMA

MILLENNIUM, 21(1) (SPR 92), 435-462.

THE TERM "INTERNATIONAL SOCIETY" HAS BEEN EMPLOYED BY BOTH REALISTS AND TRANSNATIONALISTS IN INTERNATIONAL RELATIONS. THIS PAPER ARGUES FOR ANOTHER UNDERSTANDING OF INTERNATIONAL SOCIETY BASED ON THE NOTION OF HOMOGENEITY IN THE WAY THAT SOCIETIES ARE ORGANIZED. THIS APPROACH CDNSIDERS HOW, AS A RESULT OF INTERNATIONAL PRESSURES, CONSIDERS HOW, AS A RESULT OF INTERNATIONAL PRESSURES, DOMESTIC ARRANGEMENTS. THIS TRADITION IS IDENTIFIED IN THE DOMESTIC ARRANGEMENTS. THIS TRADITION IS IDENTIFIED IN THE
THOUGHT OF THREE THINKERS: BURKE'S ANALYSIS OF THE FRENCH REVOLUTION, MARX'S ANALYSIS OF CAPITALISM AS A GLOBAL REVOLUTION, MARX'S ANALYSIS OF CAPITALISM AS A GLOBAL
PHENOMENON, AND FUKUYAMA'S ACCOUNT OF "THE END OF HISTORY."

04085 HALLIN, D.C.

SOUND-BITE DEMOCRACY

WILSON OUARTERLY, XVI (2) (SPR 92), 34-37.

THE EMERGENCE OF THE SHORT SOUND BITE AS THE PRINCIPAL MEDIUM FOR POL ITICAL DISCDURSE REFLECTS A FUNDAMENTAL CHANGE IN THE STRUCTURE OF TV NEWS STORIES AND THE ROLE OF THE JOURNALIST IN PUTTING THEM TOGETHER. TODAY, TV NEWS IS MORE "MEDIATED" BY JOURNALISTS THAN IT HAS DURING THE $1960^{\prime} S$ AND EARLY 1970'S. ANCHORS AND REPORTERS WHO ONCE PLAYED A RELATIVELY PASSIVE ROLE NOW ACTIVELY "PACKAGE" THE NEWS. THIS NEW STYLE OF REPORTING IS NOT SO MUCH A PRODUCT OF JOURNALISTIC HUBRIS AS THE RESULT OF CONVERGING TECHNOLOGICAL, POLITICAL, AND ECONOMIC FORCES THAT HAVE ALTERED THE IMPERATIVES OF TV NEWS.

04086 HALPERN, R.

RACE, ETHNICITY, AND UNION IN THE CHICAGO STOCKYARDS, 19171922

INTERNATIONAL REVIEW OF SOCIAL HISTORY, XXXVII(1) (1992),

$25-58$.

THIS ARTICLE EXAMINES THE WAYS IN HHICH UNIONIZATION IMPACTED UPON RACE RELATIONS IN CHICAGO'S MEATPACKING INDUSTRY. IT FOCUSES UPON A PERIOD WHEN A DYNAMIC WORKINGCLASS MOVEMENT SOUGHT TO OVERCOME BARRIERS IMPOSED BY A HIERARCHICAL JOB STRUCTURE AND REINFORCED BY ETHNIC AND RACIAL DIVISIONS. THE MOVEMENT DREN ITS STRENGTH FROM
SEVERAL SOURCES. THE SUPPORT OF THE CHICAGO FEDERATION OF LABOR THREW THE RESOURCES OF A POHERFUL LOCAL MOVEMENT BEHIND THE CAMPAIGN AND ENCOURAGED THE EMERGENCE OF NEW,
INCLUSIVE FORMS OF ORGANIZATION. THE EXISTENCE OF SHOP-FLOOR INCLUSIVE FORMS OF ORGANIZATION. THE EXISTENCE OF SHOP-

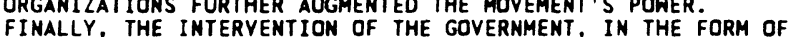
FINALLY, THE INTERVENTION OF THE GOVERNMENT, IN THE FORM OF BINDING ARBITRATION, LED TO DRAMATIC IMPROVEMENTS IN WAGES AND CONDITIONS WHICH HELPED THE MOVEMENT CONSOL IDATE ITS POSITION. ALTHOUGH THESE GAINS WERE UNDONE AND THE MOVEMENT DESTROYED, THE UNION CAMPAIGN
EXPERIENCES IN THE STOCKYARDS.

04087 HALPERT, L.

PRESIDENTIAL LEADERSHIP OF CONGRESS: EVALUATING PRESIDENT REAGAN'S SUCCESS IN THE HOUSE OF REPRESENTATIVES PRESIDENTIAL STUDIES QUARTERLY, XXI(4) (FAL 91), 717-735. THIS STUDY EXAMINES THE EXTENT OF PRESIDENT REAGAN'S SUCCESS IN THE HOUSE OF REPRESENTATIVES THROUGH AN "OUTCOMES" APPROACH, WHERE EVALUATIONS OF THE PRESIDENT'S ROLE OF "CHIEF LEGISLATOR" FOCUS ON A PRESIDENT'S VICTORY PERCENTAGE ON SELECTED KEY ISSUES. OVERALL, THE DATA INDICATE THAT PRESIDENT REAGAN DID NOT FARE WELL IN THE HOUSE DURING THIS PERIOD. HIS AVERAGE SUPPORT SCORE HAS SUBSTANTIALLY BELOW SIMILAR AVERAGES COMPILED FOR EACH OF HIS PREDECESSORS SINCE 1954, SUGGESTING THAT PRESIDENT REAGAN HAD DIFFICULTY IN RECEIVING ACCOMODATION AS "CHIEF LEGISLATOR" FROM THE HOUSE.

04088 HALVERSON, J.

PLATO'S REPUBLIC AND OURS

CRITICAL REVIEW, 5(4) (FAL 91), 453-473.

THE POLITICS OF PLATO'S "REPUBLIC" HAS BEEN ALL BUT UNIVERSALLY CONDEMNED BY MODERN LIBERAL READERS AS TOTALLY AND ODIOUSLY INIMICAL TO DEMOCRATIC IDEALS. PLATO'S PROPOSALS FOR GOVERMMENT BY AN UNELECTED ELITE, FOR PROPOSALS FOR GOVERNMENT BY AN UNELECTED ELITE, FOR
CENSORSHIP AND INDOCTRINATION, AND FOR OCCUPATIONAL CENSORSHIP AND INDOCTRINATION, ANO FOR OCCUPATIONAL
RESTRICTIONS ARE SEEN, AT BEST, AS STIFLING FREEDOM AND INDIVIDUAL INITIATIVE AND, AT HORST, AS TOTALITARIAN. IT HAS INDIVIDUAL INITIATIVE AND, AT WORST, AS TOTAL ITARIAN. IT HAS SELDOM OR NEVER BEEN NOT ICED HOW MUCH HIS POL ITY RESEMBLES PAST AND PRESENT, HAS ENDORSED MOST OF THE BASIC POL ITICAL PRINCIPLES OF THE "REPUBLIC." IF OFTEN ONLY TACITLY AMERICANS RECOGNIZE NATURAL INEQUALITIES AMONG PEOPLE; THAT SOME ARE MORE FIT THAN OTHERS FOR SOME OCCUPATIONS INCLUDING GOVERNING; AND THAT INDOCTRINATION AND CENSORSHIP 
ARE DESIRABLE IN SOME CIRCUMSTANCES. MOST IMPORTANT, THOUGH LITTLE RECOGHIZED OUTSIDE POLITICAL THEORY, IS FACT THAT THE UNITED STATES, LIKE MOST MODERN DEMOCRACIES, HAS A

GUARDIANSHIP FORM OF GOVERNMENT, COMPARABLE TO THAT OUTLINED IN THE "REPUBLIC," IN WHICH THE ELECTORAL FRANCHISE HAS

LITTLE SIGNIFICANCE.

04089 HAM, M.

A NEW PAGE

AFRICA REPORT, 37(1) (JAN 92), 18-20.

THE MOVEMENT FOR MULTI-PARTY DEMOCRACY IS LOOKING

FORWARD TO A HONEYMOON FOLLOWING ITS STUNMING OUSTER OF

PRESIDENT KENNETH KAUNDA, WHO HAD RULED FOR 27 YEARS. BUT

ITS HOPES ARE LIKELY TO BE DASHED BECAUSE ZAMBIA'S TREASURY

IS BANKRUPT, THE COUNTRY'S DEBT IS $\$ 7$ BILLION, AND THE

BLOATED CIVIL SERVICE AND COPPER COMPANIES MUST BE REDUCED

BY SOME 17,000 WORKERS.

04090 HAM, M.

DEFYING THE DICTATOR

AFRICA REPORT, 37 (3) (MAY 92), 21-24

THE INTIMIDATED AND LONG-DORMANT INTERHAL OPPOSITION TO LIFE PRESIDENT KAMUZU BANDA'S AUTOCRATIC 30-YEAR RULE AHOK IN MARCH 1992 WHEN CATHOLIC BISHOPS DISTRIBUTED A LENTEN LETTER ATTACKING BANDA'S GOVERNMENT AND CALLING ON MALAWIANS TO HORK FOR POLITICAL CHANGE. THIS SPARKED THE FIRST-EVER ANTI-BANDA DEMONSTRATIONS. THEN, A GROUP OF MALAWIAM

DISSIDENTS ASKED A PROMINENT LABOR LEADER, CHIKUFWA CHICHANA, TO ORGANIZE A NATIONAL CONFERENCE ON DEMOCRACY. BUT CHICHANA WAS ARRESTED AS HE STEPPED OFF A PLANE IN LILONGWE.

04091 HAM, $M$

END OF THE HONEYMOON

AFRICA REPORT, 37 (3) (MAY 92), 61-63.

SINCE FREDERICK CHILUBA AND HIS MOYEMENT FOR MULTI-PARTY DEMOCRACY SWEPT INTO POWER IN ZAMBIA'S OCTOBER 1991

ELECTIONS, THE NEH GOVERNMENT HAS ATTEMPTED TO IMPLEMENT THE STRUCTURAL ADJUSTMENT PROGRAM, WHICH LAY DORMANT FOR MORE THAN A YEAR UNDER THE KAUNDA ADMINISTRATION. ZAMBIA HAS RECEIVED UNPRECEDENTED PLEDGES OF FOREIGN AID, BUT THE RECORO DROUGHT AND SUSPICIONS OF POLITICS-AS-USUAL ARE THREATENING TO POSTPONE THE NECESSARY REFORMS.

04092 HAM, M.

THE WAITING GAME

AFRICA REPORT, 37 (4) (JUL 92), 24-26.

IN MAY 1992, AFTER 28 YEARS OF REPRESSION, THOUSANDS OF MALAWIANS ROSE UP AND DEMONSTRATED AGAINST THE AUTOCRATIC MALAWIANS ROSE UP AND DEMONSTRATED AGAINST THE AUTOCRATIC
RULE OF PRESIDENT-FOR-LIFE KAMUZU BANDA. THE CATALYST FOR RULE OF PRESIDENT-FOR-LIFE KAMUZU BANDA. THE CATALYST FOR THEIR ACTION WAS THE RETURN AND ARREST OF TRADE UNIONIST
CHAKUFWA CHIHANA, HAILED AS A NATIONAL HERO FOR HIS PROMISES
OF REFORM. INTERHATIONAL DONORS HAVE FROZEN S74 MILLION IN AID, WHILE MALAWIANS WATCH AND WAIT TO SEE HOW THE POLITICAL AID, WHILE MALAWIANS WATC

04093 HAM, M.

ZAMBIA: LURING INVESTMENT

AFRICA REPDRT, 37 (5) (SEP 92) 39-41.

ZAMBIA HAS OPENED ITS DOORS WIDE TO FOREIGN INYESTORS REFORMING ITS BUREAUCRATIC PROCESS TO CUT RED TAPE, AND HAS ATTRACTED \$165 MILLION IN THE FIRST YEAR OF FREDERICK CHILUBA'S ADMINISTRATION. IT IS ALSO PRIVATIZING EVERY STATE COMPANY, FROM PUBLIC UTILITIES TO SUPERMARKETS. BUT THE SIDE EFFECTS OF PRIVATIZATION ARE MORE UNEMPLOYMENT AND DEPRIVATION FOR MANY ZAMBIANS, WHO ARE BEGINNING TO FEEL THAT THE MOVEMENT FOR MULTIPARTY DEMOCRACY'S ELECTORAL

04094 HAMBURG, R.

AFTER THE ABORTIVE SOVIET COUP AND "hHAT IS TO bE DONE?" THE POST SOVIET MIL ITARY

JOURNAL OF POLITICAL AND MILITARY SOCIOLOGY, 20(2) (WIN 92), 305-322.

THE POST SOVIET MILITARY IS PART OF THE GENERAL CRISIS

OF A SOCIETY THAT IS COLLAPSING ALL AT ONCE; PARTY, MILITARY, AND OLD RULING BUREAUCRACY AFTER THE FAILURE OF THE ABORTIVE COUP TO REESTABLISH THE OLD STRUCTURE IN PART. THE MILITARY HAS RELUCTANTLY ADHERED TO THE COMMONHEALTH OF INDEPENDENT STATES AS A LOOSE COORDINATING MECHANISM. A NEH RUSSIAN MILITARY WAS CREATED IN MAY, 1992 BUT IT, TOO IS CAUGHT UP IN THE SAME PROCESS OF REDEFINITION: HITHER RUSSIA, A MERE RUSSIAN STATE OR A NEH, YET-TO-BE DEFINED REDUCED RUSSIAN EMPIRE, WITH STRONG NATIONALISTIC OVERTONES ESPECIALLY TOWARD AREAS LIKE THE BALTIC STATES, UKRAINE. MOLDOVA, AND OTHER FORMER PARTS OF THE OLD U.S.S.R. WITH LARGE NUMBERS OF ETHNIC RUSSIANS. POSSIBLE FUTURE RUSSIAM FOREIGN POLICY BEHAVIOR WITH MILITARY OVERTONES IS DISCUSSED BRIEFLY.

04095 HAMBURGER, $C$

THE DEYELOPMENT OF POLICY OM DENIZENS IN DEMMARK

NEN COMMUNITY, 18(2) (JAN 92), 293-310.

MEH COMMUNITY, 18 (2) (JAN 92), 293-310.

1990, UTILIZING TOMAS HAMMAR'S CONCENTRIC "GATE" MODEL AND
HIS CONCEPT OF "DENIZENS." NON-DANISH CITIZENS' ACCESS TO DANISH SOCIETY IS REGULATED BY GATES, WITH SECURITY AND RIGHTS INCREASING IN PROPORTION TO THE NUMBER OF GATES PASSED, CULMINATING IN NATURALIZATION AND FULL SOCIAL, LEGAL, AND POLITICAL RIGHTS. AFTER AN INITIAL PROFILE OF VARIOUS GROUPS OF FOREIGMERS LIVING IN DENMARK. THE AUTHOR DISCUSSES THE DEVELOPMENT OF POLICY MEASURES REGULATING IMMIGRATION WITH PARTICULAR REFERENCE TO THE LAW FOR FOREIGNERS. FINALLY, SHE TURNS TO THE CRITICAL ISSUE OF POLICY ON DENIZENS.

04096 HAMILL, J.

PRESIDENT DE KLERK'S OPTIONS

CONTEMPORARY REVIEW, 260(1517) (JUN 92), 291-298,

ONE ISSUE IS SET TO DOMINATE THE SOUTH AFRICAN POLITICAL
ONA AGENDA OVER THE NEXT SIX MONTHS: NAMELY, THE NATURE OF THE GOVERNMENT'S RELATIONSHIP WITH THE ANC WHICH, THEORETICALLY ARTICLE EXPLORES POST-REFERENDUM TRENDS, FIRM GOVERNMENT, BELLIGERENCE. AND COMPROMISE. IT CONCLUDES THAT THE BELLIIERENCE, AND COMPROMISE. IT CONCLUDES THAT THE REFERENDUM WILL HAVE BEEN USEFUL ONLY IF IT SERVES TO BEING THAT THE COUNTRY REMAINS SOME WAY SHORT OF THIS IDEAL.

04097 HAMILTON, C.V.

AFFIRMATIVE ACTION AND THE CLASH OF EXPERIENTIAL REALITIES ANNALS OF THE AMERICAN ACADEMY OF POLITICAL AND SOCIAL SCIENCE, (523) (SEP 92), 10-18.

THE DIFFERENT HISTORICAL EXPERIENCES OF AFRICAN AMERICANS AND OTHER IMMIGRANTS HAVE ENGENDERED DIFFERENT APPROACHES TO THE SOCIAL AND ECONOMIC DISCRIMINATION THEY HAVE ENCOUNTERED. VOLUNTARILY IMMIGRATING TO AMERICA TO IMPROVE THEIR STATUS, MOST ETHNIC GROUPS MET DE FACTO DISCRIMINATION BUT NOT DEHUMANIZATION. GLAD TO LEAVE WORSE CONDITIONS, MOST IMMIGRANTS EXPECTED LITTLE FROM THE STATE AND ADVANCED BY THEIR OWN WORK. BUT BLACKS, HHO HAD BEEN FREE IN AFRICA, ENTERED AMERICA IN CHAINS AS DE JURE PROPERTY AND HAD TO STRUGGLE FOR DE JURE HUMAN STATUS ANO FULL EQUALITY AS CITIZENS. THROUGH AFFIRMATIVE ACTION PROGRAMS DATING FROM THE MID-1930'S, BLACKS HAVE DEMANDED A FAIR PROPORTION OF JOBS. IT IS SAID THAT GHETTO POVERTY IS AN ECONOMIC AND SOCIAL, NOT A RACIAL, PROBLEM. CIVIL RIGHTS THE WELFARE OF OTHER CITIZENS ARE UNITED.

04098 HAMILTON, D.; HAMILTON, C.

IHE DUEL AGENDA OF AFRICAN AMERICAN ORGANIZATIONS SINCE THE NEW DEAL: SOCIAL WELFARE POLICIES AND CIVIL RIGHTS POLITICAL SCIENCE, 107(3) (FAL 92), 435-452

THIS ARTICLE EXAMINES THE HISTORICAL POSITION TAKEN BY

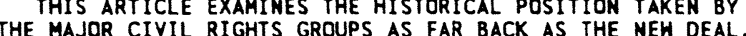
THE MAJOR CIVIL RIGHTS GROUPS AS FAR BACK AS THE NEH THE AUTHORS THE THO OLDEST AND LARGEST, THE NATIONAL AND THE NATIONAL URBAN LEAGUE (NUL). THEY CONTEND THAT THESE CIVIL RIGHTS GROUPS HAVE ALHAYS UNDERSTOOD THE EXISTENCE OF TWO AGENDAS: SOCIAL WELFARE AND CIVIL RIGHTS, AND THEY HAVE ATTEMPTED TO DEAL HITH BOTH. THE STRUGGLE TO ACHIEVE THE ATIEMPTED TO DEAL WITH BOTH. THE STRUGGLE TO ACHIEVE THE GOALS OF THE CIVIL RIGHTS AGENDA IS WELL KNOWN. MUSH LESS KNOH WHAT THOSE GROUPS ATTEMPTED TO ACHIEVE REGARDING SOCIAL WELFARE AGENDA AND HOW THEY RESPONDED TO THE
POLITICAL REALITIES FACING THEM OVER THE DECADES. INDEED, MANY OF THE ARGUMENTS MADE TODAY ABOUT SUBORDINATING THE RACE CONCERN TO THE LARGER SOCIETAL CONCERN WERE MADE DECADES AGO. MANY OF THE WARNINGS ABOUT POLITICAL BACKLASH MADE TOOAY WERE MADE DECADES BEFORE. IN OTHER HORDS, HARSH POLITICAL REALITIES FACES IN THE 1990S ARE NOT NEW TO THE CIVIL RIGHTS GROUPS, WHO HAVE ALWAYS HAD TO BALANCE LEGITIMATE CONCERNS FOR BOTH AGENDAS ON A DELICATE SCALE OF POLITICAL CALCULATION AND PRAGMATIC POLITICS. GREATER UNDERSTANDING OF THIS HISTORY OUGHT TO IMPROVE DISCUSSION OF THE POLITICS OF RACE AND SOCIAL HELFARE TODAY.

04099 HAMILTON, D.

TRIVIA PURSUI

WASHINGTON MONTHLY, 23(3) (MAR 91), 36-42.

THE PUBLIC INVESTMENT IN RESEARCH IS MUGE--ALMOST \$16 BILLION IN DIRECT FEDERAL, STATE, AND TAX-DEDUCTIBLE INDUSTRIAL SUPPORT. AN ALTHOUGH THE SUCCESS STORIES OF ACADEMIC RESEARCH ARE UNDENIABLE, THESE SUCCESSES AND THE FOUNDATION OF BASIC RESEARCH THAT HAS MADE THEM POSSIBLE, REPRESENT ONLY A TINY FRACTION OF ALL THE RESEARCH PERFORMED EACH YEAR. BEYOND THE TIP OF THIS ICEBERG, "HE AREN'T EVEN BEGINNING TO GET OUR MONEY'S WORTH." SOME ESTIMATES INDICATE THAT 80 PERCENT OF SCIENTIFIC ARTICLES COULD "JUST VANISH: WITHOUT AFFECTING THE SCIENTIFIC ENTERPRISE. THIS IS SOMEWHAT THE RESULT OF THE "PUBLISH OR PERISH" MENTALITY THAT IS PREVALENT AT MANY UNIVERSITIES AND INSTITUTIONS.

O4100 HAMILTON, L.H.

A DEMOCRAT LOOKS AT FOREIGN POLICY

A DEMOCRAT LOOKS AT FOREIGN POLICY
FOREIGN AFFAIRS, $71(3)$ (SUM 92), 32-51.

THE WORLD HAS TURNED UPSIDE DOWN, BUT U.S. FOREIGN

POLICY HAS BEEN SLOW TO CHANGE AND HAS FAILED TO DEVELOP A

COHERENT STRATEGY FOR THE FUTURE. A REPUBLICAN SITS IN THE

WHITE HOUSE, BUT DEMOCRATS ALSO BEAR RESPONSIBILITY FOR 
FOREIGN POLICY INERTIA BECAUSE THEY HAVE CEDED THE FIELD OF FOREIGN AFFAIRS TO THE PRESIDENT. IT IS NOW UP TO THE DEMOCRATS TO ARTICULATE A MORE COMPELLING FOREIGN POLICY, TO REDEFINE THE CONCEPT OF NATIONAL SECURITY, AND TO STRIKE A BETTER BALANCE BETWEEN DOMESTIC AND FOREIGN AFFAIRS. THE NEW ISSUES ARE ECONOMIC COMPETITIVENESS, WEAPONS PROLIFERATION, SUPPORT FOR DEMOCRACY, ENVIRONMENTAL PROTECTION, AND THE FIGHT AGAINST HUWAN MISERY.

04101 HAMILTON, N.L.; TEMPERO, R.M.

REGIONAL CHARTER MAKING' IN POLK COUNTY, IOWA

NATIONAL CIVIC REVIEW, 81(4) (FAL 92), 500-511.

THE AVAILABILITY OF LOCALLY-DEVELOPED AND ADOPTED HOME-

RULE CHARTERS, WHILE SERVING THE INTERESTS OF GOVERNMENT

RESPONSIVENESS, CAN AGGRAVATE FRAGMENTATION. COUNTIES HAVE

GREATER CONVENING AND COORDINATING POTENTIAL IN METROPOLITAN

REGIONS, AS EVIDENCED BY POLK COUNTY, IOWA'S LONG-TERM

REGIONS, AS EVIDENCED BY POLK COUNTY,
EFFORTS AT REGIONAL CHARTER MAKING.

04102 HAMM, R.; LING, R.; MILLER, M.

PREFERENCES, BELIEFS, AND VALUES IN NEGOTIATIONS

CONCERNING AID TO NICARAGUA

PUBLIC CHOICE, 74(1) (1991), 79-104.

THIS PAPER ARGUES THAT IN THE CONTEXT OF PUBLIC CHOICE FOR NON-MARKET GOODS, TWO ASSUMPTIONS OF THE SIMPLE MODEL OF THE RATIONAL ECONOMIC ACTOR MAY NOT HOLD. THE ASSUMPTIONS ARE THAT THERE IS A DIRECT CONMECTION BETWEEN CHOICE AND OUTCOME, AND THAT PREFERENCES ARE NOT AFFECTED BY THE ACT OF MAKING A CHOICE. IN AN EXAMPLE STUDY, PEOPLE'S PREFERENCES FOR U.S. POLICIES TOWARD NICARAGUA WERE MEASURED AND FURTHER ANALYZED INTO THEIR BELIEFS ABOUT THE EFFECTS OF THOSE POL ICIES ON NICARAGUEAN OUTCOMES. IT WAS SHOWN THAT THE PROCESS OF MAKIMG A THO-PERSON CHOICE CHANGED THE PREFERENCES, AND THAT THE SEPARATE MEASURES OF BELIEFS AND VALUES GAVE INSIGHT INTO THE PROCESS OF THE CHANGE THAT WOULD NOT HAVE BEEN AVAILABLE HAD ONLY THE PREFERENCES BEEN MEASURED. IMPLICATIONS FOR THE CONTINGENT VALUATION METHOD ARE EXPLORED AND AN ALTERNATIVE APPROACH IS PROPOSED.

04103 HAMMER, J.

ON THE' POTENTIAL IMPACT OF "RUST $V$. SULLIVAN" AS A MODEL FOR CONTENT-BASED RESTRICTIONS ON FEDERAL ARTS AND HUMANITIES FUNDING

PS: POLITICAL SCIENCE AND POLITICS, XXV(1) (MAR 92), 89-90. THE AUTHOR EXAMINES THE U.S. SUPREME COURT'S RULING IN

RUST $V$. SULLIVAN, WHICH UPHELD THE GOVERMMENT'S RIGHT TO WITHHOLD FEDERAL, FUNDS FROM FAMILY PLANING CLIMICS THAT WITHHOLD FEDERAL FUNDS FROM FAMILY PLANNING CLINICS THAT ADVISE PATIENTS ABOUT ABORTIONS. HE SPECULATES ABOUT THE
IMPACT THIS RULING MIGHT HAVE ON FEDERAL FUNDING FOR THE IMPACT THIS RULING MIG
ARTS AND HUMANITIES.

04104 HAMMOND, A.S. IV

REGULATING BROADBAND COMMUNICATION NETHORKS

YALE JOURNAL ON REGULATION $(1)$ (WIN 92), 181-236.

THE AUTHOR ARGUES THAT THE IMPENDING DEVELOPMENT OF BROADBAND COMMUNICATION NETHORKS HAS THE POTENTIAL TO EXPAND AND EQUALIZE SPEECH RIGHTS BY ENDOWING THE PUBLIC WITH MORE NUMEROUS AND MORE POWERFUL OPPORTUNITIES FOR SPEECH. TO REALIZE THESE BENEFITS, CONGRESS MUST DESIGN A NOVEL REGULATORY SCHEME THAT WILL MAXIMIZE THE SPEECH RIGHTS OF BOTH THE OWNERS AND THE USERS OF BROADBAND COMMUNICATION NETWORKS. THE REGULATORY SCHEME FOR BROADBAND COMMUNICATION NETHORKS SHOULD BE BASED ON THE PUBLIC FORUM DOCTRINE. BROADBAND COMAUNICATION NETWORKS WITH MARKET-BASED, TECHNOLOGY-DRIVEN, OR GOVERNMENT-SANCTIONED MONOPOLIIES SHOULD BE DEEMED PUBLIC FORA AND REQUIRED TO PROVIDE UNRESTRICTED PUBLIC ACCESS, BUT PUBLIC FORUM OWNERS SHOULD RETAIN THE RIGHT TO GENERATE ORIGINAL PROGRAMMING, OR SPEECH, THROUGH FULLY-OWNED SUBSIDIARIES, OTHER BROADBAND COMMUNICATION NETWORKS SHOULD BE PERMITTED TO CHOOSE BETWEEN PUBLIC AND PRIVATE FORUM STATUS.

04105 HAMMOND, G.

LOW-INTENSITY CONFLICT: WAR BY ANOTHER NAME

SMALL WARS \& INSURGENCIES, 1(3) (DEC 90), 226-238.

THIS ARTICLE SEEKS TO DO AHAY HITH THE ACRONYM LIC (LOHINTENSITY CONFLICT). LIC PRETENDS TO BE SOMETHING IT IS NOT. IT IS NOT LOW, TO BE MEASURED BY INTENSITY OR CONFLICT. IT IS A VIOLENT, ARMED THREAT TO THE STATUS QUD. ULTIMATELY, THE PSYCHOLOGY OF LIC IS YERY DIFFERENT FROM THE PSYCHOLOGY OF WAR. BUT LIC IS STILL WAR AND SHOULD BE TREATED AS SUCH. OF WAR. BUT LIC IS STILL WAR AND SHOULD BE TREATED AS SUCH. JUST WHY AND HOW AMERICANS HAVE BECOME INFATUATED HITH THE

TERM AND THE SIGNIFICANCE OF THEIR DELUSIONS

04106 HAN, Y.

CONVENTIONAL ARMS CONTROL MEASURES IN KOREA

KOREA \& WORLD AFFAIRS, 16(2) (SUM 92), 224-249.

FOR THE FIRST TIME' IN THEIR HISTORY, NORTH AND SOUTH KOREA HAVE AGREED TO ORGANIZE A JOINT MILITARY COMMISSION TO DISCUSS WAYS TO REDUCE MILITARY TENSIONS IN ORDER TO IMPROVE MUTUAL SECURITY. IT IS VERY IMPORTANT THAT THE KOREAS

DEVELOP COMMON CRITERIA IN ARMS CONTROL TALKS SO THAT EACH SIDE BELIEVES IT IS ENGAGING IN A WIN-WIN DIALOGUE. TO THIS
END, ARMS CONTROL TALKS SHOULD ADDRESS ISSUES THAT EACH SIDE REGARDS AS MOST THREATENING TO ITS SECURITY.

04107 HANDLEY, $P$.

A FIGHT ON ALL FRONTS

FAR EASTERN ECONOMIC REVIEW, 155(6) (FEB 92), 28-29.

NEARLY EVERY WEEK SOMEONE IN THAILAND DIES OF AIDS. THE

VIRUS THAT ONLY THREE YEARS AGO WAS CONFINED TO INTRAVENOUS

DRUG USERS HAS NOW SPREAD THROUGHOUT THE COUNTRY. BUT,

THAILAND HAS MADE GREAT STRIDES IN ENCOURAGING AWARENESS IN AND IN REDUCING THE SPREAD OF AIDS. THE ANTI-AIDS BATTLE IS BEING FOUGHT ON THREE FORNTS: DRUGS, PROSTITUTION AND MALE ATTITUDES TOWAROS SEX.

04108 HANDLEY, P.

AN UNEASYY CALM

FAR EASTERN ECONOMIC REVIEH, 156(20) (MAY 92), 10-11.

THAILAND'S LARGEST ANTI-GOVERNMENT DEMONSTRATIONS IM

OVER 18 YEARS ENDED IN AN EARLY MORNING TRUCE ON 11 MAY,

AVERTING A SHOWDOWN THAT THREATENED TO TURN VIOLENT AFTER A

WEEK OF PEACEFUL PROTESTS. BUT THE TRUCE CARVED OUT BETHEEN THE PROTESTERS LED BY POPULAR POLITICIAN CHAMLONG SRIMUANG, AND THE RULING COALITION BACKING PRIME MINISTER SUCHINDA KRAPRAYOON, IS NOT EXPECTED TO HOLD. HITHIN DAYS OF THE TRUCE THE GOVERNMENT PARTIES APPEARED TO BE BACKING OFF ON THE AGREEMENT. CHAMLONG'S DEMANOS THAT SUCHINDA STEP DOWN TO MAKE WAY FOR AN ELECTED PRIME MINISTER ARE STILL BEING MET BY A STEELY DEFIANCE FROM SUCHINDA. THE PROTESTERS,

NUMBERING OVER 150,000 AT TIMES, REPRESENT A CROSS SECTION OF POLITICIANS, STUDENTS, ACADEMICS AND THE BANGKOK GENERAL PUBLIC. MANY SEE THE DEMONSTRATIONS AS EVIDENCE THAT THE ORDINARY PEOPLE, AT LEAST IN BANGKOK, NO LONGER ACCEPT THE

04109 HANDLEY, $P$.

COUNTING THE COST

FAR EASTERN ECONOMIC REVIEW, 156(22) (JUN 92), 10-11.

AT THE COST OF SCORES, PERHAPS HUNDREDS OF DEATHS,

THAILAND'S PRIME MINSTER SUCHINDA KRAPRAYOON GAVE THE THAI PUBLIC HAT THEY HANTED ALL ALONG: HIS RESIGNATION AND A MORE DEMOCRATIC CONSTITUTION. BUT THE VIOLENCE THAT ROCKED THAILAND FOR DAYS HAS SEVERELY SHAKEN THE PEOPLE, THE MILITARY, THE POLITICAL PARTIES, AND MOST OF ALL, THE THAI MONARCHY, ONE OF THE COUNTRY S MOST IMPORTANT INSTITUTIONS. IING BHUMIPOL AULYADEJ NEAR MIDNIGHT ON 20 MAY WHICH FINALLY KING BHUMIPOL AULYADEJ NEAR MIDNIGHT ON 20 MAY WHICH FINALL
ENDED THE VIOLENCE THAT BEGAN THREE NIGHTS EARLIER. THE ENDED THE VIOLENCE THAT BEGAN THREE NIGHTS EARLIER. THE
DEATH TOLL IS STILL UNKNOWN. OFFICIAL HOSPITAL STATISTICS DEATH TOLL IS STILL UNKNOWN. OFFICIAL HOSPITAL STATISTICS PEOPLE ARE STILL MISSING. MANY FEAR THAT SUCHINDA AND HIS PEOPLE ARE STILL MISSING. MANY FEAR THAT SUCHINDA AND HIS CRONIES, WHO CLEARLY FEEL NO REMORS

04110 HANDLEY, P.; HIEBERT, M.

HOSTILE UNDERCURRENTS
FAR EASTERN ECONOMIC REVIEW, 155(13) (APR 92), 16 .

THAILAND HAS ANGERED CAMBODIA, LAOS, AND VIETMAM BY ITS EFFORTS TO FORCE A COMPLETE RESTRUCTURING OF THE REGIONAL ORGANIZATION SUPERVISING THE DEVELOPMENT AND THE USE OF THE MEKONG RIVER. THE MOVE, DESIGNED TO END THE VETO POWER OF THE THREE INDOCHINESE COUNTRIES HAVE ON A PROJECT TO DIVERT RIVER WATERS FOR THAILAND'S OWN USE, THREATENS TO SOUR IMPROVED RELATIONS BETWEEN BANGKOK AND HANOI AND MAY DESTROY THE MEKDNG COMMITTEE--FOUNDED THIRTY-FIVE YEARS AGO TO HELP SETTLE SUCH DISPUTES. HANOI IS WORRIED THAT THE THAI SCHEME WOULD DIVERT ENOUGH WATER FROM THE RIVER TO DISRUPT ITS FLOW IN THE MEKONG DELTA IN SOUTHERN VIETNAM. A REDUCED FLOW WOULD INCREASE SALT WATER INTRUSION THAT ALREADY THREATENS THE DELTA'S FERTILE RICE FIELDS. FAILURE TO REACH A
COMPROMISE WOULD PROBABLY SIGNAL THE END OF THE MEKONG ORGANIZATION ALTOGETHER.

04111 HANDLEY, P.

PEOPLE'S WRATH

FAR EASTERN ECONOMIC REVIEH, 156(21) (MAY 92), 10-11. THAILAND'S STRUGGLE TO PUT A BRAKE ON THE INTERVENTION OF THE MILITARY IN POLITICS AND, IN PARTICULAR, TO FORCE ARMY COMMANDER SUCHINDA KRAPRAYOON TO STEP DOWN AS UNELECTED PRIME MINISTER, ENTERED A NEW AND BLOODY PHASE ON SUNDAY 17 MAY WHEN THE GOVERNMENT DECLARED A NATIONAL EMERGENCY AND THE ARMY BEGAN FIRING ON DEMONSTRATORS IN BAHGKOK. IN THE DAYS THAT FOLLOWED, HUNDREDS OF BUILDINGS AND THOUSANDS OF DAYS THAT FOLLOWED, HUNDREDS OF BUILDINGS AND THOUSANDS OF
CARS WERE GUTTED IN THE WORST VIOLENCE SEEN IN BANGKOK FOR MARS TERE GUT 20 YEARS YET THE BULK OF THE PROTESTORS REMAINED PERE THAN 20 YEARS. YET THE BULK OF THE PROTESTORS REMAINED PEACEFUL, CALLING FOR THE RESIGNATION OF SUCHINOA AMD EARLY END TO WHAT THEY SAH AS THE UNCONSTITUTIONAL
INTERFERENCE BY THE ARMY IN POLITICS. AFTER DAYS OF ARMY CRACKDOWN, AN UNEASY CALM SPREAD ABOUT THE CITY, BUT MANY SEE IT AS ONLY A BRIEF RESPITE BEFORE FURTHER CONFLICT TAKES PLACE.

04112 HANDLEY, $P$.

TIGHT RACE FOR POWER

FAR EASTERN ECONOMIC REYIEW, 155(11) (MAR 92), 8-9. 
LESS THAN TWO WEEKS BEFORE THAIS ELECT A MEW GOVERNMENT, THERE IS STILL NO FRONTRUNHER AMONG THE TWENTY POL ITICAL PARTIES IN THE CONTEST. THE RACE BETWEEM THE THREE LEADING PARTIES, THO OF THEM ALIGNED WITH THE MILITARY JUNTA AND THE THIRD ORIGINALLY SET UP IN OPPOSITION TO THEM, HAS BECOME SO TIGHT THAT ANALYSTS ARE SPECULATING ALL THREE CDULD ULTIMATELY COME TOGETHER TO FORM A GOVERMMENT. SOME OF THE FINELY CALCULATED SCENARIOS FOR EVENTUAL POHER-SHARING HAVE BEEN UPSET, OR ARE BEING CONTINUALIY MODIFIED IN THE LIGHT OF NEW TENSIONS WITHIN THE JUMTA HIERARCHY AND THE ONGOING CORRUPTION INVESTIGATION OF OFFICIALS OF THE DEPOSED CHATICHAI ADMINISTRATION. DESPITE THE TENSE COMPETITION, THE RUN-UP TO THE 22 MARCH POLLS HAS BEEN RELATIVELY PEACEFUL.

04113 HANDY, J.

GUATEMALA: A TENACIOUS DEPOTISM

REPORT ON THE AMERICAS, 36 (3) (DEC 92), 31-37.

RIGOBERTA MENCHU'S NOBEL PEACE PRIZE ILLUMINATED THE INSEPARABIL TIY OF GUATEMALA'S MULTITUDE OF STRUGGLES: FOR ACCESS TO LAND, FOR MAYA RIGHTS, FOR A DECENT STANDARD OF LIVING AND, ABOVE ALL, FOR FREEDOM FROM MILITARY TERROR AND IMPUNITY. THE CHANGES IN GUATEMALA OVER THE LAST DECATE HAVE BEEN IMPORTANT BUT IN 1989 AND 1990, GUATEMALA STILL HAD THE WORST HUMAN RIGHTS RECORD IN LATIN AMERICAN. THE PROBLEM IS THAT WHILE THE MILITARY SOUNDS INCREASINGLY OU
THE REST OF THE COUNTRY, THEY STILL HAVE GUNS.

04114 HANF, K.; O'TOOLE, L.J. JR

REYISITING OLD FRIENOS: NETHORKS, IMPLEMENTATION STRUCTURES, AND THE MANAGEMENT OF INTER-ORGANIZATIONAL
RELATIONS

EUROPEAN JOURNAL OF POLITICAL RESEARCH, 21(1-2) (FEB 92), 163-180.

MOST OF THE CURRENT HORK ON METHORK ANALYSIS TENDS TO CONCENTRATE ON THE RELATIONSHIP BETHEEN ACTORS AND THE CONTEXT HITHIN WHICH VARIOUS ACTORS ENGAGE IN THE FORMULATION OF PUBLIC POLICY. CONSEQUENTLY, AMALYSIS OF THE INTER-ORGANIZATIONAL STRUCTURES THROUGH WHICH THIS POLICY IS IMPLEMENTED RECEIVES LESS ATTENTION. IN THIS PAPER,

ATTENTION IS DRAHN TO QUESTIONS CONCERNING THE MANAGEMENT OF INTER-ORGANIZATIIONAL NETWORKS AS THE VEHICLES FOR CARRYING OUT POLICY PROGRAMS. AT THE SAME TIME, AN ARGUMENT IS MADE FOR USING THE TERM " "NETWORK" NOT ONLY AS AN ANALYTICAL CONCEPT BUT ALSO TO DENOTE COLLCTIVITIES THAT ARE CONSCIOUSLY CONSTRUCTED FOR THE REALIZATION OF PURPOSEFUL JOINT ACTION.

04115 HANISCH, $T$.

THE RIO CLIMATE CONVENTION: REAL SOLUTIONS OR POLITICAL

SECURITY DIALOGUE, 23(4) (DEC 92), 63-74.

THERE IS NO CHANCE THAT THE CONVENTION ON CLIMATE CHANGE IN RIO CAN STOP THE TREND OF INCREASED EMISSIONS OF GREENHOUSE GASES IN THE SHORT TERM. HOHEVER, THE CONVENTION DOES MEAN SIGNIFICANT STEPS TOHARDS PROTECTING THE ASTMOSPHERE. MOST IMPORTANT IS THE ESTABLISHMENT OF A GLOBAL REGIME ITSELF, HITH A SYSTEM FOR REVIEW OF NATIONAL POLICIES. THE MAIN REASON THAT PROGRESS IS SO SLOW IS THAT RESPONDING TO CLIMATE CHANGE IN A WAY THAT REALLY MATTERS COULD INVOLVE A SIGNIFICANT INTERFERENCE HITH ECONOMIC DEVELOPMENT.

CLIMATE CHANGE RAISES THE PROBLEM OF SECURITY AND RISK AVERSION IN SEVERAL WAYS.

04116 HANKEL, $W$.

OF MONEY, MENTALITY, FREEDOMS AND RISKS

GERMAN TRIBUNE, (1476) (JUL 91), 11.

MANY GERMANS' ENTHUSIASM ABOUT UNIFICATION IS STRICTLY LIMITED. THE OVERRIDING FEAR IN THE WEST IS THAT IT MAY ALL PROVE TOO EXPENSIVE. HHILE PEOPLE IN THE EAST FEAR A LOSS OF IDENTITY, JOB AND OUTLOOK IN LIFE. AN IMPORTANT CONCEPT THAT SEEMS TO BE LACKING ESPECIALLY AMONG YOUTH OF THE EAST IS THE IDEA THAT FREEDOM AND RISK BELONG TOGETHER AND THAT THOSE WHO PREFER SECURITY OR DEPENDENCE MUST FORGO MUCH OF THEIR FREEDOM IN LIFE. FURTHERMORE, YOUNG PEOPLE IN THE WEST HAVE TWO THINGS TO LEARN: HOW HARD RECONSTRUCTION IS (NOT HAVING EXPERIENCED IT THEMSELVES) AND HOW IMPORTANT IT IS FOR SOLIDARITY WITH ONE'S UNKNOWN NEIGHBOR NOT TO GO BY THE BOARD IN A LARGER SOCIETY.

04117 HANMAM, $P$.

FALTERING STEPS

FAR EASTERN ECONOMIC REVIEW, 155(7) (FEB 92), 12

AFTER PROLONGED DEBATE AHD LEGISLATIVE WRANGL ING

MONGOLIA'S NEW DEMOCRATIC CONSTITUTION CAME INTO FORCE ON 12

FEBRUARY. ON PAPER, THE CONSTITUTION ENSHRINES A LIBERAL

POLITICAL SYSTEM, HITH POWER DIVIDED BETWEEN INDEPENDENT

LEGISLATIVE, EXECUTIVE, AND JUDICIAL ORGANS, AND CITIZENS' RIGHTS GUARANTEED BY LAW. OTHER CHANGES INCLUDE THE DROPP OF THE COUNTRY'S "PEOPLE'S REPUBLIC" EPITHET TO BECOME SIMPLY "MONGOL IA," THE REMOVAL OF THE COMMUNIST STAR FROM
THE FLAG AND THE ECONOMICALLY IMPORTANT QUESTION OF LAND THE FLAG AND THE ECONOMICALLY IMPORTANT QUESTION OF LAND RIGHTS. MONGOL IAN CITIZENS CAN NOW OWN LAND, EXCEPT FOR PASTURE USED BY NOMADIC HERDERS, WHILE FOREIGNERS WILL BE
ABLE TO LEASE LAND. IN REALITY, HOWEVER, THE CONSTITUTION IS
LIKELY TO CONSOLIDATE THE RULING POSITION OF THE FORMER COMMUNIST MONGOLIAN PEOPLE'S REVOLUTIONARY PARTY WHICH CONTROLS ABOUT $75 \%$ OF PARLIAMENT.

04118 HANMAM, $P$.

TROUBLED TRANSITION

FAR EASTERN ECONOMIC REVIEW, 155(5) (FEB 92), 49-50. MONGOLIA'S TRANSITION TO A MARKET ECONOMY' IS IN TROUBLE. ONE OF THE MAIN PROBLEMS IS THAT EVEN THOUGH MOST PRICES HAVE BEEN LIBERALIZED, FREE-ENTERPRISE GROWTH REMAINS TINY COMPARED WITH THE FALLING OUTPUT OF THE STATE SECTOR. AS A RESULT, ECONOMIC-AND POLITICAL--STABILITY IS BECOMING A MORE ELUSIVE GOAL AS INFLATION AND UNEMPLOYMENT GATHER PACE. MORE ELUSIVE GOAL AS INFLATION AND UNEMPLOYMENT GATHER PACE. IN 1991, THE ECONONY CONTRACTED ABOUT 16\%. THE DROP IN REAL INCOMES WAS MUCH LARGER AS THE OFFICIAL 46\% INFLATION RATE IS PROBABLY HALF THE TRUE FIGURE. MONGOLIIANS ARE PAINFULLY AHARE THAT THEIR LIVING STANDARDS ARE PLUMMETING. MORE THAM 8O\% OF THE COUNTRY S CONSUNER GOOOS ARE IMPORTED, SOR SHOPPERS HAVE HAD TO PAY HIGHER PRICES AS THE VALUE OF THE CURRENCY, THE TUGRIK, HAS DROPPED. THE LACK OF ACCESS TO HARD CURRENCY HAS LEFT MANY FACTORIES WITHOUT CRITICAL SPARE
PARTS AND RAH MATERIALS.

04119 HANNINEN, S.

HOW TO COMBAT POLLUTION BY WORDS

ALTERNATIVES, $17(2)$ (SPR 92), 209-230

THE QUESTION OF WHY THE LOCAL INHABITANTS OF HELSINKI

NEGLECTED TO TAKE A STAND ON ENVIROMMENTAL ISSUES IS

POLITICALLY FUNDAMENTAL AND EXTREMELY WIDE-RANGING. THE

INVISIBILITY AND SILENCE OF POLLUTION IS CLOSELY CONNECTED

WITH THE COGNITIVE CONSTRAINTS OF RISK PERCEPTION. THESE ARE RELATED TO SOCIAL CONSTRAINTS, WHICH ARE THEN LINKED TO RISK ACCEPTABILITY IN THIS ARTICLE. THE AUTHOR MAKES A

DISTINCTION AMONG FOUR DIFFERENT SOCIAL OR SOCIESEMIOTIC CONSTRAINTS TO ENVIRONMENTAL RISK PERCEPTION RELEYANT IM THIS CASE: SPATIAL, CULTURAL, ECONOMIC, AND POLITICAL. THESE OPEN UP PERSPECTIVES THROUGH WHICH THE AUTHOR THEN OUTLINES SOME OF THE OBSTACLES TO THE MOBLIZATION OF THE KYLASAARI MOVEMENT.

04120 HANRATTY, M.J.

WHY CANADA HAS LESS POVERTY

SOCIAL POLICY, 23(1) (SUM 92), 32-37.

THE AUTHOR COMPARES U.S. AND CANADIAN WELFARE POLICIES

IN AN ATTEMPT TO EXPLAIN WHY CANADA HAS LESS POVERTY THAN

THE UNITED STATES.

O4121 HANSON, C.

MEDIA BASHING

COLUMBIA JOURNALISM REVIEW, 31(4) (NOV 92), 52-55.

THE AUTHOR DISCUSSES THE "MEDIA BASHING" AT THE REPUBLICAN PARTY'S 1992 PRESIDENTIAL NOMINATING CONVENTION
IN HOUSTON.

04122 HANSON, D.

THOMAS HOBBES ON "DISCOURSE" IN POLITICS

POLITY, XXIV (2) (NIN 91), 199-226.

THE SALIENCE OF LANGUAGE IN HOBBES'S WORK HAS BEEN

RECOGNIZED, BUT INTERPRETATIONS OF HIS IDEAS ON THIS SUBJECT HAVE BEEN REMARKABLY DISCORDANT. THE PRINCIPAL REASON, THIS ARTICLE ARGUES, IS THAT HOBBES IS INTERPRETED IN THE LIGHT OF MOOERN THEORIES OF MEANING IN LANGUAGE, WHEREAS A COHERENT ACCOUNT CAN ONLY BE GIVEN BY UNDERSTANDING THE SIGNIFICATION CURRENT IN THE SEVENTEENTH CENTURY. THE AUTHOR CONTENDS THAT AN APPROPRIATELY CONTEXTUAL EXPLICATION OF SIGNIFICATION SHOWS NOT ONLY THAT HOBBES'S IDEAS ON LANGUAGE ARE VERY NEARLY THE REVERSE OF THOSE AT WORK IN MOST TWENTIETH-CENTURY PHILOSOPHY OF LANGUAGE, BUT ALSO SHEDS LIGHT ON SEVERAL IMPORTANT ASPECTS OF HOBBES'S HORK.

04123 HANSON, G.

FRACTIOUS QUEBEC

INSIGHT, 7(13) (APR 91), 36-37.

QUEBEC LIBERAL PARTY' MEMBERS RECENTLY DRAFTED A MEASURE THAT CALLS FOR REVISING THE CANADIAN FEDERATION AND GIVING QUEBEC BROAD NEW POWERS. THE "ALLAIRE REPORT" WOULD ALLOW THE PROVINCE TO GO ITS OWN WAY IF ITS DEMANDS ARE REJECTED. IT RECOMMENDS THAT THE ISSUE BE DECIDED IN A NATIONWIDE REFERENDUM IN THE FALL. SOME HOPE THAT THE MEASURE WILL LEAD REFERENDUM IN THE FALL. SOME HOPE THAT THE MEASURE WILL
TO MEANINGFUL NEGOTIATION BETWEEN QUEBEC AND THE REST OF
CANADA, BUT OTHERS FEAR THAT THE SEPARATION IS LOOMING

CANADA,
CLOSER.

04124 HANSON, G.

STARVIMG SUDAN

STARVING SUDAN

SUDAN HAS BEEN SUFFERING FROM DROUGHT AND AN EIGHT-YEAR CIVIL WAR. ADDING TO ITS WOES ARE THE POLICIES OF THE GOVERMMENT OF LT. GENERAL OMAR HASSAN AHMAD AL-BASHIR WHICH INCLUDE STRIDENT SUPPORT FOR SADOAM HUSSEIN. SOME SOURCES INDICATED THAT SUDAN DIVERTED FOOD SUPPLIES TO IRAQ AFTER THE UN EMBARGO WAS ENACTED. THIS IS IRONIC BECAUSE SUDAN IS ON THE VERGE OF A FAMINE THAT SOME DESCRIBE AS BEING "TEN 
IN 1984. THE RULING REGIME'S HOSTILITY TOWARDS THE WEST AND ITS TIES TO HUSSEIN AND LIBYA'S MUMMAR QADDAFI ARE COMPLICATING RELIEF EFFORTS.

04125 HANSON, P.; TEAGUE, E.

THE INOUSTRIALISTS AND RUSSIAN ECONOMIC REFORM

RFE/RL RESEARCH REPORT, 1(19) (MAY 92), 1-7.

THE RUSSIAN GOVERNMENT FENDED OFF THE MORE EXTREME OPPOSITION TO ITS ECONOMIC REFORMS VOICED DURING THE RECENT SESSION OF THE CONGRESS OF PEOPLE'S DEPUTIES. HOWEVER, IT APPEARS THAT THE GOVERMMENT HAD ALREADY MADE DAMAGING CONCESSIONS IN A DEAL WITH THE CENTRIST OPPOSITION--THE GROUP OF SO-CALLED "INDUSTRIALISTS" HEADED BY ARKADII VOL'SKY. THE INDUSTRIALISTS REPRESENT THE MANAGERS OF BIG STATE EMTERPRISES. IMCLUDING THOSE IN THE DEFENSE SECTOR. THEY WANT SOFT CREDIT POLICIES, LARGER SUBSIDIES FOR INDUSTRY, AND, IN GENERAL, A RETREAT FROM SHOCK-THERAPY STABILIZATION. THEY HAVE THREATENED TO ALLY THEMSELVES WITH STABILIZATION. THEY HAVE THREATENED TO ALLY THEMSEL VES WITH
HORKER ORGANIZATIONS TO BRING THE ECONOMY TO A HALT. IT IS DOUBTFUL WHETHER INFLATION CAN BE BROUGHT UNDER CONTROL IF THEIR PRESCRIPIIDNS ARE FOLLOWED, BUT THE RUSSIAN LEADERSHIP THEIR PRESCRIPIIDNS ARE FOLLOWED, BUT THE RUSSIAN LEADERSHI HAS FELL OBLIGED TO SURRENDER TO SEVERAL OF THEIR DEMANDS. BETWEEN THE DEMANDS OF THE INTERNATIONAL MONETARY FUND AND BETWEEN THE DEMANDS OF THE IMTE

04126 HANSON, $P$.

THE RUSSIAN BUDGET CRISIS

RFE/RL RESEARCH REPORT, 1(14) (APR 92), 39-42.

THE RUSSIAN GOVERNMENT IS FACING A BUDGET CRISIS THAT COULD UNDERMINE ITS REFORM PROGRAM. CAUGHT BETHEEN PARL IAMENT WANTING TO SPEND MORE MONEY AND PRESSURE FROM THE INTERMATIONAL MONETARY FUND FOR FINANCIAL DISCIPLINE, THE GOVERNMENT LACKS BOTH THE TAX-COLLECTING POWER AND THE

04127 HANSON, $P$.

WESTERN AID TO THE SOVIET UNION'S SUCCESSOR STATES RFE/RL RESEARCH REPORT, 1(18) (MAY 92), 52-55.

THE MAJOR WESTERN NATIONS AND THE IMF ARE MOVING CLOSER TO GIVING SUBSTANTIAL FINANCIAL AID TO THE SOVIET UNION'S SUCCESSOR STATES. HOWEVER, DUE TO DOMESTIC ECONOMIC DIFFICULTIES AND THE TEMPTATION TO PASS THE BUCK AMONG THEMSELVES, THE LEADING WESTERN NATIONS ARE UNLIKELY TO OFFER ASSISTANCE ON THE SCALE OF THE U.S. MARSHALL PLAN TO POSTWAR EUROPE. THE SITUATION IN RUSSIA AND THE OTHER CIS POSTWAR EUROPE. THE SITUATION IN RUSSIA AND THE OTHER MEMBER STATES HAS CAUSED CONSIDERABLE DOUBT THAT THE
FINANCIAL ASSISTANCE HOULD BE USED EFFECTIVELY. ON THE OTHER FINANCIAL ASSISTANCE HOULD BE USED EFFECTIVELY. ON THE OT
HAND, SUCCESS IN STABILIZING THE ECONOMIES OF RUSSIA AND HAND, SUCCESS IN STABILIZING THE ECONOMIES OF RUSSIA AND
OTHER CIS MEMBERS IS HIGHLY UNLIKELY WITHOUT SIGNIFICANT OTHER CIS MEMBERS IS HIGH
FOREIGN FINANCIAL AID.

04128 HANSON, R.L. THE POLITICAL ACCULTURATION OF MIGRANTS IN THE AMERICAN STATES

NESTERN POLITICAL QUARTERLY, 45(2) (JUN 92), 355-384. SUBCULTURAL VARIATIONS AMONG THE AMERICAN STATES ARE WELL DOCUMENTED, BUT MUCH LESS IS KNOWN ABOUT THE WAY IN WHICH CULTURAL VALUES ARE TRANSLATED INTO INDIVIDUAL ATTITUDES AND ACTIONS. AN ANALYSIS OF CROSS-CULTURAL MIGRANTS FROM THE 1968 COMPARATIVE STATE ELECTION PROJECT SUGGESTS THAT EARLY SOCIALIZATION IS ONLY ONE, ALBEIT VERY IMPORTANT, EXPLANATION OF HOW CULTURE WORKS. A SECOND EXPLANATION INVOLVES ADULTS' EXPERIENCE OF PRESSURES TO CONFORM. FOR NONMIGRANTS THESE TWO PROCESSES ARE MUTUALLY REINFORCING, BUT MIGRANTS' CULTURE OF RESIDENCE OFTEN CLASHES WITH THEIR CULTURE OF REARING. THE RESOLUTION OF SUCH CLASHES DEPENDS ON THE DIRECTION OF MIGRATION BUT FREQUENTLY FAVORS THE CULTURE OF REARING OVER THE CULTURE OF RESIDENCE. A LOW RATE OF CROSS-CULTURAL MIGRATION SUGGESTS THAT DISTINCT ENCLAVES ARE LIKELY TO ENDURE.

04129 HAORONG, G.

NEW CHANGES IN POLITICS

BEI JING REVIEN, 35(44) (NOV 92), 12 . TAE WOO ANNOUNCED THAT
ON OCTOBER 5, 1992, PRESIDENT ROH TAE HE WAS RESIGNING FROM THE RULING DEMOCRATIC LIBERAL PARTY, IN ORDER TO REMOVE PARTY POLITICS FROM THE REMAINDER OF HIS ADMINISTRATION AND TO REMAIN NEUTRAL IN THE UPCOMING PRESIDENTIAL ELECTION. THE MAJOR OPPOSITION PARTIES APPLAUDED WOO'S DECISION.

04130 HAPPY, J.R.

THE EFFECT OF ECONOMIC AND FISCAL PERFORMANCE ON THE EFFECT OF ECONOMIC AND FISCAL PERF INCUMBENCY VOTING: THE CANADIAN CASE
BRITISH JOURNAL OF POLITICAL SCIENCE, 22(1) (JAN 92), 117-130.

THIS STUDY EXAMINES THE EFFECT OF INCORPORATING TAXATION INTO THE INCUMBENCY VOTING MODEL USING AGGREGATE ECONOMIC DATA FOR CANADIAN FEOERAL ELECTIONS FROM 1953 TO 1988. AS MEASURED BY OPEN-ENDED QUESTIONS IN THE NATIONAL ELECTION STUDIES, TAXATION HAS NOT BEEN A SALIENT CAMPAIGN ISSUE AMONG CANADIAN VOTERS. NEVERTHELESS, VOTERS AS CONSUMERS IN THE MARKET ECONOMY HAVE AN INTEREST IN GOVERNMENT POLICIES
THAT AFFECT AFTER-TAX INCOME. FURTHERMORE, VOTERS HAVE AN INTEREST IN TAXATION AS A MEASURE OF GOVERNMENT EFFICIENCY AND THE COSTS OF PRDVIDING PUBLIC SERVICES, INDEPENDENT OF BENEFITS GENERATED BY GOVERNMENT. THE AUTHOR FINDS THAT THE ECONOMIC AND FISCAL PERFORMANCE VARIABLES BEHAVE AS EXPECTED IN THE INCUMBENCY MODEL. INCOME IMPROVEMENT HAS A POSITIVE EFFECT, WHILE THE RATE OF INFLATION AND UNEMPLOYMENT HAVE A NEGATIVE EFFECT ON INCUMBENCY VOTING. THE RELATIONSHIP BETHEEN TAXATION AND INCUMBENCY VOTING IS NEGATIVE, BOTH THROUGH ITS EFFECT ON AFTER-TAX INCOME AND ALSO DIRECTLY INDEPENDENT OF INCOME. THE RESULTS ARE CONSISTENT WITH AN INTERPRETATION WHICH SUGGESTS THAT VOTERS, RESPONDING TO THE PUBLIC AGENDA ON ECONOMIC PERFORMANCE AND TO A PRIVATE AGENDA ON TAXATION, BEHAVE BOTH AS POLITIC CONSUMERS AND AS ECONOMIC CITIZENS.

04131 HARBERGER, A.C.; DARBY, M.R.; EDWARDS, S.; KOPITS, G.; MCKINNON, R.I.

CENTRAL AND EASTERN EUROPE IN TRANSITION

CONTEMPORARY POLICY ISSUES, $X(1)$ ( JAN 92), 1-20

THE AUTHORS DISCUSS THE DRAMATIC POLITICAL AND ECONOMIC

CHANGES IN CENTRAL AND EASTERN EUROPE OVER THE PAST FEW YEARS AND SPECULATE ABOUT THE PROSPECTS FOR FUTURE DEVELOPMENT IN THE REGION.

04132 HARBIN, G.; ECKLAND, J.; GALLAGHER, J.J.; LILLIE, T. FACTORS INFLUENCING STATE PROGRESS IN THE IMPLEMENTATION OF PUBLIC LAW 99-457, PART H

POLICY SCIENCES, 25(2) (MAY 92), 103-115.

THE AUTHORS STUDY THE IMPLEMENTATION OF P.L. 99-457 (PART H), THE EDUCATION FOR THE HANDICAPPED AMENDMENTS OF 1986, WHICH PROVIDES THE STATES WITH PLANNING MONEY FROM THE FEDERAL GOVERNMENT TO DESIGN A COMPREHENSIVE INTERAGENCY, MULTIDISCIPLINARY PROGRAM OF SERVICES FOR HANDICAPPED CHILDREN AND THEIR FAMILIES. THE AUTHORS COMPILED RATINGS FROM KEY ADMINISTRATORS AND CITIZENS KNOWLEDGEABLE ABOUT THE LAW ON STATE PROGRESS IN IMPLEMENTING ITS 14 REQUIREMENTS AND ALSO ON PROPOSED INFLUENTIAL CONDITIONS THAT MIGHT AFFECT IMPLEMENTATION. ADOITIONAL DEMOGRAPHIC INFORMATION WAS OBTAINED FOR THE 50 STATES. THE FACTOR THAT SEEMED MOST INFLUENTIAL IN A SUBSET OF 35 STATES WAS THE PRIOR PRESENCE OF SYSTEMS FOR INTERAGENCY PLANNING AND DEVELOPMENT. NEITHER PRIOR HISTORY OF EARLY CHILDHOOD SERVICES, AVAILABLE RESOURCES, WEALTH OF STATE, OR GEOGRAPHIC REGION APPEARED TO RESOURCES, HEALTH OF STATE, OR GEOGRAPHIC REGION APPEARED
HAVE A SIGNIFICANT INFLUENCE ON POLICY DEYELOPMENT. THERE HAS SOME INDICATION THAT DIFFERENT FACTORS MIGHT BECOME WAS SOME INDICATION THAT DIFFERENT FACTORS MIGHT BECOME
INFLUENTIAL IN THE NEXT PHASE OF IMPLEMENTATION, POLICY INFLUENTIAL IN THE NEXT PHASE OF IMPLEMENTATION, POL
APPROVAL. IT APPEARS THAT PROGRESS IN STATE POLICY APPROVAL. IT APPEARS THAT PROGRESS IN STATE POLICY
DEVELOPMENT MAY BE LINKED TO THE SPECIAL REOUIREMENTS OF THE DEVELOPMENT MAY BE LINKED TO THE SPECIAL REQUIREME LEGISLATION ITSELF AND TO PRIOR AVAILABILITY OF
INSTITUTIONAL STRUCTURES THAT MAKE MANDATED COLLABORATIVE INSTITUTIONAL STRUCTURES
EFFORTS MORE POSSIBLE.

04133 HARBOR, B. TECHNOLOGICAL DIVERGENCE IN THE DEVELOPMENT OF MILITARY AND CIVIL COMMUNICATIONS SYSTEMS: THE CASE OF PTARMIGAN AND SYSTEM $X$

DEFENSE ANALYSIS, 7(1) (MAR 91), 81-96.

THIS PAPER DISCUSSES THE STUDY THAT ADDRESSES WHETHER INNOVATIONS IS INHERENTLY LESS EFFICIENT IN THE MILITARY THAN IN THE CIVIL SECTOR, AND WHETHER A COMMERCIAL APPROACH TO DEFENSE PROCUREMENT WILL IMPROVE IT. THE STUDY SHOWS THAT NEITHER THE ANALYSES NOR THE REMEDY SHOULD BE REGARDED AS UNIVERSALLY VALID. IT COMPARES THE TWO PRINCIPAL BRITISH TELECOMMUNICATIONS PROJECTS OF THE 1970 S AND 1980 S--THE PTARMIGAN BATTLEFIELD COMMUNICATIONS SYSTEM AND THE SYSTEM $X$ PUBLIC SWITCHING SYSTEM. WHILE THE CASE STUDY SUPPORTS OBSERVATIONS ABOUT THE SEPARATION OF CIVIL AND MILITARY TECHNOLOGY, IT SHOWS THAT THIS STEMS PRIMARILY FROM DIFFERENT REQUIREMENTS AND TECHNICAL STANDARDS, AND NOT FROM ANY INTRINSIC TENDENCIES TOWARDS COMPLEXITY OR SIMPLICITY.

04134 HARDARSON, O.T. ICELAND

EUROPEAN JOURMAL OF POLITICAL RESEARCH, 22 (4) (DEC 92), 429-435.

THE AUTHOR REPORTS THE RESULTS OF ICELAND'S APRIL 1991 PARLIAMENTARY ELECTIONS. HE ALSO DISCUSSES MAJOR ISSUES IN DOMESTIC POLITICS AND RECENT INSTITUTIONAL CHANGES IN ICELAND.

04135 HARDGRAVE, R.L. JR. AFTER THE DYNASTY: POLITICS IN INDIA AFTER THE DYNASTY: POLITICS IN INDIA CURRENT HISTORY, 91(563) (MAR 92), 106-112. INDEPENDENCE IN 1947. HE HARNS THAT SINCE THE 1989 ELECTIONS IMDIAN POLITICS HAS BECOME MORE FRAGMENTED AND LESS STABLE BECAUSE IT ENCOMPASSES NUMEROUS PARTIES THAT MUST CONSTANTLY SEEK TEMPORARY ALLIANCES IN ORDER TO REMAIN VIABLE.

04136 HARDING, H.

NEITHER FRIEND NOR FOE: A CHINA POLICY FOR THE NINETIES BRDOKINGS REYIEW, 10(2) (SPR 92), 6-11.

THE CONCEPTUAL FRAMENORK THAT GUIDED U.S. CHINA POLICY 
IN THE 1970'S AND 1980'S IS CLEARLY INADEQUATE TODAY. CHINA CAN NO LONGER BE SEEN AS AN ALLY AGAINST AN EXPANSIONIST SOVIET UNION OR AS A PIONEER IN POLITICAL AND ECONOMIC LIBERALIZATION. GIVEN CHINA'S BURGEONING TRADE SURPLUS WITH THE UNITED STATES, IT IS EVEN DIFFICULT TO PORTRAY CHINA AS A LUCRATIVE TRADING AND INVESTMENT PARTNER. BUT IN REDESIGNING U.S. CHINA POLICY, IT WOULD BE FOOLISH TO SUBSTITUTE ONE SET OF CARICATURES FOR ANOTHER. IF CHINA IS NO LONGER AN ALLY OF THE UNITED STATES, NEITHER IS IT AN AMERICAN ADVERSARY. AL THOUGH CHINA HAS RETREATED FROM THE AMERICAN ADVERSARY. ALTHOUGH CHINA HAS RETREATED FROM THE FOREFRONT OF REFORM, IT HAS NOT RETURNED TO MAOISM EITHER POLITICALLY OR ECONOMICALLY. TO BE EFFECTIVE, AMERICAN CHINA AND FOREIGN AFFAIRS.

04137 HARDING, $S$.

AFTER THE NEUTRALITY IOEAL: SCIENCE, POLITICS, AND STRONG OBJECTIVITY

SOCIAL RESEARCH, 59(3) (FAL 92), 567-588.

THERE ARE TWO KINDS OF POLITICS WITH WHICH THE NEW SOCIAL STUDIES OF SCIENCE HAVE BEEN CONCERNED. ONE IS THE OLDER NOTION OF POLITICS AS OVERT ACTIONS AND POLICIES INTENDED TO AOVANCE THE AGENDAS OF SPECIAL INTEREST GROUPS THIS KIND OF POLITICS INTRUDES INTO PURE SCIENCE THROUGH CONSCIOUSLY-CHOSEN, AND OFTEN CLEARLY ARTICULATED, ACTIONS AND PROGRAMS THAT INFLUENCE WHICH SCIENTIFIC ENDEAVORS ARE UNDERTAKEN, HOW THE RESULTS OF RESEARCH ARE INTERPRETED, AND THE SCIENTIFIC AND POPULAR NOTIONS OF NATURE AND SOCIAL RELATIONS. THIS KIND OF POLITICS IS CONCEPTUALIZED AS POLITICIZING THE SCIENCES BY ACTING ON THEM FROM THE OUTSIDE. IN ANOTHER CONCEPTUALIZATION, POWER IS EXERCISED LESS VISIBLY, LESS CONSCIOUSLY, AND THROUGH THE DOMINANT INSTITUTIONAL STRUCTURES, PRIORITIES, PRACTICES, AND LANGUAGES OF THE SCIENCES, PARADOXICALLY. THIS KIND POLITICS FUNCTIDNS THROUGH THE DEPOLITICIZATION OF SCIENCE-THROUGH THE CREATION OF AUTHORITARIAN SCIENCE.

04138 HARDY, D.; MIHAL JEK, D.

ECONOMIC POLICYMAKING IN A FEDERATION

ECONOMIC POLICYMAKING IN A FEDERATION
FINANCE AND DEVELOPMENT, $29(2)$ (JUN 92), 14-17.

FINANCE AND DEVELOPMENT, 29 (2) (JUN 92), 14-17.

CENTRALIZED FEDERATIONS IS BEING CHALLENGED IN MANY PARTS OF THE HORLD TODAY. A CRITICAL ISSUE IS THE BALANCE OF ECONOMIC POWER BETWEEN THE CENTER AND THE COMPONENT REGIONS. THE UNOERLYING THEME OF THIS ANALYSIS IS THAT THE FLEXIBILITY AND THE ACCOMOOATION OF DIVERSITY OFFERED BY A FEDERAL CONSTITUTION MAY CONFLICT WITH THE NEED FOR STABILITY. DECISIVENESS, AND EOUITY. AN ILLUSTRATION IS OFFERED OF THE TYPES OF ECONOMIC ARGUMENTS THAT GENERALLY BEAR ON THE ISSUE OF FEDERALISM, GIVEN A FRAMEWORK OF DISTINCT REGIONS UNITED IN A SINGLE STATE.

04139 HAREVEN, G.

GLASNOST IN THE PROMISED LAND

TIKKUN, 6(4) (JUL 91), 16-20,86-87

THIS ARTICLE EXAMINES THE OFTEN DIFFICULT CHALLENGES SOVIET JEWS FACE UPON THEIR MIGRATION TO ISRAEL. CHIEF AMONG THESE ARE CULTURAL AND POLITICAL DIFFERENCES. SOVIET JEWS ADAPT IN A VARIETY OF WAYS, BUT THE MAJORITY LIVE QUIETLY AND "LEARM NOT TO TALK TOO MUCH." FOR MANY, REACHING THE "HOLY LAND" IS AN EXCITING, YET SOMEWHAT DISILLUSIONING EXPERIENCE. MANY OBSERVERS ARE CONFIDENT THAT THE SOVIET JEWS WILL BE READILY ASSIMILATED INTO ISRAELI SOCIETY, YET NEW LIFE INTO ISRAELI SOCIETY.

04140 HARLESS, J.D.

LOCAL GOVERNMENT ENVIRONMENTAL ADVISORY BOARDS

NATIONAL CIVIC REVIEH, 81(1) (WIN 92), 9-18.

HISTORICALLY, CITIZENS WISHING TO SHAPE OR CHANGE ENVIRONMENTAL POLICY HAVE HAD LITTLE OPPORTUNITY TO DO SO, SHORT OF PURSUING DIRECT CONFRONTATION HITH ELECTED SHORT OF PURSUING DIRECT CONFRONTATION WITH ELECTED OFFICIALS. IN THIS ARTICLE, THE AUTHOR ARGUES FOR THE

CREATION OF FORUMS AND PROCESSES FOR BROA

04141 HARMON, C.C.

PROPAGANDA AT PISTOL POINT: THE USE AND ABUSE OF EDUCATION BY LEFTIST TERRORISTS

POLITICAL COMAUNICATION, 9 (1) (1992), 15-30.

THE COMMON TENDENCY, 9 (1) AND TO EITHER OISMISS OR DREAD THEM IS INAPPROPRIATE. MOST AND TO EITHER DISMISS OR DREAD THEM IS INAPPROPRIATE. MOST ERUCATED, AND MANY HAVE PROFESSIONAL BACKGROUNDS AS TEACHERS, COLLEGE PROFESSORS, WRITERS, LAWYERS, AND DOCTORS. THIS COLLEGE PROFESSORS, WRITERS, LAWYERS, AND DOCTORS

SOCIO-POLITICAL REALITY SUGGESTS TWO QUESTIONS FOR
REFLECTION: (1) WHAT HAVE BEEN THE EFFECTS OF EDUCATION UPON REFLECTION: (1) WHAT HAVE BEEN THE EFFECTS OF EDUCATION UPON
LEFTIST TERRORISTS AND (2) HOW HAVE TERRORISTS USED THEIR SCHOOLING AND THEIR CREDENTIALS TO ADVANCE THEIR CAUSES?

04142 HARNISCHFEGER, $U$.

GOVERNMENT AVOIDS DEBATE OM THE PILL

JAPAN TIMES (WEEKLY INTERMATIONAL EDITION), 32(16) (APR 92), 7
THE ONLY BIRTH CONTROL PILL LEGALLY AVAILABLE ON THE JAPANESE MARKET IS A HIGH-DOSAGE PILL DESIGNED FOR THE MEDICAL TREATMENT OF MENSTRUAL PROBLEMS. SINCE 1986, SIX JAPANESE PHARMACEUTICAL COMPANIES HAVE UNSUCCESSFULLY PILLS. RECENTLY, THE GOVERNMENT POSTPONED APPROVAL DUE TO FEAR THAT THE PILL WOULD DISCOURAGE THE USE OF CONDOMS AND ACCELERATE THE SPREAD OF AIDS. BUT THERE ARE THOSE HHO DOUBT THE GOVTRMMENT'S TRUE MOTIVES SOME CRIT AR SPECULATE DOUT THE GOVERMMEN'S TRUE MOTIVES. SOHE CRITICS SPECULATE THAT THE GOVERNMENT'S ARGUMENT IS A SMOKE SCREEN TO HIDE ITS FEAR OF A FURTHER DECLINE IN THE COUNTRY'S BIRTH RATE, WHICH WOULD EXACERBATE THE CURRENT HORKFORCE SHORTAGE. OTHERS
POINT TO PRESSURE FROM THE POWERFUL GYNECOLOGISTS' LOBBY.

04143 HARRIES, 0.

DRIFT AND MASTERY, BUSH-STYLE

MATIONAL INTEREST, (23) (SPR 91), 3-7

OBSERVERS OF U.S. FOREIGN POLICY HAVE GIVEN PRESIDENT BUSH HIGH MARKS FOR HIS RELATIVE INACTION WITH REGARDS TO THE CRUMBLING SOVIET EMPIRE, AND FOR HIS SHIFT ACTION IN THE PERSIAN GULF. THIS ARTICLE REASSESSES THESE TWO POLICIES. IT CONCLUDES THAT, AT LEAST UNTIL DISORDER BECOMES WIDESPREAD AND VIOLENT, A POLICY OF INACTION WITH REGARDS TO THE USSR IS PRUDENT. HOWEVER, THE AUTHOR DISAGREES WITH THE DRAMATIC U.S. RESPONSE TO SADDAM HUSSEIN'S AGGRESSION FOR THREE REASONS: THE SWIFTNESS OF THE U.S. DEPLOYMENT AND DIPLOMATIC COMMITMENT TO KUWAIT PRECLUDED ANY SUBSTANTIVE ACTION BY U.S. ALLIES; THE RELIANCE ON THE UN FOR LEGITIMACY, WHILE A GOOD SHORT TERM TACTIC, WILL HAVE DETRIMENTAL CONSEQUENCES FOR THE U.S. IN THE FUTURE; AND THE U.S. RESPONSE HAS BEEN DISPROPORTIONATE TO THE CRIME AND TO THE THREAT.

04144 HARRINGTON, L.

SHOULD THE PUBLIC FUNDING OF PRESIDENTIAL CAMPAIGMS BE ABOL ISHED?

JOURNAL OF LAH \& POLITICS, VIII(2) (WIN 92), 321-324.

THE AUTHOR ARGUES THAT THE PRESENT SYSTEM FOR THE PUBLIC FUNDING OF PRESIDENTIAL CAMPAIGNS MAY NEED SOME REFORM BUT SHOULD NOT BE ABANDONED IN ITS ENTIRETY.

04145 HARRIS, D.

THE LONG GOODBYE

FREEDOM REVIEH, 23(5) (SEP 92), 19-22.

THE AUTHOR LOOKS AT THE STATUS OF QUEBEC'S FRANCOPHONE MAJORITY AND AT THE ISSUE OF FRENCH SEPARATISM IN RECENT CANADIAN POLITICS.

04146 HARRIS, E.

SELLING DEPENDENCY

MATIONAL REVIEW, XLIV(11) (JUM 92), 40

THIS ARTICLE ARGUES THAT THE LOS ANGELES RIOTS WHICH FOLLOWED THE RODNEY KING VERDICT ARE AN INDICATION OF HOW LITTLE PROGRESS HAS BEEN MADE IN HELPING AFRICAN-AMERICANS. THE AUTHOR ARGUES THAT THE ROOT CAUSE OF THE LACK OF PROGRESS IS THE DEPENDENCY CREATED BY THE LEGACY OF SIXTIES' CIVIL-RIGHTS MOVEMENTS. SPENDING TRILLIONS OF DOLLARS ON SOCIAL PROGRAMS WILL NOT BEGIN TO SOLVE THE PROBLEMS OF THE AFRICAN-AMERICAN COMMUNITY UNTIL ITS LEADERSHIP PRESCRIBES RESPONSIBILITY RATHER THAN DEPENDENCY AND SCAPEGOATING.

04147 HARRIS, E.

TOWARDS A COMPREHENSIVE STRATEGY FOR HALTING CHEMICAL AMD BIOLOGICAL HEAPONS PROLIFERATION

ARMS CONTROL, 12(2) (SEP 91), 129-160.

CONCERM ABOUT CHEMICAL OR BIOLOGICAL WEAPONS PROLIFERATION SURFACED IN THE MID-1980S. UNTIMATELY, NATIONAL AND INTERNATIONAL NON-PROPLIFERATION EFFORTS MUST SEEK THE ACTUAL ELIMINATION OF THE WEAPONS THEMSELVES. VARIOUS MEASURES WILL BE REQUIRED TO ACHIEVE THIS WIDER NONPROLIFERATION OBJECTIVE. THIS ARTICLE DISCUSSES FDUR PARTICULAR TYPES OF MEASURE, EXPLAINING HOW EACH CONTRIBUTES PARTICULAR TYPES OF MEASURE, EXPLAINING HOW EACH CONTRIBUTES AND BIOLLGICAL WEAPONS AS WELL AS FACILITATING THEIR

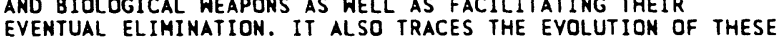
MEAUSRES IN BOTH NATIONAL AND INTERHATIONAL POLICY.

04148 HARRIS, J.

YADIM ANDREEVICH MEDVEDEV AND THE TRANSFORMATION OF PARTY IDEOLOGY, $1988-1990$

RUSSIAN REVIEW, 51(3) (JUL 92), 363-377.

MIKHAIL GORBACHEY'S ASSAULT ON IDEOLOGICAL ORTHODOXY AND HIS POLITICAL AND ECONOMIC REFORMS PROOUCED IMMENSE HIS POLITICAL AND ECONOMIC REFORMS PRODUCED IMMENSE SOVIET UNION (CPSU). DURING THE FIRST YEARS OF PERESTROIKA, THE IDEOLOGICAL DISCORD INTENSIFIED UNTIL IT WAS THE IDEOLOGICAL DISCORD INTENSIFIED UNTIL IT WAS

SECRETARIAT IN 1988, WHEN THE DIRECTION OF THE PARTY'S "IDEOLOGICAL WORK" WAS TRANSFERRED TO A NEW COMMISSION DIRECTED BY VADIM ANDREEVICH MEDVEDEY. THIS PAPER EXAMINES MEDVEDEV'S EFFORT TO DEVELOP A COHERENT IDEOLOGICAL POSITION FOR THE CPSU DURING HIS TWO-YEAR TENURE. PUBLIC

PRONOUNCEMENTS BY MEDVEDEY AND OTHER LEADERS SUGGEST THAT HE FAILED TO BRING IDEOLOGICAL COHERENCE FOR THREE INTERRELATED REASONS: GORBACHEY'S DESTRUCTION OF THE DIVIDING LINE 
BETWEEN "SOCIALIST" AND "NON-SOCIALIST" IDEOLOGIES; THE SOVIET GOVERNMENT'S INABILITY TO DEAL EFFECTIVELY WITH THE DISASTROUS CONSEQUENCES OF ITS ECONOMIC REFORMS; AND THE LEADERSHIP'S FAILURE TO DEVELOP A COHERENT AND EFFECTIVE RESPONSE TO THE GROWING NATIONALIST AND SEPARATIST MOVEMENTS IN THE SOVIET REPUBLICS.

04149 HARRIS, J.P.

BRITISH MILITARY INTELLIGENCE AND THE RISE OF GERMAN MECHANIZED FORCES, 1929-40

INTELLIGENCE AND NATIONAL SECURITY, 6(2) (APR 91), 395-417. THE PURPOSE OF THIS ARTICLE IS TO TRACE IN SOME DETAIL OF THE DEVELOPMENT OF THE BRITISH GENERAL STAFF'S UNDERSTANDING OF GERMAN MECHANI ZED FORCES AND MECHANIZED WARFARE FROM 1929 TO 1940. THE AUTHOR ARGUES THAT THE GERMAN TRIAD OF ARMORED SPEARHEADS, SPEED OF ADVANCE AND AIR SUPPORT, HAD IN FACT BEEN HIGHLIGHTED BY THE BRITISH GENERAL SUPPORT, HAD IN FACT BEEN HIGHLIGHTED BY THE BRITISH GENERAL
STAFF AS EARLY AS 1934. THE GENERAL STAFF'S ASSESSMENT OF STAFF AS EARLY AS 1934. THE GENERAL STAFF'S ASSESSMENT OF
THE BASIC THRUST OF GERHAN THINKING ON THE USE OF AIR AND THE BASIC THRUST OF GERMAN THINKING ON THE USE OF AIR
MECHANIZED GROUND FORCES WAS FAR MORE ACCURATE AND MECHANIZED GROUND FORCES WAS FAR MORE ACCURATE AND
PERCEPTIVE THAN HAS YET BEEN ACKNOWLEDGED. WHEN ASSESSING PERCEPTIVE THAN HAS YET BEEN ACKNOWLEDGED. WHEN ASSESSING
THE PERFORMANCE OF BRITISH MILITARY INTELLIGENCE AS WHOLE IN THE PERFORMANCE OF BRITISH MILITARY INTELLIGENCE AS WHOLE IN
THE 1930S, THIS REMARKABLE SUCCESS MUST BE SET AGAINST THE INITIAL UNDERESTIMATION OF THE PEACETIME EXPANSION OF THE INITIAL UNDERES
GERMAN ARMY.

04150 HARRIS, JR., T.

WE, THE PEOPLE, AND OUR DEFICIT

FREEMAN, 42(11) (NOV 92), 432-433.

THERE HAS BEEN A LOT OF CRITICISM ABOAUT THE

GOVERNMENT'S CONTINUING FAILURE TO DEAL WITH THE MOUNTING FEDERAL DEBT. SEMATOR RUDMAN HOLDS NEARLY EVERYONE RESPONSIBLE FOR THE BUDGET GRIDLOCK: THE CONGRESS. THE PRESIDENT, AND THE AMERICAN PEOPLE. THE AUTHOR SUGGESTS THAT THE PEOPLE ARE INDEED RESPONSIBLE BECAUSE THEY LOVE BIG GOVERMMENT. HE EXPLORES THE TENDENCY TO LOVE BEING ON THE RECEIVING END OF GOVERNMENT HANDOUTS AND TO VOTE ACCORDINGLY.

04151 HARRIS, L.

REFORM NOWI S. 100 AND BEYOND

JOURNAL OF LAW \& POLITICS, VIII(2) (WIN 92), 253-258.

THE AUTHOR EXAMINES S. 100, A HYPOTHETICAL BILL CONTAINING PROPOSALS FOR REFORMING THE U.S. PRESIDENTIAL ELECTION PROCESS. HE EVALUATES EACH SECTION OF THE BILL SEPARATELY, CONSIDERS SOME EMPIRICAL DATA COLLECTED BY THE SEPARATELY, CONSIDERS SOME EMPIRICAL DATA COLLECTED BY THE
HARRIS POLL IN 1988, AND OUTLINES AN ADDITIONAL "NECESSARY HARRIS POLL IN 1988 , AND OUTLINES AN ADDITIONAL
AND SIGNIFICANT" REFORM NOT CONTAINED IN S. 100.

04152 HARRIS, R.; PURIVS, D.

CONSTITUTIONAL CHANGE AND CANADA'S ECONOMIC PROSPECTS CANADIAN PUBLIC POLICY--AMALYSE DE POLITIOUES, XYII(4) (DEC 91), 379-395.

THAT THE KEY TO CANADIAN ECONOMIC PROSPERITY HAS BEEN THE DEVELOPMENT OF AN ECONOMIC UNION OF THE DIVERSE REGIONS THAT MAKE UP THE COUNTRY IS ARGUED. THE BENEFITS FROM ECONOMIC INTEGRATION ARE EXAMINED AND IT IS ARGUED THAT THESE INCREASE WITH A MOVEMENT ALONG THE SPECTRUM FROM LESS TO MORE ECONOMIC INTEGRATION. IT IS ALSO ARGUED THAT ECONOMIC INTEGRATION IMPLIES INCREASED POLITICAL INTEGRATION. PRESERVATION AND ENHANCEMENT OF THE CANADIAN ECONOMIC UNION (CEU) IS THE BEST OPTION IN TERMS OF PROVIDING A FRAMENORK WITHIN WHICH CANADIANS CAN EFFECTIVELY RESPOND TO THE EMERGING GLOBAL CHALLENGE. THE ARTICLE CONCLUDES THAT IN ORDER TO ENSURE THE CONTINUED PAROSPERITY OF CANADIANS. THE CEU SHOULD NOT ONLY BE PRESERVED BUT ENHANCED, AND THAT THIS

04153 HARRIS, R.

THE NEXT STAGE OF THATCHERISM

NATIONAL REVIEN, XLIII(1) (JAN 91), 42-43.

MANY SEE THE OUSTING OF MARGARET THATCHER AS THE END OF AN ERA IN BRITISH POLITICS. THIS ARTICLE EXAMINES THATCHER'S LEGACY AND THE CHALLENGES THAT HILL CONFRONT HER SUCCESSORS. THEY INCLUDE BALANCING THE NEED FOR A STABLE EXCHANGE RATE AND INFLATIONARY PRESSURES; THE NEED FOR FURTHER INCDME TAX CUTS AND PRIVATIZATION DF STATE-OWNED INDUSTRIES; THE NEED TO REVERSE THE EFFECTS OF "TRADE-UNION INDUCED SCLEROSIS"; AND THE NEED TO REVERSE THE COLLAPSE OF TRADITIONAL VALUES WHICH HAS LED TO FAMILY BREAKDOWN, EDUCATIONAL DECLINE, DELINQUENCY, HOMELESSNESS, AND CRIME.

04154 HARRIS, W.F. II.

THE INTERPRETABLLE CONSTITUTION

JOHNS HOPKINS UNIVERSITY PRESS, 1992, 256

THIS BOOK EXAMINES THREE FEATURES OF AMERICAM

CONSTI IUTIONALISM THAT ARE USUALLY TAKEN FOR GRANTED: THE CONSTITUTION'S AUTHORITATIVENESS, ITS WRITTEN CHARACTER, AND ITS CONSEQUENT READABILITY. A CENTRAL INSIGHT OF THE WORK IS THE VIEH OF AMERICAN POLITICS AS CONSISTING OF TWO "TEXTS"-THE FAMILIAR CONSTITUTION ITSELF AND THE WORKING POLITY THAT IT SIGNIFIES. EMRACING BOTH OF THESE "TEXTS," THE AUTHOR OFFERS A RI GOROUS METHODOLOGY FOR INTERPRETING EACH IN LIGHT OF THE OTHER. HE ALSO ATTEMPTS TO OFFER A MIDDLE GROUND BETWEEN THE TWO EXTREMES OF STRICT CONSTRUCTIONISM ON THE
ONE HAND AND HISTORICISM (THE NOTION THAT EACH GENERATION INTERPRETS THE CONSTITUTION ANEW) ON THE OTHER. IN THE PROCESS, HE DESCRIBES THE WAYS IN WHICH THE WRITTEN CONSTITUTION AND THE WORKING POLITY MUTUALLY LIMIT AND TRANSFORM EACH OTHER.

04155 HARRISON, $D$.

A MANUFACTURED PEACE

THE MIDDLE EAST, (201) (JUL 91), 17-18.

THE NORMALIZATION OF RELATIONS BETWEEN SYRIA AND LEBANON IS ANALYZED AND ITS ORIGINS ARE TRACED. CONSIDERATION IS GIVEN TO THE PROBLEMS THAT HAVE DIVIDED LEBANON AHD THE AUTHOR EXPRESSES SKEPTICISM REGARDING THE EFFECTIVENESS OF THE NEW PEACE WITH SYRIA IN SOLVING THOSE PROBLEMS. SYRIA'S ROLE AS PEACEKEEPER IN LEBANON IS THEN DISCUSSED, FOLLOHED BY HER PURSUIT OF HEGEMONY OVER LEBANON, HER EFFORTS TO BIVIDE THE CHRISTIAN COMMUNITY, HER PLANS TO REVIVE THE DIVIDE THE CHRISTIAN COMMUNITY, HER PLANS TO REVIVE THE
LEBANESE LEGISLATURE, AND HER DISBAHDING OF THE LEBANESE LEBANESE LEGISLATURE, AND HER DISBANDING OF THE LEBANESE
MILITIAS. FINALLY, CONSIDERATION IS GIVEN TO ISRAEL'S MILITIAS. FINALLY, CONSIDERATION IS GIVEN TO ISRAEL'S
REACTION TO THE DEVELOPMENTS BETHEEN SYRIA AND LEBANON AND REACTION TO THE DEVELOPMENTS BETHEE

04156 HARRISON, L.

AMERICA AND ITS IMMIGRANTS

NATIONAL INTEREST, 28 (SUM 92), 37-55

THE UNITED STATES IS ONE OF THE FEW ADVANCED COUNTRIES IN THE HORLD THAT DOES NOT EFFECTIVELY CONTROL IMMIGRATION. THERE IS COMPELLING EVIDENCT THAT MOST AMERICANS ARE OPPOSED TO CONTINUING HIGH LEVELS OF IMMIGRATION, LEGAL AMD ILLEGAL. THIS PAPER STUDIES THE PRESENT SITUATION AND CONCLUDES THAT IT IS TIME TO WORK TOWARD AN IMMIGRATION POLICY BASED ON U.S INTERESTS THAT LEAVES THE DECISIONS ABOUT WHO ENTERS THE UNITED STATES IN THE HANDS OF THE U.S. AUTHORITIES RATHER THAN INDIVIDUAL CITIZENS OF OTHER COUNTRIES, ONE THAT EMPHASIZES OUR OBLIGATIONS TO OUR OWM SOCIETY AND ITS CITIZENS, PARTICULARLY THOSE IN NEED. THE UNITED STATES NEEDS AN IMMIGRATION POLICY LESS RESPONSIVE TO THE FAILURES OF OTHER SOCIETIES AND MORE RESPONSIVE TO THE NEEDS OF ITS OWN.

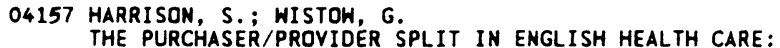
TOWARDS EXPLICIT RATIONING?

POLICY AND POLITICS, 20 (2) (APR 92), 123-130.

OLICY AND POL ITICS, 20( 2 ) (APR 92), 123-130.
AN IMPORTANT FEATURE OF THE REFDRMED NATIONAL HEALTH AN IMPORTANT FEATURE OF THE REFORMED NATIONAL HEALTH
SERVICE IS THE INTROOUCTION OF QUASI - MARKETS IN HEALTH CARE, TO BE CREATED BY SEPARATING THE "PURCHASER" AND "PROVIDER" FUNCTIONS FORMERLY CONFLATED IN THE ROLE OF DISTRICT HEALTH AUTHORITIES. THIS PAPER PRESENTS DATA FROM A STUDY OF THE FIRST FEW MONTHS UNDER THE NEW SYSTEM, FOCUSING ON THE ROLE LEGITIMIZING THEIR DECISIONS ABOUT HOW TO DO THIS.

04158 HARRISON, S.S. SOUTH ASIA AND THE UNITED STATES: A CHANCE FOR A FRESH START

CURRENT HISTORY, 91(563) (MAR 92), 97-105.

THE UNITED STATES NOW HAS AN OPPORTUNITY TO MAKE A FRESH START IN SOUTH ASIA. IT SHOULD MOVE TOWARD A MORE DETACHED FOREIGN POLICY THAT AVOIDS EMBROILMENT IN THE REGION'S MILITARY RIVALRY WHILE GIVING APPROPRIATE ATTENTION TO INDIA AS SOUTH ASIA'S MORE IMPORTANT POWER.

04159 HARRISON, T.

SOL IDARITY HITH BOSNIA

PEACE \& DEMOCRACY NEWS, 11(2) (WIN 92), 15-17

BOSNIANS ARE FIGHTING TO PRESERVE AN ETHNICALLY DIVERSE SOCIETY IN WHICH MUSLINS, SERBS, AND CROATS HAVE LIVED PEACEFULLY. THEY ARE ALSO DEFENDING THE IDEA OF A UNITARY REPUBLIC FOUNDED ON UNIVERSAL RATHER THAN ETHNICALLY -BASED RIGHTS. THEIR ENEMIES ARE INSPIRED BY A FASCISTIC IDEOLOGY OF BLDOD AND SOIL, AND THEY HILL NOT TOLERATE COEXISTENCE WITH NON-SERBS UNDER ANY CIRCUMSTANCES. AS FAR AS YUGOSLAVIA IS CONCERNED, THE WEST LONG TOLERATED--AND THEREFORE ENCOURAGED--MASSIVE HUMAN RIGHTS VIOLATIONS. AFTER A REVIEW OF THE WARFARE IN YUGOSLAVIA, THIS ARTICLE SUGGESTS THAT WE NEED TO START NOW, DRAWING THE LESSONS DF YUGOSLAVIA AND POINTING TO AN ALTERNATIVE VISION OF A DEMOCRATIC FOREIGN POL ICY, ONE WHICH APPLIES A CONSISTENT STANDARD OF HUMAN RIGHTS, INCLUDING THE ALL IMPORTANT RIGHT OF NATIONAL SELFRIGHTS, INCLUDIN
DETERMINATION.

04160 HARROP, $W$

IRAN'S EMERGING WORLD ORDER

MIDDLE EAST INSIGHT, 8(2) (SEP 91), 46-49.

THE FOREIGN POLICY OF IRAN HAS EXHIBITED SOME REMARKABLE CHANGES IN RECENT MONTHS. THE MOST SIGNIFICANT OF THESE IS THE OPEN ADMISSION THAT "ECONOMIC CONSIDERATIONS OVERSHADOW POLITICAL PRIORITIES" IN THE NEW WORLD. FAR BEYOND MERE RHETORIC, IRAN'S REVOLUTIONARY OUTLOOK HAS CHANGED AND MATURED. COOPERATION HAS REPLACED CONFRONTATION AS THE WATCHWORD IN IRANIAN POLICY FORMATION. WHILE THIS DOES NOT MEAN THAT IRAN WILL WELCOME THE WEST WITH OPEN ARMS, IT DOES SIGNAL A GREATER EMPHASIS ON PRAGMATISM OVER IDEOLOGY. 
04161 HART, A.G.

OPEN LETTER TO PRESIDENT BUSH

CHALLENGE, 35(1) (JAN 92), 44-45.

OPTIMISTIC ASSUMPTIONS ABOUT THE HEALTH OF U.S. BANKS MAY LOOK OUITE IMPLAUSIBLE WITHIN A SHORT TIME. TO REASSURE BANKS AND THE PUBLIC THAT BANKS CAN DO THEIR JOB, CONGRESS AND THE PRESIDENT MUST ADOPT A WORKABLE AND ADEQUATE PROGRAM ABDUT THE HEALTH O COAST ALONG AND MAKE PLEASANT NOISES SERIOUS AND PROLONGED DEPRESSION.

04162 HART, G.

ENGENDERING EVERYDAY RESISTANCE: GENDER, PATRONAGE AND PRODUCTION POLITICS IN RURAL MALAYSIA

JOURNAL OF PEASANT STUDIES, 19(1) (OCT 91), 93-121.

LABOR RELATIONS, FORMS OF RESISTANCE, AND CLASS

CONSCIOUSNESS IN THE MUDA REGION OF MALAYSIA HAVE BECOME INCREASINGLY DIFFERENTIATED ALONG GENDER LINES. THIS ARTICLE TRACES THE EVOLUTION OF GENDER DIFFERENCES IN LABOR RELATIONS AND SHOWS HOW THE GENDER-DIFFERENTIATED POLITICS OF PRODUCTION CONNECTS WITH POLITICAL PATRONAGE AND DOMESTIC POLITICS, AND HOW THESE STRUGGLES ARE CONDITIONED BY THE INTERPLAY OF GENDER IDEOLOGY AND LARGER POL ITICAL-ECONOMIC, STRUCTURES AND PROCESSES. THE AUTHOR SUGGESTS THAT THIS GENDERED ANALYSIS OF CLASS FORMATION IN MUDA CALLS FOR A MAJOR RETHINKING OF SCOTT'S NOTION OF EVERYDAY FORMS OF PEASANT RESISTANCE.

04163 HART, J.A.

THE EFFECTS OF STATE-SOCIETAL ARRANGEMENTS ON

INTERNATIONAL COMPETITIVENESS: STEEL, MOTOR VEHICLES, AND

SEMICONDUCTORS IN THE UNITED STATES, JAPAN, AND HESTERN EUROPE

BRITISH JOURNAL OF POLITICAL SCIENCE, 22(3) (JUL 92),

CHANGES IN INTERMATIONAL COMPETITIVENESS SINCE HORLD WAR II HAVE FAVORED GERMANY AND JAPAN OVER FRANCE, BRITAIN, AND TREND IN THREE SPECIFIC INDUSTRIES: STEEL, MOTOR VEHICLES, AND SEMICONDUCTORS. EXPLANATIONS OF CHANGES IN AND SEMICONDUCTORS. EXPLANATIONS OF CHANGES IN

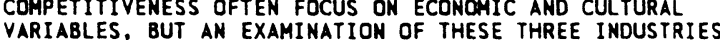
VARIABLES, BUT AN EXAMINATION OF THESE THREE INDUSTRIES
SHOWS THAT A BETTER EXPLANATION CAN BE FOUND IN THE HAY EACH COUNTRY ORGANIZES ITS STATE AND SDCIETY. STATE-SOCIETAL COUNTRY ORGANIZES ITS STATE AND SOCIETY. STATE-SOCIETAL IMPACT ON THE SPEED OF DIFFUSION OF NEW TECHNOLOGIES. THE IMPACT ON THE SPEED OF DIFFUSION OF NEN TECHNOLOGIES. THE DISPARATE CASES OF GERMANY (STRONG BUSINESS AND LABOR, WEAK DOVERMMENT) AND JAPAN (STRONG BUSINESS AND GOVERNMENT, WEAK LABOR) SUGGEST THAT THERE IS MORE THAN ONE PATH TO COMPETITIVENESS. THE LITERATURE ON COMPETITIVENESS HAS FOCUSED TOO MUCH ON JAPAN AND, THEREFORE, ON STATE

INDUSTRIAL POLICIES AS THE KEY TO INCREASING COMPETITIVENESS. THE GERMAN CASE SHONS THAT INCREASED COMPETITIVENESS IS POSSIBLE WITH A RELATIVELY WEAK STATE BUT ONLY IF THERE IS A MAJOR COMMITMENT TO UPGRADING THE SKILL LEVELS OF THE WORK FORCE.

04164 HART, T.

TRANSPORT, THE URBAN PATTERN, AND REgIONAL CHANGE, 19602010

URBAN STUDIES, 29(2) (APR 92), 483-503.

THE AUTHOR EXAMINES BRITISH TRANSPORT POLICY ANO URBAN PATTERNS SINCE 1960. HE CONCENTRATES FIRST ON THE PERIOD FROM 1960 TO 1984 AND ON DISTINGUISHING INTRA-REGIONAL TO INTER-REGIONAL CHANGE HITHIN THIS PERIOD. THEN HE EXAMINES MORE RECENT CHANGES IN POLICY, ATTITUDES, AND EVALUATION.

04165 HARTFORD, $K$

REFORM OR RETROFITTING? THE CHINESE ECONOMY SINCE TIANAMMEN WORLD POLICY JOURMAL, 9 (1) (WIN 91), 35-66.

THAT REFORMED FEATURES HAVE OFTEN BEEN PATCHED ONTO A BASICALLY UNREFORMED SET OF INSTITUTIONS AND ECONOMIC STRUCTURES INHERITED FROM THE STALINIST-MAOIST SYSTEM IS ARGUED: CHINA HAS HAD RETROFITTING BUT MOT SYSTEMIC REFORM. THIS ARTICLE EXPLORES THE CHINESE ECNDMONY FROM THE ROST-MAO ECOMOYY TO E TAMAMMEN AMD BEYOND. IT COMCLUDES THATE POST-MAO ECONOMY TO TIANANMEN AND BEYOND. IT CONCLUDES THAT RESOLVING THE PRESENT QUANDARY IS NOT THE WORK OF A PARTICULAR POL
OR OF THE INTRODUCTION OF ELECTIONS OR OF ANY SPECIFIC OR OF THE INTRODUCTION OF ELECTIONS OR OF ANY SPECIFIC CLARITY ABOUT WHAT MUST FUNDAMENTALLY CHANGE IS REQUIRED.

04166 HARTIGAN, $K$

MATCHING HUMANITARIAN NORMS WITH COLD, HARD INTERESTS: THE MATCHING HUMANITARIAN NORMS HITH COLD, HARD INTERESTS: THE MAKING OF REFUGEE POLICIES IN MEXICO AND HONDURAS,

INSTITUTIOHAL APPROACHES TO INTERNAL REIATIONS POSIT THAT NORMS AND INTERESTS INTERACT, BUT THEY PROVIDE LITTLE DESCRIPTION OF HOW THE INTERACTION PROOUCES POLICY DECISIONS. THIS ARTICLE ATTEMPTS TO INCORPARATE THE ROLE OF INSTITUTIONALIZED NORMS WITHIN AN INTEREST-BASED ANALYSIS OF POL ICYMAKING BY EXPLORING THE INTERACTIVE RELATIONSHIP BETWEEN NORMS AND INTERESTS. THE REFUGEE PROTECTION POLICIES OF MEXICO AND HONDURAS ARE ANALYZED TO REVEAL THE MECHANISMS
THROUGH WHICH POLICYMAKERS' INTEREST CALCULATIONS ARE ALTERED BY INCENTIVES AND POLICY OPTIONS PROVIDED BY AN INTERNATIONAL NORM-PROMOTING INSTITUION.

04167 HARTLEY, A.

EUROPE'S NEW POPULISH

NATIONAL INTEREST, 30(30) (WIN 92), 37-40

ANOTHER POLITICAL ERA HAS ARRIVED AND WITH IT A STYLE WHICH CAN BE DESCRBIED AS POPULISM. THIS ARTICLE STUDIES WHAT POPULISM IS AND WHY ITS VARIOUS MANIFESTATIONS DESTABILIZE EUROPEAN POLITICS JUST AT THE MOMENT WHEN THE COLLAPSE OF THE SOVIET UNION AND ITS EMPIRE IN EASTERN EUROPE SIGNALS AN END TO THE DANGER OF A MAJOR WAR. THERE ARE MANY FACTORS ENCOURAGING POPULIST POLITICS IN EUROPE TODAY WHICH ARE DESCRIBED IN THIS ARTICLE WHICH CONCLUDES TODAY WHICH ARE DESCRIBED IN THIS ARTICLE WHICH CONCLUDES UNTIL MOSCA'S POLITICAL CLASS REMEMBERS THAT IT MUST ADDRESS UNTIL MOSCA'S POLITICAL CLASS REMEMBERS THAT IT MUS INSTITUTIONS ARE NOT MADE BY SUMMIT CONFERENCES ALONE, BUT ACCUMULATE AUTHORITY THROUGH HABIT AND USE OVER A LONG PERIOD.

04168 HARTLEY, A

MAASTRICHT'S PROBLEMATICAL FUTURE

WORLD TODAY, 48(10) (OCT 92), 179-182.

DUE TO THE NARROW REJECTION OF THE MAASTRICHT TREATY IN DENMARK AND THE NARROW ACCEPTANCE IN FRANCE, THE FUTURE OF THE AGREEMENT IS PROBLEMATICAL. ALTHOUGH THE BRITISH PRIME MINISTER AND FOREIGN SECRETARY HAVE SAID THAT THE DANISH GOVERMMENT WILL FIND SOME WAY OF REVERSING THE ELECTORATE'S DECISION, IT IS UNLIKELY THAT ANOTHER VOTE CAN BE TAKEN, UNLESS THE MAASTRICHT TREATY CAN BE RENEGOTIATED, AN OPTION THAT HAS ALREAOY BEEN RULED OUT. IT APPEARS UNLIKELY THAT DENMARK WILL SIMPLY RESIGN FROM THE E.C., AND THE TREATY OF ROME PROVIDES NO MECHANISM FOR EXPELLING A MEMBER.

04169 HARTLEY, T.; RUSSETT, 8.

PUBLIC OPINION AND THE CDMMON DEFENSE: WHO GOVERNS MILITARY SPENDING IN THE UNITED STATES?

AMERICAN POLITICAL SCIENCE REVIEN, 86(4) (DEC 92), 905-915. THE AUTHORS MEASURE THE EXTENT TO WHICH MILITARY SPENDING POLICY REFLECTS PUBLIC OPINION, WHILE CONTROLLING FOR OTHER REASONABLE INFLUENCES ON POLICY. THEY USE SURVEY
DATA AS AN INDICATOR OF AGGREGATE PUBLIC OPINION ON MILITARY DATA AS AN INDICATOR OF AGGREGATE PUBLIC OPINION ON MILITARY
SPENDING AND FIND EVIDENCE THAT CHANGES IN PUBLIC OPINION SPENDING AND FIND EVIDENCE THAT CHANGES IN PUBLIC OPINION CONSISTENTLY EXERT AN EFFECT ON CHANGES IN DEFENSE SPENDING. EITHER SOVIET MILITARY SPENDING OR THE GAP BETWEEN AMERICAN EITHER SOVIET MILITARY SPENDING OR THE GAP BETWEEN AMERICAN DEFICIT AND THE BALANCE OF SOVIET CONFLICT/CDOPERATION WITH DEFICIT AND THE BALANCE OF SOVIET CONFLICT/COOPERATION WITH THE USA. THE AUTHORS ALSO EXAMINE THE HYPOTHESIS THAT PUBL
OPINION DOES NOT INFLUENCE THE GOVERNMENT BUT THAT THE GOVERNMENT SYSTEMATICALLY MANIPULATES PUBLIC OPINION AND FIND NO EVIDENCE TO SUPPORT THIS HYPOTHESIS.

04170 HARTUNG, $W$

CURBING THE ARMS TRADE

WORLD POLICY JOURMAL, IX(2) (SPR 92), 219-248

SINCE 1990 THE INTERNATIONAL ARMS TRADE HAS BEEN TRANSFORMED FROM AN IMPORTANT BUT NEGLECTED ISSUE INTO ONE OF THE MOST URGENT ITEMS ON THE WORLD'S SECURITY AGENDA. THE HEIGHTENED POLITICAL IMPORTANCE OF THE ARMS TRADE IS A CONSEQUENCE OF TWO HISTORIC EVENTS. FIRST, THE 1991 GULF WAR UNDERSCORED THE DANGERS INHERENT IN THE UNRESTRAINED PROLIFERRATIDN OF ADVANCED ARMAMENTS. THE SECDND EVENT IS THE POLITICAL DISINTEGRATION OF THE SOVIET UNION. THIS ARTICLE STATES THAT CURBING THE INTERMATIONAL TRADE IN WEAPONS AND WEAPONS TECHMOLOGY MUST BECOME A TOP PRIORITY OF THE POST-COLD WAR ERA.

04171 HARTHIG, G.

SPD FAILS TO PRESENT A CONVINCING ALTERMATIVE TO BONM COALITION

GERMAN TRIBUNE, (1516) (MAY 92), 3.

THE SOCIAL DEMOCRAT PARTY (SPD) IS ONLY REAPING MODERATE BENEFITS FROM THE GERMAN COALITION GOVERMMENT'S CURRENT STATE OF EXHAUSTION. ALTHOUGH OPINION POLLS SHOW THAT THE LEADING OPPOSITION PARTY IN THE BUNDESTAG HAS BECOME SLIGHTLY MORE POPULAR, A RELIABLE TREND REVERSAL IN FAVOR OF SLIGHTLY MORE POPULAR, A RELIABLE TREND REVERSAL IN FAYO THE SOCIAL DEMOCRATS HAS YET TO BE CONFIRMED. THE KEY OBSTACLE TO A FUTURE SPD VICTORY IS THE FACT THAT, IN ELECTIONS, AN INCUMBENT GOVERNMENT IS NOT REJECTED BY VOTERS
SOLELY ON THE BASIS OF ITS OHN INCOMPETENCE, BUT ALSO DUE TO SOLELY ON THE BASIS OF ITS OHN INCOMPETENCE, BUT ALSO DUE TO
THE PRESENCE OF A VIABLE ALTERNATIVE. AFTER TEN YEARS IN THE PRESENCE OF A VIABLE ALTERNATIVE. AFTER TEN YEARS IN
OPPOSITION IN BONM. THE SPD HAS YET TO ACHIEVE THIS POSITION IN THE EYES OF VOTERS. THIS IS LARGELY OUR TO FACTIONAL IN THE EYES OF VOTERS. THIS IS

04172 HARVEY, C.; LEWIS, S.

POLICY CHOICE AND DEVELOPMENT PERFORMANCE IN BOTSWANA ST. MARTIN'S PRESS, 1990, 341

AT INDEPENDENCE IN 1966 BOTSHANA HAS ONE OF THE WORLD'S POOREST COUNTRIES: DEVASTATED BY DROUGHT, DEPENDENT ON BRITAIN FOR HALF THE COST OF THE CURRENT BUDGET, WITH NO 
CAPITAL CITY AND ONLY A FEH MILES OF TARRED ROAD, AND ONLY 80 STUDENTS IN THE FIFTH YEAR OF SECONDARY SCHOOL. IN THE NEXT TWENTY YEARS, BOTSWANA HAD THE FASTEST RATE OF ECONOMIC GROWTH OF ANY COUNTRY IN THE WORLD. THAT WAS PARTLY DUE TO THE RECOVERY OF SEVERAL MINES WHICH HAD AN ENORMOUS IMPACT
ON THE ECONOMY. THIS BOOK ANALYZES THE MANAGEMENT OF MINERAL ON THE ECONOMY. THIS BOOK ANALYZES THE MANAGEMENT OF MINERAL WEALTH, THE EXTENT TO WHICH ECONOMIC POLICY ALSO CONTR
TO GROWTH, AND HOW RAPID GROWTH AFFECTED THE PEOPLE OF BOTSWANA, RURAL AND URBAN, RICH AND POOR.

04173 HARVEY, D.

FLEXIBILITY: THREAT OR OPPORTUNITY?

SOCIALIST REVIEW, 21(1) (JAN 91), 65-78.

THIS ARTICLE ARGUES THAT CAREFUL STUDY OF THE CHANGING DYNAMICS AND REVOLUTIONS IN CAPITALIST TECHNOLOGY AND ORGANIZATION IS A KEY STEP TOWARD GENERATING NEW VISIONS OF SOCIALISM. IT CONSIDERS SOME OF THE CHALLENGES POSED TO SOCIALISTS BY THE CHANGES WROUGHT IN THE POST-MODERN, POSTFORDIST SOCIETY TOWARDS GREATER "FLEXIBILITY." IT CONSIDERS FLEXIBILITY IN RELATION TO LABOR PROCESSES. IN LABOR MARKETS, IN QUESTIONS OF STATE POLICY, AND GEDGRAPHIC MOBILITY.

04174 HARVEY, F.; JAMES, P.

MUCLEAR DETERRENCE THEORY: THE RECORD OF AGGREGATE TESTING AND AM ALTERMATIVE RESEARCH AGENDA

CONFLICT MANAGEMENT AND PEACE SCIENCE, 12(1) (WIN 92), $17-46$

THE OVERALL PURPOSE OF THIS REVIEH IS TO ASSESS THE RECORD OF AGGREGATE EVALUATION IN ORDER TO OBTAIN GUIDANCE FOR FURTHER RESEARCH. THE INVESTIGATION UNFOLDS IN SEVERAL STAGES. FIRST STUDIES APPROPRIATE FOR REASSESSMENT ARE PLACED IN THE GENERAL CONTEXT OF DETERRENCE LITERATURE. SECOND, MODELS, DATA, AND TESTING PROCEDURES ARE PRESENTED AND EXPLAINED. THIRD, A PAIR OF CRITERIA FOR EVALUATION-VALIDITY AND RELIABILITY--ARE APPLIED TO THE ABOVE--NOTED QUANTITATIVE STUDIES. FOURTH, NEH DIRECTIONS FOR TESTING ARE SUGGESTED, HITH EMPHASIS ON A MORE UNIFIED APPROACH.

04175 HARVEY, $P$.

UNEMPLOYMENT AS A HUMAN RIGHT ISSUE

PEACE \& DEMOCRACY NEWS, $11(2)$ (WIN 92), 41-42.

HHILE PROGRESSIVES HAVE CONSISTENTLY SUPPORTED

INITIATIVES TO ASSIST THE UNEMPLOYED, THEIR ACTIVISM HAS

LACKED AN IMPORTANT DIMENSION BECAUSE OF THEIR FAILURE TO

PRESS THE CLAIM THAT EMPLOYMENT IS A HUMAN RIGHT. THE

EXISTENCE OF SUCH A CLAIM CAN GALVANIZE SUPPORT FOR A

PROGRESSIVE MOVEMENT, DEMORALIZE THE OPPOSIIIION, AND ALTER

THE TERMS OF PUBLIC DEBATE CONCERNING THE MOVEMENT'S GOALS.

THE TERMS OF PUBLIC DEBATE CONCERNING THE MOVEMENT'S GOALS.

THIS ARTICLE SUGGESTS THAT A POWERFUL HUMAN RIGHTS ARGUMENT
CAN BE MADE ON BEHALF OF THE UNEMPLOYED IN THE UNITED STATES.
IT CONCLUDES THAT SUCH A POLICY WOULD NOT BE PROBLEM-FREE,

IT CONCLUDES THAT SUCH A POLICY WOULD NOT BE PROBLEM-FREE,

BUT WHEN COMPARED WITH EXISTING SOCIAL WELFARE PROGRAMS,

EMPLOYMENT IS A CLEAR WINHER.

04176 HARHOOD, R.

SIGNS OF A NEW POLITICS

SOCIAL POLICY, 23(2) (FAL 92), 5-16

IN THE 1992 PRESIDENTIAL ELECTION, 20 MILLION AMERICANS

VOTED FOR A CANDIDATE FROM NEITHER OF THE TWO MAJOR PARTIES. THE PEROT PHENOMENON TOUCHED A CENTRAL NERVE IN THE BODY POLITIC, AND IT MOTIVATED PEOPLE--REPUBLICS AND DEMOCRATS YOUNG AND OLD-TO RESPOND BY REGISTERING A PROTEST VOTE AGAINST "POLITICS AS USUAL."

04177 HASEGAHA, T

ROCKS AND ROLLS

FAR EASTERN ECONOMIC REVIEN, 155(36) (SEP 92), 15.

RUSSIAN PRESIDENT BORIS YELTSIN'S SCHEDULED VISIT TO JAPAN IS INEYITABLY BEING COMPARED WITH HIS PREDECESSOR MIKHAIL GORBACHEV'S HISTORIC APRIL 1991 TRIP TO TOKYO. AS IN THE PREVIOUS SUMMIT, THE KEY DISPUTE BETWEEN RUSSIA (THEN THE USSR) AND JAPAN IS OVER THE KURILE ISLANDS. WHILE THE INTERNATIONAL CLIMATE IS FAR MORE CONDUCIVE TO REACHING AN AMICABLE AGREEMENT ON THE STATUS OF THIS DISPUTED TERRITORY, DOMESTIC CONCERNS IN BOTH RUSSIA AMD JAPAN THREATEN TO MAKE COMPROMISE IMPOSSIBLE. YELTSIN FEARS THAT ANY TERRITORIAL CONCESSION WILL INCENSE LARGE FACTIONS IN THE RUSSIAN PARL IAMENT. ON THE JAPANESE SIDE, LITTLE HAS BEEN DONE TO PREPARE THE JAPANESE PUBLIC TO ACCEPT ANY PROPOSAL SHORT OF RUSSIA'S HANDIMG OYER AL THE KURILES TO JAPAN THUS DIMINISHING THE POSSIBILITY OF THE THO SIDES REACHING A VIABLE COMPROMISE. IN SHORT THE SUMHIT HILL LIKELY END IN THE SAME MANNER AS THE GORBACHEY-KAIFU SUMMIT: FAILURE.

04178 HASELER, S.

ENGLAND' OUR ENGLAND

FREEDOM REVIEH, 23(2) (MAR 92), 5-6.

AT THE HEART OF BRITAIN'S UNIOUENESS IS THE FACT THAT THE COUNTRY HAS NO WRITTEN CONSTITUTION. PROPONENTS OF THE STATUS QUD ARGUE THAT THE COUNTRY IS WELL SERVED BY SLOW, EVOLUTIONARY, ORGANIC DEVELOPMENT AND THAT THE PEOPLE'S LIBERTIES ARE PROTECTED BY CUSTOM RATHER THAN RULES. BU LIVING WITHOUT A CONSTITUTION IS BECOMING INCREASINGLY
PROBLEMATICAL. IT IS PRIMARILY BECAUSE BRITAIN HAS NO CONSTITUTIONALLY-ORDAINED SEPARATION OF POWERS THAT THE EXECUT IVE HAS BECOME VERY POWERFUL AT THE EXPENSE OF PARLIAMENT.

04179 HASHI, M.

WHY THE USC CAMMOT ALONE RULE SOMALIA

WHY THE USC CANNOT ALONE RULE

THE UNITED SOMALI CONGRESS (USC), WHICH OCCUPIED THE SOMALI CAPITAL CITY OF MOGADISHU IN THE FINAL DAYS OF SIYAD BARRE'S RULE, IS TRYING TO FORM AN INTERIM GOVERNMENT FOR THE ENTIRE MATION. HOWEVER, USC'S CLAIMS OF BRINGING DOWN BARRE SINGLEHANDEDLY AND OF REPRESENTING ALL OF SOMALIA ARE HOTLY DISPUTED. THE ORGANIZATION WHICH NOW RULES IN

MOGADISHU REPRESENTS ONLY ITSELF AND THE HAWIYE CLAN. IF PEACE IS TO BE ACHIEVED, THE USC MUST DEAL WITH THE SOMALI NATIONAL MOVEMENT (SNM) WHICH CONTROLS NORTHERN SOMALILAND, THE SOMALI SALVATION DEMOCRATIC FRONT (SSDF) IN THE EASTERN REGION, AND THE SOMALI PATRIOTIC MOVEMENT (SPM) WHICH CONTROLS THE SOUTH. FAILURE TO INCLUDE THESE OTHER GROUPS IN ANY FUTURE GOVERNMENT HILL LIKELY RESULT IN CONTINUED ETHNIC AND TRIBAL WARFARE IN THE WAR-TORN NATION.

04180 HASHIM, A.

IRAQ, THE PARIAH STATE

IRAQ, HISTORY 91(561) (JAN 92), 11-16.

BY INCORPORATING KUHAIT, SADDAM HUSSEIN HOPED TO MAKE IRAQ RICH BEYOND BELIEF AND INFINITELY MORE POWERFUL. HE
PROMISED THAT THE WAR FOR KUWAIT WOULD BE "THE MOTHER OF ALL PROMISED "THAT THE WAR FOR KUWAIT WOULO BE "THE MOTHER OF ALL BATTLES," BUT IT TURNED OUT TO BE THE MOTHER OF ALL DEFEATS. IRAQ, WHICH WAS ONE OF THE MOST HIGHLY-DEVELOPED COL

IN THE MIDDLE EAST, IS NOW CRIPPLED, WITH LIMITED AFFAIRS.

04181 HASKELL, J.

THE PARADOX OF PLEBISCITARY DEMOCRACY IN PRESIDENTIAL MOMINATION CAMPAIGNS

WESTERN POLITICAL QUARTERLY, 45(4) (DEC 92), 1001-1020. THE AUTHOR ANALYZES THE PRESIDENTIAL NOMINATION CAMPAIGH AS A METHOD OF PUBLIC CHOICE. HE USES RIKER'S FAIRNESS CRITERIA TO ASSESS THE NATURE AND SEVERITY OF THE PROBLEMS SUCH CAMPAIGNS HAVE AS METHODS OF PUBLIC CHOICE. MANY OF THE VIOLATIONS OF FAIRNESS ARE OUTWEIGHED BY THE ADVANTAGES OF A PROCESS THAT PROVIDES FOR MAJORITARIAN CHOICE AND

CONSIDERABLE GRASSROOTS RETAIL POLITICKING. HOHEVER, THE VIOLATION OF THE CONDORCET CRITERION IS SEVERE IN THE CRITICAL EARLY STATES. (IT IS USUALLY MUCH LESS SEVERE LATER IN THE CAMPAIGN.) SOME REMEDIES TO MAKE THE PROCESS MORE DEMOCRATIC MAY UNDERMINE THE VERY DYNAMICS THAT MAKE IT WORKABLE AS A MAJORITARIAN METHOD OF PUBLIC CHOICE. THE AUTHOR SUGGESTS REFORMS TO ADDRESS THE MOST SERIOUS

VIOLATIONS AND THE EXCESSIVE INFLUENCE OF THE EARLY STATES.

04182 HASSAN, $M$

WAR IN THE GARDEN OF EDEN

CANADIAN FORUM, LXIX(797) (MAR 91), 6-10.

THIS ARTICLE TAKES A LOOK AT THE GULF WAR AND ARGUES THAT THE OBJECTIVE OF THE CURRENT DESTRUCTION IS NOT THE LIBERATION OF KUWAIT, NOR THE REMOVAL OF SADDAM HUSSEIN FROM LIBERATION OF KUWAIT, NOR THE REMOVAL OF SAVRAM HUS SOME POWER, NOR TAT AS ERD A REVITALIZED UNITED NATIONS. INSTEAD, MORAL IMPERATIVE AND A REVITALIZED UNITED NATIONS. INSI

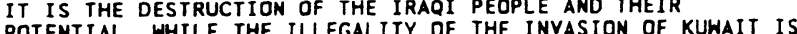
POTENTIAL. WHILE THE ILLEGALITY OF THE INVASION OF KUWAIT IS NOT A MATTER OF QUESTION, THE MASSIV

04183 HASSE, R.

GERMAN UNIFICATION AND EUROPEAN UPHEAYALS

AUSSEN POLITIK $43(2)$ (1992), 122-133

THE COLLAPSE OF THE SOCIALIST SYSTEM MAKES IT ESSENTIAL FOR EASTERN GERMANY AND THE EASTERN EUROPEAN COUNTRIES TO REMEDY THEIR PREVIOUS INEFFICIENCY AND GENERATE AN ECONOMIC UPSWING. THE FORMER COMMAND ECONOMY MUST BE REPLACED BY A

WESTERN-TYPE MARKET ECONOMY IF THE SITUATION IS TO IMPROVE. THE AUTHOR SHOWS HOW THESE TASKS CAN BE ACHIEVED AT THE SAME TIME. HE SHOWS THAT THE CORRESPONDING ECONOMIC DECISIONS WERE TAKEN UNDER THE PRESSURE OF POL ITICAL CONSTRAINTS AND THAT MANY OF THE DIFFICULTIES SINCE HAVE BEEN ROOTED IN THIS FACT. HE ALSO COMMENTS ON THE QUESTION OF HOW EASTERN GERMAN EXPERIENCE SHOULD BE ASSESSED AGINST THE BACKGROUND OF BOTH THE SYSTEMIC TRANSFORMATION IN EASTERN EUROPE AND THE INTEGRATION PROBLEMS WITHIN THE EURDPEAN COMMUNITY.

04184 HATCH, M. NUCLEAR ENERGY POLICY IN HEST GERMANY

HEST EUROPEAN POU ITICS, 14(1) (JAN 91) 73-97 THIS ARTICLE ARGUES THAT PLURALISM INCREASINGLY TYPIFIES THE POLICY PROCESS IN STATES MOVING FROM AN INDUSTRIAL TO THE POLICY PROCESS IN STATES MOVING FROM AN INDUSTRIAL POST-INDUSTRIAL ORDER. FROM AN ANALYSIS OF WEST GERMAN
NUCLEAR POWER POLICY OVER THE PAST TWO DECADES, CORPORATIST NUCLEAR POWER POLICY OVER THE PAST TWO DECADES, CORPORATIST POLITICS. THE REASONS FOR THIS ARE ATTRIBUTED TO THE NATURE 
OF POST-INDUSTRIAL ISSUES - INFORMED BY POST-MATERIALIST VALUES - THAT DIVIDE LESS ALONG TRADITIONAL CLASS AND PARTY LINES, MORE WITHIN AND ACROSS THOSE LINES, WITH POLITICAL PARTIES AND PARTY POLITICS POLARISED, THE CONSENSUS ON BASIC VALUES AND PRIORITIES REQUIRED FOR CORPORATIST ARRANGEMENTS CANNOT BE SUSTAINED.

04185 HATFIELD, M.; MCHUGH, M.

AFTER CONTAINMENT: A NEW FOREIGN POLICY FOR THE $1990 \mathrm{~S}$ SAIS REYIEN, 11(1) (WIN 91), 1-10.

SINCE THE END OF WORLD WAR II, THE CORNERSTONE OF U.S. FOREIGN POLICY HAS BEEN THE CONTAINMENT OF SOVIET POWER AND INFLUENCE. IT IS INCREASINGLY CLEAR THAT THE DRAMATIC TRANSFORMATION THAT IS NOW TAKING PLACE IN CENTRAL AND EASTERN EUROPE, AS WELL AS IN THE SOVIET UNION, HILL PROFOUNDLY ALTER EAST-WEST RELATIONS. WHAT IS LESS WELL RECOGNIZED IS THAT U.S. RESPONSE TO NORTH-SOUTH ISSUES, WHICH HAS BEEN LARGELY BEEN DETERMINED BY EAST-WEST COMPETITION IN THE POSTHAR PERIOD, MUST ALSO CHANGE. IN

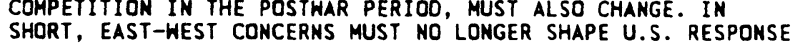
SHORT, EAST-WEST CONCERNS MUST NO LONGER SHAPE U.S. RES
TO NORTH-SOUTH CHALLENGES IN THE 1990S. THIS ARTICLE TO NORTH-SOUTH CHALLENGES IN THE 1990S. THIS ARTICLE
CONSIDERS SEVERAL OF THE NEH CHALLENGES INCLUDING DRUG CONSIDERS SEVERAL OF THE NEH CHALLENGES INCLUDING
TRAFFICKING; THE MILITARY CHALLENGE TO DEMOCRACY; MILITARIZATION; ECONOMIC DETERIORATION; AND ENVIRONMENTAL DESTRUCTION.

04186 HATT, K.; CAPUTO, T.; PERRY, B. CRIMINAL JUSTICE POLICY UNDER MULRONEY, 1984-90: NEOCONVERVATISM, EH?

CANADIAN PUBLIC POLICY--ANALYSE DE POLITIQUES, 18/3) (SEP 92), 245-260.

THE EXTENT TO WHICH THE MULRONEY GOVERNMENT HAS MOVED CRIMINAL JUSTICE POLICY IN CANADA IN A NEO-CONSERVATIVE DIRECTION IS ASSESSED. WHEN THE CRIMINAL JUSTICE LEGISLATION OF THE MULRONEY GOVERMMENT IS COMPARED TO THE PREVIOUS LIBERAL ADMINISTRATION THE FINDINGS INDICATE THAT A LAW AND ORDER APPROACH HAS NOT BEEN EVIDENT. THE STRATEGY INVOLVES: THE REAFFIRMATION OF JUSTICE AND SECURITY AS THE PRIMARY GOALS OF THE CRIMINAL JUSTICE SYSTEM; INCREASES IN THE SCOPE OF PROVINCIAL POWER; THE APPEARANCE OF BEING TOUGH ON CRIME; AND AN EMPHASIS ON EFFICIENT MANAGEMENT OF THE CRIMINAL JUSTICE SYSTEM.

04187 HATTAM, $V$.

INSTITUTIONS AND POLITICAL CHANGE: WORKING-CLASS FORMATION IN ENGLAND AND THE UNITED STATES, 1829-1896

POLITICS AND SOCIETY, 20(2) (JUN 92), 133-166.

FOR THE PAST CENTURY, ENGLISH AND AMERICAN LABOR UNIONS HAVE BEEN ADOPTING QUITE DIFFERENT STRATEGIES FOR ADVOCATING HAVE BEEN ADOPTING QUITE DIFFERENT STRATEGIES FOR ADVOCAT
WORKER'S INTERESTS AND AS A CONSEQUENCE HAVE PLAYED VERY WORKER'S INTERESTS AND AS A CONSEQUENCE HAVE PLAYED VERY
DIFFERENT ROLES IN THEIR RESPECTIVE POLITICAL ECONOMIES. DIFFERENT ROLES IN THEIR RESPECTIVE POLITICAL ECONOMIES. DIVERGENT LABOR MOVEMENT DEVELOPMENT OF THE TWO SIDES OF THE
ATLANTIC APPEARS PERPLEXING WHEN IT IS RECOGNIZED THAT FOR ATLANTIC APPEARS PERPLEXING HHEN IT IS RECOGNIZED THAT FOLLOWED A REMARKABLE SIMILAR COURSE. THIS ARTICLE EXPLORES WHY MOVEMENTS THAT WERE AT FIRST SO SIMILAR EVENTUALLY TURNED TO OUIS DIFFERENT SPHERES TO FURTHER WORKER'S TURNED TO QUITE DIFFERENT SPHERES TO FURTHER WORKER INTERESTS; AND ALSO, WHY THE AFL BROKE WITH THE WEST EUROPEAN MODEL AND ADOPTED INSTEAD
UNIONISM AT THE END OF THE CENTURY.

04188 HATTAM, V.C.

LABOR VISIONS AND STATE POWER--THE ORIGINS OF BUSINESS

UNIONISM IN THE UNITED STATES

PRINCETON UNIVERSITY PRESS, 1992, 280.

THIS BOOK EXAMINES WHY LABOR HAS PLAYED A MORE LIMITED ROLE IN NATIONAL POLITICS IN THE UNITED STATES THAN IT HAS IN OTHER ADVANCED INDUSTRIAL SOCIETIES. IT DEMONSTRATES THAT VOLUNTARISM, AS THE AMERICAN LABOR POLICY WAS KNOWN, WAS THE AMERICAN FEDERATION OF LABOR'S STRATEGIC RESPONSE TO THE OF THE COURTS WITHIN THE DIVIDED AMERICAN POLITY MADE POLITICAL ACTION LESS REWARDING FOR U.S. WORKERS THAN IT WAS FOR THEIR COUNTERPARTS ACROSS THE ATLANTIC. IN THE THREE DECADES FOLLOWING THE CIVIL WAR, WHEN LABOR'S LEGISLATIVE VICTORIES WERE CONTINUALLY ERODED BY THE COURTS, THE AFL DEVELOPED A DEEP MISTRUST OF POLITICS AND EVENTUALLY DEVISED OTHER MEANS OF ADVANCING WORKERS' INTERESTS THROUGH THE DUAL TACTICS OF COLLECTIVE BARGAINING AND INDUSTRIAL MILITANCE ON THE SHOP FLOOR. THE AFL'S STRATEGIC CALCULATION WAS NOT UNIVERSAL, HOWEYER. BY COMPARING STATE-LABOR RELATIONS OVER TIME AND ACROSS ORGANIZATIONS, THE AUTHOR DOCUMENTS THAT WORKERS' RELATION TO THE STATE CHANGED DRAMATICALLY OVER THE COURSE OF THE NINETEENTH CENTURY. THE WORKING MEN'S PARTIES IN THE $1820 S$ AND THE KNIGHTS OF IABOR IN THE 1870 S AND 1880 S IN THE $1820 S$ AND THE KNIGHTS OF LABOR IN THE $1870 S$ AND 18805
SUCCESSFULLY ESTABLISHED MORE COOPERATIVE RELATIONS WITH THE SUCCESSFULLY ESTABLISHED MORE COOPERATIVE RELATIONS WITH THE
AMERICAN STATE AND DID NOT ENGAGE IN A PROLONGED STRUGGLE AMERICAN STATE AND DID NOT ENGAGE IN A PROLONGED STRUGGLE
WITH THE COURTS. THESE ALTERNATIVE STATE-LABOR RELATIONS WITH THE COURTS. THESE ALTERNATIVE STATE-LABOR RELATIONS WERE THE PRODUC

04189 HAUBOLD, E.

TOUGH ASSIGNMENT FOR UNITED NATIONS IN CAMBODIA GERMAN TRIBUNE, (1491) (NOV 91), 2.
CAMBODIA IS BACK TO SQAURE ONE. AFTER 12 YEARS OF GUERRILLA WARFARE AND THREE YEARS OF GENOCIDE UNDER THE KHMER ROUGE REGIME, PEACE COULD BE BACK NOW THE "COMPREHENSIVE" UN' PLAN HAS BEEN SIGNED IN PARIS. THE GOVERHMENT THAT HAS HELD POWER IN PHNOM PENH FOR THE PAST DECADE IS TO BE REPLACED BY A SUPREME NATIONAL COUNCIL ON WHICH ALL PARTIES TO THE FIGHTING--THE HUN SEN GOVERMMENT AND THE THREE GUERRILLA GROUPS--ARE REPRESENTED. THE COUNCIL, CHAIRED BY PRINCE NODOROH SIHANOUK, REPRESENTS CAMBODIAN SOVEREIGNTY AND WILL ADVISE THE UN TRANSITIONAL AUTHORITY OFFICIALS HOSE TASK IS TO ENSURE THAT THE PARIS TREATY TERMS ARE OBSERVED. THE UNITED NATIONS SEEMS SET TO EMBARK ON ONE OF THE TOUGHEST ASSIGNMENTS IT HAS EVER FACED. 350 , OOO REFUGEES AHAIT REPATRIATION FROM THAILAND. TENS OF THOUSANDS OF LAND MINES MUST FIRST BE FOUND AND DESTROYED. THE SPECTER OF THE RETURN OF THE MURDEROUS KHMER ROUGE ALSO THE SPECTER OF THE RETURN OF THE
LOOMS OVER THE TRANSITION PHASE.

04190 HAUSER, E.

IRISH REFERENDUM VOTE IS A "RAY OF HOPE" GERMAN TRIBUNE, (1521) (JUN 92), 1

DENMARK'S "NAY" TO THE MAASTRICHT TREATIES WAS FOLLOWED BY AN IRISH "YES" THAT CAME AS A BREATH OF FRESH AIR FOR PLANS FOR FURTHER INTEGRATION OF NESTERN EUROPE. THE MAASTRICHT TREATIES ENVISAGE A COMMON FOREIGN AND SECURITY POLICY THAT IS INTENDED IN THE LONG TERM, TO INCLUDE THE "FORMULATION OF A COMMON DEFENSE POLICY WHICH MIGHT, IN DUE TIME, LEAD TO A COMMON DEFENSE." SO THE RESULT OF THE IRISH REFERENDUM UNDERPINS ONE OF THE TREATY TARGETS THAT COULD EMERGE AS A TOUCHSTONE OF ACCESSION TO THE EUROPEAN COMMUNITY BY PREVIOUSLY NEUTRAL APPLICANTS SUCH AS AUSTRIA, SHEDEN, FINLAND AND SWITZERLAND. THE IRISH "YES" VOTE ALSO SHOULD HALT THE TREND TOWARD OPPOSITION TO MAASTRICHT IN OTHER EUROPEAN COMMUNITY COUNTRIES, ESPECIALLY AS A FURTHER MOVE TOWARD RATIFICATION HAS BEEN MADE IN PARIS.

04191 HAUSER, E.

NATO WORRIED BY THE DISPUTE SURROUNDING MAASTRICHT GERMAN TRIBUNE, (1535) (OCT 92), 2.

NATO GENERAL SECRETARY MANFRED HORNER HAS EXPRESSED

SATISFACTION OVER FRANCE'S APPROVAL OF THE MAASTRICHT TREATY. NATO HEADQUARTERS ASSUMES THAT THE ABSTINENCE WASHINGTON HAS SHOWN DURING THE PAST TWO YEARS REGARDING THE YUGOSLAVIAN CATASTROPHES WILL ALSO BE RETAINED IN THE FUTURE YUGOSLAVIAN CATASTROPHES WILL ALSO BE RETAINED IN THE FUTURE
FOR (ALMOST) ALL CONFLICTS IN EUROPE OUTSIDE THE NATO TREATY AREA.

04192 HAUSER, E.

THE EDINBURGH SUMMITEERS CLEAR THE WAY FORWARD

GERMAN TRIBUNE, 31(1545) (DEC 92), 1-2

THE EUROPEAN SUMMIT IN EDINBURGH WAS SADDLED WITH SO MANY EXPLOSIVE ISSUES THAT IT COULD EASILY HAVE GONE WRONG, WHICH MAKES THE SUCCESS ALL THE BETTER. THE 12 LEADERS CLEARED AHAY MUCH OF THE RUBBLE THE SEEMED TO HAVE BLOCKED THE PATH TO EUROPEAN PROGRESS SINCE THE DANES VOTED AGAINST THE MAASTRICHT TREATY IN THEIR REFERENDUM IN JUNE. GERMANY'S ROLE IN THE EUROPEAN COMMUNITY IS EXPLORED IN THIS ANALYSIS OF THE EDINBURGH SUMMIT.

04193 HAUSER, E.

THE GATT TRACK RUNS UP AGAINST THE IMPENETRABILITY OF THE FARM GATE

GERMAN TRIBUNE, (1514) (MAY 92), 7

A HIGH-LEVEL SUMMIT DESIGNED TO SOLVE THE LAST PROBLEMS PLAGUING THE URUGUAY ROUND OF THE GENERAL AGREEMENT ON TARIFFS AND TRADE (GATT) ENDED IN FAILURE. THE MAIN OBSTACLE TO FINALIZATION OF THE ROUND IS THE OPENING UP OF AGRICULTURAL MARKETS. HOWEVER, THE EUROPEAN COMMUNITY, THE SCANDINAVIAN COUNTRIES, AND THE ALPINE COUNTRIES OF AUSTRIA AND SWITZERLAND, WOULD FIND IT IMPOSSIBLE TO GUARANTEE THE LIVELIHODD OF WHAT REMAINS OF THEIR FARMING POPULATION IF FOOD AND ANIMAL FEED FROM THE EXIENSIVE FARMS IN THE UNITED STATES, CANADA, AUSTRALIA, ARGENTINA AND THE MONOCULTURE OF DEVELOPING COUNTRIES WERE ALLOWED TO SWAMP THEIR CONSUMER MARKETS IN AN UNREGULATED MANNER. THUS, THE EUROPEANS REFUSED TO BUDGE ON AGRICULTURE AND THE AMERICANS REFUSED TO ALLOW THE ROUND TO FINISH. THE END RESULT, THOUGH NO ONE WAS BRAYE ENOUGH TO SAY SO, IS THAT THE URUGUAY ROUND HAS FAILED.

04194 HAUSER, J.

POPULATION, ECOLOGY AND THE NEW ECONOMICS: GUIDELINES FOR A STEADY-STATE ECDNOMY

FUTURES, 24(4) (MAY 92), 364-387.

THIS ARTICLE IS CONCERNED WITH THE NECESSITY OF MODIFYING THE WELL KNOWN CLASSICAL THEORY OF DEMOGRAPHIC TRANSITION BECAUSE OF RECENT DEVELOPMENTS, PARTICULARLY IN THE WORLDWIDE ECOLOGICAL SITUATION. IT AFFECTS STATEMENTS ABOUT DEVELOPING AS WELL AS INDUSTRIALIZED COUNTRIES AND IS URGENTLY NEEDED IN VIEW OF THE DOMINANT ROLE TRANSITION THEORY PLAYS IN PRACTICE, PLANNING AND FORECASTING. THE FINAL PART IS A DRAFT, WITH NECESSARY CONSEOUENCES, OF THE
NEW GUIDELINES FOR ECONOMIC ACTION, THAT IS ALTERNATIVES AND ROOM TO MANOEUVRE WITHIN A STEADY-STATE ECONOMY. 
04195 HAVEMAN, J.; DEARDORFF, A.; STERN, R. SOME ECONOMIC EFFECTS OF UNILATERAL AND MULTILATERAL REDUCTIONS IN MILITARY EXPENDITURES IN THE MAJOR CONFLICT MANAGEMENT AND PEACE SCIENCE, 12(1) (WIN 92), $17-46$

THE AUTHORS USE THE MICHIGAN MODEL OF WORLD TRADE AND PRODUCTION TO ASSESS THE SECORAL EFFECTS OF THE U.S. ECONOMY OF UNILATERAL AND MULTILATERAL REDUCTIONS OF MILITARY EXPENDITURES. THE FINDINGS SUGGEST THAT THE OVERALL EFFECTS ARE NOT SUBSTANTIAL. ALTHOUGH THE SECTORAL RESULTS DIFFER SIGNIFICANTLY DEPENDING ON THE ALTERNATIVE ASSUMPTIONS CONCERNING COMPENSATING MACROECONOMIC POL.ICIES, LESS THAN 1. O\% OF THE WORKFORCE MIGHT EXPERIENCE DISLOCATION IN ALL CASES. THE RESULTS OF THE MULTILATERAL REDUCTION ARE QUALITATIVELY SIMILAR TO THOSE OF A UNILATERAL REDUCTION.

04196 HAVRILESKY, T.; GILDEA, J. RELIABLE AND UNRELIABLE PARTISAN APPOINTEES TO THE BOARD OF GOVERNORS

PUBLIC CHOICE, 73(4) (1992), 397-418

ANALOGOUS IO SUPREME COURT APPOINTMENTS AND THE SUBSEQUENT INFLUENCE UPON THE DIRECTION OF COURT DECISIONS CONTROL OF FEDERAL RESERVE BOARD APPOINTMENTS PROVIDES PRESIDENTIAL INFLUENCE OVER THE DIRECTION OF MONETARY POLICY. THIS ARTICLE CONJECTURES THAT THE PRESIDENT'S PREFERENCE FOR RELIABLE APPOINTEES IS CONSTRAINED WHENEVER THE SENATE IS CONTROLLED BY THE OPPOSITION PARTY. IN ORDER TO TEST THIS CONJECTURE, THE AUTHORS FIRST TEST ANOTHER CONJECTURE--THAT RELIABLE PARTISAN APPOINTMENTS DECREASE WITH THE PRESIDENTIAL TERM IN OFFICE, WHILE CONTROLLING FOR WHETHER THE SENATE IS UNDER THE CONTROL OF THE OPPOSITION PARTY OR NOT. THE RESULTS SUGGEST SKEPTICISM TOWARD THE RECENT SPATE OF RATIONAL EXPECTATIONS. THE GREATER RELEVANCE OF MODELS OF UNCOORDINATED INTERACTION BETWEEN MULTIPLE POLITICAL AND PRIVATE PRINCIPALS AND FEDERAL RESERVE AGENTS IS ARGUED FOR.

04197 HAWATMEH, G.

ATTACKS AND COUNTER-ATTACKS

MIDDLE EAST INTERNATIONAL, (396) (MAR 91), 171-18.

THICE IN COURSE OF THE WEEK FOLLOWING THE END OF THE GULF WAR, U.S. PRESIDENT GEORGE BUSH WAS CRITICAL OF JORDAN'S PRESS. HE BLASTED THE PRESS FOR MISLEADING THE PEOPLE BY DOWNPLAYING THE SIGNIFICANCE OF IRAQ'S MILITARY
DEFEAT AND FOR ITS UNABASHED CRITICISM OF THE UNITED STATES. DEFEAT AND FOR ITS UNABASHED CRITICISM OF THE UNITED STAT
THE PRESS RESPONDED THAT IT MERELY REPORTED EVENTS AND THE PRESS RESPONDED THAT IT MERELY REPORTED EVENTS AND DIRECTED THEM TO ITS AUDIENCE. JORDANINA NEHSPAP

04198 HAWATMEH, G.

FISSURED OPINION

MIDDLE EAST INTERNATIONAL, (395) (MAR 91), 14-15.

THE SHOCK OF IRAO'S MILITARY DEFEAT HAS FISSURED PUBLIC OPINION IN JORDAN. SOME CONTINUE TO SUPPORT SADOAM HUSSEIN, ARGUING EITHER THAT THE FINAL WORD ON THE CONFLICT HASN'T BEEN HEARD OR THAT THE FACT HE STOOD UP TO THE WEST AT ALL IS PRAISEWORTHY. OTHERS BELIEVE THAT SADDAM'S CONTINUED MISHAMOLING OF THE CRISIS WILL NECESSITATE HIS EXIT FROM THE SCENE. MEANHHILE, JORDAN MUST SUFFER FROM THE DIPLOMATIC ISOLATION IMPOSED ON IT BY THE COALITION, KING HUSSEIN CONTINUES TO ADVOCATE RECONCILIATION AND DEMOCRATIC REFORMS AMONG ALL ARAB STATES.

04199 HAWATMEH, $G$.

HUSSEIN WILL KEEP ON TRYING

MIDDLE EAST INTERNATIONAL, (396) (MAR 91), 5-6.

JORDAN MAY NOT HAVE LIKED BEING BY-PASSED BY THE U.S. SECRETARY OF STATE, JAMES BAKER, DURING HIS TOUR OF THE AREA, BUT IT IS NOT TERRIBLY DISAPPOINTED BY THE EXCLUSION. JORDAN IS APPARENTLY SURE THAT SHOULD SERIOUS AND SINCERE EFFORTS BE MADE TO SOLVE THE PALESTINIAN PEACE PROBLEM AND THE ARAB-ISRAELI CONFLICT, THE KINGDOM HOULD HAVE TO BE CONCLUDED. THE BLEAKER SIDE, AS FAR AS JORDAN IS CONCERNED, IS THAT IRAO CONTINUES TO BLEED WHILE ALL ATTENTION IS FOCUSED ON POLITICAL JOCKEYING TO TACKLE THE PALESTINIAN PROBLEM, HHILE THE SAUDIS CONTINUE TO SHUN THE KINGDOM, AND WILE THE ANTI-COALITION ARAB SIDE REMAINS FRAGMENTED, UNABLE EVEN TO MEET TO PRESENT A FRONT OR A COMMON POSITION.

04200 HAWATMEH, G.

INSISTING ON CONSULTATION

MIDOLE EAST INTERMATIOMAL (398) (APR 91) 15-16.

ON U.S. SECRETARY OF STATE JAMES BAKER'S EFFORTS TO SOLVE THE PALESTINIAN PROBLEM AND THE WIDER ARAB-ISRAELI CONFLICT, THE JORDANIAN POSITION IS SUPPORTIVE OF AN INTERNATIONAL PEACE CONFERENCE BASED ON THE IMPLEMENTATION OF UN SECURITY COUNCIL RESOLUTIONS 232 AND 338 AND PALESTINIAN PARTICIPATION. A DIFFICULT ISSUE FOR JORDAN'S PROBABLY NEEDS ARAFAT'S BLESSING FOR ANY JOINT JORDANIANPALESTINIAN DELEGATION TO THE PROPOSED CONFERENCE. KING HUSSEIN ALS MUST DETERMINE WHETHER THE AMERICANS ARE ACTUALLY SERIOUS ABOUT NEGOTIATION OR WHETHER THEY ARE, ONCE AGAIN, MERELY GOING THROUGH THE MOTIONS.
04201 HAWATMEH, G.

JORDAN--NOW FOR LIBERALIZATION

MIDOLE EAST INTERNATIONAL, (431) (AUG 92), 11-12.

ALTHOUGH JORDAN'S AGE OF DEMOCRACY STRATED IN NOVEMBER 1989 WITH THE FREE ELECTION OF A NEW PARLIAMENT

CONSOLIDATION OF THE DEMOCRATIZATION PROCESS AND PERHAPS

EVEN LIBERALIZATION OF THE WHOLE POLITICAL SYSTEM HAVE JUST

BEGUN. OPENING THE WAY FOR MULTI-PARTY ELECTIONS IN THE SUMMER OF 1993 AND STRENGTHENING DEMOCRATIC RIGHTS AND PUBLIC AND INDIVIDUAL FREEDOMS ARE THE AIMS OF NEW DRAFT LAWS ON "POLITICAL PARTIES" AND "PRESS AND PUBLICATIONS." THE POLITICAL PARTY DRAFT RESOLUTION ALLOWS FOR THE FREE FORMATION AND OPERATION OF POLITICAL PARTIES, BUT ALSO INCLUDES SOME RESTRICTIONS ON FOREIGM FUMOING AMD OTHER ACTIVITIES FOR "SECURITY REASONS." THE PRESS AND PUBLICATIONS BILL IS CONSIDERABLY MORE LIBERAL THAN ITS PUBLICATIONS BILL IS CONSIDERABLY MORE LIBERAL THAN ITS
PREDECESSOR. WHILE THE MEASURES DO NOT GO FAR ENOUGH FOR PREDECESSOR. WILE THE MEASURES DO NOT GO FAR ENOUGH FOR
SOME PROPONENTS OF DEMOCRATIC REFORM, THE GOVERMMENT'S SOME PROPONENTS OF DEMOCRATIC REFORM, THE GOVERMMENT'S
ARGUMENT SEEMS TO BE THAT FREEDOMS WILL BE STRENGTHENED AS ARGUMENT SEEMS TO BE THAT FREEDOMS WILL BE STRENGTHENED AS THE ISLAMIC FUMDAMENTALISTS' STRENGTH, JORDAN IS SPLIT DOWH THE ISLAMIC FUNDAMENTALISTS' STRENGTH, JORDAN IS SPLIT
THE MIDDLE ON THE NEED FOR SOCIAL LIBERALIZATION. BUT POL MTICAL LIBERALIZATION IS TAKING ROOT, A TREND THAT IS DUE, IN NO SMALL PART, TO THE ISLAMISTS' NEW FOUND SENSE OF ACCOMMODATION TOWARDS POLITICAL PLURALISM.

04202 HAWATMEH, G

JORDAN: AN ACCORD WITH ISRAEL

MIDDLE EAST INTERNATIONAL, (437) (NOV 92), 6-7

THE AGREEMENT BETHEEN JORDAN AND ISRAEL ON THE AGENDA FOR THE NEXT PHASE OF THE PEACE NEGOTIATIONS AND MOROCCAN KING HASSAN'S VISIT TO JORDAN ARE BOUND TO GIVE IMPETUS TO THE PEACE PROCESS.

04203 HAWATMEH, G.

JORDAN: HOT THE MOMENT FOR CHANGE

MIDDLE EAST INTERNATIONAL, 436 (OCT 92), 6-7.

SOME PEOPLE CONSIDER NECESSARY IN JORDAN, A PROCESS OF CHANGE IN THE KINGDOM. HOWEVER, THE SIGNS ARE THAT THE

REGIME CONSIDERS THE TIME IS PREMATURE, AND THAT THE KING IS UNLIKELY TO INVEST HIS POPULARITY TOO DEEPLY IN POLITCAL ACTIONS. THE PALESTINIANS, WHO MAKE UP ABOUT 60 PER CENT OF ACTIONS. THE PALESTINIANS, WHO MAKE UP ABOUT 60 PER CENT OF THE POPULATION, APPEAR DIVIDED ON WHETHER TO INVITE THE KING
TO RECLAIM SOVEREIGNTY OVER THE WEST BANK. HOWEVER, THEY DO TO RECLAIM SOVEREIGNTY OVER THE WEST BANK. HOWEVER, THEY DO SEEM UNITED IN THEIR DESIRE TO BE GIVEN MORE SAY IN RUNNING AND SECUR TY DEPARTMENTS. JORDANIANS AND PALESTINIANS APPEAR UNITED IN THEIR DESIRE TO SEE FOREMOST MORE DEMOCRATIC UNITED IN THEIR DESIRE

04204 HAWATMEH, G.

PEACE TALKS: SLOW PROGRESS

MIDDLE EAST INTERNATIONAL, 417 ( JAN 92), 9-10

THE THIRD ROUND OF ARAB-ISRAELI BILATERAL TALKS, HELD IN WASHINGTON BETWEEN 13-16 JANUARY, PRODUCED AGREEMENT ON THE ISSUE OF SEPARATE PALESTINIAN REPRESENTATION WITH THE JOINT JORDANIAN-PALESTINIAN DELEGATION, BUT WAS TOO SHORT FOR ANY TANGIBLE PROGRESS ON THE SUBSTANTIVE ISSUES. THE ISRAELIS FINALLY RECOGNIZED THE TWO-TRACK APPROACH, IN WHICH THE PALESTINIANS WOULD NEGOTIATE FOR THEMSELVES, WITH TOKEN JORDANIAN PARTICIPATION, AND THE PALESTINIANS ACCEPTED LESS THAN TOTAL PARITY WITH THE JORDANIANS OR THE ISRAELIS IN THE GENERAL MEETINGS. BUT THE END OF THESE TALKS DID NOT MEAN AWAITED THEM. THE ISRAELIS DID NOT WANT TO GO THAT FAR. THE ARAB DELEGATION SUSPECT THAT SHAMIR WILL PLAY THE GAME OF STALLING.

04205 HAWATMEH, G.

RECONCILIATION

MIDDLE EAST INTERNATIONAL, (397) (APR 91) 12-13.

PARTLY BECAUSE THE KINGDOM IS INDISPENSABLE TO AMY MEANINGFUL PEACE PROCESS CONCERNING THE PALESTINIAN PROBLEM, AND PARTLY BECAUSE OF KING HUSSEIN'S IMPECCABLE CREDENTIALS AS A MAJOR PLAYER IN ARAB AND MIDDLE EASTERN AFFAIRS, JORDAN HAS NOT FOUND IT OIFFICULT TO END ITS ALIENATION FORM THE WEST, PARTICULARLY FROM SENIOR MEMBERS OF THE U.S. -LED WEST, PARTICULARLY FROM SENIOR MEMBERS OF THE U.S. - LED

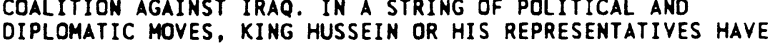
DIPLOMATIC MOVES, KING HUSSEIN OR HIS REPRESENTATIVES HAVE VISITED SYRIA, BRITAIN, CANADA, AND FRANCE IN SEARCH OF SOLUTIONS TO THE ARAB-ISRAELI
FUTURE OF THE MIDEAST REGION.

04206 HAWATMEH, G. THE PLUSES AND THE MINUSES MIDOLE EAST INTERNATIONAL, (412) (NOV 91), 4-5. HISTORY WAS MADE WHEN THE MIDDLE EAST PEACE CONFERENCE CONVENED IN MADRID ON 30 OCTOBER, FOLLOWED BY DIRECT BILATERAL TALKS ON 3 NOVEMBER. ISRAELIS SAT DOWN AT THE PEACE TABLE HITH ALL ARAB "CONFRONTATION" STATES: SYRIA, LEBANON, EGYPT, JORDAN AND, FOR THE FIRST TIME, THE PALESTINIANS. HOHEVER, DESPITE THE HISTORIC NATURE OF THE CONFERENCE, LITTLE HEADWAY HAS MADE TOWARDS REACHING 
DISAGREEMENTS OVER THE VENUE OF THE NEXT ROUND OF TALKS AND OVER THE STATUS OF THE PALESTINIAN DELEGATION MASKED DEEPER CONFLICTS WHICH HAVE YET TO BE ADDRESSED, LET ALONE RESOL HISTORY IS OFTEN NOT THE SAME AS MAKING PEACE."

04207 HAWES, D.

PARLIAMENTARY SELECT COMMITTEES: SOME CASE STUDIES IN CONTINGENT INFLUENCE

POLICY AND POLITICS, 20(3) (JUL 92), 227-236. SINCE THE SYSTEM OF DEPARTMENTALLY Y RELATED SELECT COMMITTEES WAS INTRODUCED IN THE HOUSE OF COMMONS IN 1979, COMMITTEE ACTIVITY HAS GAINED SIGNIFICANCE, BOTH IN THE PUBLIC CONSCIOUSNESS AND IN THE INFLUENCE THAT BACKBENCHERS EXERT OVER GOVERNMENT POLICY. IN THIS PAPER, THE AUTHOR STUDIES EXAMPLES OF POLICY RECOMMENDATIONS MADE IN SELECT STUDIES EXAMPLES OF POLICY RECOMMENDATIONS MADE IN SELECT COMMI ITEE REPORTS THAT WERE INITIALLY REJECTED BY GOVERNMENT VERY FACT OF COMMITTEE INVESTIGATION APPEARS TO HAVE VERY FACT OF A COMMITTEE INYES
STIMULATED ACTION OR CHANGE.

04208 HAWKINS, A.

CORPORATE STRATEGY IN SOUTH AFRICA

SOUTH AFRICA INTERMATIONAL, 22(3) (JAM 92), 133-136

ALTHOUGH THE SOUTH AFRICAN ECONOMY HAS DISTINCT POSITIVE FEATURES, IT IS ALSO HAMPERED BY POL ITICAL UNCERTAINTY, POOR PRODUCTIVITY, AN OVER-EMPHASIS ON THE EXPLOITATION OF NATURAL RESOURCES, AND CONSUMER-DRIVEN ECONOMIC CYCLES, TO ACHIEVE RAPID GROWTH, IT WILL HAVE TO TRANSFORM ITS ECONOMY TO BECOME INVESTMENT DRIVEN AND EXPORT INTENSIVE WITH THE EMPHASIS ON MANUFACTURING AND SERVICES. PRIVATE SECTOR ALLIANCES WITH FOREIGN MULTINATIONALS COULD PROVIDE SOUTH AFRICA WITH ACCESS TO THE TECHNOLOGY AND MARKETING SKILLS IT NEEDS.

04209 HAYAMA, A.

INCUMBENCY ADVANTAGE IN JAPANESE ELECTIONS

ELECTORAL STUDIES, 11(1) (MAR 92), 46-57.

IN U.S. CONGRESSIONAL ELECTIONS, INCUMBENCY ADVANTAGE HAS BEEN GROWING IN THE LAST THREE DECADES OR SO. IN 1958, 68 PERCENT OF INCUMBENT HOUSE REPRESENTATIVES WERE RE68 PERCENT OF INCUMBENT HOUSE REPRESENTATIVES WERE RE-
ELECTED BUT IN 1988 IT WAS 98 PERCENT. THE PURPOSE OF THIS ELECTED BUT IN 1988 IT WAS 98 PERCENT. THE PURPOSE OF
PAPER IS TO ANALYZE JAPANESE HOUSE OF REPRESENTATIVES
ELECTIONS IN THE $1958-90$ PERIOD AGAINST THE AMERICAN ELECTIONS IN THE 1958-90 PERIOD AGAINST THE AMERICAN
EXPERIENCE. IT CONCLUDES THAT INCUMBENCY ADVANATGE HAS, BY AND LARGE, REMAINED STABLE IN JAPAN. SEVERAL POSSIBLE REASONS ARE DISCUSSED FOR THE JAPAN-U.S DIFFERENCE. THEY INCLUDE THE FRANKING PRIVILEGE, POLITICAL ACTIVITIES AT HOME
CAMPAIGN ACTIVITIES, PARTY-LINE VOTES AND CONSTITUENCY, CAMPAIGN ACTIVITIES, PARTY-LINE VOTE
COMMITTEES, AND MONEY IN ELECTIONS.

04210 HAYDEN, J.

RECOGNITION AND RESPECT: THE TRANSITIONAL ROLE OF WOMEN IN PUBLIC LIFE

CANADIAN PARLIAMENTARY REVIEW, 14(1) (SPR 91), 21-23. THIS ARTICLE EXAMINES THE CHANGING ROLE OF' WOMEN IN PUBLIC LIFE IN CANADA FROM THE LAST 1960 S UP TO THE PRESENT. A CONFERENCE IN FEBRUARY 1981 ON WOMEN AND THE CONSTITUTION, ATTENDED BY SEYERAL HUNDRED WOMEN, IS DISCUSSED. THIS CONFERENCE INITIATED BY THE ADOPTION OF THE SECTION 28 CHARTER BY PARL IAMENT, WHICH GUARANTEES ALL RIGHTS AND FREEDOMS EQUALLY TO MALE AND FEMALE PERSONS. THE REASONS FOR THE CONTINUED DEARTH OF WOMEN IN POSITIONS OF POWER IS EXPLORED.

04211 HAYDEN, $T$.

MEMO TO THE TIKKUN COMMUNITY

TIKKUN, 7(6) (NOV 92), 19-21. COVENANT" WILL BE A RESURRECTION OF THE UNKNOWN AND UNFULFILLED PROMISE OF THE NEW FRONTIER AND THE EARLY SIXTIES. HE HAS PROVED WHAT SEEMED IMPOSSIBLE A YEAR AGO: THAT THE DEMOCRATIC PARTY COULD BE SHIFTED TO THE PRAGMATIC CENTER AND WIN BACK THE WHITE HOUSE. IN LIGHT OF THIS POLIIIICAL MIRACLE PERHAPS ANYTHING IS POSSIBLE. YET THE QUESTION REMAINS WHETHER IN THE THREE DECADES SINCE 1960 AMERICA HAS BECOME IRREVERSIBLY UNGOVERNABLE. THIS ARTICLE ASKS, CAN CLINTON'S SHIFTING PRAGMATISM SUCCEED IN GOVERNING AS IT DID IN CAMPAIGNING?

04212 HAYES, B.; JONES, F.

MAYES, 8. ; JONES, F. PAL AND POLITICAL PARTISANSHIP IN AUSTRALIA: DO WIVES' CHARACTERISTICS MAKE A DIFFERENCE?

SOCIOLOGY, 26(1) (FEB 92),81-102.

ONE OF THE MOST CONTENTIOUS ISSUES TO EMERGE OUT OF RECENT BRITISH POLITICAL SOCIOLOGY IS THE PROBLEM OF RECENT BRITISH POLITICAL SOCIOLOGY IS THE PROBLEM OF
LOCATING WOMEN IN THE POLITICAL STRUCTURE. USING RECENT LOCATING WOMEN IN THE POLITICAL STRUCTURE. USING RECENT
AUSTRALIAN DATA, THE AUTHORS EXAMINE THE CONVENTIONAL, AUSTRALIAN DATA, THE AUTHORS EXAMINE THE CONVENTIONAL, DOMINANCE, JOINT, CROSS-CLASS, AND INDIVIDUALISTIC APPROACHES TO THIS PROBLEM OF DETERMINING HOMEN'S POLITICAL IDENTIFICATION. THE RESULTS SUGGEST THAT NOT ONLY ARE A PERSON'S OWN CHARACTERISTICS IMPORTANT IN DETERMINING THEIR POLITICAL PARTISANSHIP, BUT WIVES' CHARACTERISTICS ALSO EXERT AN INDEPENDENT INFLUENCE ON THE POLITICAL CHOICES OF
THEIR HUSBANDS.

04213 HAYES, B.C.; BEAN, C.S.

THE IMPACT OF SPOUSAL CHARACTERISTICS ON POLITICAL ATTITUDES IN AUSTRALIA

PUBLIC OPINION QUARTERLY (CHICAGO), 56(4) (WIN 92), 524-529.

THE AUTHORS STUDY THE IMPACT OF SPOUSAL CHARACTERISTICS ON POLITICAL ATTITUDES IN AUSTRALIA. THEY UTILIZE EIGHT SOCIAL BACKGROUND CHARACTERISTICS FOR EACH SPOUSE, INCLUDING RELIGIOUS DENOMINATION, TRADE UNION MEMBERSHIP, EDUCATION, OCCUPATION, AND SUBJECTIVE SOCIAL CLASS. UTILIZING MULTIPLE REGRESSION, THEY ANALYZE HUSBANDS, AND WIVES A ATTITUDES REGRESSION, THEY ANALYZE HUSBANDS' AND WIVES' ATTITUDES
SEPARATELY TO ALLOW AN INVESTIGATION OF THE IMPACT OF MALE SEPARATELY TO ALLOW AN INVESTIGATION OF THE IMPACT OF MALE
AND FEMALE CHARACTERISTICS NOT ONLY ON THEIR OWN POLITICAL AND FEMALE CHARACTERISTICS NOT ONLY ON THEIR OHN POLITICAL
ATTITUDES BUT ALSO ON THOSE OF THEIR SPOUSES. THE DATA ATTITUDES BUT ALSO ON THOSE OF THEIR SPOUSES. THE DATA
ATTEST TO THE INDEPENDENT INFLUENCE OF SPOUSES ATTEST TO THE INDEPENDENT INFLUENCE OF SPOUSES
CHARACTERISTICS ON THE POL ITICAL PARTISANSHIP OF AUSTRALIAN CHARACTERISTICS ON THE POLITICAL PARTISANSHIP OF AUSTRALIAN MARRI ED COUPLES. EVEN WITH THE INCLLSION OF A RESPONDENT'
OWN CHARACTERISTICS, FOR BOTH HUSBANDS AND WIVES, CERTAIN OWN CHARACTERISTICS, FOR BOTH HUSBANDS AND WIVES, CERTAIM SPOUSAL CHARACTERISTICS EXERT A STATISTICALLY SIGNIFICAM
INDEPENDENT EFFECT. YET, FOR BOTH HUSBANDS AND WIFES, RESPONDENTS' OWN CHARACTERISTICS STILL EMERGE AS SALIENT FACTORS IN PREDICTING THEIR POLITICAL IDENTIFICATION.

04214 HAYES, F.

GOVERNMENTAL RETREAT AND THE POLITICS OF AFRICAN-AMERICAN SELF RELIANT DEVELOPMENT: PUBLIC DISCOURSE AND SOCIAL POLICY

JOURNAL OF BLACK STUDIES, 22(3) (MAR 92), 331-348.

THE BROAD PURPOSES OF THIS ARTICLE ARE TO EXAMINE THE RECENT PUBLIC DISCUSSION OF SELF-HELP WITHIN THE AFRICANAMERICAN COMMUNITY IN LIGHT OF THE REAGAN ADMINISTRATION'S RHETORIC ABOUT REDUCING THE FEDERAL GOVERNMENT'S ROLE IN PROVIDING SOCIAL WELFARE AND TO SUGGEST AN ALTERNATIVE PERSPECTIVE ON AFRICAN-AMERICAN SELF-RELIANT DEVELOPMENT IN AMERICA'S EMERGING POSTINDUSTRIAL-MANAGERIAL SOCIETY. THE INTENT IS TO EXTEND AND CONTRIBUTE TO FUTHER DISCOURSE AND RESEARCH ON THE POLITICS OF AFRICAN-AMERICAN SELF-RELIANT DEVELOPMENT. THE ARTICLE CONCLUDES THAT HHILE A COALITION OF DEVELOPMENT. THE ARTICLE CONCLUDES THAT WHILE A COALITION OF
ALL THE DISPOSSESSED MAY THEORETICALLY SERVE AS A BASE FROM ALL THE DISPOSSESSED MAY THEORETICALLY SERVE AS A BASE
WHICH TO STRUGGLE FOR SELF-RELIANT DEVELOPMENT, THAT WHICH TO STRUGGLE FOR SELF-RELIANT DEVELOPMENT, THAT
POSSIBILITY SEEMS SEEMS OUT OF SIGHT WHEN ECONOMIC

POSSIBILITY SEEMS SEEMS OUT OF SIGHT WHEN ECONOMIC
CONDITIONS CONTINUE TO HORSEN FOR THE URBAN DISPOSSESSED IN CONDITIONS CONTINUE TO HORSEN FOR THE URBAN DISPOSSESSED IN
AN EVOLVING POSTINDUSTRIAL-MANAGERIAL SOCIETY INCREASINGLY CHARACTERIZED BY CYNICAL DISILLUSIONMENT.

04215 HAYNES, J.

ONE-PARTY STATE, NO-PARTY STATE, MULTI-PARTY STATE? 35 YEARS OF DEMOCRACY, AUTHORITARIANISM, AND DEVELOPMENT IN GHANA

JOURNAL OF COMMUNIST STUDIES, 8(2) (JUN 92), 41-62.

IN 1957 , GHANA BECAME THE FIRST SUB-SAHARAN AFRICAN COUNTRY TO ATTAIN INDEPENDENCE. THE CONVENTION PEOPLE'S PARTY LED BY KHAME NKRUMAH RULED WITH A MARXIST ORIENTATION
UNTIL 1966. SINCE 1981 THE COUNTRY HAS BEEN RULED BY THE PNDC GOVERNMENT OF FLT-LT. JERRY RAWLINGS. AT THE ONSET OF PNDC RULE, THE DOMINANT IDEOLOGY APPEARED TO BE A VARIANT OF MARXISM-LENINISM. OVER THE NEXT 10 YEARS, HOHEVER, THE REGIME PRESIDED OVER A NUMBER OF POLICY CHANGES, INCLUDING THE ADOPTION OF AN IMF-SUPPORTED ECONOMIC RECOVERY PROGRAM, POLITICAL DECENTRALIZATION, AND MULII-PARTY POLITICS. THE PNDC GOVERNMENT HAS BEEN BOTH APPLAUDED FOR ITS FLEXIBILITY AND CRITICIZED FOR ITS AUTHORITARIANISM, AS IT HAS PERFORMED POLITICAL SOMERSAULTS AGAINST
DECLINE AMD POLITICAL FAILURE.

04216 HAYNES, J.

THE PNDC AND POLITICAL DECENTRALIZATION IN GHANA, 1981-91 JOURNAL OF COMMONHEALTH AND COMPARATIVE POLITICS, $29(3)$ ( NOV 92), 283-307.

THE MOTIVES AND RESULTS OF GHANA'S PROVISIONAL NATIONAL DEFENCE COUNCIL'S (PNDC) POLICY OF DECENTRALIZATION IS ANALYZED IN THIS ARTICLE. IF THE PNCD COULD CLAIM TO HAVE FOUND A WORKABLE SYSTEM OF DEMOCRACY WHICH DID NOT INVOLYE MULTI-PARTY ELECTIONS, THEN IT COULD ALSO CLAIM TO HAVE
FORMULATED AN ALTERNATIVE TO THE RANCOUR COMMONLY ASSOCIATED WITH SUCH ELECTIONS IN AFRICA. THE ARTICLE PROVIDES A WITH SUCH ELECTIONS IN AFRICA. THE ARTICLE PROVIDES A
HISTORICAL SURVEY OF LOCAL GOVERMMENT; LOOKS AT THE PNCD'S HISTORICAL SURVEY OF LOCAL GOVERMMENT; LOOKS AT THE PNCD'S
APPROACH TO DECENTRALIZATION; AND EXAMINES THE NATURE OF THE APPROACH TO DECENTRALIZATION; AND EXAMINES THE NATURE OF THE
CURRENT REFORMS AND THE CHANCES FOR A WORKABLE DEMOCRATIC CURRENT REFORMS AMD
SYSTEM TO EMERGE.

04217 HAYNIE, $S$.

LEADERSHIP AND CONSENSUS ON THE U.S. SUPREME COURT THE JOURNAL OF POLITICS, 54(4) (NOV 92), 1158-1172. FOR MORE THAN A CENTURY, THE MEMBERS OF THE U.S. SUPREME COURT REFRAINED FROM DISAGREEING WITH THEIR BRETHREN THROUGH WRITTEN OPINIONS. WHILE MANY HAVE HELD CHIEF JUSTICE STONE RESPONSIBLE FOR THE TRANSFORMATION OF THE CONSENSUS NORM IN THE TWENTIETH CENTURY, THE RESULTS OF THIS ANALYSIS SUGGEST THAT THE LEADERSHIP STYYL OF CHIEF JUSTICE HUGHES IS CRITICAL TO UNDERSTANDING THE SHIFT. CHIEF JUSTICE HUGHES
PRECIPITATED A SHIFT IN THE BEHAVIORAL EXPECTATION AMONG THE 
JUSTICES, BUT THE CHANGE WAS CONSOLIDATED UNDER THE LADERSHIP OF CHIEF JUSTICE STOME. OTHER YARIABLES ARE EXPLORED TO VALIDATE THE PROMINENT ROLE OF LEADERSHIP IN THE DECLINE OF CONSENSUS.

04218 HAYS, S.H.: KEARNEY, R.C. STATE PERSONHEL DIRECTORS AND THE DILEMMAS OF WORKFORCE 2000: A SURVEY

PUBLIC ADMINISTRATION REVIEW, 52(4) (JUL 92), 380-388. THE AUTHORS CONDUCTED A SURVEY OF THE 50 STATE PERSONNEL DIRECTORS. THEY FOUND THAT, DEMOGRAPHICALLY, THE DIRECTORS CONSTITUTE A MODEL HORK FORCE WITH SOL ID BACKGROUNDS IN THE PUBLIC PERSONNEL FIELD. FACED HITH PROBLEMS SIMILAR TO THOSE OF THEIR FEDERAL-LEVEL COUNTERPARTS, THE ATTITUDES AND ACTIONS OF STATE DIRECTORS REFLECT A CONCERN FOR SOCIAL EQUITY ISSUES AND AN ABILITY TO MEET CHALLENGES BY EMBRACING BOTH THE TRADITIONAL AND EMERGING VALUES OF PUBLIC PERSONNEL MANAGEMENT.

04219 HAYHARD, J.

POLITICAL SCIENCE IN BRITAIN

EURDPEAN JOURNAL OF POL ITICAL RESEARCH, 20(3-4) (DEC 91), 301-322.

THE AUTHOR EXAMINES THE HISTORY OF THE DISCIPLINE OF POLITICAL SCIENCE IN GREAT BRITAIN, FOCUSING ON THE ANTISCIENTISM OF BRITISH POLITICAL SCIENCE AND ON THE TECHNOCRATIC REFORMISM OF 1961-1974.

04220 HAZELTON, F.

A DEMOCRATIC CHARTER FOR IRAO

PEACE \& DEMOCRACY NEWS, 6(1) (HIN 92), 37-39

CHARTER 91 HAS BEEN LAUNCHED BY A GROUP OF EXILED IRAQI INTELLECTUALS WITH THE AIM OF GOING BEYOND IDEOLOGIES TO DEFINE THE PRINCIPLES OF A NEW IRAQ. IT IS BEGINNING TO GAIN INTEREST IN THE WESTERN MEDIA AND HAS STIRRED UP A GOOD DEAL OF INTEREST IN THE ARAB PRESS. IT WAS INFLUENCED BY CHARTER 77 IN CZECHOSLOVAKIA AND CHARTER 88 IN THE UNITED KINGDOM, BUT ITS DISTINCT CHARACTER IS CLEARLY ROOTED IN IRAQI EXPERIENCE, PARTICULARLY THE INSISTENCE ON FREEDOM FROM FEAR. ALTHOUGH IT IS A STATEMENT OF GENERAL VALUES, IT CONTAINS SPECIFIC CLAUSES WHICH HAVE INHIBITED SOME IRAQIS FROM ADOING SIGNITURES.

04221 HAZELTON, W.A.; HOY-HAZELTON, S.

SENDERO LUMINOSO: A COMMUNIST PARTY CROSSES A RIVER OF BLOOD

TERRORISM AND POLITICAL VIOLENCE, 4(2) (SUM 92), 84-102. SENDERO LUMINOSO IS FREQUENTLY DESCRIBED AS AM UNORTHODOX PERUVIAN TERRORIST ORGANIZATION IN LEAGUE WITH THE COLOMBIAN COCAINE CARTEL, RATHER THAN AS A POLITICAL THE COLOMBIAN COCAINE CARTEL, RATHER THAN AS A POLITICAL ENTITY THAT IS THE TRUE COMMUNIST PARTY OF PERU. AN
EXAMINATION OF ITS ORIGINS, ORGANIZATIONAL STRUCTURE, AND IDEOLOGY REVEALS THAT TERRORISM IS BUT A WEAPON IN SENDERO'S IDEOLOGY REVEALS THAT TERRORISM IS BUT A WEAPON IN SENDERO'
ATTEMPT TO SEIZE POHER AND IS CLEARLY SUBORDINATE TO THE ATTEMPT TO SEIZE POHER AND IS CLEARLY SUBDRDINATE TO THE PARTY'S POLITICAL-MILITARY STRATEGY OF PROTRACTED ARMED
STRUGGLE. A PRODUCT OF NUMEROUS SPLITS AND FACTIONS WITHIN THE PERUVIAN COMMUNIST MOVEMENT, SENDERO'S UNIQUE AND UNCONVENTIONAL APPROACH TO REVOLUTION IS THE CREATION OF ABIMAEL GUZMAN, THE SELF-PROCLAIMED "FOURTH SHORD OF MARXISM. " GUZMAN'S VISION OF A "NEW DEMOCRACY" HAS BROUGHT UNPARALLELED DEATH AND DESTRUCTION TO LARGE PARTS OF PERU, BUT SENDERO LUMINOSO HAS NOT ESTABLISHED THE BASE OF POPULAR SUPPORT NECESSARY FOR A VANGUARD PARTY TO WAGE A SUCCESSFUL PEOPLE'S REVOLUTION.

04222 HAZLETT, T

GEORGE OF THE BUNGLE

REASON, 24 (6) (NOV 92), 22-24.

THIS ANALYSIS OF THE CANDIDATES FOR THE 1992

PRESIDENTIAL ELECTION ARGUES THAT BUSH SQUANDERED HIS HISTORIC CHANGES, FAILING TO SEE ANYTHING IN AMERICA THAT NEEDED FIXING WHEN 88-PERCENT APPROVAL RATINGS GAVE HIM CARTE BLANCE TO PURSUE AN AMBITIOUS DOMESTIC AGENDA. HE FLICKED AHAY HIS STORE OF POLITICAL CAPITAL AND PLUNGED THE U.S. ECONOMY INTO RECESSION. THE RECOMHENDATION IS THAT IN SHOULD HOLD ITS NOSE TIGHT AND YOTE CLINTON-GORE IN 192.

04223 HAZLETT, T.

THE ROAD FROM SERFDOM: AN INTERYIEW HITH F. A. HAYEK REASON, 24(3) ( JUL 92), 28-34.

WITHIN THE ECONOMICS PROCESS, F. A. HAYEK WAS AM ACADEMIC OUTCAST WHOSE IDEALS HAD BEEN NEATLY DISPROVED TO ALL REASONABLE MEN IN THE SCIENTIFIC JOURNALS OF HIS DAY. HOHEVER THE LATE 2OTH CENTURY DECIDED TO PROVIDE A REALITY CHECK ON THE ACADEMIC SCRIBBLERS. THE TRENDS AWAY FROM KEYNESIANISM IN THE HEST AND FROM SOCIALISM EVERYWHERE ELSE WERE JUST BEGINMING TO ASSERT THEMSELVES WHEN HAYEK--OUT OF THE ECONOMICS PROFESSION FOR 30 YEARS--WAS SURPRISINGLY AWARED A NOBEL PRI ZE IN ECONOMICS IN 1974. THE GLACIAL WORLDWIDE POLICY SHIFTS OF THE 1980 S HAD BEEN CAUTIOUSLY ANTICIPATED BY HAYEK. HE SEEMED TO SENSE THAT SODN IT WOULD NOT BE A SIGN OF DISRESPECT TO BE DUBBED THE GREATED PHILOSOPHER OF CAPITALISM SINCE ADAM SMITH.
04224 HAZLETT, T.W

THE RATIONALITY OF U.S. REGULATION OF THE BROADCAST SPECTRUM

JOURNAL OF LAN AND ECONOMICS, 33(1) (APR 90), 133-176.

IN THIS ARTICLE, FIRST THE TRADITIONAL INFERENCE RATIONALE FOR LICENSING IS OUTLINED. THE NEXT SECTION DESCRIBES WHY THIS LINE OF ARGUMENT HAS BEEN REJECTED BY CONTEMPORARY ANALYSTS OF BROADCAST REGULATION. THE NEXT TWO SECTIONS EXPLAIN THE 1920 S RADIO BROADCASTING MARKET AND THE SHOCK TO THAT SYSTEM IN 1926-27. NEXT. THE 1926 "OAK LEAVES" DECISION ESTABLISHING PRIVATE PROPERTY RIGHTS TO SPECTRUM AT COMMON LAH IS DETAILED. THE LEGISLATIVE AGENDAS OF THE MAJOR BROADCASTERS, THE REGULATORS, AND PUBLIC INTEREST ADVOCATES ARE NEXT DISCUSSED. THE FEDERAL RADIO ACT OF 1927 IS INTERPRETED AS AN EQUILIBRIUM SOLUTION FOR THESE COMPETING INTERESTS. FINALLY, THE SOURCE OF ANALYTICAL CONFUSION IS

IDENTIFIED AS STEMMING FROM A FOCUS ON AUCTIONS, WHEN VESTED RIGHTS IN THE ETHER WERE QUICKLY ESTABLISHED DE JURE AND DE FACTO.

04225 HAZZARD, S.

SYSTEM FAILURE

NEW REPUBLIC, 207(13) (SEP 92), 16-17

NEW REPUBLIC, $207(13)$ (SEP 92), 16-17.

THE UNITED NATIONS PREVENTS IT FROM FUNCTIONING EFFECTIVELY.

04226 HEALEY, $N$

WHAT PRICE TRADE UNIOM REFORM?

CONTEMPORARY REVIEW, 261(1523) (DEC 92), 288-293.

REFORM OF THE LABOR MARKET HAS BEEN A CENTRAL PLANK OF THE POST-1979 CONSERVATIVE GOVERNMENT'S ECONOMIC PROGRAM. THIS ARTICLE OUTLINES THE GOVERNMENT'S LEGISLATIVE REFORMS OF THE LABOR MARKET SINCE 1979 AND CRITICALLY EXAMINES THEIR RATIONALE, CASTING DOUBT UPON THE EXTENT TO WHICH THEY HAVE CONTRIBUTED TO AN IMPROVEMENT IN THE ECONOMY'S LONG-TERM GROWTH AND PROSPECTS.

04227 HEALEY, P.

THE REORGANIZATION OF STATE AND MARKET IN PLANNING

URBAN STUDIES, 29(2) (APR 92), 411-460.

THE AUTHOR EXPLORES THE PRESENT STATE OF THE BRITISH PLANNING SYSTEM, FOCUSING ON THREE THEMES. THE FIRST CONSIDERS THE CORE PROCEDURES OF THE SYSTEM, THE MACHINERY FOR DEVELOPMENT PLANS, AND DEVELOPMENT CONTROL. HOW HAVE THESE CHANGED IN RESPONSE TO THE SWITCH BACK TO PLANNING IN GOVERMMENT POL ICY? THE SECOND FOCUSES ON THE RELATION GOVERNMENT POLICY? THE SECOND FOCUSES ON THE RELATION
BETWEEN THE PLANNING SYSTEM AND PROPERTY DEVELOPMENT BETWEEN THE PLANMING SYSTEM AND PROPERTY DEVELDPMENT
ACTIVITY. IF OEVELOPMENT IS TO BE INITIATED PRIMARILY BY THE ACTIVITY. IF DEVELOPMENT IS TO BE INITIATED PRIMARILY BY THE
PRIVATE SECTOR, IN WHAT WAYS SHOULD IT RELATE TO THE MARKET PRIVATE SECTOR, IN WHAT WAYS SHOULD IT RELATE TO THE MARK
WITH WHICH IT MOST CENTRALLY INTERACTS? THE THIRD ISSUE EXAMINES THE WAYS IN WHICH THE PLANHING SYSTEM IS RESPONDING EXAMINES THE WAYS IN WHICH THE PLANHING SYSTEM IS RESPONDING AND HOH WEL ABONSIDERATIONS OF SOCIAL AND COMMUNITY WELFARE AND HON WELL CONSIDERA
ARE BEING ADORESSED.

04228 HEARD, A.

CANADIAN CONSTITUTIONAL CONVENTIONS: THE MARRIAGE OF LAW AND POLITICS

OXFORD UNIVERSITY PRESS, 1991, 189.

AT a TIME WHEN CANADIANS HAVE LOST COUNT OF THE NUMBER OF COMMISSIONS CONSIDERING THE PROCESS AND SUBSTANCE OF CONSTITUTIONAL AMENDMENT, THIS BOOK ARGUES THAT ONE VIRTUE CIRCUMSTANCES THROUGH INFORMAL CONVENTIONS. THESE INFORMAL RULES HAVE PROFOUNDLY TRANSFORMED CANADA'S CONSTITUTION BY PERMITTING ITS LEGAL FRAMEHORK TO EVOLVE WITHOUT RECOURSE TO FORMAL AMENDMENT. THE BOOK IDENTIFIES TWO SOMEWHAT

CONTRADICTORY TRENDS IN CANADIAN ATTITUDES TOHARD

CONSTITUTIONAL CONVENTIONS: AS CANADIAN COURTS HAVE AFFIRMED THE DISTINCTION BETWEEN CONSTITUTIONAL LAW AND CONVENTION, POLITICAL ACTORS HAVE INCREASINGLY SOUGHT "JUDICIAL RESOLUTION OF ISSUES NORMALLY GOVERNED BY CONVENTION." THE BOOK EXAMINES CONVENTIONS SURROUNDING THE POWERS OF THE GOVERNOR-GENERAL AND LIEUTENANT-GOVERNORS, THE CABINET AND THE CIVIL SERVICE, LEGISLATURES, FEDERALISM AND JUDICIAL INDEPENDENCE.

04229 HEARD, A

THE CHARTER IN THE SUPREME COURT OF CANADA: THE IMPORTANCE OF WHICH JUDGES HEAR AH APPEAL

CANADIAH JOURNAL OF POL ITICAL SCIENCE, XXIV(2) (JUN 91), 289-308.

a TRADITIONAL FOCUS ON THE COLLECTIVE, INSTITUTIONAL OPERATION OF THE SUPREME COURT OF CANADA HAS OBSCURED THE PRACTICAL IMPACT ON THE CHARTER OF RIGHTS OF THE PERSONAL VIEWS HELD BY THE INDIVIDUAL MEMBERS OF THE COURT. A STUDY OF ALL THE CHARTER CASES DECIDED BY THE SUPREME COURT 1983 TO 1989 REVEALS A PROFOUND OIVERGENCE OF OPINIONS WITHIN THE COURT. THE DIFFERENCES ARE SEEN NOT ONLY IN EACH JUDGE'S OVERALL SUPPORT FOR CHARTER CLAIMS BUT ALSO IN THE WHO HAVE HEARD THE SAME CASES. THE USE OF SUBSETS OF JUDGES TO SIT ON PANELS TO HEAR CHARTER CASES HAS MEANT THAT BOTH 
THE OUTCOME OF CHARTER CASES AND THE CONTENT OF OUR RIGHTS HAVE DEPENDED TO A LARGE EXTENT UPON WHICH JUDGES HAPPENED TO SIT ON THE PANELS THAT HEARD THE CASES.

04230 HEATH, A.; PAULSON, B.

ISSUES AND THE ECONOMY

POLITICAL QUARTERLY (THE), 63(4) (OCT 93), 32-47

THE RESULT OF THE 1992 GENERAL ELECTION IN GREAT BRITIAN CAME AS A SURPRISE TO MOST PEOPLE. THIS ARTICLE CONCENTRATES ON THO THEORIES--THE THEORY OF ISSUE-VOTING THAT PREDICTED LABOR GAINS AT THE EXPENSE OF THE CENTER PARTIES AS A RESULT OF THE POLICY REVIEN; AND THE THEORY OF ECONOMIC VOTING THAT PREDICTED CONSERVATIVE LOSSES AS A RESULT OF THE RECESSION. PREDICTED CONSERVATIVE LOSSES AS A RESULT OF THE RECESS
THERE ARE MANY VERSIONS OF BOTH THESE THEORIES, BUT THE THERE ARE MANY VERSIONS OF BOTH THESE THEORIES, BUT THE
AUTHORS OF THIS PAPER FOCUS ON THE VERSIONS WHICH THEY ARE MOST FAMILIAR WITH.

04231 HEATH, A.; PIERCE, R.

IT WAS PARTY IDENTIFICATION ALL ALONG: QUESTION ORDER IT WAS PARTY IDENTISICATION ON REPORTS OF PARTY IDENTIFICATION IN BRITAIN ELECTORAL STUDIES, 11(2) (MAY 92), 93-105.

THE BRITISH VOTER IS LESS LIKELY THAN THE AMERICAN TO MAKE A DISTINCTION BETHEEN HIS CURRENT CHOICE AND A MORE GENERAL PARTISAN DISPOSITION. THIS ARTICLE INVESTIGATES WHETHER THIS DIFFERENCE MIGHT BE DUE TO A METHODOLOGICAL DIFFERENCE BETWEEN THE BRITISH AND AMERICAN ELECTION SURVEYS. A SPLIT-SAMPLE PANEL STUDY EXPERIMENT HAS CONDUCTED TO TEST THIS HYPOTHESIS. THE RESULTS SUGGEST THAT THE IMPROPER QUESTION ORDER ELICITED A SMALLER PROPORTION OF TRUE PARTY IDENTIFIERS AND PRODUCED RESPONSE UNCERTAINTY IN THE REPORTING OF PARTY IDENTIFICATION

04232 HEATH, A.; CURTICE, J.; EVANS, G.; FIELD, J.; ROWELL, R.; WI THERSPOON, $S$.

UNDERSTANDING POLITICAL CHANGE: THE BRITISH VOTER 1964-1987 PERGAMON PRESS, 1991, 334.

THIS BOOK IS THE REPORT FROM THE 1987 BRITISH ELECTION SURVEY. IT IS PRIMARILY CONCERNED WITH DOCUMENTING AND EXPLAINING TRENDS. EACH OF THE ELEVEN CHAPTERS EVALUATES AN ASPECT OF A CURRENT ARGUMENT IN THE LITERATURE WITH REFERENCE TO THE EVIDENCE SINCE 1964. THE PRINCIPAL ANTAGONIST IS THE DELAIGNMENT THESIS, BUT THE AUTHORS ALSO
ENGAGE WITH, AND FIND SERIOUS FLAWS IN, ARGUMENTS FOR POSTENGAGE WITH, AND FIND SERIOUS FLAWS IN, ARGUMENTS FOR POSTSELF-INTEREST AND AUTHORITARIAN POPULISM. THE AUTHORS ALSO DISCUSS WHETHER THERE HAS BEEN INCREASED ELECTORAL DISCUSS WHETHER THERE HAS BEEN INCREASED ELECTORAL IMPORTANCE, AND WHETHER THE ELECTORATE'S VALUES HAVE MOVED IMPORTANCE, AND

04233 HEATH, $B$

NORTHWEST TERRITORIES: THE BUILDING OF A LEGISLATURE IN THE CANADIAN ARCTIC

PARL IAMENTARIAN, LXXIII

THE LEGISLATIVE ASSEMBLY OF THE NORTHWEST TERRITORIES

HAS UNDERTAKEN THE CONSTRUCTION OF THE FIRST FULL-TIME AND PERMANENT LEGISLATIVE ASSEMBLY BUILDING IN THE TERRITORIES' HISTORY. THROUGHOUT THE PLANNING, THE GOVERNMENT HAS BEEN SENSITIVE TO THE DEMOGRAPHIC, CULTURAL, AND LINGUISTIC REALITIES OF THE NORTHHEST TERRITORIES. ITS GOALS INCLUDE PUBLIC PARTICIPATION IN THE PROJECT AND INFORMATION SHARING, IN ORDER TO MAKE CITIZENS MORE RECEPTIVE TO THE PROJECT.

04234 HEATH, D.B.

U.S. DRUG CONTROL POLICY: A CULTURAL PERSPECTIVE DAEDALUS, $121(3)$ (SUM 92), 269-292.

THE BUSH ADMINISTRATION'S DRUG CONTROL POLICY HAS BEEN DIRECTED ALMOST EXCLUSIVELY TO THE SUPPLY-SIDE OF THE PROBLEM--KEEPING DRUGS FROM ENTERING THE UNITED STATES AND, FAILING THAT, KEEPING THEM FROM THE PUBLIC. BUT RESEARCHERS AND CLINICIANS WITH EXTENSIVE EXPERIENCE HITH DRUG ABUSERS TEND TO FAVOR A DEMAND-SIDE APPROACH, INCLUDING REDUCING INTEREST IN DRUGS THROUGH EDUCATION AND PROVIDING FACILIIIIES FOR TREATMENT AND REHABILITATION. AS IS OFTEN THE CASE IM TIME OF HAR, THE CONTINUING NEEDS OF PUBLIC HEALTH AND SOCIAL WEL FARE HAVE BEEN PREEMPTED BY MILITARY GESTURES AND HARDWARE DURING THE BUSH ADMINISTRATION. FULLY 70 PERCENT OF THE GENEROUS BUDGET FOR BUSH'S DRUG POLICY HAS BEEN ASSIGNED THE GENEROUS BUDGET FOR BUSH'S DRUG POLICY HAS BEEN ASSIG
TO MILITARY OR PARAMILITARY POLICE APPROACHES AIMED AT TO MILITARY OR PARAMILITARY POLICE APPROACHES AIMED AT
INTERDICTION, ERADICATION, AND DISRUPTION OF SALES. ALTHOUGH INTERDICTION, ERADICATION, AND DISRUPTION OF SALES. ALTHOUGH
THIS HAS MADE THE WAR ON DRUGS A REALITY, IT HAS NOT CREATED

A DRUG-FREE AMERICA.

04235 HEATH, J.R.

EVALUATING THE IMPACT OF MEXICO'S LAND REFORM ON AGRICULTURAL PRODUCTIVITY

WORLD DEVELOPMENT, 20(5) (MAY 92), 695-711.

IN MEXICD, LAND REFORM LAH AND' THE TERMS OF CREDIT ACCESS SUGGEST A PRIORI THAT FARMERS IN THE LAND REFORM (EJIDO) SECTOR SHOULD BE LESS PRODUCTIVE THAN PRIVATE FARMERS. HOWEVER, ANALYSIS OF STUDIES COMPARING THE PRODUCTIVITY OF INDIVIDUAL EJIDO PARCELS AND SMALL PRIVATE HOLDINGS REVEALS NO SIGNIFICANT DIFFERENCE BETHEEN THE THO
NOT A DE FACTO DIFFERENCE IN SMALL FARMERS' CONTROL OVER RESOURCES, PARTLY BECAUSE FARMERS CIRCUMVENT RESTRICTIONS IMPLICIT IN THE LAND REFORM. THE CASE FOR FORMAL PRIVATIZATION OF THE EJIDO SECTOR MAY BE LESS COMPELLING THAN HAS BEEN SUGGESTED.

04236 HEATON, $W$.

MONGOL IA IN 1991: THE UNEASY TRANSITION

ASIAN SURVEY, XXXII(1) (JAN 92), 50-55.

AS IT MARKED ITS SEVENTIETH ANHIVERSARY, THE MONGOLIAM PEOPLE'S REPUBLIC IN 1991 CONTINUED TO UNDERGO THE POLITICAL, ECONOMIC, AND SOCIAL UPHEAVAL THAT BEGAN IN 1990. THE RULING MONGOLIAN PEOPLE'S REVOLUTIONARY PARTY, THOROUGHLY DISCREDITED BY ITS PAST FAILURES, LOST AUTHORITY; THE NATIOM SOUGHT TO ADOPT A NEW CONSTITION, A NEW NAME (REPUBLIC OF MONGOLIA), AND A NEW POLITICAL, ECONOMIC, AND SOCIAL SYSTEM: AND ECONOMIC REFORM HAS ACCOMPANIED BY SERIOUS, THOUGH PERHAPS TEMPORARY ECONOMIC DECLINE THAT REQUIRED MASSIVE INFUSIONS OF FOREIGN AID TO FORESTALL COLLAPSE.

04237 HEAZLE, $M$.

A CAPITAL OILEMMA

FAR EASTERM ECONOMIC REVIEW, 155(44) (NOV 92), 40-41.

POLITICIANS AND ECONOMISTS SAY THAT A REPEAT OF THE 1923 TOKYO EARTHQUAKE WOULD PARALYZE JAPAN POLITICALLY AND ECONOMICALLY TO AN EXTENT WHERE EVEN THE WORLD ECONOMY COULD BE SERIOUSLY AFFECTED. IN ADOITION TO THE THREAT OF A MAJOR EARTHQUAKE, TOKYO IS ALSO EXPERIENCING PROBLEMS WITH HIGH LAND PRICES AND SEVERE OVERCROHDING. AS A RESULT, MANY POLITICIANS ARE CALLING FOR A SEPARATION OF JAPAN'S POLITICAL AND ECONOMIC CENTERS AS IS THE CASE IN THE U.S. AUSTRALIA, AND THE NETHERLANDS. PREPARATIONS ARE UNDER WAY IN JAPAN'S PARLIAMENT FOR A BILL OUTLINING PLANS FOR JAPAN'S POLITICAL CAPITAL TO BE MOVED TO A NEW LOCATION, AT LEAST 60

ENVIRONS) IS A LIKELY LOCATION FOR THE COUNTRY'S NEW CAPITAL.

04238 HEBERT, F.; BRUDNEY, J.; WRIGHT, D.

CHALLENGES TO STATE GOVERNMENTS: POLICY AND ADMINISTRATIVE LEADERSHIP IN THE 1990 S

PUBLIC PROOUCTIVITY \& MANAGEMENT REVIEW, XVI (1) (FAL 92), $1-22$.

FACING NUMEROUS CHALLENGES, STATE GOVERNMENTS MUST

ATTEND TO PRODUCING A WELL-PREPARED CORPS OF ADMINISTRATIVE FATA FIIX SURVEYS AND IDENTIFY CRITICAL ADMINISTRATIVE ISSUES THAT THE
STATES NEED TO ADDRESS.

04239 HECHTER, M.

THE DYNAMICS OF SECESSION

ACTA SOCIOLOGICA, 35(4) (1992), 267-284

THIS PAPER PRESENTS AN ANALYSIS OF SECESSION BASES ON RATIONAL CHOICE PREMISES. FROM THESES PREMISES, SECESSION IS SEEN TO BE THE OUTCOME OF A SERIES OF COLLECTIVE DECISIONS MADE BY REGIONAL LEADERS AND POPULATIONS, AND BY THE LEADERS AND POPULATIONS OF HOST STATES. THIS EMPHASIS ON COLLECTIVE DECISIONS SERVES TO DIFFERENTIATE SECESSION FROM ANOTHER PROCESS THAT LEADS TO THE FORMATION OF POLITICAL UNITS - THE FRAGMENTATION OF HOST STATES. THE ANALYSIS EXPLAINS WHY SECESSION HAS BEEN SUCH A RARE OUTCOME IN MODERN HISTORY AND SUGGESTS THAT IT WILL CONTINUE TO BE RARE IN THE FORESEEABLE FUTURE.

04240 HEDGE, D.M.; SCICCHITANO, M.J. DEVOLYING REGULATORY AUTHORITY: THE FEDERAL AND STATE RESPONSE

POLICY STUDIES REVIEW, 11(1) (SPR 92), 81-90

ONE OF THE MAJOR LEGACIES OF THE REAGAN ADMINISTRATION WAS ITS DEVOLUTION OF REGULATORY AUTHORITY TO THE STATES, PARTICULARLY IN THE AREA OF ENVIRONMENTAL PROTECTION. THIS OF THE STATES MINING TRANSFERRED REGULATORY RESPONSIBILITY TO THE STATES AND HOW STATE OFFICIALS INITIALLY RESPONDED DEVOLUTION. IN A NUMBER OF STATES, REGULATORY OFFICIALS CHOSE TO VIGOROUSLY ENFORCE FEDERAL ENVIRONMENTAL STA DESPITE THE REAGAN ADMINISTRATION'S DESIRE FOR A MORE RELAXED APPROACH TO REGULATION. HOHEVER, MANY STATES LACKED THE WILLINGNESS AND ABILITY TO EFFECTIVELY SHOULDER THEIR NEW RESPONSIBILITIES. BY THE END OF THE REAGAN

ADMINISTRATION, OPPOSITION TO DEVOLUTION HAD EMERGED FROM SEVERAL QUARTERS AND, ONCE AGAIN, ADMINISTRATION OFFICIALS PARTNERSHIP.

04261 HEDLUND, R.D.; PATTERSON, S.C. THE ELECTORAL ANTECEDENTS OF STATE LegISLATIVE COMmITTEe ASSIGNMENTS

LEGISLATIVE STUDIES QUARTERLY, XVII(4) (NOV 92), 539-560. THE AUTHORS ANALYZE DATA ON COMMITTEE ASSIGNMENT REQUESTS FOR FOUR STATE LEGISLATURES TO TEST THE RE-ELECTION HYPOTHESIS--THAT LEGISLATORS RECEIVE COMMITTEE ASSIGMMENTS THAT HELP INSURE THEIR SUBSEQUENT RE-ELECTION. IN PENNSYLVANIA, WISCONSIN, IOWA, AND MAINE, THE AUTHORS 
ELECTED IN 1986 AND COMPARED IT WITH ELECTION DATA DERIVED FROM "STATE LEGISLATIVE ELECTION RETURNS IN THE UNITED STATES, 1968-86." IN GENERAL, THE RESULTS DISCONFIRM THE REELECTION HYPOTHESIS BUT SHOW THAT LEGISLATORS' STRATEGIC DECISIONS HAVE IMPORTANT EFFECTS ON COMMITTEE ASSIGNMENT SUCCESS.

04242 HEGDAL, T.S.

STRUCTURE; AND 'AGENT IN INSTITUTIONAL BARGAINING: INSTITUTIONAL DESIGN AND POLITICAL LEADERSHIP IN THE THIRD UNITED NATIONS CONFERENCE ON THE LAW OF THE SEA COOPERATION \& CONFLICT: NORDIC JOURNAL OF INTERNATIONAL POLITICS, 27(2) (JUN 92), 163-189.

THE AIM OF THIS PAPER IS TO OUTLINE IN SOME DETAIL THE INSTITUTIONAL AND INDIVIDUAL CONDITIONS THAT SHAPE LEADERSHIP PERFORMANCE. DIFFERENT FORMS OF POL LEADERSHIP PLAY DIFFERENT ROLES IN INTERNATIONAL REGIME FORMATION AND MAY CONSTITUTE A NECESSARY CONDITION FOR SUCCEEDING IN EFFORTS TO DEVELOP JOINT SOLUTIONS TO COLLECTIVE PROBLEMS. INDIVIDUAL ACTOR BEHAVIOR HOLDS INDEPENDENT EXPLANATORY POWER FOR NEGOTIATION RESULTS. ACTOR INDEPENDENT EXPLANATORY POWER FOR NEGOTIATION RESULTS.
BEHAVIOR, HOWEVER, MUST BE ANALYZED IN RELATION TO THE BEHAVIOR, HOWEVER, MUST BE ANALYZED IN RELATION TO THE
STRUCTURAL CONTEXT WITHIN WHICH THE ACTIONS OCCUR--THAT IS, STRUCTURAL CONTEXT WITHIN WHICH THE ACTIONS OCCUR--THAT IS,
THE INSTITUTIONAL SETTING OF THE NEGOTIATIONS: IF ATTEMPTS THE INSTITUTIONAL SETTING OF THE NEGOTIATIONS; IF ATTEMPTS TO PERFORM THE ROLE OF POLITICAL LEADER ARE TO SUCCEED, THE INSTITUTIONAL SETIING MUST PERMIT LEADERSHIP PERFORMANCE. THE LAW OF THE SEA CONFERENCE IS CHARACTERIZED BY THE UNUSUAL INFLUENCE OF INDIVIDUALS. THIS FACT MUST BE SEEN IN RELATION TO THE PROCEDURAL INNOVATIONS DEVELOPED THROUGH THE ORGANIZATIONAL NEGOTIATION PROCESS, WHICH PROVIDES THE NECESSARY INSTI TUTIONAL BASIS FOR THE PERFORMANCE OF BOTH FORMAL AND INFORMAL LEADERSHIP ROLES. PERFORMANCE OF POLITICAL LEADERSHIP IS NOT A GUARANTEE OF SUCCESS. ONE FACTOR THAT MAY HINDER SUCCESSFUL PERFORMANCE IS THE STRUCTURE OF THE ISSUES AT STAKE. IN THIS RESPECT, THE THIRD U.N. CONFERENCE ON THE LAH OF THE SEA DEMONSTRATES BOTH THE POTENTIALS AND THE LIMITATIONS OF POLITICAL LEADERSHIP.

04243 HEGTVEDT, $K$.

BARGAINING FOR JUSTICE: A MEANS TO RESOLVE COMPETING JUSTICE CLAIMS

SOCIAL JUSTICE RESEARCH, 5(2) (JUN 92), 155-172.

THIS PAPER REVIEWS THE FEW ATTEMPTS TO ADDRESS JUSTICE CONFLICT. THE LIMITATIONS OF THESE APPROACHES SUGGEST CONCERNS TO BE ADDRESSED IN AN ALTERNATIVE FRAMEWORK. THE CONCERNS TO BE ADDRESSED IN AN ALTERNATIVE FRAMEWORK. THE
PAPER PRESENTS A THEORETICAL DISCUSSION OF THE ALTERNATIVE PAPER PRESENTS A THEORETICAL DISCUSSION OF THE ALTERNATIVE
THAT INTEGRATES ASSUMPTIONS ABOUT DISTRIBUTION PREFERENCES, THAT INTEGRATES ASSUMPTIONS ABOUT DISTRIBUTION PREFERENCE
JUSTICE BELIEFS, CONDITIONS FOSTERING THE EMERGENCE OF JUSTICE BELIEFS, CONDITIONS FOSTERING THE EMERGENCE OF
JUSTICE CONFLICT, AND ELEMENTS OF NEGOTIATION PROCESSES AS A BASIC FRAMEWORK FOR PREDICTIONS ABOUT THE BARGAINING STRATGIES INDIVIDUALS MAY EMPLOY TO RESOLVE COMPETING STRATGIES INDIVID
JUSTICE CLAIMS.

04244 HEHIR, J.B. HITIING THE HIGH C'S: CHARACTER, CHOICE, AND COMMUNITY COMMONWEAL, CXIX(12) (JUN 92), 7-9.

THE HEALTH OF A DEMOCRACY DEPENDS UPON THE POLITICAL WISDOM AND MORAL VISION OF BOTH LEADERSHIP AND CITIZENRY, SO IT IS USEFUL TO TEST BOTH PARTS OF THE BODY POLITIC WITH THE SAME QUESTIONS. THIS IS PARTICULARLY USEFUL WHEN TESTING MORAL VISION--A QUALITY LEADERS SHOULD HAVE; BUT SINCE THEY OFTEN DO NOT, THERE IS THE NEED TO ATTENO TO THE WAY MORAL VISION IS PRESERVED AMONG THE CITIZENRY.

04245 HEHIR, J.B. JUST CAUSE? YES

COMMONWEAL, CXIX(4) (FEB 92), 8-9.

THE AUTHOR ASSESSES THE U.S. INVOLVEMENT IN THE GULF WAR, DISCUSSING BOTH THE POLITICAL AND THE MORAL DIMENSIONS.

04246 HEHIR, J.B. WORLD OF FAULTLINES

COMMONWEAL, CXIX(16) (SEP 92), 8-9.

THREE RIVETING AND PROFOUNOLY DIFFERENT SITUATIONS TESTIFY TO THE DEGREE OF CHANGE REQUIRED IN THE WAY WORLD LEADERS THINK ABOUT INTERNATIONAL POLITICS IN THE 1990'S. BOSNIA, SOMALIA, AND IRAO COULD HARDLY BE MORE DIFFERENT ON THE SURFACE, YET ANY RESPONSE TO THEM TENDS TO TAKE ANALYSIS AND PLANNING BACK TO A SIMILAR THEME--THE CHANGING CHARACTER OF INTERNATIONAL RELATIONS. EACH OF THE THREE CASES HIGHLIGHTS A DISTINCT KIND OF PROBLEM THAT ADVOCATES OF HIGHLIGHTS A DISTINCT KINO OF PROBLEM THAT ADVOCATES OF INTERNATIONAL ORDER MUST ADDRESS. BOSNIA MOST CLEARLY
REFLECTS THE ENDING OF THE COLD HAR AND THE DESIRE FOR SELFDETERMINATION. SOMALIA TESTIFIES LESS TO THE COMPLEXITY OF DETERMINATION. SOMALIA TESTIFIES LESS TO THE COMPLEXITY OF NATION AND ITS PEOPLE DO NOT COUNT ON THE SCALES OF HIGH NATION AND ITS PEOPLE DO NOT COUNT ON THE SCALES OF POLITICS AND NEW ORDER DESIGNS. IRAQ REFLECTS MORE TRADITIONAL ISSUES OF FOREIGN POL ICY: A REVISIONIST STATE
WITH A REPRESSIVE REGIME, ARGUMENTS ABOUT BALANCES OF POWER, PROLIFERATION, AND TRADE EMBARGOES. JUST BELOW THE SURFACE OF EACH SITUATION LIES A NEED FOR A LONG-TERM SYSTEMATIC EFFORT TO RECAST BOTH THE CONTENT OF SOVEREIGNTY AND THE NORM OF NONINTERVENTION TO PROVIDE A MORE ADEQUATE FRAMEHORK FOR INTERNATIONAL ORDER.
04247 HEILBRUNM, J.

WHAT GERMAN CRISIS?

NEW REPUBLIC, 207 (26) (DEC 92), 21-23.

THE FEDERAL REPUBLIC FACES HUGE PROBLEMS, BUT THEY LIE

LESS IN THE HIGHLY-PUBLICIZED RESURGENT GERMAN NATIONALISM

THAN IN THE FAILURE OF THE MAJOR POLITICAL PARTIES TO

CONFRONT THE DISLOCATIONS PRODUCED BY THE WAVES OF

IMMIGRANTS STREAMING INTO GERMANY. LEADING GERMAN

POLITICIANS HAVE EXPLOITED RATHER THAN CONFRONTED THE

IMMIGRATION PROBLEM. THIS LACK OF POLITICAL WILL HAS EXACERBATED THE ALREADY ENORMOUS DIFFICULTIES OF GETTING THE FORMER COMMUNIST EAST BACK ON ITS FEET.

04248 HEILMAN, J.G.; WALSH, R.W. INTRODUCTION: ENERGY PROGRAM EVALUATION AND POLICY DESIGN POLICY STUDIES JOURNAL, 20(1) (1992), 42-47.

IN THIS INTRODUCTION TO A SYMPOSIUM ON ENERGY POLICY,

THE AUTHORS OFFER AN OVERVIEN OF THE RELEVANT FEDERAL POLICY

THE AUTHORS OFFER AN OVERVIEN OF THE RELEVANT FEDERAL POLICY

AS THE CONTEXT FOR THEORETICAL DISCUSSION, BRIEFLY EXPLORE
THEORETICAL ISSUES, AND RELATE THE INDIVIDUAL SYMPOSIUM

THEORETICAL ISSUES, AND RELATE
PAPERS TO THE SYMPOSIUM GOALS.

04249 HEIN, J.

THE EMERGENCE OF ETHNIC MINORITIES IN FRANCE: MARKET, STATE, AND LIFE COURSE NEEDS AMONG IMMIGRANTS AND REFUGEES ETHNIC GROUPS, $9(3)(1992), 135-149$.

IMMIGRANTS WHO CAME TO WESTERN EUROPE TO WORK ARE FORMING PERMANENT ETHNIC COMMUNITIES, WHICH ARE CREATING NEH DEMANDS ON THE STATE, PARTICULARLY FOR SOCIAL SERVICES. THE EMERGENCE OF THESE MINORITIES IS ESPECIALLY PRONOUNCED IN FRANCE. THIS PAPER INVESTIGATES HOW THE TRANSITION FROM MIGRANTS TO SETTLERS AFFECTS THE SOCIAL WELFARE NEEDS OF FOUR POPULATIONS IN FRANCE: NORTH AFRICAN AND IBERIAN IMMIGRANTS, INDOCHINESE REFUGEES, AND THIRD HORLD ASYLUM SEEKERS.

04250 HEINRICH, A.

1991, A YEAR SHAPED BY A TRIO OF EVENTS

GERMAN TRIBUNE, 1498 ( JAN 92 ), $1-2$.
MEMORIES OF 1991 ARE DOMINATED BY THREE THINGS: THE GULF WAR, THE FAILED COUP D'ETAT IN MOSCON AND THE BLOODSHED IN CROATIA. THIS ARTICLE QUESTIONS WHETHER THE GULF HAR WAS WORTH THE EFFORT AND THE SACRIFICE. IT DISCUSSES THE FARWORTH THE EFFORT AND THE SACRIFICE. IT OISCUSSES THE FAR-
REACHING REPERCUSSIONS OF THE THREE-DAY MOSCOW COUP. IT ALSO REACHING REPERCUSSIONS OF THE THREE-DAY MOSCOW COUP. IT
STATES THAT THE FIGHTING IN CROATIA WAS A DISGRACE TO STATES THAT THE
HESTERN EUROPE.

04251 HEINTZE, H.; NOWAK, M.; WALLNER, J.

SATELLITE VERIFICATION AFTER THE END OF EAST-WEST SATELLITE VERIFI

CDNFRONTATION
AUSSEN POLITIK, 43(2) (1992), 195-204.

ONE OF THE CONTINUING TASKS TO MAINTAIN INTERNATIONAL SECURITY IS ARMS CONTROL, WHICH HAS NEW FUNCTIONS TO FULFILL ALONG SIDE FORMER ONES. THIS DEMANDS A VERIFICATION REGIME WHICH PRESUPPOSES INTER ALIA EFFICIENT SATELLITE REMOTE SENSING. THE AUTHORS EXAMINE THE ASSOCIATED POLITICAL, LEGAL AND TECHNOLOGICAL PROBLEMS ACCOMPANYING THIS TASK. THEY POINT OUT THAT THE AIM SHOULD BE TO BREAK UP THE SATELLITE REMOTE SENSIMG MONOPOLY OF THE SUPERPOWERS AND EVEN ENABLE PARTICIPATION FOR SMALL NATIONALS IN ALL MAJOR ASPECTS OF THE VERIFICATION PROCESS.

04252 HEINZ, O. (ED)

FEARS THAT BALKANS WAR WILL SPREAD AS WORLD LOOKS ON

GERMAN TRIBUNE, $31(1545)$ (DEC 92 ), 1 . . WOW IT HAS ACHIEVED
THERE ARE GROHING FEARS THAT SERBIA, NOW IT ITS GOALS IN CROATIA AND BOSNIA-HERCEGOVINA, MIGHT BE PLANNING TO EXTEND ITS BALKAN WAR TO MACEDONIA AND TO SEBIANCONTROLLED KOSOVO WHERE OVER 90 PER CENT OF THE POPULATION ARE ALBANIAN MUSLIMS. "INTERNATIONALIZATION OF THE CONFLICT" IS NOH A TERM ON THE POL ITICAL AGENDA. THE UN FORCES HAVE BROUGHT LITTLE HUMAN EASEMENTS TO THE PEOPLE OF BOSNIA AND HAVE BEEN UNABLE TO PROVIDE ANY MILITARY PROTECTION. THIS ARTICLE REPORTS THAT MURDER AND MAYHEM CONTINUE WHILE THE WORLD LOOKS ON IDLY.

04253 HEIPLE, J.J.

FISCAL POLICY REFORM: THE RAMIFICATIONS OF A FEDERAL LINEITEM VETO AUTHORITY AND A BALANCED BUDGET REQUIREMENT ON THE BUDGET PROCESS

JOURNAL OF LAW \& POLITICS, VIII(2) (WIN 92), 405-436.

DURING THE PAST DECADE, SOME POLICY MAKERS HAVE ADYOCATED A PRESIDENTIAL $I$ INE-ITEM YETO AUTHORITY AND A BALANCED BUDGET REQUIREMENT TO HELP CONTROL FEDERAL SPENDING AND ELIMINATE THE STAGGERING DEFICIT. IN THIS ARTICLE, THE AUTHOR DESCRIBES THESE PROPOSALS AND EXPLAINS HOW THEY COULD BE ADOPTED. THEN HE ASSESSES THE NEED FOR A FEDERAL LINEITEM VETO AND BALANCED BUDGET AMENDMENT, EXPLAINING BOTH THE PROCEDURAL AND POLITICAL NECESSITY FOR EXPRESSLY GRANTING THE PRESIDENT LINE-ITEM VETO POWER AND FOR REQUIRING AN ANNUAL BALANCED BUDGET. HE ALSO SUMMARIZES THE MAJOR STATUTORY REVISIONS TO THE BUDGET PROCESS THAT HAVE BEEN ENACTED OVER THE PAST 70 YEARS. 
04254 HEISBOURG, F.

THE EUROPEAN-AMERICAN ALLIANCE

INTERNATIONAL AFFAIRS, 68(4) (OCT 92), 665-678.

THE US-WEST EUROPEAN SECURITY COMPACT HAS ENTERED INTO A STATE OF GREAT UNCERTAINTY, WITH NATO EXPERIENCING AN

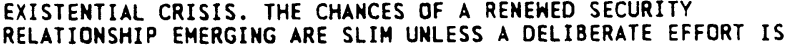
RELATIONSHIP EMERGING ARE SLIM UNLESS A DELIBERATE EFFORT IS MADE BY THE UNITED STATES TO COME TO TERMS WITH THE REALITY OF A MORE UNITED EUROPE. THE WEST EUROPEANS HAVE A LONG-TERM
INTEREST IN ENSURING THAT A CLOSER UNION WILL NOT PREVENT INTEREST IN ENSURING THAT A CLOSER UNION WILL NOT PREVENT THE MAINTENANCE OF A MILITARY ALLIANCE WITH THE UNITED STATES. SINCE THE FAILURE OF EUROPEAN INTEGRATION WOULD
HASTEN THE RENATIONALIZATION OF DEFENSE POLICIES IN EUROPE, THE INTEGRATION PROCESS HAS BECOME A CONDITION OF NATO'S SURVIVAL.

04255 HEISBOURG, F.

THE FUTURE OF THE ATLANTIC ALLIANCE: WHITHER NATO? WHETHER NATO?

WASHINGTON QUARTERLY, 15(2) (SPR 92), 127-140.

PEACE AND STABILITY IN THE EUROPE OF THE 1990 S REMAIN VERY MUCH AT ISSUE, IN THE WAKE OF THE COLD WAR. QUESTIONS HAVE EMERGED ABOUT HOW TRADITIONAL INSTRUMENTS OF COLLECTIVE SECURITY CAN BE MODIFIED AND COMBINED WITH NEW POLITICAL AND ECONOMIC FACTORS. IS THERE A CONTINUING ROLE FOR NATO? WHAT KIND OF RELATIONSHIP CAN OR SHOULD NATO ESTABLISH WITH NEWLY INDEPENDENT STATES IN CENTRAL AND EASTERN EUROPE? TO ASSESS THE PROSPECTS FOR THE EUROPEAN-AMERICAM SECURITY

RELATIONSHIP THIS PAPER WILL FIRST ANALYZE THE CHANGING NATURE OF THE INTERESTS OF THE UNITED STATES IN EUROPE. IT WIL THEN EYALUATE THE DYNAMIC OF WEST EUROPEAN INTEGRATION IN THE FACE OF NEW SECURITY CHALLENGES. POLICY RECOMMENDATIONS WILL FOLLOW.

04256 HEISLER, M.O.

MIGRATION. INTERMATIONAL RELATIONS AND THE NEW EUROPE: MIGRATION, INTERNATIONAL RELATIONS AND THE NEW EUROPE: THEORETICAL
SOCIOLOGY

SOCIOLOGY
INTERNATIONAL MIGRATION REVIEW, XXVI(2) (SUM 92), 596-622. THE TRANSFORMATIONS OF THE INTERNATIONAL SYSTEM AND THE REGIMES OF THE SOVIET UNION'S SUCCESSOR STATES AND FORMER ALLIES REMOVED BARRIERS TO EXIT FROM THOSE COUNTRIES. WESTERN EUROPE NOW CONFRONTS POSSIBLE POPULATION MOVEMENTS FROM THE EAST, AT A TIME HHEN ITS OWN SOCIETIES AND INSTITUTIONS ARE UNDERGOING CHANGE: THE ADVENT OF A SINGLE UNIFIED MARKET IN THE EUROPEAN COMMUNITY; THE ORGANIZATION OF NEW, JOINT SECURITY AND FOREIGN POLICY CAPABILITIES; AND COPING WITH GROWING MANIFESTATIONS OF POLITICAL AND SOCIAL STRESS BLAMED ON THE PRESENCE OF IMMIGRANTS. EXISTING THEORIES IN THE INTERNATIONAL RELATIONS AND MIGRATION STUDIES OFFER LITTLE GUIDANCE IN CONFRONTING PROBLEMS THAT ARE AT ONCE SOCIETAL AND INTERNATIONAL. CONCEPTUAL AND THEORETICAL LINKS ACROSS THE DOMESTIC AND INTERNATIONAL LEVELS OF ANALYSIS ARE NEEDED. AN INSTITUTIONAL POLITICAL SOCIOLOGY ORIENTATION COMPRISED OF ELEMENTS IN THE RECENT LITERATURE OF SEYERAL SOCIAL SCIENCES AND NEOLIBERAL INSTITUTIONS MAY PROYIDE THE MECESSARY INTELLECTUAL GRASP AND PRACTICAL POLICY GUIDANCE. AN ILLUSTRATIVE APPLICATIOM SUGGESTS THAT MASSIVE EAST-TO-WEST MIGRATION IS UNLIKELY. AND IT OFFERS GROUNDS FOR GUARDED OPTIMISM ABOUT THE PROSPECTS FOR STABILITY IN AND FRUITFUL INTEGRATION INTO THE WESTERN EUROPEAN ETHOS BY THE NEW REGIMES IN EAST-CENTRAL WESTERN EUROPEAN ETHOS BY THE NEN REGIMES IN EAST-CENTRAL EUROPE AND THE BALTICS. HOWEVER, IT POINTS TO A MORE GLOOMY
FUTURE FOR MANY OF THE OTHER STATES OF THE FORMER SOVIET FUTURE FOR MANY OF THE OTHER

04257 HEIZE, $P$.

THE MILITARY WIND-DOWN: BOTH FOREIGN AND GERMAN; FORCES BEING HEAVILY REDUCED

GERMAN TRIBUNE, 1479 (AUG 91), 5

THIS ARTICLE STATES THAT UNITED GERMANY HAS JOINED THE RAMKS OF COUNTRIES WITH A GREATER RESPONSIBILITY FOR SECURING PEACE IN THE NEW CLIMATE OF EAST-WEST RELATIONS. GERMANY IS ALSO MAKING A SUBSTANTIAL CONTRIBUTION TOWARD FUTURE DISARMAMENT TALKS BY REDUCING THE BUMDESWEHR'S TROOP STRENGTH THIS IS THE GREATEST CHALLENGE THE BUNDESWEHR HAS EVER FACED.

04258 HEKMAN, $S$.

THE EMBODIMENT OF THE SUBJECT: FEMINISM AND THE COMMUNITARIAN CRITIQUE OF LIBERALISM

THE JOURNAL OF POLITICS, 54(4) (NOV 92), 1098-1119. COMHUNITARIAN CRITIQUES OF LIBERALISM AND FEMINIST CRITIOUES OF TRADITIONAL POLITIICAL THEORY HAVE MUCH IN COMMON, MOST NOTABLY THE REJECTION OF THE RATIONAL DISEMBOOIED SUBJECT OF THE LIBERAL TRADITION. DESPITE THE SIMILARITIES OF THE THO CRITQUES, HOWEVER, FEMINIST AND COMMUNITARIAN ATTEMPTS TO EMBODY THE SUBJECT LEAD THEM IN SIGNIFICANTLY DIFFERENT DIRECTIONS. THIS STUDY ARGUES THAT ONE ASPECT OF THE FEMINIST CRITIQUE OF THE SUBJECT, THE ATTEMPT TO ARTICULATE THE DISCURSIVE SUBJECT, OFFERS THE MOST PROMISING ALTERNATIVE TO THE COMMUNITARIAN/LIBERALISM DEBATE THAT HAS POLARIZED BOTH POLITICAL THEORY AND FEMINIST
THEORY.

04259 HELD, D

DEMOCRACY: FROM CITY-STATES TO A COSMOPOLITAN ORDER?

POLITICAL STUDIES, 40 (1992), 10-39.

THIS ARTICLE TRACES THE DEVELOPMENT OF THE IDEA OF DEMOCRACY FROM CITY-STATES AND THE EARLY REPUBLICAN TRADITION TO LIBERALISM AND MARXISM. THE RELEVANCE OF LEADING CONCEPTIONS OF DEMOCRACY TO CONTEMPORARY CIRCUMSTANCES ARE THEN EXPLORED. IN LIGHT OF THE COMPLEX INTERCONMECTIONS AMONG STATES AND SOCIETIES, A SET OF INTERCONNECTIONS AMONG STATES AND SOCIETIES, A SET OF ARGUMENTS ARE DEVELOPED WHICH OFFER A NEW AGENDA FOR DEMOCRATIC THEORY WHICH DEPARTS FROM AN EXCLUSIVE FOCUS ON
PARTICULAR POLITICAL COMMUNITIES AND THE NATION-STATE. AFTER PARTICULAR POLITICAL COMMUNITIES AND THE NATION-ST
AN EXAMINATION OF A NUMBER OF KEY MODELS OF THE

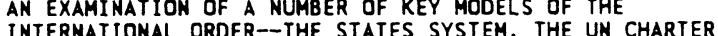

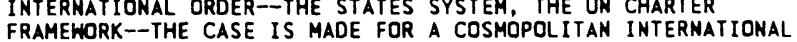
FRAMEWORK--THE CASE IS MADE FOR A COSMOPOL ITAN INTERNATIONAL DEMOCRACY. WHILE SUCH A CASE IS FRAUGHT WITH DIFFICULTIES,
STRONG GROUNDS ARE PRESENTED FOR ITS INDISPENSABILITY TO THE STRONG GROUNDS ARE PRESENTED FOR ITS INDISPENSABILITY TO THE MAINTENANCE AND DEYELOPMENT OF DEMOCRAC
ESTABLISHED BORDERS AND ACROSS THEM.

04260 HELFGOTT, R.

LABOR PROCESS THEORY YS. REFORM IN THE WORKPLACE CRITICAL REVIEW, 6(1) (WIN 92), 11-27.

THIS PAPER EXPLORES THO MAJOR SHORTCOMING OF LABOR PROCESS THEORY (LPT). THE FIRST IS THAT LPT HAS IGNORED THE EFFICIENCY OF THE WORK PROCESS, REFUSING TO ACKNOWLEDGE THE LEGITIMACY OF A TRADEOFF BETWEEN HORK "GOODNESS" AND PRODUCTIVITY. THE SECOND IS THAT LPT HAS IDENTIFED MANAGMENT'S GOAL IN ORGANIZING WORK AS GAINING CONTROL OF THE PROCESS, WHEN IN FACT, IT HAS BEEN TO MAKE THE PROCESS AS ECONOMICALLY EFFICIENT' AS POSSIBLE. LPT'S FOUNDER BELIEVED THAT IT WAS IMPOSSIBLE TO REFORM WORK UNDER CAPITALISM, BUT THIS PAPER SHOWS OTHERHISE.

04261 HELLEINER, E.

STATES AND THE FUTURE OF GLOBAL FINANCE

REVIEW OF INTERNATIONAL STUDIES, 18(1) (JAN 92), 31-50.

AS PART OF WHAT NEEDS TO BE A BROADER EFFORT' TO INCORPORATE POLITICAL ANALYSIS INTO THE STUDY OF GLOBAL INCORPORATE POLITICAL ANALYSIS INTO THE STUDY OF GLOBAL FOR THE CONTEMPORARY GLOBAL FINANCIAL SYSTEM IN LIGHT OF JAPAN'S GROWING FINANCIAL POWER. II ASKS WHETHER JAPAN'S INCREASING FINANCIAL INFLUENCE IS CREATING AN UNSTABLE HEGEMONIC VACUUM WHICH THREATENS THE EXISTING OPEN, LIBERAL GLOBAL FINANCIAL SYSTEM. IT CONCLLDES THERE EXISTS A REGIME CENTERED AROUND CENTRAL BANK COOPERATIONS. HOWEVER, THE ORIGINS OF THIS REGIME ARE IN A SERIES OF AD HOC REACTIONS TO RECENT FINANCIAL CRISES. STABILITY MAY BE MANTAINED BY THE BEHAYIOR OF THE U.S. U.K. AND JAPANESE STATES WHEC STABILTY THEORY'S MODEL IN WAYS THAT ENCOURAGE THEM TO ACT IN A LEADERSHIP ROLE.

04262 HELLEINER, G.K.

THE IMF, THE WORLD BANK, AND AFRICA'S ADJUSTMENT AND EXTERNAL DEBT PROBLEMS: AN UNOFFICIAL VIEW

WORLD DEVELOPMENT, 20(6) ( JUM 92), 779-792.

SUB-SAHARAN AFRICAN DEVELOPMENT IN THE 1990'S WILL REQUIRE SIGNIFICANT INCREASES IN TRANSFERS AND DEBT RELIEF FROM EXTERNAL OFFICIAL SOURCES. NEGOTIATION OF CONDITIONS FOR ASSISTANCE IMPOSES HEAVY COSTS UPON RECIPIENTS. ONCE GROSS MACROECONOMIC DISTORTIONS ARE OVERCOME, THE RISK OF PROGRAM FAILURE FROM UNCERTAINTY AND UNDERFUNOING TYPICALLY EXCEEDS THAT FROM ABSENCE OF FURTHER POL ICY REFORMS, THE EFFECTS OF WHICH ARE UNPROVEN. THE RELATIVE INFLUENCE OF THE INTERNATIONAL MONETARY FUND (IMF) AND WORLD BANK IN AFRICA HAS GROWN TOO LARGE. THE IMF SHOULD TRANSFER RESOURCES FROM HAS GROWN TOO LARGE. THE IMF SHOULD TRANSFER RESOURCES FROM
THE REGION AND RETREAT TO A TECHNICAL ADVI SORY ROLE. THE

THE REGION AND RETREAT TO A TECHNICAL ADVISORY ROLE.
WORLD BANK SHOULD DEVELOP CONTINGENCY FINANCING AND
COOPERATION WITH OTHER SOURCES OF ADVICE AND FINANCE.

04263 HELLER, E.

POLISH LINKS

GERMAN TRIBUNE (1527) (AUG 92) 1 .

THE VISIT OF GERMAN FOREIGN MINISTER KLAUS KINKEL TO POLAMD UNDERSCORES THE NORMALITY THAT NOW CHARACTERIZES THE RELATIONS BETWEEN THE THO STATES. GONE ARE THE BORDER DISPUTES AND THE ARGUMENTS OVER THE STATUS OF POLAND'S GERMAN MINORITY. NON, REPRESENTATIVES OF BOTH STATES REFORMING CUSTOMS POSTS, BUILDING NEW HIGHAAYS, AND 1990.

04264 HELLINGER, $D$. U.S. ASSISTANCE TO AFRICA: NO ROOM FOR DEMOCRACY TRANSAFRICA FORUM, $9(2)$ (SUM 92 ), 78-82

FOR THE LAST DECADE, A SUBSTANTIAL AMOUNT OF U.S. AID TO AFRICA HAS BEEN TIED TO STRUCTURAL ADJUSTMENT PROGRAMS DESIGNED AND PROMOTED BY THE WORLD BANK AND THE INTERNATIONAL MONETARY FUND. DESPITE THE VAST SUMS OF MONEY THAT HAVE BEEN GIVEN, AFRICA'S GDP PER CAPITA HAS DECLINED, FOREIGN DEBT HAS ALMOST DOUBLED, AND RETURNS FROM EXPORTS 
HAVE DROPPED. REALIZING THE FAILURE OF STRUCTURAL ADJUSTMENT DEYELOPMENT EXPERTS HAVE CONCLUDED THAT THE FAULT LIES NOT WITH THE PROGRAMS THEMSELVES BUT WITH THE LACK OF EFFECTIVE IMPLEMENTATION BY THE AFRICAN GOVERNMENTS. HENCE, THERE ARE CALLS FOR GOOD GOVERNANCE AND DEMOCRACY AS CONDITIONS FOR FUTURE AID.

04265 HELLMAN, D.C.

THE UNITED STATES AND ASIA IN AN AGE OF INTERNATIONAL UPHEAVAL

CURRENT HISTORY, 91(569) (DEC 92), 401-406

BEYOND THE OCCASIONAL PENTAGON' STUDY, THERE HAS BEEN NO EFFORT TO DEVISE A COMPREHENSIVE NEW U.S. STRATEGY TOWARD ASIA THAT LOOKS BEYOND COLD HAR ASSUMPTIONS OR THE CONSTRAINTS IMPOSED BY A FEDERAL BUDGET CHRONICALLY IN DEFICIT. THE MOST SIGNIFICANT FEATURE OF THE CURRENT AMERICAN APPROACH TO ASIA IS NOT WHAT HAS BEEN DONE BUT RATHER WHAT HAS NOT. THE FAILURES OF THE UNITED STATES TO CREATE INSTITUTIONS TO MANAGE A STILL INCHOATE NEW WORLD ORDER DURING THE TRANSITION FROM ONE AGE TO ANOTHER IS BOTH ASTONISHING AND HISTORICALLY UNPRECEDENTED.

04266 HELLMAN, S.

THE SWEDISH INITIATIVE ON ACCIDEMTAL NUCLEAR WAR DISARMAMENT, XIV(3) (1991), 61-73.

THE BASIC AIM OF THE SWEDISH INITIATIVE ON ACCIDENTAL NUCLEAR WAR IS TO PUT THE PREVENTION OF ACCIDENTAL NUCLEAR WAR ON THE INTERNATIONAL POLITICAL AGENDA AND IMPLEMENT PROGRAMS TO REDUCE THE RISKS. THE SWEDISH "ACTION PROGRAMME" PROPOSES STEPS TO BE UNDERTAKEN BY THE UNITED NATIONS AND OTHER INTERNATIONAL ORGANI ZATIONS.

04267 HELM, S.

ARAB RADICALS ARE NERVOUS

NORLD PRESS REVIEW, 39(9) (SEP 92), 22.

THE AUTHOR EXPLAINS THE MOTIVES BEHIND THE RECENT VIOLENCE BY HAMAS, THE ISLAMIC RESISTANCE IN THE ISRAELIOCCUPIED TERRITORIES, AGAINST THE PALESTINIAN MAINSTREAM.

04268 HELMAN, G.B.; RATNER, S.R.

SAVING FAILED STATES

FOREIGN POLICY, (89) (WIN 93), 3-20

A DISTURBING NEW PHENOMENON IS EMERGING: THE FAILED NATION-STATE, UTTERLY INCAPABLE OF SUSTAINING ITSELF AS A MEMBER OF THE INTERHATIONAL COMHUNITY. CIVIL STRIFE, GOVERNMENTAL DISINTEGRATION, AND ECONOMIC PRIVATION ARE CREATING MORE AND MORE MODERN "DEBELLATIOS." AS THESE STATES CREATING MORE AND MORE MODERN "DEBELLATIOS." AS THESE

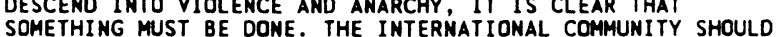
SOMETHING MUST BE DONE. THE INTERMATIONAL COMMUNITY SHOULD CONSIDER A NOVEL, EXPANSIVE, AND DESPERATELY NEE BY THE UNITED NATIOI

04269 HELMSTADTER, S.

MEDICAL INSURANCE IN RUSSIA

RFE/RL RESEARCH REPORT 1(3) ( JUL 92), 65-69

NOWHERE IS THE CURRENT SYSTEMIC DISORGANIZATION AND ECONOMIC CONFUSION IN RUSSIA MORE APPARENT THAN IN HEALTH CARE AND HEALTH CARE FINANCING. THE RUSSIAN GOVERNMENT PLANS TO INTRODUCE MEDICAL INSURANCE BY JAMUARY 1993 AT THE LATEST. HOWEVER, THE TRANSITION TO A SYSTEM OF INSURANCE IS DIFFICULT TO ENVISION, GIVEN THE PREVAILING ECONOMIC MALAISE. SOME RUSSIANS BELIEVE THAT A SYSTEM OF MEDICAL INSURANCE SHOULD BE INTRODUCED EVENTUALLY, BUT THEY FEAR THAT IT COULD LEAD TO A COMPLETE BREAKDOWN OF THE HEALTH CARE SECTOR IF IT IS INTRODUCED UNDER THE CURRENT CONDITIONS OF INSUFFICIENT ORGANIZATIONAL, ECONOMIC, AND STRUCTURAL READINESS.

04270 HELTON, A.C

U.S. REFUGEE POLICY: AFRICAN AND CARIBBEAN EFFECTS TRANSAFRICA FORUM, 9 (2) (SUM 92), 93.

THE FUTURE DOES NOT AUGER WELL FOR AFRICAN AND CARIBBEAN REFUGEES SEEKING ENTRY INTO THE UNITED STATES. HITH THE END OF THE COLD WAR, THE POL ITICAL INCENTIVES TO AID REFUGEES ARE ERODING WHIL THE ECONOMIC INCENTIVES TO DISSUADE THEM FROM ARRIVING ARE GROWING. AMERICA'S REFUGEE POLICY MUST CEASE BEING REFLECTIVE OF AN IMMIGRATION POLICY THAT HAS UNDENIABLY BEEN RACIST AND OF FOREIGN POLICY OBJECTIVES THAT IMPEDE FAIR AND JUST TREATMENT OF REFUGEES.

04271 HELVACIOGLU, 8.

THE THRILLS AND CHILLS OF POSTMODERNISH: THE HESTERM THE THRILLS AND CHILLS

STUDIES IN POLITICAL ECONOMY: A SOCIALIST REVIEH, (38) STUDIES IN POL

THIS PAPER EXAMINES THE DEBATE BETHEEN MARXISTS AND POSTMARXISTS/POSTSTRUCTURALISTS ABOUT CULTURAL, ECONOMIC AND POLITICAL CHANGES. THE OBJECT IS TO ANALYZE THE CONTRADICTION BETWEEN THE CONCEPTIONS AND THE REAL LIFE EXPERIENCES OF "POSTMODERN EXISTENCE" WITH REGARD TO FRAGMENTATION, IMMEDIACY AND EPHEMERALITY. IT FIRST COMPARES THE MAJOR PREMISES OF POST-MODERN THEORY WITH MARXIST ANALYSES OF CHANGE AND TRANSFORMATION. THE EMPHASIS IS ON A CRITIQUE OF THE POST-MOOERN APPROACH TO RADICAL DEMOCRACY
AND INTELLECTUAL PURSUIT. IT THEN EXAMINES THE PRACTICAL IMPLICATIONS OF THE THEORETICAL CALL FOR AN OPEN, IMPLICATIONS OF THE THEORETICAL CALL FOR AN OPEN, THE CONTRADICTORY EFFECTS OF CONCEIVING REALITY THROUGH THE THE CONTRADICTORY EFFECTS OF CONCE IVING REALITY THROUGH THE
POST-MODERN SPECTACLE OF "HAPPY MELANCHOLY."

04272 HELWEGE, $A$.

LATIN AMERICAN AGRICULTURAL PERFORMANCE IN THE DEBT CRISIS: SALVATION OR STAGNATION?

LATIN AMERICAN PERSPECTIVES, 17(4) (FAL 90), 57-75.

SINCE THE DEBT CRISIS BEGAN IN 1982, MOST LATIN AMERICAN COUNTRIES HAVE DEVALUED THEIR CURRENCIES SUBSTANTIALLY. WITH THIS BARRIER TO GROWTH LOWERED, MANY ECONOMISTS HAVE ANTICIPATED IMPROVED PERFORMANCE IN THE AGRICULTURAL SECTOR DURING THE MID-1980S. THIS ARTICLE LOOKS AT THE A PRIORI EXPECTATIONS FOR AGRICULTURAL PERFORMANCE GENERATED BY MAINSTREAM ECONOMIC THEORY AND THEN EXAMINES ACTUAL AGR ICULTURAL PERFORMANCE. IT CONCLUDES THAT, IN THE CONTEXT IF MACROECONOMIC CONTRACTION, LOW INTERNATIONAL PRICES, AND INSTITUTIONAL FACTORS, DEVALUATION ALONE HAS PROVEN INADEQUATE TO THE TASK OF STIMULATING AGRICULTURAL
PRODUCTION DURING THE CURRENT FOREIGN EXCHANGE CRISIS.

04273 HENDERSON, D.

INTEGRATIMG ECONOMIES: INTERHATIONAL ECONOMIC INTEGRATION INTERNATIONAL AFFAIRS, 68(4) (OCT 92), 633-654.

WHIL THE EXTENT OF INTERNATIONAL ECONOMIC INTEGRATION IS GROWING, THIS TREND IS NEITHER NEW NOR UNIFORM. AM ECONOMICALLY BORDERLESS WORLD DOES NOT NOW EXIST, NOR IS IT IN PROSPECT; AND THE HORLD ECONOMY TOOAY IS FURTHER AWAY FROM FULL INTEGRATION THAN IT HAS BEFORE THE FIRST WORLD WAR. WHETHER AND HOW FAR THE TREND TOWARDS INTEGRATION HILL CONTINUE IS NOT PREDETERMINED, BUT DEPENDS ON GOVERNMENTS THE MOST DIFFICULT ISSUES OF INTEGRATION RELATE TO CROSSBORDER MIGRATION, WHICH IS NOW A LEADING ITEM ON THE INTERNATIONAL AGENDA.

04274 HENDERSON, J.

THE 1990 ONTARIO ELECTION: LESSONS FOR CANADIANS

CANADIAN PARLIAMENTARY REVIEW, 14(1) (SPR 91), 24-25.

THIS ARTICLE AMALYZES THE AFTERMATH OF ONTARIO'S

SEPTEMBER 1990 GENERAL ELECTION, DURING WHICH THE PUBLIC'S

AFFECTION FOR THE WINNERS, DAVID PETERSON AND OTHER LIBERALS,

QUICKLY TURNED TO SCORN AND CONTEMPT. SOME OF THE FACTORS

OF THIS CHANGE THAT ARE EXAMINED INCLUDE TAXES THE PATTI

STARR AFFAIR, AND THE TIMING OF THE ELECTION. THE

DIFFICULTIES DAVID PETERSON HAS HAD IN PROVIDING SENSITIVE

AND UNDERSTANDING MANAGEMENT ARE DESCRIBED.

04275 HENDERSON, $R$.

BALANCING ACT
REASON, 24(3) (JUL 92), 46-47.

RICX HENDERSOM SUGGESTS THAT THE DEMOCRATS MAY NAVIGATE RICX HENDERSON SUGGESTS THAT THE DEROCRATS MAY NAVIGATE WOULD LIMIT CONGRESS'S POWER TO RUN DEFICITS AND MAKE IT WOULD LIMIT CONGRESS'S POWER TO RUN DEFICITS AND MAKE SOMEWHAT HARDER TO RAISE TAXES. NOT ALL OF THE USUAL SUPPORTERS OF FISCAL RESTRAINT BACK THE SPONSORS OF THIS
AMENDMENT. SOME CONSERVATIVES SEE THIS AMENDHENT AS A MEANS AMENDMENT. SOME CONSERVATIVES SEE THIS AMENDMENT AS A MEANS
FOR BIG SPENDERS TO ENACT MEW PROGRAMS AMD SOCK TAXPAYERS FOR BIG SPENDERS TO ENACT NEW PROGRAMS AND SOCK TAXPAYY
WITH HUGE NEW LEVIES. SUPPORTERS ADMIT THAT IF IT IS RATIFIED TAXES WILL INCREASE BUT AS PEOPLE START TO FEEL THE TAX BITE. THEY'LL DEMAND SPENDING RESTRAINT. SOME BELIEVE THAT VOTERS WILL "THROW THE BUMS OUT" IF THEY PERCEIVE A TAX BURDEN THAT'S TOO HEAVY.

04276 HENDERSON, $R$.

CONSUMING DEBATE

REASON, 24 (7) (DEC 92), 50-52.

AS THE NATION'S POPULATION AGES AND AS POLITICIANS

CONTINUE TO PROMISE THAT WASHINGTON CAN CURE ALL ILLS,

DEMANDS ON THE FEDERAL GOVERMMENT TO PROVIDE SERVICES WILL

INCREASE. BUT THE CURRENT INCOME-TAX CODE MAY BE SOUEEZING

ALL THE MONEY IT CAN FROM THE ECONOMY. HITHOUT MAJOR

SPENDING CUTS, FEDERAL POLICY MAKERS WILL HAVE TO FIND NEW

SOURCES OF TAX MONEY. NEW TAXES ON CONSUMPTION--PROBABLY

INCLUDING SOME FORM OF VALUE-ADOED TAX--WILL LIKELY BE PART

OF THE RECIPE.

04277 HENDRICKS, J.; LEEDHAM, C.

TOWARD A POL ITICAL AND MORAL ECONOMY OF AGING: AN ALERNATIVE PERSPECTIVE

INTERNATIONAL JOURNAL OF HEALTH SERVICES, 22(1) (1992), INTERNAT

THE ROOTS OF DEPENDENCY AND EMPOWERMENT OF THE ELDERLY IS EXPLORED AND IN THE PROCESS A DYNAMIC FRAMHORK FOR SETIING PATTERNS OF AGING IN A BROADER CONTEXT IS DISCUSSED. AFTER DISCUSSING THE ADVENT OF THE INDIVIDUAL-STRUCTURE DAIALECTIC INTO THE LIMELIGHT OF POL ITICAL ECONOMY AND SOCIAL PSYCHOLOGICAL THEORIES, THE AUTHORS EXPLORE THE CONCEPT OF HEGEMONY AND ITS RELEVANCE FOR DEPENDENCY AND EMPOWERMENT IN THE ELDERLY. THIS LEADS INTO A DISCUSSION OF THE VARIOUS FORMS OF MORAL ECONOMY AND THEIR SOCIAL POLICY IMPLICATIONS. IN CONCLUSION, A MORAL AND POL ITICAL ECONOMY 
EMPOWERMENT ACROSS THE LIFE COURSE IS PROPOSED.

\section{HENDRICKSON, D.C.}

THE RENOVATION OF AMERICAN FOREIGN POLICY

FOREIGN AFFAIRS, 71(2) (SPR 92), 48-63.

THE RENOVATION OF U.S. FOREIGN POLICY MUST TAKE ACCOUNT OF THE NATION'S VASTLY CHANGED CIRCUMSTANCES. CONTEMPORARY POLICY MUST ADDRESS RISKS AND OPPORTUNITIES UNKNOHN TO THE FOUNDERS OF THE AMERICAN STATE. BUT IT IS A GREAT MISTAKE TO BELIEVE THAT THEIR VISION IS IRRELEVANT OR THAT THEY FAILED TO ANTICIPATE MANY OF TODAY'S DILEMMAS. EVEN IF ULTIMATELY REJECTED, THEIR OUTLOOK REFLECTED A CERTAIN BELIEF ABOUT THE SIGNIFICANCE OF THE UNITED STATES IN WORLD HISTORY THAT WAS DEEPLY EMBEDDED IN THE NATION'S CONSCIOUSNESS FOR 150 YEARS. IT REFLECTED AN UNDERSTANDING OF WHEN AND WHY THE NATION MIGHT MAKE WAR THAT WAS HIGHLY SOPHISTICATED IN THE WAY IT ACCOMMODATED THE SOMETIMES CONFLICTING CLAIMS OF AMERICAN SECURITY AND NATIONAL PURPOSE. IT WAS BASED ON AN APPRECIATION OF THE FACTORS GOVERNING THE RISE AND FALL OF REPUBLICS AND EMPIRES THAT IS QUITE RELEVANT TODAY. IF THE U. $S$. IS TO ABANDON THAT OUTLOOK NOW, IT IS IMPORTANT TO UNDERSTAND THAT THIS IS HAPPENING AND THAT IT MAY BETRAY THE DISTINCTION THE USA ONCE COVETED AMONG THE NATIONS OF THE WORLD.

04279 HENIG, J.R

DEFINING CITY LIMITS

URBAN AFFAIRS QUARTERLY, 27(3) (MAR 92), 375-395.

THE CONCLUSION THAT CITIES ARE UNABLE TO ENGAGE IN REDISTRIBUTIVE POLICIES, AS ARTICULATED IN PETERSON'S "CITY LIMITS," RELIES ON A IMAGE OF CITIZENS AND OFFICIALS DETERMINED ENVIRONMENT. IN THIS PAPER, THE AUTHOR PROPOSES A MORE ACTIVE VIEW OF THE RELATIONSHIP BETHEEN PEOPLE AND THEIR INTERESTS--ONE IN WHICH POLITICAL ACTORS ARE SEEN AS AGGRESSIVELY AND CONTINUALLY REINTERPRETING AND REDEFINING AGGRESSIVELY AND CONTINUALLY REINTERPRETING AND REDEFINING
THEIR INTERESTS IN AN UNCERTAIN AND UNDETERMINED WORLD. HE THEIR INTERESTS IN AN UNCERTAIN AND UNDETERMINED WORLD. HE
SKETCHES THE ANALYTIC, EMPIRICAL, AND NORMATIVE IMPLICATIONS SKETCHES THE ANALYTIC, EMPIR
OF THIS ALTERNATIVE VIEW.

04280 HENKEL, $M$.

THE MEH "evaluative" state

PUBLIC ADMINISTRATIOM GQ(1) (SPR 91), 121-138.

THIS ARTICLE IS BASED ON A COMPARATIVE STUDY OF THREE

FORMS OF EVALUATION USED BY GOVERNMENT, THE AUDIT COMMISSION, CONSULTANTS AND THE SOCIAL SERVICES INSPECTORATE. THE PAPER ARGUES THAT THESE EVALUATIVE BODIES STRENGTHENED THE

AUTHORITY OF GOVERNMENT IN THE 1980 S AND SUPPORTED THE SHIFT FROM A PROFESSIONAL TO A MANAGERIAL CULTURE IN GOVERNMENT. THEIR CONTRIBUTION TO THOSE CHANGES CAN BE LINKED TO THE KINDS OF KNOWLEDGE THAT REASSERTED THEMSELVES IN EVALUATION AND IN GOVERNMENT IN THE 1980 S. HOWEVER, THE RESEARCH ALSO PROVIDES FURTHER SUPPORT FOR THE CRITICS OF POSITIVISM. THE DISTINCTION BETWEEN FACT AND VALUE AND BETWEEN TECHNICAL EXPERTISE AND POLITICAL ARGUMENT OFTEN BROKE DOWN IN EVALUATIVE PRACTICE.

04281 HENMAYAKE, S.K.

INTERACTIVE ETHNONATIONALISM: AN ALTERNATIVE EXPLANATION OF MINORITY ETHNONATIONALISM

POL ITICAL GEOGRAPHY $11(6)$ (NOY 92), 526-549.

THIS PAPER PRESENTS AN ALTERNATIVE EXPLANATION OF

MINORITY ETHNIC NATIONALISM. IDENTIFIED AS "INTERACTIVE

MATIONALISM," IT TAKES "MAJORITY ETHWIC NATIONALISM" AS THE MAJOR CAUSAL FACTOR IN THE EMERGENCE OF MINORITY ETHNIC NATIONALISM. ARGUING THAT THE NATION-STATE IS AN EXPRESSION NATIONAL ISM. ARGUING THAT THE NATION-STATE IS AN EXPRES OF MAJORITY ETHNIC NATIONALISM, THE AUTHOR EXPLORES A
CONTRADICTORY POLITICAL PROCESS OF THE MODERN NATION-STATE: CONTRADICTORY POLITICAL PROCESS OF THE MODERN NATION-STATE:
SIMULTANEOUS PRACTICE OF HEGEMONIC POLITICS AND EXCLUSIONARY SIMULTANEOUS PRACTICE OF HEGEMONIC POL ITICS AND EXCLUSIONAR ARE
NATIONALIST POLITICS. WHERE HEGEMONIC POLITICS HAVE BEEN NATIONALIST POLITICS. WHERE HEGEMONIC POL ITICS HAVE BEEN
SUCCESSFUL, MINORITY ETHNIC GROUPS HAVE EXTENDED THEIR SUCCESSFUL, MINORITY ETHNIC GROUPS HAVE EXTTENDED
CONSENT TO THE NATION-STATE AND. THUS, TO THE

CONSENT TO THE NATION-STATE AMD, THUS, TO THE ETHNONATIONALISM OF THE MAJORITY ETHNIC GROUP. BUT IN NATIOH-
STATES WHERE THE ETHNONATIONALIST POLITICS OF THE MAJORITY STATES WHERE THE ETHNONATIONALIST POLITICS OF THE MAJORITY
NATION HAVE BECOME TOO EXCLUSIONARY, THUS UNDERMINING THE NATION HAVE BECOME TDO EXCLUSIONARY, THUS UNDERMINING THE
HEGEMONIC POLITICS, MINORITY ETHNIC GROUPS HAVE BECOME

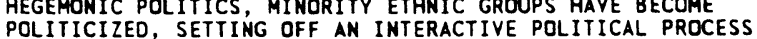
POLITICIZED, SETTING OFF AN INTERACTIVE POLITICAL PROCESS BETWEEN THE MAJORITY NATION AND MINORITY ETHNIC GROUP. THE DEVELOPMENT OF MINORITY ETHNONATIONALISM IS A RESUL INTERACTION. HOWEVER, NO OBJECTIVE LEVEL OF MAJORITY ETHNONATIONALISM CAN BE IDENTIFIED AS THE OPTIMUM STAGE FOR THE EMERGENCE OF MINORITY ETHNONATIONALISM BECAUSE EVERY CASE IS UNIQUE. THE AUTHOR USES THE INTERACTIVE NATIONALISM
MODEL TO TRACE THE DEVELOPMENT OF TAMIL ETHNONATIONALISM IN MODEL TO TRAC

04282 HENNEMANN, $G$.

KOHL LOOKS TO TAKE CONTROL OF EFFORT IN EAST GERMAN TRIBUNE, 31(1543) (DEC 92 ), 3.

ALTHOUGH THE CIRCUMSTANCES WERE FAVORABLE, THE OPPOSITION IN BONN WAS UNABLE TO PUT THE UNPOPULAR GERMANY FINANCE MINISTER AND CHAIRMAN OF THE CSE UNDER PRESSURE IN THE DEBATE ON THE 1993 BUDGET. IT SEEMS DOUBTFUL IN THE LIGHT OF WHAT CHANCELLOR KOHL HAS HAD TO SAY IF THEO HAIGEL,
FINANCE MINISTER, WILL BE ABLE TO STAY FULLY IN CHARGE OF ALL PHASES OF HIS PLAN FOR ECONOMIC CONSOLIDATION. THE OINTMENT OF LONGER-LIFE SUBSIDIES CANNOT PROMOTE THE PROCESS OF ECONOMIC RECOVERY. KOHL IS HEADING STRAIGHT FOR A 1994 "RECONSTRUCTION LIE"

04283 HENSMAN, $R$.

CLASS FORMATION AND POLITICAL TRANSFORMATION IN INDIA: ASSOCIATION FOR ASIAN STUDIES 1992 ANMUAL MEETING ASSOCIATION FOR ASIAN STUDIES, $1992,130$.

A REMARKABLE FEATURE OF POST-COLONIAL INDIA RELATES TO THE EMERGENCE OF NEW CLASSES AND THE RAPID CHANGES WHICH THEY HAVE UNDERGONE IN RESPONSE TO PRESSURES ASSOCIATED WITH THEY PROCESS OF DEVELOPMENT. THE EMERGENCE OF AN INDIAN THE PROCESS OF DEVELOPMENT. THE EMERGENCE OF AN INDIAN
NATIONAL BOURGEOISIE (WITH THE STATE PLAYING A VITAL ROLE) NATIONAL BOURGEOISIE (WITH THE STATE PLAYING A VITAL ROLE)
IN THE INDUSTRIAL SPHERE WAS PARALLELED BY THE RISE OF AN IN THE INDUSTRIAL SPHERE WAS PARALLELED BY THE RISE OF AN INDIAN AGRARIAN BOURGEOISIE (WHICH THE GREEN REVOLUTION DID MUCH TO FOSTER) . NITHIN 25 YEARS OF INDEPENDENCE THE MAJOR SEGMENTS OF THE NATIONAL BOURGEOISIE STOOD IN CONTRADICTION TO ONE ANOTHER. DURING SUBSEQUENT DECADES THE
INDUSTRIAL BOURGEOISIE THEMSELVES HAVE UNDERGONE A PROCESS INDUSTRIAL BOURGEOISIE THEMSELVES HAVE UNDERGONE A PROC OF PROLIFERATION WHICH HAS ONLY NOW BEGUN TO AITRACT
SYSTEMATIC ACADEMIC ATTENTION. BY THE SAME TOKEN, A RELATIVELY WELL-ORGANIZED WORKING CLASS-MAINLY URBAN INDUSTRIAL AND SERVICE ORIENTED--HAS UNDERGONE RAMIFICATIONS OF A DIVERSE NATURE. IN RURAL INDIA, AN AGRARIAN WORKING CLASS HAS DEVELOPED WITH ENORMOUSLY' VARYING DEGREES OF POLITICAL CONSCIOUSNESS AND LEVELS OF ORGANIZATION. BOTH RURAL AND URBAN LABOR HAVE BEEN SUBJECTED TO AN INTENSIVE PROCESS OF "CASUALIZATION" WHICH HAS HAD AN IMPACT REACHING FAR BEYOND THE WORKING CLASS. THESE BROAD ASPECTS OF CLASS FORMATION HAVE BEEN SUBJECT TO MODIFICATION THROUGH THE ASSERTION OF POLITICAL CONSCIOUSNESS BASED ON THE APPEAL OF SOCIAL CATEGORIES SUCH AS CASTE, RELIGION AND COMMUNITY.

04284 HENWOOD, D.

AFTER THE COLD WAR--ECONOMIC WAR?

MIDDLE EAST REPORT, 22(2) (MAR 91), 13-15.

THE MASSIVE VICTORY OF ANTI-IRAQ FORCES IN THE GULF WAR HAS LED TO SPECULATION THAT THE POST-COLD WAR WORLD HAS ONE BOSS: THE UNITED STATES. A CLOSER LOOK AT OPERATION DESERT SHIELD BEGINS TO REVEAL THE POLITICAL AND ECONOMIC FLAWS TO THAT ARGUMENT. THOUGH LARGELY A U.S. AFFAIR, THIS MASSIVE THAT ARGUMENT. THOUGH LARGELY A U.S. AFFAIR, THIS MASSI LEGITIMATION FROM FOREIGN POWERS. AS THE EUROPEAN COMMUNITY LEGITIMATION FROM FOREIGN POHERS. AS THE EUROPEAN COMMUNITY AND JAPAN FLEX THEIR ECONOMIC--AND INCREASINGLY POL ITICAL-MUSCLES ON THE WORLD SCENE, ECONOMIC CONFLICY BETHE

04285 HENZE, P.B.

TURKESTAN RISING

WILSON QUARTERLY XYI(3) (SUM 92), 48-58.

THE AUTHOR CONSIDERS THE RECENT HISTORY OF TURKESTAN AND THE PROSPECTS FOR ITS FUTURE.

04286 HEPER, M.

CONSOLIDATING TURKISH DEMOCRACY

JOURNAL OF DEMOCRACY, 3(2) (APR 92), 105-117.

THE GREAT OBSTACLE THAT TURKISH POLITICS CONTINUALLY CONFRONTS IS THE CHALLENGE OF LEGITIMACY. SINCE THE BEGINNING OF COMPETITIVE POLITICS IN THE MID-1940S, SEVERE TENSIONS BETHEEN THE GOVERNMENT AND THE OPPOSITION HAVE REPEATEDLY JEOPARDIZED THE LEGITIMACY OF CIVILIAN RULE AND
MULTIPARTISM. THE PERSISTENCE OF GRAVE TENSIONS IN TURKISH POLITICAL LIFE ARE DEEPLY ROOTED IN THE DIFFERING CONCEPTIONS OF DEMOCRACY ESPOUSED BY EACH OF THE COUNTRY'S TWO KEY ELITES--THE STATE ELITE AND THE POLITICAL ELITE. THIS ARTICLE EXAMINES THE ROLE OF THE PRESIDENCY AND STEPS TAKEN TOWARD DEMOCRATIC CONSOLIDATION IN TURKEY. IT CONCLLUDES THAT TURKEY MAY YET BE ABLE TO CONSOLIDATE ITS DEMOCRACY WITHIN A PARLIAMENTARY SYSTEM OF GOVERNMENT.

04287 HEPER, $M$

THE STRONG STATE AS A PROBLEM FOR THE CONSOLIDATION OF DEMOCRACY: TURKEY AND GERMANY COMPARED

COMPARATIVE POLITICAL STUDIES, 25(2) (JUL 92), 169-195. CONSOLIDATION OF A DEMOCRACY REQUIRES THE ESTABLISHMENT OF A BALANCE BETHEEN THE HORI ZONTAL AND VERTICAL DIMENSIONS OF A BALANCE BETWEEN THE HORI ONTAL AND VERTICAL DIMENSIONS OF DEMOCRACY, THAT IS, BETWEEN PARTICIPATION AND RESPONSIBLE
LEADERSHIP. THE BALANCE IN QUESTION NECESSIATES A HARMONIOUS LEADERSHIP. THE BALANCE IN QUESTION NECESSIATES A HARMONI
RELATIONSHIP BETWEEN THE STATE AND CIVIL SOCIETY. A TOO RELATIONSHIP BETHEEN THE STATE AND CIVIL SOCIETY. A TOO
STRONG STATE AS WELL AS A TOO WEAK ONE POSES DIFFICULTIES STRONG STATE AS WELL AS A TOO WEAK ONE POSES DIFFICULTIES
FOR A VIABLE DEMOCRACY TO FLOURISH. THIS ARTICLE ELABORATES FOR A VIABLE DEMOCRACY TO FLOURISH. THIS ARTICLE ELABORATES
THIS VIEN BY A COMPARISON OF THE FORTUNES OF DEMOCRACY IN THIS VIEN BY A COMPARISON OF THE FORTUNES OF TURKEY AND GERMANY. BOTH COUNTRIES HAVE HAD STR THAN THE STATE IN GERMANY, AND, AS COMPARED TO THE GERMANS, THE TURKS
FOUND IT MORE DIFFICULT TO CONSOLIDATE THEIR DEMOCRACIES.

04288 HERBST, J.

U.S. ECONOMIC POLICY TOWARD AFRICA COUNCIL ON FOREIGN RELATIONS PRESS, 1992, 96

JEFFRY HERBST ARGUES THAT THE UNITED STATES CAN BEST HELP AFRICANS TO ADDRESS THEIR CONTINENT'S ECONOMIC PLIGHT 
BY ADOPTING A REALISTIC, HIGHLY TARGETED SET OF ECONOMIC POL ICIES. HE PRESENTS A SUMHARY OF AMERICAN AID POLICY POLICIES. HE PRESENTS A SUMMARY OF AMERICAN AID POLICY
TOHARD AFRICA SINCE THE KENNEDY ADMINISTRATION AND COMPARES TOWARD AFRICA SINCE THE KENNEDY ADMINISTRATION AND U.S. POLICIES TO THE POLICIES OF THE MULTILATERAL
ORGANIZATIONS SUCH AS THE WORLD BANK. HERBST EXAMINES A ORGANIZATIONS SUCH AS THE WORLD BANK. HERBST EXAMINES A DEBT, THE ECONOMIC ROLE OF THE STATE, THE IMPACT OF ECONOMIC REFORM ON THE AFRICAN POOR, AND THE RELATIONSHIP BETHEEN ECONOMIC REFORM AND POLITICAL LIBERALIZATION. TO MAXIMIZE THE LIMITED FUNDS AVAILABLE FOR AFRICA, HE RECOMMENDS A NEW STRATEGY FOR ALLOCATING U.S. BILATERAL AID. HERBST CONCLUDES THAT THE 1990S PROMISE TO BE PARTICULARLY EXCITIMG--AND FRUSTRATING--FOR AFRICA, AND THAT PROPERLY CONSTRUCTED U.S. POLICIES CAN HAVE AN IMPACT THAT IS FAR GREATER THAN THE AMOUNT OF RESOURCES ALLOCATED TO THEM.

04289 HERBSTEIN, D.

MISSING-DERSUMED DEAD

AFRICA REPORT, 37(6) (NOV 92), 23-25.

IN 1985, QAQAWULI GODOLOZI AND THO OTHER POLITICAL ACTIVISTS FROM PORT ELIZABETH, SOUTH AFRICA, VANISHED FROM SIGHT. "THE PEBCO THREE," AS THEY ARE KNOWN, LED A COMHUNITY ORGANIZATION IN THE EASTERN CAPE THAT WAS SECRETLY AIDING ORGANIZATION IN THE EASTERN CAPE THAT WAS SECRETLY AIDIN DISAPPEARAMCE AND PRESUMED DEATHS--AS WELL AS THAT OF MANY

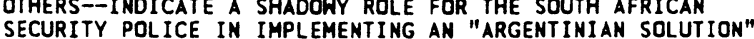
SECURITY POLICE IN IMPLEMENTIN
AGAINST POLITICAL ACTIVISTS.

04290 HEREDIA, F.

CUBAN SOCIALISM: PROSPECTS AND CHALLENGES

ATIN AMERICAN PERSPECTIVES, 18(2) (SPR 91), 18-37.

CUBA IS CURRENTLY UNDERGOING A PERIOD OF' INTENSE

REEXAMINATION AND THE VERY BASIS OF ITS EXISTENCE--SOCIALISM-HAS NOT ESCAPED THE QUESTIONING AND SCRUTINY. THIS ARTICLE CONSIDERS THE PRINCIPLE CHARACTERISTICS AND THE PREDICTABL TENDENCIES OF CUBAN SOCIALISM. IT CONSIDERS THE FOUNDATION OF CUBAN SOCIALISM IN PRINCIPLES OF FREEDOM, DEMOCRACY, AND EQUALITY. IT ANALYZES THE STRENGTHS AND WEAKNESSES OF THE ECONOMY. FINALLY, IT CONSIDERS THE CHALLENGES FOR THE FUTURE AND THE CURRENT PROCESS OF "RECTIFICATION" WHICH IS DESIGNED TO SOLVE MANY OF THE CURRENT REGIME'S PROBLEMS.

04291 HERMAN, $M$.

INTELLIGENCE AND POLICY: A COMMENT

INTELLIGENCE AND NATIONAL SECURITY, 6(1) (JAN 91), 229-239.

THIS ARTICLE EXAMINES THE EXTENSIVE COVERT INTELLIGENCE

GATHERING SYSTEMS IN THE UNITED STATES AND GREAT BRITAIN. IN LIGHT OF THE DECLINE OF THE COLD HAR, MANY ARE QUESTIONING THE EFFICACY AND USEFULNESS OF CONTINUED COVERT INTELLIGENCE THE EFFICACY AND USEFULNESS OF CONTINUED COVERT INTELLIGENC
OPERATIONS. THE ARTICLE ASSESSES THE USEFULNESS OF COVER INTELLIGENCE TO POLICYMAKERS AND OUTLINES SOME POSSIBLE REFORMS OF THE SYSTEM DES IGNED TO DEAL WITH CONTEMPORARY CHALLENGES. IT CONCLUDES THAT WHILE ROLES AND METHODS MAY CHANGE, THE NEED FOR AN OUTSIDE "OBJECTIVE" SOURCE OF

INTELLIGENCE AMD ANALYSIS MAY CONTINUE FOR SOME TIME TO COME.

04292 HERMAN, T.

A CONCEPTUAL FRAMEHORK OF NONVIOLENCE FOR PEACE RESEARCH INTERMATIONAL JOURNAL OF GROUP TENSIONS, 21(1) (SPR 91), 3-16.

THIS PAPER OFFERS A CONCEPTUAL FRAMEWORK OF SEVEN FORMS OF NONVIOLENCE FROM WHICH A MUMBER OF QUESTIONS ARE POSED FOR PEACE RESEARCH AS AN INTERDISCIPLINARY EXERCISE. THE FIRST THREE-PERSONAL TRANSFORMATION OR PSYCHO-SPIRITUAL CHANGE, PACIFISM OR NON-RETALIATION IN KIND, AND RECONCILIATION WITH AN ADVERSARY--ARE LARGELY AT THE LEVEL OF PERSONAL CHANGE FROM THE IDEA THAT CHANGED INDIVIDUALS WILL IMPROVE THE WORLD AROUND THEM. THE SECOND FOUR-NONVIOLENT STRUGGLE AND CIVILIAN-BASED DEFENSE. CONFLICT RESOLUTION, REMOVING THE CAUSES OF VIOLENT CONFLICT, AND DEVELOPING A SOUND RELATIONSHIP WITH THE EARTH-DEAL MORE HITH GROUP BEHAVIOR.

04293 HERMANN, T.

CONTEMPORARY PEACE MOVEMENTS: BETWEEN THE HAMMER OF POLITICAL REALISM AND THE ANVIL OF PACIFICISM

WESTERN POLITICAL QUARTERLY, 45(4) (DEC 92) 869-894,

THE VIABILITY AND ACCOMPLISHMENTS OF SOCIAL MOVEMENTS DEPEND MAIMLY ON THE LEYELS OF COMGRUEMCE BETHEEM THEIR IDEOLOGICAL FEATURES, PRACTICAL ASPIRATIONS, AND OPERATIVE CONTEXT. THE MAJOR IMPACT OF THIS COMPLEX LINKAGE BETWEEN INTERNAL AND EXTERMAL IMPERATIVES IS WELL DEMONSTRATED BY INTERNAL AND EXTERNAL IMPERATIVES IS HELL DEMONSTRATED BY
THE DRAMATIC IMPROVEMENT OF THE MOBILIZATION CAPABILITIES OF THE DRAMATIC IMPROVEMENT OF THE MOBILIZATION CAPABIL

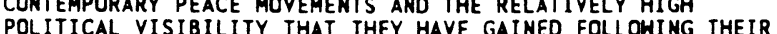
RATIONAL REPLACEMENT OF THEY HAVE GAINED FOLLOHING THEIR

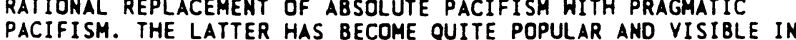
PACIFISM. THE LATTER HAS BECOME QUITE POPULAR AND VISIBLE THE PAST TWO DECADES AS IT SEEMS TO MITIGATE SUCCESSFULLY THE HISTORIC CLASH BETWEEN TOTAL WAR REJECTION AND THE DOMINANT POLITICAL REALIST ETHOS. YET, IT ALSO APPEARS THAT THIS MODIFICATION IS HIGHLY PROBLEMATIC, AS IN THE LONG RUN IT ACCOUNTS FOR MANY OF THE ACUTE DIFFICULTIES OF THE PEACE
MAINTAINING INTERNAL UNITY, EXTENSIVE PUBLIC SUPPORT, AND CONTINUOUS ACTIVITY.

04294 HERMANSSON, J

DEMOCRATIZATION OF EASTERM EUROPE: A GAME THEORETIC PERSPECTIVE

SCANDINAVIAN POLITICAL STUDIES, 15(3) (SEP 92), 217-233. THE DRAMATIC, SURPRISING PROCESS OF DEMOCRATIZATION IN EASTERN EUROPE HAS CREATED A DEMAND FOR THEORIES TO HELP SCHOLARS UNDERSTAND THESE TRANSITIONS FROM AUTHORITARIAN RULE TO DEMOCRACY. IN THIS PAPER, THE AUTHOR FOCUSES ON THE SET OF HYPOTHESES FOUND IN ADAM PRZEWORSKI'S HRITINGS ON LIBERALIZATION AND DEMOCRATIZATION, AND HE DEVELOPS SOME PROPOSALS FOR A GAME THEORETICAL INTERPRETATION OF PRZENORSKI'S IDEAS. AT THE OUTSET, THIS SEEMS TO BE DOOMED TO FAILURE BECAUSE, IN SOME CASES-I.E.. THE COLLAPSE OF COMMUNISM IN EAST GERMANY ANO CZECHOSLOVAKIA--THE PROCESS OF CHARACTERISTICS OF A GAME WERE THE SUBJECT OF DRAMATIC CHANGES. ONE MAY THEN ASK IF IT IS AT ALL POSSIBLE TO MODEL THESE PROCESSES AS A GAME-I.E. A SITUATION WHERE THE ACTORS, THEIR OPPORTUNITY SETS, AND THEIR PAYOFFS ARE WELLDEFINED? THE AUTHOR CONCLUDES WITH A SUGGESTION THAT THE SNOWBALL EFFECT, AS OBSERVED AT THE REPEATED DEMONSTRATIONS IN SUCH PLACES AS LEIPZIG AND WENZLER SOUARE, CAN BE UNDERSTOOD IN TERMS OF GRANOVETTER'S THRESHOLD MODEL OF COLLECTIVE ACTION.

04295 HERMES, G.

THE DILEMMA OF SOCIAL DEMOCRACIES: THE CASE OF NORWAY AND SWEDEN

ACTA SOCIOLOGICA, 34(4) (1991), 239-260

THE POL ITICAL LANDSCAPE IN NORWAY AND SWEDEN HAS CHANGED CONSIDERABLY AND TENSIONS BETHEEN THE SOCIAL DEMOCRATIC PARTIES AND THE TRADE UNIONS HAVE EMERGED. IN THIS ARTICLE POTENTIAL SOURCES FOR THESE DEVELOPMENTS ARE DISCUSSED AND PARTICULAR ATTENTION IS GIVEN TO THE ROLE OF THE LABOR MARKET. IT IS ARGUED THAT INCREASING SEGMENTATION OF THE LABOR MARKET HAS PRODUCED A MORE DIVERSE ORGANIZATIONAL AND INSTITUTIONAL STRUCTURE WHICH IN TURN HAS FRAGMENTED THE WORKING CLASS AND INTRODUCED NEW LINES OF SOCIAL CLEAYAGE INTO THE POLITICAL SYSTEM.

04296 HERMIDA, A.

ALGERIA: ASSASSINATION OVER-UP?

MIDOLE EAST INTERNATIONAL, 440(440) (DEC 92), 11-12.

THE FINAL REPORT OF THE SPECIAL COMMISSION INVESTIGATING THE ASSASSINATION OF ALGERIA'S HEAD OF STATE, MUHAMMAD BOUDAIF, HAS FAILED TO DISPEL SUSPICIONS OF A COVER-UP. THE COMMISSION SAYS THAT THE KEY QUESTION IS WHO HAS BENEFITTED COMMISSION SAYS THAT THE KEY QUESTION IS WHO HAS BENEFITTED
FROM THE CRIME AND POINTS THE FINGER AT THE BANNED FIS AND FROM THE CRIME AND POINTS THE FINGER AT THE BANNED FIS AND BOUDIAF. THE COMMISSION'S FINAL REPORT LEAVES MANY QUESTIONS UNANSWERED.

04297 HERMIDA, A.

ARAFAT SURVIVES THE DESERT STORM

MIDDLE EAST INTERNATIONAL, (423) (APR 92), 3

THE 15 HOURS PLO LEADER YASSER ARAFAT SPENT MISSING IN THE SAHARA DESERT AFTER HIS PLANE CRASHED HAVED RAISED QUESTIONS OVER HHO WOULD TAKE OVER IF HE DIED. HIS CLOSE BRUSH WITH DEATH HIGHL IGHTED THE PROBLEM THAT THERE IS NO APPARENT HEIR TO THE PLO LEADERSHIP. THO POSSIBLE SUCCESSORS, ABU JIHAD AND ABU IYAD, HAVE BOTH BEEN ASSASSINATED. THERE
IS TALK THAT PERHAPS FARUQ QADDUMI. THE HEAD OF THE PLO'S POLITICAL DEPARTMENT, COULD TAKE OVER, BUT QADDUMI INSISTS IN PUBLIC THAT ARAFAT IS IRREPLACEABLE. DESPITE THE RELUCTANCE TO DISCUSS ARAFAT'S SUCESSION, THE PLO DOES HAVE A FORMAL PROCEDURE TO CHOOSE A NEW LEADER. THE FIRST STEP WOULD BE TO CALL A MEETING OF THE PLO'S PARLIAMENT, THE PALESTINE NATIONAL COUNCIL. WHICH HOULD ELECT A NEH EXECUTIVE COMMITTEE TO CHOOSE A NEH LEADER.

04298 HERMIDA, A.

DEATH IN ALGIERS

AFRICA REPORT, 37 (5) (SEP 92), 49-53.

WHO PLANNED THE JUNE 1992 ASSASSINATION OF ALGERIA'S FIGUREHEAD LEADER, MOHAMED BOUDIAF--THE ISLAMIC FUNDAMENTALISTS OR THE GENERALS WHO RUN THE COUNTRY? THE MILITARY HAS USED THE MURDER AS AN EXCUSE TO CRACK DOHN ON THE FUMDAMENTALISTS, BAHMING THE ISLAMIC SALYATION FROMT (FIS). PUTTING ITS LEADERS ON TRIAL, AND DETAINING THOUSANDS OF SUPPORTERS. IN RETALIATION, THE FIS HAS CARRIED OUT DOZEN OF SUPPORTERS. IN RETALIATION, THE FI
OF LETHAL ATTACKS ON POLICE OFFICERS.

04299 HERMIDA, A.

DEMOCRACY DERAILED

AFRICA REPORT, 37(2) (MAR 92), 13-17.

FRUSTRATED WITH 30 YEARS OF AUTHORITARIAN RULE, ALGERIANS VOTED OVERWHELMINGLY FOR THE OPPOSITION ISLAMIC PARTY. BUT THE SPECTRE OF AN UNDEMOCRATIC FUNDAMENTALIS REGIME BASED ON SHARI'A LAW SENT SHOCKWAVES THROUGHOUT ALGERIAN SOCIETY AND A MILITARY TAKEOVER FOLLOWED. HOWEVER, 
TO DEFUSE THE FUNDAMENTALIST THREAT; ALGERIA'S UNDERLYING SOCIAL AND ECONOMIC PROBLEMS MUST BE ADDRESSED.

04300 HERMIDA, A.

MOVES AGAINST IRAN

MIDOLE EAST INTERNATIONAL, 439 (DEC 92 ), 5

ALGERIA'S TURBULENT RELATIONS WITH IRAN FELL TO A NEH LOW LAST MONTH, WHEN ALGIERS ANNOUNCED IT WAS SCALING DOWN ITS DIPLOMATIC REPRESENATAION IN TEHRAN TO A SYMBOLIC LEVEL AND CALLED ON IRAN TO DO THE SAME. THE ALGERIAN AUTHORITIES JUSTIFIED THEIR DECISION BY ACCUSING TEHRAN OF WAGING AN OPEN CAMPAIGN OF INTERFERENCE AND HOSTILITY DESIGNED TO PROMOTE VIOLENCE AND INSTABILITY IN THEIR COUNTRY. ALGER WANTS TO WORK WITH OTHER ARAB STATES TO COUNT

04301 HERMSEN, H.; VERBEEK, A.

EQUILIBRIA IN MULTI-PARTY SYSTEMS

BQLIC CHOICE, 73(2) (MAR 92), 147-166.

EQUILIBRIA IN MULTI-PARTY SYSTEMS IS DEALT WITH IN THIS PAPER. THE MODEL HAS A ONE-DIMENSIONAL POLICY SPACE FOR THE POSITIONS OF PARTIES AND VOTERS. FURTHERMORE IT ASSUMES AN ARBITRARY CONTINUOUS DENSITY OF VOTERS, VOTERS VOTE FOR THE MEAREST PARTY, AND PARTIES TRY TO MAXIMIZE THE NUMBER OF VOTES. SUFFICIENT AND NECESSARY CONDITIONS FOR EQUILIBRIA ARE GIVEN, AND FROM THESE CONDITIONS IT IS DEDUCED THAT FOR SYSTEMS WITH A LARGE NUMBER OF PARTIES EQUILIBRIA ARE RARE, UNLESS THE DENSITY OF VOTERS IS UNIFORM.

04302 HERNANDEZ, G.

POL ITICAL LEADERSHIP IN CUBA: BACKGROUND AND CURRENT PROJECTIONS

LATIN AMERICAN PERSPECTIVES, 18(2) (SPR 91), 55-68.

THE TRIUMPH OF THE CUBAN REVOLUTION MARKED THE BEGINNING OF A NEW TYPE OF LEADERSHIP LINKED TO A COURSE UNPRECEDENTED IN CUBA--THE PARTICIPATION OF THE BROADEST SOCIAL SECTORS IN POLITICAL LIFE. THE DEVELOPMENT OF THIS POL ITICAL LEADERSH IS THE SUBJECT OF THIS ARTICLE WHICH CONSIDERS ITS HISTORY FROM THE EARLIEST DAYS OF THE REVOLUTION TO THE PRESENT. IT EMPHASIZES THE CENTRAL ROL

04303 HERNANDEZ, R.; DILLA, H.

POLIIICAL CUI TURE AND POPULAR PARTICIPATION IN CUBA

LATIN AMERICAN PERSPECTIVES, 18(2) (SPR 91), 38-54.

IN ADDITION TO SYSTEMATIZING A PREDOMINANT IDEOLOGY, THE CUBAN REVOLUTION HAS TRANSFORMED CULTURE AND DEVELOPED NATIONAL VALUES THAT MIGHT BE CALLED A NEW CIVILITY. AS A CONSEQUENCE, STATE PROTECTION OF INDIVIDUAL AND COMMUNITY RIGHTS, ACCESS TO SOCIAL LIFE AND WORK, AND THE OPPORTUNITY FOR INDIVIDUAL PARTICIPATION--IN SHORT, THE ELEMENTS OF THE NEW CIVILITY THAT ARE IN FACT THE BASIS OF SOCIAL LIFE IN GENERAL--ARE INCORPORATED INTO THE FABRIC OF THEIR POLITICAL CULTURE. THIS ARTICLE CONSIDERS THIS POLITICAL CULTURE, ITS BASIS, AND THE EXTENT TO WHICH THE NEW VALUES LED TO PARTICIPATIOK.

04304 HERNSON, P.S.

WHY THE UNITED STATES DOES NOT HAVE RESPONSIBLE PARTIES PERSPECTIVES ON POLITICAL SCIENCE, 21(2) (SPR 92), 91-99. IN 1950, THE AMERICAN POLITICAL SCIENCE ASSOCIATION'S (APSA) COMMITTEE ON POLITICAL PARTIES PUBLISHED A REPORT DESIGHED TO PROMOTE THE EMERGENCE OF RESPONSIBLE TWO-PARTY GOVERMMENT IN THE UNITED STATES. THE REPORT GREATLY INFLUENCED THE WAYS THAT POLITICAL SCIENTISTS VIEW POLITICAL PARTIES, BUT ITS IMPACT ON THE AMERICAN PARTY SYSTEM HAS COMMITTEE'S COALS EXAMINES ITS RECOMMEMDATIONS AMD

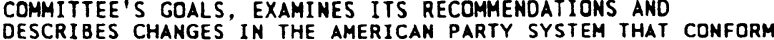
TO THEM AND THEN EXPLAINS WHY THE UNITED STATES HAS NOT DEVELOPED A PROGRAMMATIC TWO-PARTY SYSTEM.

04305 HERRERA, C.L.; HERRERA, R.; SMITH, E.R.A.N.

PUBLIC OPINION AND CONGRESSIONAL REPRESENTATION PUBLIC OPINION AND CONGRESSIONAL REPRESENTATION
PUBLIC OPINION OUARTERLY (CHICAGO), $56(2)$ (SUM 92), 185-205.

IN A DEMOCRATIC SOCIETY, CITIZENS' VIEWS ARE, AT LEAST THEORETICALLY EXP SOCIETY, CITIZENS VIEWS ARE, AT LEAST THEORETICALLY, EXPRESSED BY THEIR ELECTED REPRESENTATIVES. NATIONAL ELECTION STUDY AND A MAIL SURVEY OF THE U.S. HOUSE NATIONAL ELECTION STUDY AND A MAIL SURVEY OF THE U.S. HOUSE AND DYADICALIY. AND DYADICALLY. COLLECTIVELY, THEY FIND SOME DEGREE OF CONGRUENCE BETWEEN LEADERS AND FOLLOWERS. HOWEVER, THERE ARE SIGNIFICANT DIFFERENCES BETWEEN THEM ON HALF OF THE ISSUE ITEMS, WITH THE LEADERS USUALLY TAKING MORE EXIREME POSITIONS THAN THE FOLLOWERS. USING ACHEN'S MEASURES OF REPRESENTATION TO EVALUATE LEADERS AND FOLLOWERS DYADICALLY IN 33 DISTRICTS, THEY FIND THAT THE REPRESENTATIVES ' VIEWS ARE FAIRLY CLOSE TO THOSE OF THEIR CONSTITUENTS, THAT REPRESENTATIVES ARE EFFICIENT AT POSITIONING THEMSELVES AT THE MEAN CONSTITUENT POSITION, AND THAT REPRESENTATIVES RESPOND TO SHIFTS IN LIBERALISM/CONSERVATISM IN THEIR DISTRICTS.
04306 HERRERA, R.

THE UNDERSTANDING OF IDEOLOGICAL LABELS BY POLITICAL ELITES: A RESEARCH NOTE

WESTERN POLITICAL OUARTERLY, 45(4) (DEC 92), 1021-1036. THE AUTHOR EXPLORES THE WAYS IN WHICH POLITICAL ELITES UNDERSTAND "LIBERAL" AND "CONSERVATIVE" LABELS AND GROUPS. USING DATA FROM THE 1989 CPS CONVENTION DELEGATE STUDY, THE AUTHOR DISCUSSES (1) HOW ELITES UNDERSTAND IDEOLOGICAL TERMS (2) THE DEGREE TO WHICH ELITES CORRECTLY DEFINE IDEOLOGICAL LABELS; AND (3) HOW ELITES VIEW THEIR IDEOLOGICAL

COUNTERPARTS ON THE IDEOLOGICAL SPECTRUM. THE RESULTS SHOW THAT THE DELEGATES DISPLAY THE CHARACTERISTICS EXPECTED FROM

A POLITICALLY-SOPHISTICATED PORTION OF THE CITIZENRY.

04307 HERRING, C.; HOUSE, J.; MERO, R.

RACIALIY BASED CHANGES IN POLITICAL ALIENATION IN AMERICA SOCIAL SCIENCE QUARTERLY, 72(1) (MAR 91), 123-134.

THIS ARTICLE FOCUSES OH COMPETING EXPLANATIONS OF CHANGE IN THE NATURE AND SOURCES OF RACIAL DIFFERENCES IN POLITICAL ALIENATION. IT SUMMARIZES THREE VIEWS WHICH CAN BE TERMED (1) POLITICAL CULTURE AND SOCIALIZATION THEORIES, (2) SPIRIT OF THE TIMES THEORIES, AND (3) POLITICAL STRUCTURE AND INTEREST GROUP THEORIES. THE FINDINGS PROVIDE SUPPORT FOR POL ITICAL STRUCTURE AND INTEREST GROUP THEORIES, AS CHANGES IN POLITICAL ALIENATION WERE FOUND TO BE RACE-DIFFERENTIATED AND REFLECTIVE OF ISSUED AND EVENTS THAT WERE DIVERSE AND SALIENT

04308 HERRMANN, $P$

ROUNDUP: THE NEW POLISH CONSTITUTION

RFE/RL RESEARCH REPORT, 1(33) (AUG 92), 70-72.

THE AUTHOR SUMMARIZES THE RESULTS OF A PUBLIC OPINION SURVEY CONDUCTED IN THE SPRING OF 1992 REGARDING THE ADOPTION OF A NEW CONSTITUTION FOR POLAND. THE POLL INCLUDED QUESTIONS ON WHAT THE ROMAN CATHOLIC CHURCH'S STATUS SHOULD BE UNDER THE NEW CONSTITUTION.

04309 HERRMANM, $R$.

THE MIDDLE EAST AND THE NEH HORLD ORDER: RETHINKING U.S. POLITICAL STRATEGY AFTER THE GULF WAR

INTERNATIONAL SECURITY, 16(2) (FAL 91), 42-75.

THIS ARTICLE ASSESSES AMERICA'S POLITICAL STRATEGIES BEFORE, DURING, AND AFTER THE GULF WAR. IT EXPLORES THE BEFORE, DURING, AND AFTER THE GULF WAR. IT EXPLORES

EDMINISTRATION FAILED TO UNDERSTAND THE CHANGING DYNAMICS OF THE ARAB WORLD, HAS EXCESSIVELY PREOCCUPIED WITH DETERRENCE THINKING, AND NEVER REALIZED THAT SADDAM HUSSEIN WAS UNDETERRABLE. AFTER AN OVERVIEH OF HOH FUNDAMENTALIST UNDETERRABLE. AFTER AN OVERVIEW OF HOW FUNDAMENTALIST
MOVEMENTS AND POPULIST PRESSURES ARE CHANGING ARAB DOMESTIC MONEMENTS AND POPULIST PRESSURES ARE CHANGING ARAB DOMESTIC AND INTERMATIONAL POLITICS, IT CALLS FOR A U.S. MIDOLE EAST INSTEAD OF RELYING ON MILITARY FORCE AND SUPPORT FOR REPRESSIVE REGIMES.

04310 HERRMANH, R.K

SOVIET BEHAVIOR IN REGIONAL CONFLICTS: OLD QUESTIONS, NEW STRATEGIES, AND IMPORTANT LESSONS

WORLD POLITICS, 44(3) (APR 92), 432-465

REgIONAL CONFLICTS HAVE PLAYED A MAJOR ROLE IN U.S.

INTERPRETATIONS OF SOVIET FOREIGN POLICY, AFFECTING

JUDGMENTS ABOUT SOVIET INTENTIONS AND SERVING AS A BAROMETER OF MOSCOW'S COMPETITIVENESS. THIS STUDY LOOKS AT THE CHANGES IN SOVIET POLICY UNDER MIKHAIL GORBACHEV, PROPOSES A

STRATEGIC FRAMEWORK FOR ANALYZING SOVIET BEHAVIOR, AND

EXAMINES MOSCOW'S ACTIONS IN TERMS OF MILITARY SUPPORT,

ACTIVE INYOLVEMENT, AND THE TERMS OF PEACE. SPECIAL

ATTENTION IS PAID TO SOVIET POLICY IN SOUTHWEST ASIA. UNDER GORBACHEY SOVIET BEHAYIOR CHANGED IN WAYS THAT WERE MORE SUBTLE THAN OFTEN REALIZED. MOSCOH ACHIEVED PARTIAL SUCCESS THROUGH COMPROMISE MORE OFTEN THAN IT RETREATED IN DEFEAT. THE SHIFT TO A STRATEGY OF DETENTE HAD NUMEROUS CAUSES, BUT A SIMPLE AMERICAN PEACE-THROUGH-STRENGTH EXPLANATION THAT STRESSES EXTERNAL CONSTRAINTS AND SOVIET INTERNAL WEAKNESS IS INADEQUATE. SUCH EXPLANATIONS UNDERESTIMATE THE IS INADEQUATE. SUCH EXPLANATIONS UNDERESTIMATE THE
IMPORTANCE OF CHANGING PERCEPTIONS OF THREAT AND MISTAKENLY IMPORTANCE OF CHANGING PERCEPTIONS OF THREAT AND MISTAKENLY
AFFIRM A DETERRENCE CONCEPTION OF RECIPROCITY (FORCE BEGETS AFFIRM A DETERRENCE CONCEPTION OF RECIPROCITY (FORCE BEGE TS RESTRAINT). THE EVIDENCE IN REGIONAL CONFLICTS SUGGESTS THAT
A SPIRAL MODEL OF RECIPROCITY (ESCALATION BEGETS ESCALATION) A SPIRAL MODEL

04311 HERRNSON, P

CAMPAIGN PROFESSIONALISM AND FUNDRAISING IN CONGRESSIONAL EAMPCTIONS

THE JOURMAL OF POLITICS, 54(3) (AUG 92), 859-870.

CONTEMPORARY CONGRESSIONAL ELECTIONS REQUIRE CANDIDATES TO ASSEMBLE CAMPAIGN ORGANIZATIONS THAT CAN CONDUCT TECHNOLOGICALLY SOPHISTICATED ELECTION ACTIVITIES AND RAISE LARGE AMOUNTS OF MONEY FROM POLITICAL PARTIES, POLITICAL ACTION COMMITTEES, AND INDIVIDUALS. THIS STUDY DEMONSTRATES THAT CAMPAIGN PROFESSIONALISM--AS DEFINED BY THE NUMBER OF CAMPAIGN ACTIVITIES PERFORMED BY PROFESSIONAL POLITICAL CONSULTANTS--HAS AN IMPORTANT IMPACT ON A CANDIDATE'S FUNDRAISING SUCEESS. THE VALUE OF FIELDING A PROFESSIONAL CAMPAIGN ORGANIZATION IS UNDERSCORED BY THE FACT THAT THIS 
IS ONE OF THE FEW ASPECTS OF AN ELECTION THAT IS UNDER THE CANDIDATE'S CONTROL.

04312 HERSHBERG, T.; MAGIDSON, P.; WERMECKE, M.L. PROMOTING COOPERATION IN SOUTHEASTERN PENNSYLVANIA NATIONAL CIVIC REVIEW, 81(4) (FAL 92), 418-434 REGIONAL ACTION AND REGIONAL GOVERNANCE, BASED ON THE SHARED VALUES OF CORE CITIES AND THEIR SUBURBS, REQUIRES A STRONG CONVENING AND RESEARCH INSTITUTION RESPONSIVE TO GOVERNMENTAL, BUSINESS, AND CIVIC CONCERNS, AS IS SHOWN IN A CASE STUDY FROM SOUTHEASTERN PENHSYLVANIA.

04313 HERSHEY, M.

THE CONSTRUCTED EXPLANATION: INTERPRETING ELECTION RESULTS IN THE 1984 PRESIDENTIAL RACE

THE JOURNAL OF POLITICS, 54(4) (NOV 92), 943-976. THIS PAPER HYPOTHESIZES A PROCESS BY WHICH EXPLANATIONS FOR THE VOTE ARE CONSTRUCTED IN INTERACTION AMONG ELECTED OFFICIALS, ACTIVISTS, AND JOURMALISTS, AND DISSEMINATED THROUGH MEDIA COVERAGE. THE POSSIBLE EXPLANATIONS ARE WINNOWED TO A RELATIVE FEH, WHICH THEN BECOME "CONVENTIONAL WISDOM" ABOUT THAT ELECTION. THESE IDEAS ARE TESTED USING CONTENT ANALYSIS OF 1984 PRESIDENTIAL ELECTION COVERAGE IN 18 OPINION-LEADING NEHSPAPERS. THE PAPER DISCUSSES WHY SOME PROCESS, AND CONSIDERS THE IMPLICATIONS FOR PUBLIC POLICY.

04314 HERSPRING, D.

CIVIL-MILITARY RELATIONS IN POST-COMMUNIST EASTERN EUROPE: THE POTENTIAL FOR PRAETORIANISH

STUDIES IN COMPARATIVE COMMUNISM, 25(2) (JUN 92), 99-122.

A CLOSE INSPECTION OF DEVELOPMENTS IN EASTERN EUROPE

SUGGESTS THAT WHILE THE FEAR OF PRAETORIANISM MAY BE VALID

IN A FEW CASES, IT IS HIGHLY UNLIKELY IN THE MJORITY OF INSTANCES. THIS MEANS THAT THERE IS ALMOST NO POSSIBLITY OF
IT OCCURRING IN COUNTRIES SUCH AS ALBANIA, BULGARIA, POLAND, CZECHOSLOVAKIA, OR HUNGARY. THIS ARTICLE EXPLORES THE METHODOLOGICAL CONCERNS THAT WILL ENSURE CIVILIAN CONTROL, THE SOVIET FACTOR, AND INSTABILITY IN EASTERN EUROPE.

04315 HERSPRING, D.R.

PRACTITIONERS AND POLITICAL SCIENTISTS

PS: POLITICAL SCIENCE AND POLITICS, XXV(3) (SEP 92), 554-558.

IF CURRENT TRENDS CONTINUE, THE GAP SEPARATING FOREIGN POLICY PRACTITIONERS, WHO DEAL WITH FOREIGN AFFAIRS ON A DAILY 8ASIS, AND POLITICAL SCIENTISTS, WHO STUDY THE CONCEPTUAL AND THEORETICAL ASPECTS OF SUCH SUBJECTS, IS CONCEPTUAL AND THEORETICAL ASPECTS OF SUCH SUBJECTS, IS LIKELY TO WIDEN. THE RESULT WILL BE A FURTHER REDUCTION THE RELEVANCE OF POLITICAL SCIENCE AS A DISCIP
FORMULATING AND IMPLEMENTING FOREIGN POLICY.

04316 HERZ, $H$.

FEARS GROW AT SAME PACE AS COST UNIFICATION GERMAN TRIBUNE, 1479 (AUG 91), 3

THE ALIGNMENT OF THE ECONOMIES OF EASTERN AND WESTERN GERMANY IS PROVING MUCH MORE DIFFICULT THAN THE GERMAN GOVERMMENT HAS SO FAR CARED TO ADMIT. GERMANS WILL SOON DISCOVER WHAT SHARING A COMMON DESTINY IN A UNITED GERMANY REALLY MEANS. IF THE ECONOMIC RECONSTRUCTION IN EASTERN GERMANY FAILS BECAUSE OF CARELESS POLITICAL GROUNOWOEK OR IS EYEN UNNECESSARILY DELAYED, HESTERN GERMANY'S PROPERITY WILL ALSO BE IN JEOPARDY.

04317 HERZ, $\mathrm{H}$

ECONIMIC SUMMITEERS TRY TO $80 L$ STER CONFIDENCE GERMAN TRIBUNE, (1523) (JUL 92), 1-2.

HELP FOR THE NATIONS OF THE COMMONWEALTH OF INDEPENDENT STATES (CIS), THE HAR IN YUGOSLAVIA AND THE GATT TRADE TALKS WERE HIGH ON THE AGENDA AT THE MEETING OF THE SEVEN LEADING INDUSTRIALIZED NATIONS IN MUNICH. THERE WERE ALSO INDICATIONS THAT THE UNITED STATES OF AMERICA AND THE EUROPEAN COMUNITY WERE CLOSER TOGETHER THAN EXPECTED TO AGREEMENT ON TRADE. HOWEVER, THE OPTIMISTIC DISCUSSIONS OF FOREIGN AID AND FREEING TRADE FAILED TO MASK THE GRONING MALAISE IN MANY (IF NOT ALL) OF THE INDUSTRIALIZED STATES. THE UNITED STATES, GERMANY AND JAPAN ALL ARE EXPERIENCING SERIOUS ECONOMIC TROUBLES WHICH HAYE IMMENSE REPERCUSSIONS FOR ALL THE ECONOMIES IN THE HORLD.

04318 HERZIK, E.B.; MUSHKATEL, A.H.

INTERGOVERNMENTAL COMPLEXITY IN NUCLEAR HASTE DISPOSAL INTERGOVERMMENTAL COMPLEXITY IN NUCLEAR HASTE DISPOS
POLICY: THE INDETERMINATE ROLE OF LOCAL GOVERMMENT POLICY STUDIES REVIEH, 10(4) (HIN 92), 139-151. LOCAL GOYERMMENTS PLAY A CRITICAL, ALBEIT OFTEN OVERLOOKED, ROLE IN NUCLEAR WASTE DISPOSAL POLICY MAKING. THE CENTRALITY OF LOCAL GOVERNMENTS IN THE POLICY MAKING PROCESS RESTS ON THE SIMPLE FACT THAT IMPACTS WILL BE BORNE DISPROPORT IONATELY BY LOCAL JURISDICTIONS HOSTING AND IMMEDIATELY ADJACENT TO WASTE DISPOSAL SITES. THIS ARTICLE FOCUSES ON THE CAPACITY OF LOCAL JURISDICTIONS IN SOUTHERM NEVADA TO ABSORB AND SUPPORT AN UNDERTAKING AS LARGE AND TECHNICALLY COMPLEX AS THE PROPOSED HIGH-LEVEL NUCLEAR WASTE REPOSITORY. IT ALSO EXAMINES THE PERCEPTIONS OF LOCAL
GOVERNMENT OFFICIALS CONCERNING A MUMBER OF MANAGEMENT AND POLICY ISSUES RELATED TO THE CONSTRUCTION AND OPERATION OF POLICY ISSUES RELATED TO THE CONS
THE PROPOSED WASTE REPOSITORY.

04319 HERZIK, E.B.

THE DEVELOPMENT OF HAZARDOUS WASTE MANAGEMENT AS A STATE POLICY CONCER

POLICY STUDIES REVIEW, 11(1) (SPR 92), 141-148.

IN THE PAST DECADE, HAZARDOUS WASTE MANAGEMENT HAS

BECOME A PRIMARY CONCERN OF STATE GOVERNMENTS. THIS ESSAY

OUTLINES THE SCOPE OF THE HAZARDOUS WASTE PROBLEM TO WHICH

STATE GOVERMMENTS MUST RESPOND. THE SCOPE OF THE PROBLEM IS

THEN LINKED TO CHANGING PUBLIC PERCEPTIONS AND

INTERGOVERMMENTAL RELATIONSHIPS TO EXPLAIN THE EXPANDING

STATE GOVERNMENT POLICY ROLE IN HAZARDOUS WASTE MANAGEMENT.

04320 HERZOG, $W$.

NO WAY OUT

NEW REPUBLIC, 206(25) (JUN 92), 18-19.

ALTHOUGH THE KURDS REQUESTED AMERICAN OBSERVERS FOR

THEIR MAY 1992 ELECTIONS, THE U.S. STATE DEPARTMENT DECLINED

TO SEND OFFICIAL OBSERVERS AND REFUSED TO VALIDATE THE

PASSPORTS OF AMERICANS WHO WISHED TO GO ON AN UNOFFICIAL BASIS.

04321 HESS, $S$.

A RACE FOR SECRETARY OF STATE

BROOKINGS REVIEW, $10(2)$ (SPR 92), 54

FOR A VARIETY OF REASONS, FOREIGN POLICY IS NOT LIKELY TO BE A MAJOR ISSUE IN THE 1992 PRESIDENTIAL CAMPAIGN. BUT IT SHOULD BE SINCE THE ROLE OF THE UNITED STATES IN THE NEW WORLD ORDER IS A CRUCIAL ISSUE. WHAT IS NEEDED IS A CONCERTED EFFORT BY THE NEWS MEDIA TO COVER THE IDEAS OF THOSE WHO MIGHT BE THE FUTURE SECRETARY OF STATE OR HOLD THE KEY DEFENSE, REGIONAL, AND INTERNATIONAL ECONOMIC SLOTS IN GOVERMMENT.

04322 HESS, $S$.

ALL THE PRESIDENT'S REPORTERS: A NEW SURVEY OF THE WHITE HOUSE PRESS CORPS

PRESIDENTIAL STUDIES QUARTERLY, XXII(2) (SPR 92), 311-322. THIS ARTICLE EXAMINES THE WHITE HOUSE PRESS CORPS. IT

CONCLUDES THAT THEY ARE AN ELITIST GROUP: 53 PERCENT

ATTENDED PRIVATE SCHOOLS; 95 PERCENT ARE COLLEGE GRADUATES;

ONE-THIRD HAVE GRADUATE DEGREES; BUT ONLY 37 PERCENT HERE

JOURNALISM MAJORS; MANY MAJORED' IN ENGLISH, HISTORY, OR

POLITICAL SCIENCE. ONLY 19 PERCENT IDENTIFIED AS

CONSERVATIVE IN 1978, BUT 33 PERCENT DID SO IN 1991 (WITH 42

CONSERVATIVE IN 1978, BUT 33 PERCENT DID SO IN 1991 (WITH
PERCENT LIBERAL AND 24 PERCENT MIDOLE OF THE ROAD). THE

PERCENT LIBERAL AND 24 PERCENT MIDOLE OF THE ROAD). THE
AUTHOR CONCLUDES THE PRESS CORPS MEMBERS ARE NOT INDIVIDUAL

AUTHOR CONCLUDES THE PRESS CORPS MEMBERS ARE NOT INDIVIDU

PICTURE. THE AUTHOR ALSO CONCLUDES THAT "THEY DO NECESSARY

PICTURE. THE AUTHOR

04323 HESSENIUS, $C$.

EXPLAINING WHO WRITES TO CONGRESSMEN: A CONTEXTUAL ANALYSIS

POLITICAL GEOGRAPHY QUARTERLY, 10(2) (APR 91), 149-161.

THE STUDY OF CONSTITUENT-CONGRESSMAN RELATIONS OFTEM

IGNORES THE POTENTIAL IMPORTANCE OF THE SOCIAL NATURE OF THE CONSTI TUENCY ITSELF AS IT MAY INFLUENCE THE RELATIONSHIP. IT HAS BEEN BELIEVED THAT SEEKING CASEWORK WAS ALMOS

COMPLETELY ASSOCIATED WITH INDIVIDUAL ATTRIBUTES

FURTHERMORE, IT WAS BELIEVED THAT SOCIAL CLASS WAS NOT AN IMPORTANT PREDICTOR OF WHO WOULD WRITE. THIS PAPER SHOWS THAT SOCIAL CLASS AND THE CLASS CONTEXT OF AN INDIVIDUAL ARE IMPORTANT CONTRIBUTORS TO WHETHER OR NOT A PERSON WILL WRITE TO HIS OR HER CONGRESSMAN.

04324 HESTON, A.

INDIA'S ECONOMIC REFORMS: THE REAL THING

CURRENT HISTORY, 91(563) (MAR 92) 113-116.

IN THE PAST, SEVERAL INDIAN COMMISSIONS HAVE RECOMMENDED

DEREGULATION, BUT THEIR REPORTS HAVE BEEN IGNORED AND THE

ATTEMPTS AT REFORM HAVE BEEN INEFFECTIVE. MANY OBSERVERS BELIEVE THAT IN THE PAST YEAR INDIA HAS AT LAST ACCEPTED THE NEED FOR REFORM, HAS OVERCDME RESISTANCE TO IT, AND HAS SERIOUSLY BEGUN TO DISMANTLE THE COUNTRY'S INDUSTRIALLICENSING SYSTEM AND FOREIGN-EXCHANGE CONTROLS. OTHERS QUESTION WHETHER THESE CURRENT EFFORTS ARE REALLY DIFFERENT FROM PREVIOUS ATTEMPTS.

04325 HEUER, U.

THE NEED FOR A RADICAL CRITIQUE OF CAPITALISM

THE NEED FOR A RADICAL CRITIQUE OF CAPITALISH

SOCIALISM AND DEMOCRACY, (12) (JAN 91), 27-32.

HAYE LED MANY TO BELIEVE THAT SOCIALISM AS A POL ITICAL PHILOSOPHY IS MOW DEFUNCT. THIS ARTICLE RE-EXAMIMES

SOCIAL ISM FROM A GERMAN DEMOCRATIC PERSPECTIVE. TOPICS

EXAMINED INCLUDE: THE CONTEMPORARY CONCEPTION OF MARXISM;

WHETHER THE RECENT CHANGES SIGNAL THE "END OF HISTORY"; AND

THE NATIONAL QUESTION.

04326 HEUSER, B

NSC 68 AND THE SOVIET THREAT: A NEW PERSPECTIVE ON WESTERN 
THREAT PERCEPTION AND POLICY MAKING

REVIEW OF INTERNATIONAL STUDIES, 17 (1) (JAN 91), 17-40. LATE IN THE SUMMER OF 1950, THE U.S. ADMINISTRATION ADOPTED A POLICY PAPER ENTITLED NSC 68. THIS PAPER PAVED THE WAY FOR THE MOST COMPREHENSIVE RE-ARMAMENT PROGRAM THE UNITED STATES HAD EVER UNDERTAKEN IN TIME OF PEACE. THIS ARTICLE EXAMINES THE REASONING ADOPTED BY ADVOCATES OF NSC 68. THE AMERICAN AMD BRITISH GOVERMMENTS HAD INFORMATION WHICH LED THEM TO FEAR SOVIET AGGRESSION IN EUROPE AND ELSEWHERE. THIS PAPER ALSO EXAMINES MORE CLOSELY HOW SOME OF THE THREATS AGAINST THIRD PARTIES WERE PERCEIVED BY U.S. POLICY MAKERS. IN LIGHT OF THE FINDINGS, WESTERN THREATPERCEPTIONS OF 1950 NO LONGER SEEM UNREASONABLE. IT WAS THOUGHT THEN THAT THE SOVIET UNION MIGHT LAUNCH AN ATTACK AGAINST ANY ONE OF A NUMBER OF AREAS OF THE WORLD, AND THERE IS EVIDENCE THAT STALIN HOPING TO TAKE ADVANTAGE OF THE TURMOIL CREATED BY THE KOREAN WAR IN ORDER TO IMPLEMENT HIS OWN PLANS FOR CERTAIN PARTS OF EUROPE.

04327 HEUSER, B.

WHAT STRATEGY FOR POST-COLD WAR EUROPE?

ORBIS, 36(2) (SPR 92), 211-226.

FACED WITH THE CHALLENGE OF EXTENDING EUROPE'S LONG

PEACE INTO THE POST-COID HAR ERA. THIS ARTICLE EXAMINES THE USEFULNESS OF THE OLD INSTRUMENTS OF DETERRENCE IN RELATIONS TO THE NEW SITUATION. IT EXPLORES THE CHANGED VARIABLES, NEH THREATS AND THREAT PERCEPTIONS, THE IMPACT OF TECHNOLOGICAL CHANGE, THE FUTURE FOR TACTICAL NUCLEAR FORCES, NUCLEAR WEAPONS IN DIFFERENT CONTINGENCIES, AND, NUCLEAR WEAPONS AND ALLIANCE OPTIONS. IT CONCLUDES THAT IN ORDER TO PRESERVE THE SECURITY OF WESTERN EUROPE, NATO AND NUCLEAR WEAPONS WILL REMAIN NECESSARY IN THE FORESEEABLE FUTURE, YET ALLIANCE SOLIDARITY WILL BE THREATENED INCREASINGLY BY A GRADUALLY EMERGING DIVERGENCE OF INTERESTS

04328 HEWITT, M.

WELFARE, IDEOLOGY AND NEED: DEVELOPING PERSPECTIVE ON THE WELFARE STATE

BARNES \& NOBLE, 1992, 224.

THIS BOOK EXAMINES THE IDEOLOGICAL CONFLICT THAT EMERGED IN THE 1970'S AND 80'S BETWEEN SOCIAL DEMOCRACY AND THE NEW RIGHT OVER THE WELFARE STATE. IT EXAMINES THE STRENGTHS AND WEAKNESSES OF THESE THO POLITICAL IDEOLOGIES AND SEEKS TO IDENTIFY THE INTELLECTUAL RESOURCES OF SOCIAL DEMOCRATIC WELFARE THEORY. IT DRAWS ON MARXIST AND OISCOURSE THEORIES WF IDEOLOGY AND SEEKS TO DEVELOP AN UNDERSTANDING OF THE NATURE OF HUMAN MEED AND HOH WELFARE IDEOLOGY MIGHT BE POSITIVELY USED TO ACCOMMODATE THIS IN THE WELFARE POLITICS POSITIVELY USED

04329 HIBBING, J.; PATTERSON, S

A DEMOCRATIC LEGISLATURE IN THE MAKING: THE HISTORIC A DEMOCRATIC LEGISLATURE IN

COMPARATIVE POLITICAL STUDIES, 24(4) (JAN 92), 430-454. CHANGES IN THE RULES OF THE ELECTORAL GAME IN ESTABLISHED POLITICAL SYSTEMS NORMALLY CAN BRING ABOUT MARGINAL SHIFTS IN PARTISAN BIASES, BUT IN THE EARLY DAYS OF FRAGILE NEW DEMOCRACIES, THE ELECTORAL LAW CARRIES GREAT SIGNIFICANCE. THE HISTORIC MARCH-APRIL 1990 ELECTIONS IN HUNGARY PROVIDE AN OPPORTUNITY TO INVESTIGATE THE POLITICAL EFFECTS OF A SYSTEM THAT MERGES SINGLE-MEMBER AND PROPORTIONAL SELECTION OF PARLIAMENTARIANS. THIS SYSTEM LED TO THE IMPRESSIVE ELECTORAL VICTORY OF THE HUNGARIAN (MAGYAR) DEMOCRATIC FORUM (MDF). THE AUTHORS ANALYZE THE ELECTORAL BIASES THAT CONTRIBUTED TO THE MDF VICTORY AND, BY THE SAME TOKEN, TO THE FATE OF THE OTHER POLITICAL PARTIES. THEY EYALUATE THE ELECTORAL SYSTEM IN LIGHT OF ITS PROBABLE CONSEOUENCES FOR EFFECTIVE DEMOCRATIC GOVERNMENT IN HUNGARY.

04330 HIBBS, D.

MARKET FORCES, IRADE UNION IDEOLOGY AND TRENDS IN SWEDISH WAGE DISPERSION

ACTA SOCIOLOGICA, 34(2) (1991), 89-102

COMPRESSION OF THE DISTRIBUTION OF RELATIVE WAGES WAS AN IMPORTANT GOAL OF SWEDEN'S CENTRAL CONFEDERATION OF BLUECOLLAR TRADE UNIONS (LO) FROM THE MID 1960 S UP TO THE BREAKDOWN OF EFFECTIVE CENTRAL WAGE FORMATION IN THE EARLY 1980 . THIS ARTICLE ANALYZES LO'S SUCCESS IN ACHIEVING ITS IDEOLOGY OF WAGE EQUALITY IN THE MARKET BY COMPARING OBSERVED WAGE DISPERSION TRENDS TO THE TIME PATH OF MUMAN CAPITAL DISPERSION AND THE TIME PATH OF WAGE DISPERSION BUILT INTO THE CENTRAL FRAMEWORK WAGE AGREEMENTS. THE RESULTS OF THE COMPARISONS YIELD STRONG EVIDENCE THAT RESLLITARIAN TRADE UNION IDEOLOGY EXERTED A PONERFUL

EGALITARIAN TRADE UNION IDEOLOGY EXERTED A POWERFUL
INFLUENCE ON THE COURSE OF SHEDISH WAGE DISTRIBUTION.

04331 HIC, $M$

MARKET ECONOMY AND DEMOCRACY: TURKEY AS A CASE STUDY FOR DEVELOPING COUNTRIES AND EASTERN EUROPE ORIENT, 33 (2) (JUN 92), 205-226.

TURKEY HAS BEEN PRESENTED BY THE PRESENT GOVERMMENT AS A SHOW-CASE AND A SUCCESS STORY FOR THE DEVELOPING COUNTRIES AND EASTERN EUROPE ALIKE IN THE IMPLEMENTATION OF THE MARKET ECDNOMY AND IN EFFECTING A TRANSITION FROM AN INTENSELY
ETATISTE REGIME. THE FACT OF THE MATTER IS THAT IN THE TURKISH CASE THE BASIC PHILOSOPHY OF THE MARKET ECONOMY, ITS MAIN PRINCIPLES AND INGREDIENTS WERE LACKING. THE ECONOMY WAS GROSSLY MISMANAGED, GIVING RISE TO RAMPANT INFLATION CONCOMITANT WITH A LACKLUSTER YEARLY AVERAGE GNP GROWTH RATE. THUS, TURKEY DOES NOT AFFORD A SUCCESS STORY IN EFFECTING A TRANSITION TO THE MARKET ECONOMY, BUT AS A LESSON TO LEARN FROM IN ORDER TO AVOID THE GRAVE MISTAKES MADE UNDER THE PRETENSE OF THE MARKET ECONOMY.

04332 HICKEY, D.V.V

PERCEPTIONS, MISPERCEPTIONS, AND POLICY: TAIWAN'S ASSESSMENT OF THE DEMOCRACY MOVEMENT IN THE PEOPLE'S REPUBLIC OF CHINA

ASIAN AFFAIRS, AN AMERICAN REVIEW, 19(1) (SPR 92), 35-47. SUMMARIZES TAIHAN'S ASSESSMENT OF THE DEMOCRACY MOVEMENT THAT SWEPT THROUGH THE PEOPLE'S REPUBLIC OF CHINA DURING THE SPRING OF 1989. HE EXPLORES TAIPEI'S INTERPRETATION OF THE CAUSES, OBJECTIVES, AND CONSEOUENCES OF THE CAMPAIGN AND ATTEMPTS TO SHOW HOW THESE PERCEPTIONS
HAVE INFLUENCED TAIWAN'S POLICY TOWARD THE RIYAL REGIME IN BAVE INFL

04333 HICKEY, E.

OUT OF THE POOL

INSIGHT, $7(10)$ (MAR 91), 56-57

OF THE APPROXIMATELY 1,000 REGISTERED JOURNALISTS IN DHAHRAN, SAUDI ARABIA, ONLY ABOUT 160 ARE MEMBERS OF COMBAT POOLS, WHICH ALLOW THEM TO TALK WITH SOLDIERS. FRUSTRATED BY THE RULES, SOME TRAVEL INTO DANGEROUS TERRITORY WITHOUT MILITARY ESCORT TO GET UNCENSORED INFORMATION, BUT THEY DO SO AT GREAT RISK. HOWEVER, MANY REPORTERS--VETERANS OF VIETNAM, BEIRUT, OR NICARAGUA--SEEM MORE THAN WILLING TO TAKE THE RISK.

04334 HICKMAN, J.

THE EFFECT OF OPEN SEATS ON CHALLENGER STRENGTH IN JAPANESE LOWER HOUSE ELECTIONS

LEGISLATIVE STUDIES QUARTERLY, XVII(4) (NOV 92), 573-584. THE AUTHOR TESTS THE HYPOTHESIS THAT JAPANESE LOWER HOUSE (MULTI-MEMBER) DISTRICTS WITH MORE OPEN SEATS ATTRACT A LARGER NUMBER OF STRONG CHALLENGERS. LOWER HOUSE INCUMBENTS ARE RE-ELECTED AT HIGHER PERCENTAGE RATES THAN CHALLENGERS ARE ELECTED. USING DATA FOR THE 10 MOST RECENT ELECTIONS TO THE LOWER HOUSE, MEASURES APPROPRIATE TO THE ELECTIIONS TO THE LOWER HOUSE, MEASURES APPROPRIATE TO THE
MEDIUM-SIZED DISTRICT, SINGLE-ENTRY BALLOT ELECTORAL SYSTEM MEDIUM-SIZED DISTRICT, SINGLE-ENTRY BALLOT ELECTORAL SYSTEM WERE CONSTRUCTED FOR THE PROPORTION OF OPEN SEATS AND THE EFFECTIVE NUMBER OF STRONG CHALLENGERS IN EACH DISTRICT. ANALYSIS SHOWS THAT STRONG CHALLENGERS ENTER DISTRICT RACES
IN PROPORTION TO THE OPPORTUNITIES PRESENTED BY OPEN SEATS

04335 HICKS, A.M.: SWANK, D.H.

POLITICS, INSTITUTIONS, AND WELFARE SPENDING IN INDUSTRIALI ZED DEMOCRACIES, 1960-1982

AMERICAN POLITICAL SCIENCE REVIEW, 86(3) (SEP 92), 658-674. THE AUTHORS EXAMINE THE ROLES OF DEMOCRATIC POLITICS AND POLITICAL INSTITUTIONS IN SHAPING SOCIAL WELFARE SPENDING IN 18 CONTEMPORARY CAPITALIST DEMOCRACIES. THEY EXPLORE THE SOCIAL SPENDING CONSEQUENCES OF GOVERMMENT PARTISANSHIP, ELECTORAL COMPETITION ANO TURNOUT, THE SELF-INTERESTED BEHAYIORS OF POLITICIANS AND BUREAUCRATS, NEOCORPORATISM, STATE CENTRALIZATION, AND TRADITIONALIST PARTY LEGACIES. POOLED TIME-SERIES ANALYSES OF WELFARE EFFORT IN 18 NATIONS DURING THE 1960-1982 PERIOD SHOW THAT ELECTORAL TURNOUT AS WELL AS LEFT AND CENTER GOVERNMENTS INCREASE WELFARE EFFORT ; THAT THE WELFARE EFFORTS OF GOVERNMENTS LED BY PARTICULAR TYPES OF PARTIES SHOW SIGNIFICANT DIFFERENCES AND VARY WITH THE STRENGTH OF OPPOSITIONAL (AND JUNIOR COALITIONAL) PARTIES; AND THAT RELATIVELY NEOCORPORATIST, CENTRALIZED, OVERALL. THE FINDINGS SUGGEST THAT BOTH PARTISAM AND NONPARTISAN FACETS OF DEMOCRATIC POLITICS AND POL ITICAL INSTITUTIONS SHAPE CONTEMPORARY SOCIAL WELFARE EFFORT.

04336 HICKS, J.F.

SUPPORTING DEMOCRACY IN AFRICA

TRANSAFRICA FORUM, $9(2)$ (SUM 92), 69-77.

DESPITE ALL EFFORTS TO STIMULÁTE PRIVATE DOMESTIC INVESTMENT IN AFRICA, IT HAS FAILED TO MATERIALIZE IN SIGNIFICANT AMOUNTS. THE WAY GOVERMMENT AND THE PRIVATE SIGNIFICANT AMOUNTS. THE WAY GOVERNMENT AND THE PRIVATE
SECTOR INTERACT IN AFRICA MUST BE REDEFINED TO ENSURE A SECTOR INTERACT IN AFRICA MUST BE REDEFINED TO ENSURE CHALLENGES FACING AFRICA ARE IMMENSE, THE RECENT POLITICAL AND ECONOMIC CHANGES ON THE CONTINENT SUGGEST THAT THE FOUNDATION FOR AFRICA'S DEVELOPMENT IS SOLIDIFYING.

04337 HIDEKI, M.

GREASIMG THE WHEELS OF POWER

JAPAN QUARTERLY, XXXIX(3) (JUL 92), 303-310

JAPAN'S THO MOST RECENT POLITICAL SCANDALS HAVE BEEN REFERRED TO AS CASES OF "STRUCTURAL CORRUPTION" BECAUSE THEY WERE AIMED AT INFLUENCING THE ENTIRE LEGISLATIVE STRUCTURE WHOLE INDUSTRY, INVOLVED. THESE SCANDALS SHOW HOW THE WHEELS 
OF THE RULING LIBERAL DEMOCRATIC PARTY AND JAPANESE POLITICS AS A WHOLE ARE BEING GREASED BY CORPORATE FUNDS.

04338 HIEBERT, M.

BUILDING A RAPPOR

AR EASTERN ECONOMIC REVIEW, 155(4) (JAN 92), 19

THAI PREMIER ANAND PANYARACHUN'S MID-JANUARY VISIT TO HANOI, THE FIRST EVER BY A THAI MINISTER, MARKED AMOTHER IMPORTANT STEP IN VIETNAM'S EFFORTS TO IMPROVE ITS RELATIONS WITH ITS SOUTHEAST ASIAN NEIGHBORS, FOLLOWING THE END OF THE COLD HAR AND THE SIGNING DF THE CAMBODIAN PEACE AGREEMENT. IN ANOTHER SIGN OF WARMING RELATIONS BETHEEN THE THO LONGTIME REGIONAL RIVALS, THE THAI PREMIER CALLED ON THE UNITED STATES TO LIFT ITS TRADE EMBARGO AGAINST VIETNAM. BOTH SIDES ALSO CAME TO AGREEMENTS ON TRADE, ECONOMIC AND TECHNICAL COOPERATION.

04339 HIEBERT, $M$.

MIMG SIGALS

FAR EASTERN ECONOMIC REYIEN, 155(1) (JAN 92), 24-25.

VIETHAM, IN AN APPARENT ATTEMPT TO IMPROVE ITS HUMAN RIGHTS RECORD WITH POTENTIAL AID DONORS IN THE WEST, HAS RELEASED SEVERAL PROMINENT POLITICAL PRISONERS AND INMATES RELEASED SEVERAL PROMINENT POL ITICAL PRISONERS ANO INMATES HELD IN RE-EDUCATION CAMPS SINCE THE COMAUNIST VICTORY 16 YEARS AGO. BUT THE RECENT JAILING OF A POLITICAL ACTIVIS OEMONSTRATES THAT THE COMMUNIST PARTY WILL NOT PERMIT ANY CHALLENGE TO ITS EXCLUSIVE HOLD ON POWER. HANOI IN RECEN EDUCATION CAMPS SET UP AFTER THE DEFEAT OF THE U.S. -BACKED SAIGON GOVERMMENT IN 1975. OTHERS HOULD BE RELEASED IN FEBRUARY AND THE LAST DETAINEES WOULD BE OUT BY JUNE. BUT THE AMNESTY WOULD NOT APPLY TO 2,000 PEOPLE HELD FOR ANTIGOVERNMENT ACTIVITIES AFTER 1975. SOME BELIEVE THAT HANOI IS "TRYING TO FIT INTO THE INTERNATIONAL COMHUNITY" IN ORDER WOO AID AND INVESTMENT FROM THE WEST FOLLOH

04340 HIEBERT, $M$

DEFEATED BY VICTORY

FAR EASTERN ECONOMIC REVIEN, 151(24) (JUN 91), 24-27. THE SOVIET UNION'S ABRUPT CUTS IN AID AND CREDITS TO VIETMAM'S ONCE FORMIDABLE MILITARY HAVE INCREASED THE TROUBLES FACING VIETNAMESE GENERALS AS THEY SEEK TO ADAPT TO PEACE AND ADJUST TO THE RAPID CHANGE IN THE WORLO BROUGHT ABOUT BY THE COLLAPSE OF COMMUNISM IN EASTERN EUROPE. THE SOVIET AID CUTS HAVE COMBINED WITH INTERNAL ECONOMIC DIFFICULTIES TO PLAY HAVOC WITH THE ARMY'S PLANS TO OVERHAUL ITS FORCE STRUCTURE DEMOBILIZE HALF OF ITS TROOPS AND HALT DECL INIMG MORALE AND STAMDARDS AMONG ITS RANKS. THE DECLINING MORALE AND STANDARDS AMONG ITS RANKS. THE
PRESSURES ON THE MILITARY ALSO NECESSITATE A REVISION OF THE PRESSURES ON THE MILITARY ALSO NECESSITATE A REVISION

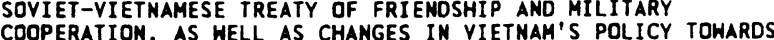
COOPERATION, AS WELL AS CHANGES
ITS SOUTHEAST ASIAN NEIGHBORS.

04341 HIEBERT, M.; THOM, K.

FAR EASTERN ECONOMIC REVIEW, 155(23) (JUN 92), 24-25.

THE UNITED NATION'S DECISION TO START DISARMING

CAMBODIA'S RIVAL ARMIES ON 13 JUNE MARKS THE MOST IMPORTANT

CHALLENGE TO THE SEVEN-HONTH-OLD UN-BROKERED PEACE ACCORD DESIGNED TO END 13 YEARS OF WAR IN THE COUNTRY. SEYERAL PROBLEMS FACE THE UN INCLUDING KHMER ROUGE INTRANSIGENCE; THE FACT THAT THE UN HAS YET TO APPROVE THE US\$1.7 BILLION BUDGET FOR THE OPERATION; ONLY TWO BATALLIONS OUT OF THE TOTAL REQUIRED NINE HAVE ARRIVED; ONLY 5,700 REFUGEES HAVE BEEN REPATRIATED IN THE FIRST MONTH (INSTEAD OF THE HOPEDFOR 10,000 A WEEK); AND THE UN HAS YET TO FIND CIVIL ADMINISTRATORS FOR KEY MINISTRIES AS MANDATED BY THE PEACE ACCORD. SOME UN OFFICIALS AND DIPLOMATS FEAR THAT THE DISARMAMENT PROCESS MIGHT HAVE TO WAIT UNTIL THE END OF THE RAINY SEASON IN OCTOBER DUE TO DELAYS IN THE ARRIVAL OF UN TROOPS AND THE LACK OF COOPERATION FROM THE CAMBODIAN FACTIONS, PARTICULARLY THE KHMER ROUGE.

04342 HIEBERT, $M$.

DYNAMICS OF DESPAIR

FAR EASTERN ECONOMIC REVIEW, 155(16) (APR 92), 26-28.

VIETNAM'S 53 ETHNIC MINORITY GROUPS TOTAL ROUGHLY EIGHT MILLION PEOPLE, OR ABOUT $13 \%$ OF THE COUNTRY'S 69 MILLION POPULATION. THE TEN LARGEST GROUPS--THE TAY, THAI, HOA (ETHNIC CHINESE), KHMER, MUONG, MUNG, HMONG, DAO, JARAI, AND EDE--EACH NUMBER' FROM 100,000 TO 1 MILLION PEOPLE. MOST' OF THE MINORITIES LIVE IN THE NORTHERN MOUNTAIN AND CENTRAL HIGHLAND REGIONS WHICH COMPRISE ABOUT $75 \%$ OF VIETNAM'S LAND HIGHLAND REGIONS WHICH COMPRISE ABOUT 75\% OF VIETNAM S AREA. THESE REGIONS ARE OF KEY STRATEGIC IMPORTANCE FOR HANOI AS THEY CONTAIN MOST OF THE COUNTRY'S FOREST AND MINERAL RESOURCES. THERE IS A HUGE GAP IN DEVELOPMENT BETWEEN THE MINORITIES IN THE HIGHLANDS AND THE VIETNAMESE IN THE CITIES: THE STANDARD OF LIVING OF MINORITY VILLAGE IS ONLY ONE FORTIETH OF THE LEVEL IN HANOI GOVERNMENT
PROMISES OF AID AND DEVELOPMENT HAVE, ON THE WHOLE, REMAINED UNFULFILLED.
04343 HIEBERT, M.

ELECTION STRATEGY

FAR EASTERN ECONOMIC REVIEW, 155(27) (JUL 92), 21. VIETHAMESE YOTERS EXPECT FEW SURPRISES WHEN THEY GO TO THE POLLS ON 19 JULY TO ELECT A NEW 395-SEAT NATIONAL ASSEMBLY FROM AMONG 602 CANDIDATES. WHILE NEW LEGISLATION PASSED BY THE OUTGOING ASSEMBLY IN APRIL ALLOWED INDEPENDENT CANDIDATES TO RUN, THOSE WHO APPLIED HAVE ALL BEEN CANDIDATES TO RUN, THOSE WHO APPLIED HAVE ALL BEEN 32 PEOPLE MATIONWIDE, INCLUDING SEVEN IN HANOI AND 11 IN HO CHI MINH CITY AND ONE, IN THE NORTHERM PORT CITY OF HAIPHONG, ARE KNOWN TO HAVE APPLIED TO RUN AS INDEPENDENT CANDIDATES. NONE OF THEM, HOWEVER, MANAGED TO QUALIFY UNDER THE STRINGENT REGULATIONS SET DOWN BY THE LEGISLATION. UNLIKE SOME OF ITS PREDECESSORS, RECENT NATIONAL ASSEMBLIES HAVE BECOME INCREASINGLY IMPORTANT PLATFORMS FOR DELEGATES TO CRITICISE UNPOPULAR POLICIES AND INCOMPETENT OR CORRUPT OFFICIALS.

04344 HIEBERT, $M$.

LOOK TO THE MORTH

FAR EASTERN ECONOMIC REVIEW, 155(31) (AUG 92), 14-15.

THE RETURN OF THE CHINESE TO LAOS SYMBOL IZES THE DRAMATIC FOREIGN-POLICY CHANGES THE LANDLOCKED COUNTRY IS PURSUING WITH ITS NEIGHBORS IN THE WAKE OF THE COLLAPSE OF COMMUNISM IN RECENT YEARS. A DOZEN YEARS EARLIER, VIENTIANE EXPELLED THE LAST REMAINING CHINESE ROAD-CONSTRUCTION WORELES FROM MORTHERM LAOS, CHARGING THEM WITH HAVING WORKERS FROM NORTHERN LAOS, CHARGING THEM WITH HAVING
"EXPANSIONIST DESIGNS" ON THEIR TINY SOUTHERN NEIGHBOR. NOW "EXPANSIONIST DESIGNS" ON THEIR TINY SOUTHERN NEIGHBOR. NOW LAO COMWUNIST LEADERS, MINDFUL OF THE SOVIET EXPERIENCE AND REALIZING THAT LAOS NEEDS FOREIGN AID AND TRADE TO DEVELOP ITS BACKWARD ECONOMY. ARE SEEKING TO IMPROVE RELAT STATES. ONLY WITH CHINA, BUT ALSO THAILAND AND THE UNITED THE LEADERSHIP OF LAOS HOPES THAT CHINA WILL HELP COUNTERBALANCE THAILAND ANO VIETNAM, WHICH HAVE BEEN FOR CENTURIES TO DOMINATE THEIR UNDERPOPULATED AND IMPOVERISHED NEIGHBOR. VIENTIANE HAS ALSO STEPPED UP ATTEMPTS TO RESOLVE THE TWO BIGGEST ISSUES STRAINING U.S. LAO RELATIONS: OPIUM PROOUCTION AND THE PROBLEM OF $522 \mathrm{U}$.S. SERVICEMEN MISSING IN ACTION SINCE THE END OF THE INDOCHINA WAR.

04345 HIEBERT, M.

FAR EASTERM ECONOMIC REVIEH, 153(31) (AUG 91), 24-25. THE CONSTRUCTION OF A NEH FIVE-STORY MARKET IN THE CHIMATOWN OF HO CHI MINH CITY MAY WELL SYMBOLIZE THE REEMERGENCE OF THE ETHNIC CHINESE AS A POWERFUL FORCE IN VIETNAM'S ECONOMY. THE NEW USS5-MILLION MARKET MARKS THE FIRST SIZABLE INVESTMENT PROJECT IN THE CITY BY A GROUP OF ETHNIC CHINESE BUSINESSMEN, WHO WERE FORCED OUT OF BUSINES BY THE ZEALOUS COMMUNIST PARTY FOLLOWING ITS VICTORY OVER THE U.S. -BACKED CAPITALIST SOUTH VIETNAM IN MID-1975. THE MARKE POLICIES. THOUSANDS OF OTHER ETHNIC CHINESE HAVE RESUMED NEW POLICIES. THOUSANDS OF OTHER ETHNIC CHINESE HAVE TRADING ACTIVITIES IN THE PAST FEW YEARS, OR HAVE PRODUCING TEXTILES AND SHOES, OR ASSEMBLING ELECTRONIC PRODUCING

04346 HIEBERT, M.

MORE OF THE SAME FAR EASTERN ECONOMIC REVIEH, 151(28) (JUL 91), 10-11. CONGRESS FROM 24-27 JUNE, INTRODUCED WIDESPREAD LEADERSHIP CHANGES AND RENEWED ITS CALL FOR CONTINUED MOVES TOWARDS FREE MARKET ECONOMY. SEVEN MEMBERS OF THE FORMER 12-MAN RUL ING POLI I BURO, INCLUDING AILING PARTY CHIEF NGUYEN VAN LINH, WERE DROPPED FROM THEIR POSTS. LINH, WHO WAS ASKED TO RETIRE, HAS REPLACED BY PREMIER DO MUOI. HOWEVER, THE PARTY CONGRESS CAREFULLY AVOIDED ANY SPECIFICS ON THE DETAILS OF REFORM. SPEECHES BY PARTY LEADERS FOCUSED ON IDEOLOGY AND WERE THIN ON THE DETAILS OF ANY NEW ECONOMIC POLICIES. LEFT UNATTENDED WERE THE CRUCIAL ISSUES OF VIETNAM'S BALANCE OF PAYMENTS PROBLEMS, THE NEED TO FIND NEW MARKETS, AND THE PACE OF REFORH OF' INEFFICIENT STATE ENTERPRISES.

04347 HIEBERT, $M$.

NEN DIRECTIONS

FAR EASTERN ECONOMIC REVIEH, 155(7) (FEB 92), 21-22. UNTIL FIVE YEARS AGO, VIETNAMESE NEWSPAPERS HERE GENERALLY DULL AND NUMBED THEIR READERS HITH ENDLESS ACCOUNTS OF HEROIC WORKERS CHURNING OUT EVER GREATER VOLUMES OF RICE OR BICYCLES IN YIETMAM'S MARCH TO A BRIGHTER FUTURE. ONE OF THE MOST STRIKING DIFFERENCES TODAY IS THE INCREASING ONE OF THE MOST STRIKING DIFFERENCES TODAY IS THE CORUPTING ROLE NEWSPAPERS PLAY IN REPORTING MISMANAGEMENT, CORRUPT AND ABUSE AMONG PARTY AND STATE BUREAUCRATS. SOME OF THESE ARTICLES HAVE LANDED REPORTERS IN TROUBLE, ESPECIAL OUTLYING PROVINCES. SOME NEWSPAPERS HAVE USED THEIR INCREASED FREEDOM TO CHAMPION GREATER SOCIAL EQUALITY' ALTHOUGH THE PRESS ALSO CHAMPIONS THE COMMUNIST PARTY MOVES TOWARDS A FREE MARKET ECONOMY, NEWSREPORTING ON SINCE THE PRE-REFORM DAYS. 
04348 HIEBERT, $M$

MO DONG, NO DEAL

FAR EASTERN ECONOMIC REYIEW, 155(25) (JUN 92), 13. THERE IS GROWING POPULAR' FRUSTRATION AT INCREASING CORRUPTION IN VIETNAM. ALTHOUGH HANOI MOUNTED A CAMPAIGN IN JUNE 1990 TO COMBAT CORRUPTION, MANY VIETNAMESE CLAIM THE PROBLEM HAS WORSENED IN THE PAST THO YEARS. HANOI RESIDENTS SAY IT IS NOW VIRTUALLY IMPOSSIBLE TO FIND A JOB, GET A LICENSE TO BUILD A HOUSE, RECEIVE TREATMENT IN A HOSPITAL, GET A CHILD INTO A NURSERY SCHOOL, OBTAIN A VISA TO TRAVEL ABROAD, OR SECURE A BUSINESS OR IMPORT-EXPORT LICENSE WITHOUT PAYING BRIBES. ALTHOUGH CORRUPTION IS WIDESPREAD IN MANY COUNTRIES OF SOUTHEAST ASIA, IT IS A RELATIVELY NEW PHENOMENON IN NORTHERN VIETNAM, WHICH HAS BEEN UNDER COMMUNIST RULE SINCE 1954. PARTY OFFICIALS APPEAR GRADUALLY TO HAVE LOST MUCH OF THEIR REVOLUTIONARY DISCIPLINE AND HAVE BECOME MORE INTERESTED IN PERSONAL PROFIT. A RECENT REPORT INDICATES THAT THE COURTS IN THE NORTH TRIED ONLY FIVE TO SEVEN CASES OF CORRUPTION EACH YEAR DURING THE VIETNAM WARS SEVEN CASES OF CORRUPTION EACH YEAR DURING THE VIETNAM WA
BUT BY 1985--WHEN THE PARTY LAUNCHED REFORMS TO MOVE THE BUT BY 1985--WHEN THE PARTY LAUNCHED REFORMS TO MOVE THE
COUNTRY TO A FREE-MARKET ECONOMY--THE NUMBER OF CASES HAD CDUNTRY TO A FREE-MARKET ECONOMY--THE NUMBER OF CASES HAD
INCREASED BY $1800 \%$ OVER 1976; BY 1988 THEY HAD SOARED BY 2 , $230 \%$.

04349 HIEBERT, M.

SLOW AWAKEMING

FAR EASTERN ECONOMIC REVIEW, 151(16) (APR 91), 18-19, LAOS ' COMMUNIST LEADERSHIP, MEETING FROM $27-29$ MARCH IN THE FIFTH CONGRESS OF THE LAO PEOPLE'S REVOLUTIONARY PARTY, FLEDGED TO CONTINUE ITS DRIVE TO ESTABLISH A FREE MARKET ECONOMY BUT RULED OUT SHARING POWER WITH OTHER POLITICAL GROUPS. THE PARTY ALSO TOOK ITS FIRST STEPS TO PREPARE FOR A GENERATIONAL CHARGE BY RETIRING THREE VETERAN LEADERS WHO HAD BEEN ACTIVE IN THE PARTY'S RULING POLITBURO SINCE IT WAS FOUNDED NEARLY FOUR DECADES AGO. THE REORGANIZATION OF THE PARTY WILL BE FOLLOWED BY EFFORTS TO STREAMLINE THE GOVERMMENT BY REDUCING THE NUMBER OF MINISTRIES AS WELL AS THE NUMBER OF VICE MINISTERS IN INDIVIDUAL MINISTRIES.

04350 HIEBERT, M.

STEADY COURSE

FAR EASTERN ECONOMIC REVIEW, 155(48) (DEC 92), 11

THE DEATH OF PRESIDENT KAYSONE PHOMVIHANE OF LAOS ON 21

NOVEMBER WILL FORCE THE COUNTRY'S RULING COMHUNIST PARTY TO

TAKE ITS FIRST MAJOR STEPS TO PREPARE FOR GENERATIONAL

CHANGE SINCE IT SEIZED PONER 17 YEARS AGO. KAYSONE, 71, HAD

LED THE PARTY SINCE IT WAS FOUNDED IN 1955 AND HAD DOMINATED

LED THE PARTY SINCE IT WAS FOUNDED IN 1955 AND HAD DOMIMAT
POLITICS IN LAOS SINCE THE GOVERNMENT OUSTED A PRO-U.S.

ROYALIST GOVERMMENT IN 1975, DIPLOMATS IN VIENTIAME SAID

ROYALIST GOVERMMENT IN 1975. DIPLOMATS IN VIENTIANE SAID
THEY HAD FEW CLUES AS TO WHO MIGHT TAKE OVER KAYSONE'S POSTS

THEY HAD FEW CLUES AS TO WHO MIGHT TAKE OVER KAYSONE'S POSTS
AS STATE PRESIDENT AND PRESIDENT OF THE RULING LAO PEOPLE'S

AS STATE PRESIDENT AND PRESIDENT OF THE RUL ING LAO PEOPLE
REVOLUTIONARY PARTY, BUT THEY EXPECTED NO MAJOR POLICY

REVOLUTIONARY PARTY, BUT THEY EXPECTED NO MAJOR POLICY

CHANGES IN THE WAKE OF HIS DEATH. INSTEAD, KAYSONE'S
POLICIES OF FREE-MARKET REFORMS AND IMPROVEMENT OF RELATIONS

WITH THE OUTSIDE WORLD ARE LIKELY TO CONTINUE.

04351 HIEBERT, $M$.

VIETNAM'S DICHOTOMY

FAR EASTERN ECONOMIC REVIEW, 155(41) (OCT 92), 46-48,

BOTH FOREIGNERS AND VIETHAMESE HAVE STEREOTYPED VIEWS ABOUT WHAT MAKES NORTH VIETHAM DIFFERENT FROM THE SOUTH. MANY ARGUE THAT CENTURIES-LONG PATTERNS OF NORTH-SOUTH MIGRATION CAUSED THE SOUTH TO ESCHEW THE TRADITIONAL CONFUCIAN HERITAGE OF THE NORTH. THESE REGIONAL DIFFERENCES HAVE BEEN ACCENTUATED BY THE COLONIAL EXPERIENCE AND, LATER, BY THE VIETNAM WAR. THE NORTH HAS A REPUTATION FOR AUSTERITY AND A MORE VIBRANT INTELLECTUAL LIFE; THE SOUTH IS FREEWHEELING, AND DEDICATED TO THE PURSUIT OF PROIFT. THE NORTH RUNS THE COUNTRY BUT THE SOUTH DRIVES THE ECONOMY.

04352 HIEBERT, $M$

WOES OF OWNERSHIP

FAR EASTERM ECONOMIC REVIEW, 155(15) (APR 92) 30

VIETNAM'S COMMUNIST AUTHORITIES, IN AN APPARENT EFFORT

TO BOOST CONFIDENCE AMONG THE COUNTRY'S STILL SKEPTICAL

PRIVATE BUSINESSMEN, HAVE IN THE PAST FEW YEARS QUIETLY

BEGUN RETURNING PROPERTY EXPROPRIATED IN AN ANTI-CAPITALIST

CRACKDOWN LAUNCHED IN HANOI NEARLY A DECADE AGO. VIETNAMESE PARTY AND POLICE OFFICIALS HAVE NOT YET SPOKEN OPENLY ABOUT THE 1983 CAMPAIGN, CODENAMED Z-30, BUT INTERVIENS WITH VICTIMS SUGGEST THAT AT LEAST 200 FAMILIES IN THE VIETNAMESE CAPITAL LOST THEIR HOUSES AND OTHER PROPERTY IN THE CRACKDOWN. THE Z-30 CAMPAIGN WAS ORIGINALLY AIMED AGAINST SMUGGLING AND CORRUPTION, BUT MANY OF THOSE AFFECTED APPEAR ONLY TO HAVE MADE THE "MISTAKE" OF BUYING OR RENOYATING HOUSES AT THE BEGINNING OF 1983 WHEN THE PARTY LINE HARDENED HOUSES AT THE BEGINNING OF 1983 WHEN

04353 HIEBERT, $M$

HOOIMG THEM HOME

FAR EASTERN ECONOMIC REVIEW, 155 (3) (JAN 92), 18-19.

THE BUSINESS VENTURES OF A DARING FEH APPEAR TO HAVE MET THE EXPECTATIONS OF VIETNAM'S COMMUNIST GOVERNMENT HHEN IT LAUNCHED ITS ECONOMIC REFORMS AND BEGAN WOOING YIETHAMESE
LIVING ABROAD FIVE YEARS AGO. SOME REFUGEES HAVE BROUGHT BACK THEIR SAVINGS, EXPERTISE, AND FOREIGN CONNECTIONS TO HELP BOOST AN ECONOMY STRUGGLING AFTER YEARS OF STAGNATION BROUGHT ON BY SOCIALIST MISMAHAGEMENT AND INTERNATIONAL ISOLATION. BUT MANY OTHER OVERSEAS VIETNAMESE STILL HESITATE IN THEIR DEALINGS WITH VIETHAM. INTENSE CRITICISM OF SOME OVERSEAS VIETNAMESE BY THE COMMUNIST PARTY'S SECURITY APPARATUS HAS MADE SOME WARY ABOUT RETURNING. SDME VIETNAMESE ECDNOMISTS BELIEVE INVESTMENT BY OVERSEAS VIETNAMESE WILL ONLY PICK UP AFTER WASHINGTON LIFTS ITS ECONOMIC EMBARGO.

04354 HIETT, $P$.

ALGERIA--GHOZALI MAKES HIS MARK

MIDOLE EAST INTERNATIONAL, (405) (JUL 91), 12-13.

AS FUNDAMENTALIST AGITATION IN ALGIERS' DIES AWAY, POLITICAL FERMENT IS CONTINUING INSIDE AND OUTSIDE THE FORMER SINGLE PARTY, THE FLN, AND INSIDE THE NEW GOVERMMENT OF SID-AHMED GHOZALI. GHOZALI'S OFFER TO SELL OFF A QUARTER OF THE COUNTRY'S BIGGEST OIL FIELD TO HELP PAY ALGERIA'S SIZABLE FOREIGN DEBT IS AN INDICATION THAT HE INTENDS TO
HEAD MUCH MORE THAN A PURELY CARETAKER GOVERNMENT OVERSEEING THE GENERAL ELECTION DUE LATER IN 1991. GHOZALI HAS ALSO CALLED FOR A CONFERENCE OF ALL POLITICAL PARTIES TO DISCUSS THE ECONOMY AND THE CONDITION UNDER WHICH THE ELECTIONS ARE TO BE HELD--ALGERIAN CODE FOR REDRAHING THE GERRYMANDERED CONSTITUENCY BOUNDARIES AND AMENDING THE ELECTORAL LAHS. UNFORTUNATELY, ASIDE FROM GHOZALI, THERE SEEMS TO BE LITTLE ELSE IN ALGERIA IN THE WAY OF UNIFIED POLITICAL ACTION.

04355 HIETT, P.

ANOTHER TRIAL BALLOON?

MIDDLE EAST INTERNATIONAL, (396) (MAR 91), 6-7.

BASSAM ABU SHARIF, AN ADVISER OF PLO CHAIRMAN YASSER ARAFAT, WAS RUMORED TO HAVE SAID THAT THE PLO MIGHT BE WILLING TO MAKE TERRITORIAL CONCESSIONS OVER THE WEST BANK AND THE GAZA STRIP IN RETURN FOR A CORRIDOR LINKING THEM. ABU SHARIF'S STATEMENT WAS QUICKLY DENIED BY SEVERAL KEY PLO LEADERS AND BY ABU SHARIF HIMSELF. HESTERN OBSERVERS ARE NOT DECIDED AS TO WHETHER THE STATEMENT WAS A MISQUOTATION, A POLITICAL GAFFE BY ABU SHARIF, OR ONE OF YASSER ARAFAT'S NOTORIOUS TRIAL BALLOONS.

04356 HIETT, $P$

HITTING THE FUNDAMENTALISTS

MIDOLE EAST INTERNATIONAL, (397) (APR 91), 15-16.

IN ALGERIA, PARLIAMENT VOTED THROUGH A SERIES OF CHANGES IN ELECTORAL LAW WHICH ARE LIKELY TO DAMAGE THE

FUNDAMENTALIST ISLAMIC SALVATION FRONT (FIS) 'S CHANCES IM THE COMING GENERAL ELECTION. IN LAST YEAR'S LOCAL AND REGIONAL ELECTIONS THE FIS WON CRUSHING VICTORIES DUE, IN PART TO FACTOR WHICH WENT BEYOND ITS POPULARITY WITH VOTERS. THE SYSTEM OF WEIGHTED PROPORT IONAL REPRESENTATION IN MULTIMEMBER CONSTITUENCIES HAD THE EFFECT OF MAGNIFYING FIS VOTES, RATHER THAN THOSE OF THE FLN, WHO HAS, UNTIL THEN, UNCHALLENGED SINCE INDEPENDENCE IN 1962. THE REFORMS SEEKS TO RECTIFY THE IMBALANCE, BUT MANY CLAIM THAT THEY GO TOO FAR IN FAVORING THE RULING FLN.

04357 HIETT, P.

INCREDUL ITY

MIDOLE EAST INTERNATIONAL, (395) (MAR 91), 18

THE REACTION OF PEOPLE' IN NORTH AFRICA' TO THE RAPID EVENTS OF THE GULF WAR WAS CHARACTERIZED BY INCREDUL ITY. THEIR STRIDENT SUPPORT FOR IRAQ AND THEIR CONFIDENCE IN ITS VAUNTED ARMED FORCES DIMINISHED AS THE BAD NEWS FILTERED THROUGH OFFICIAL NEWS SERVICES. AS DEPRESSION SETTLED ACROSS THE REGION, LEADERS OF THE MAGHREB NATIONS MULTIPLIED THEIR APPEALS FOR IRAQ'S LEADERS OF THE MAGHREB NATIONS MULTIPLIES THEIR APPEALS FOR IRAQ'S STEADILY ESCALATING OFFERS TO BE ACCEPTED. TWO MURDERS OF HIGH-PROFILE WESTERNERS IN THE REGION ALSO RAISED THE POSSIBILITY THAT ARAB NATIONALISTS MIGHT HAVE BEEN TAKEN REVENGE ON THE HEST.

04358 HIETT, P

MAURITANIA--ON COURSE FOR DEMOCRACY?

MIDOLE EAST INTERNATIONAL, (405) (JUL 91), 14

MAURITANIA IS NOW ON COURSE FOR MULTI-PARTY GENERAL AND PRESIDENTIAL ELECTIONS FOLLOWING A REFERENDUM HELD ON 12 JULY WHICH THE GOVERMMENT SAID HAD APPROVED A PROPOSED NEH CONSTITUTION BY AN OVERHHELMING MARGIN. BUT FIGURES ANNOUNCED BY INTERIOR MINISTER OULD BABA--A 98 PERCENT "YES" VOTE AND AN 85 PERCENT TURNOUT--AROUSED WIDESPREAD CRITICISM. HOHEVER DUBIOUS. THE ANMOUNCED APPROVAL DOES HERALD AN END HOHEVER DUBIOUS, THE ANNOUNCED APPROVAL DOES HERALD AN END
TO 13 YEARS OF MILITARY RULE IN MAURITANIA, BY FILLING THE TO 13 YEARS OF MILITARY RULE IN MAURITANIA, BY FILLING THE
GAP LEFT WHEN THE MILITARY SUSPENDED THE OLD CONSTITUTION WHEN THEY TOOK POWER.

04359 HIETT, $P$

PRE-ELECTION JOSTLING

MIDOLE EAST INTERNATIONAL, (398) (APR 91), 17-18

ALGERIA'S OVER FORTY POLITICAL PARTIES ARE ENGAGED IN INTENSE JOSTLING FOR POSITION AHEAD OF THE COUNTRY'S FIRSTEVER CONTESTED GENERAL ELECTION, DUE AT THE END OF JUNE 1991. 
THIS HAS CENTERED AROUND THO MAIN THEMES: THREATS OF A BOYCOTT AND MUCH TALK OF COALITIONS AND ALLIANCES. THE BOYCOTT, AND MUCH TALK OF COALITIONS AND ALLIANCES. THE
RULING FLN HAS SQUARED OFF AGAINST THE MAIN OPPOSITION PARTY, THE ISLAMIC SALVATION FRONT (FIS). HOWEVER, MANY GROUPS DECLARE THEIR DISGUST WITH BOTH PARTIES AND ARE DISCUSSING DECLARE THEIR DISGUST WITH BOTH PART IES AND ARE

04360 HIETT, P.

WIND OF CHANGE?

MIDDLE EAST INTERNATIONAL, (398) (APR 91), 18

THE WINDS OF CHANGE THAT HAVE SWEPT THROUGH MUCH OF WEST AFRICA IN RECENT MONTHS SEEM NOW TO HAVE REACHED MAURITANIA, WHERE ON 15 APRIL THE COUNTRY'S LEADER, COLONEL MAWIYA OULD SID'AHMED TAYA, ANNOUNCED IMPORTANT POLITICAL CHANGES AND ORDERED THE IMMEDIATE RELEASE OF A GROUP OF 70 BLACK MAURITANIANS WHO WERE DUE TO STAND TRIAL ACCUSED OF INVOLVEMENT IN AN ALLEGED COUP PLOT LAST YEAR. IN A SPEECH MARKING THE END OF RAMADAN, OULD TAYA SAID HE WOULD HOLD A REFERENDUM BY THE END OF 1991, TO BE FOLLOWED BY FREE GENERAL ELECTIONS. SOME OBSERVERS DOUBT THAT EVEN THESE CONCESSIONS WILL SATISFY THE DETERMINED OPPOSITION.

04361 HIFT, F.

AUSTRIA: LOOKING TOWARDS BRUSSELS

EUROPE, 322 (1) (1992), 24-25.

HITH ALL INDICATIONS POINTING TO AUSTRIA'S JOINING THE EXPANDED EUROPEAN COMMUNITY, PROBABLY IN 1995, SOME PROBLEMS REMAIN. MOST OF THEM ARE INTERNAL AND ARE EXPECTED TO BE REMAIN. MOST OF THEM ARE INTERNAL AND ARE EXPECTED RESOLVED IN LIGHT OF THE E.C. COMMISSION'S FIRM RECOMMENDATION THAT AUSTRIA BE ADMITTED. WHAT EASTERN EURC
IS REALLY LACKING TODAY IS THE CULTURE OF CONFLICT, THE UNDERSTANDING OF HOW TO RESOLVE CONFLICTS. HHAT AUSTRIA WANTS TO BE IS A CATALYST, AN AGENT HHO CAN INTERPRET CERTAIN EUROPEAN SENSITIVITES. WHILE AUSTRIA PRIZES ITS COMING MEMBERSHIP IN THE EUROPEAN COMMUNITY, THE IMPACT IN THE COMMUNITY ITSELF HON'T BE OVERLY SIGNIFICANT.

04362 HIGGINS, T.

RATIONING IN OREGON: NOT THIS WAY

COMMONWEAL, CXIX(16) (SEP 92) 5-6.

THE AUTHOR CRITICIZES OREGON'S PLAN TO CONTROL THE COST

OF MEDICAID BY INITIATING A HEALTH-CARE RATIONING SYSTEM.

04363 HIGGS, R.

ORIGINS OF THE CORPORATE LIBERAL STATE

CRITICAL REVIEW, 5(4) (FAL 92), 475-495.

MARTIN J. SKLAR'S "THE CORPORATE RECONSTRUCTION OF AMERICAN CAPITALISM," A REVISIONIST ACCOUNT OF EARLY ANTITRUST LAW AND THE POLITICAL ECONOMY OF THE PROGRESSIVE ERA, OFFERS A WEALTH OF DETAILED RESEARCH AND A PARTICULARLY YALUABLE REINTERPRETATIOH OF THE JURISPRUDENCE OF ANTITRUST LAH DURING THE PERIOD 1890-1911. HOHEVER, A NEO-MARXIST LAH DURING THE PERIOD 1890-1911. HOHEVER, A NEO-MARXIST FRAMENORK OF ANALYSIS DETRACTS FROM THE WORK AND CAUSES SKLAR TO MISREAD THE VALUABLE EVIDENCE HE HAS COMPILED. BY
MISINTERPRETING STANDARD ECONOMIC MODELS OF MARKET STRUCTURE, MISINTERPRETING STANDARD ECONOMIC MODELS OF MARKET STRUCT
HE INCORRECTLY CONCLUOES THAT LARGE CORPORATIONS COULD "RE INCORRECTL" THE MARKET IF THE GOVERMMENT DID NOT DO SO. BY VIEHING THE POLITICAL ECONOMY AS A COMPREHENSIVELY ANO TIGHTLY INTEGRATED STRUCTURE OF TECHNOLOGIES, PROPERTY RIGHTS, POL ITICAL POWERS, IDEOLOGY, AND SOCIAL CLASSES, HE FAILS TO GIVE DUE HEIGHT TO THE DIVERSITY OF INFLUENTIAL INTERESTS CONTENDING WITHIN THE POLITICAL ECONOMY,

ESPECIALLY WITHIN THE CAPITALIST CLASS, AND SHAPING ITS HISTORICAL TRANSFORMATION.

04364 HILDEBRAND, $D$

THE RESTRUCTUURING PROCESS IN CENTRAL AND EASTERN EUROPE: BUSINESS STRATEGIES FOR EC COMPANIES

WEST EUROPEAN POLITICS, 15(2) (APR 92), 147-159.

THE COMPLETION OF THE EC SINGLE MARKET AND THE OPENING OF CENTRAL AND EASTERN EUROPE CONSTITUTE MAJOR CHANGES IN THE EUROPEAN BUSINESS ENVIRONMENT HHICH CHALLENGE COMPANIES TO DEVELOP NEW BUSINESS STRATEGIES. THE SINGLE MARKET WILL BE ONE MARKETPLACE, BUT CENTRAL AND EASTERN EUROPE HAS TO BE TREATED COMPLETELY DIFFERENTLY, THIS ARTICLE DESCRIBES AND ANALYSES THE OPPORTUNITIES FOR EC COMPANIES. ON THE BASIS OF THIS ANALYSIS A BUSINESS STRATEGY FOR CENTRAL AND EASTERN EUROPE IS OUTLINED.

$04365 \mathrm{HILL}, \mathrm{E}$

THE SAVINGS AND LOAN DEBACLE AND EROSION OF THE DUAL SYSTEM OF BANK REGULATION

PUBLIUS: THE JOURAAL OF FEDERALISM, 21(3) (SUM 91), 27-42. THE CRISIS IN THE BANKING AND THRIFT INDUSTRIES' IS CATALYZING A SHIFT IN THE TRADITIONAL SYSTEM OF DUAL STATEFEDERAL BANK REGULATION TOWARD THE FEDERAL GOVERNMENT AND AWAY FROM THE STATES. EROSION IN THIS SYSTEM HAS BEEN EVIDENT FOR THE PAST DECADE DUE TO ACTIONS OF THE CONGRESS, FEDERAL REGULATORS, AND THE JUDICIARY. THE DUAL SYSTEM HAS TWO SETS OF FLAWS. ONE IS REGULATORY COMPETIIION THAT ENCOURAGES WEAK MONITORING OF FINANCIAL INSTITUTIONS BY STATES. THE OTHER IS CREATED BY THE "MORAL HAZARD" OF THE CURRENT SYSTEM OF FEDERAL DEPOSIT INSURANCE. THERE ARE THO PATHS TO REFORM. ONE IS CONTINUED EROSION OF THE POHER OF
THE STATES. THE ALTERNATIVE IS TO PROVIDE INCENTIVES THAT REINFORCE THE DUAL SYSTEM OF REGULATION AND DETER THE SOURCES OF "MORAL HAZARD."

$04366 \mathrm{HILL}, \mathrm{H}$.

IN BANDA'S IMAGE

AFRICA REPORT, 37(2) (MAR 92), 57-59.

IT IS DIFFICULT TO IMAGINE MALAWI WITHOUT LIFE-PRESIDENT NGWAZI DR. H. KAMUZU BANDA, WHO HAS RULED WITH AN IRON GRIP FOR 30 YEARS. HE CONTROLS VIRTUALLY EVERY ASPECT OF SOCIETY AND MALANIANS HAVE BEEN REDUCED TO A TRANQUILIZED

UNTHINKING STATE. BUT BANDA IS NOW A FRAIL NONAGENARIAN AND MALAWIANS ARE WAITING TO SEE WHAT THE FUTURE WILL BRING.

04367 HILL, H.

THE CYCLE OF DEPENDENCY

AFRICA REPORT, 37(1) ( JAN 92), 45-67,

TV PICTURES OF STARVING CHILDREN IN AFRICA DRAH MILLIONS

OF DOLLARS IN DONATIONS, BUT THESE IMAGES DO NOT REPRESENT A

TRUE PICTURE OF THE IMPACT OF FOOD RELIEF ON THE THIRD WORLD.

THE UNDERLYING REASONS FOR FAMINE, THE MECHANICS OF SUPPLYING AID, AND THE EFFECTS OF FOOD DONATIONS ARE MORE SOMPLICATED THAN THE TELEVISED PICTURES LEAD ONE TO BELIEYE. COMPLICATED THAN THE TELEVISED PICTURES LEAD ONE TO BELIEVE.
FOREIGN FOOD AID OFTEN CAUSES LOCAL FARMERS TO PRODUCE LESS FOREIGN FOOD AID OFTEN CAUSES LOCAL FARM

$04368 \mathrm{HILL}, \mathrm{K}_{\text {. : }}$ LEIGHLEY, J

THE POLICY CONSEQUENCES OF CLASS BIAS IN STATE ELECTORATES AMERICAN JOURNAL OF POLITICAL SCIENCE, 36(2) (MAY 92), $351-365$.

THIS PAPER TESTS THE PROPOSITION THAT AN ELECTORATE DISPROPORTIONATELY REPRESENTATIVE OF HIGHER-CLASS CITIZENS WILL BE REWARDED WITH PUBLIC POLICIES IN FAVOR OF ITS ECONOMIC INTERESTS AND AT THE EXPENSE OF THE INTERESTS OF LOWER-CLASS CITIZENS. THE AUTHORS FIND A CONSISTENT NEGATIVE RELATIONSHIP BETWEEN THE DEGREE OF CLASS BIAS FAVORING THE UPPER CLASS AND THE GENEROSITY OF INDIGENOUS STATE SOCIAL HELFARE SPENDING. THEY ALSO FIND THAT IT IS THE UNDERREPRESENTATION OF THE POOR, RATHER THAM THE OVERREPRESENTATION OF THE WEALTHY, THAT PRINCIPALLY EXPLAINS THIS RELATIONSHIP. THESE FINDINGS HAVE IMPORTANT IMPLICATIONS FOR DEMOCRATIC THEORY GENERALLY AND FOR PRESENTDAY CONCERN ABOUT THE COMPOSITION OF THE U.S. ELECTORATE.

04369 HILL, L.B. (ED.)

THE STATE OF PUBLIC BUREAUCRACY

M. E. SHARPE, 1992,240

AN EFFORT' TO REDEFINE THE FIELD OF PUBLIC ADMINISTRATION AND FOCUS ON THE POLITICAL RATHER THAN THE MANAGEMENT SIDE OF BUREAUCRACY, THIS BOOK CONCENTRATES ON THE UNIQUE PUBLIC SECTOR ASPECTS' OF GOVERNMENTAL ORGANIZATIONS. IN SO DOING. ITCTOR ASPECTS OF GOVERNMENTAL ORGANIZATIONS. IN SO DOING, IT INTEGRATES PUBLIC ADMINISTRATION WITH THE GREAT TRADITION AFFECT PUBLIC POLICY. IT CONSIDERS BOTH THE CURRENT AND AFFECT PUBLIC POLICY. IT CONSIDERS

04370 HILL, R.J.

COMMUNIST POLITICS: AN EVOLUTIONARY APPROACH

JOURNAL OF COMMUNIST STUDIES, 8(1) (MAR 92), 3-22

THE CONCEPT OF EVOLUTION, DESPITE OBVIOUS LIMITATIONS OFFERS INSIGHTS INTO DEVELOPMENTAL PROCESSES WITHIN RULING COMMUNISH AND FROM COMMUNISM. A NEW AND EVIDENTLY VIGOROUS TYPE OF POLITICAL SYSTEM HAS RAPIDLY COLLAPSED, TO BE REPLACED EVENTUALLY BY MULTI-PARTY DEMOCRACY. A SYSTEM WHOSE CENTRAL GOAL WAS INDUCED EVOLUTION TOWARD A UTOPIAN SOCIETY DISPLAYED LIMITED CAPACITY FOR ADAPTATION TO CHANGING NEEDS FOLLOWING THE DEATH OF STALIN, MODIFICATIONS TO THE SYSTEM PERMITTED THE EVOLUTION OF DIFFERENT STRAINS OF COMMUNISM, WITHOUT CHANGING THE FUNDAMENTAL CHARACTERISTICS OF THE SPECIES. IN THE 1980'S, THE SYSTEM DEMONSTRATED ITS INABILITY TO ADOPT SURVIVAL MECHANISHS IN A SOCIETY THAT PRESENTED CHALLENGES AND PRESSURES VERY DIFFERENT FROM THOSE THAT SUGGESTED VIABILITY IN THE 1930'S AND LATER. AFTER THE COLLAPSE AND NEAR-EXTINCTION OF COMMUNISM IN POWER, THOSE SOCIETIES ENTERED A NEW STAGE IN THEIR POLITICAL EVOLUTION, IN WHICH SOME "GENETIC MATERIAL" HAS BEEN TRANSFERRED, THROUGH POLITICAL CULTURE, FROM THE COMMUNIST REGIME.

$04371 \mathrm{HILL}, \mathrm{W} . \mathrm{JR}$

DETERMINISTIC QUASI-PERIODIC BEHAVIOR OF AN ARMS RACE MODEL CONFLICT MANAGEMENT AND PEACE SCIENCE, 12(1) (WIN 92), 79-98.

THREE SUCCESSIVE MODELS OF INCREASING COMPLEXITY ARE PROPOSED IN RESPONSE TO SOME STANDARD OBJECTIONS TO LINEAR TWO-NATION ARMS RACE MODELS. THE BEHAVIOR OF THE NATIONS IN TWO-NATION ARMS RACE MODELS. THE BEHAVIOR OF THE NATIONS IN ARMS RACE MODELS MAY BE MORE COMPLEX. FOR LARGE PARAMETER VALUES THE ABILITY OF DECISION MAKERS TO DIAGNOSE, MANAGE, AND CONTROL THE RACE MAY BE DIFFICULT. FURTHERMORE, GIVEN THAT UNPREDICTABILTIY IS SOMETIMES ASSOCIATED WITH THE OUTBREAK OF WAR, THIS MODEL SUGGESTS A SITUATION IN WHICH WAR CAN OCCUR WITHOUR EXPONENTIALLY INCREASING ARMAMENT. 
04372 HILLMAN, A.L.

INTERNATIONAL TRADE POLICY IN ISRAEL: ANOTHER MODEL PUBLIC CHOICE, 74(3) (OCT 92), 355-360.

THE HISTADRUT, A NON-STATE WORKERS' COLLECTIVE, HAS PLAYED A LEADING ROLE IN INFLUENCING THE MANNER OF ORGANIZATION AND THE STRUCTURE OF THE ISRAELI ECONOMY. IN THIS PAPER, THE AUTHOR PROPOSES A MODEL OF ISRAELI PROTECTIONISM THAT IS CONSISTENT WITH THE SPECIAL
INSTITUTIONAL ENVIRONMENT OF THE ISRAELI ECONOMY AS REFLECTED IN THE CENTRAL ROLE OF THE HISTADRUT.

04373 HILLMAN, $M$.

RECONCILING TRANSPORT AND ENVIRONMENTAL POLICY OBJECTIVES: THE WAY AHEAD AT THE END OF THE ROAD

PUBLIC ADMINISTRATION (LONDON), 70 (2) (SUM 92), 225-234.

TRANSPORTATION IS A MAJOR SECTOR OF THE BRITISH ECONOMY. A WIDE RANGE OF CONFL ICTS MUST BE CONFRONTED IN THE PROCESS OF ENABLING THE DEMAND FOR FOSSIL FUEL-BASED TRANSPORT (ROAD, OF ENABLING THE DEMAND FOR FOSSIL FUEL-BASED TRANSPORT (ROAD
RAIL, AND AIR) TO CONTINUE INCREASING WHILE AT THE SAME RAIL, AND AIR) TO CONTINUE INCREASING WHILE AT THE SAME TIME IMPROVING ENVIRONMENTAL QUALITY. IN THE LAST TWO
DECADES, SUCCESSIVE GOVERMMENTS HAVE ATTEMPTED TO STRIKE THE DECADES, SUCCESSIVE GOVERNMENTS HAVE ATTEMPTED TO STRIKE THE RIGHT BALANCE BETWEEN A STRATEGY OF INVESTMENT TO MEET THAT
DEMAND AND A STRATEGY TO MINIMIZE THE WIDE-RANGING ADVERSE CONSEQUENCES OF DOING SO.

04374 HILTERMANM, J.

CALCULATING "COLlateral DAMAGE"

MIDOLE EAST REPORT, 21(2) (MAR 91), 3.

THE U.S. IS MAKING N INFORMATION AVAILABLE ON IRAQI OR KUWAITI CIYILIAN CASUALTIES. BOTH WASHINGTON AND BAGHDAD HAVE AN INTEREST IN PLAYING DOWN CASUALTIES. THE U.S. WANTS TARGETS. WHILE SCATTERED REPORTS FROM REFUGEES DO NOT SUPPORT THE CLAIMS BY SOME OPPONENTS OF THE WAR THAT CASUALTIES HAVE BEEN IN THE TENS AND HUNDREDS OF THOUSANDS IN THE FIRST WEEKS OF THE WAR. IT SEEMS CLEAR THAT NEARLY ALL OF IRAQ'S CITIZENS ARE SUFFERING FROM LACK OF BASIC SERVICES AND FOOD, IF NOT FROM OUTRIGHT BOMBING.

04375 HILTERMANM, J.R.

BEHIND THE INTIFADA--LABOR AND WOMEN'S MOVEMENTS IN THE BEHIND THE INTIFADA--

PRINCETON UNIVERSITY PRESS, 1992, 283

BEFORE THE INTIFADA BEGAN, THE AUTHOR OF THIS WORK HAD ALREADY LOOKED AT LOCAL ORGANIZATIONS IN THE ISRAELIOCCUPIED WEST BANK AND GAZA STRIP AND OBSERVED THERE THE
MAIN ELEMENTS THAT WOULD EVENTUALLY BE USED TO MOBILIZE THE PALESTINIAN MASSES. IN THE FIRST COMPREHENSIVE STUDY OF THESE ORGANIZATIONS, THE AUTHOR SHOWS HOW LOCAL ORGANIZERS PROVIDED BASIC SERVICES UNAVAILABLE UNDER MILITARY RULE, WHILE RECRUITING FOR THE CAUSE OF PALESTINIAN NATIONALISM. AS PRE-EXISTING GRASS ROOTS ORGANIZATIONS WERE TRANSFO AND NEW DNES HERE ESTABLISHED, ACTIVISTS CREATED AN OCCUPATION. THE AUTHOR EXPLAINS THAT THE LEADERS OF LOCAL ORGANIZATIONS, ELECTED BY DEMOCRATIC PROCESS, BECAME DE FACTO LEADERS OF THE "INSIDE" WING OF THE PALESTINIAN NATIONAL MOVEMENT, INCREASINGLY TAKING THE INITIATIVE FROM THE "OUTSIDE" WING. EMPHASIZING THE ROLE OF WOMEN AND WORKERS AND DRAHING ON EXTENSIVE FIELDWORK PERFORMED IN THE OCCUPIED TERRITORIES BETHEEN 1985 AND 1990. THE AUTHOR ARGUES THAT IT WAS THE ORGANIZATION AND MOBILIZATION OF THE PALESTINIAN MASSES IN THE 1970 S AND 1980 S THAT MADE POSSIBLE THE SUSTAINED POPULAR INSURRECTION BEGINNING IN DECEMBER 1987.

04376 HINDELL, K.

REFORM OF THE UNITED NATIONS?

WORLD TODAY, 48(2) (FEB 92 ), 30-33.

THE END OF THE COLD WAR HAS OPENED UP MANY POSSIBILITIES FOR CHANGE IN THE UNITED NATIONS AND FOR DEALING WITH PROBLEMS THAT ARE SUSCEPTIBLE ONLY TO INTERNATIONAL SOLUTIONS--SUCH AS POLLUTION AND CLIMATE CHANGE. DESPITE THE UN'S GOOD SHOWING DURING THE GULF WAR, ITS RECORD OVER THE YEARS SUGGESTS THAT IT WILL NEED MAJOR RECONSTRUCTION TO YEARS SUGGESTS THAT IT WILL NEED MAJOR RECONSTRUCTION TO
COPE WITH THE 21 TS CENTURY. THE ARRIVAL OF ITS NEW SECRETARYCOPE WITH THE 21ST CENTURY. THE ARRIVAL OF ITS NEW SECRETARY
GENERAL AND THE ANTICIPATION OF ITS 5OTH ANNIVERSARY IN 1995 GENERAL AND THE ANTICIPATION OF ITS 5OTH ANNIVERSARY
COULD GENERATE THE RIGHT ATMOSPHERE FOR THE NECESSARY REFORMS.

04377 HINDESS, B.

POWER AND RATIONALITY: THE HESTERN CONCEPT OF POLITICAL COMHUNITY

ALTERNATIYES, $17(2)$ (SPR 92), 149-164.

SOME OF THE MOST INTERESTING CONNECTIONS BETWEEN REASON AND IMAGINATION IN WESTERM POLITICAL THOUGHT CAN BE FOUND IN THE CONCEPTUALIZATION OF POWER AND OF THE POLITICAL COMMUNITY. AFTER A SHORT DISCUSSION OF THE QUANTITATIVE UNDERSTANDING OF POWER, THE FIRST PART OF THIS PAPER EXAMINES THE IDEA OF SOVEREIGN POWER AND RELATED UNDERSTANDINGS OF POWER THAT HAVE BEEN ELABORATED IN TERMS OF THE CONCEPTUALIZATION OF IMAGINARY COMMUNITIES OF AUTONOMOUS, RATIONAL INDIVIDUALS. THE SECOND PART BEGINS BY NOTING THAT THE CONCEPTUALIZATION OF A POLITICAL COMMUNITY
IN THESE TERMS IS RADICALLY INCOMPLETE. IT CONCLUDES WITH SOME REFLECTIONS ON THE RELATIONS BETWEEN RATIONALISTIC AND OTHER DETERMINATIONS OF THE POLITICAL COMMUNITY IN WESTERN POLITICAL THOUGHT.

04378 HINE, D.

THE ITALIAN GENERAL ELECTION OF 1992

ELECTORAL STUDIES, 11(4) (DEC 92), 362-367.

THE AUTHOR DISCUSSES THE CAMPAIGH LEADING UP TO ITALY'S 1992 GENERAL ELECTIONS AND SUMMARIZES THE RESULTS OF THOSE ELECTIONS.

04379 HINE, H.

THE BLACK STUDIES MOVEMENT: AFROCENTRIC-TRADITIONALISTFEMINIST PARADIGMS FOR THE NEXT STAGE

BLACK SCHOLAR, $22(3)$ (SUM 92), 11-19.

INASMUCH AS SUFFICIENT TIMÉ HAS PASSED SINCE THE MODERN INCARNATION OF BLACK STUDIES AS AN INTELLECTUAL MOVEMENT, THE AUTHOR ASKS WHAT WE ARE TO MAKE OF ITS ACCOMPLI SHEMENTS, CONTRIBUTIONS AND SHORTCOMINGS. THIS ESSAY IS AN EXERCISE IN BLACK INTELLECTUAL HISTORY OF BOTH THE MOVEMENT OF BLACK STUDIES AND THE IDEA OF BLACK STUDIES. IT ARGUES THAT THE TORTURED BIRTH OF BLACK STUDIES HAS LONG AFFECTED HOW THIS NEWEST OF THE ACADEMIC DISCIPLINES HAS BEEN PERCEIVED AND EVALUATED. THE AUTHOR IS MUCH ENCOURAGED BY THE NUMBER O SCHOLARLY WORKS THAT HAVE APPEARED IN THE PAST DECADE CHRONICLING THE HISTORICAL AND LITERARY EXPERIENCES AND CONTRIBUTIONS OF BLACK HOMEN. SHE CDNCLUDES THAT THE LONGRANGE CONSEQUENCES OF THE CONTEMPORARY PHASE OF THE STRUGGLE PIVOTS ON THE THEORETICAL COHERENCE OF THE FIELD, THE EXTENT TO WHICH AFROCENTRISM WINS CONYERTS AND GAINS CURRENCY, AND HOW THE ENTIRE BLACK STUDIES MOVEMENTS RESPONDS TO THE BLACK FEMINIST CALL FOR GENDERING.

04380 HINICH, M.J.; MUNGER, M.C.

A SPATIAL THEORY OF IDEOLOGY

JOURNAL OF THEORETICAL POLITICS, 4(1) (JAN 92), 5-30.

IN THE SPATIAL MODEL OF POLITICS, VOTERS CHOOSE THE CANDIDATES CLOSEST TO THEM IN WEIGHTED EUCLIDEAN DISTANCE, AND CANDIDATES SEEK TO COMPETE BY POSITIONING AND REPOSITIONING THEMSELVES IN AN M-DIMENSIONAL POLICY SPACE. THIS MODEL HAS RECENTLY COME UNDER ATTACK IN A NUMBER OF SCHOLARLY CRITIQUES THAT ASSERT ITS DEPICTION OF POLITICS IS SCHOLARLY CRITIQUES THAT ASSERT ITS DEPICTION OF POLITICS UNREALISTIC BUT NEVERTHELESS RETAIN THE CHARACTER OF THE
ORIGINAL MODEL. IN THIS PAPER. THE AUTHORS OFFER A MORE RADICAL ALTERNATIVE: AN EXPLICITLY NEO-DOWNSIAN SPATIAL MODEL OF IDEOLOGY SPECIFYING THE LINKAGE BETWEEN IDEOLOGICAL MESSAGES AND POLICY POSITIONS. AFTER INDICATING THE MESSAGES AND POLICY POSITIONS. AFTER INDICATING THE
IMPORTANCE OF IDEOLOGY AS A THEORY, A FORMAL DEPICTION IS OFFERED AND AN ILLUSTRATIVE EMPIRICAL APPLICATION IS OFFERED AND
PROYIDED.

04381 HINKSON, J.

MISREADING THE DEEPER CURRENT: THE LIMITS OF ECONOMIC RATIONALITY

ARENA, 98 (1992), 112-134.

ECONOMIC RATIONALITY EMERGES AS A STRATEGY OF MONETARY CONTROL CALLED MONETARISM, AND HAS BECOME THE CENTRAL POLITICAL CONCEPT OF THE LAST DECADE IN AUSTRAILIA. THIS ARTICLE ARGUES THAT THE ATTRACTION OF ECONOMIC RATIONALITY IN RECENT TIMES HAS BEEN GENERATED OUT OF NOVEL AND DEEPGOING MATERIAL DEVELOPMENTS. AS A FIRST STAGE OF ANALYSIS, A NUMBER OF CLUES ABOUT THIS CHANGE IS GLEANED FROM CONTEMPORARY POLITICAL RHETORIC. IT IS ALSO ARGUED THAT THE CHAHGE IS SO PROFOUND THAT A NEH QUESTION MOVES INTO THE FOREGROUND: HAS THE FAMILIAR MARKET OF MODERNITY BEEN SUPERCEDED? ECONOMIC RATIONALITY IS RETHOUGHT AND EXPLORED THROUGH HAWKE'S AND KEATING'S INTERPRETATIONS. THE JOHN HEWSON "FIGHTING BACK" IS EVALUATED. THE ARTICLE CONCLUDES EMERGE FROM A THEORY OF THE PROCESSES WHICH GEMERATED IT.

04382 HIRCH, A.

INHARD FOREIGN INVESTMENT IN A POST-APARTHEID SA--SOME POLICY CONSIDERATIONS

SOUTH AFRICA INTERNATIONAL, 23(1) (JUL 92), 26-38.

THE ISSUE OF FOREIGN INYESTMENT REMAINS A POLITICIZED

ISSUE IN SOUTH AFRICA. THE FOCUS OF THIS ARTICLE IS OM DIRECT FOREIGN INVESTMENT, HOW IT CAN ASSIST THE SOUTH AFRICAN ECONOMY, AND HOW BEST TO ATTRACT IT. THE PROSPECTS FOR DIRECT FOREIGN INVESTMENT ARE ASSESSED, AND ALSO, THE ISSUE OF COMPETIO
AFRICAN STATES

04383 HIRLINGER, M.

CITIZEN-INIATED CONTACTIMG OF LOCAL GOVERNMENT OFFICIALS: A MULTIVARIATE EXPLAMATIOM

THE JOURNAL OF POLITICS, 54 (2) (MAY 92), 553-564.

CITIZEN-INITIATED CONTACTING OF LOCAL GOVERNMENT OFFICIALS REPRESENTS A SIGNIFICANT MODE OF POLITICAL PARTICIPATION IN AN URBAN CONTEXT. THIS RESEARCH POSITS THAT DIFFERENT TYPES OF CONTACTING BEHAVIOR ARE SUBJECT TO DIFFERENT EXPLANATORY MODELS. BY FOCUSING ON PARTICULARIZED AND GENERAL REFERENT CONTACTING AS THO SEPARATE ENTITIES, 
SEVERAL VARIATIONS EXIST. IN GENERAL, THE ANALYSIS SHOWS THAT PARTICULARIZED REFERENT CONTACTING IS BEST EXPLAINED BY AN INTERACTION EFFECT BETWEEN AN INDIVIDUAL'S PERCEIVED MOST SIGNIFICANT PREDICTOR OF GENERAL REFERENT CONTACTING.

04384 HIRSCH, M. LUXEMBOURG

EUROPEAN JOURNAL OF POLITICAL RESEARCH, 22(4) (DEC 92), 469-470.

THE AUTHOR LISTS THE MEMBERS OF PRIME MINISTER JACQUES SANTER'S CABINET AS OF JANUARY 1, 1991. HE ALSO OUTLINES THE MAJOR DOMESTIC ISSUES FACING THE SANTER GOVERNMENT.

04385 HIRSCHFELD, T. BUILDING CONFIDENCE IN KOREA: THE ARMS CONTROL DIMENSION KOREAN JOURNAL OF DEFENSE ANALYSIS, IV(1) (SUM 92), 23-56. SINCE UNIFICATION BECAME A DECLARED POLICY OF BOTH KOREAS, EACH HAS PUBLICLY ESPOUSED ARMS-CONTROL AND MILITARY CONFIDENCE-BUILDING MEASURES. ALTHOUGH BOTH HAVE NOW AGREED ON WHAT SORT OF MEASURES MIGHT BE USEFUL, SIGNIFICANT ON WHAT SORT OF MEASURES MIGHT BE USEFUL, SIGNIFICANT
FURTHER PROGRESS STILL DEPENDS ON PROMPT ANO SUFFICIENT FURTHER PROGRESS STILL DEPENDS ON PROMPT ANO SUFFICIENT
EVIDENCE THAT THE SUSPECTED NUCLEAR WEAPONS PROGRAM HAS EVIDENCE THAT THE SUSPECTED NUCLEAR WEAPONS PROGRAM HAS
ENDED. AGAINST THAT BACKGROUND, THIS ARTICLE SUGGESTS HOW ENDED. AGAINST THAT BACKGROUND, THIS ARTICLE SUGGESTS HOW
THE KOREAN PARTIES MIGHT PROCEED TO "DISCUSS AND CARRY OUT STEPS TO BUILD MILIRARY CONFIDENCE AND CARRY DUT ARMS STEPS TO BUILD MILIRARY CONFIDENCE AND CARRY OUT ARMS
REDUCT IONS" AS REOUIRED BY THE RECONCILIATION AGREEMENT AND REDUCTIIONS" AS REQUIRED BY THE RECONCILIATION AGREEMENT AND
DENUCLEARIZATION AGREEMENT DRAWING ON THE DECLARED POSITIONS DENUCLEARIZATION AGREEMENT DRAKING ON THE DECLARED POSIT

04386 HIRSHLEIFER, J.; RASHUSEN, E. ARE EQUILIBRIUM STRATEGIES UNAFFECTED BY INCENTIVES? JOURNAL OF THEORETICAL POLITICS, 4(3) (JUL 92), 353-367. IN A MIXED-STRATEGY NASH EQUILIBRIUM, CHANGING ONE PLAYER'S PAY-OFFS AFFECTS ONLY THE OTHER PLAYER'S EQUILIBRIUM STRATEGY MIX. THIS PAY-OFF IRRELEVANCE PROPOSITION (PIP) APPEARS TO UNDERCUT THE MAIN FOUNDATIONS OF ECONOMIC POLICY ANALYSIS SINCE, ALLEGEDLY, EQUILIBRIUM BEHAVIOR WILL NOT RESPOND TO CHANGES IN INCENTIVES. HOWEVER, THE AUTHORS SHOW THAT: (1) WHEN THE POLICY MAKER HAS THE FIRST MOVE IN A SEQUENTIAL-MOVE GAME, PIP DOES NOT HOLD; ( 2 EVEN IN A SIMULTANEOUS MOVE GAME, PIP HOLDS ONLY WHEN THE POLICY SPACE IS OISCRETE AND FOR SUFFICIENTLY SMALL PAY-OFF REVISIONS. THUS, INCENTIVES DO AFFECT BEHAVIOR IN EQUILIBRIUM.

04387 HIXSON, W.B. JR.

SEARCH FOR THE AMERICAN RIGHT WING--AN ANALYSIS OF THE SEARCH FOR THE AMERICAN RIGHT WING
SOCIAL SCIENCE RECORD, $1955-1987$

PRINCETON UNIVERSITY PRESS, 1992,392

THIS BOOK IS A SYNTHESIS OF THE PUBLISHED SCHOLARLY RESEARCH ON THE CONTEMPORARY AMERICAN RIGHT FROM THE RISE OF SENATOR JOE MCCARTHY TO THE ELECTION OF RONALD REAGAN AS PRESIDENT. THE AUTHOR FOCUSES ON THE WAY THE CONCEPTS OF INDIVIDUAL RESEARCHERS HAVE INTERACTED WITH ACCUMULATING EVIDENCE ON THE AMERICAN RIGHT, AND HOW THIS EVIDENCE HAS LED TO NEH AND MORE COMPREHENSIVE THEORIES. THE AUTH SUMMARIZES AND EVALUATES THE RESEARCH ON THE MAJOR
DEVELOPMENTS ANALYZED BY SCHOLARS-THE SOCIAL SOURCES OF "MCCARTHYISM," THE "RADICAL RIGHT" OF THE EARLY 1960S, GEORGE WALLACE'S CONSTITUENCY IN HIS PRESIDENTIAL CAMPAIGNS, AND THE EMERGING "NEW RIGHT" OF THE LATE 1970S. HE THEN COMPARES THE INTERPRETATIONS OF THE TWO MOST INFLUENTIAL STUDENTS OF THE RIGHT WING, SEYMOUR MARTIN LIPSET AND MICHAEL PAUL ROGIN. FINALLY, HE OFFERS HIS OWN EXPLANATIONS, SUGGESTING THAT THE RIGHT WING IS BOTH A MASS AND ELITE PHENOMENON, THAT ITS DURABILITY COMES FROM ITS APPEAL TO THE UPHARDLY MOBILE, ESPECIALLY IN ECONOMICALLY EXPANDING REGIONS, AND THAT FAR FROM BEING EITHER "TRADITIONALIST" OR REACTIVE, IT REPRESENTS A PROACTIVE DEFENSE OF VALUES

04388 HO, L.S.

RENT CONTROL: ITS RATIONALE AND EFFECTS

URBAN STUDIES, 29(7) (OCT 92) 1883-1190.

THE AUTHOR DISCUSSES THE RATIONALE BEHIND RENT CONTROL AND ANALYZES ITS EFFECTS, USING A CAPITAL THEORY FRAMEWORK IN COMBINATION WITH TRADITIONAL BID RENT ANALYSIS. HE FINDS THAT RECENT EXPERIENCE IN HONG KONG AND ONTARIO SUPPORTS HIS HYPOTHESIS THAT RENT CONTROL IS A SUBSTITUTE FOR PUBLIC SPENDING ON HOUSING AND. THEREFORE, IS POPULAR AMONG GOVERMMENTS WITH FISCAL CONSTRAINTS. THE THEORETICAL GOVERMMENTS WITH FISCAL CONSTRAINTS. THE THEORETICAL DISCUSSION CONFIRMS EARLIER FINDINGS AND PROVIDES ADDITIONA BEEN OBSERVED ON QUALITY AND MAINTENANCE.

04389 HOBBS, C.; HAINES, G.; LEE, I IMPLEMENTING MULTICULTURAL POLIICY: AN ANALYSIS OF THE HERITAGE LANGUAGE PROGRAM, 1971-1981

CANADIAN PUBLIC ADMINISTRATION, 34(4) (WIN 91), 664-675.

DURING THE PAST 20 YEARS, THE CANADIAN GOVERNMENT HAS BECOME MORE CONCERMED HITH MULTICULTURAL ISSUES DUE TO INCREASED IMMIGRATION FROM NON-ENGLISH AND NON-FRENCH SPEAKING COUNTRIES. ONE AREA OF CONCERM HAS BEEN THE
RETENTION OF ETHNIC, OR HERITAGE, LANGUAGES BY NEW CANADIANS. DESPITE THE GOVERNMENT'S HERITAGE LANGUAGE PROGRAM, THE PREPONDERANCE OF PREVIOUS RESEARCH SHOWS A TREND TO INCREASING LINGUISTIC ASSIMILATION TO ENGLISH OR FRENCH. THIS PAPER ATTEMPTS TO CONFIRM OR INVALIDATE THIS PAST RESEARCH BY USING RECENT CENSUS DATA, SEPARATING IT INTO NATIONAL AND PROVINCIAL COMPONENTS BASED ON MOTHER TONGUE AND THE LANGUAGE MOST OFTEN USED IN THE HOME. BY COMPARING THE LINGUISTIC SITUATION IN 1971 WITH THE 1981 DATA, IT IS POSSIBLE TO IDENTIFY THE CHANGES OVER THAT PERIDD AND ASSESS THE EFFECT OF GOVERMMENT POLICY.

04390 HOBERG, G.

SLEEPING WITH AN ELEPHANT: THE AMERICAN INFLUENCE ON CANADIAN ENVIROMMENTAL REGULATION

JOURNAL OF PUBLIC POLICY, 2(1) (JAN 91), 107-132.

THIS ARTICLE ANALYZES THE AMERICAN INFLUENCE ON CANADIAN ENVIRONMENTAL REGULATION IN ORDER TO SHOW THE INTERNATIONAL SOURCES OF DOMESTIC PUBLIC POLICY, ESPECIALLY THE MANNER IN WHICH CANADIAN POLICY DEVELOPMENT IS INFLUENCED BY THE UNITED STATES, AND THE SPECIFIC DYNAMICS OF CANADIAN REGULATORY POLICY. THE UNITED STATES INFLUENCES CANADIAN DOMESTIC PUBLIC POLICY BY THE EXPORT OF COSTS AND THE EXPORT OF KNOWLEDGE. AN ANALYSIS OF MAJOR DEVELOPMENTS IN THE AREAS OF KNOWLEDGE. AN ANALYSIS OF MAJOR DEVELOPMENTS IN THE
OF AIR POLLUTION, WATER POLLUTION, PESTICIDES, TOXIC OF AIR POLLUTION, WATER POLLUTION, PESTICIDES, TOXIC SUBSTANCE REGULATION, AND ENVIRONMENTAL IMPACT ASS ENVIRONMENTAL REGULATION IS PERVASIVE. THE MOST FREQUENT ENVIRONMENTAL REGULATION IS PERVASIVE. THE MOST FREQUENT
PATTERN IS EMULATION, WHERE VALUE CONVERGENCE COMBINED WITH PATTERN IS EMULATION, WHERE VALUE CONVERGENCE COMBINED WITH U.S. LEADERSHIP LEADS TO CANADIAN BORROWING OF U.S. POLICY
INNOVATIONS. THIS PROCESS CAN BE EITHER ELITE-ORIVEN OR INNOVATIONS. THIS PROCESS CAN BE EITHER ELITE-DRIVEN OR ACTIVIST-DRIVEN, THE LATTER BEING CHARACTERIZED BY AN
ENLARGED SCOPE OF CONFLICT, MEDIA EXPOSURE, AND PRESSURE CAMPAIGNS ON POLICYMAKERS.

04391 HOBSBAWM, E.

THE CRISIS OF TODAY'S IDEOLOGIES

NEW LEFT REVIEW, (192) (MAR 92), 55-64.

TODAY'S IDEOLOGICAL DISARRAY IS GENERALIZED BECAUSE IT HAS ITS ROOTS IN A WORLD THAT IS CHANGING MORE RAPIDLY AND BEWILDERINGLY THAN EVER BEFORE. THE DIFFERENCE BETWEEN LIBERALS AND SOCIALISTS TOOAY LIES AS MUCH IN A DIFFERENT ESTIMATE OF THE PROPENSITIES OF CAPITALISM AS IN A READINESS TO ADVOCATE DEMOCRATIC PUBLIC INTERVENTION. CAPITALISM IS NOT AMENABLE TO THE SORTS OF SOCIAL CONTROL THAT ARE REQUIRED TO MEET THE THREATS OF GRONING WORLD INEQUALITY AND ECOLOGICAL DEVASTATION. IF THE NECESSARY PUBLIC PLANNING IS MOT UNDERTAKEN BY THOSE WHO BELIEVE IN THE VALUES OF FREEDOM, REASON, AND CIVILIZATION, THEN IT WILL BE TAKEN BY REASON, AND CIVILIZATION, THEN IT WILL BE TAKEN BY
INTERVENTIONIST REGIMES OF THE NATIONALIST RIGHT BECAUSE INTERVENTIONIST REGIMES OF THE NATIONALIST RIGHT BECAUSE
THERE WILL BE A WIDESPREAD DEMAND FOR GOVERNMENT TO DO THERE WILL BE A WIDESPREAD DEMAND FOR GOVERNMENT TO DO
SOMETHING TO TACKLE THE MANIFEST CONTRADICTIONS OF RAPACIOUS SOMETHING TO TACKLE THE MANIFEST CONTRADICTIONS OF RAPAC
WESTERN CAPITALIST CONSUMERISM AND BEGGAR-MY-NEIGHBOR WESTERN CAPI
COMPETITION.

04392 HOCXETT,

JUSTICES FRANKFURTER AND BLACK: SOCIAL THEORY AND CONSTITUTIONAL INTER

POLITICAL SCIENCE, 107 (3) (FAL 92), 479-500.

AS ACTIVE PARTICIPANTS IN THE NEW DEAL, HUGO BLACK AND FELIX FRANKFURTER ADVOCATED A LIMITED ROLE FOR THE JUDICIARY IN SUPERVISING THE ECONOMIC POLICIES OF ACCOUNTABLE OFFICIALS, THE ARTICLE EXAMINES THE UNDERPINNINGS OF THE JUDICIAL PHILOSOPHIES OF THESE MEN AND DEMONSTRATES THAT THE JUSTICE'S ROLE ORIENTATIONS WERE PREDICATED UPON DIFFERING PERCEPTIONS OF SOCIAL REALITY - PERCEPTIONS DRAWN FROM DIVERGENT SOCIAL CIRCUMSTANCES AND IDEOLOGIES OF VARIOUS POLITICAL AND INTELLECTUAL RESPONSES TO THE AMERICAN INDUSTRIAL TRANSFORMATION.

04393 HODDER-WILLIAMS, R.

SIX NOTIONS OF 'POLIITICAL' AND THE UNITED STATES SUPREME COURT

BRITISH JOURNAL OF POLITICAL SCIENCE, 22(1) (JAN 92), 1-20. THE FOLLOWING SIX NOTIONS OF "POLITICAL" ARE COMMONLY USED IN DISCUSSIONS OF THE U.S. SUPREME COURT: (1) PURELY DEFINITIONAL, IN THE SENSE THAT THE SUPREME COURT, AS AN APPELLATE COURT OF LAST RESORT INEVITABLY AUTHORITATIVELY ALLOCATES VALUES; (2) EMPIRICAL, IN THE SENSE THAT LITIGANTS USE THE COURT TO TRY TO ACHIEVE THEIR OWN POLITICAL PURPOSES (3) INFLUENCE-SEEKING, IN THE SENSE THAT THE JUSTICES HAVE A NATURAL DESIRE TO PREVAIL IN ARGUMENTS WITHIN THE COURT: (4) PRUDENTIAL, IN THE SENSE THAT THE JUSTICES FREQUENTLY
CONSIDER THE PROBABLE CONSEQUENCES OF THEIR DECISIONS; (5) CONSIDER THE PROBABLE CONSEQUENCES OF THEIR DECISIONS; (5)
POLICY-ORIENTED, IN THE SENSE THAT JUSTICES ARE SAID TO USE POLICY-ORIENTED, IN THE SENSE THAT JUSTICES ARE SAID TO USE
THE COURT AND THE LAW AS A COVER FOR PURSUING THEIR OWN THE COURT AND THE LAW AS A COVER FOR PURSUING THEIR OWN
POLICY GOALS: AND (6) SYSTEMIC, IN THE SENSE THAT THE POLICY GOALS; AND (6) SYSTEMIC, IN THE SENSE THAT THE COURT'S DECISIONS FREQUENTLY HAVE CONSEQUENCES FOR OTHER
PARTS OF THE AMERICAN POLITICAL SYSTEM. THIS PAPER CONSIDERS PARTS OF THE AMERICAN POL ITICAL SYSTEM. THIS PAPER
THESE SIX NOTIONS IN THE CONTEXT OF RECENT ABORTION DECISIONS.

04394 HODESS, $R$

GERMANY'S TREUHANDANSTALDT 
EUROPE, 321(321) (

AN ENTERPRISE HAS BEEN SET UP IN GERMANY WITH THE AIM OF PUTTING ITSELF OUT OF BUSINESS IN LESS THAN FIVE YEARS. THIS ENTERPRISE IS THE TREUHANDANSTALT (THA), THE AGENCY IN CHARGE OF PRIVATIZING BUSINESS AND REAL ESTATE IN THE FORMER EAST GERMANY. WITH ITS UNIQUE MISSION, THA HAS THE TRICXY TASK OF TRANSFORMING A REGION WHOSE ECONOMY IS PLAGUED BY THE INEFFICIENCIES ACCUMULATED DURING 40 YEARS IN THE GRIP OF COMMUNISM. AFTER 1993 THA WILL LIKELY REMAIN A SORT OF HOLDING COMPANY FOR THOSE FIRMS WHICH ARE IN THE PROCESS OF BEING RECONSTRUCTED IN ORDER TO BE PRIVATIZED.

04395 HODGE, C.

THE FUTURE OF FOUR HHEELS: GOVERNMENT AND THE AUTOMOBILE INDUSTRY IN FRANCE AND WEST GERMANY

SOCIALIST REVIEW, 21(1) (JAN 91), 42-66.

A COMPARISON OF GOVERNMENT INTERVENTION IN THE

AUTOMOBILE INDUSTRIES OF WEST GERMANY AND FRANCE, 1971-1985,

DEMONSTRATES THE RESILIENCE OF INDUSTRIAL POLICY' COMMUNITIES.

THE MAINTENANCE OF ESTABLISHED RELATIONSHIPS IN SHOWN TO BE PART AND PARCEL OF THE EMERGING INDUSTRIAL SOLUTION.

INSTITUTIONS AND ORGANIZATIONS INVOLVED IN CRISIS RESOLUTION

IN THE FRENCH AND GERMAN MOTOR INDUSTRIES ARE REVEALED TO

HAVE OISSIMILAR, OVERACHING POLITICAL OBJECTIVES BEYOND THE

HAVE DISSIMILAR, OVERACHING POLITICAL OBJECTIVES BEYOND
SPECIFIC AND IMHEDIATE NEEDS THEY SEEK TO ADORESS. THE

SPECIFIC AND IMMEDIATE NEEDS THEY SEEK TO ADORESS. THE

PROBLEMS IS NOT NECESSARILY A DISSERVICE TO AN INDUSTRY'S

PROBLEMS IS NOT NECES
LONG-TERM VITALITY.

04396 HODGIN, D.

PAYING THE BILL

INSIGHT, 7 (3) (JAN 91), 30-31.

AFTER WITHHOLDING ITS PART OF THE UNITED NATIONS

ASSESSMENT TO FOSTER BUDGETARY REFORM, THE UNITED STATES IS

AGAIN PAYING UP. BUT EXPERTS SAY THAT THE U.S. WILL BE

CARRYING A HEAVIER BURDEN AT THE UN WITH LESS SAY OVER HOH

THE MONEY IS SPENT. THE MOVEMENT TO LINK U.S. PAYMENTS TO

BUDGET REFORM IS BEING SIDELINED. MANY BLAME THE BUSH

ADMINISTRATION'S DESIRE FOR UN SUPPORT IN THE GULF WHICH

ENCOURAGES A BLIND EYE TOWARD REFORM.

04397 HOETH, S.

PUBLIC-PRIVATE PARTMERSHIP IN STATE GOVERMMENT

PUBLIC PRODUCTIVITY \& MANAGEMENT REVIEW, 15(2) (WIN 91),

147-150

THE AUTHOR DISCUSSES THE INITIATIVES UNDERTAKEN BY THE NEW YORK STATE OFFICE OF MANAGEMENT AND PRODUCTIVITY TO ENHANCE GOVERNMENT EFFICIENCY AND ACCOUNTABILITY. THESE INITIATIVES INCLUDE SUCCESSFUL PRIVATE SECTOR APPLICATIONS OF PRODUCTIVITY INITIATIVES, NOVEL APPLICATIONS OF

TECHNOLOGY, AND INNOVATIVE APPROACHES TO PROBLEM SOLVING

TECHNOLOGY, AND INNOVATIVE APPROACHES TO PROBLEM SOLVING
THAT RESULT IN COST SAVINGS AND IMPROVEMENT OF SERVICES. THE

FISCAL REFORM ACT OF 1990 IS DISCUSSED AS WELL AS THE

FISCAL REFORM ACT OF 1990 IS DISCUSSED AS WELL AS THE
ACTIVITIES OF A GROUP DUBBED THE LITTLE GRACE COMMISSION.

04398 HOFFERBERT, R.I.; BUDGE, I.

THE PARTY MANDATE AND THE WESTMINSTER MODEL: ELECTION PROGRAMMES AND GOVERNMENT SPENDING IN BRITAIN, 1948-1985 BRITISH JOURNAL OF POLITICAL SCIENCE, $22(2)$ (APR 92 ), 151-182.

DO PARTY MANIFESTOS MATTER TO GOVERMMENT POLICY? DOES A GENUINE PARTY MANDATE OPERATE WITHIN THE BRITISH POLITICAL PROCESS? THESE QUESTIONS ARE GENERALLY NEGLECTED IN ANALYSES OF BRITISH POLITICS, BUT THEY ARE CRUCIAL IN ASSESSING HOW FAR POLITICAL PARTIES TRANSMIT ELECTORAL PREFERENCES INTO GOVERNMENT ACTION. THE AUTHORS ANSWER THESE OUESTIONS HITH A NOVEL USE OF EXISTING DATA, USING CONTENT ANALYSIS TO COOE AND CLASSIFY POLICY EMPHASES WITHIN THE POSTHAR ELECTION PROGRAMS OF THE CONSERVATIVE, LABOUR, AND LIBERAL PARTIES.
STATISTICAL ANALYSIS REVEALS THAT GOVERMENT PARTY PROGRAMS ARE REMARKABLY WELL REFLECTED IN POST-ELECTION POLICY PRIORITIES, MEASURED AS PERCENTAGES OF CENTRAL GOVERMMENT SPENDING IN MAJOR POLICY AREAS. THIS GIVES STRONG SUPPORT TO TRADITIONAL MANDATE THEORY WITHIN THE CONTEXT OF THE WESTMINSTER MODEL OF PARTY GOVERNMENT. THE AUTHORS ALSO CONSIDER ANOMALIES, SUCH AS A STRONG RELATIONSHIP BETWEEN LIBERAL EMPHASES AND EXPENDITURES IN THREE KEY AREAS, AND THE MORE CONSISTENT RELATIONSHIP OF EXPENDITURES WITH CONSERVATIVE RATHER THAN LABOUR PRIORITIES.

04399 HOFFMAN, B.

CURRENT RESEARCH ON TERRORISM AND LOW-INTENSITY CONFLICT STUDIES IN CONFLICT AND TERRORISM, 1 (1992), 25-38.

THE PUBLISHED LITERATURE ON TERRORISH AMD LOH INTEMSITY CONFLICT (LIC) IS SURYEYED IN ORDER TO ASSESS THE ROLE THAT RESEARCH ON TERRORISM AMD LIC CAN PLAY BOTH IN COUNTERIMG PRESENT AND LIKELY FUTURE ADVERSARIES AND ADORESSING PRESENT AND LIKELY FUTURE ADVERSARIES AND ADORESSING
EXISTING AND POTENTIALLY NEW CHALLENGES. IT ALSO SEEKS TO
PROVIDE A BASELINE ASSESSMENT OF HOW FIRM A FOUNDATION PROVIDE A BASELINE ASSESSMENT OF HOW FIRM A FOUNDATION
CURRENT RESEARCH INTO THESE SUBJECTS HAS PROVIDED. THE CURRENT RESEARCH INTO THESE SUBJECTS HAS PROVIDED. THE
ARTICLE ARGUES THAT THE NEED FOR POL ICY-RELEVANT RESEARCH IN ARTICLE ARGUES THAT THE NEED FOR POLICY-RELEVANT RESEARCH IM
BOTH TERRORISM AND LIC LOOMS LARGER THAN EVER. IT CONCLUDES BOTH TERRORISM AND LIC LOOMS LARGER THAN EVER. IT CONCLUDES
THAT WITHOUT A CLEAR CONCEPTION OF US INTERESTS AND US GOALS, THAT WITHOUT A CLEAR CONCEPTION OF
THESE EFFORTS WILL BE FOR NAUGHT.
04400 HOFFMAN, 3.

THE STATE: HAS THE 'WITHERING AWAY' THESIS FINALLY HITHERED AWAY?

JOURNAL OF COMMUNIST STUDIES, 8(1) (MAR 92), 84-106. LOGICAL AND HISTORICAL OBJECTIONS TO THE CLASSICAL MARXIST THESIS OF THE WITHERING AWAY OF THE STATE ARE NOT AS COMPELLING AS THEY SEEM. THE THESIS PRESUPPOSES A CONTRADICTORY RELATIONSHIP BETWEEN ABSTRACT NOTIONS OF SELFGOVERMMENT AND THE HIERARCHICAL SOCIAL AND POLITICAL INSTITUTIONS OF LIBERAL CAPITALISM. THIS CONTRADICTORY RELATIONSHIP CANNOT EMERGE AS LONG AS MARXISTS EMBRACE POLITICAL MODELS LIKE THE COMMUNE STATE, WHICH HAVE AM AMBIGUOUS RELATIONSHIP TO THE LIBERAL TRADITION. IT IS ONLY WITH THE DISINTEGRATION OF AN AUTHORITARIAN SOVIET STATE UNDER THE LIBERALIZING IMPACT OF GORBACHEV'S REFORMS THAT THE WITHERING AWAY THESIS CAN BECOME THEORETICALLY PLAUSIBLE AND PRACTICALLY INTERESTING.

04401 HOFMANN, D.

THE ECONOMIC OUTLOOK UNDER CLINTON

SWISS REVIEW OF WORLD AFFAIRS, 42 (9) (DEC 92), 2-3.

PRESIDENT-ELECT BILL CLINTON ENTERED THE U.S.

PRESIDENTIAL RACE WITH THE PROMISE OF UNDOING THE HARM DONE BY 12 YEARS OF REPUBLICAN ECONOMIC MISMANAGEMENT. HE HAS PLEDGED THAT, UNDER HIS LEADERSHIP, THE GOVERNMENT WILL SEE TO ALL THINGS THAT THE FREE PLAY OF MARKET FORCES HAS FAILED TO PROVIDE. BUT CLINTON AND THE DEMOCRATIC PARTY COULD QUICKLY FIND THEMSELVES GOING TOO FAR AND BEING PULLED BACK BY THE MERCILESS DISCIPLINE OF THE FINANCIAL MARKETS.

04402 HOFMANN, D

THE IMF AND WORLD BANK IN CHANGING TIMES

SHISS REVIEW OF HORLD AFFAIRS, 42(5) (AUG 92), 4-6.

THE AUTHOR EXPLAINS THE FUNCTIONS, STRUCTURE, AND

CHANGING RESPONSIBILITIES OF THE WORLD BANK AND THE INTERNATIONAL MONETARY FUND.

04403 HOFMANM, T.

SOUTH OSSETIA, A MODEL CASE: COURSE AND CAUSES OF A CONFLICT

ORIENT, 32(4) (DEC 91), 591-604.

THE DETERIORATION OF THE SOVIET UNTION SET FREE FORCES

STARTING IN 1988 WHICH ASSUMED THE CHARACTER OF PURELY NATIONALISTIC MOVEMENTS. RUSSIA HAD IN THE PAST ACTED AS A RESERVED SUPPORTER OF THE SUPPRESSED OSSETIANS, WHO IN TURM HAD BEEN TRYING TO PROMOTE THE INCORPORATION OF THEIR TERRITORY INTO THE RUSSIAN FEDERATION SINCE THE 1970S. ON THE OTHER HAND. GEORGIA POLITICALLY SUPPORTS THE ANTIRUSSAIN TENDENCIES OF THE ISLAMIC PEOPLE OF THE NORTHERM CAUCASUS. SINCE THE CURRENTLY RULING MILITARY COUNCIL IS NOT WILLING TO ACKNOWLEDGE THE SOUTH OSSETIAN SEPARATIST DEMANDS, A CONTIKUATION OF THE BRUTAL SOUTH OSSETIA CONFLICT-INCLUDING ITS POTENTIAL EXPANSION OF THE GEORGIAN-RUSSIAN
CONFLICT OF INTERESTS MUST BE EXPECTED.

04404 HOGAN, J.M.; SMITH, T.J. III POLLING ON THE ISSUES: PUBLIC OPINION AND THE NUCLEAR FREEZE

PUBLIC OPINION QUARTERLY (CHICAGO), 55(4) (WIN 91),

$34-569$

DURING THE FIRST TERM OF THE REAGAN ADMINISTRATION, MANY STATE AND LOCAL GOVERMMENTS, AS WELL AS THE U.S. HOUSE OF REPRESENTATIVES, PASSED RESOLUTIONS SUPPORTING THE NUCLEAR
FREEZE MOVEMENT. PUBLIC OPINION POLLS PLAYED A MAJOR ROLE IN THE DEBATE, AS THE MEDIA AND FREEZE ADVOCATES CITED NUMBEROUS POLLS INOICATING OVERWHELMING PUBLIC SUPPORT FOR THE INITIATIVE. BUT A COMPREHENSIVE AND DETAILED EXAMINATION OF THE NATIONAL POLLS REVEALS THAT PUBLIC SUPPORT FOR THE FREEZE WAS HEAVILY QUALIFIED. WHILE AMERICANS EXPRESSED STRONG SUPPORT FOR THE BASIC CONCEPT OF A FREEZE, THEY ALSO EXPRESSED DOUBTS ABDUT THE POSSIBILITY OF A VERIFIABLE AND BALANCED FREEZE. FURTHERMORE, THE PUBLIC DOUBTED THAT THE SOVIET UNION GENUINELY DESIRED SUCH AN AGREEMENT. THE PUBLIC DID NOT PAY MUCH ATTENTION TO THE DEBATE, AND FEH CLAIMED TO KNOW MUCH OR CARE DEEPLY ABOUT THE FREEZE INITIATIVE. STILL FEWER FELT POSITIVELY TOWARD THE POLITICAL ACTIVISTS BEHIND THE FREEZE.

04405 HOGGART, K.

RESPONSIVENESS OF INTERGOVERNMENTAL AID TO URBAN PROBLEMS IN NEW JERSEY AND NEW YORK, 1976-1984

URBAN AFFAIRS QUARTERLY, 27(3) (MAR 92), 369-419.

AFTER ESTABLISHING THAT THE DISTRIBUTION OF FEDERAL AND STATE AID TO CITIES IN NEW JERSEY AND NEW YORK WAS STABLE BETWEEN 1976 AND 1984 . THE AUTHOR EXAMINES THE RELATIONSHIP BETHEEN SOCIO-ECONOMIC CONDITIONS AND AID RECEIPIS. HHEN SINGLE YEARS ARE EXAMINED, BOTH FEDERAL AND STATE PAYMENTS SINGLE YEARS ARE EXAMINED, BOTH FEDERAL AND STATE PAYMENTS ARE FOUND TO BE BROADLY REDISTRIBUTIVE, ESPECIALLY IN NEW THE GREATEST FEDERAL LOSSES ARE FOUND FOR CITIES WITH THE THE GREATEST FEDERAL LOSSES ARE FOUND FOR CITIES WITH THE
HIGHEST SOCIO-ECONOMIC NEEDS. CHANGES IN NEW JERSEY WERE HIGHEST SOCIO-ECONOMIC NEEDS. CHANGES IN NEW JERSEY WER
MORE RESPONSIVE TO URBAN DISTRESS THAN IN NEW YORK. THE AUTHOR DISCUSSES THESE DIFFERENCES, FOCUSING ON 
DISSIMILARITIES IN THE POLITICAL COMPROMISES REACHED AT THE STATE GOVERMMENT LEVEL.

04406 HOJNACKI, M. : BAUM, L.

HEW-STYLE JUDICIAL CAMPAIGNS AND THE VOTERS: ECONOMIC ISSUES AND UNION MEMBERS IN OHIO

WESTERN POL ITICAL QUARTERLY, 45(4) (DEC 92), 921-948. IN RECENT YEARS, AN INCREASING NUMBER OF ELECTORAL CONTESTS FOR JUDGESHIPS HAVE DEPARTED FROM THE TRADITIONAL MODEL OF SMALL-SCALE, LOW-KEY, AND ISSUE-LESS CAMPAIGNS. CONTESTS FOR THE STATE SUPREME COURT IN 1986 AND 1988, WHEN THE LABOR MOVEMENT AND LABOR-RELATED ECONOMIC ISSUES WERE THE LABOR MOVEMENT AND LABOR-RELATED ECONOMIC ISSUES WERE
CENTRAL. THE AUTHORS EXPLORE RESPONSES TO THE CAMPAIGNS BY CENTRAL. THE AUTHORS EXPLORE RESPONSES TO THE CAMPAIGNS BY
COMPARING THE VOTING BEHAVIOR OF UNION MEMBERS WITH THAT OF COMPARING THE VOTING BEHAVIOR OF UNION MEMBERS WITH THAT OF
OTHER YOTERS. ON THE WHOLE, UNION MEMBERS WERE MORE LIKELY OTHER VOTERS. ON THE WHOLE, UNION MEMBERS WERE MORE LIKELY
TO SUPPORT THE LABOR-ENDORSED JUDICIAL CANDIDATES, EVEN WITH TO SUPPORT THE LABOR-ENDORSED JUDICIAL CANDIDATES, EYEN
CONTROLS FOR PARTY IDENTIFICATION AND OTHER RELEYANT CONTROLS FOR PARTY IDENTIFICATION AND OTHER RELEVANT
VARIABLES. COMPARISONS AMONG THE JUDICIAL CONTESTS AND VARIABLES. COMPARISONS AMONG THE JUDICIAL CONTESTS AND 198 BETWEEN JUDICIAL AND NONJUDICIAL CONTESTS IN 1986 AND 1988
PROVIDE FURTHER EVIDENCE THAT VDTERS WERE INFLUENCED BY THE PROVIDE FURTHER EVIDENCE THAT VOTERS WERE INFLUENCED
UNIONS' MESSAGE AND BY ECONOMIC ISSUES. THESE RESULTS UNIONS' MESSAGE AND BY ECONOMIC ISSUES. THESE RESUL TS
INDICATE THAT NEN-STYLE JUDICIAL CAMPAIGNS CAN BE EFFECTIVE IN REACHING VOTERS AND SHAPING THEIR DECISIONS.

04407 HOLBROOK, T.K.; PERCY, S.L.

EXPLORING VARIÁTIONS IN STATE LANS PROVIDING PROTECTIONS FOR PERSONS WITH DISABILITIIES

WESTERN POL ITICAL QUARTERLY, 45 (1) (MAR 92), 201-220.
THE DEGREE OF COMMITMENT TO DISABILITY RIGHTS-AS

REFLECTED IN THE STRINGENCY OF DISABILITY RIGHTS LEGISLATION-VARIES SUBSTANTIALLY ACROSS STATES. IN THIS PAPER, THE AUTHORS DEVELOP AND TEST A MOOEL OF THE DETERMINANTS OF STATE DISABILITY RIGHTS POLICY. THE RESULTS OF THE ANALYSIS INDICATE THAT COMPETITIVE DEMOCRATIC STATES AND STATES WITH A HISTORY OF POSITIVE GOVERMMENT POLICIES ARE LIKELY TO HAVE THE MOST STRINGENT LAHS. SOME VARIATION IN STATE LAHS MAY ALSO BE DUE TO OTHER, YET TO BE TESTED, INFLUENCES--SUCH AS THE RELATIVE STRENGTH OF ACTIVIST GROUPS AND THE PRESENCE OF THE RELATIVE STRENGTH
POLICY ENTREPRENEURS.

04408 HOLCOMBE, R.; PARKER, G.

COMMITTEES IN LEGISLATURES: A PROPERTY RIGHTS PERSPECTIVE PUBLIC CHOICE, 70(1) (APR 91), 11-20.

IN THE ABSÉNCE OF ANY INSTITUTIONAL STRUCTURE, A

LEGISLATURE WILL BE A NON-EXCLUSIVE RESOURCE. AS WITH ANY NON-EXCLUSIVE RESOURCE, UNRESTRICTED ACCESS REDUCES THE TOTAL VALUE OF THE RESOURCE TO ITS OWNERS BECAUSE A NONEXCLUSIVE RESOURCE HILL BE USED TOO INTENSIVELY. THIS ARTICLE EXAMINES THIS PHENOMENON AND ARGUES THAT APPLICATION OF ECONOMIC MOOELS TO POLITICS CAN BE VERY SUCCESSFUL BECAUSE MUCH OF WHAT OCCURS IN POLITICS IS PRODUCTION AND EXCHANGE. THEY ALSO ARGUE THAT WITHOUT THE RIGHTS STRUCTURE (INSTITUTIONALIZATION) PROVIDED BY COMMITTEES, LEGISLATURE ARE MON-EXCLUSIVE RESOURCES, JUST AS MUCH AS A COMMON GRAZING GROUND OR A COMMON POOL OF OIL.

04409 HOLDAR, $S$.

POLITICAL GEOGRAPHERS OF THE PAST IX: THE IDEAL STATE AND

THE POWER OF GEOGRAPHY: THE LIFE-HORK OF RUDOLF KJELLEN

POLITICAL GEOGRAPHY OUARTERLY, 11 (3) (MAY 92), 307-324

RUDOLF KJELLEN'S "GEOPOLITIK" WAS PART OF HIS ATTEMPT TO PRODUCE A SYSTEMATIC POLITICAL SCIENCE, FOCUSED ON THE STUDY OF THE STATE. HE HANTED TO CONSTRUCT A WAY TO ANALYZE THE EVOLUTION OF THE POWER OF STATES AND TO EXAMINE HOH THIS PROCESS AFFECTED INTERSTATE RELATIONS. HIS GOAL OF

OBJECTIVITY NEVER GAINED FOLLOWERS. WHILE HIS IDEAS WERE NOT RECEIVED IN SHEDEN SOME OF THEM WERE ACCEPTED IN GERMANY MOST IMPORTAKTLY BY THE "GEOPOL ITIK" SCHOOL ASSOCIATED WITH KARL HAUSHOFER.

04410 HOLLANDER, P.

ANTI-AMERICANISM: CRITIQUES AT HOME AND ABROAD, 1965-1990 OXFORD UNIVERISTY PRESS, $1992,515$.

THIS BOOK POSES THE QUESTION: HHY DO SOME PEOPLE

(INCLUDING SOME AMERICANS) HATE AMERICA? ITS ANSWER IS THAT WHILE ANTI-AMERICAN ACTIVISTS POSE AS BEING PROGRESSIVES THEY ARE IN FACT DEEPLY TRADITIONAL. WHAT BOTHERS THEM IS THEY ARE IN FACT DEEPLY TRADITIONAL. WHAT BOTHERS THAT AMERICANI ZATION--AN AGGRESSIVE FORM OF SOCIAL MLIENATION AT HOME AS IT DISPLACES TRADITIONAL YALUES. BY ALIENATION AT HOME AS IT DISPLACES TRADITIONAL VALUES. BY CONTEXT. THE AUTHOR ARGUES THAT THE FAILURE OF AMERICA'S CONTEXT, THE AUTHOR ARGUES THAT THE FAILURE OF AMERICA'S
CHIEF IDEOLOGICAL RIVAL DOES NOT REDUCE HATRED OF THE UNITED CHIEF IDEC
STATES

04411 HOLLANDER, P.

SOCIOLOGY AND THE COLLAPSE OF COMHUNISH

SOCIETY, 30(1) (NOV 92), 26-33.

THE CLOSING DECADE OF THIS CENTURY, AS IT COINCIDES HITH THE DISINTEGRATION OF MOST COMMUNIST SYSTEMS, IS A GOOD TIME TO REFLECT ON THE STATE OF THE SOCIAL SCIENCES IN THE UNITED STATES AND SOCIOLOGY IN PARTICULAR. THIS ARTICLE SUGGESTS THAT IT IS APPROPRIATE TO ASK: WHAT HAS SOCIOLOGY
CONTRIBUTED TO THEIR UNDERSTANDING, OR TO ANTICIPATING BOTH THE DISASTERS AND THE UNEXPECTED, THOUGH HELCOME, CHANGES. IT SUGGESTS THAT MUCH PEDESTRAIN RESEARCH HAS BEEN INSTITUTIONALIZED AND THAT ONE CAN MAKE A GOOD LIVING OUT IT AT THE UNIVERSITIES. IT SUGGESTS CONDITIONS UNDER WHICH SOCIOLOGY MAY RECOVER SOME OF ITS POTENTIAL AND INTELLECTUAL THRUST.

04412 HOLLIDAY, I.

ON MICHAEL OAKESHOTT

GOVERNMENT AND OPPOSITION, 27(2) (SPR 92), 131-147. THE AUTHOR OFFERS SOME' INSIGHT INTO THE HORK OF POL ITICAL THEORIST MICHAEL OAKESHOTT, THE AUTHOR OF

04413 HOLLIDAY, I

SCOTIISH LIMITS TO THATCHERISM

POLITICAL QUARTERLY (THE), 63(4) (OCT 93), 448-459.

IN EVALUATING AND ACCOUNTING FOR SCOTTISH LIMITS TO THATCHERISM, THREE MAIN TASKS ARISE. THE FIRST IS TO INVESTIGATE THATCHERISM'S DESIGNS ON SCOTLAND AS A MEANS OF DETERMINING THE EXTENT TO WHICH IT EYER SOUGHT TO APPLY THE FULL STRATEGY NORTH OF THE BORDER. THE SECOND TASK IS TO DETERMINE HOW THATCHERISM FARED IN SCOTLAND ON OCCASIONS WHEN FULL RADICAL DRIVE WAS IMPOSED. THE THIRD
CONSIDER THE IMPLICATIONS OF THIS ANALYSIS FOR CHARACTERIZATIONS OF THE SCOTTISH POLITICAL DOMAIN. THIS ARTICLE EXPLORES THESE THREE TASKS IN DETAIL.

04414 HOLLIDAY, I.

THE POLITICS OF THE CHANMEL TUNNEL

PARLIAMENTARY AFFAIRS, 45(2) (APR 92), 188-204.

EUROTUNNEL WILL BE OPERATIONAL BY 1994 AND HAS

DEMONSTRATED THAT THE PRIVATE SECTOR HAS SUCCEEDED. THIS ART ICLE DESCRIBES THE MEANS BY WHICH THIS MAJOR PROJECT WAS MANAGED BY THE BRITISH AND FRENCH POL ITICAL SYSTEMS. IT CONSIDERS THE RE-EMERGENCE OF THE CHANNEL FIXED LINK ON TO POL ICY-MAKER'S AGENDA AT THE START OF THE 1980S. IT ALSO EXAMINES WHAT MIGHT BE CALLED THE INTERNAL POLITICS OF THE CHANNEL TUNNEL PROJECT IN TERMS OF RELATIONS SPECIFIC TO
PROJECT ITSELF AND THE EXTERHAL POLITICS OF THE TUNMEL PROJECT ITSELF AND THE EXTERHAL POLITICS OF THE TUNNEL
PROJECT IN TERMS OF ITS RELATIONS TO ITS WIDER ENVIRONMENT. PROJECT IN TERMS OF ITS RELATIONS TO ITS HIDER ENVIRONMENT.
IT CONCLUDES BY CONSIDERING WHAT MAY BE LEARNED FROM CHANNEL IT CONCLUDES BY CONSI
TUNAEL PRIVATIZATION.

04415 HOLLIFIELD, J.F. MIGRATION AND INTERNATIONAL RELATIONS: COOPERATION AND CONTROL IN THE EUROPEAN COMMUNITY

INTERNATIONAL MIGRATION REVIEH, XXVI(2) (SUM 92), 568-595. INTERNATIONAL MIGRATION IN THE POST-WORLD WAR II PERIOD RAISES MANY QUESTIONS FOR THE STUDY OF INTERNATIONAL RELATIONS. THE MOVEMENT OF INDIVIDUALS ACRDSS NATIONAL BORDERS CLEARLY AFFECTS RELATIONS BETWEEN STATES, AND IT HAS HAD IN SOME CASES DRAMATIC EFFECTS ON THE INTERMATIONAL POLITICS OF STATES, PARTICULARLY THE LIBERAL DEMOCRACIES OF WESTERN EUROPE. BUT DESPITE ITS IMPORTANCE, THEORISTS OF INTERNATIONAL RELATIONS HAVE YET TO DEVELOP A FRAMEWORK FOR UNDERSTANDING INTERNATIONAL MIGRATION, ATTENTION HAS BEEN FOCUSED EITHER ON THE ECONOMICS (PUSH-PULL) OR THE POLITICS (POLICIES) OF MIGRATION, WITHOUT ANY CLEAR ATTEMPT TO EXAMINE THE WAY IN WHICH THE INTERACTION OF POLITICS AND MARKETS AFFECTS MIGRATION. SPECIAL ATTENTION IS GIVEN TO THE ROLE OF INTERNATIONAL INSTITUTIONS--SUCH AS THE EUROPEAN COMMUNITY--IN REGULATING POPULATION MOVEMENTS, AND TO THE PROSPECTS FOR THE DEVELOPMENT OF MIGRATION "REGIMES" IN EUROPE AND MORTH AMERICA. THE AUTHOR FINDS THAT

INTERNATIONAL MIGRATION REVEALS A CONTRADICTION BETHEEN THE MAIN ECONOMIC PURPOSE OF THE POSTHAR INTERNATIONAL ORDER--TO PROMOTE EXCHANGE--AND THE NATIONAL PREREQUISITES OF SOVEREIGNTY AND CITIZENSHIP.

04416 HOLLINGWORTH, P.

LATIN AMEICAN 1492-1992

WORLD TODAY, 48 (1) (JAN 92 ), 2-4.
THE AUTHOR DISCUSSES THE POLIITICAL CHANGES UNDERHAY IN LATIN AMERICA AND SOME OF THE IMPORTANT ISSUES FACING THE NEWLY-DEMOCRATIC GOVERNMENTS, INCLUDING EDUCATION AND THE NEWLY-DEMOCRAT
ENVIRONMENT.

04417 HOLLIS, $R$.

WHAT PRICE RENEWED CONFLICT IN THE MIDDLE EAST? RUSI JOURNAL, $137(5)$ (OCT 92), 50-54.

THE AFTERMATH OF THE 1990-91 GULF WAR HAS RAISED THE STAKES FOR REACHING A SETTLEMENT OF OUTSTANDING DISPUTES IN THE MIDDLE EAST AND FOR AVOIDING THE OUTBREAK OF RENEWED CONFLICTS. GIVEN THE ECONOMIC INTERDEPENDENCE BETHEEN THE
COUNTRIES OF THE REGION AND THE REST OF THE WORLD, AND THE INEQUITIES IN THE DISTRIBUTION OF POWER AND WEALTH WITHIN MUCH OF THE AREA, THE CONSEQUENCES OF FURTHER UPHEAVAL AND OF FAILURE TO EITHER NEGOTIATE OR MAINTAIN PEACE ARE TOO SERIOUS FOR REGIONAL LEADERS OR THEIR OUTSIDE ALLIES TO IGNORE. 
04418 HOLLOWAY $N$.

SPAT IN THE SUPERMARKET

FAR EASTERN ECONOMIC REYIEW, 155 (40) (OCT 92), 68-70. AS CONTROVERSY ABOUT THE MAASTRICHT TREATY ON EUROPEAN UNION INCREASES, MANY ASIANS ARE BEGINNING TO SUSPECT THAT THE EUROPEAN MONOLITH IS CRACKING EVEN BEFORE IT WAS FULLY ESTABLISHED. WHILE ASIAN BUSINESS AND ECONOMIC DECISION MAKERS WERE OPTIMISTIC ABOUT THE BENEFITS OF A UNITED EUROPE, SOME FEARED THE CREATION OF AN INCLUSIVE TRADE BLOC. ON THE OTHER HAND, THE GROWING OISORDER THAT HAS ATTENDED THE MAASTRICHT TREATY'S RATIFICATION PROCESS AND THE RESULTING CURRENCY FLUCTUATIONS HAVE SPARKED FEARS AMONG ASIANS THAT A WEAKENED, DIVIDED COMMUNITY MIGHT TURN INWARD TO AN EXTENT THAT WOULD BE DAMAGING TO TRADE WITH ASIA. THERE IS GROWING SPECULATION THAT A TWO-TIER EUROPE WILL SOON EMERGE WITH GERMANY, FRANCE, THE NETHERLANDS, BELGIUM AND LUXEMBOURG FORMING A "CORE" OF HARD CURRENCY STATES. THIS PROSPECT IS NOT ENCOURAGING FOR MANY ASIANS WHOSE ECONOMIC TIES ARE STRONGEST WITH GREAT BRITAIN STATE THAT HOULD BE STRONGEST WITH GREAT BRITAIN, A STATE THAT WOULD BE

04419 HOLLOWAY, S

CANADA WITHOUT QUEBEC

ORBIS, 36(4) (FAL 92), 531-545

CANADA'S FATE AS A UNIFIED COUNTRY HAS REACHED A CRISIS AS THE SCHEDULED REFERENDUM ON QUEBEC'S SEPARATION FROM CANADA DEMONSTRATES. THE OUTCOME WILL HAVE IMPORTANT CONSEQUENCES INTERNATIONALLY AS WELL AS WITHIN CANDA. IN ORDER TO HELP THE READER GRASP THE SITUATION, THIS ARTICLE SUGGESTS THAT ONE NEEDS TO KEEP IN MIND THE MAIN HISTORICAL FLASHPOINTS FOR THE ENGLISH-SPEAKING AND FRENCH-SPEAKING CANADIAN COMMUNITIES. IT EXPLORES THE HISTORY AND IMPLICATIONS OF THE SEPARATION IN ORDER TO UNDERSTAND THE CURRENT CRISIS AND ITS EXTERNAL IMPLICATIONS.

04420 HOLLUP, 0 .

ETHNIC IDENTITY, VIOLENCE AND THE ESTATE TAMIL MINORITY IN SRI LANKA

ROUND TABLE, 323(323) (JUL 92), 315-338.

IN SRI LANKA THERE HAS BEEN A TENDENCY TOWAROS A GROWTH IN NATIONALISM AND ETHNIC CHAUVINISM SINCE INDEPENDENCE. THIS ARTICLE ATTEMPIS TO STRESS THE IMPORTANCE OF THE SOCIOECONOMIC FACTORS UNDERLYING THE ETHNIC CONFLICT, ALONG WITH A RECOGNITION OF THE ROLE PLAYED BY IDEOLOGICAL AND CULTURAL DIFFERENCES IN SHAPING INTERETHNIC RELATIONS AND AS ROOTS TO ETHNIC ANTAGONISM. IT DEALS PRIMARILY WITH THE INDIAN TAMILS, AND HOW THEY WERE AFFECTED, BECAME VICTIMS OF INDIAN TAMILS, AND HOW THEY WERE AFFECTED, BECAME VICTIMS
AND INTERPRETED THE WAVES OF ETHNIC VIOLENCE OCCURRING IN AND INTERPRETED
THE PAST DECADE.

04421 HOLLY, D.

A DISTURBING SITUATION: CANADIAN INVESTMENT IN BRAZIL IN 'S TND THE 80'S

ETUDES INTERNATIONALES, 23(2) (JUN 92), 349-376.

THE RELATIVE DECLINE OF CANADA'S POSITION ON THE BRAZILIAN MARKET IS EXPLORED. THE PAPER ARGUES THAT THIS SITUATION IS DUE TO THE INSUFFICIENT DEVELOPMENT OF R-D IN CANADA AND THE CONSEQUENT LOW LEVEL OF TECHNOLOGICAL INNOVATION IN THAT COUNTRY. ONE SIGNIFICANT EFFECT OF THAT IS THE INABILITY OF CANADIAN ENTERPRISES TO COMPETE SUCCESSFULLY WITH THOSE OF OTHER COUNTRIES. THIS IS SUPPORTED BY THE MASSIVE CONCENTRATION OF INVESTMENTS IN BRAZIL BY CANADIAN-OWNED FIRMS IN THE MORE TRADITIONAL INDUSTIRES, THE DOMINANT POSITION OF CANADIAN-BASED AFFILIATES OF FOREIGN FIRMS, AND THEIR CONCENTRATION IN THE MOST TECHNOLOGICALLY-ADVANCED INDUSTRIES.

04422 HOLLY, S.; HADE, K.

UK EXPORTS OF MANUFACTURES: THE ROLE OF SUPPLY SIDE FACTORS SCOTTISH JOURNAL OF POLITICAL ECONOMY, 38(1) (FEB 91), 1-18.

THIS PAPER ESTIMATES A MODEL FOR THE UK EXPORTS OF MANUFACTURES USING AN EXPLICIT SUPPLY AND DEMAND FORMULATION. THIS MAKES IT POSSIBLE TO DISENTANGLE THE SEPARATE SUPPLY AND DEMAND EFFECTS FROM THE COEFFICIENTS IN THE REDUCED FORM EQUATION, AND PROVIDE AN IDEAL FRAMEWORK FOR TESTING WHETHER THE SUPPLY SIDE REFORMS OF THE 1980 S HAVE IMPROVED THE EXPORT PERFORMANCE OF UK MANUFACTURING. THE AUTHORS FIND THAT HE INCOME ELASTICITY OF THE DEMAND FOR EXPORTS HAS TENDED TO FALL OVER THE 1980 S.

04423 HOLM, H.

THE MYTH OF THE RESPONSIVE NORTH

JOURNAL OF PEACE RESEARCH, 29(1) (FEB 92), 115-120.

THE NORTH-SOUTH POLICIES OF DENMARK, CANADA, THE

METHERLANDS, NORWAY, AND SWEDEN TOWARDS THIRD WORLD DEMANDS FOR GLOBAL EOUITY AND JUSTICE ARE OFTEN REGARDED AS MODELS FOR GLOBAL EQUITY AND JUSTICE ARE OFTEN REGARDED AS MODELS THAT THIS IS A MYTH. REC "HUMANE INTERMATIONAL ISM" CHAT THIS IS A MYTH. THE "HUMANE INTERNATIONALISM" CHARACTERISTIC OF THE POLICIES OF THESE COUNTRIES IS MORE LIBERAL AND LESS RADICAL. THIS ESSAY DISCUSSES THE REASONS NEEDS TO BE DONE TO REVIVE NORTHERN RESPONSIVENESS.
MER
04424 HOLME, R.

AFTER PATERHALISH

POLITICAL QUARTERLY (THE), 63(4) (OCT 93), 404-412.

THIS ARTICLE QUERIES WHETHER PATERNALISM (BIG

GOVERNMENT) IS DEAD AND WHAT THIS MEANS FOR THOSE WHO OPPOSE THE CONSERVATIVES. IT SUGFGESTS THAT TODAYS POLITICAL CUTURE AS A WHOLE IS INIMICAL NOT ONLY TO ANY NOTION OF STURDY INDIVIDUAL SELF-RELIANCE BUT ALSO TO THE TIES OF COMMUNITY AND COOPERATION WHICH BIND INDIVIDUALS TOGETHER IN SOCIETY TO ACHIEVE THEIR COMMON PURPOSES. IT STUDIES THE THATCHER PROJECT AND WHAT IT TELLS ABOUT PATERNALISM AND THE BRITISH POLITICAL CULTURE AND THE LESSONS IT OFFERS FOR THE FUTURE.

04425 HOLST, J.J.

EUROPEAN AND ATLANTIC SECURITY IN A PERIOD OF AMBIGUITY

HORLD TODAY, 48(12) (DEC 92), 218-221.

THE AUTHOR EXAMINES THE PRESENT SECURITY REGIME IM

EUROPE AS THE BASIS FOR PRESCRIBING EUROPE'S FUTURE SECURITY POLICY.

04426 HOLT, J.

JERRY'S KIDS

NEW REPUBLIC, 206 (17) (APR 92), 19

THE AUTHOR DESCRIBES A RALLY FOR FORMER CALIFORNIA

GOVERNOR JERRY BROWN HELD IN A NEH YORK CITY PARK DURING HIS

CAMPAIGN FOR THE 1992 DEMOCRATIC PRESIDENTIAL NOMINATION.

04427 HOLT, M.F.

RETHINKING NINETEENTH-CENTURY AMERICAN POLITICAL HISTORY

CONGRESS AND THE PRESIDENCY, 19(2) (FAL 92), 97-112.

THE AUTHOR ASKS WHAT IS THE BEST APPROACH TO WRITING

NINETEENTH-CENTURY POLITICAL HISTORY, ANALYZES THE

SHORTCOMINGS OF SOME OF HIS OWN PREVIOUS APPROACHES, AND

SUGGESTS WAYS OF WRITING AN INTEGRATED HISTORY OF A

POLITICAL PARTY THAT LINKS VOTING WITH POLICY MAKING AND WITH STATE AND NATIONAL POLITICS, USING IDEAS DRAWN FROM HIS RESEARCH ON THE WHIG PARTY.

04428 HOLT, T.

DEATH PENALTY POSTER BOY

NATIONAL REVIEW, XLIV(12) (JUN 92), 26-27.

THE MEDIA PUT A ONE SIDED NATIONAL SPORTLIGHT ON THE

STORY OF VIRGINIA'S EXECUTION OF CONVICTED MURDERER, ROGER

COLEMAN. THIS REPORT ANALYZES THE FOUTH ESTATE'S NEW ROLE IN

THE JUSTICE SYSTEM. IT CONCLUDES THAT THE CASE OFFERS A

CAUTIONARY TALE ABOUT JOURNALISTIC STANDARDS AND ABOUT THE

POLITICAL PRESSURES INVOLVED IN CAPITAL CASES.

04429 HOLTMAN, C.

FROM HEGEMOMY TO DESTIMY

NEW POLITICAL SCIENCE, (20) (SUM 91), 63-80.

THE COLLAPSE OF THE SOCIALIST REGIMES IN THE SOVIET

UNION AND EASTERN EUROPE HAS BEEN PORTRAYED AS THE FINAL

TRIUMPH OF LIBERAL ISM. HOWEVER, A THESIS THAT LIBERALISM HAS

TRIUMPHED MUST DEMONSTRATE THAT LIBERALISM IS PERMANENT IN

THE FACE OF INTELLECTUAL AND MATERIAL FORCES THAT MAY COME

TO ACT ON IT. A THESIS THAT LIBERALISM IS DESERVED MUST

DEMONSTRATE THAT LIBERALISM BETTER CONDUCES TO INDIVIDUAL

SELF-DETERMINATION THAN ANY OTHER SET OF ALLOCATIONAL

PRINCIPLES THAT MIGHT BE PUT INTD PLACE. THIS ARTICLE ARGUES

THAT THE TRIUMPHALIST ARGUMENT STOPS SHORT OF BOTH INQUIRIES,

EACH OF WHICH WOULD REQUIRE SCRUTINY OF WHAT IN FACT

LIBERALISH IS.

04430 HOLTSCHI, R.

LOST ILLUSIONS IN CENTRAL AND EASTERN EUROPE

SWISS REVIEW OF WORLD AFFAIRS, 41 (12) (MAR 92), 22-23.

THE EXPERIENCE OF THE LAST TWO YEARS HAS THOROUGHLY

SMASHED THE INITIAL ILLUSIONS ABOUT A RAPID, PAINLESS

TRANSITION TO A MARKET ECONOMY AND A QUICK RISE IN

PROSPERITY IN THE FORMER EASTERN BLOC COUNTRIES. IN ORDER TO

SUCCESSFULLY TRANSFORM THEIR SYSTEMS, THESE COUNTRIES MUST

STAY THE COURSE, DEMONSTRATING PERSEVERANCE AND ECONOMIC

CONSISTENCY.

04431 HOLTZ-EAKIN, D.

ELECTIONS AND AGGREGAION: INTERPRETING ECONOMETRIC ANALYSES OF LOCAL GOVERNMENTS

PUBLIC CHOICE, 74(1) (1991), 17-42.

THE PRIMARY PURPOSE OF THIS PAPER IS TO OFFER A SIMPLE

FRAMEWORK WITHIN WHICH TO INTERPRET ANALYSES OF LOCAL FISCAL

POLICY. THE APPROACH ENCOMPASSES AS SPECIAL CASES BOTH THE

MEDIAN VOTER MODEL AND THE AVERAGE VOTER MODEL. IT RETAINS

SOME OF THE ADVANTAGES OF THE POPULAR MEDIAN VOTER APPROACH,

SOME OF THE ADVANTAGES OF THE POPULAR MEDIAN VOTER APPROAC
WHILE OFFERING A SOMEWHAT MORE GENERAL SETTING. THE KEY

WHILE OFFERING A SOMEWHAT MORE GENERAL SETTING. THE KEY
ASSUMPTION IS THAT OBSERVED TAX AND SPENDING POLICIES ARE

ASSUMPTION IS THAT OBSERVED TAX AND SPENDING POLICIES ARE

OFFICIAL HAS IMPERFECT INFORMATION CONCERHING THE TASTES OF OFFICIAL HAS IMPERFECT INFORMATION CONCERNING THE TASTES OF THE COMMUNITY'S RESIDENTS AND CHOOSES THE TAX AND SPENDING PACKAGE SO AS TO MAXIMIZE THE EXPECTED NUMBER OF VOTES WHEN FACED WITH RE-ELECTION. BECAUSE THE ALLOCATIONS THAT RESUL
FROM THIS PROCESS INCLUDE THE MOST FREOUENTLY EMPLOYED FROM THIS PROCESS INCLUDE THE MOST FREOUENTLY EMPLOYED
EMPIRICAL SPECIFICATIONS, THE MODEL SERVES AS AN ATTRACTIVE FRAMEHORK FOR EMPIRICAL ANALYSIS OF LOCAL GOVERNMENT FINANCE. 
04432 HOLZMAN, D.

NEW WAYS OF THINKING

INSIGHT, $7(2)$ (JAN 91), 48-49.

THOUSANDS OF SCHOOLS ARE TEACHING THEIR STUDENTS HOH TO THINK. TEACHERS HELP THEM TO ANALYZE DATA, ORGANIZE THOUGHTS AND APPLY THINKING TECHNIQUES TO THEIR LIVES. ALTHOUGH THERE IS NO STANDARD DEFINITION OF SUCH SKILLS, THE CONSENSUS IS THAT PUPILS RESPOND TO CREATIVE TEACHING. THIS TREND IN EDUCATION IS BEING PICKED UP BY CORPORATIONS.

04433 HOLZMAN, F.D

THE CIA'S MILITARY SPENDING ESTIMATES: DECEIT AND ITS COSTS CHALLENGE, 35(3) (MAY 92), 28-39.

DURING THE $1980^{\prime} \mathrm{S}$, THE CIA MISREPRESENTED THE MILITARY SPENDING GAP BETWEEN THE SOVIET UNION AND THE UNITED STATES. THIS LED TO DOMESTIC ECONOMIC AND DEFENSE POLICIES THAT COST THE UNITED STATES HUNDREDS OF BILLIONS OF DOLLARS IN HASTED RESOURCES.

04434 HOMER-OIXON, T.

ON THE THRESHOLD: ENVIRONMENTAL CHANGES AS CAUSES OF ACUTE CONFLICT

CONFLICT
INTERNATIONAL SECURITY, 16(2) (FAL 91), 76-116

RECENT CHANGES IN THE INTERNATIONAL SYSTEM HAVE LED MANY TO ASSERT THAT ENVIRONMENTAL PROBLEMS HAVE BECOME MORE URGENT THAN TRADITIONAL MILITARY THREATS TO MATIONAL SECURITY. THIS ARTICLE ARGUES THAT EMERGING ENVIRONMENTAL CHALLENGES ACTUALLY MAY CAUSE NEW ARMED CONFLICTS PARTICULARLY WITHIN AND BETHEEN DEVELOPING COUNTRIES. FOR EXAMPLE, ENVIRONMENTAL DEGRADATION IN THE THIRD WORLD THAT REDUCES AGRICULTURAL PROOUCTION, RETARDS ECONOMIC GROWTH DISPLACES POPULATIONS, AND DISRUPTS SOCIAL RELATIONS WILL CONTRIBUTE TO CIVIL AND INTERNATIONAL STRIFE. IT PROPOSES A FRAMEWORK FOR RESEARCH ON
THEY MIGHT BE PREVENTED.

04435 HONG, L.

DEVELOPING COUNTRIES FIGHT FOR THE RIGHT TO SUBSISTENCE BEIJING REVIEW, 35(8) (FEB 92), 12-13.

THE ISSUE OF HUMAN RIGHTS HAS BECOME ONE OF GREAT SIGNIFICANCE AND COMMON CONCERN IN THE INTERNATIONAL COMMUNITY. FOR THE THREE-FOURTHS OF THE WORLD'S POPULATION IN DEVELOPING COUNTRIES, THE RIGHT TO SUBSISTEMCE IS THE MOST IMPORTANT OF ALL HUMAN RIGHTS, HITHOUT WHICH THE OTHER RIGHTS ARE OUT OF THE QUESTION. THIS ARTICLE TRACES THE MODERN HISTORY OF DEVELPING COUNTRIES WHICH IS VIRTUALLY A HISTORY OF THEIR FIGHT FOR THE RIGHT TO SUBSISTENCE.

04436 HONG, S.; PARK, Y.; YIM, C.

THE KOREAN EXPERIENCE IN FDI AND SINO-KOREAN RELATIONS JOURNAL OF NORTHEAST ASIAN STUDIES, 10(2) (SUM 92), 66-86. IN RECENT YEARS, KOREAN OUTBOUND FOREIGN DIRECT INVESTMENT (FDI) HAS INCREASED RAPIDLY AND IT WILL BE GROWING MUCH FURTHER. NOW, KOREAN FIRMS CONSIDER THE SOCIALIST COUNTRIES TO BE ATTRACTIVE NEW PARTNERS FOR TRADE AND INVESTMENT PROJECTS. OUTBOUND KOREAN FDI COULD PLAY AN IMPORTANT ROLE IN THE INDUSTRIALIZATION OF THE LDCS IN SOUTHEAST ASIA AND CHINA. A CASE STUDY OF A KOREAN MULTINATIONAL CORPORATION REVEALS THAT THE DIRECT EMPLOYMENT EFFECT OF KOREA'S FDI IS EXTENSIVE IN TERMS OF MONEY INVESTED. THE KOREAN OUTBOUND FDI COULD PAVE A ROAD TO REGIONAL COOPERATION.

04437 HONG, $X$.

US CONTRADICTS ITSELF ON HUMAM RIGHTS

BEI JING REVIEW, 35(12) (MAR 92), 17

THIS ARTICLE ASKS WHY IS IT THAT IT IS ILLEGAL TO SPREAD COMMUNISM IN THE UNITED STATES WHILE CHIMA MUST ACCEPT THE WESTERN-STYLE MULTI-PARTY POLITICS AND PRIVATE OWNERSHIP? IT POINTS OUT THAT IN RECENT YEARS, SOME U.S. CONGRESSMEN AND NEWSPAPERS HAVE TAKEN EVERY OPPORTUNITY TO ATTACK CHINA OVER ITS ACTS TO DEAL WITH CRIMINALS INVOLVED IN THE 1989 ANTIGOVERNMENT RIOTS IN BEIJING AND IN LHASA, TIBET. IF SUCH A LOGIC IS PERMITTED, CITIZENS IN THE UNITED STATES SHOULD ENJOY THE RIGHTS TO SPREAD RUMORS, INCITE RIOTS, ASSAULT GOVERNMENT HEADQUARTERS AND PARLIAMENT, AND TORTURE SERVICEMEN AND CIVILIANS.

04438 HOOD, C.

A PUBL IC MANAGEMENT FOR ALL SEASONS?

PUBLIC ADMINISTRATION, 69(1) (SPR 91), 3-20.

THIS ARTICLE DISCUSSES: THE DOCTRINAL CONTENT OF THE GROUP OF IDEAS KNOWH AS "NEW PUBLIC MANAGEMENT" (NPM); THE INTELLECTUAL ORIGINS OF THOSE IDEAS; EXPLANATIONS FOR THEIR APPARENT PERSUASIVENESS IN THE 1980S; AND CRITICISMS WHICH HAVE BEEN MADE OF THE NEW DOCTRINES. PARTICULAR ATTENTION IS PAID TO THE CLAIM THE NPM OFFERS AN ALL-PURPOSE KEY TO BETTER PROVISION OF PUBLIC SERVICES. THIS ARTICLE ARGUES THAT NPM HAS BEEN MOST COMMONLY CRITICIZED IN TERMS OF A CLAIMED CONTRADICTION BETWEEN "EQUITY" AND "EFFICIENCY" VALUES, BUT THAT ANY CRITIQUE WHICH IS TO SURVIVE NPM'S CLAIM OF "INFINITE REPROGRAMMABILITY" MUST BE COUCHED IN
04439 HOOD, C

LOOKING AFTER NUMBER ONE? POLITICIANS' REWARDS AND THE ECOMOMICS OF POL ITICS

POLITICAL STUDIES, XL (2) (JUN 92), 207-226

THE NATURE AND LEVEL OF REWARDS TO POLITICIANS IS AN IMPORTANT ISSUE IN PUBLIC MANAGEMENT. IT RECEIVES LITTLE THEORETICAL ATTENTION IN ACADEMIC POL ITICAL SCIENCE TODAY. THIS PAPER DISCUSSES THE EXTENT TO WHICH THE CORE RENTSEEKING MODEL CAN EXPLAIN OBSERVED PATTERNS OF POLITICAL REWARDS. IT CONSIDERS THE CORE MODEL AGAINST TWO MODIFIED MODELS, USING DATA FROM AUSTRALIA AND THE UK AND A LIMITED NUMBER OF OBSERVATIONS DRAWN FROM OTHER COUNTRIES. THE CORERENT-SEEKING RATIONAL CHOICE MODEL APPEARS TO HAVE POOR EXPLANATORY POWER. A FAMILIAR OVERDETERMINATION PROBLEM ARISES IN TESTING THE EXPLANATORY CLAIMS OF MOOIFIED MODELS.

$04440 \mathrm{HOOO}, J$.

CHILDREN'S CRUSADE

REASON, 24(2) (JUN 92), 32-35.

ARMED WITH BUSIMESS RHETORIC AND DUBIOUS FACTS, THE CHILDREN'S DEFENSE FUND (CDF) HAS BECOME THE MOST POTENT LOBBYIST FOR A RENEHED WELFARE STATE. THIS ARTICLE SUGGESTS LOBBYIST FOR A RENEHED WELFARE STATE. THIS ARTICLE SUGCES
THAT, PROTECTED BY ITS SHIELD OF PIETY, THE CHILDREN'S DEFENSE FUND IS ADVANCING AN AGENDA INDISTINGUISHABLE FROM THE $1960 S$ HAR ON POVERTY IT CHARGES THAT CDF'S MISUSE OF STATISTICS SHOULD SURPRISE NO ONE FAMILIAR WITH THE PROCESS STATISTICS SHOULD SURPRISE NO ONE FAMILIAR WITH THE PROCESS FAVOR CERTAIN CONSTITUENCIES OF ADULTS--THOSE WHOSE FAVOR CERTAIN CONSTITUENCIES OF ADULTS--THOSE WHOSE LIVELIHOODS
SPDENDING.

$04441 \mathrm{HOOO}, \mathrm{J}$

CLINTON'S RECORD

NATIONAL REVIEH, XLIV(20) (OCT 92), 35-36.

THAT A DISPASSIONATE ANALYSIS OF THE CLINTON RECORD SHOWS THAT HE IS REALLY A MEDIOCRE GOVERNOR OF A POOR STATE AND THAT HE DEMONSTRATED NO SPECIAL QUALIFICATION TO LEAD AMERICA IS THE CLAIM OF THIS AUTHOR. THIS ARTICLE SURVEYS ARKANSAS'S BUDGET, ECONOMY, EDUCATION, WELFARE, AND OTHER ISSUES. IT CONCLUDES THAT IT HOULD NOT BE ACCURATE TO SAY CLINTON IS A FAILURE AS GOVERMOR--THAT HIS TENURE IN ARKANSAS SIMPLY PROVES THAT HE'S ND MIRACLE WORKER--AND THAT GOOD PUBLICITY BUILT THE REPUTATION HE ENJOYED AMONG HIS PEERS DURING THE 1980S.

04442 HOOD, J.

PACKAGE DEAL

PACKAGE DEAL
REASON, $24(5)$ (OCT 92), 32-37.

ONE INMOVATION IN WASHINGTON POLICY IS THE ALL-PURPOSE,

POLITICALLY CONNECTED THINK TANK, AN INSTITUTION DEVELOPED TO NEAR PERFECTION BY REAGANITE CONSERVATIVES. IN REACTION, DEMOCRATIC POLICY EXPERTS HAVE CREATED THINK TANKS OF THEIR OWN. THIS ARTICLE EXAMINES VARIOUS THINK TANKS THAT BILL CLINTON DRAWNS FROM IN HIS PRESIDENTIAL CAMPAIGN. THIS
ARTICLE ARGUES THT TAKEN AS A WHOLE, BILL CLINTON'S TRADEARTICLE ARGUES THT TAKEN AS A WHOLE, BILL CLINTON'S TRADEPOLICY PROPOSALS ARE THINLY VEILED EFORTS TO PANDER TO CRUDE AND THAT THE INVESTMENT-INFATUATED CLINTON CAMPAIGN SHOWS LITTLE UNDERSTANDING OF HOW REAL INVESTMENT WORKS

04443 HOOD, J.

POLITICS: 96 PEERS

REASON, 24(6) (NOV 92), 42-44.

THIS ARTICLE ARGUES' THAT THE 1996 CAMPAIGN HAS ALREADY

BEGUN AND THAT THE REPUBLICANS ARE SEARCHING FOR A NEH

RONALD REAGAN TO RALLY AROUND. IT CLAIMS THAT THE REAL

LEADER OF THE CULTURE WARRDRS IS PAT BUCHANAN, AND THE

DIFFERENCES BETWEEN AND BENNETT'S AND BUCHANAN'S CALLS TO

BATTLE COULDN'T BE MORE STRIKING. THE SUPPLY-SIDERS, THE

BUDGET CUTTERS, THE CULTURE WARRIORS, THE GOP GOVERNORS, AND

THE BUSH BRIAGATE ARE EACH ANALYZED. IT CONCLUDES THAT A

CANDIDATE STRESSING LOW TAXES, LOW SPENDING, ECONOMIC

DYNAMISM, SOCIAL TOLERANCE, A COHERENT POST-COLD WAR FOREIGN

POLICY, AND ABOVE ALL, OPTIMISM AND PROGARESS COULO FROM A

NEH RULING COALITION.

$04444 \mathrm{HOOO}$, J.

THE MYTHOLOGY OF STATE SPENDING

FREEMAN, 42(4) (APR 92) 132-133.

JOHN HOOD EXPLAINS WHY THE FACTS ABOUT EXPANDING STATE

AND LOCAL BUDGETS AREN'T REPORTED IN MOST NEWS STORIES

BECAUSE OF THE COMPOS TI TE

BECAUSE OF THE COMPOSITION OF NEWS SOURCES AND INTEREST

GROUPS IN STATE CAPITOLS. HE ARGUES THAT MANY STATES, RATHER

THAN SUFFERING THE EFFECTS OF A SLOWER NATIONAL ECONOMY,

RAISED TAXES AND SQUANDERED RESOURCES AND THUS WERE THE

PRIMARY CAUSE OF SLOW GROWTH. HE ALSO SUGGESTS THAT THE REPORTING OF THE FACTS ABDUT STA
PROCESS, BUT ONE OF NECESSITY.

04445 HOOD, S

BEIJING'S CAMBODIA GAMBLE AND PROSPECTS FOR PEACE IN

INDOCHINA: THE KHMER ROUGE OR SIHANOUK

ASIAN SURVEY, XXX(10) (OCT 90), 977-991. 
IN THE CONTINUING CAMBODIAN CONFLICT, CHINA HAS SELDOM HAD TO DEFEND ITS ACTIONS IN SUPPORT OF' THE KHMER ROUGE. FOR THE MOST PART, THIS SUPPORT HAS BEEN VIEWED BY THE INTERNATIONAL COMMUNITY AS JUSTIFIABLE BECAUSE BEIJING OPPOSED THE VIETNAMESE INVASION OF CAMBODIA, AND IT HAS BEEN LEGITIMIZED BY BEIJING'S SPONSORSHIP OF PRINCE NORODOM SIHANOUK WHO FOR THE SAKE OF RIDDING CAMBODIA OF THE VIETNAMESE, HAS RELUCTANTLY CDOPERATED HITH THE KHMER ROGUE. THIS ARTICLE SUGGESTS THAT BEIJING'S THO-TRACK POLICY OS SIMULTANEOUS SUPPORT FOR THE KHMER ROUGE AND PRINCE SIHANOUK HAS PROLONGED THE STRUGGLE IN CAMBODIA AND LIMITED THE PROSPECTS FOR LASTING PEACE IN THAT COUNTRY. THE QUESTION AT HAND IS A SERIOUS ONE PRINCIPALLY BECAUSE BEI JING'S TWOTRACK GAMBLE MAY RESULT IN A HANOI-FREE CAMBODIA, WHILE FAILING TO SAVE THE COUNTRY FROM AN ONGOING TRAGEDY NOW BEGINNING ITS THIRD DECADE.

04446 HOOGLAND, E.

IRANIAN POPULISM AND POLITICAL CHANGE IN THE GULF MIDDLE EAST REPORT, 22 (1) (JAN 92), 19-2I.

FROM A POLITICAL PERSPECTIVE, THE MAIN CONSEQUENCE OF THE PERSIAN GULF WAR HAS BEEN THE RESTORATION OF THE STATUS QUD ANTE. DISSIDENTS IN IRAQ AND KUWAIT AND HEREDITARY RULERS IN THE SHAIKHDOMS OF THE ARABIAN PENINSULA NOH REALIZE THAT THE WEST IS INTERESTED IN CONTAINING, NOT
PROMOTING, POLITICAL CHANGE. THE GULF ARAB VIEW OF IRAN AS A PROMOTING, POLITICAL CHANGE. THE GULF ARAB VIEW OF IRAN COUNTRY WITH A REPRESENTAIIVE TYPE OF GOVERNMENT MIGHT APPEAR TO HAVE SOME POLITICAL CHARACTERISTICS TYPICAL OF DEMOCRATIC GOVERNMENTS. IRANIAN POLITIICS TEND TO HAVE A POPULIST ORIENTATION ALTHOUGH IN IRAN'S VERSION OF POPULIST POLITICS, THE CONCEPT OF A LOYAL OPPOSITION DOES NOT EXIST. THIS ARTICLE SUGGESTS THAT SO LONG AS THE RULERS OF THE PERSIAN GULF STATES CONTINUE TO RESIST DEMANDS FOR POLITICAL REFORM, DISSATISFIED CITIZENS WILL BE TEMPTED TO SEE IRAN AS AN ATTRACTIVE ALTERNATIVE.

04447 HOOLE, F.; HUAMG, C.

THE POLITICAL ECONOMY OF GLOBAL CONFLICT

THE JOURNAL OF POLITICS, 54(3) (AUG 92), 834-858.

THE GLOBAL CONFLICT PROCESS AND THE GLOBAL ECONOMY ARE VIENED AS BEING INTERCONNECTED AT THE GLOBAL LEVEL THROUGH A PROCESS THAT HAS DISTINCTIVE CHARACTERISTICS AND A MOMENTUM OF ITS OWN. THIS POLITICAL ECONOMY OF GLOBAL CONFLICT IS EXAMINED FROM A BROAD-GUAGED, HISTORICAL AND DYNAMIC PERSPECTIVE. EVIDENCE IS PRESENTED FROM THE 1954-1980 TIME PERIDD THAT SUPPORTS THE VIEWPOINT THAT CHANGES IN CIVIL WAR, INTERNATIONAL WAR, SIZE OF THE GLOBAL ECONOMY, ECONOMIC INTERDEPENDENCE, AND ECONOMIC HEGEMONY ARE INTERRELATED IN A COMPLEX BEHAVIORAL PATTERN WITH HIGHER ORDER LAG STRUCTURES, AUTOREGRESSIVE COMPONENTS, AND MULT
INVOLVING SOME FEEDBACK MECHANISMS.

04448 HOOPER, E.

AIDS IN SOUTHERN AFRICA

SWISS REVIEH OF HORLD AFFAIRS, 40(8) (NOV 90), 11-13. THIS ARTICLE DISCUSSES THE PREVALENCE OF AIDS AND

SEROPOSITIVITY IN SOUTH AFRICAN COUNTRIES. STATISTICS ARE

GIVEN FOR VARIOUS AGE AND SOCIO-ECONOMIC GROUPS. MEASURES

BEING TAKEN AGAINST THE EPIDEMIC IN ZIMBABHE, PARTICULARLY

ITS AIDS CONTROL PROGRAM, ARE REVIEHED.

04449 HOPKINS, $M$

SHORY OF ITS MYTHS--RUSSIA ON THE ROAD TO REALITY

NEW LEADER, LXXV(9) ( JUL 92), 8-9.

CONDITIONS IN THE RUSSIAN REPUBLIC ARE HARDLY DIFFERENT

FROM WHAT THEY WERE BEFORE THE SOVIET UNION'S DISSOLUTION.

HOWEVER. THE RUSSIAN PEOPLE ARE STRUGGLING WITH THE FACT

HOWEVER, THE RUSSIAN PEOPLE ARE STRUGGLING WITH THE FACT

NATION IS ONE OF 15 REMHANTS OF AN EMPIRE THAT TOOK THREE

A HORLD-RESPECTED MILITARY POWER AND A GLOBAL LEADER IN

SCIENTIFIC RESEARCH TO A THIRD WORLD NATION HAS DEMORALIZED

MANY RUSSIANS.

04450 HOPKINS, T.D.

OIL SPILL REDUCTION AND COSTS OF SHIP DESIGH REGULATION

CONTEMPORARY POLICY ISSUES, $X(3)$ ( JUL 92), 59-70

THE 1990 OIL POLLUTION ACT MANDATES DOUBLE HULLS FOR NEW

OCEAN-GOING TANKERS UNLESS THE U.S. COAST GUARD CAN FIND

SUPERIOR DESIGNS TO REDUCE THE RISK OF OIL SPILLS. THIS

PAPER EXAMINES THE POLICY IMPLICATIONS OF PRESCRIBING

TANKERS HAVE MARKEDLY DIFFERING EFFECTS BOTH ON OIL

TRANSPORT COSTS AND ON THE RISK OF SPILLS. ANMUAL COSTS OF

SHIPPING OIL TO THE UNITED STATES WOULD RISE BY $\$ 462$ MILLION TO $\$ 2.047$ BILLION, DEPENDING ON WHICH OF FIVE PLAUSIBLE

DESIGNS IS SELECTED. THE CHIEF OBJECTIVE OF THESE DESIGNS IS TO REDUCE THE OUTFLOW OF OIL DURING GROUNDINGS AND

COLLISIONS. OVER THE PAST DECADE, AN AVERAGE OF ABOUT 7,500 TONS HAVE SPILLED ANMUALLY FROM THESE CAUSES IN U.S. WATERS, REPRESENTING ROUGHLY 20 PERCENT OF TRANSPORTATION-RELATED

MARITIME OIL POLLUTION IN 1990. SIMULATION RESEARCH

INDICATES THAT THE VARIOUS NEH DESIGNS HOULD PREVENT 2,600-5,
600 TONS FROM BEING SPILLED IN A TYPICAL YEAR. THIS PAPER PRESENTS COST-EFFECTIVENESS COMPARISONS OF THE ALTERNATIVES, CONTRASTING THESE WITH AVAILABLE INFORMATION ON SOCIETAL BENEFITS PER TON OF OIL SPILL PREVENTED. COSTS APPEAR SUBSTANTIAL RELATIVE TO BENEFITS, AND CONGRESS'S EMPHASIS ON DESIGN STANOARDS DEFLECTS ATTENTION FROM ALTERNATIVE RISK REDUCTION STRATEGIES, SUCH AS OPERATION AND MAINTENANCE PROCEDURES, THAT WARRANT EQUAL ATTENTION.

04451 HOPP, G.

HARS IN THE GULF--CRISIS OF ISLAM?

ORIENT, 25(3) (1991), 419-428

THE MOST RECENT CRISIS IN THE GULF HAS LEFT DEEP-SEATED

WOUNDS IN THE WAY MANY MUSLIMS SEE THEMSELVES. SECULARISTS

IN THE ARAB WORLD REGARD THIS WITH HOPE FOR A RELATION

BETWEEN RELIGION AND SOCIETY THAT IS MORE SUITED TO THE

TIMES, HOWEVER TRADITIONAL AND ISLAMIC THINKERS VIEW THIS

DEVELOPMENT WITH GREAT ANXIETY ABOUT THE UNITY AND

DEVELOPMENT WITH GREAT ANXIETY ABOUT THE UNITY AND
RESILIENCE OF THE UMMA. BOH GROUPS ARE EQUALLY HOPEFUL THAT

RESILIENCE OF THE UMMA. BOH GROUPS ARE EQUALLY HOPEFUL
THE PURIFYING EFFECT OF THE EVENT WILL WORK TO THEIR

THE PURIFYING EFFECT OF THE EVENT WILL WORK TO THEIR
RESPECTIVE ADVANTAGE. THE GULF CRISIS HAS BUILT UP OR

UNCOVERED AT LEAST THREE ZONES OF CONFLICT WITHIN ISLAM

WHICH ARE EXPLORED IN THIS ARTICLE.

04452 HORMATS, R.D.

EMERGING NEW DEMOCRACIES AMD FREE MARKET ECONOMICS

PRESIDENTIAL STUDIES QUARTERLY, XXII(4) (FAL 92), 747-764.

THE AUTHOR DISCUSSES THE EMERGING DEMOCRACIES AND MARKET

ECONOMIES IN EASTERN EUROPE. HE SEES FIVE TRANSITION PHASES: (1) FROM TOTALITARIANISM TO DEMOCRACY; (2) FROM COMMAND AND CENTRAL ECONOMIES TO FREE MARKET ECONOMIES; (3) FROM FORCED PARTICIPATION IN THE WARSAW PACT AND OCCUPATION BY THE RED ARMY TO SECURITY ARRANGEMENTS BASED MORE ON SOVEREIGN CHOICE; (4) FROM FOREIGN ECONOMIC RELATIONS CENTERED ON THE USSR TO MARKET-ORIENTED TIES TO THE EUROPEAN COMMUNITY AND THE REST OF THE WORLD; AND (5) FROM LAGGING DEVELOPMENT TO ECONOMIC MODERNIZATION. THE TRANSITIONS NILL NOT BE EASY, AND U.S. AID FOR ENTREPRENEURS IN EASTERN EUROPE WILL BE NEEDED.

04453 HORNE, G.

FACISTS IN THE REPUBLICAN CLOSET

POLITICAL AFFAIRS, 71(3) (APR 92), 35-36.

THIS ARTICLE IS A REVIEW OF THE BOOK "OLD NAZIS, THE NEW RIGHT AND THE REPUBLICAN PARTY: DOMESTIC FASCIST NETHORKS AND THEIR EFFECT ON U.S. COLD WAR POLICIES" BY RUSS BELLANT. IT DISCUSSES THE INFLUENCE WIELDING WITHIN HIGH-LEVEL

IT DISCUSSES THE INFLUENCE WIELDING WITHIN HIGH-LEVEL

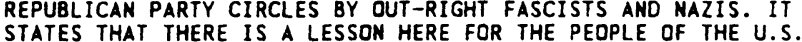

STATES THAT THERE IS A LESSON HERE FOR THE PEDPLE OF THE U.

THE UNDUE INFLUENCE OF FASCISTS IN HIGH PLACES

04454 HORNE, G.

REVERSING DISCRIMINATION: THE CASE FOR AFFIRMATIVE ACTION POLITICAL AFFAIRS, $71(2)$ (FEB 92), 7-14

AFFIRMATIVE ACTION IS THE NAME GIVEN TO A NUMBER OF

POLICIES DESIGNED TO OVERCOME PAST AND PRESENT

DISCRIMINATION AND PROVIDE OPPORTUNITY FOR THOSE

TRADITIDNALLY DENIED SUCH. ALTHOUGH AFRICAN AMERICANS ARE OFTEN SINGLED OUT AS THE SOLE BENEFICIARY THE FACT IS THAT RECIPIENTS HAVE INCLUDED LATINOS, ASIAN AMERICANS, PACIFIC I SLANDERS, NATIVE AMERICANS AND--PERHAPS THE MOST

SIGNIFICANT BENEFICIARY--NON-ETHNIC MINORITY WOMEN. AS THE 21ST CENTURY APPROACHES AND IT BECOMES CLEAR THAT A LARGER PERCENTAGE OF THE WORKFORCE WILL BE OPPRESSED MINORITIES AND NON-MINORITY WOMEN, AFFIRMATIVE ACTION LOOMS NOT AS A MATTER OF CHARITY BUT AS A TOOL TO INSURE ECONOMIC VIABILITY. OTHERHISE THE UNITED STATES RUNS THE RISK OF AN APARTHEIDSTYLE ECONOMIC GRIDLOCK WHERE THE BULK OF THE COUNTRY DOES NOT HAVE THE SKILL TO PROPEL A COMPLEX ECONOMY NOR THE CAPITAL TO CONSUME WHAT IS PRODUCED.

04455 HORNE, $G$.

THE CIVIL RIGHTS ACT OF 1991: THE CASE(S) FOR PASSAGE

POLITICAL AFFAIRS, LXX(2) (FEB 91), 18-24.

IN THE HAKE OF THE BUSH ADMINISTRATION'S REJECTION OF THE 1990 CIVIL RIGHTS BILL, SEVERAL SUPREME COURT CASES HAVE FURTHER ERODED THE RIGHTS OF MINORITIES IN THE UNITED STATES. THIS ARTICLE CONSIDERS THESE CASES: CITY OF RICHMOND $V$. CROSON, PATTERSON $Y$. MCLEAN, GRIGGS $V$. DUKE POWER, WARDS COVE PACKING V. ANTONID, PRICE-WATERHOUSE Y. HOPKINS, MARTIN IMPLLK, AND LORRANCE . ATQT TECHNOLOGIES, AND THEIR IMPLICATIONS. IT CONCLUDES THAT PASSAGE OF A NEH 1991 CIVIL

04456 HORNER, C.

CHINA ON THE RISE

COMMENTARY, 9 (6) (DEC 92), 36.

THE SURVIVAL OF CHINA, ITS WEALTH, ITS POWER, ITS STANDING, ITS FACE, ITS FUNDAMENTAL RELATIONSHIP TO THE REST OF THE WORLD MAY FINALLY BE RE-TURNING TO A CONDITION MORE IN KEEPING WITH THE TRADITIONAL CHINESE VIEH OF THE APPROPRIATE INTERNATIONAL PECKING ORDER. MUCH OF THIS HAS TO DO WITH THE COLLAPSE OF THE SOVIET EMPIRE. THERE IS SOMETHING IN THIS NEW SITUATION WHICH RESONATES WITH 
TRADITIONAL CHINESE STATECRAFT. ONE PREVAILS BECAUSE OF SUPERIOR STRATAGEM, NOT BECAUSE OF SUPERIOR POHER. THIS CHANGING SENSE OF CHINA MUST NOW BE MADE TO FIT WITH A CHINA WHICH ACTUALLY IS POWERFUL AND INFLUENTIAL.

04457 HORNSBY, C.; THROUP, D

ELECTIONS AND POLITICAL CHANGE IN KENYA

JOURNAL OF COMMONHEALTH AND COMPARATIVE POLITICS, 30(2) JUL 92 ), 172-199.

THIS ARTICLE FOCUSES UPON TWO APSECTS OF KENYA'S RECENT POLITICAL HISTORY: THE CLIENTELIST FACTIONAL SYSTEM AS IT DEVELOPED UNDER PRESIDENT KENYATTA AND HAS EVOLVED SINCE HIS DEATH IN 1978; AND THE CHANGING ROLE OF THE ELECTORAL SYSTEM IN POLITICS. IT STUDIES THE CHANGING FACTIONAL ALIGMMENTS UNDER PRESIDENT MOI; THE PURPOSES OF ELECTIONS IN KENYA AND THEIR LEGITIMATING ROLE; THE PARLIAMENTARY ELECTION PROCESS; AND, POLITICAL FACTIONS AND THE DECAY OF CLIENTILINSM UNDER MOI.

04458 HOROWITZ, D.

A DEMOCRATIC SOUTH AFRICA? CONSTITUTIONAL ENGINEERING IN A DIVIDED SOCIETY

UNIVERSITY OF CALIFORNIA PRESS, 1991, 293.

HAVING STUDIED AND WRITTEN ABOUT OTHER RACIALLY, ETHNICALLY, AND IDEOLOGICALLY DEEPLY DIVIDED POLITIES, THE AUTHO OF THIS BOOK APPROACHES THE SOUTH AFRICAN SITUATION FROM A COMPARATIVE PERSPECTIVE AND CONCENTRATES ON THESE CLEAVAGES. THE AUTHOR STRESSES THAT CONSIDERABLE BLACK ETHNIC DIVERSITY EXISTS AND WARNS THAT THE ELIMINATION OF WHITE DOMINATION MAY INCREASE INTRA-BLACK DIVISIONS. ALTHOUGH HE CONCLUDES THAT "INCLUSIVE DEMOCRACY IS IMPROBABLE IN SOUTH AFRICA," HE GOES ON TO OFFER A POTENTIAL SOLUTION. HE PROPOSES THE USE OF "INCENTIVES TO ACCOMMODATIVE BEHAVIOR" INCLUDING CHANGING THE PRESENT SINGLE MEMBER, SINGLE PLURALITY ELECTORAL SYSTEM TO AN ALTERNATIVE PREFERENTIAL ELECTORAL SYSTEM IN WHICH THERE HILL BE "VOTE POOLING" ACROSS ETHNIC OR RACIAL LINES. THIS WILL BE AN INCENTIVE TO THE "MODERATE MIDOLE." THE AUTHOR ALSO ADVOCATES FEDERALISH AND A PRESIDENTIAL SYSTEM WITH A DIRECTLY ELECTED PRESIDENT.

04459 HOROWITZ, D.

SOCIALISM BY ANY OTHER NAME

NATIONAL REVIEW, XLIV(7) (APR 92), 30-35.

THE CHANGES IN SOCIALIST EAST EUROPEAN COUNTRIES HAVE LEFT IT IMPOSSIBLE TO BELIEVE THAT SOCIALISM MIGHT HAVE HORKED IF THIS PATH OR THAT VARIANT HAD ONLY BEEN TRIED. YET NO ONE WHO CONTINUES TO IDENTIFY HITH THE LEFT REALLY ACCEPTS THIS TRUTH. THIS ARTICLE STATES THAT SOCIALISTS DO WANT TD FACE HHAT EYEN THE LEADERS OF PREVIOUSLY COMMUNIST COUNTRIES SAY, THAT SOCIALISM IS DEAD.

04460 HOROWITZ, D.

THE POLITICS OF PUBLIC TELEYISION

COME PULTY

CREATED BY THE PUBLIC BROADCASTING ACT OF 1967, THE PRESENT SYSTEM OF PUBLIC TELEVISION IS BY NOW ONE OF THE LAST EL DORADOS OF THE GREAT SOCIETY. THIS ARTICLE EXAMINES THE DEVELOPMENT OF PUBLIC TELEVISION FROM ITS RELATIVELY MODEST BEGINNINGS TO ITS TRANSFORMATION INTO A \$1.2-BILLION LEVIATHAN WHICH IS VIRTUALLY FREE OF ACCOUNTABILITY TO THE TAXPAYERS WHO SHELL OUT AN ANNUAL \$250 MILLION TO PAY FOR THE SYSTEM WHILE ALSO ENABLING IT TO GET MATCHING GRANTS FROM PRIVATE INDIVIDUALS, FOUNDATIONS AMD CORPORATIONS. FURTHERMORE, THE PBS HAS DISPLAYED A RADICAL POSTURE WHICH HAS ALIENATED A MAJOR PART OF PUBLIC TELEVISION'S AUDIENCE OF SUPPORTERS AS WELL AS ITS REPUBLICAN CONSTITUENCY IN CONGRESS.

04461 HOROWITZ, I.

THE CORRECT LINE ON CASTRO'S CUBA

NEH LEADER, LXXV(5) (APR 92), 11-13

THE UNITED STATES HAS LONG ADOPTED A DISTINCTLY NON-

INTERVENTIONIST APPROACH WITH REGARDS TO FIDEL CASTRO'S CUBA. THIS WAS /IS DUE TO FOUR FACTORS: THE GENERAL U.S. DISDAIN FOR INTERVENTION AFTER THE VIETNAM EXPERIENCE; THE TURN TO BOLIVARISM AND THE REJECTION OF MONROEISM--THAT IS, THE CONVICTION THAT LATIN AMERICA IS IN CONTROL OF ITS OWN DESTINY AND WILL SOLVE THE CUBAN PROBLEM BY CAUTERIZATION; THE SEVERELY RESTRICTIVE KENHEDY-KRUSHCHEV PACT ENDING THE CUBAN MISSILE CRISIS. AND THE FEELING THAT, IF NO POSITIVE ACTION IS TAKEN, CASTRO, LIKE THE USSR AND EASTERN EUROPEAN ACIION IS TAKEN, CASTRD, LIKE THE USSR AND EASTERN EUROPEAN COMMUNIST STATES, HILL SIMPLY DISAPPEAR. SUCH A POLICY OF CASTRO AND MAY ACTUALIY ENCOURAGE HIS TENACIOUS HOLD ON CASTRO A

04462 HOROWITZ, I.L.

REVOLUTION, LONGEVITY AND LEGITIMACY IN COMMUNIST STATES STUDIES IN COMPARATIVE INTERNATIONAL DEVELOPMENT, $27(1)$

SPR 92 ), 61-75.

THIS ARTICLE EXAMINES KEY LIMKAGES IN THE DRAMATIC TURN

OF EVENTS IN TOTALITARIAN STATES BY REVIENING THE LITERATURE
ON REGIME LEGITIMACY AND LONGEVITY IN COMMUNIST REGIMES. IT ARGUES THAT LONGEVITY IS A POOR SUBSTITUTE FOR LEGITIMACY. EASTERN EUROPE STATES, WHERE COMHUNIST RULE HAS EXTERNALLY IMPOSED, HERE RELATIVELY "EASY" TO OVERCOME. HOWEVER, CHANGES OCCURRING IN COUNTRIES WHERE QUASI-LEGITIMACY WAS CHANGES OCCURRING IN COUNTRIES WHERE QUASI-LEGITIMACY WAS
ACHIEVED BY MASS MOVEMENTS, AS IN CHINA OR THE SOVIET UNION, ACHIEVED BY MASS MOVEMENTS, AS IN CHINA OR THE SOVIET UNION
AND THOSE UNDER FAMILY DICTATORSHIPS, SUCH AS NORTH KOREA AND THOSE UNDER FAMILY DICTATORSHIPS, SUCH AS NORTH KOREA AND CUBA, ARE NOT AS SUBJECT TO COLLAPSE. THESE PSEUDO FOR OF LEGITIMACY RESIST LIBERALIZAITON IN POLITICAL TERMS,

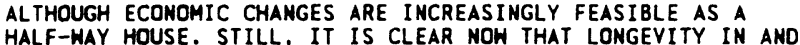
HALF-WAY HOUSE. STILL, IT IS CLEAR NOW THAT LONGEVITY IN AND OF ITSELF IS NOT A SUBSTITUTE FOR LEGITIMACY. THE FOR
A FUNCTION OF TIME, THE LATTER OF SOCIAL STRUCTURE.

04463 HOROWITZ, I.L.

SHADOW OF A MATION

HEMISPHERE, 4(2) (WIN 92), 6-7

IN ESTABLISHING A U.S. POLICY FOR PANAMA, THE CONFUSION DERIVES FROM FAILURE TO FACE THE FACT THAT PANAMA IS A NATION ARTIFICIALLY CREATED FROM THE OUTSIDE. IN THE FACE OF THE PANAMANIAN STATE'S OVERWHELMING ABSENCE OF LEGITIMACY, THE CAPACITY TO DEMOCRATIZE IS MORE PROBLEMATIC IN PAMAMA THAN PERHAPS ANYWHERE ELSE IN CENTRAL AMERICA. PANAMA IS A THAN PERHAPS ANYWHERE ELSE IN CENTRAL AMERICA. PANAMA IS A SUBSTANCE OF DEMOCRACY: ORDERLY RULE BASED ON CONSENSUS, SUBSTANCE OF DEMOCRACY: ORDERLY RUL
WITH RESPECT FOR MINORITY RIGHTS.

04464 HOROWITZ, I.L.

TOTALITARIAN OPTIONS AFTER THE COLD WAR

FREDOM REVIEH, 23(3) (MAY 92), 37-39.

IN THE WAKE OF THE SOVIET UNION'S DISINTEGRATION, WHAT WILL BE THE FATE OF THE INTERNATIONAL COMMUNIST MOVEMENT? ALTHOUGH THE PICTURE IS FAR FROH COMPLETE, SOME ANSHERS ARE ALREADY EMERGING. SCHISMS, EROSIONS, DEBATES, DEFECTIONS AND STRUGGLES FOR POWER WILL OCCUR WITHIN THE COMMUNIST MOVEMENT WITHIN INDIVIDUAL NATIONS. SOME COMMUNISTS WILL PURSUE POWER THROUGH TIGHTLY-ORGANIZED, AUTONOMOUS,

REVOLUT IONARY GROUPS THAT USE FORCE AND TERRORISM, SUCH AS THE SENDERO LUMINOSO IN PERU; OTHERS WILL RELY ON THE ORGANIZED POLITICAL PARTY THAT OPERATES WITHIN THE LEGAL STRUCTURE; SOME WILL CHOOSE THE LOOSELY-FORMED MOVEMENT THAT WORKS WITHIN VARIOUS POLITICAL PARTIES IN ORDER TO INFLUENCE EVENTS.

04465 HOROWITZ, I.L.

WAITING FOR PEROT--NOT

COMMONWEAL, CXIX(12) (JUN 92), 6-7.

ALTHOUGH MANY AMERICANS ARE JUSTIFIABLY DISGUSTEO WITH POLITICS AND WITH WASHINGTON, H. ROSS PEROT IS CERTAINLY NOT PHE ANSWER TO AMERICA'S PROBLEMS. IF ANYTHING. HIS

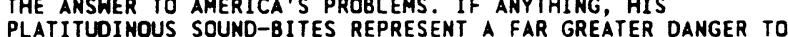
PLATITUDINOUS SOUND-BITES REPRESENT A FAR GREATER DANGER TO AMERICAN DEMOCRACY THAN THE ILLS HE PROPOSES TO REMEDY. LATENT CANDIDACY OF PEROT IS NOT SO MUCH A THIRD-PARTY PFOR BUT A CULT OF PERSONALITY BELATEDL INSINUATED INTO POLITICAL CAMPAIGN THAT LACKS CHARISMA. SUCH CULTS HAVE UGLY BUT PROPER IDENTIFI

04466 HORRIGAN, 8

HOW MANY' PEOPLE WORKED IN THE SOVIET DEFENSE INDUSTRY? RFE/RL RESEARCH REPORT, 1(33) (AUG 92), 33-39.

EXPERTS ESTIMATE THÁT THE NUMBER OF PERSONS EMPLOYED IN THE SOVIET DEFENSE INDUSTRY UNDER THE MILITARY-INDUSTRIAL COMMISSION (VOENHO-PROMYSHLENNAYA KOMISSIYA OR VPK) VARIED FROM 6.5 MILLION TO 14.4 MILLION. WHILE IT IS DIFFICULT TO DRAH ANY CONCLUSIONS ABOUT THE POL ITICAL OR SOCIAL IMPLICATIONS OF THE DISTRIBUTION OF EMPLOYEES IN THE VPK SECTOR FROM THIS DATA ALONE, IT IS EVIDENT THAT SUCH EMPLOYEES CONSTITUTE A POTENTIAL, IF NOT INEVITABLE, SOURCE OF UNREST.

04467 HORRIGAN, 8.

THE CHANGING FATE OF A RUSSIAN SECRET CITY

RFE/RL RESEARCH REPORT, 1 (47) (NOV 92), 50-54

RECENT FIRST-HAND ACCOUNTS SHED NEW LIGHT ON THE

CHANGING LIVES OF THOSE WITHIN THE ONCE-SECRET CITY OF

ARZAMAS-16, THE SITE WHERE THE FIRST SOVIET ATOMIC BOMB WAS DEVELOPED. TODAY ARZAMAS-16 REFLECTS THE PROBLEMS FACING ALL OF RUSSIA AS IT COPES WITH RAPID POLITICAL AND SOCIOECONOMIC CHANGE. THE CITY MUST DEAL WITH SUCH DIFFICULT ISSUES AS MILITARY-INDUSTRIAL CONVERSION, INDEPENDENT LABOR MOVEMENTS, THE "BRAIN DRAIN," AND ENVIRONMENTAL POLLUTION.

04468 HORSLEY, H.

RECONSIDERING INALIENABILITY FOR COMMERCIALLY-VALUABLE BIOLOGICAL MATERIALS

HARYARD JOURMAL OF LEGISLATION, 29(1) (WIN 92), 223-250.

CURRENT U S OAW PROHIBITS THE SALE OF HUMAN BODY PARTS FOR URA T.S. LAW PROHIBITS THE SALE OF HUMAN BODY PARTS TO RECOGNIZE THE DISTINCTION BETHEEN THOSE HUMAN BODY PARTS THAT HAVE ALWAYS BEEN RECOGNIZED TO HAVE INTRINSIC, FUNCTIONAL VALUE AND THOSE THAT HAVE TRADITIONALLY BEEN CONSIDERED BIOLOGICAL WASTE. PATIENTS OUGHT TO RETAIN AN ALIENABLE PROPERTY INTEREST IN NON-FUNCTIONAL TISSUE THAT 
BECOMES COMMERCIALLY VALUABLE. BOTH LEGISLATIVE AND JUDICIAL REFORMS ARE NEEDED TO ALLOW PATIENTS TO PROFIT FROM RESEARCH
CONDUCTED ON THEIR THERAPEUTICALLY-EXCISED TISSUES AND CELLS

04469 HORSLEY, $W$.

UNITED GERMANY'S SEVEN CARDINAL SINS: A CRITIQUE OF GERMANY'S FOREIGN POLICY

MILLENKIUM, 21(2) (SUM 92), 225-242

SINCE UNIFICATION, GERMANY HAS COME UNDER CRITICISM FOR ACTING UNILATERALLY AND IN ITS OHN INTEREST ON IMPORTANT ISSUES, INCLUDING THE SEVEN ENUMERATED IN THIS PAPER. RATHER THAN BEING DELIBERATE. THE APPARENT ASSERTIVENESS IN GERMAN FOREIGN POLICY IS THE RESULT OF INCOMERENT POLICY MAKING

CAUSED BY THE DIVISIONS IN THE GERMAN GOVERNMENTAL STRUCTURE. THE RESULTING PROBLEMS ARE LIKELY TO PERSIST AND EVEN HORSEN.

04470 HORT, $P$.

LISBON SUMMIT FAILS TO CONVINCE MANY A MAN IN THE STREET GERMAN TRIBUHE, (1522) (JUL 92), 1

WITH MANY PEOPLE TIRED OF EUROPEAN UNION, THE EUROPEAN SUMMIT IN LISBON ANNOUNCED PLANS TO REVIEW AND SIMPLIFY THE LEGISLATIVE OUTPUT OF THE EUROPEAN COMMISSION IN BRUSSELS. HOWEVER, BINDING DECISIONS ON CONTROVERSIAL MEDIUM-TERM FINANCES HERE HELD OVER UNTIL THE NEXT SUMMIT, TO BE HELD IN EDINBURGH IN DECEMBER. FINANCIAL ISSUES WERE ONLY ONE OF A MYRIAD OF PROBLEMS THAT THE SUMMIT REPRESENTATIVES FAILED TO GRAPPLE HITH. OTHER PRESSING PROBLEMS INCLUDE THE GROWTH OF THE EURO-BUREAUCRACY, THE DANISH "NO" VOTE TO INTEGRATION AND RICH-POOR INEQUALITY AMONG EC MEMBER STATES.

04471 HORTON, A.

THE POPE'S OWN CONFERENCE

MIDOLE EAST INTERNATIONAL, (395) (MAR 91), 19.

SINCE 2 AUGUST 1990 THE POPE HAS MADE 55 APPEALS FOR PEACE, BUT FEW OF THEM HAVE BEEN POPULAR IN PLACES HERE POWER RESIDES. JOHM PAUL II CAN HAVE HAD FEW ILLUSIONS ABOUT HIS INFLUENCE OVER EVENTS IN THE GULF. YET HE HAS

PERSISTENTLY OPPOSED THE USE OF "UNMECESSARY VIOLENCE." HE HAS RECENTLY CALLED FOR A CONFERENCE OF REPRESENTATIVES OF CATHOLIC EPISCOPATES OF COUMTRIES INYOLYED IN THE HAR TO CATHOLIC EPISCOPATES OF A CONTRIES INVOLVED IN THE WAR TO MISERABLE BY THE WAR.

04472 HORTON, R.

OIL AND POLITICS IN THE 1990'S

WORLD TODAY, $48(6)$ (JUN 92 ), 100-103

THE POY 1 (1CS OF OIL IN THE 1990'S ARE YERY DIFFERENT FROM THOSE IN THE 1960'S AND 1970'S. THE 1980'S HERE YEARS OF TRANSITION AS SUSPICION AND UNEASE BETWEEN THE POL ITICAL REALM AND THE PETROLEUM INDUSTRY GAVE WAY TO A GREATER SENSE OF INTERDEPENDENCE. MANY GOVERNMENTS NOW FEEL THAT PETROLEUM COMPANIES POSE A FAR SMALLER THREAT TO THE PUBLIC INTEREST THAN ONCE WAS WIDELY SUPPOSED. FOR THE PETROLEUM COMPANIES, THE RISKS ARE AS GREAT AS EYER--NOT LEAST BECAUSE THEY ARE' NOW EXPECTED TO ASSUME SOME OF THE RISKS FORMERLY SHOULDERED BY GOVERNMENTS. IN THIS ARTICLE, THE AUTHOR EXAMINES BOTH THE PUBLIC AND PRIVATE (CORPORATE) RISKS.

04473 HORVAT, A.

INSULAR AMERICANS

FAR EASTERN ECONOMIC REVIEW, 151(17) (APR 91), 15

IN U.S. RURAL SCHOOL DISTRICTS, THE NAME JAPAM HAROLY APPEARS IN THE CURRICULUM, AND IN WASHINGTON IT IS NOW MORE POLITICALLY FASHIONABLE TO CONDEMN JAPAN THAN TO CLAIM TO HAVE EXPERT KNOWLEDGE ABOUT IT. THE U.S. WILL NOT BE ABLE TO DEAL WITH JAPAN AS A TRADE RIVAL UNTIL AMERICANS PAY AS MUCH SERIOUS ATTENTION TO JAPAN AS THE JAPANESE DO TO THE U.S. WHILE JAPANESE BY THE MILL IONS ARE PREPARING THEMSELVES FUNCTION IN BOTH JAPANESE AND AMERICAN SOCIETY, NO MORE THAM A HANDFUL OF AMERICANS ARE CAPABLE OF COMHUNICATING ACROSS THE THO CULTURES. ONLY A SIGNIFICANT CHANGE IN AMERICAN ATTITUDES AMO BEHAYIOR WILL ALLOW AMERICAN TO REMAIM COMPETITIVE IN AN INCREASINGLY COMPLEX HORLD MARKET.

04474 HOSENBALL, M.

BCCI NO EVIL

NEH REPUBLIC, 206 (4) (JAN 92), 19-22.

THE AUTHOR EXAMINES UTAH SÉNATOR ORRIN HATCH'S INVOLVEMENT WITH THE INFAMOUS BANK OF CREDIT AND COMMERCE INTERNATIONAL.

04475 HOSENBALL, M.

THE OOD COUPLE

NEW REPUBLIC, 206 (22) (JUN 92), 27, 30-32, 34-35 DESPITE REPEATED INTEL 92), 27, 30-32, 34-35. HUSSEIN'S OVERT THREATS AGAINST HIS MEIGHBORS, PRESIDENT GEORGE BUSH ENERGETICALLY PURSUED A LONGSTANDING U.S. POLICY OF APPEASEMENT TOWARD IRAQ. FROM 1983 UNTIL ONLY DAYS BEFORE DIPLOMATIC RELATIONS RUPTURED, THE UNITED STATES WAS ONE OF SADDAM'S PRINCIPAL FINANCIAL BACKERS. IN HINDSIGHT, THE EXTENT TO WICH THE BUSH AND REAGAN ADMINISTRATIONS COLLABORATED IN SADDAM'S RUINOUS MILITARY DELUSION IS APPALLING.
04476 HOSKINS. L.

EUROCENTRISM VS. AFROCENTRISM: A GEOPOLITICAL LINKAGE ANALYSIS

JOURNAL OF BLACK STUDIES, 23(2) (DEC 92), 247-257.

IT IS SUGGESTED THAT EUROCENTRISM REPRESENTS A RACIST DIVISIVE, AHISTORICAL, AND DYSFUNCTION VIEW OF WORLD HISTORY. THE PURPOSE OF THIS ARTICLE IS TO ENEGAGE IN AN AFROCENTRIC GEOPOLITICAL LINKAGE ANALYSIS OF THE STRUGGLE BETWEEN PROBLEM WHICH IS THE INABILITY ON THE PART OF THE EUROPEANS TO TREAT, ACCEPT, AND RESPECT THE DESCENDENTS OF THE FORMER AFRICAN SLAVES AS EQUAL, FULL-FLEDGED HUMAN BEINGS.

04477 HOSKINS, C.; MCFADYEN, S.

THE MANDATE, STRUCTURE AND FINANCING OF THE CBC CANADIAN PUBLIC POLICY--ANALYSE DE POLITIQUES, 18(3) (SEP 92), 275-289.

THIS PAPER ASSESSES THE ROLE OF THE CBC, CONCENTRATING ON ITS ENGLISH-LANGUAGE AND FRENCH-LANGUAGE TELEVISION BROADCASTING SERVICES. THE RATIONALE FOR RETAINING A BROADCASTING SERVICES. THE RATIONALE FOR RETATH PUBL BC BORADCASTER IS CONSIDERED AND THE IMPL ICATIONS FOR THE MANDATE, STRUCTURE AND FINANCING OF THE IMPLICATIONS FOR THE MANDATE, STRUCTURE AND FINANCING OF TH CBC ARE EXAMINED. THE CONCLUSION IS THAT THE CBC SHOULD RESTRICT ITS MAIN TELEVISION OPERATIONS TO PRIME-TIME
COMMERCIAL-FREE NATIONAL NETHORK SCHEDULES DISTRIBUTED BY A MIXED DELIVERY SYSTEM HITH OFF-AIR AND SATELLITE TO CABLE COMPONENTS.

04478 HOSLE, $V$

THE THIRD WORLD AS A PHILOSOPHICAL PROBLEM

SOCIAL RESEARCH, 59 (2) (SUM 92), 227-262.

THE INCREASING GAP BETWEEN THE FIRST AND THIRD WORLDS RAISES SOME OF THE MOST DIFFICULT MORAL QUESTIONS OF THE MODERN ERA. IN THIS PAPER, THE AUTHOR ANALYZES THE HISTORICAL GENESIS OF THE THIRD-HORLD PROBLEM, CONCENTRATING ON THE THEORETICAL AND PHILOSOPHICAL LEVEL. HE ALSO DISCUSSES THE MORAL QUESTIONS RAISED BY THE RELATIONSHIP BETWEEN THE FIRST AND THIRD WORLD, FOCUSING ON ECONOMIC POLITICAL, AND CULTURAL ASPECTS. HE CONCLUDES THAT THE FIRST WORLD WILL NEVER OVERCOME ITS IDENTITY CRISIS IF IT DOES NOT BEGIN TO LOOK FOR AND RESPECT THE IDENTITY OF THE THIRD WORLD.

04479 HOSTON, G.

CONCEPTUALIZATION BOURGEOIS REVOLUTION: THE PREWAR CONCEPTUALIZATION BOURGEOIS REVOLUTION: COMPARATIVE STUDIES IN SOCIETY AND HISTORY, 33(3) (JUL 91),

FOR THOSE ON JAPANESE LEFT, THE SIGNIFICANCE OF THE MEIJI RESTORATION LAY IN WHAT IT COULD REVEAL ABDUT THE DYNAMIC INTERPLAY AMONG THE STATE AND ITS BUREAUCRACY, THE IMPERIAL FIGUREHEAD AT ITS APEX, AND THE JAPANESE PEOPLE--IM SHORT, IT HAD TO DO WITH THE PHENOMENON OF DEMOCRAT AND WHETHER IT WAS VIEWED AS A POSITIVE OR NEGATIVE DEVELOPMENT. FOR SOME, MEI JI WAS VIEWED AS A BOURGEOIS FOR DEMOCRACY SIXTY YEARS AGO ENVISAGED BOURGEOIS REVOLUTION AND WHAT FORCES, IN THEIR ESTIMATION, ACCELERATED OR RETARDED THE FLOWERING OF BOURGEOIS DEMOCRACY IN JAPAN. IN SO DOING, THE AUTHOR IS "INESCAPABLY" DRAWN BACK TO THE EARLIER UPHEAVALS OF FRANCE AND ENGLAND.

04480 HOSTON, G.

THE STATE, MODERNITY, AND THE FATE OF LIBERALISM IN PREWAR JAPAN

JOURNAL OF ASIAN STUDIES, 51(2) (MAY 92), 287-316,

THE PATTERNS OF JAPANESE LIBERAL ISM THAT EMERGED IN THE COURSE OF JAPAN'S RAPID INDUSTRIALIZATION FROM MEIJI TO

SHOWA IN TERMS OF THE UNIVERSAL DILEMMAS OF MODERNIZATION IN LATER INDUSTRIALIZING SOCIETIES ARE INVESTIGATED. THIS ARTI INOUSTRIALIZING SOCIETIES ARE INVESTIGATED. THIS HOULD EMBRACE WESTERN STYLE LIBERALISM TOHARD LATE NINETEENTH-CENTURY STYLE LIBERALISM OF THE SORT THAT ADVOCATED THAT THE STATE PLAY AN ACTIVE AND POSITIVE ROLE IN SUPPORTING THE MATERIAL AND SPIRITUAL DEVELOPMENT OF THE INDIVIDUAL. IT EXPLORES LIBERALISM AS POLITICAL PHILOSOPHY, INDIVIDUAL. IT EXPLORES LIBERALISM AS POLITICAL PHILOSOPHY,
THE ROOTS OF TASIHO LIBERALISM IN MEI JU JAPAN, THE MAIN CURRENTS OF TAISHO LIBERALISM, AND DRAHS CONCLUSIONS ABOUT

CURRENTS OF TAISHO LIBERALISM, AND DRANS CONCLUSIONS
LIBERALISM, THE LEFT, AND THE STATE IN TAISHO JAPAN.

04481 HOTTINGER, A.

THE ARABS: BACKWARD INTO THE FUTURE

SWISS REVIEW OF WORLD AFFAIRS, 41(11) (FEB 92), 27-29

OVER THE LAST 40 YEARS. THE MUSLIM WORLO HAS EXPERIENCED AN EVER-WIDENING GAP BETWEEN THE "TURATH"--WHAT ARABS TODAY REFER TO AS THE LEGACY OF THE GREAT ISLAMIC RELIGIOUS AND CULTURAL TRADITION-AND "MOOERNITY." THIS DICHOTOMY HAS BEEN VERY IMPORTANT IN SHAPING ARAB CULTURE AND POLITICS.

04482 HOUBERT, J.

THE INDIAN OCEAN CREOLE ISLANDS: GEO-POLITICS AND DECOLONISATION

JOURNAL OF MODERN AFRICAN STUDIES, 30(3) (SEP 92), 465-484. 
DECONONIALIZATION WAS A POLICY OF THE WEST, AS WELL AS A PROCESS REFLECTING THE RADICAL TRANSFORMATION OF THE CONFIGURATION OF PONER IN THE INTERNATIONAL SYSTEM. BRITAIN DEVISED A SYSTEM WHICH WOULD ALLOW HER TO KEEP A SUBSTANTIAL MILITARY PRESENCE EAST OF SUEZ ON A SEVERELY LIMITED BUDGET. THE CORE INTEREST OF THE UNITED STATES IN THE INDIAN OCEAN CREOLE ISLANDS WAS NUCLEAR GEO-STRATEGY. THIS ARTICLE EXPLORES THE EMERGENCE OF A STRATEGY WHEREBY SOME ISLANDS WOULD GAIN THEIR INDEPENDENCE, SHORN OF SOME OF THEIR ATTACHED SMALLER ISLANDS, WHOSE FEW INHABITANTS COULD THEN BE REMOVED, IF NEED BE, WITHOUT TOO MUCH DIFFICULTY.

CREOLIZATION AND DECOLONIZATION ARE EXAMINED.

04483 HOUSE, W.J. ; ZIMALIRANA, G.

RAPID POPULÁTION GROWTH AND POVERTY GENERATION IN MALAWI JOURNAL OF MODERN AFRICAN STUDIES, 30(1) (MAR 92), 141-161. THE AUTHOR STUDIES THE RELATIONSHIP BETWEEN MALAWI'S RAPID POPULATION GROWTH, THE COUNTRY'S ECONOMIC DEVELOPMENT, GOVERNMENT RESPONSES TO MALANI'S ECONOMIC PROBLEMS, AND GOVERNME
POVERTY.

04484 HOUSEMAN, G.L.

Y CRISIS

CHALLENGE, 35(2) (MAR 92), 56-57

IT IS TIME TO RENEN THE CALL FOR A MEANINGFUL, THOROUGH, AND DETERMINED RETURN TO SOMETHING THAT IS OBVIOUSLY VERY MUCH NEED--GOVERNMENT REGULATION. NOT JUST ANY KIND OF GOVERMMENT REGULATION, OF COURSE, FOR THERE ARE RULES THAT DESERVE CONDEMNATION. BUT THE FRANTIC RUSH TO REDUCE THE NUMBER OF PAGES IN THE "FEDERAL REGISTER," TO PROMOTE THE MERGERS-ACOUISITIONS-HOSTILE TAKEOVERS GAME, AND TO WORK TOWARDS "KEMPISH" EMPOWERMENT, AMONG OTHER EXCESSES, HAS HAD RESULTS THAT ARE NOT ONLY UNDESIRABLE BUT OUITE SIMPLY DISASTROUS FOR THE ECONOMY, FOR JOBS, FOR CONSUMER PROTECTION, AND FOR THE WELFARE OF THE COLLECTIVE SOCIAL CONSCIENCE.

04485 HOWARD, J.H.

THE ROBE AND THE CLOTH: THE SUPREME COURT AND RELIGION IN THE UNITED STATES

JOURNAL OF LAW \& POLITICS, VII(3) (SPR 91), 481-524.

THE PURPOSE OF THIS ESSAY IS TO ASSESS THE ROLE OF THE $U$. S. SUPREME COURT IN RESOLVING OISPUTES OVER RELIGIOUS
FREEDOM AND CHURCH-STATE RELATIONS IN THE UNITED STATES. THE FREEDOM AND CHURCH-STATE RELATIONS IN THE UNITED STATES. THE
AUTHOR'S GOAL IS TO TAKE STOCK OF AMERICAN EXPERIENCE IN AUTHOR'S GOAL IS TO TAKE STOCK OF AMERICAN EXPERIENCE IN
ORDER TO CLARIFY CONSTITUTIONAL CHOICES IN PROTECTING ORDER TO CLARIFY CONSTITUTIONAL. CHOICES IN PROTECTING
FREEDOM FOR, AND FROM, RELIGION. THE ARGUMENT IS DIVIDED FREEDOM FOR, AND FROM, RELIGION. THE ARGUMENT IS DIVIDED
INTO FOUR PARTS: THE U.S. CONSTITUTION SPEAKS HITH A DUAL INTO FOUR PARTS: THE U.S. CONSTITUTION SPEAKS HITH A DUAL AND UNCERTAIN VOICE ON THIS SUBJECT; THE TWO CLAUS FIRST AMENDMENT--FREE EXERCISE OF RELIGION AND THE
ESTABLISHHENT CLAUSE--COLLIDE, ESPECIALLY AS INTERPRETED IN ESTABLISHMENT CLAUSE-COLLIDE, ESPECIALLY AS INTERPRETEC THE LAST FOUR DECADES; A DIVIDED SUPREME CDURT STILL
SEARCHES FOR STANDARDS TO RESOLVE THIS CONFLICT; AND JUDICIAL REMEDIES ARE LIMITED.

04486 HOWARD, $M$.

THE LESSONS OF HISTORY

YALE UNIVERSITY PRESS, 1991, 248

SIR MICHAEL HOWARD, AN EMINENT MILITARY HISTORIAN, DISCUSSES THE PROCESSES OF HISTORICAL CHANGE THAT IGNITED THE EURDPEAN HARS OF THE THENTIETH CENTURY. HE PONDERS THE CONTINUING SIGNIFICANCE OF NATIONALISM, EXPLORES THE CONFLICTING IDEOLOGIES THAT AROSE FROM INDUSTRIALISM, AND ARGUES THAT, DESPITE THE TENDENCY OF MODERN SOCIETIES TO DEDICATE THEMSELVES TO MATERIAL WELFARE RATHER THAN HEROIC ACHIEVEMENT, ORGANIZED VIOLENCE REMAINS A NORM.

04487 HOWE, G.

JAPAN AND THE UNITED STATES: A EUROPEAN PERSPECTIVE WORLD TODAY, 48(7) (JUL 92), 126-129.

MEETINGS BETWEEN AMERICAN PRESIDENTS AMD JAPANESE PRIME MINISTERS HAVE BECOME RISKY AND UNPREDICTABLE AFFAIRS. THEY RAISE AHKHARD QUESTIONS ABOUT EACH NATION'S POSITION IN THE HORLD--QUESTIONS THAT POLITICIANS WOULD PREFER TO LEAVE LARGELY UNEXAMINED. THIS ARTICLE OFFERS A FEW REFLECTIONS, FROM AN ANGLO- OR EURO-CENTRIC PERSPECTIVE, ON THE RELATIONSHIP BETWEEN THE THO GREATEST CAPITALIST SUCCESS STORIES OF THE 2OTH CENTURY.

04488 HOWE, J.

THE CRISIS OF ALGERIAN NATIONALISM AND THE RISE OF ISLAMIC INTEGRALISH

NEW LEFT REVIEH, (196) (NOV 92), 85-101.

THE ALGERIAN NATIONAL MOVEMENT MADE EXTENSIVE USE OF
THE RELIGIOUS APPEALS DURING THE STRUGGLE FOR NATIONAL INDEPENDENCE, SINCE RELIGION SHARPLY DISTINGUISHED COLONIZER FROM COLONIZED AND FURNISHED READY-MADE THEMES OF POPULAR MOBILIZATION. IN THE AFTERMATH OF INDEPENDENCE, THE GOVERNMENT DECLARED ITS ISLAMIC CHARACTER WHILE IMPOSING A WASTEFUL STATE-SOCIALIST MODEL OF ECONOMY. LARGE DEPOSITS OF OIL AND GAS ENABLED THE ALGERIAN GOVERMMENT TO BORROH LARGE SUMS IN PURSUIT OF ITS GRANDIOSE POL ICY OF INDUSTRIALIZATION AND DEVELOPMENT, BUT THE MARKETS OF THE ADVANCED COUNTRIES REMAINED HEAVILY PROTECTED. BY THE MID-TO-LATE 1980'S,
ALGERIA WAS THE MOST DEBT-BURDENED STATE IN THE WORLD. ALGERIA'S FALLING LIVING STANDARDS AND RISING UNEMPLOYMENT HAVE AIDED THE ISLAMIC INTEGRALISTS OF THE FRONT ISLAMIQUE DU SALUT IN GATHERING POPULAR SUPPORT, CAUSING THE DLD

04489 HOWE, R.

MEANING AND STRUCTURE IN SOCIAL MOVEMENTS: MAPPING THE NETWORK OF NATIONAL CANADIAN WOMEN'S ORGANIZATIONS CANADIAN JOURNAL OF POLITICAL SCIENCE, 29(4) (DEC 91), 755-784.

SOCIAL MOVEMENTS ARE CONCEIVED OF AS NETHORKS THAT PROVIDE STRUCTURES WITHIN WHICH ORGANIZATIONS NEGOTIATE MEANING THROUGH THE CONSTRUCTION OF COLLECTIVE IDENTITIES. NETWORK ANALYSIS IS APPLIED AS A METHOD FOR MAPPING THE NETWORK ANALYSIS IS APPLIED AS A METHOD FOR MAPPIN RELATIONSHIP AMONG 33 NATIONAL CANADIAN HOMEN'S ORGANIZATIONS. THE RESULTS SHOW THAT THESE GROUPS
NETWORK THAT IS BOUND BY A COLLECTIVE IDENTITY OF NETWORK THAT IS BOUND BY A COLLECTIVE IDENTITY OF
LIBERALIZED FEMINISM. MINORITY WOMEN TEND TO BE MARGINALIZED LIBERALIIED FEMINISM. MINORITY WOMEN TEND TO BE MARGINALIZED
AND THERE ARE FEW LINKAGES WITH OTHER CORE SOCIAL MOVEMENTS. AND THERE ARE FEW LINKAGES WITH OTHER CORE SOCIAL MOVEM
INTRA-MOVEMENT POSITION HAS SIGNIFICANT EXTRA-MOVEMENT INTRA-MOVEMENT POSITION HAS SIGNIFICANT EXTRA-MOVEMENT CONSEQUENCES AS DEMONSTRATED BY THE FINDING THAT NETHORK
POSITION IS A HIGHLY SIGNIFICANT PREDICTOR OF THE PERCEIVED PFFECTIVENESS OF A SOCIAL MOVEMENT ORGANIZATION.

04490 HOWE, R.B.

HUMAN RIGHTS IN HARD TIMES: THE POST-WAR CANADIAN EXPERIENCE

CANADIAN PUBLIC ADMINISTRATION, 35(4) (WIN 92), 464-484. DO HUMAN RIGHTS SUFFER IN HARD TIMES? DOES THE IMPLEMENTATION OF PROGRAMS AGAINST DISCRIMINATION WEAKEN DURING PERIODS OF ECONOMIC DECLINE, MAKING RIGHTS A RELATIVE LUXURY AVAILABLE ONLY IN GOOD TIMES? THIS PAPER SEEXS TO ANSWER THESE QUESTIONS BY COMPARING HUMAN RIGHTS IN CANADA DURING THE HARD TIMES OF THE EARLY 1980'S TO THE PERIODS IMMEDIATELY PRECEDING AND FOLLOHING. THE COMPARISON SHOWS THAT HUMAN RIGHTS DO SUFFER IN HARD TIMES. WHILE THERE IS LITTLE EVIDENCE TO SUGGEST THAT GENERAL SUPPORT FOR HUMAN RIGHTS PROTECTION DIMINISHES, THERE IS EVIDENCE THAT POL ITICAL COMMITMENT TO IMPLEMENTING PROGRAMS OF HUMAM RIGHTS PROTECTION WEAKENS. THIS WAS REFLECTED IN THE DIMINISHED FUNDING OF ANTI-DISCRIMINATION PROGRAMS DURING DIMINISHED FUNDING OF ANT I-DISCRIMINATION PROGRAMS DURING THE EARLY 1980'S AND, IN THE CASE OF BRITISH COLUMBIA, IN
THE RADICAL RESTRUCTURING AND DOWNSIZING OF ITS PROGRAM, THE RADICAL RESTRUCTURING AND DOHNS
MAKING IT THE HEAKEST IN CANADA.

04491 HOWELL, C.

REGULATING LABOR--THE STATE AND INDUSTRIAL RELATIONS REGULATING LABOR--THE STAT

REFORM IN POSTHAR FRANCE
PRINCETON UNIVERSITY PRESS, 1992, 320

IN MAY AND JUNE OF 1968 A DRAMATIC HAVE OF STRIKES PARALYZED FRANCE, MAKING INDUSTRIAL RELATIONS A KEY ITEM ON THE GOVERMMENT AGENDA. FRENCH TRADE UNIONS SEEMED DUE FOR A GOLDEN AGE OF GROWTH AND IMPORTANCE. TODAY, HOWEVER, TRADE UNIONS ARE HEAKER IN FRANCE THAN IN ANY OTHER ADVANCED CAPITALIST COUNTRY. HOW DID SUCH EXCEPTIONAL MILITANCY GIVE WAY TO EQUALLY REMARKABLE QUIESCENCE? TO ANSHER THIS QUESTION, THIS WORK EXAMINES THE REFORM PROJECTS OF SUCCESSIVE FRENCH GOVERNMENTS TOWARD TRADE UNIONS AND INDUSTRIAL RELATIONS DURING THE POSTWAR ERA, FOCUSING IN PARTICULAR ON THE EFFORTS OF POST-1968 CONSERVATIVE AND SOCIALIST GOVERNMENTS. THE AUTHOR EXPLAINS THE GENESIS AND FATE OF THESE REFORM EFFORTS BY ANALYZING CONSTRAINTS IMPOSED UPON THE FRENCH STATE BY CHANGING ECONOMIC CIRCUMSTANCES AND BY THE ORGANIZATIONAL WEAKNESS OF LABOR. HIS APPROACH. WHICH LINKS ECONOMIC, POL ITICAL AND INSTITUTIONAL ANALYSIS, IS BROADLY THAT OF REGULATION THEORY.

04492 HOWELL, C.

THE CONTRADICTIONS OF FRENCH INDUSTRIAL RELATIONS REFORM COMPARATIVE POLITICS, 24(2) (JAN 92), 181-197.

THE AUTHOR EXPLORES THE IMPACT OF THE 1982-83 INDUSTRIAL RELATIONS REFORHS KNOHN AS THE "LOIS AUROUX." HE ARGUES THAT, CONTRARY TO THE GOALS OF THE FRENCH SOCIALISTS, THIS REFORM PACKAGE FAILED TO STIMULATE REGULAR COLLECTIVE BARGAINING BETHEEN EMPLOYERS AND TRADE UNIONS. NEVERTHELESS, THE "LOIS AUROUX" DID HAVE AN IMPORTANT IMPACT ON FRENCH INDUSTRIAL RELATIONS BECAUSE A SECONDARY COMPONENT OF THE REFORM PACKAGE CAME TO THE FORE. THIS COMPONENT--SHORN OF ITS RADICAL, ANTICAPITALIST ELEMENTS--SHARED A COMMON RADICAL, ANTICAPITALIST ELEMENTS--SHARED A COMMON
IDEOLOGICAL HERITAGE WITH THE "AUTOGESTIONMAIRE," OR SELFIDEOLOGICAL HERITAGE WITH THE "AUTOGESTIONNAIRE," OR SELFTO ENCOURAGE A DECENTRALIZED, FIRM-BASED, MICRO-CORPORATIST
FORM OF INDUSTRIAL RELATIONS THAT FIT WELL WITH THE DOMINANT FORM OF INDUSTRIAL RELATIONS THAT FIT WELL WITH THE DOMIN
MANAGERIAL EMPHASIS UPON FLEXIBILITY IN THE HORKPLACE.

04493 HOWELL, C.

THE DILEMMAS OF POST-FORDISM: SOCIALISTS, FLEXIBILITY, AND LABOR MARKET DEREGULATION IN FRANCE

POLITICS AND SOCIETY, 20(1) (MAR 92), 71-100

THIS ARTICLE FIRST LOOKS AT POSTWAR FRENCH INDUSTRIAL RELATIONS, WITH PARTICULAR EMPHASIS ON THE ACTIVIST ROLE OF THE STATE, IN ORDER TO EXPLAIN THE PARTICULAR PROBLEMS THAT THE FRENCH SITUATION POSED FOR ANY FORM OF FLEXIBILITY. THE 
NEXT SECTION THEN EXAMINES THE INITIAL DEBATE OVER LABOR MARKET DEREGULATION IN THE LATE 1970S AND THE STALEMATE BETWEEN UNIONS, EMPLOYERS, AND THE STATE THAT PREVENTED FLEXIBILITY. FOLLOWING SECTIONS LOOK AT THE ARRIVAL OF THE SOCIALISTS IN POWER IN 1981, AT THEIR INITIAL OPPOSITION TO FLEXIBILITY, AND AT THEIR CONYERSION TO FLEXIBILITY AND THEN DISCUSS THE INDUSTRIAL RELATIONS REFORM THAT MADE FLEXIBILITY POSSIBLE. THE CONCLUDING SECTION BRINGS THE STORY UP TO DATE SINCE 1986 AND ATTEMPTS TO DRAW SOME GENERAL LESSONS FROM THE FRENCH EXPERIENCE WITH LABOR MARKET DEREGULATION.

04494 HOWLETT, D.; SIMPSON, J.

THE NPT AND THE CTBT: LINKAGES, OPTIONS, AND OPPORTUNITIES ARMS CONTROL, 13(1) (APR 92), 85-107.

THE LINKAGE BETWEEN A COMPREHENSIVE TEST BAN TREATY

(CTBT) AND THE TREATY ON THE NONPROL IFERATION OF NUCLEAR WEAPONS (NPT) HAS BEEN AN ISSUE THAT HAS CONSISTENTLY CREATED CONTROVERSY DURING CONFERENCES TO REVIEW THE NPT. CREATED CONTROVERSY DURING CONFERENCES TO REVIEW DISPUTE OVER THIS LINKAGE REFLECTS A DEEP-SEATED
DISAGREEMENT OVER THE PRIME OBJECTIVE OF THE NPT--NAMELY, DISAGREEMENT OVER THE PRIME OBJECTIVE OF THE NPT--NAMELY,
WHETHER IT IS TO PREVENT HORI ZONTAL NUCLEAR PROLIFERATIOH OR TO FACILITATE NUCLEAR DISARMAMENT AND PREVENT FURTHER MODERNIZATION OF EXISTING NUCLEAR ARSENALS (I.E., VERTICAL MODERNIZATION DF
PROLIFERATION).

04495 HOWORTH, J.

FRANCOIS MITTERAND AND THE 'DOMAINE RESERYE': FROM

COHABITATION TO THE GULF WAR

FRENCH POLITICS AND SOCIETY, 10(1) (WIN 92), 43-58.

IN MARCH 1986, WHEN JACQUES CHIRAC AND FRANCOIS MITTERAND AGREED TO EMBARK ON THE FIRST EXPERIMENT IN COHABITATION, OBSERVERS AGREED THAT THE MOST DIFFICULT AREA OF COOPERATION WOULD BE THAT OF FOREIGN AND DEFENSE POLICY. IN THIS ESSAY, THE AUTHOR LOOKS AT THE EVOLUTION OF PRESIDENT MITTERAND'S POWERS IN THE GENERAL AREA OF FOREIGN POLICY.

04496 HOYNES, W.; CROTEAU, D.

THE CHOSEN FEW: NIGHTLINE AND THE POLITICS OF PUBLIC AFFAIRS TELEVISION

CRITICAL SOCIOLOGY, 18(1) (SPR 91), 19-36.

RELATIVELY LITTLE RESEARCH HAS FOCUSED ON TELEVISION PUBLIC AFFAIRS PROGRAMS AS A FORUM FOR POL ITICAL DISCUSSION. THIS ARTICLE EXPLORES THIS GENRE OF PROGRAM BY EXAMINING
GUEST LIST OF 865 EDITIONS OF ABC NEWS NIGHTLINE. IT IS GUEST LIST OF 865 EDITIONS OF ABC NEWS NIGHTLINE. IT IS AHE PROGRAM, NIGHTLINE IS ABLE TO LEGITIMIZE CERTAIN THE PROGRAM, NIGHTLINE IS ABLE TO LEGITIMIZE CERTAIN POLITICAL POSITIONS, NARROW THE RANGE OF OISCOURSE, AND CERTIFY ELITES SPOKESPEOPLE. THIS RESULTS IN THE POR
OF A CLIMATE OF DOMESTIC POLITICAL CONSENSUS AND THE PROMOTION OF AN AGENDA PARALLELING THAT OF THE U.S. GOVERNMENT.

04497 HOYT, M.

TALK RADIO: TURNING UP THE VOLUME

COLUMBIA JOURMALISM REVIEW, 31(4) (NOV 92), 44-50. THE AUTHOR LOOKS AT THE ROLE TALK RADIO' PLAYED IN THE 1992 PRESIDENTIAL CAMPAIGN AND WARNS THAT IT IS GROWING IN TERMS OF STATIONS, LISTENERS, AND POLITICAL INFLUENCE AT THE EXPENSE OF THE MAINSTREAM PRESS.

04498 HOYT, R.G.

KENNEDY CALLING: CHURCH, STATE, AND SCHOOLS

COMMONHEAL, CXIX(11) (JUN 92),

THE AUTHOR DISCUSSES PRESIDENT JOHN F. KENNEDY'S STANCE AGAINST PUBLIC AID TO PAROCHIAL SCHOOLS AND SUGGESTS SOME ARGUMENTS FOR PUBLIC AID TO RELIGIOUS SCHOOLS.

04499 HOYT, R.G.

THE LAND IS HOLY

COMMONWEAL CXIX(7) (APR 92),

B'TSELEM IS AN ISRAELI HUMAN RIGHTS ORGANIZATION THAT MONITORS THE BEHAVIOR OF THE SECURITY FORCES IN THE OCCUPIED TERRITORIES. ALTHOUGH THE ATROCITIES COMMITTED IN THE OCCUPIED TERRITORIES ARE NOT AS MURDEROUS AS THOSE PERPETRATED IN IRAO OR SYRIA THE B 'TSELEM REPORTS OF THE ISRAELI HUMAN RIGHTS' VIOLATIONS ARE CONVINCING.

04500 HROMADKOVA, A.

WHATEVER HAPPENED TO CHARTER $77 ?$

EAST EUROPEAN REPORTER CHARTER 77? 521 (1) 69

IN NOVEMBER 1989, LEADERS OF THE UNOFFICIAL MOVEMENT CHARTER 77--THE MAIN MANIFESTATION OF A "SECOND SOCIETY" IM CZECHOSLOVAKIA FOR OVER A DECADE--WERE CATAPULTED INTO POSITIONS OF OFFICIAL RESPONSIBILITY. WHILE THIS TRIUMPH VINDICATED THE VIEHS OF THOSE WITHIN THE CZECHOSLOVAK OPPOSITION WHO HAD ALHAYS INSISTED THAT THE POTENCY OF CHARTER 77 COULD NOT BE MEASURED IN THE NUMBER OF ACTUAL SIGNATORIES, IT LEFT THE CIVIC INITIATIVE WITH THE PROBLEM OF TRYING TO ADAPT TO ITS ROLE TO THE POST-OPPOSITION ERA. THIS ARTICLE ARGUES THAT IN SPITE OF THE NEH CHALLENGES AND PROBELMS FACING CHARTER 77--REGARDING ACCESS TO THE MEDIA
RADICAL CHANGE--CHARTER 77 IS MANAGING TO FORMULATE BASIC NON-PARTY POLITICAL SOLUTIONS TO SOME OF THE COUNTRY'S MOST PRESSING PROBLEMS.

04501 HSIN-CHI, K.

POWER DEPENDENCE AND DEMOCRATIC TRANSITION: THE CASE OF HONG KDNG

CHINA OUARTERLY, (128) (DEC 91), 774-793.

DEMOCRATIZATION IN A DEPENDENT POLITY MAY BE REACHED VIA

EVOLUTIONARY PROCESSES OR BY A NATIONAL STRUGGLE FOR

INDEPENDENCE. WITH HONG KONG'S SCHEDULED RETURN TO CHINESE

SOVEREIGNTY IN 1997, ONLY THE ROUTE VIA EVOLUTIONARY

PROCESSES SEEMS VIABLE. THERE ARE FAVORABLE INTERNAL

CONDITIONS FOR A DEMOCRATIC TRANSITION IN HONG KONG, AND

1997 HAS PROVIDED AN IMPORTANT IMPETUS FOR DEMOCRATIC CHANGE.

THE ARGUMENT OF THIS PAPER IS THAT THE ACTUAL PROCESS OF

CHANGE HAS BEEN LARGELY CONDITIONED BY THE EXTERNAL FACTOR

OF POWER DEPENDENCE. THE PEOPLE OF HONG KONG DO HAYE SOME

RDOM FOR MANEUVERING. ESPECIALLY WHEN THERE IS A CONFLICT OF

ROOM FOR MANEUVERING, ESPECIALLY WHEN THERE IS A CONFLIC
INTERESTS BETWEEN THE BRITISH AND CHINESE GOVERMMENTS.

04502 HUA, $X$

CHINA'S SUCCESSFUL DIPLOMACY

BEIJING REYIEH, 35(19) (MAY 92), 12-16

IN 1991. CHINA MAINTAINED ITS INDEPENDENT FOREIGN POLICY, DISPLAYED' EXTRADRDINARY INITIATIVE IN OIPLOMACY, AND SCORED GREAT SUCCESSES IN INTERNATIONAL RELATIONS, MAKING IMPORTANT CONTRIBUTIONS TO PEACE AND STABILITY IN THE ASIA-PACIFIC REGION AND THROUGHOUT THE WORLD.

04503 HUAN, G.

CHINA'S FOREIGN ECONOMIC RELATIONS

ANMALS OF THE AMERICAN ACADEMY OF POLITICAL AND SOCIAL SCIENCE, 519 (JAN 92), 176-190.

CHINA'S FOREIGN ECONOMIC RELATIONS HAVE SUFFERED SINCE

THE TIANANMEN SQUARE MASSACRE. FOLLOWING THE INCIDENT, INTERNATIONAL AGENCIES AND GOVERNMENTS SUSPENDED LOAN NEGOTIATIONS WHILE FOREIGN INVESTORS LESSENED NEW

COMMITMENTS AND TOURISM PLUNGED. THE NET EFFECT REDUCED FOREIGN EXCHANGE EARNINGS. FORTUNATELY, MEASURES TO COOL THE OVERHEATED ECONOMY AND THE LIMITED AVAILABILITY OF CREDIT REDUCED IMPORTS WHILE EXPORTS INCREASED. VARIOUS MEASURES FAVORED SPECIAL ECONOMIC ZONES AND COASTAL ENCLAVES FOR FOREIGN INVESTMENT, ESPECIALLY FROM TAIHAN AND JAPAN. THE
BALANCE OF TRADE MARKEDLY IMPROVED. SINCE MID-1990 FOREIGN BALANCE OF TRADE MARKEDLY IMPROVED. SINCE MID-1990 FOREIG
ECONOMIC SANCTIONS HAVE BEEN EASED OR LIFTED ALTOGETHER. ECONOMIC SANCTIONS HAVE BEEN EASED OR LIFTED ALTOGETHEF
HOWEVER, CONSERVATIVE ATTACXS ON REFORM POLICY, THE HOWEVER, CONSERVATIVE ATTACXS ON REFORM POLICY, THE
RECENTRALIZATION OF FOREIGN EXCHANGE CONTROL, AND STAGNATION RECENTRALIZATION OF FOREIGN EXCHANGE CONTROL, AND STA IN ECONOMIC REFORM ARE CAUSING CONCERN ABROAD. THE DIFFERENTIAL DEVELOPMENT OF INTERIOR VERSUS COASTAL AREAS AFECTS MARKETING AND CDMPET POSENESS. THE LIKELIHODO OF A SUCCESSION STRUGGLE AND THE POSSIB.
UNREST ALSO CLOUD FOREIGN VIEHS.

04504 HUAN, G.

CHINA'S POLICY TOWARDS NORTHEAST ASIA: DYNAMICS AND PROSPECT

KOREAN JOURNAL OF DEFENSE ANALYSIS, 3(2) (WIN 91), 163-186. CHINA'S POLICY TOHARDS NORTHEAST ASIA IS DETERMINED BY THREE MAJOR FACTORS: CHINA'S DOMESTIC DEVELOPMENTS AND ITS OVERALL FOREIGN AND SECURITY POLICY, THE DYNAMICS OF THE REGION, AND CHINA'S INTERACTIONS WITH COUNTRIES IN THE REGION. TO ANSHER THESE QUESTIONS, THIS ARTICLE EXAMINES EACH OF THESE FACTORS AND DISCUSSES THE POSSIBILITY OF DEVELOPMENT OF CHINA'S POLICY TOWARDS NORTHEAST ASIA IN THE NEXT FEH YEARS. IN ORDER TO COOPERATE HITH WASHINGTON ON THE KOREAN ISSUE, BEIJING CAN IMPROVE ITS OVERALL TIES HITH THE US, JAPAN, AND OTHER OECD NATIONS. SUCH AN APPROACH WILL BEST SERVE CHINA'S OVERALL INTEREST IN NORTHEAST ASIA.

04505 HUAN, G.

TAIPEI-BEIJING RELATIONS: NO LONGER A ZERO-SUM GAME WORLD POLICY JOURNAL, IX(3) (SUM 92), 563-579. ALTHOUGH THE POLITICAL AND ECONOMIC GAP BETHEEN THE PEOPLE'S REPUBLIC OF CHINA AMD THE REPUBLIC OF CHIMA (TAIWAN) IS WIDENING, RELATIONS BETWEEN TAIPEI AND BEIJING ARE BETTER TODAY THAN AT ANY TIME SINCE THE COMMUNISTS CAME ARE BETTER TODAY THAN AT ANY TIME SINCE THE COMMUNISTS CAME
TO POWER. WHILE THIS RELATIONSHIP IS STILL NOT CLOSE--OR TO POWER. WHILE THIS RELATIONSHIP IS STILL NOT CLOSE--OR
NECESSARILY EVEN CORDIAL--IT IS FAR MORE CONSTRUCTIVE THAN NECESSARILY EVEN CORDIAL--IT IS FAR MORE CONSTRUCTIVE THAM IT ONCE WAS. IN MAY 1990, TAIPEI DECLARED AN END TO ITS
FORMAL STATE OF WAR WITH BEIJING. IN DECEMBER 1991, BEIJING FORMAL STATE OF WAR WITH BEI JING. IN DECEMBER 1991, BEI
ANMOUNCED THAT "REDUCTION OF TENSIONS AND EXPANSION OF ANNOUNCED THAT "REDUCTION OF TENSIONS AND EXPANSION OF ECONOMIC COOPERATION AND CULTURAL EXCHANGES, RATHER THAN THE EARLIER GOAL OF REUNIFICATION, WOULD GUIDE ITS RELATI CHANGES ARE PROMISING. THERE IS STILE. ALTHOUGH THESE TRUST CHANGES ARE PROMISING, THERE IS STILL A LACK OF MUTUAL TRUST BETWEEN BEIJING AND TAIPEI AND LITTLE PROGRESS HAS BEEN MADE TOWARD INSTITUTIONALIZING THEIR RELATIONS. THIS ARTICLE
CONSIDERS THE PROCESS AND THE ROLE OF THE INTERHATIONAL CONSIDERS THE PROCESS AND THE ROLE OF THE INTERNATIONAL COMMUNITY. IT ARGUES THAT WASHINGTON AND TOKYO CAN BE MOST CONSTRUCTIVE IN FACILITATING PEACEFUL RELATIONS BETHEEN THE
ROC AND THE PRC BY NOT ENCOURAGING TAIWAN TO PURSUE EITHER PEACEFUL REUNIFICATION OR OUTRIGHT INDEPENEDENCE, FOR NEITHER POSITION IS PRACTICAL OR REALISTIC AT PRESENT. 
04506 HUAN, G.

THE NEW RELATIONSHIP WITH THE FORMER SOVIET UNION CURRENT HISTORY, 91 (566) (SEP 92), 253-256.

DESPITE COOPERATION IN TRADE, THERE ARE MAJOR PROBLEMS BETWEEN CHINA AND THE MEMBERS OF THE COMMONWEALTH OF INDEPENDENT STATES. THE CURRENT BEIJING LEADERSHIP CONTINUES TO BE CRITICAL OF MOSCOW, PARTIALLY DUE TO THE SHAR IDEOLOGICAL GAP BETWEEN THEM. BEIJING IS ALSO WORRIED ABOUT THE IMPACT OF THE NEWLY-INDEPENDENT CENTRAL ASIAN STATES ON THE STABILITY OF XINJIANG PROVINCE, WHERE ETHNIC TENSIONS ARE HIGH. MOREOVER, CHINA AND THE CIS STATES ARE COMPETING FOR THE RESOURCES OF THE INTERNATIONAL FINANCIAL COAMUNITY. RELATIONS BETWEEN CHINA AND THE FORMER SOVIET REPUBLICS HAVE FIVE KEY DIMENSIONS: INTERNAL DEVELOPMENTS IN EACH COUNTRY, SECURITY RELATIONS, OFFICIAL BILATERAL TIES, BILATERAL ECONOMIC TIES, AND THE TAIHAN ISSUE.

04507 HUAQIU, L.

CHINA'S DIPLOMATIC ACHIEVEMENTS IN 1992

BEIJING REVIEH, 35(52) (DEC 92), 8-11.

IN 1992, CHINA FIRMLY PURSUED "AN INDEPENDENT FOREIGN POLICY OF PEACE," ADHERING TO ITS PRINCIPLES BUT BEING FLEXIBLE WHEN DEALING WITH SPECIFIC SITUATIONS. CHINA FLEXIBLE WHEN DEALING WITH SPECIFIC SITUATIONS. CHINA ESTABLISHED NEW DIPLOMATIC RELATIONS WITH 15 COUNTRIES IN
1992 , MORE THAN IN ANY YEAR SINCE THE PEOPLE'S REPUBLIC WAS FOUNDED IN 1949.

04508 HUAQIU, L. ; CHENGXU, Y

CREATING A PEACEFUL INTERNATIONAL ENVIRONMENT

BEI JING REVIEW, 35(48) (NOV 92), 13-15

THE AUTHORS BRIEFLY TRACE THE EVOLUTION OF CHINESE FOREIGN POLICY SINCE 1979 AND CONSIDER THE POSSIBILITIES FOR MAINTAINING A PEACEFUL INTERNATIONAL ENVIRONMENT UNDER CURRENT WORLD CONDITIONS.

04509 HUAQIU, L.

PROMOTING SECURITY IN ASIA-PACIFIC REGION

BEIJING REVIEH, 35(15) (APR 92), 10-11.

CHINA ATTACHES GREAT IMPORTANCE TO SAFEGUARDING REGIONAL SECURITY AND DEVELOPING FRIENDLY RELATIONS HITH ITS NEIGHBORING COUNTRIES. CHINA IS PURSUING AN INDEPENDENT FOREIGN POLICY OF PEACE, IS PERSISTING IN ITS EFFORTS TO DEVELOP FRIENDLY RELATIONS WITH OTHER COUNTRIES ON THE BASIS OF THE FIVE PRINCIPLES OF PEACEFUL COEXISTENCE, AND IS ADHERING TO ITS STANCE AGAINST HEGEMONISM AND PONER POLITICS.

04510 HUASUN, $Q$.

CONFIDENCE-BUILDING MEAURES IN THE ASIA-PACIFIC REGION DISARMAMENT, XIV(3) (1991), 147-154.

THE MOST URGENT TASKS FACING THE ASIA-PACIFIC REGION THE MOST URGENT TASKS FACING THE ASIA-PACIFIC REGION
TODAY ARE THE SOLUTION OF "HOT SPOT" ISSUES AND BILATERAL DISPUTES AND THE STRENGTHENING OF ECONOMIC COOPERATION. THE ASIAN-PACIFIC COUNTRIES SHDUID FIRST ADVANCE THEIR DIALOGUE AND CONSULTATIONS WITH ONE ANOTHER AND TAKE PRACTICAL AND CONSULTATIONS WITH ONE ANOTHER AND TAKE PRACTICAL
MEASURES TO ENHANCE TRUST, REDUCE TENSION, RESOLVE CONFLICTS AND STRENGTHEN SECURITY. THEY COULD GRADUALLY ESTABLISH AND DEVELOP REGIONAL SECURITY MECHANISMS, FIRST IN SMALL AREAS AND THEN EXTEND THEM TO LARGER REGIONS. ISSUES OF COMMON INTEREST TO ALL THE COUNTRIES IN THE REGION SHOULD BE SOLVED THROUGH CONSULTATIONS AMONG THE COUNTRIES ON AN EQUAL BASIS.

04511 HUAXIN, L.

OVERSEAS TROOP DEPLOYMENT SPARKS DEBATE

BEIJING REYIEW, 35(33) (AUG 92), 44

ON JULY 22, 1992, THE GERMAN PARLIAMENT APPROVED THE DEPLOYMENT OF GERMAN TROOPS TO HELP ENFORCE A UNITED NATIONS EMBARGO AGAINST YUGOSLAVIA. THE DECISION REKINDLED THE OLD DEBATE OVER WHEN AND HOW GERMAN TROOPS MAY BE DEPLOYED. THE SOCIAL DEMOCRATIC PARTY SUPPORTS PARTICIPATION IN PEACEKEEPING OPERATIONS BUT OPPOSES PARTICIPATION IN PURELY MILITARY ACTIONS.

04512 HUBAND, M.

PRESSURE FROM ABROAD

AFRICA REPORT, 37(2) (MAR 92) 41-44.

FOREIGN PRESSURE ON ZAIRE IS FUEL ING THE EFFORT TO FORGE A DEMOCRATIC RESTRUCTURING, UNDERPINNED BY THE ECONOMIC AND POLITICAL CLOUT OF ITS THREE MAJOR AID DONORS--FRANCE, BELGIUM, AND THE UNITED STATES. HOWEVER, WHILE PARIS AND BRUSSELS ARE CLEAR ABOUT THE SOLUTION-CTHE REMOVAL OF BRUSSELS ARE CLEAR ABOUT THE SOLUTION--THE REMOVAL OF
PRESIDENT MOBUTU SESE SEKO--THE USA APPEARS UNDECIDED ON PRESIDENT MOBUTU SESE SEKO--THE USA APPEARS UNDECIDED
HHETHER TO CONTINUE PROPPING UP ITS LONG-TIME ALLY. WHETHER TO CONTINUE PROPPING UP ITS LONG-TIME ALLY. MEANWHILE, THE WORSENING CRISIS
POSSIBILITY OF MORE VIOLENCE.

04513 HUBAND, $M$.

SILENCING THE OPPOSITIOH

AFRICA REPORT, 37(3) (MAY 92), 55-57.

POLITICAL REFORM IN COTE D'IVOIRE HAS BEEN SHELVED SINCE 12 OPPOSITION LEADERS WERE JAILED IN MARCH 1992 AFTER THE GOVERNMENT ACCUSED THEM OF STARTING A DEMONSTRATION THAT TURNED VIOLENT. THEIR ARREST AND TRIAL DEMONSTRATES THE EXTENT TO WHICH THE COUNTRY IS STILL SUBJECT TO THE POWER
ACCUMULATED OVER 30 YEARS BY PRESIDENT FELIX HOUPHOUETBOIGHY, WHOSE FAILURE TO LAY THE GROUNDWORK FOR THE MEXT POLITICAL GENERATION IS AT THE ROOT OF THE NATION'S ANXIETY OYER ITS FUTURE.

04514 HUBAND, $M$.

THE MILITARY FACTOR

AFRICA REPORT, 37(2) (MAR 92), 31-33.

THE GROHING CLASH OF POLITICAL CULTURES THAT IS EMERGING FROM THE DEMOCRATIC MOVEMENTS THROUGHOUT HEST AND CENTRAL AFRICA IS THE STILL LARGELY-UNFOUGHT BATTLE THAT WILL DECIDE THE CHARACTER OF THE CONTINENT'S FUTURE. THE REALIZATION THAT, AFTER TWO YEARS OF POLITICAL PROTESTS, ONLY THREE OF THE REGION'S MAINLAND DICTATORS HAVE BEEN OUSTED IS FORCING THE REFORMERS TO RETHINK THEIR APPROACH. ONE COMPLICATING FACTOR IS THE MILITARY, WHICH FOR YEARS WAS USED TO PROP UP AUTOCRATIC REGIMES AND CRUSH DISSENT, BUT NOW WANTS A ROLE IN THE EMERGING DEMOCRATIC PROCESS AMD HAS THE POWER TO BACK UP ITS AMBITIONS.

04515 HUBAND, $M$.

THE REVOLVING DOOR

AFRICA REPORT, 37 (1) (JAN 92), 25-28.

ZAIRE'S DICTATOR, MOBUTU SESE SEKO, IS TRYING TO STAVE OFF OPPOSITION DEMANOS FOR DEMOCRACY BY COOPTING ITS LEADERS AND HAS APPOINTED THREE PRIME MINISTERS SINCE OCTOBER 1991. WHILE THE UNITED STATES SEEMS SATISFIED WITH MOBUTU'S POWERSHARING SCHEMES, FRANCE AND BELGIUM, AS WELL AS OTHER AFRICAN COUNTRIES, FAVOR HIS DEPARTURE BEFORE HE DRAGS THE COUNTRY DOWN WITH HIM.

04516 HUBBELL, L.

FOUR ARCHETYPAL SHADOWS: A LOOK AT THE DARK SIDE OF PUBLIC ORGANIZATIONS

ADMINISTRATION AND SOCIETY, 24(2) (AUG 92), 204-223.

UNFORTUNATELY, THERE ARE A SIGNIFICANT NUMBER OF PUBLIC SERVANTS WHO DISLIKE THEIR WORK. MANY OF THESE PEOPLE EXPERIENCE A SENSE OF ALIENATION THAT MAKES THEM FEE SEPARATE FROM THEMSELVES AND OTHERS. USING JUNG'S THEORY OF PSYCHOLOGICAL TYPE AND KEIRSEY AND BATES'S FOUR TEMPERAMENTS AS HIS STARTING POINT, THE AUTHOR GIVES SHAPE TO THE ALIENATION THAT MANY PUBLIC EMPLOYEES EXPERIENCE BY DESCRIBING FOUR ARCHETYPAL "SHADOWS" THAT AFFECT THE BEHAVIOR OF ORGANIZATIONAL EMPLOYEES: THE SELF-SEEKING CAREERIST OR THE ALIENATED INTUITIVE THINKER, THE REGULATOR OR THE ALIENATED SENSATE JUDGER, THE MANIPULATOR OR THE ALIENATED INTUITIVE FEELER, AND THE PHILISTINE OR THE ALIENATED SENSATE PERCEIVER. NONE OF THE PEOPLE WHO ARE ALIENATED SENSATE PERCEIVER. NONE OF THE PEOPLE WHO ARE
PROFOUNDED AFFECTED BY THESE SHADDOWS AFFIRM LIFE; INSTEAD PROFOUNDED AFFECTED BY THESE SHADDOWS AFFIRM LIFE; INSTEAD
THEY ENGAGE IN DEATH-DENYING AND ULTIMATELY SELF-DESTRUCTIVE THEY ENGAG
BEHAVIORS.

04517 HUBBELL, S

ACCUSATIONS AGAINST TEHRAN

MIDDLE EAST INTERNATIONAL, 439 (DEC 92 ), 4-5

THE WAR OF WORDS BETWEEN EGYPT AND IRAM HAS ESCALATED TO NEW HEIGHTS IN RECENT WEEKS. THE CATALOG OF ALLEGED IRAHIAN PERFIDY IN EGYPT CONTINUES TO GRDW, HOWEVER, THE GOVERMMENT'S INSISTENCE THAT IRAN IS BEHIND THE UPSURGE IN FUNDAMENTALIST VIOLENCE HAS LEFT SOME PROMINENT OBSERVERS UNCONVINCED, PARTICULARLY SINCE SECURITY OFFICIALS HAVE OFFERED LITTLE PROOF FOR THE ALLEGATIONS. CAIRO IS ACCELERATING ITS CONTACTS WITH THE PLO IN WHAT SOME OBSERVERS BELIEVE IS AN EFFORT TO COUNTER TEHRAN'S MOVES TO BOLSTER PALESTINIAN FACTIONS OPPOSED TO THE PEACE PROCESS.

04518 HUBBELL, S.

DREAD OF A SPLINTERED IRAQ

MIDOLE EAST INTERNATIONAL, (433) (SEP 92), 11 EGYPT REDISCOVERED ITS HISTORICAL ROOTS IN THE NONALIGNED MOVEMENT JUST IN TIME FOR THE JAKARTA SUMMIT. THE TENTH SUMMIT CONFERENCE, WHICH CONCLUDED ON 5 SEPTEMBER IN JAKARTA, PROVIDED AN IDEAL FORMAT FOR THE ADMINSTRATION OF PRESIDENT HOSNI MUBARAK TO DISTANCE ITSELF FROM ITS SUPERPONER ALLIES--CHIEFLY OVER THEIR DECISION TO ENFORCE A NO-FLY ZONE IN SOUTHERN IRAQ. EGYPTIAN OFFICIALS STRESSED THE YIEH THAT THE DE FACTO PARTITION OF IRAO WOULD CONTRIBUTE DANGEROUSLY TO THE REGION'S STABILITY. EVER SINCE THE AIR EXCLUSION ZONE WAS SET UP SOUTH OF THE 32ND PARALLEL ON 27 AUGUST, EGYPTIAN COMMENTATORS HAVE INDIGNANTLY CHIDED THE WEST FOR' THE ASYMMETRY OF ITS RESPONSE TO REGIOMAL CONFLICTS. THEY HAVE ACCUSED EGYPT'S GULF WAR ALLIES OF EMPLOYING A DOUBLE-STANDARD THAT FAVORS OIL-RICH SHEIKHDOMS OVER RESOURCE-POOR FLEDGLING REPUBLICS SUCH AS BOSNIA.

04519 HUBBELL, $S$.

EGYPT-FUMDAMENTALIST GAINS

MIDOLE EAST INTERNATIONAL, (434) (SEP 92), 11-12.

EGYPT'S ISLAMIC TREND SCORED A DRAMATIC UPSET VICTORY OH 14 SEPTEMBER WHEN CANDIDATES LOYAL TO THE MUSLIM BROTHERHOOD CAPTURED A MAJORITY OF SEATS IN ELECTIONS FOR THE LEADERSHIP OF THE PRESTIGIOUS BAR ASSOCIATION. FOR DECADES THE ORGANIZATION HAS BEEN A BATTLEGROUND FOR PARTISANS OF EGYPT'S SECULAR IDEOLOGIES--ARAB NATIONALISTS, LEFTISTS, AND 
LIBERALS--WHO REGARDED IT AS A SECURE REDOUBT FROM THE UNWELCOME INTRUSION OF THE ISLAMIC RADICALS. THE RESULTS--1 OUT OF 24 SEATS ON THE ASSOCIATION'S RULING COUNCIL ARE NOH HELD BY THE ISLAMISTS--HAVE SENT SHOCKHAVES THROUGH LIBERAL
AND SECULAR CIRCLES IN EGYPT AND ELSEWHERE IN THE WORLD. THE AND SECULAR CIRCLES IN EGYPT AND ELSEWHERE IN THE
NEW PRO-ISLAMIC LEADERSHIP NOW HOPES TO WIELD THE ORGANIZATION'S CONSIDERABLE CLOUT AMONG LANYERS, JUDGES AND LEGISLATORS TO PROMOTE "SHARI'A" AS THE SOLE SOURCE OF JURI SPRUDENCE.

04520 HUBBELL, $S$.

EGYPT: ONSLAUGHT ON THE MILTANTS

MIDOLE EAST INTERMATIONAL, 440(440) (DEC 92), 10.

EGYPTIAN INTERIOR MINISTRY OFFICIALS SAID THAT MORE THAN 600 PEOPLE--INEVITABLY DESCRIBED AS "TERRORISTS"--HERE DETAINED IN A SWEEP WHICH THE MUBARAK GOVERNMENT HOPES WILL DEAL A CRUSHING BLOW TO ISLAMIC EXTREMISTS. THE MUBARAK ADMINISTRATION HAS REAFFIRMED DEATH SENTENCES HANDED DOWN BY A MILITARY TRIBUNAL IN ALEXANDRIA AGAINST EIGHT ISLAMIC MILITANTS CONVICTED ON CONSPIRING AGAINST THE STATE. SEVERAL MILITANTS CONVICTED ON CONSPIRING AGAINST THE STATE. SEVERAL
PROMINENT CRITICS HAVE ACCUSED EGYPT OF STRESSING AN IRANIAN PROMINENT CRITICS HAVE ACCUSED EGYPT OF STRESSING

CONNECTION IN ORDER TO BOLSTER ITS OWN CASE FQR
PARTICIPATION IN A PAN-ARAB GULF DEFENSE FORCE. EGYPTIAN PARTICIPATION IN A PAN-ARAB GULF DEFENSE FORCE. EGYPTIAN
OFFICIALS HAVE BEEN PRESSED IN RECENT WEEKS TO PROVIDE OFFICIALS HAVE BEEN PRESSED IN RECENT WEEKS TO PROVIDE
STRONGER PROOF FOR THEIR ACCUSATIONS THAT ISLAMIC ACTIVISTS STRONGER PROOF FOR THEIR ACCUSATIONS THAT ISLAMIC ACT
HAD RECEIVED TRAINING IN IRANINAN-SPONSORED CAMPS IN NORTHERN SUDAN.

04521 HUBBELL, S.

EGYPT: STRIKING AT THE ISLAMISTS

MIDDLE EAST INTERNATIONAL, 438(438) (NOV 92), 9-10.

THE MUBARAK ADMINISTRATION HAS STRUCK AT WHAT IT BELIEVES TO BE THE ISLAMIC OPPOSITION'S BREEDING GROUNDUNLICENSED, FREELAND MOSQUES. AS MANY AS 40,000 INDEPENDENT MOSQUES ACROSS EGYPT WERE SET TO BE TAKEN UNDER GOVERMMENT CONTROL. THIS ARTICLE ALSO EXPLORES MUBARAK'S CRITCISM OF IRAN FOR ALLEGEDLY BANKROLLING TERRORIST ACTIVITIES BY ISLAMIC GROUPS IN EGYPT, AND MUBARAK'S MEETING WITH SHIMON PERES.

\section{HUBBELL, $S$}

LIBYA: CONTENT WITH THE STATUS QUO

MIDOLE EAST INTERNATIONAL, (437) (NOV 92), 12-13.

DESPITE THE UNITED NATIONS AIR EMBARGO AGAINST LIBYA, COL. QADHAFI'S RESOLVE TO RESIST PRESSURE FROM THE WEST' FOR THE RELEASE OF THE TWO LOCKERBIE TERRORISTS APPEARS UNDIMINISHED. SINCE THE USA, BRITAIN, AND FRANCE ARE LIKELY TO SUCCEED IN RENEWING THE SANCTIONS WHEN THEY ARE REVIEWED BY THE SECURITY COUNCIL. THE STATUS QUD WILL ALMOST CERTAINLY PREVAIL IN LIBYA FOR THE FORESEEABLE FUTURE.

04523 HUBER, J.D. RESTRICTIVE LEGISLATIVE PROCEDURES IN FRANCE AND THE UNITED STATES

AMERICAN POLITICAL SCIENCE REVIEW, 86(3) (SEP 92), 675-687.

THE AUTHOR DEVELOPS A FRAMEHORK FOR APPLYING EXISTING FORMAL MODELS OF RESTRICTIVE AMENDMENT PROCEDURES IN CONGRESS TO THE STUOY OF THE FRENCH USE OF THO RESTRICTIVE LEGISLATIVE PROCEDURES, THE PACKAGE VOTE AND "THE GUILLOTINE. "HE TESTS SIX HYPOTHESES DERIVED FROM EXISTING FORMAL MODELS AND FROM RESEARCH ON THE FRENCH NATIONAL ASSEMBLY. THE ANALYSIS SHOWS THAT THE FRENCH GOVERNMENT INVOKES THE TWO PROCEDURES ON THE SAME TYPES OF DISTRIBUTIVE AND JURISDICTIONALLY COMPLEX BILLS THAT FREQUENTLY ELICIT CLOSED RULES IN CONGRESS. MOREOVER, THE DECISION TO USE THE RESTRICTIVE PROCEDURES IS STRONGLY LINKED TO THE MAJORITY STATUS OF THE GOVERNMENT, SUGGESTING THAT THEY ARE USED TO PRESERVE AGREEMENTS AMONG PARTIES IN THE SAME WAY THAT RESTRICTIVE AMENDMENT PROCEDURES ARE USED TO PRESERVE AGREEMENTS AMONG INDIVIDUAL MEMBERS OF CONGRESS. THUS EXISTING FORMAL MODELS OF LEGISLATIVE INSTITUTIONS CAN HELP EXPLAIN HOW PROCEDURAL STRUCTURES SHAPE STRATEGIC BARGAINING BETWEEN POLITICAL PARITES IN PARLIAMENTARY SYSTEMS,

04524 HUCKFELDT, R.; SPRAGUE, J.

DISCUSSANT EFFECTS ON YOTE CHOICE: INTIMACY, STRUCTURE, AND INTERDEPENDENCE

THE JOURNAL OF POLITICS, 53(1) (FEB 91), 122-160.

POLITICAL DISCUSSION DURING AN ELECTION CAMPAIGN IS AN IMPORTANT VEHICLE OF SOCIAL INFLUENCE--A MEANS WHEREBY THE PREFERENCES OF INDIVIDUALS ARE BROUGHT INTO CORRESPONDENCE WITH POLITICAL SURROUNDINGS. THIS PAPER ADORESSES A SERIES OF QUESTIONS RELATED TO THE INFLUENCE OF POLITICAL DISCUSSION. TO WHAT EXTENT ARE POI ITICAL PREFERENCES AFFECTED BY DISCUSSION? WHAT TYPES OF DISCUSSANT RELATIONSHIPS ARE MOST LIKELY TO FOSTER POLITICAL BASIS OF AN ELECTION STUDY CONDUCTED IN SOUTH BEND, INDIANA DURING THE 1984 PRESIDENTIAL ELECTION.

04525 HUCKFELDT, R.; SPRAGUE, J.

POLITICAL' PARTIIES AND ELECTORAL MOBILIZATION: POLITICAL STRUCTURE, SOCIAL STRUCTURE, AND THE PARTY CANVASS AMERICAN POLITICAL SCIENCE REVIEN, 86(1) (MAR 92), 70-86.
THE AUTHORS ADDRESS SEVERAL QUESTIONS REGARDING PARTY MOBILIZATION EFFORTS. HHOM DO THE PARTIES SEEK TO MOBILIZE? WHAT ARE THE INDIVIDUAL AND AGGREGATE CHARACTERISTICS AND
CRITERIA THAT SHAPE PARTY MOBILIZATION EFFORTS? WHAT ARE THE INTENDED AND UNINTENDED CONSEQUENCES OF PARTISAM MOBILIZATION, BOTH FOR INDIVIDUAL VOTERS AND FOR THE ELECTORATE MORE GENERALLY? PARTY EFFORTS AT ELECTORAL MOBILIZATION INEVITABLY DEPEND UPON A PROCESS OF SOCIAL DIFFUSION AND INFORMAL PERSUASION, SO THAT THE PARTY CANVASS SERVES AS A CATALYST AIMED AT STIMULATING A CASCADING MOBILIZATION PROCESS. PARTY MOBILIZATION IS BEST SEEN AS BEING ENVIRONMENTALLY CONTINGENT UPON INSTITUT IONAL ARRANGEMENTS, LOCALLY-DEFINED STRATEGIC CONSTRAINTS, AND
PARTISAN DIYISIONS WITHIN PARTICULAR ELECTORATES. THE EFFORTS OF PARTY ORGANIZATIONS GENERATE A LAYER OF POLITICAL STRUCTURE WITHIN THE ELECTORATE THAT SOMETIMES COMPETES WITH STRUCTURE HITHIN THE ELECTORATE THAT SOMETIMES COMPETES
SOCIAL STRUCTURE AND OFTEN EXISTS INDEPENDENTLY FROM IT.

04526 HUDOLESTON, L.

POLICING THE NEW WORLO ORDER: AN ALTERNATIVE STRATEGY COMPARATIVE STRATEGY, 11(1) (JAN 92), 1-14.

AS AMERICA APPROACHES THE TWENTY-FIRST CENTURY, A PRESSING QUESTION IS: CAN AMERICA CONTINUE TO SERVE AS THE HORLD'S POLICEMAN? AMERICA'S CHALLENGE FOR THE 1990S IS TO AVOID THE TRAPPINGS OF WORLD POLICING THAT PAST SUPERPOWERS HAVE EXPERIENCED THROUGHOUT HISTORY (A LA PAX BRITANNICA). THE UNITED STATES CAN ACHIEVE THIS BY FIRST, FORMULATING ITS NATIONAL SECURITY STRATEGY TO ELEVATE THE ROLE OF THE UNITED NATIONS AS THE WORLD'S POL ICEMAN. SECOND, THE UNITED STATES NATIONAL SECURITY STRATEGY SHOULD SUPPORT ESTABLISHMENT OF A STANDING UN PEACEMAKING FORCE. THIS FORCE HOULD PROVIDE THE UNITED NATIONS AND INTERNATIONAL COMHUNITY A SHORT NOTICE MILITARY EMPLOYMENT CAPABILITY DURING THE EARLY "WARNING PERIOD" OF AN IMPENDING CRISIS. SUCH A FORCE WOULD ULTIMATELY LOWER THE UNITED STATES' PROFILE AS THE WORLD POLICEMAN IN THE EMERGING NEW WORLD ORDER.

04527 HUDECEK, J.; BROKL, L.; MANSFELDOVA, $Z$.

CZECHOSLOVAKIA

EUROPEAN JOURNAL OF POLITICAL RESEARCH, 22(4) (DEC 92), 379-386.

THE AUTHOR OUTLINES THE PARTY COMPOSITION OF THE

CZECHOSLOVAK CABINET ON JANUARY 1, 1991, AND ON DECEMBER 31,

1991. HE ALSO DISCUSSES INSTITUTIONAL CHANGES AND MAJOR

DOMESTIC POLITICAL ISSUES IN CZECHOSLOVAKIA.

04528 HUDGINS, E.

JAPAN'S PROSPERITY IS NOT A DANGER

ORBIS, 36(4) (FAL 92), 505-510.

IN THIS RESPONSE TO EDHARD A. OLSEN's ARTICLE, "TARget JAPAN AS AMERICA'S ECONOMIC FOE" EDWARD HUDGINS SUGGESTS THAT THE NEED TO MEET JAPAN'S "CHALLENGE FOR WORLD LEADERSHIP" IS NOT A DANGER. HUDGINS EXPLORES THE ARGUMENT, ECONOMICS, POLITICS, AND THE SECURITY RELATIONSHIP. HE CONCLUDES THAT THERE IS A DANGER THAT AMERICA MIGHT CHANGE ITS LIBERAL AND DEMOCRATIC SYSTEM TO A SEMI-FACIST ONE FOR THE PURPOSE OF DEALING WITH A PERCEIVED ECONOMIC ENEMY.

04529 HUDSON, 8.

QUASI-MARKETS IN HEALTH AND SOCIAL CARE IN BRITAIN: CAN THE PUBLIC SECTOR RESPOND?

POLICY AND POLITICS, 20 (2) (APR 92), 131-142.

THE CONCEPT OF THE "QUASI-MARKET" IN BRITAIN DEVELOPED IN THE 1980'S AS CONSERVATIVE GOVERMMENTS SOUGHT A WAY TO RECONCILE MARKET PRINCIPLES WITH PUBLICLY-FUNDED SERVICES. THIS PAPER EXPLORES THE NATURE OF QUASI-MARKETS WITH PARTICULAR REFERENCE TO RECENT POLICY CHANGES IN THE FIELDS OF HEALTH AND SOCIAL CARE. IT IDENTIFIES THE TENSIONS INHERENT IN THE CONCEPT, THE FEASIBILITY OF IMPLEMENTATION, AND THE LIKELY RESULTS FOR THE THO POLICY ARENAS. IT SUGGESTS THAT THE POLITICAL SENSITIVITY OF THE HEALTH AND SOCIAL CARE FIELDS IS SUCH THAT A HIGH DEGREE OF REGULATION WILL BE REQUIRED AND THAT ANY RESEMBLANCE TO A GENUINE MARKET IS UNLIKELY.

04530 HUDSON, H.

THE MAKING OF A UNION MAN AND COMMUNIST

POLITICAL AFFAIRS, $71(2)$ (FEB 92) 15-17.

THIS ARTICLE, AN EXCERPT OF A MUCH LARGER WORK, RECOUNTS THE AUTHOR'S EXPERIENCE AS A BLACK HORKER IN THE AMERICAN SOUTH. HE TELLS OF THE CHALLENGES OF POVERTY AND RACISM AND OF THE HOPE THAT CAME FROM UNITING WITH FELLOW WORKERS UNDER THE LEADERSHIP OF THE COMMUNIST PARTY. THE EFFORTS OF THE AUTHOR AND HIS FELLOW WORKERS ENABLED THEM TO INFLUENCE SHOP AUTHOR AND HIS FELLOW WORKERS ENABLED THEM TO INFLUENCE
OWNERS TO REDUCE SOME OF THEIR DISCRIMINATORY PRACTICES.

04531 HUELSHOFF, $M$.

CORPORATIST BARGAINING AND INTERHATIONAL POLITICS: REGIMES, MULTINATIONAL CORPORATIONS, AND ADJUSTMENT POLICY IN THE FEDERAL REPUBLIC OF GERMANY

COMPARATIVE POLITICAL STUDIES, 25(1) (APR 92), 3-25.

POL ITICAL SCIENCE INCOURAGES A DIVISION BETWEEN

COMPARATIVE POLITICS AND INTERNATIONAL RELATIONS. THIS

ANALYSIS SUGGESTS CONSTRUCTING A BRIDGE BETHEEN THE TWO. 
AFTER A BRIEF REVIEN ANO CRITIQUE OF CORPORATIST THEORY, THIS ARTICLE CONSIDERS THE POL ITICS OF STRUCTURAL ADJUSTMENT IN THE GERMAN STEEL AND OIL REFINING INDUSTI IMPACTS OF INTERMATIONAL REGIMES AND THE INTERNATIONALIZATION OF CAP ITAL ON DOMESTIC POLITICS. IT WILL BE SHOWN THAT, ALTHOUGH SYSTEH-AND NATIONAL-LEVEL EXPLANATIONS CANNO' REPLACE ONE ANOTHER, VALUABLE OBSERVATIONS RESULT WHEN SYSTEM-AND NATION-LEYEL EXPLANATIONS COMPLEMENT ONE ANOTHER.

04532 HUG, P.; MEIER, R. CONVERSION AS A STRATEGY OF THE TRADE UNIONS TO SECURE EMPLOYMENT

PEACE AND THE SCIENCES, 1(1) (1992), 36-38.

ALL THE HORLD OVER TODAY, JOBS WHICH ARE DEPENDENT ON THE MILITARY ARE ENDANGERED. THE MODERNIZATION OF MILITARY SECURITY POLICY LEADS TO THE MASS DESTRUCTION OF JOBS. ONLY THE VERY LARGEST ARMAMENTS CONCERMS POSSESSING ENORMOUS THE VERY LARGEST ARMAMENTS CONCERNS POSSESSING ENORMOUS RESEARCH AND DEVELOPMENT POTENTIALS TO BACK THEM UP
SURVIVE. THE TRADE UNIONS HAVE DEMANDED EFFICIENT SURVIVE. THE TRADE UNIONS HAVE DEMANDED EFFICIENT
INSTITUIONS AND PROCEDURES, HHICH SHOULD BE INVESTED WITH INSTITUIONS AND PROCEDURES, HHICH SHOULD BE INVESTED WITH MEMBERS FOR CIVILIAN JOBS. THIS ARIICLE OFFERS AN OVERVIEH MEMBERS FOR CIVILIAN JOBS. THIS ARTICLE OFFERS AN OVERVIEW TF THE SITUATION
THE TRADE UNIONS.

04533 HUGES, $R$.

A EUROPEAN GERMANY

EUROPE, (304) (MAR 91), 19

GIVEN THE SHEEPING POLITICAL CHANGES OF THE PAST TWO YEARS, THE EUROPEAN COMMUNITY AND THE HEST GERMAN GOVERMMENT ARE FACED WITH A FORMIDABLE TASK: INTEGRATION A TERRI TORY STUNTED BY 40 YEARS OF STAGMATION UNDER COMMUNIST RULE INTO A COMMUNITY ON THE VERGE OF ITS GREATEST ECONOMIC ACHI EVEMENT--COMPLETION OF THE SINGLE MARKET. SOME OBSERVERS FEEL THAT GERMANY MAY BE OISTRACTED FROM LARGER EC CONCERNS BY THE COSTS OF UNIFICATION. OTHERS ARGUE THAT THE EAST GERMANS HAVE NO EXPERI ENCE IN THE HESTERN LIBERAL DEMOCRATIC TRADITION AND WILL SLOW THE ECONOMIC INTEGRATION. HOWEVER, MANY AMALYSTS ARE OPTIMISTIC THAT THE UNIFICATION OF GERMAMY IN AN OPPORTUMITY FOR THE COMMUNITY TO PUSH FURTHER, FASTER, AND WITH EVEN GREATER SELF-ASSURANCE TOWARD THE GOALS ENVISIONED IN ITS INCEPTION.

04534 HUGGINS, $M$.

MOMENTUM 21: REGIONAL COOPERATION IN THE CHIPPEHA VALLEY NATIONAL CIVIC REVIEW, 81(4) (FAL 92), 435-448.

FACING HIGH UNEMPLOYMENT, INDUSTRIAL RESTRUCTURING, AND INTRA-REGIONAL COMPETITION, LEADERS FROM BUSINESS

GOVERMMENT, AND EDUCATION, FOUNDED A FORUM AND INITIATED A

GOVERMMENT, AND EDUCATION FOUNDED A FORUM AND INITIATED A

THREE-COUNTY REGION IN THE VICINITY OF EAU CLAIRE, WISCONSIN.

04535 HUGHES, A.

THE APPEAL OF MARXISM TO AFRICANS

JOURNAL OF COMMUNIST STUDIES, B(2) (JUN 92) 4-20

THE RECENT RETREAT FROM MARXISM IN AFRICA SHOULD NOT OBSCURE THE FACT THAT COMHUNISM WAS ATTRACTIVE TO A CONS IDERABLE NUMBER OF AFRICANS IN THE PAST. HHILE IT IS TRUE THAT, WITH FEH EXCEPTIONS, LARGE-SCALE MARXIS T POL ITICAL MOVEMENTS DID NOT EMERGE ON THE CONTINENT, RADICAL ELEMENTS AMONG THE COLONIAL AND POST-INDEPENDENCE INTELLIGENTISA AND LABOR MOVEMENTS, SUPPLEMENTED BY DISSIDENT GROUPS WITHIN THE ARMED FORCES OF THE NEH STATES, DID CHAMPION MARXIST BLLUERINTS FOR A NEW MORAL AND POLITICAL ORDER AND THE MEANS TO THE RAPID ECONOMIC TRANSFORMATION OF THEIR SOCIETIES. THE APPEAL OF MARXISM HAS ALWAYS BEEN A MIXTURE OF IDEALISM AND INSTRUMENTALISM. WHILE A SMALL NUMBER OF POLITICAL VISIONARIES AND IDEALISTS GENUIMELY SAH A MORALLY SUPERIOR SOCIAL ORDER AND MORE EFFICIENT ECONOMIC SYSTEM IN MARXISM, FREE OF THE TAINTS OF ECONOMIC EXPLOITATION AND RACISM ASSOCIATED WITH WESTERN CAPITALISM, A MUCH LARGER NUMBER OF AFRICANS TURNED TO MARXISM FOR MORE PRACTICAL REASONS ASSOCIATED WITH GAINING POLITICAL INDEPENDENCE OR CONSOLIDATING THEIR POLITICAL POWER AND ECONOMIC SELF-INTEREST IN THE POST-COLONIAL ERA. THIS OFTEN INCONSISTENT BLEND OF SELF-INTEREST AND MORAL EXHORTATION WAS A RECURRING THEME IN THE RELATIONSHIP BETWEEN THE INTERNATIONAL COMHUNIST MOVEMENT AND RADICAL ELEMENTS IN AFRICA FROM THE EARLY 1920's TO THE LATE 1980's.

04536 HUGHES, A.

THE COL APSE OF THE SENEGAMBIAN CONFEDERATION

JOURMAL OF COMMONHEALTH AND COMPARATIVE POLIIICS, 30(2) (JUL 92 ) 200-222

IN DECEMBER 1989, FOLLOWING SEVERAL MONTHS OF INCREASING FRICTION, ONE OF POST-COLONIAL BLACK AFRICA'S LONGEST SURVIVING INTERSTATE UNIONS WAS FORMALLY OISSOL VED. THIS PAPER EXAMINES THE HISTORY OF THE NINE-YEAR RELATIONSHIP AND SEEKS TO RELATE IT TO THE WIDER EXPERIENCE OF INTERSTATE INTEGRATION IN CONTEMPORARY AFRICA. IT DETERMINES THAT THE GAMBIA CANNOT TURN ITS BACK ON ITS LARGER NEIGHBOR, DAKAR. GEOGRAPHY AND ECONOMICS, IF NOT MILITARY SURVIVAL, STILL DICTATE THE NEED FOR GOOD RELATIONS WITH DAKAR.
04537 HUGHES, $M$.

CAN THE WEST AGREE ON AID TO EASTERN EUROPE? RFE/RL RESEARCH REPORT, 1(11) (MAR 92), 35-42.

THERE HAVE RECENTLY BEEN CALLS FOR A NEH MARSHALL PLAN TO HELP THE COUNTRIES OF EASTERM AND CENTRAL EUROPE, BUT CURRENT CIRCUMSTANCES RAISE QUESTIONS ABOUT THE VIABILITY OF SUCH A PLAN. HHEN THE UNITED STATES LAUNCHED THE ORIGINAL MARSHALL PLAN IN 1947, IT OCCUPIED A POSITION OF GREAT DOMINANCE IN THE WORLD ECONOMY AND HAS IN A POSITION TO ABSORB ALL THE COSTS INVOLVED, BELIEVING THAT THE RECONSTRUCTION OF WESTERN EUROPE WOULD LEAD TO EVENTUAL GLOBAL PROSPERITY. TODAY, BY CONTRAST, NO COUNTRY OCCUPIES SUCH A DOMINANT ROLE, WITH THE RESULT THAT ANY NEW MARSHALL PLAN WOULD DEPEND ON THE DIFFICULT TASK OF ACHIEVING CLOSE COOPERATION AMONG SOVEREIGN STATES. MULTINATIONAL INSTI TUTIONS, SUCH AS THE INTERMATIONAL MONETARY FUND AND THE EUROPEAN BANK FOR RECONSTRUCTION AND DEVELOPMENT, CAN HELP WITH THIS PROBLEM BUT CANMOT RESOLVE IT ON THEIR OWN.

04538 HUGHEY, $M$.

AMERICANISM AND ITS DISCONTENTS: PROSTESTANTISM, NATIVISM, C

INTERNATIONAL JOURNAL OF POLITICS, CULTURE AND SOCIETY, 5(4) (SUM 92), 533-554.

THIS PAPER RE-EXAMINES THE AMERICAN DILEMMA AT A DEEP LEVEL BY ANALYZING THE RELIGIOUS FOUNDATIONS OF THE MORMATIVE CONCEPTION OF THE AMERICAN POL ITICAL COMAUNITY, PARTICULARLY ITS EXCLUSIVE AND RESTRICTIVE EMPHASES. THE AUTHOR IS ESPECIALLY CONCERMED TO TRACE OUT THE CASUISTRIES AND SECULAR TRANSMUTATIONS OF IDEAS HHOSE ORIGINS RESTED IN RELIGION, SHOWING HOW THEY HAVE AFFECTED BOTH ACTIONS AND IDEALS AS AMERICA'S DOMINANT GROUPS HAVE SOUGHT TO DEAL HITH THE PROBLEMS AND ISSUES POSED BY AN INCREASINGLY DIVERSE SOCIETY. HE SUGGESTS THAT VALUES, IMAGES, AND IDEALS THAT ORIGINATED IN PROTESTANTISM INFLUENCE THE ORGANIZATION OF RACE, ETHNIC, RELIGIOUS, AND OTHER GROUP RELATIONS IN DIMENSIONS OF THIS RELIGIOUS LEGACY BY TAKING AS A PARADIGMATIC CASE THE EPISODIC HISTORY OF IDEOLOGICAL HERESY AGAINST AMERICANISM AND THE NATIVIST REACTIONS TO IT.

04539 HUGHEY, M.; VIDISH, A.

THE MEH AMÉRICAN PLURALISM: RACIAL AND ETHMIC SODALITIES AND THEIR SOCIOLOGICAL IMPLICATIONS

INTERMATIONAL JOURNAL OF POLITICS, 6(2) (WIN 92), 159-180. ANTERNATIONAL JOURNAL OF POLITICS, 6(2) (WIN 92 ),
HISTORICALLY IN AMERICAN SOCIETY, ETHNICITY WAS

SOMETHING TO BE OVERCOME. IN AMERICAN SOCIETY TODAY, HOWEVER, SOMETHING TO BE OVERCOME. IN AMERICAN SOCIETY TODAY, HOWEVER
ETHMICITY HAS REEMERGED AS A CENTRAL ASPECT OF PEOPLES' ETHMICITY HAS REEMERGED AS A CENTRAL ASPECT OF PEOPLES'
IDENTIIIES AND AS A COMMON FOCUS FOR COMMUNITY LIFE. THIS IDENTITIES ANO AS A COMMON FOCUS FOR COMMUNITY LIFE. THIS ARTICLE EXPLORES THE EXTRAORDINARILY COMPLEX REACTIONS BY
THE TRANSMUTATIONS OF EHTMIC IDENTITIES AND SODALITES, WHICH HAVE FDUND CONCRETE EXPRESSION IN THE DIVERSE AND CREATIVE WAVE FOUND CONCRETE EXPRESSION IN THE DIR ERSE AND CREATICH HAVE BEEN YIELDED BY THE ETHNIC CONFRONTATION WITH' THE AMERICAN SOCIAL, CULTURAL, AND POLITICAL CONTEXT.

04540 HUGICK, L.

ANTI-INCUMBENT SENTIMENT

GALLUP POLL MONTHLY, (314) (NOV 91), 16-17

ACCORDING TO A NATIONAL GALLUP POLL, VOTER RESPONSE TO INCUMBENT POLITICIANS VARIES GREATLY BY OFFICE. ALTHOUGH MOST VOTERS OPPOSE THE RE-ELECTION OF SOME OFFICEHOLDERS, VERY FEW OPPOSE INCUMBENTS ACROSS THE BOARD. GOVERMORS ARE MOST AT RISK OF LOSING THEIR JOBS IN THE CURRENT POLITICAL ENVIRONMENT, PROBABLY BECAUSE MANY STATES HAVE BEEN FORCED TO RAISE TAXES OR REDUCE SERVICES DUE TO RECESSION-RELATED BUDGET PROBLEMS.

04541 HUGICK, L.

BUSH APPROVAL REMAINS ABOVE FIFTY PERCENT; REELECTION PROSPECTS STILL FAVORABLE

GALLUP POLL MONTHLY, (315) (DEC 91), 22-27.

ACCORDING TO A GALLUP POLL CONDUCTED DECEMBER 5-8, 1991, PRESIDENT GEORGE BUSH STILL HAS THE APPROVAL OF 52 PERCENT OF THE AMERICAN PEOPLE, HHILE 42 PERCENT DISAPPROVE OF THE WAY HE IS HANOLING HIS DUTIES AND SIX PERCENT HAVE NO OPINION. BY COMPARISON, AT SIMILAR POINTS IN THEIR ADMINISTRATIONS, PRESIDENTS RONALD REAGAN AND JIMMY CARTER BOTH HAD 54 PERCENT APPROVAL RATINGS.

04542 HUGICK, L.

BUSH APPROVAL REVERTS TO PRE-SOVIET COUP LEYELS

BUSH APPROVAL REVERTS TO PRE-SOVIET COUP LE

PRESIDENT GEORGE' BUSH'S APPROVAL RATINGS IMPROVED SLIGHTLY IMMEDITELY AFTER THE FAILED SOVIET COUP IN AUGUST 1991, BUT A LATER GALLUP POLL REVEALED THAT THE INCREASE WAS ONLY TEMPORARY. WHILE INTERNATIONAL EVENTS HAVE ALLOHED BUSH TO CAPITLIZE POLITICALLY ON HIS APPARENT STRENGTH IN THE AREA OF FOREIGN POLICY, THE DOMESTIC ECONOMY HAS REMAINED HIS ACHILLES' HEEL.

04543 HUGICK, L.

BUSH APPROVAL SLIDE CONTINUES 
GALLUP POLL MONTHLY, (314) (NOV 91), 13-15. ACCORDING TO GALLUP POLLS, PRESIDENT GEORGE BUSH'S APPROVAL RATINGS DECLINED 14 POINTS BETHEEN LABOR DAY WEEKEND AND NOVEMBER 1991. ALTHOUGH BUSH'S DECLINE IS ONE OF THE LARGEST ON RECORD, HIS RATINGS ARE STILL ABOVE AVERAGE AMONG RECENT PRESIDENTS.

04544 HUGICK, L.

BUSH BEATS CUOMO BY A TWO-TO-ONE MARGIN

GALLUP POLL MONTHLY, (313) (OCT 91), 41

ACCORDING TO A GALLUP POLL, INCUMBENT GEORGE BUSH WOULD BEAT MARIO CUOMO IN A PRESIDENTIAL ELECTION CONTEST BY A MARGIN OF $63 \%$ TO 29\%. HOWEVER, AGAINST AN UNMAMED DEMOCRATIC PARTY CANDIDATE, BUSH WOULD TAKE ONLY $49 \%$ OF THE YOTE, ACCORDING TO A POLL CONDUCTED IN MID-OCTOBER 1991.

04545 HUGICK, L.; SAAD, L.

BUT PUBLIC' SEEKS MIDDLE GROUNDS ON ABORTION, SUPPORTS PENNSYLVANIA LAH

GALLUP POLL MONTHLY, (316) (JAN 92), 6-9.

ACCORDING TO A GALLUP POLL, MOST AMERICANS PREFER THE MIDOLE GROUND ON ABORTION LAWS. WHILE 31 PERCENT FAVOR MIDDLE GROUND ON ABORTION LAWS. WHILE 31 PERCENT FAVOR

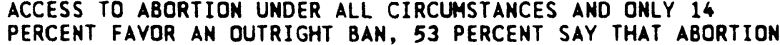
PERCENT FAVOR AN OUTRIGHT BAN, 53 PERCENT SAY THAT ABORTION
SHOULD BE LEGAL ONLY UNDER CERTAIN CIRCUMSTANCES. A SUPREM COURT RULING ON PENNSYLYANIA'S NEW ABORTION RESTRICTIONS COULD AFFECT THE OUTCOME OF THE 1992 PRESIDENTIAL ELECTION.

04546 HUGICK, L.

CLINTON TRANSITION GAINS FAYORABLE REVIEWS

GALLUP POLL MONTHLY, 327 (DEC 92), 12-17.

THE AUTHOR REPORTS ON PUBLIC OPINION POLLS TAKEN ONE

MONTH BEFORE THE INAUGURATION OF BILL CLINTON AS PRESIDENT.

THE POLLS INDICATE THAT TWO-THIRDS OF AMERICANS APPROVE OF

CLINTON'S HANDLING OF THE TRANSITION AND VIEH HIS CABINET-

LEVEL APPOINTMENTS MORE FAYORABLY THAN THOSE OF PRESIDENT

BUSH. APPROVAL RATINGS ARE PREDICTABLY HIGH AMONG DEMOCRATS

AND THOSE WHO VOTED FOR CLINTOH, AND THEY ARE AL SO SOLIDLY

POSITIVE AMONG POLITICAL INDEPENDENTS AND PEROT VOTERS.

04547 HUGICK, L.

DEMOCRATIC PARTY GAINING ON ECONOMIC ISSUES

GALLUP POLL MONTHLY, (313) (OCT 91), 53.

THE RECESSION IS TAKING A POLITICAL TOLL ON PRESIDENT

GEORGE BUSH AND THE REPUBLICAN PARTY. FORTY-FOUR PERCENT OF

AMERICANS BELIEVE THE REPUBLICAN PARTY IS BETTER ABLE TO

AMERICANS BELIEVE THE REPUBLICAN PARTY IS BETTER ABLE TO
KEEP THE COUNTRY PROSPEROUS, HHILE 41 PERCENT BELIEVE THE

KEEP THE COUNTRY PROSPEROUS, WHILE 41 PERCENT BELIEVE THE

CONSIDERED, THIS IS A STATISTICAL TIE.

04548 HUGICK, L.

DEMOCRATIC PARTY'S IMAGE AT HISTORIC LOW

GALLUP POLL MONTHLY, (312) (SEP 91), 24-32

RECENT GALLUP POLLS REVEAL DECLINES IN THE PUBLIC

APPROYAL RATINGS OF BOTH THE DEMOCRATIC AND THE REPUBLICAN

PARTIES, INDICATE THAT AMERICANS PREFER A GOVERMMENT DIVIDED

BETWEEN THE THO PARTIES, AND PREDICT THAT ECONOMIC PROBLEMS

COULD BE THE TOP ISSUE IN THE 1992 ELECTIONS.

04549 HUGICK, L.

DEMOCRATS GAIN ON BUSH IN 1992 TEST ELECTION

GALLUP POLL MONTHLY, (314) (NOV 91), 5-8.

THE TROUBLED ECONOMY HAS REVIVED DEMOCRATIC HOPES FOR A

COMPETITIVE RACE AGAINST GEORGE BUSH IN 1992. ACCORDING TO A GALLUP POLL, LESS THAN HALF OF THE REGISTERED VOTERS WANT TO RE-ELECT BUSH, AND MORE THAN ONE-THIRD ARE INCLINED TO SUPPORT ANY DEMOCRATIC NOMINEE. DOMESTIC ISSUES ARE HELPING THE DEMOCRATIC PARTY, WHILE ITS TRADITIONAL "TAX-AND-SPEND" IMAGE REMAINS A PROBLEM.

04550 HUGICK, L.

DEMOCRATS WANT TO MAKE ECONOMY THE ISSUE IN 1992

GALLUP POLL MONTHLY, (312) (SEP 91), 33-36.

DEMOCRATIC VOTERS HAVE THREE SUGGESTIONS TO HELP THEIR PARTY EFFECTIVELY CHALLENGE GEORGE BUSH IN 1992: (1) MAKE THE ECONONY THE MAJOR ISSUE; (2) USE THE PRESIDENT'S COMMITMENT TO FOREIGN POLICY AGAINST HIM; AND (3) DON'T NOMINATE ANOTHER LIBERAL PRESIDENTIAL CANDIDATE.

04551 HUGICK, L.

DISSATISFACTION WITH STATE OF NATION AT HISTORIC HIGH POINT GALLUP POLL MONTHLY, (321) (JUN 92), 16-18.

EIGHTY-FOUR PERCENT OF AMERICANS ARE DISSATISFIED WITH

THE STATE OF THE NATION, ACCORDING TO A GALLUP POLL. THE

THE STATE OF THE NATION, ACCORDING TO A GALLUP POLL. THE
LINGERING RECESSION AND THE LOS ANGELES RIOTS ARE TWO

LINGERING RECESSION AND THE LOS ANGELES RIOTS ARE TWO
FACTORS IN THE LOW LEVEL OF SATISFACTION. POLLS INDICATE

FACTORS IN THE LOW LEVEL OF SATISFACTION. POLLS INDICATE
PARALLELS WITH THE PUBLIC MOOD DURING THE PRESIDENCY OF

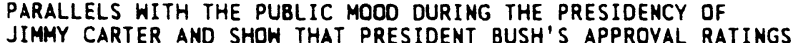
HAYE FALLEN IN CONCERT WITH PUBLIC EVALUATIONS OF THE STATE HAVE FALLEN IN
OF THE NATION.

04552 HUGICK, L.

ECONOMIC DISCONTENT AIDING DUKE AND BUCHANAN CANDIDACIES GALLUP POLL MONTHLY, (315) (DEC 91), 28-33.
ACCORDING TO A GALLUP POLL, NEITHER OF GEORGE BUSH'S CHALLENGERS FOR THE REPUBLICAN PRESIDENTIAL NOMINATIONDAVID DUKE AND PAT BUCHANAN--HAS A REALISTIC CHANCE TO UNSEAT BUSH. HOWEVER, IN STATES HARD-HIT BY THE RECESSION, BUSH'S GOP CHALLENGERS MAY ATTRACT ENOUGH SUPPORT TO CALL ATTENTION TO THEIR ANTI-GOVERMMENT, ANTI-TAX THEMES.

04553 HUGICK, L.

GALLUP/CNN/USA TODAY: NEH HAMPSHIRE POLLS

GALLUP POLL MONTHLY, (317) (FEB 92), 34-39.

THE AUTHOR SUMMARIZES THE RESULTS OF POLLS CONDUCTED

DURING THE 1992 NEW HAMPSHIRE PRESIDENTIAL PRIMARY CAMPAIGN.

04554 HUGICK, L.

GEORGIA VOTERS SHOWED VARIED RESPONSE TO NEGATIVE ADS

GALLUP POLL MONTHLY, (318) (MAR 92), 32-39.

NEGATIVE POLITICAL ADVERTISING HAS BEEN WIDELY REGARDED AS DETRIMENTAL TO THE ELECTORAL PROCESS, BUT A LOOK AT THE IMPACT OF NEGATIVE ADS IN THE 1992 GEORGIA PRESIDENTIAL

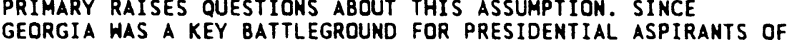
GEORGIA WAS A KEY BATTLEGROUND FOR PRESIDENTIAL ASPIRANTS OF BOTH PARTIES PRIOR TO SUPER TUESDAY, VOTERS WERE SUBJECTED
TO A BARRAGE OF NEGATIVE ADS FROM THE VARIOUS CAMPAIGNS. BUT NOT ALL OF THE BROADCAST ADS LEFT A LASTING IMPRESSION ON THE VOTERS, AND EVEN THOSE ADS THAT WERE MEMORABLE DID NOT SEEM TO CHANGE MANY VOTERS' MINDS. MOREOVER, ONE OF THE TWO MOST VISIBLE ADS SEEMS TO HAVE BACKFIRED.

04555 HUGICK, L.

GOP, DEMOCRATS EVEN ON ABILITY TO HANDLE TOP PROBLEM GALLUP POLL MONTHLY, (315) (DEC 91), 34-36.

IN A GALLUP POLL CONDUCTED IN LATE 1991, 32 PERCENT OF AMERICANS CHOSE THE REPUBLICANS WHILE 33 PERCENT NAMED THE DEMOCRATS WHEN ASKED WHICH PARTY CAN BETTER HANDLE THE UNITED STATES' MOST PRESSING PROBLEM. BY CONTRAST, THE DEMOCRATS ENJOYED A 7-8 PERCENTAGE POINT ADVANTAGE ON THIS QUESTION IN GALLUP POLLS PRIOR TO THE 1988, 1984, AND 1980 ELECTIONS.

04556 HUGICK, L.

IMAGE AS 'PARTY OF PROSPERITY' STILL ELUDES DEMOCRATS

GALLUP POLL MONTHLY, (317) (FEB 92), 7.

WHILE THE RECESSION HAS LEFT PRESIDENT GEORGE BUSH AND

THE REPUBLICAN PARTY ON THE ROPES, THE DEMOCRATIC PARTY HAS

YET TO WIN BACK THE TITLE "PARTY OF PROSPERITY." THE

DEMOCRATS' FAILURE TO APPROPRIATE THE PROSPERITY ISSUE IN AN

ELECTION YEAR DOES NOT BODE WELL FOR THEIR CHANCES OF

DEFEATING BUSH IN NOVEMBER 1992. DESPITE THE PRESIDENT'S LOW APPROVAL RATINGS ON THE ECONOMY. THE FINDINGS OF GALLUP POLLS OVER THE PAST 40 YEARS SUGGEST THAT BUSH WILL BE RETURNED TO OFFICE UNLESS VOTERS BECOME CONVINCED THA
DEMOCRATS ARE MORE LIKELY TO BRING BACK PROSPERITY.

04557 HUGICK, L.

IRAN-CONTRA PARDONS OPPOSED

GALLUP POLL MONTHLY, 327 (DEC 92), 21-22.

MORE THAN HALF OF AMERICANS POLLED ABOUT PRESIDENT

GEORGE BUSH'S PARDON OF CASPAR WEINBERGER AND FIVE OTHER

IRAN-CONTRA DEFENDANTS EXPRESSED DISAPPROVAL OF THE CHIEF

EXECUTIVE'S ACTIONS. NEARLY HALF OF THE RESPONDENTS SAID

THAT BUSH WAS MOTIVATED BY A DESIRE TO PROTECT HIMSELF FROM

LEGAL DIFFICULTIES OR EMBARRASSMENT RESULTING FROM HIS OWN

INVOLVEMENT IN THE SCANDAL.

04558 HUGICK, L.

KEEPING QUAYLE ON TICKET MAY PROVE RISKY FOR BUSH

GALLUP POLL MONTHLY, (314) (NOV 91), 18-20.

PRESIDENT GEORGE BUSH'S COMMITMENT TO KEEPING DAN OUAYLE AS HIS RUNNING MATE MAY COST HIM VOTES IN 1992. IF QUAYLE REMAINS ON THE REPUBLICAN TICKET, SIXTEEN PERCENT OF REGISTERED VOTERS SAY THEY WOULD BE LESS LIKELY TO VOTE FOR BUSH. ONLY TEN PERCENT WOULD BE MORE INCLINED TO BACK BUSH BECAUSE HE RETAINED QUAYLE.

04559 HUGICK, L.

NO PUBLIC OPINION WINMER IN BUSH-ISRAEL CLASH

GALLUP POLL MONTHLY, (313) (OCT 91), 5-9.

BOTH ISRAEL AND PRESIDENT GEORGE BUSH MAY BE LOSERS IN THE CLASH OVER U.S. LOAN GUARANTEES TO ISRAEL. ACCORDING TO GALLUP POLLS, AMERICANS WITH UNFAVORABLE VIEWS OF ISRAEL INCREASED FROM 26\% IN AUGUST 1991 TO 34\% IN SEPTEMBER 1991 MEANWHILE, BUSH'S APPROVAL RATING DROPPED FROM $70 \%$ IN EARLY SEPTEMBER TO $68 \%$ IN MID-SEPTEMBER.

04560 HUGICK, L.

ON ELECTION DAY, MOMENTUM WITH DEMOCRATS

ON ELECTION DAY, MOMENTUM WITH DEMOCRATS

NATIONAL POLLS TAKEN OVER THE COURSE OF THE FALL 1991 CAMPAIGNS SHOWED MOVEMENT TOWARD THE DEMOCRATIC PARTY POSITIONS ON THE PIVOTAL ISSUE OF THE ECONOMY AND ON A WIDE ARRAY OF OTHER CONCERNS. THE UNEXPECTED VICTORY OF HARRIS WOFFORD IN PENNSYLVANIA INDICATES THAT HEALTH CARE COULD BECOME A KEY ISSUE IN THE 1992 ELECTIONS. 
04561 HUGICK, L.

ONE NIGHT BEFORE VOTE, SUPPORT FOR THOMAS REMAINS STRONG GALLUP POLL MONTHLY, (313) (OCT 91), 23-27.

A GALLUP POLL CONDUCTED THE NIGHT BEFORE THE SENATE VOTE ON WHETHER TO CONFIRM CLARENCE THOMAS TO THE SUPREME COURT FOUND THAT 58\% SUPPORTED THOMAS WHILE 30\% OPPOSED HIM.

04562 HUGICK, L.

OPINION ON THOMAS SHIFTED AS HEARINGS PROGRESSED GALLUP POLL MONTHLY, (313) (OCT 91), 18.

ACCORDING TO A GALLUP POLL, A MAJORITY OF THE AMERICAN

PUBLIC CONTINUES TO SUPPORT CLARENCE THOMAS' CONFIRMATION AS A SUPREME COURT JUSTICE DESPITE ALLEGATIONS OF SEXUAL HARASSMENT.

04563 HUGICK, L.

POLITICAL FALLOUT FROM THE THOMAS HEARINGS

GALLUP POLL MONTHLY, (313) (OCT 91), 28-35.

A GALLUP POLL CONDUCTED AFTER THE SENATE CONFIRMED

CLARENCE THOMAS TO THE SUPREME COURT SHOWED SHARP DECLINES

IN THE PUBLIC'S RATINGS OF CONGRESS AND THE DEMOCRATIC PARTY.

IN THE PUBLIC'S RATINGS OF CONGRESS AND THE DEMOCRATIC PAA

HOHEVER, THE POLL REVEALED FEH SIGNS OF ANTI-INCUMBENT
SENTIMENT AMONG VOTERS. THE BATTLE OVER THOMAS' CONFIRMATION

HAD NO SIGNIFICANT EFFECT ON PRESIDENT BUSH'S APPROVAL

HAD NO SI

04564 HUGICK, L. PRO-LIFE WITCHITA DEMONSTRATIONS FAIL TO CHANGE OPINION ON ABORTION

GALLUP POLL MONTHLY, (312) (SEP 91), 49-53.

DESPITE THE HIGHLY-PUBLICIZED CAMPAIGN BY A "PRO-LIFE" GROUP AGAINST ABORTION CLINICS IN WICHITA, KANSAS, PUBLIC SUPPORT FOR LEGAL ABORTION REMAINS FIRM. ACCORDING TO A GALLUP POLL, 57\% OF AMERICANS OPPOSE OVERTURING THE SUPREME COURT'S ROE $V$. WADE DECISION. IN A RELATED POLL, 65\% OF VOTERS INDICATED THAT PRESIDENT BUSH'S HANDL ING OF THE ABORTION ISSUE WILL NOT BE A MAJOR FACTOR IN WHETHER THEY VOTE TO RE-ELECT HIM.

04565 HUGICK, L.; SAAD, L.

PUBLIC BELIEVES TAXES UNFAIRLY HIT MIDOLE CLASS, POOR GALLUP POLL MONTHLY, (319) (APR 92), 32-35.

SEYENTY-SEYEN PERCEHT OF AMERICAMS THIMK THAT UPPERINCOME FAMILIES PAY TOO LITTLE INCOME TAX, WHILE FIFTY-SEVEN PERCENT BELIEVE THAT MIDOLE- AND LOHER-INCOME AMERICANS PAY TOO $\mathrm{MUCH}$.

04566 HUGICK, L.

PUBLIC DIVIDED ON GATES NOMINATION

PUBLIC DIVIDED ON GATES NOMINATION
GALLUP POLL MONTHLY, (313) (DCT 91 ) 14

THE AMERICAN PUBLIC IS OIVIDED OVER WHETHER ROBERT GATES SHOULD BE CONFIRMED AS HEAD OF THE CENTRAL INTELLIGENCE SHOULD BE CONFIRMED AS HEAD OF THE CENTRAL INTELLIGENCE AGENCY. ACCORDING TO A GALLUP POLL, 35\% OF RESPONDENTS
OPPOSE GATES, 26\% FAVOR HIM, AND 39\% HAVE NO OPINION.

04567 HUGICK,

PUBLIC DIVIDED ON RUSSIAN AID

GALLUP POLL MONTHLY, (319) (APR 92), 36-38.

PRESIDENT GEORGE BUSH HAS ANMOUNCED THAT THE UNITED STATES WILL PARTICIPATE IN AN INTERNATIONAL CONSORTIUM TO PROVIDE FINANCIAL AID, LOANS, AND OTHER FORMS OF ASSISTANCE TO THE NEW GOVERMMENTS OF THE FORMER SOVIET UNION. ACCDRDING TO A GALLUP POLL. 53 PERCENT OF AMERICANS SUPPORT THE AID PLAN OUTLINED BY BUSH, WHILE 43 PERCENT OPPOSE IT. FORMER PRESIDENT RICHARD NIXON'S VIGOROUS ENDORSEMENT OF AID TO RUSSIA HAS HAD LITTLE EFFECT ON PUBLIC OPINION ON THE MATTER.

04568 HUGICK, L.

PUBLIC' HOPEFUL CLINTON CAN SOLVE NATION'S PROBLEMS

GALLUP POLL MONTHLY, (326) (NOV 92), 11-18.

THE AUTHOR REPORTS THE RESULTS OF PUBLIC OPINION POLLS

CONDUCTED DURING THE FIRST WEEK AFTER BILL CLINTON'S VICTORY IN THE 1992 PRESIDENTIAL ELECTION.

04569 HUGICK, L.

PUBLIC OPPOSES NEW AID TO SOVIET REPUBLICS

GALLUP POLL MONTHLY (315) (DEC 91) 19-21.

ACCORDING TO A POLL CONDUCTED IN LATE 1991, THE AMERICAM

PUBLIC SOLIDLY OPPOSES SENDING NEW AID ABROAD TO HELP THE

DISINTEGRATING SOVIET UNION OR ITS REPUBLICS. ONLY 21

PERCENT OF RESPONDENTS BELIEVE THAT NEW AID IS CRITICAL TO

HELP KEEP THE SITUATION IN THE USSR FROM THREATENING

HELP KEEP THE SITUATION

04570 HUGICK, L.

TAXES: BUSH AND CONGRESS

GALLUP POLL MONTHLY, (318) (MAR 92), 40-42.

PRESIDENT GEORGE BUSH AND COMGRESSIONAL DEMOCRATS DRAH SIMILAR LEVELS OF PUBLIC SUPPORT IN THEIR DISPUTE OVER TAXES AND THE ECONOMY. IN A GALLUP POLL, 38 PERCENT OF AMERICANS SAID THAT THEY TRUST BUSH MORE ON' TAXES WHLE 40 PERCENT PLACED GREATER TRUST IN DEMOCRATIC CONGRESSIONAL LEADERS. MOREOVER, THE DEMOCRATS MAY BE WINHING THE BATTLE OF IDEAS, BECAUSE THEIR APPROACHES TO STIMULATING THE ECONOMY WON
BROADER PUBLIC SUPPORT THAN REPUBLICAN PROPOSALS.

04571 HUGICK, L.

THE PEACE DIVIDEND

GALLUP POLL MONTHLY, (313) (OCT 91), 10-13.

ACCORDING TO A GALLUP POLL, THE AMERICAN PUBLIC OVERWHELMINGLY FAVORS INCREASED DOMESTIC SPENDING OVER DEFICIT REDUCTION OR TAX RELIEF AS THE BEST WAY TO USE ANY "PEACE DIVIDEND." ALTHOUGH LARGE MAJORITIES OF AMERICANS FAVOR USING SOME OF THE SAVINGS TO HELP REDUCE THE FEDERAL BUDGET DEFICIT OR CUT TAXES, RELATIVELY FEW HOULD USE MOST OF THE MONEY FOR EITHER PURPOSE. ONLY 23\% FAVOR SPENDING ANY OF THE PEACE DIVIDEND TO PROVIDE FOREIGN AID TO HELP THE SOVIETS.

04572 HUGICK, L.

THE RUBBER-GATE SCANDAL

GALLUP POLL MONTHLY, (318) (MAR 92), 2-4.

MEMBERS OF CONGRESS HHO ENGAGED IN CHECK-KITING ARE HAVING DIFFICULTY EXPLAINING THEIR ACTIONS TO THEIR

CONSTITUENTS. TO THE PUBLIC, THE RUBBER-GATE SCANDAL IS AS

MUCH ABOUT CONGRESSIONAL COMPETENCE, OR INCOMPETENCE, AS IT IS ABOUT ETHICS OR THE ABUSE OF PRIVILEGE. PUBLIC OPINION POLLS INDICATE THAT MEMBERS OF CONGRESS INCLUDED ON THE LIST OF WORST OFFENDERS WILL FACE SERIOUS PROBLEMS IF THEY CHOOSE TO RUN FOR RE-ELECTION.

04573 HUGICK, L.

THOMAS-HILL CONTROVERSY INTERRUPTED SLIDE IN BUSH APPROVAL GALLUP POLL MONTHLY, (313) (OCT 91), 47

THE CONTROVERSY OVER CLARENCE THOMAS' CONFIRMATION TO THE SUPREME COURT BRIEFLY INTERRUPTED THE SLIDE IN PRESIDENT GEORGE BUSH'S APPROVAL RATINGS. IN MID-OCTOBER 1991, WHEN THE THOMAS HEARINGS DOMINATED THE NEWS, BUSH'S APPROVAL RATIMG WAS AT 66\%. WHEN THE FOCUS SHIFTED BACK TO THE ECONOMY AND OTHER ISSUES, BUSH'S APPROVAL FELL TO $62 \%$ IN LATE OCTOBER.

04574 HUGICK, L.

WITH CUOMO ON SIDELINES, "UNDECIDED" LEADS DEMOCRATIC FIELD GALLUP POLL MONTHLY, (312) (SEP 91), 37-41.

NEARLY ONE-THIRD OF REGISTERED DEMOCRATS AND DEMOCRATIC

"LEANERS" PREFER NEW YORK GOVERNOR MARIO CUOMO WHEN HIS NAME

IS INCLUDED IN A LIST OF POTENTIAL PRESIDENTIAL CANDIDATES. NO OTHER POTENTIAL DEMOCRATIC CANDIDATE RECEIVES EVEN HALF

AS MUCH SUPPORT.

04575 HUGICK, L.

WOMEN KEY TO PRESIDENT'S LOWER RATINGS

GALLUP POL MONTHLY, (314) (NOY 91) 21-25.

DURING OCTOBER 1991, PRESIDENT GEORGE BUSH LOST SUPPORT AMONG ALL MAJOR POPULATION GROUPS, INCLUDING REPUBLICANS AND POL ITICAL CONSERVATIVES. IN ONLY ONE WEEK, BUSH'S APPROVAL RATING AMONG WOMEN FELL FROM 55 PERCENT TO 48 PERCENT.

04576 HUGICK, L.

1992 PRESIDENTIAL CAMPAIGN

GALLUP POLL MONTHLY, (317) (FEB 92), 21-33.

THE AUTHOR TRACKS THE PROGRESS OF THE 1992 PRESIDENTIAL ELECTION CAMPAIGN DURING THE MONTH OF FEBRUARY, USING PUBLIC OPINION POLLS SURVEYING ATTITUDES ABOUT THE RECESSION AND THE CANDIDATES.

04577 HUGICK, L.

1992 PRESIDENTIAL CAMPAIGH

GALLUP POLL MONTHLY, (316) (JAN 92), 16-35

BASED ON PUBLIC OPINION SURVEYS, THE AUTHOR TRACKS THE

PROGRESS OF THE 1992 PRESIDENTIAL ELECTION CAMPAIGN DURINC JANUARY. THE PRESENTATION INCLUDES THE RESULTS OF POLLS ON PRESIDENT GEORGE BUSH'S PERFORMANCE, OPINIONS OF VICE PRESIDENT DAN QUAYLE, HOW A SUPREME COURT ABORTION RULING WOULD AFFECT THE CAMPAIGM, AND PUBLIC ASSESSMENT OF PRESIDENT BUSH'S STATE OF THE UNIOH ADDRESS.

04578 HUGICK, L.

1992 PRESIDENTIAL CAMPAIGH

GALLUP POLL MONTHLY, (381) (MAR 92), 5-31.

THE AUTHOR OFFERS A CHRONOLOGY OF DEVELOPMENTS IN THE 1992 PRESIDENTIAL ELECTION CAMPAIGM DURING THE MONTH OF MARCH. BASED ON PUBLIC OPINION SURVEYS, HE CONCLUDES THAT A RESTRICTIVE IMUIGRATION POLICY HOULD FIND FAVOR HITH THE YOTERS, THAT GOVERMOR BILL CLINTON IS DOMINATING FHE VOTERS, THAT GOVERNOR BILL CLINTON IS DOMINATING FHE DEMOCRATIC FIELD IN THE SOUTH WHILE LOSING GROUND ELSEHH BUCHANAM IS CHANGING.

04579 HUGICK, L.

1992 PRESIDENTIAL CAMPAIGN

GALLUP POLL MONTHLY, (319) (APR 92), 2-25.

THE AUTHOR DISCUSSES MAJOR DEVELOPMENTS IN THE U.S.

PRESIDENTIAL ELECTION CAMPAIGN DURING THE MONTH OF APRIL

1992. HE REPORTS ON PUBLIC OPINION POLLS REGARDING AIDS AS A CAMPAIGM ISSUE AND THE PUBLIC'S RECEPTIVENESS TO VARIOUS CANDIDATES, INCLUDING BILL CLINTON, GEORGE BUSH, JERRY BROWN, 
AND H. ROSS PEROT.

04580 HUGICK, L. I

1992 PRESIDENTIAL CAMPAIGN: JUNE

GALLUP POLL MONTHLY, (321) (JUN 92), 33-52.

THE AUTHOR REPORTS ON THE PROGRESS OF THE U.S.

PRESIDENTIAL ELECTION CAMPAIGN DURING THE MONTH OF JUNE 1992

HE ANALYZES POLLS ON THE EFFECTS OF H. ROSS PEROT'S

CANDIDACY, ANTI-WASHINGTON SENTIMENT, ECONOMIC PROBLEMS, AND

THE DESIRE FOR CHANGE.

04581 HUGICK, L.

1992 PRESIDENTIAL CAMPAIGN: MAY

GALLUP POLL MONTHLY, (320) (MAY 92), 2-33.

THE AUTHOR CHRONICLES THE PROGRESS OF THE U.S.

PRESIDENTIAL ELECTION CAMPAIGN DURING MAY 1992. HE DISCUSSES YOTER ANGER, PEROT'S CANDIDACY AS A THREAT TO CLINTON ANO BUSH, AND POSSIBLE CHOICES FOR THE DEMOCRATIC PARTY'S VICEPRESIDENTIAL CANDIDATE.

04582 HUGICK, L.

1992 PRESIDENTIAL CAMPAIGN: NOVEMBER

GALLUP POLL MONTHLY, (326) (NOV 92), 2-10.

BASED ON PUBLIC OPINION POLLS, THE AUTHOR SURVEYS TRENDS

IN THE FINAL DAYS OF THE 1992 U.S. PRESIDENTIAL ELECTION. HE

DISCUSSES THE EBBING OF SUPPORT FOR H. ROSS PEROT, GOVERNOR

BILL CLINTON'S GAINS OUTSIDE THE SOUTH, THE IMPACT OF NEW

IRAN-CONTRA RELEVATIONS, AND OTHER FACTORS.

04583 HUGICK, L.

1992 PRESIDENTIAL CAMPAIGH: SEPTEMBER

GALLUP POLL MONTHLY, (324) (SEP 92), 12-45.

USING PUBLIC OPINION POLLS, THE AUTHOR TRACKS THE TRENDS IN THE 1992 PRESIDENTIAL ELECTION CAMPAIGN DURING THE MONTH

OF SEPTEMBER.

04584 HUGUES, $P$.

BONN FLEXES NEW DIPLOMATIC MUSCLE

WORLD PRESS REVIEW, $39(4)$ (APR 92), 14.

FOR 40 YEARS, WEST GERMANY CONCENTRATED ON ECONOMIC

DEVELOPMENT AND FOLLOWED THE LEAD OF ITS ALLIES ON FOREIGN

POLICY. NOW REUNITED GERMANY IS REDISCOVERING THE USES OF

FULL SOVEREIGNTY AND FINDING ITSELF AT THE HEART OF THE NEW

EUROPE. FOREIGN POLICY HAS BECOME A MORE HAZARDOUS, MORE

COMPLEX BUSINESS, AND THE SLIGHTEST SLIP PROVIDES FOREIGNERS

WITH A CHANCE TO REVIVE OLD GHOSTS. THE PERSIAN GULF CRISIS AND YUGOSLAVIA'S

04585 HULTBERG, $N$.

NEVER TO BE PUT UP FOR VOTE

FREEMAN $42(10)$ (DCT 92 ) 372-376.

IT IS THE VIEW OF MOST AMERICANS TODAY THAT AS LONG AS

LEGISLATION IS ESTABLISHED BY A MAJORITY VOTE OF THE PEOPLE, THEN PEOPLE ARE POLITICALLY FREE AND JUSTICE REIGNS. THIS MODERN VIEW HOULD BE CONSIDERED GRIEVOUSLY NAIVE BY THE FOUNDING FATHERS, WHO IN THEIR PERUSAL OF HISTORY HAD ACQUIRED A THOROUGH GRASP OF THE FOLLIES OF ANCIENT GREEK DEMOCRACIES. IN THEIR MINOS, IT WOULD BE LUDICROUS TO DETERMINE FREEDOM AND JUSTICE MERELY BY DEMOCRATIC APPROVAL OF LANS.

04586 HULTBERG, $N$

PRELUDE TO THE TOTAL STATE

FREEMAN, 42(9) (SEP 92), 354-359.

THE author argues that the helfare state is a "Prelude TO THE TOTAL STATE" AND THAT GOVERNMENT INTERVENTION ALWAYS BREEDS ECONOMIC DISLOCATIONS THAT NECESSITATE MORE

GOVERMMENT INTERVENTION.

04587 HUMMEL, C.K.

RUMMEL, C.K.

RFE/RL RESEARCH REPORT, 1 (32) (AUG 92), 25-32.

AS PART OF THE RUSSIAN ECONOMIC REFORM PROGRAM, A POLICY ON THE CONVERSION OF DEFENSE INDUSTRIES IS BEGINNING TO TAKE SHAPE. HOWEVER, THE YELTSIN GOVERNMENT IS FAR FROM UNIFIED SHAPE. HOWEVER, THE YELTSIN GOVERNMENT IS FAR FROM UNIFIED
ON THE MATTER, AS DEFENSE INDUSTRIALISTS BATTLE TO PROTECT ON THE MATTER, AS DEFENSE INDUSTRIALISTS BATTLE TO
THEIR POSITIONS AND AS REFORMERS FIGHT TO PUSH THE CONVERSION PROCESS FORHARD. THE YELTSIN ADMINISTRATION IS STRUGGLING TO CHOOSE AMONG A NUMBER OF LEGITIMATE INTERESTS STRUGGL ING TO CHOOSE AMONG A NUMBER OF LEGITIMATE INTERESTS
AND OBJECTIVES, BUT THE POLITICAL CAPITAL IT HAS EXPENDED ON AND OBJECTIVES, BUT THE POLITICAL CAPITAL IT HAS EXPENDED KEEPING THE BALANCE BETHEEN THEM HAS GRADUALLY TAKEN ITS
TOLL. CONVERSION AND ECONOMIC REFORM ARE INTERCONNECTED, AND TOLL. CONVERSION AND ECONOMIC REFORM ARE INTERCONNEC

04588 HUMMEL, C.K.

UKRAINIAN ARHS MAKERS ARE LEFT ON THEIR OHN

RFE/RL RESEARCH REPORT ARE (32) (AUG 92) 33-37.

UKRAINE INHERITED THE SECOND-LARGEST PORTION OF THE FORMER SOVIET MILITARY-INDUSTRIAL COMPLEX. ALTHOUGH CONVERTING THIS MILITARY CAPACITY TO CIVILIAN PRODUCTION IS ESSENTIIAL TO UKRAINE'S ECONOMIC REFORM, THE PRESSURES OF CONSOL IDATING POLITICAL INDEPENDENCE HAVE RELEGATED CONVERSION TO A SECONDARY POSITION. AS UKRAINIAN SOVEREIGNTY
BECOMES A REALITY, DISCUSSIONS OF CONVERSION ARE INCREASING. SINCE THE GOVERNMENT HAS YET TO ANHOUNCE A CLEAR POLICY ON CONYERSION, SOME DEFENSE ENTERPRISES ARE ALREADY TAKING MATTERS INTO THEIR OWN HANDS.

04589 HUNT, A.

A SOCIALIST INTEREST IN LAH

NEW LEFT REVIEW, (192) (MAR 92), 105-119.

THE AUTHOR CRITIQUES CHRISTINE SYPNOWICH'S "THE CONCEPT OF SOCIALIST LAW," ARGUING THAT THERE HAS BEEN A DISABLING SOCIALIST TRADITION OF HOSTILITY TO LAW. WHILE THERE HAS ALWAYS BEEN A LIBERTARIAN TRADITION WITHIN THE NEW LEFT, IT ALAS NOT ALWAYS REGISTERED THE NEED FOR FORMAL SAFEGUARDS AND HAS NOT ALWAYS REGISTERED THE NEED FOR FORMAL SAFEGUARDS AND
A RULE OF LAH. EVEN VERY MODERATE REFORMIST POLITICIANS HAVE A RULE OF LAW. EVEN VERY MODERATE REFORMIST POLITICIANS
BEEN LOATH TO SEE THEIR POHER CIRCUMSCRIBED BY RIGHTS BEEN LOATH TO SEE THEIR POHER CIRCUMSCRIBED BY RIGHTS CONTROL. BOTH THE DIRE EXPERIENCE OF STALINISM AND THE HEAVYCONTROL. BOTH THE DIRE EXPERIENCE OF STALINISM AND THE HEAVY HANDED PATERMALISM OF SOCIAL DEMOCRACY NOW REQUIRE THE LEFT NOT ONLY AS AN EXPRESSION, OR FUNCTION, OF CLASS RULE AND CAPITALIST RELATIONS BUT ALSO AS CONSTITUTIVE OF FORMS OF CAPITALIST RELATIONS BUT ALSO
LIFE THAT COULD OUTLAST THEM.

04590 HUNT, $M$.

BEIJING AND THE KOREAN CRISIS: JUNE 1950-JUNE 1951 POLITICAL SCIENCE, 107(3) (FAL 92), 453-478.

WHILE THE RECORD OF CHINA'S ROLE IN THE KOREAN WAR IS BY NO MEANS COMPLETE, THE MATERIALS NOH IN HAND ARE VOLUMINOUS AND RELIABLE ENOUGH TO INVITE A SHEEPING REAPPRAISAL OF BEIJING'S RESPONSE TO THE CRISIS AMD AN OVERALL REASSESSMENT OF THE CRISIS ITSELF. THESE NEW CHINESE MATERIALS ON THE KOREAN WAR ARE ESPECIALLY RICH FOR THE FIRST YEAR OF THE CONFLICT WHEN BEI JING MOVED TOWARD A DECISION TO INTERVENE, STRUGGLED TO FORMULATE WAR AIMS AND AN APPROPRIATE STRATEGY, AND FINALLY ACCEPTED NEGOTIATIONS AND A MILITARY STALEMATE. THIS ARTICLE BEGINS BY SKETCHING OUT SOME OF THE CENTRAL FINDINGS THAT HAVE EMERGED TO DATE. IT THEN SEEKS TO RELATE THOSE FINDINGS TO THEMES DRAHN FROM THE MORE FULLY DOCUMENTED ANGLO-AMERICAN SIDE OF THE STORY. IT FINALLY OFFERS SOME REFLECTIONS ON THE IMPLICATIONS OF THE KOREAN CASE FOR OUT GENERAL UNDERSTANDING OF INTERNATIONAL CRISES.

04591 HUNT, R.J.

GAY AND LESBIAN POLITICS

PS: POIN AND LESBIAN POLITICS

220-224.

THE AUTHOR, WHO TEACHES AT OHIO UNIVERSITY, EXPLAINS HOW

HE CAME TO DEVELOP a COURSE CALLED "GAY AND LÉSBIAN POLITICS.

" HE ALSO DISCUSSES THE PURPOSE AND CONTENT OF THE COURSE.

04592 HUNTER, J.

COVERT OPERATIONS: THE HUMAN FACTOR

LINK, 25(3) (AUG 92) $1-13$

BASED ON THREE RECENT BOOKS ABOUT U.S. -ISRAEL

"STRATEGIC COOPERATION" AND COVERT OPERATIONS IN THE MIDDLE

EAST, THE AUTHOR DISCUSSES THE IRAN-CONTRA ARMS DEAL, THE

OCTOBER SURPRISE, AND U.S. INVOLVEMENT IN THE IRAN-IRAQ WAR.

SHE ALSO LOOKS AT U.S. -ISRAELI STRATEGIC COOPERATION IN

ANGOLA AND ZAIRE.

04593 HUNTER, J.

EMIGRATION HELD UP

MIDOLE EAST INTERNATIONAL, (398) (APR 91), 18-19.

AS WESTERN DIPLOMATS FLEE ADDIS ABABA AHEAD DF

APPROACHING INSURGENT FORCES, AND AS MILLIONS ACROSS WAR-

TORN ETHIOPIA HOVER ON THE VERGE OF STARVATION, A SMALLER

DRAMA IS PLAYING ITSELF OUT. IN AN APPARENT BID FOR ISRAELI

AID, THE TEETERING GOVERNMENT OF PRESIDENT MENGISTU HAILE

MARIAM HAS HALTED THE EMIGRATION OF ETHIOPIAN JEWS TO ISRAEL.

MARI IM HAS HALTED THE EMIGRATION OF ETHIOPIAN JEWS TO ISRAEL
U.S. NEWSPAPERS QUOTED "JEHISH SOURCES" WHO DECLARED THAT

MENGISTU WAS "PLAYING THE JEWISH CARD," DEMANDING WEAPONS

AND FUEL FROM ISRAEL IN EXCHANGE FOR THE JEWS. ISRAEL'S

REACTION TO THIS PHENOMENA IS UNCERTAIN.

04594 HUNTER, J.

ISRAEL' \& TURKEY: ARMS FOR AZERBAIJAN?

MIDDLE EAST INTERNATIONAL, 436 (OCT 92), 12-13.

ISRAEL IS PROVIDING WEAPONS AND MILITARY TRAINING TO AZERBAIJAN FOR ITS HAR HITH ARMENIA OVER NAGORNO-KARABAGH. STINGER MISSILES ARE AMONG THE ARMS. AZERBAI JAN DENIES THAT STINGER MISSILES ARE AMONG THE ARMS. AZERBAIJAN DENIES THAT
ITS GOVERMMENT IS SEEKING MILTARY AID FROM ANY COUNTRY. THIS ITS GOVERNMENT IS SEEKING MILTARY AID FROM ANY COUNTRY.

04595 HUNTER, J.

MIDDLE EAST SCANDALS CLOSE IN ON BUSH

MIDDLE EAST INTERNATIONAL 436 (OCT 92), 16-17

FOREIGN POLICY SCANDALS WHICH GEORGE BUSH HAS KEPT AT BOREIGN POLICY SCANDALS HHICH GEORGE BUSH HAS KEPT AT POLLS PUT HIS RE-ELECTION INCREASINGLY UNLIKELY. WITNESSES AND DOCUMENTS HAVE BEEN SURFACING TO CHALLENGE BUSH'S CLAIM THAT HE WAS OUT OF THE LOOP IN THE IRAN-CONTRA AFFAIR, AND LAST WEEK AN UNRAVELLING COVER-UP IN A COURT CASE CONCERNING LOANS TO IRAO SET OFF A BIZARRE ROUND-ROBIN OF RECRIMINATION BY THE CIA AND THE JUSTICE OEPARTMENT. 
04596 HUNTER, R.

STARTING AT ZERO: U.S. FOREIGN POLICY FOR THE $1990 \mathrm{~S}$ WASHINGTON QUARTERLY, 15(1) (WIN 92), 27-42.

FOR THE FIRST TIME IN MORE THAN FOUR DECADES, THE UNITED STATES IS FACED WITH BASIC CHOICES AND DECISIONS IN FOREIGN POLICY. THE AFTERMATH OF THE COLD WAR IS DIFFERENT FROM AND MORE PROFOUND THAN THE AFTERMATH OF THE TWO WORLD WARS. THIS ARTICLE SUGGESTS THAT IT IS CRITICAL FOR THE AMERICAN PEOPLE AND THEIR LEADERS TO BE CLEARSIGHTED ABOUT THE UNITED STATES' SITUATION, THE CHALLENGES IT FACES, AND THE METHODS AND TOOLS IT EITHER HAS OR MUST DEVELOP TO ACCOMPLISH THOSE TASKS THAT LIE AHEAD.

04597 HUNTER, R.

THE UNITED STATES, JAPAN, AND THE FUTURE OF RUSSIA

SAIS REVIEN, $12(2)$ (SUM 92 ), 65-71.

A REVIEH OF POLICY TOWARD THE FAR EAST HAS NOT YET TAKEN PLACE AFTER THE END OF THE COLD WAR. THIS IS SO DESPITE THE CENTRALITY OF AMERICAN'S RELATIONS WITH JAPAN, AND DESPITE RUSSIA'S STILL-IMPOSING GEOGRAPHICAL AND NAVAL PRESENCE IN THE REGION. THE RUSSIAN CHALLANGE PROVIDES AN OPPORTUNITY RELATIONSHIP HITH ONE ANOTHER, TRANSCENDING STERILE AND SHORT-SIGHTED PREOCCUPATION WITH TRADE PRACTICES. ADJUSTMENTS TO THE NEW REALITIES OF THE POST-COLD WAR ERA ARE NEEDED, AND BOTH COUNTRIES WILL BENEFIT FROM THEM.

04598 HUNTER, S.; WATERMAN, R.H.

DETERMINING AN AGENCY'S REGULATORY STYLE: HOW DOES THE EPA WATER OFFICE ENFORCE THE LAW?

WESTERN POLITICAL QUARTERLY, 45(2) (JUN 92), 403-418.

DURING THE PAST TWO DECADES TWO COMPETING MODELS OF REGULATORY ENFORCEMENT BEHAVIOR HAVE EVOLVED. THE ENFORCED COMPLIANCE MODEL ADVOCATES LIMITED BUREAUCRATIC DISCRETION AND A STRICT APPLICATION OF THE LAH. ON THE OTHER HAND, THE NEGOTIATED COMPLIANCE MODEL CALLS FOR INCREASED BUREAUCRATIC FLEXIBILITY AND A GREATER RELIANCE ON BARGAINING HITH THE REGULATED INDUSTRY. IN THIS PAPER, THE AUTHORS ANALYZE ENFORCEMENT DATA FROM THE ENVIROMMENTAL PROTECTION AGENCY (EPA) TO DETERMINE WHICH REGULATORY STYLE THE EPA WATER OFFICE HAS EMPLOYED IN ITS IMPLEMENTATION OF THE CLEAN WATER ACT. THEIR ANALYSIS DEMONSTRATES THAT THE ENFORCEMENT BEHAVIOR OF THE EPA WATER OFFICE IS BEST CHARACTERIZED AS A NEGOTIATED COMPLIANCE STYLE.

04599 HUNTER, $S$.

PERSIAN GULF SECURITY: LESSONS OF THE PAST AND THE NEED FOR NEW THINKING

SAIS REVIEH, 12(1) (WIN 92), 155-166.

DESPITE OPPORTUNITIES FOR A NEW ORDER IN THE PERSIAN GULF. MANY OLD CAUSES OF INSTABILTIY AND BARRIERS IO DEVELOPING COOPERATION AND LASTING SECURITY ARRANGEMENTS PERSISTS. THIS ARTICLE EXAMINES THE PRINCIPAL THREATS TO PERSIAN GULF SECURITY, STRATEGIES FOR REGIONAL SECURITY, THE POST-COLD WAR SETTING, AND NEW THINKING ON PERSIAN GULF SECURITY. IT CONCLUDES THAT THE EVENTS OF THE LAST FEH YEARS HAVE CREATED A UNIQUE OPPORTUNITY TO DEVELOP A REALISTIC, BROAD-BASED, AND WORKABLE SECURITY SYSTEM FOR THE PERSIAN GULF.

04600 HUNTER, $S$.

THE BUSH-BAKER LEGACY: 2. IRAQ, IRAN AND THE GULF MIDDLE EAST INTERNATIONAL, 439 (DEC 92), 16-17. MANY OF THE PROBLEMS AND DILEMMAS FACED BY THE BUS ADMINISTRATION AMD MANY OF ITS POLICY MISTAKES HERE ROOTED IN THE NATURE OF REGIONAL AND U $S$, POLITICS AND DERIVED FROM THE OFTEN CONTRADICTORY GOALS THAT THE UNITED STATES PURSUED IN THE GULF. THE SAME SORT OF PROBLEMS ARE LIKELY TO BEDEYIL THE NEXT ADMINISTRATION AND TEST THE FORESIGHT AND ABILITY OF AMERICA'S NEW FOREIGN POLICY TEAM. THIS ARTICLE EXPLORES THE LEGACY OF THE 1980S, MISSED OPPORTUNITIES IN IRAN, ILLUSIONS ABOUT IRAQ, AND THE 1991 HAR AND ITS AFTERMATH.

04601 HUNTER, $S$.

THE MUSLIM REPUBLICS OF THE FORMER SOVIET UNION: POLICY CHALLENGES FOR THE UNITED STATES

WASHINGTON QUARTERLY, 15(3) (SUM 92), 57-74.

THE BREAK-UP OF THE SOVIET UNION AND THE RISE OF SEVERAL

MUSLIM STATES (AZERBAI JAN, KYRGYSTAN, KAZAKHSTAN, TAJIKISTAM,

TURKMENISTAN, AND UZBEKISTAN) IN ITS HAKE PRESENTS NEN

TURKMENISTAN, AND UZBEKISTAN) IN ITS HAXE PRESENTS NEH
CHALLENGES FOR U.S. FOREIGN POLICYMAKERS. THIS ARTICLE

EXAMINES THE HISTORICAL AND CULTURAL COMPLEXITIES OF THESE

EXAMINES THE HISTORICAL AND CULTURAL COMPLEXITIES OF THESE

PROCESS OF NATION-BUILDING THAT THEY HILL BE FACING. IT ALSO

ASSESSES THE MAGNITUDE OF THE ISLAMIC AND IRANIAN THREATS IN THE REGION AS WELL AS THE SHORT- AND LONG-TERM CONSEOUENCES OF THE UNITED STATES' CURRENT EMPHASIS ON THE TURKIC ELEMENT OF MOVEMENTS IN THE AREA.

04602 HUNTER, $S$.

THE U.S.-SAUDI RELATIONSHIP UNDER A NEH ADMINISTRATION

INSIGHT, 9 (1) (1992), 16-18.

THIS ARTICLE EXPLORES WHAT A CLINTON VICTORY AT THE
POLLS MEANS FOR SAUDI ARABIA. IT EXAMINES THE AREAS OF HUMAN RIGHTS, THE PEACE PROCESS, MAINTAINING THE CREDIBILTIY OF AMERICA'S DETERRENT POWERS, AND SUPPORTING THE TERRITORIAL INTEGRITY OF IRAQ. THE FATE OF THE U.S. AND SAUDI ARABIA OVER THE YEARS HAS BECOME CLOSELY INTERTWINED, NOT ONLY IN THE OBVIOUS SECTORS OF ENERGY AND DEFENSE POLICY, BUT ALSO IN SHARED VALUES AND IDEALS.

04603 HUNTER, S.T

THE EMERGENCE OF SOVIET MUSLIMS: IMPACT ON THE MIDDLE EAST MIDDLE EAST INSIGHT, VII(5) (MAY 92), 32-40.

THE COLLAPSE OF THE SOVIET EMPIRE AND THE EMERGENCE OF SIX NEWLY INDEPENDENT MUSLIM NATIONS WILL INEVITABLY HAVE FAR-REACHING IMPLICATIONS FOR THE MIDOLE EAST REGION ESPECIALLY THE PART THAT INCLUDES IRAN, TURKEY, PAKISTAN AND AFGHANISTAN. DEPENDING ON HOW THE PROCESS OF NATION-BUILDING EVOLVES IN THE NEHLY INDEPENDENT MUSLIM STATES AND THE FATE OF THE COMMONWEALTH OF INDEPENDENT STATES, THE TERRITORIAL AND POLITICAL MAP OF A VAST REGION STRETCHING FROM THE TRANSCAUCASUS TO THE PERSIAN GULF COULD BE REDRAWN. THIS ARTICLE SEEKS TO IDENTIFY THE MOST IMPORTANT FORCES THAT ARTICLE SEEKS TO IDENTIFY THE MOST IMPORTANT FORCES
WILL AFFECT THE PROCESS OF NATION-BUILDING IN THESE WILL AFFECT THE PROCESS OF NATION-BUILDING IN THESE
REPUBLICS. THESE INCLUDE ETHNICITY, CULTURE, ISLAM, AND ECONOMIC CONCERNS.

04604 HUNWICK, J.

AN AFRICAN CASE STUDY OF POLITICAL ISLAM: NIGERIA ANMALS OF THE AMERICAN ACADEMY OF POLITICAL AND SOCIAL SCIENCE, (524) (NOV 92), 143-155

SINCE THE EARLY 19TH CENTURY, WHEN UTHMAN B. FUDI ESTABLISHED AN ISLAMIC STATE IN NORTHERN NIGERIA, THERE HAS BEEN A CLOSE SYMBIOSIS BETWEEN RELIGION AND POLITICAL POWER. SINCE INDEPENDENCE IN 1960. THE ISSUE OF REGIONAL OR ETHNIC POWER-SHARING IN NIGERIA HAS SHIFTED TO A CONTEST BETHEEN MUSLIMS AND CHRISTIANS--WITH THE PART-MUSLIM, PART-CHRISTIAN YORUBA HELPING TO MAINTAIN A BALANCE. SINCE THE 1960'S, SAUDI ARABIA HAS PROMOTED ITS OWN AUSTERE INTERPREATION OF ISLAM, TO THE DISCOMFORT OF THE SUFI GROUPS. MORE RECENTLY, IRAN HAS BEEN A MODEL FOR YOUNGER MILITANT MUSLIMS. CALLS BY NIGERIAN MUSLIMS FOR AN ISLAMIC STATE AND WIDER APPLICATION OF SHARI'A. AS WELL AS THE QUESTION OF NIGERIAN MEMBERSHIP IN THE ORGANIZATION OF ISLAMIC CONFERENCE, HAVE AROUSED THE ANTAGONISM OF CHRISTIANS. RELIGIOUS ISSUES WERE BEHIND SEVERAL OUTBREAKS OF VIOLENCE IN THE 1980'S, SOME OF WHICH THREATENED THE INTEGRITY OF THE NIGERIAN STATE.

04605 HUO, H.

PATTERNS OF BEHAYIOR IN CHINA'S FOREIGN POLICY: THE GULF CRISIS AND BEYOND

ASIAN SURVEY XXXII(3) (MAR 92), 263-276.

THE AUTHOR OF THIS ARTICLE ATTEMPTS TO DETERMINE IF CERTAIN UNDERLYING PATTERNS OF CHINESE FOREIGN POLICY BEHAYIOR, OLD AND NEW, CAN BE DETECTED BY ANALYZING CHINA'S BEHAVIOR DURING THE GULF CRIS. A SEARCH FOR PATTERNS OF BEHAVIOR WILL CONTRIBUTE TO A FULLER UNDERSTANDING OF CHINESE FOREIGN POLICY IN THE 1990 S

04606 HUORONG, L.

UN'S ROLE IN SOLVING REGIONAL CONFLICTS ENHANCED BEI JING REVIEW, 35(4) (JAN 92), 14-15

IN A FAST CHANGING AND UNSTABLE WORLD, THE UNITED NATIONS IS MAKING GREAT EFFORTS TO RESOLVE REGIONAL CONFLICTS. DURING THE PAST YEAR, THE INTERNATIONAL ORGANIZATION HAS BEEN ACTIVE IN YUGOSLAVIA, EL SALVADOR, CAMBODIA, AND WESTERN SAHARA.

04607 HUQUE, A.S.

PERFORMANCE OF LOCAL COUNCILS IN THE COLLECTION OF REVENUE IN BANGLADESH

PUBLIC ADMINISTRATION AND DEVELOPMENT, 12(4) (OCT 92), 343-354.

IN BANGLADESH LOCAL COUNCILS HAVE SEVERAL SOURCES OF REVENUE THAT CAN BE UTILIZED FOR THE MAINTENANCE OF THE UNION- AND UPAZILA-LEVEL COUNCILS HAVE FARED MISERABLY IN THE COLLECTION OF SUCH REVENUE. AN EXAMINATION OF 12 UPAZILAS DURING 1986-1990 DEMONSTRATES THAT THEIR REVENUE COLLECTION WAS HANDICAPPED BY A LACK OF ADMINISTRATIVE SUPPORT, A DEARTH OF KNOWLEDGE AND SKILLS ON THE PART OF LOCAL LEADERS, AND THE GOVERMMENT'S FAILURE TO PLAM CAREFULLY. IN GENERAL, ORDINANCES PERTAINING TO REVENUE COLLECTION DO NOT IDENTIFY REALISTIC SOURCES OF REVENUE NOR COLLECTION DO NOT IDENTIFY REALISTIC SOURCES OF

CDNSEOUENTLY, REYENUE COLLECTION IS DONE IN AN ARBITARY, CONSEQUENTLY, REVENUE

04608 HURD, D.

FOREIGN POLICY AND INTERNATIONAL SECURITY RUSI JOURNAL, $137(6)$ (DEC 92 ), 1-4.

FOLLOHING THE COLLAPSE OF THE SOVIET UNION, THE STARK CERTAINTIES OF THE COLD WAR HAVE BEEN REPLACED BY COMPLEX INSTABILITY AND CONFLICT. THE BRITISH FOREIGN SECRETARY HERE DISCUSSES THE CHALLENGES THAT HAVE ARISEN IN THE WAKE OF THIS UPHEAVAL, INCLUDING THE CREATION OF A NEW EUROPEAN 
SECURITY SYSTEM, INCORPORATING THE FORMER EASTERN BLOCX; HOW THE INTERNATIONAL COMMUNITY SHOULD HANDLE NEW KINDS OF MORE LOCALISED CRISES; AND WAYS IN WHICH MILITARY ANO INSTITUTIONAL INSTRUMENTS CAN BE ADAPTED TO MEED THE NEW DEMANDS AND RESPONSIBILITIES IMPOSED BY THE END OF THE COLD WAR ERA.

04609 HURD, M.

POST-WAR AID: WHAT KIND AND WHO DECIDES?

REPORT ON THE AMERICAS, 25(5) (MAY 92), 9-10.

ONE OF THE MOST WIDE-RANGING POLITICAL BATTLES UNFOLDING IN THE WAKE OF THE SALVADORAN PEACE ACCORDS CONCERNS FUNDING FOR POST-HAR RECOVERY. THE BUSH ADMINISTRATION INSISTS THAT ALL FUNDING GO DIRECTLY TO THE GOVERNMENT OF EL SALVADOR, CONDITIONAL ON THE ACHIEVEMENT OF CONSENSUS ON THE NATIONAL RECONSTRUCTION PLAN (PRN). THE IMPLEMENTATION OF THE PRN WILL TEST WASHINGTON'S ABILITY TO CHANGE COURSE AND ITS TOLERANCE FOR REAL SOCIAL CHANGE IN BOTH THE ECONOMIC AND TOLERANCE FOR REAL
POLITICAL SPHERES.

04610 HURLEY, P.

PARTISAN REPRESENTATION, REALIGNMENT, AND THE SENATE IN THE $1980 S$

THE JOURMAL OF POLITICS, 53(1) (FEB 91), 3-33.

THE 1980 ELECTION WAS HERALDED BY A NUMBER OF OBSERVERS AS THE BEGINNING OF ONE OF THOSE RARE PERIODS OF PARTISAN REALIGNMENT IN AMERICAN POLITICS. THE CAPTURE OF CONTROL OF THE SENATE BY THE REPUBL ICAN PARTY GAVE SOME CREDENCE TO THIS PREDICTION, BUT SUBSEQUENT CONGRESSIONAL ELECTIONS FAILED TO SUSTAIN IT. THIS PAPER ADVANCE THE THESIS THAT THE FAILURE OF REALIGNMENT IN THE 19805 IS CONNECTED TO THE FAILURE OF THE CONGRESSIONAL REPUBLIC PARTY TO REPRESENT ADEQUATELY THE POLICY CONCERNS OF INDEPENDENTS AND DISSIDENT DEMOCRATS AS WELL AS SOME EXISTING REPUBLICAN IDENTIFIERS. THE THESIS IS TESTED BY EXAMINING TRENDS IN PARTISAM REPRESENTATION BETHEEN 1980 AND 1986. AS EXPECTED, THE LEVEL OF CONGRUENCE BETHEEN THE REPUBLICANS AND ESPECIALLY THE INDEPENDENTS IN THE ELECTORATE AND THE CONGRESSIONAL

REPUBLICAN PARTY DECLINES OVER TIME.

04611 HURRELL, A.

LATIN AMERICA IN THE NEW HORLD ORDER: A REGIONAL BLOC OF THE AMERICAS?

INTERNATIONAL AFFAIRS, 68(1) (JAN 92), 121-149.

THIS ARTICLE EXAMINES THE PROSPECTS FOR THE EMERGENCE OF A REGIONAL BLOC OF THE AMERICAS, ENCOMPASSING LATIN AND CENTRAL AMERICA, THE UNITED STATES AND CANADA, FOLLOWING CENTRAL AMERICA, THE UNITED STATES AND CANADA, FOLLOWING
PRESIDENT BUSH'S ANNOUNCEMENT OF HIS 'ENTERPRISE INITIATIVE FOR THE AMERICAS' IN THE SUMMER OF 1990. IT LOOKS AT THE INCENTIVES FOR AND THE LIMITS TO INTEREST IN THIS TYPE OF REGIONALISM IN LATIN AMERICA AND IN THE UNITED STATES. IT RETGIONAL BLOC IS LIKELY TO EMERGE IN THE AMERICAS FOLLOWS FROM A ONE-SIDED ANALYSIS OF INTER-AMERICAN RELATIONS.

04612 HURWITZ, J.; PEFFLEY, M.

TRADITIONAL VERSUS SOCIAL VALUES AS ANTECEDENTS OF RACIAL STEREOTYPING AND POLICY CONSERVATISH

POLITICAL BEHAVIOR, 14(4) (DEC 92), 395-422.

RECENT STUDIES OF RACIAL ATTITUOESS HAVE FOCUSED ON TRADITIONAL VALUES, SUCH AS INDIVIDUALISM, AS IMPORTANT ANTECEDENTS OF AMERICANS' OPINIONS ON RACIAL ISSUES, WITH MIXED RESULTS. IN THIS ESSAY, THE AUTHORS FOCUS ON ANOTHER SET OF VALUES THAT HAS ITS ROOTS IN AN OLDER RESEARCH TRADITION EXAMINING THE PSYCHOLOGICAL SOURCES OF RACIAL PREJUDICE, WHICH SUGGESTS THAT PREJUDICE AGAINST BLACKS IS PART OF A MORE ENCOMPASSING SET OF VALUES REGARDING ONE'S ACCEPTANCE OF SOCIAL DIVERSITY. THEY FIND THAT THESE VALUESCONFORMITY AND SOCIAL INTOLERANCE--ARE MUCH STRONGER PREDICTORS OF RACIAL STEREOTYPES AND RACIAL POLICY ATTITUDES THAN TRADITIONAL VALUES OF INDIVIDUALISM AND EQUALITARIANISM. THESE SOCIAL VALUES ALSO CONDITION AN ETHNOCENTRIC RESPONSE TOWARD INTERNATIONAL OUTGROUPS IN A DOMAIN AS DIVERSE AS FOREIGN AFFAIRS, THUS PROVIDING ADOITIONAL EVIDENCE OF THE PERVASIVE AND GENERAL NATURE OF VALUES RELATED TO A

REJECTION OF DIVERSITY.

04613 HUSARKA, A.

HIS KAMPF

NEW REPUBLIC, 207(23) (NOV 92), 10-11.

THE COMBINATION OF HIGH UNEMPLOYMENT, INFLATION, DISILLUSIONMENT WITH THE PACE OF CHANGE, AND THE EMERGENCE OF A VOCAL EXTREME RIGHT HAS PRODUCED A PARTICULALRY
VOLATILE SITUATION IN NEWLY-DEMOCRATIC HUNGARY. THE VOLATILE SITUATION IN NEWLY-DEMOCRATIC HUNGARY. THE
MOVEMENT'S HERO IS ISTYAN CSURKA, YICE PRESIDENT OF THE MOVEMENT'S HERO IS ISTVAN CSURKA,
RULING HUNGARIAN DEMOCRATIC FORUM.

04614 HUSBANDS, C

THE OTHER FACE OF 1992: THE EXTREME-RIGHT EXPLOSION IN

WESTERH EUROPE
PARLIAMENTARY AFFAIRS, 45(3) (JUL 92), 267-284,

THE AUTHOR SURVEYS THE RECENT HISTORY OF EXTREME-RIGHT

POL ITICAL PARTIES IN GREAT BRITAIN, AUSTRIA, OENMARK, NORHAY,

SHEDEN, FRANCE, WEST AND EAST GERMANY, ITALY, THE
NETHERLANDS, BELGIUM, AND SWITZERLAND.

04615 HUSKEY, E.

A FRAMÉWORK FOR THE ANALYSIS OF SOVIET LAH

RUSSIAN REVIEW, 50(1) (JAN 91), 53-70.

THIS PAPER AIMS TO ENHANCE UNDERSTANDING OF SOVIET LEGAL HISTORY BY RENDERING THE SOVIET LEGAL EXPERIENCE IN THREE IDEAL TYPES: THE NIHILIST IDEAL TYPE, THE STATIST IDEAL TYPE, AND THE LEGALIST IDEAL TYPE. THE APPROACHES OF EACH OF THESE TO FIVE MAJOR QUESTIONS OF LEGAL POLICY ARE COMPARED. THE QUESTIONS ARE: THE RELATIONSHIP OF LAW AND SOCIALISM, THE ROLE AND STATUS OF LAWYERS, THE NATURE OF LEGAL NORMS, LEGAL RELATIONS BETWEEN THE CITIZEN AND STATE, AND LAH AND THE ECONOMY. THE ARTICLE ALSO LINKS THE THREE APPROACHES TO
LAH TO THEIR RESPECTIVE SOURCES OF INSPIRATION AND SUPPORT IN SOVIET POLITICAL CULTURE.

04616 HUSSAIN, $M$.

AFGANISTAN: GUNS FALL SILENT

MIDDLE EAST INTERNATIONAL, 439 (DEC 92), 13-14,

THERE IS HECTIC POLITICAL AND DIPLOMATIC ACTIVITY AS AFGHANISTAN MOVES TO ESTABLISH A NEW GOVERNMENT BY THE MIDDLE OF DECEMBER AND TAKE ITS FIRST MAJOR STRIDES IN THE DIPLOMATIC FIELD. DURING HIS MEETING WITH PRESIDENT KHAN IN ISLAMABAD, AN AFGHAN ARMY CHIEF WAS TOLD THAT THE PESHAHAR ACCORD WHOULD BE IMPLEMENTED AS SODN AS POSSIBLE SO AS TO
STRENGTHEN NATIONAL UNITY AND UNDERTAKE THE GIGANTIC TASK OF STRENGTHEN NATIONAL UNITY AND UNDERTAKE THE GIGANTIC TASK REHABILITATION AND RECONSTRUCTION IN AFGHANISTAN. THE
PROMISE OF THE MILITARY IS THAT ALL ETHNIC GROUPS MUST GET THEIR DUE RIGHTS IN AFGHANISTAN AND THAT IT WILL NOT TAKE POWER.

04617 HUSSAIN, $M$

AFGHANISTAN-OFROM MARXISTS TO MUJAHEDIN

MIDDLE EAST INTERMATIONAL, (424) (MAY 92), 10-12.

AS MEMBERS OF THE MUJAHEDIN COMMISSION, HEADED BY PROFESSOR MUJADOEDI, WHO ARE TO REPALCE THE OUSTED GOVERMMENT OF DR. NAJIBULLAH, ARRIVED IN KABUL ON THE MORNING OF 28 APRIL AFTER A HAZARDOUS 16-HOUR OVERLAMD JOURNEY FROM PAKISTAN, FIGHTING BETWEEN RIVAL MUJAHEDIM FACTIONS HAS CONTINUING IN THE CAPIITAL REPORTS IMDICATED FACTIONS HAS CONTINUING IN THE CAPITAL. REPORTS INDICATED THAT THE FORCES LED BY COMMANDER AHMED SHAH MASOOD, WHO
SUPPORTS THE PROPOSED INTERIM GOVERNMENT, WERE GETTING THE SUPPORTS THE PROPOSED INTERIM GOVERNMENT, WERE GETTING THE
UPPER HANO OVER GULBUDOIN HEKMATYAR WITH THE SUPPORT OF UPPER HANO OVER GULBUDOIN HEKMATYAR WITH THE SUPPORT OF
PLANES AND HELICOPTERS FROM THE AFGHAN AIR FORCE. IT WAS PLANES AND HELICOPTERS FROM THE AFGHAN AIR FORCE. IT WAS
PERHAPS A FITTING FINALE TO THE LONG-SIMMERING AFGHAN PERHAPS A FITTING FINALE TO THE LONG-SIMMERING AFGHAN
CONFLICT THAT KABUL FELL TO THE MUJAHEDIN FORCES ALMOST CONFLICT THAT KABUL FELL TO THE MUJAHEDIN FORCES ALMOST PRECISELY ON THE 14TH ANNIVERSARY OF THE MARXIST MILITARY
COUP OF 27 APRIL 1978. IT REMAINS TO BE SEEN WHETHER THE COUP OF 27 APRIL 1978. IT REMAINS TO BE SEEN WHETHER THE PAKISTAN-BROKEF
IMPLEMENTED.

04618 HUSSAIN, M.

AFGHANISTAN--PROSPECTS FOR PEACE

MIDDLE EAST INTERNATIONAL, (425) (MAY 92), 12-13.

WITH A BLOODBATH HAVING BEEN AVERTED DURING THE TRANSFER OF POHER FROM THE COMMUNISTS TO THE ISLAMISTS IN KABUL, RECENT SIGNALS EMANATING FROM AFGHANISTAN HAVE ALSO BEEN POSITIVE, INCLUDING A WEEK-LONG CEASE-FIRE BETHEEN THE FORCES OF THE INTERIM KABUL ADMINISTRATION AND THOSE OPPOSING IT. THE LATTER ARE LED BY THE MILITANT HIZB-I ISLAMI OF GULBUDOIN HEKMATYAR, THE PRINCIPAL RIVAL OF DEFENSE MINISTER AHMAD SHAH MASOOD, WHOSE FORCES CONTROL KABUL IN AN ALLIANCE WITH REMNANTS OF THE FORMER REGIME OF PRESIDENT NAJIBULLAH. WHILE HEKMATYAR IS A PASHTUN, AFGHANISTAN'S LARGEST COMMUNITY, MASOOD IS A TAJIK, WHO COMPRISE AROUND A QUARTER OF THE POPULATION. THERE' ARE THREE IMPORTANT ROADBLOCKS TO PEACE. FIRST, THERE IS THE CONTROVERSY SPARKED BY AHMAD SHAH MASOOD'S DELICATE POWERSHARING ARRANGEMENTS WITH THE REMNANTS OF THE NAJIBULLAH REGIME. SECOND, THERE IS THE QUESTION OF THE STRICT INTERPRETATION OF THE PESHWAR ACCORD, UNDER WHICH THE INTERIM MUJAHEDIN COUNCIL OF PROFESSOR MUJADDEDI IS TO GIVE WAY, HITHIM THO MONTHS, TO AN INTERIM AFGHAN GOVERMMEMT. THE THIRD ROADBLOCK COULD BE THE ETHNIC DIVISIONS HITHIN AFGHANISTAN, WHOSE 15 MILLION PEOPLE ARE SPREAD BETWEEN AT LEAST A DOZEN MAJOR ETHNIC GROUPS.

04619 HUSSAIN, M.

AFGHANISTAA--SPECTRE OF SECTARIANISM

MIDDLE EAST INTERNATIONAL, (427) (JUN 92), 12.

THE FIRST HEEK OF JUNE SAW SOME OF THE BLOODIEST CLASHES

IN AN INTRA-AFGHAN SECTARIAN CDNFLICT THAT RESULTED IN 100

IN AN INTRA-AFGHAN SECTARIAN CDNFLICT THAT RESULTED IN 100
DEATHS, 400 WOUNDED AND OVER 1,000 CAPTURED AS PRISONERS.

DEATHS, 400 NOUNDED AND OVER 1,000 CAPTURED AS PRISONERS,
THE CLASHES BEGAN ON 2 JUNE BETWEEN THE PREDOMINANTLY

THE CLASHES BEGAN ON 2 JUNE BETWEEN THE PREDOMINANTLY
SHI' ITE HIZB-I WAHDAT, WHICH IS A COALITION OF EIGHT IRANIANSHI ITE HIZB-I WAHDAT, WHICH IS A COALITION OF EIGHT IRA BACKED PARTIES, AND THE ITTEHAD-I ISLAMI, A PRO-SAUDI
ORGANIZATION. ALTHOUGH THE CLASHES WERE SEEN AS A PROXY WAR ORGANIZATION. ALTHOUGH THE CLASHES WERE SEEN AS A PROXY HAR
ON SECTARIAN LINES, FOUGHT AT THE BEHEST OF IRAN AND SAUDI ARABIA, BOTH COUNTRIES HAVE GIVEN THE IMPRESSION THAT THEY HERE OPPOSED TO THE FIGHTING. MEANWHILE, THE RETURN OF AFGHAN REFUGEES FROM PAKISTAN TO AFGHANISTAN CONTINUES, HITH APPROXIMATELY 5,000 RETURNING EVERY DAY. 
04620 HUSSAIN, M.; HAERI, $S$.

AFGHANISTAN-WAR OF ROCKETS AND SHELLS

MIDDLE EAST INTERHATIONAL, (432) (AUG 92), 10-11.

IN THE FIRST THO WEEKS OF AUGUST AFGHANISTAN HAS

EXPERIENCED SOME OF THE HEAVIEST INTER-FACTIONAL FIGHTING SINCE THE FALL OF THE COMMUNIST REGIME. THE FORCES OF THE FUNDAMENTAL IST HIZB-I ISLAMI, HEADED BY GULBUDDIN HEKMATYAR, HAVE PITCHED THEMSELVES AGAINST THE GOVERMMENT OF BURHANUDOIN RABBANI, WHO HEADS THE JAM-I ISLAMI AMD IS SUPPORTED BY REMNANTS OF THE OLD REGIME. IN THIS WAR OF ROCKETS AND HEAYY ARTILLERY SHELLS, APPROXIMATELY 1,000 PEOPLE HAVE BEEN KILLED AND 1,500 WOUNDED AND MANY BUILDINGS HAVE BEEN DEVASTATED IN CENTRAL KABUL. HEKMATYAR HAS STEPPED UP MILITARY PRESSURE AGAINST THE GOVERNMENT BECAUSE A CONSOLIDATION OF GOVERNMENTAL POWER WOULD LEAD TO HIS OWN MARGINALIZATION. THE FIGHTING HAS BEEN ROUNDLY CRITICIZED BY AFGHANISTAN'S NEIGHBORS. IRAN HAS BEEN PARTICULARLY POINTED IN ITS CRITICISM OF THE SITUATION, ARGUING THAT ITS CONTINUATION "WILL EVENTUALLY TEMPT FOREIGN REGIONAL POWERS TO INTERFERE."

04621 HUSSAIN, M.

CENTRAL ASIA'S QUEST FOR A FUTURE

MIDDLE EAST INTERNATIONAL, (437) (NOY 92), 20-21.

AS CENTRAL ASIA'S LEADERS DEBATE THE REGION'S FUTURE, THREE QUESTIONS CURRENTLY DOMINATE THE DISCUSSION: THE ROLE OF ISLAM, NATIONAL IDENTITY, AND FOREIGN POLICY.

04622 HUSSAIN, M.

COLD WAR AGAINST ISLAM

FAR EASTERN ECONOMIC REVIEH, 155(23) (JUL 92), 22 RECENT EVENTS INVOLVING CENTRAL ASIA, LIBYA, ALGERIA, AND YUGOSLAVIA INDICATE THAT THE WEST APPLIES DIFFERENT STANDARDS TO MUSLIM AND NON-MUSLIM COUNTRIES. THIS DOUBLE
STANDARD APPLIES TO THE AREAS OF RELIGION, DEMOCRACY, MILITARY POWER, TERRORISM, AND HUMAN RIGHTS. SO-CALLED ISLAMIC FUNDAMENTALISM HAS REPLACED COMMUNISM AS THE WEST'S NEW ENEMY. HOWEVER, IN THE ISLAMIC WORLD, ISLAMIC REASSERTION IS SEEN POSITIVELY IN AT LEAST THREE BRDAD AREAS. POLITICALLY, ISLAM REPRESENTS THE FORCES CHALLENGING AN INEQUITABLE STATUS QUO WHICH IS PROPPED UP EITHER BY SECULAR CLONES OF THE WEST OR BY BACKHARD MONARCHIES BASED ON CORRUPTION AND COERCION. IN THE FIELD OF CULTURE, SYMBOLS OF AN INTERMATIONAL ISLAMIC IDENTITY WHICH DISTINGUISH BETHEEM MOOERNIZATION, WHICH MUSLIMS EAGERLY ACCEPT, AND WESTERNIZATION, WHICH MUSLIMS REJECT. FINALLY, IN FOREIGM AFFAIRS, THE ISLAMIC SPIRIT FINDS EXPRESSION IN THE ASSERTION OF A SOVEREIGNTY BASED ON CONTROL OVER NATURAL RESOURCES. THE STRUGGLE FOR LIBERATION OF OCCUPIED RESOURCES, THE STRUGGLE FOR LIBERATION OF OCCUPIED
TERRITORIES (CENTRAL ASIA, KASHMIR, PALESTINE, AFGHANISTAN, TERRITORIES (CENTRAL ASIA, KASHMIR, PALESTINE, AFGHANISTAN,
AND ERITREA) AND THE DESIRE TO SEEK MATCHING MILITARY POWER. AND ERITREA) AND THE DESIRE TO SEEK MATCHING MILITARY POWER. MUSLIM COUNTRIES, IT TOTALLY DENIES THEM TO ISLAMIC NATIONS.

04623 HUSSAIN, S.B.

SECURITY AND DEVELOPMENT IN SOUTH ASIA: TRENDS, PROSPECTS AND IMPLICATIONS; ASSOCIATION FOR ASIAN STUDIES 1992 ANNUAL MEETIMG

ASSOCIATION FOR ASIAN STUDIES, $1992,136$.

THIS PAPER INVESTIGATES THE IMPACT OF SECURITY EXPENDI TURES AS A NON-PRODUCTION CATEGORY ON THE GROWTH POTENTIAL OF VARIOUS DEVELOPING COUNTRIES OF SOUTH ASIA. PRIOR STUDIES OF MILITARY EXPENDITURES AND DEVELOPMENT EXPENDITURES AS RELATED TO ECONOMIC GROWTH IN LESS DEVELOPED COUNTRIES HAVE NOT MADE USE OF THE DISTINCTION BETWEEN PRODUCTION AND NON-PRODUCTION EXPENDITURES FOR A VARIETY OF THEORETICAL AS WELL AS EMPIRICAL REASONS. IN THIS STUDY AN EFFORT HAS BEEN MADE TO CORRELATE THE NON-PRODUCTION EXPENDITURES, INCLUDING SECURITY EXPENDITURES, IN THE ECONOMY TO THE OVERALL ECONOMIC PERFORMANCE AS MEASURED BY RATES OF GROWTH OF GNP, GDP, ETC. SPECIFICALLY, THE NATIONAL INCOME STATISTICS FROM COUNTRIES OF THE SOUTH ASIA REGION HAVE BEEN COLLECTED AND TRANSFORMED INTO NEW CATEGORIES OF PRODUCTION/NON-PRODUCTION EXPENDITURES AND LABOR INCOMES. THE RATE OF ECONOMIC GROWTH HAS THEN BEEN REGRESSED AGAINST THE GROWTH RATE OF THESE EXPENDITURES (ALONG WITH THE APPROPRIATE COMPENSATIMG FACTORS) TO EXAMINE HHETHER OR NOT A SYSTEMATIC CORRELATION CAN BE ESTABLISHED. THE RESULTS ARE INTERPRETED TO HAVE SOME INTERESTING IMPLICATIONS FOR FISCAL AND SOCIAL POLICY. THEY ALSO SHED SOME LIGHT ON THE UNDERSTANDING OF THE POLITICAL ECONOMY OF UNDERDEVELOPMENT.

04624 HUSSEIN, M.

AFGHANISTAN--A BIG QUESTION MARK

MIDDLE EAST INTERNATIONAL, (428) (JUN 92), 12.

EARLY JUNE HAS SEEN SERIOUS ATTEMPTS TO BRIDGE

AFGHANISTAN'S POLITICAL DIVIDE AND ERASE THE QUESTION MARKS HANGING OVER THE IMPLEMENTATION OF THE 24 APRIL PESHAWAR ACCORD. THE MOST IMPORTANT STEP IN BRIDGING THE DIVIDE WAS THE 16 JUNE DECISION OF THE SHI'ITE, PRO-IRANIAN HIZBWAHDAT TO JOIN THE INTERIM ADMINISTRATION. THE RULING MUJAHEDIN COUNCIL NOH HAS FIVE MEMBERS FROM EACH OF THE SEVEN PAKISTAN-BASED MUJAHEDIN FACTIONS, EIGHT FROM THE SHI'ITE HIZB-I WAHDAT, FIVE FROM HARAXAT-I ISLAMI, ANOTHER
SHI 'ITE GROUP BASED IN PAKISTAN AND NOT AFFILIATED WITH IRAN, FIVE REPRESENTATIVES OF GENERAL DOSTUM'S UZBEK MILITIA, AMD THREE INDEPENDENTS. ANOTHER POSITIVE STEP WAS THE MEETING BETHEEN AN IRANIAN DELEGATION LED BY THE FORMER AMBASSADOR TO PAKISTAN, MIR MAHMOOD MUSSAVI AND THE HIZB-I ISLAMI LEADER, GULBUDDIN HEKMATYAR ON THE DUTSKIRTS OF KABUL. THIS WAS THE FIRST PUBLIC CONTACT BETWEEN HEKMATYAR AND THE IRANIANS FOR SEVERAL YEARS. ONE OF THE MOST SERIOUS PROBLEMS NOW FACING AFGHANISTAN'S FRAGILE PEACE IS THE QUESTION OF WHETHER PRESIDENT SIBGHATULLAH MUJADDEDI WILL STEP DOWN AS SCHEDULED UNDER THE ACCORD, AND AS HE PROMISED, TO PROFESSOR BURHANUDOIN RABBANI.

04625 HUTCHINGS, K.

THE POSSIBILITY OF JUDGEMENT: MORALIZING AND THEORIZING IN INTERMATIONAL RELATIONS

REVIEW OF INTERNATIONAL STUDIES, 18(1) (JAN 92), 51-62. THE SEPARATION OF THE REALMS OF MORALITY AND' POLITICS, ON WHICH SO MUCH SOCIAL SCIENCE AND MORAL PHILOSOPHY IS FOD THIS CAN BE TRACED BACK TO KANT S CRITICAL PHILOSOPHY, AND THIS SEPARATION HAS PROBLEMATIC CONSEQUENCES FOR THE POSSIBILITY OF BOTH EXPLANATION AND EVALUATION IN THE INTERNATIONAL SPHERE. THIS ARTICLE STUDIES KANT POSITION AND DEMONSTRATES HOH THE DISCUSSION OF
INTERNATIONAL RELATIONS BOTH IN MORAL PHILOSOPHY AND IN INTERNATIONAL RELATIONS BOTH IN MORAL PHILOSOPHY A
POLITICAL THEORY, IS CONSTRUCTED BY THE KANTIAN POLITICAL THEORY, IS CONSTRUCTED BY THE KANTIAN
MORALITY/POLITICS DICHOTOMY, AND HOW THIS LIMITS AND MORALITY/POLITICS DICHOTOMY, AND HOW THIS LIMITS AND DISTORTS BOTH MORALIZING AND THEOR IZING. IT CONCLUDES THAT UNTIL WE RECOGNIZE THE IDENTITY OF THE MORAL AND POLITICAL IN THE INTERNATIONAL REALM, AND COLLAPSE THE DISTINCTION
BETHEEN SCIENCE AND ETHICS IN OUR MORALIZING AND THEORIZING ABOUT THAT REALM, OUR COMPREHENSION OF IT HILL REMAIN LIMITED AND DISTORTED.

04626 HUTCHINSON, H.R.

INTELLIGENCE: ESCAPE FROM PRISONER'S DILEMMA

INTELLIGENCE AND NATIONAL SECURITY, 7(3) (JUL 92), 327-334.

THIS ARTICLE RE-EXAMINES THE FAMOUS "PRISONER'S DILEMHA. " IT ARgues that the dilemia OF THE ORIGINAL PRISONER'S DILEMMA GAME IS NOT THAT A SOLUTION IS LACKING BECAUSE THERE IS A RATIONAL ANSWER: MON-COOPERATION. THE DILEMMA IS THAT NON-COOPERATION IS AN UNSATISFACTORY OUTCOME. YET COOPERATION IS FRAUGHT WITH UNACCEPTABLE RISKS BECAUSE THE OTHER PLAYER HAS COMPELLING REASONS NOT TO COOPERATE. A
RESOLUTION TO THIS DILEMMA FOR AN ONGOING RELATIONSHIP APPEARS TO LIE WITH THE "ITERATED VERSION" OF THE PRISONER'S DILEMMA. PLAYER INTERACTIONS OVER TIME ALLOW A MORE PROFITABLE EQUILIBRIUM TO. DEVELOP FOUNDED ON MUTUAL CONDITIONAL COOPERATION. THE ARTICLE ARGUES THAT INTELLIGENCE IS A NECESSARY FUNCTION IF CONDITIONAL COOPERATION IS CHOSEN AS A STRATEGY.

04627 HUTH, P.; BENNETT, D.; GELPI, C.

SYSTEM ÜMCERTAINTY, RISK PROPENSITY, AND INTERNATIONAL CONFLICT AMONG THE GREAT POWERS

CONFLICT AMONG THE GREAT POWERS

THE AUTHORS INVESTIVATE THE' RELATIONSHIP BETWEEN SYSTEM STRUCTURE AND THE INITIATION OF MILITARIZED DISPUTES AMONG GREAT POWERS. THE CENTRAL HYPOTHESES CONCERN THE INTERACTION BETWEEN SYSTEM UNCERTAINTY AND THE RISK PROPENSITY OF NATIONAL DECISION MAKERS. THE AUTHORS EMPLOY A RESEARCH DESIGN THAT ENABLES THEM TO INCORPORATE EXPLANATORY VARIABLES FROM VARIOUS LEVELS OF ANALYSIS INTO THEIR
THEORETICAL MODEL. THE MODEL IS TESTED BY PROBIT ANALYSIS ON THEORETICAL MODEL. THE MODEL IS TESTED BY PROBIT ANALYSIS ON
A POOLED TIME SERIES OF GREAT POWER RIVAL DYADS FROM 1816 TO 1975. THE EMPIRICAL RESULTS SUPPORT THE CENTRAL HYPOTHESIS THAT THE EFFECTS OF THE INTERNATIONAL SYSTEM ARE MEDIATED BY THE RISK PROPENSITY OF DECISION MAKERS. IN ADDITION, THE AUTHORS FIND THAT DYADIC-AND UNIT-LEVEL VARIABLES SUCH AS ARMS RACES, POWER TRANSITIONS, AND THE CURRENT AND PAST DISPUTE BEHAVIOR OF RIVALS ALSO HAVE SIGNIFICANT EFFECTS ON CONFLICT BEHAVIOR. FINALLY, THE RESULTS INDICATE THAT NUCLEAR WEAPONS DO NOT SEEM TO HAVE A SYSTEMATIC IMPACT ON THE INITIATION OF MILITARIZED DISPUTES AMONG GREAT POHERS.

04628 HUTTER, B.M.

PUBLIC ACCIDENT INQUIRIES: THE CASE OF THE RAILWAY INSPECTORATE

PUBLIC ADMINISTRATION (LONDON), 70(2) (SUM 92), 177-192. FOR MORE THAN A CENTURY, THE INVESTIGATION OF RAILROAD ACCIDENTS HAS BEEN AN IMPORTANT PART OF THE BRITISH RAILWAY INSPECTORATE'S REGULATORY ACTIVITIES. THE AUTHOR EXAMINES THE CIRCUMSTANCES AND PROCEDURES OF THESE INQUIRIES, PAYING THE CIRCUMSTANCES AND PROCEDURES OF THESE INQUIRIES, PAYING
PART ICULAR ATTENTION TO THEIR PURPOSE AND HOW THIS IS PARTICULAR ATTENTION TO THEIR PURPOSE AND HOW THIS IS
INFLUENCED BY WIDER SOCIAL AND POLITICAL CONCERNS. SHE ALSO INFLUENCED BY WIDER SOCIAL AND POLITICAL CONCERNS TRACES THE INSPECTORATE'S EFFORTS TO MAINTAIN THE INOUISITORIAL RATHER THAN ACCUSATORIAL STYLE OF THESE INQUIRIES AND DISCUSSES THEIR POSSIBLE DEMISE AS A RESULT OF A GROWING TENDEM
INVESTIGATION.

04629 HUTTON, W.

BRITAIN IN A COLD CLIMATE

INTERNATIONAL AFFAIRS, 68(4) (OCT 92), 619-632. 
WILL HUTTON ARGUES THAT AS THE LAST BRITISH PRETENTIONS TO BEING A WORLD POWER DISINTEGRATE, AN OPPORTUNITY EXISTS FOR A REASSESSMENT OF ITS FOREIGN POLICY AIMS. THESE ARE INEVITABLY LINKED TO DOMESTIC POLICY CHOICES WHICH REFLECT THE KIND OF SOCIETY THE BRITAINS WANT. THE FIRST OF THESE AIMS, THE AUTHOR CONTENDS, WHOULO CONCENTRATE ON THE DEVELOPMENT OF THE NATIONAL ECONOMY, ANY RECONSTRUCTION OF WHICH IS MOST LIKELY TO BE ACHIEVED THROUGH A STRONG ALLIANCE WITH GERMANY HITH THE CONTEXT OF THE EC.

04630 HWANG, K.K.

THE POLITICAL ORIGINS OF THE "CHAEBOL" "STATE-SOCIETY INTERACTION IN SOUTH KOREA; ASSOCIAITON FOR ASIAN STUDIES 1992 ANNUAL MEETING

ASSOCIATION FOR ASIAN STUDIES, 1992, 120

RECENT STUDIES OF THE SOUTH KOREAN ECONOMIC "MIRACLE" HAVE INCREASINGLY FOCUSED ON THE ROLE PLAYED BY THE LARGE AND PERYASIVE CONGLOMERATES--THE "CHAEBOL"--THAT DOMINATE THE ECONOMIC PLAYING FIELD IN KOREA. THIS PAPER EXAMINES THE POLITICAL FACTORS WHICH SHAPED THE HISTORICAL SETTING IN WHICH THE CHAEBOL WERE CREATED. IT BEGINS BY EXPLORING THE RISE OF A NEW ENTREPRENEURIAL CLASS AND THE NEH MILITARY REGIME IN 1961-63. THE PAPER THEN TRACES THE EVOLUTION OF THE INTIMATE RELATIONS BETHEEN THE STATE AND THE "CHAEBOL. IT EXAMINES HOW THIS RELATIONSHIP HAS CHANGED AS THE ECONOMIC POWER OF THE "CHAEBOL" HAS EXPANDED AT THE SAME TIME AS THE POLITICAL POWER OF THE SOUTH KOREAN STATE HAS BEEN CURTAILED BY RECENT EFFORTS AT DEMOCRATIZATION.

04631 HYATT, D.; MILNE, $\boldsymbol{H}$.

CAN PUBBLIC POLICY AFFECT FERTILITY?

CANADIAN PUBLIC POLICY--ANALYSE DE POLITIQUES, XVII (1) (MAR 91), 77-85.

THIS PAPER EXAMINES THE RELATIONSHIP BETHEEN A NUMBER OF GOVERMMENT PROGRAMS AND THE TOATAL FERTILITY RATE. USING A SIMPLE TIME SERIES MODEL, WHICH EXPLICITLY CONSIDERS THE LABOUR MARKET BEHAVIOUR OF WOMEN, WE FIND THAT GOVERNMENT PROGRAMS WHICH IMPLICITLY ALTER THE COSTS OF HAVING A CHILD HAVE A SMALL, BUT POSITIVE, IMPACT ON FERTILITY. THE RESULTS SUGGEST THAT DURING THE 1980S, A ONE PERCENT INCREASE IN THE SUGGEST THAT DURING THE 1980S, A ONE PERCENT INCREASE IN REAL VALUE OF UNEMPLOYMENT INSURANCE MATERNITY BENEFITS
WOULD RESULT IN AN INCREASE IN THE TOTAL FERTILITY RATE OF BETWENH 0.09 AND 0.26 PERCENT. THE PAPER IS TIMELY IN VIEH
OF THE RECENT PRO-NATALIST POLICIES INTRODUCED BY THE QUEBEC OF THE RECENT

04632 HYBNEROVA, 5 .

CENTRAL EUROPE THE CORE OF PAN-EURDPEAN SECURITY OUTLIME CENTRAL EUROPE THE CORE OF PAN-EURDPEAN SECURITY DUTLIM
OF AN ALTERNATIVE PROGRAM OF A PAN-EUROPEAN SECURITY OF AN ALT

PEACE AND THE SCIENCES, 3 (SEP 91), 38-40.

UNDER CONTEMPORARY CONDITIONS IN EUROPE A SUBSTITUTION FOR THE EXISTING BILATERAL SECURITY SYSTEM (NATO-WARSAW TREATY) SHOULD NOT BE SOUGHT AFTER IN A UNILATERAL STRUCTURE BUT IN A TRILATERAL ARRANGEMENT OF SECURITY RELATIONS. IN THE BILATERAL SYSTEM, CENTRAL EUROPE WAS PREDESTINED BY BOTH SIDES AS THE FIRST BATTLEFIELD. THE MAJOR PART OF THIS REGION HAD BEEN INTEGRATED INTO ONE OF THE TWO POLES AS A MILITARY POTENTIAL. THIS ARTICLE DISCUSSES THE PAN-EUROPEAN SECURITY OUTLINE OF AN ALTERNATIVE PROGRAM OF PAN-EUROPEAN SECURITY SYSTEM.

04633 HYDE-PRICE,

AFTER THE PACT: SECURITY IN EAST CENTRAL EUROPE IN THE $1990 \mathrm{~S}$

ARMS CONTROL, 12(2) (SEP 91), 279-303

AFTER 40 YEARS OF COMPARATIVE STABILITY AND

PREDICTABILTIY. THE EUROPEAN SECURITY SYSTEM HAS ENTERED A

PERIOD OF ACCELERATED CHANGE. THIS ARTICLE EXAMINES RECENT

DEVELOPMENTS IN SECURITY AND DEFENSE POLICIES IN POLAND,

CZECHOSLOVAKIA AND HUNGARY, AND CONSIDERS THE NATURE OF THE

NEW POLITICAL AND MILITARY RELATIONSHIPS EMERGING IN THE

REGION. IT ALSO ASSESSES THE LINKS BETWEEN THE COUNTRIES OF

EAST CENTRAL EUROPE AND THE THREE KEY PILLARS OF EUROPE'S

POST-COLD WAR SECURITY ARCHITECTURE--THE CSCE, NATO AND THE

SIMPLE SOLUTIONS TO THE SECURITY DILEMMAS OF THESE COUNTRIES.

04634 HYDE, J.

CONGRESS SKEPTICAL THAT DOD LIVED UP TO TOTAL FORCE POLICY

ARMED FORCES JOURNAL INTERNATIONAL, (MAY 91), 8.

MEMBERS OF THE SENATE APPROPRIATIONS DEFENSE

SUBCOMMITTEE AND SENIOR DEPARTMENT OF DEFENSE OFFICIALS

DISCUSSED THE APPLICATION OF DOD'S TOTAL FORCE POLICY

CONCEPT (AN INTEGRATED ACTIVE-RESERYE MIX OF PERSONMEL)

DURING OPERATIONRATED ACTIVE-RESERVE MIX OF PERSONMEL

QUESTIONED THE READINESS AND FIGHTING CAPACITY OF RESERVE

COMPONENT ROUNDOUT BRIGADES, ASKED IF MORE ANHUAL TRAINING

WAS NECESSARY FOR RESERVISTS, AMD WHETHER ACTIVE-DUTY ARMY

PERSONNEL HAD PURPOSELY GIVEN RESERVISTS UNFAVORABLE MARKS

DURING DESERT STORM. STEPHEN M. DUNCAN, ASSISTANT SECRETARY

OF DEFENSE FOR RESERVE AFFAIRS, CLAIMED THAT ALL WAS WELL

WITH THE TOTAL FORCE POLICY, THAT IT WORKED AS ADVERTISED IN

THE PERSIAN GULF, AND THAT THERE HERE NO HARD FEELINGS
BETWEEN ACTIVE AND RESERVE TROOPS.

04635 HYOEN, G.; REUTLINGER, S.

FOREIGN AID IN A PERIOD OF DEMOCRATIZATION: THE CASE OF POLITICALLY-AUTONOMOUS FOOD FUNDS

WORLD DEVELOPMENT, 20(9) (SEP 92), 1253-1260.

THE AUTHORS PROPOSE A NEW MODEL OF DISPENSING FOREIGN AID THAT TRANSCENDS THE LIMITS OF CONVENTIONAL ONE-WAY TRANSFERS AND RESPONDS TO THE PARTICULAR CHALLENGES AND OPPORTUNITIES ASSOCIATED WITH THE ONGOING PROCESS OF DEMOCRATIZATION. APPLIED SPECIFICALLY TO FOOD AID, THE MODEL ILLUSTRATES HOW SUCH DISPENSATIONS COULD BE BETTER UTILIZED IN THE CONTEXT OF POLITICALLY-AUTONOMOUS FOOD FUNDS, ADMINISTERED IN RECIPIENT FOOD-POOR COUNTRIES. IT INDICATES ADMINISTERED IN RECIPIENT FOOD-POOR COUNTRIES. IT INDI

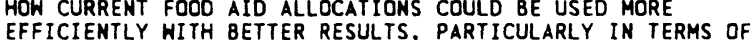
EFFICIENTLY WITH BETTER RESULTS, PARTICULARLY IN TERMS OF
STRENGTHENING THE POSITION OF THE POORER SEGMENTS OF THE POPULATION.

04636 HYLAND, F.P.

ARMENIAN TERRORISM: THE PAST, THE PRESENT, THE PROSPECTS WESTVIEW PRESS, 1991,240

DESPITE THE AMERICAN CONNECTION TO ARMENIAN TERRORISM THERE REMAINS A VOID OF HISTORICAL AND ANALYTICAL STUDIES ON THE ARMENIAN ISSUE. THIS BOOK ATTEMPTS TO FILL THIS VOID. THE AUTHOR ADDRESSES THE ORIGINS OF ARMENIAN NATIONALISM GROUPS THAT EMERGED TO EXPRESS IT, ORGANIZATIONAL CONFLICTS AND DYNAMICS THAT GAVE RISE TO DIFFERENT TYPES OF TERRORISM, VARIOUS STATE SPONSORS, LEADERS OF THE MOVEMENT, TACTICS, THE DRUG CONNECTION, AND THE PALESTINIAN CONNECTION IN BEIRUT. THE AUTHOR ALSO INCLUDES AN APPENDIX THAT COVERS MAJOR ARMENIAN TERRORIST EVENTS FROM 1921 TO 1988.

04637 HYLAND, W.G.

THE CASE FOR PRAGMATISM

FOREIGN AFFAIRS, 71(1) (1992), 38-52.

THE WORLD OF THE 1990'S WILL RESEMBLE NOTHING IN AMERICA'S PREYIOUS EXPERIENCE. THE UNITED STATES WILL BE REQUIRED TO CONDUCT A FOREIGN POLICY FOR WHICH THERE IS ALMOST NO HISTORICAL PRECEDENT, AND TO DO SO WITH LIMITED RESOURCES IN AN INCREASINGLY COMPETITIVE WORLD IN WHICH THE THREAT THAT HELD TOGETHER THE VARIOUS AMERICAN ALLIANCES WILL HAVE VANISHED.

04638 HYMAN, A.

REFUGÉS AND CITIZENS: THE CASE OF THE VOLGA GERMANS HORLD TODAY $48(3)$ (MAR 92) 41-43.

THE PLACE AND TREATMENT OF NATIONAL MINORITIES IN THE COMMONWEALTH OF INDEPENDENT STATES, AS IN THE REST OF POSTCOMMUNIST EUROPE, IS LIKELY TO BE ONE OF THE KEY ISSUES OF THE 1990'S. THE CASE OF THE THO MILLION VOLGA GERMANS IN THE FORMER SOVIET UNION IS PARTICULARLY INTERESTING BECAUSE THEY ARE NEI THER PERSECUTED NOR IN PHYSICAL DANGER; IN FACT, THEY ARE RELATIVELY PROSPEROUS, BUT MANY INTEND TO MIGRATE TO GERMANY. RUSSIAN PRESIDENT BORIS YELTSIN HAS PROPOSED THE ESTABLISHMENT OF AN AUTONOMOUS VOLGA GERMAN REPUBLIC, WITH GERMANY PROVIDING THE FINANCIAL SUPPORT TO ENSURE THE TINY REPUBLIC'S FUTURE VIABILITY.

04639 HYMAN, E.

THE DESIGN OF MICRO-PROJECTS AND MACRO-POLICIES: EXAMPLES FROM THREE APPROPRIATE TECHNOLOGY PROJECTS IN AFRICA JOURNAL OF ASIAN AND AFRICAN STUDIES, XXVII(I) (JAN 92), 134-151.

THIS PAPER PRESENTS THREE CASE STUDIES ON THE CONHECTION BETWEEN MACRO-POLICIES AND MICRO-PROJECTS IN AFRICA. THE FIRST EXAMPLE, PALM OIL EXTRACTION IN CAMEROON, SHOWS HOW TRADE RESTRICTIONS AND A DOMESTIC PRICE FLOOR HAVE ALLOWED INEFFICIENT LARGE-SCALE PRODUCTION BY PARASTATALS TO PERSIST AL THE TECHNOLOGY USED BY ARTISANAL PRODUCERS OFFERS GOOD PROSPECTS FOR INCREASING RURAL INCOMES AND EMPLOYMENT AS PROSPECTS FOR INCREASING RURAL INCOMES AND EMPLOYMENT AS
WELL AS CONSUMER BENEFITS. THE SECOND EXAMPLE, IMPROVED CHARCOAL STOVES IN KENYA, ILLUSTRATES HOW PUBLIC SECTOR R\&D TO UPGRADE SMALL-SCALE TECHNOLOGY COMBINED WITH A BENEVOLENT GOVERMMENT ATTITUDE TOWARD THE INFORMAL SECTOR CAN LEAD TO RAPID PRODUCTION AND MARKETING OF THE TECHNOLOGY. THE THIRD RAPID PRODUCTION AND MARKETING OF THE TECHNOLOGY.
EXAMPLE, FERROCEMENT FISHING BOATS IN MALAHI, WAS

EXAMPLE, FERROCEMENT FISHING BOATS IN MALAHI, WAS
UNSUCCESSFUL BECAUSE THE SCALE OF TECHNOLOGY WAS NOT WELL MNSUCCESSFUL BECAUSE THE SCALE OF TECHNOLOGY WAS NOT MATCHED TO THE LEVEL OF INVESTMENT AND ENTREPRENEURIAL
CAPACITY IN THE SECTOR AND BECAUSE GOVERNMENT CONTROLS ON CAPACITY IN THE SECTOR AND BECAUSE GOVERNMEN
THE LANDED PRICE OF FISH REDUCED INCENTIVES.

04640 HYMAN, H.

LAND OF OPPORTUNITY

LAND OF OPPORTUNITY

IN BRITAIN, THE THO MAIN PARTIES ARE FIGHTING THEIR LEAST IDEOLOGICAL TWO MAIN PARTIES ARE FIGHTING THEIR ISSUES ARE HEALTH, EDUCATION, AND HOUSING; BUT LABOUR AND THE CONSERYATIVES ARE TAKING NONCONTROVERSIAL POSITIONS AND TRYING TO SELL THEMSELVES MAINLY ON THEIR IMAGES. ONLY THE LIBERAL DEMOCRATS, WITH AN ESTIMATED 14 PERCENT SUPPORT, ARE DARING TO GO OUT ON A LIMB AND PROPOSE INHOVATIVE IDEAS. 
04641 IBE, $H$

BRIDGING DIFFERENCES OF SOCIAL SYSTEMS APAN TIMES (WEEKLY INTERNATIONAL EDITION), 32(13) (MAR 92), 11 .

JAPAN AND THE UNITED STATES NEED TO UNDERSTAND AND HELP SOLVE ONE ANOTHER'S PROBLEMS, EVEN IF IT INVOLVES

IMPLEMENTING DOMESTIC REFORMS. THEY HAVE A RESPONSIBILITY TO PREVENT FRICTIONS FROM ARISING AND CLOUDING THEIR RELATIONS. JAPANESE AND AMERICANS MUST ALSO ANALYZE AND UNDERSTAND THE DIFFERENCES IN THEIR CULTURES IN ORDER TO IMPROVE THEIR RELATIONS.

04642 ICHIRO, 0.

THE COMPENSATION SCANDAL IN JAPANESE FINANCE

JAPAN QUARTERLY, XXXIX(1) (JAN 92), 45-52.

JAPAN'S COMPENSATION SCANDAL FIRST BECAME PUBLIC

KNOWLEDGE IN JUNE 1991. FOR SMALL INVESTORS, THE REVELATIONS OF IMPROPRIETY BY BROKERAGES WERE SHOCKING AND MADDENING.

THE MINOR INYESTORS HAD BEEM LEFT TO DROHN IN DEBT HHEN

THE MINOR INVESTORS HAD BEEN LEFY HOYS HAD BEEM THROWN

STOCK PRICES PLUNGED WHILE THE BIG BOYS HAD BEEN THROWH

LIFESAVERS. MOREOVER, THE SCANDAL SPOTLIGHTED THE COZY

RELATIONSHIP BETHEEN THE SECURITIES INDUSTRY AND BIG

BUSINESS AND THE HAND-IN-GLOVE WORKINGS OF THE INDUSTRY AND

THE MINISTRY OF FINANCE, WHICH IS SUPPOSED TO REGULATE
INDUSTRY. THE DIET AND A GOVERMMENT ADVISORY PANEL ARE

INDUSTRY THE DIET AND A GOVERMMENT ADVI SORY PANEL ARE

SUPERVISORY ORGANS, AND THE FINANCIAL MARKET WILL TAKE' TIME.

04643 ICKES, B.; RYTERMAN, R.

CREDIT FOR SMALL FIRMS, NOT DINOSAURS

ORBIS, 36(3) (SUM 92), 333-348.

THERE IS GENERAL AGREEMENT ON THE GOAL OF CREATING

MARKET ECONOMIES IN THE FORMER SOCIALIST COUNTRIES.

DIFFERENCES OF OPINION CENTER ON THE MEANS OF ARRIVING AT

THAT END. THIS ARTICLE SUGGESTS THAT POLICY MUST FOCUS ON HOW TO ACCELERATE THE PROCESS OF ENTRY AND EXITS AND THAT THIS FOCUS NATURALLY DIRECTS ATTENTION TO CAPITAL MARKETS. IT CONCLUDES THAT REFORMING GOVERMMENTS SHOULD PURSUE A STRATEGY OF DEVELOPING A SOUND CREDIT MARKET, EVEN IF THIS APPROACH TAKES TIME.

04644 IDOWU, P.

"YOU HAVE TO BE PATIENT"

WEST AFRICA, 75(3909) (AUG 92), 1394-1395

IN THIS INTERYIEW HITH THE SENEGALESE MINISTER FOR

INTEGRATION, JEAN-PAUL DIAZ, HE DESCRIBES WHEN AND WHY THE

MINISTRY OF' ECONOMIC INTEGRATION HAS CREATED IN SENEGAL. THE

ALSO RECOUNTS HHAT HE HAS DONE TO PROMOTE GREATER

INTEGRATION WITHIN THE REGION. MR. DIAZ SUGGESTS THAT

INTEGRATON HS A LONG PROCESS AND THAT PATIENCE IS REQUIRED. WE HE DETAILS MEETINGS WITH THE WEST

04645 IDOWU, $P$

IBB'S' NEW IDEAL

WEST AFRICA, (3900) (JUN 92), 1006-1007.

OM MAY 25 (3900) (JUN 92), 1006-1007. PROMISED STRUCTURAL CHANGE CHANGES IN HIS ADMINISTRATION AS PART OF HIS PROGRAM TO DEAL HIS ADHIMISTRATION AS PART OF HIS PROGRAM TO FOLLOWING DAY, THE FINANCE MINISTER HAS REMOVED AND ANOTHER MINISTER RESIGNED.

04646 IDOWU, $P$.

JUSTICE ON TRIAL?

WEST AFRICA, (3901) (JUN 92), 1048

TRIAL OF FOUR NIGERIAN HUMAN

RIGHTS ACTIVISTS ON CHARGES OF CONSPIRACY AND TREASON.

04647 IDOWU, $P$

POLITICAL SHOCKWAVES

WEST AFRICA, (3917) (OCT 92), 1717

THE RESULTS OF THE PRESIDENTIAL PRIMARIES OF NIGERIA'S TWO POLITICAL PARTIES. THE SOCIAL DEMOCRATIC PARTY AND THE NATIONAL REPUBLIC CONVENTION, ARE IN LIMBO UNTIL ALL ALLEGATIONS OF "USE OF WEALTH, FALSIFICATION OF FIGURES, THREATS, FAVOURITISM, AND ALL OTHER ELECTORAL MALPRACTICES" CAN BE INVESTIGATED.

04648 IDOWN, P.; OLOHO, B.

RACE FOR PRESIDENCY

WEST AFRICA, (3882) (FEB 92), 230-232.

THE CHAIRMAN OF NIGERIA'S NATIONAL ELECTORAL COMMISSION

HAS ANMOUNCED THAT PRESIDENTIAL ELECTIONS WILL BE HELD ON

DECEMBER 5, 1992. MANY CANDIDATES, REPRESENTING A WIDE RANGE

OF VIENS, HAVE ANNOUNCED THAT THEY HILL SEEK THE PRESIDENCY.

04649 IDOWU, $P$

REASON WOULD PREYAIL

HEST AFRICA (3911) (AUG 92), 1472-1473.

THERICA, (3911) (AUG 92), 1472-1473.

GENERAL ISHAYA BAKUT ABOUT THE PROSPECTS FOR A PEACEFUL

SOLUTION TO THE CIVIL WAR IN LIBERIA.
04650 IDOWU, $P$

RESPONDING TO REALITIES

WEST AFRICA, (3886) (MAR 92 ), 414 .
THE AUTHOR REPORTS ON A CONFERENCE ON CIVIL SERVICE IN

WEST AFRICA AND SUMMARIZES SOME OF THE PROPOSALS FOR

IMPROYING THE EFFICIENCY OF THE REGION'S CIVIL SERVANTS.

04651 IDOWU, P.; OLOWO, B.

SLOW...BUT ON COURSE

HEST AFRICA, (3878) (JAN 92), 58-59.

NIGERIA'S POLITICAL TRANSITION PROGRAM BEGAN ON JULY 1 , 1987. OVER THE FIVE-YEAR TRANSITION PERIOD, THE BABANGIDA ADMINISTRATION HAS METICULOUSLY LAID AN INMOVATIVE

FOUNDATION UPON WHICH THE THIRD REPUBLIC WILL BE SOLIDLY

BUILT, IF EVERYTHING GOES ACCORDING TO PLAN.

04652 IDOWU, $P$

THAWING OF THE ICE

WEST AFRICA, (3896) (MAY 92), 838-839.

ON MAY 5, 1992 , REPRESENTATIVES OF NIGERIA AND ISRAEL SIGNED AN AGREEMENT RESTORING THE BILATERAL DIPLOMATIC TIES THAT HAD BEEN SEVERED 19 YEARS EARLIER. DESPITE HARM FEELINGS BETWEEN THE THO COUNTRIES, NIGERIA CONTINUES TO SUPPORT A HOMELAND FOR THE PALESTINIANS.

04653 IDOHU, $P$.

TOWARDS PRIVATIZATION

WEST AFRICA, (3892) (APR 92), 672.

IN THIS INTERVIEH, THE CHAIRMAN OF NIGERIA'S TECHNICAL

COMMITTEE OM PRIVATIZATIOM DISCUSSES THE PROGRESS OF HIS COUNTRY'S PRIYATIZATION PROGRAM.

04654 IDOWU, P.; ADIO-SAKA, N.; OLOWO, B.

TRANSITION BUDGE

WEST AFRICA, (3878) (JAN 92), 59-60.

NIGERIA'S 1992 BUDGET IS SIGNIFICANT BECAUSE IT IS THE

LAST BUDGET TO BE DELIVERED BY THE BABANGIDA ADMINISTRATION AND WAS SOLELY PREPARED BY THE MILITARY TO BE ADMINISTERED IN A RELAY FORM BY BOTH CIVILIAN AND MILITARY REGIMES CIVILIANS HAVE ALREADY TAKEN OVER BOTH THE COUNCIL AND THE PRESIDENTIAL MANTLE TO THE CIVILIANS IN OCTOBER 1992.

04655 IERACI, G.

CENTRE PARTIES AND ANTI-SYSTEM OPPOSTIONS IN POLARISED SYSTEMS

WEST EUROPEAN POLITICS, 15(2) (APR 92), 17-34.

THIS ARTICLE SEEKS TO SHOW THE CONNECTION BETWEEN THE

POSITIVE INTEGRATION OF ANTI-SYSTEM OPPOSITIONS AND

GOVERNMENTAL COALITIONS STRATEGIES IN FOUR EUROPEAN

POLARISED DEMOCRACIES. IT TESTS THE POSSIBILITY OF A

EXTENSION OF CO-OPERATION BETHEEN ANTI-SYSTEM OPPOSITIONS

AND CENTE PARTIES IN GDYERMMENT. THE AIM OF THIS RESEARCH

IS TO LOCATE SOME OF THE FACTORS WHICH CAN HALT THE

ENFEEBLEMENT OF THE CENTRE IN POLARISED SYSTEM.

04656 IFESTOS, P

IFESTOS, P.
PATRON-CLIENT RELATIONS IN THE EMERGING SECURITY ENYIRONMENT

JERUSALEM JOURNAL OF INTERNATIONAL RELATIONS, 14(2) (JUN

92), 35-47

IN THE POST-COLD WAR INTERNATIONAL ENVIRONMENT, AN INCREASE IN POLES OF POWER HAS ENHANCED CLIENT STATES' MANEUVERABILITY VIS-A-VIS THE PATRON. AS THE RECENT GULF CRISIS SHOWED, THIS IS ESPECIALLY SO IN TIMES OF CRISIS,

04657 IGNATIEFF, M.

SUBURBIA'S REVENGE

NEW REPUBLIC, 206 (18) (MAY 92), 10-11.

BRITAIN'S' 1992 PARLIAMENTARY ELECTIONS MERELY

CONSOI IDATED THE GREAT SEA CHANGE ELECTION OF 1979. SINCE

THE LATE $1970^{\prime} \mathrm{S}$. THE DEEP MOVEMENTS OF SOCIAL CHANGE--RISING

REAL INCOMES, DIFFUSION OF PROPERTY OWNERSHIP, THE

SUBURBANIZATION OF BRITAIN--HAVE BEEN MOVING AGAINST THE

LABOUR PARTY. ALTHOUGH THE OLD WORKING CLASS IN DECLINING

MANUFACTURING AREAS, IN THE COUNCIL ESTATES, AND IN PUBLIC-

SECTOR EMPLOYMENT HAVE REMAINED LABOURITES, THE NEH HORKINC

CLASS (ONMER-OCCUPIERS, NON-UNION, PRIVATE SECTOR, AND HIGH

TECH) HAS MOVED IN DROVES TO THE TORY PARTY. MEANHHILE, THE

LABOUR MIDDLE CLASS (PROFESSORS, CIVIL SERVANTS, TEACHERS,

UNION OFFICIALS) HAS LOST ITS PRESTIGE AND POLITICAL POWER

TO THE NEW PRIVATE-SECTOR TORY-VOTING MIDOLE CLASS (MANAGERS,

ENTREPRENEURS, BUSINESSMEN).

04658 IGNAZI, P.; YSMAL, C.

MEH AND OID EXTREME RITHT PARTIES

EUROPEAN JDURNAL OF POLITICAL RESEARCH, 22(1) (JUL 92), 101-121.

THE FRENCH AND ITALIAN EXTREME RIGHT PARTIES, THE

NATIOMAL FRONT (FN) AND THE MOVIMENTO SOCIALE ITALIANO (MSI),

NATIONAL FRONT (FN) AND THE MOVIMENTO SOCIALE I CONTEMPORARY

RIGHT RADICALISM. THE ANALYSIS OF SURVEY DATA FROM THE 
MIDDLE-LEVEL ELITES OF BOTH PARTIES--DEALING WITH THE LEVEL OF POLITICAL EXPERIENCE, THE DEGREE OF

INTEGRATION/ALIENATION VIS-A-VIS THE POLITICAL SYSTEM AND

THE VALUE SYSTEM-CONFIRMS THAT THE FN AND THE MSI DO INDEED

BELONG TO TWO OIFFERENT TYPES OF THE EXTREME RIGHT.

04659 IGNAZI, P.

THE SILENT COUNTER-REVOLUTION

EUROPEAN JOURNAL OF POLITICAL RESEARCH, 22(1) (JUL 92), 3-34.

THE AUTHOR STUDIES THE RECENT EMERGENCE OF EXTREME RIGHTWING PARTIES IN HESTERN EUROPE. USING THREE CRITERIA

(SPATIAL, HISTORICAL-IDEOLOGICAL, AND ATTITUDINAL-SYSTEMIC)

HE IDENTIFIES TWO TYPES OF EXTREME-RIGHT PARTY. ONE TYPE

INCLUDES PARTIES WITH A FASCIST IMPRINT, WHILE THE

ASSOCIATION BUT WITH A RIGHT-WING ANTISYSTEM ATTITUDE.

ASSOCIATION BUT WITH A RIGHT-HING ANTISYSTEM ATTITUDE.

CHANGES IN THE CULTURAL DOMAIN AND IN MASS BELIEFS HAVE
FAVORED RADICALIZATION AND POLARIZATION OF THE POLITICAL

FAVORED RADICALIZATION AND POLARIZATION OF THE POLITICAL
SYSTEM. THE EMERGENCE OF ATTITUDES AND DEMANDS NOT ADDRESSED

SYSTEM. THE EMERGENCE OF ATTITUDES AND DEMANDS NOT ADDRESSED
BY THE ESTABLISHED CONSERVATIVE PARTIES HAS ALSO CONTRIBUTED

BY THE ESTABLISHED CONSERVATIVE PARTIES

04660 IGUCHI, C.

INTERNÁTIONAL COOPERATION IN LUNAR AND SPACE DEVELOPMENT: JAPAN'S ROLE

SPACE POLICY, 8(3) (AUG 92), 256-268.

THIS ARTICLE DESCRIBES THE CURRENT STATE OF INTERNATIONAL COOPERATION IN THE DEVELOPMENT OF THE MOON AND OTHER CELESTIAL BODIES, ESPECIALLY IN TERMS OF THEIR VALUES AS SOURCES OF NATURAL RESOURCES WHICH SHOULD BE REGARDED AS "COMMON ASSETS OF HUMANKIND." THE NATIONAL PLANS OF THE UNITED STATES AND JAPAN ARE DISCUSSED AND THE POTENTIAL FOR TENSION BETWEEN THE DEVELOPED AND NEWLY INDUSTRIALIZING NATIONS IS HIGHLIGHTED. THE AUTHOR ARGUES THAT THERE IS WIDE SCOPE FOR JAPAN TO DEMONSTRATE ITS COMMITMENT TO THE INTERESTS OF THE INTERNATIONAL COMMUNITY BY FACILITATING TECHNOLOGY TRANSFER, ESTABLISHING A SPACE DEVELOPMENT FUND AND SETTING UP AN INTERNATIONAL CORPORATION TO BACK SPACE PROJECTS.

04661 IHEDURU, O.C.

ABANDONING STRUCTURAL ADJUSTMENT IN NIGERIA

TRANSAFRICA FORUM, 9 (3) (FAL 92) 75-88.

USING THE CASE OF NIGERIA AS AN EXAMPLE, THE AUTHOR

CRITICIZES THE NEO-LIBERAL APPROACH TO ECONOMIC DEVELOPMENT

PROMOTED IN WORLD BANK AND INTERNATIONAL MONETARY FUND

STRUCTURAL ADJUSTMENT PROGRAMS. IN CONTRAST TO THE NEO-

STRUCTURAL ADJUSTMENT PROGRAMS. IN CONTRAST TO THE NEOHE ARGUES THAT THE NIGERIAN GOVERNMENT SHOULD CONTINUE ITS PRIVATIZATION POL ICY BUT AT THE SAME TIME FOLLON THE EAST PRIVATIZATION POLICY BUT AT THE SAME TIME FOLLOW THE PROPOSING STRATEGIC INDUSTRIAL POLICIES AND DIRECTING THE PROPOSING STRATEGIC INDUSTRIAL POLI
PRIVATE SECTOR TO IMPLEMENT THEM.

04662 IHONYBERE, J.O.

THE THIRD WORLD AND THE NEH HORLD ORDER IN THE 1990'S FUTURES, 24(10) (DEC 92), 987-1002

THE AUTHOR ASSESSES THE STATUS OF THE DEVELOPING COUNTRIES AT THE END OF THE $1980^{\prime} S$, IDENTIFIES CONTEMPORARY CONSTRAINTS ON GROWTH AND DEVELOPMENT IN THE DEVELOPING FORMATIONS, AND OFFERS PROJECTIONS FOR THE FUTURE OF THIRD HORLD ECONOMIES IN VIEH OF RECENT EVENTS.

04663 IHORI, T.

INTERNATIONAL TRANSFERS AND DEFENSE EXPENDITURES IN ALLIED AND ADVERSARIAL RELATIONSHIP: JAPAN AND THE UNITED STATES JAPAN AND THE WORLD ECONOMY, 4(2) (SEP 92), 89-102.

SPENDING OM MATIONAL DEFENSE IS A GOOD EXAMPLE OF IMPURE PUBLIC GOODS WHERE ONE COUNTRY'S SUPPLY OF INTERNATIONAL PUBLIC GOODS NEED NOT BE A PERFECT SUBSTITUTE FOR ANOTHER COUNTRY'S SUPPLY. THIS FEATURE MAY REFLECT SOME REALITIES IN INTERNATIONAL DEFENSE ALLIANCES INVOLVING JAPAN AND THE UNITED STATES. THE EXAMPLES IN THIS ARTICLE OF INTERNATIONAL DEFENSE ALLIANCES SUGGEST THAT IF THE IMPURE PUBLIC GOOD IS PROVIDED NON-COOPERATIVELY, PARADOXICAL RESULTS MAY OCCUR BECAUSE OF THE DIRECT AND INDIRCT EXTERNALITY EFFECTS OF DEFENSE.

04664 IKEDA, D

THE TRIUMPH OF DEMOCRACY: TOWARD A CENTURY OF HOPE

BULLETIN OF PEACE PROPOSALS, 22(1) (MAR 91), 31-40.

PEOPLE EVERYWHERE ARE TURNING TOWARD TO SWELLING BEAT OF THE AGE OF T THE PEOPLE.S HIL' AND A HAVE OF DEMOCRACY: YET EVEN AS WE HITNESS THE END OF ONE ERA, THIS AUTHOR SUGGESTS THAT WE ARE OVERCOME WITH THE AHESOME UNCERTAINTY OF NOT BEING ABLE TO SEE WHAT LIES AHEAD, FOR WE ARE NOW IN ONE OF BEING ABLE TO SEE WHAT LIES AHEAD, FOR WE ARE NOH IN ONE OF THAT HUMAN RIGHTS ARE UNIVERSAL AND STRESSES THE IMPORTANCE OF SELF-RESTRAINT HE CONCLUDES THAT THE BUILDING OF LASTING OF SELF-RESTRAINT. HE CONCLUDES THAT THE BUILDING OF LASTING PEACE DEPENDS ON HOW MANY PEOPLE CAPABLE OF
CAN BE FOSTERED THROUGH RELIGIOUS GUIDANCE.
04665 IKEGAMI, N. JAPAN: MAINTAINING EQUITY THROUGH REGULATED FEES JOURNAL OF HEALTH POLITICS, POLICY AND LAH, 17(4) (WIN 92 ), 689-714

JAPAN WAS THE FIRST-NON-WESTERN COUNTRY TO INTROOUCE SOCIAL INSURANCE AND THE FIRST TO ACHIEVE UNIVERSAL COVERAGE. IT HAS BEEN VERY SUCCESSFUL IN HELPING TO BRING ABOUT HIGH HEALTH LEVELS AMONG ITS CITIZENS AT REASONABLE COST. CONSEQUENTLY, IT PROVIDES A UNIQUE MODEL FOR THE NEWLY INDUSTRIALIZED COUNTRIES OF HOW TO ADAPT MODERN TECHNOLOGIES IN STRUCTURING THEIR OWN HEALTH CARE SYSTEMS JAPAN'S FINANCING SYSTEM IS ORGANIZED BY THE GOVERNMENT. COVERAGE IS MANDATED FOR ALL CITIZENS AND IS SUPPLIED BY A NUMBER OF INSURANCE PLANS, WHOSE VARIETY REFLECTS THE DIFFERENCES IN THEIR DEVELOPMENT. THE COUNTRY RELIES MAINLY ON THE PRIVATE PROVISION OF HEALTH CARE, DELIVERED FROM PHYSICIAN-OWNED PROVISION OF HEALTH CARE, DELIVERED FROM PHYSICIAN-OWNED
CLINICS AND HOSPITALS. THE MOST PRESTIGIOUS FACILITIES, CLINICS AND HOSPITALS. THE MOST PRESTIGIOUS FACILITIES,
HOWEVER, ARE THE PUBLIC HOSPITALS. SERVICES ARE FRAGMENTED HOWEVER, ARE THE PUBLIC HOSPITALS. SERVICES ARE FRAGMENTED
BETWEEN CLINICS AND HOSPITALS, WHICH COMPETE FOR A SHORE OF BETWEEN CLINICS AND HOSPITALS, WHICH COMPETE FOR A SHORE
THE PATIENTS IN THEIR AREA. PATIENTS CAN CHOOSE WHERE TO SEEK MEDICAL SERVICES. PROVIDERS ARE PAID BY A NATIONALLY UNIFORM METHOD AND RATE, WHICH ARE DECIDED BY ONE CENTRAL AGENCY. INCREASES IN PAYMENT RATES ARE TIED TO THE CEILING SET BY THE GOVERNMENT'S GENERAL EXPENDITURE LIMITATIONS. A UNIFORM FEE SCHEDULE HAS HELPED TO CONTROL COSTS AND TO ENSURE EQUITABLE ACCESS. CHALLENGES REMAINING FOR JAPAN'S HEALTH CARE SYSTEM ARE CARING FOR AN INCREASINGLY ELDERLY POPULATION AND ENSURING QUALITY OF CARE.

04666 IKENBERRY, G.

A HORLD ECONOMY RESTORED: EXPERT CONSENSUS AND THE ANGLOAMERICAN POSTHAR SETTLEMENT

INTERMATIONAL ORGANIZATION, 46(1) (WIN 92), 289--322.

ALTHOUGH BRITISH AND U.S. OFFICIALS HELD MARKEDLY OIFFERENT VIEWS DURING THE NEGOTIATIONS FOR A POSTWAR ECONOMIC ORDER, THEY HERE ABLE TO REACH AGREEMENTS THAT SET THE TERMS FOR THE REESTABLISHMENT OF AN OPEN WORLD ECONOMY. THIS ARTICLE ARGUES THAT AGREEMENT WAS FOSTERED BY A COMMUNITY OF BRITISH AND AMERICAN ECONOMISTS AND POLICY SPECIALISTS WHO EMBRACED A SET OF POLICY IDEAS INSPIRED BY KEYNESIANISM AND WHO PLAYED A CRITICAL ROLE IN DEFINING GOVERMMENT CONCEPTIONS OF POSTHAR INTERESTS, SHAPING THE NEGOTIATING AGENDA, AND BUILDING COALITIONS IN SUPPORT OF NEGOTIATING AGENDA, AND

04667 IL, H.S

NEW HOPE ON THE ROAD TO REUNIFICATION

WORLD PRESS REVIEW, 39(7) (JUL 92), 18-19.

PROSPECTS FOR KOREAN REUNIFICATION ARE BETTER NOW THAN EVER BEFORE. THE THO KOREAS HAVE IMPLEMENTED A SET OF THREE FORMAL AGREEMENTS LAYING THE GROUNDWORK FOR PEACEFUL COEXISTENCE, INCREASED SOCIO-ECONOMIC COOPERATION, AND ULTIMATE UNITY. BUT IT IS TOO SOON TO PREDICT WHEN KOREANS
WILL LIVE ONCE AGAIN UNDER THE RULE OF A SINGLE GOVERNMENT.

04668 ILLARIONOV, A. EURASIAN MARKET SOCIOLOGICAL PERSPECTIVES, (6) (1990), 7-10 THIS ARTICLE ATTEMPTS TO SHOW HOW THE NEED FOR IMPLEMENTATION OF SOVEREIGNTY OF THE SOVIET UNION RESTS ON A DIVERSITY OF LIVING CONDITIONS IN ETHNIC REGIONS OF THE COUNTRY. THE AUTHOR IDENTIFIES AND ANALYZED TWO BROAD SOVIET SOCIO-ECONOMIC REALITIES; CENTRAL ASIAN AND TRANSCAUCASIAN, WITH SURPLUS LABOR, HIGH BIRTH RATE, MANY YOUTH, AND POOR EMPLOYMENT OPPORTUNITIES; AND BALTIC AND SLAV REPUBLICS, WITH LOW BIRTH RATE, FEW YOUTH, FULL EMPLOYMENT AND A SKILLED LABOR FORCE. THE INTER-DYNAMICS OF THESE TWO GROUPS IS ADORESSED. THE INTEGRATION OF THE FEDERAL MARKET IS PORTRAYED AS THE FIRST STEP TOWARD THE FUTURE OF AN ALLUNION EURASIAN ECONOMIC COMMUNITY.

04669 ILONSZKI, G; KURTAN, $S$. HUNGARY

EUROPEAN JOURNAL OF POLITICAL RESEARCH, 22 (4) (DEC 92 ), 421-427.

AS OF JANUARY 1, 1991, HUNGARY'S CABINET AND PARLIAMENT WERE DOMINATED BY THE HUNGARIAN DEMOCRATIC FORUM. ALSO REPRESENTED WERE THE INDEPENDENT SMALLHOLDERS AND CHRISTIANDEMOCRATIC PEOPLES PARTIES, WHILE SEVERAL CABINET MEMBERS DEMOCRATIC PEOPLES PARTIES, WHI
WERE DESIGNATED "INDEPENDENTS."

04670 IMAI, $K$.

STRATEGIC TOOLS OF INFLUENCING THIRD WORLD ATTITUDES: THE STRATEGIC TOOLS OF INFLUENCING COMPARATIVE STRATEGY, 11(4) (DEC 92), 409-430

THIS ARTICLE ANALYZES HOW MUCH SOVIET TOOLS FOR MAKING FRIENDS WITH CDUNTRIES IN THE SOUTH HELPED THE SOVIETS TO ACHIEVE THEIR INTENDED OBJECTIVE. WHILE SUPPORTING THE GENERALLY MEGATIYE VIEW EXPRESSED ABOUT THE EFFICACY OF SOVIET FOREIGN-POLICY INSTRUMENTS, THIS ARTICLE REVEALS EVIDENCE OF A STRONG IMPACT ARMS TRANSFERS HAD ON THIRD WORLD REGIMES. THE FINDINGS SUGGEST THAT THE GENERAL CONSENSUS IN OUR DISCIPLINE ABOUT THE POSTWAR TRANSFORMATION OF THE GLOBAL SYSTEM FROM A MILITARY TO A TRADING WORLD IS 
STILL PREMATURE, PARTICULARLY FOR THIRD WORLD COUNTRIES.

04671 IMERSHEIN, A.W.; MATHIS, M.P.; ROND, P.C. III

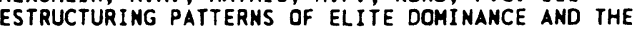
OF STATE POLICY IN HEALTH CARE

AMERICAN JOURNAL OF SOCIOLOGY, 97(4) (JAN 92), 970-993.

RECENT STATE INTERVENTION TO CONTROL HEALTH CARE COSTS BOTH REFLECT AND FOSTER CHANGES IN PREVIOUSLY PREVAILING PATTERMS OF DOMINANCE AMONG HEALTH CARE ELITES AND BETHEEN THOSE ELITES AND NON-HEALTH ELITES. THESE HEALTH POLICY OUTCOMES REFLECT A DIVERGENCE OF MATERIAL INTERESTS AND A POLITICAL FRAGMENTATION AMONG DOMINANT HEALTH ELITES AND BETHEEN THOSE AND NON-HEALTH, ESPECIALLY CORPORATE, ELITES THAT PREVIOUSLY ALLOWED HEALTH PROVIDER ELITES TO CONTROL THE HEALTH POLICY AGENDA. EMPIRICAL ANALYSIS SHOWS THAT PATTERMS OF FRAGMENTATION AMONG HOSPITAL ELITES AND COHESION AMONG BUSINESS ELITES, IN THE FORH OF BUSINESS COALITION DEVELOPMENT, CAN ACCOUNT FOR THE ADOPTION/RETENTION OF THE FOUR PREDOMINANT STATE HEALTH CARE COST CONTAINMENT POLICIES DURING 1981-87. A POLITICAL AND ECONOMIC RESTRUCTURING OF ELITE DOMINANCE IS UNDERHAY BUT IS OCCURRING UNEVENLY ACROSS STATES AND REGIONS.

04672 IMHASLY, B.

AFGHANISTAN IN THE YEAR ZERO

SHISS REVIEH OF WORLD AFFAIRS, 41(12) (MAR 92), 26-28.

IN THE SHADOW OF A MILITARY STALEMATE BETWEEN THE

MUJAHEDIN AND GOVERNMENT FORCES, RECONSTRUCTION IS BEGINNING IN AFGHANISTAN. DRAHN BY REPORTS OF REBEL SUCCESSES AND DRIVEN BY FOOD SHORTAGES IN THE REFUGEE CAMPS, EXILES HAVE BEGUN TRICKLING BACK, THOUGH THEIR RETURN IS BEING SLOWED BY OCCASIONAL BOMBARDMENTS AND AN INFRASTRUCTURE THAT HAS BEEN LARGELY DESTROYED. ESPECIALLY DAUNTING IS THE FACT THAT ENTIRE SECTIONS OF THE COUNTRY HAVE BEEN HEAVILY MINED, ESPECIALLY AROUND SUCH CITIES AS KHOST, WHERE SOVIET TROOPS AND MUJAHEDIN FOUGHT FOR YEARS.

04673 IMHASLY, B.

DEVELOPMENT VERSUS ENVIRONMENT IN INDIA

SHISS REVIEH OF HORLD AFFAIRS, 41(11) (FEB 92), 6-9.

THE DAMMING OF THE NARMADA RIVER IN WESTERN INDIA HAS RAISED OPPOSITION BOTH AT HOME ANO ABROAD BECAUSE THE RESULTING RESERVOIR WILL FLOOD 37,000 HECTARES OF WOODED LAND AND WILL FORCE THE RESETTLEMENT OF UP TO 100,000 PERSONS--MOSTLY POOR ABORIGINES. NEVERTHELESS, DUE TO THE CHRONIC WATER SHORTAGE IN THE STATE OF GUJARAT, THE INDIAN GOVERNMENT FEELS COMPELLED TO CHOOSE BETWEEN FORCED RESETTLEMENT AMD THE THREAT OF FUTURE FAMINES.

04674 IMHASLY, B

INDIA'S' CAUTIOUS APPROACH TO THE USA

SHISS REVIEH OF HORLD AFFAIRS, 41(10) (JAN 92), 27-28.

THE WORLD'S ALTERED POLITICAL SITUATION IS FORCING INDIA TO RETHINK ITS RELATIONS WITH HASHINGTON. HISTORICALLY AHCHORED IN THE NONALIGNED MOVEMENT AND GEOPOL ITICALLY IN THE SHADOW OF THE SOVIET UNION, INDIA HAS NEVER BEEN ABLE TO WARM UP TO THE UNITED STATES FOR LONG. NOW, THE NEED TO DRA CLOSER TO THE HESTERN SUPERPOWER IS BEING ACCENTUATED BY
INDIA'S ECONOMIC CRISIS AND FACILITATED BY AMERICAN ADVANCES HHILE AT THE SAME TIME, IT IS BEING AT LEAST TEMPORARILY BLOCKED BY DISAGREEMENTS OVER NUCLEAR POLICY.

04675 IMHASLY, B.

LADAKH: TROUBLE IN A HARSH PARADISE

SWISS REVIEW OF WORLD AFFAIRS, 42(9) (DEC 92), 22-23. THUS FAR, LADAKH'S REMOTENESS HAS ENABLED ITS I MHABITANTS TO RETAIN THEIR CULTURAL INDIVIDUALITY, BUT THE POLITICAL CONFLICT IN KASHMIR HAS BEGUN TO IMPINGE ON THE LADAKHIS' HARMONIOUS WAY OF LIFE. THE POLITICAL TENSIONS BETWEEN BUDDHIST LADAKH AND THE GOVERMMENT IN SRINAGAR ERUPTED INTO VIOLENT CLASHES IN THE SUMMER OF 1989.

04676 IMHASLY, B.

MAT IONALISM AND ISLAM IN BANGLADESH SHISS REVIEW OF WORLD AFFAIRS, $42(7)$ (OCT 92), 26-27.
THE GOVERHMENT OF BEGUM KHALEDA ZIA HAS DECIDED TO PROSECUTE GOLAM AZAM, CHAIRMAN OF THE JAMAAT ISLAMI PARTY. IN DOING SO, SHE HAS YIELDED TO MONTHS OF MOUNTING PRESSURE FROM THE BANGLADESHI PUBLIC, WHICH SEES GOLAM AZAM AS ONE OF THE MEN LARGELY RESPONSIBLE FOR THE BLOOOY REPRESSION THAT TRIGGERED THE COUNTRY'S 1971 WAR OF INDEPENDENCE FROM PAKISTAN. THE PARLIAMENTARY OPPOSITION HAD BEEN BOYCOTTING PAKISTAN. THE PARLIAMENTARY OPPOSITION HAD BEEN BOYCOTTING THE BUDGET SESSION OF PARLIAMENT SINCE MID-JUNE 1992, AND IT HAS THE DANGER OF A GOVERMMENT

04677 IMHASLY, B.

THE FLIGHT OF THE ROHINGYA

SWISS REVIEW OF HORLD AFFAIRS, 42(3) (JUN 92), 20-22

MUSLIM ROHINGYA FROM BURMA'S ARAKAN PROVINCE CONTINUE TO FLEE INTO NEIGHBORING BANGLADESH. THIS UNCHECKED INFLUX INTO ONE OF THE HORLD'S POOREST COUNTRIES THREATENS TO FURTHER OVERLOAD ITS PHYSICAL AND SOCIAL CAPACITY. HITH THE ONSET OF THE MONSOON SEASON, HEALTH PROBLEMS PRESENT THE GREATEST
SHORT-TERM THREAT. BURMA'S MILITARY RULERS HAYE CONSISTENTLY IGNORED INTERNATIONAL APPEALS, AND BURMESE TROOPS REPEATEDLY ATTACK THE ARAKAN VILLAGES, CLEARLY DEMONSTRATIMG THAT THE ROHINGYA ARE BEING SYSTEMATICALIY DRIVEN OUT AS A "FINAL ROHINGYA ARE BEING SYSTEMATICALLY DRIVEN OUT AS A "FINAL SOLUTION" TO THE PROBLEM OF THE MUSLIM MINORITY. THIS IS NOT STRATEGY; BUT THIS TIME THE REFUGEES COULD BECOME THE NUCLEUS OF A MUSLIM INDEPENDENCE MOVEMENT THAT MIGHT EVENTUALLY THREATEN BURMA ITSELF.

04678 IMIG, D.R.

RESOURCE MOBILIZATION AND SURVIVAL TACTICS OF POVERTY ADVOCACY GROUPS

WESTERN POLITICAL QUARTERLY, 45(2) (JUN 92), 501-520. THE DOMESTIC WELFARE CUTS OF 1981 AND 1982 LEFT NATIONALLEVEL POVERTY ADVOCATES HITHOUT FEDERAL FUNDING,

TRADITIDNALLY AN IMPORTANT SOURCE OF INCOME FOR THESE GROUPS. INFORMATION CONCERNING THE INCOMES, PROGRAMMATIC

EXPENDITURES, AND FREQUENCY OF CONGRESSIONAL TESTIMONY OF FOUR POVERTY ADVOCACY GROUPS INFORMS THIS DISCUSSION OF THE RELATIONSHIP BETHEEN FUNDING CRISIS, ENTREPRENEURIAL TACTICS, AND SURVIVAL FOR PUBLIC INTEREST GROUPS. THE EXPECTED RELATIONSHIP-THAT FUNDING CRISIS WOULD LEAD TO REDUCED RELATIONSHIP--THAT FUNDING CRISIS HOULD LEAD TO REDUCED ACTIVITY-OPROVED OVERLY SIMPLISTIC. INSTEAD, TACTICAL
CHOICES OF GROUP LEADERS CONTRIBUTED TO THEIR VARYING LEVELS OF ORGANIZATIONAL MAINTENANCE AND POL ITICAL ACTIVITY.

04679 IMLACH, A.

FREEDOM OF CHOICE IN THE SOUTH ATLANTIC

PARL IAMENTARIAN, LXXIII (4) (OCT 92), 255-257.

FALKLAND ISLAMDERS ARE PUTTING THE MEMORY OF THE 1982 ARGENTINE INVASION BEHIND THEM; HOWEVER, THEY ARE INTENT ON REMINDING THE WORLD OF THE EVENTS OF 1992, THEIR CONTINUED VULNERABILITY, AND THEIR FIRM RESOLVE TO MAINTAIN BRITISH AND COMMONWEALTH TIES, AND A WAY OF LIFE WHICH INCLUDES A DEDICATION TO THE PARLIAMENTARY SYSTEM AND THE RIGHT OF ALL PEOPLE TO CHOOSE THEIR OWH FORM OF GOVERHMENT. THIS ARTICLE EXPLORES THE THREATS TO THEIR CONTINUED RIGHT TO SELF-

04680 IMRIE, R.; THOMAS, H.

THE WRONG SIDE OF THE TRACKS: A CASE STUDY OF LOCAL ECONOMIC REGENERATION IN BRITAIN

POLICY AND POLITICS, 20(3) (JUL 92), 213-226.

THE AUTHORS ANALYZE THE KEY INTERRELATIONSHIPS BETWEEN

URBAN RENEWAL POLICIES AND PROCESSES OF LOCAL ECONOMIC

DEVELOPMENT IN BRITAIN. THEY CONSIDER THE DIRECT

DISTRIBUTIVE COSTS OF URBAN REGENERATION STRATEGIES AND

ARGUE THAT CONTEMPORARY URBAH POLICY NOT ONLY FAILS TO

ADDRESS MANY OF THE STRATEGIC ISSUES CONNECTED TO THE ADDRESS MANY OF THE STRATEGIC ISSUES CONNECTED TO THE
DISTRIBUTIVE CONSEQUENCES OF POLICY BUT IS IMPLICATED IN DISTRIBUTIVE CONSEQUENCES OF POLICY BUT IS IMPLICATED IN
CREATING AND EXTENDING SOCIO-ECONOMIC DIVISIONS IN BRITISH CREATING AND EXTENDING SOCIO-ECONOMIC DIVISIONS IN BRITISH CITIES. THEY ILLUSTRATE THESE THEMES BY PRESENTING A CASE
STUDY OF URBAN REGENERATION IN CARDIFF, SOUTH WALES. THEY STUDY OF URBAN REGENERATION IN CARDIFF, SOUTH WALES. THEY FOCUS ON HOW THE REGENERATION PLANS OF THE CARDIFF BAY OEVELOPMENT CORPORATION ARE ALTERING THE OPERATIONAL
ENVIRONMENT AND CONDITIONS OF SMALL BUSINESSES IN CARDIFF'S ENVIRONMENT AND CONDITIONS OF SMALL BUSINESSES IN CARDIFF'S
MOST IMPORTANT MANUFACTURING AREA. THE RESEARCH SUPPORTS AN EMERGING LITERATURE SUGGESTING THAT THE DEVELOPMENT AND DELIVERY OF URBAN POLICY IS PARTIAL, DIVISIVE, AND OFTEN INSENSITIVE TO THE NEEDS OF A RANGE' OF LOCAL COMMUNITY GROUPS.

04681 INBAR, E

ISRAEL AND ARMS CONTROL

ARMS CONTROL, $13(2)$ (SEP 92), 214-221.

UNTIL RECENTLY, ISRAEL HAS CONTINUOUSLY DISPLAYED A GREAT MEASURE OF SCEPTICISM IN RESPECT TO ARMS CONTROL. THIS ARTICLE POINTS OUT THE SIGNS OF CHANGE IN THE ISRAEL DISPOSTITONS TOWARD ARMS CONTROL AND ATTEMPTS TO EXPLAIN THE REAONS FOR THE NEW ATTITUDES. THE HILLINGNESS TO CONSIDER ARMS CONTROL MORE CAREFULLY IS THE RESULT OF CHANGES IN THE INTERNATIONAL AND THE REGIONAL ENVIRONMENT, AND OF NEW ISRAELI PERCEPTIONS AS TO THE LIMITATIONS ON THE UTILITY OF AVAILABLE UNILATERAL MILITARY MEANS FOR PROVIDING NATIONAL SECURITY.

04682 INDYK, M.

WATERSHED IN THE MIDOLE EAST

FOREIGN AFFAIRS, 71(1) (1992), 70-93.

THE AUTHOR TRACES THE DEVEIOPMENT OF THE GULF CRISIS AND

ASSESSES HOW IT AFFECTED THE BALANCE OF POWER IN THE REGION.

04683 INGBERMAN, D.; YAO, D.

CIRCUMVENTIMG FORMAL STRUCTURE THROUGH COMMITMENT:

PRESIDENTIAL INFLUENCE AND AGENDA CONTROL

PUBLIC CHOICE 70(2) (MAY 91) 151-180

ALTHOUGH THE FORMAL INSTITUTIONAL STRUCTURE THAT DEFINES THE TEMPORAL ORDER OF PLAY IN A POLICY GAME BETWEEN THE CONGRESS AND PRESIDENT OUGHT TO PROVIDE CONGRESS HITH AGENDA POWER. THE PRESIDENT IS TRADITIONALLY TREATED AS THE DOMINANT PLAYER IN THIS RELATIONSHIP. THE AUTHORS OF THIS PAPER SHOW THAT IF THE PRESIDENT CAN MAKE "CLEAR-CUT" COMMI TMENTS, PRESIDENTIAL COMMITMENT CAN COUNTER THE 
DOMINANCE HIERARCHY AND THE COMPLEXION EQUILIBRIUM OUTCOMES. THIS, THE DETAILS OF POL ITICAL INTERACTIONS/ (IN PARTICULAR,
THE POSSIBILITIE FOR COMMITMENT) MAY BE AS IMPORTANT AS THE FORMAL SPECIFICATION OF INSTITUTIONAL STRUCTURE.

04684 INGHAM, B.; KALAM, A.K.M. DECENTRALIZATION AND DEVELOPMENT: THEORY AND EVIDENCE FROM BANGLADESH

PUBLIC ADMINISTRATION AND DEVELOPMENT, 12(4) (OCT 92), 373-385.

IT HAS BEEN ARGUED THAT DECENTRALIZATION BRINGS TANGIBLE BENEFITS TO THE DEVELOPING WORLD, INCREASING MATERIAL WELFARE AND REDUCING THE ALIENATION TRADITIONAL SOCIETIES EXPERIENCE WHEN FACED WITH CENTRALIZED AND MODERNIZING BUREAUCRACIES. IN THEORY THIS IS PLAUSIBLE, BUT IN PRACTICE DECENTRALIZATION SELDOM LIVES UP TO ITS PROMISES DECENTRALIZATION SELDOM LIVES UP TO ITS PROMISES. "SUCCESSFUL DECENTRALIZATION OFTEN OCCURS IN CONSCIOUS OPPOSITION TO THE STATE AND, FOR THAT REASON, IS LIKELY TO BE SHORT-LIVED. DRAWING ON PAST AND RECENT EXPERIENCE IN BANGLADESH, THE AUTHOR CONCLUDES THAT THE REFORM OF LOCAL AREAS, THE VILLAGES AND THE RURAL POOR. THE DELIVERY OF BASIC NEEDS HAS NOT IMPROVED, NOR HAS THERE BEEN ANY SIGNIFICANT INCREASE IN POPULAR PARTICIPATION IN THE POLITICAL PROCESS.

04685 INGRAM, $P$

THE TRAGEDY OF TIBET

CONTEMPORARY REVIEW, 261(1520) (SEP 92), 122-125

THE CHINESE OCCUPTION OF TIBET IS A DOUBLE TRAGEDY, NOT ONLY BECAUSE OF THE MEASURELESS HUMAN MISERY IT HAS CAUSED, BUT BECAUSE TIBET WAS THE ONLY ANCIENT CULTURE TO SURVIVE INTACT INTD MODERN TIMES, WHOSE ROOTS ARE LOST IN ANTIQUITY. IT HAS BEEN PRACTIALLY DESTROYED BY THE CHINESE WHEN THEY WERE IDEALIY SUITED TO BRING THIS UNIQUE TANTRIC BUDDHIST CULTURE GENTLY INTO THE 2OTH CENTURY. TIBET IS NOW A HUGE MILITARY BASE HAVING AN ARMY OF OCCUPTATION OF MEARLY HALF A MILLION, TOGETHER WITH NUCLEAR MISSLE BASES, AND PARTS OF TIBET SUFFER FROM RADIATION AND INDUSTRIAL POLLUTION. THE TIBETAN GOVERNMENT IN EXILE IS EMBRACING A DEMOCRATI OF GOVERNMENT WHICH IT INTENDS TO TRANSPLANT TO AN INDEPENDENT TIBET. THIS ARTICLE EXPRESSES THE HOPE THAT WHEN WILL LEARN FROM, AND FOLLOW, THE TIBETAN EXAMPLE.

04686 INMAN, B.; MYE, J.; PERRY, W.; SMITH, R.

LESSONS FROM THE GULF WAR

HASHINGTON QUARTERLY, 15(1) (WIN 92), 57-76.

LESSONS THAT CAN BE DERIVED FROM THE PREHAR PERIOD, FROM THE WAR ITSELF AND FROM THE WAR'S IMMEDIATE AFTERMATH ARE EXPLORED IN THIS ARTICLE. PREVENTIVE DIPLOMACY, THE REGIONAL BALANCE OF POWER, ARMS CONTROL, MULTILATERAL MEASURES, THE PEACE PROCESS, AND ENERGY SECURITY ARE PREWAR AREAS DISCUSSED. THE HIGH TECHNOLOGY UTILIZED IN THE WAR AND THREE ASPECTS OF THE PENTAGON'S FORCES ARE CONSIDERED AS LESSONS LEARNED FROM THE WAR ITSELF.

04687 INOGUCHI. T

CHILDREN OF TRADITION

FAR EASTERN ECONOMIC REVIEW, 151(30) (JUL 91), 15.

HUMAN RIGHTS ARE AMONG A GROUP OF EMERGING' GLOBAL POLITICAL ISSUES WHICH ARE CAUSING INCREASING VEXATION AND EMBARRASSMENT IN JAPAN. WHILE ON THE SURFACE JAPAN SUPPORTS WESTERN AHD INTERMATIONAL CALLS FOR THE PROTECTION OF HUMAN RIGHTS, THERE IS AN UNDERLYING SUSPICION THAT HESTERNERS MAY BE USING HUMAN RIGHTS ISSUES IN ORDER TO EMBARRASS AND HARASS NON-HESTERN COUNTRIES. FURTHERMORE, MANY JAPANESE PREFER TO LOOK AT RESULTS RATHER THAN THE MECHANISMS THAT INDIVIDUALS CAN MAKE USE OF AFTER HUMAN RIGHTS ARE VIOLATED; THEY ARGUE THAT THE HIGH CRIME RATE IN THE UNITED STATES UNDERSCDRES THE FAILURE OF PROTECTION MECHANISMS ALONE. IN ORDER TO DEAL WITH THE GROWING INTERNATIONAL CHALLENGES WITH REGARDS TO HUMAN RIGHTS, JAPAN NEEDS TO DO TWO THINGS: VIGOROUSLY ADVANCE ITS OWN LEVEL OF HUMAN DEVELOPMENT; AND DEVISE AND PROPOSE A SET OF INDICATORS FOR MEASURING HUMAN RIGHTS ON A COLLECTIVE AS WELL AS AN INDIVIDUAL BASIS.

04688 INOGUCHI, T.

JAPAN'S FOREIGN POLICY IN EAST ASIA

CURRENT HISTORY PO

JAPAN'S EFFORTS TO STIMULATE ECONOMIC DEVELOPMENT IN

EAST ASIA AND BEYOND ARE NOT ONLY IN JAPAN'S BUSINESS AND EAST ASIA AND BEYOND ARE NOT ONLY IN JAPAN'S BUSINESS AMD NACHEVE THO MAJOR OBJECTIVES: TO ENHANCE THE WELFARE OF THE ACHIEVE TWO MAJOR OBJECTIVES: TO ENHANCE THE WELFARE OF THE PEOPLE IN THE REGION AND TO OISCOURAGE REGIONALIZATION PROTECTIONISM. JAPAN'S GOALS SHOULD NOT BE SEEN AS THE FORMATION OF A JAPANESE-LED REGIONAL ECONOMIC
PURSUIT OF A HEGEMONIC POSITION IN EAST ASIA.

04689 IONESCU, D.

ANOTHER FRONT FOR ROMANIA'S SALVATION

RFE/RL RESEARCH REPORT, 1(33) (AUG 92), 17-23.

THE DEMOCRATIC MATIONAL SALVATION FRONT HAS BORN IN LATE

MARCH 1992 AS A RESULT OF A MAJOR SCHISM IN FORMER PRIME
MINISTER PETRE ROMAN'S NATIONAL SALVATION FRONT, THE PARTY THAT HAS DOMINATED ROMANIA'S POLITICAL LIFE SINCE 1990. THE NEW MOVEMENT BASICALLY CONSISTS OF SUPPORTERS OF PRESIDENT ION ILIESCU, WHO WILL BE ITS CANDIDATE FOR THE FALL PRESIDENTIAL ELECTIONS. DESPITE ITS PROFESSED SOCIAL DEMOCRATIC ORIENTATION, THE DEMOCRATIC MATIONAL SALVATION FRONT IS WIDELY PERCEIVED AS A HAVEN FOR FORMER COMMUNISTS, WHO STRONGLY OPPOSE RADICAL REFORMS. WITH ELECTIONS DRAWING NEAR, THE TWO MOVEMENTS ARE INCREASINGLY IN COMPETITION FOR SUPPORTERS AND INFLUENCE.

04690 IONESCU, $D$.

INFIGHTING SHAKES ROMANIA'S RULING PARTY

RFE/RL RESEARCH REPORT, 1(14) (APR 92), 24-28.

ROMANIA'S RULIMG POLITICAL PARTY, THE NATIONAL SALVATION FRONT, HAS INCREASINGLY BEEN TROUBLED BY INTERNAL CONFLICTS BETWEEN A REFORMIST WING LED BY PETRE ROMAN, THE FRONT'S BETWEEN A REFORMIST WING LED BY PETRE ROMAN, THE FRONT'
NATIONAL LEADER, AND A CONSERVATIVE FACTION LOYAL TO NATIONAL LEADER, AND A CONSERVATIVE FACTION LOYAL TO
PRESIDENT ION ILIESCU, WHICH APPEARS TO FAVOR SLOWER AND PRESIDENT ION ILIESCU,
LESS RADICAL REFORMS.

04691 IONESCU, D.

NEW CHALLENGES FOR ROMANIAH-U S. RELATIONS RFE/RL RESEARCH REPORT, 1 (48) (DEC 92), 23-26.

BUCHAREST'S TIES WITH WASHINGTON IN THE POST-COMMUNIST ERA HAVE BEEN MARRED BY AMERICAN DOUBTS ABOUT ROMANIA'S COMMITMENT TO DEMOCRATIC CHANGE. THE VICTORY OF LEFTIST AND NATIONALIST FORCES IN ROMANIA'S SEPTEMBER 1992 ELECTIONS ONLY SERVED TO STRENGTHEN U.S. SKEPTICISM, PROMPTING THE U.S. HOUSE OF REPRESENTATIVES TO VOTE AGAINST MOST-FAVOREDNATION TRADING STATUS FOR ROMANIA. FOLLOWING BILL CLINTON'S ELECTORAL VICTORY, ROMANIAN OFFICIALS EXPRESSED HOPE FOR BETTER TIES UNDER THE NEW ADMINISTRATION, BUT OBSERVERS WARNED AGAINST EXAGGERATED OPTIMISM, SUGGESTING THAT BILATERAL RELATIONS WILL CONTINUE TO DEPEND ON ROMANIA'S OWN PROGRESS TOWARD DEMOCRACY.

04692 IONESCU, D.

ROMANIA
RFE/RL RESEARCH REPORT, 1(39) (OCT 92 ), 53-57.

DESPITE SUBSTANTIAL CHANGES IN THE MEDIA SINCE DECEMBER 1989, ROMANIA IS FAR FROM HAVING ACHIEVED WESTERN STANDARDS OF FREEDOM AND PROFESSIONALISM. WITH PRIVATE RADIO AND OF FREEDOM AND PROFESSIONALISM. WITH PRIVATE RADIO AND TELEVISION STATIONS STILL IN THEIR INFANCY, THE STATE
CONTINUES TO CONTROL THE LION'S SHARE OF THE BROADCAST MEDIA. MOREOVER, A RECENTLY-ADOPTED LAW GIVES PRESIDENT ION MOREOVER, A RECENTLY-ADOPTED LAW GIVES PRESIDENT ION
ILIESCU AND HIS DEMOCRATIC NATIONAL SALVATION FRONT TIGHTER ILIESCU AND HIS DEMOCRATIC NATIONAL SALVATION FRONT TIGH CONTROL OVER THESE INSTITUTIONS. BY CONTRAST, THE PRESS EN JOYS COMPLETE FREEDOM OF EXPRESSION. BUT SOARING PRICES
AND DIFFICULTIES IN DISTRIBUTION PROHIBIT THIS MEDIUM FROM ANDING A GREATER INFLUENCE ON PUBLIC OPINION.

04693 IONESCU, D.

ROMANIA ADOPTS NEW STATE SYMBOLS

RFE/RL RESEARCH REPORT, 1(43) (OCT 92), 49-51.

ON SEPTEMBER 19, 1992, ROMANIAN PRESIDENT ION ILIESCU PROMULGATED A LAW ESTABLISHING NEW STATE SYMBOLS, INCLUDEING A COAT-OF-ARMS TO REPLACE THE OLD COMWUNIST EMBLEM. ALTHOUGH THE NEH EMBLEM RESEMBLES THE ONE OF ROMANIA'S PREWAR MONARCHY, IT DOES NOT BEAR THE ROYAL INSIGNIA. THE DEMOCRATIC OPPOSITION HAS CRITICIZED THE LAH FOR DE FACTO SANCTIONING THE REPUBLIC AS ROMANIA'S FORM OF GOVERNMENT AND HAS DEPLORED HHAT IT TERMS "OFFICIAL DISREGARD" FOR THE COUNTRY'S POLITICAL IRADITIONS.

04694 IONESCU, D.

ROMANIA' STRADOLES THE FENCE ON THE YUGOSLAY CONFLICT RFE/RL RESEARCH REPORT, 1(35) (SEP 92), 27-31. ROMANIA IS SEEKING TO PLAY AN ACTIVE DIPLOMATIC ROLE IN EFFORTS TO RESOLVE THE YUGOSLAV CRISIS. RECENTLY IT OFFERED TO HOST A GATHERING OF ALL FORMER YUGOSLAV REPUBLICS, IN ORDER TO SEEK A PEACEFUL SOLUTION TO THE CONFLICT. AT THE SAME TIME, ROMANIAN OFFICIALS HAVE STRESSED THEIR DETERMINATION TO COMPLY WITH THE SANCTIONS ADOPTED BY THE U. N. SECURITY COUNCIL AGAINST SERBIA AND MONTENEGRO. IN THIS REGARD, ROMANIA HAS INVITED FOREIGN OBSERVERS TO MONITOR LAND AND HATER TRAFFIC TO AND FROM THE EMBARGOED AREA.

04695 IONESCU, D.

ROMANIA: CHARTER FOR REFORM AND DEMOCRACY WITHERS AWAY RFE/RL RESEARCH REPORT, 1(5) (JAH 92), 14-17.

THE CHARTER FOR REFORM AND DEMOCRACY, A FOUR-PARTY COALITION DOMINATED BY THE NATIONAL SALYATION FRONT (NSF), LOST ALL ITS JUNIOR MEMBERS WITHIN SIX MONTHS OF ITS CREATION. ITS FATE HAS SEALED ON JANUARY 5, 1992, WHEN THE DEMOCRATIC AGRARIAN PARTY ANNOUNCED ITS DECISION TO WITHDRAK, AS THE LIBERAL PARTY AND THE ECOLOGICAL MOVEMENT OF ROMANIA HAD ALREADY DONE. ALTHOUGH THE REASONS FOR LEAVING THE CDALITION DIFFERED FROM CASE TO CASE, THE NSF'S OWN INTERNAL CRISIS HELPED TO ALIENATE ITS POLITICAL ALLIES.

04696 IONESCU, $D$.

ROMANIA: TESTING LARGE-SCALE PRIVATIZATION 
AS A LIMITED EXPERIMENT IN PRIVATIZATION, ROMANIA WILL AUCTION OFF SIX STATE-OWNED ENTERPRISES IN JANUARY 1992. THE ENTERPRISES TO BE SOLD ARE AMONG THE MOST PROFITABLE IN THE COUNTRY. BUT MOST ROMANIAN FIRMS OPERATE AT A LOSS, MAKING THEM UNATRACTIVE TO WESTERN INVESTORS. WITH THE EXCEP OF THE FORMER NOMENKLATURA AND A NEW CLASS OF BLACK
MARKETEERS, FEW ROMANIANS HAVE FUNDS TO INVEST, SO THE FATE MARKETEERS, FEN ROMANIANS HAVE FUNDS TO INVEST, SO THE FATE
OF THE APPROXIMATELY 6,000 STATE-OWNED FIRMS SLATED FOR FUTURE PRIVATIZATION IS FAR FROM CERTAIN.

04697 IONESCU, D

ROMANIA: UNCERTAIN FUTURE FOR ECONOMIC REFORMS

RFE/RL RESEARCH REPORT, 1(46) (NOV 91), 36-42.

THE FUTURE OF ROMANIA'S ECONOMIC REFORM PROGRAM IS UNCERTAIN DUE TO THE SUCCESS OF LEFTIST AND NATIONALIST FORCES IN THE SEPTEMBER 1992 ELECTIONS. ALTHOUGH NONE OF THE PARTIES REPRESENTED IN THE NEH PARLIAMENT ADVOCATES AN OUTRIGHT HALT TO REFORMS, THE DEMOCRATIC NATIONAL SALVATION FRONT, WHICH HAS EMERGED AS THE STRONGEST POLITICAL FORCE, AND ITS POTENTIAL ALLIES APPEAR TO FAVOR SLOWER, LESS RADICAL CHANGE. THE FATE OF ROMANIA'S ECONOMIC REFORMS RADICAL CHANGE. THE FATE OF ROMANIA
DEPENDS LARGELY ON THE NEXT CABINET.

04698 IONESCU, D.

ROMANIA'S FIRST POSTCOMMUNIST CENSUS

RFE/RL RESEARCH REPORT, 1(11) (MAR 92), 57-61.

FIRST POSTCOMMUNIST CENSUS, CONDUCTED IN JANUARY 1992, SHOULD SHED LIGHT ON RECENT DEMOGRAPHIC TRENDS IN ROMAMIA, WHERE POPULATION HAS DECLINED DUE TO MASS EMIGRATION AND A FALLING BIRTH RATE. SOME CRITICS, INCLUDING REPRESENTATIVES OF THE LARGE HUNGARIAN MINORITY, HAVE ALREADY QUESTIONED THE CENSUS'S ACCURACY. THEY HAVE EXPRESSED STRONG RESERVATIONS ABOUT HOW THE DATA ON ETHNIC AND RELIGIOUS BACKGROUNDS AND OCCUPATIONS WERE REGISTERED.

04699 IONESCU, D

ROMANIA'S PUBLIC HAR OVER SECRET POLICE FILES

RFE/RL RESEARCH REPORT, 1(29) (JUL 92), 9-15.

ROMANIA HAS ENCOUNTERED SERIOUS PROBLEMS IN ITS ATTEMPTS TO EXPOSE THE ACTIVITIES OF ITS FORMER POL ITICAL POLICE, THE SECURITATE. IN FEBRUARY 1992 THE FILES OF THE ONCE-DREADED POLICE, HHICH COULD REVEAL A WEALTH OF INFORMATION ON ITS VAST NETHORK OF EMPLOYEES AND IMFORMERS, WERE DECLARED LEGALIY CLOSED FOR THE MEXT 40 YEARS. HOHEYER SOME FILES HAVE BEEY MADE PUBL IC THROUGH NOMLEGA CHANEIS SOROUSES SUSPICION THAT THE SECURITATE'S SUCCESSOR THE, AROUSING SUSPICION THAT THE SECURITATE'S SUCCESSOR, THE ROMANIAM INTELLIGENCE SERVICE, AND OTHER ROMANIAN INTELL IGENCE AGENCIES MAY BE USING BOTH AUTHENTIC AND FABRICATED
DOCUMENTS TO DISCREDIT THOSE OPPOSING THE CURRENT REGIME, INCLUDING MEMBERS OF THE FREE PRESS, AND TO SOW DISCORD IM INCLUDING
POLITICS.

04700 IONESCU, D.

ROMANIA'S RULING PARTY SPLITS AFTER CONGRESS

ROMANIA S RULING PARTY SPLITS AFTER CONGRESS

RFE/RL RESEARCH REPORT, $1(16$ ) (APR 92), 8-12.
THE MARCH 1992 CONVENTION OF THE RULING NATIONAL SALVATION FRONT PROOUCED A SPLIT IN THE PARTY. A FACTION LED BY PETRE ROMAN, THE FRONT'S REFORM-MINDED LEADER. EMERGED VICTORIOUS IN THE BATTLE OVER THE PARTY'S PLATFORM. DELEGATES LOYAL TO PRESIDENT ION ILIESCU, WHO FAVORS LESS RADICAL REFORM, WALKED OUT IN PROTEST OVER MANEUVERS TO BLOCK ILIESCU'S NOMINATION AS A CANDIDATE IN THE UPCOMING PRESIDENTIAL ELECTIONS. SOME OF THE PROTESTORS HAVE SINCE DECIDED TO FORM THEIR OWN PARTY.

04701 IONESCU, D

SOCIAL TENSION THREATENS FRAIL ROMANIAN ECONOMY RFE/RL RESEARCH REPORT, 1 (10) (MAR 92), 32-36.

IN ROMANIA, THE HAGE POLICY ADOPTED BY THE GOVERNMENT OF THEODOR STOLOJAN HAS FAILED TO WIN THE APPROVAL OF ALL THE TRADE UNIONS. THE MAIN BONE OF CONTENTION IS THE MINIMUM MONTHLY GROSS WAGE, WHICH THE GOVERMMENT RAISED FROM 7,000 LEI TO 8,500 LEI. SOME UNIONS INSIST THAT THE MINIMUM WAGE SHOULD BE MUCH HIGHER IN VIEH OF THE RECENT PRICE EXPLOSION CAUSED BY DEREGULATING PRICES, AND THEY HAVE THREATENED TO CALL STRIKES IF THEIR DEMANDS ARE NOT MET. SUCH PROTESTS WOULD JEOPARDIZE THE CHANCES OF STABILIZING THE FRAIL ROMANIAN ECONOMY BY THE END OF 1992.

04702 IONESCU, $D$

TRADE UNIONS IN ROMANIA ABANDON POLITICAL NEUTRALITY

RFE/RL RESEARCH REPORT, 1(12) (MAR 92), 12-15.

ROMANIA'S TRADE UNIONS APPEAR TO BE' LOSING THEIR POLITICAL INHIBITIONS. MORE AND MORE UNIONS ARE OPENLY TAKING SIDES IN POLITICAL DISPUTES AND SUPPORTING ONE POLITICAL ORGANIZATION OR ANOTHER. SOME UNIONS EVEN PLAN TO ESTABLISH A PARTY BASED ON THE LABOR MOVEMENT. THIS TREND SPELLS THE END OF THE PERIOD OF PROCLAIMED POLITICAL NEUTRALITY THAT STARTED AFTER THE OVERTHROW OF THE COMMUNIST REGIME IN DECEMBER 1989.

04703 IONESCU, G

THE DEEPER MEANINGS OF MR. MAJOR'S YICTORY

GOVERNMENT AND OPPOSITION, 27 (3) (SUM 92), 311-329.
THE AUTHOR OUTLINES THE REASONS FOR JOHN MAJOR'S VICTORY IN GREAT BRITAIN'S 1992 ELECTIONS, PLACING THEM IN THREE CATEGORIES: PERSONAL. NATIONAL, AND GLOBAL.

04704 IRIYE, A.

JAPAN'S DEFENSE STRATEGY

ANNALS OF THE AMERICAN ACADEMY OF POLITICAL AND SOCIAL SCIENCE, (513) ( JAN 91), 38-47.

IN 1940, JAPAN'S WEALTH, ESTIMATED IN TERMS OF NATIONAL INCOME, WAS ROUGHLY ONE-TENTH OF THAT OF THE UNITED STATES; YET JAPANESE MILITARY PONER, IN TERMS OF THE AIRCRAFT AND HARSHIPS IN THE PACIFIC, SURPASSED THAT OF AMERICA. JAPAN HAD A HELL-DEFINED, ALBEIT DISASTROUS, STRATEGY FOR

CONQUERING ASIA IN ORDER TO ESTABLISH A MORE SELF-SUFFICIENT EMPIRE. TODAY, JAPAN HAS CAUGHT UP WITH THE UNITED STATES IN ECONOMIC INDICATORS, BUT IT SPENDS FAR LESS ON DEFENSE AND IT CANMOT BE SAID TO HAVE DEVELOPED MORE THAN A RUDIMENTARY NOTIOM OF DEFENSE STRATEGY. THIS PAPER CONTRASTS THESE THO PERIODS IN RECENT JAPANESE HISTORY AND DISCUSSES POSSIBLE PERIODS IN RECENT JAPANESE HISTORY AND DISCUSSES POSSIBLE FACTORS FOR THIS DRAMATIC REVERSAL. THE AUTHOR ARGUES THAT DEFENSE STRATEGIES MUST BE SEEN AS CONSCIOUS CHOICES BY A COUNTRY'S LEADERS; THUS, WHO THEY ARE AND HOH THEY

04705 ISAKOVIC, $Z$

FROM A (COLD) WAR TO A PEACETIME ECONOMY IN CENTRALEASTERN EUROPE--PROBLEMS OF CONVERSION OF MILITARY PRODUCTION

PEACE AND THE SCIENCES, 1(1) (SEP 92), 48-51.

THE COLD WAR IS NOW FINISHED, BUT THERE IS STILL TO SOME EXTENT AN OPEN QUESTION, WHAT COULD AND SHOULD BE DONE WITH (VERY) LARGE CAPACITIES FOR ARMS PRODUCTION IN EUROPE, ESPECIALLY IN THE CENTRAL-EASTERN PART (EX-COMMUNISTS' STATES). THIS ARTICLE EXAMINES--WHY ESPECIALLY THERE? IT SUGGESTS THAT ESTABLISHING A EUROPEAN OR GLOBAL INTERMATIONAL FUMD OR BANK FOR THE FINANCING OF CONVERSION OF MILITARY PROOUCTION COULD BE USEFUL ALSO FOR THE STIMULATION OF THE DISARMAMENT PROCESS.

04706 ISARD, W. (ED.); ANDERTON, C.H. (ED.)

ECONOMICS OF ARMS REDUCTION AND THE PEACE PROCESS NORTH-HOLLAND, 1992, 270.

THIS BOOK EXAMIMES THE SUBJECT OF PEACE ECONOMICS AND ITS RAMIFICATIONS. IT PRESENTS A COMPACT SURVEY OF

SIGNIFICANT CONTRIBUTIONS ALREADY MADE TO THE FIELD AND THEN PROVIDES A BROAD THEORETICAL BACKGROUND FOR EXAMINING THE PROVIDES A BROAD THEORETICAL BACKGROUND FOR EXAMINING THE
SUBJECT BY EVALUATING FOUR DIFFERENT APPROACHES. THEY ARE: SUBJECT BY EVALUATING FOUR DIFFERENT APPROACHES. THEY ARE:
NEDCLASSICAL WELFARE THEORY, KEYNESIAN AND MODERN VERSIONS NEDCLASSICAL WELFARE THEORY, KEYNESIAN AND MODERN VERSIONS
OF MACROECONOMICS, MODERN GROWTH THEORY, AND POLITICAL OF MACROECONOMICS, MODERN GROHTH THEORY, AND POLIITICAL
CHOICE THEORY. ISSUES SPECIFICALLY EXAMINED INCLUDE: THE CHOICE THEORY. ISSUES SPECIFICALLY EXAMINED INCLUDE: THE
IMPACT OF MILITARY CUTBACKS ON THE GROWTH OF EASTERH IMPACT OF MILITARY CUTBACKS ON THE GROWTH OF EASTERH
EUROPEAN ECONOMIES; TRADE BETWEEN NATIONS; ARMS TRADE; EUROPEAN ECONOMIES; TRADE BETWEEN NATIONS; ARMS TRADE; NUCLEAR DEFENSE; AND THE BENEFITS AND COSTS OF WAR AS HIGHLIGHTED BY THE RECENT GULF WAR. MORE GENERAL TOPICS SUCH AS THE AGE-OLD NEGOTIATIONS PROBLEM OF TWO MATURE POLITICAL
LEADERS OF MAJOR POWERS IN CONFLICT AND THE PROBLEMS OF LEADERS OF MAJOR POWERS IN CONFLICT AND
DEVELOPING COUNTRIES ARE ALSO EXAMINED.

04707 ISHIBASHI, M.; REED, S.

SECOND-GENERATION DIET MEMEBERS AND DEMOCRACY IN JAPAN HEREDITARY SEATS

ASIAN SURVEY, $32(4)$ (APR 92 ) 366-379.

THE INCREASING NUMBER OF SECOND-GENERATION DIET MEMBERS COUPLED WITH THE INCREASING STABILITY OF LOCAL SUPPORT ORGANIZATIONS INDICATES THE DEVELOPMENT OF A RELATIVELY CLOSED POLITICAL CLASS IN JAPAN. THIS ARTICLE FOCUSES ON THE DIRECT INHERITANCE OF DIET SEATS. ONLY A LITTLE OVER HALF OF THE SECOND-GENERATION POL ITICIANS INHERITED THEIR SEATS DIRECTLY FROM A RELATIVE. HOWEVER, A RELATIVELY CLOSED HEREDITARY POLITICAL CLASS NEED NOT SIGNAL THE END OF EFFECTIVE DEMOCRACY. AS LONG AS POLITICAL ELITES MUST COMPETE FOR THE FAVOR OF THE ELECTORATE, DEMOCRACY CAN FLOURISH. IF THE ELECTORATE IS GIVEN NO' SIGNICANT CHOICES, DEMOCRACY COULD BECOME A FACADE.

04708 ISLAM, S.

AETT BUMPY ROAD

IN A MOOD OF SOMBRE DETERMINATION, GOVERMMENT OFFICIALS, BUSINESS LEADERS, AND OPPOSITION GROUPS ARE PREPARING FOR GUINEA'S FIRST-EVER MULTIPARTY PARLIAMENTARY ELECTIONS TO BE GUINEA'S FIRST-EVER MULTIPARTY PARL IAMENTARY ELECTIONS TO BE
HELD IN LATE 1992. THEIR HOPES FOR A DEMOCRATIC FUTURE FOR HELD IN LATE 1992. THEIR HOPES FOR A DEMOCRATIC FUTURE FOR THEIR COUNTRY ARE CLEARLY MIXED WITH FEARS THAT ITS AILING ECONOMY WILL SLOW THE PACE OF POLITICAL REFORM. THEY WARN THAT GUINEA WILL NEED MORE INTERNATIONAL HELP IF I
MEET ITS AMBITIOUS ECONOMIC AND POLITICAL TARGETS.

04709 ISLAM, S.

CARROT AND STICK

FAR EASTERN ECONOMIC REVIEN, 151(24) (JUN 91), 20-21.

THE NEW "HUMAN DEVELOPMENT REPORT 1991" PUBLISHED BY THE UNITED MATIONS DEVELOPMENT PROGRAM (UNDP) ARGUES THAT FOREIGN AID SHOULD BE CONDITIONAL ON HOH AID-RECIPIENT COUNTRIES MANAGE THEIR HEALTH AND EDUCATION PRIORITIES. IT 
ESTABLISHES A HUMAN DEVELOPMENT INDEX--WHICH RANKS COUNTRIES BY LIFE EXPECTANCY, ADULT LITERACY AND PURCHASING POWER--TO HELP AID AGENCIES MEASURE THEIR BENEFICIARIES' SOCIOECONOMIC PROGRESS. IN ADOITION, THE AGENCY HAS LAUNCHED A "HUMAN FREEDOM" INDEX THAT SEEKS TO MEASURE THE RELATIONSHIP BETWEEN FREEDOM AND DEVELOPMENT. EAST AND SOUTHEAST ASIA DO NOT FARE TOO BADLY UNDER THE HUMAN DEVELOPMENT INDEX CRITERIA, WITH BOTH REGIONS MANAGING TO SECURE IMPORTANT SOCIAL BENEFITS FROM THEIR CDUNTRIES' HIGH RATE OF ECONOMIC SOCIAL BENEFITS FROM THEIR COUNTRINES YO HIGH RATE OF ECONOMIC OF THE HUMAN FREEDOM INDEX IS JAPAN.

04710 ISLAM, $S$.

DIVIDED OVER PALESTINE

MIDOLE EAST INTERMATIONAL, (395) (MAR 91), 16-17

ANXIOUS TO AYOID A DAMAGIMG FOREIGN POIICY SPLIT IN ITS RANKS IN THE AFTERMATH OF THE GULF HAR, THE EUROPEAM COMMUNITY HAS OPTED FOR A CAUT IOUS AND' "OUIET" DIPLOMATIC EFFORT TO BRING LONG-TERM PEACE TO THE MIDDLE EAST. SPECIAL ATIENTION WILL, AS PROMISED, FOCUS ON TACKLING DEMANDS FOR A I MDEPENDENT PALESTINIAN STATE. WHILE THERE APPARENTLY IS CONSIDERABLE DISAGREEMENT OVER THE PALESTINIAN ISSUE, THERE WAS CONCORD ON ISSUES SUCH AS EC PARTICIPATION IN THE POSTHAR RECONSTRUCTION OF THE MIDOLE EAST AND ON THE FUTURE OF IRAQ.

04711 ISLAM, S

EUROPE BACK'S SAFE HAVENS

MIDDLE EAST INTERNATIONAL. (398) (APR 91), 9

WHILE THE UNITED STATES STILL VIEHS BRITISH PRIME

MINISTER JOHN MAJOR'S PROPOSALS FOR THE CREATION\$OF A UNITED NATIONS ENCLAVE FOR KURDISH REFUGEES WITH SOME SKEPTICISM, EUROPEAN COMMUNITY FOREIGN MINISTERS MADE IT CLEAR AGAIN ON 15 APRIL THAT THE PLAN CONTINUED TO HAVE THEIR FULL BACKING. THEY HAVE BEEN TRYING TO CONYINCE THE U.S. TO DROP ITS RESERVATIONS BY STRESSING THAT THE ENCLAVES WERE A "HUMANITARIAN RATHER THAN A LEGALISTIC APPROACH." EC LEADERS ARE ALSO AT PAINS TO HIGHLIGHT THAT THE COMMUNITY HAS TAKEN THE LEAD IN CHANNELLING FOOD AND EMERGENCY SUPPLIES TO THE KURDS.

04712 ISLAM, 5

EUROPE WARNS ISRAEL

MIDDLE EAST INTERMATIONAL, (405) (JUL 91), 8

THE EUROPEAM COMMUNITY' HAS WARMED ISRAEL THAT ITS HOPES OF SEEING STRONGER TRADE RELATIONS WITH THE EC DEPEND ON PROGRESS TOWARDS A MIDDLE EAST PEACE AGREEMENT. EC OFFICIALS HAVE STATED THAT ISRAEL IS IN LINE TO RECEIVE TRADE BENEFITS SIMILAR TO THE ONES BRUSSELS IS PLANNING TO GIVE ITS NORDIC NEIGHBORS. BUT "THIS COULD ONLY COME THROUGH WHEN PEACE HAS BEEN ESTABLISHED WITH ARABS AND PALESTINIANS." HOPES OF IMPROVED EC-I SRAELI COOPERATION WERE GIVEN A BOOST BY ISRAEL'S AGREEMENT TO THE APPOINTMENT OF AN EC REPRESENTATIVE TO SUPERVISE COMMUNITY AID PROJECTS IN THE OCCUPIED TERRITORIES.

04713 ISLAM, S

EUROPE--AID FOR THE MAGHREB

MIDDLE EAST INTERMATIONAL, (420) (MAR 91), 11-12.

EUROPEAN COMMUNITY FOREIGN MINISTERS MEETING IN BRUSSELS ON 2 MARCH PROMISED TO UPGRADE THE EC'S POLITICAL AND TRADE RELATIONS WITH MAGHREB COUNTRIES AND SAID THE EMPHASIS HOULD BE ON BUILDING A "NEH PARTNERSHIP" WITH THE REGION RATHER THAN ON TRADITIONAL AID. THE MAGHREB COUNTRIES WILL BE OFFERED A FREE TRADE AGREEEMENT--ON THE LINES OF THE EC'S RECENT ACCORDS WITH EASTERN EUROPEAN STATES--AS PART OF THE NEW DEAL. THE EC OFFER IS DESIGNED TO APPEASE THE MOROCCAN NEW DEAL. THE EC OFFER IS DESIGNED TO APPEASE THE MOROCCA
GOVERMMENT AFTER A DECISION BY THE EUROPEAN PARLIAMENT IN GOVERNMENT AFTER A DECISION BY THE EUROPEAN PARLIAMENT
JANUARY TO VETO UP TO S4O MILLION IN EC AID FOR RABAT

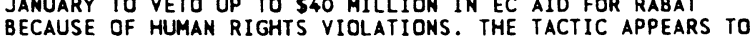
HAVE WORKED.

04714 ISLAM, $S$

EUROPE-INSISTING ON A ROLE

MIDDLE EAST INTERNATIONAL, (412) (NOV 91), 11-12

HAVING FOUGHT HARD TO SECURE A SEAT AT THE MIDDLE EAST PEACE CONFERENCE, DUTCH FOREIGN MINISTER HANS VAN DER BROEK PEACE CONFERENCE, DUTCH FOREIGN MINISTER HANS VAN DER BROEX
MADE IT CLEAR IN HIS SPEECH TO THE MEETING IN MADRID THAT MADE IT CLEAR IN HIS SPEECH TO THE MEETING IN MADRID THAT
THE EUROPEAN COMMUNITY WAS NOT GOING TO MERELY FOLLOW THE LEAD OF THE UNITED STATES. VAN DER BROEK CALLED ON ISRAEL TO LEAD OF THE UNITED STATES. VAN DER BRDEK CALLED ON ISRAEL TO SUPPORT FOR AN IMPORTANT UNITED NATIONS ROLE IN THE PEACE PROCESS. SIGNIFICANTLY, VAN DER BROEK URGED ISRAEL TO STOP PROCESS. SIGNIFICANTLY, VAN DER BROEK URGED ISRAEL TO STOP SAID THE ISRAEL I FORCES AND THE PALESTINIANS ENGAGED IN THE SAID THE ISRAELI FORCES AND THE PALESTINIANS ENGAGED IN THE
INTIFADA MUST SHOW RESTRAINT. THE EUROPEAN COMMUNITY HAS COMPLAINED IN THE PAST AT ISRAEL'S FAILURE TO PROVIDE ADEQUATE HEALTH, EDUCATION AND WATER FACILITIES TO THE PALESTINIANS. THE CLOSURE OF PALESTINIAN UNIVERSITIES HAS BEEN CRITICIZED ESPECIALLY FORCEFULLY.

04715 ISLAM, S.

EUROPE--REGIONAL DEVELOPMENT ROL

MIDDLE EAST INTERNATIONAL, (418) (FEB 92), 7-8
THE EUROPEAN COMMUNITY WILL CHAIR THE WORKING GROUP ON REGIONAL ECONOMIC DEVELOPMENT SET UP AT THE MULTILATERAL MIDOLE EAST PEACE TALKS IN MOSCOH. EC OFFICIALS SAY THEY WILL PARTICIPATE IN ALL OTHER GROUPS AS WELL BUT THAT THE COMMUNITY, GIVEN ITS OWN HISTORY OF REGIONAL INTEGRATION, COOPERATION. MEETINGS OF THE REGIONAL COOPERATION GROUP WILL BE HELD IN BRUSSELS, STARTING IN EARLY MAY. EC PLANS AND PROPOSALS INCLUDE MEASURES DESIGNED TO IMPROVE THE LIVING CONDITIONS AND HUMAN RIGHTS IN THE OCCUPIED TERRITORIES, AND TO BOOST INTRA-REGIONAL TRADE IN THE MIDDLE EAST AND BUILD NEW INFRASTRUCTURE AIMED AT LINKING ISRAEL TO ITS ARAB NEW INFRAS

04716 ISLAM, S

KEEPING UP THE PRESSURE

MIDDLE EAST INTERNATIONAL, (396) (MAR 91), 8-9

A RECENT TOUR OF THE MIDDLE EAST BY AN EC MINISTERIAL TEAM HAS CONYINCED THE EUROPEAN COMMUNITY THAT IT MUST PLAY A SIGNIFICANT ROLE IN RESOLVING THE PALESTINIAN PROBLEM. EC LEADERS ARE PREPARING TO HOLD A SPECIAL ONE-DAY SUMMIT TO STUDY PROSPECTS FOR PEACE IN THE MIDDLE EAST. WHILE ACKNOWLEDGING THAT THE UNITED STATES MUST TAKE THE LEAD IN POST-GULF WAR NEGOTIATIONS IN THE REGION, EC OFFICIALS DECLARE THAT THEY INTEND TO PLAY A KEY ROLE IN ANY FUTURE MIDDLE EAST PEACE PROCESS.

04717 ISLAM, S.

LET US IN, OR ELSE

MIDOLE EAST INTERNATIONAL, (398) (APR 91), 14.

THE EUROPEAN COMMUNITY' IS SIMMERING WITH ANGER FOLLOWING SIGNS THAT IT MAY BE EXCLUDED FROM THE REGIONAL MIDDLE EAST PEACE TALKS BEING DISCUSSED BY THE UNITED STATES AND ISRAEL. ACTING WITH UNUSUAL DETERMINATION, THE EC HAS THREATENED TO USE ITS SUBSTANTIAL ECONOMIC CLOUT IN THE REGION TO ENSURE PARTICIPATION IN THE CONFERENCE. THE ITALIAN, SPANISH, AND GREEK GOVERNMENTS HAVE BEEN PARTICULARLY INSISTENT THAT THE EC'S HUGH FINANCIAL PACKAGE FOR THE ARAB STATES AND ISRAEL

04718 ISLAM, S.; AZNAM, S.; SCHWARZ, A.

STUMBLING BLOCK

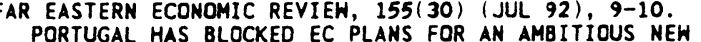
COOPERATION AGREEMENT WITH THE ASSOCIATION OF SOUTH EAST ASIAN NATIONS (ASEAN) BECAUSE OF WHAT PORTUGUESE FOREIGN MINISTER JOAO DE DEUS PINHEIRO DENOUNCED ON JULY 20 AS
INDONESIA'S "UNACCEPTABLE VIOLATION OF HUMAN RIGHTS" IN EAST TIMOR. PORTUGAL'S ACTION CAME EIGHT MONTHS AFTER TROOPS FIRED ON DEMONSTRATORS IN EAST TIMOR, A FORMER PORTUGUESE COLONY ANNEXED BY INDONESIA IN 1976. THE CONSEQUENCES NOW
INCLUDE A EUROPE-HIDE SANCTION THAT WILL BE FELT THROUGHOUT ASIA. PORTUGAL'S INTRANSIGENCE DEMONSTRATES A CLEAR GAP BETWEEN PORTUGAL'S STANCE ON THE EAST TIMOR ISSUE AND THAT OF OTHER WESTERN COUNTRIES. BUT THERE IS LITTLE EVIDENCE THAT PORTUGAL HILL CHANGE ITS POLICY.

04719 ISLAM, S.

VALUES FOR MONEY

FAR EASTERN ECONOMIC REVIEW, 151(25) (JUN 91), 9-10.

RECENT MEETINGS OF MINISTERS OF THE EUROPEAN COMHUNITY (EC) AND OF ASEAN STATES HAVE RESULTED IN GROWING CONFLICTS OVER THE EC'S ATTEMPTS TO HIGHLIGHT HUMAN RIGHTS PRIORITIES. THE EC ANNOUNCED THAT IT WAS READY TO "INCORPORATE RESPEC FOR HUMAN RIGHTS AND THE PROMOTION OF DEMOCRACY" INTC LINKS WITH ASIA. WHILE VOICING NO OBJECTION TO THE ABDUT THE EC PUSHING FOREIGN VALUES ONTO ASIAN STATES. THE EC DENIES ANY PLANS TO MAKE A DIRECT LINK BETWEEN ITS AID TO ASIA AND RESPECT FOR HUMAN RIGHTS, STRESSING INSTEAD A "CONSTRUCTIVE APPROACH" AND "ENCDURAGEMENT." HOWEVER, A CLASH OVER REPEATED EC CALLS FOR ASEAN TO JOIN IN APPLYING MYANMAR (BURMA) REVEALS THAT THE COMMUNITY MEANS BUSINESS.

04720 ISLAM, S.

WARMING FROM EUROPE

MIDDLE EAST INTERNATIONAL, (429) (JUL 92), 8 ,

EUROPEAN COMMUNITY LEADERS ENDED THEIR MID-YEAR SUMMIT IN LISBON ON 27 JUNE WITH AN APPEAL TO YITZHAK RABIN TO RESTART THE MIDDLE EAST PEACE TALKS AS QUICKLY AS POSSIBLE. THEY ALSO SENT A MESSAGE OF POLITICAL AND ECONOMIC SUPPORT TO THE MAGHREB NATIONS AND SAID THEY WERE READY TO OFFER ALGERIA, TUNISIA AND ESPECIALLY MOROCCO AN "UPGRADED PARTNERSHIP. THE COMMUNITY TRIED TO STRIKE THE PROPER BALANCE BETHEEN WELCOMING THE LABOR VICTORY--BY HAILING RABIN'S SUCCESS AS "AN ILLUSTRATION OF THE DEMOCRATIC
TRADITION IN ISRAEL WHICH... HILL REINFORCE THE PEACE PROCESS AND THE COMMITMENT TO A JUST AND LASTING SETTLEMENT"-WHILE WARNING ISRAEL THAT IT WOULO HAVE TO MOVE QUICKLY TO RECAPTURE ITS LOST INTERNATIONAL CREDIBILITY.

04721 ISLAM, S.; ROWLEY, A.

WOROS OF GOODHILL 
FAR EASTERN ECONOMIC REVIEW, 153(31) (AUG 91), 13. AFTER MONTHS OF ACRIMONIOUS WRANGL ING OVER WORDS, JAPAN AND THE EUROPEAN COMMUNITY (EC) HAVE FINALLY PLEDGED TO ADD A NEW POLITICAL AND DIPLOMATIC DIMENSION TO THEIR HITHERTO MARROH TRADE DIALOGUE. A JDINT EC-JAPAMESE STATEMENT PROMISES CLOSER EURO-JAPANESE CONSULTATION ON A RANGE OF KEY ISSUES RANGING FROM FOREIGM RELATIONS JOINT ACTION IN DEVELOPING COUNTRIES, EFFORTS TO REDUCE TRADE CONFLICTS, AND COOPERATION IN SCIENCE AND TECHNOLOGY. DESPITE THE NEW VISION AND THE WORDS OF GOODWILL, MOST OFFICIALS IN BRUSSELS REMAIN DEEPLY SKEPTICAL OF TOKYO'S TRADING POLICIES. BUT PUTTING ASIDE SUCH UNEASE, THE STATEMENT FORMALLY RECOGNIZES THE GROHING ECONOMIC ENTANGLEMENT BETHEEN THE TWO TRADING GIANTS.

04722 ITAGAKI, M.

MINISTRY MISSES CHANCE TO STREAMLINE FISCAL OUTLAYS JAPAN TIMES (WEEKLY INTERNATIONAL EDITION), 32(1) (JAN 92),

ON DECEMBER 22, 1991, THE JAPANESE FINANCE MINISTRY SUBMITTED ITS DRAFT BUDGET FOR FISCAL 1992. THE PROPOSED BUDGET FEATURES THE SLOWEST GROWTH IN DEFENSE SPENDING IN 32 YEARS AND LARGE INCREASES IN PUBLIC NORKS PROJECTS TO BE FINANCED BY MASSIVE BOND ISSUES.

04723 ITEN, 0 .

EL SALVADOR: END OF THE BLOODSHED?

SHISS REVIEW OF WORLD AFFAIRS, 42(9) (DEC 92), 11-17.

THE AUTHOR SURVEYS THE SCENE IN EL SALVADOR AND DISCUSSES THE PROSPECTS FOR A REAL PEACE BASED ON THE CHAPULTEPEC PEACE AGREEMENT.

04724 IVANOVA, E.

CURRENT FORCES IN BULGARIAN LIFE AND POLITICS EAST EUROPEAN REPORTER, 5(1) (JAN 92), 73-74.

THIS ARTICLE ARGUES THAT RESULTS OF BULGARIA'S RECENT PARLIAMENTARY ELECTIONS DO NOT BODE WELL FOR THE FUTURE OF THE COUNTRY. ALTHOUGH THE PLATFORMS OF THE THREE MAJOR VICTORIOUS GROUPS--THE UNITED DEMOCRATIC FRONT (UDF). THE BULGARIAN SOCIALIST PARTY (BSP) AND MOVEMENT FOR RIGHTS AND FREEDOMS (MRF)--ARE OUITE DIVERSE, ALL THREE ORGANIZATIONS PARTED HITH THEIR MODERATE SEGMENTS BEFORE THE ELECIION. THE RESULT IS THAT THERE IS NO "CENTER" IN BULGARIAN POL ITICS, ONLY RADICAL EXTREMISTS ON ONE SIDE OR THE OTHER. HITHOUT' CENTER WHICH SUPPORTS TOLERANCE AND LIBERALISH, THE POLARIZATION OF THE COUNTRY SEEMS INEVITABLE.

04725 IVERS, $G$

RELIGIOUS ORGANIZATIONS AS CONSTITUTIONAL LITIGANTS POLITY, XXV (2) (WIN 92), 243-266.

ORGANIZED RELIGION HAS PLAYED AN INCREASINGLY PROMINENT ROLE IN AMERICAN POLITICS OVER THE PAST TWO DECADES. ONE ASPECT OF THIS IS THE ROLE OF RELIGIOUS ORGANIZATIONS AS PARTIES IN CHURCH-STATE CASES BEFORE THE SUPREME COURT. ALTHOUGH RELIGIOUS ORGANIZATIONS HAVE BECOME MORE ACTIVE IN LOBBYING CONGRESS, LITIGATION REMAINS AN IMPORTANT WEAPON IN THEIR POLITICAL ARSENAL.

04726 IVORY, $M$.

THE POLITICS OF U.S. ENVIRONMENTAL ASSISTANCE, 1976-1986 WORLD DEVELOPMENT, 20i7) ( JUL 92), $1061-1076$

AS A RESULT OF A LAHSUIT, IN 1975 THE U.S. AGENCY FOR INTERNATIONAL DEVELOPMENT (USAID) BEGAN TO DEFINE ITS ENVIRONMENTAL MISSION FOR THE FIRST TIME. DESPITE THE FACT THAT AGRICULTURE IS ONE OF THE MAJOR BUDGETARY SECTORS AT USAID, THE ENVIRONMENTAL PROGRAMS OF THE OFFICE OF FORESTRY, ENVIRONMENTAL, AND NATURAL RESOURCES GENERALLY NEGLECTED THE ENVIRONMENTAL' SUSTAINABILITY OF AGRICULTURAL PRACTICES. THIS IS CONSISTENT WITH SEVERAL MODELS OF THE PUBLIC POLICY PROCESS, ESPECIALLY WITH RESPECT TO HOH TECHNICAL INFORMATION IS INTEGRATED INTO MISSION PLANS. THE UMIQUE SHAPE OF THE USAID ENVIRONMENTAL MISSION CAN BE EXPLAINED BY THREE FACTORS: (A) THE CONFLICTING INTERESTS OF USAID'S EXTERNAL ENVIRONMENTAL, AGRICULTURAL, AND FORESTRY CONSTITUENCIES; (B) INTERNAL ORGANIZATIONAL STRUCTURE AND THE IDEOLOGICAL PREDISPOSITION OF THE REAGAN WHITE HOUSE; AND (C) THE DEVELOPMENTAL PRIDRITIES OF RECIPIENT GOVERMMENTS. THE CASE ILLUSTRATES THE COMPLEXITY OF EXECUTIVE BRANCH PROGRAM DEVELOPMENT WHERE

INTRAORGANIZATIONAL AND DOMESTIC POLITICS CAN AFFECT INTERNATIONAL POLICY FORMULATION IN A HAY THAT DOES NOT ENCOURAGE RESOLUTION OF TECHNICAL ISSUES. IN BROAD TERMS ENCOURAGE RESOLUTION OF TECHNICAL ISSUES. IN BROAD TERHS AID'S ENVIRONMENTAL MISSION STILL IS CHARACTERIZ

UNRESOLVED TENSION BETHEEN PROOUCTION GOALS AND

SUSTAINABILITY GOALS, WHICH IS PERPETUATED BY ORGANIZATIONAL

04727 IYENGAR, S.

IS ANYONE RESPONSIBLE? HOW TELEVISION FRAMES POLITICAL I SSUES

UNIVERSITY OF CHICAGO PRESS, $1991,160$.

ELECTORAL ACCOUNTABILITY' IS THE VERY FOUNDATION OF DEMOCRATIC GOVERNANCE; TO FIX ACCOUNTABILITY, THE PUBLIC MUST DETERMINE WHO WILL BE HELD RESPONSIBLE FOR SOCIAL
PROBLEMS. THROUGH A PATTERN OF EPISODIC FRAMING THAT FOCUSES LESS ON ANALYSIS AND CONTEXT THAN ON SENSATIONAL DRAMAS OF INDIVIDUAL PERPETRATORS AND VICTIMS, TELEVISION NEWS PRFOUNDLY AFFECTS PERCEPTIONS OF POLITICAL RESPONSIBILITY. THE AUTHOR'S SOPHISTICATED PSYCHOLOGICAL EXPERIMENTS-IN WHICH SUBJECTS ARE SHOWN CAREFULLY MANIPULATED NEWS STORIES-REVEAL THAT EPISODIC FRAMING LEADS VIEHERS TO FOCUS BLAME ON INDIVIDUALS RATHER THAN ON POLITICAL PARTIES, POLITICIANS POLICIES OR SOCIETAL FACTORS. THE BOOK DEMONSTRATES IN A POWERFUL FASHION THE WAY IN WHICH TELEVISION HAS IMPOVERISHED NATIONAL POLITICAL DISCOURSE AMD AT THE SAME TIME MOLDS AMERICANS' POLITICAL CONSCIOUSNESS.

04728 JABER, $N$.

LITTLE CAUSE FOR TRIUMPH

MIDOLE EAST INTERHATIONAL, (396) (MAR 91), 13.

THE HOMECOMING OF SHAIKH JABIR AL-AHMAD AL-SABAH ON 14 MARCH, OVER A FORTHIGHT AFTER THE IRAOIS RETREATED IN DISARRAY FROM HIS CAPITAL, HAS A LESS THAN TRIUMPHANT AFFAIR. QUITE APART FROM FACING THE DAUNTING TASKS OF RESTORING SERYICES, REPAIRING DAMAGE, EXTINGUISHING THE SUFFOCATING OIL FIRE AND RESHAPING MUCH OF THE KUWAIT STATES APPARATUS, OIL FIRE AND RESHAPING MUCH OF THE KUWAIT STATES APPARATUS,
THE CDUNTRY HE RETURNED TO WAS POLITICALLY UNRECOGNIZABLE AS
THE WEALTHY AND COMPLACENT EMIRATE HE FLED ON 2 AUGUST 1990. THE WEALTHY AND COMPLACENT EMIRATE HE FLED ON 2 AUGUST 1990 THEIR CALLS FOR REFORM AND CHANGE, AND THE EMIR--UNDER HESTERM PRODDING--MAY HAVE NO CHOICE BUT TO CONCEDE TO SOME OF THEIR DEMANDS.

04729 JABER, $N$

PRESSURES ON SHAIKH SAAD

MIDDLE EAST INTERNATIONAL, (397) (APR 91), 7

KUWAITI PRIME MINISTER' SHAIKH SAAD AL-ABDULLLAH'S EFFORTS TO CREATE A NEW CABINET AND RESUME CONTROL OF THE NATION IS BEING RESISTED BY AN INCREASINGLY STRIDENT OPPOSITION. AS THE TALKS GOT UNDERHAY WITH VARIOUS GRDUPS, SHAIKH SAAD SEEMED TO BE TRYING TO PUT TOGETHER A TEAM THAT WOULD STRIKE A BALANCE BETWEEN THE STATUS QUO AND DEMANDS FOR RADICAL CHANGE. HOWEVER, SOME OPPOSITION GROUPS ARE DECLARING THEIR INTENT TO REFUSE ANY HALF-HEARTED REFORMS OR DELAYING TACTICS. THEY CALL FOR A STRICT AND CLEAR TIMETABLE FOR NEW ELECTIONS AND FOR THE RELAXATION OF THE AL-SABAH FAMILY'S CONTROL OVER THE GOVERMMENT. HOH THIS CONFLICT IS DEALT WITH COULD HAVE SIGNIFICANT REPERCUSSIONS FOR OTHER GULF STATES.

04730 JABER, $N$.

OATAR AND SAUDI ARABIA--SO MUCH FOR "BROTHERHOOD"

MIDDLE EAST INTERNATIOMAL (435) (OCT 92), 5-6.

OBSERVERS MOTE THAT THE STRANGEST THING ABOUT THE RECENT BORDER CLASH BETWEEN SAUDI ARABIA AND OATAR IS NOT SO MUCH BORDER CLASH BETHEEN SAUDI ARABIA AND QATAR IS NOT SO FURTHER UNDERMINING THE PRETENSE THAT THE GULF COOPERATION COUNCIL (GCC) IS COHESIVE ENOUGH TO PURSUE THE KIMD OF LONGCOUNCIL (GCC) IS COHESIVE ENOUGH TO PURSUE THE KINO OF LONG TERM INTEGRATION TO WHICH SO MANY OF ITS CITIZENS ASPIRE. KUWAIT AND EGYPT HAVE BEEN TRYING TO MEDIATE IN THE DISPUTE BETWEEN THE GCC'S LARGEST MEMBER AND ITS WEAKEST LINK, BUT THERE ARE INDICATIONS THAT THE QATARIS ARE IN NO MOOD TO APPEASE THEIR MORE POWERFUL NEIGHBORS. FOR SAUDI ARABIA, THIS DECLINE IN RELATIONS WITH ITS FORMER PROTEGE COINCIDES WITH MAJOR PROBLEMS WITH ITS OTHER NEIGHBORS: SAUDI
IS NOT ON SPEAKING TERMS WITH JORDAN, LET ALONE IRAO, RELATIONS HITH IRAN ARE TENSE, AND PROGRESS IS STILL UNCERTAIN IN RECENT TALKS WITH YEMEN. SUDDENLY, THE COUNTRY THAT EPITOMIZES THE ARAB "MAINSTREAM" SEEMS STRANGELY ISOLATED.

04731 JABER, $N$.

STRAINS ON THE GULF ARABS' COHESION

MIDDLE EAST INTERNATIONAL, 439 (DEC 92), 3

GULF INTELLECTUALS, AMONG WHOM THERE' IS A GROWING

FEELING THAT NOTHING SHORT OF A FULL-FLEDGED FEDERATION WITH REPRESENTATIVE INSTITUIONS CAN SEE THE STATES OF THE REGION INTD THE 21ST CENTURY, INCREASINGLY FEAR THAT AFTER A DOZEN YEARS OF RHETORIC ABOUT UNITY AND SHARED DESTINY, THE COUNTRIES OF THE GULF COOPERATION COUNCIL SERIOUSLY RISKS COMING APART AT THE SEAMS. THIS ARTICLE EXPLORES THE SAUDIQATARI DISPUTE AND ALSO THE THREAT FROM IRAN.

04732 JABER, $N$.

THE GULF--CONFLICTING VISIONS

MIDDLE EAST INTERNATIONAL, (413) (NOV 91), 12-13.

THE AILING DAMASCUS DECLARATION SHOHED NO SIGNS OF THE AILING DAMASCUS DECLARATION SHOWED NO SIGNS OF STATES MET IN CAIRO. THEIR JOINT COMMUNIOUE, COMPOSED MAINLY STATES MET IN CAIRO. THEIR JOINT COMMUNIQUE, COMPOSED MAI CONFERENCE, COULD NOT DISGUISE THE FACT THAT IN TWO DAYS OF TALKS THE MINISTERS FAILED TO MAKE PROGRESS ON THE TALKS THE MINISTERS FAILED TO MAKE PROGRESS ON THE COFTER THE GULF WAR. WHILE THE BASIC PROVISIONS FOR ECONOMIC. POL ITICAL AND MILITARY COOPERATION REMAIN UNIMPLEMENTED VARIOUS STATES IN THE GULF COOPERATION COUNCIL (GCC) ARE MAKING THEIR OWH DEALS WITH OUTSIDE POWERS INCLUDING IRAN AND THE UNITED STATES. 
04733 JABER, N.

THE GULF-IRHA FLEXES ITS MUSCLES

MIDOLE EAST INTERNATIONAL, (424) (MAY 92), 9

IRAN CAN ONLY TAKE HEART FROM ARAB GULF STATES' APPARENT DETERMINATION NOT TO MAKE AN ISSUE OUT OF ITS EXERCISE IN MUSCLE FLEXING ON THE ISLAND OF ABU MUSA. IRANIAN FORCES, WHO HAVE HAD A FOOTHOLD ON ABU MUSA FOR TWO DECADES UNDER A 1971 AGREEMENT, EXTENDED THEIR CONTROL TO THE REST OF THE ISLAND, RUN BY' THE EMIRATE OF SHARJAH, BY SEIZING ITS SCHDOL. ISLAND, RUN BY THE EMIRATE OF SHARJAH, BY SEIZING ITS SCHDO POLICE STATION AND DESALINATION PLANT. THE REACTION OF THE UNITED ARAB EMIRATES AND ITS GULF COOPERATION COUNCIL (GCC PARTNERS HAS BEEN REMARKABLY MUTED. THIS IS MOTIVATED BY A DESIRE NOT TO UPSET RELATIONS JUST AS THE GCC COUNTRIES ARE LOOKING FORWARD TO A NEW ERA OF "MODERATION IN IRAN

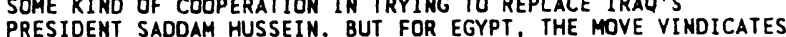
PRESIDENT SADDAM HUSSEIN. BUT FOR EGYPT, THE MOVE VINDICATES WHAT IT HAS BEEN TELLING THE GULF STATES EVER SINCE THE WAR: THE WEAKENING OF IRAQ IS BOUND THE WHET IRAN'S APPETITE. EGYPTIAN WARNINGS WERE GIVEN ADDED FORCE BY OTHER INCIDENTS
OF IRANIAN AGGRESSIVENESS, NOTABLY THE PRE-ELECTION AIR RAID NEAR BAGHDAD ON 5 APRIL. THE ABU MUSA DISPUTE ALSO HIGHLIGHTS THE GROWIMG NUMBER OF BORDER DISPUTES IN THE REGION INVOLYING A HOST OF NATIONS INCLUDING BAHRAIN, OATAR, SAUDI ARABIA, YEMEN, AND OMAN.

04734 JABER, $N$.

UNAIRED MISGIVINGS IN THE GULF

MIODLE EAST INTERNATIONAL, (433) (SEP 92), 9-10.

THE WESTERN "NO-FLY ZONE" IN SOUTHERN IRAQ HAS PROOUCED A DEAFENIMG OFFICIAL SILENCE FROM THE ARAB GULF STATES THAT UNDERLINES THEIR INABILITY TO PART WAYS WITH THE UNITED STATES NO MATTER HOW DEEP THEIR MISGIVINGS ABOUT SOME OF ITS POLICIES. ONLY KUWAIT, DESPARATE TO SEE EVERYTHING POSSIBLE DONE TO UNDERMINE SADDAM HUSSEIN AND FURTHER WEAKEN IRAO IN DHE LONGER TERM, HAS COME OUT OPENLY IN FAVOR OF THE SCHEME. THE LONGER TERM, HAS COME OUT OPENLY IN FA THA OF THE IT IS TAKEN FOR GRANTED IN THE ARAB WORLO THAT THE OVERFLIGHT BAN IS ONLY A FIRST STEP, WITH THE ULTIMATE AIM
BEING TO TOPPLE SADDAM HUSSEIN. SEVERAL ARAB PARTICIPANTS IN BEING TO TOPPLE SADDAM HUSSEIN. SEVERAL ARAB PARTICIPANTS DESERT STORM SEE THIS GOAL AS A POLITICAL IMPERATIVE. BUT
FOR KUWAIT AND SAUDI ARABIA, HOW AND BY WHOM HAVE ALMOST FOR KUWAIT AND SAUDI ARABI
BECOME SECONDARY ISSUES.

04735 JABER, $N$

UNCERTAIN REBIRTH

MIDOLE EAST INTERNATIONAL, (395) (MAR 91), 8-10.

THOUGH WORLD ATTENTION' IS NOW ON THE FUTURE OF IRAQ AND THE HIDER MIDDLE EAST, THE REBIRTH OF KUHAIT IS ALMOST AS RIFE WITH UNCERTAINTIES. AMID THE SCENES OF KUWAITI REJOICING, THE HORROR STORIES OF THE OCCUPATION AND THE ASTRONOMICAL DAMAGE ASSESSMENTS, THE GOVERNMENT'S IMMEDIATE DECLARED PRIORITIES WERE TO RESTORE SECURITY, WEED OUT "COLLABORATORS," CLEAR UP THE STREETS AND RESTORE BASIC SERVICES PENDING THE START OF RECONSTRUCTION. THE MOST CONSPICUOUS INTERIM MEASURE HAS BEEN THE BACKLASH BY ARMED GOVERNMENT SUPPORTERS AGAINST ALLEGED IRAOI SYMPATHIZERS, WHICH SEEM TO BE TAKEN MAINLY TO MEAN KUHAIT'S LARGE PALESTINIAN COMHUNITY. THIS MAY BE A PRECURSOR TO A LARGER PLAN FOR A WHOLESALE DEMOGRAPHIC SHAKE-UP TO ACHIEVE THE LONG-SOUGHT GOAL OF REDUCING RELIANCE ON EXPATRIATES, ESPECIALLY POLITICALLY UMRELIABLE ARABS. THE FUTURE OF THE RUL ING SYSTEM AND ITS OPPOSITIOM REMAINS UNCERTAIM.

04736 JABRI, V. INTERVENTION IN NAMIBIA

MANCHESTER UNIYERSIIY PRESS, $1990,198$.

MANCHESTER UNIVERSITY PRESS, $1990,198$.
USING AS A CASE STUDY THE INTERVENTION OF THE WESTERN GOVERMMENTS IN THE RECENT NAMIBIAN CONFLICT, THE AUTHOR OF GOVERMMENTS IN THE RECENT NAMIBIAN CONFLICT, THE AUTH THIS BOOK PROVIDES AN ANALYTICAL FRAMEWORK FOR THE
INTERPRETATION OF MEDIATOR DECISION-MAKING. SHE FOCUSES ON THREE ESSENTIAL QUESTIONS: WHY DO THEIR PARTIES, INCLUDING THREE ESSENTIAL QUESTIONS: WHY DO THEIR PARTIES, INCLUDING GOVERNAENTS, GROUPS, AND INDIVIDUALS, DECIDE TO MEDIATE IN SPECIFIC CONFLICTS? WHAT DETERMINES A MEDIA 'S DECISION TO ABANDON THE ROLE OF INTERMEDIARY PRIOR TO A SUCCESSFUL ABANDON THE ROLE OF INTERMEDIARY PRIOR TO A SUCCESSFUL THEIR TACTICS IN RESPONSE TO THEIR INTERESTS, RESOURCES AND THEIR TACTICS IN RESPONSE TO THEIR INTERESTS, RESOURCES AMD CONSTITUENCY, AND EXAMINES THE RANGE OF TACTICS EMPLOYED. SHE ALSO SHEDS NEH LIGHT ON THE COMPLEXITIES OF CONTEM PRECEDING THE BIRTH OF NAMIBIAN NATION.

04737 JACANAMEJOY, $G$.

TAKING RESPONSIBILITY

CULTURAL SURVIVAL QUARTERLY, 16(3) (FAL 92),

IN COLOMBIA, ELECTORAL POLIITICS AND GRASSROOTS ACTIVISH COMPLEMENT ONE ANOTHER. AN INGA INDIAN, GABRIEL MUYUY JACANAMEJOY REPRESENTS PUTUMAYO DEPARTMENT IN COLOMBIA'S SENATE. HE WAS ELECTED TO THE SENATE AND SERVES THERE AS A REPRESENTATIVE OF THE NATIONAL INDIGENOUS ORGANIZATION OF COLOMBIA. IN THIS INTERVIEW WITH JACANAMEJOY, HE COM
04738 JACKSON, A.

GOVERNMENT ACTIVISM: BUILDING A NATIONAL ECONOMY SOCIAL POLICY, 23(1) (SUM 92), 20-31.

CANADA HAS A LONG TRADITION OF ACTIVIST GOVERNMENT STEERING ECONOMIC DEVELOPMENT TO MEET BOTH THE NEEDS OF BUSINESS AND SOCIAL NEEDS. THIS POLICY HAS BROAD SUPPORT ACROSS THE SPECTRUM OF CANADIAN POLITICS. UNLIKE THE UNITED STATES, CANADA HAS CONSCIOUSLY IMPLEMENTED INDUSTRIAL STRATEGIES TO GIVE IT AN ADVANTAGE IN WORLD MARKETS AND TO BUILD UP DOMESTIC INDUSTRIAL CAPACITY. CAMADIAN INDUSTRIAL DEVELOPMENT HAS NOT BEEN LEFT TO MARKET FORCES ALONE, BECAUSE THESE HOULD HAVE FAILED TO DEEPEN AND DIVERSIFY THE BECAUSE

04739 JACKSON, A.

THE LAST, BEST LEFT?

STUDIES IN POLITICAL ECONONY: A SOCIALIST REVIEH, 37(1) (SPR 92) 161-172.

THE FOCUS ON INCOMES POLICIES IN ARTICLES ON THE SUBJECT IS FOUNDED ON THE VIEW THAT THE EXISTING COLLECTIVE BARGAINING SYSTEM IS A MAJOR FACTOR BEHIND RECENT INFLATION. AS CANADA FACES UP TO THE REALITIES OF CURRENT RESTRUCTURING, THE BOOK, "SOCIAL DEMOCRACY WITHOUT ILLUSIONS" PROVIDES A VERY LIMITED STARTING POINT. "PUTTING PEOPLE FIRST," IN CONTRAST, DOES SUGGEST WAYS TO BEGIN GENERATING LEFT-WING ANALYSIS AND POLICY FOR THE FUTURE SOCIAL DEMOCRACY IN GOVERNMENT IN ONTARIO, AND EVEN SASKATCHEWAN AND BRITISH COLUMBIA, MAY YET OFFER MODELS TO OTHERS.

04740 JACKSON, B.

REPEAL PUBLIC FINANCING? DON'T MAKE ME LAUGH

JOURNAL OF LAH \& POLITICS, VIII(2) (WIN 92), 325-328.

THE AUTHOR EXPLAINS THE VIEWS OF WASHINGTON POLITICIANS REGARDING THE PROPOSED REPEAL OF THE PUBLIC FINANCING OF STRATEGIES REGARDING THE GENERAL ISSUE OF CAMPAIGN FINANCING.

04741 JACKSON, G.

TERRORISM AND THE NEWS MEDIA

TERRORISM AMD POLITICAL VIOLENCE, 2(4) (WIN 90), 521-528.

THIS ARTICLE EXPLORES THE CONSTANTS TENSION BETHEEN THO THIS ARTICLE EXPLORES THE CDNSTANTS TENSION BETHEEN TWO
THPERATIVES IN THE NEHS MEDIA: THE DUTY TO INFORM, AND THE IMPERATIVES IN THE NENS MEDIA: THE DUTY TO INFORM, AND THE TEMPTATION TO ENTERTAIN, THE AUTHOR CONCENTRATES ON THE EFFECT THAT MEDIA COVERAGE CAN HAVE ON TERRORISM. HE

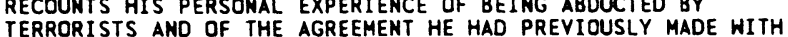
TERRORISTS AMD OF THE AGREEMENT HE HAD PREVIOUSLY MADE WITH HIS FAMILY TO NOT GIVE AND MEDIA COVERAGE TO TERRORIST ACTS. HE BELIEVES THE RESUL IING MEDIA SILENCE WAS ONE CHIEF FACTOR IN HIS RELEASE. NOT ONLY DO TERRORISTS CRAVE MEDIA BUT THE ACKNOWLEDGMENT OF TERRORIST ACTIVITIES IN A SENSATIONAL FASHIO
AND ACTIVITIES.

04742 JACKSON, J.; KINGDON, J.

IDEOLOGY, INTEREST GROUP SCORES, AND LEGISLATIVE VOTES AMERICAN JOURNAL OF POLITICAL SCIENCE, 36(3) (AUG 92), 805-823.

THIS ARTICLE REYIEWS WRTINGS BY ECONOMISTS AND POLITICAL SCIENTISTS ON THE IMPORTANCE OF IDEOLOGY IN GOVERMMENTAL DECISION MAKING. THE AUTHORS CONSIDER VARIOUS PROBLEMS IN THIS RESEARCH, DISCUSS SEVERAL SHORTCOMINGS IN THESE RECEN STUDIES IN THE CONTEXT OF THE LARGER LITERATURE ON

LEGISLATIVE BEHAVIOR, AND DEMONSTRATE THE STATISTICAL INCONSISTENCY OF THE COMMONLY USED METHODOLOGIES BASED ON INTEREST GROUP SCORES.

04743 JACKSON, J.J.

STATUS OF TREATIES IN DOMESTIC LEGAL SYSTEMS: A POLICY ANALYSIS

AMERICAN JOURNAL OF INTERNATIONAL LAW, 86(2) (APR 92),

310-340.

THERE ARE SOUND POLICY REASONS FOR A MATIONAL LEGAL SYSTEM WITH TYPICAL DEMOCRATIC INSTITUTIONS TO AVOID THE COMBINATION OF DIRECT DOMESTIC LAW APPLICATION OF TREATIES AND HIGHER STATUS FOR THOSE TREATY NORMS THAN LATER-ENACTED STATUTORY LAW. IN THIS PAPER, THE AUTHOR ADDRESSES TWO MAJOR ISSUES: THE STATUS OF TREATIES IN NATIONAL LEGAL SYSTEMS (I . E. THE QUESTION OF DIRECT APPLICATION) AND THE HIERARCHICAL STATUS IN NATIONAL LEGAL SYSTEMS WHEN DIRECTLY-APPLIED
TREATY NORMS CLASH WITH OTHER NORMS OF THE SAME SYSTEM.

04744 JACKSON, P. THE POLITICS OF THE STREETS: A GEOGRAPHY OF CARIBANA POLITICAL GEOGRAPHY QUARTERLY, 11 (2) (MAR 92), 130-151. REFLECTIONS ON THE POLITICAL SIGNIFICANCE OF STREET
PESIVALS IN THE CONTEXT OF AN INCREASINGLY POST-COLONIAL, FESTIVALS IN THE CONTEXT OF AN INCREASINGLY POST-COLONIAL,
POSTMODERM WORLD IS OFFERED. FOCUSING ON CARIBANA, AN ANNUAL POSTMODERN WORLD IS OFFERED. FOCUSING ON CARIBANA, AN
CARIBBEAN FESTIVAL IN TORONTO, THIS PAPER EXPLORES THE POLITICAL SIGNIFICANCE OF STREET FESTIVALS AND RELATED EVENTS. BASED ON FIELD OSERVATION, INTERVIEHS AND ARCHIVAL RESEARCH IN TORONTO, THE PAPER MAKES SOME COMPARISONS BETWEEN CARIBANA AND SIMILAR EVENTS IN BRITAIN AND OTHER PARTS OF THE AFRO-CARIBBEAN OIASPORA. IT SITUATES AN ANALYSIS OF CARIBANA WITHIN THE CONTEXT OF CANADA'S OFFICIAL 
COMMITMENT TO MULTICULLTURALISM ARGUING THAT THIS POLICY DEFINES THE TERMS ANO SETS THE LIMITS OF THE POLITICAL POTENTIAL OF CARIBANA HHICH ITS PARTICIPANTS CONSTANTLY THREATEN TO TRANSGRESS.

04745 JACKSON, $R$.

DIALECTICAL JUSTICE IN THE GULF WAR

REVIEW OF INTERNATIONAL STUDIES, 18(4) (OCT 92), 335-354. THAT JUSTICE IS CONSTITUTIVE OF SOCIAL LIFE GENERALLY AND THAT VARIOUS PRACTICES OF JUSTICE ARE OPERATIVE IN WORLD POLITICS IS ARGUED. NORMATIVE ISSUES ARISING FROM THE GULF WAR ARE USED TO ILLUMINATE THE ARGUMENT. THE AUTHOR'S APPROACH IS THAT OF A POLITICAL SCIENTIST AND NOT A MORAL PHILOSOPHER; HE IS MORE INTERESTED IN THE PRACTICES THAN THE THEORIES OF NORMATIVE INTERNATIONAL RELATIONS. HE CONCLUDES THAT WHETHER THE GULF WAR WILL MARK THE START OF UN GUARANTEED PEACE OR WILL BE A ONE OF A KIND EPISODE IS TOO EARLY TO SAY.

04746 JACKSON, R.A.

EFFECTS OF PUBLIC OPINION AND POLITICAL SYSTEM CHARACTERISTICS ON STATE POL ICY OUTPUTS

PUBLIUS: THE JOURNAL OF FEDERAL ISH, 22(4) (FAL 92), 31-46. RATHER THAN COMPETING WITH SOCIOECONOMIC VARIABLES AS DIRECT DETERMINANTS OF STATE POLICY, POL ITICAL SYSTEM CHARACTERISTICS MAY OPERATE AS MEDIATING FACTORS THAT EITHER FACILITATE OR IMPEDE THE TRANSLATION OF CONSTITUENCY PREFERENCES INTO POLICY. IN THIS STUDY, THE STATE OPINION LIBERALISH INDEX PRESENTED BY GERALD WRIGHT, ROBERT ERIKSON, AND JOHN MCIVER IS INCORPORATED IN MULTIPL ICATIVE REGRESSION MODELS AS A MEASURE OF CITIZEN PREFERENCES TO ADDRESS THIS THEORETICAL REFORMULATION. ALTHOUGH PERVASIVE EMPIRICAL CORROBORATION IS NOT FOUND FOR THE RECONCEPTUALIZED ROLE FOR POLITICAL VARIABLES, POLITICAL SYSTEM CHARACTERISTICS DO DEMONSTRATE SIGNIFICANT EFFECTS ON STATE POLICY. IN ADDITION, SUGGESTING THAT PUBLIC OFFICIALS RESPOND DIRECTLY TO CITIZEN PREFERENCES, EVIDENCE IS PRESENTED ON DEMOCRATIC REPRESENTATION WITHIN THE STATES.

04747 JACXSON, T.

A COUNTRY GOVERNED BY LACK OF INTEREST

WORLD PRESS REVIEW, 39(1) (JAN 92), 19-21.

AS A RESULT OF BEHIND-THE-SCENES POLITICAL BARGAINING, JAPAN'S PRIME MINISTER TOSHIKI KAIFU, WHO WAS VERY POPULAR WITH THE PUBLIC, HAS BEEN REPLACED BY KIICHI MIYAZAWA, ONE OF THE POLITICIANS IMPLICATED IN THE RECRUIT SCANDAL. THIS OF THE POL ITICIANS IMPLICATED IN THE RECRUIT SCANDAL. THIS
HAS RAISED SERIOUS QUESTIONS ABOUT THE HEALTH OF JAPANESE HAS RAISED SERIOUS QUESTIONS ABOUT THE HEALTH OF JAPAM
DEMOCRACY. AS THE COUNTRY ASSUMES A GREATER ROLE IN DEMOCRACY. AS THE COUNTRY ASSUMES A GREATER ROLE IN
INTERNATIONAL AFFAIRS, IT WILL HAVE TO MAKE HARD CHOICES. INTERMATIONAL AFFAIRS, IT WILL HAVE TO MAKE HARD CHOICES. POLITICAL REFORM SEEMS INEVITABLE IF JAPAN IS TO PLAY
ROLE MANDATED BY ITS STATUS AS AN ECONOMIC SUPERPOWER.

04748 JACKSON, $V$.

STATE SOVEREIGNTY AND THE ELEVENTH AMENDMENT IN THE U.S. SUPREMEM COURT: THE 1988 TERM

PUBLIUS: THE JOURNAL OF FEDERALISM, 22(1) (WIN 92), 39-54. DURING ITS 1988 TERM, THE U.S. SUPREME COURT ADDRESSED THO IMPORTANT ASPECTS OF THE ELEVENTH AMENDMENT, WHICH GENERALLY PROTECTS STATES FROM BEING SUED IN FEDERAL COURTS. FIRST THE COURT HELD THAT THE CONGRESS HAS POWER TO ABROGATE STATES' IMMUNITY FROM SUIT. SECOND, THE COURT MADE CLEAR THAT ABORGATION WOULD BE FOUND ONLY WHERE THE TEXT OF THE STATUTE ITSELF CLEARLY AND SPECIFICALLY SO PROVIDED. THIS ARTICLE DESCRIBES THESE DECISIONS, AND ANALYZES SOME OF THEIR IMPLICATIONS FOR JUDICIAL FEDERALISM.

04749 JACOB, J.R

THE POL ITICAL ECONOMY OF SCIENCE IN SEVENTEENTH-CENTURY ENGLAND

SOCIAL RESEARCH, 59(3) (FAL 92), 505-532.

THE VERY FIRST SCIENTISTS AND NATURAL PHILOSOPHERS WHO PROVIDED SCIENCE HITH ITS EXPERIMENTAL METHOD, ITS MECHANICAL ASSUMPTIONS, AND AN INSTITUTIONAL BASE IN THE ROYAL SOCIETY OF LONDON SAW THE LINKAGE BETWEEN SCIENCE AND THE ECONOMIC AND POLITICAL ORDER. BEGINNING HITH FRANCIS BACON IN THE EARLY SEVENTEENTH CENTURY, A TRADITION OF MORAL AND POLITICAL DISCOURSE EMERGED TO ADDRESS BASIC QUESTIONS REGARDING THE CREATION AND DISTRIBUTION OF WEALTH AND THE ROLE OF THE STATE IN RELATION TO PRIVATE PROPERTY. THIS TRADITION TOOK A CRUCIAL TURN IN RESPONSE TO WHAT ITS MIDCENTURY EXPONENTS REGARDED AS THE EXCESSES OF UTOPIANISM, CERRINGTONIANISM, AND HOBBISM. IN THE MID-SEVENTEENTH HARRINGTONIANISM, AND HOBBISM. IN THE MID-SEVENTEENTH CENTURY, ENGLISH MEN OF SCIENCE WERE DEEPLY CONCERNED WITH DEVISING A POLITICAL ECONOHY WHERE SCIENCE WOULD PLAY A KEY ROLE. ALTHOUGH THEIR THINKING IN CERTAIN BASIC RESPECTS
NOT CAPITALISTIC. THEY WORKED OUT THEIR OWN DISTINCTIVE ECONOMIC IDEOLOGY IN WHICH SCIENCE PLAYED A KEY ROLE.

04750 JACOBS, L.R.

INSTITUTIONS AND CULTURE: HEALTH POLICY AND PUBLIC OPINION IN THE U.S. AND BRITAIN

WORLD POLITICS, 44(2) (JAN 92), 179-209.

THE AUTHOR ARGUES THAT EXPLAINING INSTITUTIONAL DIFFERENTIATION REQUIRES THE INCORPORATION OF PUBLIC
PREFERENCES AND UNDERSTANDINGS INTO ACCOUNTS OF STATE DEVELOPMENT. USING PRIMARY EVIDENCE CONCERNING POLICY DISCUSSIONS AND PUBLIC OPINION, HE SUGGESTS THAT CULTURE DETERMINED THE SPECIFIC FEATURES OF BOTH THE BRITISH NATIONAL HEALTH SERVICE ACT OF 1946 AND THE AMERICAN MEDICARE ACT OF 1965, AS WELL AS THE DIFFERENCES BETWEEN THEM. EXAMINING THE INTERACT ION OF INSTI TUTIONS AND CUL TURE INSERTS DEMOCRATIC STANDARDS INTO THE TOP-HEAVY WEBERIAN DISCUSSIONS OF STATE AUTONOMY AND ACCOUNTS FOR THE SEEMINGLY INEXPLICABLE FAILURE OF POLICY MAKERS TO ENSURE COST CONTROL OVER THE HEALTH PROGRAMS.

04751 JACOBS, L.R.

THE RECOIL EFFECT: PUBLIC OPINION AND POLICYMAKING IN THE U.S. AND BRITAIN

COMPARATIVE POLITICS, 24(2) (JAN 92), 199-217.

THE GOVERNMENT HAS A DUAL CONCERN HITH RESPONDING TO AND SHAPING PUBLIC OPINION. USING ARCHIVAL EVIDENCE FROM AMERICAN PRESIDENTIAL LIBRARIES AND BRITISH CABINETS, THIS PAPER ARGUES THAT THE DEVELOPMENT OF A GOVERMMENT PUBLIC OPINION APPARATUS HAS HAD A RECOIL EFFECT IN BOTH COUNTRIES : OPINION APPARATUS HAS HAD A RECOIL EFFECT IN BOTH COUNTRIES : IN STRIVING TO HAVE AN OUTHARD EFFECT ON PUBLIC OPINION,
CREATION OF THIS APPARATUS HAS HAD THE INWARD EFFECT OF CREATION OF THIS APPARATUS HAS HAD THE INWARD EFFECT OF
HEIGHTENING SENSITIVITY TO PUBLIC OPINION. ALTHOUGH THE HEIGHTENING SENSITIVITY TO PUBLIC OPINION. ALTHOUGH THE
APPARATUS'S DEVELOPMENT AMID THE INSTITUTIONAL GUARANTEES OF APPARATUS'S DEVELOPMENT AMID THE INSTITUTIONAL GUARANTEES OF
LIBERAL DEMOCRACY HAS ENCOURAGED RESPONSIVENESS TO POPULAR LIBERAL DEMOCRACY HAS ENCOURAGED RESPONSIVENESS TO POPULAR PREFERENCES, THE GOVERNMEN
PUBLIC REMAINS A DANGER.

04752 JACOBS, $R$

DOING BUSINESS IN THE FORMER SOVIET UNION

MIDOLE EAST INSIGHT, VIII(4) (MAR 92), 60-62

THIS ARTICLE BRIEFLY RECOUNTS THE IMMENSE CHANGES THAT

HAVE TRANSFORMED THE SOVIET UNION AND HAVE LED TO ITS DEMISE. IT STATES THAT THE FIRST FLOWERS OF CAPITALISM ARE BLOOMING IN THE FORMER SOVIET UNION AND THAT OPPORTUNITIES FOR TRADE, INVESTMENT, AND BUSINESS EXIST. IT OFFERS SEVERAL GUIDING PRECEPTS TO THE WOULD-BE BUSINESSMAN: UNDERSTAND CLEARLY THE GOALS OF THE COMMERCIAL VENTURE; DO NOT LDOK FOR OVERNIGHT RETURNS: AND FIND THE BEST PARTNERS POSSIBLE-IN A COUNTRY HITHOUT LAHS, ONE MUST FIRST RELY ON PEOPLE.

04753 JACOBS, T.B.

EISENHOWER, THE AMERICAN ASSEMBLY, AND 1952

PRESIDENTIAL' STUDIES QUARTERLY, XXI' I (3) (SUM 92), 455-468.

THE AUTHOR EXAMINES OWIGHT D. EISENHOWER'S TENURE AS

PRESIDENT OF COLUMBIA UNIVERSITY, HIS YEARS AS HEAD OF NATO'S SUPREME HEADQUATERS ALLIED POWERS EUROPE (SHAPE), AND
HIS FOUNDING OF THE AMERICAN ASSEMBLY, WHICH BECAME A HIS FOUNDING OF THE AMERICAN ASSEMBLY, WHICH BECAME A
PLATFORM FOR HIS VIEWS AND A SOURCE OF ADVOCACY FOR HIS RUN PLATFORM FOR HIS VIEWS AND A SOURCE OF ADVOCACY FOR HIS
FOR THE PRESIDENCY. THE AUTHOR ALSO LOOKS AT THE 1952 FOR THE PRESIDENCY. THE AUTHOR

04754 JACOBS, $V$

GERMANY'S CHANCE TO BECOME TRAILBLAZER FOR STABILITY GERMAN TRIBUNE, 31 (1499) (JAN 92), 1 .

THE DISINTEGRATION OF THE SOVIET UNION AND OF YUGOSLAVIA HAS MADE IT CLEAR THAT REUNIFICATION HAS NOT CHANGED ONE OF THE BASIC CORNERSTONES OF GERMAN POLITICS: THE PRIORITY OF FOREIGN POLICY. THE CONTINENT CAN ONLY DEVELOP SUCCESSFULLY IF THE NEW STATES ON FORMERLY SOVIET TERRITORY ARE TIED INTO WESTERN EUROPE THROUGH A NETWORK OF AGREEMENTS GUARANTEEING LASTING STABILTIY. THE GERMAN GOVERMMENT MUST INSIST THAT THEY ARE ULTILIZED. IT MUST ASSUME THE ROLE OF TRAILBLAZER
BECAUSE THE MOST IMPORTANT PARTNERS ARE RESTRICTED IN THEIR BECAUSE THE MOST IMPORTANT PARTNERS ARE
ACTION BY DOMESTIC POLICY WEAKNESSES.

04755 JACOBSON, J.

NOTES ON SELF-DETERMINATION

NEW POLITICS, IV(1) (SUM 92), 49-59

THIS ARTICLE EXAMINES THE VIEHS OF THE AMERICAN LEFT ON NATIONALISM AND SELF-DETERMINATION. NATIONALISM IS MOST OFTEN CRITICIZED FOR BEING XENOPHOBIC, BIGOTED, ANTI-SEMITIC, AND VIOLENT. MOVEMENTS FOR SELF-DETERMINATION--A CENTRAL TENET OF MARXIST THOUGHT--ARE SIMILARLY REGARDED. THIS ARTICLE ARGUES THAT SUCH CRITICISM IS HYPOCRITICAL AND MISGUIDED. WHILE THE AMERICAN LEFT HAS QUICK TO LAMBAST THE BUSH ADMINISTRATION FOR ITS INVASION OF PANAMA, CRITICISM OF THE SOVIET MILITARY ACTIONS IN LITHUANIA WERE RELATIVELY IGNORED. ONE COLUMNIST WENT SO FAR AS TO OFFER MIKHAIL GORBACHEY SOME LESSONS FROM ABRAHAM LINCOLN ON THE GORBACHEV SOME LESSONS FROM ABRAHAM LINCOLN ON THE
DESIRABILITY OF DISCOURAGING SECESSION. THE ARTICLE DESIRABILITY OF DISCOURAGING SECESSION. THE ARTICLE
CONCLUDES THAT SELF-DETERMINATION IS NOT AN OUTDATED CONCEPT, CONCLUDES THAT SELF-DETERMINATION IS NOT AN OUTDATED CONCEPT
BUT A VITAL MOVEMENT WHICH ALL SOCIALISTS SHOULD SUPPORT.

04756 JAEGER, H.K

THE CAUSES OF AFRICA'S FOOD CRISIS

WORLD DEVELOPMENT, 20(11) (NOV 92), 1631-1645

THE AUTHOR SEEKS TO UNDERSTAND THE CAUSES OF AFRICA'S FOOD CRISIS BY EXAMINING PATTERNS OF FOOD IMPORTATION. THE ECONONETRIC RESULTS INDICATE THAT THE RISE IN FOOD IMPORTS DURING 1970-1987 CAN BE EXPLAINED BY A COMBINATION OF DEMOGRAPHIC, POLICY, AND ECONOMIC FACTORS THAT HAVE RAISED DOMESTIC DEMAND FOR IMPORTED FOOD. THESE FACTORS INCLUDE 
URBAN MIGRATION, PEAKS IN INCOME (ESPECIALLY DURING COMMOOITY BOOMS), LOWER INTERNATIONAL FOOD PRICES, AND DISTORTED EXCHANGE RATES. AFTER ACCOUNTING FOR THESE FACTORS, THE RESIDUAL TREND IN FOOD IMPORTS PER CAPITA IS NEGATIVE OVER THIS PERIOD. THE AUTHOR ALSO PRESENTS EVIDENCE SHOWING THAT, IN GHANA, POLICY REFORMS HAVE LED TO REVERSE MIGRATION FROM URBAN TO RURAL AREAS.

04757 JAFARZADEH, A.

IRANIAN DEMONSTRATIONS SIGNAL REGIME'S IMPENDING DOWNFALL WASHINGTON REPORT ON MIDOLE EAST AFFAIRS, XI(3) (AUG 92), 16, 18 .

IN IRAN, NATIONHIDE ANTI-GOVERMMENT PROTESTS ARE PRESENTING THE RULING MULLAHS WITH THEIR MOST SERIOUS CRISIS IN RECENT YEARS. ISLAMIC LEADERS ARE BLAMING THE PROTESTS LARGELY ON ECONOMIC PROBLEMS, BUT THE SLOGANS CHANTED BY LARGELY ON ECONOMIC PROBLEMS, BUT THE SLOGANS CHANTED
DEMONSTRATORS ("DEATH TO RAFSANJANI" AND "DEATH TO DEMONSTRATORS ("DEATH TO RAFSANJANI" AND "DEATH TO
KHAMENEI") GO BEYOND ECONOMIC DEMANDS AND UNDERLINE THE REJECTION OF THE ENTIRE REGIME.

04758 JAGGERS, $K$.

WAR AND THE THREE FACES OF POHER: WAR MAKING AND STATE MAKING IN EUROPE AND THE AMERICAS

COMPARATIVE POLITICAL STUDIES, 25(1) (APR 92), 26-62. VAN RAEMDONCK AND DIEHL SUGGEST THAT THE ANALYSES ON THE OUTCOMES OF WAR REPRESENT AN IMPORTANT BUT UNDERDEVELOPED SEGMENT OF PEACE RESEARCH. THIS PAPER TAKES THESE SUGGESTIONS SERIOUSLY AND EXAMINES THE IMPACT OF WAR ON STATE BUILDING USING A CROSS-SECTIONAL SAMPLE OF INTERSTATE AND 19 CIVIL WARS FROM 1815 TO 1954 , INVOLVING 28 EUROPEAN AND AMERICAN NATIONS. IT ADDRESSES CONCEPTUAL AND METHODOLOGICAL DEFICIENCIES IN THE LITERATURE WHICH LIMIT THE ABILITY TO UNTANGLE THEORETICALLY, AND TEST EMPIRICALLY, THE WAR-STATE-BUILDING RELATIONSHIP.

04759 JAHANPOUR, $F$.

THE ROOTS OF THE HOSTAGE CRISIS

WORLD TODAY, 48(2) (FEB 92), 33-36.

THE LAST OF THE U.S. HOSTAGES IN LEBANON WAS RELEASED AT THE END OF 1991. IT IS NOH QUITE CLEAR THAT THIS NASTY CHAPTER IN INTERHATIONAL RELATIONS HAD ITS ROOTS NOT IN LEBANON BUT IN THE VICTORY OF THE ISLAMIC REVOLUTION IN IRAN IN 1979. THE HOSTAGE CRISIS REPRESENTED THE PUBLIC AND MOST SENSATIONAL ASPECT OF A WAR THAT INYOLVED MANY COUNTRIES AND MANY INNOCENT VICTIMS BUT WAS BASICALLY A TEST OF STRENGTH
BETHEEN THE ISLAMIC REVOLUTION AND THE WEST, ESPECIALLY THE BETHEEN THE ISLA
UNITED STATES

04760 JAIMES, M. A. (ED.)

THE STATE OF NATIVE AMERICA--GENOCIDE, COLONIZATION, AND RESISTANCE

SOUTH END PRESS, 1991, 350.

THIS COLLECTION PRESENTS A SERIES OF ESSAYS BY NOTED AMERICAN INDIAN AUTHORS AND ACTIVISTS EXPLORING THE CIRCUMSTANCES CONFRONTED BY NATIVE PEOPLE IN THE CONTEMPORARY UNITED STATES. TOPICS DISCUSSED INCLUDE TREATY RIGHTS AND INTERMATIONAL STATUS, DEMOGRAPHY, LAND AND FISHING RIGHTS STRUGGLES, SELF-GOVERNANCE, IDENTITY, RELATIONSHIP TO FEMINISM, MILITARIZATION, ART AND LITERATURE, SPIRITUAL HUCKSTERISM, THE CASE OF LEONARD PELTIER, RESOURCE DEVELOPMENT AND URANIUM CONTAMINATION ON RESERVATIONS, RELIGIOUS FREEDOM AND THE SOCIO-CULTURAL IMPLICATIONS OF THE COLUMBUS QUINCENTENIARY CELEBRATION.

04761 JAKSIC, I.

ACADEMIC REBELS IN CHILE: THE ROLE OF PHILOSOPHY IN HIGHER EDUCATION AND POLITICS

STATE UNIVERSITY OF NEW YORK PRESS, , 1989, 259

THE PHILOSOPHERS' PRODUCTION CONŚT ITUTES A SUBSTANTIAL

PORTION OF THE INTELLECTUAL HISTORY OF CHILE AND LATIN AMERICA, THIS BOOK DESCRIBES IN DETAIL THE EVOLUTION OF PHILOSOPHICAL WORK IN CHILE, AND PAYS CLOSE ATTENTION TO THE RELATIONSHIP BETHEEN PHILOSOPHICAL ACTIVITY AND CONTEMPORARY SOCIAL AND POLITICAL EVENTS. VARIOUS CHILEAN PHILOSOPHICAL SOURCES ARE DISCUSSED FOR THE FIRST TIME IN THE LITERATURE ON CHILEAN IDEALS. THE WORK OF SUCH INTELLECTUALS AS ANDREAS BELLO, VALENTIN LETELIER, ENRIOUE MOLINA, JORGE MILLAS, JUAN RIVANO, JUAN DE DIOS VIAL LARRAIN, AND MANY OTHERS IS EXAMINED IN RELATION TO THE PRINCIPAL POLITICAL AND EDUCATIOHAL ISSUED OF THEIR TIME.

04762 JALALI, R.; LIPSET, S.M.

RACIAL AND ETHNIC CONFLICTS: A GLOBAL PERSPECTIVE POLITICAL SCIENCE QUARTERLY, 107(4) (WIN 93), 585-606. THE AUTHORS EXAMINE THE THIMG AND MATURE OF MODER ETHNIC CONFLICTS AND HOW THEY ARE MANAGED IN MULTI-ETHNIC POLITIES. THEY ARGUE THAT THE SAME CONDITIONS IN DIFFERENT COUNTRIES PRODUCE DIFFERENT RESULTS.

04763 JALONEN, 0 .; VESA, U.

SOMETHING OLD, SOMETHING NEW, SOMETHING BORROHED,

SOMETHING BLUE: FINLAND'S DEFENCE POLICY IN A CHANGING

SECURITY ENVIRONMENT

COOPERATION \& CONFLICT: NORDIC JOURNAL OF INTERNATIONAL
POLITICS, 27(4) (DEC 92), 377-395.

THE FORMULATION OF FINLAND'S MILITARY DOCTRINE IN THE POST-WWII ERA HAS BEEN RELATED TO THE MORE GENERAL PROBLEM OF FINNISH FOREIGN POLICY--ESPECIALLY HOW TO MAINTAIN GOOD RELATIONS WITHOUT BEING SUCKED INTO AN UNCOMFORTABLY CLOSE ORBIT HITH THE SOVIET UNION. WHILE THE MILITARY INSTRUMENTS OF SECURITY POLICY HAVE BEEN SECONDARY TO POLITICAL INSTRUMENTS, FINLAND HAS TRIED TO USE ITS LIMITED RESOURCES TO CREATE AN IMAGE OF CREDIBLE NATIONAL DEFENSE CAPABILITY. THIS GENERAL POLICY IS STILL BEING FOLLOWED, ALTHOUGH THE FUNDAMENTALS OF FINLAND'S SECURITY ENVIRONMENT HAVE DRASTICALLY CHANGED AND HILL CHANGE MORE AS A RESULT OF THE DEEPENING OF EUROPEAN INTEGRATION IN THE SECURITY AND FOREIGN POLICY SPHERES. FINLAND HAS CONSISTENTLY SPENT APPROXIMATELY $1.5 \%$ OF GOP IN MILITARY EXPENDITURES. THE APPROXIMATELY $1.5 \%$ OF GDP IN MILITARY EXPENDITURES. THE NIVEAU HAS BEEN A RESULT OF DOMESTIC BARGAINING, BUT AT THE
POLITICAL LEVEL THERE HAS BEEN CONSENSUS ABOUT IT. IN THE POLITICAL LEVEL THERE HAS BEEN CONSENSUS ABOUT IT. IN THE PRESSURES TO REDUCE MILITARY EXPENDITURES ARE INCREASING, ALTHOUGH NO MAJOR PEACE DIVIDEND IS EXPECTED.

04764 JAMES, A.

THE EQUALITY OF STATES: CONTEMPORARY MANIFESTATIONS OF AN ANCIENT DOCTRINE

REVIEH OF INTERNATIONAL STUDIES, 18(4) (OCT 92), 377-392.

THE INTERNATIONAL SOCIETY OF STATES IS IN SOME RESPECT A VERY PECUL IAR ONE. THE TERRITORIAL ENTITITES WHICH ARE ITS ESSENTIAL CONSTITUTENTS ARE ABOUT AS DIVERSE AS POSSIBLE IN TERMS OF SIZE AND STRENGTH. IN POINT OF STATUS THEY ARE DEEMED TO BE EQUAL. THIS ARTICLE SUGGESTS THAT ONE IMPORTANT ASPECT OF THIS HAS BEEN THE EXTENSION OF THE CONCEPT OF EQUALITY TO ENCOMPASS THE FORMAL RENUNICIATION OF MANY OF THE PRESSURES WHICH MIGHT BE THOUGHT TO BE NATURAL IN A SOCIETY WITHOUT A GOVERNMENT, AND IN WHICH THERE ARE HUGE IMBALANCES OF POWER BETWEEN ITS MEMBERS.

04765 JAMES, B.

PRESS' PARTICIPATION AS A CIVIL LIBERTY: THE MODEL OF ACADEMIC FREEDOM

JOURNAL OF COMMUNICATION, 41(1) (WIN 91), 31-52.

IN THIS ARTICLE, THE AUTHOR COMPARES AND CONTRASTS THE PRINCIPLES OF PRESS FREEDOM AND ACADEMIC FREEDOM IN BOTH ORIGIN AND PRACTICE TO EXPLORE THE POTENTIAL OF THE MODEL OF ACADEMIC FREEDOM FOR ENHANCING THE AUTONOMY OF JOURMALISTS. ACADEMIC FREEDOM FOR ENHANCING THE AUTONOMY OF JOURMALISTS.
THIS HISTORICAL AND PHILOSOPHICAL INVESTIGATION ASKS WHETHER THIS HISTORICAL AND PHILOSOPHICAL INVESTIGATION ASKS WHETHER
THE INDEPENDENCE AND COLLECTIVE STANDARDS OF INQUIRY AMONG THE INDEPENDENCE AND COLLECTIVE STANDARDS OF INQUIRY AMONG
SCHOLARS MIGHT PROVIDE A NEW WAY TO THINK ABOUT THE NATURE SCHOLARS MIGHT PROVIDE A NEW WAY TO THINK ABOUT THE NATURE
AND ORGANIZATION OF NEWSWORK THAT INCLUDES THE AUTONOMOUS INTELLECTUAL FREEDOM OF JOURNALISTS.

04766 JAMES, $C$

BANANA SPLITS

HEMISPHERE, 5(1) (FAL 92), 40-41.

CARIBBEAN BANANA PROOUCERS ARE BATTLING TO HOLD ONTO THEIR PREFERENTIAL ACCESS TO EUROPEAN MARKETS, WHICH IS JEOPARDIZED BY POLICIES RECENTLY ADOPTED BY THE EC COMMISSION. THE BANANA-EXPORTING COUNTRIES HAVE SOUGHT SUPPORT FROM THE UNITED STATES, WHERE PRESIDENT BUSH HAS BEEN SYMPATHETIC TO THEIR PLEAS WHILE SECRETARY OF STATE BAKER HAS NOT BEEN.

04767 JAMES, P.; HARVEY, F.

THE MOST DANGEROUSL GAME: SUPERPOWER RIVALRY IN

INTERNATIONAL CRISES, 1948-1985

THE JOURNAL OF POLITICS, 54(1) (FEB 92), 25-53.

THE PRESENT INVESTIGATION FOCUSES ON PATTERNS OF RESPONSE WHEN ONE SUPERPOWER IS FACED WITH A CRISIS RESULTING FROM A THREAT ATTRIBUTED TO THE OTHER. THE OBJECTIVE IS TO DETERMINE HHICH AMONG SEVERAL STRATEGIC OPTIONS CHARACTERIZES SUPERPOWER REACTIONS. SEVERAL MODELS FOR TRANSFORMING CONFLICT INTO COOPERATION ARE PRESENTED IN ABSTRACT TERMS. THESE MODELS ARE OPERATIONALIZED WITH AN EMPHASIS ON IDENTIFYING STRATEGIC OPTIONS THAT MIGHT BE PURSUED. DATA FROM THE INTERMATIONAL CRISIS BEHAVIOR PROJECT IS USED TO TEST THE PREDICTIVE POWER AND GENERAL RELEVANCE OF THE STRATEGIC OPTIONS DERIVED FROM THE MODELS. THE SIGNIFICANCE OF THE RESULTS AND DIRECTIONS FOR FURTHER RESEARCH IS DISCUSSED.

04768 JAMES, $H$.

MIGRATION, RACISM, AND IDENTITY: THE CARIBBEAN EXPERIENCE IN BRITAIN

NEW LEFT REVIEW, (193) (MAY 92), 15-55.

THE AFRO-CARIBBEAN EXPERIENCÉ OF OPPRESSION IN BRITAIN HAS HELPED TO SHAPE RESISTANCE AND FOSTER THE BIRTH OF A NEW IDENTITY FOR THIS GROUP. THE ORIGINAL CARIBBEAM MIGRANTS OF THE 1950'S AND 1960'S PROGRESSIVELY ABANDONED SOCIAL IDENTIFICATIONS BASED ON "PIGMENTOCRACY" AND ISLAND PARTICULARLISM AS THEY CAME TO TERMS WITH A SOCIETY THAT OFTEN BRANDED THEM "COLOURED" WHATEVER THEIR SHADE OR WESTERN INDIAN PROVENANCE. NEVERTHELESS, WHILE AFROCARIBBEANS HAVE DISCOVERED A LATENT SHARED IDENTITY IN BRITAIN, THERE ARE SIGNIFICANT AND, IN SOME CASES, GROWING BARRIERS TO SOLIDARITY BETWEEN THOSE OF AFRO-CARIBBEAN 
DESCENT AND THOSE WHOSE ORIGINS LIE IN INDIA, PAKISTAN, OR BANGLADESH. DIFFERENT RELIGIOUS TRADITIONS, DIFFERENT OCCUPATIONAL PROFILES, AND DIVISIVE STEREOTYPES ALL PLAY COMMON EXPERIENCE OF RACIAL OPPRESSION.

04769 JAMESON, L.; REISS, M.

THE NEW SOVIET UNION: AN UNFINISHED REVOLUTION RUSI JOURNAL, 136 (4) (WIN 91), 29-32.

THE ATTEMPTED COUP IN THE SOVIET UNION APPEARED TO FINALLY SIGNAL THE COLLAPSE OF COMHUNIST POWER AND TO HERALD IN A NEW AGE OF REFORM AND DEMOCRACY. THE AFTERMATH OF THE COUP HAS SHOWN, HOWEVER, THAT THERE CAN BE NO STRAIGHTFORWARD ANSWERS TO THE MYRIAD PROBLEMS OF THE CRUMBLING UNION FROM THE DISINTEGRATION OF CENTRAL AND LOCAL POWER STRUCTURES. THROUGH RISING CRIME AND THE GROWING INFLUENCE OF THE MAFIA, TO A CHAOT IC AND BANKRUPT ECONOHY. THE RESULTING INSTABILTIY POSES SERIOUS THREATS, NOT ONLY TO THE CENTER AND THE REPUBLICS, BUT ALSO TO EUROPE AND THE REST OF THE HORLD. THE AUTHORS ARGUE THAT IN ORDER TO ACHIEVE REFORMS, LEADERS MAY FIRST TURN TO AUTHORITARIAN ACHIEVE REFORMS, LEADERS MAY FIRST TURN TO AUTHORITARIAN
MEASURES BEFORE THE LONG SUFFERING SOVIET PEOPLE OVERCOME MEASURES BEFORE THE LONG SUFFERING SOVIET PEOPLE OVERCOME
THEIR INBRED INERTIA AND BEGIN TO TAKE INITIATIVES TO ALLEVIATE THEIR PREDICAMENTS THEMSELVES.

04770 JAMIESON, A.

IDENTITY AND MORALITY IN THE ITALIAN RED BRIGADES TERRORISM AND POLITICAL VIOLENCE, 2(4) (WIN 90), 508-520.
THE ARTICLE PROVIDES A BRIEF BACKGROUND TO THE ACTIVITIES OF THE ITALIAN RED BRIGADES, THEN EXAMINES THE GROUP'S DEVELOPMENT IN TERMS OF THREE PHASES--SOCIAL, EXISTENTIAL AND SURVIVALIST. A PERCEIVED SOCIAL AND POLITICAL IDENTITY IN THE EARLY 1970 S GAVE THE ORGANIZATION AN ILLUSORY SECURITY AND THE SELF-CONFIDENCE TO STEP UP THE ATTACK ON THE STATE. AS THE LEVEL OF VIOLENCE INCREASED THE BR BECAME SEPARATED FROM THEIR SOCIAL BASE AND CREATED AN AUTO-IDENTITY BASED ON SELF-DELUSION AND POLITICAL ALIENATION. ARMED STRUGGLE WAS SIMPLIFIED TO EXISTENTIAL ABSTRACTIONS OF MYTH AND SYMBOL. BY THE EARLY 1980 S THE EFFECTS OF LEGAL AND POLICE REPRESSION, POPULAR REJECTION AND INTERNAL CONFLICT REDUCED THE REMAINING MILITANTS TO A STRATEGY OF SIMPLE SURVIVAL. THE IRREVERS IBLE DEGENERATION OF THE GROUP'S MORALITY ACCOMPANIED THE PROCESS OF SOCIAL ESTRANGEMENT.

04771 JANACEK, $K$.

SURVEY OF MAJOR TRENDS IN 1991

RFE/RL RESEARCH REPORT, 1(12) (MAR 92), 31-32.

IN 1991 CZECHOSLOVAKIA'S TRANSITION FROM A SOVIET-STYLE COMMAND ECONOMY TO A MARKET CAPITALIST ONE GOT UNDER WAY. ALTHOUGH INFLATION SLOWED DRAMATICALLY AFTER THE LIBERALIZATION OF PRICES ON JANUARY 1, 1991, AND ALTHOUGH LI BERALIZATION OF PRICES ON JANUARY 1, 1991, AND ALTHOUGH THE BALANCES OF BOTH TRADE AND PAYMENTS WERE POSITIVE, THE RESTRICTIVE FISCAL AND MONETARY POLICIES THAT PRODUCED EXTERNAL SURPLUSES LED TO UNEMPLOYMENT ANO SUBSTANTIAL DECLINES IN OUTPUT, INVESTMENT, AND CONSUNPTION. THE COSTS
OF THE TRANSITION WERE BORNE DISPROPORTIONATELY BY SLOVAKIA.

04772 JANSEN, G.

AUTONOMY PLANS ON THE BOOKS
MIDDLE EAST INTERNATIONAL. (398) (APR 91), 8 .

ONCE THE KURDS RETURN TO IRAQ, THEY WILL HAVE TO ACCEPT THE FACT THAT THEY ARE A MINORITY UNDER AN ARAB REGIME IN BAGHDAD. THE RECENT REBELLION HAS GIVEN RISE TO TALK OF AUTONOMY FOR THE KURDS ONCE AGAIN. PREVIOUS PROMISES BY IRAO TO GRANT AUTONOMY TO THE KURDS IN 1970 AND 1974 HAVE PROVEN HOLLOW. HOWEVER, THE PLANS REMAIN ON THE BOOKS AND CAN BE REVIVED AND, IF' NECESSARY, REVISED.

04773 JANSEN, $G$.

IRAQ-DROUD AND DEFIANT

MIDDLE EAST INTERNATIONAL, (425) (MAY 92), 8-9

THE STRENGTH OF INJURED IRAQI PRIDE HAS RESULTED IN A REMARKABLE RECONSTRUCTION OF THE HAR-TORN COUNTRY. IRAO'S INFRASTRUCTURE IS BACK TO 70 PERCENT OF HHAT IT WAS. THE ROAD NETHORK HAS BEEN RENOVATED; OF THE 134 BRIDGES DESTROYED, 120 HAVE BEEN REPAIRED; ELECTRICITY SUPPLY, DOWN TO 15 PERCENT AT THE WAR'S END, IS BACX UP TO 90 PERCEMT IN BAGHDAD HERE A OUARTER OF THE COUNTRY'S POPULATIOH LIVE: AND 50 PERCENT OF THE THE WATER SUPPLY IS UNDER CONTROL THE MORALE OF THE PEOPLE SEEMS CORRESPONDINGLY IMPROVED. MOST MORALE OF THE PEOPLE SEEMS CORRESPONDINGLY IMPROVED
IRAOIS BLAME PRESIDENT BUSH AND THE HEST FOR THEIR

IRAQIS BLAME PRESIDENT BUSH AND THE HEST FOR THEIR
MISFORTUNES. THEY ARGUE THAT SADDAM HUSSEIN, DESPITE ALL HIS MISFORTUNES. THEY ARGUE THAT SADDAM HUSSEIN, DESPITE ALL HIS
FLAHS, IS BETTER THAN SOME UNKNOWN ALTERNATIVE. HOWEVER, THE FLAHS, IS BETTER THAN SOME UNKNOWN ALTERNATIVE. HOWEVER, THE FUTURE IS HORRYING. IRAQ HAS REACHED THE LIMIT CANHIBALIZATION.

04774 JANSEN, $G$.

ISLAMIC CONFERENCE: HHAT TO DO ABOUT BOSNIA?

MIDDLE EAST INTERNATIONAL, 439 (DEC 92 ). 12 .

THE EMERGENCY CONFERENCE OF THE FOREIGN MINISTERS OF THE 47 MEMBERS OF THE ISLAMIC CONFERENCE ORGANIZATION HAD ONLY ONE ITEM ON ITS AGENDA--BOSNIA. HOWEVER IT HAS TO DEAL HITH
A MUCH LARGER ISSUE: THE RELATIONSHIP OF THE MUSLIM WORLD WITH THE WEST. RELATIONS BETWEEN ISLAM AND THE WEST HAVE BEEN DETERIORATING BECAUSE MUSLIMS ARE CONVINCED THAT THE WORLD, OR WILL DO NOTHING TO HELP THOSE COUNTRIES WHEN THEY ARE IN DIFFICULTIES. BOSHIA IS CITED AS A PRIME EXAMPLE OF ARE IN DIFFICULTIE
BOTH APPROACHES

04775 JANSEN, G.

KEEPING OPTIONS OPEN

MIDDLE EAST INTERNATIONAL, (397) (APR 91), 13-14.

THE CONVENTIONAL WISDOM IS THAT SYRIA'S POSITION HAS BEEN GREATLY ENHANCED BY ITS PARTICIPATION IN ITS CAMPAIGN AGAINST IRAQ; BUT WHETHER THIS MEANS IT WILL BECOME A MAJOR POWER, A KEY FACTOR, IN THE REGIONAL EOUATION IS OPEN TO DOUBT. SYRIA WILL BECOAE ONE OF THE TWO MILITARY COMPONENTS, EGYPT BEING THE OTHER, OF THE NEW MIDDLE EAST SECURITY STRUCTURE THAT IS BEING PUT TOGETHER. BUT SOME INDICATE THAT SYRIA WILL NOT BE ABLE TO ESCAPE THE PERCEPTION OF BEING A "SOFT" STATE WITH AN UNPOPULAR MINORITY, THE ALAWITES,

RULING BY FORCE OVER A MAJORITY WHICH PARTICULARLY DISLIKES

THE PRESENT TURN IN THE POLICIES OF PRESIDENT HAFEZ AL-ASAD.

04776 JANSEN, G.

SOMALIA: AT LAST A READINESS TO HELP

MIDOLE EAST INTERNATIONAL, 440(440) (DEC 92), 7

THE ARAB COUNTRIES HAVE BEGUN TO TAKE AN INTEREST IN THE SOMAL IA OPERATION AFTER A PERIOD OF APPARENT INDIFFERENCE. MOST GDYERMMENTS SAID THEY WERE MOTIVATED BY HUMANITARIAN CONSIDERATIONS BUT A MORE REAL ISTIC AND SUBSTANTIAL CONSIDERATIONS BUT A MORE REALISTIC AND SUBSTANTIAL
CONSIDERATION IS THAT SOMALIA IS OF CONSIDRABLE STRATEGIC IMPORTANCE BECAUSE OF ITS GEOGRAPHIC SITUATION. FOR THE ARABS, US INTERVENTION IN SOMALIA IS INCREASINGLY LINKED WITH ITS NON-INTERVETION IN BOSNIA. THE RELATIVELY QUICK EFFECTIVENESS OF "PROVIDE HOPE" HAS REVIVED THE QUESTION OF WHY IT WAS NOT UNDERTAKEN SOONER?

04777 JANSEN, G.

SYRIA: ECONOMIC REVIVAL, POLITICAL STALEMATE

MIDDLE EAST INTERMATIONAL, (430) (JUL 92) 15.

THE ECONOMIC BOOM THAT SYRIA HAS BEEN ENJOYING FOR THE PAST NINE MONTHS IS SUFFICIENTLY STRONG--AND UNUSUAL--TO OFFSET THE POLITICAL SITUATION, WHICH, INTERNALLY, IS SOLIDLY FROZEN OVER AND, EXTERNALLY, IS ONE OF HOPEFUL EXPECTANCY. TWO DEVELOPMENTS HAVE SPARKED THE ECONOMIC BOOM. FIRST IS THE DEVELOPMENT OF OIL AND GAS FIELDS IN NORTHERN SYRIA WHICH HAS GIVEN THE GOVERNMENT AN ANNUAL INCOME OF $\$ 2$ BILLION, ENOUGH TO PAY FOR HALF OF THE COUNTRY'S IMPORTS. BILLION, ENOUGH TO PAY FOR HALF OF THE COUNTRY'S IMPORT
THE SECOND IS THE LIBERALIZATION OF FOREIGN CURRENCY

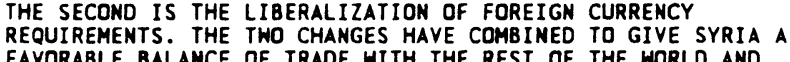
FAVORABLE BALANCE OF TRADE WITH THE REST OF THE HORLD AND HAS EASED THE UNEMPLOYMENT PROBLEM IN THE COUNTRY. ON THE POLITICAL FRONT THE REGIME IS FIRMLY ENTRENCHED IN POWER. THE SECURITY FORCES HAVE EFFECTIVELY SILENCED ANY AND ALL OPPOSITION. GENERAL ISLAMIC INFLUENCE IS ON THE RISE, BUT SYRIA S FUNDAMENTALIST MUSLIM BROTHERHOOD HAS REMAINED VERY QUIET AND CIRCUMSCRIBED. SYRIA'S EXIERNAL RELATIONS WITH ITS NEIGHBORS, MOST NOTABLY ISRAEL, HAVE IMPROVED IN THE GENERAL ATMOSPHERE OF COMPROMISE WHICH FOLLOWED THE ELECTION OF
YITZHAK RABIN TO THE POST OF PRIME MINISTER IN ISRAEL.

04778 JAMSEN, $G$

THE "AFGHANS" --AN ISLAMIC TIME BOMB

MIDDLE EAST INTERNATIONAL, 438)(438) (NOV 92), 16 '
MEMBERS OF THE ISLAMIC "INTERNATIONAL BRIGADE" RECRUITED FROM MANY MUSLIM COUNTRIES THAT FOUGHT ALONGSIDE THE AFGHAN MUJAHEDIN ARE NOW LOOKING FOR NEW JIHADS TO FIGHT. THE ANTIAMERICANISH OF THESE "AFGHANS" IS IRONIC BECAUSE IT WAS THE US, WORKING LOCALLY THROUGH SAUDI ARABIA, WHICH ENCOURAGED ARAB ISLAMISTS TO VOLUNTEER FOR SERVICE IN AFGHANISTAN IN THE '8OS. EVENTUALLY, THE US AMD SAUDI ARABIA MAY COME TO BE THREATENED DIRECTLY BY THEIR CREATION. IN THE MEANTIME IT IS OTHER GOVERNMENTS WHICH WILL HAVE TO TACKLE THIS ISLAMIC TIME BOMB.

04779 JANSEN, $G$.

THE GULF--WHO WILL PROTECT KUWAIT?

MIDDLE EAST INTERNATIONAL, (405) (JUL 91), 12

STRANGE AS IT MAY SEEM, THE EIGHT ARAB MEMBERS OF THE $U$. S. -LED ANTI-IRAQ COALITION ARE FINDING IT DIFFICULT TO PUT TOGETHER A MILITARY FORCE THAT WOULD HAVE THE SAME OBJECTIVE AS "DESERT SHIELD"--THE PROTECTION OF KUWAIT. DISAGREEMENTS AS "DESERT SHIELD"--THE PROTECTION OF KUWAIT. DISAGREEMENTS
OVER THE FORCE RANGE FROM DISPUTES OVER ITS COMPOSITION IALL OVER THE FORCE RANGE FROM DISPUTES OVER ITS COMPOSITION (ALL
ARAB VS. WESTERN PARTICIPATION), SCALE, AND PURPOSE (IS IRAQ ARAB VS. WESTERN PARTICIPATION), SCALE, AND PURPOSE (IS IRA
THE ENEMY OR IS IRAN?). MOST OBSERVERS OF THE NEGOTIATION PROCESS CONCLUDE THAT AN AGREEMENT IS UNLIKELY TO OCCUR IN PROCESS CONCLUDE

04780 JANSEN, G.

THE REALITY BEHIND THE CLICHES

MIDOLE EAST INTERNATIONAL (412) (NOV 91) 5-6.

STATEMENTS ABOUT THE MIDEAST PEACE CONFERENCE HELD IN

MADRID ARE A CONFUSING MIXTURE OF CLICHE AND ENCOURAGING NE

TRUTH. ONE THE ONE HAND. THE SEEMINGLY ENDLESS DECLARATIONS 
OF THE "HISTORIC" AND "UNPRECEDENTED" hatURE OF THE CONFERENCE ARE UNTRUE: ISRAEL MET WITH REPRESENTATIVES OF EGYPT, JORDAN, AND SYRIA AT THE END OF THE OCTOBER WAR IN 1973. FURTHERMORE, IT DOES NOT SEEM LIKELY THAT THE TALKS ARE "HISTORIC" BECAUSE THEY HILL IMPROVE THE CHANCES OF ARE HISTORIC BECAUSE THEY HILL IMPROY THE CHA FURTHER TALKS TAKING PLACE, ESPECIALL GIVEN PRIME MINISTER. BUT, ON THE OTHER HAND. THERE ARE SOME ENCDURAGING NEW BUT, ON THE DTHER HAND, THERE ARE SOME ENC THE ADVENT OF A RATIONAL, ELOQUENT, AND PERSUASIVE PALESTINIAN DELEGATION. RATIONAL, ELOQUENT, AND PERSUASIVE PALESTINIAN DELEGATION THAT ITS STATEMENTS WERE CARRIED BY MASS MEDIA TO ALL
CDRNERS OF THE HORLD WAS A GREAT BOON FOR THE CAUSE OF PALESTINAN INDEPENDENCE.

04781 JANSEN, G.

THREE TASKS AHEAD

MIDOLE EAST INTERNATIONAL, (397) (APR 91), 15.

LEBANON, ON THE SIDELINES OF THE SECOND GULF HAR, HAS BEEN QUIETLY MINDING ITS OWN BUSINESS AND TRYING TO GET ON WITH THE TASK OF SETTING ITSELF TO RIGHTS. ON THE LEVEL OF DAILY LIFE, CONDITIONS HAVE IMPROVED, BUT THE GOVERMMENT NOW HAS TO IMPLEMENT THREE DIFFICULT DECISIONS. THE FIRST IS TO COMPLETE THE DISBANDING AND DISARMING OF THE MANY MILITIAS AND FACTIONS; THE SECOND IS TO EXTEND THE AUTHORITY OF THE OVER ALI OF LEBANON: THE THIRD IS THE DECISION TO PROCEED WITH THE MOMINAIION OF FORTY NEW MEMBERS OF PARL IAMENT. MANY ARE OPTIMISTIC THAT THE "BALL IS ROLLING" AND THE FUTURE IS BRIGHTER THAN ANY RECENT PERIOD.

04782 JANSEN, $G$.

WHY A SHI ' ISTAN COULD NOT WORK

WHY A SHI ISTAN COULD NOT WORK (SEP 92), 10-11

THE FACTORS OF GEOGRAPHY, ECONOMICS AND DEMOGRAPHY THAT FAVORED THE ESTABL ISHMENT OF THE PRESENT SEMI-INDEPENDENT KURDISTAN, NORTH OF THE 36TH PARALLEL, WOULD WORK AGAINST KURDISTAN, NORTH OF THE 36TH PARALLEL, WOULD WORK AGAINST THE POSSIBLE CREATION OF A SEMI-INDEPENDENT SHI 'ISTAN, SOUTH OF THE 32ND PARALLEL. THE MOST OBVIOUS DIFFERENCE IS IN LOCATION AND SIZE. KURDISTAN IS IN THE FAR NORTH OF IRAQ REMOTE MOUNTAINS, BUT SHI ISTAN IS MUCH CLOSER YO BAGHOAD AND IS EASILY REACHED THROUGH A NETWORK OF COMMUNCATIONS. KURDISTAN IS 15,000 SQUARE MILES IN EXTENT, BUT A SHI COULD COMPRISE UP TO 54,000 SOUARE MILES. IN ADOITION, SHI 'ISTAN WOULD NOT BE AS RACIALLY HOMOGENEOUS AS THE KURDISH AREA. MOREOVER, BAGHDAD WOULD BE UNWILLING TO SEE UNDER SHI'ITE CONTROL. OTHER FACTORS WHICH MITIGATE AGAINST THE CREATION OF AN INDEPENDENT SHI'ISTAN INCLUDE THE THREAT OF IRANIAN DOMINATION AND THE COMPLICATION OF THE POSITION OF THE MILLIONS OF IRAQI SHI'ITES OUTSIDE THE BOUNDARIES OF A PROPOSED SHI'ISTAN.

04783 JANSEN, G.H.

IRAQ--DISPARATE OPPOSITION

MIDDLE EAST INTERNATIONAL, (428) (JUN 92), 11.

THE IRAOI OPPOSITION TO PRESIDENT SADDAM HUSSEIN IS NOT PROSPERING. A MEETING OF OPPOSITION GROUPS IN VIENNA IN THE THIRD WEEK OF JUNE WAS THINLY ATTENDED AND LITTLE NOTICED BY THE MEDIA. OF THE MOST IMPORTANT GROUPINGS, THOSE WITH A THE MEDIA. OF THE MOST IMPORTANT GROUPINGS, THOSE WITH A
BASE INSIDE IRAQ, ONLY JALAL TALABANI'S PATRIOTIC UNION OF KURDISTAN WAS PRESENT. THE ARE SEVERAL REASONS FOR THE
WEAKNESS OF THE OPPOSITION. THEY INCLUDE THE FACT THAT THERE WEAKNESS OF THE OPPOSITION. THEY INCLUDE THE FACT THAT ARE TOO MANY DIFFERNT GROUPS, 7 IN ALL; THAT THEY ARE UTTERLY DISPARATE--RANGING FROM COMMUNISTS THROUGH DISSIDENT BA'THISTS AND NASSERITE ARAB NATIONALISTS TO FUNDAMENTALISTS, SUNNI AND SHI'ITE; AND THE FACT THAT BOTH SYRIA AND SAU
ARABIA ARE DISTANCING THEMSELVES FROM THE CAMPAIGN TO ARABIA ARE DISTANCING THEMS
OVERTHROW SADDAM HUSSEIN.

04784 JANSEN, G.H.

THE UMH OASR TIME BOMB

MIDDLE EAST INTTRMATIOMAL, (420) (MAR 91), 8-9.

THE EAST INTERNATIONAL, 1420 ) (MAR 91 , 8 -9. HE GULF WAR TO DELIMIT THE BOUNDARY BETWEEN IRAQ AND KUQAIT IS SUPPOSED TO SETTLE AN INTERMATIONAL DISPUTE; INSTEAD, IT COULD TO SETTLE AN INTERNATIONAL DISPUTE; INSTEAD, IT COULD CONTENTION IS THE COMMERICAL PORT OF UMM OASR AND CONTENTION IS THE COMMERICAL PORT OF UMM QASR AND NEIGHBORING NAVAL FACILITIES. THE HIGHLY EXPLOSIVE ELEMENT IN THE UN COMMITTEE'S DELIMITATION IS THAT IT MOVES THE UMM QASR BOUNDARY TO THE NORTH, PUTTING MOST, IF NOT ALL, OF THE NAVAL AND COMMERICAL PORTS UNDER KUWAITI CONTROL. THIS ASTONISHING FINDING BECAUSE, DESPITE ALL THE DRAWH-OUT WRANGLING OVER THE IRAQ-KUWAIT BOUNDARY, KUWAIT HAS NEVER EVEN SUGGESTED THAT UMA OASR HAS IN KUWAIT. IRAQ, FEARING THE LOSS OF ITS ONLY ACCESS TO SEA AND THE LOSS OF BILLIONS THE UN RECOMMENDATION.

04785 JANSEN, $M$.

CYPRUS--BOUTROS GHALI'S "IDEAS"

MIDDLE EAST INTERMATIONAL, (423) (APR 92), 13-14.

ON 10 APRIL THE UN SECURITY COUNCIL ENDORSED THE REPORT OF SECRETARY-GENERAL BOUTROS GHALI ON HIS "MISSION OF GOOD OFFICES" IN CYPRUS AND HIS "SET OF IDEAS" FOR A POLITICAL
SETTLEMENT ON THE ISLAND, DIVIDED SINCE TURKEY OCCUPIED THE NORTH IN 1974. THE UN REAFFIRMED THE COUNCIL'S POSITION THAT THE SETTLEMENT MUST BE "BASED ON A STATE OF CYPRUS WITH A SINGLE SOVEREIGNTY AND INTERNATIONAL PERSONALITY AND A SINGLE CITIZENSHIP WITH ITS TERRITORIAL INTEGRITY

SAFEGUARDED, COMPRISING THO POLITICALLY EQUAL COMMUNITIES IN A BICOMMUNAL AND BI ZONAL FEDERATION."

04786 JANSEN, M.

CYPRUS: TOTAL DEADLOCK

MIDDLE EAST INTERNATIONAL, 438(438) (NOV 92), 15-16.

THE DEADLOCK BETWEEN THE UN SECRETARY GENERAL AND THE

TURKISH CYPRIOT LEADER WHICH CHARACTERIZED THE FIRST THO NEH

YORK ROUNDS OF TALKS ON A CYPRUS SETTLEMENT PERSISTED DURING THE THIRD ROUND WHICH CONVENED ON 28 OCTOBER AND ON 11 NOVEMBER WAS ADJOURNED UNTIL EARLY MARCH 1993. THE OBJECTIVE OF THESE ROUNDS WAS TO CONCLUDE A COMPREHENSIVE FRAMEWORK AGREEMENT FOR THE ESTABLISHMENT OF A BIZONAL, BICOMMUNAL FEDERAL REPUBLIC, BASED ON AN EQUAL PARTNERSHIP HITH A SINGLE SOVEREIGNTY AND INTERNATIONAL PERSONALITY AND A
SINGLE CITIZENSHIP. DIFFERENCES HAVE ARISEN BECAUSE THE UN AND THE TURKISH CYPRUS LEADERS HAVE CONFLICTING OBJECTIVES.

04787 JANYSKA, $P$

THE SCREENING ACT: IMPERFECT BUT RIGHT

EAST EUROPEAN REPORTER, 5(1) (JAN 92), 59-61.

BY FAR THE MOST CONTROVERSIAL LEGISLATION OF 1991 IN CZECHOSLOVAKIA WAS THE ACT PASSED IN OCTOBER PREVENTING CERTAIN POSITIONS IN STATE ADMINISTRATION FROM BEING HELD BY EX-EMPLOYEES OF THE SECRET POLICE OR FORMER SENIOR PARTY OFFICIALS. THE ACT WAS HOTLY DISPUTED AND ADDED TO THE COUNTRY'S POLITICAL POLARIZATION. THIS ARTICLE DEFENDS THE "SCREENING ACT." IT ARGUES THAT THE PURPOSE OF THE SCREENING ACT IS TO PROTECT THE CIVIL SERVICE AND OTHER STATE BODIES FROM FLAGRANTLY UNDEMOCRATIC FORCES. FURTHERMORE, IT CAN ALSO BE SEEN AS A PROVISIONAL ATTEMPT TO PASS JUDGMENT ON THE HHOLE PRECEDING ERA. TO SOME EXTENT, THIS MAKES THE ACT SOMETHING OF A HYBRID SUBSTITUTE FOR SOMETHING THAT SHOULD SOMETHING OF A HYBRID SUBSTITUTE FOR SOMETHING THAT SHOU EXPLICIT CONDEMNATION OF THE FORMER REGIME'S IDEOLOGY, AN ASSESSMENT OF GUILT AND INNOCENCE.

04788 JARBAHI, A.; HEACOCK, $R$.

WIMDS OR HAR, WINDS OF PEACE

MIODLE EAST REPORT, 22(2) (MAR 92), 12-16

THE CURRENT DEBATE IN THE OCCUPIED TERRITORIES PREDATED U.S. SECRETARY OF STATE JAMES BAKER'S TRIPS TO THE MIDOLE EAST REGION BY SEVERAL MONTHS. IT STARTED WITH THE OUTBREAK OF THE GULF CRISIS IN AUGUST 1990 AND EMERGED INTO THE OPEN VIRTUALLY ON THE DAY THE CEASE-FIRE CAME INTO EFFECT IN LATE FEBRUARY 1991. IT CONCERNED PROCEDURE AND SUBSTANCE, AND WAS MIRRORED BY AN EQUALLY INTENSE DEBATE ON THE "OUTSIDE"--THE PLO IN TUNIS, THE REFUGEE CAMPS IN THE ARAB COUNTRIES, AND THE PALESTINIAN DIASPORA AS A WHOLE. THIS ARTICLE CHRONICLES VARIOUS ORGANIZATIONS CLAIMING TO REPRESENT THE PALESTINIAN PEOPLE (INCLUDING THE PLO, THE DEMOCRATIC FRONT FOR THE LIBERATION OF PALESTINE (DFLP), THE PALESTINE COMMUNIST PARTY (PCP) AND THE POPULAR FRONT FOR THE LIBERATION OF PALESTINE (PFLP)). IT OUTLINES THE STEPS TAKEN TO FACILITATE THE HOLDING OF AN INTERNATIONAL PEACE CONFERENCE AND THE RESPONSE TO THE PEACE TALKS OF VARIOUS PALESTINIAN ORGANIZATIONS, FACTIONS, AND MOVEMENTS.

04789 JASIEWICZ, K.

FROM SOLIDARITY TO FRAGMENTATION

JOURNAL OF DEMOCRACY, 3(2) (APR 92), 55-69.

IN POLAND, THE DEEP SPLIT IN SOLIDARITY WHICH HAS BEGUM TO APPEAR IN THE 19905 HAD ITS ROOTS BEGINNING AS EARLY AS 1981. THE APPEARANCE OF UNITY WHICH HAS CONCEALED GROWING DIVISIONS IS BECOMING MORE VISIBLE AS TIME GOES ON. THIS ARTICLE EXPLORES: SOLIDARITY SPLTS IN THO; THE POSTSOLIDARITY ERA; POST-SOLIDARITY ORGANIZATIONS; THE IMPACT THE ELECTORAL SYSTEM; AND, WHY THE PARTIES ARE SO WEAK. POLAND S HEH DEMOCRACY IS ABOUT TO CONFRONT MANY CONSTITUTIONAL CHOICES. AMONG THESE, TWO STAND OUT AS CRUCIAL: WHETHER TO OPT FOR PARLIMENTARY AS OPPOSED TO PRESIDENTIAL GOVERNMENT, AND WHETHER TO SELECT PROPORTUNATAL

04790 JASIEHICZ, K.

POLAND

EUROPEAN JOURNAL OF POLITICAL RESEARCH, 22(4) (DEC 92),

489-504.

THE AUTHOR SUMMARIZES THE RESULTS OF POLAND'S 1991 SEJM ELECTIONS AND DISCUSSES THE POLITICAL CHANGES UNDERWAY IN THE FORMER COMMUNIST COUNTRY.

04791 JASPER, J.M. THE POLITICS OF ABSTRACTIONS: INSTRUMENTAL AND MORALIST RHETORICS IN PUBLIC DEBATE

SOCIAL RESEARCH, 59(2) (SUM 92), 315-344.

IN POLITICAL ARGUMENT INDIVIDUALS ATTEMPT TO PERSUADE OTHERS BY FINDING ASSUMPTIONS AND GROUNOS THAT CANNOT BE 
QUESTIONED. OFTEN THE MOST COMPELLING ASSUMPTIONS ARE THOSE THAT APPEAR TO BE BEYOND HUMAN CONTROL, SOMETIMES CALLED "GOD TERMS" BECAUSE THEY CAMNOT BE CHALLENGED OR REDUCED TO OTHER IDEAS. THESE UNQUESTIONED RHETORICAL REFERENCE POINTS ARE TYPICALLY QUITE ABSTRACTED FROM DAILY LIFE. MOST CAN CATEGORIZED AS EITHER MORALIST OR INSTRUMENTAL. IN THIS SIMILARITIES BETWEEN THESE THO FAMILIES OF RHETORICAL TOOLS. HE USES CASE STUDIES OF SEVERAL CONTROVERSIES--OVER FRANCE'S ENERGY SUPPLY, ABORTION, AND POLLUTION TAXES--TO SHOW HOW THESE GOD TERMS SHAPE POLITICAL DEBATES.

04792 JASTRON, R.: KAMPELMAN M.

WHY HE STILL NEED SOI

COMMENTARY, 94(5) (NOY 92), 23-29.

HOW TO ACHIEVE GLOBAL PROTECTION AGAINST MISSILE ATTACKS HITHOUT THREATENING THE SECURITY INTERESTS OF ANY NATION MAY WELL TURN OUT TO BE A MORE DIFFICULT CHALLENGE THAN THE SCIENTIFIC AND ENGINEERING TASKS THAT NOH APPEAR UMDER CONTROL. THIS ARTICLE SUGGESTS THAT UNLESS THAT CHALLENGE CAN BE MET, AND UNLESS THE ASSAULT ON SDI CAN BE OVERCOME, CAN BE MET, AND UNLESS THE ASSAULT ON SOI CAN BE OVER VULMERABLE TO OUR ONN FORCES OVERSEAS HILL BE LEFT VULNERABLE TO A DEVASTATING THREAT. IT CONCLUDES THAT THE DEFENSES DEVELOPED BY SOI
OF THE NEW WORLD ORDER.

04793 JAKARA, A.

THE COMMONWEALTH AND HUMAN RIGHTS

ROUND TABLE, 321(321) (JAN 92), 37-42.

HUMAN RIGHTS IS DESCRIBED AS THOSE BASIC FUMDAMENTAL RIGHTS TO BE ENJOYED BY ALL IRRESPECTIVE OF RACE, COLOR, CREED, GENDER, SOCIAL STATUS, OR COUNTRY OF ORIGIN. THE' DEMAND FOR HUMAN RIGHTS AND DEMOCRACY IN AFRICA IS STUDIED AS WELL AS EXPERIENCES OF ONE-PARTY RULE. THIS ARTICLE SUGGESTS THAT THE STARTING POINT MUST BE TO REAFFIRM THE AFRICAN'S STRONG COMMITTMENT TO THE RESPECT FOR HUMAN RIGHTS AND THE RULE OF LAN. IT EMPHASIZES THE NEED TO FIND FORMULA FOR MAKING HUMAN RIGHTS EMFORCEABLE, BECAUSE ONE OF THE REASOMS FOR THE FAILURE OF HUMAN RIGHTS PROTECTION IS THE ABSEMCE OF EFFECTIVE MACHIMERY DESIGMED TO ENSURE THAT THE RIGHTS GUARANTEED WILL BE RESPECTED.

04794 JEFFERSON, N.

THE WAR WITHIM

AFRICA REPORT, 37(1) (JAN 92), 62-64.

WAR CONTINUES IN NORTHERM RHANDA DESPITE A MASSIVE GOVERMMENT CRACKDOWN ON THE TUTSI, THE DISSIDENTS, HUMAN

RIGHTS ACTIVISTS, AND OTHERS SUSPECTED OF SYMPATHIZING WITH THE REBEL FORCES. LOCAL OFFICIALS FREOUENTLY INCITE THE HUTU MAJORITY TO ATTACK OR KILL THEIR TUTSI NEIGHBORS. EVEN THOUGH OPPOSITION PARTIES HAVE BEEN LEGALIZED, THE POLITICAL SITUATION IN RWANDA REMAINS GRIM.

04795 JEFFERY, L.

THE END OF COMMUNISM: CHAPTER II--A REPORT OF A SYMPOSIUH WORLD AFFAIRS, 154 (4) (SPR 92), 125-135

THREE YEARS AFTER THE TIANAMMEN MASSACRE, REPORTS INDICATE THAT CHINA IS CARRYING ON WITH SUCCESSFUL ECONOMIC REFORMS DESPITE THE POLITICAL AND ECONOMIC BACKLASH OF POST1989. HOWEVER IT IS BELIEVED THAT CHINA FACES A POLITICAL, ECONONIC, CULTURAL AND SPIRITUAL CRISIS OF VAST PROPOSTIONS. AFTER FOUR DECADES THE SYSTEM IS BANKRUPT. THIS ARTICLE EXAMINES STATE-OWNED INDUSTRY, THE PEASANTRY AMD THE NEW
PROLETARIAT, GROWING DIVERSITY, POPULAR CULTURE, THE UNDERGROUND AND THE TRANSITION' TO DEMOCRACY.

04796 JEFFREY-POULTER, $S$.

PEERS, QUEERS AND COMMONS: THE STRUGGLE FOR GAY LAW REFORM FROM 1950 TO THE PRESENT

ROUTLEDGE, 1991, 296.

THIS BOOK TRACES ONE ASPECT OF THE SHIFT IN BRITISH ATTITUDES TOWARDS HOMOSEXUALITY: THE TEDIOUS, LIMITED, BUT ESSENTIAL EFFORT TO REFORM THE LAW. UNTIL 1967 ALL FORMS OF MALE HOMOSEXUAL ACTIVITY WERE ILLEGAL, HHETHER IN PUBLIC OR PRIVATE. LESBIANISM EXISTED IN A SORT OF LEGAL LIMBO. THE POST-HOLFENDEN REFORMERS EXERTED ENORMOUS ENERGY THROUGH CLASSIC PRESSURE-GROUP ACTIVITY TO GET THE OLD LAWS CHANGED. WHILE IN SIMPLE LEGAL TERMS THE RESULTS WERE EXTREMELY LIMITED, THEY HAD TREMENDOUS SYMBOLIC IMPORTANCE BOTH TO THE LESBIAN AND GAY COMMUNITY ITSELF. AND TO THE MORAL

CONSERVATIVES WHO ROSE TO PROMINENCE IN THE $1980 \mathrm{~S}$.

04797 JELEN, T.

POL ITICAL CHRISTIANITY: A CONTEXTUAL ANALYSIS

AMERICAN JOURNAL OF POLITICAL SCIENCE, 36(3) (AUG 92),

IN THIS PAPER, AN ATTEMPT IS MADE TO ASSESS THE RELATIVE IMPORTANCE OF INDIVIDUAL ATTRIBUTES AND CONGREGATIONAL-LEVEL CONTEXTUAL VARIABLES IN EXPLAINING SUPPORT FOR NEW CHRISTIAN RIGHT FIGURES AND FOR THE REPUBLIC PARTY. USING DATA GATHERED FROM 14 RURAL MIDWESTERN CHURCHES, THE ANALYSIS SUGGESTS THE FOLLOHING: CONTEXTUAL EFFECTS ARE IMPORTANT AND OFTEN ARE STRONGER THAN THE EFFECTS OF INDIVIDUAL-LEVEL VARIABLES; THE UNIQUE EFFECTS OF CONTEXTUAL-LEVEL VARIABLES
ARE OCCASIONALLY NEGATIVE, SUGGESTING THAT SIMPLE SOCIAL LEARNING MODELS OF CONTEXTUAL EFFECTS MAY BE INADEQUATE; AND CONTEXTUAL EFFECTS ARE LIKELY TO BE WEAKER AT SIMPLER LEVELS OF CONCEPTUALIZATION.

04798 JELEN, T.; HILCOX, C.

THE EFFECTS OF RELIGIOUS SELF-IDENTIFICATION ON SUPPORT FOR THE NEW CHRISTIAN RIGHT: AN ANALYSIS OF POLITICAL ACTIVISTS

SOCIAL SCIENCE JOURNAL, 29(2) (1992), 199-210.

USING DATA FROM A MAIL SURVEY OF REPUBLICAN CONTRIBUTORS, THE EFFECTS OF RELIGIOUS SELF-IDENTIFICATIONS ON ATTITUDES TOWARD CHRISTIAN RIGHT OBJECTS MORAL MAJORITY AND PAT ROBERTSON WERE EXAMINED. AS EXPECTED, MORAL MAJORITY DREW BEST AMONG SELF-IDENTIFIED FUNDAMENTALISTS, WHILE ROBERTSON BEST AMONG SELF-IDENTIFIED FUNDAMENTALISTS, WHILE ROBERT WAS MOST POPULAR AMONG CHARISHATIC IDENTIFIERS. MULTIPLE IDENTIFIERS WERE SLIGHTLY LESS LIKELY TO SUPPORT EITHER CHRISTIAN RIGHT OBJECT THAN IDENTIFIERS WITH A SINGLE THEOLOGICAL TRADIIIION.
POLITICS ARE DISCUSSED.

04799 JENKINS, H.

EARLY RETIREMENT

INSIGHT, 7(5) (FEB 91), 36-37

THE RESIGNATION OF SOVIET FOREIGN MINISTER EDUARD SHEVARDNADZE HAS WORRIED THE WEST, BUT HAS PROVED TO BE A MORALE BOOSTER FOR SOVIET ALLIES IN THE THIRD WORLD. HE HAD BECOME A SYMBOL OF THE CHANGED THINKING THAT REDUCED THE FLOW OF AID AND HEAPONS TO THEM. HOHEVER, IT REMAINS TO BE SEEN WHETHER HIS DEPARTURE WILL REVERSE THAT TREND. ALTHOUGH HARD-LINE FACTIONS ARE GAINING CONTROL OF THE SOVIET GOVERMMENT, THE PRESSING URGENCY OF DOMESTIC CONCERNS HILL LEAVE LITTLE SURPLUS TO GIVE TO FRIENDS AND NEIGHBORS.

\section{JENKINS, $H$.}

ENDGAME?

INSIGHT, 7(5) (FEB 91), 8-12.

IN THE OPENING DAYS OF THE PERSIAN GULF WAR, IRAO'S MILLION MAN ARMY HAS SHOWN ITS CAPABILITIES TO BE LIMITED. THE AIR SUPERIORITY OF THE ANTI-IRAQ COALITION HAS SEVERED THE SPINE OF THE IRAOI STATE AND VICTORY APPEARS INEVITABLE. HOW THE TRIUMPH WILL COME ABOUT--WHETHER THROUGH NEGOTIATED SETTLEMENT, SADOAM HUSSEIN'S DEATH OR SOME OTHER MEANS--WILL SETTLEMENT, SADDAM HUSSEIN'S DEATH OR SOME OTHER MEANS-SHAPE THE FUTURE BALANCE OF POWER IN THE REGION. SADDAM HUSSEIN'S HOPE OF DRAWING THE
WAR SEEMS TO BE DIMINISHING.

04801 JENKINS, $H$.

LOOKING AHEAD

LOOKING AHEAD

WITH'THE RUSH OF ALIED FORCES ACROSS THE BORDER INTO KUWAIT AND SOUTHERN IRAQ. DESERT STORM'S ENDGAME BEINGS IN EARNEST. THE CRUCIAL QUESTION NOW BECOMES THE FUTURE OF IRAQ AND OF SADDAH HUSSEIN. IRAQ IS CURRENTLY A VOLATILE MIX OF GROUPS WHOSE NEIGHBORS VIE TO BE THE REGION'S NEXT BIG POWER. ULTIMATELY, SAUDI ARABIA AND KUWAIT MAY SEEK SHELTER UNDER THE U.S. UMBRELLA, AND--IRONICALLY--SO MAY IRAQ.

04802 JENKINS, $\mathrm{H}$.

NOT SO PACIFIC

INSIGHT, 7(2) (JAN 91), 26-28.

WITH THE DECLINE OF U.S. AND SOVIET MAVAL POWER IN THE ASIA-PACIFIC REGION AND UNRESOL VED DISPUTES IN NEIGHBORING COUNTRIES, THE CHINA SEA HILL UNDERGO SOME CHANGES. AT STAKE ARE SEVERAL GROUPS OF TINY, RELATIVELY UNKNOWH ISLANDS WITH INCREDIBLE IMPLICATIONS FOR CONTROL OF VITAL SEA LANES AND RESOURCES. THE REGION'S MIDDLE PONERS-INDIA, CHINA, AND JAPAN--MAY VIE FOR A DOMINANT ROLE IN POLICING THE WATERS. BUT THE COST OF DEFENSE IN A GRID OF COMPLEX ALLEGIANCES MAY BE PROHIBITIVE, AND A FORMAL MILITARY ALLIANCE IS UNLIKELY.

04803 JENKINS, $\mathrm{H}$.

SOONER THAN 1997?

INSIGHT, 7(7) (FEB 91), 36 .

KONG, AND A RESTIVE BEIJING IS PRESSURING FOR CONTROL FAR IN ADVANCE OF THE AGREED 1997 TURNOVER. BRITAIN'S PLAN TO BUILD A NEW AIRPORT IN THE COLONY HAS CHINESE LEADERS NERVOUS HITH FEARS THAT THE IMMENSE PROJECT COULD SUCK THE COLONY'S YAST

CASH RESERVES DRY AND UNDERMINE THE HONG KONG DOLLAR.

04804 JENKINS, $H$.

WHO PAYS?

INSIGHT, 7(8) (FEB 91), 13-15.

CONTRARY TO PAST U.S. MILITARY FORAYS, WASHINGTON'S FRIENDS IN THE PERSIAN GULF CONFLICT ARE FINDING PLENTY OF REASONS TO ANTE UP TO THE TUNE OF $\$ 51$ BILLION. GIVEN THIS, THE WHITE HOUSE, WITH ADROIT BUDGET FIGURES AND PLANS FOR SHAVING DEFENSE, IS WAGING A WAR HITH FINANCIAL ZEST. BUT THE BOTTOM-LINE SQUABBLING IS YET TO COME AND STILL COULD TEST THE FRAGILE HESTERN TOGETHERNESS.

04805 JENKINS, J.; KPOSOWA, J.

THE POLITICAL ORIGINS OF AFRICAN MILITARY COUPS: ETHNIC 
COMPETITION, MILITARY CENTRALITY, AND THE STRUGGLE OVER THE POSTCOLONIAL STATE

INTERMATIONAL STUDIES QUARTERLY, 36(3) (SEP 92), 271-292. MILITARY INTERVENTIONS ARE STRATEGIC IN UNDERSTANDING "HO GETS WHAT, WHEN AND HOW" IN POSTCOLONIAL AFRICA. BUILDING ON PAST STRUCTURAL EXPLANATIONS OF AFRICAN COUPS THE AUTHORS EXAMINE TWO HAVES OF MILITARY INTERVENTIONS AND THE AUTHORS EXAMINE TWO HAVES OF MILITARY INTERVENTIO DIFFERENT TYPES OF COUP EVENTS, AS WELL AS ANALYSIS. THEY INTENSITY INDEX, THE TRADIIIONAL FOCUS OF ANALYSIS. THEY FIND STRONG SUPPORT FOR MILITARY CENTRAL ITY AND THEORIES OF ENTHNIC PLURALITY AND COMPETITION. THEY SUGGEST THAT FUTURE WELL AS CIVILIAN GOVERHMENTS.

04806 JENMAR, R.

BLUEPRINT FOR MORE CONFLICT

FAR EASTERN ECONOMIC REVIEW, 151(19) (MAY 91), 26-27.

THIS ARTICLE EXAMINES THE UNITED NATION'S MOST RECENT PEACE PROPOSAL DESIGNED TO END TWENTY YEARS OF CIVIL WAR IN CAMBODIA. IT ARGUES THAT THE DOCUMENT IS UNBALANCED AND DANGEROUS. IT FAILS TO ADDRESS CAMBODIAN FEARS THAT PEACE COULD BRING WITH IT WORSE EVILS THAN WAR; THE EVILS MOST FEARED ARE THE RETURN OF THE KHMER ROUGE TO POWER AND CONTINUED VIETNAMESE INFLUENCE ON CAMBODIA. THE FACT THAT THE PACIFICATION PROCESS IS VOLUNTARY IS A KEY WEAKNESS OF THE PLAN; THE KHMER ROUGE IS UNLIKELY TO VOLUNTARILY DISARM. THE ARTICLE CONCLUDES WITH PROPOSED AMENDMENTS AND REFORMS FOR THE PLAN.

04807 JENNINGS, M.K.

IDEOLOGICAL THINKING ABOUT MASS PUBLICS AND POLITICAL ELITES

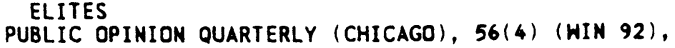

419-441.

ALTHOUGH THE CHARACTERIZATION OF THE GENERAL PUBLIC'S EYEL OF ATTITUDIMAL CONSTRAINT AND CONTINUITY AS "MODEST" HAS RESTED IN PART ON ASSUMED CONTRASTS WITH POLITICAL ELITES, THERE ARE SCARCELY ANY SYSTEMATIC, PARALLEL STUDIES OF THE THO POPULATIONS. IN THIS PAPER, THE AUTHOR UTILIZES COMPARABLE MEASURES FROM CROSS-SECTIONAL AND PANEL SURVEYS INCLUDED IN THE NATIONAL ELECTION STUDIES AND THE NATIONAL CONVENTION DELEGATE STUDIES. OVERALL, HE FINDS THAT POLITICAL PARTY ELITES HAVE A VASTLY MORE CONSTRAINED AND STABLE SET OF POLITICAL PREFERENCES--IN TERMS OF THE TRADITIONAL LIBERAL-CONSERVATIVE DIMENSION-THAN DOES THE MASS PUBLIC, A CONCLUSION THAT APPLIES WHETHER THE TEST IS A DEMANDING ONE BASED ON OPINIONS ABOUT POLICY ISSUES OR A LESS STRINGENT ONE BASED ON APPRAISALS OF SOCIO-POLITICAL GROUPS AND PROMINENT POLITICAL ACTORS. STRATIFYING THE MASS PUBLIC ACCORDING TO LEVEL OF POLITICAL ACTIVITY GENERATES CLEAR, STEP-LIKE DIFFERENCES IN CONSTRAINT AND CONTINUITY, BUT IDEOLOGICAL CONSISTENCY AMONG PARTY ELITES SUBSTANTIALLY EXCEEDS THAT OF EVEN THE MOST ACTIVE STRATUM OF THE MASS PUBLIC. THESE RESULTS DEMONSTRATE THAT, HOWEVER FLAWED THE STANDARD SURVEY INSTRUMENT MAY BE AS A MEANS OF ASCERTAINING IDEOLOGICAL THINKING IT PERFORMS EXCEEDINGLY WELL IN MAKING THE KIND OF DISTINCTIONS TO BE EXPECTED ON A PRIORI GROUNDS.

04808 JENNINGS, $P$

FIGHTING SMALL HARS IN THE SOUTH PACIFIC: THE NEW ZEALAND DEFENSE FORCE'S CAPABILTIES AND LIMITATIONS

SMALL WARS \& INSURGENCIES, 1 (3) (DEC 90), 276-302

SMALL WARS \& INSURGENCIES, 1 (3) (DEC 90), $276-302$. MILITARY EXERCISES HAVE BEEN PARTICULARLY IMPORTANT IN DEVELOPING AN UNDERSTANDING OF THE DEMANDS WHICH WILL BE PLACED ON AUSTRALIA OR NEW ZEALAND IF THEY DEPLOY FORCES ON ACTIVE OPERATIONS IN THE SOUTH PACIFIC. THE PURPOSE OF THIS ARTICLE IS TO CONSIDER THE LESSONS WHICH HAVE EMERGED FOR THE NEW ZEALAND DEFENSE FORCE AS A RESULT OF EXERCISE GOLDEN FLECE, HELO IN INVOLVED DEPLOYING NEW ZEALAND FORCES TR A FY WAR. THE PACIFIC ISLAND TO FIGHT A COUNTER-INSURGENCY WAR. THE LN MILITARY PLANNING IN THE 19905 .

04809 JENHINGS, $R$.

AN EXPANDING COURT

WORLD TODAY, 48(3) (MAR 92), 44-47

THE AUTHOR EXPLAINS THE COMPOSIIION OF THE INTERNATIONAL COURT OF JUSTICE AT THE HAGUE, LISTS SOME OF ITS MAJOR PENDING CASES, AND DISCUSSES ITS ROLE IN INTERNATIONAL AFFAIRS.

04810 JENSEN-BUTLER, C

RURAL INDUSTRIALIZATION IN DENMARK AND THE ROLE OF PUBLIC POLICY

URBAN STUDIES, 29(6) (AUG 92) 881-904.

DURING THE 1970'S AND $1980^{\prime} S$, MAJOR RELOCATIONS OF DANISH INOUSTRY TOOK PLACE TO BOTH RURAL ANO PERIPHERAL AREAS IN DENMARK. THE AUTHOR LOOKS AT THE ROLE OF PUBLIC POLICY--INCLUDING EXPLICITLY REGIONAL POLICY AND ECONOMIC AND SOCIAL POLICIES HAVING DIFFERING REGIONAL EFFECTS--IN THIS PROCESS. HE FINDS A MARKED CHANGE IN THE NATURE OF DENMARK'S PUBLIC POLICY IN THE MID-1980'S, FROM A COSTSUPPORT POLICY TO A MORE AGGRESSIVE, INNOVATORY POLICY.
04811 JENTLESON, B.W. FOREIGN POLICY FOR A POST-COLD WAR HORLD: A CLINTON ADMINISTRATION

BRDOKINGS REVIEW, 1014) (FAL 92), 32, 34.

THE AUTHOR DISCUSSES THE UNITED STATES' POSITION IN THE POST-COLD WAR WORLD AND GIVES SOME IDEAS ABOUT HOW GOVERNOR BILL CLINTON MIGHT APPROACH THE FOREIGN POLICY CHALLENGE IF HE WINS THE 1992 PRESIDENTIAL ELECTION.

04812 JENTLESON, B.W.

THE PRETTY PRUDENT PUBLIC: POST POST-VIETTMAM AMERICAN OPINION ON THE USE OF MILITARY FORCE

OPINION ON THE USE OF MILITARY FORCE (MAR 92) 49-74.

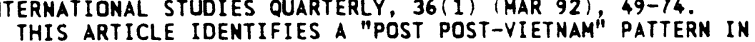
THIS ARTICLE IDENTIFIES A "POST POST-VIETNAM" PATTERN IN
TEE INT RECENT AMERICAN PUBLIC OPINION ON THE USE OF MILITARY FORCE. DATA IS DRAWN FROM EIGHT CASES OF LUL WAR. ALTHOUGH OTHER THE 1980S AND THE 1990-91 PERSIAN GULF WAR. ALTHOUGH OTHER FACTORS ENTER IN, PARTICULARLY THE "HALO EFFECT" OF QUICK-
STRIKE SUCCESSES, THE VARIATIONS IN PUBLIC SUPPORT ARE BEST STRIKE SUCCESSES, THE VARIATIONS IN PUBLIC SUPPORT ARE EXPLAINED BY DIFFERENCES IN PRINCIPAL POLICY RESTRAINT BY AM AGGRESSOR STATE, AND FORCE USED TO INFLUENCE OR IMPOSE INTERNAL POL ITICAL CHANGE WITHIN ANOTHER STATE. DISTINCTIONS ARE MADE BOTH AMONG AND WITHIN THE CASES, SHOWING THE AMERICAN PUBLIC TO HAVE BEEN MUCH MORE SUPPORTIVE OF THE USE OF FORCE WHEN THE PRINCIPAL OBJECTIVE HAS TO RESTRAIN RATHER THAN REMAKE GOVERNMENTS. THESE FINDINGS HAVE THEORETICAL IMPLICATIONS FOR THE ANALYSIS OF PUBLIC OPINION, PRESCRIPTIVE IMPLICATIONS FOR U.S. FOREIGN POLICY STRATEGY, AND NORMATIVE IMPLICATIONS FOR VIEWS OF THE ROLE OF THE PUBLIC IN THE FOREIGN POLICY PROCESS.

04813 JEONG, K.

THE NORTH KOREAN ECOMOMY: STRUCTURE, PERFORMANCE, AND INTERNATIONAL COOPERATION

KOREA \& WORLD AFFAIRS, 16 (1) (SPR 92), 22-39.
NORTH KOREA'S ECONOMIC SYSTEM IS THE WORLD'S MOST HIGHLYCENTRALIZED, SOCIALIZED, CLOSED, AND PLANNED. DESPITE THE CENTRALIZED, SOCIALIZED, CLOSED, AND PLANNED. DESPITE THE CATASTROPHIC FAILURE OF COMMUNISM IN THE SOVIET BLOC, NORTH KOREA HAS TAKEN FEW STEPS TOWARD ECONOMIC REFORM. AL THOUGH
MANY ECONOMISTS HARN THAT SIGNIFICANT ECONOMIC CHANGE IS MANY ECONOMISTS HARN THAT SIGNIFICANT ECONOMIC CHANGE IS IMPERATIVE IF NORTH KOREAN IS TO AVOID DISASTER, PYONGYANG CURRENT STATUS OF NORTH KOREAN ECONOMIC DEVELOPMENT AND CURRENT STATUS OF NORTH KOREAN ECONOMIC DEVELOPMENT AND
SPECULATES ABOUT THE FUTURE PROSPECTS OF THE COMMUNIST SPECULATES
ECONOMY.

04814 JEONG, $S$

LEGAL STATUS AND POLITICAL MEANING OF THE BASIC AGREEMENT BETHEEN THE SOUTH AND THE NORTH

KOREA \& WORLD AFFAIRS, 16(1) (SPR 92), 5-21

"THE AGREEMENT ON RECONCILIATION, NON-AGGRESSION, AND EXCHANGES BETWEEN THE SOUTH AND THE NORTH" WAS SIGNED AT THE FIFTH SOUTH-NORTH HIGH-LEVEL TALKS. IT IS THE FIRST COMPREHENSIVE AGREEMENT THAT LAYS THE FOUMDATION FOR SUBSTANTIALLY INSTITUTIONALIZING THE PROCESS TOWARD PEACEFUL COEXISTENCE BETWEEN SEOUL AND PYONGYANG. IN ORDER FOR THE BASIC AGREEMENT TO WORK, ITS LEGAL STATUS AND POLITICAL MEANING MUST BE CLARIFIED. IN THIS ARTICLE, THE AUTHOR ANALYZES THE LEGAL STATUS OF THE BASIC AGREEMENT AND ITS IMPACT ON THE KDREAN DOMESTIC LEGAL SYSTEM. HE ALSO EXAMINES THE IMPACT OF THE BASIC AGREEMENT ON SOUTH-MORTH RELATIONS AND ANALYZES ITS POLITICAL MEANING. HE DISCUSSES THE STANCE SOUTH KOREANS MUST TAKE IN ORDER TO MOVE SOUTH-NORTH RELAIIONS TOWARD UNIFICATION WHILE NOT LOSING SIGHT OF NORTH KOREAN INTENTIONS AND STRATEGIES.

04815 JERVIS, R.

POLITICAL IMPLICATIONS OF LOSS AVERSION

OLITICAL PSYCHOLOGY, 13(2) (JUN 92), 187-204.

PROPOSITIONS INTO POLITICAL OECISION-MAKING, ESPECIALLY IN

PROPOSITIONS INTO POLITICAL OECISION-MAKING, ESPECIALLY IN
INTERNATIONAL POLITICS. EVIDENCE INDICATES THAT STATESMENT

INTERNATIONAL POLITICS. EVIDENCE INDICATES THAT STATESHE
ARE INDEED RISK-ACCEPTANT FOR LOSSES. THIS HOULD HELP

ARE INDEED RISK-ACCEPTANT FOR LOSSES. THIS HOULD HELP
EXPLAIN OBSERVED PATTERNS IN BARGAINING, DETERRENCE, THE

EXPLAIN OBSERVED PATTERNS IN BARGAINING, DETERRENCE, THE
ORGINS OF WARS, AS WELL AS SUGGESTING WHY STATES ARE LESS

ORGINS OF WARS, AS WELL AS SUGGESTING WHY STATES ARE LESS

LIKELY TO BEHAVE AGGRESSIVELY WHEN DOING SO WOULD PROD

04816 JERVIS, R.

THE FUTURE OF WORLD POLITICS: WILL IT RESEMBLE THE PAST?

INTERNATIONAL SECURITY, 16(3) (WIN 91), 39-73.

AFTER DISCUSSING WHY PREDICTION IS SO DIFICULT IN INTERMATIONAL POLITICS, ROBERT JERVIS ARGUES THAT VALUES HAVE SHIFTED IN THE LIBERAL DEMOCRATIC STATES OF THE WEST, MAKING PEACE THE LIKELY STATE OF THEIR RELATIONS. IN THE FORMER SOVIET BLOC, HOWEVER, NATIONALISM ANO ECONOMIC CRISES STILL POSE A THREAT TO STABILTIY. IN THE DEVELOPING WORLD THE END OF THE COLD WAR WILL PROBABLY LEAD TO INCREASED CONFLICT, AS THERE WILL NO LONGER BE TWO ANTAGONISTIC SUPERPOHERS WITH A SHARED INTEREST IN PREVENTING ESCALATION. AS THE UNITED STATES CONFRONTS A MUCH HIDER RANGE OF CHOICE IN THE NEW HORLD, IT MUST DECIDE WHICH VALUES AND GOALS IT 
SEEKS.

04817 JESKE, J.

CRACKS BEGIN TO SHOH IN THE MATION'S CONFIDENCE

GERMAN TRI BUNE, (1512) (APR 92), 1 .

GERMAN SELF-CONFIDENCE, CHARACTERIZED BY A COMFORTABLE SENSE OF PROSPERITY AND THE YEARNING FOR INTERNAL AND EXTERNAL HARMONY, HAS BEEN SHAKEN BY POLITICAL CHANGE. THE SLOWING OF THE ECONOMY. THE INABILITY OF POLITICIANS TO RESIST THE PRESSURES OF SPECIAL INTERESTS, THE INCREASING PUBLIC DEBT. THE ECONOMIC TROUBLES OF THE EASTERN PART OF GERMANY AND GROWING INTERNATIONAL COMPETITION ALL ADO TO THE GENERAL GLOOM. HHETHER THE GERMANS WILL BE ABLE TO CONVERT CRISIS INTO TRIUMPH REMAINS TO BE SEEN.

04818 JESSON, B.

THE DISINTEgRATION OF A LABOUR TRADITION: NEH ZEALAND POLITICS IN THE 1980'S

NEW LEFT REVIEW, (192) (MAR 92), 37-54.

THE EXPERIENCE OF NEH ZEALAND'S LABOUR GOVERMMENTS IN THE 1980'S FURNISHES AN OBJECT LESSON IN THE PERILS THAT AWAIT SOCIAL DEMOCRACY WHEN IT SEEKS TO DEFEND ITS AWAIT SOCIAL DEMOCRACY WHEN IT SEEKS TO DEFEND ITS AGENT OF LAISSEZ FAIRE ECONOMICS AND CAPITALIST ADMINISTRATIONS DISMANTLED SUBSIDIES, DEREGULATED THE ADMINISTRATIONS DISMANTLED SUBSIDIES, DEREGULATED THE

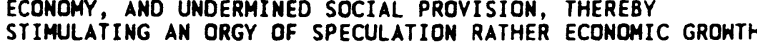
STIMULATING AN ORGY OF SPECULATION RATHER ECDNOMIC GRONTH AND BDOSTIMG UNEMPLOYMENT RATHER THAN REDEPLOYMENT. NEW ZEALAND LABOUR'S CONVERSION TO CHICAGO ECONOMICS SET THE
SCENE FOR ITS DEFEAT IN THE 1990 GENERAL ELECTION AND HAS SCENE FOR ITS DEFEAT IN THE 1990 GENERAL ELECTION AND HAS
SUBSEQUENTLY HELPED TO ENCOURAGE THE EMERGENCE OF A NEW LEFT ALLIANCE.

04819 JEWSON, N. : BOHEN, R. : MASON, D.; MULVANEY, K.; PARMAR, S. UNIVERSITIES AND ETHNIC MINORITIES: THE PUBLIC FACE NEW COMAUUNITY, 17(2) (JAN 91), 183-200.

IT IS COMMONLY ASSUMED THAT THE TRADITIONAL ACADEMIC ETHIC OF INDIVIDUAL ACHIEVEMENT RECOGNIZES NO BARRIERS OTHER THAN THOSE OF MERIT AND ABILITY. AS SUCH, EQUAL OPPORTUNITY ISSUES ARE OFTEN NOT CONSIDERED OF GREAT RELEVANCE FOR UNIVERSITIES. THIS ARTICLE PRESENTS THE FINDINGS OF RECENT RESEARCH INTO UK UMIVERSITIES' PUBL IC IMAGE IN RELATION TO ETHNIC MINORITIES. FIFTY THREE GENERAL UNDERGRADUATE PROSPECTUSES WERE EXAMINED DETERMINING THEIR TEXTUAL AND VISUAL APPEAL TO ETHMIC MINORITIES. WHILE THE PROSPECTUSES VISUAL APPEAL TO ETHNIC MINORI TIES. WHILE THE PROSPECTUSES ON THE WHOLE CAME OUT HELL IN TERMS OF DEPICTING A MULTICULTURAL SETTING, TEXTUAL ANALYSIS REVEALED LESS SUPPORT FOR THE NOTION THAT THE UNIVERSITIES WERE SENSITIVE TO THE NEEDS
AND REQUIREMENTS OF POTENTIAL ETHNIC MINORITY APPLICANTS. OVERSEAS STUDENTS, HOWEVER, WERE FREQUENTLY CATERED FOR WITHIN SPECIAL SECTIONS OF THE PROSPECTUSES. IT IS PHAT THE VISUAL MULTI-ETHNIC PRESENCE IN UNIVERSITY PROSPECTUSES SEEMS TO REFLECT A WISH TO ATTRACT A LUCRATIVE OVERSEAS MARKET, RATHER

04820 JIA, H.; ZHUANG, Q.

CHINA'S POLICY TOWARD THE KOREAN PENINSULA

ASIAN SURVEY, XXXII (12) (DEC 92), 1137-1156.

THIS ARTICLE EXAMINES CHINA'S' POLICY OPTIONS WITH REGARDS TO NORTH AND SOUTH KOREA. IT FIRST EXAMINES THE CHANGING POWER CONFIGURATION IN THE REGION IN THE POST-COLD WAR ERA AND THE INTERPLAY BETWEEN CHINA AND THE OTHER THREE MAJOR POWERS ENCIRCLING THE KOREAN PENINSULA: RUSSIA, THE UNITED STATES AND JAPAN. IT THEN ANALYZES CHINA'S POLICY TOWARD BOTH NORTH ANO SOUTH KOREA, AS WELL AS CHINA'S STAND ON INTER-KOREAN RELATIONS. IT THEN EXAMINES THE CURRENT SITUATION ON THE KOREAH PENINSULA AND OFFERS SEVERAL POSSIBLE FUTURE SCENARIOS. IT CONCLUDES THAT CHIMA SHOULD: CONTINUE TO SEEK BILATERAL AS WELL AS MULTILATERAL COOPERATION AMONG THE MAJOR POWERS; SEIZE THE OPPORTUNITY TO PLAY AN ACTIVE ROLE IN PROMOTING REGIONAL ECONOMIC COOPERATION; RECOGHIZE THAT GIVEN NORTH KOREA'S

INTERNATIONAL ISOLATION AND ITS RECENT COOL RELATIONS WITH MOSCOH, BEIJING HAS BECOME PYONGYANG'S SINGLE MOST IMPORTANT ALLY; AND TAKE ADVANTAGE OF ITS NEWLY NORMALIZED RELATIONS HITH SEOUL TO ACTIVELY BROADEN AND PROMOTE ECONOMIC POLITICAL, AND CULTURAL TIES, AND USHER IN A PERIOD' OF MUCH CLOSER COOPERATION BETWEEN THE THO COUNTRIES.

04821 JIA, $Q$.

CHANGING RELATIONS ACROSS THE TAIHAN STRAIT; BEIJING'S PERCEPTIONS

ASIAN SURVEY, XXXII(3) (MAR 92), 277-289.

THE DEVELOPMENT OF RELATIONS BETHEEN THE THO SIDES OF THE TIAWAN STRAIT IN RECENT YEARS HAS DRAHM CONSIDERABLE INTERNATIONAL ATTENTION. WILL THE THO SIDES UNITE? IF SO HOW LONG WILL IT TAKE? IF NOT, WILL BEIJING USE FORCE TO BRING ABOUT CHINA'S UNIFICATION? ADEQUATE ANSHERS TO THESE QUESTIONS. WHICH AFFECT THE STABILITY AND DEVELOPMENT NOT ONLY OF CHINA BUT THE ENTIRE ASIAN-PACIFIC REGION, REQUIRE COMPREHENSIVE EXAMINATION AND ANALYSIS OF MANY IMPORTANT FACTORS. ONE OF THESE IS BEIJING'S PERCEPTION OF THE
CHANGING RELATIONS OF THE THO SIDES. THIS ARTICLE ATTEMPTS TO EXAMINE THIS PERCEPTION, THE FACTORS THAT HELP TO SHAPE IT, AND THE IMPLICATIONS FOR THE FUTURE DIRECTION OF THE RELATIONSHIP.

04822 JIAN, $S$.

CHINA'S POSITION ON ENVIRONMENT AND DEVELOPMENT

BEI JING REVIEW, $35(24)$ (JUN 92), 12-15.

SONG JIAN, CHAIRMAN OF THE ENVIRONMENTAL PROTECTION COMMISSION OF THE STATE COUNCIL OF CHINA AND MINISTER IN CHARGE OF THE STATE SCIENCE AND TECHNOLOGY COMMISSION ADDRESSED THE UNITED NATIONS CONFERENCE ON ENVIRONMENT AND DEVELOPMENT ON JUNE 8,1992 . HE STATED THAT ENVIRONMENTAL PROTECTION AND PROMOTION OF ECONOMIC DEVELOPMENT ARE TWO ASPECTS OF ONE ISSUE. HE WARNED THAT MANKIND'S PROOUCTION, CONSUMPTION, AND DEVELOPMENT CANNOT BE SUSTAINED IF ENYIRONMENTAL NEEDS AND NATURAL RESOURCES ARE NEGLECTED.

04823 JIANG, $C$.

THE BUMPY ROAD TO MIDOLE EAST PEACE

BEIJING REVIEN, 35(3) (JAN 92), 15-17

THE CONVENING OF THE MIDOLE EAST PEACE CONFERENCE AFTER 43 YEARS OF ARAB-ISRAELI CONFLICTS DOES NOT MEAN THE ADVENT 43 YEARS OF ARAB-ISRAELI CONFLICTS DOES NOT MEAN THE ADVENT
OF PEACE IN THE REGION, BUT BRINGS A FRESH HOPE OF ENDING OF PEACE IN THE REGION, BUT BRINGS A FRESH HOPE OF ENDING
THE PROTRACTED CONFLICT. THIS ARTICLE EXPLORES THE SERIES OF SIGNIFICANT CHANGES WHICH FINALLY BROUGHT THE VARIOUS SIGNIFICANT CHANGES WHICH FINALLY BROUGHT THE VARIOUS THAT FURTHER CONCESSIONS ARE REQUIRED IF SUBSTANTIAL PROGRESS IS TO BE ACHIEVED.

04824 JIANGYONG, L.

SINO-JAPANESE COOPERATION IN A CHANGED SITUATION BEIJING REVIEH, 35(14) (APR 92), 16-17.

SINCE NORMALIIZATION, SINO-JAPANESE RELATIONS HAVE DEVELOPED RAPIDLY, THANKS TO JOINT EFFORTS BY THE TWO GOVERMMENTS AND NON-GOVERMMENTAL ORGANIZATIONS. THE YEAR 1992 MARKS THE 2OTH ANNIVERSARY OF THE NORMALIZATION, WHICH WILL BE COMMEMORATED WITH NEW EFFORTS TO IMPROVE BILATERAL RELATIONS BETHEEN THE THO ASIAN POWERS.

04825 JIAQI, G.

RESTRUCTURING GOVERNMENT ORGANIZATION IN CHINA AND TRANSFORMING GOVERNMENT FUNCTIONS FOR AN EFFICIENT AND MORE PRODUCTIVE BUREAUCRATIC PERFORMANCE

GOVERMANCE, 5(4) (OCT 92), 391-401.

THIS ARTICLE DISCUSSES THREE QUESTIONS: FIRST THE NECESSITY OF ADJUSTING THE GOVERHMENT ORGANIZATIONAL STRUCTURE AND RATIONALIZING THE ADMINISTRATIVE POLICYMAKING MECHANISM, AS WELL AS SOME PRACTICES IN CHINA; SECOND MECHANISM, AS WELL AS SOME PRACTICES IN CHINA; SECOND TRANSFORMING GOVERNMENT MANAGEMENT PROCESSES TOWARDS
ADAPTING TO THE CHANGING SOCIAL AND ECONOMIC ENVIRONMENT IN ADAPTING TO THE CHANGING SOCIAL AND ECONOMIC ENVIRONMENT IN
DEVELOPING COUNTRIES, E.G. DESCRIBING WHAT HAS BEEN DONE BY DEVELOPING COUNTRIES, E.G., DESCRIBING HHAT HAS BEEN DONE BY THIRD, CONCENTRATING ON IMPROVING EFFICIENCY AND THIRD, CONCENTRA

04826 JIAQUAN, L.

TAIWAN INDEPENDENCE, INDEPENDENT TAIWAN, AND REUNIFICATION BEI JING REVIEW, 35(32) (AUG 92), 26-29

AFTER TAIHAIN'S NATIONAL ELECTIONS IN DECEMBER 1991 MANY PEOPLE THOUGHT THAT THE DANGER POSED BY THE TAIWAN INDEPENDENCE MOVEMENT WAS DEAD BECAUSE THE OVERWHELMING MAJORITY OF THE ELECTORATE VOTED AGAINST THE TAIWAN DEMOCRATIC PROGRESSIVE PARTY, WHICH HAD CHAMPIONED THE IDEA. BUT THE THREAT OF TAIWAN INDEPENDENCE HAS NOT VANISHED. ON THE CONTRARY, IT IS MORE THREATENING NOW BECAUSE INDEPENDENCE ADHERENTS ARE OPERATING CLANDESTINELY.

04827 JIAQUAN, L.

TAIHAN INDEPENDENCE: A BLIND ALLEY

BEI JING REVIEW, 35 (23) (JUN 92), 24-27.

TAIWAN'S DECEMBER 1992 ELECTIONS CLEARLY DEMONSTRATED THAT PUBLIC SUPPORT FOR THE INDEPENDENCE OF TAIWAN IS NEGLIGIBLE BECAUSE THE DEMOCRATIC PROGRESSIVE PARTY (DPP), WHICH RAN ON THAT PLATFORM, COMMANDED ONLY 23.94 PERCENT OF THE VOTES, COMPARED TO THE KUOMINTANG'S 71.14 PERCENT. HOWEVER, SOME RADICALS IN THE DPP ARE UNWILLING TO ABANDON THE POLICY OF SEEKING INDEPENDENCE FOR TAIHAN. THEY ARGUE THAT THE ELECTORAL DEFEAT WAS UNIMPORTANT AND THAT THEY WILL WIN THE NEXT ELECTION. NEVERTHELESS, THERE IS NO DOUBT THAT DEFEAT ALSO AHAITS THEM IN THE FUTURE AND THAT THE CAMPAIGM FOR TAIWAN'S INDEPENDENCE WILL LEAD TO AN IMPASSE.

04828 JIMENEZ, M.

WAR IN. THE BORDERLAMDS

WAR IN. THE BORDERLANDS
REPORT ON THE AMERICAS, 26(1) (JUL 92), 29-33

A MULTI-AGENCY U.S. GOVERMMENT PRESENCE HAS TURNED THE U. S.- MEXICO BORDER INTO A HAR ZONE, WHERE THE RIGHTS OF IMMIGRANTS AND RESIDENTS SUFFER DAILY "COLLATERAL DAMAGE." THE UNCHECKED EXERCISE OF POLICE AUTHORITY HAS COME TO BE VIENED AS NECESSARY FOR EFFECTIVE LAH ENFORCEMENT. THIS ARTICLE SUGGESTS THAT RESPECT FOR THE DIGNITY AND INTEGRITY OF ALL PEOPLE ON THE U.S. - MEXICD BORDER IS UNLIKELY TO BE ACHIEVED UNTIL RELATIONS AMONG NATIONS EVOLVE TO THE POINT 
WHERE THE FREEDOM TO CROSS INTERNATIONAL BOUNDARIES IS RECOGNIZED AS A FUNDAMENTAL HUMAN RIGHT.

04829 JIN, S.; SHAOCHUN, C.

COMMONWEALTH SPELLS DEMISE OF SOVIET UNION

BEIJING REVIEW, 35(1) (JAN 92), 15

THE UNION OF SOVIET SOCIALIST REPUBLICS CAME TO AN ABRUPT END ON DECEMBER 21, 1992, AS THE PRESIDENT OF 11 FORMER UNION REPUBLICS AMHOUNCED THE FORMATION OF THE COMMONWEALTH OF INDEPENDENT STATES. THE COMMONWEALTH HILL BE NEITHER A STATE ENTITY NOR A SUPER-NATIONAL ORGANIZATION. RATHER, IT IS A GROUPING OF SOVEREIGN STATES BASED ON TOTAL EQUALITY.

04830 JINFANG, $Z$.

KOREANS MOVE CLOSER TOWARDS RECONCILIATION

BEIJING REVIEN, 35 (10) (MAR 92), 16

ON FEBRUARY' 19 (992 KOREAN' PRIME MINISTERS YON HYONGMUK AND CHUNG WON-SHIK MET IN PYONGYONG TO SIGN INSTRUMENTS MUK AND CHUNG WON-SHIK MET IN PYONGYONG TO SIGN INSTRUF
OF "THE AGREEMENT ON RECONCILIATION, NON-AGGRESSION OF "THE AGREEMENT ON RECONCILIATION, NON-AGGRESSION, EXCHANGES, AND COOPERATION" AND "THE JOINT DECLARATIO AGREEMENTS ENDED 47 YEARS OF MUTUAL DISTRUST AND HOSTILITIES AND OPENED UP NEW PROSPECTS FOR NATIONAL RECONCILIATION.

04831 JIMGDONG, $H$.

FACTORS INFLUENCING ANCIENT CHINESE SCIENCE AND TECHNOLOGY DURING THEIR FORMATIVE PERIOD

SOCIAL SCIENCES IN CHINA, XII(4) (NOV 91), 108-131.

THE AUTHOR EXAMINES THE FACTORS INFLUENCING ANCIENT

CHINESE SCIENCE AND TECHNOLOGY. GATHERING ACTIVITIES IN THE PRE-SCIENTIFIC OR PRE-AGRICULTURAL PERIOD WERE NOT ONLY HIGHLY SIGNIFICANT FOR THE FORMATION OF THE DISCRIMINATORY AND CLASSIFICATORY MODE OF THINKING BUT ALSO BECAME, IN PART, THE FOUNDATION OF LATER SCIENCE AND TECHNOLOGY UPON ENTERING THE PERIOD OF SCIENCE AND TECHNOLOGY THE FOLLOHING FOUR FACTORS BECAME HIGHLY SIGNIFICANT: ECONOMICS, POLITICS, PHILOSOPHY, AND PSYCHOLOGY. CHINA'S UNIQUE GEOGRAPHICAL ENVIRONMENT WAS ALSO IMPORTANT FOR ANCIENT CHINESE SCIENCE AND TECHNOLOGY.

04832 JISI, W.

UNITED STATES: FORMULATING NEH GLOBAL STRATEGY

BEIJING REVIEN, 35(10) (MAR 92), 33-35.

DUE TO THE END OF THE COLD WAR, THE UNITED STATES HAS HAD TO ADJUST ITS GLOBAL STRATEGY, BASED ON A RE-EVALUATION OF U.S. STRENGTH. MAINSTREAM U.S. POLITICIANS BELIEVE THAT A HULTI-POLAR WORLO HAS NOT YET BEEN ESTABLISHED AND THAT JAPAN AND GERMANY CAN, AT BEST, PLAY THE ROLE OF REGIONAL POWERS. HONEVER, IT IS GENERALLY ACKNOWLEDGED THAT THE STRENGTH OF THE USA HAS DECLINED AND ITS INFLUENCE IN HORLD AFFAIRS HAS BEEN REDUCED. THE BUSH ADMINISTRATION IS BUSY SELLING "GLOBALISM" WHILE "NEO-ISOLATIONISM" IS ALSO GROHING DEMANDING ECONOMIC REJUVENATION AND ATTENTION TO DOMESTIC PROBLEMS FIRST.

04833 JISONG, $W$.

THE ROLE OF NATURAL SCIENCES, TECHNOLOGY AND SOCIAL

SCIENCES IN POL ICY-MAKING IN CHINA

INTERNATIONAL SOCIAL SCIENCE JOURMAL, 132 (MAY 92),

291-298.

WITH THE EMERGENCE OF CIVILIZATION, POLICY-MAKIMG TOOK ON A NEW SIGNIFICANCE. EVENTUALLY LEADERS BEGAN TO BASE THEIR DECISIONS ON THE ACCUMULATED STORE OF HUMAN KNOHLEDGE. GIVEN THE NATURE OF THE ISSUES, TRIBAL CHIEFS BEGAN TO SURROUND THEMSELVES WITH A PANOPOLY OF ASSISTANTS AND ADVISERS. THIS ARTICLE PROPOSES TO EXAMIME THESE COLLECTIVE DECISION-MAKING PROCESSES BASED ON KNOWLEDGE AND EXPLORES ITS HISTORY IN CHINA.

$04834 \mathrm{JOB}, \mathrm{B}$. (ED.)

THE INSECURITY DILEMMA: NATIONAL SECURITY OF THIRD WORLD STATES

LYNNE RIENNER PUBLISHERS, 1992, 250.

POSITING AN "INSECURITYY DILEMMA" IN WHICH NATIONAL SECURITY, DEFINED AS REGIME SECURITY BY STATE AUTHORITIES, BECOMES PITTED AGAINST THE INCOMPATIBLE DEMANDS OF ETHNIC, SOCIAL, AND RELIGIOUS FORCES, THIS BOOK ADDRESSES THE PROBLEMS AND PROSPECTS FOR SECURITY IN THE THIRD WORLD IN THE 1990S. THE AUTHORS ADVANCE FOUR LINES OF ARGUMENT: FIRST, THERE IS A NEED TO RETHINK THE TRADITIONAL REALIST NOI IONS OF STATES, NATIONAL SECURITY, TERRITORIAL THREAT, AHD WAR. SECOND, THE SECURITY DILEMMAS OF THIRD WORLD REGIMES ARE SECOND, THE SECURITY DILEMMAS OF THIRD WORLD REGIMES BOUND UP IN THE PROCESS OF STATEBUILDING AND IN THE
PRACTICAL IMPLICATIONS OF POLITICAL DEVELOPMENT. THIRD, THE PRACTICAL IMPLICATIONS OF POLITICAL DEVELOPMENT. THIRD, THE
REPRESSIVE STRATEGIES THAT MANY THIRD WORLD REGIMES HAVE REPRESSIVE STRATEGIES THAT MANY THIRD WORLD REGIMES HAVE ADOPTED REFLECT AN UNDERLYING LOGIC ASSOCIATED WITH THE PROSPECTS. AND FINALLY, RADICALLY ALTERED RELATIONSHIPS AND PROSPECTS. AND FINALLY, RADICALLY ALTERED RELATIONSHIP CONDITIONS IN THE INTERNATIONAL SYSTEM MEAN THAT THE
SECURITY INTERESTS OF THE THIRD HORLD REGIMES AND PEOPLES HILL BE VIEWED DIFFERENTLY IN THE FUTURE BY BOTH SUPERPOWERS AND MIDDLE PONERS; AND THE CONSEQUENCE MAY WELL BE THAT TRADITIONAL REGIONAL POWERS WILL ATTEMPT TO (RE)ASSERT THEIR
SECURITY PRIORITIES AND CLAIMS TO DOMINANCE.

04835 JOFFE, $G$.

LIBYA--PREPARING FOR A TURN-AROUND?

MIDDLE EAST INTERNATIONAL, (428) (JUN 92), 6-7.

EVER SINCE 1969, LIBYA'S COLONEL QADHAF I HAS BEEN THE ARAB WORLD'S FOREMOST EXPONENT OF THE OLD DREAM OF ARAB UNITY. HOWEVER, IT SEEMS THAT THE COLONEL'S LONG-STANDING POLICY IS ABDUT TO CHANGE. EVIDENCE OF THE IMPENDING SHIFT IS FOUND IN A VIRULENT EDITORIAL IN THE WEEKLY NEWSPAPER OF THE REVOLUT IONARY COMMITTEE MOVEMENT, WHICH IS DIRECTLY CONTROLLED BY THE LIBYAN LEADER. THE' EDITORIAL ROUHDY CONDEMNED QADHAFI'S LONG-STANDING BELIEF IN, AND SUPPORT FOR, CONDEMNED QADHAFI S LONG-STANDING BELIEF IN, AND SUPPORT FOR,
ARAB UNITY, BLAMING OTHER STATES FOR THEIR LACK OF SUPPORT ARAB UNITY, BLAMING OTHER STATES FOR THEIR LACK OF SUPPOR FOR LIBYA IN ITS CURRENT CRISIS OVER THE UN SANCTIONS, AND
WARNING THE LIBYAN LEADER THAT LIBYANS, HAVING BEEN BLINDED WARNING THE LIBYAN LEADER THAT LIBYANS, HAVING BEEN BLINDED
BY HIS RHETORIC OVER ARAB UNITY FOR THE PAST THO DECADES, WOULD NO LONGER FOLLOW HIM IF HE CONTINUED ALONG THE SAME WOULD NO LONGER FOLLOW HIM IF HE CONTINUED ALONG THE IDEOLOGICAL PATH. THE EDITORIAL IS PART OF A GROWING
CAMPAIGN TO PREPARE PUBLIC OPINION FOR A CAPITULATION TO UN DEMANDS THAT IT HAND OVER THE THO ACCUSED LIBYANS TO BRITAIN DEMANDS THAT IT HAND OVER THE THO ACCUSED LIBYANS TO BRITAI
OR THE UNITED STATES. IT SEEMS THAT COLONEL OADHAFI HAS

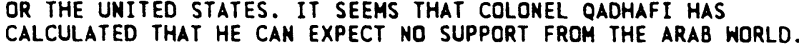
CALCULATED THAT HE CAN EXPECT NO SUPPORT FROM THE ARA
HE HAS ALSO REALIZED THAT HE CAN AFFORD, IN TERMS OF DOMESTIC SUPPORT, TO ACQUIESCE TO THE UN DEMANDS. A FURTHER LONG-TERM OBJECTIVE OF THIS SHIFT IS THE MORMALIZATION OF RELATIONS WITH THE WEST.

04836 JOFFE, G.

STILL DIVIDED

MIDOLE EAST INTERNATIONAL, (395) (MAR 91), 5.

THE REBELLION IN BOTH NORTHERN AND SOUTHERN IRAO IS BEING CARRIED OUT BY DIVERSE GROUPS ONLY LDOSELY UNITED BY THEIR HATRED FOR THE CURRENT REGIME. THE SOUTHER REVOLT IS DOMINATED BY THE SUPREME ASSEMBLY OF THE ISLAMIC REVOLUTION IN IRAO--A GROUP FORMED IN IRAN IN 1983--BUT THE GROUP IS SPLIT BY FACTIONS AND IS BEING CHALLENGED BY OTHER ISLAMIC GROUPS. IN THE NORTH, ALL THE OPPOSITION GROUPS INCLUDING THE KURDISH MOVEMENTS, THE MODERATE UMMA PARTY, THE NEH UMMA PARTY, AND THE IRAQI COMMUNIST PARTY, ARE SUPPOSED TO GATHERED UNDER AN UMBRELLA ORGANIZATION SPONSORED BY SYRIA. HOWEVER, THAT GROUP IS BEING CHALLENGED BY A RIVAL HOWEVER, THAT GROUP IS BEING CHALLENGED BY A RIVAL
ORGANIZATION IN SAUDI ARABIA, IT SEEMS UNLIKELY THAT AN ORGANIZATION IN SAUDI ARABIA, IT SEEMS UNLIKELY THAT AN
EFFECTIVE OPPOSITION CAN UNITE FROM THESE FRAGMENTS AND EFFECTIVE
FACTIONS.

04837 JOFFE, G.

T'WAS A FAMOUS VICTORY

MIDOLE EAST INTERNATIONAL, (395) (MAR 91), 6-8

DESPITE THE DEVASTATION OF KUWAIT AND THE LARGE COSTS OF THE OPERATION, DESERT STORM WAS A SPECTACULAR VICTORY FOR THE WEST, PARTICULARLY THE UNITED STATES. THE VICTORY VINDICATED CLAIMS THAT THE GULF CONFLICT WOULD "NOT BE ANOTHER VIETNAM" AND THAT THE BATTLE CDULD BE WON AT A LOH COST IN ALLIED LIVES. AFTER HINHING THE WAR, IT SEEMS LESS CLEAR WHAT THE COALITION CAN OR WILL DO TO WIN THE PEACE.
OPPOSITION GROUPS TAKE UP ARMS AGAINST A STILL POWERFUL SADDAM HUSSEIN, FURTHER VIOLENCE AND DEVASTATION OF IRAQ SEEMS INEVITABLE.

04838 JOFFE, J.

BALKANS: DOUBTFUL PRECEDENTS FOR IDEA OF TOTAL BLOCKADE

GERMAN TRIBUNE, 31(1531) (AUG 92), 1

THE WORD HAS SPREAD IN MILITARY STAFF CIRCLES THAT THERE ARE NO "FAST" MILITARY SOLUTIONS IN THE BALKAN WAR.

ENFORCING A TOTAL BLOCADE MEANS INITIALLY WAGING WAR AGAINST THE CIVILIAN POPULATION WHILE THE RULERS THAT BE SEIZE WHAT THEY CAN. THE MOST DIFFICULT QUESTION IS "HOW?" A POWER POTENTIAL AND A WILLINGNESS TO TAKE RISKS WOULD HAVE TO BE ARTERED WHICH THE HORLD IS UNHILLING TO SANCTION. THIS THERE SEEMS TO NOT BE ANY "SLOW" MILITARY SOLUTIONS EITHER.

04839 JOFFE, J.

BOSNIA: THE RETURN OF HISTORY

COMMENTARY, $94(4)$ (OCT 92), 24-29.

HISTORY ENDED IN 1990 AND THE NEW HORLD ORDER WAS IN

PLACE. THEN, THE GULF WAR OCCURRED AND FIGHTING ERUPTED IN

EUROPE. THESE HERE TO BE SEEN AS NECESSARY RESU TS OF HISTORY'S ALLEGED FINALE. THIS ARTICLE ARGUES THAT NEITHER HISTORY'S ALLEGED FINALE. THIS ARTICLE ARGUES THAT NEITHER OF THESE WOULD HAVE BROKEN DUT IN AN INTACT BIPOLAR WORLD. IT SUGGESTS THAT HISTORY HAS RETURNED WITH A VENGEANCE. THAT

IT HAS NOT ENDED; ONLY THAT GREAT MASTER OF DISCIPLINE, THE
COLD WAR, HAS TAKEN A BOW. THE LITTLE WARS HAVE JUST BEGUN.

04840 JOFFE, J.

CONSIDERING KURDISTAN AS A PRECEDENT FOR BOSHIA

GERMAN TRIBUNE, (1520) (JUN 92), 2

THIS ARTICLE ARGUES THAT THE' PRECEDENT FOR BOSHIA IS NOT KUWAIT BUT KURDISTAN, NOT THE CLASSIC WAR OVER POSSESSION AND POWER BUT HUMANITARIAN INTERVENTION. AFTER SADDAM HUSSEIN TURNED ON THE KURDS IN HIS OWN COUNTRY, THE UNITED NATIONS MILITARY FORCES ENTERED KURDISTAN AND ESTABLISHED A PROTECTIVE ZONE IN WHICH THERE WAS RELATIVE SAFETY. THE 
ARTICLE ARGUES THAT THIS MINIMAL STRATEGY COULD SERVE AS A MODEL FOR SERAJEVO. THE AIM WOULD NOT BE TO OUST SERBIAN PRESIDENT MILOSEVIC FROM POWER OR TO CONSTRUCT A NEH POLITICAL ORDER, BUT MERELY TO PROTECT THE UNFORTUNATE POSNIANS. SUCH AN ACTION WOULD REOUIRE EXPENSIVE INVOLVEMENT OF MANY UNITED NATIONS MEMBER STATES, BUT IT MIGHT SERVE TO DEFUSE THE CONFLICT IN THE BALKANS, CONFLICT WHICH COULD SPREAD TO INCLUDE GREECE, ALBANIA, BULGARIA AND EVEN TURKEY.

04841 JOFFE, J.

FOLLY OF HALF-HEARTED ACTION TO BREAK SIEGE OF SARAJEVO GERMAN TRIBUNE, 31(1537) (OCT 92), 2

THERE CAN BE NO DISCUSSION ABOUT THE HUMANITARIAN IMPERATIVE--HELP WHEREVER POSSIBLE IN SARAJEVO. NEVERTHELESS, THE AIRLIFT OPERATION IS IRRESPONSIBLE. THIS ARTICLE DETAILS THREE CONSEQUENCES WHICH FACE WHOEVER IS UNWILLING TO PROTECT THE TRANSPORT AIRCRAFT AND WHOEVER IMPOSES AN INEFFECTIVE BAN ON FLIGHTS. IN WAR THERE IS NOTHING WORSE THAN HALF-HEARTED ESCALATION, IT ALLOWS THE ENEMY TO ADJUST TO THE SITUATION, TO USE ITS STRENGTH WHEREVER THE INTERVENING PARTY IS WEAK.

04842 JOFFE, J.

FUNDAMENTAL UNDERLYING FORCES GOVERM DEBATE LEADING UP TO EC SUMMIT

GERMAN TRIBUNE, (1495) (DEC 91), 1-2.

AS THE EUROPEAN COMMUNITY HEADS TOHARDS A VITAL SUMMIT IN MAASTRICHT, FORCES HHICH HAVE BEEN WORKING AT CROSS PURPOSES WITH REGARDS TO EUROPEAN INTEGRATION MUST BE ACKNOWLEGDED AND THE RESULTING TENSION MUST BE RESOLVED. THE UNDERLYING CAUSES OF THESE FORCES ARE FOUND PRIMARILY IN THE BEHAVIOR AND MOTIVATIONS OF GREAT BRITAIN, FRANCE, AND GERMANY. THE BRITISH FEAR THE LOSS OF SOVEREIGNTY THAT WOULD ACCOMPANY AN ECONOMIC OR POLITICAL INTEGRATION OF THE EUROPEAN COMMUNITY. THEY REALIZE THAT THE MAJORITY RULES APPROACH OF THE PROPOSED UMION MAY MEAN THAT A POWERFUL GERMANY MAY BE ABLE TO SWAY EC POLICY AT BRITAIN'S EXPENSE. WHILE FRAMCE ALSO FEARS THE HEGEMONY OF A PONERFUL GERMANY, THEY ARGUE THAT THE ONLY WAY TO RESOLVE THE PROBLEM IS TO INTEGRATE TO SUCH AN EXTENT THAT, IF NEEDS BE, THE REST OF THE COMHUMITY COULD OVERRULE GERMANY'S AIMS. FOR THEIR PART, THE GERMANS UMABASHEDLY HAVE DESIGNS OF TAKING THE LEADING ROLE IN COMHUNITY ACTIVITIES. HOWEVER, THEY ARE INCREASINGLY AHARE OF THE NECESSITY OF COMPROMISE.

04843 JOFFE, J.

GERMAN HANDS-OFF OVER SOMALIA OPERATION 'BASED ON A GERMAN HANDS-OFF OVER

GERMAN TRIBUNE, 31(1545) (DEC 92) 2.

THERE IS NO CONSTITUTIONAL REASON WHY GERMANY COULD NOT HAVE TAKEN PART IN THE INTERMATIONAL MILITARY RELIEF EFFORT IN SOMALIA SUGGESTS THE AUTHOR. HE STATES IN THIS ARTICLE IN SOMALIA SUGGESTS THE AUTHOR. HE STATES IN THIS ARTICL THAT THE BONN GOVERNMENT WILL NOT FOLLOW THE OICTATES OF MORALITY BECAUSE IT HAS IIED ITS OWN HANOS FOR ITS OWN REASONS AT A POINT HERE MORALITY, REALPOLITIC, INTERESTS AND "CONCERN" MEET. MANY SOCIAL DEMOCRATS SEE THAT IT IS NOT A CASE OF GERMAN IMPERIALISM, BUT OF COLLECTIVE ACTION IN THE NAME

04844 JOFFE, J.

MIDOLE EAST TALKS: TRYING TO FIND OUTLINES FOR DISTORTED IMAGES

GERMAN TRIBUNE, (1492) (NOV 91), 1-2.

THE MIDOLE EAST PEACE TALKS IN MADRID REVEAL ONE OF THE KEY PROBLEMS THAT HAS PLAGUED THE ENTIRE PEACE PROCESS: EACH PARTY INVOLVED PERCEIVES ITSELF AS A VICTIM. THE ARAB STATES SEE A MINI-SUPERPOHER THAT HAS HUMILIATED THEM ON EVERY OCCASION. THE ISRAELIS SEE THEMSELVES SURROUNDED BY 120 MILLION ENEMIES HO HOLD THE REAL KEY TO POWER AND SUPREMACY BY VIRTUE OF GEOGRAPHY AND DEMOGRAPHY. IN HISTORIC RETROSPECT EVERYONE ALSO SEES AN ENTIRELY DIFFERENT CHAIN OF CAUSES AHD EFFECTS. IN MADRID THE ARABS ARE OPPOSED TO ISRAEL'S 1967 TERRI TORIAL GAINS. THE ISRAELIS TAKE THE HISTORIC CHAIN OF EVENTS FURTHER BACK. THEY FEEL THEY WERE DENIED PEACE BEFORE 1967, WHEN THE GAZA STRIP AMD THE WEST BANK WERE STIL ARAB-HELD AND THE ARAB AIM WAS NOT TO SET UP A PALESTINIAN STATE BUT TO ANNIHILATE ISRAEL. BOTH SIDES ARE ALSO CONCERNED ABOUT THE FUTURE, ESPECIALLY HITH REGARDS TO FUTURE MIGRATION--OF SOVIET JEHS AND OF A RETURN OF THE PALESTINIAN DIASPORA. THESE PERCEPTIONS AND FEARS DO NOT PALESTINIAN DIASPORA. THESE PERCEPTIONS AND FEARS DO
BODE WELL FOR ANY SUBSTANTIVE PROGRESS IN THE TALKS.

04845 JDFFE, J.

SHAME OF EC FAILURE IN YUGOSLAVIA

GERMAN TRIBUNE, (1505) (FEB 92), 2

EUROPE IS HAVING TO LIVE WITH THE DISGRACE OF HAVING FAILED IN YUGOSLAYIA FOR MONTHS THE EUROPE OF HAVING TRIED TO PLAY THE ROLE OF MEDIATOR AND MANAGER-PROOUCING ONLY "CEASEFIRES" WHICH HERE NOT OBSERVED LONGER THAN THE INK TOOK TO DRY ON THE AGREEMENTS. WHILE GERMANY'S INSISTENCE ON RECOGNIZING THE INDEPENDENCE OF SLOVENIA AND CROATIA WAS A FUNDAMENTAL CAUSE OF THE EC'S EVENTUAL
RECOGNITION OF THE BREAKAWAY REPUBLICS, GERMANY'S CONTINUED FAILURE TO PROVIDE PEACEKEEPING TROOPS (OR ANY OTHER FORM OF CONCRETE COMMI TMENT) IS ESPECIALLY GALLING. NOW, MUCH TO EUROPE'S CHAGRIN, UN TROOPS FROM NATIONS ACROSS THE WORLD ARE MOYING INTO YUGOSLAVIA TO ATTEMPT THE JOB THAT EUROPE SHOULD HAVE DONE.

04846 JOFFE, J.

SIGNS OF NEN STYLE SURROUND ISRAELI PM'S VISIT TO BONH GERMAN TRIBUNE, 31 (1532) (SEP 92), 1 .

THE GERMAN-ISRAELI RELATIONSHIP, FRIENDLY BUT AT A CAUTIOUS DISTANCE, IS NOW TO CHANGE, AT LEAST FROM ISRAEL'S POINT OF VIEH. NOW THAT THE ARABS HAVE LOST THEIR SOVIET PROTECTORS AND EVEN SYRIA'S PRESIDENT IS TALKING IN TERMS OF PEACE, BONA'S TIGHTROPE WALK HAS BECOME MUCH EASIER BECAUSE NOW BONN CAN GET DOWN FROM ITS RIGHTROPE AND JOIN THE RANKS OF THOSE WHO HAVE PEACE AS THEIR LONG-TERM TARGET. OIPLOMACY IN THE MIDOLE EAST IS ASSUREDLY A MINEFIELD, BUT THE REGION IS ON EUROPE'S DOORSTEP AND TOO IMPORTANT FOR PEACE TO BE LEFT FOR THE ANTAGONISTS ALONE TO SETTLE.

04847 JOFFE, J.

THE PILLARS OF THE NEW EUROPE ARE SHAKING UNDER THE STRAIN GERMAN TRIBUNE, 31(1531) (SEP 92), 1-2.

THE FATE OF A UNITED EUROPE HANGS IN THE BALANCE MORE THAN EVER BEFORE AS JUST WEEKS BEFORE THE REFERENDUM ON THE THAN EVER BEFORE AS JUST WEEKS BEFORE THE REFERENDUH ON THE MAASTRICHT TREATY, PUBLIC OPINION IN FRANCE IS IN A MAKE-ORBREAK MOOD. DOUBTS ARE GROWING BECAUSE EVEN THE LAYMAM
SEE THAT THE THREE PILLARS OF THIS PROJECT--A COMMON SEE THAT THE THREE PILLARS OF THIS PROJECT--A COMMON

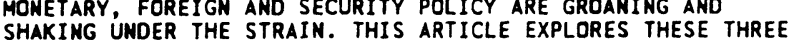
PILLARS AND CONCLUDES THAT EUROPE'S RATIONALIZATION IS PILLARS AND
SPREADING.

04848 JOHANSEN, $R$

LESSONS FOR COLLECTIVE SECURITY

WORLD POLICY JOURNAL, VIII (3) (SUM 91), 561-574.

THREE LESSONS EMBEDOED IN THE GULF CRISIS SUGGEST A SERIES OF DIPLOMATIC INITIATIVES THAT, IF IMPLEMENTED, COULD INCREASE THE EFFECTIVENESS OF UNITED NATIONS PEACEMAKING, PEACEKEEPING, AND ENFORCEMENT-ESSENTIAL INGREDIENTS FOR A
MORE PEACEFUL AND JUST INTERNATIONAL SECURITY SYSTEM. THESE LESSONS ARE: CONVENTIONAL DIPLOMATIC PRACTICES AND MILITARY POLICIES FAILED UTTERLY TO PREVENT IRAQ'S AGGRESSION; THE UNITED STATES AND THE POWERFUL COALITION IT ASSEMBLED WASTED THE MOST PROMISING OPPORTUNITY THE UN HAS EVER HAD TO DETERMINE WHETHER IT COULD FUNCTION AS INTENDED: FORCEFULLY AGAINST AGGRESSION BUT WITH A MINIMUM OF VIOLENCE; AND THE UN WAS INSTITUTIONALLY UNPREPARED TO HANDLE THE CRISIS AMD ITS AFTERMATH. NECESSARY REFORMS INCLUDE PREPLANNED ENFORCEMENT MEASURES, ESPECIALLY FOR SANCTIONS; AND THE ESTABLI ISHAENT OF A PERMANENT UN PEACEKEEPING FORCE.

04849 JOHANSEN, $R$

MILITARY POLICIES AND THE STATE SYSTEM AS IMPEDIMENTS TO MILITARY POL

POLITICAL STUDIES, 40 (1992), 99-115.

MILITARY POLICIES IMPOSE SEVERE LIMITS ON DEMOCRACY AND CALL INTO OUESTION THE VIABILITY OF THE LIBERAL DEMOCRATIC STATE. MILITARY MENTALITY UNDERMINES DEMOCRATIC CULTURE; THE COMPLEXITY OF WARFARE DEFIES PUBLIC UNDERSTANDING; SPEED REQUIRED IN DECISION-MAKING PREVENTS PUBLIC DEBATE; SECRECY MISLEADS THE PUBLIC WHILE OFTEN DISGUISING EXECUTIVE ABUSE OF PONER; VESTED INTERESTS IN HIGH MILITARY EXPENDITURE SKEH POLITICAL PROCESSES; AND CONCENTRATION OF POWER AMONG A FEH OBSTRUCTS DEMOCRATIC PARTICPATION. EVEN STATE SOVEREIGNTY, OBSTRUCTS DEMOCRACY BECAUSE INTERDEPENDENCE REQUIRES GOVERNMENTS TO BE HELD ACCOUNTABLE THROUGH TRANSNATIONAL LAW AND INSTITUTIONS TO FOREIGN AS WELL AS DOMESTIC CITIZENS SINCE BOTH ARE AFFECTED BY NATIONAL DECISION.

04850 JOHNS, $M$.

THE TRAGIC NEGLECT OF AFRICA

FREEDOM REVIEH, 23(4) (JUL 92), 26-27.

LATELY, THE UNITED STATES' HATIONAL POLITICAL LEADERSHIP AND THE MEDIA HAVE TREATED AFRICAN CRISES AS A LOW PRIORITY. HITH A FEW LAUDABLE EXCEPTIONS, THE U.S. FOREIGN POLICY ESTABLISHMENT APPROACHES AFRICA'S HARDSHIPS WITHOUT CREATIVITY, ENERGY, OR URGENCY--AND OFTEN WITH A CERTAIN AMOUNT OF CYNICISM. THE STORY OF STARVING AFRICANS-WHICH ONCE PROMPTED MUSIC VIDEOS, BENEFIT CONCERTS, AND REGULAR TV COVERAGE--HAS BEEN REDUCED TO MERE STATISTICS BURIED IN SELDOM-READ REPORTS OF HUMAN RIGHTS GROUPS AND FAMINE RELIEF CHARITIES. ALL OF THIS IS AN IMOICATIOH OF AFRICA'S STEADY SLIDE OFF THE WEST'S AGENDA.

04851 JOHNSON-FREESE, J.; HANDBERG, R.

THE TORTOISE AMD THE TORTOISE. THE MEW RACE FOR SPACE SPACE POLICY 73 (AUG 91) 199-206.

UNTIL NOW SPACE HAS BEEN DRIVEN BY INTERNATIONAL POL TICAL COMPETE HAS BEEN DRIVEN BY INTERNATIONAL EUROPE HAVE UNDERCUT THE POLITICAL INCENTIVES FOR EXPANDED SPACE ACTIVITY, AND MEANHHILE FISCAL CONSTRAINTS, ARISING FOR DIFFERENT REASONS IN THE USA, EUROPE AND THE USSR, ARE 
PUTTING UNPRECEDENTED PRESSURE ON SPACE BUDGETS. IN THE LONG TERM, HOHEVER, IT IS LIKELY THAT A NEW KIND OF COMPETITION FUELLED BY ECONOMIC MOTIVES WILL PROVIDE THE BASIS FOR A MORE DETERMINED AND PERHAPS MORE STABLE OPENING OF THE SPACE FRONTIER. DROPPING OUT OF THE SPACE RACE FOR SHORT-TERM REASONS COULD BE A COSTLY AND IRREVOCABLE DECISION.

04852 JOHNSON, B.

FREEDOM OR FAILURE?

FREEDOM REVIEH, 23(5) (SEP 92), 7-8.

SOUTH AFRICA IS STILL ON THE COURSE TO FREEDOM, BUT A

CRACK-UP IN THE HOME STRETCH IS POSSIBLE. TRUST IS

DETERIORATING AMONG PRESIDENT F.W. DEKLERK, INKATHA FREEDOM

PARTY LEADER MANGOSUTHU BUTHELEZI, AND AFRICAN NATIONAL

PARTY LEADER MANGOSUTHU BUTHELEZI, AND AFRICAN NATIONAL
CONGRESS PRESIDENT NEL SON MANDELA. BLACKS ARE LOSING

CONGRESS PRESIDENT NELSON MANDELA. BLACKS ARE LOSING

FAILURE TO CONTROL IT.

04853 JOHNSON, B.

MICHIGAN: STATE OF BENEVOLENCE

FREEDOM REVIEW, 23(4) (JUL 92), 42-43.

THE AUTHOR ATTEMPTS TO EVALUATE THE EFFECTIVENESS OF MICHIGAN'S SOCIAL POLICY.

04854 JOHNSON, C.

JAPAN IN SEARCH OF A NORMAL ROLE

DAEDALUS, 121(4) (FAL 92 ), 1-34.

OVER THE NEXT FIVE TO TEN YEARS, JAPAN WILL RE-EMERGE ON

THE WORLD STAGE AS A SIGNIFICANT POL ITICAL ACTOR. IT HILL

SHED THE CLIENT STATUS IT HAS OCCUPIED UNDER THE JAPAN-

UNITED STATES SECURITY TREATY AND, BY THE LATE 1990'S, WILL

BECOME A FULL-FLEDGED MAJOR POWER. THE GRADUAL REDUCTION OF

U.S. FORCES IN THE PACIFIC WILL ALLOH JAPANESE LEADERS

INDEPENDENT DEFENSE CAPABILITIES ALONG THE LINES THAT FORMER

PRIME MINISTER MAKASAME PROPOSED IN THE MID-1980'S. A FAST

PRIME MINISTER NAKASONE PROPOSED IN THE MID-1980'S. A FAST

FIVE YEARS HOULD PROBABLY LEAVE JAPAN UNPREPARED

FIVE YEARS HOULD PROBABLY LEAVE JAPAN UNPREPARED
DOMESTICALLY AND REGIONALLY TO MAKE THE TRANSITION AND WOULD

DOMESTICALLY AND REGIONALLY TO MAKE THE TRANSITION AND WOULO
UNDERMINE JAPANESE CONFIDENCE IN THE VALUE OF AN ALLIANCE

UNDERMINE JAPANESE CONFIDENCE IN THE VALUE OF AN ALLIANCE
WITH THE UNITED STATES. ALTHOUGH SOME POLITICAL REFORM WILL

WITH THE UNITED STATES. ALTHOUGH SOME POLITICAL REFORM WILL

BE UNAVOIDABLE, THE IDEA THAT THE JAPANESE POLITICAL SYSTEM
IS UNABLE TO PROVIDE THE LEADERSHIP FOR THIS TRANSITION IS

IS UNABLE TO PROVIDE THE LEADERSHIP FOR THIS TRANSIT

NONSENSE. REGARDLESS OF WHAT THE UNITED STATES DOES,
JAPANESE MOMENTUM IS TOWARD GREATER INDEPENDENCE FROM THE USA.

04855 JOHNSON, C.M.

THE DYNAMICS OF CONFLICT BETHEEN BUREAUCRATS AND

LEGISLATORS

M. E. SHARPE, 1992, 200

THIS WORK CHALLENGES CONVENTIONAL WISDOM AS TO THE ROLE

OF BUREAUCRACY IN PUBLIC POLICY. THE AUTHOR STUDIES CONFLICT

AND CONSENSUS IN FOUR FEDERAL AGENCIES: THE BUREAU OF

RECLAMATON, THE BUREAU OF INDIAN AFFAIRS, THE SOCIAL AND

REHABILITATIVE SERVICE, AND THE FOOD AND DRUG ADMINISTRATION.

SHE FINDS THAT CONTRARY TO THE STANDARD VIEW, SUBSYSTEMS

ARE NOT CONSENSUAL; NOT ONLY DOES CONFLICT FREQUENTLY OCCUR

WITHIN A SUBSYSTEM, BUT THAT CONFLICT IS ALSO OFTEN RESOLVED

HITHOUT OUTSIDE INTERVENTION. THE CASE STUDIES--BASED IN

PART ON EXCLUSIVE INTERVIEWS--LEAD TO SEVERAL OTHER

SIGNIFICANT FINDINGS. POLICY SUBSYSTEMS CAN PRODUCE

IMPORTANT POLICY CHANGES. BUREAUCRACIES DO NOT ALHAYS

SUPPORT EXPANSION OF THEIR PROGRAM AUTHORIYY. CONFLICT MAY

FINDS THAT THE STANDARD SELF-INTEREST MODEL IS LESS HELPFUL

ANAS THAT THE STANDARD SELF-INTEREST MOOEL IS LESS HELPFUL

HAVE SPECIFIC POLICY GOALS BASED ON THEIR ASSESSMENTS OF

GOOD PUBLIC POLICY.

04856 JOHNSON, E.

A PERMANENT UN FORCE: BRITISH THINKING AFTER SUEZ

REVIEW OF INTERNATIONAL STUDIES, $17(3)$ (JUL 91), 251-266.

UNITED NATIONS SECRETARY GENERAL DAG HAMMARSKKOID

RESPONDED TO THE BRITISH, FRENCH, AND ISRAELI INVASION OF

RESPONDED TO THE BRITISH, FRENCH, AND ISRAELI INVASION
EGYPT IN 1956 WITH THE CREATION OF THE UNITED NATIONS

EGYPT IN 1956 WITH THE CREATION OF THE UNITED NATIONS
EMERGENCY FORCE (UNEF). HIS SUCCESS IN FORGING UNEF IN A

EMERGENCY FORCE (UNEF). HIS SUCCESS IN FORGING UNEF IN A
SHORT PERIOD OF TIME WITH SO FEW GUIDELINES SPARKED A

SHORT PERIOD OF TIME WITH SO FEW GUIDELINES SPARKED A
RENEWED INTEREST, IN BRITAIN AND ELSEHHERE, IN PEACE AND

RENEWED INTEREST, IN BRITAIN AND ELSEHHERE, IN PEACE AND
SECURITY ROLE OF THE UN, AND LED TO FEELINGS OF WHAT IT

SECURITY ROLE OF THE UN, AND LED TO FEELINGS OF WHAT IT
MIGHT BE CAPABLE OF, WERE IT TO BE PROVIDED A MORE PERMANENT

MIGHT BE CAPABLE OF, WERE IT TO BE PROVIDED A MORE PERMA

FORCE. THIS ARTICLE EXAMINES THE BRITISH GOVERMMENT'S

THINKING ON THIS SUBJECT IN THE PERIOD FOLLOWING SUEZ.

INDICATES THAT AL THOUGH THE MACMILLAN GOVERNMENT WAS

PREPARED TO SHOH INTEREST IN THE IDEA AT A PUBLIC LEVEL, IT
WAS NOT HILLING TO TAKE THE LEAD IN PRESSING THE CASE FOR WAS NOT HILLING
SUCH A FORCE.

04857 JOHNSON, G.; WATSON, D.

PRIVATIZATION: PROVISION OR PROOUCTION OF SERVICE? TWO CASE STUDIES

STATE AND LOCAL GOVERMMENT REVIEN, 23(2) (SPR 91), 82-89.

DURING THE PAST DECADE THERE HAS BEEM A HIDESPREAD MOVE

TO GREATER GOVERNMENTAL RELIANCE ON THE PRIVATE SECTOR FOR
THE PROVISION AND PRODUCTION OF PUBLIC SERVICES. THIS MOVEMENT IS GENERALLY LABELED PRIVATIZATION, THIS ARTICLE EXAMINES TWO CASES WHERE A LOCAL GOVERMMENT' PRIVATIZED BOTH ITS WASTE-WATER TREATMENT AND ITS SOLID WASTE DISPOSAL FUNCTIONS, USING A FUNDAMENTALLY DIFFERENT PRIVATIZATION STRUCTURE AND PROCESS IN EACH CASE. THE STUDY CONCLUDES THAT THE STRUCTURE AND PROCESS OF PRIVATIZATION HAVE A SIGMIFICANT IMPACT ON THE SUCCESSFUL APPLICATION OF PRIVATIZATION IN A LOCAL GOVERNMENT SETTING.

04858 JOHNSON, H.

LEFTISTS IN SHEEP'S CLOTHING

NATIONAL REVIEW, XLIII(22) (DEC 91), 22-24.

THIS ARTICLE BRIEFLY OUTLINES THE "NEW CONSERVATISM"

WHICH IS GAINING MOMENTUM IN CALIFORNIA. IT IS BILLED AS A

MELDING OF LIBERALISM ON SOCIAL ISSUES WITH FERVOR FOR FREE MARKETS AND BALANCED BUDGETS. NEW CONSERVATIVE FIGURES SUCH AS REPRESENTATIVE TOM CAMBPELL AND SENATOR JOHN SEYMOUR ARE GIVING TRADITIONAL CONSERVATIVES A STIFF CHALLENGE.

TRADITIONAL CONSERVATIVES PLAN TO CAMPAIGN AGIANST THEIR FELLOW REPUBLICANS AS IF THEY WERE DEMOCRATS, CONCENTRATING ON ISSUES SUCH AS ABORTION, AND RACIAL QUOTAS.

04859 JOHNSON, $H$.

THE ANMOYINGLY SENSIBLE MAN

NATIONAL REVIEW, XLIV(20) (OCT 92), 21-22

THE RACE BETWEEN BRUCE HERSCHENSOHN AND BARBARA BOXER IS AMERICA'S HOTTEST SENATE DUEL, ONE OF THE GOP'S BEST SHOTS AT PICKING UP A SEAT, AND THE IDEOLOGICAL SHOWDOWN OF THE YEAR. IT IS ALSO A CHANCE FOR THE RIGHT TO REASSERT ITS POWER IN CALIFORNIA'S REPUBLICAN PARTY AND TO OFFER THE NATION ANOTHER LEADER IN THE MOLD OF THE LAST GREAT CALIFORNIA CONSERVATIVE. THIS ARTICLE PREDICTS THAT HERSCHENSOHN IS THE CANDIDATE HHO CAN GET THE VOLUNTEER BATTALIONS JAZZED AND THAT ONCE AGAIN A POLITICIAN OF CONVICTION MIGHT HAVE TO SHOW THE PRAGMATISITS HOW TO DO THINGS.

04860 JOHNSON, $H$.

THE FIRE THIS TIME

NATIONAL REVIEW, XLIV(10) (MAY 92), 17-18

THE AUTHOR OF THIS ARTICLE RECOUNTS A DRIVE THROUGH THE RIOT-TORN NEIGHBORHOOOS OF LOS ANGELES AND MUSES ON THE LESSONS LEARNED (AND IGNORED) FROM THE LOS ANGELES RIOTS TRIGGERED BY THE RODHEY KING VERDICT. HE ARGUES THAT THE VERDICT MAY HAVE BEEN UNJUSTIFIED, BUT IT UNDERSCORES THE PROCEDURAL ROADBLOCKS TO CONVICTING ANY ACCUSED CRIMINAL TODAY, THANKS LARGELY TO THE EFFORTS OF GROUPS LIKE THE AMERICAN CIVIL LIBERTIES UNION. WITH REGAROS TO BLACK
POVERTY, THE AUTHOR ARGUES THAT THE OLD-LINE BLACK ELITE POVERTY, THE AUTHOR ARGUES THAT THE OLD-LINE BLACK
MUST BE SUPPLANTED, ALONG WITH THE PSYCHOLOGY OF MUST BE SUPPLANTED, ALONG WITH THE PSYCHOLOGY OF VICTIMIZATION THAT THEY PEDOLE. FINALLY, HE NOTES A POSSIBL
CORRELATION BETHEEN THE LANLESSNESS IN LOS ANGELES AND THE CORRELATION BETWEEN THE LAWLESSNESS IN LOS ANGE
GENERAL DECLINE IN SOCIETAL AND MORAL VALUES.

04861 JOHNSON, H.C. JR.

DOWN FROM THE MOUNTAIN: SECULARIZATION AND THE HIGHER LEARNING IN AMERICA

REVIEH OF POLITICS, 54(4) (FAL 92), 551-588.

AT THE TURN OF THE CENTURY, AMERICA'S HIGHER EDUCATIONAL INSTITUTIONS WERE RAPIDLY DIVESTING THEMSELVES OF THEIR RELIGIOUS FUNCTIONS. THE UNIVERSITY OF ILLINOIS' ATTEMPT TO SEPARATE ITSELF FROM ITS VAGUELY PROTESTANT CHRISTIANITY WAS REPRESENTATIVE OF THIS PROCESS, HHICH WAS THE FINAL CHAPTER IN THE GRADUAL SECULARIZATION OF HIGHER LEARNING IN THE WESTERM EUROPEAN TRADITION. TO UNDERSTAND THIS PROCESS ENTAILS A HISTORICAL ANALYSIS OF THE CULTURAL AND POLITICAL CHANGES THAT BROUGHT IT ABOUT, INCLUDING A CRITICAL

DEFINITION OF SECULARIZATION AS A WAY OF THINKING AND AS A SOCIAL-POLITICAL POLICY. THE PRACTICAL PROBLEM IS LOCATED IN THE POST-REFORMATION TENDENCY TO CONFUSE AN INSTITUTION OF HIGHER LEARNING WITH A LOCAL CHURCH, AS IN THE CASE OF YALE UNIVERSITY. THE RESULT WAS A RELIGIOUS DEMAND THAT THE UNIVERSITY COULD NOT MEET AND A CORRESPONDING WITHDRAWAL OF RELIGION TO A MERELY PASTORAL AND PSYCHOLOGICAL STRATEGY IN PLACE OF ITS FORMER SUBSTANTIVE INTELLECTUAL ROLE. THANKS TO PLACE OF ITS FORMER SUBSTANTIVE INTELLECTUAL ROLE. THANKS TO
THE KANTIAN DEFENSE, NEITHER ORTHODOXY NOR THE NEW LIBERAL THE KANTIAN DEFENSE, NEITHER ORTHODOXY NOR THE NEW LIBERAL
CHRISTIANITY ANY LONGER NEEDED THE UNIVERSITY, BOTH HAVIING CHRISTIANITY ANY LONGER NEEDED THE UNIVERSITY, BOTH HAVING
RETIRED TO A SAFER AUTONOMY. THE RESULTING DILEMMA, THAT TO RETIRED TO A SAFER AUTONOMY. THE RESULTING DILEMMA, THAT
BE RELIGIOUS HAMPERS LEARNING AND TO BE LEARNED ENTAILS BE RELIGIOUS HAMPERS LEARNING AND TO BE LEARNED ENTAILS
RELIGIOUS NEUTRALITY IF NOT ITS COMPLETE ABANDONMENT,

RELIGIOUS NEUTRALITY IF NOT ITS COMPLETE ABANDONMENT,

PERSISTS IN CONTEMPORARY CONFLICTS OVER THE ROL
IN U.S. EDUCATIONAL INSTITUTIONS AT ALL LEVELS.

04862 JOHNSON, J.

AID AND' GODD GOVERHANCE IN AFRICA

ROUND AN GOOD GOVERNANCE IN AFRICA

THIS ARTICLE EXAMINES THE CHANGE OF ATTITUDES WITH REGARDS TO FOREIGN AID TO AFRICA AND THE GROWING NUMBER OF PEOPLE WHO QUESTION THE EFFECTIVENESS OF AID TO AFRICA. THESE CHANGES ARE DISCUSSED IN THE CONTEXT OF SUB-SAHARAN AFRICA IN ORDER TO: OUTLINE THE QUESTIONS WHICH ARE BEING ASKED; DESCRIBE THE STAND TAKEN BY SOME MAJOR DONORS; LOOK AT THE CRITICISMS OF ECONOMIC MANAGEMENT AND POLITICAL 
SYSTEMS IN AFRICA; EXPLAIN SOME DIFFICULTIES WHICH AFRICAN COUNTRIES FACE IN RESPONDING TO THIS CHANGE; AND EVALUATE WHAT DONORS CAN AND CANHOT DO.

04863 JOHNSON, L.K.

ON DRAWING A BRIGHT LINE FOR COVERT OPERATIONS AMERICAN JOURNAL OF INTERNATIONAL LAW, 86(2) (APR 92), 284-309.

IN CONTEMPORARY GLOBAL RELATIONS, COVERT ACTS OF HOSTILITY BETWEEN NATIONS OCCUR WITH A HIGH RATE OF FREQUENCY. THIS ANALYSIS OF COVERT OPERATIONS, AS CONDUCTED BY WESTERN INTELLIGENCE SERVICES, EXPLORES THE PROBLEM OF ASSESSING THEIR EFFECT ON INTERNATIONAL ORDER AND COMITY. THE STUDY IS ORGANIZED INTO THREE SECTIONS. THE FIRST PRESENTS A LADOER OF ESCALATION FOR COVERT OPERATIONS, BASED ON A RISING LEVEL OF INTRUSION ABROAD AS POLICY MAKERS CLIMB UPWARD FROM LOW-RISK TO HIGH-RISK ACTIVITIES. THE SECOND SECTION BRIEFLY SURVEYS LEADING ETHICAL, PHILOSOPHICAL, AND PRACTICAL ISSUES INVOLVED IN EVALUATING THE EFFECTS OF SECRET INTELLIGENCE ACTIVITIES. THE FINAL SECTION OFFERS A SET OF GUIDELINES FOR EVALUATING THE PROPRIETY OF PROPOSED COVERT OPERATIONS.

04864 JOHNSON, L.K.

SMART INTELLIGENCE

FOREIGN POLICY (89) (WIN 93), 53-69.

HITH THE COMING OF THE NEH' WORI ORDER. THE UNITED STATES MUST REORDER ITS INTELLIGENCE-GATHERING PRIORITIES. THE MOST SERIOUS RISKS TO AMERICA'S NATIONAL SECURITY AR GENERALLY SEEN AS THE GLOBAL PROLIFERATION OF NUCLEAR, BIOL OGICAL, AND CHEMICAL WEAPONS AND THE SPREAD OF CONVENTIONAL ARMAMENTS. THE UNITED STATES NEEDS A ROBUST INTELLIGENCE SERVICE WITH SENSITIVE EYES AND EARS AROUND THE GLOBE TO KEEP ABREAST OF DANGERS AND OPPORTUNITIES. IT NEEDS THOUGHTFUL ANALYSTS AND INNOVATIVE MANAGERS HHO CAN SYNCHRONIZE THE SECRET AGENCIES AMD IMPROVE COORDINATION BETWEEN THOSE WHO GATHER INTELLIGENCE AND THOSE WHO USE IT IN THE FUTURE, AMERICA'S INTELLIGENCE ESTABLISHMENT MUST BE LEANER AND MORE EFFICIENT--AND MORE HILLING TO SHARE ITS FINDINGS WITH THE UNITED NATIONS, HITH ALLIES, AND WITH THE PRIVATE SECTOR. THE UNITED STATES CAN SAVE MONEY THROUGH THE USE OF LESS-EXPENSIVE COLLECTION PLATFORMS, FEWER COVERT ACTIONS, AND AN INCREASED RELIANCE ON HUMINT (HUMAN INTELLIGENCE).

04865 JOHNSON, L.K.; GELLES, E. ; KUZENSKI, J.C. THE STUOY OF CONGRESSIONAL INVESTIGATIONS: RESEARCH STRATEGIES

CONGRESS AND THE PRESIDENCY, 19(2) (FAL 92), 137-156. THOUGH NOWHERE MENTIONED IN THE CONSTITUTION. THE POWER TO INVESTIGATE HAS EVOLVED INTO ONE OF THE MOST' POTENT TO INVESTIGATE HAS EVOLVED INTO ONE OF THE MOST POTENT WITH THE EXECUTIVE BRANCH OVER POLICY DECISIONS. THIS ESSAY WITH THE EXECUTIVE BRANCH OVER POLICY DECISIONS. THIS ESSAY ENDAVORS TO IDENTIFY THE CENTRAL FORCES IMPINGING UPON CDNG. POLITICAL SYSTEM THAT STIMULATE THE START-UP OF A AND DUTCOME. THE CONCEPTUAL FRAMENORK EMPLOYS A STIMULUSAND OUTCOME. THE CONCEPTUAL FRAMEWORK EMPLOYS A STIMULUS RESPONSE MODEL. THE VARIOUS STAGES OF A LEGISLATIVE
INVESTIGATION ARE EXAMINED (START-UP, DISCOVERY,

INVESTIGATION ARE EXAMINED (START-UP, DISCOVERY,
INTERROGATION, PRESENTMENT, REFORM, AND FOLLOW THROUGH), AND INTERROGATION, PRESENTMENT, REFORM, AND FOLLOW THROU 16 KEY RESEARCH
INVESTIGATION.

04866 JOHNSON, $N$

FAREHELL TO THE RED FLAG: SOME LESSONS OF EASTERN EUROPE'S REVOLUTION FOR THE WEST

POLITICAL QUARTERLY (THE), 62(1) (JAN 91), 24-34.

THIS ARTICLE CONSIDERS THE IMPACT OF THE COLLAPSE OF SOVIET POWER THE REASSERTION OF POLITICAL FREEDOM IN EASTERN EUROPE ON THE HEST. THE GENERAL ISSUES DISCUSSED ARE THE DISAPPEARANCE OF SOCIALISM, THE REALIZATION THAT THERE IS NO INEVITABLE PROCESS OF HISTORICAL CHANGE AT WORK IN THE WORLD, AND THE REAFFIRMATION OF NATIONAL IDENTITY. THE PRACTICAL MATTER RAISED IS THE IMMEDIATE PROSPECT OF A POLYCENTRIC WORLD AS A CONSEQUENCE OF THE REASSERTION OF NATIONAL IDENTITIES

04867 JOHNSON, $P$ EUROPE: MIRACLE OR MONSTER?

COMMENTARY, 94(2) (AUG 92), 31-37.

THE RATIFICATION, OR NOT, OF THE MAASTRICHT TREATY SHAPING THE FUTURE OF THE EUROPEAK COMMUNITY (EC) IS A MATTER OF PROFOUND IMPORTANCE NOT ONLY FOR EUROPE ITSELF BUT, IN THE LONG RUN, FOR THE UNITED STATES AS WELL. THERE IS A GL IN THE LONG RUN, FOR THE UNITED STATES AS WELL. THERE IS A COMAUNITY ETHOS THE POP D IS A READY GRIFTING INTO THREE HUGE TRADIT SYSTEMS WORL IS ALREADY DRIFTING INTO THREE HUGE TRADING SYSTEMS--THE AMERICAS, EAST ASIA AND EUROPE. THE SCENE COULD BE SET FOR THE GREATEST TRADE HARS THE HORLD HAS EVER KMOH
REAL ONES.

04868 JOHNSON, $P$

WANTED: A NEW IMPERIALISM

NATIONAL REVIEH, XLIV(24) (DEC 92), 28-32; 34 .
THE AUTHOR SUGGESTS THAT WHAT WE NEED TO DO IN THE THENTY-FRIST CENTURY-AND THAT HE CAN MAKE A START IN THE LAST YEARS OF THIS ONE--IS TO MAKE IT POSSIBLE FOR OUR COMPARATIVE AND UNPRECEDENTED FELICITY TO BE SPREAD PROGRESSIVELY TO THE REST OF THE WORLD. HE CLAIMS THAT THIS A NOBLE AIM AND THAT THE DEGREE TO WHICH AMERICA FULFILLS IT WILL DETERMINE, IN TURN, THE SOLIDIITY OF THE

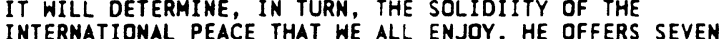
INTERNATIONAL PEACE THAT WE ALL ENJOY. HE OFFERS SEVEN
PILLARS OF THE NEW WISDOM, ADDRESSES THE CHINA QUESTION, WAR AND OUR HIDDEN RESOURCES.

04869 JOHNSON, R.; RAHMAN, S.

IMPROVED BUDGETING AND FINANCIAL MANAGEMENT AS A TOOL FOR ENHANCING THE PERFORMANCE OF LOCAL GOVERNMENT IN DEVELOPING COUNTRIES

INTERNATIONAL JOURNAL OF PUBLIC ADMINISTRATION, 15(5) (1992), 1241-1261.

THIS ARTICLE EXAMINES THE PROBLEMS THAT LOCAL THIRD WORLD GOVERHMENTS FACE IN MEETING THE CHALLENGES OF RAPID TRANSFORMATION AND CHANGE. IT SUGGESTS THAT BUDGETING USED BE USED AS MEANS FOR STRENGTHENING LOCAL GOVERNMENTS' ABILITIES TO DEAL WITH SUCH CHANGES. UNTIL NOW BUDGETING HAS NOT BEEN USED AS A KEY INTERYENTION TOOL FOR STRENGTHENING LOCAL GOVERMMENTS. A HORKING MODEL TO ASSESS THE STATE OF FINANCIAL AND RELATED MANAGEMENT CONDITIONS OF LOCAL FINANCIAL AND RELATED MANAGEMENT CONDITIONS OF LOCAL
GOVERRNMENTS IS PROVIDED. THIS MODEL CAN SERVE AS A USEFUL GOVERRNMENTS IS PROVIDED. THIS MODEL CAN SERVE AS A POINT OF REFERENCE FOR CHANGE AGENTS
STRENGTHENING OF LOCAL GOVERNMENTS.

04870 JOHNSON, S.

LAOS IN 1991: YEAR OF THE CONSTITION

ASIAN SUPVEY XXXII(1) (JAN 92) 82-87.

THE LOA PEOPLE'S DEMOCRATIC REPUBLIC IN 1991 WAS

BUFFETED BY THE SHOCK WAVES RESULTING FROM THE GREAT CRISIS IN THE INTERMATIONAL COMMUNIST MOVEMENT. NEVERTHELESS, ITS BASIC STRATEGY OF THE LAST SIX YEARS REMAINED UNALTERED:

EMBRACE LIBERAL MARKET ECONOMICS BUT PRESERVE THE LAO PEOPLES'S REVOLUTIONARY PARTY'S MONOPOLY OF POLITICAL POWER. LAOS MADE IT PLAIN IN PURSUING THIS COURSE THAT ALTHOUGH IT STILL MADE OBEISANCE TO MARXISH-LENINISM, "BUILDING SOCIALISM" HAD BECOME ONLY A REMOTE AND THEORETICAL GOAL. LAOS EXPANDED ITS RELATIONS HITH COUNTRIES OF THE WORLD, BUT ITS POVERTY, REMOTENESS, AND THE INCREASING AMOMALOUSNESS OF ITS REGIME MAKE IT DIFFICULT TO ATTRACT THE LEVEL OF FOREIGN ASSISTANCE AND INVESTMENT NECESSARY FOR SUSTAINED ECONOMIC GROWTH.

04871 JOHNSON, W.G.

HOUSING POLICY UNDER THE REAGAN PRESIDENCY: THE DEMISE OF AN IRON TRIANGLE

POLICY STUDIES REVIEW, 10(4) (HIN 92), 69-87

THE AUTHOR ANALYZES THE POLITICS OF HOUSING POLICY

DURING THE REAGAN ADMINISTRATION AND APPLIES THE CONCEPT OF "SUBGOVERNMENTS" TO THE HOUSING COAL ITION. HE ANALYZES THE DEMISE OF THE HOUSING SUBGOVERHMENT WITHIN A THEORETICAL A WORK THAT INCLUDES POLICY TYPE AS AN IMPORTANT EXPLANATORY VARIABLE. SPECIFICALLY, HE ARGUES THAT AS HOUSING POLICY SHIFTED FROM DISTRIBUTIVE TO REDISTRIBUTIVE DUE TO THE CURTAILMENT OF FUNDING, THE HOUSING COALITION CAME UMDER PRESSURE FROM EXTERNAL FORCES AND UL TIMATELY
FRAGMENTED INTO COMPETING (RATHER THAN COHESIVE) INTERESTS. FRAGMENTED INTO COMPETING (RATHER THAN COHESIVE) INTERESTS. AS A RESULT, THE U.S.
DRASTICALLY REDUCED.

04872 JOHNSON, W.R.

DEKLERK'S U.D.I.

TRAKSAFRICA FORUM, 9(3) (FAL 92), 15-29.

SOUTH AFRICA'S ALL-WHITE REFERENDUM ON MARCH 17, 1992,

GAVE F.H. DEKLERK'S NATIONAL PARTY A RENEWED MANDA'T TO

CONTINUE THE MOVEMENT TOWARD A NEW CONSTITUTION. WHILE THIS AND OTHER STEPS TAKEN BY DEKLERK CONSTITUTE ADVANCES IN THE PROCESS OF DISMANTLING APARTHEID, THEY DO NOT SIGNAL A

DESIRE FOR A COMPLETELY DEMOCRATIC, OPEN, FREE SOCIETY.

PRESSURES FROM MASS ANTI-APARTHEID MOVEMENTS HAVE FORCED THE NATIONAL PARTY GOVERMMENT TO ALTER OR REPEAL APARTHEID LAWS AS THE ONLY MEANS OF STAYING IN POHER. IN THIS RESPECT DEKLERK'S MEW STRATEGY IS ANALOGOUS TO IAN SMITH'S DESPERATE UNILATERAL DECLARATION OF INDEPENDENCE IN SOUTHERN RHODESIA. LIKE SMITH, DEKLERK IS USING THE EXTRA POLITICAL LIFE TO MAXIMIZE THE POWER AND PRIVILEGE NHITES WILL RETAIN IN THE NEW SOUTH AFRICA.

04873 JOHNSTON, D.

ANTICIPATING INSTABILITY IN THE ASIA-PACIFIC REGION

HASHIMGTON OUARTERLY, 15(3) (SUM 92) 103-112

THIS ARTICLE EXAMINES THE ASIA/PACIFIC REGION WITH EMPHASIS ON CONDITIONS THAT DIRECTLY AFFECT UNITED STATES INTERESTS. IT OUTLINES THE POLITICAL, ECONOMIC, AND SECURITY INTERESTS OF THE UNITED STATES IN THE REGION AND LISTS VARIOUS THREATS TO THE AREA'S STABILITY. THESE THREATS INCLUDE TENSION ON THE KOREAN PENINSULA, THE UNWILLINGNESS OF THE PRC TO EMBRACE REFORM, POTENTIAL FOR DOMESTIC UNRES IN MANY COUNTRIES, THE ARMS BUILDUP, AND NUMEROUS BORDER DISPUTES BETWEEN ASIAN NATIONS. IT ALSO EXAMINES MEANS OF 
DEFUSING CONFLICTS AND ENCOURAGING HARMONY SUCH AS THE DEVELOPMENT OF INTRAREGIONAL ASSOCIATIONS AND THE USE OF CONFIDENCE- AND SECURITY-BUILDING MEASURES. SPECIAL EMPHASIS IS PLACED ON THE PIVOTAL ROLE OF THE U.S. MILITARY PRESENCE
IN THE REGION.

04874 JOHNSTON, L.

THE POLITICS OF PRIVATE POLICING

POLITICAL QUARTERLY (THE), 63(3) (JUL 93), 341-349.

THE MIXED ECONOYY OF POL ICING IS BEST SEEY AS A

CONTINUUM. IN GREAT BRITAIN, THAT CONTINUUH CONSISTS OF THREE STRANDS: A PUBLIC STRAND; A PRIVATE STRAND; AND A HYBRID STRAND. THE EXISTENCE OF A MIXED ECONOMY RAISES QUESTIONS ABOUT THE NATURE AND OUALITY OF RELATIONS BETHEEN PUBLIC AND PRIVATE SECTORS OF PRIVISION; ABOUT THE CHANGING PUBLIC AND PRIVATE SECTORS OF PRIVISION; ABOUT THE CHANC CHARACTER OF THE PUBLIC-PRIVATE OIVIDE: AND ABOUT THE
MECHANISM REQUIRED TO ACHIEVE ACCOUNTABILTIY OVER ACTIVITIES OCCURRING ACROSS THAT CHANGING DIVIDE. THESE ISSUES ARE ADDRESSED BY CONSIDERING THE EXPANDED ROLE OF PRIVATE ADCURITY IN BRITAIN.

04875 JOHNSTON, M

RIGHT AND WRONG IN BRITISH POLITICS: "FITS OF MORALITY" IN COMPARATIVE PERSPECTIVE

POLITY, 29(1) (FAL 91), 1-26.

CONCEPTIONS OF RIGHT AND WRONG ARE AN INTEGRAL ASPECT OF POLITICS AND CULTURE. REACTIONS TO PUBLIC OR PRIVATE MISCONDUCT CAN ILLUMINATE BASIC POLITICAL VALUES AND COMMITMENTS. THIS ARTICLE EXPLORES CONCEPTIONS OF RIGHT AND WRONG IN GREAT BRITAIN AND COMPARES ITS FINDINGS WITH THOSE OF AN EARLIER STUDY OF AMERICAN CONCEPTIONS OF WRONGDOING. IT CONCLUDES THAT POLITICAL CULTURE IS LESS A FIXED ATTRIBUTE OF A SOCIETY THAN A GUIDE TO UNDERSTANDING ITS PARTICULAR STYLE OF JUOGEMENT, ADAPTION, AND CHANGE.

04876 JOHNSTON, R.: PATTIE, C.

CLASS DEALIGNMENT AND THE REGIONAL POLARIZATION OF VOTING PATTERNS IN GREAT BRITAIN, 1964-1987

POLITICAL GEOGRAPHY OUARTERLY, 11(1) (JAN 92), 73-86. ITICAL GEOGRAPHY QUARTERLY, 11 (1) (JAN 92), 73-86,
SURVEY DATA RELATING TO EACH BRITISH GENERAL ELECTION SURVEY DATA RELATING TO EACH BRITISH GENERAL ELECTION
OVER THE PERIOD $1964-1987$ ARE USED TO TEST THE FREQUENTLYCLAIMED ASSUMPTION THAT REGIONAL POLARIZATION INCREASED OVER CLAIMED ASSUMPTION THAT REGIONAL POLARI ZATION INCREA THE PERIOD. USE OF A LOG-LINEAR MODELLING ALLOWS THE
HYPOTHESIS TO BE EVALUATED WITH THE CHANGING REGIONAL CLASS COMPOSITION HELD CONSTANT. THE RESULTS INDICATE THAT CLASS COMPOSITION HELD CONSTANT. THE RESULTS INDICATE THAT CLASS POLARIZATION REMAINS STRONG IN THE NORTH BUT HAS DECLINED SUBSTANTIALLY IN THE SOUTH. THIS PAPER IS THE FIRST TO PRESENT THE RESULTS OF ANALYSES OF THE CHANGING GEOGRAPHY OF
VOTING IN GREAT BRITAIN, BY OCCUPATIONAL CLASS GROUPS, OYER VOTING IN GREAT BRITAIN, BY
SEYERAL GENERAL ELECTIONS.

04877 JOHNSTON, R.

PARTY IDENTIFICATION AND CAMPAIGN DYNAMICS

POLITICAL BEHAVIOR, 14(3) (SEP 92), 311-332

THE AUTHOR CONSIDERS THE ROLE OF PARTY IDENTIFICATION IN THE 1988 CANADIAN GENERAL ELECTION CAMPAIGN, USING DATA DRAWN PRIMARILY FROM A ROLLING CROSS-SECTION SURYEY. THE CANADIANS EXHIBITED PARTY COMMITMENTS THAT SHAPED THEIR REACTION TO THE EVENTS OF THE CAMPAIGN: ISSUE POSITIONS LINED UP WITH PARTY IDENTIFICATION, AS DID PERCEPTIONS OF THE ONE LEADER REHABILITATED BY THE CAMPAIGN. BUT THE CAMPAIGN ALSO CUT THROUGH PARTY GROUPS. SUCH A MIXTURE OF REIMFORCEMENT AND OISPLACEMENT MIGHT WELL TYPIFY CAMPAIGNS IN CAMADA AMD ELSEHHERE. THE AUTHOR ARGUES THAT ACADEMIC OBSERYERS IN THE UNITED STATES SHOULD TAKE CAMPAIGNS MORE SERIOUSLY THAN THEY HAVE TO DATE AND SHOULD CONSIDER ADOPTING SOME OF THE MEASUREMENT AND ANALYSIS STRATEGIES OF THE 1988 CANADIAN STUOY.

04878 JOHNSTON, R.

POLITICAL GENERATIONS AND ELECTORAL CHANGE IN CANADA BRITISH JOURNAL OF POLITICAL SCIENCE, 22(1) (JAN 92). 93-115.

THE AUTHOR CONSIOERS THE ELEMENTARY LOGIC OF AGE STRUCTURES IN PARTY PREFERENCE DATA AND PROPOSES A SIMPLE ESTIMATION MODEL WITH DEMOGRAPHIC AND HISTORICAL ELEMENTS. AS VOTERS AGE. THEIR PREFERENCES INTENSIFY. BUT THEY DO NOT INTENSIFY DRAMATICALLY AND GENERATIONAL DIFFERENCES IN PARTY INTENSIFY DRAMATICALLY AND GENERATIONAL DIFFERENCES
PREFERENCES ARE CORRESPONDINGLY WEAK. THE CANADIAN PREFERENCES ARE CORRESPONDINGLY WEAK. THE CANADIAM ACCUMULATED EXPERIENCE OF THE INDIVIDUALS THAT COMPOSE IT. ACCUMULATED EXPERIENCE OF THE INDIVIDUALS THAT COMPOSE IT. CANADA IS CONYERSION IN THE EXISTING ELECTORATE.

04879 JOHNSTON, R.J.

POLITICAL GEOGRAPHY OF CONTEMPORARY EVENTS XIII: REDISTRICTING IN ENGLAND REVISITED

POLITICAL GEDGRAPHY, $11(6)$ (NOY 92), 579-587.

THE PARLIAMENTARY BOUNDARY COMMISSION FOR ENGLAND HAS COMMENCED A GENERAL REVIEW OF ALL CONSTITUENCIES IN THE COUNTRY. THE PREVIOUS REVIEW, WHICH HAS REPORTED TO PARLIAMENT IN 1983, WAS THE SUBJECT OF A LEGAL CHALLENGE DUE TO DISPARITIES IN THE SIZE OF ELECTORATES. ALTHOUGH THE CHALLENGE LOST, IT APPEARS TO HAVE INFLUENCED THE NEW REVIEN;
ANALYSIS OF THE COMHISSION'S FIRST FOUR SETS OF RECOMMENDATIONS SUGGESTS THAT THIS IS CLEARLY THE CASE.

04880 JOHNSTONE, $D$.

OF TRANSFORMING AND BEING TRANSFORMED--AFTER SOCIALISM'S DEBACLE

WORLD POLICY JOURNAL, VIII(3) (SUM 91), 525-535.

THE TRIUMPHANT "FREE WORLD" INCLUDES THE MILLIONS OF HOMELESS CHILDREN LIVING IN THE CRIME-RIDDEN STREETS OF SCALE, AND THE GROWING NUMBER OF POOR IN THE UNITED STATES ITSELF. COMMUNISM IS NOT THE ONLY FAILURE OF THE 2OTH CENTURY. THE GREATER, OVERARCHING FAILURE IS THE FAILURE TO USE THE TREMENDOUS INCREASE IN TECHMOLOGICAL POWER TO BUILD THE BASIS FOR ANY SORT OF HUMANE AND DURABLE CIVILIZATION. THE MULTIPLE FAILURES OF THE 2OTH CENTURY REOPEN QUESTIONS THE MULTIPLE FAILURES OF THE 2OTH CENTURY REOPEN QUESTIONS
ABOUT HUMANITY'S CONSCIOUS CONTROL OF ITS DESTINY SUCH AS ABOUT HUMANITY'S CONSCIOUS CONTROL OF ITS DESTINY SUCH AS
HOW UNDERSTANDING CAN BE JOINED TO POWER IN SOCIETY, AND HOW HOW UNDERSTANDING CAN BE JOINED TO POWER IN SOCIETY, AND
INDIVIDUAL FREEDOM CAN BE RECONCILED WITH SOCIAL PURPOSE. INDIVIDUAL FREEDOM CAN BE RECONCILED WITH SOCIAL THIS ARTICLE CALLS FOR THE DIVERSIFICATION OF INTERNATIONALISH AND THE ADOPTIO
LIMITATION IN THE RICH NORTH.

04881 JONASSON, $H$. GREECE--INEXTRICABLE LINKS MIDDLE EAST INTERNATIONAL, (427) (JUN 92), 8-9 ON 18-19 MAY, CONSTANTINE MITSOTAKIS BECAME THE FIRST GREEK PRIME MINISTER EVER TO VISIT ISRAEL--SIGNIFYING AN UPTURN IN RELATIONS THAT IN THE PAST HAVE BEEN CHARACTERIZED AS COOL. HAVING FULFILLED A PRE-ELECTION PLEDGE BY GRANTING ISRAEL FULL DIPLOMATIC RECOGNITION IN MAY 1990, MITSOTAKIS'
VISIT WAS SURROUNDED BY SPECULATION--COMING AS IT DID ONLY A MONTH BEFORE ISRAEL'S GENERAL ELECTION. IN TEL AVIV,

ECONOMIC AND CULTURAL AGREEMENTS WERE SIGNED AND TALKS WERE CONDUCTED REGARDING MILITARY-INDUSTRIAL COOPERATION. MINDFUL OF ARAB SENSIBILITIES, MITSOTAKIS ALSO WENT TO JERUSALEM TO ASSURE A GATHERING OF PALESTINIAN REPRESENTATIVES THAT GREECE HAD NOT ABANDONED ITS TRADITIONAL POLICY OF SUPPORT FOR PALESTINIAN INDEPENDENCE OR ITS LONG-STANDING OPPOSITION TO ISRAELI SETTLEMENT IN THE OCCUPIED TERRITORIES. APART FROM ANCIENT HISTORICAL TIES TO PALESTINE, GREECE IS FROM ANCIENT HISTORICAL TIES TO PALESTINE, GREECE IS
INEXTRICABLY INVOLVED IN THE FATE OF ARABS AND JEWS ALIKE-INEXTRICABLY INVOLVED IN THE FATE OF ARABS AND JEWS ALIKE-
PRINCIPALLY BECAUSE OF THE PRESENCE OF THE GREEK DRTHODOX PRINCIPALLY BECAUSE OF THE PRESENCE OF THE GREEK ORTHODOX
PATRIARCH OF JERSUSALEM, HIS PALESTINIAN FLOCK AND MANY PATRIARCH OF JERSUSALEM, HIS PALESTINIAN FLOCK AND
CHURCH PROPERTIES IN BOTH ISRAEL AND THE OCCUPIED CHURCH PROPERT

04882 JONASSON, $H$.

GREECE, TURKEY AND CYPRUS: PATIENCE EXHAUSTED MIDOLE EAST INTERNATIONAL, 436 (OCT 92 ), 14. THE GOVERNMENT OF GREECE HAS RESOLVED TO BLOCK ANY AND ALL MEASURES OESIGNED TO BRING TURKEY CLOSER TO ITS GOAL OF FULL MEMBERSHIP IN THE EUROPEAN COMMUNITY UNTIL SIGNIFICANT AND LASTING PROGRESS IS MADE ON A CYPRUS SETTLEMENT. THE CRUNCH COULD COME AS EARLY AS 9 NOVEMBER 1992, WHEN THE EC AND TURKEY MEET TO EXAMINE THE IMPLEMENTATION OF THE EC'S FOURTH FINANCIAL PROTOCOL FOR TURKEY; AND
WEST EUROPEAN UNION DEFENSE ARRANGEMENT.

04883 JONASSON, H.; JANSEN, M.; POPE, H.

THE U.S. AND CYPRUS--GREEK HOPES DEFLATED, APPEASING OZAL, CYPRIOTS WARY OF BUSH

MIDOLE EAST INTERNATIONAL, (405) (JUL 91), 14-15

DESPITE A SERIES OF HOPEFUL STATEMENTS, PRESIDENT BUSH WOUND UP HIS VISITS TO GREECE AND TURKEY ON 22 JULY WITHOUT SETTLING SPECULATION ON HOW FAR HE WAS PREPARED TO PUSH FOR A SOLUTION FOR THE DIVIDED ISLAND OF CYPRUS. WHILE BUSH DECLARED THAT HE WAS WILLING TO SERVE AS A "CATALYST" BETHEEN ATHENS AND ANKARA, IT WAS NOT CLEAR EXACTLY WHAT HE MEANT. HIS RHETORIC WAS NOT SATISFYING TO GREEK CYPRIOTS LIKELY TO BE GRANTED.

04884 JONES, A.

BEYONO THE BARRICADES: THE SANDINISTA PRESS AND POLITICAL TRANSITION IN NICARAGUA

NEW POL ITICAL SCIENCE, 23 (FAL 92), 63-90.

THIS ARTICLE CONSIDERS THE RELATIONSHIP BETWEEN BARRICADA (THE OFFICAL ORGAH OF THE SANDINISTA FRONT) AND BARRICADA (THE OFFICAL ORGAN OF THE SANDINISTA FRONT) AND
THE FSLM AS IT DEVELOPED OVER THE FSLN'S YEARS IN POWER. IT THE FSLN AS IT DEVELOPED OVER THE FSLN'S YEARS IN POWER. IT EVALUATES THE IMPACT OF THE 1990 ELECTION DEFEAT ON THE
NEWSPAPER, WITH PARTICULAR REFERENCE TO THE HOST OF ECONOMIC NEWSPAPER, HITH PARTICULAR REFERENCE TO THE HOST OF ECONOM
PRESSURES THAT AROSE IN THE AFTERMATH OF DEFEAT. REFERENCE PRESSURES THAT AROSE IN THE AFTERMATH OF DEFEAT. REFERENCE IS MADE TO HOW THE PAPER'S OHN AGENDA SHAPES BARRICADA'S ROLE HITHIN THE BROADER FSLN STRATEGY--AND HOW THAT STRATE IN TURN NOW REFLECTS A GREATY VARIETY OF UNPUTS BY PROREVOLUTIONAY FORCES AND ACTORS. IN CONCLUSION, THE ATTEMPT TO TRANSFORM THE PAPER INTO A PUBLIC OPINION LEADER IS EXAMINED FOR ITS VALUE AS A CONCEPT THAT ENABLES ONE TO UNITE THE DISP
FUNCTIONING.

04885 JONES, A.

THE FIRST COMMONWEALTH FORUM FOR NON-GOVERNMENTAL 
ORGANIZATIONS: A VOICE FOR THE NGOS OF THE COMMONHEALTH DOUND TABLE (320) (OCT 91) 401-410

IN AUGUST 1991, 150 LEADERS OF NON-GOVERMMENTAL ORGANIZATIONS (NGOS) FROM AROUND THE COMMONHEALTH PLAN TO MEET TOGETHER FOR A HEEK IM HARARE FOR THE FIRST MEET TOGETHER FOR A WEEK IN HARARE FOR THE FIRST COMMONWEALTH NGO FORUM. THE MAIN THEME OF THE FORUM IS ENVIRONMENTALLY SUSTAINABLE DEVELOPMENT; ITS TWO SUB-THEMES ARE NGO-GOVERNMENT RELATIONS, AND NGOS IN POST-APARTHEID AFRICA. THIS ARTICLE CONSIDERS THE PURPOSE OF THE FORUM, ITS TIMING, ITS PARTICIPANTS, AND ITS SIGNIFICANCE.

04886 JONES, A.J. JR.

AFFIRMATIVE TALK, AFFIRMATIVE ACTION: A COMPARATIVE STUDY OF THE POLITICS OF AFFIRMATIVE ACTION

PRAEGER, $1991,288$.

THIS BOOK CONSIDERS THE ENFORCEMENT OF AFFIRMATIVE ACTION PROGRAMS. NATIONAL DATA INDICATES THAT MANY IF NOT MOST AFFIRMATIVE ACTION (AA) PROGRAMS HAVE HAD RELATIVELY LITTLE IMPACT ON HIRING AND PROMOTION PRACTICES. THE AUTHOR EXAMINES THE IMPLEMENTATION OF AFFIRMATIVE ACTION IN THE FLORIDA CITY OF GAINESVILLE, SITE OF A LARGE COSMOPOLITAN UNIVERSITY AND THE ALACHUA COUNTY SEAT. THE AUTHOR FINDS UNIVT THE SUPPOSEDIY MORE CONSERYATIYE COUNTY GOVERMMENT DID THA TETTER IN IMPLEMENTIMG AA THAN DID THE CITY. THE COUNTY FAR BETTER IN IMPLEMENTING AA THAN DID THE CITY. THE COUN GOVERNMENT SUCCEEDED IN SETTING UP AN AA PLAN THAT GOT SIGNIFICANT NUMBERS OF BLACKS AND WONEN INTO THE HIGH STATUS JOBS FROM WHICH THEY HAD PREVIOUSLY BEEN EXCLUDED. THE CITY GOVERNMENT'S EMPLOYMENT PRACTICES ACTUALLY RETROGRESSED OVER THE PERIOD STUDIED, AND THE NUMBERS OF HIGH STATUS JOB BY BLACKS AND WOMEN DROPPED. THE AUTHOR EMPHASIZES THE IMPORTANCE OF THE POSITION OF THE AA HEAD IN THE LOCAL
HIERARCHY AND THE NEED FOR "SUPPORT" FROM ELECTED OFFICIALS. HIERARCHY AND THE NEED FOR "SUPPORT" FROM ELECTED OFFICIAL
HE ALSO TELLS OF THE POOR JOB DONE BY BLACK AND WOMEN'S ADVOCACY GROUPS IN PRESSING FOR AND MONITORING AFFIRMATIVE ACTION PROGRAMS.

04887 JONES, $C$

THE DIFFUSION OF RESPONSIBILITY: AN ALTERNATIVE

PERSPECTIVE FOR NATIONAL POLICY POLITICS IN THE U.S.

GOVERNANCE, 4(2) (APR 91), 150-167.

THIS ARTICLE PROPOSES A DIFFUSION OF RESPONSIBILITY PERSPECTIVE IN ANALYZING POST-WORLD WAR II POLITICS IN THE UNITED STATES. MANY ANALYSTS TEST THE AMERICAN SYSTEM BY A RESPONSIBLE PARTY PERSPECTIVE, PROPOSING REFORMS THAT WILL ORIENT THE SYSTEM TOWARD THE GOALS OF THAT MODEL. DIVIDED GOVERMMENT HAS CHARACTERIZED MUCH OF THE PERIOD SINCE 1945 AND IDENTIFIABLE (AND WHOLLY CONSTITUTIONAL) POLITICS HAS AND IDENTIFIABLE (AND WHOLLY CONSTITUTIONAL) POLI ACCOMPANIED THAT DEVELOPMENT. THE DIFFUSION OF
RESPONSIBILITY ALTERNATIVE IS CHARACTERIZED BY A SEPARATED RESPONSIBILITY ALTERNATIVE IS CHARACTERIZED BY A SEPARATED PRESIDENCY, AN EXPANSIVE CONGRESS, COMPETITION BETWEEN THE
BRANCHES FOR SHARED POWER, AND, ABSENT A CRISIS, A TENDENCY BRANCHES FOR SHARED

04888 JONES, J.R

ENVIRONMENTAL ISSUES AND POLICIES IN COSTA RICA: CONTROL OF DEFORESTATIOM

POLICY STUDIES JOURNAL, 20(4) (WIN 92), 679-694.

DESPITE ITS WIDELY PUBLICIZED EFFORTS IN ENVIRONMENTAL CONSERVATION, COSTA RICA CONTINUES TO EXPERIENCE SEVERE DEFORESTATION DUE TO ENTRENCHED DEFORESTATION INTERESTS, WHICH ARE AIDED BY EXISTING LEGISLATION THAT UNINTENTIONALLY FAVORS DEFORESTATION AND BY THE FAILURE TO ENFORCE PROTECTIVE LAWS. COSTA RICA'S NEWEST STRATEGY INVOLVES THE MOBILIZATION OF A BROAD-BASED CONSERVATION CONSTITUENCY THROUGH ENVIRONMENTAL EDUCATION AND THE DEVELOPMENT OF A CONSERVATION AREA STRATEGY THAT HELPS TO DISTRIBUTE THE RESPONSIBILITIES AND BENEFITS OF CONSERVATION AMONG POPULATIONS ADJACENT TO PROTECTED AREAS.

04889 JONES, K.; JOHNSTON, R.J.; PATTIE, C.J.

PEOPLE, PLACES, AND REgIONS: EXPLORING THE USE OF MULTI-

LEVEL MODELLING IN THE ANALYSIS OF ELECTORAL DATA
BRITISH JOURNAL OF POLITICAL SCIENCE, 22(3) (JUL 92),

343-380

THERE HAS BEEN CONSIDERABLE RECENT DEBATE ABOUT THE IMPORTANCE OF LOCAL CONTEXT AS AN INFLUENCE ON POLITICAL ATTITUDES AND VOTING BEHAVIOR IN GREAT BRITAIN. RESOLUTION OF THAT DEBATE HAS BEEN DIFFICULT, BECAUSE ANALYTICAL METHODS HAVE NOT BEEN AVAILABLE WITH WHICH TO EVALUATE THE RELATIVE IMPORTANCE OF BOTH INDIVIDUAL VOTER CHARACTERISTICS AKD THE CHARACTERISTICS OF THEIR MILIEUX AS INDEPENDENT AND THE CHARACTERISTICS OF THEIR MILIEUX AS INDEPENE OF MULTICORRELATES OF ATTITUDES AND BEHAVIOR. THE TECHNIOUE OF MULTI LEVEL MODELING HAS BEEN DEVELOPED BY EDUCATIONAL RESEARCH TO DO JUST THAT. IT IS INTRODUCED HERE AND ILLUSTRATED, USING DATA FOR THE 1987 BRITISH GENERAL ELECTION. THE PRELIMINARY RESULTS SUGGEST THAT PLACE CLEARLY DOES MATTE AS A COMPON

04890 JONES, L.

NATIONALISM AND THE SELF

PEACE \& DEMOCRACY NEWS, 11 (2) (WIN 92), 20-22,

NATIONALISM WEST OF THE ELBE HAS A FORM OF PARIAH STATUS AMONG HESTERN LIBERALS AND THE LEFT. IT IS CURRENTLY A CATCH-
ALL TERM FOR ALL SORTS OF UGLINESS. THE ACTUAL DICTIONARY DEFINITION IS: DEVOTION TO ONE'S NATIONS: A POLICY OF NATIONAL INDEPENDENCE. THIS ARTICLE EXPLORES WESTERN HYPOCRISY REGARDING NATIONALISM USING THE CASE OF EX-

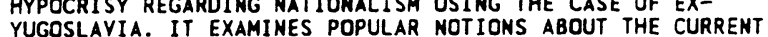
YUGOSLAVIA. IT EXAMINES OF NATIONALISH AND CONCLUDES THAT IN EASTERN EUROPE, ORIGINS OF NATIONALISM AND CONCLUDES THAT IN EASTERN E NATIONALISM DEVELOPED A STRONG ASSOCIATION WITH SELF-
DETERMINATION AND THE DESIRE TO ESCAPE FROM EMPIRE. IT HAS DETERMINATION AND THE DESIRE TO ESCAPE FROM EMPIRE. IT OUTWARD-LOOKING INTERNATIONALIST PERSPECTIVE.

04891 JONES, R. OLD QUARRELS AND NEW REALITIES: SECURITY IN SOUTHERN ASIA AFTER THE COLD WAR

WASHINGTON QUARTERLY, 15(1) (WIN 92), 105-128.

THE SHEEPING CHANGES THAT HAVE DISRUPTED COLD WAR PATTERNS HAVE FORCED INDIA AND PAKISTAN TO BEGIN A REASSESSMENT OF THEIR INTERESTS AND ALIGNMENTS. BOTH COUNTRIES WERE ABLE TO RESPOND COHERENTLY TO THE RECENT GULF WAR BUT DRAMATIC EXTERNAL CHANGES HAVE DONE NOTHING TO REDUCE THE RIVALRY BETWEEN INDIA AND PAKISTAN. THIS ESSAY EXPLORES HOH THE NATIONAL LEADERS OF INDIA AND PAKISTAN ARE RESPONDING TO THE RAPID CHANGES IN EAST-HEST RELATIONS AND TO THE CONSEQUENCES FOR THEIR REGIONAL SITUATIONS. IT CONCLUDES THAT THE ABILITY OF DELHI AND ISLAMABAD TO ADORESS THE ECONOMIC DEVELOPMENT AGENDA WILL DETERMINE WHETHER SOUTH ASIA SLIDES DEEPER INTO DESPAIR AND NUCLEAR CONFLAGRATION OR JOINS THE MORE HOPEFUL MOVEMENT OF HISTORY EVIDENT IN SO MANY OTHER PARTS OF THE WORLD.

04892 JONES, $R$.

U.S. MIGRATION: AN ALTERMATIVE ECONOMIC MOBILITY LADOER FOR RURAL CENTRAL MEXICO

SOCIAL SCIENCE OUARTERLY 73(3) (SEP 92), 496-510.

THIS STUDY CONDUCTED IN NORTH CENTRAL MEXICO TENDS TO SUPPORT THE YIEH THAT INTERMATIONAL WAGE IABOR MIGRATION LEADS TO ECONOMIC GROWTH, REINVESTMENT, AND A MORE EQUITABLE DISTRIBUTION OF PONER AND RESOURCES. ALTHOUGH U.S. MIGRATION EXPERIENCE INCREASED THE PERCENTAGE OF FAMILY PURCHASES MADE OUTSIDE THE SMALL TOWNS WHICH HERE THE FOCUS OF STUDY, MOST PURCHASES REMAINED WITHIN THE MUNICIPIO. U.S. MIGRATION INCREASED THE LEVEL OF ECONOMIC WELFARE AND POSSESSSIONS OF FAMILIES AND INCREASED RELATIVE LEVELS OF AGRICULTURAL AND HUMAN CAPITAL INVESTMENT. THUS, IT APPEARS TO OFFER POORER CLASSES A HERETOFORE UNAVAILABLE CHANNEL TO ACHIEVE ECONOMIC AND SOCIAL MOBILITY.

04893 JONES, S.F.

INDIGENES AND SETTLERS

CULTURAL SURVIVAL QUARTERLY, 16(1) (WIN 92), 30-32.

THE COMBINATION OF NEWLY-INDEPENDENT, MULTI-CULTURAL REPUBLICS AMD WEAK DEMOCRATIC INSTITUTIONS HAS FOCUSED THE ROPLD'S ATTENTION ON MINORITY RIGHTS. INDEED, THE ATTITUDE WORLD'S ATTENTION ON MINORITY IMIGHTS. INDEED, THE ATTITUDE EMERGING SA THEIR DEMOCRATIC INTENTIONS. A PRIME EXAMPLE OF BAROMETER OF THEIR DEMOCRATIC INTENTYONS. A PRIME EXAMPLE THIS IS GEORGIA, WHERE THE GOVERMMENT HAS RESTRICTED THE RIGHTS OF THE ABKHAZIANS, RUSSIANS, ADZHARS, AND OTHER MEMANDING CUL TURAL AND EDUCATIONAL EOUALITY, GREATER DEMANDING CUL TURAL AND EDUCATIONAL EQUALITY, GREATER POLITICAL AND ECONOMIC REPRESENTATION, AND EVEN SECESSION. DRIVEN BY ECDNOMIC ANXIETIES, THE LACK OF CENTRAL POWER, AND MINORITIES ARE CHALLENGING THE HEGEMONY OF THE DOMINANT MINHIC GROUPS

04894 JONES, $W$.

TERRORISM AND ELECTRICAL ENERGY INTERRUPTION: THE ROLE OF THE FEDERAL EMERGENCY MANAGEMENT AGENCY TERRORISH, 13(6) (NOV 90), 441-444.

THIS ARTICLE EXAMINES THE ROLE OF THE FEDERAL EMERGENCY MANAGEMENT AGENCY (FMEA) IN REDUCING THE CDNSEQUENCES OF MAJOR DOMESTIC TERRORIST INCIDENTS, AND IN RECOYERY ACTIVITIES REQUIRED AS A RESULT OF THOSE CONSEQUENCES. IT RECOUNTS THE LESSONS LEARNED FROM RECENT EMERGENCY

SIMULATIONS. ISSUES DISCUSSED INCLUDE: FEDERAL COORDINATING REGIONAL AND INTERNATIONAL IMPLICATIONS, SAVING LIVES, PLANS AND PREPARATIONS, ORGANIZATION FOR RESPONSE, PRIORITY SETTING, RESTORATION OF BUSINESS, RESPONSE TEMPO, AND TELECOMMUNICATIONS.

04895 JOPPKE, C

DECENTRALIZATION OF CONTROL IN U.S. NUCLEAR ENERGY POLICY POLITICAL SCIENCE QUARTERLY, 107(4) (WIN 93), 709-726. THE AUTHOR IDENTIFIES SOME TRENDS TOWARD DECENTRALIZED CONTROL IN U.S. NUCLEAR ENERGY POLICY. HE SUGGESTS THAT THE CONFLICT-ORIENTED AND FRAGMENTED AMERICAN POLITY CANNOT PROYIDE THE STABLE ENVIRONMENT REQUIRED FOR THE SUCCESSFUL IMPLEMENTATION OF A HIGHLY-COMPLEX AND INFLEXIBLE TECHNOLOGY.

04896 JORDAAN, $K$.

ZAMBIA'S 'FIRST' DEMOCRATIC ELECTION--LESSONS FOR SA

SOUTH AFRICA FOUNDATION REVIEN, 17(1) (DEC 91), 1-2.

NEWS COVERAGE OF THE ZAMBIAN ELECTION SUGGESTS THAT THE WORLD REALIZED THAT ZAMIBA IS THE FIRST COUTHRY TO 
EXPERIENCE THE "WINDS OF DEMOCRATIC PLURALISM" THAT ARE BOUND TO SHEEP ACROSS AFRICA. THIS REPORT EXAMINES THE ZAMBIAM SITUATION AND CONCL COMMON WITH THE COUNTRIES TO THE NORTH OF THEM. THE ELECTION IS EVALUATED AND THE ARTICLE CONCLUDES THAT SOUTH AFRICA SHOULD START PREPARING FOR ITS FIRST MULTI-PARTY ELECTIONS AND THAT THESE ELECTIONS SHOULD BE HIGH ON THE AGENDA OF THE AND THAT THESE ELECTIOHS

04897 JORDAN, D.: PAGE, B

SHAPING FOREIGN POLICY OPINIONS: THE ROLE OF TY NEWS JOURNAL OF CONFLICT RESOLUTION, 36(2) (JUN 92), 227-241. INCREASING INCREASING EVIOENCE OF CONNECTIONS BETHEEN PUBLIC OPINION AND U.S. FOREIGN POLICY-MAKING SUGGESTS THE IMPORTANCE OF DETERMINING WHAT INFLUENCES SHAPE THE COLLECTIVE FOREIGN POLICY PREFERENCES OF THE PUBLIC. A DATA SET INVOLVING REPEATED MEASURES OF PUBLIC OPINION AND CONTENT ANALYSES OF TV NEWS BROADCASTS BEFORE AND BETHEEN OPINION SURVEYS IS USED TO ESTIMATE THE IMPACT OF NEWS STORIES FROM VARIOUS SOURCES ON OPINION. DESPITE IDEAS ABOUT THE TWO PRESIDENCIES AND THE LIKE, THE PROCESS OF SHAPING OPINION ON FOREIGN POLICY DOES NOT APPEAR SUBSTANTIALLY DIFFERENT FROM THAT AFFECTING DOMESTIC POLICY PREFERENCES. SOME IMPLICATIONS FOR THE DEMOCRATIC CONTROL OF FOREIGM POLICY ARE DISCUSSED.

04898 JORDAN, G.; SCHUBERT, K. A PRELIMINARY ORDERING OF POLICY NETHORK LABELS EUROPEAN JOURNAL OF POLITICAL RESEARCH, 21(1-2) (FEB 92), 7-27.

THE AUTHORS CLARIFY THE RELATIONSHIPS AMONG A VARIETY OF TERMS THAT ARE USED TO DISCUSS THE INTERACTION BETHEEN GOVERMMENT/STATE AND INTEREST GROUPS. THEY START WITH A SHORT REFLECTION ON THE MAIN THEORIES OF INTEREST INTERMEDIATON INTERMEDIATION--PLURALISM AND CORPORATISM--AND ARGUE FOR RESERVING THE TERM "POLICY NETHORK AS A GENERIC LABEL EMBRACING DIFFERENT IYPES OF NETHORK RELATIONSHIPS. THEY RECORD THE VARIETY OF LABELS CURRENTLY USED TO DESCRIBE STATE/INTEREST RELATIONS, SHOW THE OVERLAP BETHEEN CERTAIN OTHER. THE EXISTIHG CONFUSIOM OF LABELS SIGNALS A GREATER YTHER. THE EXISTING CONFUSION

04899 JORGAN, $S$

LOCAL GOVERMMENT IN TRANSFORMATION: THE CASE OF CONSTI TUT IONAL REFORM IN YUGOSLAVIA

GOVERNANCE, 5(2) (APR 92), 235-242.

THE PREVIOUS COMMUNAL SYSTEM IN YUGOSLAVIA DID NOT PROVE VIABLE. GIVEN THE CHANGING SOCIAL CONDITIONS, THE NEED FOR REPEATED ESTABLISHMENT OF THE SYSTEM OF LOCAL GOVERNMENT BASED ON THE ALTERED POSITION OF CITIZENS IN THE POLITLAL SYSTEM BECOMES EVIDENT. THIS ARTICLE COMPARED THE CONSTITUTIONAL REGULATIONS OF LOCAL GOVERMMENT AMONG PARTICULAR YUGOSLAV REPUBLICS, AND BETHEEN THEM, IN THE SENSE OF POST-BEHAVIORISTIC TRENDS OF THE BOTTOIAUP APPROACH TO THE PROCESSES OF DECISION-MAKING.

04900 JOSEPH, J.

THE INTERNATIONAL POHER BROKER: A CRITICAL VIEW OF THE FOREIGN POLICY OF ARCHBISHOP MARKARIOS

MEDITERRANEAN QUARTERLY: A JOURNAL OF GLOBAL ISSUES, 3(2) (SPR 92), 17-33.

WHILE' IT IS EASY TO MAKE OBSERVATIONS ABOUT THE LEADING ROLE MARARIOS PLAYED IN THE DOMESTIC AND INTERNATIONAL POLITICS OF CYPRUS, AN UNDERSTANDING AND EXPLANATION OF HIS POLICIES AND PROTRACTED PROMINENCE REQUIRE A MORE SYSTEMATIC AND EXTENSIVE ANALYSIS. THIS ARTICLE EXAMINES ONE ASPECT OF HIS CAREER BY FOCUSING ON THE INTERMATIONAL CONTEXT, FACTORS, AND DYNAMICS THAT INFLUENCED AND SHAPED HIS POLICIES, AND THEREBY, DETERMINED THE FATE OF CYPRUS. EMPHASIS IS PLACED
ON HIS FOREIGN POLICY AS IT RELATES TO THE HANDLING OF THE CYPRUS PROBLEM AT THE INTERMATIONAL LEVEL.

04901 JOSEPH, R.

LIBERIA'S CONTINUING CRISIS

WEST AFRICA, (3918) (OCT 92), 1764-1765.

LIBERIA IS ON THE VERGE OF A VIOLENT CONFLAGRATION THAT
LIST HIL BENEFIT MO ONE. AFTER THO YEARS OF UNEASY PEACE. THE

NUMBER OF CLASHES AMONG ARMED COMBATANTS IS INCREASING AND

THE CASUALTIES ARE STEADILY MOUNTING.

04902 JOSEPH, R.

ZAMBIA: A MODEL FOR DEMOCRATIC CHANGE

CURRENT HISTORY, 91(565) (MAY 92), 199-201.

ZAMBIA'S MUL'TIPARTY ELECTIONS IN LATE 1991 MARKED THE END OF KENNETH KAUNDA'S SINGLE-PARTY RULE AND THE EMERGENCE OF A FREELY-ELECTED GOVERNMENT. IN THIS ARTICLE, THE AUTHOR, WHO HELPED ADMINISTER THE INTERMATIONAL OBSERVER MISSION DURING THE ELECTIONS, DISCUSSES THE NEH GOVERNMENT AND CONCLUDES THAT ZAMBIA COULD BECOME "A BEACON OF POLITICAL LIBERTY" IN AFRICA.

04903 JOSEPHSON, E.H.; MACEDONIA, R.M. ENHANCING TOTAL COMBAT POWER WITH FEHER FORCES
ANNALS OF THE AMERICAN ACADEMY OF POLITICAL AND SOCIAL SCIENCE, (517) (SEP 91), 174-192.

THE UNITED STATES IS PREPARING TO REDUCE ITS MILITARY FORCES TO LEVELS NOT SEEN SINCE BEFORE WORLD WAR II. HOWEVER, EVEN WITH THE DEMISE OF THE WARSAW PACT AND CHANGES IN THE SOVIET UNION, THE HORLD REMAINS AN UNCERTAIN AND OFTEN HOSTILE PLACE. THE UNITED STATES SHOULD MINIMIZE THE RISKS TO ITS SECURITY THAT COULD ARISE AS FORCES ARE REDUCED UTILIZING SENSOR-FUZED MUNITION TECHNOLOGY, WHICH CAN PROVIDE ENORMOUS GAIMS IN TOTAL COMBAT CAPABILITIES HITHOUT ATIENDANT LIABILITIES. THE MARRIAGE OF SENSOR-FUZED MUNITION TECHNOLOGY WITH MOOERN TARGET ACOUISITION AND DELIVERY SYSTEMS WILL REVOLUTIONIZE CONVENTIONAL WARFARE, JUST AS THE NUCLEAR INTERCONTINENTAL BALLISTIC MISSILE REVOLUTIONIZED IMPLICATIONS FOR MILITARY POLICY AND STRATEGY.

04904 JOSEPHSON, M.

THE BEST OF TIMES, THE WORST OF TIMES

JOURNAL OF STATE GOYERNMENT, 65(4) (FAL 92), 34-41.

THE AUTHOR ASSESSES THE STATUS OF POLITICAL INTEGRITY IN THE UNITED STATES. HE STATES THAT, WHILE GREAT STRIDES HAVE BEEN MADE IN ELIMINATING OUTRIGHT GRAFT AND CORRUPTION, U.S. PUBLIC OFFICIALS MUST GRAPPLE WITH A NEW SET OF ETHICAL ISSUES THAT HAVE GROWN OUT OF CHANGING RELATIONSHIPS AMONG INTEREST GROUPS, THE MEDIA, POLITICIANS, AND THE PUBLIC.

04905 JOSEPHSON, P.R.

SOVIET SCIENTISTS AND THE STATE: POLITICS, IDEOLOGY, AND FUNDAMENTAL RESEARCH FROM STALIN TO GORBACHEY

SOCIAL RESEARCH, 59(3) (FAL 92), 589-614.

THE HISTORY OF THE SOVIET UNION PROVIDES A UMIQUE OPPORTUNITY TO EXAMINE THE IMPACT OF POLITICS AND IDEOLOGY ON THE DEVELOPMENT OF SCIENCE. FUNDAMENTAL RESEARCH IN THE USSR REFLECTED THE TENOR OF SOVIET HISTORY AS LEADERS FASHIONED ECONOMIC PROGRAMS TO INCREASE INDUSTRIAL PRODUCTION, PURSUED THE IDEOLOGICAL GOAL OF CREATING A NEW PRODUCTION, PURSUED THE IDEOLOGICAL GOAL OF CREATING A NEW
PROLETARIAN SCIENCE, AND EXERTED POLIITICAL PRESSURES ON THE PROLETARIAN SCIENCE, AND EXERTED POLITICAL PRESSURES ON
SCIENTIFIC COMMUNITY. THE MOST IMPORTANT FACTOR IN THE SCIENTIFIC COMMUNITY. THE MOST IMPORTANT FACTOR IN THE
HISTORY OF SOVIET SCIENCE WAS THE IMPOSITION OF STALINIST POLICIES IN THE $1930^{\prime} S$, BECAUSE THIS LED TO THE IDEOLOGIZATION OF SCIENCE AND THE BELIEF THAT SOCIALIST SCIENCE WAS DISTINCT FROM BOURGEDIS SCIENCE.

04906 JOULFAIAN, M.; MARLOW, M.

INCENTIVES AND POLITICAL CONTRIBUTIONS

PUBCENTIVES AND POLITICAL CONTRIBUTIONS

THE GROWTH OF CAMPAIGN SPENDING OVER THE PAST DECADE HAS ATTRACTED CONSIDERABLE ATTENTION. RECENT STUDIES HAVE ANALYZED THE IMPACT OF CONTRIBUTIONS ON LEGISLATIVE YOTE PATTERNS AND THE EFFECTS OF CAMPAIGN SPENDING ON ELECTION OUTCOMES. THIS PAPER VIEWS POLITICAL CONTRIBUTIONS AS ONE FORM OF VOTING AND ATTEMPTS TO INCREASE UNDERSTANDING OF THE DETERMINANTS OF INDIVIDUAL DECISIONS TO UNDERSTANDING OF THE DETERMINANTS OF INDIVIDUAL DECISIONS TO CONTRIBUTE TO POL ITICAL CANDIDATES. ITS CONCLUSION IS TWOFOLD: FROM A RESEARCHER'S VIEWPOINT, THE RESEARCH SUGGESTS THE IMPORTANCE OF AGE, WEALTH, TAX RATES, AND MARITAL STATUS AS

DETERMINANTS OF POLITICAL CONTRIBUTIONS BY TOP U.S. WEALTHHOLDERS; AND FROM A POLITICIAN'S VIEWPOINT, THE RESEARCH SUGGESTS THAT INDIVIDUAL ECONOMIC YARIABLES SUCH AS MARGINAL TAX RATES ANO WEALTH ARE MAJOR DETERMINANTS OF INDIVIDUAL DECISIONS TO CONTRIBUTE TO POLITICIANS.

04907 JOYCE, P.G.; REISCHAUER, R.O.

DEFICIT BUDGETING: THE FEDERAL BUDGET PROCESS AND BUDGET REFORY

HARVARD JOURNAL OF LEGISLATION, 29(2) (SUM 92), 429-454.

SINCE 1974, THERE HAVE BEEN THREE MAJOR BUDGET PROCESS REFORMS-THE 1974 CONGRESSIONAL BUDGET ACT, THE 1985 GRAMMRUDMAN-HOLLINGS ACT, AND THE 1990 BUDGET ENFORCEMENT ACT. IN THIS PAPER, THE AUTHORS REVIEW THE BUDGET PROCESS AND BUDGET PROBLEMS FACING CONGRESS AGAINST THE BACKGROUND OF THESE THREE MAJOR PROCEDURAL REFORMS. THEY DISCUSS VARIOUS PROPOSALS FOR REFORM THAT ARE LIKELY TO BE CONSIDERED IN THE PROPOSALS FOR REFORM THAT ARE LIKELY TO BE CONSIDERED IN THE FUTURE AND ARGUE THAT PROCEDURAL REF

04908 JUDGE, A.

GORBACHEY AS DRAMATURGE: LESSONS ON SOCIAL TRANSFORMATIOM GORBACHEV AS DRAMATURGE: LESSONS

PUBLIC CHOICE, 7414) (1992) 689-700.

THIS ARTICLE EXPLORES THE DRAMATIC DIMENSIONS OF GORBACHEY'S ACTIONS AS A SOURCE OF LESSONS ON SOCIAL TRANSFORMATION IN THE FUTURE. IT IS ARGUED THAT TRANSFORMATIVE MOMENTS IN SOCIETY RESULT FROM THE IDENTIFICATION OF PEOPLE WITH AN EVOLVING DRAMA. THESE MAY THEN LEAD TO REAL CHANGE OF LASTING SIGNIFICANCE. QUESTIONS ARE RAISED ABOUT THE EXTENT TO WHICH SUCH DRAMATIZATION IS ALREADY USED AND THE OPPORTUNITIES FOR USING IT TO A FAR GREATER EXTENT IN THE FUTURE. THE LINK BETWEEN SUCH DRAMA AND THE USE OF METAPHOR IS EXPLORED IN RELATION TO WORLD GOVERNANCE. 
04909 JUDGE, D. DISORDER IN THE 'FRUSTRATION' PARLIAMENTS OF THATCHERITE BRITAIM

POLITICAL STUDIES, XL(3) (SEP 92), 532-553.

A MARKED INCREASE IN DISORDER IN THE BRITISH HOUSE OF COMMONS CHARACTERIZED PRIME MINISTER THATCHER'S TENURE IN OFFICE. IN A LEGISLATURE TRADITIONALLY RENOWHED FOR ITS MODERATION, FAIR PLAY, AND GOOD BEHAYIOR, THERE HAS GROHING CONCERN ABOUT THE EXTENT OF THE DISORDERLY BEHAVIOR. THIS CONCERM PROMPTED A PROCEDURE COMMITTEE INVESTIGATION INTO THE CONDUCT OF MP'S IN THE CHAMBER AND LED SOME COMMENTATORS TO ARGUE THAT THE LEVEL OF DISORDER CONSTITUTED A THREAT TO REPRESENTATIVE DEMOCRACY IN BRITAIN.

04910 JUDICIAL ELITE OF ISRAEL

THE JUDICIAL ELITE OF ISRAEL

INTERNATIONAL POLITICAL SCIENCE REVIEH, 13(3) (JUL 92), 235-248.

THIS STUDY UTILIZES THE RECRUITMENT OF ISRAELI SUPREME COURT JUSTICES TO EXPLORE THAT COUNTRY'S LEGAL CULTURE. THE DATA INDICATE THAT PROFESSIONAL LEGAL CRITERIA ARE THE PRIMARY VARIABLE FOR THE SELECTION OF ISRAELI JUDGES, AND THAT THE POLITICAL/LEGAL CULTURE SUPPORTS A CIVIL COURT SYSTEM WHICH OPERATES INDEPENDENTLY OF PARTISAN POLITICS. THUS, ISRAELI LEGAL CULTURE CAN BE ENCOMPASSED WITHIN A HEBERIAN FRAMEWORK: IT VALUES ADHERENCE TO SETTLED RULES. PARADOXICALLY, PRECISELY BECAUSE THE SUPREME COURT IS SEEN AS THE GUARDIAN OF FUNDAMENTAL VALUES EMBEDOED IN AN OBJECTIVE LEGAL ORDER, AUTHORITY HAS FLOWED TOWARD ISRAEL'S PREMIER NON-PARTISAN INSTITUTION.

04911 JUDIS, J.

CAMPAIGN ISSUES: TRADE

COLUMBIA JOURNALISH REVIEH, 31(4) (NOV 92), 38-39.

DURING THE 1992 PRESIDENTIAL CAMPAIGN, POLITICIANS AND POLICY MAKERS SPENT COMSIDERABLE TIME DEBATING TARIFFS, QUOTAS, MANAGED TRADE, U.S. - JAPANESE ECONOMIC RELATIONS, AND THE NORTH AMERICAN FREE TRADE AGREEMENT. THE PRESS, WHICH FORMERLY CONFINED THESE ISSUES TO THE BUSINESS SECTION, BEGAN TO GIVE THEM FRONT-PAGE COVERAGE. BUT GREATER ATTENTION HAS NOT LED TO GREATER CLARITY HHEN TRADE ISSUES ARE INYOLVED.

04912 JUDIS, J.B

STATECRAFT AND SHOWCROFT

NEW REPUBLIC, 206 (8) (FEB 92), 18-21.

THE AUTHOR PROFILES LIEUTENANT GENERAL BRENT SCONCROFT,

DRE AUTHOR PROFILES LIEUTENANT GENERAL BRENT SCOWCROFT,

SCOWCRDFT HAS SCORED SOME FOREIGN POLICY VICTORIES BUT HAS

ALSO BEEN RESPONSIBLE FOR SOME FAILURES.

04913 JUDIS, J.B.

CONSERYATISH

NEW REPUBLIC, 207 (10) (AUG 92), 28-31.

WHEN CONSERVATIVES REPEATEDLY DECLARE THAT GEORGE BUSH'S FAILURES AS PRESIDENT ARE THE RESULT OF HIS BETRAYAL OF THEIR IDEAS AND MOVEMENT, THEY ARE HARBORING ILLUSIONS BORN OF THEIR FLEETING SUCCESS UNDER RONALD REAGAN. IN FACT, THE CONSERVATIVE MOVEMENT THAT CARRIED REAGAN TO VICTORY BARELY EXISTS NOW; IT HAS DISSIPATED INTO VARIOUS CANTANKEROUS AND CONFUSED FACTIONS WHILE THE IDEAS ASSOCIATED WITH IT HAVE BECOME OBSOLETE, DISCREDITED, OR THE SUBJECT OF DISPUTES AMONG CONSERVATIVES THEMSELVES.

04914 JUDIS, J.B.

THE EXECUTIVE

NEW REPUBLIC, 206 (24) (JUN 92), 19-23

THE AUTHOR DISCUSSES H. ROS' PEROT'S PRESIDENTIAL CANDIDACY
POLICY.

04915 JUDIS, J.B

THE RED MENACE

NEW REPUBLIC, 207 (18) (OCT 92), 26-29

IF THE DEFICIT CONTIMUES TO GROW AT THE RATE IT HAS OVER THE LAST 12 YEARS, INTEREST COSTS WILL EVENTUALLY ABSORB MORE THAN A QUARTER OF THE BUDGET, MAKING IT INCREASINGLY DIFFICULT, IF NOT IMPOSSIBLE, FOR THE GOVERMMENT TO PERFORM EVEN ITS MOST BASIC FUNCTIONS. YET THE 1992 PRESIDENTIAL NOMINEES AREN'T DISCUSSING THE DEFICIT BECAUSE, OVER THE PAST TWO DECADES, THE AMERICAN POL ITICAL CLASS HAS MADE IT PAST TWO DECADES, THE AMERICAN POLITICAL CLASS HAS
IMPOSSIBLE TO DISCUSS BUDGET CUTS OR TAX INCREASES.

04916 JUOIS, J.B.

THE TARIFF PARTY

NEW REPUBLIC, $206(13)$ (MAR 92), 23-25.

THE AUTHOR LOOKS AT HOW THE CONSERVATIVE REPUBLICAN PARTY'S PERSPECTIVE ON TARIFFS AND PROTECTIONISM HAS CHANGED SINCE THE 1950'S.

04917 JUDT, T.

THE PAST IS ANOTHER COUNTRY: MYTH AND MEMORY IN POSTHAR EUROPE

DAEDALUS, 121(4) (FAL 92), 83-118.
FROM THE END OF HORLD WAR II UNTIL 1989, THE FRONTIERS OF EUROPE AND THE FORMS OF IDENTITY ASSOCIATED WITH THE TERM "EUROPEAN" WERE SHAPED BY THO DOMINANT CONCERNS: THE PATTERN OF DIVISION DRAFTED AT YALTA AND THE DESIRE--COMMON TO BOTH SIDES OF THE DIVIDE--TO FORGET THE RECENT PAST AND FORGE A NEW CONTINENT. IN THE HEST, THIS TOOK THE FORM OF A MOVEMENT FOR TRANSNATIONAL UNIFICATION TIED TO THE RECONSTRUCTION AND MODERNIZATION OT THE ECONOMY; IN THE EAST, AN ANALOGOUS UNITY WAS IMPOSED IN THE NAME OF A SHARED INTEREST IN SOCIAL REVOLUTION. THE SPECIAL CHARACTER OF THE HARTIME EXPERIENCE IN EUROPE AND THE WAYS IN WHICH THE MEMORY OF THAT EXPERIENCE WAS DISTORTED, SUBLIMATED, AND APPROPRIATED BEQUEATHED TO THE POSTWAR ERA AN IDENTITY THAT WAS FUNDAMENTALLY FALSE, DEPENDENT UPON THE ERECTION OF AN UNAATURAL AND UNSUSTAINABLE FRONTIER BETWEEN PAST AMD UNNATURAL AND UNSUSTAINABLE FRONTIER BETWEEN PAST AND
PRESENT IN EUROPEAN PUBLIC MEMORY. THE WAYS IN WHICH THE PRESENT IN EUROPEAN PUBL IC MEMORY. THE WAYS IN WHICH THE IN RECENT YEARS ARE INDICATIVE OF THE UNRESOLVED PROBLEMS THAT LIE AT THE CENTER OF THE PRESENT CONTINENTAL CRISIS SOME OF THE NEH MYTHS AND MIS-MEMORIES ATTENDANT UPON THE
COLLAPSE OF COMMUNISM ARE ALREADY SHAPING, AND MISSHAPING, COLLAPSE OF COMMUNISM ARE

04918 JUGNAUTH, A

A NEW REPUBLIIC: MAURITIUS SEVERS A CONSTITUTIONAL LINK, NOT A COMMONWEALTH CONNECTION

PARLI IAMENTARIAN, LXXIII ( 3 ) ( JUL 92), 151-154.

ON MARCH 12, 1992, MAURITIUS WAS TRANSFORMED FROM A CONSTITUTIONAL MONARCHY UNDER QUEEN ELIZABETH II TO A REPUBLIC WITH A PRESIDENT AS HEAD-OF-STATE. ALTHOUGH MAURITIUS IS COMMITTED TO ATTAINING FULL SOVEREIGNTY, IT HILL REMAIN A MEMBER OF THE BRITISH COMMONWEALTH AND MAINTAIN CLOSE TIES WITH THE UNITED KINGDOM.

04919 JULIEN, K.

THE PROBLEMS OF SMALL STATES

ROUND TABLE, 321 (321) (JAN 92), 445-50.

USING A POPULATION OF LESS THAN 3 MILLION AS A CRITERION, THE SMALL STATES OF THE WORLD WILL EXCEED 70 IN NUMBER. OF THESE, 25 FIND THEMSELVES IN THE LOW INCOME BRACKET WITH THE MAJORITY OF THE OTHERS IN THE MIDDLE INCOME GROUPING. SINGAPORE, KUHAIT AND THE UAE ARE THE ONLY ONES CLASSIFIED AS BEING IN THE HIGH INCOME GROUPING. THIS PAPER STUDIES CHARACTERISTICS OF SMALL STATES AND EXAMINES WHAT THE FUTURE WILL HOLD. IT CONCLUDES THAT THE COMMONHEALTH, UNIOUE BY ITS LARGE ACTIVE MEMBERSHIP OF SMALL STATES IS POISED TO MAKE RECENT INITIATIVES A SUCCESS.

04920 JULLIARD, J.

BELEAGUERED DEMOCRACY MOVES TO THE NEXT PHASE

WORLD PRESS REVIEW, 39(6) (JUN 92), 20-21.

POLITICS IS A STRUGGLE OF PARTIES MOTIVATED BY DIVERGENT. OR EVEN OPPOSITE, PURPOSES. ADMINISTRATION IS THE APPLICATION OF METHODS ACCEPTED BY ALL TO THE SOLUTIONS OF THE PROBLEMS OF LIFE IN SOCIETY. CLEARLY, THE LATTER IS STEADILY GAINING AT THE EXPENSE OF THE FORMER AS THE SCOPE FOR ANTAGONISM BETWEEN RIGHT AND LEFT STEADILY NARROWS. TOGETHER WITH ALL FORMS OF COLLECTIVE BEHAVIOR, POLITICS IS GRADUALLY EVOLVING FROM THE REPTILIAN TO THE RATIONAL.

04921 JURIE, J.: JURIE, C. YOUTH AND NATIONAL URBAN POLICY: THE FLORIDA EXPERIENCE
JOURNAL OF URBAN AFFAIRS, $14(2)$ (1992), 109-124. THROUGHOUT THE 1980 S CONDITIONS WORSENED FOR CHILDREN AND YOUTH IN URBAN AREAS THROUGHTOUT THE US. LACKING A NATIONAL YOUTH POLICY, FORMULATION AND IMPLEMENTATION OF YOUTH POLICY HAS BEEN LEFT TO THE STATES AND LOCALITIES. ONE OF THE MOST INNOVATIVE YOUTH POLICY RESPONSES WAS ENACTED IN FLORIDA WHERE THE STATE AUTHORIZED THE CREATION OF

CHILDREN'S SERVICES COUNCILS AT THE COUNTRY LEVEL. THIS PAPER TRACES THE EFFORTS OF FLORIDA'S URBAN COUNTIES TO DEVELOP PROGRAMS, STRATEGIES, AND THE USE OF SPECIAL TAX DISTRICTS THAT TARGET UNMET NEEDS AND CHILDRENS ISSUES. THE FLORIDA LEGISLATION AND THE EXPERIENCE OF LOCAL GOVERNMENTS OFFER ONE APPROACH FOR OTHER STATES AND LOCALITIES, AS WELL AS A MODEL FOR NATIONAL YOUTH POLICY.

04922 JUXON-SMITH, A.

LEARNING STATECRAFT

WEST AFRICA, ( 3902 ) (JUN 92), 1090.

MOST SIERRA LEONEANS ARE PLEASED ABOUT THE APPARENTLY SPONTANEOUS OVERTHROW OF THE APC GOVERMMENT AFTER 24 YEARS SPONTANEOUS OVERTHROW OF THE APC GOVERNMENT AFTER 24 YEARS OF MISRULE. BUT MANY INTERNATIONAL OBSERVERS ARE CONCERM THAT THE NATIONAL PROVISIONAL RULING COUNCIL LACKS THE COMPETENCE AND EXPERIE

04923 KA, C

AGRARIAN DEVELOPMENT, FAMILY FARMS AMD SUGAR CAPITAL IN COLONIAL TAIWAN, 1895-1945

JOURNAL OF PEASANT STUDIES, 18(2) (JAN 91), 206-240.

THIS ARTICLE ANALYSES THE CONSERVATION AND RESTRUCTURING OF TAIHANESE FAMILY FARMS IN THE COURSE OF CAPITALIST AND COLONIAL INCORPORATION. HITH INSUFFICIENT PARTICIPATION OF 
JAPANESE PRIVATE CAPITAL AT THE OUTSET OF COLONIAL RULE, A CONGRUENCE OF INTEREST BETWEEN INDIGENOUS PEASANT PROOUCERS AND THE COLONIAL STATE RESULTED IN POLICIES THAT FOSTERED THE SURVIVAL OF FAMILY FARMS. THESE FAMILY FARMS CONSTITUTED A FORMIDABLE OBSTACLE TO THE EXPANSION OF A LABOUR-HIRING CAPITALIST AGRICULTURE. UNDER SUCH CONDITIONS, UAPAMESE CAPITALIST AGRICULTURE. UNDER SUCH CONDITIONS, JAPANESE PRODUCTIVE FAMILY FARMING AGRICULTURE. THROUGH CONTRACTUAL ARRANGEMENTS WITHIN EXCLUSIVE TERRITORIES AHARDED BY THE
GOVERNMENT, JAPANESE SUGAR CORPORATIONS OBTAINED SUPPLIES OF GOVERNMENT, JAPANESE SUGAR CORPORATIONS OBTAINED SUPPL
SUGARCANE AT FAVORABLE PRICES FROM FAMILY FARMS. WHILE SUGARCANE AT FAVORABLE PRICES FROM FAMILY FARMS. WHILE PEASANT HOUSEHOLDS RETAINED COMMAND OF THEIR LABOUR POWER
AND CONTESTED THE TERMS OF EXCHANGE, JAPANESE SUGAR CAPITAL AND CONTESTED THE TERMS OF EXCHANGE, JAPANESE SUGAR CAPITAL INDUSTRY AND DETERMINED THE CONDITIONS OF CANE PRODUCTION.

04924 KAEMPFER, H. ; LOWENBERG, A.

USING THRESHOLD MODELS TO EXPLAIN INTERNATIONAL RELATIONS PUBLIC CHOICE, $73(4)(1992), 419-444$

THE OUTCOME OF POLITICAL OPPOSITION OR REVOLUTION IS A PUBLIC GOOO, WHICH SUGGESTS THAT FREE RIDING WILL DIMINISH THE EFFECTIVENESS OF THESE FORMS OF COLLECTIVE ACTION. THIS PAPER INVESTIGATES THE EXTENT TO WHICH INTERNATIONAL PRESSURE AND DEMONSTRATION EFFECTS CAN SERVE TO SIGNAL SUPPORT FOR THE OBECTIVES OF DOMESTIC GROUPS IN A TARGET COUNTRY AND THEREBY MOBILIZE COLLECTIVE ACTION IN PURSUIT OF THEIR GOALS. IT IS OF INTEREST TO KNOW NOT ONLY THE EXTENT TO WHICH INHERENT BARRIERS TO EFFECTIVE COLLECTIVE ACTION ARE OVERCOME BY OUTSIDE SUPPORT, BUT ALSO TO SHOW HOW FOREIGN ECONOMIC POLICY CAN HAVE AN IMPACT OF POLITICAL PROCESSES IN THE TARGET COUNTRY EVEN WHEN THAT POLICY ITSELF HAS MINIMAL ECONOMIC EFFECTS.

04925 KAGAN, D.

GREEN PR

INSIGHT, $7(11)$ (MAR 91), 38-40.

CORPÓRATE ENVIRONMENTALISM AND GREEN MARKETING ARE NOW OFFICIAL BUSINESS BUZZHORDS. LED BY THE MASSIVE PUBLIC RESPONSE TO EARTH DAY 1990 AND BY NUMEROUS POLLS SHOWING THAT AT LEAST 70 PERCENT OF CONSUMERS PREFER PRODUCTS THAT THAT AT LEAST 70 PERCENT OF CONSUMERS PREFER PRODUCTS THAT
ARE ENVIRONMENTALLY SAFE, MORE AND MORE COMPANIES ARE

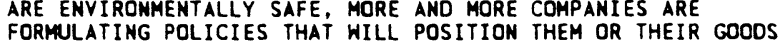
AS NONPOLLUTING, RECYCLABLE, BIODEGRADABLE, AND GENERALLY AS NONPOLLUTING, RECYCLABLE, 8IODEGRADABLE, AND GENERALLY BEATING IN THE PAST BECAUSE OF ECOLOGY DISASTERS SUCH AS OIL SPILLS AND TOXIC WASTES. THERE HAS NEVER BEEN MORE INCENTIVE SPILLS AND TOXIC WASTES, THERE HAS

04926 KAGAN, F.

THE SECRET HISTORY OF PERESTROIKA

NATIONAL INTEREST, (23) (SPR 91), 33-42.

MOST HESTERN OBSERVERS HAVE INDICATED THAT PERESTROIKA, THE AMBITIOUS SOVIET REFORM PROGRAM, SPRANG ATHENA-LIKE FULLY FORMED AND DEVELOPED FROM MIKHAIL GORBACHEV'S HEAD. YET, EVIDENCE IS NOW ACCUMULATING THAT A GROUP OF PARTY APPARATCHIKS WITH POWERFUL SPONSORSHIP BEGAN WORKING TO EFFECT REFORMS FROM WITHIN THE SYSTEM OVER THIRTY YEARS AGO. THE ADVENT OF GLASNOST AND THE PUBLICATION OF MEMOIRS AND INTERVIEHS BY THE PEOPLE HHO SURROUND GORBACHEV HAVE MADE IT CLEAR THAT PERESTROIKA ITSELF WAS MERELY THE MOST DRAMATIC EXPRESSION OF THE LONG-STANDING DESIRES OF THE INTRA-PARTY REFDRM GROUP, OR PERESTROIKISTS, AND THAT THE CHAOS THAT FOLLOWED IS, IN PART, THEIR LEGACY.

04927 KAGAN, R.A.

ADVERSARIAL LEGALISM AND AMERICAN GOYERMMEMT JOURNAL OF POLICY ANALYSIS AND MANAGEMENT, 10(3) (1991), 369-406

COMPARED TO OTHER ECONOMICALLY ADVANCED DEMOCRACIES, THE UNITED STATES IS UNIQUELY PRONE TO ADVERSARIAL, LEGALISTIC MODES OF POLICY FORMULATION AND IMPLEMENTATION, SHAPED BY THE PROSPECT OF JUDICIAL REVIEW. WHILE ADVERSARIAL LEGALISM FACILITATES THE EXPRESSION OF JUSTICE-CLAIMS AND CHA TO OFFICIAL DOGMA, ITS COSTS ARE OFTEN NEGLECTED OR
MINIMIZED. A SURVEY OF EXISTING RESEARCH, TOGETHER WITH A MINIMI ZED. A SURVEY OF EXISTING RESEARCH, TOGETHER WI CASE STUDY OF ENVIRONMENTAL REGULATION IN THE PORT OF OAKLAND, INDICATES THE EXTENT TO WHICH ADVERSARIAL LEGALISH
CAUSES (OR THREATENS) ENORMOUS DISPUTE-RESOLVING COSTS AND CAUSES (OR THREATENS) ENORMOUS DISPUTE-RESOLVING COSTS AND PROCEDURAL DELAYS, WHICH IN TURN DISTORT POLICY OUTCOMES.
ADVERSARIAL LEGALISM, MOREOVER, HAS INCREASED IN RECENT ADVERSARIAL LEGALISM, MOREOVER, HAS INCREASED IN RECE DECADES, AS AMERICANS HAVE ATTEMPTED TO IMPLEMENT THE AMBITIOUS, SOCIALLY TRANSFORMATIVE POLICIES OF ACTI LEGISLATION, AND LEGAL PROCEDURES THAT REFLECT DEEP LEGISLATION, AND LEGAL PROCEDURES THAT

04928 KAGARLITSKY, B. NEW REGIME, NEW CALAMITIES NEW POLITICS, 13(1) (SUM 92), 81-87.

THIS ARTICLE CHARACTERIZES THE YELTSIN ADMINISTRATION AS "A MUDDLEHEADED GOVERNMENT PROCEDING ALONG THE HRONG PATH." THE AUTHOR ARGUES THAT WHAT RUSSIA NEEDS NOW IS NOT LESSONS ON HOW TO BREAK INTO THE RANKS OF THE SUCCESSFUL WESTERN COUNTRIES BUT HOW TO EXTRICATE THE COUNTRY FROM THE PRESENT
CRISIS AND THEN, AT LEAST, RESTORE THE LIVING STANDARDS OF THE BREZHNEY ERA. YELTSIN'S PROMISED BENEFITS OF UNIVERSAL PRIVATIZATION WILL PROVE AS HOLLOH AS STALIN'S CLAIMS ABOUT SWIFT COLLECTIVIZATION. IF RUSSIA IS TO FOLLOW ANY WESTERN MODEL, IT SHOULD BE FDR'S NEW DEAL NOT THE SYSTEMS OF TODAY'S FREE MARKET ECONOMIES.

04929 KAGARLITSKY, B.

RUSSIA ON THE BRINK OF NEW BATTLES

NEH LEFT REVIEH, (192) (MAR 92), 85-97.

THE AUTHOR DESCRIBES THE SOCIAL AND POLITICAL

REALIGNMENT UNDERHAY IN RUSSIA DUE TO THE DRIVE FOR

MARKETIZATION ANO PRIVATIZATION.

04930 KAGARLITSKY, B.

YELTSIN'S SUCCESSFUL COUP

NEH POLITICS, 3(4) (WIN 92), 27-42.

ALTHOUGH REDUCED TO SEMI-LEGALITY IN THE WAKE OF THE AUGUST EVENTS, COMHUNIST HARDLINERS ARE REGROUPING.

DISENCHANTMENT WITH YELTSINISM IS MOUNTING. TO STABILIZE ITSELF THE REGIME MUST RESORT TO REPRESSION AND SUPPRESSION OF OPPOSITION. BUT BY DRIVING OPPOSITION UNDERGROUND, THE REGIME RISKS CREATINGS ITS OWN GRAVEDIGGERS. THE END OF THE COMMUNIST ERA DID NOT MEAN THE VICTORY OF DEMOCRACY. BUT IT DID SIGNIFY THE BEGINNING OF A NEW STAGE IN THE DEVELOPMENT OF SOCIETY WHEN THE STRUGGLE FOR SOCIALISM, ONCE AGAIN, AS WAS THE CASE IN RUSSIA AT THE END OF THE LAST CENTURY, BECOMES INSEPARABLE FROM THE STRUGGLE FOR FREEDOM.

04931 KAGIAN, J.

ENRICHED URANIUM SAGA

MIDDLE EAST INTERNATIONAL, (405) (JUL 91), 9-10.

PRESIDENT BUSH RETURNED HOME FROM EUROPE AFTER RECEIVING STRONG BACKING AT THE G7 SUMMIT IN LONDON FOR A MILITARY OPTION AGAINST IRAQ'S NUCLEAR CAPABILITIES. MEANWHILE, THE FIVE PERMANENT MEMBERS OF THE UN SECURITY COUNCIL HAVE TO DEAL WITH THE 25 JULY DEADLINE THEY GAVE SADDAM HUSSEIN TO FULLY DISCLOSE HIS NUCLEAR PROGRAM OR FACE "SEVERE CONSEQUENCES." AT THE SAME TIME, A FOURTH UN GROUP HAS EMBARKED ON ANOTHER MISSION TO EXAMINE ADDITIONAL SUSPECTED SITES IN IRAQ. WASHINGTON IS NOT YET CONVINCED THAT SADDAM SITES IN IRAQ. WASHINGTON IS NOT YET CONVINCED THAT SADDAM CLANDESTINE PROGRAMS DESIGNED TO PRODUCE ENRICHED URANIUM CLANDESTINE PROGRAMS DESIGNED TO PRODUCE ENRICHED URANIUM
FOR WARHEADS HAS FUELED AMERICAN FEARS. THE UNITED STATE FOR WARHEADS HAS FUELED AMERICAN FEARS. THE UNITED STA CONVINCE IRAQ TO FULLY DIVULGE AND DESTROY ITS NUCLEAR CAPABILITY.

04932 KAGIAN, J.

IRAQ: TESTING THE UN'S RESOLVE

MIDOLE EAST INTERNATIONAL, 438(438) (NOV 92), 12-13.

THE SCHEDULED ARRIVAL IN NEH YORK IN NOVEMBER OF IRAQ'S DUPTY PRIME MINISTER, TARIO AZIZ, MARKS BAGHDAD'S FIRST MAJOR ATTEMPT TO TEST THE POLITICAL ATMOSPHERE AT THE UNITED NATIONS FOLLOWING THE DEFEAT OF PRESIDENT BUSH. THE ARTICLE SPECULATES THAT AZIZ WILL URGE THE SECURITY COUNCIL TO REMOVE SOME OF ITS RESTRICTIONS ON IRAO'S OIL EXPORTS. UN DIPLOMATS BELIEVE PRESIDENT-ELECT CLINTON'S MIDDLE EAST POLICY WILL BE TESTED EARLY IN HIS PRESIDENCY AND THAT HE WILL RESPOND WITH A DEMONSTRATION OF STRENGTH.

04933 KAGIAN, J.

QADHAFI'S LATEST INITIATIVE

MIDOLE EAST INTERNATIONAL, (419) (FEB 92), 11-12.

WHILE LIBYA CONOUCTS A PUBLIC HEARING IN TRIPOLI ON U.S. AND BRITISH DEMANOS THAT THO LIBYANS BE EXTRADITED TO FACE CHARGES FOR THE 1988 BOMBING OF PAN AM FLIGHT 103. THE UNITED STATES, BRITAIN AND FRANCE HAVE PUT THE FINAL TOUCHES TO A RESOLUTION IMPOSING AN ARMS AND AIR EMBARGO ON LIBYA
UNTIL IT HANOS OVER THE TWO SUSPECTS. THE LIBYAN MOVE TO HOLD A HEARING IS SEEN AS ANOTHER POLITICAL MANEUVER TO GAIN TIME IN THE FACE OF AN IMMINENT UN EMBARGO. LIBYAN ATTEMPTS TO DRIVE A WEDGE BETWEEN FRANCE ON THE ONE HAND AND THE UNITED STATES AND BRITAIN ON THE OTHER BY OFFERING TO COOPERATE WITH FRANCE IN AN INVESTIGATION OF AN EARLIER DESTRUCTION OF A FRENCH PLANE HAS DONE LITTLE TO REDUCE THE UNITY OF THE THREE NATIONS.

04934 KAGIAN, J.

SURIAN, J. TERMS

MIDDLE EAST INTERNATIONAL, (395) (MAR 91), 8.

ON 3 MARCH THE UN SECURITY COUNCIL ADOPIED RESOLUTION 686, ITS 13TH ON THE GULF CRISIS SINCE 2 AUGUST, SETS OUT THE FORMAL TERMS OF SURRENDER FOR IRAO AND ENDORSES PRESIDENT BUSH'S DECISION TOR FTA IRAQ AND ENDORSES SOUTHERN IRAO UNTIL IRAQ FULLY COMPLIES HITH HIS PEACE TERMS. THE RESOLUTION REAFFIRMS THE 12 PREVIOUS SECURITY COUNCIL RESOLUTIONS AND REQUIRE TO TAKE IMMEDIATE STEPS TO IMPLEMENT THEM. IT DEMANDS THAT IRAQ: RESCIND ITS ANNEXATION OF KUHAIT RETURN ALL PRISONERS OF WAR AND KUWAITI DETAINEES; ACCEPT IN PRINCIPLE ITS LIABILITY FOR WAR DAMAGES; CEASE FURTHER
MILITARY ACTION; AND PROVIDE ALL INFORMATION AND ASSISTANCE IN IDENTIFYING IRAOI MINES, BOOBY TRAPS, AND OTHER EXPLOSIVES IN KUWAIT. 
04935 KAGIAN, J.

THE MOTHER OF RESOLUTIONS

MIDDLE EAST INTERNATIONAL, (379) (APR 91), 5-6

THE UN SECURITY COUNCIL ADOPTED ON 3 APRIL RESOLUTION WHICH, IF ACCEPTED BY IRAQ, WOULD FORMALLY END THE GULF WAR.
THE RESOLUTION SETS OUT IN GREAT DETAIL THE CONDITIONS FOR A PERMANENT CEASE-FIRE. IRAQ WOULD HAVE TO ACCEPT THE DISMANTLING OF ITS MILITARY MACHINE, INCLUDING "THE DESTRUCTIOM OF ITS CHEMICAL BIOLOGICAL AMD NUCLEAR CAPABILITIES," AS WELL AS MISSILES CAPABLE OF DELIVERING SUCH WEAPONS. IT HOULD ALSO HAVE TO AGREE TO A 1963 BORDER AGREEMEMT HITH KUHAIT AMD EYENTUALLY PAY A PERCENTAGE OF ITS FUTURE OIL EARNINGS TO AN UN-ADMINISTERED FUND TO REIMBURSE ANY COUNTRY (AS HEL UN CODINISTERED FUND REIMBURSE ANY COUNTRY (AS WELL AS CORPORATIONS AND
INDIVIDUALS) WITH CLAIMS FOR LOSS AND DAMAGES RESULTING FROM INDIVIDUALS) WITH CLAIMS FOR LOSS AND DAMAGES RESULTING FROM THE INVASION OF KUHAIT. MEANHHILE, THE SECURIIY COUNCIL WILL
KEEP IRAO UNDER MILITARY AND ECONOMIC SANCTIONS EXCEPT FOR FEEP IRAO UNDER MILITARY AND

04936 KAGIAN, J.

THE UN AND IRAO

MIDOLE EAST INTERNATIONAL, 436 (OCT 92), 11.

IT APPEARS THAT THE UNITED NATIONS HAS REESTABLISHED A FORMAL LEGAL FRAMEWORK FOR ITS RELIEF OPERATIONS INSIDE IRAQ. AFTER TALKS IN BAGHDAD, THE UN ANNOUNCED A PLAN OF ACTION WHICH HAD BEEN AGREED UPON, ALONG WITH A MEMORANDUM OF UNDERSTANDING ABOUT THE TERMS UNDER WHICH THE UN COULD OPERATE. BARRING LAST MINUTE HITCHES, THE AGREEMENT COULD BE SIGNED IN NEH YORK BEFORE THE END OF OCTOBER.

04937 KAGIAN, J.; BUTT, G.

THE UN'AND' IRAQ-LOSING PATIENCE

MIDOLE EAST INTERNATIONAL, (420) (MAR 91), 8

IN AN ATTEMPT TO DEFUSE GROHING INTERNATIONAL ANGER OVER ITS FAILURE TO IMPLEMENT A NUMBER OF UN RESOLUT IONS, IRAQ IS SENDING TO NEW YORK A HIGH-LEVEL DELEGATION HEADED BY DEPUTY PRIME MINISTER TARIQ AZIZ. HE WILL EXPLAIN IRAQ'S POSITION ON RESOLUTIONS 707 AND 715, WHICH DEAL WITH THE MONITORIMG OF WEAPONS. ON 28 FEBRUARY THE SECURITY COUNCIL STRONGLY CONDEMNED IRAO'S FAILIURE TO COMPLY WITH A UN DEADLINE TO PERMIT UN INSPECTORS TO BEGIN DESTROYING EQUIPMENT USED FOR MANUFACTURING LONG-RANGE MISSILES. IRAQ'S HOME MEDIA MANUFACTURING LONG-RANGE MISSILES. IRAQ'S HOME MEDIA
RESPONDED BY CALLING THE UN ACTION "HASTY" AND "FULL OF
FALSEHDODS " WHILE MANY ARABS AGREE HITH IRAQ THAT THE FALSEHOODS." WHILE MANY ARABS AGREE WITH IRAQ THAT THE THEY FIND IT OIFFICULT TO SUPPORT IRAQ, DUE TO THE MANY MISCALCULATIONS OF SADOAM HUSSEIN.

04938 KAGIAN, J.

THE UN AND IRAQ: BOMBS AND SANCTIONS

MIDDLE EAST INTERNATIONAL, 417 (JAN 92), 11.

THE RECENT REVELATIONS BY UNITED NATIONS INSPECTORS ABOUT IRAQ'S NUCLEAR PROGRAM HAVE FOCUSED ON IRAQI EFFORTS TO PRODUCE NUCLEAR HEAPONS. FOR THE FIRST TIME IRAQ HAS ADMITTED TO THE INTERMATIONAL ATOMIC ENERGY AGENCY (IAEA) OFFICIALS THAT IT HAD ACQUIRED FROM GERMAN COMPANIES KEY COMPONENTS FOR UP TO 10,000 GAS CENTRIFUGES TO PRODUCE ENRICHED URANIUM WHICH UN INSPECTORS BELIEVE COULD FUEL FOUR NUCLEAR BOMBS A YEAR. THE SECURITY COUNCIL HAS AUTHORIZED THE USE OF FUMDS FROM THE SALE OF IRAQI OIL TO COVER ALL EXPENSES INCURRED BY IAEA IN IRAQ, BUT IRAQ HAS SO FAR REFUSED TO SELL THE THE OIL. ALSO, THE U.S. AND SOME OF ITS WESTERN ALLIES HAVE MADE IT VERY CLEAR THAT THEY INTEND THE ECONOMIC SANCTIONS TO REMAIN IN FORCE AS LONG AS PRESIDENT SADOAM HUSSEIN IS IN POWER.

04939 KAGIAN, J.

THE UN' AND IRAQ: REBUFFED AGAIN

MIDOLE EAST INTERNATIONAL, 439 (DEC 92) 10

FOR THE TENTH TIME SINCE 3 APRIL 1991 , THE SECURITY COUNCIL, AFTER BRIEF AND CLOSED CONSULTATION, AGAIN DECIDED TO CONTINUE THE ECONOMIC SANCTIONS AGAINST IRAQ ON THE GROUNDS THAT IT CONTINUES TO FLOUT UN RESOLUTIONS AND STILL HAS DESIGNS ON KUHAIT. IRAQ IS RESPONDING BY CALLING THE CONTINUING EMBARGO IMMORAL, SHAMEFUL AND AN ACT OF GENOCIDE. IRAQ'S PLEAS ARE FALLING ON MOSTLY UNSYMPATHETIC EARS. IRAQ CLAIMS TO BE READY TO COPPERATE AND CONTIMUE DIALOGUE WITH THE COUNCIL.

04940 KAGIAN, J.

UN AMD IRAO--CRITICAL CONFRONTATION

MIDDLE EAST INTERNATIONAL, (430) (JUL 92),

THE CONFRONTATIOH BETWEEN IRAQ AND THE UNITED NATIONS HAS REACHED A CRITICAL LEVEL FOLLOHING THE REJECTION BY THE SAS REACHED A CRITICAL LEVEL FOLLOHING THE REJECTION BY THE SECURITY COUNCIL ON 20 JULY OF IRAQ'S COMPROMISE PROPOSAL
SOLVE THE DISPUTE OVER ACCESS BY UN WEAPONS INSPECTORS TO THE AGRICULTURE MINISTRY IN BAGHDAD. ALTHOUGH PAST DISPUTES OVER UN INSPECTORS HAVE BEEN SETTLED HITHOUT FORCE, HITH IRAQ EVENTUALLY CAPITULATING UNDER INTERNATIONAL PRESSURE, DIPLOMATS HAVE DETECTED A SIGNIFICANT HARDENING OF IRAO'S POSITION. THE STAND-OFF AT THE AGRICULTURE MINISTRY IS ONLY ONE OF A NUMBER OF CONFRONTATIONS BETHEEN THE UN AND IRAO. BAGHDAD HAS SUSPENDED TALKS ON THE UN PLAN TO ALLOW LIMITED
OIL SALES AND IS STILL BOYCOTTING THE UN COMISSION FIXING ITS NEW BOUNDARY WITH KUWAIT. IT IS ALSO STILL REFUSING TO RENEW AN AGREEMENT WITH THE UN WHICH ALLOWS IT TO STATION GUARDS IN IRAQ.

04941 KAGIAN, J.

UN AND IRAQ--IN THE DOCK

MIDDLE EAST INTERNATIONAL, (421) (MAR 92), 10-11.

THERE IS GRONING CONCERN AMONG UN DIPLOMATS THAT IRAQ REMAINS ON A COLLISON COURSE WITH THE UNITED NATIONS SECURITY COUNCIL. HAVING LISTENED TO THE STATEMENT BY IRAQ'S DEPUTY PRIME MINISTER, TARIQ AZIZ, AND TO HIS RESPONSES TO THE QUESTIONS POSED BY ITS MEMBERS, THE COUNCIL HAS AGAIN ORDERED IRAQ TO COMPLY IMMEDIATELY, FULLY AND

UNCONDITIONALLY WITH THE COUNCIL'S DEMANDS THAT IRAQ'S WEAPONS FACILITIES BE DESTROYED. AZIZ SHOWED NO READINESS TO DESTROY EQUIPMENT USED IN THE MANUFACTURE OF IRAQ'S MOST DANGEROUS WEAPONS. SUCH A POLICY CANMOT HELP BUT INCREASE DENSION BETWEEN IRAQ AND THE UN.

04942 KAGIAN, J.

UN AND IRAQ--PROTECTING THE SHI 'ITES

MIDDLE EAST INTERNATIONAL, (432) (AUG 92), 8.

THE UNITED STATES AND ITS GULF WAR ALLIES ARE WORKING OUT HOW TO IMPOSE A BAN ON IRAQI WAR PLANES AND HELICOPTERS IN SOUTHERN IRAQ TO PROTECT SHI'ITES THERE FROM AERIAL BOMBARDMENT. ACCOROING TO THE PLAN, ANY IRAOI AIRCRAFT FLYING BELOW THE 32ND PARALLEL WOULD BE SHOT DOWN. THE
FLY ZONE COULD LEAD TO A "SAFE HAVEN" FREE FROM IRAQI FLY ZONE CDULD LEAD TO A "SAFE HAVEN" FREE FROM IRAQI
GOVERNMENT CONTROL THAT WOULD BE ACCESSIBLE TO OUTSIDERS FROM THE UN-MONITORED DEMILITARIZED ZONE ALONG THE IRAQIKUHAIT BORDER. THIS DEVELOPMENT, HHICH WOULD INVOLVE GREATER UN INTERVENTION IN SOUTHERN IRAQ, IS EXPECTED TO BE IMPLEMENTED IN STAGES, DEPENDING ON IRAO'S MILITARY OPERATIONS IN THE SOUTH AND BAGHDAD'S RESPONSE TO UN DEMANDS THAT IT CEASE PERSECUTING THE SHI'ITES. UN OFFICIALS HAVE ACCUSED BAGHDAD OF SEEKING TO DRIVE THE SHI'ITES OUT OF THEIR TRADITIONAL LANDS BY RESETTLING THEM IN GOVERNMENTCONTROLLED VILLAGES AND OF DRAINING AREAS OF MARSHLANDS IN ORDER TO DEPRIVE THE SHI'ITES OF THEIR DISTINCTIVE 3,000YEAR-OLD CULTURE.

04943 KAGIAN, J.

UN AND LIBYA--THE LATEST SCENARIOS

MIDDLE EAST INTERNATIONAL, (426) (MAY 92), 9-10.

THERE ARE NEW INDICATIONS AT THE UNITED NATIONS THAT ARAB DIPLOMATIC EFFORTS SPEARHEADED BY EGYPT COULD SOON LEAD ARAB DIPLOMATIC EFFORTS SPEARHEADED BY EGYPT CNULD SOON LEAD WEST OVER LOCKERBIE. A MEMORANDUM SUBMITTED TO THE UN BY LIBYAN FOREIGN SECRETARY IBRAHIM M BISHARI LISTS SEVERAL LIBYAN FOREIGN SECRETARY IBRAHIM M. BISHARI LISTS SEVERAL ENCOURAGING CONCESSIONS ON LIBYA'S PART: AN AGREEMENT TO APPROPRIATE COMPENSATION IF RESPONSIBILITY IS ESTABLISHED APPROPRIATE COMPENSATION IF RESPONSIBILITY IS ESTABLI

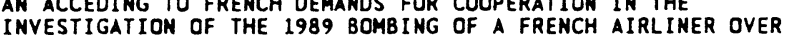
INVESTIGATION OF THE 1989 BOMBING OF A FRENCH AIRLINER
NIGER. AND THE SURRENDER OF THE LOCKERBIE SUSPECTS. IF NIGER; AND THE SURRENDER OF THE LOCKERBIE SUSPECTS. IF LIBYA'S COLONEL QADHAFI DOES NOT MAKE ANY LAST-MINUTE
CHANGES, A RESOLUTION OF THE AFFAIR SEEMS IMMINENT.

04944 KAGIAN, J. UN AND' THE CEASE-FIRE MIDDLE EAST INTERNATIONAL, (398) (APR 91), 7-9. WHILE COPING WITH THE OVERHHELMING HUMAN TRAGEDY OF THE IRAQI REFUGEES ON THREE FRONTS, THE UNITED NATIONS HAS BEGUN THE IMPLEMENTATION OF RESOLUTION 687--THE CEASE-FIRE RESOLUTION. ON 9 APRIL THE SECURITY COUNCIL UNANIMOUSLY APPROVED THE SECRETARY-GENERAL'S REPORT ON THE IMPLEMENTATION OF PARAGRAPH 5 OF RESOLUTION 687 OF 3 APRIL ESTABLISHING A DEMILITARIZED ZONE ALONG THE BOUNDARY BETWEEN IRAQ AND KUWAIT AND THE IMMEDIATE DEPLOYMENT OF A UN OBSERVER UNIT. THE SECURITY COUNCIL'S FORMAL ANNOUNCEMENT ENDING HOSTILITIES WAS MADE HHEN THE PRESIDENT OF THE COUNCIL HANDED OVER A LETTER ON 11 APRIL TO IRAQ'S UN AMBASSADOR NOTIFYING HIM THAT A CEASE-FIRE IN THE GULF WAS IN EFFECT.

04945 KAGIAN, J. UNITED MATIONS--UNANIMOUS CONDEMNATION

MIDDLE EAST INTERNATIONAL, (416) (JAN 92), 6-7 HITH THE STRONG SUPPORT OF ISRAEL'S STAUNCHEST ALLY, THE UNITED STATES, THE UN SECURITY COUNCII UMANIMOUSLY APPROYED A RESOLUTION ON 6 JANUARY STRONGLY CONDEMNING ISRAEL'S A RESOLUTION ON 6 JANUARY STRONGLY CONDEMNING ISRAEL'S
DECISION TO DEPORT 12 PALESTINIANS. ISRAEL REFUSED TO DECISION TO DEPORT 12 PALESTINIANS. ISRAEL REFUSED TO
RECONSIDER ITS DECISION. DESPITE STRONG AMERICAN APPEALS AT RECONSIDER ITS DECISION, DESPITE STRONG AMERICAN APPEALS AT LINK BETHEEN THE SECURITY COUNCIL VOTE AND THE RESUMPTION OF LINK BETHEEN THE SECURITY COUNCIL VOTE AND THE RESUMPIION THE MIDDLE EAST TALKS IN WASHINGTON: U.S. OFFICIALS POINT

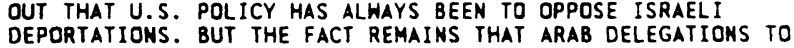
DEPORTATIONS. BUT THE FACT REMAINS THAT ARAB DELEGATI WASHINGTON THEY EXPECTED A STRONG SECURITY COUNCIL CONDEMNATION. AT THE BEHST OF THE PLO THEY INSISTED ON, AND GOT, AN UNHATERED-DOWN RESOLUTION. 
04946 KAHANE, L.H.

INTERNATIONAL TRADE POLICY IN ISRAEL: ANOTHER MODEL--REPLY PUBLIC CHOICE, 74(3) (OCT 92), 361-363.

THE AUTHOR TAKES ISSUE WITH SEVERAL POINTS MADE BY ARYE

L. HILLMAN IN HIS MODEL OF ISRAEL INTERNATIONAL TRADE POLICY.

04947 KAHANE, L.H.

THE POLITICAL ECONOMY OF ISRAELI PROTECTIONISM: AN EMPIRICAL ANALYSIS

PUBLIC CHOICE, 74(3) (OCT 92), 339-353.

THIS PAPER COMPARES THE TARIFF STRUCTURE OF ISRAEL TO THE MOST PROMINENT MODELS IN THE THEORETICAL "NEH POLITICAL ECONOMY" LITERATURE. IT IS ORGANIZED INTO FIVE SECTIONS: (1) INTRODUCTION; (2) A BRIEF HISTORICAL ACCOUNT OF COAMERCIAL POLICY IN ISRAEL FROM STATEHOOD UP TO THE LATE 1970'S; (3) THE THEORETICAL MODELS TO BE TESTED, INCLUDING AN EXPLANATION OF THE VARIABLES USED TO TEST THEM IN THE THE EMPIRICAL MODEL; AND (5) CONCLUSIONS.

$04948 \mathrm{KAHL}, J$

ON CHINA'S FAR WESTERH FRONT

SHISS REVIEW OF WORLD AFFAIRS, 42(9) (DEC 92), 7-8.

THE COLLAPSE OF COMMUNISM IN THE FORMER SOVIET UNION'S CENTRAL ASIAN REPUBLICS HAS TRIGGERED HOPES AND FEARS IN CHINA'S XINJIANG UYGUR AUTONOMOUS REGION. IN BEIJING, CHINESE RULERS FEAR THAT THE INFLUENCE OF THE CENTRAL ASIANS COULD TRIGGER DANGEROUS NEW DYNAMICS WITHIN CHINA'S OWN BORDERS, ESPECIALLY IN XINJIANG, WHERE 1.2 MILLION KAZAKHS LIVE.

04949 KAHL, J.

PSYCHIATRY GAINS GROUND IN CHINA

SHISS REYIEH OF HORLD AFFAIRS, 42(5) (AUG 92), 22-23.

UNDER MAO, PSYCHIATRY WAS DESPISED AS A "BOURGEOIS

PSEUDO-SCIENCE. " THE THEORY WAS THAT THE HUMAN SOUL COULD

PSEUDO-SCIENCE." THE THEORY HAS THAT THE HUMAN SOUL COULD

PSYCHOLOGICAL OISTURBAHCES ARISING UNDER SOCIALISH MUST HAVE

BIOLOGICAL CAUSES. THIS IDEOLOGICAL TABOO HAS BEGUN TO

BIUMLE IM CHIMA. DESPITE GREAT INITIAL DIFFICULTIES,

CRUMBLE IN CHINA. OESPITE GREAT INITIAL DIFFICULTIES, A

MENTALLY ILL IS HAYING A POWERFUL IMPACT.

04950 KAHL, J.

SHANGHAI: TEST CASE FOR ECONOMIC REFORM

SHISS REVIEN OF WORLD AFFAIRS, 42(1) (APR 92), 24-25.

THE IMPACT OF CHINA'S ECONOMIC REFORMS IS KEENLY FELT IN

SHANGHAI, THE COUNTRY'S LARGEST PORT CITY AND TRADITIONAL

COMMERCIAL METROPOLIS. A SECURITIES EXCHANGE HAS BEEN IN

OPERATION FOR TWO YEARS, AND A FEW INDIVIDUALS HAYE AMASSED

HUGE PERSONAL FORTUNES THROUGH SPECULATION. SOME LARGE

ENTERPRISES, NOW TRANSFORMED INTO STOCK COMPANIES, ARE

SERVING AS GUINEA PIGS TO SEE WHETHER PRIVATIZATION CAN

SOLVE THE PROBLEMS OF STATE-OHNED BUSINESSES THAT GENERALLY

OPERATE WITH HEAYY ANMUAL DEFICITS.

04951 KAHLER, M.

MULTILATERALISM HITH SMALL AND LARGE NUMBERS

INTERNATIONAL ORGANIZATION, 46(3) (SUM 92), 681-798.

WUTILATERAL INSTITUTIONS AS A MODE OF GOVERNANCE HAVE

ATTRACTED THE SKEPTICISM OF BOTH NEOREALISTS AND NEOL IBERALS.

MINILATERAL GOVERHANCE THROUGH GREAT POWER COLLABORATION

HAS BECOME INCREASINGLY INADEQUATE IN SEVERAL ISSUE-AREAS.

INSTI TUTIONAL DEVICES SUCH AS VOTING RULES, REPRESENTATION,

FOR SUCCESSFUL MULTILATERAL COLLABORATION WITH LARGE NUMBERS

04952 KAHN, K.

DOES BEING MALE HELP? AN IMVESTIGATION OF THE EFFECTS OF CANDIDATE GENDER AND CAMPAIGN COVERAGE ON EVALUATIONS OF $U$. S. SENATE CANDIDATES

THE JOURNAL OF POLITICS, 54(2) (MAY 92), 497-517.

THIS STUDY EXAMINES THE POSSIBILITY THAT THE NEWS MEDIA,

BY COVERING MALE AND FEMALE CANDIDATES DIFFERENTLY, MAY

BY COVERING MALE AND FEMALE CANDIDATES DIFFERENTLY, MAY

INFLUENE THE SUCCESS OFFEMALE CAMDIDATES. A CONTENT

ANALYS IS OF NEWSPAPER COVERAGE OF U.S. SENATE CAMPAIGNS

SHOWS THAT MALE ANO FEMALE SENATE CANDIDATES ARE COVERED

DIFFERENTLY IN THE NENS. AN EXPEE CAENT WATES CONDUCTED TO

EXPLORE THE CONSEQUENCES OF THESE DIFFERENCES IN COVERAGES,

AS WELL AS THE SIGNIFICANCE OF THE CANDIDATES GENDER, FOR

EVALUATIONS OF SENATE CANDIDATES. THE FINDINGS FROM THIS

CANDIDATES. THE FIMDINGS FROM TH

INFLUENCE A HOMAN'S CHANCES OF SUCCESS AT THE POLLS. MALE

AND FEMALE CANDIDATES ARE COVERED DIFFERENTLY IN THE NEWS AND THESE DIFFERENC

04953 KAHN, K.F.; GOLDENBERG, E.H.

THE MEDIA: 'OBSTACLE OR ALLY OF FEMINISTS?

ANMALS OF THE AMERICAN ACADEMY OF POLITICAL AND SOCIAL

SCIENCE, (515) (MAY 91), 104-113

DEPENDING UPON THE CIRCUMSTANCES, THE NEWS MEDIA CAN BE AN OBSTACLE TO WOMEN'S ACHIEYEMENT OF THEIR POLITICAL GOALS OR IT CAN ACT AS AN ADOITIONAL RESOURCE FOR WOMEN. II IS
QUITE CLEAR THAT THE EARLY MEDIA COVERAGE OF THE WOMEN'S MOVEMENT DID NOT HELP FEMINISM TO GROH. IN FACT, THE EARLY PRESS COVERAGE OF THE WOMEN'S MOVEMENT, WHEN THERE WAS ANY, WAS UNFLATTERING; BUT THE MOVEMENT GREH IH SPITE OF THE MEDIA. THE MEDIA TREAT MALE AND FEMALE CANDIDATES MEDIA. THE MEDIA TREAT MALE AND FEMALE CANDIDATES DIFFERENTIAL TREATMENT CAN HINDER HOMEN'S ACCESS TO THE POLITICAL ARENA. ON THE OTHER HAND, THE DISCOVERY OF THE POLIIICAL ARENA. ON THE OTHER HAND, THE DISCOVERY OF THE
GENDER GAP AND ITS PROMINENT PLAY IN THE PRESS PROBABLY GENDER GAP AND ITS PROMINENT PLAY IN THE PRESS PROBABL
HELPED HOMEN IN THE POLITICAL ARENA. THE MEDIA, BY HELPED HOMEN IN THE POLITICAL ARENA. THE MEDIA, BY
EMPHASIZING THE SIGNIFICANCE OF THE SO-CALLED "WOMEN'S VOTE, EMPHASIZING THE SIGNIFICANCE OF THE SO-CALLED "HOMEN
" MADE WOMEN APPEAR TO BE A MORE POTENT FORCE IN THE ELECTORATE.

04954 KAHN, M.

SHATTERING THE MYTH ABOUT PRESIDENT EISENHOWER'S SUPREME COURT APPOINTMENTS

PRESIDENTIAL STUDIES QUARTERLY, 22(1) (WIN 92), 47-56. THROUGH A DISCUSSION OF EACH OF EISENHOWER'S FIVE APPOINTMENTS TO THE SUPREME CDURT WITH RESPECT TO THE CRITICAL SOCIAL ISSUE FACING THE UNITED STATES IN THE 1950'S-THE ESTABLISHMENT AND SUBSEQUENT EXPANSION OF EQUAL RIGHTS FOR BLACKS--THIS ARTICLE DEMONSTRATES THAT EISENHOHER CLEARLY AND UNDENIABLEY ATTEMPTED TO INFLUENCE THE SUPRMEME COURT IN THE DIRECTION OF ENTRENCHING BROWN $V$. BOARD OF EDUCATION AND ENFORCING ITS TERMS. THIS ARTICLE DEMONSTRATES THAT PRESIDENT EISENHOWER'S SUPREME COURT APPOINTMENT RECORD WAS EXEMPLARY IN ITS CIVIL RIGHTS LEADERSHIP AND THAT IT STANDS IN PROUD CONTRAST TO BUSH'S REFUSAL TO TAKE A LEADERSHIP POSITION ON THE MAJOR POLITICAL ISSUE FACING THE SUPREME COUNT IN HIS DAY.

04955 KAIKATI, J.G.

THE EUROPEAN COMMUNITY AND COMECON: MODELS OF SUCCESS AND FAILURE IN EUROPEAN INTEGRATION

EAST EUROPEAN QUARTERLY, XXVI(3) (FAL 92), 291-307.

THE AUTHOR OFFERS A BRIEF HISTORICAL OVERVIEW OF TWO REGIONAL TRADING BLOCS, COMECON AND THE EUROPEAN COMMUNITY (E.C.), WITH EMPHASIS ON RECENT DEVELOPMENTS. HE EXPLAINS (E.C.)', WITH EMPHASIS ON RECENT DEVELOPMENTS. HE EXPLAINS MHY E.C. MEMBERSHIP IS BECOMING MORE ATTRACTIVE TO COMECON MEMBERS. HE ALSO PRESENTS THREE SCENARIOS FOR DEF
FUTURE RELATIONSHIP BETWEEN THE E.C. AND COMECON.

04956 KAIRYS, D.

PREJUCICIAL RESTRAINT: RACE AND THE SUPREME COURT TIKKUN, 7 (3) (MAY 92), 34-44; 87-88,

FEW ACROSS THE POLITICAL SPECTRUM EVEN QUESTION THE BASIC ASSUMPTION THAT GOVERNMENTAL DISCRIMINATION HAS BEEN PROHIBITED. THE PURPOSE OF THIS ARTICLE IS NOT TO EXPLORE HOW THE CURRENT CONCEPTION OF RACE IN AMERICA GAINED SUCH PROMINENCE, OR THE COMPLEX RELATIONSHIP BETWEEN CONVENTIONAL THINKING AND PRONOUNCEMENTS FROM THE SUPREME COURT. RATHER, IT STRIVES TO REVEAL THE EXTENT TO WHICH THE CONVENTIDNAL WISDOM HAS ALREADY BEEN INCORPORATED INTO SUPREME COURT DECISION. IT CONCLUDES THAT THE BASIC ASSUMPTION THAT GOVERNMENT RACISM HAS BEEN PROHIBITED BY THE COURTS IS NOW SIMPLY MISTAKEN. IT ALOSO CONCLUDES THAT THE COURT'S DOCTRINE OF PURPOSEFUL DISCRIMINATION HAS BROUGHT AN UNCEREMONIOUS END TO AMERICAN LAH'S BRIEF EXPERIMENT WITH RACIAL EQUALITY.

04957 KAK, $S$

THE, POLITICS OF QUDTAS IN SOUTH ASIA

JOURNAL OF SOCIAL, POLITICAL AND ECONOMIC STUDIES, $16(4)$ (WIN 91), 401-421.

THE MÁJOR SOUTH ASIAN STATES--INDIA, PAKISTAN, AND BANGLADESH-OOCCUPY A VAST AND POPULOUS SUBCONTINENT THAT IS HOME TO HUMDREDS OF OIVERSE PEOPLES WITH DIFFERENT LANGUAGES, RELIGIONS, AND CULTURES. MOREOVER, MOST OF THESE ETHNIC POPULATIONS ARE HORI ZONTALLY STRATIFIED INTO DISTINCT CASTES. THE EFFORT TO HOLD THESE DIVERSE PEOPLES TOGETHER IN CENTRALIZED STATES HAS LED TO THE EMERGENCE OF QUDTA SYSTEMS AS AN ESSENTIAL PART OF THE POLITICAL ORDER.

04958 KAKIZAWA, $K$

JAPAN'S POSITION ON SUSPECTED NUCLEAR WEAPONS DEVELOPMENT JAPAN'S POSITIOH

KOREAN JOURMAL OF DEFENSE ANALYSIS, IV(1) (SUM 92), 57-66. THE INTERNATIONAL COMHUNITY IS TODAY SERIOUSLY CONCERMED THAT NORTH KOREA MIGHT BE DEVELOPING A NUCLEAR WEAPONS

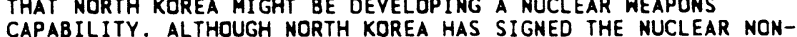
CAPABILITY. ALTHOUGH NORTH KOREA HAS SIGNED THE NUCLEAR NON
PROLIFERATION TREATY, IT HAS YET TO IMPLEMENT A SAFEFUARDS PROLIFERATION TREATY, IT HAS YET TO IMPLEMENT A SAFEFUARDS AGENCY. SINCE NORTH KOREA HAS NOT ALLOWED INSPECTIONS, THE UNITED STATES, CHINA AND JAPAN HAVE JOINED IN DECRYING ANY MOVE BY NORTH KOREA TO ACQUIRE NUCLEAR WEAPONS.

04959 KAKU, R. PERESTROIKA IN JAPAN WASHINGTON QUARTERLY, 15(3) (SUM 92), 5-14.

THIS ARTICLE ARGUES THAT UNLESS JAPAN CHANGES DRASTICALLY THROUGH PERESTROIKA-LIKE REFORMS OF ITS ECONOMIC AND POLITICAL STRUCTURES, IT IS DOOMED TO BECOME AN ORPHAN AMONG THE NATIONS, CRIPPLED BY MOUNTING DOMESTIC CRISES AND 
ANTAGONISM OVERSEAS. ONLY A NEW NATIONAL AGENDA, WHICH EMPHASIZES A GENUINE GLOBALIZATION (AS OPPOSED TO MERELY COMMERCIAL INTERNATIONALIZATION) CAN ENABLE JAPAN TO COPE WITH THE CHALLENGES OF THE FUTURE. THE CORNERSTONE OF THIS STRATEGY MUST BE THE TRANSFORMATION OF JAPAN INTO A STATE BASED ON THE VALUES OF HARMONY HITH, AND PROSPERITY FOR, THE WORLD RATHER THAN ONLY JAPAN. THE AUTHOR EXAMINES THE HISTORICAL FOUNDATIONS OF JAPAN'S CURRENT POLICY AND PROPOSES AN ETHICAL STATE INITIATIVE WHICH EMPHASIZES "KYOSEI"--THE CHALLENGE AND OPPORTUNITY OF LIVING TOGETHER WITH ALL OF THE PEOPLES OF THE WORLD. SUCH A CHANGE WOULD REQUIRE BOTH GOVERMMENT AND PRIVATE SECTOR EFFORT.

04960 KALDOR, M.

EASTERH EUROPE: TOHARDS A PEACETIME ECONOHY?

SAIS REVIEW, 12 (1) (WIN 92), 11-26.

WHILE MARKET-OREINTED REFORMS ARE AN ESSENTIAL ELEMENT OF THE TRANSITION FROM A COLD HAR ECONOMY TO A PEACETIME ECONOMY, FOCUSING SOLEY ON THIS ASPECT COULD UNDERMINE OTHER ASPECTS OF THE TRANSITION AMD PUT BOTH PROSPERITY AND ASPECTS OF THE TRANSITION AND PUT BOTH PROSPERITY AND
DEMOCRACY AT RISK. IN ORDER TO DEVELOP THIS ARGUMENT, THE DEMOCRACY AT RISK. IN ORDER TO DEVELOP THIS ARGUMENT, THE

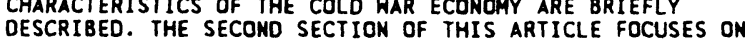
DESCRIBED. THE SECOND SECTION OF THIS ARTICLE FOCUSES ON CURRENT POLICIES IN CENTRAL AND EASTERN EUROPE, AND CONSIDERS WHETHER THEY ARE CONSISTENT WITH THE KIND OF
POL ICIES REOUIRED FOR A SUCCESSFUL TRANSITION TO A PEACETIME ECONOMY. THE LAST SECTION DISCUSSES THE IMPLICATIONS OF THIS ARGUMENT FOR WESTERN AID POLICIES.

04961 KALIPENI, E.

POLITICAL DEVELOPMENT AND PROSPECTS FOR DEMOCRACY IN MALAWI TRANSAFRICA FORUM, $9(1)$ (SPR 92), 27-40

MALAWI REMAINS ONE OF THE FEW AFRICAN COUNTRIES WHERE THE STIRRINGS OF DEMOCRATIC FERVOR ARE STILL IN THEIR INCIPIENT STAGES. THE AUTHOR DISCUSSES MALAWI'S POLITICAL DEVELOPMENT FROM COLONIALISM TO TOTALITARIANISH AND PROVIDES SOME EXPLANATIONS FOR THE CURRENT CONDITIONS. HE EXPLORES THE IMPACT ECONOMIC POLICY HAS HAD ON THE COUNTRY'S POLITICAL DEVELOPMENT AND OUTLINES SOME POSSIBLE SCENARIOS FOR THE POST-BANDA ERA.

04962 KALLICK, D.

THIRTEEM LESSONS TO LEARM FROM CANADA

SOCIAL POLICY, 23(1) (SUM 92), 2-5.

THE AUTHOR' SUGGESTS THAT THE UNITED STATES SHOULD

EMULATE CANADA IN THE FOLLOWING WAYS: PASS UNIVERSAL HEALTH

CARE; REFORM WELFARE; DEVELOP AN INDUSTRIAL POLICY; REPEAL LEAVE; PASS THE EQUAL RIGHTS AMENDMENT; MAKE GOVERMMENT RESPONSIBLE FOR YOTER REGISTRATION: REFORM CAMPAIGN FINANCING; GIVE THIRD PARTIES A CHANCE; CONSIDER NEW MODELS OF ORGANIZING; MOBILIZE A CLEAR CONSTITUENCY IN ELECTORAL POLITICS; AND REVIVE THE LABOR MOVEMENT.

04963 KALMICZKY A.

SLOVAK TELEVISION: BACK TO STATE CONTROL? RFE/RL RESEARCH REPORT, 1(45) (NOV 92), 64-68.

LESS THAN THREE YEARS AFTER THE TOPPLING OF THE CZECHOSLOVAK COMMUNIST REGIME, THERE ARE TROUBLING IMDICATIONS THAT THE SLOVAK GOVERNMENT IS DETERMINED TO REGAIN SOME INFLUENCE OVER THE MEDIA, AS EVIDENCED BY ITS TREATMENT OF SLOVAK TELEVISION. THE SLOVAK TV MANAGEMENT AFTER BEING CHARGED WITH "UNOBJECTIVE REPORTING," WAS SIMPLY REPLACED BY FOLLOWERS OF PRIME MINISTER VLADIMIR MECIAR'S RULING PARTY. THUS, THE SLOVAK GOVERNMENT HAS BROUGHT TELEVISON UNDER ITS CONTROL.

04964 KALT, J.P.; ZUPAN, M.A.

THE APPARENT IDEOLOGICAL BEHAVIOR OF LEGISLATORS: TESTING FOR PRINCIPAL-AGENT SLACK IN POLITICAL INSTITUTIONS

JOURMAL OF LAW AND ECONOMICS, 33(1) (APR 90), 103-132.

THIS ARTICLE EXAMINES THE EXTENT TO WHICH LEGISLATORS

AND REGULATORS PUSH THEIR OWN IDEOLOGICAL PREFERENCES IN THEIR POLICY DECISIONS AT THE EXPENSE OF THEIR CONSTITUENTS ' INTERESTS. IN THIS PAPER, AS IN EARLIER RESEARCH, THE AUTHORS OBSERVE THAT WHAT APPEAR TO BE IDEOLOGICAL PREFERENCES OF SENATORS ARE SIGNIFICANT IRREDUCIBLE DETERMINANTS OF OUTCOME ON AT LEAST SOME SPECIFIC REGULATORY ISSUES. THEY ARGUE THAT SUCH PREFERENCES REFLECT REAL CONSUMPTION MOTIVES THAT ARE NOT AT ODOS WITH MICROTHEORETIC APPROACHES TO THE ECONOMIES OF POLITICS. TO INVESTIGATE THE POSSIBILITY THAT EARLIER RESULTS WERE DUE TO FAILURE TO POSSIBILITY THAT EARLIER RESULTS WERE DUE TO FAILURE TO PROPERLY ACCOUNT FOR ALL RELEVANT CONSTITUENT INTERESTS, THIS ARTICLE MORE CLOSELY EXAMINES THE AUTHO
DEVELOPED MEASURES OF SENATORIAL IDEOLOGY.

04965 KAMALKHANI, $Z$.

IRANIANS IN NORWAY: ADAPTATION AND COMMUNITY FORMATIOH MIGRATION WORLD, $19(2)(1991), 8-12$

THIS ARTICLE OUTLINES THE DEVELOPMENT OF IRANIAN MIGRATION AND THE COMMUNITY SITUATION OF THE MIGRANTS DURING DIFFERENT PERIODS. THE MATERIAL PRESENTED IS BASED ON A STUDY CARRIED OUT BY THE AUTHOR BETWEEN 1985-1987 IN BERGEN, NORWAY. THE BASIC FOCUS OF THIS STUDY WAS TO DESCRIBE THE
PROCESS OF ADAPTATION AND INTEGRATION OF IRANIANS INTO NORHEGIAN SOCIETY. IN NORWAY, THE IRANIAN COMMUNITY IS DIVIDED INTO SUBCULTURAL GROUPS AND CATEGORIES ACCORDING TO RELIGION, ETHNIC ORIGIN, PLACE OF BIRTH, SEC, AGE AND NUMBER OF FAMILY MEMBERS. AT THE SAME TIME, IRANIANS SHARE A SERIES OF COMMON PROBLEMS WHICH CHARACTERIZE THEIR SITUATION AS MIGRANTS AND AFFECTS THEIR LIVES IN NORWAY. HOWEVER, IT IS AS INDIVIDUALS ANO ACCORDING TO DISTINCTIVE CHARACTERISTICS THAT THEY CONSTRUE THEIR ADAPTATIONS-ADAPTATIONS WHICH MUST TAKE INTO ACCOUNT THE ENVELOPING SET OF CIRCUMSTANCES WHICH INFLUENCE THEIR LIVES VARIOUS WAYS.

04966 KAMALUDDIN, S.

THE ARAKAN' EXODOUS

FAR EASTERN ECONOMIC REVIEW, 155(12) (MAR 92), 22-24. WHAT STARTED AS A TRICKLE OF MUSLIM REFUGEES FROM BURMA'S ARAKAN REGION INTO NEIGHBORING BANGLADESH IN 1991 HAS TUNRED INTO A FLOOD AND NON FACES DHAKA WITH A MASSIVE PROBLEM. THE TENSION ALONG THE HEAVILY POLICED BORDER AND THE BURDEN OF REFUGEES, NOW TOTALLING ABOUT 145,000, HAS FORCED DHAKA TO APPROACH THE UNITED NATIONS AND FRIENDLY COUNTRIES TO BRING PRESSURE ON RANGOON. THE RESPONSE FROM MOST ISLAMIC COUNTRIES AND SOME OF BURMA'S SOUTHEAST ASIAN NEIGHBORS HAS BEEN FAVORABLE TO BANGLADESH, BUT AUTHORITIES WORRY THAT IT MAY NOT BE ENOUGH TO PERSUADE THE RULING GENERALS IN RANGOON, WHO HAVE BEEN LARGELY IMPERVIOUS TO EXTERNAL PRESSURE. THE IMMEDIATE PROBLEM IS THE REHABILITATION OF THE REFUGEES LIVING IN OVER-CROWDED, MAKESHIFT CAMPS.

04967 KAMALUDDIN, $S$.

TRADE HITHOUT TARIFF

FAR EASTERN ECONOMIC REVIEW, 153(32) (AUG 91), 16-17. SMUGGLIMG HAS LONG BEEN ENDEMIC TO THE SOUTH ASIAN SUBCONTINENT, GIVEN THE SCARCITY OF CONSUMER GOODS, NONCONVERTIBILITY OS CURRENCIES AMD HIGH TARIFF BARRIERS. THE SMUGGLED CONTRABAND INCLUDES ELECTRONIC GADGETS, POLYESTER GARMENTS, GOLD CIGARETTES CATTLE, AMD YOUMG HOMEM IN THE PAST THO DECADES SHUGGLING HAS BECOME SUCH AOMEN. IN THE AND SMUGGLERS HAVE EVOLVED SUCH EXTENSIVE LINKS HITH CORRUPT POLITICIANS AND OFFICIALS THAT SUCCESSIVE REGIMES HAVE

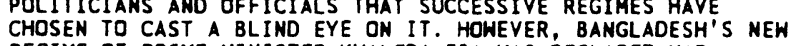
REGIME OF PRIME MINISTER KHALEDA ZIA HAS DECLARED WAR REGIME OF PRIME MINISTER KHALEDA ZIA HAS DECLARED WAR
AGAINST SHUGGLERS. IN ITS FIRST SALVO, IT HAS REOPENED TWO AGAINST SHUGGLERS. IN ITS FIRST SALVO, IT HAS REOPENED TH
MAJOR CASES OF GOLD SMUGGLING, WICH HAD BEEN DEALT WITH MAJOR CASES OF GOLD SMUGGLING, WICH HAD BEEN
RATHER CASUALY BY THE PREYIOUS GOVERNMENT.

04968 KAMBARA, T.

THE ENERGY SITUATION IN CHINA

CHINA QUARTERLY, (131) (SEP 92), 608-636

WITH A POPULATION OF MORE THAM ONE BILLION PEOPLE, CHINA REQUIRES VAST SUPPLIES OF ENERGY FOR INDUSTRIAL AND ECONOMIC DEVELOPMENT. THROUGHOUT THE 1980'S, THE DISAPPOINTING GROWTH OF OIL AND COAL OUTPUT WAS OFFSET BY A DRAMATIC DECLINE IN ENERGY INTENSITY, THEREBY FACILITATING THE MAINTENANCE OF A BASIC BALANCE BETWEEN OVERALL PRODUCTION AND CONSUMPTION. HOWEVER, THE PROBABLE MAINTENANCE OF SUCH A BALANCE DURING THE 1990'S MAY NOT OBVIATE CHINA'S CHRONIC ENERGY DEFICIENCY, ESPECIALLY GIVEN THE UNEVEN DISTRIBUTION OF RESOURCES. ALTHOUGH RECENT INVESTMENT AND TECHNOLDGICAL INITIATIVES COULD HELP OVERCOME CONSTRAINTS, THE FORMULATION OF AN INTEGRATED PLAN THAT PERMITS THE REFORM OF ENERGY PRICES AND REGULATORY SYSTEMS IS ESSENTIAL IF CONSTRAINTS ARE TO BE ELIMINATED ALTOGETHER.

04969 KAMER, $H$.

A TRIUMPH OF REALISH IN MAASTRICHT

SHISS REVIEW OF WORLD AFFAIRS, 41(10) (JAN 92), 14.

AT THE MAASTRICHT SUMMIT, THE LEADERS OF THE EUROPEAM

COMMUNITY MEMBER NATIONS ARTICULATED LOFTY GOALS AND GREAT VISIONS. BUT, ON CLOSE EXAMINATION, THEY APPEAR TO HAVE TAKEN ONLY VERY SMALL STEPS TOWARD THE GOAL OF A UNITED EUROPE. THIS DISCREPANCY BETWEEN WORD AND DEED IS NOTHING NEH IN THE HISTORY OF EUROPEAN INTEGRATION. AS LONG AS THE IDEA MOVES FDRWARD AND THE MOMENTUM IS NOT LOST, PEOPLE EXPECT THE RHETORIC TO BE YEARS AHEAD OF THE REALITY.

04970 KAMER, $\mathrm{H}$.

RECONSTRUCTION WITH RISKS IN THE EAST OF EUROPE

SWISS REVIEH OF WORLD AFFAIRS, 11(11) (FEB 92), 4-5.

SWISS REVIEH OF WORLD AFFAIRS, $41(11)$ (FEB 92), $4-5$.
THE AUTHOR LOOKS AT THE MANY PROBLEMS CREATED BY THE OISINTEGRATION OF THE SOVIET UNION AND RUMINATES ABOUT THE PROSPECTS FOR THE CREATION OF A SUCCESSFUL NEW STATE.

04971 KAMER, $\mathrm{H}$.

SIGNS OF STRESS IN THE ATLANTIC ALLIANCE

SWISS REVIEW OF WORLD AFFAIRS, 42( 2 ) (MAY 92), 4-5.

THE AUTHOR LOOKS AT THE POLITICAL, ECONOMIC, AND TRADE TENSIONS CURRENTLY AFFECTING THE RELATIONS BETWEEN THE UNITED STATES AND THE COUNTRIES OF WESTERH EUROPE.

04972 KAMER, H.

THE TORIES TRIUMPH

SWISS REVIEW OF WORLD AFFAIRS, 42(2) (MAY 92), 5. 
ON APRIL 9, 1992, BRITONS CONFOUNDED THOSE WHO HAD PREDICTED A LABOR VICTORY IN THE NATIONAL ELECTIONS, GIVING AN ABSOLUTE MAJORITY TO THE CONSERVATIVES IN THE HOUSE OF COMMONS. THUS, BRITISH VOTERS CLEARLY OPTED FOR A CONTINUATION OF THE POLICIES OF THE 1980'S, THOUGH PERHAPS WITH SOME MODIFICATIONS. THEY TURNED THEIR BACKS ON SEPARATIST AND REGIONALIST TENDENCIES AND REJECTED EFFORTS TO INTRODUCE A PROPORTIONAL ELECTORAL SYSTEM FOR WESTMINSTER. THEIR DESIRE FOR REFORM AND THEIR WISH TO MAINTAIN THE STATUS QUO APPEARED TO BE ABOUT EVENLY BALANCED.

04973 KAMIENIECKI, S. : LACKIE, P.

MEASURING HIGH-TECHNOLOGY CAPACITY ACROSS THE 50 STATES POLICY STUDIES REVIEW, 11(1) (SPR 92), 110-117.

OLICY STUDIES REVIEW, 11(1) (SPR 92), 110-117. THIS STUDY CONCEPTUALIZES AND OPERATIONALIZES STATE HIGH-
TECHNOLOGY CAPACITY AND DEMONSTRATES ITS POTENTIAL UTILITY TECHNOLOGY CAPACITY AND DEWONSTRATES ITS POTENTIAL UTILI IN COMPARATIVE STATE STUDIES. THE ANALYSIS IS PRIMARILY CONCERNED WITH IDENTIFYING AND RECORDING THE QUANTITY OF
HIGH-TECH RESOURCES THAT ARE AVAILABLE IN EACH STATE AND CAN BE EMPLOYED IN PUBLIC POLICY. DRAWING UPON A GRDUP OF LIKELY INDICATORS OF HIGH-TECH AVAILABILITY, THE STUDY IDENTIFIES FIVE DIMENSIONS OF THE CONCEPT AND RANKS THE INDIVIDUAL STATES ALONG THESE DIMENSIONS. THE PAPER THEN ANALYZES THE RELATIONSHIPS AMONG THE FIVE COMPONENTS OF HIGH-TECHNOLOGY CAPACITY AND SEVERAL STATE ENERGY AND ENVIRONMENTAL POLICIES.

04974 KAMH, F

NON-CONSEQUENTIALISM, THE PERSON AS AN END-IN-ITSELF, AND THE SIGNIFICANCE OF STATUS

PHILOSOPHY AND PUBLIC AFFAIRS, 21(4) (FAL 92), 354-297. THE GENERAL TOPIC OF THIS ARTICLE IS THE STRUCTURE OF A NON-CONSEOUENTIALIST MORAL THEORY. THE AUTHOR CONSIDERS THE JUSTIFICATION OF OPTIONS, FOCUSING ON THEIR REPRESENTATION OF THE IDEA THAT PERSONS ARE END-IN-THEMSELVES, IN THE SENSE THAT THEY HAVE A POINT EVEN IF THEY DO NOT BRING ABOUT GREATER GOOD. HE THEN CONSIDERS THE FORM AND JUSTIFICATION OF CONSTRAINTS AND SHOWS HOW THEY ARE CONSISTENT HITH THE PRESENCE OF OPTIONS IN A MORAL SYSTEM. HE ALSO EXAMINES TWO
PROMINENT PROPOSALS FOR CHARACTERIZING CONSTRAINTS, THE HARMPROMINENT PROPOSALS FOR CHARACTERIZING CONSTRAINTS, THE HARMNOT AID DISTINCTION AND THE INTENTION-FORESIGHT DISTINCTION. RATHER THAN AGENT INFORCED.

04975 KAMNIKAR, E.; KAMMIKAR, J.; VOCINO, T

KAMMIKAR, E; K KAMNIKAR, J.; VOCINO, T.
STATE EXECUTIVES JOIN WITH STATE TALENT TO IMPROVE STATE GOVERNMENT

PUBLIC PROOUCTIVITY \& MANAGEMENT REVIEW, 15(2) (WIN 91), 151-158.

AN OVERVIEH OF THE ALABAMA MANAGEMENT IMPROVEMENT PROGRAM, A JOINT PRIVATE-PUBLIC SECTOR MANAGEMENT REVIEW OF MAJOR DEPARTMENTS AND AGENCIES. OVER AN EIGHT-MONTH PERIOD, JOINT STUDY TEAMS OF LOANED BUSIMESS EXECUTIVES, STATE EMPLOYEES, AND CONSULTANTS CONDUCTED MANAGEMENT REVIENS OF THE STATE GOVERMMENT. OVER 9O0 WRITTEN IMPROVEMENT RECOMNENDATIONS TO REDUCE COSTS, INCREASE EFFICIENCY, IMPROVE EFFECTIVENESS, AND IDENTIFY LONG-RANGE POLICY AND ORGANIZATIONAL CHANGES HERE MADE AS A RESULT OF THE PROGRAM. THE PURPOSE OF THE ARTICLE IS TO PROVIDE AN OVERVIEW OF THE PROCESS OF SETTING UP THE PROGRAM, A SUMMARY OF THE RESULTS, AMD AN AHALYSIS OF THE SUCCESS OF THE MANAGEMENT REVIEN. THE STORY IS PRESENTED IN FIVE PARTS; THE INITIATIVE, THE PROCESS, RECOMMENDATIONS, IMPLEMENTAION, AND SUMMARY AND ANALYSIS.

04976 KANDEH, J.D

POLITICIZATION OF ETHNIC IDENTITIES IN SIERRA LEONE AFRICAN STUDIES REVIEN, 35(1) (APR 92), 81-99.

THE AUTHOR TRACES THE IMPACT OF STATE FORMATION AND CLASS FORMATION ON THE EMERGENCE AND DEVELOPMENT OF COMPET ITIVE ETHNO-POL ITICAL IDENTITIES IN SIERRA LEONE. THE POLITICI ZATION OF CREOLE, MENDE, TEMNE, AND LIMBA IDENTITY DESERVES SCRUT INY DUE TO' THE DOMINANT ROLE THESE IDENTITIES HAVE PLAYED IN SHAPING POLITICAL PROCESSES IN POST-COLONIAL SIERRA LEONE. NOT ONLY IS SIERRA LEONE A CULTURALLY-PLURAL AND INTENSELY-STRATIFIED SOCIETY, ITS POST-COLONIAL

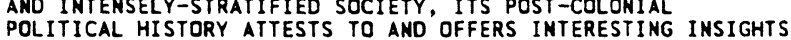
POLITICAL HISTORY ATTESTS TO AND OFFERS INTERESTING INSIGHTS
ABOUT THE INTIMATE CONNECT IONS AMONG CLASS, ETHNICITY, AND STATE FORMATION. FROM THE END OF THE 19TH CENTURY UNTIL
INDEPENDENCE, THE MOST DIVISIVE ETHNO-REGIONAL CONFLICT IM INDEPENDENCE, THE MOST DIVISIVE ETHNO-REGIONAL CONA
SIERRA LEONE PITTED COLONY CREOLE ELITES AGAINST

SIERRA LEONE PITTED COLONY CREOLE ELITES AGAINST
PROTECTORATE AFRICAN ELITES. THE CREOLES, SEPARATIST IN PROTECTORATE AFRICAN ELITES. THE CREOLES, SEPARATIST
THEIR POLITICAL ATTITUDES ANO ASPIRATIONS, REJECTED THEIR POLITICAL ATTITUDES AND ASPIRATIONS, REJECTED
POLITICAL EOUALITY WITH PROTECTORATE AFRICANS WHILE THE POLITICAL EQUALITY WITH PROTECTORATE AFRICANS WHILE THE LATTER RESENTED BOTH THE ASSERTIONS OF SUPERIORITY BY CREOLES AND THEIR RELATIVE DOMINANCE IN SIERRA LEONE
POLITICS PRIOR TO DECOLONIZATION. THIS POLARIZATION PERSISTS POLITICS PRIOR TO DECOLONIZATION. THIS POLARIZATIOH P TODAY, BUT ITS POLITICAL SIGNIFICANCE HAS PALED IN COMPARISON TO BOTH THE RIFT BETHEEN THE MENDES OF THE SOUTH AND THE TEMHES OF THE NORTH AND THE CONTEMPORARY
OF LIMBA CULTURAL ENTREPRENEURS AND POLITICIANS.

04977 KANOIYOTI, D.

WOMEN, ISLAM AND THE STATE

MIDOLE EAST REPORT, $21(6)$ ( NOV 91), 9-13.
MOST COMMENTARY ON GENDER AND POLITICS IN THE MIDDLE EAST ASSIGNS A CENTRAL PLACE TO ISLAM, BUT THERE IS LITTLE AGREEMENT ABOUT THE ANALYTIC WEIGHT IT CARRIES IN ACCOUNTING FOR THE SUBORDINATION OF WOMEN OR THE ROLE IT PLAYS IN RELATION TO WOMEN'S RIGHTS. THE RISE OF ISLAMIST MOVEMENTS HAS STIMULATED NEW INTEREST IN THE RELATIONSHIP BETWEEN RELIGION AND POLITICS IN THE REGION, AND THE ROLE OF THE STATE IN EXPRESSING AND IMPLEMENTING THIS RELATIONSHIP. THIS ARTICLE EXAMINES THREE DISTINCT COMPONENTS OF THE ARTICLE EXAMINES THREE DISTINCT COMPONENTS OF THE
RELATIONSHIP BETWEEN ISLAM, THE STATE, AND THE POLITICS OF RELATIONSHIP BETWEEN ISLAM, THE STATE, AND THE POLITIC
GENDER COMPROMISE: LINKS BETWEEN ISLAM AND CULTURAL GENDER COMPROMISE: LINKS BETWEEN ISLAM AND CUL TURAL
NATIONALISM; PROCESSES OF STATE CONSOLIDATION AND THE MODES NATIONALISM; PROCESSES OF STATE CONSOLIDATION AND THE MODES
OF CONTROL STATES ESTABLISH OVER LOCAL KIN-BASED RELIGIOUS OF CONTROL STATES ESTABLISH OVER LOCAL KIN-BASED RELIGIOUS
AND ETHNIC COMMUNITIES; AND INTERNATIONAL PRESSURES THAT AND ETHMIC COMMUNITIES; AND INTERNATI

04978 KANESALIMGAM, $V$

ENHANCING THE NEGOTIATING STRENGTH AND CAPACITY OF COLLECTIVE SELF-RELIANCE OF DEVELOPING COUNTRIES OF SOUTH ASIA

SOUTH ASIA JOURNAL, 5(2) (OCT 91), 131-142.

ATTEMPTS BY THE GROUP OF 77 (G77) LESS DEVELOPED NATIONS TO NEGOTIATE TOWARDS THE CREATION OF A NEW INTERNATIONAL ECONOMIC ORDER (NIEO) HAVE REACHED A STALEMATE. THE GENERAL VIEW IS THAT THE UTILITY OF THE GLOBAL DIALOGUE IS RAPIDLY DIMINISHING. ONE WAY TO BREAK OUT OF THIS DEADLOCK IS TO PROMOTE REGIONAL COOPERATION. THIRD WORLD COUNTRIES ARE BEGINHING TO REALIZE THAT IT IS IMPERATIVE TO ENHANCE THEIR CAPACITY OF SELF RELIANCE THROUGH SOUTH-SOUTH COOPERATION-ESPECIALLY IN THE ECONOMIC AND TECHNICAL SPHERES. REGIONAL COOPERATION WILL ALSO EXPAND SOUTH-SOUTH TRADE, INCREASE JOINT PRODUCTION AND MARKETING VENTURES, ALLOW FOR THE CREATION OF JOINTLY OWNED DEVELOPMENT FINANCING FACILITIES, AND ENCOURAGE THE FORMULATION OF JOINT AGRICULTURAL POLICIES. ENHANCEMENT OF COLLECTIVE SELF-RELIANCE WILL ALSO IMPROVE THE NEGOTIATING STRENGTH OF DEVELOPING COUNTRIES.

04979 KANG, C.

THE PROS AND CONS OF THE POLITICAL CHOICE BETHEEN THE PRESIDENTIAL SYSTEM AND THE CABINET SYSTEM FOR KOREA'S POLITICAL DEVELOPMENT

KOREA \& WORLD AFFAIRS, 16(4) (WIN 92), 695-713.

SOUTH KOREA IS IN THE MIDST OF A LIVELY DEBATE ABOUT WHETHER TO REFORM THE COUNTRY'S PRESIDENTIAL SYSTEM OF GOVERMMENT. THIS PAPER EXAMINES THE RELATIVE MERITS OF BOTH THE PRESIDENTIAL AND THE PARLIAMENTARY SYSTEMS IN THE SOUTH KOREAN CONTEXT.

04980 KANG, M.: LEE, K.

INDUSTRIAL SYSTEMS AND REFORM IN NORTH KOREA: A COMPARISON WITH CHINA

WORLD DEVELOPMENT, 20(7) (JUL 92), 947-958.

THE AUTHORS DESCRIBE THE NORTH KOREAN ECONOMIC SYSTEM AND RECENT REFORM EFFORTS. THE NORTH KOREAN REFORM PROGRAM SINCE THE MID-1980'S HAS BEEN MOTIVATED BY THE INCREASING SERIOUSNESS OF PROBLEMS TYPICAL OF CENTRALLY-PLANNED SOCIALIST ECONOMIES. THE AUTHORS COMPARE CHINESE AND NORTH KOREAN REFORM MEASURES. SINCE THERE IS NOTHING INNOVATIVE ABOUT NORTH KOREAN REFORM MEASURES, MOST OF WHICH HAVE BEEN TRIED IN OTHER SOCIALIST ECONOMIES, THEIR IMPACT HAS BEEN QUITE LIMITED.

04981 KANGAS, 0.

THE POLITICS OF UNIVERSALISM: THE CASE OF FINNISH SICKNESS INSURANCE

JOURNAL OF SOCIAL POLICY, 21(1) (JAN 92), 25-52.

THIS STUOY IDENTIFIES THE GENERAL STRUCTURAL, POLITICAL, AND INSTITUTIONAL CONFIGURATIONS THAT INFLUENCED THE EMERGENCE OF NATIONAL HEALTH INSURANCE IN FINLAND. DUE TO LATE INDUSTRIALIZATION, THE FINMISH CASE ALLOHS THE EVALUATION OF THE IMPORTANCE OF THE AGRARIAN VERSUS WORKING CLASS INTERESTS IN THE EMERGENCE OF THE SCANDINAVIAN MODEL. THE STUDY ALSO DISCUSSES HOW THE CONTENDING THEORETICAL APPROACHES TO THE DEVELOPMENT OF THE WELFARE STATE SERVE TO EXPLAIN THE CHARACTERISTICS OF FINNISH SICXNESS PROVISIONS. AFTER THE HISTORICAL OVERVIEH, THE RESULTS OF THE HISTORICAL PROCESSES ARE EXAMINED BY COMPARING THE QUALITY OF FINNISH PROCESSES ARE EXAMINED BY COMPARING THE QUALITY OF FIN
HEALTH INSURANCE WITH THE SWEDISH, GERMAN, AND BRITISH SYSTEMS.

04982 KANGQIN, Z.

CIS FACES UNCERTAIN FUTURE
BEI JING REVIEH, 35 (12) (MAR 92), 13.

THE COMMONHEALTH OF INDEPENDENT STATES (CIS) THOUGH ONLY THREE MONTHS OLD, IS ALREADY SHOWING SIGNS OF UNCERTAINTY AS MEMBER STATES ARE HAGGLING OVER THEIR OWN POLITICAL ECONOMIC AND MILITARY INTERESTS. THIS ARTICLE DETAILS THE DIVISION OF LEGACY AND THE DESTABILIZING FACTORS BEARING ON THE PRESENT SITUATION. THE DIVISION OF PROPERTY, RESOURCES AND ENTERPRISES OF THE FORMER SOVIET UNION IS A KNOTTY PROBLEM. FORMER UNION ENTERPRISES HAVE BEEN LOCALIZED, BUT SINCE THE DISTRIBUTION IS UNBALANCED--RUSSIA GETS A BIGGER PART--DISPUTES ARE LIKELY TO ERUPT AT ANY TIME. 
04983 KANJIRATHINKAL, M.; HICKEY, J. MEDIA FRAMING AND MYTH: THE MEDIA'S PORTRAYAL OF THE GULF WAR CRITICAL SOCIOLOGY, 19(1) (1992), 103-112.

THIS IS AN ANALYSIS OF THE MEDIA'S FRAMING OF THE PERSIAN GULF WAR IN MYTHOLOGICAL CATEGORIES. WE CONTEND THAT THROUGH CAREFUL FRAMING THE MEDIA TRANSFORMED POLITICAL AND MILITARY EVENTS INTO MYTHICAL DRAMAS TO EVOKE DEEPLY HELD BELIEFS IN THE MASSES AND ACHIEVE POLITICAL AIMS. FOLLOWING JOSEPH CAMPBELL'S MODEL OF THE "HERO'S JOURNEY," THE MEDIACREATED MYTH OF THE PERSIAN GULF WAR CONSISTED' OF FOUR MAIN STAGES: THE HERO;S QUEST, THE ENCOUNTER HITH EVIL, FULFILLMENT, AMD RETURN.

04984 KANTH, R.K.

TRICKLE-UP SELF-DETERMINATION: BIRTH OF A NOTION CHALLENGE, 35(3) (MAY 92), 45-46.

AFTER ALMOST 40 YEARS OF DEVELOPMENT THEORY, IDEOLOGY, AND PRACTICE CUTTING ACROSS THE POLITICAL SPECTRUM, IT IS NEARLY IMPOSSIBLE TO BELIEVE THAT ALMOST ALL OF THE PANACEAS ADVOCATED BY THE ANHOINTED SEERS AND SAVANTS RESTED ON ONE INDELIBLE, IF NOXIOUS, PRINCIPLE: THAT A SET OF EXPERTS, LARGELY THROUGH SELF-SELECTION, HAD THE RIGHT AND THE
CAPACITY TO PLAN, THINK, EXPERIMENT, AND HOPE ON BEHALF OF CAPACITY TO PLAN, THINK, EXPERIMENT, AND HOPE ON BEHAL
OTHERS UPON WHOM THEIR PLANS WERE TO BE FOISTED. BOTH OTHERS UPON WHOM THEIR PLANS WERE TO BE FOISTED. BOTH
CAPITALIST MODERNIZERS AND MARXIST REVOLUTIONARIES HAD PREFABRICATED PLANS, REQUIRING ONLY THE SEIZURE OF STATE POWER OR THE UNHITTING ACQUIESCENCE OF COMMON PEOPLES SO THESE PLANS COULD BE IMPLEMENTED, WITH A SOVEREIGN DISREGARD FOR THE SIMPLE DEMOCRATIC POLITICAL PRECEPT THAT IT IS THE PEOPLE, FOR BETTER OR FOR WORSE, WHO NEED TO EXERCISE THE RIGHT OF CHOICE OVER THEIR DESTINIES, EVEN IF THESE CHOICES DO NOT MAXIMIZE A NET DIVIDEND AS DEFINED BY POLITICAL ECONOMISTS, LEFT OR RIGHT.

04985 KANTOR, B.

SAVING AND INVESTMENT--OWNERSHIP AND CONTROL IN SA SOUTH AFRICA INTERNATIONAL, 23(2) (OCT 92), 82-90.

THE SHAPE OF THE PRESENT SOUTH AFRICAN ECONOMY, WHERE SIX MAJOR CORPORATIONS LOOM VERY LARGE, HAS EMERGED AS A RESULT OF A VARIETY OF FACTORS. THESE INCLUDE HISTORY, EXCHANGE CONTROLS, TAXATIDN, INFLATION, AND GOVERNMENT SPENDING VERSUS REVENUES. THE DOMINANCE OF THE ECONOMY BY A HANDFUL OF MAJOR CORPORATIONS IS NOT UNIOUE TO SOUTH AFICA AND THOSE WHO PROPOSE VARIOUS FORMS OF UNBUNDLING OR ANTITRUST LEGISLATION MAY DO MORE HARM THAN GOOD.

04986 KAPCIA, A.

THE FOURTH CONGRESS OF THE CUBAN COMMUNIST PARTY: TIME FOR A CHANGE?

JOURNAL OF COMMUNIST STUDIES, 8(1) (MAR 92), 180-186.

TO DESCRIBE THE FOURTH CONGRESS OF THE CUBAN COMMUNIST PARTY, HELD IN OCTOBER 1991. AS A CRUCIAL MEETING IS AN UNDERSTATEMENT. THE CLIMATE SURROUNDING THE CONGRESS WAS ONE OF CONSIDERABLE GLOOM AND FOREBODING AS CUBANS STRUGGLED TO COPE WITH THE ONGOING CRISIS CREATED BY THE COLLAPSE OF COMMUNISM IN THE SOYIET UNION AND EASTERN EUROPE.

04987 KAPITSA, M.S.

THE EVOLVING SITUATION IN NORTHEAST ASIA AND THE KOREAN PROBLEM

KOREA \& WORLD AFFAIRS, 16(3) (FAL 92), 493-502

THE BASIC TENDENCIES AND GENERAL DIRECTION OF THE DEVELOPMENT OF NORTHEAST ASIA ARE BEING SHAPED PRIMARILY BY FORCES UNDERLYING THE INTERRELATIONSHIPS AMONG FOUR MAJOR POWERS: CHINA, JAPAN, RUSSIA, AND THE UNITED STATES. IN THIS PAPER, THE AUTHOR SPECULATES ABOUT THE LIKELY DEVELOPMENT OF THESE MAJOR ACTORS AND HOW THE POWER BALANCE IN NORTHEAST ASIA WILL AFFECT THE KOREAN PROBLEM.

04988 KAPLAN, D.

MATIONALISM AT A MICRO-SCALE: EDUCATIONAL SEGREGATION IN MONTREAL

POLITICAL GEOGRAPHY QUARTERLY, 11(3) (MAY 92), 259-282. HOW THE PATTERNS OF SPATIAL AND INSTITUTIONAL SEGREGATION AMONG FRENCH-AND ENGLISH-SPEAKERS IN MONTREAL ISALND COMBINE TO REINFORCE THE BOUNDARIES BETWEEN THE TWO NATIONAL GROUPS IS THE FOCUS OF THIS PAPER. WHILE ESTABLI SHED ALONG DENOMINATIONAL LINES, EDUCATION HAS HISTORICALLY DIVIDED THE THO LANGUAGE COMMUNITIES, HISTORICALLY DIVIDED THE THO LANGUAGE COMMUNITIES,
SUPPLEMENTING THE PREVAILING PATTERNS OF RESIDENTIAL SEGREGATION. THIS ASPECT HAS ALSO MADE EDUCATION AN ESPECIALLY DIVISIVE POL IITICAL ISSUE AND HAS BEEN THE FOCUS ESPECIALLY DIVISIVE POLITICAL ISSUE AND HAS BEEN THE FOCUS
OF PROVINCIAL EFFORTS TO ALTER MONTREAL'S LINGUISTIC BALANCE BOTH SOCIALLY AND DEMOGRAPHICALLY.

04989 KAPLAN, L.

IMPLICATIONS FOR THE UNITED STATES

ARMS CONTROL, 12(3) (DEC 91)

LAHRENCE S. KAPLAN ARGUES THAT THERE IS LITTLE LIKELIHOOD THAT THE FUNCTIONS WHICH NATO ASSUMES TODAY WILL BE TAKEN OVER BY OTHER ORGANIZATIONS--THAT THERE IS NO SUBSTITUTE FOR THE AMERICAN PRESENCE IN NATO, EVEN IF THE
FORM OF THE ORGANIZATION IS CHANGED AND AMERICAN AUTHORITY IS REDUCED. NOT ONE NATION HAS OEMANDED ANY IMMEDIATE REMOVAL OF AMERICAN TROOPS FROM EUROPE. HE CONCLUDES THAT IN THE SHORT RUN THERE IS NO ALTERNATIVE TO NATO.

04990 KAPLAN, R.

CRUEL MARCH

NATIONAL REVIEW, XLIV(8) (APR 92), 26, 28

MARCH WAS THE CRUELEST MONTH FOR THE FRENCH SOCIALIST PARTY (PS). "DISASTER," AND "BITTER VOTERS REJECT PS," SAID THE NEWSPAPERS AS THE PS OBTAINED LESS THAN 20 PER CENT OF THE VOTE FOR THE FIRST TIME SINCE 1971. WHAT THESE ELECTIONS SHOWED IS THAT YOU CAN CHANGE YOUR STRIPES AS MUCH AS YOU WANT--THE PS HAS EVEN GIVEN THE FREE MARKET A LUKEWARM INDORSEMENT--BUT YOU WILL STILL BE JUOGED BY YOUR WORKS, AND THE FRENCH YOTERS' EYALLATIOU OF MANAGEMENT WAS HARSH INDEED.

04991 KAPLAN, $R$.

LEFT IN THE FOG

FREEDOM REVIEW, 23(2) (MAR 92), 24-28.

THE AUTHOR LOOKS AT FRANCE''S SOCIALIST PARTY AND

ENDEAVORS TO EVALUATE WHAT THE SOCIALIST GOVERNMENT HAS

ACCOMPLISHED AND WHAT ITS PROSPECTS ARE FOR THE FUTURE.

04992 KAPLAN, R.

WATCH ON THE RHINE

NATIONAL REVIEW, XLIV(20) (OCT 92), 24; 26

THE EUROPEAN MOVEMENT STARTED AS A SCHEME TO PREVENT A FOURTH WAR BETWEEN FRANCE AND GERMANY. THROUGHOUT THE SEVENTIES AND EIGHTIES THE DRIVING FORCE OF THE EC BECAME PROTECTED AND REGULATED ECONOMIC GROWTH. THE COMPETITION BETWEEN THE TWO VISIONS OF EUROPE MIGHT HAVE REMAINED RELATIVELY UNDRAMATIC BUT PUBLIC OPNION FORCED SOME LEADERS TO REPRESENT THEIR GRIEVANCES. THIS ARTICLE ARGUES THAT THE DISORDER OF THE PAST FEW HEEKS ARE REVEALING ANO MOS T REVEALING OF ALL WAS THE GERMAN WILLINGNESS TO CLOSE RANKS WITH THE FRENCH. THE IDEA OF A UNION ON THE RHINE IS THE STRONGEST POL ITICAL CURRENT IN WESTERN EUROPE. FOR FORTY YEARS THIS IDEA WAS PUSHED FORHARD ON FRANCE'S TERMS. NOW IT WILL BE ON GERMANY'S.

04993 KAPLAN, R.D.

CONTINENTAL DRIFT

NEW REPUBLIC, 207 (27) (DEC 92), 15-18, 20.

THE HISTORY OF U.S. INTERVENTIOM IN HAITI SHOULD BE A CAUTIONARY TALE FOR THOSE NOW EAGERLY PURSUING OPERATION RESTORE HOPE IN SOMALIA. MILITARY INTERVENTION CAN DO LITTLE RESTORE HOPE IN SOMALIA. MILITARY INTERVENTION CAN DO LITTLE MO HEAL THE BODY POLITIC OF A LAND THAT LACKS THE BASIS OF A MODERN POLITICAL CULTURE, DUE TO GEOGRAPHICAL ISOLATIOM, HAITI'S PROBLEMS ON U.S. SUPPORT FOR THIS OR THAT HAITIAN HAITI S PROBLEHS ON U.S. SUPPORT FOR THIS OR THAT HAITIAN RULER--AS SOMALIA'S PROBLEMS ARE NOW BEING BLAMED ON U.S.
SUPPORT FOR MOHAMMED SIAD BARRE--IS A GRAVE SIMPLIFICATION. SUPPORT FOR MOHAMMED SIAD BARRE--IS A GRAVE SIMPLIFICATION. AFRICA IS FULL OF HAITIS. MANY AFRICAN NATIONS SEEM DOOMED
TO GO OVER THE EDGE INTO ANARCHY AND DESTITUTION FOR THE TO GO OVER THE EDGE INTO
SAME REASONS HAITI HAS.

04994 KAPLAN, R.D.

GREEK TAKEOUT

NEW REPUBLIC, 207(26) (DEC 92), 20-21.

SOME OBSERVERS EXPECT THE SÉRBS TO PARTICIPATE IN A U.N. CEASE-FIRE AFTER SARAJEVO HAS FALLEN AND THEY HAVE

"CLEANSED" ALL THE TERRITORY THEY NEED IN BOSNIA. THEY COULD USE THIS HIATUS TO PREPARE FOR MORE INTENSE COMBAT IN KOSOVO, WHERE ALBANIAN MILITANTS ARE ALREADY FIGHTING SERBIAN TROOPS ON A SMALL SCALE. THE TURKISH GOVERNMENT, WHICH IS UNDER STRONG POPULAR PRESSURE TO INTERVENE TO HELP FELLOW MUSLIMS, HAS INTIMATED THAT A SERB ADVANCE INTO KOSOVO WOULD BE A "CASUS BELLI." A SERBIAN-ALBANIAN-TURKISH WAR IS A REAL POSSIBILITY, WITH THE POTENTIAL FOR ALSO INVOLVING GREECE AND BULGARIA.

04995 KAPLIN, H.

A PROPOSED PROCESS FOR MANAGING THE FIRST AMENDMENT ASPECTS OF CAMPUS HATE SPEECH

JOURNAL OF HIGHER EDUCATION, 63(5) (SEP 92), 517-38.

HITH A PROBLEM LIKE HATE SPEECH, PROCESS QUESTIONS ARE A CRITICAL CONSIDERATION. A CAREFULLY STRUCTURED PROCESS FOR DECISION MAKIMG IS A NECESSITY. THIS ARTICLE PROPOSES SUCH A PROCESS. SUGGESTIONS FOR IMPLEMENTATION ARE ALSO INCLUDED, PROCESS. SUGGESTIONS FOR IMPLEMENTATION ARE ALSO INCLUDED, ALONG WITH CRITERIA FOR EVALUATING HATE SPEECH PROCESSES AND A DISCUSSION OF FIRST AMENDMENT PRICIPLES CIRCUMSCRI
INSTITUTION'S DISCRETION TO REGULATE HATE SPEECH.

04996 KAPS, $C$

PARTMERS IN LEADERSHIP

EUROPE, 318 ( JUL 92), 12-14

IN THE AFTERMATH OF THE COLLAPSE OF THE SOVIET EMPIRE, THE END OF THE COLD WAR, AND GERMAN UNIFICATION, THE DOMESTIC SITUATION IN BOTH THE U.S. AND GERMANY HAS SUBSTANTI IALLY DETERIORATED. INTERNATIONALLY, THE COMMON SECURITY ISSUES HAVE LOST THEIR IMPORTANCE AS THE OVERRIDING PRINCIPLE GOVERNING THE GERMAN-U.S. RELATIONSHIP. AS THIS 
COMMON BOND HAS DISAPPEARED, WELL-KNOWM ISSUES SUCH AS INTEREST RATES, FISCAL POLICIES, TRADE RELATIONS, AND FAIR COMPETITION, APPEAR TO DOMINATE THE DAILY EXCHANGES AMONG POLITICIANS. THIS ARTICLE DISCUSSES THE COMPLICATIONS OF GERMAN-U.S. RELATIONS.

04997 KAPSTEIN, E.

BETWEEN POWER AND PURPOSE: CENTRAL BANKERS AND THE POLITICS OF REGULATORY CONYERGENCE

INTERNATIONAL ORGANIZATION, 46(1) (WIN 92), 265-288. IN THE EARLY 1980S, CENTRAL BANKERS FACED THE CHALLENGE OF MAINTAINING PUBLIC CONFIDENCE IN THE COMMERICAL BANKS THAT WERE AT THE MEART OF THE INTERNATIONAL PAYMENTS SYSTEM. IN ANALYZING CENTRAL BANK COOPERATION AND THE PROCESSES IN ANALYZING CENTRAL BANK COOPERATION AND THE PROCESSES LEADING TO THE ADOPTION OF A SINGLE INTERNATIONAL CAPITAL
ADEQUACY STANDARD, THIS ARTICLE ARGUES THAT AGREEMENT ON A ADEQUACY STANDARD, THIS ART ICLE ARGUES THAT AGREEMENT ON A
UNIFORM STANDARD WAS DUE TO A COMBINATION OF POLITICAL POWER UNIFORM STANDARD WAS DUE TO A COMBINATION OF POLITICAL POHE
AND SHARED PURPOSE ON THE PART OF THE UNITED STATES AND BRITAIN. THE CONDITIONS UNDER WHICH EPISTEMIC COMMUNITIES ARE LIKELY TO ARISE ARE EXPLORED.

04998 KAPSTEIN, E.B.

THE POLITICAL ECONOMY OF NATIONAL SECURITY MCGRAW-HILL, 1992, 232

THIS BOOK EXAMINES THE UNDERLYING TENSION BETWEEN NATIONALISTIC CONCEPTIONS OF SECURITY AND THE GLOBALIZATION OF ECONOMIC ACTIVITY. THE AUTHOR ANALYZES GLOBAL ECONOMIC ISSUES WITHIN AN HISTORICAL FRAMEWORK. HE ALSO USES A COMPARATIVE ANALYSIS OF THE UNITED STATES, THE FORMER SOVIET UNION, WESTERN EUROPE AND BRAZIL. HE INTROOUCES THREE MAJOR THEORETICAL APPROACHES THAT CONCEPTUALIZE THE POLITICAL ECONOMY OF NATIONAL SECURITY: NEO-MERCANTILISM, LIBERALISM, AND MARXISM. HE STUDIES THE RELATIONSHIP BETWEEN NATIONAL SECURITY AND ECONOMIC PERFORMANCE BY EXAMINING DEFENSE SPENDING, BUDGETING, AND THE ECONOMY'S ROLE IN THE MOBILIZATION OF HAR. HE ALSO EXTENSIVELY EXAMINES THE MILITARY INDUSTRIAL COMPLEX OF MAJOR NATIONS, AS WELL AS THE WEAPONS PROCUREMENT PROCESS IN THE UNITED STATES, THE FORMER SOVIET UNION AND WESTERN EUROPE. FINALLY, THE AUTHOR EXAMINES THE ECONOMIC RELATIOHS OF MILITARY ALIES, THE ARMS TRADE, AND THE PROBLEM OF PROVIDING NATIONAL SECURITY IN A GLOBAL ECONOMY.

04999 KAPUR, A.

IMDIA'S EVOLVING DEFENSE POSTURES AND POLICIES

STUDIES IN CONFLICT AND TERRORISM, 15(4) (1992), 339-356.

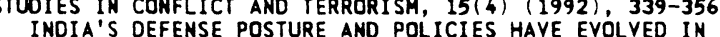
RESPONSE TO ITS EXTERNAL AND DOMESTIC CIRCUMSTANCES. THE RESPONSE TO ITS EXTERNAL AND DOMESTIC CIRCUMSTANCES. THE CONCEPT THE DISTRIBUTC CONCEPT, THE DISTRIBUTION OF MILTIARY CAPABILTIES, AND THE EXTERNAL AND INTERNAL SETTING CONCERNING EACH PER SECOND PART IS ANALYTICAL, TRACING THE PATTERN OF DEVELOPMENT OF INDIAN SECURITY SYSTEMS AS IT STANDS TODAY. THE FINAL SECTION DEALS WITH

05000 KAPUR, A.

NUCLEAR ARMS CONTROL ON THE KOREAN PENINSULA IN A CHANGING WORLD

KOREAN JOURNAL OF DEFENSE ANALYSIS, IV(2) (HIN 92), 33-54. THIS PAPER EXAMINES HOW POST-COLD WAR CHANGES HAVE AFFECTED SECURITY AND NUCLEAR ARMS POLICIES OF THE WORLD'S NATIONS. SPECIAL EMPHASIS IS PLACED ON THE KOREAN PENINSULA, ITS SECURITY, ITS RELATIONS WITH OTHER NORTH ASIAN NATIONS, AND HOW NUCLEAR DISARMAMENT MIGHT BE ACHIEVED IN THE REGION. QUESTIONS EXAMINED INCLUDE: CAN NORTH ASIAN ARMS CONTROL BECOME A COMMON DENOMINATOR TO CREATE A PROCESS OF STRATEGIC DISCOURSE AND EVENTUALLY A STRUCTURE OF SECURITY IN NORTH ASIA; WHAT ARE THE LIKELY NEGATIVE AND POSITIVE ATMOSPHERICS IN NORTH ASIA FOR SUCH A PROCESS AND STRUCTURE TO EMERGE AND TO SOLIDIFY; HOW WILL THE VISIONS, INTERESTS, AND INTERNAL DEVELOPMENTS OF THE MAJOR POWERS (THE U.S., JAPAN, RUSSIA, AND CHINA) AND THE LESSER POWERS AFFECT THE PACE, DIRECTION AND THE SCOPE OF IMPROVEMENT OF THESE PROCESSES; AND CAN BILATERAL SECURITY DIALOGUE, AS BETHEEN NORTH AND SOUTH KOREA CREATE AD HOC SECURIYY WEBS OR STRATEGIC BARGAINS THAT CAN GENERATE REGIONAL COOPERATION ON A FUNCTIONAL ARMS CONTROL BASIS? THE AUTHOR ARGUES THAT AS THE EXTENDED SUPERPOWER NUCLEAR DETERRENCE AND SECURITY UMBRELLA IS SUPERPOWER NUCLEAR DETERRENCE AND SECURITY UMBRELLA PENINSULA, THE NEED TO DEVELOP INDIGENOUS SOLUTIONS IS LIKELY TO GROW IN IMPORTANCE.

05001 KARAGANOV, S.A.

RUSSIA I: A MOSCOW VIEH ON THE HEST'S ROLE

WORLD TODAY, 48(7) (JUL 92), 122-124.

THE AUTHOR SUMMARIZES VARIOUS ARGUMENTS AND SCENARIOS REGARDING THE NEED FOR WESTERN AID TO STABILIZE THE

SITUATION IN RUSSIA AND ASSURE THE SUCCESS OF ITS TRANSITION

TO A MORE DEMOCRATIC POLITICAL SYSTEM AND A MARKET ECONOMY.

05002 KARATHYCKY, A.

GETTING IT' ALL WRONG: THE FALL OF SOVIETOLOGY

FREEDOM REVIEW, 23(2) (MAR 92), 32-35.
THE RAPID DISINTEGRATION OF THE SOVIET STATE PROVES THAT MIKHAIL GORBACHEY, GENNADY YANAYEV, AND BORIS PUGO WEREN'T THE ONLY LOSERS IN THE FAILED COUP. THE LANDSCAPE IS NOH LITTERED HITH THE CASUALTIES OF SOVIET EXPERTS PROVED WRONG. HOHEVER, SOVIET EXPERTS ARE A TOUGHER LOT THAN COUP PLOTTERS AND KREMLIN LEADERS. EVEN THOSE WHO ERRED SPECTACULARLY ARE DETERMINED TO PERSEYERE, SCRAMBLING FROM DAY TO DAY TO KEEP UP WITH EVENTS THEY SPENT YEARS DENYING.

05003 KARATHYCKY, A.

THE UKRAINIAN FACTOR

FOREIGN AFFAIRS, 71(3) (SUM 92), 90-107

THE LOOSELY-CONFEDERATED COMMONHEALTH OF INDEPENDENT STATES WAS HASTILY COBBLED TOGETHER PRIMARILY TO SATISFY UKRAINIAN CONCERNS. YET UKRAINE HAS TURNED OUT TO BE THE COMMONHEALTH'S MOST RELUCTANT PARTNER, AS UKRAINIAN PRESIDENT LEONID KRAVCHUK HAS PURSUED' A POLICY AIMED AT ENSURING A WEAK CONFEDERATION. UKRAINE HAS CONSISTENTLY ENSURING A WEAK CONFEDERATION. UKRAINE HAS CONSISTENTLY STRUCTURES AND HAS BLOCKED EFFORTS TO BUILD A CENTRAL CIS STRUCTURES AND HAS BLOCKED EFFORTS TO BUILD A CENTRAL CIS BUREAUCRACY. THE MAIN THEME OF UKRAINIAN STATECRAFT HAS BEEN THAT SOVEREIGNTY AT EVERY TURN.

05004 KARAWAN, I.A.

MONARCHS, MULLAS, AND MARSHAL: ISLAMIC REGIMES? ANNALS OF THE AMERICAN ACADEMY OF POLITICAL AND SOCIAL SCIENCE, (524) (NOV 92), 103-119.

THE AUTHOR STUDIES THREE REGIME TYPES THAT CLAIM TO REPRESENT "ISLAM IN POHER": THE CONSERVATIVE DYNASTIC REGIME OF SAUDI ARABIA, THE POPULIST CLERICAL REGIME OF IRAN, AND THE AUTHORITARIAN MILITARY REGIMES OF SUDAN AND PAKISTAN. THESE REGIMES ARTICULATE DIFFERENT INTERPREATIONS OF ISLAM THAT REFLECT THE INTERESTS AND IDEOLOGY OF THOSE WHO CONTROL THE STATE MACHINERY, THE INFLUENCE OF SOCIETY'S HISTORICAL LEGACY, AND SPECIFIC CHARACTERISTICS OF THE IMMEDIATE SITUATIONAL SETTING. THE ISLAMIC LEGITIMIZATION OF ALL THREE TYPES HAS BEEN CONTESTED ON RELIGIOPOLITICAL GROUNDS BY DOMESTIC RIVALS FOR POWER AND EXTERNAL RIVALS FOR LEADERSHIP IN THE MUSLIM WORLD. THE MOST EFFECTIVE CHALLENGES TO REGIME LEGITIMACY HAVE BEEN MANIFESTED IN THE ISLAMIZED MILITARY REGIMES. THE PREDICAMENT OF "THE ISLAM OF THE MARSHALS" IS REGIMES. THE PREDICAMENT OF "THE ISLAM OF THE MARSHALS" IS
DUE TO SEVERAL FACTORS: THEIR LACK OF THE POLITICAL CAPITAL DUE TO SEVERAL FACTORS: THEIR LACK OF THE POLITICAL CAPITAL
AVAILABLE IN THE SAUDI "ISLAM OF WEALTH" OR THE LEGITIMACY AVAILABLE IN THE SAUDI "ISLAM OF HEALTH" OR THE LEGITIMACY GENERATED BY THE REVOLUTIONARY CHANGE UNDER CHARISMATIC ANTIPOLITICAL CHARACTER, MANIFESTED IN THEIR DISTRUST OF ANTIPOLITICAL CHARACTER, MANIFESTED IN THEIR DISTRUST OF POLITICAL MOVEMENTS THAT SUPPORTED THEIR ISLAMIZATION PROGRAMS AND WHOSE LEADERS ASPI
THEORETICIANS AND ORGANIZERS.

05005 KARL, T.L.

EL SALVADOR'S NEGOTIATED REVOLUTION

FOREIGN AFFAIRS, 71(2) (SPR 92), 147-164.

THE AUTHOR DISCUSSES THE TREATY ENDING THE WAR IN EL SALVADOR AND HHAT IT MEANS FOR THE FUTURE OF THE COUNTRY.

05006 KARLAN, P.; BAER, D.; BRADEN, M.; DONATELLI, F.; DONILON, T.; HARRIS, L.; LYNK, M.; MELLMAN, M.

CAMPAIGN DISCOURSE

JOURNAL OF LAH \& POLITICS, VIII(2) (HIN 92), 229-248.

THIS ARTICLE REPORTS ON A SEMINAR ON U.S. PRESIDENTIAL CAMPAIGNS AND ON PORPOSALS FOR REFORMING THE WAY PRESIDENTIAL ELECTION CAMPAIGNS ARE CONDUCTED.

05007 KARLHOFER, F.; PELINKA, A.

AUSTRIAN POL ITICAL SCIENCE: THE STATE OF THE ART EUROPEAN JOURNAL OF POLITICAL RESEARCH, 20(3-4) (DEC 91), 399-411.

THE AUTHORS EXAMINE THE DELAYED ESTABLISHMENT OF POLITICAL SCIENCE IN AUSTRIA, THE DEVELOPMENT OF THE DISCIPLINE AT AUSTRIAN UNIVERSITIES, AND THE STATUS OF POLITICAL SCIENCE OUTSIDE THE UNIVERSITY.

05008 KARLSON, $N$.

BRINGING SOCIAL NORMS BACK IN

SCANDINAYIAN POLITICAL STUDIES, 15(3) (SEP 92), 249-268. THE AUTHOR OFFERS A RATIONALISTIC, INDIVIDUALISTIC EXPLANATION OF SOCIAL NORMS AND PRESENTS THO DIFFEREMT EXPLANATORY MODELS FOR AGGREGATE SOCIAL PHENOMENA. HE ARGUES EXPLANATORY MODELS FOR AGGREGATE SOCIAL PHENOMENA. HE ARGU
THAT THE EMERGENCE OF SUCH NORMS CAN BE GIVEN A KIND OF
SOCIO-CU OF SOCIO-CULTURAL EVOLUTIONARY EXPLANATION, WITH BOUNDEDLY
RATIONAL ACTORS, IN SOCIAL INTERACTION SITUATIONS HAVING THE RATIONAL ACTORS, IN SOCIAL INTERACTION SI TUATIONS HAVING THE
CHARACTERISTICS OF COMMUNITY. THEIR MAINTENANCE IN LARGER CHARACTERISTICS OF COMMUNITY. THEIR MAINTENANCE IN LARGER BEHAVIORAL HABITS. THESE RESULTS ARE RELEVANT FOR SEVERAL AREAS OF POLITICAL SCIENCE.

05009 KARMI, G,

IS PALESTINIAN AUTONOMY THE ONLY ALTERnATIVE? MIDOLE EAST INTERNATIONAL, 436 (OCT 92), 16-17.

THE SEVENTH ROUND OF U.S. -SPONSORED MIDDLE EAST PEACE TALKS ARE TO RESUME IN WASHINGTON. THIS ARTICLE DETAILS THE ISRAELI AGENDA AND SUGGESTS THAT WHAT ISRAEL IS OFFERING THE 
PALESTINIANS IN THESE TALKS IS TOO LITTLE. IT ALSO SUGGESTS THAT AN ALTERHATIVE PROPOSAL HHOULD BE PUT TO THE PEAC CONFERENCE, WICH IS THAT PALESTINIANS SEEK TO BECOME CITIZENS OF ISRAEL.

05010 KARP, $B$.

TEACHING THE GLOBAL PERSPECTIVE IN AMERICAN NATIONAL GOVERNMENT--A SELECTED RESOURCE GUIDE

PS: POLITICAL SCIENCE AND POLITICS, 25(4) (DEC 92), 703-705

DESPITE A GROHING RECOGNITION THAT THE UNDERGRADUATE CURRICULUM MUST BE INTERNATIONALIZED, RELATIVELY LITTLE HAS BEEN DONE TO INFUSE A GLOBAL PERSPECTIVE IN ONE PLACE WHERE POLITICAL SCIENCE TEACHERS CAN REACH LARGE NUMBERS OF STUDENTS-THE INTRODUCTORY AMERICAN NATIONAL GOVERMMENT COURSE. THIS ARTICLE SUGGESTS MATERIALS AND SOURCES OF COURSE. THIS ARTICLE SUGGESTS MATERIALS AND SOURCES OF
INFORMATION THAT CAN BE USED TO BRING A GLOBAL PERSPECTIVE INFORMATION THAT CAN BE USED TO BRING A GLOBAL PERSPECTIVE TO THE AMERICAN NATIONAL GOVERNMENT COURSE, WHICH IS WIDELY
TAKEN BY AMERICAN COLLEGE STUDENTS AS THE FIRST (AND OFTEN TAKEN BY AMERICAN COLLEGE STUDE
ONLY) POLITICAL SCIENCE COURSE.

05011 KARP, J.

PASSING THE MUCK

FAR EASTERN ECONOMIC REVIEH, 155(43) (OCT 92), 31-32,

ASIA'S ENVIRONMENTAL PROBLEMS HAVE, UNTIL RECENTLY, BEEN LARGELY IGNORED BY GOVERNMENTS WHICH WERE MORE INTERESTED IN ENCOURAGING GROWTH. THIS HAS STARTED TO CHANGE AS THE PEOPLE OF SOME ASIAN COUNTRIES BEGIN TO PUT PRESSURE ON THEIR GOVERMMENTS' TO DO SOMETHING ABOUT POLLUTION. A GOOD EXAMPLE CAN BE FOUND IN HONG KONG WHERE HIGH SPEED DEVELOPMENT TRADITIONALLY TOOK PRIORITY OVER POLLUTION CONTROL. HOWEVER, THE COLONY'S NEH GOVERNOR, CHRIS PATTEN, HAS PROPOSED EXTENSIVE REFORMS OF HONG KONG'S SEWAGE FACILITIES AND HAS CONSISTENTLY ADVDCATED CLOSER REGULATION OF DEVELOPMENT AND INDUSTRY. PATTEN'S PROPOSALS HAVE DRAWN SOME CRITICISM FROM BUSINESS GROUPS WHO RESENT THE REGULATIONS, AND FROM ENVIRONMENTALISTS WHO FEEL THE GOVERMOR HAS NOT GONE FAR ENOUGH. HOWEVER, ON BALANCE, HIS REFORMS SIGNAL A GROHING AWARENESS OF ENVIRONMENTAL CONCERNS.

05012 KARP, J.; KAYE, L.

SHALOM TÓ CHINA

FAR EASTERN ECONOMIC REVIEH, 155(2) (JAN 92), 12-13.

ISRAEL'S 40-YEAR OUEST FOR NORMALIZATION OF ITS

RELATIONS WITH THE PEOPLE'S REPUBLIC OF CHINA WILL END ON 22 JANUARY, WHEN FOREIGN MINISTER DAVID LEVY ARRIVES IN PEKING
EN ROUTE TO MOSCOW FOR THE THIRD ROUND OF MIDOLE EAST PEACE TALKS. IN EXCHANGE FOR DIPLOMATIC RECOGNITION, JERUSALEM TALKS. IN EXCHANGE FOR DIPLOMATIC RECOGNITION, JERUSALEM
WILL ALLOW LEVY'S COUNTERPART, OIAN QICHEN, TO PARTICIPATE IN THE MOSCOH TALKS, AS BEFITS CHINA'S SENSE OF SELFIN THE MOSCON TALKS, AS BEFITS CHINA'S SENSE OF SELFIT EASIIER FOR OTHER THIRD HORLD COUHTRIES, SUCH AS INDIA OR IT EASIER FOR OTHER THIRD WORLD COUNTRIES, SUCH AS INDIA OR EVEN INDONESIA, TO FOLLOW SUIT. THE OFFICIAL NORMALIZATION OF RELATIONS FOLLOWS YEARS OF SECRET DIPLOMAT
CONTRACTS--AND SOME RECENT PUBLICIZED ONES.

05013 KARRER, C.

DIFFICULT RECONSTRUCTION IN NORTHERN IRAQ SWISS REVIEW OF WORLD AFFAIRS, 42(9) (DEC 92), 18-19. THE KURDISH AREA IN NORTHERN IRAQ IS FOR ALL PRACTICAL PURPOSES AUTONOMOUS, BUT THE STATUS OF THE KURDISH REGIONAL GOVERNMENT IS UNCLEAR, BECAUSE IT HAS NOT BEEN INTERNATIONALLY RECOGNIZED. SINCE THE KURDISH REGIONAL GOVERMMENT TOOK POLITICAL POWER AND A LEGISLATIVE BODY WAS CREATED, THE SITUATION HAS IMPROVED. NEVERTHELESS, THE FUTURE IS VERY UNCERTAIN FOR THE KURDS.

05014 KARSH, E.

NEUTRALIZATION: THE KEY TO AN ARAB-ISRAELI PEACE BULLETIN OF PEACE PROPOSALS, 22 (1) (1991), 11-24.

IN AN ATTEMPT TO ILLUSTRATE THE MERITS OF NEUTRALIZATION IN THE ARAB-ISRAELI CONTEXT, THIS ARTICLE ANALYZES THE ESSENCE OF THIS CONCEPT ANO THE FACTORS WHICH BEAR UPON ITS POLITICAL FEASIBILITY. IT ALSO DELINEATES THE PROPOSED NEUTRALIZATION PACKAGE AND IMDICATES THE REGIONAL AND GLOBAL ADVANTAGES RESULTING FROM ITS IMPLEMENTATION.

05015 KARUNARATME, N.D.

A CRITICAL REVIEW OF CONTEMPORARY AUSTRALIAN FOREIGN POLICY SCANDINAVIAM JOURMAL OF DEVELOPMENT ALTERMATIVES, $X I(1)$ (MAR 92), 95-107.

IN 1984, AUSTRALIA DEFINED THREE TYPES OF FOREIGN AID HUMANITARIAN AID DESIGNED TO ALLEVIATE POVERTY IN THE RECEIPIENT NATIONS, AID INTENDED TO FURTHER AUSTRALIA'S STRATEGIC AND FOREIGN POLICY INTERESTS, AND AID DESIGNED TO PROMOTE THE RECIPIENT'S ECONOMIC DEVELOPMENT AND FOSTER MUTUALLY-BENEFICIAL TRADE AND COMMERCE. RECENTLY, AUSTRALIA HAS ADDED A FOURTH GOAL: TO APPROVE ONLY AID PROJECTS ARE ECOLOGICALLY-SOUND AND WILL MEET THE CRITERIA OF ENVIRONMENTAL SUSTAINABILITY. WHILE THESE FOUR GOALS
SOMETIMES CONFLICT WITH ONE ANOTHER, THE MAJOR THRUST OF AUSTRALIAN AID IS TO ENHANCE THE ECONOMIC WELFARE OF THE DONOR AND RECIPIENT BY THE TRANSFER OF RESOURCES AND KNOHHOW ON CONCESSIONAL TERMS. AID IS CERTAINLY NO FREE LUNCH
FOR THE RECIPIENT BECAUSE IT IS CONDITIONED TO GENERATE BOTH ECONOMIC AND NONECONOMIC BENEFITS FOR THE DONOR.

05016 KASLOW, A. GETTING TOUGH IN MUNICH EUROPE, 318 ( JUL 92), 18-20.

THE GERMAN HOSTS ARE LOOKING FORHARD TO HOST A SUMMIT IN MUNICH WHICH WILL BE ATTENDED BY LEADERS FROM THE WORLD'S RICHEST COUNTRIES. REACHING A GLOBAL IRADE ACCORD, AIDING THE FORMER COMMUNIST BLOC, AND ADDRESSING ENVIRONMENTALLY DISASTROUS NUCLEAR POWER PLANTS TOP THE AGENDA. BUT THE SEVEN LEADING INDUSTRIAL NATIONS -- THE UNITED STATES, THE UNITED KINGDOM, CANADA, FRANCE, GERMANY, ITALY, AND JAPAN ARE MORE CONCERMED WITH THEIR OWN DEFICIENCEIES THAN WITH TACKLING TOUGH INTERNATIONAL PROBLEMS.

05017 KASLOH, A.; MACDONALD, S. MIDDLE EASTERN ECONOMIES AFTER THE GULF WAR

MIDOLE EAST INSIGHT, VIII(4) (MAR 92), 56-59

THIS ARTICLE EXAMINES THE EFFECTS OF THE GULF WAR ON ECONOMIES THROUGHOUT THE MIDDLE EAST. IT ALSO PREDICTS THE FCTORE COURSE OF THE ECONOMIES OF SAUDI ARABIA, KUHAIT, THE FUTURE COURSE OF THE ECONOMIES OF SAUDI ARABIA, KUWAIT, THE GULF STATES, JORDAN, YEMEN, THE PALESTIMIANS, EGYPT, SYRIA, LEBANON, AND THE MAGHREB COUNTRIES. ITS OVERALL CONCLUSION IS THAT ALTHOUGH THE GULF WAR WREAKED HAVOC ON THE ECONOMIES OF NEARLY ALL MIDDLE EASTERN STATES, IT DID LITTLE TO ADJUST
THE GREAT IMBALANCE BETWEEN THE OIL-RICH STATES OF THE GULF AND THE "HAVE-NOTS" IN THE REST OF THE ARAB WORLD. SIMPLY PUT, THE ARAB GULF STATES INVESTED IN THEIR OWN PROTECTION AND CEASED TO ASSIST OTHER ARAB COUNTRIES AND CAUSES THAT FAILED TO SUPPORT THE ALLIED COALITION AGAINST IRAQ. MANY COUNTRIES NEIGHBORING BUT NOT DIRECTLY INVOLVED IN THE CONFLICT LOST SIZABLE PORTIONS OF THEIR REVENUES AND SAH GOVERMMENT ECONOMIC REFORMS DERAILED.

05018 KASLOW, A.

MONEY AND STAYING POWER IN THE MIDDLE EAST PEACE PROCESS MIDDLE EAST INSIGHT, 8(3) (1992), 36-38.

AS ARAB DELEGATES ARRIVED IN WASHINGTON FOR THE SECOND PHASE OF MIDDLE EAST PEACE NEGOTIATIONS, THEY DISCOVERED THAT ECONOMIC SECURITY ISSUES WILL LOOM LARGE THROUGHOUT AND BEYOND THE PEACE TALKS. SHORT-TERM FINANCIAL HELP IS NEEDED TO KEEP THE BARGAINERS AT THE TABLE AND THE TALKS ON TRACK. LONG-TERM ECONOMIC DEVELOPMENT AND COOPERATION ACROSS BORDERS COULD HELP STABLILIZE THE REGION BY CREATING THE BORDERS COULD HELP STABLILIZE THE REGION BY CREATING THE PRAC ICAL SIDE OF SUSTAINABLE PEACE. THIS ARTICLE DESCRIBES THE SITUATION IN JORDAN AND LEBANON,
COOPERATION AND REGIONAL STABILITY.

05019 KASLOH, A.

WATCHIMG THE HOT SPOTS: THE CONGRESS AND EUROPE EUROPE, 322 (1) (1992) 6-7

THIS ARTICLE EXPLORES SOME OF THE ISSUES CONGRESS WILL BE DEALIMG WITH THIS YEAR THAT WILL AFFECT EUROPE. THESE ISSUES INCLUDE: TRADE; ASSISTANCE FOR THE EX-SOVIET REPUBLICS; YUGOSLAVIA; AND INTERNATIONAL ECONOMIC POLICY. IT IS SUGGESTED THAT AS AMERICANS FOCUS OH DOMESTIC ECONOMIC CONCERNS, THE HAR IN FORMER YUGOSLAVIA, THE DETERIORATING ECONOMY IN RUSSIA, AND OVERALL E.C. -U.S. RELATIONS HILL STILL BE KEY ISSUES FACING THE NEN 103RD CONGRESS.

05020 KASS, I.

THE U.S. -SOVIET STRATEGIC RELATIONSHIP AMNALS OF THE AMERICAN ACADEMY OF POLITICAL AND SOCIAL SCIENCE, (517) (SEP 91), 25-38.

THE U.S.-SOVIET STRATEGIC RELATIONSHIP IS BEING TRANSFORMED BY THE REYOLUTIONARY EVENTS IN EUROPE AND BY DYNAMICS INTERMAL TO THE SOVIET UNION. AT PRESENT, THE RELATIONSHIP IS ASYMMETRICAL: HITH THE USA AT THE APEX OF ITS GLOBAL INFLUENCE AND THE USSR AT ITS NADIR, THE SUPERPOWERS REMAIN EQUAL ONLY IN THEIR ENDURING CAPABILITY TO DESTROY ONE ANOTHER. THE FUTURE HOLDS MORE PERIL THAN PROMISE. FIRST, THE USSR SEEKS TO FUNDAMENTALLY REDEFINE WHAT ITS ARMED FORCES WILL LOOK LIKE AND HOW THEY WILL BE SOVIET NATIONAL SECURITY CALCULUS; NOH IS NOT TOO SOON TO IDENTIFY AND PURSUE THE EMERGIMG TECHMOLOGIES UPOM HHICH THE US AND PURSUE THE EMERGING TECHNOLOGIES UPON WHICH THE U.S. BREAKDOWN OF CENTRAL AUTHORITY IN THE SOVIET UNION THREATENS TO SHEEP AHAY THE STABILITY AND PREDICTABILITY THAT HAVE, TO SHEEP AWAY THE STABILITY AND PREDICTABILITY THAT HAVE, HITHERTO, DEFINED THE SUPERPOHER RELATIONSHIP. INSOFAR AS EMPIRES DO NOT FADE AHAY PEACEFULLY, THE DISINTEGRATION OF TOU.S. SECURITY.

05021 KASSEBAUM, N.L.

THE UNITED STATES AND THE HORN OF AFRICA MEDITERRANEAN QUARTERLY: A JOURNAL OF GLOBAL ISSUES, 3(3) ( SUM 92), 77-81.

THE END OF THE COLD HAR OFFERS THE BATTERED NATIONS OF THE HORN OF AFRICA NEW OPPORTUNITIES AND POSSIBILITIES. THIS ARTICLE CONSIDERS A SERIES OF IMPORTANT POL ICY QUESTIONS WHICH NOW CONFRONT THE UNITED STATES. THEY INCLUDE: HON DOES 
THE UNITED STATES ENCOURAGE THE FORMATION OF HUMANE AND RESPONSIVE GOVERMMENTS IN THE REGION; HOW DOES WASHINGTON REACT TO ANARCHIC HUMANITARIAN DISASTERS IN WHICH STATE GOVERMMENT HAS DISAPPEARED (AS IN SOMALIA); WHAT SHOULD BE THE REACTION TO HARD-LINE ISLAMIC FUNDAMENTALIST STATES IN AFRICA (AS IN SUDAN); AND HOW WHOULD THE UNITED STATES RESPOND TO DEMANDS FOR REORGANIZATION OR NEH STATES (IN RESPOND TO DEMANDS FOR REORGANIZATION OR NEN STATES (IN ERITREA, NORTHERN SOMALIA, AND POSSIBLY SOUTHERN SUDAN)? IT
CONCLUDES THAT THE ROLE OF THE UNITED STATES IS TO RECOGNIZE AND SUPPORT POSITIVE CHANGE, EVEN IF THIS MEANS ABANDONING AND SUPPORT POSITIVE CHANGE, EVEN
OLD RELATIONSHIPS AND IDEOLOGIES.

05022 KASTMER, R.

MOST PEDPLE ' JUST NOT OPEN TO ARGUEMENTS OF THE FAR RIGHT' GERMAN TRIBUNE, 31 (1542) (NOV 92),

HISTORIAN FRITZ RISCHER CAUSED' THE FIRST MAJOR POST-WAR DEBATE AMONG GERMAN HISTORIANS WITH HIS BOOK, "REACHING FOR WORLD POWER" WHICH HE ARGUED THAT THE GERMAN GOVERNMENT DELIBERATELY PROVOKED HAR IN 1914. THIS CHALLENGED THE ASSERTION THAT GERMANY HAD OMLY SOMEHOW BECOME EMBROILED IN THE FIRST WORLD WAR. IN THIS ARTICLE, FISCHER IS INTERVIEWED ON POLITICAL TRENDS IN GERMANY.

05023 KATE, A.T

TRADE LIBERALIZATION AND ECONOMIC STABILIZATION IN MEXICO: LESSONS OF EXPERIENCE

WORLD DEVELOPMENT, 20(5) (MAY 92), 659-672.

THE AUTHOR SURVEYS THE MEXICAN TRADE LIBERALIZATION PROCESS DURING THE 1980'S. SPECIAL ATTENTION IS PAID TO THE CIRCUMSTANCES THAT TRIGGERED IT, TO THE MACROECONOMIC ENVIRONMENT, AND TO THE DESIGN OF THE PROCESS, PARTICULARLY THE SPEED AND EXTENT OF THE TRADE REFORMS. HE ARGUES THAT ALTHOUGH FAR-REACHING LIBERALIZATION MEASURES WERE IMPLEMENTED IN A RELATIVELY SHORT PERIOD OF TIME THE EXPOSURE OF DOMESTIC INDUSTRY TO FOREIGN COMPETITION WAS DELAYED CONSIDERABLY IS A RESULT OF THE EXCHAMGE RATE MANAGEMENT DURING THE PROCESS.

05024 KATES, R.; HAARMANN, V.

WHERE THE POOR LIVE: ARE THE ASSUMPTIONS CORRECT? ENYIRONMENT $34(4)$ (MAY 92), 4-11.

PIRONMENT, 34 (4) (MAY 92) 4-11.

CONVENT IONAL WISDOM HAS LONG HELD THAT THE POOREST

PEOPLE IN THE WORLD LIVE ON THE MOST DEGRADED AND LEAST PRODUCTIVE LAND. BUT WOULD A COMPARISON OF A DETAILED MAP OF ASSUMPTION? THE EVIDENCE POINTS BOTH WAYS.

05025 KATSUHIKO, T.

MONGOLIA: A DISTANT NEIGHBOR DRAHS CLOSER

JAPAN OUARTERLY, XXXIX(4) (OCT 92), 434-439.

THE AUTHOR LOOKS AT THE HISTORICAL BACKGROUND OF MONGOLIAN-JAPANESE RELATIONS AND AT HOH THESE BILATERAL RELATIONS ARE CHANGING.

05026 KATZ, C.; BALDASSARE, M.

USING THE ' $L$-WORD' IN PUBLIC: A TEST OF THE SPIRAL OF SILENCE IN CONSERVATIVE DRANGE COUNTY, CALIFORNIA

PUBLIC OPINION QUARTERLY (CHICAGO), 56(2) (SUM 92), 232-235.

ACCORDING TO THE SPIRAL OF SILENCE THEORY, INDIYIDUALS WHO HOLD VIEWPOINTS THEY PERCEIVE AS BEING IN THE MINORITY OR AS LOSING GROUND FEAR THAT EXPRESSING THESE VIEWS WILL LEAD TO SOCIAL ISOLATION; THUS, THEY TEND TO KEEP SILENT. THE AUTHORS STUDY THIS THEORY IN THE POLITICAL CONTEXT OF ORANGE COUNTY, CALIFORNIA, WHERE REPUBLICANS OUTNUMBER DEMOCRATS BY 55 TO 35 PERCENT. THEY FOCUS ON SURVEYS TAKEN DURING THE 1988 PRESIDENTIAL ELECTION CAMPAIGN.

05027 KATZ, C.J.

MARX ON THE PEASANTRY: CLASS IN ITSELF OR CLASS IN STRUGGLE?

REVIEW OF POLITICS, 54(1) (HIN 92), 50-71.

DESPITE THE CENTRALITY OF CLASS TO HIS WORK, MARX NEVER OFFERED A SYSTEMATIC ANALYSIS OF THE CONCEPT OF CLASS, OFFERED A SYSTEMATIC ANALYSIS OF THE CONCEPT OF CLASS, LEAVING HIS INTERPRETERS TO DISTILL ITS MEANING FROM HIS
HISTORICAL WRITINGS. MARX'S USAGE OF THE TERM GAVE RISE TO A HISTORICAL WRITINGS. MARX'S USAGE OF THE TERM GAVE RISE
CONTROVERSY OVER THE RESPECTIVE ROLES PLAYED BY OBJECTIVE CONDITIONS AND SUBJECTIVE EXPERIENCES IN HIS DEFINITION OF CONDITIONS AND SUBJECTIVE EXPERIENCES IN HIS DEFINITIOM CLASS. IN ONE VIEW, MARX DEFINED CLASS EXCLUSIVELY IN STRUCTURAL TERMS BY REFERENCE TO THE POSITION OF ITS MEMBERS

CULTURAL TRADITIONS AND CONSCIOUSNESS INTO HIS DEFINITION OF CLASS. THIS ESSAY ASSESSES THIS DEBATE IN LIGHT OF MARX'S STUDIES OF THE 19TH CENTURY FRENCH PEASANTRY. THE AUTHOR ARGUES THAT THESE WRITINGS RECOMMEND AGAINST THE STRUCTURAL READING IN FAVOR OF THE VIEN THAT MARX ASSIGNED EQUAL WEIGHT TO OBJECTIVE AND SUBJECTIVE DETERMINATIONS IN HIS CONCEPTION OF CLASS.

05028 KATZ, C.J.; MAHLER, Y.A.

THREE VIEWS OF THE LATIN AMERICAN DEBT CRISIS

COOPERATION \& CONFLICT: NORDIC JOURNAL OF INTERNATIONAL

POLITICS, 27(2) (JUN 92), 191-213.

THE AUTHORS EXAMINE THE LATIN AMERICAN DEBT CRISIS FROM
THE PERSPECTIVE OF THREE MAJOR PARTICIPANTS: PRIVATE AND OFFICIAL CREDITORS, THE DEBTORS THEMSELVES, AND THE U.S. GOVERHMENT. WIDE DIFFERENCES IN THE VIEWS OF THESE

PARTICIPANTS HELP TO EXPLAIN ITS INTRACTABILITY.

05029 KATZ, M.

ANALYSING THE CHANGING FOREIGN AND DOMESTIC POLITICS OF THE FORMER USSR

STUDIES IN COMPARATIVE COMMUNISM, 25(2) (JUN 92), 139-150. THE AUTHOR ARGUES THAT TRADITIONAL SOVIETOLOGY IS NOT THE MOST FRUITFUL METHOO FOR STUDYING A SITUTION IN WHICH THE MOST FRUITFUL METHOO FOR STUDYING A SITUTION

RAPID CHANGE IS OCCURING. HE EXAMINES TRADITIONAL
SOVIETOLOGY AND CDNSIDERS IT IT IS NO LONGER AS USEFUL AS A SOVIETOLOGY AND CONSIDERS IT IS NO LONGER AS USEFUL AS
METHODOLOGY AS IT ONCE WAS. HE THEN OUTLINES COMPARATIVE METHODOLOGY AS IT ONCE WAS. HE THEN OUTLINES COMPARATIVE
HISTORICAL ANALYSIS AND DISCUSSES WHY IT MIGHT BE A MORE HISTORICAL ANALYSIS AND DISCUSSES WHY IT MIGHT BE A MORE
APPROPRIATE METHODOLOGY FOR ANALYZING THE CURRENT SITUATION. APPROPRIATE METHOOOLOGY FOR ANALYZING THE CURRENT SITUATION. FINALLY, HE DISCUSSES TWO EXAMPLES OF THE VERY DIFFEREN
RESULTS WHICH DIFFERENT METHODOLOGIES MIGHT YIELD WHEN RESULTS WHICH DIFFERENT METHODOL

05030 KATZ, M.N.

SUPERPOWER CONFLICT RESOLUTION: LESSONS FOR THE FUTURE ANMALS OF THE AMERICAN ACADEMY OF POLITICAL AND SOCIAL SCIENCE, (518) (NOY 91), 177-187.

DESPITE THE SIGNIFICANT PROGRESS THAT IHE UNITED STATES AND THE SOVIET UNION HAVE MADE IN COOPERATING TO RESOLVE REGIONAL CONFLICTS, MANY OF THESE CONFLICTS CONTINUE. ONE REASON FOR THIS IS THAT THE SOVIET AND AMERICAN GOVERMMENTS HAVE HAD DIFFERING EXPECTATIONS REGARDING THE OUTCOME OF SUPERPOWER CONFLICT RESOLUTION EFFORTS. EVEN WHEN SOVIET AND AMERICAN AIMS ARE SIMILAR, THERE ARE OTHER OBSTACLES TO CONFLICT RESOLUTION. AMONG THESE ARE THE LACK OF COMMITMENT TO DEMOCRACY ON THE PART OF ONE OR MORE OF THE LOCAL ANTAGONISTS IN REGIONAL CONFLICTS AND INVOLVEMENT BY OTHER EXTERMAL PARTIES IN THE CONFLICTS. THERE IS NO GUARANTEE THAT THE SUPERPOWERS CAN SUCCESSFULLY RESOLVE REGIONAL CONFLICTS EVEN IF THEY ADOPT A COMMON APPROACH TO CONFLICT RESOLUTION, BUT ADOPTING A COMHON APPROACH MAY AT LEAST RESOLUTION, BUT ADOPTING A COMHON APPROACH MAY AT LEAST ALLOW WASHINGTON AND MOSCOW TO UNLINK THEIR OVERALL
RELATIONS FROM THOSE CONFLICTS THAT CANHOT BE RESOLVED.

05031 KATZ, R.S.; BARDI, L.; BILLE, L.; DESCHOUWER, K.; FARRELL,

D.; KOOLE, R.; MAIR, P.; MORLINO, L. DEMOCRACIES, 1960-1990

DEMOCRACIES, 1960-1990
EUROPEAN JOURNAL OF POLITICAL RESEARCH, 22 (3) (OCT 92), EUROPEAN

THE AUTHORS EXPLAIN THREE PRINCIPLE MEASURES BY WHICH PARTY MEMBERSHIP STRENGTH CAN BE ASSESSED OVER TIME AND ACROSS NATIONAL BOUNDARIES. THEN THEY EXPLORE TRENDS IN PARTY MEMBERSHIP IN WESTERN EUROPE AND PRESENT DATA ON
PARTIES IN AUSTRIA, BELGIUM, DENMARK, FINLAND, WEST GERMANY, IRELAND, ITALY, THE NETHERLANDS, NORHAY, SWEDEN, AND THE UNITED KINGDOM.

05032 KATZ, R.S.

UNITED STATES OF AMERICA

EUROPEAN JOURNAL OF POLITICAL RESEARCH, 22(4) (DEC 92), 543-547.

THE AUTHOR LISTS THE MEMBERS OF PRESIDENT GEORGE BUSH'S CABINET AS OF JANUARY 1 , 1991, AND SUMMARIZES SOME OF THE MAJOR POLITICAL ISSUES FACING THE BUSH ADMINISTRATION.

05033 KATZMANN, R.A.

THE JUDICIAL CONFIRMATION PROCESS

BROOKINGS REYIEN, 10(1) (HIN 92)

IDEOLOGY AND INTEREST GROUPS HAVE LONG INFLUENCED THE JUDICIAL CONFIRMATION PROCESS. IN TODAY'S CONFIRMATION HEARINGS, WHAT HAS CHANGED IS THE WAY IDEOLOGY IS EXPLORED AHD HOW INTEREST GROUPS OPERATE. BEFORE THE ROBERT BORK NOMINATION, IT HAS THOUGHT UNSEEMLY TO DELVE INTO SPECIFIC CASES. BEFORE BORK, INTEREST GROUPS TENDED TO LOBBY SENATORS DIRECTLY; NOH THEY USE THE NEHS MEDIA TO GENERATE GRASSROOTS PRESSURE. RECENT CONFIRMATION PROCEEDINGS HAVE ALSO RENEWED

THE PRESIDENT AND THE SENATE IN CHOOSING JUDGES.

05034 KATZNELSON, I.

THE STATE TO THE RESCUE? POLITICAL SCIENCE AND HISTORY THE STATE

SOCIAL RESEARCH, $59(4)$ (WIN 92), 719-738.

SOCIAL RESEARCH, 59(4) (WIN 92), 719-738. POLITICAL DEVELOPMENT SCHOOL AND ITS PROMISE FOR RECONNECTING THE DISCIPLINES OF HISTORY AND POLITICAL SCIENCE TO PRODUCE A NEH SYNTHESIS.

05035 KAUFFMAN, L.

EMERGING FROM THE SHADOW OF THE SIXTIES SOCIALIST REVIEH, $20(4)(D C T$ QO) $11-20$.

IN FEBRUARY 1988, SOME 700 STUDDENT ACTIVISTS FROM 130 CAMPUSES AROUND THE UNTIED STATES GATHERED AT RUTGERS UNIVERSITY IN AN ATTEMPT TO "BREAK WITH A DECADE OF POLITICAL DRIFT AND CRISIS WITHIN PROGRESSIVE STUDENT CIRCLES BY GALVANIZING A UNITED VOICE OF THE STUDENT LEFT." 
WHILE THE CONFERENCE ENDED IN FAILURE, IT WAS A TURNING POINT IN THE HISTORY OF CONTEMPORARY YOUTH AND STUDENT MOVEMENTS. THOUGH IT FAILED TO PRODUCE A "UNIFIED VOICE": OR A VIABLE NATIONAL ORGANIZATION, IT PLAYED A MAJOR ROLE IN CAMPUSES, HELPING CREATE AS SENSE FOR THE FIRST TIME IN NEARLY A DECADE THAT THERE EXISTED A STUDENT MOVEMENT AMOUNTING TO SOMETHING MORE THAN THE SUM OF ITS COMPONENT PARTS. SHAKING THE LEGACY OF THE SIXTIES AND FINDING NEH GROUND HAS BEEN A DIFFICULT TASK.

05036 KAUFMAN, E.

ISRAELI PERCEPTIONS OF THE PALESTINIANS' 'LIMITED VIOLENCE' IN THE INTIFADA

TERRORISM AND POLITICAL VIOLENCE, 34(4) (WIN 92), 1-38. IN LIGHT OF THE AVOWED INTENTION OF COMMUNICATING TO ISRAELIS A NEED TO END OCCUPATION OF THE WEST BANK AMD GAZA, THIS STUDY EXAMINES THE SHORT-TERM EFFECT OF THE USE OF 'LIMITED' VIOLENCE IN THE INTIFADA. A CONSCIOUSLY MODERATE MESSAGE-ACCEPTANCE OF A THO-STATE SOLUTION-IS A DRASTIC MOVE AWAY FROM THE IDEA OF LIBERATING ALL OF PALESTINE, BUT
EVIDENCE SHOWS THAT IT IS BLURRED BY THE MERELY RELATIVE EVIDENCE SHOWS THAT IT IS BLURRED BY THE MERELY RELAT MOVE AWAY FROM TERROR AS A MEANS TO ATTAIN THE GOAL.
EXAMINATION OF THE INTERRELATIONSHPS BETHEEN ISRAEL AND THE INTAFADA LEADS TO THE CONCLUSION THAT IN TERMS OF ISRAELI OPINION, THE INCONSISTENCY BETWEEN AIMS AND MEANS IS HIGHLY COUNTERPRODUCTIVE.

05037 KAUFMAN, R.G.

THE UNITED STATES AND NAVAL ARMS CONTROL BETWEEN THE THO WORLD WARS: IMPLICATIONS FOR CONTEMPORARY AND FUTURE ARMS CONTROL

MILLENNIUM, 21(1) (SPR 92), 29-52.

THE AUTHOR SUMMARIZES THE ARMS CONTROL EXPERIENCE OF THE UNITED STATES BETWEEN THE TWO HORLD HARS AND THE LESSONS THAT CAN BE DRAWN FROM IT. HE ARGUES THAT WESTERN ARMS NEGOTIATORS MUST BE WARY OF DANGERS, ESPECIALLY WHEN DEALING WITH NON-DEMOCRATIC SOCIETIES, IF THEY ARE TO AVOID THE ERRORS OF THEIR PREDECESSORS.

05038 KAUFMAN, S.

DECISION MAKING AND CONFLICT MANAGEMENT--PROCESSES IN LOCAL GOVERNMENT: MANAGING LOCAL GOVERMMENT--PUBLIC ADMINISTRATION IN PRACTICE

SAGE PUBLICATIONS, 1991, 115-134.

THIS CHAPTER EXAMINES THE PROCESS OF MAKING DECISIONS, DISTINGUISHING WHAT IS GENERAL IO ALL DECISION CONTEXTS AND WHAT IS SPECIFIC TO THE FIELD OF LOCAL GOVERNMENT. THE FIRST PHAT IS SPECIFIC TO THE FIELD OF LOCAL GOVERNMENT. THE PART EXAMINES MECHANISMS OF INDIVIDUAL DECISION MAKING,
IDENTIFYING ITS MAIN INGREDIENTS AND HEAKNESSES. THE SECOND PART EXPLORES SIMILARITIES AND DIFFERENCES AMONG DECISIONMAKING TASKS ACCORDING TO CONTEXT, WITH EMPHASIS ON THE INTERACTION OF THE LOCAL GOVERMMENT OFFICIAL WITH HIS OR HER ENVIRONMENT, WHETHER INTERNAL OR EXTERNAL. THE THIRD PART DESCRIBES THE ROLE OF CONFLICT MANAGEMENT IN LOCAL GOVERMMENT DECISIONS. THE CHAPTER CONCLUDES WITH SOME PRESCRIPTIONS FOR LOCAL GOVERMMENT DECISION MAKING AND MANAGEMENT OF THE CONFLICT THAT ACCOMPANIES IT

05039 KAUFMANN, $H$.

A EUROPEAN CENTRAL BANK AND MONETARY STABILITY IN EUROPE JERUSALEM JOURNAL OF INTERNATIONAL RELATIONS, 14(2) (JUN 92 ) 13-34.

THE EUROPEAN COMMUNITY HAS DECIDED TO MOVE TOWARD AN ECONOMIC AND MONETARY UNION BY THE END OF THIS DECADE. PART OF THIS PROGRAM IS THE INTRODUCTION OF A NEW CENTRAL BANKING SYSTEM CONSISTING OF A EUROPEAN CENTRAL BANK AS THE APEX OF THE EUROPEAN SYSTEM OF CENTRAL BANKS AND THE CREATION OF A NEW CURRENCY. THIS ARTICLE INVESTIGATES THE DESIRABILITY OF SUCH A DEVELOPMENT AS COMPARED TO STAYING WITH THE PRESENT EUROPEAN MONETARY SYSTEM.

05040 KAUL $H$.

WHO CARES? GENDER INEQUALITY AMD CARE LEAVE IN THE NORDIC COUNTRIES

ACTA SOCIOLOGICA, 34(2) (1991), 115-125.

THIS ARTICLE COMPARES LEAVES OF ABSENCE FOR CHILD CARE IN THE FIVE NORDIC COUNTRIES. DESPITE DIFFERENCES IN THE LENGTH OF THE TIME PERIODS AND IN ECONOMIC COMPENSATION, SIMILARITIES IN THE LEGISLATIONS' STRUCTURES POINT TOWARDS A FUNDAMENTAL PATRIARCHAL MENTALITY. WHEN APPLIED TO THE GENDER-STRUCTURED WORKING WORLD, PARENTS USE THE LEGAL RIGHTS IN A WAY THAT PRESERVES THE UNEQUAL SHARING OF ECONOMIC AND PRACTICAL PARENTING. THE STUDY SHOWS THE ECONOMIC AND PRACTICAL PARENTING. THE STUDY SHOWS THE WHEN TRYING TO EXPLAIN BOTH THEIR ATTACHMENT TO WORK AND THE WHEN TRYING TO EXPLAIN BOTH THEIR ATTACHMENT TO KOR
SHARING OF CARE RESPONSIBILITIES BETWEEN PARENTS.

05041 KAUS, $M$

F.O.B. STORY

NEW REPUBLIC, 207(27) (DEC 92), 10-11

THE AUTHOR PROFILES MICKEY KANTOR, WHO CHAIRED GOVERNOR

BILL CLINTON'S 1992 PRESIDENTIAL CAMPAIGN BUT REPRESENTS THE KIND OF LAWYER-LOBBYIST CLINTON HAS PROMISED TO FIGHT IN
WASHINGTON.

05042 KAUS, $M$

PARADIGM'S LOSS

NEH REPUBLIC, 207(5) (JUL 92), 16, 18, 22.

THE NEW PARADIGM SOCIETY IS A GROUP FOUNDED BY

REPUBLICAN JAMES PINKERTON AND DEMOCRAT ELAINE KAMARCK TO EXPLORE THE POSSIBILITY OF A LEFT-RIGHT CONSENSUS ON DOMESTIC POLICY. THE NEW PARADIGM ENVISIONS A FORM OF GOVERMMENT ACTIVISM THAT WOULD EXPAND INDIVIDUAL CHOICE, EMPOWER THE POOR, AND REPLACE OLD-STYLE BUREAUCRACY WITH DECENTRALIZED, FLEXIBLE, AND ADAPTABLE INSTI IUTIONS.

DEMOCRATIC CANDIDATE BILL CLINTON HAS BEEN EXPRESSING MANY

OF THESE SAME IDEAS IN HIS CAMPAIGN SPEECHES.

05043 KAUS, $M$.

RFK ENYY

NEH REPUBLIC, 206(26) (JUN 92) 13-14.

BILL CLINTON HAS SOMETIMES BEEN COMPARED TO BOBBY KENNEDY, AMD CLINTON HIMSELF HAS ENCOURAGED THE ANALOGY. BUT SUCH COMPARISONS ARE UNFAIR TO CLINTON. A DEMOCRATIC PRESIDENTIAL CANDIDATE IN 1992 CANNOT, AND SHOULD NOT, SAY PRESIDENTIAL CANDIDATE IN
WHAT KENNEDY SAID IN 1968.

05044 KAUS, $M$.

SOUND-BITTEN

NEW REPUBLIC, 207(18) (OCT 92), 16, 18.

THE AUTHOR EXPLAINS THAT THE MAJOR TV NETWORKS CHANGED

THEIR METHOD OF COVERING CAMPAIGN SPEECHES IN THE 1992

PRESIDENTIAL CAMPAIGN BUT PRESIDENT GEORGE BUSH SEEMED TO BE

FOLLOWING THE SAME STRATEGY HE USED IN THE 1988 CAMPAIGN.

05045 KAUS, $M$.

THE END OF EQUALITY

NEW REPUBLIC, 206(25) (JUN 92), 21, 24-27.

BILL CLINTON'S APPROACH TO IMPROVIMG THE U.S. ECONOMY EMPHASIZES EDUCATION AND TRAINING TO PREPARE AMERICA'S WORKFORCE FOR THE TECHMOLOGY OF TOMORROW. WHILE THIS "SKILLS SOLUTION" HAS SOME VALIDITY, IT COULD LEAD TO GREATER SOCIAL INEQUALITY. WHAT THE SKILLS SOLUTION IGNORES IS THE POSSIBILITY THAT GREATER STRATIFICATION BASED ON SKILLS-POSSIBILITY THAT GREATER STRATIFICATION BASED ON SKILLS-MERI TOCRATIC STRATIFICATION--WILL
AMERICAN SENSE OF SOCIAL EQUALITY.

05046 KAUS, $M$.

THE POLICY HUSTLER

MEH REPUBLIC, 207 (24) (DEC 92), 16-18, 20, 22-23.

THE AUTHOR PROFILES ROBERT REICH, LECTURER IN PUBLIC

POLICY AT HARVARD'S KENNEDY SCHOOL OF GOVERNMENT AND ONE OF PRESIDENT-ELECT BILL CLINTON'S TOP ADVISORS ON ECONOMIC POLICY.

05047 KAUS, $M$.

WELFARE WAFFLE
NEW REPUBLIC, 207 (16) (OCT 92), 10-12

DEMOCRATIC PRESIDENTIAL CANDIDATE BILL CLINTON HAS

PROMISED TO "END WELFARE AS WE KMOW IT," BUT HE HAS NOT MADE

THE EXACT DETAILS OF HIS PLAN CLEAR TO THE VOTERS.

05048 KAVAN, J.

THE SCREENING ACT: IMPERFECT AND WRONG

THIS ARTICLE CRITICIZES CZECHOSLOVAKIA'S "SCREENING ACT,

" A PIECE OF LEgISLATION DESIGNED TO PREVENT CERTAIN

POSITIONS IN STATE ADMINISTRATION FROM BEING HELD BY EX-

EMPLOYEES OF THE SECRET POLICE OR FORMER SENIOR PARTY

OFFICIALS. THE CHIEF CRITICISM OF THE SCREENING ACT IS THAT IT INDISCRIMINATELY PROHBITS WHOLE CLASSES OF PEOPLE FROM ATTAINING STATE POSITIONS. IT ARGUES THAT THE MEASURE CREATES GUILT BY ASSOCIATION. SUCH A POLICY IS ANTITHETICAL TO CZECHOSLOVAKIA'S NEWLY-CREATED BILL OF RIGHTS.

05049 KAVANAGH, D.

CHANGES IN THE POLITICAL CLASS AND ITS CULTURE

PARL IAMENTARY AFFAIRS, 45(1) (JAN 92), 18-32.

SOME OF THE MAIN SOCIAL AND STYLISTIC CHANGES AMONG THE BRITISH POLITICAL CLASS IN THE PAST THO DECADES ARE DESCRIBED AND ANALYZED IN THIS ARTICLE. THE TERM POLITICAL DESCRIBED AND ANALYZED IN THIS ARTICLE. THE TERM POLITICAL CLASS ENABLES IT TO LOOK NOT ONLY AT POLITICIANS BUT ALSO
CIVIL SERVANTS AND POLITICAL ENTREPRENEURS. IT CONCLUDES THAT THE MOST NOTICEABLE CHANGE IS THE GREAT CASUALTY OF THE THAT THE MOST NOT ICEABLE CHANGE IS THE GREAT CASUALTY POLITICS, AND WITH IT THE CONSENSUS SEEKING FIXERS.

05050 KAVANAGH, 0

PRIVATE OPINION POLLS AND CAMPAIGN STRATEGY

PARLIAMENTARY AFFAIRS, 45(4) (OCT 92), 518-527,

THE RISE OF PRIVATE OPINION POLLING BY POLITICAL PARTIES IS ONE SYMPTOM OF HOW POLITICAL PARTIES TODAY MORE SELFCONSCIOUSLY ATTEMPT TO ORCHESTRATE AND MANAGE THEIR ELECTION CAMPAIGNS, IN PRINCIPLE THERE IS NO DIFFERENCE BETHEEN PRIVATE AND PUBLIC OPINION POLLS. THE AUTHOR SUGGESTS THAT IT DEPENDS ON THE USE MADE OF THEM. THIS ARTICLE EXPLORES THE BACKGROUND OF BRITISH OPINION POLLS AND PRIVATE POLLING 
AND THE ELECTION CAMPAIGN.

05051 KAVOOSSI, $M$.

THE ROLE OF INTERNATIONAL BUSINESS IN POST-WAR IRAN

MIDOLE EAST INSIGHT, VIII(5) (MAY 92), 52-57.

TO MOVE AWAY FROM NEGATIVE ECONOMIC GROWTH, THE LEADERSHIP OF IRAN IS TRYING TO ENCOURAGE FOREIGN BUSINESS PARTICIPATION, ESPECIALLY BY SEEKING ASSISTANCE FROM
EUROPEAN BUSINESS IN POST-WAR RECONSTRUCTION EFFORTS. HOWEVER, EFFORTS TO COAX FOREIGN BUSINESSMEN INTO IRAN ARE HAMPERED BY THE COUNTRY'S LACK OF INFRASTRUCTURE UNCERTAINTY ABOUT ISLAMIC BUSINESS LANS AND IRAN'S POOR ECONOMIC CONDITIONS. THIS ARTICLE OUTLINES THE GENERAL ECONOMIC AND FINANCIAL CONDITIONS OF IRAN AND DISCUSSES THEIR IMPLICATIONS FOR INTERMATIOMAL FIRMS. IT COMCLLSS THEIR IMPLICATIONS FOR INTERNATIONAL FIRMS. IT CONCLUDES BUSINESS ADVANTAGES AND OPPORTUNITIES, THERE REMAINS A GREAT DEAL TO BE DONE BEFORE IRAN IS AN OPTIMAL INYESTMENT SITE.

05052 KAYE, D.

STRUGGLING WITH INDEPENDENCE: CENTRAL ASIAN POLITICS IN IET WORLD

MIDDLE EAST INSIGHT YIII(6) (JUL 92), 27-32.

ALTHOUGH A YEAR HAS PASSED SINCE THE SOVIET UNION WAS TOSSED INTO THE DUSTBIN, ITS LEGACY DOMINATES THE POLITICAL LANDSCAPE OF CENTRAL ASIA. THE NAMES, THE APPARAT, AND THE COMMUNIST BUREAUCRACY REMAIN THE SAME; ANY SYSTEMIC REFORM WOULD MEAN THEIR LOSS OF POWER. AS A RESULT, IT SEEMS CLEAR THAT ECONOMIC AND POLITICAL CHANGE WILL PROCEED, UZBEKISTAN, KAZAKHSTAN, AND KYRGYZSTAN ARE GRIPPED BY SIMILAR TRENDS: ECONOMIC DESPERATION, ETHNIC DISHARMONY, AND POLITICAL INSTABILITY.

05053 KAYE, H.

THE CATERPILLAR STRIKE: AN AVOIDABLE SETBACK

POLITICAL AFFAIRS, 71(4) (MAY 92), 26-27.

LABOR UNIONS ARE BEGINNING TO REALIZE THAT A ROUTINE APPROACH OF MERELY SETTING UP PICXET LINES AND "HAITING OUT" AN EMPLOYER IS AN INSUFFICIENT STRATEGY TO FACILITATE CHANGE. THEY ARE RECOGNIZING THE NEED TO PREPARE A FIGHTING STRATEGY THAT MOBILIZES ALL THE ALLIES AND FRIENDS OF THE WORKERS, ACROSS BOTH THE NATION AND THE WORLD. IN ADOITION, INCREASED EMPHASIS IS BEING PLACED ON INVOLVEMENT OF THE RANK AND FILE UNION MEMBERS IN ALL ASPECTS OF A STRIKE. GIVEN THESE LESSONS. THE ENDING OF THE CATERPILLAR STRIKE GIVEN THESE LESSONS, THE ENDING OF THE CATERPILLAR STRIKE WAS AN AVOIDABLE SETBACK. THE STRIKE ENDED IN THE 13,000 WORKERS HAVING TO GO BACK TO WORK UNDER TERMS THE COMPANY
OFFERED AT THE START OF THE STRIKE. THE CATERPILLAR WORKERS OFFERED AT THE START OF THE STRIKE. THE CATERPILLAR WORK
SHOWED A HIGH DEGREE OF MILITANCY AND SOLIDARITY IN THE SHOWED A HIGH DEGREE OF MILITANCY AND SOLIDARITY IN THE COURSE OF THEIR FIVE-MONTH STRIKE AGIANST ONE OF THE MOST
POWERFUL CORPORATIONS IN THE U.S. AND THE HORLD. BUT WITHOUT POWERFUL CORPORATIONS IN THE U.S. AND THE HORLD. BUT WITHOUT MOVEMENTS COULD HAVE BROUGHT TO BEAR, THE HORKERS WERE MOVEMENTS COUL

05054 KAYE, H.J.

THE EDUCATION OF DESIRE: MARXISTS AND THE WRITING OF HISTORY

ROUTLEDGE, 1992, 211

THE AUTHOR FOCUSES ON THE STUDY OF MARXIST HISTORY AND SOCIAL THOUGHT, ESPECIALLY IN GREAT BRITAIN. EXAMINING THE HORKS OF SUCH INTELLECTUALS, WRITERS, AND SCHOLARS AS ANTONIO GRAMSCI, CHRISTOPHER HILL, GEORGE RUDE, V.G. KIERNAN, E.P. THOMPSON, LEO HUBERMAN, AND JOHN BERGER, THE AUTHOR ASSESSES THE CONTRIBUTIONS WHICH THESE FIGURES HAVE MADE TO HISTORICAL STUDY AND POLITICAL THEORY AND WHICH THEY MIGHT YET MAKE TO THE REFORMATION AND REINYIGORATION OF RADICALDEMOCRATIC AND SOCIALIST HISTORY AND POLITICS. FORMULATING THE MARXIST HISTORICAL PROJECT AS "THE EDUCATION OF DESIRE," HE ASSERTS THAT THIS PROJECT REMAINS ESSENTIAL AND, INDEED, HAS BECOME INCREASINGLY IMPERATIVE IN THE FACE OF THE RELATED CRISES OF HISTORY AND SOCIALISM AND CONSERVATIVE PROCLAMATIONS ABOUT "THE END OF HISTORY."

05055 KAYE, L.

AFTER THE BANQUET

FAR EASTERN ECONOMIC REVIEW, 155 (28) (JUL 92) 13

IN MONGOLIA'S FIRST FREE ELECTION AS A PARLIAMENTARY DEMOCRACY, THE MONGOLIAN PEOPLE'S REVOLUTIOMARY PARTY (MPRP) RODE TO AN UNASSAILABLE MAJORITY ON THE BACK OF POPULAR FRUSTRATION WITH FALLING LIVING STANDARDS DUE TO THE COUNTRY'S SWITCH FROM A PLANNED TO A MARKET ECONOMY. THE PARTY CAPTURED 71 OF THE 76 SEATS IN THE NEWLY RECONSTITUTED PARLIAMENT--A SHEEP THAT CAUGHT EVEN THE MPRP BY SURPRISE. NOW THE PARTY FACES A HORSENING DEBT AND A POTENTIAL TRADE CRISIS. THE ONLY WAY THE EX-COMMUNIST PARTY CAN DELIVER ON CRISIS. THE ONLY WAY THE EX-COMMUNIST PARTY CAN DELIVE ANFUSIONS FROM THE WEST AND JAPAN. IF THE PARTY CAN MAKE IT THFOSIONS FROM THE WEST AND JAPAN. IF THE PARTY CAN MAKE IT THROUGH THE COMING FOUR-YEAR TERM WITH ITS MANDATE INTACT AND ITS AID DONORS STILL ON ITS SIDE, IT CAN PROVE TO ASIAN COMMUNISTS THAT A REGIME CAN RISK SOME POLITICAL PLURALISH AND LIVE TO TELL THE TALE. IF IT FAILS, THO
POSSIBILITIES LOOM: A SLIDE BACK INTO ISOLATION AND
AUTHORITARINAISM, OR INCREASING ECONOMIC RELIANCE UPON NEIGHBORING CHINA. 05056 KAYE, L.; CHENG, E.

FAR EASTERN ECONOMIC REVIEW, 155(28) ( JUL 92), 48-52. WITHIN A MERE 18 MONTHS, CHINA HAS ESTABLISHED THO STOCK MARKETS, ONE IN SHANGHAI, THE OTHER IN SHENZHEN--AND LISTED 34 CDUNTERS. OTHER WOULD-BE EXCHANGES HAVE SPRUNG UP ALL OVER THE COUNTRY, ONLY TO BE NIPPED IN THE BUD BY PEKING. FOREIGNERS HAVE BEEN ALLOWED TO ACQUIRE UP TO ONE THIRD OF QUOTED COMPANIES. THESE REMARKABLE CHANGES ARE FURTHER EVIDENCE THAT REFORMISTS ARE IN CONTROL OF CHINA'S GOVERMMENT. IN THE INITIAL STAGES, PENT-UP DEMAND FOR, AND

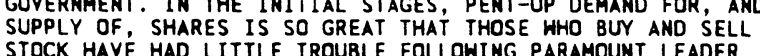
STOCK HAVE HAD LITTLE TROUBLE FOLLOWIMG PARAMOUNT LEADER
DENG XIAOPING'S INJUNCTION: "TO GET RICH IS GLORIOUS." THEIR DENG XIAOPING'S INJUNCTION: "TO GET RICH IS GLORIOUS."
HOLDINGS OF STOCKS ARE NOW WORTH RMB 60 BILLION (US\$I1 HOLDINGS OF STOCKS ARE NOW WORTH RMB 60 BILLION (US\$11
BILLION). HOWEVER, THE FUTURE IS NOT NEARLY SO CERTAIN; BILLION). HOHEVER, THE FUTURE IS NOT NEARLY SO CERTAIN;
CHINA'S ECONOMIC MANAGERS MUST DEAL WITH THE RAPID EXPANSION CHINA'S ECONOMIC MANAGERS MUST DEAL WITH THE RAPID EXPANSIO
OF SHARE-HOLDER DEMOCRACY. AND IF THE ENTIRE EXPERIMENT PROVES A SUCCESS, DOCTRINAIRE COMMUNISTS HAVE A DANGEROUS THING TO CONTEND WITH: A FLOURISHING CAPITALIST INSTITUTION IN THE CHINESE ECONOMY.

05057 KAYE, L.

BACK IN THE GAME

FAR EASTERN ECONOMIC REVIEH, 156(23) (JUM 92),

CHINA'S WILLINGNESS TO GO ALONG WITH THE WESTERN MOVES AGAINST IRAQ DURING THE GULF CRISIS WAS AN IMPORTANT FIRST STEP IN CHINA'S RETURN TO INTERNATIONAL RESPECTABILITY. NOH PEKING CAN AFFORD TO ASSERT ITS DIPLOMATIC INDEPENDENCE, INSTEAD OF MERE COMPLIANCE WITH INTERNATIONAL NORMS. IT HAS DONE SO BY SELECTIVELY SIDING WITH THE THIRD WORLD OH CRITICAL ISSUES. CHINA HAS STALLED AN INTERMATIONAL ACCORD TO CURTAIL ARMS SHIPMENTS TO THE MIDDLE EAST. IT HAS MADE GREAT EFFORTS TO BECOME THE CHAMPION OF THIRD WORLD CAUSES AT THE UPCOMIONG RIO SUMMIT. AND IT REITERATED ITS SUPPORT FOR SERBIA BY ABSTAINING FROM THE UN SECURITY COUNCIL VOTE FOR ECONOMIC SANCTIONS AGAINST SERBIA.

05058 KAYE, L.

CHINA FEELS THE CHILL

FAR EASTERN ECONOMIC REVIEW, 155(1) (JAN 92), 14. WHATEVER THE DUTCOME OF SOVIET CENTRAL ASIA'S QUEST FOR A NEW SELF-DEFINITION--WHETHER IT WINDS UP DOMINATED BY MUSLIM RELIGIOSITY OR PAN-TURKIC NATIONALISM--IT WILL MUSLIM RELIGIOSITY OR PAN-TURKIC NATIONALISH-OIT WILL CONFRONT CHINA HITH A NO-HIN SITUATION. THE NEWLY FREED
CENTRAL ASIAN REPUBLICS ABUT CHINA'S OIL-RICH HESTERNMOST CENTRAL ASIAN REPUBLICS ABUT CHINA'S OIL-RICH HESTERNMOST PROVINCE OF XINJIANG, WHICH HAS BEEN RESTIVE SINCE A TWO-DAY
RIOT IN EARLY 1989 LEFT 22 POLICE AND CIVILIANS DEAD. NEARLY RIOT IN EARLY 1989 LEFT 22 POLICE AND CIVILIANS DEAD. EXTRACTION. THEREFORE, IT IS NO COINCIDENCE THAT CHINA HAS CRACKED DOWN HARSHLY ON ANYTHING WHICH RESEMBLES CRACKED DOWN HARSHLY ON ANYTHING WHICH RESEMBLES
NATIONALISTIC SENTIMENT OR OPPOSITION TO THE REGIME.

05059 KAYE, L.

DENG SPEAKS OUT

FAR EASTERN ECONOMIC REVIEW, 155(6) (FEB 92), 10-11.

CHINA'S MEDIA HAS BEEN PUSHED INTO THE POLITICAL FRONT LINE AS PROPAGANDA POLICY BECOMES THE LATEST BONE OF CONTENTION BETHEEN THE COMMUNIST PARTY'S REFORMIST AND CONSERVATIVE CAMPS. PARAMOUNT LEADER DENG XIAOPING AND HIS LIBERAL ALLIES SEEM TO HAVE MOUNTED A CONCERTED BID TO WREST BACK CONTROL OF PROPAGANDA ORGANS, WHICH HAVE BEEN A STRONGHOLD OF HARDLINERS SINCE THE 1989 PEKING MASSACRE. DENG AND PRESIDENT YANG SHANGKUN ALSO MADE WELL-PUBLICIZED TRIPS TO THE FRONTIER BOOM TOWNS OF GUANGDONG PROVINCE JUST ACROSS THE BORDER FROM HONG KONG, CONFIRMING THE ENDORSEMENT OF THE AREA'S FREE-WHEELING ECONOMIES. DENG USED THE VISIT, HIS FIRST PUBLIC APPEARANCE IN A YEAR, TO WARN HIS OPPONENTS THAT HIS "REFORM AND OPEN DOOR" POLICIES PRESENTED THE "ONLY WAY OUT" FOR CHINA.

05060 KAYE, $L$.

DENGISM ENSHRINED

FAR EASTERN ECONOMIC REVIEW, 155(42) (OCT 92), 10-11.

THE IMAGE OF DENG XIAOPING, CHINA'S PARAMOUNT LEADER, DOMINATED THE 14TH CONGRESS OF THE CHINESE COMMUNIST PARTY (CCP). IN HIS KEYNOTE ADDRESS AT THE CONGRESS, GENERAL SECRETARY JIANG ZEMIN CITED DENG 13 TIMES (HE CITED MAO ONLY 11) AND PRAISED THE LEADER'S ECONOMIC REFORMS. HOWEVER, HIS POSITION IS NOT UNSHAKABLE. IT REMAINS UNCLEAR WHO DENG HAS CHOSEN TO SUCCEED HIM. HIS ENEMIES AMONG HARD-LINE FACTIONS IN THE PARTY ARE DETERMINED AND MANY. SOME OBSERVERS HAVE NOTED THAT DENG'S GROWING POPULARITY AND YISIBILITY ARE A NOTED THAT DENG'S GROWING POPULARITY AND VISIBILITY ARE
SIGN OF WEAKNESS: HE MUST RELY ON A MAO-LIKE CULT OF SIGN OF WEAKNESS: HE MUST RELY ON A MAO-LIKE CULT OF
PERSONALITY TO ACHIEVE HIS AIMS. WHATEVER THE CASE, IT IS PERSONALITY TO ACHIEVE HIS AIMS. WHATEVER THE CASE, IT
CLEAR THAT CHINA IS FIRMLY ON A PATH TOWARD ECONOMIC

CLEAR THAT CHINA IS FIRMLY ON A PATH TOWARD ECONOMIC

LIBERALIZATION. HOWEVER, EVEN DENG AGREES THAT ECONOMIC
REFORMS SHOULD NOT BE ACCOMPANIED BY POLITICAL PLURALISM.

05061 KAYE, L.

FALTERING STEPPES 
FAR EASTERN ECONOMIC REVIEH, 155(14) (APR 92), 16-18. MONGOLIA, MOSCOW'S FIRST ASIAN SATELLITE TO EMERGE FROM THE COMMUNIST FOLD, TYPIFIES THE OPPORTUNITIES AND RISKS THAT CHINA FACES IN THE POST-SOVIET WORLD. CHINA ENJOYS ADVANTAGES IN MONGOL IA THAT NO OTHER POTENTIAL SUPPLIER OR INVESTOR CAN MATCH INCLUDING PROXIMITY, COMPLEMENTARITY, FAMILIARITY AND STRATEGIC INTEREST. THESE FACTORS, GIVEN FULL PLAY, COULD TURN MONGOLIA FROM THE UNOFFICIAL 16TH REPUBLIC OF THE SOVIET UNION INTO THE DE FACTO 22ND PROVINCE OF CHINA. MONGOL NATIONALISTS ARE PLEADING FOR AID FROM THE WEST IN AN ATTEMPT TO AVOID THIS FATE.

05062 KAYE, L.

HINTERLAND OF HOPE

FAR EASTERN ECONOMIC REVIEW, 155(2) (JAN 92), 16-17.

LEGACIES OF WAR AND COLONIALISM HAVE COME TOGETHER IN A GRANDIOSE PLAN FOR THE DEVELOPMENT OF A FORGOTTEN DELTA REGION IN NORTHEAST ASIA RICH IN NATURAL RESOURCES. IF THE UNITED NATIONS DEVELOMENT PROGRAM (UNDP) RECOMMENDATIONS FOR THE TUMEN DELTA AND HINTERLAND--IN THE CHINA-RUSSIA-NORTH KOREA TRI-BORDER AREA-MATERIALIZE, MARSHLAND WILL GIVE WAY TO A NEW METROPOL IS TO SERVE AS A HUB FOR THE GROWTH OF INDUSTRY AND TRADE IN THE JAPAN SEA LITTORAL. NOT
THE DEVELOPMENT PROJECT HAVE SIGNIFICANT ECONOMIC IMPLICATIONS, THE FACT THAT THE SIX PARTICIPANTS IN THE PROJECT--CHINA, NORTH KOREA, SOUTH KOREA, RUSSIA, MONGOLIA, AND JAPAN--ARE WILLING TO EVEN DISCUSS SUCH
SIGN OF CHANGING INTERNATIONAL CONDITIONS.

05063 KAYE, L.

IN FROM THE COL

FAR EASTERN ECONOMIC REVIEN, 155(4) (JAN 92), 15-16.

CHINA'S DRIVE TO REPAIR THE DAMAGE DONE TÓ ITS

INTERNATIONAL STANDING BY THE JUNE 1989 CRACKDOWN WILL MOVE INTO HIGH GEAR WHEN PREMIER LI PENG VISITS THE UN AND A NUMBER OF EUROPEAN COUNTRIES IN LATE JANUARY AND EARLY AT HOME MAKING IT MORE LIKELY THAT HE WILL BE GIVEN A SECOND TERM AS PREMIER. THE TRIP REPRESENTS THE GRADUAL ENDING OF CHINA'S INTERHATIONAL ISOLATION. IT ALSO SIGNALS THAT LI--THOUGHT BY SOME TO BE A "DISPOSABLE" POLITICIAN WHO WOULD BE OUSTED AFTER HIS DOING THE DIRTY WORK OF THE TIANANMEN CRACKDOWN--IS LIKELY TO REMAIN A KEY FIGURE IN CHINESE POLITICS.

05064 KAYE, L.

LEANING TO THE RIGHT

FAR EASTERM ECONOMIC REVIEW, 155(12) (MAR 92), 10

THE GLOVES ARE FINALLY OFF IN THE CHINESE COMMUNIST PARTY'S FACTIONAL FRAY. AT THE BEHEST OF PATRIARCH DENG PARTY S FACTIONAL FRAY. AT THE BEHEST OF PATRIARCH DENG BIAOPING, THE POLITBURO TIPPED THE PRECARIOUS POST-1989 BALANCE BETWEEN REFORMISTS AND HARDLINERS BY PRONOUNCING LEFT DEVIATIONISM TO BE A GREATER THREAT THAN THAT OF THE BEHIMD-THE-SCENES RUI ING COALITION OF HARDLINE STALINISTS BEHIND-THE-SCENES RULING COALITION OF HARDLINE STALINISTS
AND REFORHIST NEO-AUTHORITARIANS. IN HIS OFFENSIVE, DENG MAY BE SEIZING AN ACTUARIAL AS HELL AS A POLITICAL ADVANTAGE BE SEIZING AN ACTUARIAL AS WELL AS A POLITICAL ADVANTAGE. ARE SIMPLY TOO SICK AND WEAK TO FIGHT BACK. OLD WAR HORSES LIKE LI XIANNIAN, 83, VICE-PRESIDENT HANG ZHEN, 84, AND FORMER PEKING MAYOR PENG ZHEN, 90, ARE ALL REPORTED TO BE NEAR DEATH. ECONOMICS CHIEF CHEN YUN, 87, WAS APPARENTLY STILL LUCID ENOUGH TO ENGAGE IN A FURIOUS DEBATE WITH DENG OVER POL ICY DIRECTIONS. BUT HE SEEMS TO BE FAR LESS AMBULATORY THAN DENG, 87, WHO WAS ABLE TO LAUNCH THE CURRENT CAMPAIGN WITH A WELTER OF LECTURES AND "PHOTO OPPORTUNITIES" IN THE SOUTHERN SPECIAL ECONOMIC ZONES EARLY IN 1992.

05065 KAYE, L.; AWAMOHARA, S.

PEKING PILGRIMAGE

FAR EASTERN ECONOMIC REVIEH, 155(40) (OCT 92), 10-11.

SOUTH KOREAN PRESIDENT ROH TAE WOO MADE THE FIRST-EVER VISIT OF A SOUTH KDREAN HEAD OF STATE TO CHINA JUST ONE MONTH AFTER THE NORMALIZATION OF RELATIONS BETWEEN THE THO NATIONS. WHILE IN PEKING, ROH WON CHINA'S IMPLICIT AGREEMENT TO USE ITS GOOD OFFICES TO GET NORTH KOREA TO PERMIT BILATERAL INSPECTIONS OF ITS NUCLEAR FACILITIES. FURTHERMORE, ROH AND CHINESE LEADERS CONCLUDED BILATERAL TRADE AND INVESTMENT AGREEMENTS. THE CHINA VISIT IS THE CAPSTONE OF ROH'S NORTHERN POLICY OF SEEKING NORMALIZATION WITH MOSCOW AND PEKING IN A BID TO ENHANCE THE LEGITIMACY OF HIS OWM REGIME AND ISOLATE PYONGYANG. THIS STRATEGY--GREATLY AIDED BY THE SOVIET DEMISE--HAS SUCCEEDED SO WELL THAT SOUTH KDREA NOW RISKS OVER-EXTENDING ITSELF WITH NEH COMMERCIAL VENTURES AND DIPLOMATIC MISSIONS OPENING UP FROM TIRANA TO TASHKENT. AND DIPLOMATIC MISSIONS OPENING UP FROM TIRANA IO TASHKENT. HOWEVER, SOUTH KOREA COULD HARDLY REFUSE PEKING'S ABRUPT OFFER OF NORMALIZATION AFTER YEARS OF PREPARATION. SOME ARGUE THAT CHINA PUSHED FOR THE STRENGTHENING OF TIES IN ORDER TO EMPHASIZE CHIM
SECURITY AND ECONOMY.

05066 KAYE, L.

REFORMIST ONSLAUGHT

FAR EASTERN ECONOMIC REVIEH, 155(14) (APR 92), 13.
OLD NEHS IS STILL NEWS IN CHINA; BELATED COVERAGE IN THE OFFICIAL MEDIA OF PATRIARCH DENG XIAOPING'S JANUARY VISIT TO SOUTH CHINA OFFERS THE LATEST CLUE TO THE CURRENT STATE OF THE BATTLE BETWEEN REFORMISTS AND HARDLINERS IN THE RULINC COMMUNIST PARTY. ALL MAJOR NEWSPAPERS IN THE CAPITAL BANNERED DENG'S REMARKS, ALONGSIDE A PHOTOGRAPH OF THE 87YEAR-OLD PATRIARCH LOOKING SPRY AND COMMANDING. PROMINENT COVERAGE WAS ALSO GIVEN TO DENG'S EXHORTATIONS FOR DOUBLEDIGIT ECONOMIC GROWTH RATES, A 10O-YEAR COMMITMENT TO REFORM AND ACCELERATED DEVELOPMENT FOR SOUTHERN COASTAL INVESTMENT ENCLAVES. IN ADOITION, THE PRESS ALSO REPORTED STATEMENTS OF NATIONAL PARTY CONGRESS (NPC) DELEGATES WHICH ARE CRITICAL OF HARD-LINE LEADERS. SUCH STATEMENTS HOULD HAVE BEEN UNTHINKABLE IN OFFICIAL PRINT JUST A FEW MONTHS AGO, WHEN

THE MEDIA WAS STILL FIRMLY IN THE GRIP OF HARDLINERS.

05067 KAYE, L.

REFORMIST ROADSHOW

FAR EASTERH ECONOMIC REVIEW, 155(25) (JUN 92), 19.

AS CHINA'S CONSERVATIVE OLD GUARD STRUGGLES TO MAINTAIN ITS POWER AND INFLUENCE, IT IS DISCOVERING THAT THE TIDE OF REFORM IS SHELLING EVER LARGER. THE LATEST MANIFESTATION OF REFORM IS SHELLING EVER LARGER. THE LATEST MANIFESTATION OF
CHINA'S REFORMIST TREND IS THE PUBLICATION OF "THE TIDE OF CHINA'S REFORMIST TREND IS THE PUBLICATION OF "THE TIDE OF HISTORY, " A COMPENDIUM OF ESSAYS BY PROGRESSIVE ACADEMICS AND INTELLECTUALS IN SUPPORT OF PATRIARCH DENG XIAOPING'S RESULTED IN THE BANNING OF THE WORK, BUT THE HARD-LINERS

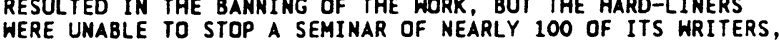
WERE UNABLE TO STOP A SEMINAR OF NEARLY 100 OF ITS WRE EDITORS, AND INFLUENTIAL READERS. THE SEMINAR WAS THE BIGGEST GATHERING OF DISSIDENT INTELLECTUALS INSIDE CHINA
SINCE THE 1989 CRACKDOWN ON THE PRO-DEMOCRACY MOVEMENT. SUCH A MEETING WOULD HAVE BEEN IMPOSSIBLE WITHOUT BACKING AT THE HIGHEST LEVELS. AS THOUGH TO CONFIRM THE EBB OF THE HARDLINERS' FORTUNES, ALL NATIONAL MEDIA SUDDENLY CHOSE TO PLAY UP A HEEK-OLD SPEECH BY PARTY CHIEF JIANG ZEMIN CALLING FOR FASTER GROHTH, MORE FOREIGN INVOL VMENT AND GREATER DECENTRALIZATION OF THE ECONOMY. WITH THE SPEECH, JIANG MANAGED TO UPSTAGE PRIME MINISTER LI PENG'S MEETINGS WITH VARIOUS WORLD LEADERS AT THE RIO EARTH SUMMIT. ALONG WITH THESE REFORMIST INDICATIONS, HOWEVER, THERE HAVE ALSO BEEN HINTS THAT REFORM IS WELCOME IN ECONOMICS BUT TABOO IN POLITICS.

05068 KAYE, L.

SAYING FACES

FAR EASTERN ECONOMIC REVIEW, 155(44) (NOV 92), 13-14. CHINA AND JAPAN USED EMPEROR AKIHITO'S SIX-DAY VISIT TO CHINA TO LAY TO REST THE GHOSTS OF THE PAST. JAPAN GOT OFF WITH AN EXPRESSION OF REGRET FOR ATROCITIES COMMITTED DURING ITS 1931-45 OCCUPATION OF CHINA. FOR ITS PART, CHINA COULD ITS 1931-45 OCCUPATION OF CHINA. FOR ITS PART, CHINA COU POINT TO THE PRESTIGE OF AN IMPERIAL VISIT TO DEFLECT
CRITICISH OF THE 1989 TIANANMEN SQUARE INCIDENT. THE TRIP CRITICISH OF THE 1989 TIANANMEN SQUARE INCIDENT. THE TRIP HAS BEEN THE HIGHEST-LEVEL STATE VISIT THAT CHINA HAS BEEN ABLE TO ARRANGE SINCE 1989. OBSERVERS SAH IT AS A BENCHMARK IN THE RESTORATION OF PEKING'S INTERNATIONAL LEGITIMACY AND A HARBINGER OF INCREASED JAPANESE INVESTMENT IN CHINA. THE SYMBOLIC SINO-JAPANESE RAPPROCHEMENT ALSO SENDS A WARNING SIGHAL TO THE U.S., TOKYO'S MAI

05069 KAYE, L.

SITTING ON THE FENCE

FAR EASTERN ECONOMIC REVIEW, 155(13) (APR 92), 13.

MORE INTERESTING THAN WHAT CHINA'S PREMIER LI PENG SAID IN HIS ANNUAL REPORT ON THE GOVERMMENT HAS WHAT HE FAILED TO SAY. THE SPEECH KEYNOTES THE FORTHIGHT-LONG SESSION OF THE NATIONAL PEOPLE'S CONGRESS (NPC), CHINA'S PARLIAMENT. EXPECTATIONS HAD BEEN RAISED BY THE PRO-REFORM RHETORIC OF PARAMOUNT LEADER DENG XIAOPING, BUT LI AND OTHER POTENTIAL CONTENDERS IN CHINA'S IMMINENT' SUCCESSION STRUGGL STUDIOUSLY AVOIDED OVER-COAMITMENT TO EITHER SIDE OF THE COMMUNIST PARTY'S FACTIONAL SPLIT BETHEEN HARDLINERS AHD REFORMISTS. IN HIS SPEECH, LI REHASHED SEVERAL OF DENG'S LATEST CROP OF REFORMIST CATCH PHRASES. BUT HE CONSPICUOUSLY OMITTED MANY OF THE PATRIARCH'S MORE POINTED PRONOUNCEMENTS HE FAILED TO CRITICIZE "LEFT DEVIATIONISM," WHICH THE RULING PARTY HAD ALREADY OFFICIALLY PRONOUNCED TO BE MORE DANGEROUS THAN THAT OF THE RIGHT. HE BALKED AT ENDORSING DENG'S $10 \%$ GNP GROHTH-RATE TARGET. AND HE DROPPED DENG'S COMMITMENT TO "A HUNDRED YEARS" OF REFORM. AT THE SAME TIME, LI HENT OUT OF HIS WAY TO REASSERT HARDLINE LEFTIST POSITIONS THAT ARE REPORTEDLY ANATHEMA TO DENG.

05070 KAYE, L.

UNCERTAIN PATRIMONY

FAR EASTERN ECONOMIC REVIEW, 155(43) (OCT 92), 10-12. ALTHOUGH CHINA'S PARAMOUNT LEADER DENG XIAOPING SUCCEEDED IN GETTING HIS THEORY OF "SOCIALISM WITH CHINESE CHARACTERISTICS" ENSHRINED DURING THE COMMUNIST PARTY'S 14TH CONGRESS, IT REMAINS UNCERTAIN WHETHER THE FUTURE OF HIS ECONOMIC REFORMS HAS BEEN ASSURED AFTER HIS DEATH. OVERALL, NEARLY HALF OF THE PARTY CENTRAL COMMITTEE'S 309 FULL AND ALTERNATE MEMBERS WERE NEW FACES, MOSTLY YOUNG AND MIDDLEAGED TECHNOCRATS. THE POLITBURO SHED EIGHT ELDERLY MEMBERS 
AND ADDED 14 UP-AND-COMING YOUNGER OFFICIALS, INCLUDING PARTY SECRETARIES FROM COASTAL CITIES AND PROVINCES THAT HAVE BEEN IN THE VANGUARD OF ECONOMIC REFORM. HOWEVER, SOME OBSERYERS NOTE THAT THE LARGE NUMBER OF NEW APPOINTEES DOES THE POLICY INCLINATIONS OF MANY ARE UNKNOWN. FURTHERMORE, THE FACT THAT DENG FAILED TO OUST HARD-LINE CONSERVATIVES INCLUDING PREMIER LI PENG AND PARTY SECRETARY JIANG ZEMIN INDICATES THAT HIS VICTORY WAS NOT COMPLETE.

05071 KEALEY, G.S

THE SURVEILLANCE STATE: THE ORIGINS OF DOMESTIC INTELLIGENCE AND COUNTER-SUBVERSION IN CANADA, 1914-21 INTELLIGENCE AND NATIONAL SECURITY, $7(3)$ (JUL 92), 179-210. THERE HAS BEEN A LACK OF HISTORICAL SCHOLARSHIP ON THE ROYAL CANADIAN MOUNTED POLICE (RCMP) AND ITS SUCCESSOR ROYAL CANADIAN MOUNTED POLICE (RCMP) AND ITS SUCCESSOR
AGENCY, THE CANADIAN SECURITY INTELLIGENCE SERVICE (CSIS). AGENCY, THE CANADIAN SECURITY INTELLIGENCE SERVICE
HOWEVER, RECENT LAWS HAVE ENABLED SCHOLARS TO ACCESS HOWEVER, RECENT LAWS HAVE ENABLED SCHOLARS TO ACCESS
PREVIOUSLY UNAYAILABLE INFORMATION ON THE SUBJECT. THIS ART ICLE ARGUES THAT THE TIME HAS ARRIVED FOR A RE-

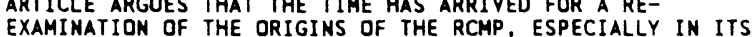
EXAMINATION OF THE ORIGINS OF THE RCMP, ESPECIALLY IN ITS SECURITY SERVICE, AND FOR A RECONSIDERATION OF THE ROLE THE
CANADIAN STATE HAS PLAYED IN THE AREA OF SURVEILLANCE AND CANADIAN STATE HAS PLAYED IN THE AREA OF SURVEILLANCE
COUNTER-SUBVERSION IN THE THENTIETH CENTURY. SPECIAL COUNTER-SUBVERSION IN THE TWENTIETH CENTURY. SPECIAL
EMPHASIS IS PLACED ON THE RELATIONSHIP BETHEEN THE BIRTH OF THE NEW RCMP AND THE CANADIAN LABOR REVOLT.

05072 KEANE, A.D.

FEDERAL REGULATION OF SOLID WASTE REDUCTION AND RECYCLING HARVARD JOURNAL OF LEGISLATION, 29 (1) (WIN 92), 251-279. REAUTHORIZATION OF THE RESOURCE CONSERVATION AND RECOVERY ACT (RCRA), WHICH EXPIRED IN 1988, IS ONE OF THE TOP PRIORITIES OF THE 102ND CONGRESS. ALTHOUGH RCRA IS THE NATION'S PRIMARY STATUTE GOVERNING BOTH SOLID AND HAZARDOUS WASTE MANAGEMENT PRACTICES, THE MAJOR FOCUS OF REGULATIONS ISSUED TO IMPLEMENT RCRA SINCE THE EARLY 1980'S HAS BEEN ON HAZARDOUS WASTE. BY CONTRAST, SOLID WASTE REGULATION HAS BEEN LEFT ALMOST EXCLUSIVELY' TO MUNICIPALITIES AND STATES.

05073 KEANE, J.

DEMOCRACY AND THE MEDIA-WITHOUT FOUNDATIONS

POLITICAL STUDIES, 40 (1992), 116-129

IN EXPLORING WHETHER OR NÓT THE FREE AND EQUAL COMAUNICATION OF CITIZENS IS A FEASIBLE IDEAL AT THE END OF COMMUNICATION OF CIIIZENS IS A FEASIBLE IDEAL AT THE END OF THE THENTIETH CENTURY, THIS ARTICLE PRESENTS A NEW ACCOUN OF THE IMPORTANCE OF THE MEOIA TO DEMOCRACY. IT OFFERS COMMUNICATIONS, IN A RISK-RIDOEN SOCIETY AND SPELLS OUT THE COMMUNICATIONS, IN A RISK-RIDOEN SOCIETY, AND SPELLS OUT THE IMPLICATIONS OF THESE ARGUMENTS FOR CONVENTIONAL VIEHS OF DEMOCRACY. AFTER CONSIDERING AND REJECTING FOUNDATIONALIST AND RELATIVIST ACCOUNTS OF DEMOCRACY, IT OFFERS A NOVEL
CONCEPTION OF DEMOCRACY AS A PROJECT OF FLEXIBLY CONTROLLING CONCEPTION OF DEMOCRACY
THE EXERCISE OF POHER.

05074 KEARNEY, R.; SHEEHAN, R.

SUPREME COURT DECISION MAKING: THE IMPACT OF COURT COMPOSITION ON STATE AND LOCAL GOVERMMENT LITIGATION THE JOURNAL OF POLITICS, 54(4) (NOV 92), 1008-1025. THIS ARTICLE EXAMINES THE PARTICIPATION AND SUCCESS RATES OF STATE AND LOCAL GOVERNMENTS BEFORE THE U.S. SUPREME COURT DURING 1953-1989. THE AUTHORS FIND THAT THEY HAVE EXPERIENCED GREATER ACCESS TO THE COURT OVER TIME, AND THAT THEY HAVE BEEN WINNING AN INCREASINGLY HIGHER PROPORTION OF CASES WHEN APPEARING AS DIRECT PARTIES, WITH SOME INTERESTING VARIATIONS DEPENDING ON THE TYPE OF CASE AND LITIGANTS. TIME-SERIES ANALYSIS INDICATES THAT THE MOST IMPORTANT FACTOR IN STATE AND LOCAL SUCCESS IS THE INCREASINGLY CONSERVATIVE IDEOLOGY OF THE COURT FROM THE WARREN YEARS TO THE REHNOUIST COURT AN EXCEPTION TO IMPROVED PERFORMANCE IS FEDERALISM CASES. THE FINDINGS HAVE IMPLICATIONS FOR THE FUTURE CHARACTER OF AMERICAN FEDERALISM AND THE DEVELOPMENT OF A GENERAL MODEL OF JUDICIAL DECISION MAKING.

05075 KEARNS, A.

AFFORDABILITYY FOR HOUSING ASSOCIATION TENANTS: A KEY ISSUE FOR BRITISH SOCIAL HOUSING POLICY

JOURNAL OF SOCIAL POLICY, 21(4) (OCT 92), 525-549.

AS A RESULT OF CHANGES TO THE FINANCIAL REGIME FOR HOUSING ASSOCIATIONS, AFFORDABILITY HAS BECOME A MAJOR CONCER IN SOCIAL RENTED HOUSING IN BRITAIN. THIS PAPER CONCERN IN SOCIAL RENTED HOUSING IN BRITAIN. THIS PAPER
ASSESSES THE IMPLICATIONS OF TRYING TO CONSTRUCT A FINANCE SYSTEM FOR HOUSING ASSOCIATIONS BASED ON A REGIME OF SYSTEM FOR HOUSING ASSOCIATIONS BASED ON A REGIME OF
"AFFORDABLE RENTS" AND THE "SAFETY NET" OF HOUSING BENEFITS "AFFORDABLE RENTS" AND THE "SAFETY NET" OF HOUSING BENEFITS BUT WITH THE STATE DECLINING TO DEFINE THE CENTRAL CONCEPT OF AFFORDABILITY. USING EXAMPLES FROM A NUMBER OF WESTERN GOVERMMENT'S PRESENT POSITION IS CRITICIZED, AND A ROUTE OUT GOVERMMENT'S PRESENT POSITION IS CRITICIZED, AND A ROUTE OUT
OF THE POLICY VACUUM IS SUGGESTED BASED ON THE PREMISE THAT OF THE POLICY VACUUM IS SUGGESTED BASED ON THE PREMISE
HOUSING IS A MEANS RATHER THAN AN END, HITHIN A BROADER SOCIAL POLICY. GIVEN THE POLITICAL CONSTRAINTS, ONE SOLUTION LIES IN STUDIES OF THE EXPENDITURE PATTERNS AND STANDARDS OF LIVING OF DIFFERENT GROUPS OF HOUSING ASSOCIATION TENANTS AND IN THE CREATION OF A SECTOR-SPECIFIC ORGANIZATIONAL
SUBSIDY IN ADOITION TO THE USUAL PRODUCER AND CONSUMER SUBSIDIES.

05076 KEARNY, E.; HEINEMAN, $R$.

SCENARIO FOR A CENTRIST REVOLT: THIRD PARTY PROSPECTS IN A TIME OF IDEOLOGICAL POLARIZATION

PRESIDENTIAL STUDIES QUARTERLY, 22(1) (WIN 92), 107-118. THE IMPLICATIONS OF THE IMPACT OF THE IDEDLOGICALLY SPECIFIC CANDIDACIES OF PAT ROBERTSON AND JESSE JACKSON IN THE 1988 PRESIDENTIAL NOMINATIONS CAMPAIGN ARE EXPLORED. THE THAN PRAGMATIC CANDIDATES IS EXAMINED. THE PAPER CONCLUDES WITH A DESCRITPION OF HOW THE POLITICAL CENTER MIGHT ORGANIZE TO PROTECT ITSELF AND ITS TRADITION OF FLEXIBLE IN TIMES OF CRISIS.

05077 KEARSLEY, H.

RETHINKING MARITIME POWER THEORY COMPARATIVE STRATEGY, 11(2) (1992), 195-212.

IN LIGHT OF THE END TO THE COLD WAR A NEW LOOK AT THE CONCEPTS SURROUNDING MARITIME POWER AND THOSE COUNTRIES THAT USE IT IS REQUIRED. THE REFOCUSING OF MAVAL THEORY SO AS TO INCLUDE MOST OF THE INTERNATIONAL COMMUNITY IS THE DRIVING FORCE BEHIND THE CREATION OF AN INPUT/OUTPUT MODEL OF MARITIME POHER. THIS ARTICLE DISCUSSES AN INPUT-OUTPUT DIAGRAM. THE INPUTS ARE BROKEN INTO THREE MAJOR AREAS: PHYSICAL, ECONOMIC, AND POLITICAL.

05078 KEATING, M.

LOCAL ECONOMIC DEVELPMENT POLITICS IN FRANCE

JOURNAL OF URBAN AFFAIRS, 13(4) (1991), 443-460.

LOCAL DEVELOPMENT POLICY IN FRANCE FOR MUCH OF THE POSTWAR ERA HAS DOMINATED BY THE CENTRAL STATE. THE DECENTRALIZATION PROGRAM OF THE 1980S INCREASED LOCAL THEM SINCE THE LATE 1980S THE CENTRAL STATE HAS BEEM TRYING TO REINTEGRATE LOCAL DEVELOPMENT INITIATIVES INTO NATIONAL ECONOMIC POL ICY. CAPITAL MOBILITY HAS INTENSIFIED NATIONAL ECONOMIC POLICY. CAPITAL MOBILITY HAS INTENSIFIED INTERURBAN COMPETITION FOR DEVELOPMENT IN FRANCE, YET THE
ROLE OF THE CENTRAL STATE AND THE POSITION OF A POWERFUL ROLE OF THE CENTRAL STATE AND THE POSITION OF A POWERFUL LOCAL ELECTED ELITE INTEGRATED INTO NATIONAL POLITICS GIVE
FRENCH LOCAL DEVELOPMENT POLITICS A DIFFERENT CHARACTER FROM FRENCH LOCAL DEVELOPMENT POL
THAT FOUND IN NORTH AMERICA.

05079 KEATING, M.

REGIONAL AUTONOMY IN THE CHANGING STATE ORDER: A FRAMEHORK OF ANALYSIS

REGIONAL POLITICS \& POLICY, 2(3) (FAL 92), 45-61.

NEW FORMS OF REGIONALISM AND NATIONALISM ARE EMERGING WHICH CANNOT BE ACCOMMODATED WITHIN THE FAMILAR CATEGORIES. THE CHANGING NATURE OF BOTH THE STATE AND THE INTERNATIONAL
ORDER OPENS UP NEW POSSIBILTIES AND FORMULAS FOR TERRITORIAL ORDER OPENS UP NEW POSSIBILTIES AND FORMULAS FOR TERRITORIAL AUTONOMY. THIS ART ICLE SKETCHES OUT A FRAMEHORK OF ANALYSIS AND NORTH AMERICA. IT EXAMINES THE BASIS AND FUNCTIONS OF THE NATION STATE AND THE WAY IN WHICH THESE ARE CHANGING IN THE CONTEMPORARY WORLD. IT ALSO EXAMINES THE GROWTH OF INTERNATIONAL REGIMES, FOCUSING ON THE EC AND NAFTA AND THE EFFECT OF THESE ON THE STATE AND ITS ABILITY TO MANAGE TERRITORY. IT BRIEFLY CONSIDERS THE WAY IN WHICH THE NEW CONJUNCTURE ALTERS THE TERMS OF SOME QUESTIONS WHICH HAVE FUELED THE DEMAND FOR THE TERRITORIAL AUTONOMY. FINALLY, IT EXAMINES SOME OF THE FACTORS WHICH MIGHT EQUIP TERRITORIES TO ESTABLISH THEIR AUTONOMY IN THE NEH CONTEXT,

05080 KEATING, M.

THE CATALAN ELECTIONS OF MARCH 1992

REGIONAL POLITICS \& POLICY, 2(3) (FAL 92), 94-99.

THE FOURTH ELECTIONS TO THE AUTOMOMOUS PARLIAMENT OF CATALONIA ON 15 MARCH 1992 PRODUCED THE FOURTH SUCCESSIVE VICTORY FOR JORDI PUJOL'S CONVERGENICA I UNIO. WITH HIS DISTINCTIVE BLEND OF CENTRE-RIGHT CHRISTIAN DEMOCRACY AND ANOTHER FOUR YEARS OF POWER TO GIVE HIM AN UNBROKEN REIGN OF 16 YEARS. THIS ARTICLE EXAMINES THE PARTIES, THE CAMPAIGN AND THE RESULTS.

05081 KEATING, $S$.

WHO'S IN CHARGE?

INSIGHT, 7(14) (APR 91), 48-49.

A MULTIIFACETED RUMOR' IS CIRCULATING THROUGH THE INTERNATIONAL INTELLIGENCE COMMUNITY THAT SOVIET LEADER INTERNATIONAL INTELLIGENCE COMMUNITY THAT SOVIET LEADER HARD - L INERS AND IS NOW A MERE PUPPET TO THEIR DEMANDS HARD-LINERS AND IS NOW A MERE PUPPET TO THEIR DEMANDS. EVIDENCE SUPPORTING THIS RUMOR INCLUDES: TOP-FLIGHT MIL PERSONNEL WEARING FATIGUES AND PICKING POTATOES;
AMBIGUOUS KREMLIN POLICY TOHARO THE BALTICS; AND AMBIGUOUS KREMLIN POLICY TOWARD THE BALTICS; AND GORGBACHEV'S MOVING TO THE RIGHT ON ECONOMIC AND SECURITY ISSUES. IN ADDITION, THE RESIGNATION OF EDUARD SHEVARDNADZE, KREMLIN, AND THE VIRTUAL ABANDONING OF THE 500-DAY ECONOMIC REFORM PLAN POINTS TO A DRAMATIC CHANGE OF COURSE. OBSERVERS POSTULATE THAT THE KEY DATE OF CHANGE MAY HAVE BEEN NOVEMBER $7,1990$. 
05082 KEATING, W.; KRUMHOLZ, N.; PERRY, D. THE 90-YEAR WAR OVER PUBLIC POWER IN CLEVELAND JOURNAL OF URBAN AFFAIRS, $13(4)(1991), 397-418$.

MANY AMERICANS HAVE THEIR OWN MUNICIPAL POHER SYSTEMS BUT NONE HAS HAD TO WITHSTAND THE KIND OF SUSTAINED AND OFTEN BITTER STRUGGLE OVER ITS EXISTENCE AS CLEVELAND. AFTER REVIEWING THE DEBATE OVER MUNICIPAL POWER IN A NUMBER OF U.S CITIES, THE AUTHORS TRACE THE CONFLICT BETHEEN PUBLIC AND PRIVATE POWER SYSTEMS IN CLEVELAND OVER THE PAST 90 YEARS. THE ECONOMIC, LEGAL, AND POLITICAL ASPECTS OF PUBLIC V.
PRIVATE MUNICIPAL POWER ARE REVIEWED AND ANALYZED. THE AUTHORS SUGGEST THAT THE CLEVELAND EXPERIENCE MAY PROVIDE GUIDANCE TO OTHER CITIES CURRENTLY CONSIDERING THE ESTABLISHMENT OF THEIR OWN MUNICIPAL POWER SYSTEMS. THEY CONCLUDE THAT THE MOST COMPELLING REASON FOR MUNICIPAL OWNERSHIP IS THE INFUSION OF DEMOCRATIC CONTROL.

05083 KEBSCULL, H.

POLITICAL CORRUPTION: MAKING IT THE "SIGNIFICANT OTHER" IN POLITICAL CORRUPTION

PS: POLITICAL SCIENCE AND POLITICS, 25(4) (DEC 92 ), 705-709.

DESPITE THE PREVALENCE OF REAL AND PRESUMED CORRUPTION AND SCANDAL, POLITICAL SCIENTISTS HAVE NOT PLACED A HIGH PRIORTIY ON THE SYSTEMATIC ANALYSIS OF THESE TOPICS OR THEIR INJECTION INTO STANDARD TEXTBOOKS AND COURSES ON AMERICAN OR FOREIGN GOVERNMENTS AND POLITICS. HARVEY KEBSCHULL SUGGESTS THAT IF STUDENTS OF POLITICS ARE TO ACHIEVE A MORE ACCURATE UNDERSTANDING OF POLITICS, THEY NEED TO HAVE AN APPRECIATION OF THE CAUSES AND CONSEQUENCES OF SCANDAL AND CORRUPIION AS WELL AS OF THE FORMAL INSTITUTIONS AND PROCESSES OF GOVERNMENT AND POLITICS. HE EXAMINES THE PERVASIVENESS OF SCANDAL AND CORRUPTION.

05084 KECHICHIAN, J.

POLITICAL REFORMS IN KUWAIT AND THE GCC STATES

MIDDLE EAST INSIGHT, 8(2) (SEP 91), 40-43.

IN THE WAKE OF THE GULF WAR, IT MAY BE USEFUL TO ASK WHETHER POLITICAL REFORMS WILL BE INTRODUCED IN KUHAIT AND THE GULF COOPERATION COUNCIL (GCC) STATES, IF HUMAN RIGHTS WILL BE RESPECTED, AND GENUINE SOCIAL PARTICIPATION ENCOURAGED. IF THE "TRIALS" OF IRAQI COLLABORATORS IN KUWAIT ARE ANY INDICATION, REAL REFORMS MAY NOT BE AS FORTHCOMING AS MANY HOPED FOR, OR, SHOULD THEY BE INTRODUCED, MAY BE AS MANY HOPED FOR, OR, SHOULD THEY BE INTRODUCED, MAY BE
MORE GRADUAL THAN ANTICIPATED. DESPITE THE HORRIFIC RECORD MORE GRADUAL THAN ANTICIPATED. DESPITE THE HORRIFIC RECORD
OF THE GULF WAR, AND THE TREMENDOUS INTERNATIONAL PRESSURES OF THE GULF WAR, AND THE TREMENDOUS INTERNATIONAL PRESSURES IMPOSED ON THE AL-SABAH RULING FAMILY TO RESCIND SOME OF
MOST OBTUSE POLICIES, PRECIOUS LITTLE HAS CHNAGED SINCE MOST OBTUSE POLICIES, PRECIOUS LITTLE HAS CHNAGED SINCE FEBRUARY 27, 1991. STILL, THE GULF WAR PRESENTED A RAR
OPPORTUNITY FOR THE GCC STATES TO INTRODUCE EFFECTIVE POLITICAL REFORMS AIMED AT LIBERATING BOTH POPULATIONS AND RULERS FROM DEEPLY INGRAINED SERATING BOTH POPULATI RULERS FROM DEE
RESTRICTIONS

05085 KECK, M.

BRAZIL: IMPEACHMENT

REPORT ON THE AMERICAS, 36(3) (DEC 92) 4-7

UNDONE BY CHARGES OF CORRUPTION AND INFLUENCE PEDOLNG,

BRAZILIAN PRESIDENT FERNANDO COLLOR DE MELO HAS BEEN

IMPEACHED AND FACES TRIAL BY THE BRAZILIAN SENATE. THIS

ARTICLE EXPLORES: WHY THIS HAS OCCURED SINCE CORRUPTION AND INFLUENCE PEDOL ING IN BRAZIL ARE NOTHING NEH: WHAT SPARKED THE MASSIVE DEMONSTRATIONS CALLING FOR IMPEACHMENT; AND WHY COLLAR WAS UNABLE TO CD-OPT ENOUGH CONGRESSIONAL SUPPORT TO SURVIVE THE CRISIS. IT CONCLUDES THAT IT REMAINS TO BE SEEN WHETHER OR NOT BRAZILIANS WILL SEIZE THIS RARE OPPORTUNITY TO LOOK BEYOND THIS PARTICULAR DRAMA TOHARDS MORE SHEEPING REFORM.

05086 KECK, M.

BRAZIL'S PT: SOCIALISM AS RADICAL DEMOCRACY

REPORT ON THE AMERICAS, 25(5) (MAY 92) 24-29.

THE WORKERS PARTY (PT) OF BRAZIL IS THE MOST IMPORTANT NEW POL ITICAL PARTY TO FORM ON THE LEFT IN LATIN AMERICA IN THE LAST QUARTER OF A CENTURY. THE PT'S EFFORTS TO BUILD SOCIALISM BY EXTENDING DEMOCRACY TO THE EXCLUDED HAS MET WITH GREAT SUCCESS. HINNING POL ITICAL OFFICE AND GOVERNING ARE CENTRAL TO ITS GRASSROOTS STRUGGLE. THE PARTY FACES THE CHALLENGE OF SOCIAL EQUALITY WITH A SIGNIFICANT ADVANTAGE, HAYING RECOGNIZED AND LEARNED FROM ITS OWN EXPERIENCE THAT HAVE EFFORT TO RETHINK LEARNED FROM ITS OWN EXPERIENCE THAT THE EFFORT TO RETHINK SOCIALISM IS INEXTRICAB

05087 KEDOURIE, E.

IRAQ: THE MYSTERY OF AMERICAN POLICY

COMMENTARY, $91(6)$ (JUN 91 ), 15-19.

THIS ARTICLE ARGUES THAT RESPONSIBILITY FOR THE CRISIS WHICH ERUPTED WITH THE INVASION OF KUWAIT ON 2 AUGUST, 1990, LIES HEAVILY ON THE POLICIES THAT VARIOUS POWERS CHOSE TO FOLLOH VIS-A-VIS IRAQ. ABOVE ALL, THE UNITED STATES, WHICH CAME TO BE THE PREDOMINANT POWER IN THE AREA AND HHICH, POSSIBLY AS EARLY AS 1980, DURING THE DYING DAYS OF THE CARTER ADMINISTRATION, BEGAN ITS "TILT" TOWARD SADDAM
HUSSEIN, IS RESPONSIBLE FOR THE GULF CRISIS. THE INORDINATE FEAR OF IRANIAN-LED ISLAMIC FUNDHANTALISM LED THE UNITED STATES TO SIDE WITH IRAQ, AND TO CONTINUE TO SUPPORT SADDAM HUSSEIN DESPITE HIS BRUTALITY AGAINST HIS OHN PEOPLE AND HIS THINLY-VEILED DESIGNS ON THE PERSIAN GULF. UNFORTUNATELY, THE UNITED STATES HAS APPARENTLY NOT LEARNED FROM EXPERIENCE. ITS FAILURE TO DELIVER THE KNOHCKOUT BLOH TO SADOAM HUSSEIN AND ITS POLICIES WHICH ALLOW HUSSEIN TO USE HELICOPTERS AND TANKS AGAINST HIS OWN PEOPLE ARE SIGNS THAT THE UNITED STATES REMAINS COMMITTED TO THE "INTEGRITY OF THE IRAQI STATE,"

$05088 \mathrm{KEE}, \mathrm{J} . \mathrm{E}$.; SHANNON, J.

THE CRISIS AND ANTICRISIS DYNAMIC: REBALANCING THE AMERICAN FEDERAL SYSTEM

PUBLIC ADMINISTRATION REVIEW, 52 (4) (JUL 92), 321-329. FOCUSING ON DYNAMIC CHANGES GENERATED BY PERIODS OF CRISIS AND ANTI-CRISIS, THE AUTHORS EXPLAIN THE EBB AND FLOW OF POWER AND RESPONSIBILITY IN THE U.S. FEDERAL SYSTEM. OF POWER AND RESPONSIBILITY IN THE U.S. FEDERAL SYSTEM. OURING TIMES OF NATIONAL CRISIS, SUCH AS WAR, GOVERNMENTAL MAJOR INITIATIVES EMERGE, WHILE STATES AND LOCALITIES ARE LESS ACTIVE. DURING PEACETIME. THE OPPOSITE TENDENCIES AND TREMDS TAKE HOLD TRENDS TAKE HOLD, GENERATING CONSIDERABLY MORE ACTIVITY IN STATES AND LOCALITIES THAN IN WASHINGTON. THE AUTHORS APPLY THIS MODEL TO THREE MAJOR PHASES IN THE HISTORY OF AMERICA
FEDERALISM, PAYING SPECIAL ATTENTION TO THE MOST RECENT FEDERALISM, PAYING SPECIAL ATTENT ION TO THE NOST RECENT PERIOD IN WICH THE FEDERAL GOVERNHENT RETAINS LEADERSHP REGULATORY AND SOCIAL INSURANCE AREAS WHILE STATES AND LOCALITIES CONSTANTLY REACT TO FISCAL PRESSURES. THE AUTHORS DISCUSS THE IMPLICATIONS OF THIS EXPLANATION AND THE CURREMT CRISES AT THE STATE-LOCAL LEVEL AND TOO FEW AT THE CENTRAL LEVEL.

05089 KEECH, $H$.

RULES, DISCRETION, AND ACCOUNTABILITY IN MACROECONOMIC POL ICYMAKING

GOVERNANCE, 5(3) (JUL 92), 259-278.

ARGUMENTS FOR RULES RATHER THAN DISCRETION IN THE MACROECONOMIC POLICYMAKING FACILITATE THE UNDERSTANDING OF SOME FUNDAMENTAL ISSUES OF DEMOCRATIC THEORY. THIS ARTICLE REVIEWS FOUR SUCH ARGUMENTS, AND RELATES THEM TO ISSUES OF DELEGATION AND ACCOUNTABILTIY IN REPRESENTATIVE GOVERNMENT.

05090 KEEL, JR., E.

TOWARD A'NEH NATIONAL DEFENSE STRATEGY: POLICING THE BATTLEFIELDS OF THE COLD WAR

COMPARATIVE STRATEGY, 11(4) (DEC 92), 357-372.

THE ABRUPT ENDING OF THE COLD WAR HAS LEFT A VACUUM IN OUR STRATEGIC THINKING. OUR INSTRUMENTS OF STATECRAFT CONTINUE TO BE INFLUENCED BY OBSOLETE PARADIGMS AND OUTMODED INSTITUTIONS THAT ARE WASTEFUL AND COUNTERPRODUCTIVE. NEW WAYS OF STRUCTURING OUR FOREIGN RELATIONS AND, PARTICULARLY OUR DEFENSE ESTABLISHMENT MUST BE FOUND. WE MUST FIND THE LEADERSHIP TO FORMULATE AND ARTICULATE A NEW VISION OF AMERICA'S ROLE IN THE NEH HORLD ORDER.

05091 KEENES, E.

REARRANGING THE DECK CHAIRS: A POLITICAL ECONOMY APPROACH TO FOREIGN POLICY MANAGEMENT IN CAMADA

CAMADIAN PUBLIC ADMINISTRATION, 35(3) (FAL 92), 381-401.

THE AUTHOR REVIEWS THE 1982 REORGANIZATION DF THE CANADIAN GOVERMMENT'S INSTITUTIONS AND PROCESSES OF FOREIGN ECONOMIC POLICY. HE ARGUES THAT THE REORGANIZATION IS MOST FRUITFULLY SEEN AS A RESPONSE TO CHANGES IN THE INTERNATIONAL POLITICAL ECONOMY AND AN ATTEMPT TO LINK
FOREIGN ECONOMIC POLICY TO DOMESTIC INDUSTRIAL STRATEGY.

05092 KEENLEYSIDE, T.; GATTI, P.

STILL THE GREAT HHITE BLANK? CANADA IN THE AMERICAN, BRITISH AND FREMCH PRESS

AMERICAN REVIEN OF CANADIAN STUDIES, 22(1) (SPR 92), 39-64. THE PURPOSE OF THIS STUDY IS TO EXPLORE THE IMAGE OF CANADA PRESENTED BY THE PRESS OF THE UNITED STATES, BRITAIN, AND FRANCE, THREE COUNTRIES WHICH, IN VIEW OF THEIR MULTIFACETED HISTORICAL AND CONTEMPORARY TIES TO CANADA, MIGHT BE EXPECTED TO GIVE IT RELATIVELY EXTENSIVE AND SYMPATHETIC ATTENTION. THE STUDY IS AL SO USEFUL IN SHEDDING LIGHT ON THE IMPACT, IF ANY, OF THESE DEVELOPMENTS ON THE LEVEL AND CHARACTER OF THE U.S. PRESS ATTENTION TO CANADA. FINALLY IN CONTRAST WITH EARLIER ANALYSES, THIS ONE OFFERS THE READERS OF THE INTERNATIONAL PRESS.

05093 KEEP, J.

ZHELEZZNOVOOSK AND AFTER: TOWARDS A NEW RUSSO-GERMAN RELATIONSHI

EAST EUROPEAN QUARTERLY, XXVI(4) (WIN 92), 431-446.

IN JULY 1990, GERMAN CHANCELLOR HEL MUT' KOHL AND SOVIET PRESIDENT MIKHAIL GORBACHEV CONCLUDED NEGOTIATIONS THAT ALLOHED THE SUBSEQUENT "THO PLUS FOUR" TALKS TO PRDCEED SMOOTHLY AND BROUGHT ABOUT THE PEACEFUL REUNIFICATION OF 
GERMANY. IN THE TWO YEARS SINCE THESE NEGOTIATIONS ADDITIONAL SEISMIC SHOCKS HAVE OCCURRED--MOST NOTABLY, THE COLLAPSE OF THE SOVIET UNION. THIS HAS PRESENTED BONN WITH THE PROBLEM OF REDEFINING ITS RELATIONS WITH THE SUCCESSOR STATES, INCLUDING RUSSIA, UKRAINE, AND THE BALTIC REPUBLICS. IN TURN, YELTSIN'S RUSSIAN GOVERNMENT HAS HAD TO DEVISE FROM SCRATCH A NEW FOREIGN POLICY CONCEPT, IN WHICH GERMANY INEVITABLY OCCUPIES A CENTRAL PLACE, TO THE CONSTERNATION OF THE LEFT-CONSERYATIVE AND NATIONALIST ELEMENTS.

05094 KEFFER, S.; KING, S.; KRAFT, S PROCESS PHILOSOPHY AYO MIMIMALISM: IMPLICATIONS FOR PUBLIC POLICY

ENVIRONMENTAL ETHICS, 13(1) (SPR 91), 23-48,

THIS PAPER IS AN INVESTIGATION OF' THE IMPLICATIONS OF PROCESS PHILOSOPHY FOR ENYIRONMENTAL PUBLIC POLICY FROM THE PERSPECTIVES OF AN ECONOMIST, A ZOOLOGIST, AND A PHILOSOPHER USING PROCESS PHILOSOPHY, ESPECIALLY ITS VIEW OF NATURE AND ITS ETHIC, THEY DEVELOP A PROCESS-BASED ENVIRONMENTAL ETHIC EMBODYING MINIMALISM AND BENEFICENCE. FROM THIS PERSPECTIVE, THEY CRITICIZE THE PHILOSOPHY CURRENTLY UNDERLYING PUBLIC POLICY AND EXAMINE SOME ALTERNATIVE APPROACHES BASED ON PHENOMENOOLOGY AND ETHMOMETHODOLOGY. THEY CONCLUDE THAT PROCESS PHILOSOPHY, MINUS ITS VALUE HIERARCHY, IS A POHERFUL TOOL CAPABLE OF SUPPORTING BOTH RADICAL AND MODERATE CHANGES IN ENVIRONMENTAL POLICY.

05095 KEGLEY, C. JR.; RAYMOND, G.

MUST WE FEAR A POST-COLD WAR MULTIPOLAR SYSTEM?

JOURNAL OF CONFLICT RESOLUTION, 36 (3) (SEP 92), 573-585.

THIS ARITCLE PLACES TWO RECENT EXEMPLARY DEDUCTIVE

MODELS UNDER EXAMIMATION, IN ORDER TO EVALUATE THE VALIDITY

OF THEIR CONCLUSIONS ABOUT THE ALLEGED STABILITY OF THE COLD

WAR'S BIPOLAR COMPETITIVE HORLD RELATIYE TO THAT OF

MUR'S BIPOLAR COMPETITIVE HORLD RELATIVE TO THAT OF

MULTIPOLAR SYSTEMS. A REVIEN OF THE EMPIRICAL EVIDENCE

GENERATED BY INDUCTIVE INVESTIGATIONS OF THIS RELATIONSHIP

MULTIPOLAR SYSTEMS ARE INHERENTLY UNSTABLE WOULD BE

MULTIPOLAR SYSTEMS ARE INHERENTLY UNSTABLE WOULD BE

PREMATURE, AND THAT, IF INTERVENING VARIABLES ARE CONSIDERED, EQUALLY PLAUSIBLE.

05096 KEGLEY, C. JR.

THE LONG POSTHAR PEACE DURING THE COLD hAR: SOME NEH CONVENTIONAL HISDOMS RECONSIDERED

JERUSALEM JOURNAL OF INTERNATIONAL RELATIONS, 14(4) (OEC 92), 1-18.

THE CDLD HAR PERIOO CONSTITUTES THE LONGEST PERIOD OF GREAT-POWER PEACE IN THE MODERN ERA. THE PROSPECTS FOR PRESERVING THIS PEACE IN THE NEH POST-COLD WAR WORLD DEPEND LARGELY ON AN ACCURATE UNDERSTANDING OF ITS NATURE AND CAUSES. THIS ARTICLE QUESTIONS SOME OF THE CONVENTIONAL EXPLANATIONS AND CALLS FOR A MORE ELABORATE THEORETICAL GROUNDING FOR APPROACHING THE PERTINENT ISSUES.

05097 KEHLER, D.

THE TRENTON TEA PARTY: THE STORY OF NEW JERSEY'S TAX REVOLT

POLICY REVIEW, (60) (SPR 92), 46-49.

THE AUTHOR EXPLAINS HOW THE ISSUE OF INCREASED TAXES HAS LED TO A DRAMATIC DECLINE IN PUBLIC APPROVAL OF NEW JERSEY'S GOVERNOR JIM FLORIO.

05098 KEITHLEY, J.

SEX DISCRIMINATION AND PRIVATE INSURANCE: SHOULD SEX DIFFERENCES MAKE A DIFFERENCE?

POLICY AND POLITICS, 20(2) (APR 92), 99-110.

THE AUTHOR ARGUES THAT BRITISH INSURANCE COMPANIES SHOULD ABANDON THEIR POLICY OF CHARGING DIFFERENTIAL
PREMIUMS AND OFFERING DIFFERENT BENEFITS TO WOMEN AND MEN ON PREMIUMS AND OFFERING DIFFERENT BENEFITS TO WOMEN AND MEN ON THE BASIS OF GENDER-SPECIFIC MORBIDITY AND MORTALITY TABLES.
ALTHOUGH THE 1975 SEX DISCRIMINATION ACT (SDA) PERMITS SUCH ALTHOUGH THE 1975 SEX DISCRIMINATION ACT (SDA) PERMITS SUCH PRACTICES, SUBSEQUENT LEGAL JUDGMENTS, PARTICULARLY IN THE
EUROPEAN COURT, HAVE CHALLENGED THEM. THE SPIRIT OF BOTH THE EUROPEAN COURT, HAVE CHALLENGED THEM. THE SPIRIT OF BOTH THE SDA AND RECENT EUROPEAN COMMUNITY LEGISLATION IS TO OUTLAW
UNEOUAL TREATMENT WHICH ARGUABLY REFLECTS UNFAIR, CULTURALLYUNEQUAL TREATMENT WHICH ARGUABLY REFLECTS UNFAIR, CULTURAL
BASED, OR OUTDATED STEREOTYPES ABOUT THE CAPABILITIES AND BASED, OR OUTDATED STEREOTYPES ABDUT THE CAPABILITIES AND NEEDS OF EITHER SEX. IN HER DISCUSSION, THE AUTHOR DRA

05099 KELEGAMA, S

LIBERALIZATION AND INDUSTRIALIZATION: THE SRI LANKAN EXPERIENCE OF THE 1980 S

SOUTH ASIA JOURNAL, 5(3) (JAN 92), 251-288.

SRI LANKA PROVIDES A GOOD CASE' STUDY OF EXPORT-LED INDUSTRIALIZATION. IN 1977 SRI LAMKA MADE A COMPLETE DEPARTURE FROM WHAT HAS UNTIL THEN AN INHARD LOOKING REGIME AFFLICTED WITH SEVERE FOREIGN EXCHANGE SHORTAGES AND SLOW ECONOMIC GROWTH. A NEW POLICY PACKAGE FOR EXPORT-LED INDUSTRIALIZATION WAS IMPLEMENTED IN 1977. THIS PAPER TAKES A BROAD LOOK AT THE DEVELOPMENTS IN THE INDUSTRIAL SECTOR DURING THE 1978-89 PERIOD AND OFFERS AN EXPLANATION FOR THE ALSO EXAMINES HOW EFFECTIVE LIBERALIZATION HAS BEEN IN ENHANCING THE INDUSTRIAL GROWTH PROCESS.
05100 KELEHER, E.P.

EMPEROR KARL AND THE SIXTUS AFFAIR: POLITICO-NATIONALIST REPERCUSSIONS IN THE REICH GERMAN AND AUSTRD-GERMAN CAMPS AND THE DISINTEGRATION OF HABSBURG AUSTRIA, 1916-1918 EAST EUROPEAN QUARTERLY, XXVI(2) (SUM 92), 163-184. IN THE FIRST YEAR OF HIS BRIEF REIGN DURING WORLD WAR I, EMPEROR KARL WORKED TIRESLESSLY FOR A PEACE THAT WOULD INSURE THE CONTINUED EXISTENCE OF AUSTRIA-HUNGARY. THE REVELATION OF HIS ROLE IN THE UNSUCCESSFUL SIXTUS NEGOTIATIONS INSPIRED GERMAH NATIONALIST ELEMENTS IN BOTH AUSTRIA AND GERMANY TO ACCUSE THE IMPERIAL FAMILY OF BETRAYING THE GERMAN ALLIANCE IN THE INTEREST OF SELFISH BETRAYING THE GERMAN ALLIANCE IN THE INTEREST OF SELFISH DYNASTIC POLITICS. IN ORDER TO DEHONSTRATE GOOD FAITH TO BERLIN, KARL RELUCTANTLY SUBMITTED AUSTRIA-HUNGARY TO A REVISION OF THE DUAL ALLIANCE, WHICH WAS MORE THAN EVER DOMINATED BY GERMANY. THE APPARENT STRENGTHENING OF THE ALLIANCE DURING GERMANY'S GREAT SPRING OFFENSIVE OF 1918
SEALED THE DOOM OF THE HABSBURG EMPIRE. THE ENTENTE REACTED SEALED THE DOOM OF THE HABSBURG EMPIRE. THE ENTENTE REACTED BY SUPPORTING THE DISSOLUTION OF THE DUAL MONARCHY AND THE INDEPENDENCE OF ITS SLAV SUBJECTS. MEANHHILE, THE GERMANS OF
AUSTRIA GAVE SERIOUS CONSIDERATION TO CLOSER POLITICAL TIES AUSTRIA GAVE SERIOUS CONSIDERA
HITH GERMANY AFTER THE HAR.

05101 KELLEHER, C.M.

THE NEW GERMANY: UNIFICATION ONE YEAR ON

BROOKINGS REVIEW, 10(1) (WIN 92), 18-25

ONE YEAR AFTER FORMAL REUNIFICATION IS FAR TOO EARLY TO DEFINITELY ASSESS THE PROGRESS AND PROBLEMS OF UNIFIED GERMANY. GERMANY'S SECURITY ARRANGEMENTS, ECONOMY, AND DOMESTIC POLITICS ARE EVOLVING RAPIDLY WITHIN EUROPEAN AND ATLANTIC FRAMEHORKS THAT ARE THEMSELVES IN FLUX. BUT THE DIMENSIONS OF LONGER-TERM NATIONAL POLICY ARE ALREADY IMPLICATIONS AND COSTS OF GERMAN REUNIFICATION.

05102 KELLER, A.

ISRAEL, THE U.S. AND THE PEACE PROCESS

NEW POLITICS, 3(4) (WIN 92 ), $12-18$.
AT THE BEGINNING OF 1990, SHAMIR SUCCEEDED IN WRECKING AT THE BEGINNING OF 1990 , SHAMIR SUCCEEDED IN WRECKINC
EFFORTS TO OPEN ISRAELI-PALESTINIAN NEGOIATIONS IN CAIRO. EFFORTS TO OPEN ISRAELI-PALESTINIAN NEGOIATIONS IN CAIRO.
THEN, THE INVASION OF KUHAIT BY IRAQ OIVERTED WASHINGTON'S THEN, THE INVASION OF KUHAIT BY IRAQ DIVERTED WASHINGTON'S
ATTENTION FOR MANY MONTHS. MOREOVER, AMERICAN AID TO ISRAEL ATTENTION FOR MANY MONTHS. MOREOVER, AMERICAN AID TO ISRAEL
IS NOW BECOMING A CONTROVERSIAL ITEM ON THE CONGRESSIONAL IS NOW BECOMING A CONTROVERSIAL ITEM ON THE CONGRESSIONAL AGENDA. THE MOST PRDFOUND EFFECT OF MADRID WAS IN THE OCCUPIED TERRITORIES. THE TEN DAYS OF ISRAELI-ARAB POS
MADRID TALKS IN WASHINTON ENDED WITH NOTHING ACHIEVED.

05103 KELLER, E.J. DROUGHT, WAR, AND THE POLITICS OF FAMINE IN ETHIOPIA ANO

ERITREA
JOURNAL OF MODERN AFRICAN STUDIES, 30(4) (DEC 92), 609-624. POLITICAL DECISIONS EXACERBATED THE CONSEQUENCES OF DROUGHT IN ETHIOPIA AND ERITREA DURING THE MID-1980's, PRODUCING ADDITIONAL FAMINE AND SUFFERING. DESPITE BEING FACED HITH A NATURAL DISASTER OF ENORMOUS PROPORTIONS, THE GOVERMMENT OF THE PEOPLE'S DEMOCRATIC REPUBLIC OF ETHIOPIA CONTINUED TO PURSUE ITS EXPENSIVE, ILL-CONCEIVED SOCIALIST STRATEGY OF DEVELOPMENT, ALONG HITH ITS WAR EFFORTS. THIS LED TO RELIANCE ON FOREIGN RELIEF AID TO REPLACE THE FUNDS THAT WERE BEING SPEND ON MILITARY OBJECTIVES. THE BROADER IMPLICATION OF THESE POLICIES WAS THE PERSISTENCE OF CONDITIONS THAT THREATENED ALL ASPECTS OF NATIONAL AS WELL AS REGIONAL SECURITY AND ULTIMATE

05104 KELLER, L.; PERRY, D.

THE STRUCTURES OF GOVERNMENT; MANAGING LOCAL GOVERMMENT-PUBLIC ADMINISTRATION IN PRACTICE

SAGE PUBLICATIONS, 1991 , 31-58.

THE STRUCTURES OF THE U.S. LoCAL STATE ARE THE

SCAFFOLDING OF GOVERMANCE. THE INSTITUTIOMAL FORM AMD

FOUNDATION OF THE LOCAL PUBLIC AGENCY AND ITS ADMINISTRATION.

THEREFORE, IT IS IMPORTANT TO ARTICULATE THESE STRUCTURES

CLEARLY AND UNDERSTAND THEIR VARIOUS FORMS TO BETTER
THE PROCESS OF LOCAL PUBLIC MANAGEMENT. THIS CHAPTER

THE PROCESS OF LOCAL PUBLIC MANAGEMENT. THIS CHAPTE
OVERVIEWS THE TYPES OF LOCAL GOVERHMENT (COUNTY,

OVERVIEWS THE TYPES OF LOCAL GOVERMMENT (COUNTY,
MUNICIPALITY, TOWN, TOWNSHIP, VILLAGE, AND SPECIAL DISTRICT)

MUNICIPALITY, TOWN, TOWNSHIP, VILLAGE, AND SPECIAL DISTRICT
THAT HAVE BEEN DEVELOPED IN AN ATTEMPT TO MEET A GROWING

TIST OF DEMANDS INCLUDING WELFARE, HOUSING, PUBLIC

LIST OF DEMANDS INCLUDING WELFARE, HOUSING, PUBLIC

EMPLOYMENT, HEALTH SERVICES, EDUCATION, TRANSPORTATION,

PUBLIC UTILITIES, PUBLI
ECONOMIC DEVELOPMENT.

05105 KELLEY, J.

FREE SPEECH/HATE SPEECH: A STUDENT'S VIEW

PEACE \& DEMOCRACY NEWS, $11(2)$ (NIN 92), 39-40.

A COLLEGE STUDENT, JENHIFER KELLEY ARGUES THAT THE ISSUE OF FREE SPEECH PROVIDES THE OPPORTUNITY TO EXAMINE THE APPROPRIATENESS AND EFFECTIVENESS OF EFFORTS TO CURB INTOLERANCE AND HATRED THROUGH SPEECH CODES. THE ACADEMIC COMMUNITY MUST CONTINUE TO SEEK EFFECTIYE MEANS OF DEALING WITH ALL FORMS OF PREJUDICE, HOWEVER, SHE SUGGESTS THAT CONTROLLING SPEECH DOES NOT WORK; NOR WILL IT EVER BE AN 
EFFECTIVE WEAPON AGAINST HATRED AND PREJUDICE. HATRED IS A IGNORANCE AND OF YIOLENT, INTOLERANT ATTITUDES AMD PRACTICES. SHE SUGGESTS THAT WE MUST TAKE ON THE FAR MORE DIFFICULT TASK OF UNDERSTANDING THE ORIGINS OF HATE AND PREJUDICE, AND EXPLORE MORE EFFECTIVE ALTERNATIVES TO SPEECH AND CONDUCT RESTRICTIONS.

05106 KELLOUGH, J.; ELLIOT, E.

DEMOGRAPHIC AND ORGANIZATIONAL INFLUENCES ON RACIAL/ETHNIC AND GENDER INTEGRATION IN FEDERAL AGENCIES

SOCIAL SCIENCE QUARTERLY, 73(1) (MAR 92), 1-12

THIS ARTICLE EXAMINES' SEVERAL THEORETICALLY IMPORTANT DEMOGRAPHIC AND ORGANIZATIONAL INFLUENCES ON THE RACIAL/ETHNIC AND GENDER INTEGRATION OF FEDERAL GOVERNMENT DEPARTMENTS AND AGENCIES. DATA ON 30 GOVERMMENT

ORGANIZATIONS FROM 1982, 1984, 1986, AND 1988 ARE POOLED TO PRODUCE 120 OBSERVATIONS WHICH ARE THEN ANALYZED WITH A GLS REGRESSION PROCEDURE. FINDINGS INDICATE THAT THE VARIABLES ANALYZED EXPLAIN FROM 54 TO 70 PERCENT OF THE VARIATION IN DEPARTMENTAL AND AGENCY WORK FORCE DIVERSITY.

05107 KELLOUGH, J.E.

AFFIRMATIVE ACTION IN GOVERNMENT EMPLOYMENT

AFFIRMATIVE ACTION IN GOVERMMENT EMPLOYMENT

SCIENCE, (523) (SEP 92), 117-130.

THE AUTHOR TRACES THE DEVELOPMENT OF AFFIRMATIVE ACTION POLICY IN EMPLOYMEMT AT THE FEDERAL, STATE, AND LOCAL LEVELS OF GOVERMMENT. HE NOTES RECENT FEDERAL POLITICAL APPOINTMENTS AND DISCUSSES RESEARCH THAT HAS ATTEMPTED TO ASSESS THE EFFECTS OF AFFIRMATIVE ACTION.

05108 KELLY, D.

HOODROW WILSON AND THE CREATION OF CZECHOSLDVAKIA EAST EUROPEAM QUARTERLY, XXVI (2) (SUM 92), 185-207.

FOLLOHING WORLD WAR I, U.S. PRESIDENT WOODROH WILSON ACHIEVED AN ALMOST HEROIC STATURE IN EASTERN EUROPE AND RECEIVED THE ADULATORY PRAISE THAT HE WAS DENIED IN HIS OWN COUNTRY. IN THIS PAPER, THE AUTHOR EXAMINES THE REASONS FOR WILSON'S ACCLAIM IN EAST-CENTRAL EUROPE AND COMPARES THE AMERICAN LEADER'S IMPACT WITH THAT OF NATIVE LEADERS FOCUSING ON THE CASE OF THE CZECHOSLOVAKS FROM 1914 TO 1918.

05109 KELLY, J.

RUNNING INTO THE SAND

NATIONAL REVIEN, XLIII(5) (APR 91), 31-33.

THE SWIFT VICTORY OF COALITION FORCES IN THE GULF NOW LEAVE MAN WONDERIMG ABOUT THE FUTURE OF THE MIDOLE EAST. THE AUTHOR OF THIS ARTICLE ATTACKS TWO COMMONLY-HELD NOTIONS AUTHOR OF THIS ARTICLE ATTACKS TWO COMMONLY-HELD NOTIONS
ABOUT THE REGION: THAT THE GULF CRISIS (AS HELL AS EVERY ABDUT THE REGION: THAT THE GULF CRISIS (AS WELL AS EVERY
OTHER CRISIS) WAS ROOTED IN THE PALESTINIAN PROBLEM AND THE OTHER CRISIS) WAS ROOTED IN THE PALESTINIAN PROBLEM AND THE
FACT THAT INSTABILITY WILL CONTINUE UNTIL THAT PROBLEM IS FACT THAT INSTABILITY WILL CONTINUE UNTIL THAT PROBLEM IS
SOLVED; AND THE IDEA THAT DEMOCRACY HAS A CHANCE IN IRAQ OR SOLVED; AND THE IDEA THAT DEMOCRACY HAS A CHANCE IN IRAQ ELSEWHERE IN A REGION WITH NO DEMOCRATIC MACHINERY OR THE UNITED STATES HAS AT THE MOMENT TO IMPOSE ORDER ON THE THE UNITED STATES HAS AT THE

05110 KELLY, J.

THE EMPIRE STRIKES BACK: THE TAKING OF JOE DOHERTY FORDHAM LAW REVIEN, LXI(2) (NOV 92), 317-400.

IN THIS ARTICLE, THE AUTHOR SUMMARIZES THE EIGHT YEAR DIPLOMATIC AND LEGAL EFFORT TO RETURN JOE OOHERTY, A MEMBER OF THE PROVISIONAL IRISH REPUBLICAN ARMY, FROM THE UNITED STATES TO THE UNITED KINGDOM, WHERE HE HAS WANTED FOR HIS ROLE IN THE DEATH OF A BRITISH SOLDIER AND FOR HIS ESCAPE FROM PRISON. IT RECOUNTS THE UNSUCCESSFUL EFFORTS OF THE UNITED STATES AND THE UNITED KINGDOM TO EXTRADITE DOHERTY, AND THE TWO GOVERMMENTS' RENEGOTIATION OF THEIR EXISTING EXTRADICTION TREATY SO AS TO HAVE ADVERSE RETROACTIVE APPLICATION TO DOHERTY. THE ARTICLE THEN EXAMINES THE SUCCESSFUL EFFORT OF THE UNITED STATES JUSTICE DEPARTMENT TO DEPORT DOHERTY TO THE UNITED KINGDOM.

05111 KELLY, J.B.

CASE STUDY: ARABIAN FRONTIERS AND ANGLO-AMERICAN RELATIONS GOVERNMENT AND OPPOSITION, 27(3) (SUM 92), 368-384.

IN MAY 1933 KING ZBDUL AZIZ IBN SAUD OF SAUDI ARABIA GRANTED AN OIL CONCESSION TO STANDARD OIL COMPANY OF CALIFORNIA, WHICH SET IN MOTION A OISAGREEMENT OVER THE BOUNDARIES OF SAUDI ARABIA THAT INVOLVED WASHINGTON AND LONDON AS WELL AS THE ARABS.

05112 KELLY, M.E.

FREE TRADE: THE POLITICS OF TOXIC WASTE

REPORT ON THE AMERICAS, XXYI (2) (SEP 92) 4-7.

ENVIRONMENTAL ISSUES HAVE MOVED TO THE CENTER OF THE PUBLIC AND CONGRESSIONAL DEBATES OVER THE NORTH AMERICAN FREE TRADE AGREEMENT (NAFTA), WITH MUCH OF THE FOCUS ON THE U.S. -MEXICAN BORDER AREA. CRITICS OF NAFTA IN BOTH THE UNITED STATES AND MEXICO ARE CONCERNED THAT THE TRADE NEGOTIATIONS HAVE BEEN PUT ON A FAST TRACK TO BOLSTER THE POL ITICAL FORTUNES OF PRESIDENTS GEORGE BUSH AND CARLOS SALINAS DE GORTARI. IN THE RUSH TO COMPLETE NAFTA, THE
ADDRESS THE BORDER'S CURRENT ENVIRONMENTAL AND HEALTH PROBLEMS OR TO PROVIDE THE NECESSARY RESOURCES AND INFRASTRUCTURE TO HANDLE WHAT IS EXPECTED TO BE A SIGNIFICANT INCREASE IN U.S. INDUSTRIAL INVESTMENT IN MEXICO UNDER A FREE-TRADE ACCORD.

05113 KELLY, R.M.; HORN, J.D.; SAINT-GERMAIN, M.A. PUBLIC OFFICIALS: A DIFFERENT ANMALS OF THE AMERICAN ACADEMY OF POLITICAL AND SOCIAL SCIENCE, (514) (MAR 91), 77-87.

THE AUTHORS QUESTION THE EXTENT TO WHICH WOMEN IN PUBLIC OFFICE EXHIBIT A DIFFERENT VOICE FROM THAT OF MALE OFFICEHOLDERS. THEY EXPLORE RATIONALES THAT JUSTIFY A DIFFERENT VOICE AS WELL AS HOW THIS DIFFERENCE MANIFESTS ITSELF IN POLITICS. THEN THEY PRESENT A MODEL OF THE DIFFERENT TYPES OF VOICES FEMALE PUBLIC OFFICIALS HAVE EXERCISED. THE RESEARCH INDICATES THAT AS THE NUMBER OF WOMEN IN PUBLIC OFFICE GROWS, INCREASING DIFFERENCES HILL BE SEEN NOT SO MUCH BETHEEN FEMALE AND MALE OFFICEHOLDERS AS AMONG FEMALE OFFICEHOLDERS THEMSELVES. IN THE FUTURE, WOMEN IN PUBLIC OFFICE WILL ADVOCATE A WIDER VARIETY OF' POLICY GOALS AND, AS WOMEN IN PUBIC OFFICE INCREASE IN NUMBER, A REDEFINITION OF THE POL ITICAL HILL EMERGE.

05114 KELLY, S.G.

INTRASTATE NATURAL GAS REGULATION: FINDING ORDER IN THE CHAOS

YALE JOURNAL ON REGULATION, 9 (2) (SUM 92), 355-406,

IN THE MID-1980' $\mathrm{S}$, CUSTOMERS THREATENED TO BYPASS LOCAL GAS DISTRIBUTION COMPANIES IN FAVOR OF OTHER SUPPLIERS AND CHEAPER FUELS. IN RESPONSE, STATES BEGAN TO REFORM THEIR NATURAL GAS REGULATORY POLICIES TO LOWER DELIVERED PRICES TO
POTENTIAL BYPASSERS. IN THIS PAPER, THE AUTHOR ARGUES THAT THE MOST PROMISING MEANS OF REFORM IS TO "UNBUNDLE" TRADITIONAL LOCAL GAS UTILITY SERVICES-THAT IS, TO MAKE GAS TRANSPORTATION SERVICES AVAILABLE TO CUSTOMERS SEPARATELY FROM GAS RETAIL SALES SERVICES. THE AUTHOR OFFERS A SYSTEMATIC REVIEW OF INTRASTATE REGULATORY POLICIES AND OUTLINES THE BEST METHOD OF MAINTAINING OPEN ACCESS TO MARKETS AND RETAINING SUFFICIENT REGULATORY CONTROL OVER LOCAL UTILITY COMPANIES HHILE MAXIMIZING COMPETITION AND MINIMIZING THE ADVERSE EFFECTS OF COST-SHIFTING AND STRANDED INVESTMENT. HE ASSERTS THAT REGULATORY BODIES MUST RECOGNIZE THE COMPETITIVE CHARACTER OF UNBUNDLED GAS RETAILING SERVICE AND THE MONOPOLISTIC NATURE OF BOTH UNBUNDLED GAS

TRANSPORTATION SERVICES AND THE SERVICES THAT REMAIN BUNDLED, IN ORDER TO PROMOTE MOST EFFECTIVELY THE PRIMARY GOAL OF UNBUMDLING: PREYENTION OF UNECONOMIC BYPASS BY PROYIDING MARKET-PRICED NATURAL GAS TO END USERS.

05115 KELMAN. H.

ACKNOWLEDGING THE OTHER'S NATIONHOOD: HOW TO CREATE A MOMENTUM FOR THE ISRAELI -PALESTINIAN NEGOTIATIONS JOURNAL OF PALESTINE STUDIES, 22(85) (FAL 92), 18-38. THAL OF PALESTINE STUDIES, 22 (85) (FAL 92), 18 CEGOTRE IS NOH A GENUT NEGOT IATIONS, ON THE ISRAELI AS WELL AS THE PALESTINIAN THE AUTHOR ARGUES THAT CREATING MOMENTUM REQUIRES A COMMITMENT TO CERTAIN PRINCIPLES THAT INSPIRE HOPE. HE PROPOSES THAT THIS COMMITMENT MIGHT TAKE THE FORM OF MUTUAL ACKNOWLEDGMENT OF EACH OTHER'S NAT IONHOOD-AN ACKNOWLEDGMENT THAT IS BASED ON PRINCIPLE, THAT IS PHRASED IN SOME WAY THA THE OTHER SIDE FINDS MEAHINGFUL, THAT GOES BEYOND THE HALF HEARTED AMD AMBIGLOUS STATEMENTS MADE HERETOFORE, BUT THAT DOES SO WITHOUT THREATENING THE

05116 KELMAN, $M$

LESSONS OF THE THOMAS AFFAIR

NEW LEADER, LXXIV(12) (NOV 91), 5-7

THIS ARTICLE MAKES A FEW CONCLUSIONS ABOUT LESSONS LEARNED FROM THE CLARENCE THOMAS SUPREME COURT NOMINATION HEARINGS. ONE IS THAT, GIVEN THE JUSTICES' LIFETIME TENURE,
THE COMPOSITION OF THE SUPREME COURT TENDS TO REFLECT A BALANCE OF IDEOLOGICAL BELIEFS HELD OVER SEVERA ADMINISTRATIONS. A PERSISTENT SHIFT IN VOTER IDEOLOGY CAN ULTIMATELY AFFECT THE COURT; YET A RADICAL SHIFT SHOULD OCCUR ONLY WHEN THE "NEW IDEOLOGY" IS SUFFICIENTLY ENTRENCHED TO RESULT IN THE ELECTION OF BOTH A STRING OF LIKE-MINDED CHIEF EXECUTIVES AND A SERIES OF COOPERATIVE SENATES. UNTIL THIS HAPPENS, THE SENATE SHOULD PLAY AN EQUAL ROLE IN THE CHOOSING OF MOMINEES. ANOTHER CONCLUSION IS THAT THE REFUSAL OF BOTH SIDES TO SPEAK FRAMKLY ABOUT THE ISSUES SURROUNDING SEXUAL HARASSMENT HAS FORCED SEXISM (LIKE RACISM) TO "GO UNDERGRDUND."

05117 KELSO, B.J.

A LEGACY OF INEOUITY

AFRICA REPORT, $37(6)$ (NOY 92) 35-37

APARTHEID STILL HAUNTS NAMIBIA, DESPITE THO YEARS OF INDEPENDENCE AND THE GOVERMMENT'S' POLICY OF NATIONAL RECONCILIATION. THE BEST JOBS ARE STILL HELD BY WHITES; UNEMPLOYMENT IS NEARLY 50 PERCENT; WHITE FARMERS OWN MOST OF THE BEST LAND; AND AN UNCONTROLLABLE INFLUX OF RURAL PEOPLE TO THE CITIES IS EXACERBATING THE RISING RACIAL TENSION. 
HOWEVER, SHAPO HAS PROMISED TO END THE INEQUITIES WITH A SECOND, BLOODLESS "LIBERATION STRUGGLE."

05118 KEMP, G.; STAHL, S.

THE CONTROL OF THE MIDDLE EAST ARMS RACE

CARNEGIE ENDOWMENT FOR INTERNATIONAL PEACE, 1991, 232.

THIS BOOK EXAMINES THE KEY PARAMETERS OF THE ISSUE OF ARMS CONTROL IN THE MIDOLE EAST. IT FOCUSES ON THREE PRINCIPAL ZONES OF CONFLICT--THE ARAB-ISRAELI, THE PERSIAN GULF, AND THE INDIA-PAKISTAN CONFLICTS. IT EXAMINES THE THREAT PERCEPTIONS OF MOST STATES IN THE REGION; THE PROCESS BY WHICH ARMS SUPPLIERS AND CONSUMERS HAVE TENDED JOINTLY TO CONSPIRE TO FUEL AN ARMS RACE: THE HISTORY OF ARMS CONTROL-BOTH IN GENERAL AND IN THE REGION: AND THE FEASIBILITY OF APPLYING WHAT IS KNOWN ABOUT ARMS CONTROL AND ITS PROCESSES TO THE MIDDLE EAST. THE BOOK STRESSES THE MEED FOR WORK ON POLITICAL SETTLEMENTS TO ACCOMPANY OR EVEN PRECEDE EFFORTS TO ACHIEVE REGIONAL ARMS CONTROL. IT ALSO CONSIDERS THE UTILITY OF CONFIDENCE-BUILDING MEASURES AND SECURITY GUARANTEES.

05119 KEMP, 1.

THE diALECTICS OF VILLAGE AND STATE IN MODERN THAILAND JOURNAL OF SOUTHEAST ASIAN STUDIES, $22(2)$ (SEP 91),

THE AUTHOR USES THE "VILLAGE COMMUNITY" AS THE FOCUS FOR AN ANALYSIS OF THE SOCIAL ORGANIZATION OF RELATIONS BETHEEN AGENTS OF THE STATE AND ITS SUBJECTS IN THAILAND, IN ORDER TO BRIDGE TWO DISTINCT AND SOMETIMES CONTRADICTORY THEMES. THE FIRST IS THE MANNER IN WHICH SOCIAL CONNECTIONS WITHIN THE COUNTRYSIDE AND WITH THE STATE ARE HANDLED IN PRACTICE. THE SECOND IS THE WAY THE CONCEPTS OF "COMMUNITY" AND, MORE SPECIFICALLY, "VILLAGE COMMUNITY" ARE USED TO REPRESENT AND STRUCTURED AND WHAT ACTUALLY HAPPENS.

05120 KEMP, K.; HUDLIN, C.

CIVIL SUPREMACY OVER THE MILITARY: ITS NATURE AND LIMITS ARMED FORCES AND SOCIETY, 19(1) (FAL 92), 7-26.

THE PRINCIPLE OF CIVIL SUPREMACY OVER THE MILITARY IS AN IMPORTANT PRINCIPLE OF AMERICAN CONSTITUTIONAL GOVERNMENT. THIS ARTICLE LOOKS AT THE PRINCIPLE FROM ANOTHER POINT OF VIEW. HERE IT IS SEEN AS A MORAL PRINCIPLE APPLICABLE TO INDIVIDUAL OFFICERS AND SOLDIERS. THE PRINCIPLE STATES THAT (1) THE ENDS OF GOVERNMENT POLICY ARE TO BE SET BY CIVILIANS THE MILITARY IS LIMITED TO DECISIONS ABOUT MEANS: AND (2) THE MILITARY IS LIMITED TO DECISIONS ABOUT MEANS: AND (2)
IT IS FOR THE CIVILIAN LEADERSHIP TO DECIDE WHERE THE LINE IT IS FOR THE CIVILIAN LEADERSHIP TO DECIDE WHERE THE LINE
BETWEEN ENDS AND MEANS IS TO BE DRAWN. THE ARTICLE DEFENDS BETWEEN ENDS AND MEANS IS TO BE DRAWN. THE ARTICLE DEFENDS
THIS TWO-POINT PRINCIPLE AND DISCUSSES ITS LIMITS BY APPEAL TO GENERAL PHILOSOPHICAL CONSIDERATIONS AND BY RELFECTION ON TISTORICAL EXAMPLES.

05121 KEMP, R.L.

MUNICIPAL PLANNING SERVICES: NEW TECHNIQUES FOR HARD TIMES NATIONAL CIVIC REVIEN, 81(1) (WIN 92), 86-89.

LARGE NEW REVENUE SOURCES ARE A THING OF THE PAST FOR $U$. S. MUNICIPALITIES. MUNICIPAL PLANNING OFFICIALS HAYE BEEN FORCED TO BECOME MORE CREATIVE, INNOVATIVE, AND PRODUCTIVE TO MAKE BETTER USE OF THEIR DEPARTMENTAL RESOURCES--HUMAN, FINANCIAL, AND TECHNOLOGICAL. NEH PLANNING PRACTICES AND TECHMIQUES THAT STRESS THESE CHARACTERISTICS ARE NOW COMMONPLACE IN LOCAL GOVERMMENTS THROUGHOUT THE NATION.

05122 KENEN, P.B.

THE EUROPEAN CENTRAL BANK AND MONETARY POLICY IN STAGE THREE OF EMU

INTERNATIONAL AFFAIRS, 68(3) (JUL 92), 457-474.

IF ALL GOES ACCORDING TO THE PLAN ADOPTED AT THE

MAASTRICHT SUMMIT, THE EUROPEAN COMMUNITY WILL HAVE A SINGLE

CENTRAL BANK BEFORE THE END OF THIS CENTURY AND A SIMGLE

CURRENCY SOON THEREAFTER. IN THIS PAPER, THE AUTHOR ATTEMPTS TO DESCRIBE THE EUROPEAN CENTRAL BANK (ECB), DRAHING ON THE TEXT OF THE TREATY APPROVED AT MAASTRICHT AND FILLING SOME OF THE GAPS FROM THE EXPERIENCE OF THE UNITED STATES, WHERE THE FEDERAL RESERVE SYSTEM HAS HAD TO SOLYE SOME OF THE SAME PROBLEMS THAT WILL CONFRONT THE ECB. HE BEGINS BY REVIEWING THE RECOMMENDATIONS OF THE DELORS REPORT, WHICH WAS THE BASIS FOR THE TREATY, AND THEN TURNS TO THE TREATY ITSELF BEFORE CONSIDERING SOME OPERATIONAL PROBLEMS THAT THE TREATY POSES BUT DOES NOT SOLVE.

05123 KENEZ, $P$.

LOOKING BACKWARD: NATIONALISM ON THE RISE IN HUMGARY NEW LEADER, LXXV(12) (SEP 92), 6-8.

THE NATIONALIST WINDS BLOWING WITH GALE FORCE THROUGHOUT MOST OF EASTERN EUROPE CAN, TO SOME EXTENT, ALSO BE FELT IN HUNGARY TO BE SURE. THE COUNTRY'S ETHMIC HOMOGENEITY AND HISTORICAL TRADITIONS MILITATE AGAINST A MONSTER LIKE SERBIAN PRESIDENT BUDAPEST. NEVERTHELESS, THE PROMINENT--AND BITTERLY DIVISIVE-POLITICAL ISSUES OF THE DAY ARE ENTIRELY ABSTRACT ONES AND HAVE LITTLE TO DO WITH THE COUNTRY'S PRESSING ECONOMIC AND SOCIAL PROBLEMS. THE MODERATE LEFT AND RIGHT ARE DISTINGUISHABLE NOT BY OIFFERING VERSIONS OF CAPITALISM NOR
BY CONTRASTING IDEAS ABOUT HOW TO HELP THOSE SUFFERING FROM THE ECONOMIC TRANSITION BUT BY THEIR DISTINCT UNDERSTANDINGS OF WHAT CONSTITUTES A GOOD HUNGARIAN. THE MAIN REPOSITORY OF NATIONALIST THOUGHT IS THE CENTER-RIGHT GOVERNING COALITION, A FRACTIOUS ALLIANCE DOMINATED BY THE HUNGARIAN DEMOCRATIC FORUM.

05124 KENNEDY, D.

TURNING TO MARKET DEMOCRACY: A TALE OF THO ARCHITECTURES

PEACE AND THE SCIENCES, 3 (SEP 91), 19-25.

THIS ARTICLE FOCUSES NOT ON WHETHER OR HOW A NEW EUROPE IS EMERGING, BUT ON WHICH EUROPE WE ARE BUILDING. IT FOCUSES ON THIS QUESTION BECAUSE CENTRAL AND EASTERN EUROPEAN SOCIETIES CONFRONTED NOT WITH ENTRY INTO A UNIFORM WESTERN SYSTEM OF MARKET DEMOCRACY, BUT WITH A CHOICE BETWEEN AT LEAST THO DIFFERENT REGIMES OF MARKET DEMOCRACY. BENEATH THE NEW COOPERATIVE AND INTERDEPENDENT SPIRIT THERE LIES A SET OF CHOICES ABOUT THE WAY MARKET RELATIONS WILL BE IMAGINED, STRUCTURED, SANCTIONED OR STABILIZED, AND ABOUT THE FORM MODERN DEMOCRATIC STATE POWER HILL ASSUME. ALTHOUGH THESE CHOICES IMPLICATE THE SECURITY ARRANGEMENTS AND POLITICAL BEST ILLUSTRATE BY THE CHOICES INVOLVED IN JOINING THE INTERNATIONAL MARKET. THIS ESSAY EXPLORES THESE CHOICES BY INTERNATIONAL MARKET. THIS ESSAY EXPLORES THESE CHOICES BY FOCUSING UPON TWO RADICALLY DIFFERENT REGIMES : THE EUROPEAM
COMMUNINITIIES' EFFORTS TO CREATE AN "INTERNAL MARKET" BY 1992 AND THE INTERNATIONAL TRADE REGIME BEING EXTENDED TO 1992 AND THE INTER
EASTERN EUROPE.

05125 KENNEDY, M.

THE CONSTITUTION OF CRITICAL INTELLECTUALS: POLISH PHYSICIANS, PEACE ACTIVISTS AND DEMOCRATIC CIVIL SOCIETY STUDIES IN COMPARATIVE COMMUNISM, XXIII (3-4) (FAL 90), 281-304.

THIS ARTICLE DESCRIBES THE ROLE OF CIVIL SOCIETY IN THE TRANSFORMATION OF EASTERN EUROPE, FOLLOWED BY A DISCUSSION OF THE RELATIONSHIP BETWEEN INTELLECTUALS AND CIVIL SOCIETY. THE AUTHOR ARGUES THAT FOCUS SHOULD BE PLACED ON HOW ORDINARY INDIVIDUALS BECOME CRITICAL INTELLECTUALS, FOR IT IS ON THIS FOUNDATION THAT A DEMOCRATIC CIVIL SOCIETY CAN BE CONSTRUCTED. IT CONSIDERS TWO EXAMPLES: HOW NORMALLY APOLITICAL PRACTICAL POLISH PHYSICIANS WERE ABLE TO CREATE A CRITICAL INTELLECTUAL COMMUNITY IN 1980-81; AND HOW POLISH PEACE ACTIVISTS WERE ABLE TO EXERT INFLUENCE IN $1985-88$ PEACE ACTIVISTS WERE ABLE TO EXERT INFLUENCE IN 1985-88
WITHOUT ANY INSTITUTIONAL CREDENTIALS FOR LEGITIMATING THEIR WITHOUT ANY INSTI TUTIONAL CREDENTIALS FOR LEGITIMATING THE KNOWLEDGE WITHIN A CULTURE THAT
LITTLE VALUE TO PEACE MOVEMENTS.

05126 KENNEDY, P. (ED.)

GRAND STRATEGIES IN WAR AND PEACE

YALE UNIVERSITY PRESS, $1991,224$.

IN THIS BOOK, SEVERAL AUTHHORS DISCUSS HOW VARIOUS NATIONS HAVE SOUGHT TO INTEGRATE THEIR POLITICAL, ECONOMIC AND MILITARY GOALS IN ORDER TO PRESERVE THEIR LONG-TERM INTERESTS IN TIMES OF WAR AND PEACE. THE BOOK ANALYZES CLASSIC EXAMPLES OF EUROPEAN GRAND STRATEGIES AND OFFERS ADVICE ON THE PROPER BALANCE OF PRIORITIES THAT SHOULD BE
CARRIED OUT BY THE UNITED STATES TODAY. THE BOOK BEGINS WITH CARRIED OUT BY THE UNITED STATES TODAY. THE BOOK BEGINS WITH BROADENED FROM A PREOCCUPATION WITH BATTLEFIELD OPERATIONS TO A CONSIDERATION OF SUCH FACTORS AS THE MANAGEMENT OF NATIONAL RESOURCES, THE VITAL ROLE OF DIPLOMACY, AND THE WILLINGNESS OF THE GENERAL POPULACE TO SUPPORT THE BURDENS OF WAR OR THE COST OF LARGE DEFENSE FORCES IN PEACETIME. OTHER CHAPTERS ANALYZE BRITISH GRAND STRATEGIES IN THE WAR OF SPANISH SUCCESSION AND THE THO HORLD WARS; GRAND STRATEGY IN THE ROMAN EMPIRE, IMPERIAL SPAIN, GERMANY, FRANCE AND THE SOVIET UNION; AND THE AMERICAN GRAND STRATEGY TODAY AND IN THE FUTURE.

05127 KENMELLY, E.

LABOR AFTER THE FALL

INSIGHT, 8(30) (JUL 92), 6-13

THANKS TO A CONGRESSIOMAL EFFORT TO FOSTER HORLO

DEMOCRACY IN THE EARLY 1980S, THE AFL-CIO HAS RECEIVED

MILLIONS OF U.S. TAX DOLLARS FOR ITS OPERATIONS ABROAD. WITH THE FALL OF COMMUNISM, HOWEVER, QUESTIONS HAVE ARISEN ABOUT THE UNION GROUP'S SPENDING AS IT RELATES TO IDEOLOGY AND POLITICS. CRITICS BOTH IN CONGRESS AND OVERSEAS CONPLAIN THAT A PRIVATE ORGANIZATION IS RECEIVING GOVERNMENT FUNDING TO PURSUE ITS OWN AGENDA.

05128 KENHEY, $P$.; RICE, T.

A MODEL OF' NOMINATION PREFERENCES

AMERICAN POLITICS QUARTERLY, 20(3) (JUL 92), 267-286.

IN THIS ARTICLE, THE AUTHORS DEVELOP A MODEL THAT DETAILS HOW INDIVIDUALS COME TO PREFER ONE CANDIDATE OVER OTHERS DURING THE PRESIDENTIAL NOMINATION CAMPAIGN. THE MODEL PLACES THE FORCES THAT INFLUENCE NOMINATION PREFERENCES INTO A SIMULTANEOUS AND DYNAMIC FRAMEHORK. EMPIRICAL TESTS USING THE 1980 NES PANEL INDICATE THAT THE MODEL PERFORM HELL. 
05129 KENMY, C.; MCBURNETT, M. A DYNAMIC MODEL OF THE EFFECT OF CAMPAIGN SPENDING ON
CONGRESSIONAL VOTE CHOICE AMERICAN JOURNAL OF POLITICAL SCIENCE, 36(4) (NOV 92), 923-937.

AN EXPLICITLY DYNAMIC MODEL OF THE RELATIONSHIP BETHEEN SPENDING AND VOTES IN A SINGLE HOUSE DISTRICT IN 1984 ARE ESTIMATED. BY DEFINING SPENDING AS THE LAG OF CONTRIBUTIONS, THE AUTHORS ARE ABLE TO INVESTIGATE WHICH EXPENDITURE SCHEMES SEEM TO BENEFIT CANDIDATES MOST. THEY FIMD STATISTICALLY SIGNICANT EFFECTS FOR CHALLENGER SPENDING BUT NOT FOR THAT OF THE INCUMBENT. THEY ALSO FOUND THAT MONEY HAS THE GREATEST EFFECT ON THE PREFERENCES OF THOSE INDIVIDUALS WHO DID NOT VOTE, SUGGESTING THAT THE PEOPLE ONES LEAST LIKELY TO FOLLOH THROUGH ON THE COMMITMENT.

05130 KENNY, $C$.

PARTISANSHIP AND POLITICAL DISCUSSION

POLITICAL GEOGRAPHY QUARTERLY, 10(2) (APR 91), 97-109.

THE OUESTIOM OF HOH INDIVIDUALS AFFECT EACH OTHER

POLITICALLY HAS DRAHN CONSIDERABLE INTEREST IN THE SOCIAL

SCIENCES FOR SOME TIME. UNFORTUNATELY, LITTLE IN THE WAY OF A THEORETICAL FORMULATION OF THE SOCIAL INTERACTION PROCES HAS BEEN DEVELOPED. USING PARTY IDENTIFICATION AS AN ATTITUDE SUBJECT TO SOCIAL INFLUENCE, THIS PAPER EVALUATES THE GENERAL HYPOTHESIS THAT INDIVIDUAL PARTY IDENTIFICATION IS AFFECTED BY THE PARTY IDENTIFICATION OF A POLITICALLY SIGNIFICANT OTHER, AS WELL AS SPECIFIC HYPOTHESES ABOUT THE CONDITIONS THAT FACILITATE THIS PROCESS. USING DATA COLLECTED SPECIFICALLY FOR THIS TASK IN SOUTH BENO, INDIANA, THE ANALYSES INDICATE THAT INDIVIDUAL PART ISANSHIP' RESPONDS TO DISCUSSANT PARTISANSHIP, AND THAT THIS EFFECT IS ENHANCED IN SITUATIONS OF HOMOGENEOUS POLITICAL CONTENT, FREQUENT DISCUSSION, AND WHERE THE PARTISANSHIP OF THE DISCUSSANT IS KNOWN.

05131 KENMY, $C$

POLITICAL PARTICIPATION AND EFFECTS FROM THE SOCIAL ENVIRONMENT

AMERICAN JOURHAL OF POLITICAL SCIENCE, 36(16) (FEB 92), 259-267.

THE DISTINCTION BETHEEN INDIVIDUALLY AND SOCIALLY BASED FORMS OF PARTICIPATION AS AFFECTED BY SOCIAL ENVIRONMENT IS FORMS OF PARTICIPATION AS AFFECTED BY SOCIAL ENVIROM
EXAMINED IN THIS PAPER. USING SURVEY RESPONSES THE EXAMINED IN THIS PAPER. USING SURVEY RESPONSES THE
RELATIONSHIP BETHEEN POL ITICAL DISCUSSION PARTNERS IS RELATIONSHIP BETWEEN POLITICAL DISCUSSION PARTNERS IS INDIVIDUALLY AND SOCIALLY BASED PARTICIPATORY ACTS. THE INDIVIDUALLY AND SOCIALLY BASED PARTICIPATORY ACTS. THE BASED AND SOCIALLY BASED PARTICIPATION ARE AFFECTED BY THOSE MODIFICATION OF THIS DISTINCTION IS IN ORDER.

05132 KEOHANE, D.

THE APPROACH OF BRITISH POLITICAL PARTIES TO A DEFENCE ROLE FOR THE EUROPEAN COMMUNITY

GOVERNMENT AND OPPOSITION, 27(3) (SUM 92), 299-310

THE ISSUES OF DEFENSE AND EUROPEAN UNITY DID NOT PLAY A PROMINENT ROLE IN BRITAIN'S 1992 GENERAL ELECTION. HOWEVER THE CONSERVATIVE MANIFESTO DID CLAIM THAT DEFENSE COULD NOT BE TRUSTED TO THE OPPOSITION PARTIES AND THAT THEIR POLICIES WOULD PRODUCE HUGE JOB LOSSES IN THE DEFENSE SECTOR. LABOUR WAS CONTENT TO PLEDGE ITSELF TO ACCEPT THE EUROPEAN COMMUMITY SOCIAL CHAPTER BUT IT ESCHEWED DISCUSSION OF COMMUNITY SECURITY POLICY. THE LIBERAL DEMOCRATS' MANIFESTO EMPHASIZED THE PARTY'S BELIEF IN THE SHARING OF BRITAIN'S SOVEREIGNTY IN AN INTEGRATED COMHUNITY AND ADVOCATED THE DEVELOPMENT OF A COMMON E.C. FOREIGN AND SECURITY POLICY.

05133 KERMAGHAN, $K$

CAREER PUBLIC SERVICE 2000: ROAD TO RENEWAL OR IMPRACTICAL VISION?

CANADIAN PUBLIC ADMINISTRATION, 34(4) (WIN 91), 551-572. CAREER PUBLIC SERVICE FACES MAJOR CHALLENGES IN CANADA AND IS THE SUBJECT OF A RECENT WHITE PAPER, "PUBLIC SERVICE 2000." THE WHITE PAPER OFFERS A VISION OF A NEW PUBLIC SERVICE CULTURE THAT IS RESULTS- AND CLIENT-ORIENTED AND BASED ON THE PRECEPTS OF SERVICE, INNOVATION, PEOPLE, AND ACCOUNTABILITY. AMONG THE OBSTACLES TO SUCCESSFUL IMPLEMENTATION OF THIS VISION ARE RESISTANCE BY PUBLIC SERYICE UNIONS, LACK OF UNDERSTANDING ABOUT THE MAGNITUDE OF THE COMMITMENT REQUIRED TO CREATE A NEW PUBLIC SERVICE
CULTURE, AND THE POSSIBLE LACK OF POLITICAL WILL TO CUL TURE, AND THE POSSIBLE LACK OF POLITICAL WILL TO IMPLEMENT THE WHITE PAPER'S PROPOSALS. THE FEDERAL GOVERMMENT CAN ENHANCE THE PROSPECTS FOR CAREER PUBLIC
SERYICE THROUGH A RENEWAL OF COMMITMENT TO CAREER SERVICE, SERVICE THROUGH A RENEWAL OF COMMITMENT TO CAREER SER
INCLUDING THE ALLOCATION OF MORE RESOURCES TO CAREER INCLUDING THE ALLOCATION OF MORE RESOURCES TO CAREER
PLANHING AND DEVELOPMENT AND GREATER SENSITIVITY TO THE THREAT OF UNDUE POLITICIZATION OF THE PUBLIC SERVICE.

05134 KERNAGHAN, $K$.

EMPOWERMENT AND PUBLIC ADMINISTRATION: REVOLUTIONARY

ADVANCE OR PASSING FANCY?

CANADIAN PUBLIC ADMINISTRATION, 35(2) (SUM 92), 194-214.
THE AUTHOR STUDIES THE ORIGINS AND MEANING OF EMPOWERMENT, THE EXTENT TO WHICH IT HAS BEEN INTRODUCED IN CANADIAN PUBLIC ORGANIZATIONS, AND THE OBSTACLES TO ITS SUCCESSFUL IMPLEMENTATION. HE ANALYZES THE POLITICAL AND MANAGERIAL IMPLICATIONS OF EMPOWERING EMPLOYEES AND ORGANIZATIONS AND ASSESSES THE COMPATIBILITY OF EMPOWERMENT WITH THE CONSTITUTIONAL CONVENTION OF MINISTERIAL RESPONSIBILITY. HE ARGUES THAT EFFECTIVE IMPLEMENTATION OF EMPOWERMENT IS A DIFFICULT, RISKY ENDEAVOR, BUT THE PAYOFF IS LIKELY TO BE WORTH THE PRICE.

05135 KERMOHAN, $R$.

A BREATHING-SPACE IN SCOTLAND

CONTEMPORARY REVIEW, 260(1517) (JUN 92), 281-186.

IT IS NOT EASY TO SAY WHETHER THE DISCONTENTS THAT HAVE GIVEN BRITISH POLITICS A \$SCOTTISH QUESTION' HAVE BEEN EASED, INFLAMED, OR MERELY REDEFINED BY THE CONSERVATIVE YICTORY INFLAMED, OR MERELY REDEFINED BY THE CONSERVATIVE VICTORY
IN THE BRITISH GENERAL ELECTION. THE CONSERVATIVES STILL
FACE THE PROBLEM OF HAVING TO FIND THEIR TEAM OF SCOTTISH MINISTERS FROM A DANGEROUSLY HEAK PARLIAMENTARY BASE AND THE POLITICAL ONE OF COUNTERING THE CLAIM THAT THEY HAVE NO MALDATE TO GOVERM SCOTLAND. THE OTHER PARTIES ARE FRUSTRATED. THIS ARTICLE EXPLORES CONTRADICTORY THEMES IN SCOTTISH OPPOSTION POLITICS. IT SUGGESTS THAT THE FUTURE MOOO OF SCOTLAND HILL BE MUCH INFLUENCED BY THE CONDITION OF BRITAIM AND THE WAY THE MAJOR STYLE OF CONSERVATISH IS APPLIED IN SCOTTISH CONDITIONS.

05136 KERSTEIN, $R$

GROWTH POLITICS IN TAMPA AND HILLSBOROUGH COUNTRY: STRAINS IN PRIVATISTIC REGIMES

JURMAL OF URBAN AFFAIRS, 13(1) (1991), 55-76.

THIS ARTICLE EXAMINES POLITICAL REGIMES IN TAMPA AND HILLSBOROUGH COUNTY DURING THE POST-WORLD HAR II PERIOD. A PRIVATIST-CORPORATE REGIME CHARACTERIZED TAMPA'S POLITICS AND POLICY UNTIL THE LATE 1980S. A MORE PLURALISTIC REGIME TOOK HOLD DURING THE ADMINISTRATION OF MAYOR SAMDY FREEDMAN. THE COUNTY'S POLITICS MOVED FROM A CARETAKER TO A PRIVATISTCORPORATE REGIME DURING THE 1980'S. THIS REGIME WAS SOON CHALLENGED BY CIVIC AND ENVIRONMENTAL GROUPS AND A GROHTH MANAGEMENT REGIME IS NOW BECDMING DOMINANT. THE REGIME TRANSITION IN THE COUNTRY OPENS THE POSSIBILITY FOR A MORE COMMUNITY ORIENTED REGIME TO COALESCE IN THE CITY.

05137 KERWIN, C. : FURLONG, $S$.

TIME AND RULEMAKING: AN EMPIRICAL TEST OF THEORY JOURNAL OF PUBLIC ADMINISTRATION RESEARCH AND THEORY, 2(2) JOURNAL OF PUBLIC
(APR 92), 113-156.

RULEMAKING IS AMONG THE MOST IMPORTANT AND CONTROVERSIAL FUNCTIONS PERFORMED BY PUBLIC AGENCIES. THIS RESEARCH EXAMINES THE FACTORS INFLUENCING RULEMAKING BY THE ENVIRONMENTAL PROTECTION AGENCY. THE AUTHORS DEVELOP A NUMBER OF MEASURES FOR EACH OF SEVERAL VARIABLES TO DETERMINE THEIR INDIVIDUAL AND COMBINED EFFECTS ON DELAY IN RULEMAKING. WHILE THIER MODELS DO ACCOUNT FOR A SUBSTAMTIAL AMOUNT OF THE VARIATION IN THE TIME IT TAKES TO ISSUE RULES,
THEIR PERFORMACE IS ERRATIC AND MUCH REMAINS TO BE EXPLAINED.

05138 KESSELMAN, J.

INNOVATION IN PUBLIC DEBT MANAGEMENT TO REDUCE THE FEDERAL DEFICIT

CANADIAN PUBLIC POLICY--ANALYSE DE POLITIQUES, 18(3) (SEP $92), 327-352$

BY IMPLEMENTING NEW METHODS OF DEBT MANAGEMENT, THE GOVERMMENT OF CANADA COULD SIGNIFICANTLY REDUCE ITS LARGEST OUTLAY, DEBT SERVICE COSTS. THIS PAPER ASSESSES THE ADVANTAGES, OPERATION, AND ECONOMICS OF ONE SUCH INNOVATION-U.S. DOLLAR DENOMINATED TREASURY BLLS (USDTBS). AVERAGE ANNUAL SAVINGS FROM USDTBS COULD RANGE FROM \$250 MILLION TO MORE THAN S1 BILLION, DEPENDING UPON HOW THEY HERE APPLIED AND ECONOMIC CIRCUMSTANCES. ANY EXCHANGE RATE LOSSES WOULD BE MORE THAN OFFSET BY THE INTEREST SAVINGS. EXCHANGE RISKS WOULD BE JUSTIFIED BY THE REDUCED RISKS ASSOCIATED WITH THE TOTAL PUBLIC DEFICIT--THE SUM OF DEBT SERVICE CHARGES PLUS THE FISCAL OPERATING DEFICIT. REDUCING DEBT SERVICE COSTS THROUGH USDTBS IS SHOWN TO BE MORE ATTRACTIVE THAN MOST OTHER MEANS OF CURBING THE DEFICIT.

05139 KESSELMAN, M.

HOW SHOULD ONE STUDY ECONOMIC POLICY MAKIMG? FOUR CHARACTERS IN SEARCH OF AN OBJECT

MORLD POLITICS, 44(4) (JUL 92), 645-672.

BY FOCUSING ON SOME MAJOR CONTRIBUTIONS TO POLITICAL ECONOMY AND ECONOMIC POL ICY MAKING HITHIN ADYANCED CAPITALISH, THE AUTHOR SEEKS TO ANALYZE THE RELATION BETWEEN STRUCTURAL CONSTRAINTS AND POLITICAL CHOICE. HE ARGUES THAT RECENT LITERATURE INSIGHTFULLY DESCRIBES IMPORTANT POLITICAL DEVELOPMENTS, PROVIDES EXCELLENT ACCOUNTS OF THE INTERPLAY OF STRUCTURE AND AGENCY IN CONCRETE HISTORICAL SETTINGS, AND DEVELOPS IMPRESSIVE THEORY THAT ADVANCES KNOWLEDGE OF HOW POLITICAL FORCES AFFECT ECONOMIC POLICY OUTCOMES. HOWEVER, RECENT SCHOLARSHIP GENERALLY DISPLAYS THREE INTERRELATED SHORTCOMINGS: IT DOES NOT ADEQUATELY CONCEPTUALIZE THE
STRUCTURAL DYNAMICS OF DEMOCRATIC CAPITALISM: IT ADOPTS AN 
ECONOMISTIC PERSPECTIVE CONCERNING THE ORGANIZATION OF INTERESTS AND SOCIAL IDENTITIES; AND IT CONFINES ATTENTION TO WHAT IS, FAILING TO CONSIDER WHAT MIGHT BE.

05140 KESSLER, M.; ROTH, M.

FRENCH BLOCK HOPES OF A SWIFT GATT AGREEMENT

GERMAN TRIBUNE, 31(1538) (OCT 92), 6

IF IT HAD BEEN UP TO BRITISH PRIME MINISTER, JOHN MAJOR, A DECISION ABOUT THE GATT HOULD HAVE BEEN AT THE TOP OF THE AGENDA OF THE EC SPECIAL SUMMIT IN BIRMINGHAM. AS EXPECTED, THE FRENCH LOCKED A SWIFT AGREEMENT IN THE NEGOTIATIONS BETWEEN THE USA AND THE EUROPEAN COMMUNITY. MOST GOVERMMENTS ARE PREPARING THEMSELVES FOR THE TIME HHEN THERE IS NO NEW GATT AGREEMENT.

05141 KESSLER, $S$.

TOCOUEYILL'S PURITANS: CHRISTIAMITY AMD THE AMERICAN FOUNDING

THE JOURNAL OF POLITICS, 54(3) (AUG 92), 776-792.

TOCOUEYIL CONSIDERED THE PURITANS AMERICA'S FOUNDERS BECAUSE OF THEIR FORMATIVE INFLUENCE ON AMERICA'S NATIONAL CHARACTER. THIS ANALYSIS AMSWERS THE VEXING QUESTION OF HOH CAN TOCQUEVILLE ASSERT THAT THE PURITANS FOUND A COUNTRY WHICH, AS HE DESCRIBES IT, WAS MORE SECULAR THAN RELIGIOUS IN THE 1830S? THIS PAPER SHOWS THAT HE DEFENDS HIS ASSERTION BY LINKING THE DEMISE OF THE RELIGIOUS ELEMENTS OF AMERICAN PURITANISM TO CERTAIN SECULAR TENDENCIES FOSTERED BY CHRISTIANITY.

05142 KETKAR, K.; KETKAR, S,

BANK NATIONALIZATION, FINANCIAL SAVINGS, AND ECONOMIC DEVELOPMENT-A CASE STUDY OF INDIA

JOURNAL OF DEVELOPING AREAS, 27(1) (OCT 92), 69-84,

THE PRINCIPAL OBJECTIVE OF THIS PAPER IS TO EVALUATE THE IMPACT OF STEPPED-UP BANK BRANCH EXPANSION AND ENHANCED PRIORITY SECTOR CREDIT ALLOCATIONS FOLLOWING BANK NATIONAL IZATION ON THE SAVINGS, INVESTMENT, AND GRONTH PERFORMANCE OF THE INDIAN ECONOMY. IT REVIEWS THE RELEVANT LITERATURE ON THE DETERMINANTS OF SAVING AND INVESTMENT, AND ALSO CONSIDERS THE LIKELY EFFECTS ON THEM OF BAMK ALSO CONSIDERS THE LIKELY EFFECTS ON THEM OF BANK
NATIONALIZATION. IT SPECIFIES STOCHASTIC SAVINGS, INVESTMENT, GOVERMMENT EXPENDITURES AND GROWTH EQUATIONS. THE DATA SOURCES ARE DISCUSSED AND THE EMPIRICAL RESULTS ARE SOURCES ARE
PRESENTED.

05143 KEYFITZ, N.

CONSUMERISM AND THE NEW POOR

SOCIETY $29(2)$ (JAN 92$), 42-47$

SOCIETY, 29(2) (JAN 92), 42-47. OUT OF IT. UNDERSTANDING THE BEHAVIOR OF THE MIDDLE CLASS IS NECESSARY FOR UNDERSTANDING THE STATUS AND ATTITUDES OF THE POOR. THIS ARTICLE EXPLORES MIDOLE CLASS CULTURE AND ITS EFFECT ON THE POOR. IT SUGGESTS THAT THE PREVIOUS GENERATION WAS FAR FROM SEEING THE INCREASE IN AVERAGE NATIONAL INCOMES AS A SOLUTION TO THE PROBLEM OF POVERTY. IT CONCLUDES THAT THE MIDDLE CLASS ECONOMY OF TODAY WOULD GET ALONG NEARLY AS WELL IF MOST OF THE POOR DISAPPEARED, THAT AUTOMATION OF PRODUCTION WORKS AGAINST ABSORPTION OF THE GROWING NUMBERS OF ENTRANTS INTO THE LABOR MARKET, AND THAT AS LONG AS THE POOR ARE REGARDED AS BARELY HUMAN, DOWNWARD SUPPORT WILL BE RESISTED BY THE AUTHORITIES.

05144 KEYS, D.

SA GOVERNMENT VIEW ON FOREIGN TRADE AND INVESTMENT SOUTH AFRICA INTERNATIONAL 22(4) (APR 92), 169-171.

DEREK KEYS, PROMINENT SOUTH AFRICAN CAPTAIN OF INDUSTRY, RECENTLY APPOINTED TO A CABINET POST WITHIN THE GOVERNMENT, REPRESENTS THE RELATIVELY RECENT RECOGNITION BY THE RULING NATIONAL PARTY FOR A PRIVATE SECTOR INPUT AT THE HIGHEST POL ICY MAKING LEVELS. IN THIS ADDRESS TD A CONFERENCE ON 24 FEBRUARY 1992, MR KEYS ESCHEWS IDEOLOGICAL REPARTEE FOR A SOBER DETAILING OF FOUR BASIC ECONOMIC IMPERATIVES, A BASIC ECONOMIC SCENARIO, A SUCCINCT ANALYSIS OF PAST ECONOMIC IMPERFECTIONS, AND A BRIEF OUTLIME OF THE ROAD AHEAD FOR SOUTH AFRICA.

05145 KHADIAGALA, $G$.

SECURITY IN SOUTHERN AFRICA: CROSS-MATIONAL LEARNING JERUSALEM JOURNAL OF INTERNATIONAL RELATIONS, 14(3) (SEP 92), 82-97.

THIS ARTICLE ANALYZES REGIONAL TRANSFORMATIONS IN SOUTHERN AFRICA SINCE THE 1970S. BUILDING ON THE THEORETICAL MODEL OF THE CONTAGION OF CROSS-NATIONAL VALUES, IT ARGUES MODEL OF THE CONTAGION OF CROSS-NATIONAL VALUES, IT ARGUES LEARMING, PROYIDING BOIH POSITIVE AND NEGATIVE LESSONS FOR LEARNING, PROVIDING BOTH POSITIVE AND NEGATIVE LESSONS FOR DECISISNMAKERS; POSITIVE LESSONS HAVE ENAMATED LARGELY FROM SUCCESSFUL MODELS OF SOCEIOECONOMIC CHANGE, AND SOME OF THE NEGATIVE
ACTION.

05146 KHADIAGALA, G

THOUGHTS ON AFRICA AND THE NEW WORLD ORDER

ROUND TABLE, 324(324) (OCT 92), 431-450.

A REVIEW OF THE INTERNATIONAL AND DOMESTIC DIMENSIONS OF
THE AFRICAN STATE IN THE OLD AND NEW ORDERS INTRODUCES THIS ARTICLE, WHICH ALLOWS THE FOLLOWING QUESTIONS TO BE ANSWERED WHAT HAVE BEEN THE INTERNATIONAL CONTRIBUTIONS TO AFRICAN STATEHOOD? WHAT IS THE RELATIONSHIP BETWEEN STATEHOOD AMD NATIONHOOD IN AFRICA? WHAT HAS BEEN THE PERFORMANCE OF THE AFRICAN STATE IN THE THREE DECADES OF INDEPDENDENCE? WHY SHOULD STATEHOOD AND NATIONHOOD BE THE FOUNDATIONS FOR AFRICA'S PLACE IN A NEW WORLD ORDER? THE AUTHOR CONCLUDES THT ALTHOUGH THE ARCHITECTURAL OUTLINES OF THE NEW ORDER ARE STILL BEING DEFINED, THE CHALLENGES OF THIS ORDER HOLD MORE PROMISES FOR STRENGTHENING THE BASIS OF AFRICAN STATEHOOD THAN EVER BEFORE.

05147 KHADKA, N.

GEOPOLITICS AND DEVELOPMENT: A NEPALESE PERSPECTIVE ASIAN AFFAIRS, AN AMERICAN REVIEW, 19(3) (FAL 92), 134-157. NEPAL IS A COUNTRY SANOWICHED BETWEEN TWO COMPETING ASIAN POWERS, INDIA AND COMMUNIST CHINA. NEPAL'S WISH TO FOLLOW AN INDEPENDENT FOREIGN POLICY IS DICTATED BY ITS FOLLOH AN INDEPENDENT FOREIGN POLICY IS DICTATED BY ITS CONSTRAINED BY ITS GEDGRAPHY.

05148 KHALILY, M.; MEYER, R.

FACTORS INFLUUENCING THE DEMAND FOR RURAL DEPOSITS IN BANGLADESH: A TEST FOR FUNCTION FORM

JOURNAL OF DEVELOPING AREAS, 26(3) (APR 92), 371-382.

IN RECENT YEARS, THERE HAS BEEN AN UPSURGE OF INTEREST AMONG POLICYMAKERS, ACADEMICIANS, AND INTERNATIONAL AGENCIES TOWARD THE MOBILIZATION OF RURAL SAVINGS THROUGH FINANCIAL INTERMEDIARIES IN DEVELOPING COUNTRIES. THE OBJECTIVES OF THIS PAPER ARE THREEFOLD: FIRST, TO ANALYZE THE FACTORS INFLUENCING THE DEMAND FOR RURAL DEPOSITS USING BANGLADESH AS A CASE STUDY; SECOND TO PRESENT AND EVALUATE THE SIMULATED EFFECTS OF INTEREST RATES AND BANK BRANCHES ON RURAL DEPOSITS; AND THIRD, TO TEST THE IMPACT OF CHOOSING ALTERNATIVE FUNCTIONAL FORMS OF DEMAND FOR RURAL DEPOSITS USING THE BOX-COX PARAMETRIC TRANSFORMATION. THREE POLICY SCENARIES ARE INTRODUCED: (1) A CHANGE IN INTEREST RATES : (2) A CHANGE IN BANK BRANCHES; AND (3) A SIMULTANEOUS CHANGE IN BANK BRANCHES AND INTEREST RATES. THE REGRESSION RESULTS REPORTED IN THIS PAPER SATISFACTORILY EXPLAIN THE EXPECTED RELATIONSHIP BETWEEN RURAL BANK DEPOSITS AND THE SEVERAL INDEPENDENT VARIABLES INCLUDED IN THE ANALYSIS.

05149 KHAN, H.A.; HOSHINO, E.

IMPACT OF FOREIGN AID ON THE FISCAL BEHAVIOR OF LDC GOVERMMENTS

WORLD DEVELOPMENT, 20(10) (OCT 92), 1481-1488.

THE AUTHORS EXAMINE THE IMPACT OF FOREIGN AID ON THE BEHAVIOR OF FIVE LESS-DEVELOPED COUNTRIES IN SOUTH AND SOUTHEAST ASIA. THE RESPONSE TO FOREIGN AID IS MEASURED IN TERMS OF PUBLIC INVESTMENT AND CONSUMPTION AS WELL AS TAXATION. THE AUTHORS UTILIZE A NONLINEAR THREE-STEP LEAST SOUARES METHOD TO ESTIMATE THE IMPACT. THE RESULTS CONFIRM
THE HYPOTHESIS THAT AID DOES AFFECT CONSUMPTION, INVESTMENT, THE HYPOTHESIS THAT AID DOES AFFECT CONSUMPTION, INVESTME PARTICULAR, GRANTS AND LOANS HAVE DIFFERENT EFFECTS ON INVESTMENT AND TAXATION.

05150 KHAN, $K$.

ECONOMIC POLICY AND ECONOMIC DEVELOPMENT IN PAKISTAN ORIENT, 25(3) (1991), 429-448.

UP TO NOW, ESTIMATES OF THE ECONOMIC DEVELOPMENT IN PAKISTAN HAVE MAINLY BEEN UNDERTAKEN BY USING ECONOMIC INDICATORS AT THE MACRO LEVEL. EMPIRICAL EXPERIENCE OF THE PAST DECADE HAS SHOWN THAT IT IS POSSIBLE TO HAVE TO REGARD THE TOTAL ECONOMIC DEVELOPMENT AS A FAILURE DESPITE POSITIVE QUANTITATIVE DEYELOPMENTS. THIS ARTICLE NOTES THAT REGIONAL DISPARITIES, STRUCTURAL DISTORTIONS, EMPLOYMENT PROBLEMS, POVERTY AND EXTERMAL DEPEMDENCY HAVE CONSISTENTLY INCREASED. PAKISTAN HAS GOTTEN INTO SUCH A DIFFICULT SITUATION THAT NO KIND OF ECONOMIC REFORM HAS MUCH CHANGE OF SUCCESS WITHOUT FUNDAMENTAL CHANGES IN THE POLITICAL AND INSTITUTIONAL SECTORS.

05151 KHAN, R.

PAKISTAN IN 1991: LIGHT AND SHADOWS

ASIAN SURVEY, XXXII(2) (FEB 92), 197-206.

THO 1990 EVENTS AND THEIR AFTERMATH DOMINATED PAKISTAN'S NATIONAL AGENDA IN 1991. THE FIRST WAS THE PEACEFUL TRANSFER OF POWER FOLLOWING THE NATIONAL ELECTIONS OF OCTOBER 1990. MIAN NAWAZ SHARIF WAS INDUCTED AS PRIME MINISTER AND THE RUL ING ISLAMIC DEMOCRATIC ALLIANCE ENJOYED MORE THAN A TWOTHIRDS MAJORITY IN PARLIAMENT. ITS OPPOSITION, THE PEOPLE'S DEMOCRATIC ALLIANCE CHARGED THAT THE ELECTIONS WERE STOLEN, AND ITS LEADER, BENAZIR BHUTTO, BITTERLY CRITICIZED THE GOYERMMENT WHIL THE BICKERING AND INFIGHTING IS NOTHING DUT OF THE ORDINARY FOR PAKISTANI POLITICS, WHAT IS REMARKABL ORDINARY FOR PAKISTANI POLITICS, WHAT IS SYSTEM. THE SECOND EVENT WAS THE CESSATION OF UNITED STATES AID TO PAKISTAN IN OCTOBER 1990. THE AID CUTOFF. PROMPTED BY PAKISTAN'S GROHING NUCLEAR WEAPONS PROGRAM, STRAINED RELATIONS WITH THE UNITED STATES AND EXERTED IMMENSE
PRESSURE ON PAKISTAN'S ECONOMY. NEYERTHELESS, THE GDP GREW 
AT A HEALTHY RATE OF $5.6 \%$, EXPORTS ROSE 8Y $22 \%$ AND DIRECT FOREIGN INVESTMENT BY 15\%. OTHER SIGNIFICANT EVENTS INCLUDE PAKISTAN'S ABOUT-FACE ON THE ISSUE OF AFGHANISTAN: PAKISTAN NOW SUPPORTS A NEGOTIATED SETTLEME

05152 KHARE, $H$

ELECTION 1992

NORLD PRESS REVIEH, 39(5) (MAY 92), 9-10.

THE AUTHOR GIVES A FOREIGN CORRESPONDENT'S VIEH OF WHAT

IS WRONG WITH THE U.S. PRESIDENTIAL ELECTION PROCESS AND WHY SO MANY AMERICANS HAVE BECOME DISENCHANTED WITH PRESIDENT GEORGE BUSH.

05153 KHASHAN, H.

LIMITS OF ARAB DEMOCRACY

HORLD AFFAIRS, 153(1) (SPR 91), 127-135

THIS ARTICLE STATES THAT THE ARAB WORLD STANDS IN TOTAL DISARRAY. THE IDEA OF ARAB SOLIDARITY HAS CRUMBLED. THE RECENT GULF WAR REVEALS THE HUGE GAP THAT HAS OPENED IN INTER-ARAB RELATIONS. MANY ARAB REGIMES ARE UNABLE TO COPE INTER-ARAB RELATIONS. MANY ARAB REGIMES ARE UNABLE TO COPE
WITH MOUNTING DOMESTIC OPPOSITION AND APPEAR TO BE OFFERING IMPORTANT POLITICAL CONCESSIONS THAT WERE UNTHINKABLE A FEW YEARS AGO. THE OBJECTIVE OF THIS ARTICLE IS TO ASCERTAIN THE YEARS AGO. THE OBJECTIVE OF THIS ARTICLE IS TO ASCERTAIN THE THE PROGRESSION OF THE ARAB DRIVE TOWARDS DEMOCRACY.

05154 KHASHAN, H.; HARIK, J.

THE PLIGHT OF KURDS

BULLETIN OF PEACE PROPOSALS, 23(2) (1992), 147-158.

AT THE HEART OF THE KURDISH PREDICAMENT IS THE DENIAL OF ETHNIC IDENTIFICATION AND SELF-DETERMINATION FOR NEARLY 23 MILLION KURDS, THE VAST MAJORITY OF WHOM LIVE IN TURKEY, IRAN, IRAQ AMD SYRIA. THE OBJECTIVE OF THIS PAPER IS TO PROVIDE A CLOSE EMPIRICAL ASSESSMENT ABOUT THE STATE OF KURDISH ETHNICITY. THE FOLLOWING FOUR DIMENSIONS WILL BE EXPLORED: (1) THE MAGNITUDE OF DEPRESSED SOCIAL AND ECONOMIC CONDITIONS: (2) THE NATURE OF ETHNIC AND CULTURAL CONDITIONS (3) THE WEAKNESS OF GROUP SOL IDARITY: AND (4) THE RANGE OF POL ITICAL DEMANDS. LEBANON IS THE ONLY PLACE IN THE MIDDLE GOVERMMENTAL INTERVENTION.

05155 KHILNANI, $N$.

THE FOLLIES, FUMBLINGS, AND FRUSTRATIONS OF IMDIA'S RECENT FOREIGN POLICY

ROUND TABLE, 321(321) ( JAN 92), 57-60.

TODAY INDIA'S MOVES ON THE INTERMATIONAL CHESSBOARD ARE LOOKED UPON WITH SUSPICION. ITS IMMEDIATE NEIGHBORS THINK OF IT AS A PREDATORY POWER. IF THE SITUATION ON INDIA'S IT AS A PREDATORY POWER. IF THE SITUATION ON INDIA'S SIMK STI T DOWER AND THE COUNTRY'S POLICY POSTURES, AND SINK STILL LOWER AND THE COUNTRY'S POLICY, POSTURES, AND THAT ACHDIAM POLICY MOULOERS SHOULD AWAKEN TO THE COMPLETELY THAT INDIAN POLICY HOULDERS SHOULD AWAKEN TO THE COMPLETELY POLICY. INDIA MUST REALISTICALLY AND RATIONALLY ALTER ITS POLICY AND MUST ADOPT A BOLD POSTURE IN DEFENDING ITS NATIONAL INTERESTS.

05156 KIAI, M.

ATTAINING REAL DEMOCRACY IN KENYA

TRANSAFRICA FORUM, 9(1) (SPR 92), 84-87

IN KENYA, THE MOI REGIME IS SEARCHING FOR WAYS AND MEANS TO REMAIN IN POWER WITHOUT UNDERTAKING ANY REFORMS, AND THE USE OF FORCE IS NOT PRECLUDED. KENYA RELIES HEAVILY ON FOREIGN ASSISTANCE AND TOURISH, HHICH GIVES THE INTERNATIONAL COMUNITY A GREAT DEAL OF LEVERAGE OVER MOI. THE MOI REGIME HAS ALHAYS SUCCUMBED TO INTERHATIONAL PRESSURE, AND MEMBERS OF THE INTERNATIONAL COMMUNITY-ESPECIALLY THE USA--SHOULD NOT HESITATE TO PUT PRESSURE ON MOI TO ENSURE THAT DEMOCRACY FINALLY COMES TO KENYA.

05157 KIDOER, R.E.

SAFETY NO BARRIER TO TEST BAN

BULLETIN OF THE ATOMIC SCIENTISTS, 47(3) (APR 91), 32-34. THIS ARTICLE CONTAINS AN ASSESSMENT OF THE SAFETY OF US NUCLEAR WARMEADS HITH PARTICULAR ATTENTION GIVEN TO THE EXTENT TO WHICH ADOITIONAL NUCLEAR EXPLOSIVE TESTS MIGHT BE NEEDED TO IMPROVE THEIR SAFETY. FIVE QUESTIONS ARE EXPLORED: (1) ARE NUCLEAR WEAPONS SAFE: (2) DO WE NEED TO INCREASE THE NUMBER OF NUCLEAR TESTS TO ENSURE THE SAFETY OF THE NUCLEAR NUMBER OF NUCLEAR TESTS TO ENSURE THE SAFETY OF THE NUCLEAR
ARSENAL? (3) ARE THERE HAYS TO DEAL WITH THE HARHEAD SAFETY ARSENAL? (3) ARE THERE HAYS TO DEAL WITH THE HARHEAD SAFETY
QUESTION OTHER THAN THROUGH TESTING? (4) SHOULD INSENSITIVE QUESTION OTHER THAN THROUGH TESTING? (4) SHOULD INSENSITIVE HIGH EXPLOSIVES BE ADDED TO ALL NUCLEAR WEAPONS? (5) WHAT PROGRAM TO MAKE HARHEADS MORE INTERCHANGEABLE WITH DELIVERY PROGRAM TO MU
VEHICLES?

05158 KIDRON, $P$

ATTEMPTS TO DERAIL BAKER

MIDOLE EAST INTERMATIONAL (398) (APR 91), 12-13.

U.S. SECRETARY OF STATE JAMES BAKER'S SECDND VISIT TO ISRAEL WITHIN FIVE HEEKS CAME AT A TIME OF INTENSE POLITIICAL INFIGHTING AMONG ISRAEL'S RULING LIKUD PARTY. IN AN APPARENT
ATTEMPT TO DERAIL IN PEACE PROCEEDINGS, HOUSING MINISTER ARIEL SHARON LAUNCHED A HIGHLY YISIBLE DRIVE TO STEP UP CONSTRUCTION WORK IN THE SETTLEMENTS, A MOVE THAT IS CERTAIN TO RILE ARABS AND AMERICANS ALIKE. HIS MOVE WAS STRIDENTLY OPPOSED BY FOREIGN MINISTER DAVID LEVY, WHO IS THOUGHT BY MANY TO BE A KEY COMPETITOR WITH SHARON FOR THE POSITION OF PART, HE MADE AMBIGUOUS STATEMENTS WHICH HERE VAGUELY SATISFYING TO BAKER, YET DIDN'T ANGER HIS RIGHT-WING ALLIES.

05159 KIDRON, $P$.

ISRAEL AND LEBANON: COMMITMENT TO STAY

MIDDLE EAST INTERNATIONAL, 438(438) (NOV 92), 7-8.

CRITICS OF YITZHAK RABIN COMPLAIN THAT HIS BENT FOR

DISSECTING PROBLEMS VERBALLY IS NOT MATCHED BY A SIMILAR

INCISIVENESS IN PURSUING A PRACTICAL SOLUTION. THIS ARTICLE

EXAMINES A CASE IN POINT WHICH WAS RABIN'S COMMENTARY ON THE RECENT FLARE-UP ALONG ISRAEL'S BORDER WITH LEBANON, WHICH WITNESSED TWO WEEKS OF ARTILLERY AND ROCKET DUELS BETWEEN, CALLS FOR EXPANSIONISH AND LIKUO IN DISARRAY.

05160 KIDRON, $P$.

ISRAEL--PARTIAL SETTLEMENT FREEZE

ISRAEL-DPARTIAL SETTLEMENT FREEZE
MIDOLE EAST INTERNATIONAL, (421) (AUG 92), 5-7

CONTRARY TO THE IMPRESSION CAREFULLY CREATED BY THE NEH ISRAELI GOVERNMENT, ITS LOUDLY-TRUMPETED "FREEZE" ON NEW SETTLEMENTS IN THE' OCCUPIED TERRITORIES WILL NOT BRING SETTLEMENT ACTIVITY TO AN ABRUPT HALT. ALTHOUGH PRIME
MINISTER YITZHAK RABIN AND HIS MINISTERS HAVE INDEED SHELVED MINISTER YITZHAK RABIN AND HIS MINISTERS HAVE INDEED SHELVED
PLANS TO ESTABLISH NEW SETTLEMENTS. THEY WILL PRESS AHEAD PLANS TO ESTABL ISH NEW SETTLEMENTS, THEY WILL PRESS AHEAD
HITH EXPANSION (THICKENING") OF EXISTING SETTLEMENTS, ALBEIT ON A REDUCED SCALE. HOWEVER, OF SOME 15,000 HOUSING UNITS APPROVED FOR CONSTRUCTION IN THE OCCUPIED TERRITORIES BY THE DUTGOING LIKUD HOUSING MINISTER ARIEL SHARON, 6,800 HAVE BEEN FROZEN. THE NATIONAL BUDGET WILL THUS BE PARTLY RELIEVED OF THE BURDEN OF SHARON'S COMMITMENT TO PURCHASE ANY UNIT THE CONTRACTORS FAIL TO SELL TO THE GENERAL PUBLIC. TOTAL SAVINGS FROM THE HALT COULD REACH \$500 MILLION. THESE POTENTIAL SAVINGS HIGHLIGHT THE RABIN GOVERNMENT'S STRESS ON ITS SLOGAN OF "REORDERING NATIONAL PRIORITIES," ITS AIM BEING TO SERVE "THOSE 3,900,000 OF ISRAEL'S 4,000,000 JEWS WHO DO NOT LIVE IN THE TERRITORIES." THIS PRAGHATIC POLICY ABJURES AMY IDEOLOGICAL EMNITY TOWARDS THE SETTLEMENT MOVEMENT WHILE HIGHLIGHTING THE NEEDS OF "GREEN LINE" ISRAEL. RABIN HAS ALSO DEFTLY DEFUSED RIGHT-WING CRITICISM OF HIS POLICIES TOHARDS NEGOTIATION HITH ARAB STATES IN THE MIDDLE EAST.

05161 KIDRON, $P$

ISRAEL-DOLITICAL UNCERTAINTY

MIDDLE EAST INTERNATIONAL, (423) (APR 92), 9-11.

WITH TWO MONTHS TO GO BEFORE THE GENERAL ELECTION IN JUME, ISRAEL'S POL ITICAL PARTIES ARE PICKING CANDIDATES, PUTTIMG TOGETHER CAMPAIGN SCHEMES AND HONIMG PROPAGANDA STRATEGIES. BUT WHILE PARTY SPOKESMEN FEIGN UNBOUNDED CONFIDENCE. THE PICTURE IS CONFUSED AND UNCERTAIN. OF THE MA POR PARTIES, PIKUD UNDER YITZHAK SHAMIR ENTERS THE CAMPAIGN FROM A COMMANDING POSIIION, HAVING BEEN IN OFFICE WITHOUT INTERRUPTION FOR THE PAST 15 YEARS. HOWEVER, INTERNAL DISARRAY AND ECONOMIC PROBLEMS DIMINISH LIKUD'S ELECTABILITY. MEANWHILE, THE OPPOSITION LABOR PARTY HAS LAUNCHED ITS CAMPAIGN WITH A DEFT HAND. AFTER REPLACING ITS JADED LEADER SHIMON PERES WITH THE MORE HIDELY POPULAR YITZHAK RABIN, LABOR REGISTERED AN INNOVATION IN ISRAELI POLITICS BY ABANDONING THE TRADITIONAL METHOD OF SELECTING CANDIDATES BY A COMMITTEE OF PARTY BOSSES, AND HOLDING PRIMARIES TO PERMIT RANK AND FILE MEMBERS TO ELECT THE SLATE OF CANDIDATES. FEW OBSERVERS EXPECT EITHER BLOC TO HIN 61 SEATS IN THE 120-MEMBER LEGISLATURE. THEREFORE, UNCERTAINTY AND COALITION GOVERNMENT SEEM DESTINED TO CONTINUE.

05162 KIDRON, $P$

ISRAEL--SILWAN IS JUST THE BEGINNING

MIDOLE EAST INTERNATIONAL, (415) (DEC 91), 5-6.

A CONFIDENTIAL MASTER-PLAN LEAKED TO THE ISRAELI PRESS DELIMEATES THE GROUNDWORK FOR MASSIVE JEWISH COLONIZATION OF THE ARAB NEIGHBORHOODS OUTSIDE THE HALLS OF JERUSALEM'S OLD CITY. THE PLAN PINPOINTS TWENTY-TWO ARAB MEIGHBORHOODS FOR CONSTRUCTION OF A TOTAL OF SOME 4,000 HOUSING UNITS

EXCLUSIVELY FOR ISRAELIS. THE PLAN'S UNABASHED AIM IS CONTROL AND DOMINATION. BY PLANTING ISRAELIS IN SIGNIFICANT NUMBERS AT KEY POINTS IN THE CITY'S NORTHERM AND SOUTHERN NUMBERS AT KEY POINTS IN THE CTYY S NORTHERN AND SOUTHERN QUARTERS, THE PLANNERS EVIDENTLY INTEND TO FRAGMENT EXISTING DESIGNED TO ENSURE THAT NO SIGNIFICANT PORTION OF JERUSALEM DESIGNED TO ENSURE THAT NO SIGNIFICANT PORTION OF JERUSALEM REMAINS EXCLUSIVELY ARAB; IN THIS HAY, ITS SPONSORS PALESTINIANS TO SERVE AS THEIR CAPITAL.

05163 KIDRON, $P$.

ISRAEL: TROUBLE IN THE COALITION

MIDOLE EAST INTERNATIONAL, 436 (OCT 92), 7 .

PRIME MINISTER RABIN'S GOVERMMENT ENJOYS A CLEAR 
PARLIAMENTARY MAJORITY WITH LABOUR PARTY VOTES BEING SUPPLEMENTED BY THOSE OF HIS COALITION PARTNERS, THE LEFTLEANING MERETZ FACTION AND THE ORTHODOX SHAS PARTY. LABOUR ATTACHES PARTICULAR IMPORTANCE TO SHAS, THE ONLY RELIGIOUS PARTY TO HAVE SHITCHED TO RABIN AFTER PREYIOUSLY SUPPORTING LIKUD. HOWEVER, THE GOVERMMENT'S MAJORITY IS FAR FROM SECURE. WHILE IN BROAD AGREEMENT WITH RABIN'S POLICY, SHAS IS LOCKED IN AN ONGOING SOUABBLE OVER RELIGIOUS ISSUES WITH THE SECULAR LEADERS OF MERETZ. THE CONFLICT COULD HAVE A PAINFUL EFFECT ON THE COALITION AND THE PARTIES.

05164 KIDRON, P.

ISRAEL: VIOLENCE MARKS THE START OF THE SIXTH YEAR OF THE INTIFADA

MIDDLE EAST INTERNATIONAL, 440(440) (DEC 92), 3-4. THE FIFTH ANNIVERSARY OF THE PALESTINIAN INTIFADA BROUGHT ITS PREDICTABLE WAVE OF VIOLENCE, WITH WIDESPREAD CLASHES THROUGHOUT THE OCCUPIED TERRITORIES BELYING OFFICAL ISRAELI CLAIMS THAT THE UPRISING IS ON THE WANE. THE RENEWED ISRAELI CLAIMS THAT THE UPRISING IS ON THE WANE. THE RENEWED STRATEGY. THIS REPORT DESCRIBES THE DISILLUSIONMENT AND GLOOM IN SRAEL AND PONDERS WHAT TO DO WITH GAZA.

05165 KIDRON, $P$.

KNIVES MAKE THE REPRESSION HARSHER

MIDDLE EAST INTERNATIONAL, (397) (APR 91), 8-9.

IN A CALCULATED BID TO BLOCK THE OIPLOMATIC INITIATIVES CAUTIOUSLY FLOATED DURING THE RECENT VISIT OF U.S. SECRETARY OF STATE JAMES BAKER, HARD-LINERS ARE MAKING POLITICAL HAY FROM A SPATE OF KILLINGS AND KNIFE ATTACKS ON ISRAELI CIVILIANS. INSOFAR AS THEIR WORDS ARE DIRECTED AT AN ALARMED PUBLIC, THEIR MESSAGE IS FINDING FERTILE SOIL. THE CALLS FROM HARD-LINE FACTIONS IN ISRAEL FOR MORE REPRESSION AND MASS DEPORTATIONS HAVE BEEN TEMPERED SOMENHAT BY CENSURE FROM THE UNITED STATES AND FROM THE ISRAELI MILITARY ADMINISTRATION WHO WARNS THAT FURTHER RESTRICTIONS ON PALESTINIAN ECONOMIC ACTIVITY HOULD EXACERBATE UNEMPLOYMENT, ADDING THOUSANDS OF JOBLESS YOUNGSTERS TO THE POOL OF POTENTIAL RECRUITS TO RESISTANCE GROUPS.

05166 KIDRON, $P$.

LULL FOR RABIN

MIDDLE EAST INTERNATIONAL, (437) (NOV 92), 9-10.

IN OCTOBER 1992, PRIME MINISTER YITZHAK RABIN'S HOLD ON OFFICE SEEMED TO BE SLIPPING AS THE LABOR PARTY'S

PARLIAMENTARY MAJORITY WAS IMPERILED BY A SOUABBLE BETWEEN ITS TWO COALITION PARTNERS, THE MERETZ AND THE SEPHARDI ORTHODOX SHAS PARTY. BUT IN EARLY WITHDRAHING FROM THE COALITION.

05167 KIDRON, $P$

RABIN'S BALANCING ACT THREATENS HIS COMMITMENT TO PEACE MIDDLE EAST INTERNATIONAL, (429) (JUL 92), 3-4

CONTRARY TO FIRST IMPRESSIONS, YITZHAK RABIN'S ADVENT TO POWER DOES NOT NECESSARILY MARK A DECISIVE AND IRREVERSIBLE CHANGE IN OFFICIAL ISRAELI POLICY ON FUNDAMENTAL ISSUES SUCH AS THE OCCUPIED TERRITORIES. THE FINAL ELECTION RETURNS INDICATE THAT RABIN'S LABOR PARTY ENDED UP WITH 44 KNESSET SEATS AND ITS MERETZ ALLIES ENDED UP HITH 12, A TOTAL WHICH IS FIVE SHORT OF A MAJORITY. RABIN HAS REMAINED FIRM IN HIS DESIRE NOT COOPERATE WITH ISRAEL'S SMALL COMMUNIST AND ARAB DEMOCRATIC PARTIES. THEREFORE, HE HAS BEEN FORCED TO LOOK TO THE RELIGIOUS PARTIES AND THOSE OF THE FAR RIGHT. THE INFLUENCE OF THE RIGHT-HING PARTIES IS EVIDENT IN LABOR'S RECENT ANNOUNCEMENTS THAT THE PARTY OPPOSES THE EMERGENCE OF A PALESTINIAN STATE AND THAT ANY TREATY WITH THE PALESTINIANS MUST BE APPROVED BY THE ISRAELI ELECTORATE.

05168 KIDRON, $P$.

SHAMIR BUCKLES UNDER THE SETTLERS' CLOUT

MIDDLE EAST INTERNATIONAL, (416) (JAN 92), 3-4.

THE INCREASINGLY STRIDENT PROTESTS OF ISRAELI SETTLERS IN THE OCCUPIED TERRITORIES POSE A NEH THREAT TO THE ALREADY TENUOUS MIDEAST PEACE PROCESS. THE RECENT DEPORTATION OF 12 PROMINENT PALESTINIANS IN REPRISAL FOR THE KILLING OF A JEWISH SETTLER IN THE GAZA STRIP IS A SIGN THAT ISRAELI AUTHORITIES ARE BENDING TO SETTLER PRESSURE. THE SETTLERS HAVE LONG SPEARHEADED DEMANDS FOR AN "IRON FIST" POLICY TO CRUSH THE PALESTINIAN INTIFADA AND TO PUT AN END TO THEIR
TRAVAILS. EGGED ON BY PARTIES OF THE FAR RIGHT, THE SETTLERS TRAVAILS. EGGED ON BY PARTIES OF THE FAR RIGHT, THE SETT
HAVE RAISED THE PITCH OF THEIR CAMPAIGN IN RECENT HEEKS, HAVE RAISED THE PITCH OF THEIR CAMPAIGN IN RECENT HEEKS,
WITH INTENSIVE POLITICAL LOBBYING BACKED UP BY "DIRECT WITH INTENSIVE POLITICAL LOBBYING BACKED UP BY "DIRECT ACTION." MANY OBSERVERS NOTE THAT THE SETTLERS SEEM

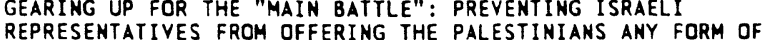
REPRESENTA

05169 KIDRON, $P$.

SHAMIR'S DANGEROUS GAMBLE

MIDDLE EAST INTERNAT IONAL (414) (DEC 91)

WHEN YITZHAK SHAMIR RULED THAT THE ISRAELI DELEgATION TO THE PEACE TALKS HOULD GO TO WASHINGTON ON 9 DECEMBER, FIVE DAYS LATER THAN THE DATE SPECIFIED IN THE INVITATION, HE
APPEARED TO BE EMBARKING ON AN ENORMOUS POLITICAL GAMBLE. REACHING HIS DECISION HHEN IT WAS ALREADY APPARENT THAT THE ARAB DELEGATIONS HOULD TURN OUT AT THE APPOINTED TIME, THE ISRAELI PRIME MINISTER SEEMED INTENT ON DISCARDING THE LAST SHREDS OF CREDIBILITY ABOUT ISRAEL'S PROCLAIMED DESIRE FOR PEACE. THE MOTIVATIONS FOR SHAMIR'S ACT ARE DIVERSE, BUT ONE COMES TO THE FOREFRONT: ISRAEL'S DESIRE TO "TEACH AMERICA A LESSON" AND ENSURE THAT THE UNITED STATES DOES NOT TAKE CONTROL OF THE NEGOTIATIONS.

05170 KIDRON, $P$.

SHROUDS OVER THE BAKER VISIT

MIDDLE EAST INTERNATIONAL, (396) (MAR 91), 4-5

MANY DAYS AFTER JAMES BAKER'S DEPARTURE FROM ISRAEL, VERY FEW COULD CLAIM REAL KNOWLEDGE OF THE TALKS HE CONDUCTED THERE. RUMORS AND CONFLICTING REPORTS OF THE CONTENT OF THE TALKS ABOUND. SOME OF THESE INCLUDE PROGRESS CONTENT OF THE TALKS ABOUND. SOME OF THESE INCLUDE PROGRESS TOWARD: A "TWO-PRONGED" APPROACH INYOL VING PARALLEL EFFORTS PALESTINIANS; A REGIONAL PEACE CDNFERENCE UNDER THE AUSPICES PALESTINIANS; A REGIONAL PEACE CONFERENCE UNDER THE AUSPICES OF THE TWO SUPERPOHERS; AND A SERIES OF "GESTURES" DESIGNED TO IMPROVE CONFIDENCE. THERE WERE LITTLE OR NO SIGNS THAT THE UNITED STATES WAS USING ANY SIGNIFICANT PRESSURE ON
ISRAEL OR THAT THE TALKS WERE GOING TO PRODUCE ANYTHING MORE THAN TALKS IN PREVIOUS YEARS HAVE. HOHEVER, EVEN THE RUMORS OF A POSSIBLE SETTLEMENT INVOLVING TERRITORIAL CONCESSIONS RAISED THE IRE OF PRIME MINISTER YITZHAK SHAMIR'S HARD-LINE ALLIES WHO THREATENED TO ABANDON SHAMIR'S UNEASY COALITION IF THE GOVERNMENT DEMONSTRATED ITS HILLINGNESS TO CONSIDER GIVING UP TERRITORY.

05171 KIDRON, $P$.

HAITING FOR BAKER

MIDOLE EAST INTERNATIONAL, (395) (MAR 91), 11-13.

WITH THE TERMINATION OF THE GULF FIGHTING

PRONOUNCEMENTS FROM WASHINGTON ABOUT AN IMMINENT DOPLOMATIC INITIATIVE TO RESOLVE THE ARAB-ISRAEL CONFLICT HAVE CAUSED JITTERS IN ISRAEL. THE FAR-REACHING DEPENDENCY UPON THE U.S. MAKES ISRAELIS HIGHLY SENSITIVE TO U.S. INTENTIONS, AND POLICIES, PARTICULARLY IN VIEW OF THE TOUGH-MINDED MOOD CURRENTLY EXUDED BY THE BUSH ADMINISTRATION, IN THEIR CONFUSION MANY ISRAELI MINISTERS ANO KEY GOVERNMENT FIGURES HAVE ISSUED CONFLICTING STATEMENTS ABDUT ISRAEL'S POSITION HAVE ISSUED CONFLICTING STATEMENTS ABDUT ISRAEL'S POSITION
ON THE FUTURE OF ITS RELATIONS WITH THE ARAB STATES AND THE ON THE FUTURE OF ITS RELATIONS WITH THE ARAB STATES AND THE
OCCUPIED TERRITORIES. IRONICALLY, THE ONLY POLITICAL LEADER WHO HAS YET TO SPELL OUT HIS VIEWS ON THE CURRE
CONTROVERSY IS PRIME MINISTER YITZHAK SHAMIR.

$05172 \mathrm{KIEH}, \mathrm{G}$. JR.

COMBATANTS, PARTONS, PEACEMAKERS, AND THE LIBERIAN CIVIL CONFLICT

STUOIES IN CONFLICT AND TERRORISM, 15(2) (1992), 125-144. THIS PAPER EXAMINES THE VARIOUS MAJOR ACTORS' IN THE LIBERIAN CIVIL CONFLICT, THE IMPACT OF THE CONFLICT, AND THE EFFORTS TO RESOLVE IT PEACEFULLY. THE CONFLICT IS THE BYPRODUCT OF THE PROBLEMS OF UNDERDEVELOPMENT AND REPRESSION
THAT HAVE UNDERGIRDED THE LIBERIAN POLITY SINCE THE COUNTRY BECAME INDEPENDENT IN 1847. THE PATH TO PEACE, STABILITY, AND DEMOCRACY MUST BE HOL ISTIC: IT MUST COMBINE POLITICAL AND SOCIOECONOMIC FREEDOMS AND OPPORTUNITITES.

$05173 \mathrm{KIEH}, \mathrm{G.K}$.

COMBATANTS, PATRONS, PEACEMAKERS, aNo THE LIBERIAN CIVIL CONFLICT

STUDIES IN CONFLICT AND TERRORISM, 15(2) (APR 92), 125-144.

THIS PAPER EXAMINES THE VARIOUS MAJOR ACTORS IN THE LIBERIAN CIVIL CONFLICT, THE IMPACT OF THE CONFLICT, AND THE EFFORTS TO RESOLVE IT PEACEFULLY. FIRST, THE MAJOR

COMBATANTS ARE IDENTIFIED AS THE NATIONAL PATRIOTIC FRONT OF LIBERIA (NPFL), THE MAJOR INSURGENCY MOVEMENT, THE

LIBERIA (NPFL), THE MAJOR INSURGENCY MOVEMENT, THE BREAKAHAY FACTION FROM THE NPFL, AND THE ARMED FORCES, THE REMNANTS OF THE LIBERIAN ARMY THAT SUPPORTED THE DOE REGIME. SECDND. THE EXTERNAL PLAYERS ARE THE ECONOMIC COMMUNITY OF WEST AFRICAN STATES, NIGERIA, THE IVORY CDAST, LIBYA, BURKINA FASO, AND THE UNITED STATES. THE CONFLICT IS THE BYBURKINA FASO, AND THE UNITED STATES. THE CONFLICT IS
PRODUCT OF THE PERENNIAL PROBLEMS OF SOCIOECONOMIC PRODUCT OF THE PERENNIAL PROBLEMS OF SOCIDECONOMIC
UNDERDEVELOPMENT AND POLITICAL REPRESSION THAT HAVE UNDERGIRDED THE LIBERIAN POLITY SINCE THE COUNTRY BECAME INDEPENDENT IN 1847. ACCORDINGLY, IN ORDER TO RESOLVE THE INDEPENDENT IN 1847. ACCORDINGLY, IN ORDER TO RESOLVE THE
CONFLICT COMPLETELY, CONCERTED EFFORTS MUST BE MADE TO CONFLICT COMPLETELY, CONCERTED EFFORTS MUST BE MADE TO
ADORESS THESE PROBLEMS. IN OTHER WORDS. THE CESSATION OF ADORESS THESE PROBLEMS. IN OTHER WORDS, THE CESSATION
MILITARY HOSTILITIES AND THE HOLDING OF FREE AND FAIR MILITARY HOSTILITIES AND THE HOLDING OF FREE AND
ELECTIONS ARE IMPORTANT, BUT INSUFFICIENT STEPS. ELECTIONS ARE IMPORTANT, BUT INSUFFICIENT STEPS.
ALTERNATIVELY, THE PATH TO PEACE, STABILITY AND DEMOCRACY ALTERNATIVELY, THE PATH TO PEACE, STABILITY AND
MUST BE HOLISTIC: IT MUST COMBINE POLITICAL AND SOCIOECONOMIC FREEDOMS AND OPPORTUNITIES.

$05174 \mathrm{KIEH}, \mathrm{J}$. JR.

THE ROOTS OF WESTERN INFLUENCE IN AFRICA: AN ANALYSIS OF THE CONDITIONING PROCESS

SOCIAL SCIENCE JOURNAL, 29(1) (1992), 7-20.

THE ARTICLE EXAMINES THE ISSUE OF THE DOMINANCE OF WESTERN CULTURAL IMPERIALISM IN AFRICA, AND THE RESISTANCE 
TO ITS CONTINUATION. THE STUDY ARGUES THAT THE MAJOR HESTERN POWERS HAVE MAINTAIHED THEIR CULTURAL HEGEMONY OF THE AFRICAN CONTINENT THROUGH A WEB OF SOCIALIZATION AGENTS HOWEVER, DESPITE THE PERVASIVENESS OF WESTERN CULTURAL IMPERIALISM, THE LAST TWO DECADES HAVE WITNESSED THE REEMERGENCE OF RESISTANCE TO THE CONTINUATION OF WESTERM CULTURAL IMPERIAL ISM. THIS RESISTANCE HAS EMANATED FROM FIVE MAJOR SOURCES: RADICAL AND NATIONALIST REGIMES, THE LIBERATED AFRICAN CHRUCH, MASS MOVEMENTS, THE NEW BREED OF RADICAL AFRICAN INTELLECTUALS AND THE DEVELOPMENT OF POLITICAL CONSCIOUSNESS AS A CONSEQUENCE OF THE CONTRADICTIONS IN THE FOREIGN POLICIES OF THE MAJOR WESTERN POWERS.

05175 KIELINGER, T.

GERMAN FOREIGN POLICY FACES A TEST OF CREDIBILITY GERMAN TRIBUNE, (1525) (JUL 92), 1, 4.

IN SPITE OF WIDESPREAD CRITICISM, GERMANY DID HAVE LEGITIMATE REASONS TO NOT OFFER MILITARY AID TO THE ANTIIRAQ COALITION AND NOT TO BACK ITS DIPLOMATIC DECLARATIONS ON YUGOSLAVIA HITH FORCE. THE MAIN REASON WAS FEAR THAT THE SOVIET UNION, FEARING A RESURGENT MILITANT GERMANY, WOULD SOVIET UNION, FEARING A RESURGENT MILITANT GERMANY, WOULD

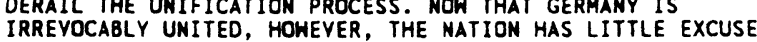
IRREVOCABLY UNITED, HOHEVER, THE NATION HAS LITTLE EXCUSE OPERATIONS, EVEN IF THEY REQUIRE THE USE OF GERMAN TROOPS OPERATIONS, EVEN IF THEY REQUIRE THE USE OF GERMAN TROOPS. IF GERMANY REFUSES TO AMEND ITS CONSTITUTION TO ALLOW THE
USE OF GERMAN FORCES IN UN PEACEKEEPING OPERATIONS, THE INTERNATIONAL REPERCUSSIONS COULD BE CONSIDERABLE.

05176 KIELINGER, $T$

THE EUROPEAN COMMUNITY TO HIT THE SERBS WITH SANCTIONS GERMAN TRIBUNE, (1493) (NOV 91), 3

THE EUROPEAN COMMUNITY HAS DECIDED TO IMPOSE SANCTIONS AGAINST YUGOSLAVIA IN A BID TO HALT THE SERBIAN ONSLAUGHT. HOWEVER, THE FIGHTING CONTINUES. IF NOTHING ELSE, THE EXAMPLE OF YUGOSLAVIA SHOHS THAT THE EXISTING CONTRACTUAL COMMUNITIES ARE NO LONGER EFFECTIVE WHEN IT COMES TO DEALING WITH TODAY'S FOREIGN AND SECURITY POLICY DECISION-MAKING CIRCUMSTANCES. NATO IS SIMPLY NOT DESIGNED FOR EUROPEAN CONFLICTS IN THE POST-COMHUNIST ERA, AND, IN STRUCTURAL AND INSTITUTIONAL TERMS, THE EUROPEAN COMHUNITY IS NOHHERE NEAR ABLE TO DECLARE ITSELF RESPONSIBLE FOR THE SETTLEMENT OF CURRENT OF FUTURE FOREIGN POLICY CONFLICTS.

05177 KIELINGER, T

YUGOSLAYIA: EC MUST SEND A CLEAR MESSAGE

GERMAN TRIBUNE, (1476) (JUL 91), 1-2.

THERE HAS BEEN A BREATHING SPACE IN THE STRUGGLE OVER THE FUTURE OF YUGOSLAVIA, BUT DIPLOMACY OF ANY KIND WILL BE DOOMED TO FAILURE IF THE MILITARY LEADERSHIP IN BELGRADE CONTINUES TD FUNCTION AS AN INDEPENDENT BACKGROUND POWER, HEEDLESS OF ITS POL ITICAL PROMISES. A KEY FACTOR IN DETERMINING WHETHER CROATIA AND SLOVENIA'S ATTEMPTS TO SECEDE FROM THE FEDERATION WILL END IN PEACE OR CIVIL WAR IS
THE BEHAVIOR OF THE EUROPEAN COMHUNITY. CONCRETE, DETERMINED, AND CONTINUED INSISTENCE ON A PEACEFUL SOLUTION TO THE PROBLEM (WITH THE THREAT OF AID SUSPENSION IF VIOLENCE CONTINUES) IS A VITAL PRECONDITION FOR PEACE.

05178 KIELMAS, $M$

CAN OIL SANCTIONS AGAINST LIBYA WORK?

MIDDLE EAST INTERNATIONAL, (414) (DEC 91 ), 10 .
IF THE LAST FEW WEEKS OF RHETORIC ARE TO BE BELIEVED

ECONOMIC SANCTIONS AGAINST LIBYA, FOLLOWING U.S. AND BRITISH ALLEGATIONS THAT LIBYA WAS RESPONSIBLE FOR THE LOCKERBIE TRAGEDY, WILL BE STRENGTHENED. THE OIL INDUSTRY, HHICH HAS NEVER BEEN IN THE HABIT OF RECOGMIZING POL ITICAL PROBLEMS, SAYS THE EXERCISE AGAINST LIBYA HILL DEGENERATE INTO AS MUCH OF A FARCE AS IT DID AGAINST SOUTH AFRICA. PAST ATTEMPTS TO LIMIT AMERICAN AND BRITISH BUSINESS CONTACTS WITH LIBYA HAVE BEEN REMARKABLY UNSUCCESSFUL AND THERE IS LITTLE REASON TO BELIEVE THAT THE FUTURE WILL BE MUCH DIFFERENT.

05179 KIELMAS, $M$

KUWAIT AND IRAQ: PAYING FOR RECONSTRUCTION

MIDDLE EAST INTERNATIONAL, (396) (MAR 91) 23-24.

BANKS HAVE ALWAYS MADE MONEY OUT OF WAR AND THIS LAST

GULF CONFLICT WILL BE NO EXCEPTION. KUWAIT HAS AMPLE

FINANCIAL RESOURCES AND ASSETS TO BEGIN THE COSTLY

RECONSTRUCTION EFFORTS REOUIRED TO REVIVE THE OIL INDUSTRY

RECONSTRUCTION EFFORTS REOUIRED TO REVIVE THE OIL INDUSTRY
MOST OBSERVERS PREDICT A SHIFT AND VAST INFLOW OF FOREIGN

MOST OBSERVERS PREDICT A SWIFT AND VAST INFLOW OF FOREIGN
INVESTMENT AS SOON AS THERE IS AN INTERNATIONALLY RECOGNIZED INVESTMENT AS SOON AS THERE IS AN INTERNATIONALLY RECOGNIZED
KUWAITI GOVERMMENT DEMONSTRABLY IN CONTROL OF THE COUNTRY. KUWAIT I GOVERNMENT DEMONSTRABLY IN CONTROL OF THE COUNTRY.
IRAQS FORTUNES, ON THE OTHER HAND, LOOK INCREASINGLY BLEAK AS FEN INTERNATIONAL BANKS ARE LIKELY TO BE WILLING TO INVEST IN ITS RECONSTRUCTION, REGARDLESS OF THE EVENTUAL FATE OF SADDAM HUSSEIN.

05180 KIELMAS, M.

KUWAIT: LITIGATION ON THE CARD

MIDOLE EAST INTERNATIONAL, 440(440) (DEC 92 ), 14.

THE ONGOING SCAMDAL ABOUT THE KUWAIT INYESTMENT OFFICE'S (KIO) ILL-FATED INVESTMENTS IN SPAIN IS ABOUT TO TAKE A MORE
POLITICALLY PRECARIOUS TURN. THE NEH MANAGEMENT AT KIO IS DETERMINED TO PURSUE ITS CLAIMS ABOUT ALLEGED MISMANAGEMENT OF KIO'S SPANISH AFFAIRS ALL THE WAY TO THE SPANISH COURTS. WITH THE SPANISH ECONOMY FACING A DOWNTURM IN 1993, A GENERAL ELECTION SCHEDULED FOR OCTOBER 1993 AND CORRUPTION IN ALL LEVELS OF GOVERMMENT A MAJOR ISSUE, THERE ARE A LOT OF PEOPLE WHO STAND TO GAIN
KUWAIT-SPAIN CONNECTION.

05181 KIERANS, E.

THE SOURCE OF ALL OUR TROUBLES

CANADIAN FORUM, LXXI (809) (MAY 92), 10-13

SINCE THE QUEBEC ACT OF 1774 , QUEBEC HAS ALWAYS BEEN RECOGNIZED AS FULLY DISTINCT IN LANGUAGE, CULTURE AND CIVIL LAW. THIS ARTICLE BRIEFLY OUTLINES THE HISTORY OF QUEBEC. IT STATES THAT IN 1946 OTTAWA COMMITTED ONE THE GREATEST POLITICAL BLUNDERS IN CANADIAN HISTORY. CANADIANS ARE STILL SUFFERING THE CONSEQUENCES.

05182 KIERHAN, B.

THE CAMBODIAN CRISIS, 1990-1992: THE UN PLAN, THE KHMER ROUGE, AND THE STATE OF CAMBODIA

BULLETIN OF CONCERNED ASIAN SCHOLARS, 24(2) (APR 92), 3-24. THIS ARTICLE EXAMINES THE EVENTS AND CHANGES THAT HAVE
THIN LED TO THE UNITED NATIONS-BROKERED NEGOTIATIONS FOR PEACE IN CAMBODIA. IT ARGUES THAT THREE FACTORS EXPLAIN THE DRAMATIC CAMBDDIA. IT ARGUES THAT THREE FACTORS EXPLAIN THE DRAMATIC ACCELERATION OF THE CAMBODIAN PEACE NEGOTIATIONS FROM JUNE
TO OCTOBER 1991: THE WORLD'S CONTINUING ISOLATION OF THE TO OCTOBER 1991: THE HORLD'S CONTINUING ISOLATION OF THE PHNOM PENH REGIME; THE REALIZATION THAT, DESPITE THIS ISOLATION, THE STATE OF CAMBOOIA GOVERMMENT COULD NOT BE
OVERTHROWN MILITARILY; AND, CHINA'S ACHIEVEMENT OF ITS MAJOR OVERTHROWN MILITARILY; AND, CHINA'S ACHIEVEMENT OF ITS MAJOR STRATEGIC GOALS IN COUNTRIES NEIGHBORING CAMBODIA, ALLOH
BEIJING TO CAPITALIZE ON ITS PREDOMINANCE IN MAINLAND SOUTHEAST ASIA AND BROKER A SETTLEMENT THAT WOULD ENSURE THE KHWER ROUGE AND THEIR ALLIES A SHARE IN CAMBODIA'S POLITICAL FUTURE DESPITE THEIR COMPARATIVE MILITARY WEAKNESS. THESE FACTORS HAVE LED TO A PEACE AGREEMENT WHICH MADE PRINCE NORODOM SIHANOUK THE CAMBODIAN HEAD OF STATE AFTER A TWENTY YEAR EXILE. HOWEVER, THE KHMER ROUGE IS UNLIKELYY TO COOPERATE WITH THE UN PLAN FOR DISMANTLING THE COUNTRY'S WARRING FACTIONS. KHMER ROUGE INTRANSIGENCE IS LIKELY TO DELAY OR EVEN DESTROY THE ENTIRE PEACE PROCESS.

$05183 \mathrm{KIHL}, \mathrm{Y}$. NORTH KOREA'S FOREIGN RELATIONS: DIPLOMACY OF PROMOTIVE

ADAPATION
JOURNAL OF NORTHEAST ASIAN STUDIES, $X(3)$ (FAL 91), 30-45.

DRAL OF NORTHEAST ASIAN STUDIES, $X(3)$ (FAL 91), 30-45.
DRAMATIC CHANGES IN EAST EUROPE AND THE SOVIET UNION DRAMATIC CHANGES IN EAST EUROPE AND THE SOVIET UNION
RESULTED IN NORTH KOREA'S DOUBLING ITS EFFORT TO SHIELD AND RESULTED IN NORTH KOREA'S DOUBLING ITS EFFORT TO SHIELD AND
DEFEND ITSELF FROM DISTURBANCES EMANATING FROM THE OUTSIDE. DEFEND ITSELF FROM DISTURBANCES EMANATING FROM THE OUTSIDE. YET, PRESIDENT KIM IL SUNG OF NORTH KOREA HAS ALSO OPTED FOR NEW DIPLOMATIC MOVES OF REALIGNMENT IN EXISTING TIES WITH
CHINA AMD THE SOVIET UNION AND IS ALSO SEEKING NEW RELATIONS CHINA AMD THE SOVIET UNION AND IS ALSO SEEKING NEW RELATIONS WITH JAPAN AND THE UNITED STATES. NORTH KKOREA'S DIPLOMATIC ADAPTATION IN 1990-91, SUCH AS ITS BALANCING DIPLOMATIC ACTS
VIS-A-VIS THE MAJOR ALLIES AND ADVERSARIES, IS EXAMINED, AND VIS-A-VIS THE MAJOR ALLIES AND ADVERSARIES, IS EXAMINED,
SO IS THE NORTH KOREAN DILEMMA OF RECONCILING NATIONAL SO IS THE NORTH KOREAN DILEMMA OF RECONCILING NATIONAL DIPLOMACY IS TEMPORARILY STALLED, ITS UN DIPLOMACY IS LIKELY TO BE ACTIVATED AS A RESULTS OF THE SIMULTANEOUS ENTRY INTO THE UNITED NATIONS WITH SOUTH KOREA IN 1991.

05184 KIHL, Y.W.

NEW ENVIRONMENT AND CONTEXT FOR KOREAN REUNIFICATION KOREA \& WORLD AFFAIRS, 16(4) (WIN 92), 621-637. THE ARENA OF INTER-KOREAN RELATIONS CONTINUES TO CHANGE AS A RESULT OF THE NEW ENVIRONMENT IN GLOBAL AND REGIONAL POLITICS. IN AN EFFORT TO CATCH UP WITH THE CHANGING TIMES, NORTH AND SOUTH KOREA HAVE AGREED TO INITIATE A NEW DETENTE. IN THIS ESSAY. THE AUTHOR DISCUSSES THE HISTORICAL MEANING AND SIGNIFICANCE OF THIS NEW INTER-KOREAN RAPPROCHEMENT AND AGREEMENT ON PEACEFUL COEXISTENCE, THE MOTIVATION FOR THIS NEW RELATIONSHIP, AND THE IMPACT AND IMPLICATIONS OF THIS DEVELOPMENT ON EACH COUNTRY'S POLICY AND STRATEGY FOR PEACE AND REUNIFICATION.

$05185 \mathrm{KIHL}$, Y.W.

MORTH AND SOUTH KOREA: THE POLITICS OF REUNIFICATION; ASSOCIATION FOR ASIAN STUDIES 1992 ANNUAL MEETING ASSOCIATION FOR ASIAN STUDIES, 1992, 117

RELATIONS BETWEEN NORTH AND SOUTH KOREA HAVE BEEN CHARACTERIZED BY THREE PATTERNS: A REDUCTION OF TENSION ON THE KOREAN PENINSULA; A GREATER REALISM ON THE PART OF LEADERSHIP IN BOTH NATIONS; AND A MOVE AWAY FROM CONFRONTATION TOWARD CONTACT AND CONFLUENCE. THIS PAPER EXAMINES ADDITIONAL RECENT DEVELOPMENTS INCLUDING SIMULTANEOUS ENTRY OF NORTH AND SOUTH KOREA INTO THE UNITED NATIONS, PROMOTION OF INTER-KOREAN EXCHANGES IN SPORTS, ART ACADEMIA AND TRADE, AND A NEW FLEXIBILITY IN UNIFICATION POLICIES. IT ALSO DISCUSSES THE RECENT REUNIFICATION POLICY PLANS PUT FORHARD BY NORTH AND SOUTH KOREA IN AN ATTEMPT TO MAKE THEM SOUND MORE FLEXIBLE AND REALISTIC. NORTH KOREA HAS UNDER THE CONFEDERATION THAT REFLECTS THE SO-CALLED "ONE 
NATION, ONE STATE, THO SYSTEMS AND THO REGIONAL GOVERMMENTS" PRINCIPLE. SOUTH KOREA HAS ALSO TAKEN MORE "SENSIBLE" MEASURES SUCH AS THE NEWLY ESTABLISHED COMMON FUND FOR UNIFICATION THAT WOULD MAKE THE PROPOSED KOREAN COMMONHEALTH OR THE KOREAN NATIONAL COMMUNITY PLANS MORE REALISTIC AND WORKABLE.

05186 KILGOUR, M.; BRAMS, S. PUTTING THE OTHER SIDE "ON NOTICE" CAN INDUCE COMPLIANCE IN ARMS CONTROL

JOURNAL OF CONFLICT RESOLUTION, 36(3) (SEP 92), 395-414. IT IS IMPORTANT TO BEAR IN MIND THAT THERE STILL EXIST AROUND THE WORLD LARGE ARSENALS OF BOTH CONVENTIONAL AND AROUND THE WORLD LARGE ARSENALS OF BOTH CONVENTIONAL AND
NUCLEAR WEAPONS. IF ARHS CONTROL IS TO BE SUCCESSFUL, IT NUCLEAR WEAPONS. IF ARMS CONTROL IS TO BE SUCCESSFUL, IT
MUST INCLUDE PROCEDURES FOR VERIFYING ARMS-CONTROL TREATIES, INCLUDING THOSE ENFORCED BY REGIONAL AND INTERMATIONAL INCLUDING THOSE ENFORCED BY REGIONAL AND INTERMATIONAL
ORGANIZATIONS. IN THIS ARTICLE, THE AUTHORS SHOW THAT IF A ORGANIZATIONS. IN THIS ARTICLE, THE AUTHORS SHOW THAT IF A
PLAYER IN A TWO-PERSON GAME PUBLICLY REVEALS IN ADVANCE AND PLAYER IN A TWO-PERSON GAME PUBLICLY REVEALS IN ADVANCE AND
CREDIBLY COMAITS ITSELF TO AN INSPECTION STRATEGY, IT MAY NOT ONLY HELP ITS ADVERSARY, WHO IS THERBY BETTER' INFORMED, BUT IT MAY ALSO HELP ITSELF BY GIVING AHAY THIS INFORMATION.

05187 KIM, D.

THE ONCE AND FUTURE KOREA

FOREIGN POLICY, (86) (SPR 92), 40-55.

NOTED KOREAN POLITICAL OPPOSITION FIGURE, KIM DAE JUNG, ARGUES THAT THE END OF THE COLD HAR POSES A SERIES OF SCEMARIOS RANGING FROM "THE MIGHTMARE OF DANGEROUS NATIONALISM AND NUCLEAR CONFLICT TO THE DREAM OF PEACEFUL REUNIFICATION AND STABILITY." HE ARGUES THAT THE REAL DILEMMA ON THE KOREAN PENINSULA IS THAT THE LESSONS OF THE COLD HAR'S END--AND THE UNRAVELING OF THE COMMUNIST BLOC-HAVE NOT IMMEDIATELY BEEN APPRECIATED BY NORTH KOREA. NOR HAVE THESE LESSONS PROVIDED USABLE LEVERAGE TO SOUTH KOREA OR TO THE FOUR GREAT POWERS DIRECTLY CONCERNED WITH DYNAMICS ON THE KOREAN PENINSULA: CHINA, JAPAN, THE FORMER SOVIET UNION, AND THE UNITED STATES. HOWEVER, THE KOREAN PEOPLE ARE EAGER TO MOVE FORHARD TOWARDS THE GOAL OF UNIFICATION. KIM CONCLUDES THAT THE TIME TO BEGIN REUNIFICATION IS AT HAND. SUCCESS WILL DEPEND ON THE VISION AND COURAGE OF TODAY'S SUCCESS WIL
LEADERSHIP.

05188 KIM, H.N.

THE KOREAS: IN SEARCH OF REUNIFICATION

CURRENT HISTORY 1 (569) (DEC 92) 430-435

THE END OF THE COLD WAR AND THE DEMISE OF SOVIET-STYLE COMMUNISM HAVE SPURRED NORTH KOREA TO CONSIDER THE POSSIBILITY OF REUNIFICATION WITH THE SOUTH. PROGRESS TOWARD THIS GOAL GAINED MOMENTUM THROUGHOUT 1991 AND EARLY 1992 BUT HAS NOW STALLED BECAUSE RECENT NORTH KOREAN ACTIONS HAVE
RENEHED SOUTH KOREAN FEARS ABOUT THE NORTH'S TRUE MOTIVES.

$05189 \mathrm{KIM}, \mathrm{I} . \mathrm{J}$

THE NORMALIZATION OF CHINESE-SOUTH KOREAN DIPLOMATIC RELATIONS

KDREA \& WORLD AFFAIRS, $16(3)$ (FAL 92) 483-492.

ON AUGUST 24, 1992, THE REPUBLIC OF KOREA AND THE PEOPLE'S REPUBLIC OF CHINA ESTABLISHED DIPLOMATIC RELATIONS, ENDING MORE THAN FOUR DECADES OF HOSTILITY. IN THIS PAPER, THE AUTHOR REVIEWS HOW SINO-KOREAN RELATIONS EVOLVED WITHIM THE CONTEXT OF THE COLD WAR, PRESIDENT ROH TAE WOO'S NORTHERN POLICY, AND RECENT DRAMATIC CHANGES IN INTERNATIONAL AFFAIRS. HE ALSO SPECULATES ABOUT HOW THE SEOUL-BEIJING RELATIONSHIP WILL AFFECT THE REUNIFICATION OF THE TWO KOREAS AND THE EMERGENCE OF A NEW INTERMATIONAL ORDER IN NORTHEAST ASIA.

05190 KIM, J.

FAR EASTERN ECONOMIC REYIEH, 155(15) (APR 92), 23. THE MOST REMARKABLE ACHIEVEMENTS OF SOUTH KOREAN PRESIDENT ROH TAE WOO'S ADMINISTRATION HAVE BEEN THE STRENGTHENING OF THE COUNTRY'S DEMOCRATIC POLITICAL PROCESS AND THE PURSUIT OF A FOREIGN POLICY OF RAPPROCHEMENT HITH CHINA AND THE SOVIET UNION, WHICH IS LARGELY RESPONSIBLE FOR IN THE WAKE OF THE 24 MARCH PARL IAMENTARY ELECTIONS, HOWEVER, THESE THO ACCOMPLISHMENTS ARE COMING INTO CONFLICT. STUNNED BY THE ELECTORAL DEFEAT OF THE HIS RUL ING DEMOCRATIC LIBERAL PARTY (DLP), ROH IS BEING 作 TOWARDS SOLVING PRESSING DOMESTIC PROBLEMS. THE GOVERMMENT MUST BE HARY, HOWEVER, OF VOTER-INDUCED MYOPIA ON FOREIGN ISSUES. ANY LET UP IN THE SO-CALLED NORTHERN POLICY WOULD RISK SACRIFICING THE SUBSTANTIAL GAINS THAT HAVE RESULTED FROM CLOSER TIES WITH PYONGYANG'S FORMER PATRONS. HHILE ECONOMIC CONCESSIONS TO MOSCON AND BEIJING CARRY A HIGH PRICE, SUCH COSTS ARE FAR OUTHEIGHED BY ADVANCES IN THE NORTH-SOUTH DIAL
REUNIFICATION.

$05191 \mathrm{KIM}, \mathrm{K}$

MARX, SCHUMPETER, AND THE EAST ASIAN EXPERIENCE

DEMOCRACY, 3(3) (JUL 92), 17-31.

THE WORLD IS CURRENTLY UNDERGOING THO EPOCH-MAKING
HISTORICAL DEVELOPMENTS: THE COLLAPSE OF SOVIET AND EAST EUROPEAN SOCIALISM, AND THE GRADUAL EVOLUTION OF MODERNIZING AUTHORITARIAN REGIMES, PARTICULARLY IN EAST ASIA, INTO DEMOCRACIES. IN SHORT, IT CAN BE SAID THAT THE THE WORLD MAY BE ENTERING THE AGE OF DEMOCRACY. IN ORDER TO COMPREHEND THE MEANING OF THESE RECENT HISTORICAL DEVELOPMENTS, THIS ARTICLE FIRST CONSIDERS THE THEORIES THAT PREDICTED THE OPPOSITE OF WHAT ACTUALLY HAPPENED, MOST NOTABLY THOSE OF KARL MARX AND JOSEPH SCHUMPETER. IT CONSIDERS THE REASONS WHY THESE THEORIES DID NOT ACCURATELY PREDICT RECENT WORLD EVENTS. IT THEN CONCLUDES THAT IT IS IN THE NATURE OF CAPITALISM THAT IT SECRETLY NURTURES AND EVENTUALLY CAPITALISH THAT IT SECRETLY NURTURES AND EVENTUALLY UNLEASHES DEMOCRATIC FORCES, A FACT WHICH IS SUPPORTED BY
THE EXPERIENCES OF KOREA AND TAIWAN. SOCIALISH, ON THE OTHER THE EXPERIENCES OF KOREA AND TAIWAN. SOCIALISH,
HAMD, IS CLEARLY INCDMPATIBLE WITH DEMOCRACY.

05192 KIM, P.S

NORTH KOREAN GOVERMMENT IN TRANSITION: WHO SERVES THE PEOPLE?; ASSOCIATION FOR ASIAN STUDIES 1992 ANNUAL MEETINC ASSOCIATION FOR ASIAN STUDIES, 1992, 119.

THIS PAPER PRESENTS AN ISSUE WITH REGARDS TO CONTINUITY AND CHANGE IN THE NORTH KOREAN POWER STRUCTURE. IN EARLY 1981 THE PARTY CENTRAL COMMITTEE HAD A TOTAL OF 248 MEMBERS. THE LARGEST GROUP IN THE COMMITTEE WAS THAT OF THE TECHNOCRATS (ECONOMISTS, MANAGERS, AND TECHNICIANS). THE PROMINENCE OF THE TECNOCRATS DID NOT CORRESPOMD TO THE LEVEL OF POWER THEY ENJOYED IN THE MORTH KOREAN POWER STRUCTURE. KEY POSTS IN THE PARTY, GOVERMMENT, AND ECONOMIC ORGANS ARE ASSIGNED TO PARTY MEMBERS; HIGHER RANKING CENTRAL COMMITTEE MEMBERS ARE ALSO FOUND IN THE ARMED FORCES, EDUCATIONAL AND CULTURAL INSTITUTIONS, AND OTHER SOCIAL ORGANIZATIONS. THE RECRUITMENT AND TRAINING OF THESE CADRES HAS LONG ENGAGED THE UTMOST ATTENTION OF THE PARTY LEADERSHIP. THIS IS BEACUSE THE CADRES HERE REGARDED AS THE COMHANDING PERSONMEL OF THE REVOLUTION AND BECAUSE THE OUTCOME OF THAT REVOLUTION WAS BELIEVED TO HINGE ON THE QUALITY OF IDEOLOGICAL AND TECHNICAL GUIDANCE THE CADRES COULD BRING TO BEAR ON THEIR VARIED ENDEAVORS.

$05193 \mathrm{KIM}$, P.S.

WHO SERVES THE PEOPLE? EDUCATIONAL BACKGROUNDS OF SOUTH KHO SERVES THE PEOPLE? EDUCATIONAL AMERICAN REVIEH OF PUBLIC ADMINISTRATION, 22(4) (DEC 92 ), AMERICAN
307-325.

THIS STUDY INVESTIGATES THE EDUCATIONAL BACKGROUNDS OF GOVERMMENT EMPLOYEES IN SOUTH KOREA AND COMPARES THEM TO THOSE OF GOVERMMENT EMPLOYEES IN JAPAN. PRIMARY ATTENTION IS GIVEN TO CHANGES IN PUBLIC EMPLOYMENT PRACTICES BASED ON VARIABLES OF EDUCATIONAL BACKGROUND (I. E., EDUCATION LEVEL, INSTITUT IONAL PATH, AND FIELD OF STUDY). FINDINGS INDICATE THAT THERE ARE MANY SIMILARITIES BETWEEN THE SOUTH KOREA AND JAPANESE GOVERNMENT WORK FORCES AND THAT THE "BEST PRODUCT" POLICY IN PUBLIC EMPLOYMENT PRACTICES IS COMMON IN
BOTH COUNTRIES. IN THIS SETTING. THE PUBLIC BUREAUCRACY IS A MAJOR INSTRUMENT FOR POLICY MAKING AND IMPLEMENTATION.

05194 KIM, S

SINGAPORE IN 1990: CONTINUITY AND STABILITY

ASIAN SURVEY, XXXI (2) (FEB 91), 172-178.

OVERALL, 1990 WAS A GOOD YEAR FOR SINGAPORE IN THE PRINCIPAL ARENAS OF POLITICS, THE ECONOMY, AND DIPLOMACY, POLITICALLY, THE MOST IMPORTANT DEVELOPMENT WAS IHE CHANGE OF HELMSMANSHIP ON NOVEMBER 28, 1990. LEE KUAN YEW STEPPED ASIDE IN 1990 AFTER 31 YEARS IN OFFICE, MAKING HAY FOR GOH CHOK TONG TO TAKE OVER AS THE SECOND PRIME MINISTER OF THE REPUBLIC. IN THE ECONOMIC FIELD, SINGAPORE ENJOYED THE FOURTH CONSECUTIVE YEAR OF STRONG AND BROAD-BASED GROHTH. DIPLOMATICALLY, IT CONTINUED TO PLAY A VERY ACTIVE ROLE IN ITS FOREIGN POLIICY ENDEAVORS, UNUSUAL FOR A TINY STATE IN THE REGION AS HELL AS INTERNATIONALLY.

05195 KIM, S.

SINGAPORE IN 1991: ENDORSEMENT OF THE NEW ADMINSTRATION ASIAN SURYEY, XXXII(2) (FEB 92), 119-125.

ASIAN SURVEY, XXXII 2) (FEB 92), 119-125. POLICY IN SINGAPORE DURING 1991. POLITICS IN 1991 OPERATED IN THE CONTEXT OF A CORPORATE STATE THAT IS MAINLY RUN BY
RULING PEOPLE'S ACTION PARTY (PAP) TECHNOCRATS. ON THE WHOLE, THE ATMOSPHERE WAS TRANQUIL, ALTHOUGH THERE WERE THO MAJC
POL ITICAL EVENTS. THE FIRST AND MOST IMPORTANT WAS THE POL ITICAL EVENTS. THE FIRST AND MOST IMPORTANT WAS THE ENDORSEMENT OF GOH CHOK TONG'S ADMINISTRATION IN THE AUGUS
GENERAL ELECTION: THE SECOND WAS THE ELECTED PRESIDENT ACT GENERAL ELECTION; THE SECOND WAS THE ELECTED PRESIDENT WHICH CAME INTO EFFECT IN NOVEMBER. THE ACT CHANGES
SIMGAPORE'S POLITICAL SYSTEM TO THE EXTENT THAT IT PROVIDES SIMGAPORE'S POL ITICAL SYSTEM TO THE EXTENT THAT IT PROVIDES A KIND OF CHECK AND BALANCE BETWEEN THE PRESIDENCY AND THE CABINET, HEADED BY THE PRIME MINISTER. SINGAPORE SAH ANOTHER GOOD YEAR OF 6.5\% ECONOMIC GROWTH IN 1991. FOREIGN RELATIONS MAINLY CENTERED ON ECONOMIC RATHER THAN ON POLITICAL AND SECURITY ISSUES. THE CITY-STATE CONCENTRATED ON GOOD RELATIONS WITH ITS NEIGHBORS AND
REGIONALIZATION OF ITS ECONONY.

$05196 \mathrm{KIM}, \mathrm{S}$

THE POLIITICAL PROCESS OF DECENTRALIZATION IN PERU, 1985- 
1990

PUBLIC ADMINISTRATION AND DEVELOPMENT, 12(3) (AUG 92), 249-266

THIS PAPER, USING PERU AS A CASE STUDY, ARGUES THAT THE MOST POTENT FACTOR IN THE IMPLEMENTATION OF DECENTRALIZATION IN DEVELOPING COUNTRIES IS \$POLITICAL' IN NATURE AND OPERATION. PRESIDENT GARCIA NEEDED TO CONTROL APRA FOR A REGIONAL POWER BASE AFTER 1990. THUS THE WHOLE

CEDENTRALIZATION PROCESS WAS HIGHLY POLITICIZED, AND GARCIA'S STRATEGY WAS SUCCESSFUL IN THAT REGIONAL

GOVERMMENTS CAM TO BE CONTROLLED BY APRA AFTER THE 1989 AND 1990 REgIONAL ELECTIONS. THE PERUVAIN CASE SHOWS HOH FAR DECENTRALIZATION CAN BE USED FOR PERSONALISTIC OR PARTISAN INTERESTS IN A FRAGILE DEMOCRACY.

05197 KIM, S.S.

CHINA AS A REgIONAL PONER

CURRENT HISTORY, 91(566) (SEP 92), 247-252.

DUE TO THE END OF THE COLD WAR, BEIJING IS UNSURE OF ITS PLACE IN A HORLD NO LONGER DOMINATED BY SUPERPOWER RIVALRY, AND CHINA IS IN THE GRIP OF AN UNPRECEDENTED LEGITIMACY-
IDENTITY CRISIS. NOT SINCE THE FOUNDING OF THE PEOPLE'S IDENTITY CRISIS. NOT SINCE THE FOUNDING OF THE PEOPLE'S
REPUBLIC IN 1949 HAVE THE QUESTIONS OF INTERNAL AND EXTERNAL REPUBLIC IN 1949 HAVE THE QUESTIONS OF INTERNAL AND EXTERNAL CHINA THREAT LOOMS LARGE IN THE SECURITY CALCULUS OF EVERY CHINA THREA LOONS LARGE IN THE SECURI TY CALCULUS OF EVERY ASIAN STATE. YET CHINA'S IDENTITY AS A REGIONAL PONER IS RELATIONS PIVOT AROUND THE ASIA-PACIFIC REGION, BEIJING HAS YET TO FORMULATE A COHEREMT DEFINITION OF ITS PLACE IN ASIAM YET TO FORMULATE A COHER
INTERNATIONAL RELATIONS.

05198 KIM, S.S

INTERNATIONAL ORGANIZATIONS IN CHINESE FOREIGN POLICY ANMALS OF THE AMERICAN ACADEMY OF POLITICAL AND SOCIAL SCIENCE, 519 ( JAN 92), 140-157.

DESPITE CHINA'S MUCH-HERALDED ENTRY INTO THE UNITED NATIONS IN 1971, A COMPREHENSIVE NETHORK OF LINKAGES BETHEEN CHINA AND THE REST OF THE WORLD WAS NOT ESTABLISHED UNTIL THE 1980'S, WHEN BEIJIMG JOINED PRACTICALLY ALL IMPORTANT INTERNATIONAL ORGANIZATIONS. INCREASED PARTICIPATION IN INTERNATIONAL ORGANIZATIONS, MADE POSSIBLE BY THE OPEN-DOOR POLICY, HAS CREATED NEW OPPORTUNITIES, PAY-OFFS, AND PENALTIES. CHINESE FOREIGN POLICY BEHAVIOR, MANIFEST IN THE VARIOUS DOMAINS OF GLOBAL POLITICS, FOLLOWS A REAL, IF UNSTATED, MAXI/MINI PRINCIPLE-MAXIMIZING CHINA'S RIGHTS WHILE MINIMIZING ITS RESPONSIBILITIES. IT ALSO SEEKS TO

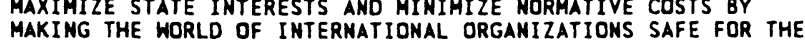
MAKING THE WORLD OF INTERNATIDNAL ORGANIZATIONS SAFE FOR THE
DRIVE FOR MODERNI ZATION AND STATUS. POLICY PRONOUNCEMENTS DRIVE FOR MODERNIZATION AND STATUS. POLICY PRONOUNCEMENTS
AND ADJUSTMENTS OVER TIME ON VARIDUS GLOBAL ISSUES AND PROBLEMS SHOW INTERNATIONAL ORGANIZATIONS, IN GENERAL, AND PROBLEMS SHOW INTERNATIONAL ORGANIZATIONS, IN GENERAL, AND
ECONOMIC AND FUNCTIONAL ORGANIZATIONS, IN PARTICULAR, TO HAVE SHORTENED THE CHINESE GLOBAL LEARNING CURVE. THE PROSPECTS OF POST TIANANMEN CHINESE GLOBAL POL ICY REMAIN
UNCERTAIN AS THE OLD LIMITATIONS HAVE BEEN GREATLY INCREASED UNCERTAIN AS THE OLD LIMITATIONS HAVE BEEN
AND THE NEW POSSIBILITIES GREATLY REDUCED.

05199 KIM, T.; CHA, Y

PROSPECTS FOR CHANGE AND LIBERALIZATION IN MORTH KOREA WASHINGTON QUARTERLY, 15(3) (SUM 92), 155-170.

THIS ARTICLE EXAMINES PROSPECTS FOR POLITICAL CHANGE IN NORTH KOREA AS PORTENDED BY RECENT TRENDS AND SPECULATES OH THE POSSIBLE DIRECTIONS THAT THE NATION MIGHT TAKE IN THE YEARS AHEAD. SPECIFICALLY, IT IDENTIFIES SEVERAL MAJOR INTERNAL AND EXTERNAL FACTORS FOR CHANGE IN NORTH KOREA, EVALUATES THE POSSIBILITY OF A STABLE LEADERSHIP SUCCESSION BY KIM JONG-IL (SON AND HEIR APPARENT OF PRESIDENT KIM ILSUNG) AND PROPOSES SEVERAL POLICY OPTIONS FOR SOUTH KOREA AND THE UNITED STATES TO HELP INDUCE REFORMS AND OPEN TO THE OUTSIDE HORLD. IT CONCLUDES THAT, FOR THE SAKE OF THE LONGTERM SURVIVABILITY OF THE REGIME, NORTH KOREA WILL INITIATE NEW AND SIGNIFICANT, OFTEN SURPRISING, POLICY CHANGES IN THE COMING YEARS.

05200 KIM, T

SOUTH KOREA'S NUCLEAR DILEMMAS

KOREA \& WORLD AFFAIRS, 16 (2) (SUM 92), 250-293.

DECADES OF HARDENED HOSTILITY CONTINUE ON THE KOREAM PENINSULA, AND THE NUCLEAR DILEMMAS FACING SOUTH KDREA ARE EXTREMELY COMPLICATED AND INEXTRICABLY INTERWOVEN. THIS ESSAY IDENT IFIES SEVEN NUCLEAR DILEMMAS FACING SOUTH KOREA ESSAY IDENT IFIES SEVEN NUCLEAR DILEMMAS FACING SOUTH KOREA
AND DELVES INTO THE ORIGINS OF EACH. THEY STEM LARGELY FROM AND DELVES INTO THE ORIGINS OF EACH. THEY STEM LARGELY FRO THREE SOURCES: (1) NORTH KOREA'S NUCLEAR AMBITIONS, (2) NUCLEAR NORTH-SOUTH RELATIONS BETWEEN THE USA AND SOUTH KOREA CONFLICTING WITH THE TRADITIONAL EAST-WEST ALLIANCE BETWEEN THE THO COUNTRIES, AND (3)

05201 KIM, H.

POWER TRANSITIONS AND GREAT POWER HAR FROM WESTPHALIA TO WATERLOO

HORLD POLITICS, 45(1) (OCT 92), 153.

THE AUTHOR EXTENDS RECENT RESEARCH ON THE POHER TRANSITION AND HEGEMONIC STABILITY THEORY TO THE PRE-
IMDUSTRIAL ERA. HE IMPROVES ON THE ORIGINAL POWER TRANSITION THEORY BY RELAXING AN ASSUMPTION AND BY EXTENDING THE EMPIRICAL DOMAIN. HE EXAMINES THE EMPIRICAL RECORD PRIOR TO THE INDUSTRIAL REYOLUTION TO DETERMINE WHETHER THE POWER TRANSITION AND HEGEMONIC STABILITY THEORY HOLDS FOR THAT PERIOD. THE DATA FOR 1648 TO 1815 INDICATE STRONG SUPPORT FOR THE POWER TRANSITION CONTENTION THAT A ROUGH EQUALITY OF POWER BETWEEN RIVAL SIDES INCREASES THE LIKEL IHOOD OF WAR. THAT IS, WHEN THE CHALLENGING GREAT POWER, WITH ITS ALLIES' SUPPORT, CATCHES UP WITH THE DOMINANT POWER, GREAT POWER WAR IS MOST' LIKELY.

05202 KIM, H.

WHEN DO POWER SHIFTS LEAD TO WAR?

AMERICAN JOURNAL OF POLITICAL SCIENCE, 36(4) (NOV 92),

396-922.

THE AUTHORS PRESENT AND TEST A CHOICE-THEORETIC MODEL OF WAR DECISIONS DURING SHIFTS IN POWER. THE MODEL ASSUMES A RISING STATE THAT OVERTAKES A DECLINING STATE IN CAPABILITIES. POWER SHIFTS ARE MORE LIKELY TO LEAD TO WAR AS THE CHALLENGER BECOMES MORE RISK-ACCEPTANT, THE DECLINING STATE MORE RISK-AVERSE, THE EXPECTED COSTS OF WAR DECREASE, THE RISING STATE'S DISSATISFACTION WITH THE STATUS QUO THE RISING STATE'S DISSATISFACTION WITH THE STATUS QUO
INCREASES, AND DURING PERIODS OF EQUALITY BETWEEN THE TWO INCREASES, AND DURING PERIOOS OF EQUALITY BETWEEN THE TWO
SIDES. THE AUTHORS FIND THAT EXPECTD SUPPORT FROM ALLIES SIDES. THE AUTHORS FIND THAT EXPECTD SUPPORT FROM
MUST BE INCLUDED IN THE CALCULATION OF A NATION'S MUST BE INCLUDED IN THE CALCULATION OF A NATION'S HEGEMONIC DECLINE AND WAR ARE DISCUSSED.

05203 KIMCHE, D.

THE IMPORTANCE OF PRENEGOTIATION: OBSERVATIONS OF A FORMER DIPLOMAT

JERUSALEM JOURNAL OF INTERMATIONAL RELATIONS, 13(1) (MAR 91), 90-95

THIS ARTICLE IS A PRACTITIONERS PORTRAYAL OF HOW PRENEGOTIATION WAS AND WAS NOT USED IN ISRAELI-LEBANESE NEGOTIATIONS. DRAHING FROM HIS EXPERIENCE, THE AUTHOR DERIVES A MUMBER OF CONCLUSIONS: BEFORE FORMAL NEGOTIATIONS, PARTIES MUST DERIVE A COMMON LANGUAGE AND GAIN A "MUTUAL UNDERSTANDING" OF EACH OTHER'S DIFFERENT VALUE ORIENTATIONS : THEY MUST UNDERSTAND EACH OTHER'S DEMANDS AND NEEDS SO AS TO DISCOVER AND BUILD COMMON GROUND; AND PRENEGOTIATION IS NECESSARY FOR PARTIES TO COMPREHENSIVELY DELINEATE THE TOPICS TO BE DISCUSSED AND THE GOALS TO BE ACHIEVED.

05204 KIMMERLING, B.

SOCIOLOGY, IDEOLOGY, AND NATION-BUILDING: THE PALESTINIANS AND THEIR MEANING IN ISRAELI SOCIOLOGY

AMERICAN SOCIOLOGICAL REVIEW, 57(4) (AUG 92), 446-460.

THE ANALYTIC FRAMEWORK THAT GUIDES RESEARCH AND ANALYSIS THE ANALYTIC FRAMEHORK THAT GUIDES RESEARCH AND ANALYSIS
IS OFTEN VALUE-LADEN AND CONFORMS TO A HEGEMONIC CULTURE OR IS OFTEN VALUE-LADEN AND CONFORMS TO A HEGEMONIC CULTURE OR STRUGGLING COUNTER-CULTURE. THE AUTHOR OISCUSSES FIVE KINDS OF FRAMENORK DECISIONS: THE SOCIOPOLITICAL BOUNDARI

COLLECTIVITY UNDER INYESTIGATION, THE HISTORICAL PERIODIZATION OF THE SOCIETY, THE TERMINOLOGY USED TO CHARACTERIZE SOCIOLOGICAL PROCESSES AND PHENOMENA, THE HAY THE RESEARCH PROBLEM IS POSED, AND THE SUBJECTS DEEMED
APPROPRIATE FOR INVESTIGATION. IN A CASE STUDY OF ISRAEL, HE APPROPRIATE FOR INVESTIGATION. IN A CASE STUDY OF ISRAEL, HE SHOWS THAT THE PALESTINIAN MINORITY AND JEHISH-ARAB CONFL WERE CHARACTERIZED BY MAINSTREAM ISRAELI SOCIOLOGISTS IM ACCORDANCE WITH DOMINANT ZIONIST PERSPECTIVES. CUL TURAL COMMITMENTS, PERCEIVED EXISTENTIAL NEEDS, AND CLASS,
AND NATIONAL INTERESTS HAYE SHAPED THE WAY ISRAELI SOCIOLOGISTS PORTRAY THE BASIC FEATURES OF ISRAELI SOCIETY.

05205 KINCAID, J.; WILLIAMS, R.F

THE STATES' 'LEAD IN RIGHTS PROTECTION

JOURNAL OF STATE GOVERNMENT, 65(2) (APR 92), 50-52.

A LOT OF ATTENTION IS GIVEN TO THE RIGHTS AFFORDED AMERICAN CITIZENS BY THE BILL OF RIGHTS TO THE U.S. CONSTITUTION, BUT STATE CONSTITUTIONS ARE EQUALLY IMPORTANT AND OFTEN EXPAND FEDERAL PROTECTION. MANY TIMES STATE COURTS HAVE GIVEN LIBERAL INTERPRETATIONS OF STATE CONSTITUTIONAL GUARANTEES. THIS TREND, SOMETIMES REFERRED TO AS THE NEW JUDICIAL FEDERALISM, CAN SERVE AS AN EXAMPLE TO DEVELOPING DEMOCRACIES AS A MEANS OF PROTECTING AND SUPPORTING THEIR ETHNIC DIVERSITY.

05206 KIND, C.

CRITICAL GLANCES AT GERMANY

SHISS REVIEW OF WORLD AFFAIRS, 42(1) (APR 92), 11

THE COLLAPSE OF THE SOVIET SUPERPOWER. THE LIBERATION OF THE COLLAPSE OF THE SOVIET SUPERPOWER, THE LIBERATI
EAST CENTRAL EUROPE FROM COMMUNIST RULE, AND GERMAN EAST CENTRAL EUROPE FROM COMMUNIST RULE, AND GERMAN REUNIFICATION HAVE LOOSENED THE RIGID PARAMETERS OF THE EAS WEST CONFLICT, HHICH FORMERLY SERVED AS THE DRIVING FORCE BEHI THE EXPL WESION OF NATIOMAL PST CONFL ICTS IN THE EAST POSE AND THE EXPLOSION OF NATIONALIST CONFLICTS IN THE EAST POSE
NEW DILEMMAS--INCLUDING HOW FAR THE OPERATIONAL ZONE OF THE NEW DILEMMAS--INCLUDING HOW FAR THE OPERATIONAL ZONE OF THE
WEST EUROPEAN-ATLANTIC COMMUNITY CAN BE EXTENDED WITHOUT WEST EUROPEAN-ATLANTIC COMMUNITY CAN BE
CALLING ITS VERY NATURE INTO QUESTION.

05207 KING, A.

THE HOLISTIC PATH TO A GLOBAL SOCIETY

INTERMATIONAL SOCIAL SCIENCE JOURNAL, 131(131) (FEB 92), 
57-68.

ONE OF THE DETERMINING FEATURES OF OUR AGE IS THE RECOGNITION BY BOTH POLITICAL LEADERS AND THE PUBLIC AT LARGE OF THE REALITY AND DEPTH OF THE INTERDEPENDENCE OF THE NATIONS. THIS IS MANIFEST, NOT ONLY THROUGH THE EXTENSION OF ECONOMIC CO-OPERATION AND INTERNATIONAL TRADE, BUT ALSO IN MANY OTHER AREAS SUCH AS ENVIRONMENTAL ISSUES. THIS ARTICLE EXPLORES THE MOST COGENT INSTANCE OF GROWING INTERDEPENDENCE WHICH IS THE DEVELOPMENT OF THE EUROPEAN COMMUNITY. IT SUGGESTS THAT EUROPE SEEMS DESTINED TO ADVANCE TOHARDS INTEGRATION ON A BROAD FRONT.

05208 KING, D.

CONTEXTUAL INFLUENCE ON INDONESIANS' ELECTORAL BEHAVIOR; ASSOCIATION FOR ASIAN STUDIES 1992 AMNUAL MEETING ASSOCIATION FOR ASIAN STUDIES, $1992,153$.

ORTHODOX THEORIES OF DEYELOPMENT, BOTH NEO-CLASSICAL AND NEO-MARXIST, HAVE CONTENDED THAT ECONOMIC GROWTH CREATES NEW NEO-MARXIST, HAVE CONTENDED THAT ECONOMIC GROWTH CREATES NEW
ECONOMIC AND POLITICAL RESOURCES AS WELL AS NEW TENSIONS AND ECONOMIC AND POLITICAL RESOURCES AS WELL AS NEW TENSIONS AND
CONFLICTS AND THIS OFTEN LEADS TO POLITICAL MOBILIZATION AND CONFLICTS AND THIS OFTEN LEADS TO POLITICAL MOBILIZATION AA
PARTICIPATION BY AFFECTED GROUPS AND CLASSES. FROM THIS THEORETICAL PERSPECTIVE, ONE MIGHT EXPECT HIGHER LEVELS OF THEORETICAL PERSPECTIVE, ONE MIGHT EXPECT HIGHER LEVELS OF VOTER TURNOUT AND MORE ELECTORAL COMPETITION IN REGIONS WHICH HAVE EXPERIENCED HIGHER LEVELS OF VOTER TURNOUT AND MORE ELECTORAL COMPETITION IN REGIONS WHICH HAVE EXPERIENCE
HIGHER LEVELS OF ECONOMIC GROWTH. THIS PAPER ATTEMPTS TO TEST THIS (GENERAL, COMPARATIVE) HYPOTHESIS IN THE INDONESIAN CONTEXT. TO WHAT EXTENT DO SOCIO-ECONOMIC TRAITS OF AREAL UNITS (OR GROUPS OF PEOPLE LIVING HITHIN DEFINED TERRITORIAL UNITS) "EXPLAIN" THE ELECTORAL OUTCOMES IN THOSE UNITS? USING QUANTITATIVE INDICATORS CONSTRUCTED FROM DISTRICT-MUNICIPALITYLEVEL (TK-2) CENSUS AND ELECTORAL AGGREGATE DATA HITH NATIONAL COVERAGE, THIS PAPER DESCRIBES AND EVALUATES STATISTICALLY ALTERNATIVE, LINEAR MODELS OF INDONESIAN ELECTORAL BEHAVIOR IN SEVERAL GENERAL ELECTIONS. THE ANALYSIS CONSIDERS THE POSSIBLE DIFFERENCES BETWEEN URBAN AND RURAL, AND AMONG REGIONS.

05209 KING, D.; WALKER, J.

THE PROVISION OF BENEFITS BY INTEREST GROUPS IN THE UNITED STATES

THE JOURNAL OF POLITICS, 54(2) (MAY 92), 394-426.

WITH A SAMPLE OF NEARLY 900 VOLUNTARY ASSOCIATIONS, THE AUTHORS GIVE A DETAILED ACCOUNT OF WHAT MEMBERSHIP BENEFITS AUTHORS GIVE A DETAILED ACCOUNT OF WHAT MEMBERSHIP BEN ARE PROVIDED BY INTEREST GROUPS, AND THEY PLACE THESE
RESULTS IN THE CONTEXT OF A TYPOLOGY OF GROUPS. USING A RESULTS IN THE CONTEXT OF A TYPOLOGY OF GROUPS. USING A MULTIVARIATE ANALYSIS OF MEMBERSHIP I NDUCEMENTS, THEY SHOW A MERE BY-PRODUCT MADE POSSIBLE BY THE PROVISION OF SELECTIVE MATERIAL INCENTIVES. THE AUTHORS ALSO SHOW THAT SELECTIVE MATERIAL INCENTIVES. THE AUTHORS ALSO SHO ABOUT HALF OF THE GROUPS IN WASHINGTON, DC, COUNT
INSTITUTIONS--NOT AUTONOMOUS INDIVIDUALS--AMONG THEIR MEMBERS, AND THEY CALL FOR A THEORY OF GROUP MEMBERSHIP THAT MEMBERS, AND THEY CALL FOR A THEORY OF GROUP
ACCOUNTS FOR THE DIFFERENCES AMONG MEMBERS.

05210 KING, D.

UNRAVELING FABRIC, MISSING THE BEAT: CLASS AND GENDER IN AFRO-AMERICAN SOCIAL ISSUES

BLACK SCHOLAR, $22(3)$ (SUM 92), 36-44.

IT HAS BEEN SUGGESTED THAT THE VANISHIMG, DIMINISHING, FACK MAN HAS BECOME THE PENUL TIMATE SOCIAL, ISSUE FOR AFRICAN AMERICANS. DEBORAH KING DISAGREES. HER PAPER DISCUSSES HOW SOCIAL PROBLEMS ARE CONSTRUCTED AND HOW SUCH CONSTRUCTIONS ARE A PRODUCT OF CULTURAL, SOCIOHISTORICAL, AND POLITICAL ECONOMIC DYNAMICS. IN FOCUSING ON ITS CONSTRUCTION, THE PAPER TREATS THE DECLARATION OF ANY SOCIAL PROBLEM OR ISSUE AS AN INSTANCE WHERE MEANING IS PROBLEMATIC. IT CRITICALLY EXAMINES THE HIDELY HELD, AND APPARENTLY UNPROBLEMATIC, ASSUMPTION THAT AFRICAN AMERICAN MALES ARE THE SOCIAL ISSUE. IT ALSO CONSIDERS HOH THEORETICAL WORKS AND EMPIRICAL STUDIES IN THE LITERATURE ON AFRICAN AMERICANS AND SELECTED SOCIAL CONDITIONS ARE PART OF AND CONTRIBUTES TO THIS CONSTRUCTION. IT IDENT I FIES AND UNDERSTANDING OF THE AFRICAM AMERICAN COMMUNITY.

05211 KING, D.E.

THE THAI PARLIAMENTARY ELECTIONS OF 1992: RETURN TO DEMOCRACY IN AN ATYPICAL YEAR

ASIAN SURVEY, XXXII(12) (DEC 92 ), 1109-1123.

FOR THAILAND, 1992 WAS MARKED BY UNPRECEDENTED STREET PROTESTS, VIOLENCE, AND CRISIS. HOWEVER, 1992 WAS ALSO THE YEAR IN WHICH THAI VOTERS PARTICIPATED IN THO SIGNIFICANT YEAR IN WHICH THAI VOTERS PARTICIPATED IN THO SIGNIFICANT
ELECTIONS (HELD ON 22 MARCH AND 13 SEPTEMBER). THE ELECTIONS WERE IMPORTANT BECAUSE OF THREE FEATURES: MILITARY LEADERS WERE IMPORTANT BECAUSE OF THREE FEATURES: MILITARY L
CDOPTED POLITICAL PARTIES IN A BID TO SUPPORT THEIR COOPTED POLITICAL PARTIES IN A BID TO SUPPORT THEIR INVOLVEMENT IN POLITICS: THE PRIME MINISTER CREATED AN INDEPENDENT ELECTION-MONITORING BOOY; AND POLITICIANS IN
BDTH ELECTIONS PRESENTED TO THE ELECTORATE A SEEMINGLY CLEAR BOTH ELECTIONS PRESENTED TO THE ELECTORATE A SEEMINGLY CLEAR
CHOICE BETWEEN PRO-MILITARY AND PRO-DEMOCRACY PARTIES. THIS ARTICLE ASSESSES THESE CHANGES AND THEIR IMPLICATIONS FOR THAI POLITICS. IT CONCLUDES THAT THESE FEATURES ARE ALL TEMPORAL AND DO NOT REPRESENT A BASIC CHANGE IN THAI ELECTORAL POLITICS; RATHER, THEY MAKE 1992 AN ATYPICAL YEAR.
05212 KING, D.S.; WARD, H.

WORKING FOR BENEFITS: RATIONAL CHOICE AND THE RISE OF WORKWELFARE PROGRAMMES

POLITICAL STUDIES, XL(3) (SEP 92), 479-495.

THE AUTHORS DEVELOP A RATIONAL-CHOICE EXPLANATION FOR THE RECENT ADOPTION OF WORK-WELFARE PROGRAMS IN GREAT BRITAIN AND THE UNITED STATES. SUCH PROGRAMS REQUIRE THE RECIPIENTS OF WELFARE OR UNEMPLOYMENT BENEFITS TO PARTICIPATE IN A TRAINING PROGRAM OR WORK ACTIVITY IN EXCHANGE FOR RECEIVING THEIR BENEFITS AND REFLECT A NEW RIGHT (IN CONTRAST TO A SOCIAL DEMOCRATIC) CONCEPT OF SOCIAL CITIZENSHIP. SUCH POLICIES ARE DESIGNED TO GENERATE A PARTIAL SEPARATING EOUILIBRIUM UNDER WHICH SOME CLAIMANTS PARTIAL SEPARATING EQUILIBRIUM UNDER WHICH SOME CLAIMANTS IDENTIFIED BY THE STATE AS UNDESERVING ARE DISCOURAGED FROM
SEEKING BENEFITS. THE PROGRAMS ARE INTENDED TO OVERCOME THE SEEKING BENEFITS. THE PROGRAMS ARE INTEND
PROBLEMS OF FREE-RIDING AND FALSE CLAIMS.

05213 KINGSLEY, G.A.

U.S. ENERGY CONSERVATION POLICY: THEMES AND TRENDS POLICY STUDIES JOURNAL, 20(1) (1992), 115-123.

THE AUTHOR SURVEYS CURRENT U.S. ENERGY CONSERVATION POLICY. OF PARTICULAR INTEREST ARE THE PREVAILING POLICY TRENDS OF (A) RELUCTANT INVOLVEMENT BY THE FEDERAL GOVERMMENT AND (B) INCREASING REGULATORY INTERVENTIONISM BY PUBLIC UTILITY COMMISSIONS. UNDERLYING THE POLICY TRENDS IS A FUNDAMENTAL UNCERTAINTY REGARDING THE MARKET PRICE OF ENERGY AND THE APPROPRIATE ROLE OF GOVERNMENT. THIS UNCERTAINTY ALSO EXPLAINS WHY ISSUES OF ENERGY CONSERVATION AND EFFICIENCY HAVE NOT STOOD ON THEIR OWN MERIT BUT HAVE ACHIEVED POLITICAL POTENCY ONLY DURING PERIODS OF HIGH MARKET PRICES FOR ENERGY OR WHEN COMBINED WITH ENVIRONMENTAL CONSERVATION ISSUES

05214 KINGSTON, R.C.

THE AMERICAN APPROACH TO COMBATING TERRORISM TERRORISM AND POLITICAL VIOLENCE, 4(3) (FAL 92), 102-106. THE U.S. GOVERNMENT CONSIDERS THE PRACTICE OF TERRORISM BY ANY INDIVIDUAL OR GROUP A POTENTIAL THREAT TO ITS NATIONAL SECURITY AND WILL RESIST THE USE OF TERRORISM BY ALL LEGAL MEANS AVAILABLE. U.S. POLICY IS BASED UPON THE ALL LEGAL MEANS AVAILABLE. U.S. POLICY IS BASED UPON THE
CONVICTION THAT TO GIVE IN TO TERRORISTS' DEMANDS PLACES EVEN MORE AMERICANS AT RISK. THUS, A NO-CONCESSIONS POLICY EVEN MORE AMERICANS AT RISK. THUS, A NO-CONCESSIONS POL
IS THE BEST WAY OF ENSURING THE SAFETY OF THE GREATEST IS THE BEST WAY OF
NUMBER OF PEOPLE.

05215 KINKEL, $K$.

MINISTER WARNS AGAINST MARKING TIME ON EUROPEAN INTEGRATION GERMAN TRIBUNE, $31(1538)$ (OCT 92), 5

THIS IS NO TIME TO BE FAINT-HEARTED ABOUT GOING FOR EUROPEAN UNION, SAYS GERMAN FOREIGN MINISTER, KLAUS KINKEL. THERE IS NO ALTERNATIVE TO THE IDEAL OF EUROPEAN INTEGRATION. MR. KINKEL STATES THAT THEY DON'T WANT TO MARK TIME HALFHAY, NOW THAT NATIONALISM AND XENOPHOBIA HAVE REARED THEIR UGLY
HEADS AGAIN AFTER THEY THOUGH THEY HAD LONG BEEN BURIED. TO STAND STILL WOULD BE TO GIVE THE WRONG SIGHAL.

05216 KINMUCAN, M.J.

POLITICAL ECONOMY AND MILITARISH

PS: POLITICAL SCIENCE ANO POLITICS, $X X V(3)$ (SEP 92), 506-516

THOMAS R. DYE AND HARMON ZEIGLER HAVE PRESENTED DATA AND ANALYSIS LEADING THEM TO CONCLUDE THAT "MILITARISM IS A MUCH MORE PERVASIVE CHARACTERISTIC OF SOCIALIST NATIONS THAN CAPITALIST NATIONS." HOWEVER, DYE AND ZEIGLER'S CONCLUSIONS ARE DEBATABLE BECAUSE OF THE DEFINITIONS AND MEASURES THEY CHOSE TO USE FOR SOCIALISM AND MILITARISM.

05217 KINSLEY, M.

A CAPITAL GAINS PRIMER

NEW REPUBLIC, 206 (6) (FEB 92), 17-18, 20.

THE AUTHOR EXPLAINS WHY PRESIDENT GEORGE BUSH'S PROPOSED

CAPITAL GAINS TAX CUT WOULD BOTH BENEFIT THE WEALTHY AND HEAVY HAND OF GOVERMMENT.

05218 KINSLEY, M.

BUCHANAN AGAIN

NEW REPUBLIC, 206 (8) (FEB 92), 6

THE AUTHOR DISCUSSES THE CHARGE THAT PAT BUCHANAM, A

CANDIDATE FOR THE REPUBLICAN PARTY'S PRESIDENTIAL NOMINATION,

IS ANTI-SEMITIC.

05219 KINSLEY, M.

DEMOCRATIC MISTAKES

NEW REPUBLIC, $206(6)$ (FEB 92), 6

THE RECESSION IS THE REASON FOR THE PRECIPITOUS FALL IN PRESIDENT GEORGE BUSH'S APPROVAL RATINGS, AND THE CANDIDATES FOR THE DEMOCRATIC PRESIDENTIAL NOMINATION ARE HARPING ON THE ECONOMIC ISSUES. BUT THE ECONOMY IS ALMOST CERTAIN TO IMPROVE BEFORE THE PRES IDENTIAL ELECTION, AND THE DEMOCRATIC CANDIDATES HILL BE DEPRIVED OF THAT ISSUE. THE DEMOCRATS MIGHT MAKE AN ISSUE OF SADDAM HUSSEIN'S CONTINUED RULE,
HE COULD FALL AT ANYTIME AND DEPRIVE THEM OF THAT ISSUE, 
ALSO.

05220 KINSLEY, M.

MESSAGE: I DON'T CARE

NEW REPUBLIC, 206 (17) (APR 92) 6.

PRESIDENT GEORGE BUSH HAS BECOME KNOWN FOR HIS WAY OF

TALKING, FOR RAMBLING, AND FOR FREQUENTLY CONTRADICTING

HIMSELF' IN HIS PUBLIC STATEMENTS.

05221 KINSLEY, M.

TRB FROM LONDON: TEA AND PUNDITS

NEW REPUBLIC, 206 (18) (MAY 92), 4.

DESPITE PRE-ELECTION POLLS FORECASTING A LABOUR VICTORY,

THE TORIES EKED OUT A MAJORITY IN BRITAIN'S 1992 ELECTIONS

AND JOHN MAJOR RETAINED THE PRIME MINISTERSHIP. THE

CONSENSUS EXPLANATION IS THAT THE VOTERS' GENERAL DISCONTENT

AND DESIRE FOR A CHANGE WAS FINALLY OVERCOME BY A FEAR OF

HIGHER TAXES AMD A DISTRUST OF NEIL KINHOCK, WHO WAS WIDELY

PERCEIVED AS DEVIOUS AND LACKING SUBSTANCE.

05222 KINSLEY, M.

TRB FROM WASHINGTON: ACCOUNTS RECEIVABLE

NEN REPUBLIC, $206(23)$ ( JUN 92), 6, 50.

ACCORDING' TO THE INTERNAL REYENUE SERVICE'S BEST

ESTIMATE, THE "TAX GAP"-THAT IS, THE DIFFERENCE BETHEEN

WHAT PEOPLE OWE IN TAXES AND WHAT THEY ACTUALLY PAY--IS $\$ 110$ $\$ 127$ BILLION IN 1992. ALTHOUGH MICHAEL DUKAKIS TRIED TO MAKE AN ISSUE OF THIS IN 1988 , HE FAILED. H. ROSS PEROT IS
TO MAKE IT AN ISSUE IN THE 1992 PRESIDENTIAL CAMPAIGN.

05223 KINSLEY, M

TRB FROM WASHINGTON: AIR ON AN L STRING

NEW REPUBLIC, 207(8-9) (AUG 92), 6

WHILE PRESIDENT BUSH'S REELECTION CAMPAIGH IS TRYING TO

PAINT A PORTRAIT OF BILL CLINTON AS A DAMGEROUS LIBERAL, THE

ARKANSAS GOVERNOR IS VIGOROUSLY REJECTING THE LABEL. CLINTON BELIEVES THAT THE DEMOCRATIC PARTY SHOULD BE MORE MODERATE, MORE MAINSTREAM, AND LESS LIBERAL.

05224 KINSLEY, M.

TRB FROM WASHINGTON: ARTS AND CRAFTS

NEW REPUBLIC, 206 (11) (MAR 92) 6, 41 .

THE RISE AND FALL OF JOHM FROHMMAYER AS CHAIRMAN OF THE NATIONAL ENDOHMENT FOR THE ARTS IS A METAPHOR FOR GEORGE

BUSH AS A PERSON AND AS A PRESIDENT. BUSH KNOWS WHAT'S RIGHT AND HE'LL DO IT--IF THERE'S NO REASON NOT TO. HE SINCERELY WANTS TO BE VIRTUOUS. HE JUST DOESN'T WNAT IT VERY BADLY. IF THERE'S A CHOICE BETHEEN VIRTUE AND SOMETHING ELSE BUSH

05225 KINSLEY, M.

TRB FROM WASHINGTON: ASK A SILLY QUESTION

NEW REPUBLIC, $207(2)$ ( JUL 92 ), 6.

THE AUTHOR COMTRASTS THE QUESTIONS ASKED OF PRESIDENT GEORGE BUSH BY PROFESSIONAL JOURNALISTS DURING A WHITE HOUSE PRESS CONFERENCE WITH THE QUESTIONS ASKED OF H. ROSS PEROT BY ORDINARY CITI ENS DURIMG A TELEYISION CALL-IN SHOW. HE FINDS THAT THE ORDINARY CALLERS WERE MORE CONCERNED ABOUT SUBSTANCE, WHILE THE PROFESSIONAL JOURNALISTS WERE MORE INTERESTED IN PROCESS.

05226 KINSLEY, M.

TRB FROM WASHINGTON: BALANCING ACT

NEW REPUBLIC, 206 (26) (JUN 92), 6, 45

THE AUTHOR DISCUSSES SOME ARGUMENTS AGAINST A BALANCED BUDGET AMENDMENT AND EXPLAINS BILL CLINTON'S PLAN TO REFORM THE BUDGET-MAKING PROCESS.

05227 KINSLEY, $M$.

TRB FROM HASHINGTON: BETWEEN BORK AND ROE

NEW REPUBLIC, $207(24)$ (DEC 92 ) , 6 .
DESPITE SOME HAJOR CHANGES IN PHILOSOPHY, THE DEMOCRATIC PARTY THINKING HAS NOT CHANGED IN ITS ATTITUDE TOHARD JUDGES AND THE PROPER USE OF THE CONSTITUTION. BILL CLINTON'S VICTORY HAS BEEN HIDELY CELEBRATED AS AN OPPORTUNITY TO RETURN TO THE GOLDEN AGE OF THE WARREN CDURT. IN PARTICULAR, IT HAS BEEN GREETED WITH A SIGH OF RELIEF ABOUT THE CONSTITUTIONAL RIGHT TO CHOOSE ABORTION. BUT MORE IMPORTANT THAN THE JUDICIAL REAFFIRMATION OF ROE $V$. WADE IS THE PASSAGE OF THE FREEDOM OF CHOICE ACT WHICH WOULD GUARANTEE ABORTION RIGHTS THROUGH NATIONAL LEGISLATION.

05228 KINSLEY, M.

TRB FROM HASHINGTON: BIG TENT BLUES

NEH REPUBLIC, $206(25)$ (JUM 92), 6

ACCORDING TO THE REPUBLICAN' PARTY'S "BIG TENT"

PHILOSOPHY THE GOP HAS RODM FOR PRO-CHOICE ADVOCATES, GAYS, BLACKS, AND TRADITIONAL OUTSIDERS. BUT, IN FACT, THE REPUBLICAN POSITIONS ON SUCH ISSUES AS ABORTION AND HOMOSEXUALS IN THE MILITARY LEAVE LITTLE ROOM FOR FLEXIBILITY OR ACCOMMODATION.

05229 KINSLEY, M.

TRB FROM HASHINGTON: CAN BE STAND PAT?
NEN REPUBLIC, 206 (4) (JAN 92), 6.

THE AUTHOR ARGUES THAT PAT BUCHANAN'S BACKGROUND AS A JOURNALIST AND SOME OF THE OPINIONS THAT HE HAS EXPRESSED WILL BE FERTILE GROUNO FOR NEGATIVE ADVERTISING BY GEORGE BUSH IN THE CAMPAIGN FOR THE 1992 REPUBLICAN NOMINATION FOR PRESIDENT.

05230 KINSLEY, M.

TRB FROM WASHINGTON: COLONEL OF TRUTH

NEW REPUBLIC, 206(10) (MAR 92), 6

THE AUTHOR COMMENTS ON ARKANSAS GOVERNOR BILL CLINTON'S

PERSONALITY AS REVEALED BY HIS MANEUVERINGS TO AVOID

ENTERING MILITARY SERVICE DURING THE VIETHAM WAR.

05231 KINSLEY, M.

TRB FROM WASHINGTON: DEAD TO IRONY

NEW REPUBLIC, 207(16) (OCT 92) 6.

PRESIDENT GEORGE BUSH HAS BEEN BUSY "REINYENTING"

HIMSELF ON THE CAMPAIGN TRAIL. THE DISTINCTION BUSH LIKES TO MAKE BETWEEN WHAT HE CALLS HIS "CAMPAIGN MODE" AND HIS OTHER MODES IS ONE OF HIS MORE CHARMING BITS OF DISINGENUOUSNESS. IT CLEARLY REVEALS HIS UNSPOKEN BELIEF THAT WHEN HE IS IN HIS CAMPAIGM MODE. THE NORMAL RULES OF HONEST DISCOURSE DO NOT APPLY.

05232 KINSLEY, M.

TRB FROM HASHINGTON: ENDGAME

NEW REPUBLIC, $207(20)$ (NOV 92), 6, 49

FOR DEMOCRACY TO WORK PROPERLY, IT IS NOT ENOUGH THAT SUCCESS BE REWARDED. FAILURE MUST' BE PUNISHED. TO RE-ELECT AH INCUMBENT WHO HAS FAILED IS TO BETRAY THE PRINCIPLE OF DEMOCRATIC ACCOUNTABILITY. SAYING "NO" TO A FAILED INCUMBENT REMAINS THE BEST REASON FOR VOTERS TO CHOOSE BILL CLINTON OVER GEORGE BUSH.

05233 KINSLEY, M.

TRB FROM HASHINGTON: FLATLINER

NEW REPUBLIC, 206(15) (APR 92), 6

JERRY BROWN, WHO IS RUNMING FOR THE DEMOCRATIC

NOMINATION FOR PRESIDENT IN 1992, CLAIMS HE WOULD LIKE TO REPLACE THE FEDERAL INCOME TAX, THE SOCIAL SECURITY PAYROLL TAX, AND THE FEDERAL GASOLIME TAX WITH A FLAT 13 PERCENT TAX ON PERSOMAL INCOME AND A SIMILAR VALUE-ADDED TAX (VAT) ON BUSINESS. THE ONLY DEDUCTIONS WOULD BE FOR MORTGAGE INTEREST, RENT, AND CHARITABLE CONTRIBUTIONS. BUT THE VAT IS

ESSENTIALLY A SALES TAX, SO THE CONSUMER HOULD END UP PAYING MOST OR ALL OF IT.

05234 KINSLEY, M.

TRB FROM HASHINGTON: H.R.P., R.I.P.

NEW REPUBLIC, 207 (7) (AUG 92), 6.

NEW REPUBLIC, 207(7) (AUG 92), 6. BOWED OUT OF THE 1992

PRESIDENTIAL CAMPAIGN BECAUSE HIS PROPOSED ECONOMIC POLICY

PRESIDENTIAL CAMPAIGN BECAUSE HIS PROPOSED ECONOMIC POLICY AND BUDGET CUTS HERE

05235 KINSLEY, $M$.

TRB FROM WASHINGTON: HAPPY FAMILIES

NEW REPUBLIC, $206(24)$ ( JUN 92), 6

THE AUTHOR ANALYZES VICE PRESIDENT DAN QUAYLE'S CHAMPIONING OF "TRADITIONAL FAMILY VALUES" IN THE 1992 ELECTION CAMPAIGN. HE ARGUES THAT FREE MARKET CAPITALISM, IN
ITS CONSTANT STIMULATION AND GRST PHASE OF ITS

DEMOBILIZATION BELIEVE THAT THE GOVERNMENT HAS FAILED TO LIVE UP TO ITS COMMITMENTS, PARTICULARLY THOSE INVOLVING THE REDUCTION OF THE SECURITY FORCES. IF THE TWO SIDES DO NOT MEET THE EARLY OEADLINES, A NEW NEGOTIATING IMPASSE MAY DEVELOP.

05236 KINSLEY, M.

TRB FROM WASHINGTON: HE'LL DO

NEW REPUBLIC, $206(16)$ (APR 92), 4, 45.

THE AUTHOR QUESTIONS THE FITTNESS OF ARKANSAS GOVERNOR BILL CLINTON TO BE THE DEMOCRATIC NOMINEE FOR PRESIDENT IN 1992. HE NOTES THAT FEN PEOPLE KMOH WHERE CLINTON STANDS ON IMPORTANT PROBLEMS BECAUSE THE "CHARACTER ISSUE" HAS DOMINATED THE DEMOCRATIC PRIMARY CAMPAIGNS.

05237 KINSLEY, M.

TRB FROM WASHINGTON: HE'LL DO TOO

NEW REPUBLIC, 206 (20) (MAY 92), 6, 49

THE AUTHOR DISCUSSES THE PLUSES AND MINUSES OF $H$. ROSS

PEROT'S RUNAING FOR THE U.S. PRESIDENCY AS AN INDEPENDENT CANDIDATE IN 1992.

05238 KINSLEY, M

TRB FROM WASHINGTON: LAST RESORT

NEW REPUBLIC, 206 (22) (JUN 92), 6 .

AMERICAN VOTERS ARE HYPOCRITES ABOUT FEDERAL SPENDINGHATING IT IN PRINCIPLE, CHERISHING IT IN ACTUALITY. BOTH POLITICAL PARTIES CATER TO THIS HYPOCRISY, AND THE BUDGET DEFICIT IS THE RESULT. A BALANCED BUDGET AMENDMENT, IF IT WORKED, MIGHT LEAD TO REDUCED SPENDING OR HIGHER TAXES OR A 
BUDGET DEBATE.

05239 KINSLEY, M.

TRB FROM WASHIMGTON: OH, GROW UP

NEH REPUBLIC, 206(14) (APR 92), 6

THE AUTHOR DISCUSSES THE CONGRESSIONAL BANKING SCANDAL

AND HOW IT WENT FROM BEING AN INCONSEQUENTIAL NEWS ITEM HHEN

IT WAS FIRST REVEALED IN 1990 TO FRONT PAGE HEADLINES IN 1992.

05240 KINSLEY, M.

TRB FROM HASHINGTON: QUACK

NEW REPUBLIC, 206(9) (MAR 92)

THE AUTHOR COMPARES PRESIDENT GEORGE BUSH'S PROPOSAL FOR HEALTH CARE REFORM AND THE HERITAGE FOUNDATION'S PROPOSAL.

UPON WHICH BUSH'S PLAN IS BASED.

05241 KINSLEY, M.

TRB FROM WASHINGTON: REAGAN'S HEIR

WITHIN THE REPUBLICAN PARTY, SOME CONSERVATIVES FEEL THAT GEORGE BUSH HAS ABANDONED RONALD REAGAN'S POLICIES AND THAT'S WHY THE U.S. ECONOMY IS IN A RECESSION. BUT, IN FACT, BUSH IS REAGAN'S LEGITIMATE HEIR. HIS POLICIES ARE AM EXTENSION OF REAGAN'S, AND THE COUNTRY'S PROBLEMS ARE MORE THE RESULT OF THOSE POLICIES THAN OF ANY IMAGINED DEPARTURE FROM THEM. IF REAGAN WERE IN OFFICE TODAY, HE'S BE IN THE SAME BOAT THAT BUSH IS IN, PADDLING IN THE SAME DIRECTION.

05242 KINSLEY, M.

TRB FROM WASHINGTON: REVISIONIST HISTORY

NEH REPUBLIC, 207 (15) (OCT 92), 6.

OF ALL GEORGE BUSH'S CAMPAIGN FABRICATIONS, POSSIBLY THE MOST AUDACIOUS AND CERTAINLY THE MOST CENTRAL IS HIS CONCEIT THAT THE DEMOCRATIC CONGRESS FORCED HIM TO BREAK HIS NO-NEWTAXES PLEDGE. THIS CONTENTION RAISES BUSH'S FAVORITE ISSUE, TRUST, IN TWO OIFFERENT WAYS. FIRST, THE ASSERTION ITSELF IS DISHONEST AND THE DISHONESTY IS ESPECIALLY STRIKING SINCE IT CONCERNS EVENTS THAT OCCURRED ON THE PUBLIC STAGE ONLY TWO YEARS AGO. SECONDLY, "CONGRESS FORCED ME" IS BUSH'S ONLY DEFENSE AGAINST THE CHARGE THAT HE IS ALREADY A PROVEN BETRAYER OF THE VOTERS' TRUST.

05243 KINSLEY, M.

TRB FROM WASHINGTON: SANTA CLAUSE

NEW REPUBLIC, 206 (13) (MAR 92), 6 .

THE CONSTITUTIOMAL ITY OF CALIFORNIA'S PROPERTY TAX UNDER

PROPOSITION 13 IS BEING REVIEHED BY THE U.S. SUPREME COURT.

05244 KINSLEY, M.

TRB FROM HASHINGTON: SERYES HIM RIGHT

NEH REPUBLIC, $207(5)$ ( JUL 92 ), 6,65 . 65 VOTES AHAY FROM
H. ROSS PEROT IS THREATENING TO TAKE YOTES

GEORGE BUSH IN THE 1992 PRESIDENTIAL ELECTION.

05245 KINSLEY, M.

TRB FROM WASHINGTON: SHOH JOBS

NEH REPUBLIC, 207 (14) (SEP 92), 6

THE AUTHOR ANALYZES THE BUSH CAMPAIGN'S CLAIM THAT

GOVERNOR BILL CLINTON'S ECONOMIC STRATEGY WOULD COST THE

UNITED STATES 2.6 MILLION JOBS. HE ASSESSES THE BUSH CLAIMS REGARDING JOB LOSSES DUE TO DEFENSE CUTBACKS, CLINTON'S HEALTH CARE PROPOSAL, HIGHER FUEL -EFFICIENCY' STANDARDS FOR AUTOMOBILES, PAYROLL TAX INCREASES, AND UNSPECIFIED BUSINESS TAX INCREASES.

05246 KINSLEY, M.

TRB FROM WASHINGTON: SPINACH, PLEASE

NEH REPUBLIC, $207(23$ ) (NOV 92), 6 .
PRESIDENT-ELECT BILL CLINTON FACES TWO CONTRADICTORY ECONOMIC CHALLENGES. ONE IS STIMULATING A SLUGGISH ECONOMY IN THE SHORT TERM. THE OTHER IS REDUCING THE FEDERAL DEFICIT, HHICH IS SAPPING THE NATION'S LONG-TERM ECONOMIC STRENGTH. ANY SHORT-TERM STIMULUS--A TAX CUT, A SPENDING INCREASE, OR SOME COMBINATION OF THE TWO-WILL INCREASE THE DEFICIT, THUS WORSENING THE LONG-TERM PROBLEM. GOING FOR A SHORT-TERM STIMULUS WOULD BE A MISTAKE. IN FACT, IT COULD VERY LIKELY WRECK CLINTON'S PRESIDENCY.

05247 KINSLEY, M.

TRB FROM WASHINGTON: STAY MAD

NEW REPUBLIC, 207 (21) (NOY 92), 6.

THE AUTHOR LISTS SOME OF THE CONTRADICTORY STANDS THAT PRESIDENT GEORGE BUSH HAS TAKEN ON ISSUES DURING HIS 1992 REELECTION CAMPAIGN.

05248 KINSLEY, M.

TRB FROM HASHINGTON: TAKING EXCEPTION

NEW REPUBLIC, 206(1-2) (JAN 92), 6.

THE U.S. SUPREME COURT HAS AGREED TO HEAR THO IMPORTANT CASES INVOLVING THE TAKING CLAUSE OF THE FIFTH AMENDMENT DURING ITS 1991-92 TERM. THE CASES WILL DO MORE THAM ESTABLISH NEW PRECEDENTS IN TAKING CASES; THEY HILL REVEAL
WHETHER THE CONSERVATIVE COURT HILL BE CONTENT TO FOLLOW THE
RHETORIC OF JUDICIAL RESTRAINT OR WILL USE ITS POWER TO IMPOSE ITS POLITICAL AGENDA ON THE ELECTED BRANCHES OF GOVERNMENT.

05249 KINSLEY, M.

TRB FROM WASHINGTON: TAXONOMY

NEW REPUBLIC, 207(10) (AUG 92), 8, 49

THE AUTHOR ANALYZES PRESIDENT BUSH'S CHARGE THAT BILL CLINTON RAISED TAXES 128 TIMES DURING HIS TERMS AS GOVERNOR OF ARKANSAS.

05250 KINSLEY, M.

TRB FROM WASHINGTON: THE IP WORD

NEW REPUBLIC, 207(6) (AUG 92), 6.

THE AUTHOR COMPARES THE POSIITIONS OF BILL CLINTON, H.

ROSS PEROT, AND GEORGE BUSH REGARDING THE NEED FOR A U.S.

INDUSTRIAL POLICY AND WHAT SUCH A POLICY SHOULD ENCDMPASS.

05251 KINSLEY, M.

TRB FROM WASHINGTON: TWILIGHT ZONES

NEW REPUBLIC, 206 (21) (MAY 92), 6.

THE LOS ANGELES RIOTS HAVE ONCE AGAIN FOCUSED ATTENTION ON HUD SECRETARY JACK KEMP'S PROPOSALS TO ENCOURAGE ENTERPRISE ZONES IN THE INNER CITY THROUGH TAX INCENTIVES AND LESS REGULATION. BUT THERE IS NO EVIDENCE TO SUGGEST THAT ENTERPRISE ZONES ARE THE SOLUTION TO URBAN PROBLEMS, AND THEY WOULD INCREASE THE DEFICIT JUST LIKE A TRADITIONAL SPENDING PROGRAM. A CONGRESSIONAL BUDGET OFFICE REPORT HAS CONCLUDED THAT THE LOH-INCOME HOUSING TAX CREDIT, WHICH REPRESENTS THE SAME PHILOSOPHY AS ENTERPRISE ZONES, IS A VERY POOR VALUE FOR THE MONEY BECAUSE IT HAS REDUCED THE OVERALL HOUSING SUPPLY, BENEFITTED INVESTORS MORE THAN TENANTS, AND SIPHONED OFF VAST SUMS OF MONEY TO LAHYERS, ACCOUNTANTS, AND BANKERS.

05252 KINSLEY, M.

TRB FROM WASHINGTON: 128 SKIDOO

NEH REPUBLIC, 207 (13) (SEP 92), 6, 49

AT THE 1992 REPUBLICAN CONVENTION, PRESIDENT GEORGE BUSH SAID THAT THE ELECTION WAS ABOUT "TRUST" AND "CHARACTER" AND THEN DEMONSTRATED HIS DEFECTS IN EXACTLY THOSE DEPARTMENTS. IN DOING SO, HE REVEALED NOT JUST HIS CONTEMPT FOR THE TRUTH BUT HIS CONTEMPT FOR THE AMERICAN POLITICAL PROCESS AND HIS FELLOW CITIZENS AS WELL. THE QUESTION OF WHO HAS RAISED TAXES MOST OFTEN--BUSH AS PRESIDENT OR CLINTON AS GOVERNOR TAXES MOST OFTEN-CBUSH AS PRESIDENT OR CLINTON AS GOVERNOR
OF ARKANSAS--ILLUSTRATES THE BUSH CAMPAIGN'S DISREGARD FOR THE TRUTH.

05253 KINSLEY, M

FROM HASHINGTON: 178 AMD COUNTING

NEW REPUBLIC, 207 (17) (OCT 92 ) 6 ,

THE AUTHOR ANALYZES BILL CLINTON'S CHARGES THAT, IF PRESIDENT GEORGE BUSH IS RE-ELECTED, HIS ADMINISTRATION WILL BE FORCED TO SUBMIT A BUDGET CALLING FOR DRASTIC REDUCTIONS IN SOCIAL SECURITY AND MEDICARE.

05254 KIONKA, R.

ARMED INCIDENTS AGGRAVATE RUSSIAN-ESTONIAN RELATIONS RFE/RL RESEARCH REPORT, 1(34) (AUG 92), 34-37.

RUSSIA REGARDS ITS TROOPS STATIONED IN ESTONIA, LATVIA,

AND LITHUANIA AS A SINGLE ORGANIZATIONAL UNIT AND UNTIL

RECENTLY MAINTAINED A SIMILAR APPROACH TOWARD THE THREE BALTIC STATES. HOHEVER, IN THE SUMMER OF 1992, RUSSIA ABANDONED ITS EVEN-HANDED STANCE AND BEGAN ACCUSING ESTONIA OF ARMED ATTACKS ON RUSSIAN MILITARY PERSOHNEL. WHILE CONFUSION WITHIN THE ESTONIAN DEFENSE MINISTRY MAY PARTLY ACCOUNT FOR THE FREQUENCY OF THE INCIDENTS, THE SHIFT IN RUSSIA'S APPROACH IS ATTRIBUTABLE CHIEFLY TO THE NATURE OF ITS DIPLOMATIC RELATIONS HITH ESTONIA, WHICH ARE MORE COMPLEX THAN ITS RELATIONS WITH THE OTHER BALTIC STATES.

05255 KIONKA, R.

BALTIC STATES DEYELOP A NEW OSTPOLITIK

RFE/RL RESEARCH REPORT, 1 ( 8 ) (FEB 92), 21-25.

AS THE ONLY FORMER SOVIET REPUBLICS NOT TO HAVE JOINED THE COMMONHEALTH OF IMDEPENDENT STATES, THE BALTIC STATES MUST NOW ESTABLISH RELATIONS WITH THE NEW ENTITY THAT ARE QUALITATIVELY DIFFERENT FROM THOSE IT HAD WITH THE SOVIET UNION. OUTDATED PERCEPTIONS OF THE BALTIC STATES ON THE PART OF SOME MEMBER STATES, COMBINED WITH POWER STRUGGLES WITHIN THE COMMONWEALTH, HAVE SO FAR PRODUCED SHAKY FOUNDATIONS ON WHICH TO BULID THIS RELATIONSHIP. TWO MAJOR ISSUES ARE WHICH TO BULID THIS RELATIONSHIP. TWO MAJOR ISSUES ARE CAUSING ILL FEELING 8ETWEEN THE BALTIC STATES AND THE
COMMONHEALTH: IMBALANCES IN TRADE RELATIONS AND DIFFICULTIES COMMONHEALTH: IMBALANCES IN TRADE RELATIONS AND DIFFICULTIES IN NEGOTIATING THE
BALTIC TERRITORY.

05256 KIONKA, R.

ESTONIA
RFE/RL RESEARCH REPORT, 1(39) (OCT 92), 62-65.

THE MOST DRAMATIC CHANGES IN THE ESTONIAN MEDIA BEGAM ABOUT THREE YEARS AGO, WHEN THE COUNTRY WAS IN THE THROES OF ITS STRUGGLE FOR INDEPENDENCE. THE RESULT WAS THAT UNCENSORED, VARIEGATED MEDIA WERE IN PLACE BY THE TIME THE 
REPUBLIC FORMALLY GAINED ITS INDEPENDENCE. HOWEVER, SUBSTANTIVE, STRUCTURAL, AND REGULATORY PROBLEMS CONTINUE TO HAMDICAP THE ESTONIAM MEDIA. THE DEYELOPMENT OF A HIGHQUALITY RUSSIAN-LANGUAGE PRESS PRESENTS A SPECIAL CHALLENGE TO THE NEW STATE. DURING THE PAST YEAR, THE GREATEST IMPETUS FOR CHANGE HAS COME FROM MARKET REFORMS, A TREND THAT ESTONIA'S NEW PARLIAMENT SEEMS LIKELY TÓ SUPPORT.

05257 KIONKA, R.

ESTONIÁ

ON JUNE 28, 1992, ESTONIAN CITIZENS WENT TO THE POLLS IN A NATIONAL REFERENDUH TO APPROYE THE COUNTRY'S FIRST POSTWAR NONCOMMUNIST CONSTITUTION. APPROVAL OF THE DRAFT

CONSTITUTION HAD SEEMED CERTAIN UNTIL EARLY JUNE, WHEN ITS OPPONENTS STEPPED UP EFFORTS TO DEFEAT THE BILL AMD REINSTATE THE 1938 CONSTITUTION, WHICH HAD GIVEN THE OFFICE OF THE PRESIDENT GREATER POWERS THAN THE CURRENT DRAFT. GIVEN THE OPPOSITION'S RIGHTIST ORIENTATION AND THE EXECUT IVE-CENTERED SYSTEM OF GOVERMMENT IT WANTS TO RESTORE, SUPPORTERS OF THE NEH DRAFT CONSTITUTION FEAR THAT THEIR OPPONENTS WISH TO RESTORE RIGHT-HING AUTHORITARIAN RULE IN OPPONENTS
ESTONIA.

05258 KIONKA, $R$.

FOOO SHORTAGES AND POLITICAL METAPHORS IN ESTONIA RFE/RL RESEARCH REPORT, 1(13) (MAR 92), 31-33.

AS THE PRICE OF FOOD RISES AND AVAILABILITY FALLS,

POLITICAL RHETORIC IN ESTONIA IS ACQUIRING AN DODLY-CULINARY TONE. THE INCREASED USE OF FOOD IMAGERY IS NOTABLE AMONG ESTONIAN POLITICIANS. FAR FROM BEING TRIVIAL. THE USE OF
FOOO METAPHORS IS AN EXPRESSION OF A PROBLEM LIKELY TO HAVE FOOO METAPHORS IS AN EXPRESSION OF A PROBL
FAR-REACHING EFFECTS ON ESTONIAN SOCIETY.

05259 KIONKA, $R$.

FREE-MARKET COALITION ASSUMES POWER IN ESTONIA

RFE/RL RESEARCH REPORT, 1(46) (NOV 91), 6-11.

ON SEPTEMBER 20, 1992 , VOTERS IN ESTONIA ENDORSED SWEEPING ECONOMIC CHANGES BY ELECTING A COALITION THAT PROMISED FREE-MARKET REFORMS.

05260 KIONKA, R.

PLEA FÓR SPECIAL POWERS TOPPLES ESTONIAN GOVERMMENT RFE/RL RESEARCH REPORT, 1 (7) (FEB 92), 31-34.

ESTONIAN PRIME MINISTER EDGAR SAVISAAR ASKED THE SUPREME COUNCIL TO DECLARE AN ECONOMIC STATE OF EMERGENCY, TO GRANT HIM SPECIAL POWERS FOR IMPLEMENTING IT, AND TO ESTABLISH A COMMISSION TO DEFINE THOSE SPECIAL POWERS. AFTER A WEEK OF UNSUCCESSFUL ATTEMPTS TO FORM SUCH A COMMISSION, SAVISAAR'S UNSUCCESSFUL ATTEMPTS TO FORM SUCH A COMMISSION, SAVISAAR'S
SUPPORT IN THE SUPREME COUNCIL HAD ERODED SO BADLY THAT HE SUPPORT IN THE SUPREME COUNCIL HAD ERODED SO BADLY THAT RE STEPPED DOWN. HE WAS REPLACED BY THE POLITICALLY-NEUTRAL TIIT VAHI, WHO SEEMS
ITS ECONOMIC CRISIS.

05261 KIPUROS $K$

SELF-ASSURED YELTSIN LEAVES SOME QUESTIONS UNANSHERED GERMAN TRIBUNE, (1495) (DEC 91) 2 .

SO OFTEN DID BORIS YELTSIN REITERATE DURING HIS VISIT TO BONN THAT HE HAD NOT COME AS A PETITIONER OR SUPPLICANT THAT HIS PRDTESTS COULD REASONABLY BE REGARDED AS PART OF HIS METHOD. BUT MO DISPLAY OF SELF-ASSURANCE, NO MATTER HOH DEMONSTRATIVELY MADE, COULD SET ASIDE THE FACT THAT YELTSIN'S POLITICAL FUTURE WOULD BE A LITTLE NEARER TO ITS' END IF HE WERE TO RETURN FROM BONN EMPTY-HANDED. GIVEN THE UNCERTAINTIES OF A SOVIET UNION IN THE THROES OF DISINTEGRATION, SUCH A RETURN WOULD NOT BE IN GERMANY'S INTEREST. GERMANY HAS A VITAL ROLE IN AIDING A PEACEFUL TRANSFORMATION TO A NEW POLITICAL STRUCTURE CAPABLE NOT ONLY OF REVIVING THE MORIBUND RUSSIAN ECONOMY, BUT ALSO OF CONTROLLING THE NUCLEAR WEAPONS NOW SCATTERED AMONG SEVERAL SOVIET REPUBLICS.

05262 KIRBY, $S$.

NEW WORLD ORDER: A FLAWED STRATEGY FOR MORTHEAST ASIA KOREAN JOURMAL OF DEFENSE ANALYSIS, 3(2) (WIN 91), 39-64.

IN PROVIDING THE ANSWER TO THE QUESTION-SHOULD NORTHEAST ASIA WANT A NEW WORLD ORDER?--THIS ARTICLE MAKES REFERENCE TO EACH ASPECT OF IT. IT SUGGESTS THAT THE RELIANCE OF THE NEW HORLD ORDER ON CONTINUED AMERICAN-SOVIET COOPERATION IS A NECESSARY BUT NOT A SUFFICIENT CONDITION FOR THE CREATION OF A NEH ORDER IN NORTHEAST ASIA. ALSO, FOR THE CREATION OF A NEH ORDER IN NORTHEAST ASIA. ALSO,
THAT AISA SHOULD HANT THE U.S. TO OVERCOME ITS PREFERENCE THAT AISA SHOULD WANT THE U.S. TO OVERCOME ITS PREFERENCE FOR THE LARGELY BILATERAL AND MONO-DIMENSIONAL RELATIONSHIPS
THAT TYPIFIED ITS EARLIER COLD HAR COMMITMENT TO THE REGION.

$05263 \mathrm{KIRCH}, \mathrm{A}$.

RUSSIANS AS A MINORITY IN CONTEMPORARY BALTIC STATES BULLETIN OF PEACE PROPOSALS, $23(2)(1992), 205-212$. THE RUSSIAN GUESTION IS AND WILL CONTINUE TO BE IMPORTANT FOR THE THREE BALTIC REPUBLICS OF ESTONIA, LATVIA, AND LITHUANIA. THIS ARTICLE EXPLORES THREE CONCEPTIONAL QUESTIONS: (1) THE CENTRAL FACTORS OF THE SITUATION OF NATIONAL CONFRONTATION IN THE BALTIC STATES TODAY ARE NOT ETHNICAL INTOLERANCE AND DISCRIMINATION OF RIGHTS OF
MATIONAL MINORITIES, (2) AFTER THE GROUNOS OF CONFLICTS HAYE BEEN NEUTRALIZED, THERE WILL STILL BE CONSIDERABLE DIFFICULTIES IN THE POLITICAL AND CULTURAL ADAPTION AND INTEGRATION OF MON-INOIGNENOUS IMMIGRANTS INTO THE SOCIETIES 作 GUARANTEES OF THE INTERESTS OF INDIGENOUS PEOPLE ARE CONFIRMED BY THE RIGHT TH SELF-DETERMINATION. THE NATIONAL INTERESTS OF FOREIGN INHABITANTS MUST BE GUARANTEED ON THE BASIS OF HUMAN RIGHTS IN GENERAL ANO BY THE PRINCIPLES OF CULTURAL AUTONOMY OF NATIONAL MINORITIES.

05264 KIRCHGASSMER, G.; SCHIMMELPFENNIG, J. CLOSENESS COUNTS IF IT MATTERS FOR ELECTORAL VICTORY: SOME EMPIRICAL RESULTS FOR THE UNITED KINGDOM AND THE FEDERAL REPUBLIC OF GERMANY

PUBLIC CHOICE, 73(3) (APR 92), 283-300.

IT HAS BEEEN ARGUED, THAT CLOSENESS COUNTS NOT ONLY WITH RESPECT TO THE OVERALL DECISION OF A GENERAL ELECTION, BUT ALSO WITH RESPECT TO THE OUTCOME IN SUBELECTORATES. THIS PROPOSITION IS TESTED USING DATA BOTH FROM THE LAST GERMAN BUNDESTAGSWAHL AS WELL AS THE UNITED KINGDOM GENERAL ELECTION IN 1987. THIS ARTICLE FINDS THAT EXPECTED CLOSENESS COUNTS FOR TURNOUT ON THE LEVEL OF THE INDIYIDUAL ELECTORAL DISTRICT, BUT NOT ON ANY LEVEL BELOW, E.G. ON THE LEVEL OF PRECINCTS. THEREFORE, CLOSENESS SEEMS TO COUNT ONLY IF IT IS RELEVANT FOR ELECTORAL VICTORIES OR DEFEATS.

05265 KIRK, D.

JAPANESE EYE VIEW

MATIONAL REVIEH, XLIV(11) (JUN 92), 24-25.

JAPAN IS FACING INCREASIMGLY SERIOUS CHALLENGES ON BOTH THE DOMESTIC AND FOREIGN POLICY FRONTS CHALLEES ON BOTH STOCK MARKET IS FALLING, MANUFACTURING PROFITS ARE DROPPING-PERHAPS AS MUCH AS 70 PERCENT, THE GROSS NATIONAL PRODUCT IS SHOWING "NEGATIVE GROWTH," AND REAL ESTATE IS DOWH BY 5 PERCENT. ON THE FOREIGN POLICY FRONT, JAPANESE LEGISLATORS CONTINUE TO DEBATE OVER THE POSSIBLE USE OF JAPANESE TROOPS IN UNITED MATIONS PEACEKEEPING OPERATIONS--A PROSPECT THAT FRIGHTENS BOTH THE JAPANESE LEFT AND MOST OF THE NATIONS OF ASIA. THIS DEBATE MASKS A MORE SERIOUS FOREIGN POLICY DILEMMA: HOW TO CREATE AN AGRESSIVE AND COHERENT FOREIGN POLICY IN THE FACE OF RECEDING UNITED STATES INFLUENCE AND CONTINUING REGIONAL DISTRUST.

05266 KIRK, D.

MIDDLE-EAST WAR DIARY

NATIONAL REVIEW, XLIII(3) (FEB 91), 26-27.

THIS ARTICLE PRESENTS A JOURNALIST'S EYE-WITNESS ACCOUNT OF THE FIRST DAYS OF THE PERSIAN GULF WAR. HIS EXPLOITS TOOK HIM TO BAGHDAD DURING THE FIRST FEH DAYS OF BOMBING, TO AMMAN, JORDAN AFTER MOST JOURNALISTS WERE INVITED TO LEAVE AMMAN, JORDAN AFTER MOST JOURNALISTS WERE INVITED TO LEAVE IRAQ, TO DAMASCUS, HOME OF AMERICA'S ERSTWHILE ENEMY HAFEZ
ASSAD, AND FINALLY TO TURKEY. THE AUTHOR FINDS A MOOD OF ASSAD, AND FINALLY TO TURKEY. THE AUTHOR FINDS A MOOD OF
FOREBODING AND UNEASE THROUGHOUT THE MIDOLE EAST, BUT LITTLE FOREBODING AND UNEASE THROUGHOUT THE MIDOLE EAS
DEFINITIVE VIEWS ON THE FUTURE OF THE REGION.

05267 KIRK, D.

NORTH KOREA WOOS THE CAPITALISTS

NEH LEADER LXXY(6) (MAY 92) 9-11

NORTH KDREA BEGAN AWAKENING TO ECONOMIC IF NOT POLITICAL REALITY IN 1991 WHEN ITS THO BIG TRADING PARTNERS--THE SOVIET UNION AND CHINA--BOTH BEGAN DEMANDING PAYMENT IN HARD HESTERN CURRENCY RATHER THAN IN THE SOFT CURRENCIES OF THE COMMUNIST COUNTRIES. HARD HIT BY THIS AND OTHER CHANGES, THE NORTH KOREAN GOVERMMENT IS EMBARKING ON A PROGRAM DESIGNED TO ENCOURAGE FOREIGN INVESTMENT FROM THE UNITED STATES, JAPAN AND SOUTH KOREA, WHILE MAINTAINING ITS RIGID AUTHORITARIAN CONTROL AND SOCIALIST ECONOMIC SYSTEM. THE GOVERMMENT OF XIM IL-SUNG QUICKLY MOVED TO HAVE ITS NUCLEAR AGENCY IN ORDER TO REMOVE THE FINAL BARRIER TO RELATIONS WITH CAPITALIST NATIONS. SEVERAL LARGE SOUTH KDREAN FIRMS ARE POISED TO MOVE NORTH, BUT WHETHER JAPANESE OR AMERICAN FIRMS WILL FOLLOH SUIT REMAINS TO BE SEEN.

05268 KIRK, D.

REGRESSIVE RECOVERY IN KUWAIT

NEW LEADER, LXXIV(11) (OCT 91), 8-9

AS THE RULING ELITE HAGGLE OVER DEMOCRATIC REFORM AND SEAL THE FATE OF KUHAIT'S "TRAITOROUS" PALESTINIAN MINORITY, A LEGION OF FOREIGN TECHNICIANS IS EAGERLY REBUILDING THE SMOKING EMIRATE. AT LEAST A THIRD OF THE 700,000 KUWAITI PASSPORT HOLDERS ARE BELIEVED TO BE LIVING ABROAD, MOSTLY IN VILLAS AND APARTMENTS SCATTERED ACROSS EUROPE. TO LURE THE SOJOURNERS HOME, AND TO PROMOTE A MATIONAL REBUILDING EFFORT, SOJOURNERS HOME, AND TO PROMOTE A NATIONAL REBUILDING THE GOVERNMENT HAS OFFERED EXIRAORDINARY FINAHCIAL WO WANT INCENTIVES. IT HAS ALSO REOPENED BANKS FOR CITIZENS HHO WANT TO DRAW ON THEIR SAVINGS. KUHAITIS, HOWEVER, ARE NOT QUITE CONVINCED THAT THEY MUST SACRIFICE THEIR EASY LIVES FOR THE TOIL OF RECONSTRUCTION. AND GIVEN THE RATE AT WHICH FOREIGN CONTRACTORS ARE FLOCKING TO KUWAIT, THEY PROBABLY WON'T HAYE TO. THE DOWNSIDE, AS THE COUNTRY'S LEADERS SEE IT, IS THAT CONTINUED RELAINCE ON OUTSIDERS HILL THWA
KUWAITIS A MAJORITY IN THEIR OWN LAND. 
05269 KIRK, D.

SOUTH KOREA'S YEAR OF CONFRONTATIONS

NEW LEADER, LXXY(3) (MAR 92), 3-5.

THE TRUE TEST OF THEIR POLITICAL SYSTEM WILL BE WHETHER SEOUL'S POLITICIANS AND GENERALS CAN MANAGE TO SORT OUT THE POWER STRUGGLE GOING ON THERE WITHOUT ANYONE RESORTING TO THE KIND OF FORCE THAT HAS BEEN DOMINANT THROUGHOUT SOUTH KOREA'S HISTORY. PERHAPS THE PARADOX OF CONTEMPORARY KOREAM POLITICS IS THAT STAUNCH CONSERVATIVE CHUNG JUY YOUNG AND HOTHEADED RADICAL KIM DAE JUNG--BOTH PURSUING REFORM, THOUGH NATURALLY FROM DIFFERENT DIRECTIONS-POSE THE GRAVEST DANGER NO POL ITICAL STABILITY AND DEMOCRATIC RULE, OR AT THE TO POLITICAL STABILITY AND DEMOCRATIC RULE, OR AT THE
MINIMUM TO DEMOCRATIC LIBERAL RULE. THIS ARTICLE EXPLORES THE RECENT UNREST IN THIS COUNTRY.

05270 KIRKLAND, F

GOVERNMENTAL POLICY AND COMBAT EFFECTIVENESS: FRANCE 19201940

ARMED FORCES AND SOCIETY, 18(2) (WIN 92), 175-192.

FRENCH GOVERNMENTAL POLICY AND LEGISLATION BETHEEN THE

WORLD HARS HAD UNINTENDED EFFECTS ON THE MORALE AND

EFFICIENCY OF MILITARY OFFICERS. THESE EFFECTS CAN BE

OISCERNED FROM AN ANALYSIS OF ARTICLES IN MILTARY JOURNALS

BETWEEN 1920 AND 1940. THE THIRD-ORDER EFFECTS ON EFFICIENCY

INCLUDED THE OFFICER'S GROHING INABILITY TO COOPERATE ACROSS

BRANCHES, UNWILLINGNESS TO ATTEND TO TECHMOLOGICAL

DEVELDPMENTS, AND UNQUESTIONING ACCEPTANCE OF AN OBSOLETE

MILITARY DOCTRINE. THE FRENCH EXPERIENCE ILLUSTRATES

PROCESSES THROUGH WHICH UNEXAMINED GOVERMMENTAL ACTION CAN

DEGRADE THE COMBAT EFFECTIVENESS OF AN ARMED FORCE.

05271 KIRKPATRICK, J.

THE USE OF FORCE IN THE LAW OF NATIONS

WORLD AFFAIRS, 153(3) (WIN 91), 102-112.

SENATOR DANIEL PATRICK MOYNIHAN, HAS WRITTEN A BOOK, "ON THE LAW OF NATIONS" WHICH IS REVIEWED IN THIS ARTICLE. THE BOOK IS SIMULTANEOUSLY A HARSH, PARTISAN ATTACK THAT SEEKS TO CRIMINALIZE THE ACTIONS OF THE REAGAN ADMINISTRATION, ACTIONS OF WHICH MOYNIHAN DISAPPROVES, AND A SHEEPING ACTIONS OF WHICH MOYNIHAN DISAPPROVES, AND A SHEEPING COMMENTARY ON INTERNATIONAL LAW AND ORGANIZATIONS. THE
THESIS, SIMPLY STATED, IS THAT INTERNATIONAL LAW WAS ONCE THESIS, SIMPLY STATED, IS THAT INTERNATIONAL LAH WAS ONCE
CHERISHED AND RESPECTED BY AMERICANS, BUT BY 1990 HAD BECOME CHERISHED AND RESPI
LARGELY IGNORED.

05272 KIRONDE, J.M.L.

RECEIVED CONCEPTS AND THEORIES IN AFRICAN URBANIZATION AND MANAGEMENT STRATEGIES: THE STRUGGLE CONTINUES

URBAN STUDIES, 29(8) (DEC 92), 1277-1292.

VARIOUS CONCEPTS, THEORIES, AND ATTITUDES IN DEFINING AND SOLVING AFRICAN URBAN PROBLEMS REFLECT ASSIMILATED AND ACQUIRED NOTIONS AND STANDARDS RATHER THAN INDIGENOUS ONES. CONCEPTS RELATED TO URBAN SANITATION, HATER SUPPLY, URBAN AGRICULTURE, URBAN TRANSPORT, AND ASPECTS OF HOUSING SUPPLY NEED TO BE REDEFINED TO REFLECT LOCAL CIRCUMSTANCES.

05273 KIRP, $D$.

THE PITFALLS OF "FETAL PROTECTION"

SOCIETY, 28 (3) (MAR 91), 70-76.

THIS ARTICLE EXAMINES THE ONGOING CONFLICT OVER "FETAL PROTECTION": THE IDEA THAT FERTILE WOMEN SHOULD BE KEPT OUT OF JOBS WHERE EXPOSURE TO TOXIC CHEMICALS MAY MEAN FETAL VULNERABILITY. SUPPORTERS OF FETAL PROTECTION SITUATE THEMSELVES ON THE MORAL HIGH GROUND OF PROTECTORS OF FUTURE GENERATIONS. HOWEVER, THIS HAY OF THINKING OVERSIMPLIFIES A TREACHEROUS POLICY TERRAIN MARKED AT EVERY JUNCTURE BY COMPETING INTERESTS AND OBLIGATIONS, A TERRAIN NOT WELL DEFINED BY EITHER THE LANGUAGE OF DISCRIMINATION OR THE

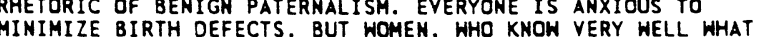
IT MEANS BIRTH DEFECTS. BUT WOMEN, WHO KNOW VERY WELL WHAT FORCED OUT OF LUCRATIVE JOBS AT LEAST NOT WITHOUT A THOROUGH EXPLORATION OF ALTERNATIVES.

05274 KIRSCHMER, B.H.

ELECTRONIC DEMOCRACY IN THE 21ST CENTURY

NATIONAL CIVIC REVIEH, 80(4) (FAL 91), 406-412.

THE ADVENT, HIDE AVAILABILITY, AND USE OF LOH-COST, USERFRIENDLY PERSONAL COMPUTER TECHNOLOGY NOH OFFERS A LINK BETWEEN GOVERMMENT AND CITIZENS THAT COULD REVOLUTIONIZE THE NATURE OF CIVIC PARTICIPATION IN THE 21ST CENTURY. DURING THE 199'S, READILY ACCESSIBLE PUBLIC INFORMATION UTILITIES AND MAINTENANCE OF CIVIC INFRASTRUCTURE IN U.S. COMMUNITIES.

05275 KISER, E. ; TONG, $X$.

DETERMINANTS OF THE AMOUNT AND TYPE OF CORRUPTION IN STATE FISCAL BUREACRACIES: AN ANALYSIS OF LATE IMPERIAL CHINA COMPARATIVE POLITICAL STUDIES, 25(3) (OCT 92), 300-331.

A PRINCIPAL-AGENT MODEL OF' RELATIONS BETHEEN RULERS AND STATE OFFICIALS IS USED TO DERIVE SEVERAL PROPOSITIONS CONCERNING THE AMOUNT AND TYPE OF CORRUPTION IN STATE BUREACRACIES. THE MODEL IS APPLIED TO THE FISCAL BUREAUCRACIES OF MING AND OING CHINA, FOCUSING ON HOH
PROBLEMS RULERS FACED MEASURING TAXABLE ASSETS AND MONITORING AND SANCTIONING STATE TAX COLLECTORS RESULTED IN A HIGH LEVEL OF CORRUPTION. ATTEMPTS BY MING AND QUIN RULERS TO REFORM THEIR FISCAL SYSTEMS ARE ANALYZED, AND THE CAUSES OF THE GENERAL FAILURE OF THESE REFORMS AND OF REGIONAL VARIATIONS IN REFORM SUCCESS ARE DISCUSSED.

05276 KISER, G.C.

PRESIDENTIAL PRIMARIES: STEPPING STONES TO THE VICEPRESIDENTIAL NOMIMATION?

PRESIDENTIAL STUDIES QUARTERLY, XXII(3) (SUM 92), 493-518.

BY EXAMINING THE RECORD EXTENDING BACK TO 1912, THE AUTHOR CHALLENGES THE CONVENT IONAL WISDOM THAT VICEPRESIDENTIAL CANDIDATES ARE SELECTED VIA THEIR ROLES IN PRESIDENTIAL CANDIDATES ARE SELECTED VIA THEIR ROLES IN
PRESIDENTIAL PRIMARIES. HE FINDS THAT VERY FEW PRIMARY PRESIDENTIAL PRIMARIES. HE FINDS THAT VERY FEW PRIMARY
ENTRANTS EVER RECEIVED THE VICE-PRESIDENTIAL NOMINATION AND THOSE THAT DID WERE AMONG THE WEAKEST PRIMARY CANDIDATE CONTENDERS. PRIMARY RIVALS WERE NOMINATED "ONLY WHEN THE PRESIDENTIAL NOMINEE MUCH NEEDED THEIR HELP TO LAND HIS OHM NOMINATION, TO WIN THE ELECTION, OR BOTH." AN EXCEPTION WAS
1980 WHEN RONALD REAGAN SELECTED GEORGE BUSH, HIS STRONGEST 1980 WHEN RONALD REAGAN SELECTED GEORGE BUSH, HIS STRONG
PRIMARY CONTENDER, AS HIS RUNHING MATE. RICHARD NIXON SUGGESTED THAT STRENGTH IN THE PRIMARIES SHOULD BE A MAJOR CONSIDERATION FOR CHOOSING A RUNNING MATE, ALTHOUGH HE NEVER USED THAT CRITERION HIMSELF. IN 1988, MICHAEL DUKAKIS CONSIDERED SEVERAL OF HIS PRIMARY RIVALS AS A RUNHING MATE BUT FINALLY CHOSE SOMEONE ELSE.

05277 KISHIMA, T.

POLITICAL LIFE IN JAPAN--DEMOCRACY IN A REVERSIBLE WORLD PRINCETON UNIVERSITY PRESS, 1992, 169.

TO UNDERSTAND HOW CHANGE OCCURS IN POLITICS, WE SHOULD TURN FROM CONCENTRATING ON INTERNATIONAL POL ITICAL ACTIONS TO EXPLORING EVERYDAY LIFE, ESPECIALLY MARGINAL FRAMES OF MIND IN WHICH PEOPLE ARE OPEN TO QUESTIONING EXISTING IDEAS AND INSTITUTIONS. IN SO CONTENDING, THE AUTHOR OF THIS BOOK OFFERS FRESH UNDERSTAMDING OF CONTEMPORARY JAPANESE POL ITICIANS AND THE JAPANESE POLITICAL PROCESS, WHILE SHE ALSO PROPOSES AN INNOVATIVE METHOD OF LOOKING AT POLITICS IN GENERAL. SHE POINTS OUT THAT TAKEN-FOR-GRANTED VALUES AND BELIEFS ARE REVEALED AS ARBITRARY WHEN PEOPLE EXPERIENCE BELIEFS ARE REVEALED AS ARBITRARY WHEN PEOPLE EXPERIENCE
INTRUSIONS OF THE MARGINAL OR "LIMINAL." SOCIAL MARGINALS, INTRUSIONS OF THE MARGINAL OR "LIMINAL." SOCIAL MARGINALS,
SUCH AS OUTCASTES OR SO-CALLED MISFITS, ARE THE MOST LIKELY SUCH AS OUTCASTES OR SO-CALLED MISFITS, ARE THE MOST LIKELY
PEOPLE TO INYOKE THESE INTRUSIONS, BUT MORE ORDINARY FOLK PEDPLE TO INVOKE THESE INTRUSIONS, BUT MORE ORDINARY FOLK ARE SUBJECTED TO THEM UNDER SPECIAL CONDITIONS RANGING THE SEEMINGLY TRIVIAL-DDAYREAMING, DANCING, OR GETTING ECSTATIC RITUAL.

05278 KISLOV, A.

CONVERSIOON: RUSSIAN EXPERIENCE AND PERSPECTIVES PEACE AMD THE SCIENCES, 1(1) (SEP 92), 52-53.

THE AUTHOR BELIEVES THAT OF MOST PARAMOUNT SIGNIFICANCE WAS AND STILL IS THE PROBLEM OF DISARMAMENT AND CONVERSION OF MILITARY INDUSTRY INTO A CIVILIAN ONE FOR THE FORMER USSR. HE STATES THAT AT PRESENT, RUSSIA DOES NOT HAVE ANY PROGRAM AT ANY LEVEL: MACRO, MICRO OR REGIONAL, AND THAT CONVERSION NEEDS AN OPTIMIAL COMBINATION OF ALL THESE LEVELS FOR ITS SUCCESSFUL IMPLEMENTATION. HE CONCLUDES THAT THE STAKES INVOLVED IN ENSURING A SMOOTH TRANSITION FROM POL ITICAL CONFRONTATION TO A PEACE ECONOMY ARE TOO HIGH TO BE LEFT ENTIRELY TO UNCONTROLLED CHANCES.

05279 KITAZUME, T.; MASAKI, H.

BUSH VISIT MÁRKS FUMDAMENTAL SHIFT IN BILATERAL RELATIONS JAPAN TIMES (WEEKLY INTERNATIONAL EDITION), 32(3) (JAN 92), 1,5 .

1.5.S. PRESIDENT GEORGE BUSH'S JANUARY 1992 VISIT TO JAPAN DEMONSTRATED THAT THE NATURE OF RELATIONS BETWEEN THE THO COUNTRIES HAS CHANGED FUNDAMENTALLY, DUE TO THE END OF THE COLD WAR. THE TALKS BETWEEN BUSH AND PRIME MINISIER KIICHI MIYAZAWA WERE MARKED BY JAPANESE CONCESSIONS ON TRADE, WH POLITICAL TIES WITH ASIA'S ECONOMIC GIANT.

05280 KITAZUME, T

BUSH VISIT 'SPOTLIGHTS 'TRADE FRICTION' BETHEEN COUNTRIES JAPAN TIMES (WEEKLY INTERNATIONAL EDITION), $32(2)$ (JAN 92) $1,5$.

JAPANESE OFFICIALS HAD HOPED THAT THE BUSH-MIYAZAWA SUMMIT OF JANUARY 1992 WOULD PROVIDE AN OPPORTUNITY TO REDEFINE BILATERAL RELATIONS FOR THE NEXT HALF-CENTURY,
BUSH INSISTED ON FOCUSING ON TRADE ISSUES. ONE FOREIGN BUSH INSISTED ON FOCUSING ON TRADE ISSUES. ONE FOREIGN MINISTRY OFFICIAL DESCRIBED THE BUSH VISIT AS "PART OF AN TO HINGE ON HIS ECONOMIC PROGRAM.

05281 KITAZUME, T.

BUSINESS AS USUAL HITH NEW REGIME

JAPAN TIMES (WEEKLY INTERNATIONAL EDITION), 32(1) (JAN 92),

1,6 .

THE JAPANESE GOVERNMENT BELIEVES THAT THE COLLAPSE OF THE SOVIET UNION HILL NOT SUBSTANTIALLY CHANGE ITS RELATIONS WITH MOSCOW. BUT TOKYO OFFICIALS ACKNOWLEDGE THAT THE 
TRANSITION TO THE NEH COMMONWEALTH OF INDEPENDENT STATES MAY CREATE A CERTAIN VACUUM IN JAPAN'S BILATERAL DIALOGUE WITH
MOSCOW, INCLUDING TALKS ON THE LONGSTANDING DISPUTE OVER THE MOSCOW, INCLUDING TALKS ON THE LONGSTANDING DI
SOVIET-OCCUPIED ISLANDS NORTHEAST OF HOKKAIDO.

05282 KITAZUME, T.

GOVERNING PARTY MUST SOON FACE THE MUSIC

JAPAN TIMES (WEEKLY INTERNATIONAL EDITION), 32(16) (APR $92), 1,6$.

A SERIES OF POLITICAL SCANDALS EMBARRASSING TO BOTH THE LIBERAL DEMOCRATIC PARTY AND OPPOSITION MEMBERS HAS HIGHLIGHTED THE NEED FOR POLITICAL REFORM IN JAPAN AND HAS CATAPULTED IT INTO A MAJOR ISSUE THAT NEEDS TO BE ADDRESSED BEFORE THE JULY 1992 UPPER HOUSE ELECTIONS. SHARING THE NATIONAL SPOTLIGHT IS THE QUESTION OF WHETHER JAPANESE SELFDEFENSE FORCES HILL BE PERMITTED TO PARTICIPATE IN UNITED NATIONS' PEACEKEEPING MISSIONS.

05283 KITAZUME, T.

JAPAN, U.S. MUST FOLLOW THROUGH ACTIOH PLAM: KURIYAMA

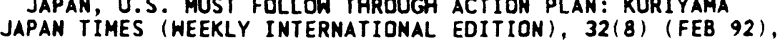
8.

TAKAKAZU KURIYAMA, TOKYO'S AMBASSADOR TO WASHINGTON, "ACTION PLAN" ADOPTED BY PRESIDENT BUSH AND PRIME MINISTER MIYAZAWA PLAN" ADOPTED BY PRESIDENT BUSH AND PRIME MINISTER MIYAZAWA IN JANUARY 1992. IN ADDIIION TO REACHING TRADE SHOUID COOPERATE IN MIYZAHA STATED THAT THE TWO NATIONS SHOULD COOPERATE

05284 KITAZUME T

REPORT URGES JAPAN TO BROADEN ITS DIPLOMATIC ROLE JAPAN TIMES (WEEKLY INTERNATIONAL EDITION), 32 (1) (JAN 92 ),

THE JAPANESE FOREIGN MINISTRY'S 1991 ANNUAL REPORT ADVISES JAPAN TO MOVE AWAY FROM ITS TRADITIONAL "CHECKBOOK DIPLOMACY" AND TO PLAY A LARGER ROLE IN MULTINATIONAL EFFORTS TO MAINTAIN GLOBAL SECURITY, INCLUDING UNITED NATIONS PEACEKEEPING OPERATIONS. STRIVING FOR A SUCCESSFUL CONCLUSION TO THE URUGUAY ROUND OF GATT TALKS SHOULD ALSO BE A PRIORITY. A MAJOR DIPLOMATIC CHALLENGE FOR JAPAN WILL BE TO SIMULTANEOUSLY PROMOTE REFORMS IN THE FORMER SOVIET UNION AND SETTLE THE DISPUTE WITH MOSCOW OVER THE KURILE ISLANDS, ACCORDING TO THE REPORT.

05285 KITAZUME, T.

SPECULATION CENTER ON DUAL DIET ELECTION

JAPAN TIMES (WEEKLY INTERNATIONAL EDITION), 32(17) (APR

$92), 1,6$

DESPITE REPEATED DENIALS BY THE GOVERMMENT AND LIBERAL DEMOCRATIC PARTY (LDP) LEADERS, SPECULATION LINGERS THAT PRIME MINISTER KIICHI MIYAZAWA WILL DISSOL VE THE LOWER HOUSE PRIME MINISTER KIICHI MIYAZAWA HILL DISSOLVE THE LOWER HOUSE AND CALL ELECTIONS FOR BOTH DIET CHAMBERS IN THE SUMMER OF
1992 . SIMULTANEOUS ELECTIONS GENERALLY FAVOR THE GOVERNING PARTY AND HOULD LIKELY MINIMIZE LDP LOSSES IN THE UPPER PARTY
HOUSE.

05286 KITAZUME, T

TALKS WITH RUSSIA LAUNCHED TO RESOLVE DISPUTE OVER ISLES JAPAN TIMES (WEEKLY INTERNATIONAL EDITION), $32(7)$ (FEB 92), 1,6 .

JAPAN HAS OFFICIALLY ENTERED MEGOTIATIONS WITH THE RUSSIAN FEDERATION ON THE LONG-STANDING DISPUTE OVER FOUR ISLANDS NEAR HOKKAIDO THAT WERE OCCUPIED BY THE USSR AT THE END OF HORLD WAR II. THE CONFLICT IS DELAYING A FULL-SCALE JAPANESE AID PACKAGE TO RUSSIA, BECAUSE TOKYO HAS LINKED ECONOMIC ASSISTANCE TO A SOLUTION OF THE TERRITORIAL DISPUTE.

05287 KITAZUME, T.

TIME IS RIPE TO SOLVE ISLANDS ISSUE

JAPAN TIMES (WEEKLY INTERNATIONAL EDITION), 32(13) (MAR $92), 1,6$.

IN MARCH 1992, RUSSIAN FOREIGN MINISTER ANDREI KOZYREY VISITED JAPAN FOR TALKS CONCERNING RUSSO-JAPANESE RELATIONS, FOREIGN AID, AND THE FOUR DISPUTED KURILE ISLANDS. ALTHOUGH THE NEGOTIATIONS PRODUCED NO IMMEDIATE RESOLUTION TO THE TERRITORIAL DISPUTE, THE JAPANESE FOREIGN MINISTER CONFIRMED THAT RUSSIA HAS INDICATED A WILLINGNESS TO HONOR A 1956 SOVIET-JAPANESE JOINT DECLARATION THAT CALLS FOR THE FUTURE RETURY OF THO OF THE ISLAMDS HE THAT CALLS FOR THE FUTURE OF THE TERRITORIAL DISPUTE DEPENDS ON THE SURVIVAL OF RUSSIAN PRESIDENT BORIS YELTSIN KOZYREY URGED JAPAN TO RUSSIAN PRESIDENT BORIS YELTSIN. KOZYREV URGED JAPAN TO EXTEND GREATER ECONOMIC ASSISTANCE TO FURTHER
REFORM EFFORTS AND HELP HIM STAY IN POHER.

05288 KITSCHELT, H.

THE FORMATION OF PARTY SYSTEMS IN EAST CENTRAL EUROPE POLITICS AND SOCIETY, 20(1) (MAR 92), 7-50

THE FORMATION OF PARTY SYSTEMS IN EAST CENTRAL EUROPE IS DISCUSSED IN THIS ARTICLE. IN THE FIRST PART, THE AUTHOR DISTINGUISHES OIMENSIONS OF POLITICAL CLEAVAGES THAT MAY CHARACTERIZE THE SHAPE OF PARTY SYSTEMS. IN THE SECOND PART HE ADVANCES THREE EMPIRICAL PROPOSITIONS TO CHARACTERIZE ONE LIKELY PATH OF CLEAVAGE FORMATION IN POSTCOMMUNIST REGIMES.
THE AUTHOR ARGUES THAT THE ECONOMIC INSTITUTIONS AMD RESOURCES THAT THE DECEASED COMMUNIST SYSTEMS BEQUEATHED TO THE DEHOCRATIC SUCCESSOR REGIMES WILL HAVE A POHERFUL INFLUENCE ON EMERGING POLITICAL PREFERENCES, INTERESTS, AND PARTY STRATEGIES. IN THE THIRD PART, HE ILLUSTRATES THIS ARGUMENT IN A CROSS-NATIONAL COMPARISON OF PARTY SYSTEM
FORMATION IN CZECHOSLOVAKIA, HUNGARY, POLAND, AND RUMANIA.

05289 KITSCHELT, H.

THE 1990 GERMAN FEDERAL ELECTION AND THE NATIONAL UNIFICATION

WEST EUROPEAN POLITICS, 14(4) (OCT 91), 121-148.

THE DECEMBER 1990 GERMAN ELECTION RESULTED IN A DRAMATIC hEAKENING OF SEVERAL POLITICAL PARTIES AND A MODERATE STRENGTHENING OF THE GOVERNMENT COALITION. THIS ARTICLE EXPLAINS THE ELECTORAL OUTCOME IN TERMS OF THE INTERPRETIVE FRAMES EACH PARTY EMPLOYED TO ADDRESS THE ISSUE OF UNIFICATION IN THE ELECTION CAMPAIGN IN LIGHT OF THEIR PAST VOTER APPEALS AND STANCES ON THE GERMAN OUESTION. WITHIM THE SOCIAL DEMOCRATIC AND THE GREEM LEFT-LIBERTARIAM DISCOURSE. IT WAS PARTICULARLY DIFFICULT TO ASSIGN A MEANGINFUL ROLE TO THE CONCEPT OF THE NATION AND NATIONAL UNIFICATION.

05290 KLAK, T.H.; HEY, J.K.

GENDER AND' STATÉ BIAS IN JAMAICAN HOUSIMG PROGRAMS

HORLD DEVELOPMENT, 20 (2) (FEB 92), 213-227.

THE AUTHORS EXAMINE WOMEN'S ACCESS TO JAMAICA'S NATIONAL HOUSING TRUST (NHT), WHICH WAS CREATED TO FINANCE HOUSING FOR THOSE MOST IN NEED. THEY IDENTIFY TWO GENDER BIASES. ( 1 THE STRONGER GENDER BIAS IS CREATED BY ECONOMIC OBSTACLES, CULTURAL PREJUDICES, AND INSTITUTIONAL RULES THAT PREVENT MANY HOMEN, ESPECIALLY POORER ONES, FROM BECOMING ELIGIBLE FOR HOUSING LOANS. DESPITE WOMEN'S GREATER HOUSING NEED, NHT ALLOCATES MOST OF ITS LOANS TO MEN. (2) AMONG ELIGIBLE LOAN RECIPIENTS, WHO ARE PRIMARILY MORE SECURE FORMAL SECTOR EMPLOYEES, WOMEN HAVE A HIGHER PROBABILITY OF OBTAINING A LOAN. ADOITIONALLY, WHILE MOST OF NHT'S LOANS GO TO STATE EMPLOYEES, MEN IN BOTH THE PUBLIC AND PRIVATE SECTORS CAPTURE A DISPROPORTIONATE SHARE OF NHT'S LOANS.

05291 KLARE, M.

THE WAR THAT CAME IN FROM THE COLD: DRUGS, MILITARISM AND THE "MONROE DOCTRINE"

RADICAL AMERICA, 23(2) (1990), 15-20.

THIS ARTICLE EXAMINES THE PRESSURE BEING PUT ON THE DEPARTMENT OF DEFENSE, FROM INSIDE AND OUTSIDE, TO TAKE ON ANTI-DRUG OPERATIONS AS A MAJOR MILITARY PROGRAM. THE AUTHOR PRESENTS EVIDENCE TO SUPPORT THIS ACTIVITY, INCLUDING AN ANNUAL REPORT FROM SECRETARY OF DEFENSE CHENEY AND AN ISSUE OF "AVIATION WEEK AND SPACE TECHMOLOGY." WHY THE MILITARY OF "AVIATION HEEK AND SPACE TECHMOLOGY." WHY THE MILITARY ESTABLISHMENT IS BEING MOVED INTO THE LEAD AGENCY ROLE IN LOOKED AT IN THE CONTEXT OF THIS ISSUE.

05292 KLEHR, H.; HAYNES, J.

THE EMD

THE DEMISE OF COMMUNISM IN THE SOVIET UNION HAS LED TO A SERIOUS SPLIT HITHIN THE COMMUNIST PARTY OF THE UNITED STATES. MUCH OF THE DISSENSION HAS BEEN DIRECTED AT GUS HALL, THE LONG-TIME U.S. PARTY LEADER.

05293 KLEIMAN, M.A.R.; CAULKINS, J.P.

HEROIN POLICY FOR THE NEXT DECADE

ANNALS OF THE AMERICAN ACADEMY DF POLITICAL AND SOCIAL SCIENCE, 521 (MAY 92), 163-174.

THE SUPPLY OF HEROIN IN THE UNITED STATES APPEARS TO HAVE GROWN SUBSTANTIALLY IN RECENT YEARS, ALTHOUGH IT IS NOT CLEAR WHAT IMPACT THIS HAS HAD ON CONSUMPTION. CONYENTIONAL INDICATORS HAVE SHOWH ONLY MODEST INCREASES IN USE, BUT FOR A VARIETY OF REASONS ONE WOULD NOT EXPECT DRAMATIC INCREASES IN THE EARLY YEARS OF A NEW HEROIN EPIDEMIC. IT IS EVEN LESS CLEAR WHAT, IF ANYTHING, SHOULD BE DONE. DRUG CONTROL RESOURCES ARE FINITE. MAKING HEROIN A NEW POLICY FOCUS COULD IMPOSE SUBSTANTIAL OPPORTUNITY COSTS AS RESOURCES ARE DIYERTED FROM OTHER WORTHY PROGRAMS. ON THE OTHER HAND, THE HISTORY OF COCAINE IN THE LATE 1970'S AND EARLY 1980's DEMONSTRATES THAT "WAIT AND SEE" CAN BE AN EXTREMELY EXPENSIVE OPTION. A PRUDENT COURSE MAY BE TO IMPLEMENT RELATIVELY LOW-COST INTERVENTIONS THAT HOULD BE USEFUL EVEN IF A NEW EPIDEMIC NEVER MATERIALIZES AND TO ENHANCE MONITORING. IF THE ENHANCED MONITORING PROGRAMS WERE TO GIVE MONITORING. IF THE ENHANCED MONI TORING PROGRAMS WERE TO GI STRONG SIGNS OF INCREASING USE, PARTICULARL
BOLDER INTERVENTIONS MIGHT BE HARRANTED.

05294 KLEIMAN, M.A.R.

NEITHER PROHIBITION NOR LEGALIZATION: GRUDGING TOLERATION IN DRUG CONTROL POLICY

DAEDALUS, $121(3)$ (SUM 92 ), 53-84.

THE AUTHOR ARGUES THAT NEITHER PROHIBITION NOR

LEGALIZATION WORKS IN THE REALM OF DRUG CONTROL POLICY.

05295 KLEIN, P.

INSTITUTIONALISTS, RADICAL ECONOMISTS, AND CLASS

PAGE 414 
JOURNAL OF ECONOMIC ISSUES, 26(2) (JUN 92), 535-544. RADICAL ECONOMISTS STILL PLACE CONSIDERABLE EMPHASIS ON CLASS IN DISSECTING THE STRUCTURE AND FUNCTIONING OF "CAPITALIST COUNTRIES." INSTITUTIONALISTS RARELY FOCUS EXPLICITLY ON CLASS IN ANALYZING MODERN MARKET-ORIENTED ECONOMIES. THIS ARTICLE EXPLORES WHY THIS DIFFERNCE EXISTS, BY EXAMINING MARXIST, PAUL SWEEZEY'S, NON-MARXISTS, AND MODERN RADICAL VIEWS OF CLASS. IT CONCLUDES THAT WHILE A CONCERN FOR THE IMPLICATIONS OF CLASS FOR RESOURCE ALLOCATIONS, THEY DO NOT AND CANMOT SHARE THE RADICAL'S VIEW THAT ONE'S LEGAL RELATIONSHIP TO THE MEANS OF PRODUCTION IS THE ONLY OR EVEN NECESSARILY THE PRINCIPAL FACTOR

DETERMINING HOW THE ECONOMY WILL FUNCTION.

05296 KLEPSCH, E.A.

THE DEMOCRATIC DIMENSION OF EUROPEAN INTEGRATION
GOVERMMENT AND OPPOSITION, 27(4) (FAL 92), 407-413.

SINCE 1952, THERE HAVE BEEN THO VIEWS OF EUROPEAN INTEGRATION. THE FIRST REGARDS EUROPEAN INTEGRATION AS THE
REMOVAL OF STATE POHERS FROM THE NATIONAL ADMINISTRATIONS IN SPECIFIC SECTORS. THIS DELIBERATELY RESTRICTIVE APPROACH, SPECIFIC SECTORS. THIS DELIBERATELY RESTRY BELIEYES IT IS ENOUGH TO LIMIT THE ACTIVITIES OF MATIONAL BUREAUCRACIES AT THE EUROPEAN LEVEL. THE SECOND VIEW IS ALSO BASED ON REMOVING THE EXERCISE OF STATE POWER FROM THE NATIONAL ADMINISTRATIONS IN CERTAIN RESTRICTED AREAS. HOWEVER, IT IS NOT SATISFIED WITH A TECHNOCRATIC AND BUREAUCRATIC APPROACH BUT IS CONCERNED TO PRESERVE HARD-WON RIGHTS IN THE AREA OF THE CONTROL AND EXERCISE OF SOVEREIGNTY. A HISTORICAL REVIEW OF THE EUROPEAN COMMUNITY REVEALS THAT IT IS ON THE WAY TOWARDS DEMOCRATIZATION, THAT IT HAS MADE A OEGREE OF
PROGRESS BUT THAT THE ACHIEVEMENTS ARE STILL INSUFFICIENT

05297 KLIER, T.; MCPHERSON, M.

DOES DURATION OF POLITICAL CONTROL MATTER? INTERSTATE DIFFERENCES IN BRANCH-BANKING LAHS

PUBLIC CHOICE, 70(1) (APR 91) 41-50.

THIS PAPER STUDIES WHETHER THE LENGTH OF TIME A

PARTICULAR PARTY HAS BEEN IN CONTROL AS A MAJOR INFLUENCE ON LEGISLATIVE OUTPUT. IT CONSIDERS HHETHER THE PROCESS IS BEST MODELED USING A VARIABLE INVOLVING LONG-TERM DOMINANCE OF THE LAW-HAKING APPARATUS BY ONE PARTY. AS AN EXAMPLE, DIFFERENCES ACROSS STATES IN BRANCH BANKING LAHS ARE' DIFFERENCES ACROSS STATES IN BRANCH BANKING LAHS ARE
EXAMINED. IT CONCLUDES THAT, IN TERMS OF WHICH XIND OF EXAMINED. IT CONCLUDES THAT, IN TERMS OF WHICH KIND OF LEGISLATION WILL BE ENACTED, DEMOCRATIC AND REPUBLICAN
CONTROL EXERT EQUAL BUT OPPOSITE EFFECTS ON LEGISLATIVE CONTROL EXERT EQUAL BUT OPPOSITE EFFECTS ON LEGISLATI
RESULTS. IN OTHER WORDS, LENGTH OF CONTROL MATTERS RESULTS. IN OTHER HORDS, LENGTH OF CONTROL MATTERS
INDEPENDENTLY OF PARTY AFFILIATION, BUT PARTY AFFILIATION INDEPENDENTLY OF PARTY AFFILIATION, BUT PARTY AFFILIATION
AFFECTS THE NATURE OF THE OUTCOME OF THE POLITICAL PROCESS.

05298 KLINGEMANN, H.; WATTENBERG, M.P.

DECAYING VERSUS DEVELOPING PARTY SYSTEMS: A COMPARISON OF PARTY IMAGES IN THE UNITED STATES AND WEST GERMANY

BRITISH JOURNAL OF POLITICAL SCIENCE, 22(2) (APR 92), 131-149.

THE AUTHORS TRACE CITIZENS' ATTITUDES TOWARD THE TWO MAJOR PARTIES IN THE UNITED STATES SINCE 1952 AND IN WEST GERMANY SINCE 1969, EMPLOYING OPEN-ENDED DATA FROM EACH COUNTRY'S NATIONAL ELECTION STUDY TIME SERIES. DESPITE SIMILAR DECLINING TRENDS IN PARTY IDENTIFICATION IN THE TWO COUNTRIES, THE PATTERNS OF CHANGE IN PARTY IMAGES ARE MARKEDLY DIFFERENT. IN THE UNITED STATES, VOTERS HAVE BECOME INCREASINGLY NEUTRAL TOWARDS THE TWO PARTIES AS THE FOCUS HAS TURNED MORE AND MORE TOWARDS THE CANDIDATES. IN CONTRAST, HEST GERMAN VOTERS HAVE COME TO HAVE A MORE BALANCED VIEW OF THE PARTIES, SEEING BOTH POSITIVE AND NEGATIVE FEATURES IN EACH. THUS, IN BOTH CASES, THERE HAS BEEN A DECLINE IN BUT FOR DIFFERENT REASONS. IN THE USA. THIS DECLINE CAN BE SEEN AS A SIGN OF THE DECAY OF AN AGEING AND OUTDATED PARTY SYSTEM. IN HEST GERMANY, IT IS THE DEVELOPMENT OF REALISTIC AND BALANCED VIEWS OF A'PARTY SYSTEM THAT IS JUST REACHING FULL MATURITY. THE IMPLICATIONS FOR ANALYZING PARTY SYSTEM DEVELOPMENT IN EASTERN EUROPE ARE DISCUSSED.

05299 KLINGSBERG, E.

ROMANIA: TRADE AND HUMAN RIGHTS

FREEDOM REVIEW, 23(4) (JUL 92), 22-23.

THE U.S. CONGRESS WILL SOON DEBATE THE STATE

DEPARTMENT'S PROPOSAL TO RESTORE ROMANIA'S MOST FAVORED NATION (MFN) TRADING STATUS. RECENT DEVELOPMENTS INDICATE THAT ROMANIANS MAY FINALLY BE ON THE VERGE OF OVERCOMING THE CURRENT REGIME'S DISDAIN FOR HUMAN RIGHTS AND FREE MARKET INITIATIVES. HOWEYER, A PREMATURE RESTORATION OF MFN STATUS COULD IMPEDE ROMANIA'S PRECARIOUS PROGRESS BECAUSE IT WOULD PLACE THE UNITED STATES' SEAL OF APPROVAL ON THE NATIONAL SALVATION FRONT GOVERNMENT AND COULD BE EXPLOITED FOR
PARTISAN ADVANTAGE IN UPCOMING ELECTION CAMPAIGNS.

05300 KLINTWORTH, G.

SHORD OF JUSTICE

FAR EASTERM ECONOMIC REVIEW, 155(39) (OCT 92), 21

THE APPARENTLY INCREASING WILLINGNESS OF THE UNITED
NATIONS TO INTERVENE IN WHAT WAS ONCE CONSIDERED "INTERMAL AFFAIRS" OF NATIONS HAS CAUSED MANY TO REASSESS THE SIGNIFICANCE AND LIMITS OF SOVEREIGNTY. THIS ARTICLE ARGUES THAT HUMANITARIAN INTERVENTION MUST BE GAUGED BY THE FOLLOWING CRITERIA: THE HUMAN VALUES THREATENED OUGHT TO $8 E$ FUNDAMENTAL ONES; THE SITUATION SHOULD BE ONE OF EXTREME DEPRIVATION SUFFICIENT TO PROVOKE UNIVERSAL CONDEMNATION: THERE MUST BE A SUSTAINED AND HEAVY LOSS OF LIFE, OR AN IMMINENT THREAT OF WIDESPREAD KILLING; THE STATE AUTHORITIES AGAINST WHOM SUCH MEASURES ARE TO BE TAKEN MUST BE SHOWN TO BE UNABLE OR UNHILLING TO PREVENT GENOCIDE, SYSTEMATIC CRUELTY AND WIDESPREAD PERSECUTION; AND GENUINE ATTEMPTS TO FIND A PEACEFUL SOLUTION THROUGH NEGOTIATIONS, CEASEFIRES HUMANITARIAN APPEALS AND DIPLOMATIC AND ECONOMIC SANCTIONS SHOULD HAVE BEEN MADE AND EXHAUSTED. FURTHERMORE INTERVENTION SHOULD BE IMPARTIAL. LIMITED, NON-COERCIVE, SUPERVISED BY THE UN SECURITY COUNCIL, AND SHOULD BE SUPERVISED BY THE UN SECURITY COUNCIL, AND SHOULD BE FOLLOWED BY A PROMPT DISENGAGEMENT. THERE IS GROWING
AGREEMENT SUCH INTERVENTION MAY BE JUSTIFIED IN BOSHIA. THE AGREEMENT SUCH INTERVENTION MAY BE JUSTIFIED IN BOSHIA. THE SAME CRITERIA MAY ALSO APPLY TO VIETNAMESE INTERVENTION IN
CAMBODIA (DESIGNED TO SAYE VIETNAMESE CIVILIANS THREATENED CAMBODIA (DESIGNED TO
BY THE KHMER ROUGE).

05301 KLOTI, U.

POLITICAL SCIENCE IN SWITZERLAND

EUROPEAN JOURNAL OF POLITICAL RESEARCH, 20(3-4) (DEC 91), 413-424.

THE AUTHOR ENDEAVORS TO EXPLAIN THE CHARACTER OF SWISS POLITICAL SCIENCE, IN TERMS OF BOTH ITS HISTORICAL DEVELOPMENT AND ITS PRESENT STATE, BY PURSUING THREE PATHS: (1) A BRIEF HISTORICAL SKETCH, REVEALING THAT SWISS POLITICAL SCIENCE IS STILL IN ITS INFANCY; (2) A SURVEY OF PROFESSORSHIPS AND TEACHING PROGRAMS, SHOHING THE FAIRLY MODEST ROLE PLAYED BY POLITICAL SCIENCE IN SHISS

UNIVERSITIES; AND (3) A DESCRIPTION OF THE STATE OF RESEARCH IN THE FIELD, INDICATING THAT THE INTELLECTUAL CONTRIBUTION OF SWISS POLITICAL SCIENTISTS IS GROWING AND IS ATTRACTING MORE ATTENTION BUT IS ALSO THE SOURCE OF INCREASING CONTROVERSY.

05302 KLUTINGM, R.

POWER INDUSTRY POWER STRUGGLE: FREE TRADE OR PROTECTION? GERMAN TRIBUNE, 1479 (AUG 91), 7.

THE EUROPEAN COMMISSION IN' GERMANY WANT FREE TRADE IN ELECTRIC POWER. MOST ELECTRICITY GENERATING COMPANIES IN ELECTRIC POWER. MOST ELECTRICITY GENERATING COMPANIES IN
EUROPE WANT TO KEEP THEIR OWN EXCLUSIVE OPERATION ZONES. EUROPE WANT TO KEEP THEIR OHN EXCLUSIVE OPERATION ZONES.
THIS ARTICLE DISCUSSES THE ARGUMENT BETWEEN THE COMMISSION THIS ARTICLE DISCUSSES THE ARGUMENT BETWEEN THE COMMISSION
AND THE POWER INDUSTRY WHICH HAS GONE ALMOST UNMOTICED BY THE GERMAN PUBLIC.

05303 KLYZA, C.M.

A WINDOW OF AUTONOMY: STATE AUTONOMY AND THE FOREST SERVICE IN THE EARLY $1900^{\prime}$

POLITY, XXV (2) (WIN 92), 173-196.

THE PURPOSE OF THIS PAPER IS TO DEMONSTRATE THAT STATE AUTONOMY CAN AND DOES EXIST, TO EXAMINE THE FACTORS THAT CONTRIBUTE TO THE SUCCESSFUL EXERCISE OF SUCH AUTONOMY, AND TO ARGUE THAT STATE AUTONOMY IS BEST UNDERSTOOD WITHIN'A SPECIFIC HISTORICAL CONTEXT. IT IS DIVIDED INTO SIX SECTIONS: (1) A DISCUSSION OF THE IDEA OF STATE AUTONOMY AND ITS IMPORTANCE TO UNDERSTANDING PUBLIC POLICY IN MODERN OEMOCRATIC NATIONS; (2) AN ARGUMENT TO RE-FOCUS THE STATE AUTONOMY DEBATE, MOVING FROM THE MACRO-THEORETICAL LEVEL TO THE ACTUAL POL ICY LEVEL; (3) A CASE STUDY OF THE FEDERAL FORESTRY AGENCY FROM 1898 TO 1907 TO ILLUSTRATE THE OPENING OF A WINDOW OF STATE AUTONOMY; (4) THE CLOSING OF THIS WINDOW OF AUTONOMY FROM 1907 TO 1910: (5) AN ANALYSIS OF THIS EXAMPLE OF STATE AUTONOMY; AND (6) A OISCUSSION OF ITS

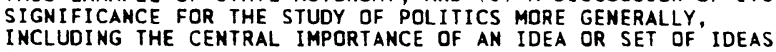

TO SERVE AS THE GUIDE FOR AUTONOMOUS STATE BEHAVIOR.

05304 KNAAP, G.; JUELICH, S.

THE FISCAL IMPACTS OF DETACHMENT: IS IT BETTER TO GIVE THAN TO RECEIVE?

STATE ANO LOCAL GOVERNMENT REVIEW, 24(1) (WIN 92), 28-35. ALTHOUGH ANNEXATION IS A COMMON MEANS OF MUNICIPAL GROWTH, IN METROPOLITAN AREAS HITH MANY LOCAL GOVERMMENTS THE TERRI TORY ANNEXED BY ONE GOVERNMENT MAY 8 E DETACHED FROM ANOTHER. USING A CASE STUDY APPROACH, THIS ARTICLE TAKES UP THREE ISSUES: THE WAYS A FISCAL IMPACT STUDY OF DETACHMEN OIFFERS FROM A SIMILAR ANNEXATION STUDY; THE POTENTIAL INTERGOVERNMENTAL REVENUES TO INFLUENCE ANNEXATION AND
DETACHMENT ACTIVITY; AND THE LIMITATIONS OF FISCAL IMPACTS DETACHMENT ACTIVITY; AND THE LIMITATIONS OF FISCAL IMPACTS
AS MOTIVATION FOR ANMEXATION AND DETACHMENT. FISCAL IMPACTS AS MOTIVATION FOR ANNEXATION AND DETACHMENT. FISCAL IMPAC
ARE SHOWN AS A LIMITED EXPLANATION FOR LOCAL BOUNDARY ARE SHOWN
DECISIONS.

05305 KNAPP, A.

THE CUMUUL DES MANDATS, LOCAL POHER AND POLITICAL PARTIES IN FRANCE

WEST EUROPEAN POLITICS, 14(1) (JAN 91), 18-40.

FRENCH POLITICIANS SHOW AN UNUSUAL APPETITE FOR COMBINING LOCAL AND NATIONAL ELECTIVE OFFICES, THE PRACTICE 
KNOWN AS THE CUMUL DES MANDATS. THIS FEATURE OF THE FRENCH POLITICAL SYSTEM HAS ARISEN FRDM THE SPECIFIC CHARACTERISTICS OF CENTRAL-LOCAL RELATIONS IN FRANCE AND FROM THE WEAKNESS OF FRENCH POLITICAL PARTIES, HICH IT HAS IN TURN REINFORCED. THE CUMUL HAS SURVIVED BOTH THE 'NATIONALISATION' OF FRENCH POLITICS UNDER THE FIFTH
REPUBLIC AND THE DECENTRALIZATION LEGISLATION OF THE EARLY 1980S, WHICH REMOVED SOME OF ITS FUNCTIONS FOR LOCAL GOVERMMENT. WHILE MULTIPLE OFFICE-HOLDING IS NOH LIMITED BY LAW, THE INCENTIVES TO COMBINE THE POSTS OF DEPUTY AND MAYOR FOR' THE SAME TOWN ARE UNDIMINISHED.

05306 KNIGHT, A.

THE PECUL IARITIES OF MEXICAN HISTORY: MEXICO COMPARED TO LATIN AMERICA, 1821-1992

JOURNAL OF LATIN AMERICAN STUDIES, 24 (1992), 99-144.

THE AUTHOR OFFERS SOME GENERALIZATIONS ABOUT MEXICAM HISTORY IN THE NATIONAL PERIOD, STRESSING BOTH BROAD PATTERNS OF SOCIO-ECONOMIC DEVELOPMENT AND SPECIFIC POLITICOCULTURAL FACTORS. HIS PURPOSE IS TO EXPLAIN THE DISTINCTIVENESS, AS WELL AS THE COMMONALITY, OF MEXICO'S DISTINCTIVENESS, AS WELL AS THE COMMONALITY, OF MEXICO'S
HISTORY COMPARED TO THE HISTORY OF LATIN AMERICA, IN GENERAL, HISTORY COMPARED TO THE HISTOR
DURING THE NATIONAL PERIOD.

05307 KNIGHT, R.

HAIDER, THE FREEDOM PARTY AND THE EXTREME RIGHT IN AUSTRIA PARL TAME'TTAYY AFFAIRS $45(3)$ A D THE EXTREME RIGH

WITHIN THE CONTEXT OF AUSTRIA'S POSTWAR HISTORY AND POSTNAZI POLITICAL CULTURE, THE AUTHOR ENDEAVORS TO EXPLAIN THE CONHECTIONS BETHEEN JORG HAIDER'S APOLOGETICS FOR NAZI EMPLOYMENT POLICY, THE ILLEGAL NEO-NAZI ACTIVITIES OF THE WEHRSPORTGRUPPE TRENCK, AND THE "FORGETFULNESS" OF KURT WALDHEIM. THESE CONNECTIONS DO NOT JUSTIFY LABELLING AUSTRIAN SOCIETY "NED-NAZI" OR "EXTREME RIGHT" BUT DO HELP EXPLAIN WHY HAIDER HAS BECOME A MAJOR FORCE IN AUSTRIAN POLITICS AND WHY NEO-NAZI GROUPS ARE FEELING MORE SELFCONFIDENCE. HAIDER HAS BENEFITED FROM THE STRUCTURAL WEAKENING OF AUSTRIA'S TWO-PARTY SYSTEM, HIS OWN POLITICAL SKILL, AND THE CHANGES IN EASTERN EUROPE THAT HAVE MADE IMMIGRATION AN IMPORTANT ISSUE.

05308 KHIGHT, V.C.

ZIMBABHE: THE POLITICS OF ECONOMIC REFORM

CURRENT HISTORY, 91 (565) (MAY 92), 219-223.

IN ZIMBABHE, PRESIDENT ROBERT MUGABE'S DESIRE FOR A ONEPARTY STATE CLASHES WITH INTERHATIONAL PRESSURE TO MAINTAIN A MULTIPARTY SYSTEM, CREATING ACUTE TENSIONS. BECAUSE MUGABE A MULTIPARTY SYSTEM, CREATING ACUTE TENSIONS. BECAUSE MUGABE
IS DEPENDENT ON HESTERH DONORS TO HELP THE COUNTRY WITH ITS IS DEPENDENT ON HESTERN DONORS TO HELP THE COUNTRY WITH I CURRENT ECONOMIC PROBLEMS, HE MUST MAINTAIN DEMOCRATIC
INSTITUTIONS OR HE WILL JEOPARDIZE THE COUNTRY'S ECONOMIC INSTITUT

05309 KHIPPER, H.

IBERO-AMERICAN SUMMIT FINDS NO SOLUTIONS

GERMAN TRIBUNE, (1527) (AUG 92),

THE RECENT SUMMIT OF THE IBERO-AMERICAN COMMUNITY, HELD IN MADRID, DID LITTLE MORE THAN OUTLINE THE IMHENSE PROBLEMS FACING SOUTH AND CENTRAL AMERICA. WHILE ALL GOVERMMENTS AT THE SUMAHIT AGREED TO ENDORSE VALUES SUCH AS REPRESENTATIVE DEMOCRACY AND MARKET ECONOMY, MUCH REMAINS TO BE DONE. THE DELEGATES AT THE SUMMIT CONTIMUED TO CALL FOR THE OPENING OF INDUSTRIAL COUNTRIES' MARKETS AND THE END OF PROTECTIONISM. THE IBERO-AMER ICAN COMMUNITY HAS EMERGED AS A LIVING FORUM FOR NORTH-SOUTH DIALOGUE WHOSE VALUE CANNOT BE UNDERSTATED. MANY HEADS OF STATE AND GOVERNMENT MADE USE OF THE MADRID SUMMIT TO APPEAL TO THE CONSCIENCE OF THE DEVELOPED NORLD.

05310 KNUTSEN, T.

ANSWERED PRAYERS: FUKUYAMA, LIBERALISM AND THE END-OFHISTORY DEBATE

BULLETIN OF PEACE PROPOSALS, 22(1) (MAR 91), 77-86.

THIS ARTICLE EXPLORES FRANCIS FUKUYAMA'S ARGUMENT IN HIS 'END OF HISTORY' THESIS, IN AN EFFORT TO UNDERSTAND WHY ALL THE ATTENTION HAS BEEN GIVEN TO HIS PAPER. IT CLARIFIES AND CRITIQUES HIS ARGUMENT. IT SUGGESTS THAT KOJEVE'S CONTROVERSIAL INTERPRETATION OF HEGEL HAS FORCED FUKUYAMA TO CONCLUDE UNHITTINGLY THAT THE ECLECTIC RECONSTRUCTION OF CLASSIC LIBERALISM IS FIT FOR THE GRAVE. IT MAY BE THIS UNWITTING DE(CON)STRUCTION OF LIBERALISM TRIUMPHANT WHICH, IN THE FINAL INSTANCE, ACCOUNTS FOR THE ASTONISHING ATTENTION THIS ARTICLE RECEIVED.

05311 KNUTTILA, M.

STATE THEORIES: FROM LIBERALISM TO THE CHALLENGE OF STATE TH

FEMINISH
FERNHOOK PUBLISHING, 1992, 179.

MURRAY KHUTTILA OFFERS AN INTRODUCTION TO A VARIETY OF DIFFERENT PERSPECTIVES ON THE STUDY OF THE STATE. IN THE TEXT, MAJOR HISTORICAL AND CONTEMPORARY THEORIES FROM SEVERAL SOCIAL SCIENCE TRADITIONS ARE DISCUSSED. THESE THEORETICAL APPROACHES ARE SITUATED WITHIN THE PARTICULAR SOCIAL ANO POL ITICAL ENVIRONMENT IN WHICH THEY DEVELOPED. TOPICS EXPLORED ARE: CLASSICAL LIBERALISM; SOCIOLOGICAL
MARXISM: NEO-MARXIST THEORIES OF THE STATE: THE ANARCHIST CRITIOUE; AND, FEMINISM AND THE SEARCH FOR ALTERNATIVE THEORIES.

05312 KOAR, J.

BUSH'S CHANCE WITH THE PEACE DIVIDEND

GERMAN TRIBUNE, (1502) (FEB 92), 2 .

IN HIS RECENT STATE OF THE UNION ADDRESS, GEORGE BUSH ANNOUNCED DRASTIC DISARMAMENT MEASURES IN THE FIELD OF STRATEGIC NUCLEAR WEAPONS. HOWEVER, DUE TO GROWING CRITICISH OF HIS NEGLECT OF DOMESTIC POLICY, HE SPENT THE BULK OF HIS TIME ADORESSING DOMESTIC CONCERNS. BUSH'S UNWILLINGNESS TO DISCUSS THE LAMDMARK DISARMAMENT PROPOSALS IS REGRETTABLE IN AND OF ITSELF. IN ADDITION, BUSH DOES NOT SEEM TO REALIZE THAT THE PEACE DIVIDEND WHICH MAY RESULT FROM LESSENED INTERNATIONAL TENSION COULD BE PART OF THE SOLUTION TO DOMESTIC ILLS.

05313 KOBAYASHI, $Y$.

JAPAN MUST ADOPT A PRO-ASIAN POLICY

JAPAN TIMES (WEEKLY INTERNATIONAL EDITION), 32(2) (JAN 92),

11 .

IN THINKING ABOUT ITS FUTURE, JAPAN SHOULD CERTAINLY ATTACH IMPORTANCE TO ITS RELATIONS WITH THE UNITED STATES, BUT IT SHOULD ALSO FOSTER CLOSE TIES WITH ITS ASIAN BUT IT SHOULD ALSO FOSTER CLOSE TIES WITH ITS ASIAN
NEIGHBORS AND BE PREPARED TO PLAY A CENTRAL ROLE IN ASIAN AFFAIRS.

$05314 \mathrm{KOCH}, \mathrm{J}$.

EXPLANATION OF GROUP ECONOMIC OUTCOMES--DETERMINANTS AND CONSEQUENCES

AMERICAN POLITICS QUARTERLY, 19(2) (APR 91), 211-228.

PREVIOUS STUDIES OF GROUP ECONOMIC VOTING HAVE NOT EXAMINED HOW CITIZENS EXPLAIN GROUP ECONOMIC PROBLEMS AND HOW THOSE CASUAL EXPLANATIONS MIGHT AFFECT THE ROLE OF GROUP ECONOMIC CONDITIONS AND THE CONSEQUENT FORMATION OF CITIZENS' POLITICAL PREFERNECES. THIS RESEARCH ADDRESSES THREE OUESTIONS: (A) HOW DO CITIZENS EXPLAIN GROUP ECONOMIC PREDICAMENTS? (B) ARE THERE MEANINGFUL, SYSTEMATIC VARIATIONS IN THE EXPLANATIONS OFFERED BY CITIZENS FOR BOTH INDIVIDUAL AND GROUP ECONOMIC PROBLEMS THAT COINCIDE WITH OUR UDNERSTANDING OF DIFFERING GROUP SCHEMAS, SOCIETAL VALUES, AND ECONOMIC PREDICAMENTS? (C) DO CITIZENS' EXPLANATIONS OF GROUP PROBLEMS DETERMINE THE EFFECT THAT ASSESSMENTS OF GROUP ECONOMIC PREDICAMENTS HAVE ON POLITICAL PREFERENCES? THE RESEARCH PRESENTED HERE INDICATES CITIZENS ARE MORE LIKELY TO CITE POLITICAL OR SOCIAL FACTORS TO ARE MORE LIKELY TO CITE POLITICAL OR SOCIAL FACTORS TO EXPLAIN GROUP ECONOMIC PROBLEMS. MEMBERS OF DISADVANTACED GROUPS ARE MORE LIKELY TO CITE POLITICAL EXPLANATIONS.
ASSESSMENTS OF GROUP ECONOMIC HELL-BEING THAT ARE EXPLAINED
BY REFERENCE TO POL ITICAL FACTORS HAVE A LARGER EFFECT ON BY REFERENCE TO POL ITICAL FACTORS HAVE A LARGER EFFECT ON
POLITICAL PREFERENCES THAN THOSE EXPLAINED BY SOCIAL FACTORS.

$05315 \mathrm{KOCH}, \mathrm{M}$

EUROPE'S MORAL OBLIGATION TO HELP THE REFUGEES

GERMAN TRIBUNE, (1526) (JUL 92 ), 3.

AS THE CONFLICT IN YUGOSLAVIÁ CONTINUES UNABATED, THE NUMBER OF REFUGEES ATTEMPTING TO FLEE THE WAR ZONES IS GROWING. THE BEST SOLUTION FOR THESE PEDPLE WOULD BE AN END TO THE WAR. BUT AS LONG AS SERBIA'S WAR POLICY IS STOPPED NEITHER FROM INSIDE NOR FROM OUTSIDE THE COUNTRY, EUROPE IS MORALLY BOUND TO LEND A HAND WITH THE SECOND-BEST SOLUTION: TEMPORARY RECEPTION OF THE REFUGEES IN CONDITIONS THAT ARE IN KEEPING WITH HUMAN DIGNITY. THE MUCH VAUNTED WESTERN EUROPEAN COMAUITY OF VALUES HAS SO FAR PROVED A LAMENTABLE FAILURE ON THIS ISSUE. ONLY GERMANY AND ITALY HAVE PROVIDED AID WORTH MENTIONIMG. MORE THAN 100,000 REFUGEES FROM WHAT USED TD BE YUGOSLAVIA HAVE SOUGHT AND FOUND REFUGE IN GERMANY. BRITAIN AND FRANCE HAVE IN CONTRAST EACH LET IN A FEW HUNDRED.

\section{KOCHER, $V$.}

RAFSANJANI'S PRAGMATIC ISLAMIC REPUBLIC

SHISS REVIEH OF WORLD AFFAIRS, 42(3) (JUN 92), 25-26. CANDIDATES IN THE 1992 ELECTIONS FOR IRAN'S FOURTH MAJLIS WERE UNITED ON AT LEAST ONE ISSUE: THE IRANIAN ECONOMY BADLY NEEDS A STRONG PROGRAM TO GET IT MOVING AGAIN. WHILE THE ORIGIN OF THE COUNTRY'S ECONOMIC MISERY CLEARLY LIES IN THE IRAN-IRAQ WAR, THE TEHERAN REGIME MUST ACCEPT RESPONSIBILITY FOR THE LAGGING RECOVERY IN THE FOUR YEARS SINCE THE FIGHTING ENDED.

05317 KDCHER, $V$.

SYRIA'S ECONOMIC OPENING

SWISS REVIEW OF WORLD AFFAIRS, 42(6) (SEP 92), 11.

AN ESTIMATED $75 \%$ OF SYRIA'S TOTAL WORKFORCE IS EMPLOYED IN THE STATE-RUN AND OUASI-GOVERMMENTAL SECTOR. BUT THE PRESENCE AND GROWING INFLUENCE OF A MEH GROUP OF UPWARDLYMOBILE ENTREPRENEURS AND SKILLED WORKERS ARE A SIGN OF THE GOVERNMENT'S NEW PRIORITIES SINCE THE GULF CRISIS AND ITS NEH FRIENDSHIP HITH THE UNITED STATES. IT IS A KIND OF SYRIAN PERESTROIKA. 
05318 KOECHLIN, T.; LARUDEE, M. THE HIGH COST OF NAFTA

CHALLENGE, 35(5) (SEP 92), 19-26.

THE NORTH AMERICAN FREE TRADE AGREEMENT (NAFTA) WILL CAUSE A SHIFT IN INCOME FROM HAGES TO PROFITS BOTH IN THE UNITED STATES AND IN MEXICO. ITS LIKELY NET EFFECT WILL BE TO ORIVE DOWN WAGES WHILE INCREASING UNEMPLOYMENT ON BOTH SIDES OF THE BORDER AND TO WORSEN THE LIVING STANDARD OF THE AVERAGE U.S. AND MEXICAN WORKER.

05319 KOELBLE, T.

RECASTING SOCIAL DEMOCRACY IN EUROPE: A NESTED GAMES EXPLAMATION OF STRATEGIC ADJUSTMENT IN POLITICAL PARTIES

POLITICS AND SOCIETY, 20(1) (MAR 92), 51-70.

ALL MAJOR WORKING-CLASS-BASED PARTIES, SOCIAL DEMOCRATIC, SOCIALIST, OR OTHERHISE, FACE SIMILAR SETS OF DILEMYAS.

THIS ARTICLE DISCUSSES RECASTING SOCIAL DEMOCRACY IN EUROPE, WITH A NESTED GAMES EXPLANATION OF STRATEGIC ADJUSTMENT IN POLITICAL PARTIES. IT REPRESENTS ONLY A FIRST AND TENTATIV STEP IN AN ATTEMPT TO ANALYZE INTRAPARTY POLITICS IN A RIGOROUS AND FORMAL MANNER. THE ARGUMENT HOLDS THAT SOCIAL DEMOCRATIC PARTIES ARE SEARCHING FOR A NEH POLITICAL AND ELECTORAL STRATEGY AND THAT THE ABILITY OF "CONSERVATIVE" ELEMENTS IS AN IMPORTANT VARIABLE IN EXPLAINING WHY SOME PARTIES ADOPT A VOTE-MAXIMIZING STRATEGY OUICKLY, WHEREAS OTHER PARTIES EXPERIENCE SIGNIFICANT ADJUSTMENT PROBLEMS.

05320 KOELBLE, T.A.

SOCIAL DEMOCRACY BETWEEN STRUCTURE AND CHOICE

COMPARATIVE POLITICS, 24 (3) (APR 92) 359-372.

THIS ARTICLE JUXTAPOSES THE ARGUMENTS OF PRZEWORSKI AND SPRAGUE, ESPING-ANDERSEN, AND DUNLEAVY AND HUSBANDS CONCERNING THE CRISIS OF SOCIAL DEMOCRACY. IT SUGGESTS THAT, WHILE PRZENORSKI AND SPRAGUE OFFER IMPORTANT EXPLANATIONS OF THE ELECTORAL PROBLEMS OF SOCIAL DEMOCRACY, THEY OVERSTATE THE INFLUENCE OF STRUCTURAL VARIABLES. ESPING-ANDERSEN ARGUES THAT A PARTY'S STRATEGY AFFECTS ITS ELECTORAL FORTUNES AND SHOULD THEREFORE BE TREATED AS AN EXPLANATORY YARIABLE DUNLEAYY AMD HUSBANDS MAINTAIN THAT THE BRITISH VARIABLE DUNLEAY AN WITHIN THE WORKIMG CLASS; THEY IMPLY THAT SOCIAL DEMOCRACY'S ELECTORAL DECLINE IS CAUSED BY BOTH UNFAVORABLE STRUCTURAL DEVELOPMENTS AND WRONG POLITICAL CHOICES. THE ARTICLE DEVELOPMENTS AND WRONG POLITICAL CHOICES. THE ARTICLE
CONCLUDES THAT, WHILE EACH AUTHOR PROVIDES IMPORTANT INSIGHTS, NONE PAYS ENOUGH ATTENTION TO THE FORMATION OF INTRAPARTY COALITION-BUILOING THAT SHAPES ELECTORAL STRATEGIES AND POLICY CHOICES.

05321 KOETZ, A.: OTTE, M.

CRISIS AND REFORM OF THE UN DEYELOMENT SYSTEM AUSSEN POLIIIK $43(2)$ (1992) $185-194$

SSEN POLITIK, $43(2)(1992), 185-194$.
BOTH THE UNITED NATIONS AND DEVELOPMENT AID GENERALLY HAVE A PROBLEMATIC IMAGE IN INDUSTRIALIZED COUNTRIES. IN THE PAST, MANY UN ACTIVITIES WERE EXTREMELY INEFFICIENT ACTIVITIES WERE OFTEN DETERHINED BY BUREAUCRATIC MOMENTUM, INTERESTS BEARING NO RELEVANCE ON THE ISSUES CONCERNED, AND IDEOLOGICAL ORIENTATIONS. NOW DEMANDS ARE BEING MADE TO AN UNPRECEDENTED EXTENT ON WESTERN RESOURCES BY THE CONSEQUENCES OF THE COLLAPSE OF COMMUNISM. THE INCREASINGLY SCARCE FUNDS OF WESTERN DONOR COUNTRIES CAN NO LONGER BE MADE AS READILY AVAILABLE AS BEFORE. THE AUTHORS EXAMIME THE PROBLEM AGAINST THIS BACKGROUND. THEY CONCLLDE THAT THE WAY THE RELEVANT UN ORGANIZATIONS HORK CAN BE SUBSTANTIALLY IMPROVED AND THEIR QUESTIONED LEGITIMACY THUS RESTORED.

$05322 \mathrm{KDFF}, \mathrm{A}$.

MURDER OR MISCONCEPTION? JUST-HAR THEORIES AND THE SOLDIER'S DILEMMA IN THE VIETNAM WAP

MICHIGAN JOURNAL OF POLITICAL SCIENCE, 15(15) (FAL 92), 64-100.

IN ORDER TO UNDERSTAND THE ACTIONS OF THE INDIVIDUAL SOLDIER IN AN ARMED CONFLICT, ONE MUST FOCUS ON THE CONTEXT OF A GIVEN CONFLICT, AS WELL' AS HOW THE SOLDEIR ATTEMPTS TO DEFINE THE ENEMY. IN THIS PAPER, THE AUTHOR REVIEWS DIFFERENT THEORIES OF THE CONDUCT OF SOLDIERS AND HOW ONE ASSIGNS RESPONSIBILITY FOR THEIR ACTIONS. HE ARGUES THAT THE CONDUCT OF AMERICAN SOLDIERS TOWARDS THE VIETHAMESE IN THE VIETNAM HAR CAN BE TRACED TO THE BLURRED LINE BETHEEN ENEMY AND CIVILIAN IN THAT CONFLICT. UTILIZING VARIOUS SOURCES OF AND CIVILIAN IN THAT CONFLICT. UTILIZING VARIOUS SOURCES SURVEY DATA, AS WELL AS HYPOTHETICAL CASE STUDIES AND A
COMPARISON HITH WORLD WAR II. THE PAPER ILLUSTRATES THE COMPARISON WITH WORLD WAR II, THE PAPER ILLUSTRATES THE
IMPORTANCE OF TAKING INTO ACCOUNT THE PSYCHOLOGICAL ASPECTS IMPORTANCE OF TAKING INTO ACCOUNT THE PSYCHC

05323 KOGAN, $M$.

EDUCATION: PROBLEMS AND CONSTRAINTS FOR THE NEXT GOVERMMENT POL ITICAL QUARTERLY (THE), 62(2) (APR 91), 225-234.

THIS ARTICLE DISCUSSES THE EDUCATION SITUATION THAT BRITAIN'S NEXT GOVERNMENT WILL FACE. THE AUTHOR ARGUES THAT EDUCATION'S RISE TO THE TOP OF THE POLITICAL AGENDA HAS BROUGHT INTO PROMINENCE FOUR SETS OF ISSUES THAT EMERGE IN DIFFERENT FORMS AT ALL LEVELS OF EDUCATION. THESE ISSUES, DESCRIBED IN THE ARTICLE, ARE: (1) THE CONTEXT OF THE
GOVERMMENT AND MANAGEMENT OF EDUCATION; AND (4) THE SOCIAL AND ECONOMIC ASPECTS OF EDUCATIONAL POLICY.

$05324 \mathrm{KOH}, \mathrm{B}$

NORTHEAST ASIA IN THE POST-COLD WAR ERA: MINIMUM ORDER AND OPTIMUM ORDER

KOREAN JOURNAL OF DEFENSE ANALYSIS, 3(2) (WIN 91), 105-122. AN OUTLINE OF THE POST-COLD WAR ORDER IN NORTHEAST AISA, WHICH IS DEFINED FUMCTIONALLY RATHER THAN GEDGRAPHICALLY TO INCLUDE THE UNITED STATES, THE SOVIET UNION, CHINA, JAPAM, THE TWO KOREAN STATES, TAIHAN, AND MONGOL IA IS OFFERED. BORROWING CONCEPTS FORM THE NEW HAVEN SCHOOL OF INTERNATION LEGAL STUDIES, THE AUTHOR EXAMINES THE PROSPECTS FOR "MINIMUM ORDER" AND "OPTIMUM ORDER. " THE FORMER ENTAILS "MINIMUM ORDER" AND "OPTIMUM ORDER." THE FORMER ENTAILS "MINIMIZING UNAUTHORIZED VIOLENCE AND OTHER CDERCION," WHILE THE LATTER NECESSITATES "THE GREATEST PRODUCTIDN AND WIDEST
DISTRIBUTION OF ALL DEMANDED VALUES THAT CAN BE ATTAINED DISTRIBUTION OF ALL DEMANDED VALUES THAT CAN BE ATTAINED WITH AVAILABLE RESOURCES." THE CONCLUSION IS DRAWN THAT
PROSPECTS SEEM MUCH BETTER FOR MINIMUM REGIONAL ORDER THAM FOR MINIMUM WORLD ORDER IN THE POST-COLD WAR ERA.

$05325 \mathrm{KOH}$, B.H

THE INTER-KOREAN AGREEMENTS OF 1972 AND 1992: COMPARAT IVE ASSESSMENT

KOREA \& WORLD AFFAIRS, 1613) (FAL 92) 463-482

THE AUTHOR COMPARES FOUR DIMENSIONS OF THE INTER-KOREAN AGREEMENTS OF 1972 AND 1992: CONTEXT, NEGOTIATING PROCESS, CONTENTS, AND IMPLEMENTATION. BASED ON THE COMPARISON, HE SPECULATES ON THE PROSPECTS FOR FUTURE AGREEMENTS AS I
KOREAN RELATIONS EVOLVE IN THE MONTHS AND YEARS AHEAD.

05326 KOHAK, E.

ASHES, ASHES...CENTRAL EUROPE AFTER FORTY YEARS

DAEDALUS, 121(2) (SPR 92), 197-215.

THE AUTHOR DISCUSSES THE EFFECTS OF FOUR DECADES OF

COMMUNISM IN EASTERN AND CENTRAL EUROPE.

05327 KOHEN, $S$.

CONTACTS WITH CENTRAL ASIAN STATES A FOUNDATION FOR PANTURKISM

WASHINGTON REPORT ON MIDDLE EAST AFFAIRS, XI(3) (AUG 92),

17-18.

THE PAN-TURKIC FEVER IS SPREADING IN TURKEY, WITH MANY TURKS EXPRESSING A DESIRE TO SEE TURKEY LEADING THE TURKIC REPUBLICS EMERGING FROM THE BREAK-UP OF THE SOVIET UNION. ALTHOUGH TURKISH OFFICIALS USE MODERATE LANGUAGE AND SET MODERATE GOALS, SOME OBSERVERS FORESEE A VAST TURKISH ZONE OF INFLUENCE STRETCHING FROM THE ADRIATIC, ENCOMPASSING THE MUSLIM POPULATION IN THE BALKANS, TO THE EASTERN EDGES OF CENTRAL ASIA.

05328 KOHLI A.

INDIAN DEMOCRACY: STRESS AND RESILIENCE JOURHAL OF DEMOCRACY, 3(1) (JAN 92), 52-64.

THE SUSTAINED FUNCTIONING OF DEMOCRACY IN INDIA HAS PROVEN TO BE SOMETHING OF A THO-EDGED SWORD. FOUR DECADES OF ELECTORAL POLITICS HAVE STRENGTHENED DEMOCRATIC HABITS AND EXPECTATIONS, BUT THEY HAVE ALSO UNLEASHED NEW FORCES IN INDIA'S POVERTY-STRICKEN, HIERARCHY-RIDDEN SOCIETY THAT ARE NOW BEGINNING TO STRAIN DEMOCRACY ITSELF. THIS ARTICLE DISCUSSES THREE TRENDS ASSOCIATED WITH THESE FORCES: THE CHANGING NATURE OF THE CONGRESS PARTY; THE GROWING POL ITICAL
ACTIVISM OF VARIOUS SOCIOECONOMIC GROUPS; AND THE FRAGMENTED MATURE OF THE COUNTRY'S OPPOSITION PARTIES.

05329 KOHNO, M.

RATIONAL FOUNDATIONS FOR THE ORGANIZATION OF THE LIBERAL DEMOCRATIC PARTY IN JAPAN

WORLD POLITICS, 44(3) (APR 92), 369-397.

THE CONVENTIONAL SCHOLARLY APPROACH-- HHICH FOCUSES ON FACTORS UNIQUE OR DISTINCTIVE TO JAPANESE HISTORY, CULTURE, AND SOCIAL BEHAVIOR--CANNOT ADEQUATELY EXPLAIN RECENT
CHANGES IN THE RULING LIBERAL DEMOCRATIC PARTY (LDP). THIS PAPER PROPOSES AN ALTERNATIVE, RATIONAL CHOICE EXPLANATION BASED ON THE STANDARD MICRO-ANALYTIC ASSUMPTIONS. THE PATTERN OF THE LDP'S FACTIONALIZATION IS PRIMARILY DETERMINED BY THE ELECTORAL INCENTIVES OF TWO SETS OF DETERMINED BY THE ELECTORAL INCENTIVES OF TWO SETS OF
RATIONAL ACTORS, LDP POLITICIANS AND LDP SUPPORTERS RATIONAL ACTORS, LDP POLITICIANS AND LDP SUPPORTERS
OPERATING UNDER INSTITUTIONAL CONSTRAINTS, SUCH AS ELECTORAL OPERATING UNDER INSTITUTIONAL CONSTRAINTS, SUCH AS ELECTORAL
LAWS AND POL ITICAL FUNDING REGULATIONS. THE ORGANIZATIONAL LAWS AND POL ITICAL FUNDING REGULATIONS. THE ORGANIZATIONAL
NORMS ORIGINATE IN THE PROMOTION INCENTIVES OF THE LDP NORMS ORIGINATE IN THE PROMOTION INCENTIVES OF THE
POLITICIANS WHOSE STRATEGIES ARE INFLUENCED BY THE UNCERTAINTY IN THE DYNAMICS OF THE INTER-FACTIONAL POLITICAL PROCESS.

05330 KOHOUT, J.

THE WHAT, HHO, HOW, AND WHY OF GPALS COMMAND-AND-CONTROL COMPARATIVE STRATEGY, 11(2) (1992), 149-162.

COMMAND AND CONTROL OF ANTIMISSILE DEFENSES PRESENTS ENORMOUS TECHNICAL CHALENGES. THE BUSH ADMINISTRATION'S SHIFT TOWARD GLOBAL PROTECTION AGAINST LIMITED STRIKES (GPALS), HOWEVER, INVOLVES A FINE INTERCTION BETWEEN THE COMMAND AND CONTROL ASPECTS OF MISSILE DEFENSES AND THE POLITICAL IMPACT OF AN EVENTUAL GPALS SYSTEM. WHILE MOUNTING 
A GLOBAL DEFENSE AGAIMST A SMALL MISSILE ATTACX, REGARDLESS OF LAUNCH SITE OR TARGET LOCATION, WOULD APPEAR TO BE A MORE AWESOME COMMAND-AND-CONTROL CHALLENGE THAN THAT POSED BY ITS PREDECESSOR SDI CONCEPT OF A U.S. DEFENSE AGAINST A MASSIVE SOVIET ATTACK THE MATURE OF THE GPALS MISSION MAY RENDER CONTROL MORE MANAGEABLE AT LOWER COMMMAND ECHELONS. THE GLOBAL FUNCTION OF GPALS MAY EVEN HOLD OUT THE POSSIBILITY OF PLACING MISSILE DEFENSES UNDER THE AUSPICES OF MULTINATIONAL ORGANIATIONS WITHOUT REDUCING U.S. MILITARY OR POLITICAL RETURN FROM THE SYSTEM. MUCH OF THE UNIQUE POTENTIAL OF GPALS WILL BE RELATED TO ITS HYBRID SURFACEAND SPACE-BASED CONFIGURATION.

05331 KOIRALA, N.

NEPAL IN 1990: END OF AN ERA

ASIAN SURVEY, XXXI(2) (FEB 91), 134-139.

THIS ARTICLE TRACES THE PAINFUL PROCESS OF

DEMOCRATIZATION AND REFORM IN NEPAL. IT RECOUNTS THE GROWING PROTESTS AGAINST ONE-PARTY RULE AND THE NEPALI RULING ELITE'S BUMBLING AND VIOLENT ATTEMPTS TO MAINTAIN POWER AND ORDER. IT CONSIDERS THE CONCESSIONS BY THE KING THAT LED TO A NEW CONSTITUTION AND THE BEGINHING OF MULTI-PARTY D NEW CONSTITUTION AND THE BEGINNING OF MULTI-PARTY
DEMOCRACY. THIS ARTICLE ALSO EXAMINES THE STATE OF THE DEMOCRACY. THIS ARTICLE ALSO EXAMINES THE
ECONOMY AND FOREIGN RELATIONS OF MEPAL.

05332 KOKOTT, J.B.

FRENCH CASE MOTE

AMERICAN JOURNAL OF INTERNATIONAL LAH, 86(4) (OCT 92), 824-829.

PURSUANT TO ARTICLE 54 OF THE FRENCH CONSTITUTION, THE FRENCH CONSEIL CONSTITUTIONNEL HAS DECLARED THAT THE TREATY ON EUROPEAN UNION, SIGNED IN MAASTRICHT IN FEBRUARY 1992 INCLUDES PROVISIONS CONTRARY TO THAT CONSTITUTION. AS A RESULT, FRENCH RATIFICATION OF THE TREATY WILL
PRIOR ADOPTION OF A CONSTITUTIONAL AMENDMENT.

05333 KOLAKOWSKI, L.

AMIDST MOVING RUINS

DAEDALUS, $121(2)$ (SPR 92), 43-56

THE AUTHOR OFFERS A BRIEF HISTIORY OF COMMUNISM, ASSESSES THE CONTRIBUTION OF MIKHAIL GORBACHEV, AND DISCUSSES THE

RELATIONSHIP BETWEEN COMMUNISM AND NATIONALISM.

05334 KOLESNIK, S.

ADVERTISING AND CULTURAL POLITICS

JOURNAL OF COMMUNICATION, 41(2) (SPR 91), 46-54.

IN THE SOVIET UNION, THE OFFICIAL APPROACH TO CULTURE HAS BEEN UNIDIMENSIONAL, AN APPROACH THAT GREATLY IMPOVERISHED ALL CULTURAL SPHERES, ESPECIALLY IN THE IMPOVERISHED ALL CUL TURAL SPHERES, ESPECIALLY IN THE
PRODUCTION OF CONSUMER GOOOS. DURING THE LONG YEARS OF A PRODUCTION OF CONSUMER GOOOS. DURING THE LONG YEARS OF A STATE MONOPOLISTIC SOCIALISM, THE AESTHETIC COMPONENT OF
MASS CONSUMER PRODUCTS RECEIVED LITTLE OR NO ATTENTION. THE MASS CONSUMER PRODUCTS RECEIVED LITTLE OR NO ATTENTION. ESTABLISHMENT OF POLITICAL AND IDEOLOGICAL PLURALISM IN SOVIET LIFE AND THE DEVELOPMENT OF MARKET RELAT

COMMERCIALIZATION. DRIVEN BY UNEVEN CHANGES ACROSS SOCIETY, COMMERCIAL I ZATION. DRIVEN BY UNEVEN CHANGES ACROSS
SOVIET ADVERTISING HAS COME TO EMBODY A PARADOX: BY SOVIET ADVERTISING HAS COME TO EMBODY A PARADOX: BY FOLLOHING WESTERN MODELS TO SELL OFTEN NONEXISTENT CONSUM GOODS, IT IGNORES ITS OWN ACHIEVEMENTS DF

05335 KOLINSKY, E.

POLITICAL PARTICIPATION AND PARLIAMENTARY CAREERS: WOMEN'S QUOTAS IN WEST GERMANY

WEST EUROPEAN POLITICS, 14(1) (JAN 91), 56-72.

DRAHING ON A SURYEY OF WOMEN CAMDIDATES AMD

PARL IAMENTARY HANDBOOKS, THIS ARTICLE EXAMINES THE EFFECTS

OF WOMEN'S QUOTAS IN WEST GERMAN POLITICAL PARTIES. SINCE

THE MID-1980S. THE NUMBER OF HOMEN MEMBERS IN LAMD

PARLIAMENTS AND IN THE BUNDESTAG INCREASED SHARPLY, IN

PARTICULAR FOR THE SPD AND GREENS. IN THE CDU AND SPD, WOMEN REQUIRE A TRACK-RECORD OF OFFICE-HOLDING BEFORE THEIR NOMINATION, WHILE THE PARTY ORGANIZATION CARRIERS LITTLE WEIGHT IN FDP AND GREENS, CDU AND FDP WOMEN TEND TO LINK POLITICAL SUCCESS TO PERSONALITY WHILE WOMEN IN THE SPO AND GREENS LOOK FOR AN END TO A MALE-DOMINATED PARTY CULTURE. THE FOCUS ON WOMEN APPEARS TO FAVOUR THE ACADEMICALLY QUALIFIED, ESPECIALLY IN THE GREENS AND THE SPD.

05336 KOLLE, H.

FEARS ABOUT THE NEW CURRENCY OF EUROPE

GERMAN TRIBUNE, (1505) (FEB 92) 6 ,

A GROWING NUMBER OF GERMAN CITIZZENS AND EXPERTS ARE BECOMING WARY ABOUT THE PROMISES OF A COMMON EUROPEAN BECOMING WARY ABOUT THE PROMISES OF A COMMON EUROPEAN CURRENCY (ECU). THEY ACKNOWLEDGE THAT CURRENCY UNION HILL TRAYEL. BUT, THEY ARGUE, THESE ADVANTAGES WILL BE BROUGHT TO TRAVEL. BUT, THEY ARGUE, THESE ADVANTAGES WILL BE BROUGHT
NOTHING BY CURRENCY DEVALUATION, HHICH WILL GAIN MOMENTUM NOTHING BY CURRENCY DEVALUATION, WHICH WILL GAIN MOMENTUM WITH THE CURRENCY UNION. INSTEAD OF MOVING AHEAD TO CURRENCY THEY CALL FOR THE CONTINUATION AND FURTHER DEVELOPMENT OF THE EUROPEAN MONETARY SYSTEM WITH ITS THE DEUTSCHMARK AS THE ANCHOR OF STABILITY.
05337 KOLLE, H.

THIRD WORLD IS UNHAPPY ABOUT IMF AID TO CIS

GERMAN TRIBUNE, (1515) (MAY 92), 6-7.

MANY THIRD HORLD COUNTRIES EXPRESSED CONCERN ABOUT THE \$24 BILLION AID PACKAGE DESIGNED BY THE INTERNATIONAL MONETARY FUND FOR RUSSIA. THEY ARGUE THAT THE STATE OF THE RUSSIAN ECONOMY, BAD THOUGH IT IS, IS NOTHING IN COMPARISON TO THE NEED DEMONSTRATED BY MANY THIRD WORLD STATES. THE IMF DECISION IS SEEN BY SOME AS EVIDENCE OF AN ATTITUDE SHIFT AMONG THE HORLD'S DONOR COUNTRIES. MANY ARE BEGINNING TO ARGUE THAT MANY UNDERDEVELOPED STATES ARE RESPONSIBLE FOR THEIR OWN FATE. THEY ARGUE THAT AID WITHOUT INTERNAL REFORM IS SIMPLY HASTED MONEY. THEREFORE, THE AID PACKAGE TO RUSSIA HAS SEVERAL CONDITIONS ATTACHED WHICH REOUIRE RUSSIA TO DEMONSTRATE MEANINGFUL ECONOMIC REFORMS.

05338 KOLLMAN, K.; MILLER, J.H.; PAGE, S.E. ADAPTIVE PARTIES IN SPATIAL ELECTIONS

AMERICAN POLITICAL SCIENCE REVIEW, 8614) (DEC 92), 929-937.

THE AUTHORS DEVELOP A MODEL OF' TWO-PARTY SPATIAL

ELECTIONS THAT DEPARTS FROM THE STANDARD MODEL IN THREE RESPECTS: THE PARTIES' INFORMATION ABOUT VOTERS' PREFERENCES IS LIMITED TO POLLS; PARTIES CAN BE EITHER OFFICE-SEEKING OR IDEOLOGICAL; PARTIES ARE NOT PERFECT OPTIMIZERS--THAT IS, THEY ARE MODELLED AS BOUNDEDL Y-RATIONAL ADAPTIVE ACTORS. THE THEY ARE MODELLED AS BOUNDEDLY-RATIONAL ADAPTIVE ACTORS. THE
AUTHORS USE COMPUTER SEARCH ALGORITHMS TO MODEL THE ADAPTIVE AUTHORS USE COMPUTER SEARCH ALGORITHMS TO MODEL THE ADAPT BEHAVIOR OF PARTIES AND SHOW THAT THREE DISTINCT SEARCH ALGORITHMS LEAD TO SIMILAR RESULTS. THE FINDINGS SUGGEST THAT CONVERGENCE IN SPATIAL VOTING MODELS IS ROBUST TO ADAPTIVE PARTY IN A COMPLEX ISSUE SPACE MAY NOT BE ABLE TO ADAPTIVE PARTY IN A COMPLEX ISSUE SPAC
DEFEAT A WELL-POSITIONED INCUMBENT.

05339 KOLOOZIEJ, E.A.

U.S.-SOVIET COOPERATION: THE ROLE OF THIRD STATES ANHALS OF THE AMERICAN ACADEMY OF POLITICAL AND SOCIAL SCIENCE, (518) (NOV 91), 118-131.

U.S.-SOVIET COOPERATION IN THE DEVELOPING WORLD MUST BE PURSUED WITHIN A MULTILATERAL SETTING SINCE THE SUPERPOWERS, ACTING ALONE OR TOGETHER, ARE NOT CAPABLE OF DEFINING REGIONAL SECURITY SYSTEMS. IN ELICITING THE COOPERATION OF REGIONAL STATES IN DEFINING PEACEFUL SECURITY REGIMES AROUND THE GLOBE, THE UNITED STATES AND THE SOVIET UNION SHOULD BASE THEIR COOPERATION ON THE FOLLOWING ASSUMPTIONS OR PRINCIPLES: FIRST, CURRENT UNDERSTANDINGS SHOULD BE CODIFIED TO ESTABLISH A SOLID FOUNDATION FOR FUTURE COOPERATION. SECONDLY, IMPEDIMENTS TO FURTHER COOPERATION SHOULD BE CLEARLY DELINEATED TO LIMIT MISUNDERSTANDINGS. THIRDLY, BOTH SHOULD BE SENSITIVE TO THE LIMITS OF THEIR POWER AS A FUNCTION OF THE DEMANDS OF OTHER STATES TO HAVE A SAY IN REGIONAL SECURITY. FOURTH, THESE LIMITS SHOULD NOT HINDER CAUTIOUS BUT OPTIMISTIC EXPECTATIONS OF ADVANCING CAUTIOUS BUT OPTIMISTIC EXPECTATIONS OF ADVANCING COOPERATION BECAUSE BOTH WASHINGTON AND MOSCOW, WHETHER UNDER CENTRALIZED OR FEDERATED AUTHORITY, HAVE POWERFUL THEIR COOPERATION AT THE REGIONAL LEVEL.

05340 KOLOOZIEJ, E.A.

WHAT IS SECURITY AND SECURITY STUDIES? ARMS CONTROL, 13(1) (APR 92), 1-31.

THE EMBARRASSING FAILURE OF SECURITY ANALYSTS AND PRACTITIONERS TO ANTICIPATE--MUCH LESS PREDICT--THE END OF THE COLD WAR PUTS SECURITY STUDIES IN A PARLDUS STATE. PART OF THE EXPLANATION FOR THIS AHKWARD LAPSE CAN BE FOUND IN THE NARROW CONCEPTION OF SECURITY UNDERLYING MUCH THINKING AND WRITING ABOUT THE SUBJECT. THIS PAPER OUTLINES AN EXPANDED FRAMEWORK FOR SECURITY STUDIES SUGGESTED BY THE REVOLUTIONARY BEHAVIOR OF THE SOVIET ELITES AND PEOPLES IN ENDING THE COLD WAR AND IN REVEALING THE PRINCIPLE STRUCTURAL COMPONENTS OF THE SECURITY DILEMMA CONFRONTING THE WORLD COMMUNITY. IT DEFINES INTERNATIONAL SECURITY AND SKETCHES THE FOUR CENTRAL DIMENSIONS OF THE CONTEMPORARY SECURITY DILEMMA. EXAMPLES ARE DRAWN PRINCIPALLY FROM EUROPE AND NORTHEAST ASIA, WHERE THE SECURITY INTERESTS OF THE FORMER SOVIET REPUBLICS ARE PROFOUNDLY ENGAGED.

05341 KOLS, B.

A CLEAR-CUT CHOICE FOR THE HHITES OF SOUTH AFRICA GERMAN TRIBUNE, (1505) (FEB 92), 2.

SOUTH AFRICA'S PRESIDENT DE KLERK HAS SELECTED 17 MARCH AS THE DAY OF DECISION. IN A REFERENDUM, HITE SOUTH AFRICANS WILL HAVE TO DECIDE HHETHER THEY WANT PROGRESS OR RETROGRESSION, PEACE OR A NEW WAR AGAINST THE COUNTRY'S BLACK MAJORITY. THE RULING WHITE CLASS IS BEING ASKED TO BLACK MAJORI TY. THE RULING WHITE CLASS IS BEING ASKED TO YOLUNTARILY ABOL ISH ITSELF. WHILE THE CHOICE COULD NOT HAVE VOLUNTARILY ABOLISH ITSELF. WHILE THE CHOICE COULD APOCALYPSE AND PEACEFUL TRANSITION" REMAINS CLEAR.

$05342 \mathrm{KOLS}, \mathrm{B}$

UN CONSIDERS BREAD-FOR-ARMS APPROACH TO TROUBLE SPOTS GERMAN TRIBUNE, 31(1531) (AUG 92), 2

IN AFRICA THOSE WHO SUFFER MOST FROM THE NEW DISORDER ARE THOSE COUNTRIES WHICH PARTICULARLY BENEFITTED FROM THE 
COLD WAR OR WERE ITS PARTICULAR VICTIMS. AT PRESENT A GREAT DEAL OF THE ASSISTANCE PROVIDED BENEFITS TO THOSE HHOSE UNCONTROLLED YIOLENCE IS ONE OF THE MAIN REASONS FOR THE CATASTROPHE. BREAD FOR GUNS IS ONE OF THE SUGGESTIONS THE UN NOW INTENDS TAKING UP. TO REWARD THOSE WHO SURRENDER THEIR ARMS BY GIVING THEM FOOD IS A LEAST A TENTATIVE APPROACH TO DISARMAMENT IN THE COUNTRIES CONCERNED. IT CAN HARDLY FUNCTION, HOWEVER, AS LONG AS NEW INSTRUMENTS OF WAR CAN BE OBTAINED ON THE NEXT CORMER.

05343 KONORACKE, M. APPRENTICES' SORCERER

NEW REPUBLIC, 207 (5) (JUL 92), 14, 16

BILL CLINTON HAS MADE UPGRÁING WORKER SKILLS A CENTRAL

PART OF HIS AGENDA BOTH AS GOVERNOR OF ARKANSAS AND AS A

PRESIDENTIAL CANDIDATE. HIS CAMPAIGM HAS ADVANCED SUCH IDEAS PRESIDENTIAL CANDIDATE. HIS CAMPAIGN HAS ADVANCED SUCH IDEAS AS YOUTH APPRENTICESHIPS, LIFETIME LEARNING, AND A EUROPEAN-
STYLE TAX ON CORPORATIONS FOR WORKER TRAINING. THE PRESS AND RIVAL CANDIDATES HAVE FOCUSED MOSTLY ON HIS PROPOSALS FOR RIVAL CANDIDATES HAVE FOCUSED MOSTLY ON HIS PROPOSALS FOR HIS IRAINING INITIATIVES ARE LIKELY TO DO MORE TO ADVANCE HIS TRAINING INITI
FUTURE PROSPERITY.

\section{KONDRACKE, M.}

GREASEMAN

NEW REPUBLIC, 206(14) (APR 92), 19-20, 22

THE AUTHOR PROFILES ARKANSAS GOVERNOR BILL CLINTON, THE LIKELY DEMOCRATIC CANDIDATE FOR PRESIDENT IN NOVEMBER 1992.

05345 KONDRACKE, $M$,

PUNCH-PULLER

NEW REPUBLIC, 206 (11) (MAR 92), 14-16

THE AUTHOR DISCUSSES PAUL TSONGAS' POSITIONS ON SOME OF

THE ISSUES IN THE CAMPAIGN FOR THE DEMOCRATIC PARTY'S

PRESIDENTIAL NOMINATION IN 1992.

05346 KONDRACKE, M.

THE ASPIN PAPERS

NEW REPUBLIC, 206(17) (APR 92), 11-12

NOW THAT THE COLD WAR HAS ENDED, QUESTIONS MUST $8 E$

ANSWERED CONCERNING THE SIZE AND SHAPE OF THE U.S. MILITARY

BUDGET. BASICALLY, THERE ARE FOUR MAJOR PROPOSALS. THE BUSH

ADMINISTRATION WANTS A FOUR PERCENT ANMUAL REDUCTION IN THE

NATION'S $\$ 270$ BILLION MILITARY BUDGET OVER FIVE YEARS.

NATION'S \$270 BILLION MILITARY BUDGET OVER FIVE YEARS

REPRESENTATIVE LES ASPIN, CHAIRMAN OF THE HOUSE ARMED
SERVICES COMMITTEE AND LEADER OF A NATIONAL DEMOCRATIC

ESTABLISHMENT CONSENSUS, HOULD DOUBLE THAT CUT, SAVING $\$ 110$

ESTABLISHMENT CONSENSUS, HOULD DOUBLE THAT CUT, SAVING $\$ 110$

BILLION OVER FIVE YEARS. SENATOR SAM NUMN, CHAIRMAN OF THE SENATE ARMED SERVICES COMHITTEE, IS TAKING A MIDDLE POSIT
BETWEEN BUSH AND ASPIN. YARIOUS LIBERALS IN AND OUT OF BETWEEN BUSH AND ASPIN. VARIOUS LIBERALS IN AND OUT OF 15 CONGRESS THINK THE BUDGEY SHOULD BE CUT BY AS MUCH AS 15
PERCENT PER YEAR, PROVIDING A PEACE DIVIDEND OF UP TO $\$ 450$ PERCENT PER YEAR, PROVIDIM
BILLION OVER FIVE YEARS

05347 KONOVALOV, A.

CONVERSION PROBLEMS IN THE EVOLVING RUSSIA

PEACE AND THE SCIENCES, 1(1) (1992), 31-35.

RECENT EVENTS HAVE SERIDUSLY CHANGED THE MILITARY

STRATEGIC LANDSCAPE IN EUROPE AND WORLDWIDE. THESE FACTORS

HAVE LEAD TO THE NECESSITY TO RECONSIDER ALL THE TRADITIONAL

APPROACHES TOWARDS THE MILTARY SECURITY PROBLEM. CONVERSION IN THE CLASSICAL SENSE OF THE WORD, I.E. REARRANGEMENT OF MILITARY INDUSTRY FOR THE PRODUCTION OF CIVIL GOOOS IS DETAILED IN THIS ARTICLE AS WELL AS LIQUIDATION OF WEAPONS ALREADY PRODUCED, AND THE HUMAN FACTOR--WHICH IS A CHANGE IN THE PUBLIC MENTALITY. IT CONCLUDES THAT THE SOVIET DEFENSE INDUSTRY CONVERSION WILL BE A HUGE AND MULTIDIMENSIONAL PROBLEM AND THAT ITS SOLUTION WILL BE A PAINFUL AND TIME CONSUMING PROCESS. THE OPPORTUNITIES DO EXIST AND SHOULD BE USED.

05348 KONVITZ, J.W.

MISSING THE BOAT: PORT CITY PLANNING IN GLASGOW DURING WORLD HAR II

URBAN STUDIES, 29(8) (DEC 92), 1293-1304.

WORLD WAR II MARKED A DECISIVE EXPANSION OF PLANHING FOR PORT CITIES IN WESTERN EUROPE AND THE UNITED KINGDOM. THE STUDY OF PLANS FOR GLASGOW REVEALS THAT PLANNERS FAILED TO PREPARE ADEQUATELY FOR THE MODERNIZATION OF PORT FACILITIIES AND WATERFRONT-RELATED INDUSTRY AND THE IMPROVEMENT OF

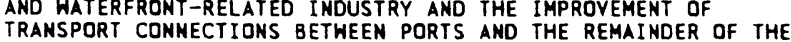
TRANSPORT CDNMECTIONS BETWEEN PORTS AND THE REMAINDER
CITY. A COMPREHENSIVE ASSESSMENT OF PORT MATTERS WAS

CITY. A COMPREHENSIVE ASSESSMENT OF PORT MATTERS WAS
COMPROMISED BY POLITICS-FIRST, IN BRINGING ABOUT GOVERNMENT COMPROMISED BY POLITICS--FIRST, IN BRINGING ABOUT GOVERNMENT
INTERVENTION IN MATTERS OF PORT ADMINISTRATION AND, SECONDLY, INTERVENTION IN MATTERS OF PORT ADMINISTRATION AND, S
IN GENERATING OPPOSITION BETWEEN GLASGOW'S MUNICIPAL IN GENERATING OPPOSITION BETWEEN GLASGOW'S MUNICIPAL
AUTHORITIES AND THE CENTRAL GOVERNMENT ON WHETHER GLASGOH AUTHORITIES AND THE CENTRAL GOVER
SHOULD DOMINATE THE CLYDE VALLEY.

05349 KONYA, I.

IMRE KONYA: NOW IS THE TIME

EAST EUROPEAN REPORTER, 5(1) (JAN 92), 34-35

THIS ARTICLE CONTAINS EXCERPTS OF A SUMMARY REPORT BY

IMRE KONYA, PARL IAMENTARY FACTION LEADER OF THE HUNGARIAM

DEMOCRATIC FORUM (MDF). THE REPORT DISCUSSES THE FIRST YEARS
OF MDF-LED GOVERMMENT AND CALLS FOR A TOUGHER ACTION PLAN FOR THE NEXT. CRITICS HERE SIWFT TO ATTACK THE DOCUMENT FOR ITS APPARENTLY AUTHORITARIAN TONE--ESPECIALLY THE IMPLICATION THAT NOW THE GOVERNING COALITION HAD DEMONSTRATED ITS CREDENTIALS BEFORE THE HORLD, IT COULD PURSUE ITS REAL AGENDA--INDICATIVE, IN THEIR EYES, OF THE MDF'S INTENTION TO ESTABLISH ITSELF AS A PARTY-STATE. ALSO CRITICIZED WAS ITS "JUSTITIA" PLAN FOR LEGISLATION THAT WOULD LIFT THE TERM OF LIMITATION ON CERTAIN CRIMES COMMITTED UMDER THE FORMER REGIME.

05350 KOPSTEIN, J.; RICHTER, $K$.

COMMUNIST SOCIAL STRUCTURE AND POST-COMMUNIST ELECTIONS: VOTING FOR REUNIFICATION IN EAST GERMANY

STUDIES IN COMPARATIVE COMMUNISM, 25(4) (DEC 92), 363-380. IN 1990, THE CITIZENS OF THE GDR PARTICIPATED IN THE IN 1990, THE CITIZENS OF THE GDR PARTICIPATED IN THE ARTICLE EXPLORES THE SOCIOLOGICAL UNDERPINNINGS OF THE ARTICLE EXPLORES THE SOCIOL BY THE LEFT. A COALITION OF VOTERS COMBINED TO BRING THE CONSERVATIVES TO POWER AND PAVE THE WAY FOR UNIFICATION. A HYPOTHESIS IS TESTED BY INFERRING A RELATIONSHIP BETWEEN THE OUTCOMES IN THE VOTING DISTRICTS AND THE SOCIAL CHARACTERISTICS OF THE PROVINCES. THE RELATIONSHIP BETWEEN PERFORMANCE OF THE PARTIES AND OCCUPATIONAL STRUCTURE, SETTLEMENT STRUCTURE, AND OTHER SOCIAL DEMOGRAPHIC CHARACTERISTICS OF THE PROVINCES ON THE OTHER. THE CONCLUSIONS CHALLENGE AS TOO SIMPLISTIC THE NOTION THAT THE VOTE FOR RAPID UNIFICATION WAS MERELY A PRODUCT OF WEST GERMAN LARGESSE.

05351 KORCELLI, P.

INTERNAL MIGRATIONS IN EUROPE: POLISH PERSPECTIVES FOR THE $1990 \mathrm{~S}$

INTERNATIONAL MIGRATION REVIEN, XXVI(2) (SUM 92), 292-304.

THIS ARTICLE PRESENTS ESTIMATES OF THE SIZE OF

EMIGRATION FROM POLAND DURING THE 1980S AS WELL AS

THE AUTHOR ANTICIPATES A CONTRACTION OF THE VOLUME OF

POPULATION DUTFLOW BY SOME 50 PERCENT: FROM ABOUT 100,000 TO

ABOUT 50,000 PER YEAR, ON THE AVERAGE. THESE PROJECTIONS ARE BASED UPON THE EXAMINATION OF THE ROLE OF A NUMBER OF INCENTIVES AND BARRIERS TO MIGRATION, INCLUOING ECONOMIC, INCENTIVES AND BARRIERS TO MIGRATION, INCLUOING ECONOMIC, DEMOGRAPHIC AND POL ITICAL FACTORS. IN THE FINAL SECTION
PROSPECTS CONCERNING IMMIGRATION TO POLAND ARE BRIEFLY PROSPECTS
DISCUSSED.

05352 KORDESH, R.L.

COMMUNITY FOR CHILDREM

NATIONAL CIVIC REVIEH, 80(4) (FAL 91), 374-380.

IF CIVIC LEADERS AND INSTITUTIONS ARE TO STRENGTHEN THE SENSE OF COMAUNITY IN THEIR CITIES, THEY MUST DEVELOP YOUNG PEOPLE WHO ARE PRACTICED IN COMMUNITY. CHILDREN MUST UNDERSTAND THE CONCEPT OF COMMUNITY IN ORDER TO BUILD AND GOVERN WHEN THEY BECOME POLITICALLY - AND ECONOMICALLYRESPONSIBLE AS ADULTS.

05353 KORDONSKY, S.

THREE MYTHS AND FOUR PILLARS OF PERESTROIKA

SOCIOLOGICAL PERSPECTIVES, (4) (1990), 18-24.

THIS ARTICLE EXAMINES FOUR SOVIET GROUPS WITH WELLTHOUGHT OUT INTERESTS THAT HAVE EVOLVED IN THE EARLY 19905 IN THE CONTEXT OF PERESTROIKA: (1) PROGRESSIVES, WHO WANT A MARKET ECONOMY WITH LESS STATE PLANNING AND LESS PARTY LEADERSHIP; (2) COMMUNISTS, HANT TO PRESERYE AND INCREASE THE LEADING ROLE OF THE STATE IN THE PARTY AND IN THE ECDNOMY; (3) FUNDAMENTALISTS, HHO OPPOSE INDUSTRIALIZATION, REJECT THE EXPERIENCE OF WORLD ECONOMIC PROGRESS AND BELIEVE THAT RUSSIA SHOULD DEVELOP AN ECOLOGICALLY PURE NON-MARKET ECONOMY UNALIENATED FROM THE PRODUCERS OF MATERIAL WEALTH; AND (4) APPARATCHIKS, WHO HAYE NO PROGRAM BUT WHO COME OUT AS A WHOLE REGARDING VARIOUS POLITICAL GROUPINGS AND WHO INCLUDE AT TIMES MEMBERS OF ALL THREE ABOVE GROUPS.

05354 KOREY, $W$.

HELSINKI'S UNCERTAIN FUTURE

NEW LEADER, LXXV (3) (MAR 92 ), $8-11$.
THE FUTURE OF THE EFFECTIVENESS OF THE CONFERENCE ON SECURITY AND COOPERATION IN EUROPE (CSCE)--AT A TIME WHEN EUROPE IS FACING A BURGEONING RACISM AND AN EXPLOSIVE NATIIONALISM-IS FAR FROM CERTAIN. WHAT IS EVIDENT IS THAT NATIIONALISM-IS FAR FROM CERTAIN. WHAT IS EVIDENT IS THAT TWO ALMOST AXIOMATIC FEATURES OF THE HELSINKI PROCESS HAYE
PRACTICALLY BEEN DISCARDED. FIRST, NO LONGER CAN A CSCE PRACTICALLY BEEN DISCARDED. FIRST, NO LONGER CAN A CSCE
STATE PREVENT VIGOROUS ACTION TO PROTECT HUMAN AND MINORITY STATE PREVENT VIGOROUS ACTION TO PROTECT HUMAN AND MINORITY RIGHTS ON THE GROUNDS THAT THIS WOULD VIOLATE THE HELSINKI FINAL ACT'S PRINCIPLE OF NONINTERVETION IN A COUNTRY'S INNER
AFFAIRS. SECOND, THE DILUTION OF THE PRINCIPLE OF CONSENSUS AFFAIRS. SECOND, THE DILUTION OF THE PRINCIPLE OF CONSENSUS
THAT GUIDED ALL PRE-MOSCOW RESOLUTIONS AND ACTIONS. THIS THAT GUIDED ALL PRE-MOSCOW RESOLUTIONS AND ACTIONS. THIS
ARTICLE SUGGESTS THAT THE TASK OF THE HELSINK PROCESS IS FAR FROM COMPLETED.

05355 KOREY, $W$.

UNFINISHED HELSINKI BUSINESS

NEW LEADER, LXXIV(15) (NOV 91), 13-14. 
WHEN THE CONFERENCE ON SECURITY AND COOPERATION IN EUROPE (CSCE) SUMMIT OF I AUGUST 1975 APPROVED THE HELSINKI FINAL ACT, IT STRUCK A BALANCE BETWEEN SATISFYING SECURITY CONCERNS (THEN THE CARDINAL COMMUNIST OBJECTIVE) AND ASSURING HUMAN RIGHTS (THE HEST'S PRIMARY AIM). WITH THE END OF THE COLD WAR, THE 19-21 NOVEMBER, 1990 PARIS SUMMIT ADOPTED A CHARTER FOR A NEW EUROPE THAT' STRESSES NOT ONLY "HUMAN RIGHTS AND FUNDAMENTAL FREEDOMS" BUT "DEMOCRATIC GOVERNMENT... BASED ON THE WILL OF THE PEOPLE, EXPRESSED REGULARLY THROUGH FREE AND FAIR ELECTIONS." WHILE THE PARIS SUMMIT OPENED THE WAY TO A FUTURE OF EXPANDING DEMOCRATIC RIGHTS, A RISING TIDE OF RACISM, BIGOTRY AND ANTI-SEMITISM-ESPECIALLY IN EASTERN EUROPE--THREATENS TO ENGULF WHAT PROGRESS HAS BEEN MADE.

05356 KORN, J.

INSTITUTIONAL REFORMS THAT DON'T MATTER: CHADHA AND THE LEGISLATIYE VETO IN JACKSOH-YAMIK

HARVARD JOURNAL OF LEGISLATION, 29(2) (SUM 92), 455-516.

IN IMMIGRATION AND NATURALIZATION SERVICE V. CHADHA, THE .S. SUPREME COURT DECLARED THAT THE LEGISLATIVE VETO WAS UNCONSTITUTIONAL. THE JACKSON-VANIK AMENDMENT, WHICH LINKS MOST-FAVORED-NATION TRADING STATUS TO THE FREEDOM OF EMIGRATION, INCLUOED SEVERAL LEGISLATIVE VETO PROVISIONS THAT WERE INVALIDATED BY THIS RULING. THE AUTHOR ANALYZES BETWEEN THE EXECUTIVE AND LEGISLATIVE BRANCHES UNDER JACKSONBETWEEN THE EXECUTIVE AND LEGISLATIVE BRANCHES UNDER JACKSON-
VANIK. WHEN THE STATUTE HAS ENACTED, ITS LEGISLATIVE VETO VANIK. WHEN THE STATUTE WAS ENACTED, ITS LEGISLATIVE VETO PROVISIONS WERE VIEWED AS AN IMPORTANT INSTITUTIONAL REFORM THAT ENHANCED CONGRESS CAPACITY TO ENGAGE IN INTERNATIONAL TRADE POLICY-MAKING. THE CHADHA DECISION HAD ONLY A MINIMAL IMPACT ON THE BALANCE-OF-POWER BETWEEN THE BRANCHES UNDER JACKSON-VANIK. WHILE CHADHA DID AFFECT THE DISAPPROVAL RESOLUTION PROCEDURE IN JACKSON-VANIK, IT DID NOT AFFECT CONDITIONS BILLS, WHICH ARE A MORE IMPORTANT TOOL FOR ALLOCATING POWER BETWEEN THE EXECUTIVE AND LEGISLATIVE BRANCHES UNDER THE STATUTE. MOREOVER, THE EXECUTIVE COULD NOT FULLYY TAKE ADVANTAGE OF ITS LEGAL VICTORY IN CHADHA FOR POLITICAL REASONS AND, THEREFORE, A DIFFERENT LEGISLATIVE VETO PROVISION IN JACKSON-VANIK. THE APPROVAL REQUIREMENT OVER BILATERAL TRADE AGREEMENTS, REMAINS IN FORCE.

05357 KORNAI, J.

THE SOCIALIST SYSTEM-THE POLITICAL ECONOMY OF COMMUNISM PRINCETON UNIVERSITY PRESS, 1992, 507. TO UNDERSTAND THE DRAMATIC COLLAPSE OF THE SOCIALIST
ORDER AND THE CURRENT TURMOIL IN THE FORMERLY COMUUIST WORLD, THIS WORK EXAMINES THE MOST COMMON PROPERTIES OF ALL SOCIALIST SOCIETIES. THE AUTHOR DISTINGUISHES BETWEEN THO TYPES, OR HISTORICAL PHASES, OF SOCIALISM. THE "CLASSICAL

SOCIALISM" OF STALIN, MAO, AND THEIR FOLLOWERS IS
TOTALITARIAN AND BRUTALLY REPRESSIVE, BUT ITS COMPONENTS FIT TOGETHER AND MAKE UP A COHERENT EDIFICE. ASSOCIATED HITH TOGETHER AND MAKE UP A COHERENT EDIFICE. ASSOCIATED WITH NAMES LIKE TITO, KADAR, DENG, AND GORBACHEV, "REFORM
SOCIALISH" RELAXES REPRESSION, BUT BRINGS ABOUT A SHARPENING SOCIALISH" RELAXES REPRESSION, BUT BRINGS ABOUT A SHARPENINC OF INNER CONTRADICTIONS AND THE EVENTUAL DISSOLUTION OF THE
SYSTEM. THE AUTHOR ARGUES THAT THE WEAK ECONOMIC PERFORMANCE SYSTEM. THE AUTHOR ARGUES THAT THE WEAK ECONOMIC PERFORMANCE FROM THE PERSONALITIES OF TOP LEADERS OR MISTAKES MADE' BY LEADING ORGANIZATIONS AND PLANNERS.

05358 KORMAROVSKI, M.

LEGACY OF LENIN'S EMPIRE

AR EASTERN ECONOMIC REVIEW, 155(12) (MAR 92), 14-16.

THE RUSSIA-LED COMMONHEALTH OF INOEPENDENT STATES FACES SIGNIFICANT CHALLENGES FROM THE LARGE MUSLIM ZONE ALONG THE FORMER SOVIET UNION'S SOUTHERN BORDERS WHICH EMBRACES SUCH COUNTRIES AS AFGHANISTAN, IRAN, PAKISTAN AND TURKEY.

DEVELOPMENTS IN SOUTHWEST ASIA OVER THE PAST DECADE HAVE HAD AN ENORMOUS IMPACT ON BOTH SOVIET FOREIGN AND DOMESTIC POLICIES. THE PRESENT SITUATION IN THE REGION IS ALSO EXERTING A POWERFUL INFLUENCE ON NEIGHBORING CENTRAL ASIA AND TRANS-CAUCASIAN REPUBLICS. FUTURE DEVELOPMENTS IN THE VAST AREA STRETCHING FROM THE HINDU KUSH TO THE BLACK SEA, WHERE SEPARATIST TENDENCIES STEMMING FROM FUNDAMENTALIST AND PAN-TURKIC SETTLEMENT HAVE SPARKED INSTABILITY IN THE MUSLIMPOPULATED NORTHERH CAUCASUS AND TATARSTAN, ARE OF GROWING CONCERN TO THE RUSSIAN LEADERSHIP AND MAY' WELL AFFECT THE STABILITY OF THE FEDERATION ITSELF. IN REVIEHING THE STATE OF AFFAIRS IT INHERITED FROM THE SOVIET UNION, MOSCOW FACES THE TASK OF BOTH MAINTAINING CONTINUITY WITH THE PAST AND THE TASK OF BOTH MAINTAINING CONTINUITY WITH THE PAST AND
SEEKING NEW LINKS HITHIN THE FRAMEWORK OF CHANGED REGIONAL SEEKING NEW LINKS WITHIN
AND GLOBAL RELATIONSHIPS.

05359 KOROSENYI, A.

REYIYAL OF THE PAST OR NEH BEGIMNING? THE MATURE OF POSTCOMMUNIST POLITICS

POLITICAL QUARTERLY (THE), 62(1) (JAN 91), 52-74.

THE AUTHOR ARGUES THAT A HIDE RANGE OF POLITICAL PARTIES HAVE BEEN FLOURISHING IN EAST CENTRAL EUROPE AFTER THE COLLAPSE OF COMMUNISM, AND THAT THREE MAJOR TYPES OF REGIMES EMERGED BY 1990. THESE THREE REGIMES ARE DETAILED. ( 1 DOMINANT NON-AUTHORITARIAN PARTY SYSTEMS, LED BY THE
CZECHOSLOVAKIA, CROATIA, AMD SLOVENIAL. (2) DOMINANT AUTHORITARIAH PARTY SYSTEMS REVIVED IN ROMAHIA AND BULGARIA. (3) COMPETITIVE MULTI-PARTY SYSTEMS CAME INTO EXISTENCE IN HUNGARY AND EAST GERMANY.

05360 KORT, M.

THE SOVIET COLOSSUS--THE RISE AND FALL OF THE USSR M. E. SHARPE, 1992,352

THIS BOOK' IS AN INTRODUCTION TO THENTIETH-CENTURY SOVIET HISTORY WITHIN THE CONTEXT OF RUSSIAN HISTORY AS A WHOLE. THE AUTHOR BEGINS BY SHOWING HOW AND WHY THE TSARS DEVELOPED POWERFUL CENTRALIZED INSTITUTIONS THAT UNDERMINED THE POLITICAL, CIVIL AND ECONOMIC FREEDOMS OF THE RUSSIAN PEOPLE. HE THEN EXPLAINS HOW THE BOLSHEVIKS' ATTEMPT TO BUILD SOCIALISM IN A BACKWARD COUNTRY PRODUCED THE STRONG CENTRALIZED BUREAUCRACY THAT WAS CHARACTERISTIC OF THE SOVIET UNION. HE THEN SURVEYS THE POST-STALIN YEARS OF HALFWAY REFORMS AND "STAGNATION." THE AUTHOR CONCLUDES BY DISCUSSING GORBACHEV'S PLACE IN THE CONTINUUM OF RUSSIAN AND SOVIET HISTORY AND HIS ROLE IN UNLEASHING THE FORCES THAT

FINALLY TOPPLED THE SOVIET COLOSSUS.

05361 KOSAI, Y.; MATSUYAMA, $K$

JAPANESE ECONOMIC CODPERATION

MMALS OF THE AMERICAN ACADEMY OF POLITICAL AND SOCIAL SCIENCE, (513) (JAN 91), 62-75.

JAPANESE OFFICIAL DEVELOPMENT ASSISTANCE (ODA) TOTALED \$9.13 BILLION IN 1988, HHICH PUT JAPAN NECK-AND-NECK WITH THE UNITED STATES FOR THE POSITION OF LARGEST DONOR COUNTRY. SINCE JOINING THE DEVELOPMENT ASSISTANCE COMMITTEE IN 1961 ,
JAPAN HAS STEADILY INCREASED ITS AID EFFORT UNTIL IT IS NOW JAPAN HAS STEADILY INCREASED ITS AID EFFORT UNTIL IT IS
ONE OF THE MAJOR SOURCES OF ECONOMIC HELP. THIS ARTICLE OUTLINES THE DISTINCTIVE CHARACTERISTICS OF JAPANESE ODA, SUCH AS ITS EMPHASIS ON LOANS TO ASIA, AND DISCUSSES THE VARIOUS FACTORS THAT HAVE SHAPED THESE CHARACTERISTICS. IN RECOGNITION OF THE FACT THAT YEN CREDITS ARE CENTRAL TO JAPANESE ASSISTANCE, THE SIGNIFICANCE AND IMPACT OF YEN CREDITS ARE EXAMINED. FINALLY, SOME RECENT DEVELOPMENTS IN JAPANESE ASSISTANCE AND SOME ISSUES THAT REMAIN TO BE RESOLVED ARE REVIEWED.

05362 KOSEKI, M.; TADAKI, J.M. GATT SHOULD NOT HINGE ON SUBSIDIES: E.C. OFFICIAL JAPAN TIMES (WEEKLY INTERNATIOMAL EDITION), 32(18) (MAY $92), 18$.

IRADE REPRESENTATIVES FROM JAPAN, CANADA, THE UNITED STATES, AND THE EUROPEAN COMMUNITY MET APRIL 24-26, 1992, TO STATES, AND THE EUROPEAN COMMUNITY MET APRIL 24-26, 1992, GATT TALKS. THE REPRESENTATIVES DISCUSSED MARKET ACCESS, GATT TALKS. THE REPRESENTATIVES DISCUSSED MARKET ACCESS,
SERVICES, SUBSIDIES, AND OTHER TRADE ISSUES AS ALL THE SERVICES, SUBSIDIES, AND OTHER TRADE ISSUES AS ALL THE
IMPACT OF THE GATT NEGOTIATIONS ON THE POLITICAL SITUATION.

05363 KOSIBA, $H$.

WEEKLY REVIEW: 2-8 DECEMBER 1992

WFE RESEARCH REPORT, 1(50) (DEC 92), 70-79

THE EDITOR SUMMARIZES MAJOR NEHS EVENTS IN THE BALTIC STATES, EASTERN EUROPE, AND THE COMMONHEALTH OF INDEPENDENT STATES DURING THE WEEK OF DECEMBER 2-8, 1992. HE REPORTS ON ESTONIAN-RUSSIAN TALKS, TENSION BETWEEN ROMANIA AND THE DISINTEGRATING YUGOSLAVIA, THE SITUATION IN ARMENIA, DEMONSTRATIONS BY RUSSIAN-SPEAKERS IN KAZAKHSTAN, AND OTHER EVENTS.

05364 KOSIBA, H.; VINTON, L. WEEKLY REVIEH: 21-27 OCTOBER 1992 RFE/RL RESEARCH REPORT, 1(44) (NOV 92), 71-77 MAJOR NEWS STORIES DURING THE HEEK OF OCTOBER 21-27, 1992, IN EASTERN EUROPE AND THE COMMONHEALTH OF INDEPENDENT STATES INCLUDED MOLDOVA'S APPEAL TO THE UNITED NATIONS PROTESTING RUSSIAN INTERFERENCE IN ITS INTERNAL AFFAIRS, THE SIGNING OF A GOOD WILL TREATY BY MOLDOVA AND UKRAINE, THE BULGARIAN PRIME MINISTER'S REQUEST FOR A VOTE OF CONFIDENCE, THE AGREEMENT ON A CUSTOMS UNION FOR THE CZECH AMD SLOVAK REPUBLICS, THE COMMUNIST PARTY'S VICTORY IN LITHUANIA'S PARLIAMENTARY ELECTIONS, ANTI-GOVERNMENT DEMONSTRATIONS IN MOSCOW, AND TENSION IN THE SANDZAK.

05365 KOSIBA, H.

WEEKLY' REVIEW: 25 NOVEMBER-1 DECEMBER 1992

RFE/RL RESEARCH REPORT, 1 (49) (DEC 92), 65-72.

THE EDITOR REPORTS ON MAJOR POLITICAL DEVELOPMENTS IN THE COMMONWEALTH OF INDEPENDENT STATES, THE BALTIC STATES, THE COMMONWEALTH OF INDEPENDENT STATES, THE BALTIC STATES, AND EASTERN EUROPE DURING THE WEEK OF NOVEMBER 25-DECEMBER 1 , 1992. REPORTS SUMMARIZE DEVELOPMENTS IN THE BOSHIAN CRISIS,
AN OFFICIAL VISIT BY ROMANIAN REPRESENTATIVES TO MOLDOVA, A AN OFFICIAL VISIT BY RDHANIAN REPRESENTATIVES TO MOLDOVA, A MEETING OF SLOVAK AND HUNGARIAN OFFICIALS, THE NOMINATION OF A PRIME MINISTER IN LITHUANIA, THE ABOL
RULE IN TAJIKISTAN, AND OTHER EVENTS.

05366 KOSIBA, H. (ED.); SHEEHY, A. (ED.) WEEKLY' REVIEH: 11-17 NOVEMBER 199

RFE/RL RESEARCH REPORT, $1(47$ ) (NOV 92), 63-70

THE EDITORS SUMMARIZE MAJOR POLITICAL DEVELOPMENTS IN EASTERN EUROPE AND THE COMMONHEALTH OF INDEPENDENT STATES 
DURING THE HEEK OF NOVEMBER 11-17, 1992. THEY REPORT ON RUSSIAN PRESIDENT YELTSIN'S OFFICIAL TRIP TO HUNGARY, A VISIT BY TOP EUROPEAN COMMUNITY OFFICIALS TO BULGARIA, EVENTS.

05367 KOSIBA, H. (ED.); SABBAT-SWIDLICKA, A. (ED.) WEEKLY REVIEW: 28 OCTOBER-3 NOVEMBER 1992 RFE/RL RESEARCH REPORT, 1 (45) (NOV 92), 69-77. THE EDITORS REPORT ON MAJOR POLITICAL DEVELOPMENTS IM THE COMMONHEALTH OF INDEPENDENT STATES, THE BALTIC STATES, BULGARIA, CZECHOSLOVAKIA, HUNGARY, POLAND, ROMANIA, ANO YUGOSLAVIA DURING THE WEEK OF OCTOBER 28-NOVEMBER 3, 1992.

05368 KOSLOWSKI, R. MARKET INSTITUTIONS, EAST EUROPEAN REFORM, AND ECONOMIC

JOURNAL OF ECONOMIC ISSUES, 26(3) (SEP 92), 673-706.

MARKET ECONOMIES HAVE NOT EMERGED BECAUSE EAST EUROPEAN COUNTRIES LACK THE POLITICAL, LEGAL, ECONOMIC AND SOCIAL INSTITUTIONS OF A MARKET ECONOMY. THIS ARGUEMENT PROCEEDS IN SIX SECTIONS. SECTION ONE DEMONSTRATES THE AFFINITY OF CERTAIN QUARTERS OF EAST-CENTRAL EUROPEAN THOUGHT HITH THE INSTITUTIONALIST CRITIQUE OF NEOCLASSICISM. SECTION TWO EXAMINES THE RELATION OF THE STATE TO MARKET ECONOMIES BY FOCUSING ON THE STATE'S ROLE IN ESTABLISHING PROPERTY RIGHTS AND PROVIDING A FRAMEWORK FOR EXCHANGE. SECTION THREE FOCUSES ON PRIVATIZATION AND THE ESTABLISHMENT OF SOCIAL LEGITIMACY OF NEW PROPERTY RIGHTS. SECTION FOUR ARGUES THAT CAPITALISM PRESUPPOSES A LARGE STATE REGULATORY FRAMEWORK. SECTION FIVE ARGUES THAT CORPORATIONS PRESUPPOSE CERTAIN SOCIAL SKILLS AND HABITS THAT CANNOT BE ASSUMED IN THE POSTTOTALITARIAN CONTEXT. A BRIEF CONCLUSION SUMS UP THE ARGUMENTS MADE, IDENTIFIES SOME POLICY IMPLICATIONS, AND ADVANCES AN AGENDA FOR FURTHER RESEARCH IN SECTION SIX.

05369 KOSOVA, W.

NEW REPUBLIC, 206 (15) (APR 92), 20, 22-23, 25.

FOLLOWING A SCATHING GAO REPORT' ON INEFFICIENCY AND INCOMPETENCE WITHIN THE UNITED STATES IMMIGRATION AND NATURALIZATION SERVICE, PRESIDENT BUSH APPOINTED GENE MCNARY NATURALIZATION SERVICE, PRESIDENT BUSH APPOINTED GENE MCNARY TO CLEAN UP THE AGENCY AND OVERHAUL ITS MANAGEMENT. HOHEVER, DURING HIS TWO-YEAR TEMUP
MADE REAL PROGRESS.

05370 KOSTOVA, D.

PARLIAMENTARY ELECTIONS IN BULGARIA, OCTOBER 1991

JOURMAL OF COMMUNIST STUDIES, 8 (1) (MAR 92) 196-203.

THE AUTHOR TRACES THE COURSE OF RECENT POLITICAL CHANGE IN BULGARIA AND LOOKS AT THE PARLIAMENTARY ELECTIONS OF OCTOBER 1991.

05371 KOTOVSKY, G

THE FORMER SOVIET UNION IN THE ERA OF PRIMITIVE ACCUMULATION AND KLEPTOCRATIC RULE

STUDIES IN POLITICAL ECONOMY: A SOCIALIST REVIEW, 138

(SUM 92 ), 167-174

THIS ARTICLE SEEKS TO DETERMINE WHAT IS REPLACING THE SOVIET SYSTEM. WESTERN ANALYSTS TEND TO VIEW THE POST-SOVIET COMMONWEALTH OF INDEPENDENT STATES (CIS) IN COLD WAR TERMS: THUS THEY DISCUSS BORIS YELTSIN AND THE "PROGRESSIVES" VERSUS THE "HARD-LINE CONSERVATIVES." THIS ARTICLE ARGUES THAT IN REALITY THE DOMINANT FORCE IN POST-SOVIET POLITICS IS THE SCRAMBLE OF FORMER APPARATCHIKS FOR PRIVATE OWNERSHIP OF THE COUNTRY'S PRODUCTIVE ASSETS, AND THE EMRGENT CLASS POLITICS THAT GO WITH THIS.

05372 KOTSONIS, Y.

ARKHANGEL'SK 1918: REGIONALISM AND POPULISM IN THE RUSSIAN CIVIL WAR

RUSSIAN REVIEW, 51(4) (OCT 92 ), 526-544.

THE AUTHOR EXAMINES THE ROLE OF REGIONAL IDENTITY AND THE RELATIONSHIP BETWEEN SUPPORT AND POWER IN ARKHANGEL'SK DURING THE RUSSIAN CIVIL WAR BY FOCUSING ON THO PROCESSES THAT CULMINATED DURING THE SUMMER AND AUTUMN OF 1918. THE FIRST IS THE DEVELOPMENT OF THE NORTH, INCLUDING THE LEGACY INHERITED FROM THE IMPERIAL PERIOD, FOUR YEARS OF WAR AND REVOLUTION, AND A SUCCESSION OF THREE REGIMES. THE SECOND IS THE EVOLVING OUTLOOK OF THE POPULIST LEADERS WHO SOUGHT TO OVERTHROW THE BOLSHEVIKS AFTER THE COUP D'ETAT OF OCTOBER
1917 , BEGINNING IN THE EUROPEAN NORTH. IN ESSENCE, HE FINDS 1917, BEGINNING IN THE EUROPEAN NORTH. IN ESSENCE, HE FINDS BRING DOWN THE BOLSHEVIKS BUT NEVER REALLY MERGED IN SUCH A BRING DOWN THE BOLSHEVIKS BUT NEVER

05373 KOUASSI, E.; WHITE, J.

THE IMPACT OF REDUCED EUROPEAN SECURITY ROLES ON AFRICAN RELATIONS; EUROPE AND AFRICA: THE NEH PHASE

LYNHE RIENMER PUBLISHERS, 1992, 27-40.

THE LESSENING OF ECONOMIC AFFINITIES BETHEEN EUROPE AND AFRICA, THE CREATION OF AUTONOMOUS REGIONAL MACHINERIES FOR COLLECTIVE SECURITY, AND THE EMERGENCE OF ALTERNATIVE SOURCES OF ARMS ARE INDICATORS OF AND RESPONSES TO REDUCED
EUROPEAN SECURITY ROLES IN AFRICAN RELATIONS. THIS ARTICLE SUGGESTS THAT NOW AFRICA HILL HAVE TO MEET ITS OWN SECURITY NEEDS BECAUSE EUROPEAN, U.S. AHD (FORMER) SOVIET COMMITMENTS IN THIS FIELD HAVE BEEN DIMISHING. IN THE FUTURE, IF THERE IS A REAL DEMOCRACY, POLITICAL AND SOCIAL TENSIONS SHOULD DIMISH AND ALSO THE NEED FOR A FOREIGN SECURITY ROLE.

05374 KOVACIC, W.E. REGULATORY CONTROLS AS BARRIERS TO ENTRY IN GOVERNMENT PROCUREMENT

POLICY SCIENCES, 25(1) (FEB 92), 29-42.

THIS PAPER EXAMINES HOW REGULATORY CONTROLS AFFECT THE GOALS OF STIMULATING ENTRY INTO PUBLIC PROCUREMENT MARKETS AND INCREASING RIVALRY FOR GOVERMMENT CONTRACT AWARDS. IT AND INCREASING RIVALRY FOR GOVERMMENT CONTRACT AWARDS. IT
BEGINS BY DESCRIBING SEVERAL OF THE MOST IMPORTANT TRENDS IN BEGINS BY DESCRIBING SEVERAL OF THE MOST IMPORTANT TRENDS IN
THE EVOLUTION OF THE MODERN GOVERNMENT CONTRACTS REGULATORY THE EVOLUTION OF THE MODERN GOVERMMENT CONTRACTS REGULATORY
SYSTEM. THEN IT IDENTIFIES THE PRINCIPAL EFFICIENCY-RELATED SYSTEM. THEN IT IDENTIFIES THE PRINCIPAL EFFICIENCY-RELATE
BENEFITS THAT ARE OFTEN PRESUMED TO FLOW FROM EXPANDED

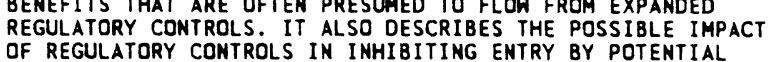
OF REGULATORY CONTROLS IN INHIBITING ENTRY BY POTENTIAL SUPPLIERS OR INDUCING EXIT BY EXISTING FIRMS. FINALLY, IT
EMPHASIZES THAT PROPER ASSESSMENT OF COSTS IS ESSENTIAL TO REACHING SENSIBLE CONCLUSIONS ABOUT THE DESIRABILITY OF ADOPTING NEW REGULATORY MEASURES.

05375 KOVALSKI, N.

EUROPE: NEW CHALLENGES AT THE END OF THE XXTH CENTURY PEACE AND THE SCIENCES, 1(1) (SEP 92), 20-24.

TODAY, AMONG OTHER CHALLENGES, THE' THREE MOST DANGEROUS ONES FOR EUROPE ARE: UNSTEADY GEOSTRATEGICAL BALANCE ON THE CONTINENT; NATIONALISM; AND DEFORMATIONS OF SPIRITUAL LIFE AND ETHIC PRINCIPLES. THIS ARTICLE EXPLORES THE NATURE OF THESE CHALLENGES AND WHETHER IT IS POSSIBLE TO MEET THEM ADEQUATELY. IT ALSO STUDIES WHAT CAN BE DONE BY THE REASONABLE EUROPEAN FORCES IN THIS CONNECTION.

05376 KOVEN, $R$.

MUSLIM IMMIGRANTS AND FRENCH NATIONALISTS

SOCIETY, 29(4) (MAY 92), 25-33.

FRENCH SOCIETY HAS BEEN INCREASINGLY ACTING AS IF MANY OF ITS BASIC ASSUMPTIONS ABOUT ITSELF HERE UNDER CHALLENGE FROM AN ALIEN PRESENCE THAT IT IS HAVING DIFFICULTY ABSORBING. THAT PRESENCE IS THE 3.3 MILLION NORTH AFRICAN ARAB IMMIGRANTS AND THEIR FRENCH-BORN SONS AND DAUGHTERS. THE FRENCH HUMAN RIGHTS MESSAGE CREATES A CONTRADICTION WITH THE CENTRALIZED NATURE OF FRENCH STATEHOOD. INTEMPERATE WORDS BY LEADERS OF THE MAIN PARTIES ILLUSTRATE THE EXPLOSIVENESS OF THE IMMIGRATION ISSUE. PART OF THE PROBLEM IS THAT THE CRISIS CAN BE LARGELY ATTRIBUTED TO LINGERING INDIGESTION OVER FRANCE'S BITTER DEFEAT IN ALGERIA. THE GULF WAR WAS A TEST FOR THE DEPTH OF FRENCH RACISM AND FOR THE EXTENT OF MAGHREBIN INTEGRATION INTO SOCIETY. WHILE A RETURN TO THE PRINCIPLES OF THE FRENCH REVOLUTION STRESSES INDIVIDUAL INTEGRATION AND ASSIMILIATION, THE RIGHT TO BE DIFFERENT LEADS STRAIGHT TO GHETTOS AND ISOLATION. THIS ARTICLE SUGGESTS THAT THE SOLUTION NOW LIES WITHIN A BROADER EUROPEAN COMMUNITY POLICY.

05377 KOVEN, S.; HADWIGER, D.

CONSOLIDATION OF RURAL SERVICE DELIYERY PUBLIC PRODUCTIVITY \& MANAGEMENT REVIEH, 15(3) (SPR 92), 315-328

FISCAL REALITIES IN RURAL AND SMALL-TOWN POLITICS NECESSITATE NEW AND INNOVATIVE THINKING AS LOCAL LEADERS GRAPPLE WITH THE PROBLEM OF PROVIDING SERVICES TO CITIZENS IN JURISOICTIONS SUFFERING FROM DETERIORATING ECONOMIC BASES. IT IS HYPOTHESIZED THAT SERVICE CONSOLIDATIONS WOULD RESULT IN SIGNIFICANT SAVINGS AND THAT SUCH ARRANGEMENTS MAY ALSO ALLOW JURI SDICTIONS TO MAINTAIN ESSENTIAL SERVICES. IN THEORY, CONSOLIDATION OFFERS ADVANTAGES OF SAVINGS THROUGH ECDNOMY OF SCALE, BUT LARGER SIZE IN ITSELF WILL NOT ENSURE GREATER EFFICIENCY AND POLITICAL IMPEDIMENTS CONSTRAIN THE ADOPTION OF STRUCTURAL REFORM. HOWEVER, JUST AS MANY FARM COMMUNITIES HAVE BEEN FADING FOR DECADES, RURAL GOVERNMENTS GRADUAL EXIT.

05378 KOHALEHSKI, D.; PORTER, K

ECOPROTEST: ALIENATION, DEPRIVATION, OR RESOURCES?

SOCIAL SCIENCE QUARTERLY, 73(3) (SEP 92), 523-534.

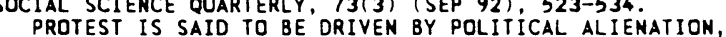
RELATIVE DEPRIVATION, AND RESOURCE AVAILABILTIY. YET DEBATE
SURROUNDS THE MEANINGS OF THE THREE PERSPECTIVES, THEIR SURROUNDS THE MEANINGS OF THE THREE PERSPECTIVES, THEIR APPLICABILITY TO MODERATE AND MILITANT PROTEST, AND THEIR RELEVANCE TO POSTINDUSTRIAL POLITIES. THE EXTENT TO WHICH THE OTHER THO IS ALSO UNCLEAR. THIS STUDY TESTS THE THREE THE OTHER TWO IS ALSO UNCLEAR. THIS STUDY TESTS THE THREE PERSPECTIVES WITH DATA ON PROTEST AGAINST A NUCLEAR WASTE
FACILITY. ALL THREE PERSPECTIVES HELP EXPLAIN BOTH MODERATE AND MILITANT PARTICIPATION.

05379 KOYDL, $W$.

COMING TO TERMS WITH A NEH BALKANS REALITY

GERMAN TRIBUNE, (1507) (MAR 92), 2. 
THE RELUCTANCE OF SOME EUROPEAN COMMUNITY MEMBERS TO RECOGNIZE THE SOVEREIGN INDEPENDENCE OF BOSNIA-HERCEGOVINA IS LAMENTABLE. NOT ONLY DOES IT INDICATE THAT COMMUNITY MEMBERS ARE REFUSING TO ACKNONLEDGE THE REALITY OF YUGOSLAVIA'S BREAK-UP, IT ALSO DENIES THE COMMUNITY A ROLE IN MANAGING AND RESOL VING POTENTIALLY VIOLENT CONFLICTS IN BOSNIA-HERCEGOVINA. A SIMILAR CASE COULD BE MADE FOR MACEDONIA.

\section{KOYDL, $W$}

CONFERENCE HOLDS OUT HOPE FOR A COOL MIDDLE EAST PEACE GERMAN TRIBUNE, (1493) (NOV 91), 2.

AT FIRST GLANCE MUCH OF THE PROCEEDINGS AT THE MADRID MIDOLE EAST PEACE CONFERENCE HAD A FAMILIAR RING: THE PETTY SOUABBLING BETHEEN SYRIANS AND ISRAELIS OVER THE CONFERENCE VENUE, THE VERBAL ATTACKS STEEPED IN VITRIOL, AND THE HARD BARGAINING. BUT IN THE FINAL ANALYSIS THE CONFERENCE DID GET OFF TO A SURPRISINGLY GOOD START. PEACE, AS PRESIDENT BUSH PUT IT, NEED NO LONGER BE A DREAM. THERE ARE TWO REASONS WHY THE PROSPECTS OF COMMON -SENSE AGREEMENT BETWEEN ARABS AND ISRAELIS ARE SO PROMISING: THE FAVORABLE SITUATION IN HORLD ISRAELIS ARE SO PROMISING: THE FAVORABLE SITUATION IN HORL
HISTORY, AND THE SKILL OF U.S. SECRETARY OF STATE JAMES HISTORY,
BAKER.

05381 KOYDL, $H$.

TRUKEY TAKES THE LEAD AT 11-MATION ISTAMBUL BLACK SEA SUMMIT

GERMAN TRIBUNE, (1522) (JUL 92), 5.

THE HEADS OF STATE AND GOVERMMENT OF 11 BLACK SEA COUNTRIES MET IN ISTANBUL TO SIGN A DECLARATION OF INTENSIFYING ECONONIC AND POLITICAL COOPERATION. IT WAS NO COINCIDENCE THAT TURKEY TOOK ON THE ROLE OF A SELF-ASSURED HOST. IT WAS JUST ANOTHER EXPRESSION OF TURKEY'S IMPORTANCE, WHICH SEEMS TO BE GROWING BY THE MONTH, IN A GEOPOLITICALLY IMPORTANT PART OF THE WORLD. TURKEY IS INCREASINGLY BEING VIEWED AS A CRITICAL ELEMENT IN MANY POLITICAL AND CULTURAL SPHERES INCLUDING THE BALKANS, THE BLACK SEA, THE CAUCASUS, CENTRAL ASIA AND THE MIDDLE EAST. THEREFORE, IT IS BECOMING INCREASINGLY VITAL FOR WESTERN EUROPE TO SEEK FURTHER INTEGRATION OF TURKEY INTO EUROPEAN SECURITY AND ECONOMIC STRUCTURES INCLUDING THE ECONOMIC COMMUNITY AND THE WESTERN EUROPEAN UNION (WEU).

05382 KOYDL, H. YELTSIN IS ACCLAIMED IN AMERICA BUT THE GOING IS SLOW IN RUSSIA GERMAN TRIBUNE, (1521) (JUN 92), 2.

THE ENIBUNE, (1521) (JUN 92), 2 . THE ENTHUSIASIIC RECEPTION OF BORIS YELTSIN BY AMERICAM
AWMAKERS IS A SIGN THAT HE, LIKE HIS PREDECESSOR MIKHAIL LAWMAKERS IS A SIGN THAT HE, LIKE HIS PREDECESSOR MIKHAI GORBACHEV, HAS WON CONSIDERABLE INTERNATIONAL PRAISE.
HOWEVER, ACCLAIM IN FOREIGN CAPITALS IS PROVING TO BE LITTLE HOWEVER, ACCLAIM IN FOREIGN CAPITALS IS PROVING TO BE LITTLE
SOLACE WHEN YELTSIN RETURNS HOME TO FACE GROWING DOMESTIC SOLACE WHEN YELTSIN RETURNS HOME TO FACE GROWING DOMESTIC DISSATISFACTION. AS THOUGH HE WERE FOLLOWING PROMPTS FROM PRE-ARRANGED TEXT, HE IS REPEATING THE VERY MISTAKES THAT WERE HIS PREDECESSOR'S UNDOING: HESITANTLY DELAYING REFORMS, OFFERING HIS FELLOW COUNTRYMEN NO PROSPECT FOR THE FUTURE AND MAKING ONE CONCESSION AFTER ANOTHER TO THE GROWING
FORCES OF SOVIET CONSERVATISM. FOR MONTHS KEY LEGISLATION ON FORCES OF SOVIET CONSERVATISM. FOR MONTHS KEY LEGISLATION ON
ECONOMIC TRANSFORMATION OF RUSSIA, INCLUDING THE FALTERING ECONOMIC TRANSFORMATION OF RUSSIA, INCLUDING THE FALTERING
PRIVATIZATION PROGRAM, BANKRUPTCY LEGISLATION AND SETTING UP PRIVATIZATION PROGRAM, BANKRUPTCY LEGISLATION AND SETT
A FUNCTIONING TAXATION SYSTEM HAVE LAIN DORMANT. MORE OMINOUSLY, IT IS BECOMING INCREASINGLY APPARENT THAT COMMUNIST' TECHMOCRATS STILL RETAIN A FIRM GRIP ON MANY OF THE REINS OF POWER.

05383 KOZMINSKI, A.

TRANSITION FROM PLANNED TO MARKET ECONOMY: HUNGARY AND POLAND COMPARED

STUDIES IN COMPARATIVE COMMUNISM, 25(4) (DEC 92), 315-334.

SIMILARITIES AND DEFFERENCES BEFORE 1989 ARE PRESENTED IN THIS ARTICLE ABOUT THE TRANSTION FROM A PLANNED TO A MARKET ECONOMY IN HUNGARY AND POLAND. SHOCK TREATMENT AND THE ACCELERATED TRANSITION SCENARIO IN POLAND IS COMPARED WITH HUNGARY'S GRADUAL TRANSITION. A MODEL OF TRANSTION IS PROPOSED AND IT IS CONCLUDED THAT THOSE WHO SUCCEED WILL HAVE TO ADOPT PRAGMATIC POLICIES WHICH ARE ECLECTIC IN NATURE AND NOT BOUNDED BY ANY SPECIFIC ECONOMIC THEORY.

05384 KOZYREV, A.

RUSSIA: A CHANCE FOR SURVIVAL

FOREIGN AFFAIRS, 71(2) (SPR 92), 1-16

THE AUTHOR, WHO IS RUSSIA'S FOREIGN MINISTER, LOOKS AT THE HISTORICAL BACKGROUND TO THE DRAMATIC CHANGES OCCURRING THE HISTORICAL BACKGROUND TO THE DRAMATIC CHANGES OCCURRI
IN RUSSIA AND DISCUSSES THE POSSIBILITIES FOR THE FUTURE.

05385 KPUNDEH, S.; RILEY, S.

POLITICAL CHOICE AND THE NEH DEMOCRATIC POLITICS IN AFRICA ROUND TABLE, 323(323) (JUL 92), 263-272

A PERIOD OF MAJOR POLITICAL CHANGE HAS BEEN INITIATED IN AFRICA. THIS ARTICLE ADORESSES SEVERAL KEY ISSUES: HOW MUCH POL ITICAL CHOICE HILL BE INVOLVED IN THE NEH DEMOCRATIC POLITICS THAT IS EMERGING IN AFRICA? WHAT ARE THE POLICY IMPLICATIONS OF THE NEW DEMOCRATIC GOVERNMENTS? HOW GENUINELY DEMOCRATIC WILL THE NEW REGIMES BE GIVEN THAT
THEIR VERBAL ESPOUSAL OF DEMOCRACY MOSTLY MAY BE TAILORED TO THE NEED TO ASSUAGE AID DONORS? IT CONCLUDES THAT POLITICAL CHOICE MAY REMAIN LIMITED BY OLD STYLES OF POLITICS AND THE CONSTRAINTS WHICH CONTINUE TO BE IMPOSED BY COMPETING DOMESTIC DEMANDS AND EXTERMAL DONOR PRESSURES.

05386 KRAEMER, K.L.; GURBAXANI, J.; KING, J.L. ECONOMIC DEVELOPMENT, GOVERMMENT POLICY, AND THE DIFFUSION OF COMPUTING IN ASIA-PACIFIC COUNTRIES

PUBLIC ADMINISTRATION REVIEH, 52(2) (MAR 92), 146-156. THE AUTHORS STUDY THE IMPACT OF INDUSTRIAL POLICY ON THE DIFFUSION OF INFORMATION TECHNOLOGY IN NINE ASIA-PACIFIC NATIONS. THEY FIND THAT SUCH EFFORTS HAVE NOT HAD THE SIGNIFICANT DIRECT EFFECTS ON THE DIFFUSION OF COMPUTER TECHNOLOGY THAT MIGHT HAVE BEEN EXPECTED. WHILE SOME GOVERMMENT FISCAL AND TRADE POLICIES HAVE FACILITATED INCREASES IN COMPUTING EXPENDITURES, THE LEVEL OF ECONOMIC DEVELOPMENT HAS BEEN A MORE IMPORTANT PREDICTOR.

05387 KRAEMER, $S$.

RE: START--ADVISE, DON'T CONSENT

NATIONAL INTEREST, 29 (FAL 92), 39-48.

THE FULL U.S. SENATE WILL CONSIDER THE STRATEGIC ARMS REDUCTION COMMITTEE (START) AT A TIME OF NATIONAL

REDUCTION COMMITTEE (START) AT A TIME OF NAT IONAL

REASSESSHENT WHICH INYARIABLE COMES AFTER A NATIONAL
ELECTION. THE SENATE'S CONSIDERATION WILL PRESENT A UNIQUE ELECTION. THE SENATE'S CONSIDERATION WILL PRESENT A UNIQUE
OPPORTUNITY TO SET THINGS RIGHT WITH START, TO SAFEGUARD AMERICAN SECURITY AND GLOBAL STABILTIY, AND TO ESTABLISH THE ENDURIMG FOUNDATION OF A NEW STRATEGIC FRAMEWORK FOR THE POST-COLD HAR ERA. AFTER SUGGESTING SEVEN SAFEGUARDS FOR THE SENATE THIS ARTICLE SUGGESTS THAT ONLY WITH THE SENATE THIS ARTICLE SUGGESTS THAT ONLY WITH THE ESTABLISHMENT OF A NEW STRATEGIC FRAMEHORK AND A NEW GRAMD
BARGAIN CAN THE FREEDOM AND SECURITY OF AMERICA AND THE BARGAIN CAN THE FREEDOM AMD SECURITY OF AMER
WORLD BE SAFEGUARDED FOR FUTURE GENERATIONS.

05388 KRAFT, A. AFRICAN AMERICAN COMMUNISTS IN ALABAMA POLITICAL AFFAIRS, 71(2) (FEB 92), 47-49

THIS ARTICLE EXAMINES RECENT SCHOL ARSHIP ON THE COMMUNIST MOVEMENT IN THE AMERICAN SOUTH DURING THE GREAT DEPRESSION. IT REFUTES THE COMMON OPINION THAT THE COMMUNIST PARTY HINDRED RATHER THAN HELPED BLACK AMERICANS IN THEIR STRUGGLE FOR CIVIL RIGHTS. IT ARGUES THAT HISTORIANS WRITING ABOUT THIS PERIOD IN THE SOUTH HAVE NOT UNDERSTOOD THE STRENGTH OF THE COMHUNIST MOVEMENT OR THE GREAT ROLE OF VIOLENCE IN CURBING THE MOVEMENT. FURTHERMORE, THEY IGNORE THE FACT THAT RACIAL DIVISIONS WERE OFTEN BROKEN DOWN BY WORKING CLASS CONSCIOUSNESS.

05389 KRAFT, E.

BOSNIA'S MUSLIMS AS A MATIONALITY

SWISS REVIEW OF WORLD AFFAIRS, 42(5) (AUG 92), 24-25. SW REVIEH OF WORLD AFFAIRS, $42(5)$ (AUG 92), 24-25.
WITH THREE PARTIES TO THE CONFLICT, CHARACTERIZED LARGELY BY THEIR RELIGIDUS AFFILIATIONS. THE STRUGGLE IN LARGELY BY THEIR RELIGIOUS AFFILIATIONS, THE STRUGGLE IN
BOSNIA-HERZEGOVINA APPEARS, AT FIRST GLANCE, AS PRIMARILY A BOSNIA-HERZEGOVINA APPEARS, AT FIRST GLANCE, AS PRIMAR RELIGIOUS WAR. IN PARTICULAR, THE DESIGNATION "MUSLIM" GENERATES CONFUSION. BUT IN REAL ITY THE DISPUTE REVOLVES AROUND THE ETHNIC IDENTITY OF A PARTICULAR GROUP, WHICH SHOULD NOT BE LINKED TO ISLAMIC TRENDS ELSEWHERE IN THE SHOULD NOT BE

05390 KRAFT, M.E.

PUBLIC AND STATE RESPONSES TO HIGH-LEVEL NUCLEAR HASTE DISPOSAL: LEARNING FROM POLICY FAILURE

POLICY STUDIES REVIEW, 10(4) (WIN 92), 152-166. NUCLEAR WASTE POLICY IN THE UNITED STATES HAS FAILED LARGELY BECAUSE OF PUBLIC AND STATE GOVERNMENT OPPOSITION TO REPOSITORY SITING. BUT THAT RESULT HAS NOT INEVITABLE. BETTER POLICY DESIGN AND GREATER ATTENTION TO THE CRUCIAL TASKS OF POLICY LEGITIMATION, BOTH BY THE U.S. CONGRESS AND BY THE DEPARTMENT OF ENERGY, MIGHT HAVE SIGNIFICANTLY IMPROVED THE CHANCES FOR SUCCESSFUL IMPLEMENTATION. EVEN THOUGH THE PROGRAM NOW HAS A HIGHLY UNCERTAIN FUTURE, THIS ESSAY OFFERS SUGGESTIONS FOR POLICY LEARNING AND CHANGE THAT MAY INCREASE THE PROBABILITY OF SUCCESS.

05391 KRAMER, F.A.

USING THE CLASSICS TO EXPAND PUBLIC AOMINISTRATIVE THOUGH AN EXHORTORY NOTE

AMERICAN REVIEH OF PUBLIC ADMINISTRATION, 22(4) (DEC 92), 301-306.

PUBLIC ADMINISTRATORS NEED TO DEVELOP CRITICAL-THINKING SKILLS. THE MENTAL EXERCISE REOUIRED TO ASSESS THE VALIDITY OF MYTHS AND METAPHORS CAN HELP DEVELOP THIS CAPACITY TO OF MYTHS AND METAPHORS CAN RELP DEVELOP THIS CAPACITY TO THINK BEYOND BOUNDARIES OF PROBLEMS. DRAWING FROM THE WORKS
OF DIVERSE AUTHORS, SUCH AS PERCY BYSSHE SHELLEY AND NEISON OF DIVERSE AUTHORS, SUCH AS PERCY BYSSHE SHELLEY AND NEISO
GOODMAN, THIS ESSAY SHOWS HOW THE CONFLICT INHERENT IN GOODMAN, THIS ESSAY SHOWS HOW THE CONFLICT INHERENT IN METAPHORS CAN BE AN EXERCISE IN CREATIVITY. EXAMPLES
RELEVANT TO PUBLIC ADMINISTRATION ARE ORAHN FROM HOMER'S RELEVANT TO
"ODYSSEY."

05392 KRAMER, G.

LIBERALIZATION AND DEMOCRACY IN THE ARAB WORLD 
MIDOLE EAST REPORT, 22(1) (JAN 92), 22-25; 35.

IN A LONG-TERM PERSPECTIVE, LIBERALIZATION AND DEMOCRACY ARE DESIRABLE AND EVEN NECESSARY TO ENHANCE ECONOMIC EFFICIENCY, POLITICAL LEGITIMACY AND STABILTIY IN THE ARAB WORLD. REGIMES THAT PREVIOUSLY WERE ABLE TO MONOPOLIZE POLITICAL DECISION-MAKING BY RELYING ON RENT AND REPRESSION SEEM AT LAST TO HAVE ACXNOWLEDGED THEIR VULNERABILITY AND IMPOTENCE IN THE FACE OF THE SOCIOECONOMIC CRISIS AT HOME AND POLITICAL CHALLENGES ABROAD. HOWEVER, AS LONG AS POLITICAL LIBERALIZATION IS INITIATED FROM THE TOP, AS A PREEMPTIVE STRATEGY OF SYSTEM MAINTENANCE TO WIN URBAN MIDDLE CLASS SUPPORT FOR ECONOMIC AUSTERITY MEASURES AFFECTING FIRST AND FOREMOST THE LIVING STANDARD OF THE POOREST SECTIONS OF SOCIETY, STABILITY AND DEMOCRACY REMAIN AT RISK.

05393 KRAMER, $H$

THE EC AMD THE STABILIZATION OF EASTERN EUROPE AUSSEN POLITIK, 43(1) (1992), 12-21.

THE EUROPEAN COMMUNITY (EC) HAS BEEN SUBSTANTIALLY AFFECTED BY THE FUMDAMENTAL CHANGES IN THE SOCIALIS GOVERMMENT OF EASTERN EUROPE, EVEN THOUGH THE STABILITY OF ITS OWN TERRITORY MIGHT SUGGEST THAT IT HAS HARDLY BEEN INFLUENCED AT ALL. THIS ARTICLE EXAMINES THE EXTENT TO WHICH THE FORMER POLITICAL APPROACH IN GERMANY IS STILL APPLICABLE AND DISCUSSES THE ALTERNATIVES.

05394 KRAMER, J.M.

THE NUCLEAR POWER DEBATE IN EASTERN EUROPE

RFE/RL RESEARCH REPORT, 1 (35) (SEP 92), 59-65.

AN INTENSE DEBATE IS UNDERHAY OVER THE FUTURE STATUS OF NUCLEAR POWER IN POSTCOMMUNIST EASTERN EUROPE. COMMERCIAL NUCLEAR PONER STATIONS ARE CURRENTLY OPERATING IN BULGARIA, CZECHOSLOVAKIA, AND HUNGARY AND ARE UNDER CONSTRUCTION IN THREE EAST EUROPEAN COUNTRIES. NEARLY ALL THE REACTORS ARE SOVIET-DESIGNED. IN 1977. ROMANIA BECAME THE FIRST, ANO TO DATE THE ONLY, EAST EUROPEAN STATE TO BASE ITS NUCLEAR PROGRAM PRIMARILY ON WESTERN TECHNOLOGY WHEN IT SIGNED AN AGREEMENT HITH CANADA TO SUPPLY IT WITH FIVE REACTORS FOR A AUCLEAR POWER STATION AT CERMAVODA.

05395 KRAMER, M.

EASTERN EUROPE GOES TO MARKET

EASTERN EUROPE GOES TO MARKET
FOREIGN POLICY, (86) (SPR 92), 134-157

THE TASK OF' REPLACING DYSFUNCTIONAL STATE-CONTROLLED ECONOMIES HITH VIABLE FREE MARKET SYSTEMS IS FORMIDABLE UWDER THE BEST OF CIRCUMSTANCES. IN EASTERN EUROPE. THE TASK HAS BEEN FURTHER COMPLICATED BY A SERIES OF EXTERMAL SHOCKS AND BY THE LACK OF CLEAR GUIDANCE FROM PAST EXPERIENCE. THIS ARTICLE CONSIDERS HHY THE POST-COMMUNIST ECONOMIC

ARAMSIT

DIFFICULTY AND WHAT MIGHT BE DONE TO IMPROVE THE SITUATION.

IT OUTLINES FOUR BASIC PROBLEMS: DISRUPTION OF FOREIGN TRADE, THE AMBIGUITY OF PROPERTY RIGHTS, WORKER RESISTANCE, AND
UNCERTAINTY ABOUT THE APPROPRIATE SEQUENCING OF REFORMS.

05396 KRAMER, M.

MILITARY CONYERSION AND ECONOMIC REFORM: IMPLICATIONS FOR THE POST-SOVIET ERA

RUSI JOURNAL, 137(2) (APR 92), 43-49.

THIS ARTICLE EXAMINES THE ISSUES AND CHALLENGES FACING THE FORMER SOVIET REPUBLICS AS THEY SEEK TO CUT THEIR MILITARY SPENDING AND CONVERT DEFENSE INDUSTRIES TO CIVILIAN PRODUCTION. IT FIRST OFFERS PRELIMINARY COMMENTS ABOUT MILITARY CONVERSION AND LAYS OUT A COMPARATIVE FRAMEHORK FOR UNDERSTANDING ISSUES THAT ARISE IN THE POST-SOVIET CONTEXT. IT THEN REVIEWS THE LARGELY UNSUCCESSFUL ATTEMPTS BY THE SOVIET GOVERMMENT TO PROMOTE CONVERSION BETHEEN THE LATE SOVIET GOVERMMENT TO PROMOTE CONVERS ION BETWEEN THE LATE
1980 S AND AUGUST 1991 WHEN MIKHAIL GORBAHCEY HAS IN POWER. 1980 S AND AUGUST 1991 WHEN MIKHAIL GORBAHCEY HAS IT ALSO ASSESSES THE PROSPECTS FOR CONVERSION AND
DEMILITARIZATION IN THE FORMER SOVIET REPUBLICS, WITH

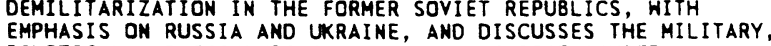
POLITICAL AND ECONOMIC IMPLICATIONS OF POST-SOVIET

CONVERSION.

05397 KRAMER, M.

MUSAHI'S GAME

NEW REPUBLIC, 206(12) (MAR 92), 16, 18-19.

THE AUTHOR REPORTS ON THE DEATH' OF SAYYID ABBAS AL-

MUSAHI THE SHIITE CLERIC WHO LED THE PARTY OF GOD IM

LEBANON AND WAS KILLED BY ISRAELI OPERATIVES.

05398 KRAMER, $M$

THE ARMIES OF THE POST-SOVIET STATES

CURRENT HISTORY, 91 (567) (OCT 92), 327-333.

DESPITE INITIAL ATTEMPTS BY THE RUSSIAH GOVERNMENT TO PRESERVE A JOINT MILITARY STRUCTURE UNDER THE AUSPICES OF THE COMMONHEALTH OF INDEPENDENT STATES, THE FORMER REPUBLICS MOVED SWIFTLY TO CREATE THEIR OWN ARMIES. THIS COMPELLED RUSSIA TO FORM ITS OWN NATIONAL ARMED FORCES, LEAVING THE CIS WITH VIRTUALLY NO MILITARY. THUS, IT HOULD $B E$ EXTRAORDINARILY DIFFICULT FOR THE POST-SOVIET ARMIES TO PRESENT A DANGER EVEN REMOTELY COMPARABLE TO THE SOVIET MILITARY THREAT DURING THE COLD HAR.
05399 KRAMER, R.M.; LORENTZEN, H.; MELIEF, H.B.; PASQUINELLI, S. PRIVATIZATION IN FOUR EUROPEAN COUNTRIES--COMPARATIVE STUDIES IN GOVERNMENT-THIRD SECTOR RELATIONSHIPS

M. E. SHARPE, 1993, 256.

ALONG WITH THE UMPRECEDENTED EXPANSION OF THE WELFARE STATE DURING THE PAST THENTY-FIVE YEARS, NONPROFIT ORGANIZATIONS (NPOS) HAVE GROWN IN NUMBER AND IMPORTANCE, BOTH IN NORTH AMERICA AND EUROPE. SINCE THESE VOLUNTARY NPOS-THE "THIRD SECTOR"--SEEM DESTINED TO ASSUME EVER LARGER ROLES IN THE PROVISION OF WELFARE SERVICES, IT IS IMPORTANT TO LEARN MORE ABOUT THEM. A CROSS-NATIONAL SURVEY IS PART ICULARLY HELL-SUITED TO INFORM SOCIAL POLICY DEBATE ABOUT PRIVATIZATION AND THE WELFARE STATE. BASED ON A COMPARATIVE STUDY, THIS BOOK HELPS ANSWER QUESTIONS SUCH AS: WHY AND HOW ARE NPOS USED TO IMPLEMENT PUBLIC POLICY AND WITH WHAT CONSEQUENCES? HOW CAN VOLUNTARY AGENCIES PRESERVE WITH WHAT CONSEQUENCES? HOW CAN VOLUNTARY AGENCIES PRE
THEIR AUTONOMY WHEN RECEIVING PUBLIC FUNDS? HOW CAN THEIR AUTONOMY WHEN RECEIVING PUBLIC FUNOS? HOW CAN
GOVERMMENTS OBTAIN ACCOUNTABILUTY FOR PUBLIC FUNDS WHEN THEY GOVERMMENTS OBTAIN ACCOUNTABILUTY FOR PUBLIC FUNDS WHEN THEY
SUPPORT VOLUNTARY ORGANIZATIONS? THIS BOOK UTILIZES DATA SUPPORT VOLUNTARY ORGANIZATIONS? THIS BOOK UTILIZES DATA FROM COMPARATIVE CASE STUDIES OF 90 VOLUNTARY AGENCIES IN ENGLAND, THE NETHERLANDS, ITALY, AND NORWAY, BY LINKING THE MACRO (SECTORAL) AND THE MICRO (ORGANIZATIONAL) LEYELS, THE
BOOK PROVIDES A BASIS FOR DISTINGUISHING THE EFFECTS OF BOOK PROVIDES A BASIS FOR DISTINGUISHING THE EFFECTS OF
DIFFERENT FISCAL POLICIES AND SOCIOPOLITICAL CONTEXTS ON THE STRUCTURE AND PERFORMANCE OF VOLUNTARY AGENCIES IN WELFARE STATES.

05400 KRAPAUSKAS, $V$

MARXISH AND NATIONALISH IN SOVIET LITHUANIAN HISTORIOGRAPHY JOURNAL OF BALTIC STUDIES, 23(3) (FAL 92), 239-260.

THIS STUOY ANALYZES THREE OUESTIONS: (1) HOW AND TO WHAT EXTENT DID MARKISM INFLUENCE SOVIET LITHUANIAN

HISTORIOGRAPHY? (2) DID THE HISTORICAL TRADITIONS OF INDEPENDENT LITHUANIA SURVIVE IN SOME FORM? (3) DID SOVIET

LITHUANIAN HISTORIANS PROOUCE SERIOUS SCHOLARSHIP?

05401 KRASTEVA, A.

GODE TO TOTALITARIANISM', OR, DOES THE INFORMATION SOCIETY HAVE A CHANCE IN BULGARIÁ?

FUTURES, 24(2) (MAR 92), 130-137.

THE OBJECTIVE OF THIS ARTICLE IS TO ANALYSE THE COURSE

OF THE INFORMATION REVOLUTION IN COMMUNIST BULGARIA AND ITS PROSPECTS IN POST-COMMUNIST DEVELOPMENT. THE FIRST,

RETROSPECTIVE PART REYEALS THE SPECIFICITIES OF

INFORMATIZATION IN BULGARIA AS COMPARED TO THE DEVELOPED COUNTRIES. SPECIAL ATTENTION IS PAID TO THE DISCREPANCY BETWEEN THE AIMS AS DECLARED BY THE STATE AND THE ACTUAL INFORMATION REVOLUTION UNFOLDING IN POST-COMMUNIST BULGARIA.

05402 KRAUSE, J.

RISKS OF NUCLEAR PROLIFERATION FOLLOWING THE DISSOLUTION OF THE SOCIET UNION

AUSSEN POLITIK, 43(4) (1992), 352-361.

ONE OF THE MOST DISCONCERTING RISKS ACCOMPANYING THE DISSOLUTION OF THE USSR IS THE RISK OF A FURTHER PROLIFERATION OF NUCLEAR WEAPONS. VIOLENT REGIMES WITH NUCLEAR AMBITIONS ARE WAITING FOR THE CHANCE TO EXPLOIT CHAOS AND ANOMY IN THE FORMER SOVIET UNION TO THEIR OWN ENDS. THIS ARTICLE EXAMINES THE INDIVIDUAL PROBLEMS INVOLVED AND THE LIKELY CONSEQUENCES FOR THE INTERNATIONAL COMMUNITY.

05403 KRAUSE, $K$.

POST-HELSINKI CONVENTIONAL ARMS CONTROL: THE QUALITATIVE DIMENSION

ARMS CONTROL, 12(2) (SEP 91), 211-230.

THE EUROPEAN AND THE GLOBAL SECURITY ENVIRONMENTS ARE

ENTERING A PERIOD IN WHICH, AS THE USE OF FORCE ON A LARGE

SCALE BECOMES LESS LIKELY, THE NEED FOR MILITARY

TECHNOLOGICAL INNOVATION AND MODERNIZATION BECOME LESS

PRESSING. THIS ARTICLE EXPLORES FOUR LINKED ARGUMENTS

(MILITARY/STRATEGIC, TECHNOLOGICAL, ECONOMIC AND POLITICAL),

(MILITARY/STRATEGIC, TECHNOLOGICAL, ECONOMIC AND POLITICAL), OF CONVENTIONAL ARMS CONTROL TOWARDS QUALITATIVE ISSUES. OF CONVENTIDNAL ARMS CONTROL TOWARDS QUALITATIVE ISSUES.
EACH IS ELABORATED IN THIS ARTICLE. THE END OF ARMS CONTROL
ASS AS WE KNOW IT, AND THE MILITARY/STRATEGIC, TECHMOLOGICAL,
ECONOMIC AND POLITICAL ARGUMENTS ARE EXPLORED. THE ARTICLE ECONOMIC AND POLITICAL ARGUMENTS ARE EXPLORED. THE ARTICLE
CONCLUDES THAT THE COLD WAR IS OVER AND THE CENTRAL EUROPEAN CONCLUDES THAT THE COLD WAR IS OVER AND THE CENTRAL EUROPEAN
CONFRONTATION ELIMINATED, BUT THAT THIS SHOULD BE SEEN NOT CONFRONTATION ELIMINATED, BUT THAT THIS SHOULD BE SEEN NOT
AS THE END, BUT THE END OF THE BEGINNING OF THE PROCESS OF AS THE END, BUT THE END OF THE BEG
BUILDING SECURITY WITHIN THE SCCE.

05404 KRAUSS, E.; REICH, S.

IDEOLOGY. INTERESTS, AND THE AMERICAN EXECUTIVE: TOWARD A IDEOLOGY, INTERESTS, AND THE AMERICAN EXECUTIVE: TOWARD THEORY
POLICY

INTERNATIONAL ORGANIZATION, 46(4) (FAL 92), 857-898.

THIS ARTICLE SUGGESTS THAT EXECUTIVE RESPONSES TO FOREIGN ECONOMIC CHALLENGES FOLLOW A PREDICTABLE PATTERN. IT ARGUES THAT BOTH THE DEGREE AND TYPE OF EXECUTIVE RESPONSE CAN BE PREDICTED BASED ON THO FACTORS: WHETHER A SECTOR IS CHARACTERIZED AS HIGH TECH AND WHETHER IT IS CONSIDERED TO 
THE U.S. CHIEF EXECUTIVE HAS USED TRADE POLICY AS A SURROGATE FOR IMDUSTRIAL POILY. BUT IN SO DOING. THE STRATEGIC CONSIDERATIONS ASSOCIATED WITH INOUSTIRAL POLICIES HAVE BEEN BYPASSED. THE MAJOR EFFECT IS THAT THE EXECUTIVE FAILS TO INTERVENE ONLY IN THE REALM OF AN
POLICY WHICH RESULTS IN A STAGNANT ECONOHY.

05405 KRAUSS, E.S. POLITICAL ECONOMY: POLICYMAKING AND INDUSTRIAL POLICY IN JAPAN

PS: POLITICAL SCIENCE AND POLITICS, XXV(1) (MAR 92), 44-57.

THE AUTHOR DISCUSSES JAPAN'S POLIITICAL ECONOMY, JAPANESE ECONOMIC AND INOUSTRIAL POLICY, AND THE PROCESS OF POLICYMAKING. HE OFFERS SOME COMPARISONS WITH U.S. POLICY IN THESE AREAS AND SOME OBSERVATIONS ABOUT HOW AMERICAN PERCEPTIONS OF JAPANESE ECONOMIC AND INDUSTRIAL POLICY AFFECT U.S.-JAPANESE RELATIONS.

05406 KRAUZE, E.

OLD PARADIOMS AND NEN OPENINGS IN LATIN AMERICA JOURNAL OF DEMOCRACY, 3(1) (JAN 92), 15-24.

LATIN AMERICAN HISTORY HAS LONG BEEN DOMINATED BY FOUR GRAND AND ENDURING PARADIGMS: MILITARISM, MARXISM (BOTH REVOLUT IONARY AND ACADEMIC). DEMAGOGIC POPULISM, AND THE REVOLUTIONARY AND ACADEMIC), DEMAGOGIC POPULISM, AND THE
CLOSED ECONOMY. THIS ARTICLE CONSIDERS EACH PARADIGM AND CLOSED ECONOMY. THIS ARTICLE CONSIDERS EACH PARADIGM AND
CONCLUDES THAT, FOR DIFFERENT REASONS, ALL FOUR HAVE ENTERED CONCLUDES THAT, FOR DIFFERENT REASONS, ALL FOUR HAVE ENTERED
INTO A COMMON AND DEFINITIVE CRISIS. THE AUTHOR CONCLUDES INTO A COMMON AND DEFINITIVE CRISIS. THE AUTHOR CONCLUDES
THAT, ON THE WHOLE, THE PICTURE IS FAR FROM DISCOURAGING. THE PARADIGMATIC CHANGES SIGNAL THE HIGHEST DEGREE OF MATURITY THAT LATIN AMERICA HAS ATTAINED THIS CENTURY.

05407 KRAVCHUK, R.S.

LIBERALISM AND THE AMERICAN ADMINISTRATIVE STATE PUBLIC ADMINISTRATION REVIEN, 52(4) (JUL 92), 374-379. THE AUTHOR ARGUES THAT AMERICAN LIBERAL THOUGHT IS A MAJOR SOURCE OF FRUSTRATION TO THOSE WHO SEEK A THEORETICAL BASE THAT INTEGRATES DEMOCRATIC AND BUREAUCRATIC THEORY. BUILOING ON BENJAMIN BARBER'S DISTINCTION AHONG THREE DISPOSITIONS IN AMERICAN LIBERALISH (MINIMALIST, AMARCHIST, AND REALIST), THE AUTHOR CONTENDS THAT THE TENSIONS AMONG THESE STRANDS OF LIBERALISM GENERATE A CONFLICT BETHEEN DEMOCRATIC AND BUREAUCRATIC PERSPECTIVES ON GOVERNANCE AND PRECLUDES AN EFFECTIVE INTEGRATION OF THE TWO. HE CONTRASTS THIS APPROACH WITH THAT OF DAVID ROSENBLOOM, WHO ARGUES THAT THE CONSTITUTIONAL SEPARATION OF POWERS IS THE PRIMARY BARRIER TO A UNIFIED THEORY OF AMERICAN PUBLIC ADMINISTRATION. THE AUTHOR BELIEVES THAT AN AWARENESS OF THE INHERENT PROBLEMS POSED BY LIBERAL THOUGHT CAN BE USED TO ESTABLISH SOME PRACTICAL GUIDELINES FOR AMERICAN PUBLIC ESTABLISH SOME
ADMINISTRATORS.

05408 KREGEL, J.A.; MATZNER, E.

AGENDA FOR THE RECONSTRUCTION OF CENTRAL AND EASTERN EUROPE AGENDA FOR THE RECONSTRUCTION OF

SOCIO-ECONOMIC RECONSTRUCTION CALIS FOR A STRONG DEMOCRATIC STATE CAPABLE OF INSPIRING ITS CITIZENS TO SELFINTERESTED VOLUNTARY COOPERATION. ACHIEVING THIS INVOLVES EFFECTIVELY ELABORATING THIS CONSTRUCTIVE PROJECT AND
ORGANIZING A SOCIAL CONSENSUS FOR ITS IMPLEMENTATION.

05409 KREININ, M.E.; PLUMMER, M.G.

EFFECTS OF ECONOMIC INTEGRATION IN INDUSTRIAL COUNTRIES ON ASEAN AND THE ASIAN NIE'S

WORLD DEVELOPMENT, 20(9) (SEP 92), 1345-1366

THE AUTHORS ASSESS THE EFFECTS' OF THE PROPOSED NORTH AMERICAN FREE TRADE AREA, THE SECOND ENLARGEMENT OF THE EUROPEAN COMMUNITY (EC), AND EUROPE 1992 ON THE ASSOCIATION OF SOUTHEAST ASIAN NATIONS (ASEAN) AND SOUTH KOREA. BY MATCHING THE COMMODITIES EXPORTED BY ASEAN OR SOUTH KOREA TO AN INTEGRATING MARKET (SUCH AS THE UNITED STATES) HITH THOSE EXPORTED TO THE SAME MARKET FROM "INTERNAL" SOURCES (SUCH AS CANADA), THEY IDENTIFY THE INDUSTRIES THAT WOULD BEAR THE BRUNT OF THE DISCRIMINATION. AS A TERMS-OF-TRADE EFFECT, TOTAL TRADE DIVERSION IS ESTIMATED AT 4\% OF ASEAN EXPORTS AND 5\% OF SOUTH KOREAN EXPORTS TO NORTH AMERICA AND AS $8 \%$ AND 5\% OF THEIR RESPECTIVE EXPORTS TO THE EC. EUROPE 1992 IS EXPECTED TO HAVE FURTHER DISCRIMINATORY INFLUENCES. THE AUTHORS ALSO ASSESS THE EFFECT OF INTEGRATION ON DIRECT FOREIGN INVESTMENT IN ASEAN AND SOUTH KOREA.

05410 KREMENYUK, V.A.

RULES OF CONDUCT IN THE SETTLEMENT OF REGIONAL CONFLICTS ANHALS OF THE AMERICAN ACADEMY OF POLITICAL AND SOCIAL SCIENCE, (518) (NOV 91 ), 143-152.

THE SETTLEMENT OF REGIONAL CONFLICTS HAS DEFINITELY JOINED THE U.S, -SOVIET AGENDA. BOTH SUPERPOHERS HAVE ENGAGED IN TALKS ON THE APPROACHES TO SUCH SETTLEMENT IN THEIR BILATERAL RELATIONS AND IN THEIR RELATIONS WITH THIRD PARTIES-PARTICIPANTS TO CONFLICTS. THIS DEVELOPMENT HAS EMERGED ONLY RECENTLY AND DEMANDS MORE ATTENTION ON THE PART OF RESEARCHERS. THIS TASK NECESSITATES FINDING AN APPROACH SHARED BY THE UNITED STATES AND THE USSR IN DEALING HITH REGIONAL CONFLICTS. FOR THIS PURPOSE, IT IS NECESSARY TO
ADHERED TO A COLLISION COURSE IN THEIR ATTITUDES TOWARD REGIONAL CONFLICTS AND, FIRST OF ALL, TO FIND WHAT TYPES OF REGIONAL CONFLICTS AND, FIRST OF ALL, TO FIND WHAT TYP ACT IONS AND DECISIONS THEY SHOULD AVOID IN ORDER TO ESTABLISH THE NECESSARY LEVEL OF TRUST AND, SECONDLY, WHAT TYPE OF ACTIONS THEY COULD ENVISAGE IN ORDER TO ESTABLISH PATTERN OF COOPERATION. WITHOUT SUCH A STUDY, IT HOULD BE EFFORTS TO SETTLE CONFLICTS IN DIFFERENT AREAS OF THE WORLD.

05411 KREMP, H.

AFTER POLAND'S ELECTION, A MATTER OF HHERE THE POHER LIES GERMAN TRIBUNE, (1492) (NOV 91), 2

AFTER THE ELECTORAL VICTORY OF THE OPPONENTS OF REFORM IN POLAND AND THE TOTAL FRAGMENTATION OF THE POLISH PARLIAMENT, IT IS HARDLY SURPRISING THAT PRESIDENT WALESA HAS LAID CLAIM TO THE POST OF PRIME MINISTER TOO. HE IS NO FRIEND OF PARLIAMENTARY DEMOCRACY IN HIS COUNTRY, HAVING CALLED SINCE THE SUMMER OF 1991 FOR A CONSTITUTIONAL CHANGE TO A PRESIDENTIAL SYSTEM AND FOR SPECIAL, EMERGENCY POWERS. HOWEVER, THE RECENT ELECTION, POLAND'S FIRST FREE ELECTION IN 60 YEARS, INDICATES THAT SUPPORT FOR WALESA, AS WELL AS FOR MORE RADICAL REFORM FACTIONS, IS DECLINING. IN ADDITION, THE ELECTION RESULTS HAVE SHOWN THAT CONSENSUS BETWEEN THE ELECTION RESULTS HAVE SHOWN THAT CONSENSUS BETWEEN
SOLIDARITY AND THE CATHOLIC CHURCH NO LONGER EXISTS. THESE SOLIDARITY AND THE CATHOLIC CHURCH NO LONGER EXISTS. THES
TRENDS AUGUR ILL FOR DEVELOPMENTS THROUGHOUT EASTERN AND CENTRAL EUROPE.

05412 KREMP, $H$.

ALGERIA AND THE CRESCENT OF ISLAM

GERMAN TRIBUNE, 1500 (JAN 92 ), 3.

THE STRUGGLE FOR POWER IN ALGERIA IS A REMINDER TO EUROPEANS THAT THEY ARE SURROUNDED BY THE ISLAMIC CRESCENT A CRESENT MOON OF LAND THAT EXTENDS FROM THE FORMER OTTOMAN EMPIRE, FROM THE MAGHREB IN THE WEST TO PAKISTAN, INDONESIA AND THE PHILIPPINES IN THE EAST AND DOWN SOUTH INTO THE HEART OF AFRICA. THE VITALITY OF ISLAM FAR DUTWEIGHS, IN THEORY AND IN PRACTICE. THE HISTORIC EXPERIMENT OF LEMINISH AND SOCIALISM IN THE THIRD WORLD. THIS ARTICLE OUTLINES THE EVENTS IN ALGERIA BY DISCUSSING THE EFFECTS OF ISLAM AND GEOGRAPHY ON THE COUNTRY. HALF THE WORKING POPULATION ARE UNEMPLOYED. MOST OF THESE PEOPLE HAVE NEITHER HOPE NOR A MEANINGFUL SENSE OF IDENTITY. THEY FEEL ENCIRCLED BY POLITICAL CORRUPTION, ISLAM AND THE MEDIA AND HAVE RESORTED TO OUTBREAKS OF VIOLENCE SINCE 1986.

05413 KREMP, $H$.

ALGERIA AND THE CRESENT OF ISLAM

GERMAN TRIBUNE, 1500 (JAN 92 ), 3.

THE STRUGGLE FOR POWER IN ALGERIA IS A REMINDER TO EUROPEANS THAT THEY ARE SURROUNDED BY THE ISLAMIC CRESENT, A CRESCENT MOON THAT EXTENDS FROM THE FORMER OTTOMAN EMPIRE' AND THE FORMER SOVIET UNION, FROM THE MAGHREB IN THE WEST TO PAKISTAN, INDONESIA AND THE PHILIPPINES IN THE EAST AND DOWN SOUTH INTO THE HEART OF AFRICA. THIS ARTICLE STATES THAT THE VITALITY OF ISLAM FAR OUTHEIGHTS, IN THEORY AND IN PRACTICE, THE HISTORIC EXPERIMENT OF LENINISM AND SOCIALISM IN THE THIRD HORLD. THE ARTICLE DISCUSSES THE EVENTS IN ALGERIA, THE ECONOMIC MODELS IT PRODUCED, THE PLURALISTIC 1989 CONSTITUTION AND THE LIBERALIZATION OF THE ECONOMY A YEAR
LATER PROVED UNSUITABLE FOR SOLVING THE COUNTRY'S PROBLEMS.

05414 KREMP, H.

CRISES OF SELF-UNDERSTANDNG ON BOTH SIDES OF THE ATLANTIC GERMAN TRIBUNE, (1523) (JUL 92), 5

THE END OF THE COLD WAR AND THE RESULTING TRANSFORMATION OF EUROPE HAS SPARKED INCREASINGLY HEATED DEBATE ABOUT THE CONTINUED ROLE OF THE UNITED STATES IN WESTERN EUROPE. AS THE RAISON D'ETRE OF THE NORTH ATLANTIC TRATY ORGANIZATION (NATO)--THE SOVIET THREAT--HAS DISAPPEARED, MANY ARE CALLING FOR A MORE "EUROPEAN" AND LESS "ATLANTIC" EURDPE. HOWEVER, SOME STATES IN NEWLY-LIBERATED EAST EUROPE WANT NOTHING MOR THAN FOR THE UNITED STATES TO MAINTAIN ITS TIES HITH EUROPE. AMERICANS ARE DIVIDED OVER THE ISSUE AS WELL. THE BUSH ADMINISTRATION IS INCREASINGLY ISOLATED IN ITS CALLS FOR CONTINUED INYOL VEMENT IN EUROPE. THESE CHANGES PORTEND FURTHER UNCERTAINTY IN THE FUTURE.

05415 KREMP, H.

NATO DELEGATES WARN OF NEW, VAGUER THREATS TO PEACE GERMAN TRIBUNE, (1503) (FEB 92), 1,5

U.S. VICE-PRESIDENT DAN QUAYLE USED A DEFENSE CONFERENCE IN MUNICH TO INCREASE HIS PERSONAL PRESTIGE AND TO BOOST IN MUNICH TO INCREASE HIS PERSONAL PRESTIGE AND TO BOOST PUBLIC CONFIDENCE IN THE UNITED STATES. HE SPOKE OF THE CRITICAL CHARACTER OF THE GATT TALKS FOR BOTH EUROPE AND THE
UNITED STATES: HE ALSO REITERATED AMERICA'S COMMITMENT TO UNITED STATES; HE ALSO REITERATED AMERICA'S COMMITMENT TO NATO AND ASKED FOR THE EUROPEAN SUPPORT NEEDED TO JUSTIFY TO AMERICAN VOTERS THE U.S. COMMITMENT IN EUROPE. MANY AT THE COFNERENCE AGREED THAT SINCE THE END OF THE COLD WAR AND THE DISSOLUTION OF THE SOVIET UNION, SECURITY HAS COMPRISED A COMBINATION OF MILITARY, POLITICAL, ECONOMIC, SOCIAL AND LARGELY UNKNOWN. THERE IS NO CLEAR PICTURE OF A THREAT TO PEACE, BUT AS MANY SPEAKERS NOTED IN CONNECTION WITH THE PROLIFERATION OF WEAPONS OF MASS DESTRUCTION AND THE 
UNCERTAIN OUTLOOK FOR THE COMMONWEALTH OF INDEPENDENT STATES, A NEH, MORE VAGUE PROSPECT OF THREAT HAS ARISEN.

05416 KREMP, $H$.

THE EURO FORCE DEBATE CONTINUES

GERMAN TRIBUNE, (1518) (JUN 92), 1.

PROPONENTS OF THE PROPOSED FRANCO-GERMAN "EURO-CORPS" ARGUE THAT IT WILL STRENGTHEN THE NATO ALLIANCE. HOHEVER, THERE IS SIGNIFICANT EVIDENCE THAT THE CORPS--ORIGINALLY' THE PROPOSAL OF FRENCH PRESIDENT MITTERAND--IS INTENDED TO REDUCE THE U.S. MILITARY PRESENCE IN EUROPE AND TO DIMINISH NATO'S RELEVANCE AND INFLUENCE. FRANCE IS OPPOSED TO ANY STREMGTHENING OF NATO'S POLITICAL ROLE, DISAPPROVES OF THE NORTH ATLANTIC COOPERATION COUNCIL AS A FORUM FOR DEBATE WITH THE FORMER SOVIET BLOC REJECTS INSTITUTIONAL TIES BETWEEN NATO AND THE CSCE, AND IS STALLING ON A MATO RAPID RESPONSE FORCE UNDER BRITISH COMMAND. IT IS, THEREFORE, RESPONSE FORCE UNDER BRITISH COMMAND. IT IS, THEREFORE, QUITE INCREDIBLE THAT THE CORPS WAS CREATEE
INTENTION OF STRENGTHENING THE ALLIANCE.

05417 KREMP, $H$. WESTERN EUROPE MUST GET BOTH FEET FIRMLY BACK ON ATLANTIC GROUND

GERMAN TRIBUNE, (1515) (MAY 92), 2

THERE IS NO MISTAKING THE SIGNS OF CONTINENTAL DRIFT IN ATLANTIC ALLIANCE AND EUROPEAN COMMUNITY INSTITUTIONS. THE UNITED STATES, SUBJECT TO INCREASINGLY PRESSING BUDGET CONSTRAINTS, IS MAKING MOVES TO DISENGAGE FROM EUROPE. MANY PREDICT THAT NATO WILL LAST ONLY A FEW MORE YEARS. OTHER EUROPEAN INSTITUTIONS SUCH AS THE EC AND THE CSCE ARE SEEKING TO FILL THE GAP, BUT THEIR INABILITY TO DO SO IS DEEKING TO FILL THE GAP, BUT THEIR INABILITY TO DO SO IS ELSEWHERE. IF WESTERN EUROPE IS TO GAIN A FIRM FOOTING ONCE MORE AMID THE DISORDER IN EUROPE, IT MUST REEMPHASIZE THE ATLANTIC ALLIANCE. IT MUST CONVINCE THE UNITED STATES OF THE NECESSITY OF REMAINING ENGAGED IN EUROPE. IN ADDITION, THE EUROPEAN COMMUNITY MUST LEND EASTERN CENTRAL EUROPE ECONOMIC ASSISTANCE TO SECURE STABILITY AND GRONTH.

05418 KRENZLER, H.; KAISER, $W$.

THE TRANSATLANTIC DECLARATION: A NEW BASIS FOR RELATIONS BETWEEN THE EC AMD THE USA

AUSSEN POLITIK, 42(4) (1991), 363-372.

THE AMERICAN PRESIDENT GEORGE BUSH EXPECTS THE EUROPEAN COMMUNITY (EC) AND ITS MEMBER STATES TO BECOME "PARTMERS IN COMMUNITY (EC) AND ITS MEMBER STATES TO BECOME "PARTT
WORLD LEADERSHIP." THE EC FOR ITS PART IS WILLING TO WORLD LEADERSHIP. " THE EC FOR ITS PART IS WILLING TO
SHOULDER GREATER INTERNATIONAL RESPONSIBILITY. THROUGH THE SHOULDER GREATER INTERNATIONAL RESPONSIBILITY. THROUGH THE
TRANSATLANTIC DELCARATION OF 23 NOVEMBER 1990 BOTH SIDES TRANSATLANTIC DELCARATION OF 23 NOVEMBER 1990 BOTH SIDES
HAVE CREATED A NEW BASIS FOR THEIR RELATIONS. THIS ARTICLE HAVE CREATED A NEW BASIS FOR THEIR RELATIONS. THIS ARTICLE EXAMINES THIS CHANGING TRANSATLANTIC RELATIONSHIP WITH EMPHASIS ON THE IMPLICATIOMS
TRANSATLANTIC DECLARATION.

05419 KREUTZ, A.

THE RISE AND FALL OF SOVIET AND EASTERN EUROPEAN COMMUNISM: AN HISTORICAL PERSPECTIVE

STUDIES IN POLITICAL ECONOMY: A SOCIALIST REVIEW, 38

(SUM 92), 109-138.

THIS ARTICLE OFFERS A RETROSPECTIVE ANALYSIS OF THE EVENTS WHICH LED TO THE FALL OF THE COMMUNIST REGIMES IN THE SOVIET UNION AND EASTERN EUROPE. THE AUTHOR RECALLS HOW IN 1917 MOST OF EASTERN EUROPE AND THE CZARIST EMPIRE HAD NOT ONLY BEEN BARELY TOUCHED BY CAPITALISM, BUT HAD ALSO BEEN LARGELY UNTOUCHED BY MANY EARLIER CURRENTS OF WEST EUROPEAN HISTORY, SUCH AS URBAN-BASED SYSTEMS OF PROPERTY AND LAW, OR FORMS OF CHRISTIANTIY OPEN TO SCIENTIFIC ADVANCE AND SOCIAL CHANGE, ALL OF WHICH HAD BEEN CRUCIAL IN FOSTERING WEST EUROPEAN CAPITALIST DEVELOPMENT. THE EAST'S HANDICAPS WERE WELL UNDERSTOOD BY THE RUSSIAN MARXISTS BUT THEY STAKED THEIR FUTURE ON THE BEL IEF THAT CAPITALISM WAS NEARING ITS DEMISE; AND ON THE SHEER HISTORICAL WILL AND ORGANIZATIONAL FORCE EMBODIED IN THE YANGUARD PARTY. THE ANALYSIS FOLLOWS THE FATE OF THIS EXPERIMENT TO ITS ENCOUNTER WITH ITS FINAL CONTRADICTIONS IN THE LATE 1980S. IT SEEKS TO SET THE SYSTEM'S REAL ACHIEVEMENTS AMD LETHAL HEAKNESSES IN THEIR ESSENTIAL HISTORICAL CONTEXT.

05420 KREYENBUHL, T.

THE MAFIA AND ITALIAN POLITICS

SWISS REVIEW OF WORLD AFFAIRS, 42(5) (AUG 92), 26-27. WHILE THE MAFIA ORGANIZATIONS ARE NOT IN THEMSELYES POLITICAL GROUPS. THERE ARE MAFIA SYMPATHIZERS IN ITALY'S LEGISLATURES, REGIONAL GOVERMMENTS, AND COURTS. THE RECENT ASSASSINATIONS OF TWO MAGISTRATES HAVE FOCUSED PUBLIC ASSASSINATIONS OF TWO MAGISTRATES HAVE FOCUSED PUBLIC MAFIA AND THE POLITICAL SPHERE IN ITALY. SUSPICIONS ARE RIFE MAFIA AND THE POLITICAL SPHERE IN ITALY. SUSPICIONS ARE RIFE THAT THE RESPONSIBLE PARTIES
BUT IN THE PALAZZI OF ROME.

05421 KRIESBERG, L.

INTERNATIONAL CONFLICT RESOLUTIOM

YALE UNIVERSITY PRESS, 1992, 288

THE ENDING OF THE COLD WAR IN MANY WAYS IS THE

CULMINATION OF DECADES OF PEACEMAKING EFFORTS. THIS BOOK
EXAMINES THE MANY STEPS CONSTITUTING THE DE-ESCALATION OF INTERNATIONAL CONFLICTS, FOCUSING ON AMERICAN-SOVIET AND ARAB-ISRAELI STRUGGLES SINCE 1948. THE AUTHOR ANALYZES THE CONDITIONS THAT LEAD TO DE-ESCALATION INITIATIVES, THE STRATEGIES OF INITIATIVE-TAKING THAT LEAD TO NEGOTIATIONS, THE PROCESSES OF NEGOTIATION THAT RESULT IN DE-ESCALATION AGREEMENTS, AND THE KINDS OF AGREEMENTS THAT ENDURE AND FOSTER ADDITIONAL MOVEMENT TOWARD PEACE.

05422 KRIESI, H.; DUYVENDAK, J.W.; GIUGNI, M.G.; KOOPMANS, R. NEW SOCIAL MOVEMENTS AND POLITICAL OPPORTUNITIES IN WESTERN EUROPE

EUROPEAN JOURMAL OF POLITICAL RESEARCH, 22(2) (AUG 92), 219-244.

THE AUTHORS PRESENT A NUMBER OF CONCEPTS AND HYPOTHESES CONCERNING THE IMPACT OF THE POLITICAL OPPORTUNITY STRUCTURE ON THE MOBILIZATION PATTERN OF NEN SOCIAL MOVEMENTS IN WESTERN EUROPE. THE HYPOTHESES REFER TO THE GENERAL LEVEL OF MOBILIZATION IN A GIVEN COUNTRY, THE GENERAL FORMS AND STRATEGIES OF ACTION EMPLOYED, THE SYSTEM LEVEL AT WHICH MOBILIZATION IS TYPICALLY ORIENTED, AND THE DEVELOPMENT OF MOBILIZATION IS TYPICALLY ORIENTED, AND THE DEVELOPMENT OF TESTED IN A COMPARATIVE ANALYSIS OF FRANCE, GERMANY, TESTED IN A COMPARATIVE ANALYSIS OF FRANCE, GERMANY, SWITZERLAND, AND THE NETHERLANDS. THE ANALYSIS REVEALS
COUNTRY-SPECIFIC VARIATIONS IN THE MOBILIZATION PATTERNS OF NEW SOCIAL MOVEMENTS, WHICH ARE LARGELY IN LINE WITH THE THEORETICAL EXPECTATIONS AND SERVE TO CONFIRM THE RELEVANCE OF THE POLITICAL PROCESS APPROACH FOR THE STUDY OF SOCIAL MOVEMENTS.

05423 KRISHNA, S

INDIA AND SRI LANKA: A FATAL CONVERGENCE

STUDIES IN CDNFLICT AND TERRORISM, 15(4) (1992), 267-282.

INDIA'S DECISIDN TO INTERVENE MILITARILY IN THE SRI

LANKAN CIVIL WAR WAS PRECEDED BY THO SIGNIFICANT HISTORICAL DEYELOPMENTS: (1) THE EMERGENCE OF A STRONG SINHALA ETHNIC INDENTITY IN SRI LANKA; AND (2) AN EMERGING FOREIGN POLICY OF REGIONAL HEGEMONEY IN NEH DELHI. TOGETHER, THESE TWO DEVELOPMENTS HAVE MOVED INEXORABLY TOWARDS A FATAL CONVERGENCE ACROSS THE PALK STRAITS. TRAGICALLY, THERE APPEARS TO BE NO EASY SOLUTIONS TO SUCH CONFLICT IN THE INDIAN SUBCONTINENT.

05424 KRISHNA, S.

NATIONAL INSECURITY AND FOREIGN POLICY: INDIA IN THE SUBCONTINENT; ASSOCIATION FOR ASIAN STUDIES 1992 ANHUAL SUBCONTI

ASSOCIATION FOR ASIAN STUDIES, 1992, 136.

WHILE NO ONE CAN DENY THE HISTORICAL PROGRESSIVENESS OF NATIONALISM (ESPECIALLY IN THE ANTI-COLONIAL STRUGGLES), IT IS INCREASINGLY OBVIOUS THAT ATTEMPTS TO FIXATE NATIONAL IDENITY MEET WITH ALL KINDS OF RESISTANCE FROM VARIOUS GROUPS IN DONESTIC SOCIETY. THIS PRODUCES A HIGHLY INSECURE ENVIRONMENT FROM THE PERSPECTIVE OF STATE ELITES BENT ON REMAKING THEIR SOCIETIES INTO MODERN, UNIFIED
ONE PROMINENT ASPECT OF THIS INSECURITY IS AN

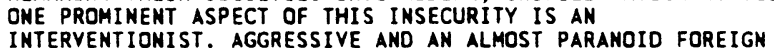
POLICY POSTURE. THIS PAPER EXAMINES THE HISTORICAL ROOTS OF INDIA'S FOREIGN POLICY-MAKING FROM SUCH A PERSPECTIVE. IT SUGGESTS THAT INDIAN POSTURES WITHIN THE REGION ARE BETTER CONCEPTUALIZED IN TERMS OF THE INSECURITY OF A STATE WHEREIN MODERN NATIONALISM IS ONLY ONE OF MANY COMPETING FORMS OF SELF-IDENTITY. THE PAPER ALSO ARGUES THAT CONYENTIONAL APPROACHES TO THE STUDY OF FOREIGN POLICY, THOSE THAT TAKE THE BASIC UNITS OF aNALYSIS AS "GIVENS" and NOT AS SOCIALLY CONSTRUCTED AND HISTORICALLY REPRODUCED CATEGORIES, FAIL TO SEE THE INTIMATE CONNECTIONS BETHEEN NATIONAL INSECURITY AND AGGRESSIVE FOREIGN POLICY. THE THEORETICAL ARGUMENTS OF THE PAPER ARE SUPPORTED BY HISTORICAL EXAMPLES OF INDIAN FOREIGN POLICY-MAKING IN RECENT DECADES.

05425 KRISHNA, S.

STRATEGIES OF CO-OPTION, HEGEMONY AND RESISTANCE; ASSOCIATION FOR ASIAN STUDIES 1992 ANMUAL MEETIMG ASSOCIATION FOR ASIAN STUDIES, 1992, 129-130.

THIS ARTICLE ARGUES THAT THERE IS A SENSE IN WHICH INDIA'S HISTORY SIMCE INDEPENDENCE CONSISTS ESSENTIALLY OF A
DYNAMIC OF ACTION AND REACTION BETHEEN, ON THE ONE HAND, A STATE THAT HAS SYSTEMATICALLY AUGMENTED AND ELABORATED STATE THAT HAS SYSTEMATICALLY AUGMENTED AMD ELABORATED
INSTRUMENTS OF COERCIVE POWER AND, ON THE OTHER, POPULAR MOVEMENTS RESISTING THE ENCROACHMENTS OF THESE INSTITUTIONS MOVEMENTS RESISTING THE ENCROACHMENTS OF THESE INSTITUT
ON THE CIVIL DEMOCRATIC RIGHTS AND LIVELIHOOD OF LARGE ON THE CIVIL DEMOCRATIC RIGHTS AND LIVELIHOOD OF LARGE
SEGMENTS OF THE POPULATION. THE LATTER HAVE FOUND VARIOUS SEGMENTS OF THE POPULATION. THE LATTER HAVE FOUND VARIOUS
FORMS OF EXPRESSION. THEY RANGE, FOR EXAMPLE, FROM REGIONAL
POLITICAL MOVEMENTS CHALLENGING THE PARTY IN POWER AT THE POL ITICAL MOVEMENTS CHALLENGING THE PARTY IN POHER AT THE CENTER TO REVOLUTIONARY MOVEMENTS ENGAGED IN POLITICAL ACTIVISM OUTSIDE THE PARLIAMENTARY FRAMEHORK; ANO FROM
MOVEMENTS OSTENSIBLY AIMED AT SAFEGUARDING THE ENVIRONMENT MOVEMENTS OSTENSIBLY AIMED AT SAFEGUARDING THE ENVIRONMEN FROM THE DEPREDATIONS OF THE DOMINANT CLASSES TO LABOR
STRUGGLES IN VARIOUS FORMS IN ORDER TO COPE WITH THE WAYS IN WHICH INDUSTRY SEEKS TO LIMIT THE EFFECTIVENESS OF ORGANIZED TRADE UNIONS. THE RESPONSE OF THE STATE TO THESE PRESSURES HAS BEEN TO WAVER BETWEEN EXERCISING HEGEMONY AND OFFERING LIMITED CO-OPTION TO SOME OF THE FORCES OF OISSENT. 
05426 KRISLOV, S.

PROPERTY AS A CONSTITUTIONAL RIGHT IN THE NINETEENTH CENTURY: OR WHAT HAVE WE LEARNED SINCE CORWIN?

PUBLIUS: THE JOURNAL OF FEDERALISM, 22(2) (SPR 92), 47-68. THE EVOLUTION OF DUE PROCESS FROM AN INMOCUOUS PARAPHRASE OF THE OLD ENGLISH CONCEPT "THE LAN OF THE LAND" INTO A STRONG BASTION OF PROPERTY RIGHTS UNTIL ITS CURTAILMENT IN CONSTITUTIONAL DECISIONS IN 1937 HAS BEEN BEAUTIFULLY DELINEATED IN THE WRITINGS OF EDWARD CORHIN. LATER HRITERS HAVE CONCENTRATED LARGELY ON EXTRAPOLATING THAT HISTORY TO COVER THE METAMORPHOSIS OF PROTECTED LIBERTY INTO PERSONAL RIGHTS, WHICH HAS EVEN REQUIRED A MODEST REVIVAL OF PROPERTY PROTECTION. STILL, CORWIN HAS BEEN AMENDED ON SEVERAL KEY POINTS. (1) WE NOW UNDERSTAND THAT THE NINETEENTH-CENTURY BATTLE OVER PROPERTY WAS NOT BETWEEN PROPERTY AND PERSONS, BUT BETHEEN THE OLDER CONCEPT OF "PROPERTY AS POSSESSION" AND A DYNAMIC CAPITALIST VIEW OF "PROPERTY AS CREATION OF SOCIAL VALUE." (2) THE TRANSFORMATION OF "DUE PROCESS" IN POPULAR CONTROVERSY, WHICH CORHIN WAS ACUTE ENOUGH TO ADVANCE AS A FACTOR, SEEMS TO HAVE BEEN THE MOST DECISIVE FACTOR, PARTICULARLY ALTERING THE DEBATE ON THE FOURTEENTH AMENDMENT. (3) CORWIN'S SEARCH THE DEBATE ON THE FOURTEENTH AMENDMENT. (3) CORWIN'S SEARCH
FOR A TRANSFORMING CASE REPRESENTING A DECISIVE CONCEPTUAL CHANGE SEEMS MISPLACED. THE COMPLEX ECONOMIC-REGULATION DUECHANGE SEEMS MISPLACED. THE COMPLEX ECONOMIC-REGULATION DUE-
PROCESS CASES ALLOWED A MOVE FROM "PROCEDURE TO SUBSTANCE" WITHOUT ANY VISIBLE TRANSFORMATION OF LEGAL RULES.

$05427 \mathrm{KROH}, \mathrm{F}$.

"CLIQUES AND OLD BOY NETWORKS": POWER RETENTION STRATEGIES OF THE FORMER EAST GERMAN POWER ELITE AUSSEN POL ITIK, 43(2) (1992), 144-152.

THE RECONSTRUCTION OF EASTERN GERMANY IS A DIFFICULT TASK FOR THE FEDERAL REPUBLIC OF GERMANY. THE OBJECTIVE PROBLEMS ARE COMPOUNDED BY THE OBSTACLES RESULTING FROM THE BEHAVIOR OF THE POLITICAL CLASS IN THE FORMER COMMUNIST STATES. THIS ARTICLE EXAMINES THE EFFORTS BY FORMER ELITES TO SAFEGUARD THEIR INFLUENCE AND FORMER PRIVILEGES IN INDUSTRY AND IN THE MEDIA. OTHER FIELDS ARE TAKEN INTO ACCOUNT. THE AUTHOR HAS BASED HIS ANALYSIS ON EXTENSIVE INVESTIGATIONS, WHICH INCLUDE NUMEROUS DETAILED INTERVIENS WITH THE PERSONS CONCERNED.

05428 KROMBACH, H.

INTERNATIONAL RELATIONS AS AN ACADEMIC DISCIPLINE MILLENNIUH, 21(2) (SUM 92), 243-262.

MUCH CURRENT RESEARCH AND TEACHING IN INTERNATIONAL RELATIONS IS RESTRICTED TO NARROW THEORETICAL AND EMPIRICAL AREAS. IN ORDER TO UNDERSTAND THE GLOBAL DIMENSIONS OF AREAS. IN ORDER TO UNDERSTAND THE GLOBAL DIMENSIONS OF
POLITICAL LIFE, SCHOLARS MUST REPLACE THEIR CURRENT POLITICAL LIFE, SCHOLARS MUST REPLACE THEIR CURRENT
PARTICULARIST INOUIRIES WITH A HOLISTIC APPROACH TO THE PARTICULARIST INQUIRIES WITH A HOLISTIC APPROACH TO THE
DISCIPLINE, FOUNDED ON A DIALECTICAL EPISTEMOLOGY AND DISCIPLINE, FOUNDED ON A DIALECTICAL EPISTEMOLOGY AND POLITICAL PHILOSOPHY. THE GLOBAL ECOLOGICAL CRISIS, WHICH HIGHLIGHTS THE FUNDAMENTAL RELAT IONSHIP BETHEEN HUMAN
HISTORY AND NATURE, CAN ONLY BE UNDERSTOOD THROUGH PHILOSOPHICAL REFLECTION.

05429 KROSNICK, J

THE STABILITY OF POLITICAL PREFERENCES: COMPARISONS OF SYMBOLIC AND NONSYMBOL IC ATTITUDES

AMERICAN JOURNAL OF POLITICAL SCIENCE, 35(3) (AUG 91), 547-576.

IT HAS OFTEN BEEN ARGUED THAT POLITICAL ATTITUDES YARY ALONG A CONTINUUM FROM HIGHLY SYMBOL IC TO NONSYMBOLIC AND THAT SYMBOL IC POLITICAL ATTITUDES ARE MORE STABLE ACROSS THE LIFE CYCLE THAN ARE NONSYMBOLIC POLITICAL ATTITUDES. THE EVIDENCE USED TO SUPPORT THIS CONTENTION SHOWS THAT THE OVERTIME CONSISTENCY OF ATTITUDE REPORTS IS HIGH FOR SYMBOLIC ATTITUDES, SUCH AS POLITICAL PARTY AFFILIATION, AND LOH FOR NONSYMBOL IC ATTITUDES, SUCH AS ATTITUDES TOWARD
SPECIFIC GOVERMMENT POLICIES. THIS PAPER REPORTS THREE INVESTIGATIONS THAT DECOMPOSED TEST-RETEST CORRELATIONS BETWEEN ATTITUDE REPORTS INTO COMPONENTS DUE TO ATTITUDE CHANGE AND ATTITUDE MEASUREMENT UNRELIABILITY. DATA FROM 1956-60, 1972-76, AND 1980 NATIONAL ELECTION PANEL STUDIES (NES) REVEALED THAT REPORTS OF SYMBOL IC ATTITUDES WERE MORE CONSISTENT OVER TIME BECAUSE THEY CONTAINED LESS RANDOM MEASUREMENT ERROR, NOT BECAUSE THESE ATTITUDES WERE MORE PERSISTENT OVER TIME. THE DIFFERENCES IN MEASUREMENT PRECISION ACROSS ATTITUDE OBJECT CATEGORIES APPEAR TO BE DUE TO DIFFERENCES IN THE FORMAT OF THE SURVEY QUESTIONS USED TO MEASURE THEM. IT THEREFORE SEEMS THAT THE PERSISTENCE AND MEASURE THEM. IT THEREFORE SEEMS THAT THE PERSISTENCE AND
POTENCY OF POL ITICAL ATTITUDES YARY MORE ACROSS CITIZENS POTENCY OF POL ITICAL ATTITUDES VARY MORE ACROSS CITIZENS
THAN THEY DO ACROSS ATTITUDE OBJECT CATEGORIES. ALL OF THESE THAN THEY DO ACROSS ATTITUDE OB JECT CATEGORIES. ALL OF THES FINDINGS SUGGEST THE NEED FOR REVISION OF CONVENTIONAL
WISDOM ABOUT THE VIABILITY OF SOME CENTRAL ASSERTIONS OF WISDOM ABOUT THE VIA

05430 KRUEGER, R.D.

THE ECONOMICS OF ARMS TRANSFERS: THE SAUDI AWACS SALE AND THE ISRAELI LAVI FIGHTER

COMPARATIVE STRATEGY, 11(3) (JUL 92), 331-342.

IN 1981 THE REAGAN ADMINISTRATION MADE A DRAMATIC CHANGE IN U.S. ARMS TRANSFER POLICY, WHICH MADE CONVENTIONAL ARMS
TRANSFERS AN ESSENTIAL ELEMENT OF THE U.S. GLOBAL DEFENSE POSTURE AND A KEY ELEMENT OF U.S. FOREIGN POLICY. THE SAUDI POSTURE AND A KEY ELEMENT OF U.S. FOREIGN POL ICY. THE SAUDI
AHACS SALE IN 1981 AND THE FORMAL GO-AHEAD FOR THE ISRAELI AHACS SALE IN 1981 AND THE FORMAL GO-AHEAD FOR THE ISRAELI
LAVI FIGHTER IN 1982 WERE THE IMMEDIATE EFFECTS OF THIS ARMS LAVI FIGHTER IN 1982 WERE THE IMMEDIATE EFFECTS OF THIS
TRANSFER POLICY CHANGE. BOTH OF THESE MIDDLE EAST ARMS TRANSFER POLICY CHANGE. BOTH OF THESE MIDDLE EAST ARMS
IRANSFER ISSUES HAD MAJOR ECONOMIC IMPLICATIONS FOR THE U.S. TRANSFER ISSUES HAD MAJOR ECONOMIC IMPLICATIONS FOR THE U.
ECONOMY, INCLUDING THE MAINTENANCE OF THE U.S. DEFENSEECONOMY, INCLUDING THE MAINTENANCE OF THE U.S. DEFENSE-
INDUSTRIAL BASE, INTERNATIONAL TRADE BALANCE ISSUES, AND TECHNOLOGY TRANSFER.

05431 KRUGLANSKI, A.

ON METHODS OF GOOD JUDGMENT AND GOOD METHOOS OF JUDGMENT:

POLITICAL DECISIONS AND THE ART OF THE POSSIBLE

POLITICAL PSYCHOLOGY, 13(3) (SEP 92), 455-476.

GOOO POLITICAL JUDGMENT IS DISCUSSED IN LIGHT OF RELEVANT PSYCHOLOGICAL CONSIDERATIONS. THE DUALISM BETWEEN RATIONAL/NORMATIVE AND SUBRATIONAL/HEURISTIC MODES OF JUDGMENT IS REEXAMINED. IT IS CONCLUDED THAT BOTH REPRESENT DIFFERENT ASPECTS OF THE SAME PROCESS WHEREBY ALL JUDGMENTS ARE PENDERED. THE ARTICLE ALSO COMCLUDES THAT AL GODO METHOD ARE RENOERED. THE ARTICLE ALSO CONCLUDES THAT A GODD METHOD OF JUDGMENT REPRESENTS AT BEST A NECESSARY, NOT A SUFFICIENT CONDITION FOR JUDGMENTAL ACCURACY. THE IMPLICATIONS OF THIS
ANALYSIS FOR POLITICAL JUDGMENT AND DECISION-MAKING ARE ANALYSIS FOR
CONSIDERED.

05432 KRUGMAN, $P$.

INCREASING RETURNS AND ECONOMIC GEOGRAPHY

JOURMAL OF POL ITICAL ECDNOMY 99(3) (JUN 91), 483-499.

THIS PAPER DEVELOPS A SIMPLE MODEL THAT SHOWS HOW A COUNTRY CAN ENDOGENOUSLY BECOME DIFFERENTIATED INTO AN INDUSTRIALIZED "CORE" AND AN AGRICULTURAL "PERIPHERY." IN ORDER TO REALIZE SCALE ECONOMIES WHILE MINIMIZING TRANSPORT COSTS, MANUFACTURING FIRMS TEND TO LOCATE IN THE REGION WITH LARGER DEMAND, BUT THE LOCATION OF DEMAND ITSELF DEPENDS ON THE DISTRIBUTION OF MANUFACTURING. EMERGENCE OF A COREPERIPHERY PATTERN DEPENDS ON TRANSPORTATION COSTS, ECONOMIES OF SCALE, AND THE SHARE OF MANUFACTURING IN NATIONAL INCOME.

05433 KRZYK, B.

THE MYSTERIOUS HEIR IN THE NORTH

WORLD PRESS REVIEW, 39 (7) (JUL 92), 19-20.

THE AUTHOR SUMMARIZES WHAT IS KNOWN ABOUT KIM JONG IL, HEIR APPARENT TO KIM IL SUNG AS LEADER OF NORTH KOREA, POINTING OUT DISCREPAK

05434 KUBALKOVA, $V$.

THE POST-COLD WAR GEOPOLITICS OF KNOWLEDGE: INTERNATIONAL THE POST-CDLD WAR GEOPOL ITICS OF KNO

STUDIES IN THE FORMER SOVIET BLOC
STUDIES IN COMPARATIVE COMMUNISM, 25(4) (DEC 92), 405-418.

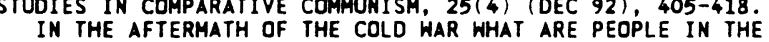
FORMER SOVIET BLOC THINKING, AND WHAT WILL THEY BE THINKING ABOUT INTERMATIONAL RELATIONS? THIS PAPER SUBSCRIBES TO THE VIEW THAT WITH THE END OF THE EAST/WEST IDEOLOGICAL DIVIDE, INTERNATIONAL STUDIES CAN FINALLY BECOME GLOBAL AND
THAT QUESTION. THREE ISSUES ARE DISCUSSED: (1) ARE THAT QUESTION. THREE ISSUES ARE DISCUSSED: (1) ARE INTERNATIONAL STUDIES NATIONAL OR INTERNATIONAL? (2) WHAT
ARE THE EMERGING POST-COMMUNIST THEORIES OF INTERNATIONAL RELATIONS? (3) WHAT APPROACHES TO INTERNATIONAL RELATIONS STUDIES HILL BE PARTICULARLY RELEVANT TO THE SCHOLARLY COMWUNITY IN THE FORMER SOVIET BLOC?

05435 KUCHE, L.

FREE, INDEPENDENT, PLURALISTIC BUT NOT YET GIRDED BY TENDENZSCHUTZ

GERMAN TRIBUNE, (1475) (JUL 91), 13.

THE EUROPEAN COMMUNITY OFFICIALS IS NO RESPECTER OF SECTORS WHEN IT COMES TO HARMONIZING LEGISLATION IN PREPARATION FOR THE SINGLE EUROPEAN MARKET. EC OFFICIALS ARE NOW PROBING THE POSSIBILITY OF STAMDARDIZING FRAMEWORK CONDITIONS FOR THE NEHSPAPER AND MAGAZINE INDUSTRY IN THE COMMUNITY. THEIR INITIAL PROPOSALS WERE MET BY CONSIDERABLE CRITICISM FROM THE PRESS. JOURNALISTS WERE OUICK TO POINT OUT THAT THE PRESS IS NOT JUST ANOTHER IMDUSTRY OR MANUFACTURER OF A PRODUCT TRADED LIKE ANY OTHER. THEY CALLED FOR PROVISIONS WHICH RECOGNIZE AND PROTECT THE SPECIAL POLITICAL AND CULTURAL ROLE THE PRESS PLAYS IN A DEMOCRATIC SOCIETY.

05436 KUECHLER, M.

THE RDAD TO GERMAN UNITY: MASS SENTIMENT IN EAST AND WEST GERMANY

PUBLIC OPINION QUARTERLY (CHICAGO), 56(1) (SPR 92), 53-76.

THIS PAPER EXPLORES PUBLIC SENTIMENT REGAROING THE PURSUIT OF UMIFICATION IN BOTH EAST AND WEST GERMANY FROM EARLY 1989 TO SPRING 1991, WHEN FORMAL UNIFICATION WAS ACHIEVED. PUBLIC OPINION DATA FROM VARIOUS SOURCES SHOW THAT THE GERMAN MASSES HERE SUPPORTIVE BUT ALSO SOMEWHAT

RELUCTANT WITH REGARD TO OUICK AND COMPREHENSIVE UNIFICATION. THE STRONG PUSH FOR UNIFICATION BY THE POLITICAL LEADERSHIP WAS NOT A RESPONSE TO GRASSROOTS SENTIMENT; QUITE THE CONTRARY: THE MASSES FOLLOWED THEIR LEADERS. POTENTIAL ECONOMIC GAINS WERE MORE IMPORTANT THAN IDEALISTIC PANGERMAN SENTIMENTS OR NATIONAL CHAUVINISM. WILE THE EAST 
GERMANS DISPLAYED MORE ENTHUSIASM AT FIRST, THEIR DISAPPOINTMENT STEADILY ROSE AFTER THE FACT. AS OF EARLY 1991. THERE WERE SOME WARNING SIGNS OF LOOMING INTERNAL STRIFE. HOWEVER, AS LONG AS THE WEST GERMAN ECONOMY CONTINUES TO PROSPER. THERE SEEMS TO BE NO IMMINENT THREAT TO POLITICAL CONTINUITY AND STABILITY IN UNITED GERMANY.

05437 KUEH, Y.Y.

FOREIGN INVESTMENT AND ECONOMIC CHANGE IN CHINA

CHINA QUARTERLY, (131) (SEP 92), 637-690.

SINCE 1978, CHINA'S POLICY OF OPENING TO THE OUTSIDE WORLD HAS INCLUDED EFFORTS TO INCREASE FOREIGN DIRECT

INVESTMENT (FDI). IN THIS ESSAY, THE AUTHOR DISCUSSES THE IMPORTANCE OF "ECONOMICALLY OPENED COASTAL AREAS"

(ECONOCOAS) AND SUGGESTS REASONS FOR THEIR CHOICE AS

(ECONOCOAS) AND SUGGESTS REASONS FOR THEIR CHOICE AS
RECIPIENTS OF FOREIGN INVESTMENT. THEN HE EXAMINES OVERALL RECIPIENTS OF FOREIGN INVESTMENT. THEN HE EXAMINES
QUANTITATIVE TRENDS IN FOREIGN INVESTMENT AND ITS

QUANTITATIVE TRENDS IN FOREIGN INVESTMENT AND ITS DISTRIBUTION AMONG ECONOCOAS AND ECONOMIC SECTORS, BEFORE HE ANALYZES THE CONTRIBUTION OF FOREIGN INVESTMENT TO OVERALL CAPITAL FORMATION AND ITS IMPACT ON OUTPUT AND INCOME GROWTH. HE USES THE AVAILABLE STATISTICAL EVIDENCE TO INVESTIGATE
THE FOREIGN TRADE PERFORMANCE OF FOREIGH-FUNDED ENTERPRISES, THE FOREIGN TRADE PERFORMANCE OF FOREIGH-FUNDED ENTERPRISES, WITH PARTICULAR REFERENCE TO THE CENTRAL PROBLEM OF FOREIGI
EXCHANGE BALANCE REQUIREMENTS. FINALLY, HE LOOKS AT FUTURE TRENDS IN FOREIGN INVESTMENT AND HIGHLIGHTS THE MAJOR POLICY TRENOS IN FOREIGN INVES
ISSUES OF THE $1990^{\prime} \mathrm{S}$.

05438 KUEHNELT-LEDDIHN, E.

WHY SOCIALISM REFUSES TO DIE

NATIONAL REVIEW, XLIV (7) (APR 92), 34-37.

THE IMMEDIATE REACTION TO THE COLLAPSE OF THE COMMUNIST REGIMES IN EASTERN EUROPE HAS THAT MORALLY AND

INTELLECTUALLY SOCIALISH WAS NOW BANKRUPT. BUT IT DID NOT TAKE LONG FOR A COUNTEROFFENSIVE TO BEGIN. THIS ARTICLE STATES THAT THE DISINTEGRATION OF THE USSR DID NOT SPELL THE END OF THE SOCIALIST CREED, OF THE SOCIALIST PARTIES, OR EVEN OF SOCIALIST CONYICTIONS AND TENDENCIES HITHIN NONSOCIALIST POLITICAL MOVEMENTS.

05439 KUENBACHER, $K$.

GERMAN UNIFICATION--A LONG TERM TASK

AUSSEN POLITIK, 43(2) (1992), 134-143

AN OBJECTIVE ANALYSIS OF THE PROBL EMS FACING EASTERN GERMANY IS THE KEY TO UNDERSTANDING THE NEH SITUATION THERE. GERMANY IS THE KEY TO UNDERSTANDING THE NEH SITUATION TH AN EQUALLY IMPORTANT FACTOR, HOHEVER, IS THE PERSONAL BOTH ASPECTS. THE GOVERMMENTS OF THE NEH REGIONAL STATES IN EASTERM GERMANY ARE CONFRONTED IN PARTICULAR BY THE HUMAN EASTERN GERMANY ARE CONFRONTED IN PARTICULAR BY THE HUMAN ASPECT. THE AUTHOR OBJECTS TO THE ACCUSATION MADE BY SOME WEST GERMANS THAT THE EAST GERMANS ARE NOT DOING THEIR UTMOST TO IMPROVE THEIR ECONOMIC AND SOCIAL SITUATION. AT
THE SAME TIME HE CALLS UPON POLITICIANS IN WESTERN GERMANY THE SAME TIME HE CALLS UPON POL ITICIANS IN WESTERN GERMANY
TO OVERCOME THEIR TRADITIONAL PETTY QUARRELS AND, INSTEAD, TO TAKE UP AND OVERCOME THE NATIONAL CHALLENGE IN THE EASTERN GERMANY.

05440 KUHN, P.

EDUCATION AND PEDAGOGY ACCORDING TO THE CONCEPT OF THE

EGYPTIAN MOSLEM BROTHERHOOD UNDER HASAN AL-BANNA

ORIENT, 33(2) (JUN 92), 253-264.

IN THE PROGRAM OF THE REFORMED ISLAMIC UNION OF THE

MOSLEM BROTHERHOOD, WHICH WAS ESTABLISHED BY HASAN AL BANNA IN EGYPT IN 1928, THE SECTORS OF EDUCATION AND PEDAGOGY PLAYED A PERTINENT ROLE FROM THE BEGINNING. THROUGH AN ANALYSIUS OF MAINLY ARABIC SOURCES IT BECOMES CLEAR THAT THE MOSLEM BROTHERS DID NOT ACTUALLY HAVE THEIR OWN ISLAMIC PEDAGOGICAL CONCEPT WHICH DIFFERED SUBSTANTIALLY FROM THE CLASSICAL BASIC CONCEPTS, ON THE OTHER HANO, HOWEVER, THEY DID BRING FORTH NEWS ON VARIOUS QUESTIONS CONCERNING THESE TOPICS WHICH INFLUENCE THE THINKING OF MANY MOSLEMS TO THIS DAY. THE MOSLEM BROTHERS CONTRIBUTED TO THE EDUCATION OF A LARGE CIRCLE OF EGYPTIAN MOSLEMS THROUGH THEIR MANIFOLD PROGRAM.

05441 KUKATHAS, $C$.

ARE THERE AHY CULTURAL RIGHTS?

POLITICAL THEORY, 20(1) (FEB 92), 105-139.

IT IS ARGUED THAT WHILE ONE IS RIGHT TO BE CONCERNED

ABOUT THE CULTURAL HEALTH OF MINORITY COMMUNITIES, THIS

ABOUT THE CULTURAL HEALTH OF MINORITY COMMUNITIES, THIS
GIVES ONE INSUFFICIENT REASON TO ABANDON, MODIFY, OR

REINTERPRET LIBERALISM. FAR FROM BEING INDIFFERENT TO THE

REINTERPRET LIBERALISM. FAR FROM BEING INDIFFERENT TO THE
CLAIMS OF MINORITIES, LIBERALISM PUTS CONCERN FOR MINORITIES

CLAIMS OF MINORITIES, LIBERALISM PUTS CONCERN FOR MINDRITIES
AT THE FOREFRONT. ITS VERY EMPHASIS ON IMDIYIDUAL RIGHTS

AT THE FOREFRONT. ITS VERY EMPHASIS ON INDIVIDUAL RIGHTS

BESPEAKS NOT HOSTILITY TO THE INTERESTS OF COMMUNITIES BUT

WARINESS OF THE POWER OF THE MAJORITY OVER MINORITIES.

CONCLUDED THAT THE NEED IS TO REASSERT THE FUNDAMENTAL IMPORTANCE OF INDIVIDUAL LIBERTY OR INDIVIDUAL RIGHTS AND TO
QUESTION THE IDEA THAT CULTURAL MINORITIES HAVE COLLECTIVE QUESTION

05442 KUKLINSKI, J.H.; BOLLAND, J.; LUSKIN, R.C

WHERE IS THE SCHEMA? GOING BEYOND THE "S" WORD IN
POLITICAL PSYCHOLOGY

AMERICAN POLITICAL SCIENCE REVIEH, 85(4) (OEC 91),
1341-1356.

SCHEMA THEORY HAS GAINED WIDE CURRENCY TODAY AMONG SCHOLARS WHO STUDY POLITICAL ATTITUDES, BELIEFS, VALUES,
RECOLLECTIONS, OR OTHER PERCEPTIONS AND ORIENTATIONS THAT CITIZENS MAY EXHIBIT. BUT HOW MUCH DOES SCHEMA CONCEPTUALIZATION ACTUALLY CONTRIBUTE TO UNDERSTANDING POLITICAL BEHAVIOR AND ATTITUDES? HOW MUCH POTENTIAL DOES SCHEMA THEORY HAVE FOR FUTURE CONTRIBUTIONS? THE AUTHORS ADORESS THESE QUESTIONS, ARGUING FOR A MORE SATISFYING POLITICAL PSYCHOLOGY THAN IS OFFERED BY RESEARCH EMANATING FROM SCHEMA CONCEPTUALIZATIONS.

05443 KULINSKI, J.; SIGELMAN, L.

WHEN OBJECTIVITY IS NOT OBJECTIVE: NETHORK TELEVISION NEWS COVERAGE OF U.S. SENATORS AND THE "PARADOX OF OBJECTIVITY" THE JOURNAL OF POLITICS, 54 (3) (AUG 92), 810-833. THE JHIS ANALYSIS OF NETHORK COVERAGE OF U.S. SENATORS DURING THE 1970 S ANO 1980 S FINDS THAT THE NETWORKS FOLLOW DURING THE 1970 S AND 1980 S FINDS THAT THE NETHORKS FOLLOW OBJECTIVE ROUTINES, WHICH NORMALLY ENSURE BALANCED REPORTING OF POLITICAL AFFAIRS. DURING TIMES OF SEISMIC CHANGE IN THE POLITICAL LANDSCAPE, HOWEVER, THESE VERY ROUTINES CAN PRODUCE HAT MIGHT BE INTERPRETED AS BIASED COVERAGE. THE EXAMPLE OF THIS PHENOMENON. THE AUTHORS LABEL THIS THE "PARADOX OF OBJECTIVITY," A PHENOMENON THAT GREA

05444 KUMAR, D.

THE AFFIRMATIVE ACTION DEBATE IN INDIA

ASIAN SURVEY, XXXII(3) (MAR 92), 290-302

INDIA MAY WELL HAVE THE LARGEST AFFIRMATIVE ACTION PROGRAM IN THE HORLD. THE SCOPE OF ITS VARIOUS POLICIES HAS BEEN STEADILY ENLARGED, GIVING RISE TO AN ACTIVE DEBATE IN THE PRESS. IT IS THIS DEBATE AND, IN PART ICULAR THE ATTITUDES OF INTELLECTUALS, THAT IS THE SUBJECT OF THIS ARTICLE. THREE ISSUES ARE DISCUSSED: THE QUALITY OF POLICY MAKING, THE MODERN ROLE OF CASTE, AND INDIAN ATTITUDES TO MERIT.

05445 KUMAR, $K$.

THE $1989^{\circ}$ REVOLUTIONS AND THE IDEA OF EUROPE

POLITICAL STUDIES, XL(3) (SEP 92), 439-461.

THE AUTHOR EXAMINES THE 1989 REVOLUTIONS IN THEIR SPECIFICALLY EUROPEAN CONTEXT, FOCUSING ON THE SORT OF SPECIFICALLY EUROPEAN CONTEXT, FOCUSING ON THE SORT OF EUROPE THE REVOLUTIONARIES ASPIRE TO, THE MEANING OF "THE
RETURN TO EUROPE," THE EXTENT TO WHICH A "CENTRAL EUOPREAN RETURN TO EUROPE," THE EXTENT TO WHICH A "CENTRAL EUOPREAN WAY" EXISTS AND WHAT PART IT MIGHT PLAY IN EUROPE'S FUTURE, AND REALIS

05446 KUMAR, P.C. SUPPLY-SIDE TAX POLICIES FOR DEVELOPING COUNTRIES: SURVEY AND SYNTHESIS

DEVELOPMENT POLICY REVIEH, 10(1) (MAR 92), 5-13.

IN THE 1980'S BUDGET DEFICITS AND EXTERNAL DEBT POSED A DILEMMA FOR MANY DEVELOPING COUNTRIES. IF SUPPLY - SIDE POLICIES ENHANCE TAX REVENUES, AS CLAIMED BY THEIR SUPPORTERS, THEN DEVELOPING COUNTRIES SHOULD GIVE THEM SERIOUS CONSIDERATION IN DESIGNING TAX STRATEGIES TO PROMOTE ECONOHIC GROWTH AND DEVELOPMENT.

05447 KUO, C

THE PRC AND TAIWAN: FUJIAN'S FALTERING UNITED FRONT ASIAN SURVEY, XXXII(8) (AUG 92), 683-695.

THE UNIFICATION OF TAIHAN WITH CHINA IS ONE OF THE MAJOR OBJECTIVES OF THE CHINESE GOVERMMENT IN THE 1990S. THE CHINESE COMMUNIST PARTY HAS CALLED ON ALL ELEMENTS--PARTY CADRES, GOVERNMENT OFFICIALS, INTELLECTUALS, DEMOCRATIC PARTIES, AND SOCIAL ORGANIZATIONS--FOR A UNITED FRONT TO SERVE THIS END. ONE OF THE TASKS THE FRONT IS EXPECTED TO PURSUE, SUPERVISED BY THE CENTRALIZED, TOTALITARIAN, PARTYSTATE MACHINERY, IS TO INFLUENCE TAIWANESE INVESTORS IN CHINA FOR THE PURPOSE OF UNIFICATION. HOWEVER, THIS ARTICLE USES ORGANIZATIONAL ANALYSIS TO ARGUE THAT THE UNITED FRONT'S POLITICAL INFLUENCE ON TAIWANESE INVESTORS TOWARD UNIFICATION HAS BEEN AND WILL BE VERY LIMITED. ECONOMIC UNIFICATION HAS BEEN AND WILL BE VERY LIMITED. ECONOMIC
LIBERALIZATION, THE MOBILITY OF TAIWANESE INVESTORS, LOCALISM, AND IDEOLOGICAL-ORGANIZATIONAL WEAKNESSES HAVE CASUED SUCH PROBLEMS AS INERT IA, QUANTIFICATION OF GOALS, AND GOAL DISPLACEMENT IN THE FRONT, THUS CONSTRAINING ITS AND GOAL DISPLACEMENT IN THE FRONT, THUS CONSTRAINING ITS EFFECTIVENESS. THIS ARGUMENT IS EXAMINED AT THE FRONT LINE
OF CHINA-TAINAN INTERACTION: FUJIAN PROVINCE AND ESPECIALLY OF CHINA-TAIHAN INTERACTION: FUJIAN PROVINCE AND ESPECIA
THE CITY OF XIAMEN, WHERE MORE THAN HALF OF TAIWANESE THE CITY OF XIAMEN, WHERE MORE THAN

05448 KURLAND, $N$

THE ABRAHAM FEDERATION: A NEW FRAMEWORK FOR PEACE IN THE MIDOLE EAST

AMERICAN-ARAB AFFAIRS, (36) (SPR 91), 87-94.

MO RATIONAL DIALOGUE AND NO GENUINE STEPS TOWARDS PEACE AMONG ARABS AND JEWS IN THE MIDDLE EAST ARE POSSIBLE WITHIN TRADITIONAL CONCEPTUAL AND IDEOLOGICAL FRAMEHORKS. COMPETING INTEREST GROUPS OFFER COMPETING FRAMEWORKS, ALL OF WHICH SUFFER FROM FAULTY ASSUMPTIONS, SEMANTIC AMBIGUITIES, ANO 
POORLY-DEFINED, OFTEN CONTRADICTORY, OBJECTIVES. A NEW AND MORE REALISTIC FRAMENORK IS DEMANDED. THIS ARTICLE OFFERS ONE POSSIBLE ALTERNATIVE: THE "ABRAHAM FEDERATION." IT "COLIECTIVIST" FORM OF NATION-STATE AND IN ABANDONING THE "COLLECTIVIST" FORM OF NATION-STATE AND IN ABANDONING THE FEUDALISTIC "WAGE-SYSTEM" ECONOMIC POLICIES OF ALL EXISTING NATIONS. IT HOULD BE BASED ON A RADICALLY NEW PROCESS OF NATION BUILDING, GROUNDED UPON THE INHERENT SOVEREIGNTY OF EVERY INDIVIDUAL AND THE SANCTITY OF THE FAMILY UNIT, WHERE "OHNERSHIP-SHARING" ECONOMICS

05449 KURTH, J.

THE POST-MODERN STATE

NATIONAL INTEREST, 28 (SUM 92), 26-36.

THE NATION-STATE WAS THE MOST DISTINCTIVE AND MOST EFFECTIVE FORM OF SOCIAL ORGANIZATION IN THE MODERN ERA, THAT GREAT EPOCH THAT BEGAN HALF A MILLENNIUM AGO AND HAS ONLY RECENTLY COME TO AN END. THIS PAPER TRACES THE DEVELOPMENT OF MODERNITY AND THE NATION-STATE, AMERICAN EXCEPTIONALISM, AMERICA IN THE POST-MODERN WORLD AND THE NEW LANDSCAPE. IT SUGGESTS THAT IT APPEARS THAT THE POST-MODERN CAMP WILL PREVAIL AND THAT THE AMERICAN PEOPLE WILL BECOME CAMP HILL PREVAIL AND THAT THE AMERICAM
TAKERS RATHER THAN MAKERS OF HISTORY.

05450 KUSHNER, J.

THE EFFECT OF URBAN GROWTH ON MUNICIPAL TAXES

CANADIAN PUBLIC ADMINISTRATION, 35(1) (SPR 92), 94-102.

A COMMON BELIEF AMONG MUNICIPAL OFFICIALS IS THAT URBAN GROWTH ENABLES A MUNICIPALITY TO EARN "TAX PROFITS" WHICH ENABLES THE MUNICIPALITY TO REDUCE TAX RATES. THE RATIONALE IS THAT URBAN GROWTH INCREASES TAX ASSESSMENT, WHICH IN TURN CAN BE USED TO FINANCE EXISTING SERVICES, THEREBY REDUCING THE TAX BURDEN ON EXISTING TAXPAYERS. CONVERSELY, BY THIS RATIONALE, IF THE MUNICIPALITY DOES NOT EXPERIENCE GROWTH, TAXES WILL NECESSARILY BE HIGHER. THIS PAPER EXAMINES THES ASSUMPTIONS ABOUT THE RELATIONSHIP BETHEEN URBAN GROWTH AND MUNICIPAL TAXES.

05451 KUSLER, J.

WETLANOS DELINEATION: AN ISSUE OF SCIENCE OR POLITICS? ENVIRONMENT, 34(2) (MAR 92), 6-11; 29-37.

UNTIL POLLITICALLY ACCEPTABLE CRITERIA ARE ADOPTED, SOME OF THE NATION'S REMAINING 103 MILLION ACRES OF WETLAND MAY BE IN JEOPARDY. THE RECENT PUBLICATION OF THE PROPOSED 1991 U.S. "FEDERAL MANUAL FOR IDENTIFYING AND DELINEATING JURIOICTIONAL HETLANDS" CAUSED AN UPROAR OF CRITICISM AMONG SCIENTISTS. MANY FEEL THAT THE NEW MANUAL'S DELINEATION CRITERIA ARE TOO NARROW AND FAVOR LANDOWNERS AND DEVELOPERS CRITERIA ARE TOO NARROW AND FAVOR LANDOWNERS AND DEVEL
WHO SEEK TO EXCLUDE FROM FEDERAL JURISDICTION THE MORE WHO SEEK TO EXCLUDE FROM FEDERAL JURISDICTION THE MORE
FRAGILE, LESS RECOGNI ZABLE WETLAND AREAS. DEBATE OVER THE FRAGILE, LESS RECOGNIZABLE WETLAND AREAS. DEBATE OVER THE CRITERIA HAS EXACERBATED THE ALREADY STRAINED RELATIONSHIP
BETHEEN ENVIRONMENTAL SCEINTISTS AND THE BUSH ADMINISTATION.

05452 KUSSBACH, E.

EUROPEAN CHALLENGE: EAST-WEST MIGRATION

INTERNATIONAL MIGRATION REVIEH, XXVI(2) (SUM 92), 646-667.

THIS ARTICLE EXAMINES THE LEGAL, POLITICAL, AND ECONOMIC ASPECTS OF THE CONSIDERABLE INCREASE IN EAST-HEST MIGRATION WHICH FOLLOWED THE COLLAPSE OF COMMUNISM IN EASTERN EUROPE. IT CONCLUDES THAT EAST-WEST MIGRATORY MOVEMENTS ARE A MAJOR POLITICAL AND HUMANITARIAN CHALLENGE AND CONCERN OF ALL EUROPEAN GOVERNMENTS (OF BOTH IMMIGRATION AND EMIGRATION COUNTRIES). ONLY THROUGH CLOSE COOPERATION WHICH IS FOCUSED ON THE ELIMINATION OF THE ROOT CAUSES OF MIGRATION WILL THE MIGRATION MOVEMENTS BE CONTROLLED. THEREFORE, ECONOMIC ASSISTANCE HITH THE LONG-TERM VISION OF FOSTERING DEVELOPMENT IN EASTERN EUROPE IS VITAL. FURTHERMORE, SHORTTERM REFORMS IN THE ADMINSTRATIVE AND LAW ENFORCEMENT ARENAS ARE ALSO REQUIRED.

05453 KUTTAB, D. AT LEAST THEY MET

MIDOLE EAST INTERNATIONAL, (396) (MAR 91), 7-8.

MARCH 12 MARKED THE FIRST TIME THAT A U. S. SECRETARY OF STATE AND A WIDE-RANGING PALESTINIAN DELEGATION MET FOR TALKS. THE MEETING BETHEEN JAMES BAKER AND THE PALESTINIANS ALSO REPRESENTED THE END OF A PALESTINIAN BOYCOTT ON MEETING U.S. OFFICIALS AFTER THE U.S. VETO OF A UN RESOLUTION CALLING FOR INYESTIGATION INTO THE KILLING OF SEYEM PALESTINIAN WORKERS IN RISHON LEZION IN MAY 1990. WHILE NOT MUCH WAS ACCOMPLI ISHED AT THE MEETING--THE PALESTINIAN DELEGATES REITERATED THEIR INSISTENCE THAT THE PLO IS THEIR DELEGATES REITERATED THEIR INSISTENCE THAT THE PLO IS THEIR ONLY TRUE REPRESENTATIVE--SOME OBSERVERS
A HOPEFUL SIGN FOR FUTURE NEGOTIATIONS.

05454 KUTTAB, D.

BAKER BRINGS NO JOY

MIDDLE EAST INTERNATIONAL, (398) (APR 91), 13-14

THE SECOND MEETING ON, APRIL BETWEEN A PALESTINIAN DELEGATION AND U.S. SECRETARY OF STATE BAKER IN A MONTH SERVED TO DAMPEN PALESTINIAN OPTIMISM. ALTHOUGH BAKER'S PROPOSAL OF A REGIONAL PEACE CONFERENCE WAS NOT FLATLY REJECTED, THE U.S. UNWILLINGNESS TO PRESS ISRAEL ON THE
ISSUES OF SETTLEMENTS AND DEPORTATION AND THE LACK OF FLEXIBILITY ON THE ISSUE OF PLO PARTICIPATION IN THE PEACE PROCESS DIMINISHED WHAT LITTLE HOPE FOR SUBSTANTIAL PROGRESS TOHARDS PEACE THAT HAD EXISTED.

05455 KUTTAB, D.

EUPHORIA QUICKLY FADES

MIDDLE EAST INTERNATIONAL (413) (NOY 91) 4-5.

THE PALESTINIAN DELEGATION TO THE MADRID PEACE

CONFERENCE RETURNED TO THE OCCUPIED TERRITORIES HITH A HERO'S HELCOME AND AN OPPORTUNITY TO EXPLAIN TO THE PALESTINIAN PUBLIC EXACTLY WHAT THE PEACE PROCESS ENTAILED. THE DELEGATION CAME HOME WITH AN IMPORTANT MISSION: TO LOWER EXPECTATIONS AND DEFLATE WHAT THEY CONSIDERED EXAGGERATED HOPES. THE INITIAL EUPHORIA AT THEIR ARRIVAL WORE OFF AS THE ANMDUNCEMENT OF THE CREATION OF PALESTINIAN "POLITICAL ACTION COMMITTEES" CAUSED WIDESPREAD CONTROVERSY AND DIVISION AMONG THE PALESTINIAN COMMUNITY. IN ADDITION, ISRAELI POLICY IN THE OCCUPIED TERRITORIES ALSO HELPED TO DAMPEN THE EARLY EXCITEMENT. THREE NEW SETTLEMENTS WERE OPENED IN THE WEST BANK IN ADDITION TO THE INAUGURATION OF A NEW SETTLEMENT IN THE GOLAN HEIGHTS. MORE PALESTINIANS WERE KILLED, INCLUDING A YOUTH IN JERUSALEM'S OLD CITY ON 14 NOVEMBER.

05456 KUTTAB, 0

ISRAEL: INTIFADA ALIVE AND KICKING

MIDDLE EAST INTERNATIONAL, 440(440) (DEC 92), 4-5

OM THE EVE OF ITS FIFTH ANNIVERSARY NO ONE IN ISRAEL DOUBTED THAT THE PALESTINIAN UPRISING HAS ALIVE AND KICKING. THIS REPORT DESCRIBES RECENT ATTACKS WHICH TOOK PLACE IN THE GAZA STRIP WHEN THREE ISRAELI SOLDIERS WERE KILLED. THE TARGETS OF RECENT ATTACKS HAVE ALL BEEEN SOLDIERS, NOT CIVILIANS. THE FAILURE OF THE PEACE TALKS TO PRODUCE ANY CONCRETE RESULTS IS THE MAIN SOURCE OF FRUSTRATION THAT FUELS THE INCREASE IN ATTACKS AGAINST ISRAELIS.

05457 KUTTAB, D.

LAND DAY DISUMITY

MIDDLE EAST INTERNATIONAL, (397) (APR 91), 11-12.

SINCE 1976, WHEN SIX PALESTINIANS LIVING IN ISRAELI HERE KILLED IN PROTESTS AGAINST LAND SEIZURE, 30 MARCH HAS BEEN A DAY WHICH UNIFIES ALL PALESTINIANS. BUT THE GULF WAR LEFT ITS MARK ON THIS YEAR'S LAND DAY EVENTS. MEETINGS OF THE COMMITTEE TO DEFEND THE LAND ANO THE COMMITTEE OF HEADS OF ARAB LOCAL COUNCILS AND OTHER ISRAELI GROUPS INCLUDING THE ISRAELI COMMUNIST PARTY AND ISLAMIC FUMDAMENTALISTS WERE MARKED BY APATHY AND INTERNAL DIVISION.

05458 KUTTAB, D.

MIXED REACTIONS

MIDDLE EAST INTERMATIONAL, (395) (MAR 91), 13-14.

AFTER IRAQ'S DEFEAT IN THE GULF HAR, MANY PALESTINIANS, ALTHOUGH STILL SUPPORTIVE OF SADDAM HUSSEIN IN HIS STAND AGAINST THE HEST, ARE RETURNING THEIR ATTENTION TO THEIR OWN FUTURE. MANY EXPECT ISRAEL, THE U.S., AND SOME OF THE ARAB ALLIES TO ATTEMPT TO FIND AN ALTERNATIVE LEADERSHIP TO THE PLO. HOHEVER, THERE IS NO STGN THAT THIS HILL NORK. THE MOST LIKELY SCENARIO IS THAT THE INTIFADA WILL CONTINUE AS BEFORE AND PALESTINIANS WILL CONTINUE TO ADVOCATE A THO-STATE SOLUTION.

05459 KUTTAB, D.

MORE DEPORTATIONS TO COME

MIDDLE EAST INTERNATIONAL, (397) (APR 91), 11.

ON 31 MARCH THE ISRAELI GOVERNMENT VOTED IN CLOSED

CABINET SESSION FOR EXTRAORDINARY MEASURE AGAINST

PALESTINIANS, INCLUDING STEPPING UP THE POLICY OF DEPORTATION, DESPITE INTERNATIONAL CONDEMNATION. ACCORDING TO THE ISRAELI MEDIA, THE GOVERMMENT PLANS TO DEPORT A PALESTINIAN POLITICAL LEADER FROM EVERY TOWN, VILLAGE, OR CAMP FROM WHERE A PALESTINIAN SUSPECTED OF KILLING ISRAELIS COMES. THE ISRAELI MOVE WAS PROMPTED BY THE INCREASE IN THE NUMBER OF STABBINGS AGAINST ISRAELIS AS WELL AS A SHOOTING INCIDENT IN WHICH AN ISRAELI SETTLER WAS KILLED. EVEN WITHOUT THIS NEW MEASURE, LIFE CONTINUES TO DETERIORATE FOR 1.7 MILLION PALESTINIANS IN THE OCCUPIED TERRITORIES.

05460 KUTTAB, D.

OCCUPIED TERRITORIES--KILLINGS ON THE RISE

MIDDLE EAST INTERNATIONAL, (422) (APR 92), 10.

THE TOLL OF INTIFADA-RELATED DEATHS IN MARCH 1992 WAS 15 THE HIGHEST MONTHLY TOTAL FOR OVER A YEAR. EIGHTEEM

PALESTINIANS HAVE BEEN KILIED BY THE ISRAEI IS IN ALL OF 1992.

PALESTINIANS HAVE BEEN KILLED BY THE ISRAELIS IN ALL OF 1992. ISRAELI. VIOLENCE IS BECOMING MORE CONCENTRATED, IF NOT
VICIOUS. PALESTINIAN CASUALTIES AT DEMONSTRATIONS ARE IN VICIOUS. PALESTINIAN CASUALTIES AT DEMONSTRATIONS ARE IN

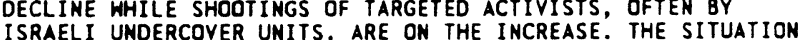
ISRAELI UNOERCOVER UNITS, ARE ON THE INCREASE. THE SITUATION HAS BECOME SO ACUTE THAT PALESTINIAN LEADER FAISAL HUSSEINI HELD A PRESS CONFERENCE ON 19 MARCH AT WHICH HE CHA ISRAELI SECURITY FORCES WITH SUMMARILY EXECUTING PALESTINIANS. HE SAID THAT ALTHOUGH THE ISRAELIS USUALLY HAD
TIME AND OPPORTUNITY TO ARREST PALESTINIAN ACTIVISTS, THEY WERE CHOOSING TO KILL THEM INSTEAD. 
05461 KUTTAB, D.

PALESTINE: BATTLES WITH THE SETTLERS

MIDOLE EAST INTERNATIONAL, 417 (JAN 92), 11-12.

THE TUG OF WAR BETWEEN ISRAELI SETTLERS AND AM

INIDENTIFIED GROUP, OR GROUPS, OF PALESTINIAN GUNMEN

CONTINUES, DESPITE ISRAELI ASSERTIONS THAT THE ORDERS TO DEPORT 12 PALESTINIANS HOULD DETER PALESTINIANS FROM USING FIREARMS. SEVEN ISRAELI SETTLERS WERE INJURED WHEN A BUS WAS SHOT AT MEAR RAMALLAH ON 14 JANUARY, TWO OF THEM SERTOUSLY. SHOT AT NEAR RAMALLAH ON 14 JANUARY, TWO OF THEM SERIOUSLY. FIVE NEW SETTLEMENTS, BUT WERE STOPPED BY THE ISRAELI ARMY.

PRISONER'S HUMGER STRIKE REIGNITES THE INTIFADA: ISRAEL'S PRI SONER'S HUNGER STRI

MIDDLE EAST INTERNATIONAL, 436 (OCT 92), 3-4.

THE HUNGER STRIKE BY THOUSANDS OF PALESTINIAN SECURITY PRISONERS DEMANDING IMPROVMENTS IN THEIR PRISON CONDITIONS, WHICH BEGAN ON 27 SEPTEMBER, HAS PUT NEW LIFE INTO THE NEARLY FIVE-YEAR OLD INTIFADA. THE WAVE OF PROTESTS IN SUPPORT OF THE PRISONERS SUCCEEDED NOT ONLY IN GETTING SOME IMPROVEMENTS BUT ALSO IN REMINDING THE ISRAELIS THAT THE OCCUPIED TERRITORIES REMAIN DANGEROUSLY VOLATILE. ISRAEL, AT FIRST, TRIED TO INGORE THE STRIKE BUT FOUND THAT IT HAS UNABLÉ TO, AND HASITLY ORDERED LARGE TROOP REINFORCEMENTS INTO THE TERRITORIES TO STIFLE THE UPHEAVAL. THEN IT REALIZED THAT THE HAVE OF UNREST COULD NOT BE PUT DOWN BY NORMAL POLICING PROCEDURES ANO BEGAN TO NEGOTIATE.

05463 KUTTAB, D.

TERRITORIES: A HARDENING OF POSTIONS

MIDDLE EAST INTERNATIONAL, 438 (438) (NOV 92), 10-11. THE COMING TRANSITION IN THE UNITED STATES AND THE VERY SLOW PACE OF THE PEACE TALKS HAVE LEFT THEIR MARKS ON THE OCCUPIED TERRITORIES. THIS ARTICLE SUGGESTS THAT THE RABIN GOVERMMENT IS MD DIFFERENT TO ITS PREDECESSOR. THE LACK OF PROGRESS ON PROGRES ON THE PEACE FRONT HAS RESULTED IN THE HARDENING OF POSITIONS AMONG PALESTINIANS AS WELL. ONE RAY OF HOPE IS
FAST PACE OF THE NATION-BUILDING CAMPAIGN THAT IS TAKING FAST PACE
PLACE.

05464 KUTTAB, D

THE PALESTINIAN GAMBLE PAYS OFF

MIDOLE EAST INTERMATIONAL (412) (NOV 91), 3-4.

FOR PALESTINIANS, GOING TO THE INTERNATIONAL MIDEAST

PEACE CONFERENCE IN MADRID WAS BOTH A GAMBLE AND A CHALLENGE. FOR SOME TIME THE AMERICANS HAD BEEN TRYING TO CONVINCE THEM OF THE ADVANTAGE OF TAKING PART IN THE PEACE PROCESS. THEY WERE TOLD THAT ITS REWARDS WOULD FAR OUTWEIGH THE DRAWBACKS OF THE RESTRICTIONS THAT THE ISRAELIS WERE INSISTING ON. AFTER A THREE-DAY PUBLIC PLENARY AND ONE DAY OF BILATERAL TALKS, THE PALESTINIANS AGREED THAT THE AMERICANS HAD BEEN RIGHT. THE LEADERS OF THE PALESTINIAN DELEGATION WERE ABLE TO RECEIVE INPUT FROM THE PLO CHAIRMAN YASSIR ARAFAT AND FROM REPRESENTATIVES FROM EAST JERUSALEM. IN ADDITION, THEY WERE TREATED ON AN EQUAL BASIS HITH ALL OTHER DELEGATIONS AT THE CONFERENCE. THE PEACE PROCESS IS CREATING A NEW BREED OF PALESTINIAN DECISIONMAKERS. THE COMBINATION OF LEADERS FROM THE OCCUPIED TERRITORIES AND THE SMALL GROUP OF AIDES AROUND ARAFAT IS PROOUCING A NEH DYNAMIC WITHIN THE PALESTINIAN NATIONAL MOVEMENT WITH FIGURES SUCH AS HANAN ASHRAHI AND FAISAL HUSSEINI COMING TO THE FOREFRONT.

05465 KUTTAB, D.

THE PALESTINIANS--CONSEQUENCES OF THE DEPORTATION ORDERS MIDDLE EAST INTERNATIONAL, (416) (JAN 92), 45 . DOPPOT 12 PALESTINIANS JUST ONE DAY BEFORE THE PALESTINIAN DELEGATION WAS TO LEAVE FOR WASHINGTON LEFT NO CHOICE FOR THE PALESTINIANS BUT TO SUSPEND THEIR DEPARTURE. PRESSURE HAD BEEN BUILDING UP BEFORE THE DEPARTURE DATE AS ISRAELI SETTLEMENT ACTIVITY AND POLICIES IN THE OCCUPIED TERRITORIES WERE CAUSING INTERNAL RIFTS. IT WAS BECOMING MORE AND MORE DIFFICULT FOR THE PALESTINIAN DELEGATION TO EXPLAIN WHY THEY DIFFICULT FOR THE PALESTINIAN DELEGATION TO EXPLAIN WHY THEY PEACE HHILE THE ISRAEL SETTLERS AND THE ARMY WERE HAYING A PEACE WHILE THE ISRAELI SETTLERS AND THE ARMY WERE HAV THE OCCUPIED TERRITORIES. THE PALESTINIAN DECISION TO SUSPEND THEIR DEPARTURE FOR HASHINGTON WAS COUPLED WITH AN ESCALATION OF THEIR DIPLOMATIC OFFENSIVE. COUPLED WITH AN ESCALATION OF THEIR DIPLOMATIC OFFENSIVE. BY THE DECISION OF OTHER ARAB STATES TO DELAY THEIR DELEGATIONS' DEPARTURE FOR WASHINGTON AS HELL.

05466 KUTTAB, D.

THE REAL ISSUES AT STAKE

MIDOLE EAST INTERNATIONAL, (415) (DEC 91), 4

THE SECOND ROUND OF MIDEAST PEACE TALKS BEGAN IN THE SOMEWHAT UNLIKELY VENUE OF THE CORRIDORS OF THE U.S. STATE DEPARTMENT. WHEN THE ISRAELI DELEGATIOM DEMANDED TO MEET WITH THE JOINT JORDANIAN-PALESTINIAN DELEGATION (AS OPPOSED TO NEGOTIATING HITH THE THO GROUPS AS SEPARATE ENTITIES), THE U.S. RESPONDED BY HAVING THE THREE HEADS OF THE
DELEGATIONS MEET INFORMALLY IN THE CORRIDORS. THE CONTINUED ISRAELI INSISTENCE ON MEETING HITH THE JOINT DELEGATION SEEMED IN PART TO REFLECT THE FEAR THAT A UNIQUE PALESTINIAN IDENTITY WAS BEING RECOGNIZED. THEY COMPLAINED AT THE HIGHPROFILE AND INDEPENDENT ROLE THAT THE PALESTINIAN DELEGATION HAD PLAYED IN MADRID. FOR PALESTINIANS, THE IDEA OF A JOINT DELEGATION WAS SIMPLY AN INSTRUMENT TO ENABLE THEM TO TAKE PART IN THE TALKS. THE END RESULT WAS THO HEEKS OF LARGELY INEFFECTUAL TALKS.

05467 KUTTHER, R.

USEFUL IDIOTS

NEW REPUBLIC, 207(3-4) (JUL 92), 18, 20

THE AUTHOR ENUMERATES REASONS WHY H. ROSS PEROT MAY

INITIALLY APPEAL TO LIBERALS AND THEN EXPLAINS WHY PEROT'S

YIEHS ARE NOT REALLY CONSISTENT WITH A LIBERAL VIEWPOINT.

05468 KUUMBA, M.

EXAMINING POPULATION CONTROL IN AFRICA

TRANSAFRICA FORUM $9(1)$ (SPR 92) 69-77.

AFRICA HAS THE WORLD'S LOWEST' RATE OF ECONOMIC GROWTH ANO DEVELOPMENT COUPLED WITH THE HORLD'S FASTEST-GROWING POPULATION. DEVELOPMENT POLICY MAKERS IN THE WEST HAVE LINKED THESE THO FACTS AND DETERMINED THAT THE HIGH RATE OF POPULATION GROWTH IMPEDES ECONOMIC DEVELOPMENT. IN AN ATTEMPT TO ACCELERATE DEVELOPMENT IN AFRICA, POPULATION CONTROL MEASURES HAVE BECOME CRITICAL TO DEVELOPMENT AND ASSISTANCE PROGRAMS. IN THIS ARTICLE, THE AUTHOR ARGUES THAT POPULATION CONTROL MEASURES ARE, IN FACT, AN ATTEMPT TO MAINTAIN POLITICAL AND ECONOMIC CONTROL OF AFRICA AND ITS RESOURCES. SHE ARGUES THAT HIGH POPULATION GROWTH RATES ARE SYMPTOMS--NOT CAUSES--OF THE FUNDAMENTAL ECONOMIC AND SOCIAL PROBLEMS AFFLICTING AFRICA.

05469 KHAK, T

DESIGNING THE NON-NUCLEAR KOREAN PENINSULA: PROBLEMS AND PROSPECTS

KOREAN JOURHAL OF DEFENSE ANALYSIS, IV(1) (SUM 92),

221-244.

THIS PAPER HAS FOUR MAIN PURPOSES: TO EXAMINE THE

NUCLEAR CAPABILITY AND INTENTIONS OF MORTH KOREA AND THEIR EFFECTS ON SECURITY AND PEACE ON THE KOREAN PENINSULA, TO DISCUSS THE FOUR MAJOR POWERS' NUCLEAR SECURITY POLICY ON THE KOREAN PENINSULA IN THE CONTEXT OF NEWLY CHANGING INTERNATIONAL SECURITY ENVIRONMENT IN THE 1990S, TO ANALYZE THE SOUTH'S PROPOSAL FOR A NUCLEAR-FREE KOREA AND THE NORTH KOREAM NUCLEAR-FREE-ZONE PROPOSAL AND TO MAKE POL ICY KOREAN NUCLEAR-FREE-ZONE PROPOSAL, AND TO MAKE POLICY RECOMMENDATIONS WITH

05470 KHARTENG, C.

THE ARABS, isRAEL AND BLACK AFRICA: THE POLITICS OF COURTSHIP

ROUND TABLE, 322(322) (APR 92), 167-182

AS A RESULT OF THE ARAB-ISRAELI CONFLICT, AND THE NEED TO MOBILIZE AFRICA'S DIPLOMATIC SUPPORT, BLACK AFRICA HAS BEEN A TARGET OF ARAB-ISRAELI COMPETITION. THS PURPOSE OF THIS ARTICLE IS TO HIGHLIGHT SOME OF THE MAJOR POLITICAL. ECONOMIC, CULTURAL AND STRATEGIC FACTORS THAT HAVE INFLUENCED BLACK AFRICA'S RELATIONS WITH BOTH ISRAEL AND THE ARAB WORLD, IN THE CONTEXTS OF ARAB-ISREALI COMPETITION AND RIVALRY IN AFRICA. IT EXAMINES SOME OF THE RELATIVE STRENGTHS AND WEAKNESSES OF THE METHODS AND STRATEGIES THAT ISRAEL AND THE ARABS HAVE USED TO HOO BLACK AFRICA. A
PRINCIPAL ASSUMPTION REMAINS THAT THE OUTCOME OF BOTH ISRAELI AND THE ARAB EFFORTS TO NOO BLACK AFRICA DEPENDS ON ALIENATE THE BLACK AFRICANS.

05471 KHIK, P.

THE TEAMSTERS VICTORY: A SUCCESSFUL STRATEGY NEW POLITICS, 13(1) (SUM 92), 155-166.

THE ELECTION OF RON CAREY AS GENERAL PRESIDENT OF THE INTERNATIONAL BROTHERHOOD OF TEAMSTERS IS THE CULMINATION OF SEVERAL VICTORIES BY REFORM ELEMENTS AMONG THE RANK-AND-FILE OF THE UNION. A CRUCIAL ELEMENT IN THE REFORMIST'S VICTORY WAS THE TEAMSTERS FOR A DEMOCRATIC UNION (TDU), AN INSURGENT CAUCUS THAT INSISTED THE GOVERMMENT AUTHORIZE DIRECT ELECTION OF THE UNION'S LEADERS INSTEAD OF PLAM FOR FEDERAL IRUSTEESHIP. THE ELECTION RESULTS ARE NOT ONLY A YICTORY FOR TRUSTEESHIP. THE ELECTION RESULTS ARE NOT ONLY A VICTORY FOR
TEAMSTERS MEMBERS, BUT ALSO FOR A RANK-AND-FILE STRATEGY FOR REFORM AND REVITALIZATION OF THE LABOR MOVEMENT.

05472 KYLE, $K$

UPHEAVAL IN ISRAEL

TORLD TODAY IN

SINCE YITZHAK RABIN FORMED ISRAEL'S NEW COALITION GOVERMMENT HITH ABNORMAL DISPATCH AFTER THE JUNE 1992 ELECTION, HE HAS KEPT UP A HURRIED PACE. HE HAS DECREED THAT HOUSING STARTS ON THE WEST BANK BE HALTED; AMERICAN-ISRAEL RELATIONS HAVE BEEN RESTORED TO THEIR OLD CORDIALITY AND PRESIDENT BUSH HAS ENDORSED THE DESPERATELY-NEEDED U.S. LOAN GUARANTEES; SOME LIMITED CONFIDENCE-BUILDING GESTURES HAVE 
HAVE BEEN REACTIVATED WITHOUT SOME OF THE PETTIFOGGING TABIN'S PREDECESSOR, YITZHAK SHAMIR. YET IT IS STILL FAR TOO EARLY TO TELL WHETHER THE CLIMATE OF MOVEMENT AND OPTIMISM CREATED BY RABIN'S VICTORY CAN BE TRANSLATED INTO RESULTS AND HHETHER HIS TIMETABLE FOR PALESTINIAN AUT
REALIZATION.

05473 L'ANGE, G.

ANGOLAN PARTENTS

SOUTH AFRICA FOUNDATION REVIEW, 18(12) (DEC 92), 4-5.

ALTHOUGH AT THE TIME OF THE ELECTION IDEOLOGICAL

DIFFERENCES BETWEEN THE TWO MAJOR PARTIES HERE INSIGNIFICANT, PAST ANTAGONISMS MAY HAVE BEEN TOO ENTRENCHED TO ADAPT TO THE NEW REALITY. THIS ARTICLE EXPLORES WHAT WENT WRONG AND SUGGESTS THAT IT IS ESSENTIAL THAT THE REASONS ARE FOUND. IT EXPLORES THE ELECTION CAMPAIGN, ETHNIC RIVALRY,

INTERNATIONAL OPINION AND THE ROLE OF SA.

05474 LABOR COMMISSION, CPUSA

FREE TRADE AGREEMENTS: THE THREAT TO LABOR

POLITICAL AFFAIRS, LXX(4) (APR 91), 16-20

EVEN WHILE U.S. LABOR IS FIGHTING BACK AGAINST THE

BRUTAL ANTI-LABOR OFFENSIVE, INTENSIFIED UNDER THE REAGN-

BUSH ADMINISTRATIONS, A NEH AND EVEN DEEPER ATTACK ON

LABOR'S RIGHTS, WAGES, HOURS, AND WORKING CONDITIONS IS

BEING SHAPED: THE RISE OF FREE TRADE AGREEMENTS. THIS

ARTICLE CONSIDERS THE SIZE OF THE PROBLEM AND ITS

RAMIFICATIONS; THE IMPACT OF THE PROGRAM ON LABOR, IN THE $U$.

S. AND ABROAD, INCLUDING SOME OF THE PAINFUL COSTS ALREADY
BEING INFLICTED: AND THE NEED FOR DEVELOPING COUNTER-

MEASURES TO DEFEND AND ADVANCE THE RIGHTS AND CONDITIONS OF THE HORKING CLASS.

05475 LACHMAN, D.

SOUTH AFRICA'S ECONOMIC CHALLENGES

FINANCE AND DEVELOPMENT, $29(2)$ (JUN 92), 6-9.

THE AMELIORATION OF POVERTY IN THE YEARS AHEAD WILL NEED TO BE HIGH ON THE POLITICAL AND ECONOMIC AGENDA OF THE NEW SOUTH AFRICA. THE EXTENT OF POVERTY IN THE COUNTRY IS SEVERE. THIS SUGGESTS THAT REDISTRIBUTION POLICIES ALONE WILL NOT BE SUFFICIENT TO CDNQUER IT. THIS ARTICLE EXPLORES THE SOUTH AFRICAN NEED TO MOVE TO A PATH OF REDISTRIBUTION WITH GROWTH SUFFICIENT TO GENERATE THE RESOUCES NECESSARY TO SATISFY THE LONGER-TERM NEEDS OF THE LEAST PRIVILEGED SECTORS OF SOCIETY. LONGER-TERM NEEDS OF THE LEAST PRIVILEGED SECTORS OF SOCIEY
IT ANALYZES THE DIFFICULT CHOICES WITH WHICH ANY FUTURE IT ANALYZES THE DIFFICULT CHOICES WITH WHICH ANY FUTURE
GOVERNMENT IN SOUTH AFRICA WILL BE CONFRONTED AS IT ATTEMPTS TO IMPROVE INCOME DISTRIBUTION WHILE PROMOTING ECONOMIC GROWTH.

05476 LADD, H.F.

POPULATION GROWTH, DENSITY, AND THE COSTS OF PROVIDING PUBLIC SERVICES

URBAN STUDIES, 29(2) (APR 92), 273-295.

RECENT POLICY INTEREST IN MANAGING LOCAL POPULATION GROWTH HAS DRAWN ATTENTION TO THE FISCAL PRESSURES THAT POPULATION GROWTH IMPOSES ON LOCAL GOVERNMENTS. THIS PAPER USES 1985 DATA FOR 247 LARGE COUNTY AREAS TO DETERMINE THE SEPARATE IMPACTS ON LOCAL GOVERNMENT SPENDING OF THO DIMENSIONS OF RESIDENTIAL DEVELOPMENT PATTERNS: THE RAPIDITY OF POPULATION GROWTH AND THE INTENSITY OF LAND USE AS MEASURED BY GROSS RESIDENTIAL DENSITIES. BASED ON A REGRESSION MODEL THAT CONTROLS FOR OTHER DETERMINANTS OF PER CAPITA SPENDING, IT PROVIDES CAREFUL ESTIMATES OF THE NONLINEAR IMPACTS OF POPULATION GROWTH AND POPULATION DENSITY ON THREE TYPES OF LOCAL GOVERMMENT SPENDING: CURRENT ACCOUNTS, CAPITAL OUTLAYS, AND SPENDING ON PUBLIC SAFETY.

05477 LADHA, $K$

A SPATIAL MODEL OF LEGISLATIVE VOTING WITH PERCEPTUAL ERROR PUBLIC CHOICE, 68(1-3) (JAN 91), 151-174.

THIS PAPER PRESENTS A UNIOIMENSIONAL SPATIAL MODEL OF VOTING IN WHICH MEMBERS OF CONGRESS VOTE BASES ON AN IMPRECISE PERCEPTION OF ROLL-CALL ALTERNATIVES. THE MODEL IS APPLIED TO THE SENATE ROLL-CALL VOTES OF 1977 TO ESTIMATE THE IDEAL POINTS OF THE SEMATORS, AND TO EXAMINE THE ROLE OF A LIBERAL-CONSERVATIVE DIMENSION IN DESCRIBING VOTES ON ECONOMIC ISSUES RELATIVE TO SOCIAL ISSUES. IN LIGHT OF THE SPATIAL MODEL, THE PAPER ARGUES THE "STANDARD" MODELS OF ROLL-CALL VOTING ARE NOT BASED ON A THEORY OF CHOICE, AND HENCE THAT IT IS DIFFICULT TO INTERPRET THEIR RESULTS. ALTERNATIVES TO STANDARD MODELS, BASED ON THE SPATIAL MODEL, ARE DEVELOPED AND ARE USED TOL, BASED ON THE SPATIAL MOOEL, IN DECIDING A SPECIFIC ECONOMIC ISSUED. COAL STRIP-MINING.

05478 LADHA, $K$.

THE CONDORCET JURY THEOROM, FREE SPEECH, AND CORRELATED VOTES

AMERICAN JOURNAL OF POLITICAL SCIENCE, 36(3) (AUG 92),

617-634.

THE CONDORCET JURY THEOREM PROVIDES A THEORETICAL BASIS

FOR DEMOCRACY. UNFORTUNATELY, THE THEOREM IS KNOWN TO HOLD

ONLY UNDER THE UNREALISTIC ASSUMPTION THAT VOTES ARE

INDEPENDENT. THIS PAPER GENERALIZES THE THEOREM TO
CORRELATED VOTES. THE GENERALIZED THEOREM PROVIDES AN ANALYTICAL BASIS FOR FREE SPEECH. NUMERICAL EXAMPLES SEEK TO
ILLUSTRATE THE MAIN RESULTS.

05479 LADNER, A.

SWITZERLAND

EUROPEAN JOURNAL OF POLITICAL RESEARCH, 22(4) (DEC 92 ),

527-536.

THE AUTHOR REPORTS ON SHITZERLAND'S 1991 ELECTIONS

INCLUDING THE RESULTS OF THE NATIONAL REFERENDUM AND THE

LEGISLATIVE CONTESTS.

05480 LAFER, G.

MINORITY UNEMPLOYMENT, LABOR MARKET SEGMENTATION, AND THE FAILURE OF JOB-TRAINING POLICY IN NEW YORK CITY

URBAN AFFAIRS QUARTERLY, 28(2) (DEC 92), 206-235. JOB-TRAINING POLICY RESTS ON THE ASSUMPTIONS THAT EMPLOYMENT OPPORTUNITIES ARE PLENTIFUL, THAT ADEQUATE EDUCATION IS THE KEY, AND THAT INCREASING THE UPWARD MOBILITY OF BLACK AND HISPANIC HORKERS SERVES THE INTERESTS OF EMPLOYERS AS WELL AS EMPLOYEES. IN THIS PAPER, THE AUTHOR CHALLENGES THESE ASSUMPTIONS BY PRESENTING DATA INDICATING CHALLENGES THESE ASSUMPTIONS BY PRESENTING DATA INDICATING NUMBER OF PEOPLE WHO NEED THEM. HE ARGUES THAT LABOR MARKET SEGMENTATION AND THE INTEREST OF EMPLOYERS IN MAINTAINING A SEGMENTATION AND THE INTEREST OF EHPLOYERS IN MAINTAINING A GOOD JOBS AND CREATE BARRIERS TO UPWARD MOBILITY FOR
MINORITY WORKERS.

05481 LAGON, M.P.; FINEL, B.I

THE ILLOGICAL OF AMERICAN ARMS CONTROL DOGMA: LESSONS FROM THE CARTER AND BUSH EXPERIENCES

WORLD AFFAIRS, 154(2) (FAL 91), 56-68.

THE EVENTS OF THE PAST HALF-DECADE STRONGLY SUGGEST THAT THE 1970'S ARMS CONTROL PROCESS WAS NOT ONLY UNSUCCESSFUL BUT EVEN COUNTERPRODUCTIVE. THERE ARE FOUR BASIC REASONS WHY ARMS CONTROL HAD SO LITTLE UTILITY: (1) ARMS CONTROL DID NOT ADDRESS THE REAL SOURCES OF INSECURITY IN THE WORLD; (2) IT WAS BASED ON THE FALSE NOTION THAT MORE ARMS MADE HAR MORE LIKELY; ( 3 ) IT DID NOT INCREASE COOPERATION BUT MERELY PROVIDED ANOTHER AREA OF CONFLICT; AND (4) ARMS CONTROL, IN IN PLACE AN UNSTABLE STATUS QUO.

05482 LAGON, M.P.

THE INTERMATIONAL SYSTEM AND THE REAGAN DOCTRINE: CAN REALISM EXPLAIN AID TO FREEDOM FIGHTERS? BRITISH JOURNAL OF POLITICAL SCIENCE, 22(1) (JAN 92), 39-70

STRUCTURAL REALISM STRESSES THE INTERMATIONAL BALANCE OF POWER, INTERNATIONAL CONDITIONS, LIMITS ON AN INDIVIDUAL GOVERNMENT'S FREEDOM TO MAKE POLICY, AND NATIONAL INTERESTS. SOURCES OF THE REAGAN DOCTRINE ARE FOUND IN THE INTERNATIONAL ENVIRONMENT AS A WHOLE AND IN THE INOIVIDUAL COUNTRIES WHERE THE REAGAN ADMINISTRATION OPENLY AIDED INSURGENTS: AFGHANISTAN, NICARAGUA, ANGOLA, AND CAMBODIA. IN THIS PAPER, THE AUTHOR CONCLUDES THAT THE STRUCTURAL REALIST PERSPECTIVE IS NECESSARY TO EXPLAIN THE REAGAN DOCTRINE BUT NOT SUFFICIENT. IN PARTICULAR, IT FAILS TO ACCOUNT FOR THE ROLE OF POLITICAL ELITES AND THEIR BELIEFS IN POLICY-MAKING.

05483 LAHAY, Y

SORE HINMERS IN SLOVAKIA

WORLD PRESS REVIEW, 39(10) (OCT 92), 18

VLADIMIR MECIAR, THE LEADER OF THE MOVEMENT FOR

DEMOCRATIC SLOVAKIA, WON THE JUNE 1992 SLOVAK ELECTIONS. HIS

PARTY HAS PLEDGED ITSELF TO ATTAINING SLOVAKIA'S

INDEPENDENCE FROM THE CZECHOSLOVAKIAN FEDERAL STATE.

05484 LAIRD, R.

THE RENOVATION OF FRENCH DEFENSE POLICY

ARMS CONTROL, 12(3) (DEC 91), 99-119.

THE PURPOSE OF THIS ARTICLE IS TO IDENTIFY THE DYMAMICS OF CHANGE HITHIN THE FRENCH DEFENSE COMMUNITY IN THE WAKE OF THE REVOLUTION OF 1989. THE BASIS OF FRENCH POLICY HAS CHANGED, AS HAS THE ENVIRONMENT WITHIN WHICH THE CLASSICAL DEFENSE CONCEPT WAS FRAMED. HITH A CHANGE IN THE OBJECTIVE BASIS OF POLICY THERE IS A STRUGGLE TO PROVIDE A NEW INTELLECTUAL STRUCTURE TO DEFINE DEFENSE POLICY IN A WAY INTELLECTUAL STRUCTURE TO DEFINE DEFENSE POL ICY IN A WHICH SEEMS RELEVANT TO THE FRANCE OF TODAY, NOT OF
YESTERDAY. THE MITTERRAND ADMINISTRATION IS SEEKING TO FRAME YESTERDAY. THE MITTERRAND ADMINISTRATION IS SEEKING TO FRAME POLICY FOR THE NEXT TEN YEARS AT A CRITICAL JUNCTURE IN TERM IT HOPES TO SHAPE THE LONGER-TERM POLICY MUCH AS DE TERM IT HOPES TO SHAPE THE LON
GAULLE DID IN THE MID 1960 S

05485 LAKE, D.A.

POWERFUL PACIFISTS: DEMOCRATIC STATES AND WAR AMERICAN POLITICAL SCIENCE REVIEH, 86(1) (MAR 92), 24-37. DEMOCRACIES ARE LESS LIKELY TO FIGHT WARS WITH' EACH OTHER AND MORE LIKELY TO PREVAIL IN WARS WITH AUTOCRATIC STATES. THE AUTHOR OFFERS AN EXPLANATION OF THIS PHENOMENON DRAHN FROM THE MICROECONOMIC THEORY OF THE STATE. STATE RENTSEEKING CREATES AN IMPERIALIST BIAS IN A COUNTRY'S FOREIGN 
POLICY. THIS BIAS IS SMALLEST IN DEMOCRACIES, WERE THE COSTS TO SOCIETY OF CONTROLLING THE STATE ARE RELATIVELY LOH, AND GREATEST IN AUTOCRACIES, hHERE THE COSTS ARE HIGHER. AS A RESULT OF THIS BIAS, AUTOCRACIES ARE MORE EXPANSIONIST AND, IN TURN, WAR-PRONE. IN THEIR RELATIONS WITH EACH OTHER, WHERE THE ABSENCE OF THIS IMPERIALIST BIAS IS MANIFEST, THE RELATIVE PACIFISM OF DEMOCRACIES APPEARS. IN ADDITION, BECAUSE DEMOCRACIES ARE CONSTRAINED BY THEIR SOCIETIES FROM EARNING RENTS, THEY DEVOTE GREATER ABSOLUTE RESOURCES TO SECURITY, ENJOY GREATER SOCIETAL SUPPORT FOR THEIR POLICIES, AND TEND TO FORM OVERHHELMING COUNTERCOALITIONS AGAINST EXPANSIONIST AUTOCRACIES. IT FOLLOWS THAT DEMOCRACIES WILL BE MORE LIKELY TO WIN WARS.

05486 LAL, $V$.

FIJI: COUPS IN PARADISE

ZED BOOKS, , 1990, 268

DURING 1987, THE PACIFIC ISLAND OF FIJI WAS THROWN INTO TURMOIL BY THO MILITARY COUPS, FOLLOHING THE ELECTORAL VICTORY OF A NEW POLITICAL COALITION REPRESENTING RELATIVELY UNDER-PRIVILEGED ETHNIC FIJIANS AND THE DESCENDENTS OF INDIAN INDENTURED LABORERS. THIS BOOK RECOUNTS THE STORY OF TRAUMATIC EVENTS AND PROVIDES A COMPREHENSIVE HISTORY OF FI JI'S EMERGENCE TO INDEPENDENCE, COMPLEX CONSTITUTIONAL ARRANGEMENTS, AND THE SUBSEQUENT YEARS DURING WHICH A CONSERVATIVE GOVERNMENT, DOMINATED BY THE CHIEFLY CLASS, INTERFERENCE IN THE ISLAND'S AFFAIRS BY U.S. AND AUSTRALIAN INTERESTS.

05487 LAL

PARADISE LOST; FIJI: COUPS IN PARADISE

ZED BOOKS,. 1990, 232-234.

THIS CHAPTER BRIEFLY SUMMARIZES THE RESULTS OF THE 1987

MILITARY COUP IN FIJI AND THE ENSUING REPRESSION OF INDIANS IN FIJI. PREDICTIONS OF A TIME OF SEVERE REPRESSION, ISOLATION AND ECONOMIC HARASSMENT HAVE APPARENTLY COME TRUE. THE PROSPECTS FOR OVERCOMING THE DEEP-SEATED RACISH, TRIBALISH, AND COMHUNALISM ARE NOT ENCOURAGING.

05488 LAL, $V$.

RACIAL POLITICS IN TURBULENCE; FIJI: COUPS IN PARADISE ZED BOOKS, 1990, 155-167.

THIS CHAPTER EXAMINES THE RACIAL AND ETHNIC CONFLICTS THAT HAVE OFTEN CHARACTERIZED POLITICS IN FIJI. NATIVE FIJIANS ARE SOUARED OFF AGAINST THE DESCENDANTS OF INOIAN FIJIANS ARE SOUARED OFF AGAINST THE DESCENDANTS OF INOIAN
WORKERS IMPORTED BY THE BRITISH IN THE COLONIAL ERA. THE RULING ALLIANCE PARTY, ADEPT AT USING ANY POSSIBLE TACTIC TO MAINTAIN ITS HOLD ON POWER, HAS USED ETHNIC AND RACIAL MAINTAIN ITS HOLD ON POWER, HAS USED ETHNIC AND RACIAL CONCLUDES THAT THE ALLIANCE TACTICS ARE VERY DANGEROUS TO CONCLUDES THAT THE ALLIANCE TACTICS

05489 LAL $Y$.

SOLDIERS IN PARADISE; FIJI: COUPS IN PARADISE

ZED BOOKS, , 1990, 192-221

AFTER ONE MONTH AND THO DAYS IN OFFICE, FIJI'S NFP/FLP COALITION WAS FORCED FROM POWER BY A MILITARY COUP. THIS CHAPTER EXAMINES THE EYENTS THAT LED TO AND FOLLOWED THE COUP ON 14 MAY 1987. THE DAY "DEMOCRACY DIED IN FIJI." IT EXAMINES THE ROLE AND/OR PARTICIPATION OF THE FIJIAH MILITARY, THE ARMY COMMANDER, THE GOVERNOR-GENERAL. THE QUEEN OF ENGLAND, AND THE FORMERLY RULING ALLIANCE PARTY.

05490 LAL, $Y$

THE EXTERMAL DIMENSION; FIJI: COUPS IN PARADISE

ZED BOOKS,., 1990, 222-231.

THE MAY 1987 COUP IN FIJI LED TO ALLEGATIONS AND COUNTERALLEGATIONS OF PARTICIPATION OR COMPLICITY BY OUTSIDE POWERS. THIS CHAPTER EXAMINES THESE ALLEGATIONS HITH EMPHASIS ON THE POSSIBILITY OF US/CIA INVOLVEMENT ANO PARTICIPATION BY THE BRITISH COMMONHEALTH. IT CONSIDERS POL ICY STATEMENTS, BOTH PUBLIC AND PRIVATE, MADE BY OUTSIDE POHERS WITH REGARDS TO THE POSSIBILITY AND IMPLICATIONS OF A RISE TO POHER OF THE "LEFTIST" FIJI LABOR PARTY.

05491 LAL, $Y$.

THE RISE AND FALL OF THE FIJI LABOUR PARTY; FIJI: COUPS IN PARADISE

ZED BOOKS, , 1990, 168-191.

THIS CHAPTER CHRONICLES THE ORIGINS, DEVELOPMENT AMD

DEMISE OF THE FI JI LABDUR PARTY (FLP). IN HISTORICAL

PERSPECTIVE, THE FORMATION OF THE FLP AND THE STATEMENTS OF

ITS LEADERS SAW THE REBIRTH OF THE "AGITATIONAL POLITICS"

LABORERS ON THE SUGAR PLANTATIONS. THE FLP CAME INTO BEING

AFTER THE ALLIANCE GOVERNMENT UNILATERALLY IMPOSED A HAGE

FREEZE IN NOVEMBER 1984. THE ADVENT OF THE FLP GAVE RISE TO

COMMUNAL STRIFE, POLITICAL SPLINTERING AND DISORDERS, AND

THE USUAL WIN-AT-ALL-COSTS TACTIC OF THE RULING ALLIANCE PARTY.

05492 LALL, S.

TECHNOLOGICAL CAPABILITIES AND INDUSTRIALIZATION
WORLD DEVELOPMENT, 20(2) (FEB 92), 165-186.

THIS PAPER REVIEWS THE IMPLICATIONS FOR INDUSTRIAL STRATEGY OF RECENT RESEARCH ON TECHNOLOGICAL CAPABILITIES AT THE FIRM AND NATIONAL LEVELS. AFTER EXPLORING THE NATURE AND DETERMINANTS OF MICROLEVEL TECHMOLOGICAL DEVELOPMENT, A SIMPLE FRAMEWORK FOR EXPLAINING THE GROWTH OF NATIONAL CAPABILITIES IS SET OUT, BASED ON THE INTERPLAY OF INCENTIVES, CAPABILITIES, AND INSTITUTIONS. EACH MAY SUFFER MARKET FAILURE AND SO REOUIRE CORRECTIYE INTERVENTION. THE EXPERIENCE OF SOME INDUSTRIALIZING COUNTRIES IS DESCRIBED TO ASSESS THE VALIDITY OF THIS FRAMEWORK. IT IS CONCLUDED THAT INTERVENTIONS, CAREFULLY AND SELECTIVELY APPLIED, ARE NECESSARY FOR INDUSTRIAL SUCCESS.

05493 LALOR, P.

BENDING TO THE STORM: PALESTINIAN OPTIONS IN THE PEACE PROCESS

WORLD TODAY, 48 (1) (JAN 92), 12-16.

WORLD TODAY, $48(1)$ ( JAN 92 ), $12-16$.
THE 1991 MADRID PEACE CONFERENCE WAS PRECEDED BY MONTHS OF WIDE-RANGING, SOMETIMES FIERCE, DEBATE AMONG THE OF HIDE-RANGING, SOMETIMES FIERCE, DEBATE AMONG THE
PALESTINIANS. DURING THE DISCUSSIONS, THE OPPONENTS OF PALESTINIAN INVOLVEMENT IN THE PEACE PROCESS WERE PALESTINIAN INVOLVEMENT IN THE PEACE PROCESS WERE OVERWHELMED BY THE FORCE OF CURRENT REALITIES AND THE
ARGUMENTS FOR SAYING "YES" TO THE AMERICAN PROPOSAL. BY THE TIME THE PALESTINIAN NATIONAL COUNCIL ENDED ITS MEETING IN ALGIERS IN SEPTEMBER, THE TREND TOWARD PARTICIPATION IN THE AMERICAN-SPONSORED PEACE PROCESS HAD BECOME UNSTOPPABLE.

05494 LAMARCHE, G.

THE U.S.' "HATE SPEECH" DEBate

PEACE \& DEMOCRACY NEWS, 11 (2) (WIN 92), 35-38.

THE UNITED STATES IS IN THE MIDST OF ONE OF ITS PERIODIC DEBATES ABOUT THE BORDERS OF FREE SPEECH AND EQUALITY. GARA LAMARCHE PRESENTS THO IMPORTANT PERSPECTIVES THAT HAVE BEEN MISSING FROM THE DEBATE. THE FIRST IS AN INTERMATIONAL PRESPECTIVE: VIRTUALLY EVERY OTHER COUNTRY ON EARTH PUNISHED RACIST EXPRESSION. SECOND IS HOW MINORITIES AND OTHERS WHO HAVE LACKED POLITICAL POWER ARE DISADVANTAGED BY CURBS ON SPEECH AND EXPRESSIONS, AND HOW THEY HAVE BEEN TARGETED IN MANY U.S. CENSORSHIP BATTLES. THE AUTHOR EXPLORES FREE SPEECH AND INTERNATIONAL LAW AND HATE SPEECH LAHS AROUND THE WORLD. HE MOVES ON TO THE IMPACT OF U.S. CENSORSHIP LAHS ON WORLD. HE MOVES ON TO THE IMPACT OF U.S. CENSORSHIP LAHS ON
MINORITIES AND THE ST. PAUL CASE. HE CONCLUDES THAT IT IS MINORITIES AND THE ST. PAUL CASE. HE CONCLUDES THAT IT IS
TECHNICALLY IMPOSSIBLE TO WRITE AN ANTI-SPEECH CODE THAT

TECHNICALLY IMPOSSIBLE TO WRITE AN ANTI-SPEECH CODE THAT
CANNOT BE TWISTED AGAINST SPEECH NOBODY MEANS TO BAR.

05495 LAMBECK, M.S

WORLD-WIDE TRIBUTES TO WILLY BRANDT, VISIONARY

INTERNATIONAL STATESMAN

GERMAN TRIBUNE, (1536) (OCT 92), 1-2

THE AUTHOR TRACES THE POLITICAL CAREER OF FORMER GERMAN CHANCELLOR WILLY BRANDT, A NOBEL PEACE PRIZE WINNER WHO DIED IN OCTOBER 1992.

05496 LAMONT-BRDWN, R.

THE YAKUSA: JAPAN'S GANGSTERS

CONTEMPORARY REVIEW, 1519(261) (AUG 92), 80-83.

TODAY'S "YAKUSA" MOBSTERS, JAPAN'S EQUIVALENT OF THE

MAFIA, HAVE EVOLVED INTO A NEH BREED OF HOODLUM WHO IS

FORGING A FRESH PHILOSOPHY OF PERSONAL AGGRANDIZEMENT AND PRIVATE FORTUNE AMASSING AS COMPARED TO THEIR FORERUNMERS WHO BENT THEIR WILLS TO THE HHIM OF GANGLAND BOSSES. BY THE EARLY 1980S THERE WERE AROUND 219,800 GANGSTERS DIVIDED INTO 125-150 GANGS. WHILE THE CORE OF "YAKUSA" BUSINESS STILL REMAINS THE TRADITIONAL CRIME OUTLETS, THE GANGS ARE BEGINNING TO SET UP OPERATIONS AND NETWORKS OVERSEAS. "YAKUSA" PRESENCE HAS BEEN NOTED IN BANGKOK, SEOUL, HAWAII, THE WEST COAST OF THE UNITED STATES, AND HONG KONG. AS THE $1990 S$ EVOLVE THE "YAKUSA" PLAN TO DIVERSIFY FURTHER. THEIR CORE ACTIVITIES OF SEX AND GAMBLING ARE STILL SAFE AND THE JAPANESE HYPBRID ECONOMY OF NEO-FEUDAL CORPORATISM STILL PRODUCES A QUALITY OF LIFE THAT MAKES LIFE DEPRESSINGLY POOR FOR HUNDREDS OF THOUSANDS. THEY SEE THEIR IMMEDIATE FUTURE ROLE IN EXPANDING INTO BUSINESS CADRES AND THE INTERNATIONAL SCENE.

05497 LAMPE, D.

COURT OPINION: LOCAL GOVERMMENTS NO LONGER DEEP POCKETS OF FIRST RESORT

NATIONAL CIVIC REVIEW, 80(4) (FAL 91), 422.

MATIONAL CIVIC REVIEW, 80 (4) (FAL 91) 422 .
A NEW YORK STATE APPELLATE COURT HAS OVERTURNED ANOTHER A NEW YORK STATE APPELLATE COURT HAS OVERTURNED ANOTHER
COURT'S RULING THAT ORDERED THE TOWN OF OYSTER BAY TO PAY $\$ 821,000$ TO A YOUNGSTER WHO SUFFERED AN EYE INJURY WHILE PLAYING WITH A FRIEND IN A TOWN-OWMED DRAINAGE SUMP. PLAYING WITH A FRIEND IN A TOWN-OWNED DRAINAGE SUMP. SERIOUS OBSTACLE FOR THOSE HHO BELIEVE THAT ANY ACCIDENT THAT OCCURS ON PUBLIC PROPERTY WILL SECURE THEM AN ACTIONABLE LAWSUIT WITH THE MUNICIPAL GOVERNMENT AS DEFENDANT.

05498 LAMPE, D.

HEALTHY COMHUNITIES: PROPOSED STATE-LEVEL HEALTH CARE

REFORM PLANS SEEK TO REDUCE COSTS AND INCREASE ACCESS NATIONAL CIVIC REVIEN, 81(2) (SPR 91), 174-178. 
FINANCIAL BARRIERS TO BASIC HEALTH CARE REPRESENT THE SINGLE LARGEST ACCESS PROBLEM FOR MILLIONS OF AMERICANS. TO HELP OVERCOME THIS FUNDAMENTAL OBSTACLE, 12 STATES HAVE BEEN AWARDED A TOTAL OF S8.4 MILLION TO DEVELOP A HIDE RANGE OF AWARDE A EXPAND HEALTH INSURANCE COVERAGE AND CONTAIN COSTS, PLANS TO EXPAND HEALTH INSURANCE COVERAGE AND CONTAIN CC INITIATIVES IN HEALTH CARE FINANCING REFORM PROGRAMS. THIS INITIATIVES IN HEALTH CARE FINANCING REFORM PROGRAMS. THIS ARTICLE INCLUDES BRIEF DESCRIPTIONS OF THE PLANS ADOPTED IN ARKANSAS, COLORADO, FLORIDA, IOHA, MINNESOTA, NEW MEXICD,
NEW YORK, NORTH DAKOTA, OKLAHOMA, OREGON, VERMONT, AND NEW YORK, NOR
WASHINGTON.

05499 LAMPE, D.

STATE REVENUES (FROM ALL SOURCES) UP SEVEN PERCENT NATIONAL CIVIC REVIEW, 80 (4) (FAL 91), 426-427.

ACCORDING TO THE CENSUS BUREAU, TOTAL STATE GOVERMMEN REVENUE GREW TO \$625 BILLION IN FY1990, AN INCREASE OF ABOUT SEVEN PERCENT. MEANHHILE, EXPENDITURES EXPANDED TO $\$ 572$ BILLION, AN INCREASE OF NINE PERCENT.

05500 LAMPE, D.

STATE SPENDING GROWTH OUTSTRIPS REVENUE GROWTH

MATIONAL CIVIC REVIEH, 81(3) (SUM 92), 376-377.

STATE GOVERHMENT SPENDING GREW MORE THAN TWICE AS FAST

AS REYENUES BETWEEN 1990 AND 1991 TOTAL STATE OUTLAYS WERE

AS REVENUES BETWEEN 1990 AND 1991. TOTAL STATE OUT
UP 10 PERCENT, HHILE REVENUES GREH ONLY 4 PERCENT.

05501 LAMPE, $D$

STUDY CORRELATES DISSATISFACTION WITH CANDIDATES AND LOH PRIMARY TURMOUT

MATIONAL CIVIC REVIEN, 81(1) (WIN 92), 70-71.

THE COMMITTEE FOR THE STUDY OF THE AMERICAN ELECTORATE HAS RELEASED A REPORT HHICH INDICATES THAT DISSATISFACTION WITH THE CANDIDATES IS CAUSING CITIZENS TO REMAIN ON THE SIDELINES AND NOT VOTE. IN THE 1992 DEMOCRATIC PARTY PRIMARIES, RECORD LOW TURNOUTS WERE REPORTED IN FLORIDA, GEORGIA, NEW YORK, TENNESSEE, AND TEXAS.

05502 LAMPE, $D$.

THE POLITICS OF ENVIRONMENTAL EOUITY

NATIONAL CIVIC REVIEW, 81(1) (WIN 92), 27-35

THE MEDIA HAS FOCUSED ATTENTION ON THE DEMOGRAPHIC CHARACTERISTICS OF COMHUNITIES IN WHICH ENVIRONMENTALLYSENSITIVE FACILITIES AND LAND USES ARE OFTEN SITED. DOES THE PLACEMENT OF THESE GENERALLY UNWELCOME FACILITIES REFLECT ACTIVE DISCRIMINATION AGAINST TRADITIONALLY DISEMPOWERED POPULATIONS, UNEVEN ENFORCEMENT PATIERNS, OR A BREAKDOWN OF DEMOCRATIC PROCESS?

05503 LAMPE, J.R. (ED.)

CREATING CAPITAL MARKETS IN EASTERN EUROPE

CREATING CAPITAL MARKETS IN EASTERN EUROPE

EXPLAINING HOH CRUCIAL TOOLS FOR PRIVATIZING LARGE-SCALE EXPLAINING HOH CRUCIAL TOOLS FOR PRIVATIZING LARGE-SC

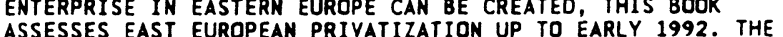
ASSESSES EAST EUROPEAN PRIVATIZATION UP TO EARLY 1992 . THE AUTHORS COMPARE WESTERN EUROPE'S POST-WORLD WAR II FINANC INSTI IUTIONS WITH EASTERN EUROPE'S LEGACY OF INSTITUTIONS LAST SEEN BEFORE THE WAR. THEY ALSO CONTRAST THE CONTINENTAL EUROPEAN RELIANCE ON COMMERCIAL BANKS TO ALLOCATE CREDIT CAPITAL WITH ANGLO-AMERICAN USE OF STOCK MARKETS. THE AUTHORS CONCLUDE THAT THE PACE OF PRIVATIZATION MUST BE ACCELERATED IF THE TRA

05504 LANCASTER, C.

NEW DIRECTION FOR U.S. FOREIGN AID

TRANSAFRICA FORUM, $9(2)$ (SUM 92), 53-67

WHILE AFRICA HAS NEVER CLAIMED A HIGH PRIORITY IN U.S. FOREIGN POLICY AND U.S. AID LEVELS TO THE CONTINENT HAVE HISTORICALLY BEEN LOW, THE BASES FOR ALLOCATING AID HAVE FLUCTUATED GREATLY COLD WAR RIVALRY PROVIDED A STRONG INCENTIVE FOR AMERICAN AID TO AFRICAN CDUNTRIES, BUT OVER THE YEARS THIS INCENTIVE ALTERHATED IN IMPORTANCE WITH SUCH CONCERNS AS HEALTH, RURAL DEVELOPMENT, INFRASTRUCTURAL DEVELOPMENT, AND HUMAN RIGHTS. FUNDIMG FOR AFRICAN AID PROGRAMS HAS TENDED TO RISE AND FALL ACCORDING TO THE LATEST TRENDS IN DEVELOPMENT THINKING. WITH THE END OF THE COLD WAR, AMERICAN AID TO AFRICA IS LIKELY TO DECLINE FURTHER UNLESS THE CONSTITUENCY FOR AFRICA CAN PROVIDE THE POLITICAL FOUNDATIONS ANO GUIDANCE FOR FUTURE U.S. POLICIES TOWARD AFRICA.

05505 LANDAU, J.

SOVIET WORKS ON MIDDLE EASTERN POLITICAL PARTIES

MIDOLE EASTERN STUDIES, 28(3) (JUL 92), 588-591.

MIDDLE EASTERN STUDIES, 28(3) (JUL 92), 588-591. PARTIES ARE VERY FEH SOVIET MONGRAPHS ON INDIVIDUAL

PARTIES IN THE MIDDLE EAST. THESE POLITICAL PARTIES ARE
USUALLY REFERRED TO IN THE CONTEXT OF GENERAL POLITICS, WITH USUALLY REFERRED TO IN THE CONTEXT OF GENERAL POLITICS, WITH
A RIGID IDEOLOGICAL APPROACH CRITICIZING OR IGNORING MOST NON-COMMUNIST PARTIES. THE PRINCIPAL VARIABLE DISTINGUISHING THE WRITERS IS THE HARSHNESS OF THE BLAME ASCRIBED.

05506 LANDE, C.H.

VOTERS AND PARTIES AT PHILIPPINE ELECTIONS: PATTERN OF
GEOGRAPHIC AND SOCIO-ECONOMIC CLEAVAGE; ASSOCIATION FOR ASIAN STUDIES 1992 ANNUAL MEETING ASSOCIATION FOR ASIAN STUDIES, 1992, 152-153.

FROM THE TIME OF PHILIPPINE INDEPENDENCE IN 1946 UNTIL THE IMPOSITION OF MARTIAL LAW IN 1972, PHILIPPINE POLITICS REVOL VED AROUND THE COMPETITION OF THO CLIENTELISTICALLYSTRUCTURED POLITICAL PARTIES THAT WERE VIRTUALLY IDENTICAL IN THEIR GEOGRAPHICALLY NATION-WIDE AND SOCIO-ECONOMICALLY DIVERSE SOURCES OF SUPPORT. THIS MEANS THAT, HHILE THERE HAS A HIGH DEGREE OF LONG-TERM POLITICAL STABILITY, ELECTIONS PROVIDED THE VOTER LITTLE OPPORTUNITY FOR SIGNALING THEIR ENDED WITH MARTIAL LAN. SINCE THE RESTORATION OF COMPETITIVE ELECTIONS DURING THE LAST YEARS OF THE MARCOS GOVERNMENT, A NEW, IF AS YET UNSTABLE, PARTY SYSTEM HAS EMERGED. THE AIM OF THIS PAPER IS TO DISCERN TO WHAT EXTENT SIGNIFICANT GEOGRAPHIC AND SOCIO-ECONOMIC CLEAVAGES MARK THE DIFFERENCE BETWEEN THE SEVERAL POST-MARCOS POLITICAL PARTIES. THE STUDY IS BASED ON THE ANALYSIS OF THE PHILIPPINE NATIONAL ELECTIONS OF 1981, 1986, 1987, AND THE CONSTITUTIONAL PLEBISCITE OF 1986. MULTIPLE REGRESSION ANALYSIS AND MAPS ARE EMPLOYED AS A MEANS OF ANSWERING THE ISSUE POSED ABOVE. THE ANALYSIS SHOWS THAT LINGUISTIC-REGIONAL VARIABLES WERE THE STRONGEST PREDICTORS OF PARTY SUPPORT, BUT SOCIOECONOMIC VARIABLES WERE OF SOME PREDICTIVE VALUE, ESPECIALLY FOR A COALITION OF CANDIDATES OF THE RADICAL LEFT.

05507 LANDELL-MILLS, $P$.

GOVERNANCE, CUL TURAL CHANGE, AND EMPOWERMENT
JOURNAL OF MODERN AFRICAN STUDIES, 30(4) (DEC 92), 543-568. JOURNAL OF MODERN AFRICAN STUDIES, 30(4) (DEC 92), $543-568$.
THE FIRST THREE DECADES OF AFRICAN INDEPENDENCE HAVE BEEN AN ECONOMIC, POLITICAL, AND SOCIAL DISASTER. THIS IS BEEN AN ECONOMIC, POLITICAL, AND SOCIAL DISASTER. THIS IS LARGELY BECAUSE AFRICANS ENDEAVORED TO ADOPT WESTERN MODELS THAT WERE PRIMARILY ATTEMPTS BY AFRICAN LEADERS TO THAT WERE PRIMARILY ATTEMPTS BY AFRICAN LEADERS TO RATIONALIZE THEIR AUTHORITARIAN REGIMES. A BETTER
UNDERSTANDING OF THE CULTURAL CONTEXT IN WHICH GOVERMMENTS MUST FUNCTION IS NEEDED. AFRICA WILL ONLY EMERGE FROM ITS CURRENT DIFFICULIIES IF IT CAN PROGRESSIVELY REMODEL ITS INSTITUTIONS IN HARMONY HITH THE TRADITIONS, BELIEFS, AND STRUCTURES OF ITS COMPONENTS SOCIETIES. THE CHALLENGE IS TO BUILD ON THE ELEMENTS THAT ARE COMPATIBLE WITH MODERNIZATION AND DEVELOPMENT, REJECTING THOSE THAT ARE NOT AND, HHERE NECESSARY AND APPROPRIATE, BORROWING WISELY FROM FOREIGN MODELS. THE NURTURING OF CIVIL SOCIETY THROUGH THE DEVELOPMENT OF ITS ASSOCIATIONAL LIFE WILL BOTH DEEPEN AND BROADEN POPULAR PARTICIPATION IN, AND CONTROL OF, ITS INSTITUTIONS.

05508 LANDFRIED, C. JUDICIAL POLICY-MAKING IN GERMANY: THE FEDERAL CONSTITUTIONAL COURT

WEST EUROPEAN POLITICS, 15(3) (JUL 92), 50-67. THE MOST POHERFUL POL ICY-MAKER AMONG GERMAN COURTS IS THE MOST POHERFUL POLICY-MAKER AMONG GERMAN COURTS IS
THE CONSTITUTIONAL COURT. IN THIS ESSAY, THE AUTHOR ARGUES THAT THE DANGER OF JUDICIAL REVIEN IS THE JUDICIALIZATION OF THAT THE DANGER OF JUDICIAL REVIEN IS THE JUDICIALIZATION OF
POLITICS. MORE AND MORE POLITICAL QUESTIONS ARE DECIDED BY POLITICS. MORE AND MORE POLITICAL QUESTIONS ARE DEC

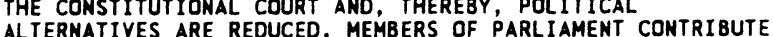
ALTERNATIVES ARE REDUCED. MEMBERS OF PARLIAMENT CONTRIBUTE TEGAL ARGUMENTS IN LEGISLATION AND JUDGES BY EXCEEDING THEIR LEGAL ARGUMENTS IN LEGISLATION AND JUDGES BY EXCEEDING THEIR COMPETENCE IN SOME CASES. WHILE IT IS A SIMPLIFICATION TO THE POLITICAL ELITE THE GROWING INFLUENCE OF JUDICIAL THE POLITICAL ELITE, THE GROWING INFLUENCE OF JUDICIAL

05509 LANDY, $J$.

THE U.S. IN A CHANGING WORLD

PEACE \& DEMOCRACY NEWS, 6(1) (WIN 92), 3-7.

IT IS SUGGESTED THAT THE ESSENTIALS OF A PROGRESSIVE FOREIGN POL ICY WOULD BE THE PROMOTION OF GLOBAL DEMOCRACY, ECONOMIC COOPERATION, SOCIAL JUSTICE AND DEMILITARIZATION. IT IS ALSO SUGGESTED THAT THE U.S. POLITICAL CULTURE HAS BECOME SO CORRODED THAT IT IS DIFFICULT TO SUGGEST SUCH A FOREIGN POLICY WITHOUT SOUNDING LIKE A NAIVE DREAMER. IN ARGUING FOR A NEW INTERNATIONAL ETHOS FOR THE U.S., IT IS NECESSARY TO PROPOSE AN ALTERNATIVE POLICY THAT ACKNOWLEDGES THE LEGITIMATE NEEDS OF THE AMERICAN PEOPLE FOR A DECENT AND SECURE ECONOMIC LIFE. A FUNDAMENTALLY NEW KIND OF INTERNATIONAL MONETARY AND DEVELOPMENT FUND IS NEEDED, ONE THAT CAN ENGAGE IN DEMOCRATIC STRATEGIC INTERNATIONAL

PLANNING, AND ALLOCATE MAJOR CAPITAL AND RESOURCES, BOTH TO POORER COUNTRIES AND TO WORKERS AND INDUSTRIES IN WEALTHIER COUNTRIES DISLOCATED BY FOREIGN PROOUCTION OR ECOLOGICAL

RETOOLING.

05510 LANE, C.

WAR AND REMEMBRANCE

NEW REPUBLIC, $206(8)$ (FEB 92), 9-11.

THE AUTHOR DISCUSSES THE HAR IN EL SALVADOR, THE U.S. ROLE. AND THE EL SALVADOREAN PEOPLE'S ATTEMPT TO FIND MEANING IN ALL THE DESTRUCTION. 
05511 LANE, J.; ERSSON, $S$.

FROM POLITICAL SOCIOLOGY TO POLITICAL INSTITUTIONALIZATION; POLITICS AND SOCIETY IN WESTERN EUROPE

SAGE PUBLICATIONS, 1991, 15-51.

THIS CHAPTER SURVEYS THEORETICAL APPROACHES THAT ARE RELEVANT TO THE STUDY OF WEST EUROPEAN POLITICS. THE ANALYSIS OF HEST EURDPEAN POLITICS HAS STRUGGLED WITH TWO METHODOLOGICAL PROBLEMS. FIRST, THERE IS A TENSION BETWEEN THE USE OF THE CASE STUDY METHOD AND A GENUINE COMPARATIVE FRAMENORK OR MODEL. SECOND, THE STUDY OF POLITICS OR THE POLITICS IN HESTERN EUROPE' STARTED FROM A POLITICAL SOCIOLOGY PERSPECTIVE, BUT HAS GRADUALLY MOVED TOWARD AN INSTITUTIONALIST APPROACH. THEORETICAL APPROACHES SURVEYED INCLUDE: SOCIAL STRUCTURE, DEMOCRATIC STABILITY, CLEAVAGES CONDITIONS FOR POLYARCHY, POLITICAL CULTURE, SOCIAL OF POLITICAL COHESION, CONSENSUS DEMOCRACY, CORPORATISM, AND POLITICAL COHESION, CONSENSUS DEM

05512 LANE, J.; ERSSON, $S$.

POLITICAL PARTIES; POLITICS AND SOCIETY IN HESTERN EUROPE SAGE PUBLICATIONS, 1991, 102-158.

THE WEST EUROPEAN COUNTRIES ARE DESCRIBED AS TYPICALLY MULTI-PARTY SYSTEMS, BECAUSE A BASIC TRAIT OF THE MAJOR DEMOCRACIES IN EUROPE IS THE OPERATION OF MORE THAN THO PARTIES IN EACH COUNTRY UNDER RULES OF CDOPERATION AMD COMPETITION. THIS CHAPTER EXAMINES POLITICAL PARTIES, MAKING A DISTINCTION BETWEEN STRUCTURAL AND NON-STRUCTURAL PARTIES THE STRUCTURAL PARTIES MAY BE DIVIDED INTD ETHNIC, AGRARIAN, RELIGIOUS AND CLASS-BASED PARTIES. AMONG THE NON-STRUCTURAL PARTIES, THE AUTHORS OISTINGUISH BETWEEN CENTER, LIBERAL, CONSERVATIVE, ENVIRONMENTAL, DISCONTENT (POPULIST), AND ULTRA-RIGHTIST PARTIES. THE CHAPTER CONSIDERS HOW MAMY PARTIES THERE ARE ACCORDING TO THESE PARTY TYPE CATEGORIES IN WEST EUROPEAN POLITICAL SYSTEMS, AND OUTLIMES THEIR CHARACTERISTIC PROPERTIES.

05513 LANE, R.

POLITICAL CULTURE: RESIDUAL CATEGORY OR GENERAL THEORY? COMPARATIVE POLITICAL STUDIES, 25(3) (OCT 92), 362-387.

POLITICAL CULTURE AS A CONCEPT FOR EMPIRICAL POLITICAL ANALYSIS HAS BEEN SO PROMISCUDUSLY EMPLOYED WITHIN THE POLITICAL SCIENCES AS TO RENDER IT MEANINGLESS. IN AN EFFORT TO LOCATE SOME BASIC STRUCTURAL PRINCIPLES THAT WILL REORIENT POLITICAL CULTURE STUDIES IN A MORE CONSTRUCTIVE DIRECTION, SIX CASE STUDIES FROM A CLASSIC COMPENDIUM IN THE DIRECTION, SIX CASE STUDIES FROM A CLASSIC COMPENDIUM IN THE
FIELD ARE ANALYZED IN COMPARATIVE PERSPECTIVE. THE RESULTING FIELD ARE ANALYZED IN COMPARATIVE PERSPECTIVE. THE RESUL TING MODELS OF THE SEVERAL POLITICAL CULTURES CAN BE INTEGRATED
WITH FORMAL POLITICAL DECISION-MAKING MODELS TO PROVIDE THE WITH FORMAL POLITICAL DECISION-MAKING MODELS TO PROVIDE
FOUNDATION FOR A FORMAL THEORY OF CULTURAL RATIONALITY.

05514 LANE, T.

TRANSFORMING POLAND'S ECONOMY

FINANCE AND DEVELOPMENT, 29(2) (JUN 92), 10-13.

IN 1992 POLAND MOVED TOWARDS A MARKET ECONOMY. BECAUSE POLAND WAS THE FIRST SOCIALIST COUNTRY TO ADOPT SUCH A RADICAL PROGRAM OF STABILIZATION AND REFORM, ITS EARLY EXPERIENCE IS OF PARTICULAR INTEREST TO OTHER COUNTRIES CONTEMPLATING MARKET-ORIENTED REFORMS, ESPECIALLY THE FORMER REPUBLICS OF THE SOVIET UNION. ALTHOUGH THE SITUATION REMAINS TOO FLUID TO PERMIT AN OVERALL ASSESSMENT, THIS ARTICLE ATTEMPTS TO PROVIDE AN ACCOUNT OF THE PROGRAM AND AN EXPLANATION OF THE COURSE OF EVENTS DURING ITS FISCAL YEAR.

05515 LANGBEIN, J.H.

ON THE MYTH OF WRITTEN CONSTITUTIONS: THE DISAPPEARANCE OF CRIMINAL JURY TRIAL

HARVARD JOURNAL OF LAW AND PUBLIC POLICY, 15(1) (WIN 92), $119-128$

AMERICANS ARE ACCUSTOMED TO VIEHING THE BILL OF RIGHTS AS AN UNQUALIFIED SUCCESS STORY. BUT ONE CHAPTER OF THE BILL OF RIGHTS STORY HAS BEEN A SPECTACULAR FAILURE: THE FRAMERS EFFORT TO EMBED JURY TRIAL AS THE EXCLUSIVE MODE OF PROCEEDING IN CASES OF SERIOUS CRIME.

05516 LANGGUTH, G.

THE SINGLE EUROPEAN MARKET--ALSO AN OPPORTUNITY FOR EASTERN EUROPE?

AUSSEN POLITIK, 43(2) (1992), 107-114.

FOLLOHING THE DEMISE OF THE COMMUNIST SYSTEM AS A RESULT OF ITS ECONOMIC WEAKNESSES THE RECONSTRUCTION OF THE RUINED EASTERN EUROPEAN COUNTRIES HAS BECOME A DECISIVELY IMPORTANT TASK. IT WILL CO-DETERMINE THE FUTURE DEVELOPMENT SECURITY IN EUROPE. GERD LANGGUTH, HEAD OF THE MISSION OF THE IN EUROPE. GERD LANGGUTH, HEAD OF THE MISSION OF THE EUROPEAN COMMISSION IN BONN AND AUTHOR OF NUMEROUS
PUBLICATIONS ON THE PROBLEMS OF THE FORMERLY DIVIDED AND NOW PUBLICATIONS ON THE PROBLEMS OF THE FORMERLY DIVIDED AND NOW
CONVERGING EUROPEAN CONTINENT, EXAMINES THE CONTRIBUTION THE CONVERGING EUROPEAN CONTINENT, EXAMINES THE CONTRIBUTION THE EUROPEAN COMMUNITY CAN MAKE TOWARD FULFILLING THIS TASK
ARTICLE EXPLORES THE EC SINGLE MARKET AND ECONOMIC AND ARTICLE EXPLORES THE EC SINGLE MARKET AND ECONOMIC AND POLITICAL GOALS

05517 LANGGUTH, G.

WILL THE GATI SYSTEM SURVIVE? AUSSEN POLITIK, 43(3) (JUL 92), 220-229.
DUE TO THE MOMENTOUS CHANGES IN HHAT WERE CALLED EASTWEST RELATIONS, OTHER IMPORTANT PROBLEMS OF HORLD POLITICS HAVE UNFORTUNATELY FAILED TO ATTRACT AS MUCH PUBLIC ATTENTION. THIS APPLIES PARTICULARLY TO THE NEGOTIATIONS ON THE FUTURE OF WORLD TRADE CURRENTLY TAKING PLACE WITHIN THE FRAMEWORK OF THE GENERAL AGREEMENT ON TARIFFS AND TRADE. THE TRANSLATIC ALLIANCE, ONE OF THE MOST IMPORTANT FACTORS OF GLOBAL STABILITY, AND THE INTEGRATION OF CENTRAL AND EASTERH EUROPE INTO THE WESTERN CULTURAL AREA, THUS PUTTING AN END TO EAST-WEST CONFRONTATION ONCE AND FOR ALL, DEPEND ON AN ARRANGEMENT WHICH PREVENTS THE TENDENCIES TOHARD ECONOMIC ISOLATIONISM IN DEVELOPED REGIONS.

05518 LANGHORNE, R.

THE REGULATION OF DIPLOMATIC PRACTICE: THE BEGINNINGS TO

THE VIENMA CONVENTION ON DIPLOMATIC RELATIONS, 1961

REVIEW OF INTERNATIONAL STUOIES, 18 (1) (JAN 92), 3-18.

HAS SO OFTEN BEEN UNSAYOURY, HAVE MORE RECENTLY BEEN HIGHLY HAS SO OFTEN BEEN UNSAVOURY, HAVE MORE RECENTLY BEEN HIGHLY REGARDED. THIS ARTICLE TRACES THE COURSE OF EVENTS WHICH FIMALLY BROUGHT DEVELOPMENTS TO A CONCLUSION WITH THE SIGNING OF THE VIENNA CONVENTION ON DIPLOMATIC RELATIONS IN 1961. IT TRACES THE BEGINNINGS OF DIPLOMACY, THE CODIFICATION OF INTERNATIONAL LAH, UNSUCCESSFUL CODIFICATION OF DIPLOMATIC PRACTICE, AND CONTINUING EFFORTS MADE IN THIS ARENA. THE 1961 VIENNA CONFERENCE IS EXAMINED.

05519 LANGKAU-HERRMANM, M.; SESSAR-KARPP, E. WOMEN IN PUBLIC ADMINSTRATION IN THE FEDERAL REPUBLIC OF GERMANY

WOMEN AND POLITICS, $1(4)$ (1991), 55-68.

THE SITUATION OF WOMEN IN THE PUBLIC SERVICE IN THE FEDERAL REPUBLIC IS PARTICULARLY SIGNIFICANT BECAUSE THE GOVERMMENT IS ONE OF THE MOST IMPORTANT EMPLOYERS OF WOMEN AND IS IN A POSITION TO SET AN EXAMPLE FOR PRIVATE INDUSTRY. THIS ARTICLE REPORTS ON THE PRESENT STATUS OF WOMEN IN PUBLIC SERVICE IN THE FEDERAL REPUBLIC OF GERMANY AS SETERMINED FROM STATISTICAL INFORMATION AS WELL AS FROM A SERIES OF EMPIRICAL INVESTIGATIONS BY THE AUTHORS. THESE INCLUDE: DATA FROM INTERVIEWS IN 1985 AND WITH 24 TOP WOMEM ADMINISTRATORS IN 7 FEDERAL MINISTRIES, AND INFORMATIOM ADMINISTRATORS IN 7 FEDERAL MINISTRIES, AND INFORMATION
GATHERED IN $1981-82$ FROM A SURVEY OF 80 HOMEN AND 24 MEN IN
THE PUBLIC SERVICE.

05520 LANGSTON, T.S.

IDEOLOGUES AND PRESIDENTS--FROM THE NEW DEAL TO THE REAGAN REVOLUTION

JOHNS HOPKINS UNIVERSITY PRESS, 1992, 264.

THIS BOOK CONSIDERS HOW IDEOLOGUES--PEOPLE DRIVEN TO POLITICS BY THE FORCE OF IDEALS--HAVE INFLUENCED PRESIDENTIAL ADMINISTRATIONS AND EVEN THE PRESIDENCY ITSELF. IT APPROACHES THIS QUESTION THROUGH CASE STUDIES OF THREE KEY PRESIDENTS WHOSE PROGRAMS CHANGED THE DIRECTION OF THE MODERN DOMESTIC AGENDA. IN CHAPTERS ON FRANKLIN ROOSELVELT,
LYNDON JOHNSON, AMD RONALD REAGAN, THE BOOK ILLUSTRATES THE LYNDON JOHNSON, AND RONALD REAGAN, THE BOOK ILLUSTRATES THE
GROWING ROLE OF IDEOLOGUES IN NATIONAL POLITICS. THESE "PEOPLE OF IDEAS" FORM A CLASS OF POLITICAL ACTORS DISTINCT NOT ONLY FROM PRAGMATIC PROFESSIONAL POLITICIANS BUT ALSO FROM NON-IDEOLOGICAL "EXPERTS" WITH WHOM IDEOLOGUES COMPETE FOR POWER. HHETHER THEY ARE LIBERAL OR CONSERVATIVE, THEY ARE A CREATIVE YET DESTRUCTIVE FORCE IN POLICYMAKING. THE AUTHOR PRESENTS EVIDENCE FROM A VARIETY OF THEORETICAL PERSPECTIVES--AMONG THEM PARTY-SYSTEMS AND DE-ALIGMMENT THEORY, "NEH CLASS" THEORY, AND ANTHROPOLGICAL APPROACHES TO IDEOLOGY.

05521 LANKOWSKI, C. (ED.) EUROPE'S EMERGING IDENTITY: REGIONAL INTEGRATION YS. OPPOSITION MOVEMENTS IN THE EUROPEAN COMMUNITY

LYNNE RIENNER PUBLISHERS, 1992, 285.

WITH MARKET INTEGRATION AS ITS PRINCIPAL FEATURE, ECEUROPE HAS FORGED AN AMBIGUOUS UNITY: EVERY ADVANCE' IN MARKET INTEGRATION, ARGUE THE AUTHORS OF THIS COLLECTION, PRODUCES PATTERNS OF DISINTEGRATION IN THE LIVES OF EUROPE'S CITIZENS. AND INTEGRATION HAS MAGNIFIED TRANSFORMATIONS ALREADY UNDERHAY IN THE MODALITIES AND CONTENT OF POLITICAL PARTICIPATION AT THE GRASSROOTS LEVEL, AS NEW COLLECTIVIST IDENTITIES AND NEW INTERESTS ARE BEING PURSUED BY FEMINISTS, PACIFISTS, ECOLOGISTS, REGIONALISTS, AND OTHERS IN EUROPE'S' SOCIAL MOVEMENT SECTORS. THE AUTHORS REINTERPRET EC POLITICS AND INSTITUTIOHAL DEVELOPMENT FROM THE POINT OF VIEW OF EUROPE'S SOCIAL MOVEMENTS, EXPLORING HOW SYSTEM BUILDING AT EUROPE'S SOCIAL MOVEMENTS, EXPLORING HOW SYSTEM BUILDING
THE REGIONAL LEVEL IS AFFECTING THE RELATIONSHIP BETWEEN THE REGIONAL LEVEL IS AFFECTING THE RELATIONSHIP BETH
CENTRIFUGAL AND HOMOGENIZING FORCES. FOLLOWING AN CENTRI FUGAL AND HOMOGENIZING FORCES. FOLLOWING AN
INTRODUCTORY OVERVIEW OF THE FORMS OF OPPOSITION TO EUROPEAN INTRODUCTORY OVERVIEW OF THE FORMS OF OPPOSITION TO EUROPEAN INTEGRATION, EACH AUTHOR SURVEYS BRIEFLY THE HISTORY OF ANT EC SENTIMENT IN A PARTICULAR COUNTRY AND ANALYZES ITS ORGANIZATIONAL FORMS, SOCIAL BASES, STRATEGIES, THE MANNER IN WHICH THE LOCAL POLITICAL SYSTEM HAS DEALT WITH OPPOSITION, AND THE SIGNIFICANCE OF THAT OPPOSITION FOR THE EC AND FOR THE COUNTRY'S DEVELOPMENT.

05522 LANOIE, P.

GOVERMMENT INTERVENTION IN OCCUPATIONAL SAFETY: LESSONS 
FROM THE AMERICAN AND CAMADIAN EXPERIENCE CANADIAN PUBLIC POLICY--ANALYSE DE POLITIQUES, 188(1) (MAR 92 ), 62-75.

THROUGH A CRITICAL REVIEW OF THE RESEARCH SURROUNDING THE PERFORMANCE OF NORTH AMERICAN OSH AUTHORITIES IN PROVIDING INSURANCE AND PROMOTING SAFETY. THIS PAPER ATTEMTPS TO ANSWER QUESTIONS RELATING TO SAFETY IN THE WORKPLACE. THIS REVIEW COVERS ALL ASPECTS OF GOVERMMENT INTERVENTION IN OSH AND CONSIDERS THE GROWING BODY OF CANADIAN LITERATURE ON THIS TOPIC. ALSO, THE PAPER DISCUSSES DIFFERENT ALTERNATIVES OFFERED TO POLICY-MAKERS.

05523 LanOUe, D.J.

ONE THAT MADE A DIFFERENCE: COGNITIVE CONSISTENCY, POLITICAL KNOWLEDGE, AND THE 1980 PRESIDENTIAL DEBATE PUBLIC OPINION QUARTERLY (CHICAGO), 56(2) (SUM 92), 168-184.

STUDIES OF THE 1960 AMD 1976 PRESIDENTIAL DEBATES STUDIES OF THE 1960 AND 1976 PRESIDENT I AL DEBATES
UNCOVERED LITTLE EVIDENCE TO SUGGEST THAT THESE EVENTS SIGNIFICANTLY AFFECTED VOTER CHOICES. AS A RESULT, SCHOLARS HAVE TURMED INCREASINGLY TO COGNITIVE CONSISTENCY THEORIES TO EXPLAIN VIENER REACTIONS (OR NONREACTIONS) TO DEBATES. IN THIS PAPER. THE AUTHOR ARGUES THAT A VOTER'S LEVEL OF POL ITICAL KNONLEDGE IS A KEY MEDIATING VARIABLE DETERMINING WHETHER OR NOT HE IS INFLUENCED BY DEBATES. ALTHOUGH THE 1980 CARTER-REAGAN DEBATE WAS LARGELY IGNORED, VOTERS WITH GENERALLY LOW LEVELS OF KNOWLEDGE WERE PART ICULARLY AFFECTE
BY IT AND SIGNIFICANT SHIFTS IN CANDIDATE PREFEENCE DID OCCUR AMONG THIS GROUP. THIS EVIDENCE SUGGESTS THAT THE DEBATE HAS AN IMPORTANT FACTOR IN RONALD REAGAN'S BID TO UNSEAT HIS DEMOCRATIC OPPONENT.

05524 LAMOUE, D.J.; BOHLER, S.

THE SOURCES OF TACTICAL VOTING IN BRITISH PARLIAMENTARY ELECTIONS, 1983-1987

POLITICAL BEHAVIOR, 14(2) (JUN 92), 141-158.

USING DATA FROM THE U.K. GENERAL ELECTION SURVEYS OF 1983 AND 1987, THE AUTHORS TEST DIFFERENT APPROACHES TO TACTICAL VOTING. SPECIFICALLY, THEY ARE CONCERNED WITH HOW THE COMPETITIVE SITUATION IN EACH CONSTITUENCY AFFECTS VOTERS' LIKELIHOOD OF VOTING TACTICALLY, AS WELL AS THE ROLE OF VOTERS' ATTITUDES AND PERSONAL CHARACTERISTICS. THEY FIND THAT VOTERS ARE LESS SENSITIVE TO THE ACTUAL MARGINALITY OF A DISTRICT THAN TO WHETHER OR NOT THEIR PARTY HAS A CHANCE OF WINNING THE SEAT. IN ADOITION, PARTY IDENTIFICATION-OF WINNING THE SEAT. IN ADDITION, PARTY IDENTIFICATION-PARTI ICULARLY INTENSE LOYALTY--DAMPENS THE TENDENCY TO VOTE
TACTICALLY, REGARDLESS OF THE TYPE OF DISTRICT. THE AUTHORS TACTICALLY, REGARDLESS OF THE TYPE OF DISTRICT. THE AUT
ALSO CONSIDER DIFFERENCES IN TACTICAL VOTING BETHEEN ALSO CONSIDER DIFFERENCES IN TACTICAL VOTING BETHEEN
CONSTITUENCIES WHERE LABOR DOMINATES VERSUS DISTRICTS WHERE CONSTITUENCIES WHERE LABOR DOMINATES VERSUS DISTRICTS WHERE THE CONSERVATIVES ARE STRONGEST. FINALLY, THEY DISCUSS
BROADER IMPLICATIONS OF THESE FINDINGS FOR THE STUDY OF
VOTHG VOTING BEHAVIOR.

05525 LANOUE, G.R. SPLIT VISIONS: MINORITY BUSINESS SET-ASIDES
ANHALS OF THE AMERICAN ACADEMY OF POLITICAL AND SOCIAL SCIENCE, (523) (SEP 92), 104-116.

IN THE 1970'S AND 1980'S, PROGRAMS ASSISTING AND PREFERRING BUSINESSES OWNED BY WOMEN AND CERTAIN MINORITY GROUP MEMBERS MUSHROOMED AT EVERY LEVEL OF GOVERNMENT. THEY WERE RELATIVELY UNCONTROVERSIAL AND REMAINED ALMOST TOTALLY UNSTUDIED. THEN, IN 1989, THE SUPREME COURT IN CITY OF RICHMOND $Y$. CROSON INVALIDATED THE USE OF RACIAL CLASSIFICATIONS IN LOCAL PUBLIC CONTRACTING PROGRAMS UNLESS THEY WERE USED AS TEMPORARY, MARROWLY-TAILORED REMEDIES FOR IDENTIFIED DISCRIMINATION. CROSON HAS TRIGGERED A FLURRY OF ITIGATION ACROSS THE COUNTRY ALONG WITH AN AVALANCHE OF STUDIES COMMISSIONED TO HELP JURISDICTIONS PRESERVE THEIR MINORITY BUSINESS PROGRAMS. THE OUTCOME OF THE CONFLICT OVER THESE PROGRAMS MAY DEFINE THE LIMITS OF USING RACIAL

CLASSIFICATION IN A YARIETY OF PUBLIC POLICY AREAS.

05526 LAPIDUS, I.M.

THE GOLDEN AGE: THE POLITICAL CONCEPTS OF ISLAM ANMALS OF THE AMERICAN ACADEMY OF POLITICAL AND SOCIAL SCIENCE, (524) (NOV 92), 13-25.

THE PRESENT ROLE OF ISLAM IN MIDDLE EASTERN POLITICS IS A RECONSTRUCTION, NOT A CONTIMUATION, OF THE HISTORICAL PARADIGMS. IN THE PRE-MODERN ERA, THERE WERE TWO ISLAMIC PARADIGMS: ONE WAS OF AN INTEGRAL STATE AND SOCIETY UNIFIED UNDER THE POLITICAL AND MORAL LEADERSHIP OF A CHARISHATIC UNDER THE POLITICAL AND MORAL LEADERSHIP OF A CHARISHATIC
RELIGIOUS TEACHER; THE OTHER, OF A SOCIETY DIVIDED BETWEEN RELIGIOUS TEACHER; THE OTHER, OF A SOCIETY DIVIDED
STATE AND RELIGIOUS INSTITUTIONS AND DIFFERENTIATED STATE AND RELIGIOUS INSTITUTIONS AND DIFFERENTIATED
POLITICAL AND RELIGIOUS ELITES-DTHE LATTER BEING THE POLITICAL AND RELIGIOUS ELITES--THE LATTER BEING THE
CUSTODIANS OF THE TRUE ISLAM. THE SECOND TRADITION MADE ROOM CUSTODIANS OF THE TRUE ISLAM. THE SECOND TRADITION MADE ROOM FOR PURELY SECULAR MONARCHICAL CONCEPTS AND A SECULAR POLITICAL CULTURE. IN THE MODERN ERA, THE HISTORICAL ISLAMIC PARADIGMS HAVE HAD LITTLE INFLUENCE ON STATE FORMATION. EVEN THE AVOHEDLY ISLAMIC STATES DO NOT REALLY HARK BACK TO THE PAST BUT REPRESENT, FOR THE MOST PART, CONTEMPORARY NATIONAL
STATES APPEALING TO A NEW CONCEPT OF NATIONAL-STATE ISLAM.

05527 LARDNER, T. JR.
WEST AFRICA, (3882) (FEB 92), 244-245.

THE AUTHOR DESCRIBES SOME OF THE CHALLENGES FACING BOUTROS-BOUTROS GHALI AS HE BEGINS HIS TERM AS THE SIXTH SECRETARY-GENERAL OF THE UNITED NATIONS.

05528 LARDNER, T. JR. RESTORING HOPE TO SOMALIA

HEST AFRICA, (3926) (DEC 92), 2140-2141.

THE AUTHOR REPORTS ON THE EVENTS LEADING UP TO U.S.

PRESIDENT GEORGE BUSH'S DECISION TO SEND AMERICAN TROOPS TO SOMALIA ON A HUMANITARIAN MISSION TO HELP DISTRIBUTE FOOD TO THE STARVING AFRICANS.

05529 LARDNER, T. JR.

THE SOMALI TRAGEDY

WEST AFRICA, 75(3887) (MAR 92), 448-449.

SOMALIA IS THE LATEST ACT IN THE IGNOBLE TRADITION OF AFRICAN TRAGI-COMEDY. TRAGIC, BECAUSE IN JUST UNDER FOUR MONTHS OF FRENZIED AND OFTEN TIMES MINDLESS VIOLENCE, MORE MHAN 30,000 PEOPLE (MOST OF THEM CHILDREN) HAVE BEEN KILLED THAN 30,000 PEOPLE (MOST OF THEM CHILDREN) HAVE BEEN KILLED
OR WOUNDED. COMIC--IF THERE IS INDEEED MIRTH IN MISERY-OR WOUNDED. COMIC-IIF THERE IS INDEEED MIRTH IN MISERY-BECAUSE OF THE PLAIN ABSURDITY OF THO CLAN WAR-LORDS, BOTH THE CARCASS OF WHAT WAS ONCE A HATION OF SORTS.

05530 LARDY, N.R.

CHINESE FOREIGN TRADE

CHINA QUARTERLY, (131) (SEP 92), 691-720

FROM THE MID-1980'S ONWARD THE PACE OF DOMESTIC ECONOMIC REFORMS ACCELERATED IN CHINA, MAKING IT MORE LIKELY THAT INCREASED FOREIGN TRADE WOULD BE ECONOMICALLY BENEFICIAL. IN THE 1990'S CHINA'S FOREIGN TRADE WILL PROBABLY EXPAND CONSIDERABLY AND PLAY AN EVEN MORE POSITIVE ROLE IN CONTRIBUTING TO ECONOMIC GROWTH.

05531 LARRABEE, F.

DOWN AMD OUT IN WARSAW AND BUDAPEST: EASTERN EUROPE AND EAST-WEST MIGRATION

INTERNATIONAL SECURITY, 16(4) (SPR 92), 5-33.

TO DATE, LITTLE SCHOLARLY WORK HAS BEEN DEVOTED TO THE IMPLICATIONS AND POLICY DILEMMAS POSED BY THE POTENETIAL MIGRATIONS FRON THE SOVIET UNION AND EASTERN EUROPE. THIS ARTICLE SEEKS TO HELP FILL THE CURRENT VOID IN SCHOLARLY LITERATURE. THE FIRST SECTION EXAMINES THE PATTERN AND POSSIBLE DIMENSIONS OF MIGRATION FROM THE FORMER SOVIET UNION. THE SECOND SECTION DISCUSSES THE PROBLEMS POSED FOR
EASTERN EUROPE BY INCREASED MIGRATION FROM THE FORMER SOVIET EASTERN EUROPE BY INCREASED MIGRATION FROM THE FORMER SOVIET UNION AND THE EFFORTS UNDERTAKEN BY THESE COUNTRIES TO COPE WITH THIS INCREASED MIGRATION. THE THIRD SECTION FOCUSES ON THE PROBLEM OF MIGRATION WITHIN EASTERN EUROPE ITSELF. THE FUURT SECTION EXAMINES THE IMPACT OF MIGRATION FROM THE EAST TO THE FEDERAL REPUBLIC OF GERMANY AND THE POLICY DILEMMAS THAT THIS MIGRATION POSES. THE FINAL SECTION EAST AND WEST MIGHT COOPERATE TO CONTROL AND MANAGE THE EAST AND WEST MIGHT

05532 LARSEN, B.; SHAH, A.

COMBATTING THE GREENHOUSE EFFECT

FINANCE AND DEVELOPMENT, 29(4) (DEC 92), 20-23 AS COUNTRIES WORLDWIDE DEBATE HON STRONGLY TO RESPOND TO THE THREAT OF GLOBAL WARMING, CUTTING ENERGY SUBSIDIES AND LEYYING CARBON TAXES RANK HIGH ON THE LIST OF POTENTIAL TOOLS. RECENT WORLD BANK STUDIES SHOW THAT SETTING ENERGY PRICES RIGHT MAKES GOOD ECONOMIC AS WELL AS ENVIRONMENTAL SENSE AND A MODEST DOMESTIC CARBON TAX NOULD BE APPROPRIATE FOR MANY COUNTRIES.

05533 LARSON, D.

LONG OVERDUE: THE SINGLE GUARANTEED MINIMUM INCOME PROGRAM UNIVERSITY OF DETROIT MERCY LAW REVIEW, 69(3) (SPR 92), 353-380.

THE SUGGESTION OF A GUARANTEED MINIMUM INCOME GENERATES CONFLICTING EMOTIONS IN THE UNITED STATES. THIS ARTICLE PROVIDES AN OVERVIEH OF INCOME SUPPORT PROGRAMS. IT FIRST EXAMINES PROPOSALS FOR A GUARANTEED INCOME. BECAUSE NO PROPOSAL FOR A COMPREHENSIVE GUARANTEED INCOME PROGRAM HAS BEEN ADOPTED, IT NEXT DISCUSSES SPECIFIC INCOME MAINTENANCE PROGRAMS. A SHORT DESCRIPTION OF EACH PROGRAM AND SELECTED STATISTICAL INFORMATION ARE PRESENTED.

05534 LARUE, J.; ROTHENBERG, L.

INSTITUTIÓNAL FEATURES OF CONGRESSIONAL DECISIONS: THE INSTITUTIONAL FEATURES OF CONGRESSIONAL PUBLIC CHOICE, 73(3) (APR 92) 301-318

A PERVASIVE THEME OF THE CONGRESSIONAL POLITICS LITERATURE IS THAT THE COMMITTEE SYSTEM IS FUNDAMENTAL IN DETERMINING THE POLICY STATUS OUO. SUCH AN ASSERTION HINGES CRUCIALLY UPON COMMITTEES CONTROLLING THEIR JURISDICTIONS; CONGRESSIONAL DELEGATION IS UNDERMINED IF A COMMITTEE CAN ASSERT AUTHORITY OVER ANY ISSUE DOMAIN AT ANY TIME. THIS ANALYSIS EXAMINES WHETHER REPRESENTATIVES WILL SACRIFICE POLICY INTERESTS TO PRESERVE INSTITUTIONAL FEATURES OF THE LEGISLATURE. THE EFFORT IN 1987 TO CURB SMOKING ON AIRPLANES 

SERVES AS A VEHICLE TO ANALYZE HOW SENSITIVE MEMBERS ARE TO
SUCH FEATURES. THE RESULTS DEMONSTRATE THAT A SIZABLE NUMBER SUCH FEATURES. THE RESULTS DEMONSTRATE THAT A SIZABLE NUMBER PUT ASIDE THEIR POLICY PREFERENCES AND VOTED AGAINST LIMITS ON A SHOKING FOR INSTITUTIONAL REASONS. THESE FINOINGS HAVE IMPORTANT IMPLICATIONS BOTH FOR SPECIFYING THE DETERMI OF POLICY

05535 LASATER, M. BEYOND CONTAINMENT IN ASIA: AN AMERICAN STRATEGY FOR THE $1990 \mathrm{~S}$

KOREAN JOURNAL OF DEFENSE ANALYSIS, 3(2) (WIN 91), 83-104. THIS ARTICLE WILL ADORESS THE FUTURE OF U.S. STRATEGY IN ASIA, PARTICULARLY THE EAST ASIA-PACIFIC REGION. THE ARTICLE WILL FIRST CONSIDER THE BACKGROUND OF AMERICAN STRATEGY IN FOR THE REGION SET FORTH BY THE BUSH ADMINISTRATION JUST PRIOR TO THE IRAQI WAR. AND, FINALLY, IT WILL SUGGEST WHAT MIGHT BE AN APPROPRIATE U.S. STRATEGY IN THE REGION GIVEN CURRENT INTERNATIONAL TRENDS AND THE LESSONS LEARNED FROM THE U.S. VICTORY IN THE PERSIAN GULF WAR.

05536 LASHMAR, P.

LURCHING TOWARD DEMOCRACY

AFRICA REPORT, 37 (2) (MAR 92), 68-71.

WHEN THE GOVERMMENT OF EQUATORIAL GUINEA DECIDED LATE IN 1991 TO JOIN AFRICA'S DEMOCRACY MOVEMENT, IT DID SO IN A 1991 TO JOIN AFRICA'S DEMOCRACY MOVEMENT, IT DID SO IN A STYLE TYPICAL OF THE RULE OF PRESIDENT OBIANG--DISSIDENTS WERE ROUNDED UP AND IMPRISONED. NUOGED TOWARD DEMOCRACY BY INTERNATIONAL DONOR NATIONS AND AGENCIES HHOSE AID COMPRISE 70 PERCENT OF THE COUNTRY'S ECONOMY, OBIANG HAS OUTLINED
REFORMS THAT WILL ENSURE THAT HIS GOVERMMENT RETAINS CONTROL.

05537 LASHMAR, P

WALKING A TIGHTROPE

WEST AFRICA, (3884) (FEB 92), 326.

IN EARLY' 1992 PRESIDENT TEOOORO OBIANG NGUEMA MBASOGO MADE EARL 1992, PRESIDENT TEOURO OBIANG NGUEMA MBASOGO DEMOCRACY-WHICH WERE UNEXPECTED IN THEIR NUMBER, SPEED, AND APPARENT SCOPE. HE DISMISSED ALL HIS MINISTERS TO FORM A TRANSITIONAL GOVERMMENT INCLUDING MEMBERS OF THE OPPOSITION, AND HE INTROOUCED A BILL TO ALLOW THE FORMATION OF NEH PARTIES IN THE ONE-PARTY STATE. BUT THERE ARE THOSE WH QUESTION OBIANG'S MOTIVES BECAUSE HIS GOVERNMENT IS DEPENDENT ON FOREIGN AID FOR SURVIVAL AND AID DONORS WILL NO LONGER TOLERATE REPRESSIVE REGIMES.

05538 LASKIER, M.

DEVELOPMENTS IN THE JEHISH COMMUNITIES OF MOROCCO 1956-76 MIDOLE EASTERN STUDIES, 26(4) (OCT 90), 465-505.

THIS STUDY PROBES THE POL ITICAL CONFLICTS AND CHALLENGES WHICH FACED THE JEHISH COMMUNITY OF INDEPENDENT MOROCCD DURING THE THO DECADES AFTER THE DISSOLUTION OF THE FRENCH AND SPANISH PROTECTORATES AS WELL AS THE INTERNATIONAL ZONE OF TANGIER. THE AUTHOR EMPHASIZED INTERNAL COMMUNAL PROBLEMS JUDEO-MUSLIM RELATIONS, AND THE QUESTION OF EMIGRATION. THE PERIOD UNDER STUDY IS DIVIDED INTO SEVERAL SECTIONS: EARLY PHASES OF INDEPENDENCE: LATE 1955-OCTOBER 1958; DIFFICULY TIMES: OCTOBER 1958-MAY 1960; TRANSITION TO THE ERA OF HASAM II: MAY

05539 LASZLO, E.

CHANGING RAEALITIES OF CONTEMPORARY LEADERSHIP: NEW CHANGING RAEALITIES OF CONTEMPORAR

FUTURES 24(2) (MAR 22 ) 167-172

UTURES, $24(2)$ (MAR 92), $167-172$. HAS GRADUALYY SHIFTED TD THE PRIVATE SECTOR. TODAY, GLOBAL HAS GRADUALLY SHIFTED TO THE PRIVATE SECTOR. TODAY, GLOBAL CORPORATIONS INTERACT WITH MANY PROCESSE THATIIRE SOCIETIES FOR THE WELL-BEING AND EVEN THE SURVIVAL OF ENTIRE SOCIE EASTERN EUROPE NEED TO ADAPT NOT ONLY TO EMERGING GLDBAL MARKETS BUT ALSO TO GLOBAL ACTORS ON THE MARKETS BY

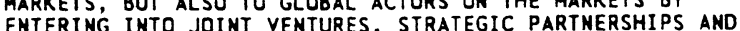
ENTERING INTO JOINT VENTURES, STRATEGIC PARTNERSHIPS AND OTHER INMOVATIVE FORMS OF COOPERATION WITH CAPITAL AND TECHNOLOGY-STRONG MULTINATIONAL ENTERPRIZES. THE ECONOMIES THAT MEET THE CHALLENGE OF COMPETITION IN TODAYS ENVIRONMENT ARE THOSE HHO MUSTER THE DILIGENCE AND MOTIVATION TO ENTER GLOBAL MARKETS IN MUTUALL

05540 LATEEF, $S$

ATTITUDES TOWARDS SOCIAL LEGISLATION; MUSLIM HOMEN IN INDIA ZED BOOKS, $1990,55-73$.

ONE IMPORTANT ISSUE BEFORE THE MUSLIM COMMUNITY IN INDIA TODAY IS THE LEGAL RIGHTS OF MUSLIM WOMEN. THIS CHAPTER EXAMINES THE ATTITUDES OF DIFFERENT MUSLIM COMMUNITIES TO VARIOUS SOCIAL LEGISLATIONS ENACTED BY GOVERMMENT, BY USING THEIR WRITTEN REPRESENTATIONS TO GOVERNMENT AS AN INDICATION OF THEIR MOTIVATIONS AND TO THE CONCERNS OF OTHER COMMUNITIES ON THE SAME ISSUES. THE SIMILARITY IN VIEWS EXPRESSED BY MUSLIM AND OTHER COMMUNITIES IN THE SAME REGION SUGGESTS THAT ATTITUDES TOHARDS HOMEN'S ROLES AMD RIGHTS WERE LESS AFFECTED BY RELIGIOUS CONSIDERATIONS THAN BY
REGIONAL ONES.

05541 LATEEF, $S$

COMPETING REALITIES; MUSLIM HOMEN IN INDIA

ZED BOOKS, , 1990, 1-15.

THIS CHAPTER INTRODUCES A STUDY ON MUSLIM WOMEN IN CONTEMPORARY WOMEN IN INDIA. IT TAKES INTO ACCOUNT THREE KEY ELEMENTS: THE EXTENT TO HHICH THEY ARE AFFECTED BY THE ECONOMIC, SOCIAL, AND POLITICAL CONDITIONS IN INDIA; THE STATUS AND ROLE OF WOMEN IN GENERAL INDIA; AND THE INFLUENCE OF ISLAM. IN SHORT, IT EXAMINES THE MANNER AND EXTENT TO WHICH THE STATUS OF MUSLIM WOMEN IS BEING AFFECTED BY BEING INDIAN, BEING MUSLIM, AND BEING WOMEN. THESE FACTORS HAVE A
BEARING ON THE ATTITUDES, PRACTICES, AND CAPACITY OF MUSLIM WOMEN TO ASSIMILATE AN ADAPT TO SOCIAL CHANGES IN INDIA.

05542 LATEEF, $S$.

CONFRONTING THE ISSUES; MUSLIM HOMEN IN INDIA ZED BOOKS, , 1990, 179-191.

IN INDIÁ, HITH THE INTRODUCTION OF NEW POLITICAL RULES IN THE 19TH CENTURY, THE MUSLIM COMMUNITY EXPERIENCED A DISTANCING BETHEEN PUBLIC AND PRIVATE RELIGIOUS CUSTOMS AND PRACTICES WHICH PREYIOUSLY HAD BEEN FUSED. PUBLIC RELIGION WAS USED TO UNITE DISPARATE COMMUNITIES FOR SECULAR AND POLITICAL ENDS. PRIVATE RELIGION CONTINUED TO MODERATE THE ACTIONS OF COMMUNITY MEMBERS TO CONFORM TO BROAD TENETS, WHILE SIMULTANEOUSLY ACCOMMODATING AND INCORPORATING NEH ELEMENTS WHICH WERE INTRODUCED AS A RESULT OF SOCIAL, POLITICAL, AND ECONOMIC CHANGES. FOR WOMEN, THIS WAS A SETBACK SINCE THE POLITICIZATION OF RELIGION IMPLIED THE PRACTICES SPECIFIC TO WOMEN.

05543 LATEEF, $S$.

GRONTH' OF THE INDIAN HOMEN'S MOVEMENT AND THE ATTACK ON PURDAH; MUSLIM WOMEN IN INDIA ZED BOOKS, $1990,74-94$. 19 . PURDAH-THE PRACTICE OF THE SECLUSION OF WOMEN--AND THE GROWTH OF THE INDIAN HOMEN'S MOVEMENT TO ASSESS THE MANMER
AND PACE OF CHANGE IN INDIA. PURDAH IS REGARDED AS ISLAMIC AND PACE OF CHANGE IN INDIA. PURDAH IS REGARDED AS ISLAMIC AND IS SEEN AS HISTORICALLY RESPONSIBLE FOR THE LIMITED PARTICIPATION OF WOMEN IN ACT IVITIES OUTSIDE THE DOMESIIC SPHERE. THE CHAPTER EXAMINES THE RELIGIOUS BASIS FOR PURDAH AND THE INVOLVEMENT OF MUSLIM WOMEN IN THE HOMEN'S MOVEMENT TO ESTABLISH THE EXTENT TO WHICH PURDAH MAY HAVE IMPINGED ON WOMEN'S ACTIVITIES OUTSIDE THE COMMUNITY. IT ALSO EXAMINES
THE EXTENT TO WHICH THE UNIVERSALITY IF PROBLEMS FACED BY THE EXTENT TO WHICH THE UNIVERSALITY IF PROBLEMS FACED BY INDIAN WOMEN, IRRESPECTIVE OF COMMUNITY, CASTE OR CLASS COOPERATION AND CONSENSUS BETWEEN WOMEN OF DIFFERENT COMMUNITIES DESPITE POLITICAL CURRENTS TO THE CONTRARY.

05544 LATEEF, $S$.

MUSLIM HOMEN IN INDIA

ZED BOOKS, $1990,238$.

THIS BOOK INVESTIGATES THE STATUS AND ROLE IN SOCIETY OF MUSLIM WOMEN IN INDIA. BASED ON A SURVEY OF NINE MAJOR INDIAN CITIES IN DIFFERENT STATES, IT CREATES A NEH CONTEXT IN WHICH ISSUES SUCH AS EDUCATION, LITERACY, SOCIAL LEGISLATION, AND PURDAH--THE PRACTICE OF THE EXCLUSION OF HOMEN--CAN BE UNDERSTOOD. THE AUTHOR LOOKS AT THE INFLUENCE OF HISTORICAL FACTORS ON MUSLIM WOMEN'S POSITION IN INDIAN SOCIETY. SHE CONSIDERS THE SOCIAL. ECONOMIC AND POLITICAL CHANGES RESPONSIBLE FOR A SPLIT BETWEEN THE PUBLIC AND PRIYATE RESPONSIBL FOR A SPLIT BETHEEN TOPEICS EXAMINED PRIVATE IN ISLAMIC PRACTICES IN IND MUSL IM ATTITUDES TO INCLUDE: MUSL SOCIAL LEGISLATION, THE PARTICIPATION OF MUSL IM WOMEN IN WOMEN'S MOVEMENTS, THE ISSUE OF PURDAH, AND

05545 LATHAM, A.; SLACK, M. RESTRUCTURING THE EUROPEAN DEFENCE MARKET: IMPLICATIONS FOR NORTH AMERICA

CAMADIAH DEFER ICA THIS ARTICLE REVIEWS RECENT DEVELOPMENTS IN EUROPEAN THIS ARTICLE REVIEWS RECENT DEVELOPMENTS IN EUROPEAN
DEFENSE INDUSTRIAL POLICY AND PRESENTS VARIOUS PERSPECTIVES DEFENSE INDUSTRIAL POLICY AND PRESENTS VARIOUS PERSPECTI NORTH AMERICAN DEFENSE INDUSTRY AND GOVERMMENT POL ICY. THE NORTH AMERICAN DEFENSE INDUSTRY AND GOVERMMENT POLICY. THE ARTICLE CONCLUDES WITH SOME OBSERVATIONS ABOUT THE POSSIBLE IMPLICATIONS OF EUROPEAN DEFENSE INDUSTRIAL DEY

05546 LATHAM, N. HOW VALUABLE ARE THE AMRED FORCES IN CONTRIBUTING TO THE SECURITY OF BRITAIN?

RUSI JOURNAL, 137(5) (OCT 92), 27-33.

COMMANDER LATHAM DEFINES THE TERM 'SECURITY' AS AN INDIVIDUAL, NATIONAL AND INTERNATIONAL REQUIREMENT, THE ACHIEVEMENT OF WHICH IS DEPENDENT UPON THE POLIIICAL ECONOMIC AND SOCIAL TRENDS DOMINANT IN THE WORLD. WITH THE END OF THE COLD WAR AND THE NEW INTERNATIONAL REALIGNMENTS THAT HAYE SUBSEOUENTLY OCCURRED. HE ARGUES THAT THE SECURITY OF BRITAIN AND HER ALLIES IN PARTICULAR, WILL FOCUS 
INCREASINGLY ON THE NON-MILITARY ASPECTS OF SECURITY, WITH SMALLER, MOBILE MILITARY UNITS AS DEFENSE, RATHER THAN ON THE CURRENT SUPERSTRUCTURE OF WEAPONS AND ARMED FORCES.

05547 LATONA, R.

SPAIN AIMS FOR THE E.C. FIRST TIER

EUROPE, 316 (MAY 92), 27-29.

PRIME MINISTER FELIPE GONZALEZ IS PUSHING SPAIN TOWARD

THE E.C. FIRST TIER. "FINISHING UP IN THE SECOND TIER IS

SIMPLY OUT OF THE QUESTION:" EMPHASIZED DEPUTY PRIME

MINISTER NARCIS SERRA. "IT WOULD SIDELINE US FROM THE DECISION-MAKING PROCESS JUST AT THE MOMENT WHEN THE OUTLINES OF A BRAND-NEW EUROPEAN FUTURE GO ON THE DRAWING BOARD." GONZALES IS CONVINCED THAT THE PAY-OFF OF FIRST TIER E.C. IS HORTH THE TREMENDOUS RISKS. IT ONLY REMAINS TO BE SEEN HOW FAR THE OTHER ECONOMIC AND POLITICAL PLAYERS IN THE GAME WILL BACK HIM UP ON THIS.

05548 LAUBER, $V$.

CHANGIMG PRIORITIES IN AUSTRIAN ECONOMIC POLICY WEST EUROPEAN POLITICS, 15(1) (JAM 92) 147-172

THE BASIC FEATURES OF "AUSTROKEYNESIAN" ECONOMIC POLICY TOOK SHAPE IN THE 195OS CORPORATISM COOPERATION AND SUPPORT WERE ONE OF ITS PRECONDITIONS. ITS INSTRUMENTS CONSISTED OF WERE ONE OF ITS PRECONDITIONS. ITS INSTRUMENTS CONSIS A HARD CURRENCY POLICY, INVESTMENT PROMOTION, WAGE MODERATION AND DEFICIT SPENDING, WITH THE OVERALL GOAL OF ACHIEVING MAXIMUM ECONOMIC GROWTH AND STABILITY. AFTER 1975 DEFICIT SPENDING EXPANDED CONSIDERABLY; THIS SECURED BOTH "AUSTROKEYNESIANISH'S" APOTHEOSIS AND ITS DOWNFALL. IN 198586 A MAJOR POLICY REVERSAL INITIATED BUDGET CONSOLIDATION, A SUBSTANTIALLY GREATER RELAINCE ON MARKET MECHANISMS AND THUS
A CUTBACK OF CORPORATIST (AND TO SOME EXTENT STATE) POHER OVER ECONOMIC POLICY.

05549 LAURANCE, E.

POLITICAL IMPLICATIONS OF ILLEGAL ARMS EXPORTS FROM THE UNITED STATES

POLITICAL SCIENCE, 107(3) (FAL 92), 501-534.

THIS ARTICLE ANALYZES ARMS EXPORTS WHICH ARE ILLEGAL IN THE SENSE THAT IF THE FACTS WERE KNOWN AT THE TIME OF THE TRANSACTION, THEY WOULD VIOLATE U.S. ARMS EXPORT LAWS OR THE LAHS OF THE RECIPIENT COUNTRY. THESE EXPORTS ARE PRIVATE AND INVOLVE TECHNOLOGY AND WEAPONS SUITED MAINLY FOR CONVENTIONAL WARFARE AS OPPOSED TO THE STRATEGIC SYSTEMS THAT HAVE BEEN THE FOCUS O F THE EFFORT TO CONTROL THE FLOW OF TECHMOLOGY FROM WEST TO EAST. THE ARTICLE FOCUSES ON THE OF TECHM
1980 S.

05550 LAURELL, A.C.

DEMOCRACY IN MEXICO: WILL THE FIRST BE THE LAST? NEW LEFT REVIEW, (194) (JUL 92), 33-53.

THE RULING PRI HAS FAILED TO' 33 - 33 . THE CORRUPTION AND ELECTORAL FRAUD THAT HAVE SUSTAINED IT FROM SO LONG. OPPOSITION PARTIES ARE PERMITTED TO NOMINATE CANDIDATES, AND THOSE OF THE RIGHTWING PAN ARE EVEN OCCASIONALLY ALLOWED TO WIN, BUT IN ALL DECISIVE TESTS--SUCH AS THE PRESIDENTIAL ELECTION--THE PRI ENSURES THAT ITS GRIP ON THE LEVERS OF STATE POHER IS MAINTAINED. THE PRI HAS BEEN PARTICULARLY ANXIOUS TO BLOCK THE PRD AND ITS LEADER, CUAUTHEMOC CARDENAS, BECAUSE THEY CAN SO EASILY BE PRESENTED AS MORE AUTHENTIC REPRESENTATIVES OF THE NATIONAL REVOLUTIONARY TRADITION THAN THE PRI ITSELF.

05551 LAURENCE, $P$

BUTHELEZI'S GAMBLE

AFRICA REPORT, 37(6) (NOV 92), 13-18

SOME CRITICS HAVE PORTRAYED MANGOSUTHU BUTHELEZI, CHIEF MINISTER OF THE KHAZULU AND FOUNDER OF THE INKATHA FREEDOM PARTY, AS A "PUPPET" OF THE APARTHEID STATE. HHILE BUTHELEZ IS AN ASTUTE POLITICIAN, HE DOES NOT HAVE THE CLOUT TO MOLD A SETTLEMENT TO HIS WISHES. HOWEVER, HE DOES HAVE THE CAPACITY TO PLAY A SPOILER ROLE--AS NELSON MANDELA AND F.H. DEKLERK HAVE RECENTLY LEARNED--AND THEREFORE CANHOT BE WRITTEN OFF.

05552 LAURENCE, P. COMING TO A COMPROMISE

AFRICA REPORT, 37 (2) (MAR 92), 45-48.

AS THE GOVERMMENT OF PRESIDENT F.W. DEKLERK AND THE AFRICAM MATIONAL COMGRESS HAMMER OUT A BLUEPRINT FOR A FUTURE DEMOCRATIC SOUTH AFRICA, IT IS CLEAR THAT BOTH SIDES BROADLY AGREE ON THE NEED FOR A PROVISIONAL GOVERNMENT. ALTHOUGH THEY DIFFER ON HOW IT SHOULD BE CONSTITUTED AND HOH TO FORMULATE A NEW CONSTITUTION, BOTH SIDES SEEM AGREEABLE TO FORKING TOWARD A COMPROMISE.

05553 LAURENCE, $P$.

COMPETITIOH OR COALITION?

AFRICA REPORT, 37(3) (MAY 92), 64-67.

ON THE FACE OF IT, SOUTH AFRICA'S MARCH 1992 WHITES-ONLY REFERENDUM WAS A TRIUMPH FOR THE PRO-NEGOTIATION FORCES, INCLUDING PRESIDENT F.W. DEKLERK'S NATIONAL PARTY, ENGLISHSPEAKING WHITES, AND THE AFRICAN NATIONAL CONGRESS (ANC). BUT THERE ARE SHARP DISAGREEMENTS OVER THE TRANSITION
PROCEDURE, WHICH WILL PROBABLY INTENSIFY COMPETITION BETWEEN THE ANC AND THE NATIONAL PARTY TO WIN PUBLIC SUPPORT.

05554 LAURENCE, $P$.

DEADLOCKED

AFRICA REPORT, 37(4) (JUL 92), 55-57.

BEFORE THE AFRICAN NATIONAL CONGRESS (ANC) SUSPENDED ITS NEGOTIATIONS WITH THE GOVERMMENT OF PRESIDENT F.W. DEKLERK ON JUNE 23, 1992, THE TWO SIDES WERE DEADLOCKED ON WHETHER A 70 OR 75 PERCENT MAJORITY OF THE ELECTED NATIONAL ASSEMBLY WOULD BE NEEDED TO RATIFY A NEH CONSTITUTION. THE IMPASSE REFLECTED BOTH PARTIES' UNCERTAINTY OVER THE SIZE OF ITS POPULAR SUPPORT. THE DEKLERK GOVERNMENT IS CONFIDENT OF WHITE SUPPORT AS WELL AS A MAJORITY FROM THE COLORED AND INDIAN COMMUNITIES, BUT THE ANC HAS ACKNOHLEDGED A MEED TO CONSOL IDATE ITS SUPPORTERS AND PUT IM PLACE MECHAMISMS TO ENSURE THAT ITS VOTERS GO TO THE POLLS.

05555 LAURENCE, $P$

NEGOTIATIONS IMPASSE

SOUTH AFRICA FOUNDATION REYIEH, 18(7) (JUL 92), 3

ON JUNE 21, 1992, AFRICAN NATIONAL CONGRESS' PRESIDENT NELSON MANDELA SUSPENDED BILATERAL TALKS WITH THE DEKLERK ADMINISTRATION TO PROTEST THE MASSACRE IN BOIPATONG. ON JUNE 24. THE ANC AND ITS ALLIES ANNOUNCED THAT THEY WERE WITHDRAWING FROM CODESA. IN THE FOLLOWING DAYS, THERE WERE INDICATIONS OF FLEXIBILITY BY BOTH THE GOVERNMENT AND THE
ANC, ALTHOUGH THERE WAS NO AGREEMENT TO RESUME NEGOTIATIONS

05556 LAURENCE, $P$.

THE ISSUE OF POLITICAL POWER BEHIND THE DEADLOCK AT CODESA

II SOUTH AFRICA FOUNDATION REVIEW, 19(6) (JUN 92), 1-2 THE CONVENTION FOR A DEMOCRATIC SOUTH AFRICA (CODESA) HAD NO SOONER DEADLOCKED AT ITS MUCH-HERALDED SECOND PLENARY SESSION ON 15 AND 16 MAY THAN MANEUVERING FOR ADVANTAGE IN THE NEXT ROUND OF TALKS BEGAN. IN THE SECOND PLENARY SESSION THE ADVERSARIES AGREED THAT THE FINAL CONSTITUTION FOR A NONRACIAL SOUTH AFRICA SHOULD BE DRAFTED AND ADOPTED BY A
POPULARLY ELECTED NATIONAL ASSEMBLY. THAT SIGNIFICANT AGREEMENT WAS, HOWEVER, MARRED BY DISAGREEMENT ON THE SIZE OF THE MAJORITY REQUIRED TO ADOPT THE CONSTITUTION. AFTER ALL COMPROMISES WERE OFFERED, THE POSITIONS OF THE NATIONAL PARTY (NP) OF F.W. DE KLERK AND THE AFRICAN NATIONAL CONGRESS (ANC) WERE STILL SEPARATED BY FIVE PERCENTAGE POINTS ON THE CRUCIAL ISSUE OF REGIONAL GOVERNMENT. MANY FEAR THAT THE RETURN TO HARD-LINE POSITIONS FOLLOHING THE DEADLOCK WILL STALL NEGOTIAITONS IN AT LEAST THE SHORT-TERM FUTURE.

05557 LAURENCE, P

THE YEAR OF NEGOTIATIONS

AFRICA REPORT, 37(1) (JAN 92), 48-50.

IN SOUTH AFRICA HISTORIC NEGOTIATIONS BETHEEN F.W. DEKI ERK'S GOVERMMENT AND BLACK POL ITICAL ORGANIZATIONS OPENED IN DECEMBER 1991. ONE POSSIBLE OUTCOME IS THE FORMATION OF AN INTERIM ADMINISTRATION IN WHICH THE NATIONAL PARTY AND THE AFRICAN NATIONAL CONGRESS HOULD SHARE POHER. BUT WHATEVER THE RESULT, DEKLERK SEEMS CONFIDENT THAT HE CAM OBTAIN THE APPROYAL OF THE WHITE ELECTORATE IN A REFERENDUM.

05558 LAUTH, T.

STATE BUDGETING: CURRENT CONDITIONS AND FUTURE TRENDS INTERNATIONAL JOURNAL OF PUBLIC ADMINISTRATION, 15 (5)

1992), 1067-1096.

BUDGETING IS A CENTRAL ELEMENT OF STATE GOVERMMENT. THIS ARTICLE EXAMINES CURRENT STATE FISCAL CONDITIONS, THE IMPAC OF POLITICAL AND ADMINISTRATIVE INSTITUTIONS ON STATE BUDGETING, AND BUDGET REFORM IN THE STATES IN ORDER TO IDENTIFY TRENDS AND EXPECTATIONS FOR THE 1990S. EXISTING RESEARCH IS USED AS A BASIS FOR IDENTIFYING TRENDS AND LIKELY DEVELOPMENTS.

05559 LAVEIST, T.A.

THE POLITICAL EMPONERMENT AND HEALTH STATUS OF AFRICANAMERICANS: MAPPING A NEH TERRITORY

AMERICAN JOURNAL OF SOCIOLOGY, 97(4) (JAN 92) 1080-1095. THIS PAPER MEASURES THE IMPACT OF BLACK POL ITICAL GAINS ON BLACK AND WHITE POSTHEONATAL MORTALITY. TWO DIMENSIONS OF BLACK POLITICAL EMPOWERMENT ARE CONSIDERED: ABSOLUTE POLITICAL POWER AND RELATIVE POLITICAL POWER. THE STUDY COVERS ALL U.S. CENTRAL CITIES WITH A POPULATION OF AT LEAST 50,000 RESIDENTS AND $10 \%$ BLACKS. FINDINGS INDICATE THAT 50,000 RESIDENTS AND $10 \%$ BLACKS. FINDINGS INDICA ABSOLUTE BLACK POL ITICAL POWER DID NOT INFLUENCE POSTNEONATAL MORTALITY FOR BLACKS OR WHITES. HOWEVER, THERE IS A NEGATIVE ASSOCIATION BETWEEN RELATIVE BLACK POLITICAL
POWER AND THE BLACK POSTNEONATAL MORTALITY RATE. BLACK POWER AND THE BLACK POSTNEONATAL MORTALITY RATE. BLACK
POLITICAL POWER HAD NO SIGNIFICANT EFFECT ON WHITE POSTNEONATAL MORTALITY.

05560 LAVER, M.; HUNT, B.

POLICY AND PARTY COMPETITION

ROUTLEDE, 1992,328

THE OPERATION OF FREE ELECTIONS IS TAKEN AS A KEY 
ELEMENT IN MOST WORKING DEFINITIONS OF WESTERN-STYLE LIBERAL DEMOCRACY. PARTY COMPETITION IS ONE OF THE CENTRAL CONCERNS OF WESTERN POLITICAL SCIENCE. THIS BOOK LOOKS IN DETAIL AT CONSIDERS THIS FROM THO INTERACTING PERSPCETIVES, ONE THEORETICAL, ONE EMPIRICAL. IT REVIEWS A RANGE OF THEORETICAL ARGUMENTS ABOUT THE ROLE OF POLICY IN PARTY COMPETITION AND ILLUSTRATES THESE ARGUMENTS WITH A COMPLETELY NEW DATA SET, ONE ASSEMBLED ESPECIALLY FOR THE BOOK AND PUBLISHED IN FULL. IN A LONG APPENDIX. ITS CENTRAL PURPOSE IS TO CONSIDER HOW MUCH LIGHT THEORIES OF PARTY COMPETITION THROW ON THE PRACTICE OF PARTY COMPETITION IN THE THENTY FOUR PARLIAMENTARY DEMOCRACIES THAT FORM THE CORE OF THIS STUDY.

05561 LAVIN, F.

AFTER MEXICO AND CANADA, HO?

FAR EASTERM ECONOMIC REYIEW, 155(44) (NOY 92), 54

THE SIGNING OF THE NORTH AMERICAN FREE-TRADE AGREEMENT (NAFTA) IS AN INDICATION THAT THE NATIONS OF NORTH AMERICA WISH TO LAY THE FOUNDATIONS FOR A NEW ECONOMIC FRAMEWORK THAT WILL TAKE ADVANTAGE OF THE COLLAPSE OF THE SOVIET UNION. DESPITE SOME CLAIMS TO THE CONTRARY, NAFTA CAN BE A POWERFUL ENGINE FOR FACILITATING FREE TRADE. THIS ARTICLE ARGUES THAT THE UNITED STATES IS NOW RECOGNIZING WHAT ASIAM ENTREPRENEURS HAVE KNOWN FOR SOME TIME: NO COUNTRY CAN SHUT ITSELF OFF FROM ANY PART OF THE WORLD WI THOUT GRAVE CONSEQUENCES FOR ITS GROWTH. THE ARTICLE SUGGESTS WAYS IN WHICH NAFTA CAN BE EXPANDED TO INCLUDE LATIN AMERICA AND ASIA. EMPHASIS IS PLACED ON THE FACT THAT NAFTA CAN COMPLEMENT CURRENT INTERMATIONAL STRUCTURES SUCH AS THE GENERAL AGREEMENT ON TARIFFS AND TRADE (GATT) AND THE GROUP OF SEVEN IMDUSTRIALIZED STATES $(G-7)$. THE BOTTOM LINE IS THAT THE U.S. SHOULD BEGIN TALKING TO ANY COUNTRY COMMITTED TO FREE TRADE.

05562 LAH, I LOOSE PLANKS IN PARTY PLATFORMS COMMONHEAL, CXIX(18) (OCT 92), 9-13. THE AUTHOR OUTLINES SOME OF THE PLANKS IN THE DEMOCATIC AND REPUBLICAN PARTY PLATFORMS FROM 1848 TO THE PRESENT.

05563 LAW, J.

DISAPPEARING MIDDLE EAST

MIDDLE EAST INTERHATIONAL, (434) (SEP 92), 10.

DESPITE THE ONGOING ARAB-ISRAELI PEACE PROCESS AND OTHER SIGNIFICANT EVENTS WHICH HAVE TAKEN PLACE IN THE MIDDLE EAST, THE UNITED STATES SEEMS SINGULARLY UNINTERESTED IN THE REGION. RECENTLY, MAJOR AMERICAN NEWSPAPERS SUCH AS THE "WASHINGTON POST AND THE "NEW YORK TIMES" HAVE COMPLETELY NEGLECTED THE MIDDLE EAST IN ITS COVERAGE OF WORLD EVENTS. WHAT LITTLE REPORTING OF EVENTS RELATED TO THE REGION THAT
DOES TAKE PLACE CONCENTRATES ON OLD SCANDALS AND ISSUES SUCH DOES TAKE PLACE CONCENTRATES ON OLD SCANDALS AND ISSUES SUCH
AS THE IRAN-CONTRA AFFAIR COVERT U.S. AID TO IRAO, AND THE AS THE IRAN-CONTRA AFFAIR, COVERT U.S. AID TO IRAQ, AND THE DOMESTIC ISSUES IS UNDERSTANDABLE IN A PRESIDENTIAL CAMPAIGN YEAR, THE USA'S LACK OF INTEREST IN THE MIDOLE EAST CAN ONLY LEAD TO UNEXPECTED (AND OFTEN UNDESIRED) EVENTS IN THE FUTURE.

\section{LAH, J.}

SIMPLISTIC OPTIMISM IN THE U.S.

MIDDLE EAST INTERNATIONAL, (429) ( JUL 92), 4-5

THE U.S. ADMINISTRATION'S REACTION TO THE ISRAELI LABOR PARTY'S ELECTORAL VICTORY HAS BEEN JOYOUS, THOUGH SIMPLISTIC. BUSH ADMINISTRATION OFFICIALS HAVE EMPHASIZED LABOR LEADER YITZHAK RABIN'S "GOOD PERSONAL RELATIONSHIP" WITH PRESIDENT BUSH AND SECRETARY BAKER, HIS ADVOCACY OF A FREEZE ON NEW SETTLEMENTS AND HIS PROMISE TO NEGOTI ATE AN AUTONOMY AGREEMENT WITH THE PALESTINIANS WITHIN A YEAR. THEY ALSO EMPHASIZE THAT RABIN, UNLIKE OUTGOING PRIME MINISTER YITZHAK SHAMIR, IS A MAN THEY CAN TRUST. HOWEVER, A CLOSER LOOK AT THE SITUATION REVEALS THAT THE BUSH ADMINISTRATION IS SUFFERING FROM A SEVERE CASE OF OPTIMISTIC MYOPIA. WHEN AN OBJECTIVE OBSERVER EXAMINES WHAT RABIN IS READY TO OFFER AND WHAT THE PALESTINIANS COULD REASONABLY ACCEPT, THE GAP BETWEEN THE THO IS STILL QUITE EVIDENT.

05565 LAW, J.

THE US: THE PROBLEMS FACING CLINTON

MIDDLE EAST INTERNATIONAL, 440(440) (DEC 92), 6.

THE GROWING TURBUL ENCE OF THE WORLD IS ATIRACTING

CLINTON'S INCREASING ATTENTION. THIS ARTICLE DETAILS THE PROBLEMS IN SOMALIA, BOSNIA, RUSSIA AND IRAQ, AS WELL AS THE VIOLENCE RISING TO NEW HEIGHTS IN THE OCCUPIED TERRITORES. IT SUGGESTS THAT CLINTON WILL MEED TO UNDERSTAND THAT THE PROBLEM IS THAT IT IS THE ISRAELIS WHO ARE OCCUPYING PALESTINIAN TERRITORY AND THAT THE PALESTINIANS CANNOT AND WILL NOT CONCEDE ANY MORE, AND THAT WITHOUT SOME SORT OF INTERVENTION BY THE ADMINISTRATION, THE NEGOTIATIONS WILL CONTINUE TO GO NOWHERE.

05566 LAH, J.

WAITIING FOR THE PENMY TO DROP
MIDOLE EAST INTERNATIONAL, 439 (DEC 92), 5-6.

PRESIDENT CLINTON HAS BEEN GETTING SOME PRAISE FROM FORMER MENTORS WHO HAVE RADICALLY DIFFERENT VIEWS ON THE MIDDLE EAST FROM THOSE THAT THE PRESIDENT HAS EXPRESSED. AS HE TAKES OFFICE, HE IS FACING SEVERAL CHALLENGES IN THE OVER IRAN AND ITS NUCLEAR WEAPONS PROGRAM ARE SOME OF THEM.

05567 LAWLER, P.

CLASSICAL ETHICS, JEFFERSON'S CHRISTIAN EPICUREANISM, AND AMERICAN MORALITY

PERSPECTIVES ON POLITICAL SCIENCE, 20(1) (WIN 91), 17-22. THIS ARTICLE EXAMINES THE TENSION BETWEEN REASON AND REVELATION THAT IS SAID TO UNDERLIE MUCH OF THE THOUGHT OF THE FOUNDERS OF THE AMERICAN POLITICAL SYSTEM. IT SPECIFICALLY CONCENTRATES ON THE WRITINGS OF THOMAS
JEFFERSON AND ON JEFFERSON'S RATIONALE FOR DECLARING THAT HE JEFFERSON AND ON JEFFERSON'S RATIONALE FOR DECLARING THAT
IS BOTH A CHRISTIAN AND AN EPICUREAN. IT CONCLUOES THAT JEFFERSON DISSOLVES THE TENSION BY NOT TAKING THE MORAL CLAIMS OF EITHER REASON OR REVELATION SERIOUSLY ENOUGH. HOWEVER, OUR PERCEPTION OF THE GOODNESS OF LIBERTY DEPENDS UPON THE CREDIBILITY OF BOTH CLASSICAL AND CHRISTIAN THOUGHT UPON ARGUMENTS AND EXPERIENCES THAT EVEN OUR FOUNDERS DID NOT TAKE SERIOUSLY ENOUGH.

05568 LAWMICZAK, R.

POST-CMEA INTEGRATION OF SOVIET AND EAST EUROPEAN ECONOMIES-CHALLENGES AND PERSPECTIVES

INTERNATIONAL SOCIAL SCIENCE JOURNAL, 131(131) (FEB 92), 91-106.

IN $i$ IGHT OF CONTRASTING OPINIONS AND CONCEPTIONS EAST AND WEST, THERE EMERGES A SERIES OF QUESTIONS: HOW CAN ONE EXPLAIN THE DIVERGENCE OF VIEWS EXPRESSED BY THOSE OUOTED ON THE USEFULNESS OF MAINTAINING THE REGIONAL INTEGRATION OF THE CMEA COUNTRIES; WHAT ARE THE CHANCES OF CENTRAL AND EAST EUROPEAN COUNTRIES FOR SUBREGIONAL INTEGRATION IN A LONGTERM PERSEPECTIVE OF 20-30 YEARS; WHAT WILL BE THE RELATIONSHIP OF CENTRAL AND EAST EUROPE TO THE EC; AND, WHAT RELATIONSHIP OF CENTRAL AND EAST EUROPE TO THE EC; AND,
ROLE WILL THE SOVIET UNION PLAY IN THE INTEGRATION OF ROLE WILL THE SOVIET UNION PLAY IN THE INTEGRATION
CENTRAL AND EAST EUROPE. AN ATTEMPT TO ANSHER THESE CENTRAL AND EAST EUROPE. AN ATTEMP
QUESTIONS IS MADE IN THIS ARTICLE.

05569 LAWRANCE, E.C.

POVERTY AND THE RATE OF TIME PREFERENCE: EVIDENCE FROM POVERTY AND

JOURNAL OF POLITICAL ECOMOMY, 99(1) (FEB 91), 54-77.

THIS PAPER USES THE PANEL STUDY OF INCOME DYNAMICS TO STUDY THE INTERTEMPORAL PREFERENCES OF RICH AND POOR HOUSEHOLDS IN THE UNITED STATES. SUBJECTIVE RATES OF TIME PREFERENCE, IDENTIFIED FROM ESTIMATION OF CONSUMPTION EULER EQUATIONS, ARE THREE TO FIVE PERCENTAGE POINTS HIGHER FOR HOUSEHOLDS WITH LOW PERMANENT INCOMES THAN FOR THOSE WITH HIGH PERMANENT INCOMES. CONTROLLING FOR RACE AND EDUCATION WIDENS THIS DIFFERENCE. HITH AGE AND FAMILY COMPOSITION HELD CONSTANT. TIME PREFERENCE RATES VARY FROM 12 PERCENT FOR INCOME DISTRIBUTION TO 19 PERCENT FOR NONWHITE FAMILIES WI THOUT A COLLEGE EDUCATION HHOSE LABOR INCOMES ARE IN THE BOTTOM FIFTH PERCENTILE. SUCH DIFFERENCES IMPLY VERY DIFFERENT PATTERNS OF CONSUMPTION OVER THE LIFE CYCLE AND SUGGEST ONE POSSIBLE EXPLANATION FOR OBSERVED HETEROGENEITY IN SAVINGS BEHAVIOR ACROSS SOCIOECONOMIC CLASSES.

05570 LAHRENCE, $S$.

PARTICIPATION THROUGH MOBILIZATION OF THE LAW: INSTITUTIONS PROVIDING INDIGENTS WITH ACCESS TO THE CIVIL COURTS

POLITY, XXIII(3) (SPR 91), 423-442.

THIS ARTICLE EXAMINES THE MOBILIZATION OF LAH AS A METHOD OF POPULAR PARTICIPATION IN JUDICIAL DECISION MAKING. THE AUTHOR DIFFERENTIATES BETHEEN REACTIVE AND PROACTIVE APPROACHES, CHARACTERIZING THE FIRST AS PARTICIPATORY AND THE LATTER AS REPRESENTATIVE OR REPUBLICAN. SHE EXPLORES THESE MODES OF LEGAL ACTION IN THE CONTEXT OF INSTITUTIONS THAT PROVIDE COUNSEL TO THE PDOR, SEARCHING FOR A STRUCTURE THAT BEST COMBINES RESPONSIVENESS TO THE NEEDS OF THE POOR WITH PLANMED LEgaL CHANGE.

05571 LAWSON, $F$.

ECONOMIC LIBERALIZATION IN SYRIA AND IRAO DURING THE 1980S ; THE LIMITS OF EXTERNALIST EXPLANATIONS

NEW POLITICAL SCIENCE, 21-22 (SPR 92), 185-206

NEW POLITICAL SCIENCE, 21-22 (SPR 92), $185-206$.
STRUCTURAL TRANSFORMATIONS IN THE THIRD WORLD ARE STRUCTURAL TRANSFORMATIONS IN THE THIRD WORLD ARE
EXPLAINED BY TWO DISAGREEING SCHOOLS OF THOUGHT--ORTHODOX DEPENDENCY THEORY AND STRUGGLES AMONG POHERFUL SOCIAL FORCES BASED WITHIN THESE COUNTRIES' RESPECTIVE DOMESTIC POLITICAL ARENAS. THIS ESSAY SKETCHES THE CONTOURS OF THE CURRENT DEBATE BETWEEN THESE THO INFLUENTIAL SCHOOLS OF THOUGHT. IT ARGUES ON THE BASIS OF TWO RECENT CASES FROM THE CONTEMPORARY ARAB WORLD THAT THOSE WHO POSIT EXTERNAL DETERMINANTS FOR MAJOR SHIFTS IN THE THIRD WORLD ECONOMIC POLICIES NEED TO RETHINK THEIR POSITIONS. THE TWO CASES PRESENTED FOR CONSIDERATION, SYRAI AND IRAQ IN THE MID TO LATE 1980 , ARE NOTABLE FOR' THEIR RESPECTIVE REGIMES' HAVING SHIFTED FROM LONGSTANDING PROGRAMS ESPOUSING STATE 
INTERVENTION AND THE REDISTRIBUTION OF INDIGENOUS WEALTH TO ONES PROMOTING THE VIRTUALLY UNHINDERED EXPANSION OF PRIVATE INTERPRISE.

05572 LAWUYI, T.; FALOLA, T. THE INSTABILITY OF' THE NAIRA AND SOCIAL PAYMENT AMONG THE YORUBA

JOURNAL OF ASIAN AND AFRICAN STUDIES, XXVII(3-4) (1992), 216-228

THE AUTHORS ASSESS THE IMPACT OF THE STRUCTURAL ADJUSTMENT PROGRAM (SAP) ON THE CULTURE OF LEISURE AMONG THE YORUBA. THEY ARGUE THAT THE PROGRAM HAS NECESSITATED PRICE SHIFTS THAT FORCE INDIVIDUALS AND GROUPS TO ADJUST IN ORDER TO ENSURE SURYIVAL OR PROGRESS. THE ADJUSTMENTS INYOL YE THE CREATIOM OF NEH SOCIAL GROUPS PEDUCTIONS IN THE SCALE OF CREATIOH OF NEW SOCIAL GROUPS, REDUCTIONS IN THE SCALE OF CEREMONIES, AND CREATIVE REORGANIZATION OF THE SYSTEM OF GIFT-GIVING. THE INVOLVEMENT OF INDIVIDUALS IN SOCIAL OUTLETS SERVES TO SUSTAIN THE SENSE OF REALITY AND GOOD CONDUCT. JUDGED AGAINST HISTORICAL ANTECEDENTS, THE RUPTURE TO SOCIETY CAUSED BY THE INTRODUCTION OF THE SAP HAVE MERELY LEISURE IS EVALUATED.

05573 LAWUYL, 0.

ETHNICITY, POLITICAL LEADERSHIP AND THE SEARCH FOR A STABLE NIGERIAN SOCIETY

SCANDINAVIAN JOURNAL OF DEVELOPMENT ALTERMATIVES, $11(3$ (SEP 92), 127-136.

THE ENTIRE NATION OF NIGERIA HAS, SINCE THE

NATIONALISTS' MOVEMENT, BEEN A DRAMATURGICAL THEATER. THE BASIC NEEDS REMAIN THE' SAME FOR THE ACTORS AS WELL AS THE SPECTATORS, IN THAT ELECTIONS SET THE TONE FOR CONFLICT AND MILITARY COUPS ARE JUSTIFIED AS CONFLICT-RESOLUTION MECHANISMS. HOWEVER THERE IS NO POLITICAL STABILTIY. AT ISSUE ARE NEEDS WHICH ARE CHALLENGED BY MORE GENERAL CONCEPTIONS OF COLLECTIVE IDENTITY. THIS ARTICLE ARGUES THAT THE FEDERAL CHARACTER THEORY MAY NOT SATISFY BASIC NEEDS AND MAY FURTHER DESTROY THE IDEAL FOR A MERIT SYSTEM WHERE REWARD FOR VARIOUS ACTIVITIES ARE KNOWN AND WHERE PROCEDURES FOR THE ATTAINMENT OF THE REWARDS ARE CLEARLY DELINEATED.

05574 LAZAR, I.; MOORE, E.

HEALTH POLIICY: BEYOND CHICKEN SOUP AND BAND-AIDS JOURMAL OF URBAN AFFAIRS, 14(3-4) (1992), 291-310. THE AUTHORS REVISIT YESTERDAY'S IDEAS AND POLICIES THAT HAVE LED TO THE PRESENT CRISIS IN U.S. HEALTH CARE. DAVE LED TO THE PRESENT CRISIS IN U.S. HEAL ACCESS, RISING COSTS, AND INEOUITIES IN THE DWINDLING ACCESS, RISING COSTS, AND INEQUITIES IN THE
OISTRIBUTION OF SERVICES ARE AMONG THE PROBLEMS THAT HAVE OISTRIBUTION OF SERVICES ARE AMONG THE PROBLEMS THAT HAVE BEEN PRODUCED BY SHORT-TERM, POLITICALLY-EXPEDIENT DECISIONS
MADE WITHOUT REFERENCE TO ONE ANOTHER. THE AUTHORS CREATE A MADE WI THOUT REFERENCE TO ONE ANOTHER. THE AUTHORS CREATE HEALTH CARE SYSTEM FOR A MYTHICAL COUNTRY, IN ORDER TO ILLUMINATE THE RANGE OF POSSIBILITIES BASED ON WHAT CAN BE LEARNED FROM EXPERIENCES IN THE USA AND OTHER CDUNTRIES. THEY ARGUE THAT REFORM MUST OCCUR THROUGHOUT THE SYSTEM AND CHANGES MUST BE BASED ON THE PERCEPTION OF HEALTH CARE MAINTENANCE AS A PUBLIC NECESSITY.

05575 LAZARE, F.

THE BALTICS GO IT ALONE

WORLD PRESS REVIEW, 39 (2) (FEB 92), 44.

THE THREE BALTIC STATES HAVE GAINED POLITICAL AUTONOMY, BUT ECONOMIC INDEPENDENCE REMAINS A DISTANT GOAL. NONE HAS YET FORMULATED A SPECIFIC ECONOMIC REFORM PROGRAM OR FOUND THE KEY TO FUTURE RELATIONS WITH THE OTHER BALTIC STATES OR THE FORMER SOVIET REPUBLICS.

05576 LAZARUS, $S$

NO SURPRISE

NEW REPUBLIC, 207(24) (DEC 92 ), 10

SOME TOP REPUBLICANS HAVE ACCUSED IRAN-CONTRA

INDEPENDENT COUNSEL LAHRENCE WALSH OF SABOTAGING PRESIDENT GEORGE BUSH'S RE-ELECTION BID BY INCLUDING MATERIAL PLACING BUSH AT A JANUARY 7, 1986, WHITE HOUSE ARMS-FOR-HOSTAGES MEETING IN THE INDICTMENT OF FORMER DEFENSE SECRETARY CASPAR WEINBERGER.

05577 LAZIC. M.

CIVIL WAR IN YUGOSLAYIA

NEW POLITICS, 3(4) (WIN 92), 134-139.

THE POLITICAL ANO ECONOMIC FEATURES OF THE NEWLY CREATED STATE OF YUGOSLAVIA IN 1918 WERE DIVIDED AMONG THE CROATS AND THE SERBS. THIS IMBALANCE CREATED FRUITFUL GROUND FOR SHIFTING THE CONFL ICT TO THE ETHMIC TERRAIN. PRESENTLY THE STUGGLE FOR PONER AMONG THE REPUBLICS' PARTY BUREAUCRATS COINCIDES WITH THE SUDDEN COLLAPSE OF THE EAST EUROPEAN COINCIDES WITH THE SUDDEN COLLAPSE OF THE EAST EUROPEAH

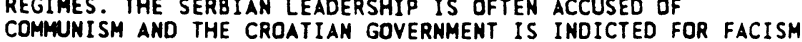
COMHUNISM AND THE CROATIAN GOVERNMENT IS INDICTED FOR FACISM. THIS ARTICLE OFFERS A BRIEF CHRONOLOGY THAT INDICATES THAT BOTH SIDES PREFERRED VIOLENCE RATHER THAN POLITICAL MEANS FROM THE VERY BEGINNING OF THE CURRENT CONFLICT. IT SUGGESTS THAT THE RATIONAL AND JUST SOLUTION FOR YUGOSLAVIA IS THAT RECIEVE ITS ECONOMC, POL ITICAL AND LEGAL PROTECTION.
05578 LEACH, J.A.

A REPUBLICAN LOOKS AT FOREIGN POLICY OREIGN AFFAIRS, 71(3) (SUM 92), 17-31.

THE CHALLENGE FOR U.S. LEADERSHIP IN THE DECADE AHEAD WILL BE TO CHART A COURSE THAT IS INCLUSIVE, NOT EXCLUSIVE, OF PERSPECTIVES DEVELOPED BEYOND ITS SHORES. THE UNITED STATES MUST LOOK TO CONSTRUCTIVE INTERNATIONALISM; TO PACIFIC-ISM, RATHER THAN PACIFISM; TO ATLANTICISM, RATHER THAN MERE ALLIANCE-ISM; TO LEADERSHIP OF THE AMERICAS, RATHER THAN INSULAR AMERICA FIRST-ISM.

05579 LEBLANC, J.

ECONOMIC STRUGGLE AND THE COMMUNIST PARTY

POLITICAL AFFAIRS, 71(12) (DEC 92), 14-19.

THE AMERICAN COMMUNIST PARTY IS OPTIMISTIC ABOUT THE FUTURE OF ITS IDEOLOGY IN THE UNITED STATES. AGAINST A BACKGROUND OF GREAT PROMISE AND ALSO DIRE NEED, THIS ARTICLE DETAILS THE MAIN TASKS OF THE PERIOD AHEAD. WHICH ARE TO ORGANIZE A MASS STRUGGLE IN URBAN, SUBURBAN, AND RURAL AMERICA FOR IMMEDIATE RELIEF AND RADICAL SOLUTIONS TO THE
DEEPING CRISIS ERODING EVERY SECTOR OF THE U.S. ECONOMY. IT SUGGESTS THAT THIS IS THE MANDATE OF THE 1992 ELECTIONS.

05580 LEBOVICS, H.

ECONOMIC POSITIVISM AS RHETORIC

INTERNATIONAL REVIEW OF SOCIAL HISTORY, 37(2) (1992), 44-251.

HERMAN LEBOVICS, IN A DEBATE WITH MICHAEL SMITH CONCERNING THE MELINE TARIFF, SITUATES HIS WORK IN A WAY WHICH MAKES MANIFEST BOTH THE AGREEMENT (WHICH IS SIGNIFICANT) AND THE DISAGREEMENT BETWEEN THEM ON HOW TO UNDERSTAND THE CREATION OF SOCIAL STABILTY IN THE NEW FRENCH REPUBLIC. HE PRESENTS THO KINDS OF ANSWERS, FIRST IN THE ARENA OF ECONOMIC DISPUTES AND THEN TO CRITIQUE SMITH'S POSING OF THE QUESTIONS AND MODES OF RESPONDING TO THEM. LEBOVICS CONCLUDES BY SUGGESTING THAT SMITH CONCERN HIMSELF WITH ASPECTS OF BUSINESS HISTORY INSTEAD OF RECYCLING UNEXAMINED IDEAS TO RE-ENACT OLD IDEOLOGICAL COMBATS.

05581 LECA, J.

FRENCH POLITICAL SCIENCE: SOME PROBLEMS AND DIFFICULTIES IN THE SOCIAL ORGANIZATION OF THE DISCIPLINE EUROPEAN JOURNAL OF POLITICAL RESEARCH, 20(3-4) (DEC 91), 323-340.

THE AUTHOR OFFERS AN OVERVIEW OF THE ORGANIZATION OF POLITICAL SCIENCE IN FRANCE, INCLUDING THE AREAS OF RESEARCH AND THE INDUCED BIASES, SUCH AS HISTORICAL AND PHILOSOPHICAL BIASES. HE ARGUES THAT FRENCH POLITICAL SCIENCE IS A BIASES. HE ARGUES THAT FRENCH POLITICAL SCIENCE IS A
PROFESSION BUT NOT YET A SOCIALLY-LEGITIMATE DISCIPLINE.

05582 LECOMTE, B.

COMMUNISM CONFRONTS ISLAM

WORLD PRESS REYIEW, 39(7) (JUL 92), 10-12.

AFTER BEING SHEPT UP IN EVENTS THAT THEY NEITHER WANTED NOR CONTROLLED, THE CENTRAL ASIAN REPUBLICS WERE, FOR THE MOST PART, CONTENT TO MERELY CHANGE LABELS IN 1991. WITH THE EXCEPTION OF A FEW EXPIATORY VICTIMS, THEY HAVE KEPT THEIR LEADERS AND POLITICAL STRUCTURES. NEVERTHELESS, AN EARTHQUAKE IN THE FORM OF A RETURN TO ISLAM HAS STRUCK THE WHOLE OF CENTRAL ASIA, PARTICULARLY UZBEKISTAN AND TAJIKISTAN. IT IS A RELIGIOUS RESURGENCE THAT PORTENDS COMPELLING POLITICAL CHANGE.

05583 LEDEEN, $M$

BUSTING THE BUREAUCRACY

AMERICAN SPECTATOR, 25(10) (OCT 92), 41-42

THE TRUE HORROR OF BUREAUCRACY LIES NOT IN ITS SIZE OR ITS COSTS--WHICH ARE NEVERTHELESS STAGGERIMG--BUT IN ITS INEVITABLY SINISTER EFFECTS ON ENTERPRISE AND INNOVATION. IT MATTERS NOT WHETHER THE PRESIDENT IS LIBERAL OR CONSERVATIVE, REPUBLICAN OR DEMOCRAT; THE BUREAUCRACY MOVES RELENTLESSLY FORWARD, EXPANDING ITS OWN SPHERE OF INFLUENCE AT THE CITIZEN'S EXPENSE.

05584 LEDEEN, M.

COMMON SENSE, 1992

AMERICAN SPECTATOR, 25(6) (JUN 92), 23-26.

CONTRARY TO THE CONVENTION WISDOM, THE ONLY HOPE FOR IMPROVED GOVERMMENT LIES IN REDUCING BOTH THE NUMBERS OF PUBLIC EMPLOYEES AND THE AMOUNT OF MONEY THEY GET TO SPEND. PEOPLE, EAST AND HEST UNDERSTAND THIS SEEMING PARADOX, WHICH PEOPLE, EAST AND WEST UNDERSTAND THIS SEEMING PARADOX, WHICH THEMSELVES. THEY WANT INSTI TUTIONS OVER WHICH THEY CAN

THEMSELVES. THEY WANT INSTITUT IONS OVER WHICH THEY CAN

EXERCISE GREATER CONTROL. INSTITUTIONS THAT ARE SMALLER, LEANER, AND MORE EFFICIENT. THIS MEANS A GREATER RELIANCE ON THE PRIVATE SECTOR AND ON LOCAL GOVERNMENT THAN ON NATIONAL BUREAUCRACIES THAT ARE POLITICALLY AND GEOGRAPHICALLY REMOTE FROM THE GREAT MASS OF THE CITIZENRY. THIS ARTICLE CONCL
THAT IT IS ONLY FITTING THAT THIS LATEST CHAPTER IN THE ENDLESS STRUGGLE AGAINST EVIL BE CONOUCTED DESPITE OUR LEADERS.

05585 LEDEEN, $M$

IRAQ'S GERMAN CONNECTION 
COMMENTARY, 91(4) (APR 91), 27-30.

FOR HELL OVER A DECADE, HUNDREDS--POSSIBLY EVEN THOUSANDS--OF GERMAN BUSINESSMEN, SCIENTISTS, AND MIDDLEMEN HAD PLAYED THE KEY ROLE IN IRAQ'S \$50-BILLION PROGRAM TO PRODUCE HEAPONS OF MASS DESTRUCTION. THE BEST ESTIMATES OF THE AMERICAN GOVERNMENT SUGGEST THAT NEARLY 70 PERCENT OF IRAQ'S NUCLEAR, CHEMICAL, AND BIOLOGICAL CAPABILITY WAS PROVIDED BY GERMANS. GIVEN THAT THIS PHENOMENON HAD BEEN REPORTED IN DETAIL IN THE GERMAN, BRITISH, AMERICA, SPANISH REPORTED IN DETAIL IN THE GERMAN, BRITISH, AMERICA, SPANISH
AND DUTCH MEDIA FOR YEARS, RECENT CLAIMS OF IGNORANCE BY THE AND DUTCH MEDIA FOR YEARS, RECENT CLAIMS
GERMAN GOVERNMENT ARE SOMENHAT SUSPECT.

05586 LEE, A.

VALUES, GOVERMMENT PERFORMANCE, AND PROTEST IN SOUTH KOREA ASIAN AFFAIRS, AN AMERICAN REYIEH, 18(4) (WIN 92), 240-253. THE AUTHOR' FOCUSES ON THE SOCIAL AND CULTURAL

TRANSFORMATION OF SOUTH KOREAN SOCIETY AS A PART OF ECONOMIC DEVELOPMENT AND ITS IMPACT ON THE POPULAR PROTEST MOVEMENT. HE ARGUES THAT THE EROSION OF SUPPORT FOR AUTHORITARIAN POLITICAL INSTITUTIONS AND PRACTICES BEGINS WITH CHANGES THROUGH CITIZENS' EXPOSURE TO MODERN IDEAS AND WAYS OF LIFE. A PERSON'S LEVEL OF EDUCATION SEEMS TO BE THE MOST POWERFUL VARIABLE IN EXPLAINING VALUE CHANGES, BUT AGE IS ALMOST EQUALLY IMPORTANT IN SOUTH KOREA BECAUSE THERE HAS BEEN SIGNIFICANT DIFFERENCE IN THE LIFESTYLES OF YOUNGER AND OLDER GENERATIONS. THE AUTHOR ENDEAVORS TO EXPLAIN CONFLICT WITHIN SOUTH KOREA BY ANALYZING THE RELATIONSHIPS BETHEEN THE GENERAL PUBLIC'S VALUES IN RELATION TO GOVERNMENT PERFORMANCE, SOCIAL CYNICISM, CONFIDENCE IN MAJOR POLITICAL INSTITUTIONS, AND ATTITUDES TOWARD POLITICAL PROTEST, USING THE 1985 PUBLIC OPINION STUDY FOR NATIONAL DEVELOPMENT. HE ALSO EVALUATES THE EXTENT TO WHICH AUTHORITARIAN-LIBERTARIAM VALUES PERSIST OR ARE CHANGING AND THEIR INFLUENCE UPON SOUTH KOREANS' POLITICAL ORIENTATIONS AND PROTEST POTENTIAL.

05587 LEE, C.D.; LEE, D.R.

THE GENDER GAP

FREEMAN, 42(3) (MAR 92), 100-103.

FOR 60 YEARS, WOMEN VOTED IN NATIONAL ELECTIONS MUCH THE SAME AS MEN YOTED. BUT, BEGINNING IN 1980, A PHENOMENON THAT SAME AS MEN VOTED. BUT, BEGINNING IN 1980, A PHENOMENON THAT BECAME KNOWN AS "THE GENDER GAP" APPEARED, WHEN WOMEN VOTED LARGER PERCENTAGES THAN MEN. FEMINISTS HAVE APPLAUDED THE GENDER GAP AS EVIDENCE THAT HOMEN ARE BEGINNING TO DISPLAY THE SOLIDARITY TO ASSERT THEMSELVES POL ITICALLY.

THE SOLIDARITY TO ASSERT THEMSELVES POLITICALLY. NO EVIDENCE THAT WOMEN ARE BEING LED LIKE LEMMINGS IN POL ITICAL SUPPORT OF A WOMEN'S AGENDA. INDEED, IT IS INSULTING TO WOMEN AS INTELLIGENT AND INDEPENDENT CITIZENS TO SUGGEST THAT A SISTERHOOD OF POLITICAL SOLIDARITY CAN EVER BE A REALISTIC POSSIBILITY.

05588 LEE, C.H.

THE GOVERNMENT, FINANCIAL SYSTEM, AND LARGE PRIVATE ENTERPRISES IN THE ECONOMIC DEVELOPMENT OF SOUTH KOREA WORLD DEVELOPMENT, 20(2) (FEB 92), 187-197.

THE AUTHOR EXPLORES THE MAIN CHARACTERISTICS OF THE GOVERNMENT-BUSINESS RELATIONSHIP IN SOUTH KOREA IN THE PAST THREE DECADES TO ASCERTAIN HOW IT MAY HAVE CONTRIBUTED TO SOUTH KOREA'S ECONOMIC DEVELOPMENT. HE VIEWS THE GOVERNMENT AND LARGE PRIVATE ENTERPRISES IN SOUTH KOREA AS A QUASIINTERNAL ORGANIZATION. AS SUCH, EXTENSIVE INTERVENTION BY THE GOVERNMENT IN SOUTH KOREA'S FINANCIAL SYSTEM CAN BE VIEWED AS AN INTERNAL CAPITAL MARKET AND, CONSEQUENTLY, IT COULD HAVE LED TO A MORE EFFICIENT ALLOCATION OF CREDIT THAN POSSIBLE IN A FREE-MARKET FINANCIAL SYSTEM. MOREOVER, THE QUASI-INTERNAL ORGANIZATION HAS MADE IT POSSIBLE FOR THE GOVERNMENT TO EFFICIENTLY IMPLEMENT ITS DEVELOPMENTAL POLICIES. HOWEVER, FOR THE QUASI-INTERNAL ORGANIZATION TO BE SUCCESSFUL IN ACCELERATING THE PACE OF ECONOMIC DEVELOPMENT, THE COUNTRY MUST HAVE A POL ITICAL LEADERSHIP COMHITTED TO THE GOAL OF ECONOMIC DEVELOPMENT AND MUST ADOPT AN OUTHARDORIENTED DEVELOPMENT POLICY.

05589 LEE, D.; MCKENZIE, R.

COUNTERVAILING IMPOTENCE

SOCIETY, 30(1) (NOV 92), 34-40.

THERE ARE REASONS TO BELIEVE THAT IT WAS THE STRUCTURE OF BUSINESS WHICH PROMPTED GOVERMENT TO GROW IN SIZE AND POWER DURING MOST OF THIS CENTURY. THOSE SAME REASONS ALSO EXPLAIN WHY GOVERNMENT IS NOW IN THE BEGINNING STAGES OF DECLINE. THIS ARTICLE SUGGESTS THAT BECAUSE OF WIDENING GLCLAL MOBI AR OF RESOUCES AHD TAPITAS THE PATTERN OF COOPERATION BETWEEN BUSINESS AND GOVERMMENT IS BREAKING DOWN THROUGH THROUGH A PROCESS OF COUNTERVAILING IMPOTENCE. THE GLOBALIZATION OF ECONOMIC ACTIVITY THAT IS UNDERMINING ANY ECONOMIC POHER THAT BUSINESS MAY HAVE BEEN ABLE TO EXERCISE THROUGH UNREGULATED MARKETS IS ALSO UNDERMINING
GOVERNMENT TO PROTECT BUSINESS WITH REGULATION.

05590 LEE, D.

FREEDOM AND THE PROSPECT FOR SOVIET ECONOMIC REFORM

FREEMAN, 42(2) (FEB 92), 68-72.

NO MATTER HOW MUCH THE SOVIET CITIZENS AND THEIR LEADERS
HAVE BECOME INTERESTED IN ECONOMIC REFORM, THE MOVE TO A MARKET ECONOMY WILL BE DIFFICULT. THIS ARTICLE DESCRIBES THE FUNDAMENTAL PROBLEM FACING SOVIET REFOMERS WHICH WILL BE THE CONNECTION BETHEEN MARKET INSTITUTIONS AND TOLERANCE FOR ECONOMIC FREEDOM. HITHOUT MARKET INSTITUTIONS, THE SOVIETS WILL BE HARD PRESSED TO ALLOH ECONOMIC FREEDOM AND WITHOUT TOL MARKET INSTITUTIONS. SOME SUPERFICIAL PROBLEMS ARE EXPLORED.

05591 LEE, H.

ROK SELF-RELIANT DEFENSE AND THE US COMMITMENT KOREAN JOURNAL OF DEFENSE ANALYSIS, IV(1) (SUM 92), 191-220.

THE US-KOREAN RELATIONSHIP MIGHT BE METAPHORED BY A MATURING ADULT-CHILD RELATIONSHIP. BOTH COUNTRIES NEED TO CONSIDER SERIOUSLY HOW TO MODERNIZE THE PARTNERSHIP AND AVOID PUTTING AT RISK THE TRADITIONAL COOPERATION BETWEEN THE TWO COUNTRIES. IN SPITE OF THEIR ORIGINAL SPIRIT TO ENSURE KOREAN SECURITY, US SECURITY COMMITMMENTS COULD ACTUALLY BY DESTABILIZING THE NATIONAL SECURITY OF SOUTH KOREA AND THE REGION BY UNDERMINING THE DEMOCRATIC FOUNDATION OF ITS POLITICAL SYSTEM.

05592 LEE, J.; STANLEY, T.; VON PAGENHARDT, R. TO UNITE OUR STRENGTH: ENHANCING UNITED NATIONS PEACE AND SECURITY

UNIVERSITY PRESS OF AMERICA, 1992, 180.

IN THE 1990'S THE UN'S POTENTIAL HAS BEEN REBORN. NOW THE WORLD MUST FIND WAYS TO INCORPORATE ELEMENTS OF THAT SUCCESS INTO THE UN SYSTEM. NO SINGLE REFORM OR EVEN EXPANSION OF UN MILTARY POWER CAN ACHIEVE THE NECESSARY CHANGES: RATHER A SERIES OF POLITICAL AND MILITARY INNOVATIONS ARE NEEDED SOON TO DEVELOP A UN PEACE AND SECURITY SYSTEM. SPECIFIC RECOMMENDATIONS IN MANY AREAS ARE OFFERED.

05593 LEE, K.; LEE, H.Y. STATES, MARKETS, AND ECONOMIC DEVELOPMENT IN EAST ASIAN CAPITALISM AND SOCIALISM

DEVELOPMENT POLICY REVIEN, 10(2) (JUN 92), 107-130.

THE AUTHORS STUDY STATE ACTIVISM IN THE DIFFERENT CAPITALIST AND SOCIALIST ECDNOMIC SYSTEMS OF EAST ASIA. COMMUNIST CHINA, SOUTH KOREA, JAPAN, AND TAIHAN CAN BE CONSIDERED TO BE SOMEWHERE IN A CONTINUUM RANGING FROM PURE CAPITALIST MARKET ECONOMY TO A CENTRALLY-PLANNED SOCIALIST ECONOHY. THE AUTHORS INVESTIGATE THE DIFFERENT MECHANISMS OF STATE ACTIVISM IN THE FOUR ECONOMIES, WHICH ARE RESPONSIBLE FOR THE DIFFERENCES IN THE ECONOMIC OUTCOME
THEY ALSO DISCUSS THE NATURE OF STATES, FOCUSING ON THE RELATIONSHIP BETHEEN POLITICAL AUTHORITY AND ECONOMIC ACTIVITY.

05594 LEE, K.Y.; RAMOS, F.

DISCIPLINE VS DEMOCRACY

FAR EASTERN ECONOMIC REVIEN, 155(49) (DEC 92), 29.

THE PHILIPPINE BUSINESS CONFERENCE ON DEMOCRACY AND DEVELOPMENT PROVIDED A FORUM FOR AIRING TWO WIDELY DIFFERING VIEWS ON DEMOCRACY. THIS ARTICLE CONTAINS EXCERPTS FROM THE SPEECHES OF THO ASEAN STATESMEN: SINGAPORE'S SENIOR MINISTER LEE KUAN YEW AND PHILIPPINE PRESIDENT FIDEL RAMOS. LEE ARGUES THAT DISCIPLINE IS A FAR MORE VITAL PRECONDITION TO ECONOMIC GROWTH THAN IS DEMOCRACY. HE NOTES THAT "THE EXUBERANCE OF DEMOCRACY LEADS TO UNDISCIPLINED AND DISORDERLY CONDITIONS WHICH ARE INIMICAL TO DEVELOPMENT." RAMOS PRAISES THE SACRIFICES OF THE PEOPLE OF THE PHILIPPINES FOR THE SAKE OF FREEDOM AND DEMOCRACY. HE ARGUES THAT THE KIND OF DISCIPLINE NEEDED IS NOT THAT HHICH IS IMPOSED FROM ABOVE BUT THAT WHICH COMES FROM WITHIN.

05595 LEE, M.

DEMOCRACY

FAR EASTERN ECONOMIC REVIEH, 155(47) (NOV 92), 31.

ON 14 NOVEMBER THE HONG KONG LEGISLATIYE COUNCIL (LEGCO VOTED STRONGLY IN FAVOR OF THE LIMITED DEMOCRATIC REFORMS PROPOSED BY GOVERNOR CHRIS PATTEN. MARTIN LEE, CHAIRMAN OF PROPOSED BY GOVERNOR CHRIS PATTEN. MARTIN LEE, CHAIRMAN THE UNITED DEMOCRATS OF HONG KONG, ARGUES THAT THE LEGCD
VOTE MARKS THE END OF THE COLONIAL ERA IN HONG KONG. THE VOTE MARKS THE END OF THE COLONIAL ERA IN HONG KONG
LARGE MARGIN BY WHICH THE PROPOSALS WERE APPROVED

LARGE MARGIN BY WHICH THE PROPOSALS WERE APPROVED
DEMONSTRATES THAT THE DEMOCRATIC TIDE WHICH HAS SWEPT

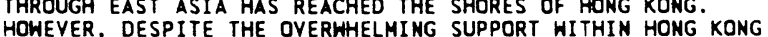
HOWEVER, DESPITE THE OVERHHELMING SUPPORT WITHIN HONG KONG FOR DEMOCRATIZATION, A SECTOR OF THE BUSINESS COMMUNITY LED BY PRO-PEKING BUSINESSMAN VINCENT LO HAS COME OUT FIRMLY ARGUES THAT THIS RESISTANCE TO REFORM AMOUNTS TO A DESIRE TO ARGUES THAT THIS RESISTANCE TO REFORM AMOUNTS TO A DESIRE

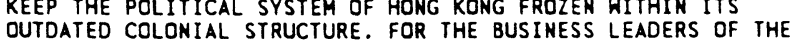
OUTDATED COLONIAL STRUCTURE. FOR THE BUSINESS LEADERS MOST CAPITALIST ECONOMY IN THE HORLD TO SIDE WITH THE KONG IS SHORT-SIGHTED AND RUNS AGAINST THE MOOD OF BUSINESS LEADERS ELSEHHERE IN ASIA.

05596 LEE, R.

LEgal Parameters of aDministration IN a DEMOCRATIC SOCIETY 
ADMINISTRATION AND SOCIETY, 23(2) (AUG 91), 201-226. THE PREMISE OF LIMITED GOVERMMENT IN A DEMOCRATIC SOCIETY IS A DECEIVINGLY SIMPLE ONE, MAMELY, THAT GOVERNMENT SHOULD BE EMPOWERED TO ACT IN ORDER TO MEET THE NEEDS OF THE CITIZENRY AND SHOULD BE HELD ACCOUNTABLE OR BE LIMITED IN THE EXERCISE OF THAT POWER. DEMOCRATIC SOCIETIES HAVE ENGINEERED A VAST ARRAY OF MECHANISMS FOR CONTROLLING GOVERNMENT. THIS ARTICLE EXAMINES THE CASE OF AUSTRALIA. STARTING IN THE 1970 , AUSTRALIA LAUNCHED A SET OF REFORMS THAT HAS COME TO BE CALLED THE "NEW ADMINISTRATIVE LAH." TODAY, THERE ARE TWELVE MAJOR CHARACTERISTICS OF THE AUSTRALIAN SYSTEM, SOME OF WHICH ARE CDMMON IN THE UNITED STATES. EXPERIENCE UNDER THIS SYSTEM SHOWS POSITIVE RESULTS, BUT SOME TROUBLING ASPECTS OF ADMINISTRATIVE LAK CONTINUE.

05597 LEE, T.

RESTORING THE BALANCE

FREE CHINA REVIEW, 42(11) (NOV 92), 42-43.

ON SEPTEMBER 2, 1992, U.S. PRESIDENT GEORGE BUSH ANMOUNCED HIS DECISION TO AUTHORIZE THE SALE OF $150 \mathrm{~F}-16 \mathrm{~A} / \mathrm{B}$ FIGHTERS TO THE REPUBLIC OF CHINA, ENDING RESTRICTIONS ON ADVANCED AIRCRAFT SALES TO TAIWAN. CONCERN FOR REGIONAL SECURITY WAS CITED AS THE REASON FOR THE SALE, HHICH WAS SECURITY WAS CITED AS THE REASON FOR THE SALE, WHICH WAS
GREETED WITH APPLAUSE IN TAIPEI AND WITH ANGER IN PEKING. IT GREETED WITH APPLAUSE IN TAIPEI AND WITH ANGER IN PEKING. IT RIFT IN U.S. - MAINLAND CHINESE RELATIONS IN DECADES.

05598 LEE, $W$

CRIMES OF THE HEART: POLITICAL LOYALTY IN SOCIALIST CHINA STUDIES IN COMPARATIVE COMMUNISM, XXV(3) (SEP 92), 228-241. THE ERUPTION AND SUBSEOUENT REPRESSION OF CHINA'S DEMOCRACY MOVEMENT HAVE REOPENED THE DEBATE ON THE CONCEPT OF LOYALTY IN CHINA. IN THIS ESSAY, THE AUTHOR CONSIDERS SEVERAL ASPECTS OF THIS DEBATE: WHAT SHOULD BE THE OBJECT OF LOYALTY? ARE THERE DIFFERENT TYPES OF LOYALTY IN CHINA? HAS THE EXPANSION OF CERTAIN OUTLETS FOR PUBLIC EXPRESSION ACTUALLY HELPED CHINESE INTELLECTUALS WHO ARE STRUGGLING WITH THE QUESTION OF LOYALTY? THE ANSWERS TO THESE QUESTIONS SHED LIGHT ON THE DYMAMICS OF THE CHINESE COMMUNIST PARTY'S METHODS AND ALSO FURTHER THE UNDERSTANDING OF HHY CHINESE INTELLECTUALS BEHAVE AS THEY DO UNDER SOCIALIST RULE.

05599 LEEBAERT, D.

INMOVATIONS AND PRIVATE INITIATIVES AS FRONTIERS FALL WASHINGTON QUARTERLY, 15(2) (SPR 92), 107-126.

THE FUTURE OF AN INTERNATIONAL TRADING SYSTEM BASED ON PRINCIPLES OF FAIRNESS AND OPENNESS IS VERY MUCH IN DOUBT AS IT CONFRONTS GRONING PRESSURES OF REGIONALISM, TECHNOLOGICAL IT CONFRONTS GROWING PRESSURES OF REGIONALI ISM, TECHNOLOGICAL INMOVATION, AND A CHANGING GEOPOL ITICAL ENVIRONMENT. AS THE CREATIVE ASPECTS OF GOVERMMENT BECOME EVER MORE DOUBTFUL, WHAT ORGANIZATIONAL ARRANGEMENTS BEST ACHIEVE PRODUCTIVITY AND INNOVATION? WHA PRECEDENTS EXIST AND WHAT

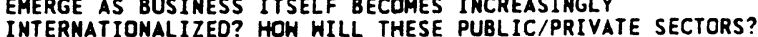
INTERNATIONALIZED? HOW HILL THESE PUBLIC/PRIVATE SECTORS? DECADE? THIS ARTICLE ADORESSES ALL THESE QUESTIONS.

05600 LEECH, D

EMPIRICAL ANALYSIS OF THE DISTRIBUTION OF A PRIORI VOTING POWER: SOME RESULTS FOR THE BRITISH LABOUR PARTY CONFERENCE AND ELECTORAL COLLEGE

EUROPEAN JOURNAL OF POLITICAL RESEARCH, 21(3) (APR 92), 245-265.

THE AUTHOR OFFERS AN EMPIRICAL ANALYSIS OF A PRIORI VOTING POHER USING POWER INDICES DERIVED BY REGARDING THE BRITISH LABOUR PARTY CONFERENCE AND ELECTORAL COLLEGE AS WEIGHTED MAJORITY GAMES. HE SHOWS THAT BOTH MAIN POWER INDICES, THE SHAPLEY-SHUBIK AND THE BANZHAF, MAY BE COMPUTED WITH REASONABLE ACCURACY BY AN APPROXIMATION METHOD BASED ON PROBABLISTIC-VOTING ASSUMPTION. THE RESULTS SHOW VOTING POWER TO BE MORE CONCENTRATED THAN VOTING WEIGHT AND THAT SOME LARGE TRADE UNIONS ARE ENHANCED AT THE EXPENSE OF SMALLER AFFILIATED ORGANIZATIONS AND CONSTITUENCY PARTIES (AND, IN THE ELECTORAL COLLEGE, MP'S). THE RESULTS ALSO PROVIDE INSIGHTS INTO THE COMPARATIVE PROPERTIES OF THE TWO CLASSICAL POHER INDICES.

05601 LEEDEEN, $M$.

LEFTIST LIARS AMD IDEOLOGICAL SUICIDE

AMERICAN SPECTATOR 24(10) (OCT 91) 16-17.

THIS ARTICLE STATES THAT HORLO EVENTS SINCE 1980 DIFFER SO WIDELY FROM WHAT LEFTISH RHETORIC WOULD HAVE PREDICTED SO WIDELY TROM WHAT LEFTISH RHETORIC WOULD HAVE PREDICTED THAT THE LEFT'S IDEOLOGUES HAVE HAD TO RESORT TO MYTHS

DISTORTIONS. THEY HAVE ENTERED A BATTLE THAT IT TAKES SUFFICENT EVIDENCE.

05602 LEEGE, D.C.

COALITIONS, CUES, STRATEGIC POLITICS, AND THE STAYING

POWER OF THE RELIGIOUS RIGHT, OR WHY POLITICAL SCIENTISTS

OUGHT TO PAY ATTENTION TO CULTURAL POLITICS

PS: POLITICAL SCIENCE AND POLITICS, XXV(2) (JUN 92), 198-204

THE AUTHOR RELIES ON TWO ASSUMPTIONS TO EXPLAIN
FLUCTUATIONS IN THE RELIGIOUS RIGHT'S INVOLVEMENT IN THE AMERICAN POL ITICAL AGENDA: (1) THE VOTERS-AS-RESOURCES AMERICAN POLITICAL AGENDA: (1) THE VOTERS-AS-RESOURCES
ASSUMPTION AND (2) THE MULTIPLE-POINTS-OF-ACCESS ASSUMPTION, ASSUMPIION AND (2) THE MULTIPLE-POINTS-OF-ACCESS ASSUMPTION. EMPIRICAL FINDINGS, INCLUDING (1) AM UNDERSTANDING OF EMPIRICAL FINDINGS, INCLUDING (1) AN UNDERSTANDING OF DIFFERENCES BETWEEN ELECTORAL AND GOVERNING COALITIONS, OF
DIFFICULTIES IN MAINTAINING UNWIELDY POLITICAL AND RELIGIOUS DIFFICULTIES IN MAINTAINING UNWIELDY POLITICAL AND REL
COALITIONS, AND OF THE USES OF STRATEGIC POLITICS BY COALITIONS, AND OF THE USES OF STRATEGIC POLITICS BY ABOUT CLERICAL CUE-GIVING AND PARISHIONER RECEPTIVITY TO CUES; AND (3) AN EXPLORATION OF OTHER EMPIRICAL EVIDENCE ABOUT THE CURRENT ALIGNMENTS OF IMPORTANT SECTORS OF THE ELECTORATE AND THE STAYING POWER OF MORAL ISSUES.

05603 LEEGE, D.C. : KELLSTEDT, L.A.

REDISCOVERING THE RELIGIOUS FACTOR IN AMERICAN POLITICS

M. E. SHARPE, 1993, 272 .

THIS BOOK ADORESSES HHETHER AND HOW RELIGION AND

RELIGIOUS INSTITUTIONS AFFECT AMERICAN POLITICS. FOR SOME TIME, AMALYSTS HAYE ARGUED THAT THE CONFLICTS OF THE NEH DEAL ERA RENDERED CULTURAL DIFFERENCES TRIVIAL AND PLACED ECONOMIC INTERESTS AT THE TOP OF THE POLITICAL AGENDA. THE AUTHORS DISAGREE. THEY FIND THAT RELIGIOUS HORLDVIEWS ARE STILL INSINUATED IN AMERICAN POLITICAL INSTITUTIONS, AND STILL INSINUATED IN AMERICAN POLITICAL INSTITUTIONS, AND RELIGIOUS INSTITUTIONS STILL ARE POINTS OF REFERENCE. THE
BOOK PROFITS FROM THE NEW RELIGIOSITY MEASURES EMPLOYED IN BOOK PROFITS FROM THE NEH RELIGIOSITY MEASURES EMPLOYED IN
THE 1990 NATIONAL ELECTION STUDIES. IT DISCUSSES THE STUDY THE 1990 NATIONAL ELECTION STUDIES. IT DISCUSSES THE STUDY OF RELIGION IN THE CONTEXT OF POLITICS; EXAMINES RELIGION AS A SOURCE OF GROUP ORIENTATION; CONSIDERS RELIGIOUS PRACTICES AOR DOCTRINAL AND WORLD VIEWS; AND, EXPLORES THE SOURCES OF FOR DOCTRINAL AND WORLD
RELIGIOUS SOCIALIZATION.

05604 LEEPER, $M$.

THE IMPACT OF PREJUDICE ON FEMALE CANDIDATES: AN EXPERIMENTAL LOOK AT VOTER INFERENCE

AMERICAN POLITICS QUARTERLY, 19(2) (APR 91), 248-261. CURRENT RESEARCH SUGGESTS THAT GENDER PREJUDICE NO LONGER IMPEDES NOMEN FROM WINNING TOP-LEVEL POL ITICAL POSITIONS. NEVERTHELESS, THE NUMBER OF WOMEN IN ALL LEVELS OF POLITICAL OFFICE REMAINS STARTLINGLY LOW-MERITING A CLOSER LOOK AT THE ROLE OF GENDER PREJUDICE. THIS STUDY TAKES AN EXPERIMENTAL LOOK AT HOW VOTERS RESPOND TO FEMALE CANDIDATES PUSHING UNAMBIGUOUS, TOUGH POLICY STANDS. INTERESTINGLY, VOTERS SEEM TO INFER THAT WOMEN POSSESS TRADITIONAL "FEMININE" STRENGTHS EVEN WHEN THEY EMIT A CLEAR "MASCULINE" MESSAGE. THEREFORE, FEMALE CANDIDATES SHOULD NOT FEAR VISCERAL REACTIONS FROM VOTES IF THEY ASSUME AN
AGGRESSIVE CAMPAIGN POSTURE. RATHER, THIS "MASCULINE" SEEKING TOP-LEVEL OR ADMINISTRATIVE POSITIONS.

05605 LEESON, $R$.

FIMANCIAL DEREGULATION AND ACCESS TO HOME OWNERSHIP IN AUSTRALIA: AN EXAMINATION OF THE EVIDENCE

AUSTRALIA: AN EXAMINATION OF THE EVIDENCE
URBAN STUDIES, 29 (7) (OCT 92), $1191-1194$.

SRBAN STUDIES, 29(7) (OCT 92), 1191-1194. SOME WRITERS HAVE SUGGESTED THAT THE DEPOSIT GAP (THE
DIFFERENCE BETHEEN BORROWING CAPACITY AND THE PRICE OF A DIFFERENCE BETWEEN 8ORROWING CAPACITY AND THE PRICE OF A HOUSE) HAS WIDENED IN AUSTRALIA SINCE FINANCIAL DEREGULATION, MAKING HOME OWNERSHIP LESS ACCESSIBLE. THIS PAPER EXAMIMES THEIR CONTENTION.

05606 LEFF, E.

ENVIRONMENTALISM: FUSING RED AND GREEN

REPORT ON THE AMERICAS, 25(5) (MAY 92), 35-37. LATIN AMERICA'S ENVIRONMENTAL MOVEMENT QUESTIONS THE CENTRAL IZED POWER OF ELITES, ECOCIDAL DEVELOPMENT, AND THE RATIONALITY OF ECONOMIC GROHTH-OA VISION THAT COULD RENEW THE TRADITIONAL BANNERS OF THE LEFT. A NEW LEFT THAT FUSES RED AND GREEN AS IT REACHES FOR A NEH UTOPIA COULD LAUNCH A NEW CYCLE OF SOCIAL CHANGE, CAPABLE OF TRANSCENDING THE CIVILIZATION RATIOHALE OF MODERNITY. THE ENVIRONMENTAL ISM BEING BORN MAY WELL PROVE TO BE THE THEORY AND PRAXIS THAT
WILL ALLOW HUMANITY TO SURVIVE INTO THE TWENTY-FIRST CENTURY.

05607 LEGGETT, J.

GLOBAL WARMING: THE HORST CASE

BULLETIN OF THE ATOMIC SCIENTISTS, 48(5) (JUN 92 ), 28-33. THE EARTH SUMMIT IM RIO MAY NOT PRODUCE THE RESULTS DESIRED BY ENVIRONMENTAL SCIENTISTS. FOOT-DRAGGING GOVERNMENTS REMAIN BLIND TO THE POSSIBILITY OF A RUNAHAY GREENHOUSE EFFECT. THIS ARTICLE OFFERS A HORST-CASE SCENARIO AND SUGGESTS THAT WHEN EVALUATING MILITARY THREATS, POLICY IS PREDICATED ON A WORST-CASE ANALYSIS. THE POINT IS NOT THAT A WORST-CASE SCENARIO WILL HAPPEN, BUT THAT IT COULD. THAT A WORST-CASE SCENARIO HILL HAPPEN, BUT THAT IT COULD. IT ARGUES THAT FOOT-DRAGGING GOVER

05608 LEGUTKO, R.

THE FREE MARKET IN A REPUBLIC

CRITICAL REVIEH, 5(1) (HIN 91), 37-52.

IN POLAND, THE PRACTICAL DIFFICULTIES ENCOUNTERED IN THE STURGGLE TO CREATE A CAPITALIST SOCIETY ARE LEADING MANY 
HAYEKIAN LIBERALS TO THE REALIZATION THAT SOCIAL FACTORS CRUCIAL TO THE CREATION AND STABILITY OF SUCH A SOCIETY ARE INVISIBLE WITHIN THE CLASSICAL LIBERAL INTELLECTUAL HORIZON AHD ARE UNDERMINED BY ITS ETHNIC OF EGALITARIAN INDIVIDUALISM. THEREFORE, PARADOXICALLY, A MAJDR STEP FORWARD IN THE CREATION OF A LIBERAL SOCIETY HAS BEEN THE ABANDONMENT OF SIGNIFICANT ELEMENTS OF LIBERAL IDEOLOGY IN ABANOONMENT OF SIGNIFICANT ELEMENTS OF LIBERAL IDEOLOGY ARTICLE CONCLUDES THAT THE PHILOSOPHY OF REPUBLICANISM SEEMS A MORE APPEALING ALTERNATIVE.

05609 LEHMAN, H.P.; MCCOY, J.L. THE DYMAMICS OF THE THO-LEYEL BARGAINING GAME: THE 1988 BRAZILIAN DEBT NEGOTIATIONS

WORLD POLITICS, $44(4)$ (JUL 92), 600-644.

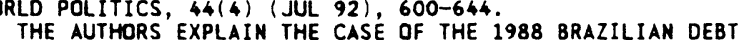
THE AUTHORS EXPLAIN THE CASE OF THE 1988 BRAZILIAN DEBT
RESCHEDULING AGREEMENT AS A TWO-LEVEL GAME IN WHICH EACH OF RESCHEDULING AGREEMENT AS A TWO-LEVEL GAME IN WHICH EACH
THE TWO MAJOR NEGOT IATORS (THE BRAZILIAN STATE AND THE THE TWO MAJOR NEGOT IATORS (THE BRAZILIAN STATE AND THE
INTERNATIONAL BANK ADVISORY COMMITTEE) HAD TO SATISFY ITS INTERNATIONAL BANK ADVISORY COMMITTEE) HAD TO SATISFY ITS
OWN CONSTITUENTS WHILE TRYING TO NEGOTIATE AN INTERNATIONAL AGREEMENT. THEY ARGUE THAT THE INTERACTION BETWEEN THE DOMESTIC AND INTERNATIONAL LEVELS MUST BE UNDERSTOOD IN ORDER TO EXPLAIN THE RESULTS OF INTERNATIONAL DEBT NEGOTIATIONS. THE TWO-LEVEL MODEL ILLUSTRATES HOW DOMESTIC CONSTRAINTS AND OPPORTUNITIES AFFECT INTERMATIONAL OUTCOMES, AND IT HIGHLIGHTS THE IMPORTANCE OF THE RATIFICATION PROCESS.

05610 LEHMAN, H.P.

THE PARADOX OF STATE POWER IN AFRICA: DEBT MANAGEMENT

POLICIES IN KENYA AND ZIMBABWE

AFRICAN STUDIES REVIEH, 35 (2) (SEP 92 ), 1-34.

THE STATE IS CONSIDERED STRONG WHEN' ITS GOVERMING APPARATUS GENERATES A SET OF INTERESTS, OBJECTIVES, AND CAPABILITIES THAT IS SEPARATE OR AUTONOMOUS FROM SOCIETAL INTERESTS. A WEAK STATE IS CDNSUMED BY SOCIETAL INTERESTS, DOMESTIC OR FOREIGN, THAT WEAKEN THE EFFECTIVENESS OF STATE POLICY. PARADOXICALLY, AFRICAN STATES APPEAR TO BE STRONG AND WEAK AT THE SAME TIME. THE THESIS OF THIS PAPER IS THAT A CONTINUUM OF STRONG-WEAK STATES IS NOT SUITED FOR THE A CONTI INUUN CHARACTERISTICS FOUND IN AFRICA TODAY. NEITHER STATE SPECIAL CHARACTERISTICS FOUND IN AFRICA TODAY. NEITHER STATE NOR SOCIETAL INTERESTS DOMINATE ONE ANDTHER IN MOST AFRICAN
COUNTRIES. THE THO SETS OF INTERESTS HAVE SHOWN THE ABILITY COUNTRIES. THE THO SETS OF INTERESTS HAVE SHOWN THE ABIL
TO, AT TIMES, MERGE THEIR OBJECTIVES INTO THE GOVERNING TO, AT TIMES, MERGE THEIR OBJECTIVES INTO THE GOVERNING
APPARATUS AND, AT OTHER TIMES, TO CONFLICT AGAINST EACH APPARATUS AND, AT OTHER TIMES, TO CONFLICT AGAINST EACH
OTHER AS TWO AUTONOMOUS AGENTS AND, AT STILL OTHER TIMES, TO OTHER AS TWO AUTONOMOUS AGENTS AND, AT STILL OTHER TIMES
COOPERATE TOGETHER IN ORDER TO ADVANCE THEIR DISTINCT COOPERATE TOGETHER IN ORDER TO ADVANCE THEIR DISTINCT
INTERESTS. ALL OF THESE POSSIBILITIES OCCUR IN THE CURRENT INTERESTS. ALL OF THESE POSSIBILITIES OCCUR IN THE CURR
ENYIRONMENT OF PROFOUND ECONOMIC STRESS AND POLITICAL

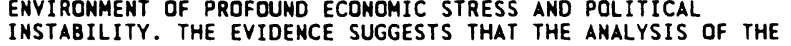
INSTABILITY. THE EVIDENCE SUGGESTS THAT THE ANALYSIS OF THE AFRICAN STATE SHOULD FOCUS LESS ON THE STRONG/WEAK DICO AND MORE ON THE CONTEXTUAL AND RELATIONAL LINKAGES TO
DOMESTIC AND FOREIGN SOCIETAL INTERESTS. UNDERSTANDING THESE RELATIONSHIPS BETWEEN STATE AND SOCIETY AND THE LEVEL OF AUTONOMY ACCORDED TO THE STATE MAY BE ADVANCED BY A MORE SPECIFIC EXAMINATION OF POLICY CHOICES.

05611 LEHMAN, J.

U.S. DEFENSE POLICY OPTIONS: THE 1990'S AND BEYOND ANHALS OF THE AMERICAN ACADEMY OF POLITICAL AND SOCIAL SCIENCE, (517) (SEP 91), 193-202.

AMERICAN MATIONAL SECURITY STRATEGY NEEDS A MAJOR OVERHAUL, INCLUDING A SUBSTANTIAL REDUCTION IN STRATEGIC AND THEATER NUCLEAR WEAPONS. THE FORCE STRUCTURE NEEDS RECONFIGUATION AHAY FROM HEAVY POSITIONAL FORCES FOR THE GARRISONING OF NATO AND TOWARD MORE FLEXIBLE, DEPLOYABLE FORCES. THE NEW FORCE STRUCTURE SHOULD BE SHIFTED TO A HIGHER PERCENTAGE OF RESERVE MANNING, WITH BOTH ACTIVE AND RESERVE FORCES DEPENDING ENTIRELY ON VOLUNTARY ENLISTMENT. EMPHASIS SHOULD REMAIN ON USING HIGH-TECHNOLOGY AND HIGHQUALITY PERSONNEL TO SUBSTITUTE FOR HIGH NUMBERS. THE OBSTACLE TO RATIONAL NATIONAL SECURITY POLICY IN THE 1990's.

05612 LEHMAN, R.

ARMS CONTROL, NEGOTIATIONS AND THE KOREAN PENINSULA KOREAN JOURNAL OF DEFENSE ANALYSIS, IV(1) (SUM 92), 11-22. FOR MOST OF THE WORLD, THE COLD WAR IS OVER. HORLD SECURITY HAS BEEN ENHAHCHED BY THE STRENGTHENING OF HUMAN RIGHTS, INTERNATIONAL TRADE, AND THE RULE OF LAH. THE KOREAN PENINSULA IS NOT BARRED FROM THE OPPORTUNITIES PRESENTED IN THIS NEW ERA, NOR FREE FROM THE NECESSITY TO RESPOND TO ITS CHALLENENGES. MUCH WORK HAS BEEN DONE THAT COULD IMPROVE THE
CHANCES FOR STABILITY IN THIS HISTORICALLY TENSE REGION. CHANCES FOR STABILITY IN THIS HISTORICALLY TENSE REGION.
AGREEMENTS REACHED BY THE NORTH AND SOUTH, COUPLED HITH AGREEMENTS REACHED BY THE NORTH AND SOUTH, COUPLED WITH NUMEROUS OTHER MULTILATERAL AND BILATERAL EFFORTS, HAVE
PAVED THE WAY FOR IMPROVED RELATIONS AND A SAFER, MORE PAVED THE WAY FOR IMPROVED RELATIONS AND A
PROMINSING ENVIRONMENT FOR THE TWO KOREAS.

05613 LEHNEBACH, $S$.

UNIFICATION CELEBRATED WITH FEELINGS OF AMBIVALENCE GERMAN TRIBUNE, (1535) (OCT 92), 1.

THE SECOND ANNIVERSARY OF GERMAN UNIFICATION WAS MARKED BY FRUSTRATION IN EASTERN GERMANY AND INDIFFERENCE, OR EVEN REJECTION, IN WESTERN GERMANY. POLITICIANS RECALLED THE
HISTORIC MOMENTS OF 1989 AND ADMITTED THAT THEY HAD BEEN MISTAKEN ABOUT THE SPEED AND DYNAMICS OF AN EASTERN RECOVERY. MANY OBSERVERS CLAIM THAT THE WALL NOW IN THE MINDS OF MANY GERMANS IS HIGHER THAN THE CONCRETE VERSION AND THAT WESTERN AND EASTERN GERMANS HAVE BECOME EVEN MORE ESTRANGED.

05614 LEHOVICH, $V$.

STOLPIN AND THE BIRTH OF MODERN COUNTERINSURGENCY

STUDIES IN CONFLICT AND TERRORISM, 15(3) (1992), 185-200. PETER STOLYPIN CREATED AN APPROACH TO ARRESTING THE IDEOLOGICAL INSURGENCES THEN THREATENING THE RUSSIAN EMPIRE. HIS STRATEGYIES HAD STRIKING SIMILARITIES TO THE SUCCESSFUL POST-WAR ANTI-COMMUNIST CAMPAIGNS IN MALAYA AND THE PHILIPPINES. IT MET THE GOALS AND RHETORIC OF THE AMERICAN EFFORT IN VIETNAM. THIS ARTICLE CONCLUDES THAT DESPITE HIS ACHIEVEMENTS, STOLYPIN WOULD NOT HAVE CHANGED THE COURSE OF
HISTORY AND AVERTED THE BOLSHEVIK REVOLUTION HAD HE LIVED ON.

05615 LEI, 0.

CHINA'S EXPERIENCES AND LESSONS FROM THE UTILISATION OF FOREIGH CAPITAL

CHINA REPORT, 28(3) (JUL 92), 183-192

CHINA'S PARAMOUNT LEADER, OENG XIAOPING ONCE NOTED THAT "IT IS NECESSARY TO ACQUIRE' FOREIGN FUNDS AND TECHNOLOGICAL KNOW-HOW TO HELP CHINA'S ECONOMIC DEVELOPMENT. THIS ARTICLE CONSIDERS CHINA'S UTILIZATION OF FOREIGN CAPITAL. IT BRIEFLY OUTLINES THREE STAGES OF CHINA'S USE OF FOREIGN CAPITAL: LIMITED USE OF FOREIGN FUNDS FROM A SINGLE SOURCE IN THE INITIAL YEARS AFTER LIBERATION; A "STAGNANT STAGE" DURING THE SIXTIES AND SEVENTIES; AND A NEW STAGE BEGINNING IN 1979. IT THEN EXAMINES SEVERAL "EFFECTS" OF FOREIGN CAPITAL. FACILITIES; HELPING THE TECHNOLOGICAL TRANSFORMATION OF OLD ENTERPRISES; HELPING TO EXPAND DOMESTIC AND INTERNATIONAL MARKETS; HELPING TO CREATE MORE EMPLOYMENT OPPORTUNITIES; AND HELPING TO PROMOTE TOURISM. IT THEN CONSIDERS MAJOR PROBLEMS CONHECTED WITH THIS PHENOMENON: THE ABSENCE OF COUNTRY-WIDE UNIFIED PLANS AND MANAGEMENT; AN IRRATIONAL COUNTRY-WIDE UNIFIED PLANS AND MANAGEMENT; AN IRRATIONAL
PATTERN OF FOREIGN FUND UTILIZATION; THE FACT THAT THE PATTERN OF FOREIGN FUND UTILIZATION; THE FACT THAT THE
DISTRIBUTION OF FOREIGN INVESTMENT IS NOT IN CONFORMITY WITH DISTRIBUTION OF FOREIGN INVESTMENT IS NOT IN CONFORMITY
CHINA'S DEVELDPMENT STRATEGY; AND THE FACT THAT FOREIGN CHINA'S DEVELOPMENT STRATEGY; AND THE FACT THAT FOREIGN
INVESTMENT IS COMPETING WITH INDIGENOUS PRODUCTS FOR MARKETS INVESTMENT IS COMPETING WITH INDIGENOUS PRODUCTS FOR MARKETS
AND CAUSING IMBALANCE OF PAYMENTS. IT CONCLUDES WITH SOME AND CAUSING IMBALANCE OF PAYMENTS. IT CONCLUDES WITH SOME
BRIEF RECOMMENDATIONS FOR CHINA'S FOREIGN CAPITAL STRATEGY BRIEF RECOMMENDAT
FOR THE NINETIES.

05616 LEI, Z.; XIAOBING, Y.

CHINA'S POPULATION POLICY

BEI JING REVIEN, 35(15) (APR 92), 17-20.

THE STANDING COMMITTEE OF THE POLITICAL BUREAU OF THE CENTRAL COMMITTEE OF THE COMMUNIST PARTY OF CHINA (CPC) HAS ADOPTED A PROGRAM EMPHASIZING THE IMPORTANCE AND URGENCY OF STRICTLY CONTROLLING POPULATION GROWTH. JIANG ZEMIN, GENERAL SECRETARY OF THE CPC CENTRAL COMMITTEE, HAS STATED THAT CHINA'S PLAN FOR CURBING POPULATION GROWTH IN THE NEXT DECADE REQUIRES STRONG PARTY LEADERSHIP, INCREASED FINANCIAL SUPPORT, EXTENSIVE PUBLICITY, AND EDUCATION.

05617 LEIBFRIED, S.; PIERSON, P.

PROSPECTS FOR' SOCIAL EUROPE

POLITICS AND SOCIETY, 20(3) (SEP 92), 333-366.

THE EUROPEAN COMMUNITY (EC) IS TAKING ON CHARACTERISTICS OF A SUPRANATIONAL ENTITY, POSSESSING EXTENSIYE

TRANSNATIONAL BUREAUCRATIC COMPETENCIES, UNIFIED JUDICIAL CONTROL, AND SIGNIFICANT AUTONOMY TO DEVELOP, MOOIFY OR SUSTAIN POLICIES. THIS ARTICLE APPRAISES THE CURRENT STATUS AND MEDIUM-TERM PROSPECTS FOR SOCIAL EUROPE. THE INSTI TUTIONAL, POLITICAL, CULTURAL AND TECHNICAL BARRIERS TO EXTENDING EC SOCIAL POL ICY COMPETENCE ARE HIGH. HOWEVER, IF THE PROCESS OF ECONOMIC (AND, INCREASINGLY, POL ITICAL) INTEGRATION CONTINUES, THERE' WILL ALSO BE MOUNTING PRESSURE TO DEVELOP SOMETHING MORE THAN THE PRESENT, OUITE LIMITED EC PRESENCE IM SOCIAL POL ICY. THE ARTICLE DEFENDS THE ARGUMENT THAT A MODERATE VERSION OF THE NEOFUNCTIONALIST VIEW OF EUROPEAN INTEGRATION CAN BE APPLIED TO SOCIAL POLICY DEVELOPMENT.

05618 LEIBMAN, M.I.

CIVIL DISOBEDIENCE: A THREAT TO OUR SOCIETY UNDER LAW

FREEMAN, 42(7) (JUL 92), 262-265.

AMERICA'S GREATEST ACCOMPLISHMENT IS THE FASHIONING OF A SOCIETY THAT OPERATES UNDER THE RULE OF LAW. ORDER IS THE "SINE QUA NON" OF THE CONSTITUTIONAL SYSTEM IF THERE IS TO BE ANY POSSIBILITY FOR LONG-TERM JUSTICE. THE LAW SOCIETY IS THE PINHACLE OF MAN'S STRUGGL TO DATE AND THE FOUNDATION THE PINNACLE OF MAN'S
FOR HIS FUTURE HOPE.

05619 LEICHT, R.

RICHARD VON WEIZSACKER DELIVERS A STRONG WARNING TO POLITICAL PARTIES

GERMAN TRIBUNE, (1521) (JUN 92), 3

GERMAN PRESIDENT RICHARD YON WEIZSACKER HAS RECENTLY BEEN OUTSPOKEN IN HIS CRITICISM OF GERMAN POLITICAL PARTIES. THE PRESIDENT HAS ACCUSED THEM OF BEING OBSESSED BY POWER 
AND OF EXERTING A QUESTIONABLE INFLUENCE ON SOCIETY. WHILE MANY GERMAN CITIZENS AND POLITICIANS ARE EQUALLY OUTRAGED AT CASES OF PARTY CORRUPTION AND SCANDAL, WHAT THE
ARGUING GOES MUCH DEEPER. HE ARGUES THAT THE CONSTITUTIONALLY DESIRED SYSTEM OF CHECXS AND BALANCES HAS BEEN SUSPENDED BY GROHING PARTY CONTROL OVER ALL OF GERMAN POLITICS. HE FEARS THAT GERMANY IS MOVING TOWARDS AN EXTREMELY DANGEROUS POLITICAL MONOCULTURE AND A MASSIVE LOSS OF DIVERSITY. THE RECENT PUBLICATION OF THE PRESIDENT'S FEARS IN A BOOK MAY SPARK SOME OISCUSSION OF THE ISSUE, BUT THE UNDERLYING PROBLEM CAN ONLY BE CHANGED BY THE PARTIES THEMSEL VES.

05620 LEICHTER, H.M. (ED.)

HEALTH POLICY REFORM IN AMERICA-INNOVATIONS FROM THE STATES

M. E. SHARPE, 1992, 240.

IN THE 1990 S THE STATES WILL PROVIDE LEADERSHIP IN OEALING HITH THE MAJOR PROBLEMS FACING THE U.S. HEALTH DELIVERY SYSTEM. THESE PROBLEMS INCLUDE DRAMATIC INCREASES IN COSTS, QUESTIONS OF ACCESS TO HEALTH CARE, THE AIDS IN COSTS, QUESTIONS OF ACCESS TO HEALTH CARE, THE AIDS CRISIS, PRENATAL AND CHILD CARE, AND FAILURES IN THE QUALITY OF HEALTH SERVICES. THIS BOOK DEALS WITH THESE AND RELATED ISSUES. EMPHASIS IS ON THE UNIQUE APPROACHES THAT VARIOUS ARE DRAWH FROM OREGON, RORTH CAROLINA, TEXAS, HAWAII, AND ARE DRAWN FROM DI

05621 LEIER, $M$.

WHICH SIDE ARE THEY ON? SOME SUGGESTIONS FOR THE LABOUR BUREAUCRACY DEBATE

INTERNATIONAL REVIEW OF SOCIAL HISTORY, 36(3) (1991), 412-427.

ALTHOUGH THE ARGUMENT THAT LABOR BUREAUCRACY HAS DIED NEEDS TO BE RE-FORMULATED, THE PARADIGM OF THE LABOR BUREAUCRACY REMAINS A USEFUL ONE. SUCH A REFOMULATION MUST SHIFT THE FOCUS FROM DIFFERENCES OF IDEOLOGY SEPARATING THE LEADERS FROM THE MEMEBERS AND INSTEAD MUST TURN TO AN ANALYSIS OF THE POWER RELATIONSHIP BETWEEN THE TWO. THE PAPER WILL TRACE THE RECENT THISTS AND TURNS IN THE DEBATE AND WILL SUGGEST WAYS IN WHICH IT IS POSSIBLE TO VIEN THE LABOR BUREAUCRACY AS A DISTINCT LAYER OF THE UNION MOVEMENT.

05622 LEIFER, M.

PEOHER-SHARING AMD PEACEMAKING IN CAMBODIA?

SAIS REVIEW, 12(1) (WIN 92), 139-154.

THE CAMBODIAN CONFLICT ELUDED RESOLUTION FOR SO LONG BECAUSE IT DID NOT LEND ITSELF TO ANY OF THE GENERAL WAYS OF OYERCOMING AN INTERMAL WAR FUELLED BY INTERMATIONAL RIVALRY. GENUINE COMPROMISE AMD POHER-SHARING AMONG ADVERSARIES HAVE MOT BEEN A PART OF THE PONER-SHARING AMONG ADVERSARIES HAVE INDOCHINA. AT ISSUE IS WHETHER THE MEASURE OF COMPROMISE INDOCHINA. AT ISSUE IS WHETHER THE MEASURE OF COMPROMISE REACHING IN THE POL ITICAL SETTLEMENT OF OCTOBER 1991 IS RENEWED CONFRONTATION. THIS ARTICLE EXPLORES THE ORIGINS OF RENEWED CONFRONTATION. THIS ARTICLE EXPLORES THE ORIGINS OF THE CONFLICT, THE CHANGE OF STRATE
DEADLOCK, AND THE CHINA FACTOR.

05623 LEIGH, M.

IS THE PRESIDENT ABOVE CUSTOMARY INTERNATIONAL LAW? AMERICAN JOURNAL OF INTERNATIONAL LAW, 86(4) (OCT 92), 757-763.

IN ITS EFFORTS TO HALT THE SPREAD OF DRUGS AND INTERNATIONAL TERRORISM, THE BUSH ADMINISTRATION HAS BEGUN TO ADVOCATE, MORE AMD MORE VEHEMENTLY. THE USE OF SO-CALLED "NONCONSENSUAL EXTRATERRITORIAL ARRESTS" (I. E. KIDNAPPING TO BRING ALLEGED OFFENDERS WHO CANNOT BE OBTAIMED THROUGH NORMAL EXTRADITION PROCEDURES BEFORE U.S. COURTS TO ANSWER FOR CRIMES AGAINST U.S. CITIZENS PERPETRATED ANYHHERE IN THE WORLD. WHILE THE ADOPTION OF SUCH A POLICY IS ALARMING FOR BOTH LEGAL AND POLITICAL REASONS, MORE ALARMING STILL IS THE JUSTICE DEPARTMENT'S RATIONALE THAT THE PRESIDENT, IN PURSUANCE OF HIS FOREIGN AFFAIRS POWERS, CAN COMMIT OR ORDER THE VIOLATION OF INTERNATIONAL LAH AT WILL BY SENDIMG U.S. AGENTS TO ABDUCT FOREIGN CRIMINAL SUSPECTS HITHOUT THE CONSENT OF THE TERRITORIAL SOVEREIGN STATES.

05624 LEIGHLEY, J.; NAGLER, J.

INDIVIDUAL AND SYSTEMIC INFLUENCES ON TURNOUT: WHO VOTES? 1984

THE JOURNAL OF POLITICS, 54(3) (AUG 92), 728-740.

THIS PAPER ADDRESSES THREE MAIN OUESTIDNS CONCERNING

YOTING TURNOUT. FIRST, ARE INDIVIDUAL DEMOGRAPHIC

CHARACTERISTICS AS INFLUENTIAL IN PREDICTING TURNOUT IN 1984 AS THEY HAD BEEN FOUND TO BE IN PRED SECOND TURNOUT IN 1984 CHARACTERISTICS LESSEN IN IMPORTANCE WHEN SYSTEMIC FACTORS ARE CONTROLLED EFFECT OF INDIVIDUAL CHARACTERISTICS YARY ACROSS DIFFERENT REGIONS? THIS ARTICLE FINDS THAT RACE AND SEX HAVE BECOME MUCH STRONGER PREDICTORS OF TURNOUT THAN THEY HERE IN 1972 ,

05625 LEIGHLEY, J.

PARTICIPATION AS A STIMULUS OF POLITICAL CONCEPTUALIZATION
THE JOURNAL OF POLITICS, 53(1) (FEB 91), 198-214.

THOUGH THE SCHOOL OF PARTICIPATORY DEMOCRACY CLAIMS THAT POL ITICAL PARTICIPATION AFFECTS INDIVIDUALS' CONCEPTUALIZATION OF POLITICS, FEW EMPIRICAL STUDIES HAVE ADORESSED THIS QUESTION. THIS PAPER CONSIDERS BENMETT' (1975) ARGUMENT THAT PARTICIPATION WHICH INVOLVES THE CONFLICT OF IDEAS AND REQUIRES INDIVIDUAL INITIATIVE AND INPUT ENHANCES CONCEPTUALIZATION. IT IS HYPOTHESIZED THAT CAMPAIGH, AND NATIONAL AND LOCAL PROBLEM-SOLVING ACTIVITIES ENHANCE CONCEPTUALIZATION BUT THAT EXPRESSIVE ACTIVITIES DO MOT. THE ANALYSIS, WHICH USES DATA FROM THE 1976 AMERICAN WATIONAL ELECTION STUDY, SUPPORTS THE HYPOTHESIS, WITH THE EXCEPTION OF LOCAL PROBLEM-SOLVING ACTIVITIES. THESE FINDINGS SUGGEST THAT BENNETT'S CRITERIA ARE INCOMPLETE, AND THAT CHARACTERISTICS OF THE PARTICIPATORY EXPERIENCE (E.G., SUCCESS OR FAILURE) MAY DETERMINE THE NATURE OF ITS EFFECT ON CONCEPTUALIZATION.

05626 LEIGHLEY, J.E.: NAGLER, J.

SOCIOECONOMIC CLASS BIAS IN TURMOUT, 1964-1988: THE VOTERS REMAIN THE SAME

AMERICAN POLITICAL SCIENCE REVIEH, 86(3) (SEP 92), 725-736.

THE AUTHORS ASK WHETHER CLASS BIAS IN THE AMERICAN

ELECTORATE HAS INCREASED SINCE 1964. THEY ANALYZE THE CENSUS BUREAU'S CURRENT POPULATION SURVEY AND THE NATIONAL ELECTION STUDIES FOR SEVEN CONSECUTIVE PRESIDENTIAL ELECTIONS FROM 作 CHANGES IN CLASS BIAS ARE SENSITIVE TO WHICH MEASURE OF SOCIOECONOMIC CLASS IS USED--INCOME, EDUCATION, OR OCCUPATION. THEY ARGUE THAT INCOME IS THE APPROPRIATE MEASURE SINCE GOVERMMENT POLICIES THAT DISCRIMINATE BASED ON SOCIOECONOMIC CLASS ARE MOST LIKELY TO DO SO BASED ON INCOME. MOREOVER, THERE ARE MEASUREMENT PROBLEMS ASSOCIATED WITH USING EITHER EDUCATION OR OCCUPATION OVER TIME. THE ANALYSIS SHOWS THAT THERE HAS BEEN ALMOST NO CHANGE IN CLASS BIAS IN THE ELECTORATE SINCE 1964.

05627 LEITENBERG, M.

A RETURN TO SVEROLOVSK: ALLEGATIONS OF SOVIET ACTIVITIES RELATED TO BIOLOGICAL WEAPONS

ARMS CONTROL, 12(2) (SEP 91), 161-190.

BEGINNING IN 1979 AND CONTINUING THRDUGH THE 1980S, SEVERAL AMERICAN ADMINISTRATIONS RAISED TWO UNRELATED CHARGES AGAINST THE SOVIET UNION DEALING WITH CHEMICAL AND BIOLOGICAL WEAPONS. ONE OF THESE CHARGES CONCERNED THE CAUSE OF AN OUTBREAK OF ANTHRAX IN SVERDVLOSK. THE PURPOSE OF THIS PAPER IS TO TRANSMIT NEWLY AVAILABLE INFORMATION PUBLISHED IN THE USSR TO A HIDER WESTERN AUDIENCE ABOUT THE EVENTS IN SVERDLOVSK. IT REVIEWS BRIEFLY WHAT HAPPENED IN SVERDLOVSK, AND THEN TURNS TO NEW INFORMATION WHICH APPEARED IN THE AND THEN TURNS TO NEW INFORMATION WHICH APPEARED IN THE
SOVIET PRESS IN 1990 AND 1991. THE AUTHOR HAS SELECTED WHAT SOVIET PRESS IN 1990 AND 1991 . THE AUTHOR HAS SELECTED WHA SEEM TO BE THE MOST IMPORTANT ITEMS
SEVERAL CASES HAS ADDED EMPHASIS.

05628 LEITH, J.C.

THE STATIC WELFARE ECONOMICS OF A SMALL DEVELOPING COUNTRY'S MEMBERSHIP IN A CUSTOMS UNION: BOTSWANA IN THE SOUTHERN AFRICAN CUSTOMS UNION

WORLD DEVELOPMENT, 20(7) (JUL 92), 1021-1028.

THE AUTHOR EXPLAINS THE COMPARATIVE STATIC WELFARE ECONOMIC METHODOLOGY FOR EVALUATION OF THE GAIN OR LOSS DUE TO A SMALL COUNTRY'S MEMBERSHIP IN AN EXISTING CUSTOMS UNION. HE THEN APPLIES THIS METHODOLOGY TO THE CASE OF BOTSHANA'S MEMBERSHIP IN THE SOUTHERN AFRICAN CUSTOMS UNION, USING HIGHLY DISAGGREGATED DATA TO CALCULATE THE COMPONENTS OF THE WELFARE CHANGES AND THE NET WELFARE BENEFIT OR COST FOR FOUR RECENT YEARS. THE RESULT IS A NET COST TO BOTSHANA OF UP TO 3.25\% OF GDP.

05629 LEJEUNE, A.

ELECTIONS, NOT A MOMENT TOO SOON

NATIONAL REVIEW, XLIV(7) (APR 92), 24-26.

BRITISH OPINION POLLS OVER MANY MONTHS HAVE SHOWN THE

CONSERVATIVE AND LABOR PARTIES VIRTUALLY NECK-IN-NECK, WITH MANY SMALLER PARTIES -- THE LIBERAL DEMOCRATS, THE ULSTER UNIONISTS, THE SCOTTISH AND THE WELSH NATIONALISTS -ADDING TO THE COMPLEXITY OF WHAT MAY HAPPEN IF NEITHER OF THE LEADING PARTIES GAINS A CLEAR MAJORITY. THIS ARTICLE DISCUSSES MANY OF THE ISSUES BEING DEALT WITH IN THE CAMPAIGN.

05630 LELIEVRE, $S$.

PERSOMALITY AND APPROVAL: REQUIREMENTS FOR ELECTION PARL IAMENTARIAN, LXXIII(2) (APR 92) III)

ALDERMEY IS A SELF-GOVERNING JURISDICTION ON ONE OF THE ISLANDS OF THE BAILIWICK OF GUERNSEY WITHIN THE CHANNEL ISLANDS GROUP. IN THIS ARTICLE. THE AUTHOR DESCRIBES ISLANDS GROUP. IN THIS ARTICLE, THE AUTHOR DESCRIBES
ALDERMEY'S ELECTORAL SYSTEM AND REPORTS THE RESULTS OF THE ANMUAL ELECTION IN DECEMBER 1991 AND A BY-ELECTION IN ANNUAL ELECTION
JANUARY 1992.

05631 LEMAITRE, $P$

THE WEST: GUILTY OR NOT GUILTY?

BULLETIN OF PEACE PROPOSALS, 22(4) (DEC 91), 445-447 
THIS ARTICLE ARGUES THAT THE WEST HAS A SIGNIFICANT SHARE OF RESPONSIBILITY FOR THE ATTEMPTED COUP IN THE SOVIET UNION. THE QUESTION OF GUILT IS NOT ONLY OF HISTORIC INTEREST. IF DEMOCRACY IS NOT EXTENDED AND LIVING CONDITIONS OF THE SOVIET PEDPLE ARE NOT IMPROVED, ANTI-WESTERN SOCIAL UPHEAVALS WILL BE THE PROBABLE RESULT WITHIN A PERIOD OF FIVE TO TEN YEARS, THE REASON FOR THE MISTAKEN WESTERN POL ICY IS THAT THE WEST HAS BEEN THINKING IN TERMS OF ABSOLUTES, OF ALL OR NOTHING, INSTEAD OF IN TERMS OF PROCESSES. THE WEST HAS OVERESTIMATED THE COHESIVE FORCE OF THE COMMUNIST SYSTEM AND UNDERESTIMATED THE ABILITY OF DEMOCRATIC-CAPITALISTIC PRINCIPLES TO UNDERMINE TOTALITARIAN REGIMES. THE WEST HAS NOT SUPPORTED THE SEEDS OF CHANGE AND THEREBY HAS NOT CONTRIBUTED TO THE "ISLANDS OF HOPE" AMONG A DESPAIRING SOVIET POPULATION.

05632 LEMARCHAND, R. AFRICA'S TROUBLED TRANSITIONS JOURMAL OF DEMOCRACY 3(4) (OCT 92), 98-109.

ALTHOUGH THE CHALLENGES TO DEMOCRATIZATION IN AFRICA ARE LEGION, THREE DEMAND SUSTAINED ATTENTION. THE FIRST STEMS FROM THE CRISES AND UNCERTAINTIES THAT HAVE ACCOMPANIED THE DEMISE OF AUTOCRATIC REGIMES AND THAT INEVITABLY THREATEN DEMISE OF AUTOCRATIC REGIMES AND THAT INEVITABLY THE TRANSITION FROM LIBERALIZATION TO DEMOCRATIC
CONSOLIDATION. A SECOND SOURCE OF UNCERTAINTY, WHICH FEEDS UPON THE INTERNAL CRISES AND CONFLICTS GENERATED BY LIBERALIZATION, IS THE ARRAY OF STRATEGIC COUNTERMEASURES THAT AFRICAN AUTOCRATS HAVE DEVISED TO STAVE OFF THREATS
THEIR HEGEMONY. YET ANOTHER UNKNOWN IN THE POLITICAL THEIR HEGEMONY. YET ANOTHER UNKNOWN IN THE POLITICAL
EQUATION IS THE IMPACT OF STRUCTURAL ADJUSTMENT PROGRAMS ON THE PROSPECTS FOR DEMOCRACY.

05633 LEMARCHAND, R.

UNCIVIL STATES AND CIVIL SOCIETIES: HOW ILLUSION BECAME REALITY

JOURNAL OF MODERN AFRICAN STUDIES, 30(2) (JUN 92), 177-191.

THE KEY QUESTIONS WHICH ARE ADORESSED IN THIS ARTICLE ARE: 1) THROUGH WHAT SPECIFIC HISTORIC STRUCTURES AND PROCESSES DOES THE STATE MANIFEST ITSELF, AND WHAT ARE THE CONSEQUENCES FOR AN UNDERSTANDING OF THE DYNAMICS OF STATESOCIETY INTERACTIONS IN CONTEMPORARY AFRICA? 2) HOW IS THE STATE PERCEIVED BY MEMBERS OF CIVIL SOCIETY? 3) WHAT ARE THE CONSTI IUENT ELEMENTS OF THE LATTER? 4) WHAT DOES IT ALL MEAN FROM THE STANDPOINT OF GOVERNANCE? THE CONCEPT OF STATE IS DEFINED AS AN ENSEMBLE OF MICRO-PROCESSES CONSPIRING TO MOULD SOCIAL ACTION INTO REGULARIZED FORMS OF BEHAVIOR, INTO "DOS" AND "DON'TS" THROUGH A COMPLEX COMBINATION OF INCENTIVES AND PEMALTIES.

05634 LEMBCKE, J.

THE POLITICAL, ECONOMIC, AND CULTURAL COMPLEXITIES OF COUNTERREVOLUTION

CRITICAL SOCIOLOGY, 17(2) (SUM 90), 111-116.

THE STUNMING VICTORY OF THE UNO COALITION IN NICARAGUA'S 1990 ELECTIONS WAS OEPICTED BY SOME AS A SIMPLE REJECTION OF THE RULING SANDINISTAS BY THE NICARAGUAN PEOPLE. HOWEVER, THE REALITY IS FAR MORE COMPLEX. FROM THE VANTAGE POINT OF THE AUTHOR'S EXPERIENCE AS AN ELECTION OBSERVER IN THE CITY OF COMALAPA, POLITICAL, ECONOM

05635 LEMCO, J.

CANADA AND THE CRISIS IN CENTRAL AMERICA

PRAEGER PUBLISHERS, 1991,216

WRITTEN FROM THE PERSPECTIVE OF A CANADIAN SCHOLAR

LIVING AND WORKING IN THE UNITED STATES, THIS BOOK PRESENTS

THE FIRST SCHOLARLY INVESTIGATION OF CANADIAN POLICY

INTERESTS IN CENTRAL AMERICA. THE AUTHOR EXAMINES CANADA'S

SIZABLE INTEREST IN CENTRAL AMERICA AND HELPS FILL A GAP IN

THE LITERATURE ON CANADA'S FOREIGN POLICY. THE BOOK OFFERS A RARE LOOK AT NOT ONLY CANADA'S CENTRAL AMERICAN POLICY GOALS BUT HOW THESE GOALS RELATE TO CANADIAN-U.S. RELATIONS AND LATIN AMERICAN POLITICS. THE AUTHOR CONCLUDES THAT THE CANADIAN GOVERMMENT DOES WANT TO HELP ENCOURAGE THE PEACE PROCESS, REDUCE ECONOMIC INEQUALITY, ANO PROMOTE SOCIAL JUSTICE IN CENTRAL AMERICA, WHILE RETAINING A MEASURE OF INDEPENDENCE FROM THE UNITED STATES.

05636 LEMIEUX, $V$

L'UTILITE POLITIQUE DES RIYAUX

CANADIAN JOURNAL OF POLITICAL SCIENCE, 29(4) (DEC 91), 735-755.

FEW STUDIES HAVE SHOWN THAT THE PRESENCE OR ACTION OF RIVALS OR NEUTRALS, OUTSIDE A COALITION, IS AN IMPORTANT FACTOR IN ITS FORMATION OR EVOLUTION. THIS ARTICLE PROPOSES A STRUCTURAL APPROACH WHICH UMDERLINES THE COHESION REQUIREMENTS IN COALITION FORMATION AND EVOLUTION. FIVE REQUIREMENTS IN COALITION FORMATION AND EVOLUTION. FIVE
RESEARCH PROPOSITIONS ARE FORMULATED. THE LAST THREE BEARING RESEARCH PROPOSITIONS ARE FORMULATED, THE LAST THREE BEARING
UPON THE POLITICAL USEFULNESS OF RIVALS. THE PROPOSITIONS ARE APPL POLITICAL USEFULNESS OF RIVALS. THE PROPOSITIONS ELECTORAL SYSTEM REFORM IN QUEBEC. THIS APPLICATION LEADS TO THE CONCLUSION THAT THE PROPOSITIONS HAVE A CERTAIN HEURISTIC CAPACITY BUT THAT SOME OF THEM HAVE TO BE ALTERED FOR MORE APPROPRIATENESS IN FUTURE RESEARCH.
05637 LEMIEUX, V.

THE SCHOLLAR AND THE EXPERT

CANADIAN JOURNAL OF POLITICAL SCIENCE, XXV(4) (DEC 92), 651-660.

MANY POLITICAL SCIENTISTS ARE ADDING THE ROLE OF EXPERT TO THEIR ROLE AS UNIVERSITY PROFESSORS, ACTING AS CONSULTANTS FOR VARIOUS ORGANIZATIONS, COMMITTEES, OR COMMISSIONS. THEY EXPRESS THEMSELVES THROUGH THE MEDIA AMD/OR BY PARTICIPATING IN MEETINGS OR CONFERENCES ORIENTED TOWARD PROBLEM-SOLVING. UNFORTUNATELY, THERE ARE SOME DISCONNECTED EXPERTS AND SOME NAIVE TÉCHNOCRATS AMONG THEM. THERE ARE ALSO ALLEGED EXPERTS WHO ARE OPENLY PARTISAN. ON THE OTHER HAND, SOME POLITICAL SCIENTISTS REMAIN TRUE SCHOLARS WHILE ACTING AS EXPERTS. THEY LIMIT THEMSELVES TO SCHOLARS WHILE ACTING AS EXPERTS. THEY LIMIT THEMSELV EXPLAINING THE CHOICES TO BE MADE RATHER THAN BEING
ADVOCATES. THEIR EXPERIENCES ENRICH THEIR TEACHING, RESEARCH, AND WRITING AS WELL AS THE TRAINING OF YOUNG RESEARCHERS.

05638 LENDVAI, P.

CENTRAL EUROPE I : WHAT ABOUT THE HUNGARIAN MINORITIES? WORLD TODAY, 48(12) (DEC 92), 215-216

A NEW DESTABILIZING FACTOR HAS EMERGED IN CENTRAL AND EASTERN EUROPE: THE LARGE HUNGARIAN MINORITIES IN ROMANIA, SERBIA, AND CZECHOSLOVAKIA. THE DEEP-ROOTED MUTUAL SUSPICION BETWEEN THE HUMGARIANS AND THE SUCCESSOR STATES OF THE AUSTRO-HUNGARIAN MONARCHY IS NO LONGER TUCKED AWAY IN THE COMMUNIST CLOSET. HHAT BEGAN IN THE EARLY 1980'S AS AN INCREASINGLY PUBLIC DEBATE BETWEEN BUDAPEST AND THE OTHER CENTRAL EUROPEAN COMMUNIST CAPITALS HAS NOW BECOME AN OPEN EMOTIONAL CONFLICT, INVOLYING BORDERS AND MINORITIES AS WELL AS ECONOMIC ISSUES.

05639 LENMON, $D$.

FIVE MORE YEARS

EUROPE, (317) ( JUN 92), 20-22.

ON 10 APRIL, 1992 , JOHN MAJOR LED THE BRITISH

CONSERVATIVE PARTY TO A HISTORIC FOURTH TERM OF OFFICE.

MAJOR'S PARTY LOST GROUND TO THE LABOUR PARTY, BUT MANAGED

TO MAINTAIN A 21-SEAT MAJORITY IN PARLIAMENT. AFTER HIS

VICTORY, ONE OF MAJOR'S FIRST MOVES WAS TO RESHUFFLE HIS CABINET, REPLACING SOME THATCHER APPOINTED MINISTERS WITH MORE OF HIS OWN PEOPLE AND INCLUDING TWO WOMEN IN THE PREVIOUSLY ALL-MALE CABINET. MAJOR AND THE CONSERVATIVES FACE SIGNIFICANT CHALLENGES: UNEMPLOYMENT HAS DOUBLED DURING FACE SIGNIFICANT CHALLENGES: UNEMPLOYMENT HAS DOUBLED

HIS TENURE AND THE NUMBER OF PERSONAL AND CORPORATE
BANKRUPTCIES HAS INCREASED. ON THE FOREIGN FRONT MAJOR NEEDS BANKRUPTCIES HAS INCREASED. ON THE FOREIGN FRONT MAJOR NEEDS
TO TRANSFORM RELATIONS HITH EUROPE FROM BEING PERCEIVED AS A TO TRANSFORM RELATIONS HITH EUROPE FROM BEING PERCEIVED AS A
THREAT TO THE UNITED KINGDOM'S SOVEREIGNTY TO BEING REGARDED THREAT TO THE UNITED KINGDOM'S SOVEREIGNTY TO BEING REGARDED
AS AN OPPORTUNITY FOR GROWTH AND EXPANSION. DESPITE THESE CHALLENGES, MAJOR'S VICTORY IS AN INDICATION THAT THE CONSERVATIVES ARE TRIUMPHANT AND THE SOCIALIST LEFT IS IN CONSERVATIYE
DISARRAY.

05640 LENMON, D.

LONDON: RE-EVALUATION

EUROPE, (311) (NOV 91), 12-13

BRITAIN IS BEING FORCED INTO A FUMDAMENTAL REVIEW OF ITS NUCLEAR WEAPONS' PROGRAM AND THE CONCEPT OF AN INDEPENDENT DETERRENT FOLLOWING THE PROPOSALS AND COUNTERPROPOSALS ON NUCLEAR ARMS CUTS FROM WASHINGTON AND MOSCOW. PLANS TO REPLACE AGING BRITISH NUCLEAR WEAPONS SYSTEMS WILL COME UNDER RENEHED SCRUTINY OVER THE COMING MONTHS, AND SOME MAY BE SHELVED. FOR BRITAIN, THO ISSUES MUST BE FACED IMMEDIATELY. THE FIRST IS THE PLAN TO REPLACE THE AGED POLARIS NUCLEAR SUBMARINE HITH A NEW TRIDENT SUBMARINELAUNCHED SYSTEM THAT WILL HAVE NEARLY 1,000 WARHEADS AT ITS OISPOSAL. THE SECOND ISSUE CONCERNS THE PROGRAM FOR A TACTICAL AIR-TO-SURFACE MISSILE (TASM) TO REPLACE 200 DATED FREE-FALL TACTICAL NUCLEAR BOMBS THAT REQUIRE WARPLANES TD FLY DIRECTLY OVER THEIR TARGET. BRITISH DEFENSE SECRETARY TOM KING'S INITIAL RESPONSE WAS TO SAY THAT THERE HOULD BE NO CHANGE IN BRITAIN'S TRIDENT OR TASM PROGRAMS. HOWEVER, GROWING OPPOSITION IN AN ELECTION YEAR MAY COMBINE WITH PRESSURE FROM THE CONTINENT TO CONVINCE BRITAIN'S RULERS TO CHANGE THEIR MINDS.

05641 LENOIR, G.

STILL FIGHTING APARTHEID

NUCLEAR TIMES, $8(2)$ (SUM 90), 30-34.

THIS ARTICLE LOOKS AT THE HOPE FOR ENDING APARTHEID GENERATED BY NELSON MANDELA'S RELEASE FROM PRISON IN SOUTH AFRICA, AND THE WORK THAT NEEDS TO BE DONE YET TO ACHIEVE THE GOAL. THE AUTHOR ARGUES THAT SANCTIONS AGAINST SOUTH AFRICA SHOULD BE MAINTAINED. ANTI-APARTHEID ACTIVITIES IN AHE U.S. ARE DISCUSSED, AS WEL AS THE DISTORTIONS BY MAINSTREAM NEWS COVERAGE OF THE SITUATION IN SOUTH AFRICA.

05642 LENTINI, $P$

POST-CPSU COMMUNIST POLITICAL FORMATIONS

JOURNAL OF COMMUNIST STUDIES, 8(4) (DEC 92), 280-292.

DESPITE THE RUSSIAN GOVERNMENT'S BAN ON THE COMMUNIST PARTY OF THE SOVIET UNION (CPSU), COMMUNIST ORGANIZATIONS
HAVE SURYIVED IN THE COHHONWEALTH OF INDEPENDENT STATES AND 
ARE ATTEMPTING TO INFLUENCE GOVERNMENTAL DECISION MAKING, ARE WORKING TO PROTECT THE INTERESTS OF FORMER CPSU MEMBERS, AND ARE LAYING CLAIM TO FORMER CPSU FUNDS AND OTHER ASSETS. AMONG THESE GROUPS ARE THE RUSSIAN COMMUNIST NORKERS PARTY, COMAUNIST UNITY, COMMUNISTS FOR CIVIL RIGHTS, THE UNION OF COMWUNISTS, THE PEOPLE'S PARTY OF FREE RUSSIA, THE SOCIALIST HORKERS PARTY, THE ALL-RUSSIAN COMMUNIST PARTY, THE LABOR PARTY, AND THE DEMOCRATIC REFORM MOVEMENT.

05643 LEONARD, D.

BELGIUM GETS A NEH LEADER

EUROPE, (320) (OCT 92), 20-21.

THE AUTHOR PROFILES JEAN-LUC DEHAENE, BELGIUM'S NEW PRIME MINISTER, AND EXPLAINS THE POLITICAL EVENTS THAT BROUGHT HIM TO POWER.

05644 LEOMARDI, R.; GARMISE, S

CONCLUSIONS: SUB-NATIONAL ELITES AND THE EUROPEAN COMMUNITY REGIONAL POLITICS \& POLICY, 2(1,2) (SPR 92), 247-274.

THE AUTHORS OF THIS ARTICLE ATTEMPT TO DRAH SOME GENERAL CONCLUSIONS ON THE IMPACT OF REGIONAL ISM ON THE EUROPEAN COMHUNITY AND THE ROLE THAT THE REGIONS WILL BE ABLE TO PLAY CDMHUNIT AND THE ROLE THAT THE REGIONS WILL BE ABLE IN THE POST-1992 EUROPE. THEY LOOK AT THE POSSIBLE CONNECTION BETHEEN REGIONAL GOVERNMENT AND ECONOMIC GROWTH BY ANALYZING THE COMPARATIVE ECONOMIC PERFORMANCE OF 168
REGIONS IN THE EUROPEAN COMMUNITY DURING THE PAST DECADE AND REGIONS IN THE EUROPEAN COMMUNITY DURING THE PAST DE DRAW CONCLUSIONS ON THE ROLE THAT VIABLE REGIONAL INSTITUTIONS CAN PLAY IN HELPING TO ACHIEVE ECONOMIC GROWTH AND DEVELOPMENT. THEY CONCLUDE WITH AN ANALYSIS OF THE IMPLICATIONS OF THE PROVISIONS OF THE MAASTRICHT TREATY FOR THE REGIONS, AND HOW THESE PROVISIONS SERVE TO IDENTIFY AN INCREASINGLY IMPORTANT ROLE FOR THE REGIONS IN THE EUROPEAN COMMUNITY AFFAIRS.

05645 LEONARDI, R.

THE REGIONAL REFORM IN ITALY: FROM CENTRALIZED TO REGIONALIZED STATE

REGIONAL POLITICS \& POLICY, 2(1,2) (SPR 92), 217-246. THE QUESTION: HETHER THE REGIONALIZATION OF TRADITIONALLY CENTRALIZED NATION-STATES LEADS TO A DECLINE IN ECONOMIC EFFICIENCY AND RATIONALITY OR WHETHER ECONOMIC PERFORMANCE IS ENHANCED BY THE CREATION OF INTERMEDIATE FORMS OF INSTITUTIONAL ARRANGEMENT IS EXPLORED IN THIS ARTICLE. IT ANALYZES THE ISSUE BY EXAMINING ONE OF THE FIRST EXTENSIVE EXAMPLES OF POLITICAL DECENTRALIZATION IN THE 1970S: THE REGIONALIZATION OF ITALIAN GOVERNMENT OVER THE LAST TWO DECADES. THE ANALYSIS SHOWS THAT DECENTRALIZATION OF UNITARY STATES IS NOT A \&LINEAR' PROCESS THAT DEVELOPS OVER TIME IN AN EVEN MANHER THROUGH A CLEAN QUALIATIVE LEAP OVER TIME IN AN EVEN MANHER THROUGH A CLEAN QUALIATIVE LEAP
FROM ONE SYSTEM OF INSTITUIONS TO ANOTHER. IT CONCLUDES THAT FROM ONE SYSTEM OF INSTITUIONS TO ANOTHER. IT CONCLUDES THAT IT MAKES LITTLE SENSE TO ABOLISH ALL 8ARRIERS TO ECONOMIC INTERACTIONS AHONG MEMBER STATES WHILE AT THE SAME MAINTAINING RESTRICTIONS ON SUB-NATIONAL LEVELS OF
GOVERNMENT FROM INTERACTING ACROSS NATIONAL BOUNDARIES.

05646 LEONARDI, R THE ROLE OF SUB-NATIONAL INSTITUIONS IN EUROPEAN INTEGRATION

REGIONAL POLITICS \& POLICY, 2(1,2) (SPR 92), 1-13

THE ARTICLES IN THIS VOLUME REPRESENT THE OUTCDME OF THE PROJECT, 'THE EUROPEAN COMMUNITY, REGIONS, AND EUROPEAN INTEGRATION: A COMPARATIVE STUDY OF POLICY SECTORS IN PREPARING FOR 1992'. THE SURVEY OF SUB-NATIONAL POLITICAL AND ECONOMIC ELITES CONSTITUTES THE FIRST LARGE-SCALE COMPARATIVE STUDY EVER CONDUCTED OF LOCAL POLITICAL SYSTEMS AND THE ACTIVITIES OF SUB-NATIONAL INSTITUTIONS WITHIN THE CDNTEXT OF THE EC. THE RESULTS OF THE RESEARCH WORK CONDUCTED IN EACH COUNTRY AND POLICY SECTOR IS DISCUSSED IN SEPARATE ARTICLES IN THE CONTEXT OF EACH INDIVIDUAL COUNTRY'S EXPERIENCE WITH REGIONAL FORMS OF SUB-NATIONAL GOVERNMENT. IN THE CONCLUSION, AN ATTEMPT IS MADE TO PLACE THE NATIONAL RESPONSES IN COMPARATIVE PERSPECTIVE AND TO DISCUSS THE IMPLICATIONS OF THE MAASTRICHT SUMMIT.

05647 LEPAGE, F.O.

SINO-AMERICAN RELATIONS POST-TIANAMMEN

PACIFIC REVIEW, 4(1) (1991), 63-67

THIS PAPER ARGUES THAT THE CONFLICT BETHEEN PRESIDENT GEORGE BUSH AND CONGRESS REGARDING U.S.-CHINA RELATIONS IS BOTH THE RESULT OF ESSENTIAL DIFFERENCES BETWEEN THEM IN WAYS OF ACHIEVING HUMAN RIGHTS, AND ALSO A BYPRODUCT OF A FUMDAMENTAL LACK OF UNDERSTANDING OF THE CHINESE EXPERIENCE. THE PAPER PRESENTS A RATIONALE FOR BUSH'S POSTURE TOHARDS POST-TIANAMEN CHINA AND CONTENDS THAT THIS APPROACH HAS NOT HITH THE ECONOMICS OF HUMAN RIGHTS.

05648 LEPINGWELL, J.

TOWARDS A POST-SOVIET ARMY

ORBIS, 36(1) (WIN 92), 87-104

OVER THE PAST FIVE YEARS, MOSCOW HAS TRANSFORMED THE

SOCIET ARMY: REDUCED IT IN SIZE, REDEPLOYED IT, AND GIVEN IT

A NEW MISSION. NOW IT IS ON THE BRINK OF AN EVEN MORE FAR-
NEW SECURITY CONCERNS: WHERE WILL THE PROCESS OF

TRANSFORMATION END? WILL THE SOVIET ARMY REMAIN A UNIFIED MILITARY FORCE? OR WILL IT SPLINTER INTO A NUMBER OF NEW NATIONAL ARMIES BEING FORMED IN THE FORMER SOVIET REPUBLICS? IN ATTEMPTING TO ANSWER THESE QUESTIONS, THIS ARTICLE EXAMINES BOTH THE PROCESS OF SOVIET MILITARY REFORM TO DATE AND THE FORCES DRIVING THE NEW PROCESS OF REFORM.

05649 LEPINGWELL, J.

U.S. -RUSSIAN COOPERATION IN MISSILE DEFENSE

RFE/RL RESEARCH REPORT, 1(33) (AUG 92) 49-56.

WHILE THE RUSSIAN GOVERMMENT HAS EXPRESSED A DESIRE TO COOPERATE HITH THE USA ON THE DEVELOPMENT OF A JOINT DEFENSE AGAINST BALLISTIC MISSILE ATTACKS, CONSIDERABLE UNCERTAINTY REMAINS CONCERNING RUSSIA'S INTERESTS AMD CAPABILITIES IN THIS AREA. RUSSIA'S INITIAL GOALS APPEAR TO BE THE ESTABLISHMENT OF A JOINT EARLY HARNING SYSTEM TO COMPENSATE FOR THE LOSS OF RADAR STATIONS IN THE FORMER SOVIET REPUBLICS, AS WELL AS COOPERATION ON THE DEVELOPMENT OF REPUBLICS, AS WELL AS COOPERATION ON THE DEVELOPMENT OF
SYSTEMS TO DEFEND AGAINST SHORT-RANGE BALLISTIC MISSILES SYSTEMS TO DEFEND AGAINST SHORT-RANGE BALLISTIC MISSILES. TECHNOLOGIES SEEMS UNLIKELY, GIVEN RUSSIA'S TECHNOLOGICAL TECHNOLOGIES SEEMS UNLIKELY, GIVEN RUS

05650 LEPINGHELL, J. (ED.); REISCH, A.A. (ED.)

RFE/RL RESEARCH REPORT, 1(40) (OCT 92), 51-56.

THE EDITORS SUMMARIZE IMPORTANT MILITARY DEVELOPMENTS IN THE COHHONHEALTH OF INDEPENDENT STATES, THE BALTIC STATES, CZECHOSLOVAKIA, HUNGARY, POLAND, AND ROMANIA DURING LATE SEPTEMBER 1992 .

05651 LEPINGWELL, J.H.R.; REISCH, A.A.

MILITARY AND SECURITY NOTES

RFE/RL RESEARCH REPORT, 1(44) (NOV 92), 57-61.

IN LATE OCTOBER 1992, BELARUS RATIFIED THE CFE TREATY;

THE USA PLEDGED TO HELP BELARUS DISPOSE OF ITS NUCLEAR

WEAPONS; RUSSIAN TROOPS WERE ORDERED TO RETURN FIRE IF THEY WERE ATTACKED IN ABKHAZIA; DENMARK OFFERED TO ASSIST WITH THE WITHDRAWAL OF SOVIET TROOPS FROM THE BALTIC STATES ; SWEDISH AND HUNGARIAN LEADERS MET TO DISCUSS GREATER MILITARY COOPERATION; AND YUGOSLAVIAN LEADERS ANHOUNCED A PLAN TO REORGANIZE THE FEDERAL ARMY.

05652 LEPINGWELL, J.W.R.

SOVIET CIVIL-MILITARY RELATIONS AMD THE AUGUST COUP WORLD POLITICS, 44(4) ( JUL 92), 539-572.

THIS PAPER TESTS THE OBJECTIVE (PROFESSIONALIZATION) AND SUBJECTIVE (PARTY PENETRATION) MODELS OF SOVIET CIVILMILITARY RELATIONS. THEN THE OBJECTIVE MODEL IS USED TO
INVESTIGATE THE FACTORS LEADING TO MILITARY PARTICIPATION IN INVESTIGATE THE FACTORS LEADING TO MILITARY PARTICIPATION IN,
AND HITHORAHAL FROM, THE COUP OF AUGUST 1991. THE OBJECTIVE MODEL POINTS TO THE IMPORTANCE OF THREATS TO PROFESSIONAL AUTONOMY AND NATIONAL UNITY, THE POLITICIZATION OF THE MILITARY, ANO DECLINING REGIME LEGITIMACY AS THE PRIMARY CAUSAL FACTORS IN THE PARTICIPATION OF THE MILITARY IN THE COUP. IT ALSO STRESSES THE IMPORTANCE OF MILITARY PROFESSIONALISM AS A BARRIER TO INTERVENTION AND AS A CAUSE OF MILITARY PARALYSIS DURING THE COUP. FURTHERMORE, THE MODEL POINTS TO THE IMPORTANCE OF DEMOCRATIC LEGITIMACY IN FUTURE CIVILIAN CONTROL AND TO THE NEED FOR INCREASED MILITARY PROFESSIONALISM TO FORESTALL THREATS TO THE POSTSOVIET REGIME.

05653 LEPINGHELL, J.H.R. (ED.); REISCH, A.A. (ED.) MILITARY AND SECURITY NOTES

RFE/RL RESEARCH REPORT, 1(42) (OCT 92), 40-46 THE EDITORS REPORT ON EAST-WEST SECURITY ISSUES,

MILITARY CONCERNS WITHIN THE COMMONHEALTH OF INDEPENDENT STATES, SECURITY ISSUES IN THE BALTIC STATES, AND MILITARY DEVELOPMENTS IN CZECHOSLOVAKIA, HUMGARY, POLAND, AND ROMANIA IN EARLY OCTOBER 1992. THEY DISCUSS THE RESTRUCTURING OF THE CIS HIGH COMMAND. THE SIGNING OF A RUSSIAN-AZERBAIJANI SECURITY AGREEMENT, RUSSIAN PROTESTS OVER BLACK SEA FLEET DEPLOYMENT, THE BISHKEK SUMMIT, TROOP WITHDRAWAL FROM THE BALTIC STATES, POLAND'S DESTRUCTION OF CONVENTIONAL WEAPONS, AND OTHER EVENTS.

05654 LEPINGWELL, J.W.R. (ED.); REISCH, A.A. (ED.) MILITARY AND SECURITY NOTES

RFE/RL RESEARCH REPORT, 1(46) (NOV 91) 47-52.

THE EDITORS SUMAARIZE MAJOR DEVELOPMENTS INVOLVING THE ARMED FORCES AND MILITARY POL ICY IN THE COMHONWEAL TH OF ARMED FORCES AND MILITARY POLICY IN THE COMMONWEALTH OF INDEPENDENT STATES, THE BALTIC STATES, BULGARIA, HUNGARY,
CZECHOSLOVAKIA, POLAND, AND YUGOSLAVIA DURING EARLY NOVEMBER 1992.

05655 LEPINGWELL, J.H.R. (ED.); REISCH, A.A. (ED.) MILITARY AND SECURITY NOTES RFE/RL RESEARCH REPORT, $1(50)$ (DEC 92), 65-69 THE EDITORS SUMMARIZE MAJOR DEVELOPMENTS INVOLVING SECURITY AND DEFENSE IN THE COMMONWEALTH OF INDEPENDENT STATES, THE BALTIC STATES, HUNGARY, POLAND, AND ROMANIA DURING EARLY DECEMBER 1992. EVENTS INCLUDE A MEETING BETHEEN 
RUSSIAN PRESIDENT YELTSIN AND U.S. PRESIDENT BUSH, A MEETING OF ESTONIAN AND RUSSIAN FOREIGN MINISTERS TO DISCUSS TROOP WITHDRAWAL, AND THE BEGINNING OF HUNGARIAN "OPEN SKIES" FLIGHTS OVER ROMANIA.

05656 LEPINGWELL, J.W.R. (ED.); RESICH, A.A. (ED.) MILITARY AND SECURITY NOTES

RFE/RL RESEARCH REPORT, 1(49) (DEC 92), 59-64. THE EDITORS SUMMARIZE MAJOR DEVELOPMENTS CONCERNING SECURITY AND DEFENSE IN THE COMMONWEALTH OF INDEPENDENT STATES, THE BALTIC STATES, BULGARIA, CZECHOSLOVAKIA, HUMGARY, POLAND, AND ROMANIA DURING LATE NOVEMBER 1992.

05657 LEPINGWELL, J.W.R. (ED.); REISCH, A.A. (ED.) MILITARY AND SECURITY NOTES

RFE/RL RESEARCH REPORT, $1(48)$ (DEC 92), 55-59.

THE RESEARCH REPORT, $1(48)$ (DEC 92 ), $55-59$.
THE EDITORS SUMMARIZE MAJOR DEVELOPMENTS INVOLVING THE THE EDITORS SUMMARIZE MA JOR DEVELOPMENTS INVOLVING THE
ARMED FORCES AND SECURITY ARRANGEMENTS IN THE BALTIC STATES, THE COMMONWEALTH OF INDEPENDENT STATES, BULGARIA, HUNGARY, POLAND, AND THE FORMER YUGOSLAYIA DURING NOVEMBER 1992.

05658 LERNER, M. STOPPING DAVID DUKE AND PATRICK BUCHANAN: A STRATEGY FOR THE $1990 \mathrm{~S}$

NATIONAL REVIEW, XLIV(1) (JAN 92), 37-44.

THE CANDIDACIES OF DAVID DUKE AND PATRICK BUCHANAN FOR THE REPUBLICAN PRESIDENTIAL NOMINATION ARE LIKELY TO GIVE NEW PUBLICITY AND RESPECTABILITY TO ONLY BARELY DISGUISED RACIST, ANTI-SEMITIC, AND XENOPHOBIC IDEAS IN AMERICAN POLITICS. THE ULTRARIGHTISTS HAVE LEARNED HOW TO APPEAL TO MANY DECENT AMERICANS BY SPEAKING TO REAL AND LEGITIMATE NEEDS, TO ACKNOWLEDGE THE PAIN IN THEIR LIVES, AND TO GIVE THEM THE SENSE THAT THEY ARE BEING RECOGNI ZED AND RESPECTED. THIS ARTICLE SUGGESTS THAT BECAUSE THE GOAL IS TO FIND WAYS TO DISLOOGE THIS SECTOR OF THE POPULATION FROM THE RIGHT, THERE IS A NEED TO UNDERSTAND WHAT THESE LEGITIMATE NEEDS ARE AND TO SPEAK TO THEM IN A WAY THAT SEPARATES THE LEGITIMATE RECOGNITION OF THEIR PAIN FROM THE ILLEGITIMATE EXPRESSION OF THE PAIN IN RACIST OR XENOPHOBIC DIRECTIONS. THIS ARTICLE CONCLUDES THAT IT IS URGENT FOR A UNITED FRONT AGAINST FACISM TO CONCENTRATE ON A POLITICS OF MEANING AND A MASS PSYCHOLOGY OF COMPASSION IN ORDER TO RESIST THE DESTRUCTIVE POSSIBILITIES OF THE COMING DECADES.

05659 LERNER, $M$.

THE SIXTIES GENERATION RETURNS

TIKKUN, $7(6)$ (NOV 92 ) $7-9$.

AMERICAN POLITICS SINCE THE LATE SIXTIES HAS BEEN LARGELY DEFINED BY PEOPLE'S COMPLEX REACTIONS TO THE EXPERIENCES OF THE THE SIXTIES, STATES THIS ARTICLE. THE REPUBL ICANS HAVE BEEN RUNNING AGAINST THE SIXTIES FOR THE REPUBLICANS HAVE BEEN RUNNING AGAINST THE SIXTIES FOR THE

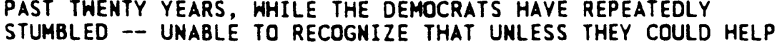
STUMBLED -- UNABLE TO RECOGNIZE THAT UNLESS THEY COULD HELP PEOPLE COME TO TERMS HITH THE SIXTIES, IT WOULD COME BACX TO HAUNT THEM. THE DEMOCRATS WERE TORN BY CONTRADICTORY NEEDS: ON THE HAND TO APPEAL TO THAT PART OF THEIR PARTY THAT FEELS THAT ITS NEEDS WERE FIRST ADDRESSED BY THE SOCIAL MOVEM OF THE SIXTIES WHILE AT THE SAME TIME HOLDING ON THOSE
SEGMENTS OF THE PARTY WHO FELT DEEPLY OFFENDED BY THE SPIRIT OF THE SIXTIES.

05660 LERNER, M.J

STATE NATURAL DEATH ACTS: ILLUSORY PROTECTION OF INDIVIDUALS' LIFE-SUSTAINIMG TREATMENT DECISIONS HARVARD JOURNAL OF LEGISLATION, 29(1) (WIN 92), 175-222. MANY STATES HAVE PASSED NATURAL DEATH ACTS AUTHORIZING LIVING WILLS UNDER CERTAIN CONDITIONS. ALTHOUGH THE NATURAL DEATH ACTS PROFESS TO PROTECT INDIVIDUAL AUTONOMY AND SELFDETERMINATION. THEY ACTUALLY SERIOUSLY RESTRICT AN INDIVIDUAL'S RIGHT TO CONTROL TREATMENT DECISIONS. THE CLASS OF PEOPLE PROTECTED BY THESE STATUTES IS NARROWED THROUGH THE TERMINAL-CONDITIOY REOUIREMENT, WHILE THE EXCLUSION OF NUTRITION AND HYDRATIOM FROM THE TYPES OF TREATMENTS THAT CAN BE WITHDRAWN RESTRICTS THE INDIVIDUAL'S RIGHT TO REFUSE TREATMENT. NATURAL DEATH ACTS PROTECT THE MEDICAL PROFESSION'S CONTROL OVER TREATMENT DECISIONS AT THE EXPENSE OF REDUCING THE PATIENT'S CONTROL OVER THOSE DECISIONS. MOREOVER, PRACTICAL PROBLEMS ARISE WHEN IMPLEMENTING LIVING WILLS, WHICH FURTHER FRUSTRATE INDIVIDUAL AUTONOMY AND SELFDETERMINATION.

05661 LEROY, M.H.; KOZIARA, K.S.; SCHWARZ, J.L. THE LAW AND ECONOMICS OF COLLECTIVE BARGAINING FOR HOSPITALS: AN EMPIRICAL PUBLIC POL BY ANALYSIS OF HOSPITALS: AN EMPIRICAL PUBLIC

YALE JOURNAL ON REGULATION, 9 (1) (WIN 92), 1-72.

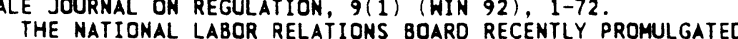
THE NATIONAL LABOR RELATIONS BOARD RECENTLY PROMULGATED A RULE THAT PREDESIGNATES EIGHT HOSPITAL BARGAINING-UNIT CLASSIFICATIONS. THE RULE, WHICH IS AN UNUSUAL DEVIATION FROM ADJUDICATORY PROCEDURES, IS INTENDED TO FACILITATE ADMINISTRATIVE APPROVAL HITHOUT INCREASING STRIKE ACTIVITY OR CAUSING OTHER UNDESIRABLE COLLECTIVE-BARGAINING RESULTS. 574 HOSPITALS DESIGNED TO TEST THE ECONOMIC CONCLUSIONS THAT
THE NLRB REACHED IN ITS "FInAL RULE." THE aUthORS CONCLUDE THAT THE DATA SUPPORT THE NLRB'S DETERMINATION THAT DESIGNATING THE EIGHT CLASSIFICATIONS IS UNLIKELY TO CAUSE UNDESIRABLE BARGAINING CONSEQUENCES.

05662 LESLIE, $D$.

MODELLING HOURS OF WORK IN A LABOUR SERVICES FUNCTION SCOTTISH JOURNAL OF POLITICAL ECONOMY, 38 (1) (FEB 91), 19-31.

LABOR SERVICES ARE THO-DIMENSIONAL, CONSISTING OF A STOCK (NUMBERS EMPLOYED) DIMENSION AND A FLOW (HOURS OF WORK) OIMENSION. HOURS ARE, THEREFORE, TREATED AS AN "AS IF" FACTOR OF PRODUCTION WITH A WELL-DEFINED MARGINAL PHYSICAL PRODUCT. THE PURPOSE OF THIS PAPER IS TO OUERY THE APPROPRIATENESS OF THIS FORMULATION IN LABOR DEMAND MODELS APPROPRIATENESS OF THIS FORMULATION IN LABOR DEMAND MODELS. IT REVIEWS THE MAIN PREDICTIONS OF THE CONVENTIONAL MODEL
AND EXPLAINS THE PROBLEMS ASSOCIATED HITH THIS SPECIFICATION. AND EXPLAINS THE PROBLEMS ASSOCIATED WITH THIS SPECIFICATION.
IT ALSO DEVELOPS AN ALTERMATIVE FRAMEWORK WITH COMPARATIVE STATIC PROPERTIES.

05663 LESLY, E.

PENMIES FROM HEAVEN

WASHINGTON MONTHLY, 23(4) (APR 91), 40-45.

THE IDEA OF TAXING CHURCHES HAS BEEN INTELLECTUALLY MOTHBALLED FOR YEARS, AND IS USUALLY ASSOCIATED ONLY WITH EXTREME SECULAR HUMANISTS AND FAIR-TAX FANATICS. HOHEVER, AN ANALYSIS OF THE CONSTITUTION, SEVERAL RECENT SUPREME COURT RULINGS, AND THE WRITINGS OF' SEVERAL CHURCH-AND-STATE EXPERTS, REVEALS THAT TAXING CHURCHES MAY NOT ONLY BE LEGAL, BUT MAY BEGIN WITH LOCAL GOVERNMENTS SUBJECTING CHURCHES TO' REAL ESTATE TAXES BEFORE THE END OF THE DECADE.

05664 LETOURMEAU, P.

A UNITED GERMANY BETWEEN A DECLINING HEST AND A DISINTEGRATED WEST

ETUDES INTERMATIONALES, 23(1) (MAR 92), 77-96.

GERMAN UNIFICATION IS BOTH A CAUSE AND AN EFFECT OF THE RESTRUCTURING OF ALLIANCES NOW TAKING PLACE WITH THE END OF THE LONG POSTWAR ERA. THE TRADITIONAL POLICY OF SEEKING NONISOLATION, AT TIMES NOT WITHOUT AMBIVALENCE, IS DESTINED TO CHANGE AND COULD BECOME MORE ASSERTIVE. THO ITEMS TESTIFY TO THIS CHANGE IN DIRACTION: THE DEBATE OVER NARMALIZATION,

THIS CHANGE IN DIRACTION: THE DEBATE OVER NARMALIZATION,
WHICH HAS BROUGHT DOWN TABOOS IN GERMANY, AND THE LEADERSHP WHICH HAS BROUGHT DOWN TABOOS IN GERMANY, AND THE LEADERSH
ROLE THAT BONN HAS OPENLY TAKEN, FOR THE FIRST TIME SINCE ROLE THAT BONN HAS OPENLY TAKEN, FOR THE FIRST TIME SINCE
1945 , ON THE ISSUE OF RECONGNITION WITHOUT FURTHER DELAY OF 1945, ON THE ISSUE OF RECONGNITION WITHOUT FURTHER DELAY OF
SLOVENIA AND CROATIA BY THE EUROPEAN COMMUNITY AS OF JANUARY $15,1992$.

05665 LEVEAU, R.

MAGHREBI IMMIGRATION TO EUROPE: DOUBLE INSERTION OR DOUBLE EXCLUSION?

ANNALS OF THE AMERICAN ACADEMY OF POLITICAL AND SOCIAL SCIENCE, (524) (NOV 92), 170-180

DURING THE 1970 's, SIGNIFICANT MUMBERS OF MIGRANTS FROM THE MAGHREB, TURKEY, HESTERN AFRICA, AND INDIA SETTLED IN EUROPE, IN WHAT THEY CONSIDERED TO BE A LASTING EXILE. THEY VIEWED ISLAM AS AN INSTRUMENT FOR BUILDING NEW IDENTITIES AND TRANSNATIONAL SOLIDARITIES FOR THE PURPOSE OF NEGOTIATING WITH THE STATES AND SOCIETIES WHERE THEY SETTLED. BUT THAT PEACEFUL APPROACH HAS BEEN TAKEN AS AN UNACCEPTABLE CHALLENGE BY SECULAR SOCIETIES, WHICH ARE NO LONGER ACCUSTOMED TO DEALING WITH RELIGIOUS VALUES AS A WAY OF COLLECTIVE SELF-ASSERTION. IN THE FUTURE, EUROPE WILL INCLUDE 5-6 MILLION MUSLIMS AND IT WILL BE NECESSARY TO ESTABLISH A NEW DOCTRINAL FRAMEWORK OF CUL TURAL PLURALISM THAT INCLUDES ISLAM.

05666 LEVENTHAL, $P$

WHY BOTHER PLUGGING EXPORT LEAKS?

ORBIS, 36(2) (SPR 92), 167-180.

THE QUESTION, "IS IT POSSIBLE TO PLUG THE LEAKS IN MUCLEAR EXPORT CONTROLS?" IS RAISED. AND PERHAPS MORE TO THE POINT, GIVEN THE APPARENT LACK OF WILLPOWER AMONG GOVERMMENTS AND INDUSTRY TO DO SO, SHOULD AN ATTEMPT EVEN BE MADE? AFTER EXAMINING THE NUCLEAR CONTROL REGIME AND NON PROLIFERATION PARALYSIS, THIS ARTICLE CONCLUDES THAT FREQUENTLY LAX ENFORCEMENT OF EXISTING EXPORT CONTROLS ON ITEMS RELEVANT TO NUCLEAR WEAPONS PRODUCTION MAKES IT EASIER FOR THIRD WORLD STATES TO ACOUIRE SUCH WEAPONS.

05667 LEYER, W.F.

LOCAL AUTHORITY RESPONSES TO ECONOMIC CHANGE IN WEST CENTRAL SCDTLAND

URBAN STUDIES, $29(6)$ (AUG 92),935-948.

THE AUTHOR DESCRIBES THE INDUSTRIAL DECLINE AMO THE RESUI AUG UNEMPLOYMEMT IN THE GLASGOH URBA AREA. THE POLITICAL ATTITUDES OF MANY OF THE LOCAL GOVERMMENT AUTHORITIES HAVE MADE IT DIFFICULT FOR THEM TO FORMULATE AND IMPLEMENT POLICIES AIMED AT ACHIEVING ECOMOMIC REGENERATION IN THE AREA. CONSEQUENTLY, A SPECIALIST REGIONAL DEVELOPMENT AGENCY, THE PRIVATE SECTOR, AND VOLUNTARY/COMHUNITY

ORGANIZATIONS HAVE TAKEN RESPONSIBILITY FOR INTERVENING IN THE LOCAL ECONOMY. DUE TO THE CURRENT POLITICAL CLIMATE, THE
EMPHASIS HAS BEEN PLACED ON VALUE-FOR-MONEY IN TERMS OF COST 
PER JOB CREATED AND ACCURACY IN TARGETING JOB CREATION TO THE MOST DISADVANTAGED.

05668 LEVERNIER, $N$.

THE EFFECT OF RELATIVE ECONOMIC PERFORMANCE ON THE OUTCOME OF GUBERNATORIAL ELECTIONS

PUBLIC CHOICE, 74(2) (1992), 181-190.

THE INFLUENCE OF ECONOMIC CONDITIONS ON GUBERMATORIAL ELECTIONS IS EXAMINED. THE PURPOSE IS TO DETERMINE WHAT EFFECT STATE ECONOMIC CONDITIONS, RELATIVE TO NATIONAL ECONOMIC CONDITIONS, HAVE ON THE SHARE OF THE VOTE RECEIVED BY THE INCUMBENT PARTY IN GUBERNATORIAL ELECTIONS. A MODEL OF ELECTION OUTCOMES IS DISCUSSED AND A SET OF ECONOMETRIC EQUATIONS THAT EXPLAINS THE MODEL IS ESTIMATED. IN SECTION 3 THE EMPIRICAL RESULTS ARE REPORTED AND THE RESULTS ARE DISCUSSED. THE RESULTS OF THE PAPER INDICATE THAT ECONOMIC CONDITIONS HAVE ONLY A MINOR EFFECT ON THE SHARE OF THE VOTE RECEIVED BY THE INCUMBENT PARTY.

05669 LEVESQUE, J.

FROM THE' "COMMON EUROPEAN HOME" TO THE DISINTEGRATION OF THE WARSAH PACT... AND ALSO OF THE USSR

ETUDES INTERHATIONALES, $23(1)$ (MAR 92), 37-56.

GORBACHEY SOUGHT TO' CARRY OUT A PLAH TO TRANSFORM THE INTERMATIONAL ORDER IN EUROPE. THE PROCESS HAVING GOT OUT OF HAND, THE USSR DID NOT STEP IN TO PRESERVE THE OBJECTIVES OF ITS EUROPEAN POL ICY. IT ATTEMPTED TO ADJUST TO EASTEM EUROPE'S NEW POLITICAL SITUATION BY MAKING GREAT EFFORTS TO PRESERVE THE WARSAH PACT. THE COLLAPSE OF EASTERM EUROPE'S REGIMES AND THE PROGRESS IVE DISINTEGRATION OF THE WARSAH PACT LARGELY CONTRIBUTED TO GORBACHEV'S LOSING CONTROL OF THE POLITICAL SITUATION IN THE USSR AND GREATLY ACCELERATED ITS BREAKUP.

05670 LEVIE, $M$ PARTY POOPER

NEH REPUBLIC, $206(1-2)$ (JAN 92), 13-14.

"INDEPENDENTS" NOW COMPRISE THE LARGEST POLITICAL GROUPING IN THE UNITED STATES, WITH 37\% OF AMERICANS PREFERRING THAT LABEL. THIS HOULD SEEM TO INDICATE THAT THERE IS ROOM IN THE U.S. POLITICAL SYSTEM FOR MORE THAN THO MAJOR PARTIES, BUT THE ELECTORAL SYSTEM HAS NEVER EMBRACED INDEPENDENT OR THIRD-PARTY CANDIDATES AND THE DETERRENTS ARE NOH GREATER THAN EVER.

05671 LEVIN-WALDMAN, 0.

PLANT CLOSURE, REGULATION, AND LIBERALISM: THE LIMITS TO PLANT CLOSURE, REGULATION,

UNIVERISTY PRESS OF AMERICA, 1992, 185

THE PROBLEM OF PLANT CLOSURE AND THE FAILURE OF SOCIETY TO FORMULATE AM EFFECTIYE SOLUTIOM TO THE PROBLEM IS THE FOCUS OF THIS BOOK. THE AUTHOR ASKS WHY HAVE WE AS A SOCIETY BEEN ABLE TO REGULATE ANY NUMBER OF ECONOMIC ISSUES, BUT NOT THIS ONE. THE BOOK ADDRESSES: PLANT CLOSINGS' CHALLEN LIBERALISM; UNDERSTANDING LIBERALISM; THE EVOLVING PUBLIC/PRIVATE RELATIONSHIP; STRATEGIES FOR DEALING WITH PLANT CLOSURE; ISSUES IN PLANT
FAILURE OF LIBERALISM TO ADAPT.

05672 LEVIN, A.E.

THE FIRST STEPS IN RUSSIA'S NEW SCIENCE POLICY RFE/RL RESEARCH REPORT, 1(42) (OCT 92), 51-56.

IN APRIL 1992, PRESIDENT BORIS YELTSIN ISSUED A SPECIAL DECREE ON URGENT MEASURES RELATED TO SCIENCE, ENUNCIATING IMPORTANT NEW POLICY GUIDELINES. THE RUSSIAN ACADEMY OF SCIENCES AND THE RUSSIAN MINISTRY OF SCIENCE (HIGHER SCHOOLS) AND TECHNOLOGY ARE TRYING TO ADAPT TO THE HARSH REALITIES OF THE NATIONAL ECONOMY AND TO FIND REALISTIC WAYS TO REFORM NATIONAL SCIENCE AND HIGHER EDUCATION.

05673 LEVINE, A.L. (ED.) ; LAMBRIGHT, H.H. ; LOGSDON, J.M.; MCCURDY, H.E.; SHAFRITZ, J.M.

THE FUTURE OF THE U.S. SPACE PROGRAM: A PUBLIC ADMINISTRATION CRITIQUE

PUBLIC ADMINISTRATION REVIEW, 52(2) (MAR 92), 183-203.

IN THIS SYMPOSIUM, THE AUTHORS OFFER CRITIQUES OF THE 1990 AUGUSTINE COMMITTEE REPORT ON THE FUTURE OF THE U.S. SPACE PROGRAM FROM PUBL IC ADMINISTRATION PERSPECTIVES. THEY CONSIDER HOW THE COMMITTEE APPROACHED ISSUES DEALING WITH THE CIVILIAN SPACE PROGRAM'S HUMAN RESOURCE NEEDS, THE ORGANIZATIONAL CULTURAL APPROACH USED BY THE COMMITTEE, HOW ORGANIZATIONAL CULTURAL APPROACH USED BY THE COMMITTEE, HOH STRUCTURE OF NASA AND THE SPACE PROGRAM, THE NEED FOR

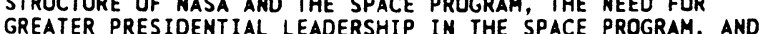
GREATER PRESIDENTIAL LEADERSHIP IN THE SPACE PROGRAM, AND DIMENSIONS OF THE CIVILIAN SPACE PROGRAM.

05674 LEVINE, H.M. (ED.

WHAT IF THE AMERICAN POLITICAL SYSTEM HERE DIFFERENT? M.E. SHARPE, 1992, 308

THIS BOOK SPECULLATES ON HOW AMERICAN POLITICS WOULD BE CHANGED IF THE COUNTRY'S POLITICAL INSTITUTIONS AND HISTORICAL DEVELOPMENT HERE DIFFERENT. WRITTEN BY POLITICAL SCIENTISTS AND HISTORIANS, THE CHAPTERS ASK SUCH QUESTIONS
AS: WHAT IF THERE WERE NO WRITTEN CONSTITUTION ANO BILL OF RIGHTS? A UNITARY RATHER THAN FEDERAL SYSTEM? THREE MAJOR PARTIES? A PARL IAMENTARY SYSTEM? NO JUDICIAL REVIEW? NO LEGACY OF SLAVERY OR COLD WAR? SPECIFIC GUARANTEES OF GENDER EQUALITY IN THE 1787 CONSTITUTION? NO WELFARE LEGISLATION?

05675 LEVINE, J.

AN EXPORT SALES COMPANY

JOURNAL OF STATE GOVERNMENT, 65(3) (SUM 92), 30-33.

THE INTERNATIONAL TRADE DIVISION OF OREGON'S DEPARTMENT OF ECONOMIC DEVELOPMENT IS UNIQUE AMONG STATE EXPORT TRADE EFFORTS. THE PROGRAM APPLIES HIGHLY-SELECTIVE CRITERIA IN DETERMINING WHICH FIRMS TO ASSIST AND PROVIDES IN-DEPTH ASSISTANCE TO THE FORTUNATE FEH THAT ARE CHOSEN. ALTHOUGH PROGRAMS IN AUSTRALIA AND NEW YORK STATE CONTAIN SIMILAR ELEMENTS, OREGON'S IS MORE HIGHLY FOCUSED, CREATIVE, AND EFFECTIVE. OTHER STATE GOVERMMENTS SHOUID GIVE SERIOUS CONSIDERATION TO ADOPIING OREGON'S APPROACH.

05676 LEVINE, S.: ROBERTS, N.

ELECTIONS AND EXPECTATIONS: EVIDENCE FROM ELECTORAL

SURYEYS IN NEW ZEALAND

JOURMAL OF COMMONHEALTH AND COMPARATIVE POLITICS, $X X I X(2)$ (JUL 91), 129-152.

IT HAS RECENTLY BEEN NOTED THAT "IT IS SURPRISING THAT SURVEYS HAVE MOT MORE OFTEN QUESTIONED VOTERS NOT ONLY ON THEIR OWN VOTE, BUT ALSO AS TO WHOM THEY EXPECTED TO WIN NATIONALLY AND IN THEIR OWN CONSTITUENCY." THIS OBSERVATION QUITE PROPERLY DRANS ATTENTION TO A FACTOR GENERALLYY OVERLOOKED IN ELECTORAL STUDIES, WHETHER OF A SOCIOLOGICAL OR OF A PSYCHOLOGICAL CHARACTER: THE EFFECT ON VOTING BEHAVIOR OF VOTERS' EXPECTATIONS ABOUT OUTCOMES. USING A BOOY OF DATA ASSEMBLED IN NEW ZEALAND, THIS ARTICLE EXAMINES THE CONNECTIONS BETWEEN VOTING PREFERENCES AND EXPECTED ELECTION RESULTS.

05677 LEVINE, S.I.

CHINA AND AMERICA: THE RESILIENT RELATIONSHIP

CURRENT HISTORY, 91 (566) (SEP 92), 241-246.

SOME PROCLAIM THAT THE END OF THE COLD WAR HAS DIMINISHED THE IMPORTANCE OF U.S.-SINO RELATIONS. THIS MISCONCEPTION DERIVES FROM A NARROH VIEW OF CHINA AS PRIMARILY AN ANTI-SOVIET PARTNER IN THE SO-CALLED "STRATEGIC TRIANGLE." A MORE ACCURATE VIEW IS THAT THE DISPERSAL OF THE STRATEGIC ILLUSIONS THAT GRIPPED THE USA AMD CHINA DURING THE COLD WAR HAS PRESENTED THE TWO COUNTRIES HITH A NEW SET OF TOUGHER CHALLENGES CONCERNING INTERMATIONAL SECURITY, OF TOUGHER CHALLENGES CONCERNING INTERNATIONAL SECURITY,
ENVIRONMENTAL PROTECTION, TRADE, DEVELOPMENT, AND HUMAN AND ENVIRONMENTAL PROTECTION, TRADE, DEVELOPMENT, AND HUMAN AND
POLITICAL RIGHTS. THESE GLOBAL ISSUES CANNOT BE ADDRESSED POL ITICAL RIGHTS. THESE GLOBAL ISSUES CANNOT BE ADORES
WITHOUT FULL CHINESE PARTICIPATION. THEREFORE, U.S. WITHOUT FULL CHINESE PARTICIPATION. THEREFORE, U.S.
POL ICYMAKERS MUST NOT SUCCUMB TO THE TEMPTATION TO TREAT POLICYMAKERS MUST NOT SUCCUMB TO THE TEMPTATION TO TREAT THEY MUST INSTEAD CONTINUE TO ENGAGE THEIR CHINESE COUNTERPARTS IN BOTH BILATERAL AND MULTILATERAL FORUMS

05678 LEVINE, S.I.

SECOND CHANCE IN CHINA: SIMO-SOVIET RELATIONS IN THE 1990'S ANNALS OF THE AMERICAN ACADEMY OF POLITICAL AND SOCIAL SCIENCE, 519 ( JAN 92), 26-38.

THE RECENT NORMALIZZATION OF SINO-SOVIET RELATIONS REPRESENTS AN IMPORTANT ELEMENT IN THE EVOLVING POST-COLD WAR SYSTEM OF GLOBAL AND EAST ASIAN POLITICS. UNLIKE THE SINO-SOVIET SECURITY ALLIANCE CUM IDEOLOGICAL PARTNERSHIP OF THE 1950'S, THE NEW RELATIONSHIP IS BOTH PRAGMATIC AND LIMITED. THE IMPROVED SECURITY ATMOSPHERE IS EVIDENCED BY MUTUAL FORCE REDUCTION AGREEMENTS AND THE RESUMPTION OF MILITARY EXCHANGES. BORDER AND REGIONAL TRADE ARE AN INCREASINGLY IMPORTANT ELEMENT IN THE ECONOMIC RELATIONSHIP, ALTHOUGH CENTRALIZED TRADE STILL PREDOMINATES. CHINESE LEADERS ARE VERY DISTURBED BY THE WEAKENIMG OF COMMUNIST PARTY CONTROL AND THE EROSION OF SOCIALIST VALUES IN THE USSR. POLITICAL UNCERTAINTIES IN BOTH COUNTRIES PARTICULARLY THE SOVIET UNION, SUGGEST ALTERNATIVE SCENARIOS FOR THE FUTURE OF SINO-SOVIET RELATIONS. IN ANY EVENT, THE RELATIONSHIP WILL BE LESS CENTRAL TO EACH COUNTRY THAN IN THE PAST DUE TO THE ALTERED INTERNATIONAL ENVIRONMENT IN THE ASIA-PACIFIC REGION.

05679 LEVITAN, D.

BUOGET BALANCING: THE STATE GOVERMMENT WAY

MATIONAL CIVIC REVIEW, 81(3) (SUM 92), 375-376.

FORTY-FOUR STATES REQUIRE THE GOVERNOR TO SUBMIT

BALANCED BUDGETS, AND 37 ALSO REOUIRE THE GOVERNOR TO SIGN A

BALANCED BUDGET. HOWEVER, 13 STATES, INCLUDING SEVEN OF THE

MOST POPULOUS, ARE ALLOWED TO CARRY OVER A BUDGET DEFICIT

FROM OME YEAR TO THE MEXT, HHICH PROVIDES GREATER

FLEXIBILITY IN MEETING THE BALANCED BUDGET REQUIREMENT.

05680 LEVITAN, D.

HAS THE FEDERAL GOVERMMENT MADE A SERIOUS COMMITMENT TO

SOUNO FISCAL MANAGEMENT? WE HOPE SO

NATIONAL CIVIC REVIEW, 81(1) (WIN 92), 78-79.

CONGRESS HAS MANDATED FINANCIAL MANAGEMENT REFORM IN ITS

CHIEF FINANCIAL OFFICER (CFO) ACT OF 1990, PUBLIC LAW 101- 
576. THE CFO ACT WILL LAY THE FOUNDATION FOR COMPREHENSIVE REFORM OF FEDERAL FINANCIAL MANAGEMENT OY ESTABLISHING A LEADERSHIP STRUCTURE, PROVIDING FOR LONG-RANGE PLANNING, REQUIRING AUDITED FINANCIAL STATEMENTS, AND IMPROVING ACCOUNTABILITY REPORTING.

05681 LEVITAN, D.; PFEIFFER, D. THE AMERICANS WITH DISABILITIES ACT OF 1990: A COMPLIANCE OVERVIEH

NATIONAL CIVIC REVIEW, 81(2) (SPR 91), 143-154.

HAILED BY MOST BUT CONDEMNED BY SOME. THE AMERICANS WITH DISABILITIES ACT EXTENDS FORMAL CIVIL RIGHTS PROTECTIONS TO A LARGE AND HITHERTO NEGLECTED SEGMENT OF THE U.S POPULATION. A LARGE AND HITHERTO NEGLECTED SEGMENT OF THE U.S POPUL THE AUTHORS OFFER AN OVERVIEH OF ITS PROVISIONS AND
ESTIMATE THE COSTS OF COMPLIANCE TO BOTH PUBLIC AND PRIVATE SECTOR ORGANIZATIONS

05682 LEVITAN, S.A.; MILLER, E.I.

ENTERPRISE ZONES ARE NO SOLUTION FOR OUR BLIGHTED AREAS CHALLENGE, 35(3) (MAY 92), 4-8.

EVEN IN THE BEST OF TIMES, POVERTY AND HIGH UNEMPLOYMENT REMAIN THE RULE FOR BLIGHTED AREAS. TO ALLEVIATE THE PROBLEMS OF DISTRESSED URBAN AREAS, THE BUSH ADMINISTRATION HAS ADVOCATED THE DESIGNATION OF SOME NEIGHBORHOODS AS ENTERPRISE ZONES, WHERE BUSINESSES WOULD BE ENTITLED TO SPECIAL TAX REDUCTIONS AND RELIEF FROM REGULATION. THE UNDERLYING RATIONALE FOR SUCH ZONES IS THAT REDUCING TAXES, REGULATION, AHD OTHER GOVERMMENT-IMPOSED BARRIERS WILL PRODUCE AN INFUSION OF CAPITAL INTO DEPRESSED NEIGHBORHOOOS. THIS, IN TURN, WILL LEAD TO MORE BUSINESS OPERATIONS AND AN OVERALL NET GAIN IN INVESTMENT AND JOBS. BUT THERE IS NO EMPIRICAL EVIDENCE THAT REDUCING FEDERAL TAXES AND RELAXING REGULATIONS WILL ALLEVIATE THE PROBLEMS OF THE INHER CITIES, BECAUSE TAXES AT BEST PLACE A SECONDARY ROLE IN BUSINESS INVESTMENT DECISIONS.

05683 LEVITSKY, S.; LAPP, T

SOL IDARISMO AND ORGANIZED LABOR
HEMISPHERE

GLOBAL ECONOMIC RESTRUCTURING IS UNDERCUTTING ORGANIZED LABOR IN LATIN AMERICA AND THE WORLD. IN COSTA RICA, THE RAPID GROWTH OF AN ALTERNATIVE LABOR MOVEMENT CALLED
"SOLIDARISMO" IS POSING A CHALLENGE TO THE MAINSTREAM TRADE "SOLIONS AND IS FORCING ORGANIZED LABOR TO CONSIDER INMOVATIVE IDEAS ON WORKERS' RIGHTS AND UNION STRATEGIES.

05684 LEVITSKY, S.

TAMING THE HONDURAN MILITARY

HEMISPHERE, 4(3) (SUM 92), 36-38.

THE LACK OF CIVILIAN CONTROL OVER THE HONOURAN MILITARY IS PARTICULARLY EVIDENT IN THE JUDICIAL SYSTEM. THE HONDURAN MILITARY REFUSES TO ALLOW ITS MEMBERS TO BE TRIED IN CIVILIAN COURTS, EVEN WHEN THEY COMMIT COMMON CRIMES THAT HAVE NOTHING TO DO WITH THEIR MILITARY DUTIES. DESPITE WIDESPREAD OPPOSITION TO THIS POLICY, FEH POLITICIANS OR JUDGES HAVE HAD THE COURAGE TO CHALLENGE IT.

05685 LEVY-GARBOUA, L.

GENERAL INTEREST AND REDISTRIBUTION WITH SELF-INTERESTED VOTERS: SOCIAL CONTRACT REVISITED

PUBLIC CHOICE, 69(2) (FEB 91) 175-198.

THIS ARTICLE PROVIDES A RATIONAL SOLUTION TO THE LASTING PARADOX THAT CITIZENS BE MORE CONCERHED WITH "GENERAL INTEREST" THAN MOST ECONOMIC AGENTS. THE AUTHOR SHOHS THAT IN THE FACE OF FUNDAMENTAL POLITICAL UNCERTAINTY, THE SOCIAL CONTRACT PROVIDES SELF-INTEREST VOTERS AN EFFECTIVE MECHANISM O F SELF-INSURANCE THAT LIMITS THE AMOUNT OF INVOLUNTARY TRANSFERS. THE AUTHOR'S POSITIVE THEORY OF VOTER BEHAVIOR AND GENERAL INTEREST HAS BUT A FORMAL RESEMBLANCE WITH THE NORMATIVE THEORY OF WELFARE JUDGMENTS AND SOCIAL JUSTICE, EVEN WHEN THE EFFICIENCY ASPECTS OF REDISIRIBUTION ARE NOT CONSIDERED, THERE IS ND WAY IN WHICH THE FINAL DISTRIBUTION OF INCOMES COULD BE EQUAL IF THE INITIAL POLITICAL CHANCES IN ORDER TO MAXIMIZE THEIR PROBABILITY OF POLITICAL CHANCES IM

05686 LEYY, J.; BARNETT, M.

ALLIANCE FORMATION, DOMESTIC POLITICAL ECONOAY, AND THIRD WORLD SECURITY

JERUSALEM JOURMAL OF INTERMATIONAL RELATIONS, 14(4) (DEC 92), $19-40$

FOCUSING ON THE TRADE-OFFS POLITICAL LEADERS MAKE AMONG DOMESTIC AND INTERNATIONAL GOALS, THIS ARTICLE ARGUES THAT IN THESE STATES, CHOICES BETHEEN EXTERNAL ALLIANCES AND INTERNAL ALLIANCES AND INTERNAL MILITARY PREPARATIONS AS ALTERNATIVE SECURITY STRATEGIES ARE OFTEN DETERMINED MORE DOMESTIC POLITICAL AND ECONOMIC CONSIDERATIONS THAN BY
SYSTEMIC STRUCTURES AND THREATS. ALTHOUGH THE FOCUS HERE IS ON THIRD WORLD COUNTRIES, THIS ARGUMENT ALSO HAS IMPORTANT IMPLICATIONS FOR THE GREAT POWERS OF THE PAST.
05687 LEVY, M. JR. CONFUCIANISM AND MODERNIZATION

SOCIETY, 29(4) (MAY 92), 15-18.

SOME OF THE MOST SUCCESSFUL CASES OF MODERMIZATION HAVE BEEN IN SOCIETIES, OR COUNTRIES, IN WHICH THE CONFUCIAN ETHIC HAS, FOR MANY CENTURES, LOOMED LARGE IN THE RELIGIOUS ASPECTS OF LIFE. THIS ARTICLE EXPLORES THE CONUNDRUM THAT THIS POSES AND CONCLUDES THAT CONFUCIANISM WOULD NEVER HAVE LED TO FIRST-COMER EMERGENCE OF MODERNIZATION. IT COULD NOT BECOME EFFECTIVE AS A RELIGIOUS, ETHICAL STIMULUS TO MODERNIZATION EVEN FOR LATECOMERS UNTIL THESE LATECOMERS HAD MODERNIZATION EVEN FOR LATECOMERS UNTIL THESE LATECOMERS HAD HATE ACHEI VED A VIABLE NATIONAL CORPORATE STATE. ONCE THIS HAD
BEEN ACHIEVED, THE CONFUCIAN ETHIC BECAME A VERY IMPORTANT BEEN ACHIEVED, THE CONFUCIAN ETHIC BECAME A VERY IMPORTANT
FACTOR IN THE COUNTRIES HHOSE SUCCESS WE FIND SO SPECTACULAR.

05688 LEVY, R.

CASE' STLOY: THE SCOTTISH CONSTITUTIONAL CONVENTION,

NATIONALISH, AND THE UNION

GOVERNMENT AND OPPOSITION, 27(2) (SPR 92), 222-234.

THE AUTHOR OISCUSSES SCOTLAND'S STATUS WITHIN THE UNITED KINGDOM AND THE IMPETUS BEHIND THE FORMATION OF THE SCOTTISH CONSTITUTIONAL CONVENTION.

05689 LEHIS-BECK, M.; SOUIRE, P. THE TRANSFórMation OF THE AMERICAN STATE: THE NEW ERA-NEH DEAL TEST

THE JOURMAL OF POLITICS, 53(1) (FEB 91), 106-121.

POLITICAL SCIENTISTS USUALLY VIEW THE NEW DEAL AS

TRANSFORMING THE AMERICAN STATE. THIS PAPER PROPOSES A MODEL OF THE STATE, AND THEN TESTS IMPORTANT HYPOTHESES ABOUT IT. MORE SPECIFICALLY, THE AUTHORS FOCUS ONT THE NEW ERA-NEW DEAL PERIOD TO TEST HOW, IF AT ALL, THE AMERICAN STATE CHANGED DURING THIS CRITICAL TIME IN ITS HISTORY. THEY SYSTEMATICALLY ANALYZE FIVE STATE FUNCTIONS: STABILIZATION, REDISTRIBUTION, REGULATION, POLICE PONER, AND ADMINISTRATION. WITHIN EACH CATEGORY, QUANTITATIVE POLICY MEASURES ARE EVALUATED. ALTHOUGH THE FDR ADMINISTRATION PRODUCED MANY NOTABLE CHANGES IN GOVERNMENT POLICY AND STRUCTURE, THE AUTHOR'S ANALYSIS SUGGESTS THAT THE AMERICAN STATE, MEASURED AUTHOR'S ANALYSIS SUGGESTS THAT THE AMERICAN STATE, MEASURED
IN THESE SEVERAL WAYS, WAS NOT TRANSFORMED FROM THE NEW ERA IN THESE SEVERAL

05690 LEWIS, B.

RETHINKING THE MIDOLE EAST

FOREIGN AFFAIRS, 71(4) (FAL 92), 99-119.

MOMENTOUS EVENTS MAY HAPPEN QUICKLY, BUT TIME IS NEEDED TO UNDERSTAND THE CHANGES CAUSED, REVEALED OR ACCELERATED BY THOSE EVENTS. IT IS BECOMING INCREASINGLY CLEAR THAT MANY CHANGES ARE UNDERWAY IN THE MIDOLE EAST. WHILE THESE VARY CONSIDERABLY IN THEIR SCOPE, SCALE, AND RANGE, FEW THINGS AND FEH PARTICIPANTS REMAIN AS THEY WERE BEFORE. THESE CHANGES ARE RELATED TO TWO SEQUENCES OF EVENTS: ONE SHORTTERM AND REGIONAL (THE WAR IN KUHAIT AND IRAO) AND THE OTHER LONG-TERM AND GLOBAL (THE END OF THE COLD WAR AND THE DISSOLUTION OF THE SOVIET UNION). SOME CHANGES MAY PERHAPS BE ASCRIBED DIRECTLY TO THESE EVENTS, BUT OTHERS HAD BEEN IN PROGRESS FOR SOME TIME AND WERE REVEALED, PERHAPS ALSO ACCELERATED, BY THE RECENT CATACLYSMIC EVENTS IN THE MIDDLE EAST AND IN INTERNATIONAL AFFAIRS.

05691 LEWIS, C.W.; TENZER, M.J.

POLITICAL STRATEGIES FOR HI-TECH DEVELOPMENT: THE CASE OF

A UNIVERSITY-RELATED RESEARCH PARK
INTERNATIONAL JOURNAL OF PUBLIC ADMINISTRATION, $15(9)$

(1992), 1757-1801.

FOR A DECADE THE DEVELOPMENT OF A RESEARCH PARK AT THE UNIVERSITY OF CONNECTICUT HAS BEEN FRUSTRATED BY A SERIES OF BUREAUCRATIC AND POLITICAL OBSTACLES. PROBLEMS ASSOCIATED WITH CONTRACTING OUT TO A PRIVATE DEVELOPER AND USING A
MIXED-IMPLEMENTATION MODEL, THE REGULATORY REVIEWS BY STATE AGENCIES, AND THE ROLE OF LOCAL AUTHORITIES HAVE BEEN COMPOUNDED BY ADOPTION OF MULTIPLE OBJECTIVES AND THE INTERVENTION OF EXOGENOUS FACTORS. PLURAL ACTORS AND POLYLATERAL POLITICAL RELATIONSHIPS RESTRICT THE UNIVERSITY'S ABILITY TO CONTROL AND GUIDE THE PROJECT AND TO ACHIEVE THE DESIRED BENEFITS. AMONG THE MANY LES THIS CASE ARE THE NEED FOR CAREFUL DESIGN OF THE
DEVELOPMENTAL MODEL, REALISTIC POLITICAL ASSESSMENTS AND DEVELOPMENTAL MODEL, REALISTIC POL ITI ICAL ASSESSMENTS AND
ECONOMIC ANALYSES, AND RECOGNITION THAT SUCH PROJECTS ECONOMIC ANALYSES, AND RECOGNITION THAT SUCH PROJECTS
REQUIRE DECADES BEFORE THEY ARE LIKELY TO SUCCEED.

05692 LEWIS, G.B.; ALLEE, C.L.

THE IMPACT OF DISABILITIES ON FEDERAL CAREER SUCCESS PUBLIC ADMINISTRATION REVIEW, $52(4)$ (JUL 92), 389-397. THE AUTHORS ASSESS THE IMPACT OF ANTI-DISCRIMINATION LEGISLATION ON THE CAREERS OF DISABLED FEDERAL EMPLOYEES. USING AN ANNUAL SAMPLE DRAHN FROM OPM'S CENTRAL PERSONNEL DATA FILE BETWEEN 1977 AND 1989 , THE AUTHORS STUDY HIRING
PATTERNS, GRADE-LEVEL ASSIGNMENTS, AND PROMOTIONS. THEY FIND PATTERNS, GRADE-LEVEL ASSIGNMENTS, AND PROMOTIONS. THEY FIND
THAT DISABLED FEDERAL EMPLOYEES HAVE MADE FEH GAINS IN THE THAT DISABLED FEDERAL EMPLOYEES HAVE MADE FEH GAINS IN
FEDERAL WORK FORCE EXCEPT IN NUMBERS. WHILE THEY ARE FEDERAL WORK FORCE EXCEPT IN NUMBERS. WHILE THEY ARE
CAUTIOUS IN ATTRIBUTING THESE FINDINGS TO DISCRIMINATORY PRACTICES, THE AUTHORS SUGGEST THAT GREATER ATTENTION BE PAID TO WHAT HAPPENS TO THE CAREER PATHS OF DISABLED 
AMERICANS.

05693 LEWIS, J.; HUA, D.; XUE, L. BEI JIHG'S DEFENSE ESTABLI SHMENT: SOLYING THE ARMS-EXPORT DILEMMA

INTERNATIONAL SECURITY, 15(4) (SPR 91), 87-109

THIS ARTICLE PRESENTS AN ANALYSIS OF HOW CHINA'S

MILITARY HIGH COMMAND OPERATES AND HOW IT RELATES TO THE WEAPON-EXPORT CORPORATIONS. IT THEN TRACES THE DEVELOPMENT OF THE COMPLEX WEB OF NATIONAL, INSTITUTIONAL, AND PERSONAL INCENTIVES UNDERLYING CHINA'S ARMS SALES POLICY. THE AUTHOR'S DISCUSSION EXPLAINS WHY AN APPRECIATION OF CHINA'S REASONS FOR SELLING ARMS IS CRUCIAL TO BRINGING CHINA INTO ANY COOPERATIVE HEAPON-CONTROL REGIME. THEY ARGUE THAT THE SELECTION OF CHINESE LEADERS TO BE PERSUADED, THE PRECISE TERMS OF ANY UNDERSTANDINGS, AND THE PROCESS' BY WHICH A WEAPON-CONTROL REGIME HOULD BE CREATED ARE DECISIVE FACTORS IN PERSUADING CHINA TO JOIN SUCH A REgIME.

CHINA'S BALLISTIC MISSILE PROGRAMS: TECHNOLOGIES, STRATEGIES, GOALS

INTERNATIONAL SECURITY, 17(2) (FAL 92) 5-40

CONTINUED SALES OF BALLISTIC MISSILES TO COUNTRIES IN THE MIDOLE EAST AND SOUTH ASIA HAVE INTENSIFIED

INE MIDOLE EAST AND SOUTH ASIA HAVE INTENSIFIED INTERHATIONAL INTEREST IN CHINA'S ADVANCED HEAPONS. THIS
ARTICLE FOCUSES ON PROGRAMS TO HALT THESE SALES AND THEIR ARTICLE FOCUSES ON PROGRAMS TO HALT THESE SALES AND THEIR
PURPOSES. IT DESCRIBES THE TECHNOLOGICAL AND STRATEGIC BACKGROUND OF CHINA'S CURRENT PROGRAMS FOR THE MODERNIZATION OF ITS BALLISTIC MISSILE FORCES. THE AUTHORS SEEK TO LAY THE GROUNDWORK FOR A MORE FACTUAL DISCUSSION OF THOSE WEAPONS AND THEIR POTENTIAL MISSIONS, AND TO MAKE THE CASE FOR ENCOURAGING CHINA TO SHIFT FROM MILITARY TO PEACEFUL ROCKET TECHNOLOGIES.

05695 LEWIS, J.; DAVIES, C.

PROTECTIVE LEGISLATION IN BRITAIN, 1870-1990: EQUALITY, DIFFERENCE AND THEIR IMPLICATIONS FOR WOMEN

POLICY AND POLITICS, 19(1) (JAN 91), 13-26.

PROTECTIVE LEGISLATION SETS SPECIAL CONDITIONS AROUND WOMEN'S PARTICIPATION IN THE LABOR MARKET AND INYOLVES CONSIDERATION OF HOURS, HAGES AND REPRODUCTIVE HAZARDS. FROM THE LATE NINETEENTH CENTURY, ARGUMENTS HAVE BEEN COUCHED IN HHAT CDNTEMPORARY FEMINIST THEORY CALLS THE EQUALITY VERSUS DIFFERENCE DEBATE--THE CALL, ON THE ONE HAND FOR IDENTICAL TREATMENT OF THE THO SEXES AND ON THE OTHER FOR RECOGNITION OF WOMEN'S SPECIAL NEEDS. THIS PAPER EXAMINES THE POSITIONS OF WOMEN'S SPECIAL NEEDS. THIS PAPER EXAMINES THE POSITIONS
OF FEMINISTS AND ANTI-FEMINISTS AND OF MEN-AS EMPLOYERS AND OF FEMINISTS AND ANTI-FEMINISTS AND OF MEN--AS EMPLOYERS AND
EMPLOYEES, AS TRADE UNIONISTS AND POLITICIANS--AND REVIEWS EMPLOYEES, AS TRADE UNIONISTS AND POLITICIANS-AND REYIEWS THE LEGISLATION DEVELOPMENTS AT THE TURN OF THE CENTURY AND AGAIN MORE RECENTLY. ARGUING THAT ALL HAVE IGNORED THE
STRUCTURAL DETERMINANTS OF WOMEN'S INFERIOR POSITION IN THE STRUCTURAL DETERMINANTS OF WOMEN'S INFERIOR POSITION IN THE
LABOR MARKET, IT CALLS FOR A REFORMULATION BASED ON THE LABOR MARKET, IT CALLS

05696 LEHIS, M.

THE BOY IN THE BUBBL

NEW REPUBLIC, 207(17) (OCT 92), 25, 28-29.

TRIP HITH VICE PRESIDENT DAN QUAYLE DURING HIS 1992 RE-ELECTION BID.

05697 LEHIS, $P$.

THE ANATOMY OF RULING PARTIES: DISSECTIMG TRHE VITAL ORGANS JOURNAL OF COMHUNIST STUDIES, 8(3) (SEP 92), 8-26. THE LENGTHY RULE OF THE COMHUNIST PARTY IN HUMGARY AND POLAND COULD MORE ACCURATELY BE DESCRIBED AS THAT OF ITS APPARATUS AND LEADING GROUPS WITHIN THE NATIONAL BODY. RECENT WORK ON DEVELOPMENTS IN THOSE COUNTRIES HAS UNDERTAKEN THE DISSECTION OF SUCH VITAL ORGANS. THE HEAK SOCIAL ROOTS OF COMMUNIST POWER AND POLITICAL INSTABILITY AFTER 1953 REFLECTED INITIAL SIMILARITIES; LATER, HOWEVER, DIFFERENCES, SUCH AS THE PROBLEMS OF CONTROLLING THE POLISH APPARATUS, THE STRONGER HOLD EXERTED BY KADAR OVER THE PARTY ORGANIZATION AND THE FURTHER INSTITUTIONAL I ZATION OF COMMUNIST POWER, WERE LIHKED WITH SUBSEQUENT DIFFERENCES IN TERMS OF REFORM AND POLITICAL DEVELOPMENT.

05698 LEHIS, P.G.

SAINTS AND DEMONS: COMMUNISM, POST-COMMUNISM, AND POLITICAL EVOLUTION IN POLAND

JOURMAL OF COMMUNIST STUDIES, 8(1) (MAR 92), 41-62. THE TERMINAL STATE OF POLISH COMMUNISM AND ITS FAILURE TO EVOLVE WERE EVIDENT DURING 1980-81, WELL BEFORE THE COLLAPSE OF POWER IN 1989. THE ANALYS IS OF POLITICS IN TERMS COLLAPSE OF PONER IN 1989 . THE ANALYSIS OF POLITICS IN TERMS CONTEXT BECAUSE THESE WERE PRECISELY THE TERMS IN THE POLISH COMMUNIST PERIOD HAS GENERALLY UNDERSTOOD. THE FAILURE OF COMAUNIST PERIOD HAS GENERALLY UNDERSTOOD. THE FAILURE OF POLITICAL EVOLUTION IN POLAND HAS MOST OBVIOUSLY REFLECTED IN THE COUNTRY'S POOR ECONOMIC RECORD AND ITS INABIL INTRODUCE EFF
RESISTANCE.

05699 LEHIS, $S$

A PROMISE BETRAYED
WORLD POLICY JOURNAL, VIII(3) (SUM 91), 539-550

THIS ARTICLE IS AN INTERVIEW HITH FORMER CANADIAN AMBASSADOR, STEPHEN LEWIS. LEWIS IS CRITICAL OF THE UNITED NATION'S ROLE IN THE RECENT GULF CRISIS, CHARGING THAT THE UN MERELY BOWED TO THE DEMANDS AND MUSCLE-FLEXING OF THE UNITED STATES. THE GULF WAR WAS INEVITABLE ONLY BECAUSE AS EARLY AS SEPTEMBER 1990, GEORGE BUSH DECIDED THAT HE HAS GOING TO HAVE A WAR, AND BECAUSE THE UNITED NATIONS SECURITY COUNCIL ABDICATED ITS RESPONSIBILITY. IN THE FUTURE, A MORE AGGRESSIVE SECRETARY GENERAL, INCREASED EFFORTS BY REGIONAL SECURITY ORGANIZATIONS (FOR EXAMPLE: THE ARAB LEAGUE) TO KEEP THE PEACE, THE USE OF UN PEACEKEEPING FORCES AS TRIP WIRES TO DETER CONFLICT, AND A MORE ASSERTIVE ROLE FOR THE MIDDLE POHERS SUCH AS CANADA, NEW ZEALAND, AND HOLLAND, WILL BE NECESSARY IF THE UN IS TO MAINTAIN ANY SEMBLANCE OF LEGITIMACY

05700 LEWIS, $W$

ALGERIA: THE FAILED REVOLUTION

MEDITERRANEAN OUARTERLY: A JOURNAL OF GLOBAL ISSUES, $3(4)$

(FAL 92 ), 66-74.

THE ALGERIAN EXPERIMENT IN DEMOCRACY HAS ABRUPTLY HALTED ON 11 JANUARY 1992. AND THE COUNTRY HAS RETURMED TO

AUTOCRATIC RULE. DECLARING THAT SOCIAL PEACE AND CIVIL ORDER HERE THREATED BY ISLAMIC REVOLUTION, THE ARMY REVOKED THE ELECTORAL PROCESS AND BECAME THE LAST REDOUBT OF STATE AUTHORITY. THE FUNDAMENTALIST MOVEMENT HAVE BEEN DRIVEN UNDERGROUND AND IT HOULO APPEAR THAT THE GOVERNMENT HAS RADICALIZED THE SALVATION FRONT, PLACING ITS CONTROL IN THE HANDS OF ACTIVISTS PREPARED TO WEAKEN THE STATE BY CHALLENGING ITS CAPACITY TO RESTORE ORDER. THIS ARTICLE CONCLUDES THAT IN THE PROCESS. THE MILITANTS HAVE REGISTERED SOME SIGNIFICANT GAINS IN SECURING A MEASURE OF SUPPORT WITHIN THE ARMY.

05701 LEYENAAR, M.

WOMEN IN PUBLIC ADMINISTRATION IN THE NETHERLANDS WOMEN AND POLITICS, 1(4) (1991), 41-54.

THIS ARTICLE REVIEHS THE CURRENT POSITION OF WOMEN IN GOVERMMENTAL SERVICE IN THE NETHERLANDS AS HELL AS THE CONCRETE POLICIES TAKEN BY THE GOVERNMENT TO INCREASE THE NUMBER OF WOMEN EMPLOYEES. THE FIRST SECTION DESCRIBES THE GENERAL SITUATION OF WOMEN IN THE LABOR MARKET IN THE NETHERLANDS WITH SPECIAL ATTENTION TO THOSE IN GOVERMMENTAL SERVICE. THE SECOND SECTION DISCUSSES THE POLICIES TAKEN BY THE GOVERMMENT TO STRENGTHEN THE POSITION OF ITS WOMEN EMPLOYEES. THE LAST SECTION CONTAINS THE RESULT OF INTERVIEWS HELD WITH WOMEN IN THE DEPARTMENT OF ECONOMICS AND DISCUSSES OTHER RESEARCH FINDINGS CONCERMING BARRIERS AND DISCUSSES OTHER RESEARCH FINDINGS CONCERNING BARRI
FOR THE ADVANCEMENT OF WOMEN IN PUBLIC ADMINISTRATION.

05702 LI, Y.

U.S.-E.C. TRADE ROW

BEI JING REVIEW, 35(47) (NOV 92), 16

ON NOVEMBER 5,1992 , U.S. TRADE REPRESENTATIVE CARLA HILLS ANMOUNCED THAT THE UNITED STATES HAD NO CHOICE BUT TO TAKE RETALIATORY TRADE MEASURES AGAINST THE EUROPEAN COMMUNITY, DUE TO THE BREAKDOWN IN NEGOTIATIONS. THE FIRST PUNITIVE TARIFFS WILL BE AIMED PRIMARILY AT FRANCE.

05703 LIANGQI, L.

DIALOGUE ON SOCIALIST MARKET ECONOMY

BEI JING REVIEH, 35(43) (OCT 92), 34-38.

THIS IS AN INTERVIEH WITH GONG YUZHI, FORMER DEPUTY-HEAD OF PROPAGANDA OF THE CHINESE COMMUNIST PARTY'S CENTRAL COMMITTEE IN CHARGE OF THEORETICAL WORK. GONG DISCUSSES THE CONCEPT OF THE SOCIALIST MARKET ECONOMY AND EXPLAINS WHY THE MARKET ECONOMY IS NOT LIMITED TO A CAPITALIST SYSTEM. HE PREDICTS THAT CHINA WILL MAKE GREATER EFFORTS TO FULLY

DEVELOP A MARKET ECONOMY, FOLLOWING THE 14TH PARTY CONGRESS.

05704 LIANGQI, L.

TIBET'S HISTORICAL STATUS

BEI JING REVIEW, 35(52) (DEC 92), 20-21.

IN THIS INTERVIEW, A SCHOLAR OF TIBETAN HISTORY RESPONDS TO CRITICISM OF THE CHINESE GOVERNMENT'S WHITE PAPER

ENTITLED "TIBET: ITS OWNERSHIP AND HUMAN RIGHTS SITUAIION." HE ARGUES THAT THE DALAI LAMA IS MISTAKEN WHEN HE CLAIMS

THAT TIBET IS AN INDEPENDENT COUNTRY SUBJUGATED BY CHINA.

05705 LIBAL, H.

TWO UNEXPLAINED IMCIDENTS IN EX-YUDGOSLAYIA

GERMAN TRIBUNE, 31(1543) (DEC 92$), 2-3$.

THO BLOODY ANO AS YET UNEXPLAINED INCIOENTS REINFORCE SUSPIC? JN THAT THERE ARE FORCES AT HORK IN THE REGION IN THE SOUTH OI FORMER YUGOSLAVIA. WITH AN INTEREST IN CREATING DISTURBANCES AND ARMED CONFRONTATIONS BETWEEN MACEDONIANS AND ALABANIANS, OR BETHEEN ALBANIANS AND THE SERBIAN POLICE OR ARMY. THE PROSPECTS FOR PEACFUL REFORM IN THIS REGION ARE POOR.

05706 LIBECAP, G.D.

BUREAUCRATIC ISSUES AND ENVIRONMENTAL CONCERNS: A REVIEH OF THE HISTORY OF FEDERAL LAND OWMERSHIP AND MANAGEMENT 
HARVARD JOURNAL OF LAW AND PUBLIC POLICY, 15(2) (SPR 92), $467-488$.

THE AUTHOR REVIEWS THE HISTORY OF FEDERAL OHNERSHIP OF PUBLIC LANDS, BEGINNING HITH THE GENERAL REVISION ACT OF 1891, WHICH BECAME THE BASIS FOR PERMANENT BUREAUCRATIC MANAGEMENT OF FEDERAL LAMDS. IN ADDITION. HE SUAMARIZES SOME CRITICISMS OF THE MANAGEMENT OF THE ENVIRONMENT ON FEDERAL LANDS AND EXPLORES THE CRITICAL INSTITTUTIONAL FACTORS AFFECTING DECISION MAKING WITHIN THE FEOERAL LAND MANAGEMENT AGENCIES. THE INSTITUTIONAL STRUCTURE CRITICALLY AFFECTS HOW THE BLM AND THE FOREST SERVICE WILL RESPOND TO PRESSURES FOR ALTERMATIVE MANAGEMENT OF FEDERAL LANDS INVOLVING PRIVATE PROPERTY RIGHTS AND MARKET PROCESSES.

05707 LICHTENSTEIN, C.

U.S. RESTRUCTURING LEGISLATION: REVISING THE INTERNATIONAL ACT 1978 , FOR THE WORSE?

FORDHAM LAW REVIEH, LXं(6) (MAY 92), 37-52.

THE FEDERAL DEPOSIT INSURANCE CORPORATION IMPROVEMENT ACT OF 1991 CONTAINS SEYERAL SECTIONS DEALING HITH THE REGULATION OF FOREIGN BANKS IN THE UNITED STATES. IN THIS ARTICLE, THE AUTHOR GIVES A CRITICAL ANALYSIS OF THE NEW FOREIGN-BANK LEGISLATION. AFTER ARGUING THAT THESE LEGISLATIVE CHANGES DO NOT ADEQUATELY ADDRESS THE EMERGING GLOBAL FINANCIAL MARKETPLACE, THE ARTICLE OFFERS A MODEST PROPOSAL FOR REVISING TH U.S. REGULATORY STRUCTURE.

05708 LICHTMAN, A.; ISSACHAROFF, S.

BLACK/WHITE VOTER REGISTRATION DISPARITIES IN MISSISSIPPI: LEGAL AKD METHODOLOGICAL ISSUES CHALLENGING BUREAU OF CENSUS DATA

JOURNAL OF LAH \& POLITICS, VII(3) (SPR 91), 525-558.

THE CHALLENGE BY BLACK POL ITICAL GROUPS TO THE MISSISSIPPI DUAL REGISTRATION REQUIREMENTS (WIDELY THOUGHT TO BE DISCRIMINATORY) WAS BLOCKED BY A MAJOR EVIDENTIARY HURDLE: INFORMATION FROM A NOVEMBER 1984 CURRENT POPULATION SURVEY (CPS) CLAIMED THAT THE LEVEL OF BLACK VOTER REGISTRATION. THIS ARTICLE EXPLAINS HOW A STUDY BY OPERATION PUSH CHALLENGED THE CENSUS. IT IDENTIFIES THE PROBLEMS WITH THE CENSUS SURVEY OF BLACX AND WHITE VOTER REGISTRATION; THE CENSUS SURVEY OF BLACK AND WHITE VOTER REGISTRAT
PROVIDES EXPLANATIONS FOR INACCURACIES IN SURVEYS OF PROVIDES EXPLANATIONS FOR INACCURACIES IN SURVEYS OF
REGISTRATION RATES; AND CONSIDERS THE RACIAL DIFFERENCES IN REGISTRATION RATES; AND CONSIDERS THE RACIAL DIFFERENCES IN
OVERREPORTING OF REGISTRATION AND TURNOUT. THE ARTICLE ALSO OVERREPORTING OF REGISTRATION AND TURNOUT. THE ARTICLE ALSO
PROVIDES A NEH METHOD FOR ANALYZING BLACK AND WHITE YOTER PROVIDES A NEW METHOD
REGISTRATION RATES.

05709 LIDDLE, R.H.

INDONESIA'S DEMOCRATIC PAST AND FUTURE

COMPARATIVE POLITICS, 24(4) (JUL 92), 443-462.

WOULD-BE DEMOCRATIZERS IN INDONESIA FACE THO DAUNTING OBSTACLES: (1) POLITICAL POWER IS HELD BY A MILITARY ELITE THAT BELIEVES DEMOCRACY IS INCOMPATIBLE WITH NATIONAL UNITY AND ECONOMIC DEVELOPMENT; (2) THE POLITICAL AND ECONOMIC STRATEGIES ADOPTED BY THE ELITE HAVE WULTIPLIED MANY TIMES OVER THE POL ITICAL RESOURCES IT POSSESSES RELATIVE

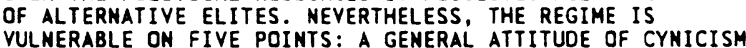
TOWARD THE REGIME'S DEMOCRATIC PRETENTIONS, A PERSISTENT TENSION BETHEEN CIVILIAN AND MILITARY SUB-ELITES, AN EXAGGERATED ELITE PERCEPTION OF THE DANGERS FROM MASS POLITICAL CLEAVAGES, A GULF BETWEEN RICH AND POOR WIDELY ATTRIBUTED TO GOVERHMENT POLICIES, AND A SERIES OF SUCCESSION-RELATED HAIRLINE CRACKS WITHIN THE TOP MILITARY LEADERSHIP. DEMOCRATIZERS MAY BE ABLE TO EXPLOIT THESE VULNERABILITIES THROUGH STRATEGIES OF CHANGING ELITE BELIEFS ABOUT THE ROLES OF EXECUTIVES AND PARTY SYSIEMS IN DEMOCRACIES AND OF IMPROVING THE POLITICAL RESOURCE POSITION OF NON-ELITES.

05710 LIDOLE, R.H.

INDONESIA'S THREEFOLD CRISIS

JOURNAL OF DEMOCRACY, 3(4) (OCT 92), 60-74.

IN INDONESIA TODAY, THE SUHARTO GOVERMMENT IS FACIMG A SUCCESSION CRISIS. IN ADOITION, A CRISIS OF COMHUNITY, OF THE INTEGRITY OF THE INDONESIAN NATION-STATE, HAS DEVELOPED TOVERMMENT'S BURDENS. IT IS HARD TO EVALUATE WHETHER THE IMPACT OF THESE THO CRISIS ON THE "NEW ORDER" WILL PROMOTE DEMOCRATIZATION, MAINTENANCE OF THE STATUS QUD, OR INCREASED REPRESSION OVER THE LONG TERM. AT PRESENT, IT APPEARS THAT THE SUCCESSION CRISIS IS TERM. AT PRESENT, IT APPEARS THAT THE SUCCESSION CRISIS IS OF THE NEH ORDER THE STRONG PRES WDECY HHILE THE COMMUNITY CRISIS HAS BEGUN' TO LOOSEN THE SECOND PILLAR, THE ARMY'S CRISIS HAS BEGUN TO LOOSEN THE SECOND PILLAR, THE ARMY'S DIRECT ROLE IN NATIONAL POLITICAL LIFE. HOWEVER, THESE PROCESSES HAVE ONLY JUST BEGUN AND MAY BE REVERSED IF
DECISIVE STEPS ARE TAKEN SOON. ON THE OTHER HAND, IF THE CRISES ARE PROLONGED, MAJOR REGIME TRANSFORMATION HILL CRISES ARE PROLONGED, MAJOR REG

05711 LIDDLE, R.H.

PRESIDENTIAL SUCCESSION AND THE PROSPECTS FOR

DEMOCRATIZATION IN INDONESIA; ASSOCIATION FOR ASIAN

STUDIES 1992 ANNUAL MEETING

ASSOCIATION FOR ASIAN STUDIES, 1992, 155.
THE FORTHCOMING PRESIDENTIAL SUCCESSION IN IMDONESIA CREATES POSSIBILITIIES FOR OLD AND NEW FORCES TO INCREASE THEIR INFLUENCE, HHICH COULD LEAD TO A MORE DEMOCRATIC POLITICAL PROCESS. PRESIDENT SUHARTO, NOH 70, SEEMS UNWILLING TO RETIRE, BUT HE IS LIKELY TO EITHER STEP DOWN OR DIE IN OFFICE DURING THE 1990S. AT THIS POINT, THE TOP MILITARY LEADERSHIP WILL ATTEMPT TO CONTROL THE SUCCESSION, ENSURING THAT ONE OF THEIR OWH BECOMES THE NEH PRESIDENT. MANY OTHER GROUPS--JUNIOR MILITARY OFFICERS, QUASI-MILITARY AND CIVILIAN BUREAUCRATIC FACTIONS, MIDDLE- AND UPPER-CLASS BUSINESS PEOPLE, PROFESSIONALS, ISLAMIC "ABANGAN, "CHRISTIAN INTELLECTUALS AND ORGANIZATIONS, ACTIVIST NON-GOVERMMENTAL ORGANIZATIONS PURSUING DEVELOPMENT AND ENVIRONMENTAL AGENDAS AND UNIVERSITY STUDENTS--ARE LIKELY TO SEEK TO PLAY A ROLE
IN THIS PROCESS, AT LEAST TO THE EXTENT OF EXPANDING THEIR IN THIS PROCESS, AT LEAST TO THE EXTENT OF EXPANDING
ROON TO MANEUVER UNDER THE NEW PRESIDENT. THIS PAPER ASSESSES THE POLITICAL RESOURCES OF THESE VARIOUS GROUPS AND ASSESSES THE POLITICAL RESOURCES OF THESE VARIOUS GROUPS
THE PROBABLE DYNAMIC OUTCOME OF THE SUCCESSION PROCESS.

05712 LIDDLE, R.W.

THE POLITICS OF DEVELOPMENT POLICY

WORLD DEVELOPMENT, 20(6) (JUN 92), 793-807.

THE AUTHOR CRITICIZES THEORIES OF THE CAUSES OF

UNDERDEVELOPMENT IN THE THIRD HORLD FOR A LACK OF ATTENTION TO POLICY, FOR FOCUSING ON ABSTRACTED AND NARROHLY-CONCEIVED VARIABLES, AND FOR AN EXCESSIVE CONCERN HITH GENERALIZATION. HE ASSESSES AND REFORMULATES TWO MORE PROMISING APPROACHES: (1) ANALYSIS OF THE CALCULATIONS OF POLITICIANS AND OFFICIALS WHEN THEY MAKE POLICY DECISIONS AND (2) ANALYSIS OF THE IMPLICATIONS OF CERTAIN ECONOMIC VARIABLES AND POLICIES FOR THE POLITICS OF POLICY MAKING. THEN HE ILLUSTRATES THE MERITS OF THESE APPROACHES WITH CASES FROM CURRENT RESEARCH ON THE POLITICS OF DEVELOPMENT POLICY IN INDONESIA.

05713 LIDSKOG, R.; ELAMDER, I. REINTERPRETING LOCATIONAL CONFLICTS: NIMBY AND NUCLEAR WASTE MANAGEMENT IN SWEDEN

POLICY AND POLITICS, 20(4) (OCT 92), 249-264.

AFTER A DESCRIPTION OF SWEDEN'S NATIONAL POLICIES REGARDING NUCLEAR ENERGY AND NUCLEAR WASTE MANAGEMENT, THE AUTHORS CRITICALLY EXAMINE THE CONVENTIONAL WAY OF AUTHORS CRITICALLY EXAMINE THE CONVENTIONAL WAY OF
INTERPRETING LOCAL CONFLICT IN TERMS OF NIMBY (NOT IN MY INTERPRETING LOCAL CONFLICT IN TERMS OF NIMBY (NOT IN MY
BACKYARD). THEY ANALYZE A LONGSTANDING LOCAL CONFLICT OVER BACKYARD). THEY ANALYZE A LONGSTANDING LOCAL CONFLICT OVER
THE ISSUE OF NUCLEAR WASTE MANAGEMENT IN SWEDEN AND CONCLUDE THE ISSUE OF NUCLEAR WASTE MANAGEMENT IN SWEDEN AND CONCLUDE THAT THE LOCAL PROTEST IN THIS CASE SHOULD NOT BE DISHISSED
AS A PURELY SELFISH REACTION TO A RESPONSIBLE POLICY IN THE PUBL PUREL SELFISH REACTION TO A RESPONSIBLE POLICY PUBLIC INTEREST. INSTEAD, THEY SUGGEST THAT THE LOCAL
PROTEST GROUPS, BY BRINGING INTO FOCUS THE ISSUE OF WASTE PROTEST GROUPS, BY BRINGING INTO FOCUS THE ISSUE OF WASTE
PRODUCTION, ARE CONTRIBUTING TO A LONG-TERM RESPONSIBLE POLICY FOR STOPPING THE PRODUCTION OF ANY FORM OF HAZARDOUS POLICY

05714 LIE, J.

THE CONCEPT OF MODE OF EXCHANGE AMERICAN SOCIOLOGICAL REVIEH, 57(4) (AUG 92), 508-523. THE NEOCLASSICAL CONCEPT OF THE MARKET FAILS TO CONSIDER SOCIAL RELATIONS AND STRUCTURES. THE AUTHOR PRESENTS SOCIOLOGICAL CONCEPT OF "MODE OF EXCHANGE" AS AN ALTERNATIVE AND DISTINGUISHES FOUR MODES OF EXCHANGE BASED ON WHETHER TRADE IS OPEN TO POPULAR PARTICIPATION ANO WHETHER TRADE IS PRIMARILY HITHIN A REGION OR ACROSS REGIONS. THE SOCIAL STRUCTURAL CONDITIONS THAT UNDERLIE EACH MODE OF EXCHANGE INCLUDE THE LEVEL OF STRATIFICATION AND POLITICAL CENTRALIZATION. THE POWER STRUGGLE AMONG GROUPS FOR CONTROL OVER TRADE, RATHER THAN INDIVIDUAL UTILITY MAXIMIZATION, IS A CRITICAL FACTOR IN COMMERCIAL DEVELOPMENT. THE AUTHOR APPLIES THIS FRAMEWORK TO THE COMMERCIAL DEVELOPMENT OF ENGLAND AND JAPAN.

05715 LIEBERTHAL, $K$.

CHINA'S POLITICAL SYSTEM IN THE 1990 S

JOURNAL OF NORTHEAST ASIAN STUDIES, 10(1) (SPR 91), 71-77.

ANALYSTS DIFFER GREATLY IN THEIR ASSESSMENTS OF' THE LONGTERM STABILITY OF THE CHINESE POLITICAL SYSTEM. THIS ARTICLE ARGUES THAT CHINA'S PROBABLE FUTURE IS ONE OF CONTINUED ARGUES THAT CHINA'S PROBABLE FUTURE IS ONE OF CONTINUED
POLITICAL MUDDLING THOUGH. THE ARTICLE EXAMINES THE TYPES OF POLITICAL MUDDLING THOUGH. THE ARTICLE EXAMINES THE TYPES OF
RELATIONSHIPS THAT WILL DEVELOP BETWEEN THE RAPIDLY GROWING RELATIONSHIPS THAT WILL DEVELOP BETWEEN THE RAPIDLY GROWING
COASTAL AREAS AND THE MORE SLOWLY ADVANCING INTERIOR; AND COASTAL AREAS AND THE MORE SLOWLY ADVANCING INTERIOR:
THE EFFICACY OF THE POLITY IN DEALING HITH LOOMING THE EFFICACY OF THE POLITY IN DEALING WITH LOOMING
ENVIRONMENTAL AND DEMOGRAPHIC CRISES. TO ADORESS THESE ENVIRONMENTAL AND DEMOGRAPHIC CRISES. TO ADORESS THESE PROBLEMS, THIS ARTICLE ASSESSES THE POL ITICAL SYSTEM'S
OVERALL STRENGTHS, DEFICIENCIES, AND CHALLENGES IN THE OVERALL STRENGTF
COMING YEARS.

05716 LIEBERTHAL, $K$

THE FUTURE' OF HONG KONG

ASIAN SURYEY, XXXIII (7) (JUL 92), 666-682.

THE FUTURE OF HONG KONG IS AN ISSUE OF GREAT UNCERTAINTY. THIS ARTICLE OUTLINES TWO POSSIBLE SCENARIOS FOR THE FUTURE OF HONG KONG AS THE DATE FOR ITS TRANSFER TO PRC SOVEREIGNTY APPROACHES. ONE IS CAUTIOUSLY OPTIMISTIC. IT POINTS TO EIGHT FACTORS WHICH FAVOR BASIC STABILITY AND REASONABLE GROWTH. 
HAVE PLACED ON STABILITY; HONG KONG'S PROSPERITY; THE ADVATANGES TO THE PRC OF CONTIMUING HONG KONG'S "SEPARATE STATUS"; THE EFFORTS OF KEY HONG KONG CHINESE BUSINESSMEN TO BUILD BRIDGES TO THE MAINLAND; THE "TAIWAN CONMECTION": THE GROWTH OF JAPANESE INVESTMENT IN HONG KONG; AND HONG KONG'S SKILLS AND FACILITIES. THE SECOND, MORE PESSIMISTIC,

SCENARIO POINTS TO THE GRONING FEAR AND FLIGHT IN THE COLONY; THE THREAT OF POLITICAL INSTABILITY IN THE PRC; THE TENSION BETWEEN HONG KONG'S LAISSEZ FAIRE ECONOMICS AND THE PRC'S INTERVENTIONIST STANCE; AND INTERNAL STRESSES.

05717 LIEBERTHAL, K. (ED.); LAMPTON, D. (ED.) BUREAUCRACY, POLITICS, AND DECISION MAKING IN POST-MAO CHINA

UNIVERSITY OF CALIFORNIA PRESS, 1992, 384

USING A MODEL OF "INSTITUTIONAL PLURALISH," THIS VOLUME SHARPENS OUR VIEW OF THE INNER HORKINGS OF THE CHINESE BUREAUCRACY. THE CONTRIBUTORS' INTERVIEWS WITH POLITICALLY WELL-PLACED BUREAUCRATS AND SCHOLARS, ALONG WITH DOCUMENTARY AND FIELD RESEARCH, ILLUMINATE THE BARGAINING AND MANEUVERING AMONG OFFICIALS ON THE NATIONAL, PROVINCIAL, AND LOCAL LEVELS.

05718 LIGHT, M.

MOSCOW'S RETREAT FROM AFRICA

JOURMAL OF COMMUNIST STUDIES, 8(2) (JUN 92), 21-40.

LOMG BEFORE MIKHAIL GORBACHEY CAME TO POHER, SOVIET POLICY MAKERS KNEW THAT THE COSTS OF FURTHER INVOLVEMENT IN AFRICA WERE TOO HIGH. ALREADY DOUBTING WHETHER POOR AFRICAN COUNTRIES COULD BECOME PROPER SOCIALIST STATES, BY 1985 THEY UNDERSTOOD THAT THEIR POLICY IN AFRICA WAS HINDERING THE ACHIEVEMENT OF HIGHER-PRIORITY FOREIGN POLICY GOALS. BUT IT WAS PERESTROIKA THAT MOST PROFOUNOLY AFFECTED SOVIET POLICY IN AFRICA. FOREIGN AID AND MILITARY INVOLVEMENT BECAME A CONTROVERSIAL ISSUE AND, AS THE DOMESTIC ECONONY DETERIORATED, THE SOVIET UNION CEASED TO HAVE THE MEANS TO PURSUE AN ACTIVE POLICY IN AFRICA. WHAT HAD BEGUN AS DELIBERATE RETRENCHMENT TURNED INTO FORCED RETREAT.

05719 LIHUA, Y

SOUTH AFRICAN REFERENDUM: A DECISIVE 'YES'

BEIJING REVIEW, 35(15) (APR 92), 12-13.

ON FEBRUARY 20,1992 , SOUTH AFRICAN PRESIDENT F.H. DEKLERK ANHOUNCED THAT A WHITES-ONLY REFERENDUM WOULD BE HELD TO DECIDE WHETHER POLITICAL REFORMS SHOULD CONTINUE. THE CONSERVATIVE PARTY CLAIMED THAT CONTINUED REFORM WOULD LEAD TO DOMINATION BY THE AFRICAN NATIONAL CONGRESS AND THE SOUTH AFRICAN COMMUNIST PARTY AND HOULD MEAN THE POLITICAL SOUTH AFRICAN COMUNIST PARTY AND WOULD MEAN THE POLIT
SUICIDE OF WHITES. NEVERTHELESS, 68.7 PERCENT OF THE SUICIDE OF WHITES. NEVERTHELESS, 68.7 PERCEN
ELECTORATE VOTED TO PROCEED HITH THE REFORM.

05720 LIJPHART, A.

DEMOCRATIZATION AND CONSTITUTIONAL CHOICES IN CZECHOSLOVAKIA, HUNGARY, AND POLAND, 1989-1991 JOURNAL OF THEORETICAL POLITICS, 4(2) (APR 92), 207-223. CZECHOSLOVAKIA, HUNGARY, AND POLAND HAVE MADE DIFFERENT CONSTITUTIONAL CHOICES REGARDING THEIR NEW ELECTORAL SYSTEMS AND THEIR NEW FORMS OF GOVERMMENT. STEIN ROKKAN HAS OFFERED TWO EXPLANATIONS FOR THE ADOPTION OF PROPORTIONAL REPRESENTATION IN CONTINENTAL HESTERN EUROPE CIRCA 1900: (1) THE LOGIC OF DEMOCRATIZATION (WHICH REQUIRES A BARGAIN BETHEEN THE OLD, ESTABLISHED PARTIES AND THE NEH PARTIES) AND (2) THE NEEDS OF ETHNICALLY-DIVERSE SOCIETIES. THESE EXPLANATIONS, WHICH CAN BE LOGICALLY EXTENDED TO THE CHOICE OF PARLIAMENTARIANISH OR PRESIDENTIALISM, ARE ALSO THE BEST RATIONALES FOR THE CONSTITUTIONAL CHOICES OF CZECHOSLOVAKIA, HUNGARY, AND POLAND CIRCA 1990. THESE FACTORS WERE REINFORCED, BUT NOT FUNDAMENTALLY DETERMINED, BY THE ATTACHMENT TO SINGLE-MEMBER DISTRICT REPRESENTATION, THE DISTRUST OF POLITICAL PARTIES, THE INFLUENCE OF EARLIER AND FOREIGN DEMOCRATIC MODELS, AND INACCURATE ASSESSMENTS OF PARTISAN STRENGTH.

05721 LIKHOTAL, A.

THE NEW RUSSIA AND EURASIA

SECURITY DIALOGUE, 23(3) (SEP 92), 9-18.

FOR RUSSIA, THE CIS REPRESENTS THE LAST CHANGE TO KEEP FORMER SOVIET REPUBLICS TOGETHER IN A LOOSE STRUCTURE. NEH CONFRONTATIONS ARE INEVITABLE IF THE CIS COLLAPSES: EUROPEAN SECURITY AND THE BALANCE OF FORCES IN THE ASIA/PACIFIC MAY BE JEOPARDI ZED. FORMATION OF DEMDCRACY IS A LONG PROCESS IN RUSSIA. THE MAJOR THREAT OF RETURN TO TOTALITARIANISM MAY COME FROM EXTERNAL PRESSURES OF NATIONAL COMMUNIST REGIMES FROM COLLAPSE OF THE ARMY AND FROM FLOWS OF REFUGEES. THIS, AUTHOR ARGUES THAT THE WEST MUST NOT ENCOURAGE NATIONALISM, CONFRONTATION OR THE RESORT TO FORCE FROM ANYONE.

05722 LILE, S.E.

FAMILY TAX BURDENS: HOW DO THE STATES COMPARE? JOURNAL OF STATE GOVERMMENT, 65(4) (FAL 92), 6-15 STATE AND LOCAL TAXES CAN HAVE A SIGNIFICANT IMPACT ON THE RELATIVE ECONOMIC HELL-BEING OF PEOPLE IN DIFFERENT LOCATIONS. IN THIS ARTICLE, THE AUTHOR PRESENTS THE RESULTS OF A STUDY COMPARING THE TAX BURDEN FOR FAMILIES AT
DIFFERENT INCOME LEVELS IN MAJOR CITIES. THE DATA INDICATES WIDE VARIATIONS IN HOW DIFFERENT TYPES OF TAXES ARE USED AMD VARIATIONS IN THE DEGREE
REGRESSIVE OR PROGRESSIVE.

05723 LILIENTHAL, A.M.

USING ISRAEL TO PANDER FOR THE JEWISH VOTE HASN'T CHANGED SINCE 1948

WASHINGTON REPORT ON MIDOLE EAST AFFAIRS, XI(3) (AUG 92),

45. 91.

THE AUTHOR LOOKS AT HOW U.S. PRESIDENTIAL CANDIDATES
HAVE SUPPORTED ISRAEL IN ORDER TO COURT THE JEWISH VOTE.

05724 LIM, D.

INTER-KOREAN RELATIONS ORIENTED TOWARD RECONCILIATION AND COOPERATION

KOREA \& WORLD AFFAIRS, 16(2) (SUM 92), 213-223.

THE AUTHOR LOOKS AT RECENT PROGRESS IN IMPROVING

RELATIONS BETHEEN NORTH AND SOUTH KOREA, FOCUSING ON THE

AGREEMENT ON RECONCILIATION, NON-AGGRESSION, AND EXCHANGES

AND COOPERATION BETHEEN THE SOUTH AND THE NORTH, WHICH WENT

INTO EFFECT ON FEBRUARY 19, 1992.

05725 LIM, J.

MARX'S THEORY OF IMPERIALISM AND THE IRISH NATIONAL QUESTION

SCIENCE AND SOCIETY, 56(2) (SUM 92), 163-178.

THE IRISH MATIONAL QUESTION IS LOCATED ON A TURNING POINT IN THE EVOLUTION OF MARX'S AND ENGEL'S THOUGHT WITH RESPECT TO NATIONAL AND COLONIAL ISSUES. DISCUSSING THE IRISH NATIONAL QUESTION, MARX AND ENGELS SUCCEEDED IN ESCAPING FROM THEIR EARLIER EUROCENTRIC VIEW. THE IRISH QUESTION INVOLVES A MATTER OF PRINCIPLE IN THE MARXIST THEORY OF NATIONALISH, BRIDGING THE GAP BETWEEN THE FOUNDERS OF MARXISM IN THE CLASSICAL ERA OF CAPITALISM AND LENIN IN THE ERA OF IMPERIALISM.

05726 LIMAGY, $S$.

UNITED STATES--INDIAN DEFENSE COOPERATION

STUDIES IN CONFLICT AND TERRORISH, 15(4) (1992), 317-338.

THIS ARTICLE EXAMINES THE CHANGING NATURE OF U.S.-INDIAN

DEFENSE RELATIONS DURING THE PAST DECADE. SPECIFICALLY, IT COVERS THE MOTIVATIONS, MANNER, AND MANIFESTATIONS OF THE QUALITATIVE AND QUANTITATIVE EXPANSION OF MILITARY

COOPERATION. PARTICULAR ATTENTION IS PAID TO THE POLICY AND PERCEPTUAL CHANGES THAT FACIIITATED DEFENSE COOPERATION AND THE MECHAMISMS DEVELOPED TO IMPLEMEMT THE MUTUALLY AGREED THE MECHANISHS DEVELOPED TO IMPLEMENT THE MUTUALLY AGREED CLOSE U.S. - IMDIAN DEFENSE TIES ARE NOTED.

05727 LIN, C

CONTROLLIMG RAPID INFLATION: EAST ASIA VERSUS LATIN AMERICA; LATIN AMERICA VS. EAST ASIA: A COMPARATIVE DEVELOPMENT PERSPECTIVE

M. E. SHARPE, $1989,128-190$. THIS CHAPTER REVIENS THE DIVERGENCE IN THE EXPERIENCES OF INFLATION AND STABILIZATION BETWEEN EAST ASIA AND LATIN AMERICA DURING THE POSTWAR DECADES. IT ALSO REVIEWS THE REFORM OF TRADE POLICIES AND KEY INSTITUTIONS IN THE EAST ASIAN COUNTRIES THAT HELPED THEM ESTABLISH A SUSTAINABLE PATTERN OF ECONOMIC GROWTH, AND THE RELATIVE LACK OF SUCH REFORMS IN THE LATIN AMERICAN COUNTRIES, WHICH LED TO THE PERPETUATION OF THE VISCOUS CIRCLE OF BALANCE OF PAYMENTS CRISES, PERSISTENT INFLATION, AMD SLUGGISH ECONOMIC GROWTH. TOPICS INCLUDING THE INTERACTIONS BETWEEN EXPORT GROWTH AND DOMESTIC PRICE STABILITY; THE CONSEQUENCES OF DIFFERENT POLICY RESPONSES TO EXTERNAL SHOCKS, AND THE LATEST

STABILIZATION EFFORTS IN LATIN AMERICA, ARE ALSO DISCUSSED.

05728 LIN, C.

LATIN AMERICA VS. EAST ASIA: A COMPARATIVE DEVELOPMENT PERSPECTIVE

M.E. SHARPE, $1989,231$.

DURING THE EARLY $1980 S$, A NUMBER OF LATIN AMERICAN COUNTRIES EXPERIENCED SEVERE DEBT-SERVICE PROBLEMS, RAPID INFLATION, AND STAGNANT ECONOMIC GRONTH. BY CONTRAST, MOST EAST ASIAN COUNTRIES, WHICH HAD ATTAINED RAPID ECONOMIC GROWTH AND STABLE DOMESTIC PRICES DURING THE 1960S, MANAGED TO CONTROL THE RESURGENT INFLATION AND EXTERNAL DEFICITS RAPIDLY, THEREBY RESUMING NONINFLATIONARY ECONOMIC GROWTH ALONG WITH THE RECOVERY OF THE HORLD ECONOMY IN 1983. THIS BOOK SEEKS TO EXAMINE AND EXPLAIN THIS DIVERGENCE IN BOOK SEEKS TO EXAMINE AND EXPLAIN THIS DIVERGENCE IN
ECONOMIC PERFORMANCE BETHEEN MANY COUNTRIES IN THE TWO ECONOMIC PERFORMANCE BETHEEN MANY COUNTRIES IN THE TWO
REGIONS. IT EXAMINES THE MAJOR LATIN AMERICAN COUNTRIES' REGIONS. IT EXAMINES THE MAJOR LATIN AMERICAN COUNTRIES
ECONOMIC PROBLEMS AND DEVELOPMENT EXPERIENCES IN LIGHT OF ECONOMIC PROBLEMS AND DEVELOPMENT EXPERIENCES IN EXPERIENCES OF THE EAST ASIAN COUNTRIES, PARTICULARLY TAIWAN EXPERIENCES OF THE
AND SOUTH KOREA.

05729 LIN, C.

LATIN AMERICA VS. EAST ASIA: A COMPARATIVE DEVELOPMENT PERSPECTIVE

M.E. SHARPE, 1989, 191-198. THIS CHAPTER SUMMARIZES THE DIVERGENT EXPERIENCES OF THE 
EAST ASIAN AND LATIN AMERICAN COUNTRIES WITH RESPECT TO EXPORT EXPANSION, ECONOMIC GROWTH,A ND PRICE STABILIZATION, AND DISCUSSES THE POLICY IMPLICATIONS FOR THE LATIN AMERICAN
COUNTRIES FROM THE PERSPECTIVES OF THE EAST ASIAN COUNTRIES.

05730 LIN, C

POLICY REFORMS, INTERNATIONAL COMPETITIVENESS, AND EXPORT PERFORMANCE: CHILE AND ARGENTINA VERSUS TAIWAN AND SOUTH KOREA; LATIN AMERICA VS. EAST ASIA: A COMPARATIVE DEVELOPMENT PERSEPCTIVE

M.E. SHARPE, 1989, 7-72.

THIS CHAPTER COMPARES THE EXPORT AND MACROECONOMIC

PERFORMANCE OF CHILE AND ARGENTINA VERSUS TAIWAN AND KOREA

IN THE PERIOD BEFORE THE FIRST OIL SHOCK. IT DISCUSSES THE

IN THE PERIOD BEFORE THE FIRST OIL SHOCK. IT DISCUSSES
KEY FACTORS UNDERLYING THE DIVERGENCE IN PERFORMANCE

KEY FACTORS UNDERLYING THE DIVERGENCE IN PERFORMANCE

INCLUDING THE DIFFERENCES IN TRADE POLICIES AND IN THE
CONTROL OF INFLATION. IN ADDITION, THIS CHAPTER REVIEWS THE

EXTENSIVE POLICY REFORMS OF CHILE AND ARGENTINA IN THE 1970 S EXTENSIVE POLICY REFORMS OF CHILE AND ARGENTINA IN THE 1970
AND DISCUSSES THE ASSOCIATED DIFFICULTIES IN LIGHT OF THE AND DISCUSSES THE ASSOCIATED DIFFICULTIES IN LIGHT OF THE MORE SUCCESSFUL REF

05731 LIN, C.

POLICY RESPONSE TO EXTERNAL SHOCKS: BRAZIL VERSUS TAIHAN AND SOUTH KOREA; LATIN AMERICA VS. EAST ASIA: A

COMPARATIVE DEVELOPMENT PERSPECTIVE

M.E. SHARPE, , 1989, 73-127.

THIS PAPER CONTRASTS THE POLICY RESPONSES AND

DEVELOPMENT EXPERIENCES OF BRAZIL IN THE 1970 S AND THE EARLY $1980 S$ WITH THOSE OF TAIHAN AND SOUTH KOREA. IT EMPHASIZES THE SIGNIFICANCE OF SOUTH KOREA AS AN INTERMEDIATE CASE BETHEEN BRAZIL AND TAIHAN IN POLICY MANAGEMENT AND DEVELOPMENT EXPERIENCE. THIS CHAPTER ATTRIBUTES THE ULTIMATE DIVERGENCE IN MACROECONOMIC PERFORMANCE BETWEEN BRAZIL AND TAIWAN TO THE AUTHORITIES; CONTRASTING POLICY STANCES WITH RESPECT TO PRICE STABILIZATION AND EXTERNAL ADJUSTMENT WHEN THEY WERE CONFRONTED WITH THE VAST CHANGES IN EXTERMAL ENVIRONMENT THAT OCCURRED IN THE 1970 S AND THE EARLY 1980 S.

05732 LIN, C.; MOSHER, S.W.

THE REAL CHINESE POWER TRIP

FREEDOM REVIEH, 23(3) (MAY 92), 13-18.

THE NATURE OF FACT IONAL CONFLICT IN BEIJING HAS

UMDERGONE A SIGNIFICANT TRANSFORMATION SINCE THE TIANANMEN

SOUARE UPRISING--ONE THAT IS NOT GENERALLY UNDERSTOOD. THE

SQUARE UPRISING--ONE THAT IS NOT GENERALLY UNDERSTOOD. THE "NATIONAL PROSPERITY THROUGH SCIENCE AND TECHNOLOGY" CAMPAIGN RECENTLY INAUGURATED BY BEIJING IS PARTICULARL DIFFICULT TO EXPLAIN IN REFORM VS. ORTHODOX TERMS AND SUGGESTS THE NEW STRENGTH OF MANAGERIAL-TECHNOCRATIC FORCES AT WORK INSIDE THE PARTY AND GOVERMMENT. THIS NEH PARADI
SUGGESTS THAT ZHOU JIAHUA AND ZHU RONGJI, TWO SO-CALLED SUGGESTS THAT ZHOU JIAHUA AND ZHU RONGJI, THO SO-CALLED "RHE TECHNOCRATIC MOLD. CHINA, FAR FROM BEING POISED FOR A GORBACHEV-LIKE BREAKTHROUGH, MAY BE ON THE BRINK OF A LONG PERIOD OF POLITICAL STABILITY AND ECDNOMIC STAGNATION SIMILAR TO THAT ENDURED BY THE SOVIET UNION FROM 1964 TO 1982 .

05733 LIN, Y

BETWEEN GOVERMMENT AND LABOR: MANAGERIAL DECISION-MAKING IN CHINESE INDUSTRY

STUDIES IN COMPARATIVE COMMUNISM, 25(4) (DEC 92), 381-404. A CENTRAL GOAL OF THE POST-MAO REFORM IN CHINA HAS BEEM TO REVIVE THE AILING INDUSTRIAL ECONOMY. THIS PAPER EXAMINES ARGUMENTS IN CONTEXT OF CHANGES IN MANAGERIAL DECISIONMAXING IN CHINA'S PUBLIC SECTOR INDUSTRIAL ENTERPRISES IN THE 1980S. THE ARTICLE SUBMITS THAT PARTIAL STRUCTURAL CHANGES BROUGHT ABOUT BY REFORM HAVE TENDED TO WEAKEN THE LINKAGE BETWEEN COST-SENSITIVITY AND BUDGET CONSTRAINT AND HAVE LED MANAGERS TO TIGHTEN CONTROL OVER

05734 LINCOLN, E.J.

JAPAH IN THE 1990'S: A NEW KIND OF WORLD POWER

BROOKINGS REVIEH, 10(2) (SPR 92), 12-17

AS THE COLD WAR ENDS, THE UNITED STATES MUST RETHINK ITS FOREIGN POLICIES, INCLUDING ITS RELATIONSHIP WITH JAPAN. THE COLLAPSE OF THE SOVIET THREAT AND JAPAN'S ECONOMIC COLLAPSE OF THE SOVIET THREAT AND JAPAN'S ECONOMIC
PROMINENCE UNDERSCORE THE COUNTRY'S UNIQUE POSITION AS AN ECONOMIC GIANT AND A MILITARY PYGMY. MANY U.S. OBSERVERS ARE ECONOMIC GIANT AND A MILITARY PYGHY. MANY U.S. OBSERVERS ARE ABERRATION THAT CANNOT CONTINUE. AN OPPOSING VIEW IS THAT JAPAN OFFERS A RADICALLY NEW PATTERN FOR MAJOR NATION-STATES
THAT THE USA SHOULD TRY TO FOSTER. HOW JAPAN CHOOSES TO THAT THE USA SHOULD TRY TO FOSTER. HOW JAPAN CHOOSES TO INTERACT WITH THE WORLD IS UP TO THE JAPANESE PEOPLE AND
THEIR GOVERMMENT. BUT THE USA CAN AND SHOULD ENCOURAGE JAPAN TO CONTINUE TO DEVELOP AS A NONHILITARY WORLD POHER.

05735 LIND, M.

SERBICID

NEW REPUBLIC, 206 (25) (JUN 92), 16, 18.

THE AUTHOR DISCUSSES THE SITUATION IN YUGOSLAVIA, HHERE REPEATED INTERMATIONAL PEACEKEEPING EFFORTS HAVE FAILED.
05736 LIND, M.

THE CATALYTIC STATE

NATIDNAL INTEREST, 27 (SPR 92), 3-12.

A CATALYTIC STATE IS ONE THAT SEEKS ITS GOALS LESS BY RELYING ON ITS OWN RESOURCES THAN BY ACTING AS A DOMINANT ELEMENT IN COALITIONS OF OTHER STATES, TRANSHATIONAL INSTITUTIONS, AND PRIVATE SECTOR GROUPS, WHILE RETAINING ITS DISTINCT INDENTITY AND ITS OHN GOALS. THE GOALS OF THE STATE REMAIN THE SAME--LEGITIMACY, PROSPERITY AND SECURITY. THIS ARTICLE REVIEWS THE MODERN STATE FROM SUZERAIN TO INTEGRAL STATE, GLOBAL TRENDS, THE RESURGENC OF SOCIETY, AND THE REINVENTION OF THE STATE. THE BIG QUESTION IS: CAN AMERICA REINVENTI
ADAPT?

05737 LIND, M.

THE EXORCISM

NEW REPUBLIC, 207(24) (DEC 92), 20-21.

PRESIDENT GEORGE BUSH LOST HIS RE-ELECTION BID BECAUSE HE RAN AS THE CAMDIDATE OF THE RADICAL RIGHT AGAINST TWO CENTRISTS, BILL CLINTON AND ROSS PEROT. THE RESULTS OF RIGHTHING ECONOMICS ALIENATED REAGAN DEMOCRATS, WILE RIGHT-HING MORAL ZEALOTRY DROVE ANAY INDEPENDENTS AND MODERATE REPUBLICANS. THANKS TO THE FAR RIGHT, THE REPUBLICANS ARE NOW A MINORITY PARTY AT ALL LEVELS OF GOVERMMENT.

05738 LIND, M.

THE FISSION THING

NEW REPUBLIC, 207 (14) (SEP 92), 18-20.

GOVERNOR BILL CLINTON HAS SET FORTH THREE ELEMENTS OF A

NEW DEMOCRATIC LINE ON FOREIGN POLICY: THE PROMOTION OF DEMOCRACY, COMMITMENT TO MULTILATERAL INSTITUTIONS, AND DOMESTIC ECONOMIC RENEWAL. HOWEVER, IN ALL LIKELIHOOD, THE NEW FOREIGN POLICY CONSENSUS AMONG DEMOCRATS IS MERELY THE BEGINNING OF NEW FIGHTS. THE FAULT LINES OF A CLINTON ADMINISTRATION ARE ALREADY OPENING, AND ALTHOUGH THEY ARE UNLIKELY TO BE AS DEEP OR AS IRRECONCILABLE AS THE COLD WAR RIFT, THEY COULD PROVE TROUBLESOME FOR A FIRST-TERM PRESIDENT.

05739 LINDEN, M.

MIL ITARY EXPENDITURE, GOVERMMENT SIZE, AND ECONOMIC GRONTH IN THE MIDOLE EAST IN THE PERIDD 1973-1985

JOURMAL OF PEACE RESEARCH, 29(3) (AUG 92) 265-270.

THE AUTHOR DERIVES AN AUGMENTED THO-SECTOR GROWTH MODEL TO ANALYZE THE EFFECTS OF THE MILITARY BURDEN AND GOVERNMENT EXPENDITURE ON THE GROWTH OF GNP IN SELECTED MIDOLE EASTERN EXPENDITURE ON THE GROWTH OF GNP IN SELECTED MIDOLE EASTERN BURDEN AND RELATED ACTIVITIES HAD A NEGATIVE EFFECT ON THE BURDEN AND RELATED ACTIVITIES HAD A NEGATIVE EFFECT ON THE GOVERMMENT SECTOR, OIL PRICES, AND CAPITAL FORMATION HAD GOVERNMENT SECTOR, OIL PRICES, AND CAPITAL FORMATION HAD POSITIVE EFFECTS ON ECONOMIC GROWTH. THE DIFFERENCE IN
MARGINAL PRODUCTIVITY IN DIFFERENT SECTORS WAS RELATIVELY
SMALL AND THE POSITIVE EXTERNALITY EFFECT OF THE GOVERNMENT SMALL AND THE POSITIVE EXTERNALITY EFFECT OF THE GOVERNMENT
OM PRIVATE CONSUMPTION WAS FAIRLY LARGE. COUNTRY-SPECIFIC ON PRIVATE CONSUMPTION WAS FAIRLY LARGE. COU.
FACTORS HAD A MINOR EFFECT ON THE RESULT.

05740 LINDEN, R.

THE NEW INTERNATIONAL POLITICAL ECONONY OF EAST EUROPE STUOIES IN COMPARATIVE COMMUNISM, 25(1) (MAR 92), 3-22. FOR ALL OF THE NEW DEMOCRACIES IN EASTERN EUROPE THERE ARE POWERFUL FACTORS INHIBITING THEIR "MOVE WEST." THIS ARTICLE EXPLORES THE REGION BEFORE THE REVOLUTIONS, AND THE PUSH TOWARD TO THE WEST SINCE THE REVOLUTIONS. THE FACTORS CONTRIBUTING TO RESTRAINING INTEGRATION OF THE EAST AND WEST ARE THEN EXAMINED. A DIFFERENTIATION IS EVIDENT IN BOTH DOMESTIC AND FOREIGN POLICY BETWEEN STATES OF CENTRAL EUROPE AND THOSE OF SOUTHEASTERN EUROPE.

05741 LINDQUIST, E.A. NEW CHALLENGES

CANADIAN PUBLIC ADMINISTRATION, 35(2) (SUM 92), 127-159. THE AUTHOR INTRODUCES CONCEPTS THAT WILL HELP PUBLIC ADMINISTRATION PRACTITIONERS AND SCHOLARS TO DESCRIBE AND ANALYZE THE STRUCTURE AND DYNAMICS OF POLICY COMMUNITIES. ANALYZE THE STRUCTURE AND DYNAMICS OF POL ICY COMMUNITIES.
FIRST, HE DRAWS FROM THE POLITICAL SCIENCE LITERATURE TO FIRST, HE DRAWS FROM THE POLITICAL SCIENCE LITERAT
IDENTIFY DIFFERENT NETHORKS IN POLICY COMMUNITIES, IDENTIFY DIFFERENT NETHORKS IN POLICY COMMUNITIES,
CONSIDERING HOW THE ROLE OF PUBLIC MANAGERS CHANGES FROM NETHORK TO NETHORK. THEN HE MODELS POLICY COMMUNITIES AS NETWORK TO NETHORK. THEN HE MODELS POLICY COMMUNITIES
"LEARNING" ENTITIES CONSISTING OF ADVOCACY COALITIONS "LEARNING" ENTITIES CONSISTING OF ADVOCACY COALITIONS
RESPONDING TO POLICY CHALLENGES IN COMPETITIVE AND COOPERATIVE INTERACTIONS. HE CONCLUDES THAT PUBLIC MANAGERS HAVE A SPECIAL STEWARDSHIP FUNCTION IN FACILITATING MORE HAVE A SPECIAL STEWARDSHIP FUNCTION IN FACILITATI
PRODUCT IVE LEARNING WITHIN POLICY COMMUNITIES.

05742 LIMDSAY, I.

THE AUTONOAY OF SCOTTISH POLITICS

NEW LEFT REVIEW, (191) (JAN 92), 43-48.

THE AUTHOR IS THE ORGANIZER OF THE SCOTTISH

CONSTITUTIONAL CONVENTION, A BODY THAT CAMPAIGNS FOR A SCOTTISH ASSEMBLY AND HAS UNITED A VARIETY OF CIVIC GROUPS AND POLITICAL PARTIES TO PURSUE THAT GOAL. IN THIS ESSAY, SHE EXPLAINS HOW AND WHY SCOTIISH OPINION HAS RESISTED THE THATCHERITE ONSLAUGHT SO STRONGLY. 
05743 LINDSAY, J.; SAYRS, L.; STEGER, W. CHOICE AMERICAN POLITICS QUARTERLY, 20(1) (JAN 92), 3-25 WHAT EXPLAINS PRESIDENTIAL DECISIONMAKING ON FORIEGM POLICY? THIS QUESTION IS ADDRESED BY ASSESSING THE RELATIVE INFLUENCE OF THE INTERNATIONAL AND DOMESTIC ENVIRONMENTS ON PRESIDENTIAL FOREIGN POLICY CHOICE. UNLIKE PREVIOUS STUDIES, WHICH HAVE FOCUSED ON THE RELATIVELY SMALL NUMBER OF PRESIDENTIAL DECISIONS TO USE FORCE, THE AUTHORS LOOK AT THE BROAD RANGE OF CONFLICTUAL AND COOPERATIVE POLICIES THAT PRESIDENTS HAVE PURSUED. USING DATA FROM THE CONFLICT AND PEACE DATA BANK, THEY ESTIMATE A MODEL OF PRESIDENTIAL FOREIGN POLICY CHOICE OVER THE YEARS 1948 THROUGH 1978. THE RESULTS INDICATE THAT PRESIDENTS RESPOND MOSTLY TO THE RHYTHMS OF INTERNATIONAL EVENTS AND NOT DOMESTIC POLITICS WHEN MAKING FOREIGN POLICY. IN PARTICULAR, LITTLE EVIDENCE IS FOUND TO SUPPORT THE FINDINGS OR EARL IER RESEARCH THAT
PUBLIC APPROVAL INFLUENCES PRESIDENTIAL DECISIONMAKING ON FOREIGN POLICY.

05744 LINDSAY, J.M.

CONGRESS AND FOREIGM POLICY. WHY THE HILL MATTERS

POLITICAL SCIENCE OUARTERLY 107 (4) (HIN 93),607-628.

POLITICAL SCIENCE QUARTERLY, $107(4)$ (WIN 93), 607-628.
THE AUTHOR DISCUSSES THE ROLE CONGRESS PLAYS IN MAKING AMERICAN FOREIGN POLICY. HE ARGUES THAT WHILE CONGRESS SELDOM ENACTS ITS OWN SUBSTANTIVE PREFERENCES INTO LAN, IT EXERCISES CONSIDERABLE, IF LARGELY UNMOTICED, INFLUENCE OVER U.S. FOREIGN POLICY.

05745 LINDSAY, J.M.; RIPLEY, R.B. FOREIGN AND DEFENSE POLLICY IN CONGRESS: A RESEARCH AGENDA FOR THE 1990'S

LEGISLATIVE STUDIES QUARTERLY, XVII(3) (AUG 92), 417-449.

SINCE THE END OF THE VIETNAM WAR, THE U.S. CONGRESS HAS RECLAIMED A ROLE FOR ITSELF IN THE MAKING OF FOREIGN AND DEFENSE POLICY. ALTHOUGH THE SURGE IN CONGRESSIONAL ACTIVISM HAS ATTRACTED COHSIDERABLE NORMATIVE COMMENTARY, POLITICAL SCIENTISTS HAVE DEVOTED RELATIVELY LITTLE EFFORT TO EXPLORING THE CAUSES AND CONSEQUENCES OF RENEWED CONGRESSIONAL INTEREST IN FOREIGN POLICY. TO STIMULATE MORE EMPIRICIAL STUDY IN THIS AREA, THIS PAPER SUMMARIZES THE EXISTING WORK ON CONGRESSIONAL FOREIGN AND DEFENSE POLICY AND IDENTIFIES OPPORTUNITIES FOR NEW RESEARCH.

05746 LINDSAY, T.

ARISTOTLE'S QUALIFIED DEFENSE OF DEMOCRACY THROUGH "POLITICAL MIXING"

THE JOURNAL OF POLITICS, 54(1) (FEB 92), 101-119.

THE THEORETICAL FOUNDATION OF THIS DEFENSE OF DEMOCRATIC JUDGMENT, AND THE INITIAL FOCUS OF THIS ESSAY, IS ARISTOTLE'S AGRUMENT FOR COLLECTIVE SUPERIORITY, WHICH HOLDS THAT A MULTIPLICITY OF NONEXPERTS CAN SURPASS THE POLITICAL COMPETENCE OF THE EXPERT FEH. THE AUTHOR ARGUES THAT THERE ARE THO VERSIONS OF COLLECTIVE SUPERIORITY HERE THAT EXIST IN A TENSION WITH EACH OTHER: THE FIRST DEFENSE OF DEMOCRACY IS ULTIMATELY DEFECTIVE, WHILE THE SECDND AIMS AT MODERATING THE FIRST. ARTISTOTLE'S POLITICAL SCIENCE STRIKES A BAL
AND OFFERS AN ALTERNATIVE TO THE MODERN DICHOTOMY OF HOBBESIAN PESSIMISM AND PROGRESSIVIST OPTIMISM.

05747 LINDSAY, T.

JAMES MADISON ON RELIGION AND POLITICS: RHETORIC AND REALITY

AMERICAN POLITICAL SCIENCE REVIEH, 85(4) (DEC 91),

$1321-1337$

THE U.S. SUPREME COURT'S RECENT RULING IN OREGON $V$. SMITH SHIFTED THE BURDEN IN FREE EXERCISE CASES FROM LEGISLATURES TO MINORITY RELIGIOUS CLAIMS AND HAS PROVOKED FIERCE OPPOSITION, MOST NOTABLY FROM NONPREFERENTIALIST RICHARD J. NEUHAUS, WHO WARNS THAT IT COULD BE THE FOUMDATION OF MAJORITY TYRANMY. NEUHAUS CITES MADISON'S "MEMORIAL ANO REMONSTRANCE AGAINST RELIGIOUS ASSESSMENTS," WHICH IS UNIVERSALLY INTERPRETED TO ARGUE THAT THE SUPERIORITY OF RELIGION TO POLITICS PROSCRIBES MAJORITARIAN HEGEMONY OVER RELIGIOUS PRACTICES. IN THIS ESSAY, THE AUTHOR CONTENDS THAT THE APPEALS IN "MEMORIAL" ARE BETTER UNDERSTOOD AS RHETORIC THAN AS REFLECTING MADISON'S TRUE VIEW. MADISON WAS HOSTILE NOT ONLY TO RELIGIOUS ESTABLISHMENTS BUT TO RELIGION ITSELF. THIS HOSTILITY WAS THE BASIS OF HIS REJECTION OF THE NONPREFERENTIALISTS' UTILITY-BASED ARGUMENT FOR GOVERNMENT SUPPORT OF RELIGION. THUS, IHE NONPREFERENTIALIST NEUHAUS SEEKS TO PROTECT THUS, THE NONPREFERENTIALIST NEUHAUS SEEKS TO PROTECT RELIGION FROM HOSTILITY BY ADHERING TO A POSITION THAT WAS RELIGION AND TO ITS NONPREFERENTIAL SUPPORT.

05748 LINDSAY, T.

LIBERTY, EQUALITY, POWER: ARISTOTLE'S CRITIQUE OF THE DEMOCRATIC "PRESUPPOSITION"

AMERICAN JOURNAL OF POLITICAL SCIENCE, 36(3) (AUG 92), 743-761.

A CHIEF CONCERN OF DEMOCRATIC THEORISTS, TODAY AND PERENNIALLY, IS THE POTENTIAL TENSION BETHEEN DEMOCRACY'S
TWIN PILLARS -- EQUALITY-DERIVED MAJORITY RULE AND INDIVIDUAL LIBERTY. RECONCILING THESE PRINCIPLES IN PRACTICE IS PERHAPS THE GAUGE OF DEMOCRATIC HEALTH. ON THIS ISSUE, THE AUTHOR FINDS IN ARISTOTLE'S DEMOCRATIC ANALYSIS A TIMELESS PERSPICACITY. ARISTOTLE'S CRITIQUE OF WHAT HE CALLS THE DEMOCRATIC "PRESUPPOSITION" LAYS BARE FOR US THE COMPLEX, RELATIVE SUPER- AND SUBORDINATION OF FORCE, EQUALITY, AND FREEDOM LYING AT THE HEART OF DEMOCRATIC JUSTICE. IN SO DOING, ARISTOTLE REFUTES HOBBES'S CHARGE THAT HIS AFFECTION FOR DEMOCRACY ONES TO HIS BLINDNESS TO REALPOLITIK.

05749 LINDSEY, B.

PERSONAL BEST: THE SPIRITUAL SIDE OF CAPITALISM

REASON, 24(3) (JUL 92), 21-27.

CAPITALISM SINCE ITS INCEPTION HAS BEEN DERIDED AS A SPIRITUALLY STUNTED SYSTEM. ALTHOUGH OBSESSIVE MATERIALISM AND CRASS COMMERCIALISM ARE UNDENIABLY A PART OF MODERN CAPITALISM, THEY DO NOT CONSTITUTE ITS WHOLE. THIS ARTICLE SUGGESTS THAT THERE IS MUCH MORE TO CAPITALISM THAN THINGS: CAPITALISM IS ALSO ABOUT CREATIVITY, INGENUITY, DEDICATION, ANO PERSEVERANCE; II IS ABOUT TEAYWORK AND COMPETITION; IT IS ABCUT THE FULFILLMENT GAINED FROM NORKING HARD TO DO A JOB WELL; IT IS ABOUT PURSUING YOUR DREAMS, HOWEVER HUMBLE OR GRAND. COMMERCIAL LIFE, AT ITS BEST, GENERATES SPIRITUAL AS WELL AS MATERIAL ABUNDANCE. IT CONCLUDES THAT THE MOTIVE FORCE OF CAPITALISH IS NOT SOME HISTORICAL AUTOPILOT, BUT RATHER THE POWER OF ENTRPRENEURIAL IMAGINATION--THAT THE MARKET PROCESS IS FUNDAMENTALLY A SPIRITUAL PHENOMENON.

05750 LINER, B.

BEYOND TURF BATTLES

NATIONAL CIVIC REVIEH, 81(1) (WIN 92), 5-8

WHILE THE FEDERAL GOVERNMENT HAS RETAINED OYERALL

REGULATORY AND ENFORCEMENT AUTHORITY, THE RESPONSIBILITY FOR IMPLEMENTATION OF ENVIRONMENTAL POLICY HAS FALLEN PRIMARILY TO THE STATES AND LOCALITIES. MOREOVER, DURING THE PAST DECADE, THE RESPONSIBILITY OF PAYING FOR A CLEANER

ENVIRONMENT HAS ALSO FALLEN TO THE JUNIOR FEDERAL PARTNERS.

05751 LING, $H$.

FOREIGN AID POLICY IN THE USA, JAPAN, AMD GERMANY

BEIJING REVIEN, 35(46) (NOV 92), 31-33.

THE AUTHOR COMPARES U.S., JAPANESE, AMD GERMAN FOREIGM

AID POLICIES AND SPECULATES ABOUT FUTURE AID PATTERNS.

05752 LING, T.; MYERS, R.H.

SURVIVING THE ROUGH-AND-TUMBLE OF PRESIDENTIAL POLITICS IN AN EMERGING DEMOCRACY: THE 1990 ELECTIONS IN THE REPUBLIC OF CHIMA ON TAIHAM

CHINA QUARTERLY, (129) (MAR 92), 123-148.

THE AUTHOR DISCUSSES THE BACKGROUMD TO TAINAN'S 1990 PRESIDENTIAL ELECTIONS AND THE ISLAND'S RECENT POLITICAL DEVELOPMENT.

05753 LINGLE, C.

COLLECTIVISM AND COLLECTIVE CHOICE: CONFLICTS BETWEEN

CLASS FORMATION AND ETHNIC NATIONALISM

ETHNIC GROUPS, 9(3) (1992), 191-201

WITH THE DEMISE OF AUTHORITARIAN SOCIALISM, QUESTIONS ARISE CONCERMING WHY THE CONCEPTUALIZATION OF CLASS SEEMS TO HAVE BEEN SHAMPED BY THE RESURGENCE OF ETHNIC NATIONALISM IN EASTERM AMD CENTRAL EUROPE AND THE FORMER SOVIET UNION. IN THIS PAPER, THE AUTHOR ARGUES THAT, WHILE AUTHORITARIAN SOCIALISM IS NEITHER THE PRIMARY NOR THE SUFFICIENT CAUSE, IT PROMOTED VARIOUS CONOITIONS THAT PROVIDE FERTILE GROUND FOR ETHNIC COLLECTIVE ACTION, INCLUDING THE FOLLONING: A COLLECTIVIST MENTALITY, SYSTEMATIC POLITICAL DOMINATION AND COMPULSION, SYSTEMIC SHORTAGES AND ACCOMPANYING ECONOMIC INSECURITY, AND PURPOSEFUL NEGLECT OF THE ROLE OF THE ENTREPRENEUR UNDER CENTRAL PLANNING. IN ADDITION, ETHNICBASED ORGANIZATIONS PROVIDED ALTERNATIVE INSTITUTIONS TO FILL THE VACUUM LEFT IN THE WAKE OF THE COLLAPSE OF SOCIALISM AND THE DEMISE OF THE COMMUNIST PARTIES. ECONOMIC AND POLITICAL CONDITIONS ARISING FROM THE MYTHS AMD ILLUSIONS OF AUTHORI TARIAN SOCIALISM SEEM TO HAVE SUPPORTED THE DEVELOPMENT OF INTEREST GROUPS BASED ON NATIONAL. ETHMIC, RACIAL, OR CULTURAL CHARACTERISTICS RATHER THAN CLASS.

05754 LINGLE, C.

THE EC SOCIAL CHARTER, SOCIAL DEMOCRACY AND POST-1992 EUROPE

WEST EUROPEAN POLITICS, 14(1) (JAN 91), 129-138

THE PROPOSAL BY THE EC COUNCIL OF MINISTERS TO ESTABLISH A 'SOCIAL CHARTER' HAS THE INTENTION OF HARMONISING VARIOUS ASPECTS OF WORKING CONDITIONS IN THE MEMBER STATES. HOWEVER, THE SOCIAL CHARTER, AND THE PHILOSOPHY UNDERLYING IT, CAN BE CRITICISED ON SEVERAL GROUNDS FOR ITS RESTRICTIVE IMPLICATIONS AND UNDESIRABLE ECONOMIC, LEGAL AND POLITICAL EFFECTS, IT ALSO LEANS TOWARDS FAVOURING A SOCIAL DEMOCRATIC IDEDLOGY AND PARTICULAR ORGANISED INTERESTS AT THE EXPENSE OF GENERAL PUBLIC ONES. ATTENTION SHOULD BE GIVEN TO SECURING EFFECTIVE DECENTRALIZATION IN THE EC TO COUNTERACT THE DANGERS IMPLICIT IN BUREAUCRATISATION AND SOCIAL REGULATION. 
05755 LINGYING, W.

BRITAIN: CONSERVATIVES' FUTURE POLICY

BEIJING REVIEH, 35(29) (JUL 92) 15-17.

THE AUTHOR LOOKS AT THE REASONS THE CONSERVATIVES WOM THEIR FOURTH CONSECUTIVE VICTORY IN GREAT BRITAIN'S 1992 NATIONAL ELECTIONS AND SPECULATES ABOUT THE TYPES OF POLICIES JOHN MAJOR'S ADMINISTRATION WILL PURSUE IN THE FUTURE.

05756 LINKLATER, A.

THE QUESTION OF THE NEXT STAGE IN INTERMATIONAL RELATIONS THEORY: A CRITICAL-THEORETICAL POINT OF YIEH

MILLENMIUM, 21(1) (SPR 92), 77-100.

TRADITIONAL WAYS OF THINKING ABOUT INTERNATIONAL RELATIONS ARE BEING INCREASINGLY CHALLENGED BY ALTERNATIVE RELATIONS ARE BEING INCREASINGLY CHALLENGED BY ALTERNATI APPROACHES--INCLUDING MARXISM, CRITICAL THEORY, POSTMODERNISM, AND FEMINISM--RESULTING IN A FAR-REACHING DEBATE ON WHAT INTERNATIONAL RELATIONS IS, AND SHOULD BE, ABOUT. THE AUTHOR ARGUES THAT CRITICAL THEDRY POSSESSES A VISION POWERFUL ENOUGH TO REVITALIZE THE FIELD AND THAT THE COMMON PROJECT OF INTERNATIONAL RELATIONS SHOULD BE TO IDENT ANSWER THE NORMATIVE, SOCIOLOGICAL, AND PRAXEOLOGICAL
QUESTIONS RAISED BY SYSTEMS OF INCLUSION AND EXCLUSION IN WORLD POLITICS.

05757 LINN, B.

INTELLIGENCE AND LOH-INTENSITY CONFLICT IN THE PHILIPPINE WAR, 1899-1902

INTELLIGENCE AND NATIONAL SECURITY, 6(1) (JAN 91), 90-114. THE AMERICAN SOLDIERS WHO FOUGHT DURING THE PHILIPPINE WAR BETHEEN 1899 AHD 1902 HAD TO DISCOVER THE IMPORTANCE OF INTELLIGENCE IN LON-INTENSITY CONFLICT THROUGH BITTER EXPERIENCE. FOR MUCH OF THE HAR, AMERICAN INTELLIGENCE WAS AS DIFFUSE, UNCONNECTED AND DISORGANI ZED AS THE RESISTANCE SOLDIERS ENCOUNTERED IN THE FIELD. AS A RESULT OF INDIFFERENCE AND MISPLACED OPTIMISM AT HEADQUARTERS, THE U.S. ARMY FAILED TO CREATE A COHERENT PROGRAM TO GATHER AND DISPERSE INTELLIGENCE FOR ALMOST TWO YEARS AFTER THE DISPERSE INTELLIGENCE FOR ALMOST TWO YEARS AFTER THE OUTBREAK OF FIGHTING. THIS NEGLECT, IN TURN, LED TO AN
EXTENSIVE INTEREST IN LOCAL INTELLIGENCE BY FILED OFFICERS EXTENSIVE INTEREST IN LOCAL INTELLIGENCE BY FILED OFFICERS
WHO, ALMOST BY ACCIDENT OBTAINED INFORMATION ON GUERRILLA WHO, ALMOST BY ACCIDENT OBTAINED INFORMATION ON GUERRILLA
LEADERS AND STRONGHOLDS OR FOCUSED ON THE VITAL GUERRILLA INFRASTRUCTURE. HOHEVER, THE LACK OF CENTRALIZATION BECAME A INFRASTRUCTURE. HOHEVER, THE LACK OF CENTRALIZATION BECAME A POSITIVE BOON AS UNKNOWN AND UNTRAINED OFFICERS HERE ABLE
STEP INTO THE VOID AND DEVELOP AND IMPLEMENT INTELLIGENCE STEP INTO THE VOID AND DEVELOP AND IMPLEMENT INTELLIGENCE METHODS SINGULA

05758 LINTNER, B.

BURMA AND ITS NEIGHBORS

CHINA REPORT, 28 (3) (JUL 92 ) 225-258.

AFTER DECADES OF NEUTRALITY AND A STRICTLY NON-ALIGNED FOREIGN POLICY, BURMA HAS BECOME CHINA'S PRINCIPAL ALLY IN ASIA, RIVALING EVEN PAKISTAN IN STRATEGIC AND ECONOMIC IMPORTANCE TO BEI JING. WITH COUNTRIES CLOSELY ALLIED HITH CHINA ON BOTH ITS WESTERN AND EASTERN BORDERS, DEVELOPMENTS IN BURMA SHOULD BE OF UTMOST CONCERN TO INDIA'S SECURITY PLANNERS. HOWEYER, INDIA HAS YET TO FORMULATE A

COMPREHENSIVE BURMA POLICY. THIS PAPER DISCUSSES CHINA'S AND INDIA'S DIVERGING PERCEPTIONS OF BURMA AND ITS RULING STATE LAW AND ORDER RESTORATION COUNCIL (SLORC), BURMA'S OWN FOREIGN POLICY SINCE INDEPENDENCE FROM BRITAIN IN 1948, NEH DELHI'S POLICY ALTERNATIVES HITH REGARDS TO BURMA, AND CHINA'S NEH, SOMEHHAT DIMINISHED, ROLE AS A PRIMARILY REGIONAL PONER.

05759 LINTNER, B.

BURMA'S NEH FRONT

FAR EASTERN ECONOMIC REVIEW, 155(1) (JAN 92), 21-22. THE TIMING OF THE BURMESE ARMY'S CROSS-BORDER RAID INTO BANGLADESH ON 20-21 DECEMBER MAY SEEM DIPLOMATICALLY DISASTROUS GIVEN THAT IT CAME LESS THAN A MONTH AFTER BANGLADESHI FOREIGN MINISTER MUSTAFIZUR RAHMAN VISITED RANGOON TO SETTLE A NUMBER OF BILATERAL ISSUES. BUT THE

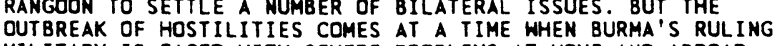
OUTBREAK OF HOSTILITIES COMES AT A TIME WHEN BURMA'S RULIMG
MILITARY IS FACED HITH SEVERE PROBLEMS AT HOME AND ABROAD MILITARY IS FACED WITH SEVERE PROBLLES AT HOME AND ABROAD
AND COULD PROVE USEFUL FOR RANGOON TO DIVERT THE ATTENTION AND CDULD PROVE USEFUL FOR RANGOON TO DIVERT THE ATTENTION
OF THE COUNTRY'S POPULATION. THE RAID WAS DIRECTED AGAINST OF THE COUNTRY'S POPULATION. THE RAID WAS DIRECTED AGAINST
ONE OF THE MOST VULNERABLE OF BURMA'S MANY ETHNIC MINORITIES ONE OF THE MOST VULNERABLE OF BURMA'S MANY ETHNIC MINORITIES,
THE BENGALI-RELATED ROHINGYA MUSLIMS OF ARAKAN. IN RESPONSE, THE BENGALI - RELATED ROHINGYA MUSLIMS OF ARAKAN. IN RESPONSE,
MILITANT GROUPS AMONG THE MUSLIM MINORITY HAVE BEEN ARMING MILITANT GROUPS AMONG THE MUSLIM MINORITY HAVE BEEN ARMING
THEMSELVES AND FURTHER CONFLICT SEEMS INEVITABLE. BURMA'S THEMSELVES AND FURTHER CONFLICT SEEMS INEVITABLE. BURMA'S STRAINED RELATIONS BETHEEN DHAKA AND RANGOON.

05760 LINTNER, B.

CENTRIFUGAL FORCES

FAR EASTERN ECONOMIC REVIEW, 155 (8) (FEB 92), 16

THE BURMESE ARMY'S CROSS-BORDER FORAYS INTO THAILAND DURING ITS CAMPAIGN AGAINST KAREN REBELS BASED ALONG THE THAI-BURMESE FRONTIER AND A RAID ON A BANGLADESH MILITARY POST IN LATE 1991 HAVE HIGHLIGHTED RANGOON'S DISREGARD FOR NEIGHBORING COUNTRIES IN ITS DRIVE TO ELIMINATE WHAT IT
VIEWS AS ITS OPPONENTS. PERHAPS AS ALARMING FOR BURMA'S NEIGHBORS, PEKING--RANGOON'S MAIN ARMS SUPPLIER AND PRINCIPAL FOREIGN PATRON--HAS SHOWN LITTLE INCLINATION TO CURB ITS PROTEGE, AND INDEED SEEMS SET TO FURTHER ADD TO THE ARSENAL ALREADY SHIPPED TO THE BURMESE JUNTA. BURMA'S LACK OF RESPECT FOR INTERNATIONAL BORDERS IS THOUGHT TO BE CAUSED IN PART BY THE SHEER SIZE OF ITS MILITARY FORCES (WHICH HAS INCREASED FROM 190,000 TO 300,000 IN A MATTER OF YEARS).

05761 LINTNER, B.; TASKER, R.

GENERAL MALAISE

FAR EASTERN ECDNOMIC REVIEN, 155(6) (FEB 92), 15

WHEN THE AUTHORITIES IN RANGOON ANMOUNCED' ON 29 JANUARY THAT THE MILITARY-DOMINATED BURMESE GOVERNMENT HAS BEEN EXPANDED TO INCLUDE SEVEN NEW MINISTERS, OF WHOM FOUR HERE CIVILIANS, FEH OBSERVERS WERE PREPARED TO INTERPRET THE MOVE AS A STEP TOWARDS ANY REAL CHANGE OF BURMA'S STRICTLY CENTRALIZED POWER STRUCTURE. OF FAR MORE SIGNIFICANCE WERE REPORTS FILTERING OUT OF BURMA THAT THE JUNTA LEADER GENERAL SAH MAUNG, IS BECOMING INCREASINGLY UNABLE TO SERVE AS HEAD OF THE COUNTRY. NO IMPORTANT POLICY CHANGES ARE EXPECTED AS A RESULT OF THE NEH CABINET LINE-UP, BUT THE DETERIORATING STATE OF SAH MAUNG'S HEALTH COULD HAVE FARREACHING CONSEQUENCES FOR THE STATE LAH AND ORDER RESTORATION COUNCIL (SLORC), AS DIVISIONS WITHIN THE RULING MILITARY ARE BECOMING INCREASIMGLY EVIDENT.

05762 LINTNER, 8.

OFF WITH THEIR HEADS

FAR EASTERN ECONOMIC REVIEH, 151(19) (MAY 91), 9-10.

HHEN RADIO RANGOON ANHOUNCED ON 23 APRIL THAT BURMA'S MAIN OPPOSITION PARTY, THE NATIONAL LEAGUE FOR DEMOCRACY (NLD), HAD FORMALLY DROPPED ITS CHAIRMAN TIN U AND GENERAL SECRETARY AUNG SAN SUU KYI FROM ITS LEADERSHIP, FEH BURMESE OR FOREIGN OBSERVERS WERE SUPPLIED. A YEAR AFTER DENYING THE NLD ITS OVERWHELMING ELECTORAL VICTORY, THE RULING STAIE LAH AND ORDER RESTORATION COMMITTEE (SLORC) FURTHER TIGHTENING OF THE MILITARY'S GRIP IN POWER WAS ACCOMPANIED BY WIDESPREAD INTERROGATIONS AND ARRESTS OF SUSPECTED OPPOSITION SYMPATHIZERS.

05763 LINTNER, B.

OME-WAY' "OPEN DOOR"

FAR EASTERN ECONOMIC REVIEH, 151(27) (JUL 91), 28-29.

AFTER THE CRACKDOWW ON PRO-DEMOCRACY DEMONSTRATORS IM 1988, BURMA HAS SEEN A WORLDWIDE EMIGRATION WAVE UNPRECEDENTED IN BURMA'S HISTORY. THE EXODUS IS LIKELY TO CONTINUE DESPITE THE REOPENING OF BURMA'S UNIVERSITIES AND THE DECLARATION BY THE MILITARY GOVERNMENT IN RANGOON THAT THE SITUATION HAS "RETURNED TO NORMAL."IN FACT, ACADEMIC LIFE IS ANYTHING BUT NORMAL. TENS OF THOUSANDS OF STUDENTS HAVE BEEN KILLED, ARRESTED, FLED TO THE THAI BORDER, OR HAVE
GONE INTO EXILE IN THIRD COUNTRIES. PERHAPS EVEN MORE IMPORTANTLY, THE SAME HAS HAPPENED TO THOUSANDS OF TEACHERS AND LECTURERS AS WELL. SINCE 1988, BURMESE SOURCES INDICATE, MORE THAN 100,000 PEOPLE HAVE LEFT THE COUNTRY. THE RESULTANT BRAIN DRAIN THREATENS TO CRIPPLE THE ECONOMY.

05764 LINTNER, 8.

THE ODD COUPLE

FAR EASTERN ECONOMIC REVIEH, 151(28) (JUL 91), 39-41. ECONOMIC RELATIONS BETWEEN BURMA AND JAPAN HAVE LONG BEEN BASED MORE ON IRRATIONAL EMOTIONS THAN ON SOUND BUSINESS PRACTICES. JAPAN'S MOTIVATION FOR PROVIDING LARGE AMOUNTS OF FINANCIAL ASSISTANCE TO BURMA IS BASED ON REASONS SUCH AS THE PROSPECTS FOR A LUCRATIVE MARKET FOR JAPANESE PRODUCTS, THE RE-ESTABLISHMENT OF A JAPANESE FOOTHOD IN ASIA, AND THE PROSPECTS OF SECURING UNDER-EXPLOITED AND UNEXPLORED NATURAL RESOURCES IN BURMA. THESE DESIRES HAS LED JAPAN TO DEAL WITH THE STATE LAW AND ORDER RESTORATION COMMITTEE (SLORC), THE MILITARY GROUP RESPONSIBLE FOR THE MASSACRE OF PRO-DEMOCRACY STUDENT DEMONSTRATORS. HOHEVER, A FEELING IS GROWING AMONG MANY OBSERVERS THAT JAPANS LACK OF A COMPREHENSIVE POLICY TOWARD BURMA IS ENDANGERING THE LOSS
OF THE UNIQUE POSITION THAT JAPAN ONCE HELD. JAPAN WILL NEED OF THE UNIQUE POSITION THAT JAPAN ONCE HELD. JAPAN HILL NEED
TO MOUNT A PUBLIC-RELATIONS OFFENSIVE IF IT IS TO REGAIN THE GOODWILL IT ONCE ENJOYED.

05765 LINTNER, B.

THE SECRET MOVER

FAR EASTERN ECONOMIC REVIEW, 156 (18) (MAY 92), 20-21.

THE ANNOUNCEMENT THAT THE HEAD OF BURMA'S RULING STATE LAW AND ORDER RESTORATION COUNCIL (SLORC). GENERAL SAW MAUNG WAS STEPPING DOWN IN FAVOR OF GENERAL THAN SHWE CAME AS LITTLE SURPRISE TO MOST OBSERVERS OF BURMA'S POLITICAL SCENE. HOHEVER. THE RELEASE OF SEVERAL POL ITICAL PRISONERS FOLLOWING THAN SHWE'S TAKING CONTROL OF SLORC WAS QUITE UNEXPECTED. MANY ANALYSTS, UNABLE TO BELIEVE THAT THE HARDLINE GENERAL WOULD EMBARK ON SUCH A LIBERAL MOVE, SEE THE HAND OF BURMA'S ERSTHHILE LEADER, GENERAL NE WIN, IN THE
EVENTS. ALTHOUGH NE WIN NO LONGER TAKES PART IN THE DAY TO DAY DECISIONMAKING, HE IS KNOWN TO HAVE INTERVENED ON A NUMBER OF OCCASIONS TO SOLVE PROBLEMS HITHIN THE MILITARY 
DISPLEASED WITH THE REPRESSIVE TACTICS OF THE SLORC. OTHERS ARGUE THAT THE ACTION IS PROMPTED BY NE HIN'S DESIRE NOT TO GO DONN IN HISTORY AS A TYRANT.

05766 LINTNER, B.

THE SLORC SHOW

FAR EASTERN ECONOMIC REVIEW, 155(27) (JUL 92), 14-15.

A RECENT MEETING BETWEEN BURMA'S RULING STATE LAW AND ORDER RESTORATION COMMITTEE (SLORC) AND 28 POLITICAL REPRESENTATIVES LAID THE GROUNDWORK FOR A NEW CONSTITUTION AND, IN THEORY, A CIVILIAN GOVERMMENT. THE MEETING IS TO BE FOLLOWED BY A HATIONAL CONVENTION SCHEDULED FOR DECEMBER 1992, OR JANUARY 1993. THE CONVENTION WILL COMPRISE LOCAL ADMINISTRATORS, PROFESSIONALS, MEMBERS OF PARLIAMENT ELECTED IN MAY 1990, AND REPRESENTATIVES OF 135 NATIONAL GROUPS IN BURMA. ITS MAIN TASK WILL BE TO DRAFT A NEN CONSTITUTION. THE NEXT STEPS INCLUDE THE FORMATION OF A CONSTITUENT ASSEMBLY, A REFERENDUM, AND NEW ELECTIONS. HOWEVER, THESE PLANS DO NOT MEAN THAT THE SLORC IS ABOUT TO GIVE UP POWER. SLORC OFFICIALS HAVE ALREADY INDICATED THAT THE MAIN OPPOSITION LEADER, AUNG SAN SUU KYI, WILL NOT BE ALLOWED TO PLAY a ROLE IN THE POLITICAL PROCESS. MOST ANALYSTS AGREE THAT WITHOUT AUNG SAN SUU KYI, WHO LED THE OPPOSITION THAT WITHOUT AUNG SAN SUU KYI, WHO LED THE OPPOSITION NATIONAL LEAGUE FOR DEMOCRACY TO A LANDSLIDE ELECTION VICTORY IN 1990 , BURMA'S STIFLED OPPOSITION IS UNLIKELY TO
CHALLENGE SLORC PLANS FOR THE COUNTRY'S FUTURE POLITICAL COURSE.

05767 LINZ, J.J.; STEPAN, A. POLITICAL IDENTITIES AND ELECTORAL SEQUENCES: SPAIN, THE SOVIET UNIOH, AND YUGOSLAVI

DAEDALUS, $121(2)$ (SPR 92), 123-139.

DEMOCRATIC THEORY AND PRACTICE SHOULD HAVE SOME SPACE FOR PEACEFUL NEGOTIATED SECESSION. IDEALLY, IF A GIVEN TERRITORIAL UNIT CANNOT BUILD A SINGLE CONSOLIDATED DEMOCRACY WITHIN THAT UNIT, THERE SHOULD BE ROOM FOR A PEACEFUL, NEGOTIATED SECESSION THAT WILL NOT FURTHER COMPLICATE THE BUILDING OF DEMOCRACIES IN THE SUCCESSOR STATES. IN THIS ESSAY, THE AUTHORS EXPLORE HOW THE SEQUENCE OF ELECTIONS IN ITSELF CAN PLAY AN IMPORTANT ROLE IN TRANSFORMING POL ITICAL IDENTITIES AND HELPING INTEGRATE OR DISINTEGRATE STATES, ESPECIALLY IN HIGHLY HETEROGENEDUS MULTIMATIONAL OR MULTICULTURAL POLITIES. THEY FOCUS ON THE CASES OF SPAIN, YUGOSLAVIA, AND THE SOVIET UNION.

05768 LIPATTI, $V$.

THE CSCE AND INNOVATIONS IN THE PRACTICE OF MULTILATERAL DIPLOMATIC MEGOTIATIONS

INTERNATIONAL SOCIAL SCIENCE JOURNAL, 132 (MAY 92), 299-304.

SINCE THE EARLY 1970S, WITH THE IMPROVEMENT IN

SINCE THE EARLY 1970S, WITH THE IMPROVEMENT IN

INTERNATIONAL RELATIONS THAT THE TIMES HAVE SEEN,
INMOVATIONS HAVE APPEARED IN THE SPIRIT AND PRACTICE OF

INNOVATIONS HAVE APPEARED IN THE SPIRIT AND PRACTICE OF MULTILATERAL DILOMATIC NEGOTIATIONS. THE NEH PROCEDURES DEVISED AND INTRODUCED BY THE CONFERENCE ON SECURITY AND CO THIS ARTICLE EXAMIMES THEM AND THEIR SCOPE.

05769 LIPMAN, $S$.

AFTER THE DUST SETTLES

NATIONAL REVIEW, III(2) (FEB 91), 36, 38-39.

THIS ARTICLE CONSIDERS THE FUTURE OF THE MIDOLE EAST FOLLOWING THE RESOLUTION OF THE GULF CRISIS. IT ARGUES THAT THE U.S. NEEDS TO DEFINE VICTORY NOT ONLY ON THE BATTLEFIELD, BUT ALSO IN TERMS OF POLITICS. IT CONCLUDES THAT THE PERSIAN GULF WAR WILL GIVE THREE EFFECTS: IT HILL DETERMINE THE ATTITUDE OF THE UNITED STATES TO THE MIDOLE EAST; IT WILL PROBABLY BREAK NOT ONLY SADOAM HUSSEIN BUT IRAQI SOCIETY; AND IT WILL SET THE TONE FOR INTER-ARAB POLITICS. THE AUTHOR ARGUES THAT THE BEST POSSIBLE COURSE FOR THE U.S. IS A SWIFT AND CERTAIN MILITARY VICTORY FOLLOWED BY THE CREATION OF AN ARAB SECURITY ARRANGEMENT (HITH EMPHASIS ON SAUDI ARABIA AN EGYPT). THE U.S. ALSO MUST TAKE STEPS TO AVOID THE "LEBANONIZATION" OF IRAQ.

05770 LIPMAN, S.

CAN HE SAVE CULTURE?

NATIONAL REVIEW, XLIII(15) (AUG 91), 36-38, 53.

THIS ART ICLE CONSIDERS THE ISSUE OF CUL TURE--THE REALM OF MEANING AND VALUE--AND ITS INFLUENCE ON VIRTUALLY EVERY ACTION. IT ARGUES THAT THE LEFT, IN AND OUT OF GOVERNMENT, KNOWS FULL WELL THAT HE HHO CONTROLS CULTURE CONTROLS NOT JUST HOW PEOPLE LIVE BUT HOW THEY PERCEIVE THEMSELVES. JUST HOW PEOPLE LIVE BUT HOW THEY PERCEIVE THEMSELVES. THEREFORE, THEY USE THEIR POWERFUL INFLUENCE ON CULTURE IN
AMERICA TO FORHARD THEIR AGENDA OF "PRIMITIVISM, FEMINISM, AMERICA TO FORWARD THEIR AGENDA OF "PRIMITIVISM, FEMINISM,
RACIALISM, MULTICUL TURALISM, AND SEXUAL RADICALISM." HOWEVER, RACIALISM, MULTICUL TURALISM, AND SEXUAL RADICALISM." HOWEVER, AS THE RECENT FUROR OVER NEA FUNDING OF CONTROVERSIAL
PROJECTS INDICATES, THE CONSERVATIVE RIGHT HAS YET TO PROJECTS INDICATES, THE CONSERVATIVE RIGHT HAS YET TO SUGGEST WHAT CONTENT

05771 LIPPERT, B.

PROSPECTS OF PAN-EUROPEAN POLITICAL COOPERATION -- AN EC/EPC PERSPECTIVE
PEACE AND THE SCIENCES, 4 (DEC 91), 46-55.

IN CONTRAST TO OTHER EUROPEAN INSTITUTIONS OR REGIMES, WHICH LIKEWISE ARE UNDERGOING SUBSTANTIAL TRANSFORMATIONS, MOST OF ALL THE CSCE AND THE COUNCIL OF EUROPE. THE EUROPEAN COMMUNITY TODAY IS PERCEIVED AS AN EFFICIENT AND EFFECTIVE POL ITICAL SYSTEM AND ATTRACTS AS THE GRAVITATION CENTER OF POLITICAL AMD ECONOMIC COOPERATION IN INTEGRATION IN EUROPE. THE EC/EPC TODAY OFFERS BOTH A VISION OF EUROPE (EUROPEAN UNION) AMD A SOPHISTICATED INSTITUTIONAL SYSTEM FOR DECISION MAKING AND PROBLEM SOLVING.

05772 LIPPINCOTT, R.C.; STOKER, R.P.

POLICY DESIGN AND IMPLEMENTATION EFFECTIVENESS: STRUCTURAL CHAMGE IN A COUNTY COURT SYSTEM

POLICY STUDIES JOURNAL, 20(3) (1992), 376-387.

THE AUTHORS EXAMINE' THE SUCCESSFUI IMPLEMENTATION OF A MAJOR STRUCTURAL CHANGE IN A COUNTY CRIMINAL COURT, AN INSTITUTION PARTICULARLY RESISTANT TO REFORM. THEY ATTRIBUTE IMPLEMENTATION EFFECTIVENESS PRIMARILY TO POLICY DESIGN FACTORS, ESPECIALLY THE ESTABLISHMENT BY TOP STATE SUPREME COURT OFFICIALS OF AN INSTITUTIONAL MECHANISM TO IMPLEMENT THEIR SELECTED POLICY GOALS. COMPOSED OF KEY COUNTY COURT PARTICIPANTS AT THE "BOTTOM," THE MECHANISM FACILITATED LATERAL COORDINATION AMONG DIVERGENT INTERESTS BY PROVIDING A FORUM FOR BARGAINING AND RESOLVING DISPUTES. THE BARGAINING ENTAILED THE DISTRIBUTION OF BENEFITS, AS WELL AS THE EXTERNALIZATION AND REDISTRIBUTION OF COSTS, ARISING THE EXTERMALIZATION AND STRUCTURAL CHANGES.

05773 LIPSCHUTZ, R.D RECONSTRUCTING WORLD POLITICS: THE EMERGENCE OF GLOBAL CIVIL SOCIETY

MILLENAIUM, 21(1) (SPR 92), 389-420

WORLD POL ITICS IS BEING TRANSFORMED BY THE BIRTH OF NONIISRLD POL INSTITUTIONALIZED, TRANSNATIONAL POLI IICAL NETWORKS THAT ARE BEST DESCRIBED BY THE TERM "GLOBAL CIVIL SOCIETY. "THIS PHENOMENON HAS ITS ORIGINS IN THE FOLLOWING: (1) THE GROWING ROLE OF LIBERAL PRINCIPLES AS AN OVERARCHING SET OF GLOBAL NORMS; (2) THE STATE'S DECLINING COMPETENCE AND HILLINGNESS TO UNDERTAKE WELFARE FUNCTIONS; AND (3) THE GROWING CAPABILITIES OF ELITES, FOSTERED BY THE MOBILIZATION OF SOCIETIES DURING THE COLD WAR. WHILE NOT A REPLACEMENT FOR THE STATE SYSTEM, GLOBAL CIVIL SOCIETY MAY BE SEEN IN TERMS OF A CHALLENGE TO THE GRAMSCIAN HEGEMONY OF STATIST WORLD POLITICS.

05774 LIPSET, S.M

AFFIRMATIVE ACTION AND THE AMERICAN CREED

HILSON QUARTERLY, XVI(1) (WIN 92), 52-62.

DESPITE THE GREAT CIVIL RIGHTS TRIUMPHS OF THE 1960's, THE POLITICS OF RACE STILL OCCUPIES CENTER STAGE IN AMERICAN LIFE. YET WHAT APPEARS TO BE A CONFLICT BETHEEN BLACKS AND HHITES IS MORE A STRUGGL BETHEEN THE AMERICAN PUBLIC AND THE NATION'S POLITICAL ELITE OVER THE TRUE MEANING OF EQUALITY. THE FAULT LIES WITH NATIONAL LEADERS WHO HAVE EQUAL TTY. THE FAULT LIES WITH NATIONAL LMEADERS WIMD OBJECTIONABLE AND UNFAIR.

05775 LIPSET, S.M.

EQUAL CHANCES YERSUS EOUAL RESULTS AMUALS OF THE AMERIS ANNALS OF THE AMERICAN ACADEMY OO

SCIENCE, (523) (SEP 92), 63-74. INDIVIDUAL OPPORTUNITY AND TO ENSURE EQUAL GROUP INDIVIOUAL OPPORTUNITY AND TO ENSURE EQUAL GROUP REPRESENTATION. THE FORMER MEANING PREDOMINATED UNTIL 1969, WHEN THE NIXON ADMINISTRATION INTROOUCED NUMERICAL QUOTAS GOALS IN HIRING. SUBSEQUENTLY, REPUBLICANS OPPOSED AND

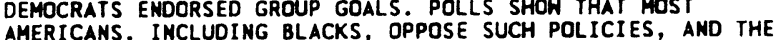
AMERICANS, INCLUDING BLACKS, OPPOSE SUCH POLICIES, AND THE DEMOCRATIC PARTY HAS BEEN HURT BY SUPPORTING THEM. DESPITE
THE STRENGTH OF AMERICAN EGALITARIAMISM, BLACKS HAVE BEEN AN OPPRESSED CASTE FOR MOST OF THE NATION'S HISTORY. HOW BEST TO RESOLVE THIS CONTRADICTION BETHEEN AN EGALITARIAN CREED AND THE LEGACY OF SLAVERY REMAINS THE AMERICAN DILEMMA.

05776 LIPSHITZ, G.

IMMIGRATION AND INTERMAL MIGRATION AS A MECHANISM OF POLARIZATION AND OISPERSION OF POPULATION AND DEVELOPMENT: THE ISRAELI CASE

ECONOMIC DEVELOPMENT AND CULTURAL CHANGE, 39(2) (JAN 91), 391-408.

THIS ARTICLE SEEKS TO ADD TO SPATIAL FLOW THEORY HITH AN ANALYSIS OF THE SPATIAL RESULTS OF POPULATION MIGRATION. IT CONCLUDES THAT MIGRATION THAT LEADS TO GEOGRAPHICAL

POLARIZATIOM OF THE POPULATIOM IS MOT MECESSARILY

ACCOMPANIED BY GEOGRAPHICAL POLARIZATION OF DEVELOPMENT. IT DEMONSTRATES THAT THE GEOGRAPHICAL DISPERSION OF IMMIGRANTS DEMONSTRATES THAT THE GEOGR ISRAELI IN THE 1950S TENDED TO TO THE NATIONAL PERIPHERY OF ISRAELI IN THE 1950S TENDED DECREASE POLARIZATION IN THE SPATIAL DISTRIBUTOL OF THE POPULATION BUT, AT THE SAME TIME, INCREASE

05777 LIPTON, D.S. HOW TO MAXIMIZE UTILIZATION OF EVALUATION RESEARCH BY 
POL ICYMAKERS

ANNALS OF THE AMERICAN ACADEMY OF POLITICAL AND SOCIAL SCIENCE, 521 (MAY 92), 175-188.

TO CONDUCT EVALUATION RESEARCH AND PREPARE REPORTS THAT ARE MOST LIKELY TO BE UTILIZED BY POLICYMAKERS, ONE MUST UNDERSTAND THE POLICYMAKERS' PERCEPTION OF RESEARCH AND RESEARCHERS. POLICYMAKERS BELIEVE IT IS THEIR JOB TO IMPLEMENT THEIR CONSTITUENTS' DEMANDS REGARDLESS OF THE RESULTS OF EVALUATION RESEARCH, WHICH IS ONLY ONE CONTENDING JUDGMENT AMONG MANY DESIDERATA. THE MORE COMPLEX THE EVALUATION, THE MORE JARGON, THE MORE EQUIVOCAL THE CONCLUSIONS, THE MORE CAVEATS IN THE PREAMBLE, THE MORE SENSITIVE THE ISSUE, THE MORE COMPLEX THE WRITING, THE MORE OBSCURE THE EVALUATOR, THE MORE LIKELY THAT THE REPORT HILL BE DISCARDED BY LEGISLATORS AND OTHER POLICYMAKERS. EFFECTIVE REPORTS FOCUS ON FINDINGS CRITICAL TO POLICY ISSUES, PRESENT JARGON-FREE FINDINGS CONCISELY AND CLEARLY, AVOID MAKING RECOMMENDATIONS, AND RELEGATE DISCUSSIONS OF METHOOOLOGY TO THE APPENDIX.

05778 LISKA, G.

TOWARD A NEW WORLD ORDER: THE TALE OF THO CITIES KOREAN JOURNAL OF DEFENSE ANALYSIS, IV(2) (WIN 92), 125-148.

THIS PAPER REVIEWS PROBLEMS CONNECTED HITH THE FUTURE OF WORLD ORDER FROM CONVERGING PERSPECTIVES, CENTERED ON THE QUESTION OF THE KIND AND DEGREE OF BASIC CHANGES IN POSTCOLD WAR WORLD POLITICS. IT FIRST SPECULATES ABOUT THE REASONS FOR THE PEACEFUL RESOLUTION OF THE U.S.-SOVIET CONFLICT. IT THEN CONSIDERS THE FUTURE. THE POST-COLD HAR ENVIRONMENT IS AN EXTREMELY COMPLEX ONE IN WHICH POLARITY INVITING CONFRONTATION IS UNCERTAINLY YIELDING TO A PLURALISM FAVORABLE TO INTEGRATION. A "NEW" EAST-WEST DIMENSION TO HORLD POLITICS IMPLIES POSSIBLE CENTERS FOR A NEW HORLD ORDER: AN ESSENTIALLY OCEANIC ONE AROUND THE U.S. LAND-BRIDGE BETWEEN THE ATLANTIC AND THE PACIFIC, AND AN ESSENTIALLY CONTINENTAL ONE AROUND THE GERMAN-RUSSIAN EURASIAN HEARTLAND. THE LATTER POINTS SOUTHEASTHARD TO AND BEYOND THE INDIAN OCEAN. THE EXISTENCE OF THE LATTER POSSIBILITY ALSO MERITS THE CONSIDERATION OF ALTERNATIVE EUROPEAN IDENTITIES AND OF THE ASIAN TRIANGLE SURROUNDING KOREA.

05779 LITAN, R.E.

INTERSTATE BANKING AND PRODUCT-LINE FREEDOM: HOULD BROADER POWERS HAVE HELPED THE BANKS?

YALE JOURNAL ON REGULATION, $9(2)$ (SUM 92), 521-542.

THE BANKING PROBLEMS OF' THE 1980'S PROMPTED CONGRESS TO ENACT THE FEDERAL DEPOSIT INSURANCE CORPORATION IMPROVEMENT ACT OF 1991 (FDICIA). ADVOCATES OF STRUCTURAL REFORM HAVE CRITICIZED THE FDICIA BECAUSE IT DOES NOT INCLUDE BROADER CRITESTED THE FDICIA BECAUSE IT DOES NOT INCLUDE BROADER THIS PAPER, THE AUTHOR PREDICTS WHAT EFFECTS THE ABSENCE OF THIS PAPER, THE AUTHOR PREDICTS WHAT EFFECTS THE ABSENCE OF
SUCH REFORMS WILL HAVE ON THE U.S. BANKING INDUSTRY. HIS SUCH REFORMS WILL HAVE ON THE U.S. BANKING INDUSTRY. HIS
PREDICTIONS ARE DERIVED FROM COUNTER-FACTUAL EXERCISES IN PREDICTIONS ARE DERIVED FROM COUNTER-FACTUAL EXERCISES IN THE BANKING INDUSTRY OF THE 1980'S IF THE REFORMS HAD BEEN THE BANKING INDUSTRY OF THE 1980'S IF THE REFORMS ENACTED THEN. THESE EXERCISES SUGGEST THAT BROADER
INTERSTATE POWERS NOULD BE MORE EFFECTIVE THAN EXPANDED INTERSTATE POWERS WOULD BE MORE EFFECTIVE THAN EXPANDED
PRODUCT-LINE AUTHORITY AT REDUCING BANK FAILURE BUT THEY PRODUCT-LINE AUTHORITY AT REDUCING BANK FAILURE, BUT THEY
ALSO INDICATE THAT NEITHER REFORM WOULD SIGNIFICANTLY REDUCE THE NUMBER OF BANK FAILURES DURING THE MEXT SEVERAL YEARS. NEVERTHELESS, IT APPEARS THAT BROADER INTERSTATE AUTHORITY, COUPLED WITH BROADER PRODUCT-LINE FREEDOM SUBJECT TO SUITABLE SAFEGUARDS, WOULD STRENGTHEN THE INDUSTRY BY MITIGATING THE RISKS ASSOCIATED WITH BANKING AND LOWERING THE PRICES OF FINANCIAL SERVICES. THUS, STRUCTURAL REFORM OF

05780 LITVAK, I.A.

PUBLIC POLICY ANO HIGH TECHNOLOGY SME'S: THE GOVERMMENT EMBRACE

CANADIAN PUBLIC ADMINISTRATION, 35(1) (SPR 92), 22-38.

GOVERHMENTS IN INDUSTRIALIZED COUNTRIES, INCLUDING CANADA, ARE COMMITTED TO STIMULATING THE FORMATION AND GROWTH OF INMOVATIVE, HIGH-TECHNOLOGY COMPANIES. IN THE COURSE OF PROMOTING TECHNOLOGY-BASED ENTERPRISES, SPECIAL RELATIONSHIPS OFTEN EVOLVE BETHEEN GOVERNMENT AS BENEFACTOR AND SMALL- AND MEDIUM-SIZED FIRMS (SME'S) AS CLIENTS. THE AUTHOR EXAMINES THE CHARACTERISTICS OF 29 CANADIAN SME'S, ALL OF WHICH HAVE RECEIVED SUBSTANTIAL GOVERNMENT R+D AND RELATED SUPPORT. THE BOTTOM LINE IS THAT THE "GOVERNMENT EMBRACE" FREQUENTLY PRODUCES MIXED BLESSINGS, BOTH FOR THE FIRMS AND THEIR FOUNDERS. SOME RELATIONSHIPS PROVE TO BE COSTLY, PARTICULARLY IN TERMS OF THE TECHMOLOGY DIRECTION THAT THE RECIPIENT FIRMS FEEL OBLIGED TO PURSUE. EQUALLY IMPORTANT, BECAUSE GOVERNMENT POLICIES FAVOR START-UP YENTURES, THEY MAY INADVERTENTLY ENCDURAGE ENTREPRENEURICAL VENTURES, THEY MAY INADVERTENTLY ENCDURAGE ENTREPRENEURICAL YIABLE BUSINESS ORGANIZATIONS FIRMS PRIOR TO THEIR BECOMING AUTHOR DRAHS A NUMBER OF LESSONS FOR POLICY CONSIDERATION, AUTHOR DRAWS A NUMBER OF LESSONS FOR POLICY CONSIDERATIOM, RANGING FROM COMPANY-SPECIFIC INCENTIVES TO STRATEGIC
INDUSTRIAL/TRADE POLICIES CRITICAL TO THE PROMOTION OF HIGHINDUSTRIAL/TRADE POLI
TECHNOLOGY COMPANIES.
05781 LIU, A.P.L. THE "WENZHOU MODEL" OF DEVELOPMENT AND CHINA'S MODERNIZATION

ASIAN SURVEY, XXXII(8) (AUG 92), 696-711.

ONE OF THE MOST SIGNIFICANT ASPECTS OF THE POST-MAO ECONOMIC AND SOCIAL DEVELOPMENT OF CHINA WAS THE RISE OF MANY ENTREPRENEURIAL RURAL COMMUNITIES, ESPECIALLY THOSE ALONG THE EASTERN COAST. SOME OF THESE HAD BEEN PROMOTED BY CHINESE JOURMAL ISTS AND SCHOLARS AS "MODELS" FOR EMULATIOM BY OTHER RURAL COMMUNITIES. THE TERM "MODEL" MEANT THAT A COMHUNITY'S SOCIAL AND ECONOMIC PROGRAM BEST REPRESENTED THE DEVELOPMENTAL STRATEGY OF THE CURRENT NATIONAL LEADERSHIP. ACCORDINGLY, THE POST-1980 "MODELS" HAD, IN DIFFERENT WAYS, ACHIEVED THE FOLLOWING: A RAPID RISE IN PERSONAL INCOME, USE OF THE PROF IT MOTIVE AND THE MARKET MECHANISM,

SPECIALIZATION, FLEXIBLE PATTERNS OF OWNERSHIP, AND RELIANCE ON INDIGENOUS RESOURCES. THIS ARTICLE DEALS HITH ONE OF THE MOST FAMOUS "MODELS": WENZHOU MUNICIPALITY IN ZHEJIANG PROYINCE. THE ANALYSIS THROWS INTO RELIEF MANY IMPORTANT ASPECTS AND
ECONOMIC DEVELOPMENT

05782 LIU, L. REFORM: THE THEME OF THE DEVELOPMENT OF CHINESE ADMINISTRATIVE SCIENCE

GOVERNANCE, 5(4) (OCT 92), 459-471.

REFORM HAS BECOME THE THEME OF THE DEVELOPMENT OF ADMINISTRATIVE SCIENCE DURING THE LAST DECADE AND OUTLINES THE FRAMEWORK OF ADMINISTRATIVE REFORM IN CHINA. THE AIM OF THIS ARTICLE IS TO PROVIDE AN OVERVIEW OF CHINESE ADMINISTRATIVE REFORM THROUGH A GENERAL INTRODUCTION AND DISCUSSION OF THE MAIN RESEARCH PROBLEMS IN ADMINISTRATIVE SCIENCE.

05783 LIU, P.

NO TURNIMG BACK

FREE CHINA REVIEW, 42(7) (JUL 92), 54-56.

IN THE FIVE YEARS SINCE THE REPUBL IC OF CHINA GOVERMMENT BEGAN OFFICIALLY ALLONING ITS CITIZENS TO VISIT MAINLAND CHINA, ONE OF THE MOST DRAMATIC SIDE EFFECTS HAS BEEN A BOOM IN CROSS-STRAITS INVESTMENT. MANY ECONOMISTS BELIEVE THAT THE FLOW OF CAPITAL ACROSS THE STRAITS HAS BECOME AN IRREVERSIBLE TREND. MOREOVER, THE PROFITABLE RETURNS ON SUCH INVESTMENTS PROMISE THAT ECONOMIC LINKS WILL BECOME INCREASINGLY IMPORTANT IN THE FUTURE.

05784 LIU, P. WHO'S GOING TO FOOT THE BILL?

FREE CHINA REVIEW, 42(11) (NOV 92), 18-21. THE REPUBLIC OF CHINA'S MASSIVE SIX-YEAR NATIONAL DEVELOPMENT PLAN IS ENTERING ITS SECOND YEAR, AND CONSTRUCTION ON A NUMBER OF MAJOR INFRASTRUCTURE PROJECTS IS IN HIGH GEAR. THE GOAL IS TO PLACE TAIHAN AMONG THE RANKS OF THE DEVELOPED NATIONS WITHIN THE DECADE. TO ACCOMPLISH THIS, LARGE-SCALE CONSTRUCTION PROJECTS HAVE BEEN PLANNED TO UPGRADE THE ISLAND'S OVERBURDENED INFRASTRUCTURE, SUSTAIN ECONOMIC GROWTH, BALANCE REGIONAL DEVELOPMENT, AND IMPROVE THE QUALITY OF LIFE. HOWEVER, THE GOVERNMENT IS FACING PROBLEMS IN FINANCING THE SIX-YEAR DEVELOPMENT PLAN. IT MAY BE FORCED TO SCALE DOWN SOME PRDJECTS OR EXTEND THE COMPLETION DATE FOR THE PLAN.

05785 LIU, $Y$.

REFORM FROM BELOW: THE PRIVATE ECONOMY AND LOCAL POLITICS IN THE RURAL INDUSTRIALIZATION OF HENZHOU

CHINA QUARTERLY, (130) (JUN 92), 293-316.

CHINESE SCHOLARS HAVE OFFERED FIVE ARGUMENTS TO EXPLAIN THE RISE OF PRIVATE INDUSTRY IN WENZHOU: THE HISTORICAL TRADITION OF ENTREPRENEURSHIP, THE LACK OF STATE INVESTMENT AND THE WEAKENING OF STATE CONTROL DUE TO WENZHOU'S GEOGRAPHIC ISOLATION, THE DESTITUTION OF LOCAL ECONOMIC LIFE, THE STATE REFORM POL ICY, AND THE OPEN-MINDEDNESS AND WILLINGNESS TO TAKE RISKS FOUND AMONG WENZHOU CADRES. ALTHOUGH THESE ARGUMENTS HAVE SOME VALIDITY, THEY ARE INSUFFICIENT TO EXPLAIN WHY WENZHOU BECAME THE FIRST AREA IN CHINA TO ACHIEVE A PREDOMINANCE OF PRIVATE INDUSTRY. IT IS THE UNIQUE HISTORICAL LEGACY OF THE 1949 POLITICAL TRANSFORMATION IN WENZHOU THAT ULTIMATELY ACCOUNTS FOR THE FASTER DEVELOPMENT OF LOCAL PRIVATE INDUSTRY. WENZHOU'S SELFLIBERATION BY AN INDEPENDENT LOCAL GUERRILLA FORCE PROVIDED THE WENZHOU CADRES WITH EXCEPTIONAL COHERENCE AND SOLIDARITY THAT HAS ENABLED THEM TO RESIST THE STATE-IMPOSED THAT HAS ENABLLD THEM TO RESIST THE STATE-IMPOSED
COLLECTIVIZATION AND TO PROTECT THE LOCAL PRIVATE ECONOMIC COLLECTIVIZATION AND TO PROTECT THE LOCAL PRIVATE ECONOMIC
ACTIVITIES. THIS PROTECTION BY THE LOCAL AUTHORITY SHELTERED ACTI IVITIES. THIS PROTECTION BY THE LOCAL AUTHORITY SHELTERED
THE HOUSEHOLD FARMING AND PEASANT SIDELINES BEFORE 1978 AND THE HOUSEHOLD FARMING AND PEASANT SIDELINES BEFORE 1978 AND
ENABLED THE PRIVATE SECTOR TO DOMINATE THE WENZHOU ECONOMY ENABLED THE PRIVATE SECTR
AFTER THE 1978 REFORM.

05786 LIVERNASH, R.

THE GROWING INFLUENCE OF NGOS IN THE OEVELOPING WORLD ENVIRONMENT, 34 (5) (JUN 92), 12-20.

NONGOVERMMENTAL ORGANIZATIONS (NGOS) IN THE DEVELOPING WORLD HAVE NOT ACHIEVED AS MUCH SUCCESS AS HAVE THEIR 
NORTHERN COUNTERPARTS, MOSTLY BECAUSE OF LIMITED FUNDING, INTERNAL WEAKNESSES, AND GOVERNMENTAL INTOLERANCE. THROUGH INCREASED INTERACTION WITH LOCAL GOVERMMENTS, NORTHERM NGOS, COMMUNICATION NETWORKS, INTERNATIONAL ASSOCIATIONS, AND THE JUDICIAL SYSTEM, HOWEVER, NGOS IN THE DEVELOPING WORLD CAN HELP TO REDUCE POVERTY AND ILLUMINATE THE LINKS BETWEE POVERTY, DEVELOPMENT, AND ENVIRONMENTAL DEGRADATION.

05787 LIVINGSTON, R.

UNITED GERMANY: BIGGER AND BETTER

FREIGN POLICY, (87) (SUM 92), 157-174.

BOTH EUROPEANS AND AMERICANS ARE ANXIOUS ABOUT THE POTENTIAL POWER OF THE NEWLY-UNIFIED GERMAMY. BY EVERY STANDARD EXCEPT SIZE OF TERRITORY AND OWNERSHIP OF NUCLEAR WEAPONS, GERMANY IS IMDEED ONCE AGAIN THE ASCENDANT STATE IN EUROPE. HOWEVER, AS THIS ARTICLE ARGUES, MOST FEARS ABOUT GERMANY ARE UNFOUNDED. THEY MI SUNDERSTAND--OR UNDERESTIMATETHE PROFOUND CHANGES THAT TRANSFORMED GERMANY IN THE POSTHAR DECADES. HITH REGAROS TO GERMANY, THE UNITED STATES SHOULD NOT PUSH THE UNIFIED GERMANY TO GO BEYOND ITS THO CHOSEN AREAS OF FOREIGM POLICY EMPHASIS: THE EUROPEAN COMMUNITY AND AREAS OF FOREIGN POLICY EMPHASIS: THE EUROPEAN COMMUNITY AH EASTERN EUROPE. GOING BEYOND HOULD RISK SPLINTERING THE
DOMESTIC CONSENSUS UPON WHICH ITS ENHANCED INYOLVEMENT RESTS DOMESTIC CONSENSUS UPON WHICH ITS EMHANCED INVOL VEME AND COULD REVIVE APPREHENSIONS ON THE PART OF OTHER COUNTRIES. THE ARTICLE CONCLUDES THAT PHE UNITED GERMANY IS AEEM THIS CENTURY, THE HESITANT AND GUILT-RIDDEN FEDERAL SEEN THIS CENTURY, THE HESITAY
REPUBLIC OF $1949-90$ INCLUDED.

05788 LIVINGSTON, $S$

THE POLITICS OF INTERMATIONAL AGENDA-SETTING: REgAN AND NORTH-SOUTH RELATIONS

INTERNATIONAL STUDIES QUARTERLY, 36(3) (SEP 92), 313-330. AN APPROACH TO INTERMATIONAL AGENDA-SETTING IS OFFERED THROUGH A STUDY OF THE REAGAN ADMINISTRATION'S ATTEMPT TO REMOVE NORTH-SOUTH RELATIONS FROM THE INTERNATIONAL AGENDA IN THE EARLY 1980S. THE ADMINISTRATION INITIALLY FAILED TO SECURE ITS DESIRED AGENDA CHANGE. THIS ARTICLE SUGGESTS THAT IT IS THROUGH AGENDA ACCESS POINTS THAT AGENDA POLITICS PROCEEDS. CONTROL OF OR LOCATION AT THESE POINTS IS NECESSARY FOR AGENDA SUCCESS.

05789 LIVIMGSTONE, $K$. CAN DEMOCRACY SURYIVE IN RUSSIA? NEW LEFT REVIEW, (192) (MAR 92) 98-104. THE AUTHOR DISCUSSES THE RECENT DRAMATIC CHANGES IN RUSSIA AND THE OTHER FORMER SOVIET REPUBLICS AND SPECULATES RUSSIA AND THE OTHER FORMER SOVIET REPUBL.
ABOUT THEIR PROSPECTS FOR A BETTER FUTURE.

05790 LLOYD, J.

CISOS
NEW REPUBLIC, 206(1-2) (JAN 92), 18, 20.

NEW REPUBLIC, 206(1-2) (JAN 92), 18, 20.
THE AUTHOR DESCRIBES THE CHADTIC CONDITIONS IN THE FORMER SOVIET UNION AS THE NEW LEADERS OF THE COMMONWEALTH OF INDEPENDENT STATES NEGOTIATE, AGREE TO, AND THEN BREAK AGREEMENTS AMONGST THEMSELVES

05791 LO, C.

THE CHINESE COMMUNIST PARTY'S PERCEPTION OF CRISIS AND METHODS OF CRISIS SOLVING DURING THE 1989 DEMOCRATIC MOVEMENT: A LEGAL PERSPECTIVE

ASIAN AFFAIRS, AN AMERICAN REVIEW, 19(2) (SUM 92), 97-120. ONE MIGHT SEE THAT A POLITICAL CRISIS COULD PROVIDE A TEST OF THE CHINESE COMMUNIST PARTY'S COMMITMENT TO THE "RULE OF LAH." THERE WAS NEVER AS TOUGH A TEST FOR DENG AND THE PARTY'S COMMITMENT TO LAH AS THE 1989 DEMOCRATIC MOVEMENT WHICH CULMINATED IN THE MASSACRE BY THE MILITARY IN BEIJING ON \& JUNE 1989, FOLLOWED BY A NATIONWIDE PURGE. THE INCIDENT SHOWS THE LIMITS OF REFORM. IN ORDER TO EVALUATE IT, THIS ARTICLE PRESENTS THE COMHUNIST LEADERSHIP'S MENTALITY IN CRISIS MANAGEMENT UNDER AN ATMOSPHERE OF AN APPARENT HIGHER DEGREE OF POLITICAL TOLERANCE SHOWN BY THE REGIME IN THE REFORM ERA.

05792 LO, C.W.H.

DENG XIAOPING'S IDEAS ON LAH: CHINA ON THE THRESHOLD OF A LEGAL ORDER

ASIAN SURVEY, XXXII (7) ( JUL 92), 649-665.

DENG XIADPING'S IDEAS ON LAH' HAVE HAD AN UNPARALLELED SIGNIFICANCE IN CHINESE HISTORY. DURING HIS LEADERSHIP, LAW HAS ADVANCED BEYOND THE INSTRUMENTAL FUNCTIONS OF MARXIST POL ITICAL RULE. IT HAS INCREASINGLY BEEN SEEN AS A CHANMEL FOR ECONOMIC MODERMIZATION AND AS THE SOLE LEGITIMATE MEANS FOR ECONOMIC MODERMIZATION AND AS THE SOLE LEGITIMATE MEANS LEGAL REFORM BY INTRODUCING A HIGHLY INSTITUTIONALIZED LEGAL REFORM BY INTRODUCING A HIGHLY INSTITUTIONALIZED CRIMINAL JUSTICE SYSTEM IN 1980, DENG CULMINATED HIS CONSOLIDATING THE BASIC FRAMEHORK FOR A COMPREHENSIVE LEGAL ORDER AT THE THIRTEENTH PARTY CONGRESS. HOWEVER, AS DENG REGARDED "RULE BY LAH" AS OCCURRING UNDER PARTY TUTELAGE, IT WAS AN UNDEMOCRATIC "RULE OF LAH." IT SEEMS THAT WHILE DENG RESOLVED THE MAOIST DILEMMA OF CHOOSING BETWEEN A LEGAL AND A LAWLESS SOCIETY, HE REMAINED UNRESOLVED AS TO THE RELATIONSHIP BETWEEN LAN AND PARTY LEADERSHIP WITHIN THE
PROCESS OF SOCIAL REGULATION.

05793 LOBMEYER, $H$

ISLAMIC IDEOLOGY AND SECULAR DISCOUSE: THE ISLAMISTS OF SYRIA

ORIENT, 25(3) (1991), 395-418

THE EVENTS AND THE ISLAMIST DISCOURSE SINCE THE 1960 S IS ANALYZED, PART ICULARLY THE ANTI-ALAHI AGITATION. THE ANALYSIS SHOWS THAT THE DISCOURSE IS NOT AN ISLAMIC, BUT A SECULAR ONE AND THAT ISLAM ONLY SERVES AS A MEANS OF MOBILIZATION: THE ALANIS ARE NOT REFERRED TO AS APOSTATES WHO RULE REAL MUSLIMS BUT AS A MINORITY WHO RULES OVER THE MAJORITY. THAT ALSO MEANS THAT THE ISLAMISTS PERCEIVE THE ALAHI DOMINANCE IN THE REGIME AS DICTATORSHIP. THE ISLAMISTS' POLITICAL PROGRAM OF 1980 IS BASED ON SECULAR RATHER THAN ISLAMIC VALUES.

05794 LOBOV, $V$

THE FUTURE OF THE SOVIET ARMED FORCES: OUTLINES OF MILITARY DOCTRINE AND STRUCTURE

MEDITERRANEAH OUARTERLY: A JOURNAL OF GLOBAL ISSUES, 3(1)

(WIN 92 ), 15-24

VLADIMIR LOBOV, CHIEF OF STAFF OF THE ARMED FORCES OF THE USSR, DISCUSSES THE POLITICAL CHANGES THAT HAVE AFFECTED THE SOVIET ARMED FORCES. THESE INCLUDE SIGNIFICANT

IMPROVEMENT IN RELATIONS BETHEEN THE USSR AND THE WEST: DRASTIC TRANSFORMATIONS IN EASTERN EUROPE LEADING TO THE DISINTEGRATION OF THE WARSAH PACT; THE GULF WAR; IMPORTANT ARMS-CONTROL AGREEMENTS IN THE AREAS OF STRATEGIC AND CONVENT IONAL WEAPONS; AND THE DECLARATION OF INDEPENDENCE BY SOME FORMER SOVIET REPUBLICS. THESE CHANGES NECESSITATE REFORMS IN THE SOVIET MILITARY STRUCTURE AND DOCTRINE. LOBOV DISCUSSES VARIOUS AREAS OF REFORM INCLUDING: SEPARATION OF RESPONSIBILITIES FOR MILITARY MANAGEMENT: DEFINITION OF THE MILITARY-ADMINISTRATIVE DIVISION OF THE COUNTRY

MOOIFICATION OF THE ARMED FORCES PERSONNEL STRUCTURE;

MODIFICATION OF THE INDUCTION SYSTEM OF THE ARMED FORCES ;

AND SPECIFICATION OF MILITARY TECHNOLOGY POLICY.

05795 LOCHHEAD, C.

FARM WARS

INSIGHT, 7(3) (JAN 91), 39-41.

ALTHOUGH THE DEADLINE HAS PASSED FOR ENDING THE TALKS OF THE GENERAL AGREEMENT OF TARIFFS AND TRADE (GATT), THE UNITED STATES AND THE EUROPEAN COMMUNITY REMAIN DEADLOCKED OVER AGRICULTURE. THE STICKING POINT IS GOVERMMENT SUBSIDIES THAT CREATE SURPLUSES AND DEFLATE WORLD MARKETS. IF THE TWO SIDES ARE UNABLE TO REACH AN AGREEMENT, U.S. AGRICUL TURE SIDES ARE UNABLE TO REACH AN AGREEMENT, U.S. AGRICULTURE
WILL HAVE TO SHRINK, AND THE FARMERS OF EASTERN EUROPE WILL WILL HAVE TO

05796 LOCHHEAD, C.

LUXURY TAX IS SINKING YACHTS AND REVENUES

INSIGHT, $7(32)$ (AUG 91), 22-25.

WHEN' IT WAS UNVEILED, THE TEN PERCENT LUXURY TAX ON YACHTS, AIRPLANES, HIGH-PRICED AUTOMOBILES, JEHELRY AND FURS WAS HAILED BY ITS SPONSORS AS BOTH A REVENUE RAISER AND A LEVELER OF THE RICH. BUT LESS THAN ONE YEAR LATER, IT IS THE EMPTINESS OF THAT PROMISE THAT HAS BECOME PAINFULLY CLEAR. NOT ONLY IS THE U.S. YACHT INDUSTRY BEING STRANGLED, THE FEDERAL DEFICIT IS BALLOONING TO RECORD LEVELS, AND A NEW CONGRESSIONAL STUDY HAS DETERMINED THAT THE TAX- FAR FROM RAISING MONEY--IS ACTUALLY COSTING THE TREASURY S5 FOR EVERY $\$ 1$ IT BRINGS IN.

05797 LOCXERBIE, B.

PROSPECTIVE VOTING IN PRESIDENTIAL ELECTIONS, 1956-1988 AMERICAN POLITICS QUARTERLY, 20(3) (JUL 92), 308-325.

AN ANALYSIS OF THE AMERICAN NATIONAL ELECTION STUDIES OF 1956 THROUGH 1988 SUPPORTS THE ARGUMENT THAT VOTERS LOOK BOTH BACKHARD AND FORWARD WHEN DECIDING FOR HHOM TO VOTE. ALTHOUGH BOTH RETROSPECTIVE AND PROSPECTIVE ECONOMIC EVALUATIONS ARE IMPORTANT, AND THE LEVEL OF IMPORTANCE OF EACH VARIES SOMEHHAT OVER TIME, IT IS CLEAR THAT EVALUATIONS OF FUTURE PERFORMANCE ARE AN IMPORTANT INFLUENCE ON VOTE CHOICE. EVEN WHEN PLACED IN A CAUSAL MODEL HITH BOTH PARTY IDENTIFICATION AND RETROSPECTIVE EVALUATIONS PRIOR TO THEM, THE PROSPECTIVE EVALUATIONS REMAIN A FORCEFUL INFLUENCE ON VOTE CHOICE.

05798 LOCKERBIE, B.

THE TEMPORAL PATTERN OF ECONOMIC EVALUATIONS AND VOTE THE TEMPORAL PATTERN OF ECON

PUBLIC CHOICE, 69(3) (MAR 91), 279-294.

ECONOMICS HAS LONG BEEN THOUGHT TO INFLUENCE VOTE CHOICE. UNFORTUMATELY THE TEMPORAL PATTERM OF ECONOMIC EVALUATION IS LITTLE STUDIED. USING THE SENATE ELECTIONS OF 1956 THROUGH 1988, THIS RESEARCH PRESENTS ASSESSHENT OF THE ROLE OF RETROSPECTIVE AND PROSPECTIVE EVALUATION OH VOTE CHOICE. THE FINDINGS OF THIS RESEARCH SUPPORT THE ARGUMENT THAT PEOPLE LOOK TO THE FUTURE WHEN MAKING THE VOTE DECISION. CONSEQUENTLY, THIS RESEARCH ALSO ARGUES THAT THE SIMPLE REWARD/PUNISHMENT VIEW OF VOTING DOES NOT REFLECT THE RICHNESS OF ECONOMIC VOTING. FINALLY, A CAUSAL MOOEL IS 
CONSTRUCTED TO DEMONSTRATE THAT THESE PROSPECTIVE EVALUATION EXERT AN INFLUENCE ON VOTE CHOICE INDEPENDENT OF BOTH PARTY IDENTIFICATION AND RETROSPECTIVE EVALUATIONS.

05799 LOCXHART, C; ; GALVIN, R.

POL ICY IMPLICATIONS OF DISCRETE IDIOSYNCRATIC GOODS: THE CONTRASTING CASES OF MEDICAL CARE AND POST-GRADUATE EDUCATION

POLITY, XXIV(2) (WIN 91), 295-312.

THIS ARTICLE ANALYZES DISCRETE IDIOSYNCRATIC GOODS AND THEIR IMPLICATIONS FOR THEORIES OF DISTRIBUTIVE JUSTICE. THE AUTHORS ARGUE THAT THE DIFFICULTIES ASSOCIATED WITH AUTHORS ARGUE THAT THE DIFFICULTIES ASSOCIATED WITH PRACTICAL EFFORTS TO OISTRIBUTE SUCH GOODS JUSTLY ARE
INHERENT IN THE CHARACTERISTICS OF THE GOODS THEMSELVES INHERENT IN THE CHARACTERISTICS OF THE GOODS THEMSELVES. USING MEDICAL CARE AND POST-GRADUATE EDUCATION AS EXAMPLES, WAYS TO DISTRIBUTE THESE GOODS MORE FAIRLY.

05800 LOCKHHEAD, C.

SPENDING SPREE

INSIGHT, 7(8) (FEB 91), 18-19

LAST'FALL'S BUDGET AGREEMENT BETWEEN CONGRESS AND THE BUST ADMINISTRATION CALLED FOR A COMBINATION OF TAX INCREASES AND SPENDING CUTS TO REDUCE THE FEDERAL DEFICIT BY $\$ 500$ BILLION OVER FIVE YEARS. YET, FOUR MONTHS LATER, THE DEFICIT IS BALLOONING TO UMPRECEDENTED LEVELS. THE ADMINISTRATION'S $\$ 1.45$ TRILLION BUDGET PROPOSAL UNDERSCORES A RECORD $\$ 318$ BILLION DEFICIT. THE KEY PROBLEM IS SIMPLE: CONGRESS CONTINUES TO SPEND MORE THAN THE GOVERNMENT TAKES IN; THE CUTS ARE ACTUALLY JUST A REDUCTION IN PROJECTED SPENDING INCREASES.

05801 LODGAARD, $S$.

GLOBAL SECURITY AND DISARMAMENT: REGIONAL APPROACHES

BULLETIN OF PEACE PROPOSALS, 22 (4) (DEC 91), 377-386. THIS ARTICLE EXAMINES SEVERAL OF THE PROBELLMS FACING THE NATIONS OF THE HORLD. IT PRESENTS REGIONAL APPROACHES AS A VIABLE SOLUTION TO MANY OF THEM. POROUS BORDERS AND FREER REIN TO MARKET FORCES ARE LIKELY TO WIDEN THE GAPS BETHEEN RICH AND POOR: REGIONAL COOPERATION BETWEEN COUNTRIES IN THE SOUTHERN HEMISPHERE MAY HELP STEM THAT TREND. POROUS BORDERS AND HEAVY RELIANCE ON MARKET FORCES FACILITATE ARMS TRADE: REGIONAL COOPERATION AMONG BUYERS AS WELL AS SUPPLIERS CAN CULTURAL. ETHNIC AND NATIONALIST IDEALS, WHEREAS IN ECONOMIC CULTURAL, ETHNIC AND NATIONALIST IDEALS, WHEREAS IN ECONOM TERMS SECESSION MAY NOT BE SUCH AN ATTRACTIVE PROPOSITION: REGIONAL INTEGRATION MAY BE A BETTER WAY OUT. IT CONCLUDES THAT THE UN SHOULD TAKE A MUTI-PRONGED APPROACH TO
TRADE PROBLEM. THIS WOULD MEAN BUILDING ON REGIONAL COOPERATION AMONG RECIPIENT AS WELL AS SUPPLIER STATES; COORDINATING THEIR INITIATIVES WITH AN EYE TO MUTUAL REINFORCEMENT; ENCOURAGING STEPS TOWARDS NON-OFFENSIV DEFENSE; EQUIPPING ITSELF FOR A GREATER VARIETY OF MILITARY TASKS IN THE THIRD HORLD TO SUBSTITUTE FOR MAJOR POWER INTERVENTION THERE; AND INVESTING MORE IN THE STUDY OF THE PROMOTION OF CONVERSION.

05802 LODGAARD, S.

VERTICAL AND HORIZONTAL PROLIFERATION IN THE MIDOLE EAST/PERSIAN GULF

BULLETIN OF PEACE PROPOSALS, 22(1) (MAR 91), 3-10. MAJOR NAYAL COMBATANTS ROUTINELY CARRY MUCLEAR WEAPONS. THIS PROBLEM HAS GLOBAL AS HELL AS REGIONAL RAMIFICATIONS. IN THIS ARTICLE, WITHDRAHAL OF NAVAL NUCLEAR WEAPONS IS CONSIDERED IN GENERAL TERMS, AS A GLOBAL MATTER. THE HORI ZONTAL DIMENSION IS MORE AMENABLE TO RATIER. ARRANGMENTS AND IS DISCUSSED IN TERMS OF CONFIDENCE-BUILOING MEASURES AIMED AT THE ESTABLI IHMENT OF A NUCLEAR WEAPONOF THE GAME SHOULD MO LONG AR BE Z

05803 LODGE, J.

INTERHAL SECURITY AND JUDICIAL COOPERATION BEYOND MAASTRICHT

MARASTRICHT POL ITICAL VIOLEMCE (3) (FAL 92) 1-29.

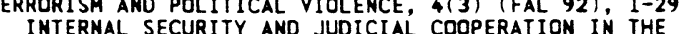
INTERNAL SECURITY AND JUDICIAL COOPERATION IN THE
EUROPEAN COMMUNITY (EC) HAVE DEVELOPED DUTSIDE THE FRAMEWORK EUROPEAN COMMUNITY (EC) HAVE DEVELOPED DUT SIDE THE FRAMEHOR OF TREATIES. THE COMPLETION OF THE SINGLE MARKET AND THE INTERNATIONAL CDOPERATION ON THESE ISSUES IMPERATIVE. THIS INTERNATIONAL COOPERATION ON THESE ISSUES IMPERATIVE. THIS
ESSAY EXAMINES THE EC'S SECURITY COMPETENCE; THE SCOPE OF ESSAY EXAMINES THE EC'S SECURITY COMPETENCE; THE OPERATIOMAL ISSUES AMO SECURITY COOPERATION WITHIN SCHENGEN OPERATIONAL 1SSUES AND SECURITY COOPERATION WITHIN SCHEM AND WITH CENTRAL AND EASTERN EUROPE. IT CDNCLUDES THAT STREAMLINING THE MULTIPLICI
ACTIVITIES IS IMPERATIVE.

05804 LODGE, J.

PARL IAMENTS AFTER MAASTRICH

PARLIAMENTARIAN, LXXIII(2) (APR 92), 105-106.

THE AGREEMENT ON POLITICAL UNION REACHED BY THE EUROPEAN COMMUNITY (E.C.) HEADS OF GOVERMMENT IN DECEMBER 1991 WILL ENHANCE THE ROLE OF NATIONAL PARL IAMENTS IN THE COMHUNITY. THIS IS SIGNIFICANT BECAUSE SEVERAL OTHER FEATURES OF THE
AGREEMENT CREATE THE IMPRESSION THAT THE CENTER OF GRAVITY IN E.C. DECISION MAKING HAS FIRMLY MOVED AWAY FROM NATIONAL GOVERNMENTS TOWARDS A SUPRA-NATIONAL FEDERAL GOVERNMENT.

05805 LODGE, M.; CONOVER, P.J.; FELDMAN, S.; MCGRAW, K.M.; MILLER, A.H.

WHERE IS THE SCHEMA? CRITIQUES

AMERICAN POLITICAL SCIENCE REVIEH, 85(4) (DEC 91), 1357-1380.

THIS SYMPOSIUM FEATURES THREE CRITIQUES OF THE ARGUMENT ABOUT SCHEMA THEORY OFFERED BY JAMES $H$. KUKLINSKI, ROBERT $C$.

LUSKIN, AND JOHN BOLLAND. FIRST, MILTON LODGE AND KATHLEEN $M$.

MCGRAW RESPOND FROM THE PERSPECTIVE OF COGNITIVE PSYCHOLOGY

THEN PAMELA J. CONOVER AND STANLEY FELDMAN CONSIDER SCHEMA CONCEPTUALIZATION PRIMARILY IN TERMS OF PROBLEMS OF

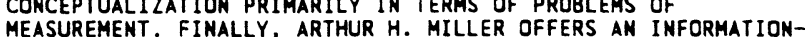
PROCESSING APPROACH TO POLITICAL SCHEMAS.

05806 LOOGE, T.

POST-MODERN BOLSHEVIKS--SA COMHUNISTS IN TRANSITION

SOUTH AFRICA INTERNATIONAL, 22 (4) (APR 92), 172-179.

MEMBERS OF THE SOUTH AFRICAN COMMUNIST PARTY (SACP)

CONTINUE TO OCCUPY LEADERSHIP POSITIONS WITHIN THE AFRICAN

NATIONAL CONGRESS (ANC) DISPROPORTIONATE TO THE RELATIVE

SIZES, IN TERMS OF MEMBERSHIP, OF THE TWO ORGANIZATIONS.

SIMILARLY, THE PARTY IS WELL REPRESENTED WITHIN THE

ORGANIZED LABOR MOVEMENT. DESPITE THIS, THE SACP'S POSITION IN BOTH CASES IS NOT A HEGEMONIC ONE. ITS INFLUENCE HAS BEEN LESSENED BY THE NEW OPENMESS WITHIN ITS RANKS THANKS TO THE COLLAPSE OF WORLD COMHUNISM, AND BY THE GROWIHG DIFFERENCES BETHEEN THE ANC AND ITS OLD ALLY, IN TERMS OF POLICY, RESOURCES, AND SUPPORT. IF THE SACP IS TO REMAIN TRUE TO ITS PRINCIPLES, IT MAY BE FORCED INTO BECOMING A PARTY OF OPPOSITION IN A POST-APARTHEID SOUTH AFRICA; AND THIS, IRONICALLY, COULD HELP UNDERPIN MULTIPARTY DEMOCRACY IN THE FUTURE.

05807 LOESCH, A.

CZECHOSLOVAKIA AND GERMANY SIGN A "GOOD-NEIGHBOR" PACT GERMAN TRIBUNE, (1505) (FEB 92), 1, 3.

THE COLLAPSE OF THE IRON CURTAIN HAS LAID THE FOUNDATION FOR POLITICAL CONVERGENCE. ALTHOUGH GERMANY AND

CZECHOSLOVAKIA'S MUTUALLY INFLICTED WOUNDS HAVE NOT YET CZECHOSLOVAKIA'S MUTUALLY INFLICTED WOUNDS HAVE NOT

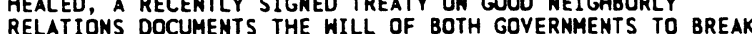
RELATIONS DOCUMENTS THE WILL OF BOTH GOVERMAENTS TO BREAK THROUGH THE VICIOUS CYCLE OF FEAR AND MUTUAL MISTRUST AND PROCESS, HOWEVER, IS BOUND TO REMAIN INCOMPLETE AS LONG AS PROCESS, HOWEVER, IS BOUND TO REMAIN INCOMPLETE AS LONG AS THE ENTIRE REALITY IN THE RELATIONSHIP BETWEEN THE GERMANS AND CZECHS IS NOT INCLUDED. ISSUES SUCH AS REPARATIONS FOR PAST MISDEEDS (HITLER'S OCCUPATION OF CZECHOSLOVAKIA, THE EXPULSION OF
ADORESSED.

05808 LOFFELHOLZ, T

START TREATY A STEP IN THE RIGHT DIRECTION GERMAN TRIBUNE, (1477) (JUL 91), 1-2.

ON 17 JULY IN LONDON, MIKHAIL GORBACHEV AND GEORGE BUSH AGREED ON THE LAST MOOT POINTS OF THE START TREATY WHICH IS TO BE SIGMED AT THE MOSCOH SUMMIT AT THE END OF THE MONTH. THE START TREATY MEANS NO MORE AND NO LESS THAN THAT THE SUPERPOWERS HAVE AGREED FOR THE FIRST TIME TO DISARM, RATHER THAN JUST ENDORSE ARMS LIMITS, IN A SECTOR THAT IS OF CRUCIAL SIGNIFICANCE FOR THEIR RESPECTIVE SECURITY. WHILE SOME CRITICIZE THE AGREEMENT BECAUSE IT CALLS FOR REDUCTIONS SIGNIFICANTLY SMALLER THAN THOSE CALLED FOR AT THE HEIGHT OF THE COLD WAR, THE HISTORIC SIGNIFICANCE OF THE AGREEMENT SHOUID NOT BE OVERLOOKED. START REPRESEMTS AN IMPORTANT FIRST STEP IN THE DISARMAMENT PROCESS

05809 LOFFELHOLZ, T.

UNEXPECTED CRISES A THREAT TO STABILITY OF DEMOCRACY GERMAN TRIBUNE, (1533) (SEP 92), 3.

IN GERMANY, HARDLY A DAY PASSES WITHOUT RIOTS, WITHOUT ATTACKS ON REFUGEE HOSTELS, WITHOUT DUTBURSTS OF HATE IN SOME FORM OR ANOTHER. THIS IS HARDLY SURPRISING SINCE MORE THAN $40 \%$ OF THE FORMER EAST GERMANS ARE VIRTUALLY UNEMPLOYED AND MANY INDUSTRIES ARE SUFFERING THROUGH HARD TIMES. THE STABILITY OF GERMAN DEMOCRACY IS AT STAKE. IT DEPENDS ON HOH THE NATION COMES TO TERMS WITH ITS DECLINING STAME
LIVING AND HOW IT DEALS WITH THE SOCIAL UNREST.

05810 LOGERFO, J.

PRINCIPLES AND POLITICS: PRESIDENT BUSH AND THE CONSERVATIVES

CONTEMPORARY REVIEH, 260(1515) (APR 92), 175-181.

THIS ARTICLE IS AN ASSESSMENT OF THE' BUSH ADMINISTRATION AFTER BEING IN OFFICE FOR FOUR YEARS. THE AUTHOR IS CRITICAL OF PRESIDENT BUSH IN EVERY WAY. HE CONCLUDES THAT THE CONSERVATIVES WILL SUPPORT BUSH IN THE UPCOMING ELECTION BECAUSE THEY KNOH THAT AN ARMY OF DEHOCRATIC POLITICAL APPOINTEES IN THE FEDERAL BUREAUCRACY WILL BE A SOURCE OF ENDLESS TORMENT TO THEM. 
O5811 LOGGARD, S.

COMPETING SCHEMES FOR EUROPE: THE CSCE, NATO AND THE EUROPEAN UNIOM

SECURITY DIALOGUE, 23(3) (SEP 92), 57-68.

THE CORE OF EC INTEGRATION IS ECONOMIC, POINTING TOWARDS A COMON CURRENCY AND A CENTRAL BANK. THE WESTERN EUROPEAN UNION IS EMERGING AS THE SECURITY POLICY ARM OF THE EC, AND ALSO AS A MEANS TO STRENGTHEN THE EUROPEAN PILLAR OF THE ATLANTIC ALLIANCE. THIS ARTICLE SUGGESTS THAT A NEH ATLANTIC CONNECTION SEEMS TO BE IN THE OFFING. CONSIDERABLE ACTIVITY IS UNFOLDING ON THE ARENA EC/WEU/CSCE AND THAT OF NATO/NACC/CSCE. RUSSIA MAY FIND ITSELF PLACED ON THE SIDELINES OF EUROPEAN POLITICS.

05812 LOGSDON, J.

INTERNATIONAL COOPERATION IN THE SPACE STATION PROGRAM SPACE POLICY, 7(1) (FEB 91), 35-45.

AS THE INTERMATIONAL PARTNERSHIP TO DESIGN AND OPERATE A SPACE STATION COMPLEX COMES UP FOR REAPPRAISAL, THIS ARTICLE REVIEHS THE EXPERIENCE TO DATE AND ASKS WHETHER THE PARTMERSHIP CAN BE MAINTAINED. THE MOST FUNDAMENTAL LESSON IS THAT SUCCESSFUL COLLABORATION CANNOT BE BUILT ON A WEAK IS THAT SUCCESSFUL COLLABORATION CANMOT BE BUILT ON A HEAK
FOUNDATION. THERE ALWAYS WAS A MAJOR ASYMMETRY BETWEEN THE USA AND ITS PARTNERS, AND THIS WAS COMPOUNDED BY MUTUAL MISTRUST. IF INTERHATIONAL COLLABORATION IS THE ONLY WAY MISTRUST. IF INTERNATIONAL COLLABORATION IS THE ONLY HAY BURDENS AND PROSPECTS OF SUCH ENTERPRISES IS ESSENTIAL.

05813 LOMASKY, L.

THE IMPORTANCE OF BEING EARNEST

REASON, $24(2)$ ( JUN 92), 36-39.

THIS ARTICLE EXPLORES THE PRECIPITOUS DECLINE IN GEORGE BUSH'S POPULARITY RATINGS FROM 90-PERCENT-PLUS HEIGHTS TO DEPTHS EMBOLDENING A COTERIE OF UNDISTINGUISHED CHALLENGERS. IT SUGGESTS THAT GEORGE BUSH IS A TEXAN WHOSE THO-STEP IS GALLUP AND ROPER, WHO SEEMINGLY NEVER MAKES A DECISION WITHOUT CONSIDERING HOW IT HILL PLAY IN THE MEDIA. ALSO, THAT ONE DISTRUSTS BUSH NOT BECAUSE HE WON'T BE BRAVE IN A FIGHT BUT BECAUSE THERE IS NO WAY OF TELLING WHAT HE HILL TAKE TO BE HORTH FIGHTING FOR. IT CONCLUDES THAT ADHERENCE TO PRINCIPLES MATTER AND THAT IS THE ONE LESSON OF THE POLLS THAT GEORGE BUSH WILL NOT OR CAN NOT LEARN.

05814 LOMBRA, R.E.; KAUFMAN, H.M.

MODELING CENTRAL BANK BEHAVIOR: WHAT HAVE HE LEARNED? JOURNAL OF POLICY MODELING, 14(2) (APR 92), 227-248.

WITHIN THE LITERATURE ON MONETARY AND FISCAL POLICY THERE EXISTS A WIDE RANGE OF RESULTS ON THE ROLE AND EFFECTS OF POLICY, BOTH DOMESTICALLY AND INTERMATIONALLY. THIS ARTICLE FOCUSES ON VARIOUS INADEQUACIES ASSOCIATED WITH THE ARTICLE FOCUSES ON VARIOUS INADEQUACIES ASSOCIATED WITH THE MODELING OF CENTRAL BANK BEHAVIOR AS AN IMPORTANT SOU REGULATIONS IN INFLUENCING CAUSAL RELATIONSHIPS AND THE REGULATIONS IN INFLUENCING CAUSAL RELATIONSHIPS AND THE
DYNAMIC ADJUSTMENT OF THE FINANCIAL SYSTEM TO DISTURBANCES IS HIGHL IGHTED. AT THE PRACTICAL LEVEL THE EVOLUTION OF IS HIGHLIGHTED. AT THE PRACTICAL LEVEL, THE EVOLUTION
MONETARY POLICY IN THE UNITED STATES IS REVIEWED AND COMPARED TO POLICY PROCEDURES IN OTHER MAJOR COUNTRIES, WITH SPECIAL EMPHASIS ON THE IMPLICATIONS FOR EMPIRICAL STUDIES.

05815 LONG, D.

J.A. HOBSON AND IDEALISM IN INTERNATIONAL RELATIONS REYIEW OF INTERNATIONAL STUDIES, 17 (3) (JUL 91), 285-304. THIS PAPER CRITICALLY ASSESSES THE WORK OF J.A. HOBSON AND ITS RELATION TO IDEALISM AS A CATEGORY OF INTERNATIONAL RELATIONS THOUGHT. AN EXAMINATION OF HOBSON'S HRITINGS ON INTERNATIONAL RELATIONS SHOH THAT THERE ARE THREE DISTINCT STANDS OF THOUGHT, THREE MODES OF IDEALISH. THESE MODES OF IDEALIST THOUGHT DIFFER ON FUNDAMENTAL PROPOSITIONS ABOUT INTERNATIONAL RELATIONS AS WELL AS IN THEIR PRESCRIPTIONS FOR A REFORMED WORLD ORDER. IN SHORT, CONSIDERATION OF HOBSON'S HORK DESTABILIZES THE MONOLITHIC CATEGORY OF IDEALISM IN INTERNATIONAL RELATIONS.

05816 LONG, J. A.

FEDERAL ISM AND ETHNIC SELF-DETERMINATION: NATIVE INDIANS IN CANADA

JOURMAL OF COMMONWEALTH AND COMPARATIVE POLITICS, $X X I X(2)$

( JUL 91), 192-211.

THIS ARTICLE EXAMINES THE ISSUE OF INDIAN SELFDETERMINATION WITHIN THE CONTEXT OF CANADIAN FEDERALISM. SPECIFICALLY, IT FOCUSES ON THE INDIAN SELFGOVERMMENT AS AN EMERGENT ETHMO-POL ITICAL MOVEMENT THAT SEEKS TO ALTER THE TRADITIONAL LEGAL AND POLITICAL STATUS OF INDIAN PEOPLES WITHIN THE CANADIAN FEDERAL SYSTEM AND THE REACIIONS OF THE FEDERAL AND PROVINCIAL GOVERMMENTS ANO THE REACTIONS OF THE FEDERAL AND PROVINCIAL GOVERNMENTS TO THAT MOVEMENT. HAVING RESISTED ASSIMILATION FOR OVER A CENTURY, INDIAN PEOPLES NOH CHALLENGE THEIR HISTORICAL POSITION AND ARGUE FOR GREATER
CONTROL OVER THEIR ONN AFFAIRS THROUGH CONSTITUTIONALLY ENTRENCHED SELF-GOVERNMENT. THE SELF-DETERMINATION MOVEMENT ENTRENCHED SELF-GOVERMMENT. THE SELF-DETERMINATION MM

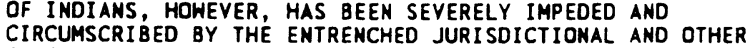
INTERESTS OF THE NATIONAL AND PROVINCIAL GOVERMMENTS.
05817 LONG, N.E.

SEEKING THE POLITY'S BOTTOM LINE: A CONCEPTUAL NOTE ADMINISTRATION AND SOCIETY 24(2) (AUG 92), 107-116. SOMEHOH SCHOLARS HAVE LOST SIGHT OF WHAT OUGHT TO BE THE BOTTOM LINE FOR THE POLITY: THE CONDITION OF THE INDIVIDUAL. POLITICAL SCIENCE, PUBLIC ADMINISTRATION, URBAN POLITICS, AND POLICY ANALYSIS HAVE ALL LOST SIGHT OF THIS CONCERN THAT WAS ONCE THE FOCUS OF CLASSICAL POLITICAL PHILOSOPHY. SCHOLARS MUST ESTABLISH SYSTEMATIC INVENTORIES OF THE PRINCIPAL DIMENSIONS OF THE HUMAN CONDITION AGAINST WHICH ONE CAN MAKE COMPARISONS AS ACTORS, STRUCTURES, AND PROCESSES CHANGE.

05818 LONG, $S$.

TAIHAN'S NATIONAL ASSEMBLY ELECTIONS

CHINA QUARTERLY, (129) (MAR 92), 216-228

ALTHOUGH TAIHAN'S DECEMBER 1991 ELECTIONS FOR THE NATIONAL ASSEMBLY PROLONGED THE OVERWHELMING DOMINANCE OF THE RULING KUOMINTANG, THEY WERE UNPRECEDENTED IN A NUMBER OF RESPECTS. THEY REPRESENTED A HUGE LEAP TOHARDS A GENUINELY PLURALIST POLITICAL SYSTEM IN TAIHAN, EVEN THOUGH GENUINELY PLURALIST POLITICAL SYSTEM IN TAINAN, EVEN THOUGH THEY WERE MARRED BY ELECTORAL IRREGULARI IIES AND DISTORTED
BY THE PROMINENCE OF THE INDEPENDENCE ISSUE AND INTERVENTION FROM BEIJING.

05819 LONGSTAFF, S.

THE QUEBEC-CANADA CRISIS

MEW POL ITICS, IV(1) (SUM 92), 27-40.

IN 1980, WHEN QUEBEC VOTERS WERE ASKED BY RENE LEVESQUE IN A REFERENDUM TO GIVE HIS PARTI QUEBECOIS (PO) GOVERNMENT A MANDATE TO NEGOTIATE QUEBEC'S DISENGAGEMENT FROM THE REST OF CANADA, THERE WERE FEH ENGLISH-SPEAKING VOICES ON THE LEFT QUESTIONING THE LEGITIMACY OF THIS NATIONALIST PROJECT. NOW, WITH ANOTHER VOTE ON SOVEREIGNTY IN THE OFFING-QUEBEC'S CURRENT LIBERAL GOVERNMENT, HEADED BY ROBERT BOURASSA, HAS PROMISED TO HOLD A SECOND REFERENDUM BY OCTOBER 26, 1992--THE MOOD HAS CHANGED. THIS ARTICLE EXAMINES WHAT HAS HAPPENED IN THE MEANTIME. IT OUTLINES THE KEY EVENTS IN CANADA'S ONGOING STRUGGLE TO REMAIN A FEDERAL STATE. THESE INCLUDE: THE CONSTITUTIONAL SQUABBLES BETHEEN LEVESQUE AND PRIME MINISTER PIERRE TRUDEAU; THE COMING TO POWER OF THE CONSERVATIVES; THE MEECH LAKE CONSTITUTIONAL ACCORDS; THE FREE TRADE ELECTION; AND THE FAILURE OF MEECH LAKE.

05820 LONGWORTH, R.

EASTERN EUROPE: THE PARTY'S OVER

BULLETIN OF THE ATOMIC SCIENTISTS, 48 (1) (JAN 92), 22-29.

THE EUPHORIA THAT ACCOMPANIED THE OVERTHROH OF COMMUNIST REGIMES IN EASTERN EUROPE INCREASED AS PEOPLE LOST THEIR FEGIMES IN EASTERN EUROPE "TNCREASED AS PEOPLE LOST THEIR FEAR OF THE POL ICE OR OF "THE POWER" AS MANY EAST EUROPEANS
CALLED THOSE WHO RULED THEIR LIVES. BUT NOW THERE IS FEAR CALLED THOSE WHO RULED THEIR LIVES. BUT NOH THERE IS FEAR DIFFICULT BUT, ECONOMICALLY SPEAKING, PREDICTABLE. EVEN MORE, THERE IS A FEAR OF THE POLITICAL FUTURE AMONG MEN AND WOMEN WHO KNOH TOO WELL THAT, WITH RARE EXCEPTIONS AND FOR BRIEF TIMES, THEIR HOMELANDS HAVE NEVER EXISTED WITHOUT DICTATORS OR FOREIGN SUZERAINTY.

05821 LONGWORTH, R.

THE ROAD TO 1992

EUROPE, 313 ( JAN 92), 6-7.

THE HISTORY OF EUROPEAN FREE COMMERCE IS ONE OF BATTLES, DISAPPOINTMENTS AND FRUSTRATIONS AS WELL AS SUCCESS. THE WHOLE POINT TO THE COMMUNITY WAS TO MAKE COMMERCE BETHEEN ITS MEMBERS SO THOROUGH, SO ROUTINE, THAT A NEW WAR WAS UNTHINKABLE. THE NATIONALISM THAT NOW THREATENS TO RIP EASTERN EUROPE APART FEEDS ON POVERTY. WHEN POVERTY ENDS THEN NATIONALIST HATREDS WILL FADE INTO THE BACKGROUND. IT IS NOT NECESSARY TO LOVE ONE'S NEIGHBORS BUT IS IS NECESSARY TO UNDERSTAND THAT THEY ARE MORE VALUABLE AS CUSTOMERS THAN AS TARGETS. THIS IS THE GREATEST LESSON OF THE EUROPEAN COMMUNITY.

05822 LOONEY, R.

ECONOMIC DEVELOPMENT IN IRAQ: FACTORS UNDERLYING THE RELATIVE DETERIORATION OF HUMAN CAPITAL FORMATION

JOURNAL OF ECONOHIC ISSUES, 26(2) (JUN 92), 615-622. SINCE 1980, THE IRAQI ECONONY HAS BEEN ADVERSELY AFFECTED BY THREE SEPARATE FACTORS; THE WARS WITH IRAN AND THE COALITION FORCES, INVESTMENT POLICY, AND INTERMATIONAL THE COALITION FORCES, INVESTMENT POL ICY, AND INTERNATIONAL
SANCTIONS. IRAQ'S ABILITY TO RECONSTRUCT ITS ECONOMY IN THE SANCTIONS. IRAQ'S ABILITY TO RECONSTRUCT ITS ECONOMY IN THE
FUTURE WILL DEPEND LARGELY ON THE COUNTRY'S STOCK OF HUMAN FUTURE WILL DEPEND LARGELY ON THE COUNTRY'S STOCK OF HUMAN
CAPITAL. THIS ARTICLE EXPLORES WHETHER HUMAN CAPITAL IN IRAO CAPITAL. THIS ARTICLE EXPLORES WHETHER HUMAN CAPITAL IN IRAO DETERIORATED DURING THE 1980S AND, IF SO, WHY AND IN WHAT SUFFERED AT' THE EXPENSE OF MILITARY EXPENDITURES.

05823 LOONEY, $R$

STRUCTURAL AND ECONOMIC CHANGE IN THE ARAB GULF AFTER 1973 MIDDLE EASTERN STUDIES, 26(4) (OCT 90), 514-535.

THE AIM OF THIS PAPER IS TO EXAMINE ATTEMPTS AT ECONOMIC DEVELOPMENT AND INDUSTRIALIZATION AND PROVIDE AN OVERVIEH OF THE MAIN STRUCTURAL CHANGES THAT HAVE TAKEN PLACE DURING THE 
POST 1973-74 PERIOD IN THE ECONOMIES OF THE ARAB GULF STATES. EMPHASIS IS ON DETERMINING THE EXTENT TO WHICH THESE COUNTRIES HAVE BEEN ABLE TO ACHIEVE THEIR MAJOR ECONOMIC OBJECTIVE: THE DIVERSIFICATION OF THEIR ECONOMICS AWAY FROM OIL, AND IN PARTICULAR THE DEVELOPMENT OF A VIABLE, DIVERSIFIED INDUSTRIALIZED BASE. THE ARTICLE ATTEMPTS TO GAIN SOME INSIGHT INTO THE MORPHOLOGY OF THE REGION'S INDUSTRIAL DEYELOPMENT, TO EXAMINE THE UNDERLYING FACTORS RESPONSE FOR THE AREA'S INOUSTRIAL DEVELOPMENT, AND TO INDICATE THEIR RELATIVE SIGNIFICANCE. IT ALSO PROVIDES SYSTEMATIC INFORMATION CONCERNING INDUSTRIAL ACTIVITY AND APPRAISES THE PROSPECTS AND THE DIRECTION OF ITS FUTURE DEVELOPMENT.

05824 LOONEY, R.

THE ECONOMICS OF MIDOLE EAST MILITARY EXPENDITURES: THE ECONOMICS OF MIDOLE EAST MILITARY EXPENDI

BULLETIN OF PEACE PROPOSALS, 22(4) (DEC 91), 407-418. IN VIEW OF THE LIKELY ACCELERATION IN DEFENSE EXPENDITURE FOLLOWING THE RECENT ROUND OF HOSTILITIES IN THE GULF, THIS STUDY EXAMINES THE RELATIONSHIP BETHEEN DEFENSE SPENDING AND ECONOHIC PERFORMANCE IN FOUR OF THE MAJOR COUNTRIES OF THE MIDDLE EAST REGIDN--EGYPT, SYRIA, ISRAEL, AND SAUDI ARABIA. IT CONCLUDES THAT THE TRADITIONAL "GUNS $V S$ BUTTER" THEORY DOES NOT HOLD TRUE IN THE MIDOLE EAST REGION. INSTEAD, IT SEEMS THAT DEFENSE EXPENDITURES ACTUALLY STIMULATED ECONOMIC GROWTH.

05825 LOONEY, $R$

THE POLITICAL ECONOMY OF DEFENSE BUDGETARY TRADEDFFS IN THE MIDOLE EAST

NEH POLITICAL SCIENCE, 21-22 (SPR 92), 207-228

IN THE AFTERMATH OF THE KUWAIT CONFLICT, THERE IS LIKELY TO BE AN INCREASE IN DEFENSE SPENDING IN MANY OF THE MIDDLE EASTERN AND NORTH AFRICAN COUNTRIES. THE PURPOSE OF THIS PAPER IS TO EXAMINE THE RELATIONSHIP BETWEEN DEFENSE SPENDING IN BUDGETARY ALLOCATIONS IN TWELVE MIDDLE EASTERN AND NORTH AFRICAN/MEDITERRANEAN COUNTRIES. LITTLE IS KNOWN ABOUT HOW THESE GOVERMMENTS SET PRIORITIES FOR THEIR SHRNKING REVENUES BETHEEN MAJOR EXPENDITURE CATEGORIES. THE STUDY ADORESSES: HHAT THE COUNTRY PATTERNS IN DEFENSE STUDY ADORESSES: WHAT THE COUNTRY PATTERNS IN DEFENSE EXPENDITURES, BUDGETARY ALLOCATIONS AND ARMS IMPORTS ARE; IF A CAUSAL BUDGETARY TRADE-OFF EXISTS BETHEEN DEFENSE SPENDING AND THESE BUDGETARY CATEGORIES; IF THE TRADEOFFS VARY OYER

TIME; AND, IF THE BUDGETARY
VARIES BY COUNTRY GROUPINGS.

05826 LOONEY, R.E.

REAL OR ILLUSORY GROWTH IN AN OIL-BASED ECONOMY: GOVERNMENT EXPENDITURES AND PRIVATE SECTOR INVESTMENT IN SAUDI ARABIA

WORLD DEVELOPMENT, 20(9) (SEP 92), 1367-1375.

THE PURPOSE OF THIS PAPER IS TO DETERMINE WHETHER AND TO WHAT EXTENT "DUTCH DISEASE" EFFECTS HAVE OFFSET THE POTENTIALLY POSITIVE HIRSCHMAN-TYPE INDUCEMENTS PROVIDED BY MASSIVE GOVERMMENT EXPENDITURES INTENDED TO STIMULATE PRIVATE SECTOR INVESTMENT IN SAUDI ARABIA. THE MAJOR FINDING IS THAT INFRASTRUCTURE INVESTMENT DOES NOT APPEAR TO HAVE PLAYED A STRONG ROLE IN STIMULATING PRIVATE SECTOR INVESTMENT IN SAUDI ARABIA. INSTEAD, THE PRIVATE INVESTORS APPEAR TO BE MUCH MORE SENSITIVE TO SHORTER-RUN CURRENT CONDITIONS CREATED BY GOVERNMENT EXPENDITURES.

05827 LOPATIN, $V$.

THE ARMY AND THE ECONOMY: ECONOMIC ASPECTS OF SOVIET MILITARY REFORM

GLOBAL AFFAIRS, 6(1) (WIN 91), 1-22.

THE AUTHOR ARGUES THAT ALTHOUGH THE NEED FOR MILITARY REFORM HAS BEEN ACKNOWLEDGED AT ALL POLITICAL AND MILITARY LEADERSHIP LEVELS IN THE USSR, ITS PREPARATION AND REVIEW ARE BEING DELAYED. THE REFORM OF $1924-25$ IS CONSIDERED
RELEVANT AND IS DESCRIBED. THE DRAFT CONCEPT OF THE OFFICIAL MILITARY REFORM AND THE ISSUES SURROUNDING IT AR ALSO DISCUSSED.

05828 LOPEZ-GARZA, M.

LOS ANGELES: ASCENDANT CHICANO POWER

REPORT ON THE AMERICAS, XXVI(2) (SEP 92), 34-38.

THE AUTHOR TRACES THE EXPANSION OF MEXICAN-AMERICAN POLITICAL POWER IN LOS ANGELES FROM HORLD WAR II TO THE PRESENT.

05829 LOPTSON, P.

HEGEL NÁTURALIZED

NEH LEFT REVIEH, (193) (MAY 92), 120.

THE AUTHOR CRITIOUES RICHARD' BLACKBURN'S ARGUMENT THAT THE HEGEL-MARX CONCEPTION OF HUMAN FREEDOM TAKES TOO LITTLE ACCOUNT OF THE FRAILTY OF ITS PLANETARY SETTING.

05830 LORBER, $Z$.

TACTICAL MISSILES: ANYONE CAN PLAY

BULLETIN OF THE ATOMIC SCIENTISTS, 48(2) (MAR 92), 3840 THE REAL MISSILE THREATS ARE IN THE THIRD WORLD FROM UNSOPHISTICATED, SHORT-RANGE MISSILES THAT COUNTRIES CAN
EASILY MAKE AND USE AGAINST EACH OTHER. THIS KIND OF BALLISTIC MISSILE TECHNOLOGY IS READILY AVAILABLE--AND THE MISSILE TECHNOLOGY CONTROL REGIME IS PRACTICALLY POWERLESS TO STOP ITS SPREAD. FURTHER MEASURES MUST BE TAKEN TO STOP MISSILE-WIELDING AGGRESSORS. THE WORLD WAS FORTUMATE THAT SADOAM HUSSEIN GOT TOO GREEDY BEFORE HE HAS EOUIPPED TO ENFORCE HIS GRAB FOR TERRITORY AND CONTROL. BUT WE CANMOT COUNT THICE ON THAT KIND OF LUCK.

05831 LORENZ, A.W.

PRO-ISRAEL PAC'S OUTSPENDING ARAB-AMERICAN PAC'S 369 TO 1 WASHINGT

22-25.

DURING 1991, 58 PRO-ISRAEL POLITICAL ACTION COMNITTEES CONTRIBUTED MORE THAN $\$ 1.4$ MILLION TO U.S. CONGRESSIONAL CANDIDATES, WITH INCUMBENT SENATOR ARLEN SPECTER, A

REPUBLICAN FROM PENMSYLVANIA, RECEIVING THE LARGEST DONATION. ONLY ONE PRO-ARAB POLITICAL ACTION COMMITTEE CONTRIBUTED TO ANY U.S. POLITICAL CANDIDATE IN 1991, DONATING \$3,000 TO 10 CANDIDATES.

05832 LORIMER, R.

TY, RADIO, BOOKS, FILM: GOVERMMENT SUPPORT FOR CULTURE SOCIAL POLICY, 23(1) ( SUM 92), 73-76.

CANADIANS HAVE ACCESS TO AN UNUSUALLY WIDE VARIETY OF TY CHAMNELS, RADIO STATIONS, BDOKS, MAGAZINES, AND FILMS. THIS RICH MIXTURE IS DUE IN PART TO THE COMBINATION OF U.S., FRENCH, BRITISH, AND CANADIAN MEDIA SOURCES. BUT IT IS' ALSO DUE TO' GOVERMMENT INVESTMENT IN MAINTAINING A MEDIA ENVIRONMENT THAT INFORMS ITS CITIZENS AND BINDS THE COUNTRY TOGETHER. THE CANADIAN GOVERMMENT PROVIDES FINANCIAL SUPPORT FOR MANY PROJECTS THAT WOULD NOT BE PRODUCED IF MAKING A PROFIT HERE THE ONLY INCENTIVE. GOVERMMENT REGULATIONS STRESS THE RESPONSIBILITY THAT GOES ALONG WITH A PRIVATE PRODUCER'S RIGHT TO DISSEMINATE HIS PROOUCTS TO THE PUBLIC. FINALLY, CANADIAN GOVERMMENT STRESSES DOMESTIC PRODUCTION, GOING TO SOME LENGTHS TO ENSURE THAT CANADIAN VOICES ARE AVAILABLE AMONG THE CACAPHONY OF IMPORTED ENTERTAINMENT PRODUCTS.

05833 LORRAIN, D.

THE FRENCH MODEL OF URBAN SERYICES

WEST EUROPEAN POLITICS, 15(2) (APR 92), 77-92.

THIS ARTICLE EXPLORES THE NATURE OF THE FRENCH MOOEL OF URBAN SERYICES AND MORE ESPECIALLY ITS DISTINGUISHING FEATURES RELATIVE TO OTHER EUROPEAN COUNTRIES. THE ARTICLE ATTEMPTS TO ANSHER THE BASIC QUESTIONS: HITH SUCH A FRAGMENTED COMHUNAL SYSTEM HOH AMD HHY HAS AH EFFECTIVE SYSTEM OF SERVICE DELIVERY EMERGED? THE ANSWER LIES IN EXAMINING THE COMPLEX AND FLEXIBLE RELATIONSHIPS WHICH EXIST BETHEEN THE VARIDUS ACTORS INYOLVED--RELATIONSHIPS WHICH EMERGED ESSENTIALLY IN THE NINETEENTH CENTURY.

05834 LOSMAN, D.L.

THE U.S. DEFENSE INDUSTRIAL BASE: STATUS AND PROSPECTS GLOBAL AFFAIRS, 6(2) (SPR 91), 111-131.

THIS ARTICLE EXAMINES THE INTEGRATED NATURE OF THE DEFENSE BASE IN THE CONTEXT OF THE TOTAL U.S. INDUSTRIAL SCENE. IT IS ARGUED THAT ANY PROBLEMS OR TRENDS IN THE GENERAL MANUFACTURING ECONOMY, INCLUDING INFLATION, INTEREST RATES, ENERGY PRICES, UNION PRACTICES, ENVIRONMENTAL LEGISLATION, GLOBALIZATION, AND INVENTORY MANAGEMENT, WILL GENERALLY ALSO CHARACTERIZE THE DEFENSE INDUSTRIAL BASE. IN ADDITION, THE RELATIVELY UNIQUE CHALLENGES FACED BY DEFENSE PRODUCTION BASE ARE DISCUSSED.

05835 LOTT, JR., J.; DAVIS, M.

A CRITICAL REVIEW AND AN EXTENSION OF THE POLITICAL SHIRKING LITERATURE

PUBLIC CHOICE, $74(4)$ (1992), 461-484

AN EMPIRICAL METHODOLOGY AND A SET OF RESULTS THAT BOTH SHEDS SOME LIGHT ON QUESTIONS OF SHIRKING OF POLITICAL CANDIDATES IS PRESENTED HHICH INDICATES WHY MUCH OF THE
PREVIDUS RESEARCH HAS LED TO SUCH DIFFERENT CONCLUUSIONS. THE PREVIOUS RESEARCH HAS LED TO SUCH DIFFERENT CONCLUSIONS. GOALS OF THIS PAPER ARE TO EVALUATE PREVIOUS EMPIRICAL EVIDENCE, TO EMPLOY POOLED TIME-SERIES CROSS-SECTIONAL DATA TO ANSWER THE QUESTIONS OF HOW WELL POL ITICAL MARKETS ARE
ABLE TO SORT OUT OF OFFICE THOSE POLITICIANS WHO DEVIATE ABLE TO SORT OUT OF OFFICE THOSE POLITICIANS WHO DEVIATE FROM THE INTERESTS OF THEIR CONSTITUENTS, TO OISCUSS HOW OBSERVABLE LAST-PERIOD PROBLEMS AFFECT THE USEFULLMESS OF SUNK INVESTMENTS IN GUARANTEEING POLITICAL REPUTATION, AND TO ADDRESS THE QUESTION OF WHE

05836 LOTTER, H.P.P.

RELIGION AND POLITICS IN A TRANSFORMING SOUTH AFRICA JOURMAL OF CHURCH \& STATE, 34(3) (SUM 92), 475-502. THE AUTHOR ASSESSES THE ADEQUACY OF THE POLICIES OF A FEW SELECTED SOUTH AFRICAN CHRISTIAN GROUPS ON SOCIOPOLITICAL TRANSFORMATION. HE DISCUSSES THE ROLE OF RELIGION IN IDENTIFYING INJUSTICE IN SOUTH AFRICA AND THE CONTRIBUTION THAT RELIGION MAKES IN FACILITATING AND NURTURING DIALOGUE AND DELIBERATION. HE ALSO SCRUTINIZES THE DIFFERENT STRATEGIES FOR THE TRANSFORMATION OF INJUSTICE 
INTO JUSTICE AS WELL AS THE EXTENT TO WHICH RELIGIOUS VIEWPOINTS CONTRIBUTE TO A GENERAL CONSENSUS ON PRINCIPLES OF JUSTICE FOR THE NEW SOUTH AFRICA. HE STUDIES FOUR IMPORTANT POLICY DOCUMENTS, CONCERNED MAINLY WITH ISSUES OF SOCIAL JUSTICE, RELEASED BY VARIOUS GROUPS OF CHRISTIANS IN THE LAST FEW YEARS. THESE DOCUMENTS, WHICH ARE REPRESENTATIVE OF THE PRINCIPAL POLITICAL ACTORS AND CONTAIN DEFINITE POLICIES ON SOCIOPOLITICAL JUSTICE, ARE "KERK EN SAMELWING," "THE KAIROS DOCUMENT," "THE ROAD TO DAMASCUS," AND "A RELEVANT PENECOSTAL HITNESS." HE ALSO REFERS TO THE

05837 LOURY, G.C

INCENTIVE EFFECTS OF AFFIRMATIVE ACTION

ANNALS OF THE AMERICAN ACADEMY OF POLITICAL AND SOCIAL SCIENCE, (523) (SEP 92), 19-29.

THE AUTHOR USES A FORMAL ECONOMIC MODEL TO ILLLUSTRATE A CONCERN OFTEN RAISED BY CRITICS OF AFFIRMATIVE ACTION--THAT IT MAY DISCOURAGE ITS BENEFICIARIES FROM ACOUIRING WORK SKILLS. IRONICALLY, THIS CAN HAPPEN FOR REASONS ANALOGOUS TO THOSE EVOKED TO EXPLAIN WHY DISCRIMINATION MAY DISCOURAGE THOSE EVOKED TO EXPLAIN WHY DISCRIMINATION MAY DISCOURAGE ARE LESS LIKELY TO SUCCEED, FEWER FIND IT WORTHWILE TO ARE LESS LIKELY TO SUCCEED, FENER FIND IT WORTHWILE TO
BECOME SKILLED. SIMILARLY, HHEN UNSKILLED WORKERS ARE MORE BECOME SKILLED. SIMILARLY, WHEN UNSKILLED WORKERS ARE MORE
LIKELYY TO SUCCEED, FEWER DEEM IT NECESSARY TO BECOME SKILLED. DISCRIMINATION CAN LEAD TO THE FORMER SITUATION; AFFIRMATIVE ACTION CAN LEAD TO THE LATTER. AFFIRMATIVE ACTION CAN LEAD EMPLOYERS TO PATRONIZE MINORITY HORKERS BY HOLDING THEM TO A LOWER STANDARD, AND THIS CAN HAVE THE EFFECT OF MAKING SKILL ACQUISITION LESS IMPORTANT FOR MINORITY WORKERS. THE AUTHOR EXAMINES THE LABOR MARKET CONDITIONS UNDER WHICH THIS COUNTERPRODUCTIVE EFFECT OF AFFIRMATION ACTION IS MOST LIKELY TO OCCUR.

05838 LOVE, S.

IDEAL SPEECH ANDEMINSIST DISCOURSE: HABERMAS RE-VISIONED WOHEN AND POLITICS, 11(3) (1991), 101-122.

MODERN OR POSTMODERN? THIS DEBATE WHICH HAS LONG RAGED AMONG POLITICAL THEORISTS NOW PLAYS A CENTRAL ROLE IN FEMINIST THEORY. ALTHOUGH TRADITIONAL THEORISTS TYPICALLY CHOOSE A SIDE, FEMINISTS THEORISTS OFTEN SPLIT THE DIFFERENCE. SINCE FEMINIST STRUGGLES REQUIRE UNITY AND DIVERSITY. THEY CONSTRUCT AND DECONSTRUCT "WOMAN" TO SUIT "HER" PURPOSES. THIS STRATEGY RAISES THE POLITICAL QUESTIONS WHO DECIDES WHO "WE" ARE? HOW SHOULD THAT DECISION BE MADE? IN THIS ARTICLE, THE AUTHOR ARGUES THAT JURGEN HABERMAS'S IDEAL SPEECH SITUATION RE-VISIONED AS "SOLIDARITY-INIDEAL SPEECH SITUATION RE-VISIONED AS "SOLIDARITY-IN-
PROCESS" HELPS ANSWER THOSE QUESTIONS. IT PROVIDES A PROCESS" HELPS ANSWER THOSE QUESTIONS.
DISCOURSE ETHIC FOR FEMINIST THEORISTS.

05839 LOVECY, J.

COMPARATIVE POLITICS AND THE FIFTH FRENCH REPUBLIC EUROPEAN JOURNAL OF POLITICAL RESEARCH, 21(4) (JUN 92), 385-408.

WITHIN THE LAST FEW YEARS SOMETHING AKIN TO A PARADIGMSHIFT HAS BEEN UNDERHAY IN THE FRENCH POLITICAL SCIENCE LITERATURE DEALING HITH CONTEMPORARY FRANCE. PREVIOUSLY THIS LITERATURE HAD OVERHHELMINGLY FOCUSED ON THE DISTINCTIVENESS AND SPECIFICITY OF FRANCE'S INSTITUTIONAL ARRANGEMENTS UNDER THE FIFTH REPUBLIC. THUS, IT HAD BEEN CONCERNED WITH ELABORATING PARTICULARLIST CONCEPTS AND TYPOLOGIES TO CHARACTERIZE BOTH THE POLITICAL REGIME AND THE POLITICAL FORCES OPERATING WITHIN, AND SHAPED BY, THAT INSTITUTIONAL FRAMEWORK. IN CONTRAST, A GROWING BOOY' OF RECENT WRITING IS INFORMED BY A SHARED CONVICTION THAT THE CONTEMPORARY PERIOD IS INDEED WITNESSING "LA FIN DE L'EXCEPTION FRANCAISE." SUCH WORKS ARE CONCERNED HITH LOCATING AND IDENTIFYING THE SOURCES OF CHANGE THROUGH WHICH FRENCH DEMOCRACY IS NOH, IN THE VIEW OF THESE AUTHORS, COMING TO BE MORE CLOSELY ALIGNED WITH THE FORMS AND PROCESSES CHARACTERISTIC OF LIBERAL DEMOCRACY ELSEWHERE. THIS PAPER FOCUSES ON THO DISTINCT APPROACHES FOUND AMONG THESE RECENT WRITINGS: (1) THAT POPULARIZED BY FURET, JUILLARD, AND ROSANYALLON IN "LA REPUBLIQUE DU CENTRE" AND (2) THE APPROACH EXEMPLIFIED BY THE WORK OF COHEN-TANUGI.

05840 LOVELAND, I.

LABOR AND THE CONSTITUTION: THE \&RIGHT' APPROACH TO REFORM? PARLIAMENTARY AFFAIRS, 45(2) (APR 92), 173-187.

THE LABOR PARTY HAS COMMITTED ITSELF TO CONSTITUTIONAL AMENDMENT, TO A POLICY WHICH IT CLAIMS AMOUNTS TO THE MOST RADICAL CHANGE IN THE BRITISH CONSTITUTION PROPOSED BY ANY POLITICAL PARTY THIS CENTURY. THIS ARTICLE EYALUATES THE EXTENT TO WHICH LABOR'S PROPOSALS COUID EFFECT SIGNIFICANT CXTENT TO WHICH LABOR'S PROPOSALS COULD EFFECT SIGNIFICANT THAT SIGNIFICANT BREAK HITH THE VALUES AND PRACTICES ESPOUSED BY THE THATCHER ADMINISTRATIONS, THE PROSPECT OF THESE REFORMS HAVING A MARKED LONG TERM INFLUENCE ON CONSTITUTIONAL ARRANGEMENTS IS VERY LIMITED INDEED.

05841 LOVELL, D.

EARLY FRENCH SOCIALISM AND POLITICS: THE CASE OF VICTOR CONSIDERANT
HISTORY OF POLITICAL THOUGHT, 13(2) (SUM 92), 257-281. FROM ITS BEGINHINGS, SOCIALISM HAS EMBODIED A RADICAL UNCERTAINTY ABOUT THE ROLE AND STATUS OF POLITICS AND THE STATE. VICTOR CONSIDERANT MADE AN ATTEMPT TO SOLVE THE SOCIAL AND POLITICAL QUESTIONS. THIS ARTICLE SUGGESTS THAT CONSIDERANT'S CONVICTIONS ABOUT THE EXPERIMENTAL AND VOLUNTARTY MATURE OF SOCIALISM REVEAL AN UNDERLYING CONSISTENCY BASED ON A TYPE OF CONSTITUTIONALISM. HIS WRITINGS WERE UNUSUAL AMONG HIS CONTEMPORARIES IN THAT HE WROTE ABOUT THE POLITICAL QUESTION, AND IN REASSESSING WHICH WAS THE MOST BENIGN POLITICAL REGIME UNDER WHICH SOCIALISM COULD PROSPER.

05842 LOVELL, $R$.

CITIZEN'S CHARTER: THE CULTURAL CHALLENGE

PUBLIC ADMINISTRATION (LONDON), 70(3) (FAL 92), 395-404. OVER THE PAST 10 YEARS, GREAT BRITAIN HAS MADE ADMIRABLE STRIDES IN IMPROVING MANAGEMENT WITHIN THE CIVIL SERVICE. IF THE IMPROVEMENTS IN CUSTOMER SERVICE MANOATED BY THE THE IMPROVEMENTS IN CUSTOMER SERVICE MANDATED BY THE
CITIZEN'S CHARTER OF 1991 ARE TO BE EFFECTIVE AND LONGCITIZEN'S CHARTER OF 1991 ARE TO BE EFFECTIVE AND LONC
LASTING, CHANGES IN STRUCTURES AND SYSTEMS MUST BE LASTING, CHANGES IN STRUCTURES AND SYSTEMS MUST BE

05843 LOVERIDGE, S. : SMITH, T. FOSTERING PARTNERSHIPS BETWEEN LOCAL GOVERMMENTS AND RURAL BUSINESSES

PUBLIC PRODUCTIVITY \& MANAGEMENT REVIEN, 15(3) (SPR 92), $329-340$.

VOLUNTEER VISITOR AND BUSINESS RETENTION AND EXPANSION (VVBR\&E) PROGRAMS USE DONATED TIME TO INCREASE THE PRODUCTIVITY OF LOCAL GOVERMMENTS' ECONOMIC DEVELDPMENT EFFORTS. BY CREATING A PARTHERSHIP FOR DEVELOPMENT BETWEEN THE BUSINESS COMMUNITY AND LOCAL GOVERNMENT VVBR\&E CAN HAVE A POSITIVE EFFECT ON THE ECONOMY AT TWO LEVELS: INDIVIDUAL FIRM NEEDS CAN BE MET, AND COMMUNITY-HIDE OBSTACLES TO GROWTH CAN BE OVERCOME. IN HELPING A BROAD-BASED SET OF CITIZENS TO AGREE ON A SET OF HRITTEN RECOMMENDATIONS, VVBRG\&E FOSTERS AN ONGOING PARTNERSHIP FOR DEVELOPMENT BETHEEM LOCAL GOVERMMENT AND BUSINESS.

05844 LOVIBOND, S

FEMINISM AND PRAGMATISM: A REPLY TO RICHARD RORTY

NEW LEFT REVIEW, (193) (MAY 92), 56-74.

RICHARD RORTY HAS SOUGHT TO SHOW THE RELEVANCE OF HIS BRAND OF PRAGMATISM TO THE CONCERNS OF FEMINISTS. IN THIS ESSAY, THE AUTHOR ARGUES THAT RORTY'S CRITIOUE OF A FEMINISM CAST IN "REALIST" AND "UNIVERSALIST" TERMS WRONGLY CONTENDS THAT PROPONENTS OF THE LATTER ARE UNAHARE OF THE CONCEPTUA ITSELF.

05845 LOWASSA, E.N.; BISSONNET, M.; CATLEY, R.; KHAN, A.R. PARL IAMENTARIAN, LXXIII (1) (JAN 92), 14-15 THIS IS A REPORT OF A PANEL OISCUSSION ON THE ROLE OF THE PRESS IN A DEMOCRACY, WHICH WAS HELD AT THE $37 T H$ COMMONWEALTH PARLIAMENTARY CONFERENCE IN SEPTEMBER 1991. ALTHOUGH THE PARTICIPANTS AGREED THAT THE PRESS HAS A VITAL ROLE TO PLAY IN A DEMOCRACY, THEY FOCUSED ON PROBLEMS CREATED BY INACCURATE OR SENSATIONALI ZED PRESS COVERAGE, MONOPOLY OWNERSHIP OF THE MEDIA, CONFLICT OF INTEREST, AND SO FORTH. THE CONSENSUS WAS FOR REGULATION, EITHER A SELFIMPOSED CODE OF CONDUCT OR STATUTORY REGULATION.

05846 LOWELL, F.K.

PUBLIC FINANCING OF ELECTIONS: A PHILOSOPHICAL RESPONSE JOURNAL OF LAH \& POL ITICS, VIII ( 2 ) (WIN 92), 329-332. SHARE A FUNDAMENTAL BELIEF THAT POLITICS IS TOO IMPORTANT TO BE LEFT TO THE PEOPLE. THE PUBLIC FINANCING PROVISIONS OF THE FEDERAL ELECTION CAMPAIGN ACT OF 1971, AS AMENDED, AS WELL AS THE STATE AND LOCAL CLONES THAT SUPPORTERS OF PUBLIC FINANCING WOULD ENACT ARE REPUGNANT BECAUSE THEY TEND EITHER TO PREEMPT OR LIMIT DIRECT PUBLIC PARTICIPATION IN CAMPAIGNS. THE EFFECT OF SUCH SCHEMES, IN SHORT, IS ANTI-DEMOCRATIC. WHATEVER PROBLEMS MAY BE BUILT INTO THE AMERICAN POLITICAL SYSTEM, IT IS STILL PREFERABLE FOR THE COSTS OF CAMPAIGNS TO BE PAID DIRECTLY BY THE GOVERNED AND NOT THROUGH A FILTER DESIGNED AND CONTROLLED BY THE GOVERNORS.

05847 LOWENBERG, A.D.; YU, B.T

THE ROLE OF THE INTELLECTUAL IN ECONOMIC DEVELOPMENT: A THE ROLE OF THE INTELLECTUAL

WORLD DEVELOPMENT, 20(9) (SEP 92), 1261-1277.

DEPENDING ON THE NATURE OF THE COMMITMENT THAT IS IMPLICIT IN THE CONSTITUTION OF A SOCIETY, THE RULES MAY EITHER RIGIDLY REINFORCE EXISTING INSTITUTIIONS OR ALLOW FOR AN EFFICIENT PROCESS OF INSTITUTIONAL INNOVATION. THE AUTHORS ARGUE THAT INTELLECTUALS ARE A REFLECTION OF THE CONSTITUTIONAL BACKDROP AGAINST HHICH THEY OPERATE AND, CONSEQUENTLY, PROFESSIONAL INTELLECTUAL ACTIVITY WILL EITHER ENHANCE EFFICIENCY BY REDUCING THE COSTS OF POLITICAL EXCHANGE OR WILL ENTRENCH INEFFICIEMT STRUCTURES. THEY PRESENT EMPIRICAL EVIDENCE TO SHOW THAT INTELLECTUALS HAVE A 
SYSTEMATICALLY DIFFERENT IMPACT ON ECONOMIC PERFORMANCE IN DIFFERENT TYPES OF SOCIETIES.

05848 LOWENTHAL, M.

TRIBAL TONGUES: INTELLIGENCE CONSUMERS, INTELLIGENCE PRODUCERS

WASHINGTON QUARTERLY, 15(1) (HIN 92), 157-172.

MOST ANALYSES OF THE U.S. INTELLIGENCE PROCESS PAY LIP SERVICE TO THE CONSUMER-PRODUCER RELATIONSHIP. A MAJOR

PROBLEM IS THAT THE CONSUMER-PRODUCER RELATIONSHIP RESEMBLES

THAT OF THO CLOSELY RELATED TRIBES THAT BELIEVE, MISTAKENLY,

THAT THEY SPEAK THE SAME LANGUAGE AND WORK IN THE SAME

THAT THEY SPEAK THE SAME LANGUAGE AND WORK IN THE SAME
MANNER FOR AGREED OUTCOMES WHEN REALITY SUGGESTS SOMETHING

MANMER FOR AGREED OUTCDMES WHEN REALITY SUGGESTS SOMETHING
WHOLLY DIFFERENT. THIS PAPER ARGUES THAT CONSUMERS PLAY A

WHOLLY DIFFERENT. THIS PAPER ARGUES THAT CONSUMERS PLAY A
MUCH GREATER ROLE THROUGHOUT THE INTELLIGENCE PROCESS AND AT

MUCH GREATER ROLE THROUGHOUT THE INTELLIGENCE PROCESS AND
ALL STAGES IN THAT PROCESS THAN IS CUSTOMARILY REALIZED.
THERE REMAINS MUCH THAT CAN BE DONE-EVEN WITHIN CURRENT

STRUCTURES AND PROCESSES--TO IMPROVE COMMUNICATIONS BETWEEN THE TWO GROUPS.

05849 LOWERY, D. ; DEHOOG, R.H. ; LYONS, W.E.

CITIZENSHIP IN THE EMPOWERED LOCALITY: AN ELABORATION, A

CRITIQUE, AND A PARTIAL TEST

URBAH AFFAIRS QUARTERLY, 28(1) (SEP 92), 69-103.

ALTHOUGH LIBERAL AND COMMUNITARIAN INTERPRETATIONS OF CITIZENSHIP DIFFER PROFOUNDLY, THEY OFFER ESSENTIALLY

SIMILAR PRESCRIPTIONS IN SUPPORT OF EMPOWERED LOCALITIES. IN

THIS PAPER. THE AUTHORS ARGUE THAT THE REJECTED ALTERNATIVE

OF CONSOLIDATED GOVERNMENT BETTER PROMOTES BOTH

INTERPRETATIONS OF EFFECTIVE CITIZENSHIP. THEY DEVELOP THIS

ARGUMENT BY MORE FULLY SPECIFYING THE BEHAVIORAL

IMPLICATIONS OF THE TWO VIEWS OF CITIZENSHIP AND

THEORETICALLY LINKING THOSE BEHAVIORS TO FRAGMENTED AND

CONSOL IDATED URBAN INSTITUTIONS USING THE EXIT, VOICE,

LOYALTY, AND NEGLECT MODEL INTRODUCED BY LYONS AND LOWERY IN

1986. THEN THEY TEST THE CENTRAL PROPOSITION DERIVED FROM

THAT ANALYSIS USING A COMPARISON GROUP DESIGN.

05850 LOWERY, D.; GRAY, Y.

HOLDING BACK THE TIDE OF BAD ECONOMIC TIMES: THE

COMPENSATORY IMPACT OF STATE INDUSTRIAL POLICY

SOCIAL SCIENCE OUARTERLY, 73(3) (SEP 92), 483-495.

SOCIAL SCIENCE QUARTERLY, 73(3) (SEP 92), 483-495,

INDUSTRIAL POLICIES BY THE AMERICAN STATES, IT IS

INDUSTRIAL POLICIES BY THE AMERICAN STATES, IT IS
APPROPRIATE TO CONSIDER THE OUESTION OF POLICY IMPACT. IN

APPROPRIATE TO CONSIDER THE OUESTION OF POLICY IMPACT. IN
THIS PAPER, AN ANSHER IS SOUGHT USING NEH DATA ON GROSS

THIS PAPER, AN ANSHER IS SOUGHT USING NEH DATA ON GROSS STATE PRODUCT AND A NEW MEASURE OF STATE INDUSTRIAL POLI
ACTIVISM. THE PAPER DISCUSSES THE ECONOMIC ORIGINS OF ACTIVISH. THE PAPER DISCUSSES THE ECONOMIC ORIGINS OF INDUSTRIAL POLICY AND DESCRIBES THE DEVELOPMENT AND TESTING OF AN IMPACT MODEL FOR THO MEASURES OF ECONOMIC DISTRESS FOR
THE 1982 TO 1986 PERIOD. CONCLUSIONS ARE DRANH CONCERNING THE 1982 TO 1986 PERIOD. CONCLUSIONS ARE DRANH CONCERNING
THE COMPLICATED EARLY IMPACT OF STATE INOUSTRIAL POLICY.

05851 LOWI, T.J. ; SCHAIN, M.A.

CONDITIONAL SURRENDER: CHARLES DE GAULLE AND AMERICAM OPINION

PS: POLITICAL SCIENCE AND POLITICS, XXV(3) (SEP 92),

498-506.

THE AUTHORS EXPLORE THE CURRENT PUBLIC ASSESSMENT OF CHARLES DE GAULLE'S LEADERSHIP IN THE UNITED STATES THROUGH A SURVEY OF OPINION LEADERS DRAWN FROM THE AMERICAN POLITICAL SCIENCE ASSOCIATION AND THE CONFERENCE GROUP ON FRENCH POLITICS AND SOCIETY. THEY ENDEAVOR TO CAPTURE THE ATTITUDES OF THESE TEACHERS TOWARD DE GAULLE AND TO ASSESS THE AMOUNT AND TYPE OF INFORMATION ABOUT HIM THAT IS PASSED ALONG TO UNIVERSITY STUDENTS. FOR COMPARATIVE PURPOSES, THEIR SURVEY IS A REPLICATION OF A FRENCH NATIONAL SURVEY SPONSORED BY THE CHARLES DE GAULLE INSTITUTE OF PARIS.

05852 LOHI, T.J.

THE STATE IN POLITICAL SCIENCE: HOW WE BECOME WHAT WE STUDY AMERICAN POLITICAL SCIENCE REVIEW, 86(1) (MAR 92), 1-7 AMERICAN POLITICAL SCIENCE IS A PRODUCT OF THE AMERICAN STATE. THERE ARE POLITICAL REASONS WHY PARTICULAR

SUBDISCIPLE ARE POLITICAL REASONS WHY PARTICULAR "SUBDISCIPLINES BECAME HEGEMONIC HITH THE EMERGENCE OF THE "SUBDISCIPLINES OF OUR TIME ARE PUBLIC OPINION, PUBLIC POLICY, SUBDISCIPLINES OF OUR TIME ARE PUBLIC OPINION, PUBLIC POLICY, AND PUBLIC CHOICE. EACH IS A CASE STUDY OF CONSONANCE WITH THE THOUGHT-WAYS AND METHODS OF A MODERN BUREAUCRATIZE GOVERNMENT COMMITTED TO SCIENTIFIC DECISION MAKING. FOLLONING LEVIATHAN TOO CLOSELY RESULTS IN THREE PRINCIPAL CONSEOUENCES: (1) FAILURE TO CATCH AND EVALUATE THE REPLACEMENT OF LAH BY ECONOMICS AS THE LANGUAGE OF THE STATE, (2) THE LOSS OF PASSION IN POLITICAL SCIENCE DISCOURSE, AND (3) THE FAILURE OF POLITICAL SCIENCE TO APPRECIATE THE

SIGNIFICANCE OF IDEOLOGICAL SEA CHANGES ACCOMPANYING REGIME CHANGES.

05853 LOWNDES, V.; STOKER, G.

AN EVALUATION OF NEIGHBORHOOD DECENTRALISATIOM POLICY AND POLITICS, 20(1) (JAN 92), 47-61.

THE AUTHORS EVALUATE A RADICAL DECENTRALISATION

INITIATIVE UNDERTAKEN BY THE LONDON BOROUGH OF TONER HAMLETS.

THEY CONSIDER THE DEGREE TO WHICH THE INITIATIVE HAS
IMPROVED SERVICE DELIVERY AND INYOLVED RESIDENTS IN DECISION MAKING. DECENTRALISATION EMERGES AS HAVING ADVANTAGES BUT

05854 LOWNDES, V.: STOKER, G.

AN EVALUATION OF NEIGHBOURHOOD DECENTRALISATION

POLICY AND POLITICS, 20(2) (APR 92), 143-152.
THE AUTHORS CONTINUE THEIR EVALUATION, BEGUN IN A PREVIOUS PAPER, OF A RADICAL DECENTRALISATION INITIATIVE IN THE LONDON BOROUGH OF TOWER HAMLETS BY CONSIDERING THE SCHEME FROM THE PERSPECTIVE OF STAFF AND COUNCILLORS. DECENTRALISATION CLEARLY PRESENTS DIFFERENT ADVANTAGES AND DECENTRALISATION CLEARLY PRESENTS DIFFERENT ADVANTAGES AND
DISADVANTAGES TO THE VARIOUS STAKEHOLDERS INVOLVED IN ITS DISADVANTAGES TO THE VARIOUS STAKEHOLDERS INVOLVED IN ITS
INTRODUCTION. IN A CONCLUDING SECTION, THE AUTHORS MOVE INTRODUCTION. IN A CONCLUDING SECTION, THE AUTHORS MOVE
BEYOND THESE PARTICULAR PERSPECTIVES TO CONSIDER HOW THE EXPERIENCE OF TOWER HAMLETS CAN BE UTILIZED IN DEBATES ABOUT THE FUTURE ORGANIZATION AND ROLE OF LOCAL GOVERMMENTS.

05855 LUBAL, S.; KRAUSZ, E.; WOLF, Y.

AGGRESSION AS AN ETHNIC-DEPENDENT CONSTRUCT: JUDGMENTAL DIFFERENCES AMONG EUROPEAN AND ORIENTAL JEHS IN ISRAEL INTERNATIONAL JOURNAL OF GROUP TENSIONS, 21(4) (WIN 91), 287-314.

THERE ARE DIFFERENT TYPES OF MINORITY GROUPS AS WELL AS DIFFERENT SOCIETIES WITHIN WHICH THEY OPERATE. THIS ARTICLE IS INTRODUCED BY A SHORT REVIEW OF THE DIFFERENT ASPECTS OF ETHNIC STRATIFICATION, OR WHAT IS TERMED AS ETHNIC GAP IN ISRAELI SOCIETY. THIS STUDY ATTEMPTS TO EXPLORE ETHNIC DIFFERENCES IN PERCEPTION OF AGGRESSION IN ISRAEL. ORIENTAL JEWS, AS VICTIIMS OF DISCRIMINATION CAN BE HYPOTHESIZED TO ASSIGN GREATER IMPORTANCE TO DAMAGE INVOLVED IN AGGRESSIVE ACTS. THE CENTRAL FINDING POINTS TO A SYSTEMATIC DIFFERENCE IN THE MODEL ACCORDING TO WHICH AGGRESSION IS JUDGED BY MEMBERS OF THE THO PRIMARY JEWISH ETHNIC GROUPS IN ISRAEL.

05856 LUCAS, $M$.

A HESTERN THO-TRACK POLICY TOHARD THE SOVIET UNION BULLETIN OF PEACE PROPOSALS, 22(4) (DEC 91), 387-398.

IN ORDER TO PREVENT A NEW DIVISION OF EUROPE AND THE INSTABILITY IT WOULD BRING IN ITS WAKE, THE SOVIET UNION MUST BE INTEGRATED INTO AN ENLARGED POLITICAL, SECURITY ECONOMIC, AND LEGAL PAN-EUROPEAN SPACE. THE SINGLE MOST IMPORTANT DEVELOPMENT SHAPING EVENTS IN THE SOVIET UNION-AND HENCE A KEY DETERMINANT OF WESTERN POLICY--IS THE DISINTEGRATION OF THE CENTRALIZED SOVIET STATE AND, LINKED TO IT, THE CHANGING RELATIONSHIP AND POLITICAL STRUGGLE BETWEEN THE CENTER AND THE REPUBLICS. THIS ARTICLE ANALYZES THE CURRENT REPUBLIC-CENTER DEVELOPMENTS AND THEIR AY IMPLICATIONS. IT ALSO OFFERS SUGGESTIONS FOR A "THO TRACK" POLICY DESIGNED TO FOSTER POLITICAL AND ECONOMIC INTEGRATION OF EASTERN EUROPE AND THE SOVIET UNION INTO WESTERN STRUCTURES. THE THO TRACKS CATER TO THE NEEDS OF BOTH THE CENTER AND THE PERIPHERY (REPUBLICS) IN THE SOVIET UNION.

05857 LUCH, E.; GATI, T.

WHOSE COLLECTIVE SECURITY

WASHINGTON QUARTERLY, 15(2) (SPR 92), 43-56

THE END OF THE COLD WAR MEANS THE PASSING NOT JUST OF THE SOVIET THREAT BUT OF AN ENTIRE WAY OF THINKING ABOUT INTERNATIONAL SECURITY AND THE INTERNATIONAL

RESPONSIBILITIES OF THE UNITED STATES. U.S. STRATEGY, SO LONG BASED ON THE MILITARY AND POLITICAL DICTATES OF CONTAINMENT, MUST BE RECONCEPTUALIZED IF THE U.S. NATIONAL INTEREST IS TO BE WELL SERVED IN THE YEARS AHEAD. THIS ARTICLE STATES THAT MULTILATERAL CRISIS MANAGEMENT, PEACEKEEPING, AND COLLECTIVE SECURITY SHOULD BE AS' FUNDAMENTAL TO THE DEFENSE OF U.S. NATIONAL SECURITY INTERESTS IN THE 1990 S AS PARTICIPATION IN NATO HAS BEEN IN THE PAST.

05858 LUCIO, M.

EMPLOYER IDENTITY AND THE POLITICS OF THE LABOR MARKET IN SPAIN$$
\text { SPAIN }
$$

TEST EUROPEAN POLITICS, 14(1) (JAN 91), 41-55.

THE CONFEDERATION OF SPANISH BUSINESS ORGANIZATIONS (CEOE) HAS RARELY BEEN SYSTEMATICALLY ANALYSES IN TERMS OF ITS ROLE IN THE POL ITICAL AND ECONOMIC DEVELOPMENT OF SPAIN. IT IS ARGUED THAT THE CEOE HAS INDEED BEEN INFLUENTIAL IN IT IS ARGUED THAT THE CEOE HAS INDEED BEEN INFLUENTIAL IN ECONOMIC POLICY-MAKING AND THE FORMATION OF PRO-FREE MARKE
POLICIES IN SPAIN, ALBEIT IN A WAY NOT USUALLY UNDERSTOOD WITHIN MANY OF THE HIGHLY FORMALISTIC AND THE WITHIN MANY OF THE HIGHLY FORMALISTIC AND THE STATES AND SOCIO-ECONOMIC ACTORS. THE CEOE HAS PLAYED A PART STATES AND SOCIO-ECONOMIC ACTORS. THE CEOE HAS PLAYED A PART IN FORGING AN IDENTITY WITHIN THE EMPLOYER CLASS THROUGH ITS INTERVENTIONS WHICH IS ONE OF THE PIVOTS OF SPAIN'S LIMITE
ENGAGEMENTS WITH CONCERTED STATE AND SOCIALLY-ORIENTED RESPONSES TO CRISIS AND ECONOMIC DEVELOPMENT SINCE THE MID1970 S.

05859 LUCK, E.C.

MAKING PEAC

FOREIGN POLICY, (89) (WIN 93), 137-140, 142-155.

TO INTERVENE OR NOT TO INTERVENE HAS BECOME THE CRITICAL

QUESTION IN U.S. FOREIGN POLICY DEBATE. DESPITE GRAPHIC 
SCENES OF REPRESSION, VIOLENCE, AND STARVATION IN BOSNIAHERZEGOVINA, SOMALIA, AMD THE FORMER SOVIET REPUBLICS, INFLUENTIAL VOICES ARE URGING THE UNITED STATES AND ITS ALLIES TO LOOK THE OTHER WAY AND TO FORSAKE ADOITIONAL INTERNATIONAL RESPONSIBILITIES. BUT PASSIVITY IN AN ERA
SWEEPING CHANGES ACROSS THE GLOBAL GEOPOLITICAL MAP IS MYOPIC AND RISKY, BOTH IN TERMS OF AMERICA'S INTERESTS AND THE LOST OPPORTUNITIES TO BUILD A STRONGER SYSTEM OF COLLECTIVE SECURITY.

05860 LUDHAM, $S$.

THE GNOMES OF WASHINGTON: FOUR MYTHS OF THE 1976 IMF CRISIS POLITICAL STUDIES, XL(4) (DEC 92), 713-727.

THE IMF SETTLEMENT OF DECEMBER 1976 LOOMS LARGE IN POPULAR AND PARTISAN VIEWS OF THE POLITICS OF THE 1970S. IT IS ARGUED HERE THAT CONVENTIONAL ACADEMIC WISDOM HAS COME TO EMBODY SEVERAL MISLEADING MYTHS ABOUT ITS IMPACT ON ECONOMIC POLICY. EVIDENCE IS PRESENTED TO CHALLENGE FOUR SUCH MYTHS WHICH SUGGEST THAT THE IMF FORCED THE LABOUR GOVERNMENT TO WAUCH AM ATTACK OM PUBL IC SPEMDIT LAUNCH AM ATTACK ON PUBLIC SPENDING, INTRODUCE CASH LIMITS ABANDON THE PURSUIT OF FULL EMPLOYMENT THROUGH DEMAND ABANDON THE
MANAGEMENT.

05861 LUDLOW, $P$.

THE MAASTRICHT TREATY AMD THE FUTURE OF EUROPE WASHINGTON OUARTERLY 15(4) (FAL 92) 119-137. WASHINGTON QUARTERLY, 15(4) (FAL 92), 119-137.
WHETHER OR NOT THE EC HILL ACTUALLY MAKE THE PROGRESS THAT THE MAASTRICHT TREATY ALLOWS FOR DEPENDS NOT JUST ON THE TREATY ITSELF BUT ON THE POLITICAL WILL AND ENYIRONMENT OF THOSE WHO OVER THE NEXT MONTHS AND YEARS SEEK TO IMPLEMENT IT. THE TREATIES ENABLE, THEY DO NOT GUARANTEE. THIS ESSAY LOOKS AT BOTH POINTS. IT DISCUSSES HOH THE MAASTRICHT TREATY CONSOLIDATES AND EXTENDS THE EC SYSTEM AND WEIGHS THE PROBABILTIES OF SUCCESS.

05862 LUFRANO, $R$ NANJING SPRING: THE 1989 STUDENT MOVEMENT IN A PROVINCIAL CAPITAL

BULLETIN OF CONCERNED ASIAN SCHOLARS, 24(1) (JAN 92), 19-42.

IN THE SPRING OF 1989 THE STUDENTS OF NANJING WORKED HARD TO BUILD A COHERENT STUDENT MOVEMENT. THIS ESSAY TRACES THE DEYELOPMENT OF THAT MOVEMENT AND ANALYZES ITS SIGNIFICANCE. THE ACCOUNT COVERS THE PERIOD FROM THE DEATH OF HU YAOBANG TO THE DAY WHEN THE LAST POSTER HAS TORN DOWN ON THE NANJING UNIVERSITY CAMPUS, AND FOCUSES ON THE ROLE OF THE STUDENTS, THE UNIVERS ITY AUTHORITIES, THE LOCAL ROLE
GOVERMMENT, AND THE TOWNSPEOPLE. THE AUTHOR CONCLUDES HITH GOVERNMENT, AND THE TOWNSPEOPLE. THE AUTHOR CONCLUDES HITH
THE HOPE THAT THE FUTURE HILL BRING ABOUT A FREER AND BETTER THE HOPE

05863 LUGAR, R.

SEMATOR RICHARD LUGAR: THE NEH CONGRESS AND EUROPE EUROPE, 322 (1) (1992), 8-11.

SENATOR RICHARD LUGAR, FORMER CHAIRMAN OF THE SENATE FOREIGN RELATIONS COMMITTEE AND AN EXPERT ON FOREIGN POLICY ISSUES IN THE SEMATE, SPEAKS OUT ON THE KEY ISSUES THE 103RD CONGRESS WILL FACE WITH REGARD TO EUROPE WHEN THEY CONVENE IN JANUARY. HIS COMMENTS ABOUT PREDICTIONS OF THINGS TO COME, IN TERMS OF U.S. RELATIONS WITH EUROPE ARE DETAILED. HE DISCUSSES AMERICAN FORCES IN EUROPE, ECONOMICS, TRADE, NATO, DEFENSE, SECURITY, AND DOMESTIC PROBLEMS.

05864 LUGAR, R

THE REPUBLICAN COURSE

FOREIGN POLICY, (86) (SPR 92), 86-98

U.S. SENATOR RICHARD G. LUGAR (R-INDIANA) PROVIDES A REPUBLICAN VIEN OF AMERICA'S ROLE IN THE WORLD. HE ARGUES THAT THE ROLE SHOULD BE THAT OF LEADERSHIP AND THAT THE UNITED STATES HAS "THE WISDOM, THE POL ITICAL WILL. THE MILITARY CAPABILITY, AND THE ECONOMIC STRENGTH TO PERFORM THAT ROLE BETTER THAN ANY OTHER." DEMOCRATIC PARTY CALLS FOR PROTECTIONISM AND ISOLATIONISM ONLY INHIBIT AMERICA'S PROGRESS TOWARDS ITS POSITION AS WORLD LEADER. PRESIDENT GEORGE BUSH AND THE REPUBLICAN PARTY ARE BEST QUALIFIED TO PROIVDE THAT LEADERSHIP IN 1992 AND BEYOND.

05865 LUJIA, S.

EUROPE CALLS FOR PEACE

BEIJING REVIEW, 35(30) (JUL 91), 17

LEADERS OF THE MEMBER COUNTRIES IN THE CONFEREMCE ON SECURITY AND COOPERATION IN EUROPE (CSCE) ISSUED A STRONG SECURITY AND COOPERATION IN EUROPE (CSCE) ISSUED A STRONG
APPEAL FOR PEACE DURING THEIR JULY 1992 SUMMIT MEETING IN APPEAL FOR PEACE DURING THEIR JULY 1992 SUMMIT MEETING IN
HELSINKI, FINLAND. DUE TO THE GROWING ETHNIC CONFLICTS AND HELSINKI, FINLAND. DUE TO THE GROWING ETHNIC CONFLICTS OTHER CRISIS SITUATIONS, DISAPPOINTMENT, ANXIETY, AND UNCERTAINTY SET THE TONE FOR THE TALKS. THE MEMBERS AGREED TO CREATE A CSCE PEACE-KEEPING MECHAN
SEND OBSERVERS TO NAGORNO-KARABAKH.

05866 LUKACS, J.

FINLAND VINDICATED

FOREIGN AFFAIRS, 71(4) (FAL 92), 50-63.

THE AUTHOR BRIEFLY SKETCHES THE HISTORY RUSSO-FINMISH
RELATIONS AND DISCUSSES THE PRESENT STATUS OF THE RELATIONSHIP.

05867 LUKASHUK, A.

BELARUS

RFE/RL RESEARCH REPORT, 1(39) (OCT 92), 18-21.

THE MASS MEDIA IN BELARUS ARE EXCHANGING GLASNOST FOR SECURITY. FACED HITH SERIOUS FINANCIAL AND PRODUCTION PROBLEMS, EDITORS HAVE MANAGED TO OBTAIN SUBSIDIES FROM THE AUTHORITIES TOTALING 200 MILLION RUBLES. IN THE ABSENCE OF LAWS RESTRICTING MONOPOLISTIC PRACTICES, THE COUNCIL OF MINISTERS HAS BECOME A COFOUNDER OF NINE PUBLICATIONS ACCOUNTING FOR MORE THAN $80 \%$ OF BELARUSIAN PERIODICALS IN CIRCULATION. THE GOVERNMENT ALSO RUNS RADIO AND NATIONAL TELEVISION. A NEW BUREAUCRACY TO OVERSEE THE MEDIA WAS RECENTLY ESTABLISHED.

05868 LUKASHUK, A.

BELARUS'S KGB: IN SEARCH OF AN IDENTITY

RFE/RL RESEARCH REPORT, 1(47) (NOY 92), 17-21.

SINCE AUGUST 1991, HHEN BELARUS BECAME AN INDEPENDENT STATE, THE KGB HAS UNDERGONE VERY LITTLE REFORM. NOT ONLY HAS THE BELARUSIAN STATE SECURITY SERVICE RETAINED THE NOTORIOUS NAME OF THE KGB, THERE HAVE BEEN NO PERSONNEL OR SIGNIFICANT STRUCTURAL CHANGES. THE ABSENCE OF LEGISLATION TO REFORM THE STATE SECURITY SERVICE AND THE SHAKY POLITICAL SITUATION IN THE REPUBLIC HAVE GIVEN THE KGB'S LEADERS AN OPPORTUNTY TO SET UP A "NEW" STATE SECURITY SERVICE, BUT THEY CONTINUE TO ESPOUSE COMMUNIST IDEOLOGY AND THE REVIVAL OF FORMER ALL-UNION KGB RELATIONS TO AN EXTENT INCOMPATIBLE WITH BELARUS'S NEHLY-ACQUIRED SOVEREIGNTY AND NEUTRALITY. NEVERTHELESS, BELARUS'S OPPOSITION LEADERS REGARD THE KGB AS THE ONLY FORCE CAPABLE OF FIGHTING STATE CORRUPTION, ECONOMIC CRIME, AND THE MAFIA.

05869 LUKASHUK, A.

BELARUSIAN DRAFT CONSTITUTION: A CONTROVERSIAL STEP FORWARO RFE/RL RESEARCH REPORT, 1(43) (OCT 92), 43-48.

THE DRAFT OF BELARUS'S FIRST NONCOMMUNIST CONSTITUTION REPRESENTS A STEP FORHARD, ALBEIT A CONTROVERSIAL ONE, ON THE ROAD TOWARD DEMOCRACY AND SOVEREIGNTY. BASED ON INTERNATIONALLYY-RECOGNIZED PRINCIPLES, THE DRAFT CONSTITUTION DECLARES BELARUS TO BE A UNITARY STATE RULED BY LAW, INTRODUCES THE DIVISION OF POWERS, AHD PROCLAIMS THE RIGHTS AND FREEDOMS OF CITIZENS AS THE HIGHEST VALUES OF SOCIETY. HOWEVER. THE MANNER IN WHICH THESE NORMS ARE TO BE APPLIED IS DEEPLY ROOTED IN THE PAST, WHICH IS LIKELY TO APPLIED IS DEEPLY ROOTED IN THE PAST, WHICH IS LIKELY TO
NEUTRALIZE THEIR EFFECT. THE DRAFT REFLECTS THE TENSE SOCIAL AND ECOMOMIC SITUATION IN THE REPUBLIC AND MIRRORS THE AND ECONOMIC SITUATION IN THE REPUBLIC A

05870 LUKE, T.

POWER AND POLITICS IN HYPERREALITY: THE CRITICAL PROJECT OF JEAN BAUDRILLARD

SOCIAL SCIENCE JOURNAL, 28(3) (1991), 347-368

THIS ARTICLE DESCRIBES AMD EXAMINES THE CRITICAL THINKING OF JEAN BAUDRILLARD, ESPECIALLY IN RELATION TO HIS VIEWS OF MODERNITY AND POSTMODERNITY. AT THE CENTER OF HIS CRITIQUE OF MODERN AND POSTMODERN SOCIETY IS HIS NOTION OF HYPERREALITY, OR THE FABRICATED SYSTEM OF MEANING THAT LIMITS HUMAN' PARTICIPATION IN THE WORLD TO THE ROLE OF CONSUMER OR RESPONDER, RATHER THAN PRODUCER OR INITIATOR. IN CONTRAST TO BAUDRILLARD, TRADITIONAL CONCEPTIONS OF HUMAN ORGANIZATION HILL BE EXAMINED IN ORDER TO ASSESS THE IMPACT THE BAUDRILLARD'S WORK HAS ON SOCIAL SCIENTIFIC VIEWS OF COLLECTIVE AND POLITICAL ACTION.

05871 LUKEFAHR, $R$ AFTER THE RIOTS--CRAFTING THE GREAT SOCIETY (AGAIN) FREEDOM REVIEW, 23(4) (JUL 92), 35-41.

IN 1968, THE KERNER COMMISSION ISSUED A MAJOR REPORT ON THE UNITED STATES' SOCIAL PROBLEMS AND THE CAUSES OF URBAM VIOLENCE. IN THIS ARTICLE, THE AUTHOR COMPARES THE KERNER COMMISSION'S VIEW OF URBAN PROBLEMS IN 1968 AND THOSE PROBLEMS TODAY.

05872 LUKIN, V.P. OUR SECURITY PREDICAMENT

FOREIGN POL ICY, (88) (FAL 92), 57-75.

THE AUTHOR DISCUSSES HOW THE RECENT DRAMATIC CHANGES IN RUSSIA ARE AFFECTING ITS DEFENSE AND FOREIGN POLICIES. HE WARNS THAT RUSSIA FACES SERIOUS OR POTENTIALLY SERIOUS WARNS THAT RUSSIA FACES SERIOUS OR POTENTIALLY SERIOUS PROBLEMS HITH ALMOST ALL THE LARGE COUNTRIES ON ITS
PERIPHERY, PARTLY BECAUSE RUSSIA IS ASSUMING A NEW ROLE AS PERIPHERY, PARTLY BECAUSE RUSSIA IS ASSUMING A NEW ROLE AS STABILITY AND THE SECURITY OF THEIR BORDERS.

05873 LUMET, A.

A CALL TO ARMS

NATIONAL REVIEH, XLIV(25) (DEC 92), 37-37; 53.

MORE UNDER-THIRTY VOTERS ARE IDENIFYING THEMSELVES AS CONSERVATIVE THAN EVER BEFORE. ONE OF THE BIGGEST DIFFERENCES BETWEEN YOUNG AND OLDER CONSERVATIVES IS THAT THE "BABY CONS" haVE NO GUILT ABOUT THEIR VIEWS. AMY LUMET 
SUGGESTS THAT PERHAPS CONSERVATIVE IS THE WRONG WORD FOR THEM AT THIS POINT BECAUSE THERE IS A LOT THEY THEY WANT TO CHANGE. AN IMPROVED PAST IS THEIR MODEL. SHE SUGGESTS THAT

05874 LUMPE, L.; GRONLUND, G.; WRIGHT, D.

THIRD WORLD MISSILES FALL SHORT

BULLETIN OF THE ATOMIC SCIENTISTS, 48(2) (MAR 92), 30-37 THE THREAT TO THE UNITED STATES FROM THIRD HORLD MISSILES HAS BEEN GROSSLY EXAGGERATED. THE SPREAD OF BALLISTIC MISSILES IS AN IMPORTANT PROBLEM THAT MERITS SERIOUS ATTENTION. BUT IT IS IMPORTANT TO DEFINE THE NATURE OF THE PROBLEM BEFORE DETERMINING THE APPROPRIATE SOLUTIONS TO IT. FEARS OF THIRD WORLD MISSILES DO NOT JUSTIFY SPENOING BILLIONS OF DOLLARS ON MISSILE DEFENSES TO PROTECT THE UNITED STATES. THE BILLIONS OF DOLLARS SPENT FOR SDI WOULD UNITED STATES. THE BILLIONS OF DOLLARS SPENT
OFFER PROTECTION FROM FRIENDS, NOT ENEMIES.

05875 LUNAK, $P$.

HISTORY, REALITY, AND CENTRAL EUROPE'S SECURITY

SAIS REVIEH, 12(2)' (SUM 92), 129-139.

SOME SEE HISTORY AS A KEY OF INTERPRETATION FOR THE PRESENT AND THE FUTURE OF CENTRAL EUROPE, WHILE OTHERS CLAIM THAT HISTORY CAN DECEIVE RATHER THAN GUIDE. THIS ARTICLE TRACES THE EFFORTS OF HUNGARY, POLAND AND CZECHOSLOVAKIA TO FIND THEIR FOREIGN POLICY IDENTITIES IN AN ATMOSPHERE IN WHICH RELIANCE ON HISTORY AND ITS REFUSAL AWKWARDLY COEXIST. AS THEY HAVE LOOKED TO BOTH HISTORY AND THE PRESENT FOR A SOLUTION TO THEIR SECURITY DILEMMA THEY REALIZE THAT THEY WILL HAVE TO PURSUE THEIR GOALS TOGETHER.

05876 LUND, H.R.

HOBBES ON OPINION, PRIVATE JUDGMENT, AND CIVIL HAR HISTORY OF POLITICAL THOUGHT, XIII(1) (SPR 92), 51-72. ROBERT KRAYNAK'S INTERPRETATION OF "BEHEMOTH OR THE LONG PARLIAMENT" EMPHASIZES THE ROLE OF IDEAS, AS OPPOSED TO ECONOMIC INTERESTS. IN HOBBES' EXPLANATION OF CIVIL CONFLICT. IT ALSO RIGHTLY NOTES DIDACTIC CONTINUITIES BETHEEN "BEHEMOTH" AND HOBBES' EARL IER WORK HOWEVER, IT OVERESTIMATES THE EXTENT TO WHICH HOBBES TREATS THE GENERAL IDEA OF OPINION AS AN ELIMINABLE PRODUCT OF "ARTIFICAL" HISTORICAL RELATIONS RATHER THAN AS A PERMANENT FEATURE OF HUMAN PSYCHOLOGY AND ACTION. THUS, IT DISCOUNTS THE EXTENT HUMAN PSYCHOLOGY AND ACTION. THUS, IT DISCOUNTS THE EXTEM OPINION AND CIVIL HAR WAS A PRODUCT OF HIS PHILOSOPHY RATHER OPINION AND CIVIL WAR WAS A PRODUCT OF HIS PHILOSOPHY RATHER THAN A HISTORY OF CIVILIZATION. HOBBES TOOK OPINION PER SE
TO BE A SIGNIFICANT AMD INELIMINABLE FEATURE OF POLITICAL TO BE A SIGNIFICANT AND INELIMINABLE FEATURE OF POL ITICAL ILLUSTRATE THE DANGERS OF THE MISTAKEN (AND ERADICABLE) OPINION REGARDING PRIVATE JUDGMENT.

05877 LUNDSTORM M.

IS ANTI-RATIONALISM RATIONAL? THE CASE OF F.A. HAYEK SCANDINAVIAN POLITICAL STUDIES, 15(3) (SEP 92), 235-248.

THE AUTHOR CONSIDERS THE CRITICISM OF CONSTRUCTIVISH AND RATIONALISH IN POLITICS AS PRESENTED IN THE POLITICAL THEORY OF F.A. HAYEK. HAYEK'S THESIS IS THAT GOAL-DIRECTED RATIONALITY IN POLITICS IS COUNTER-FINAL. THE MAIN ARGUMENT OF THIS PAPER IS THAT, ON CLOSE EXAMINATION, HAYEK APPEARS TO BE A CONSTRUCTIVIST HIMSELF. THE PURPOSE OF HAYEK'S ANTIRATIONALISM IS PRIMARILY IDEOLOGICAL AND INSTRUMENTAL. HE WANTS TO INDUCE CERTAIN ANTI-RATIONALISTIC BELIEFS BECAUSE HE BELIEVES RATIONALISM HAS BAD CONSEQUENCES. YET THIS VERY PROJECT CAN BE CONSIDERED A CASE OF GOAL-DIRECTED RATIONALITY. FURTHERMORE, HAYEK MIXES ABSTRACT PHILSOPHICAL DOCTRINE HITH EMPIRICAL THEORY. IN HIS CRITIQUE OF
CONSTRUCTIVISM, HAYEK CONFUSES THO NOTIONS OF "RATIONALITY." ON THE ONE HAND, HE ARGUES AGAINST EPISTEMOLOGICAL RATIOMAL ISM ASSOCIATED WITH DESCARTES AND, ON THE OTHER, HE ARGUES AGAINST THE SUBJECTIVISTIC, ACTION-ORIENTED NOTION OF RATIONALITY ASSOCIATED WITH THE IDEA OF "ECONOMIC MAN," ARGUMENTS AGAINST CARTESIAN RATIONALITY DO NOT, HONEVER, IMPLY THE IMPOSSIBILITY OF GOAL-DIRECTED RATIONALISH IN' POL ITICS. THE SO-CALLED INFORMATION PROBLEM CANNOT BE SOLVED AT AN EPISTEMOLOGICAL LEVEL. IT IS A PRACTICAL PROBLEM, WHICH HAYEK HAS CERTAIN IDEAS ABOUT SOLVING. THEREFORE, HAYEK'S THESIS OF "TACIT KNOHLEDGE" IS NOT AN EXPRESSION OF SKEPTICISM AS IS OFTEN BELIEVED.

05878 LUPIA, A.

BUSY VOTERS, AGENDA CONTROL, AND THE POHER OF INFORMATIOM AMERICAN POL IT ICAL SCIENCE REVIEH, 86(2) (JUN 92), 390-403. THE CORRESPONDENCE BETHEEN INDIVIDUAL PREFERENCES AND ELECTDRARR SPONDENCE BETHEEN INDIVIDUAL PREFERENCES AND INFORMATION ASYMMETRIES AMONG ELECTORAL PARTICIPANTS AND THE PRESENCE OF INDIVIDUALS OR GRDUPS WHO EXERCISE SOME FORM OF PRESENCE OF INDIVIDUALS OR GROUPS WHO EXERCISE SOME FORM AGENDA CONTROL. WHILE THE EFFECTS OF AGENDA CONTROL IN
POLITICAL DECISION-MAKING ARE WIDELY RECOGNIZED, THE EFFECTS POLITICAL DECISION-MAKING ARE WIDELY RECOGNIZED, THE EFFECTS OF INFORMATION ASYMMETRIES ARE NOT AS WELL UNDERSTOOD. SINCE INFORMATION ASYMMETRIES ARE FUNDAMENTAL CHARACTERISTICS OF MOST ELECTIONS, A DEEP UNDERSTANDING OF THE CORRESPONDE BETHEEN INDIVIDUAL PREFERENCES AND ELECTORAL RESULTS REQUIRES A SERIOUS CONSIDERATION OF THE EFFECTS OF
INFORMATION. IN THIS PAPER, THE AUTHOR DEVELOPS A
GENERALIZABLE AGENDA-CONTROL MODEL THAT ASSUMES THAT MOST VOTERS ARE NOT NATURALLY INCLINED TO INVEST IN POLITICAL INFORMATION. THE MOOEL ALLOWS THE AUTHOR TO PROVIDE A DYNAMIC DESCRIPTION OF HOW VOTERS AND POLITICAL ELITES CAM ADAPT TO THE INFORMATION PROBLEMS THAT CHARACTERIZE POLITICAL DECISION-MAKING. IT ALSO ALLOWS HIM TO DEMONSTRATE THE EFFECT OF THOSE ADAPTATIONS ON ELECTORAL RESULTS.

05879 LURIE, I

JOBS IMPLEMENTATION IN 1991: THE PROGRESS OF TEN STATES PUBLIUS: THE JOURNAL OF FEDERALISM, 22(3) (SUM 92), 79-92. THE JOB OPPORTUNITIES ANO BASIC SKILLS TRAINING PROGRAM (JOBS) PROVIDES AN ARRAY OF SERVICES INTENDED TO INCREASE THE EARNING CAPACITY AND LABOR-FORCE PARTICIPATION OF WELFARE RECIPIENTS. BECAUSE THE LAH GIVES STATES DISCRETION WELFARE RECIPIENTS. BECAUSE THE LAH GIVES STATES DISCRETION JOBS IMPLEMENTATION IS UNDERHAY. DURING FEDERAL FY1991, MOST JOBS IHE TEN STATES MADE INCREMENTAL CHANGES TO THE PROGRAMS THEY HAD IN PLACE BEFORE JOBS. AS A GROUP. THEY SPENT ENOUGH TO DRAW DOWN 43 PERCENT OF THEIR FEDERAL JOBS FUNDS. TO OBTAIN EDUCATION, TRAINING, AND EMPLOYMENT SERVICES, STATE WELFARE AGENCIES ARE CONTRACTING WITH MANY ORGANIZATIONS. MOST STATE WELFARE AGENCIES ARE ALSO OBTAINING RESOURCES FROM OTHER AGENCIES WITHOUT PAYMENT.

05880 LUSK, G.

DEMOCRACY AND LIBERATION MOVEMENTS: THE CASE OF THE SPLA MIDOLE EAST REPORT, 22(1) (JAN 92), 30-31.

THE SUDAN PEOPLE'S LIBERATION ARMY (SPLA) HAS BEEN FIGHTING A SUCCESSION OF KHARTOUM GOVERNMENTS SINCE 1983. THOUGH ITS STATED GOAL IS TO BUILD A UNIFIED "NEW SUDAN," IT IS WIDELY PERCIEVED AS REPRESENTING THE INTERESTS OF THE SOUTH, WHERE MOST OF ITS FIGHTING IS DONE AND WHICH IT NOH ALMOST ENTIRELY CONTROLS. THIS ARTICLE REPORTS ON THE FIRST SERIOUS COUP ATTEMPT IN THE SPLA ON AUGUST 1991. MANY SOUTHERN LEADERS TOOK SIDES HITH WHICHEVER GROUP THEY VIEHED AS THE MATURAL VICTOR. HOWEVER, A HIDESPREAD FEELING AMONG LESS PROMINENT PEOPLE WAS THAT THE QUARREL MUST BE RECONCILED AND THAT FAILURE TO DO SO COULD MEAN THE END OF THE SPLA.

05881 LUSK, G.

SUDAN-CIVILIANS BEAR THE BRUNT

MIDOLE EAST INTERNATIONAL, (415) (DEC 91), 11.

IN SUDAN BOTH THE GOVERNMENT AMD THE SUDAN PEOPLE'S LIBERATION ARMY (SPLA) HAVE BEEN DEVOTING THEIR ENERGIES TO REGULAR ATTACKS ON CIVILIANS, WHILE ACQUIRING NEH HEAYY WEAPONRY FOR PLANNED MAJOR CONFRONTATIONS. MUCH OF THIS
WEAPONRY IS CHINESE-MADE AND WAS PAID FOR BY IRAN. IRANIAN WEAPONRY IS CHINESE-MADE AND WAS PAID FOR BY IRAN. IRAMI
PRESIDENT RAFSANJANI HAS SPOKEN OUT IN SUPPORT OF THE GOVERMMENT'S "ISLAMIC REVOLUTION." MILITARY AGREEMENTS BETWEEN IRAN AND SUDAN HAVE FACILITATED THE DELIVERY FROM CHINA TO SUDAN OF FIGHTER PLANES, BATTLE TANKS, ARMORED PERSONMEL CARRIERS, ROCKET SYSTEMS, AND HEAVY ARTILLERY. SLOAN "UNTIL THE END OF THE WAR IN THE SOUTH."

05882 LUSK, G.

SUDAN: THE CRISIS DEEPENS

MIDOLE EAST INTERNATIONAL, 438(438) (NOV 92), 14-15.

THIS ARTICLE REPORTS ON THE WAVES OF PROPAGANDA WHICH ARE FLOWIMG OVER SUDAN AS THE CRISIS DEEPENS. THE FIGHTING, AND GROHING INTERNATIONAL PRESSURE ON THE GOVERMMENT HAVE HEIGHTENED TENSIONS HITHIN BOTH THE RULING NATIONAL ISLAMIC FRONT AND THE OPPOSITIONS. WHILE MANY IN THE TRADITIONAL PARTIES ARE CONTENT TO STAY IN OPPOSITION IN THE BELIEF THAT PONER WILL ONE DAY BE THEIRS, THE SECULARISTS HOW SEE REMOVING THE GOVERNMENT AS AN URGENT TASK. INTERNATIONAL CONDEMHATION IS DETAILED.

05883 LUSK, G.

SUDAN: HHEELING AND DEALING

MIDOLE EAST INTERNATIONAL, 440(440) (DEC 92), 13-14. THE SUDANESE GOVERNMENT IS UNDER INCREASING PRESSURE-ESPECIALLY ECONOMIC ANO EXTERNAL. IT IS DETERMINED TO STAY IN POWER AND IS DIVIDED BETWEEN THOSE WHO WILL FIGHT TO THE BITTER END AND THOSE READY TO OPEN UP TO ANYONE HILLIMG TO BITTER END AND THOSE READY TO OPEN UP TO ANYONE HILLING
HORK WITH THEM, AT HOME OR ABROAD. BEYOND THE TANGLE OF WORK WITH THEM, AT HOME OR ABROAD. BEYOND THE TANGLE OF
ATTEMPTED DEALS AND LOBBYING STANCES BROAD TRENDS ARE ATTEMPTED DEALS AND LOBBYING STANCES BROAD TRENDS ARE
DISTINGUISHABLE. WITHIN THE OPPOSITION NATIONAL DEMOCRATIC DISTINGUISHABLE. WITHIN THE OPPOSITION NATIONAL DEMOCRATIC ALLIANCE THE SECULARIST "MODERN FORCES" ARE FURTHER AHAY
FROM THE "SECTARIANS" THAN EVER, ARGUING THAT SUDAN FACES FROM THE "SECTARIANS" THAN EVER, ARGUING THAT SUDAN
THE CHOICE BETHEEN A UNITED SECULAR COUNTRY AND AN THE CHOICE BETHEEN A UNITED SECULAR COUNTRY AND AN INDEPENDENT SOUTH. MEANS
INCREASED SUBSTANTIALLY.

05884 LUSTIG, $N$.

THE NORTH AMERICAN FREE TRADE AGREEMENT: A MEXICAN PERSEPCTIVE

SAIS REVIEW, 12(1) (WIN 92), 57-68.

ONLY A FEH YEARS AGO, A PROPONENT OF A FREE TRADE AGREEMENT BETHEEN MEXICD ANO THE UNITED STATES WOULD HAVE FACED HARSH CRITCISM IN MEXICD, AND INDIFFERENCE IN THE U.S. 
FIRST, WHY DID ATTITUDES TOWARDS SEEKING A FREE TRADE AGREEMENT CHANGE? SECOND, WHAT IS THE LIKELY ECONOMIC IMPACT POLITICAL CONFIGURATION IN SUPPORT OF, AND IN OPPOSITION TO, THE INITIATIVE? IT CONCLUDES THAT A FREE TRADE AGREEMENT IS LIKELY TO BE APPROVED.

05885 LUTHER, K.; MULLER, $W$. AUSTRIAN CONSOCIATIONALISM: VICTIM OF ITS OWN SUCCESS? WEST EUROPEAN POLITICS, 15(1) (JAN 92), 201-206.

AUSTRIA WAS LONG CONSIDERED ONE OF THE PRIME EXAMPLES OF CONSOCIATIONAL DEMOCRACY. THIS CONCLUDING ARTICLE SUMMARIZES THE VARIOUS POSITIONS OF SCHOLARS ON THIS ISSUE WITH EMPHASIS ON RECENT CHANGES IN AUSTRIA'S POLITICAL SYSTEM. THE DISTINGUISHING FEATURES OF A CONSOCIATIONAL DEMOCRACY ARE THE COEXISTENCE OF FIRST, A VERTICALLY FRAGMENTED SOCIAL STRUCTURE WITH ENCAPSULATED AMD MUTUALLY HOSTILE SUBCULTURES AND SECOND, OVERARCHING ELITE BEHAYIOR DESIGNED TO STABILIZE BE UMDE THPEAT , THE EIABILITY OF WHICH WOULD OTHERHISE MATURE OF AUSTRIAN POLITICS HAS CHANGED. IT ARGUES THAT THE AUSTRIAN POLITY HAS BEEN TRANSFORMED AS A RESULT OF A AUSTRIAN POLITY HAS BEEN TRANSFORMED AS A RESULT OF
COMPLEX INTERPLAY BETHEEN ON THE ONE HAND AUSTRIA'S COMPLEX INTERPLAY BETHEEN ON THE ONE HAND AUSTRIA'S
POLITICAL SOCIOLOGY AND VALUE SYSTEM AND ON THE OTHER THE BEHAVIOR OF ITS POLITICAL ELITES. IN ADDITION, ALTERATIONS BEHAVIOR OF ITS POLITICAL ELITES. IN ADOITION, ALTERATIONS TO AUSTRIA S EXTERNAL ENVIRONMENT HAVE ALSO MATTERED IN AUSTRIAN POLITICS. IN PARTICULAR, THE EXTERNAL THREAT AND ECONOMIC ISOLATION WHICH ORIGINALLY FACILITATED AUSTRIAN CONSOCIATIONALISM NO LONGER APPLY.

05886 LUTHER, K.; MULLER, $H$. CONSOCIATIONALISM AND THE AUSTRIAN PQLITICAL SYSTEM WEST EUROPEAN POLITICS, 15(1) (JAN 92), 1-15.

THIS ESSAY FIRST CONSIDERS THE ORIGINS AND NATURE OF AUSTRIA'S TRADITIONAL SUBCULTURES, OR LAGER. SECOND, IT OUTLINES THE CRISES OF MATIONAL IDENTITY. DEMOCRATIC LEGITIMACY AMD ECONOMIC DISTRIBUTION THAT FATALLY UNDERMINED THE FIRST AUSTRIAN REPUBLIC OF 1918-1934 AND RESULTED IN A SHORT CIVIL WAR, AUTHORITARIAN RULE AND FASCISM. THIRD, IT HIGHLIGHTS THE COEXISTENCE IN THE SECOND REPUBLIC OF SEGMENTATION (ALBEIT CONSIDERABLY ATTENUATED) AND SOCIAL, ECONOMIC AND POLITICAL STABILITY, A COMBINATION THAT LED TO AUSTRIA BEING LABELLED AN EXAMPLÉ OF CONSOCIATIONAL DEMOCRACY. THE CONSOCIATIONAL LITERATURE'S ASSERTIONS ON AUSTRIA HERE BASED IN THE MAIN ON DEVELOPMENTS BETHEEN 1945 AND 1966. WHICH IS THUS TERMED THE "CLASSIC" PHASE OF AUSTRIAN CONSOCIATIONALISM. THE ESSAY CONCLUDES BY IDENTIFYING SIX "CORE CHARACTERISTICS" OF AUSTRIAN POLITICS DURING THIS PERIOD.

05887 LUTHER, K.

CONSOCIATIONALISM, PARTIES AND THE PARTY SYSTEM WEST EUROPEAN POLITICS, 15 (1) (JAN 92) 45-98.

THIS ARTICLE PROVIDES A DETAILED ANALYSIS OF CHANGES SIMCE "CLASSIC" CONSOCIATIONALISH (1945-66) WITHIN AND BETWEEN AUSTRIA'S "LAGER" PARTIES. FIRST, THEIR INTRASUBCULTURAL LINKAGES ARE EXAMINED (ORGANIZATIONAL PENETRATION AND MOBILIZATION OF THEIR RESPECTIVE SUBCULTURES THE DEGREE OF PARTY HIERARCHICAL CONTROL OVER THE "LAGER" SECOND, THE ARTICLE INVESTIGATES THE "LAGER" PARTIES' ROLE IN INTER-SUBCULTURAL INTERACTION IN THE PARTY SYSTEM'S VARIOUS ARENAS. THIS INVOLVES CHANGES TO BOTH STRUCTURE OF THE "LAGER" PARTIES' INTERACTION (TRADITIONALLY CHARACTERIZED BY HIGH LEVELS OF CONCENTRATION, PERVASIVENESS OF PARTY ACTIVITY, AS HELL AS BY PREVAILING "PROPORZ" AND SEGMENTAL AUTONOMY) AND TO ITS STYLE. VARIOUS INDICATORS OF CHANGE TO AUSTRIA'S PARTIES AND PARTY SYSTEM ARE IDENTIFIED, INCLUDING DEPILLARIZATION, DECLINING LEVELS OF ORGANIZATIONAL PENETRATION, OF HIERARCHICAL CONTROL AND OF THE LAGER PARTIES' MOBILIZATIONAL CAPACITY. EMPHASIS IS PLACED UPON ORGANIZATIONAL FACTORS AS EXPLANATIONS OF "LAGER"-BASED POLITICS' PERSISTENCE, AS WELL AS UPON LIKELY FURTHER AND POSSIBLY OUITE RAPID CHANGE IN PARTIES AND PARTY SYSTEM.

05888 LUTTBEG, $N$

LEGISLATIVE CAREERS IN SIX STATES: ARE SOME LEGISLATURES MORE LIKELY TO BE RESPONSIVE?

LEGISLATIVE STUDIES QUARTERLY, 17(1) (FEB 92), 49-68. THE CAREERS OF MEMBERS OF THE LOHER HOUSES OF SIX STATE EGISLATURES IS FOCUSED ON TO SEE HOW STATES DIFFER IN THE COMPETITION THAT LEGISLATORS TYPICALLY EXPERIENCE OVER A COMPETITION THAT LEGISLATORS TYPICALLY EXPERIENCE OVER A
CAREER. ALL SIX STATES LOSE EXPERIENCED LEGISLATORS OUICKLY. CAREER. ALL SIX STATES LOSE EXPERIENCED LEGISLATORS OUICKLY. VOLUNTARILY THAN BECAUSE OF ELECTORAL DEFEAT. THESE FINDINGS RAISE THE OUESTION RAISE THE QUESTION WHO IS LESS RESPONSIVE: THE LEGISLATOR WILLING TO RETIRE VOLUNTARILY OR THE SECURE INCUMBENT? THE AUTHORS EXPECT MORE RESPONSIVENE
COMPETITIVE POLITICAL SYSTEM.

05889 LUTTBEG, N.R.

THE VALIDITY AND ELECTORAL IMPACT OF MEDIA ESTIMATIONS OF

"BEST" OR "HORST" STATE LEGISLATORS

LEGISLATIVE STUDIES QUARTERLY, XVII(3) (AUG 92), 395-408.
MANY MEHS ORGANIZATIONS RANK OR RATE STATE LEGISLATORS AS "BEST" OR "WORST," AS "MOST EFFECTIVE" OR "LEAST EFFECTIVE. "THIS STUDY ASSESSES THE VALIDITY OF SUCH RATINGS AND THEIR IMPACT AT THE POLLS. THE AUTHOR CONCLUDES THAT MEDIA RANKINGS CANMOT BE DISMISSED AS INVALID NOR CAN THEIR IMPACT AT THE POLLS BE COMPLETELY DISCOUNTED. ALTHOUGH THE EFFECTS ARE SMALL, IT HELPS TO BE RANKED AS AMONG THE BEST AMD IT HURTS TO $8 E$ AMONG THE HORST.

05890 LUTTWAK, E.

GET REAL

NEW REPUBLIC, 207(21) (NOV 92), 22-23.

EVER SINCE THE RABIN GOVERMMENT WAS FORMED, ITS SPOKESMEN AND NEGOTIATORS HAVE OFFERED "AUTONOMY" TO THE PALESTINIANS. THIS IS A VAGUE CONCEPT, WHOSE CONCRETE MEANING CAN ONLY BE DEFINED BY DETAILED BARGAINING BETHEEN THE THO SIDES. BUT TO DATE THERE HAS BEEN NO SUCH BARGAINING IN THE WASHINGTON PEACE TALKS. UNWILLING OR UNABLE TO NEGOTIATE IN EARNEST, THE PALESTINIANS HAVE PREFERRED TO BRACKET THE ISRAELI OFFER WITH A DEMAND FOR TOTAL INDEPENDENCE IN ALL THE CONTESTED TERRITORIES AND A STRATEGY OF NEW INTIFADA AGITATIONS.

05891 LUTTHAK, E.; BARTLEY, R.

IS AMERICA ON THE WAY DOWN?

COMMENTARY, 93(3) (MAR 92), 15-27.

THE IDEA THAT THE UNITED STATES IS IN DECLINE MIGHT ITSELF HAVE BEEN EXPECTED TO DECLINE WITH THE COLLAPSE OF THE SOVIET UNION AND ITS EMERGENCE AS THE ONLY REMAINING SUPERPOWER. BUT, DECLINISM, HAS NOH SHIFTED ITS FOCUS FROM THE POLITICAL, IDEOLOGICAL AND MILITARY CONFLICT WITH THE SOVIET UNION TO THE ISSUE OF ECONOMIC COMPETITION ESPECIALLY (THOUGH NOT EXCLUSIVELY) WITH JAPAN. UNLIKE THE DECLINISM OF THE LATE 80 'S MOREOVER, THIS LATEST MUTATION HAS FOUND SUPPORT NOT ONLY AMONG LIBERALS; FOR WHOM IT SERVED AS A HEAPON AGAINST THE ARMS BUILD-UP SPONSORED BY RONALD REAGAN, BUT ALSO AMONG CONSERVATIVES SUCH AS THE AUTHORS OF THIS DEBATE. TO THE QUESTION, IS AMERICA ON THE WAY DOWN?, EDWARD N. LUTTWAK SAYS YES AND ROBERT L. BARTLEY SAYS NO.

05892 LUTTWAK, E.

OBSESSION

NEH REPUBLIC, 206 ( 8 ) (FEB 92), 11-12.
PRESIDENT GEORGE BUSH SEEMS SO PREOCCUPIED WITH SECURITY

ISSUES, ESPECIALLY IN THE MIDDLE EAST, THAT HE HAS LITTLE

TIME FOR IMPORTANT INTERNATIONAL TRADE ISSUES. THIS WAS

OBVIOUS ON HIS MUCH-PUBLICIZED TRIP TO JAPAN AND SOUTH KOREA

IN DECEMBER 1991.

05893 LUTTHAK, E.

THE U.S. - JAPANESE CRISIS

WASHIMGTON OUARTERIY 15(4) (FAL 92), 111-118,

THE DEEPENING CRISIS IN U.S. -JAPANESE RELATIONS MUST

HAVE SUBSTANTIAL REPERCUSSIONS FOR EACH SIDE AND ALSO HAVE SUBSTANTIAL REPERCUSSIONS FOR EACH SIDE, AND ALSO FURTHER EROSION OF THE INTERNATIONAL TRADING SYSTEM, ONE OF THE FOUNDATIONS OF INTERNATIONAL SECURITY, QUITE ASIDE FROM ITS CRUCIAL ECONOMIC IMPORTANCE. THIS ARTICLE EXPLORES THE RESPECT DEFICIT AND JAPAN'S REFORM DILEMHA, AND THEN LOOKS TO THE FUTURE. IT CONCLUDES THAT IF EACH SOCIETY SUCCESSFULLY CONFRONTS ITS OWM SHORTCDMINGS, THE WAY WILL BE
OPEN FOR AN EVEN BROADER AND MUCH HAPPIER INTERDEPENDENCE BASED ON NEW RULES OF CONDUCT FOR BOTH SIDES.

05894 LUTTHAK, E.

VICTORY THROUGH AIR POWER

COMMENTARY, 92(2) (AUG 91), 27-30.

OPERATION DESERT STORM'S HUGE SUCCESS WAS LARGELY DUE TO

THE PERFORMANCE OF THE COALITION AIR FORCES. THIS ARTICLE

RECOUNTS THE AIR WAR STRATEGIES AND EXAMINES SOME LESSONS

THAT MIGHT BE LEARNED FROM THE EXPERIENCE. CONCLUSIONS INCLUDE: INTERHATIONAL CONTEXT HAS CRUCIAL NOT MERELY IN A BROAD DIPLOMATIC SENSE BUT ALSO SPECIFICALLY IN REGARD TO THE AIR HAR; BEACUSE IRAQ WAS DIPLOMATICALLY ISOLATED BEFORE IT WAS ATTACKED, THE BDMBARDMENT WENT UNCHALLENGED BY ANY THIRD PARTY INTERYENTION; THE SUCCESS OF THE BOMBARDMENT WAS LARGELY DUE TO THE "CONVENTIONAL" MATURE OF THE WAR (BOMBARDMENT IS STILL OF LITTLE USE AGAINST ELUSIVE GUERRILLAS): AND, STRATEGIC THOUGHT HAS BECOME MORE IMPORTANT THAN EVER IN AN AIR CAMPAIGN.

05895 LUTZ, D.

THE STATE CONSTItUTIONAL PEDIGREe OF THE U.S. BILL OF RIGHTS

PUBLIUS: THE JOURMAL OF FEDERALISM, 22(2) (SPR 92), 19-46. A DIRECT COMPARISON BETHEEN THE U.S. BILL OF RIGHTS AND PROMINENT ENGLISH COMMON LAW DOCUMENTS SHOWS THAT THE FIRST TEN AMENDMENTS TO THE U.S. CONSTITUTION HAVE ONLY A LIMITED RELATIONSHIP TO ENGLISH ANTECEDENTS. NOR WERE THE AMENDMENT PROPOSALS BY THE STATE RATIFYING CONVENTIONS THE PRIMARY SOURCE OF THE U.S. BILL OF RIGHTS. INSTEAD, THIS FAMOUS ADOITION TO THE FEDERAL CONSTITUTION WAS A SUMMARY OF THE COMHON CORE FOUND IN THE SEVEN EXISTING STATE BILLS OF 
RIGHTS. JAMES MADISON'S USE OF THIS SOURCE RESTED UPON COLONIAL DEVELOPMENTS IN RIGHTS THEORY, CONTRASTING NOTIONS OF RIGHTS IN ENGLAND AND AMERICA, COMPETING NOTIONS OF LIBERTY IN AMERICA IN THE 1780S, AND THE POLITICAL EXIGENCIES SURROUNDING THE RATIFICATION OF THE U.S. CONSTITUTION.

05896 LUTZ, D.

THE STATE CONSTITUTIONAL PREDIGREE OF THE THE U.S. BILL OF RIGHTS

PUBLIUS: THE JOURNAL OF FEDERALISM, 22(2) (SPR 92), 19-46.

DIRECT COMPARISON BETWEEN THE U.S. BILL OF RIGHTS AND PROMINENT ENGLISH COMMON LAW DOCUMENTS SHOWS THAT THE FIRST PROMINENT ENGLISH COMMON LAH DOCUMENTS SHOWS THAT THE FIRST TEN AMENDMENTS TO THE U.S. CONSTITUTION HAVE ONLY A LIMITED RELATIONSHIP TO ENGLISH ANTECEDENTS. INSTEAD, THIS ADDITION
TO THE FEDERAL CONSTITUTION WAS A SUMMARY OF THE COMMON CORE TO THE FEDERAL CONSTITUTION WAS A SUMMARY OF THE COMMON COR FOUND IN THE SEVEN EXISTING STATE BILLS OF RIGHTS. MADISON'S USE OF THIS SOURCE RESTED UPON COLONIAL
DEVELOPMENTS IN RIGHTS THEORY, CONTRASTING NOTIONS OF RIGHTS DEVELOPMENTS IN RIGHTS THEORY, CONTRASTING NOTIONS OF RIGHTS IN ENGLAND AND AMERICA, COMPETING NOTIONS OF LIBERTY IN AMERICAN IN THE 1780S, AND THE POLITICAL EXIGENCIES SURROUNDING THE RATIFICATION OF THE U.S. CONSTITUTION.

05897 LUTZ, E.; MUNASINGHE, M.

ACCOUNTING FOR THE ENVIRONMENT

FINANCE AND DEVELOPMENT, 28(1) (MAR 91), 19-21

ECONOMISTS HAVE INCREASINGLY BEEN ATTEMPTING TO ACCOUNT

FOR NATURAL RESOURCES IN THEIR CALCULATIONS OF NATIONAL

PRODUCTS AND INCOMES. WITH THE RISE IN AWARENESS OF

ENYIRONMENTAL ISSUES IN THE 1980S, ATTENTION IS NOW TURNING TO THE NEED TO BETTER UNDERSTAND THE VALUE OF ENVIRONMENTAL RESOURCES AND SERVICES AND TO IMPROVE THE CURRENT UNITED NATIONS SYSTEM OF NATIONAL ACCOUNTS (SNA) TO ACCOUNT FOR THE ENVIRONMENT IN INCOME ESTIMATION. THIS ARTICLE TRACES THE RISE OF THIS CONSCIOUSNESS AND THE WORK BEING DONE BY THE WORLD BANK STAFF IN THIS DIRECTION.

05898 LUTZ, E.; YOUNG, M.

INTEGRATION OF ENVIRONMENTAL CONCERNS INTO AGRICULTURAL POL ICIES OF INDUSTRIAL AND DEVELOPING COUNTRIES

POL ICIES OF INDUSTRIAL AND DEVELOPING CDUNTE
WORLD DEVELOPMENT, 20 (2) (FEB 92), 241-253.

THE AUTHORS DISCUSS THE TYPES OF ENVIRDNMENTAL AND RESOURCE-RELATED AGRICULTURAL POLICY ADJUSTMENTS THAT COULD RESOURCE-RELATED AGRICULTURAL POLICY ADJUSTMENTS THAT COU PROPERLY ADDRESS THE COSTS OF RESOURCE DEGRADATION AND INCREASE LONG-TERM PROSPECTS FOR SUSTAINABLE DEVELOPMENT. VARIOUS PUBLIC POLICY APPROACHES-OSUCH AS THE POLLUTER-PAYS PRINCIPLE, FISCAL MEASURES, AND REGULATIONS--ARE DISCUSSED AND ANALYZED HITH REGARD TO THEIR ENVIRONMENTAL AND RESOURCE IMPACTS. THE PAPER PROVIDES ILLUSTRATIVE EXPERIENCES FROM LESSONS AND INSIGHTS REVELANT TO POLICY-MAKING IN DEVELOPING COUNTRIES.

05899 LUXEMBURG, C.J.

A FREE LOMBARDY?

FREEDOM REVIEW, 23(4) (JUL 92), 16-18

IN MAY 1992, AFTER 16 BALLOTS, ITALY'S ELECTORAL COLLEGE FINALLY CHOSE OSCAR LUIGI SCALFARO, A CHRISTIAN DEMOCRAT, TO REPLACE FRANCESCO COSSIGA. RESENTMENT AGAINST THE EXPENSIVE, INEFFECTIVE CENTRAL GOVERNMENT IN ROME IS HIGH. IN LOMBARDY,
UMBERTO BOSSI AND HIS NORTHERN LEAGUE GAINED STRENGTH IN THE ELECTIONS AND ARE THREATENING SEPARATISM.

05900 LYCETT, A.

ADDIS ABABA DIARY

NEW AFRICAN, (282) (MAR 91), 12.

THIS ARTICLE PRESENTS PERSONAL EXPERIENCE AND ENCOUNTERS OF THE AUTHOR WHILE IN THE ETHIOPIAN CAPITAL OF ADOIS ABABA. HE REMARKS ON THE RETURN OF ISRAELI REPRESENTATIVES AFTER THE RESUMPTION OF DIPLOMATIC RELATIONS IN 1989, AND OF THE BOMB THAT BLEW UP IN THE HOTEL WHERE THE ISRAELIS STAY. HE NOTES THE GRADUAL DISAPPEARANCE OF THE ONCE UBIOUITOUS EAST EUROPEAN ADVISORS; ONLY A HANDFUL OF RUSSIANS AND CUBANS REMAIN. HE ALSO CONSIDERS MAHY OF THE VESTIGES OF THE "OLDFEMAIN. HE ALSO CONSIDERS MAHY OF THE VESTIGES OF THE "OLDFASHIONED EMPIRE" WHICH ARE EVIDENT: THE USE OF THE JULIAN
CALENDAR (WHICH IS SEVEN YEARS BEHIND THE GREGORIAN VERSION CALENDAR (WHICH IS SEVEN YEARS BEHIND THE GREGORIAN VERSION
OF THE WEST), AND THE SETTING OF APPOINTMENTS BY HOURS AFTER DAWN.

05901 LYCETT, A.

DE KLERK MEETS THE LOST TRIBE

NEH AFRICAN, (287) (AUG 91), 35

SOUTH AFRICAN PRESIDENT F W. DE XLERK MADE AM INTERESTING SIDE JOURNEY ON A RECENT STATE VISIT TO KENYA. HE FLEW TO ELDORET, SOME 200 MILES NORTHWEST OF THE CAPITAL, NAIROB HHERE HE MET WITH DESCENDANTS OF AFRIKAANERS WHO MADE A TREK NORTH AROUND THE TURN OF THE CENTURY. AT ONE MADE A TREK NORTH AROUND THE TURN OF THE CENTURY. AT OME ALTHOUGH OIMINISHED IN NUMBERS, THEIR EXISTENCE WAS EVIDENCE THAT AFRIKAANERS COULD LIVE AND THRIVE UNDER BLACK RULE.

05902 LYCETT, A.

MENGISTU'S ABOUT FACE

NEW AFRICAN, (282) (MAR 91), 9-11.
A YEAR AFTER THE POPULAR OVERTHROW OF COMMUNISM BEHIND THE IRON CURTAIN, ETHIOPIA, ONE OF THE SOVIET UNION'S MOST ZEALOUS CLIENT STATES IN AFRICA IS BEGINNING TO CHALLENGE MARXIST ORTHODOXY. PRESIDENT MENGISTU HAILE MARIAM IS FACING GUERRILLA INSURRECTION AND ECONOMIC COLLAPSE, AND HAS TURNED TO THE WEST. THERE ARE TENTATIVE MOVES TOWARDS ECONOMIC LIBERALIZATION, PARTICULARLY IN LAND TENURE AND AGRICULTURAL MARKETING. A TANGIBLE SPIRIT OF GLASNOST PREVAILS AS THE PRESIDENT STRUGGLES TO FIND A POLITICAL CONSENSUS WHICH WILL SATISFY NOT ONLY HIS HEARY PEOPLE BUT ALSO THE NEW SUPPORTERS HE IS WOOING. HOWEVER, HIS EFFORTS MAY BE TOO LITTLE, TOO LATE, AS THE ERITREAN AND TIGREAN REBELS LITTLE, TOO LATE, AS THE ERITREAN AND TIGREAN REBELS
CONTINUE TO WIN VICTORIES AGAINST GOVERNMENT FORCES.

05903 LYDON, C.

CAMPAIGN COVERAGE: SEX, HAR, AND DEATH

COLUMBIA JOURMALISM REVIEH, 31(1) (MAY 92), 57-60.

THE AUTHOR LOOKS AT THE MEDIA'S ROLE PARTICULARLY THAT OF THE MEWS MAGAZINES, IN ELEVATING ARKANSAS GOVERNOR BILL CLINTON TO THE FORERUNMER IN THE CONTEST FOR THE 1992 DEMOCRATIC PRESIDENTIAL NOMINATION.

05904 LYMAN, B.

URBAN PRIMACY AND WORLD-SYSTEM POSITION

URBAN AFFAIRS QUARTERLY, 2811) (SEP 92), 22-37.

THE LEVEL OF URBANIZATION HAS PERMANENTLY INCREASED IN

VIRTUALLY EVERY COUNTRY, CITIES HAVE GROWN DRAMATICALLY, AND

NATIONAL URBAN PRIMACY HAS INCREASED IN LESS-DEVELOPED

COUNTRIES. THIS CROSS-NATIONAL STUDY APPLIES GENERALIZED

LEAST-SOUARES PANEL REGRESSIONS OF WORLD-SYSTEM POSITION,

LEVEL OF ECONOMIC DEVELOPMENT, AND LAND AREA TO A

STANDARDIZED URBAN PRIMACY INDEX. THE DATA INDICATES THAT PERIPHERAL AND SEMI-PERIPHERAL NATIONS BECAME MORE PRIMATE FROM 1930 TO 1970, WHILE CORE NATIONS REMAINED STABLE. THE TREND TOWARD HIGHER URBAN PRIMACY AMONG PERIPHERAL NATIONS SLACKENED DRAMATICALLY IN THE 1970'S. NATIONAL CITY-SIZE DISTRIBUTIONS CLEARLY DIVERGED IN THE THENTIETH CENTURY, AND HORLD-SYSTEMS THEORY PROVIDES INSIGHT INTO THE INTERNATIONAL INFLUENCES THAT MEDIATE INTERNAL URBAN PROCESSES

05905 LYMAN, $S$.

THE ASSIMILATION-PLURALISM DEBATE: TOWARD A POSTMODERN RESOLUTION OF THE AMERICAN ETHMORACIAL DILEMMA

RESOLUTION OF THE AMERICAN ETHNORACIAL DILEMMA
INTERNATIONAL JOURMAL OF POLITICS, 6(2) (WIN 92), 181-210.

THE DISCDURSE ON ASSIMILATION AND PLURALISM TAKES A NEH

TURN IN POST-MODERNIST THOUGHT. IN CONVENTIONAL AND

TURN IN POST-MODERNIST THOUGHT IN CONVENTIONAL AND

MODERNIST DISCOURSES THE CONCEPTS ARE TREATED AS POLARITIES POINTING UP TWO DICHOTOMOUS METAPHORS OF SOCIAL STRUCTURE-THE MELTING POT AND THE MOSAIC. EACH IDEALIZED OUTCOME IS REGARDED AS UNCOMPLETED IN EVERY PRESENTIST ANALYSIS OF THE ISSUE. AFTER AN INVESTIGATION OF THESE THO IDEALS, THE AUTHOR CONCLUDES THAT AMERICA IS A SOCIETY WHOSE UTLIMATE ETHWORACIAL DIMENSIONS ARE IN A PROBLEMATIC STATE OF CONFLICTED DEFERRAL.

05906 LYNCH, J

THE INSTITUTIONAL FRAMEHORK OF COLONIAL SPANISH AMERICA JOURNAL OF LATIN AMERICAN STUDIES, 24 (1992), 69-82.

SPAIN ASSERTED ITS PRESENCE IN AMERICA THROUGH AN ARRAY OF INSTITUTIONS. TRADITIONAL HISTORIOGRAPHY STUDIED THESE IN DETAIL, DESCRIBING COLONIAL POLICY AND AMERICAN RESPONSES IN TERMS OF OFFICIALS, TRIBUNALS, AND LAWS. THE AGENCIES OF EMPIRE WERE TANGIBLE ACHIEVEMENTS AND EVIDENCE OF THE HIGH QUALITY OF SPANISH ADMINISTRATION. BETWEEN CROWN AND SUBJECT THERE WERE SOME 20 MAJOR INSTITUTIONS, WHILE COLONIAL

OFFICIALS NUMBERED IN THE THOUSAMDS.

05907 LYNCH, T.; CRUISE, P.

FEDERAL BUDGETING PROGNOSIS: MADISON'S NIGHTMARE INTERNATIONAL JOURNAL OF PUBLIC ADMINISTRATION, 15(5) (1992), 1053-1066.

THE PROCESS OF BUDGETING FOR THE FEDERAL GOVERMMENT HAS BROKEN DOWN, LEADING TO ANNUAL GRIDLOCK, MISLEADING BUDGET ACCORDS, AND EVER LARGER NATIONAL DEFICITS. THIS PROCESS FAILURE HAS ITS ROOTS IN THE VERY SAFEGUARDS CREATED BY FOUNDING FATHER JAMES MADISON. A "MADISONIAN NIGHTMARE" OF PARTISAN POLITICS AND POHERFUL, STABLE INTEREST GROUPS NOW MAKES ACHIEYII

05908 LYNK, M.V.

REGULATING POLITICAL ACTIVITY: NOTES ON A HYPOTHETICAL

STATUTE TO REGULATE PRESIDENTIAL PRIMARY AND GENERAL ELECTION CAMPAIGHS

JOURNAL OF LAW \& POLITICS, VIII(2) (WIN 92), 259-270. THE AUTHOR ANALYZES $S$. 100 , A HYPOTHETICAL BILL CONTAINING PROPOSALS TO REFORM THE U.S. PRESIDENTIAL ELECTION PROCESS.

05909 LYONS, P.; FITZGERALD, K.; RHEINBOLT, R. MILITARIZING THE THIRD HORLD

NUCLEAR TIMES, 8(2) (SUM 90), 27-29.

THIS ARTICLE DISCUSSES THE FLOW OF ARMS TO THE THIRD WORLD AS EAST-WEST TENSIONS DECREASED IN THE 1980S. IT NOTES 
WHICH NATIONS ARE THE SUPPLIERS AND HHICH ARE THE PURCHASERS A MAP-CHART SHOHIMG THE MOYEMENT OF ARMS, AMOUNTS PAID BY VARIOUS COUNTRIES, AND EXAMPLES OF WEAPONS AND WEAPONS SYSTEMS DEVELOPED AND TRADED SUPPLEMENTS THE ARTICLE.

05910 LYONS, T.

POST-COLD WAR U.S. POLICY TOWARO AFRICA

BROOKINGS REVIEW, 10(1) (WIN 92), 32-33.

DURING THE COLD WAR, THE PRIMARY GOAL OF WASHINGTON'S AFRICAN POLICY WAS TO PREVENT THE SOVIET UNION FROM DOMINATING THE CONTINENT. NOW THAT THE EAST-HEST IDEOLOGICAL COMPONENT HAS BEEN REMOVED FROM U.S. -AFRICAN RELATIONS, SOME WASHINGTON POLICIES ARE DRAMATICALLY CHANGING. THE CHANGES ONE EXAMPLE OF EVOLVING POLICY.

05911 LYONS, H.; SCHEB, II, J.

IDEOLOGY AND CAMDIDATE EVALUATION IN THE 1984 AND 1988 PRESIDENTIAL ELECTIONS

THE JOURNAL OF POLITICS, 54(2) (MAY 92), 573-586.

DATA FOR THIS ARTICLE ARE TAKEN FROM' THE 1984 AND 1988 AMERICAN NATIONAL ELECTION STUDIES CONOUCTED BY THE CENTER FOR POLITICAL STUDIES AT THE UNIVERSITY OF MICHIGAN. THE FOR POL ITICAL STUDIES AT THE UNIVERSITY OF MICHIGAN. PRESIDENT EXPECTING THOSE HITH DIFFERENT LEVELS OF PRESIDENT, EXPECTING THOSE WITH DIFFERENT LEVELS OF CONCEP TUALIZATION TO VARY IN THEIR USE OF LIBERAL-

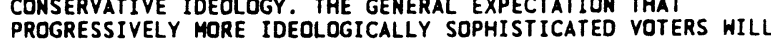
PROGRESSIVELY MORE IDEOLOGICALLY SOPHISTICATED VOTERS WILL INTEGRATE THEIR IDEOLOGICAL AND PARTY IDENTIFICATIONS AND THEIR POSITIONS OF POLICY ISSUES IN A MORE CONSISTE PREDICTABLE MANNER THAN THEIR LESS SOPHISTICATED COUNTERPARTS IS CONFIRMED. THERE IS SOME EVIDENCE REPUBLICAN'S APPARENT STRATEGY IN 1988 TO APPEAL TO VOTERS AT THE LOWEST LEVEL OF IDEOLOGICAL SOPHISTICATION.

05912 LYONS, W.E.; DEHOOG, R.H.; LOHERY, D. THE POLITICS OF DISSATISFACTION--CITIZEN, SERVICES, AND URBAN INSTITUTIONS

M. E. SHARPE, $1992,256$.

THIS SURVEY OF URBAN POLITICAL BEHAVIOR IS BASED ON AN INNOVATIVE RESEARCH SURVEY CONDUCTED IN THO VERY DIFFERENT COMMUNITIES: LEXINGTON AND LOUISVILLE, KENTUCKY. THE AUTHORS REACH THO GENERAL CONCLUSIONS BEARING ON LONGSTANDING ISSUES IN THE URBAN POLITICS LITERATURE. THEY FIMD FIRST THAT THE COMPLEXITY OF THE LOCAL POLITICAL WORLD-WHY CITIZENS BECOME DISSATISFIED AND HOW THEY RESPOND POLITICALLY--CAN BE CITIZENS' ACTUAL SITUATIONS. THE SECOND CONCLUSION IS THAT IN THE DESIGN OF URBAN INSTITUTIONS THERE IS MORE SUPPOR FOR THE HYPOTHESES OF TRADITIONAL REFORMERS, WHICH STRESS THE CENTRALIZATION OF LOCAL GOVERMMENTAL INSTITUTIONS, FOR THOSE OF PUBLIC CHOICE PROPONENTS OF FRAGMENTATION. INDEED, THE BOOK EXPOSES PUBLIC CHOICE APPROACHES TO URBAN GOVERNANCE AS EXERCISES IN HISHFUL THINKING. BOTH FINDINGS OFFER A SHARP DEPARTURE FROM RECENT WORK IN URBAN POLIT
AND WILL HEIGHTEN THE DEBATE OVER HOW LOCAL GOVERMMENT AND WILL HEIGHTEN THE
SHOULD BE ORGANIZED.

05913 M'BAYE, $S$.

CONTRASTING ACHIEVEMENTS

WEST AFRICA, (3926) (DEC 92), 2136-2137.

FROM THE LATE 1970'S TO THE PRESENT, SENEGAL HAS UNDERGONE MAJOR POLITICAL AND ECONOMIC CHANGES DESIGNED TO GENERATE ECONOMIC GROWTH AND DEVELOPMENT. ON THE POLITICAL FRONT, THE AGREEMENT BETHEEN THE GOVERNMENT AND THE TWO OPPOSITIION PARTIES TO FORM A COALITION GOVERNMENT HAS BROUGHT A MINIMUM LEVEL OF STABILITY. ON THE ECONOMIC FRONT, SENEGAL STARTED AS EARLY AS 1978 TO IMPLEMENT A SHORT-TERM STABILIZATION PROGRAM, WHICH HAS BEEN FOLLOWED BY MEDIUMAND LONG-TERM ADJUSTMENT PROGRAMS AIMED AT IMPROVING THE INVESTMENT CLIMATE.

05914 M'BAYE, $S$.

REBUILDING THE CONTINENT

WEST AFRICA, (3895) (MAY 92), 797-798

IT IS TRUE THAT THE AFRICAN CONTINENT HAS EXPERIENCED TREMENDOUS DIFFICULTIES, ECONOMIC FAILURES, AND HUMAN RIGHTS ABUSES. BUT IT IS EQUALLY TRUE THAT AFRICA HAS EMBARKED UPON FAR-REACHING POLITICAL, ECONOMIC, AND SOCIAL REFORM PROGRAMS THAT HAVE PRODUCED POSITIVE RESULTS, WHICH ARE OFTEN THAT HAVE PRODUCED POSITIVE RESULTS, WHICH ARE OFTEN
OVERLOOKED, AND THAT PROMISE MORE CHANGE IN THE FUTURE.

05915 MA, R.

HAN AND TIBETAM RESIDENTIAL PATTERNS IN LHASA CHINA OUARTERLY (128) (DEC 91), $814-835$

ETHNIC CONFL ICT REMAINS SURPRISINGLY PERSISTENT THROUGHOUT THE WORLD. THIS PERSISTENCE IS PARTICULARLY SURPRISING IN SOCIALIST COUNTRIES, WHICH HAVE PURSUED SOCIAL POLICIES DESIGNED TO ACHIEVE EQUALITY AND DIMINISH ETHNIC DIFFERENCES. THIS PAPER EXAMINES THE HAN-TIBETAN RELATIONSHIP IN THE TIBET AUTONOHOUS REGION, BASED ON A 1988 SURVEY, AND ENDEAVORS TO DRAH SOME UNIVERSAL CONCLUSIONS ABOUT ETHNIC RELATIONSHIPS.
05916 MA'OZ,M

SYRIAN-ISRAELI RELATIONS AND THE MIDOLE EAST PEACE PROCESS JERUSALEM JOURNAL OF INTERNATIONAL RELATIONS, 14(3) (SEP 92 ) , 1-21

THE POSIITIONS OF SYRIA AND ISRAEL REGARDING THE PEACE PROCESS REMAIN VERY FAR APART: ALTHOUGH DAMASCUS, SINCE 1988 HAS ADOPTED A MORE FLEXIBLE ATTITUDE TOWARD ISRAEL

JERUSALEM SINCE THE EARLY 1980 S HAS HARDENED ITS STAND ON THE GOLAN ISSUE. ATTEMPTS TO BRIDGE THE TWO POSITIONS ARE LIKELY TO REMAIN DIFFICULT.

05917 MAASDORP, G.

ECONOMIC PROSPECTS FOR SA IN SOUTHERN AFRICA

SOUTH AFRICA INTERNATIONAL, 22(3) (JAN 92), 121-127.

THE ANNOUNCEMENT OF THE EC COMMON MARKET, THE END OF THE COLD WAR, AMD POLITICAL REFORM WITHIN SOUTH AFRICA ALL OPEN UP THE WORLD TO SOUTH AFRICA. THIS ARTICLE EXAMINES THE ECONOMIC PROSPECTS FOR THE COUNTRY IN THE SOUTHERN AFRICAN REGION. IT EXAMINES EACH COUNTRY IN THE REGION AND ASSESES THE PROSPECTS OF ECONOMIC COOPERATION AND TRADE. IT CONCLUDES THAT PROSPECTS FOR TRADE. PARTICULARLY IN COMMOOITIES SUCH AND MACHINERY, APPLIANCES, TRANSPORTATION EOUIPMENT AMD BUIDING MATERIALS, ARE GOOD. FOREIGN EXCHANGE EWIPMENT AND BUILOING MATERI ALS, ARE GODD. HHICH WOU HAYE SHORTAGES CAN BE OVERCOME BY COUNTERTRADE, WHICH WOULD HAYE THE ADDITIONAL BENEFIT OF EASING REGIONAL FEARS OF SOUTH AFRICA'S ECONOMIC DOMINANCE. IMPORTS OF SERVICES, SUCH AS POWER AND WATER, FROM THE REGION WOULD FURTHER AMELIORATE POTENTIAL IMBALANCES. ANOTHER POSSIBLE

05918 MACALLISTER, I.; STUDLAR, D. GENDER AND REPRÉSENTATION AMOMG LEGISLATIVE CANDIDATES IN AUSTRALIA

COMPARATIVE POLITICAL STUDIES, 25(3) (OCT 92), 388-411,

IN THIS ARTICLE, THE AUTHORS APPLY MULTIVARIATE ANALYSIS TO MATCHED MASS-ELITE SURVEY DATA COLLECTED DURING THE 1987 AUSTRALIAN FEDERAL ELECTION TO ANALYZE THE POLICY VIEWS OF MALE AND FEMALE CANDIDATES AND TO COMPARE THEM TO ATTITUDES AMONG THEIR CONSTITUENTS. FOR CANDIDATES, PARTY DOMINATES POL ITICAL ATTITUDES, WITH MUCH LESS INFLUENCE FOR CONSTITUENCY OPINION AND LITTLE AT ALL FOR GENDER EXCEPT ON THE QUESTION OF ADVANCEMENT FOR WOMEN.

05919 MACBRIDE, N.H.

THE POLITICS OF PUBLIC ACCOMMODATIONS: THE SEARCH FOR A CONSTITUTIONAL BASIS FOR TITLE II

JOURNAL OF LAW \& POLITICS, VIII(2) (WIN 92), 437-476.

EFFORTS TO DEAL WITH RACIAL DISCRIMINATION DURING THE EARLY $1960^{\prime} S$ PROVIDE A PRIME CASE STUDY OF THE INFLUENCE OF POLLITICS ON THE THREE BRANCHES OF GOVERNMENT HHEN DEALING PITH WITH CIVIL RIGHTS. THE DRAFTING AND INTERPRETATION OF TITLE AND CONSTITUTIONAL ISSUES SURROUNDING SUCH LEGISLATION.

05920 MACCIARONI, G.

IHE GARBAGE CAN MODEL \& THE STUDY OF POLICY MAKING: A CRITIOUE

POLITY, 24(3) (SPR 92), 459-482.

WHILE THE USE OF THE GARGAGE CAN MODEL OF ORGANIZATIONAL CHOICE HAS MANY VIRTUES, THIS ARTICLE ARGUES THAT IT IS ULTIMATELY TOO INDETERMINATE TO PROVIDE FULLY SATISFACTORY CONSIDERATION BY GOVERNMENT WHILE OTHERS DO NOT. USING TAX REFORM AND DEREGULATION AS ILLUSTRATIVE CASES, THE AUTHOR POINTS TO SEVERAL SOURCES OF THE MODEL'S INDETERMINACY AND SUGGESTS HOW THESE PROBLEMS CAN BE OVERCOME WHILE PRESERYING THE STRENGTHS OF THE MODEL.

05921 MACDERMOTT, J.

EMPLOYEES ÁND SERVANTS

NEW POLITICS, 13(1) (SUM 92), 149-154.

THIS ARTICLE EXAMINES THE REAONS WHY THE PROBLEM OF INDUSTRIAL INEQUALITY IS PECULIARLY INTRACTABLE. IT ARGUES THAT STILL EXTANT PREMODERN CONCEPTIONS GOVERNING INDUSTRIAL RELATIONS, ESPECIALLY OUR DETERMINATION TO CONTINUE TREATING OWNERS, ENTREPREMEURS AND MANAGERS AS PRIVILEGED, SUPERIOR BEINGS MAKE IT INEVITABLE THAT WORKERS CONTINUE TO BELONG TO AND MUST BE TREATED AS AN INFERIOR ESTATE. THE RESULT IS THAT THERE IS NO REASON TO THINK THAT THIS INEQUALITY WILL CHANGE UNTIL A REVOLUTION IS BEGUN IN THE WAY PEOPLE THINK ABOUT INDUSTRIAL MATTERS.

05922 MACDONALD, D.

THE ROLE OF THE MAJOR POWERS IN THE REUNIFICATION OF KOREA HASHINGTON QUARTERLY, 15(3) (SUM 92), 135-154.

DIVIDED KOREA IS THE LAST OUTPOST OF THE BI-POLAR ERA.

THIS ARTICLE EXAMINES THE FACTORS, BOTH DOMESTIC AND

INTERAATC EXAMAT AFFECT THE COURSE OF KOREA'S FUTURE WITH INTERNAT TA INTERESTS AND POSITIONS OF THE FOUR MAJOR POWERS IN THE REGION--THE UNITED STATES, CHINA, THE USSR/RUSSIA, AMD JAPAN. IT CONCLUDES THAT ALTHOUGH THE IMPETUS FOR REUNIFICATION MUST COME FROM THE KOREAN'S THEMSELYES, THE MAJOR POHERS CAN 
DO MUCH TO FACILITATE THE PROCESS. ONE POSSIBLE COURSE OF ACTION IS SIX-POWER TALKS WHICH ADDRESS THE GENERAL SUBJECT OF NORTHEAST ASIAN SECURITY AND THEN THE SPECIFIC ISSUE OF KOREAN UNIFICATION.

05923 MACDONALD, M.

THE SIRON'S SONG: THE POLITICAL LOGIC OF POWER-SHARING IN SOUTH AFRICA

JOURNAL OF SOUTHERN AFRICAN STUDIES, 18(4) (DEC 92), 709-761.

THE PAPER DOES TWO THINGS. FIRST, IT DEALS WITH THE WORK OF AREND LIJPHART AND DONALD HOROHITZ ON SOUTH AFRICAN POLITICS, AND PARTICULARLY THE RELATIONSHIP OF THEIR ETHNIC MODELS TO THE PROPOSALS LI JPHART AND THE NATIONAL PARTY ARE MAKING FOR A NEW CONSTITUTION FOR SOUTH AFRICA. SECOND, THE ANALYSIS OF LIPJPHART AND HOROWITZ SETS UP A DISCUSSIOH OF THE POWER POLITICS OF THE NATIONAL PARTY'S PROPOSALS FOR POWER-SHARING INSTITUTIONS, WHICH IS THE TARGET OF THE PAPER, THE THESIS IS THAT POWER-SHARING IS AN AGGRESSIVE AS WELL AS A DEFENSIVE PROPOSAL ON THE PART OF THE NATIONAL PARTY, THAT THE ARGUMENT FOR ITS WORKABILITY IS SUSPECT, ANO THAT THE ENDS POWER-SHARING IS SAID TO PROMOTE--MODERATION AND STABILTIY-MIGHT END UP MODERATING AND STABILIZING SOME OF THE INEQUALITITES OF APARTHEID.

05924 MACDONALD, $S$.

TURKEY'S 1991 ELECTIONS: CONDEMNED TO RELIVE THE PAST? MIDDLE EAST INSIGHT, 8(3) (1992), 25-30

WILL TURKEY BE CONDEMNED TO RELIVE THE PAST OF SYSTEMIC BREAKDOWN AND MILITARY REGIMES? A POSITIVE INDICATION THAT DEMIREL HAS LEARNED HIS HISTORY WAS THAT HE AGREED THAT HE WOULD NOT PURSUE EARLIER STATEMENTS THAT HE WOULD SEEK TO FORCE OZAL OUT OF THE PRESIDENCY BEFORE THE END OF HIS TERM IN 1996. EQUALLY IMPORTANT, THE TURKEY OF 1991 IS NOT THE SAME AS IN PAST DECADES WHEN MILITARY COUPS ENDED

PARLIAMENTARY DEADLOCKS. THE ECONOMY IS MORE BROAD BASED AND MORE DIVERSIFIED AND POLITICAL LINKAGES HITH DEMOCRATIC PARTIES AND INSTITUTIONS IN WESTERN EUROPE AND ELSEWHERE ARE MORE FIRMLY CEMENTED. 05925 MACDONALD, S.E.; LISTHAUG, OL; RABINOHITZ, G.
ISSUES AND PARTY SUPPORT IN MULTIPARTY SYSTEMS AMERICAN POLIIICAL SCIENCE REVIEH, 85(4) (DEC 91), 1107-1132.

THE AUTHORS PROBE THE RELATIONSHIP BETWEEN PARTY ISSUE POSITION AND MASS EVALUATION OF POLITICAL PARTIES IN MULTIPARTY SYSTEMS. THEY UTILIZE TWO COMPETING THEORIES OF MASS-ELITE LINKAGE: THE DIRECTIONAL THEORY AND THE MASS-ELITE LINKAGE: THE DIRECTIONAL THEORY AND THE
TRADITIONAL SPATIAL THEORY OF ELECTIONS. THE ALTERNATE TRADITIONAL SPATIAL THEORY OF ELECTIONS. THE ALTERNATE
MODELS ARE EVALUATED WITH 1989 NORWEGIAN SURVEY DATA, WHICH MODELS ARE EVALUATED WITH 1989 NORWEGIAN SURVEY DATA, WHICH
IS UNIQUE IN PROVIDING EXTENSIVE INFORMATION ON THE ISSUE IS UNIQUE IN PROVIDING EXTENSIVE INFORMATION ON THE IS
POSITIONS OF ALL PARTIES WITH POTENTIAL FOR ACHIEVING REPRESENTATION IN THE PARLIAMENT. RESULTS SUGGEST THAT THE REPRESENTATION IN THE PARL I AMENT. RESULTS SUGGEST THAT THE
DIRECTIONAL THEORY PROVIDES A BETTER DESCRIPTION OF THE DIRECTIONAL THEORY PROVIDES A BETTER DESCRIPTION OF THE RELATIONSHIP. CONSISTENT WITH DIRECTIONAL THEORY, WHEN
PARTIES OCCUPY A CENTRIST POSITION ON AN ISSUE, THEY ARE NOT EVALUATED ON THE BASIS OF THAT ISSUE. VOTERS NEITHER LOVE NOR HATE A PARTY IN THE MIDDLE. THUS, IN ORDER - TO BUILO SUPPORT ON THE BASIS OF ISSUES, PARTIES MUST OFFER SOME STRONG STANDS.

05926 MACFARLANE, L.

HUMAN RIGHTS AND THE FIGHT AGAINST TERRORISM IN NORTHERN IRELAND

TERRORISM AND POLITICAL VIOLENCE, 4(1) (SPR 92), 89-99. AFTER A DISCUSSION OF THE UNITED KINGDOM'S

RESPONSIBILITIES UNDER THE EUROPEAN CONVENTION OF HUMAN RIGHTS AND THE POLITICAL BACKGROUND TO THE RE-EMERGENCE IN 1968-69 OF TERRORI SM AND THE STATIONING OF BRITISH TROOPS IN THE PROVINCE, THE ARTICLE ANALYZES THOSE HUMAN RIGHTS ISSUES WHICH DERIVE FROM THE WAR THE FIGHT AGAINST TERRORISM HAS BEEN CONDUCTED OVER THE PAST 20 YEARS. THE ISSUES DISCUSSED ARE; DEATHS RESULTING FROM THE ACTIONS OF THE SECURITY FORCES, COMPLAINTS OF ILL-TREATMENT BY THE POLICE DURING INTERROGATION, THE DETENTIONING OF TERRORIST SUSPECTS, AND

05927 MACHACEK, J.

PRIVATIZATION: MORE THAN AN ECONOMIC GOAL

EAST EUROPEAN REPORTER, 5 (1) (JAN 92), 55-58,

OVERSHADOWED BY GROWING DOUBTS HANGING OVER THE COUNTRY'S CONTINUATION AS A FEDERAL STATE, IN 1991 CZECHOSLOVAKIA NONETHELESS BEGAN IMPLEMENTING THE REFORMS THAT WILL LEAD TO THE CREATION OF A MARKET ECONOMY. PERHAPS THE MOST IMPORTANT OF THESE FOR AN ECONOMY IN WHICH PROPERTY WAS MORE THOROUGHLY "SOCIALIZED" THAN ELSEWHERE IN CENTRAL WAS MORE THOROUGHLY "SOCIALIZED" THAN ELSEWHERE IN CENTR CRITICISM FOR ITS SLOW START, THE GOVERMMENT CAN POINT CRITICISM FOR ITS SLOW START, THE GOVERMMENT CAN POINT CONSIDERABLE PROGRESS IN 1991, THOUGH THE SUCCESS OF ITS IN CENTRAL EUROPE TO DISTRIBUTE SHARES AMONG A BROAD SECTION IN CENTRAL EUROPE TO DISTRIBUTE SHARES AMONG A BROAD SECTIOM OF THE POPULATION-WILL NOT BE KNOWN FOR SEVERAL MONTHS TO COME. THIS ARTICLE EXAMINES THE MAIN METHODS AND UNDERLYING ISSUES OF PRIVATIZATION IN CZECHOSLOVAKIA.
05928 MACHAN, T.

CAN POLITICIANS REALLY CARE?

FREEMAN, 42 (11) (NOV 92), 425

THIS ARTICLE DEFINES HHAT IT MEANS TO CARE, IT SUGgESTS THAT IN MOST CASES WHAT POLITICIANS MEAN BY CARING IS NOTHING MORE THAN GIVING SOME EVIDENCE OF EMOTIONAL SYMPATHY WITH THE LOT OF SOME BLOCK OF VOTERS. THE ONLY WAY A POLITICIAN CAN SHOW GENUINE CARE IS BY MAKING CERTAIN THAT GOVERNMENT PROTECTS INDIVIDUAL RIGHTS. IT SHOULD BE AN EASY TASK, BECAUSE THERE IS ONE THING WE ALL NEED: RESPECT FOR OUR HUMAN RIGHTS. IN THAT WE ARE ALL ALIKE, AND POLITICIANS NEED NOT KNOW US PERSONALLY IN ORDER TO BE CARING. PERHAPS SOME POLITICIAN WILL EMERGE WHO WILL GENUINELY CARE FOR US AND DEVOTE HIMSELF TO SECURING DUR BASIC RIGHTS TO FIFE, LIBERTY, AND THE PURSUIT OF HAPPINESS.

05929 MACHAN, T.R.

THE BILL OF RIGHTS AND MORAL PHILOSOPHY

FREEMAN, 42(7) (JUL 92), 270-272.

THE DECLARATION OF INDEPENDENCE SIMPLY BUT CLEARLY STATED THAT EACH INDIVIDUAL HAS BASIC RIGHTS TO LIFE, LIBERTY, AND THE PURSUIT OF HAPPINESS. THE FRAMERS OF THE U. S. CONSTITUTION MADE THE POINT IN MORE DETAIL BY ADOING THE BILL OF RIGHTS, SO AS TO SINGLE OUT SOME RIGHTS AS DESERVING SPECIAL MENTION WITHOUT BELITTLING OTHERS NOT LISTED. THE CENTRAL THESIS OF THESE DOCUMENTS IS THE DOCTRINE OF INDIVIDUAL RIGHTS.

05930 MACHOWSKA, E.

LETTER FROM HARSAH

CHURCH AND STATE, 45(4) (APR 92), 8(80)-9(81).

THE ASSOCIATION FOR A NON-IDEOLOGICAL STATE (NEUTRUM)

BELIEVES THAT THE DEVELOPMENT OF DEMOCRACY IN POLAND DEPENDS ON RESPECT FOR THE SEPARATION OF CHURCH AND STATE.

UNFORTUNATELY, THE INFLUENCE OF THE ROMAN CATHOL IC CHURCH IN ALL ASPECTS OF PUBLIC LIFE APPEARS TO BE INCREASING IN POLAND.

05931 MACINTOSH, D. : GREENHORN, D.; HAWES, M.

TRUDEAU, TAIWAN, AND THE' 1976 OLYMPICS

AMERICAN REVIEN OF CANADIAN STUDIES, 21 (4) (WIN 91),

423-448.

THE TAIWAN ISSUE CAN ONLY BE UNDERSTOOD IN THE BROADER CONTEXT OF CANADA'S FOREIGN POLICY AND THE INTERNATIONAL OLYMPIC COMMITTEE'S (IOC) "THO CHINA" DILEMAA. THE FIRST PART OF THIS PAPER ADORESSES THE NEW FOREIGN POLICY INITIATIVES THAT PIERRE TRUDEAU INSTAGATED WHEN HE BECAME SPECIFINALY TO SPECIFICALLY TO CANADA'S RECOGNITION OF THE PEOPLE'S REPUBLIC OF CHINA IN 1970. IT THEN TURNS TO A BRIEF EXAMINATION OF THE HISTORY OF THE QUESTION OF CHINESE PARTICIPATION IN THE OLYMPIC MOVEMENT. NEXT, THE DIPLOMATIC EVENTS LEADING UP TO THE CRISIS IS TRACED. THIS IS FOLLOWED BY AN ATTEMPT TO DOCUMENT THE EVENTS AND EXCHANGES BETWEEM THE CANADIAN GOVERMMENT AND THE IOC IMMEDIATELY PRECEDING THE GAMES IN JULY 1976. FINALLY, THE PAPER EXAMINES THE AFTERMATH OF THE TAIWAN CONTROVERSY ANO PUTS THE EVENTS IN THE PERSPECTIVE OF CANADA'S FOREIGN POLICY, WEIGHING THE POSITIVE AND NEGATIVE CONSEQUENCES FOR CANADA.

05932 MACKENZIE, C

WHY AMERICANS AVOID THE POLLS

WORLD PRESS REVIEH, 39(5) (MAY 92), 11

THERE IS NO SINGLE REASON WHY THE UNITED STATES HAS ONE OF THE LOWEST VOTER-TURNOUT RATES IN THE WORLD. AWKWARD REGISTRATION PROCEDURES, LACKLUSTER CAMPAIGNS AND CANDIDATES, THE IRRELEVANCE OF POLITICS IN MANY PEOPLE'S LIVES, PUBLIC MISTRUST OF OFFICIALS, AND FEELINGS OF BEING DISCONMECTED

FROM GOVERNMENT HAYE ALL BEEN ADVANCED AS EXPLANATIONS.

05933 MACKENZIE, K.

AZERBAIJAN AND THE NEIGHBOURS

WORLD TODAY, 48(1) (JAN 92), 1-2.

IN AZERBÁ JAN, POLITICAL DISCUSSION IS DOMINATED BY THE ARMENIAN QUESTION. BUT QUESTIONS OF RELATIONS HITH THE OTHER FORMER SOVIET REPUBLICS ANO WITH NEIGHBORING COUNTRIES, LIKE IRAN AND TURKEY, MUST ALSO BE CONSIDERED BY THE NEW

GOVERNMENT LED BY PRESIDENT AYAZ MUTALIBOY.

05934 MACKENZIE, $R$.

A WAR HERO

INSIGHT, 7 (11) (MAR 91), 8-13.

DESERT STORM WAS A REMARKABLE VICTORY, HHAT ONE EXPERT CALLS A "PERFECT MILITARY OPERATION " MUCH OF THE CREDIT GOES TO GENERAL H. NORMAK SCHWARZKOPF, LEADER OF THE U.S. CENTRAL COMMAMD THOUGH CAREFUL STRATEGY WITH HIS OFFICERS AND JOINT CHIEFS CHAIRMAN COL IN POWELL, SCHWARZKOPF MOUNTED A CAMPAIGN THAT CAUGHT SADDAM HUSSEIN OFF GUARD. THERE IS SPECULATION THAT THE MILITARY SUCCESS MAY GARNER FIFTH STARS FOR SCHHARZKOPF AND POWELL. HHATEVER HAPPENS, DESERT STORM MADE A HERO OUT OF SCHWARZKOPF AND WILL BE STUDIED AND EHULATED FOR YEARS TO COME. 
05935 MACKENZIE, $R$

GEMERAL PAR EXCELLENCE

INSIGHT, 7 (11) (MAR 91) 14-16

U.S. GENERAL NORMAN SCHWARZKOPF IS KNOW FOR HIS LOVE FOR HIS TROOPS. DISPARAGE THEM AND HE WILL REACT WITH A QUICX TEMPER. COLLEAGUES CALL THE GENERAL A CONSUMMATE SOLDIER. HIS TRAINING STARTED YOUNG, AS THE SON OF AN ARMY GENERAL, AND CONTINUED THROUGH WEST POINT AND TWO TOURS OF VIETNAM.
THE GENERAL WAS READY FOR THE FIGHT OF DESERT STORM, AND IT SHOWED.

05936 MACKIE, T.T.

GENERAL ELECTIONS IN HESTERN MATIONS DURING 1990

EUROPEAN JOURNAL OF POLITICAL RESEARCH, 21(3) (APR 92), 317-332.

THE AUTHOR SUMMARIZES THE RESULTS OF IMPORTANT 1990 NATIONAL ELECTIONS IN AUSTRALIA, AUSTRIA, DENMARK, BULGARIA, GERMANY, ROMANIA, CZECHOSLOVAKIA, GREECE, HUNGARY, IRELAND, JAPAN, NEW ZEALAND, POLAND, AND THE UNITED STATES

05937 MACKIE, T.T.

UNITED KINGDOM

EUROPEAN JOURNAL OF POLITICAL RESEARCH, 22(4) (DEC 92), $537-542$.

THE AUTHOR LISTS THE MEMBERS OF PRIME MINISTER JOHM MAJOR'S CABINET AS OF JANUARY 1, 1991, AND OUTLINES SOME OF THE MAJOR NATIONAL ISSUES FACING BRITAIN.

05938 MACKIMLAY, J.; CHOPRA, J.

SECOND GENERATION MULTINATIONAL OPERATIONS

WASHINGTON QUARTERLY 15(3) (SUM 92), $113-134$.

THE END OF THE COLD HAR MARKS THE REBIRTH OF THE UNITED NATIONS AND THE START OF ITS SECOND GENERATION AS AN INSTITUTION. IN A REJUVENATED UN, NOWEHERE IS THE NEED FOR CHANGE MORE ACUTE THAN IN THE AREA OF PEACEKEEPING. THIS ARTICLE EXPLAINS HOW A MORE EFFECTIVE UN INSTRUMENT FOR ASSURING PEACE AND SECURITY COULD BE DEVELOPED. IT ARGUES THAT A HUMANE, BUT MORE PROACTIVE, CONCEPT OF OPERATIONS CAN BE DEVELOPED FROM EXISTING DOCTRINE AND DEMONSTRATES HOW MILITARY COMMAND AND POLITICAL CONTROL SHOULD FLOW FROM THE SECURITY COUNCIL, THROUGH THE SECRETARY GENERAL, DOWN TO THE COMMANDER IN THE FIELD. THE KEY FACTOR IN THE IMPLEMENTATION OF SUCH A PROGRAM IS THE WILL OF THE MAJOR POWERS TO SUPPORT IT.

05939 MACKUEN M.B. ERIKSON R.S. SIIMSON J.A.

PEASANTS OR BANKERS? THE AMERICAN ELECTORATE AND THE U.S. PEANANTS

AMERICAN POLITICAL SCIENCE REVIEW, 86(3) (SEP 92), 597-611.

THE USUAL MODEL OF ELECTORAL REACTION TO ECONOMIC THE USUAL MODEL OF ELECTORAL REACTION TO ECONOMIC CONDIT IONS ASSUMES THE "RETROSPECTIVE ECONOMIC VOTER WHO PERSONAL ECONOMIC EXPERIENCE (VOTER AS "PEASANT"). A SECOND PERSONAL ECONOMIC "EXPERIENCE (VOTER AS "PEASANT"). MODEL ASSUMES A "SOPHISTICATED" ECONOMIC VOTER WHO INCORPORATES NEN INFORMATION ABOUT THE FUTURE INTO PERS ECONOMIC EXPECTATIONS (VOTER AS "BANKER"). USING THE COMPONENTS, BOTH RETROSPECTIVE AND PROSPECTIVE, OF THE INDEX OF CONSUMER SENTIMENT (ICS) AS INTERVENING VARIABLES BETHEEN ECONOMIC CONDITIONS AND APPROVAL, THE AUTHORS FIND THAT THE PROSPECTIVE COMPONENT FULLY ACCOUNTS FOR THE PRESIDENTIAL APPROVAL TIME SERIES. WITH AGGREGATE CONSUMER EXPECTATIONS ABOUT LONG-TERM BUSINESS CONDITIONS IN THE APPROVAL EQUATION, NEITHER THE USUAL ECONOMIC INDICATORS NOR THE OTHER ICS COMPONENTS MATTER. MOREOVER, SHORT-TERM CHANGES IN CONSUMER EXPECTATIONS RESPOND MORE TO CURRENT FORECASTS THAN TO THE CURRENT ECONOMY. THE QUALITATIVE RESULT IS A RATIONAL EXPECTATIONS OUTCOME: THE ELECTORATE ANTICIPATES THE ECONOMIC FUTURE AND REHARDS OR PUNISHES THE PRESIDENT FOR ECONOMIC EVENTS BEFORE THEY HAPPEN.

05940 MACKUEN, M.B.; ABRAMSON, P.R.; ERIKSON, R.S.; OSTROM, C.W. JR.; STIMSON, J.A.

QUESTION WORDING AND MACROPARTISANSHIP

AMERICAN POLITICAL SCIENCE REVIEW, 86(2) (JUN 92), 475-486. IN 1989, MACKUEN, ERIKSON, AND STIMSON USED GALLUP POLL DATA TO SHOW THAT CHANGING LEVELS OF MACROPARTISANSHIP (THE THO-PARTY DIVISION OF PARTISANS) RESPOND TO PRESIDENTIAL APPROVAL RATINGS AND PERCEPTIONS OF THE ECONOMY AND PREDICT NATIONAL ELECTION RESULTS. IN 1991, ABRAMSON AND OSTROM ARGUED THAT THE NES AND GSS OUESTIOMS MORE COMHOMLY USED BY SCHOLARS GENERATE MACROPARTISANSHIP MEASURES LESS SENSITIVE SCHOLARS GENERATE MACROPARTISANSHIP MEASURES LESS SENSI OUTCOMES.TERM FACTORS AND LESS PREDICTIVE OF ELECTION DATA FROM CBS MEHS AND "NEW YORK TIMES" TIELEPHONE SURVEYS TO DATA FROH CBS NEHS AND "NEW YORK TIMES" TELEPHONE SURVEYS TO BUTTRESS THEIR EARLIER ANALYSES, ARGUING AGAINST SUBSTANTIAL EFFECTS OF THE DIFFERENT QUESTION HORDINGS. THEN
AND OSTROM EXPLAIN THEIR CONTINUING RESERVATIONS.

05941 MACLAURY B.K.

REDISCOVERING THE COMMON GOOD

BRDOKINGS REVIEW, $10(3)$ (SUM 92 ), 3.

A NATIONAL SERVICE CORPS COULD NOT ONLY PROVIDE

STRUCTURED LEARNING ENVIRONMENT FOR OTHERHISE UNEMPLOYED YOUNG PEOPLE--OFFERING THEM AN OPPORTUNITY TO BROADEN THEIR
HORIZONS, LEARN VALUABLE SKILLS, AND UNDERSTAND THE IMPORTANCE OF DISCIPLINE AND RESPONSIBILITY--BUT COULD ALSO HELP PROTECT THE ENVIRONMENT AND REBUILD THE U.S.

INFRASTRUCTURE

05942 MACLEOD, A.

JAPAN, ITS DEFENSE POLICY AND THE FUTURE OF ITS ALLIANCE HITH THE UNITED STATES

ETUDES INTERNATIONALES, 23(1) (MAR 92), 97-120.

THE DISINTEGRATION OF THE SOVIET UNION AND THE GULF WAR HAVE FORCED JAPAN TO QUESTION ITS DEFENSE POLICY. JAPAN CAN NO LONGER IGNORE THE VARIOUS SIGNS OF DETENT IN EAST ASIA. THE QUESTION IS ASKED: HILL JAPAN CONTINUE FOR MUCH LONGER TO PLAY A SECOND ROLE IN THE UNITED STATES' SYSTEM OF BILATERAL ALLIANCES IN THE ASIA-PACIFIC REGION WHICH THAT COUNTRY CAN AFFORD LESS AND LESS? THIS IS THE REAL DILEMMA OF JAPANESE DEFENSE POLICY: IT CAN NEITHER REMAIN AS IT IS NOR CAN IT EASILY CHANGE DIRECTION.

05943 MACMANUS, S.

"MAD" ABOUT mandates: tHe ISSUE of WHO ShOULD PAY For what RESURFACES

PUBLIUS: THE JOURNAL OF FEDERALISM, 21(3) (SUM 91), 59-77. A MANDATE IS DEFINED AS A "LEGAL REQUIREMENT, CONSTITUTIONAL PROVISION, STATUTORY PROVISION, DR ADMINISTRATIVE REGULA OR PROVIDE A SERVICE MEETING MINIMUM A SPECIFIC ACTIVITY OR PROVIDE A SERVICE MEETING MINIMUM
STATE STANDARDS." IN 1990, LOCAL GOVERMMENT OFFICIALS IN FLORIDA AND WISCONSIN WERE SUCCESSFUL IN BRINGING UNFUNDED STATE MANDATES TO THE ATTENTION OF VOTERS. IN EACH CASE, THE VOTERS SIDED WITH THE LOCAL GOVERNMENT. IN ANTICIPATION OF A "MANDATE REVOLT" IN THE 1990S. THIS ARTICLE HIGHLIGHTS THE EXPERIENCES OF FLORIDA AMD WISCONSIN AND REVIENS THAT MOST RECENT RESEARCH ON UNFUNDED STATE MANDATES. IT IDENTIFIES THE MAJOR HYPOTHESES THAT CAN BE DRAHN FROM THESE STUDIES AND EXPERIENCES.

05944 MACMANUS, S.A.

ENOUGH IS ENOUGH: FLORIDIANS' SUPPORT FOR PROPOSITION THREE LIMITING STATE MANDATES ON LOCAL GOVERMMENT

STATE AND LOCAL GOVERMMENT REVIEN, 24(3) (FAL 92), 103-112. FRUSTRATION WITH UNFUNDED STATE MANDATES LED FLORIDA'S

LOCAL GOVERMHENT OFFICIALS TO PUSH FOR PROPOSITION THREE,

CONST I TUTIONAL AMENDMENT LIMITING THE PRACTICE. ALTHOUG

VOTERS APPROVED THE AMENDMENT, SUPPORT FOR IT WAS MORE

DIVIDED THAN FOR THE OTHER THREE AMENDMENTS ON THE SAME

BALLDT. POST-ELECTION SURVEY RESULTS SHOH THAT VOTERS HERE

MORE PRONE TO VOTE AGAINST STATE GOVERNMENT THAN FOR LOCAL

GOVERMMENTS. UNDECIDED VOTERS TENDED TO VOTE "YES," AND

SUPPORT WAS LOWER AMONG GROUPS TRADITIONALLY FAVORING TAXING AND SPENDING LIMITS. NENSPAPER
BEEN INFLUENTIAL ON THE ISSUE.

05945 MACMANUS, S.A.

HOW TO GET MORE HOMEN IN OFFICE: THE PERSPECTIVES OF LOCAL ELECTED OFFICIALS (MAYOR AND CITY COUNCILORS)

URBAN AFFAIRS QUARTERLY, 28(1) (SEP 92), 159-170.

A MAIL SURVEY OF FEMALE MAYORS AND COUNCIL MEMBERS SHOWS THAT THESE OFFICIALS PERCEIVE THE RETICENCE OF HOMEN TO RUN FOR OFFICE AS THE MAJOR BARRIER TO GETTING MORE WOHEN ELECTED. FACTORS RANGING FROM THE METHOO OF ELECTING COUNCIL MEMBERS TO THE TIMING OF ELECTIONS, LENGTH ANO STRUCTURE OF TERMS, COUNCIL SIZE, RUN-OFF REOUIREMENTS, AND MEDIA

COVERAGE ARE NOT SEEN AS MAJOR ROADBLOCXS. THERE IS NO

EVIDENCE THAT THE PRESTIGE OF THE MAYOR'S OFFICE MAKES IT TOUGHER FOR HOMEN TO CAPTURE MAYORAL POSITIONS THAN COUNCIL SEATS.

05946 MACMIILLAN, G.

THE REFERENDUM, THE COURTS AND REPRESENTATIVE DEMOCRACY IN IRELAND

POLITICAL STUDIES, XL (1) (MAR 92), 67-78.

FOUR REFERENDUMS HELD IN IRELAND BETHEEN 1983 AND 1987 ARE EXAMINED. IT IS ARGUED THAT THE 1939 IRISH CONSTITUTION CREATED A TENSION BETWEEN REPRESEMTATIYE DEMOCRACY AMD JUDICIAL REVIEW, AS WELL AS BETWEEN PARLIAMENTARY SUPREMACY AND SOVEREIGNTY OF THE PEOPLE. THIS IS ENCAPSULATED IN AND SOVEREIGNTY OF THE PEOPLE. THIS IS ENCAPSULATED IN ARTICLE 6, WHICH STATES THAT ALL EXECUTIVE, JUDICIAL AND
LEGISLATIVE AUTHORITY IS DERIVED FROM THE PEOPLE UNDER GOD. LEGISLATIVE AUTHORITY IS DERIVED FROM THE PEOPLE UNDER GOD. LEGISLATION WHICH PRECIPITATED THE 1984 AND 1987 REFERENDUMS LEGISLATION WHICH PRECIPITATED THE 1984 AND 1987 REFERENDUMS AND TO REFUSE INJUNCTIONS IN THE 1983 AND 1986 REFERENDUMS. THESE FOUR REFERENDUMS HERE CALLED IN RESPONSE TO INTEREST GROUP PRESSURE WHICH INDICATES SHIFTS IN IRELAND AWAY FROM THE TRADITIONAL WESTMINISTER MODEL THAT HAS OPERATED IN PRACTICE IN IRELAND SINCE 1922

05947 MACNEIL, R.

LOOKING FOR MY COUNTRY

AMERICAN REVIEW OF CANADIAN STUDIES, 21 (4) (WIN 91), 383-408.

ROBERT D'NEIL EXPRESSES HIS CONCERN ABOUT THE SPIRITUAL FRAGMENTATION OF THE ENGLISH-CANADIAN NATION. DRAHING UPON HIS EXPERIENCES IN THE UNITED STATES, HE SEEKS TO IDENTIFY 
THE VALUES, OLD AND NEW, THAT MIGHT FORM THE BASIS FOR RENEWED CANADIAN IDENTITY. CURRENT PROBLEMS NOTHITHSTANDING, HE CONCLUDES THAT CANADIANS HAVE INDEED CREATED A "KINDER, GENTLER NATION," ONE THAT IS WAITING TO BE RESCUED BY THE METAPHORIC "MOUNTIE IN A CANOE."

05948 MACSHANE, D.

FAREWELL 'TO THE SOVIET UNIONS

PEACE \& DEMOCRACY NEWS, 6(1) (WIN 92), 35-36.

THE SOVIET TRADE UNION MOVEMENT IS DEAD, AND NEW UNIONS

ARE ARISING. THIS ARTICLE EXPLORES THE THREE MAJOR

CHALLENGES WHICH WAIT FOR SOVIET TRADE UNIONS--POLITICAL,

ECONOMIC, AND ORGANIZATIONAL. THE OFFICIAL UNIONS ARE

REFORMING THEMSELVES INTO FEDERATIONS BASED ON THE RUSSIAN

REFORMING THEMSELVES INTO FEDERATIONS BASED ON THE RUSSIAN

AND OTHER REPUBLICS. ALSO EXPLORED IS POST-PUTSCH UNIONISM

AND THE LURE OF THE FREE MARKET. THE GRONTH OF INDEPENDENT

OF LITTLE FLAMES, WHOSE FIRE MAY BURN A LOT BRIGHTER.

05949 MACSHANE, D.

THE NEW INTERNATIONAL WORKING CLASS

NEW POLITICS, 13(1) (SUM 92), 134-148.

THE TRADE UNION QUESTION IS MORE CENTRAL THAN EVER TO

THE INTERNAL POLITICAL DEVELOPMENT OF MANY COUNTRIES. FAR

FROM BEING SETTLED WITH THE COLLAPSE OF COMHUNISM IT IS ONLY

NOW FORCING ITS WAY ONTO THE GLOBAL, AS OPPOSED TO THE

NORTHERN INDUSTRIAL, AGENDA. YET AS TRADE UNIONS SPREAD

THEIR WINGS HORLDWIDE, THEY FIND IT MORE, NOT LESS

DIFFICULT TO UNITE ON A TRANSFRONTIER BASIS AGAINST THE

INCREASED CONCENTRATION OF CAPITAL, MADE MOST EVIDENT BY THE UNCONTROLLED BANKING SYSTEM ORIENTED TOWARD UNEARNED INCOME, THE SPREAD OF "OLIGARCHY CAPITALISM" AND THE REACH OF MULTINATIONAL CORPORATIONS (MNCS). NOURISHING THE MEH WORKERS' INTERNATIONALISM WILL REQUIRE MONEY AND THEORETICAL ANO ORGANIZATIONAL HORK.

05950 MACY, J.

"GOD HELPS THOSE WHO HELP THEMSELYES": MEW LIGHT ON THE THEOLOGICAL-POLITCAL TEACHING IN ROUSSEAU'S "PROFESSION OF FAITH DF THE SAVOYARD VICAR"

AMERICAN JOURMAL OF POLITICAL SCIENCE, 36(4) (NOV 92), 615-632.

THE RELATIONSHIP BETHEEN "THE SAVOYARO VICAR'S PROFESSION OF FAITH" AND ROUSSEAU'S OWN RELIGIOUS VIEWS HAS BEEN A MATTER OF SOME CONTROYERSY. THIS ARTICLE EXAMINES SEYERAL FOOTNOTES APPENDED TO THE PROFESSION THAT CLARIFY ROUSSEAU'S APPRECIATION AND CRITIOUE OF THE YICAR. THE AUTHDA CONCLUDES THAT ROUSSEAU'S THEOLOGICAL-POLITICAL TEACHING REGARDING RELIGIOUS DOCTRINES AND BELIEFS IS BASED ON POLITICAL PRAGMATISM RATHER THAN ON AN ULTIMATE COMMITMENT TO THE TRUTH OF RELIGIOUS TENETS.

05951 MADDOCK, $N$.

LOCAL MANAGEMENT OF AID-FUNDED PROJECTS PUBLIC ADMINISTRATION AND DEVELOPMENT, 12(4) (OCT 92), 399-407.

LOCAL MANAGEMENT MEANS GIVING RESPONSIBILITY FOR THE IMPLEMENTATION AND MANAGEMENT OF DEVELOPMENT PROJECTS TO PEOPLE AND INSTITUTIONS IN THE RECIPIENT COUNTRY. THE MAIN ARGUMENTS FOR LOCAL MANAGEMENT ARE THAT IT OFFERS THE POTENTIAL TO INCREASE THE RESPONSIBILIITY AND ACCOUNTABILITY OF NATIONAL INSTITUTIONS AND SHOULD HELP TO BUILD A CADRE OF EXPERIENCED LOCAL PROJECT MANAGERS HOHEVER, THERE ARE SOME CONSTRAINTS ON THE EFFECTIYENESS OF LOCAL MANAGEMENT, INCLUDING THE LIMITED SUPPLY OF GOOD MANAGERS AND THE DIFFICULTY OF ENSURING ADHERENCE TO DONORS' PROCEDURES AND REGULATIONS. THE ROLE OF DONOR AGENCIES UNDER LOCAL MANAGEMENT IS YET TO BE CLEARLY DEFINED. DONOR AGENCIES WILL FACE DIFFICULT PROFESS IONAL JUDGMENTS ON WHETHER, WHEN, AND MANAGED BY NATIONAL INSTITUTIONS.

05952 MADISON, $G$.

THE POLITICS OF POSTMODERNITY

CRITICAL REVIEW, 5(1) (WIN 91), 53-80.

SOME OF THE PRINCIPAL FEATURES AND TASKS OF A POLITICS OF POSTMODERNITY IS DAL FEATURES AND TASKS OF A POLITICS REFLECT ON THE DEMOCRATIC REVOLUTIONS OF 1989 IN EASTERN REFLECT ON THE DEMOCRATIC REVOLUTS THEY MIGHT HAVE TO OFFER. HHAT IS CALLED FOR IS A RENEWED THEORY OF DEMOCRACY AND A WHAT IS CALLED FOR IS A RENEWED THEORY OF DEMOCRACY ANO A HOW SUCH TRADITIONAL LIBERAL CONCEPTS AS THE INDIVIDAL REASON, UNIVERSALITY, AND FREEDOM CAN BE REFORMULATED IN A GENUINELY POSTMETAPHYSICAL, POSTMODERH FASHION.

05953 MAGANG, $D$.

A NEW BEGINMING: THE PROCESS OF DEMOCRATIZATION IN AFRICA PARL IAMENTARIAN, LXXIIII(4) (OCT 92), 235-239

THIS ARTICLE IS BASES ON A JUNE 1992 ADDRESS GIVEN BY HON. DAVID MAGANG TO A CONFERENCE ON DEMOCRACY IN AFRICA HELD IN BONN, GERMANY. HE CALLS FOR AN END TO UNOEMOCRATIC GOVERNMENT ACROSS AFRICA WHICH IS FRUSTRATED BY ALIEN POLITICAL PROCESSES AND ECONOMIC FAILURE. HE PONDERS WHETHER AFRICANS CAN REVIVE THEIR DEMOCRATIC TRADITIONS AHD IF THE
INTERNATIONAL COMMUNITY CAN, FOR ONCE, CONTRIBUTE APPROPRIATE ASSISTANCE.

05954 MAGAS, B.

THE WAR IN YUGOSLAVIA

RUSI JOURNAL, 136(4) (HIN 91), 33-37.

THERE APPEARS TO BE NO END IN SIGHT TO THE DE FACTO CIVIL WAR IN WHAT IS STILL CALLED YUGOSLAYIA. WITH THE FEDERATION VIRTUALLY COLLAPSED, THE FEDERAL ARMY HAS ALLIED ITSELF TO A CONSERVATIVE SERBIAN REGIME IN AN ATTEMPT TO EITHER BRING THE COUNTRY TOGETHER AGAIN BY FORCE OR CARVE OUT A GREATER SERBIA FROM SURROUNDING REPUBLICS. THE AUTHOR EXPLORES THE UNDERLYING REASONS FOR THE DESTRUCTION OF THE POST-WAR SETTLEMENT IN YUGOSLAVIA AND THE SERBIAN DRIVE TO PULL THE COUNTRY BACK INTO A CENTRALIZED, CONSERVATIVE PAST AGAINST THE TIDE OF LIBERALIZATION IN THE REST OF EASTERN AGAINST THE TIDE OF LIBERALIZATION IN THE REST OF EASTERN
EUROPE. SHE CONCLUDES THAT THE FAILURE OF REFORM AND THE RESORT TO FORCE IS AN MUCH A TRAGEDY FOR THE SERB NATION AS RESORT TO FORCE IS AN MUCH A TRAGEDY
IT IS FOR THOSE IT SEEKS TO DEFEAT.

05955 MAGER, A.

THE PEOPLE GET FENCED : GENDER, REHABILITATION AND AFRICAN NATIONALISM IN THE CISKEI AND BORDER REGION, 1945-1955 JOURNAL OF SOUTHERN AFRICAN STUDIES, 18(4) (DEC 92),

$761-782$

AN ATTEMPT IS MADE IN THIS PAPER TO SHOW HOW AFRICAN NATIONALISM BRINGS INTO RELIEF ITS OWN DEPLOYMENT OF OLD AND NEW FORMS OF PATRIARCHAL CONTROL. WOMEN--WIVES AND HOUSEHOLD HEADS--STRUGGLED BOTH TO LIVE HITHIN AND RESHAPE THIS CONTROL THROUGH THEIR OWN ENGAGING WITH STATE INITIATIVES AROUND LAND USE, CATTLE CULLING AND RESETTLEMENT. WOMEN DEPENDENT ON MEN WITH CATTLE PARTICIPATED IN MALE-LED RESISTANCE, WHILE INDEPENDENT HOUSEHOLD HEADS SOMETIMES OPTED TO COLLABORATE IN EXCHANGE FOR LAND.

05956 MAGGS, G.E.

REDUCING THE COSTS OF STATUTORY AMBIGUITY: ALTERNATIVE APPROACHES AND THE FEDERAL COURTS STUDY COMMITTEE

HARVARD JOURNAL OF LEGISLATION, 29(1) (WIN 92), 123-174. THE AUTHOR ENUMERATES THE COSTS OF STATUTORY AMBIGUITY AND EVALUATES THE EFFICACY OF POTENTIAL SOLUTIONS TO THE
PROBLEM PROPOSED BY THE CONGRESSIONAL FEDERAL COURTS STUDY PROBLEM PROPOSED BY THE CONGRESSIONAL FEDERAL COURTS STUD
COMHITTEE. HE ANALYZES THE PRIMARY TYPES OF STATUTORY COMMITTEE. HE ANALYZES THE PRIMARY TYPES OF STATUTORY AMBIGUITY AND THEIR ASSOCIATED COSTS BASED ON A STUDY OF ALSO COMPARES THE STUDY COMMITTEE'S PROPOSALS TO PREVIOUS EFFORTS AIMED AT REDUCING THE COSTS OF STATUTORY AMBIGUITY AND SUGGESTS AVENUES FOR FURTHER RESEARCH.

05957 MAGHRAOUI, A.

PROBLEMS OF TRANSITION TO DEMOCRACY: ALGERIA'S SHORT-LIVED EXPERIMENT HITH ELECTORAL POLITICS

MIDDLE EAST INSIGHT, VIII (6) (JUL 92), 20-26.

DURING THE PAST THREE YEARS, ALGERIA BECAME THE FIRST ARAB COUNTRY TO BE GENUINELY INVOLVED IN A SERIOUS AND PROMISING EXPERIMENT HITH MULTIPARTY DEMOCRACY. THE STRENGTH OF THE ISLAMIC SALVATION FRONT IN ALGERIA'S ELECTIONS RAISES QUESTIONS ABOUT THE PROSPECTS OF NEW ISLAMIC REGIMES AND HOW DEMOCRATIC THEY HOULD BE.

05958 MAGUIRE, D.

WHEN THE STREETS BEGIN TO EMPTY: THE DEMOBILIZATION OF THE BRITISH PEACE MOVEMENT AFTER 1983

WEST EUROPEAN POLITICS, 15(4) (OCT 92), 75-94.

THIS ARTICLE EXAMINES THE DEMOBILIZATION OF THE BRITISH PEACE MOVEMENT AFTER THE PEAK OF ITS MASS ACTIVITIES IN THE 1980S. THE MAIN ARGUMENT OF THIS STUDY IS THAT MOVEMENTS IN DECLINE MANAGE IDEOLOGICAL DISORIENTATION, INTERNAL DISUNITY, AND MASS DEFECTION IN IDENT IFIABLE WAYS. IN THE CASE OF THE AND MASS DEFECTION IN IDENTIFIABLE WAYS. IN THE CASE
BRITISH PEACE MOVMENT, THE CLOSURE OF THE MOVEMENT'S BRITISH PEACE MOVMENT, THE CLOSURE OF THE MOVEMENT'S
POLITICAL OPPORTUNITY STRUCTURE AND INCREASED INTERHAL COMPETITION SAW THE MOVEMENT RETREAT FROM MASS PROTEST ON THE STREETS TO SMALL SCALE DISRUPTIONS AT MILITARY BASES. THIS ALLOWED THE MOVEMENT'S MAIN INSTITUTIONAL ALLY, THE THIS ALLOWED THE MOVEMENT S MAIN INSTITUTIONAL ALLY, THE
LABOUR PARTY, TO WITHDRAW ITS POLITICAL SUPPORT, THUS ENDING LABOUR PARTY,
THE CAMPAIGN.

05959 MAHBUBANI, $K$.

JAPAN ADRIFT

FOREIGM POLICY, (88) (FAL 92), 126-144

JAPAN NOW FACES ITS MOST DIFFICULT. IF NOT PRECARIOUS, STRATEGIC ENVIRONMENT SINCE WORLD WAR II. THE SOVIET THREAT THAT DREW JAPAN COMFORTABLY INTO THE WESTERN CAMP AND PROVIDED THE GLUE FOR THE U S - JAPANESE SECURITY RELATIONSHIP IS NOH GOME. HEITHER THE USA NOR JAPAN, EACH FOR ITS OWN REASONS, IS YET PREPARED TO ABANDON THE MUTUAL SECURITY TREATY (MST). BUT THE STRATEGIC PILLARS UPON WHICH THE MST RESTED HAVE ERODED, LEAVING THE JAPANESE TO WONDER WHETHER--AND UNDER WHAT CIRCUMSTANCES--THE USA WOULD BE WILLING TO COME TO JAPAN'S DEFENSE IN THE FUTURE.

05960 MAHLER, $V$.

DOMESTIC \& INTERNATIONAL SOURCES OF TRADE POLICY: THE CASE OF AGRICULTURE IN THE EUROPEAN COMHUNITY \& THE UNITED 
STATES

POLITY, 29(1) (FAL 91), 27-48

AGRICULTURE TRADE POLICY HAS LONG BEEN A SOURCE OF TENSION BETHEEN THE EUROPEAN COMMUNITY AND THE UNITED STATES. THIS ARTICLE EXAMINES THE REASONS FOR THESE DIFFERENCES, EXPLORING EXPLANATIONS THAT HAVE CENTERED ON MARKET FORCES, ON DOMESTIC SOCIAL AND POLITICAL INTERESTS AND INSTITUTIONS, ON THE INTERNATIONAL SYSTEM, AND ON THE IDEAS AND INDIVIDUALS INVOLVED. THE AUTHOR CONCLUDES THAT ALL OF- THESE HAVE BEEN FACTORS IN THE COMPLEX RELATIONS BETWEEN THE EUROPEAN COMHUNITY AND THE U.S.

05961 MAHNKEN, T.G.

BALLISTIC MISSILE PROLIFERATION: SEEKING GLOBAL SOLUTIONS TO REGIONAL PROBLEMS

DI SARMAMENT, XIV(3) (1991), 1-20.

THE HAR IN THE PERSIAH GULF REPRESENTED A TURNIMG-POINT IN INTERNATIOMAL RELATIONS, A TRIUMPH OF COLLECTIVE SECURITY AND A WARNING TO POTENTIAL REGIONAL HEGEMONS HORLDWIDE. HOWEVER, THE SPREAD OF WEAPONS OF MASS DESTRUCTION AND THE MEANS OF DELIVERY WILL CONTINUE TO JEOPARDIZE REGIONAL STABILITY. SUCH THREATS ARE LIKELY TO INCREASE IN THE FUTURE, STABILITY. SUCH THREATS ARE LIKELY TO INCREASE IN THE FUTURE,
OHING TO BOTH THE EXPANDING LIST OF PROUCERS OF MISSILE OHING TO BOTH THE EXPANDING LIST OF PROUCERS OF MISSILE
TECHNOLOGY AND THE GROWING LETHALITY OF SUCH WEAPONS. HHILE TECHNOLOGY AND THE GROWING LETHALITY OF SUCH WEAPONS. WHILE

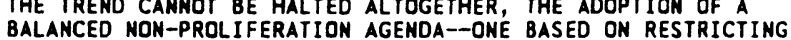
BALANCED NON-PROLIFERATION AGENDA--ONE BASED ON RESTRICTING
THE SUPPLY OF, AND REDUCING THE DEMAND FOR, SUCH WEAPONS-THE SUPPLY OF, AND REDUCING THE OEMAND FOR, SUCH WEAPONSMILITARY TECHMOLOGY AND OF CHANNELLING SUCH PROLIFERATION AS MILITARY TECHMOLOGY AND OF CHANNELLING SUCH
DOES OCCUR ALONG LESS DESTABILIZING PATHS

05962 MAHONY, $R$.

DEEP WATER

REASON, 23(9) (FEB 92), 54-55

THE MOST SERIOUS PROBLEM CONFRONTING MEXICO CITY, ONE THAT COULD TURN THE CITY OF 20 MILLION PEOPLE INTO A GHOST TOWN, IS THAT IT IS RUNMING OUT OF WATER. GOVERMMENT OFFICIALS CAUSED THE SHORTAGE, PARTLY BY CHARGING ABSURDLY LOW PRICES FOR WATER. RECENT NEWS HAS FRIGHTENED THEM INTO SCALING BACK THE SUBSIDIES, BUT NOT BOLOLY ENOUGH. MEXICO'S TIMIDITY ABOUT SETTING UP A WATER MARKET IS SIMILAR TO CALIFORNIA'S RELUCTANCE TO LET FARMERS SELL THE WATER RIGHTS TO HIGHER--MOSTLY URBAN AND DROUGHT-STRICKEN--BIDDERS. IN BOTH CASES, URBAN WATER USERS WILL SUFFER. IN MEXICO, THE POOR SUFFER THE MOST.

05963 MAIER, C.S.

UNSAFÉ HAVEN

NEW REPUBLIC, $207(16)$ (OCT 92), 20-21

THE FURY IN BOSNIA HAS REAWAKENED INTEREST IN THE SOCALLED "MINORITIES TREATIES" IMPOSED UPON THE NEW,

RECONFIGURED STATES OF EASTERN EUROPE DURING THE 1919 PARIS PEACE CONFERENCE. IN RESPONSE TO THE TROUBLE IN EASTERN EUROPE TODAY, MIGHT THE UNITED STATES AND THE EUROPEAN COMMUNITY DUST OFF THESE PACTS, WHICH WERE DESIGNED TO PROTECT THE SUBSTANTIAL MINORITIES STRANDED ACROSS REDRAWN FRONTIERS? UNFORTUNATELY, SUCH TREATIES WOULD LIKELY PROVE AS TROUBLESOME TOOAY AS THEY DID IN THE 1920's.

05964 MAIER, $K$

BITING THE BULLET

AFRICA REPORT, 37(3) (MAY 92), 43-46

ON MARCH 5, 1992, THE MIGERIAN GOVERMMENT FLOATED THE NAIRA AS PART OF ITS PROGRAM TO GET THE ECONOMY BACK ON TRACK AND INADVERTENTLY SPARKED NEW INFLATION. AS THE MILITARY PREPARES TO TURN OVER POWER TO CIVILIAN POLITICIANS, WHO ARE NOW ENGAGED IN THE ELECTION CAMPAIGN, THE NEXT DIFFICULT STEPS ARE TO CUT THE MASSIVE BUDGET DEFICIT AMD RESTRICT THE MONEY SUPPLY. THE PROBLEMS OF RAMPANT PUBLIC CORRUPTION AND DRUG TRAFFICKING MUST ALSO BE DEALT WITH IF NIGERIA IS TO HAVE AN HONEST GOVERMMENT.

05965 MAIER, K.

ETERMAL EMMITIES

AFRICA REPORT, 37(3) (MAY 92), 47-48,

IN NIGERIA'S MIDOLE-BELT REGION, THE ETHNIC MINORITIES OF TIVS AND JUKUNS HAVE LIVED SIDE-BY-SIDE IN FEAR AND HATRED FOR HUNDREDS OF YEARS SPORADICALLY. THEIR EMMITY ERUPTS INTO WAR, AS IT DID IN OCTOBER 1991. SINCE THAT TIME, THE CONTINUING SKIRMISHES HAVE KILLED APPROXIMATELY 5,000 PEOPLE; THOUSANDS MORE HAVE FLED FOR THEIR LIVES; AND DOZENS PEOPLE; THOUSANDS MORE HAVE FLED FOR THEIR
OF VILLAGES HAVE BEEN BURNED TO THE GROUND.

05966 MAIER, $K$.

PARTY POLITICS

AFRICA REPORT, 37(4) ( JUL 92), 34-35.

IF ALL GOES ACCORDING TO SCHEDULE, GHANA HILL HAVE A DEMOCRATICALLY-ELECTED GOVERMMENT IN NOVEMBER 1992. AFTER A REFERENDUM ON THE CONSTITUTION, WHICH SAH CONTROVERSY OVER A CLAUSE INDEMNIFYING MEMBERS OF THE PNDC GOVERMMENT FROM PROSECUTION FOR PAST CRIMES, POLITICAL PARTIES HAVE BEEN LEGALIZED. GHANIANS ARE GEARING UP FOR THE START OF THE ELECTION CAMPAIGN AND WAITING TO SEE IF FLT. -LT. JERRY RAWLINGS, OFTEN CONSIDERED GHANA'S MOST CHARISMATIC LEADER,
WILL RUN FOR PRESIDENT.

05967 MAIER, $K$

THE FLAHED FINALE

AFRICA REPORT, 37(4) ( JUL 92), 46-48.

THE LAST MONTHS BEFORE PRESIDENT IBRAHIM BABANGIDA TURNS OVER HIS MILITARY GOVERNMENT TO CIVILIANS ARE SHAPING UP AS A REAL HEADACHE FOR THE PEOPLE OF NIGERIA. IN THE NORTH, THERE ARE ETHNIC CLASHES. IN THE SOUTH, PEOPLE ARE SUFFERING THE EFFECTS OF THE HARSH AUSTERITY MEASURES TAKEN TO RESTRUCTURE THE ECONOMY. PERHAPS MOST OMINOUS FOR THE RETURN TO DEMOCRACY, THE GOVERNMENT IS SYSTEMATICALLY REPRESSING DISSIDENTS, UNDERMINING THE DEMOCRATIC PRINCIPLES THAT ARE SUPPOSED TO GOVERN THE TRANSITION TO CIVILIAN RULE.

05968 MAIER, K.

THE RISE OF MONEYTOCRACY

AFRICA REPORT, 37 (5) (SEP 92), 68-71.

THE LEGISLATIVE ELECTIONS IN JULY 1992 PROOUCED

MAJORITIES FOR THE SOCIAL DEMOCRAT PARTY IN BOTH HOUSES OF

NIGERIA'S SOON-TO-BE CIVILIAN ASSEMBLY. DESPITE THE VAST

NIGERIA'S SOON-TO-BE CIVILIAN ASSEMBLY. DESPITE THE VAST
SUMS OF MONEY SPENT BY CANDIDATES IN THE PRIMARIES, THE

OVERWHELMING MOOD OF THE VOTERS WAS APATHY. MEANWHILE, THE

OVERHHELMING MOOD OF THE VOTERS WAS APATHY. MEANWHILE, THE
GOVERNMENT'S CRACKDOWN ON DISSIDENTS CONTINUED APACE, WITH

GOVERMMENT'S CRACKDOWN ON DISSIDENTS CONTINUED APACE,

UNIVERSITY FACULTY JOINING STUDENTS AND HUMAN RIGHTS

ADVOCATE

05969 MAIER, $K$

VOODOO DEMOCRACY

AFRICA REPORT, 37 (1) (JAN 92), 33-35.

NIGERIAN PRESIDENT IBRAHIM BABANGIDA IS TIGHTLY

CONTROLLING THE TRANSITION TO CIVILIAN RULE AND HAS EVEN

CREATED THE THO COMPETING POLITICAL PARTIES. BUT OLD

CAMPAIGN PROBLEMS HAVE RESURFACED--BRIBERY, ELECTION-RIGGING,

FORGERY, AND OTHER VICES OF TRADITIONAL NIGERIAN POLITIICS.

OTHER TOUGH PROBLEMS FOR THE GOVERNMENT HAVE BEEN OUTBREAKS

OF RELIGIOUS AND ETHNIC VIOLENCE IN THE NORTH AND CONDUCTING

AN ACCURATE CENSUS TO DETERMINE THE COUNTRY'S POPULATION.

05970 MAILER, $\mathrm{M}$.

REPUBLICAN CONVENTION REVISITED: BY HEAVEN INSPIRED

NEW REPUBLIC, 207(16) (OCT 92), 22, 24, 26-27, 30-35.

THE AUTHOR DESCRIBES THE 1992 REPUBLICAN NATIONAL

CONVENTION AND REFLECTS ON WHAT IT REVEALED ABOUT THE STATUS

OF THE PARTY.

05971 MAINGOT, A.P.

HAITI AND ARISTIDE: THE LEGACY OF HISTORY

CURRENT HISTORY, $91(562)$ (FEB 92), 65-69.

CURRENT HISTORY, 91 (562) (FEB 92), 65-69.

EXPIA THE OYERTHRO OF JEAN-BERTRAMD IN AN ATTEMPT TO

ONLY INTERNATIONALLY-CERTIFIED FREELY-ELECTED PRESIDENT.

05972 MAINGOT, A.P.

HAITI: THE FUTILITY OF HALF MEASURES

HEMISPHERE, 5(1) (FAL 92), 4-5.

HAITI STAMDS AS A TESTAMENT TO THE VERITY OF GEORGE SANTAYANA'S WARNING THAT THOSE WHO FORGET OR DISREGARD HISTORY WILL BE FORCED TO RELIVE IT. THIS IS ESPECIALLY REVELANT IN UNDERSTANDING THE FAILURE OF BOTH THE UNITED STATES AND THE INTER-AMERICAN SYSTEM TO FORCE POLITICAL CHANGES ON THE ISLAND. THE FAILED ECONOMIC EMBARGO,

ORIGINALLY DESIGNED TO FORCE A RETURN OF PRESIDENT JEANBERTRAND ARISTIDE TO POWER, HAS TO BE UNDERSTOOD IN LONG TERM AS HELL AS SHORT-TERM PERSPECTIVES. WITH NO UNITY OF PURPOSE, A HISTORICAL AVERSION TO THIRD-PARTY INYOLYEMENT, AND WITH THE SOURCES OF WEALTH SHRINKING, STRUGGLES FOR CONTROL OF THE GOVERMMENT HAVE BEEN CONSTANT AND

INCREASINGLY DESTRUCTIVE IN HAITI.

05973 MAINHARING, S.

BRAZILIAN PARTY UNDERDEVELOPMENT IN COMPARATIVE PERSPECTIVE POLITICAL SCIENCE QUARTERLY, 107(4) (WIN 93), 677-708.

BRAZILIAN POLITICAL PARTIES ARE EXCEPTIONALLY

UNDERDEVELOPED, DUE TO A COMBINATION OF TEMPORARY PROBLEMS AND ENTRENCHED CHARACTERISTICS OF THE COUNTRY'S POLITICAL SYSTEM. FOUR ENDURING FEATURES THAT CREATE OBSTACLES TO PARTY-BUILOING ARE THE LIMITED POLITICAL PARTICIPATION DUE TO ABJECT POVERTY AND LIMITED INFORMATION, THE DOMINANCE OF TO ABJECT POVERTY AND LIMITED INFORMATION, THE DOMINAM THE BUREAUCRACY DUE TO ITS MASSIVE INTERVENTION AND
REGULATORY POWERS, THE COMBINATION OF PRESIDENTIALISM AND A REGULATORY POWERS, THE COMBINATION OF PRESIDENTIAL FRACTIONALIZED MULTI PARTY SYS
PREFERENCE FOR WEAK PARTIES

05974 MAIR, $P$

THE QUESTION OF ELECTORAL REFORM

NEH LEFT REVIEW, (194) (JUL 92), 75-97.

THE AUTHOR DISCUSSES THE BRITIISH ELECTORAL SYSTEM,

COMPARES IT TO OTHERS IN WESTERN EUROPE, AND EXAMINES SOME PROPOSALS FOR REFORMING IT.

05975 MAIRA, L.

LATIN AMERICA AND THE CHALLENGES OF THE NEH INTERNATIONAL 
ORDER

SECURITY DIALOGUE, 23(3) (SEP 92), 69-80.

IN LATIN AMERICA, ECONOMIC OIFFICULTIES ENCOURAGED MOVEMENTS TOWARD DEMOCRACY, AS WELL AS REGIONAL COOPERATION. THE POST COLD WAR ERA, HOWEVER, HAS REDUCED LATIN ALERMICA'S FREEDOM OF ACTION, INCREASING ITS DEPENDENCE ON THE USA. CURRENT CHALLENGES: TO DEFEND THE PRICE FOR BASIC EXPORT PRODUCTS, TO DEVELOP A CONCERTED APPROACH TO MEET THE CHANGES DERIVING FROM THE DIMINISHING U.S. HEGEMONY; TO TO MODERMITY WEALTH; TO CONSOLIDATE TOOAY'S VULNERABLE DEMOCRATIC SYSTEMS.

05976 MAJEED, A.

HAS THE WAR SYSTEM REALLY BECOME OBSOLETE?

BULLETIN OF PEACE PROPOSALS, $22(4)$ (DEC 91), 419-426.

MANY SCHOLARS ARE CURRENTLY ARGUING THAT' THE NOTION THAT WAR SHOULD BE USED TO RESOLVE CONFLICTS OF INTEREST HAS

INCREASINGLY BEEN DISCREDITED AND ABANDONED, AND THAT WAR IS INCREASINGLY BECOMING OBSOLETE. THIS ARTICLE ARGUES THAT SUCH A VIEW IS RATHER UNJUSTIFIED, TOO OPTIMISTIC AND SOMEWHAT PREMATURE. AN ANALYSIS OF INTERNATIONAL RELATIONS, IN PROPER PERSPECTIVE, WOULD INDICATE THAT THE ROLE OF FORCE IN INTERNATIONAL RELATIONS HAS INCREASED RATHER THAM DECLINED. CONTEMPORARY INTERNATIONAL RELATIONS ARE CHARACTERIZED BY THE EMERGENCE OF VARIOUS AND DIVERSE NEH CENTERS OF POLITICAL DECISIONMAKING. THIS HAS NOT MEANT THE END OF CONFLICT, ONLY A SHIFT IN THE TYPE OF CONFLICT.

\section{MAJONE, G.}

CROSS-NATIONAL SOURCES OF REGULATORY POLICYMAKING IN EUROPE AND THE UNITED STATES

JOURNAL OF PUBLIC POLICY, 2(1) (JAN 91), 79-106.

BECAUSE EVENTS OCCUR TOO FAST AND IDEAS MATURE TOO SLOWLY FOR RESPONSES TO BE DESIGNED ANEW FOR EACH PRESSING PROBLEMS, POLICY INMOVATION OFTEN RELIES ON PRE-EXISTING MODELS FOREIGN OR DOMESTIC. THIS SEEMS TO BE ESPECIALLY TRUE FOR REGULATORY POLICYMAKING, SINCE PUBLIC REGULATION IS TYPICALLY INTRODUCED IN CONDITIONS OF CRISIS. THIS PAPER EXAMINES SEVERAL CASES OF POLICY INNOVATION IN THE AREA OF ECONOMIC AND SOCIAL REGULATION WHERE THE INFLUENCE OF FOREIGN MODELS IS OUITE CLEAR: THE DEVELOPMENT OF FOREIGN MODELS IS QUITE CLEAR: THE DEVELOPMENT OF
COMPETITION POLICY IN EUROPE IN THE 1950S. THE GROWTH OF COMPETITION POLICY IN EUROPE IN THE 1950S, THE GROWTH EUROPEAN COMMUNITY REGULATION, AND THE IMPACT OF THE AMERICAN DEREGULATION MOVEMENT ON THE TELECOMMUNICATIONS
POLICIES OF DIFFERENT EUROPEAN COUNTRIES. THE ANALYSIS SHOWS POLICIES OF DIFFERENT EUROPEAN CDUNTRIES. THE ANALYSIS SHOHS
THAT WHILE UTILIZATION OF PREEXISTING MOOELS IS A COMMON THAT WHILE UTILIZATION OF PREEXISTING MOOELS IS A COMMON
FEATURE OF POLICY INMOVATION, SUCH MODELS ARE NOI LITERALLY FEATURE OF POLICY INNOVATION, SUCH MODELS ARE NOI LITERAL TRANSLATED INTO CURRENT POLICY. MORE OR LESS EXTENSIVE ADAPTATIONS TO A PARTICULAR POLITICAL, INSTITUTIONAL AND
ECONOMIC CONTEXT ARE USUALLY REQUIRED. WE ALSO IDENTIFY TWO ECONOMIC CONTEXT ARE USUALLY REQUIRED. WE ALSO IDENTIFY TWO
DISTINCT WAYS - PUSH OR PULL - IN WHICH FOREIGN MODELS CAN DISTINCT WAYS - PUSH OR
AFFECT DOMESTIC POLICY.

05978 MAKINDA, S.M.

KENYA: OUT OF THE STRAITJACKET, SLOWLY

WORLD TODAY, 48(10) (OCT 92), 188-192.

THE AUTHÓR BRIEFLY DESCRIBES THE RULE OF PRESIDENT DANIEL ARAP MOI, ANALYZES THE DOMESTIC FACTORS THAT CONTRIBUTED TO THE DECISION TO ADOPT A MULTIPARTY SYSTEM, AND DISCUSSES THE PROSPECTS AS WELL AS THE COSTS AND BENEFITS OF MULTIPARTY POLITICS IN KENYA.

\section{MAKSOUD, C.}

THE ARAB WORLD'S QUANDARY

WORLD POLICY JOURNAL, YIII (3) (SUM 91), 551-559.

THE UNITED NATIONS' RESPONSE TO IRAQ'S INYASION OF KUWAIT HIGHLIGHTS THE SELECTIVE AND OPPORTUNISTIC USE THAT IS MADE OF THE SECURITY COUNCIL BY ITS MOST POWERFUL MEMBERS, PARTICULARLY THE UNITED STATES. THIS HAS GIVEN RISE TO SERIOUS CONCERNS ABOUT THE UN'S ABILITYY TO SERVE AS AN EFFECTIVE INSTRUMENT OF CRISIS MANAGEMENT AND INTERNATIONAL COOPERATION. THE ARAB HORLD ESPECIALLY IS ENGAGED NOH IN A CRITICAL RETHINKING OF THE UNITED NATIONS IN LIGHT OF THE ROLE IT PLAYED IN THE GULF WAR. IT IS ALSO LOOKING INTROSPECTIVELY AT ITS OWN RESPONSE TO THIS TRAGIC EVENT. REFORM OF THE ARAB LEAGUE (AN AMENDMENT TO THE CHARTER TO MAKE RESOLUTIONS BINDING ONLY IF ADOPTED BY A THO-THIRDS MAJORITY, AND AN INCREASE IN DEVELOPMENT ASSISTANCE) IS AN
IMPORTANT FIRST STEP TO ENSURE BETTER COOPERATION WITH THE UN IN THE FUTURE, AND A SWIFTER, MORE UNIFIED, AND MORE EFFECTIVE RESPONSE TO FUTURE PROBLEMS AND CONFLICTS.

05980 MAKWETU, $M$.

THE POST APARTHEID ECONOMY--A PAC VIEH

SOUTH AFRICA FOUNDATION REVIEW, 16(11) (NOV 90), 6.

MLAMLI MAKHETU, ACTING PRESIDENT OF THE PAN AFRICANIST CONGRESS (PAC) OUTLINES HIS ORGANIZATION'S PLANS AND STRATEGIES FOR A POST-APARTHEID ECONOMY IN SOUTH AFRICA. HE OISCUSSES GENERAL PRINCIPLES HITH REGAROS TO THE REDISTRIBUTION OF WEALTH; THE ROLE OF BUSINESSES; LAND AND LAND OWNERSHIP; MONOPOLIES; THE STATE; NATIONALIZATION; AND FOREIGN INVESTMENT. THE EMPHASIS IS PLACED ON EOUITY AND INDEPENDENCE.
05981 MALABY, M.; WEBBER, D.

FEDERALISM IN THE 1OIST CONGRESS

PUBLIUS: THE JOURMAL OF FEDERALISM, 21(3) (SUM 91), 77-92. THIS ANALYSIS EXAMINES IMPORTANT CONGRESSIONAL VOTERS AFFECTING FEDERALISM DURING THE 101ST CONGRESS (1989 AND 1990). IT BUILDS ON PREVIOUS ATTEMPTS TO IDENTIFY AND QUANTIFY THE VOTING OF MEMBERS OF CONGRESS ON FEDERALISM ISSUES. IN ADDITION TO REPORTING THE "FEDERALISM SCORES" FOR EACH MEMBER OF THE 101ST CONGRESS, THE OBJECTIVES OF THIS ANALYSIS ARE TO CONTRIBUTE TO THE DEVELOPMENT OF A DYNAMIC THEORY OF FEDERALISM BY INFERRING FROM CONGRESSIONAL ROLL-
CALL VOTES THE UNDERLYING PATTERNS OF FEDERALISM ORIENTATION,
IDENTIFYING AND ESTIMATING IMPORTANT CORRELATES OF IDENTIFYING AND ESTIMATING IMPORTANT CORRELATES OF
FEDERAL ISM, AND COMPARING HOUSE AND SENATE ORIENTATIONS FEDERAL ISM, AND COMPARING HOUSE AND SENATE ORIENTATIONS
TOWARDS FEDERALISM BY ANALYZING PATTERNS UNDERLYING VOTES COMHON TO BOTH CHAMBERS.

05982 MALCOLM, $N$.

HEADS IN THE SAND

NATIONAL REVIEW, XLIV(14) (JUL 92), 34-36

EVER SINCE THE DANES REJECTED THE MAASTRICHT TREATY ON EUROPEAN UNION ON JUNE 2, THE ATMOSPHERE IN THE COUNCIL CHAMBERS OF THE EUROPEAN COMUUNITY HAS BEEN FRANTIC HITH INDECISION. THE ONLY CONSISTENT POLICY HAS BEEN THE DESPERATE ONE OF PRETENDING THAT THE DANISH VOTE NEVER HAPPENED. THE TRUTH IS THAT MAASTRICHT CAN BE SALVAGED ONLY IF IT IS REWRITTEN. BUT THE GOVERNMENTS OF THE EC WILL NEITHER REWRITE IT NOR ADMIT THAT IT CANMOT BE SALVAGED.

05983 MALCOLM, N.

OUT OF MANY, NOT QUITE ONE

NATIONAL REVIEW, XLIV(1) (JAN 92), 24; 25

IN DECEMBER, 11 HEADS OF GOVERNMENT MET AMD AGREED TO TURN A CENTRALIZED UNION INTO A LOOSE, COOPERATIVE ASSOCIATION OF SOVEREIGN STATES, HILE ON DECEMBER 9,12 HEADS OF GOVERMMENT HAD MET TO CONSIDER A PLAN TO TURN THEIR ASSOCIATION OF SOVEREIGN STATES INTO SOMETHING RESEMBLING A FEDERAL UNION. THE DIFFERENCES OUTMUMBER THE SIMILARITIES BUT SOME OF THE SIMILARITIES ARE TOO STRONG TO BE IGNORED. BUT SOME OF THE SIMILARITIES ARE TOO STRONG TO BE IGNOR
BOTH ARE--OR WERE--INTENDED AS UNIONS OF STATES WITH BOTH ARE-OR WERE--INTENDED AS UNIONS OF STATES WITH
SEPARATE NATIONAL IDENTITIES. ANOTHER SIMILARITY IS THE SEPARATE NATIONAL IDENTITIES. ANOTHER SIMILARITY IS THE
DEVOTION TO CENTRAL ECONOMIC PLANHING. THIS ARTICLE PROBES DEVOTION TO CENTRAL ECONOMIC PLANNING. THIS ARTICLE PROBES
THE BRITISH POSITION IN THE FORMATION OF THE EC AND OFFERS ADOITIONAL COMPARISIONS OF THE TWO RECENT CONFERENCES.

05984 MALCOLM, N

RECONSTRUCTIING RUSSIA

HORLD TOOAY 48(10) (OCT 92), 183-187.

IT IS BECOMING CLEAR THAT WHILE RUSSIAN SOCIETY IS, IN EUROPEAN TERMS, INDEED EXCEPTIONAL, IT DOES NOT FIT THE CRUDE AUTHORITARIAN STEREOTYPE. THERE IS NO NEED YET TO DESPAIR OF THE PROSPECTS FOR A SUCCESSFUL POLITICAL TRANSITION. HOWEVER, THE TRANSITION IS THREATENED BY IMHEDIATE DANGERS AND IT SHOWS EVERY SIGN OF BEING A LONG, PAINFUL PROCESS THAT WILL HAVE MANY UNIQUELY RUSSIAN FEATURES.

05985 MALEKAFZALI, F.; MOSER, R.

PRIMORDAL, INSTRUMENTAL IDENTITIES AND THE FORMATION OF ETHNIC COLLECTIVE MOYEMENTS

CANADIAN REVIEW OF STUDIES IN NATIONALISM, XIX(1) (1992), $31-41$

THIS STUDY EXAMINES THE DEVELOPMENT OF AZERI NATIONALISM IN THE FORMER SOVIET UNION AND IRAN IN ORDER TO GENERATE HYPOTHESES ON THE OPPORTUNITIES AVAILABLE FOR THE DEVELOPMENT OF ETHNIC COLLECTIVE ACTION AIMED AT THE FORMATION OF A SEPARATE, INDEPENDENT STATE BY SIMILAR ETHNIC GROUPS LIVING ACROSS INTERNATIONAL BORDERS. GIVEN THE ONGOING NATURE OF THE AZERI OUESTIONS ANY RIVE THE REQUIRES A RELATIVELY NARROW FOCUS: THIS ARTICLE CONCENTRATES ON THE EVENTS OF 1989-1990. THESE EVENTS HAVE TOGETHER REMAINED AS THE SINGLE MOST VISIBLE MANIFESTATION OF AZERI NATIONALISM IN RECENT MEMORY. AS A RESULT, THEY ARE OF PARTICUL.AR VALUE FOR THE PURPOSE OF EXAMINING THE PROPOSITIONS OFFERED IN THIS ARTICLE.

05986 MALEY, W.; SAIKAL, F.H.

POLITICAL' ORDER IN POST-COMMUNIST AFGHANISTAN

LYNNE RIENNER .PUBL ISHERS, 1992,80

THIS STUDY OF THE RECENT POLITICAL CHANGES IN AFGHANISTAN IS DIVIDED INTO FIVE PARTS. THE FIRST PART PROVIDES HISTORICAL BACKGROUND. IN THE SECOND PART, THE PROVIDES HISTORICAL BACKGROUND. IN THE SECOND PART, THE
AUTHORS TRACE THE PROCESS BY WHICH THE COMMUNIST REGIME UNRAYEL TD E IDENTFYING BOTH DOMESTIC AND INTERMATIONAL FACTORS THAT PLAYED A ROLE IN NAJIBULLAH'S DOWHFALL. THE FACTORS THAT PLAYED A ROLE IN NAJIBULLAH'S DOWNFALL. THE
THIRD SECTION EXAMINES THE ISSUES CONFRONTING THE ISLAMIC THIRD SECTION EXAMINES THE ISSUES CONFRONTING THE ISLAMIC INTERIM GOVERNMENT DURING THE PREPARATIONS FOR ELECTIONS
THE FOURTH PART POSES OUESTIONS RELATING TO THE FUTURE THE FOURTH PART POSES QUESTIONS RELATING TO THE FUTURE CONSTITUTIONAL STRUCTURE OF AFGHANISTAN. FINALLY, THE NATIONS SHOULD PLAY IN THE REBUILDING OF AFGHANISTAN. 
05987 MALIA, M.

LENINIST ENDGAME

DAEDALUS 121 (2) (SPR 92) 57-75.

THE AUTHOR DISCUSSES DIFFERENT COMMUNIST MODELS, EFFORTS TO REFORM SOVIET COMMUNISM, AND WHY THE SOVIET UNION WAS ULTIMATELY DOOMED.

05988 MALIA, M.

THE YELTSIN REVOLUTION

NEW REPUBLIC, 206 (6) (FEB 92), 21-25.

TO DATE, THE SECOND RUSSIAN REVOLUTION HAS EXPERIENCED

THREE PHASES. THE FIRST PHASE WAS GORBACHEY'S PERESTROIKA.

THE SECOND WAS THE ACTUAL DEMISE OF COMMUNISM. NOW BORIS

YELTSIN AND THE RUSSIAN DEMOCRATS HAVE LAUNCHED A THIRD

PHASE: BUILDING $A$ POST-COMHUNIST ORDER AMD RETURNING RUSSIA

TO EUROPE BY CREATING A "NORMAL SOCIETY."

05989 MALIA, M.

YELTSIN AND US

COMMENTARY, 93(4) (APR 92), 21-28.

TWO QUESTIONS ARE RAISED: WHAT MANNER OF MAN IS YELTSIN? AND MIGHT HE NOT BE THE PHOENIX OF TRADITIONAL RUSSIAN AUTOCRACY, REBORN FROM THE ASHES OF LENINISH? BOTH YELTSIN AND THE RUSSIAN NATIONAL TRADII OF LENE HAD, UNTIL VERY RECENTLY, AN ALMOST UNANIMOUSLY BAD PRESS IN THE HEST. YECENTLY, AN ALMOST UNANIMOUSLY BAD PRESS IN THE WEST HISTORICALLY UNPRECEDENTED ENDEAYOR THAT LIES AHEAD FOR HIM, THE RUSSIAN REPUBLIC HAS AN EQUIVALENT MANDATE, AND MORE OF OF A PROGRAM THAN DID THE FOUNDER OF MODERN AMERICAN IN 1932 THIS ARTICLE SUGGESTS THAT HE DESERVES LESS OF A RAH
THAN HE HAS SO FAR RECEIVED FROM THE UNITED STATES.

05990 MALIK, I

ETHNICITY AND CONTEMPORARY SOUTH ASIAN POLITICS: THE KASHMIR CONFLICT AS A CASE STUDY

ROUND TABLE, 322(322) (APR 92), 203-215

CONTEMPORARY ETHNO-NATIONAL FORCES IN SOUTH ASIA DEFINE THEMSELVES IN TERMS OF COMMONALITY IN HISTORICAL, CULTURAL, LINGUISTIC, RELIGIOUS AND TERRITORIAL TRADITIONS. THE DISTRIBUTION OF ETHNIC COMMUNITIES ACROSS THE INTERMATIONAL BORDERS, OR THEIR CLAIMS FOR SEPARATISM AS IN THE CASE OF KASMIR, HAVE CREATED SERIOUS POLITICAL AND DIASPORIC QUESTIONS BOTH IN TERMS OF THEIR OWN ETHNIC IDENTITY OR BY CAUSING INTERNATIONAL CONFLICTS QUESTIONING THE VALIDITY OF POST-COLONIAL INTERNATIONAL BOUNDARIES. THIS ARTICLE SUGGESTS THAL INTERNATIONAL BOUNDARIES. THIS ARTICLE SUGGESTS THAT BOTH STATE AND NATIONALISM AS TWO CONCEPTS AND OVERARCHING SUPERSTRUCTURES ARE SERIOUSLY CONFRONTED HITH AN ASSERTIVE ETHNIC-LED DEFIANCE. IT EXPLORES: THE PROBLEM IN THEORIZATION; RELIGION IN IDENTITY FORMATION; THE KASMIR
CONFLICT AS A TEST CASE: AND THE RAMIFICATIONS OF THE CONFLICT
DISPUTE.

05991 MALIK, I.F.

ISSUES IN CONTEMPORARY SOUTH AND CENTRAL ASIAN POLITICS: ISLAM, ETHNICITY, AND THE STATE

ASIAN SURVEY, XXXII (10) (OCT 92), 888-901.

IN RECENT YEARS, PARALLEL DEVELOPMENTS SUCH AS ETHNONATIONALIST MOVEMENTS DEMANDING PARTICIPATORY SYSTEMS ALONG WITH CONCURRENT TRENDS FOR REGIONAL INTEGRATION HAVE HAD A SIGNIFICANT IMPACT ON MUSLIM SOCIETIES. WHILE MANY MOVEMENTS EMPHASIZE HISTORICAL, CULTURAL, LINGUISTIC, RELIGIOUS AND TERRITORIAL COMMONALITIES, THE HAPHAZARD DISTRIBUTION OF MANY ETHNIC COMMUNITIES ACROSS INTERNATIONAL BORDERS HAS EXACERBATED INTERSTATE AND INTRASTATE TENSION IN THOSE REGIONS. THIS ARTICLE EXAMINES SOME OF THE CONFLICTS AND PROBLEMS THAT ARE CREATED BY THE TANGLLD WEB OF ETHNIC, RELIGIOUS, AND NATIONAL IDENTITIES ACROSS CENTRAL AND SOUTH ASIA. IT SPECIFICALLY EXAMINES ETHNIC, RELIGIOUS, CULTURAL, AND NATIONAL TENSIONS IN AFGHANISTAN, KASHMIR, AND THE PAKISTANI REGION OF SINDH. IT ALSO PRESENTS AN MORE GENERAL OVERVIEH OF SIMILAR PROBLEMS AND TENSIONS IN CENTRAL ASIA. IT CONCLUDES THAT THE MUSLIMS OF CENTRAL AND SOUTH ASIA HAVE TO ADJUST TO THE CHANGED EXIGENCIES OF THE CURRENT SITUATION. RATHER THAN BANKING ON RHETORICAL NOSTALGIA, THEY MUST WORK TONARDS ESTABLISHING PLURALISTIC SOCIETIES IN WHICH THERE IS EQUITY BETHEEN VARIOUS RELIGIOUS, ETHNIC, AND NATIONAL GROUPS.

05992 MALIK, M.

PAUL PRIMES THE PUMP

FAR EASTERN ECONOMIC REYIEH, 155(14) (APR 92), 33-34. NEW AUSTRALIAN PRIME MINISTER PAUL KEATING FOUND HIMSELF NOT ONLY LAGGING IN THE OPINION POLLS BEHIND OPPOSITION LEADER JOHN HEWSON, BUT BADLY SURPRISED WHEN HEWSON'S PROPOSED SALES TAX PACKAGE WHICH HILL SHIFT SOME TAX BURDEN PROPOSED SALES TAX PACXAGE, WHICH HILL SHIFT SOME TAX BURDEN FROM DIRECT TAXATION TO A TAX ON GODDS AND SERVICES-EXPECTED TO BE A HUGE ELECTORAL MILLSTONE--SEEMED TO BE EASILY ACCEPTED BY MOST VOTERS. KEATING'S RESPONSE WAS TO PRODUCE 800,000 NEW JOBS IN THE NEXT FOUR YEARS. HE PROPOSED TO PUT AS2.3 BILLION (USS1.74 BILLION) INTO PUBLIC WORKS-ROADS, RAILROADS AND THE NATIONAL ELECTIRICTY SYSTEM-WITHOUT RAISING TAXES. HE FORECAST THAT IT WOULD PRODUCE A 4 75\% EXPANSION IN ECONOMIC ACTIVITY IN 1992 AND 1993. THAT
KEATING, AN ALMOST FANATICAL ADVOCATE OF FREE TRADE POLICIES SHOULD RESORT TO PRIMING THE ECONOMIC PUMP IN AN EFFORT TO DRAW AUSTRALIA FROM THE FISCAL MIRE IS MORE THAN ELECTIONORIENTED POLITICS. BOTH BUSINESS AHD CONSUMER CONFIDENCE HAVE PLUMMETED IN THE PAST 15-MONTH RECESSION AND KEATING CANNOT AFFORD TO LET THE FIRST STIRRINGS OF ECONOMIC RECOVERY IN LATE 1991 DISAPPEAR IN INTERNECINE POLITICAL
POSTURING.

05993 MALIK, Y.; SINGH, V.

BHARATIYA' JANATA PARTY: AN ALTERMATIVE TO THE CONGRESS (I)? ASIAN SURVEY, 2(4) (APR 92), 318-336.

THE RESULTS OF THE 1989 AND 1991 PARLIAMENTARY ELECTIONS HAVE DRASTICALLY CHANGED THE NATURE OF THE PARTY SYSTEM IN INDIA. GONE ARE THE DAYS OF A DOMINANT ONE-PARTY SYSTEM. THE 1991 EMMERGENCE OF THE BHARATIYA JANATA (BJP) POSE A MAJOR CHALLENGE BOTH TO SECULARIST POLITICAL IDEOLOGY AND TO THE CENTRIST PARTIES THAT HAVE RULED INDIA SINCE IT BECAME INDEPENDENT IN 1947. THIS ARTICLE EXPLORES THE ROOTS OF THE BJP'S IDEOLOGY, IDEOLOGICAL BASIS AND FACTIONAL DIVISIONS, BJP'S IDEOLOGY, IDEOLOGICAL BASIS AND FACTIONAL DIVISIONS,
PUBLIC POLICIES AND ELECTORAL PERFORMANCE, AND THE PARTY'S PUBLIC POLICIES AND ELECTORAL PERFORMANCE, AND THE PARTY
ASSESSMENTS AND PROSPECTS. IT CONCLUDES THAT THE BJP'S ASSESSMENTS AND PROSPECTS. IT CONCLUDES THAT THE BJP'S
FUTURE SUCCESS IS DEPENDENT ON ITS PERFOMANCE IN THE STATES FUTURE SUCCESS IS DEPENDENT ON ITS PERFOMANCE IN THE STATES,

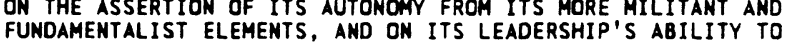
SHOW FLEXIBILITY IN DEALING WITH THE ISSUES INVOLVING SHOW FLEXIBILITY IN DEA

05994 MALLICK, $R$

AGRARIAN REFORM IN WEST BENGAL: THE END OF AN ILLUSION WORLD DEVELOPMENT, 20(5) (MAY 92), 735-750.

THE AUTHOR ARGUES THAT WEST BENGAL'S AGRARIAN REFORMS HAVE FAILED DESPITE A CONSENSUS OF SUCCESSFUL IMPLEMENTATION IN THE DEVELOPMENT LITERATURE. A FUNDAMENTALLY INACCURATE LITERATURE HAS BEEN CREATED BY UNCRITICALLY ACCEPTING STATISTICS AND POLITICAL POSITIONS AND DISCOUNTING OR IGNORING CONTRARY EVIDENCE. THE FAILURE OF PROGRAMS TO BRING SIGNIFICANT EMPOWERMENT OR MATERIAL BENEFITS TO THE LOWER CLASSES IS DUE TO RURAL ELITE DOMINANCE OVER THE LOCAL STATE BUREAUCRACY AND RULING PARTIES.

05995 MALLON, F.E. INDIAN COMMUNITIES, POLITICAL CULTURES, AND THE STATE IN LATIN AMERICA, 1780-1990

JOURNAL OF LATIN AMERICAN STUDIES, 24 (1992), 35-54.

THE AUTHOR STUDIES THE MODERN HISTORIES OF PERU, BOLIVIA, AND MEXICD, FOCUSING ON SOME OF THE PAST AND POTENTIAL FUTURE CONTRIBUTIONS OF INDIGENOUS POLITICAL CULTURES TO THE FUTURE CONTRIBUTIONS OF INDIGENOUS POLITICAL CULTURES

05996 MALNES, $R$

PHILOSOPHICAL ARGUMENT AND POLITICAL PRACTICE: ON THE PHILOSOPHICAL ARGUMENT AND POLIT

SCANDINAVIAN POLIITICAL STUDIES, 15(2) (JUN 92), 117-134. THE AUTHOR DISCUSSES METHODOLOGICAL ISSUES IN NORMATIV POLITICAL THEORY. HIS BASIC ASSUMPTION IS THAT NORMATIVE THEORY HAS A DUAL PURPOSE IN BOTH ESTABL I SHING VALID PRINCIPLES OF DIFFERENTIATING RIGHT FROM WRONG AND INFLUENCING ACTIONS AND INSTITUTIONS IN THE RIGHT DIRECTION. HE BEGINS BY DISTINGUISHING BETWEEN THO APPROACHES TO NORMATIVE POLITICAL THEORY: ONE STRESSES THE INTERPRETATION OF EXISTING IDEAS AND CONVENTIONS: THE OTHER TAKES ON THE CONSTRUCTIVIST TASK OF FIMDING OUT WHAT IS REALLY RIGHT. THEN HE EXPLORES THE RELATIONSHIP BETWEEN THEDRY AND PRACTICE. THE QUESTION IS HOW PHILOSOPHICAL ARGUMENTS CAN INSTIGATE PRACTICAL REFORM. HE ARGUES THAT PRACTICAL CONSIDERATIONS SHOULD BE INCORPORATED AS AN EXPLICIT ELEMENT OF NORMATIVE POLITICAL THEORY. PHILOSOPHICAL THEORIES, IN PARTICULAR, SHOULD ENTER INTO DIALOGUE WITH THE MORAL CONVENTIONS OF EVERYDAY LIFE, WHOSE NORMATIVE FORCE PEOPLE ALREADY ACKNOWLEDGE.

05997 MANAEY, 0

THE INFLUENCE OF HESTERN RADIO ON THE DEMOCRATIZATION OF SOVIET YOUTH

JOURMAL OF COMMUNICATION, 41(2) (SPR 91), 72-91.

THIS ARTICLE EXAMINES THE INFLUENCE OF WESTERN RADIO ON THE SOVIET AUDIENCE WITH EMPHASIS ON YOUNG PEOPLE. IT PRESENTS A SCIENTIFIC SOCIOLOGICAL ANALYSIS WHICH FIRST EXAMINES THE PROCESS BY WHICH YOUNG PEOPLE COME TO BE INFLUENCED BY WESTERM RADID. IT THEN EYALUATES HOW THIS INFLUENCED BY WESTERN RADIO. IT THEN EVALUATES HOW THIS
PROCESS AFFECTS THE DEMOCRATIZATION OF SOCIETY, THE PROCESS AFFECTS THE DEMOCRATIZATION OF SOCIETY, THE
DEVELOPMENT OF SOCIAL ACTIVITY AND YOUNG PEOPLE'S SELFDEVELOPMENT OF SOCIAL ACTIVITY, AND YOUNG PEOPLE'S SELFCONSCIOUSNESS. SURVEYS OF SOVIET YOUTH AND CONTENT ANALYSIS OF "PROBLEM REPORTS" ARE USED TO ANALYZE THE SUBJECT MATTER IT CONCLUDES THAT THE OPENNESS TOWARD BROADCASTS FROM RADIO LIBERTY AND OTHER HESTERN STATIONS DURING PERESTOIKA HAS ONLY INCREASED THE LEVEL OF DISTRUST OF SOVIET MEDIA
THOSE TEENAGERS HHO TEND TO BE POORLY ADAPTED TO THE ESTABLISHED SOCIAL ACTIVITIES OF THEIR PEERS

05998 MANCHANDA, $R$.

FROZEN WASTE

FAR EASTERN ECONOMIC REVIEW, 155(47) (NOV 92), 28-29. 
FOR THE PAST EIGHT YEARS, INDIAN AND PAKISTANI TROOPS HAVE FACED EACH OTHER ACROSS THE "SIACHEN FRONT," A REGION OF TRULY UNINHABITABLE GLACIERS AND MOUNTAINS. A DISPUTE OYER TERRITORY SPARKED BY A MOUNTAINEERING EXPEDITION HAS ESCALATED INTO A TENSE STANDOFF BETHEEN SOME 5,000 TROOPS. SOME $50 \%$ OF THE INDIAN TROOPS SENT TO THE FRONT ARE EVACUATED AS CASUALTIES, BUT ONLY A TIMY FRACTION ARE KILLED AMD HOUMDED IN COMBAT. MOST SUCCUMB TO THE EXTREME CONDITIONS. INDIA SPENDS MORE THAN $10 \%$ OF ITS ANMUAL DEFENSE BLOGET TO MAINTAIN ITS PRESENCE ON THE FRONT. PAKISTAN'S COSTS ARE LESS (ITS POSITIOMS ARE ON LOWER GROUMD) BUT ARE STILL CONSIDERABLE. BOTH SIDES REALIZE THE FUTILITY OF THE VENTURE, BUT SIX ROUNDS OF MEGOTIATIONS HAVE FAILED TO RESULT IN A SETTLEMENT.

05999 MANCHAKDA, $R$.

UNEQUAL EXCHANGE

FAR EASTERN ECONOMIC REVIEW, 154(52) (JAN 92), 10-11. CHINESE PREMIER LI PENG'S VISIT TO NEH DELHI WAS A TRIUMPH FOR PEKING, BUT INDIA GAINED LITTLE FROM THE EXERCISE, AND MAY HAVE EVEN DAMAGED ITS CREDIBILITY BY ITS WEAK RESPONSE TO CHINA'S AGGRESSIVE INITIATIVE ON HUMAN RIGHTS ISSUES. EVEN THE MUCH ANTICIPATED TRADE-OFF--INDIAN CONCESSIONS ON TIBET AND CHINA'S CRITICISM OF TERRORISM IN
THE KASHAIR--DID NOT COME OFF AS INTENDED. A JOINT COMMUNIQUE CONTAINED NO EXPLICIT MENTION OF KASHMIR, NOR ANY ALLUSION TO PAKISTANI-SPONSORED TERRORISH IN THE KASHMIR VALLEY. IN STRIKING CONTRAST, INDIAN SUPPORT FOR THE CHINESE POSITION ON TIBET HENT BEYOND EVEN THAT GIVEN BY THEN PRIME MINISTER RAJIV GANDHI DURING HIS 1988 TRIP TO CHINA. THE COMMUNIQUE ALSO STRESSED THE CONVICTION OF BOTH GOVERNMENTS THAT FOR DEVELOPING COUNTRIES "THE RIGHT TO SUBSISTENCE AND DEVELOPMENT IS A BASIC HUMAN RIGHT."

06000 MANDEL, $R$.

PUBLIC OPINION AND SUPERPOWER STRATEGIC ARMS

ARMED FORCES AHD SOCIETY, 17(3) (SPR 91) 409-428.

THIS ARTICLE COMBINES A THEORETICAL CONTEXT HITH

LONGITUDINAL AND CROSS-SECTIONAL DATA TO EXAMINE PUBLIC

OPINION IN THE UMITED STATES AND HESTERM EXROPE SPANMIMG

ROUGHLY 1978 TO 1986 ON ISSUES RELATED TO SUPERPOWER

STRATEGIC ARMS. THE FINDINGS INCLUDE THAT IN THE EARLY 1980 S

THE PUBLIC'S HIGH EMOTIONAL FEAR-OF GLOBAL NUCLEAR WAR,

THE PUBLIC'S HIGH ENOTIONAL FEAR-OF GLOBAL NUCLEAR WAR,
SOVIET MILITARY SUPERIORITY, AND THE THREAT OF POSSIBLE

SOVIET MILITARY SUPERIORITY, AND THE THREAT OF POSSIBLE
SOVIET ATTACK-CONVERGED WITH A PREFERENCE FOR CONFRONTATION-

-FOR AMERICAN MILITARY SUPERIORITY, ARMS ESCALATION, AND

-FOR AMERICAN MILITARY SUPERIORITY, ARMS ESCALATION, ANO

NUCLEAR RETALIATION AGAINST AN ATTACK--AND THAT BRITAIN,

FRANCE, AND THE UNITED STATES EXHIBITED THIS HIGH EMOT IONAL

DEAR ANO CON

06001 MANDELBAUM, M.

COUP DE GRACE: THE END OF THE SOVIET UNION

FOREIGN AFFAIRS, 71(1) (1992), 164-183.

THE ATTEMPTED HARD-LINE COUP OF AUGUST 1991 OCCURRED

BECAUSE OF ALL THE CHANGES THAT HAD TAKEN PLACE IN THE

SOVIET UNION, AND IT FAILED FOR THE SAME REASON. THE

CONSPIRATORS STRUCK TO RESTORE THE OLD ORDER; THE RESULT OF

THEIR FAILURE WAS TO PUT IT OUT OF ITS MISERY. WHAT BEGAN AS

A COUP D'ETAT TO PRESERVE THE SOVIET UNION TURNED OUT TO THE COUP DE GRACE.

\section{MANDEL3AUM, M.}

NOT SO SLICK

NEW REPUBLIC, $206(22$ ) (JUN 92 ), 14, 16-17.
THE AUTHOR CONSIDERS BILL CLINTON'S "SLICK HILLIE" IMAGE

AND EXPLAINS WHY CLINTON DID NOT FIGHT IN THE VIETNAM HAR.

06003 MANFRASS, $K$

EUROPE: SOUTH-NORTH OR EAST-WEST MIGRATION?

INTERMATIONAL MIGRATION REVIEW, XXVI(2) (SUM 92), 388-400

A DUALISH IN EUROPE BETHEEN IMMIGRATION OF EUROPEAN AND NON-EUROPEAN ORIGINS INCREASINGLY CHARACTERIZED THE $1970 S$ AND THE 1980S: I.E. THE TIME SPAN FOLLOHING THE PHASE OF THE MASSIVE LABOR MIGRATION OF THE 1950 S AND 1960 S AFTER THE BREAK MARKED BY THE END OF ACTIVE RECRUITMENT IN 1973-74. THE RESULT WAS, ON THE ONE HAND, THE INTEGRATION OF A CONSIDERABLE NUMBER OF IMMIGRANTS OF EUROPEAN ORIGIN INTO THE SOCIETY OF THE HOST COUNTRY. ON THE OTHER HAND, IT RESULTED IN THE NON-INTEGRATION OF IMMIGRANTS OF NONEUROPEAN ORIGIN AND THEIR SOCIAL ISOLATION AS WELL AS SCENARIOS OF CONFLICT WITH THIS GROUP. THE CONSEQUENCES OF THE PROCESS OF EUROPEAN INTEGRATION HIGHLIGHTED THIS DUALISH. THE PROCESS OF EUROPEAN INTEGRATION HIGHLIGHTED THIS DUALISH. IT WAS BENEFICIAL FOR MOST OF THE IMMIGRANTS OF EUROPEAN ORIGIN IN TERMS OF IMPROVED SOCIAL AND LEGAL STATUS AND ESPECIALLY IN TERMS OF FREE MOVEMENT. THE DUALISM WAS DIKEWISE EMPHASIZED BY INCREASING IMMIGRATION FLOWS FROM DIFFERENT PARTS OF THE

06004 MAMGXUSUWONDO, S.

COOPERATION AND INDONESIA

INDONESIAN

THIS ARTICLE EXAMINES THE RECENT SUCCESS OF EAST AND
SOUTHEAST ASIAN ECONOMIES, WHICH THE AUTHOR ATTRIBUTES TO THEIR OUTWARD-ORIENTED TRADE AND OTHER RELATED POLICIES. THE ABILITY AND READINESS OF MAJOR MARKETS IN ADVANCED

INDUSTRIAL COUNTRIES TO ABSORB LARGE QUANTITIES OF EXPORTS FROM THE REGION IS CONSIDERED, ALONG WITH THE CONCURRENT INCREASE IN IMPORTS BY THE REGION. INDONESIA IS PRESENTED AS AN EXAMPLE. THE NEED FOR COOPERATION IN THE REGION IS CONSIDERED.

06005 MANION, $M$

POLITICS AND POLICY IN POST-MAO CADRE RETIREMENT

CHINA QUARTERLY, (129) (MAR 92), 1-25

ALTHOUGH REGULATIONS AND CONSTITUTIONS HAD STIPULATED

FIXED TERMS OF OFFICE FOR MANY POSITIONS IN CHINESE

GOVERMMENT, CADRE RETIREMENT HAD NOT BEEN ENFORCED OR WIDELY

PRACTISED BEFORE THE REFORMS OF 1978, WHEN THE GOVERMMEMT

INTROOUCED REGULATIONS TO CHANGE THE DE FACTO LIFE-LONG

TENURE FOR CADRES. THE ENSUING EFFORT TO INSTITUTE ROUT INE

AGE-BASED RETIREMENT FROM OFFICE IS AN EXCELLENT EXAMPLE OF POLICY IN POST-MAD CHINA. ON THE ONE HAND, CADRE RETIREMENT POLICY REPRESENTED A SERIOUS REFORM EFFORT. ON THE OTHER, POLICY REPRESENTED A SERIOUS REFORM EFFORT. ON THE OTHER

MANY TOP LEADERS WANTED TO BE EXEMPT FROM MANDATORY

RETIREMENT. HHAT ULTIMATELY ALLOWED LEADERS TO SELECTIVELY PROTECT CAREERS AND POLITICAL FLEXIBILITY WAS THE PRINCIPLE OF STRATIFICATION.

06006 MANION, M.D

PARENTAL RELIGIOUS FREEDOH, THE RIGHTS OF CHILDREN, AND

THE ROLE OF THE STATE

JOURMAL OF CHURCH \& STATE, 34(1) (WIN 92), 77-92.

WHEN THE COURT SEEKS TO DIFFERENTIATE THE PROTECTED RELIGIOUS RIGHTS OF PARENTS AND THE RIGHTS OF THEIR CHILDREN AND TO RECONCILE CONFLICTING DEMANDS IN THIS AREA, IT IS LIKE NEGOTIATING A MINE FIELD. IT OFTEN POSES A THREE-LEGGED DILEMMA OF PARENTAL FREE RELIGIOUS EXERCISE, STATE ACCOMMODATION AND/OR NEUTRAL NONESTABLISHMENT, AND THE FUNDAMENTAL HUMAN RIGHTS OF THE CHILD.

06007 MANISUZZAMAN, T.

ARMS TRANSFERS, MILITARY COUPS, AND MILITARY RULE IN DEYELOPING STATES

JOURNAL OF CONFLICT RESOLUTION, 36(4) (DEC 92), 733-755.

THROUGH THE USE OF CROSS-NATIONAL AGGREGATE DATA

ANALYSIS AS WELL AS CASE-BY-CASE STUDIES, THE AUTHORS HAVE

ANALYSIS AS WELL AS CASE-BY-CASE STUDIES, THE AUTHORS HA

EXAMINED THE IMPACT OF ARMS TRANSFERS ON CIVIL-MILITARY

ARMS TRANSFER FACILITATES THE OCCURRENCE OF COUP D'

LENGTHENS THE PERIOD OF MILITARY RULE. THE STUDY ALSO

LENGTHENS THE PERIOD OF MILITARY RULE. THE STUDY ALSO

MIGHT BE THE RESULT RATHER THAN THE CAUSE OF MILITARY RULE.

06008 MANKO, J.M.

MUNICIPAL SUPERFUND LIABILITY FOR HOUSEHOLD HAZARDOUS

WASTE COLLECTION AND DISPOSAL

WATIONAL CIVIC REVIEH, 81(1) (WIN 92), 95-97.

THE AUTHOR DISCUSSES THE QUESTION OF WHETHER

MUNICIPALITIES SHOULD BE LIABLE FOR MUNICIPAL SOLID WASTE

DISPOSAL IN SUPERFUND SITES AND HOW THE U.S. ENVIROMMENTAL

PROTECTION AGENCY HAS RESPONDED TO THE ISSUE.

06009 MANN, J.

NOODLER

NEW REPUBLIC, 207(18) (OCT 92), 21-23.

THE CONVENTIONAL HISDOM ABDUT GEORGE BUSH IS THAT HE HAS BEEN A CONSISTENT CHINA LOVER AND THAT HIS STEADFAST YIEWS ABOUT CHINA CONTRAST WITH HIS OPPORTUNISTIC BEHAVIOR ON OTHER ISSUES. ACCORDING TO THIS VIEW, ONE OF THE VERY FEH PRINCIPLES ON WHICH BUSH HAS BEEN UNYIELDING IS HIS BELIEF
IN STRONG U.S. TIES HITH THE COMMUNIST LEADERSHIP IN BEIJING BECAUSE BUSH WAS INVOLVED IN PRESIDENT NIXON'S OPENING TOWARD CHINA AND SERVED AS HEAD OF THE U.S. LIAISON OFFICE IN BEI JING. BUT THESE ASSUMPTIONS ARE WRONG. BUSH WAS AT BEST A MARGINAL FIGURE DURING THE NIXON-KISSINGER OPENING TO CHINA, AHD THE HISTORICAL RECORD DEMONSTRATES THAT BUSH HAS FLIP-FLOPPED ON CHINA THE WAY HE HAS ON EVERYTHING ELSE.

06010 MANK, T.E.

THE HRONG MEDICINE: TERM LIMITS WON'T CURE WHAT AILS CONGRESSIONAL ELECTIONS

BROOKINGS REVIEW, 10(2) (SPR 92), 23-25.

THE AUTHOR ARGUES THAT LIMITING THE TERMS OF

REPRESENTATIVES WILL NOT SOLVE THE PROBLEMS OF THE U.S. CONGRESS.

06011 MANSBRIDGE, J. TATE, K.

RACE IRUMPS GENDER: THE THOMAS NOMINATION IN THE BLACK RACE TRUMPS PS: POL ITICAL

$488-492$.

TCAL SCIENCE AND POLITICS, XXV(3) (SEP 92 ),

RACE AND GENDER ARE INTIMATELY INTERTWINED IN THE LIVES OF BLACK WOMEN IN THE UNITED STATES. IN THE SENATE

CONFIRMATION HEARINGS THAT PITTED CLARENCE THOMAS AGAINST ANITA HILL, RACE PROVED STRONGER THAN GENDER AS THE GREAT 
MAJORITY OF BLACX WOMEN SIDED WITH THOMAS.

06012 MANSFIELD, E.

THE CONCENTRATION OF CAPABILITIES AND INTERNATIONAL TRADE INTERNATIONAL ORGANIZATION, 46(3) (SUM 92), 731-764.

THIS STUDY PROVIDES SOME OF THE FIRST STATISTICAL

RESULTS BEARING ON THE ISSUE OF THE EFFECTS OF DISTRIBUTION OF POWER HAVE ON TRADE, AND THE IMPACT OF INTERNATIONAL POLITICAL AND ECONOMIC VARIABLES ON THE LEVEL OF GLOBAL TRADE. THE RESULTS INDICATE THAT BOTH INTERMATIONAL POLITICAL AND ECONOMIC VARIABLES HELP SHAPE PATTERNS OF GLOBAL COMMERCE. THERE IS SUBSTANTIAL EVIDENCE THAT THE CONCENTRATION OF CAPABILITIES IS RELATED AT LEAST AS STRONGLY TO TRADE AS HEGEMONY IS AND THAT THE NATURE OF THE RELATIONSHIP BETWEEN CONCENTRATION AND COMMERCE IS MUCH MORE COMPLEX AND RICHER THAN IS COMMONLY THOUGHT.

06013 MANSFIELD, E.

THE CONCENTRATON OF CAPABILITIES AND THE ONSET OF HAR JOURMAL OF CONFLICT RESOLUTION, 36(1) (MAR 91), 3-24. RECENT EMPIRICAL RESEARCH HAS PRODUCED NO CONSENSUS OF HHAT RELATIONSHIP EXISTS BETWEEN THE CONCENTRATION OF WHAT RELATIONSHIP EXISTS BETWEEN THE CONCENTRATION OF CAPABILITIES AMD THE ONSET OF HAR. THE PURPOSE OF THIS ARTICLE IS TO PRESENT EMPIRICAL RESULTS BASED ON CONCENTRATION ON WAR THAN HAVE BEEN RELIED ON IN THE PAST. CONCENTRATION ON WAR THAN HAVE BEEN RELIED ON IN THE PAST. THE RESULTS SUGGEST THAT ALTHOUGH WAR IS RELATED TO THE
CONCENTRATION OR CAPABILITIES. THIS RELATIONSHIP IS MUCH MORE COMPLEX THAT IS OFTEN HYPOTHESIZED.

06014 MANSFIELD, $\mathrm{H}$.

ONLY AMEND

NEW REPUBLIC, 207(2) (JUL 92), 13-14

THE U.S. CONSTITUTION WAS FRAMED SO AS TO OISCOURAGE PRECISELY THE KIND OF MOMENTARY ENTHUSIASM THAT H. ROS PEROT REPRESENTS, TO MITIGATE AGAINST POPULAR WHIMS, AND TO ENCOURAGE THE "COOL AND DELIBERATE SENSE" OF THE PEOPLE. IT DOES THIS BY PLACING BARRIERS TO OUICK ACTION BY A TEMPORARY MAJORITY AND BY SEPARATING POWERS BOTH WITHIN THE FEDERAL GOVERMMENT AND BETWEEN STATES AND FEDERAL GOVERNMENTS. IT ALSO DOES THIS BY THE VERY ACT OF SPECIFYING A FORMAL
STRUCTURE OF OFFICES WITH DEFINED POWERS AND MEANS OF SELECTION.

06015 MANSFIELD, M.

LABOR EXCHANGES AND THE LABOR RESERVE IN TURN OF THE CENTURY SOCIAL REFORM

JOURNAL OF SOCIAL POLICY, 21(4) (OCT 92), 435-468.

THE AUTHOR DESCRIBES A MAJOR DEBATE IN TURN OF THE THE AUTHOR DESCRIBES A MAJOR DEBATE IN TURN OF THE
CENTURY SOCIAL REFORM THROUGH A CLOSE READING OF THE CENTURY SOCIAL REFORM THROUGH A CLOSE READING OF THE
PUBLISHED WORKS OF CHARLES BOOTH, J.A. HOBSON, WILLIAM PUBLISHED WORKS OF CHARLES BOOTH, J.A. HOBSOM, WILLIAM
BEVERIDGE, A.C. PIGOU, AND OTHERS. HIS AIM IS TO RECONSTRUCT BEVERIDGE, A.C. PIGOU, AND OTHERS. HIS AIM IS TO RECONSTRUCT THE EMERGENCE AND ELABORATION OF A THEORY OF LABOR MARKET DISORGANIZATION, UNDERSTOOD AS THE ABSENCE OF EFFECTIVE NORMS GOVERNING EMPLOYMENT RELATIONSHIPS IN URBAN LABOR
HARKETS SUBJECT TO CHRONIC OVER-SUPPLY. HE TAKES ISSUE HITH MARKETS SUBJECT TO CHRONIC OVER-SUPPLY. HE TAKES ISSUE A TENDENCY IN THE HISTORIOGRAPHY OF SOCIAL POLICY TO
FRAGMENT THIS DEBATE INTO THE DEVELOPMENT OF TWO DISTINCT COMCEPTUAL FRAMEWORKS CORRESPONDING TO THE SOCIAL PROBLEMS CONCEPTUAL FRAMEWORKS CORRESPONDING TO THE SOCIAL PROBLEMS
OF POVERTY AND UNEMPLOYMENT MORE OR LESS AS THEY ARE TODAY.

06016 MANSFIELD, $P$.

WHY THE ARABS WANT TO KEEP IRAQ INTAC

MIDDLE EAST INTERNATIONAL, (435) (OCT 92), 16-17.

THE ARAB STATES WERE DIVIDED IN THEIR ATTITUDES TOWARDS IRAQ DURING THE GULF CRISIS BUT THEY ARE REMARKABLY UNANIMOUS TODAY IN SAYING THAT THE IRAQI STATE MUST BE PRESERVED WITHIN ITS PRESENT BORDERS. THIS MAY SEEM SURPRISING GIVEN THE OFT-REPEATED ARAB CLAIM THAT NATIONAL BORDERS IN THE MIDDLE EAST WERE DRAHN UP BY WESTERN IMPERIALISTS FOR THE PURPOSE OF DIVIDING THE ARABS. HOWEVER, THE ARABS HAVE SEVERAL REASONS NOT TO HORK TOWARDS THE DISSOLUTION OF IRAQ. FIRST, WILE THE SECESSION OF IRAOI KURDISTAN, LEADING TO THE CREATION OF A KURDISH NATIONAL STATE, WOULD BE OF MUCH GREATER CONCERN TO TURKS AND IRANIANS THAN TO ARABS, IT HOULD SERIOUSLY DIMINISH ARAB RESOURCES. BUT MORE ALARMING FOR IRAQ'S ARAB NEIGHBORS IS THE PROSPECT OF SOUTHERN IRAO BECOMING A NEH SHI'ITE STATE. EITHER, AS IS MOST LIKELY, IT WOULD NOT WORK, IN WHICH CASE INSTABILITY THROUGHOUT THE REGION WOULD BE VASTLY INCREASED, OR, IF IT DID WORK AND FORMED DIRECT POLITICAL LINKS WITH IRAN, IT WOULD MEAN A HUGE BDOST TO IRAN'S POWER IN THE IRAN, IT HOULD MEAN A HUGE BDOST TO IRAN S POWER IN THE REGION AND ITS

06017 MANSINGH, S

BEIJING AND THE OVERSEAS CHINESE

CHINA REPORT, $27(4)$ (OCT 91), 309-328

THE TOPIC' OF THIS PAPER IS BEIJING'S DEALINGS WITH OVERSEAS CHINESE WHICH CONTAINS MANY VARIABLES INCLUDING ROLES PLAYED BY THE CHINESE IN A GIVEN COUNTRY, THEIR TIES WITH TAIHAN, LOCAL SENTIMENT TOWARD THEM, AND THE BILATERAL RELATIONS BETWEEN THAT COUNTRY AND CHINA, WHICH IN TURN DEPENDS LARGELY ON BEIJING'S GENERAL FOREIGN POLICY
ORIENTATION AT THE TIME. THE SUBJECT OF OVERSEAS CHINESE IS IMPORTANT NOT ONLY BECAUSE OF THE NUMBERS INVOLYED, BUT BECAUSE OF THE CONTINUING SALIENCE OF ETHNICITY IN NATIONAL BECAUSE OF THE CONTINUING SALIENCE OF ETHNICITY IN NATIONAL AND INTERNATIONAL POLITICS. CHINA'S OBJECTIVES OF ATTRACTING FOR THE MODERNIZATION OF CHINA, AS WELL AS FOR ITS REUNIFICATION APPEAR TO HAVE BEEN ADVANCED IN THE LAST REUNIFICATION
DECADE OR SO.

06018 MANTING, $Z$.

PERU CAUGHT IN POLITICAL TURBULENCE

BEIJING REVIEW, 35(17) (APR 92), 15-16.

THE POLITICAL SITUATION IN PERU HAS BECOME VERY

COMPLICATED SINCE PRESIDENT ALBERTO FUJIMORI SEIZED POWER,

SUSPENDED THE CONSTITUTION, AND OISSOLVED CONGRESS. SOME

COMNENTATORS SEE IT AS A CONTINUATION OF THE STRUGGLE

BETWEEN PERU'S TRADITIONAL POLITICAL FORCES AND THE NEH

FORCES REPRESENTED BY FUJIMORI.

06019 MANTRIPRAGADA, K.G.

DEPOSITORS AS A SOURCE OF MARKET DISCIPLINE

YALE JOURNAL ON REGULATION, 9 (2) (SUM 92), 543-574.

IN 1991. THE U.S. TREASURY ISSUED A REPORT CONTAINING

SPECIFIC PROPOSALS FOR REFORMING DEPOSIT INSURANCE. SOME OF

THESE PROPOSALS HERE INCORPORATED IN THE FEDERAL DEPOSIT

INSURANCE CORPORATION IMPROVEMENT ACT OF 1991 (FDICIA). ONE

CONTROVERSIAL ELEMENT OF THE FDICIA IS A PLAN FOR REFORMING

THE DEPOSIT INSURANCE SYSTEM BY SHIFTING SOME OF THE RISK OF

THEMSELVES. THIS PROPOSAL RESTS ON THE PREMISE THAT

THEMSEL VES. THIS PROPOSAL RESTS ON THE PREMISE THAT

DEPOSITORS HO BEAR SOME OF THE RISK OF BANK FAILURE ARE

LIKELY TO DISCIPLINE WEAK INSTITUTIONS BY THREATENING TO

WITHDRAH THEIR DEPOSITS. IN THIS ESSAY, THE AUTHOR EVALUATES
THE COSTS AND BENEFITS OF DEPOSITOR OISCIPLIME AND ASSESSES

THE COSTS AND BENEFITS OF DEPOSITOR DISCIPLINE AND ASSESSES

PROMOTE DEPOSITOR DISCIPLINE. HE SUGGESTS THAT A MATURITY

BASED COVERAGE LIMIT HOULD BE PREFERABLE TO THE DOLLAR-BASED

LIMIT RETAINED BY THE ACT.

06020 MANUEL, F.E.

A REQUIEM FOR KARL MARX

DAEDALUS, 121(2) (SPR 92), 1-19.

THE AUTHOR PROFILES KARL MARX AND EXAMINES SEVERAL

ASPECTS OF HIS IDEOLOGY, FOCUSING ON THE LURE OF POPULAR

SCIENTIFIC SOCIALISM, THE GLOBAL DIFFUSION OF MARXIST

THOUGHT, MARXISM AND ETHNICITY, AND THE DENIAL OF INDIVIDUAL

RIGHTS.

06021 MANZA, J.

POSTINDUSTRIAL CAPITALISM, THE STATE, AND THE PROSPECTS

FOR ECONOMIC DEMOCRACY

JOURMAL OF POLITICAL AND MILITARY SOCIOLOGY, 20(2) (WIN

92), $209-242$.

THIS PAPER OFFERS A FIRST CUT AT AN AMALYSIS OF THE

PROBLEMS OF ANY TRANSITION FRON POSTINDUSTRIAL CAPITALISM TO

ECONOMIC DEMOCRACY. THE AUTHOR'S APPROACH EMPHASIZES AN

INSTITUTIONAL ANALYSIS OF THE EVOLVING OPPORTUNITIES THAT

HAVE EMERGED WITHIN THE POLITICAL AND ECONOMIC STRUCTURES OF

SUCH SOCIETIES. HE ARGUES THAT POSTINDUSTRIAL TRENDS IN

THESE SOCIETIES ARE CREATING MOMENTUM FOR THE CREATION OF

INCOME GUARANTEES AND ENCOURAGING THE GROWTH OF INFORMAL

ECONOMIC ACTIVITY. THE EMPHASIS ON EDUCATION AND ADVANCED

VOCATIONAL SKILLS IN A POSTINDUSTRIAL ECONOMY PROVIDES A

FOUNDATION FOR THE CREATION OF NEW PARADIGMS OF LIFELONG

LEARNING WICH WOULD EMPOWER INDIVIDUALS WITH NEH

CAPACITIES. FINALLY, PRODUCTION IN SUCH ECONOMIES

INCREASINGLY REQUIRES SHARING OF KNOWLEDGES AND NON-

HIERARCHICAL WORK PLACES. HE CONCLUDES THAT BY TAKING

ADVANTAGE OF THIS EMERGING INSTITUTIONAL ARCHIPELAGO OF

POSTINDUSTRIAL CAPITALISM, ECONOMIC DEMOCRACY POTENTIALLY

OFFERS A FEASIBLE PROGRAM OF SOCIAL TRANSFORMATION WHICH

MIGHT AVOID THE "TRANSITION TROUGH" THAT, AS ADAM PRZEWORSKI

(1985) HAS ELEGANTLY ARGUES, WOULD LIKELY PLAGUE ANY

TRANSITION FROM CAPITALISH TO SOCIALISM.

06022 MANZETTI, L.

THE EVOLUTION OF AGRICULTURAL INTEREST GROUPS IN ARGENTINA

JOURNAL OF LATIN AMERICAN STUDIES, 24(3) (OCT 92), 585-616.

BECAUSE OF THE ECONOMIC IMPORTANCE OF AGRICULTURE IN

ARGENTINA, AGRICULTURAL INTEREST GROUPS PLAY AN IMPORTANT

ROLE IN POLITICS. IN THIS ESSAY, THE AUTHOR EXPLAINS THE

EVOLUTION OF ARGENTINE AGRICULTURAL INTEREST GROUPS

ACCORDING TO A RATIONAL CHOICE PARADIGM. THEN HE DISCUSSES

THE MAJOR ISSUES SHAPING THE BEHAVIOR OF THESE RURAL

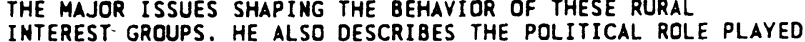

INTEREST GROUPS. HE ALSO DESCRIBES THE POLITICAL ROLE
BY RURAL PRESSURE GROUPS SINCE ARGENTINA RETURNED TO

BY RURAL PRESSURE GROUPS SINCE ARGENTINA RETURNED TO

DEMOCRACY IN 1983 AND CONSIDERS HHAT ROLE SUCH GROU

06023 MANZO, K.; MCGOHAN, P

AFRIKANER' FEARS AND THE POLITICS OF DESPAIR: UNDERSTANDING CHANGE IN SOUTH AFRICA

INTERNATIONAL STUDIES QUARTERLY, 36(1) (MAR 92), 1-24. THIS ARTICLE CONSIDERS THREE RELATED OUESTIONS: WHY HAS 
THE AFRIKANERDOMINATED GOVERNMENT OF PRESIDENT F.W. DE KLERK DECIDED AT THIS TIME TO INITIATE A PROCESS OF POLITICAL REFORM? IS THERE ANY CHANCE AT ALL THAT A NEGOTIATED SETTLEMENT TO THE COUNTRY'S PROBLEMS CAN BE REACHED? AND, WHAT THEORETICAL PERSPECTIVE BEST ENABLES US TO ANSHER THESE QUESTIONS? IN SEEKING ANSWERS, THE AUTHORS USE DATÁ COLLECTED IN A 1988 MAIL QUESTIONNAIRE FROM A NATIONWIDE SAMPLE OF ELITE AFRIKANER POLITICIANS, CIVIL SERVANTS, BUSINESSMEN, CLERGY, ACADEMICS, AND JOURNALISTS. THEIR THEORETICAL PERSPECTIVE QUESTIONS BOTH NEO-MARXIST AND NEOLIBERAL VERSIONS OF "MODERNIZATION THEORY" WITH THEIR EXCESSIVE FOCUS OH CAPITALIST DEVELOPMENT AS THE MOTOR OF CHANGE AND. IN CONTRAST, STRESSES HOW BLACK POLITICAL CHANGE AND, IN CONTRAST, STRESSES HOW BLACK POLITICAL TRANSFORMATION. THE AUTHORS DEMONSTRATE THE FUNDAMENTAL ROLE OF INDIVIDUAL ATTITUDES IN THE CIRCLE OF RECIPROCAL OF INDIVIDUAL ATTITUDES IN THE CIRCLE OF RECIPROCAL INFLUENCE BETWEEN THE ECONOMY AND THE POLITY. THEIR EVIDENCE INDICATES THAT PROMINENT AFRIKANERS APPEAR WILLING TO
A FEDERAL SYSTEM IN WHICH POWER WOULD BE SHARED AMONG A FEDERAL SYSTEM IN WHICH POWER WOULD BE SHARED AMONG
PARTICIPATING RACIAL GROUPS, BUT THEY ARE NOT YET PREPARED PARTICIPATING RACIAL GROUPS, BUT THEY ARE NOT YET PREPARED OPPONENTS. THEY THUS SEE NEGOTIATIONS AS LIKELY, BUT WHETHER THEY WILL RESULT IN A "POST-APARTHEID" SOUTH AFRICA WILL DEPEND UPON CONTINUING BLACK RESISTANCE TO RACE-BASED POLITICS.

\section{MANZO, $K$.}

GLOBAL POWER AND SOUTH AFRICAN POLITICS

ALTERNATIVES, $17(1$ ) (WIN 92), 23-66.

IN ORDER TO MAKE SENSE OF THE POLITICS OF THE PRESENT IN SOUTH AFRICA, THIS ARTICLE DEMONSTRATES HOW SOUTH AFRICAN POL ITICS ARE AN EFFECT OF GLOBAL POWER RELATIONS. IT IS ABOUT THE LOCAL EFFECTS OF GLOBAL POWER RELATIONS INVOLVING WESTERN WHITE PEOPLE AND AFRICAN/ASIAN BLACK PEOPLE, ABOUT HOW THOSE RELATIONS OF POWER HAVE NORMALIZED CERTAIN SOCIAL PRACTICES BUT NOT OTHERS, CDNDITIONED THE NATURE OF RESISTANCE TO DOMINATION, AND PRODUCED MULTIPLE AND OFTEN OVERLAPPING IDENTITES--WESTERN, CHRISTIAN, AFRICAN, CIVILIZED, BARBARIC, WHITE, BLACK, AND SO ON. THE ATTITUDE CIVILIZED, BARBARIC, WHITE, BLACK, AND SO ON. THE ATTITUDE
TOWARD POHER, RESISTANCE, STRUGGLE, AND SOCIAL CHANGE THAT TOWARD POHER, RESISTANCE, STRUGGLE, AND SOCIAL CHANGE THAT
INSPIRED THIS WORK IS FOUCAULDIAN. THE AUTHOR SUMMARIZES INAT THAT ATTITUDE IS AND HOW IT LEADS AWAY FROM MANY CONVENTIONAL INTERPRETATIONS OF THE SOUTH AFRICAN SITUATION.

06025 MAOCHENG, $Z$.

PROLIFERATION OF BALLISTIC MISSILES AND REGIONAL SECURITY DISARMAMENT, XIV(3) (1991), 44-60.

THERE HAS BEEN A PROLIFERATION OF MISSILES TO ALL PARTS OF THE HORLD BUT, BEYOND A DOUBT, THE REGION MOST AFFECTED HAS BEEN THE MIDOLE EAST. IN THIS ESSAY, THE AUTHOR EXPLAINS
THE CAUSES OF MISSILE PROLIFERATION AND OUTLINES THE FACTORS THE CAUSES OF MISSILE PROLIFERATION AND OUTLINES THE FACTORS MISSILE TECHNOLOGY.

06026 MAOR, $M$.

INTRA-PARTY CONFLICT AND COALITION BEHAVIOR IN DENMARK AND NORHAY: THE CASE OF HIGHLY-INSTITUT IONALIZED PARTIES SCANDINAVIAN POLITICAL STUDIES, 15(2) (JUN 92), 99-116. THE AUTHOR ANALYZES THE IMPACT OF INTRA-PARTY CONFLICTS ON THE COALITIONAL BEHAVIOR OF HIGHLY-INSTITUTIONALIZED EITHER PREYENT OR AND NORHAY, FOCUSING ON HOW

ORGANIZATIONAL RIGIDITY--THAT IS, THE LACK OF HETEROGENEOUS AND DIFFUSED MECHANISHS FOR INTERNAL DISSENT--DOES NOT ALLOH NEGOTIATIONS INDUCE INTERNAL CONFLICTS, MEMBERS MAY BE FORCED TO LEAVE THE PARTY AS THEIR PRIMARY MECHANISM FOR THE EXPRESSION OF DISSENT. EMPIRICAL FINDINGS SUPPORT THE THESIS THAT IN MULTI-PARTY SYSTEMS WHERE MINORITY SITUATIONS OCCUR, THE MOST FOR HIGHLY-INSTITUTIONALIZED PARTIES IS THE FORMATION OF INFORMAL MINORITY GOVERNMENTS. WHEN SUCH PARTIES FORM FORMAL MINDRITY GOVERMMENTS THE PARTY EL SUCH PARTIES FORM MINDRITY GOVERNMENTS, THE PARTY ELITES TEND TO IMPOSE
STRUCTURAL CONSTRAINTS ON THE DAY-TO-DAY OPERATION OF THE STRUCTURAL CONSTRAINTS ON THE DAY-TO-DAY OPERATION OF THE COPE HITH DERIVATIVE INTERNAL CONFLICTS.

$06027 \mathrm{MAOZ}, \mathrm{Z}$.; ASTORNO, A.

WAGING HAR, WAGING PEACE: DECISION MAKING AMD BARGAINING IN THE ARAB-ISRAELI CONFLICT, 1970-1973

INTERNATIONAL STUDIES QUARTERLY, 36(4) (DEC 92), 373-400. THIS STUDY APPLIES ASPECTS OF A THEORY OF INTERNATIONAL PROCESSES (TIP) IN ORDER TO SHED LIGHT ON THE DECISIONS AND BARGAINING PROCESSES THAT TOOK PLACE IN THE ARAB-ISRAEL I BARGAINING PROCESSES THAT TOOK PLACE IN THE ARAB-ISRAELI CONFLICT DURING THE 1970-1973 PERIOD. KEY INGREDIENTS OF TIP REYIEHED EMPIRICAL MEASURES ARE DEVELOPED TO TEST THESE REVIEHED. EMPIRICAL MEASURES ARE DEVELOPED TO TEST THESE
PROPOSTIONS. THE AUTHORS ANALYZE $44 \mathrm{KEY}$ DECISIONS MADE BY PROPOSTIONS. THE AUTHORS ANALYZE 44 KEY DECISIONS MADE BY
ISRAEL, EGYPT, JORDAN, SYRIA, THE PLO, AND THE UNITED STATES DURING THE PERIOD. THE IMPLICATIONS OF THE APPROACH AND THE FINDS ARE DISCUSSED.

06028 MAPEL, D.

DEMOCRATIC VOLUNTARISM AND THE PROBLEM OF JUSTIFYING
POLITICAL BONDS

POLITY, XXIII (2) (WIN 90), 233-254.

IS THERE A MORAL BASIS FOR POLITICAL OBLIGATION? RECENT DEMOCRATIC THEORISTS HAVE RAISED POWERFUL OBJECTIONS TO THE VERY IDEA OF A NONYOLUNTARY DUTY TO OBEY THE STATE. YET, THIS ARTICLE CONTENDS, A SATISFACTORY ACCOUNT OF OUR POLITICAL BONDS MUST INCLUDE THE IDEA OF VOLUNTARILY ACQUIRED OBLIGATIONS, AS WELL AS THE IDEA OF A RATIONALLY GROUNDED, NONVOLUNTARY MORAL DUTY TO COMPLY WITH JUST INSTITUTIONS. THESE DUTIES, THE AUTHOR ARGUES, ARE NEITHER AS UNPOLITICAL NOR AS DEMANDING AS RECENT DEMOCRATS SUGGEST, AS UNPOLITICAL NOR AS DEMANDING AS RECENT DEMOCRATS SUGGEST,
AND HE CONCLUDES THAT MANY OF THE FEARS THAT DEMOCRATS AND AND HE CONCLUDES THAT MANY OF THE FEARS THAT DEMOCRATS AND LIBERALS HAVE ABOUT A RATIONALLY JUSTIFIED DUTY TO
BE RELIEVED BY A FULLLER UNDERSTANDING OF DEMOCRATIC BE RELIEVED
VOLUNTARISH.

06029 MARAM, $S$

JUSCELINO KUBITSCHEK AND THE 1960 PRESIDENTIAL ELECTION JOURNAL OF LATIN AMERICAN STUDIES, 24(1) (FEB 92), 123-146. BRAZILIAN SPECIALISTS HAVE LONG RECOGNIZED THE IMPORTANCE OF THE 1960 PRESIDENTIAL ELECTIONS, WHICH SET IN MOTION A PROCESS THAT CULMINATED IN A 21-YEAR MILITARY DICTATORSHIP. SCHOLARLY LITERATURE IGNORES THE REASONS WHY BRAZIL'S LARGEST POLITICAL PARTY NOMINATED FOR PRESIDENT A WEAK CANDIDATE. THE AUTHOR SUGGESTS THAT HIS MOMINATION HAD MUCH TO DO WITH A COMPLEX SERIES OF MANOEUVRES CARRIED OUT BY BRAZIL'S PRESIDENT KUBITSCHEK. AN ANALYSIS OF KUBITSCHEK'S ACTIONS AND MOTIVATION IS OFFERED IN THIS ARTICLE WHICH IS AIDED BY ORAL HISTORY AS A SUPPLEMENTARY RESEARCH SOURCE.

06030 MARANDO, V.; REEVES, M.

COUNTIES AS LOCAL GOVERNMENTS: RESEARCH ISSUES AND QUESTIONS

JOURHAL OF URBAN AFFAIRS, 13(1) (1991) 45-54.

COUNTIES ARE ASSUMING MORE IMPORTANT RESPONSIBILITIES AS URBAN GOVERNMENTS AND THEY ARE INCREASINGLY BECOMING OBJECTS OF STUDY FOR URBAN RESEARCHES. THIS ARTICLE ARGUES THAT SOME OF STUDY FOR URBAN RESEARCHES. THIS ART ICLE ARGUES THAT
RECENT STUDIES HAVE NOT RECOGNIZED THAT COUNTRIES ARE RECENT STUDIES HAVE NOT RECOGNIZED THAT COUNTRIES ARE
DIFFERENT FROM CITIES AS RESEARCH UNITS. THEORIES AND DIFFERENT FROM CITIES AS RESEARCH UNITS. THEORIES AND
RESEARCH METHOOS APPLIED TO CITIES OFTEN NEED MODIFICATION RESEARCH METHODS APPLIED TO CITIES OFTEN NEED MODIFICATION
BEFORE THEY CAN BE TRANSFERRED TO THE STUDY OF COUNTIES.
THIS ARTICLE OFFERS SEVERAL OBSERVATIONS ON RESEARCHING THIS ARTICLE OFFERS SEVERAL OBSERVATIONS ON RESEARCHING COUNTIES, TAKING INTO ACCOUNT THEIR RELATIONSHIP
GOVERNMENT AND THEIR UNIQUE ROLES AS LOCALITIES.

06031 MARANDO, $Y$

GENERAL REVENUE SHARING: TERMINATION AND CITY RESPONSE STATE AND LOCAL GOVERNMENT REVIEN, 22(3) (FAL 90), 98-107. WHEN THE FEDERAL GENERAL REVENUE SHARING (GRS) PROGRAH WAS TERMINATED IN 1986, PROPENENTS AMD OPPONENTS OF GRS DEBATED THE IMPACT THIS TERMINATION HOULD HAVE ON CITIES. THIS STUDY COMPARES WHAT OFFICIALS OF 153 CITIES EXPECTED TO BE THE CONSEQUENCE OF GRS LOSS BEFORE THE TERMINATION OF THE PROGRAM WITH ACTIONS THE CITIES TOOK TO RAISE REVENUES AND REDUCE EXPENDITURES AFTER TERMINATION. THE FINDINGS INDICATE THAT THE PLANS CITIES MADE FOR COPING WITH FRS LOSS DID NOT CORRESPOND TO THEIR LATER ACTIONS. MOST CITIES PURSUED A MIXED STRATEGY OF RAISING REVENUES AND CUTTING EXPENDITURES.

06032 MARANTO, $R$

DOES FAMILIARITY BREED ACCEPTANCY? TRENDS IN CAREERNONCAREER RELATIONS IN THE REAGAN ADMINISTRATION

ADMINISTRATION AND SOCIETY, 23(2) (AUG 91) 247-266.

A NUMBER OF RESEARCHERS ASSERT THAT RELATIONS BETHEEN CAREERISTS AND POLITICAL APPOINTEES IN WASHINGTON TYPICALLY START BADLY BUT IMPROVE OVER THE COURSE OF AN ADMINISTRATION. THIS ARTICLE TESTED THAT PROPOSITION BY SURVEYING 1,045 HIGH-LEVEL CAREERISTS AND 242 POL ITICAL APPOINTEES SERVING
IN THE WASHINGTON, OC OFFICES OF 15 FEDERAL ORGANIZATIONS. IN DEFENSE ORGANIZATIONS, BOTH CAREER AND NONCAREER OFFICIALS FELT THAT RELATIDNS STARTED WELL AND CHANGED LITTLE OVER THE COURSE OF THE REAGAN ADMINISTRATION. IN DOMESTIC ORGANIZATIONS, BOTH APPOINTEES AND CAREERISTS FEL THAT CAREER - NONCAREER RELATIONS WERE PROBLEMATIC BUT IMPROVED SINCE THE FIRST YEARS OF THE ADMINISTRATION. APPARENTLY, HOWEVER, THESE FINDINGS REFLECT LEADERSHIP CHANGES IN A FEH ORGANIZATIONS RATHER THAN A BROADER CHANGES IM

06033 MARANTO, R.; TUCHMAN, P.S KMOHING' THE' RATIONAL PEASANT: THE CREATION OF RIVAL INCENTIVE STRUCTURES IN VIETNAM

JOURNAL OF PEACE RESEARCH, 29(3) (AUG 92), 249-264.

OURNAL OF PEACE RESEARCH, 29(3) (AUG 92), 249-264. PARTICIPATION IN ANTI-REGIME ACTIVITY BASED ON THE WORKS OF TULLOCK, MASON, AND OTHERS AND APPLIES IT TO VIETHAM IN 19451975. CONCERNS FOR PHYSICAL SECURITY AND EXPECTATIONS OF VICTORY BY ONE SIDE OR ANOTHER DOMINATED THE VIETNAMESE PEASANT'S OECISION CALCULUS TO THE RELATIVE EXCLUSION OF SUCH FACTORS AS IDEOLOGY AND PROVISION OF PUBLIC GOODS. THE CRITICAL FACTOR IN CREATING AN ATTRACTIVE INCENTIVE STRUCTURE IS SOUND INTELLIGENCE OBTAINED THROUGH LOCAL FORMS 
CONG EXCELLED IN THIS REGARD, BUT SUBSEQUENT GOVERMMENTAL ATTENTION TO LOCAL ORGANIZATION AND DEPLOYMENT OF FORCES NARROWED THE GAP CONSIDERABLY, AS DID THE TET OFFENSIVE
DECIMATION OF VIET CONG FORCES IN THE SOUTH. ANOTHER FACTOR DECIMATION OF VIET CONG FORCES IN THE SOUTH. ANOTHER REDUCED MATERIAL REHARDS FOR SUPPORTING THE ANTI-REGIME EFFORT. THE VILLAGE EMERGED AS THE KEY UNIT IN OVERCOMING THE FREE-RIDE PROBLEM IN REVOLUTIONARY PARTICIPATION. THE APPARENT SUCCESS WITHIN THE VILLAGE OF THE OPPOSITION OR REGIME AND BEHAVIOR OF LOCAL CADRES OR OFFICIALS SHAPED VILLAGERS' PERCEPTIONS OF THE CREDIBILITY AND CAPABILITY OF EACH SIDE TO THREATEN PHYSICAL SECURITY. VILLAGERS'

JUDGMENTS ON THE BALANCE OF TERROR AT ANY TIME IN TURN

CONDITIONED THEIR RESPONSE TO THE OTHER AVAILABLE INCENTIVES.

06034 MARANTO, R.; SKELLEY, B.D.

NEUTRALITY: AN EMDURING PRIMCIPLE OF THE FEDERAL SERVICE AMERICAN REVIEN OF PUBLIC ADMINISTRATION, $22(3)$ (SEP 92),

173-188.

ALTHOUGH MANY PROPONENTS OF CIVIL SERVICE REFORM QUESTION THE PRINCIPLES OF CLASSICAL AMERICAN PUBLIC ADMINISTRATION AND SPECIFICALLY REJECT ITS NEUTRAL MONETENCE MODEL OF FEDERAL SERVICE, THE PRINCIPLE OF NEUTRAL ITY CONTINUES TO BE AN IMPORTANT BELIEF AMONG FEDERAL CAREER EXECUTIVES. THIS CONCLUSION IS BASED ON AN ANALYSIS 242 POLITICAL APPOINTEES FROM 15 FEDERAL ORGANIZATIONS IN 242 P
1987.

06035 MARASINGHE, L

ETHNIC POLITICS AND CONSTITUTIONAL REFORM: PROVINCIAL COUNCILS OF SRI LANKA; ASSOCIATION FOR ASIAN STUDIES 1992 ANNUAL MEETING

ASSOCIATION FOR ASIAN STUDIES, 1992, 134.

THE UNDERLYING BASIS FOR THE ESTABLISHMENT OF PROVINCIAL COUNCILS IN SRI LANKA WAS TO PROVIDE FOR THE

DECENTRALIZATION OF POHER TO COMMUNITIES THAT MAY BE FOUND WITHIN EACH PROVINCIAL COUNCIL. THE ETHNICITY OF THESE COMMUNITIES BECAME IMPORTANT AND INDEED RELEVANT TO THE PROVINCIAL COUNCILS OF THE EASTERN AND NORTHERN PROVINCES OF THE ISLAND. THESE WERE TAMIL AND MUSLIM COMMUNITIES HHICH WERE PARTICULARLY AFFECTED BY MANY COMPLEX SOCIO-ECONOMIC PROBLEMS. THE SOLVING OF THESE PROBLEMS THROUGH DEVOLUTION OF POWER TO THE PROVINCIAL COUNCILS IN 1988 RAISED THO COMPLEX CONSTITUTIONAL ISSUES. FIRST, COULD THERE BE A DEVOLUTION OF PONER UNDER ARTICLES 76 AND 83 AS PRESENTLY ARTICULATED IN THE SRI LANKA CONSTITUTION, PARTICULARLY IN THE ABSENCE OF A REFERENDUM? SECOND, WHAT KIND OF POWER WOULD THE CONSTITUTION PERMIT WITH AND WITHOUT A REFERENDUM? THIS PAPER DEALS HITH THESE ISSUES FROM THE STAMDPOINT OF CONSTITUTIONAL THEORY. TAKING BOTH THE LAW AND POLITICAL REALITY INTO CONSIDERATION.

06036 MARCOUX, A. ECONOMICS AND ETHNICS IN THE PUBLIC POLICY OF THE FREE SOCIETY

FREEMAN, 42(12) (DEC 92), 481-482.

EFFICIENCY AND ETHICS EACH HAVE A MEANINGFUL ROLE IN THE MAKING OF PUBLIC POLICY. A PROPER UNDERSTANDING OF THE NATURE OF EFFICIENCY AND ETHICS AS EYALUATIONAL CRITERIA WHICH REVEALS THEM TO BE COMPLEMENTARY IS EXAMINED IN THIS ARTICLE, WHICH SUGGESTS THAT ALTHOUGH ONE SHOULD NOT FAVOR INEFFICIENT GOVERNMENT POLICIES, NEITHER SHOULD ONE FAVOR UNETHICAL POLICIES ON THE GROUNDS OF THEIR SUPPOSED EFFICIENCY. IT EXPLORES WHAT THE CORRECT COURSE IS HHEN CONSIDERING ISSUES OF PUBLIC POLICY.

06037 MARCUS, A.

THE OTHER KURDISH REVOLT

COMMONWEAL, CXIX(20) (NOV 92), 9-10.

SINCE 1984. THE TURKISH MIIITARY AND THE KURDISTAM WORKERS PARTY HAYE BEEN FIGHTING FOR CONTROL OF SOUTHEAST TURKEY, A MOUNTAINOUS REGION THAT IS HOME TO ABOUT HALF OF TURKEY'S 10-12 MILLION KURDS. MORE THAN 5,000 PEOPLE HAVE OIED IN THE FIGHTING, AND EVERY DAY BRINGS REPORTS OF A MEN SKIRMISH. AS THE FIGHTING SPREADS, SO DO REPORTS OF HUMAN RIGHTS ABUSES AGAINST THE LOCAL CIVILIAN POPULATION. ALTHOUGH KURDISH DEPUTIES HAVE BEEN ELECTED TO THE TURKISH LEGISLATURE THEY ARE BOOED AMD EVEM PHYSICALLY THREATENED WHEN THEY ATTEMPT TO SPEAK ABOUT CULTURAL RECOGNITION AND AUTONOMY.

06038 MARCUS, A.A.

CONTROYERSIAL ISSUES IN ENERGY POLICY

SAGE PUBLICATIONS, 1992 IN ENER

SAGE PUBLICATIONS, 1992 , 200. A KEY LONG-TERM CHALLENGE FACED BY THE UNITED STATES ANO
OTHER LEADING ECONOMIES INVOLVES BREAKING THE LINK BETHEEN ECONOMIC GROWTH AND OIL CONSUMPTION. THIS BOOK EXAMINES U.S ENERGY POLICY-MAKING AND REVEALS THE SHORTCOMINGS AND FAILURES--AS WELL AS THE SURPRISING SUCCESSESS--OF PAST ENERGY POLICY EFFORTS. THE AUTHOR REVIEWS EVENTS THAT TRANSPIRED IN THE PERSIAN GULF AFTER AUGUST 1990, AND THEN EXAMINES TRENDS IN ENERGY PRODUCTION/CONSUMPTION HORLDWIDE SINCE THE FIRST ENERGY SUPPLY CRISIS OF 1973.
06039 MARCUS, $J$.

FRANCE: PUNISHING THE SOCIALISTS

WORLD TODAY, 48(6) (JUN 92), 99-100.

FRANCE'S' 1992 REGIONAL AND LOCAL ELECTIONS PROVIDED AN OPPORTUNITY FOR VDTERS TO PUNISH THE RULING SOCIALIST GOVERMMENT. AT THE SAME TIME, THEY OFFERED LITTLE COMFORT TO THE MAINSTREAM CONSERVATIVE OPPOSITION PARTIES. OVERALL, THEY HERE A VOTE AGAINST ESTABLISHED PARTIES AND ESTABLISHMENT POL ITICIANS; THE EXTREME RIGHT-HING NATIONAL FRONT AND THE TWO ENVIRONMENTAL PARTIES WON NEARLY ONE-THIRD OF ALL VOTES.

06040 MARCUS, J.

ISRAEL'S GENERAL ELECTION: REALIGNMENT OR UPHEAVAL?

INTERNATIONAL AFFAIRS, 68(4) (OCT 92), 693-706.

A CLEAR WIN FOR THE LABOR PARTY IN' THIS YEAR'S GENERAL ELECTION IN ISRAEL HAS OPENED UP NOT ONLY OPPORTUNITIES FOR DECISIVE GOVERMMENT, BUT ALSO NEH HOPE FOR PEACE IN THE MIDDLE EAST. THE AUTHOR EXAMINES THE COMPLICATED ISRAEL I MIDOLE EAST. THE AUTHOR EXAMINES THE COMPL ICATED ISRAEL
POLITICAL SCENE BEFORE AND AFTER THE RECENT ELECTION POLITICAL SCENE BEFORE AND AFTER THE RECENT ELECTION
CAMPAIGN. HE DRAHS THE READERS ATTENTION TO A POSSIBLE NEW CAMPAIGN. HE DRAWS THE READERS ATTENTION TO A POSSIBLE NEW
PHASE IN ISRAELI POLITICS GENERATED BY INSTITUIONAL REFORM, PHASE IN ISRAEL I POL ITICS GENERATED BY INSTI ITUIONAL REFORM, THE INFLUX OF NEW VOTERS FROM THE FORMER SOVIET UNION AND ALLY, THE UNITED STATES, AFTER THE GULF WAR.

06041 MARCUS, M.L.

LEARNING TOGETHER: JUSTICE MARSHALL'S DESEGREGATION OPINIONS

FORDHAM LAW REVIEW, LXI(1) (OCT 92), 69-104.

THE AUTHOR EXAMINES THE INFLUENCE OF JUSTIICE THURGOOD MARSHALL ON THE SUPREME COURT'S CURRENT SCHOOL DESEGRATION AGENDA. JUSTICE MARSHALL WAS PART OF THE MAJORITY IN DESEGREGATION CASES DURING HIS EARLIER YEARS ON THE HIGH COURT; SUBSEQUENTLY, HOWEVER, HIS ROLE BECAME ONE OF DISSENTER. THE AUTHOR ANALYZES THE DIVISIVE ISSUES FACING THE COURT IN DESEGRATION LITIGATION, MARSHALL'S POSITIONS ON SUCH ISSUES, AND HIS LEGACY TO THE COURT IN THIS AREA. FINALLY, THE AUTHOR ASSESSES THE VITALITY OF MARSHALL'S HIS RETIREMENT.

06042 MARINI, $F$.

LITERATURE AND PUBLIC ADMINISTRATION ETHICS AMERICAN REVIEH OF PUBLIC ADMINISTRATION, 22 (2) (JUN 92), 111-126.

- INTEREST IN PROFESSIONAL ETHICS EDUCATION FOR PUBLIC ADMINISTRATORS HAS BEEN BOOMING FOR THE PAST THO DECADES. TEACHING PUBLIC ADMINISTRATION ETHICS ENTAILS A VARIETY OF APPROACHES. THIS PAPER ARGUES THAT LITERATURE IS AN EFFECTIVE MAIN SOURCE FOR EXPLORING PUBLIC ADMINISTRATION ETHICS FOR THE FOLLOWING REASONS: STUDENTS ARE RECEPTIVE TO LITERATURE AND LEARN FROM IT: THERE IS AN ELEMENT OF LITERATURE AND LEARN FROM IT': THERE IS AN ELEMENT OF STORYTELLING IN THE SCHOLARLY APPROACH TO ETHICS; LITERAT OFFERS AN EMPATHETIC DIMENSION; AND GOOD LITERATURE OF LASTING VALUE, INSTEAD OF MORE PROSAIC METHODS WITH SHORTLIVED VALUE, CONTRIBUTES TO LIFELONG EDUCATION AS WELL AS PROFESSIONAL TRAINING. THIS PAPER OFFERS EXAMPLES OF HOW
SCHOLARS CAN USE CERTAIN WORKS OF LITERATURE TO TEACH PUBLIC SCHOLARS CAN USE CERTAIN HORKS OF LITERATURE TO TEACH PUB
ADHINISTRATION ETHICS AND HOW THIS LITERATURE RELATES TO CENTRAL OUESTIONS OF PUBLIC ADMINISTRATION ETHICS. THIS APPROACH CAN BE USEFUL TO PRACTITIONERS IN THEIR EXPLORATION OF PROFESSIONAL ETHICS AS WELL AS TO PUBLIC ADMINISTRATION TEACHERS AND STUDENTS.

06043 MARINI, $F$.

THE USÉS OF LITERATURE IN THE EXPLORATION OF PUBLIC ADMINISTRATION ETHICS: THE EXAMPLE OF ANTIGONE PUBLIC ADMINISTRATION REVIEW, 52(5) (SEP 92), 420-426. SOPHOCLES' "ANTIGONE" IS A FRUITFUL SOURCE OF OPPORTUNITIES TO REFLECT UPON THE ETHICAL CHALLENGES FACING MODERN PUBLIC ADMINISTRATORS. THE PLAY IS OFTEN USED IN SCHOOLS TO GENERATE DISCUSSION ABOUT CIVIL DISOBEDIENCE AND THE IMPLICATIONS OF CHALLENGES TO AUTHORITY. EACH CHARACTER FACES ETHICAL ISSUES. FOR EXAMPLE, KING CREON IS CHALLENGED TO MEET HIS OBLIGATION TO UPHOLD AND ENFORCE THE LAH DESPITE FAMILY TIES AND PERSONAL CONSIDERATIONS. THUS, "ANTIGONE" AND SIMILAR WORKS ARE USEFUL FOR ILLUSTRATING DISCUSSIONS ABOUT PUBLIC ETHICS.

06044 MARINI, J.

POLITICS, RHETORIC, AND LEGITIMACY: THE ROLE OF POLITICS, RHETORIC, AND LEGITIMACY:

POLITICAL COMMUNICATION, $9(1)(1992), 1-13$

THE WATERGATE SCANDAL HAS GENERATED CONSIDERABLE POLITICAL RHETORIC AND COUNTLESS HORKS ON THE LEGAL AND CONSTITUTIDNAL PROBLEMS POSED BY AN IMPERIAL PRESIDENCY. IT HAS HAD A CONTINUING INFLUENCE ON POLITICS SURROUNDING THE INSTITUTIONAL TENSION BETHEEN CONGRESS AND THE PRESIDENT. IT ILLUMINATED THE COLLISION COURSE UPON WHICH CONGRESS AND THE PRESIDENT HAD EMBARKED IN THE AFTERMATH OF THE VIETNAM HAR DURING THE WATERGATE CRISIS, ONE NEGLECTED ASPECT OF THE 
INSTITUTIONAL TENSION BETHEEN THE PRESIDENT AND CONGRESS WAS THE DISPUTE BETWEEN THE BRANCHES OVER THE CONTROL OF THE BUREAUCRACY. THE EXECUTIVE BUREAUCRACY HELD THE KEY TO THE BALANCE OF POWER BETHEEN THE POLITICAL BRANCHES. THE NIXON STRATEGY OF THE ADMINISTRATIVE PRESIDENCY STRETCHED THE LIMITS OF THE USE OF PRESIDENTIAL POWER AND PRECIPITATED A CONSTITUTIONAL CRISIS.

06045 MARKOVITS, A.; REICH, S.

THE LATEST STAGE OF THE GERMAN QUESTION: PAX GERMANICA IN THE NEW EUROPE

ARMS CONTROL, 12(3) (DEC 91), 60-76

THE COLLAPSE OF THE POSTWAR SECURITY ORDER CREATED A SECURITY VACUUM IN EUROPE. GERMANY, THE KEY CONTINENTAL EUROPEAN PARTNER OF THE UNITED STATES IN NATO, NOW FACES A CHOICE IN THE PROCUREMENT OF ITS SECURITY. THE CHANGES THAT HAVE TAKEN PLACE IN THE EUROPEAM STATE SYTEM RAISE A NUMBER HAVE TAKEN PLACE IN THE EUROPEAN STATE SYTEM RAISE A NUMBER
OF IMPORTANT QUESTIONS ABOUT GERMAN SECURITY SECURITY POLICY IN THE POST-POSTWAR HORLD: HOW DOES GERMANY DEFINE ITS SECURITY INTERESTS IN THIS WORLD? WHAT ARE THE ELEMENTS OF CONTINUITY AND CHANGE IN GERMAN SECURITY POLICY? WHAT INSTITUTIONS AND INSTITUTIONAL CONFIGURATION DO THE GERMANS FAVOR FOR THE CONSTRUCTION OF A EUROPEAN SECURITY ORDER? WHAT ARE THE IMPLICATIONS OF THE CHANGED INTERNATIONAL ENVIRONMENT FOR THE FUTURE OF THE GERMAN-AMERICAN RELATIONSHIPS? THE GERMAN RESPONSE TO THESE QUESTIONS FRAMES THE SECURITY DEBATE IN EUROPE AND BEAR DIRECTLY UPON THE
PROSPECTS FOR THE STABILTIY OF THE FUTURE EUROPEAN ORDER.

06046 MARKOVITS, A.S.; OTTO, A.

GERMAN LABOR AND EUROPE ' 92

COMPARATIVE POLITICS, 24(2) (JAN 92), 163-180.

TWO KEY VARIABLES AFFECT THE ATTITUDE OF GERMAN TRADE UNIONS TOWARD EUROPE 1992: UMION IDEOLOGY AND PERCEIVED ECONOMIC INTEREST. BASED ON A COMPARATIVE ANALYSIS OF FOUR KEY UNIONS--THO LEADING ACTIVIST UNIONS FUNDAMENTALLY CRITICAL OF GERMANY'S POLITICAL ECONOMY AND TWO LEADING ACCOMHODATIONIST UNIONS EMPHASIZING THE COMMON INTERESTS AND SOCIAL PARTNERSHIP BETHEEN LABOR AND CAPITAL--THE AUTHORS ARGUE THAT IDEOLOGY IS PRESENTLY A MORE POTENT FORCE THAN ECONOMIC INTEREST IN THE UNIONS' VIEW OF THE EUROPEAN INTERNAL MARKET. THE ACTIVIST UNIONS, REGARDLESS OF THE INTERNAL MARKET'S PROSPECTIVE MATERIAL IMPACT ON THEIR MEMBERSHIP, ARE FAR MORE CRITICAL OF 1992 THAN THEIR
ACCOMMODATIONIST COUNTERPARTS. THE AUTHORS DO NOT DISCOUNT ACCOMMODATIONIST COUNTERPARTS. THE AUTHORS DO NOT DISCOUN THE IMPORTANCE OF ECONOMIC INTEREST IN INFLUENCING UN
BEHAVIOR BUT SIMPLY SUGGEST THAT UNDER CONDITIONS OF BEHAVIOR BUT SIMPLY SUGGEST THAT UNDER CONDITIONS OF
UNCERTAINTY AND ANTICIPATION UNIONS FALL BACK ON LEARNED UNCERTAINTY AND ANTICIPATION UNIONS FALL BACK ON LEARNED
BEHAVIOR AND TRUSTED TERRAIN IN FORMULATING THEIR VIENS. BEHAVIOR AND TRUSTED TERRAIN IN FORMULATING THEIR VIEWS. HOWEVER, THE CLOSER THE INTERNAL MARKET COMES TO ACTUAL LIKELY TO BE DEFINED BY ECONOMIC INTEREST.

06047 MARKOWITZ, $N$.

A VIEH OF SOCIALIS

POLITICAL AFFAIRS, 71(12) (DEC 92), 23-31.

COUNTER-REVOLUTIONS HAVE TAKEN PLACE IN MANY OF THE FORMER SOCIALIST COUNTRIES, AND THE MULTIFACETED IDEOLOGY INDUSTRY OF WORLD CAPITALISM IS PROCLAIMING A "POSTCOMMUNIST" ERA. THIS ARTICLE SUGGESTS THAT AT THE SAME TIME MARXIST-LENNISTS ARE REGROUPING. IT DISCUSSES THE "GREAT BETRAYAL" OF GORBACHEV, LEININ'S CONCEPT OF NEP, SOCIALISM, AND POST-WAR RECONSTRUCTION. IT SUGGESTS THAT WHAT SHOULD BE STRIVEN FOR TODAY IS A NEW ACTIVE PROLETARIAN

INTERNATIONALISM BASED ON CONSTRUCTIVE CRITICISM AND

SOLIDARITY WITH THE GROWING MUMBERS OF PEOPLE IN EASTERN

EUROPE AND THE SOVIET UNION OPPOSED TO THE CAPITALIST PATH OF DEVELOPMENT WHICH THE COUNTER-REVOLUTIONARY GOVERMMENTS PUSH.

06048 MARKS, G. (ED.) ; DIAMOND, L. (ED.)

REEXAMINING DEMOCRACY

SAGE PUBLICATIONS, $1992,352$.

NO LIVING POLITICAL SCIENTIST OR SOCIOLOGIST IS MORE FREOUENTLY CITED BY OTHER SCHOLARS THAY SEYMOUR MARTIM LIPSET. THIS COLLECTION OF ESSAYS PAYS TRIBUTE TO LIPSET'S SCHOLARSHIP BY EXPLORING HIS CORE THEME: THE CONDITIONS, PROBLEMS, DYNAMICS, VALUES, AND INSTITUTIONS OF DEMOCRACY, BOTH IN THE UNITED STATES AND COMPARATIVELY THROUGHOUT THE WORLD.

06049 MARKS, G.N.; BEAN, C.S

SOURCES OF ELECTORAL SUPPORT FOR MINOR PARTIES: THE CASE OF THE AUSTRALIAN DEMOCRATS

ELECTORAL STUDIES, 11(4) (DEC 92), 311-333.

ELECTORAL SUPPORT FOR A POL ITICAL PARTY COMES

PREDOMINANTLY FROM FOUR SOURCES (SOCIAL-STRUCTURAL, PARTISAN,

IDEOL JGICAL, OR CONTEMPORARY POL I IICAL FACTORS) AND THE BASIS OF A PARTY'S SUPPORT IS CRITICAL FOR ITS LONG-TERM SURVIVAL. THE DEMOCRATS, AUSTRALIA'S PRINCIPAL MINOR PARTY SINCE 1977, HAVE ONLY A WEAK SOCIAL-STRUCTURAL BASE AND IT HAS BEEN DECLINING. THE MOST CONSISTENT SOCIOLOGICAL FACTOR ASSOCIATED WITH THE DEMOCRAT VOTE IS TERTIARY EDUCATION,
DEMOCRAT VOTE DOES NOT HAVE A STRONG IDEOLOGICAL BASE,
ALTHOUGH POSTMATERIALISM AND ENVIRONMENTALISM ARE ASSOCIATED WITH DEMOCRAT SUPPORT TO SOME EXTENT. MUCH OF THE SUPPORT FOR THE DEMOCRATS COMES FROM PARTISANSHIP AND CONTEMPORARY POLITICAL FACTORS. THE DEMOCRATS' PARTISAN BASE DECLINED BETWEEN 1979 AND 1987 BUT HAS SINCE ENJOYED A RESURGENCE. OF THE CONTEMPORARY POL ITICAL FACTORS, EVALUATIONS OF THE PARTY
LEADERS HAVE A STRONG INFLUENCE ON THE DEMOCRAT VOTE AND SO, TO A LESSER EXTENT, DO ECONOMIC EVALUATIONS.

06050 MARKS, T.

MARK ING REVOLUTION: SENDERO LIMINOSO IN PERU

SMALL WARS \& INSURGENCIES, 3(1) (SPR 92), 22-46.

SMALL WARS \& INSURGENCIES, 3(1) (SPR 92), 22-46.
RECENT REPORTS FROM PERU MAKE CLEAR THAT THE INSURGENCY THERE CONTINUES TO RAGE. THOUGH SEVERAL RIVAL INSURGENT THERE CONTINUES TO RAGE. THOUGH SEVERAL RIVAL INSURGENT
MOVEMENTS ARE AT HAND, IT IS ONE IN PARTICULAR, SENDERO MOVEMENTS ARE AT HAND, IT IS ONE IN PART ICULAR, SENDERO
LUMINOSO, UPON WHICH ATTENTION HAS FOCUSED. BRUTAL AND LUMINOSO, UPON WHICH ATTENTION HAS FOCUSED. BRUTAL AND SECRETIVE, IT HAS IMPRESSED ALL WITH ITS RELATIVE
EFFECTIVENESS AS IT PURSUES THE SELF-PROFESSED GOAL OF MAKING A TRUE MAOIST REVOLUTION. IRONICALY, WHILE DECADES OLD, SENDERO REMAINS A MYSTERY IN ALL BUT ITS GENERAL OUTLINES. THIS ARTICLE EXPLORES WHAT IS KNOWN ABOUT SENDERO
LUMINOSO.

06051 MARKUSEN, A.; YUDKEN, J.

BUILDING A NEH ECONOHIC ORDER

TECHNOLOGY REVIEN, 95(3) (APR 92), 22-29.

THE UNITED STATES NEEDS A VISIONARY TECHNOLOGY POLICY THAT DEEMPHASIZES DEFENSE AND FOCUSES ON THE ENVIRONMENT, PUBLIC HEALTH, AND COMHUNITY STABILITY. FOR 50 YEARS THE NATION PURSUED A MILITARY-ORIENTED INDUSTRIAL POLICY THAT PAID OFF HANDSOMELY IN NEH TECHMOLOGIES AND COMPETITIVE ADVANTAGES FOR SOME INDUSTRIES. THIS ARTICLE EXPLORES WAYS IN WHICH THE U.S. CAN REDIRECT ITS R\&D--AND ECONOMIC DEVELOPMENT--AWAY FROM DEFENSE AND TOWARD SUCH NURTURING AREAS AS HEALTH AND STABILITY.

06052 MARKUSEN, A.

DISMANTLING THE COLD WAR ECONOMY

WORLD POLICY JOURNAL, IX(3) (SUM 92), 389-400.

AFTER NEARLY FOUR DECADES OF THE COLD HAR IT IS APPARENT

THAT THE STRUCTURAL DAMAGE TO MAJOR PORTIONS OF THE WORLD

ECONOMY RESULTING FROM THE CONFLICT IS FAR MORE SERIOUS THAM

ECONOMY RESULTING FROM THE CONFLICT IS FAR MORE SERIOUS THAN

ANYONE HAS PREVIOUSLY ACKNOWLEDGED. THE NEED TO CONY
GLOBAL COLD WAR ECONOMY, AND THE POTENTIAL GAINS OF

GLOBAL COLD HAR ECONOMY, AND THE POTENTIAL GAINS OF

CONVERSION, ARE THEREFORE ENORMOUS. ALTHOUGH THE NEED TO
CONVERT THE COLD HAR ECONOMY IS AN URGENT ONE, THE CHALLENGE CONVERT THE COLD WAR ECONONY IS AN URGENT ONE, THE CHALL THUS FAR HAS BEEN MET LARGELY BY HEAK AND INEFFECTUAL
MEASURES. THIS ARTICLE EXAMINES THE REASONS FOR THIS POSTCOLD WAR PARALYSIS AND OFFERS GLOOHY FORECASTS OF WHAT THE FUTURE WILL BE LIKE IF CONVERSION IS NOT UNDERTAKEN SOON. IT CONCLUDES THAT IF COUNTRIES LIKE THE UNITED STATES DO NOT SET UP A PLANNING APPARATUS TO OVERSEE CONVERSION, DEFENSE CUTS WILL EITHER DEEPEN THE HORLDWIDE RECESSION OR THEY WILL NOT BE ACHIEVABLE AT ALL. THE LATTER CASE IS THE WORST OF BE SOUANDERED ON UNNECESSARY WEAPONRY SIMPLY TO KEEP PEOPLE EMPLOYED. THEREFORE, THE PEACE EFFORT REQUIRES AS MUCH IF NOT MORE GUIDANCE AND VISION AS PAST WAR EFFORTS DID.

06053 MARLOW, M.

PRIVATIZATION AND GOVERMMENT SIZE

PUBLIC CHOICE, 68(1-3) (JAN 91), 273-276.

A PARTIAL LIST OF THE PROPOSED CONSTRAINTS ON GOVERMMENT SIZE INCLUDES BALANCED BUDGET RULES, TAX REDUCTION, FISCAL DECENTRALIZATION AND PRIVATIZATION. PRIVATIZATION TRANSFERS PROGRAMS FROM THE PUBLIC SECTOR TO THE PRIVATE SECTOR AND HAS RECEIVED GREAT ENTHUSIASM FROM MANY CRITICS OF GROWING GOVERMMENT. THIS PAPER EXAMINES THE ABILITY OF PRIVATIZATION EFFORTS TO CONTROL GOVERNMENT SIZE. A BUDGET CONSTRAIN VIEN OF GOVERNMENT SHOWS THAT PRIVATIZATION NEED NOT ALTER OF GOVERMMENT SHOWS THAT PRIVATIZATION NEED NOT ALTER
SPENDING WHEN IT IS IMPLEMENTED WITHOUT A RULE FORBIDOING REUSE OF THE FUNDING BACKING NEHLY PRIVATIZED PROGRAMS. ONLY WHEN THESE FUNDS ARE ELIMINATED FROM THE BUDGET PROCESS CAN THESE FINDS NOT BACK NEW PROGRAMS OR EXPAND EXISTING PROGRAMS.

06054 MARMOR, T.R.; BOYUM, D.

AMERICAN MEDICAL CARE REFORM: ARE WE DOOMED TO FAIL? DAEDALUS, 121(4) (FAL 92), 175-194.

THE AUTHORS DISCUSS SOME OF THE CENTRAL ISSUES IN U.S. HEALTH CARE POLICY, INCLUDING THE QUESTION OF RATIONING, THE PROBLEM OF WASTE, THE IMPORTANCE OF PREVENTION, THE EFFICIENCY OF COMPETITION VERSUS REGULATION, AND WHETHER MEALTH CARE IS A RIGHT. THEY ALSO EXAMINE THE IMPACT OF POLITICS, INSTITUTIONS, AND IDEOLOGY ON THE HEALTH CARE

06055 MARONEY, H.

"WHO HAS THE BABY?" NATIONALISM, PRONATALISM AND THE CONSTRUCTION OF "DEMOGRAPHIC CRISIS" IN QUEBEC: 1960-1988 STUDIES IN POLITICAL ECONOWY: A SOCIALIST REVIEW, 39(39) (FAL 92 ), 7-36.

IN THE AFTERMATH OF THE FAILED 1980 SOVEREIGNTYASSOCIATION REFERENDUM, DEMOGRAPHIC POLITICS HAVE COME TO 
THE FORE IN QUEBEC. THE AIM OF THIS PAPER IS TO ANALYZE A FIRST DEVELOPMENTAL STATE OF WHAT THE AUTHORS CALL DEMOGRAPHIC PRONATALISM (1980-1988), FOCUSING PARTICULARLY ON ITS DISCURSIVE MOMENT. THIS ANALYSIS TAKES INTO ACCOUNT THE RELATION OF THE DEMOGRAPHIC DISCUSSION TO QUEBEC'S UNRESOL VED NATIONAL QUESTION ON THE ONE HAND, AND TO GENDER, CLASS AND EHTNIC/RACE INEQUITIES ON THE OTHER; ACTUAL POPULATION PATTERNS; AND THE POSITIONING OF FEMINIST, NATIONALIST AND POLITICAL ACTORS ON THE DISCURSIVE FIELD CONSTITUTED BY THE DEMOGRAPHIC DEBATE.

06056 MARR, P.

THE ISLAMIC REVIVAL: SECURITY ISSUES

MEDITERRANEAN QUARTERLY: A JOURNAL OF GLOBAL ISSUES, $3(4)$

(FAL 92 ), 37-50.

RECENT EVENTS SUGGEST THAT THE ISLAMIC REVIVAL IS NOT ONLY HERE TO STAY BUT IS LIKELY TO BE A LEADING DOMESTIC POLITICAL FORCE SHAPING THE MEDITERRANEAN REGION DURING THE COMING DECADES. THIS ARTICLE EXPLORES THE IMPACT OF RECENT
DEVELOPMENT IN THE ISLAMIC REVIVAL IS LIKELY TO HAVE ON DEVELOPMENT IN THE ISLAMIC REVIVAL IS LIKELY TO HAVE ON
REGIONAL STABILITY AND HOW IT MIGHT AFFECT U.S. AND WESTERN REGIONAL STABILITY AND HOW IT MIGHT AFFECT U.S. AND WESTERN
SECURITY INTERESTS. IT SUGGESTS ASPECTS OF THE REVIVAL WHICH SECURITY INTERESTS. IT SUGGESTS ASPECTS OF THE REVIVAL WHICH
SHOULD BE THE FOCUS OF ATTENTION FOR STRATEGIC PLANNERS AND SHOULD BE THE FOCUS OF ATTENTION FOR STRATEGIC PLANNERS AND POLICYMAKERS. IT CONCLUDES THAT POLICYMAKERS NEED TO DEVELOP
A BETTER UNDERSTANDING OF THE DIFFERENTIATED AIMS AND GOALS A BETTER UNDERSTANDING OF THE DIFFERENTIATED AIMS
OF VARIOUS ISLAMIC MOVEMENTS AS THEY DEVISE MORE OF VARIOUS ISLAMIC MOVEMENTS AS THEY DEVIS
SOPHISTICATED WAYS OF DEALING HITH THEM.

06057 MARRESE, $M$.

SIZES FOREIGN PARTMERS

RFE/RL RESEARCH REPORT, 1(17) (APR 92), 25-33.

THE HUNGARIAN PRIVATE SECTOR HAS GROWN RAPIDLY SINCE 1988, WHEN LEGISLATION WAS PASSED ALLOWING STATE ENTERPRISES TO ISSUE STOCX. BY THE END OF 1991, APPROXIMATELY 5,600 JOINT VENTURES HITH FOREIGN FIRMS HAD BEEN ESTABLISHED AND THE NUMBER OF PARTLY OR WHOLLY PRIVATELY-OWNED CORPORATIONS EXCEEDED 45,000. ON THE OTHER HAND, PROGRESS ON THE "LARGE" AMD "SMALL" PRIVATIZATION PROGRAMS haS DISAPPOINTING, OWING TO BUREAUCRATIC DELAYS; AND THE COOPERATIVE SECTOR REMAINED LARGELY UNTOUCHED BY PRIVATIZATION. THE STATE PROPERTY AGENCY HAS PROMISED TO DECENTRALIZE THE PRIVATIZATION PROCESS IN 1992.

06058 MARSH, D.; RHODES, R.

IMPLEMENTING THATCHERISM: POLICY CHANGE IN THE 1980S PARLIAMENTARY AFFAIRS, 45(i) (JAN 92), 33-51

THIS ARTICLE HAS THO AIMS. FIRST IT EXAMIMES THE INFLUENCE OF THE THATCHER GOVERMMENT ON POLICY MAKING AND POLICY OUTCOMES IN FOUR AREAS WHICH ARE SAID TO DEMONSTARTE THAT THERE HAS A CLEAR THATCHER EFFECT: HOUSING, INDUSTRIAL RELATIONS, PRIVATIZATION, AND LOCAL GOVERNMENT. THE SECOND RELATIONS, PRIVATIZATION, AND LOCAL GOVERNMENT. THE SECOND SOME POLICY AREAS THAN IN OTHERS AND MORE GENERALLY, WHY SOME POLICY AREAS THAN IN OTHERS AND, MORE GENERALLY, HHY THE THATCHER EFFECT WAS LIMITED. IT ARGUES THAT THE MAJO RADICAL POL ICY CHANGE HAS THAT THEY OPERATED WITH A TOP-DOWM RADICAL POLICY CHANGE HAS
MODEL OF POLICY MAKIMG.

06059 MARSH, D.

MONEY CHANGES EVERYTHING

WORLD PRESS REVIEW, 39(11) (NOV 92), 22-23.

THE POLITICIANS WHO LAUNCHED EUROPE TONARD POLITICAL AND MONETARY UNION IN DECEMBER 1991 KNEW THAT THEY WERE TREADING A NARROW CAUSEHAY. HOWEVER, THEY COULD NOT HAVE FORESEEN HOH QUICKLY THE WAVES OF CONFUSION AND HUBRIS WOULD BE LAPPING AROUND THEIR ANKLES. THE ROAD FROM MAASTRICHT HAS BEEN PAVED WITH MISCALCULATIONS. FROM THE BEGINNING, UNCERTAINTY WAS INHERENT IN THE TREATY, REFLECTING THE PATCHWORK OF NEBULOUSLY-HORDED COMPROMISES INTENDED TO SATISFY THE DEMANDS OF THE 12 SIGNATORIES.

06060 MARSH, J.O. JR.

PERSONHEL: ACTIVE ANO RESERVE FORCES

ANHALS OF THE AMERICAN ACADEMY OF POLITICAL AND SOCIAL SCIENCE, (517) (SEP 91), 94-105.

THE ALL-VOLUNTEER FORCE, CREATED AFTER THE VIETNAM WAR, REPRESENTED AN EFFORT TO FIND AN ALTERNATIVE TO THE DRAFT, WHICH MANY PEOPLE CONSIDERED UNFAIR. THE CURRENT SYSTEM HAS BEEN LARGELY SUCCESSFUL IN ATTRACTING, TRAINING, AND WEAPONRY OF THE MODERN MILITARY. THE ALL-VOLUNTEER FORCE HAS WEAPONRY OF THE MODERN MILITARY. THE ALL-VOLUNTEER FORCE HAS
BEEN STRUCTURED TO PROVIDE INCENTIVES TO ATTRACT AND RETAIN BEEN STRUCTURED TO PROVIDE INCENTIVES TO ATTRACT AND RET
MIDOLE- AND SENIOR-LEVEL NONCOMMISSIONED PERSONNEL WITH MIDOLE- AND SENIOR-LEVEL NONCOMMISSIONED PERSONNEL WITH
IMPORTANT EXPERIENCE AND KEY JOB SKILLS. AS THE FORCE IS IMPORTANT EXPERIENCE AND KEY JOB SKILLS. AS THE FORCE IS PROPER MIX BETWEEN ACTIVE AND RESERVE COMPONENTS, INCLUDING THE MATIONAL GUARD AND ACTIVE RESERVES, AS HEL AS COMBAT THE NATIONAL GUARD AND ACTIVE RESERVES, AS HELL AS COMBAT
AND SUPPORT UNITS. THERE HILL BE RENEHED DISCUSSION OF NATIONAL SERVICE, THE SIZE OF FORCE STRUCTURE, AND INVOLUNTARY SEPARATION. DECISIONS TO MERGE OR ABOLISH UNDERSTRENGTH UNITS WILL CREATE A DILEMMA FOR CONGRESSIONAL BUDGET-CUTTERS AND MEMBERS OF CONGRESS TRADITIONALLY PROTECTIVE OF RESERVE COMPONENTS FROM THEIR RESPECTIVE DISTRICTS.
06061 MARSH, M. IRELAND

EUROPEAN JOURNAL OF POLITICAL RESEARCH, 22 (4) (DEC 92 ), 437-442.

IRELAND'S PARLIAMENT HAS NEARLY 47 PERCENT FIANNA FAIL MEMBERS, HHILE PRIME MINISTER CHARLES HAUGHEY'S CABINET IS OVERWHELMINGLY DOMINATED BY THE FIANNA FAIL.

06062 MARSHALL, $P$.

SO NEARLY BUT NOT QUITE (YET?)--THE FRUSTRATIONS OF THE URUGUAY ROUND

ROUND TABLE, 324(324) (OCT 92), 451-456.

THE REASONS WHY THE URGUAY ROUND HAS YET TO BE CONCLUDED ARE EXPLORED. THE CONVENTIONAL ANSWER IS THAT NEGOTIATIONS ARE STALLED ON A DISAGREEMENT BETWEEN THE UNITED STATES AND THE EUROPEAN COMMUNITY OVER THE LIBERALIZATION OF AGRICULTURAL TRADE. THE HOPE IS THAT AN AGREEMENT CAN BE REACHED BEFORE THE END OF 1992. IN A STUDY OF HAT HAS GONE WRONG, THIS ESSAY IS OIVIDED INTO THREE PARTS--THEORY, PRACTICE, AND DISTRACTION.

06063 MARSHALL, $P$

THO TYPES OF RIGHTS

CANADIAN JOURNAL OF POLITICAL SCIENCE, XXV(4) (DEC 92 ), 661-676.

THE EXPRESSION "HUMAN RIGHTS" IS OFTEN USED TO DENOTE THO DISTINCT ITEMS: ONE IS A GUARANTEE GIVEN IN POSITIVE LAH; THE OTHER IS A MORAL CLAIM PURPORTEDLY INMATE TO HUMAN BEINGS. THESE TWD ITEMS COMMONLY ARE CONFLATED, IMPLYING THAT THEY HAVE A NECESSARY CONNECTION. HISTORICALLY, THEY DO
NOT; POSITIVE HUMAN RIGHTS HAVE BEEN DEFENDED BY THOSE WITH NO CONCEPT OF INNATE RIGHTS, WHILE BELIEVERS IN EXTENSIVE INMATE RIGHTS HAVE ARGUED FOR LIMITED POSITIVE RIGHTS. THE DEFENSE OF POSITIVE RIGHTS OF THE TYPE NOW FOUND IN

INTERMATIONAL TREATIES WOULD BE SERVED BY DISTINGUISHING IT FROM JUSTIFICATIONS OF THE CONTENTION THAT HUMAN BEINGS HAVE RIGHTS.

06064 MARSHALL, $R$

ISRAEL IN LEBANON: TURNING NEIGHBORS INTO EMEMIES HASHINGTON REPORT ON MIDOLE EAST AFFAIRS, XI(3) (AUG 92), 21-22.

DURING ISRAEL'S 1992 ELECTION CAMPAIGN BOTH YITZHAK

RABIN AND YITZHAK SHAMIR SUGGESTED THAT THE UNITED STATES AND ISRAEL HAVE A COMMON INTEREST IN FIGHTING THE THREAT OF ISLAMIC FUNDAMENTALISM. PORTRAYING MUSLIMS AS FAMATIC ISLAAIC FUNDAMENTALISM. PORTRAYING MUSLIMS AS FANATIC
OPPONENTS OF WESTERN VALUES SERVES A DOUBLE PURPOSE FOR THE OPPONENTS OF WESTERN VALUES SERVES A DOUBLE PURPOSE FOR THE
ISRAELI GOVERNMENT. IT PROVIDES A RATIONALE FOR THE CLAIM ISRAELI GOVERNMENT. IT PROVIDES A RATIONALE FOR THE CLAIM THAT ISRAEL IS A STRATEGIC ALLY OF THE USA AND, THEREF
DESERVES LARGE AMOUNTS OF AID. IN ADDITION, IT' IS A DESERVES LARGE AMOUNTS OF AID. IN ADDITION, IT IS A CONVENIENT JUSTIFIC

06065 MARSHALL, S.E.

WHO SPEAKS FOR AMERICAN WOMEN? THE FUTURE OF ANTI-FEMINISM ANNALS OF THE AMERICAN ACADEMY OF POLITICAL AND SOCIAL SCIENCE, (514) (MAR 91), 50-62.

THIS PAPER EXPLORES THE ANTI-FEMINIST MOVEMENT IN THE POST-E.R.A. PERIOD. IT PRESENTS A HISTORICAL OVERVIEW OF AMERICAN ANTI-FEMINIST MOVEMENTS, EXAMINES THEIR BASES OF SUPPORT AMONG BOTH SYMPATHIZERS AND ACTIVISTS, AND DETAILS THE ORGANIZATION AND ACTIVITIES OF THE THO LARGEST ANTIFEMINIST GROUPS, THE EAGLE FORUM AND CONCERNED HOMEN FOR AMERICA. CONCLUDING COMMENTS SPECULATE ON THE FUTURE OF THE INTERNAL AND EXTERNAL BARRIERS TO ITS CONTINUED SUCCESS.

06066 MARSOT, A.

POLITICAL ISLAM IN ASIA: A CASE STUDY

ANMALS OF THE AMERICAN ACADEMY OF POLITICAL AND SOCIAL

SCIENCE, (524) (NOV 92), 156-169.

THE PHENOMENON OF ISLAMIC RESURGENCE, OR FUNDAMENTALISH, IS OFTEN VIEWED AS A MIDDLE EASTERM ISSUE EVEN THOUGH MAJOR MUSLIM NATIONS ARE FOUND IN ASIA, HHERE MOST OF THE MORLD'S MUSLIMS LIVE. THE INTENSITY AND CHARACTER OF THIS PHENOMENON DEPENDS ON SEVERAL FACTORS, SUCH AS GEOGRAPHY, HISTORICAL BACKGROUND, AND THE RELATIVE SIZE OF THE MUSLIM COMMUNITIES. WHILE IT IS BOTH A RELIGIOUS AND A POLITICAL PHENOMENON, THE ISLE IT IS BOTH A RELIGIOUS AND A POLITICAL PHENONENON,

THE GLOBAL ISSUES OF MODERNIZATION AND DEVELOPMENT.

06067 MARTEL, J.

BANKRUPTCY LAN AND THE CANADIAN EXPERIENCE: AN ECONOMIC APPRAISAL

CANADIAN PUBLIC POLICY--ANALYSE DE POLITIQUES, XVII(1) (MAR 91), 52-63.

THE PAPER OFFERS AN OVERVIEH OF THE CANADIAN BANKRUPTCY SYSTEM AND LOOKS AT THE DIFFERENT ROLES A BANKRUPTCY LAH SHOULD PLAY--THAT IS AVOIDING A COMMON PROPERTY PROBLEM RESPECTING PRE-BANKRUPTCY ENTI TLEMENTS, AND INCREASING THE FLOW OF INFORMATION BETWEEN ALL PARTIES IN ORDER TO ELEMINATE INEFFICEINT FIRMS. STATISTICAL EVIDENCE ON THE USE OF LIQUIDATION AND REORGANIZAITON PROCEDURES AND ON THE 
CHARACTERISTICS OF FIRMS USING EACH PROCEDURE ARE SUPPLIED. FINALLY, THE AUTHOR LOOKS AT THE RATIONALE AND THE POSSIBLE IMPACT OF SOME PROPOSED AMENDMENTS OT THE CAMADIAM

BANKRUPTCY ACT.

06068 MARTENSON, $S$.

GERMAN-CZECH TREATY READY FOR SIGMATURES

GERMAN TRIBUNE, (1501) (JAN 92), 2.

CONTROVERSY HAS SURROUNDED THE GERMAN-CZECHOSLOVAK TREATY ON GOOD-NEIGHBORLY RELATIONS WHICH IS TO BE SIGNED IN FEBRUARY BEFORE RATIFICATION. BONN COALITION TALXS HAVE ENDED OBJECTIONS TO THE TREATY RAISED BY THE CHRISTIAN DEMOCRATS' BAVARIAN ALLY, THE CSU. THE CONTROVERSY WAS LARGELY DUE TO HISTORICAL ACRIMONY EXTENDING BACK OVER CENTURIES. DESPITE SOME DISAGREEMENT, MANY OBSERVERS ARE CONFIDENT ABOUT THE PROSPECTS FOR RECONCILIATION.

06069 MARTENSON, $S$.

YOUNG SPD LAND PREMIER WAITING IN THE WINGS

GERMAN TRIBUNE, 31(1543) (DEC 92),

RUDOLF SCHARPING, PREMIER OF THE RHINELAND-PALATINATE, IS NOT PARTICULARLY WELL-KNOWN OUTSIDE THE LAND. THE AUTHOR BELIEVES THAT, IN NATIONAL TERMS, SCHARPING IS A KEY FIGURE IN THE SOCIAL DEHOCRATS. SCHARPING HAS GAINED A REPUTATION FOR DILIGENCE AND HAS ACQUIRED A CONSIDERABLE RESERVE OF CONFIDENCE. SINCE HE IS NOT SUSPECTED OF GETTING INVOLVED IN BONN POLITICS TO PUT HIMSELF INTO THE LIMELIGHT, HE CONTINUES TO BE HELD IN HIGH ESTEEM.

06070 MARTIN, B.

REVOLUTIONARY SOCIAL DEFENCE

BULLETIN OF PEACE PROPOSALS, 22(1) (MAR 91), 97-106.

HISTORY SO FAR HAS PROVIDED NO CLEARCUT EXAMPLE OF HOH A

GRASS-ROOTS CHALLENGE TO THE MILITARY, LEADING TO ITS GRASS-ROOTS CHALLENGE TO THE MILITARY, 'CEADING TH ITS REPLACEMENT BY SOCIAL DEFENSE MIGHT OCCUR. THIS AUTHOR TAKES A LOOK AT THE RISE OF MASS WARFARE AND REVOLUTIONARY DEFCLUDES THAT THE KEY TO SOCIAL DEFENSE MAY BE ITS LINK CONCLUDES THAT THE KEY TO SOCIAL DEFENSE MAY BE ITS LINK WITH SOCIAL MOVEMENTS WITH THE POTENT IAL FOR REVOLUTIONARY CHANGE IN SOCIAL STRUCTURE, AND THAT IN SOME CIRCUMSTANCES THE SURVIVAL OF SOCIAL DEFENSE MAY DEPEND ON THE CAPAC AND WILLINGNESS FOR UNDERTAKING SOCIAL OFFENSE--THE CONCERTED USE OF NON-VIOLENT
POTENTIAL AGGRESSOR REGIMES

06071 MARTIN, C.H.; STRONACH, B.

POLITICS EAST AND WEST--A COMPARISON OF JAPANESE AND BRITISH POLITICAL CULTURE

M. E. SHARPE, 1992, 352.

THIS BOOK COMPARES STABILITY AND CHANGE IN THE POLITICAL CULTURE OF THE RELATIVELY NEW ASIAN DEMOCRACY JAPAN AND THE MUCH OLDER HESTERN DEMOCRACY GREAT BRITAIN. WHILE THE DEMOCRATIC POLITY EMERGED INCREMENTALLY AND INDIGENOUSLY IN BRITAIN, IT WAS ESSENT IALLY A MODERN AND, IN MANY WAYS, FOREIGN IMPLANT IN JAPAN. THE AUTHORS ANALYZE LONG-TERM TRENDS AND RECENT CHANGES IN POLITICAL ATTITUDES, SUPPORT FOR GOVERNMENT INSTITUTIONS, PARTICIPATION, VOTING BEHAVIOR, AND POLICY-MAKING IN THE TWO NATIONS.

06072 MARTIN, D.

COMPETING MOTIVES IN THE FORMATION OF AMERICAN PUBLIC ADMINISTRATION

INTERMATIONAL JOURNAL OF PUBLIC ADMINISTRATION, 16(2)

(1992), $187-210$

THE INTELLECTUAL STUDY OF PUBLIC ADMINISTRATION WAS

THE INTELLECTUAL STUDY OF PUBLIC ADMINISTRATION WAS
DEVELOPED BY THO SEPARATE GROUPS WITH TWO DISTINCTIVE

DEVELOPED BY THO SEPARATE GROUPS WITH TWO DISTINCTIVE
ORIENTATIONS TO THE FIELD, CALLED HERE THE "PUBLIC SERVICE"

ORIENTATIONS TO THE FIELD, CALLED HERE THE "PUBLIC SERVICE"
AND THE "PUBLIC MANAGEMENT" ORIENTATIONS. BOTH ORIENTATIONS

AND THE "PUBLIC MANAGEMENT" ORIENTATIONS. BOTH ORIENTAT

HAVE COEXISTED IN PUBLIC ADMINISTRATION DESPITE THE

ORIENTATIONS PROYIDES MUCH DF THE PUBLIC ADMINISTRATION'S

CONFUSION OVER ITS SENSE OF PURPOSE AND IDENTITY, BUT ALSO

CONFUSION OVER ITS SENSE OF

06073 MARTIN, D.A.

ECONOMIES AS IDEOLOGY: ON MAKING "THE INYISIBLE haND" INVISIBLE

REVIEW OF SOCIAL ECONOMY, 48(3) (FAL 90), 272-287.

THE PURPOSE OF THIS PAPER IS TO SHOH THAT DEMIGRATION OF

ADAM SMITH'S "INVISIBLE HAND" PURGES THE METAPHYSICAL CORE

FROM HIS ARGUMENT. EOUATING THE INVISIBLE HAND TO PERFECT

COMPETITION REMOVES THE CRITICAL COORDINATING ROLE OF

PROVIDENCE FROM SMITH'S SYSTEM. THE AUTHOR ARGUES THAT

COMPETITION WAS NOT THE CAUSAL FORCE SMITH VIEHED AS

NECESSARY TO ACHIEVING AN OPTIMAL OUTCOME; RATHER, SMITH

CLAIMED THAT ROLE FOR DIVINE WISDOM.

06074 MARTIN, J.

YOUTH AND THE CUBAN REVOLUTION: NOTES ON THE ROAD

TRAVERSED AND ITS PERSPECTIVE

LATIN AMERICAN PERSPECTIVES, 18(2) (SPR 91), 95-100.

FOR THE PAST THIRTY YEARS CUBAN YOUTH HAS EXPERIENCED UNINTERRUPIED UPHARD SOCIAL MOBILITY AS INDICATED BY THE INCREASE IN THE LEVELS OF SCHOOLING AND THE AGE GROUP
COMPOSITION OF THE OCCUPATIONAL STRUCTURE. THESE INDICATORS ARE THE RESULT OF A POLICY, MAINTAINED THROUGHOUT THE HISTORY OF THE REVOLUTION, OF GIVING PRIORITY TO MASS EDUCATION AND GUARANTEEING ACCESS TO IT TO YOUNG PEOPLE OF ALL SOCIAL SECTORS. HITHIN THIS GENERAL FRAMEWORK, THIS ARTICLE PRESENTS AN HISTORICAL APPROACH TO THE ISSUE WHICH ALLONS AN APPRECIATION OF CHANGES IN THE ROLE OF CUBAN YOUTH WITH REGARD TO SOCIETY AS A HOLE--CHANGES SHAPED BOTH BY WITH REGARD TO SOCIETY AS A HOLE--CHANGES SHAPED BOTH BY THE TRANSFORMATIONS IN THE COUNTRY'S ECONOMIC AND SOCI
SITUATION AND BY THE AGE GROUP'S INTERNAL DYNAMICS.

06075 MARTIN, J.A.; THORSIN-HAMM, G

SWEDISH AND AMERICAN APPROACHES TO IMPROVING WORKING HOMEN'S STATUS: CONTEXT AND COMPARABLE WORTH

INTERNAT IONAL JOURMAL OF PUBLIC ADMINISTRATION, 14(5) 1991), 893-922.

RECENTLY, COMPARABLE MORTH HAS BEEN OFFERED AS ONE IMPORTANT TOOL FOR REDUCING STATUS DISPARITY BETWEEN WORKING MEN AND WOMEN. USING A COMPARATIVE ANALYSIS OF STRATEGIES FOR ENHANCING WOMEN'S STATUS IN AMERICAN AND SWEDISH PUBLIC ORGANIZATIONS, THIS ARTICLE ARGUES THAT TO BE AN EFFECTIVE TOOL FOR LESSENING STATUS DISPARITY, THE NOTION OF COMPARABLE HORTH MUST EXTEND WELL BEYOND ATTEMPTS TO EQUALIZE WAGES IN JOBS HELD PREDOMINANTLY BY EITHER MEN OR WOMEN. THE AUTHOR CONCLUDES THAT BOTH THE SWEDISH AND AMERICAN COMPARABLE WORTH APPROACHES ARE LIMITED PRIMARILY BECAUSE THEY ATTEMPT TO MAKE STATUS DISPARITY BETHEEN WORKING MEN AND WOMEN SOMETHING OTHER THAN A GENDER ISSUE.

06076 MARTIN, L.

DISMANTLING DETERRENCE?

REVIEH OF INTERNATIONAL STUDIES, 17(3) (JUL 91), 215-224. FOR DECADES THE COLD WAR PROVIDED A RECIPE NOT ONLY FOR THE EUROPEAN BALANCE OF POWER BUT ALSO FOR THE STRATEGIC SYSTEM OF DETERRENCE WHICH STABILIZED THE MAIN MUCLEAR FORCES. IN 1990 IT WOULD BE PREMATURE TO CONCLUDE THAT THE DANGERS OF SOVIET POWER ARE PAST, BUT THEY ARE UNDENIABLY DANGERS OF SOVIET POWER ARE PAST, BUT THEY ARE UNDENIABLY
LESSENED. THE RECENT CHANGES IN EASTERM EUROPE AND THE LESSENED. THE RECENT CHANGES IN EASTERN EUROPE AND THE
SOVIET UNION TEMPT THE UNITED STATES TO REVISE ITS OWN SOVIET UNION TEMPT THE UNITED STATES TO REVISE ITS OWN
SYSTEM OF NUCLEAR DETERRENCE TO FIT NEW TIMES AND WIDER
AREAS. THIS ARTICLE ARGUES THAT THE FUTURE OF NUCLEAR AREAS. THIS ARTICLE ARGUES THAT THE FUTURE OF NUCLEAR
DETERREMCE WILL BE GREATLY CONDITIONED BY HOW THE EUROPEAN DETERRENCE WILL BE GREATLY CONDITIONED BY HOW THE EUROP
BALANCE IS REVISED AND STABILIZED. AFTER ASSESSING THE BALANCE IS REVISED AND STABILIZED. AFTER ASSESSING THE ARTICLE CONCLUDES THAT EVEN IN EUROPE, THIS IS NOT THE TIME ARTICLE CONCLUDES THAT, EVEN IN EUROPE, THIS IS NOT THE TO DISMANTLE DETERRENCE. RATHER IT IS AN OPPORTUNITY TO
ADJUST IT; MAKE IT LESS EXPENSIVE, OPPRESSIVE AND INTRUSIVE AND RETAIN IT AS THE LATENT SOURCE OF STABILITY WITHIN THE NATO POWERS CAN RECAST THEIR RELATION
HHOLE BUILD A NEH, CONTINENTAL ORDER.

06077 MARTIN, L.

INSTITUTIONS ARE COOPERATIONS: SANCTIONS DURING THE FALKLANDS ISLANDS CONFLICT

INTERNATIONAL SECURITY, 16(4) (SPR 92), 143-178.

IN 1982, A LONG-RUNHING DISPUTE BETHEEN GREAT BRITAIN AND ARGENTINA ABOUT SOVEREIGNTY OVER THE FALKLAND ISLANDS BROKE INTO OPEN CONFLICT WHEN ARGENTINE FORCES INVADED THE ISLANDS. SANCTIONS BOTH PRECEDED AND ACCOMPANIED BRITISH MILTARY ACTION. THIS ARTICLE EXAMINES BRITAIN'S SUCCESS IN GAINING THE COOPERATION OF OTHER STATES. THE HIGH LEVEL OF COOPERATION CANNOT BE EXPLAINED ON THE BASIS OF NATIONAL SELF-INTEREST. RESISTANCE TO IMPOSING SANCTIONS INCREASED AS THE CRISIS ESCALATED AND DERIVED PRIMARILY FROM POLITICAL CONCERNS ABOUT SUPPORTING BRITAIN IN WAR AND FROM THE ECONOMIC COSTS OF SANCTIONS. THE AUTHOR ARGUES THAT BRITISH MANIPULATION OF THE EUROPEAM ECONOMIC COMMUNITY'S INSTITUTIONAL INCENTIVES OVERCAME MEMBERS' RESISTANCE.

06078 MARTIN, L.

INTERESTS, POWER, AND MULTILATERALISM

INTERNATIONAL ORGANIZATION, 46(4) (FAL 92), 765-792.

MULTILATERALISM CHARACTERIZES PATTERNS OF INTERACTION AMONG STATES AND THE FORMAL ORGANIZATIONS THEY CONSTRUCT. THE UTILITY OF MULTILATERAL NORMS VARIES, WHICH LEADS TO HYPOTHESES ABOUT THE CONDITIONS UNDER WHICH MULTILATERALISM MAY BE A SOLUTION. WITHIN CONSTRAINTS, STATES CHOOSE INSTITUTIONS THAT HILL SERYE THEIR INTERESTS. THE VULNERABILITY OF PATTERNS OF INTERNATIONAL COOPERATION TO DTE UNDERLYING STATE BEHAYIOR.

06079 MARTIN, L.

MATIONAL SECURITY IN A NEH HORLD ORDER

HORLD TODAY, 48( 2 ) (FEB 92 ), 21-26.

THE AUTHOR CONSIDERS HOW THE NEW HORLD ORDER ENVISIONED

BY PRESIDENT BUSH WILL IMPACT SECURITY AND HHETHER THE

TRADITIONAL NATIONAL SECURITY FRAME OF REFERENCE IS STILL

APPROPRIATE.

06080 MARTIN, L.L.

COERCIVE COOPERATION--EXPANDING MULTILATERAL ECONOMIC SANCTIONS

PRINCETON UNIVERSITY PRESS, 1992 , 
THIS STUOY SHOWS THAT MULTILATERAL, OR COOPERATIVE, SANCTIONS ARE COERCIVE NOT ONLY IN THEIR PRESSURE ON THEIR TARGET BUT ALSO IN THEIR ORIGIN: THE SANCTIONS THEMSELVES FREQUENTLY RESULT FROH COERCIVE POLICIES, WITH ONE INTERESTED STATE ATTEMPTING TO CONVINCE OTHERS THROUGH PERSUASION, THREATS, AND PROMISES. TO ANALYZE THIS PROCESS, THE AUTHOR USES A METHODOLOGY WHICH COMBINES GAME-THEORETIC MODELS, STATISTICAL ANALYSIS, AND CASE STUDIES. SHE TESTS HER HYPOTHESES AGAINST NINETY-NINE CASES OF ECONOMIC SANCTIONS SINCE 1945 AND THEN AGAINST FOUR DETAILED CASE STUDIES-THE U.S. - LED PIPELINE EMBARGO, HIGH-TECHNOLOGY SANCTIONS AGAINST THE SOVIET UNION, U.S. SANCTIONS AGAINST LATIN AMERICAN NATIONS FOR HUMAN RIGHTS VIOLATIONS, AND BRITISH SANCTIONS AGAINST ARGENTINA DURING THE FALKLANDS WAR. THE AUTHOR EMPHASIZES THAT CREDIBLE COMMITMENTS GAIN INTERNATIONAL COOPERATION, AND SHE CONCLUDES THAT THE INVOL VEMENT OF INTERNATIONAL INSTITUTIONS AND THE WILLINGNESS OF THE MAIN "SENDER" TO BEAR HEAVY COSTS ARE THE CENTRAL FACTORS INFLUENCING CREDIBILITY.

06081 MARTIN, P.

BANKING REFORM IN CZECHOSLOVAKIA

RFE/RL RESEARCH REPORT, 1(15) (APR 92), 29-33.

THE CZECHOSLOVAK PARLIAMENT HAS ADOPTED TWO LAWS

REGULATING THE OPERATIONS OF THE CZECHOSLOVAK STATE BANK AND

THE COUNTRY'S OTHER BANKING INSTITUTIONS. DESPITE THE FACT THAT THE LAWS MAKE THE STATE BANK AN INDEPENDENT RESERVE BANK, IT APPEARS TO BE POL ITICALLY VULNERABLE. THE NEW BANKING LANS AND THE PRIVATIZATION PROCESS COULD BE THE
START OF THE CREATION OF A FINANCIAL SYSTEM IN LINE WITH INTERNATIONAL STANDARDS.

06082 MARTIN, P.

MAJOR ISSUES CONFRONT THE CHURCHES IN CZECHOSLOVAKIA RFE/RL RESEARCH REPORT, 1(29) (JUL 92), 61-65.

THE CZECHOSLOVAK GOVERNMENT AND FEDERAL ASSEMBLY HAVE REJECTED A DRAFT LAH ON THE RESTITUTION OF PROPERTY TO CHURCHES AND RELIGIOUS COMMUNITIES. REACTING SHARPLY TO THIS UNEXPECTED MOVE, SLOVAK CATHOLIC BISHOPS HAVE ASKED CATHOLICS IN SLOVAKIA NOT TO VOTE FOR POLITICAL PARTIES THAT REJECTED OR HINDERED THE ADOPTION OF THE LAH. TENSION IN CHURCH-STATE RELATIONS IS LIKELY TO CONTINUE UNTIL THE GOVERNMENTS AND PARLIAMENTS ELECTED IN JUNE 1992 REACH A COMPROMISE ON THE ISSUE. AT THE SAME TIME, THE CATHOLIC CHURCH IN THE CZECH REPUBLIC IS GRAPPLING WITH THE PROBLEM OF INTEGRATING INTO THE MAINSTREAM CHURCH PRIESTS AND BISHOPS WHO WORKED UNDERGROUND DURING THE COMMUNIST REGIME. THE VATICAN'S RULING ON CELIBACY IS COMPLICATING THIS ISSUE.

06083 MARTIN, $P$.

RISING UNEMPLOYMENT IN CZECHOSLOVAKIA

RFE/RL RESEARCH REPORT, 1 (3) (JAN 92), 38-42

IN NOVEMBER 1991, CZECHOSLOVAKIA'S' NATIONAL UNEMPLOYMENT RATE STOOD AT 6.3\% AND WAS EXPECTED TO REACH 11-12\% IN EARLY 1992. ALSO IN NOVEMBER, 11.1\% OF THE SLOVAK WORK FORCE WAS UNEMPLOYED, AND THIS FIGURE WAS EXPECTED TO RISE TO $20 \%$ BY EARLY 1992. GRONING UNEMPLOYMENT AND FALLING REAL WAGES ARE CAUSING SOCIAL TENSION IN SLOVAKIA. IF THE TENSION CONTINUES, POLITICAL GROUPS CALLING FOR SLOVAK POLITICAL AUTONOMY AND A SLOWER PACE OF ECONOMIC REFORM COULO WIN SUPPORT FROM DISGRUNTLED VOTERS IN THE PARLIAMENTARY ELECTIONS SCHEDULED FOR JUNE 1992 .

06084 MARTIN, P.

SLOVAKIA: CALCULATING THE COST OF INDEPENDENCE RFE/RL RESEARCH REPORT, 1(12) (MAR 92), 33-38.

WHILE POLITICIANS IN THE CZECH AND SLOVAK REPUBLICS AWAITED THE UNCERTAIN OUTCOME OF THE PROTRACTED DEBATE OVER WHETHER BOTH NATIONS SHOULD CONTINUE TO COEXIST WITHIN ONE FEDERAL STRUCTURE OR SPLIT INTO THO SOVEREIGN STATES, THREE GROUPS OF ECONOMISTS PREPARED REPORTS GAUGING THE IMPACT OF CZECHOSLOVAKIA'S BREAKUP ON THE SLOVAK ECONOMY. ALL THREE GROUPS CONCLUDED THAT THE CONTINUATION OF ECONOMIC COOPERATION BETWEEN THE CZECH AND SLOVAK REPUBLICS WOULD BENEFIT BOTH NATIONS, WHEREAS THE DISSOLUTION HOULD ADVERSELY AFFECT THEIR ECONOMIES, ESPECIALLY SLOVAKIA'S.

06085 MARTIS, K.; KOVACS, D.; KOVACS, Z.; PETER, P. THE GEOGRAPHY OF THE 1990 HUNGARIAN PARLIAMENTARY ELECTIONS POLITICAL GEOGRAPHY QUARTERLY, 11(3) (MAY 92), 283-306. ONE OF THE BEST EXAMPLES OF THE IMMEDIATE EMERGENCE OF A COMPETITIVE MULTI-PARYTY ELECTORAL SYSTEM IN CENTRAL AND EASTERN EUROPE IS HUNGARY. THE 1989 HUNGARIAN PARLIMENTARY EASTERN EUROPE IS HUNGARY. THE 1989 HUNGARIAN PARLIMENTARY
ELECTION LAW CALLED FOR THE ELECTION OF A 386-MEMBER SINGLEELECTION LAW CALLED FOR THE ELECTION OF A 386-MEMBER SINGLE-
CHAMBER PARLIMENT BY WAY OF BOTH SIMGLE-MEMBER DISTRICTS AND CHAMBER PARLIMENT BY WAY OF BOTH SINGLE-MEMBER DISTRICTS AMD
PROPORTIONAL ALLOCATION. TEN ELECTORAL MAPS ILLUSTRATE THE PROPORTIONAL ALLOCATION. TEN ELECTORAL MAPS ILLUSTR SIGNIFICANT GEOGRAPHICAL VARIATION IN BOTH VOTER
PARTICIPATION AND POLITICAL PARTY SUPPORT IN THESE ELECTIONS. IN THE END, THE LARGEST PARTY TO EMERGE, THE HUNGARIAN DEMOCRATIC FORUM, GAINED 43 PERCENT OF THE TOTAL SEATS AND FORMED A COALITION GOVERMMENT WITH TWO SMALL CENTER-RIGHT PARTIES.
06086 MARTYNIUK, J.

ROUNDUP: ATTITUDES TOWARD UKRAINE'S BORDERS

RFE/RL RESEARCH REPORT $1(35)$ (SEP 92) 66-67.

SINCE UKRAINE DECLARED INDEPENDENCE, ONE OF ITS MOST VEXING POLITICAL ISSUES HAS BEEN THE COUNTRY'S BORDERS. A SURVEY CONDUCTED BY THE SOCIOLOGICAL ASSOCIATION OF UKRAINE IN MAY 1992 SHOWED THAT AN OVERHHELMING MAJORITY (82\%) OF THE RESPONDENTS WANTED THE BORDERS TO REMAIN INTACT.

06087 MARTYNIUK, J.

UKRAINIAN INDEPENDENCE AND TERRITORIAL INTEGRITY RFE/RL RESEARCH REPORT, 1(13) (MAR 92), 64-68.

THE QUESTION OF UKRAINE'S BOROERS HAS BEEN ONE OF THE MAJOR REASONS FOR THE STEADILY DETERIORATING RELATIONS BETWEEN RUSSIA AND UKRAINE. ACCORDING TO A SURVEY CONDUCTED IN SEPTEMBER AND OCTOBER 1991, EIGHTY-THREE PERCENT OF UKRAINE'S ADULT POPULATION HAS OPPOSED TO ANY BORDER CHANGES, COMPARED WITH FOUR PERCENT WHO SAID THAT PARTS OF UKRAINE SHOULD BELONG TO RUSSIA. THE SURVEY ALSO SHOWED THAT EIGHTYEIGHT PERCENT OF THOSE RESPONDENTS WHO HAD MADE UP THEIR MINDS HOW THEY WOULD VOTE IN THE REFERENDUM ON UKRAINIAN INDEPENDENCE SUPPORTED INDEPENDENCE. THOSE RESULTS INDEPENDENCE SUPPORTED INDEPENDENCE. THOSE RESULTS
CORRELATED CLOSELY WITH THE RESULTS OF THE DECEMBER 1991 CORRELATED
REFERENDUM.

06088 MARTZ, J.

PARTY ELITES AND LEADERSHIP IN COLOMBIA AND VENEZUELA JOURNAL OF LATIN AMERICAN STUDIES, 24(1) (FEB 92), 87-122. THIS ARTICLE FOCUSES ON THE PARTY SYSTEMS OF COLOMBIA AND VENEZUELA BECAUSE OF THEIR HEURISTIC POTENTIAL FOR A PROBING OF SIMILARITIES AND CONTRASTS. IT CONCENTRATES
PRIMARILY UPON LEADERSHIP AND THE RDLE OF PARTY ELITES. THE FIRST SECTION ASSESSES THE RESPECTIVE PATTERNS OF DEVELOPMENT OF THE MAIN COLOMBIAN AND VENEZUELAN PARTIES, NOTING IN PARTICULAR THE CONTRASTS WHICH HAD EMERGED PRIOR TO THE RENEWAL OF DEMOCRATIC FORMS ANO THE INTROOUCTION OF THE MODERN ERA IN THE LATE 1950S. INSTITUTIONAL AND ORGANIZATIONAL STRUCTURES ARE EXAMINED AND THE CONFLICT BETWEEN ELITIST CONTROL AND THE GROWING DEMANDS FOR INTERNAL DEMOCRATIZATION OF THE PARTIES IS ADDRESSED.

06089 MARUKO, $M$.

BREAK FREE OF U.S., EX-DIPLOMAT URGES

JAPAN TIMES (WEEKLY INTERNATIONAL EDITION), 32(15) (APR $92), 3$.

THE JAPANESE GOVERMMENT SHOULD PURSUE ITS ONM IDEAS AND MEASURES TO IMPROVE THE INTERNATIONAL COMMUNITY, RATHER THAN BLINDLY FOLLOHING THE UNITED STATES, ACCORDING TO MOTOFUMI ASAI. THE FORMER DIPLOMAT ALSO BELIEVES THAT THE MOST PROMISING PATH FOR JAPAN IS TO USE ITS ENORMOUS ECONOMIC ASSETS TO SOLVE WORLDWIDE ECONOMIC, SOCIAL, AND ENVIROMMENTAL PROBLEMS.

06090 MARUKO, M.; MURAKAMI A. JAPANESE GROWERS FEAR GOUVERMMENT'S RECXLESS RUSH TO IMPORT RIC JAPAN TIMES (WEEKLY INTERNATIONAL EDITION), 32(14) (APR

THE PROSPECT OF LIBERALIZIMG JAPAN'S LONG-PROTECTED RICE MARKET HAS LEFT FARMERS STRUGGLING TO FIND WAYS TO SURVIVE. MANY ARE COMPALINING ABOUT THE GOVERHMENT'S LACK OF LEADERSHIP IN PREPARING THE COUNTRY FOR AN OPEN RICE MARKET AMD ARE CRITICIZING THE GOVERNMENT FOR FAILING TO PROVIDE A COHERENT VISION OF JAPAN'S AGRICULTURAL FUTURE.

06091 MARX, A.W.

THE STATE, ECONOMY, AND SELF-DETERMINATION IN SOUTH AFRICA POLITICAL SCIENCE QUARTERLY, 107 (4) (WIN 93), 655-676.

THE AUTHOR EXPLORES THE CAUSES OF RECENT SHIFTS IN

OPPOSITION IDEOLOGY AND STRATEGY IN SOUTH AFRICA, AS REVEALED IN RESPONSES TO ECONOMIC CHANGE, STATE POLICY, AND DELIBERATIONS WITHIN THE OPPOSITION. HIS DISCUSSION OF THE INTERACTION OF THESE PROCESSES HIGHLIGHTS THE SIGNIFICANCE OF THE BLACK OPPOSITION IN DETERMINING PAST AND POTENTIAL FUTURE CONFLICT IN SOUTH AFRICA.

06092 MASAKI, H.

ABE ARREST ANOTHER BLOH TO MIYAZAHA

JAPAN TIMES (WEEKLY INTERMATIONAL EDITION), 32(4) (JAN 92), 1,6 .

OM JANUARY 13, 1992, JAPANESE PRIME MINISTER KIICHI MIYAZAHA'S EFFORTS TO STRENGTHEN HIS FRAGILE GRIP ON POWER WERE OEALT A SERIOUS BLOW BY THE ARREST OF CLOSE ALLY FUMIO WERE DEALT A SERIOUS BLOW BY THE ARREST OF CLOSE ALLY FUMIO
ABE FOR ALLEGEDLY TAKING BRIBES. ABE'S ARREST CAME AT A VERY ABE FOR ALLEGEDLY TAKING BRIBES. ABE'S ARREST CAME AT
AWKWARD TIME FOR THE PRIME MINISTER, WHO IS TRYING TO AWKWARD TIME FOR THE PRIME MINISTER, WHO IS TRYING TO AND FROM DECLINING APPROVAL RATINGS.

06093 MASAKI, $H$.

ASEAN FREE-TRADE PACT PLAN WOULD LOWER REGIONAL TARIFFS JAPAN TIMES (HEEKLY INTERNATIONAL EDITION), 32(9) (MAR 92), 17 .

THE SIX ASEAN COUNTRIES HAVE AGREED TO FORM A FREE-TRADE AREA WITHIN 15 YEARS, PRIMARILY ON THE BASIS OF THE COMMON 
EFFECTIVE PREFERENTIAL TARIFF PLAN (CEPT). JAPAN'S FOREIGN MINISTRY PREDICTS THAT A FREE-TRADE AREA AMONG ASEAN MEMBERS WOULD INCREASE TRADE AND INVESTMENT TIES BETHEEN ASEAN AND THE REST OF THE HORLD. THE MINISTRY FURTHER ADVOCATES THE REMOVAL OF TRADE AND INVESTMENT BARRIERS AMONG BOTH ASEAN AND NON-ASEAN COUNTRIES.

06094 MASAKI, $H$.

MASAKI, H.

JAPAN TIMES (HEEKLY INTERNATIONAL EDITION), 32(14) (APR

$92), 1,6$.

JAPAN'S GOVERMING LIBERAL DEMOCRATIC PARTY WON BOTH CONTESTED SEATS IN THE LOWER HOUSE BY-ELECTIONS IN GUNMA PREFECTURE ON MARCH 29, 1992. THE VICTORY WILL PROBABLY GIVE SOME BREATHING SPACE--ALBEIT TEMPORARILY--TO THE EMBATTLED SOME BREATHING SPACE-ALBEIT TEMPORARILY--TO

06095 MASAKI, H.

FORUM MAY EASE CIS NUCLEAR MERCENARY FEARS

JAPAN TIMES (WEEKLY INTERNATIONAL EDITION), 32(7) (FEB 92), 3.

SOME OBSERVERS FEAR THAT FORMER SOVIET NUCLEAR EXPERTS, FACING DEEP CUTS IN DEFENSE SPENDING BY THE CIS, MAY BE HIRED AWAY BY WOULD-BE NUCLEAR POWERS IN THE THIRD HORLD, INCLUDING IRAN, IRAQ, AND LIBYA. JAPAN MAY HOST AN INTERNATIONAL CONFERENCE TO DISCUSS WAYS TO HALT THE POTENTIAL EXDOUS. THE PROPOSED CONFERENCE, WHICH WOULD BE HELD IN TOKYO, WOULD BE ATTENDED BY LEADERS OF THE G-7 NATIONS AND THE MEMBERS OF THE CIS.

06096 MASAKI, H.

LDP DEFEATED IN MIYAGI BY-ELECTION

JAPAN TIMES (WEEKLY INTERNATIOHAL EDITION), 32(11) (MAR 92), 1,8 .

UPPER HOUSE BYTG LIBERAL DEMOCRATIC PARTY'S DEFEAT IN THE 1992, WAS A SERIOUS BLOW TO PRIME MINISTER KIICHI MIYAZAWA'S ALREADY FRAGILE GRIP ON POWER.

06097 MASALHA, N.

EXPULSION "OF THE PALESTINIANS--THE CONCEPT OF "TRANSFER" IN ZIONIST POLITICAL THOUGHT, 1882-1948

IN ZIONIST POLITICAL THOUGHT, 1882-1948,
THE INSTITUTE FOR PALESTINE STUDIES, $1992,250$.

THE INSTITUTE FOR PALESTINE STUDIES, 1992, 250. BASED ON DECLASSIFIED ISRAELI STATE AND PRIVATE ARCHIVAL MATERIAL, THIS STUDY INCLUDES LENGTHY CITATIONS ON TRANSFE
TAKEN FROM DEBATES AT THE HIGHEST LEVELS OF THE ZIONIST TAKEN FROM DEBATES AT THE HIGHEST LEVELS OF THE ZIONIST
LEADERSHIP AT LEAST A DECADE BEFORE THE 1948 WAR. BY SHOWING THE PERSISTENCE AND PROMINENCE OF THE CONCEPT IN ZIONIST PLANNING FROM THE END OF THE LAST CENTURY, THE BCOK SHEDS LIGHT ON THE EVENTS OF 1948 AND FORMS PART OF THE HISTORICAL BACKGROUND OF THE PALESTINIAN EXODUS AND DIASPORA.

06098 MASLIN, V.

CONFLICT PREVENTION AND RESOLUTION: THE ROLE OF NGO'S PEACE AND THE SCIENCES, 1(1) (SEP 92), 10-11.

CURRENT CONFLICTS MAY HAVE VERY DANGEROUS DESTABILIZING IMPLICATIONS NOT ONLY FOR RUSSIAN AND EUROPEAN SECURITY, BUT FOR THE INTERNATIONAL SITUATION AS A WHOLE, BECAUSE THEY HAVE A VERY STRONG TREND TO INTERHATIONALIZATION. TWO FEATURES ARE QUITE NOTICEABLE--THE FLARE OF THESE CONFLICTS IS ROOTED IN THE TOTALITARIAN SYSTEM AND. THE FORMER SOCIALIST SYSTEM PRACTICALLY HAS MO EXPERIENCE IN CONFLICT MANAGEMENT AND CONFLICT RESOLUTION BY PEACEFUL MEANS. THE ROLE OF NGO'S IN THE WORLD SITUATION TODAY IS EXAMINED.

06099 MASON, D.M.

LET CONGRESS BE CONGRESS: AN AGENDA FOR LEGISLATIVE REFORM POLICY REVIEH, (62) (FAL 92), 31-36.

THE AUTHOR ENUMERATES SOME OF THE PROBLEMS WITH THE U.S. EFFICIENCY.

06100 MASON, T.

HOMEN'S PARTICIPATION IN CENTRAL AMERICAN REVOLUTIONS: A THEORETICAL PERSPECTIVE

COMPARATIVE POLITICAL STUDIES, 25(1) (APR 92), 63-89. EVIDENCE FROM NICARAGUA AND EL SAL VADOR INDICATES THAT
ERA SUBSTANTIAL NUMBERS OF HOMEN FROM HUMBLE BACKGROUNDS HAVE PARTICIPATED IN THOSE NATION'S GUERRILLA ARMIES, AND NOT PARTICIPATED IN THOSE NATION'S GUERRILLA ARMIES, AND NOT
SIMPLY IN SUPPORT ROLES BUT AS COMBAT SOLDIERS AS WELL. THIS SIMPLY IN SUPPORT ROLES BUT AS COMBAT SOLDIERS AS WELL. THIS ARTICLE ANALYZES THE DYNAMICS OF SOCIETAL CHAHGE BY WHICH NONELITE HOMEN ARE MOBILIZED FOR PARTICIPATION IN GUERR IL
INSURGENCIES. WHEN THE REGIME REPRESSES THIS POLITICAL INSURGENCIES. WHEN THE REGIME REPRESSES THIS POLITICAL
ACTIYISM. IT SELDOM DISCRIMINATES BETWEEN MALES AND FEMALES ACTIYISM, IT SELDOM DISCRIMINATES BETHEEN MALES AND FEMALES
IN THE APPLICATION OF REPRESSION. FACED WITH THE THREAT OF VIOLENCE, WOMEN HAVE JOINED INSURGENT ORGANIZATIONS THAT VIOLENCE, WOMEN HAVE JOINED INSURGENT ORGANIZATIONS THAT
PROMISE, IF NOTHING ELSE, SECURITY FROM STATE REPRESSION.

06101 MASSEY, A.

managing CHANGE: politicians and experts in the age of PRIVATIZATION

GOVERMMENT AND OPPOSITION, 27(4) (FAL 92), 486-501.

THE AUTHOR COMPARES THE AMERICAN AND BRITISH EXPERIENCES WITH PRIVATIZATION POLICIES. FIRST, HE EXPLORES THE
PERCEIVED NEED FOR CHANGE IN THE PUBLIC SECTOR, OUTLINING THE RATIONALE PROVIDED BY THE NEW RIGHT. NEXT, HE EXPLAINS THE IMPORTANCE OF MANAGERIAL AND PROFESSIONAL PONER TO THIS PROCESS OF CHANGE. THEN HE DISCUSSES THE ROLE OF PRIVATIZATION AS A "CUTTING EDGE" USED BY

LIBERAL/CONSERVATIVE GOVERNMENTS /GOVERNMENTS CONVENTIONALLY LABELLED AS "CONSERVATIVE" EVEN THOUGH THEY HAVE ADOPTED IDEOLOGICALLY-LIBERAL POLICIES). HE CONCLUDES WITH A CASE STUDY OF THE PRIVATIZATION OF THE BRITISH ELECTRICAL SUPPLY INDUSTRY.

06102 MASSEY, D.

POLITICS AND SPACE/TIME

NEW LEFT REVIEW, (196) (NOV 92), 65-84.

ARCHITECTURE AND "THE BUILT ENVIROMMENT" ARE NOW INFUSED BY A SHOPPING-MALL CULTURE THAT DEPRIVES LIVED SPACES OF BOTH COHERENCE AND COMPLEXITY. IN THIS ESSAY, THE AUTHOR ARGUES THAT THIS CONCEPTUALIZATION OF SPACE IS NOW WIDELY SHARED AND LIES BEHIND THE APPROACH OF ERNESTO LACLAU'S "NEH REFLECTIONS ON THE REVOLUTION OF OUR TIME." SHE IS CONCERNED THAT SUCH SCHOLARS VIEH GEOGRAPHIC SPACE AS A PASSIVE AND DEPOLITICIZED ARENA, SEEING ONLY TIME AS THE DOMAIN OF CONTRADICTION AND DYNAMISM. SHE POINTS OUT THAT RADICAL AND FEMINIST GEOGRAPHERS HAVE UNDERMINED ANY SUCH DICHOTOMY OF SPACE AND TIME. THEY HAVE SHOWN NOT ONLY THAT SPACE IS SOCIALLY CONSTRUCTED BUT THAT SOCIETY IS SPATIALLY CONSTRUCTED; THEREFORE, CHAOS, CONTRADICTION, AND CHANGE ARE INTEGRAL TO THE SPATIAL.

06103 MASSON, P.; MCDONALD, D.

THE MACROEECONOMIC EFFECTS OF GERMAN UNIFICATION

FINANCE AND DEVELOPMENT, 28(1) (MAR 91), 6-9.

BEYOND THE CERTAINTY OF GERMAN UNIFICATION LIE MANY QUESTIONS ABOUT ITS ECONOMIC EFFECTS, DOMESTIC AND FOREIGN. THIS ARTICLE SEEKS TO EXAMINE THESE EFFECTS WITHIN A DETAILED OUANTITATIVE FRAMEWORK. IT UTILIZED A STUDY DONE WITHIN THE INTERNATIONAL MONETARY FUND (IMF). IT CONCLUDES THAT THE PATH TAKEN BY EAST GERMANY WILL HAVE MAJOR IMPLICATIONS FOR THE ECONOMY OF THE UNITED GERMANY, BUT THAT THE INTERNATIONAL EFFECTS OF UNIFICATION MAY BE RELATIVELY MODERATE.

06104 MASTERS, R.: BENTE, G.; FREY, S. DOMINANCE AMD ATTENTION: IMAGES AND LEADERS IN GERMAN, DOMINANCE AND ATTENTION: IMAGE

POLITY, XXIII (3) (SPR 91), 373-394.

POLITY, XXIII (3) (SPR 91), 373-394. COMMUNICATION IN MODERM POLITICS. THE WAY IN WHICH LEADERS ARE PRESENTED TO THE PUBLIC ON TV SHAPES AND MEASURES THEIR ARE PRESENTED TO THE PUBLIC ON TV SHAPES AND MEASURES THEI STATUS, AND THEIR POWER CAN NO LONGER BE FULLY UNDERSTOOD WITHOUT REFERENCE TO TELEVISION COVERAGE. THIS ARTICLE, BASED ON A CROSS-NATIONAL STUDY OF NIGHTLY NEHSCASTS IN GERMANY, FRANCE, AND THE UNITED STATES, FINDS THAT THE FREQUENCY WITH WHICH THE IMAGES OF LEADERS APPEAR ON TV
REFLECTS THE DIFFERENT PATTERHS OF POLITICAL DOMINANCE IN REFLECTS THE DIFFERENT PATTERNS OF POLITICAL DOMIMANCE IN
THE THREE HATIONS. THE AUTHORS LINK THIS TO DIFFERENT SOCIAL AND POLITICAL SYSTEMS AND ANALYZE THE IMPLICATIONS FOR LEADERSHIP.

06105 MASTHAK, T.

CIVIL SOCIETY IN SLOVENIA: FROM OPPOSITION TO POHER STUDIES IN COMPARATIVE COMMUNISM, XXIII (3-4) (FAL 90), 305-318.

"CIVIL SOCIETY" IS THE CONCEPT THAT SUMMARIZED DEMOCRATIZATION--OR THE TRANSFORMATION FROM TOTALITARIANISM TO DEMOCRACY--IN SLOVENIA, AS ELSEWHERE IN SOCIALIST EUROPE. THIS ARTICLE DESCRIBES: THE FORMATION OF CIVIL SOCIETY IN THE LATE 1970S AND EARLY 1980S; ITS POLITICIZATION, OR THE FORMATION OF POLITICAL SOCIETY IN THE SECOND HALF OF THE FORMATION OF POLITICAL SOCIETY IN THE SECOND HALF OF THE 1990S.

06106 MASTNAK, T.

FINIS YUUgOSLLAVIAE

EAST EUROPEAN REPORTER, 5(1) (JAN 92), 3-7.

IN YUGOSLAVIA. THE PROCESS OF DEMOCRATIZATION HAS PROVED MORE DIFFICULT THAN IN OTHER EAST EUROPEAN COUNTRIES BECAUSE THE STATE HAD WITHERED AWAY TO A MUCH GREATER DEGREE THAN THE STATE HAD WITHERED AWAY TO A MUCH GREATER DEGREE THAN
ELSEWHERE. ON THE ONE HAND, THE STATE WAS NOT ONLY
SYMBOL SYMBOLIZED BUT ACTUALLY SUBSTITUTED BY A CHARISMATIC LEADERMARSHALL TITO; ON THE OTHER, THE SYSTEM OF SELF-MANAGEMENT RENDERED THE STATE A NON-STATE BY SOCIALIZING IT, WHILE IT
THE SAME TIME IT DESOCIALIZED CIVIL SOCIETY BY MAKING IT THE SAME TIME IT DESOCIALIZED CIVIL SOCIETY BY MAKING IT FUNCTION LIKE A STATE. AFTER TITO'S DEATH, THE SITUATION IN YUGOSLAVIA WAS CHARACTERIZED BY THE DISSOLUTION OF SOCIALIST IDEOLOGY, THE GRADUAL DECLINE OF THE PARTY, AND THE FALLING APART OF THE SYSTEM GENERALLY. THEREFORE, THE KEY ELEMENT YUGOSLAVIA'S DESPERATE AND VIOLENT SITUATION MIGHT BE DEFINED AS THE ABSENCE OF BOTH STATE AND CIVIL SOCIETY.
YUGOSLAVIA--ESPECIALLY IN THE REGIONS DOMINATED OR AFFECTED BY SERBIAN FASCISM--COMHUNISM--IS LAPSING INTO THE STATE OF NATURE. 
06107 MASUGI, $K$

MATURAL RIGHT AND OVERSIGHT: THE USE AND ABUSE OF NATURAL LAW IN THE CLARENCE THOMAS HEARINGS

POLITICAL COMHUNICATION, 9 (4) (1992), 231-250.

THE AUTHOR SUMMARIZES THE SIGNIFICANCE OF NATURAL RIGHT THINKING FOR CLARENCE THOMAS'S HRITINGS ON THE SEPARATION OF POWERS AND CIVIL RIGHTS. HE RECOUNTS AND ANALYZES THE ARGUMENTS RAISED AGAINST THOMAS DURING HIS SUPREME COURT CONFIRMATION HEARINGS BY DIFFERENT INTEREST GROUPS, SCHOLARS, AND SENATORS ON THE JUDICIARY COMMITTEE. HE CONCLUDES WITH SOME REFLECTIONS ON THE PLACE OF NATURAL RIGHT THINKING IN CONSTITUTIONAL SCHOLARSHIP.

06108 MASUGI, K. (ED.)

INTERPRETING TOCQUEVILLE'S DEMOCRACY IN AMERICA

ROMMAN AND LITTLEFIELD, 1991, 526.

THIS BOOK IS A COLLECTION OF ESSAYS ON ALEXIS DE TOCOUEVILLE'S "DEMOCRACY IM AMERICA." THE AUTHORS PROBE TOCOUEVILLE'S UNDERSTANDING OF THE MODERN HORLD FROM THE PERSPECTIVE OF POLITICAL THEORY. THEY PROVIDE ORIGINAL ANALYSES, RANGING FROM CLOSE TEXTUAL EXEGESES TO ANALYSES, RANGING FROM CLOSE TEXTUAL EXEGESES TO
APPLICATIONS OF TOCOUEVILLE'S METHOD-IN ONE CASE TO APPLICATIONS OF TOCQUEVILLE'S METHOD-IN ONE CASE TO CONTEMPORARY ASIA. RACE, HOMEN'S LIBERATION, CAPITALISM,
BUREAUCRACY, INDIVIDUALISH, RELIGION AND ALIENTATIOM ARE BUREAUCRACY, INDIVIDUALISM, RELIGION AND ALIENTATION ARE
AMONG THE SUBJECTS CONSIDERED. THE BOOK DOES NOT SEEK TO AMONG THE SUBJECTS CONSIDERED. THE BOOK DOES NOT SEEK TO COVER EVERY FACET OF TOCQUEVILLE'S ANALYSIS OF AMERICA, BUT RATHER TO BRING OUT SIGNIFICANT THEMES, ESPECIALLY THOSE
INTEREST TO POLITICAL THEORISTS, WHICH HAVE OTHERWISE NOT INTEREST TO POLITICAL THE

06109 MASYA, J.

COMMITTEE OPTIONS IN KENY

PARL IAMENTARIAN, LXXIII (3) (JUL 92), 213-214.

THE AUTHOR EXPLAINS THE KENYAN MATIONAL ASSEMBLY'S RULES REGARDING THE FORMATION OF COMMITTEES, THEIR JURISDICTION, AND THEIR OPERATION.

06110 MATES, $P$.

THE NEW SLOVAK CONSTITUTION

RFE/RL RESEARCH REPORT, 1(43) (OCT 92), 39-42.

THE SLOVAK MATIOMAL COUNCIL ADOPTED A NEW CONSTITUTION ON SEPTEMBER 1, 1992-TAKING ANOTHER STEP IN SLOVAKIA'S DRIVE TO BECOME A SOVEREIGN, INDEPENDENT STATE. THE CONSTITUTION HAS DRAFTED RATHER HASTILY IN AN EFFORT TO MEET THE DEADLINE SET BY THE MOVEMENT FOR A DEMOCRATIC SLOVAKIA, THE RULING PARTY. AS A RESULT, IT IS A RATHER UMBALANCED, ECLECTIC DOCUMENT. THE MOST CONTROVERSIAL ISSUES ARE THE' RCLCTIC DOCUMENT. THE MOST CONTROVERSIAL ISSUES ARE THE RELAT IONSHIP BETHEEN THE SLOVAK CONSTI TUTION AND THE FEDERAL ONE, THE RELATIONSHIP BETWEEN THE EXECUTIVE
BRANCHES OF GOVERNMENT, AND MINORITY RIGHTS

06111 MATHEHS, D.G.; DE HART, J.S.

SEX, GENDER, AND THE POLITICS OF ERA: A STATE AND THE NATION

OXFRD UNIVERSITY PRESS, 1991, 283.

THIS BOOK CONTRIBUTES TO THE EFFORT TO DETERMINE WH THE EQUAL RIGHTS AMENDMENT, AT ONE POINT A SEEMINGLY SURE-FIRE CERTAINTY, FAILED TO ACHIEVE RATIFICATION. THE AUTHORS FOCUS ON THE CRITICAL BATTLE FOR RATIFICATION IN NORTH CAROLINA. HOWEVER, THE AUTHORS ALSO UTILIZE THE NATIONAL AS WELL AS THE STATE PICTURE BECAUSE OF THE POWERFUL INTER-RELATIONSHIP BETWEEN POLITICAL EFFORT AND FUND-RAISING ACTIVITIES AT THE NATIONAL AND STATE LEVEL. THE AUTHORS CONCERN THEMSELVES MAINLY WITH THE PIVOTAL DECADE FROM 1972 TO 1982. THEIR ANALYSIS UTILIZIES

06112 MATHIS, S.; BASTIN, H.

TAX DISCOUNTING VS. CROHDING OUT

CONTEMPORARY POLICY ISSUES, $X(2)$ (APR 92), 54-62.

THE "CRONOING OUT" EFFECT OF DEBT-FINANCED GOVERNMEMT SPENDING ON THE PRIVATE SECTOR CONSUMPTION-SAVING DECISION AND ON PRIVATE INVESTMENT BEHAVIOR HAS BEEN A CONTROVERSIAL SUBJECT FOR SEVERAL YEARS. DO INCREASES IN DEBT-FINANCED GOVERNMENT SPENDING STIMULATE PRIVATE CONSUMPTION AND SAVINGS IN THE SHORT RUN, AS WELL AS PRIVATE CONSUMPTION IN SUBSEQUENT PERIODS? OR DOES THE REALIZATION THAT FUTURE TAXES MUST BE RAISED TO FINANCE REPAYMENT OF THE DEBT RESULT IN A LACK OF STIMULUS FOR CONSUMPTION AS WELL AS MO DETRIMENTAL IMPACT ON SUBSEQUENT PRIVATE SAVING? THIS PAPER EMPIRICALLY TESTS FOR THE PRESENCE AND/OR MAGNITUDE OF TAX DISCOUNTING AND CRONDING OUT, CAREFULLY DISTINGUISHING BETHEEN THE THO AND DECOMPOSES GOVERNMENT DEBT INSTRUMENTS ACCORDING TO THEIR MATURPOSES GOVERNMENT DEBT INSTRUMENTS DUE TO A REORIENTATION OF DEBT STRUCTURE. THE RESULTS DO NOT DUE TO A REORIENTATION OF DEBT STRUCTURE. THE RESULTS DO NOT SUPPORT THE EXISTENCE OF TAX DISCOUNTING, SUGGESTING INSTEAD GOVERMMENT DEFICITS DO STIMULATE CURRENT CONSUMPTION.
THAT GOS

06113 MATHUR, $K$.

THE STATE AND THE USE OF COERCIVE POHER IN INDIA ASIAN SURVEY, 32(4) (APR 92), 337-349.

IN INDIA THERE IS A RISE IN SOCIAL CONFLICT, THE ECONOMY DOES NOT SHOH AN ADEOUATE RATE OF GROWTH, AND DEMOCRATIC INSTITUTIONS, NOW BEING CITED AS REASONS FOR THE INABILITY
TO COPE WITH THE SOCIAL AND ECONOMIC PROBELMS, ARE LOSING THEIR DEMOCRATIC CHARACTER AND ARE UNABLE TO STEM THE TIDE OF VIOLENCE IN SOCIETY. THIS ARTICLE ATTEMPTS TO EXAMINE SOME OF THESE ISSUES AND PARTICULARLY FOCUSES ATTENTION ON THE PROCESSES AND THE INSTITUTIONS BY WHICH THE INDIAN STATE HAS EXPANDED ITS CAPACITY TO USE COERCIVE POWER. IT REVIEHS: THE STATE AND SOCIETY; UNDEMOCRATIC ELEMENTS IN THE CONSTITUTION; POL ICE AND PARAMILITARY FORCES; AND, CONCLUDES HISTORICAL AND SOCIAL PROCESSES OF STATE AND NATION BUILDING.

06114 MATLAND, R.E.; BROWM, D.D.

DISTRICT MAGNITUDE'S EFFECT ON FEMALE REPRESENTATION IN U. S. STATE LEGISLATURE

LEGISLATIVE STUDIES QUARTERLY, XVII(4) (NOV 92), 469-492. WITHIN THE UNITED STATES, A NUMBER OF SCHOLARS HAVE CONSIDERED THE EFFECT OF DISTRICT MAGNITUDE ON FEMALE REPRESENTATION IN STATE LEGISLATURES. A CONTROVERSY EXISTS AS TO WHETHER WOMEN ARE BETTER REPRESENTED IN SYSTEMS WITH MULTIMEMBER DISTRICTS THAN IN THOSE WITH SINGLE-MEMBER DISTRICTS ONLY. THIS PAPER PRESENTS THE THEDRETICAL REASONS WHY MULTIMEMBER DISTRICTS SHOULD GIVE HOMEN AN ADVANTAGE, WHY MULTIMEMBER DISTRICTS SHOULD GIVE HOMEN AN ADVAN REVIEHS THE EMPIRICAL LITERATURE, PROPOSES SEVERAL
HYPOTHESES THAT WOULD RECONCILE THE INCONSISTENT RESULTS IN THE EMPIRICAL LITERATURE, AND THEN TESTS THOSE HYPOTHESES IN THE EMPIRICAL LITERATURE, AND THEN TESTS THOSE HYPOTHESES IN CONFIRMATION OF THE EFFECT OF DISTRICT MAGNITUDE AND CAST SERIOUS DOUBT ON THOSE STUDIES THAT SHOW LITTLE EFFECT.

06115 MATSUZAKI, $M$.

EARLY GENERAL ELECTION MAY BE MIYAZAWA'S LAST OPTION JAPAN TIMES (WEEKLY INTERNATIONAL EDITION), $32(9)$ (MAR 92),

IN THE THREE MONTHS SINCE THE MIYAZAWA GOVERMMENT MADE ITS DEBUT, LITTLE HAS BEEN ACHIEVED. THE GOVERNING LIBERAL DEMOCRATIC PARTY (LDP) HAS BEEN ROCKED BY SCANDALS INVOLVING THE KYOWA CORP AND SAGAHA KYUBIN. APPREHENSION IS SPREADING HITHIN THE LDP THAT THE NIGHTMARE OF THE 1989 RECRUIT SCANDAL HILL BE REPEATED. THERE IS SPECULATION THAT THE LOWER HOUSE OF THE DIET WILL SOON BE DISSOLVED AND A GENERAL ELECTION CALLED.

06116 MATSUZAKI, M.

JAPAN'S POL ITICAL MUSCLE LIES IN THE POWER TRIANGLE JAPAN TIMES (WEEKLY INTERNATIONAL EDITION), 32(13) (MAR $92), 4$.

TRUE POLITICAL POWER IN JAPAN BELONGS TO THE THREE TOP LEADERS OF THE TAKESHITA FACTION OF THE LIBERAL DEMOCRATIC PARTY, AND NOT TO PRIME MINISTER KIICHI MIYAZAHA, WHO IS LIKELY TO BE OUSTED FOLLONING THE UPPER HOUSE ELECTIONS IN JULY 1992.

06117 MATSUZAKI M.

JUST HO Is GoImg to COME to miYazaha's Rescue? JAPAN TIMES (WEEKLY INTERHATIONAL EDITION), 32 (7) (FEB 92), 4.

BUSINESS IN THE DIET HAS BEEN STALLED SINCE THE BEGINNING OF DELIBERATIONS ON THE FY1992 NATIONAL BUDGET IN THE HOUSE OF REPRESENTATIVES BUDGET COMMITTEE. THE STALEMATE IS DUE TO OPPOSITION DEMANDS THAT KEY FIGURES IN THE KYOWA CORP. AND RECRUIT SCANDALS BE SUMMONED TO TESTIFY BEFORE THE DIET. THE LIBERAL DEMOCRATIC PARTY IS FIGHTING THESE DEMANDS, AMD IT IS QUESTIONABLE HOW LONG PRIME MINISTER KIICHI MIYAZAHA CAN SURVIVE THE TURMOIL.

06118 MATSUZAKI, M.

KANEMARU READY TO COME TO MIYAZAWA'S RESCUE

JAPAN TIMES (WEEKLY INTERNATIONAL EDITION), 32(4) (JAN 92),

THE NEXT SESSION OF THE DIET, SCHEDULED TO OPEN ON JANUARY 24, 1992, WILL UNDOUBTEDLY FOCUS ON THE KYOWA MINISTER MIYAZAHA'S ROLE IN THE RECRUIT STOCKS-FOR-FAVORS SCANDAL.

06119 MATSUZAKI, M.

MIYAZAHA MAY BE LEFT TO THIST IN THE HIND JAPAN TIMES (WEEKLY INTERNATIONAL EDITION), 32(17) (APR 92 ) 4 .

THE INVESTIGATION OF A MAJOR SCANDAL INYOLVING SAGAWA KYUBIN SEEMS TO BE MAKING LITTLE HEADWAY, BUT THE POLITICAL RAMIFICATIONS WILL BE ENORMOUS IF PUBLIC OFFICIALS ARE ARRESTED ON BRIBERY CHARGES. AT STAKE IS THE FATE OF PRIME MINISTER KIICHI MIYAZAWA'S GOVERMMENT AND THE POSSIBILITY OF ELECTIONS FOR BOTH DIET CHAMBERS IN JULY 1992

06120 MATSUZAKI, M.

POLITICAL REALIGNMENT: IT'S TIME TO BRUSH OFF THE RUST JAPAN TIMES (WEEKLY INTERNATIONAL EDITION), 32(15) (APR $92), 4$.

IN JAPAN, CONSERVATIVE AND OPPOSITION LEADERS ARE PROMOTING THE IDEA OF A MAJOR POLITICAL REALIGNMENT, WHICH THEY FORESEE BECOMING A REALITY AFTER THE 1992 UPPER HOUSE ELECTIONS. 
06121 MATSUZAKI, M.

POLITICIANS SHOULD LEARN FROM JAPAN'S OLYMPIANS JAPAN TIMES (WEEKLY INTERMATIONAL EDITION), 32(11) (MAR 92 ) 4 . THROUGH THEIR ATTITUDES AND FRAME OF REFERENCE, JAPANESE POLITICIANS HAVE INDICATED THAT THEY ARE NOT YET READY FOR THE NEH REALITY OF POST-COLD WAR INTERNATIONAL RELATIONS. BUT IT WOULD BE TRAGIC IF JAPAN'S POLITICIANS PREVENT THEIR COUNTRY FROM CONTRIBUTING TO THE ONGOING MOVES TO BUILD A COUNTRY FROM CONTRIBUTING TO THE ONGOING MOVES TO BUILD A NEW INTERNATIONAL ORDER. DOMESTICALLY, THE ADMINISTRATION OF PRIME MINISTER KIICHI MIYAZAWA HAS EMBARKED UPON A COURSE
REFORMS, PROMPTED BY RECENT SCANDALS, BUT MANY OUESTION MIYAZAHA'S COMMI TMENT TO REFORM.

06122 MATSUZAKI, M.

SPECULATIOM MOUNTS ON MIYAZAHA'S $X$-DAY

JAPAN TIMES (WEEKLY INTERMATIONAL EDITION), 32(2) (JAN 92),

THE AUTHOR LOOKS AT CRITICISMS OF JAPANESE PRIME MINISTER KIICHI MIYAZAWA AND AT SPECULATION THAT HE WILL BE FORCED TO RESIGN AFTER ONLY A SHORT TIME IN OFFICE.

06123 MATTAIR, T.

ACHIEVING PEACE: RECOMMENDATIONS FOR U.S. POLICY MIDDLE EAST POLICY, 1(4) (1992), 1-16.

IN THE POST-COLD WAR ERA. THE UNITED STATES HAS CONTINUING NATIDNAL INTERESTS IN THE MIDDLE EAST. THE UNRESOLVED ARAB-ISRAELI CONFLICT JEOPARDIZES ALL OF THESE INTERESTS, WHEREAS THE COMPREHENSIVE RESOLUTION OF THE CONFLICT WOULD PROMOTE ALL OF THEM. THIS REPORT IS INTENDED TO OFFER GUIDANCE ABOUT THE U.S. ROLE IN PROMOTING PEACE BETHEEN ARABS AND ISRAELIS. IT EXAMINES U.S. INTERESTS AMD OBJECTIVES, DRAWS CONCLUSIONS THAT SHOULD GUIDE THE UNTIED OBJECTIVES, DRAWS CONCLUSIONS THAT SHOULD GUIDE THE UNTIED NEGOTIATIONS THAT BEGAN IN MADRID IN OCTOBER, 1991.

06124 MATTAIR, T.

BILATERAL DIPLOMACY, REgIONAL VIOLENCE, AND THE MOSCOW DERENCE

MIDDLE EAST POLICY, 1(1) (1992), 55-84.

SEVERAL WEEKS AFTER THE MADRID CONFERENCE AND THE INITIAL BILATERAL TALKS THAT FOLLOWED, THE UNITED STATES AND THE SOVIET UNIDN INVITED ALL OF THE RELEVANT PARTIES TO RESUME THE BILATERAL TALKS IN WASHINGTON, D.C. ON DECEMBER 4 1991. THIS INVITATION WAS EXTENDED AFTER THE ADMINISTRAT
CONCLUDED THAT THE PARTIES THEMSELVES HOULD NOT REACH ANY CONCLUDED THAT THE PARTIES THEMSELVES WOULD NOT REACH ANY
AGREEMENT ON A VENUE FOR THE CONTINUATION OF THESE TALKS AND AGREEMENT ON A VENUE FOR THE CONTINUATION OF THESE TALKS
THAT UNITED STATES INTERVENTION WOULD BE NECESSARY. THIS ARTICLE EXPLORES: THE ROUGH ROAD TO HASHINGTON; THE PROCEDURAL AND SUBSTANTIVE DEADLOCKS AT THE WAŚHINGTON TALKS U.N. VOTES, REGIONAL VIOLENCE, ISRAELI POLITICS

SUBSTANTIVE DEADLOCKS AND THE ISRAELI FAR-RIGHT REVOLT; AND,

ISRAELI ELECTIONS, U.S. LOAN GUARANTEES, THE MOSCOW

CONFERENCE AND THE FUTURE.

06125 MATTAIR, T.

ISRAELI' FOREIGM POLICY AFTER THE GULF WAR

MIDOLE EAST POLICY, 1(2) (1992), 85-95.

THE PERSIAN GULF WAR OF 1991 AND THE DECLINE OF THE SOVIET UNION LEFT ISRAEL IN A SUPERBLY ADVANTAGEOUS POSITION: MUCH OF THE MILITARY MACHINERY OF IRAQ, ISRAEL'S MOST POWERFUL ARAB ADVERSARY, WAS DESTROYED; THE ARAB WORLD WAS DIVIDED AND CONFUSED; AND THE INHERITORS OF THE SOVIET EMPIRE WERE NO LONGER IN A POSITION TO OFFER AN ALTERNATIVE TO THE UNITED STATES. THIS ARTICLE OISCUSSES THIS ISRAEL FOREIGN POLICY OF THE GULF WAR.

06126 MATTAIR, T.

THE BUSH ADMINISTRATION AND THE ARAB-ISRAELI CONFLICT AMERICAN-ARAB AFFAIRS, (36) (SPR 91), 52-72.

IN THE MIOST OF ANOTHER MAJOR U.S. DIPLOMATIC EFFORT, AND IN LIGHT OF THE MANY PREVIOUS EFFORTS THAT HAVE

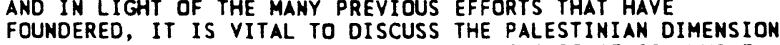
FOUNDERED, IT IS VITAL TO DISCUSS THE PALESTINIAN DIMENSION
OF THE ARAB-ISRAEL I CONFLICT AND MIDOLE EAST PEACE. WHILE
THE PALESTINIAN OUESTION MAY NOT BE THE MOST IMPORTANT FACTOR FOR THE STABILITY AND PEACE OF THE ENTIRE MIDDLE EAST, FACTOR FOR THE STABILITY AND PEACE OF THE ENTIRE MIDDLE EAST
THE PALESTINIAN-ISRAELI IS THE SEMINAL ISSUE OF THE ARABTHE PALESTINIAN-ISRAEL I IS THE SEMINAL ISSUE OF THE ARAB-
ISRAELI CONFLICT AND THE KEY TO ARAB-ISRAELI PEACE. THIS ISRAELI CONFLICT AND THE KEY TO ARAB-ISRAELI PEACE. THIS JAMES BAKER FOLLOWING THE GULF CRISIS. IT EXAMINES THE MOOD IN ISRAEL. THE WEST BANK, AND GAZA. IT CONCLUDES THAT M IN ISRAEL, THE WEST BANK, AND GAZA. II CONCLUDES THAT A STATE SEEMS HIGHLY UNLIKELY GIVEN THE POSITION OF ISRAEL AND THE UNITED STATES. HOWEVER A POL ITICAL COMPROMISE CREATING THE UNITED STATES. HOWEVER, A POL ITICAL COMPROMISE CREA ING AN AUTONOMOUS PALESTINIAN ENTITY FEDERATED WITH JORDAN IS
PERHAPS MORE LIKELY AND, BY ENDING THE ISRAELI OCCUPATION, WOULD GREATLY ALLEVIATE THE BITTERNESS AND FEAR THAT HAVE LED THE PALESTINIANS TO STRUGGLE AGAINST ISRAEL.

06127 MATTAIR, T.

THE PEACE PROCESS: CAN IT BRIDGE WATER THIS TROUBLED?

MIDDLE EAST POLICY, 1(2) (1992) 57-84

THE WEEKS BEFORE THE SCHEDULED RESUMPTION OF BILATERAL
TALKS IN WASHINGTON IN FEBRUARY, 1992, WERE FILLED WITH SUCH VIOLENCE IN THE MIDOLE EAST THAT THE TALKS AND THE PEACE THEY WERE DESIGNED TO FOSTER SEEMED IN SERIDUS JEOPARDY. THIS ARTICLE DISCUSSES THE ARAB-ISRAELI VIOLENCE IN REGARDS TO THE PEACE PROCESS

06128 MATTEI, F.; NIEMI, R.

UNREALIZED PARTISANS, REALIZED INDEPENDENTS, AND THE INTERGENERATIONAL TRANSMISSION OF PARTISAN IDENTIFICATION

THE JOURMAL OF POLITICS, 53(1) (FEB 91), 161-174. RECENT STUDIES ARGUE THAT THERE HAS BEEN A DRAMATIC CHANGE IN THE INTERGENERATIONAL TRANSMISSION OF PARTISANSHIP AND INDEPENDENCE AND THAT THE GROWTH IN INDEPENDENTS IS LARGELY ACCOUNTED FOR BY "UNREALIZED PARTISANS." THIS PAPER LARGELY ACCOUNTED FOR BY "UNREALIZED PARTISANS." THIS PAPI
SHOWS THAT BOTH CONCLUSIONS ARE A FUNCTION OF IGNORING SIZABLE NUMBERS OF FAMILIES IN WHICH PARENTS' PARTISANSHIP SIZABLE NUMBERS OF FAMILIES IN WHICH PARENTS' PARTISANSH
IS INDETERMINATE. UNREALIZED PARTISANSHIP HAS BEEN AN IMPORTANT CAUSE OF DEALIGNMENT, BUT IT ACCOUNTS FOR MUCH IMPORTANT CAUSE OF DEALIGNMENT, BUT IT ACCOUNTS FOR LESS THAN THE
INDEPENDENTS.

06129 MATTHEI, C.

U.S. LAND REFORM MOVEMENTS: THE THEORY BEHIND THE PRACTICE SOCIAL POLICY, 22(4) (SPR 92), 36-45.

NEARLY EVERYONE AGREES THAT U.S. HOUSING POLICY HAS FAILED AND THAT A RADICALLY NEW APPROACH IS NEEDED. AN EFFECTIVE HOUSING POLICY MUST ACHIEVE THREE OBJECTIVES: IT MUST PROVIDE DECENT, AFFORDABLE HOUSING TO THOSE WHO MOST NEED IT, WITH THE ESSENTIAL BENEFITS OF HOME OWNERSHIP WHERE APPROPRIATE. IT MUST PRESERVE AFFORDABILITY, HITHOUT REQUIRING AN ENDLESS SUCCESSION OF SUBUSIDIES. AND IT MUST BUILD AN ECDNOMIC BASE IN THE COMMUNITY, TO ENABLE IT TO MEET A GREATER SHARE OF ITS OWN NEEDS OVER TIME. MEETING THESE REQUIREMENTS WILL ULTIMATE PRODUCE A DIFFERENT CONCEPTION OF PUBLIC-PRIVATE PARTNERSHIPS AND OF PROPERTY ITSELF. THE HOUSING CRISIS IS PRIMARILY A STRUCTURAL PROBLEM, ROOTED IN THE FAILURE TO ACKNOWLEDGE THE LEGI TIMACY, QUANTIFY THE CONTRIBUTIONS, AND CRAFT A FAIR BALANCE' OF PRIVATE AND PUBLIC INTERESTS. UNFORTUNATELY, MOST POLICY MAKERS, THE GENERAL PUBLIC, AND EVEN A LARGE SEGMENT OF THE MAKERS, THE GENERAL PUBLIC, AND EVEN A LARGE SEGMENT OF THE
NONPROFIT DEVELOPMENT SECTOR STILL TREAT HOUSING AS A SOCIAL NONPROFIT DEVELOPMENT SECTOR STILL TREAT HOUSING AS
SERVICE OR COMMODITY SUPPLY PROGRAM. AS SUCH, IT IS
CONSIDERED TO $8 E$ A PROBLEM OF POOR PEOPLE AND THEIR CONSIDERED TO $8 E$ A PROBLEM OF POOR PEOPLE AND THEIR
DEFICIENCIES, TO BE ADDRESSED BY PROVIDING CHARITABLE DEFICIENCIES, TO BE ADDRESSED BY PROVIDING CHARITABLE
SUBSIDIES TO THE MEEDY OR INCENTIVES TO THE MARKET TO SUBSIDIES TO THE NEED

06130 MATTHEWS, B.

DEMOCRATIC INSTITUTIONS AND ELECTIONS IN SRI LANKA; ASSOCIATION FOR ASIAN STUDIES 1992 ANNUAL REPORT ASSOCIATION FOR ASIAN STUDIES, 1992, 134.

SRI LANKA HAS IDENTIFIED ITSELF AS A SOCIALIST DEMOCRACY FOR THENTY YEARS. DESPITE THE FACT THAT ONE-THIRD OF THE COUNTRY IS STILL BEYOND THE REACH OF REPRESENTATIVE GOVERNMENT, SRI LANKA MAINTAINS A DEMOCRACY. IT CAN BE ARGUED THAT IT IS A DEMOCRACY UNDER SIEGE, BUT A SYSTEM OF MULTIPARTY ELECTIONS REMAINS IN PLACE. THIS PAPER DISCUSSES THIS ISSUE FROM THREE PERSPECTIVES. FIRST, THE AUTHOR MAINTAINS THAT ALTHOUGH PARLIAMENT HAS HAD MUCH OF ITS AUTHORITY TRANSFERRED TO AN EXECUTIVE PRESIDENCY, IT STILL CONTINUES TO SHARE SIGNIFICANTLY IN POLITICAL POWER AND
INFLUENCE. SECONDLY, THE IMPLICATIONS OF THE LOCAL ELECTIONS OF 11 MAY 1991 WARRANT REVIEW, AS THESE HERE NOT ONLY REASONABLY FREE AND FAIR (UNUSUAL IN SRI LANKA) BUT WERE CONTESTED ON NATIONAL RATHER THAN REGIONAL ISSUES. THIRDLY, THE AUTHOR SHOWS HOW THE ALL PARTY CONFERENCE IS ANOTHER SIGNIFICANT FORUM WHERE POLITICAL DISCUSSION IS CARRIED OUT AND CONSENSUS ARRIVED AT.

06131 MATTHEWS, B.

TROUBLE IN SRI KOTHA: STRAINS AND PERILS OF DEMOCRACY IN SRI LANKA

ROUND TABLE, 322 (322) (APR 92), 215-228.

THE UNCERTAINTIES OF SRI LAMKA'S CURRENT DILEMMA OF DEMOCRATIC GFOVERMMENT IS DISCUSSED BY FOCUSING ESPECIALLY ON ITS PARLIAMENT. THE AUTHORITY OF PARLIMENT HAS BEEN MUCH ON ITS PARLI IAENT. THE AUTHORITY OF PARLIMENT HAS BEEN MUCH REDUCED BUT IT CONTINUES TO INVOLVE ITSELF SIGNIFICANTLY IN
SEVERAL LEVELS OF POLITICAL POWER AND INFLUENCE. THIS
ART ICLE EXAMINES: THE ROLE OF PARLIAMENT; UNP INVOL VEMENT; ARTICLE EXAMINES: THE ROLE OF PARLIAMENT; UNP INVOLVEMENT;
PRESIDENTIAL STYLE; AND THE NATURE OF THE CONSTITUTIONAL PRESIDENTIAL STYLE; AND THE NATURE OF THE CONSTITUTIONAL
CRISIS. IT CONCLUDES THAT THE TRADITIONS OF DEMOCRACY IN SRI CRISIS. IT CONCLUDES THAT THE TRADITIONS OF DEMOCRACY IN
LANKA ARE TOO RESPECTED TO BE PUT ASIDE IN RESPONSE TO LANKA ARE TOO RESPECTED TO BE PUT ASIDE
WHATEVER FORCES PERIODICALLY BUFFER IT.

06132 MATTHEWS, D.

NCR FOCUS: PUTTING THE PUBLIC BACK INTO POLITICS NATIONAL CIVIC REVIEW, 80(4) (FAL 91), 343-351. IN JUNE 1991, THE KETTERING FOUNDATION PUBLISHED "CITIZENS AND POLITICS: A VIEH FROM MAIN STREET AMERICA," STUDY BASED ON INTERVIEWS CONDUCTED BY A PUBLIC ISSUES RESEARCH FIRM. THE STUDY ILLUMINATES AMERICANS' ATTITUDES TOWARD POLITICS AS REVEALED IN FOCUS GROUPS WHERE RANDOMLYSELECTED INDIVIDUALS DISCUSSED HOW CITIZENS VIEH THE POLITICAL SYSTEM. 
06133 MATTHEHS, $R$.

BUTTER FOR GUNS: THE GROWTH OF UNDER-THE-COUNTER TRADE MORL TODAY 48(5) (MAY 92), 87-92

THE AUTHOR EXAMINES THE GROHTH OF THE UNDER-THE-COUNTER ARMS TRADE BETWEEN WEAPONS PRODUCERS AND THIRD WORLD COUNTRIES, SUCH AS IRAQ.

06134 MATTHEHS, T.; RAVENHILL, J.

AUSTRALIA'S ECONOMIC MALAISE: A NORTHEAST ASIAN SOLUTION? PACIFIC REVIEH, 4(1) (1991), 45-55.

THE AUTHORS ARGUE THAT ALTHOUGH AUSTRALIA APPEARS TO BE IN A GOOD POSITION TO TAP INTO THE ECONOMIC DYHAMISM OF THE MORTHEAST ASIAN REGION, THO PROBLEMS UNDERMINE ITS ABILITY TO EXPLOIT THE OPPORTUNITIES IT PRESENTS: (1) AUSTRALIA'S SHARE OF MORTHEAST ASIA'S IMPORTS HAS BEEN FALLING COMMOOITY BY COMMODITY, AT THE SAME TIME AS THESE ECOMOMIES HAVE BEEN SHARPLY INCREASING THEIR SHARE OF WORLD IMPORTS; (2) AUSTRALIA'S INABILITY OVER THE SAME PERIOD TO INCREASE THE SHARE OF MERCHANDISE EXPORTS IN ITS GDP. THESE PROBLEMS ARE EXAMINED IN THIS ARTICLE.

06135 MAUCERI, $P$

MILITARY POLITICS AND COUNTER-INSURGENCY IN PERU JOURMAL OF INTERAMERICAN STUDIES AND WORLD AFFAIRS, $33(4)$ JOURNAL OF INTERAMER

THIS ARTICLE ARGUES THAT THE VIRTUAL MONOPOLY ON DECISION-MAKING EXERCISED BY THE PERUVIAN MILITARY IN THE AREA OF COUNTER-INSURGENCY DOES NOT MEAN THAT A CONSISTENT AND NATIONAL COUNTER-INSURGENCY STRATEGY HAS BEEN INSTITUTED. RATHER, THE CONFLICTS AND CONTRADICTIONS HITHIN THE MILITARY HAVE BEEN REFLECTED IN ITS APPROACH TOHARDS INSURGENTS. THE ARTICLE FOCUSES ON THE MILITARY'S ROLE THE TRANSITION TO CIVILIAN RULE AND THE IMPACT OF THE REVOLUTIONARY EXPERI ENCE OF THE 1970S ON THE MILITARY IMPL ICATIONS WHICH THE LACK OF A COHERENT NATIONAL COUNTERINSURGENCY STRATEGY HAS HAD FOR PERU, ANO HOW CHANGES IN U.S. POLICY WILL LIKELY AFFECT MILITARY POLITICS.

06136 MAUERSBERG, $\mathrm{N}$.

THE RADICAL RIGHT GAINS IN TWO LAND ELECTIONS

GERMAN TRIBUNE, (1511) (APR 92), 1-2

EXTREME RIGHT-WING PARTIES MADE SIGNIFICANT GAINS IN TWO GERMAN LAND (PROVINCE) ELECTIONS. THE MAIN REASON WAS DISSATISFACTION WITH POLICIES ON POLITICAL ASYLUW. IN BADENWURTTEMBERG, THE CHRISTIAN DEMOCRATS, CHANCELLOR KOHL'S PARTY, LOST THEIR ABSOLUTE MAJORITY AS THE RIGHT-WING RADICAL REPUBLICANS POLLED ALMOST 11 PERCENT OF THE VOTE TO PICK UP 15 SEATS IN THE NEW ASSEMBLY. IN THE NORTHERN LAND OF SCHLESWIG-HOLSTEIN, THE SOCIAL DEMOCRATS ALSO LOST OF SCHLESWIG-HOLSTEIN, THE SOCIAL DEMOCRATS ALSO LOST MA URITY THE EXTREME RIGHT PARTY IN THIS CASE HAS THE GERMAN PEOPLE'S UMION, WHICH POLLED MORE THAN 6 PERCENT. THE GERMAN PEOPLE'S UNION, WHICH POLLED MORE THAN 6 PERCENT. THE ELECTIONS SIGNAL THAT A LARGE MAJORITY OF GERMANS NO LONGER WANT HUNDREDS OF THOUSANDS OF FOREIGNERS SETTLING IN GERMANY EVERY YEAR AND THAT THE GROWING PUBLIC DEBT IS AN INADEOUATE RESPONSE TO THE FINANCING NEEDS IN EASTERN GERMANY. NATIONAL POLITICS IN GERMANY WILL LIKELY SEE FUNDAMENTAL CHANGES IN THE NEAR FUTURE.

06137 MAURER, J.H.

CHURCHILL'S MAVAL HOL IDAY: ARMS CONTROL AND THE ANGLO-

GERMAN NAVAL RACE, 1912-1

JOURMAL OF STRATEGIC STUDIES, 15(1) (MAR 92), 102-127. ON THREE SEPARATE OCCASIONS BEFORE 1914, HINSTON

CHURCHILL INVITED THE GREAT NAVAL POWERS TO JOIN BRITAIN IN TAKING A "MOL IDAY" FROM THEIR COMPETITION IM BUILDING BATTLESHIPS. THE LEADERS OF WILHELMINE GERMANY REJECTED THE PROPOSAL, AND MOST OF THE OTHER GREAT POHERS AGREED THAT A NAYAL HOLIDAY WAS UNREALISTIC AND UNDESIRABLE. THIS PAPER EXAMINES THE PROPOSAL, FOCUSING ON THREE MAJOR FACTORS: CHURCHILL'S MOTIVE IN PROPOSING THE HOLIDAY SCHEME; HOH GERMANY MIGHT HAVE EXPLOITED THE SCHEME FOR STRATEGIC ADVAKTAGE; AND WHY GERMANY REJECTED THE PLAM.

06138 MAUSER, G.A.; KOPEL, D.8. SORRY, WRONG NUMBER: WHY MEDIA POLLS ON GUN CONTROL ARE OFTEN UNRELIABLE

POLITICAL COMMUNICATION, 9(2) (1992), 69-92.

WITHOUT ARGUING FOR OR AGAINST GUN CONTROL, THE AUTHORS AMALYZE THE INTERVIEHING AMD SAMPLING METHODS USED BY MEDIA ANALYZE THE INTERVIEHING AND SAMPL ING METHODS USED
POLLS AND ARGUE THAT SOME POLLS CLAIMING IMPRESSIVE

POLLS AND ARGUE THAT SOME POLLS CLAIMING IMPRESSIVE MAJORITIES FOR V
MOT BE ACCURATE.

06139 MAUZY, DK.

SINGAPORE: SUCCEEDING THE FOUNDER; ASSOCIATION FOR ASIAM STUDIES 1992 ANNUAL MEETING

ASSOCIATION FOR ASIAN STUDIES, 1992, 155

ON NOVEMBER 28, 1990, LEE KUAN YEW, THE WORLD'S LONGESTSERVING ELECTED LEADER ( 31 YEARS) AND THE ONLY PRIME

MINISTER SINGAPORE HAS EVER KNOWN, YOLUNTARILY STEPPED ASIDE FOR THE SUCCESSION OF GOH CHOK TONG AS PRIME MINISTER. THE
SIMPLE SHEARING-IN CEREMONY WAS HIDELY LABELED A "NON-EVENT, "YET IT CLEARLY ALSO MARKED a MOMENTOUS OCCASION. IT HAS THE LONG-ANTICIPATED CULMINATION OF A LENGTHY PROCESS OF IDENTIFYING, CO-OPTING, AND TESTING POTENTIAL SUCCESSORS, AND OF ALLOWING THE "SUCCESSOR TEAH" TO CHOOSE A LEADER

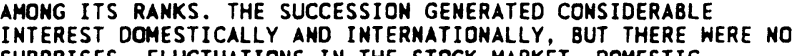
SURPRISES, FLUCTUATIONS IN THE STOCK MARKET, DOMESTIC ANXIETIES, INTERNATIONAL CONCERMS, OR DISRUPTIONS OF
SINGAPORE'S "BUSINESS AS USUAL" DEMEANOR. THIS PAPER EXPLORES THE SUCCESSION PROCESS AND OUTCOME IN SINGAPORE. SUCCESSES HAVE BEEN IN PREVENTING INFIGHTING AND MINIMIZING UNCERTAINTY AND INSTABILITY. THE PROBLEMS ARE, FIRST OF ALL, CONTAINING THE POLITICAL INFLUENCE OF A LIVING PAST LEADER (THE FOUNDER IN FACT), AND SECOND, HANDL ING THE DOMESTIC PRESSURES FOR CHANGE GENERATED BY THE SUCCESSION ITSELF. BOTH PROBLEMS ARE COMPOUNDED BY THE RELUCTANCE OF THE SUCCESSORS, HAVING BEEN GROOMED TO PLAY A "CUSTODIAL ROLE," TO AGREE TO SUBSTANTIAL POLITICAL CHANGE THAT HOULD ALLOW' FOR A FULLER EXERCISE OF DEMOCRATIC RIGHTS ANO LIBERTIES.

06140 MAVROGORDATOS, G.T.

GREECE
EUROPEAN JOURNAL OF POLITICAL RESEARCH, 22(4) (DEC 92),

417-419.

AS OF JANUARY 1, 1991, THE NEW DEMOCRACY PARTY

CONTROLLED 51 PERCENT OF THE SEATS IN THE GREEK PARLIAMENT

AMD 100 PERCENT OF THE CABINET POSTS.

06141 MAXFIELD, $S$

BANKERS' ALLIANCES AND ECONOMIC POLICY PATTERHS: EVIDENCE FROM MEXICO AND BRAZIL

COMPARATIVE POLITICAL STUDIES, 23(4) (JAN 91), 419-458.

THIS ARTICLE SUGGESTS AN ORGANIZATIONAL OR' INSTITUTIONAL EXPLANATION OF ECONOMIC POLICY PATTERNS WHICH DIFFERS SIGNIFICANTLY FROH STATE- OR SOCIETY-CENTERED EXPLANATIONS AND THOSE BASED ON INTERNATIONAL FACTORS. BANKERS' ALLIANCES, DEFINED AS INTEREST COALITIONS OF PUBLIC AND PRIVATE FINANCIERS, PLAY AN IMPORTANT ROLE IN SHAPING ECONOMIC POLICY. THE STRONGER THE BANKERS ALLIANCE, THE MORE LIKELY THAT LONG-RUN ECONOMIC POLICY PATTERNS HILL FEATURE ORTHODOX POLICIES SUCH AS TIGHT MONETARY POLICY AND LIMITED GOVERMMENT INTERVENTION IN FINANCIAL OR FOREIGN EXCHANGE MARKETS. THE HISTORICAL ORGANIZATION OF STATE ECONOMIC AGENCIES, AND OF CAPITAL, CREATE NATIONAL ENVIRONMENTS MORE OR LESS CONDUCIVE TO FORMATION OF STRONG BANKERS' ALLIANCES. THE THREE KEY VARIABLES CENTER ON: (A) THE TIMING AND ACTORS INVOLVED IN CENTRAL BANK FORMATION, (B) THE RELATIONSHIP BETWEEN EH CENTRAL BANK AND OTHER STATE ECONOMIC POLICYBETWEEN EH CENTRAL BANK AND OTHER STATE ECONOMIC POLICY
MAKING AGENCIES, AND (C) THE EXTENT OF CONGLOMERATION MAKING AGENCIES, AND (C) THE EXTENT OF CONGLOMERATION BETWEEN INDUSTRIAL AND FINANCIAL ENTERPRISES AND ITS IMPAC
ON STATE CONTROL OF INVESTMENT FINANCING. COMPARATIVE ON STATE CONTROL OF INVESTMENT FINANCING. COMPARATIVE
HISTORY OF THE MEXICAN AND BRAZILIAN CASES PROVIDES HISTORY OF THE MEXICAN AND BRAZILIAN CASES PROVIDES
PRELIMINARY EVIDENCE WITH WHICH TO EXPLORE THE PROPOSED PRELIMINARY EVIDENCE WITH WHICH TO EXPLORE THE PROPOSED RELATIONSHIP BETWEEN ORGANI ZATIONAL FEATURES OF THE STATE AND ECONOMIC POLICY PATTERNS.

06142 MAXFIELD, S

THE INTERMATIONAL POLITICAL ECONOMY OF BANK

NATIONALIZATION: MEXICO IN COMPARATIVE PERSPECTIVE LATIN AMERICAN RESEARCH REVIEW, 27(1) (1992), 75-104. IN BOTH MEXICO AND FRANCE WHERE BANK NATIONALIZATIONS WERE IMPLEMENTED THE COUNTRIES FELL FAR SHORT OF THEIR GOALS. THIS ARTICLE PLACES THE MEXICAN BANK NATIONALIZATION IN COMPARATIVE CONTEXT BY HIGHLIGHTING THE ROLE OF INTERNATIONAL PRESSURES IN MOTIVATING THE NATIONALIZATION DECISION AND SHAPING DOMESTIC DEBATES OVER IMPLEMENTATION IN DIFFERENT COUNTRIES. IT ALSO HIGHLIGHTS THE WAYS IN WHICH INTERNATIONAL FACTORS SHAPED THE RELATIVE STRENGTH OF OPPONENTS AS WELL AS ASSESSING THE MEDIUM-TO-LONG-RUN IMPACT OF THE NATIONALIZATIONS.

06143 MAXHELL, M.

THE GULF HAR AND POLITICAL SCIENCE

PS: POLITICAL SCIENCE AND POLITICS, 25(4) (DEC 92), 693-695.

A LIKELY ROLE OF THE POLITICAL SCIENTIST, TO "EDUCATE THE NATION"--IS FRUSTRATED BY A PARADOX WITHIN INTERNATIONAL RELATIONS (IR) THEORY ITSELF. IN THE IR VIEW OF THINGS, CITIZENS DO NOT TAKE PART IN DECISIONS ABOUT WAR. IR IS CONCERNED HITH THE INTERACTION AMONG STATES, NOT WITH THE WISHES OF PEOPLE WITHIN STATES. THIS ARTICLE SUGGESTS THAT WISHES OF PEOPLE WITHIN STATES. THIS ARTICLE SUGGESTS THAT THIS VIEW IS BASED PARTLY ON AN EPISTEMOLOGICAL QUIRK OF DISCIPLINE--TRADTIONAL IR SCHOLARS SEE STATES NOT
SEYERAL FLAWS OF LOGIC IN THIS VIEW ARE EXPLORED.

06144 MAY, A.

CASTE, Class, and SOCIAL CHANGE: AN INSTITUTIONALIST PERSPECTIVE

JOURNAL OF ECONOMIC ISSUES, 26(2) (JUN 92), 553-560.

AS GUNHAR MYRDAL'S STUDY OF RACE RELATIONS SHOWS, CLASS ANALYSIS IS OFTEN DIFFICULT TO APPLY WHEN ANALYZING THE UNITED STATES. THIS ARTICLE ASKS IF THE CONCEPT OF CLASS IS 
A USEFUL CONCEPT FOR INSTITUTIONALISTS, AND IF THERE IS A DIFFERENCE BETWEEN THE MARXIAN NOTION OF CLASS AND THE USE OF CLASS AND CASTE BY INSTITUTIONALISTS? THE PAPER EXAMINES THESE OUESTIONS AND ATTEMPTS TO DETERMINES WHAT ROLE CASTE AND CLASS DISTINCTIONS PLAY IN PROMOTING PROGRESSIVE SOCIAL CHANGE. IT CONCLUDES THAT IN THE END, MYRDAL EXPOSED THE ACTUAL SOCIAL AND ECONOMIC RELATIONS WITH OUR BELIEF IN EQUAL OPPORTUNITY.

06145 MAY, E.R.

INTELLIGENCE: BACKING INTO THE FUTURE

FOREIGN AFFAIRS, 71(3) (SUM 92), 63-72.

THE U.S. CONGRESS IS CONSIDERING LEGISLATION TO

REORGANIZE THE INTELLIGENCE COMMUNITY. EARLY IN 1992, THE

CHAIRMEN OF THE SENATE AND HOUSE INTELLIGENCE COMMITTEES

DAVID BOREN AND DAVID MCCURDY, INTRODUCED NEARLY IDENTICAL

DAVID BOREN AND DAVID MCCURDY, INTRODUCED NEARLY IDENTICAL

BILS TO REPLACE THE OLD MANDATES AND RESHAPE THE STRUCTURE

HOULD SOL $Y$ THE PROBLEMS OF THE PAST, NOT THE PROBLEMS OF

THE FUTURE.

06146 MAYER, $F$

MANAGING DOMESTIC DIFFERENCES IN INTERNATIONAL

NEGOTIATIONS: THE STRATEGIC USE OF INTERMAL SIDE-PAYMENTS INTERNATIONAL ORGANIZATION, 46(4) (FAL 92), 793-818.

WHEN NATIONS NEGOTIATE, OFTEN THE TOUGHEST BARGAINING IS NOT BETWEEN NATIONS BUT HITHIN THEM. THIS ARTICLE USES A NEGOTIATION FRAMEWORK TO ANALYZE THE CONSEQUENCES OF THE LIMITS OF WHAT IS POSSIBLE. IT ARGUES THAT LIMITS NEED NOT BE A LIABILITY. IT SHOWS THAT THE EFFECT OF DOMESTIC DIFFERENCES ON INTERNATIONAL NEGOTIATIONS DEPENDS ON THE CONFIGURATIDN OF DOMESTIC INTERESTS. IT EXPLORES A PARTICULAR DIMENSION OF THE DOMESTIC PROCESS: THE ABILTIY TO LINK ISSUES WHICH ALLOH FACTIONS TO MAKE INTERNAL SIDEPAYMENTS. IT DEMONSTRATES THAT INTERNAL ISSUE LINKAGE CAN HAVE PROFOUND EFFECTS ON THE EXTERNAL BARGAIN AND EXPLORES THE STRATEGIC IMPLICATIONS OF SIDE-PAYMENTS FOR THOSE WHO WOULD MANAGE DOMESTIC DIFFERENCES IN INTERNATIONAL NEGOTIATIONS.

06147 MAYER, F.W.

DOMESTIC POLITICS AND THE STRATEGY OF INTERNATIONAL TRADE JOURNAL OF POLICY ANALYSIS AND MANAGEMENT, 10(2) (1991), 222-247.

THE ARTICLE FIRST EXAMINES DEFINITIONS OF "FREE TRADE" AND "PROTECTION," AND EXPLAINS HOW THE CONVENTIONAL

UNDERSTAMDING OF THESE TERMS IS ERRONEOUS. THE AUTHOR ARGUES THAT THE US CANMOT UMILATERALIY CHOOSE FREE TRADE OR PROTECT US MARKETS. NEXT. AN INTERMATIONAL STRATEGIC TRADE GAME IS DESCRIBED AND ITS RELATION TO US POLICY EXPLORED. TO CHARACTERIZE THE POLITICAL ECONOMY OF INTERNATIONAL TRADE, THE ARTICLE ADORESSES THREE QUESTIONS: (1)WHAT IS THE TRADE GAME? (2) WHO ARE THE PLAYERS? (3) HOW DO THEY PLAY? THE AUTHOR CONTENDS THERE ARE MANY GAMES IN TRADE; THAT THE RELEVANT PLAYERS ARE NOT UNITARY ACTORS BUT RATHER COMPOSED OF FACTIONS WITH OIFFERING INTERESTS; AND THAT THE WAY IN WHICH NATIONS PLAY DEPENOS ON THE NATURE OF THEIR INTERNAL NEGOTIATIONS.

06148 MAYER, M.

POLITICS IN THE POST-FORDIST CITY

SOCIALIST REVIEW, 21(1) (JAN 91), 105-124.

MANY ARE BEGINNING TO QUESTION WHETHER THE LOCAL

POLITICAL REALM IS STILL A SIGNIFICANT ARENA FOR LEFTISTS, PROGRESSIVES, AND SOCIAL MOVEMENTS WHO SEEK TO RESIST THE SOCIAL EFFECTS OF NEOCONSERVATIVE POLITICS AND ECONOMIC RESTRUCTURING. HOWEVER, WHILE GLOBAL RESTRUCTURING HAS CERTAINLY CONSTRAINED LOCAL POLITICS SEVERELY, IT HAS ALSO GIVEN A NEW IMPORTANCE TO LOCALITIES. THIS ARTICLE EXAMINES HOW POST-FORDIST RESTRUCTURING BEARS UPON URBAN DEVELOPMENT AND, CONVERSELY, HOW LOCAL POLITICS FITS INTO THIS PROCESS OF RESTRUCTURING.

06149 MAYER, N.; PERRINEAU, P.

WHY DO THEY VOTE FOR, PE PEM?

EUROPEAN JOURNAL OF POLITICAL RESEARCH, 22(1) (JUL 92), 123-141.

THE RESULTS OF A SURVEY CONDUCTED AFTER THE SECOND ROUND OF FRANCE'S 1988 PRESIDENTIAL ELECTION ILLUSTRATE THE INADEQUACY OF THE CLASSICAL MODELS OF VOTING BEHAVIOR AS FAR INADEQUACY OF THE CLASSICAL MODELS OF VOTING BEHAVIOR AS FAR
AS THE VOTE FOR JEAN-MARIE LE PEN IS CONCERNED. THE MAJORITY AS THE VOTE FOR JEAN-MARIE LE PEN IS CONCERMED. THE MA OF LE PEN VOTERS IDENTIFY THEMSELVES NEITHER NITH THE NATIONAL FRONT NOR THE EXTREME RIGHT; THEY SHOW NO ELECTORAL STABILITY AND NO STRONG SOCIOLOGICAL SPECIFICITY. THEY LESS EDUCATED THAN THE AVERAGE FRENCHMAN AND DO NOT
CORRESPOND TO THE PROFILE OF THE RATIONAL VOTER. WITH THE EXCEPTION OF A SMALL HARD-CORE OF REGULAR VOTERS--WHO ARE EXCEPTION OF A SMALL HARD-CORE OF REGULAR VOTERS--WHO ARE LE PEN SUPPORTERS ARE PROTEST VOTERS WHO COME ANO GO.

06150 MAYER, $R$.

HANNAH ARENDT, LENINISM, \& THE DISAPPEARANCE OF AUTHORITY POLITY, 24(3) (SPR 92), 399-416.
THIS ARTICLE CONTENDS THAT THE EARLY SOCIALIST MOVEMENT WAS CONCERNED ABOUT THE MODERN CRISIS OF AUTHORITY AND THAT THE TYPE OF AUTHORITY THAT HANNAH ARENDT DESCRIBED PLAYS AN IMPORTANT PART IN LENIN'S THEORY. FAR FROM OISAPPEARING. THE AUTHOR CONCLUDES, AUTHORITY HAS IN FACT REEMERGED IN PRECISLY THOSE REGIMES THAT ARENDT CALLS "ANTI-AUTHORITARIAN.

06151 MAYER, W.G.

DO YOU TAKE THIS MAN? VOTERS AND VOWS

COMMONHEAL, CXIX(4) (FEB 92), 6-7.

THE AUTHOR SPECULATES ABOUTT HOW THE REVELATION OF GOVERNOR BILL CLINTON'S ALLEGED MARITAL INFIDELITY WILL AFFECT THE VOTING IN THE NEH HAMPSHIRE PRIMARY AND BEYOND.

06152 MAYNES, C.

A NECESSARY HART

A NECESSARY WAR?
FOREIGN POLICY, (82) (SPR 91), 159-177.

THIS ARTICLE--WRITTEN ON 16 JANUARY 1991--EXAMINES THE FOUR ISSUES USUALLY GIVEN TO SUPPORT THE USE OF MILITARY FORCE IN THE GULF CRISIS: OIL, ORDER, SECURITY, AND ISRAEL. IT SEEKS TO CONSIDER WHETHER ANY ONE OF THOSE REASONS, OR ALL OF THEM TOGETHER JUSTIFY HAR. THE COSTS TO THE UNITED STATES WILL NOT END WITH SUCCESS IN THE CURRENT SHOW-DOWN WITH IRAQ BUT WILL CONTINUE AS LONG AS THE UNITED STATES IS HEAVILY INYOL VED IN THE REGION AS IT NOW SEEMS LIKELY TO BE FOR SOME TIME TO COME. THE ARTICLE ALSO CONSIDERS POSSIBLE ALTERNATIVE STRATEGIES FOR THE UNITED STATES TO FOLLOW OTHER

06153 MAYOR, $F$.

THE ROLE OF THE SOCIAL SCIENCES IN A CHANGING EUROPE INTERMATIONAL SOCIAL SCIENCE JOURMAL, 132 (MAY 92), 277-282.

THIS ARTICLE CONSIDERS THE ROLE OF THE SOCIAL SCIENCES FROM A GLOBAL PERSPECTIVE IN THE FACE OF THE CHALLENGES ARISING FROM THE FAR-REACHING TRANSFORMATIONS THAT THE WORLD IS UNDERGOING. IT CALLS ATTENTION TO CONCEPTUAL AND INSTITUTIONAL TRANSFORMATIONS OF SUCH A SCOPE THAT THEY FORCE US TO ADOPT NEW APPROACHES AND STRATEGIES, AND THE MOST REFINED EVALUATING AND DECISION-MAKING SYSTEMS. IT SUGGESTS THAT HE TAKE ADVANTAGE OF EVERY EXPERIENCE USING SUGGESTS THAT HE TAKE ADVANTAGE
MODERN INTEGRATIONAL METHODS.

06154 MAZARR, M.J.

MILITARY TARGETS FOR A MINIMUM DETERRENCE: AFTER THE COLD HAR HOH MUCH IS EMOUGH?

JOURNAL OF STRATEGIC STUDIES, 15(2) (JUN 92), 147-171.

THE AUTHOR DEFENDS THE CONCEPT OF MINIMUM DETERRENCE AS A STRATEGY FOR THE UNITED STATES, GROUNDING HIS ANALYSIS IN
THE SPECIFICS OF NUCLEAR STRIKE PLANNING.

O6155 MAZARR, M.J. MORTH KOREA'S NUCLEAR PROGRAM: THE WORLD RESPONDS, 19891992

KOREA \& WORLD AFFAIRS, 16(2) (SUM 92), 294-318.

FEW ISSUES OF INTERNATIONAL SECURITY GARNERED AS MUCH ATTENTION FROM MID-1991 THROUGH APRIL 1992 AS NORTH KOREA'S APPARENT DRIVE TO ACQUIRE NUCLEAR WEAPONS. THIS ESSAY EXAMINES THE MAJOR ELEMENTS OF SOUTH KOREAN AND U.S. POLICY TOWARD THE NORTH DURING THIS PERIOD.

06156 MAZEY, S.; RICHARDSON, J.

BRITISH PRESSURE GROUPS IN THE EUROPEAN COMMUNITY: THE CHALLENGE OF BRUSSELS

PARLIAMENTARY AFFAIRS, 45(1) (JAN 92), 92-107.

THERE HAS BEEN A PROLIFERATION OF INTEREST GROUP LOBBYING AT THE EC LEVEL. THE CENTRAL AIM OF THIS ARTICLE IS EVALUATE THE RESPONSE OF BRITISH INTEREST GROUPS TO THE GROWING IMPORTANCE OF EUROPEAN DECISIONMAKING. THO KEY QUESTIONS UNDERPIN THIS ANALYSIS: FIRST, WHAT PROBLEMS DO INTEREST GROUPS ENCOUNTER WHEN LOBBYING? SECONDLY, HOH DO INTEREST GROUPS RECONCILE THE NEED TO LOBBY BOTH WHITEHA AND BRUSSELS? IT CONCLUDES THAT NOT ONLY MUST BRITISH DECISION-HAKING, BUT BRITISH GOVERNMENT MUST ALSO BE BETTER ORGANI ZED.

06157 MAZIARSKI, $W$.

THE POWERLESSNESS OF THE POWERFUL: WALESA NOW

EAST EUROPEAH REPORTER, 5 (1) (JAN 92), 22-23.

FOLLOWING HIS ELECTION AS POLAND'S PRESIDENT IN DECEMBER 1990. LECH HALESA SPENT 1991 TRYING TO FULFULL HIS CAMPAIGN PROMISE TO "ACCELERATE" THE COUNTRY'S ECONOMIC AND POLITICAL CHANGES. HHILE HIS PERFORMANCE HAS BEEN MIXED, THE FEARS OF MANY OF OPPOSITION CAMPS CONCERNING HALESA'S ALLEGED MANY OF OPPOSITION CAMPS CONCERNING WALESA'S ALLEGED AUTHORITARIANISM PROVED UNGROUNDED. WALESA ALSO MANAGED TO BEHIND THE GOVERMMENT'S STRIMGENT ECONOMIC REFORMS DESPITE BEHIND THE GOVERNMENT'S STRINGENT ECONOMIC REFORMS DESPIT ATTACKS ON IT FROM HIS SUPPORTERS. YET IF WALESA'S MORAL AUTHORITY GREW THROUGHOUT 1991, HIS POLITICAL AUTHORITY DECLINED. THUS, FOR THE MOMENT, HALESA HAS LOST THE INITIATIVE IN THE "WAR AT THE TOP" THAT HE STARTED IN EARLY 1990. BUT WITH POLAND HITHOUT EFFECTIVE GOVERMMENT FOR 
NEARLY SIX MONTHS, EVEN HIS OPPONENTS CONCEDE THAT THE ISSUE IS NOT SOME MUCH ONE OF WALESA AS OF LEADERSHIP IN POLAND IN GENERAL.

06158 MAZUR, A.

SYMBOLIC REFORM IN FRANCE: EGALITE PROFESSIONHELLE DURINC THE MITTERAND YEARS

WEST EUROPEAN POLITICS, 15(4) (OCT 92), 39-56.

THIS ARTICLE EXAMINES THE 1983 EGALITE PROFESSIONNELLE LAW ADOPTED UNDER THE SOCIAL GOVERMMENT. USING A POLICY PROCESS APPROACH, THE ANALYSIS SHOWS HOW THE 1983 LAW FAILED TO GO BEYOND SYMBOLIC REFORM IN POLICY FORMULATION AND IMPLEMENTATION. IN SYMBOLIC POLICY THE OUTCOME FAILS BOTH TO EFFECTIVELY REALLOCATE RESOURCES AND TO GENERATE POLICY FEEDBACK. THE ARTICLE CONCLUDES THAT WHILE SYMBOLIC POLICY IN THE CASE OF EGALITE PROFESSIONNELLE BROUGHT PUBLIC ATTENTION TO PROBLEMS OF GENDER DISCRIMINATION IM EMPLOYMENT IT FAILED TO GENERATE A PERMANENT POLICY COMHUNITY, INSIDE AND OUTSIDE OF GOVERNMENT, INTERESTED IN THE ENFORCEMENT OF PROGRAMMES FROM THE 1983 LAH.

06159 MBOWENI, T.

THE POST-APARTHEID ECONOMY--AN AND VIEW

SOUTH AFRICA FOUNDATION REVIEW, 16(11) (NOV 90), 5

TITO MBOWENI, AN AND ECONOMIST, OFFERS A TENTATIVE OUTLINE OF THE AND'S POST-APARTHEID ECONOMIC PLANS AND POLICIES. HE DISCUSSES THE CURRENT ECONOMIC SITUATION; AND GROWTH STRATEGIES; MINING; AGRICULTURE; HUMAN RESOURCES; FINANCE; PUBLIC SECTOR; PRIVATE SECTOR; AND FOREIGN INVESTMENT.

06160 MCADAMS. A.J.

GERMANY DIVIDED--FROM THE WALL TO REUHIFICATION PRINCETON UNIVERSITY PRESS, 1993, 272

THIS BOOK COMPREHENSIVELY EXAMINES THE FORTY-YEAR RELATIONSHIP BETHEEN EAST AND WEST GERMANY AND THE PROBLEMS OF CONTEMPORARY GERMAN UNITY. HHEN THE BERLIN WALL WAS OPENED ON NOVEMBER 9, 1989, THERE WAS WIDESPREAD SURPRISE AT THE RUSH TO UNIFICATION: GERMANY WAS REUNITING WHEN JUST ABOUT EYERYONE, POLITICAL PARTICIPANT AND OBSERVER ALIKE, HAD BECOME ACCUSTOMED TO IT BEING DIVIDED. THIS WORK DISSECTS THE COMPLEX PROCESS BY WHICH EAST AND WEST GERMAN LEADERS MOYED OVER THE YEARS FROM FIRST PURSUING THE IDEAL DEADERS MOVED OVER THE YEATS FROH FIRST PURSUING THE IDEAL INESCAPABLE REALITY OF DIVISION, AND THEN, FINALLY, TO MEETING THE CHALLENGES OF UNANTICIPATED REUNIFICATION. THE MEETING THE CHALLENGES OF UNANTICIPATED REUNIFICATION
AUTHOR DRAWS ON AN UNPRECEDENTED SERIES OF INTERVIENS AUTHOR DRAHS ON AN UNPRECEDENTED SERIES OF INTERYIEHS
CONDUCTED THROUGHOUT THE 1980 S AND EARLY 1990S WITH CONDUCTED THROUGHOUT THE 1980 S AND EARLY $1990 \mathrm{~S}$ WITH
OFFICIALS OF THE FEDERAL CHANCELLERY, THE FOREIGN OFFICE, OFFICIALS OF THE FEDERAL CHANCELLERY, THE FOREIGN OFFICE,
AND THE MINISTRY OF INTRA-GERMAN RELATIONS OF THE FEDERAL AND THE MINISTRY OF INTRA-GERMAN RELATIONS OF THE FEDERAL THE SED CENTRAL COMMITTEE OF THE GERMAN DEMOCRATIC REPUBLIC IN EAST BERLIN.

06161 MCAFEE, $K$.

STORM SIGNALS--STRUCTURAL ADJUSTMENT AND DEVELOPMENT ALTERNATIVES IN THE CARIBBEAN

SOUTH END PRESS, 1991,240

TWO VERY DIFFERENT' PROCESSES ARE SHAPING THE LIVES OF THE POOR IN THE CARIBBEAN TODAY. ON THE ONE HAND, THE REGION HAS BEEN THE TARGET OF A SERIES OF U.S. -INSPIRED POLICIES. ON THE OTHER HAND, LOCAL PEOPLE--OFTEN WITH THE HELP OF NONGOVERMMENTAL ORGANIZATIONS--HAVE INITIATED THEIR OWM CARIBBEAN-CENTERED DEVELOPMENT ALTERNATIVES. THIS BOOK IS ABOUT THE CONFLICT BETWEEN THESE DIVERGENT PERSPECTIVES. IT REVEALS THE LIMITATIONS AND DAMAGE DONE BY CURRENTLY FASHIONABLE AND EXTERNALLY IMPOSED DEVELOPMENT STRATEGIES. IT ALSO DEMONSTRATES THE VITALITY IN POPULAR GRASS-ROOTS INITIATIVES. THE AUTHOR CALLS FOR OFFICIAL POLICIES-NATIONAL AND MULTILATERAL--THAT CEASE TO HINDER THESE NEH ALTERNATIVES.

06162 MCALLISTER, I.

PARTY ELITÉ, VOTERS AND POLITICAL ATTITUDES: TESTING THREE EXPLANATIONS FOR MASS-ELITE DIFFERENCES CANADIAN JOURNAL OF POL ITICAL SCIEMCE, XXIY (2) (JUN 91), 237-268.

EARLY CLASSICAL DEMOCRATIC THEORISTS SAH EDUCATION AS THE SOLUTION TO MASS-ELITE POLITICAL DIFFERENCES. BY CONTRAST, LATER DEMOCRATIC ELITISTS SAH LITTLE THAT HOULD REDUCE MASS-ELITE DIFFERENCES. MORE RECENTLY MODERN ELITE THEORISTS HAVE ARGUED THAT ELITES ARE MORE POLARIZED ON THEORISTS HAVE ARGUED THAT ELITES ARE MORE POLARIZED ON POLITICAL ISSUES THAN MASS PUBLICS, AND THAT POLITICAL CONFLICT CAN BE MODERATED BY THE ABILITY OF ELITES TO DOWNPLAY POTENTIALLY DIVISIVE ISSUES. USING AUSTRALIA AS A CASE STUDY, THESE THREE APPROACHES TO MASS-ELITE DIFFERENCES
ARE ANALYZED USING A MATCHED SURVEY OF VOTERS AND CANDIDATES ARE ANALYZED USING A MATCHED SURVEY OF VOTERS AND CANDID CONDUCTED AT THE AUSTRALIA 1987 FEDERAL ELECTION. THE RESULTS SHOH LITTLE SUPPORT FOR EDUCATION AS A FACTOR REDUCING MASS-ELITE DIFFERENCES AND POINT TO THE DEMOCRATIC FIXED AND ENDURING. THE RESULTS ALSO CONFIRM THE EXISTENCE OF MORE INTENSE ISSUE POLARIZATION AMONG ELITES THAN AMONG VOTERS.
06163 MCALLISTER, I.; STUDLAR, D.

REGION AND VOTING IN BRITAIN, 1979-87: TERRITORIAL POLARIZATION OR ARTIFACT?

AMERICAN JOURNAL OF POLITICAL SCIENCE, 36(16) (FEB 92), 168-199

THE TERRITORIAL INTERPRETATION OF A MORTH-SOUTH POL ITICAL DIVIDE IN GREAT BRITAIN IS TESTED USING DATA COLLECTED AT THE 1979, 1983, AND 1987 GENERAL ELECTIONS. USING MULTIVARIATE ANALYSIS, THE AUTHORS ESTIMATE HOW WUCH OF THE REGIONAL VARIANCE IN VOTING CAN BE EXPLAINED BY SOCIAL COMPOSITION, POLITICAL ATTITUDES, ATTITUDES TOWARD PARTY LEADERS, CONSTITUENCY EFFECTS, AND LOCAL ECONOMIC AND POLITICAL CULTURE. THE RESULTS INDICATE THAT TERRITORIAL EFFECTS ARE SMALL ONCE THE STATEWIDE EFFECTS OF OTHER VARIABLES ARE TAKEN INTO ACCOUNT. THE BULK OF REGIONAL VOTING CAN BE ATTRIBUTED TO SOCIAL COMPOSITIONAL EFFECTS: THERE IS ONLY LIMITED EVIDENCE FOR A TERRI TORIAL EFFECT, AND THEN ONLY VIA LOCAL POLITICAL CULTURE.

06164 MCALLISTER, I. ; MAKKAI, T.

RESOURCE AND SOCIAL LEARNING THEORIES OF POLITICAL PARTICIPATION: ETHNIC PATTERNS IN AUSTRALIA
CANADIAN JOURNAL OF POLITICAL SCIENCE, XXV(2) (JUN 92), CANADIAN

POLITICAL PARICIPATION IS CENTRAL TO LIBERAL DEMOCRACY, YET THERE ARE SUBSTANTIAL VARIATIONS IN THE LEVELS OF PARTICIPATION OBSERVABLE AMONG DIFFERENT SOCIAL GROUPS EMPIRICAL THEORIES EXPLAIN THESE VARIATIONS BY THE DIFFERENT SOCIO-ECONOMIC RESOURCES INDIVIDUALS POSSESS AND BY THEIR RESULTING LEVELS OF TRUST AND EFFICACY IN THE POLITICAL SYSTEM. THIS ARTICLE USES AUSTRALIA AS A CASE STUDY. THE RESULTS SHOW THAT IMMIGRANTS SOCIALIZED IN COUNTRIES LACKING CONTINUOUS DEMOCRATIC TRADITIONS HAVE GREATER POITICAL TRUST, BUT ALSO DISPLAY MORE AUTHORITARIAN VALUES. DIFFERENCES EMERGE NOT ONLY IN THE TYPE OF PARTICPATIONS BEING ANALYZED, BUT AMONG ETHNIC GROUPS.

06165 MCALLISTER, I.; DARCY, R.

SOURCES OF SPLIT-TICKET VOTING IN THE 1988 AMERICAN ELECTIONS

POLITICAL STUDIES, XL(4) (DEC 92), 695-712.

DIVIDED PART ISAN CONTROL OF THE AMERICAN NATIONAL

GOVERNMENT IS NOT A NEW PHENOMENON. OF THE 41 PRESIDENTS FROM HASHINGTON TO BUSH, 20 SAH THE HOUSE OF REPRESENTATIVES UNDER THE CONTROL OF THE OPPOSING PARTY. WHILE DIVIDED CONTROL OF GOVERMMENT IS NOTHING NEH, HOWEVER, ITS RECENT CAUSES ARE. BEFORE 1955, DIVIDED CONTROL WAS DUE TO ELECTION REYERSALS IN THE OFF YEAR - EASILY INTERPRETABLE IN TERMS OF REVERSALS IN THE OFF YEAR - EASILY INTERPRETABLE IN TERMS OF NEGATIVE RETROSPECTIVE JUDGEMENTS OR SHITCHED POLICY CHOICES
ON THE PART OF THE ELECTORATE. AFTER 1955, ON THE OTHER HAND, ON THE PART OF THE ELECTORATE. AFTER 1955, ON THE OTHER HAND, REPRESENTATIVES CONTROLLED BY THE OPPOSING PARTY. BY REPRESENTATIVES CONTROLLED BY THE OPPOSING PARTY. BY ANALYZING DATE COLLECTED DURING THE 1988 NATIONAL

THE AUTHORS DISTINGUISH BETHEEN CONGRESSIONAL AND PRESIDENTIAL TICKET-SPLITTING AND FIND THEIR CAUSES TO BE
COMPLEX. IT IS CAUSED, IN PART, BY CONGRESSIONAL INCUMBENCY COMPLEX. IT IS CAUSED, IN PART, BY CONGRESSIONAL INCUMB BALLT FORMATS, BUT WIDER SOCIAL FORCES ARE ALSO RESPONSIBLE FOR TICKET-SPLITTING.

06166 MCANENY, L.

HUGE MAJORITY BACKS SHIFT FROM INTERNATIONAL TO DOMESTIC AGENDA

GALLUP POLL MONTHLY, (316) (JAN 92), 12-13.

ACCORDING TO A GALLUP POLL, FOUR' IN FIVE AMERICANS WANT THE U.S. GOVERMMENT TO CONCENTRATE ON INTERNAL ISSUES AND SCALE DOWN ITS INTERNATIONAL INVOLVEMENTS. THIS MEANS THAT PRESIDENT GEORGE BUSH WILL NOT BE ABLE TO RELY ON HIS FOREIGN POLICY EXPERTISE AS A CENTRAL THEME IN HIS 1992 REELECTION CAMPAIGN.

06167 MCANENY, L.

MRS. PRESIDENT BUSH, CLINTON, QUAYLE? MANY AMERICANS HOULD PREFER IT

GALLUP POLL MONTHLY, (318) (MAR 92), 54-55

ACCORDING TO A GALLUP POLL, MANY AMERICANS PERCEIVE

BARBARA BUSH, HILLARY CLINTON, AND MARILYN QUAYLE AS BETTER

PRESIDENTIAL TIMBER THAN THEIR MORE FAMOUS HUSBANDS, WHETHER

ON THEIR OWN MERITS OR THEIR HUSBANDS' LACK OF THEM.

06168 MCANENY, L.

20 YEARS LATER WATERGATE STILL TARMISHES NIXON'S IMAGE GALLUP POLL MONTHLY, (321) (JUN 92), 19-23.

THENTY YEARS AFTER THE WATERGATE' SCANDAL DROVE HIM FROM OFFICE, RICHARD NIXON'S ELDER-STATESMAN EFFORTS ARE PROVING ONLY MARGINALLY SUCCESSFUL IN REVAMPING HIS IMAGE. ACCOROING TO A PUBLIC OPINION POLL 50 PERCENT OF AMERICANS STILL CONSIDER NIXON AN OUTCAST, WHILE 42 PERCENT FEEL THAT HE HAS REGAINED A POSITION OF PROMINENCE IN PUBLIC LIFE. MOREOVER, NIXON STILL FINISHES LAST IN A RANKING OF HOW LIVING EXPREISDNETS HAVE CONDUCTED THEMSELVES SINCE LEAVING OFFICE.

06169 MCBETH, J.

CLARK'S CURTAIN CALL 
FAR EASTERN ECONOMIC REVIEW, 153(31) (AUG 91), 14-15. BOWING TO PRESSURE FROM AN ERUPTING MT. PINATUBO, PHILIPPINE NEGOTIATIONS HAVE REACHED AGREEMENT WITH THE UNITED STATES ON THE SHAPE OF A NEW 10-YEAR BASES ACCORD, WHICH LEAVES ROOM FOR AN UNOETERMINED WITHDRAWAL PERIOD. COVERING ONLY THE HEAVILY-DAMAGED BUT STILL VIABLE SUBIC NAVAL BASE, IT FORMS PART OF A BROADER UMBRELLA TREATY WHICH WILL BRING MANILA NEARLY US\$2.4 BILLION IN DIRECT BASES COMPENSATION AS WELL AS OTHER NON-RELATED ASSISTANCE AMOUNTING TO MORE THAN US\$4.5 BILLION. THE AGREEMEHT OCCURRED ONLY AFTER 14 MONTHS OF "INTENSE, ACERBIC, ABRASIVE, YET CATHARTIC" NEGOTIATIONS BETHEEN THE U.S. AND THE PHILIPPINES. THE DEAL NOW HAS TO BE APPROVED BY A THO-THIRDS VOTE OF THE 23-MAN PHILIPPINE SENATE.

06170 MCBETH, J.

POSITION VACANT

FAR EASTERN ECONOMIC REVIEW, 151(24) (JUN 91), 34-38. UNLIKE CORAZON AQUINO, THE NEXT PRESIDENT OF THE PHILIPPINES, TO BE ELECTED IN MAY 1992, NILL HAVE TO DO MUCH MORE THAN SURVIVE, WHICH MANY SEE AS HER GREATES ACHIEVEMENT. DESPITE THE CURRENT PLETHORA OF PRESIDENTIAL HOPEFULS, THE WINNER IS LIKELY TO BE THE CANDIDATE OF THE RUL ING LAKAS NG DEMOKRATIKONG PILIPINO (LDP). THE THO LEADING LDP CONTENDERS ARE DEFENSE SECRETARY FIDEL RAMOS, A FORMER GENERAL WHO TOOK PART IN THE ORIGINAL ARMY REVOLT AGAINST FERDINAND MARCOS AND THEN STOOD BESIDE AQUINO THROUGH SIX COUP ATTEMPTS, AND HOUSE OF REPRESENTATIVES SPEAKER RAMON MITRA. WHILE IT IS STILL FAR TOO EARLY TO DETERMINE THE SIZE OF THE PRESIDENTIAL FIELD, CONVENTIONAL WISOOM SUGGESTS THAT ANY PRESIDENTIAL NOMINEE WHO MISSES OUT IN THE NOMINATION RACE FOR ONE OF THE MAJOR PARTIES WILL HAVE THE ALMOST IMPOSSIBLE TASK OF RUNNIMG AS AN INDEPENDENT.

06171 MCBETH, J.

REDS DOWN BUT NOT OUT

FAR EASTERN ECONOMIC REVIEW, 151 (24) (JUN 91), 44-48. MILITARY ARMY, THE NEW PEOPLE'S ARMY (NPA), MAY HAVE BEEN IM GENERAL DECLINE THROUGHOUT MUCH OF PRESIDENT CORAZON AQUINO'S TERM, BUT IT IS CLEAR THE ARMED FORCES OF THE PHILIPPINES (AFP) WILL BE UNABLE TO BREAK THE BACK OF THE
MOVEMENT OR ACHIEVE WHAT IT CALLS A "STRATEGIC VICTORY" BEFORE THE PRESIDENT LEAVES OFFICE ON 30 JUNE 1992. A NUMBER OF FACTORS HAVE CONTRIBUTED TO THE COMHUNIST DECLINE IN THE LAST THREE YEARS. ONE IN PARTICULAR HAS BEEN A STEADY IMPROVEMENT IN MILITARY COORDINATION AND INTELLIGENCEIMPROVEMENT IN MILITARY COORDINATION AND INTELLIGENCELEADERSHIP TO KEEP PACE HITH CHANGING POLITICAL CONDITIONS AT A TIME WHEN COMMUNISH ITSELF IS UNDER NORLDWIDE SIEGE. HOWEVER, OPTIMISTIC PREDICTIONS STILL ALLOH FOR AT LEAS FIVE YEARS BEFORE THE AFP WILL BE ABLE TO ERADICATE THE COMMUNIST INSURGENTS--AND THEN ONLY WITH IMPROVED LEADERSHIP A UNIFIED AND BETTER MOTIVATED FIGHTING FORCE AND A GOVERNMENT MORE HILLING TO SPEND ON RURAL DEVELOPMENT IN KEY AREAS.

06172 MCBETH, J.

SPLITTING THE PACK

FAR EASTERN ECONOMIC REVIEW, 151(17) (APR 91), 26-27. WITH THE NEXT PRESIDENTIAL ELECTIONS BARELY A YEAR AWAY, CONTENDERS FOR THE PHILIPPINES' HIGHEST OFFICE HAVE ALREADY LAUNCHED THEIR POLITICAL CAMPAIGNS. THE FIELD IS BROAD, PLACING YOUNG AND RELATIVELY UNTESTED CANDIDATES WHO THEIR POLITICAL TEETH IN THE "PEOPLE POWER" MOVEMENT ALONGSIDE THE COUNTRY'S MORE TRADITIONAL OLIGARCHS. ALTHOUGH THE PRIMCIPAL PLAYERS CAY ALREADY BE IDEMTIFIED--SO FAR TEN CANDIDATES HAVE EITHER DECLARED THEMSELVES OR MADE IT CLEAR THAT THEY ARE IN THE RUNMING--ONE CRUCIAL INGREDIENT IS MISSING: WHO PRESIDENT AQUINO MAY ANOINT AS HER CHOSEN SUCCESSOR.

06173 MCBETH, J.

\section{THE FINAL TEST}

FAR EASTERM ECONOMIC REYIEH, 151(24) (JUM 91), 33 PHILIPPINES' PRESIDENT CORAZON AQUINO HAS NOW ENTERED THE FINAL STRETCH OF HER SIX-YEAR PRESIDENCY, BUOYED BY A LOWER INTEREST RATES AND AN ECONOMY THAT IS SHOWING SIGNS OF RESURGENCE. HILE THERE HAS BEEN MUCH CRITICISM OF THE OPPORTUNITIES MISSED BY THE AQUINO ADMINISTRATION, SOME PROGRESS HAS BEEN MADE: THE MONOLITHIC BUSINESS ELITE HAS FRAGMENTED TO A DEGREE, POPULIST MOVEMENTS HAVE MULTIPLIED, FRAGMENTED TO A DEGREE, POPULIST MOVEMENTS HAVE MULTIPLIED, BRINGING WITH THEM A HEIGHTENED SENSE OF POLITICAL CONSCIOUSNESS, AND THERE HAS BEEN A SLOW BUT PERCEPTIBLE GROWTH IN THE MIDOLE CLASS. A CRITICAL DAY FOR THE PHILIPPINES IS 11 MAY 1992, WHEN THE COUNTRY'S 30 MILLION VOTERS GO TO THE POLLS TO ELECT AQUINO'S NEH SUCCESSOR AND CHOOSE A NEW SENATE AND HOUSE OF REPRESENTATIVES.

06174 MCBURNETT, M.

THE INSTABILITY OF PARTISANSHIP DUE TO CONTEXT

POLITICAL GEOGRAPHY OUARTERLY, 10(2) (APR 91), 132-148. RECENT RESEARCH SHOWS THAT CERTAIN CONDITIONS CAN LEAD
TO CHANGE IN PARTY ATTACHMENT BY INDIVIDUALS. THIS ESSAY DEVELOPS AND TESTS THREE HYPOTHESES DERIVED FROM THE ESTABLISHED LITERATURE THAT SUGGEST INDIVIDUAL PARTISANSHIP IS UNSTABLE. THE HYPOTHESES--ARRAYED IN ORDER OF INCREASING COMPLEXITY--ARE: LENGTH OF RESIDENCE AFFECTS PARTISANSHIP: THE INFORMATION FLOH DURING ELECTIONS CONTRIBUTES TO CHANGE IN PARTY ATTACHMENT; AND INTERACTION AMONG PARTISANS AFFECTS PARTISANSHIP. STRONG INSATIABILITY IS INOICATED THROUGH INTERACTION EFFECTS NOT FOUND IN OTHER MODELS. THE AUTHOR CONCLUDES WITH A DISCUSSION OF THE CONSEOUENCES FOR VOTECHOICE MODELS.

06175 MCCABE, A.; FITZGERALD, M. PROSPECTS FOR NUCLEAR WASTE

FIE

NICY STUDIES REVIEN, 1014) (WIN 92), 167-179.

THE NUCLEAR HASTE POLICY ACT OF 1982 AUTHORIZED THE U.S. DEPARTMENT OF ENERGY (DOE) TO EVALUATE MONITORED RETRIEVABLE STORAGE (MRS) AS AN OPTION FOR MANAGING SPENT FUEL AND HIGHLEVEL RADIOACTIVE WASTE. IN 1987, DOE SOUGHT CONGRESSIONAL APPROVAL FOR CONSTRUCTION OF AN MRS AT A SITE IN TENHESSEE, DESPITE ADAMANT OPPOSITION FROM THE STATE GOVERNMENT. AS A RESULT OF THE DOE-TENMESSEE DISPUTE, AN AMENDMENT IN LATE 1987 MULLIFIED DOE'S PROPOSAL AND ESTABLISHED THE MRS COMMISSION AND HIGH-LEVEL NUCLEAR WASTE NEGOTIATOR. THIS PAPER ANALYZES DOE'S SITING ATTEMPT IN TENNESSEE, THE ACTIONS OF THE COMMISSION AND NEGOTIATOR, AND THE PROSPECTS FOR IMPLEMENTATION OF NUCLEAR WASTE POLICY.

06176 MCCALL, C.; ARMSTRONG, P.; CLARKSON, S.; CUNMINGHAN, F. MCROBERTS, K.; PANITH, L.; ROTSTEIN, A.; WATKINS, M. THREE NATIONS

CANADIAN FORUM, LXX(807) (MAR 92), 4-6

AT THE HEART OF CANADA'S CURRENT CONSTITUTIONAL CRISIS IS THE NATIONAL QUESTION" THE DEMOCRATIC RIGHT OF FREE PEOPLES TO SELF-GOVERMMENT--THE CAPACITY TO ORGANIZE AS COMMUNITIES OF EQUALS WHO LIVE AND HORK TOGETHER ON A SHARINGS BASIS. THIS ARTICLE EXPLORES THE ISSUE OF WHETHER CANADA, QUEBEC, AND THE ABORIGINAL PEOPLES CAN BE RECONCILED WITH ONE ANOTHER WITHIN THE EXISTING FEDERATION, WHILE WITH ONE ANOTHER WITHIN THE EXISIING FEDERATION, WHIL EROSIVE ECONOMIC FORCES OF CONTINENTALISM AND GLOBALIZATION. EROSIVE ECONOMIC FORCES OF CONTINENTALISM AND GLOBALIZATION. IT CONCLUDES THAT THE PRESENT SITUATION IS URGENT AND THAT
SOLUTION MUST BE ACHIEVED BY PEOPLE OF GOOD HILL FROM ALL SOLUTION MUST BE ACHIEVED

06177 MCCALLUM, B.T.

MONEY AND PRICES IN COLONIAL AMERICA: A NEM TEST OF COMPETING THEORIES

JOURNAL OF POLITICAL ECONOMY, 100(1) (FEB 92), 143-161. SCHOLARS HAVE RECENTLY REOPENED A LONG-STANOING CONTROVERSY OVER MONETARY EXPERIENCES IN COLONIAL AMERICA. THE MAIN SUBSTANTIVE ISSUE CONCERNS LARGE, RAPID INCREASES IN STOCKS OF PAPER CURRENCY THAT WERE FOLLOWED BY NEGLIGIBLE CHANGES IN PRICE LEVELS. THE "BACKING THEORY," OR ANTICLASSICAL INTERPRETATION, IS THAT PRICES FAILED TO RESPOND TO MAJOR INCREASES IN TOTAL MONEY SUPPLIES. THE "QUANTITY THEORY," OR CLASSICAL HYPOTHESIS, IS THAT SPECIE WAS EXPORTED IN AMOUNTS THAT LEFT TOTAL MONEY STOCKS APPROXIMATELY UNCHANGED. THIS PAPER DEVELOPS AND APPLIES A STRATEGY FOR RESOLVING THIS FUNDAMENTAL DISAGREEMENT DESPITE THE ABSENCE OF DATA ON STOCKS AND FLOWS OF SPECIE.

06178 MCCARL, S.R.

ERIC VOEGELIN'S THEORY OF CONSCIOUSNESS

AMERICAN POLITICAL SCIENCE REVIEW, 86 (1) (MAR 92), 106-111.

THE SELF STANDS IN THE WAY OF UNDERSTANDING ANO APPRECIATING CONSCIOUSNESS. THE SELF IS A REFLEXIVE, ASYMMETRICAL BIT OF CONSCIOUSNESS THAT DISPLACES THE WOLE OF CONSCIOUSNESS AND THE OPEN NATURE OF CONSCIDUSNESS. SUCH OISPLACEMENTS OF CONSCIOUSHESS ARE EXPRESSIONS OF GNOSTIICISM SOME POLITICAL MOVEMENTS (E.G., FASCISH) ARE EXPRESS
SUCH RESTRICTIONS OF THE HORIZON OF CONSCIOUSNESS. TO SUCH RESTRICTIONS OF THE HORIZON OF CONSCIOUSNESS. TO SELERSTAND AND APPRECIATE CONSCIOUSNESS REQUIRES A DEGREE OF SELFLESSNESS ON THE PART OF THE INOUIRER. PHILSOPHY AND SELFLESSNESS NECESSARY FOR PARTICIPATING IN. APPRECIATING, SELFLESSNESS NECESSARY FOR PARTICIPATING IN, APPRECIATI
AND UNDERSTANDING CONSCIOUSNESS. SUCH PHILOSOPHIZING AND UNDERSTANDING CONSCIOUSNESS. SUCH PHILOSOPHIZING
ENHANCES THE POSSIBILITY OF MORE INCLUSIVE JOINT POLITICAL ACTION.

06179 MCCARHEY, J

MARX AMD JUSTICE AGAIN

MARX AND JUSTICE AGAIN

NORMAN GERAS HAS ARGUED THAT' KARL MARX'S CRITIOUE OF CAPITALISM ENTAILED THE YIEH THAT II HAS UN JUST THOUGH MARX HIMSELF WAS UMAHARE OF IT. IN THIS ESSAY, THE AUTHOR DEFENDS MARX'S CONSISTENCY ON THE GROUNDS THAT, WHILE THE WAGE CONTRACT UNDER CAPITALISM DOES NOT VIOLATE PREVAILING STANDARDS OF BOURGEOIS RIGHT, THE THEFT OF SURPLUS LABOR FROM THE COLLECTIVE WORKER IN CAPITALIST PRODUCTION DOES DO SO. THUS, IT WAS NOT MARX BUT CAPITALISM THAT WAS INCONSISTENT AND CONTRADICTORY. 
06180 MCCARTAN, B.

DEFENSE OR OPULENCE? TRADE AND SECURITY IN THE 19905

SAIS REVIEN, 11(1) (WIN 91) 133-145.

THIS ARTICLE DISCUSSES THAT ORIGINS AND APPLICATIONS OF U.S. SECURITY RESTRICTIONS ON IMPORTS AND INVESTMENT. IT ALSO ANALYZES THE UNDERLYING CONCEPTIONS OF NATIONAL SECURITY FROM WHICH SUCH RESTRICTIONS SPRING. TO RESOLVE THE TENSION BETHEEN ITS COMAITMENT TO FREE TRADE AND ITS CONCERNS ABOUT NATIONAL SECURITY, THE UNITED STATES MUST NOT ONLY SCRUTINIZE ITS TRADE ANO INVESTMENT POLICY, BUT ALSO REEXAMINE HOW HIDELY IT CASTS THE NET OF NATIONAL SECURITY OVER ECONOMIC ACTIVITY.

06181 MCCARTHY, A.

A SCHOOL FOR THE ELECTED

COMMONHEAL, CXIX(19) (NOV 92), 9-10.

THE AUTHOR LOOKS AT THE CHANGES IN CONGRESS PROOUCED BY REDISTRICTING, VOTER DISGUST HITH THE INCUMBENTS, AND THE 1992 ELECTIONS.

06182 MCCARTHY, A.

THE CHARACTER ISSUE: BILL, FRAMKLIN, AMD PERICLES

COMMONHEAL, CXIX(9) (MAY 92), 8-9

THE AUTHOR LOOKS AT THE PARALLELS BETHEEN BILL CLINTON AND FRANKLIN DELANO ROOSEVELT, FOCUSING ON QUESTIONS ABOUT AND FRANKLIN DELANO ROOSEVELT, FOCUSING ON QUESTIONS ABOU
THEIR CHARACTER AND MORAL FITNESS TO SERVE AS PRESIDENT.

06183 MCCARTHY, A.

THE EMPTY TUBE: TY TRASHES POLITICS

COMMONHEAL, CXIXI7) (APR 92) 8-9

HONOEVER WINS THE 1992 PRESIDENTIAL ELECTION WILL HAVE DONE SO AS THE RESULT OF A POLITICAL PROCESS WARPED ALMOST BEYOND RECOGNITION BY TELEVISION. IN THE PRIMARIES, THE METHORK BOSSES DECIDE WHICH CANDIDATES ARE VIABLE AND WHICH ARE NOT BY CHDOSING WHO TO COVER AND WHO MAY APPEAR ON THE TELEVISED DEBATES. IN ADOITION, THE NETWORK PERSONALITIIES PRESIDING OVER THE DEBATES DECIDE WHICH ISSUES ARE IMPORTED AND WHICH CANDIDATES' PROGRAMS MERIT ATTENTION BY THE QUESTIONS THEY ASK. THE ARBITRARINESS AND SUPERFICIALITY OF THE TELEVISION COVERAGE IS FURTHER COMPLICATED BY THE POLITICAL ADVERTISING, WHICH ASSAULTS VIEWERS DAY AND NIGHT PRIOR TO PRIMARY ELECTIONS.

06184 MCCARTHY, A.

THEY JUST' DON'T GET IT

COMMONWEAL, CXIX(17) (OCT 92), 9-10.

THE AUTHOR LOOKS AT THE REPUBLICAN ATTEMPTS TO MAKE HILLARY CLINTON'S POLITICAL ROLE AN ISSUE IN THE 1992 PRESIDENTIAL CAMPAIGN AND AT MRS. CLINTON'S ACHIEVEMENTS AS FIRST LADY OF ARKANSAS.

06185 MCCARTHY, P.

CAN FRAMCE SURYIYE GERMAN REUMIFICATIOM?

SAIS REVIEW, 12(1) (WIN 92) 85-100.

GERMAN UNIFICATION HAS LAID BARE PROBLEMS THAT WERE INHERENT IN THE DIFFUCLT FRAMCO-GERMAN DIALOGUE. IN THIS INHERENT IN THE DIFFUCLT FRANCO-GERMAN DIALOGUE. IN THIS ARTICLE THE AUTHORS SITUATE THE FRANCO-GERMAN RELATIONSHIP IN ITS HISOTIRICAL CONTEXT AND EXAMINES THE POLITICAL AND ECONOMIC ISSUES IT HAS FACING IN MID-1989. THEN THEY SEE HOW THE FRENCH LIVED THE MONTHS AFTER THE BREACHING OF THE
IN CONCLUSION, THEY ANALYZE THE WAYS IN WHICH FRANCE IS ADAPTING TO A SITUATION WHICH, WHLE SEEMING STRIKINGLY NOVEL, OFFERS NEW VERSIONS OF OLD ISSUES.

06186 MCCARTNEY, J.

BLACK POWER IDEOLOGIES--AN ESSAY IN AFRICAN-AMERIAN POLITICAL THOUGHT

TEMPLE UNIVERSITY PRESS, 1992, 256

IN A SYSTEMATIC SURVEY OF THE MANIFESTATIONS AND MEANINGS OF BLACK PONER IN AMERICA, THIS BOOK ANALYZES THE IDEOLOGY OF THE BLACK POHER MOVEMENT IN THE 1960S AND PLACES IT IN THE CONTEXT OF BOTH AFRICAN-AMERICAN AND WESTERN POLITICAL THOUGHT. IT DEMONSTRATES, THROUGH AN EXPLORATION OF BLACK HISTORICAL ANTECEDENTS, HOW THE BLACK POHER VERSUS THE MAINSTREAM COMPETITION OF THE SIXTIES HAS NOT UNIQUE IN AMERICAN HISTORY. TRACING THE EVOLUTION OF BLACK SOCIAL AND POLITICAL MOVEMENTS FROM THE 18TH CENTURY TO THE PRESENT THE AUTHOR FOCUSES ON THE IDEAS AND ACTIONS OF THE LEADERS OF EACH MAJOR APPROACH. LEADERS AND ORGANIZATIONS EXAMIMED INCLUDE: THE PAN-NEGRO NATIONALIST MOVEMENT IN THE 18TH CENTURY: BISHOP TURNER; FREDERIC DOUGLASS; BOOKER T. WASHINGTON; W.E.B. DU BOIS; THE NAACP: THE URBAN LEAGUE; WASHINGTON; W.E.B. DU BOIS; THE NAACP; THE URBAN LEAGUE; MARCUS GARVEY'S REAWAKENING OF THE SEPARATIST

06187 MCCARUS, $C$

CONTEMDERS FOR POWER

WEST AFRICA, (3900) (JUN 92 ), 1013

ON MAY 31, 1992, POLITICAL EXILE ALPHA CONDE RETURNED TO GUINEA AFTER ATTENDING THE PAN-AFRICAN CONFERENCE IN DAKAR. CONDE EXPRESSED FRUSTRATION THAT THE PRO-DEMOCRACY MOVEMENT WAS SPLIT INTO FACTIONS AND DECLARED THAT HE WAS READY TO COLLABORATE WITH MRI BA AND THE NATIONAL UNION FOR THE REPUBLIC.
06188 MCCARUS, C.

THIS ISN'T A DEMOCRACY

WEST AFRICA, (3906) (JUL 92 ), 1243

DR. DOMINGOS FERHANDES GOMEZ HAS RETURNED FROM EXILE IM PORTUGAL TO LEAD HIS OPPOSITION MOVEMENT AGAINST THE GOVERNMENT OF GUINEA BISSAU. ALTHOUGH THE GOVERNMENT HAS LEGALIZED OPPOSITION PARTIES, GOMEZ SAYS THAT GUINEA BISSAU IS FAR FROM BEING A DEMOCRACY.

06189 MCCLEAN, I.; FOSTER, C.

THE POLITICAL ECONOMY OF REGULATION: INTERESTS, IDEOLOGY, VOTERS AND THE UK REGULATION OF RAILWAYS ACT 184 PUBLIC ADMINISTRATION, 70(3) (FAL 92), 313-332.

GOVERNMENT REGULATION OF THE RAILWAYS IN THE UNITED KINGOOM DATES BACK TO THE 1840S. THIS ARTICLE EXPLORES HHY REGULATION OCCURRED AND WHY IT TOOK THE FORMS IT DID. GLADSTONE'S ACTIONS ARE EVALUATED IN RELATION TO THE STAMDARD HYPOTHESES ABOUT THE ORIGINS OF REGULATION. HYPOTHESES ON THE MOTIVES OF MPS VOTING FOR AND AGAINST REGULATION ARE TESTED.

06190 MCCLOSKEY, D.

THE ESSENTIAL RHETORIC OF LAH, LITERATURE AND LIBERTY

CRITICAL REVIEW, 5(2) (SPR 91), 203-224.

THIS ARTICLE REVIEWS THREE RECENT BOOKS--RICHARD POSNER'S "LAW AND LITERATURE", STANLEY FISH'S "DOING WHAT COMES NATURALLY", AND JAMES BOYD WHITE'S "JUSTICE AS TRANSLATION". THESE BOOKS STRUGGLE OVER THE RELATIONSHIP OF LAH AND LITERATURE. FISH AND HHITE DEFEND THE RELEVANCE OF LITERATURE TO LAH. POSNER TRIES TO KILL THE MASCENT LAH AND LITERATURE MOVEMENT BY HUGGING IT TO DEATH. POSHER'S LITERARY CRITICISM IS BELLES-LETTRISTIC, CONCERNED CHEIFLY WITH HOW "GREAT" A WORK IS. FISH'S IS SOCIAL, EMPHASIZING THE INTERPRETATIVE COMMUNITY. WHITE ATTEMPTS TO MAKE A NEW COMMUNITY, IN WHICH WE COME TO UNDERSTAMD ONE ANOTHER BY AN EFFORT OF' TRANSLATION. WITE'S VISION IS ATTRACTIVE, THOUGH IT SURRENDERS SCIENCE TO NON-TRANSLATION. THE ARTICLE CONCLUDES THAT EVEN IN SCIENCE IT IS TRANSLATION, AND RHETORIC, ALL THE WAY DOWN.

06191 MCCOLM, R.B.

THE COMPARATIVE SURVEY OF FREEDOM: 1992

FREEDOM REVIEH, 23 (1) (JAN 92), 5-6, 11-12.

THE PAST THREE YEARS HAVE SEEN THE GREATEST EXPANSION OF FREEDOM IN HISTORY. MORE THAN ONE-THIRD OF THE HORLD'S
NATIONS, ENCOMPASSING NEARLY 30 PERCENT OF THE EARTH'S POPULATION, HAVE CONSCIOUSLY CHOSEN TO ALTER THEIR POLITICAL SYSTEMS TO PROVIDE MORE OPEN AND DEMOCRATIC FORMS OF GOVERMMENT. WORLDHIDE, THERE ARE 89 DEMOCRACIES AND ANOTHER GOVERMMENT. WORLDWIDE, THERE ARE 89 DEMOCRACIES AND
32 COUNTRIES IN SOME FORM OF DEMOCRATIC TRANSITION.

06192 MCCONNELL, M.

CAMPAIGN FINANCE REFORM: A SENATOR'S PERSPECTIVE JOURNAL OF LAH \& POLITICS, VIII(2) (WIN 92), 333-338. IN THIS ARTICLE, U.S. SENATOR MITCH MCCONNELL ARGUES AGAINST LIMITING THE AMOUNT OF MONEY THAT CAN BE SPENT ON POLITICAL CAMPAIGNS. HE OPPOSES LIMITING CAMPAIGN SPENDING BECAUSE ALL AMERICANS HAVE A VESTED INTEREST IN THE ELECTORAL PROCESS AND A 200-YEAR TRADITION OF PARTICIPATING IN IT. MUCH TO THE CHAGRIN OF SOME WHO WOULD LIKE TO SOUEEZE INDIVIDUALS OUT OF THE PROCESS, CITIZENS ARE DETERMINED THAT THEY WILL BE INVOLVED BEYOND JUST VOTING. INVOLUNTARY OR COERCED SPENDING LIMITS ARE UNCONSTITUTIONAL BECAUSE THEY ARE A DE FACTO LIMIT ON FREE SPEECH. THE SUPREME COURT HAS RULED THAT CAMPAIGN SPENDING IS ANALOGOUS TO SPEECH AND THAT SPENDING LIMITS, BY THEMSELVES, ARE UNCONSTITUTIONAL. A SPENDING LIMIT IS A TWO-PRONGED RESTRICTION ON SPEECH BECAUSE IT RESTRICTS THE TOTAL AMOUNT OF SPEECH AVAILABLE TO THE CANDIDATE BY REDUCING WHAT HE CAN SPEND ON MASS COMMUNICATION AND IT RESTRICTS THE TOTAL NUMBER OF CITIZENS WHO CAN PARTICIPATE IN THE PROCESS BY MAKING DONATIONS.

06193 MCCONHELL. M.W.

SHOULD CONGRESS PASS LEGISLATION RESTORING THE BROADER INTERPRETATION OF FREE EXERCISE OF RELIGION?

HARVARD JOURMAL OF LAH AND PUBLIC POLICY, 15(1) (WIN 92), $181-190$.

SINCE THE SUPREME COURT'S 1990 RULING IN THE CASE OF EMPLOYMENT DIVISION, DEPARTMENT OF HUMAN RESOURCES, VS. SMITH, SOME FIRST AMENDMENT EXPERTS HAVE CALLED FOR CONGRESS TO PASS LEGISLATIOM RESTORING THE PREVIOUS, BROADER TO PASS LEGISLATION RESTORING THE PREVIOUS,

06194 MCCONMELL, $W$

CANADA: FROM BENETT'S $\$$ NEW DEAL' TO THE MEECH LAKE ACCORD ROUND TABLE, $322(322)$ (APR 92), 153-166.

IN THE HALF-CENTURY OR SO EXTENDING FROM THE JUDICAL EMASCULATION OF CANADIAN PRIME MINISTER BENNETT'S NEW DEAL BY THE SUPREME COURT OF CANADA, UNTIL THE COLLAPSE IN 1990 OF PRIME MINISTER BRIAN MULRONEY'S MEECH LAKE ACCORD, THE CONSTITUTIONAL PROCESS OF CANADA HAS EXPERIENCED MUCH TURBULENCE. THE HISTORY OF CONFLICT OURING THIS PERIOD OF TIME IS EXPLORED IN THIS ARTICLE WHICH CONCLUDES THAT 
CANADIANS WOULD PREFER A NEW FEDERALISM NOT TO BE CRAFTED EXCLUSIVELY BY THE FIRST MINISTERS, BUT DESIRE TO PARTICIPATE IN A MORE OPEN AND DEMOCRATIC PROCESS IN SEEKIMG CONSTITUTIONAL CHANGE.

06195 MCCORMICK, C.

SELF-GOVERNMENT FOR ABORIGINAL PEOPLE

CANADIAN PARL IAMENTARY REVIEN, (WIN 91), 12-15.

THIS ARTICLE EXAMINES SOME' OF THE BACKGROUND FACTORS SURROUNDING THE ISSUE OF ABORIGINAL SELF-GOVERNMENT IN CANADA. THE AUTHOR HOPES TO ISOLATE SOME OF THE PROBLEMS THAT HAVE SURFACED IN THE DISCUSSIONS AND NEGOTIATIONS OF THE LAST TEN YEARS. IT CONSIDERS SEVERAL MISPERCEPTIONS WHICH COMPLICATE NEGOTIATIONS, CHIEF OF WHICH IS THE IDEA WHICH COMPLICATE NEGOTIATIONS, CHIEF OF WHICH IS THE IDEA THATMENT OF THE POPULATION. A FURTHER MISPERCEPTION IS THE SEGMENT OF THE POPULATION. A FURTHER MISPERCEPTION IS THE IDEA THAT ABORIGINES ARE INCAPABLE OF SELF-GOVERNMENT. AN EXAMINATION OF HISTORY REVEALS OTHERHISE AND PROVIDES A
STROMG ARGUMENT FOR THE GUARANTEE OF BASIC HUMAN RIGHTS AND SELF-DETERMINATION TO CANADA'S NATIVE POPULATION.

06196 MCCORMICK, J.; HITTKOPF, E.

AT THE WATER'S SDGE: THE EFFECTS OF PARTY, IDEOLOGY, AND

ISSUES ON CONGRESSIONAL FOREIGN POLICY VOTIING, 1947' TO 1988

AMERICAN POLITICS QUARTERLY, 20(1) (JAN 92), 26-53.

THIS RESEARCH EVALUATES THO DIFFERENT PERSPECTIVES ON CONGRESSIONAL-EXECUTIVE RELATIONS ACROSS FOUR MAJOR FOREIGN POLICY ISSUE AREAS USING CONGRESSIONAL VOTING FROM 1947 TO 1988. BOTH A BIPARTISAN PERSPECTIVE AND A

PARTISAN/IDEOLOGICAL PERSPECTIVE ARE EVALUATED ACROSS HIGH POLITICAL ISSUES-ONATIONAL SECURITY AND FOREIGN RELATIONS VOTES--AND LOW POLITICS ISSUES--FOREIGN AID AND TRADE VOTES. IN ADDITION, THE AUTHORS EXAMINE THE IMPACT OF THE VIETNAM WAR ON VOTING IN EACH ISSUE AREA. IN GENERAL, THEY FIND THAT ALTHOUGH HIGH POLITICS ISSUES ELICIT MORE BIPARTISANSHIP THAN LOW POLITICS, PARTY AND IDEOLOGY SEEM TO ACCOUNT BETTER FOR CONGRESSIONAL VOTING ACROSS ALL FOUR ISSUE AREAS. THE EFFECT OF THE VIETNAM WAR IS TO LESSEN BIPARTISANSHIP AND TO EFFECT OF THE VIETNAM WAR IS TO LESSEN BIPARTISANSHIP AND TO EXACERBATE PARTISAN AND IDEOLOGICAL DIVISIONS, ESPECIALLY ON
NATIONAL SECURITY VOTES AND SOMEWHAT LESS SO ON FOREIGN AID NATIONAL
VOTES.

06197 MCCOY, $M$

GENDER OR ETHNICITY: WHAT MAKES A DIFFERENCE? A STUDY OF GENDER OR ETHNICITY:

WOMEN TRIBAL LEADERS
WOMEN AND POLITICS, 12(3) (1992), 57-68

ALTHOUGH IMCREASING NUMBERS OF NATIVE AMERICAN WOMEN ARE PARTICIPATING IN ELECTIVE TRIBAL POLITICS, THEIR POLITICAL BEHAVIOR IS LARGELY UNKNOWN AND UNRESEARCHED. THIS STUDY LOOKS AT WHETHER ETHNICITY OR GENDER HAS MORE EFFECT ON THE POLITICAL BEHAVIOR OF WOMEN TRIBAL LEADERS AND WHETHER THE LITERATURE CONCERNING ANGLO FEMALE POLITICAL ELITES IS ETHNOCENTRIC. THE STUDY'S MOST SIGNIFICANT FINDING MAY BE THAT THE DISADVANTAGED CONDITION OF A POLITICAL MINORITY MAY HAVE MORE INFLUENCE ON POLITICAL BEHAVIOR THAN EITHER GENDER OR ETHNICITY.

06198 MCCRAH, D.

THE ELECTORAL CYCLE IM NEH ZEALAND

JOURMAL OF COMMONHEALTH AND COMPARATIVE POLITICS, 30(2)

( JUL 92 ), 243-253.

SINCE' THE ADVENT OF NEW ZEALAND'S TWO-PARTY SYSTEM, THE GOVERNING PARTY'S SHARE OF THE VOTE HAS GENERALLY CHAHGED IN ACCORDANCE WITH THE EROSION THEORY PUT FORTH BY SCHOLARS AT THE UNITVERSITY OF MICHIGAN. THE ELECTORAL CYCLE, HONEVER, HAS TRACED A DISTINCTIVE PATTERN WHICH HAS BEEN REPEATED IN FULL OR IN PART UNDER ALL SEVEN GOVERMMENTS SINCE 1935. WHEN THE INEVITABLE DECLINE IN THE GOVERNMENT'S SHARE OF THE VOTE HAS BEGUN, IT HAS ALHAYS BEEN ACCOMPANIED BY A SURGE TO THE MONOR PARTIES OR NON-VOTING, OR BOTH, RATHER THAN TO THE OFFICIAL OPPOSITION. IF THE GOVERMMENT HAS REMAINED IN POWER OFFICIAL OPPOSITION. IF THE GOVERMMENT HAS REMAINED IN POHE AFTER THE SURGE TO THESE PROTEST OPTIONS, THE SUBSEQUENT
DISSIPATION OF THE PROTEST VOTE HAS OFTEN ENABLED THE DISSIPATION OF THE PROTEST VOTE HAS OFTEN ENABLED THE
GOVERNMENT TO REVERSE THE EROSION PROCESS TEMPORARILY AT THE GOVERNMENT TO REVERSE THE EROSION PROCESS TEMPORARILY AT
FOLLOWING ELECTION. IT HOULD SEEM THAT WEAK OR UNPOPULAR FOLLOHING ELECTION. IT HOULD SEEM THAT WEAK OR UNPOPULAR
OPPOSITIONS HAVE BEEN A PERSISTENT FACTOR IN SHAPING NEN OPPOSITIONS HAVE BEEN A PEE

06199 MCCREADY, D.J.; BLOCK, W.; MALONEY, M.A.

WEALTH TAXES: FURTHER ARGUMENTS AGAINST

CANADIAN PUBLIC ADMINISTRATION, 35(4) (WIN 92), 534-548.

THE AUTHORS DEBATE THE PROS AMD CONS OF ADOPTING A

WEALTH TAX IN CANADA. MCCREADY ARGUES THAT THE ECONOMIC SYSTEM MUST OFFER REWARDS OR THERE HILL BE NO INCENTIVE TO PERFORM ANY ECOMOMIC ACTIYITY. INDEED, SINCE ECONOMICS INVOLVES THE ALLOCATION OF SCARCE RESOURCES, THOSE RESOURCES MUST BE USED TO ACHIEVE THE HIGHEST STANDARD OF LIVING POSSIBLE AND THAT REQUIRES BEING ON WHAT ECONOMISTS CALL "THE PROOUCTION POSSIBILITIES CURVE." WITHIN THAT CONTEXT, THERE IS GREATER OPPORTUNITY FOR THE LESS-ADVANTAGED TO BENEFIT THAN IF PRODUCERS ARE PUNISHED IN ORDER TO REDISTRIBUTE RESOURCES, FOR THEN PRODUCERS HILL NOT PRODUCE.
06200 MCCROSSAN, P.

PARLIAMENT AND THE PRIVATE MEMBER

CANADIAN PARLIAMENTARY REVIEN, (HIN 91), 7-9.

THIS ARTICLE CONSIDERS THE TENSION THAT EXISTS BETHEEN POLITICAL PARTIES AND THE INDIVIDUAL MEMBER OF PARLIAMENT IM CANADA. CANADA'S PARLIAMENTARY SYSTEM IS ORGANIZED ON A PARTY BASIS. THERE NEEDS TO BE PARTY DISCIPLINE TO MAKE THE SYSTEM WORK. THEREFORE, A FUNDAMENTAL TENET OF WORKING WITHIN THE SYSTEM IS THAT ONE SELDOM HAS THE LUXURY OF VOTING AGAINST ONE'S PARTY EXCEPT WHEN THE CONFLICT WITH PERSONAL CONVICTION OR REGIONAL INTEREST IS MOST EXTREME. HOWEVER, IF PARLIAMENTARY REFORM AND THE RIGHTS OF PRIVATE MEMBERS MEAN ONLY THAT MEMBERS HAVE AN ACKNOWLEDGED RIGHT TO DISAGREE WITH THEIR PARTY'S POSITIONS IN SUCH EXTREME SITUATIONS, THE REFORMS AND THE RIGHTS OF PRIVATE MEMBERS
HOULD NOT AMOUNT TO MUCH.

06201 MCCURRY, S.

THE THO FACES OF REPUBLICANISM: GENDER AND PROSLAVERY

THE TWO FACES OF REPUBLICANISM: GENDER AND PROSLAVERY
POLITICS IN ANTEBELLUM SOUTH CAROLINA
JOURNAL OF AMERICAN HISTORY, 78(4) (MAR 92), 1245-1264.

JOURAL OF AMERICAN HISTORY, 78(4) (MAR 92), 1245-1264.
NOWHERE DID PROSLAVERY REPUBLICANISM FIND MORE MOMENTOUS EXPRESSION THAN IN THE SOUTH CAROLINA LOW COUNTRY, AND NOWHERE WAS ITS SOCIAL BASIS MORE STARKLY DISPLAYED IN WAYS THAT CONFOUND A CONVENTIONAL FOCUS ON THE PUBLIC SPHERE IN THE INTERPRETATION OF THE YEOMANRY'S POLITICS. NOT ONLY WAS THE GREAT MAJORITY OF THE POPULATION--SLAVES AND WOMEN-PROPERTYLESS AND DISFRANCHISED AND THE POLIITICAL CULTURE THEREBY DEFINED PRIMARILY IN TERMS OF WHOM IT EXCLUDED, BUT THE CONCENTRATION OF HEALTH IN LAND AND SLAVES WAS SO ADVANCED THAT IT GAVE DECISIVE SHAPE TO RELATIONS BETWEEN YEOMEN AND PLANTERS AS WELL AS BETWEEN MASTERS AND SLAVES. INEQUALITY AND RELATIONS OF POWER TOOK MANY FORMS IN THE SOUTH CAROLINA LOW COUNTRY. TO CONFRONT THE RELATIONS OF PONER IN YEOMAN HOUSEHOLDS, INCLUDING GENDER RELATIONS, AND THE POLITICAL PRIVILEGES TO WHICH THEY ENTITLED MALE HOUSEHOLD HEADS IS TO REVEAL A COMPLICATED YEOMAN REPUBLICANISH THAT WAS LESS THAN EGALITARIAN AND "DEMOCRATIC. " the patterns revealed in the low country speak to a CHARACTERISTIC OF REPUBLICAN POLITICAL CULTURE ALL OVER THE SOUTH AND COMPEL AN INTERPRETATION OF REPUBL ICANISM IN THE ANTEBELLUM SOUTH QUITE DIFFERENT FROM THE ONE THAT CURRENTLY ANTEBELLUM
PREVAILS.

06202 MCDERMOTT, A.

WORLD TRADE: THE URUGUAY ROUND AND DEVELOPING COUNTRIES BULLETIN DF PEACE PROPOSALS, 23 (1) (MAR 92) 57-66.

THIS ARTICLE EXAMINES THE ISSUES AND OBSTACLES INVOLVED IN THE URUGUAY ROM OF THE GENERAL AGREEMENT OM TARIFFS AND TRADE (GATT). IT EMPHASIZES THE ISSUES WHICH ARE OF CRITICAL IMPORTANCE TO THE DEVELOPING NATIONS OF THE WORLD. THESE ISSUES INCLUDE: AGRICULTURE, PROTECTION OF INTELLECTUAL PROPERTY, TRADE IN SERVICES, AND THE MULTI-FIBER AGREEMENT (MFA). THE ARTICLE OUTLINES THE MAIN COMPONENTS OF THE "DRAFT FINAL ACT" OF GATT DIRECTOR AUTHUR DUNKEL. THE ARTICLE CONCLUDES THAT THE URUGUAY ROUND WILL LIKELY BE THE LAST ROUND UNDER GATT IN ITS PRESENT FORM. A NUMBER OF CHANGES IN THE WORLD INDICATE A MOVE AWAY FROM MULTILATERAL TOWARDS BILATERAL TRADE AGREEMENTS. SUCH A TREND WILL BE MOST DETRIMENTAL TO THE DEVELOPING WORLD WHOSE LACK OF FINANCIAL RESOURCES AND TECHNOLOGICAL SOPHISTICATION PUT THEM AT A DISADVANTAGE IN BILATERAL NEGOTIATIONS HITH LARGER INDUSTRIALIZED STATES.

06203 MCDONAGH, E.L.

REPRESENTATIVE DEMOCRACY AND STATE BUILDING IN THE PROGRESSIVE ERA

AMERICAN POLITICAL SCIENCE REVIEN, 86(4) (DEC 92), 938-950. THE AUTHOR DRAWS UPON STATE-BUILDING AND LEGISLATIVE ITERATURES TO INVESTIGATE HOW CONSTITUENCY-BASED REPRESENTATIVE INSTITUTIONS IN THE PROGRESSIVE ERA NATIONALIZED INNOVATIVE PUBLIC POLICIES, THEREBY EXPANDING THE AUTHORITY OF THE FEDERAL GOVERNMENT' AS A COMPONENT OF STATE-LEVEL REFERENDA VOTES AS MEASURES OF GRASSROOTS VIENS, STATE-LEVEL REFERENDA VOTES AS MEASURES OF GRASSROOTS
MULTIVARIATE ANALYSIS DISCLOSES THE IMPACT OF DISTRICT MULTIVARIATE ANALYSIS DISCLOSES THE IMPACT OF DISTRICT
OPINION, PARTY, AND DISTRICT ECONOMY AS MAJOR DETERMINANTS OPINION, PARTY, AND DISTRICT ECONOMY AS MAJOR DETERMINANTS
OF HOUSE ROLL CALL VOTING ON LANDMARK REGULATORY LEGISLATION OF HOUSE ROLL CALL VOTING ON LANDMARK REGULATORY LEGISLATIOM
AUTHORI ZING FEDERAL INTERVENTION IN MARKET RELATIONSHIPS, AUTHORIZING FEDERAL INTERVENTION IN MARKET RELATIONSHIPS,
STATE SUFFRAGE QUALIFICATIONS, AND LIFESTYLE BEHAYIORS STATE SUFFRAGE QUALIFICATIONS, AND
INVOLVING INTOXICATING BEVERAGES.

06204 MCDONALD, H.

CASTING ASIDE HISTORY

FAR EASTERN ECONOMIC REYIEH, 151(18) (MAY 91), 23-27.

THE INDIAN CASTE SYSTEM IS ONE OF THE WORLD'S MOST RIGID AND EXPLOITATIVE AMONG THE HORLD'S HIERARCHICAL SOCIAL INSTITUTIONS. HOWEVER, AFTER THOUSANDS OF YEARS, THE DEMOCRATIC ORDER AND ECONOMIC REDISTRIBUT ION SINCE INDIAN INDEPENDENCE HAVE GIVEN THE NUMERDUS LOWER CASTES THE POTENTIAL TO REALIZE THEIR POLITICAL RIGHTS. THIS GATHERING SOCIAL REVOLT COULD COME TO FRUITION AT THE GENERAL ELECTION SCHEDULED FOR LATE MAY 1991. HOWEVER, THE CASTE AND COMMUNAL TURMOIL ALSO STRADOLES, AND SOMETIMES CONTRADICTS, CLASS AND 
REGIONAL INTERESTS. IN THIS CONFUSION OF CONFLICTING LOYALTIES, EYEN THE POLITICAL PARTIES CHAMPIONING THE MAJORITY LOWER CASTES MAY NOT BE ASSURED OF A CLEAR ELECTORAL VICTORY.

06205 MCDONALD, H.

COTERIE CAPERS

FAR EASTERN ECONOMIC REVIEW, 151(27) (JUL 91), 10-11. THE CONGRESS PARTY RETURNED TO POWER AS A MINORITY GOVERNMENT IN INDIA ON 21 JUNE WITH VETERAN GANOHI-FAMILY LOYALIST P. $V$. NARASIMHA RAO HEADING A CABINET PACKED WITH OTHER FAMILY FOLLOWERS. RAO-WIDELY ACKNOWLEDGED AS ONLY AN INTERIM LEADER FOR A PARTY WHICH IS SEARCHIMG FOR NEH FOCUS-DEFTLY BEAT OFF A DIRECT CHALLENGE FOR THE PRIME MINISTERSHIP FROM SHARAD PAWAR, THE CHIEF MINISTER OF MAHARASHTRA STATE. RAO ALSO PROMISED A NEH BUDGET AND A MORE OPEN DOOR TO FOREIGN INVESTMENT IN AN EFFORT TO STAVE OFF IMPENDING ECONOMIC CRISIS.

06206 MCDONALD, H.

CURSE OF YICTORY

FAR EASTERN ECONOMIC REVIEW, 155(9) (MAR 92), 11-12.

THE OUTCOME OF RECENT ELECTIONS IN THE VIOLERCE-TORH STATE OF PUNJAB HAS BEEN A SWEEPING SUCCESS FOR THE CURRENT GOVERNMENT OF NEN DELLI AND A TOTAL FAILURE FOR INDIA. PRIME MINISTER P.V. NARASIMHA RAO'S RULING CONGRESS PARTY HAS BEEN BROUGHT CLOSE TO A MAJORITY IN THE CENTRAL PARLIAMENT, BUT THE ALIENATION OF THE SIKHS HAS NEVER BEEN SO COMPLETE AND OBVIOUS. ONLY ABOUT 22 PERCENT OF PUNJAB'S ELIGIBLE VOTERS TURNED OUT FOR THE 19 FEBRUARY VOTING. AS A RESULT, FEW SIKHS WILL REGARD THE INCOMING CONGRESS STATE ADMINISTRATION AS REPRESENTATIVE. FURTHERMORE, IT IS HARD TO SEE NEW DELHI TURNING TO REDRESS ANY OF THE LONG-STANDING GRIEYANCES OF THE SIKHS RELATING TO WATER, TERRITORY, LANGUAGE AND THE DESECRATION OF THEIR GOLDEN TEMPLE BY THE ARMY ASSAULT IN 1984.

06207 MCDONALD, H.

FRACTURED MANDATE

FAR EASTERN ECONOMIC REVIEH, 151(26) (JUN 91), 10-12.

THE INDIAN GENERAL ELECTIONS PROOUCED NO CLEAR WINNERS. AFTER RESULTS FOR SOME 90\% OF THE 511 CONTESTED SEATS WERE IN, THE CONGRESS PARTY--WITH 217 SEATS--WAS THE LARGEST SINGLE GROUPING IN PARLIAMENT BUT WAS STILL SHORT OF A MAJORITY. THANKS TO A WAVE OF SYMPATHY FOLLOHING THE ASSASSINATION OF RAJIY GANDHI, CONGRESS FARED WELL IN THE SOUTHERN AND WESTERN STATES, BUT THE LEADERLESS PARTY LOST SOUTHERN AND WESTERN STATES, BUT THE LEADERLESS PARTY LOST
ITS HOLD IN THE POPULOUS NORTHERN STATES. THE POLITICAL ITS HOLD IN THE POPULOUS NORTHERN STATES. THE POLITICAL
CONFUSION HAS BEEN COMPOUNDED BY A CONTINUING ECONOMIC CRISIS, WHICH THE INCOMING GOVERMMENT WILL HAVE TO COPE WITH. WITH FOREIGN EXCHANGE RESERVES BARELY ENOUGH TO MEET A FEH WEEKS' IMPORTS, NEW DELHI WILL HAVE TO NEGOTIATE WITH THE IMF FOR IMMEDIATE CREDITS, WHICH CAN BE OBTAINED ONLY WITH TOUGH FISCAL SACRIFICES--A DIFFICULT PROPOSITION FOR A GOVERMMENT WITHOUT A STRONG POPULAR MANDATE.

06208 MCDONALD, H.

MINORITY BLUES

FAR EASTERN ECONOMIC REVIEW, 155(5) (FEB 92), 25-26.

MEMBERS OF SOUTH AFRICA'S INDIAN MINORITY' HAVE LONG FEL THE CONSEQUENCES OF WHITE HOSTILITY AS THE STRUCTURES OF APARTHEID CAUSED MANY INDIANS TO LOSE THEIR LAND AND BUSINESSES. INDIAN LAWYERS, ACADEMICS AND TRADE UNIONISTS WERE USEFUL TO THE STRUGGLING AFRICAN NATIONAL CONGRESS (ANC), PARTICULARLY AFTER IT WAS BANHED IN 1960 AND ITS LEADERSHIP DEPLETED BY ARREST AND EXILE. BUT IF THE INDIANS FEEL WHITE HOSTILITY ON ONE SIDE, THEY HAVE ALSO BEEN ACUTELY NERYOUS ABOUT THE AFRICANS, WHO TEND TO STEREOTYPE INDIANS AS BUSINESSMEN, RICH, CLANNISH, AND CONTEMPTUOUS OF OTHERS. THEY FEAR THAT BECAUSE THEIR NUMBERS--A DIMINISHING 3\% OF THE POPULATION--ARE SO INSIGNIFICANT IN THE NATIONAL

06209 MCDONALD, H.

PAYING FOR THE PAST

FAR EASTERN ECONOMIC REVIEW, 154(52) (JAN 92), 16-18.

A RECENT CENSUS IN INDIA REVEALS THAT THE COUNTRY'S POPULATION OF 855 MILLION WILL DOUBLE IN 35 YEARS' TIME UNLESS THE GROWTH RATE IS SOON LOWERED SHARPLY. MANY KNOWLEDGABLE INDIANS ARE STARTING TO REALIZE THAT THIS IS NOT THE RESULT OF DEMOGRAPHIC INEVITABILITY, BUT OF
POLITICAL FAILURE. THE POPULATION-POLICY FAILURE OF THE POLITICAL FAILURE. THE POPULATION-POLICY FAILURE OF THE
$1980 S$ IS USUALLY ATTRIBUTED TO THE EXCESSES OF INDIRA 1980 S IS USUALLY ATTRIBUTED TO THE EXCESSES OF INDIRA SANJAY, LED A PRO-STERILIZATION CAMPAIGN WHICH LAPSED INT CONJAY, LED A PRO-STERILIZATION CAMPAIGN WHICH LAPSED INTO COERCION, WITH MEN BEING DRAGGED OFF FOR VASECTOMY IN
CLINICS. THIS ABUSE WAS A PRINCIPAL CAUSE OF GANDHI'S SUBSEQUENT ELECTORA WAS A PRINCIPAL CAUSE OF GANOHI'S SUBSEQUENT ELECTORAL DEFEAT. IT GAVE FAMILY PLANNING SUCH BAD NAME THAT POLITICIANS HAVE SHIED AWAY FROM THE SUBJECT EVER SINCE. A RESUMPTION OF FAMILY PLANAING COMBINED WITH CONCENTRATION ON BASIC EDUCATION AND HEALTH (RATHER THAN NECESSARY FIRST STEP TOWARDS REDUCING POPULATIDN GROWTH.
06210 MCDONALD, H.

RAO'S NEW DOWRY

FAR EASTERN ECONOMIC REVIEW, 155(7) (FEB 92), 40-41. NEH DELHI'S EFFORTS TO ENCOURAGE FOREIGN INVESTMENT, REFLECTED IN YET ANOTHER PACKAGE OF LIBERALIZATION MEASURES, ARE BEARING FRUIT. INHARD INVESTMENT HAS RISEN SHARPLY AS OVERSEAS BUSINESSMEN BEGIN TO REALIZE THAT DEEP-ROOTED REFORMS ARE UNOERHAY. THE REFORMS INCLUDE REMOVING MANY OF THE SHACKLES ON THE OPERATIONS OF FOREIGN JOINT VENTURES UNDER THE NOTORIOUS FOREIGN EXCHANGE REGULATION ACT (FERA), REMOVING THE NEED FOR FOREIGN INDUSTRIAL AND TRADING VENTURES TO SEEK THE ENDORSEMENT OF THE RESERVE BANK OF INDIA (RBI) FOR EVERY MINOR CHANGE IN THEIR OPERATIONS, AND ALLOWING FOREIGN FIRMS TO BORROW MONEY AND ACCEPT DEPOSITS ON THE SAME TERMS AS LOCAL COMPANIES. AS A RESULT, SOME 270 PROJECTS WORTH AN ESTIMATED RS5 BILLION HAVE BEEN' PROPOSED IN 1991.

06211 MCDONALD, H.; DALAL, S.; MANCHANDA, R.

RIOT AND RECRIMINATION

FAR EASTERN ECONOMIC REVIEN, 155(51) (DEC 92), 8-9.

THE DESTRUCTION OF THE AYODHYA MOSOUE BY HINDU MILITANTS HAS PRECIPITATED A POLITICAL SHOWDOWN BETWEEN INDIA'S RULING CONGRESS PARTY AND THE HINDU NATIONALIST BHARATIYA JANATA PARTY (BJP) THAT HILL BE FOUGHT VICIOUSLY OVER THE COMING MONTHS, AND COULD LEAD TO A SNAP GENERAL ELECTION SOMETIME NEXT YEAR. ONCE THE IMMEDIATE CRISIS DIES DOWN, THE DIFFICULT TASK OF CONGRESS LEADERS WILL BE TO REDEFINE THEIR POLITICAL VISION AND TO PROJECT A POSITIVE IMAGE OF THEIR ECONOMIC REFORMS. IF AND WHEN THE ELECTION TAKES PLACE, THE CONGRESS PARTY WILL HAVE TO STRUGGLE FOR THE HEARTS OF' THE HINOU MAJORITY, ESPECIALLY IN THE NORTHERN AND CENTRAL STATES WHERE THE BJP ALREADY HAS NEARLY EQUAL SUPPORT. WHO WINS COULD DECIDE WHAT INDIA WILL BE: SECULAR, TECHNOCRATIC AND ECONOMICALLY OPEN AS ADVOCATED BY THE CONGRESS; OR AN INDIA FOR THE HINOUS, WITH RELIGIOUS MINORITIES KEPT IN THEIR PLACE AMD FOREIGNERS RESTRICTED TO A MINOR PLACE IN THE ECONOMY.

06212 MCDONALD, $H$.

ROUND ONE TO RAO

FAR EASTERN ECONOMIC REVIEW, 155(8) (FEB 92), 10-11.

AFTER GENERAL ELECTIONS IN JUNE 1991 THE CONGRESS PARTY GOVERNMENT IN NEW DELHI FACED ENORMOUS HURDLES: IT LACKED A MAJORITY IN PARL IAMENT; THE ECONOMY HAS IN DEEP TROUBLE; INDIA'S MAIN FOREIGN BACKER, THE SOVIET UNION, WAS ON THE ROPES; PRIME MINISTER NARASIMHA RAO WAS A COMPROMISE CANDIDATE FACING POWERFUL FACTIONAL RIVALS. IN A SHORT SPAN OF SIX MONTHS, THE PRIME MINISTER HAS ACHIEVED A REMARKABLE TURNAROUND IN NATIONAL POLITICS--CONVERTING WEAKNESS INTO STRENGTH. HE HAS MADE A START ON ECONOMIC REFORM, MOVED CLOSER TO THE WEST IN FORIEGN POLICY AND KEPT HIS FACTIONAL RIVALS AND THE OPPOSITION AT BAY. HOWEVER, MUCH REMAINS TO BE DONE.

06213 MCDONALD, H.; MANCHANDA, R.

SHATTERED COVENANT

FAR EASTERN ECONOMIC REVIEH, 155(50) (DEC 92), 10-11. DESPITE PLEAS OF HINDU LEADERS AND THE DELAYING TACTICS OF INDIA'S PRIME MINISTER P.V. NARASIMHA RAO, THOUSANDS OF HINDU VOLUNTEERS DESTROYED A MUSLIM MOSQUE IN THE CITY OF AYODHYA. FOR THO DAYS, THE TOWN HAS THE DOMAIN OF AN
ESTIMATED 200,000 HINDU VOLUNTEERS WHO--WHATEVER THEIR
LEADERS HAD SAID--HAD COME TO TEAR DOWN THE MOSOUE AND START LEADERS HAD SAID--HAD COME TO TEAR DOWN THE MOSQUE AND START BUILDING A TEMPLE ON THE SAME SPOT, WHERE THEY BELIEVE THE DEITY RAM OF THE HINDU EPICS WAS BORN. WITH THE MOSOUE DESTRUCTION, INDIA WAS PLUNGED INTO POLITICAL CRISIS. TRAINS TAKING HINDU MILITANTS BACK FROM AYODHYA. ABOUT 500 PEOPLE DIED IM POLICE FIRINGS AND MOB CLASHES OVER THE MEXT TWO DAYS, WITH THE HEAVIEST TOLL IN BOMBAY. THE VIOLENCE ROCKED THE GOVERMMENT AND COULD MARK A SHIFT IN INDIA'S SIMCE INDEPENDENCE, TOWARDS HINDU CHAUVINISM.

06214 MCDONALD, H.

THE MEH FRONTIER

FAR EASTERN ECONOMIC REVIEW, 155(5) (FEB 92), 22-23.

RAPID POLITICAL CHANGE IN SOUTH AFRICA PRESENTS THE

ASIAN REGION HITH OPPORTUNITIES ANO DANGERS, AS THE FORMAL

DISHANTLING OF APARTHEID AND THE ARDUOUS PROGRESSION TOWARDS MA JORITY -RU WAS ONCE A PARIAH STATE. THE OPPORTUNITIES COME FROM THE IMMENSE MINERAL WEALTH OF SOUTH AFRICA, THE SOUND INFRASTRUCTURE OF THE "FIRST WORLD" SIDE OF ITS DUAL ECONOMY, AND ITS PROSPEROUS WHITE, INDIAN, AND COLORED (MIXED RACE) POPULATIONS. HOHEVER, THE RISKS ARE THAT EVEN WITH THE BEST GOOOWILL AND ECONOMIC UNDERSTANDING AT THE TOP, LEADERS WILL NOT BE ABLE TO RESTRAIN THEIR COMMUNITIES AND THE COUNTRY WILL COLLAPSE INTO A DESTRUCTIVE BLOODBATH.

06215 MCDONALD, H.

THE RAVAGED YALLEY

FAR EASTERN ECONOMIC REVIEN, 151(25) (JUN 91), 8-9. 
NEAR TOTAL OBSERVANCE OF A STRIKE CALLED BY SEPARATISTS AND A FLURRY OF ARMED CLASHES IN THE NORTH-WESTERN STATE OF JAMHU AND KASHMIRE IN THE DAYS BEFORE INDIA'S MID-JUNE GENERAL ELECTION HAVE BEEN A REMINDER OF A DEEPENING PROBLEM THAT AWAITS WHATEVER GOVERMMENT COMES TO POWER IN NEW DELHI. DESPITE THE ECONOMIC HARDSHIP AND AN ESTIMATED 2,900 DEATHS AMONG COMBATANTS AND CIVILIANS SINCE THE INDEPENDENCE MOVEMENT ERUPTED IN DECEMBER 1989, KASHMIR HAS EMERGED FROM ITS SECOND WINTER OF CONFLICT WITH THE ALIENATION OF ITS MUSLIM MAJORITY FROM INDIA MORE DEEPLY INGRAINED, AND FEH SIGNS THAT THE SUPPORT FOR UNDERGROUND MILITANTS IS WANING. HEAVY-HANDED AND INEPT SECURITY MEASURES TAKEN BY A

SUCCESSION OF STATE GOVERNORS HAYE INCREASED THE GAP BETWEEN THE SEPARATISTS AND THE CENTRAL GOVERMMENT.

06216 MCDONALD, H.

THE TOLL OF TERROR

FAR EASTERN ECONOMIC REVIEH, 155(14) (APR 92), 24-26. INDIA IS IN A DEEP BIND WITH REGARDS TO HUMAN RIGHTS. A SUCCESSION OF PRIVATE AND GOVERNMENT REPORTS LISTING A MOUNTIMG TOL OF ABUSES THAT AS AMNESTY IMTERMATIOMAL CLAIMS IN ITS LATEST REPORT (ON TORTURE, RAPE, AND DEATH IN CUSTODY) APPEAR "SYSTEMATIC" AND "ROUTINE"--AND ARE NOT CONFINED TO THE STATES WHERE THERE IS CLEARLY AN OUTSIDE FORCE STIRRING UP INSURGENCY. ALTHOUGH A SYSTEM BASED ON COMMON LAN REMAINS IN PLACE AND FUNDAMENTAL RIGHTS ARE GUARANTEED IN THE CONSTITUTION, IN PRACTICE THERE HAS BEEN A STEADY EROSION OF BOTH OF THESE SAFEGUARDS. SPECIAL LAWS RELATED TO NATIONAL SECURITY ENABLE DETENTION HITHOUT TRIAL FOR UP TO THO YEARS. TO MANY OBSERVERS, PUNJAB'S RISING DEATH TOLL FROM POLITICAL VIOLENCE IS THE MOST WORRYING. IT CONTAINS A SUSPICIOUSLY HIGH NUMBER OF "NON-HARDCORE AND OTHERS" AMONG THE ALLEGED TERRORISTS KILLED, AS WELL AS A
HIGH PROPORTION OF CIVILIAN DEATHS ATTRIBUTED TO TERRORISTS NOT HAVING A CLEAR MOTIVE.

06217 MCDONALD, H

TREK TO THE POLLS

FAR EASTERN ECONOMIC REVIEW, 151(17) (APR 91), 12-13.

NEPAL HAS LAUNCHED ITSELF WITH GREAT PUBLIC EAGERNESS INTO CAMPAIGNED FOR ITS FIRST MULTIPARTY ELECTIONS IN MORE THAN THIRTY YEARS. THE IMMEDIATE CONCERN IS THAT THE ENTHUSIASM FOES NOT LEAD TO WIDESPREAD VIOLENCE AND PARTISAN INTERFERENCE. ALL OF THE MAJOR PARTIES HAVE SIMILAR PLATFORMS IN THAT THEY PROMISE TO DEVOTE MORE RESOURCES TO EDUCATION, HEALTH, AND VILLAGE DEVELOPMENT. THE ROLE OF NEIGHBORING INDIA IS A KEY DIFFERENCE BETWEEN THE MAIN CONTENDERS, THE NEPALI CONGRESS PARTY AND THE NEPAL COMMUNIST PARTY-UNIFIED MARXISTS AND LENINISTS. INTERIM LEADER K.P. BHATTARAI IS PREPARING FOR ANY POSSIBLE OUTBREAK OF YIDLENCE AND DISORDER BY INDUCTING SOME 42,000 RETIRED OF VIDLENCE AND DISORDER BY INDUCTING SOME
POLICE AND EX-SERVICEMEN FOR TEMPORARY DUTY.

06218 MCDONALD, H.; MANCHANDA, R.

WIDOWS AND ORPHAS
FAR EASTERM ECONOMIC REVIEH, 151(23) (JUN 91), 10-11.

AS THE FUNERAL PROCEEDINGS FOR THE ASSASSINATED RAJIV

GANDHI WENT ON, LEADERS OF INDIA'S CONGRESS PARTY ATTEMPTED TO SEEK A NEW FIGURE FROM THE FAMILY THAT HAS PROVIDED FOUR GENERATIONS OF THE PARTY'S LEADERS AND PRIME MINISTERS. HOWEVER, THEIR NOMINATION OF GANDHI'S HIDOW, SONIA, WAS REJECTED BY HER, THUS ENDING THE POSSIBILITY OF "SYMPATHY
VOTE." AS CONGRESS SCRAMBLED TO FIMD A WORTHY SUCCESSOR, ALL POLITICAL PARTIES IN INDIA ATTEMPTED TO DECIDE HOW TO RESHAPE THEIR MESSAGE, TO EITHER CAPITALIZE UPON OR NEUTRALIZE THE RESPONSE TO GANDHI'S MURDER. IN ADOITION, THEY WORKED TO MOTIVATE THEIR WORKERS FOR YET MORE WEEKS OF ACTIVITY INTO THE SUMMER HEAT, TO MUSTER EXTRA POLITICAL FUNDS, AND TO MAKE SURE THAT MOUNTING ELECTORAL VIOLENCE AND THE ANMUAL MONSOON DO NOT KEEP VOTERS AT HOME. CDNGRESS ULTIMATELY CHOSE P.V. NARASHIMHA RAO AS INTERIM PARTY LEADER.

06219 MCDONALD, H.

WIND OF CHANGE

FAR EASTERH ECONOMIC REVIEN, 155(10) (MAR 92), 36-37.

INDIA IS TO CARRY OUT A HHOLESALE REVAMP OF ITS TRADING SYSTEM, STARTING WITH AN IMMEDIATE MOVE TO PARTIAL CONVERTABILITY OF ITS CURRENCY, THE RUPEE. FOR 60\% OF TRADE AND SERVICE PAYMENTS, THE RUPEE'S VALUE HILL BE SET BY A FREE MARKET--WHICH, IF IT MIRRORS THE BLACK MARKET LEVEL, SUGGESTS A SHARP DISCOUNT FROM THE OFFICIAL RATE. THE GOVERNMENT'S NEW BUDGET TAKES INDIA'S OPENING TO THE GLOBAL ECONOMY FAR BEYOND THE PARLIAMENTARY STEPS AMNOUNCED SOON AFTER THE PRESENT MINORITY CONGRESS PARTY GOVERNMENT TOOK OFFICE IN JUNE 1991. NEW MEASURES INCLUDE FURTHER PROGRESS TOWARDS FAR-REACHING REFORMS IN TARIFFS, BANKING AND TAXATION.

06220 MCDONALD, S.

LEARNING A LESSOM

LEARNING A LESSON
AFRICA REPORT, $37(5)$ (SEP 92), 27-29.

ETHIOPIA'S' FIRST "DEMOCRATIC" ELECTIONS WERE FLAWED, HITH INTERNATIONAL OBSERVERS DECLARING THAT THE VOTE HAS NEITHER FREE MOR FAIR. HHILE THE PROCESS ITSELF WAS A
VALUABLE LESSON IN DEMOCRACY FOR ETHIOPIA, TO CREATE A TRUE FEDERATED STATE, THE GOVERMMENT WILL HAVE TO TACKLE THE THORNY ISSUE OF FAIR REPRESENTATION FOR ALL THE COUNTRY'S VARIED ETHNIC GROUPS

06221 MCDONELL, G

TOXIC WASTE MANAGEMENT IN AUSTRALIA: WHY DID POLICY REFORM FAIL?

ENVIRONMENT, 33(6) (JUL 91), 10-13, 33-39.

THREE YEARS' WORK TO DEVELOP A SCIENTIFICALLY SOUND AND PUBLICLY ACCEPTABLE STRATEGY FOR MINIMIZING AND DISPOSING OF AUSTRALIA'S TOXIC WASTES HAS FOUNDERED BECAUSE OF PUBLIC RESISTANCE. THIS ARTICLE SEEKS TO DETERMINE WHAT WENT WRONG, AND TO OUTLINE WAYS IN WHICH THE COMMONWEALTH AND OTHER COUNTRIES CAN AVOID THE SAME OUTCOME IN OVERHAULING MAJOR POLICIES IN THE FUTURE. IT SEEKS TO PURSUE SOME ESSENTIAL AND BASIC, BUT OFTEN UNMOTICED, ASPECTS OF DESIGNING CHANGE AND BASIC, BUT OFTEN UNNOTICED, ASPECTS OF DESIGNING IN COMPLEX AREAS OF PUBLIC POLICY, ESPECIALLY IN THE UNUSUALLY COMPLEX AREA OF ENVIRONMENTAL MANAGEMENT.
IMPORTANT CONSIDERATIONS INCLUDE: THE NEED FOR COST-BENEFIT IMPORTANT CONSIDERATIONS INCLUDE: THE NEED FOR COST-BENEFIT ANALYSIS, THE ADMINISTRATIVE RESOURCES AND THE POLITICAL AND INSTITUTIONAL CONSTRAINTS THAT WOULD ACT TO STRUCTURE AND SHAPE THE CHANGE PROCESS, AND THE AMOUNT OF TIME IT TAKES
FOR MEANINGFUL POLICY REFORM TO TAKE PLACE.

06222 MCDOUGALL, J.

MORTH AMERICAN INTEGRATION AND CANADIAN DISUNITY CANADIAN PUBLIC POLICY - ANALYSE DE POLITIQUES, XVII $(4)$ DEC 91), 395-408

THAT THE SOCIO-ECONOMIC INTEGRATION OF NORTH AMERICA IS UNDERMINING CANADIAN UNITY IS ARGUED. CONTINENTAL INTEGRATION NEED NOT PRODUCE A NORTH AMERICAN POLITICAL UNION, BUT IT IS COMPLICATING THE \&RE-CONSTITUTION' OF CANADA IN RESPONSE TO QUEBEC'S DEMANDS FOR GREATER AUTONOMY. WHILE THE COUNTRY'S FUNDAMENTAL ECONOMIC AMD SOCIAL CHARACTERISTICS ARE NOT COMPATIBLE WITH A MORE HIGHLYCENTRALIZED UNION, A \$BOTTOM UP' DEFINITION OF THE FEDERAL GOVERMMENT'S ROLE COULD STILL RESULT IN SIGNIFICANT CENTRAL POWERS. TO THIS EXTENT, THE FEDERAL GOVERNMENT'S PROPOSED AMENDMENTS TO SECTION 91 AND 121 OF THE CONSTITUTION ACT, 1982 SEEM BOTH REALISTIC AND DESIRABLE.

06223 MCDOUGALL, J.

THE CANADA-U.S. FREE TRADE AGREEMENT AND CANADA'S ENERGY TRADE

CANADIAN PUBLIC POLICY--ANALYSE DE POLITIQUES, XVII(1)

(MAR 91), 1-13.

THIS ARTICLE ATTEMPTS TO ASSESS THE DIFFERENCE THE CANADA-U.S. FREE TRADE AGREEMENT WILL MAKE TO CANADA'S INTERPROVINCIAL AND INTERNATIONAL TRADE IN ENERGY SOURCES. IT ARGUES THAT THE THE AGREEMENT IS NOT LIKELY TO HAVE A LARGE EFFECT ON CANADIAN ENERGY DEVELOPMENTS INVOLVING EXPORTS TO THE UNITED STATES. THE REASON FOR THIS IS THAT THE AGREEMENT LEAVES BOTH COUNTRIES' REGULATORS WITH SUBSTANTIAL POHER TO SET TERMS AND CONDITIONS ON THE
CONSTRUCTION OF NEH OR EXPANDED ENERGY TRANSMISSION SYSTEMS THESE POINTS ARE ILLUSTRATED WITH REFERENCE TO RECENT AND PENDING REGULATORY DECISIONS HITH RESPECT TO CANADIAN NATURAL GAS EXPORTS TO THE AMERICAN NORTHEAST.

06224 MCDOWALL, D.

THE ROAD TO SPIRITUAL RECONCILIATION IN PALESTINE MIDOLE EAST INTERNATIONAL, (396) (MAR 91), 24-25. THIS ARTICLE EXAMINES THE IDEAS ON THE ARAB-ISRAEL CONFLICT AS CONTAINED IN BEYOND OCCUPATION, A COMPILATION OF FOURTEEN DIFFERENT VIEWPOINTS ON THE ISSUE. THE BOOK RAISES TWO (AMONG MANY OTHERS) CRITICAL ISSUES. ONE IS THE NECESSITY OF ELIMINATING "OTHERNESS" AS A BLOCK IN THE NEGOTIATION AND RECONCILIATION PROCESS; AS LONG AS ONE IOR BOTH) GROUPS ARE UNHILLING TO ACCORD OTHERS, NO PROGRESS WILL BE MADE. ANOTHER IS THE DIFFERENCE BETWEEN ISRAEL'S RIGHT TO EXIST ( A GENERALLY ACCEPTED PRECONDITION TO PEACE) AND THE RIGHT OF THE JENISH COMMUNITY IN PALESTINE TO LIVE

IN PEACE AND SECURITY.

06225 MCELROY, R.H.

MORALITY AND AMERICAN FOREIGN POLICY--THE ROLE OF ETHICS IN INTERNATIONAL AFFAIRS

PRINCETON UNIVERSITY PRESS, 1992, 216.

MOST INTERNATIONAL RELATIONS SPECIALISTS SINCE WORLD HAR II HAVE ASSUMED THAT MORALITY PLAYS ONLY THE MOST PERIPHERAL ROLE IN THE MAKING OF SUBSTANTIVE FOREIGN POLICY DECISIONS. THIS BOOK SHOWS THAT MORAL NORMS CAN, AND DO, SIGNIFICANTLY THIS BOOK SHOWS THAT MORAL NORMS CAN, AND DO, SIGNIFI
AFFECT INTERNATIONAL AFFAIRS BY THEIR INFLUENCE ON AFFECT INTERNATIONAL AFFAIRS BY THEIR INFLUENCE ON
INDIVIDUAL DECISIONMAKERS, DOMESTIC PUBLIC OPINION, AND INDIVIDUAL DECISIONMAKERS, DOMESTIC PUBLIC OPINION, AND
NATIONAL REPUTATION ABROAD. THE AUTHOR INVESTIGATES FOUR NATIONAL REPUTATION ABROAD. THE AUTHOR INVESTIGATES FOUR CENTURY: U.S. FOOD AID TO THE SOVIET UNION DURING THE RUSSIAN FAMINE OF 1921 PRESIDENT NIXON'S DECISIDN TO ALTER RUSSIAN FAMINE OF 1921, PRESIDENT NIXON'S DECISION TO ALTER
U.S. POLICIES ON BIOCHEMICAL WEAPONS PRODUCTION IN 1969, THE SIGNING OF THE PANAMA CANAL TREATIES IN 1978, AND THE BOMBING OF ORESDEN DURING WORLD WAR II. THE FIRST THREE OF THESE CASES ILLUSTRATE THE INFLUENCE OF ETHICS IN FOREIGN
POLICY. THE FOURTH DEMONSTRATES THE LIMITS OF INTERHATIONAL 
NORMS.

06226 MCELROY, W.

WHAT DOES AFFIRMATIYE ACTIOM AFFIRM?

FREEMAN, $42(3)$ (MAR 92 ), 96-99.

THE AUTHOR LOOKS AT THE CONTRADICTIONS IN THE

AFFIRMATIVE ACTION LAWS THAT SOMETIMES PREVENT WHITE MALES FROM BEING HIRED OR PROMOTED.

06227 MCFADOEN, E.

CLINTON'S FUNNY-NUMBER FACTORY

AMERICAN SPECTATOR, 25(11) (NOV 92), 48-50.

THE CONGRESSIONAL BUDGET OFFICE WAS ESTABLISHED IN 1974

IN THE WAKE OF WATERGATE. CBO DIRECTOR ROBERT REISCHAUER

OVERSEES A STAFF OF MORE THAN 200 AND A BUDGET OF $\$ 23$

MILLION. CBO STATISTICS AND ANALYSES ARE OFFICIALLY

INCORPORATED IN JUST ABOUT EVERY BILL DEALING WITH TAXES,

REVENUE EXPENDITURES, AND ECONOMIC PLANS. THE AGENCY'S

INFLUENCE HAS GROWN SINCE THE 1990 BUDGET AGREEMENT BECAUSE NEH PROPOSALS THAT AFFECT THE DEFICIT MUST NOW BE CLEARED BY MEH PROPOSALS THAT AFFECT THE DEFICIT MUST NOH BE CLEARE
THE CBO BEFORE COMING TO A SENATE OR HOUSE VOTE. BILL THE CBO BEFORE COMING TO A SENATE OR HOUSE VOTE. BILL
CLINTON OFTEN REFERRED TO CBO ECONOMIC STATISTICS DURING THE CLINTON OFTEN REFERRED TO CBO ECONOMIC STATISTICS DURING THE
1992 PRESIDENTIAL CAMPAIGN, BUT MANY CONSERVATIVES QUESTION 1992 PRESIDENTIAL CAMPAIGN, BUT MANY CONSERVATIVES QUESTION THE CBO'S IMPARTIALITY AND ACCURACY BECAUSE
DO NOT PAINT A ROSY PICTURE OF REAGANOMICS.

06228 MCFADDEN, E.

THERE'S NO ACCOUNTING FOR CONGRESS

AMERICAN SPECTATOR, 25(7) (JUL 92), 24-29.

PRESS ACCOUNTS PRESENT THE GAO AS A NONPARTISAN,

VIGILANT OFFICE FULL OF EMPLOYEES POURING OVER BUDGETS AND EXPENSE ACCOUNTS FOR WASTE OR FRAUD AND ANSWERING TO NO ONE. THIS ARTICLE SUGGESTS THAT MAYBE THE PICTURE FIT TWENTY OR THIRTY YEARS AGO, BUT NO MORE. THE RELATIONSHIP BETHEEN GAD AND DEMOCRATIC LEADERS HAS GOTTEN SO THAT THE AGENCY WILL TAILOR-MAKE THE AUDIT TO THE REQUESTER'S LIKING. IF A REPORT DOES NOT MEET WITH REQUESTER APPROVAL, IT IS NEVER PUBLICLY RELEASED, EVEN IF THE INFORMATION IS IN THE PUBLIC'S OR CONGRESS'S INTEREST.

06229 MCFATE, P.

WHERE DO WE GO FROM HERE? VERIFYING FUTURE ARMS-CONTROL AGREEMENTS

WASHINGTON QUARTERLY, 15(4) (FAL 92), 75-86.

THE END OF THE COLD HAR AND THE WAR IN THE PERSIAN GULF CALIS FOR NEW THINKING ON OLD SUB JECTS. CLEARLY THE ARMSCONTROL PROCESS IN IN FUL SHING: FORMAL BILATERAL AND MULTILATERAL AGREEMENTS ARE BEING FORMULATED OR NEGOTIATED; MULTILATERAL AGREEMENTS ARE BEING FORMULATED OR NEGOTIATEE
RECIPROCAL ACTION AND UNILATERAL STEPS ARE BEING TAKEN; RECIPROCAL ACTION AND UNILATERAL STEPS ARE BEING TAKEN; MONITOR AND CONFIRM THESE MEASURES; AMD EXISTING AGREEMENTS MUST CONTINUE TO BE IMPLEMENTED. THIS ARTICLE EXAMINES THE ROLE OF VERIFICATION AND VERIFICATION OVERKILL. IT CONCLUDES WITH AN ASSESSMENT OF FUTURE CHALLENGES.

06230 MCFAUL, M.

RUSSIA 'S EMERGING POLITICAL PARTIES

JOURNAL OF DEMOCRACY, 3(1) (JAN 92), 25-40.

THE SUDDEN AND UNANTICIPATED IMPLOSION OF THE SOVIET SYSTEM HAS CREATED A COLOSSAL POL ITICAL VACUUM. WHETHER THIS
VACUUM WILL BE FILLED BY A MARKET ECONOMY AND MULTI PARTY DEMOCRACY REMAINS UNCERTAIN. A KEY ROLE IN THIS TRANSITIONAL PERIOD WILL BE PLAYED BY THE DEMOCRATIC FORCES OF THE RUSSIAN REPUBLIC. THIS ARTICLE CONSIDERS THE PROCESS OF DEMOCRATIZATION THAT HAS BEEN UNDERWAY IN RUSSIA FOR SEVERA YEARS. IT EXAMINES THE ELECTIONS OF 1989 AND 1990 AND THE PROL IFERATION OF POLITICAL PARTIES INCLUDING THE DEMOCRATIC PLATFORM (REPUBLICAN PARTY). THE DEMOCRATIC PARTY OF RUSSIA, AND THE RUSSIAN SOCIAL DEMOCRATIC PARTY. THE ARTICLE CONCLUDES THAT THE PROCESS OF DEMOCRATIZATION, AND OF AVOIDING A RETURN TO TOTALITARIANISM OR A SHIFT TO VISCERAL POPULISM, WILL BE A LONG AND ARDUOUS ONE.

06231 MCFERSON, H.M.

DEMOCRACY AND DEVELOPMENT IN AFRICA

JOURNAL OF PEACE RESEARCH, 29(3) (AUG 92), 241-248.

A SHORT THREE YEARS AGO, THE AFRICAN CONTINENT WAS DOMINATED BY UNREPRESENTATIVE, MOSTLY PREDATORY REGIMES THAT HAD LOST WHATEVER LEGITIMACY THEY MAY HAVE INITIALLY POSSESSED. IN 1992, AL THOUGH UNREPRESENTATIVE REGIMES STILL OUTNUMBER DEMOCRATIC GOVERMMENTS, A DRAMATIC PROCESS IS UNDERHAY TO RESTORE THE FUNDAMENTALS OF POLITICAL LEGITIMACY. UNDERHAY TO RESTORE THE FUNDAMENTALS OF POL ITICAL LEGIT
BECAUSE OF AFRICA'S POVERTY, OBSERVERS WHO PERCEIVE BECAUSE OF AFRICA'S POVERTY, OBSERVERS WHO PERCEIV ECONOMIC PROGRESS AS LOGICALLY AND CHRONOLOGICALLY SUPERORDINATE TO POLITICAL PLURALISM SEE THIS PROCESS AS
ANOMALOUS. BUT IN AFRICA THIS PROPOSITION IS COUNTERFACTUAL: ANOMALOUS. BUT IN AFRICA THIS PROPOSITION IS COUNTERFACTU PREDATORY AUTHORITARIANISM HAS BEEN A CENTRAL CAUSE OF AFRICA'S ECONOMIC UNDERDEVELOPMENT--NOT ITS HANDMAIDEN.
CORRESPONDINGLY, POLITICAL PLURALISM IS A NECESSARY (THOUGH CORRESPONDINGLY, POLITICAL PLURALISM IS A NECESSARY (THOUG
NOT SUFFICIENT) CONDITION FOR AFRICAN ECONOMIC RECOVERY.

06232 MCGANM, J.

ACADEMICS TO IDEOLOGIES: A BRIEF HISTORY OF THE PUBLIC POLICY RESEARCH INDUSTRY
PS: POLITICAL SCIENCE AND POLITICS, 25(4) (DEC 92). 733-740.

PUBLIC POLICY RESEARCH INSTITUTES ARE A TWENTIETHCENTURY PHENOMENON AND IN MANY WAYS UNIOUE TO THE UNITED STATES. THE EARLY VERSIONS (OF THINK TANKS), SET UP BY PRIVATE CAPITAL LONG BEFORE THE PROLIFERATION OF TAX-FUNDED SOCIAL AGENCIES, WERE ORGANIZED TO ALLEVIATE PROBLEMS OF THE POOR. THIS ARTICLE TRACES THE ORIGINS OF THESE INSTITUTIONS TO THE BROOKING INSTITUTION, WHICH WAS ESTABLISHED IN 1916. USING THIS AS A STARTING POINT, IT DIVIDES THE HISTORY OF THE PUBLIC POLICY RESEARCH INDUSTRY INTO FOUR TIME PERIOOS THAT SPAWNED MANY OF THE THINK TANKS THAT EXIST TODAY AND CONTINUES ON HITH A HISTORY OF THE PUBLIC POLICY RESEARCH INDUSTRY.

06233 MCGARTH, M; GRANT, G.

SUPPORTING "MEEDS-LED" SERYICES: IMPLICATIONS FOR PLANMIMG AND MANAGEMENT SYSTEMS (a CASE STUDY IN MENTAL HANDICAP SERVICES

JOURNAL OF SOCIAL POLICY, 21(1) (JAN 92), 71-97.

MANY OF THE PRINCIPLES OF THE 1989 COMMUNITY CARE WHITE PAPER BEAR A STRIKING RESEMBLANCE TO THE WELSH MENTAL HANDICAP SIRATEGY LAUNCHED SIX YEARS EARL IER. THIS PAPER HANDICAP STRATEGY LAUNCHED SIX YEARS EARLIER. THIS PAPER
CONSIDERS THE LESSONS TO BE LEARMED FROM THE WELSH STRATEGY FOR THE DEVELOPMENT OF NEEDS-LED SERVICES AS PROMULGATED BY THE HHITE PAPER SIMILARITIES AND DIFFERENCES BETHEEN THE THE POLICY INITIATIVES ARE IDENTIFIED BEFORE CONSIDERING THE TWO POLICY INITIATIVES ARE IDENTIFIED BEFORE CONSIDERING THE CONCEPTUAL BASIS OF NEEDS-LED SERVICES. ATTENTION IS DRAWN TO THO INTERDEPENDENT DIMENSIONS OF NEEDS-LED SERVICES, USER PARTICIPATION AND MANAGEMENT DELEGATION, AS A MEANS OF

DEPICTING THREE UNDERLYING MODELS--EACH WITH DIFFERENT VALUE STANCES. DRAWING UPON A CASE STUDY OF ONE AREA IN WALES, THE AUTHORS TEST THE EXPECTATIONS FOR NEEDS-LED SERVICES IN TERMS OF LOCAL PLANNING AND MANAGEMENT REOUIREMENTS FOR THE THREE MODELS AGAINST THE EXPERIENCES OF THOSE CHARGED WITH IMPLEMENTING THEM. IMPLICATIONS FOR THE WHITE PAPER ARE EXPLORED IN CONNECTION WITH USER INVOL VEMENT STRATEGIES AND ASSESSMENT AND CARE MANAGEMENT PRACTICES.

06234 MCGILL, P.

ANXIETY ON THE ROAD TO WORLD LEADERSHIP

HORLD PRESS REVIEN, 39(8) (AUG 92), 16-18.

JAPAN'S NEW ROLE AS AN ECONOMIC SUPERPOWER IS CREATING DILEMAAS FOR THE COUNTRY'S LEADERSHIP AND THE JAPANESE

PEDPLE. THE JAPANESE ARE RELUCANT TO ASSUME A ROLE OF MORAL LEADERSHIP BECAUSE THEY FEEL CONSTRAINED BY HISTORY AND

IRADITION. BUT THE BIGGEST DILEMMA FOR JAPAM IS DECIDING ITS

FUTURE MILITARY ROLE IN THE WORLD.

06235 MCGINNIS, M.D.

DETERRENCE THEORY DISCUSSION: BRIDGING OR BROADENING THE GAP? AR COMENT ON HAGNER'S 'RATIONALITY AMD MISPERCEPTION IN DETERRENCE THEORY'

JOURNAL OF THEDRETICAL POLITICS, 4(4) (OCT 92), 443-457.

FOR SEVERAL DECADES, NUCLEAR DETERRENCE THEORISTS HAVE DEBATED THE RELATIVE IMPORTANCE OF RATIONALITY AND PSYCHOLOGY IN EXPLAINING THE BEHAVIOR OF NATIONAL POLICY MAKERS DURING INTERNATIONAL CRISES. R. HARRISON HAGNER HAS CASTIGATED PSYCHOLOGICAL CRITICS FOR IGNORING RECENT ADVANCES IN GAME THEORY THAT PROVIDE A MEANS TO INCDRPORATE MISPERCEPTION AND OTHER PSYCHOLOGICAL FACTORS INTO RATIONAL MODELS OF DETERRENCE SITUATIONS. IN THIS PAPER. THE AUTHOR CONTESTS WAGNER'S ASSERTION THAT THIS LINK CAN BEST BE ACHIEVED BY SIGNALLING GAME MODELS OF NUCLEAR AND OTHER FORMS OF DETERRENCE. INSTEAD, HE ARGUES THAT CONTINUED RELIANCE ON THESE MODELS WILL WIDEN THE GAP BETHEEN RATIONAL DETERRENCE THEORISTS AND THEIR CRITICS. ALTHOUGH SIGNALLING GAME MODELS CONTRIBUTE TO A BETTER UNDERSTANDING OF THE RATIONAL BASIS OF DETERRENCE THEORY, THESE SAME MODELS DIVERT ATTENTION FROM ALTERHATIVE APPROACHES THAT OFFER MORE PROMISE FOR LINKING FORMAL MODELS AND EMPIRICAL ANALYSIS.

06236 MCGOVERN, G.

"COME hOME AMERICA," THE MEH hORLD ORDER, AND THE 1992 ELECTION

SAIS REVIEN, 12(2) (SUM 92), 141-148.

WITH THE EMERGENCE OF CONSERVATIVE COLUMNIST PATRICK BUCHANAN AS A PRESIDENTIAL CHALLENGER RUNNING ON HHAT APPEARS TO BE AN "AMERICA FIRST" PLATFORM, SEVERAL COMMENTATORS HAVE WRITTEN OR SPOKEN ABOUT A "MCGOVERNCOMMENTA "ORS HAVE WRET TEN OR SPOKEN ABOUT A "MCGOVERNBUCHANAN" AXIS. THIS LED GEORGE MCGOVERN TO ACCEPT AN
INVITATION FROM THE EDITOR OF "SAIS REVIEW" TO CLARIFY THIS INVITATION FROM THE EDITOR OF "SAIS REVIEW" TO CLARIFY THI
MISCONCEPTION AND TO ADORESS HIMSELF IN A LARGER SENSE TO MISCONCEPTION AND TO ADORESS HIMSELF IN A LARGER SENSE TO AMERICA"S ROLE IN THE POST-COLD WAR HORLD. MR. MCGOVERN OUR POSITION IN THE WORLD AND OUR DOMESTIC CONDITION ARE OUR POSITION IN THE WORLD AND OUR DOMESTIC CONDITION ARE MUST COME HOME TO THE IDEALS ON WHICH AMERICA WAS FOUNDED.

06237 MCGRAH, K.M.

MANAGING BLAME: AN EXPERIMENTAL TEST OF THE EFFECTS OF POLITICAL ACCOUNTS

AMERICAN POLITICAL SCIENCE REVIEW, 85(4) (DEC 91), $1133-1158$ 
PUBLIC OFFICIALS ARE NOT PASSIVE BYSTANDERS IN THE ELECTORAL PROCESS. RATHER, THEY ACTIVELY TRY TO SHAPE OR MANAGE CITIZEN PERCEPTIONS OF EVENTS (PARTICULARLY THOSE INVOLVING NEGATIVE OUTCOMES) THROUGH EXPLANATIONS OR ACCOUNTS. CITIZEN UNDERSTANDINGS OF POLITICAL ACCOUNTABILITY AND HOH THEY ARE SHAPED BY PUBLIC OFFICIALS REPRESENT CRITICAL MISSING COMPONENTS OF MODELS OF ELECTORAL BEHAVIOR. THE DISTINCTION BETHEEN EXCUSES AND JUSTIFICATIONS PROVIDES A VALUABLE CONCEPTUAL FRAMEHORK FOR UNDERSTAMDING THE IMPACT OF POLITICAL ACCOUNTS ON A VARIETY OF JUDGMENTS AND PSYCHOLOGICAL PROCESSES. THE AUTHOR EXAMINES SATISFACTION WITH VARIOUS EXCUSES AND JUSTIFICATIONS AND THEIR IMPACT ON WITH VARIOUS EXCUSES AND JUSTIFICATIONS
SUBSEQUENT EVALUATIONS OF THE OFFICIAL.

06238 MCGREAL, P.

BACK TO THE FUTURE: THE SUPREME COURT'S RETROACTIVITY JURI SPRUDENCE

HARVARD JOURNAL OF LAH AND PUBLIC POLICY, 15(2) (SPR 92), 595-620.

THE AUTHOR SUMAARIZES THE U.S. SUPREME COURT'S RETROACTIVITY DOCTRINE THROUGH THE 1980'S. HE ASSESSES THE COMPETING POSITIONS ON THE CURRENT COURT AS ILLUSTRATED IN JAMES B. BEAM DISTILLING CO. V. GEORGIA AND AMERICAN TRUCKING ASSOCIATIONS $V$. SHITH. HE EMDORSES JUSTICE SCALIA'S HISTORICALLY-BASED RETROACTIVITY APPROACH AND EXAMINES THE IMPLICATIONS OF SCALIA'S DOCTINE FOR OTHER AREAS OF CONSTITUTIONAL LAH AND THEORY BEYOND THE NARROW AREA OF RETROACTIVITY.

06239 MCGREGOR, J.P.

CZECHOSLOVAKIA: A NEW STYLE FOR THE MINISTRY OF FOREIGN AFFAIRS

RFE/RL RESEARCH REPORT, 1(3) (JAN 92), 22-26.

IN POSTCOMHUNIST CZECHOSLOVAKIA, THE FEDERAL MINISTRY OF FOREIGN AFFAIRS IS THE CENTER OF FOREIGH POLICY-MAKING AND ENJOYS UNRIVALED CONTROL OVER FOREIGN POLICY. PART OF THE MINISTRY'S POWER OERIVES FOM ITS CONSTITUTIONAL MANDATE, PART FROM ITS POTENTIAL RIVALS' LACK OF INTEREST, AND PART FROM THE PERSONAL AUTHORITY OF MINISTER JIRI DIENSTBIER, WHO IS ONE OF CZECHOSLOVAKIA'S MOST INFLUENTIAL POLITICIANS UNDER DIENSTBIER, THE MINIST
REORGANI ZED AND REFORMED.

06240 MCGUINN, B.

THE ISLAMIC CHALLENGE IN EgYPT: HAS IT REACHED A POINT OF NO RETURN?

INSIGHT, 9(1) (1992), 61-70.

IN EGYPT, RECENT DISTURBANCES ARE OF A DIFFERENT ORDER FROM THOSE PAST AND THEY ARE GIVEN A POWERFUL RESONANCE IN LIGHT OF SEVERAL NEW TRENDS AFFECTING THE MIDOLE EAST IN GENERAL AND EGYPT IN PARTICULAR. THIS ARTICLE RECONSIDERS THE EGYPT SITUATION BY EXAMINING THE TRENDS IN THE POST-COLD WAR MIDOLE EAST AND NEW CHALLENGES TO EGYPTIAN SECURITY. IT EXPLORES FUNDAMENTALIST ACTIVISM IN EGYPT BY THE ISLAMIC GROUP, THE STRUGGLE HITH IRAN TO DEFINE THE NEH REGIONAL
ORDER AND IMPLICATIONS FOR AMERICAN POLICY IN THE MIDDLE EAST.

06241 MCGUIRE, J.

UNION POLITICAL TACTICS AND DEMOCRATIC CONSOLIDATION IN ALFONSIN'S ARGENTINA. 1983-1989

LATIN AMERICAN RESEARCH REVIEH, 27(1) (1992), 37-74. THIS ARTICLE AKALYZES THE RELATIONSHIP BETHEEN THE PERONIST UNION LEADERSHIP, AND ONE OF ARGENTINA'A MAIN POLITICAL PARTIES, THE PERONIST PARTIDO JUSTICIALISTA. THE FIRST THO SECTIONS DESCRIBE THE FACTIONS EMERGENCE AND PRESENTS SOME PRELIMINARY EVIDENCE TO SUPPORT THE CLAIM THAT PRESENTS SOME PREL IMINARY EVIDENCE TO SUPPORT THE CLAIM THAT ARGENTINE UNION LEADERS ARE RELATIVELY AUTONOMOUS FROM RANK
AND FILE. THE FINAL SECTION RETURNS TO THE ISSUE OF HOW THE POLITICAL TACTICS CHOSEN BY UNION LEADERS INFLUENCE DEMOCRATIC CONSOLIDATION.

06242 MCGURN, $W$.

BAKER: ENOUGH AND IN TIME?

NATIONAL REVIEW, XLIV(19) (OCT 92), 22, 24, 26

NAT THE AUTHOR LOOKS AT THE CAMPAIGY 22 , 24,26 . KETY TO BE PURSUED BY GEORGE BUSH UMDER THE TUTELAGE OF JAMES BAKER.

06243 MCGURN, $W$.

BLAME IT ON RIO

MATIONAL REVIEW, XLIY (11) (JUN 92), 23-26.

THE ANNOUNCEMENT OF PRESIDENT GEORGE BUSH THAT HE WILL ATTEND THE UNITED MATIONS "EARTH SUMMIT" IN RIO DE JANERIO IS TYPICAL OF AN ADMINISTRATIDN BENT ON REACHING OUT TO CONSTITUENCIES THAT WILL ONLY USE THE OCCASION TO BASH THE PRESIDENT WHILE ERODING SUPPORT IN ITS OWN BASE. WHATEVER BUSH DOES IN RIO, IT IS LIKELY THAT HE WILL BE ACCUSED OF BETRAYING THE FREE-MARKET CHAMPIONS OF THE RIGHT AMD-ACCORDING THE THE ENVIRONMENTALLY CONSCIOUS LEFT--OF NOT
GOING FAR ENOUGH TO PROTECT THE ENVIRONMENT.

06244 MCGURN, $H$.

HE WAS WARNED
NATIONAL REYIEW, XLIV(23) (NOV 92), 44-45.

MR. BUSH'S DEFEAT WAS PREDICTABLE BUT NOT INEVITABLE. THIS ARTICLE STATES THAT ALL HE NEEDED WAS A CHANGE OF HEART - AND MIND. IT STATES THAT BUSH'S CAMPAIGN FOCUSED TOO MUCH ON HIS OPPONENT'S SHORTCOMINGS AND NOT ENOUGH ON ISSUES.

06245 MCGURN, $W$.

IS THE POPE CAPITALIST?

AMERICAN SPECTATOR, 24(8) (AUG 91), 12-16.

IN SHARP CONTRAST TO THE FAITH THAT U.S. BISHOPS CONTINUE TO PLACE IN THEIR GOVERMMENT TO REDRESS PROBLEMS, POPE JOHN PAUL II PLACES HIS TRUST IN HUMAN CREATIVITY NURTURED IN FREEDOM AND CULTIVATED BY VIRTUE. A RECENT ENCYCLICAL IS NOT AN ENDORSEMENT OF A SPECIFIC SYSTEM, BUT ENCYCLICAL IS NOT AN ENDORSEMENT OF A SPECIFIC SYSTEM, BUT
IT DOES RECDGNIZE THAT THE MARKET'S FOUNDATION ON FREE IT DOES RECDGHIZE THAT THE MARKET'S FOUNDATION ON FREE
ASSOCIATIONS AND CONTRACTS BETHEEN LABOR AND CAPITAL BEST ASSOCIATIONS AND CONTRACTS BETHEEN LABOR AND CAPITAL BEST
ENABLES MAN TO CARRY OUT "HIS ROLE AS A COOPERATION WITH GOD ENABLES MAN TO CARRY OUT "HIS ROLE AS A COOPERATION WITH AMERICA CONTINUE TO CONCENTRATE ON THE POPE'S QUALIFYING REMARKS ABOUT THE NATURE OF CAPITALISM AND IGNORE THE REMARKS ABOUT THE NATURE OF CAPTT,
CENTRAL MESSAGE IN THE PROCESS.

06246 MCGURN, $W$. JIMHY, GO HOME

AMERICAN SPECTATOR, 24(5) (MAY 91), 24.

THIS ARTICLE RECOUNTS THE EXPERIENCE OF THE AUTHOR AS AN INTERNATIONAL OBSERVER OF THE ELECTIONS IN EL SALVADOR HELD IN MARCH. HE FINDS IT IRONIC THAT PRESIDENT ALFREDO CRISTIANI HAS MADE GREAT STRIDES IN ECONOMIC REFORM, ASSERTING CIVILIAN CONTROL OVER THE MILITARY, AND NEGOTIATING HITH THE FMLN REBELS, AND HAS BEEN REWARDED FROM WASHINGTON BY A FREEZE IN MILITARY AID AND A THREAT TO BOYCOTT THE NATION'S COFFEE EXPORTS. MEANHHILE, THE FMLN CONTINUES TO KILL CITIZENS.

06247 MCGURN, W.

LAMAR'S CHOICE

NATIONAL REVIEH, XLIII(15) (AUG 91), 20-21.

AMONG GEORGE BUSH'S STATED GOALS FOR EDUCATIONAL REFORM IN AMERICA ARE THE INSTITUTION OF A VOUCHERS PROGRAM TO FOSTER CHOICE IN EDUCATION AND THE IMPLEMENTATION OF NATIONAL TESTING PROGRAM. BUSH HAS CONSISTENTLY CALLED FOR NATIONAL TESTING PROGRAM. BUSH HAS CONSISTENTLY CALLED FOR
THESE REFORMS ONLY TO FIND HIS CAUSE UNDERMINED BY HIS OWH THESE REFORMS ONLY TO FIND HIS CAUSE UNDERMINED BY HIS OWN
SECRETARY OF EDUCATION, LAMAR ALEXANDER. THE SECRETARY SEEMS SECRETARY OF EDUCATION, LAMAR ALEXANDER. THE SECRETARY SEEMS
MORE CONCERNED WITH PASSING A BILL (ANY BILL) IN CONGRESS MORE CONCERMED WITH PASSING AOBILL (ANY BILL) IN CONGR "THAN WITH THE GOALS OF HIS BOSS. HIS WILLINGNESS TO "COMPROMISE" WITH CONGRESS DEMOCRATS IS ALL THE MORE UNFORTUNATE BECAUSE OF THE GROWING SUPPORT FOR THE VERY
PROGRAMS HE SEEMS SO WILLING TO ABANDON: YOUCHERS AND PROGRAMS

06248 MCGURN, $W$.

MEMO TO THE PRESIDENT

NATIONAL REVIEW, XLIV(1) ( JAN 92), 21-22.

"ON THE SCENE" BY WILLIAM MCGURN PONDERS HHETHER THE PRESIDENT SHOULD PUT HIS POLITICAL EGGS IN THE STATE OF THE UNION BASKET. IN A FICTIOUS MEMO FROM FORMER PRESIDENT CARTER, GEORGE BUSH IS ADVISED IN THE AREAS OF THE BUDGET, THE RECESSION, GROWTH PACKAGES, LAYOFFS, ECT. THE ARTICLE CONCLUOES THAT IF BUSH STICKS TO HIS GUNS ON THE BUDGET PACKAGE, HE CAN STEER THE NATION BACK TO THE KINDER, GENTLER GOP WHERE TAX CUTTING WAS STILL VOODOO ECONOMICS AND COUNTRY CLUB WAS AN HONORABLE HORD.

06249 MCGURN, $W$.

MR. CLINTON COMES TO TOWM

NATIONAL REVIEW, XLIV(14) (JUL 92), 28-30.

DEMOCRATIC PRESIDENTIAL CANOIDATE BILL CLINTON HAS MADE GREAT STRIDES IN CULTIVATING AN IMAGE AS A MODERATE. HE GOT GREAT STRIDES IN CULTIVATING AN IMAGE AS A MODERATE. HE GOT
THROUGH THE PRIMARIES WITH JUST TOKEN PROMISES TO INTEREST THROUGH THE PRIMARIES WITH JUST TOKEN PROMISES TO INTEREST
GROUPS. HE FAVORS THE FREE TRADE AGREEMENT HITH MEXICO. HE TOLD AN INNER-CITY AUDIENCE IN DETROIT THAT THEY HAVE TO TOLD AN INNER-CITY AUDIENCE IN DETROIT THAT THEY HAVE TO
START UNDERSTANDING THE FEARS AND CONCERNS OF THE MIDDLE CLASS. HE HAS CALLED FOR CUTS IN GOVERNMENT JOBS AND CLASS. HE HAS CALLED FOR CUTS IN GOVERMMENT JOBS AND
ENTITLEMENTS. HOHEVER, MANY ARGUE THAT CLINTON'S HIFE, ENTITLEMENTS. HOWEYER, MANY ARGUE THAT CLINTON'S HIFE,
HILLARY, AND THE TYPE OF LEFT-WING PEOPLE THAT ARE ATTRACTED HO A DEMOCRATIC CAMPAIGN THREATEN TO DESTROY THIS IMAGE. IF BILL CLINTON COULD BE JUDGED IN ISOLATION, WITHOUT THE BILL CLINTON COULD BE JUDGED IN ISOLATION, WITHOUT THE
HILLARY FACTOR, HE WOULD BE HUCH MORE CREDIBLE AS A BREAK HILLARY FACTOR, HE WOULD BE HUCH MORE CREDIBLE AS A BREAK
WITH THE FAILED DEMOCRATIC AGENDA OF THE LAST THO CAMPAIGNS. WITH THE FAILED DEMOCRATIC AGENDA OF THE LAST THO CAMPAIGMS.
THE MOST SIGNIFICANT THING CLINTON COULD DO TO SHIFT THE THE MOST SIGNIFICANT THING CLINTON COULD DO TO SHIFT THE
CENTER OF GRAVITY IN HIS CAMPAIGN IS CHOOSE THE RIGHT CENTER OF GRAYI

06250 MCGURN, $W$

NEW AMERICAN ORDER

NATIONAL REYIEW, XLIII (5) (APR 91) 33-35

WHILE THE GULF WAR MAY NOT SUCCEED AS THE HARBINGER OF THE NEW HORLD ORDER, THIS ARTICLE ARGUES THAT A NEW AMERICAN ORDER WILL EMERGE. THIS IS A POLITY IN WHICH THE COMMON AMERICAN CITIZEN EXPRESSES HIS DISLIKE FOR THE PRESS, CLERGY, AND DEMOCRATS WHO LISTENED TO DOOMSDAYERS AND DRAGGED THEIR FEET ON THE WAR. THE MILITARY VICTORY IN THE GULF WAS A POLITICAL VICTORY FOR CONSERVATIVES AT HOME AS WELL. 
06251 MCGURN, $N$.

NDT KAFKAESOUE

NATIONAL REVIEW, XLIV(4) (MAR 92), 21-22.

IN CZECHOSLAVAKIA, THIS ARTICLE DISCUSSES THE SITUTATION OF POST-COMMUNIST NATIONALISM AND ECONOMIC REFORM. THE AUTHOR DISCUSSES HIS VISIT TO THE COUNTRY AND HIS VIEHS OF WHAT IS HAPPENING THERE. ONE FACTOR MAKING THE SITUATION UNIQUE IS THAT THE COMMUNISTS THERE HAVE CLEVERLY CHOSEN TO MAKE THEIR STAND UNDER THE COVER OF NATIONALISM.

06252 MCGURN, $H$.

ON THE SCENE: CAMPAIGN FEVER

NATIONAL REVIEW, XLIV(16) (AUG 92), 19-20

PRESIDENT GEORGE BUSH'S CAMPAIGN FOR REELECTION SEEMS TO BE SUFFERING FROM LACK OF COMPETENCE AND LACK OF DIRECTION. DAN QUAYLE, ALTHOUGH BUSH HAS NO INTENTION OF DUMPING HIM.

06253 MCGURH, $W$.

RUBBER CONGRESSMEN

MATIONAL REVIEW, XLIV(7) (APR 92), 21-22

THE DISCOVERY OF 296 CONGRESS MEMBERS BOUNCING CHECKS WAS ONE OF THE FACTORS LEADING TO THE PUBLIC'S

DISENCHANTMENT WITH GOVERNMENT. THIS ARTICLE DISCUSSES THE ERRANT BANKING, SOME OF THE PROPOSED MEASURES TO DEAL HITH IT, AND HOW PRESIDENT BUSH COULD POSSIBLY USE THE PROBLEM TO HIS ADVANTAGE IN THE 1992 ELECTION.

06254 MCGURN, $W$.

TARGETING THOMAS

MATIONAL REVIEH, XLIII(16) (SEP 91), 21-22

THIS ARTICLE' EXAMINES THE PROSPECTSS OF RECENT SUPREME COURT NOMINEE CLARENCE THOMAS. IT CONCLUDES THAT THOMAS'S CRITICS ARE LOOKING MORE ANO MORE LIKE DEFENDERS OF SPECIAL INTERESTS RATHER THAN CHAMPIONS OF EQUAL RIGHTS. FURTHERMORE, A MONTH AWAY FROM THE HEARINGS, THE CIVIL-RIGHTS COMMUNITY LACKS A UNIFIED FRONT, AND THE PUBLIC BICKERING--BETWEEN THE NATIONAL AND LOCAL OFFICES OF THE NAACP--SUGGESTS IT IS NOT GOING TO PULL TOGETHER. IF THE HEARINGS GO BADLY THOMAS MIGHT STILL BE DENIED HIS SEAT. BUT IT IS OBVIOUS FROM TALKING WITH EVEM HIS FIERCEST CRITICS THAT IT IS NOH CLARENCE THOMAS'S GAME TO LOSE.

06255 MCGURN, $W$.

THE DEMOCRATS' ALBATROSS

NATIONAL REVIEH, XLIV(15) (AUG 92), 16-17.

THE 1992 DEMOCRATIC PARTY CONVENTION IS SUPPOSED TO HERALD A NEW, IMPROVED PARTY, WITH AN ALL-SOUTHERN, BABYBERALD A NEW, IMPROVED PARTY, WITH AN ALL-SOUTHERN, BABY DEMOCRATIC LEADERSHIP COUNCIL. HOHEVER, ALL OF THE RHETORIC OF BILL CLINTON AND AL GORE ABOUT PERSONAL RESPONSIBILITY, FAITH AND FAMILY CANMOT MASK THEIR SUPPORT FOR AN ISSUE FAITH, AND FAMILY CANNOT MASK THEIR SUPPORT FOR AN ISSUE THAT IS PROFOUNDLY LIBERAL: ABORTION ON DEMAND. A SMALL CASEY, REALIZE THAT ABORTION ON DEMAND IS AN ENTIRE CULTURE CANE NOT JUST A POLITICAL POSITION. THIS CULTURE IS STILL UNACCEPTABLE TO A LARGE PORTION OF AMERICANS. HOWEVER, THEIR WARNINGS ARE NOT HEEDED AS THE DEMOCRATS CLING TO THEIR ALBATROSS WHICH MAY SPELL ELECTORAL DEFEAT IN NOVEMBER.

06256 MCGURN, $W$.

THE RISE AND FALL OF CIVIL RIGHTS

NATIONAL REVIEH, XLIII(7) (APR 91), 21-25.

AS RIGHT AND LEFT GIRD THEMSELVES FOR THE RESUMPTION OF THE BATTLE OVER CIVIL RIGHTS, THE UNTALKED-OF FACT IS THAT THE PRO-QUOTA BRIGADE HAS SPENT ITS AMMUNITION. A KEY REASON IS THAT PUBLIC PERCEPTION OF THE CIVIL RIGHTS MOVEMENT HAS GONE FROM "A MORAL CRUSADE" TO "THE EXPRESSION OF A PARTICULAR INTEREST GROUP." IN WASHINGTON THE SHIFT IS BECOMING OBVIOUS AS REPUBLICANS ARE AGGRESSIVELY MOVING TO SHUT THE BACK DOOR TO A SOCIETY BASED ON QUOTAS, SET-ASIDES, AND RACIAL PREFERENCES.

06257 MCGURN, $W$.

THE THO BOBS

NATIONAL REVIEH, XLIII(22) (DEC 91), 34-38.

ELEVEN YEARS AFTER REAGAH TOOK THE WHITE HOUSE WITH A BRAND-NEW GOP MAJORITY IN THE SENATE, SEVEN YEARS AFTER HIS MANDATE HAS RENEWED AND THE ESTABLI SHED BELTHAY HISDOM ABOUT THE INEVITABILITY OF ONE-TERM PRESIDENCIES WAS TURNED ON ITS HEAD, AND SCARCELY THREE YEARS AFTER VICE PRESIDENT GEORGE BUSH WAS SHEPT INTO THE OVAL OFFICE AS THE ANNOINTED HEIR OF THE REAGAN REVOLUTIOH, THE REPUBLICAN PARTY REMAINS A GOOD AND GRACIOUS SOSER. AND GRACIOUS LOSER. AT A TIME WHEN REPUBLICAN PARTY HOUSES OF CONGRESS HAVE BEEN SHRINKING: IN THE SENATE FROM HOUSES OF CONGRESS HAVE BEEN SHRINKING: IN THE SENATE FROM 53 REPUBLICANS AT THE OUTSET OF THE REAGAN ADMINISTRAT 43 TODAY; IN THE HOUSE, FROM 192 IN 1982 TO 166 TODAY.
PRES IDING OVER THESE DISASTROUS LOSSES ARE THE BEST SPORTS PRESIDING OVER THESE DISASTROUS LOSSES ARE THE BEST SPORTS DOLE AND BOB MICHEL, SENATE AND HOUSE MINORITY LEADERS. BOTH MEN HAVE MORE IN COMMON WITH THE CONGRESS PRESIDENT BUSH IS ATTACKING THAN THE ONE HE WOULD LIKE. BOTH SEEM TO VALUE
LOSING GRACIOUSLY MORE HIGHLY THAN FIGHTING FOR THE HIN.

06258 MCGURN, $W$.

THE YEAR OF THE WOMEN

NATIONAL REVIEW, XLIV (13) (JUL 92), 21-22.

1992 HAS BEEN TOUTED AS "THE YEAR OF THE WOMEN." THIS

ARTICLE DISCUSSES CAMPAIGNS AND ELECTIONS WITH FEMALE

CANDIDATES AND THE REASONS FOR THEIR APPARENT SUCCESS.

ELECTIONS IN CALIFORNIA, TEXAS, MAINE, AND ILLINOIS.

06259 MCGURN, W.

WHERE DO WE GO FROM HERE?

NATIONAL REVIEW, XLIV (18) (SEP 92), 37-38

THE AUTHOR REPORTS ON THE 1992 REPUBLICAN PARTY

CONVENTION AND OISCUSSES PRESIDENT BUSH'S STRATEGY IN HIS RE-

ELECTION CAMPAIGN.

06260 MCGURN, $W$.

YANKEES GO HOME

AMERICAN SPECTATOR, 25(2) (JAM 92), 42; 44-45.

UNLESS THE JESSE JACKSONS OF THE PHILIPPINE SENATE HAVE

A SUDOEN CHANGE OF HEART, AFTER MEARLY A CENTURY THE U.S

A SUDOEN CHANGE OF HEART, AFTER NEARLY A CENTURY THE U.S.

THIS ARTICLE SUGGESTS THAT THE UNITED STATES HILL MANAGE

THIS ARTICLE SUGGESTS THAT THE UNITED STATES HILL MANAGE,
BUT WONDERS ABOUT THE PEOPLE LEFT BEHIND. IT HOPES THAT THE

PHILIPPINE GOVERMMENT LEADERS HIL AT LOMG LAST ASSUME

RESPONSIBLITY FOR THE COUNTRY'S PROBLEMS AND DESTINY.

06261 MCHUGH, J.T.

WHAT IS THE DIfFERENCE BETHEEN A PERSON AND A HUMAN BEING WITHIN THE LAW?

REVIEH OF POLITICS, 54(3) (SUM 92), 445-461.

THE DIFFERENCE BETHEEN THE LEGAL TERMS "PERSON" AND

"HUMAN BEING" REPRESENTS MORE THAN A QUESTION OF STANDING OR

MERE SEMANTICS. WITHIN LIBERAL DEMOCRATIC SOCIETIES, SUCH AS CANADA AND THE UNITED STATES, SUCH DISTINCTIONS MAY INDICATE SUBSTANTIVE DIFFERENCES REGARDING FUNDAMENTAL CONCEPTS, SUCH AS CITIZENSHIP, MEMBERSHIP IN SOCIETY, AND THE SCOPE AND ESSENTIAL NATURE OF RIGHTS AND LIBERTIES. IN PARTICULAR, JUDICIAL DECISIONS REGARDING ABORTION HAVE REL IED UPON SUCH OISTINCTIONS IN ORDER TO ARTICULATE SOME OF THE

06262 MCINNES, S.; BILLINGSLEY, P.

CANADA'S IMDIANS: NORMS OF RESPONSIBLE GOVERMMENT UNDER FEDERAL ISH

CAMADIAN PUBLIC ADMINISTRATIOY 35(2) (SUM 92) $215-236$. THE AUTHORS EXAMINE THE APPLICATION OF NORMS OF RESPONSIBLE GOVERMMENT IN INDIAN GOVERNMENTS. THEY ARGUE THAT CANADA'S INDIANS DO NOT NEED TO TAKE LESSONS FROM NONINDI ANS ON THE IMPORTANCE OF THE ACCOUNTABILITY OF LEADERS. INDIANS ON THE IMPORTANCE OF THE ACCOUNTABILIYY OF LEADERS. THOSE IN A SELF-GOVERNMENT SETTING, ARE MORE DIRECT AND POTENTIALIY RICHER IN PRACTICE THAN THOSE TYPICALLY ENJOYED BY MOST NON-INDIAN CANADIAN CITIZENS.

06263 MCINTYRE, R.S

FINAL CUT
NEW REPUBLIC, 207(16) (OCT 92), 16-17.

PRESIDENT GEORGE BUSH CONTINUES TO MAKE A CAPITAL GAINS TAX CUT THE CENTERPIECE OF HIS ECONOMIC STRATEGY. MEANHHILE, SUPPLY-SIDE ZEALOTS ARE PROMOTING THE IDEA THAT THE

PRESIDENT CAN CUT THE CAPITAL GAINS TAX SIMPLY BY EXECUTIVE FIAT.

06264 MCKAY, D.

IS EUROPEAN POLITICAL SCIENCE INFERIOR TO OR DIFFERENT FROM AMERICAN POLITICAL SCIEMCE?

EUROPEAN JOURHAL OF POLITICAL RESEARCH, 20(3-4) (DEC 91), 459-466.

EUROPEAN POLITICAL SCIENCE IS DIFFERENT FROM, NOT INFERIOR TO, THE AMERICAN YARIETY. AMERICAN POLITICAL SCIENCE IS UNDOUBTEDLY MORE PROFESSIONALIZED AND, IN THIS SENSE, MAINTAINS MORE CONSISTENT STANDARDS THAN ITS EUROPEAN COUNTERPART. THE AMERICAN PROFESSION HAS CERTAINLY PRODUCED A GREATER VOLUME OF TOP-NOTCH RESEARCHERS, BUT THIS IS PRIMARILY A FUNCTION OF NUMBERS. IT IS DOUBTFUL WHETHER THE AVERAGE AMERICAN SCHOLAR IS MUCH DIFFERENT FROM THE AVERAGE EUROPEAM AMERICAM STAMDARDS HAYE NOT BECOME THE BEMCHMARK FOR OUAL ITY POLITICAL SCIEMCE RESEARCH CONDUCTED OUTSIDE THE UNITED STATES, EITHER IN CONCEPTUAL OR METHODOLOGICAL TERMS.

06265 MCKEAN, M.A.

SUCCESS ON THE COMMONS: A COMPARATIVE EXAMINATION OF SUCCESS ON THE COMMONS: A COMPARATIVE EXAMINATION OF JOURAL

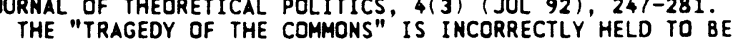
THE EVENTUAL FATE OF ALL RESOURCES THAT ARE USED COLLECTIVELY RATHER THAN BY INDIVIDUAL PRIVATE OWNERS. THE AUTHOR REVIEHS SEVERAL EXAMPLES OF SUCCESSFUL COLLECTIVE MANAGEMENT OF ENVIRONMENTAL RESOURCES--INSTITUTIONAL REGIMES THAT HAVE OPERATED FOR DECADES OR EVEN CENTURIES HITHOUT PRODUCING DEGRADATION OF RESOURCES. THEN SHE EXPLORES THE FEATURES SHARED BY THESE HISTORICALLY UNCONNECTED 
INSTITUTIONAL REGIMES IN ORDER TO BEGIN SPECIFYING THE CHARACTERISTICS OF REGIMES THAT CIRCUMVENT TRAGEDY.

SUCCESSFUL SYSTEMS USUALLY HAVE WELL-DEFINED COMMUNITIES OF ELIGIBLE USER-MANAGERS AND CLEAR, EASILY-ENFORCED AND ENYIRONMENTALLY-CAUTIOUS RULES TO CONSTRAIN RESOURCE USE. BUT THEY VARY GREATLY IN TERMS OF THE ALLOCATION OF THE HARVESTED SUPPLY OF THE RESOURCE, FROM HIERARCHICAL SYSTEMS OF RIGHTS HITH UNEQUAL ALLOCATION TO VERY EGALITARIAN SYSTEMS THAT ASSIGN EQUAL SHARES BY LOTTERY.

06266 MCKELVEY, R.D.; RIEZMAN, R.

SENIORITY IH LEGISLATURES

AMERICAN POLITICAL SCIENCE REVIEN, 86(4) (DEC 92), 951-965. THE AUTHORS CONSTRUCT A STOCHASTIC MODEL OF A

LEGISLATURE WITH AN ENDOGENOUSLY-DETERMINED SENIORITY SYSTEM. THEY MODEL THE BEHAVIOR OF THE LEGISLATORS AS WELL AS THEIR CONSTITUENTS AS AN INFINITELY REPEATED DIVIDE-THE-DOLLAR GAME. THE GAME HAS A STATIONARY EQUILIBRIUM, THE LEGISLATURE GAME. THE GAME HAS A STATIONARY EQUILIBRIUA, THE LEGISLA
IMPOSES A NON-TRIVIAL SENIORITY SYSTEM ON ITSELF, AND INCUMBENT LEGISLATORS ARE ALWAYS REELECTED.

06267 MCKENDRICK, D

INDONESIA IN 1991: GROWTH, PRIYILEGE, AND RULES

ASIAN SURVEY XXXII (2) (FEB, 92), 103-110.

THIS ARTICLE BRIEFLY EXAMINES DEVELOPMENTS AND PROBLEMS WITH REGARDS TO ECONOMIC, DOMESTIC AND FOREIGN POLICY IN INDONESIA DURING 1991. THE INDONESIAN ECONOMY CONTINUED TO GROW AT 6\%, A RATE THAT ALLOHS FOR AN ADOITIONAL TWO MILLION PEOPLE TO ENTER THE WORK FORCE. HOWEVER, THERE IS GROWING CONCERN OVER ISSUES INCLUDING CONGLOMERÁTION, WEAK COMMERCIAL LAW, AND LABOR RELATIONS, ALL OF WHICH RAISE ELEMENTAL QUESTIONS OF FAIRNESS. IN THE POLITICAL SPHERE, PRESIDENT SUHARTO GEARED UP FOR ANOTHER RE-ELECTION BID BY WOOING MUSLIMS. DESPITE TALK ABOUT GREATER DEMOCRATIZATION, THE INDONESIAN PARLIAMENT HAS NOT MADE MUCH PROGRESS TOHARD BECOMING A FUNCTIONING LEGISLATIVE BODY. IN THE REALM OF FOREIGN AFFAIRS, INDONESIA'S MEDIATION OF THE CAMBODIAN PEACE TALKS AND ITS NON-ALIGNED STANCE DURING THE GULF WAR WON WORLDWIDE PRAISE. HOWEVER, QUESTIONS ABOUT INDONESIA'S VIOLATIONS OF HUMAN RIGHTS, ESCPECIALLY IN EAST TIMOR, CONTINUE TO CLOUD ITS INTERNATIONAL IMAGE.

06268 MCKENZIE, R.B.

THE THOMAS/HILL HEARINGS: A MEW LEGAL HARASSMENT

FREEMAN, 42(1) (JAN 92), 25-17

THE CLARENCE THOMAS CONFIRMATION HEARINGS WERE NOT ABOUT THE PERVERSION OF SEX BUT OF GOVERNMENT PROCESSES AND AUTHORITY. THE INCONSISTENCIES AND CONTRADICTIONS THAT WERE AUTHORITY. THE INCONSISTENCIES AND CONTRADICT IONS THAT
REVEALED DIDN'T INVOLVE THE TESTIMONY BUT THE HEARINGS

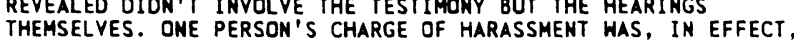
HARASSING ANOTHER PERSON. AND THE CHARGE WAS BEING MADE, MOT TO SHED LIGHT ON JUDGE THOMAS'S ALLEGED TRANSGRESSIONS BUT BECAUSE HE HAD BECOME IMPORTANT.

06269 MCKENZIE, W.P.

A PRAGUE FALL

RIPON FORUM, (DEC 90), 22-23.

THIS ARTICLE EXAMINES THE SITUATION IN POST-COMMUNIST

CZECHOSLOVAKIA. THE MOST PRESSING ISSUE IS SEEN TO BE ETHNIC TENSIONS, PRIMARILY BETHEEN THE CZECHS AND THE SLOVAKS, WITH SLOVAKIA DESIRING GREATER SELF-DETERMINATION. THESE ETHNIC CONCERNS ARE EXPLORED. CZECHOSLOVAKIA'S ECONOMIC PROBLEMS AND ENVIRONMENTAL POLLUTION ARE ALSO ADDRESSED.

06270 MCKEOWN, P.; CONNOLLY, M.

EDUCATION REFORM IN NORTHERN IRELAND: MAINTAINING THE DISTANCE?

JOURNAL OF SOCIAL POLICY, 21(2) (APR 92), 211-232.

THE AUTHORS INVESTIGATE THE EXTENT TO' WHICH EDUCATIONAL

REFORM IN NORTHERN IRELAND HAS DEVELOPED ALONG SEPARATE

LINES ANO COMMENT ON THE DEGREE TO WHICH A PART OF THE

UNITED KINGDOM CAN MOVE INDEPENDENTLY FROM THE REMAINDER,

WITH RESPECT TO KEY SOCIAL POLICIES. THEN THEY EXAMINE THE

UNIQUE FEATURES OF EDUCATION IN NORTHERN IRELAND AND DISCUSS

THE MAIN ELEMENTS OF THE RELEVANT LEGISLATION. THEY ALSO MAKE COMPARISONS WITH THE THEMES UNDERPINNING RECENT

DEVELOPMENTS IN BRITAIN.

06271 MCKNIGHT, D.

TRACK THÓ DIPLOMACY--AN INTERMATIONAL FRAMEHORK FOR CONTROLLING ORBITAL DEBRIS

SPACE POLICY, 7(1) (FEB 91), 13-22

THIS ARTICLE EXAMINES THE SIZE, EXTENT, AND IMPLICATIONS OF THE GROWING AMOUNT OF SPACE DEBRIS ORBITING THE EARTH. IT PROPOSES A FRAMEWORK FOR MULTINATIOMAL COOPERATION THAT WILL PROPOSES A FRAMEWORK FOR MULTINATIONAL COOPERATION THAT WILL
HELP CONTROL THE GROWTH OF ARTIFICIAL SPACE DEBRIS THROUGH IRACK TWO DIPLOMACY. THIS STYLE OF DIPLOMATIC PROCESS EMPHASIZES THE USE OF CITIZEN-TO-CITIIZEN INTERACTION. WITH OISCUSSIONS AND NEGOTIATIONS BEING PERFORMED AT THE LOWEST LEVEL POSSIBLE, MANY OF THE LIABILITIES OF FORMER GOVERMMENTTO-GOVERMMENT INTERACTIONS ARE AVOIDED. THE PROPOSED ORBITAL OEBRIS ACTION COMMITTEE HOULD BE THE INTERNATIONAL GROUP RESPONSIBLE FOR THE DEVELOPMENT OF ACTION PLANS TO BE DELIVERED TO SPACE FARING COUNTRIES REPRESENTING CONSENSUS
PROCEDURES AND POLICIES TO CONTROL ORBITAL DEBRIS.

06272 MCKNIGHT, S.

THE FORGOTTEN WAR: THE IRAQI ARMY AND THE IRAN-IRAQ WAR

SMALL WARS \& INSURGENCIES, 2 (1) (APR 91), 91-102.

RECENT EVENTS HAVE CONFIRMED FOR MANY THAT WE HAVE

LITTLE TO LEARN FROM STUDYING \$THIRD RATE' FORCES AT WAR. THIS ARTICLE EXAMINES THE IRAN-IRAQ WAR AND SUGGESTS THAT DESPITE IRAQ'S FAILURE TO INFLICT MORE THAN MINIMAL

CASUALTIES ON COALITION FORCES IN 1991 ITS ACHIEVEMENTS IN THE EARLIER CONFLICT DO MERIT STUDY. IT EXPLORES THE IRANIAN WAR EFFORT, OUTSIDE AID, IRAQI DEFEAT AT KHORRAMSHAHR, IRAQI REFORM, AIRPOWER, FORTIFICATIONS, CHEMICAL WEAPONS AND MISSILES, AND THE KARBALA 5 OFFENSIVE. IT CONCLUDES THAT THE LIMITS OF OF IRAQI SUCCESSES ARE IMPORTANT TO REALIZE AS

THEY HELP EXPLAIN WHY DESERT STORM WENT SO WELL.

06273 MCLAUGHLIN, S.I.

THE CAYMAN ISLANDS: THE EVOLUTIONARY APPROACH TO POLITICAL DEVELOPMENT

PARL IAMENTARIAN, LXXIII (2) (APR 92), 113-115.

THE CAYMAN ISLANDS CAN BE COUNTED AMONG THE TERRITORIES THAT ZEALOUSLY GUARD AND NURTURE PARLI AMENTARY PRACTICES. THIS HAS CONTRIBUTED TO THE ISLANDS POLITICAL STABILITY AND SUSTAINED POLITICAL DEVELOPMENT.

06274 MCLAURIN, R.

FOUNDATIONS OF THE SAUDI-AMERICAN SECURITY RELATIONSHIP MIDDLE EAST INSIGHT, VIII (4) (MAR 92), 36-42.

THIS ARTICLE EXAMINES AMERICAN-SAUDI RELATIONS OVER THE PAST FEW DECADES. IT CHRONICLES THE SOMETIMES CLOSE SECURITY COOPERATION BETHEEN THE THO STATES, BUT ALSO RECOUNTS THE NUMEROUS POL ITICAL DISPUTES BETWEEN THE TWO. IT EMPHASIZES THE INVIGORATING EFFECT THAT THE GULF CRISIS AND OPERATION DESERT STORM HAVE HAD ON U.S. -SAUDI RELAITONS. HOWEVER, PROGRESS IN SECURITY COOPERATION HAS NOT MOVED APACE WITH THAT IN THE POLITICAL REALM. MORE THAN A YEAR AFTER THE END OF COMBAT OPERATIONS IN THE GULF, SAUDI ARABIA AND THE UNITED STATES HAVE STILL NOT REACHED AGREEMENT ON THE TERMS OR MAGNITUDE OF THE U.S. MILITARY PRESENCE. IN ADOITION, SUBSTANTIAL OPPOSITION EXISTS TO SIGNIFICANT U.S. ARMS SALES TO SAUDI ARABIA AND MANY IN THE KINGDOM ARE DISMAYED OVER THE CLOSENESS OF THE EMBRACE WITH THE UNITED STATES. THE ART ICLE CONCLUDES, HOWEVER, THAT THESE THREATS AND PROBLEMS ARTICLE CONCLUDES, HOWEVER, THAT THESE

06275 MCLAURIN, R.

FROM PROFESSIONAL TO POLITICAL: THE REDECLINE OF THE LEBANESE ARMY

ARMED FORCES AND SOCIETY, 17(4) (SUM 91), 545-568.

FOR ALL ITS WEAKNESSES AND TRAVAILS, THE LEBANESE ARMY DID NOT FALL VICTIM IO THE DISEASE OF POLITICIZATION IN SUPPORT OF A SPECIFIC PERSONALITY UNTIL AFTER THE FAILED AMERICAN INTERVENTION OF 1982-1984. WHEN FOR THE FIRS THE ARMY DEVELOPED A LIMITED COMBAT CAPABILITY AND
ORIENTATION, INSTEAD IT ENTERED INTO THE POLITICAL ARENA. ORIENTATION, INSTEAD IT ENTERED INTO THE POLITICAL ARENA. OTHER REGIONAL ARMIES: DECLINE OF COMBAT CAPABILITIES, NEW FORMS OF FRAGMENTATION, AND WIDESPREAD DEMORALIZATION.

06276 MCLAURIN, R.

HIDDEN AGENDAS AMIDST OPPOSING OBJECTIVES--THE NEWEST INCARMATION OF THE MIDDLE EAST PEACE PROCESS MIDDLE EAST INSIGHT, 8(2) (SEP 91), 15-23.

THE LEADERS OF EGYPT, ISRAEL, JORDAN, LEBANON, SAUDI ARABIA, SYRIA, AND THE UNITED STATES APPEAR PUBLICLY TO AGREE ON ONE THING ONLY: THAT THE POST-GULF WAR PERIOD HAS CREATED A UNIQUE ENVIRONMENT IN WHICH A DEFINITIVE AND PEACEFUL SETTLEMENT OF THE ARAB-ISRAELI CONFLICT IS POSSIBLE. WHAT IS REMARKABLE ABOUT THIS UNHONTED--PROBABLY UNPRECEDENTED--CONSENSUS IS THAT PUBLIC ATTITUDES, ELITES' PRIVATE ASSESSMENTS, EXPERT VIEHS, AND POL ITICAL REALITIES ALL POINT TO A CONCLUSION THAT IS 180 DEGREES REMOVED. EVIDENCE SUGGESTS THAT EACH GOVERMMENT IS PURSUING A STRATEGY THAT RECOGNIZES AND TAKES INTO ACCOUNT THE IMPOSSIBILITY OF ACHIEVING A COMPREHENSIVE PEACE, AT LEAST IN THE FORESEEABLE FUTURE. IN OTHER WORDS, THE PUBLIC CONSENSUS OF THE POLITICAL LEADERSHIPS ABOUT THE THE TIMLINESS OF A PEACEFUL RESOLUTION OF THE CONFLICT IS SHARED AND QUITE INTENTIONAL DECEPTION. YET, EACH HAS COMPELLING REASONS TO PURSUE THIS DECEPTION, AND TO USE THE
"PEACE PROCESS" AS A DUPLICITOUS VEHICLE TO REALIZE OTHER "PEACE PROCESS" AS A DUPLICITOUS VEHICLE TO REALIZE OTHER
AIMS. FOR SYRIA, IT IS THE CULTIVATION OF BETTER TIES WITH AIMS. FOR SYRIA, IT IS THE CULTIVATION OF BETTER TIES WITH THE UNITED STATES. FOR ISRAEL, IT IS THE SEC
FINANCIAL ASSISTANCE FROM THE UNITED STATES.

06277 MCLAURIN, R.

INTERVIEW: AMBASSADOR WALID AL-MOUALEM--SYRIAN AMBASSADOR TO THE UNITED STATES AND MEMBER OF THE SYRIAN DELEGATION TO THE PEACE TALKS

INSIGHT, 9 (1) (1992), 19-21

THIS INTERVIEH WITH AMBASSADOR WALID AL-MOUALEM, THE SYRIAN AMBASSADOR TO THE UNITED STATES COVERS INTERNATIONAL RELATIONS, THE PEACE TALKS, LEBANNON, COOPERATION WITH IRAN, 
STRATEGY, IRAQ, NUCLEAR ARMS, SECURITY, AND ECONOMICS. IT THE LACK OF CLOSE CDOPERATION OR INTIMACY BETHEEN THE UNITED STATES AND SYRIA AND WHETHER OR NOT THE OUTCOME OF THE AMERICAN PRESIDENTIAL ELECTION
HAVE ANY INFLUENCE OF THE US ROLE IN THE PEACE TALKS.

06278 MCLAURIN, R.

STRATEGIC EVOLUTION IN OMAN

INSIGHT, 9 (1) (1992), 38-42.

SINCE ITS EMERGENCE FROM THE LONG PERIOD OF BRITISH QUAISI-COLONIAL CONTROL, OMAN HAS DISTINGUISHED ITSELF FROM ITS NEIGHBORS BY CHARTING AND PURSUING ITS OWN COURSE IN REGIONAL AND GLOBAL AFFAIRS. PERHAPS THE SINGLE MOST STRIKING PHENOMENON ABOUT OMAN AND THE CHARACTERISTIC THAT MAY PROVIDE THE GREATEST UNDERSTANDING ABOUT ITS DOMESTIC AND FOREIGN POLICIES, IS ITS INSULARITY. THIS ARTICLE EXPLORES THE DHOFAR INSURGENCY AND THE NEW ERA, THE STRATEGY OF ECONOMIC COOPERATION AND THE STRATEGY OF POLITICAL DEVELOPMENT. IT CONCLUDES THAT THE EFFORT TO ESTABLISH A BROAD, POPULAR SUPPORT ROOT STRUCTURE FOR POLITICAL LEGITIMACY OVER THE LONGER TERM IS FULLY CONSISTENT WITH THE SULTAN'S FORWARD-LOOKING POLICIES AND TIES IN WELL WITH BOTH SULTAN'S FORWARD-LOOKING POLICIE
ECONOMIC AND FOREIGN POLICIES.

06279 MCLAURIN, R.D.

LEBANON: INTO OR OUT OF OBLIVION?

CURRENT HISTORY, 91(561) (JAN 92), 29-33

TOOAY, LEBANON IS IN A TRANSITIONAL PHASE. THE CURRENT SITUATION IS THE LEAST VIOLENT IN THE LAST TWO DECADES, BUT IT IS CERTAINLY NO MORE STABLE. LEBANON HAS LOST WHAT REMAINED OF ITS AUTONOHY AND HAS DONE SO WITHOUT HEALING THE INTERMAL WOUNDS THAT GAVE VARIOUS FOREIGN PARTIES ENTREE TO THE COUNTRY. TOOAY'S LEBANON CANNOT ENDURE, AND THE QUESTION IS WHAT DIRECTION IT HILL TAKE.

06280 MCLEAN, I.; MORTIMORE, R.

APPORTIONMENT AND THE BOUNDARY COMMISSION FOR ENGLAND ELECTORAL STUDIES, 11(4) (DEC 92), 293-309.

THE AUTHORS INTRODUCE THE THEORETICAL ISSUES INVOLVED IN POLITICAL APPORTIONMENT AND THEN APPLY THE THEORY TO THE APPORTIONMENT OF PARLIAMENTARY SEATS IN THE UNITED KINGDOM. THEY SHOW THAT THE PRESENT ARRANGEMENT DOES NOT MEET DESIRABLE AND ACHIEVABLE STANDARDS AND THAT THE DEFECTS LEAD PARTS OF THE COUNTRY. THESE DEFECTS HAVE ARISEN PARTLY THROUGH MANIPULATION FOR PARTY ADVANTAGE BUT LARGELY BECAUSE THROUGH MANIPULATION FOR PARTY ADVANTAGE BUT LARGELY BECAUSE
OF A FAILURE OF ALL CONCERNED TO UNDERSTAND THE THEORY OF APPORTIONMENT.

06281 MCLEAN, I.; URKEN, A.

DID JEFFERSON OR MADISON UNDERSTAND CONDORCET'S THEORY OF SOCIAL CHOICE

PUBLIC CHOICE, 73(4) (1992), 445-458.

THIS PAPER HAS DESIGNED TO TEST THE HYPOTHESIS THAT, THROUGH A KMOWLEDGE OF SOCIAL CHOICE, JEFFERSON AND/OR MADISON WAS IN A POSITION TO INDUCE EQUILIBRIA IN THE INSTITUTIONS THEY DESIGNED (THE PARL IAMENTARY RULES OF CONGRESS, AND THE STRUCTURE OF CHECKS AND BALANCES RESPECTIVELY). THE AUTHORS EXAMINED ALL THE KNOWN PRIMARY DOCUMENTS WHICH APPEAR TO BEAR ON THE QUESTION, AND NONE OF THEM SHOWS ANY HINT THAT EITHER JEFFERSON OR MADISON UNDERSTDOD THE SOICAL CHOICE COMPONENTS OF CONDORCET'S WORK. THEY FIND THAT THE HYPOTHESIS FAILS. THE CONSTITUTION, THE "FEDERALIST PAPERS" AND JEFFERSON'S "MANUAL" ARE ALL MASTERPIECES BUT THEY ARE NOT MASTERPIECES OF HERESTHETICS.

06282 MCLEAN, I.

RATIONAL CHOICE AND THE VICTORIAN VOTER

POLITICAL STUDIES, XL(3) (SEP 92), 496-515

THE AUTHOR SURVEYS RECENT WORK' ON THE RELATIONSHIP

BETHEEN VOTERS AND POLITICIANS IN VICTORIAN BRITAIN, WITH

PARTICULAR ATTENTION TO THE ADMINISTRATIONS OF PEEL AND

GLADSTONE. HE ARGUES THAT RATIONAL-CHOICE INTERPRETATIONS OF

BEHAVIOR MAY BE MORE POWERFUL THAN TRADITIONAL NAMIERITE OR

STRUCTURALIST APPROACHES. BUT MAINSTREAM RATIONAL CHOICE

ALONE IS TOO THIN TO EXPLAIN WHY PEEL REPEALED THE CORN LAWS

OR WHY GLADSTONE TRIED TO GIVE HOME RULE TO IRELAND.

06283 MCLEAN, I.; DAWES, R.M. ; ORBELL, J.M.

HHAT SHOUID RATIONAL COGNIIIVE MISERS DO?

AMERICAN POLITICAL SCIENCE REVIEW, 85(4) (DEC 91),

1417-1420.

IN THE JUNE 1991 ISSUE OF "AHERICAN POLITICAL SCIENCE REVIEN," JOHN ORBELL AND ROBYN DAHES ARGUED THAT PRISONER'S DILEMMA GAMES ARE SHAPED IN PART BY COGNITIYE MISERS-PLAYERS WHO ASSUME THAT OTHER PLAYERS ARE LIKE THEMSELVES, IN SUCH GAMES, THIS PROOUCES MORE PLAY AND A HIGHER EXPECTED PAYOFF BY COOPERATORS THAN BY DEFECTORS. IN THIS ESSAY, IAIN MCLEAN AGREES WITH ORBELL AND DAHES' CONCLUSIONS BUT TAKES ISSUE WITH THEIR REASONING AND THEIR MOOELS. IN TURN, ORBELL AND DAWES RETORT, ARGUING THAT PLAYERS IN THE PRISONER'S
06284 MCLURE, C.E. JR. INCOME TAX REFORM IN COLOMBIA AND VENEZUELA: A COMPARATIVE HISTORY

HORLD DEVELOPMENT, 20(3) (MAR 92), 351-367.

THE AUTHOR COMPARES THE COURSE OF INCOME TAX REFORM IN COLOMBIA AND VENEZUELA SINCE THE LATE 1950'S. BRIEF HISTORIES OF INCOME TAX REFORM IN EACH COUNTRY DESCRIBE BOTH WHAT WAS PROPOSED IN MAJOR STUDIES AND WHAT WAS ENACTED. THE PRESENT COLOMBIAN INCOME TAX STRUCTURE IS MUCH BETTER THAN THE VENEZUELAN SYSTEM, AND COLOMBIA HAS MADE BETTER USE OF LOCAL TAX EXPERTS.

06285 MCMAHON, D.; CURTICE, J.; HARROP, M.; HEATH, A. BRITISH JOURNAL OF POLITICAL SCIENCE, 22(4) (OCT 92), 419-443.

ANALYSIS OF THE BRITISH ELECTION STUDIES SUGGESTS THAT MIGRATION BETHEEN THE NORTH AND SOUTH OF BRITAIN HAS POLITICAL EFFECTS, WITH SOUTHERLY MIGRATION LEADING VOTERS AWAY FROM THE LABOR PARTY AND NORTHERLY MIGRATION TOWARD SOCIAL AND POLITICAL CHARACTERISTICS, EXPERIENCE OF SOCIAL SOCIAL AND POLITICAL CHARACTERISTICS, EXPERIENCE OF SOCIAL MOBILITY, AND CHANGES IN LOCAL POLITICAL ENVIRONMENT. IT
APPEARS TO BE A NEW PHENOMENON, WHICH WAS NOT APPARENT IM APPEARS TO BE A NEW PHENOMENON, WHICH WAS NOT APPARENT IN
EARLIER ELECTION STUDIES. THE RESULTS SUPPORT THE HYPOTHESIS EARLIER ELECTION STUDIES. THE RESULTS SUPPORT THE HYPOTHES THAT THE NORTH-SOUTH DIVIDE CONSTITUTES A NEH POLITICAL CLEAVAGE DISTINCT FROM SOCIAL CLASS AND THE
FAMILIAR SOCIAL BASES OF VOTING BEHAVIOR.

06286 MCMICHAEL, S.

RUSSIA'S NEW MILITARY DOCTRINE

RFE/RL RESEARCH REPORT, 1(40) (OCT 92), 45-50.

THE FIRST STATEMENT' OF RUSSIAN MILITARY DOCTRINE UNDER THE PRESIDENCY OF BORIS YELTSIN WAS PUBLISHED IN DRAFT FORM IN MAY 1992. IT SHOWS DIRECT LINKS TO SOVIET MILITARY DOCTRINE, BUT IT ALSO INCORPORATES RADICALLY NEW THEMES ANO CONCEPTS REVEALING THE INFLUENCE OF RUSSIAN CIVILIAN ANALYSTS AND WESTERN MILITARY DOCTRINE. OVERALL, IT IS FAR MORE DEFENSIVE AND LESS THREATENING THAN ANY SINCE THE MID1920'S. IF IMPLEMENTED, IT WOULD TRANSFORM THE EXISTING ARMED FORCES AND SUBSTANTIALLY ALTER THE ROLE PLAYED BY RUSSIA IN INTERNATIONAL SECURITY AFFAIRS.

06287 MCMICHAEL, S.

RUSSIAN OPPOSITION TO A JOINT GLOBAL DEFENSE SYSTEM RFE/RL RESEARCH REPORT, 1 (28) (JUL 92), 57-62.

SINCE PRESIDENT BORIS YELTSIN DECLARED HIS INTEREST IN JOINT U.S. -RUSSIAN DEVELOPMENT OF A GLOBAL SYSTEM OF PROTECTION AGAINST LIMITED NUCLEAR STRIKES (GPALS), IT HAS PROTECTION AGAINST LIMITED NUCLEAR STRIKES (GPALS), IT HAS BECONE EVIDENT THAT THERE IS SIGNIFICANT OPPOSITION TO THE
CONCEPT IN RUSSIA. IN GENERAL. OPPONENTS BELIEVE THAT SUCH A CDNCEPT IN RUSSIA. IN GENERAL, OPPONENTS BELIEVE THAT SUCH SYSTEM IS A PLOY TO OBTAIN RUSSIAN AGREEMENT TO ABANDON THE ANTIBALLISTIC MISSILE TREATY. THEY ALSO FEAR THAT THE USA WILL EXPLOIT RUSSIAN SCIENCE, THAT A GPALS SYSTEMS WOULD REDUCE STRATEGIC STABILITY, AND THAT IT COULD LEAD TO
ANOTHER ARMS RACE. IN DEFERENCE TO THE STRONG OPPOSITION, ANOTHER ARMS RACE. IN DEFERENCE TO THE STRONG OPPOSITION, INTEREST IN GPALS BUT DECLINE TO MAKE ANY FIRM COMMITMENTS TO IT IN THE NEAR FUTURE.

06288 MCMILLAN, J.

TALKING TO THE ENEMY: NEGOTIATION IN WARTIME

COMPARATIVE STRATEGY, 11(4) (DEC 92) 447-462.

DIPLOMACY IN WARTIME CAN BE A POWERFUL COMPLEMENT TO

MILTARY FORCE IN PURSUING THE POLICY OBJECTIVES FOR WHICH

THE WAR IS BEING FOUGHT. WARTIME NEGOTIATIONS ARE MOST

EFFECTIVE HHEN USED WITH COMBAT IN A SERIES OF SYNERGISTIC

COMBINATIONS. THE PROPER USE OF WARTIME NEGOTIATIONS

REQUIRES A RECOGNITION THAT THEORIES OF PEACETIME AND

COERCIVE DIPLOMACY ARE NOT APPLICABLE ON ACCOUNT OF THE

PASSIONS, UNCERTAINTY, AND FRICTION OF HAR. IN PLACE OF THESE THEORIES, IT IS NECESSARY TO DEVELOP A DOCTRINE OF WARTIME NEGOTIATIONS.

06289 MCNALLY, V.J.

CHURCH-STTATE RELATIONS AND AMERICAN INFLUENCE IN BRITISH COLUMBIA BEFORE CONFEDERATION

JOURNAL OF CHURCH \& STATE, 34(1) (WIN 92), 93-110. IN THE 1860'S, SETTLERS FROM CALIFORNIA AND THE OREGON IN THE $1860^{\prime} S$, SETTLERS FROM CALIFORMIA AND THE ORE
AND WASHINGTON TERRITORIES HERE A POWERFUL AND EVEN AND WASHINGTON TERRITORIES WERE $A$ POWERFUL AND EVEN
INDISPENSABLE IMPETUS IN BRITISH COLUMBIA. IN FACT, INDISPENSABLE IMPETUS IN BRITISH COLUMBIA. IN FACT, AMERICANS FORMED THE INFLUENTIAL MIDDLE CLASS IN THE PROVINCE DURING THE IMPORTANT FORMATIVE DECADE BEFDRE CONFEDERATION. IN EXAMINING CHURCH-STATE RELATIONS IN BRITISH COLUMBIA, IT IS ESSENTIAL TO TAKE THIS AMERICAN
INFLUENCE INTO ACCOUNT, ESPECIALLY DURING THIS EARLY PERIOD.

06290 MCNAUGHER, T.L.

FSX AND THE NEW WORLD ORDER

BROOKINGS REVIEW, 10(2) (SPR 92), 52.

IN 1989, THE U.S. AGREEMENT TO COLLABORATE WITH JAPAN IN DEVELOPING THE FSX, A NEW TACTICAL AIRCRAFT, BECAME A

LIGHTNING ROD IN BILATERAL RELATIONS. MANY AMERICANS VIEWED THE FSX PROJECT AS A TECHMOLOGY-GIVEAWAY THAT HOULD SPEED 
JAPAN'S ENTRY INTO THE U.S. -DOMINATED AEROSPACE BUSINESS. NOW THAT THE FSX PROJECT HAS SURVIVED AMERICAN DOUBTS, THE AIRCRAFT'S RISING PRICE TAG IS MAKING IT LOOK LIKE A BAD BARGAIN TO THE JAPANESE, WHO BLAME THE SPIRALING COSTS ON U. S. PARTICIPATION. THE PROJECT MAY YET COME TO A HALT AMID BITTER RECRIMINATIONS ON BOTH SIDES OF THE PACIFIC. THIS WOULD BE UNFORTUNATE BECAUSE THE FSX, WHILE IT IS BUT A SMALL LINK IN THE ARRAY OF TIES BETWEEN JAPAN AND THE USA, HAS IMPORTANCE EXTENDING WELL BEYOND ITS MERE MILITARY CAPABILITIES.

06291 MCNEW, J.

WHOSE POLITICS? MEDIA DISTORTIONS OF ACADEMIC CONTROVERSIES VIRGINI

THE CURRENT CURRICULUM CONTROVERSY--A.K. A. POLITICAL CORRECTMESS--IN AMERICAN HIGHER EDUCATION IS DEFINED BY THE AUTHER AS MFERMENT OVER WHAT KNOWLEDGE IS MOST IMPORTANT TO TEACH" IS NOT NEW. SHE CALLS THE CONTEMPORARY OPPOSING CAMPS THE ANCIENTS AND THE MODERNS, THE SAME NAMES SWIFT USED FOR HIS COMBATANTS. HER PAPER BEGINS BY OFFERING AN ALERNATIVE STORY, A MODERN'S HISTORY OF THE PRESENT CONFLICT. SHE CONCLUDES THAT THE MOST CONVINCING THEORISTS, THE LIVELIEST SCHOLARS, AND THE MOST PERSUASIVE CRITICS ARE THE ONES SUPOORTING CHANGES ASSOCIATED WITH THE MODERN AGENDA.

06292 MCQUAID, K.K.

GUIDED DESIGN SIMULATIONS IN INTRODUCTORY-LEVEL AMERICAN

POLITICS AND STATE AND LOCAL POLITICS COURSES

PS: POLITICAL SCIENCE AHD POLITICS, XXV(3) (SEP 92), $532-534$

THE AUTHOR EXPLAINS A SERIES OF SIMULATIONS THAT SHE HAS DEVELOPED, BASED ON THE GUIDED DESIGN FORMAT, WHICH MAY BE USED IN TEACHING INTRODUCTORY COURSES IN AMERICAN POLITICS OR STATE AND LOCAL POLITICS.

06293 MCQUEEN, H.

THE ROBOTICS OF RE-MILITARIZATION

ARENA, (91) (1990), 60-77.

JAPAN'S FUTURE CAPACITY TO PROJECT MILITARY POWER BEYOND

ITS HOME ISLANDS WILL DEPEND ON DUAL PURPOSE HIGH TECHNOLOGY ITS HOME ISLANDS WILL DEPEND ON DUAL PURPOSE HIGH TECHNOL AND NOT ON ANY RECOMBINATION OF HIGH MORALE WITH LABORMILITARY POWER BEYOND ITS TERRITORIAL WATERS (NOT A LIKELY MILITARY POWER BEYOND ITS TERRITORIAL WATERS (NOT A LIKELY PROPER-COMPUTERS AND NEW MATERIALS IN SATELLITES AND MISSILES. SUPER-COMPUTERS AND NEW MATERIALS IN SATELLITES ANO MISSI THIS ARTICLE CONSIDERS THE TECHNOLOGICAL AND MILITARY
IMPLICATIONS AND POSSIBILITIIES OF REMILITARIZATION IN JAPAN. IMPLICATIONS AND POSSIBILITIES OF REMILITARIZATION IM JAPAN'S UNIQUE ADVANTAGES IN PERSONNEL; DUAL PURPOSE TECHNOLOGY; HIGH TECHNOLOGY
AND STATIONS, ARE EXAMINED.

06294 MCQUILLAN, L.; ORTEGA, L.

CONFERENCE COMMITTEE PARTICPATION AND PARTY LOYALTY FUTURES, $24(7)$ (SEP 92 ), 485-494.

THIS PAPER COMPARES THE PREFERENCES OF CONFEREES TO THOSE OF NONCONFEREES, CHAIRMEN, AND PARTY LEADERS. THE STATISTICAL TESTS ARE CONSTRUCTED TO REFLECT CONGRESSIONAL RULES AUTHORIZING THE PRESIDING OFFICERS TO SELECT CONFEREES THE EVIDENCE SUPPORTS THE VIEW THAT CONFEREE PREFERENCES ARE DISTINCT FROM NONCONFEREE PREFERENCES, HOWEVER CONFEREES ARE NOT ALIGNED WITH THE CHAIRMEN AS PREDICTED. THE PAPER PRESENTS AN INSTITUTIONAL PROFILE OF THE CONFERENCE COMMITTEE AND DEVELOPS THE TESTABLE HYPOTHESES.

06295 MCSHERRY, J.P.

MILITARY POWER, IMPUNITY, AND STATE-SOCIETY CHANGE IN LATIN AMERICA

CANADIAN JOURNAL OF POLITICAL SCIENCE, XXV(3) (SEP 92), 463-488.

THE TRANSITION FROM MILITARY TO CIVILIAN RULE IN LATIN AMERICA HAS THROWN A SEARCHL IGHT UPON THE LEGACY OF MILITARY REPRESSION FROM THE ERA OF THE NATIONAL SECURITY STATES AND THE PROBLEM OF STILL-POWERFUL, UNREPENTANT ARMED FORCES. THESE INTERTWINED PROBLEMS HAVE PROFOUND IMPLICATIONS FOR THESE INTERTHINED PROBLEMS HAVE PROFOUND IMPLICATIONS F
THE POTENTIAL FOR FUNDAMENTAL CHANGE IN A REGION LONG CHARACTERIZED BY EXTREME SOCIAL INEQUALITY AHD POLITICAL INSTABILITY. CIVILIANIZATION OF THE MILITARY STATE DOES NOT NECESSARILY MEAN THE DEMOCRATIZATION OR DEMILITARIZATION OF A BURNING AND CONTROVERSIAL ISSUE THROUGHOUT THE REGION. A BURNING AND CONTROVERSIAL ISSUE THROUGHOUT THE REGION. MILITARY IN VIRTUALIY ALL STATES WAS FOR GUARANTEES AGAINST MILITARY IN VIRTUALLY ALL STATES WAS FOR GUARANTEES AGA ACCOUNTABILITY FOR HUMAN RIGHTS CRIMES--A DEMAND THAT IMPLICITY PLACES THE MILITARY ABOVE THE LAH. THIS ISSUE STRIKES AT THE VERY HEART OF THE TRANSFORMATION OF SECURITY STATES AND THE DEMOCRATIZATION OF POWER. ADOITIONALLY, DESPITE THE TRANSITION FROM MILITARY RUL STRUCTURES OF THE NATIONAL SECURITY APP

06296 MCSHERRY, M

EVERYTHING is CHANGING

NATIONAL REVIEH, XLIV(15) (AUG 92), 17-20.

SEVERAL SIGMIFICANT CHANGES INCLUOING THE ASSASSINATION
OF RAJIV GANDHI, THE COLLAPSE OF THE SOVIET UNION, THE APPOINTMENT OF V.P. NARASIMHA RAD AS PRIME MINISTER, AND THE IMPENDING BANKRUPTCY OF THE COUNTRY HAVE LED TO A PROFOUND SHIFT IN INDIA'S ECONOMIC ORIENTATION. SOCIALISM, FORMERLY THE FAVORITE NOUN OF INDIAN POLITICIANS, HAS BEEN REPLACED BY "SUPPLY-SIDE," AND "MARKET ECONOMY." POLICIES OF DECENTRALIZATION, DEREGULATION, AND PRIVATIZATION ARE BEGINNING TO CHANGE THE ECONOMIC LANDSCAPE. FOREIGM INVESTMENT IS GRADUALLY INCREASING AND TRADE IS ON THE RISE. HOWEVER, THE GIGANTIC PROBLEMS THIS CQUNTRY OF HUNDREDS OF CONFLICT--STILL REMAIN TO BE TACKLED.

06297 MCVOY, E.

IDEOLÓGICAL CONFLICT: AN ANALYSIS OF COMMUNISH-SOCIALISM VERSUS DEMOCRATIC CAPITALISM IN THE UNITED STATES, PART INTERNAT

IDEOLOGY AS A SOURCE OF SOCIAL CONFLICT, ILLUSTRATED BY THE CONFLICT OF OPPOSING IDEOLOGIES OF SOCIALISH-COMMUNISM AND DEMOCRATIC CAPITALISM IN THE UNITED STATES IS DEALT WITH IN THIS ARTICLE. SOCIOLOGICAL CONCEPTS AND THEORIES ARE APPLIED TO THIS TYPE OF CONFLICT. SIGNIFICANT EVENTS OF THE PAST CENTURY ARE DESCRIBED BRIEFLY AND ARE RELATED TO THEORIES OF CONFLICT.

06298 MCWHIRTER, C.; MELAMEDE, G. BREAKING AWAY

AFRICA REPORT, 37(6) (NOY 92), 59-61.

ERITREA WILL LIKELY BECOME THE FIRST COUNTRY TO SECEDE FROM AN INDEPENDENT AFRICAN COUNTRY. AFTER 30 YEARS OF WAR, THE TASK FOR THE NOW VICTORIOUS ERITREAN PEOPLE'S LIBERATION FRONT IS TO TRANSFORM ITSELF FROM A GUERRILLA ARMY THAT GOVERNED LARGE SECTIONS OF THE PROVINCE INTO AN ADMINISTRATION DEDICATED TO REBUILDING THE ECONOMY, REPAIRING SHATTERED INFRASTRUCTURE, ABSORBING HUNDREDS OF THOUSANDS OF RETURNING EXILES, AND ATTRACTING FOREIGN INVESTMENT.

06299 MCHHIRTER, C.; MELAMEDE, G. THE ETHNICITY' FACTOR THE ETHNICITY FACTOR
AFRICA REPORT, 37(5) (SEP 92), 30-33.

EIGHTEEN MONTHS AFTER THE COLLAPSE OF THE MENGISTU REGIME, INTERNECINE HARFARE IS THREATENING TO TEAR ETHIOPIA REGIME, INTERNECINE WARFARE IS THREATENING TO TEAR ETHIOPIA APART. PRESIDENT MELES ZENAHI, HHO HAS PROMISED HIS COUNT ETHNIC DIVERSITY IN A FEDERATED ETHIOPIA WILL HELP UNIFY THE COUNTRY. BUT LOW-LEVEL FIGHTING CONTINUES, AND THERE ARE SPORADIC OUTBREAKS OF "ETHNIC CLEANSING" CAMPAIGNS.

06300 MCWILLIAMS, W.C WHAT CLINTON SHOULD DO: LET DEMOCRATS BE DEMOCRATS COMMONWEAL, CXIX(13) (JUL 92), 4-5.

WHILE DEMOCRATS SHOULD TRY TO WIN OVER DEFECTORS AND INDEPENDENTS, THEIR FIRST TARGET IN THE 1992 PRESIDENTIAL ELECTION CAMPAIGN SHOULD BE MONDALE DEMOCRATS--NOT REAGAN DEMOCRATS-AND GOVERNOR CLINTON SHOULD TRY TO STRENGTHEN HIS CLAIMS ON THE PARTY'S OLD GUARD. CLINTON'S RUNNING MATE, IN ADDITION TO BEING "PRESIDENTIAL" AND ENDOWED WITH CHARISMA, SHOULD BE SOMEONE WHO REASSURES UNEASY ELEMENTS OF THE TRADITIONAL DEMOCRATIC COALITION.

06301 MEAD, L.

THE DEMOCRATS' DILEMMA

COMMENTARY, 93(1) (JAN 92), 43-47.

SINCE THE LATE 1960S, A SEA CHANGE HAS COME OVER AMERICAN POLITICS. MOST LIBERAL AND MOST DEMOCRATS WOULD LOVE TO RETURN TO A POLITICS CENTERED ON ECONOMIC EQUALITY. SHORT OF AN ECONOMIC COLLAPSE, THEIR HOPE THAT WORKERS WILL DEMAND REDRESS IS AN IMPLAUSIBLE SCENARID. ON THE WAY TO A MORE REDISTRIBUTIVE POLITICS, THE GHETTO IS THE LIDN IN THE PATH WHICH IS THE DEMOCRAT'S DILEMMA: THEY DO NOT APPROVE THE DISORDERS OF THE GHETTO, BUT THEY FIND IT IMPOSSIBL CLEARLY TO DISAPPROVE OF THEM. RESTRAINED BY A FEAR OF SEEMING TO FORCE VALUES ON CULTURAL AND RACIAL MINORITIES THEY SELDOM CONDEMN BAD BEHAVIOR OPENLY, OR INVOKE PUBLIC AUTHORITY AGAINST IT. THIS DEMOCRATIC DILEMHA IS TYPICAL
A PERIOD WHEN BASIC SOCIAL VALUES ARE IN QUESTION. THIS ARTICLE SUGGESTS THAT A MORE EFFECTIVE STRATEGY FOR CLASS THAT GENERATED LIBERAL PRESIDENTIAL MAJORITIES IN THE CLASS THAT GENERATED

06302 MEAD, $\mathrm{H}$.

SAUL AMONG THE PROPHETS--THE BUSH ADMINISTRATION AND THE NEW WORLD ORDER

WORLD POLICY JOURNAL, VIII(3) (SUM 91), 375-420.

IHIS ARTICLE SURVEYS RECENT CHANGES IN INTERNATIONAL POLITICS AND THE UNITED STATES, RESPONSES TO THEM. THE AUTHOR CHRONICLES THE OFTEN VACILLATING POLICY AND RHETORIC OF THE BUSH ADMINISTRATION AS IT MOVED FROM NEW WORLD ORDER EUPHORIA TO INCREASING OISCOMFITURE AT HOW HORLD EVENTS HERE PASSING AMERICA BY. HE CONCLUDES THAT THE END OF THE COLD HAR AND THE CRISIS IN THE HORLD ECONOMIC ORDER HAVE LEFT THE 
BUSH ADMINISTRATION BEREFT OF AN APPROPRIATE FRAMENORK FOR ANALYZING, MUCH LESS COPING WITH, GLOBAL POLITICAL AND ECONOMIC DEVELOPMENTS. AMERICAN LEADERS OF THE FUTURE WILL (HOPEFULLY) BE FREE OF THO OF THE BLINDERS THAT HAVE HAMPERED BUSH AND HIS COHORTS: THE ASSUMPTION OF U.S. SUPERIORITY, AND THE BELIEF THAT STABILITY IS THE NORM IN HORLD POLITICS.

06303 MEDEMA, S.

PROBING THE LEGAL-ECONOMIC NEXUS: TAKINGS, 1978-1988 JURNAL OF ECOMOMIC ISSUES, 26(2) (JUN 92), 525-544.

RECENTLY, SEVERAL PROMINENT SUPREME COURT CASES HAVE DEALT WITH GOVERNMENT REGULATORY TAKINGS OF PRIVATE PROPERTY. BY EXAMINING THE MATTER THROUGH THE LENS OF THE LEGALECONOMIC NEXUS, THIS ARTICLE SUGGESTS THAT CONFLICT BETHEEN ECONOMIC INTERESTS IS RESOL VED THROUGH THE CHOICE PROCESS, A PROCESS THROUGH WHICH ECONOMIC RIGHTS AND HENCE ECONOMIC OUTCOMES ARE CREATED AND RECREATED BY THE VARIOUS FORCES BROUGHT TO BEAR FROM WITHIN AND HITHOUT ECONONY AND LAH, THE OUTCOME OF WHICH IS A PARTICULAR SOCIAL (RE) CONTRUCTION OF REALITY. THE DECISIONMAKING CRITERIA, THE OUTCOMES OF REALITY. THE DECISIONMAKING CRITERIA, THE OUTCOMES OF
SPECIFIC TAKINGS CASES, AND THE EXECUTIVE ORDER ARE SPECIFIC TAKINGS CASES, AND THE EXECUTIVE ORDER ARE THE LEGAL-ECONOMIC NEXUS.

06304 MEDLER, J.R.; MUSHKATEL, A. ENVIRONMENTAL POL ICY, NEW FEDERALISM, AND NEW PRIVATISM: POLICY CONFLICTS IN THE COASTAL ZONE

POLICY STUDIES REVIEW, 11 (1) (SPR 92), 100-109.

PUBLIC POLICIES DEVELOPED UNDER THE NEH FEDERALISM OF THE 1970'S AND THE NEH PRIVATISH OF THE 1980'S HAVE PRODUCED A VARIETY OF POLICY PROBLEMS FOR STATES, ESPECIALLY IN THE AREA OF ENVIRONMENTAL POLICY. THIS PAPER LOOKS AT ENVIRONMENTAL POLICY MAKING IN THE COASTAL ZONE, GIVING PARTICULAR ATTENTION TO THE CONFLICTS BETHEEN THE DESIRE TO PROTECT RENEWABLE RESOURCES AND THE NEED FOR ECONOMIC GROWTH. THESE CONFLICTS ARE ILLUSTRATED BY AN EXAMINATION OF COMPREHENSIVE LAND USE PLANNING IN OREGON AND THE FEDERAL GOVERNMENT'S PROPOSAL TO DEVELOP SEABED MINIMG ON THE GORDA RIDGE.

06305 MEDLEY, J.W.

FLATTENED

NEW REPUBLIC, 207 (22) (NOV 92), 14-16

ALTHOUGH PRESIDENT GEORGE BUSH WANTED ANOTHER TERM IN THE WHITE HOUSE, HE DID NOT RELISH CAMPAIGNIMG. HIS EGO WAS IN THE RACE, BUT HIS HEART WASN'T. HIS AMBIVALENCE PERMEATED IN THE RACE, BUT HIS HEART WASN T. HIS AMBIVALENCE
HIS CAMPAIGH, MAKING IT UNDISCIPLINED, UNFOCUSED,

HIS CAMPAIGN, MAKING IT UNDISCIP
UNATTRACTIVE, AND INEFFECTIVE.

06306 MEESE, E. III

RELIGIOUS EXERCISE: HOH FREE?

HARVARD JOURNAL OF LAW AND PUBLIC POLICY, 15(1) (WIN 92), 163-168.

PERHAPS NO PROVISION OF THE BILL OF RIGHTS HAS GENERATED MORE CONTROVERSY IN RECENT YEARS THAN THE ESTABLISHMENT CLAUSE OF THE FIRST AMENDMENT. IN THIS ESSAY, THE AUTHOR EXAMINES THE IMPACT OF THE 1990 SUPREME COURT RULING ON FREE EXERCISE IN THE CASE OF EMPLOYMENT DIVISION, DEPARTMENT OF HUMAN RESOURCES, VS. SMITH.

06307 MEHRA, A.

THE POLITICS OF URBAN REDEVELOPMENT--A STUDY OF OLD DELHI SAGE PUBLICATIONS, 1991, 176.

SHAHJAHANABAD, A SEVENTEENTH CENTURY CREATION OF THE MUGHAL EMPEROR, SHAHJAHAN, HAS NOH BEEN SWALLOWED UP BY THE BURGEONING CAPITAL CITY OF INDIA--DELHI. IN THE PROCESS, IT HAS SUFFERED FROM DECADES OF NEGLECT. THIS BOOK EXAMIMES THE PROCESS OF REDEVELOPING SHAHJAHANABAD AMD EXAMINES THE INTERFACE BETHEEN SOCIETY AND POLITICS INVOLVED IN PLANS FOR URBAN RENEWAL. STARTING WITH THE PREMISE THAT URBAN POLITICS HAS AN ALLL-PERVADING INFLUENCE ON THE URBAN ENVIRONMENT IN CONTEMPORARY INDIA, THE AUTHOR IDENTIFIES THE FORCES THAT HAVE AGGRAVATED THE DECAY OF SHAHJAHANABAD. IN ADOITION, HE
DISCUSSES THE PROBLEMS FACED BY THE INHABITANTS OF THE CITY IN THE WAKE OF THE DEGENERATION HHICH AFFLICTS IT.

06308 MEIER-HALSER, R.

GERMANY, FRANCE AND BRITAIN ON THE THRESHOLD TO A NEH EUROPE

AUSSEN POLITIK, 43(4) (1992), 334-342

REINHARD MEIER-WALSE EXAMINES THE CONSEOUENCES OF THE END OF THE COLD WAR FOR THE WESTERN EUROPEAN POHER TRIANGLEEND OF THE COLD HAR FOR THE WESTERN EUROPEAN POW GERMANY, FRANCE, AND BRITAIN--AND FOR THE THREE SUPRANATIONAL ASSOCIATIONS ON WHICH THESE THREE STATES EXER A SUBSTANTIAL INFLUENCE. THE STRIKING FEATURE OF THIS ANALYSIS, WHICH SOLELY REFLECTS THE AUTHOR'S PERSONAL VIEWS, IS ITS PARTICULARLY SCEPTICAL APPRAISAL OF NATO PROSPECTS.

06309 MEIER, K.; HOLBROOK, T

"I SEEN MÝ OPPORTUNITIES AND I TOOK "EM:" POLITICAL CORRUPTION IN THE AMERICAN STATES

THE JOURMAL OF POLITICS, 54(1) (FEB 92), 135-155.

THIS STUDY IS AN EMPIRICAL EXAMINATION OF POLITICAL
CORRUPTION IN THE AMERICAN STATES. USING THE NUMBER OF PUBLIC OFFICIALS AHO ARE COMYICTED OF CRIMES INVOLVING PUBLIC OFFICIALS HO ARE CONVICTED OF CRIMES INVOLVING
CORRUPTION AS THE DEPENDENT VARIABLE, FOUR EXPLANATIONS OF CORRUPTION AS THE DEPENDENT VARIABLE, FOUR EXPLANATIONS OF
CORRUPTION ARE EXAMINED. THE AUTHORS FIND THAT CORRUPTION IS ASSOCIATED WITH SEVERAL DECISIVE FACTORS. THE STUDY SHOWS SOME EVIDENCE THAT PROSECUTION OF CORRUPT PUBLIC OFFICIALS WAS SUBJECT TO PARTISAN AND RACIAL TARGETING DURING THE REAGAN ADMINISTRATION AND RACIAL TARGETING DURING THE CARTER ADMINISTRATION.

06310 MEIER, K.; MCFARLANE, D

STATE POLICIES ON FUNDING OF ABORTIONS: A POOLED TIME SERIES AMLYSIS

SOCIAL SCIENCE QUARTERLY, 73(3) (SEP 92), 690-698. DURING THE 1980S, ONE OF THE FEW WAYS THAT STATE GOVERMMENTS COULD AFFECT ABORTION POLICIES WAS TO FUND OR NOT FUND ABORTIONS FOR MEDICAID-ELIGIBLE WOMEN. THIS STUDY FINDS THAT FUNDING DECISIONS RESULT FROM BUREAUCRATIC/POLICY INERTIA, THE STRENGTH OF ADVOCACY GROUPS, AND THE POLITICAL FORCES IN THE STATE.

06311 MEIER, K.J. ; STEWART, J. JR. REGULATION IN THE 1990S--POLITICS, BUREAUCRACY, AND ECONONICS

M. E. SHARPE, 1993,368

IN THE LAST THREE DECADES, THE AMOUNT OF REGULATION IN AMERICAN SOCIETY HAS EXPLODED AT THE FEDERAL, STATE, AND LOCAL LEVELS. GIVEN THIS GREAT INCREASE, ONE WOULD THINK THAT REGULATION WAS PERCEIVED AS A UNIVERSAL GOOO. IN FACT, THE PUBLIC PERCEPTION OF REGULATION IS EXACTLY THE REGULATION IN AMERICA IS FAIRLY COMPLEX, AND SIMPLE GENERALIZATIONS ARE ALWAYS INCOMPLETE AND OFTEN WRONG. THIS BOOK EXAMINES A WIDE RANGE OF REGULATORY SITUATIONS TO DETERMINE WHY REGULATORY POLICY EXISTS AS IT DOES TODAY. IT OFFERS A MULTIDISCIPLINARY VIEW, ADORESSES BOTH EMPIRICAL AND NORMATIVE ISSUES, AND COVERS A HIDE RANGE OF SUBSTANTIVE REGULATORY POLICIES: DEPOSITORY INSTITUTIONS, CONSUMER PROTECTION, ENVIRONMENTAL PROTECTION, REGULATING OCCUPATIONS, WORKPLACE SAFETY AND HEALTH, ANTITRUST POLICY, AND INSURANCE.

06312 MEIER, K.J.; STEWART, J. JR.

BUTEAUCRACIES: EDUCATIOMAL TUE POL POLIES

AMERICAN REVIEN OF PUBLIC ADMINISTRATION, 22(3) (SEP 92), 157-172.

DO BUREAUCRACIES HITH DIFFERENT LEVELS OF

REPRESENTATIVENESS PRODUCE DIFFERENT POLICY OUTPUTS AND HAVE DIFFERENT POLICY IMPACTS? THIS RESEARCH ADDRESSES THESE QUESTIONS USING DATA FROM THE PUBLIC SCHOOL DISTRICTS IN FLORIDA. THE ANALYSIS SHOWS THAT HHEN ONE FOCUSES ON (A) BUREAUCRATS WHO EXERCISE OISCRETION; (B) A DEMOGRAPHIC FACTOR WITH A LASTING IMPACT--E.G., RACE; AND (C) POLICY MEASURES THAT ARE CLEARLY SALIENT TO THE CHOSEN DEMOGRAPHIC FACTOR, IT IS POSSIBLE TO DETECT THE RELATIONSHIPS BETWEEN
BUREAUCRATIC REPRESENTATION AND PUBLIC POLICY OUTPUTS AND BUREAUCRATI
OUTCOMES

06313 MEIER, K.J.

THE POLITICS OF DRUG ABUSE: LANS, IMPLEMENTATION, AND CONSEQUENCES

WESTERN POLITICAL QUARTERLY, 45(1) (MAR 92), 41-70 ALTHOUGH STATE GOVERMMENTS PROVIDE THE OVERWHELMING BULK OF ORUG ENFORCEMENT EFFORTS, THE VARIATIONS IN STATE DRUG CONTROL POLICIES AND IMPLEMENTATION ARE RARELY STUDIED. THIS ANALYSIS ATTEMPTS TO EXPLAIN BOTH STATE POLICIES AND THE IMPLEMENTATION OF THOSE POLICIES WITH A MODEL USING ENVIRONMENTAL, POLITICAL, INTEREST GROUP, AND BUREAUCRATIC FORCES. THE ANALYSIS SHOWS THAT AGENCIES MAY IMPLEMENT DRUG CONTROL LAWS IN A MANMER THAT MITIGATES THE HARSH IMPACT OF THESE LAHS. A SUGGESTIVE LOOK AT DRUGS AND CRIME IMPLIES

06314 MEIER, R.

AMERICAN FOREIGN POLICY AFTER THE COLD WAR

SWISS REVIEW OF WORLD AFFAIRS, 42(2) (MAY 92), 27-28. DESPITE SOME SIMPLISTIC CAMPAIGN SLOGANS, THE UMITTE STATES IS NOT RETREATING FROM HORLD AFFAIRS. HOHEVER, EVEN IN THE VIEW OF SOME CONFIRMED INTERNATIONALISTS, AMERICA IS PLAGUED WITH ACUTE ECONOMIC AND SOCIAL PROBLEMS' IN THE POSTCOLD WAR ERA AND NEEDS TO CONCENTRATE MORE ON DOMESTIC COLD WAR ERA AND NEEDS TO CONCE
ISSUES, AT LEAST TEMPORARILY.

06315 MEIER,

TAIWAN'S DIVIDED RELATIONSHIP TO CHINA

SHISS REVIEW OF WORLD AFFAIRS, 40(8) (NOV 90), 14-15

IN OISCUSSING TAIHAN'S RELATIONSHIP TO MAINLAND CHINA, THIS ARTICLE LOOKS AT THE POSITIONS OF ADVOCATES OF INDEPENDENT AND PROPONENTS OF REUNIFICATION, FINDING THE TWO SIDES NOT SO FAR APART AS IS GENERALLY BELIEVED. THE ECONOMIC DEVELOPMENT OF TAIHAN AND MAINLAND CHINA ARE COMPARED. THE MEANING OF REUNIFICATION TO THE REGIME IN TAIPEI IS EXAMINED. 
06316 MEISSNER, B.

THE TRANSFORMATION OF THE SOVIET UNION

AUSSEN POLITIK, 43(1) (1992), 54-61.

IN 1990 THE SOVIET UNION BEGAN MOVING INTO A PHASE OF ACCELERATED CHANGE. SO FAR THE EFFECTS HAVE BEEN, ON THE ONE HAND, DEMOCRATIC-LIBERAL STRUCTURAL CHANGES IN RUSSIA AMD, ON THE OTHER HAND, SIGNS OF A DISSOLUTION OF THE COHESION OF THE UNION. THE DOYEN OF WEST GERMANY RESEARCH ON EASTERN EUROPE AND THE SOVIET UNION, BORIS MEISSNER, WHO HAS CONSTANTLY KEPT ABREAST OF DEVELOPMENTS IN THE SOVIET UNION AS EMERITUS PROFESSOR AT THE UNIVERSITY OF COLOGNE, OUTLINES AHIS SITUATION IN THIS ARTICLE.

06317 MEISSNER, D.

\section{MANAGING MIGRATIONS}

FOREIGY POL ICY (86) (SPR 92), 66-85.

MIGRATION HAS ALHAYS BEEN Á FORCE FOR CHANGE, AND IT

WILL BE ESPECIALLY POWERFUL IN THE POST-COLD WAR ERA. TO THE EXTENT THAT COUNTRIES HAVE MIGRATION POLICIES AT ALL, MOST HANDLE THEM AS MARROW, PARTICULARISTIC FUNCTIONS. YET THE CAUSES OF INTERNATIONAL MIGRATION ARE DEEPLY EMBEDOED IN THE SOCIAL, ECONOMIC, AND POL ITICAL CONDITIONS OF THE CURRENT TIMES. TO BE EFFECTIVE, POL ICY MUST GO BEYOND CONVENTIONAL CONTROL AND HUMANITARIAM MEASURES, SO THAT MANAGING MIGRATION PRESSURES BECOMES A PART OF COUNTRIES' CENTRAL ECONOMIC, POLITICAL AND SECURITY OBJECTIVES. IN ORDER TO DEAL WITH THE GROWING PROBLEMS POSED BY MIGRATION, POLICYMAKERS SHOULD ALSO RECOGNIZE THE FIVE BASIC CATEGORIES OF MIGRANTS: LEGALLY ADMITTED IMMIGRANTS, CONTRACT LABOR MIGRANTS, ILLEGAL IMMIGRANTS, ASYLUM-SEEKERS, ANO REFUGEES. THEY SHOULD ALSO MOVE TOWARDS A "NEW FORM OF CONTAIMMENT": PREYENTING A MIGRATIOM RATIONALE AMD MENTALITY FROM TAKING HOLD.

06318 MELDRUM, A.

BANQUETS AND BANTER

AFRICA REPORT, 37(1) (JAN 92), 51-54.

THE 28TH COMMONWEALTH SUMMIT IN ZIMBABHE PRODUCED NO SURPRISES, BUT THE DELEGATES DID AGREE ON A VAGUE RESOLUTION SURPRISES, BUT THE DELEGATES DID AGREE ON A VAGUE RESOLUTION AND A LIBERATED SOUTH AFRICA OVER THE NEXT DECADE. THE RIFT AND A LIBERATED SOUTH AFRICA OVER THE NEXT DECADE. THE RI 1989 SUMMIT HAS SMDOTHLY PATCHED OVER SO THAT ALL MEMBERS, INCLUDING BRITAIN, COULD ENDORSE THE 1991 PROPOSAL.

06319 MELDRUM, A.

DEATH OF AN AFRICAN FIRST LADY

AFRICA REPORT, 37 (2) (MAR 92), 54-55

ZIMBABWE'S FIRST LADY, SALLY MUGABE, DIED ON JANUARY 27 1992. HER DEATH HAS LEFT PRESIDENT ROBERT MUGABE WITHOUT HIS CLOSEST POLITICAL ADVISER AND CONFIDANTE JUST AS HE IS BEING CONFRONTED BY SOME OF THE MOST SERIOUS ECONOMIC AND POLITICAL CHALLENGES OF HIS 11 YEARS IN OFFICE.

06320 MELDRUM, A.

HUNGRY TO YOT

AFRICA REPORT, 37 (6) (NOV 92), 26-30

ANGOLA'S HISTORIC 1992 ELECTIONS TOOK PLACE ACCORDING TO

THE PEACE PLAN, BUT UNITA LEADER JOMAS SAVIMBI HAS CHARGED

THAT WIDESPREAD FRAUD ROBBED HIM OF VICTORY. EFFORTS ARE

UNDERWAY TO BRING PRESIDENT DOS SANTOS AND SAVIMBI TOGETHER

TO NEGOTIATE A POSSIBLE SECOND ROUND OF PRESIDENTIAL

ELECTIONS AND AVOID THE VERY REAL THREAT OF RENEWED CIVIL HAR.

06321 MELDRUM, A

REFUGE FROM REMAMO

AFRICA REPORT, 37 (3) (MAY 92), 28-32

THE SMALL CITY OF CHIMOIO IS NOW HOME TO 700,000

REFUGEES DESPERATE FOR A HAVEN FROM MOZAMBIQUE'S GRUELING

CIVIL HAR. THE PEACE NEGOTIATIONS CONTINUE TO GRIND ON AFTER

TWO YEARS. STUMBLING BLOCKS INCLUDE RENAMO'S UNCERTAINTY

ABOUT WHAT IT WANTS TO GAIN FROM THE SETTLEMENT. MEANHHILE,

RENAMO IS BEING RESUPPLIED WITH WEAPONS, ALLEGEDLY FROM THE

SOUTH AFRICAN MILITARY AND OTHER SOURCES, ALTHOUGH SOUTH

AFRICA CLAIMS THAT IT HAS STOPPED AIDING THE REBELS.

06322 MELDRUM, A.

RIGHTING THE LAND HRONG

AFRICA REPORT, 37 (4) (JUL 92), 17-19.

AFRICA REPORT, 37 (4) (JUL 92 ), 17-19.

ZIMBABWE'S PARLIAMENT ENACTED A LAW TO RIGHT THE INEOUITIES

OF THE COLONIAL SYSTEM BY EMPOWERING THE GOVERNMENT TO BUY

OF THE COLONIAL SYSTEM BY EMPOWERING THE GOVERNMENT TO BUY

HALF THE WHITE-OWNED LAND FOR REDISTRIBUTION IN SMALL PLOTS

TO BLACK FARMERS. ALTHOUGH WHITE OPPOSITION HAS SOFTENED

SOMEWHAT SINCE THE LAW WAS PASSED, THE QUESTION REMAINS

WHETHER THE MUGABE GOVERNMENT CAN DEVISE A RESETTL

SCHEME THAT WILL SATISFY THE BLACK MAJO
MAINTAINING THE LAND'S PROOUCTIVITY.

06323 MELDRUM, A.

THE KAUNOA OPTION?

AFRICA REPORT, $37(4)$ (JUL 92), 13-16.

IN ZIMBABHE, PRESIDENT ROBERT MUGABE'S CONTROL OVER THE
GOVERMMENT DIMINISHED OVER THE PAST YEAR. ZIMBABHE'S

STRUCTURAL ADJUSTMENT PROGRAM HAS INCREASED UNEMPLOYMENT AND INFLATION, CORRUPTION IS GROWING, AND MUGABE'S TOP-HEAVY ADMINISTRATION DOESN'T HAVE ANY SOLUTIONS TO THE PROBLEMS. THE SITUATION HAS BECOME A BREEDING GROUND FOR THE GROWING OPPOSITION, WHICH HAS ITS EYE ON GAINING POWER IN 1995, IF NOT SOONER. MEANHHILE, MANY OBSERVERS ARE WONDERING WHAT POLITICAL OPTIONS ARE LEFT FOR THE VETERAN LEADER WHO IS OUT OF STEP WITH THE DEMOCRATIZATION TREND.

06324 MELDRUM, A.

UNITING THE OPPOSITION?

AFRICA REPORT, $37(2)$ (MAR 92), 52-56.

THE RETURN TO ZIMBABWE OF VETERAN NATIONALIST NDABANINGI SITHOLE, FOLLOWING SEVEN YEARS' EXILE IN THE UNITED STATES SITHOLE, FOLLOWING SEVEN YEARS EXILE IN THE UNITED STATES, TO PRESIDENT ROBERT MUGABE'S DE FACTO ONE-PARTY GOVERNMENT ALTHOUGH SITHOLE WAS WRITTEN OFF YEARS AGO AS A SPENT FORCE, ALTHOUGH SITHOLE WAS WRITTEN OFF YEARS AGO AS A SPENT FORCE, HIS RETURN INTO A RAPIDLY CHANGING POLITICAL CLIMATE COULD
SPAWN AN ALLIANCE OF TINY MINORITY PARTIES DETERMINED TO END SPAWN AN ALLIANC
ZANU-PF RULE.

06325 MELISSEN, J.

THE THOR SAGA: ANGLO-AMERICAN NUCLEAR RELATIONS, U.S. IRBM DEVELOPMENT AND DEPLOYMENT IN BRITAIN, 1955-59

JOURNAL OF STRATEGIC STUDIES, 15(2) (JUN 92), 172-207.

AT THE END OF THE 1950'S, THE FIRST USAF INTERMEDIATE-

RANGE BALLISTIC MISSILE, NAMED "THOR," WAS BASED IN BRITAIN. THIS ACCOUNT OF THE THOR DEPLOYMENT FOCUSES ON THE POLITICS AND DIPLOMACY OF THE EPISODE, BASED ON RECENTLY-DECLASSIFIED AMERICAN AND BRITISH ARCHIVAL MATERIAL. IT SURVEYS THE ORIGINS OF IRBM DEVELOPMENT PRIOR TO THE THOR NEGOTIATIONS, THE BARGAINING POSITIONS OF THE EISENHOWER ADMINISTRATION AND THE MACMILLAN GOVERNMENT, THE MOTIVES UNDERLYING ANGLOAMERICAN NUCLEAR ALLIANCE POLITICS, AND THE ROLE PLAYED BY THE RUSSIAN SPUTNIK DEVELOPMENT.

06326 MELLING, $M$

SIX REASONS NOT TO RUN FOR OFFICE

HORLD PRESS REVIEN, 39(6) (JUN 92), 25

MANY PEOPLE LAMENT THE LACK OF QUALIFIED, HONEST

CANDIDATES TO RUN FOR PUBLIC OFFICE. THE AUTHOR LISTS

SEVERAL REASONS WHY GOOD MEN AND HOMEN SHY AWAY FROM RUNNING

SEVERAL REA
FOR OFFICE.

06327 MELLMAN, M.S.

NEGATIVE ADS, PRESIDENTIAL DEBATES, AND POSITIVE POLITICAL DISCOURSE

JOURNAL OF LAW \& POLITICS, VIII(2) (WIN 92), 271-276.

THE AUTHOR DISCUSSES ADVERTISING, DEBATES, ANO POLITICAL RHETORIC IN THE CONTEXT OF $S$. 100, A HYPOTHETICAL BILL CONTAINING PROPOSALS TO REFORM THE U.S. PRESIDENTIAL ELECTION PROCESS. THE HYPOTHETICAL LEGISLATION WOULD GIVE PREFERENCE TO CERTAIN TYPES OF INFORMATION, RESTRICT THE
FLOW OF OTHER INFORMATION, AND REDUCE THE OVERALL VOLUME OF FLOW OF OTHER INFORMATION, AND REDUCE THE O'
COMMUNCATION BETWEEN CANDIDATES AND YOTERS.

06328 MELVIN, $S$.

THE REBIRTH OF MEXICO

FREEMAN, 42(2) (FEB 92), 192-195.

SALINASTROIKA IS THE WORD COINED TO DESCRIBE THE TRANSFORMATION THE MEXICAN ECONOMY HAS UNDERGONE SINCE CARLOS SALINAS DE GORTARI BECAME PRESIDENT IN 1988. THE DIFFERENCE BETWEEN IT AND THE PERESTROIKA IT IS DERIVED FROM IS THAT SALINASTROIKA IS ACTUALLY HORKING. THE AUTHOR REGARDED MEXICO AS A DESPERATELY POOR, CORRUPT, THIRD WORLD COUNTRY HITH AN ABYSMAL ECONOMY, A SOCIALIST-LEANIMG GOVERNMENT, AND AN ANTI-AMERICAN POPULACE. HE RECOUNTS WHAT GOVERNMENT, AND AN ANTI-AMERICAN POPULACE. HE RECOUNTS
HE LEARNED ON HIS VISIT THERE AS HE SAH THAT MEXICO HAS
HARDWORKING, FRIENDLY, EFFICIENT, OPEN AND DEVELOPING ECONOMICALLY AT AN ASTOUNDING PACE.

06329 MEN, Q.

A SETBACK IN CONSTITUTIONAL DEAL

BEIJING REVIEW, $35(47)$ ( NOV 92), 14.

ON OCTOBER 26, 1992 , QUEBEC YOTERS REJECTED A PROPOSED CONSTITUTIONAL REFORM, WICH WOULD HAVE CONSTITUTIONALLY

INTEGRATED QUEBEC WITH THE REST OF CANADA, REFORMED THE

SENATE, DECENTRALIZED FEDERAL POHERS, AND RECOGNI ZED THE

SENATE, DECENTRALIZED FEDERAL POWERS, AND RECOGNIZED THE

RIGHT OF NATIVE PEOPLES TO SELF-GOVERMMENT. THE NEGATIVE

VOTE HAS PLACED PRIME MINISTER BRIAN ML

06330 MENDELSOHN, J.

DISMANTLING THE ARSENALS: ARMS CONTROL AND THE NEW WORLD DI SMANTLI

BRDOKINGS REVIEW, 10(2) (SPR 92), 34-39.

THE COLLAPSE OF COMMUNISM ANO THE PROMISE OF IMPROVED EAST-WEST RELATIONS HAVE TRANSFORMED THE WORLD OF ARMS CONTROL. GOALS THAT HERE ONCE UNTHINKABLE ARE NOW AT THE TOP OF THE AGENDA. TRENDS THAT HERE ALWAYS DANGEROUS BUT ONLY OF SECONDARY CONCERN DUE TO THE PRIMARY EAST-WEST CONFRONTATION- SUCH AS THE SPREAD OF HEAPONS IN THE THIRD WORLD--HAVE NOW 
OF DEEP DISTRUST BETWEEN EAST AND WEST AND INTENDED TO INFORM ADVERSARIES ABOUT ONE ANOTHER'S MILITARY PROGRAMS ARE NOW AVAILABLE TO MONITOR AGREEMENTS, BUILD TRUST, AND REDUCE TENSIONS.

06331 MENDES, E.P.

a "PUSH-PULL" plan for a flexible CANAdIAN fEDeralism CANADIAN PARLIAMENTARY REVIEW, 14 (1) (SPR 91), 4-7. DRIVEN BY A LARGE CONSENSUS IN QUEBEC, AT LEAST AMONG FRANCOPHONES, THAT THE TIME HAS COME FOR SOME SORT OF SOVEREIGNTY, CANADA WILL SOON HAVE TO RESTRUCTURE ITS CONFEDERATION BARGAIN. FOR THOSE IN QUEBEC AND ELSEWHERE WHO BELIEVE IN A CANADIAN CONFEDERATION WHICH INCLUDES QUEBEC, THE HERCULEAN TASK IS TO DEVISE A RESTRUCTURED CONSTITUTIONAL FRAMEWORK TO ALLOW QUEBEC TO "PUSH" AWAY FROM CANADA AT THIS TIME, BUT THEN ALSO TO DEVISE INSTITUTIONAL STRUCTURES WICH WILL IM THE FUTURE ENTICE OUEBEC TO "PULL" TOWARDS CANADA. ENGLISH-SPEAKING CANADA WILL ONLY BECOME INTERESTED IN SUCH AN ENTERPRISE IF THE INSTITUTIONAL REFORMS ARE ALSO BENEFICIAL TO THE VARIOUS REGIONAL ASPIRATIONS IN THE REST OF THE COUNTRY. THIS ARTICLE ARGUES THAT FEDERAL INSTITUTIONS AND PROCESSES MUST REFLECT CERTAIM NEH POLITICAL PRINCIPLES THAT HAVE EMERGED IN CANADA.

06332 MENDES, $P$.

DISSENT AND INTOLERANCE IN THE MELBOURNE JEHISH COMMUNITY ARENA, (96) (SPR 91) 18-21.

SINCE ISRAEL'S INVASION OF LEBANON IN 1982, A NUMBER OF ATTEMPTS HAVE BEEN MADE TO PRESENT ALTERNATIVE OR DOVISH VEIWS ON THE MIDOLE EAST CONFLICT WITHIN THE MELBOURNE JEWISH COMMUNITY. SUCH ATTEMPTS HAVE BEEN CHARACTERIZED BY THE FDLLOWING: THE MODERATE MATURE OF THE VIEWS PRESENTED (ROUGHLY AKIN TO THE "LAND FOR PEACE" VIEWS ADVOCATED BY THE ISRAELI PEACE MOVEMENT AND A CONSIDERABLE SECTION OF THE ISRAEL I LABOR PARTY); THE EXTREME, ALMOST HYSTERICAL REACTION THEY HAVE PROVOKED FROM THE MORE CONSERVATIVE SECTIONS OF THE JEWISH COMMUNITY; AND THE SUBSEQUENT ASSAULTS BY THE POLITICAL HAWKS ON THE LEGITIMACY AND INTEGRITY OF THE DISSENTERS.

06333 MENDILOW, J.

PUBLIC PARTY FUNDING AND PARTY TRANSFORMATION IN MULTIPARTY SYSTEMS

COMPARATIVE POLITICAL STUDIES, 25(1) (APR 92), 90-117. THE CHANGES IN THE ISRAELI PARTY SYSTEM SINCE THE INCEPTION OF PUBLIC PARTY FUNDING IN 1969 IS ANALYZED AND COMPARED WITH PARTY TRANSFORMATIONS ELSEWHERE WITH A VIEH TO COMPARING THE INTENDED AND THE ACTUAL IMPACTS OF SUCH FUNDING ON MULTIPARTY SYSTEMS. ALTHOUGH THE OVERALL EFFECT FUNDING ON MULTIPARTY SYSTEMS. ALTHOUGH THE OVERALL EFFECT IS IN LINE WITH THE CATCH-ALL-THESIS, THERE ARE IMPORTNANT POTENTIAL CONSEQUENCES THAT RUN COUNTER TO IT CHIEF AMONG THEM IS THE GREATER FACILITY OF IDEOLOGICAL AND SECTIONAL NEH PARTIES TO ESTABLISH THEMSELVES. THE RESULT CAN BE A FARYDTERS PRESENTED WITH A WIDE CHOICE OF COMPETING IDEOLOGICAL AND CATCH-ALL PARTIES.

06334 MENDIS, $P$.

THE ECONOMICS OF POVERTY ALLEVIATION: THE JANASAVIYA PROGRAMME IN SRI LANKA

SOUTH ASIA JOURNAL, 5(3) (JAN 92), 289-298.

AFTER THE INTRODUCTION OF LIBERALIZED TRADE AND OPEN ECONOMIC POLICIES IN 1977, THE INEQUAL ITY DF INCOME DISTRIBUTION HAS WIDENED IN SRI LANKA. THE RE-ELECTED 1989 GOVERMMENT RECOGNIZED THE FAILURE OF THE FREE MARKET ECONOMY AND INTRODUCED A MASSIVE POVERTY ALLEVIATION PROGRAM KNOWH AS JANASAVIYA IN ORDER TO INTEGRATE THE POOREST INCOME GROUPS INTO THE MAINSTREAM OF THE PROOUCTION PROCESS. THIS ARTICLE EXAMINES THIS PROGRAM, ITS AIMS, AND ITS EFFICACY. IT CONCLUDES THAT WHILE THE PROGRAM HAS ACHIEVED SIGNIFICANT SHORT-TERM GAINS, ITS KEYNESIAN NATURE MAKES IT UNLIKELY, OVER THE LONG TERM, THAT IT WILL OPERATE WELL IN SRI LANKA.

06335 MENDLESON, $H$.

BRENNAN'S REVOLUTION

COMMENTARY, 91 (2) (FEB 91), 36-39.

JUSTICE WILLIAM J. BRENMAN JR. LED THE WARREM COURT REVOLUTION AND SUSTAINED IT FOR YEARS THEREAFTER. IF A GREAT MAN IS ONE WHO LEAVES HIS MARK UPON THE SOCIAL ORDER, BRENNAN, WHO RETIRED FROM THE SUPREME COURT IN 1990,' IS A GREAT MAN INDEED. HOWEVER, THIS ARTICLE ARGUES THAT HE WAS NOT NECESSARILY A GREAT JUDGE. BRENMAN'S STYLE OF JUDICIAL ACTIVISM RAN COUNTER TO THE IDEA OF ORIGINAL INTENT. HE ACTIVISH RAN COUNTER TO THE IDEA OF ORIGINAL INTENT. HE ARGUED THAT IN CRUCIAL CASES COURTS SHOULD LOOK BEYOND THE PEDESTRIAN WORDS OF THE WRITTEN DOCUMENT TO THE IDEALS THAT
(ACCORDING TO HIM) INSPIRED THEM. INDEED, THE VERY PURPOSE (ACCORDING TO HIM) INSPIRED THEM. INDEED, THE VERY PURPOSE OF THE CONSTITUTION WAS TO MAKE THOSE IDEALS "TRANSCENDENT"
BY PUTTING THEM "BEYOND THE REACH OF TEMPORARY MAJORITIES"BY PUTTING THEM "BEYOND THE REACH OF TEMPORARY MAJORITI IES"
AND (ONE MIGHT ADD) UNDER THE GUARDIANSHIP OF TEMPORARY JUDICIAL MAJORITIES INSTEAD.

06336 MENDOZA, M.S.; FARRIS, P.L. THE IMPACT OF CHANGES IN GOVERMMENT POLICIES ON ECONOMIC PERFORMANCE (THE ARCH MODEL)
JOURNAL OF POLICY MODELING, 14(2) (APR 92), 209-220.

THE AUTHORS INVESTIGATE THE IMPACT OF CHANGES IM GOVERNMENT POLICY FROM DIRECT CONTROL TO FREE MARKET ON SPATIAL MARKET INTEGRATION, USING A BIVARIATE EXPONENTIAL AUTOREGRESSIVE CONDITIONAL HETEROSKEDASTICITY (ARCH) MODEL. CAUSAL RELATIONSHIPS AND THE MAGNITUDE OF IMPACT OF NEH INFORMATION ON PRICE DISCOVERY BETWEEN GEOGRAPHIC MARKETS DURING DIFFERENT POLICY REGIMES ARE DETERMINED BY THE GRANGER CAUSALITY TEST AND DYNAMIC MULTIPLIERS, RESPECTIVELY. THE FINDINGS SHOW THAT INTERVENTION POLICIES IMPAIR THE EFFICIENCY OF ARBITRAGE IN INTEGRATING SPATIAL MARKETS. PRICE ADJUSTMENTS BETHEEN REGIONAL MARKETS ARE SLOWER DURING PERIOOS OF GOVERMMENT REGULATION THAN DURING PERIOOS OF DECONTROL. HIGHLY-VOLATILE PRICES AND A LONGER ARCH PROCESS ALSO TEND TO CHARACTERIZE THE FORMER MORE THAN THE LATTER. DATA FOR THE PHILIPPINE COPRA MARKETS SUPPORT THE IMPORTANCE OF TAKING HETEROSKEDASTICITY INTO ACCOUNT IN TESTING SPATIAL INTEGRATION.

06337 MENELL, P.S.

INSTITUTIONAL FANTASYLANDS: FROM SCIENTIFIC MANAGEMENT TO

FREE MARKET ENVIRONMENTALISM

HARVARD JOURNAL OF LAH AND PUBLIC POLICY, 15(2) (SPR 92), 489-510.

JUST AS TRADITIONAL ECONOMIC ANALYSIS OF ENVIRONMENTAL PROBLEMS OFTEN IGNORES THE IMPERFECTIONS OF PUBLIC

INSTITUTIONS. THE FREE MARKET ENVIRONMENTALIST PERSPECTIVE REFLECTS A COMPARABLY NAIVE VIEW OF INSTITUTIONS BY FOCUSING MARROWLY AND SIMPLISTICALLY UPON THE DELINEATION AND ENFORCEMENT OF PROPERTY RIGHTS. THIS ARTICLE EXPLORES THE UTOPIAN PARALLELS BETWEEN SCIENTIFIC MANAGEMENT AND FREE MARKET ENVIRONMENTALISM BY EXPLORING THE LIMITATIONS OF THE ANALYTICAL FRAMEWORK IN "FREE MARKET ENYIRONMENTALISM" BY TERRY R. ANDERSON AND DONALD R. LEAL.

06338 MENGIN, $F$

RETHINKING THE EUROPE-TAIWAN RELATIONSHIP

PACIFIC REVIEW, (1) (1991), 25-35.

THIS ARTICLE ARGUES THAT THE LINKS BETWEEN EUROPE AND

TAIHAN ARE NEWLY DEVELOPED AND ESSENTIALLY COMMERCIAL AND NONOFFICIAL IN NATURE. IT HIGHLIGHTS SOME OF THOSE LINKS, ASSESSES THE EXTENT OF THEIR SUCCESS AND FAILURE, AND INVESTIGATES THEIR DURABILITY AND SIGNIFICANCE. THE SCOPE OF THE RELATIONSHIP IS DRAWN AND THE PROCESS OF FRIENDLY NORMALIZATION IS EXAMINED.

06339 MENGISTEAB, $K$

AVERTING ETHIOPIA'S DISINTEGRATION

TRANSAFRICA FORUM, (1) (SPR 92) 3-13.

THE LONG, DEVASTATING CIVIL HARS IN ETHIOPIA AND ERITREA ARE LARGELY OVER. THEY WERE THE CULMINATION OF YEARS OF

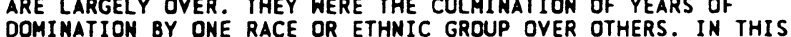
ESSAY, THE AUTHOR DISCUSSES THE CIVIL WARS WITHIN THE ESSAY, THE AUTHOR DISCUSSES THE CIVIL WARS WITH UNEQUAL CONTEX OF ETHIOPIAN HISTORY AND IOENTIFIES THE UNEQUAL

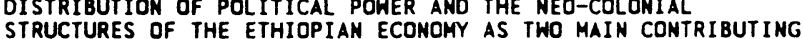
STRUCTURES OF THE ETHIDPIAN ECONOMY AS TWO MAIN CONTRIBUTING FACTORS. HE ARGUES THAT UNLESS THE NEW GOVERMMENT IN ADDIS ABABA BEGINS TO ADDRESS THESE ISSUES WITHIN THE FRAMENORK
POLITICAL DEMOCRACY, ETHIOPIA RISKS TOTAL DISINTEGRATION.

06340 MENGJUN, J.

MINSK SUMMIT: THE LOOSE ENDS

BEIJING REVIEH, 35(9) (MAR 92), 13.

TO SETTLE DISPUTES AMONG MEMBER STATES OVER THE FATE OF THE FORMER SOVIET RED ARMY, THE COMMONHEALTH OF INDEPENDENT STATES HELD A SUMMIT MEETING ON FEBRUARY 14, 1992. AFTER INTENSE DISCUSSIONS, AGREEMENTS WERE FINALLY REACHED ON NINE OF THE 13 MILITARY ISSUES ON THE AGENDA, INCLUDING THE STATUS OF STRATEGIC FORCES, THE UNIFIED' COMMAND OF CIS ARMED FORCES, AND A UNIFIED DEFENSE BUDGET.

06341 MENKE-GLUCKERT, $W$.

BERLIN: DELIGHT AND RELIEF

EUROPE, (311) (NOV 91), 13-14.

GERMANS WHO HAVE FOR YEARS LIVED AMID THE WORLD'S

HEAVIEST CONCENTRATION OF NUCLEAR WEAPONS ARE UNDERSTANDABLY DELIGHTED HITH PRESIDENT GEORGE BUSH'S INITIATIVE TO SLASH THE U.S. MUCLEAR ARMS ARSENAL AND PRESIDENT MIKHAIL GORBACHEV'S RESPONSE NOT ONLY TO MATCH BUT ALSO TO EXCEED THE U.S. REDUCTIONS. HEL COMING THE INITIATIVES, CHANCELLOR HELMUT KOHL SAID THEY CONSTITUTE "A DECISIVE STEP ON THE WAY TO MORE SECURITY AND STABILITY IN EUROPE." THE GERMANS WERE ESPECIALLY GLAD TO HEAR THAT THE THOUSANDS OF TACTICAL ESPECIALLY GLAD TO HEAR THAT THE THOUSANDS OF TACTICAL NUCLEAR WEAPONS SCATTERED OUTSIDE RUSSIA IN THREE SOVIE REPUBLICS-WHICH COULD HAVE BEEN SEIZED BY DISS REBEL GROUPS--WOULD BE
ADMINISTRATIVE CONTROL.

06342 MENKE-GLUCKERT, $H$.

THE NEH ERA

EUROPE, 318 ( JUL 92), 9-11.

FOR MONTHS THE DOYEN OF FOREIGN MINISTERS HANS-DIETRICH GENSCHER PLANNED HIS RESIGNATION. WHEN HE ANNOCUNCED THAT HE WOULD RESIGN ON MAY 17 AFTER 18 YEARS IN OFFICE, THE WELL- 
GUARDED SECRET CAUSED A SENSATION BOTH IN GERMANY AND ABROAD. OUTSIDE OF GERMANY. HIS RESIGNATION AND THE STRIKE WERE SEEN BY SOME AS NOT COINCIDENTAL, RATHER THE BEGINNING OF AN ECONOMIC AND POLITICAL CRISIS. THIS ARTICLE DISCUSSES "THE NEW ERA" AS GERMANY BEGINS TO FEEL THE EFFECTS OF REUNIFICATION.

06343 MENKES, J

THE CHANGING ROLE OF THE MILITARY IN DEMOCRATIC SOCIETIES: A POLISH PERSPECTIVE

ARMS CONTROL, 13(2) (SEP 92), 222-233.

THE PURPOSE OF THIS ANALYSIS IS TO EXAMINE WHETHER THE ROLE OF THE MILTARY IN POLAND IS INDEED CHANGING AND, IF SO, TO WHAT EXTENT. THE ANALYSIS FOCUSES BOTH ON THE FACT AND THE SUBSTANCE OF CHANGE. THE SOCIAL ROLE OF THE MILITARY CAN BE CATEGORIZED INTO THO GROUPS OF FUNCTIONS: INTERNAL AND EXTERNAL. THE ANALYSIS STARTS WITH AN EXAMINATION OF THESE. INTERNAL COMPRISES EDUCATION, PUBLIC RESCUE, AND AID TO THE CIVIL POWER. THE EXTERNAL FUNCTIONS OF THE MILITARY INCLUDES A DISCUSSION OF THE EXTERNAL THREATS OF PARTICULAR RELEVANCE TO POLAND.

06344 MENSAH, J.

CONTRADICTORY INTENTIONS
WEST AFRICA, 75(3887) (MAR 92), 453

J.H. MENSAH RESPONDS TO JERRY RAWLINGS' SPEECH AND ARGUES THAT SOME OF THE DELIBERATE OMISSIONS IN RAWLINGS' STATEMENT ARE ABSOLTELY DEADLY. HE CHARGES THAT RAWLINGS SEEMS TO BELIEVE THAT HE HAS THE POHER TO FIX A CROOKED PLAYIMG FIELD AND COMPEL OTHER GHANAIANS TO COMPETE ON IT BUT THAT THIS WILL NOT HAPPEN. AS SOON AS IT IS LEGALLY POSSIBLY, THE AUTHENTIC LEADERS OF THE MAJOR STRANDS OF POLITICAL OPINION IN GHANA HILL EMERGE FROM 10 YEARS OF ENFORCED SILENCE. THE FIRST THING THEY HILL DO IS TO INSIST ON MAKING SURE THAT THE GROUND RULES OF GHANAIAN POLITICS ARE ESTABLISHED THROUGH A DEMOCRACTIC PROCESS OF DEBATE, CONSULTATION AND COMPROMISE, AND ARE MANIFESTLY SEEN TO' BE FAIR.

06345 MENTZER, M.S.; FIZEL, J.L.

AFFIRMATIVE ACTION AND ETHNIC INEQUALITY IN CANADA: THE IMPACT OF THE EMPLOYMENT EQUITY ACT OF 1986

ETHNIC GROUPS, 9 (4) (1992), 203-217.

THE CANADIAN EMPLOYMENT EQUITY ACT OF 1986 DESIGNATES ABORIGINAL PEOPLES AND "VISIBLE MINORITIES" AS PROTECTED GROUPS AND MANDATES AFFIRMATIVE ACTION COVERAGE FOR THESE MINORITIES. BUT THE ACT'S IMPACT IS DIFFICULT TO PREDICT BECAUSE ITS WORDING IS VERY VAGUE AND HISTORICALLY CANADIAN COURTS HAVE NOT SHARED THE JUDICIAL ACTIVIST TRADITION OF COURTS HAVE NOT SHARED THE JUDICIAL ACTIVIST TRADITION OF
THE UNITED STATES. THE AUTHORS DESCRIBE POTENTIAL WEAKNESSES IHE UNITED STATES. THE AUTHORS DESCRIBE POTENTIAL WEAKNESSES IN THE CANADIAN LEGISLATION AND ANALYZE INCOME DATA FROM 63
ETHNIC GROUPS TO DETERMINE WHETHER THOSE COVERED BY THE ACT ETHNIC GROUPS TO DETERMINE WHETHER THOSE

06346 MENZEL, D.C

ETHICS ATTITUDES AND beMAVIORS IN LOCAL GOVERMMENTS: AM EMPIRICAL ANALYSIS

STATE AND LOCAL GOVERMMENT REVIEN, 24(3) (FAL 92), 94-102. THE PUBLIC ADMINISTRATION LITERATURE HAS LITTLE SYSTEMATIC DOCUMENTATION OF THE ETHICAL BELIEFS, ATTITUDES, PRACTICES, AND BEHAVIORS OF LOCAL GOVERNMENT EMPLOYEES, ALTHOUGH ANECDOTAL AND PRESCRIPTIVE ACCOUNTS ABDUND. PUBLISHED MATERIAL ON THE SUBJECT CONSISTS MAINLY OF CODES ADOPTED BY PROFESSIONAL GROUPS AND STATEMENTS OF EXPECTATIONS INCLUDED IN CHARTERS, ORDINANCES, AND PERSONNEL PROCEDURE POLICIES ISSUED BY CITY AND COUNTY GOVERNMENTS. IN A STEP TOWARD CLOSING THIS GAP IN THE LITERATURE, THIS ARTICLE REPORTS THE RESULTS OF A CONFIDENTIAL SAMPLE SURVEY OF EMPLOYEES OF TWO LOCAL GOVERNMENTS IN FLORIDA.

06347 MENZEL, D.C.; BENTON, J.E.; CIGLER, B.A.; MARANDO, V.L.; PARKS, R.B.; REEVES, M.M.; SVARA, J.H.; WAUGH, W.L. JR.
SETTING A RESEARCH AGENDA FOR THE STUDY OF THE AMERICAN COUNTY

PUBLIC ADMINISTRATION REVIEW, 52(2) (MAR 92), 173-182.

THE AUTHORS PROYIDE A COL, LITERATURE ON COUNTY GOVERNMENT AS HELL AS AN OVERVIEW OF RESEARCH ON THAT TOPIC SINCE THE TURN OF THE CENTURY. THEY THAT A COUNTY GOVERNMENT RESEARCH AGENCY FOR THE 1990' GOVERNMENT PS ON THE RELATIONSHIP BETHEEN STRUCTURE PROFESSIONAL MANAGEMENT; SERVICE DELIVERY, ADMINISTRATIVE RESPONSIVENESS, AND EQUITY; COUNTY RESPONSIVENESS TO CHANGING ENVIRONMENTAL CONDITIONS; COUNTY GOVERNMENTS AS DEMOCRATIC INSTITUTIONS: AND THE ROLE OF COUNTIES IN THE AMERICAN FEDERAL SYSTEM;

06348 MERELMAN, R.M.

CULTURAL IMAGERY AND RACIAL CONFLICT IN THE UNITED STATES: THE CASE OF AFRICAN-AMERICAMS

BRITISH JOURNAL OF POLITICAL SCIENCE, 22(3) (JUL 92), $315-342$

THE AUTHOR RELATES RECENT MARXIST CULTURAL THEORY TO THE CULTURAL DYNAMICS OF RACIAL-GROUP CONFLICT IN THE UNITED
STATES. AFTER OUTLINING A TYPOLOGY OF CULTURAL RELATIONS BETWEEN DOMINANT AND SUBORDINATE GROUPS, HE EXAMINES DATA ON AFRICAN-AMERICAN CULTURAL PENETRATION OF U.S. PUBLIC CULTURE. THE DATA INDICATE THAT SINCE THE LATE 1960'S THE "IMAGERIAL HEGEMONY" HAS YIELDED TO "IMAGERIAL PROJECTION" FOR AFRICANAMERICANS. HE SPECULATES ABOUT SOME INTERPRETATIONS AND CONSEQUENCES OF THIS PHENOMENON.

06349 MERIFIELD, J.

THE INSTITUTIONAL AND POLITICAL FACTORS WHICH INFLUENCE

TAXATION
PUBLIC CHOICE, 69(3) (MAR 91), 295-310.

THE ABILITY OF POLITICIANS TO CONCENTRATE THE BENEFITS OF SPENDING, WHILE DISPERSING THE COSTS OF TAXATION MAKES TAXATION ATTRACTIVE (DISTRIBUTIVE POLITICS), BUT THE DEGREE TO WHICH IT IS ATTRACTIVE VARIES WIDELY AMONG THE STATES. THE OBJECTIVE OF THE RESEARCH WAS TO DEVELOP A FULLY THE OBJECTIVE OF THE RESEARCH WAS TO DEVELOP A FULLY
SPECIFIED MODEL OF PER CAPITA TAX REVENUES OF STATES SPECIFIED MODEL OF PER CAPITA TAX REVENUES OF STATES
GOVERMMENTS (NOT STATE PLUS LOCAL), AND THEREBY IDENTIFY THE GOVERMMENTS (NOT STATE PLUS LOCAL), AND THEREBY IDEN POLTICIAL AND INSTITUTIONAL FACTORS WHICH CAUSE THE
ATTRACTIVENESS OF TAXATION TO VARY. THE RESULTING MODEL ATTRACTIVENESS OF TAXATION TO VARY. THE RESULTING MODEL
INCLUDES 17 SIGNFICANT EXPLANATORY VARIABLES, WHICH TOGETHER INCLUDES 17 SIGNFICANT EXPLANATORY VARIABLES, WHICH TOGETH
ACCOUNT FOR ALL BUT 10 PERCENT OF THE VARIATION IN PER CAPITA TAX REVENUE. THIRTEEN OF THE SIGNIFICANT VARIABLES ARE INSTITUTIONAL OR POLITICAL FACTORS, THUS PROVIDING DECISIONMAKERS SPECIFIC OPTIONS FOR INFLUENCING THE FUTURE SIZE OF GOVERNMENT.

06350 MERKUR, R.

ECONOMIC HOPE OUT OF COLLAPSE OF SOVIET BLOC

GERMAN TRIBUNE, 1498 ( JAN 92), 5-6.

THE TRANSITION OF THE FORMER SOVIET UNION TO AN OPEN,

DEMOCRATIC SOCIETY MUST NOT BE ALLOWED TO FOUNDER ON

ECONOMIC HARDSHIP; EXTERNAL HELP IS NEEDED, STATES THIS

ARTICLE. IT WAS HRITTEN BY THE GERMAN ECONOMICS MINISTER,

JURGEN MOLLEMANN, AFTER A VISIT TO MOSCOW. THE FACE OF EVENTS IN THE FORMER SOVIET UNION HAS OUTDATED SOME OF THE DETAILS HE MENTIONS.

06351 MERON, T.

DEMOCRACY AND THE RULE OF LAH

WORLD AFFAIRS, 153(1) (SUM 90), 23-27.

THIS ARTICLE BRIEFLY EXAMINES SOME OF THE IMPORTANT

PROVISIONS OF THE DOCUMENT PRODUCED BY THE LATEST HUMAN-

RIGHTS-RELATED MEETING OF THE CONFERENCE ON SECURITY AND

COOPERATION IN EUROPE (CSCE) AT COPENHAGEN. JUDGED BY ANY

STANDARD, THE COPENHAGEN DOCUMENT IS ONE OF THE MOST

IMPRESSIVE AND ENLIGHTENED STATEMENTS OF HUMAN RIGHTS AND

FUNDAMENTAL FREEDOMS. BUT MOST IMPORTANT AND POTENTIALLY THE

MOSTAMENTAL FREEDOMS. BUT MOST IMPORTANT AND POTENTIALLY THE

LAW PROVISIONS. THE ARTICLE EXAMINES THE PROVISIONS OF THE

DOCUMENT DEALING WITH PLURALISM, VOTING AND ELECTIONS,

GOVERNMENT UNDER LAH, AND THE PROTECTION OF HUMAN RIGHTS.

06352 MERRILL, M.; HILENTZ, S.

THE BIG HOUSE

NEW REPUBLIC, 207(21) (NOV 92), 16-17.

SEVERAL STATES HAVE ALREADY' PASSED CONGRESSIONAL TERM LIMITS, AND OTHERS ARE LIKELY TO DO SO. BUT TERM LIMITS WILL DO LITTLE TO CURE WHAT AILS CONGRESS AND COULD EVEN MAKE MATTERS WORSE. MOREDVER, THE COURTS MAY RULE THAT SUCH STATEIMPOSED LIMITATIONS ARE UNCONSTITUTIONAL. WHETHER TERM

LIMITS ARE CONSTITUTIONAL OR NOT, THERE IS A BETTER, WHOLLY CONSTITUTIONAL PROPOSAL FOR CONGRESSIONAL REFORM--ENLARGING

THE MEMBERSHIP OF THE HOUSE OF REPRESENTATIVES.

06353 MERRILL, T.H.

THE ROLE OF INSTITUTIONAL FACTORS IN PROTECTING INDIVIDUAL LIBERTIES

HARVARD JOURNAL OF LAW AND PUBLIC POLICY, 15(1) (WIN 92), 85-92.

THE AUTHOR DISCUSSES THE ROLE OF INSTITUTIONAL FACTORS IN PROTECTING INDIVIDUAL LIBERTIES AND BEGINS BY IDENTIFYING THREE INSTITUTIONAL FACTORS THAT HELP TO GUARANTEE THE ROBUSTNESS OF INDIVIDUAL LIBERTIES. THE FIRST FACTOR IS THE EXTENT AND HEALTH OF A SYSTEM OF PRIVATE PROPERTY RIGHTS. THE SECOND INSTITUTIONAL FACTOR OF SOME IMPORTANCE IS A GOVERMMENT DIVIDED EITHER VERTICALLY BY FEDERALISM OR HORIZONTALLY BY SEPARATION OF POWERS, OR BOTH. THE THIRD IS AN INDEPENDENT JUDICIARY ENFORCING A BILL OF RIGHTS.

06354 MERSEBURGER, P.

A CORNERSTONE TO STRENGTHEN THE ROLE OF THE UN GERMAN TRIBUNE, (1503) (FEB 92), 2, 10.

THE CAMP DAVID MEETING OF PRESIDENTS BUSH AND YELTSIM THE CAMP DAVID MEETING OF PRESIDENTS BUSH AND YELTSIN
SUCCEEDED IN SOOTHING HASHINGTON'S IRRITATIOM AT THE WAY IN SUCCEEDED IN SOOTHING WASHINGTON'S IRRITATION AT THE WAY IN
WHICH MIKHAIL GORBACHEY HAS DISMISSED. YELTSIN WAS GRANTED WHICH MIKHAIL GORBACHEV WAS DISMISSED. YELTSIN WAS GRANTED
FULL AMERICAN HONORS AND FINALLY ACKNOWLEDGED AS THE LAST FULL AMERICAN HONORS AND FINALLY ACKNOWLEDGED AS THE LAST SOVIET LEADER'S LEGITIMATE HEIR. ABOVE ALL. THE CAMP DAVID MEETING REAFFIRMED THE BASIC CONSENSUS ABOUT COLLECTIVE
SECURITY HITHOUT WHICH THE SENDING OF AM INTERMATIONAL FORCE, U.N.-ENDORSED BUT U.S. LED, TO THE GULF WOULD NOT HAVE BEEN POSSIBLE. IT THUS SHOWED THAT A MOST IMPORTANT CORNERSTONE LAID AS PART OF A NEW ORDER BASED ON STRENGTHENING THE UN'S 
ROLE WAS STILL INTACT, HOWEVER, MUCH REMAINS TO BE ACCOMPLISHED BEFORE THE NEW WORLD ORDER IS A REALITY.

06355 MESSAS, $K$. DEMOCRATIZATION OF MILITARY REGIMES: CONTENDING EXPLANATIONS JOURNAL OF POLITICAL AND MILITARY SOCIOLOGY, 20(2) (WIN $92), 243-256$

DURING THE 1970S AND 1980S, THE MILITARY WITHDREW FROM ACTIVE PARTICIPATION INT HE POLITICS OF A NUMBER OF COUNTRIES IN THE CARIBBEAN, CENTRAL AND SOUTH AMERICA, ASIA, AFRICA, MEDI TERRANEAN EUROPE, AND THE MIDOLE EAST. THESE EVENTS CHALLENGED PREVIOUSLY HELD BELIEFS THAT MILITARY INTERVENTION IN POLITICS HAS CONCLUSIVE AND IRREVERSIBLE. IN ADOITION, THESE ACTS OF HITHDRAHAL GENERATED A NEH HAVE OF SCHOLARLY INTEREST IN THE RELATIONSHIP BETWEEN SOCIETY AND THE MILITARY IN GENERAL, AND IN PARTICULAR. THE PROCESS OF TRANSITION FROM MILITARY (OR AUTHORITARIAN) RULE TO CIVILIAN (AND HOPEFULLY DEMOCRATIC) FORMS OF GOVERMMENT. THIS ARTICLE EXPLORES THE FACTORS THAT INDUCED THE MILITARY, DESPITE THEIR MONOPOLY OF FORCE, TO RETURN POWER TO CIVILIAN GROUPS. SPECIFICALLY. THIS DISCUSSION IS INTENDED TO ENCOURAGE A POLITICS AND THE WAYS IN WHICH TRANSITION TO CIVILIAN RULE POLITICS AND THE WAYS
MIGHT BE MADE EASIER.

06356 METCALF, L.

CENTRIPETAL AND CENTRIFUGAL FORCES IN THE CMEA: PROSPECTS FOR THE FUTURE

STUDIES IN COMPARATIVE COMMUNISM, 25(2) (JUN 92), 123-138.

THE PROFOUND CHANGES IN PUBLIC AND POLITICAL LIFE OF THE EAST EUROPEAN COUNTRIES AND THE IMPLEMENTATION OF FUNDAMENTAL ECONOMIC REFORMS IN MANY MEMBER-STATES OF THE COUNCIL FOR MUTUAL ECONOMIC AID (CMEA) ARE PUTTING ON THE AGENDA THE NEED TO ACCELERATE THE RESTRUCTURING OF THE MECHANISM FOR THEIR MULTILATERAL INTERACTIONS AND TO WORK OUT FUNDAMENTAL DECISIONS REGARDING A CHANGEOVER TO NEW CONDITIONS OF COOPERATION IN THE CMEA. THIS ARTICLE EXPLORES THE COLLAPSE OF CMEA AND THE LACK OF A SUCCESSOR

ORGANIZATION. SOVIET AND EAST EUROPEAN INTERESTS ARE EXAMINED AS WELL AS THE IMPEDIMENTS TO THE CREATION OF A NEW TRADE REGIME.

06357 METZ, A.

ISRAEL, THE RELIGIOUS PARTIES, THE COALITION NEGOTIATIONS OF MARCH-JUNE 1990, AND BEYOND

NEW POLITICAL SCIENCE, 21-22 (SPR 92), 117-136.

A CONTINUING TREND' IN ISRAEL IS THE INFLUENCE OF THE RELIGIOUS PARTIES AND THEIR IMPACT ON THE POLITICAL SYSTEM. RELIGIOUS PARTIES AND THEIR IMPACT ON THE POLITICAL CONTEMPORARY GENERAL CONTEXT, PROVIDING SOME HISTORICAL CONTEMPORARY GENERAL CONTEXT, PROVIDING SOME HISTORICAL
BACKGROUND. A CASE STUDY IS PRESENTED ON THE SPRING 1990 BACKGROUND. A CASE STUDY IS PRESENTED ON THE SPRING 1990
POLITICAL STALEMATE IN ISRAEL. HHICH RESULTED IN THE POLITICAL STALEMATE IN ISRAEL, HHICH RESULTED IN THE COALITION. THIS CASE STUDY DEMONSTRATES THE GREAT IMFLUENCE COALITION. THIS CASE STUDY DEMONSTRATES THE GREAT IMFLUENCE THE RELIGIOUS PARTIES HAVE ON THE ISRAELI POLITICAL SYSTEM. CONSIDERATION IS GIVEN TO THE IMPLICATIONS OF THIS SYSTEM

06358 METZ, A.

MEXICAN CHURCH-STATE RELATIONS UNDER PRESIDENT CARLOS SALINAS DE GORTARI

JOURNAL OF CHURCH \& STATE, 34(1) (HIN 92), 111-130.

THE AUTHOR EXAMINES THE STATUS OF CHURCH-STATE RELATIONS IN MEXICO UNDER THE ADMINISTRATION OF PRESIDENT CARLOS SALINAS DE GORTARI. HE TRACES SALIMAS' OVERTURES TO THE ROMAN CATHOL IC CHURCH UPON ASSUMING OFFICE IN 1988; DEVELOPMENTS IN THE SUMMER OF 1989. INCLUDING A BISHOPS' CONFERENCE LETTER TO SALINAS CALLING FOR CONSTITUTIONAL REFORMS AS PART OF AN ONGOING CAMPAIGN; THE ANNOUNCEMENT OF A VISIT TO MEXICO BY POPE JOHN PAUL II AND REACTIONS TO IT: THE DECLARATION OF AN EXCHANGE OF PERSONAL ENVOYS BY THE POPE AND SALINAS IN FEBRUARY 1990; THE POPE'S MAY 1990 VISIT, WHICH SERVED AS AN IMPETUS FOR RENEWED DISCUSSION OF THE CHURCH-STATE ISSUE IN MEXICO; AND SIGNIFICANT TRENDS IN LATE 1990 TO MID-1991.

06359 METZ, D.

NEO NAZIS PARADE VIOLENCE ON STREETS AS LAH AND ORDER GERMAN TRIBUNE, (1476) (JUL 91), 13

POLICE ESTIMATES INOICATE THAT THERE ARE 2,000 HARD-CORE NOE-NAZIS IN EASTERN GERMANY HITH ANOTHER 15,000
SYMPATHIZERS. THEY SEEM TO BE MORE AGGRESSIVE, MORE READY TO SYMPATHIZERS. THEY SEEM TO BE MORE AGGRESSIVE, MORE

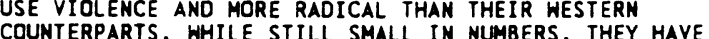
COUNTERPARTS. WHILE STILL SMALL IN NUMBERS, THEY HAVE OF A POLICE LAW AND HAVE PARADED THEMSELVES AS DEFENDERS OF OF A POL ICE LAW AND HAVE PARADED THEMSELVES AS DEFENDER ORDER AND SECLRITY. THEIR INITIAL TARGETS HAVE BEEN FOREIGNERS AND PIMPS, BOTH OF WHO ARE RAPIDLY LEAVING THE
CITY OF DRESDEN, THOUGHT BY SOME TO BE THE CAPITAL OF THE NED-NAZI MOVEMENT IN THE EAST.

06360 METZGER, A.

ANXIETIES IN IRAQI KURDISTAN
MIDOLE EAST INTERNATIONAL, 436 (OCT 92), 19-20

THE FUTURE OF THE HOMELAND OF THE PEOPLE IN IRAOI KURDISTAN IS EXPLORED. THE IRAQI KURDS ARE SQUEEZED INTO A QUADRANGEL OF FOUR MORE OR LESS HOSTILE COUNTRIES, TO FIND AN OULET THEY HAVE TO DEPEND ON ONE OF THEM. TURKEY--THE LIFE-LINE--AND THE PKK ARE EXPLORED AS POSSIBILITIES. KURDISTAN IS SEEKING INTERNATIONAL RECOGNITION AND AID.

06361 MEURS, $M$

POPULAR PARTICIPATION AND CENTRAL PLANMING IN CUBAN SOCIALISM: THE EXPERIENCE OF AGRICULTURE IN THE 1980's WORLD DEVELOPMENT, 20(2) (FEB 92), 229-240.

IN THE $1980^{\circ} \mathrm{S}$, CUBA INSTITUTIONALIZED MECHANISMS OF CENTRAL PLANNING AND POPULAR PARTICIPATION UNDER THE SYSTEM OF MANAGEMENT AND PLANHING OF THE ECONOMY (SDPE). THIS PAPER EXAMINES THE IMPLEMENTATION OF THE SDPE IN CUBAN AGRICULTURE, FINDING THAT THESE MECHANISMS HAVE YIELDED A NUMBER OF THE EXPECTED PRODUCTIVE RESULTS. HOHEVER, TENSIONS, WHICH HAVE DEVELOPED BETHEEN PARTICIPATION AND CENTRAL PLANNING, HAVE PREVENTED SDPE FROM FULFILLING ITS GREATEST POTENTIAL. THESE TENSIONS ARE LINKED TO THE SPECIFIC FORMS OF PARTICIPATION AND THE MATERIAL INCENTIVES USED. ALTERNATIVE FORMS OF MATERIAL INCENTIVES AND BROADER POPULAR INPUT INTO PLANNING MATERIAL INCENTIVES AND BROADER POPULAR INPUT INTO PLANNING
TARGETS COULD REDUCE THESE TENSIONS AND IMPROVE AGRICULTURAL TARGETS COULD

06362 MEYER, C.A.

A STEP BACK AS DONORS SHIFT INSTITUTION-BUILDING FROM THE PUBLIC TO THE PRIVATE SECTOR

NORLD DEVELOPMENT, 20(8) (AUG 92), 1115-1126.

FRUSTRATED WITH PUBLIC SECTOR INEFFICIENCY IN DEVELOPING COUNTRIES, MANY DONORS HAVE SHIFTED SUPPORT TO NONPROFIT, NONGOVERMMENTAL ORGANIZATIONS. THIS PAPER EXAMINES THE PREFERENCE OF THE NONPROFIT OVER THE PUBLIC SECTOR FROM THE DONOR AMD HOST COUNTRY PERSPECTIVES. THE AUTHOR UTILIZES CASE STUDIES FROM AGRICULTURAL AND NATURAL RESOURCE INSTITUTIONS IN ECUADOR AND THE DOMINICAN REPUBLIC TO EXPAND UPON CURRENT THINKING ABOUT THE ROLE OF THE NONPROFIT SECTOR. MONPROFITS ARE FOUND TO POSSESS SUBSTANTIALLY GREATER FLEXIBILITY FOR DONOR PURPOSES AND AVOID MANY OF THE PITFALLS OF THE POLITICAL PROCESS. HOWEVER, THEY ARE SUBJECT TO FREE-RIDER PROBLEMS AND BEAR NO RESPONSIBILITY TO THE GENERAL PUBLIC.

06363 MEYER, F.; BAKER, R.

AN OVERVIEH OF STATE POLICY PROBLEMS

POLICY STUDIES REVIEW, 11(1) (SPR 92), 75-80.

THE AUTHORS BRIEFLY REVIEH CONCEPTS OF FEDERALISM, WITH THE INTENT OF INOUIRING WHETHER THE STATE GOVERNMENTS HAVE BECOME ENTREPRENEURIAL AS A RESULT OF THE REAGAN DEVOLUTION. AN OVERVIEN SUGGESTS THAT SUPPORT FOR A THEORY OF
CYCLICALITY IS NOT CONSISTENTLY EVIDENT IN THE STATES.

CYCLICALITY IS NOT CONS ISTENTLY EVIDENT IN THE STATES.

NECESSARY RESOURCES ARE NOT ALWAYS PRESENT TO ALLOH THE
STATES TO BE THE POLICY ENTREPRENEURS IN THE UNITED STATES.

06364 MEYER, G.

VITO MARCANTONIO-RADICAL POLITICIAN, 1902-1954

STATE UAIVERSITY OF NEW YORK PRESS, 1989, 303

THIS BOOK IS THE FIRST STUDY TO FULLY EXPLORE VITO MARCANTONIO'S UNIQUE STATUS AS A RADICAL POLITICIAN WHO, DESPITE MASSIVE OPPOSITION, HELD HIGH PUBLIC OFFICE FOR FOURTEEN YEARS. AS CONGRESSIONAL REPRESENTATIVE TO HARLEM, HE BECAME THE LEADER OF THE MOST IMPORTANT THIRD PARTY IN THE UNITED STATES, THE AMERICAN LABOR PARTY, AND ACHIEVED NATIONAL STATURE AS A SPOKESMAN FOR THE LEFT. THE BOOK DEMONSTRATES MARCANTONIO'S TRANSCENDENCE OF A NUMBER OS AMERICAN TRUISM. THE AUTHOR EXPLORES THE EFFICIENCY OF MARCANTONIO'S POLITICAL MACHINE, THE UNUSUAL ALLIANCE OF HIS THO MAJOR POLITICAL BASES (EAST HARLEM AND EL BARRIO), AND HIS OPEN RELATIONSHIP WITH THE COMMUNIST PARTY.

06365 MEYER, $P$.

EFFICIENCY AMD PRIVACY IN PUBLIC SUBSIDIES TO PRIVATE BUSINESSES IN THE UNITED STATES AND THE UNITED KINGDOM JOURNAL OF ECONOMIC ISSUES, 26(2) (JUN 92), 661-170. THE EFFICIENCY OF GOVERMMENT PROGRAMS REOUIRES THE ACOUISITION OF INFORMATION ON BUSINESS ACTIVITIES AND OECISIONS. HOWEVER, PROTECTION OF THE COMPETITIVE POSITION OF BUSINESSES REQUIRES THAT SOME INFORMATION ABOUT THEIR OPERATIONS BE PROTECTED FROM PUBLIC EXPOSURE. THIS PAPER FOCUSES ON THE NEED TO UNDERSTAND THE ROLE THAT INFORMATION FLOWS PLAY IN SHAPING PUBLIC PROGRAMS. THE SPECIFICS EXAMINED ARE FORCES SHAPING DIFFERENT BUT COMPARABLE GRANT PROGRAMS IN THE UNITED STATES AND IN GREAT BRITAIN.

PROGRAMS IN THE UNITED STATES AND IN GREAT BRITAIN.
DEVELOPMENT POLICY COMMON TO BOTH COUNTRIES--ENTERPRISE DEVELOPMENT POLICY COMMON TO BOTH COUNTRIES--ENTERPRISE
ZONES--IS ALSO EXAMINED. THE ARTICLE CONCLUDES THAT THE ZONES--IS ALSO EXAMINED. THE ARTICLE CONCLUDES THAT THE
PUBLIC DESIRE TO CONTROL CAPITAL ALLOCATION IS A PREREQUISTE PUBLIC DESIRE TO CONTROL CAPITAL ALLOCATION IS A PREREQUISTE PRIVATE USE OF PUBLIC FUNDS.

06366 MEYER, P.F.

GORBACHEV AND POST-GORBACHEV POLICY TOWARD THE KOREAN

PENINSULA: THE IMPACT OF CHANGING RUSSIAN PERCEPTIONS ASIAN SURVEY, XXXII(8) (AUG 92), 757-772. 
THE EVOLUTION OF MOSCOW'S RELATIONS WITH THE KOREAN PENINSULA MIRRORS PROFOUND CHANGES IN RUSSIAN FOREIGN POLICY IN THE SEVEN YEARS SINCE GORBACHEV CAME TO POWER. THE SOYIETS SHIFTED FROM A COI HAR MARXIST PERSPECTIVE TO GORBACHEY'S "NEH THINKING" DIPLOMACY THAT STRESSED THE NEED TO CREATE AN EXTERNAL CLIMATE CONDUCIVE TO DOMESTIC ECONOMIC DEVELOPMENT BUT, AT THE SAME TIME, WAS ACTIVIST

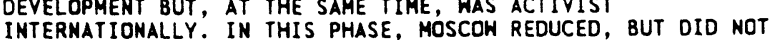
INTERNATIONALLY. IN THIS PHASE, MOSCOW REDUCED, BUT OID NOT COMPLETELY ABANDON ITS OBLIGATIONS TO TRADITIONAL COLD HAR ALLIES AND, AT LEAST ON A RHETORICAL LEVEL, ASSUMED

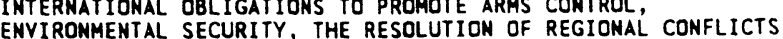
ENVIRONMENTAL SECURITY, THE RESOLUTION OF REGIONAL CONFLICTS, AND OTHER COMMON OBJECTIVES. WHILE THIS POLICY HAS NOT B
EXPL ICITLY REJECTED, IT HAS BEEN MODIFIED IN SIGNIFICANT EXPLICITLY REJECTED, IT HAS BEEN MODIFIED IN SIGNIFICANT WAYS SINCE BORIS YELTSIN'S JUNE 1991 ELECTION AS RUSSIA'S
PRESIDENT. THE FAILED AUGUST COUP AGAINST GORBACHEV, AND THE USSR'S DISSOLUTION IN DECEMBER 1991. INCREASINGLY, RUSSIAN POLICYMAKERS HAVE TURNED THEIR ATTENTION INWARD TO FOCUS ON THE GROWING ECONOMIC AND POLITICAL CRISIS. THIS ARTICLE TRACES THE IMPACT OF THESE CHANGES ON THE KOREAN PENINSULA.

06367 MEYER, S

HOW THE THREAT (AND THE COUP) COLLAPSED: THE

POLITICIZATION OF THE SOVIET MILITARY

INTERNATIONAL SECURITY, 16(3) (WIN 91), 5-38.

STEPHEN MEYER EXPLORES THE POLITICIZATION OF THE SOVIET MILITARY, A PROCESS THAT CONTRIBUTED TO THE FAILURE OF THE AUGUST 1991 COUP AND HAS UNDERMINED THE CAPABILITIES OF SOVIET GENERAL PURPOSE FORCES. HE ARGUES THAT POLITICAL DIVISIONS SPLIT THE RED ARMY ALONG GENERATIONAL, HIERARCHIAL, AND EHTNIC LINES, UNDERMINING DISCIPLINE, MORALE, COHESION, AND MILITARY EFFECTIVENESS. THESE FISSURES LED MOST MILITARY
UNITS TO STAND ASIDE DURING THE COUP ATTEMPT BECAUSE MANY UNITS TO STAND ASIDE DURING THE COUP ATTEMPT BECAUSE COMMANDERS FEARED THAT INVOLVEMENT WOULD PRO
COMPLETE COLLAPSE OF MILITARY INSITUTIONS.

06368 MEYER, T.

GERMAN LINKS HITH AMERICA REMAIN CRUCIAL IN POST-COMMUNIST ERA

GERMAN TRIBUNE, 1539 (NOV 92), 1.

LITTLE MORE THAN A CHANGE IN EMPHASES IN FOREIGN

POLICIES IS EXPECTED IF BILL CLINTON IS ELECTED PRESIDENT.

THERE IS NO REASON FOR APPREHENSION. POL ICY EMPHASES MAY

CHANGE BUT BASIC OUTLINES ARE UNLIKELY TO. WHOEVER IS

ELECTED, BUSH OR CLINTON, DOMESTIC POLICY WILL HAVE HIS

FIRST PRIDRITY. YET THE QUESTION REMAINS: WHAT IS STATE OF

GERMAN-AMERICAN RELATIONS IN A HORLD THAT HAS UNDERGONG
DRASTIC CHANGE? IT IS A RELATIONSHIP THAT IS ALHAYS

DRASTIC CHANGE? IT IS A RELATIONS
IMPORTANT AND ALWAYS SENSITIVE.

06369 MEYER, T.; WIEDEMANN, $G$.

SHORD OF CHANGE: NATO SECRETARY GENERAL HORNER REVIEWS FIRST THREE YEARS

GERMAN TRIBUNE, (1476) (JUL 91), 5

SINCE HE TOOK OVER AS NATO SECRETARY-GENERAL ROUGHLY THREE YEARS AGO, MANFRED WORNER HAS OVERSEEN FAR-REACHING CHANGES IN EUROPE. THE CHANGE OF GOVERNMENTS IN EASTERH EUROPE, THE DECLINE OF THE WARSAW PACT AND REFORM IN THE SOVIET UNION HAVE ALL REDUCED THE SECURITY THREAT TO NATO COUNTRIES. HOWEVER, WORNER SEES AN IMPORTANT ROLE FOR NATO AT LEAST FOR THE NEXT THO DECADES. HE POINTS TO THE AT LEAST FOR THE NEXT THO DECADES. HE POINTS TO THE UNION AS JUSTIFICATION FOR CONTINUING THE ALLIANCE. HOWEVER, UNION AS JUSTIFICATION FOR CONTINUING THE ALLIANCE. HOWEVER, HE ALSO SPEAKS OPTIMISTICALLY OF A "NEW EUROPE" WHICH HOULD INCLUDE EASTERN EUROPE AND THE SOVIET

06370 MEYERS, G.; WEBB, S.

NEW THRUST IN LABOR
POL ITICAL AFFAIRS, 71(4) (MAY 92), 13-18.
THE TRADE UNION MOVEMENT HAS SUFFERED A DECADE OF UNRELENTING ASSAULT UPON ITS IDEALS AND ACTIVITIES. HOWEVER, UNRELENTING ASSAULT UPON ITS IDEALS AND ACTIVITIES. HOWEVER, THIS ARTICLE ARGUES THAT THE CORPORATE OFFENSIVE AGAINST LABOR CAN BE HALTED IN THE 1990S. FURTHERMORE, DESPITE THE FACT THAT THE BUSH ADHINSTRATION IS NO LESS ANTI-LABOR THAM ITS PREDECESSOR, A NEW UPSHING OF LABOR IS ON THE AGENDA. THIS ASSERTION IS BACKED BY THE MATURATION OF THE MULTIRACIAL, MULTI-NATIONAL, MALE-FEMALE WORKING CLASS. THIS "NEW" WORKING CLASS THINKS AND RESPONDS DIFFERENTLY NEARLY A DECADE OF UNINTERRUPTED CLASS WARFARE. THE
COMMUNIST PARTY (USA) HAS PLAYED A KEY ROLE IN DEVELOPING COMMUNIST PARTY (USA) HAS PLAYED A KEY ROLE I
THE MASS CHARACTER OF THE NEW LABOR MOVEMENT.

06371 MEYERS, G.

TASKS FOR THE LEFT IN LABOR

POLITICAL AFFAIRS, LXX(8) (AUG 91), 23-27

THE TRADE UNION MOVEMENT IS NOT ONE HOMOGENEOUS MASS, AS INVARIABLY PORTRAYED BY THE MASS MEDIA. UNDERSTANDING THIS FACT IS ESSENTIAL TO THE SUCCESS OF THE COMMUNIST PARTY (USA)'S WORK IN THIS VITAL ARENA OF THE CLASS STRUGGLE. IT IS THE KEY TO THE TASK OF BUILDING UNITED FRONT COALITIONS OF THE LEFT AND CENTER FORCES AROUND ISSUES THAT MOVE THE TRADE UNIONS IN A PROGRESSIVE DIRECTION. SUCH A COALITION MIGHT CONSIDER: A NATIOMALLY COORDINATED CAMPAIGN TO
ORGANIZE THE UNORGANIZED, WITH SPECIAL ATTENTION TO THE SOUTH; THE FIGHT FOR CLASS UNITY AND FOR RACIAL AND SEX EOUALITY; INDEPENDENT POLITICAL ACTION; ORGANIZING THE JOBLESS; TRADE UNION DEMOCRACY; INTERNATIONAL UNION UNITY; AND CONSOLIDATION OF THE LEFT IN LABOR.

06372 MEYERSON, A.

A CASE OF "ElEPHANTIASIS": THE IDENTITY CRISIS OF THE REPUBLICAN PARTY

POLICY REVIEW, (60) (SPR 92), 2-3.
THE AUTHOR LOOKS AT THE STATUS OF THE REPUBLICAN PARTY AS PRESIDENT GEORGE BUSH PREPARES TO RUN FOR RE-ELECTION IN 1992. ALTHOUGH THE REPUBLICAN PARTY IS SUFFERING ITS MOST

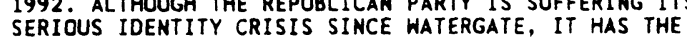
SERIOUS IDENTITY CRISIS SINCE WATERGATE, IT HAS THE
POTENTIAL TO BUILD A CENTER-RIGHT GOVERNING MAJORITY THAT

POTENTIAL TO BUILD A CENTER-RIGHT GOVERNING MAJORITY THAT
COULD DEFINE AMERICAN POLITICS FOR THE NEXT GENERATION.

06373 MEYERSON, A.

CAPTAIN OF ENTERPRISE

POLICY REVIEN, (60) (SPR 92), 10-19.

THE AUTHOR INTERVIEWS CHRISTOPHER C. DEMUTH, PRESIDENT OF THE CONSERVATIVE AMERICAN ENTERPRISE INSTITUTE. DEMUTH ANSWERS QUESTIONS ABOUT THE ECONOMIC ACHIEVEMENTS AND FAILURES OF THE REAGAN AND BUSH ADMINISTRATIONS, THE AMERICAN ENTERPRISE INSTITUTE'S AGENDA ON BEHALF OF THE FREE BUSINESS COMMUNITY AND THE CONSERVATIVE POLITICAL MOVEMENT.

06374 MEYERSON, A.

CONSCIENCE OF A CULTURAL CONSERVATIVE

POLICY REVIEW, (59) (WIN 92), 8-17.

PAUL M. WEYRICH, PRESIDENT OF THE FREE CONGRESS

FOUNDATION AND CHAIRMAN OF THE COALITIONS FOR AMERICA, IS

ONE OF THE UNITED STATES' LEADING STRATEGISTS AND ORGANIZERS

FOR CULTURAL CONSERVATISM. DURING THE PAST TWO YEARS, HE HAS PLAYED A MAJOR ROLE IN THE ELECTION CAMPAIGNS OF PRESIDENT BORIS YELTSIN IN RUSSIA, PRESIDENT ZHELYU ZHELEV IN BULGARIA, AND OTHER EMERGING DEMOCRATIC LEADERS IN THE CRUMBLING SOVIET BLOC. IN THIS INTERVIEW, WEYRICH DISCUSSES HIS

POLITICAL ACTIVITIES AND THE IDEOLOGY UNDERLYING THEM.

06375 MEYERSOM

DOMESTIC STORM: BUSH'S NEW TAX PROMISE AND WHAT HE MUST DO TO KEEP IT

POL ICY REVIEH, (62) (FAL 92), 2-3

PRESIDENT GEORGE BUSH STARTED THE CAMPAIGN TAX-AND-SPEND DEBATE CORRECTLY IN HIS ACCEPTANCE SPEECH AT THE REPUBLICAM DEBATE CORRECTLY IN HIS ACCEPTANCE SPEECH AT WIE REPUBLICA CONVENTION, AND HE HAS A FIGHTING CHANCE TO WIN A SECOND HE REALLY WILL KEEP HIS PROMISE ON TAXES.

06376 MEYERSON, A.

TRACTOR-SEAT COMHON SENSE: REPRESENTATIVE CHARLES W.

STENHOLM ON THE RISE OF THE CENTRIST DEMOCRATS

POLICY REVIEH, (62) (FAL 92), 58-64.

REPRESENTATIVE CHARLES H. STENHOLM OF TEXAS HEADS THE CONSERVATIVE DEMOCRATIC FORUM, WHICH CLAIMS 59 MEMBERS AND IS GROWING IN CONGRESSIONAL INFLUENCE. IN THIS INTERVIEH, STENHOLM OISCUSSES HOW FORUM MEMBERS DIFFER FROM REPUBLICANS AND OTHER DEMOCRATS, HOW THE FORUM HAS INFLUENCED PAST LEGISLATION, AND WHAT ITS ROLE WILL BE IN FUTURE

CONGRESSIONAL YOTING.

06377 MEYROWITZ, J.

THE PRESS REJECTS A CANDIDATE

COLUMBIA JOURNALISM REVIEW, 30(6) (MAR 92), 46-48,

DEMOCRATIC PRESIDENTIAL ASPIRANT LARRY AGRAN, THE FORMER MAYOR OF IRVINE, CALIFORNIA, WHO VIED FOR HIS PARTY'S NOMINATION IN 1992 RECEIVED VERY LITTLE PRESS COVERAGE. THE MEDIA USUALLY DESCRIBED HIM AS "A DARK MORSE," "A FRINGE CANDIDATE, OR "AN OBSCURE CONTENDER." HE WAS BARRED FROM MOST OF THE TELEVISED DEBATES, AND WHENEVER HE WAS ALLOWED TO PARTICIPATE IN FORUMS WITH THE MAJOR CANDIDATES, HE WAS OFTEN IGNORED IN THE

06378 MHATRE, S.L.; DEBER, R.B.

FROM EQUAL ACCESS TO HEALTH CARE TO EQUITABLE ACCESS TO FROM EQUAL ACCESS TO HEALTH CARE TO EQUITABLE ACCESS TO HEALTH: A REYT

IHTERMATORAL JOURMAL OF HEALTH SERYICES, 22(4) (1992), T45-668.

HAVING ACHIEVED EOUALITY OF ACCESS TO HEALTH CARE, CANADIAN POLICYMAKERS ARE SETTING NEW POLICY GOALS, WITHIN RESOURCE CONSTRAINTS, PRIMARILY TO ACHIEVE EQUITY OF ACCES TO HEALTH. ACROSS CANADA, PROVINCIAL ROYAL COMHISSIONS HAVE EXPLORED A NUMBER OF POLICY OPTIONS TO ACHIEVE THIS GOAL. THIS PAPER REVIEWS AND ANALYZES THESE OPTIONS WITHIN THE CONTEXT OF SUCH CHALLENGES AS INSUFFICIENT ACCESS TO HIGHTECHNOLOGY CARE AND THE LIMITS OF MEDICAL CARE AND SUCH FACTORS AS ECONOMIC AND DEMOGRAPHIC TRENDS, FEDERALPROVINCIAL DISPUTES, AND IDEOLOGICAL BELIEFS. PARTICULAR ATTENTION IS GIVEN TO THE IMPLICATIONS OF A BROADER DEFINITION OF HEALTH AND THE CONCEPT OF REGIONAL HEALTH 
AUTHORITIES.

06379 MICHEL, R.C. MICHELMIC GROWTH AMD IMCOME EQUALITY SINCE THE 1982 RECESSION JOURNAL OF POLICY ANALYSIS AND MANAGEMENT, 10(2) (1991), 181-203.

THIS PAPER tests the "RISIMG TIDE" AND "TRICKLE DOWN" HYPOTHESIS OF INCOME GROWTH BY EXAMINING SEVERAL MEASURES OF INCOME INEQUALITY BETWEEN 1983 AND 1987. A CLOSE LOOK AT HOUSEHOLD INCOMES BETHEEN THOSE YEARS SHOWS THAT POST-TAX INCOME GROWTH HAS BEEN CONCENTRATED AMOMG THE 20 PERCENT OF AMERICAN HOUSEHOLDS WITH THE HIGHEST INCOMES. THE MIDDLE INCOME CLASSES HAVE EXPERIENCED ONLY MODEST INCOME GROWTH OVER THIS PERIOD, AND THE 20 PERCENT OF AMERICAN HOUSEHOLDS WITH THE LOWEST INCOMES HAVE EXPERIENCED A DECLINE IN INCOME. THESE RESULTS HOLD WHETHER THE ANALYSIS IS BASED ON A SUMMARY MEASURE OF INCOME EQUALITY SUCH AS THE GINI COEFFICIENT, OR ON A LESS TECHNICAL MEASURE SUCH AS AVERAGE INCOME. FURTHERMORE, INCOME GROWTH SEEMS TO BE DECREASING MOST RAPIDLY FOR GROUPS OF HOUSEHOLDS THAT HISTORICALLY HAVE HAD THE LOWEST INCOMES: FEMALE-HEADED HOUSEHOLDS, BLACKS, AND HISPANICS. FINALLY, THO STANDARD EXPLANATIONS OF THE' INEQUALITY TREND--THAT THE DISTRIBUTIONAL CHANGES ARE THE INEQUALITY TREND--THAT THE DISTRIBUTIONAL CHANGES ARE THE THE LOWER HAGE AREAS OF SOUTH-ARE TESTED BY DISAGGREGATING THE LOWER
THE DATA.

06380 MICHEL, R.H.; ARMEY, D.; GOOOLING, W.F. HOUSE REPAIRS: WHAT WE' $L L$ DO WHEN WE REACH MAJORITY POLICY REVIEW, (59) (WIN 92), 62-65.

HOULD THERE BE SIGNIFICANT REFORMS IF THE HOUSE OF REPRESENTATIVES WERE CONTROLLED BY THE REPUBLICAN PARTY RATHER THAN THE DEMOCRATS? IN THIS ARTICLE, REPUBLICAN MINORITY LEADER ROBERT H. MICHEL AND CONGRESSMEN DICK ARMEY ENDEAVOR TO INSTITUTE IF THERE HERE A REPUBLICAN MAJORITY IN THE HOUSE.

06381 MICHELSON, M.C.; HEISMAN, R.L.

FAR EASTERN ECONOMIC REVIEN, 155(51) (DEC 92), 14.

IF PRESIDENT-ELECT BILL CLINTON AND SOME MEMBERS OF CONGRESS HAVE THEIR WAY, ASIAKS DOING BUSINESS IN THE UNITED STATES WILL FIND THEMSELVES PAYING HIGHER TAXES NEXT YEAR. HOWEVER, CLINTON'S PLAN TO TARGET FOREIGN COMPANIES WHO PROFITS OVERSEAS" WILL NOT ACCRUE THE REVENUE ITS SUPPORTERS PROFITS OVERSEAS" WILL NOT ACCRUE THE REVENUE ITS SUPPORTERS HAVE CLAIMED. FURTHERMORE, IT WILL CAST DOUBT ON AMERICA'S COMMITMENT TO OPEN MARKETS. FINALLY, IT WILL ULTIMATE
THE U.S. ECONOMY AS FOREIGN COMPANIES REDUCE THEIR THE U.S. ECONOMY AS FOREIGN COMPANIES REDUCE THEIR
INVESTMENTS AND AMERICAN JOBS ARE LOST. UNLESS BUSINESSMEN INVESTMENTS AND AMERICAN JOBS ARE LOST. UNLESS BUSINESSMEN ACT QUICKLY TO PERSUADE AMERICAN POLICYMAKERS THAT SUCH PLAN THREATENS THEIR OWN STATED GOALS--MORE JOBS AND INCREASED COMPETITIVENESS--A SPECIAL TAX ON FOREIGN-OWNED FIRMS IN THE U.S. MAY PROVE ONE OF THE FIRST ACTS OF THE CLINTON ADMINISTRATION.

06382 MICHITOSHI, T.

MIYAZAHA KIIICHI: A STATESMAN ON TRIAL

JAPAN QUARTERLY, XXXIX(1) (JAN 92), 6-16.

THE AUTHOR REPORTS ON THE ELECTION OF MIYAZAHA KIICHI AS JAPAN'S 49TH PRIME MINISTER, MIYAZAWA'S TIES TO THE TAKESHITA FACTION OF THE LIBERAL DEMOCRATIC PARTY, AND HIS PERFORMANCE AS JAPAN'S CHIEF EXECUTIVE.

06383 MICHITOSHI, T

THE CHALLENGE OF THE FLOATING VOTE

JAPAN QUARTERLY, XXXIXX(4) (OCT 92), 426-433.

CAPRICIOUS VOTERS NOW PLAY A CRITICAL ROLE IN JAPANESE POLITICS. IN THE 1989 HOUSE OF COUNCILORS ELECTIONS, THE RULING LIBERAL DEMOCRATIC PARTY SUFFERED A CRUSHING DEFEAT AND LOST ITS MAJORITY IN THE UPPER HOUSE BECAUSE THE SOCIAL DEMOCRATIC PARTY OF JAPAN (SDPJ) AND THE RENGO NO KAI ATTRACTED THE FLOATING VOTE. IN 1992, THE SDPJ FLOUNDERED AND THE RENGO NO KAI WAS TROUNCED BECAUSE NEITHER PARTY IMPRESSED THE FLOATING VOTERS WHILE THE FLEDGLING JAPAN NEW PARTY OFFERED YOTERS HOPE AND WAS REWARDED AT THE POLLS.

06384 MICHTA, A.

EAST-CENTRAL EUROPE IN SEARCH OF SECURITY

SAIS REVIEW, 11(1) (WIN 91), 59-72.

THE CHALLENGE FACING THE WEST TODAY IS HOW TO GRADUALLY INCORPORATE THE CLOSE TO 140 MILLION EAST EUROPEANS INTO THE POL ITICAL AND ECONOMIC STRUCTURES OF AN INCREASINGLY INTEGRATED EUROPE. NOW RELEASED FROM DIRECT SOVIET CONTROL. THE EAST EUROPEANS ARE FACED HITH STAGGERING ECONOMIC PROBLEMS AND NO EXPERIENCE IN THE WORKINGS OF REPRESENTATIVE GOVERNMENT. A NECESSARY PRECONDITION FOR THE SUCCESS OF DEMOCRATIC REFORM IS A STABLE SECURITY FRAMEWORK TO REPLACE THE NOW DEFUNCT HARSAH PACT STRUCTURES. HOWEVER, THE OUTCOMES OF THE 1990 ELECTIONS IN EASTERN EUROPE POINT TO A DEEPENING DIVISION BETWEEN THE POL ITICS OF POLAND CZECHOSLOVAKIA, AND HUNGARY ON THE ONE HAND, AND ROMANIA,
BULGARIA, YUGOSLAVIA, AND ALBANIA ON THE OTHER, A SUCCESSFUL REINTEGRATION OF THE MORE REFORM-ORIENTED POLAMD,

CZECHOSLOYAKIA, AND HUNGARY WITH THE REST OF THE' CONTINENT IS THE NECESSARY FIRST STEP ON THE ROAD TO A VIABLE COLLECTIVE SECURITY SYSTEM AND CONSEOUENTLY, TO POLITICAL AND ECONOMIC COOPERATION IN EUROPE AS A WHOLE.

06385 MIDOENDORP, $C$.

LEFT-RIGHT' SELF-IDENTIFICATION AND (POST)MATERIALISM IN THE IDEOLOGICAL SPACE

ELECTORAL STUDIES, 11(3) (SEP 92), 249-260

LEFT-RIGHT SELF-IDENTIFICATION APPEARS TO BE ASSOCIATED IN THE DUTCH ELECTORATE WITH THE TWO DIMENSIONS COMPRISING THE \$IDEOLOGICAL SPACE': SOCIO-ECONOMIC (EGALITARIAN) LEFTRIGHT ANO POLITICO-CULTURAL LIBERTARIANISM-AUTHORITARIANISM. THIS STUDY SHOWS THE STABLE TWO-DIMENSIONALITY OF THIS ¿SPACE'. THE STUDY CONCLUDES THAT NEITHER LEFT-RIGHT SELFIDENTIFICATION OR (POST)MATERIALISM SEEM FRUITFUL APPROACHES TO THE REALM OF IDEOLOGY AND VALUES. THE RESULTS OF THIS STUDY CHALLENGE BOTH THE NIEMOLLER-VAN DER EIJK POSITION ON LEFT-RIGHT SELF-IDENTIFICATION AND THE VAN DETH-GEURTS

POSITION ON (POST) MATERIALISM.

06386 MIDDENDORP, C.P.

IDEOLOGY IN DUTCH POLITICS: THE OEMOCRATIC SYSTEM IDEOLOGY IN DUTCH POLITICS

YAN GORCUM, $1991,370$.

THIS BOOK IS A STUDY OF THE STRUCTURE AND CHANGING CHARACTERISTICS OF IDEOLOGY IN THE NETHERLANOS. IT IS BASED ON FOUR SURVEYS OF THE DUTCH PUBLIC, CONDUCTED AT FIVE-YEAR INTERVALS BETWEEN 1970 AND 1985. THE CORE OF THESE SURVEYS IS A SERIES OF 55 VALUE STATEMENTS. TAKEN TOGETHER, THE STATEMENTS ON HUMAN NATURE, THE RELATION BETWEEN MAN AND
SOCIETY, AUTHORITY, DEMOCRACY, CLASS RELATIONS, AND THE ROLE SOCIETY, AUTHORITY, DEMOCRACY, CLASS RELATIONS, AND THE POLITICAL VALUES. THESE CORE QUESTIONS WERE ALSO POSED TO MEMBERS OF THE DUTCH PARLIAMENT IN 1971 AND 1981. THUS, LONGITUDINAL CHANGE IN POLITICAL VALUES IS MAPPED FOR BOTH ELITES AND THE PUBLIC, AND THE THO GROUPS ARE COMPARED WITH EACH OTHER.

06387 MIDLARSKY, M.

THE ORIGINS OF DEMOCRACY IN AGRARIAN SOCIETY: LAND INEQUALITY AND POLITICAL RIGHTS

JOURNAL OF CONFLICT RESOLUTION, 36(3) (SEP 92), 454-477. THREE MODELS FOR THE DEVELOPMENT OF DEMOCRACY IN AGRARIAN SOCIETY DURING THE PERIOD FROM 1973 TO 1989 ARE EXAMINED EMPIRICALLY. BUILDING ON ACCOUNTS OF THE DEVELOPMENT OF DEMOCRACY IN ANCIENT ATHENS AND PRIOR DEVELOPMENT OF DEMOCRACY IN ANCIENT ATHENS AND PRIOR
SYSTEMATIC STUDIES, IT IS SUGGESTED THAT AGRICULTURAL SYSTEMATIC STUDIES, IT IS SUGGESTED THAT AGRICULTURAL
DENSITY IS RELATED TO LAND INEQUALTIY, WHICH IN TURN LEADS DENSITY IS RELATED TO LAND INEQUALTIY, WHICH IN TURN LEADS
TO INCREASED POLITICAL RIGHTS IN FROMERLY TRIBAL/HEREDITARY TO INCREASED POLITICAL RIGHTS IN FROMERLY TRIBAL/HEREDITARY AOLI CONSEQUENCE OF THIS LAND INEOUALITY, HHICH IN TURN LEADS TO INCREASED POL ITICAL RIGHTS AFTER SOME VIOLENT POL ITICAL TO INCREASED POLITICAL RIGHTS AFTER SOME VIOLENT POLITICAL
UPHEAVAL. THE THIRD MODEL SUGGESTS URBANIZATION AND TRADE UPHEAVAL. THE THIRD MODEL SUGGESTS URBANI ZATION AND TRADE BEGIN THE PROCESS, AND IN TURN ECONOMIC DEVELOPMENT THEN
LEADS TO INCREASED POLITICAL RIGHTS. SUPPORT IS FOUND FOR LEADS TO INCREASED POLITICAL RIGHTS. SUPPORT IS FOUND FOR THE ATHENIAN AND ECONOMIC DEVELOPMENT MODELS, THEREFOR EMPHASIZING THAT POLITICAL VIOLENCE RECEIVES THE LEAST DEMOCRACY IN AGRARIAN SOCIETY IS THE ROBUST INFLUENCE OF LAND INEQUALITY ON POLITICAL RIGHTS, DISCOVERED UNDER A VARIETY OF ANALYTIC CONDITIONS.

06388 MIDRE, $G$

BREAD OR SOLIDARITY? ARGENTINE SOCIAL POLICIES, 1983-1990 JOURNAL OF LATIN AMERICAN STUDIES, $24(2)$ (MAY 92), 343-374. THE AUTHOR DESCRIBES THE INTRODUCTION OF PAN ("PROGRAMA ALIMENTARIO NACIONAL") AND "BONO NACIONAL SOL IDARIO DE EMERGENCIA," THO SOCIAL POLICIES DESIGNED TO PROVIDE NOURISHMENT' TO ARGENTINA'S POOR FAMILIES. STUDYING THE INTRODUCTION OF THESE SOCIAL POLICIES ILLUMINATES THE VALUESTRUCTURE UPON WHICH ARGENTINE SOCIETY IS BUILT, HIGHLIGHTS SOME OF THE MAIN FUNCTIONS THAT HELFARE PROGRAMS PERFORM IN STRUCTURING THE RELATIONSHIP BETHEEN SOCIETY AND THE POLITICAL SYSTEM, AND ILLUSTRATES SOME KEY FEATURES OF THE ARGENTINE POLITICAL SYSTEM THAT INFLUENCE ITS ABILITY TO FORMULATE A COHERENT SOCIAL POLICY.

06389 MIDTTUN, A.

THE EUROPEAN MARKET FOR AVIATION: A SOCIOLOGICAL INOUIRY INTO THE POL ITICAL ECONOMY OF A COMPLEXLY ORGANIZED MARKET JOURNAL OF ECONOMIC ISSUES, 26(4) (DEC 92), 1063-1094.

THIS PAPER PRESENTS AH AMALYTICAL ALTERYATIVE TO TRADITIONAL OUANTITATIVE MARKET ANALYSIS BASED ON A DISCRETE STRUCTURAL AND PROCESSUAL ANALYSIS, WHERE INSTITUTIONS MULTIPLE ACTOR ORIENTATIONS, AND GENERALIZED EXCHANGE ARE CENTRAL ELEMENTS. THIS APPROACH DRAHS ON A BROAD TRADITION OF INSTITUTIONAL ECONOMICS AND ECONOMIC SOCIOLOGY AND IS STRONGLY INFLUENCED BY WHAT HAS EMERGED AS A SCANDINAVIAN TRADITION IN POL ITICAL ECONOMY. IT ARGUES THAT THE MORE THE IN A GIVEN TRANSACTION SYSTEM, THE LESS LIKELY IS THE 
EXPLANATORY POWER OF QUANTITATIVE, MARGINALISTIC SUPPLY/DEMAND MODELS. AND THE MORE LIKELY IS THE NEED FOR

06390 MIECZKOWSKI, B.

DYSFUNCTIONAL BUREAUCRACY

UNIVERSITY PRESS OF AMERICA, INC., 1991, 312.

"OYSBORGS" (DYSFUNCTIONAL ORGANIZATIONS) ARE EXAMINED THROUGH THE ESTABLISHMENT OF A THEORY OF THE DYSBORG AND SOME OF ITS THEORETICAL ANTECEDENTS; THE STUDY OF CONDITIONS UNDER WHICH DYBORGIAN ELEMENTS RECEDE IN FAVOR OF FUNCTIONAL BUREAUCRACY; AND THE REFORMULATION OF A THEORY OF BUREAUCRACY IN ACADEMIA. INCLUDED, AS WELL, IS A STUDY OF THE POLITICS OF BUREAUCRACY IN COMMAND ECONOMIES, AND AN INOUIRY INTO THE EXISTENCE OF CONVERGENCE AND DIVERGENCE IN THE OPERATION OF THE INSTITUTIONS OF BUREAUCRACY IN THE EAST AND WEST. AN EFFORT IS MADE TO TIE IT TO THE EARLIER WRITINGS OF DIFFERENT AUTHORS.

06391 MIECZKOWSKI, T.; ANGLIN, M.D.; COLETTI; S.; JOHNSON, B.D.;

RADELMANN, E.A.; WISH, E.D. 1990 's

JOURNAL OF URBAN AFFAIRS, 14(3-4) (1992), 337-357.

THE AUTHORS REVIEN AND ANALYZE CURRENT DRUG POLICY IN THE UNITED STATES. THEY STUDY THE DRUG-USING POPULATION, THE SOCIETAL CONSEQUENCES OF DRUG USE, ASPECTS OF TREATMENT OF COMPULSIVE DRUG USE, TREATMENT EFFICACY AND MODALITIES, WAYS OF FUNDING DRUG RESEARCH AND TREATMENT PROGRAMS, AND
PUNITIVE AND NON-PUNITIVE APPROACHES TO DRUG POLICY.

06392 MIHAILESCU, I.

THE SOCIAL SCIENCES IN A CHANGING ROMANI

INTERNATIONAL SOCIAL SCIENCE JOURNAL, 131(131) (FEB 92), 153-158.

THE DEMOCRATIZATION MOVEMENT WHICH HAS BEEN TRANSFORMING THE CENTRAL AND EASTERN EUROPEN COUNTRIES HAD IMPORTANT REPERCUSSIONS ON THE ROLE AND STATUS OF THE SOCIAL SCIENCES IN THESE SOCIETIES. THIS ARTICLE DESCRIBES THE CHANGES IN
THIS RESPECT IN ROMANIA. IT EXPLORES THE ROMANIAN REVOLTUION WHICH IS THE TERM TO DENOTE THE CHANGES WHICH HAVE TAKEN PLACE IN ROMANIA SINCE DECEMBER 1989.

06393 MIHAJLOV, M.

BACK IN YUGOSLAVIA

NEW LEADER, LXXIV(1) (JAN 91), 6-8

THE AUTHOR OF THIS ARTICLE RECOUNTS HIS IMPRESSION UPON

HIS RETURN TO YUGOSLAVIA AFTER YEARS OF EXILE. ONLY OVER THE HIS RETURN TO YUGOSLAVIA AFTER YEARS OF EXILE. ONLY OVER THE
PAST YEAR, UNDER PRESSURE FROM THE 1989 EVENTS IN EASTERN PAST YEAR, UNDER PRESSURE FROM THE 1989 EVENTS IN EASTERN EUROPE AND THE DESTRUCTION OF THE COMAUNIST PARTY IN MOST OF THE REPUBLICS, HAVE YUGOSLAV AUTHORITIES ALLOWED MULTI-PARTY
ELECTIDNS. THE RESULT HAS BEEN THE OUSTING OF THE COMMUNISTS ELECTIONS. THE RESULT HAS BEEN THE OUSTING OF THE COMHUNISTS IN SLOVENIA, CROATIA, BOSNIA HERCEGOVINA, AND MACEDONIA, AND THE RETENTION OF COMHNIST CONTROL IN SERBIA AND MONTENEGRO. THIS ELECTORAL RESULT COMBINES WITH NATIONALISTIC EUPHORIA TO CREATE A SITUATION IN HHICH CIVIL WAR SEEMS A DISTINCT POSSIBILITY. THE RELATIVE PEACE ON
UNDERLYING TENSION AND CONFLICT.

06394 MIHAJLOV, M.

HHY BOSNIA IS NOT A GQUAGMIRE'

NEH LEADER, LXXV(10) (AUG 92) 5

TODAY THE MAIN ARGUMENT AGAINST TAKING DIRECT ACTION TO

HALT THE ATROCITIES BEING COMMITTED IN BOSNIA AND

HERZEGOVINA IS THAT U.S. AND EUROPEAN FORCES WOULD FIMD

THEMSELVES CAUGHT IN A "VIETNAM-LIKE QUAGMIRE." THIS ARTICLE SUGGESTS THAT THIS IS WRONG. IF THE INTERNATIONAL COMMUNITY WERE TO INTERVENE TO STOP THE PRESENT SENSELESS BLOODSHED
AND HUMAN SUFFERING, IT WOULD BE EMBRACED BY THE ORDINARY PEOPLE AS A LIBERATOR, NOT AN OCCUPIER. THE LONGER THE HORLD REMAINS PARALYZED BY ITS VISIONS OF A QUAGMIRE, THE MORE DIFFICULT AND COSTLY IT WILL BE TO RESTORE EVEN A MINIMUM OF JUSTICE WHERE TERRORISM REIGNS.

06395 MIHALISKO, $K$.

BELARUS

RFE/RL RESEARCH REPORT, 1(7) (FEB 92), 6-10

THE BELARUSIAN CAPITAL OF MINSK WAS CHOSEN TO BE THE OFFICIAL RESIDENCE OF THE COORDINATING BODIES OF THE COMHONWEALTH OF INDEPENDENT STATES, BUT SOME MATIONALLYMINDED POLITICIANS ARE CONCERNED THAT THE ROLE WILL INTERFERE WITH THE TASK OF BUILDING AN INDEPENDENT AND EURDPEAN-ORIENTED BELARUSIAN STATE. AT THE MOMENT, HOWEVER, THE FUTURE COMMONHEALTH IS NOT HIGH ON BELARUSIANS POLITICAL AGENDA: ABOVE ALL. THEY ARE CONCERNED HITH THE FATE OF THE INCUMBENT GOVERNMENT AND SUPREME SOVIET, WHICH FATE OF THE INCUMBENT GOVERNMENT AND SUPREME SOVIET, WHICH IS UNDER WAY TO DISSOLVE THE PARLIAMENT SO THAT BELARUS CAM ENTER A NEW ERA WITH A NEW SET OF LEADERS.

06396 MIHALISKO, K.

BELARUS MÓVES TO ASSERT ITS OWM MILITARY POLICY RFE/RL RESEARCH REPORT, 1(11) (MAR 92), 47-50.

AT THE SUMMIT MEETING OF LEADERS OF THE COMMONHEALTH OF
INDEPENDENT STATES ON FEBRUARY 14, 1992, BELARUS DECLARED IT WILL HAVE ITS OWN ARMY AT THE END OF A TWO-YEAR TRANSITIONAL PERIOD. BECAUSE OF THE POLITICAL AND MILITARY SITUATION IN BELARUS, THIS PLAN IS FRAUGHT WITH THE POTENTIAL FOR CONFRONTATION. THE COMMANDER OF THE CIS BELARUSIAN MILITARY DISTRICT, GENERAL ANATOLII KOSTENKO, IS A POWERFUL OPPONENT OF NATIONAL ARMIES, AND HE CAN COUNT ON SUPPORT FROM THE NUMEROUS RIGHT-WING MEMBERS OF THE BELARUSIAN PARLIAMENT. THE SEMI-UNDERGROUND COMMUNIST PARTY CONTINUES TO REGARD A STRONG AND UNITED COMMONWEALTH ARMY AS ITS BEST HOPE FOR AN EVENTUAL SETTLING OF SCORES WITH DEMOCRATS AND "NATIONALISTS.

06397 MIHALISKO, $K$.

BELORUSSIA: SETTING SAIL HITHOUT A COMPASS

RFE/RL RESEARCH REPORT, 1 (1) (JAN 92), 39-41.

IN 1991, IMPORTANT STRIDES WERE MADE IN THE DEVELOPMENT OF BELORUSSIA'S SENSE OF STATEHOOO. THE PUBLIC BEGAN TO HOLD BELORUSSIAN RATHER THAN SOVIET LEADERS ACCOUNTABLE FOR IMPORTANT ISSUES AND PROBLEMS; MINSK STARTED TO ANSHER TO ITS OWN POPULATION RATHER THAN TO THE LEADERHIP IN MOSCOW. A TURNING POINT CAME IN APRIL WHEN STAGGERING CONSUMER PRICE INCREASES TOOK EFFECT THROUGHOUT THE USSR. IN A SERIES OF STRIKES AND DEEONSTRATIONS, TENS OF THOUSANDS OF FACTORY WORKERS VENTED THEIR ANGER AT THE BELORUSSIAN AUTHORITIES, WHO HAD SILENTLY ACCEPTED POLICIES FROM MOSCOW THAT HAD PRODUCED THESE AND OTHER HARDSHIPS.

06398 MIHALISKO, K.

PUBLIC CONFIDENCE IN THE UKRAINIAN LEADERSHIP

RFE/RL RESEARCH REPORT, $1(43)$ (OCT 92), 8-14.

ACCORDING TO A PUBLIC OPINION POLL, PRESIDENT LEONID

KRAVCHUK IS THE MOST AUTHORITATIVE FIGURE ON THE UKRAINIAN POL ITICAL LANDSCAPE, ENJOYING THE CONFIDENCE OF 44\% OF THE POPULATION. HOWEVER, THE PRESIDENT'S POPULARITY RATIMG IS UNEVEN GEOGRAPHICALLY; IT IS HIGHEST IN NATIONAL - MINDED WESTERN UKRAINE AND LOWEST IN EASTERN UKRAINE, WHERE LABOR STRIFE IS A PROBLEM. UKRAINE'S ETHNIC RUSSIAN RESIDENTS ARE LESS SUPPORTIVE OF KRAVCHUK THAN ETHNIC UKRAIMIANS ARE. THE POLL REVEALS THAT DISSATISFACTION WITH VITOLD FOKIN, WHO RECENTLY RESIGHED AS PRIME MINISTER, IS FAIRLY BRDAD-BASED. HIS SUCCESSOR, LEONID KUCHMA, IS A PRODUCT OF THE INDUSTRIAL THAT CRUCIAL REGION. WHETHER HE AND KRAYCHUK CAN APPEASE THE THAT CRUCIAL REGION. WHETHER HE AND KRAYCHUK CAN APPEAS
EAST HITHOUT ALIENATING THE WEST REMAINS TO BE SEEN.

06399 MIHALISKO, $K$.

UKRAINE ASSERTS CONTROL OVER NONSTRATEGIC FORCES

RFE/RL RESEARCH REPORT, 1(4) (JAN 92), 50-53.

SINCE THE FAILED COUP D'ETAT IN AUGUST 1991, UKRAINE HAS MADE A DETERMINED EFFORT TO ESTABLISH ITS OWN ARMED FORCES FROM CONVENTIONALLY-ARMED UNITS OF THE FORMER SOVIE MILITARY. THE PROCESS IS HELL AHEAD OF SCHEDULE DUE TO THE REMARKABLE CHAIN OF EVENTS THAT BEGAN WITH THE UKRAINIAN INDEPENOENCE REFERENDUM AND THE BIRTH OF THE COMHONMEALTH OF INDEPENDENT STATES. BUT CONFLICTS OVER THE DIVISION OF ARMY ASSETS HAVE ARISEN, AND ARE BOUND TO ARISE IN THE FUTURE, THAT COULD SERIOUSLY UNDERMINE THE COMHONHEALTH.

06400 MIKHEEV, V.; OSTROVIDOVA, H.

A PROBLEM OF SOVEREIGNTY: THE SOVIET AND YUGOSLAY CASES

KOREA \& WORLD AFFAIRS, 16(1) (SPR 92), 100-119.

THE AUTHOR EXAMINES THE MAJOR TRENDS OF

"SOVEREIGNIZATION" IN THO FORMERLY SOCIALIST STATES,

YUGOSLAVIA AND THE SOVIET UNION. HE DISCUSSES THE

INTERNATIONAL CONSEQUENCES OF "SOVEREIGNIZATION" AND THE LESSONS THAT ASIA'S SOCIALIST STATES CAN LEARN FROM EASTERN EUROPE.

06401 MILANI, M.

IRAN'S ACTIVE NEUTRALITY DURING THE KUWAIT CRISIS: REASONS AND RAMIFICATIONS

NEW POLITICAL SCIENCE, 21-22 (SPR 92), 41-60.

SINCE 1989, IRANIAN FOREIGN POLICY' HAS BECOME

INCREASINGLY MODERATE. IRAN'S ACTIVE NEUTRALITY DURING THE IRAQI OCCUPATION OF KUWAIT IS SYMPTOMATIC OF THIS MODERATION. RAFSANJANI'S NEW THINKING WAS PART OF HIS STRATEGY TO REBUILD IRAN'S SHATTERED ECONOMY AND TO IMPROVE RELATIONS WITH THE WEST AND WITH THE ARABS OF THE PERSIAN GULF. IRAN BENEF ITED ENORMOUSLY FROM THE KUWAIT HAR AND IRAN HAS BECOME THE REGION'S MOST POWERFUL INDIGENOUS FORCE.

06402 MILEUR, J.M.

THE POLITICS OF E.E. SCHATTSCHNEIDER

PS: POLITICAL SCIENCE AND POLITICS, XXV(2) (JUN 92), PS: POLITIC $176-180$.

E.E. SHATTSCHNEIDER'S POLITICS DEFY EASY CATEGORIZATION. WIDELY RESPECTED AND HONORED WITHIN THE DISCIPLINE OF POL ITICAL SCIENCE, HE NEYERTHELESS SEEMS TO BE A KIND OF ANT I - HERO WHO WAS A BIT OUT OF STEP WITH HIS PEERS. HE WAS ALSO OUT OF STEP WITH THE REFORMIST POLITICS OF HIS TIME BECAUSE HE SHARED THE GENERAL OPTIMISM OF PROGRESSIVES BUT WAS MORE CONCERNED WITH POLITICS THAN WITH DEMOCRACY. HE ARGUED THAT "THE CORE OF THE DIFFICULTIES WITHIN THE 
GOVERMMENT OF THE UNITED STATES IS POLITICAL."

06403 MILGATE, M.; STIMSON, $S$.

RICARDIAN POLITICS

PRINCETON UNIVERSITY PRESS, 1992, 176

THIS BOOK EXAMINES THE COMPELLING BUT NEGLECTED EVIDENCE OF HOH CLASSICAL ECONOMIST DAVID RICARDO DEPLOYED ECONOMIC THEORY TO CONSTRUCT A NEW VIEH OF POLITICS. THE AUTHORS ANALYZE THE CASE FOR A MORE INCLUSIVE POLITICAL SOCIETY AND FOR A MORE REPRESENTATIVE AND DEMOCRATIC GOVERNMENT, DISCUSS HOW HIS ARGUMENT WAS STRUCTURED BY HIS ECONOMICS, AND EXPLICITLY DRAH OUT COMPARISONS WITH BENTHAM AND' JAMES MILL. RICARDO WROTE AT A CRITICAL MOMENT, WHICH SAH THE CONSOLIDATION OF CAPITALIST INDUSTRY AND THE EMERGENCE OF MODERN DEMOCRATIC POLITICAL IDEOLOGY. BY ATTENDING TO THIS HISTORICAL CONTEXT, THIS BOOK RECOVERS A MORE ACCURATE PICTURE OF HIS THOUGHT, WHILE CONTRIBUTING TO THE CURRENT RENEWAL OF RESEARCH ON' THE RELATIONSHIP BETWEEN ECONOMIC AND POLITICAL THOUGHT IN EARLY NINETEENTH-CENTURY BRITAIN.

06404 MILIBAND, $R$.

THE SOCIALIST ALTERMATIVE

JOURAAL OF DEMOCRACY, 3(3) (JUL 92), 118-124

THE COLLAPSE THE SOVIET EMPIRE HAS LED MANY TO DECLARE SOCIALISM DEAD AND CAPITALISM ASCENDANT. IN OPPOSITION TO THIS LINE OF REASONING. THIS ARTICLE ARGUES THAT THERE DOES INDEED EXIST A RADICAL ALTERMATIVE ON THE LEFT TO CAPITALIST DEMOCRACY. THIS ALTERNATIVE IS SOCIALIST DEMOCRACY, WHICH HAS NOTHING WHATSOEVER TO DO WITH SOVIET COMMUNISM. THE ARTICLE SUGGESTS THAT CAPITALIST DEMOCRACY IS A CONTRADICTION IN TERMS. ONE THE ONE HAND, CAPITALISM IS A SYSTEM OF ECONOMIC ORGAMIZATION THAT DEMANDS THE EXISTENCE OF A RELATIVELY SMALL CLASS OF PEOPLE WHO OWH AND CONTROL THE MAIN MEANS OF INDUSTRIAL, COMMERCIAL AND FINANCIAL ACTIVITY. ON THE OTHER HAND, THERE IS DEMOCRACY WHICH IS BASED ON THE DENIAL OF SUCH PREPONDERANCE, AND WHICH REQUIRES A ROUGH EQUALITY OF CONDITION THAT CAPITALISH REPUDIATES BY ITS VERY NATURE. EVEN THE ADVOCATES OF CAPITALISM ACKNONLEDGE THAT PROBLEMS SUCH AS UNEMPLOYMENT, POLLUTION, DRUGS, AND CRIME ARE PART AND PARCEL OF THE SYSTEM. SOCIALIST DEMOCRACY PROVIDES A VIABLE, ALBEIT NOT VERY LIKELY AT THE PRESENT, ALTERNATIVE TO CAPITALISM.

06405 MILIBAND, R. (ED.); PANITCH, L.

NEW WORLD ORDER? SOCIALIST REGISTER 1992

MONTHLY REVIEH PRESS, $1992,360$.

IN THIS VOLUME, SEVENTEEN SCHOLARS ANALYZE TOPICS IN THIS VOLUME, SEVENTEEN SCHOLARS ANALYZE TOPICS
RANGING FROM U.S. MILITARY POLICY TO PERESTROIKA TO RANGING FROM U.S. MILITARY POLICY TO PERESTROIKA TO
HOLLYYOOD'S VERSION OF THE NEW WORLD. THE COMMON THEME HOLLYYWOOD'S VERSION OF THE NEH WORLD. THE COMMON THEME
LINKING THE ESSAYS IS THE NEW WORLD ORDER. GENERAL

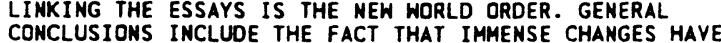
OCCURRED IN THE NORLD IN THE PAST DECADE: FROM THE IMPACT OF THE GLOBALIZATION OF CAPITAL TO THE UMITED STATES. NEH THE GLOBALIZATION OF CAPITAL TO THE UNITED STATES' NEH STATUS AS THE ONLY TRUE SUPERPOWER LEFT ON EARTH. BUT THERE ARE DISTURBING PARALLEL TRENDS: CAPITAL MAY BE GLOBAL, BUT
CONDITIONS IN THE THIRD WORLD HAVE WORSENED. THE U.S. MAY BE CONDITIONS IN THE THIRD WORLD HAVE WORSENED. THE U.S. MAY
THE ONLY REMAINING SUPERPOWER, BUT IT SUFFERS INTERMAL THE ONLY REMAINING SUPERPOWER, BUT IT SUFFERS INTERMAL
CRISIS AND A LOSS OF ITS ECONOMIC HEGEMONY TO GERMANY AND JAPAN. AND THEN THERE IS THE LUMBERING SHIFT OF THE FORMER COMMUNIST COUNTRIES OF EASTERN EUROPE TOWARDS PERIPHERAL CAPITALISM AND AN UNKNOWN FUTURE. SUCH IS THE NEW WORLD ORDER OF TODAY.

06406 MILKIS, S.M.

E.E. SCHATTSCHNEIDER, THE NEW DEAL, AND THE REJECTION OF THE RESPONSIBLE PARTY DOCTRINE

PS: POLITICAL SCIENCE AND POLITICS, XXV(2) (JUN 92),

180-186

THE AUTHOR DISCUSSES E.E. SCHATTSCHNEIDER'S VIEWS ON THE AUTHOR DISCUSSES E.E.
RESPONSIBLE PARTY GOVERHMENT.

06407 MILLAR, T.B.

A NEH WORLD ORDER?

WORLD TODAY, 48(1) ( JAN 92), 7-9

THE AUTHOR ANALYZES SOME OF PRESIDENT GEORGE BUSH'S

STATEMENTS ABDUT HIS VISION OF A NEW WORLD ORDER.

06408 MILLARD, $M$

JAPAN'S FIRST BLUE-EYED POLITICIAN IN YUGAWARA JAPAN TIMES (WEEKLY INTERNATIONAL EDITION), 32(17) (APR

92), 1,7

MARUTEI TSURUNEN, A FINM WHO JAPANIZED HIS MAME, RECENTLY MADE HISTORY BY BECOMING THE FIRST NON-ASIAN NATURALIZED CITIZEN TO WIM A PLACE IN THE JAPANESE NOVRALIEN CIITEN HE HAS ELECTED TO THE TOWN ASSEMBLY IN YUGARARA. IN THE PAST, TSURUMEN HAS BEEN INVOLVED WITH RELIGIOUS AND SOCIAL CONCERNS, AND HE SAYS THAT HE CONSIDERS RELIGIOUS AND SOCIAL CONCERNS, AND HE SAYS THAT HE CONS
POLITICS TO BE AN EXTENSION OF HIS PAST INVOLYEMENTS.

06409 MILLER, A.; BORRELLI, S

CONFIDENCE IN GOVERMMENT DURING THE 1980

AMERICAN POLITICS QUARTERLY, 19(2) (APR 91), 147-173.

DATA FROM THE AMERICAN NATIONAL ELECTION STUDIES ARE

USED TO EXAMINE TRENDS IN POLITICAL TRUST FOR THE PERIOD OF
1980 TO 1988. THE DATA REVEAL A SUBSTANTIAL GROWTH IN TRUST DURING THE FIRST HALF OF THE EIGHTIES, FOLLOWED BY PLUMMETING CONFIDENCE IN GOVERMHENT AT THE END OF THE DECADE. A NUMBER OF PLAUSIBLE EXPLANATIONS FOR THESE SHIFTS IN PUBLIC TRUST ARE EXAMINED. THE ANALYSIS REVEALS THAT THE DOWNTURN IN TRUST AFTER 1984 HAS NOT A RESPONSE TO THE IRANCONTRA SCANDAL OF 1986. RATHER, IT REFLECTED THE EMERGING PERCEPTION THAT REAGAN LACKED COMPASSION, AS WELL AS GROWING DISSATISFACTION WITH FOREIGN AND DOMESTIC POLICIES.

06410 MILLER, A.

ECONOMIC MODELS AND POLICY ON GLOBAL HARMING

ENVIRONMENT, 33(6) (JUL 91), 3-5, 43-44

UNITED STATES OFFICIALS OFTEN CITE STUDIES THAT CONCLUDE THAT SUBSTANTIAL GREENHOUSE GAS REDUCTIONS MIGHT IMPOSE SUBSTANTIAL COSTS ON THE ECONOMY TO JUSTIFY THEIR INACTION ON THE ISSUE. DESPITE THE EMPHASIS POLICYMAKERS ATTACH TO ECONOMIC MODELS, THERE IS SURPRISINGLY LITTLE DISCUSSION OF THEIR VALIDITY AND UNCERTAINTIES. THIS ARTICLE EXAMINES SOME OF THE STUDIES AND CONCLUDES THAT THE MODELS ARE A FORM OF STATISTICAL ECONOMICS THAT DREW WIDESPREAD CRITICISM IN THE $1970 S$ AND EARLY 1980 S FOR FAILING TO CONSIDER MICRO-ECONOMIC 1970S AND EARLY $1980 S$ FOR FAILING TO CONSIOER MICRO-ECO AND ENGINEERING ASPECTS OF ENERGY USE. MOST SCENARIOS
PERFORMED THO DECADES AGO AND DRAWH FROM THAT KIND OF PERFORMED THO DECADES AGO AND DRAWN FROM THAT KIND OF
MACROECDNOMICS WERE DRAMATICALLY WRONG ABOUT THE ENERGY MACROECONI
FUTURE.

06411 MILLER, A.; BORELLI $S$.

POLICY AND PERFORMANCE ORIENTATIONS IN THE UNITED STATES ELECTORAL STUDIES, 11(2) (MAY 92), 106-121

IN 1980 AND 1984 UNITED STATES ELECTIONS MARKED A MAJOR TURNING POINT IN THE IDEOLOGICAL ORIENTATION OF PUBLIC POLICY. MANY ARGUED THAT THESE ELECTIONS REFLECTED A POLICY MANDATE BY THE ELECTORATE WHO PREFERRED REAGAN'S CONSERVATIVE POLICIES. TWO DIMENSIONS ARE EMPLOYED TO COMPARE VOTING DECISIONS IN THE ELECTIONS FROM 1952 TO 1984. THIS ARTICLE CONCLUDES THAT IN 1984 REAGAN ENJOYED A LANDSLIDE RE-ELECTION VICTORY BECAUSE A SUBSTANTIAL FRACTION OF THE ELECTORATE VOTED AGAINST THEIR OWN POLICY. THE 1984 ELECTION OUTCOME, WAS A REHARD, NOT A MANDATE.

06412 MILLER, B.

EXPLAINING GREAT POWER CDOPERATION IN CONFLICT MANAGEMENT WORLD POLITICS, 45(1) (OCT 92), 1-46.

THE AUTHOR EXPLAINS GREAT POHER COOPERATION IN CONFLICT MANAGEMENT THROUGH A THEORETICAL MODEL THAT REFINES RECENT COOPERATION THEORY BY DISTINGUISHING BETHEEN TYPES AND DEGREES OF INTERNATIONAL COOPERATION. IT ALSO CHALLENGES THE DEMINANCE OF DECISION-MAKING ANALYSIS IN THE CRISIS

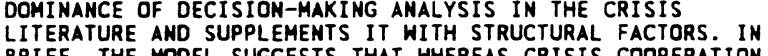
BRIEF, THE MODEL SUGGESTS THAT WHEREAS CRISIS CDOPERATION
(CRISIS MANAGEMENT) IS CONDITIONED BY STRUCTURAL ELEMENTS, (CRISIS MANAGEMENT) IS CONDITIONED BY STRUCTURAL ELEMENT COOPERATION IN NORMAL DIPLOMACY (CONFLICT RESOLUTION)
DEPENDS ON STATE ATTRIBUTES AND COGNITIVE FACTORS. SUCH A DEPENDS ON STATE ATTRIBUTES AND COGNITIVE FACTORS. SUCH MODEL CAN ACCOUNT FOR THE FACT THAT UNINTENDED WARS CAN BREAK OUT BETHEEN RELATIVELY MODERATE AND SIMILAR ACTORS WHILE IMMODERATE ANO DISSIMILAR STATES CAN MANAGE CRISES
EFFECTIVELY. AT THE SAME TIME, THE MODEL EXPLAINS WHY SOME EFFECTIVELY. AT THE SAME TIME, THE MODEL EXPLAINS WHY SOME STATES ARE ABLE TO COOPERATE IN NORMAL DIPLOMACY
OTHERS, EVEN WHEN MORE ACTORS ARE COOPERATING

06413 MILLER, B.

GPS PRÓVES ITS WORTH IN OPERATION DESERT STORM

ARMED FORCES JOURNAL INTERNATIONAL, (APR 91), 16,20

THE U.S. MILITARY SERVICES ARE MAKING MAJOR STRIDES IN EXPANDING THE USE OF THE NAVSTAR GLOBAL POSITIONING SYSTEM (GPS), SPURRED IN PART BY THE HIGHLY ACCURATE SATELLITEBASED NAVIGATION SYSTEM IN THE PERSIAN GULF HAR. ANY LINGERING DOUBT'S ABOUT GPS'S PROFOUND MILITARY UTILITY WERE SWEPT AWAY DURING DESERT STORM BY ITS PERFORMANCE IN THE AIR FORCE, NAYY AND ARMY.

06414 MILLER, B

PRESIDENTIAL ADORESS: CONTENDING NARRATIVES--THE POLITICAL LIFE OF THE INDIAN EPICS

JOURNAL OF ASIAN STUDIES, 50(4) (NOY 91), 783-817.

IN HER PRESIDENTIAL ADDRESS, BARBARA STOLER MILLER EXAMINES THE CONNECTIONS BETHEEN RELIGION AND NATIONAL POLITICS IN PRESENT-DAY ASIA. SHE BELIEVES IT IS NECESSARY TO INVESTIGATE THE UNDERLYING CULTURAL PATTERNS AND CONCEPTUAL SYSTEMS OF THE PAST. SHE CAUTIONS THAT SCHOLARS CONCEPTUAL SYSTEMS OF THE PAST. SHE CAUTIONS THAT SCHOLARS OFTEN MASK THE SERIOUSNESS OF THEIR WORK. MUCH OF PRESENTDAY SCHOLARSHIP IS SEARCHING FOR LINKS BETWEEN THE CONTROL OF KNOHLEDGE AND THE EXERCISE OF POH

06415 MILLER, D.

A DOMESTIC AGENDA TO STRENGTHEN AMERICA

WASHINGTON QUARTERLY, 15(2) (SPR 92), 205-224.

THIS RESEARCH SURVEY FOCUSES ON THE DOMESTIC AGENDA THE UNITED STATES MUST CONSIDER IF IT IS TO FREE ITSELF OF THE CONSTRAINTS THAT LIMIT ITS ABILITY TO EXERCISE EFFECTIVE INTERNATIONAL LEADERSHIP IN THE YEARS AHEAD. IT BEGINS BY LISTING U.S. VULNERABILITIES, AND CONCLUDES WITH A STATEMENT 
THAT THE U.S. MUST FOCUS ON THESE ISSUES IF IT IS TO SUCCEED AS AN INTERNATIONAL POHER.

06416 MILLER, D.

DELIBERATIVE DEMOCRACY AND SOCIAL CHOICE

POLITICAL STUDIES, 40 (1992), 54-67.

THIS PAPER CONTRASTS THE LIBERAL CONCEPTION OF DEMOCRACY AS THE AGGREGATION OF INDIVIDUAL PREFERENCES WITH THE DELIBERATIVE CONCEPTION OF DEMOCRACY AS A PROCESS OF OPEN DISCUSSION LEADING TO AN AGREED JUDGEMENT ON POLICY. SOCIAL CHOICE THEORY HAS IDENTIFIED PROBLEMS--THE ARBITRARINESS OF DECISION RULES, VULNERABILITY TO STRATEGIC VOTING--WHICH ARE OFTEN HELD TO UNDERMINE DEMOCRATIC IDEALS. CONTRARY TO OFTEN HELD TO UNDERMINE DEMOCRATIC IDEALS. CONTRARY DEMOCRACY IS LESS VULNERABLE TO THESE DIFFICULTIES THAM DEMOCRACY IS LESS VULNERABLE TO THESE DIFFICULTIES THAN PIBERAL DEMOCRACY. THE PROCESS OF DISCUSSION TENDS TO PRODUCE SETS OF POLICY PREFERENCES THAT ARE SINGLE PEAKED; AND WITHIN A DELIBERATE SETTING IT MAY BE POSSIBLE TO VARY THE DECISIO
DECIDED.

06417 MILLER, D

THE REASON OF METAPHOR: A STUDY IN POLITICS

SAGE PUBLICATIONS, 1992, 268.

THE ESSAYS ASSEMBLED IN THIS VOLUME ARE ALL CONCERNED, IN DIFFERENT WAYS, WITH ANALYZING THE LIMITATIONS OF, AND EXPLORING ALTERNATIVES TO, THE DOMINANT POSITIVIST

CONCEPTION OF POLITICS. THE VIEWS EXPRESSED HERE PROVIDE THE BASIS FOR BOTH A COHERENT THEORETICAL CRITIQUE OF POSITIVISM AND AN ALTERNATIVE PHILOSOPHY OF POLITICS. THE BOOK EXAMINES POLITICS AS A LOCATION; THE HEST AND MODERN TIMES; INDIA AND OCCIDENTAL ACCIDENCE, AND THE POLITICS OF IRRESOLUTION.

06418 MILLER, G.

PICKING A GOVERNOR IN ARIZONA

NEW LEADER, LXXIV(1) (JAN 91), 12-13.

ON 26 FEBRUARY, ARIZONA WILL BE THE SCENE OF THE FIRST GUBERNATORIAL RUNOFF ELECTION EVER HELD IN THE UNITED STATES.

VOTERS HOPE THAT AT LEAST FOR THEM IT WILL ALSO BE THE LAST. THEIR DUBIOUS DISTINCTION IS COSTING THEM \$2.65 MILLION. THEIR DUBIOUS DISTINCTION IS COSTING THEM \$2.65 MILLION.
THE OUSTER OF FORMER GOVERNOR EVAN MECHAM GAVE IMPETUS TO A THE OUSTER OF FORMER GOVERNOR EVAN MECHAM GAVE IMPETUS TO A
MOVEMENT TO CHANGE ARIZONA'S LAWS TO REQUIRE THAT GOVERNORS MOVEMENT TO CHANGE ARI ZONA'S LAWS TO REQUIRE THAT GOVERNORS
BE ELECTED BY A MAJORITY. NOW DEMOCRAT TERRY GODDARD AND BE ELECTED BY A MAJORITY. NOW DEMOCRAT TERRY GODDARD AND REPUBLICAN FIFE SYMINGOTN FACE EACH OTHER IN AN "OVERTIME" RUIMED JUST ENOUGH YOTES TO PREVENT EITHER MAJOR CANDIDATE GAINED JUST ENOUGH VOTES TO PREVENT EITHER MAJOR CANDIDATE
FROM RECEIVING A MAJORITY. ARI ZONA'S VOTERS, ALREADY PLAGUED FROM RECEIVING A MAJORITY. ARI ZONA'S VOTERS, ALREADY PLAGUED
BY WIDESPREAD APATHY ARE LIKELY TO APPROVE THE ABOLITION OF BY WIDESPREAD APATHY ARE LIKELY TO APPROVE
THE MAJORITY REQUIREMENT IN THE FUTURE.

06419 MILLER, J.

DIRECT DEMOCRACY AND THE PURITAN THEORY OF MEMBERSHIP THE JOURNAL OF POLITICS, 53(1) (FEB 91), 57-74

THIS ESSAY EXPLORES THE POLITICAL IMPLICATIONS OF SEVENTEENTH CENTURY AMERICAN CONGREGATIONALISM. THE ESSAY DESCRIBES THE PURITAN THEORY OF CHURCH MEMBERSHIP AND RELATED IT TO CONTEMPORARY LIBERAL AND DEMOCRATIC NOTIONS OF CITIZENSHIP. THE AUTHOR SHAPELY DISTINGUISHES BETWEEN THE POLITICAL THEORIES OF DEMOCRACY AND LIBERALISM, AND DISCOVER THAT THE PURITANS WERE "PROTO-DEMOCRATS" IN THEIR ADVOCACY OF SMALL, HIGHLY AUTONOMOUS PARTICIPATORY COMMUNITIES. THE PURITAN THEORY OF COVENANTED CHURCH MEMBERSHIP REVEALS THE NATURE OF CITIZENSHIP IN A DIRECT DEMOCRACY. "UNIVERSAL MEMBERSHIP" IS MORE CHARACTERISTIC OF THE LARGE NATION THAM IT IS OF THE SMALL DEMOCRATIC COMMUNITY BECAUSE THE LATTER PLACES MORE PONER AND RESPONSIBILITY IN THE HANDS OF THE CITIZENRY AND BECAUSE DEMOCRACY IS IDENTIFIED HITH ITS CITIZENS RATHER THAN WITH ITS LEADERS OR AGENTS.

06420 MILLER, J.

TELEYISION AND THE AMERICAN PRESIDENTIAL CAMPAIGM HORLD TODAY, 48(4) (APR 92), 60-61.

THE TUTHO 48 (4) (APR 92), 60-61. MAKING OF A CANDIDATE'S IMAGE IN THE U.S. PRESIDENTIAL CAMPAIGN.

06421 MILLER, J.

THE RISE AND FALL OF DEMOCRACY IN EARLY AMERICA, 1630-1789: THE RISE AND FALL OF DEMOCRACY IN EARLY

PENN STATE PRESS, 1991, 154.

THIS BOOK CHRONICLES THE EMERGENCE AND DECLINE OF CLASSICAL, DIRECT DEMOCRACY IN VARIOUS PERIODS IN COLONIAL AND EARLY AMERICAN HISTORY. THE AUTHOR EXAMINES THE LOCAL AND EARLY AMERICAN HISTORY. THE AUTHOR EXAMINES THE LOCAL AND SHOWS THAT THEIR SEEMINGLY STRICT AND EXCLUSIVE STANDARDS ACTUALLY REVEAL THE SERIOUSNESS AND HONOR WITH WHICH THEY REGARDED CITIZENSHIP. THIS DEMOCRATIC CULTURE WAS THREATENED BY A CENTRALIZED GOVERNMENT DISTANT FROM MOST CITIZENS AND PRONE TO DICTATORIAL EDICTS THAT ERODE LOCAL SOVEREIGNTY AND DEMOCRACY, EVEN WHEN CONDUCTED IN THE NAME OF UNIVERSAL INDIVIDUAL RIGHTS AND "SOCIAL JUSTICE." THE AUTHOR ARGUES THAT THE FEDERALIST POLICIES OF CENTRALIZED GOVERMMENT AND ECONOMIC FREEDOM-BOTH CORROSIVE OF TRADITIONAL LOCAL. DEMOCRATIC COMMUNITIES AND STABLE SOCIAL
RELATIONS--CONSTITUTED THE BEGINNING OF THE END FOR REAL DEMOCRACY IN AMERICA. THE FEDERALISTS' DECEPTIVE AND MANIPULATIVE USE OF DEMOCRATIC LANGUAGE WAS CALCULATED TO ELIMINATE THE ONLY REAL PRACTICE OF DEMOCRACY IN AMERICA-LEAVING THE TRUE ELITE TO RUN THE COUNTRY FOR THEIR OWN INTERESTS.

06422 MILLER, J.J.

NEW REPUBLIC, 207 (23) (NOV 92), 12-13

DESPITE PRESIDENT GEORGE BUSH'S ADVOCACY OF SCHOOL

CHOICE THROUGH A VOUCHER SYSTEM, SOME CONSERVATIVES ARE

BACKING AWAY FROM THE IDEA. THEY FEAR THAT A LARGE INFLUX OF

PUBLIC, TAX MONEY INTO PRIVATE SCHOOLS WOULD ALLOW THE

GOVERNMENT TO INCREASE ITS REGULATORY ROLE IN PRIVATE

PRIVATE AND PAROCHIAL SCHOOLS.

06423 MILLER, M.

CITIZEN GROUPS: HOM DO THEY REPRESENT?

SOCIAL POLICY, 22(4) (SPR 92), 54-56

THE AUTHOR' DISTINGUISHES BETHEEN TWO CATEGORIES OF CITIZENS GROUPS: (1) DEMOCRATIC, VOLUNTARY MEMBERSHIP ORGANIZATIONS AND (2) SOCIAL AGENCIES AND PUBLIC INTEREST ORGANIZATIONS. THEN HE ENUMERATES THE VIRTUES AND DISADVANTAGES OF EACH TYPE OF ORGANIZATION.

06424 MILLER, M.C.

CONGRESSIONAL COMMITTEES AND THE FEDERAL COURTS: A NEOINSTI ITUTIONAL PERSPECTIVE

WESTERN POLITICAL QUARTERLY, 45(4) (DEC 92), 949-970.

USING A NEO-INSTITUTIONAL PERSPECTIVE, WHICH COMBINES THE TRADITIONALIST SCHOLAR'S INTEREST IN UNDERSTANDING GOVERNMENTAL BODIES AS INSTITUTIONS WITH THE BEHAVIORALISTS' EMPHASIS ON EMPIRICAL INDIVIDUAL-LEVEL RESEARCH, THIS PAPER EXAMINES HOW THREE CONGRESSIONAL COMMITTEES (INTERIOR, ENERGY AND COMMERCE, AND JUDICIARY) DIFFER IN THEIR GENERAL APPROACHES AND REACTIONS TO FEDERAL COURT DECISIONS. THE CONSTITUENCY-ORIENTED INTERIOR COMMITTEE RARELY REACTS AT ALL TO COURT DECISIONS, AND THEN ONLY IF CLIENTELE PRESSURES ALL TO COURT DECISIONS, AND THEN ONLY IF CLIENTELE PRESSURES FORCE IT TO DO SO. THE POHER-ORIENTED ENERGY AND COMMERCE
COMMITTEE TREATS THE COURTS AS JUST ONE MORE POLITICAL ACTOR COMMITTEE TREATS THE COURTS AS JUST ONE MORE POLITICAL ACTOR
IT WILL NOT HESITATE TO OVERTURN FEDERAL CDURT DECISIONS IT HILL NOT HESITATE TO OVERTURN FEDERAL COURT DECIS
WHEN POLITICAL CONSIDERATIONS REQUIRE IT. THE POLICYWHEN POLITICAL CONSIDERATIONS REQUIRE IT. THE POLICYINSTITUTION WITH A GREAT DEAL OF RESPECT, ALTHOUGH AFTER INSTITUTION WITH A GREAT DEAL OF RESPECT, ALTHOUGH COFTER DECISIONS THAT IT PERCEIVES TO BE UNFAVORABLE TO ITS POLICY DECISIONS THAT
PREFERENCES.

06425 MILLER, M.C.

POLITICAL ADS: DECODING HIDDEN MESSAGES

COLUMBIA JOURNALISM REVIEW, 30(5) (JAN 92), 36-39.

THE AUTHOR ANALYZES FOUR SPOT ADS USED BY THE 1988 BUSHQUAYLE CAMPAIGN AND ENDEAVORS TO UNCOVER THE LARGER MESSAGES THEY WERE INTENDED TO CONVEY OR UNDERSCORE.

06426 MILLER, N.P.; SHEERS, N.

RELIGIOUS FREE EXERCISE UNDER STATE CONSTITUTIONS JOURNAL OF CHURCH \& STATE, 34(2) (SPR 92), 303-323.

THIS ESSAY SURVEYS STATE CONSTITUTIONAL FREE-EXERCISE JURISPRUDENCE IN ORDER TO ASCERTAIN WHAT RELIGIOUS FREEDOM PROTECTIONS EXIST AGAINST STATE LAWS THAT ARE FACIALLYNEUTRAL TOHARDS RELIGION. IT THEN ARGUES THAT THE MAJORITY OF THE STATES' CONSTITUTIONS CONTAIN PROVISIONS THAT HOULD ALLOW STATE COURTS TO CONTINUE TO APPLY STRICT SCRUTINY TO LEGISLATION CHALLENGED BY FREE-EXERCISE CLAIMS. PART I SURVEYS THE LEVEL OF JUDICIAL SCRUTINY GIVEN BY THE VARIOUS STATES TO CHALLENGED LEGISLATION IN REL IGIOUS FREEDOM CASES. PART II EXAMINES THE STRUCTURE ANO SUBSTANCE OF THE STATES CONSTITUTIONAL PROVISIONS FOR FREE EXERCISE. SPECIAL CMPHASIS IS GIVEN TO THOSE STATES THAT HAVE NOT DEVELOPED AN INDEPENDENT ANALYSIS FOR DECIDING STATE FREE-EXERCISE CLAIMS. INDEPENDENT ANALYSIS FOR DECIDING STATE FREE-EXERCISE CLAIMS THIS ESSAY THEN SUGGESTS PROBABLE DIRECTIONS FOR POST-SHITH
FREE-EXERCISE DEVELOPMENT IN THOSE STATES ON THE BASIS OF THEIR CONSTITUTIONS AND CASE LAH.

06427 MILLER, R.

HISTORICAL SOURCES OF COMFLICT IN SOUTHEAST ASIA: CAMBOOIA AT THE VORTEX CONFLICT, 10(3) (1990), 205-214.

THIS ARTICLE DISCUSSES HOW HISTORICAL AND CURRENT REGIONAL SITUATIONS AFFECT THE FUTURE OF CAMBODIA AND EQUILIBRIUM IN SOUTHEAST ASIA AS A WHOLE. THE SALIENT GEOPOL ITICAL FEATURES OF SOUTHEAST ASIA ARE: ITS LOCATION BETHEEN THO GREAT PEOPLES AND ANCIENT CUL TURES, INDIA AND CHINA; THE "FAULT LINE" BETWEEN THE REGION'S SO-CALLED
INDIANIZED AND SINICIZED STATES; THE REGION'S LONG HISTORY AS A COLLECTION OF INDEPENDENT, HIGHLY DEVELOPED, HIGHLY CENTRALIZED, INDIGENOUS SOCIETIES AND CULTURES UNTIL COLONIZED BY EUROPEAN POHERS; AND AFTER A HISTORICALLY SHORT PERIOD OF EUROPEAN DOMINATION, THE REGION'S DIVISION TODAY INTO TWO COMPETING GROUPS OF INDEPENDENT NATIONS WITH WIDELY DIFFERENT ORIGINS, YALUE SYSTEMS, AND GOALS. 
06428 MILLER, R.

FOLLY QUAGMIRE, OR INEYITABILITYO

STUDIES IN CONFLICT AND TERRORISM, 15(2) (1992), 99-124.

THIS ARTICLE TRACES THE POLICY CHOICES THAT SUCCESSIVE AMERICAN PRESIDENTS FACED REGARDING VIETNAM IN THE CONTEXT OF WORLD WAR II AND THE ENSUING COLD WAR. IT DESCRIBES THE CHOICES MADE AS MAINSTREAM POLITICAL DECISIONS AT THE TIME, DESPITE THE DEEPENING AND ULTIMATELY UNSUCCESSFUL ENGAGMEN INTO WHICH THOSE DECISIONS LED THE UNITED STATES. FINALLY, IT NOTES THE ULTIMATE IRONY THAT, ALTHOUGH U.S. POLICIES LED TO DEFEAT IN VIETHAM, THEY ACHIEVED THEIR LARGE OBJECTIVE OF ENSURING THAT THE REST OF SOUTHEAST ASIA REMAINED OUT OF THE

MILLR S

A RUNHING START AT THROHING THE RASCALS OUT

INSIGHT, 8(33) (AUG 92), 12-13,36, 38.

THREE MONTHS BEFORE ELECTION DAY, THE HIGHEST TURNOVER

IN THE HOUSE OF REPRESENTATIVES SINCE 1964 IS ALREADY

ASSURED. 1992 MAY ALSO BE A BANMER YEAR FOR VOTER

ASSURED. 1992 MAY ALSO BE A BANMER YEAR FOR VOTER
INITIATIVES TO LIMIT HOUSE MEMBERS TO ANYWHERE FROM SIX TO

INITIATIVES TO LIMIT HOUSE MEMBERS TO ANYWHERE FROM SIX TO
12 YEARS IN OFFICE. WHILE MANY ANALYSTS DECLARED THE

12 YEARS IN OFFICE. WHILE MANY ANALYSTS DECLARED THE
MOVEMENT DEAD BEFORE ARRIVAL LAST FALL, VOTER OUTRAGE SEEMS MOVEMENT DEAD BEFORE ARRIVAL LAST FALL, VOTER OUTRAGE SEE
ALIVE AND WELL. AT PRESENT 31 STATES LIMIT THE TERMS OF

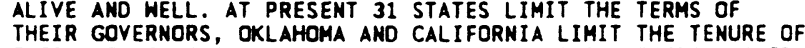
THEIR GOVERNORS, OKLAHOMA AND CALIFORMIA LIMIT THE TENURE OF
THEIR STATE LEGISLATORS, AND IN 1990 COLORADO YOTERS PASSED THEIR STATE LEGISLATORS, AND IN 1990 COLORADO YOTERS PASSED YEARS IN OFFICE. THE FIFTEEN STATES CONSIDERING TERM LIMIT INITIATIVES THIS FALL FOR FEDERAL LAHMAKERS INCLUDE CALIFORNIA, FLORIDA, MICHIGAN AND OHIO. SHOULD THE 15 STATES JOIN COLORADO, 154 OF THE 435 MEMBERS OF THE HOUSE AND 32 OF THE 100 SEMATORS WOULD HAVE TO THINK ABOUT FINDING NEW JOBS AFTER A SHORT STINT IN WASHINGTON.

06430 MILLER, $S$.

HIGH TECH, HIGH COST--AND HYPE?

INSIGHT, 8(45) (NOV 92), 6-9, 30-31.

IN ORDER TO CATCH AND PASS JAPAN IN INDUSTRIAL

TECHNOLOGY, BILL CLINTON'S ECONOMIC PLAN INCLUDES A PROPOSAL TO CREATE 170 MANUFACTURING EXTENSION CENTERS TO HELP SMALL MANUFACTURERS HITH TECHNOLOGY DEVELOPMENT. BUT A LOOK AT THE PROTOTYPES ON WHICH THE PLAN IS BASED RAISES OUESTIONS ABOUT WHETHER THE COST OF S510 MILLION ANNUALLY BY 1996 IS WARRANTED.

06431 MILLER, $S$.

THE BABY BOOM VOTE IS AN ELUSIVE PRIZE

INSIGHT, 8(27) (SEP 92), 8-9, 26-28.

ALTHOUGH BILL CLINTON AND AL GORE MAY DENY IT, THEY ARE

BUSY TRYING TO CAPTURE THE VOTES OF BABY BOOMERS AND THE MTY GENERATION. BUT IT'S A TASK EASIER SAID THAN DONE. THE BOOMERS AND THEIR YOUNGER SIBLINGS HAVE BEEN KNOWN TO THROW A FEW POLITICAL CURVES IN THE PAST DECADE, MOREOVER, BOOMERS AREN'T THAT ENAMORED OF LEADERS FROM THEIR OWN AGE GROUP.

06432 MILLER, $S$.

THE SOVIET COUP AND THE BENEFITS OF BREAKDOWN ORBIS, 36(1) (WIN 92), 69-86.

THOUGH MANY AMERICANS CAN APPRECIATE THE BENEFITS THAT RESULTED WHEN THE KREMLIN LOST CONTROL OF ITS SECURITY FORCES IN AUGUST, FEWER REALIZE THAT BENEFITS ARE ALSO LIKELY TO RESUL T AS THE CENTRAL GOVERNMENT IN THE KREMLIN CONTINUES TO LOSE POHER. THIS ARTICLE EXAMINES THE BACKGROUND TO THE COUP AND WHY THE COUP FAILED. IT ALSO EXPLORES WHERE GORBACHEY WAS IN ALL THIS AND THE HESTERN RESPONSE TO THE COUP. IT CONCLUDES THAT THE UNITED STATES SHOULD NOT BECOME ALARMIST OVER EXPRESSIONS OF RUSSIAN NATIONALISM, SINCE SOME SURGE OF NATIONALIST SENTIMENT IS INEVITABLE.

06433 MILLER, $S$.

VOTERS GET TURNED IN TO POHER

INSIGHT, 8(42) (OCT 92 ) 14-16.

PAUL' WEYRICH'S NATIONAL EMPOWERMENT TELEVISION NETHORK IS YOUNG BUT ALREADY MAKING ITS MARK. IT AIMS TO STEER INFLUENCE--AND NOT JUST IN PRESIDENTIAL ELECTIONS.

06434 MILLER, S.M.; VELZ, O.T.

DO UNITED STATES PRESIDENTIAL ADMINISTRATIONS INFLUENCE DONETARY POLICY?

JOURNAL OF POLICY MODELING, 14(2) (APR 92), 221-226.

STUDENTS OF POLITICAL SYSTEMS OFTEN USE' THE UNITED STATES TO ILLUSTRATE THE BENEFITS OF THE SEPARATION OF STATES TO ILLUSTRATE THE BENEFITS OF THE SEPARATION OF
POWERS. THE CONDUCT OF MONETARY AND FISCAL POLICY REPRESENTS ON ECONOMIC ASPECT OF THIS SEPARATION. WHILE ICY CAN ARGUE, ON ECONOMIC ASPECT OF THIS SEPARATION. WHILE ONE CAN ARGUE, ON TECHNICAL GROUNDS, THAT INDEPENDENT SETS OF POLICYMAY DETERMINE FISCAL AND MONETARY POLICY, ACTUAL PRACTICE
SUGGESTS A CLOSER LINKAGE THAN IS IMPLIED BY THE WRITTEN SUGGESTS A CLOSER LINKAGE THAN IS IMPLIED BY THE DOCUMENTATION ON THE INSTITUTIONAL DIVISION OF RESPONSIBILITIES. FIRST, ECONOMIC ANALYSIS IDENTIFIES
NECESSARY LONG-RUN LINKAGE BETHEEN MONETARY AND FISCAL POLICY BECAUSE OF THE GOVERNMENT BUDGET CONSTRAINT. NEH
GOVERMMENT DEBT ENTERS THE ECONOMY THROUGH THE BUDGET DEFICIT, WITHOUT WHICH THE STOCK OF GOVERMMENT DEBT CANNOT GROW OVER TIME. THUS, IF ONE DESIRES SOME CONSTANT LONG-RUN RELATIONSHIP BETWEEN OUTSTANDING GOVERNHENT DEBT ANO GROSS NATIONAL PRODUCT, THE GOVERMMENT DEFICIT MUST ALSO BE SOME CONSTANT FRACTION OF GROSS NATIONAL PRODUCT. SECONDLY, THE PRESIDENT SUBMITS A BUDGET TO CONGRESS, THE OPENING MOVE IN THE ANNUAL STRUGGLE OVER SPENDING AND TAXING PLANS. MOREOVER, THE PRESIDENT'S POWER TO APPOINT THE CHAIR OF AND FILL VACANCIES ON THE FEDERAL RESERVE BOARD OF GOVERNORS GIVES THE PRESIDENT CONSIDERABLE INFLUENCE OVER THE CONDUCT OF MONETARY POLICY.

06435 MILLER, T.C.

THE IMPLICATIONS OF SELF-INTEREST

JOURNAL OF THEORETICAL POLITICS, 4(4) (OCT 92), 395-412. CONSISTENT APPLICATION OF THE ASSUMPTION THAT

INOIVIDUALS ARE MOTIVATED BY SELF-INTEREST LEADS TO A POPULIST POLICY PRESCRIPTION. TO INCREASE POLITICAL FREEDOM UNDER CONSERVATIVE (LIMITED) DEMOCRACY AND RATES OF ECONOMIC GRONTH UNDER COMPETITIVE CAPITALISM, IT IS NECESSARY TO OISTRIBUTE INCOME DIRECTLY TO WORKERS. ADAM SMITH'S DUAL DEFINITION OF SELF-INTEREST (SELF-SERYING PASSIONS AND SELFSERVING ECONOMIC RATIONALITY) PROVIDES THE PRIMARY BASIS FOR THIS POLICY PRESCRIPTION. EMPIRICAL SUPPORT FOR SMITH'S OUAL DEFINITION OF SELF-INTEREST IS PROVIDED BY 2OTH-CENTURY FINDINGS ON THE STRUCTURE AND EVOLUTION OF THE HUMAN BRAIN.

06436 MILLER, T.C.

WHAT ADAM SMITH AND JAMES MADISON WOULD SAY ABOUT THE AMERICAN POLITICAL ECONOMY TODAY

PUBLIC ADMINISTRATION REVIEW, 52(1) (JAN 92), 70-76.

THE AUTHOR CONTENDS THAT PUBLIC ADMINISTRATORS NOULD GAIN A GREAT DEAL FROM POPULIST REFORMS FOCUSING ON A REVITALIZATION OF MADISONIAN DEMOCRACY AND CAPITALISM AS ENYISIONED BY ADAM SHITH. SHE ARGUES THAT BOTH THE RIGHT AND THE LEFT HAVE TURNED THE VIEHS OF SMITH AND MADISON UPSIDE DOWN, GENERATING A POLITICAL ECONOMY THAT SUSTAINS AND EXACERBATES ECONOMIC INJUSTICE. PUBLIC ADMINISTRATION PROFESSIONALS, AS AGENTS OF THAT SYSTEM, HAVE BECOME PART OF THE PROBLEM. ONLY THROUGH POPULIST REVITALIZATION CAN PUBLIC ADMINISTRATION ITSELF BECOME REVITALIZED.

06437 MILLER, W.E.

GENERATIONAL CHANGES AND PARTY IDENTIFICATION

POLITICAL BEHAVIOR, 14(3) (SEP 92), 333-352.

THE AUTHOR STUDIES THE PARTY IDENTIFICATION OF NON-BLACK VOTERS HITHIN THREE BROADLY-BOUNDED COHORTS OR POLITICAL GENERATIONS CONSISTING OF THOSE WHO FIRST VOTED PRIOR TO 1932, THOSE OF THE MEN DEAL ERA, AND THOSE WHO HAVE REACHED VOTING AGE SINCE 1964. INTER-AMD INTRA-GENERATIONAL COMPARISONS ARE GIVEN FOR THREE POLITICAL ERAS REFLECTED IN NES DATA: 1952-1960, 1964-1976, AND 1980-88. OUTSIDE THE SOUTH THE POST-MEW DEAL GEMERATION HAS MORE PRO-DEMOCRATIC IN 1964-1976 THAN WAS THE NEH DEAL GENERATION. HOWEVER, IT ALSO LED THE SURGE AHAY FROM THE DEMOCRATS AND TO THE GOP IN 1980-88. NEVERTHELESS, IN THE LATTER PERIOD IT WAS LESS DOMINANTLY REPUBLICAN THAN WERE THE MEMBERS OF THE NEW DEAL GENERATION. IN THE SOUTH THE BETTER-EDUCATED VOTERS OF THE POST-NEW DEAL GENERATION LED THE REALIGNMENT THAT LARGELY ERODED THE DEMOCRATIC PLURALITY BETHEEN 1960 AND 1988. NATIONALLY, THE POL ICY PREFERENCES OF THE POST-NEW DEAL
GENERATION' IN THE $1980^{\circ}$ 'S FURTHER POLARIZED PARTY OIFFERENCES BETWEEN DEMOCRATS AND REPUBLICANS. THIS OCCURRED LARGELY BECAUSE OF THE SUBSTANTIALLY GREATER LIBERAL CAST OF POSTNEW DEAL DEMOCRATS' PREFERENCES. ON OTHER ISSUES, PARTY DIFFERENCES WERE MAINTAINED, BUT REPUBLICANS AS WELL AS INDEPENDENTS AND DEMOCRATS IN THE POST-NEW DEAL GENERATION EXHIBITED VISIBLY MORE LIBERAL PREFERENCES THAN DID THEIR PARTISAN COUNTERPARTS IN THE NEW DEAL GENERATION.

06438 MILLER, W.E.

THE PUZZLE TRANSFORMED: EXPLAINING DECLINING TURNOUT

POLITICAL BEHAVIOR, 14(1) (MAR 92), 1-44.

THIS ANALYSIS OF THE DECLINE IN AGGREGATE VOTING TURNOUT IN THE UNITED STATES BETHEEN THE 1950'S AND 1980'S

ATTRIBUTES THE DECLINE TO CHANGE IN THE GENERATIONAL COMPOSITION OF THE ELECTORATE. IN PARTICULAR, THE POST-NEN DEAL GENERATION, WHICH CONTINUES TO GROW IN SIZE, VOTES AT A RATE WELL BELOH' THAT OF OLDER GENERATIONS. A MINOR PART OF THE GEMERATIONAL DIFFERENCES IN TURNOUT CAN BE ATTRIBUTED TO GENERATIONAL DIFFERENCES IN PARTY IDENTIFICATION AND SOCIAL GENERATIONAL DIFFERENCES IN PARTY IDENTIFICATION AND SOC
CONNECTEDNESS, AS MEASURED BY SUCH INDICATORS AS HOME CONNECTEDNESS, AS MEASURED BY SUCH INDICATORS AS HOME OWNERSHIP AND CHURCH ATTENDANCE. THE LARGER PORTION EXPLAINED WITH VARIABLES CONTAINED IN THE NATIONAL ELECTION EXPLAINED WITH VARIABLES CONTAINED IN THE NATIONAL ELECTION STUDIES. THE GENERATIONAL DIFFERENCES IN TURNOUT ARE NOT BE ACCOUNTED FOR BY A DECLINING SENSE OF POLITICAL EFFICACY OR CITIZEN DUTY OR BY LESSENED INTEREST IN CAMPAIGNS AND ELECTION RESULTS.

06439 MILLS, G.

ZAMBIA AND THE WINOS OF CHANGE 
WORLD TODAY, 48(1) (JAN 92), 16-18.

ON NOVEMBER 1, 1991, ZAMBIAN PRESIDENT KENNETH KAUNDA STEPPED DOWN AFTER 27 YEARS IN POWER. THIS ARTICLE TRACES

THE EVENTS THAT SIGNALLED ZAMBIA'S DESIRE FOR A MORE
DEMOCRATIC GOVERNMENT AND LED UP TO KAUNDA'S OUSTER.

06440 MILLS, S.A.

PAROCHIAID AND THE ABORTION DECISIONS: SUPREME COURT JUSTICE WILLIAM J. BRENNAN JR. VERSUS THE U.S. CATHOLIC HIERARCHY

JOURNAL OF CHURCH \& STATE, 34(4) (FAL 92), 751-774. WHEN WILLIAM J. BRENHAN JR. WAS NOMINATED FOR ASSOCIATE JUSTICE OF THE U.S. SUPREME COURT IN 1956, SOME QUESTIONS AROSE ABOUT WHETHER, AS A CATHOLIC, HE WOULD BE MORE

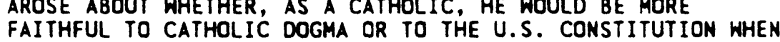
FAITHFUL TO CATHOLIC DOGMA OR TO THE U.S. CONSTITUTION WHEN THE TWO WERE IN CONFLICT. THIS ESSAY LOOKS AT BRENNAN'S
RECORD ON FIRST AMENDMENT ISSUES, SUCH AS PAROCHIAID AND RECORD ON F

06441 MILNER, H.

INTERNATIONAL THEDRIES OF COOPERATION AMONG NATIONS: STRENGTHS AND WEAKNESSES

NORLD POLITICS, 44(3) (APR 92), 466

CDOPERATION AMONG NATIONS HAS BEEN THE FOCUS OF A HIDE RANGE OF STUDIES IN THE PAST DECADE. THE RECENT

INTERNATIONAL RELATIONS LITERATURE HAS TENDED TO FOCUS OM THE SYSTEMIC LEVEL OF ANALYSIS. IT HAS ALSO USED GAME THEORY AS ITS CENTRAL TOOL OF ANALYSIS. IN THIS ARTICLE, THE AUTHOR EVALUATES RECENT INTERNATIONAL RELATIONS LITERATURE, ARGUING THAT THESE METHODOLOGICAL CHOICES HAVE CONTRIBUTED TO BOTH ITS GREATEST STRENGTHS AND ITS GREATEST WEAKNESSES IN EXPLAINING COOPERATION AMONG NATIONS.

06442 MILNER, H.

THE ASSUMPTION OF ANARCHY IN INTERNATIONAL RELATIONS THEORY: A CRITIOUE

REVIEW OF INTERNATIONAL STUDIES, 17(1) (JAN 91), 67-86. OVER THE LAST DECADE, NUMEROUS SCHOLARS, ESPECIALLY THOSE IN THE NEO-REALIST TRADITION, HAVE POSITED ANARCHY AS THE SINGLE MOST IMPORTANT CHARACTERISTIC UNDERLYING THE SINGLE MOST IMPORTANT CHARACTERISTIC UNDERLYING INTERNATIONAL RELATIONS. THIS ARTICLE EXPLORES IMPLICATIONS
OF SUCH AN ASSUMPTION. IN DOING SO, IT REOPENS OLDER DEBATES OF SUCH AN ASSUMPTION. IN DOING SO, IT REOPENS OLDER DEBAT
ABOUT THE NATURE OF INTERNATIONAL POLITICS. IT EXAMINES ABOUT THE NATURE OF INTERNATIONAL POLITICS. IT EXAMINES VARIOUS CONCEPTS OF "ANARCHY" EMPLOYED IN INTERNATIONAL RELATIONS LITERATURE. IT PROBES THE SHARP DICHOTOMY BETHEEN
DOMESTIC AND INTERMATIONAL POLITICS THAT IS ASSOCIATED WITH THIS ASSUMPTION. THE AUTHOR QUESTIONS THE VALIDITY AND THIS ASSUMPTION. THE AUTHOR QUESTIONS THE VALIDITY AND SUGGESTIONS OF A MORE FRUITFUL WAY TO UNDERSTAND THE INTERMATIONAL SYSTEM, ONE THAT COMBINES ANARCHY WITH INTERNATIONAL SYST
INTERDEPENDENCE.

06443 MILTON, R.M.

INSTITUTIONAL INCENTIVES FOR RESOURCE MOBILIZATION: AN ANALYSIS OF IRRIGATION SYSTEMS IN NEPAL

JOURNAL OF THEORETICAL POLITICS, 4(3) (JUL 92), 283-308. THE AUTHOR STUDIES THE EFFECTS OF INSTITUTIONAL ARRANGEMENTS ON RESOURCE MOBILIZATION IN THREE IRRIGATION SYSTEMS IN NEPAL. APPLYING TOOLS OF INSTITUTIONAL ANALYSIS, SHE TESTS THREE HYPOTHESES CONCERNING THE INFLUENCE OF (1) DECISION-MAKING AUTONOMY, (2) EXTENT OF EXTERNAL AGENCY INYOL VEMENT, AND (3) RELIABILITY OF WATER DELIVERY ON FARMERS' INCENTIVES TO MOBILIZE THEIR OWN RESOURCES FOR SYSTEM OPERATION AND MAINTENANCE COSTS. FINDINGS INDICATE THE FOLLOWING: (1) THE MORE CONTROL FARMERS HAVE IN SYSTEM DECISIONS, THE MORE LIKELY IT IS THAT THEY WILL CONTRIBUTE THEIR OWN RESOURCES; (2) INDIRECT INTERVENTION TENDS TO PROMOTE FARMER FINANCING OF RECURRENT COSTS TO A GREATER EXTENT THAN DOES DIRECT OUTSIDE INVOLVEMENT; AND (3) RELIABLE WATER DELIVERY IS THE KEY TO EFFECTIVE LOCAL RESOURCE MOBILIZATION.

06444 MIN, P.

A COMPARISON OF THE KOREAN MINORITIES IN CHINA AND JAPAN INTERNATIONAL MIGRATION REVIEW, 29(1) (SPR 92), 4-21. APPRAOXIMATELY 1.8 MILLION KOREANS ARE SETTLLD IN CHINA AND SOME 700,000 KOREANS ARE LOCATED IN JAPAN. THIS ARTICLE AND SOME 700, 000 KOREANS ARE LOCATED IN JAPAN. THIS ARTICLE COMPARES THE KOREAN MINORITIES IN CHINA AND JAPAN IN THEIR
DIFFERENTIAL LEVELS OF CULTURAL AUTONOMY AND ETHNIC IDENTITY. DIFFERENTIAL LEVELS OF CULTURAL AUTONOMY AND ETHNIC THE KOREAN MINORITY GROUPS SETTLED IN THE THO ASIAN
SOCIETIES HAVE MADE RADICALLY DIFFERENT KINDS OF ADJUSTMENT. SOCIETIES HAVE MADE RADICALLY DIFFERENT KINDS OF ADJUSTMENT
IN EXPLAINING THE DIFFERENTAIL LEVELS OF ETHNICITY BETWEEN IN EXPLAINING THE DIFFERENTAIL LEVELS OF ETHNICITY BETWEEN THE TWO KOREAN MINORITY GROUPS, THE PAPER FOCUSES ON THE BASIC DIFFERENCES IN MINORITY POLICY BETWEEN THE TWO
COUNTRIES; THE DIFFERENCE IN THE CONTEXT OF MIGRATION; THE COUNTRIES; THE DIFFERENCE IN THE CONTEXT OF MIGRATION;
EXISTENCE OR ABSENCE OF A TERRIRORIAL BASE; AND THE EXISTENCE OR ABSENCE OF A TERRIRORIAL BASE;
DIFFERENTIAL LEVELS OF INFLUENCE FROM KOREA.

06445 MINARIK, J.J.

CAPITAL GAINS TAXATION, GROWTH, AND FAIRNESS CONTEMPORARY POLICY ISSUES, $X(3)$ (

THE QUESTION AT THE HEART OF THE CAPITAL GAINS TAX DEBATE IS WHETHER IT IS APPROPRIATE TO TAX SOME PEOPLE AT A DIFFERENT RATE THAN OTHERS HAVING THE SAME INCOME BUT FROM
DIFFERENT SOURCES. THOSE WHO JUSTIFY SUCH A PREFERENCE BASE THEIR ARGUMENTS ON THE CONCEPTS OF ECONOMIC EFFICIENCY AND FAIRNESS. HOWEVER, RECENT EXPERIENCE WITH CAPITAL GAINS TAX REDUCTIONS AND INCREASES STRONGLY SUGGESTS THAT A CHANGE IN THE CURRENT LAW WOULD YIELD LITTLE OR NO BENEFIT. THE BURDEN OF PROOF SHOULD REST ON THOSE WHO WOULD VIOLATE THE BASIC PRINCIPLE OF EQUAL TAX RATES ON INCOMES FROM WHATEVER SOURCE.

06446 MING, L.

CHINA MOVES CLOSER TO GATT

BEI JING REVIEH, 35(26) (JUM 92), 13-16.

CHINA'S RECENT REFORMS OF ITS ECONOMIC AND FOREIGN TRADE SYSTEMS HAVE ENSURED BASIC COMPLIANCE WITH THE REQUIREMENTS OF THE GENERAL AGREEMENT ON TARIFFS AND TRADE (GATT). SINCE 1982 CHINA HAS SENT OBSERVERS TO ATTEND THE GATT SESSIONS 1982 CHINA HAS SENT OBSERVERS TO ATTEND THE GATT
AND EXPECTS TO BE ADMITTED TO MEMBERSHIP SOON.

06447 MING, L.

CHINA'S DEBT REPAYMENT CAPACITY STRENGTHENED

BEIJING REVIEW, 35(14) (APR 92), 22-23.

ALTHOUGH CHINA'S FOREIGH DEBT REPAYMENT WILL REACH A NEW HIGH IN 1992, IT HAS ENCOUNTERED NO DIFFICULTY IN FULFILLING ITS OBLIGATIONS. BECAUSE CHINA'S FISCAL POLICIES CONTINUE TO ENJOY A GOOD INTERNATIONAL REPUTATION, DEVELOPED COUNTRIES AND WORLD FINANCIAL INSTITUTIONS ARE WILLING TO PROVIDE LOANS FOR THE COUNTRY'S MODERNIZATION PROGRAM.

06448 MINITER, R.

THE ENVIRONMENT: TROUBLE IN PARADISE

REASON, 24(4) (AUG 92), 48-49.

THIS ARTICLE DISCUSSES THE NNLP, THE NATIONAL NATURAL LANDMARK PROGRAM, WHICH IS ADMINISTERED BY THE U.S. PARK SERVICE IN FARAHAY HASHINGTON, D.C. BEGUN IN 1962, THE PROGRAM HAS DESIGNED TO RECOGNIZE AREAS OF GREAT NATURAL SIGNIFICANCE; IT'S THE ENVIRONMENTAL COUNTERPART TO THE NATIONAL HISTORIC LANDMARK PROGRAM. ACROSS THE COUNTRY THERE ARE 590 NATIONAL NATURAL LANDMARKS, BUT THE PROGRAM IS UNDER FIRE, AND ONLY THREE NEW SITES HAVE BEEN DESIGNATED SINCE NOVEMBER 1989. SINCE 1981 THE PARK SERVICE HAS BEEN REQUIRED TO NOTIFY LANDOWNERS THAT THEIR PROPERTY IS ABOUT TO BE TO NOTIFY LANDOWNERS THAT THEIR PROPERTY IS ABOUT TO BE
LISTED AS A LANDMARK. BUT THE ARTICLE CHARGES THAT THE PARK LISTED AS A LANDMARK. BUT THE ARTICLE CHARGES THAT THE PARK
SERVICE DELIBERATELY AVOIDS NOTIFYING PROPERTY OWNERS THAT SERVICE DELIBERATELY AVOIDS NOTIFYING PROPERTY OWNERS THAT
THEIR LAND IS UNDER CONSIDERATION AS A LANDMARK UNTIL IT'S THEIR LAND IS UNDER CONSIDERAT
TOO LATE FOR THEM TO OBJECT.

06449 MINKENBERG, M.

THE NEW RIGHT IN GERMANY

EUROPEAN JOURNAL OF POLITICAL RESEARCH, 22(1) (JUL 92), 55-81.

BASED ON THE THEORY THAT EXPLAINS THE NEOCONSERVATIVE UPSURGE OF THE 1980'S AS A REACTION AGAINST THE POSTMATERIALIST CHANGES IN VALUES OF THE PRECEDING DECADES, THIS PAPER ANALYZES THE RELATIONSHIP BETWEEN NEDCONSERVATISM AND THE RISE OF THE NEW RIGHT PARTIES IN WEST GERMANY IN THE LATE 1980'S. SECDNDARY ANALYSIS OF SURVEY DATA DEMONSTRATES POLITICS" AND "NEW POLITICS" DIMENSIONS AND RELATED VARIANTS OF CONSERVATISH. THE NEW RIGHT, IN PARTICULAR THE REPUBLICAN PARTY, IS NEITHER A RADICALIZATIION OF THE CENTRE OF GERMAN SOCIETY NOR A SIMPLE MOBILIZATION OF RIGHT-WING EXTREMISTS. RATHER, THE NEW GROUPS ARE THE PRODUCT OF THE DISINTEGRATION OF THE ESTABLISHED PARTIES THAT ARE LOSING VOTER SUPPORT TO THE PARTIES OF THE NEN LEFT AND THE NEW RIGHT IN AN ALMOST SYMMETRICAL FASHION.

06450 MINKLER, M.; COLE, T.

THE POLITICAL AND MORAL ECONOMY OF AGING: NOT SUCH STRANGE BEDFELLOWS

INTERNATIONAL JOURMAL OF HEALTH SERVICES, 22(1) (1992), $113-124$

POL ITICAL ECONOMY PROVIDES A VALUABLL FRAMEWORK FOR UNDERSTANDING HOW POLITY, ECONOMY, AND SOCIETY SHAPE THE CONDITIONS, EXPERIENCES TREATMENT AND MEALTH OF OIDER PEOPLE. THE AUTHORS OF THIS ARTICLE DEVELOP E.P. THOMPSON'S
CONCEPT OF MORAL ECONOMY AS A USEFUL CDMPLEMENT TO CONCEPT OF MORAL ECONOMY AS A USEFUL CDMPLEMENT TO
CONTEMPORARY POLITICAL ECONOMIC ANALYSIS IN PROBLEM AREAS CONTEMPORARY POLITICAL ECOMOMIC ANALYSIS IN PROBLEM AREAS INVOLVING MORAL CONFLICT. DEFINED AS THE SHARED ASSUMPTIONS
UNDERLYING NORMS OF RECIPROCITY IN WHICH AN ECONOMIC SYSTEM UNDERLYING NORMS OF RECIPROCITY IN WHICH AN ECONOMIC SYST
IS GROUNDED, MORAL ECONOMY IS SEEN AS HOLDING PARTICULAR IS GROUNDED, MORAL ECONOMY IS SEEN AS HOLDING PARTICULAR
RELEVANCE FOR THE STUDY OF AGING. THE EVOLUTION OF PENSION RELEVANCE FOR THE STUDY OF AGING. THE EVOLUTION OF PENSION
SYSTEMS, THE "SENIOR REVOLT" AGAINST CATASTROPHIC COVERAGE SYSTEMS, THE "SENIOR REVOL T" AGAINST CATASTROPHIC COVERAGE
IN THE UNITED STATES, AND DEBATES OVER THE ALLOCATIDN OF IN THE UNITED STATES, AND DEBATES OVER THE ALLOCATIDN OF HEALTH RESOURCES BETWEEN GENERATIONS ARE USED TO ILLUSTRATE THE UTILITY OF A COMBINED POLITICAL AND MORAL ECONOMY FOR ENRICHING UNDERSTANDING IN THESE AREAS. MARX'S CONCEPT OF A MORALITY OF EMANCIPATION IS DESCRIBED AS HOLDING PARTICULAR PROMISE FOR THE DEVELOPMENT OF A NEW MORAL ECONOMY OF OLD AGE THAT WOULD MOVE BEYOND ALIENATION BY GIVING BROAD
ATTENTION TO OUALITY OF LIFE ISSUES AT EACH STAGE OF THE ATTENTION TO
LIFE COURSE.

06451 MINKLEY, G.

CLASS AND CULTURE IN THE HORKPLACE: EAST LONDON,

INDUSTRIALIZATION, AND THE CONFLICT OVER WORK, 1945-1957 
JOURMAL OF SOUTHERN AFRICAN STUDIES, $18(4)$ (DEC 92) $739-760$.

THIS PAPER ATTEMPTS TO RE-ASSESS NOTIONS OF 'CHEAP MATIVE LABOR' AMD ITS IMPACT OM CLASS AMD CULTURE IN THE WORKPLACES OF THE CITY IN THE 194OS AND 1950S. IT SEEKS TO AMPLIFY CONCERNS OF THE COMPLEXITY OF HORKING-CLASS FORMATION IN THIS PERIOD AND SUGGESTS THE NEED TO HISTORICIZE THESE PROCESSES. THE PAPER MOVES FROM A GENERAL ECDNOMIC OVERVIEW OF EAST LONDON IN THE PERIOD, TO A CLOSER EXAMINATION OF THE IMPACTS ON, AND SHAPIMG CAPABILTIES OF, BLACK WORKERS OUT OF THE DOMAINS OF HORK AND MIGRANCY. IT CONCLUDES WITH A SUGGESTED IMPLICATION FOR EXPLAINING THE NATURE OF EAST LONDON'S INDUSTRIALIZATION AS 'DEPENDENT'.

06452 MINORU, S.

JAPANESE AND THE RUSSIAN STRUGGLE TOHARD A NEW SYSTEM JAPAN QUARTERLY, XXXIX(2) (APR 92), 176-185.

THE AUTHOR EXPLAINS WHY SOME JAPANESE FEEL A SPECIAL AFFINITY FOR RUSSIA AND SPECULATES ABOUT HOW THE BREAK-UP OF THE SOVIET UNION WILL AFFECT FUTURE RELATIONS BETWEEN THE JAPANESE AND THE RUSSIANS.

06453 MINTZ, A.; HUANG, C.

GUNS VERSUS BUTTER: THE INDIRECT LINK

AMERICAN JOURNAL OF POLITICAL SCIENCE, 35(3) (AUG 91), 738-757.

STUDIES OF THE GUNS VERSUS BUTTER TRADE-OFF FOUND NO EVIDENCE FOR THE EXISTENCE OF A TRADE-OFF IN THE PRE-REAGAN ERA (SEE RUSSETT 1982; DOMKE, EICHENBERG, AND KELLEHER 1983; MINTZ 1989). THIS STUDY EXTENDS PRIOR RESEARCH BY EXAMINING NOT ONLY THE DIRECT, IMMEDIATE EFFECTS OF DEFENSE SPENDING BUT ALSO THE INDIRECT IMPACT OF ARMS EXPENDITURES ON EDUCATION SPENDING. A THREE-EQUATION MODEL IS SPECIFIED AND EMPIRICALLY ESTIMATED USING DATA FROM 1953 TO 1987. THE RESULTS SHOW NO NEGATIVE SHORT-TERM EFFECTS BUT DO SHOW SIGNIFICANT INDIRECT LONG-TERM TRADE-OFFS

06454 MIRSKY, G.I.

CENTRAL ASIA'S EMERGENCE

CURRENT HISTORY, 91(567) (OCT 92), 334-338.

THE REDRAHING OF THE MAP OF THE SOVIET UNION HAS FOCUSED ATTENTION ON THE FIVE FORMER SOVIET REPUBLICS THAT MAKE UP CENTRAL ASIA. A REGION ONCE CONSIDERED THE ESOTERIC DOMAIN OF SOVIET ETHNIC SPECIALISTS, IT HAS BECOME ONE OF THE MOST CLOSELY WATCHED AREAS IN THE WORLD BECAUSE OF ITS MUSLIM POPULATION AND ITS STRATEGIC PROXIMITY TO THE MIDOLE EAST AND SOUTH ASIA.

06455 MISCAMBLE, W.D.

GEORGE $F$. KENNAN AND THE MAKING OF AMERICAN FOREIGN POLICY, $1947-1950$

PRINCETON UNIVERSITY PRESS, 1992, 432

WHEN GEORGE C. MARSHALL BECAME SECRETARY OF STATE IN JAMUARY OF 1947. HE FACED NOT ONLY A STAGGERING ARRAY OF SERIOUS FOREIGN' POLICY QUESTIONS BUT ALSO A STATE DEPARTMENT RENDERED INEFFECTIVE BY NEGLECT, MALADMINISTRATION, AND LOH MORALE. SOON AFTER HIS ARRIVAL MARSHALL ASKED GEORGE $F$. KENNAN TO HEAD A NEH COMPONENT IN THE DEPARTMENT'S STRUCTURE-THE POLICY PLANHING STAFF. THIS HORK SCRUTINIZES KENNAN' SUBSEQUENT INFLUENCE OVER FOREIGN POLICYMAKING DURING THE CRUCIAL YEARS FROM 1947 TO 1950. IT ARGUES THAT AMERICAN FOREIGN POLICY WAS NOT SIMPLY A WORKING OUT OF A CLEARLY DELINEATED STRATEGY OF CONTAINMENT. FAR FROM DICTATING POLICIES, THE FAMOUS CONTAINMENT DOCTRINE HAS ACTUALLY

06456 MISKIN, A. MEDIATIONS: AID'S "FREE MARKET DEMOCRACY" MIDDLE EAST REPORT, $22(6)$ (NOV 92) 33-34.

TWO HISTORIC TRANSFORMATIONS ARE SHEEPING MUCH OF THE WORLD TODAY - THE ESTABLISHMENT OF OPEN ECONOMIES AND THE MOVEMENT TOWARO MORE ACCOUNTABLE DEMOCRATIC GOVERNANCE." THIS ASSERTION, EXTRACTED FROM A US AGENCY FOR INTERNATIONAL DEVELOPMENT (AID) DOCUMENT IS DISPUTED IN THIS ARTICLE, WHICH SUGGESTS THAT IN MUCH OF THE THIRD HORLD, GENUINE DEMOCRATIZATION IS MORE LIKELY TO HINOER THAN TO FACILITATE IMPOSITION OF THE STRUCTURAL ADJUSTMENT DECREED BY THE IMF AND PUSHED BY WASHIMGTON.

06457 MISSER, F.

"30 YEARS HAR|" YOW REBELS

NEW AFRICAN, (287) (AUG 91), 15-16.

AS RWANDA PREPARES FOR ITS FIRST MULTI-PARTY ELECTIONS IN OCTOBER 1991, DISCONTENT IS MOUNTING. THE RHANDA PATRIOTIC FRONT (RPF) GUERRILLAS HAVE OISMISSED THE ELECTIONS AS A SHAM HAND HAVE VOWED TO FIGHT ON, FOR THIRTY YEARS IF MECESSARY OPPOSITION PARTIES FEAR THE' ELECTIONS WILL BE NEITHER FREE NOR FAIR. ONE OPPOSITION GROUP, THE REPUBLICAN DEMOCRATIC MOVEMENT (RDM) HAS ACCUSED THÉ GOVERNMENT OF ATTEMPTING TO INTIMIDATE ITS CRITICS BY THE ARBITRARY ARREST OF FOUR JOURHALISTS.

06458 MISSER, F.

RHAMDA: THE HAR CONTINUES
NEW AFRICAN, (282) (MAR 91), 16.

SKIRMISHES BETHEEN GOVERMMENT TROOPS AND THE REBELS OF THE RWAMDAN PATRIOTIC FRONT (RPF) CONTINUES WITH SPORADIC INCURSIONS AND RAIDS FROM THE UGANDAN SIDE OF THE BORDER. THE RWANDAN GOVERMMENT HAS FREQUENTLY ACCUSED UGANDA OF COMPLICITY WITH THE RPF. THE REBELS CAPTURED THE SECOND LARGEST TOWN IN THE COUNTRY AND LIBERATED ALL PRISONERS THERE. FRENCH PARATROOPERS ASSISTED IN THE EVACUATION OF MOST FOREIGNERS FROM KIGALI, THE CAPITAL.

06459 MISTERAVICH, D.

THE LIMITS OF ALTERHATIVE DISPUTE RESOLUTION: PRESERVING THE JUDICIAL FUMCTION

UNIVERSITY OF DETROIT MERCY LAW REVIEW, 70(1) (FAL 92), 37-46.

THE GROWING PRESSURE TO ARGUE PRIVATELY RAISES CONCERN FOR THE FUTURE ROLE OF THE PUBLIC JUDICIARY. IF DISPUTES DO NOT COME BEFORE THE COURTS, JUDGES CANNOT MAKE RULINGS WHICH GOVERN FUTURE DISPUTES. THIS ESSAY APPROACHES THE PRESERVATION OF THE COURT'S CORE FUNCTION AS ITS PRIMARY FOCUS. IT EXPLORES ALTERNATIVE DISPUTE REVOLUTION $V$. INFORMAL DISPUTE RESOLUTION $V$. ADJUCIDCATION AND THE CORE JUDICIAL FUNCTION. IT CONCLUDES THAT ASSIGNING CASES FOR ALTERNATIVE PROCEDURES TO PRESERVE THE JUDICIAL FUNCTION
HILL SERVE THE INTERESTS OF BOTH THOSE HHO ARE CONCERNED WILL SERVE THE INTERESTS OF BOTH THOSE HHO ARE CONCERNED AMD THOSE WHO SEEK TO PROMOTE THE VALUE ASSOCIATED WITH AND THOSE WHO SEEK TO PRO

06460 MITCHELL, A.

NATIONHOOD: THE END OF THE AFFAIR

POLITICAL QUARTERLY (THE), 63(2) (APR 92), 122-142.

MATIONAL IDENTITY IN BRITAIN FOCUSES ON INSTITUIONS TO A UNIQUE DEGREE. AS A RESULT. THEIR DEBATE ON 'EUROPE' IS CONCERNED MORE WITH SYMBOLS AND ABSTRACTIONS THAN THE REALITIES OF NATIONAL STRENGTH OR ECONOMIC PONER. THIS ARTICLE SUGGESTS THAT SOVEREIGNTY, THE POWER OF PARLIMENT, THE CROWN, AND THE END OF A THOUSAMD YEARS OF HISTORY ALL PREOCCUPY THEM TO A DEGREE RARE IN OTHER COUNTRIES WHICH ARE CONCERNED HITH MORE VITAL INTERESTS. IT CONCLUDES THAT THE WORLD'S FIRST INDUSTIAL NATION IS BECOMING THE FIRST INDUSTRIAL SOCIETY TO UNDEVELOP, THE FIRST NATION TO GIVE UP.

06461 MITCHELL, C. POLITICAL AFFAIRS, LXX(2) (FEB 91), 13-17.

THE SHEEPING REVOLUTIONS OF EASTERM EUROPE HAVE CAUSED SOME TO QUESTION THE VALIDITY OF SOCIALISM AND THE NEED FOR A COMMUNIST PARTY. THIS ARTICLE RESPONDS BY EXAMINING THE HISTORICAL CONTRIBUTION OF THE U.S. COMMUNIST PARTY TO PROGRESS IN THE UNITED STATES. IT OUTLINES THE VITAL ROLE COMUMISTS PLAYED IN THE TRADE UNIDN MOVEMENT. IN THE METYET-COMPL ETED ORGANIZING OF THE SOUTH, ANO IN PROMOTING INTEGRATION OF WHITE AND BLACK WORKERS.

06462 MITCHELL, C.R.

CLASSIFYING CONFLICTS: ASYMMETRY AND RESOLUTION ANMALS OF THE AMERICAN ACADEMY OF POLITICAL AND SOCIAL SCIENCE, (518) (

ONE REASON THAT PROTRACTED, INTRANATIONAL CONFLICTS RESIST RESOLUTION ARISES FROM THEIR ASYMMETRIC STRUCTURE. THE AUTHOR EXAMINES AND ILLUSTRATES THE CONCEPT OF ASYMMETRY, ARGUING THAT ASYMMETRY IS MORE COMPLEX THAN A SIMPLE MATTER OF POWER IMBALANCE. HE OUTLINES VARIOUS DIMENSIONS OF ASYMMETRY AND EXAMINES SOME IMPLICATIONS OF LEGAL AND STRUCTURAL ASYMMETRIES FOR CONFLICT RESOLUTION. FINALLY, HE OFFERS SOME SUGGESTIONS CONCERNING THE POSSIBLE IMPACT OF ASYMMETRIC STRUCTURE ON FEASIBLE PROCEDURES FOR CONFLICT RESOLUTION AND ON THE CONTENT OF LASTING SOLUTIONS TO PROTRACTED, INTRANATIONAL CONFLICTS.

06463 MITCHELL, D.

BUSH'S RASPUTIM

NATIONAL REVIEH, XLIV(25) (DEC 92), 28-31.

THE OUESTION OF HHY GEORGE BUSH HENT BACK ON HIS SOLEMN TAX PLEDGE IS ADDRESSED IN THIS ARTICLE. THE AUTHOR DEMONSTRATES HOW BUDGET DIRECTOR RICHARD DARMAN STEERED HIM IN THAT DIRECTION BY SYSTEMATICALLY DISTORTING TRENOS AND MANIPULATING NUMBERS. THE CONCLUSION IS DRAWN THAT WHATEVER DARMAN'S MOTIVES, THE RESULTS ARE MORE TAXES, HIGHER DEFICITS-AND BIL CLINTON.

06464 MITCHELL, D.; QUINLAN, A.

FISCAL FOLLY

REASON, 23(1) (MAY 91), 45-46.

BUDGET DIRECTOY RI 1 45-46. THAT HE HAD TO RENEGE ON HIS NO-NEW-TAXES PLEDGE AND ENTER A BUDGET SUMMIT WITH THE DEMOCRATS. THE STATES REASONS FOR THIS ABRUPT REVERSAL WERE TO REDUCE THE DEFICIT AND STRENGTHEN THE ECONOMY. UNFORTUNATELY FOR DARMN, EVEN AFTER FIVE MONTHS SINCE THE BUDGET WAS SIGNED INTO LAH, HIS SKEPTICS HAVE BEEN PROVEN RIGHT, AND HIS BUDGET A DISASTER. ESTIMATES OF THE 1991 BUDGET DEFICIT HAVE CLIMBED FROM $\$ 206$ TO $\$ 298$ BILLION. THE HIGHER TAXES COMBINED WITH OTHER 
FACTORS TO CAUSE AN ECONOMIC SLOHDOWN.

06465 MITCHELL, D.

ICONOGRAPHY AND LOCATIONAL CONFLICT FROM THE UNDERSIDE: FREE SPEECH, PEOPLE'S PARK, AND THE POLITICS OF HOMELESSNESS IN BERKELEY, CALIFORNI

POLITICAL GEOGRAPHY QUARTERLY, 11(2) (MAR 92), 152--169. A NARRATIVE ACCOUNT OF THE HISTORICAL GEOGRAPHY OF STRUGGLE IS DEVELOPED SHOWING THAT LOCATIONAL CONFLICT IS SYMBOLIC CONFLICT OVER THE CONSTRUCTION OF MEANINGS WITHIN PARTICULAR LANDSCAPES. THE CONGRUENCE OF ISSUES IN BERKELEY, AND CENTERED AROUND THE UNIVERSITY OF CALIFORNIA,

UNDERSCORES THE COMPLEXITY, AS WELL AS THE IMPORTANCE, OF THE SYMBOL IC NATURE OF CONFLICT OVER THE USE AND CONTROL OF SPACE. THIS PAPER REVOLVES AROUND THE NOTION THAT USING PUBLIC SPACE AS A POLITICAL, SOCIAL AND SHELTER BASE BY THOSE EXCLUDED FROM THE DECISION-MAKING PROCESS IS UNDERSTOOD BY THOSE PEOPLE AS A LEGITIMATE AND RIGHTFUL USE OF PUBLIC SPACE.

06466 MITCHELL, G.

THE IMPACT OF U.S. IMMIGRATION POLICY ON THE ECONOMIC "QUALITY" OF GERMAN AND AUSTRIAN IMMIGRANTS IN THE 1930S INTERNATIONAL MIGRATION REVIEN, 26(3) (FAL 92), 940-967. INTERNATIONAL MIGRATION REVIEW, 26 (3) (FAL 92 ), 940-967. STATES IMUIGRATION POL STY DURING TSED TO EVALUATE UNITED "LIKELY TO BECOME A PUBLIC CHARGE" CLAUSE (THE LPC CLAUSE) CONSULAR OFFICERS WERE EXPECTED TO DISTINGUISH AMONG INTENDED IMMIGRANTS ON THE BASIS OF THEIR LIKELIHOOD OF BECOMING PUBLIC CHARGES AT ANY TIME SUBSEOUENT TO THEIR ARRIVAL IN THE UNITED STATES. THE RESULTS OF A EUROPEAN ECONOMIC QUALITY COMPARISON BETHEEN LPC REFUGEES AND POST LPC REFUGEES SUGGEST THAT THE LPC CLAUSE DID NOT RESULT IN ANY SIGNIFICANT OUALITY DISTINCTIONS BETWEEN THE IMMIGRANTS
OF THE TWO GROUPS. 06467 MITCHELL, G.J.; BOX, M.; HEFLIN, H.T.; HOLLINGS, E.F.;

CON: SHOULD CONGRESS DEBATE THE PROOUCT LIABILITY FAIRNESS CONGRESSIONAL DIGEST, 71(11) (NOV 92), 271,273,275,277,279,

IN THESE EXCERPTS FROM THE SENATE DEBATE ON S.640, THE PRODUCT LIABILITY FAIRNESS ACT, THE SPEAKERS ARGUE THAT THE BILL WILL NOT ACHIEVE UNIFORMITY IN PRODUCT LIABILITY LAW, AS ITS ADVOCATES CONTEND. RATHER, IT HILL UNDERMINE LONGSTANDING PRINCIPLES OF FEDERALISM AND OVERTURN BOTH
EVOLVING AND WELL-ESTABLISHED LIABILITY STANDARDS.

06468 MITCHELL, J.

THE 1992 ELECTION IN SCOTLAND IN CONTEXT

THE 1992 ELECTION IN SCOTLAND IN CONTEXT
PARLIAMENTARY AFFAIRS, 45(4) (OCT 92), 612-626.

THE 1992 ELECTION RESULTS IN SCOTLAND CONFOUNDED

POLITICIANS, PUNDITS AND OPINION POLLS. IT IS POSSIBLE THAT AN APPEARANCE OF BRITISH HOMOGENEITY HIDES CONSIDERABLE OIVERSITY. THE FIRST PART OF THIS ARTICLE DISCUSSES HISTORICAL CLEAVAGES IN SCOTTISH POLITICS DRAWING OUT RELEVANT ASPECTS OF SCOTTISH POLITICAL CULTURE. THIS IS
FOLLOWED BY A DISCUSSION OF THE PARTY SYSTEM AND RECENT FOLLOWED BY A DISCUSSION OF THE PARTY SYSTEM
DEBATES IN THE LEAP UP TO THE 1992 ELECTION.

06469 MITCHELL, J.M.; SCOTT, E.

EVIDENCE ON COMPLEX STRUCTURES OF PHYSICIAN JOINT VENTURES YALE JOURNAL ON REGULATION, $9(2)$ (SUM 92), 489-520.

PHYSICIAN OWNERSHIP OF HEALTH CARE FACILITIES HAS BECOME A CONTROVERSIAL ISSUE IN THE NATIONAL DEBATE OVER HOW TO CONTROL RISING HEALTH CARE COSTS. PROPONENTS OF PHYSICIAM OWNERSHIP CONTEND THAT PHYSICIAN INVESTMENT IN HEALTH CARE FACILITIES BROADENS ACCESS TO HEALTH CARE BY INCREASING THE FINANCING AVAILABLE FOR SUCH FACILITIES. CRITICS OF PHYSICIAN OWNERSHIP CONTEND THAT SUCH ARRANGEMENTS LEAD TO HIGHER PRICES FOR MEDICAL SERVICES AND MORE FREQUENT USE OF UNMECESSARY MEDICAL PROCEDURES, WITHOUT IMPROVING THE QUALITY OF CARE. IN THIS PAPER, THE AUTHORS REVIEH THE DEBATE AND PRESENT EMPIRICAL EVIDENCE BASED OH A STUDY OF MORE THAN 2600 CLINICS IN FLORIDA. THE EVIDENCE INDICATES THAT PHYSICIAN INVESTMENT IN HEALTH CARE CLINICS IS MORE WIDESPREAD THAN PREVIOUSLY BELIEVED AND THAT PHYSICIAN INVESTMENT TENDS TO INCREASE BOTH THE FREQUENCY OF REFERRALS TO THE CLINICS AND THE COST OF THE SERVICES PROVIDED BY THE CLINICS. THUS, THE AUTHORS ARGUE THAT CURRENT LEGISLATION PROHIBITING OR RESTRICTING PHYSICIAN JOINT VENTURES IS INADEQUATE. NEW LEGISLATION IS NEEDED TO STRENGTHEN PROHIBITIONS AND RESTRICTIONS ON INDIRECT PHYSICIAN INYESTMENT.

06470 MITHCELL, J.

PROTESTANT THOUGHT AND REPUBLICAN SPIRIT: HOH LUTHER PROTESTANT THOUGHT ANC

ENCHANTED THE WORLD
AMERICAN POLITICAL SCIENCE REVIEW, 86(3) (SEP 92), 688-695. ARGUMENTS ABOUT THE EMERGENCE OF MODERN POLITICAL THEORY OFTEN CLAIM THAT PROTESTANTISM'S SIGNIFICANCE WAS THAT IT EVACUATED THE POLITICAL HORLD AND THAT A MORE PROPERLY POLITICAL ETHIC TOOK ITS PLACE--A "DISENCHANTED" ETHIC. IN
THIS PAPER, THE AUTHOR CONSIOERS MARTIN LUTHER'S UNDERSTANDING OF BIBLICAL HISTORY, HIS THOUGHTS ON THE CHRISTIAN PRINCE, AND' HIS VIEN OF THE BONDS OF UNION AMONG CHRISTIANS, IN ORDER TO UNDERSTAND THE RELATIONSHIP BETWEEN THE POLITICAL AND SPIRITUAL REALMS. HE SUGGESTS THAT EVEN THOUGH LUTHER ARGUES FOR THE SEPARATION OF THE THO REALMS, HIS POLITICAL REALM IS BY NO MEANS DISENCHANTED. HIS POLITICS CAN ONLY BE UNDERSTOOD IN LIGHT OF HIS CLAIMS ABOUT THE PURVIEW OF GOD THE FATHER AND GOD THE SON. POLITICAL POLITICS AND RELIGION IN PROTESTANT THOUGHT.

06471 MITRA, S

DEMOCRACY AND POLITICAL CHANGE IN INDIA

JOURNAL OF COMMONWEALTH AND COMPARATIVE POLITICS, 30(1)

(MAR 92), 9-38.

THE FACTORS RESPONSIBLE FOR THE RESILIENCE AND

ROBUSTNESS OF INDIA'S REPRESENTATIVE DEMOCRACY THAT HAS SO

FAR WEATHERED SEVERAL POLITICAL CRISES AND WITNESSED

FAR WEATHERED SEVERT POLITICAL CHANGES IN INDIA IS ANALYZED. THIS

IMPORTANT POL ITICAL CHANGES IN INDIA IS ANALYZED. THIS
ARTICLE POINTS OUT THE UNRESOLVED POLITICAL ISSUES WHOSE

EMERGENCE IS CURRENTLY POSING A CHALLENGE OF THE KIND THAT INDIA HAS NOT SEEN BEFORE. ONE OF THE ASPECTS OF THIS CRISIS INDI A HAS NOT SEEN BEFORE. ONE OF THE ASPECTS OF THIS CRIS
IS THE CONFLICT BETWEEN THE COMMITMENT TO MAJORITARIAN DEMOCRACY AND THE POSSIBILITY OF THE RISE OF A COMMUNAL MAJORITY INTOLERANT TOHARDS THE MINORITIES. THE PROBLEMS IN INDIA ARE GERMANE TO THE PROCESS THAT HAS MADE DEMOCRACY POSSIBLE INT THE FIRST PLACE.

06472 MIYAKE, $W$.

TOWARD CLOSER SINO-JAPANESE TIES

JAPAN TIMES (WEEKLY INTERNATIONAL EDITION), 32(18) (MAY 92), 11.

THE AUTHOR EXPLAINS THE RULING LIBERAL DEMOCRATIC PARTY'S RELUCTANCE TO SEND THE JAPANESE EMPEROR TO MAINLAND CHINA FOR AN OFFICIAL STATE VISIT AFTER EXAMINIMG CHINESE ASSURANCES REGARDING THE PURPOSES OF SUCH A VISIT, HE ARGUES THAT IT WOULD CONTRIBUTE TO GOOD RELATIONS BETHEEN THE TWO COUNTRIES.

06473 MIYAO, T

JAPAN'S URBAN ECOMOMY AMD LAND POLICY

ANNALS OF THE AMERICAN ACADEMY OF POLITICAL AND SOCIAL

SCIENCE, (513) (JAN 91), $130-138$.
THE APPRECIATION OF LAND ALONG WITH OTHER ASSETS HAS HELPED BOOST THE JAPANESE ECONONY THROUGH THE WEALTH EFFECT ANO HAS MADE JAPAN THE RICHEST NATION IN THE WORLD IN TERMS OF THE VALUE OF ASSETS. HONEVER, THERE ARE SOME SERIOUS OF THE VALUE OF ASSETS. HONEVER, THERE ARE SOME SERIOUS PROBLEMS ASSOCIATED WITH LAND IN TOKYO AND OTHER LARGE CITIES. AMONG THEM ARE INEFFICIENT LAND USE, INADEQUATE PUBLIC INFRASTRUCTURE, AND AN INCREASING DISPARITY BETWEEM THE HAVES AND HAVE-NOTS DUE TO LAND-PRICE ESCALATION. TO
SOL VE THESE PROBLEMS, IT IS ESSENTIAL THAT THE GOVERNMENT SOLE THESE PROBLEMS, IT IS ESSENTIAL THAT THE GOVERNMENT REMOVE EXCESSIVE REGULATIONS OVER LAND USE AND TRANSACTIONS
AND REFORM THE PRESENT LAND-TAX SYSTEM. JAPAN'S LAND PROBLEM AND REFORM THE PRESENT LAND-TAX SYSTEM. JAPAN'S LAND PROBLEM
MUST BE DEALT HITH BY ENCOURAGING THE SUPPLY OF LAND AND THE EFFICIENT USE OF LAND.

06474 MMOOKIN, R.; BIRKE, R.

SADDAM'S FOLLYY: PLAYING CHICKEN WITH GEORGE BUSH NEGOTIATION JOURNAL, 8(1) (JAN 92), 41-48.

A NUMBER OF LESSONS MAY BE GLEANED FROM SADDAM'S FAILURES AND PRESIDENT BUSH'S SUCCESSES THAT HAVE APPLICATION WELL BEYOND THE CONFINES OF THE GULF WAR. SADDAM IS A BRILLIANT EXAMPLE OF A LOUSY COMPETITIVE NEGOTIATOR. THE INVASION AND OCCUPATION OF KUWAIT WAS AN ECONOMIC AND MILTARY FAILURE FOR IRAQ AND SADDAM HUSSEIN. WHILE HE DOES RETAIN DICTATORIAL CONTROL OF IRAQ, SADDAM'S INFLUENCE, POWER, AND PRESTIGE AS AN ARAB LEADER HAVE BEEM SUBSTANTIALLY DIMINISHED. THE AUTHORS OF THIS PAPER STATE THAT IT ISN'T FASHIONABLE TO GRADE NEGOTIATORS, BUT IF THEY HAD TO ASSIGN "GRADES, THEY WOULD GIVE BUSH AND "A" AND

06475 MOADDEL, M.

IDEOLOGY AS EPISODIC DISCOURSE: THE CASE OF THE IRANIAN REVOLUTION

AMERICAN SOCIOLOGICAL REVIEW, 57(3) (JUN 92), 353-379.

SOCIOLOGICAL RESEARCH ON IDEOLOGY AND REYOLUTION HAS BEEN GUIDED BY THREE MODELS: THE SUBJECTIVIST MODEL, WHICH PROPOSES THAT IDEOLOGY RE-ORIENTS DISORIENTED AND DISCONTENTED INDIVIDUALS IN SITUATIONS OF SOCIAL STRAIN; THE ORGANIZATIONAL MODEL, WHICH ANALYZES IDEOLOGY IN TERMS OF ORGANIZED CONTENTION FOR POWER AND EMPHASIZES THE ORGANIZED CONTENTION FOR POWER AND EMPHASIZES THE
ORGANIZATIONAL CONTEXT IN WHICH IDEOLOGICAL PRODUCERS ORGANIZATIONAL CONTEXT IN WHICH IDEOLOGICAL PRODUCERS
RESPOND TO CHALLENGES TO THEIR AUTHORITY; AND THE MARXIAN RESPOND TO CHALLENGES TO THEIR AUTHORITY; AND THE MARXIAN
MODEL. HHICH ATTRIBUTES CAUSAL PRIMACY TO CLASS CONFLICT IN MODEL, HHICH ATTRIBUTES CAUSAL PRIMACY TO CLASS CONFLICT IN ITS ANALYSIS OF IDEOLOGICAL DYNAMICS. THE AUTHOR SUGGEST
FOURTH MODEL: ONE THAT TREATS IDEOLOGY AS AN EPISODIC FOURTH MODEL: ONE THAT TREATS IDEOLOGY AS AN EPISODIC
DISCOURSE CONSISTING OF GENERAL PRINCIPLES, CONCEPTS, SYMBOLS, AND RITUALS THAT SHAPE HUMAN ACTIONS IN A PARTICULAR HISTORICAL PERIOD AND CONSIDERS REVOLUTIONARY PHENOMENON AS A PARTICULAR MODE OF HISTORICAL ACTION 

REVOLUTION IS STUDIED TO DEMONSTRATE THE UTILITY OF THIS
EPISODIC DISCOURSE MODEL.

06476 MOBERLY, $P$.

SETBACK IN SOUTH AFRICA

HORLD TODAY, 48(8-9) (AUG 92), 137-139.

THE AUTHOR DISCUSSES THE NEGOTIATING IMPASSE REACHED IN MID-1992 IN THE CONFERENCE FOR A DEMOCRATIC SOUTH AFRICA (CODESA). THE ACTUAL BREAK CAME ON THE ISSUE OF THE PRECISE PERCENTAGE THAT WOULD BE REQUIRED IN AN ELECTED ASSEMBLY FOR DECISIONS ON THE FUTURE CONSTITUTION.

06477 MOCKAITIS. T.

THE ORIGINS OF BRITISH COUNTER-INSURGENCY

SMALL WARS \& INSURGENCIES, 1(3) (DEC 90), 209-225.

AS THE MOST SUCCESSFUL COUNTER-INSURGENCY CAMPAIGN OF

THE POST-WAR PERIOD, THE CASE OF MALAYA HAS RECEIVED

CONSIDERABLE ATTENTION FROM STRATEGISTS AND HISTORIANS. BY

THE LATE 1960 S THE APPARENT FAILURE OF BRITISH METHODS TO

WORK IN VIETHAM LED TO A REAPPRAISAL OF THE MALAYAN

WORK IN VIETHAM LED TO A REAPPRAISAL OF THE MALAYAN
EXPERIENCE. TO APPRECIATE THE IMPORTANCE OF THE PRINCIPLE OF

EXPERIENCE. TO APPRECIATE THE IMPORTANCE OF THE PRINCIPLE
MINIMUM FORCE TO BRITISH COUNTER-INSURGENCY, THIS ARTICLE

MINIMUM FORCE TO BRI THE COLONIAL CONFLICTS OF THE LATE NINETEETH CENTURY,

THE PRINCIPLE OF MINIMUM FORCE ENSHRINED IN COMMON LAW HAS

STRENGTHENED BY A CHANGE IN THE ATTITUDE OF EDUCATED BRITONS

TOWARDS ACCEPTABLE CONDUCT IN WARFARE. TRADITION AND

EXPERIENCE HAS GIVEN BRITAIN AN ARMY ALMOST IDEALLY SUITED

TO COUNTER-INSURGENCY, BUT IT HAS BEEN
CONVERT THAT EXPERIENCE INTO DOCTRINE.

06478 MODY, A.; DAHLMAN, C.

PERFORMANCE AND POTENTIAL OF IMFORMATION TECHNOLOGY: AN INTERNATIONAL PERSPECTIVE

WORLD DEVELOPMENT, 20(12) (DEC 92), 1703-1719.

THE RISING INFORMATION CONTENT OF ECONOMIC ACTIVITY WORLOWIDE IS MAKING USE OF INFORMATION TECHNOLOGY (I.T.) INCREASINGLY RELEVANT IN A BROAD RANGE OF ACTIVITIES AND COUNTRIES. EFFECTIVE PLANNING AND ORGANIZATIONAL

CAPABILITIES ARE ESSENTIAL TO SUCCESSFUL ADOPTION OF THE NEH TECHNOLOGIES; MANAGERIAL SKILLS AND ENTREPRENEURSHIP ARE KEY TO THE EFFECTIVE USE OF I.T. IN ADDITION TO HUMAN CAPITAL DEVELOPMENT, I.T. DIFFUSION REQUIRES A STRATEGY FOR GENERATING LARGE INVESTMENTS IN TELECOMMUNICATIONS. WHILE PRO-ACTIVE MEASURES DESIGNED TO ACCELERATE THE DIFFUSION OF I.T. HAVE THEIR PLACE, THEY NEED TO BE COMPLEMENTED BY REDUCING BARRIERS TO THE INTERNATIONAL FLOW OF SERVICES AND INVESTMENT.

06479 MOELLENDORF, D.

RACISM AND RATIONALITY IN HEGEL'S PHILOSOPHY

HISTORY OF POLITICAL THOUGHT, 13(2) (SUM 92), 243-256.

ISTORY OF POLITICAL THOUGHT, 13(2) (SUM 92), 243-256.
THIS PAPER IS AN EXHIBITION OF THE RELEVANT PASSAGES OF HEGEL'S 'PHILOSOPHY OF SUBJECTIVE SPIRIT' AND AN ATTEMPT TO LINK THEM TO HEGEL'S OTHER CLAIMS ABOUT AFRICAN CULTURE AND THE SLAVE TRADE. IT ARGUES THAT HEGEL'S PHILOSOPHY OF SPIRI IS TAINTED BY THE UNUSUAL CAUSAL ROLE WHICH HE GIVES TO A
BIOLOGICAL CATEGORY, NAMELY RACE. IT ARGUES FURTHER THAT HIS BIOLOGICAL CATEGORY, NAMELY RACE. IT ARGUES FURTHER
PHILOSOPHY OF SPIRIT IS NOT NECESSARILY RACIST, ONLY PHILOSOPHY OF SPIRIT IS NOT NECESSARILY RACIST, ONLY
CONTINGENTLY SO, THAT IS THAT HIS RACISM DOES NOT FOLLOH FROM ANY OF HIS FUNDAMENTAL CLAIMS ABOUT SPIRIT.

06480 MOHAMEDI, $F$.

HOW ISRAEL GETS ITS CREDIT RATING

MIDDLE EAST REPORT, 22(2) (MAR 92), 33-34.

A "C" RATING FROM THE UNITED STATES GOVERMMENT CREDIT EVALUATORS, COMING AFTER WASHINGTON HAS HELD UP THE $\$ 10$ BILLION LOAN GUARANTEE FOR MORE THAN FOUR MONTHS, MUST COME AS SOMETHING AS A SHOCK FOR ISRAEL. A "C" GRADE PUTS ISRAEL IN THE COMPANY OF COLOMBIA, CZECHOSLOVAKIA, LESOTHO, MEXICO, TUNISIA, TURKEY, AND VENEZUUELA, AS FAR AS THE CREDIT RISK EVALUATORS OF THE OFFICE OF MANAGEMENT AND BUDGET (OMB) ARE CONCERNED. THE BUSH ADMINISTRATION DID NOT HOLD UP ISRAEL'S LOAN GUARANTEES ON BUDGETARY GROUNDS. BUT THE NEH REGULATIONS UNDER THE BUDGET REFORM ACT HHEREBY A RISK PREMIUM ATTACHED TO A LOAN GUARANTEE MUST BE ACCOUNTED FOR "ABOVE THE LINE" IN THE BUDGET, HAS PROVIDED CONGRESSIONAL CRITICS WITH A NEW TOOL FOR RESTRICTING AID.

06481 MOHAMEDI, F.

STATE AMD BOURGEOISIE IN THE PERSIAN GULF MIDDLE EAST REPORT, 22 (6) (NOV 92), 35-37

IN MOST CASES OF SERIOUS INDIVIDUAL WEALTH ACCUMULATION IN THE PERSIAN GULF. THE STATE BUDGET OR RULING FAMILY IN THE PERSIAN GULF, THE STATE BUDGET OR RULING FAMILY LARGESSE WAS THE SOURCE. SOME ATTRIBUTE THE FRAILTY OF THIS BOURGEOISIE CLASS TO ITS VIRTUAL TOTAL DEPENDENCE ON THE GOVERMENT FOR INCOHE. THIS ARTICLE EXPLORES CRISIS MANAGEMENT AND CREDIT LIMITS AND CONCLUDES THAT BUSINESS WANTS A CURB ON ROYAL EXCESSES AND LESS PRINCELY MEDOLING IN
LOCAL BUSINESS.

06482 MOHAMOUD, A.A.

SOMALIA'S TRAGEDY

WEST AFRICA, (3926) (DEC 92), 2142-2143.

IN FORECASTING THE FUTURE OF AFRICA, SOME EXPERTS
PREDICTED THAT HOMOGENEOUS SOCIETIES SHARING COMMON ORIGINS, CUSTOMS, LANGUAGE, AND HISTORY WOULD HAVE NO PROBLEMS FORMING NATION-STATES. IT WAS EXPECTED THAT SOMALIA, A
HOMOGENEOUS SOCIETY, COULD EVOLVE INTO A STABLE DEMOCRACY IN HOMOGENEOUS SOCIETY, COULD EVOLVE INTO A STABLE DEMOCRACY THE POST-COLONIAL PERIOD. ON THE OTHER HAND, NEIGHBORIMG ETHIOPIA, WITH ITS TRADITIONALLY-HOSTILE ETHNIC GROUPS, WAS
EXPECTED TO DISINTEGRATE INTO SMALL ETHNIC-CONTROLLED AREAS. EXPECTED TO DISINTEGRATE INTO SMALL ETHNIC-CONTROLLED AREAS. WHILE SOMALIA HAS DISINTEGRATED, THE ETHIOPIAN STATE APPEARS SOCIETY THAT, LIKE SOMALIA, IS TORN BY INTERMAL STRIFE.

06483 MOHAN, A.

THE HISTORICAL ROOTS OF THE KASHMIR CONFLCIT

STUDIES IN CONFLICT AND TERRORISH, 15(4) (1992), 283-308.

KASHMIR, WICH ALMOST EVERYONE BELIEYED HAD RECEDED FROM THE FOCUS OF THE WORLD'S POLITICAL ATTENTION AND THE CONCERNS OF CURRENT HISTORY, IS ONCE AGAIN IN THE HEADLINES. THIS ARTICLE EXPLORES ITS EARLY HISTORY, THE DOGRA RULE AND BRITISH PARAMOUNTCY. ALSO EXAMINED ARE WAR, THE KASHMIR ISSUE IN THE U.N., UNCIP'S CONCILIATION, AND ATTEMPTS AT MEDIATION. A STUDY OF PAKISTANI TERRORISM, DOMESTIC

DEVELOPMENTS AND KASHMIR'S FUTURE CONCLUDE THE ARTICLE.

06484 MOLINAR, J.

COUNTING THE MUMBER OF PARTIES: AN ALTERNATIVE INDEX AMERICAN POLITICAL SCIENCE REVIEH, $85(4)$ (DEC 91), 383-1392.

THE AUTHOR PROPOSES AN ALTERNATIVE INDEX TO OPERATIONALIZE THE VARIABLE NUMBER AND SIZE OF PARTIES IN A PARTY SYSTEM. HE PRESENTS A CRITICAL OVERVIEH AND IDENTIFIES THE WEAKNESSES OF THE THO MOST COMMON INDICES: ( 1 ) LAAKSO
AND TAAGEPERA'S EFFECTIVE NUMBER OF PARTIES AND (2) KESSELMAN AND WILDGEN'S HYPERFRACTIONALIZATION. THEN HE EXPLAINS THE COMPUTATIONAL LOGIC OF HIS ALTERNATIVE, "NUMBER OF PARTIES," AND COMPARES IT HITH THE OTHER THO, USING HYPOTHETICAL CASES. AFTER THAT, HE CONTRASTS THE LAAKSOTAAGERPERA INDEX WITH HIS OWN, USING DATA FROM ELECTIONS BETWEEN 1945 AND 1981. HE CONCLUDES THAT HIS IMDEX OUTPERFORMS THE OTHER THO AS AN OPERATIONALIZATION OF THE VARIABLE NUMBER AND SIZE OF PARTIES.

06485 MOLITOR, $K$.

INSECURITY INCREASED DOUBTS ABOUT THE PATH TO EUROPEAN UNITY

GERMAN TRIBUNE, 31(1532) (SEP 92), 2.

THE POSSIBILITY OF EUROPEAN UNITY IS QUESTIONED BY SOME WHO DECLARE THAT THE MAASTRICHT TREATY IS DEAD. THE ORDINARY EUROPEAN SEES FEW PERSONAL BENEFITS HORTH MENTIONING FROM MEMBERSHIP OF A POLITICAL COMHUNITY. MANY PEOPLE ARE WORRIED MEMBERSHIP OF A POLITICAL COMWUNITY. MANY PEOPLE ARE WORR ABOUT LOSING NATIONAL IDENTITY. THE AUTHOR ARGUES THAT
WITHOUT A COMHON CURRENCY TO MAKE EUROPE A TOUGH COMPETITOR WITHOUT A COMMON CURRENCY TO MAKE EUROPE A TOUGH COMPETITOR THE COMMUNITY WILL NOT BE ABLE TO HOLD ITS OWN AGAINST THE UNITED STATES AND JAPAN. THE EUROPEAN COMMUNITY HAS HELPED TO KEEP THE PEACE, AND ENLARGEMENT TO INCLUDE ERSTHHILE EAST
BLOC COUNTRIES WILL IMPROVE THEIR ECDNOMIC AND DEMOCRATIC BLDC COUNTRIE
PROSPECTS.

06486 MOLITOR, $\mathrm{H}$

THE FREE DEMOCRATS FIND THEMSELVES IN A CORNER GERMAN TRIBUNE, (1536) (OCT 92), 3

FOR MORE THAN TWO DECADES, GERMANY'S LIBERAL FREE DEMOCRATS (FDP) HAVE HELD THE BALANCE OF POWER IN GOVERMMENT
COALITIONS. BUT THAT HAS CHAMGED, AND THE FDP IS NOH FIGHTING FOR THE CONTINUED EXISTENCE OF THE COALITION. THE FDP IS NOT CONSIDERING LEAVING THE COALITION, BUT IT IS WILLING TO MAKE CONCESSIONS ON MAJOR, FUNDAMENTAL LIBERAL ISSUES.

06487 MOLLEMANN, J.

ECONOMIC HOPE OUT OF COLLAPSE OF SOVIET BLOC

GERMAN TRIBUNE, 1498 (JAN 92 ), 5-6.

THE TRANSITION OF THE FORMER SOVIET UNION TO AN OPEN,

DEMOCRATIC SOCIETY MUST NOT BE ALLOWED TO FOUNDER ON ECONOMIC HARDSHIP; EXTERNAL HELD IS NEEDED. THIS ARTICLE WAS WRITTEN BY THE GERMAN ECONOMICS MINISTER AFTER HIS VISIT TO MOSCON. THE PACE OF EVENTS IN THE FORMER SOVIET UNION HAS OUTOATED SOME OF THE DETAILS HE MENTIONS.

06488 MOLLENKOPF, J.H.

A PHOENIX IN THE ASHES--THE RISE AND FALL OF THE KOCH COALITION IN NEW YORK CITY POLITICS

PRINCETON UNIVERSITY PRESS, 1992, 280

IN THE YEARS FOLLOWING ITS MEAR 8ANKRUPTCY IN 1976 UNTIL IN THE YEARS FOLLOWING ITS NEAR 8ANKRUPTCY IN 1976 UNTIL THE END OF THE 1980S, NEW YORK CITY CAME TO EPITOMIZE THE DEBT-DRIVEN, DEAL-ORIENTED, ECONOMIC BOOM OF THE REAGAN ERA.
EXPLORING THE INTERPLAY BETHEEN SOCIAL STRUCTURAL CHANGE AND EXPLORING THE INTERPLAY BETHEEN SOCIAL STRUCTURAL CHANGE AND POLITICAL POWER DURING THIS PERIOD, THE AUTHOR OF THIS BOOK ASKS WHY A CITY WITH A LARGE MINORITY POPULATION AND A LONG TRADITION OF LIBERALISM ELECTED A CONSERVATIVE MAYOR WHO PROMOTED REAL ESTATE DEVELOPMENT AND BELITTLED MINORITY ACTIVISTS. THROUGH A CAREFUL ANALYSIS OF VOTING PATTERNS, POL ITICAL STRATEGIES OF VARIOUS INTEREST GROUPS, AND POLICY
TRENDS, HE EXPLAINS HOW MAYOR EDWARD KOCH CREATED A POWERFUL POLITICAL COALITION AND WHY IT ULTIMATELY FAILED. KOCH 
ABANDONED HIS ORIGINAL ELECTORAL BASE IN ORDER TO APPEAL TO WHITE ETHNICS APPREHENSIVE ABOUT LOSING THEIR DOMINANT POSITION AND TO CAPITALIZE ON TENSIONS BETWEEN BLACK AMD LATINO POPULATIONS. HE ALSO FORGED ALLIANCES WITH THE REGULAR DEMOCRATIC ORGZMIZATIONS AMD THE REAL ESTATE DEVELOPMENT INDUSTRY. IN EXAMINING HOW THIS DEMOCRATIC MAYOR MANAGED THE DIFFERENCES OF INTEREST BETHEEN HIS ELECTORAL BASE AND HIS ALLIES IN GOVERNMENT, THE AUTHOR REVEALS MUCH ABOUT THE CREATION AND EXERCISE OF POWER IN THE POSTINDUSTRIAL CITY AND ABOUT THE FUTURE OF URBAN LIBERALISM.

06489 MOLS, M.

CONCERTATION: REgIONALISM IN LATIN AMERICA

AUSSEN POLITIK, 43(1) (1992), 72-81.

DEYELOPMENTAL TENDENCIES WORLOWIDE WOULD APPEAR TO BE MOVING IN OPPOSITE OIRECTIONS. ON THE ONE HAND, IN EASTERM EUROPE THE SOVIET UNION IS DISINTEGRATING AS THE LAST MAJOR COLONIAL EMPIRE, AND IN YUGOSLAVIA AND I NDOCHINA TOO THE DAYS OF A "MUTUALITY" IMPOSED BY ONE NATION UPON ANOTHER WOULD SEEM TO BE NUMBERED. ON THE OTHER HAND, NOT ONLY IN WESTERN AND CENTRAL EUROPE THERE IS A CLEAR TREND TOHARDS JOINING FORCES BEYOND NATIONAL FRONTIERS. THIS ARTICLE DESCRIBES THE GROWING LINKAGES ON THE SOUTH AMERICAN CONTINENT.

\section{MOLS, M.}

LATIN AMERICA'S INTERMATIONAL SITUATION

AUSSEN POLITIK, 43(3) (JUL 92), 297-305.

THE CESSATION OF EAST-WEST CONFRONTATION, HHICH ATTRACTS ALL THE ATTENTION AND TO A LARGE EXTENT DETERMINES POLITICAL CONSIDERATIONS THROUGH ITS MANIFOLD IMPLICATIONS, IS ONLY ONE OF SEVERAL ELEMENTS IN THE FAR-REACHING TRANSFORMATION TAKING PLACE WORLDWIDE. LESS NOTICED BUT BY NO MEANS UNIMPORTANT ARE THE RECENT DEVELOPMENTS IN LATIN AMERICA. THIS ARTICLE ANALYZZS THE NEH POLITICAL TRENDS IN LATIN AMERICA AND SETS THEM IN A GLOBAL CONTEXT.

06491 MOMOH, $E$.

SIERRA LEONE: REVOLUTION IN CRISIS?

WEST AFRICA, 75( 3925 ) (DEC 92), 2092-2093.

SIX MONTHS AFTER SEIZING POWER. THE NPRC IS GRADUALLY REALIZING THAT MAKING PROMISES HITH THE HELP OF THE GUN IS A LOT EASIER THAM MAKING GODO THOSE PROMISES. IN THIS REPORT, EDOIE MOMOH LOOKS AT THE STRASSER-LED MILITARY REGIME'S PROBLEMS. HE SUGGESTS THAT THERE ARE THO MAIM CAMPS OPERATING WITHIN THE NPRC. STRASSER HIMSELF APPEARS TO HANT TO KEEP IT THAT HAY SO IONG AS HIS PERSOMAL POSITION IS NOT TO KEEP IT THAT WAY SO LONG AS HIS PERSONAL POSITION IS NOT THREATENED. ALSO, THAT THE DIVISION IN THE
SOMEWHAT CLUMSY AND INCOHERENT POLICIES.

06492 MOMOH, J.

MOMOH ANSWERS STRASSER

WEST AFRICA, (3902) (JUN 92), 1090-1091.

IN THIS STATEMENT, SIERRA LEONE'S OUSTED PRESIDENT JOSEPH MOMOH GIVES HIS VERSION OF THE EVENTS THAT LED TO THE 1992 COUP AGAINST HIS REGIME.

06493 MOMOH, J.

RENEWED ULIMO OFFENSIVE

WEST AFRICA, (3915) (SEP 92), 1608.

THE UNITED LIBERATION MOVEMENT FOR DEMOCRACY IN LIBERIA (ULIMO) HAS GAINED A DECISIVE VICTORY OVER REBEL LEADER CHARLES TAYLOR'S NPFL BY ADVANCING AS FAR AS THE PO RIVER BRIDGE, WHICH DEMARCATES THE TERRI TORIES HELD BY THE NPFL AND THE INTERIM GOVERMMENT. BOMIE AND CAPE MOUNT COUNTIES AND MOST OF LOFA COUNTY APPEAR TO BE UNDER ULIMO'S FRAGILE CONTROL.

06494 MOMOH, J. ROCKY ROAD TO PEACE

WEST AFRICA, (3884) (FEB 92), 314.

RECENT DÉYELOPMENTS IN LIBERIA RAISE HOPES FOR THE EYENTUAL ACHIEVEMENT OF PEACE IN THE WEST AFRICAN COUNTRY. BUT THERE ARE ALSO I NDICATIONS THAT PEACE AND NORMALITY ARE BUT THERE ARE ALSO INDICATIONS THAT PEACE AND NORMALITY ARE STILL FAR AHAY, AS

$06495 \mathrm{MOMOH}, J$.

HHO'S DELAYING PEACE?

WEST AFRICA, (3892) (APR 92), 674

THE HEAD OF ECOMOG, GENERAL ISHAYA BAKUT, BLAMES NPFL LEADER CHARLES TAYLOR' FOR THE DELAY IN IMPLEMENTING THE LEADER CHARLES TAYLOR FOR THE
YAMASSOUKRO 4 PEACE ACCORD.

06496 MOMOH, J. HHY TALKS DEADLOCKED

WEST AFRICA, (3900) (JUM 92), 1011.

SINCE THE BAMAKO CEASEFIRÉ AGREEMENT OF NOVEMBER 28, 1990. SEVERAL PEACE INITIATIVES HAVE BEEN EXPLORED BUT' NON HAS YIELDED ENDURING RESULTS. RELATIONS BETWEEN LIBERIA'S INTERIM GOVERMMENT AND THE NPFL GOVERNMENT CONTINUE TO DETERIORATE. OLD RECRIMINATIONS AND ANIMOSITIES CONTINUE TO RESURFACE IN VARYING FORMS.
06497 MONCRIEF, G.; THOMPSON, J.

ELECTORAL STRUCTURE AND STATE LEGISLATIVE REPRESENTATION: A RESEARCH NOTE

THE JOURMAL OF POLITICS, 54(1) (FEB 92), 246-258.

USING DATA FROM 10 STATES, THE AUTHORS COMPARE

CHARACTERISTICS OF LEGISLATORS ELECTED FROM THE DIFFERENT DISTRICT TYPES. THEY FIND THAT NONHATIVE LEGISLATORS ARE MORE LIKELY TO REPRESENT URBAN SINGLE-MEMBER DISTRICTS (SMDS); EDUCATIONAL ATTAINMENT IS A FUNCTION OF THE URBAN/RURAL NATURE OF THE DISTRICT AND IS NOT RELATED TO ELECTORAL TYPE; AND THAT LEGISLATORS FROM SMOS HAVE LONGER LEGISLATIVE SERVICE THAN THOSE FROM MULTIMEMBER DISTRICTS (MMDS). THEY ALSO FIND COMPELLING EVIDNECE THAT BLACKS ARE (MMDS). THEY ALSO FIND CDMPELLING EVIDNECE THAT BLACKS ARE ADVANTAGED BY SMDS, ESPECIALLY URBAN SMDS, AND THAT HOMEN
ARE ELECTED MORE FREQUENTLY FROM MMOS, ESPECIALLY URBAN MHOS.

06498 MONCRIEF, G.; HADDON, M.; HOYER, R.; THOMPSON, J.

FOR WHOM' THE BELL TOLLS: 'TERM LIMIT'S AND STATE LEGISLATURES LEGISLATIVE STUDIES QUARTERLY, 17(1) (FEB 92), 37-48. THIS NOTE IS AN INITIAL EFFORT TO ASSESS THE POTENTIAL EFFECT OF ENACTING THE LIMITATION OF TERMS OF OFFICE FOR STATE LEGISLATORS. THE AUTHORS DEVELOP A COHORT ANALYSIS TO MEASURE HOW MANY OF THE LEGISLATORS CURRENTLY SERVING WOULD BE AFFECTED BY TERM LIMITATIONS. THEY FIND THAT MOST STATE LEGISLATORS DO NOT STAY IN THE INSTITUTION FOR AS LONG AS 12 YEARS. VARIATION IN RETENTION RATES IS RELATED TO CHAMBER,
TO SOUIRE'S OPPORTUNITY TYPE, AND ESPECIALLY TO LEGISLATIVE PROFESSIONALISH.

06499 MONCRIEF, G.

THE INCREASE IN CAMPAIGN EXPENDITURES IN STATE LEGISLATIVE ELECTIONS: A COMPARISON OF FOUR NORTHWESTERN STATES

WESTERN POLITICAL QUARTERLY, 45(2) (JUN 92), 549-558. THE AUTHOR ANALYZES STATE LEGISLATIVE CAMPAIGN

EXPENDITURE DATA FOR TWO TIME PERIODS IN FOUR STATES. HE FINDS THAT THE INCREASE IN EXPENDITURES IS CONDITIONED BY THO CONTEXTUAL FACTORS: THE DEGREE OF COMPETITION FOR PARTY CONTROL OF THE CHAMBER AND THE LEVEL OF STATE LEGISLATI

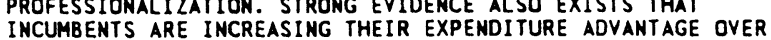
INCUMBENTS ARE INCREASING THEIR EXPENDI TURE ADVANTAGE OVER CHALLENGERS AND THAT
LEGISLATIVE OFFICE.

06500 MONCRIEFF, A.

THAILAND: STAGGERING BACK TO DEMOCRACY

WORLD TODAY 48(3) (MAR 92) 48-50.

THE AUTHOR LOOKS AT THE ACCOMPLISHMENTS AND FAILURES OF THAILAND'S GOVERMMENT DURING THE TENURE OF THE NATIONAL PEACEKEEPING COUNCIL AND ASSESSES THE POSSIBILITIES FOR FUTURE POLITICAL STABILITY AND A RETURN TO DEMOCRACY.

06501 MONDAK, J.

INSTITUTIONAL LEGITIMACY, POLICY LEGITIMACY, AND THE SUPREME COURT

AMERICAN POLITICS OUARTERLY, 20(4) (OCT 92), 457-477.

AS THEY RELATE TO THE SUPREME COURT, INSTIITUTIONAL LEGITIMACY AND POLICY LEGITIMACY HAVE MOST FREQUENTLY BEEN STUDIED IN ISOLATION. IN THIS ARTICLE, A HOLISTIC FRAMENORK IS PROPOSED AND EXAMINED. THE POLITICAL CAPITAL HYPOTHESIS HOLDS THAT THE SUPREME COURT CAN INTRODUCE INSTITUTIONAL SUPPORT IN ITS EFFORTS TO GENERATE LEGITIMACY FOR PARTICULAR POLICIES, BUT THAT THE COURT RISKS ITS INSTITUTIONAL BACKING BY ADVANCING CONTROVERSIAL EDICTS. THEREFORE, INSTITUTIONAL LEGITIMACY FUNCTIONS AS AN EXPENDABLE POLITICAL CAPITAL HITH WHICH THE SUPREME COURT CAN CONFER SOME INCREMENT OF POL ICIY LEGT IMACY.

06502 MONDAK, J.

SUBSTANTIVE AND PROCEDURAL ASPECTS OF SUPREME COURT DECISIONS AS DETERMINANTS OF INSTITUTIONAL APPROVAL AMERICAN POL ITICS OUARTERLY 19(2) (APR 91) 174-18B. PUBLIC EVALUATIONS OF THE SUPREME COURT ARE INFLUENCED BY RESPONSE TO THE CDURT'S RULINGS, BUT THE SPECIFIC APPRAISALS REQUIRE IDENTIFICATION. IN PARTICULAR, PREVIOUS APPRAISALS REQUIRE IDENTI IFICATION. IN PARTICULAR, PREVIOUS
INYESTIGATORS HAVE BEEN UNABLE TO DETERMINE IF SUPPORT OF INVESTIGATORS HAVE BEEN UNABLE TO DETERMINE IF SUPPORT
THE SUPREME COURT MOVES IN RESPONSE TO THE SUBSTANTIVE ASPECTS OF DECISIONS, PUBLIC CONCERN WITH DEMOCRATIC PROCEDURE, OR ATTENTION TO BOTH SUBSTANCE AND PROCEDURE. THIS ARTICLE PRESENTS THE RESULTS OF AN EXPERIMENT DESIGNED TO DISTINGUISH THE POSSIBLE INFLUENCES OF SUBSTANTIVE AND PROCEDURAL CONCERNS. FINDINGS REVEAL THAT THE SUBSTANTIV ASPECTS OF COURT RULINGS EXERT SIGNIFICANT INFLUENCE ON EVALUATIONS OF THE SUPREME COURT, AFFECTING INSTITUTIONAL SUPPORT, CONFIDENCE IN THE COURT'S JUSTICES, AND SPECIFIC SUPPORT OF EACH OF THE THREE DECISIONS THAT WERE STUDI
CONTRAST, CONCERN WITH THE DEMOCRATIC IMPLICATIONS OF CONTRAST, CONCERN WITH THE DEMOCRATIC IMPLICATIONS OF
ACTIVIST RULINGS FAILED TO ALTER ANY DIMENSION OF COURT APPROVAL.

06503 MONEY, J.; TSEBELIS, G.

CICERO'S PUZZLE: UPPER HOUSE POWER IN COMPARATIVE PERSPECTIVE

INTERNATIONAL POLITICAL SCIENCE REVIEW, 1311) (JAN 92), 
$25-44$.

THIS PAPER ANALYZES THE LEGISLATIVE INFLUENCE OF UPPER HOUSES IN BI CAMERAL LEGISLATURES. IT REUNITES TWO ANALYTICAL TRADITIONS AND PROVIDES A UNIQUE MODEL OF UPPER HOUSE POLITICAL POWER IN BOTH FEDERAL AND UNITARY SYSTEMS. FOR THOSE STATES USING A NAVETTE, OR SHUTTLE, SYSTEM, THE AUTHORS MODEL SENATORIAL PONER AS A FUNCTION OF THE INSTITUTIONAL FEATURES OF THE SYSTEM: STOPPING RULES, HHERE A BILL IS INTRODUCED, AND THE NUMBER OF SHUTTLES BETWEEN

06504 MONGUSH, M.

REMOTE AND FORLOR

FAR EASTERN ECONOMIC REVIEN, 155(4) (JAN 92), 25-26.

THIS ARTICLE EXAMINES THE BACKGROUND AND UNCERTAIM FUTURE OF THE TINY SIBERIAN REGION OF TUVA. THIS MOUNTAINCIRCLED EMCLAVE ON THE MONGOL IAN BORDER HAS ONE OF THE LOWEST LIVING STANDARDS IN THE RUSSIAN REPUBLIC DESPITE GOLD, SIIVER TO SOYIET DOMINAT AN FOR DECADES, AND THE FUTURE PROSPECTS ARE NOT MUCH BETTER. A FRESH CULTURAL ONSLAUGHT LOOMS UNDER ARE NOT MUCH BETTER. A FRESH CULTURAL ONSLAUGHT LOOMS UND
THE RUSSIAN-LED COMMONHEALTH OF INDEPENDENT STATES WHICH THE RUSSIAN-LED COMMONHEALTH OF INDEPENDENT STATES WHICH
INCLUDES TUVA. ALTHOUGH ETHNIC RUSSIAN MIGRANTS COMPRISE INCLUDES TUVA. ALTHOUGH ETHNIC RUSSIAN MIGRANTS COMPRISE
ABOUT A THIRD OF TUVA'S TOTAL POPULATION OF 300,000 , NATIVE ABOUT A THIRD OF TUVA'S TOTAL POPULATION OF 300,000 , NATIVE
TUVANS ARE NEITHER RUSSIANS NOR SLAVS BUT TURKIFIED MONGOLS. ALTHOUGH TUVA IS NOW A SELF-PROCLAIMED FULL REPUBLIC, ITS DEPENDENCE ON THE OUTSIDE IS NEARLY COMPLETE AND IS UNLIKELY DEPENDENCE ON THE OUTSIDE

06505 MONIAC, R.

NATO REVISES NUCLEAR STRATEGY FOR THE POST COLD-HAR AGE GERMAN TRIBUNE, 31(1538) (OCT 92) 1-2.

ELIMINATION OF THE EAST-WEST CONFLICT HAS NOW REACHED NATO NUCLEAR STRATEGY. IN THE FUTURE NATO HILL DISCUS NUCELAR MATTERS AT REGULAR MEETINGS OF THE DEFENSE PLANNING COMMITTEE. NUCLEAR WEAPONS WILL GAIN AN ENTIRELY NEW MEANING AND PLAY A COMPLETELY NEW ROLE IN THE CONTEXT OF ANY FUTURE DEMONSTRATION OF MILITARY POHER THAT NATO MIGHT HAVE TO UNFOLD.

06506 MONK-TURNER, E.

SEXUAL NUAHCES WITHIN INTERNAL LABOR MARKETS: "THE POLITICS OF BEING KNOWN"

SOCIAL SCIENCE JOURNAL, 29(2) (1992), 227-240.

THE AUTHOR ANALYZES THE BENEFIT OF BEING KNOWN WITHIN AM ORGANIZATION FOR WOMEN COMPARED TO MEN. DUAL/INTERMAL LABOR MARKET THEORISTS MAINTAIN THAT HIGHER-LEVEL POSITIONS WITHIN ORGANIZATIONS ARE PRIMARILY FILLED FROM INTERNAL SOURCES. NAMELY, THROUGH PROMOTION OF ALREADY EMPLOYED WORKERS IN LADOER POSITIONS. AN ARGUMENT IS MADE THAT THIS PROCESS LADDER POSITIONS. AN ARGUMENT IS MADE THAT THIS PROCESS BIAS HELP MAINTAIN THE GLASS CEILING WHICH KEEPS WOMEN OUT OF TOP LEYEL POSITIONS WITHIN ORGANIZATIONS.

06507 MONK, $P$

COPING WITH THE END OF HISTORY: PYONGYANG AMD THE REALM OF FREEDOM

KOREAN JOURMAL OF DEFENSE ANALYSIS, IV(2) (WIN 92), 95-124.

THE RAPID FALL OF THE SOVIET EMPIRE GIVES CREDENCE TO THE IDEA THAT AUTHORITARIAN COMMUNIST-LED REGIMES ARE NOT THE MONOLITHIC ENTITIES THAT OUTSIDERS SOMETIMES DEPICT THEM TO BE. THIS PAPER EXAMINES THE COMMUNIST REGIME IN NORTH KOREA, ITS HISTORY, PROPAGANDA AND ITS FUTURE. IT ARGUES
THAT KIM IL-SUNG AND HIS FOLLOWERS FACED, AND CONTINUE TO FACE, ARTICULATE AND TRENCHANT OPPOSITION FROM WITHIN THEIR OWN MOVEMENT. THEY SUPPRESSED THIS OPPOSITION NOT BY APPEALS TO CULTURAL TRADITION, BUT BY MEANS OF PURGES AND PROPAGANDA. THE ANALYSIS CONCLUDES BY RECOMMENDING "PATIENCE AND IMAGINATION" ON THE PART OF THOSE OUTSIDE POWERS WHO DEAL WITH NORTH KOREA.

06508 MONTEFIORE, S.S. CURIOUS GEORGIA

NEW REPUBLIC, 206(26) (JUN 92), 17-18, 20

EDUARD SHEVARDNADZE, FORMERLY THE SOVIET FOREIGM MINISTER UNDER MIKHAIL GORBACHEV, HAS RETURNED TO HIS HOME IN GEORGIA AND IS SERVING AS THE UNELECTED PRESIDENT OF THE STATE COUNCIL.

06509 MONTEIRO, T.

THE CRIMINALIZATION OF AFRICAN AMERICANS

POLITICAL AFFAIRS, LXX(4) APR 91$), 4-12$

THIS ARTICLE CONSIDERS THE "CRIMINALIZATION" OF AMERICA'S AFRICAN AMERICAN COMMUNITY. IT ARGUES THAT THEY ARE VICTIMS OF EXTREME LEVELS OF IMPRISONMENT, POLICE VIOLENCE AND MURDER HIGH UNEMPLOYMENT, HOMELESSNESS, ILLITERACY, AND DISEASE. RACISM CONTINUES TO PLAY A LARGE ROLE IN DETERMINING WHO IS ARRESTED, IMPRISONED, AND THE SEVERITY OF PUNISHMENT. CRIMINALIZATION IS AN IDEOLOGICAL, LEGAL, AND POLITICAL PROCESS. IN IDEOLOGICAL TERMS, IT TARGETS AFRICAN AMERICAN MALES AS A DANGER TO SOCIETY. POLITICALLY, AND LEGALLY, THE RECENT HAVE OF "GET TOUGH" MEASURES AND LEGISLATION IS AIMED PARTICULARLY TO BLACKS.
THE ARTICLE CONCLUDES THAT THIS PHENOMENON IS A THREAT TO
DEMOCRACY IN AMERICA.

06510 MONTGOMERY, J.

ACESSING THE EUROPEAN COMMUNITY MARKET

SOUTH AFRICA INTERNATIONAL, 23(2) (OCT 92), 93-94. GIVEN THE IMPORTANCE OF THE EUROPEAN COMMUNITY AS A MARKET FOR SOUTH AFRICAN EXPORTS, THE FUTURE TRADING RELATIONSHIP BETHEEN THESE THO AREAS OF THE WORLD MERITS CAREFUL CONSIDERATION. THERE ARE A NUMBER OF QUESTIONS OPEN TO SOUTH AFRICA. ALL OF THEIR OPTIONS HAVE DISADVANTAGES AS WELL. THE TIME IS APPROACHING WHEN SOUTH AFRICA HILL HAVE TO DECIDE HOW BEST TO ACCESS THE EC MARKET.

06511 MONTGOMERY, J.

MAASTRICHT' IN ENGLISH

SOUTH AFRICA INTERNATIONAL, 22(3) (JAN 92), 147-148. DESPITE RESERVATIONS, BRITAIN AT MAASTRICHT ENDORSED

FURTHER MOVES TOWARDS CLOSER UNION WITHIN THE EUROPEAN COMAUNITY. THE PRIME MINISTER, JOHN MAJOR, HOHEVER INSISTED ON THE UK'S RESERVING THE RIGHT TO REFUSE TO MOVE TO THE THIRD STAGE OF ECONOMIC AND MONETARY UNION WITHOUT PRIOR ENDORSEMENT BY HER PARLIAMENT AND GOVERNMENT AND SECURING THE TRANSFORMATION OF THE "SOCIAL CHARTER" FROM A BINDING TO A NON-BINDING DECLARATION FOR EC MEMBERS. NONETHELESS, BRITAIN IS FIRMLY PART OF THE STEADY PROGRESS TOWARDS
EUROPEAN UNION, ALTHOUGH THE ACHIEVEMENT OF THAT GOAL LOOKS TO BE SOME WAY OFF.

06512 MONTGOMERY, J.

THE EC AND SOUTH AFRICA--OPENING FOR BUSINESS? SOUTH AFRICA INTERNATIONAL, 22(2) (OCT 91), 102-103. PROSPECTS FOR TRADE WITH AND INVESTMENT' IN SOUTH AFRICA AND THE REGION HAVE CONSIDERABLY IMPROVED WITH SOUTH AFRICA'S RE-ENTRY INTO THE HORLD COMUNITY. THE FORMATION OF A SINGLE EUROPEAN MARKET POSES SOME POTENTIAL PROBLEMS FOR SOUTH AFRICA, BUT TRENDS IN TRADE WITH THE UNITED KINGDOM SHOW EVERY SIGN OF CONTINUED EXPANSION.

06513 MONTGOMERY, J.

THE UK--THE YEAR OF ELECTIONS

SOUTH AFRICA FOUNDATION REVIEW, 18(4) (APR 92), 4-6. DESPITE GREAT BRITAIN'S PREOCCUPATION WITH ECONOMIC

RECESSION, EUROPEAN ECONOMIC AND MONETARY UNION, AND THE 9 APRIL GENERAL ELECTION, EVENTS IN THE SOUTH AFRICA HAVE ALSO RECEIVED THEIR SHARE OF BRITISH INTEREST. RECENT POLLS INDICATE THAT MANY BRITISH CITIZENS ARE PLEASED WITH THE POL.ITICAL CHANGES AND REFORMS IN SOUTH AFRICA. HOWEVER, MUCH NEEDS TO BE DONE TO INFORM POTENTIAL INVESTORS ABOUT THE NEEDS TO BE DONE TO INFORM POTENTIAL INVESTORS ABO

DIMINISHED RISK OF INVESTING IN SOUTH AFRICA. MANY

INSTABILITY AND VIOLENCE ON ANY POTENTIAL INVESTMENT.

06514 MONTGOMERY, J.

SOUTH AFRICA INTERNATIONAL, 23(1) (JUL 92), 53-54

AHIDST UK MEDIA PREOCCUPTION WITH THE FUTURE OF THE MONARCHY, DENMARK'S REJECTION OF MAASTRICHT AND DOUBTS CONCERNING THE FUTURE OF THE EXCHANGE RATE MECHANISM AND THE EARTH SUMAIT IN RIO, REPORTS ON SOUTH AFRICA CONTINUE TO UNDERMINE ECONOMIC AND POLITICAL CONFIDENCE.

06515 MONTJOY, R.; O'TOOLE, L.

POLICY INSTRUMENTS AND POLITICS: MULTIPLE REGRESSION AND INTERGOVERMMENTAL AID

STATE AND LOCAL GOVERMMENT REVIEW, 23(2) (SPR 91), 51-59. THE INSTITUTIONAL SETTING IN WHICH AID PROGRAMS ARE CREATED PROVIDES POLITICAL INCENTIVES FOR PARTICIPANTS TO EMPHASIZE PORK BARREL POLITICS OVER SUBSTANTIVE TARGETING. THIS ARTICLE ARGUES THAT A CLASS OF DECISION RULES MAY ENCOURAGE PARTICIPANTS TO ESCAPE PAROCHIAL IMPASSES BY BINDING THEMSELVES TO UNCERTAIN FUTURE DISTRIBUTIONS DRIVEN BY SUBSTANTTIVE CRITERIA. THE USE OF REGRESSION AMALYSIS IN THE DESIGN OF INTERGOVERMMENTAL AID FORMULAS OFFERS PROMISE AS A BINDING MECHANISM. EXPERIENCE FROM A VIRGINIA CASE IS EMPLOYED TO HIGHLIGHT THE STRENGTHS AND LIMITATIONS.

06516 MOODIE, M.

TRANSPARENCY IN ARMAMENTS: A NEH ITEM FOR THE NEW SECURITY AGEMDA

WASHINGTON QUARTERLY, 15(3) (SUM 92), 75-82.

THE UNITED NATIONS ASSEMBLY PASSED, ON 9 DECEMBER, 1991, A RESOLUTION ON "TRAMSPARENCY IN ARMAMENTS" (TIA). THE TIA, RESOLUTION CALLS UPON THE UM SECRETARY GEMERAL TO ESTABI ISH A REGISTER OF CONYENTIONAL ARMS. INCLUDING TRANSFERS, FOR WHICH MEMBER STATES ARE REOUESTED TO PROYIDE DATA ACCORDING TO CATEGORIES SUCH AS TANKS, ARMORED VEHICLES, WARSHIPS AND MISSILE SYSTEMS. THE TIA RESOLUTION IS HOPED TO BE AN IMPORTANT FIRST STEP IN REDUCING THE SPREAD OF ARMAMENTS THROUGHOUT THE WORLD. THIS ARTICLE EXAMINES HOW THE RESOLUTION EVOLVED AND ASSUMED THE FORM APPROVED BY THE GENERAL ASSEMBLY. IT ALSO CONSIDERS SOME LONG-TERM QUESTIONS RAISED BY THE RESOLUTION INCLUDING THOSE RELATING TO THE PROPER PERSPECTIVE ON THE ROLE AND IMPACT OF ARMS TRANSFERS, THE VALUE OF TRANSPARENCY IN MILITARY MATTER, THE LOCUS OF 
RESPONSIBILITY FOR EFFECTIVE TRANSPARENCY, NORTH-SOUTH DIFFERENCES ON THIS ASPECT OF THE ARMS-CONTROL AGENDA, AND THE FUTURE OF INTERNATIONAL INSTITUTIONS THAT ADORESS SECURITY QUESTIONS.

06517 MOOHAMEDI, F.

POLITICAL ECONOMY: OPEC SINCE THE GULF HAR

MIDOLE EAST REPORT, 22(3) (MAY 92), 39-40

AS KUWAIT PREPARES TO RETURN TO THE MARKET, WITH IRAQI EXPORTS LOOMING ON THE HORI ZON AND OIL DEMAND GROWTH DEPRESSED BY POOR ECONOMIC CONDITIONS WORLOWIDE, OPEC ONCE AGAIN FACES ITS HISTORIC DILEMMA OF CONTROLLING SUPPLY VOLUNARILY AND STABILIZING OIL PRICES AT A LEVEL THAT PROYIDES FOR THE MINIMAL REVENUE NEEDS OF MEMBER STATES. THIS COLUMN REPORTS ON THE UPS AND DOWN OF OIL PRICES, THE 1990 PEC MEETING, AND POSTHAR DYNAMICS. THE PRESENT INCOME REQUIREMENT SUGGESTS THAT THE SAUDIS WILL NOT TRASH THE MARKET AS THEY DID IN 1986.

06518 MOOMSEN, J.

CANADA-CARIBBEAN RELATIONS: WHEREIN THE SPECIAL RELATIONSHIP?

POLITICAL GEOGRAPHY QUARTERLY, 11(5) (SEP 92), 501-513.

CANADA AND CARIBBEAN HAVE A LONG-STANDING RELATIONSHIP FOSTERED BY A COMMON INTEREST IN RESISTANCE TO BRITISH IMPERIALISM AND AMERICAN ECONOMIC HEGEMONY. THIS PAPER TRACES THE HISTORICAL ROOTS THROUGH A SERIES OF FORMAL BILATERAL AGREEMENTS CULMINATING IN THE ONE, KNOWN AS CARIBCAN, RATIFIED IN 1986. THE AUTHOR CONCLUDES THAT TODAY, THE CONTEMPORARY ECONOMIC BASES OF THIS RELATIONSHIP ARE

06519 MOON, B.E.; DIXON, H.J.

BASIC NEEDS AND GROWTH-WELFARE TRADE-OFFS

INTERNATIONAL STUDIES QUARTERLY, 36(2) (JUN 92), 191-212. CAN NATIONS ACHIEVE BOTH GROWTH AND EQUITY OR MUST ONE VALUE BE SACRIFICED TO ATTAIN THE OTHER? THE CONTROVERSY OVER TRADE-OFFS BETWEEN AGGREGATE ECONOMIC PERFORMANCE AND SOCIAL WELAFRE LIES AT THE HEART OF RECENT DEBATES ON SOCIAL WELAFRE LIES AT THE HEART OF RECENT DEBATES ON
DEVELOPMENT POLICY. THIS STUDY REVIEWS THESE DEBATES, DEVELOPMENT POLICY. THIS STUDY REVIEWS THESE DEBATES,
IDENTIFIES THE SPECIFIC FORMS OF LIKELY TRADE-OFFS, AND IDENTIFIES THE SPECIFIC FORMS OF LIKELY TRADE-OFFS, AND
EXAMINES THE EVIDENCE OVER A TWENTY-FIVE YEAR PERIOD FOR A SAMPLE OF 104 NATIONS. THE AUTHORS EMPLOY A CROSS-NATIONAL SAMPLE OF 104 NATIONS. THE AUTHORS EMPLOY A CROSS-NATIONAL
PANEL DESIGN TO ASK THO QUESTIONS: (1) DOES BASIC NEEDS PANEL DESIGN TO ASK THO QUESTIONS: (1) DOES BASIC NEEDS
ACHIEVEMENT COMPROMISE FUTURE GROWTH? (2) DOES RAPIO GROWTH ACHIEVEMENT COMPROMISE FUTURE GROWTH? (2) DOES RAPID GROWTH UNDERMINE FUTURE NEEDS ACHI EVEMENT? THEY FIND NO EVIDENC FOR THE ORTHODOX VIEH THAT BASIC NEEDS FULFILLMENT OR IHAT BASIC NEEDS ATIAIMMENT FACILITATES LONG-TERM ECONOMIC THAT BASIC NEEDS ATTAINMENT FACILITATES LONG-TERM ECONOMIC GROWTH. THE EVIDENCE IS SOMEWHAT LESS CLEAR REGARDING THE
SECOND OUESTION, AL THOUGH IT APPEARS THAT RAPID GROWTH DOES SECOND QUESTION, ALTHOUGH IT APPEARS THAT RAPID GRO
NOT PRODUCE SUBSTANTIAL BASIC NEEDS IMPROVEMENTS.

06520 MOON, D.

THE DETERMINANTS OF TURMOUT IN PRESIDENTIAL ELECTIONS: AN INTEGRATIVE MODEL ACCOUNTING FOR INFORMATION

POLITICAL BEHAVIOR, 14(2) (JUN 92), 123-140.

THE AUTHOR PRESENTS A MODEL OF TURMOUT THAT EXTENDS THE RIKER AND ORDESHOOK MODEL TO ACCOUNT FOR THE PURCHASE OF NEH INFORMATION FOR ASSESSING OUTCOME-CONTINGENT BENEFITS AND THAT SEEKS TO INTEGRATE THE VARIOUS INSTITUTIONAL,

SOCIOLOGICAL, PSYCHOLOGICAL, AND ECONOMIC FACTS THAT HAVE BEEN ADVANCED TO ACCOUNT FOR TURNOUT IN U.S. PRESIDENTIAL ELECTIONS. PERSONAL AND INSTITUTIONAL DATA FROM THE 1972 AND 1976 ICPSR NES PANEL STUDY AND VOTE VALIDATION SURVEY ARE USED TO TEST THE MODEL. THE RESULTS SUGGEST THAT A VARIETY OF FACTORS ARE IMPORTANT IN INFLUENCING THE TURNOUT DECISION, INCLUDING THE PERCEIVED DIFFERENCE BETWEEN THE CANDIDATES (IN 1976). SENSE OF SOCIAL DUTY. SENSE OF ATTACHMENT TO RELEVANT GROUPS, POLITICAL EFFICACY, RESOURCE CONSTRAINTS, RESIDENCE, AND THE COSTS OF REGISTERING (IN 1976). CLOSENESS OF THE ELECTION ALSO SEEMED TO HAVE A SIGNIFICANT IMPACT IN 1976.

06521 MOON, $D$.

WHAT YOU USE STILL DEPENDS ON WHAT YOU HAVE: INFORMATION EFFECTS IN PRESIDENTIAL ELECTIONS, 1972-1988

AMERICAN POLITICS QUARTERLY, 20(4) (OCT 92), 427-441. THIS ARTICLE EXTENDS EARLIER WORK ON THE EFFECTS OF INFORMATION ON THE VOTE CHOICE DECISION. THE GENERAL MOOEL PREDICTS THAT VOTERS AT HIGHER LEVELS OF INFORMATION WILL PREDICTS THAT VOTERS AT HIGHER LEVELS OF INFORMATION WILL USE MORE CUES TO VOTE CHOICE AND WILL RELATE THEM MORE COHESIVELY THAN THOSE AT LOWER LEVELS. MORE SPECIFICALLY, THOSE AT HIGH LEVELS OF INFORMATION WILL BE CHOICES. EARL IER WORKS SHOHED SUPPORT FOR THIS HYPOTHESIS IM CHOICES. EARLIER WORKS SHOHED SUPPORT FOR THIS HYPOTHESIS IN THE 1976 PRESIDENTIAL ELECTION. THE RESULTS PRESENTED HERE SHOW THAT, ALTHOUGH THERE ARE SIGNIFICANT DIFFERENCES IN HOW CUES TO VOTE CHOICE ARE USED ACROSS ELECTIONS, THE PATTERN OF DIFFERENCES ACROSS INFORMATION LEVEL
FIVE ELECTIONS BETHEEN 1972 AND 1988.

06522 MOONEY, C.

PUTTING IT ON PAPER: THE CONTENT OF WRITTEN INFORMATION
USED IN STATE LAWMAKING

AMERICAN POLITICS QUARTERLY, 20(3) (JUL 92), 345-365.

WHAT KINDS OF INFORMATION DO STATE LEGISLATORS CONSIDER IN THEIR LEGISLATIVE DELIBERATIONS? THIS ARTICLE EXAMINES FOUR DIMENSIONS OF THE CONTENT OF THE WRITTEN INFORMATION STATE REPRESENTATIVES IN INDIANA, MASSACHUSETTS, AND OREGON USED IN 1989; HHETHER IT WAS POLICY OR POLITICAL INFORMATION, ONE-SIDED OR MULTISIDED, IN AGREEMENT OR DISAGREEMENT WITH THE POSITION OF THE LEGISLATOR USING IT, AND WHETHER IT HAD ANY HARD OR SOFT SCIENTIFIC CONTENT. LEGISLATORS ARE FOUND TO USE INFORMATIOH HEAVILY DOSED HITH POLITICAL PREFERENCES, WITH WHICH THEY AGREE. HOWEVER, THEY ALSO USE A SUBSTANTIAL WITH WHICH THEY AGREE. HOWEVER, THE
AMOUNT OF SCIENTIFIC INFORMATION.

06523 MDORE-SIERAY, D.

IN THE THROES OF CHANGE

WEST AFRICA, (3899) ( JUM 92), 959.

ALTHOUGH MANY DUTSIDE OBSERVERS MAY VIEW THE RECENT UPHEAVAL IN SIERRA LEONE WITH MISGIVING, SIERRA LEONEANS ARE REACTING DIFFERENTLY. THEY ARE MORE LIKELY TO GREET THE CHANGE OF GOVERMMENT WITH A SIGH OF RELIEF, EVEN THOUGH THAT
RELIEF MAY PROVE TO BE SHORT-LIVED.

06524 MOORE, B.

AFRICAN-AMERICAN WOMEN IN THE U.S. MILITARY ARMED FORCES AND SOCIETY, 17(3) (SPR 91), 363-384

THIS ARTICLE IS A COMPARISON OF BLACK WOMEN WITH WOMEN OF DIFFERENT RACIAL AND ETHNIC BACKGROUNDS AND BLACK MEN IN THE U.S. MILITARY. DEVELOPMENTAL ANALYSIS IS USED TO EXAMINE HISTORICAL TRENDS AND TO HYPOTHESIZE ABOUT THE FUTURE OF BLACK WOMEN ON ACTIVE DUTY. RESULTS OF STATISTICAL ANALYSIS CONFIRM PREVIOUS FINDINGS THAT AFRICAN-AMERI CAN WOMEN ARE ACCESSING THE MILITARY AT A FASTER PACE THAN OTHER RACIAL AND ETHNIC FEMALE GROUPS IN THE UNITED STATES; THEY ARE MORE CONCENTRATED IN THE ARMY THAN OTHER BRANCHES OF THE MILITARY; THEY ARE MOSTLY ASSIGNED TO ADMINISTRATIVE AND SUPPORT OCCUPATIONS; AND THEY ARE MORE LIKELY TO BE SINGLE PARENTS THAT ARE MILITTARY WOMEN AND MEN IN COMPARISON GROUPS. THE ARTICLE PONDERS THE CONSEQUENCES OF THESE FINDINGS FOR THE FUTURE STABILITY OF THE PARTICIPATION OF BLACK WOMEN IN THE FUTURE STABILITY
U.S. MILITARY

06525 MOORE, C.D.

HEALTHRIGHT: FILLING THE GAP IN A HIGH-ACCESS STATE NATIONAL CIVIC REVIEW, 81(2) (SPR 91), 137-142

MINNESOTA HAS JOINED THE RANKS OF STATE GOVERMMENTS SEEKING TO PROVIDE BETTER HEALTH CARE AT MORE REASONABLE COSTS. IT HAS ADOPTED A HEALTH CARE REFORM PLAN THAT
ADDRESSES THE PARADOX OF AMERICANS HAVING RESTRICTED ACCESS TO SERVICE IN THE MOST TECHNICALLY ADVANCED HEALTH CARE SYSTEM IN THE WORLD.

06526 MOORE, C.M.

COMMUNITY IS WHERE COMMUNITY HAPPENS

NATIONAL CIVIC REVIEN, 80(4) (FAL 91), 352-357.

COMMUNITY MEMBERS SHARE AN IDENTITY, SPEAK A COMMON LANGUAGE, AGREE UPON ROLE DEFINITIONS, SHARE COMMON VALUES, ASSUME SOME PERMANENT MEMBERSHIP STATUS, AND UNDERSTAND THE ALSO ESSENTIAL IN CREATING AND RECREATING COMMUNITY. COMMUNITY IS FORGED FROM A STRUGGLE AMONG PEOPLE TO DETERMINE HOW THEY CAN LIVE TOGETHER.

06527 MOORE, G.

GENDER AND INFORMAL NETHORKS IN STATE GOVERNMENT SOCIAL SCIENCE QUARTERLY, 73(1) (MAR 92), 46-61. THIS RESEARCH EXAMINES THE NETHORK STRUCTURES AND POSITIONS OF WOMEN AND MEN MANAGERS IN STATE BUREAUCRACIES PARTIALIY SUPPORT A RATIONAL-TECHNICAL MODEL SINCE NETWORK POSITIOMS DO NOT DIFFER GREATLY BETHEEN MEN AMD WOMEN WITH SIMI SOME SUPPORT IN MEN'S SLIGHTLY HIGHER FORMAL POSITIOMS AMD PREDOMINANCE IN THE NETWORKS.

06528 MOORE, M.

RETREAT FROM DEMOCRACY IN SRI LANKA?

JOURHAL OF COMMONHEALTH AND COMPARATIVE POLITIICS, 30(1)

(MAR 92), 64-84.

THIS STUDY OF THE CURRENT PROSPECTS FOR DEMOCRACY IN SRI LANKA FOCUSES ON THREE SETS OF ISSUES, NAMELY, THE REASONS LANKA FOCUSES ON THREE SETS OF ISSUES, NAMELY, THE
WHY SRI LANKA HAS FORMERLY SO DEVIANT AS TO HAVE A FUNCTIONING LIBERAL DEMOCRACY; THE CAUSES OF BREAKDOWN OF FUNCTIONING LIBERAL DEMOCRACY; THE CAUSES OF BREAKDOWM THE LIBERAL DEMOCRATIC POLITY; AND, THE NATURE OF DEMOCRATIZATION. THE ARTICLE CONCLUDES THAT WHILE THE SOCIAL CLASS BASIS OF LIBERAL DEMOCRACY HAS DISAPPEARED FROM SRI LANKA, RECENT DEVELOPMENTS INTRINSIC TO SRI LANKAN POLITICS, AND THEIR SPECIAL LINKS WITH WESTERN LIBERAL DEMOCRACIES, SHOW THAT THERE REMAIN STROHG FORCES SUPPORTIVE OF SOME KIND OF DEMOCRATIC REGIME. 
06529 MOORE, P.

A NEW PHASE IN THE BOSNIAN CRISIS?

RFE/RL RESEARCH REPORT 1131) (JUL 92), 1-7

A NUMBER OF RECENT DEVELOPMENTS COUID AFFECT THE OUTCOME OF THE CONFLICT IN THE FORMER YUGOSLAV REPUBLIC OF BOSNIA AND HERZEGOVINA. FIRST, IT APPEARS INCREASINGLY LIKELY THAT THE SERBS AND CROATS WILL PARTITION THE EMBATTLED REPUBLIC BETWEEN THEMSELVES AT THE MUSLIMS' EXPENSE; THE CROATS HAV PROCLAIMED THEIR OWN STATE, AND THE SERBS HAVE LAUNCHED A MASSIVE OFFENSIVE AIMED AT LINKING SERBIAN-INHABITED ENCLAVES AND DRIVING OUT THE MUSLIM POPULATION. SECONDLY, THERE IS A SENSE OF URGENCY WITHIN THE INTERNATIONAL COMMUNITY, ADOING WEIGHT TO THE VIEW THAT SOMETHING MUST BE DONE SOON TO END AN INTOLERABLE SITUATION. HOWEVER, POLICYMAKERS IN WASHINGTON AND OTHER MAJOR CAPITOLS ARE DIVIDED OVER WHAT THEIR GOALS SHOULD BE AND HOW TO ACHIEVE THEM. HHATEYER THE RESULT OF THEIR DISCUSSIONS, BOSNIA AMD HERZEGOVINA'S FUTURE SEEMS BLEAK DUE TO THE COMPLEXITY OF THE PROBLEMS AND THE INTENSITY OF INTERCOMMUNAL HATRED.

06530 MOORE, $P$

CHRONOLOGY OF EVENTS

RFE/RL RESEARCH REPORT, 1(50) (DEC 92), 32-37.

THE AUTHOR PROVIDES A CHRONOLOGY OF MAJOR EVENTS IN THE DISINTEGRATION OF YUGOSLAVIA, BEGINNING HITH THE DEATH OF JOSIP BROZ TITO ON MAY 4, 1980, AND ENDING WITH PANIC'S ANNOUNCEMENT ON DECEMBER' 1 , 1992, THAT HE HILL RUN AGAINST ANNOUNCEMENT ON DECEMBER 1,1992 , THAT
MILOSEVIC FOR THE SERBIAN PRESIOENCY.

06531 MOORE, $P$

CONFERENCE REPORT: FORMER YUGOSLAVIA, PROSPECTS AND PROBLEMS

RFE/RL RESEARCH REPORT, 1(50) (DEC 92), 1-6.

OUTSIDE ACTORS DO NOT SEE THEIR DIRECT INTERESTS

THREATENED IN THE CONFLICT IN THE FORMER YUGOSLAVIA, NOR ARE

THEY IN GENERAL SHOWING AN INTEREST IN PLAYING TRADITIONAL POWER POLITICS AT THE EXPENSE OF THE BALKANS. HOWEVER, THEY ARE UNDER PRESSURE FROM PUBLIC OPINION TO "DO SOMETHING." YET THEY LACK A POPULAR AND LEGAL MANOATE FOR ARMED INTERVENTION. HENCE, THEY HAVE TENDED TO ACT CHIEFLY THROUGH INTERMATIONAL BOOIES, HHOSE TRACK RECORD IS OUESTIONABLE. THE KEY TO AVERTING AN EXPANSION OF THE CONFLICT TO KOSOVO, MACEDONIA, AND ELSEWHERE LIES IN DETERRING SERBIA. THIS MIGHT BE ACCOMPL ISHED IN A NUMBER OF WAYS INCLUDIMG SUPPORTING THE DEMOCRATIC OPPOSITION TO SERBIAN PRESIDENT SLOBODAN MILOSEVIC. IN ANY EVENT, THERE WILL REMAIN THE LONGSLOBODAN MILOSEVIC. IN ANY EVENT, THERE WILL REMAIN THE LONG
TERH PROBLEM OF HOW PEOPLE ARE TO LIVE WITH OR NEXT TO EACH TERH PROBLEM OF HOW PEOPLE ARE TO LIVE WITH OR NEXT TO EACH
OTHER WHEN THEY HAVE SHOWN THEMSEL VES UNHILLING TO DO SO. OTHER WHEN THEY HAVE SHOWN THEMSELVES UNWILLING TO DO SO.
THE KEY TASK FOR INTERNATIONAL SECURITY STRUCTURES IN THE WAKE OF THE YUGOSLAV CRISIS WILL BE TO DEVELOP MECHANISMS TO WAKE OF THE YUGOSLAV CRISIS WILL BE TO DEVELOP MECHANISMS
DEAL EFFECTIVELY WITH SUCH SITUATIONS IN THE ABSENCE OF A DEAL EFFECTIVELY WITH

06532 MOORE, $P$.

CROATI

RFE/RL RESEARCH REPORT, 1(39) (OCT 92), 82-85.

THE CROATIAN PRESS, WHICH WAS FAIRLY LIBERAL BY MOST EAST EUROPEAN STANDARDS IN THE 1980'S, BECAME INCREASINGLY PLURALISTIC FOLLOWING THE FORMAL END OF THE COMMUNIST ERA IN 1990. TWO DEVELOPMENTS HAVE HELPED SHAPE THE EVOLUTION OF THE POSTCOMMUNIST MEDIA LANDSCAPE--THE WAR WITH THE SERBS AND THE 1992 GENERAL ELECTION CAMPAIGN. GOVERHMENT ATTEMPTS TO SILENCE PERIODICALS AND JOURNAL ISTS HAVE OFTEN BEEM
FISTED AND SEEM UNLIKELY TO SUCCEED IN THE LONG RUN.

06533 MOORE, $P$

DIPLOMATIC RECOGNITION OF CROATIA AND SLOVENIA

RFE/RL RESEARCH REPORT, 1(4) (JAN 92), 9-14.

ON JANUARY 15, 1992, ELEVEN MEMBER STATES OF THE

EUROPEAN COMMUNITY, SEVERAL OTHER EUROPEAN STATES, AND

CANADA FOLLOHED GERMANY'S LEAD IN GIVING DIPLOMATIC

RECOGNITION TO CROATIA AND SLOVENIA. THIS CULMINATED SEVERAL MONTHS OF OFTEN ACRIMONIOUS EUROPEAN DEBATE ON HOW BEST TO BRING PEACE TO YUGOSLAVIA. IN THE COURSE OF THE DISCUSSIONS, A SECOND BUT NO LESS IMPORTANT ISSUE AROSE: THE OUESTION OF GERMANY'S ROLE IN THE BALKANS AND IN EUROPEAN POLITICS IN GENERAL.

06534 MOORE, $P$

ETHNIC CLEANSING IN BOSNIA: OUTRAGE BUT LITTLE ACTION RFE/RL RESEARCH REPORT, 1 (34) (AUG 92) 1-7. IN AUGUST 1992 INTERNATIONAL ATTENTION WAS FOCUSED ON
THE SERBIAN POLICY OF "ETHNIC CLEANSING," INTENDED TO CHANGE SETTLEMENT PATTERHS AND BORDERS IN BDSNIA AND HERZEGOVINA. PUBLIC OPINION IN MANY COUNTRIES DEMANDED THAT SOMETHING BE PUBLIC OPINION IN MANY COUNTRIES DEMANDED THAT SOMETHING BE INTERNATIONAL BODIES COULO PRODUCE A OUICK OR EASY PLAN OF INTERNATIONAL BODIES COULD PRODUCE A QUICK OR EASY PLAN ACTION, OWING TO THE COMPLEXITY OF THE SITUATION IN THE FORMER YUGOSLAVIAN REPUBLICS AND TO A GENERAL LACK WILLINGNESS TO MOUNT AND SUSTAIN A MAJOR MILITARY
INTERVENTION. IT SEEMED LIKELY THAT THE SERBS MIGHT SUCCEED IN KEEPING WHAT THEY HAD TAKEN BY FORCE AND THAT THE BIG LOSERS MIGHT BE THE BOSHIAN MUSLIMS.
06535 MOORE, $P$

ISLAMIC ASPECTS OF THE YUGOSLAV CRISIS

RFE/RL RESEARCH REPORT $1(28)$ (JUL 92 ) 37-42.

IN MARCH 1992, FIGHTING SPREAD TO BOSNIA AND HERZEGOVINA, YUGOSLAVIA'S MUSLIM HEARTLAND. THE INTERNATIONAL MEDIA ARE SPECULATING ABOUT WHETHER HOSTILITIES WILL CONTINUE TO SPILL OVER INTO REGIONS SUCH AS KOSOVO, THE SANDZAK, AND MACEDONIA-ALL OF WHICH HAVE LARGE ISLAMIC POPULATIONS. MANY OBSERVERS BELIEVE THAT SUCH AN ESCALATION WOULD INEVITABLY LEAD TO THE DIRECT OR INDIRECT INVOLVEMENT OF NEIGHBORING COUNTRIES, SUCH AS ALBANIA, GREECE, ANO TURKEY. TURKEY HAS CLOSE, HISTORICAL LINKS WITH THE BALKAN MUSLIMS; AND, AS A LARGE REGIONAL POWER, IT IS PARTICULARLY CONCERNED ABOUT THE DANGERS OF ESCALATION AS WELL AS ABOUT OTHER SOURCES OF IMSTABILITY IN SOUTHEASTERN EUROPE. CONSEQUENTLY, TURKEY HAS BEEN PURSUING AN ACTIVE DIPLOMACY AIMED AT DEVELOPING AND REINFORCING INTERNATIONAL COOPERATION REGARDING THE YUGOSLAY CRISIS. IN A CONTINUATION OF EARLIER POLICIES, IT IS SEEKING CLOSER COOPERATION THROUGHOUT THE BLACK SEA REGION AS A WHOLE.

06536 MOORE, $P$.

ISSUES IN CROATIAN POLITICS

RFE/RL RESEARCH REPORT I (44) (NOV 92), 9-12.

THE CENTRAL ISSUE IN CROATIAN DOMESTIC POLITICS IS THE PROGNOSIS FOR DEMOCRACY IN THE FACE OF WHAT MANY REGARD AS THE AUTHORITARIAN TENDENCIES OF PRESIDENT FRANJO TUDJMAN ANO HIS PARTY. ATTENTION IS CURRENTLY FOCUSED ON TUDJMAN'S TACTICS AGAINST A NEOFASCIST PARTY AND AGAINST THE PRESS. IN INTERNATIONAL RELATIONS, THE KEY PROBLEMS INVOLVE THE U.N. ADMINISTERED AREAS CLAIMED BY BOTH SERBS AND CROATS, THE CRISIS IN BOSNIA AND HERZEGOVINA, AND RELATIONS WITH SLOVENIA. HOW SUCCESSFULLY CROATIA HANDLES THESE ISSUES WILL PROBABLY INFLUENCE HOW WELL IT IS RECEIVED INTO THE EUROPEAN AND INTERNATIONAL COMMUNITIES OVER THE LONG TERM.

06537 MOORE, $P$.

KOSOVO COULD SPARK AMOTHER BALKAN WAR

RFE/RL RESEARCH REPORT, 1(50) (DEC 92), 18-20.

A SEEMINGLY IRRECONCILABLE CONFLICT OF PRINCIPLES

UNDERLIES THE DISPUTE BETHEEN SERBS AND ALBANIANS OVER

KOSOVO. THE SERBS HAVE SOUGHT TO CONSOLIDATE THEIR CONTROL OVER THE AREA BY INSTITUTING REPRESSIVE MEASURES: BUT THE ALBANIANS HAVE PROVED RESILIENT, DEVELOPING A SHADOH ALBANIANS HAYE PROVED RESILIENT, DEVELOPING A SHADOW BELIEVE THAT KOSOYO COULD BE THE MEXT TARGET OF SERBIANBELIEVE THAT KOSOVO COULD BE THE NEXT TARGET OF SERBIANTHE CONFLICT COULD EASILY TURN INTO A GENERAL BALKAN THE CONFLICT COU

06538 MOORE, $P$.

THE 'ALBAHIAN QUESTION' IN THE FORMER YUgOSLAVIA RFE/RL RESEARCH REPORT, 1(14) (APR 92), 7-15. THE DENIAL OF MANY BASIC HUMAN AND POLITICAL RIGHTS TO THE ALBANIAN POPULATION OF YUGOSLAVIA HAS PROMPTED THE ALBANIAN MINORITY TO ORGANIZE ITSELF POLITICALLY. ALONG WITH THE ALBANIANS IN ALBANIA PROPER, YUGOSLAVIA'S ALBANIANS HAVE BEGUN TO SERIDUSLY CONSIDER THE POSSIBILITY OF UNITING KOSOVO AND THE PREDOMINATELY ALBANIAN AREAS OF MACEDONIA,
MONTENEGRO, AND SERBIA WITH THE REPUBLIC OF ALBANIA IF THE REPRESSION CONTINUES. BUT THE ESTABLISHMENT OF A GREATER ALBANIA IS UNLIKELY TO BE A PEACEFUL UNDERTAKING. THE POSSIBILITY OF OPEN WARFARE BETHEEN THE ALBANIANS, ON ONE HAND, AND THEIR SOUTH SLAV NEIGHBORS, ON THE OTHER, OR EVEN
OF A MORE GENERAL BALKAN CONFLAGRATION, CANMOT BE RULED OUT.

06539 MOORE, $P$

THE FIRST MONTH OF THE BOSNIAN PEACE PROCESS

RFE/RL RESEARCH REPORT, 1 (40) (OCT 92), $1-5$

THE UNITED NATIONS AND THE EUROPEAN COMMUNITY HAVE

SUCCEEDED IN BRINGING TOGETHER SERBIAN, CROATIAN, AND BOSNIAN DELEGATIONS TO DISCUSS CONSTITUTIONAL QUESTIONS CONCERMING THE FUTURE OF BOSNIA AND HERZEGOVINA, BUT SUBSTANTIVE PROGRESS SEEMS ELUSIVE. MEANWHILE, THE FIGHTING IN BOSNIA HAS INTENSIFIED, REPORTS OF SERBIAN MASSACRES OF MUSLIMS CONTINUE, AND THE SAFETY OF RELIEF OPERATIONS REMAINS IN QUESTION. PUBLICITY IN THE INTERNATIONAL MEDIA ABOUT ALLEGED ISLAMIC FREEDOM FIGHTERS COMING TO BOSNIA FROM THE MIDDLE EAST APPEARS SOMEWHAT EXAGGERATED, BUT THERE HAVE BEEN SIGNS THAT THE SERBS MAY BE ATTEMPTING TO EXTEND "ETHNIC CLEANSING" TO THE SANDZAK AND VOJVODINA. THE UN IS TRYING TO IMPROVE RELIEF OPERATIONS, WHILE DISCUSSIONS TRYING TO IMPROVE RELIEF OPERATIONS, WHILE DISCUSSIONS CONTINUE IN THE UNITED STATES AND ELSEWHERE ABOUT WHAT THE INTERHATIONAL

06540 MOORE, $P$.

THE INTERNATIONAL RELATIONS OF THE YUGOSLAV AREA RFE/RL RESEARCH REPORT, 1(18) (MAY 92), 33-38 THE MOST IMPORTANT DEVELOPMENT SURROUNDING THE RECOGNITION OF BOSNIA AND HERZEGOVINA BY THE EUROPEAN COMMUNITY AND THE UNITED STATES IN APRIL 1992 WAS WASHINGTON'S ASSUMPTION OF AN INCREASINGLY ACTIVE ROLE IN YUGOSLAVIA. MEANHHILE, THE E.C. DISPLAYED GREATER PUBLIC 
HARMONY THAN IT HAD DURING THE EARLIER DEBATE OVER RECOGNIZING SLOVENIA AND CROATIA, WHICH HAD PROMPTLY SET TO WORK CONSOLIDATING THEIR INTERNATIONAL STATUS. BOSNIA AND HERZEGOVINA HAD BEEN SUBJECTED TO SERBIAN AGGRESSION EVEN BEFORE OBTAINING RECOGNITION, WHILE A GREEK VETO HAD BLOCKED EARLY RECOGNITION OF MACEDONIA. MANY ASPECTS OF THE YUGOSLAY CRISIS HAVE A NOTABLE ISLAMIC DIMENSION.

06541 MOORE, $P$.

THE LONDON CONFERENCE ON THE BOSNIAN CRISIS

RFE/RL RESEARCH REPORT, 1(36) (SEP 92) 1-6.

INTERNATIONAL POLITICAL PRESSURE FOR ACTION REGARDING YUGOSLAVIA GREH DURING AUGUST 1992 AMID REPORTS OF LARGESCALE HUMAN RIGHTS VIOLATIONS IN BOSNIA, PRIMARILY BY SERBS AGAINST MUSLIMS. ACCORDINGLY, THE LONDON CONFERENCE BROUGHT TOGETHER THE MAJOR PLAYERS TO AGREE ON A CODE OF CONDUCT AND A MECHANISM TO MAINTAIN DIPLOMATIC MOMENTUM AIMED AT STEMMING AND EVENTUALLY ENDING THE CONFLICT. SOME OBSERVERS NOTED THAT, FOR THE FIRST TIME, ALL PARTIES AGREED TO A
NOE NOTED THAT, FOR THE FIRST TIME, ALL PARTIES AGREED TO A CONFERENCE HAD PRODUCED LITTLE MORE THAN FORMAL AGREEMENTS CONOM PEOPLE HHO HAD PREYIOUSLY BOEN UMAN FORMAL AGREEMENTS FROM PEOPLE WHO HAD PREVIOUSLY BEEN UNWILLING OR UNABLE TO
KEEP THEIR PROMISES. MEANHHILE, THERE WAS GROWING CONCERN KEEP THEIR PROMISES. MEANHHILE, THERE WAS GROHING CONCERN THAT THE CON
MACEDONIA.

06542 MOORE, $P$.

YUGOSLAVIA: ETHNIC TENSION ERUPTS INTO CIVIL WAR

RFE/RL RESEARCH REPORT, 1(1) (JAN 92), 68-73.

THE YEAR 1991 MARKED A HATERSHED IN YUGOSLAV HISTORY BECAUSE IT WITNESSED BOTH THE COLLAPSE OF THE FEDERAL SYSTEM FOUNDED BY JOSIP BROZ TITO AND THE OUTBREAK OF A CIVIL WAR. DESPITE PEACE-MAKING EFFORTS BY THE EUROPEAN COMMUNITY AND THE UNITED NATIONS, IT SEEMED CLEAR THAT SERBIA AND THE BORDERS BETWEEN THE YUGOSLAV REPUBLICS.

06543 MOORE, $S$.

ALL PAIN, NO GAIN

NATIONAL REVIEW, XLIII(16) (SEP 91), 33-35.

THE NEWS THAT CONGRESS AND THE PRESIDENT MAY HOLD ANOTHER BIPARTISAN BUDGET SETTLEMENT IN 1993 IS NOT GOOO NEWS FOR AMERICANS. THE PAST SUMHITS HAVE OSTENSIBLY BEEN FOR BUDGET REDUCTION PURPOSES, AND THE RHETORIC INSIDE THE BOR BUDGET REDUCTION PURPOSES, AND THE RHETORIC INSIDE THE GLAWCE AT THE FIGURES REVEALS THAT THE DEF ICIT HAS INCREASED ASTRONOMICALLY SINCE THE PREVIOUS SUMIIT. THE PREDICTED 1991 DEFICIT OF S161 BILLION WIL BE S282 BILIION. THE WITE DEFICIT OF S161 BILLION WILL BE \$282 BILLION. THE WHITE
HOUSE NOW ADMITS THAT NEXT YEAR'S DEFICIT SPENDING WILL HOUSE NOW ADMITS THAT NEXT YEAR'S DEFICIT SPENDING HILL
SURGE TO $\$ 348$ BILLION--ALMOST TRIPLE THE PRE-BUDGET-SUMMIT SURGE TO

06544 MOORE, $S$

BALANCING ACT

NATIONAL REVIEW, XLIV(11) (JUM 92), 42-44.

THE FACT THAT VIRTUALLY EVERY PRO-SPENDING SPECIALINTEREST GROUP--THE AFL-CIO, THE MATIONAL EDUCATION ASSOCIATION. THE AMERICAN ASSOCIATION OF RETIRED PERSONS, GOVERMMENT EMPLOYEE UNIONS, AMD MOST DEFENSE CONTRACTORS-OPPOSES A BALANCED BUDGET AMENDMENT IS PROOF THAT THE AMENDMENT HILL LIKELY DO WHAT IS NEEDED TO ELIMINATE THE BUDGET DEFICIT: CUT SPENDING. HILE THE INTEREST GROUPS' OPPOSITION TO THE AMENDMENT IS UNDERSTANDABLE, WHAT IS LESS OBVIOUS IS THE REASON THE CONSERYATIVE RIGHT OPPOSES (FOR THE MOST PART) THE AMEMDMENT MANY FEAR THAT THE AMENDMENT WILL SIMPLY LEAD TO HIGHER TAXES. THE TRUTH IS THAT WILE THE AMENDMENT MAY DO BOTH (CUT SPENDING AND RAISE TAXES) IT IS UNLIKELY THAT THERE IS ANY OTHER WAY TO ELIMINATE THE GROWING DEFICITS (TO SAY NOTHING OF THE HUGE NATIONAL DEBT).

06545 MOORE, S.

BIG-TOWN BLUES

NATIONAL REVIEH, XLIV(19) (OCT 92), 52-54.

THE AUTHOR DISAGREES HITH THE ARGUMENT THAT U.S. CITIES

ARE IN SUCH BAD SHAPE BECAUSE THEY HAVE BEEN NEGLECTED BY

THE BUSH AND REAGAN ADMINISTRATIONS. HE ARGUES THAT

AMERICA'S CITIES ARE DECAYING DUE TO LIBERAL DEMOCRATIC

POLICIES AND FASHIONABLE, OFTEN WELL-INTENTIONED LEFT-WING

SOCIAL AND ECONOMIC EXPERIMENTATION. HE CONTENDS THAT THE

SINGLE MOST IMPORTANT FACTOR HAS BEEN THE ENDLESS CYCLE OF

SINGLE MOST IMPORTANT FACTOR H
OVERSPENDING AND OVERTAXING.

06546 MOORE, S.

READ OUR LIPS: THE TAX REVOLT LIVES

REASON, $24(2)$ (JUN 92 ) $40-45$.

RESON, 24(2) (JUN 92), 40-45.
THE MOST SIGNIFICANT ELECTION RESULT FROM SUPER TUESDAY

THIS YEAR WAS THAT OKLAHOMA VOTERS OVERWHELMINGLY APPROVED A LITTLE-NOTICED BALLOT INITIATIVE REQUIRING A THREE-FOURTHS VOTE OF THE LEGISLATURE TO ENACT ANY SUBSEQUENT TAX INCREASE. THIS IS THE MOST RESTRICITVE ANTITAX MEASURE IN ANY STATE. LEGISLATORS HAVE BEGUN TO REALIZE THAT THEY HAVE MADE CATASTROPHIC MISCALCULATIONS OF THE INTENSITY OF PUBLIC CONNECTICUT AND NEW JERSEY IS REVIEWED IN THIS ARTICLE,
WHICH CONCLUDES THAT THE ONLY POLITICIANS WHO SEEM TO BE IGNORING THE FURY OF THE ANTITAX MOVEMENT IN AMERICA TDDAY ARE GEORGE BUSH AND THE DEMOCRATIC LEADERS OF CONGRESS. IT SUGGESTS THAT ALONG WITH FLORIO AND HEICKER, THEY MAY BE THE NEXT POLITICAL CASUALTIES OF THE GREAT TAX REVOLT OF THE 19905 .

06547 MOORE, S.

REFORM AFOOT

NATIONAL REYIEH, XLIV(9) (MAY 92), 36-39.

THIS ARTICLE REPORTS THAT THE REAL AGENTS OF CHANGE IN

TODAY'S AMERICA ARE GOVERNORS. THEY ARE EXPERIMENTING WITH A WIDE VARIETY OF MARKET-BASED POLICY PRESCRIPTIONS:

PRIVATIZATION; SUPPLY-SIDE TAX CUTS; HELFARE REFORMS THAT

PEWARD RATHER THAN DESTROY THE WORK ETHIC; ENTERPRISE ZONES;

AND VOUCHERS FOR EDUCATION AND HEALTH CARE. LARGE DEBTS ARE;

AND VOUCHERS FOR EDUCATION AND
THE REASON FOR THESE MEASURES.

06548 MORA, E.

HOMEN'S EQUALITY: THE HORKING CLASS CAUSE

POLITICAL AFFAIRS, 71(2) (FEB 92), 26-30.

THE DEBATE ON HOMEN'S EQUALITY' TOUCHES ON FUMDAMENTAL

QUESTIONS: THE NATURE OF CAPITALIST SOCIETY, THE ROLE OF THE CLASS STRUGGLE, THE RELATIONSHIP OF IDEOLOGY TO MATERIAL REALITY, AND THE STRATEGY AND TACTICS OF STRUGGLE. THE
REALITY IS THAT THE SITUATION OF WOMEN IN CAPITALIST SOCIETY
IS BAD AND GETTING WORSE. MILLIONS OF AMERICAN WOMEM IS BAD AND GETTING WORSE. MILLIONS DF AMERICAN WOMEN
EXPERIENCE CONDITIONS OF LIFE AT THE LOWEST RUNG OF THE CADOER: POVERTY, POOR HEALTH, POLITICAL UNDERREPRESENTATION, SOCIAL DISCRIMINATION, SEXUAL HARASSMENT ANO VIOLENCE. IT IS INCREASINGLY CLEAR THAT STRUGGLES FOR EQUALITY OF THE RACIALLY AND NATIONALLY OPPRESSED, AND WOMEN, MUST BE SEEN IN THE CONTEXT OF THE CLASS STRUGGLE, THE MAIN DYNAMIC OF CAPITALIST SOCIETY. CURRENT CONDITIONS ARE SUCH THAT THE COMMUNIST WORKERS' MOVEMENT CAN MAKE GREAT STRIDES FORWARD IN THE STRUGGLE FOR THE EQUALITY OF HOMEN.

06549 MORALES, E.

THE POLITICAL ECONOMY OF COCAINE PRODUCTION: AN ANALYSIS OF THE PERUVIAN CASE

LATIN AMERICAN PERSPECTIVES, 17(4) (FAL 90), 91-109.

FOUR KEY SOCIAL, ECONOMIC, A ND POLITICAL EVENTS ARE

PRESENT IN THE INTERNATIONAL COCA BELT. THEY ARE: THE

PERUYIAN TRADITIONAL PEASANTRY AND ITS CUL TURE: THE UNDERGROUND CASH ECONOMY; THE INTERNATIONAL DRUG POLICY IMPOSED BY THE UNITED STATES, WHOSE EFFORTS ARE TO CONTROL THE PROOUCTION OF THE COCA LEAF AND INTERDICT THE TRAFFIC OF COCAINE; AND THE ALLEGED SUPPORT OF DRUG TRAFFICKERS BY THE GUERRILLA MOVEMENTS. THIS ARTICLE EVALUATES THE ROLE OF FOREIGN AID AND POLITICAL PRESSURE VIS-A-VIS THE INTERNAL RESISTANCE AND ASSESSES THE ROLE OF THE NATIONAL ELITES AND THE NEWLY RICH IN THE NORTH-SOUTH HISTORICAL CONTINUUM. THIS ARTICLE ALSO ANALYZES THE POLITICAL MEANING OF THE COCAINE INDUSTRY. FROM A CRITICAL PERSPECTIVE IT EXAMINES SOCIAL AND ECONOMIC POLICIES AS WELL AS THE RESULT OF INTERNATIONAL AID THAT LED TO AN IRRATIONAL USE OF LAND IN THE RAIN FORESTS. BASED ON THE SUPPORTING DATA, ALTERNATIVE POLICIES OF CONTROL INT THE PRODUCTION OF COCA AND COCAINE ARE SUGGESTED.

\section{MORAN, M.}

GERMANY STEPS OUT OF THE SHADOHS

NEH LEADER, LXXV(2) (FEB 92), 12-14.

TO THE DISMAY OF MANY OF ITS NATO ALLIES, THE REUNIFIED GERMAN STATE HAS STEPPED OUT OF HORLD HAR II'S SHADOW AND BLUNTLY ASSERTED ITS SOVEREIGNTY. THE MOST DRAMATIC IN A SERIES OF RECENT EVENTS DEMONSTRATING THIS INCREASINGLY APPARENT ATTITUDE HAS BEEN ITS SUCCESSFULLY PRESSURING THE EUROPEAN COMHUNITY INTO RECOGNIZING YUGOSLAVIA'S BREAKAHAY REPUBLICS, CROATIA AND SLOVENIA. THE NEH INTERNATIONAL
STANCE IS LARGELY THE RESULT OF OLD THINKING, INHERITED FROM PREVIOUS POST-WAR GOVERNMENTS. THE MOST BASIC PRECEPT OF, REMAINS UNCHANGED: DOMESTIC TRANQUILITY AT ALL COSTS.

06551 MORAN, M.

SWEDEN'S TEMPERATE REVOLUTION

NEW LEADER, LXXIV(11) (OCT 91), 131-14.

FOR ALMOST TWO CENTURIES SWEDEN HAS BEEN OUITE CONTENT TO STAND APART FROM THE POWER STRUGGLES AND IDEOLOGICAL DEBATES RAGING ELSEWHERE IN EUROPE. ALTHOUGH INITIALLY THIS TENDENCY TO REMAIN ALOOF EARNED IT A REPUTATION IN THE WEST
AS A PERMANENT OUTSIDER, EVENTUALLY IT CAME TO BE HERALDED AS A PERMANENT OUTSIDER, EVENTUALLY IT CAME TO BE HERALDED AS A UTOPIA: A COUNTRY THAT PROSPEROUSLY FUSED COMPASSIO
AND PRODUCTIVITY, DEMOCRACY AND SOCIALISM. BUT ON 15 AND PRODUCTIVITY, DEMOCRACY AND SOCIALISM. BUT ON 15 SEPTEMBER, WHEN THEY WENT TO THE POLLS, SHEDEN'S VOTERS SEEMED TO SUGGEST THAT THEY WERE READY TO GIVE UP THEIR ISOLATIONISM, AND THE BEST DAYS OF THEIR MARKET SOCIALISH
WERE PAST. THEY TURNED AGAINST THE LONG-DOMINANT SOCIAL HERE PAST. THEY TURNED AGAINST THE LONG-DOMINANT SOCIAL
DEMOCRATIC PARTY, THE INVENTOR OF THEIR UNIQUE SYSTEM, AND REPLACED IT WITH A CONSERVATIVE GOVERNMENT HEADED BY CARL BILDT, WHO PROMISED TO CUT TAXES AND LEAD SHEDEN INTO THE EUROPEAN MAINSTREAM. 
06552 MORAN, $M$

TALKING TO YOUNG GERMANS

NEW LEADER, LXXV(14) (NOV 92), 12-14.

IT IS NOT SURPRISING THAT THE RECENT ACTIVIES OF NEONAZI AND RIGHT-WING GROUPS HAVE AROUSED WIDESPREAD FEELINGS OF DISGUST AND OUTRAGE AMONG THE GERMAN YOUNG. THEIR CONCERMS EXTEND TO A VARIETY OF DOMESTIC AND FOREIGN ISSUES. CHIEF AMONG THESE ARE THE STATE OF THE ENVIRONMENT, AND GERMANY'S PLACE IN AN INCREASINGLY COOPERATIVE EUROPE AND AN EMERGENT POST-SOVIET WORLD. A LARGE SEGMENT OF THE COUNTRY'S YOUTH IS ATTRACTED TO THE IDEA OF BEING FOREMOST A EUROPEAN, RATHER THAN A GERMAN, IN PART BECAUSE OF A OISTATE FOR THE NATIONALISM OF GERMANY'S PAST. BENEATH THE TURMOIL OF REUNIFICATION, THE HOSTILITY TOWARD RFUGEES AND THE DEBATE OVER THE EC, ONE CAN SEE A GLIMMER OF OPTIMISM.

06553 MORAN, M.

THE STATE OF SLOVENIA

NEW LEADER, LXXV(10) (AUG 92), 6-8

NOT EVERYTHING HAS BEEN SMOOTH SAILING IN SLOVENIA, IN

SPITE OF HER BEING ABLE TO AVOID THE KIND OF WAR THAT' IS

GOING ON NEXT DOOR IT. IN THE MONTHS SINCE LAST OCTOBER

WHEN THE NEW STATE ASSUMED DE FACTO CONTROL OF ITS AFFAIRS,

IT HAS ENDURED A HRENCHING RECESSION, A CHANGE IN GOVERNMENT, A REFUGEE CRISIS, AND THE EVER-PRESENT FEAR THAT SOMEDAY THE FEDERAL ARMY MIGHT RETURN. NEVERTHELESS, AT PRESENT AM AIR OF NORMALITY, BORDERING ON OPTIMISM, IS PERVASIVE. SLOVENIA HAS GONE FROM A NEAR CASUALIY, IM YUGOSLAYIA'S SLOVENIA HAS GONE FROM A NEAR CASUAL TY IN YUGOSLAVIA'S PARTICIPANT IN FREE TRADE NEGOTIATIONS WITH THE EUROPEAN PARTICIPANT

06554 MORATA, F.

REGIONS AND THE EUROPEAN COMMUNITY: A COMPARATIVE ANALYSIS OF FOUR SPANISH REGIONS

REGIONAL POLITICS \& POLICY, 2(1,2) (SPR 92), 187-216.

SPAIN'S ENTRY INTO THE EC HAS CREATED PROBLEMS OF POLITICAL AND INSTITUTIONAL NATURE WHICH HIGHLIGHT THE SHORTCOMINGS OF THE 1978 CONSTITUTIONAL AGREEMENT ON REGIONS. THE INTERCONHECTION BETWEEN TWO PROCESSES ARE ILLUSTRATED IN THIS ARTICLE THROUGH THE USE OF DATA COLLECTED AS PART OF A CROSS-NATIONAL PROJECT LOOKING AT THE ROLE OF REGIONS IN THE EUROPEAN COMMUNITY IN PREPARING FOR THE OPENING OF THE SINGLE MARKET AT THE END OF 1992. IT ALSO EXAMINES THE ATTITUDES OF THE REGIONAL RESPONDENTS TOWARD THE CREATION OF NEW COMMUNITY INITIATIVES AND POLICY STRUCTURES THAT COULD INCREASE THE POWER AND RANGE OF COMMUNITY ACTIONS IN THE POST-1992 CONTEXT.

06555 MOREL, B.F.

PROLIFERATION OF MISSILE CAPABILITY

DISARMAMENT, XIV(3) (1991) 21-43.

DSARMAMENT, XIV(3) (1991), 21-43.

THE PURPOSE OF THE MISSILE TECHNOLOGY CONTROL REGIME (MTCR) IS TO CONTAIN THE SPREAD OF MISSILE CAPABILITY BY DENYING THIRD WORLD COUNTRIES ACCESS TO MISSILE TECHNOLOGY, BUT THE MTCR COUNTRIES CANHOT DO MORE THAN COOPERATIVELY CONTROL THEIR OWN EXPORTS OF THE RELEVANT TECHNOLOGY. IT IS CONCEIVABLE THAT MORE COUNTRIES WILL BE PERSUADED TO JOIN THE MTCR, AND THAT WOULD STRENGTHEN THE MTCR SIGNIFICANTLY BUT WOULD NOT PERMANENTLY SOLVE THE PROBLEMS RAISED BY THE DENY THIRD WORLD COUNTRIES WEAPON SYSTEMS THAT SOME MEMBERS, SUCH AS THE UNITED STATES, HAVE IN THEIR ARSENALS AND ARE STILL ACTIVELY DEVELOPING. THE SPREAD OF TECHNOLOGICAL CAPABILITIES IS INEVITABLE. VIRTUALLY ALL THE COUNTRIES OF THE WORLD WILL, ULTIMATELY, HAVE THE CAPABILITY OF DOING WHAT IS TOOAY THE PRIVILEGE OF A FEW. THE MTCR CAN ONLY BUY TIME BY DELAYING THE PROCESS OF PROL IFERATION. IT MUST BE SUPPLEMENTED BY POLICY INITIATIVES INVOLVING THE COUNTRIES THAT DO NOT BELONG TO THE MTCR, WITH THE GOAL OF ESTABLISHING A WORLD ORDER IN WHICH LONG-RANGE WEAPONS OF MASS DESTRUCTION ARE NOT A THREAT.

06556 MORELLO, T.

JAPANESÉ MUSCLE

FAR EASTERN ECONOMIC REYIEH, 155(3) (JAN 92), 13.

THE FIRST TOP-LEVEL APPOINTMENT BY NEW UN SECRETARYGENERAL BOUTROS GHALI HAS GIVEN THE IMPRESSION THAT JAPAN IS USING ITS FINANCIAL MUSCLE TO SECURE MORE SENIOR UN POSTS. SCARCELY A WEEK AFTER TAKING OVER ON 1 JANUARY FROM JAVIER PEREZ DE CUELLAR, GAHLI NAMED YASUSHI AKASHI, UM UNDERSECRETARY FOR DISARMAMENT AFFAIRS, AS HIS SPECIAL UNDERSECRETARY FOR DISARMAMENT AFFAIRS, AS HIS SPECIAL REPRESENTATIVE IN CHARGE OF THE MASSIVE, MULTI -BILLION-
DOLLAR UN PEACEKEEPING OPERATION IN CAMBODIA. WHILE AKASHI DOLLAR UN PEACEKEEPING OPERATION IN CAMBOOIA. WHILE IS A SEASONED AND RESPECTED DIPLOMAT, HIS SELECTION
SURPRISED ASEAN DELEGATIONS AND OTHERS CLOSELY INVOLVED IN SURPRISED ASEAN DELEGATIONS AND OTHERS CLOSELY INVOLVED THE CAMBODIAN PEACE EFFORT. MANY EXPECTED PAKISTANI UN OFFICIAL RAFEEUDDIN AHMED TO CONTINUE HIS WORK WITH THE CAMBODIAN PEACE PROCESS. THE CHANGE IS THOUGHT TO HAVE BEEN
INFLUUENCED BY TIMELY REMINDERS THAT JAPAN HAS PLEDGED TO PICK UP MUCH OF THE BILL FOR THE UN TRANSITIONAL AUTHORITY IN CAMBODIA.
06557 MORGAN, A.; WILCOX, C.

ANTI-FEMINISM IN WESTERY EUROPE: $1975-1987$

WEST EUROPEAN POLIIICS, 15(4) (OCT 92) 151-169.

THIS STUDY TRACES THE DEVELOPMENT OF ANTI-FEMINIST

ATTITUDE TRENDS IN WESTERN EUROPE FROM 1975-1987. IT FOCUSES IN PARTICULAR ON THE SOURCES OF AND CHANGES IN OPPOSITION TO WOMEN'S PARTICIPATION IN POLITICS BY NOTING THE PERCENTRAGES OF EUROBAROMETER SURVEY RESPONDENTS WHO AGREED IN 1975, 1983, AND 1987 THAT 'POLITICS SHOULD BE LEFT TO MEN'.

06558 MORGAN, D.: SHIH, $M$.

TARGETING STATE AND FEDERAL AID TO CITY NEEDS

STATE AND LOCAL GOVERMMENT REVIEN, 23(2) (SPR 91), 60-68.

THIS RESEARCH TESTS THE RELATIVE RESPONSIVENESS OF STAIE

AND FEDERAL AID TO URBAN SOCIAL, ECONOMIC, AND FISCAL MEEDS FOR U.S. CITIES WITH POPULATIONS OF 25,000 AND OVER. USING ACTUAL DOLLARS AS THE DEPENDENT VARIABLE, NUMBERS OF NEEDY PERSONS AS PREDICTORS, AND HIERARCHICAL REGRESSION

TECHNIQUES, THE RESULTS SHOW THAT BOTH THE MATIOMAL

GOVERMMENT AND THE STATES PROVIDE SOME FINANCIAL ASSISTANCE TO CITIES ON THE BASIS OF NEED EVEN AFTER POPULATION IS

TAKEN ACCOUNT. THE ANALYSIS REVEALS THAT A FEH STATES ARE

TAKEN ACCDUNT. THE ANALYSIS REVEALS THAT A FEH STATES ARE
TARGETING URBAN NEEDS MORE EFFECTIVELY THAN THE NATIONAL

TARGETING
GOVERNMENT.

06559 MORGAN, D.R. : WATSON, S.S

POLICY LEADERSHIP IN COUNCIL-MANAGER CITIES: COMPARING MAYOR AND MANAGER

PUBLIC ADMINISTRATION REYIEH, 52(5) (SEP 92), 438-446. THE AUTHORS USE DATA FROM A 1987 INTERNATIONAL CITY MANAGEMENT ASSOCIATION SURVEY TO COMPARE THE POWERS OF MAYORS AND CITY MANAGERS IN COUNCIL-MANAGER CITIES. UNDER COUNCIL-MANAGER GOVERMMENT, MAYORAL LEADERSHIP IS MORE LIKELY TO STRESS THE OFFICEEHOLDER'S INFORMAL SOURCES OF POWER. COMPARING MANAGERS IN CITIES OF DIFFERENT SIZE, THE AUTHORS FIND THOSE WORKING IN LARGER MUNICIPALITIES

TYPICALLY HAVE LESS POWER THAN THEIR SMALLER CITY PEERS. TURNING TO MAYOR-MANAGER RELATIONSHIPS, THE AUTHORS FIND THEM TO BE CLOSE IN MOST COUNCIL-MANAGER JURISDICTIONS, WITH MANAGERS PLAYING THE DOMINANT ROLE IN SMALLER CITIES HHILE THE MAYORS SEEM DOMINANT IN LARGER ONES. THE AUTHORS DISCUSS THE IMPLICATIONS OF THESE FINDINGS, ESPECIALLY THE NEED FOR LARGER CITIES TO REASSESS THE FORMAL POWER OF THEIR

MAYORALTY GIVEN THE COMPLEX CHALLENGES FACING URBAN AREAS.

06560 MORGAN, D.R.

THE PITFALLS OF PRIVATIZATION: CONTRACTING WITHOUT

AMERICAN REYIEH OF PUBLIC ADMINISTRATION, 22(4) (DEC 92 ),

251-270.

MOST AUTHORITIES AGREE THAT PRIVATIZATION WORKS BEST WHEN THERE IS VIGOROUS COMPETITION AMONG ALTERNATIVE SERVICE PROVIDERS. BUT COMPETITION MAY BE DIFFICULT TO ACHIEVE FOR CERTAIN SERVICES, SUCH AS PUBLIC UTILITIES, WHICH CAN BE PROVIDED BY A LIMITED NUMBER OF PRIVATE FIRMS. THIS RESEARCH FIRST CONSIDERS THE THEORETICAL ISSUES SURROUNDING THE USE OF PRIVATE COMPANIES IN NATURAL MONOPOLIES. THEN IT PROVIDES AN EXTENSIVE CASE STUDY OF THE PROBLEMS THAT CONFRONTED OKLAHOMA CITY IN ITS EFFORTS TO PRIVATIZE ITS WASTEWATER TREATMENT SYSTEM. DUE TO THE LACK OF COMPETITIVE BIDDING AND RISING COSTS, OKLAHOMA CITY WAS EVENTUALLY FORCED TO MAKE MAJOR CHANGES IN ITS PROCEDURES FOR HANOLING ITS SEWAGE DISPOSAL PLANTS. HOWEVER, THE CITY OID NOT RETURN TO MUNICIPAL OPERATION AND IS NOW SATISFIED WITH ITS CURRENT WASTEWATER TREATMENT PLANTS.

06561 MORGAN, J.

WIDE HORIZONS, SLENDER MEANS

INTERNATIONAL AFFAIRS, 68(4) (OCT 92), 603-618.

JAMES MORGAN BELIEVES THAT OTHER MAJOR POWERS ARE ALL FACING CHALLENGES HHICH OFFER UNUSUAL OPPORTUNITIES FOR BRITAIN. THE DEVELOPING WORLD IS EVOLVING IN A MANNER THAT IS PECULIARLY FAVORABLE TO BRITISH INTERESTS. BY REFUSING TO MAKE A FULL COMMITMENT TO THE MAASTRICHT TREATY BRITAIN IS COMING DEBATE OM IMPL EMENTATIOM THEREBY PERMITS FREE HAND TO DEPLOY HHATEVER METHODS ARE NEEDED TO FABRICATE WHAT WILL BE PRESENTED AS A FULL REALIZATION OF THE AIMS OF WHAT WILL BE PRESENTED AS A FULL REALIZATION OF THE AIMS OF ECONOMIC AND MONETARY UNI
THIS COUNTRY'S INTERESTS.

06562 MORGAN, M.; SHANAHAN, J.

TELEVISION AND THE CULTIVATION OF POLITICAL ATTITUDES IM ARGENTINA

JOURNAL OF COMMUNICATION, 41(1) (WIN 91), 88-103.

THIS ARTICLE EXPLORES THE RELATIONSHIP BETHEEN TELEVISION VIEWING AND POLITICAL VALUES IN ARGENTINA. THE AUTHOR'S SKETCH THE HISTORY OF TELEVISION IN ARGENTINA AND PROVIDE SOME BASIC DATA ABOUT ARGENTINE PROGRAMMING. THIS SERVES AS A PRELUDE TO AN ANALYSIS OF ASSOCIATIONS BETWEEN AHOUNT OF TELEVISION EXPOSURE AND POLITICAL ATTITUDES AMONG ARGENTINE ADOLESCENTS, CONCENTRATING ON THEIR ATTITUDES TOWARDS GOVERNMENT AUTHORITY, FREEDOM OF SPEECH, AND THE 
STATE'S ROLE IN SOCIETY.

06563 MORGAN, M.; SHAMAHAN, J.

TELEVISION VIEHING AND VOTING 1972-1989

ELECTORAL STUDIES, 11(1) (MAR 92), 3-20.

SOME OF THE EARLIEST AND MOST PERSISTENT CONCERNS ABOUT MASS COMMUNICATION (AND TELEVISION IN PARTICULAR) REVOLVE AROUND ITS IMPL ICATIONS FOR THE ELECTORAL PROCESS. ON ONE HAND, THE IDEA OF AN INFORMED AND ACTIVE CITIZENRY IS CENTRAL TO DEMOCRATIC PRINCIPLES AND PRACTICES, AND NO TECHNOLOGY IN HUMAN HISTORY HAS HAD THE POTENTIAL TO INFORM AND ACTIVATE AS MANY PEOPLE AS QUICKLY AND AS PERVASIVELY AS TELEVISION. ON THE OTHER HAND, THE SHEER VOLUME OF TELEVISION. ON THE OTHER HAND, THE SHEER VOLUME OF
INFORMATION TELEVISION DISSEMINATES, THE AMOUNT OF TIME INFORMATION TELEVISION DISSEMINATES, THE AMOUNT OF TIME
PEOPLE ATTEND TO IT, AND THE SPECIFIC IMAGES OF POLITICAL PEOPLE ATTEND TO IT, AND THE SPECIFIC IMAGES OF POLITICAL PHENOMENA TELEVISION SELECTS TO PRESENT (OR FAILS TO PRESENT) CAN ALL HAVE THE OPPOSITE FUNCTION--TELEVISION MAY NUMB THE ELECTORATE, PROMOTE CYNICISM AND DISAFFECTION, INHIBIT INTEREST AND THE ACQUISITION OF INFORMATION, AND ULTIMATELY SUPPRESS PARTICIPATION IN A DEMOCRATIC POLITICAL SYSTEM. THIS STUDY EXAMINES EMPIRICALLY THE RELATIONSHIP OF
TELEVISION VIEWING WITH VOTING BEHAVIOR IN THE LAST FIVE U.S PRESIDENT IAL ELECTIONS (1972 THROUGH 1988). IT EXPLORES THE ASSOCIATION OF TELEVISION EXPOSURE WITH VOTING BEHAVIOR, IN TERMS OF WHETHER OR NOT PEOPLE SAY THEY VOTED AT ALL AND WHO THEY SAY THEY VOTED FOR (OR WOULD HAVE, IF THEY HAD VOTED).

06564 MORGAN, R.

POLITICAL ACTS, POLITICAL ACTS AND CONSTITUTIONAL INTERPRETATION

POLITY, XXIII(2) (WIN 90), 291-294.

THIS ARTICLE CRITIQUES DENHIS GOLDFORD'S ATTEMPT TO ADVANCE THE CURRENT DEBATE OVER ACCEPTABLE MODES OF CONSTITUTIONAL INTERPRETATION. THE AUTHOR FINDS THAT GOLDFORD'S LACK OF SYMPATHY FOR DEMOCRATIC CONSTITUTIONALISM AS A FORM OF GOYERMMENT AND CONSEOUENT FAILURE TO UNDERSTAMD THE PERMISSIBLE ROLE OF A CONSTITUTIONAL COURT WITHIN THE BOUNOS OF THAT FORM.

06565 MORIATY, P.

ECOLOGICALLY SUSTAINABLE DEYELOPMENT?

ARENA, $\quad(100)(1992), 27-31$

VARIOUS AUSTRALIAN GOVERNMENT ORGANIZATIONS HAVE PRODUCED A NUMBER OF DOCUMENTS WHICH, ADVOCATING ECOLOGICALLY SUSTAINABLE DEVELOPMENT, ARGUE THAT ECOLOGICAL ECOLOGICALLY SUSTAINABLE DEVELOPMENT, ARGUE THAT ECOLOGICAL SUSTAINABILITY AND CONTINUED ECONOMIC GROWTH ARE COMP DESPITE THE POPULARITY OF ECOLOGICALLY SUSTAINABLE
DEVELOPMENT WITH GOVERMMENTS, THE UNITED NATIONS AND EVEN DEVELOPMENT WITH GOVERMMENTS, THE UNITED NATIONS AND EVEN ENVIRONMENTALISTS, THE AUTHOR ARGUES THAT WE CANNOT HAV BOTH. HE EXAMINES THE DIFFICULTIES AUSTRALIA FACES IN
IMPROVING ENERGY EFFICIENCY DRAMATICALLY, OR IN SHITCHING TO IMPROVING ENERGY

06566 MORICI, P.

FREE TRADE WITH MEXICD

FOREIGN POLICY, (87) (SUM 92), 88-103

THIS ARTICLE் EXAMINES THE TRENDS AND EVENTS WHICH HAVE LED TO THE PROPOSAL OF A U.S. - MEXICO FREE TRADE AGREEMENT WHICH WOULD RESULT IN THE CREATION OF A NORTH AMERICA FREE TRADE AGREEMENT (NAFTA) EMBRACING CANADA, THE UNITED STATES AND MEXICO. THE AUTHOR ARGUES THAT ALTHOUGH THERE ARE UNDENIABLY SHORT TERM COSTS AND DRAWBACKS TO THE AGREEMENT, THE LONG TERM BENEFITS JUSTIFY ITS IMPLEMENTATION. FOR THE UNITED STATES, A FREE TRADE AGREEMENT COULD BE A KEY ELEMENT IN A NEW NATIONAL STRATEGY TO FOSTER COMPETITIVENESS. INITIALLY, IT HOULD PROVIDE U.S. BUSINESSES WITH THE OPPORTUNITY TO COMBINE INEXPENSIVE MEXICAN LABOR HITH MORE HIGHLY SKILLED U.S. WORKERS IN JOINT PRODUCTION VENTURES.
FOR MEXICD, FREE TRADE WOULO MARK THE CLIMAX OF A GRADUAL SHIFT AWAY' FROM NATIONALIST ECONOMIC POLICIES. A NAFTA WOULD ALLOW THE NATIONS OF NORTH AMERICA TO REMAIN COMPETIIIVE WITH OTHER TRADING BLOCS IN THE HORLD, NOTABLY THE EUROPEAN COMMUNITY AND JAPAN.

06567 MORITAN, R.

THE DEVELOP ING WORLD AND THE NEW WORLD ORDER WASHINGTON QUARTERLY, 15(4) (FAL 92), 149-156. AT THE END OF THE COLD WAR A MARROH FOCUS ON PEACEKEEPING IS NOT ENOUGH. THIS AUTHOR SUGGESTS THAT HE SHOULD BE FAR MORE AMBITIOUS IN OUR THINKING ABOUT THE OPPORTUNITIES FOR INTERNATIONAL COOPERATION AND IN OPPORTUNITIES FOR INTERNATIONAL COOPERATION AND IN
DEVELOPING FRESH ROLES FOR THE UN. HE SUGGESTS THAT THE TIME DEVELOPING FRESH ROLES FOR THE UN. HE SUGGESTS THAT THE TIME
IS RIPE FOR PROGRESS IN THE CONSTRUCTION OF MULTILATERAL IS RIPE FOR PROGRESS IN THE CONSTRUCTION OF MULTILATERAL
MECHANISMS FOR DISARMAMENT AND SECURITY WITHIN REGIONS IN MECHANISMS FOR DISARMAMENT AND SECURITY WITHIN REGIONS IN
CONFLICT THAT WILL COMPLEMENT AND STRENGTHEN EXISTING GLOBAL CONFLICT THAT WILL COMPLEMENT AND STRENGTHEN EXISTIMG GLOBAL
REGIMES, EVEN AS WE ATTEMPT TO IMPROVE THOSE REGIMES. THERE REGIMES, EVEN AS WE ATTEMPT TO IMPROVE THOSE REGIMES. THER
ARE OPPORTUNITIES FOR PARTNERSHIP BRIDGING TRADITIONAL DIVISIONS OF EAST, WEST, NORTH, AND SOUTH.

06568 MORLINO, L.

POLITICAL SCIENCE IN ITALY: TRADITION AND EMPIRICISM EUROPEAN JOURNAL OF POLITICAL RESEARCH, 20(3-4) (DEC 91), 341-358.

IN ORDER TO ASSESS THE STATUS OF ITALIAN POLITICAL
SCIENCE IN 1990, THE AUTHOR CONSIDERS HOW THE DISCIPLINE WAS SHAPED IN THE 1950'S AND 1960'S, HOW IT DEFINED ITSELF AT THE END OF THE 1960'S, THE DIFFICULTIES THAT AROSE DURING THE "TAKE-OFF" PERIOD AND HOW THESE AFFECTED ITS SUBSEQUENT DEVELOPMENT, HOW IT GREW AND BECAME INSTITUTIONALIZED, AND HOW ITS CONTENT EVOLVED.

06569 MOROZOV, G.

UNITED MATIONS CHARTER AND TODAYS REALITIES

PEACE AND THE SCIENCES, 1(1) (1992), 26-30.

THE POLITICAL PICTURE OF THE POST-WAR HORLD AFTER THE UNITED NATIONS WAS FOUNDED HAS CHANGED RADICALLY. UN ACTIVITY HAS REFLECTED THAT THE BASIC FEATURES OF THE POSTACT IVITY HAS REFLECTED THAT THE BASIC FEATURES OF THE POST-
WAR DEVELOPMENT OF THE WORLD AND IN MANY CASES ITS ROLE IN SOLVING INTERNATIONAL PROBLEMS HAS PROVED INADEQUATE. HOWEVER THE CHARTER HAS WITHSTOOD THE TEST OF TIME AND ITS HOWEVER THE CHARTER HAS WITHSTOOO THE TEST OF TIME AND INTERNATIONAL LAW. THIS ARTICLE DEALS HITH THE PROBLEM OF INTERNATIONAL LAW. THIS ARTICLE DEALS HITH THE PROBLEM OF
ADAPTING THE UN CHARTER TO PRESENT-DAY REALITIES. IT OFFERS ADAPTING THE UN CHARTER TO PRESENT-DAY REALITIES. IT OFFERS
SPECIFIC PROPOSALS WHICH COULD BE CARRIED OUT BY ADOPTING SPECIFIC PROPOSALS WHICH COULD BE CARRIED
PROTOCOLS ADDITIONAL TO THE UN CHARTER.

06570 MORRIS, D.R.

SOUTH AFRICA: THE POLITICS OF RACIAL TERMINOLOGY POLITICAL COMMUNICATION, 9 (2) (1992), 111-121.

A MAJOR FACTOR IN THE COMPLEXITIES OF THE SOUTH AFRICAN LANDSCAPE IS THE BEHILDERING PROLIFERATION OF RACIAL TERMINOLOGY AND AMERICAN MEDIA USE OF THE TERMS. IN THIS ESSAY, THE AUTHOR SURVEYS TRENDS IN THE RACIAL TERMINOLOGY EMPLOYED IN SOUTHERN AFRICA SINCE 1652.

06571 MORRIS, M.

AFRICAN AMERICANS AND THE NEW HORLD ORDER

WASHINGTON QUARTERLY, 15(4) (FAL 92), 5-22.

AFRICAN AMERICANS HAVE AN URGENT AND COMPELLING NEED TO BECOME FULLY ENGAGED IN HELPING TO SHAPE U.S. FOREIGN POLICY FOR THE CHANGING TIMES. THIS ESSAY SUGGESTS THAT A NEW WORLD ORDER IS INDEED UNFOLDING; THAT BLACK AMERICANS HAVE VITAL INTERESTS AT STAKE THAT DEMAND THEIR ENGAGMENT IN INTERNATIONAL AFFAIRS; AND THAT BLACKS ARE IN A POSITION TO MAKE IMPORTANT CONTRIBUTIONS TO THE COUNTRY'S EFFORTS TO FORMULATE A RESPONSIBLE APPROACH TO GLOBAL LEADERSHIP FOR THE FUTURE.

06572 MORRIS, M.

POISONED HELLS: THE POLITICS OF WATER IN THE MIDOLE EAST MIDDLE EAST INSIGHT, 8(2) (SEP 91) 35-39.

EMERGING WATER SHORTAGES, COMBINED WITH A DETERIORATION IN WATER QUALITY, PRESENT AN ALARMING PROGNOSIS FOR THE MIDOLE EAST--IN PART ICULAR FOR EGYPT, JORDAN, ISRAEL, AND THE OCCUPIED TERRITORIES, TURKEY, SYRIA, AND IRAQ. ANALYSTS HAVE FORECAST A REGIONAL ANNUAL HATER DEFICIT OF 100,000 CUBIC METERS A YEAR BY THE YEAR 2000. IT HAS BEEN PREDICTED THAT, BY THE TURN OF THE CENTURY, WATER HILL BE THE DOMINANT RESOURCE ISSUE OF THE MIDOLE EAST. CONTROL OVER THE SUPPLY OF FRESH WATER SOURCES COULD AFFECT THE POLITICS OF THE REGION, SHAPE INTER-ARAB ALLIANCES, AND EVEN ALTER THE SUBSTANCE AND OUTCOME OF THE ARAB-ISRAELI DISPUTE. IN ADDITION, CONFLICTS OVER HATER COULD COMBINE WITH OTHER UNDERLYING FORCES OF INSTABILITY, SERVING AS A CATALYST FOR REGION-WIDE VIOLENCE.

06573 MORRIS, S.

POLITICAL REFORMISM IN MEXICO: SALINAS AT THE BRINK JOURNAL OF INTERAMERICAN STUDIES AND WORLD AFFAIRS, 34(1) (SPR 92 ), 27-58.

REFLECTING RECENT TRENDS IN IHE LITERATURE THAT STRESS STRATEGIC CALCULATION, UNFOLDING PROCESSES, AMD SEQUENTIAL PATTERNS, THIS ARTICLE CHRONICLES THE POL ITICAL STRATEGIES AND REFORM INITIATIVES OF PRESIDENT SALINAS DURING THE 19891991 PERIOD, CULMINATING IN THE FEDERAL ELECTIONS OF AUGUST 1991. IT BEGINS WITH A BRIEF OVERVIEH OF THE REFORMIST SETTING, THEN DISCUSSES THE YARIOUS REFORM COMPONENTS, AND FINALLY UNDERTAKES A GENERAL ASSESSMENT OF THEIR POLITICAL IMPACT. THOUGH THE DYNAMIC OF THE REFORMS INVOLVE A VARIETY OF ACTORS AND STRATEGIES, THE FOCUS OF ATTENTION HERE IS PRIMARILY ON POLITICAL REFORM AND THE INITIATIVES OF SALINAS AND THE PRI.

06574 MORRIS, S.D.

CORRUPTION AND POLITICS IN CONTEMPORARY MEXICO

UNIVERSITY OF ALABAMA PRESS, 1991, 202.

THIS BOOK FRAMES THE ISSUE OF CORRUPTION IN MEXICO THEORETICALLY AND THEN OUTLINES ITS VARIATIONS, RANGE, AND EXTENT. EMPLOYING TECHNIQUES OF PUBLIC OPINION SURVEY AND CONTENT ANALYSIS, THE AUTHOR PROVIDES DATA ON THE OCCURENCE OF CORRUPTION AND PUBLIC ATIITUDES TOHARDS THE PROBLEM. HE ALSO TRACES THE CYCLICAL PATTERN OF THE SIX-YEAR PRESIDENTIAL TERM AS IT MOVES FROM THE "CLEAN SWEEP" ANTICORRUPTION CAMPAIGNS THAT TYPIFY THE FIRST THO YEARS OF EACH TERM, TO THE FINAL PERIOD IN WHICH INCUMBENTS SCRAMBLE TO ASSURE THEMSELVES THE MATERIAL BASIS FOR A LUXURIOUS RETIREMENT. IN ADDITION, THE AUTHOR ATTEMPTS TO EXPLAIN THE CAUSES OF CORRUPTION IN MEXICO AS WELL AS THE OVERALL IMPACT 
OF THE PHENOMENON ON MEXICAN ATTITUDES AND SOCIAL, POLITICAL AND ECONOMIC LIFE. THE AUTHOR'S CONCLUSIONS ARE LESS THAN SANGUINE: THE MEXICAN SYSTEM IS SO RELIANT ON CORRUPTION THAT IT MIGHT WELL DISINTEGRATE IN THE FACE OF SERIOUS REFORM.

06575 MORRIS, T.

DETERMINANTS OF PUBLIC CASH ASSISTANCE USE AMONG REFUGEES IN CALIFORNIA

AMERICAN REVIEN OF PUBLIC ADMINISTRATION, 22(3) (SEP 92), 227-241.

THE AUTHOR SELECTED A RANDOM SAMPLE OF CASE RECORDS OF REFUGEES APPLYING FOR PUBLIC CASH ASSISTANCE IN CALIFORNIA IN 1984 AND THEN FOLLOWED UP ON THEIR STATUS IN 1987, TO SEE HOW MANY WERE STILL RECEIVING SUCH ASSISTANCE. FACTORS COMMON TO THOSE LEAVING PUBLIC CASH ASSISTANCE INCLUDED BEING UNDER 30 YEARS-OF-AGE, SINGLE, A SECONOARY MIGRANT TO CALIFORNIA, ON AFCD, REFERRRED TO THE EMPLOYMENT SERVICES TRAINING PROGRAM, ANO HAVING PREVIOUS U.S. WORK EXPERIENCE TRA NING PROGRAM, AND HAVING PREVIOUS U.S. HORK EXPERIENCE
AND ONE OR MORE DEPENDENTS. HOWEVER, THIS PATTERN DIFFERED ADR MALE AND FEMALE REFUGEES. BEING SINGLE AND HAVING LIVED FOR MALE AND FEMALE REFUGEES. BEING SINGLE AND HAVING LIVED IN THE UNITED STATES FOR SOME TIME WERE MUCH MORE IMPORTANT
DETERMINANTS FOR MALES THAN FEMALES FOR GETTING OFF PUBLIC DETERMINANTS FOR MALES THAN FEMALES FOR GETTING OFF PUBLIC
CASH ASSISTANCE. IN ADOITION, LACK OF TRAINING ANO WORK CASH ASSISTANCE. IN ADDITION, LACK OF TRAINING ANO WORK
EXPERIENCE AND NEEDING ESL TRAINING PREVENTED MORE WOMEN THAN MEN FROM GETTING OFF PUBLIC CASH ASSISTANCE.

06576 MORRISON, D.C.

STARBURST

NEW REPUBLIC, 206 (17) (APR 92), 21-23.

AS THE STAR HARS DEBATE DRAGS ON INTO ITS TENTH YEAR, WASHINGTON RUNS THE RISK OF ONCE AGAIN MINDLESSLY RECYCLING RECENT HISTORY. WASHINGTON IS FORGING A COMMITMENT TO DEPLOY A "THIN" SENTINEL-STYLE ABM NETHORK TO FEND OFF SUCH CHIMERICAL DANGERS AS MAVERICK LAUNCHES FROM THE FORMER SOVIET UNION AND ICBM ATTACKS BY THIRD WORLD ROGUES.

06577 MORRISON, J.S.

ETHIOPIA CHARTS A NEH COURSE

JOURMAL OF DEMOCRACY, 3(3) (JUL 92), 125-137.

ON 27 MAY 1991 , TROOPS OF THE ETHIOPIAN PEOPLE'S REVOLUTIONARY DEMOCRATIC FRONT (EPRDF) MARCHED INTO ADOIS ABABA, PUTTING AN END TO 17 YEARS OF BRUTAL MILITARY
DICTATORSHIP. THIS ARTICLE ASSESSES THE PERFORMANCE OF THE DICTATORSHIP. THIS ARTICLE ASSESSES THE PERFORMANCE OF TH
EPRDF AND ITS PARTNERS OVER THE ENSUING YEAR. IT EXAMINES EPRDF AND ITS PARTNERS OVER THE ENSUING YEAR. IT EXAM
THE TRANSITIONAL GOVERNMENT OF ETHIOPIA (TGE) AND ITS THE TRANSITIONAL GOVERMMENT OF ETHIOPIA (TGE) AND ITS
ATTEMPTS TO SOLVE THE NATION'S PRESSING ECONOMIC PROBLEMS ATTEMPTS TO SOLVE THE NATION'S PRESSING ECONOMIC PROBLEMS
AND RESOLVE SEEMINGLY INTRACTABLE ETHNIC CONFLICTS. THE AND RESOLVE SEEMINGLY INTRACTABLE ETHNIC CONFLICTS. THE
TGE'S INEXPERIENCE AND APPARENT UNHILLINGNESS TO SHED ITS TGE'S INEXPERIENCE AND APPARENT UNHILLINGNESS TO SHED ITS
INSULAR WAYS HAVE COMPOUNDED THE PROBLEMS FACED BY ETHIOPIA. THE RESULT HAS BEEN A TENDENCY TO LURCH FROM CRISIS TO
CRISIS, WITH A STYLE OF DECISION-MAKING MARKED BY DRIFT, CRISIS, WITH A STYLE OF DECISION-MAKING MARKED
CONFUSION, ISOLATION, AND RISING FRUSTRATION.

06578 MORRISON, M.

THE OZONE SCARE

INSIGHT, 8(13) (MAR 92), 6-13; 34-36.

WITH THE AID OF A CONVERTED SPY PLANE, SCIENTISTS WORKING ON A NASA-LED PROJECT RECENTLY TAPPED ATMOSPHERIC DATA THAT SET OFF A POL ITICAL STORM. THE EARTH'S PROTECTIVE OZONE LAYER APPEARED TO BE RAPDILY THINNING OVER THE MORTHERN HEMISPHERE. THE ALARM THAT ENSUED PRESSURED THE WHITE HOUSE TO GET TOUGHTER ON CFCS, COMMON CHEMICALS TIED TO THE DEPLETION. BUT SOME SCIENTISTS ARE CRYING FOUL. THEY CLAIM THE FACTS HAVE BEEN THISTED BY THOSE HAD SOMETHING TO GAIN-CTHAT THE THREAT IS OVERBLOWN AND THEY DECRY SKY-ISFALLING RHETORIC FROM RESEARCHERS, POLITICIANS AND THE MEDIA.

06579 MORRISON, P.A.: CLARK, W.A.V. LOCAL REDISTRICTING: THE DEMOGRAPHIC CONTEXT OF BOUNDARY DRAWING

NATIONAL CIVIC REVIEW, 81(1) (HIN 92), 57-63.

THE GOAL OF MINORITY REPRESENTATION HAS BEEN PURSUED AT THE EXPENSE OF POLICY-MAKING BODIES OF MANAGEABLE SIZE AND ELECTORAL DISTRICTS ADHERING TO THE PRINCIPLES OF COMPACTNESS, CONTIGUITY, AND UNIFORM POPULATION SIZE. IN THIS ARTICLE. THE AUTHORS ASK HHETHER LOCAL REDISTRICTIMG PLANS IN COSMOPOLITAN COMMUNITIES CAN BE DEYISED TO RESPECT THE INTERESTS OF DIVERSE POPULATIONS HITHOUT SUCCUMBING TO BYZANTINE COMPLEXITY.

06580 MORRISON, R.; FINGER, B MOTES ON PARTICIPATORY ECONOMICS NOTES ON PARTICIPATORY ECONOMICS NEW POLITICS, $13(1)$ (SUM 92), 103-114.
IN TWO COMPLEMENTARY BOOKS, MICHAEL ALBERT AND ROBIN IN TWO COMPLEMENTARY BOOKS, MICHAEL ALBERT AND ROB HAHNEL PRESENT A STRAIGHTFORWARD MODEL OF A FUTURE
DECENTRALIZED SOCIALIST INDUSTRIAL ORDER. THEIR IDEAS ABOUT PARTICIPATORY ECONOMICS RAISE THE KIND OF QUESTIONS THOSE INTERESTED IN FUNDAMENTAL AND DEMOCRATIC SOCIAL CHANGE NEED TO ADDRESS: THE RELATIONSHIP BETHEEN ECONOMIC MEANS AND SOCIAL ENDS; THE DISTINCTION BETWEEN SOCIALISM AND INDUSTRIALISM; AND THE DIALECTIC BETWEEN A MARKET AND PLANNING. HOWEVER, THIS ARTICLE ARGUES THAT PARTICIPATORY ECONOMICS IS NOT FOCUSED ON WHAT THE AUTHORS BELIEVE TO BE
THE CENTRAL ISSUE FACED TODAY: THE TRANSFORMATION OF AN INDUSTRIAL SOCIAL ORDER TO AN ECOLOGICAL ONE. PARTICIPATORY ECONOHICS IS BASICALLY ANOTHER MESSAGE ABOUT THE REFINEMENT OF AN INDUSTRIAL WORLD, MORE ABOUT POWER AND CONTROL, AND LESS ABOUT FREEDOM AND COMMUNITY AND THE REGENERATION OF THE INEXTRICABLY LINKED HUMAN AND NATURAL ECOLOGIES.

06581 MORROCK, R.

POLITICAL SYMBOL ISM IN CURRENT AMERICAN FILMS

JOURNAL OF PSYCHOHISTORY, 20(2) (FAL 92), 243-248.

THIS AUTHOR SUGGESTS THAT IS IS NO ACCIDENT THAT,

FOLLOWING THE FIRST MILITARY DEFEAT IN U.S. HISTORY

(VIETNAM), THE HOTTEST POLITICAL ISSUES HAVE BEEN LIFE/DEATHRELATED: ABORTION, RIGHT TO DIE, DEATH PEANALTY, GUN CONTROL AND TOXIC WASTE. ON ONE SIDE ARE THE ADVOCATES OF

TRADITIONAL VALUES, AND ON THE OTHER THOSE WHO SEEK TO REPLACE THESE VALUES WITH NEN ONES. IN THE YEAR BEFORE THE ELCTION, THESE TWO POINTS OF VIEN WERE REPRESNTED BY A PAIR OF BLOCKBUSTER MOVIES, GERMINATOR 2 AND HOOK. THIS ARTICLE ANALYZES THE POLITICAL IMPLICATIONS OF THE TWO MOVIES AND ANALYZES THE POLITICAL IMPLICATIONS
DRAWS SOME INTERESTING CONCLUSIONS.

06582 MORROH, D.

REGIONAL POLICY AS FOREIGN POLICY: THE AUSTRIAN EXPERIENCE REGIONAL POLITICS \& POLICY, 2(3) (FAL 92), 27-44.

THE STABILITY OF THE AUSTRIAN STATE HAS BEEN CRUCIAL TO THE POLITICAL STABILITY OF EUROPE THROUGHOUT THE TWENTIETH CENTURY. THE PURPOSE OF THIS ARTICLE IS TO EXAMINE THE ROLE OF TRANSFRONTIER REGIONAL CONTACT AS ONE KIND OF RESPONSE TO EXTERNAL FACTORS. IT ASKS WHETHER THE AUSTRAIN EXAMPLES OF TRANSFRONTIER REGIONAL CO-OPERATION ARE EVIDENCE THAT A \&EUROPE OF THE REGIONS' CAN PROVIDE A NEW DEMOCRATIC FRAMEHORK IN AN INTEGRATED EUROPE OR WHETHER ULTIMATELY REGIONAL POLICY CAN NEVER HOPE TO SUPPLANT INTER-STATE COOPERATION.

06583 MORTIMORE, $R$.

THE BRITISH GENERAL ELECTION OF 1992

ELECTORAL STUOIES, 11(4) (DEC 92), 352-355.

THE BRITISH GENERAL ELECTION OF APRIL 1992 BROKE NEW GROUND BECAUSE THE CONSERVATIVE PARTY WAS RETURNED FOR A FOURTH CONSECUTIVE TERM HITH A HORKING MAJORITY. IN ADOITION, IT WILL BE REMEMBERED AS AN ELECTION IN WHICH THE POLLSTERS FAILED TO ACCURATELY FORECAST THE OUTCOME.

06584 MORTON, $R$.

ADJUSTING THE ELECTORAL PENDULUM FOR VARIANCE

ELECTORAL STUDIES, 11(1) (MAR 92), 58-61.

THE ELECTORAL PENDULUM, OR SWINGOMETER, IS A SIMPLE
THER

THE ELECTORAL PENDULUM, OR SWINGOMETER, IS A SIMPLE
PRESENTATIONAL DEVICE EMPLOYED BY THE MEDIA AND BY MANY PRESENTATIOKAL DEVICE EMPLOYED BY THE MEDIA AND BY MANY POLITICAL COMMENTATORS AT ELECTION TIMES. IT IS COMST

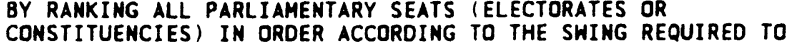
CONSTITUENCIES) IN ORDER ACCORDING TO THE SWING REQUIRED TO UNSEAT THE INCUMBENT MEMBER. AS A SIMPLE ILLUSTRATIVE AND PREDICTIVE DEVICE, ITS APPEAL IS OBVIOUS. HOWEVER, IT IS NOT WITHOUT ITS SHORTCOMINGS. USING NEW ZEALAND AS AN EXAMPLE. THIS NOTE SUGGESTS AN ADJUSTMENT TO THE CALIBRATION
IMPROVES THE PENDULUM PREDICTIVE ACCURACY WITHOUT

SACRIFICING ITS SIMPLICITY AND APPEAL.

06585 MORTON, $R$

AN ANALYSIS OF LEGISLATIVE INEFFICIENCY ANO IDEOLOGICAL BEHAVIOR

PUBLIC CHOICE, 69(2) (FEB 91), 211-222

THIS PAPER EXPLORES THE THEOORY OF LEGISLATIVE

INEFFICIENCY AND THE ROLE OF IDEOLOGICAL PREFERENCES OF

LEGISLATORS. IT IS SHOWN THAT INEFFICIENCY CAN BE CAUSED BY

MANY FACTORS OTHER THAN LEGISLATIVE IDEOLOGICAL BEHAVIOR.

THREE MAJOR SOURCES ARE EMPHASIZED: COST OF VOTING AND

POLICY POSITION INFORMATION ASYMMETRIES ACROSS GROUPS OF

VOTERS AND BARRIERS TO ENTRY IN POLITICAL COMPETITION.

IDEOLOGICAL PREFERENCE OF LEGISLATORS IS NOT A CAUSE OF

INEFFICIENCY INDEPENDENTLY. LEGISLATORS WHO CARE ABOUT BOTH

POL ICY AND HINNING WILL GIVE INEFFICIENT REPRESENTATION TO THEIR CONSTITUENTS ONLY WHEN GROUPS OF VOTERS ARE PREVENTED FROM PARTICIPATING EQUALLY IN THE LEGISLATIVE PROCESS.

06586 MORTON, R.

GROUPS IN RATIONAL TURNOUT MODELS

AMERICAN JOURNAL OF POLITICAL SCIENCE, 35(3) (AUG 91), 758-776.

A MODEL OF THE STRATEGIC CALCULUS OF VOTING THAT INCORPORATES THE BEHAYIOR OF GROUPS IS PRESENTED. IF CANDIDATES CHOOSE DIFFERENT POSITIONS, POSITIVE TURNOUT IS POSSIBLE IN (PARTIAL) EOUILIBRIUM AND' IS GENERALLY LARGER THAN THAT HITHOUT GROUP RATIONALITY. NEVERTHELESS, IF CANDIDATES ARE PROBABILITY MAXIMIZERS AND A UNIQUE (GENERAL) EQUILIBRIUM EXISTS, THE CANDIDATES WILL CHOOSE EQUIVALENT POSITIONS AND TURNOUT WILL BE ZERO EVEN WITH GROUP RATIONALITY. BUT IF CANDIDATES CARE ABOUT BOTH POLICY AND WINNING, THEY HILL CHOOSE DIFFERENT POSITIONS AND CAUSE POSITIVE TURNOUT. THIS TURNOUT WILL BE LARGER THAN THAT WOULD OCCUR WITHOUT GROUP RATIONALITY. GROUP RATIONALITY, ALONE, CANMOT EXPLAIN POSITIVE TURNOUT IN A (GENERAL) 
EQUILIBRIUM THEORY OF ELECTIONS; IT DOES IMPLY LARGER TURMOUT IN CONJUNCTION WITH POLICY-ORIENTED CANDIDATES THAN WOULD BE PREDICTED SOLELY BY INDIVIDUALISTIC RATIONAL BEHAVIOR.

06587 MOSES, R.

PREPARING FOR THE NEGOTIATING PROCESS: THE PSYCHOLOGICAL DIMENSION

JERUSALEM JOURNAL OF INTERNATIONAL RELATIONS, 13(1) (MAR

91), $77-89$

THIS ARTICLE SUGgeSTS A MOLE RANGE OF HIDDEN

PSYCHOLOGICAL FACTORS AND MOTIVATIONS--FOR INDIVIDUAL

NEGOTIATORS AS WELL AS GROUPS OF NEGOTIATORS--THAT MAY BE USEFUILY CONSIDERED BEFORE INITIATION ANTICIPATING THESE FACTORS--INCLUDING A RANGE OF UNCONSCIOUS PROCESSES SUCH AS ANXIETY AND COMPETITIVE WISHES TO SUCCEED, THE RANGE OF EXPECTATIONS THAT INDIVIDUALS BRING WITH
THE VARIOUS INDIVIDUAL AND GROUP IDENTITIES, AND THE THE VARIOUS INDIVIDUAL AND GROUP IDENTITIES, AND THE NEGOTIATIONS OCCUR--BOTH NEGATIVE CONSEQUENCES AND POSITIVE POSSIBILITIES CAN BE MANAGED.

06588 MOSHER, S

CHINA: THE ARMS MAFIA

REASON, 23(10) (MAR 92), 48-49.

A SECRET U.S. DEFENSÉ INTELLIGENCE AGENCY STUDY CIRCULATED IN 1991 CONCLUDED, IN THE WORDS OF ONE BUSH ADMINISTRATION OFFICIAL, THAT "IT IS THE OFFICIAL POLICY OF THE CHINESE GOVERMMENT TO COVERTLY SELL MISSILES TO WHOEVER CAN PAY FOR THEM." THIS ARTICLE SUGGESTS THAT THIS IS A GET RICH QUICK SCHEME OF THE COMMUNIST ELITE. THE SCIONS OF CHINA'S RULING FAMILIES RUN THE FIRMS THAT SELL ARMS, AND THE CLANS THEY REPRESENT SIPHON OFF A HEALTHY PERCENTAGE OF THE FIRMS' PROFITS. IT CONCLUDES THAT GIVEN THE MILLIONS OF DOLLARS OF EASY PROFITS TO BE MADE FROM ARMS SALES,

CONTINUED DUPLICITY AND EVASION OF INTERMATIONAL

RESPONSIBLITY OF THE CHINESE SEEMS LIKELY.

06589 MOSHER, S.

CONSERVATIVE'S DAY

FAR EASTERN ECONOMIC REVIEH, 155(27) (JUL 92), 25.

HONG KONG'S PRO-DEMOCRACY FORCES SUFFERED A DOUBLE DEFEAT WHEN THE LEGISLATIVE COUNCIL (LEGCO) DEFEATED A MOVE OEFEAT WHEN THE LEGISLATIVE COUNCIL (LEGCO) DEFEATED A MOVE FOR FASTER DEMOCRATIC REFORM AND SCRAPPED A VOTING SYSTE THAT BENEFITTED LIBERAL POLITICIANS IN THE 1991 LEGCO INCREASED PRESSURE ON BRITAIN NOT TO APPOINT A MEMBER OF THE MAIN LIBERAL PARTY, THE UNITED DEMOCRATS, TO THE EXECUTIVE COUNCIL (EXCO), THE COLONY'S POL ICYMAKING BODY. THE ISSUE OF POLITICAL REFORM HAS BEEN VERY MUCH IN THE RECENT NEWS, ESPECIALLY AFTER ALASTAIR GOODLAD, BRITAIN'S MINISTER
RESPONSIBLE FOR HONG KONG, PROVOKED VEHEMENT PROTESTS FROM RESPONSIBLE FOR HONG KONG, PROVOKED VEHEMENT PROTESTS FROM
PEKING BY SAYING THE BASIC LAH COULD BE AMENDED TO ALLOH FOR A FASTER PACE OF DEMOCRATIZATION.

06590 MOSHER, $S$.

DECLARING AN INTEREST

FAR EASTERN ECONOMIC REVIEW, 151(24) (JUN 91), 11-12. A FORMAL VISIT TO HONG KONG IN MAY BY CANADIAN PRIME MINISTER BRIAN MULRONEY, AND AN ALMOST SIMULTANEOUS SPEECH ON THE COLONY'S HUMAN RIGHTS SITUATION BY A TOP U.S. OFFICIAL. HAVE UNDERSCORED THE WAY WESTERN LEADERS HAVE BEGUN TRYING TO INFLUENCE EVENTS IN HONG KONG RATHER THAN MERELY ECHOING BRITISH POLICY. UNTIL RECENTLY, FOREIGN OFFICIALS RESTRICTED THEIR REMARKS TO BLAND AVOWALS OF FAITH AND SUPPORT FOR THE 1984 SINO-BRITISH JOINT DECLARATION, WELL AWARE OF CHINA'S SENSITIVITY TO ANY

INTERNATIONALIZATION OF THE HONG KONG ISSUE AND ANY MOVES TOWARD THE DEVELOPMENT OF A MULTI-CHINA POLICY. BUT AS HONG KONG'S SITUATION HAS BECDME MORE APPARENTLY UNTENABLE, SOME HESTERN LEADERS HAVE BEGUN TO BITE THE BULLET AND SPEAK OUT PUBLICLY ON LOCAL AFFAIRS.

06591 MOSHER, S.

PATRIOIISM IS ENOUGH

FAR EASTERN ECONOMIC REVIEN, 155(15) (APR 92), 16 CONTROL OF CRIME AND THE ADMINISTRATION OF JUSTICE, NOH THE MOST PUBLICLY DEBATED ISSUES IN HONG KONG (AFTER MONEY), THE MOST PUBLICLY DEBATED ISSUES IN HONG KONG (AFTER MONEY), A SENIOR BEIJING SECURITY OFFICIAL. A NEHSPAPER REPORT A SENIOR BEIJING SECURITY OFFICIAL. A NEHSPAPER REPORT TARGETED FOR ARREST AFTER CHINA REGAINS SOVEREIGNTY OF THE TARGETED FOR ARREST AFTER CHINA REGAINS SOVEREIGNTY OF THE COLONY IN 1997 . ACCORDING TO THE REPORT, A DEFECTING CHINESE WAS KEEPING A BLACKLIST OF PEOPLE CONSIDERED OBSTRUCTIVE TO CHINA'S CONTROL OF MONG KONG. CHINESE OFFICIALS DENY THE TRUTH OF THE ALLGEATION AND CLAIM THAT ANY "CRIMINALS" OR OTHER OFFENDERS WOULD BE DEALT WITH ON THE BASIS OF THEIR PATRIOTISM. ONE OFFICIAL STATED, "IF HE LOVES THE COUNTRY AND LOVES HONG KONG, HE IS GOOD. THAT IS OUR MEASURE OF RIGHT AND WRONG."

06592 MOSHER, $S$.

SHADOW OF CHINA
FAR EASTERN ECONOMIC REVIEH, 155(5) (FEB 92), 18 PEKING'S ANMOUNCEMENT ON 23 JANUARY THAT IT PLANS TO APPOINT LOCAL "CONSULTANTS" ON HONG KONG'S DEVELOPMENT IN SIGNALS A NEW ERA OF POLITICAL JOCKEYING IN THE TERRITORY. THE MOVE SUGGESTS THAT WHILE THE FUTURE SPECIAL ADMINISTRATIVE REGION (SAR) WILL BE RUN BY HONG KONG PEOPLE, PEKING INTENDS TO EMPLOY ITS OWN MEANS OF DETERMINING WHO THOSE PEOPLE ARE. RATHER THAM RELYING ON THE ELECTORAL THOSE PEOPLE ARE, RATHER THAN RELYING ON THE ELECTORAL
PROCESS. CHINESE OFFICIAL SPOKESMEN HERE QUICK TO DENY THAT PROCESS. CHINESE OFFICIAL SPOKESMEN WERE QUICK TO DENY THAT
THE APPOINTMENT OF CONSULTANTS WOULD CREATE A SECOND POWER THE APPOINTMENT OF CONSULTANTS WOULD CREATE A SECOND POHER OF COLONIAL RULE. BUT THE APPOINTEES COULD BECOME A OF COLONIAL RULE. BUT THE APPOINTEES COULD BECOME A
COUNTERHEIGHT TO THE LEGISLATIVE COUNCIL AND ITS TROUBLESOME COUNTERWETG
MEMBERS.

06593 MOSHER, $S$.

SOWING DIVISION

FAR EASTERN ECONOMIC REVIEW, 155(3) (JAN 92), 13.

AN EIGHT-DAY VISIT BY THE HEAD OF THE CHINESE STATE COUNCIL'S HONG KONG AND MACAU AFFAIRS OFFICE, LU PIMG, MARKED ANOTHER STAGE IN CHINESE INVOLVEMENT IN THE COLONY'S INTERNAL AFFAIRS. WHILE LU'S TALKS HITH GOVERNOR SIR DAVID WILSON APPARENTLY ACCOMPLISHED LITTLE, THE VISIT SCORED A NOTABLE SUCCESS FOR THE "DIVIDE AND RULE" TACTICS CHINA HAS BEEN TRYING TO USE AGAINST LOCAL LIBERALS. LU VISITED COMMUNITY LEADERS AND POLITICIANS OF ALL STRIPES, BUT, IN CLEAR EFFORT TO SPLIT THE LIBERAL CAMP, HE DECLINED TO MEET WITH MEMBERS OF THE UNITED DEMOCRATS OF HONG KONG, THE MAIN LIBERAL GROUP WHICH WON 11 OUT OF 18 SEATS IN THE DIRECT ELECTIONS TO THE LEGISLATIVE COUNCIL IN THE SEPTEMBER 1991 ELECTIONS.

06594 MOSHER, S.

STOPPING THE ROT

FAR EASTERN ECONOMIC REVIEW, 151(30) (JUL 91), 22. IMPORTANT CONCESSIONS ON NATIONALITY IN A NEWLY

PUBLISHED DRAFT OF MACAU'S FUTURE BASIC LAW HAVE HELPED TO

BOOST THE CONFIDENCE OF THE TERRITORY'S HARASSED CHINESE

BOOST THE CONFIDENCE OF THE TERRITORY'S HARASSED CHIMES
RESIDENTS AT A TIME HHEN LAH AND ORDER APPEARS TO BE

CRUMBLING AND A NEWLY INSTALLED PORTUGUESE GOVERNOR IS STILL

FINDING HIS FEET. UNLIKE THE HONG KONG BASIC LAN, THE MACA

VERSION PLACES NO RESTRICTIONS ON FOREIGN PASSPORT HOLDERS

TAKING IMPORTANT POSTS IN THE MACAU ADMINISTRATION AFTER 1999. ANOTHER KEY CONCESSION IS THE ABSENCE OF A PROVISION FOR THE CHINA'S PEOPLE'S LIBERATION ARMY TO BE STATIONED IM MACAU AFTER 1999 . ANO MACAU'S BASIC LAH IS STRONGER THAM
HONG KONG'S IN LIMITING IMMIGRATION FROM THE MAINLAND.

06595 MOSHER, S.W. (ED.)

KOREA IN THE 1990S--PROSPECTS FOR UNIFICATION TRANSACTION PUBLISHERS, 1992,172

FOR THE FIRST TIME SINCE THE CONCLUSION OF THE KOREAN CIVIL WAR, WHICH BRANCHED OUT TO INCLUDE THE UNITED STATES AS A KEY PLAYER IN A SOLUTION BASED ON PARTITION, THE ISSUE OF KOREAN UNIFICATION IS ON THE DIPLOMATIC, POLITIICAL, AND ECONOMIC AGENDA. THIS COLLECTION OF ESSAYS CONSIDERS THE PROSPECTS FOR UNIFICATION. WHILE THE DISINTEGRATION OF HORLD COMMUNISM IS A NECESSARY CONDITION FOR REUNIFICATION, THE CONSENSUS IS THAT SUCH A DEVELOPMENT IS NOT A SUFFICIENT CONDITION. THE AUTHOR'S CONCERN IS NOT SIMPLY TO ARGUE THE CASE FOR OR AGAINST REUNIFICATION OF KOREA, BUT TO MOVE FORHARD IN SUCH A WAY AS TO SAFEGUARD A DEMOCRATIC FUTURE FOR THE SOUTH AND OPEN UP THE TRAGICALLY CLOSED AND STAGMANT SOCIETY CREATED IN THE NORTH. IN THIS REGARD, THE

CONTRIBUTORS EXAMINE A VARIETY OF FOREIGN AS WELL AS DOMESTIC POLICY CONCERNS THAT NEED TO BE CLEARED AWAY AS A PRELUDE TO REUNIFICATION.

06596 MOSS, JR., A.

A DEMOCRATIC PARTY APPROACH TO LATIN AMERICA

JOURNAL OF INTERAMERICAN STUDIES AND WORLD AFFAIRS, 34(2)

(SUM 92 ), 1-18.

THIS IS A GOOD TIME FOR THE REAL NORTH-SOUTH ISSUES TO

BE RESUMED IN THE WESTERN HEMISPHERE, ARGUES THIS ARTICLE.

IT SUGGESTS THAT THE ISSUES ARE: THE PURSUIT OF DEMOCRACY

AMD UGES

AND HUMAN RIGHTS; THE UNRESOLVED ISSUE OF CUBA; ECONOMIC

COOPERATION FOR TRADE AND MUTUAL BENEFIT; COOPERATION FOR

ENVIRONMENTAL PROTECTION; AND, THE FIGHT AGAINST ILLEGAL

DRUG TRAFFICKING. IT CONCLUDES THAT A STRONG, COHERENT

ISSUES.

06597 MOSSUZ-LAVAU, J.

WOMEN AND POLITICS IN FRANCE

FRENCH POL ITICS AND SOCIETY 10(1) (HIN 92) $1-8$.

THE AUTHOR TRACES THE EYOLUTION OF FEMALE VOTING

BEHAVIOR IN FRANCE AND THEN ENDEAVORS TO EXPLAIN THE

CHANGING TRENDS IN THE WAY FRENCH WOMEN VOTE.

06598 MOTIVANS, A.

OPENNESS TO THE HEST IN EUROPEAN RUSSIA

RFE/RL RESEARCH REPORT, 1(47) (NOV 92), 60-62.

A RECENT PUBLIC OPINION POLL SURVEYED THE ATTITUDES OF 
THE RUSSIAN PEOPLE TOWARD THE WESTERN ORIENTATION OF THE GOVERNMENT'S REFORM PROGRAMS, THEIR PERCEPTIONS OF THE WEST, AND THEIR RECEPTIVENESS TO WESTERN POLITICAL AND ECONOMIC MODELS. THE SURVEY REVEALED THAT ATTITUDES TOWARD THE WEST REFLECT THE LARGER CONFLICT OVER THE DIRECTION OF POLITICAL AND ECONOMIC REFORM AND DEEPLY DIVIDE RUSSIAN SOCIETY.

06599 MOTLEY, C.B.

THE HISTORICAL SETTING OF BROWN AND ITS IMPACT ON THE SUPREME COURT'S DECISIOM

FORDHAM LAW REVIEH, LXI(1) (OCT 92), 9-18.

THE AUTHOR PROVIDES AN OVERVIEW OF THE BROWN V. BOARD OF EDUCATION DECISION IN ITS HISTORICAL CONTEXT. IN ADOITION TO ANALYZING SEVERAL SUPREME COURT DECISIONS THAT PRECEDED BROWN, SHE FOCUSES ON THE ROLE OF THURGOOD MARSHALL AS STRATEGIST AND TACTICIAN DURING THIS OYNAMIC PERIOD. SHE CONCLUDES BY EXAMINING THE IMMEDIATE IMPACT OF BROWN ON THE CIVIL RIGHTS MOVEMENT IN THE UNITED STATES.

06600 MOTOO, F.

CHANGING TIMES FOR VIETNAM AND JAPAN

JAPAN OUARTERLY, XXXIX(2) (APR 92) 168-175.

THE AUTHOR DISCUSSES HAMOI'S CHANGING POLITICAL POLICY AND HOW IT IS REFLECTED IN THE PRESENT SITUATIOM IN VIETHAM. THEN HE REMARKS ON THE IMPLICATIONS OF RECENT CHANGES FOR RELATIONS BETWEEN JAPAN AND VIETNAM.

06601 MOTYL, A.

EMPIRE OR STABILITY?

WORLD POLICY JOURNAL, YII

IT IS NOW WIDELY ACKNOWLEDGED THAT WASHINGTON'S PRESUMED PARTNER IN THE NEH WORLD ORDER, THE USSR, MAY BE TERMINALLY ILL. ECONOMIC COLLAPSE, SOCIAL CHAOS, POLITICAL UNGOVERHABILITY, AND NATIONALIST STRIFE MAY ALL PORTEND AN EVENT OF GREAT HISTORICAL SIGNIFICANCE--THE DISINTEGRATIOM OF A SUPERPOWER. IN EVALUATIMG WESTERN POLICY GOALS WITH REGARD TO THE SOVIET EMPIRE, STABILITY MUST BE A KEY CONSIDERATION. THIS ARTICLE ARGUES THAT IT IS ONLY THROUGH THE BREAKUP OF THE SOVIET EMPIRE THAT LASTING STABILITY CAN COME TO EASTERN EUROPE. THE AUTHOR SUGGESTS THAT, NOTHI THSTANDING GORBACHEV'S RECENT CEASE-FIRE WITH NINE REPUBLICS, THE SOVIET UNION'S COLLAPSE IS NOT A PREFERENCE BUT AN INEVITABILITY; THAT PROTRACTED COLLAPSE IS FAR MORE DANGEROUS THAN RAPID COLLAPSE; AND THAT STABILITY AND SECURITY CAN BE ENHANCED BY ACCELERATING SOVIET COLLAPSE AND SKILLFULLY MANAGING THE POST-SOVIET ORDER.

06602 MOTYL, A.J.

CONCEPTS AND SKOCPOL: AMBIGUITY AND VAGUENESS IN THE STUDY OF REVOLUTION

JOURNAL OF THEORETICAL POLITICS, 4(1) (JAN 92), 93-112. JACK GOLDSTONE HAS IDEMT TFIED THREE GEMERATIONS OF HISTORICAL AND THEORETICAL DEVELOPMENTS IN THE STUDY OF
REVOLUTION AND SUGGESTED THAT THE THIRD, AS TYPIFIED BY REVOLUTION AND SUGGESTED THAT THE THIRD, AS TYPIFIED BY THEDA SKOCPOL, REPRESENTS AN ADVANCE OVER ITS PREDECESSORS
THIS PAPER ARGUES THE OPPOSITE BY CRITICALLY ANALYZING THE THIS PAPER ARGUES THE OPPOS ITE BY CRITICALLY ANALYZING THE
WORK THAT HAS DEFINED MOST THIRD-GENERATION SCHOLARSHIP, WORK THAT HAS DEFINED MOST THIRD-GENERATION SCHOLARSHIP,
"STATES AND SOCIAL REVOLUTIONS." THE REASONS FOR SKOCPOL'S INABILITY TO TRANSCEND EARLIER SCHOLARSHIP ARE FOUND IN HER CASUAL APPROACH TO CONCEPTUAL CLARITY, SPECIFICALLY IN HER TENDENCY TO INDULGE IN AMBIGUITY AND YAGUENESS WITH RESPECT TO THE CENTRAL CONCEPTS OF THE BOOK--STRUCTURE. STATE, POTENT IAL AUTONOHY, CRISIS, AND REVOLUTION. IN LIGHT OF THESE CONCEPTUAL OBSTACLES, THIS PAPER PROPOSES A POSSIBLE CONCEPTUAL SOLUTION TO THE PROBLEMS BESETTING THE STUDY OF REVOLUTION.

06603 MOUW, C. ; MACKUEN, M.

the strategic Configuration, personal influence, and PRESIDENTIAL POWER IN CONGRESS

WESTERN POLITICAL QUARTERLY, 45(3) (SEP 92), 579-608.

THE AUTHORS EXTEND THE LONG LIME OF RESEARCH ON

PRESIDENTIAL PERSUASION IN CONGRESS BY EXAMINING THREE MAJOR CONSIDERATIONS. FIRST, THEY SHOH THAT PERSUASION CAN BEST BE ANALYZED THROUGH THE DEVELOPMENT OF A BASELINE MODEL. THEM THEY STUOY THO MAJOR THEORETICAL PERSPECTIVES REGARDING PRESIDENTIAL INFLUENCE: (1) BARGAINING POLITICS, CHARACTERIZED BY THE COMMON "BAHK ACCOUNT MODEL" AMD NEUSTADT'S "POLITICAL INVESTMENT MODEL" AND (2) PLEBISCITARY POLITICS, CHARACTERIZED BY NEUSTADT'S "PRESIDENTIAL PRESTIGE MODEL" AND KERNELL'S "GOING PUBLIC MODEL." EMPIRICAL MODEL" AND KERNELL'S "GOING PUBLIC MODEL." EMPIRICAL ANALYSES OF THE EISENHOWER AND REAGAN PRESIDENCIES PROVIDE SPARSE SUPPORT FOR THESE PROPOSITIONS. IN THEIR PLACE, THE AUTHORS SUGGEST THAT PRESIDENTIAL PERSUASION BE STUDIED UMDERSTAND THAT LEGISLATIVE RESULTS CORE DETERTION. THEY UNDERSTAND THAT LEGISLATIVE RESULTS ARE DETERMINED BY THE IDEOLOGICAL COMPOSITION OF CONGRESS AND THE WAY THE PRESIOENT AND GPPOSING PARTY LEADERSHIP FORM THE STRATEGIC AGENDA.

06604 MOUH, C.J.; HACKUEN, M.B.

THE STRATEGIC AGENDA IN LEgISLATIVE POLITICS

AMERICAN POLITICAL SCIENCE REVIEN, 86(1) (MAR 92), 87-105. THE AUTHORS EXAMINE THE POLITICS OF THE STRATEGIC AGENDA.
ABSTRACTING A POLITICS ON THE LIBERAL-CONSERVATIVE DIMENSION, THEY ANALYZE KEY VOTE ROLL CALL DATA FROM THE U.S. HOUSE OF REPRESENTATIVES OURING THE EISENHOWER AND REAGAN ADMINISTRATIONS. THE DATA SUGGEST THAT POLITICIANS SET THE POLICY AGENDA IN A STRATEGIC FASHION. BECAUSE THEY CONSIDER SUCH FACTORS AS LONG-TERM POLITICAL GOALS, THE CHANGING INSTITUTIONAL SETTING, AND PLEBISCITARY PRESIDENTIAL POLITICS, AGENDA-SETTERS PROPOSE LEGISLATION THAT ONLY IMPERFECTLY REFLECTS THEIR AND THE MEMBERSHIP'S HISHES ON THE ISSUE AT HAND. THUS, AS THE FINAL STAGE IN THE POL ITICAL PROCESS, THE STRATEGIC SELECTION OF AN AGENDA PROVIDES A MEANS BY WHICH FACTORS OTHER THAN POLICY PREFERENCES AFFECT POLICY OUTCOMES. THE ANALYSES AFFIRM THE STRATEGIC AGENDA AS A CORE ELEMENT IN POLITICAL LIFE.

06605 MOYER, H.W.

THE DISPOSAL OF EUROPEAN COMMUNITY FOOD SURPLUSES: MARKET DEVELOPMENT THROUGH FOOD AID AND EXPORT REFUNDS

POLICY STUDIES JOURNAL, 20(3) (1992), 459-472.

AT ITS INCEPTION THE EUROPEAN COMMUNITY (EC) WAS HIGHLY DEPENDENT UPON FOOD IMPORTS, SO EC INSTITUTIONS WERE NOT DESIGNED TO FACILITATE OVERSEAS MARKET DEVELOPMENT FOR FOOD DESIGNED TO FACILITATE OVERSEAS MARKET DEVELOPMENT FOR SUFFICIENT IN FOOD, GENERATING LARGE SURPLUSES IN CEREALS AND DAIRY PRODUCTS. MARKET DEVELOPMENT HAS NEVER BEEN AN OFFICIAL EC POLICY GOAL, BUT THERE IS EVIDENCE THAT THE EC HAS USED FOOD AID TO ENCOURAGE THIRD WORLD COUNTRIES TO INCREASE FOOO IMPORTS FROM EUROPE. EVIDENCE ALSO EXISTS THAT THE EC HAS USED EXPORT SUBSIDIES AS A MEANS OF COMPETING FOR AN INCREASED SHARE OF PROMISING INTERNATIONAL MARKETS,

THOUGH THIS EFFORT HAS NOT BEEN TOTALLY SUCCESSFUL.

06606 MOYO, B.

AFRICA'S CONCERNS

WEST AFRICA, (3890) (APR 92), 580-581.

THE AUTHOR EXAMINES THE 1992 PARTY PLATFORMS OF GREAT

BRITAIN'S THREE MAJOR POLITICAL PARTIES--LABOUR,

CONSERVATIVE, AND LIBERAL DEMOCRATS--FOCUSING ON THE PLANKS

MOST IMPORTANT TO AFRICA.

06607 MOYO, B.

BETTER LUCK, 1992

WEST AFRICA, ( 3877 ) ( JAN 92), 15-16.

THE YEAR 1991 WAS A TIME OF DRAMATIC POLITICAL CHANGE IN SOUTHERN AFRICA. WITH THE ELECTION OF A NEW PRESIDENT IN

SOUTHERN AFRICA, WITH THE ELECTION OF A NEW PRESIDENT

ZAMBIA BEING PERHAPS THE CLIMAX IN THE REGION. OTHER

SIGNIFICANT EVENTS INCLUDED THE SIGNING OF A PEACE AGR

ZIMBABHE, THE CELEBRATION OF THO YEARS OF INDEPENDENCE IN

NAMIBIA, AND THE ENDING OF SANCTIONS AGAINST SOUTH AFRICA.

06608 MOYO, B.

POVERTY REDUCTION PLEDG

WEST AFRICA, (3890) (APR 92), 592

THE LABOUR PARTY HAS PLEDGED TO INCREASE BRITAIN'S AID

TO POOR COUNTRIES WITHIN THE LIFETIME OF THE NEXT PARLIAMEN

IF IT WINS THE 1992 ELECTIONS. ACCORDING TO A PARTY REPORT,

A LABOUR GOVERMMENT NOULD MEET THE AID LEVEL RECOMMENDED BY

THE UNITED NATIONS (7\% OF GNP) AND WOULD FOCUS ITS AID ON

THE AGRICULTURAL, HEALTH, AND EDUCATION SECTORS.

06609 MOYO, B.

QUESTIONS OF ECONOMIC POWER

WEST AFRICA, (3894) (MAY 92), 748-749.

THE AUTHOR SUMMARIZES MAJOR CONCLUSIONS PRESENTED IN THE UNITED NATIONS DEVELOPMENT PROGRAMME'S 1992 REPORT ON HUMAN DEVELOPMENT AND GLOBAL ECONOMIC DISPARITIES.

06610 MOYO, B.

U.S. STANCE CRITICISED

NEST AFRICA, (3899) (JUN 92 ), 976

THE EUROPEAN COMMUNITY HAS ACCUSED THE UNITED STATES OF THREATENING THE OUTCOME OF THE 1992 EARTH SUAMIT BY REFUSING TO SIGN THE BIOLOGICAL DIVERSITY TREATY. MOREOVER, THE PROSPECT OF THE SUMMIT PRODUCING A FRUITFUL DEBATE ON A WIDE RANGE OF ISSUES NOH APPEARS SLIM, DUE TO THE ACRIMONY BETWEEN DEVELOPED AND DEVELOPING COUNTRIES ; A MAJOR ISSUE IS WHO SHOULD PAY THE COST OF ENYIRONMENTAL PROTECTION.

06611 MOYO, B.

UNCTAD'S UNITY OF PURPOSE

HEST AFRICA, (3886) (MAR 92), 419

THE UNITED MATIONS COMFERENCE ON TRADE AND DEVELOPMENT (UNCTAD), WHICH HAS FORMED IN 1964 AS A TRADE AND DEVELOPMENT WATCHOOG FOR THE DEVELOPING COUNTRIES, WAS RECENTLY RESTRUCTURED. FOUR COMMITTEES WERE FORMED TO WORK IN THE FOLLOWING AREAS: COMMODITIES, POVERTY ALLEVIATION, SERVICE SECTORS, AND ECONOMIC COOPERATION AMONG DEVELOPING COUNTRIES.

06612 MOYO, B.

VISIONS OF BRUTALITY

WEST AFRICA, (3889) (MAR 92), 542-543.

THE AUTHOR DISCUSSES THE ROLE DF NON-GOVERMMENTAL 
ORGANIZATIONS (NGO'S) IN UNCOVERING HUMAN RIGHTS ABUSES IN AFRICA AKD HELPING TO REDUCE THE INCIDENCE OF TORTURE, FALSE IMPRISONMENT, AND MURDERS.

06613 MOYO, J.

STATE POLITICS AND SOCIAL DOMINATION IN ZIMBABWE JOURNAL OF MODERN AFRICAN STUDIES, 30(2) (JUN 92), 305-330. A GREAT DEAL HAS BEEN WRITTEN FROM ALL MANNER OF PERSPECTIVES ABOUT THE SITUATION IN AFRICA BOTH BEFORE AND PERSPECTIVES ABOUT THE SITUATION IN AFRICA BOTH BEFORE AND SELDOM YIELDED A MAINSTREAM UNDERSTANDING OF BASIC ASPECTS OF STATE POLITIICS. THIS ARTICLE MAKES BRIEF REFERENCES TO, THO APPROACHES WHICH HAVE DOMINATED THE STUDY OF ZIMBABNE'S FIRST DECADE OF INDEPENDENCE. THE FIRST IS AFRO-MARXISM, AND THE SECOND IS MEO-COLONIALISM.

06614 MRUSEK, $K$.

CHEMICAL HEAPONS BAN AGREED--AFTER 9 YEARS

GERMAN TRIBUNE, 31 (1532) (SEP 92), 2 .

SIX COUNTRIES HAVE VOICED RESERVATIONS ABOUT THE RESULT OF THE LONGEST-EVER UN DISARMAMENT TALKS, BUT THEIR OBJECTIONS DIFFER AND THE DOUBTS ARE NOT VOICED BY HOMEGENOUS GROUP OF COUNTRIES. MINOR CONCESSIONS WERE MADE TO THE DEVELOPMENT COUNTRIES WITH THE AIM OF NOT UPSETTING STATES THAT CLEARLY ALREADY HAVE THE LITTLE MAN'S ATOMIC BOMB--OR WANT TO HAVE IT. THIS IS THE FIRST TIME IN THE HISTORY OF ARMS CONTROL THAT AGREEMENT HAS BEEN REACHED ON THE ELIMINATION OF AN ENTIRE ARMS CATEGORY. SIXTY-FIVE COUNTRIES ARE CERTAIN TO RATIFY THE TREATY.

06615 MUBBUBANI, $K$.

THE HEST AND THE REST

NATIONAL INTEREST, 28 (SUM 92), 3-13.

A NEH CONSENSUS HAS DEVELOPED THAT THE WEST MERELY HAS TO HOLD A STEADY COURSE IN THE POST-COLD WAR ERA. THIS ESSAY WILL CHALLENGE THIS WIDELY HELD ASSUMPTION. IT ARGUES THAT "STEADY AS SHE GOES" IS NOT A VIABLE OPTION FOR THE WEST: THAT WHILE IT MAY NOT FACE ANY IMMEDIATE MILITARY THREAT, THE HEST FACES SERIOUS AND GROWING DANGERS OF OTHER KINDS: THAT IT CANNOT AFFORD TO TURN ITS BACK ON THE THIRD WORLD BECAUSE THE COLD HAR IS OVER; THAT IN A SHRINKING AND INCREASINGLY OVERCROWDED WORLD, IN WHICH THE POPULATION OF INCREASINGLY OVERCROWOED WORLD, IN WHICH THE POPULAT THE WEST CONSTITUTES AN EVER SMALLER PERCENTAGE, A COMPREHENSIVE NEW STRATEGY IS NEEDED; AND THAT AN AGGRESSIV EFFORT TO EXPORT WESTERN VALUES TO THE NON-HEST DOES NOT CONSTITUTE SUCH A STRATEGY, ALREAOY SERIOUS PROBLEMS.

06616 MUDA, M.

MALAYSIA'S FOREIGN POLICY AND THE COMMONWEALTH ROUND TABLE, (320) (OCT 91), 455-466.

THE PURPOSE OF THIS ARTICLE IS TO EXAMINE MALAYSIA'S CONNECTION WITH THE COMMONHEALTH IN THE PAST TEN YEARS SINCE DR. MAHATHIR MOHAMAD TOOK OVER THE POLITICAL LEADERSHIP OF THE COUNTRY IN 1981. FIRST, SOME GENERAL OBSERVATIONS ARE MADE OF THE PLACE OF THE COMMONWEALTH IN MALAYA'S, LATER MALAYSIA'S, FOREIGN POLICY. IN PARTICULAR, THE ARTICLE SEEKS TO CONSIDER MALAYSIA'S APPARENTLY GROWING DISENCHANTMENT WITH THE COMMONHEALTH IN THE EARLY 1980S, AND THE "REVIEW" OF MALAYSIA'S POSITION IN THE ORGANIZATION IN 1986 LEADING TO THE HOSTING OF THE COMMONHEALTH HEADS OF GOVERMMENT MEETING (CHOGH) IN 1989. BEYOND THIS, THE ARTICLE SEEKS TO MAKE SOME GENERAL OBSERYATIONS AS TO WHY THE COMMONWEALTH WAS (AND PERHAPS STILL IS) NOT REGARDED BY THE GOVERNMENT AS AN INSTRUMENT OF THE FIRST IMPORTANCE IN MALAYSIA'S POLITICAL AND ECONOMIC POLICIES.

06617 MUELLER, C.

THE GEMDER GAP AND WOMEN'S POLITICAL INFLUEMCE

ANHALS OF THE AMERICAN ACADEMY OF POLITICAL AND SOCIAL

SCIENCE, (514) (MAR 91), 23-37.

A GENDER GAP OF SIX TO EIGHT PERCENTAGE POINTS

DIFFERENTIATED THE VOTE OF WOMEN FROM THAT OF MEN IN THE

PRESIDENTIAL ELECTIONS OF THE 1980's. WOMEN SHOWED A GREATER

PREFERENCE FOR DEMOCRATIC CANDIDATES; COUPLED WITH AM

PREFERENCE FOR DEMOCRATIC CANDIDATES; COUPLED WITH AN

INCREASED RATE OF VOTING RELATIVE TO MEN, THIS INCREASED

FEMALE INFLUENCE ON ELECTORAL POLITICS FOR THE FIRST TIME
SINCE THE SUFFRAGE PERIDO. DESPITE THE FACT THAT FEMALE

VOTING BEHAVIOR DOES NOT CORRESPOND TO MANY CRITERIA OF

GROUP POLITICS, THE LARGE NUMBERS OF FEMALE VOTERS ARE

BEGINNING TO HAVE AN IMPACT ON THE NATURE OF CAMPAIGH

DISCOURSE AND ISSUES. THESE CHANGES WERE PARTICULARLY HOMEN VOTERS.

06618 MUELLER, J.

DUELING, HAR AND THE UTILITY OF FORCE: A RESPONSE TO AKHTAR MAJEED

BULLETIN OF PEACE PROPOSALS, 23(1) (MAR 92), 103-107.

THE AUTHOR OF THIS ARTICLE DEFENDS HIS PROPOSITION THAT

WAR BETWEEN DEVELOPED NATIONS IS RAPIOLY BECOMING OBSOLETE.

HE EXPANDS ON THE EVIDENCE PROVIDED BY THE CASE OF EUROPE.

HE ALSO FURTHER EXPLAINS HIS COMPARISONS OF THE

DISAPPEARANCE OF DUELING AND SLAVERY TO THE GRADUAL
DISAPPEARANCE OF WAR AS A CONFLICT RESOLUTION MECHANISM.

06619 MUELLER, J.

PEARL HARBOR: MILITARY INCONVENIENCE, POLITICAL DISASTER INTERNATIONAL SECURITY, 16(3) (WIN 91), 172-203.

FIFTY YEARS AFTER THE JAPANESE ATTACK THAT BROUGHT THE UNITED STATES INTO WORLD HAR II, JOHN MUELLER RECONSIDERS PEARL HARBOR. HE CONCLUDES THAT JAPANESE BOMBS AND TORPEDOES DID LITTLE MILITARILY SIGNIFICANT DAMAGE., MANY DESTROYED U. S. SHIPS AND PLANES WERE OBSOLETE; OTHERS' WERE RAPIDLY REPARIED OR REPLACED. MUELLER ARGUES THAT THE PEARL HARBOR REPARIED OR REPLACED. MUELLER ARGUES THAT THE PEARL HARBOR ATTACK WAS NONETHELESS A POLITICAL DISASTER, BECAUSE IT
IMPELLED THE UNITED STATES INTO A LONG WAR AGAINST JAPAN IN IMPELLED THE UNITED STATES INTO A LONG WAR AGAINST JAPAN ASIA WHEN A LESS COSTLY

06620 MUELLER, K.J.

STATE GOVERMMENT POLICIES AND RURAL HOSPITALS:

FACILITATING CHANGE

POLICY STUDIES JOURNAL, 20(2) (1992), 168-181.

THIS PAPER BEGINS WITH A DISCUSSION OF THE GENERAL

POLICY PROBLEM OF ASSISTING RURAL HOSPITALS THAT ARE

EXPERIENCING SEVERE FINANCIAL STRESS. A METHODOLOGY SECTION

DESCRIBES HOW DATA WERE COLLECTED FROM THE 50 U.S. STATES

THEN THE PAPER DESCRIBES AND GROUPS THE PARTICULAR STATE

POLICIES USED FOR ANALYSIS. STATISTICAL ANALYSIS FOLLOWS,

DESIGN. FINALLY, THE FINDINGS ARE DISCUSSED AND IMPLICATIONS ARE DRAWN.

06621 MUHLEMANH, C.

LATIN AMERICAN: NEW AND OLD

SHISS REVIEW OF WORLD AFFAIRS, 42(3) (JUN 92), 4-5.
AT THE BEGINNING OF 1992, A DEMOCRATIZING IREND SEEMED TO BE FIRMLY IN PLACE IN LATIN AMERICA. BUT THE ATTEMPTED COUP IN VENEZUELA AND DEVELOPMENTS IN PERU PROVE THAT THE REGION'S ECONOHIC REFORMS AND POL ITICAL TREND TOWARD PLURALISM AND ELECTED GOVERMMENT ARE BY NO MEANS SECURE. THIS IS PARTLY BECAUSE INNOVATIONS NEED TIME TO BE TESTED THIS IS PARTLY BECAUSE INNOVATIONS NEED TIME TO BE TESTED
AND PROVED, ESPECIALLY IN A POLITICAL CULTURE LIKE LATIN AND PROVED, ESPECIALLY IN A POLITICAL CULTURE LIKE AMERICA'S, WHICH IS CHARACTERIZED BY THE ADOITIVE
INTEGRATION OF METHODS AHD MODELS THAT ARE MOSTLY ADOPTED FROM THE OUTSIDE.

06622 MUIR, J.

A CREDIBLE alternative to SADDAM

MIDDLE EAST INTERNATIONAL, (437) (NOV 92), 3-4.

MORE THAN 260 DELEGATES FROM VIRTUALLY' EVERY IRAQI OPPOSITION GROUP MET IN SALAHUDDIN IN OCTOBER 1992. THE MAIN OBJECTIVE OF THE CONFERENCE WAS TO UNIFY THE OPPOSITION AND ESTABLISH CREDIBLE LEADERSHIP FOR OPPOSITION ACTIVITY, INSIDE AND OUTSIDE IRAQ. THE U.S. - LED WESTERN COALITION PARTNERS WANT TO EXTRICATE THEMSELVES FROM IRAQ BUT RECOGNIZE THAT THEY CANNOT DO SO WHILE SADOAM HUSSEIN REMAINS IN POWER. SO THEY ARE ENCOURAGING A UNIFIED OPPOSITION AS A MEANS OF UNDERMINING SADOAM AND OFFERING IRAQIS AN ALTERNATIVE THAT COULD PRODUCE A PEACEFUL TRANSITION.

06623 MUIR, J.

IRAQI KURDISTAN--THEY ALL WON THE ELECTION

MIDDLE EAST INTERNATIONAL, (426) (MAY 92), 11-13.

THE KURDISH ELECTION, HELD RECENTLY IN NORTHERN IRAO,

TURNED FROM A JOYFUL EXERCISE IN SELF-EXPRESSION INTO A

DISASTER-LIMITATION OPERATION IN WHICH IT WAS NARROHLY SAVED

BY A POLITICAL ACCOMHODATION BETWEEN THE TWO MAIN FACTIONS, APPROVED BY FIVE SMALLER PARTIES WHICH LOST OUT IN THE POLLS. THE TWO MAJOR PARTIES, MAS'UD BARZANI'S KURDISH DEMOCRATIC PARTY (KDP) AND JALAL TALABANI'S PARTIOTIC UNION OF KURDISTAN (PUK), WERE ALLOCATED AN EQUAL FIFTY SEATS EACH IN THE NEW KURDISH NATIONAL ASSEMBLY, THOUGH THAT WAS NOT THE STRICT RESULT OF THE POLL. A SEPARATE VOTE FOR "LEADER" HAD PROVED INCONCLUSIVE, SO A RUN-OFF BETWEEN TALABANI AND PROVED INCONCLUSIVE, SO A RUN-OFF BETWEEN TALABANI AND
BARZANI IS SCHEDULED TO TAKE PLACE IN THO MONTHS. THE BARZANI IS SCHEDULED TO TAKE PLACE IN THO MONTHS. THE
ANMOUNCEMENT OF THE TIED RESULT WAS GREETED WITH JUBILANT CELEBRATION THROUGHOUT IRAOI KURDISTAN. AS FAR AS MOST CELEBRATION THROUGHOUT IRAOI KURDISTAN. AS FAR AS MOST PRESERVING THEIR UNITY AND FOILING THE DIRE PREDICTIONS OF PRESERVING THEIR
THEIR ENEMIES.

06624 MUIR, J.

ISRAEL AND LEBANON: PEAK OF DANGER

ISRAEL AND LEBANON: PEAK OF DANGER
MIDDLE EAST INTERNATIONAL, $438(438)$ (NOV 92), 8.

THE LATEST FLARE-UP OF CROSS-BORDER VIOLENCE IN SOUTHERN LEBANON REACHED A CRITICAL PEAK OF DANGER WHICH SET ENOUGH ALARM BELIS RINGING FOR THE USUAL DEFUSING MECHANISMS TO BE ACTIVATED IN TIME TO HEAD OFF A DRAMATIC EXPLOSION. THIS ARTICLE EXPLORES THE CYCLE WHICH BEGAN AGAIN IN NOVEMBER THE ESCALATION IN THE SOUTH WAS SERIOUS ENOUGH TO DISRUPT THE WASHIMGTON TALKS AMIDST ACRIMONIOUS EXCHANGES.

06625 MUIR, J.

LEBANON--CHRISTIANS FEEL THE PRESSURE

MIDOLE EAST INTERNATIONAL, (421) (AUG 92), 9-10. 
THE LEBANESE GOVERNMENT'S DECISION TO PUSH AHEAD WITH PARLI IMENTARY ELECTIONS, DESPITE WIDESPREAD OPPOSITION TO SUCH A SWIFT PLEBISCITE AMONG LEBANON'S CHRISTIAN POPULATION, PLACES THE FUTURE OF THE COUNTRY IN SOME UNCERTAINTY. POLLING IS TO BE HELD IN THREE STAGES--IN THE BEQAA AND THE NORTH ON 23 AUGUST, IN BEIRUT AND THE MOUNTAINS ON 30 AUGUST, AND IN THE SOUTH ON 6 SEPTEMBER. VOTERS WILL BE CHOOSING 128 DEPUTIES. THERE ARE FEARS, EXPRESSED OPENLY IN THE CHRISTIAN CAMP AND QUIETLY SHARED BY MANY MUSLIMS, THAT THE ELECTIONS MAY SIMPLY BE AN EXERCISE HHICH WILL COMPLETE THE EMERGENCE OF A LOCALLY STRONG LEBANESE STATE AS A SORT OF EXTENDED SYRIAN DICTATORSHIP.

06626 MUIR, J.

LEBANON--CLOSING THE HOSTAGE FILE

MIDDLE EAST INTERNAT IONAL. (428) (JUN 92), 8-9.

ON 17 JUNE, THE LAST THO WESTERN HOSTAGES HELD IN LEBANON, THE GERMAN AID HORKERS HEINRICH STRUEBIG AND THOMAS KEMPTNER, WERE RELEASED. THE LEBANESE GOVERNMENT HOPES THAT THE CLOSING OF THE HESTERH HOSTAGE CHAPTER HOULD HERALD AN THE CLOSING OF THE HESTERN HOSTAGE CHAPTER HOULD HERALD AM
IMPROVEMENT IN ITS OWN FORTUMES. IT HOPES THAT THE S216MILLIDN IN PROMISED AID FROM THE EUROPEAN COMUNITY, HELD MILLION IN PROMISED AID FRDM THE EUROPEAN COMMNITY, HELD BITHOUT DELAY. AN EC DELEGATION HAS EXPECTED IN BEIRUT WITHOUT DELAY. AN EC DELEGATION HAS EXPECTED IN BEIRUT BARELY A WEEK AFTER THE RELEASES. HOWEVER, POLITICAL
UNCERTAINTY LOOMS AHEAD AS THE COUNTRY PREPARES FOR ITS UNCERTAINTY LOOMS AHEAD AS THE COUNTRY PREPARES FOR ITS FIRST PARLIAMENTARY ELECTIONS SINCE 1972. THE CONTINUED ISRAELI OCCUPATION OF SOUTHERN LEBANON AND THE PRESENCE OF LARGE NUMBERS OF CHRISTIIANS FROM THE DRUZE-CONTROLLED SHUF MOUNTAINS WHO ARE DISPLACED AND UNABLE TO GO HOME AND VOTE
IN THEIR OWN CONSTITUENCIES PROMISE FURTHER UNCERTAINTY AND TURMOIL.

06627 MUIR, J.

LEBANON--TASKS TO BE TACKLED

MIDOLE EAST INTERMATIONAL, (405) (JUL 91), 11-12.

THE GOVERMHENT OF LEBAHON STILL FACES TWO MAIN OBSTACLES IN ITS DRIVE TO IMPOSE ITS AUTHORITY OVER THE COUNTRY: HIZBULLAH, ALIAS THE ISLAMIC RESISTANCE, WHICH ALONE OF THE LEBANESE MILITIAS IS REFUSING TO DISBAND AND DISARM; AND THE ISRAELIS AND THEIR SOUTHERN LEBANON ARMY (SLA) ALLIES, WHO HAVE SHOWN EVERY SIGN OF DETERMINATION TO FOIL A COMEBACK BY THE LEBANESE STATE AND ITS ARMY. THE CURBING OF HISBULLAH AND THE TAKEOVER OF THE SLA-OCCUPIED JIZZIN ZONE TOP THE LIST OF ACHIEVEMENTS WHICH ARE WIDELY REGARDED AS NECESSARY IF CONFIDENCE IN THE COUNTRY'S STABILITY
AND INVESTMENTS AND FOREIGN AID SECURED.

06628 MUIR, J.

LEBANON: ISRAELI ATTACK
MIDOLE EAST INTERMATIONAL, 417 (JAN 92), 12.

MIDOLE EAST INTERNATIONAL, 417 (JAN 92), 12 .
THE ISRAELI DEMOLITION OF A LEBANONESE TERRORIST BASE IS SEEN IN THE LEBANESE CONTEXT AS PART OF ISRAEL'S GENERAL POLICY OF SELF ASSERTION IN THE SOUTH WHERE THE ISRAELI PRESENCE IS A CONTINUING IRRITANT AS WELL AS PROVIDING THE MAIN FOCUS FOR THE LEBANESE-ISRAELI SEGMENT OF THE FRUITLESS WASHINGTON TALKS. WHETHER THE ISRAEL IS HAD ANY PARTICULAR MOTIVE FOR LAUNCHING THE ATTACK AT THAT PRECISE MOMENT WAS FAR FROM CLEAR.

06629 MUIR, J.

LEBANON: THE BAMOWAGON ROLLS ON

MIDOLE EAST INTERNATIONAL, 440(440) (DEC 92), 8-9.

IN LEBANON, THE PRIME MINISTER, RAFIO AL-HARIRI IS THE ULTIMATE MR. FIX-IT, THE ROSS PEROT HHO MADE IT. THE LEBANESE-BORN SAUDI' BILLIONAIRE'S ARRIVAL IN OFFICE AT THE END OF OCTOBER HAS USHERED IN A NEW ERA OF PERHAPS DANGEROUSLY HIGH HOPES, AFTER THE TROUGH OF DEPRESSION INTO WHICH THE COUNTRY HAD SLUMPED UNDER PRESIDENT'S HRAWI'S FIRST THO PRIME MINISTERS. HARIRI SAYS THE COUNTRY HILL BE BACK ON ITS FEET IN SIX MONTHS, AND THAT IN THO YEARS IT HILL BE ABLE TO LIVE NORMALLY, WITH OR WITHOUT HIM. FOR THE TIME BEING EVEN THE SKEPTICS ARE GIVING HIM THE BENEFIT OF THE DOUBT. THIS ARTICLE DETAILS THE DOUBTS AND ANXIETIES THAT DO EXIST.

06630 MUIR, J.

MODERATION, COMMITMENT AND DEMOCRACY

MIDDLE EAST INTERNATIONAL, (396) (MAR 91), 11-12.

A RECENT CONFERENCE OF IRAQI OPPOSITION GROUPS WAS A

DISPLAY OF UNITY AMD AN ASSURANCE THAT ALL SECTORS OF

IRAQ'S PATCHHORK' SOCIETY WOULD BE GIVEN THEIR FAIR SHARE IN THE DEMOCRATIC, PLURALISTIC SYSTEM WHICH THE OPPOSITION THE DEMOCRATIC, PLURALISTIC SYSTEM WHICH THE OPPOSITION GROUPS AGREE IS THE ONLY ALTERNATIVE TO SADDAM HUSSEIN'S FROM ULTRA-CONSERVATIVE TRIBESMEN AND EX-GENERALS, THROUGH FROM ULTRA-CONSERVATIVE TRIBESMEN AND EX-GENERALS, THROUGH RADICAL SHI'ITE AYATOLLAHS, COMMUNISTS, DEMOCRATS, LIBER

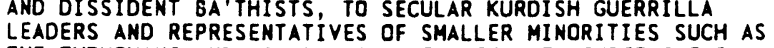
THE TURKOMANS AND ASSYRIANS. THEY MET WITH THREE CLEAR PRIORITIES: TO UNIFY AND ORGANIZE THEMSELVES AS A CREDIBLE ALTERNATIVE TO SADDAM, TO STEP UP DIRECT SUPPORT FO THE UPRISING, AND TO SEEK OUTSIDE BAKING AND SYMPATHY, BOTH FOR THE INSURRECTION AND THE OPPOSITION.
06631 MUIR, J.

SYRIANS REFUSE THE BAIT

MIDDLE EAST INTERNATIONAL, (413) (NOV 91), 5-6.

ISRAEL'S ATTEMPTS TO ANGER SYRIA DURING AND IMMEDIATELY FOLLOWING THE MADRID PEACE TALKS HITH GOADING SPEECHES AND CONTINUED SETTLEMENT OF THE DISPUTED GOLAN HEIGHTS FELL ON RELATIVELY DEAF EARS. WHILE THE SYRIANS WERE MORE THAN HILLING TO EXHCANGE HARSH RHETORIC HITH THE ISRAELIS, THEY SEEMED SINGULARLY UNWILLING TO REFUSE TO ATTEND THE NEXT ROUND OF TALKS. CLEARLY, THE DAYS ARE GONE WHEN THE ISRAELIS COULD RELY ON SYRIA TO WRECK ANY UNCOMFORTABLE PEACE PROCESS BEING PROMOTED. HITH THEIR ONE-TIME SOVIET PATRONS IN DISARRAY ANO THE INCREASE OF INFLUENCE OF THE UNITED STATES SYRIA HAS LITTLE CHOICE BUT TO PRESENT A MORE MODERATE FACE TO THE WORLD.

06632 MUIR, J.

THE ARABS FALL INTO LINE

MIDDLE EAST INTERNATIONAL, (405) (JUL 91), 4-5.

THE VAST INTERNATIONAL AND REGIONAL CHANGES OF THE PAST THO OR THREE YEARS HAVE SUDDENLY CRYSTALLIZED TO PRODUCE A SITUATION WHERE, FOR THE FIRST TIME IN HISTORY, ISRAEL'S ARAB ADVERSARIES ARE LINING UP TO WOO HER WITH ADVANCE CONCESSIONS, AND FALLING OVER ONE ANOTHER IN THEIR RUSH TO ACCEPT AMERICAN PEACE PROPOSALS. THE DRAMATIC CHANGE HAS LED ACCEPT AMERICAN PEACE PROPOSALS. THE DRAMATIC CHANGE WAS LED BY SYRIA WHO SUPPORTED THE PEACE PROCESS, EVEN TO THE POINT OF GRANTING SIGNIFICANT CONCESSIONS TO ISRAEL. SYRIA WAS
FOLLOWED BY EGYPT AND SAUDI ARABIA. IT SEEMS INCREASINGLY FOLLOWED BY EGYPT AND SAUDI ARABIA. IT SEEMS INCREASINGLY TAKE PLACE IN THE NEAR FUTURE.

06633 MUIR, J.

THE SLAYING OF ABBAS MUSAWI PORTENDS A SPIRAL OF VIOLENCE MIDOLE EAST INTERNATIONAL, (419) (FEB 92), 3-4.

ON 16 FEBRUARY RADICAL ISLAMIC CLERIC SHAIKH ABBAS

MUSANI, ALONG WITH HIS WIFE AND SON, HERE KILLED IN AN ISRAELI HELICOPTER ATTACK. THE ASSASSINATION CAUSED A WAVE OF SHOCK AND APPREHENSION IN LEBANON AND WIDESPREAD CRITICISM ACROSS THE MIDDLE EAST. THE TIMING OF SAYYID ABBAS ASSASSINATION MAY HAVE BEEN INFLUENCED BY THE KILLING OF THREE ISRAELI SOLDIERS AT GALED. HOWEVER, THERE IS EVIDENCE THAT THE ATTACK WAS THE CULMINATION OF MONTHS OF PREPARATION AND PLANNING. MANY NOH FEAR THAT THE ASSASSINATION HILL ESCALATE VIOLENCE IN ALREADY VOLATILE SOUTHERN LEBABON.

06634 MUIRHEAD, 8.

PERCEPTION AND REALITY: THE GATT'S CONTRIBUTION TO THE PERCEPTION AND REALITY: THE GATT'S CONTRIBUTION TO THE DEVELOPMENT

AMERICAN REVIEW OF CANADIAN STUDIES, 20(3) (FAL 90), 279-302.

THERE IS AN ASSUMPTION AMONG A LARGE NUMBER OF HISTORIANS AND POLITICAL SCIENTISTS THAT THE LIBERAL GOVERMMENTS OF THE POSTHAR PERIOD "SOLD OUT" CANADA TO THE UNITED STATES. THIS ARTICLE EXAMINES THIS CLAIM AND CONCLUDES THAT THE MULTILATERAL GATT CONTRIBUTED TO THE ESTABL ISHMENT OF A CANADA-UNITED STATES BILATERAL RELATIONSHIP, NOT BECAUSE OF CANADIAN GOVERMMENT INACTION, BUT BY ECONOMIC AND POL ITICAL REALITIES. THE ARTICLE EXAMINES THREE GATT TARIFF ROUNDS: GENEVA (1947), ANNECY, FRANCE (1949), AND TORQUAY, ENGLAND (1950-51) TO DEMONSTRATE ITS ARGUMENT.

06635 MUKERJEE, D

MARRIAGE OF CONVENIENCE

FAR EASTERN ECONOMIC REVIEH, 155(31) (AUG 92), 13. A JOINT INDO-AMERICAN NAVAL EXERCISE OFF INDIA'S WEST COAST WAS A LANDMARK IN THE RELATIONS BETHEEN THE TWO COUNTRIES. ALTHOUGH THE EXERCISE WAS A MODEST AFFAIR--IT INVLOVED A DESTROYER AND FRIGATE ON EACH SIDE--IT DEMONSTRATES THAT AFTER DECADES OF ANTAGONISM THE THO COUNTRIES ARE LOOKING FOR A FRAMEWORK WHICH WILL ALLOW THEM TO HORK TOGETHER DESPITE STRONG RESERVATIONS ABOUT EACH OTHER'S POLICIES. THE UNITED STATES SHARES WITH INDIA A DESIRE TO CONTAIN MILITANT ISLAM AND TO MONITOR AND CONTROL MILITARY DEVELOPMENTS IN SOUTH ASIA AMD THE INDIAN OCEAN. INDIA HOPES FOR AMERICAN SUPPORT IN HALTING PAKISTAN'S EFFORTS TO INTERMATIONALIZE THE KASHMIR CONFLICT; INDIA IS ALSO GRATEFUL FOR AMERICAN ENCOURAGEMENT OF LARGE-SCALE FOREIGM AID TO INDIA FROM THE HORLD BANK AND THE IMF. HOWEVER, ISSUES SUCH AS NON-PROLIFERATION, INTELLECTUAL HOWEVER, ISSUES SUCH AS NON-PROL IFERATION, INTELLECTUAL
PROPERTY, AND HUMAN RIGHTS REMAIN POTENTIAL POINTS OF PROPERTY, AND HUMAN RIGHTS REMAIN

06636 MUKWENA, $R$.

ZAMBIA'S LOCAL ADMINISTRATION ACT, 1980: A CRITICAL APPRAISAL OF THE INTEGRATION OBJECTIVE PUBLIC ADMINISTRATION AND DEVELOPMENT, 12(3) (AUG 92), 237-248.

IN 1980 ADMINISTRATIVE REFORMS WERE ANNOUNCED IN ZAMBIA WHICH AIMED AT INTEGRATING THE PARTY, CENTRAL GOVERNMENT DEPARTMENTS, AND LOCAL AUTHORITIES. TO DATE THE ENYISAGED 
INTEGRATION HAS NOT BEEN REALIZED. THE PROBLEMS AND PROSPECTS OF THE ENVISAGED INTEGRATION ARE EXAMINED, AS WELL AS THE OYSFUNCTIONS OF POLITICAL CONTROL IN THE ZAMBIAN CONTEXT. LOCAL COUNCILS, CENTRAL GOVERNMENT DEPARTMENTS AND PARAPOSTALS REQUIRE COORDINATION AND NOT INTEGREATION WITH THE PROSPECTS FOR THIS DEVELOPMENT.

06637 MULCAHY, K.

THE BUSH ADMINISTRATION AND NATIONAL SECURITY POLICYTHE BUSH ADMINISTRATION AND NATION
MAKING: A PARLIMINARY ASSESSMENT

MAKING: A PARLIMINARY ASSESSMENT

THE BUSH ADMINISTRATION'S APPROACH TO NATIONAL SECURITY POLICY-MAKING, AT LEAST AS JUDGED BY THE EARLY RECORD, CAN BE CHARACTERIZED ACCORDINGLY: MANAGERIAL, COLLEGIAL INCREMENTAL AND PRAGMATIC. EACH OF THESE ELEMENTS WILL BE CONSIDERED IN TURN AS PART OF A PRELIMINARY ASSESSMENT OF WHETHER THE BUSH ADMINISTRATION'S APPROACH TO AMERICAN NATIONAL SECURITY IS ADEQUATE TO DEAL HITH THE CHALLENGES THAT THE UNITED STATES WILL FACE IN WORLD AFFAIRS DURING THE "POST-COLD WAR ERA" OF THE $1890 \mathrm{~S}$

06638 MULLEN, R.

THE GENERAL ELECTIONS OF 1992

CONTEMPORARY REYIEW, 260 (1516) (MAY 92), 225-229.

THE RESULTS OF THE GENERAL ELECTIONS OF 1992 WERE A

SURPRISE TO MOST BRITAINS. HITH AN OVERALL MAJORITY OF 21 SEATS, JOHN MAJOR LED HIS PARTY TO AN ASTOUNDING VICTORY. FOR THE FIRST TIME SINCE THE DAYS OF LORD LIVERPOOL IN THE EARLY NINETEENTH CENTURY, ONE PARTY HAD HON FOUR ELECTIONS IN A ROW. HIS ACHIEVEMENT IS ALL THE MORE IMPRESSIVE WHEN ONE CONSIDERS THE CIRCUMSTANCES SURROUNDING THE ELECTION. THIS ARTICLE EXPLORES THESE CIRCUMSTANCES AND THE PART THAT NEIL KINNOCK PLAYED AS JOHN MAJOR'S ONE GREAT ALLY.

06639 MULLER-ROMMEL, F.; PRIDHAM, G.

SHALL PARTIES IN 'WESTERN EUROPE

SAGE PUBLICATIONS, 1991, 232.

THIS BOOK IS THE FIRST SYSTEMATIC ANALYSIS OF SMALL

PARTIES IN WESTERN EUROPE. SMALL PARTIES HAVE HAD INCREASING

IMPACT IN RECENT DECADES AND HAVE BEGUN TO CHALLENGE THE

TRADITIONAL VIEW THAT SMALL PARTIES DO NOT MATTER. THE

AUTHORS FORMULATE FIVE DISTINCT APPROACHES TO THE STUDY OF

SMALL PARTIES: A CONCEPTUAL DEFINITIONAL APPROACH;

NUMERICAL DEFINITIONAL APPROACH; A DIACHRONIC APPROACH; A

CLASSIFICATORY APPROACH; AND A SYSTEMATIC APPROACH. THESE

ARE APPLIED TO NATIONAL CASE STUDIES INCLUDING ITALY, GREECE.

- BELGIUM, DENHARK, GREAT BRITAIN AND THE NETHERLANDS.

06640 MULLER, E.N.; DIETZ, H.A.; FINKEL, S.E.

DISCONTENT AND THE EXPECTED UTILITYY OF REBELLION: THE CASE OF PERU

AMERICAN POLITICAL SCIENCE REVIEW, 85(4) (DEC 91),

1261-1282

DISCONTENT THEORIES OF REBELLION POSTULATE THAT

POLITICIZED DISCONTENT WILL HAVE A STRONG INDEPENDENT EFFECT

ON AN INDIVIDUAL'S POTENTIAL TO PARTICIPATE IN REBELLIOUS

POLITICAL ACTION. EXPECTED UTILITY THEORIES POSTULATE THAT

PARTICIPATION IN REBELLIOUS ACTION IS MOTIVATED BY THE

EXPECTATION OF REWARD AND THAT DISCONTENT IS RELEVANT ONLY

INSOFAR AS INDIVIDUALS BELIEVE THAT COLLECTIVE ACTION CAN BE SUCCESSFUL AND THAT THEIR PARTICIPATION IS IMPORTANT TO THAT END. IN THIS PAPER, THE AUTHORS TEST THESE THEORIES HITH DATA FROM A NATIONAL SAMPLE AND A SAMPLE OF STUDENTS AT A PROTEST-PRONE UNIVERSITY IN PERU. THE RESULTS PROVIDE NO EVIDENCE FOR THE DISCONTENT MOOELS BUT STRONGLY SUPPORT THE EXPECTED UTILITY MODELS.

06641 MULLER, F.

A GLOBAL CHALLENGE FOR A COOPERATIVE APPROACH IN EUROPE, THE ENERGY ISSUE

PEACE AMD THE SCIENCES, 3 (SEP 91), 17-18.

THIS ARTICLE DISCUSSES THE GLOBAL CHALLENGE FOR A

COOPERATIVE APPROACH IN EUROPE, FOCUSING ON THE ENERGY ISSUE.

IT BEGINS BY DEFINING THE ALL-EUROPEAN NETHORKING AHD THE

ROLE OF ENERGY. ALSO DISCUSSED ARE: ENERGY PRODUCTION,

ROLE OF ENERGY. ALSO DISCUSSED ARE: ENERGY PRODUCTION,
CONSUMPTION AND TRADE. THE ENVIRONMENTAL BURDEN, THE

CONANGING VALUE SYSTEM, AREAS OF POTENTIAL COOPERATION, AND

CHANGING VALUE SYSTEM, AREAS OF P
AN ALL-EUROPEAN ENERGY REGIME.

06642 MULLER, J.

CARL SCHMITT, HANS FREYER AND THE RADICAL CONSERVATIVE

CRITIQUE OF LIBERAL DEMOCRACY IN THE WEIMAR REPUBLIC

HISTORY OF POLITICAL THOUGHT, 12(4) (WIN 92), 695-716.

DURING THE WEIMAR REPUBLIC, GERMANY WAS A LIBERAL,

DEMOCRATIC, CAPITALIST, WELFARE STATE. THE TENSIONS BETWEEN THESE VARIOUS CHARACTERISTICS OF THE HEIMAR REPUBLIC HELPED BRING ABOUT ITS DEMISE. THIS ESSAY EXPLORES THE SHARED CRITIQUE OF SUCH A REGIME DEVELOPED BETWEEN 1918 AND 1933 BY CARL SCHMETT AND HANS FREYER. THE APPROACH PURSUED HERE ATTEMPTS TO PUT SMITT'S WORKS INTO MORE HISTORICALLY ACCURATE PERSPECTIVE. IN THE CASE OF BOTH FREYER AND SCHMITT, THEIR GIFTS HELPED UNDERMINE SUPPORT FOR LIBERAL DEMOCRACY
HOWEVER, FOCUSES ON THEIR SOCIAL ANO POLITICAL THOUGHT RATHER THAN ON THEIR INFLUENCE.

06643 MULLER, $H$.

AUSTRIAN GOVERMMENTAL INSTITUTIONS: DO THEY MATTER? WEST EUROPEAN POLITICS, 15(1) ( JAN 92), 99-131. THIS ESSAY EXAMINES THE RELEYANCE OF THE FORMAL POWER OF THE MAIN AUSTRIAN GOVERNMENTAL INSTITUTIONS (PARL IAMENT,

PRESIDENT, CABINET, ADMINISTRATION, CONSTITUT IONAL COURT, JUDICIARY, AUDIT OFFICE, FEDERAL ISM AND DIRECT DEMOCRACYi. IT FOCUSES ON DEYELOPMENTS SINCE "CLASSIC" CONSOCIATIONALISM (1945-66), DURING WHICH AUSTRIA'S POLITICAL "CORE

(1945-66), DURING WHICH AUSTRIA'S POLITICAL "CORE
INSTITUTIONS" WERE LARGELY DETERMINED BY THE COUNTRY'S TWO

MAJOR POLITICAL SUBCULTURES, THE ELITES OF WHICH STAFFED KEY POSITIONS WITHIN THEM. AUSTRIA'S INSTITUTIONAL FRAMEHORK THUS REFLECTED RATHER THAN CONSTRAINED THE SUBCULTURES' ACCOMMODATIVE INTERACTION AND LACKED THE POLITICAL SALIENCE ENVISAGED BY THE CONSTITUTION. HOWEVER, INSTITUTIONS
PREVIOUSLY UNDER CONTROL OF LAGER ELITES OR PRACTICING "SELF RESTRAINT" ARE NOW FAR LESS IMCLINED MERELY TO REFLECT THE WISHES OF THOSE SUBCULTURES. AUSTRIA'S FORMAL INSTITUTIONAL FRAMEHORK HAS THUS BECOME MORE SALIENT AND MANY CONSTITUENT INSTITUTIONS NOW COMPRISE ARENAS, THE RULES OF WHICH ARE HIGHLY RELEVANT FOR THE POLITICAL PROCESS. MOREOVER, FORMAL GOVERNMENTAL INSTIITUTIONS' TENDENCY TO BECOME ACTORS IN THEIR OWH RIGHT HAS MADE THE POLITICAL PROCESS MORE COMPLETE AND LESS PREDICTABLE.

06644 MULLER, W.C.

AUSTRIA

EUROPEAN JOURNAL OF POLITICAL RESEARCH, 22(4) (DEC 92),

357-361.

THE AUTHOR PRESENTS 1992 POLITICAL DATA FOR AUSTRIA, INCLUDING CHANGES IN THE COMPOSITION OF THE UPPER HOUSE OF THE LEGISLATURE AND THE COMPOSITION OF THE CABINET. HE ALSO DISCUSSES INSTITUTIONAL CHANGES AND SUMMARIZES MAJOR

NATIONAL ISSUES.

06645 MULLINGS, B.

INVESTING IN PUBLIC HOUSING AND RACIAL DISCRIMINATION: IMPLICATIONS IN THE $1990^{\prime}$ 'S

NEH COMMUNITY IN THE 1990'S

IN GREAT BRITAIN, HOUSING INVESTMENT POLICY HAS TENDED TO IGNORE THE IMPACT OF RACIAL DISCRIMINATION ON THE HOUSING OPTIONS OPEN TO BLACK HOUSEHOLDS AND THEIR ABILITY TO OPTIONS OPEN TO BLACK HOUSEHOLDS AND THEIR ABILITY TO PUBLIC EXPENDITURE FOR HOUSING, WHICH HAVE BECOME A FEATURE OF LOCAL HOUS ING INVESTMENT IN THE 1980'S AND 1990'S. HAVE CAUSED MANY LOCAL AUTHORITIES TO ABANDON THE COMPREHENSIVE, NEEDS-BASED HOUSING POLICIES ADOPTED IN THE 1970'S AND RESORT TO "MARKET" ALTERNATIVES. THE IMPACT OF THIS SHIFT IN INVESTMENT POLICY AND PRACTICE HAS SERVED FURTHER TO MARGINALIZE BLACK HOUSEHOLDS IN THE WORST PUBLIC HOUSING ESTATES, BECAUSE SUCH ESTATES ARE LEAST LIKELY TO BE QUICKLY SLOTTED INTO ANY INVESTMENT PROGRAM. THE CURRENT POLICY, WHICH ADVOCATES INDIVIDUAL ENTERPRISE IN SECURING GOOD HOUSING AND THE REMOVAL OF LOCAL CONTROL, HAS AGAIN FAILED TO RECOGNIZE THAT MANY BLACK HOUSEHOLDS ARE NOT ABLE TO COMPETE WITH MANY WHITE HOUSEHOLDS FOR DECENT, AFFORDABLE HOUSING.

06646 MULLINS, $D$.

FROM LOCAL POLITICS TO STATE REgULATION: THE LEGISLATION AND POLICY ON RACE EQUALITY IN HOUSING

NEW COMMUNITY, 18(3) (APR 92) 401-413.

THE AUTHOR EXPLAINS THE IMPL ICATIONS OF RECEMT

FUMDAMENTAL CHANGE IN BRITISH HOUSING LEGISLATION AND POLICY PROMOT ING RACIAL EQUALITY IN HOUSING. THE LOCAL POL ITI ICAL MODEL OF RACE EQUALITY HAS BEEN REPLACED BY A REGULATORY MODEL, POLICED BY THE HOUSING CORPORATION AND THE COMMISSION UNDER THE NEW LEGISLATION.

06647 MULLINS, D.R.; ROSENTRAUB, MS

FISCAL PRESSURE? THE IMPACT OF ELDER RECRUITMENT ON LOCAL EXPENDITURES

URBAH AFFAIRS QUARTERLY, 28(2) (DEC 92), 337-354. SEVERAL STATES AND CITIES HAVE DEVELOPED POLICIES DESIGNED TO ATTRACT RETIREES, HOPING TO POSITION THEIR COMMUNITIES AS FUTURE HOMES FOR THE RETIREMENT YEARS OF HIGHSPENDING, LOW-SERVICE-CONSUMING ELDERS. IN THIS PAPER, THE AUTHORS FOCUS ON ISSUES OF PUBLIC EXPENDITURES. ALTHOUGH POPULATIONS NEARING RETIREMENT AGE SEEM TO HAVE LOWER DEMANOS FOR PUBLIC GOOOS, THESE PREFERENCES QUICKLY CHANGE AND COMMUNITIES WITH LARGE PROPORTIONS OF RETIREES IN THEIR POPULATION SPEND MORE FOR PUBLIC SERVICES. THIS MAY PROOUCE POLITICAL TENSIONS. THUS, THERE MAY BE NO ECONOMIC BOOM IN
ATIRACTING RETIREMENT OR PRE-RETIREMENT-AGE POPULATIONS TO A AT TRACTING
COMHUNITY.

06648 MULLINS, K.; WILDAVSKY, A.

THE PROCEDURAL PRESIDENCY OF GEORGE BUSH

POL IIICAL SCIENCE QUARTERLY, 1(107) (SPR 92), 31-62.

THE AUTHORS ATTEMPT TO DEFINE THE ELUSIVE PRESIDENTIAL 
LEADERSHIP STYLE OF GEORGE BUSH.

06649 MUNASINGHE, M.; KING, K.

ACCELERATING OZONE LAYER PROTECTION IN DEVELOPING COUNTRIES WORLD DEVELOPMENT, 20(4) (APR 92), 609-618

THE AUTHORS ARGUE THAT THE BENEFITS OF OZONE PROTECTION FAR OUTWEIGH THE COSTS. THEREFORE, THE PRIMARY OBJECTIVE OF INTERNATIONAL AND NATIONAL ACTION SHOULD BE BENEFIT MAXIMIZATION VIA ACCELERATED PHASEOUT OF OZONE DEPLETING SUBSTANCES ACROSS COUNTRIES AND ECONOMIC SECTORS. DEVELOPING COUNTRIES ABOUND WITH OPPORTUNITIES FOR EARLY LOW UNIT ABATEMENT COST PHASEOUT THROUGH WELL-DESIGNED POLICIES AND PROJECTS. HOHEVER, THE CURRENT INTERNATIONAL FRAMEWORK PROVIDED BY THE MONTREAL PROTOCOL TENDS TO FOCUS ON PROJECTLEVEL INCREMENTAL COST MINIMIZATION AND DOES NOT PROVIDE INCENTIVES FOR EARLY ACTION. THE AUTHORS PROPOSE

MODIFICATIONS TO REMEDY THESE SHORTCOMINGS.

06650 MUNI, $S$

THE POST-COLD WAR THIRD HORLD: UNCERTAIN PEACE AND ELUSIVE THE POST-COLD

BULLETIN OF PEACE PROPOSALS, 23(1) (MAR 92), 93-102.

THE EMD OF THE COLD HAR HAS EMCOURAGED OPTIMISTIC PREDICTIONS OF WORLDWIDE PEACE AND PROSPERITY. THIS ARTICLE CHALLENGES THESE CLAIMS BY EXAMINING THE PROBLEMS FACED BY MANY OF THE UNDER-DEVELOPED NATIONS OF THE WORLD. IT OUTLINES CHALLENGES INCLUDING AN INCREASED FLOW OF ARMS TO THIRD WORLD COUNTRIES, GROWING TENSION AND REGIONAL CONFLICTS, CRUSHING FOREIGN DEBT, AND A TREND TOHARD PROTECTIONIST TRADING BLOCS THROUGHOUT THE INDUSTRIALIZED WORLD. THE THIRD WORLD COUNTRIES FACE A FUTURE OF UNCERTAINTY AND OF TOUGH POLITICAL DECISIONMAKING

06651 MUNOZ, 0 .

ECONOMY AND SOCIETY IN CHILE: FRUSTRATION AND CHANGE IN THE HISTORICAL PROCESS

INTERNATIONAL SOCIAL SCIENCE JOURNAL, 143(143) (NOV 92), 487-502.

FRUSTRATION AND CHANGE ARE PERMANENT FEATURES OF THE ECONOMIC AND SOCIAL HISTORY OF CHILE. IN THIS ARTICLE THE AUTHOR ATTEMPTS TO OUTLINE THE HISTORICAL DEVELOPMENT OF CHARACTERISTIC FEATURES. HE REFERS BRIEFLY TO THE COL ONIAL ORIGINS AND THE FIRST CENTURY OF INDEPENDENCE, STRESSING IN PARTICU AND THE FIRST CENTURY OF INDEPENDENCE, STRESSING IN PARTICULAR THE CHARACTERISTICS SPECIFIC TO THE CONQUEST OF CHILE, HICH WERE TO DETERMINE THE SECULAR CONDITIONS FOR NATIONAL DEVELOPMENT, AND THE CONSOL IDATION OF THE REPUBLIC
DURING THE SECOND HALF OF THE NINETEENTH CENTURY. HE ALSO DURING THE SECOND HALF OF THE NINETEENTH CENTURY.
DISCUSSES IN GREAT DETAIL THE ECONOHIC AND SOCIAL

DISCUSSES IN GREAT DETAIL THE ECONOMIC AND SOCIAL

06652 MUNRO, R.H.

AWAKENIMG DRAGON: THE REAL DANGER IN ASIA IS FROM CHINA POLICY REVIEW, (62) (FAL 92), 10-17

AFTER ALMOST A CENTURY OF' FALSE STARTS, CHINA SEEMS FIRMLY EMBARKED ON A COURSE OF EXPLOSIVE ECONOMIC GRONTH AND MILITARY ASSERTIVENESS THAT WILL INDEED REVERBERATE THROUGHOUT ASIA AND THE HORLD. THE IMPLICATIONS FOR THE ECONOMIC AND SECURITY INTERESTS OF THE UNITED STATES ARE ENORMOUS. CHINA IS THE ONLY MAJOR COUNTRY IN THE WORLD WHOSE MILITARY IS EXPANDING RAPIDLY. AND IT IS THE FIRST EXAMPLE OF A COMMUNIST POLITICAL SYSTEM ON ITS WAY TO MEETING THE ECONOMIC ASPIRATIONS OF ITS PEOPLE.

06653 MUNSTER, $P$

HOLLAMD'S AMBIVALENT DRUG POLICY

SWISS REVIEH OF HORLD AFFAIRS, 42(7) (OCT 92), 18-19.

FOR A LONG TIME THE METHERLANDS WAS REGARDED AS A "BLACK SHEEP" IN THE INTERMATIONAL WAR AGAINST NARCOTICS. MORE RECENTLY. THE UNDENIABLE SUCCESSES OF ITS TOLERANT DRUG POLICY HAVE BEEN RECOGNIZED INTERNATIONALLY. NEVERTHELESS, THE CONTINUATION OF THAT POLICY APPEARS SERIOUSLY ENDANGERED, BOTH BY INTERNAL AMBIVALENCE AND BY THE PUSH FOR HARMONIZATION OF DRUG POLICY AMONG EUROPEAN COMMUNITY MEMBERS.

06654 MUNSTER,

EC DEBATES ITS NATURE AS THE QUEUE OUTSIDE LENGTHENS

GERMAN TRIBUNE, (1518) ( JUN 92), 3

SHITZERLAND HAS JOINED SIX OTHER COUNTRIES, AUSTRIA, SHEDEN, FINLAND, MALTA, CYPRUS AND TURKEY, ON THE LISTS OF APPL ICANTS FOR MEMBERSHIP IN THE EUROPEAN COMMUNITY. IF THE NORHEGIANS FOLLOH SUIT. THE WHOLE OF THE EUROPEAN FREE TRADE ASSOCIATION (EFTA), THE RICHEST PART OF WESTERN EUROPE, HILL ASSOCIATION (EFTA), THE RICHEST PART OF WESTERN EUROPE, WILL BE TRYING TO JOIN. WHAT IS MOST REMARKABLE ABOUT THIS TREND IS THE OBVIOUS RELUCTANCE WITH WHICH THEIR APPLICATIONS ARE BEING CONSIDERED. RATHER THAN WELCOMING THE APPLICATIONS AS
PROOF OF THEIR OHN SUCCESS, MANY EC STATES SEE THE GROWTH OF PROOF OF THEIR OHN SUCCESS, MANY EC STATES SEE THE THE COMAUNITY ONLY IN TERMS OF DIMINI

06655 MUNSTER, H.

EUROPEAN INTEGRATION DEPENDS ON THE SUCCESS OF FARM-POLICY REFORM

GERMAN TRIBUNE, (1477) : JUL 91), 7,9.
THE AIM OF THE EUROPEAN COMMUNITY'S AGRICULTURAL POLICY AS IT STANDS IS TO ENABLE THE COUNCIL OF MINISTERS TO FIX PRODUCER PRICES AT LEVELS THAT PERMIT THE FARMER TO EARN A REASONABLE LIVING. THE COUNCIL IS THEN EQUIPPED WITH THE FUNDS IT NEEDS TO BUY PRODUCE AT THESE SUPPORT PRICES. HOWEYER, THE CURRENT REALITY IS THAT THE MINISTERS ARE CURRENTLY FORCED TO ADJUST THE PRICE TO THE FUNDS AND STORAGE CAPACITY THEY HAVE AT THEIR DISPOSAL, BOTH OF WHICH ARE INSUFFICIENT. FAILURE OF THE AGRICUL TURAL MINISTERS TO RESOLVE THIS DILEMMA WILL HAVE A SIGNIFICANT IMPACT ON THE TREATIES FOR POLITICAL AND MONETARY UNION. IT IS HIGHLY UNL IKELY THAT THE EC WOULD BE ALLOWED TO DEMONSTRATE ITS EFFECTIVENESS IN OTHER AREAS IF IT FAILS IN AGRICULTURE.

06656 MURAKAMI, A.

TOKYO'S GENEROSITY TOWARD MYAMMAR QUESTIONED

JAPAN TIMES (WEEKLY INTERNATIONAL EDITION), 32(14) (APR

92 ) 3.

DESPITE TOKYO'S POLICY ON OFFICIAL DEVELOPMENT

ASSISTAMCE, WHICH STATES THAT GOVERMMENTS THAT HAVE HUGE MILITARY BUDGETS OR SUPPRESS DEMOCRACY MOVEMENTS AND HUMAN RIGHTS WILL NOT RECEIVE AID, JAPAN GAVE MYANMAR S61.3 MILLION IN 1991. HOWEVER, THERE ARE SOME INDICATIONS OF A DHIF IN JAPAN'S ATTITUDE TOWARD MYANMAR. FOR EXAMPLE, IN TO THE SMALL COUNTRY TO URGE DEMOCRATIC REFORM.

06657 MURAVCHIK, J.; FROHMHAYER, J.; LAFFER, A.B.

CONSERVATIVES FOR CLINTON

NEW REPUBLIC, 207(19) (NOV 92), 22-23

THREE PROMINENT CONSERVATIVES--JOSHUA MURAVCHIK, JOHN FROHMMAYER, AMD ARTHUR B. LAFFER--EXPLAIN WHY THEY ARE SUPPORTING GOVERNOR BILL CLINTON'S CANDIDACY FOR THE PRESIDENCY.

06658 MURAVCHIK, J. EASTERN EUROPE'S "TERRIBLE THOS"

OURNAL OF DEMOCRACY, 3(1) (JAN 92), 65-72.

THIS ARTICLE BRIEFLY EXAMINES SOME OF THE PROBELMS FACED BY EASTERN EUROPE'S NASCENT DEMCORACIES. IT TRACES A COMMON PATTERN IN THE DEMOCRATIC REVOLUTIONS OF THE REGION. FIRST CAME THE FORMATION OF AN ANTI-COMMUNIST UNITED FRONT, USUALLY LIBERAL OR NATIONALIST IN CHARACTER. IN THE FIRST FREE ELECTIONS IN POLAND, CZECHOSLOVAKIA, HUNGARY, AND IN MOST OF THE YUGOSLAV REPUBLICS. THESE FRONTS BESTED THE COMHUNISTS. IN BULGARIA, ROMANIA, ALBANIA, SERBIA, AND MONTENEGRO, HOWEVER, THE COMMUNISTS HERE ABLE TO HIN EARLY ELECTIONS. FOLLOWING THE INITIAL ELECTIONS, THE DEMOCRATIC ELECTIONS. FOLLOWING THE INITIAL ELECTIONS, THE DEMOCRATIC
FORCES SPLIT INTO AS MANY AS 120 PARTIES. DISAGREEMENT OVER FORCES SPLIT INTO AS MANY AS 120 PARTIES. DI SAGREEMENT
THE FUTURE COURSE OF POLITICAL AND ECONOMIC REFORMS IS THE FUTURE COURSE OF POLITICAL AND ECONOMIC REFORMS IS
WIDESPREAD. IN ADOITION, NATIONALISTIC AND ETHNIC CONFLICT WIDESPREAD. IN ADOITION, NATIONALISTIC AND ETHNIC CONFLICT IS ON THE RISE; DESPITE THESE PROBLEMS WHICH CHARACTERIZE
EASTERN EUROPE'S "TERRIBLE TWOS," THE ARTICLE CONCLUDES WITH EASTERN EUROPE'S "TERRIBLE TWOS," THE ARTICLE CONCLUDES WITH
OPTIMISM. THE COMMON SENSE DISPLAYED BY THE PEOPLE, AND THE ALMOST COMPLETE REVULSION FOR TOTALITARIANISM IN EASTERH ALMOST COMPLETE REVULSION FOR TOTALITARIANISM IN EASTERN REGION.

06659 MURAVCHIK, J.

LOSING THE PEACE

COMMENTARY, 94(1) ( JUL 92), 37-43.

WITH THE SOVIET THREAT GONE, AMERICANS HAVE NOT YET DECIDED WHETHER TO TURN THEIR ATTENTION INWARD UNTIL SOME NEW MENACE DEMANDS A RESPONSE OR TO TRY ACTIVELY TO SHAPE THE INTERNATIONAL ENVIRONMENT SO AS TO PREVENT SUCH A MENACE FROM ARISING. TODAYS CHOICE IS BETWEEN AN ORIENTATION THAT TURNS OVERHHELMINGLY INHARD AND ONE THAT CONTINUES TO DEVOTE A CONSIDERABLE MEASURE OF ATTENTION AND TREASURE TO THE WORLD OUTSIDE. THIS ARTICLE SUGGESTS THAT AN AMERICA WITH A STRONG ARM AND AN OPEN HAND IS THE FORCE MOST LIKELY TO KEEP ANOTHER OUTSIDE MENACE FROM APPEARING.

06660 MURAVCHIK, J.

PATRICK J. BUCHANAN AND THE JEHS

COMMENTARY, 91(1) (JAN 91), 29-2?

NOTED CONSERVATIVE AND COLUMNIST PATRICK J. BUCHANAN HAS RECENTLY STIRRED UP CONTROVERSY WITH HIS DECLARATION THAT THE ONLY GROUPS FOR WAR IN THE MIDDLE EAST ARE THE ISRAELI DEFENSE MINISTRY AND ITS "AMEN CORNER" IN THE UNITED STATES. THIS REMARK LED TO ALLEGATIONS OF ANTI-SEMITISM, WHICH BUCHANAN STAUNCHLY DENIED. THIS ARTICLE EXAMINES BUCHANAN'S PAST WRITINGS AND STATEMENTS AND FINDS MUCH EVIDENCE TO PAST WRITINGS AND STATEMENTS AND FINDS MUCH EVIDENCE TO
SUPPORT THE CLAIM THAT BUCHANAN FITS THE ANTI-SEMITIC SUPPORT THE CLAIM THAT BUCHANAN FITS THE ANTI -SEMITIC DESCRIPTION. THIS EVIDENCE INCLUDES THE FACT THAT BUCHANAM
IS HOSTILE TO ISRAEL; EMBRACES THE PLO DESPITE BEING AT IS HOSTILE TO ISRAEL; EMBRACES THE PLO DESPITE BEING AT JEHS ARE TRYING TO DRAG AMERICA INTO THE WAR FOR THE SAKE OF JEHS ARE TRYING TO DRAG AMERICA INTO THE HAR FOR THE SAKE
ISRAEL; SPRINKLES HIS COLUMNS WITH TAUNTING REMARKS ABOUT ISRAEL; SPRINKLES HIS COLUMNS WITH TAUNTING REMARKS ABOUT THINGS JEWISH; RALLIES TO THE DEFENSE OF NAZI HAR CRIMINALS: AND IMPLIES THAT THE GENERALLY ACCEPTED INTERPRE
THE HOLOCAUST MIGHT BE A SERIOUS EXAGGERATION.

06661 MURAVCHIK, J.

THE STRANGE DEBATE OVER BOSNIA 
COMMENTARY, 94 (5) (NOV 92), 30-37.

THE CARNAGE IN BOSNIA HAS OPENED A NEW CHAPTER IN THE AMERICAN FOREIGN-POLICY DEBATE. THIS ARTICLE EXPLORES THE FOLLOWING OUESTIONS: SHOULD THE UNITED STATES USE FORCE TO OPPOSE AGGRESSION FAR FROM HOME? ARE OWR OWN NTIONAL INTERESTS AT STAKE? WILL A MOOEST APPLICATION OF ARMERICAN ARMS DO THE JOB OR ONLY LEAD US INTO A QUAGMIRE? SHOULD WE TURN TO REGIONAL OR INTERNATIONAL ORGANIZATIONS RATHER THAH TAKE THE INITIATIVE OURSEL VES? CAN OR SHOULD AMERICA BE THE
WORLD'S POL ICEMAN? IT CONCLUDES THAT AS TECHNOLOGY BRINGS WORLD'S POL ICEMAN? IT CONCLUDES THAT AS TECHNOLOGY BRI
OTHERS COUNTRIES CLOSER, OUR OWN FATE IS INCREASINGLY ENTHINED WITH THEIRS. THE PRESENT DANGER IS FROM A POSSIBLE AMERICAN ABDICATION OF POWER.

06662 MURAY, L.

MAASTRICHT IN TROUBLE

CONTEMPORARY REVIEW, 260(1517) (JUN 92), 299-302

THE MAASTRICHT TREATY WAS WORKED OUT WHEN POLITICS AND THE SITUATION WERE DOMINATED BY THE FACTS OF $A$ DIVIDED EUROPE. NOW POLITICS MUST BE WORKED OUT FOR A LESS DIVIDED AND MUCH LARGER EUROPE. THE EC HAS HAS TO RECOGNIZE THAT IT MUST BE RADICALLY CHANGED. THIS ARTICLE SUGGESTS THAT MUCH WILL DEPEND ON WHAT HAPPENS TO THE TREATY. IF IT HAS TO BE RENEGOTIATED, MEMBERSHIP IN THE EUROPEAN COMMUNITY COULD BE MADE EASIER. THE LATEST PROPOSAL IS TO SET UP A NEH SUPRANAT IONAL EEC-EXECUTIVE AND THIS HAS CHANGED THE PICTURE AND PUT A QUESTION MARK AGAINST THE PRESENT TEXT OF THE MAASTRICHT TREATY.

06663 MURAY, L.

POST-COMMUNIST REFLECTIONS

CONTEMPORARY REVIEN, 261(1521) (OCT 92), 185-188.

DISMANTLING SOCIALISM IS NOT EASY. ECONOMISTS HAVE PRODUCED A CONCENTRATED PICTURE OF THE SOYIET SYSTEM THAT SHOWS SHOWS HOW HARD IT IS, AND WILL CONTINUE TO BE, TO MAKE REGIMES AS WELL AS THE WEST. ONE SHDULD NOT FORGET THAT OLD REGIMES AS WELL AS THE WEST. ONE SHDULD NOT FORGET THAT
STYLE COMMUNIST PARTIES ARE STILL ALIVE AND SOMETIMES KICKING. THIS ARTICLE CONCLUDES THAT THERE ARE STILL
THOUSANDS HHO BELIEVE THAT THE ELITE OF THE COMMUNIST PARTY CAN REVIVE THE HILL TO RULE.

06664 MURAY, L.

STILL THE GULF CRISIS

CONTEMPORARY REVIEW, 259(1506) (JUL 91), 23-26

THE AFTERMATH OF THE GULF CRISIS HAS' SHOWH THAT THE SUCCESS OF THE "BLITZKRIEG" OF THE WESTERN ALLIES AGAINST THE IRAQI ARMY HAS ONLY HAD THE LIMITED SUCCESS OF ENDING THE OCCUPATION OF KUWAIT. SADDAM HUSSEIN REMAINS IN POWER, THE SHI'ITES AND KURDS IN IRAQ ARE UNLIKELY TO SECURE ANY MEANINGFUL DEGREE OF AUTONOMY, ARAB-ISRAELI PEACE SEEMS NO CLOSER, AND WESTERN ATTEMPTS TO ENCOURAGE THE DEVELOPMENT OF THE GULF COOPERATION COUNCIL (GCC) HAVE LARGELY FAILED. IN ADDITION, THE CLOUT OF THE SUPERPOHERS--ESPECIALLY THE SOVIET UNION--HAS BEEN REDUCED; THE RISING STARS IN THE INTERNATIONAL SCENE ARE THE EUROPEAN COMMUNITY (NOTABLY GERMANY) AND JAPAN.

06665 MURAY, L.

THE BALKANS: PAST AND PRESENT

CONTEMPORARY REVIEH, 261(1519) (AUG 92), 72-75.

THIS ARTICLE OFFERS A BRIEF DUTLINE OF THE HISTORY OF THE VARIOUS NATIONS AND PEOPLES IN THE BALKANS REGION. IT TRACES THE GROHTH AND DEYELOPMENT OF THE SERBS, SLOYENES, CROATS, MONTENEGRANS, MACEDONIANS, MOSLEM SERBS, AS WELL AS OTHER, SMALLER GROUPS. IT ALSO CHARTS THE INFLUENCE THAT VARIOUS GREAT POWERS--AUSTRIA-HUHGARY, THE OTTOMAN EMPIRE, RUSSIA, AND THE SOVIET UNION--HAVE WIELDED IN THE REGION.' IT THERE IS MOAT THE BREAK-UP OF THE SOVIET UNTON MEANS THAT THERE IS NO BIG POWER OR SUPERPOHER INFLUENCE IN THE BALKANS . THIS MEANS THAT THE VARIOUS DIVERSE GROUPS IN THE REGION ARE LEFT TO RESOLVE THEIR OFTEN CENTURIES-OLD DISPUTES ON THEIR OHN. THE RESULT HAS BEEN THE BLOODY CONFLICTS THAT
HAVE CHARACTERIZED FORMER-YUGOSLAVIA IN THE PAST FEH YEARS

06666 MURAY, L.

THE SOVIET INHERITANCE

COMTEMPORARY REY EH, 260(1515) (APR 92), 190-194.

THE SEQUENCE OF CHAMGES IN THE LATE SOVIET UNION, SOME AT FIRST SIGHT POOSITIVE AND FUNDAMENTAL, HAS, INEVITABLY, DISTRACTED ATTENTIDN FROM MANY LEGAL, POL ITICAL, AND PRACTICAL PROBLEMS. THE NUMBER OF TREATIES THAT' THE USSR HAD MADE CAL PROBEMS. THE NUMBER OF TREATIES THAT THE USSR HAD OF THE NEH SITUATION. ETHNIC MINORITY ISSUES, OLD ALLIANCES AND THE CONTROL OF NUCLEAR WEAPONS ARE ALL OLD UNRESOLVED PROBLEMS. THIS ARTICLE CONCLUDES THAT IT IS LACK OF CONTROL AND THE ALMOST COMPLETE FREEDOM OF ACTION OF OFFICIALS AND
BUREAUCRATS WHO ACT IN THEIR OWN PERSONAL INTERESTS WHICH IS THE MAIN POL ITICAL FACTOR IN A PERPLEXING SITUATION.

06667 MURDOCK, G.

PATROLLING THE BORDER: BRITISH BROADCASTING AND THE IRISH QUESTION IN THE 1980S

JOURNAL OF CDMHUNICATION, 41(4) (FAL 91), 104-115.
INDEPENDENCE FROM GOVERNMENT AND THE ABILITY TO PROVIDE AN ADEOUATE BASIS FOR INFORMATION AND DEBATE ON ISSUES OF NATIONAL SECURITY AS RAISED BY THE STRUGGLE OVER NORTHERN IRELAND MAY BE THE ULTIMATE TEST OF PUBLIC BROADCASTING'S ROLE IN A MATURE DEMOCRACY. THIS ARTICLE DETAILS THE PROTRACTED AND ONGOING STRUGGLE OVER THE IRISH QUESTION BETWEEN THE REQUIREMENTS OF THE SECURITY ESTABLISHMENT AND JOURNALISTIC CONCEPTIONS OF THE CITIZENRY'S RIGHT TO KNOW. THE STRUGGLES OVER THE BROADCAST COVERAGE OF IRISH TERRIORISH AND COUNTER INSURGENCY STRATEGIES ARE PART OF A TERRINRISH AND COUNTER INSURGENCY STRATEGIES ARE PART OF BROADCASTING'S INDEPENDENCE FROM GOVERNMENT AND, AT THE SAME TIME, OCCUPY A UNIQUE STATUS WITHIN THIS BROADER STRUGGLE.

06668 MURPHY, B.

ETHICS IN LOCAL GOVERMMENT ADMINISTRATION; MANAGING LOCAL GOVERMMENT-PUBLIC ADMINISTRATION IM PRACTICE SAGE PUBLICATIONS, 1991, 156-170.

ETHICAL CONSIDERATIONS ARE NOT ALIEN TO THE ADMINISTRATIVE PROCESS. THERE IS NOTHING PURELY MECHANICAL ABOUT MANAGEMENT. IF THE PURPOSE OF GOVERNMENT IS TO BE "THE INSTRUMENT OF HUMANITY, OR SOCIAL BETTERMENT," PUBLIC SERVANTS--ELECTED AND APPOINTED--MUST MAKE CHOICES ABOUT THE MEANS AND STRATEGIES OF IMPROVING THE HUMAN CONDITION. THE NEUTRAL PUBLIC SERVANT IS A CREATION OF FICTION. THIS CHAPTER EXAMINES HOW ETHICS AND PUBLIC ADMINISTRATION INTERACT AT THE LOCAL LEVEL OF GOVERMMENT.

06669 MURPHY, B.S.

CONSIDERATIONS ON THE AMERICAN EXPERIENCE: REPRESENTATIVE SELF-GOVERNMENT IN EASTERN EUROP

PRESIDENTIAL STUDIES QUARTERLY, XXII14) (FAL 92), 741-746. MOST OF THE EMERGING DEMOCRACIES OF CENTRAL AND EASTERN EUROPE AND THE FORMER SOVIET UNION HAVE HAD LITTLE PRIOR DEMOCRATIC EXPERIENCE. THEY ARE LOOKING TO THE HEST, ESPECIALLY THE UNITED STATES, FOR GUIDANCE. THEY NEED TO LEARN FROM THE AMERICAN HERITAGE. INCLUDING THE FUNDAMENTAL IMPORTANCE OF PROPERTY RIGHTS, AN AREA IN WHICH THEY HAVE IMPORTANCE OF PROPERTY RIGHTS, AN AREA IN WHICH THEY HAVE HAD LITTLE OR NO PAST EXPERIENCE. PRIVATIZATION MAY BE KEY TO THE FUTURE OF CENTRAL AND EASTERN EUROPE. AS THE WNITED STATES ENDEAVORS TO HELP EAST EUROPEANS FIND THEIR WAY, AMERICANS NEED TO REMEMBER THAT THE FOUNDING FATHERS PROPERTY RIGHTS. THEY NEED TO UNDERSTAND THE IMPORTANCE OF THE FIFTH AMENDMENT "TAKING CL AUSE, "THE CONSTITUTION'S THE FIFTH AMENDMENT "TAKING CLAUSE, "THE CONSTITUTION'S COMMERCE CLAUSE, AND
BUSINESS CONTRACTS.

06670 MURPHY, D.

OPERATION \$RING': THE BLACK BERETS IN AZERBAIJAN JOURNAL OF SOVIET MILITARY STUDIES, 511) (MAR 92), 80-96. THE CONTINUED EXCESSES OF THE MOSCOW-CONTROLLED \$BLACK BERETS' IN THE BALTICS CAST A SHADOW ON GORBACHEV'S BENIGN REFORM IMAGE AND LENT SUPPORT TO THOSE WHO REMAINED UNCONVINCED THAT A DEMOCRATIC ASSOCIATION OF TRULY SOVEREIGN STATES WOULD EVER EMERGE AGAINST HARDLINE OPPOSTION. THIS ARTICLE REVIEWS THE EVENTS IN AZERBAI JAN WHICH OCCURRED DURING THE TIME OF REFORM AND CONCLUDES THAT IF NO SERIOUS EFFORTS ARE MADE TO RESOLVE THE PROBLEM PEACEFULLY, THIS ETHNIC HOSTILITY, WITH ITS RELIGIOUS OVERTONES, COULD BE TRANSFORMED INTO AN INTERMATIONAL CONFLICT INVOLVING NEIGHBORING MUSLIM COUNTRIES.

06671 MURPHY, J.

THE NEED FOR INTERNATIONAL COOPERATION IN COMBATING TERRORISM

TERRORISM, 1316) (NOV 90), 381-396.

AN ELABORATE INTERNATIONAL LEGAL SYSTEM HAS BEEN ESTABLISHED TO COMBAT TERRORISM. BUT THIS SYSTEM HAS TWO PRIMARY DEFICIENCIES: THERE ARE SERIOUS GAPS IN THE CURRENT LAW, AND THE LAH ALREADY ON THE BOOKS IS NOT BEING IMPLEMENTED VIGOROUSLY. THIS PAPER EXAMINES THE SPECIFIC NATURE OF THE GAPS AND RECOMMENDS THE ESTABLISHMENT, UNDER THE AUSPICES OF THE UNITED NATIONS SECURITY COUNCIL, OF A THE AUSPICES OF THE UNITED NATIONS SECURITY COUNCIL, OF
COMMITTEE TO OVERSEE IMPLEMENTATION OF THE ANTITERRORIST COMMITTEE TO OVERSEE IMPLEMENTATION OF THE ANTITERRORIST
CONVENTIONS. THE PAPER ALSO EXAMINES SOME RECENT WORK OF
A CDNVENTIONS. THE PAPER ALSO EXAMINES SOME RECENT WORK OF A LESS WELL-KNOWN BRANCH OF THE UNITED NATIONS, THE CO ON CRIME PREVENTION AND CONTROL. FINALLY, THE PAPER
CONSIDERS THE POSSIBILITY OF ESTABLISHING AN INTERNATIONAL CRIMINAL COURT WITH JURISDICTION OVER DRUG TRAFFICKING AND CRIMINAL COURT WITH JURISDICTION OVER DRUG TRAFFICKING AND RELATED ACTS OF TERRORISM, A PROPOSAL THAT IS CURRENT COMMISSION.

06672 MURPHY, R.D.

PEOPLE AND PEDAGOGUES: E.E. SCHATTSCHNEIDER AND THE DEMOCRATIC CREED

PS: POLITICAL SCIENCE AND POLITICS, $X X V(2)$ (JUN 92), 172-176.

THE AUTHOR COMMENTS ON E.E. SCHATTSCHNEIDER'S PUBLIC PHILOSOPHY AND ON HIS IDEAS ABOUT CITIZENSHIP AND CITIZEN EDUCATION. 
06673 MURPHY, R.H.

THE EFFECTS OF THE GULF WAR ON INTRAREgIONAL RELATIONS MIDDLE EAST INSIGHT, VII (5) (MAY 92), 7-12.

THE GULF WAR TRAUMATIZED THE REGION AND INTRODUCED SOME CHANGES IN INTRAREGIONAL RELATIONSHIPS. THIS ARTICLE EXAMINES THESE HITH SPECIFIC REFERENCES TO IRAQ, IRAN, THE GULF COOPERATION COUNCIL (GCC) STATES--INCLUDING KUWAIT, OMAN, AND SAUDI ARABIA--AMD THE ISLAMIC FUNDAMENTALIST MOVEMENT. GENERAL LESSONS FOR THE REGION INCLLOE: THE WORLD RESPONSE TO THE IRAQI INVASION HAS REMINDED ANTAGONISTS IN THE REGION THAT IF THEY CHOOSE TO SETTLE DISAGREEMENTS BY FORCE, THEY RISK STIMULATING OUTSIDE MILITARY INTERVENTION : THE REVELATION OF IRAQ'S HUGE MILITARY BUILDUP IS A REMINDER OF THE NEED TO PURSUE VIGOROUSLY A REGIONAL ARMS CONTROL PROGRAM; AND THERE IS EVERY REASON TO WELCOME THE NEW LEVEL OF SAUDI INVOL VEMENT IN THE PEACE PROCESS.

06674 MURRAY, B.

CAN SPACE EXPLORATION SURVIVE THE END OF THE COLD WAR? SPACE POLICY, 7(1) (FEB 91), 23-34

THE FIRST, HEROIC AGE OF' SPACE EXPLORATION HAS DRIVEN BY NATIONAL RIVALRY BETEWEEN THE USA AND USSR. THERE HAVE INDEED BEEN RECENT ACHIEVEMENTS, BUT AS THE COLD WAR ENDS THE SUPERPOWERS ARE TURNING THEIR ATTENTION TO DOMESTIC ISSUES AND THE PROSPECT LOOMS OF A PROLONGED HIATUS IN SPACE EXPLORATION. THE ONLY WAS FORHARD IS THROUGH INTERNATIONAL COOPERATION, BUT THIS WELL NEVER HAPPEN WITHOUT A SERIOUS INVESTMENT OF POLITICAL WILL. A WELL-PLANNED, LONG-TERH STRATEGY FOR THE EXPLORATION OF MARS COULD PROVIDE THE NECESSARY FOCUS.

06675 MURRAY, B.

RED ARMY SWORDS AND FREE MARKET PLOUGHSHARES

JOURNAL OF NORTHEAST ASIAN STUDIES, 10(2) (SUM 92), 26-52.

THE RECORD OF MILITARY REFORM, DEMOBILIZATION, AND

CONVERSION IN THE CHINESE AND SOVIET MILITARIES ARE REVIEWED. LESSONS ARE DRAWN FROM THE CHINESE EXPERIENCE AND APPLIED TO THE CURRENT DEBATE ON THE PROGRESS OF MILITARY REFORM IN THE SOVIET UNION. THE CHINESE MILTARY REFORM MODEL IS OFFERED AS AN ALTERNATIVE THAT COULD SATISFY THE DEMANDS OF SOVIET LIBERALS, PREDISPOSED TO AN AMERICAN MODEL. AS WELL AS SOVIET CENTRALISTISM PREDISPOSED AS A PRAETORIAN MODEL.

06676 MURRAY, $C$.

CAUSES, ROOT CAUSES AND CURES

NATIONAL REVIEH, XLIV(11) (JUN 92), 30-32.

THE LOS ANGELES RIOTS WHICH FOLLOWED THE RODNEY KING YERDICT OPENED A NEH AND EXPLOSIVELY DANGEROUS PERIOD IN AMERICAN RACE RELATIONS. THIS ARTICLE MAKES THO CONCLUSIONS ABOUT THE EVENTS AND THEIR IMPLICATIONS: THE RODNEY KING VERDICT WAS AN EXPRESSION OF WHITE FEAR ABOUT BLACK CRIME; VERDICT WAS AN EXPRESSION OF WHITE FEAR ABOUT BLACK CRIME AND THE WHITE REACTION TO THE RIOTS WILL BE PROFOUNDL OIFFERENT FROM THE REACTION IN THE 1960S, BECAUSE A CONSENSUS OF WITES NO LONGER ACCEPTS THAT WHITES ARE TO
BLAME FOR BLACK PROBLEMS. THE AUTHOR ARGUES THAT BOTH OF BLAME FOR BLACK PROBLEMS. THE AUTHOR ARGUES
THESE PERCEPTIONS ARE GROUNDED IN REALITY.

06677 MURRAY, C.

THE LEGACY OF THE 60'S

COMMENTARY, 94 (1) ( JUL 92), 23-30.

THE THESIS OF THIS PAPER IS THAT THE CONDITIONS IN SOUTHCENTRAL LOS ANGELES IN 1992 THAT PRODUCED THE RIOT ARE IMPORTANTLY A PRODUCT OF THOSE REFORMS OF A QUARTER-CENTURY AGO. THE AUTHOR BRIEFLY RESTATES THE CORE ARGUMENT WHICH IS THAT BEGINMING IN THE EARLY 1960'S, AMERICAN SOCIAL POLICY TOWARD POOR AND DISADVANTAGED YOUTHS UNDERWENT A TRANSFORMATION IN WELFARE, EDUCATION, AND CRIMINAL JUSTICE. HE SUGGESTS THAT FOR MOST OF AFFLUENT AMERICA, THE SOCIAL POLICIES OF THE 60'S ARE OVER AND DONE WITH. HOWEVER, WITHIN THE INNER CITY THE 60'S REMAIN IN FULL FLOHER. HE CONCLUDES THAT THE ONLY WAY THAT INNER-CITY COMMUNITIES HILL AGAIN BEGIN TO FUNCTION AS COMMUNITIES IS IF THE INDIVIOUALS WITHIN THEM ARE AGAIN PERMITTED AND REOUIRED TO TO ENGAGE IN
SELF-GOVERMMENT.

06678 MURRAY, C.

THOMAS JEFFERSON GOES EAST

NATIONAL REVIEH, XLIV(4) (MAR 92), 21-29.

AFTER SOME TWENTY YEARS, THE AUTHOR OF THIS ARTICLE RETURNS TO THAILAND AND FINDS A NATION THAT IS SIGNIFICANTLY DEVELOPING AND IMPROVING. HE CONCLUDES THAT MODERNITY DOES NOT HAVE TO MEAN THAT TRADITIONAL MECHANISMS DETERIORATE: IT CAN MEAN THAT THEY GET BETTER AND MORE PRACTICAL. TECHNOLOGY CAN MEAN THAT THEY GET BETTER AND MORE PRACTICAL. TECH CAN MAKE IT EASIER FOR PEOPLE TO WORK WHERE THEY LIVE, EASIER FOR THEM TO TAKE CONTROL OVER THEIR CHILDREN'S
EDUCATION, AND EASIER FOR A CENTRAL GOVERMMENT THAT IS SO INCLINED TO DECENTRALIZE ITS OWN INSTITUTIONS. THE PROBLEM IN THAILAND (AND IN THE UNITED STATES) IS THAT CENTRAL GOVERMMENTS ARE SELDOM INCLINED TO DECENTRALIZE THEIR OWN INSTITUTIONS. THEREFORE, THE INELUCTABLY DESTRUCTIVE ASPECT OF MODERNITY IS POLITICAL, NOT TECHNOLOGICAL.

06679 MURRAY, $M$.

BLOCKAGE AGAINST CUBA
POLITICAL AFFAIRS, 7117) (AUG 92), 13-16.

BOTH DEMOCRATS AND REPUBLICANS ALIKE ARE CLAIMING CUBA AS THE UNFINISHED BUSINESS OF THE COLD WAR. THE CENTERPIECE OF THEIR STRATEGY IS ENFORCING AND STRENGTHENING A FULL TRADE EMBARGO MEANT TO CAUSE AN ECONOMIC CRISIS CAPABLE OF BRINGING CUBA TO ITS KNEES. WITH OR WITHOUT THE NEW LEGISLATION TO INTERNATIONALIZE THE EMBARGO, CUBANS CALIM THAT THE EMBARGO IS ALREADY A BLOCKADE. THIS ARTICLE CLAIMS THAT THERE IS GROWING OPPOSITION TO WASHINGTON'S COLD WAR WITH CUBA AND ALTERNATIVE SOLUTIONS ARE BEING SEARCHED FOR.

06680 MURRAY, S.

CRIOLLOISM AND NATIONALISM: THE MEANIMG OF MEXICO'S INDEPENDENCE STRUGGLE, 1760-1821

CANADIAN REVIEH OF STUDIES IN NATIONALISM, XIX(1) (1992), THE EVENTS PRIOR TO THE EMERGENCE OF AN INDEPENDENT MEXICAN NATION-STATE IN 1921 REFLECT THE TURBULENCE AND VOLATILITY OF THIS PIVOTAL PERIOD IN MEXICD'S HISTORY. THIS ARTICLE EXPLORES KEY EVENTS ON BOTH CONTINENTS WHICH GRADUALLY ERODED SPAIN'S TRADITIONAL AUTHORITY IN NEW SPAIN. THE PRACTICE OF APPOINTING MUMBERS OF SPANISH-BORN HHITES SEVENTY TO ONE OVER SPANIARDS BORN IN AMERICA (CRIOLLOS) ALTERNATIVES TO MEXICO'S COLONIAL RELATIONSHIP WITH SPAIN.

06681 MURRELL, P.

PRIVATIZATION COMPLICATES THE FRESH START

ORBIS, 36(3) (SUM 92), 323-332.

QUICK PRIVATIZATION OF STATE ENTERPRISES IS OFTEN VIEHED AS A NECESSARY AND SUFFICIENT CONDITION FOR THE SUCCESS OF ECONOMIC REFORM IN EASTERN EUROPE. WITH PRIVATE OWNERS AND MARKET COMPETITION, IT IS ASSUMED, LARGE INCREASES IN THE EFFICIENCY AND OUTPUT OF THE ENTERPRISES WILL ENSUE, AND THESE INCREASES WILL MORE THAN REPAY THE POLITICAL, SOCIAL, AND ORGANIZATIONAL COSTS INCURRED IN THE PRIVATIZATION PROCESS. THIS ARTICLE EXPLORES THE TRADE-OFF, THE COSTS OF NONINTERVENTION IN THE STATE SECTOR, THE VALUES OF EXISTING INSTITUTIONS, AND REFORM POLICY. IT CONCLUDES THAT THE STRUCTURE AND RHYTHM OF THE ECONOMIC TRANSITION MUST CERTAINLY BE ATTUNED TO THE NEEDS OF THE DEMOCRATIC

TRANSITION FROM THE OLD POLITICAL STRUCTURES.

06682 MURSI, A.

A SECRETARY-GENERAL ON THE FIRING LINE

WORLD PRESS REVIEN, 39(10) (OCT 92), 12-13

THE APPOINTMENT OF BOUTROS BOUTROS GHALI AS SECRETARY-

GENERAL OF THE UNITED NATIONS HAS HAILED BY MANY THIRD WORLD LEADERS AS A STEP IN THE RIGHT DIRECTION. THEREFORE, NO ONE EXPECTED BOUTROS GHALI TO BE THE TARGET OF SO MUCH CRITICISH SO EARLY IN HIS TENURE. BUT MANY OF HIS FORMER THIRD WORLD SUPPORTERS BELIEVE THAT HE HAS NOT BEEN THE STRONG ADVOCATE FOR THEM THAT THEY EXPECTED. THE PARTIES TO THE INTERNATIONAL CAMPAIGN AGAINST HIM ARE NOT UNITED BY A SINGLE POLITICAL OR PHILOSOPHICAL PERSPECTIVE. NEVERTHELESS, THEY HAVE LAUNCHED A PUBLIC MOBILIZATION AGAINST THE SECRETARY-GENERAL ON A SCALE UNPRECEDENTED IN U.N. HISTORY.

06683 MURTHY, $P$.

JAPAN AND CHINA IN THE NINETIES: THE BUMPY ROAD TO CONSOLIDATION OF TIES

CHINA REPORT, 27(4) (OCT 91), 275-298.

THE ENVIRONMENT IS MUCH MORE FAVORABLE THAN EVER BEFORE

FOR JAPAN AND CHINA TO CONSOL IDATE THEIR BILATERAL

RELATIONSHIP ON THE BASIS OF COMMON INTERESTS AND NEEDS.

THIS ARTICLE EXPLORES THE ECONOMIC BASES OF JAPAK-CHINA

RELATIONS AND THE POLITICAL ASPECTS OF JAPAN-CHINA RELATIONS. IT THEN TURNS TO AN ANALYSIS OF UNITED STATES, SOVIET UNION AND JAPAN-CHINA RELATIONS AND ROUNDS THIS OUT TO INCLUDE JAPAN, CHINA AND THE HORLD. IT CONCLUDES THAT WE MAY HAVE TO HAIT TIL THE END OF THE PRESENT CENTURY OR THE BEGINNING OF THE NEXT TO KNOW IF THEIR BILATERAL RELATIONSHIP WILL HAVE ANY BEARING ON THE PROBLEM OF KDREAN UNIFICATION OR THE CONCLUSION OF A PEACE TREATY BETWEEN JAPAN AND THE SOVIET UNION.

06684 MUSIL, J.

CZECHOSLOVAKIA IN THE MIDDLE OF TRAMSITION

DAEDALUS, $121(2)$ (SPR 92), 175-195.

THE AUTHOR DISCUSSES THE ONGOING TRANSITION IN

CZECHOSIOYAKIA. FOCUSING ON THE IMPORTANCE OF

CONSTITUTIONAL' TRANSITION, THE ECONOMIC TRANSFORMATION, THE

TRANSITION TO A CIVIL SOCIETY, AND THE ROLE OF WESTERN AID.

06685 MUSLIH, M.

THE SHIFT IN PALESTINIAN THINKING

CURRENT HISTORY, 91 (561) (JAN 92), 22-28.

THE NEW WAVE IN PALESTINIAN POLITICS IS NOT LIKELY TO BE BASED ON THE OLD FORMULA OF TOTAL PLO-DOMINANCE NOR TO EXCLUSIVELY REFLECT THE EXPANDING ROLE OF PALESTINIAN ACTIVISTS IN THE OCCUPIED TERRITORIES. INSTEAD, IT HILL REST ON INTERACTION BETWEEN PALESTINIANS IN THE OCCUPIED TERRITORIES AMD THOSE LIVING IN EXILE. 
06686 MUSLIH, M.

TOWARDS COEXISTENCE: AN ANALYSIS OF THE RESOLUTIONS OF THE PALESTINE NATIONAL COUNCIL

JOURMAL OF PALESTINE STUDIES, XIX(4) (SUM 90), 3-29.

THE MOMENTOUS DECISIONS TAKEN AT THE NINETEENTH

PALESTINE NATIONAL COUNCIL (PNC), WHICH ENABLED YASSER

ARAFAT TO RECOGNIZE ISRAEL AND RENOUNCE TERRORISM, WERE THE

PRODUCT OF A GRADUAL EVOLUTION THAT HAD BEEN TAKING PLACE

OVER MANY YEARS. THE ORGANIZATION'S LONG MARCH TO THE THO-

STATE SOLUTION DEFINITIVELY EMBRACED IN ALGIERS IS A MATTER

STATE SOLUTION DEFINITIVELY EMBRACED IN ALGIERS IS A MATT
OR PUBLIC RECORD, SPELLED QUT IN A CONTINUOUS CHAIN OF

OR PUBLIC RECORD, SPELLED QUT IN A CONTINUOUS CHAIN OF
RESOLUTIONS EXTENOING OVER A PERIOO OF THO DECADES. THIS

RESOLUTIONS EXTENOING OVER A PERIOO OF THO DECADES. THIS

CHANGES IN PALESTINIAN POLITICAL THINKING THAT THEY REVEAL.

06687 MUSOKE, D.

UGANDA--STRUGGLE FOR STABILITY

NEW AFRICAN, (282) (MAR 91), 20.

UGANDAN PRESIDENT YOWERI MUSEVENI DECLARED HIS HOPE THAT HIS NATION WILL BE "CROWNED BY PEACE AND STABILITY" BY THE END OF 1991. HIS STATEMENT WAS BELIED BY THE RAGGED UGANDA PEOPLE'S ARMY (UPA) WHICH ATTACKED SEVERAL VILLAGES IN THE KUMI DISTRICT. YOHERI IS ALSO IN THE PROCESS OF PREPARING THE ARMY FOR A NEH CONSTITUTION AND A RETURN TO CIVILIAN RULE. UGANDA'S TROUBLES ARE COMPOUNDED BY INCREASING NUMBERS OF REFUGEES FROM SUDAN AND RWANDA.

06688 MUTUA, M.W.

THE CHANGING OF THE GUARD

AFRICA REPORT, 37 (6) (NOV 92), 56-58

A SPLIT WITHIM THE FORUM FOR THE RESTORATION OF

OEMOCRACY (FORD) HAS PROPELLED FOUR YOUNG KENYAN POLITICIANS

IMCLUDING PAUL MUITE AND GITOBU IMANYARA, INTO THE

LEADERSHIP OF THE MAIN OPPOSITION PARTY. ALONG HITH

OCTOGENARIAN OGINDA ODINGA, HHO IS VIEWED AS A CANDIDATE FOR

A TRANSITIONAL PRESIDENCY, THIS NEW BREED IS SEEN AS A

POPULAR ALTERNATIVE TO PRESIDENT DANIEL ARAP MOI AND HIS

RULING PARTY. BUT ANOTHER FORD FACTION LED BY KENNETH MATIBA

RULING PARTY. BUT ANOTHER FORD FACTION LED BY KENNETH MATIBA

HAS ELECTED ITS OWN LEADERSHIP. WHICH FORD FACTION LEADS

OPPOSITION IN THE FORTHCOMING ELECTIONS
DIFFERENCE BETWEEN HINNING AND LOSING.

06689 MUTUA, M.W.

THE LAST CHAPTER?
AFRICA REPORT, $37(5)$ (SEP 92), 54-56.

THE NEXT FEH MONTHS WILL PROBABLY HRITE THE FINAL CHAPTER IN PRESIDENT MOBUTU SESE SEKO'S RULE, HICH HAS LASTED NEARLY THREE DECADES. ZAIRE'S NATIONAL CONFERENCE IS DETERMINED TO REDUCE MOBUTU'S ROLE TO A TITULAR ONE AND PROCEED HITH THE COUNTRY'S TRANSITION TO DEMOCRACY. HOHEVER, THE DICTATOR IS DETERMINED TO REINVIGORATE HIS NOW-TENUOU HOLD ON POWER. THE OUTCOME MAY ULTIMATELY DEPEND ON WHO CONTROLS THE ZAIRIAN SECURITY FORCES

06690 MUTUA, M.H.

THE TROUBLED TRANSITION

AFRICA REPORT, 37 (5) (SEP 92), 34-38

THE FORUM FOR THE RESTORATION OF DEMOCRACY (FORD) MAY HAVE MISSED THE BOAT IN KENYA'S TRANSITION TO MULTI-PARTY DEMOCRACY. UNABLE TO CHANGE FROM A PRESSURE GROUP INTO A POLITICAL PARTY WITH A WELL-DEFINED PLATFORM, FORD IS NOW SPLIT INTO TWO CAMPS AMD DOMINATED BY AMBITIOUS POLITICIANS ANXIOUS FOR THE LIMELIGHT AND WILLING TO EXPLOIT ETHNIC DIVISIONS. PRESIDENT DANIEL ARAP MOI MAY SNATCH THE UPCOMING ELECTION FROM A DIVIDED OPPOSITION.

06691 MUTZ, D.

MASS MEDIA AND THE DEPOLITICIZATION OF PERSONAL EXPERIENCE AMERICAN JOURNAL OF POLITICAL SCIENCE, 36(2) (MAY 92).

483-508.

THIS STUDY COMBINES CONTEMPORARY RESEARCH ON THE EFFECTS OF MASS COMMUNICATION WITH FINDINGS ON SOCIOTROPIC VOTING TO BUILD A GENERAL MODEL THAT EXPLAINS THE ORIGINS AND EFFECTS OF ECONOMIC PERCEPTIONS. THIS MOOEL IS THEN TESTED IN THE CONTEXT OF RETROSPECTIVE PERSONAL AND SOCIAL CONCERNS ABOUT CONTEXT OF RETROSPECTIVE PERSONAL AND SOCIAL CONCERNS ABOUT UNEMPLOYMENT. SURVEY EVIDENCE SUGGESTS THAT RETROSPECTIVE ASSESSMENTS OF UNEMPLOYMENT RESULT PRIMARILY FROM MEDIATED INFORMATION RATHER THAN FROM DIRECT EXPERIENCES. MASS MEDIA ARE FOUND TO HAVE AN "IMPERSONAL IMPACT," INFLUENCING SOCIAL, BUT NOT PERSONAL PERCEPTIONS OF THE ISSUE, WHILE PERSONAL EXPERIENCES WITH UNEMPLOYMENT INFLUENCE EXCLUSIVELY PERSONAL LEVEL JUDGMENTS. MASS MEDIA ALSO INFLUENCE THE WEIGHTING OF POCKETBOOK AS OPPOSED TO SOCIOTROPIC CONCERNS BY MEANS OF DRIMING ALL CONSIDERATIONS THAT SURROUND ECONOMIC ISSUES, HIGH LEVELS OF DXPOT TO ECOMOMIC MEHS PRIME THE IMPORTANCE OF COLLECTIVE PERCEPTIONS TO POLITICAL EVALUATIONS AND DECREASE THE IMPORTANCE OF PERSONAL CONCERNS.

06692 MUTZ, D.C.

IMPERSONAL INFLUENCE: EFFECTS OF REPRESENTATIONS OF PUBLIC OPINION ON POLITICAL ATTITUDES

POLITICAL BEHAVIOR, 14(2) (JUN 92), 89-122.

"IMPERSONAL INFLUENCE" IS INFLUENCE THAT DERIVES FROM
INDIVIDUALS' PERCEPTIONS OF OTHERS' ATTITUDES, BELIEFS, OR EXPERIENCES. "OTHERS" IN THIS CASE REFERS NOT TO THE CLOSE FRIENDS AND ACQUAINTANCES THAT CONCERNED THE AUTHORS OF SUCH CLASSICS AS "THE PEOPLE'S CHOICE" AND "PERSONAL INFLUENCE" BUT RATHER TO THE ANONYMOUS "OTHERS" OUTSIDE AN INOIVIDUAL'S REALM OF PERSONAL CONTACTS. MODERN MASS MEDIA FACILITATE THE INFLUENCE OF ANONYMOUS OTHERS BY DEVOTING CONSIDERABLE TIME AND ATTENTION TO PORTRAYING TRENDS IN MASS OPINION. THIS STUDY EXPLORES THE RATIONALE FOR THEORIES OF IMPERSONAL INFLUENCE, SYNTHESIZING EXISTING RESEARCH FINDINGS FALLING UNDER THIS GENERAL THEORETICAL FRAMEWORK AND INVESTIGATING UNDER THIS GENERAL THEORETICAL FRAMEHORK AND INVESTIGATING ITS PSYCHOLOGICAL UNOERPII
REPRESENTATIVE SURVEYS.

06693 MUZAFFAR, C.

FUNDAMENTALIST FALLACY

FAR EASTERN ECONOMIC REVIEW, 155(16) (APR 92), 23

IN THE WEEKS FOLLOWING THE MILITARY COUP IN ALGERIA THAT ROBBED THE ISLAMIC SALVATION FRONT (FIS) OF AN ELECTION VICTORY THAT MANY SAW AS INEVITABLE, THE TERM "ISLAMIC FUNDAMENTALISH" HAS REGAINED PROMINENCE IN THE MAINSTREAM INTERNATIONAL MEDIA. AS A DESCRIPTION OF THE FIS AMD OTHER ISLAMIC MOVEMENTS ELSEWHERE, THE TERM IS TOTALLY INACCURATE AND MISLEADING. IT IS USED BY THE MAINSTREAM MEDIA AND BY POWERFUL VESTED INTERESTS IN THE WEST AND IN THE MUSLIM HORLD FOR CERTAIN ULTERIOR POLITICAL AND IDEOLOGICAL MOTIVES. CONTRARY TO POPULAR BELIEF, "ISLAMIC FUMDAMENTALISTS" DO NOT INSIST UPON STRICT ADHERENCE TO TRADITIONAL ORTHODOX TENETS, NOR DO THEY REJECT EVERYTHING IN LIBERALISM AND MODERNITY. IN FACT, THEY ARE OFTEN PASSIONATELY DEYOTED TO SOCIAL TRANSFORMATION.

06694 MYANT, M.

ECONOMIC REFORM AND POLITICAL EVOLUTION IN EASTERN EUROPE JOURNAL OF COMMUNIST STUOIES, 8(1) (MAR 92), 107-127.

EXAMINATION OF THE RELATIONSHIP BETHEEM ECOMOMIC REFORM AND POLITICAL EVOLUTION IN POLAND, CZECHOSLOVAKIA, AND HUNGARY--FOCUSING ON PAST CHANGES TO THE ECONOMIC' MANAGEMENT SYSTEM IN RESPONSE TO DECLINING ECONOMIC PERFORMANCE-SUGGESTS THAT ECONOMIC REFORM MADE LITTLE DIFFERENCE EITHER SUGGESTS THAT ECONOMIC REFORM MADE LITTLE DIFFERENCE EITHER
TO THE OPERATION OF THE SYSTEM OR TO ITS PERFORMANCE. FIVE TO THE OPERATION OF THE SYSTEM OR TO ITS PERFORMANCE. FIVE BARRIERS EXISTED TO EFFECTIVE ECDNOMIC REFORM IN THE PAST AND, WHILE IDEAS EMERGED FOR OVERCOMING THESE BARRIERS, IT ECONOMIC SYSTEM COULD BE CHANGED SUBSTANTIALLY. CURRENT ECONOMIC SYSTEM COULD BE CHANGED SUBSTANTIALLY. CURRENT NEH OBSTACLES HAVE EMERGED, AND DIFFICULTIES IN IMPLEMENTING NEH OBSTACLES HAVE EMERGED, AND DIFFICULTIES IN IMPLEMEN ECONOMIC POLICY ARE IMFI
POLITICAL STRUCTURES.

06695 MYERS, $R$

AFTER THE COLD HAR

SOCIETY, 28(3) (MAR 91), 28-34.

THE END OF THE COLD WAR AND THE RESULTANT CHANGES HAVE CAST SERIOUS DOUBT ON THE REALIST PARADIGM THAT HAS LARGELY HELD SWAY IN AMERICAN POLICY, THEORY, AND PRACTICE. THIS ARTICLE EXAMINES THE EFFECT THAT THE END OF THE COLD WAR HAS HAD (AND WILL CONTINUE TO HAVE) ON THE TEACHING OF INTERNATIONAL RELATIONS AS A DISCIPLINE, AND, BY EXTENSION, ON U.S. FOREIGN POLICY. IT CONSIDERS FOUR FACTORS WHICH HELP EXPLAIN WHY THE OLD PARAMETERS OF INTERNATIONAL RELATIONS ARE IN FLUX: CHANGING ATTITUDES AND PERCEPTIONS OF THE UNITED STATES AND THE SOVIET UNION TOWARD EACH OTHER; THE INFORMATION AND COMMUNICATION EXPLOSION; THE INCREASED EMPHASIS ON HUMAN RIGHTS; AND THE GROWTH OF ENVIRONMENTRELATED CONCERNS. THESE CHANGES ARE LIKELY TO FORCE THE REINTRODUCTION OF CONSIDERATIONS OF MORALITY INTO INTERNATIONAL POLICYMAKING AND THEORY.

06696 MYERS, R.

RETHINKING HUMAN RIGHTS

SOCIETY, 30(1) (NOV 92), 58-63.

THE IDEA OF HUMAN RIGHTS HAS BEEN COMMON TO MAMY CULTURES, INCLUDING CHINA AND THE UNITED STATES. THE PUPOSE OF THIS ESSAY IS TO TRY TO FIND THE REASON FOR THE INTENSITY OF FEELING ABOUT HUMAN RIGHTS AND DIFFERING INTERPRETATIONS OF WHAT HUMAN RIGHTS IS ALL ABOUT. IT IS THE HOPE THAT THESE OF WHAT HUMAN RIGHTS IS ALL ABOUT. IT IS THE HOPE THAT THESE
CONSIDERATIONS WILL HELP RESOLVE THIS CONFOUNDING OUESTION CONSIDERATIONS WILL HELP RESOLVE THIS CONFOUNDING QUESTION AND WILL LEAD TOWARD CONVERGENCE, OR AT THE VERY LEAST,
IDENTIFYING THE REAL ISSUE, AND TO IMPROVMENT OF THE PROSPECTS FOR CLOSER SINO-U.S. RELATIONS.

06697 MYLES, J.

YEMEN'S GROWING PAINS

MIDDLE EAST INTERNATIONAL, 438(438) (NOV 92), 18-19.

ON THE FACE OF IT YEMEM HAS FAILED THE GREATEST TEST OF UNIFICATION. IN REALITY, THE GREAT SURPRISE OF YEMENI UNIFICATION IS NOT THAT IT HAS REVEALED ITSELF TO BE FLAWED, BUT THAT IT HAS MANAGED TO COME SO FAR AND REMAIN INTACT IN THE FACE OF DAUNTING OBSTACLES. THIS ARTICLE REPORTS ON THE BOOST WHICH YEMEN RECEIVED FROM RETURNEE'S REPATRIATED SAVINGS AND THE ENTHUSIASTIC RESPONSE OF OIL COMPANIES TO IN SAN'A, THE LINGERING WORRY IS THAT IF THE LEVEL OF 
DISCONTENT RISES TOO MUCH, SALIH MAY BE TEMPTED TO CANCEL THE EXPERIEMENT WITH DEMOCRACY ALTOGETHER.

06698 MYLROIE, L.

STILL STANDING

NEW REPUBLIC, 206(15) (APR 92), 11-12.

SINCE U.S. TROOPS LIBERATED KUWAIT AND WITHDREW, THE

BUSH ADMINISTRATION'S POLICY TOWARD IRAQ HAS BEEN INCOHERENT.

THE KURDS AND THE POORER IRAQIS HAVE BEEN AMONG THOSE TO

SUFFER THE MOST BECAUSE U.S. POLICY HAS ALLOWED SADDAM

HUSSEIN TO STAY IN POWER.

06699 NACHMAN, M.R. JR.

LIMITS ON FREE SPEECH AND PRESS

PRESIDENTIAL STUDIES QUARTERLY, XXII (4) (FAL 92), 731-739.

THE AUTHOR SUMMARIZES SOME IMPORTANT U.S. SUPREME COURT

RULINGS REGARDING THE LIMITATIONS ON FREE SPEECH AND FREEDOM

OF THE PRESS. HE CITES JAMES MADISON'S DECLARATION THAT THE

GOVERNMENT.

06700 NACHRICHTEN, $K$.

ANOTHER NEO-NAZI GROUP BANNED, PAPERS SEIZED

GERMAN TRIBUNE, 31 (1545) (DEC 92), 3 .

THE GERMAN INTERIOR MINISTER HAS BANNED SEVERAL NEO-NAZI ORGANIZATIONS AND AS THE BAH WHEN INTO EFFECT, HOUSES WERE ORGANIZATIONS AND AS THE BAN WHEN INTO EFFECT, HOUSES
SEARCHED, AND ASSETS BELONGING TO THE ORGANIZATIONS SEARCHED, AND ASSETS BELONGING TO THE ORGANIZATIONS IMPOUNDED. ARRESTS HAVE BEEN MADE. THE BAN HAS BEEN DESCRIBED AS A RENEHED CLEAR WARNING AGAINST EXTREMISM. THE INTERIOR MINISTRY IS GIVING CAREFUL
BANS OF RIGHT-WING EXTREMIST GROUPS.

06701 NADEEM, $S$.

OUTRAGED TO BE DOING SO WEL

FAR EASTERN ECONOMIC REVIEH, 151(23) (JUN 91), 30.

ON 28 MAY AMNESTY INTERNATIONAL TURNED 30. THAT IT HAS SET UP DURING THE COLD WAR, SURVIVED THE POLITICALLY AND ECONOMICALLY TURBULENT TIMES THAT FOLLOWED AND HAS CONSISTENTLY KEPT GROWING IN SIZE AND STATURE DURING THE LAST THREE DECADES IS NO MEAN ACHIEVEMENT. HOHEVER, THE ANNIVERSARY IS NO OCCASION FOR CELEBRATION. THE FACT THAT AN ORGANIZATION LIKE AMNESTY INTERNATIONAL HAS TO REMAIN IN BUSINESS IS AN INDICATION THAT THE HORLD CONTINUES TO BE ONE OF PERSECUTION AND IMPRISONMENT, UNFAIR TRIALS, TORTURE, EXECUTIONS, KIDNAPPINGS, AND MURDERS. IF AMNESTY

INTERMATIONAL HAD SUCCEEDED IT WOULD BE EXTINCT BY NOW.

06702 NADELMANN, E.A.

THINKING SERIOUSLY ABOUT ALTERNATIVES TO DRUG PROHIBITION DAEDALUS, $121(3)$ (SUM 92), 85-132.

THE AUTHOR HAS FOUR MAJOR OBJECTIVES IN THIS PAPER. THE FIRST IS TO IDENTIFY AND UNDERSTAND THE ESSENTIAL DIFFERENCES THAT SEPARATE THOSE IN THE REASONABLE MIDDLE GROUND OF THE DEBATE OVER DRUG PROHIBITION VERSUS ORUG LEGALIZATION. THE SECOND IS TO OFFER NEH WAYS OF THINKING ABOUT RADICAL ALTERNATIVES TO CURRENT DRUG PROHIBITION POLICIES, TO IDENTIFY THE SORTS OF QUESTIONS THAT MUST BE ASKED, AND TO SUGGEST HOW THEY MIGHT BE ADDRESSED. THE THIRD IS TO PROVIDE EVIDENCE IN SUPPORT OF THE PROPOSITION THAT EVEN A RADICAL DECRIMINATIONALIZATION OF DRUG USE WILL NOT PRODUCE THE SORTS OF DRAMATIC INCREASES IN SUBSTANCE ABUSE THAT CRITICS OF LEGALIZATION FEAR. THE FOURTH IS TO PROPOS A DRUG REGULATORY MODEL THAT ELIMINATES MANY OF THE WORS
CONSEQUENCES OF DRUG PROHIBITION WITHOUT REPRODUCING THE UNFORTUNATE CONSEQUENCES OF CURRENT ALCOHOL AND TOBACCO CONTROL POLICIES.

06703 NADER, G.

INTERVIEW WITH HIS MAJESTY SULTAN QABOOS BIN SAID AL SAID OF THE SULTANATE OF OMAN

INSIGHT 9 (1) (1992) 33-37.

SULTAN QABDOS DRAWS HIS STRENGTH AND HIS VISION FROM THO MILLENMIA OF HISTORY AND THE INNATE CHARACTER OF THE OMANI PEOPLE. IT IS THIS VISION THAT HAS LED THE ECONOMIC AND SOCIAL TRNASFORMATION OF THE PAST 22 YEARS--THE OMAMI RENAISSANCE. THIS INTERVIEW REVEALS A PROCESS OF DEVELOPMENT RARELY EQUALLED IN SO SHORT A PERIOD, PARTICULARLY SO SINCE IT OCCURRED HITHOUT THE SOCIAL UPHEAVAL AND DISLOCATION THAT USUALLY ACCOMPANIES RAPID ENCONOMIC CHANGE. THIS INTERYIEH COVERS ECONOMICS, EDUCATIOM, FOREIGM TRADE. IMYESTMENT, GRONTH, CONSERYATIOH, CUL TURE, INTERMATIONAL RELATIONS, DEFENSE, DIPLOMACY, AND POLICY.

06704 NADER, G.

THE MIDDLE EAST PEACE PROCESS AFTER THE U.S. ELECTIONS INSIGHT, $9(1)(1992), 3-9$

PRESIDENT-ELECT CLINTOM HAS MADE IT CLEAR THAT HE IS STRONGLY COMMITTED TO THE CONTINUATION OF THE ARAB-ISRAELI PEACE PROCESS. THERFORE, CLINTON'S OBJECTIVES WILL BE EXACTLY THE SAME AS BUSH'S: TO MOVE ON AS MANY FRONTS AS POSSIBLE HHILE PROMOTING A STEP-BY-STEP PROCESS IN BOTH THE ISRAELI-PALESTINIAN AND ISRAELI-SYRIAN ARENAS WHICH WILL SERVE AS CATALYSTS FOR OTHER BILATERAL TALKS WITH LEBANON
THAT CLINTON FACES IN THE SELCTION OF MEMBERS OF THE NEW ADMINISTRATION. IT CONCLUDES THAT THE ROUTE THAT BILL CLINTON SELECTS WILL OETERMINE THE LIKELIHOOD OF THE SUCCESS OF THE AMERICAN ROLE AND THE SUCCESS OF THE TALKS.

06705 NADIROV, $N$

A SCATTERED PEOPLE SEEKS ITS NATIONHOOD

CULTURAL SURVIVAL QUARTERLY, 16(1) (WIN 92), 38-40.

THE KURDS WELCOMED THE OCTOBER REVOLUTION AND

PARTICIPATED IN THE CONSOLIDATION OF SOVIET POWER, BASED ON PROMISES OF SELF-DETERMINATION UNDER COMMUNIST RULE. DURING THE EARLY YEARS OF THE SOVIET UNION, THE STATE ALLOWED THE KURDISH PEOPLE TO EXPERIENCE A SOCIAL, CULTURAL, AND NATIONAL REVIVAL. BUT, UNDER STALIN, ALL THIS CAME TO A HALT AND THE KURDS WERE VICTIMS OF A FORCED RELOCATION. RESETTLED THROUGHOUT NINE REPUBLICS, THE KURDISH PEOPLE ALMOST LOST THEIR SENSE OF THEMSELVES AS A NATION.

06706 NAGAHO, $H$.

THE PHILIPPINES' NEH START AND JAPAN

JAPAN QUARTERLY, XXXIX(3) (JUL 92), 311-320.

JAPANESE AID FOR THE PHILIPPINES IS NOT NEW; SINCE 1979

JAPAN HAS BEEN THE ISLAND'S LARGEST AID DONOR. WHAT IS NEW IS THE RECENT SURGE OF PHILIPPINE NATIONALISM, EXEMPLIFIED IS THE RECENT SURGE OF PHILIPPINE NAT IONALISM, EXEMPLIFIED HAVE AT LAST DECIDED TO TAKE FIRM CONTROL OF THEIR OWN FATE. WHATEVER NEW AID PACKAGES AND INVESTMENTS JAPAN POURS INTO THE PHILIPPINES, THE JAPANESE MUST CONSIDER THE NEH FILIPINO ATTITUDE AND SEE TO IT THAT, UNLIKE PAST AID, THE FUNDS WORK ATTITUDE AND SEE TO IT THAT, UNLIKE

06707 MAGEL, S.; BIEVENUE, L.

SOCIAL SCIENCE, LAW, AND PUBLIC POLICY

UNIVERSITY PRESS OF AMERICA, 1992, 344.

A GRAND SWEEP OF THE RELATIONS AMONG SOCIAL SCIENCE, LAH AND PUBLIC POLICY OVER THE PAST 30 YEARS IS PROVIDED. THE EMPHASIS IS ON THREE STAGES IN SOCIAL SCEINCE DEVELOPMENT THEY INCLUDE DECISIONS, AND MULTI-CRTICIAL DECISION-MAKING WITH DECISION-AIDING SOFTWARE. THE APPLICATIONS ARE IN LAW, PUBLIC POLICY, AND OTHER SUBSTANTIVE ASPECTS OF SOCIAL SCIENCE. THE BOOK PROVIDES AN INTEGRATION OF THE BEHAVIORALISM OF THE 6OS, THE POLICY RELEVANCE OF THE 7OS, AND THE SOFTHARE REVDLUTION OF THE $80 \mathrm{~S}$

06708 NAGLER, J.; LEIGHLEY, J.

PRESIDENTIAL CAMPAIGN EXPENDITURES: EYIDENCE ON ALLOCATIONS AND EFFECTS

PUBLIC CHOICE, 73(3) (APR 92), 319-334.

THIS PAPER ANALYZES THE IMPACT OF PRESIDENTIAL CAMPAIGM SPENDING ON ELECTION RESULTS. ANALYSES OF EXPENDITURES AND SPENDING ON ELECTION RESULTS. ANALYSES OF EXPENDITURES AND VOTING ARE OFTEN PLAGUED BY SIMULTANEITY BETWEEN CAMPAIGN
SPENDING AND EXPECTED VOTE SHARE. HOWEVER, GAME-THEORETIC SPENDING AND EXPECTED VOTE SHARE. HOWEVER, GAME-THEORETIC
MODELS OF RESOURCE-ALLOCATION DECISIONS MADE BY A CENTRAL MODELS OF RESOURCE-ALLOCATION DECISIONS MADE BY A CER
ACTOR (I.E. A PRESIDENTIAL CAMPAIGN) SUGGEST THAT ACTOR (I.E., A PRESIDENTIAL CAMPAIGN) SUGGEST THAT
CANDIDATES WILL SPEND MORE IN CLOSE RACES AND IN RACES CANDIDATES WILL SPEND MORE IN CLOSE RACES AND IN RACES
LIKELY TO BE PIVOTAL. THIS ARTICLE PROVIDES EMPIRICAL LIKELY TO BE PIVOTAL. THIS ARTICLE PROVIDES EMPIRICAL SUPPORT FOR THIS THEORY; USING FEDERAL COMHUNICATIONS COMMISSION DATA FROM THE 1972 PRESIDENTIAL ELECTION, IT FINDS THAT EXPENDITURES WERE HIGHER IN STATES WHERE THE ELECTION WAS EXPECTED TO BE CLOSER AND IN STATES LIKELY TO
BE PIVOTAL. THESE TWO FACTORS ARE USED AS INSTRUMENTS IN A BE PIVOTAL. THESE TWO FACTORS ARE USED AS INSTRUMENTS IN SPENDING ON VOTES. IT FINDS THAT, CONTRARY TO PREYIOUS THEORY AND RESEARCH, PRESIDENTIAL CAMPAIGN SPENDING SIGNIFICANTLY INCREASES A CANDIDATE'S VOTE SHARE.

06709 NAGLER, J

THE EFFECT OF REGISTRATION LAWS AND EDUCATION ON U.S. VOTER TURMOUT

AMERICAN POLITICAL SCIENCE REVIEW, 85(4) (DEC 91),

1393-1406.

RESTRICTIVE REGISTRATION LAHS DO NOT DISSUADE INDIVIDUALS WITH LOWER LEVELS OF EDUCATION FROM VOTING ANY MORE THAN THEY DISSUADE INDIVIDUALS HITH HIGHER LEYELS OF EDUCATION. THIS FINDING CONTRADICTS THE RESULTS OF WOLFINGER AND ROSENSTONE'S CLASSIC ANALYSIS OF TURNOUT, BECAUSE THEIR CONCLUSION WAS ACTUALLY AN ARTIFACT OF THE METHODOLOGY THEY EMPLOYED. EXAMINING PREDICTED PROBABILITIIES GENERATED BY A NONLINEAR MODEL, SUCH AS PROBIT OR LOGIC, MAY PRODUCE SPURIOUS RESULTS WHEN USED TO DETERMINE INTERACTIVE EFFECTS BETHEEM THO IMDEPEMDENT YARIABLES. BY RESPECIFYING THE MODEL BETHEEN THO INDEPENOENT VARIABLES. BY RESPECIFYING THE MODEL OF TURNOUT TODEXPLICITLY INCLUDE TERMS TO TEST INTERACTIVE HYPOTHESES ANO REANALYZING THE DATA FROM THE 1972 "CURREN POPULATION STUDY" ALONG WITH DATA FROM THE 1984 SURVEY, IT IS APPARENT THAT NO SUBSTANTIVE INTERACTIVE EFFECT BETWEEN REGISTRATION LAHS AND INDI
EXISTS AT THE MICRO LEVEL.

06710 NAHAYLO, B.

UKRAINE
RFE/RL RESEARCH REPORT, 1(39) (OCT 92), 10-17

THE DEVELOPMENT OF A FREE PRESS IN UKRAINE IS A SLOW AND OIFFICULT PROCESS THAT HAS BEEN BECOME MORE PAINFUL DUE TO THE EXPOSURE TO NEH MARKET FORCES. WHILE NEWSPAPERS STRUGGLE 
TO SURVIVE THE SURGE IN PRICES AND THE SHORTAGE OF NEWSPRINT, THE GOVERNMENT RETAINS FIRM CONTROL OVER RADIO AND TELEVISION, THE QUALITY OF WHICH STILL LEAVES MUCH TO BE DESIRED.

06711 MAHAYLO, B.

UKRAINE

RFE/RL RESEARCH REPORT, 1(27) (JUL 92), 50-56. UNDER PRESSURE FROM RUKH. THE UKRAINIAN MATIONAL DEMOCRATIC MOVEMENT. THE IDEA OF A DEMOCRATIC LAH-BASED STATE HAS SUPPLANTED THE NOTION OF A SOCIALIST RECHTSSTAAT AND HAS BECOME IDENTIFIED WITH THE CONCEPT OF THE NEW INDEPENDENT UKRAINE. DESPITE THE IMMENSE PROBLEMS OF MOVING FROM THE OLD LEGAL AND POLITICAL ORDER TO THE NEW, UKRAINE HAS BEGUN A MAJOR OVERHAUL OF ITS EXIST ING LEGAL SYSTEM AND WILL SOON ADOPT A NEH CDNSTITUTION. IN A RELATIVELY SHORT WILL SOON ADOPT A NEH CONSTITUTION. IN A RELATIVELY DISMANTLING THE SOVIET ONE-PARTY, IMPERIAL SYSTEM AND LAYING THE FOUNDATIONS OF UKRAINIAN OEMOCRACY.

06712 NAHAYLO, B.

UKRAINE AND MOLDOVA: THE VIEN FROM KIEY RFE/RL RESEARCH REPORT, 1(18) (MAY 92), 39-45. THE ESCALATION OF THE ARMED CONFLICT IN MOLDOYA POSES SERIOUS PROBLEMS FOR THE NEWLY-INDEPENDENT UKRAINIAN STATE. WHILE THE UKRAINIAN MINORITY IN MOLDOVA IS LARGELY PEACEFUL, THERE IS ALSO A STRONG AND ARMED RUSSIAN COMMUNITY, SUPPORTED BY RUSSIAN ULTRANATIONALIST FORCES, THAT' MAS SHOWN ITSELF HOSTILE TO BOTH ROMANIAN AND UKRAINIAN CULTURE. MOREOVER, IN 1991 BUCHAREST REOPENED THE LONGSTANDING TERRITORIAL DISPUTE OVER NORTHERN BUKOVINA AND SOUTHERN BESSARABIA. THIS ARTICLE EXAMINES THE COMPLEX HISTORICAL BACKGROUND TO PRESENT UKRAINIAN-MOLDOVAN RELATIONS FROM KIEV'S VIEHPOINT AND THE SITUATION OF MOLDOVA'S 600,000 UKRAINIAHS.

06713 NAIDOO, $K$.

THE POLITICS OF YOUTH RESISTANCE IN THE 1980S: THE DILEMMAS OF A DIFFERENTIATED DURBAH JOURNAL OF SOUTHERN AFRICAN STUDIES, 18(1) (MAR 92), 143-165.

AFRICANS AND ASIANS AND COLOURED HAVE BEEN VICTIMS OF GOVERNMENT POLICY, AND HAVE COME TO ACCEPT RACIAL
DESIGNATION. THIS PAPER INVESTIGATES THE OBJECTIVE AND DESIGNATION. THIS PAPER INVESTIGATES THE OBJECTIVE AND
SUBJECTIVE CONDITIONS AFFECTING THE OPPRESSED COMHUNITIES IN SUBJECTIVE CONDITIONS AFFECTING THE OPPRESSED COMHUNITIES IN OF YOUTH RESISTANCE IN THE 1980S. THE YOUTH ARE DIVIDED INTO OF YOUTH RESISTANCE IN THE 1980S. THE YOUTH ARE DIVIDED INTO AT LEAST FIVE CATEGORIES: PRIMARY, SECONDARY AND TERTIAR CONTEXT OF YOUTH EXPERIENCE IS STUDIED. IT IS CONCLUDED THAT CONTEXT OF YOUTH EXPERIENCE IS STUDIED. IT
MASS YOUTH SOLIDARITY REMAINS GOAL ELUSIVE.

06714 NAIR, V.K.

DEFENCE FORCES AND NUCLEAR WEAPONS IN CHINA'S FOREIGM POLICY

CHINA REPORT, 28(3) (JUL 92), 215-224.

IN LESS THAN THREE DECADES, CHINA HAS CREATED A MASSIVE NUCLEAR FORCE STRUCTURE. THIS ARTICLE EXAMINES THE NUCLEAR CHARACTER OF THE CHINESE REGIME, THE PART THESE FORCES WIL PLAY AS AN INSTRUMENT OF FOREIGN POLICY AND THE CONSTRAINTS THAT HOULD BE PLACED ON THE OTHER ACTORS IN THE INTERACTION AT REGIONAL AND GLOBAL LEYELS. IT EXAMINES CHINA'S NUCLEAR STRATEGY IN ITS ENTIRETY INCLUDING OBJECTIVES, DEPLOYMENT POLICIES AND WEAPONS CAPABILITIES. SPECIAL EMPHASIS IS PLACED ON EXTERNAL FACTORS AFFECTING CHINA'S NUCLEAR POLICY, MOST NOTABLY THE NUCLEARIZATION OF INDIA.

06715 NAITAO, $W$.

CAPO IS DEDICATED TO THE CAUSE OF EDUCATION

BEIJING REVIEN, 35(29) (JUL 92), 21-24.

THE CHINA ASSOCIATION FOR PROMOTING DEMOCRACY (CAPD), ONE OF THE EIGHT DEMOCRATIC PARTIES IN CHINA, REGARDS EDUCATION AS A BASIC REQUIREMENT FOR NATIONAL DEVELOPMENT AND IS MAKING AN UNREMITTING EFFORT TO PROMOTE RESPECT FOR TEACHERS AND IMPROVE THE EDUCATIONAL SYSTEM.

06716 NAITAO, $W$.

CPWDP: SHARING EXPERTISE

BEIJING REVIEH, 35(37) (SEP 92), 21-24.

THE CHINESE PEASANTS AND HORKERS DEMOCRATIC PARTY

(CPWDP) IS THE OLDEST OF CHINA'S EIGHT "DEMOCRATIC" PARTIES. TAKING ADVANTAGE OF ITS MEMBERS' EXPERTISE, THE PARTY PLAYS AAKING ADVANTAGE OF ITS MEMBERS EXPERTISE, THE PARTY GOVERNMENT AFFAIRS IN THE FIELDS OF MEDICINE, PUBLIC HEALTH, EDUCATION, AND SCIENCE AND TECHNOLOGY.

06717 NAITAO, W.

DEMOCRATIC LEAGUE DEVOTED TO POVERTY RELIEF

BEIJING REVIEH, 35(26) (JUN 92), 25-29.

THE AUTHOR PROFILES THE CHIMA DEMOCRATIC LEAGUE, THE LARGEST OF CHINA'S EIGHT "DEMOCRATIC" PARTIES. THE LEAGUE, WHICH HAS TARGETED THE ELIMINATION OF POVERTY IN POOR RURA AREAS AS ITS MAJOR GOAL, PROMOTES LOCAL ECONOMIC DEVELOPMENT.
06718 NAITAO, $W$. DEMOCRATIC PARTIES (1): RCK WORKS FOR CLOSER MAINLANDTAIWAN TIES

BEI JING REYIEW, 35(12) (MAR 92), 24-27.

THE REVOLUTIONARY COMMITTEE OF THE KUOMINTANG (RCK) IS A SPLIT FROM THE KUOMINTANG. SINCE, ITS FOUNDING, THE RCK HAS
CO-OPERATED AND MAINTAINED CLOSE AND FRIENDLY RELATIONS WITH THE COMMUNIST PARTY OF CHINA. SINCE THE FOUNDING OF NEW CHINA IN 1949, THE RCK HAS PARTICPATED IN THE ADMINISTRATION OF GOVERNMENT AFFAIRS AS ONE OF THE DEMOCRATIC PARTIES UNDER THE MULTI-PARTY CO-OPERATION SYSTEM LED BY THE CHINESE COMMUNIST PARTY AND AS A MEMBER OF THE CHINESE PEOPLE'S POLITICAL CONSULTATIVE CONFERENCE. THE PRINCIPAL EMPHASIS OF THE PARTY'S WORK IS OUTLINED IN THIS ARTICLE.

06719 NAITAO, $H$.

DEMOCRATIC PARTIES (11): CONTRIBUTING TO DEVELOPMENT OF

BEIJING REVIEW, 35(12) (MAR 92), 28-30.

THE JIUSAN SOCIETY, A POLITICAL PARTY COMPOSED OF INTELLECTUALS IN SCIENTIFIC, TECHNOLOGICAL, CULTURAL, EDUCATIONAL AND MEDICAL CIRCLES, WAS ESTABLISHED IN 1946 TO COMMEMORATE THE VICTORY OF THE CHINESE PEOPLE IN THE WAR OF RESISTANCE AGAINST JAPAN AND HORLD WAR II. AS ONE OF CHINA'S EIGHT DEMOCRATIC PARTIES, THE JUISAN SOCIETY, DRAWING ON THE RESOURCES OF ITS INTELLIGENTSIA, HAS WORKED HARD TO PROMOTE THE ECONOMIC DEVELOPMENT OF POVERTY - STRICKEN SOUTHHEST CHINA. WITH THE PROGRESS OF ITS WORK, THE SOCIETY'S ORGANIZATION HAS UNDERGONE REMARKABLE DEVELOPMENT.

06720 NAITAO, $W$.

RENDERING DIRECT SERYICE TO ECONOMIC DEVELOPMENT BEIJING REVIEW, 35(52) (DEC 92), 22-25.

THE CHINA DEMOCRATIC NATIONAL CONSTRUCTION ASSOCIATION IS CONSIDERED A POLITICAL PARTY, EVEN THOUGH ITS MAJOR CONCERN IS ECONOMIC POLICY. THE MEMBERS OF THE PARTY ARE ACTIVELY INVOL VED IN ESTABLISHING INTERNATIONAL BUSINESS CONTACTS AND OTHER ACTIVITIES DESIGHED TO FURTHER CHINA'S ECONOMIC GROWTH.

06721 NAITAO, $W$.

STATE-OWNED ENTERPRISES NO LONGER STATE RUN

BEIJING REVIEW, 35(46) (NOV 92), 17-21.

ON JULY 24, 1992, THE STATE COUNCIL PROMULGated "THE REGULATIONS CONCERNING MANAGEMENT MECHANISM TRANSFORMATION OF STATE-OWHED INDUSTRIAL ENTERPRISES A THESE NEH OF STATE OWNED INDUSTRIAL ENTERPRISES. THESE NEH REGULATIONS CLEARLY ESTABLISH THE RIGHTS OF MANY INDUSTRIES MARKET IN THE FUTURE.

06722 NAITAO, $W$

TOSGL: WORKING TOWAROS REUNIFICATION

BEI JING REVIEW, 35(51) (DEC 21), 24-26.

THE AUTHOR SUMMARIZES THE HISTTORY OF THE TAIWAN

DEMOCRATIC SELF-GOVERMMENT LEAGUE, WHICH WAS FOUNDED IN 1947 TO PROTEST THE AUTOCRACY AND CORRUPTION OF THE KOUMINTANG.

TODAY, THE LEAGUE CONTINUES TO FUNCTION IN MAINLAND CHINA.

06723 NAKAMURA, A.

ENVIRONMENTALISM AND THE GROWTH MACHINE: THE SYSTEM OF

POLITICAL ECONOMY AND "KOGAI" CONTROL IN JAPAN

GOVERNANCE, 5(2) (APR 92), 181-186

THE PRIMARY OBJECTIVE OF THIS ARTICLE IS TO EXAMINE BOTH THE ROLE OF GOVERNMENT AND THE FUNCTION OF PUBLIC ADMINISTRATION IN THE AREAS OF ECONOMIC DEVELOPMENT AND ENVIRONMENT PROTECTION IN JAPAN. IT FIRST ELUCIDATES SEVERAL IMPORTANT MECHANISMS OF JAPAN'S ECONOMIC GROWTH. IT ALSO DESCRIBES A NUMBER OF HISTORICAL DEVELOPMENTS WHICH HAVE HELPED ALLEVIATE THE STATE OF POLLUTION, WHICH IS CALLED KOGAI, IN JAPAN. THIS ANALYSIS OF THE JAPANESE EXPERIENCE MAY REVEAL SEVERAL LESSONS GERMANE TO THE BASIC QUESTIONS OF
THE ROLE AND FUNCTION OF PUBLIC AUTHORITY IN ENVIRONMENTAL ISSUES, ESPECIALLY IN NEWLY INDUSTRIALIZED COUNTRIES.

06724 NANCY, J.

THE COMPEARANCE: fROM tHE EXISTENCE Of "COMHUNisM" to THE COMMUNITY OF "EXISTENCE"

POLITICAL THEORY, 20 (AUG 92), 371-398.

THIS ARTICLE STATES THAT THE "POSTMODERn" haS ALREADY COME TO CLOSURE; PERHAPS IT NEVER HAPPENED. MORE ACCURATELY, THAT WHICH THIS TERM MAY HAVE DESCRIBED OR REFLECTED APPEARS TO HAVE BEEN ONLY THE BRIEF AND INVERTED APPEARANCE OF ANOTHER OCCURRENCE. THE "POSTMODERN" DEFINED ITSELF AS A STRAINED RELATIONSHIP, A RELATIONSHIP IO A GENERAL STRAINED RELATIONSHIP, A RELATIONSHIP TO A GENERAL FOUNDATION COULD ANY LONGER BE PRESENTED. THE LEADING TARGET FOUNDATION COULD ANY LONGER BE PRESENTED. THE LEADING TARGET HAS, OF COURSE, ANY COMMON SUBSTANTIALITY, ANY SUBJECT HUMAN HISTORY AND THE BODY POLITIC -- ALL COMMUNISM, THEREFORE. NOTHING IN FACT SITUATES THE POSTMODERN BETT
THAN THE POLYMORPHIC CONSTELLATION OF ALL THE "ENDS OF THAN THE POLYMORPHIC CONSTELLATION OF ALL THE "ENDS OF OR AS A KIND OF ORGANICISM. 
06725 MAQVI $S$.

THE DIMENSIONS OF A NEW INTERNATIONAL ECONOMIC ORDER SOUTH ASIA JOURNAL, 5 (1) (JUL 92), 1-16.

IN GENERAL, HORLD WELFARE IS MAXIMIZED IF COUNTRIES ARE LINKED TOGETHER BY A FREE FLOH OF COMMODITIES, PEOPLE AND MONEY. CONTRARILY, TRADE WARS, RESTRICTIONS ON INTERNATIONAL MIGRATION, AND CAPITAL FLOWS LOWER WORLD WELFARE. IN THIS PAPER, THE CHALLENGES AND ISSUES THAT ANY EFFICIENT AND EQUITABLE DESIGN FOR A NIEO MUST ADORESS IS OUTLINED. THIS IS FOLLOWED BY $A$ REVIEW OF THE OBVIOUS INADEQUACIES OF SUCH INTERNATIONAL AGENCIES AS THE UNCTAD, THE GATT, AND THE IMF TO MEET THE CHALLENGE OF A VASTLY CHANGED HORLD. THEN AN ATTEMPT IS MADE TO IDENTIFY THE SALIENT FEATURES OF THE PROPOSED AGENDA FOR REFORMING THE EXISTING WORLD ECONOMIC ORDER. THE CONCLUDING REMARKS OFFER A PICTURE OF WHAT IT COULD TAKE TO BUILD THE NEW ORDER ON SURER ECONOMIC AND MORAL FOUNDATIONS.

06726 NARAYANA, E.

BUREAUCRATIZATION OF NON-GOVERNMENTAL ORGANIZATIONS: AN ANALYSIS OF EMPLOYEE'S PERCEPTIONS AND AITITUDES PUBLIC ADMINISTRATION AND DEVELOPMENT, 12(2) (MAY 92), 123-138.

THE KEY CONCERM OF THIS ARTICLE IS TO MEASURE THE EXTENT TO WHICH NON-GOVERNMEMTAL ORGANIZATIONS (NGOS) ARE

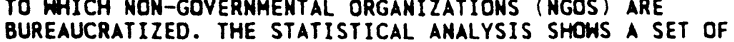
BUREAUCRATIZED. THE STATISTICAL ANALYSIS SHOWS A SET OF RELATIONSHIPS BETWEEN EACH OF EIGHT CHARACTERISTICS OF BUREAUCRACY ON THE ONE HAND AND THE MULTITUDE OF INDEP VARIABLES ON THE OTHER. IT CAN BE INFERRED THAT THE
BUREAUCRATIC CHARACTERISTICS OF NGOS HAVE NOT CRYSTALLIZED. BUREAUCRATIC CHARACTERISTICS OF NGOS HAVE NOT CRYSTALLIZED.
ONLY SOME POSTULATES OF BUREAUCRATIC THEORY ARE PREVALENT IN ONLY SOME

06727 NARDIN, T.

INTERHATIONAL ETHICS AND INTERMATIONAL LAN

REVIEW OF INTERNATIONAL STUDIES, 18(1) (JAN 92), 19-30. A FAMILIAR THESIS ABOUT THE RELATION BETHEEN INTERNATIONAL ETHICS AND INTERNATIONAL LAH IS ARGUED. THE PURPOSIVE AMD PRACTICAL ASSOCIATION OF THE INTERNATIONAL SYSTEM IS EXAMINED. OBJECTIONS TO THE PRACTICE--PURPOSE DISTINCTION--IS SCRUTINIZED. NORMATIVE OBJECTIONS ARE OFFERED AND THE ARTICLE CONCLUDES THAT FOR INTERNATIONAL LAW TO PROVIDE A CONSISTENCE AND AUTHORITATIVE HAY OF DEALING WITH THE QUESTION OF LAWFULNESS, THE ANSWERS IT GENERATES MUST DERIVE FROM ITS ONM TRADITIONS AND PROCEDURES AND NOT FROM THE ARGUMENTS OF MORALISTS OR PHILOSOPHERS.

06728 NAROCHNITSKAYA, N.; BABAK, V.; NADEIN-RAYEVSKI, V. MODERN RUSSIAN MATIONALISM: SOURCES, ESSEMCE, PROSPECTS MEDITERRANEAN QUARTERLY: A JOURNAL OF GLOBAL ISSUES, $3(4)$ (FAL 92), 94-107. THE DESTRUCTION OF THE INSTITUTIONS OF THE SOVIET STATE AND THE DECOMPOSITION OF THE USSR HAVE CAUSED EUPHORIA IN AND THE DECOMPOSITION OF THE USSR HAVE CAUSED EUPHORIA IN
ONE PART OF THE SOCIETY AND A FEELING OF PAIN AND DEFEAT IN ONE PART OF THE SOCIETY AND A FEELING OF PAIN AND DEFEAT ANOTHER PART, RESULTING IN INCREASED ALIENATION. THIS ARTICLE EXPLORES THESE COMPLICATED DYNAMICS, TOGETHER WITH AN OBVIOUS WEAKNESS OF NEH LEGISLATION AND AN AHKHAR THE FIRST DEMOCRATIC PHENOMENA, WHICH HAVE LED TO DISAPPOINTMENT AND HAVE GIVEN A POWERFUL NEH IMPETUS TO WHAT
APPEARS TO BE A RAPID ESCALATION--A VERTIABLE AYALANCHE--IN APPEARS TO BE A RAPID ESCALATION--A VERTIABLE AVALANCHE--IN THE GROWTH OF RUSSIAN NATIONALISM. IT CONCLUDES THAT THE REVIVAL OF RUSSIAN NATIONALISM IS A REALITY OF CURRENT SOCIAL LIFE AND THAT A SOPHISTICATED POLICY, TAKING INTO
ACCDUNT DIFFERENT TRENDS IN THE RUSSIAN MATIONALISM MOVEMENT ACCDUNT DIFFERENT TRENDS IN
SHOULD BE ADOPTED FOR THEM.

06729 NASH, J.; SULLIVAN, $K$.

RETURM TO PORFIRISIMO

CULTURAL SURVIVAL QUARTERLY, 16(2) (SPR 92), 13-16, MEXICAN PRESIDENT CARLOS SALINAS DE GORTARI IS TURNING TO AN EXPORT-DRIVEN ECONOMY TO SOLVE THE COUNTRY'S PRESSING INTERMAL PROBLEMS. HE HAS BACKED THE FREE TRADE AGREEMENT WITH CAMADA AND THE UNITED STATES AND HAS ACCEPTED THE INTERNATIONAL MONETARY FUND'S CONDITIONS FOR PARTICIPATION IN THE GLOBAL ECONOHY. MEXICO'S MIDOLE AND LOWER CLASSES WILL BEAR THE COST OF SALINAS' ECONOMIC POLICIES, WHICH THREATEN INDIGENOUS PEOPLES IN "EJIDOS" (COMHUNALLY-HELD LANDS) AND WILL ELIMINATE STATE-SUBSIDIZED CREDIT AND CROPDISTRIBUTION AGENCIES THAT HAVE OFFERED SOME SECURITY TO THE COUNTRY'S SMALL FARMERS IN THE PAST.

06730 NASH, M.

HUNGARY: AN ASPIRANT STATE

CONTEMPORARY REYIEH, 260(1514) (MAR 92), 113-119.

THE APPLICATION OF AUSTRIA FOR FULL MEMBERSHIP OF THE EUROPEAN COMMUNITY HAD SIGNIFICANT IMPL ICATION ALSO FOR HUNGARY WHICH KNOWS THAT ONCE AUSTRIA IS SAFELY INSIDE, IT WILL DRAW HUNGARY AFTER IT. HUMGARY HAS ALRADY TAKEN ITS FIRST STEP TOWARDS EVENTUAL MEMBERSHIP. FIRST IT WILL HAVE TO EXPAND AND RESTRUCTURE ITS ECONOMY, DEMONSTATE ITS COMMI TMENT TO DEMOCRACY AND RECOGNIZE THE RIGHTS OF ETHNIC MINORITIES. IT IS NOT HUNGARY'S INTENTION TO SEEK MEMBERHSIP OF NATO, BUT TO SEEK CLOSE ASSOCIATE MEMBERSHIP OF A NEWLY
NATO, AND THE WESTERN EUROPEAN UMION. THE MOTTO OF MANY HUNGARIAN POLITICIANS IS "FAST CHANGE WITH AS FEW VICTIMS AS POSSIBLE".

06731 NASH, M.

THE UK PRESIDENCY OF THE EUROPEAN COMMUNITY CONTEMPORARY REVIEH, 261(1520) (SEP 92), 113-116.

THE PRESIDENCY OF THE EUROPEAN COMMUNITY IS ONE OF THOSE CONVENTIONS WHICH HAVE GROWN UP AND HAVE BECOME

INSTITUTIONALIZED. THE PRESIDENCY ROTATES AMONG THE MEMBER NATIONS EVERY SIX MONTHS AND GREAT BRITIAN ANTICIPATED ITS TURN IN THE SECOND HALF OF THE YEAR 1992. THE REAL LEITMOTIF OF ITS PRESIDENCY IS ECONOMIC AND FINANCIAL CONVERGENCE WITHIN THE MEMBER STATES. THIS ARTICLE SUGGESTS THAT BOTH THE UK AND THE EUROPEAN COMMUNITY WILL NOT BE QUITE THE SAME THE OTHER SIDE OF THE CURRENT PRESIDENCY. BRITAIN MUST EMPHASISE THAT THE STATE HOLDING THE PRESIDENCY HAS A DUTY FIRST AND FORMOST TO MANAGE COMMUNITY AND INTER-GOVERNMENTAL BUSINESS, AND IT WUST BE SEEN TO PRIORITIZE THIS. IN SO DOING THE UK MAY FIND THAT MUCH OF THAT ROLE LEAVES AN INDELIBLE IMPRINT UPON ITSELF.

06732 NASH, N.

FORCED CELEBRATIONS

FAR EASTERN ECONOMIC REVIEW, 151(17) (APR 91), 18-19. THE CONTINUING FAILURE OF CHINA'S ATTEMPT TO FORCE TIBET INTO THE MOULD OF AN OBEDIENT MINORITY AREA WITHIN THE PEOPLE'S REPUBLIC HAS BENE DRAMATIZED BY PEKING'S CLUMSY ATTEMPTS TO CELEBRATE THE FORTIETH ANMIVERSARY OF 23 MAY 1991 OF THE SO-CALLED PEACEFUL LIBERATION OF TIBET. THE AUTHORITIES IN PEKING HAVE CHOSEN TO MARK THE EVENT BY A LAVISH PROGRAM OF FESTIVITIES IN LHASA, BACKED BY PROPAGANDA ABOUT THE ECONOMIC MODERNIZATION OF REMOTE RURAL AREAS, AND THE SELECTIVE HONORING OF SOME TIBETAN CULTURAL SYMBOLS. BUT
THE TRUE NATURE OF THE OCCASION HAS BEEN UNDERLINED BY MILITARY BUILD-UP DESIGNED TO INSURE THAT TIBETAN MATIONALISTS DO NOT CELEBRATE THE OCCASION IN WAYS THAT MIGHT NOT BE TO PEKING'S LIKING.

06733 NASH, N.

THE LAMA'S LEGACY

FAR EASTERN ECONOMIC REVIEH, 155(28) (JUL 92), 19-20. ON 27 JUNE, 1992, THE CHINESE GOVERNMENT ANNDUNCED THAT IT HAD APPROVED AN EIGHT-YEAR-OLD "LIVING BUDDHA," AS THE $17 T H$ "KARMAPA, OR HEAD OF THE KARMA KAGYU, OME OF TIBETAN UUDHISM'S FOUR MAIN SECTS. IT WAS THE FIRST TIME SINCE CHINESE COMMUNISTS--THAT PEKING HAD MADE AN ENDORSEMENT OF SUCH SIGNIFICANCE TO TIBET BUDOHISM. A FEW WEEKS EARLIER, SUCH SIGNIFICANCE TO TIBET BUDOHISM. A FEH HEEKS EARLIER,
KARMA KAGYU REPRESENTATIVES HAD DISCOVERED THE YOUNG BOY' IN KARMA KAGYU REPRESENTATIVES HAD DISCOVERED THE YOUNG BOY
EAST TIBET. HE IMWEDIATELY ASSUMED HIS MONASTIC NAME AND EAST TIBET. HE IMMEDIATELY ASSUMED HIS MONASTIC NAME AND TITLE, YGEN THINLEY RINPOCHE, THUS FORESTALLING ANY CHINESE
INTERVENTION IN THE DISCOVERY PROCESS. CHINA IS CURRENTLY AT INTERVENTION IN THE DISCOVERY PROCESS. CHINA IS CURRENTL
PAINS TO SHOW A PUBLIC FACE OF TOLERANCE OF RELIGIOUS

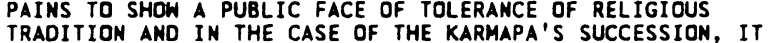
TRADITION AND IN THE CASE OF THE KARMAPA'S SUCCESSION, IT COULD DO LITTLE ELSE. HOHEVER, MANY IN TIBET FEAR THAT CHIMA WILL ATTEMPT TO USE THE NEH

06734 NASR, $S$.

DEMOCRACY AND THE CRISIS OF GOVERMABILITY IN PAKISTAN ASIAN SURVEY, $22(6)$ ( JUN 92), 521-537.

DE USHER IN AN ERA OF PRDGRESS AND PROSPERITY IN THEIR COUNTRY THE TRAVAILS OF THE PAST FDUR YEARS OF DEMOCRACY HAVE BEEN FAR FROM COMFORTING. THIS ARTICLE OFFERS AN ANALYTICAL NARRATIVE WICH SEEKS TO EXPLICATE THE EVIDENT DECAY OF PAKISTAN'S POLITICAL INSTITUTIONS SINCE 1988 BY IDENTIFYING THOSE VARIABLES THAT HAVE CONTROLLED THE DEVELOPMENT OF DEMOCRACY IN THAT COUNTRY THUS FAR, AND WILL DISCERN CAUSAL RELAIIONS BETWEEN KEY VARIABLES WITH A VIEW TO ELUCIDATING THE DIALECTIC OF THE DEMOCRATIZATION PROCESS IN PAKISTAN AND POINT TO HAZARDS LIKELY TO THREATEN ITS ORDERLY DEVELOPMENT.

06735 NASRALLAH, $F$.

RENEWED RIFT BETWEEN DAMASCUS AND WASHIMGTON? MIDDLE EAST INTERMATIONAL, (423) (APR 92), 16-18.

IN THE MONTHS PRECEDING THE CRISIS IN THE GULF, AND THEN AFTER THE END OF THE SECOND GULF HAR, SYRIA DID MUCH TO IMPROYE ITS STANDING IN THE EYES OF THE UNITED STATES: IT COOPERATED ON THE HOSTAGE FRONT BY USING ITS GOOD OFFICES AND COORDINATING BETWEEN WASHINGTON AND TEHRAN, WHICH AND COORDINATING BETWEEN WASHINGTON AND TEHRAN, WHICH RESULTED IN THE FREEDOM OF MOST NESTERN HOSTAG RETICENTLY EMBARKED ON A SEMBLANCE OF ECONOMIC
LIBERALIZATION; IT FREED A NUMBER OF POLITICAL PRISONERS; LIBERALIZATION; IT FREED A NUMBER OF POLITICAL PRISONERS; AND IT ENGAGED IN A HIGH-PROFILE DESTRUCTION OF OPIUM FI
IN LEBANON. THESE ACTIONS CULMINATED A DECADE OF GRADUAL IN LEBANON. THESE ACTIONS CULMINATED A DECADE OF GRADUAL RAPPROCHEMENT BETWEEN SYRIA AND THE UNITED STATES. HOWEVER, THERE IS EVERY INDICATION THAT A U.S.-SYRIAN RELATION CAN ONLY BE TACTICAL. A NUMBER OF FACTORS--SYRIA'S COMPLICITY IN THE HOSTAGE SAGA IN LEBANON, ITS ABYSMAL
RIGHTS RECORD AND ITS POSITION ON HASHINGTON'S LIST OF STATES SPONSORING TERRORISM--MITIGATE AGAINST A DEEPER, LONGER LASTING "STRATEGIC RELATIONSHIP" BETHEEN THE THO 
COUNTRIES. DISAGREEMENTS OVER SYRIA'S ROLE IN THE PERSIAN GULF AND LEBANON HAVE ALSO PUSHED THE TWO STATES FURTHER APART.

06736 NASRALLAH, $F$.

SYRIA'S POST-HAR GAINS AND LIABILITIIES

MIDDLE EAST INTERNATIONAL, (396) (MAR 91), 20-21. THERE IS NOT QUESTION THAT THE GULF CRISIS HAS BROUGHT UNQUESTIONABLE GAINS FOR THE SYRIAN REGIME. IN THE SHORT TERM HAFEZ AL-ASSAD MANAGED TO END HIS DIPLOMATIC ISOLATION AND MARGINALIZATION; THE SYRIAN REGIME WAS GIVEN A "GREEN LIGHT" BY AMERICA TO TAKE OVER LEBANON; ANO TRADE CONTACTS WITH EUROPE RESUMED. HOWEVER IN THE LONG TERM, THE LIABILITIES OF SYRIA'S SIDING WITH THE ANTI-IRAQ COALITION LIABILITIES OF SYRIA'S SIDING WITH THE ANTI-IRAQ COALITION MAY OUTWEIGH THE SHORT-TERM GAINS. AMERICA'S EMBRACE OF THE OIL-RICH GULF MONARCHIES MIGHT ERODE THE LEGITIMACY OF THE VERY REGIMES AMERICA WAS TRYING TO PROTECT ; IF IT ENCOURA DEMOCRACY IN THE REGION, THERE WILL BE LITTLE ROOM FOR AIS MISSION BY JOINING THE CDALITION AND HELPING THE U.S., AIS MISSION BY JOINING THE CDALITION

06737 NASRALLAH, F.

SYRIA'S STRATEGIC REDEPOLYMENT IN LEBANON MIDOLE EAST INTERNATIONAL, 436 (OCT 92), 18-19.

THE CRITERIA HAS BEEN SET OUT BY WHICH THE SYRIAN FORCES IN LEBANON ARE TO REDEPLOY. THERE IS MO MENTION OF A TIMETABLE FOR A FINAL SYRIAN RETREAT BUT OF A STRATEGIC REDEPOLYMENT OF FORCES. THIS ARTICLE DETAILS CONTRADICTORY INTERPRETATIONS, THE REGIONAL AND DOMESTIC PERSPECTIVE, AND THE U.S. FACTOR.

06738 NASUTION, A.

RECENT ECONOMIC REFORM IN INDONESIA

INDONESIAN QUARTERLY, 19(1) (WIN 91), 12-26.

THIS ARTICLE CONSIDERS THE PERIOD IN INDONESIA BETHEEN 1986 AND 1990, WHEN THE COUNTRY ADOPTED A SERIES OF DEREGULATION MEASURES COVERING NEARLY ALL ASPECTS OF THE INDONESIA'S CASE IS PRESENTED AS INSTRUCTIVE FOR DEVELOPING INDONESIA'S CASE IS PRESENTED AS INSTRUCTIVE FOR DEVELOPIM
COUNTRIES. THE OIL DEPENDENCY OF INDONESIA'S ECONOMY IS DISCUSSED IN THIS CONTEXT. ALSO, THE STABILIZATION PROGRAM DISCUSSED IN THIS CONTEXT. ALSO, THE STABILIZATION PROGRAM
OF 1983-1986, THE OBJECTIVE OF WHICH WAS TO BRING THE LEVEL OF DOMESTIC AGGREGATE DEMAND IN LINE HITH THE LEVEL AND OF DOMESTIC AGGREGATE DENAND IN LINE HITH THE LEVEL AND GROWTH OF PRODUCTIVE CAPACITY OF THE ECONOMY, ANO THE ADJUSTMENT PROGRAM OF $1986-199$
DEREGULATION, ARE EXAMINED.

06739 NATHAN, J.

A NEW HORLD ORDER? POLICY OR PLATITUDE

VIRGINIA QUARTERLY REVIEW, 68 (3) (SUM 92), 421-440.

SEVERAL YEARS AGO, THE BUSH ADMINISTRATION CALLED FOR A NEW WORLD ORDER, YET THE SUBSTANCE OF AMERICAN POLICY SEEMED MORE AN EXERCISE IN UNABASHED NATIONAL NARCISSISM THAN ANY NEW, ENTHUSIASTIC EMBRACE OF MULTILATERAL INSTITUTIONS. THIS ARTICLE ARGUES THAT INSTEAD OF TRANSCENDING HISTORY, THE BUSH ADMINISTRATION HAS MADE SUBMISSION TO EVENTS A VIRTUE. POLICIES ONCE PROFFERED ENTHUSIATICALLY, HAVE EVANESCED. THE EVENTS IN PANAMA AND COLUMBIA, THE DRUG WAR, ENERGY POLICY,

06740 NATHAN, J.

REVISING THE WAR POWER ACTS

ARMED FORCES AND SOCIETY, 17(4) (SUM 91), 513-544.

THIS ARTICLE ARGUES THAT THERE WERE UNINTENDED

AMBIGUITIES AND UNFORSEEN EXIGENCIES IN THE ORIGINAL WAR

POHERS LEGISLATIOM THAT HAYE CONFOUMDED SYSTEMATIC

APPLICATION OF THAT ACT. ALSO INHIBITING CONGRESS HAS BEEN

APPLICATION OF THAT ACT. AL SO INHIBITING CONGRESS HAS BEEN

ACCEPTANCE OF AN INCORRECT FORMULA-THAT THE HAR POWERS ACT
"REPORT" TRIGGERS THE WITHDRAHAL OF U.S. TROOPS NO LATER

THAN 90 DAYS AFTER THEY WERE FIRST COMMITTED. IN FACT, IT IS NOT THE REPORT THAT TRIGGERS THE 90-DAY CLOCK, BUT THE MILITARY ACTIVITY ITSELF THAT STARTS IT, IRRESPECTIVE OF ANY REPORT. AN IMPROVED WAR POWERS ACT WOULD REQUIRE THE EXECUTIVE TO PROVIDE REPORTS THAT ARE MORE TIMELY AND MORE EXECUT TVE TO PROVIDE REPORTS THAT ARE MORE TIMELY AND MORE EXTENSIVE. IT WOULD RETHINK THE OBLIGATION THAT TROOPS RETURN WITHIN 90 DAYS. AND IT WOULD COMPEL MORE THOROUG CONSULTATIONS PURSUANT TO ANY MILITARY UNDERTAKING. AN IMPROVED WAR POWERS STATUTE WOULD COME TO GRIPS HITH THE "STANDING" OF CONGRESS IN COUR

06741 NATORP, $K$

SOUTH AFRICANS BECOMING AWARE OF WHAT DEMOCRACY MEANS GERMAN TRIBUNE, 31 (1499) (JAN 92) 2

ONLY NOW ARE WHITE SOUTH AFRICANS GRADUALLY REALIZING THAT DEMOCRACY CAN ALSO MEAN A LOSS OR AT LEAST A SHARING OF POWER AND THAT OTHER PARTIES AND OTHER SECTIONS OF THE POPULATION CAN HAVE FUNDAMENTALLY DIFFERENT VIEWS. THE CLASH BETWEEN DE KLERK AND MANDELA WHICH WAS FOLLOWED BY A CONCILIATORY HANDSHAKE, WAS A FIRST LESSON IN DEMOCRACY. IN THE END THE TWO POLITICIANS WILL HAVE NO CHOICE BUT TO COME TO SOME AGREEMENT. CONFIDENCE CANHOT GROW IN AN ATMOSPHERE OF UNCERTAINTY, AND THE ECONOMY CANMOT GROH HITHOUT
CONFIDENCE IN SOUTH AFRICA'S NEW LEADERSHIP. A STAGHATING ECONOMY WOULD DESTABLIIZE THE NEW SOUTH AFRICA WHICH DE CLERK AND MANDELA INTEND BUILDING, REGARDLESS OF HOW PERFECT ITS FUTURE CONSTITUION MAY BE.

06742 NATTRASS, $N$

CONTROVERSIES ABOUT CAPITALISM AND APARTHEID IN SOUTH AFRICA: AN ECONOMIC PERSPECTIVE

JOURNAL OF SOUTHERM AFRICAN STUDIES, $17(4)$ (DEC 91),

$654-678$

THE CONTROVERSY ABOUT THE RELATIONSHIP BETHEEN APARTHEID AND CAPITALISM IS REVIWED FROM AN ECONOMIC PERSPECTIVE. ON THE METHODOLOGICAL SIDE IT IS ARGUED THAT DIFFERENT UNDERSTANDINGS OF WAGE DETERMINATION AND OF THE DISTINCTION BETWEEN THE INTERESTS OF CAPITAL AND CAPITALISM, HAVE BEEN A BETWEEN THE INTERESTS OF CAPITAL AND CAPITALISM, HAVE BEEM
SOURCE OF CONFUSION. THE OLD LIBERAL-RADICAL DEBATE WAS SOURCE OF CONFUSION. THE OLD LIBERAL-RADICAL DEBATE CONCERNED HITH THE CLASH BETHEEN NEO-CLASSICAL AND ALTERNATIVE ECONOMIC PERSPECTIVES, OVER THE PAST DECADE, ADWEVER, SOCIAL-DEMOCRATIC IDEAS HAVE BECOME MORE POPULAR AND REPRESENT A POTENTIAL MIDOLE GROUND BETHEEN THE OLD AND REPRESENT A POTENTIAL MIDOLE GROUND BETWEEN THE OLD EXTREMES. A MOVE TOWARDS POSITIVE DISCUSSION HAS BEEN
EASIER BY RECENT DEVELOPMENTS IN THE POL ITICAL SPHERE TOHARDS A NEGOTIATED TRANSITION AHAY FROM APARTHEID.

06743 NATZ, M.

YEMENI UNITY AND SAUDI SECURITY

MIDDLE EAST POLICY, 1(1) (1992), 117-135.

NOW THAT YEMEN IS UNITED, TENSION BETWEEN YEMEN AND SAUDI ARABIA HAS ARISEN OVER A NUMBER OF ISSUES, INCLUDING THEIR COMMON BORDER, OIL, ECONOMIC RELATIONS, YEMENI FOREIGN POLICY DURING THE GULF CRISIS AND SAUDI INVOLVEMENT IN YEMEN'S INTERMAL AFFAIRS. THIS STUDY ATTEMPTS TO SHOW THAT THIS SAUDI-YEMENI TENSION IS NOT LIKELY TO ABATE, BUT WILL CONTINUE AND MAY EVEN INCREASE. THE STUDY EXAMINES: THE LIKELY SERIOUSHESS OF SAUDI-YEMENI TENSION; THE RELATIVE STRENGTHS AND WEAKNESSES OF SAUDI ARABIA AND YEMEN; AND THE POSSIBILITY OF OTHER STATES AIDING YEMEN IN ITS DISPUTE WITH THE KINGDOM.

06744 NAU, H.

WINNING THE PEACE

NATIONAL REVIEH, XLIII(5) (APR 91), 35-37

THE CONVENTIONAL WISDOM IS THAT THE UNITED STATES CANMOT LEAD A LONG-TERM PEACE EFFORT IN THE MIDOLE EAST WITHOUT LEAD A LONG-TERM PEACE EFFORT IN THE MIDOLE EAST WITHOUT EXHAUSTING ITS OWN ECONOMIC RESOURCES. THIS ARTICLE ARGUES EXHATSTING ITS OWN ECONOMIC RESOURCES. THIS ARTICLE ARGUES THAT CONVENTIONAL WISDOM IS WRONG. IT DRAWS ON THREE LESSONS FROM EUROPE: WAR NEVER ENSURES PEACE; PEACE IS NOT POSSIBLE AND THE BEST ROAD TO POLITICAL COMMUNITY, BEHIND A SHIELD OF AND THE BEST ROAD TO POLITICAL COMMUNITY, BEHIND A SHIELD OF DEFENSE, IS OPEN COMHERCE. IT ARGUES THAT THE U.S. SHOULD ACTIVELY PURSUE THE GOALS OF PEACE AND OPEN COMMERCE IN THE REGION. THE
INACTION.

06745 NAUMANN, $K$

THE ROLE OF THE "BUNDESWEHR" IN A CHANGING SECURITY ENVIRONMENT

RUSI JOURNAL, $137(5)$ (OCT 92), 12-16

IN THIS ARTICLE, GENERAL NAUMANN DISCUSSES THE THREEFOLD ROLE OF THE BUNDESHEHR: AS A PROTECTOR OF NATO TERRITORY; AS A MILITARY COMPONENT IN THE BALANCE OF EUROPEAN STABILITY; AND FINALLY, THE OPPORTUNITIES FOR THE BUNDESWEHR AS PART OF AN INTERNATIONAL CORPS JOINTLY RESPONSIBLE FOR INTERNATIONAL SECURITY IN A PERIOD OF POLITICAL AND MIL ITARY UPHEAVAL. HE SUGGESTS THAT THE QUANITY OF FORCES IS PRIMARILY DETERMINED BY INTERNATIONAL AGREEMENTS AND THEN BY RESOURCES AVAILABLE.

06746 NAUMKIN, $V$

ISLAM IN THE STATES OF THE FORMER USSR

ANNALS OF THE AMERICAN ACADEMY OF POLITICAL AND SOCIAL SCIENCE, (524) (NOV 92 ), 131-142.

THE RICH INTELLECTUAL LIFE OF ISLAM WAS ELIMINATED UNDER THE SOVIET SYSTEM, BUT A VIGOROUS IF UNSOPHISTICATED POPULAR TRADITION REMAINED. AFTER PERESTROIKA, AN ISLAMIC MOVEMENT EMERGED AS A FORM OF POLITICAL PROTEST IN THE CENTRAL ASIAN REPUBLICS. SECULAR NATIONALISM AND ETHNIC CONFLICT WITHIN AND BETWEEN THE NEW REPUBLICS ALSO PROVIDED POLITICAL DYMAMICS. THROUGHOUT THE CHANGE, ISLAM HAS SERVED AS A
SYMBOL OF IDENTITY, A FORCE FOR MOBILIZATION, AND A PRESSURE SYMBOL OF IDENTITY, A FORCE FOR MOBILIZATION, AND A PRESSUR
FOR DEMOCRACY. EVEN IF IT IS SUCCESSFUL POLITICALLY, IT FOR DEMOCRACY. EVEN IF IT IS SUCCESSFUL POL
FACES ECONOMIC CHALLENGES BEYOND ITS GRASP.

06747 NAVARRO, V.; ENGELMANM, H.O.; GOERTZEL, T.

NATAR, O T ENGELMANN, H.O.; GOERTZEL, CAPITALISM VERSUS DEBATE ON
SOCIALISM INTERNATIONAL JOURMAL OF HEALTH SERVICES, 22(4) (1992),

THIS SERIES OF EXCHANGES FOCUSES ON THE QUESTION OF WHETHER CAPITALISM HAS PROVED TO BE A BETTER SYSTEM THAN SOCIALISM FOR IMPROVING PEOPLE'S LIVES. 
06748 NAVARRO, $V$ HAS SOCIALISM FAILED? AN ANALYSIS OF HEALTH INDICATORS UNDER SOCIALISM INTERNATIONAL JOURNAL OF HEALTH SERYICES, 22(4) (1992), 583-601.

THE AUTHOR REFUTES THE WIDELY-HELD ASSUMPTION THAT CAPITALISM HAS PROVEN SUPERIOR TO SOCIALISM IN RESPONDING TO HUMAN NEEDS. HE SURVEYS THE HEALTH CONDITIONS OF THE HORLD'S POPULATION, CONTINENT BY CONTINENT, AND SHOHS THAT SOCIALISM AND SOCIALIST FORCES HAVE BEEN, FOR THE MOST PART, BETTER ABLE TO IMPROVE HEALTH CONDITIONS THAN CAPITALISM AND CAPITALIST FORCES. IN THE UNDERDEVELOPED WORLD, SOCIALIST FORCES AND REGIMES HAVE, MORE FREQUENTLY THAN NOT, IMPROVED HEALTH AND SOCIAL INDICATORS MORE THAN CAPITALIST' FORCES AND REGIMES; IN THE DEVELOPED WORLD, COUNTRIES WITH STRONG SOCIALIST FORCES HAVE BEEN BETTER ABLE TO IMPROVE HEALTH CONDITIONS THAN THOSE COUNTRIES LACKING, OR HAVING WEAK, SOCIALIST FORCES. THE SOCIALIST EXPERIENCE HAS, OF COURSE, ALSO INCLUDED NEGATIVE DEVELOPMENTS THAT HAVE NEGATED IMPORTANT COMPONENTS OF THE SOCIALIST PROJECT. STILL, THE EVIDENCE SHOWS THAT THE HISTORICAL EXPERIENCE OF SOCIALISM HAS NOT BEEN ONE OF FAILURE. FOR THE MOST PART, IT HAS BEEN HAS NOT BEEN ONE OF FAILURE. FOR THE MOST PART, IT HAS
MORE SUCCESSFUL THAN CAPITALISM IN IMPROVING THE HEALTH MORE SUCCESSFUL THAN CAPITALISM IN IMPR
CONDITIONS OF THE WORLD'S POPULATION.

06749 NAYAR, 8.

THE POLITICS OF ECONOMIC RESTRUCTURING IN INDIA: THE PARADOX OF STATE STRENGTH ANO POLICY WEAKNESS JOURNAL OF COMMONWEALTH AND COMPARATIVE POLITICS, 30(2) JUL 92 ), 145-171.

IN THE WAKE OF HIS ACCESSION TO POWER IN 1984, RAJIV GANDHI UNDERTDOK A MAJOR EFFORT AT ECONOMIC RESTRUCTURING. THE STRIKING FEATURE PERTAINING TO HIS ENDEAVOURS IS THE VARIANT OUTCOMES IN TERMS OF SUCCESS OR FAILURE. THE ANALYTICAL PUZZLE FOR INVESTIGATION IS WHY THE SAME STATE ENCOUNTERED VARIANT OUTCOMES WITHIN THE SAME BROAD ARENA OF ECONOMIC RESTRUCTURING. IT CONCLUDES THAT THE STATE HAD BEEN TOO SUCCESSFUL IN CHANGING ECONOMY AND SOCIETY IN ACCORDANCE WITH ITS VISION, BUT THE CHANGED ECONOMIC STRUCTURE HAD BECOME A FETTER ON THE STATE'S POLICY FLEXIBILITY, BLOCKING FURTHER NECESSARY CHANGE BY RENDERING ECONOMIC POLICY REFORM DIFFICULT.

06750 NAYAR, $K$.

KASMIR: RE-READING ITS PAST IN ORDER TO PROFFER A PRACTICABLE SOLUTION

ROUND TABLE, 323(323) (JUL 92), 303-314

NOTHING HAS BEDEVILLED INDO-PAKISTAN RELATIONS MORE THAN THE STATE OF JAMMU AND KASHMIR. HAD THE MAJARAJA DECIDED OM KASHMIR'S ACCESSION AHEN GREAT. BRITIAN HAD THE AUTHORITY TO SASE IT THROUGH THERE WOUID HAYE BEEN NO TROUBLE BUT, AFTER SEE IT THROUGH, THERE WOULD HAVE BEEN NO TROUBLE. BUT, AFTER TERRITORY. THIS ARTICLE ASSESSES: KASHMIR ACCESSION AND PLEBISCITE PROPOSALS: THE SECURI KY COUNCIL DEBATE: THE UN COMMISSION; AND, DEVELOPMENTS SINCE 1960 . IT SUGGESTS THAT COMMISSION; AND, DEVELOPMENTS SINCE 1960 . IT SUGGESTS THAT
THE PRESENT LINE OF CONTROL BETHEEN INDIA AND PAKISTAN SHOULD BECOME AN INTERNATIONAL BORDER.

06751 NCGURN, $W$.

THE TRIALS OF CLARENCE THOMAS

NATIONAL REVIEN, XLII(14) (AUG 91), 36-40.

THE NOMINATION OF CLARENCE THOMÁS TO THE U.S. SUPREME COURT HAS PROVIDED THE POLITICAL LEFT WITH A DANGEROUS CHALLENGE: HOW TO OPPOSE HIS APPOINTMENT WITHOUT DIVIDING THEIR OWN CONSTITUENCY. THOMAS'S MESSAGES OF SELF-HELP AND FAMILY YALUES, HIS SKEPTICISM ABOUT GOVERNMENT-IMPOSED QUOTAS, AND ABOVE ALL HIS RE-AFFIRMATION OF THE VALIDITY OF THE AMERICAN PROPOSITION THREATEN THE HEGEMONY OF AN OSSIFIED CIVIL-RIGHTS ESTABLISHMENT AND ITS RULING PARTY. THE BATTLE OVER THOMAS'S APPOINTMENT PITS FEMINIST AND PROQUOTA FACTIONS AGAINST BANK-AND-FILE BLACK DEMOCRATS. THE RESULTING CONFUSION WILL LIKELY RESULT IN APPROVAL OF HIS NOMINATION.

06752 NDUBISI, F.; DYER, $M$.

THE ROLE OF REGIONAL ENTITIES IN FORMULATING AND IMPLEMENTING STATE-WIDE GROWTH POLICIES

STATE AND LOCAL GOVERNMENT REVIEH, 24(3) (FAL 92), 117-127. ALTHOUGH MANY STATES CURRENTLY HAVE SOME FORM OF STATE PLANMING LEGISLATION, THE DEGREE OF RESPONSIBILITY GIVEN TO REGIONAL PLANNING ENTITIES VARIES FROM STATE TO STATE. THIS REGIONAL PLANHING ENTITIES VARIES FROM STATE TO STATE. THIS
ARTICLE COMPARES AND CONTRASTS THE RESPONSIBILITIES OF SUBARTICLE COMPARES AND CONTRASTS THE RESPONS IBILITIES OF SUB-
STATE REGIONAL COUNCILS IN DEVELOPING AND IMPLEMENTING STATE STATE REGIONAL COUNCILS IN DEVELOPING AND IMPLEMENTING STATE
LAND DEVELOPMENT AND GROWTH MANAGEMENT PROGRAMS. THE LAND LAND DEVELOPMENT AND GROWTH MANAGEMENT PROGRAMS. THE LAND REGULATION SYSTEMS OF SEVERAL STATES ARE REVIENED, BASED ON A FIVE-SYSTEM TYPOLOGY THAT REFLECTS A HIERARCHY OF REGIONAL
INYOLVEMENT IN STATE LAND REGULATION. THIS ANALYSIS SUGGESTS INVOL VEMENT IN STATE LAND REGULATION. THIS ANALYSIS SUGGES THE SUCCESS OF STATE-HIDE INITIATIVES IN LAND-USE REGULATION AND GRONTH MANAGEMENT.

06753 NEANDER, J.

BOTH BOUQUETS AND BRICKBATS FOR AND ABRASIVE OSSI SOCIAL DEMOCRAT
GERMAN TRIBUNE, (1477) (JUL 91), 4-5.

THIS ARTICLE PROFILES WOL FGANG THIERSE, A LEADING SOCIAL DEMOCRAT AND SPOKESMAN FOR THE INTERESTS OF FORMER EAST GERMANY. THIERSE IS A FAST AND IMAGINATIVE SPEAKER AND IS THE LOUDEST, MOST AGGRESSIVE POLITICIAN FROM FORMER EAST GERMANY. HOWEVER, HIS OUTSPOKEN TACTICS HAVE NOT EARNED HIM MUCH PRAISE WITHIN THE RANKS OF THE SOCIAL DEMOCRAT PARTY. MANY OF HIS COLLEAGUES HOPE THAT HE WILL TONE DOWN HIS RHETORIC, WHICH THEY CLAIM IS ENCOURAGING THE DIVISION BETWEEN THE TWO HALVES OF NOW-UNIFIED GERMANY.

06754 NECKERMANN, $P$

WHAT WENT WRONG IN GERMANY AFTER THE UNIFICATION?

EAST EUROPEAN QUARTERLY, XXVI (4) (WIN 92) 447-469.

DESPITE THE INTENSE PUBLIC DESIRE FOR THE REUNIFICATION OF GERMANY, THE MONEYMOON DIDN'T LAST LONG BECAUSE BOTH EAST AND WEST GERMANS UNDERESTIMATED THE VAST SCDPE OF THEIR

DIFFERENCES AND THE PROBLEMS THEY WOULD ENCOUNTER.

06755 NEDERMAN, C.J.

FREEDOM, COMMUNITY, AND FUNCTION: COMMUNITARIAN LESSONS OF MEDIEVAL POLITICAL THEORY

AMERICAN POLITICAL SCIENCE REVIEW, 86(4) (DEC 92), 977-988.

THE COMMUNITARIAN CRITIOUE OF LIBERAL INDIVIDUALISM IS EXPERIENCING SOMETHING OF A DECLINE. ONE OF THE REASONS FOR THE FAILURE OF COMHUNITARIANS TO MAKE A LASTING IMPACT ON LIBERAL THEORY MAY BE THE HISTORICAL PRECEDENTS TO WHICH COMMUNITARIANS HAVE TURNED, SUCH AS ARISTOTLE AND CIVIC REPUBLICANISM. IN THIS PAPER, THE AUTHOR ARGUES THAT COMMUNITARIAN THEORY MAY MORE FRUITFULLY DRAW UPON A MODEL OF THE RELATION BETWEEN INDIVIDUAL AND COMHUNITY DERIVED FROM THE LATIN MIDOLE AGES. THIS APPROACH--COMMUNAL FUMCTIONALISM--CLAIMS THAT THE COMMUNITY IS ESSENTIALLY COMPOSED NEITHER OF INDIVIDUALS NOR CITIZENS BUT RATHER OF FUNCTIONAL GROUPS OR PARTS ARRANGED ACCORDING TO THEIR CONTRIBUTION TO THE COMMUNITY. THE AUTHOR CONSIDERS THO VARIANTS OF THIS FRAMEWORK, JOHN OF SALISBURY'S PHYSIOLOGICAL VERSION AND MARSIGLIO OF PADUA'S CIVIC ACCOUNT. HE CLOSES HITH AN EVALUATION OF THE RELEVANCE, AND ALSO SOME OF THE LIMITATIONS, OF THE COMMUNAL FUNCTIONALIST MODEL IN RELATION TO THE REQUIREMENTS OF CONTEMPORARY COMMUNITARIAN THEORY.

06756 NEE, V.; YOUNG, F.W.

PEASANT ENTREPRENEURS IN CHINA'S "SECOND ECONOMY": AN INSTITUTIONAL AMALYSIS

ECONOMIC DEVELOPMENT AND CULTURAL CHANGE, 39(2) (JAN 91), 293-310.

THE PROMOTION OF A MARKET-ORIENTED POLICY IN CHINA AFTER 1978 SET THE STAGE FOR EXPLOSIVE GROWTH IN THE NUMBER OF PEASANT HOUSEHOLDS SHIFTING FROM SUBSISTENCE AGRICULTURE TO PRODUCTION FOR THE MARKETPLACE. THIS ARTICLE SEEKS TO

IDENTIFY THE INSTITUTIONAL CONTEXT THAT PROMOTES OR INHIBITS THE RISE OF SUCH PEASANT ENTREPRENEURSHIP IN CHINA AFTER
MARKET REFORM.

06757 NEEDLER, M.

EL SALVADOR: THE MILITARY AND POLITICS

ARMED FORCES AND SOCIETY, 17(4) (SUM 91), 569-588.

THIS ARTICLE CONSIDERS WHETHER THE CONFLICT IN EL SALVADOR, CONCEPTUALIZED BY THE U.S. GOVERMMENT AS A BATTLE IN THE COLD WAR, BECOMES MORE AMENABLE TO SOLUTION IF SEEN STRICTLY ON ITS OWN TERMS. THE CURRENT STRUGGLE SEEMS MORE INTELLIGIBLE AS THE LATEST EPISODE IN THE POST-CONOUEST STRUGGLE OF A SPANISH-DESCENDED ELITE TO MAINTAIN CONTROL OF ITS LAND AGAINST THREAT FROM AN INDIAN-DESCENDED PEASANTRY. THE MILITARY AND PARAMILITARY CONDUCT OF THE STRUGGLE HAS ALIENATED THE NONINVOLVED CIVILIAN POPULATION FROM THE GOVERNMENT HITHOUT DRAWING THEM TO THE GUERRILLA CAUSE. SINCE NEITHER SIDE CAN WIN MILITARILY UNDER PRESENT CIRCUMSTANCES, A NEgOtIATED SETTLEMENT MAY BE ATTAINABLE.

06758 NEEDLER, $M$

PAPUA NEH GUINEA: WHERE THE STONE Age MEETS tHe SPACE AGe CONTEMPORARY REVIEW, 259(1506) (JUL 91), 19-22.

THE DISCOVERY BY' THE OUTSIDE, "WHITE," HORLD OF THE HIGHLANDS PEOPLES OF NEW GUINEA IS SO RECENT THAT MOVIES EXIST OF THE FIRST CONTACT. ALTHOUGH MANY TRIBES OF THE ISLAND NATION (WHO SPEAK OVER 700 LANGUAGES) ARE STILL LIVING RELATIVELY TRADITIONAL LIVES, THEY ARE LEARNING TO ACCOMMODATE THE OUTSIDERS AND THEIR NEH TECHNOLOGY. MANY OF THE TRIBES DISPLAY THE CAREFUL CALCULATIONS, MATERIALISM, THE TRIBES DISPLAY THE CAREFUL CALCULATIONS, MATERIALISM, AND LIVELY SENSE OF SELF-INTEREST THAT WILL
THRIVE IN THE PAUPA NEW GUINEA OF THE FUTURE.

06759 NEFF, D

AMERICA'S UMCONDITIONAL HAND-OUTS TO ISRAEL

MIDDLE EAST INTERNATIONAL, 435 (OCT 92 ), 3.

AS THE 3 NOVEMBER PRESIDENTIAL ELECTION APPROACHES, WASHINGTON HAS INCREASED ITS HAND-OUTS OF RECORD AMOUNTS OF MONEY, LOAN GUARANTEES, AND SOPHISTICATED WEAPONRY TO ISRAEL. THE LATEST GIFT TO ISRAEL IS THE CONTROVERIAL S10-BILLION IN LOAN GUARANTEES. A RECENT CONGRESSIONAL BILL, SIGNED BY PRESIDENT BUSH, GUARANTEES ONE HUNDRED PERCENT OF THE LOAN 
AND SCARECLY MENTIONS THE POSSIBILITY OF ISRAEL USING THE MONEY TO BUILD HOUSING UNITS IN THE OCCUPIED TERRITORIES. THE SAME BILL ALSO GAVE ISRAEL S3-BILLION IN ECOMOMIC AND MILITARY AID. IN ADDITIOM. THE WHITE HOUSE HAS ANMOUNCED THAT IT WILL PROYIDE ISRAEL HITH ADYANCED APACHE AND BLACX HAWK HELICOPTERS AND WILL POSITION OVER S300-MILLION WORTH OF MILITARY EQUIPMENT IN ISRAEL. BEYOND SUCH DIRECT OF MILITARY EQUIPMENT IN ISRAEL. BEYOND SUCH DIRECT FINANCIAL TRANSFERS, THE BUSH ADMINISTRATION IS ALREADY
HOLDING A SERIES OF TALKS WITH ISRAEL THAT COULD ULTIMATELY HOLDING A SERIES OF TALKS WITH ISRAEL THAT COULD ULLIMATE BE MORE PROF ITABLE THAN MERE ANMUAL AID. THESE INCLUOE
DISCUSSIONS ON HOW TO INCREASE MILITARY TECHNOLOGY-SHARING DISCUSSIONS ON HOH TO INCREASE MILITARY TECHNOLOGY-SHARING BETWEEN THE THO COUNTRIES. SOME SEE THE MOT IVATION OF S. ACTIONS SIMPLY AS AN UNABASHED ATTEMPT BY PRESIOEN ELECTIONS.

06760 NEFF, $D$.

BAKER'S ACHIEVEMENT

MIDOLE EAST INTERMATIONAL, (405) (JUL 91), 5-6

U.S. SECRETARY OF STATE JAMES BAKER HAS FASHIONED SOMETHING OF AN ARAB ALLIANCE IN FAVOR OF A PEACE CONFERENCE AND HAS PLACED THE BALL CLEARLY IN ISRAELI'S COURT, LEAVING ISRAEL PUBLICLY PERCEIVED AS THE NATION RESPONSIBLE FOR DETERMINING WHETHER A SERIOUS PEACE EMERGES OR THE DEADLOCK CONTINUES. BAKER'S PROPOSAL WAS A COMPROMISE ON TWO STICKING POINTS: UN REPRESENTATION AND THE NATURE OF THE PEACE CONFERENCE. THE UNITED STATES PROPOSED THE CONFERENCE TO BE CHAIRED BY ITSELF AND THE USSR WITH THE UN PRESENT AS A SILENT OBSERVER, ALONG WITH THE EUROPEAN COMMUNITY. AS FOR THE CONFERENCE, THE U.S. PROPOSED IT RECONVENE EVERY SIX MONTHS IF ALL PARTIES AGREED. WHILE MANY PROCEDURAL ISSUES, AS WELL AS THE LARGE OBSTACLE OF ISRAEL'S CONTINUED SETTLEMENT OF THE OCCUPIED TERRITORIES REMAIN IN THE PATH SOWARD PEACE, THE FACT THAT BAKER WAS ABLE TO SECURE THE APPROYAL OF SEVERAL ARAB STATES--EGYPT, JORDAN, LEBANOH, APPROVAL OF SEVERAL ARAB STATES--EGYPT, JORDAN,
SYRIA, AND SAUDI ARABIA--IS A PROMISING SIGN.

06761 NEFF, D.

BAKER'S DEXTERITY

MIDDLE EAST INTERNATIONAL, (412) (NDV 91), 6-7.

THE HOLDING OF THE MIDEAST PEACE CONFERENCE WAS YIEWED BY SOME AS LARGELY DUE TO THE DIPLOMATIC ABILITY AND PERSISTENCE OF U.S SECRETARY OF STATE JAMES BAKER. HIS OPENING SPEECH ON 30 OCTOBER SET THE MOOD BY PLEASING ARABS WITH ITS MENTION IHAT THE TALKS WERE BASED ON THE LAND-FORPEACE UN RESOLUTION 242, WHILE AT THE SAME TIME PACIFYIMG THE ISRAELIS BY NOTING THAT "TERRITORIAL COMPROMISE IS ESSENTIAL FOR PEACE." BAKER DISPLAYED HIS DIPLOMATIC DEXTERITY BY REWARDING THE PALESTINIANS FOR THEIR HUMILIATING ACCEPTANCE OF ISRAEL'S CONDITIONS FOR THE COMPOSITION OF THEIR DELEGATION. HIS APPROVAL OF AN ALTERNATE LIST OF PALESTINIAN "ADVISERS" AND HIS INSISTENCE THAT THE PALESTINIANS HAVE THE SAME 45-MINUTE PERIOD TO PRESENT THEIR CASE IN THE PLENARY SESSION AS OTHER DELEGATIONS AWARDED THE PALESTINIANS THE RECOGNITION THEY HAD NEVER BEFORE RECEIVED.

06762 NEFF, D.

BUSH AND SHAMIR READY FOR A SHOOT-OUT

MIDDLE EAST INTERMATIOMAL (421) (MAR 92), 3-4. DETERIORATING RELATIONS BETWEEN ISRAEL AND THE UNITED STATES TOOK ANOTHER PLUNGE IN MARCH WHEN BUSH ADMINISTRATION OFFICIALS LEAKED THAT ISRAEL WAS SELLING SECRET AMERICAN OFFICIALS LEAKED THAT ISRAEL WAS SELLING SECRET AMERICAN
MILITARY TECHNOLOGY TO OTHER COUNTRIES, INCLUDING CHINA AND MILITARY TECHNOLOGY TO OTHER COUNTRIES, INCLUDING CHINA ANO
SOUTH AFRICA, BOTH ON AMERICA'S EMBARGO LIST. WASHINGTON'S SOUTH AFRICA, BOTH ON AMERICA'S EMBARGO LIST. WASHINGTON'S
WILLINGNESS TO TALK ABOUT SUCH A SENSITIVE SUBJECT IS AN WILLINGNESS TO TALK ABOUT SUCH A SENSITIVE SUBJECT IS AN INDICATION OF HOW TOUGH THE ADMINISTRATION IS READY TO BE IM ITS POTENTIAL SHOOT-OUT WITH ISRAELI PRIME MINISTER SHAMIR OVER A FREEZE ON SETTLEMENTS IN THE OCCUPIED TERRITORIES A STATEMENTS THAT NO POHER CAN STOP ISRAEL'S SETTLEMENTS HAS PROYOKED AH INCREASIMG MUMBER OF CRITICAL LEAKS FROM PROVOKED AN INCREASING NUMBER OF CRITICAL LEAKS FROM WASHINGTON, RANGING FROM THE RELEASE OF A NEGATIVE REPORT OM TECHMOLOGY TRANSFER TO SOUTH AFRICA.

06763 NEFF, $D$.

BUSH LEAVES THE KURDS AT SADDAM'S MERCY

MIDDLE EAST INTERNATIONAL, (379) (APR 91), 3-4.

ALTHOUGH PRESIDENT BUSH'S POPULARITY REMAINS AT A HISTORIC HIGH OF AROUND 90 PERCENT, THERE IS SLOWLY DAWNING IN AMERICA A SENSE OF HORROR ABOUT THE DESTRUCTIVENESS OF THE WAR AGAINST IRAQ. GROWING FRUSTRATION AND OISILLUSIONMENT FED ON DAILY REPORTS OF THE SLAUGHTER OF REBELS AND CIVILIANS IN THE SHI'ITE SOUTH AND KURDISH NORTH BY SADDAM'S TRIUMPHANT ARMY WHILE THE U.S. ARMY SAT ON ITS HANDS ACROSS SOUTHERN IRAQ. THE ANNOUNCEMENT OF THE BUSH ADMINISTRATION THAT IT WOULD DO NOTHING DURING THE CIVIL WAR IN IRAQ MADE IT CLEAR THAT THE AMERICAN STRATEGY STOPPED WITH THE COMBAT.

06764 NEFF, D.

BUSH'S IRAQI CONTINGENCY PLANS

MIDOLE EAST INTERNATIONAL, (432) (AUG 92), 3-4.
THE HOTLY CONTESTED CAMPAIGN FOR PRESIDENT OF THE UNITED STATES HAS LED TO SOME UNUSUAL EVENTS IN THE FIRST HALF OF AUGUST. JAMES BAKER, ONE OF AMERICA'S MORE ESTEEMED SECRETARIES OF STATE, HAS SUDDENLY REASSIGNED TO HEAD PRESIDENT BUSH'S RE-ELECTION CAMPAIGN. PRESIDENT BUSH ANNOUNCED THAT THE UNITED STATES HAS READY TO GRANT ISRAEL'S LONG-DELAYED REOUEST FOR \$10 BILLION IN LOAN GUARANTEES. A STORY SURFACED IN THE NEW YORK TIMES WHICH CLAIMED THAT WASHINGTON WAS SEEKING A CONFRONTATION WITH SADOAM HUSSEIN ON THE DAY OF THE OPENING OF THE REPUBLICAN CONVENTION ON 17 AUGUST, TO "HELP THE PRESIDENT GET RE-ELECTED." THESE CHANGES HAVE FAR-REACHING AND MOSTLY NEGATIVE IMPLICATIONS FOR THE MIDOLE EAST PEACE PROCESS. IT IS INACCRUATE TO ATTRIBUTE THESE EVENTS SOLELY TO ELECTION-YEAR POLITICS, BUT ATTRIBUTE THESE EVENTS SOLELY TO ELECTION-YEAR POLITICS, BUT
IT IS ALSO IMPORTANT TO REMEMBER THAT ANYTHING IS POSSIBLE IN IS ALSO IMPORTANT

06765 NEFF, $D$.

CAN BUSH SEIZE HIS OPPORTUNITIES?

MIDDLE EAST INTERNATIONAL, (395) (MAR 91), 10-11.

THE 10O-HOUR GROUND CAMPAIGN THAT SMASHED IRAQ'S ARMY, FREED KUHAIT AND BROUGHT TOTAL VICTORY TO THE COALITION FORCES HAS SENT PRESIDENT BUSH'S POPULARITY SOARING. ALTHOUGH BUSH ADMITTED HE WAS STILL TOO ENGROSSED IN TYING UP THE LOOSE ENDS OF THE WAR, HE WAS CLEARLY AWARE THAT HE HAD TO MOVE FAST TO CAPITALIZE ON HIS POST-WAR POPULARITY. POSSIBLE FUTURE GOALS OF BUSH AND THE AMERICANS INCLUDE PROGRESS ON: SECURITY ARRANGEMENTS IN THE GULF REGION, ARMS CONTROL AND PROLIFERATION, ARAB-ISRAELI ISSUES, AND ECONOMIC COOPERATION IN THE REGION. BUSH CURRENTLY ENJOYS A--PERHAPS UNIQUE--OPPORTUNITY TO USE HIS POLITICAL CLOUT TO EFFECT CHANGE IN ISRAEL;S POLICY TOWARDS PALESTINE AND THE OCCUPIED TERRI TORIES.

06766 NEFF, D.

CLINTON SPELLS TROUBLE

MIDDLE EAST INTERNATIONAL, 436 (OCT 92), 4-5.

A LANDSLIDE VICTORY APPEARS TO BE LOOMING FOR DEMOCRATIC CONTENDER BILL CLINTON AS THE PRESIDENTIAL CAMPAIGN ENTERS THE FINAL WEEKS BEFORE POLLING ON 3 NOVEMBER. ISRAEL AMD THE THE FINAL WEEKS BEFORE POLLING ON 3 NOVEMBER. ISRAEL AND THE MIDOLE EAST HAVE NOT FIGURED AS AN ISSUE IN THE CAMPAI
CLINTON PRESIDENCY COULD SPELL DEEP TROUBLE FOR THE CLINTON PRESIDENCY COULD SPELL DEEP TROUBLE FOR THE

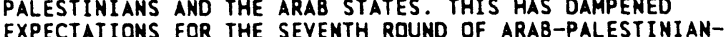
ISRAELI TALKS WHICH OPENED IN HASHINGTON IN OCTOBER.

06767 NEFF, D.

CLINTON'S SUSCEPTIBILITY TO ISRAEL'S ADVOCATES MINT THE QUESTION OF HOW SUSCEPTIBLE BILL CLINTON WILL BE TO THE INFLUENCE OF ISRAEL'S ADVOCATES IS A TROUBLING ONE. THIS QUESTION RECEIVED UNEXPECTEDLY MELODRAMATIC PUBLIC AIRING IN EARLY NOVEMBER WITH THE SUDDDEN RESIGNATION OF THE PRESIDENT OF THE POHERFUL PRO-ISRAEL LOBBY, AIPAC, AFTER HE HAD BRAGGED ABOUT ZIONIST INFLUENCE ON CLINTON. THE SCANDAL CAME AS AIPAC WAS SUFFERING A PERIOD OF CONTROVERSY--NOT BECAUSE OF PUBLIC CONCERN ABOUT ITS LOBBYING POWERS BUT BECAUSE OF INTERNAL DISPUTES. MEANHHILE, THE BUSH ADMINISTRATION IS WINDING DOWM AMID A SWIRL OF SCANDALS.

06768 NEFF, D.

FLAWS IN BAKER'S DOCTRINE

MIDDLE EAST INTERNATIONAL, (415) (DEC 91), 5.

THE HASHINGTON PHASE OF THE MADRID PEACE CONFERENCE IS TURNING OUT TO BE THE BIG NON-EVENT OF THE YEAR AS FAR AS THE MEDIA AND AMERICANS IN GENERAL ARE CONCERNED. THIS NEGLECT IS A REFLECTION OF THE BUSH ADMINISTRATION'S SHUNNING OF BOTH SIDES MORE THAN IT IS OF BEING CROWDED OFF THE FRONT PAGE BY OTHER NEWS STORIES. U.S. OFFICIALS HAVE MAINTAINED SUCH A COOL DISTANCE FROM THE AMERICAN TALKS THAT MAINTAINED SUCH A COOL DISTANCE FROM THE AMERICAN TALKS THA ANYTHING TO DO WITH THE PROCESS. THAT IMPRESSION WAS ANYTHING TO DO WITH THE PROCESS. THAT IMPRESSION WAS
REINFORCED BY SECRETARY OF STATE BAKER'S SUDDEN DECISION TO REINFORCED BY SECRETARY OF STATE BAKER'S SUDDEN DECISION TO
TRAVEL TO THE SOVIET UNION. THIS ALOOF ATTITUDE RESULTS FROM TRAVEL TO THE SOVIET UNION. THIS ALOOF ATTITUDE RESULTS FROY THE BADLY MISTAKEN SUPPOSITION BY THE ADMINISTRATION

06769 NEFF, D.

GEARING UP FOR ROUND THO

MIDOLE EAST INTERNATIONAL, (413) (NOV 91), 3-4.

AS THE SECOND ROUND OF MIDEAST PEACE TALKS APPROACHES, THE PRINCIPAL PLAYERS ARE FILLED WITH A MIX OF ANTICIPATION AND APPREHENSION. ANTICIPATION WAS HIGHEST ABOUT THE PALESTINIAN-ISRAELI TALKS, WHICH APPEAR TO HAVE THE GREATEST CHANCE OF PROGRESS. BUT THERE IS MUCH CONCERN OVER HOH YITZHAK SHAMIR IS TO BE CONYINCED TO HALT ISRAEL'S ACCELERATING ESTABLISHMENT OF SETTLEMENTS IN THE OCCUPIED TERRI TORIES. A LARGE MEASURE OF THE PALESTINIANS' SUCCESS WILL DEPEND ON PRESIDENT BUSH'S FORTITUDE. HIS DECLINING POPULARITY RATINGS HAVE WORRIED SOME OBSERVERS WHO FEAR HE MAY GIVE IN TO ISRAELI DEMANDS FOR THE SIO-BILLION LOAM GUARANTEE FOR ISRAELI SETTLEMENTS. THE ACTUAL TALKS (SCHEDULED TO BE HELD IN WASHINGTON) HILL FOCUS ON THO 
SUBSTANCE OF WHAT AUTONOMY INVOLVES.

06770 NEFF, $D$.

MORE WORDS, NO DEEDS

MIDOLE EAST INTERNATIONAL, (398) (APR 91), 11-12.

U.S. SECRETARY OF STATE, JAMES BAKER, HAS MADE A TOUR OF THE MIDOLE EAST WITH VISITS TO EGYPT, ISRAEL, AND SYRIA, AND MEETINGS WITH THE FOREIGN MINISTERS OF JORDAN AND SAUDI ARABIA. THIS TRIP AND A PROPOSED ONE IN THE FUTURE WAS CONDUCTED IN THE NAME OF FORWARDING THE PEACE PROCESS. BAKER PROCLAIMED THAT PEACE IN THE MIDDLE EAST WILL NOT OCCUR UNLESS THE PARTIES THEMSELYES REALLY WANT IT. THESE PROCLAMATIONS AND THE SUGGESTION THAT THE UNITED STATES IS PLAYING THE ROLE OF THE HONEST BROKER IN THE ARAB-ISRAELI CONFLICT ARE AT THE HEART OF THE TRUE PROBLEM: ISRAEL WOULD RATHER HAVE LAND THAN PEACE, AND THE UNITED STATES CONTINUES TO DISPLAY ITS WILLINGNESS TO SUPPORT ISRAEL WITH LARGE AMOUNTS OF FINANCIAL AID.

06771 NEFF, D.

PURSUING ISRAEL'S GOALS

MIDOLE EAST INTERNATIONAL, (397) (APR 91), 9-10.

THE GULF WAR MIGHT JUST AS WELL NOT HAVE HAPPENED AS FAR AS THE ISRAELI-PALESTINIAN CONFLICT IS CONCERNED. WASHINGTON HAS ALREADY MISSED ITS CHANCE TO UTILIZE POST-WAR MOMENTUM TO ADVANCE THE PEACE PROCESS. NEARLY TWO MONTHS AFTER THE WAR'S END, THE BUSH ADMINISTRATION WAS BACK TO DOING BUSINESS AS USUAL FOCUSING ON THE SAME OLD PROBLEMS HITH THE SAME LACK OF IMAGINATION OR FORCEFULNESS. THE U.S WILLINGNESS TO COOPERATE WITH ISRAEL IN DELAYING ANY TRUE MOVE TOWARDS A SOLUTION OF THE PALESTINIAN PROBLEM IS EVIDENCE OF THE POWER OF PRO-ISRAEL LOBBY GROUPS IN WASHINGTON.

06772 NEFF, D.

SETTLEMENTS BRING BUSH TO THE CROSSROADS

MIDDLE EAST INTERMATIONAL, (418) (FEB 92), 3-4.

CONFLICT BETWEEN THE UNITED STATES AND' ISRAEL IS

OCCURRING AT A TIME WHEN ISRAEL IS BEING LED BY ITS MOST

AGGRESSIVE PRO-SETTLEMENT LEADER (YITZHAK SHAMIR) AND

AMERICA BY ITS MOST DETERMINED ANTI-SETTLEMENT PRESIDENT (GEORGE BUSH). BUSH AGAIN FORCEFULLY EXPRESSED OPPOSITION TO SETTLEMENTS ON 24 JANUARY THROUGH HIS SECRETARY OF STATE, JAMES BAKER, WHO MET ISRAELI AMBASSADOR SHOVAL AND BLUNTLY TOLD HIM THAT THE UNITED STATES WOULD NOT FINANCE ISRAELI PROGRAMS (I.E SETTLEMENTS) CONTRARY TO U.S. POLICY. THE PROBLEM FOR BUSH IS HOW TO HELP THE SOVIET IMMIGRANTS STILL COMING TO ISRAEL, ALBEIT AT A GREATLY REDUCED RATE, AND AT COMING TO ISRAEL, ALBEIT AT A GREATLY REDUCED RATE, AND AT THE SAME TIME ENSURE THAT ANY SUCH AID IS NOT USED BY THE
SHAMIR GOVERNMENT IN ITS CURRENT RUSH TO ESTABLISH NEW SETTLEMENTS. ISRAEL SO FAR HAS SETTLED MORE THAN THIRTEEN PERCENT OF THE IMMIGRANTS IN THE OCCUPIED TERRITORIES, DESPITE A FORMAL CDMMITMENT NOT TO DO SO.

06773 NEFF, $D$.

THE COMPLEX AND MURKY DEALS TO HELP SADDAM

MIDDLE EAST INTERNATIONAL, (427) (JUN 92) 3-4.

SADDAM HUSSEIN'S TENACIOUS GRIP ON POWER IN IRAQ HAS CAUSED THE BUSH ADMINISTRATION TO SUFFER A CONSIDERABLE LOSS OF PRESTIGE. WHAT IS MORE DAMAGING, HOWEVER, IS THE GROWING MUMBER OF ALLEGATIONS THAT THE UNITED STATES HELPED SADDAM HUSSEIN TO INCREASE HIS POWER. FROM 1982, WHEN WASHINGTON REMOVED IRAQ FROM THE LIST OF TERRORIST NATIONS, TO JUST DAYS BEFORE IRAQ INVADED KUWAIT IN AUGUST 1990, THE REAGAN AND BUSH ADMINISTRATIONS HEAPED PRIVATE INTELLIGENCE, TRADE CONCESSIONS, DIPLOMATIC SUPPORT AND \$5 BILLION IN EASY LOANS OF THE \$5 BILLION, IRAO DEFAULTED ON \$1.9 BILLION, LEAVING THE AMERICAN TAXPAYER STUCK HITH THE BILL. OTHER CRITICS CHARGE THAT WASHINGTON ALLONED IRAQ TO ILLEGALLY USE U.S. COMMODITY LOANS TO BUY WEAPONS INSTEAD OF AMERICAN GRAIN, TO ENGAGE IN WIDESPREAD BRIBERY AND TO PURCHASE TECHNOLOGY TO MAKE NUCLEAR WEAPONS. THE CRITICS FURTHER CHARGED THAT THE ADMINISTRATION MISLED CONGRESS ABOUT IRAQ'S HUMAN RIGHTS RECORD AND ITS SUPPORT OF TERRORISM, AND THEN CRIMINALLY STALLED INVESTIGATIONS INTO IRAQ'S SCANDALOUS BEHAVIOR. NOH, THE CRITICS CHARGE. THE BUSH ADMINISTRATION IS INVOLYED IN A MASSIVE COVER-UP OF ITS FAILED POLICY.

06774 NEFF, D.

THE EMPTY RING TO BUSH'S "NEH HORLD ORDER"

MIDOLE EAST INTERNATIONAL, (396) (MAR 91) 3-6.

IN ARAB EYES, U.S. PRESIDENT GEORGE BUSH'S RHETORIC OF A NEH HORLD ORDER AND OF THE SANCTITY OF UN RESOLUTIONS PROVED TO BE SOMENHAT HOLLOW AS RELATIONS IN THE REGION RETURNED TO STATUS QUO ANTE AFTER THE END OF THE GUIL HAR. SECRETARY OF STATE JAMES BAKER'S TOUR THROUGH THE REGION RESULTED IN THE SAME TIRED PHRASES ABOUT THE NEED FOR RECIPROCITY AND THE IMPOSSIBILITY OF IMPOSING PEACE ON PARTIES WHO DO NOT WANT IT. IN SHORT, A HUGH OPPORTUNITY TO TAKE ADVANTAGE OF THE VAST POLITICAL CLOUT OF THE U.S. AND MOVE ON A SOLUTION TO THE ARAB-ISRAELI PROBLEM WAS WASTED. FURTHERMORE, THE EARLY STRONG TALK OF ARMS CONTROL IN THE REGION DISAPPEARED AS THE U.S. GOVERMMENT ANNOUNCED ITS PLANS TO SEND LARGE QUANTITIES
OF ARMS TO ITS ALLIES IN THE MIDOLE EAST.

06775 NEFF, D.

THE LEGACY OF BUSH AND BAKER

MIDDLE EAST INTERNATIONAL, 438(438) (NOV 92), 17-18.

PRESIDENT GEORGE BUSH AND SECRETARY OF STATE JAMES BAKER WILL BE LEAVING OFFICE AS AMONG THE GREATEST BENEFACTORS ISRAEL EVER HAD. THIS REPORT DETAILS THE RESULTS OF THE BUSH ADMINISTRATION'S NEARLY FOUR YEARS IN OFFICE. IT: REAFFIRMED THE STRATEGIC ALLIANCE WITH ISRAEL; INCREASED AID TO ISRAEL; SUSPENDED TALKS WITH THE PLO; HELPED END ISRAEL'S INTERNATIONAL ISOLATION; AND PRESSED MOSCOW TO ALLOW EMIGRATION OF SOVIET JEWS.

06776 NEFF, D.

THE U.S. AND IRAQ-HINTS OF A SOFTENING

MIDDLE EAST INTERNATIONAL, (405) (JUL 91),

FOR THE MOST PART, U.S. PRESIDENT GEORGE BUSH HAS

MAINTAINED HIS HARD LINE AGAINST IRAQ AND HAS CONTINUED TO

USE ECONOMIC SANCTIONS AND THE THREAT OF MILITARY FORCE TO

CONVINCE IRAQ TO COMPLY WITH UN RESOLUTIONS, STOP ITS

REPRESSION OF KURDS AND SHI'ITES, AND REVEAL ALL THE DETAILS

ABOUT ITS NUCLEAR PROGRAM. HOWEYER, THERE ARE SOME

INDICATIONS THAT THE PRESIDENT'S LINE MAY BE SOFTENING.

FACED WITH THE PROSPECT OF WIDESPREAD STARVATION IN IRAO

(AND NO IMMEDIATE HOPES FOR THE OVERTHROW OF SADOAM HUSSEIN), BUSH HAS HINTED THAT IRAQ MAY BE ALLOWED TO EXPORT ITS OIL HIN THE REVEUE BEING OIVIDACD BETHEEN REPARATIONS TO KUNAI BUSH'S HINTS HAVE BEEN ECHOED BY HIS EUROPEAN ALLIES

06777 NEFF, D.

THE U.S. AND ISRAEL--A RELATIONSHIP IN CRISIS

MIDOLE EAST INTERNATIOMAL (422) (APR 92 I

THE SPECIAL U.S. - I SRAELI RELATIONSHIP WHICH HAS EXISTED

FOR A QUARTER OF A CENTURY IS FALLING APART. EVIDENCE OF

THIS CHANGE CAN BE FOUND IN SEVERAL ACTIONS BY PRESIDENT BUSH AND HIS ADMINISTRATION. THE BUSH ADMINISTRATION HAS OPENLY SENT AN INSPECTION TEAM TO ISRAEL TO DETERMINE WHETHER ISRAEL IS CHEATING ON ITS PROMISES NOT TO RE-EXPORT SECRET TECHNOLOGY. BUSH CONTINUES TO STAND FIRM IN OPPOSING THE $\$ 10$ BILLION HOUSING LOAN GUARANTEE. THERE ARE REPORTS THAT THE ADMINISTRATION HAS DECREED U.S. OFFICIALS SHOULD LIMIT THEIR MEETINGS WITH ISRAELIS TO FORMAL OFFICIAL FUNCTIONS, ANOTHER WAY OF APPLYING PRESSURE. THESE CHANGES COULD CAUSE AMERICAN POL ICYMAKERS TO SERIOUSLY RECONSIDER THE COSTS AND BENEFITS OF CONTINUING THE "SPECIAL" RELATIONSHIP.

06778 NEFF, D.

THE UNITED STATES--KEEPING CLEAR OF THE MIRE

MIDOLE EAST INTERNATIONAL, (416) (JAN 92), 5-6.

THE U.S. POSITION ON THE BILATERAL MIDEAST PEACE TALKS SEEMS INCREASINGLY INCONSEQUENTIAL. U.S. OFFICIALS HAVE BEEN COMPLETELY NON-COMMITTAL IN PUBLIC ABOUT THE SPUTTERING TALKS, MAINTAINING THE ROLE AS ALOOF OBSERVERS RATHER THAM THE INTIMATE ACTORS AND CATALYSTS THAT THE AMERICANS, WITH THEIR OVERWHELMING AID PROGRAMS, ARE IN THE MIDDLE EAST. HOWEVER, THE ISSUE OF U.S. LOAN GUARANTEES TO ISRAEL--WHICH WILL RETURN TO THE FOREFRONT IN A FEW WEEKS-WILL FORCE THE AMERICANS TO TAKE A STAND ONE WAY OR THE OTHER. THE TACTIC FOLLOWED WILL LIKELY BE A GUARANTEE LINKED TO ISRAEL'S COMPLETE FREEZE OF SETTLEMENTS IN THE WEST BANK, THE GOLAN HEIGHTS, THE GAZA STRIP, AND OCCUPIED ARAB JERUSALEM.

06779 NEFF, D.

U.S. AND ISRAEL--A FIRM, PUblic "No, UNLESS . . ." MIDDLE EAST INTERNATIONAL, (420) (MAR 91), 4-6 ALTHOUGH EVERY U.S. ADMINISTRATION SINCE 1967 HAS OPPOSED THE ESTABLISHMENT OF ISRAELI SETTLEMENTS IN THE OCCUPIED TERRITORIES, NONE OF THEM HAS BEEN HILLING TO TAKE ANY ACTION TO BACK UP THIS POLICY. ONLY IN 1992 HAVE PRESIDENT BUSH AND SECRETARY OF STATE BAKER FINALLY- FIRMLY, PUBLICLY AND UNEQUIVOCALLY --LINKED U.S. FINANCIAL ASSISTANCE WITH SETTLEMENTS. BAKER WENT BEFORE CONGRESS ON 24 FEBRUARY AND LAID OUT THE ADMINISTRATION'S POLICY: NO GUARANTEES FOR ISRAEL'S $\$ 10$ BILLION LOAN REQUEST UNLESS ALL NEW SETTLEMENTS ARE HALTED; IF ISRAEL INSISTED ON COMPLETING HOUSING UNITS ALREADY UNDER CONSTRUCTION, IT NONETHELESS HAD TO HALT ALL NEW SETTLEMENTS AND THE COST OF CDMPLETING EXISTING ONES HOULD BE DEDUCTED FROM THE LOANS; THE ADMINISTRATION VIEWED NEW SETTLEMENTS AS NOT JUST THE CONSTRUCTION OF HOUSING NEW SETTLEMENTS AS NOT JUST THE CONSTRUCTION OF HOUSING SEWERS, AND WATER LINES: AND THE ADMINISTRATION HOULD BE THE SOLE ARBITER OF WHAT CONSTITUTED A VIOLATION OF THE SOLE ARBITER OF WHAT CONSTITUTED A VIOLATION OF THE DECLARED HIS SUPPORT FOR BAKER'S POLICY.

06780 NEFF, D.

UNITED STATES--CANDIDATES TILT TO ISRAEL

MIDOLE EAST INTERNATIONAL, (430) (JUL 92), 6-7.

AS THE CAMPAIGN FOR PRESIDENT HEATS UP, THE MIDDLE EAST PEACE PROCESS AND THE ARAB-ISRAELI CONFLICT WILL LIKELY RECEIVE INCREASING ATTENTION FROM BOTH MAJOR CANDIDATES FOR 
PRESIDENT. BILL CLINTON IS A CHRISTIAN ENTHUSIAST FOR ISRAEL. ALBERT GORE, HIS RUNNING MATE, COULD BE A CHARTER MEMBER OF OTHER SIDE GEORGE BUSH HILL BE UMDER STROMG PRESSURE TO BELIEVE THAT TO GET RE-ELECTED HE MUST GAIN JEHISH SUPPORT. THE RESULT IS LIKELY TO BE A FURTHER PRO-ISRAEL TILT TO HIS MIDOLE EAST POLICIES. REGARDLESS OF WHO LOSES THE ELECTION, THE PALESTINIANS AND THE PEACE PROCESS ARE LIKELY TO LOSE AS WELL.

06781 NEFF, D.

UNITED STATES: BUSH UNDER PRESSURE

MIDDLE EAST INTERNATIONAL, 417 (JAN 92), 10-11.

AMERICA'S QUADRENNIAL PRESIDENTIAL CAMPAIGN IS ALREADY WELL UNDER WAY, AND BEFORE IT CONCLUDES AT THE BALLOT BOX ON 3 NOVEMBER THE MIDOLE EAST WILL SURELY PAY IN A NUMBER OF 3 NOVEMBER THE MIDOLE EAST WILL SURELY PAY IN A NUMBER OF WAYS. AMONG THE MORE OBVIOUS RESULTS WILL BE THE FATE OF ISRAEL'S REQUEST FOR \$2OBN IN LOAN GUARANTEES, AND VERY LIKELY, THE SURVIVAL OR NOT OF SADDAM HUSSEIN. THIS ARTICLE ARGUES THAT PRESIDENT BUSH IS AT HIS WEAKEST EVER. BUSH IS
EXPECTED TO MAKE BOLD MOVES TO RECAPTURE VOTER'S FAVOR IN EXPECTED TO MAKE
THE MONTHS AHEAD.

06782 NEFF, D.

US AND ISRAEL--WASHINGTON SHOWS ITS CLOUT

MIDOLE EAST INTERNATIONAL, (414) (DEC 91), 4-5

THE BILATERAL TALKS WHICH WERE TO FOLLOW THE MADRID PEACE CONFERENCE GOT OFF TO A ROCKY START AS ISRAEL INSISTED ON A LOCATION FOR THE TALKS CLOSE TO THE MIDDLE EAST HHILE THE ARABS OPTED FOR MADRID OR SOME OTHER EUROPEAN SITE. IN THE END, THE UNITED STATES SIMPLY STEPPED IN AND DECLARED WASHINGTON TO BE THE NEXT SITE FOR THE TALKS. ANGERED AT THE ANMOUNCEMENT (AND THE LACK OF PRIOR CONSULTATION), ISRAEL DECLARED THAT IT HOULD NOT SEND SENIOR NEGOTIATING TEAMS UNTIL FIVE DAYS AFTER HASHINGTON'S 4 DECEMBER DATE FOR STARTING THE TALKS. ISRAEL ALSO PROFESSED TO BE ANGERED OVER A SET OF POSITION PAPERS THAT THE UNITED STATES INCLUDED ALONG WITH ITS INVITATIONS ISSUED TO ISRAEL AND EACH OF THE ARAB PARTIES OVER HOW THEY MIGHT CONOUCT THEIR NEGOTIATIONS.

06783 NEFF, D.

WHAT DID GLASPIE TELL SADDAM?

MIDDLE EAST INTERMATIOMAL (379) (APR 91),

EIGHT MONTHS AFTER THE EVENT, AMBASSADOR APRICL $C$.

GLASPIE FINALLY GOT HER CHANCE ON 20 MARCH TO GIVER HER VERSION OF WHAT HAPPENED IN HER LAST (AND ONLY) INTERVIEN WITH SADDAM HUSSEIN. GLASPIE HAD BEEN MUZZLED BY THE STATE DEPARTMENT SINCE THAT 25 JULY MEETING LAST YEAR, LEAVING THE STRONG IMPRESSION THAT SHE HAD BEEN LESS THAN FORCEFUL IN WARNING SADDAM NOT TO ATTACK KUWAIT. IN HER TESTIMONY BEFORE THE SENATE FOREIGN RELATIONS COMMITTEE, GLASPIE STRENUOUSLY INSISTED THAT SHE MADE IT CLEAR THAT THE U.S. FAVORED SETTLEMENTS BEING MADE IN NON-VIOLENT MANNER, NOT BY THREATS, NOT BY INTIMIDATION, AND CERTAINLY NOT BY AGGRESSION.

06784 NEFF, D.

WHY BUSH WON'T INTERVENE

MIDDLE EAST INTERNATIONAL, (398) (APR 91), 5-6.

DESPITE WIDESPREAD MEDIA COVERAGE OF THE SUFFERING OF IRAQ'S KURDISH REFUGEES, U.S. PRESIDENT GEORGE BUSH REMAINS ADAMANT IN HIS POLICY OF KEEPING THE U.S. MILITARY OUT OF THE SITUATION. HIS RATIONALE IS FOUND IN THE DESIRE TO AVOID FURTHER ENTANGLEMENTS THAT COULD LEAD TO "ANOTHER VIETNAM. OPERATION DESERT STORM HAD A STRICT TIMETABLE AND CLEAR OBJECTIVES; AN OPERATION TO ASSIST THE KURDS COULD RESULT IN INCREASED CASUALTIES AND A GROWING ESCALATION THAT MIGHT ONLY END WITH THE U.S. OCCUPATION OR BAGHDAD.

06785 NEGRINE, $R$.

REPORTING PARLIAMENTARY COMMITTEES: THE INYESTIGATION OF THE ROVER GROUP SALE TO BRITISH AEROSPACE

PARLIAMENTARY AFFAIRS, 45(3) (JUL 92), 399-408.

IN COVERING THE WORK OF PARLIAMENTARY SELECT COMMITTEES, THE MASS MEDIA ENABLES THE PUBLIC TO GAIN A BETTER UNDERSTANDING OF ISSUES AND INCREASES THE POWER OF SELECT COMMITTEES BY PUBLICIZING THEIR HORK. IF THE MEDIA IS TO FULFILL THESE FUNCTIONS TO THE FULLEST EXTENT POSSIBLE, FULFILL THESE FUNCTIONS TO THE FULLEST EXTENT POSSIBLE,
SELECT COMMITTEES THEMSELVES MUST PLAY THEIR OWN PART MORE EFFECTIVELY. THESE PROBLEMS AND THE COMPLEX INTERPLAY OF
SOMETIMES CONFLICTING INTERESTS BETHEEN THE MASS MEDIA AND SOMETIMES CONFLICTING INTERESTS BETWEEN THE MASS MED

SELECT COMHITTEES LIE AT THE HEART OF THE BRITISH
AEROSPACE/ROVER CASE, WHICH IS THE FOCUS OF THIS PAPER.

06786 NEHER, C.D.

POLITICAL SUCCESSION IN THAILAND

ASIAN SURYEY XXXII(7) (JUL 92) 585-605.

THIS ESSAY ASSESSES THE HISTORY OF SUCCESSION IN MODERN THAI POLITICS. IT EXAMINES THAILAND'S MANY POLITICAL CHANGES AND INSTANCES OF SUCCESSION BEGINNING WITH THE 1932 REVOLT THAT OVERTHREW THE ABSOLUTE MONARCHY. IT ARGUES THAT THAILANO HAS NOT INSTITUTIONALIZED A SYSTEMATIC SUCCESSION PROCESS BUT THAT SUCCESSION NEVERTHELESS HAS BEEN SMOOTH ENOUGH NOT TO OBSTRUCT GOVERNMENTAL PROCESSES. IT DEHONSTRATES THAT REGIMES ARE SUCCEEDED MOST OFTEN BY
REGIMES OF THE SAME TYPE. ELECTIONS HAVE BEEN HELD LARGELY TO LEGITIMATE THE RULING PERSONNEL AND POLICIES RATHER THAN TO EFFECT CHANGES IN LEADERSHIP. THE ESSAY CONCLUDES WITH A CLOSE EXAMINATION OF A POSSIBLE EXCEPTION TO THIS GENERAL

PATTERN: THE MAY 1992 CRISIS.

06787 NEHER, C.D.

POLITICAL SUCCESSION IN THAILAND; ASSOCIATION FOR ASIAN STUDIES 1992 ANNUAL MEETING

ASSOCIATION FOR ASIAN STUDIES, 1992, 155.

SINCE 1932, POLITICAL SUCCESSION IN THAILAND HAS

REVOLVED AROUND MILITARY FACTIONS DETERMINING THE NATION'S

LEADERSHIP. IN THE PAST 60 YEARS THERE HAVE BEEN 13

SUCCESSFUL COUPS AND UNCONSTITUTIONAL OVER-THROWS OF

SUCCESSFUL COUPS AND UNCONSTITUTIONAL OVER-THROWS OF

GOVERNING INSTITUTIONS, AND SEVEN UNSUCCESSFUL CDUP ATTE

COUPS GENERALLY TAKE PLACE WHEN ONE MILITARY FACTIDN
BELIEVES ITS PREROGATIVES ARE THREATENED BY THE REGIME IN

BELIEVES ITS PREROGATIVES ARE THREATENED BY THE REGIME IN

RULING PERSONNEL AND POLICIES RATHER THAN TO EFFECT CHANGES IN LEADERSHIP. NEVERTHELESS, THAI POLITICS IS CHARACTERIZED BY A SURPRISING CONTINUITY OF POLICY, REGARDLESS OF THE SUCCESSION PROCEDURE AND REGARDLESS OF WHETHER SUCCESSORS ARE MILITARY OR CIVILIAN. THE 1991 MILITARY COUP D'ET
PROVIDE MATERIAL FOR A CASE STUDY TO ANALYZE THESE PROPOSITIONS.

06788 NEILD, $R$

AFTER ARMS CONTROL

BULLETIN OF PEACE PROPOSALS, 23(1) (MAR 92), 23-28.

THIS ARTICLE ARGUES THAT, WITH THE ENDIMG OF THE COLD WAR AND THE DISINTEGRATION OF THE SOVIET UNION, THE ISSUE OF HOW BEST TO ACHIEVE REDUCTIONS IN ARMS NEEDS TO BE CONSIDERED AGAIN. IT CRITICIZES THE OLD IDEA THAT ARMS REDUCTIONS SHOULD BE THE RESULT OF BARGAINING OVER BALANCE IN ARMS CONTROL NEGOTIATIONS. IT PRESENTS A NEW METHOD OF ARMS CONTROL FOR EUROPE: THE CREATION OF A COMMON DEFENSE REVIEW (CDR) BY THE CONFERENCE ON SECURITY AND COOPERATION IN EUROPE (CSCE) AT WHICH MEMBER NATIONS, HAVING AGREED ON COMMON SECURITY OBJECTIVES, WOULD PRESENT THEIR DEFENSE PROGRAMS TO BE CRITICIZED BY ONE ANOTHER. SUCH A COURSE WOULD UTILIZE THE IMPORTANT CONCEPT THAT THE MAKING OF AGREEMENTS SHOULD COME AS A SEQUEL TO COOPERAT
ABOUT HOW JOINTLY TO ACHIEVE COMMON SECURITY.

06789 NEIMARK, $M$

AMERICAN JEWS AND PALESTINE: IMPACT OF THE GULF HAR MIDDLE EAST REPORT, 22 (2) (MAR 92), 19-23.

AMERICAN JEWS HAYE AN OBVIOUS INTEREST IN THE STATE OF ISRAEL AND IN U.S. FOREIGN POLICY IN THE MIDDLE EAST. LIKE OTHER AMERICANS, JEWS WERE DIVIDED ON THE MERITS OF MILITARY INTERVENTION AGAINST IRAQ, AND MOST ENDED UP SUPPORTING THE WAR ONCE THE U.S. OFFENSIVE BEGAN. WHAT DISTINGUISHES AMERICAN JEWISH POSITIONS ON THE WAR IS THE PART ISRAEL AND THE ISRAELI PEACE MOVEMENT PLAYED IN THEIR DECISION-MAKING CALCULUS, WITH THE RESULT THAT MANY PROGRESSIVE JEHS EITHER REMAINED SILENT OR ACTIVELY JOINED THE PRO-INTERVENTION RANKS. A YEAR AFTER THE WAR, THE MAINSTREAM JEWISH PEACE CAMPS IN BOTH ISRAEL AND THE UNITED STATES ARE STILL FEELING REPERCUSSIONS. TO THE SURPRISE OF SOME ACTIVISTS, THE ANGER THAT DIVIDED THE PRO- AND ANTI-HAR FACTIONS HAS NOT LINGERED. THIS ABSENCE OF ACRIMONY PRIMARILY REFLECTS THE URGENCY THE PEACE CAMP FEELS ABOUT ENDING SETTLEMENT ACTIVITY. IT ALSO REFLECTS THE AMBIVALENCE FELT TOOAY BY MANY OF THE WAR'S SUPPORTERS IN THE UNITED STATES.

06790 NEJAD, H.

THE MIDOLE EAST--BUILDING A COMMUNITY OF NATIONS

BULLETIM OF PEACE PROPOSALS, 23(2) (1992) 159-168.

WAR AND OTHER FORMS OF POLITICAL VIOLEHCE ARE AS OLD AS HUMAN CIVILIZATION. IN THIS CENTURY THE MIDDLE EAST HAS EXPERIENCED MORE INTERSTATE, CIVIL AND EXTRASYSTEMIC WARS THAN ANY OTHER PART OF THE HORLD. THE UNDERLYING FACTORS USUALLY DIVIDED INTO FIVE INTERRELATED TYPES: ECONOMIC, POLITICAL, IDEOLOGICAL, TERRITORIAL AND EXTERMAL. THE PURPOSE OF THIS PAPER IS TO EXPLICATE THE UNDERLYING
CONDITIONS AND TO TO SUGGEST CERTAIN POLITICAL CHOICES AND CONDITIONS AND TO TO SUGGEST CERTAIN POL ITICAL CHOICES AND
PROPOSALS WHICH SHOULD GREATLY REDUCE POLITICAL VIOLENCE AND PROPOSALS HICH SHOULD GREATLY REDUCE POLITICAL VIOLENCE
FOSTER POSITIVE PEACE AND DEYELOPMENT IN THE MIDDLE EAST.

06791 NELSEN, B.F.

EXPLAINING PETROLEUM POLICY IN BRITAIN AND NORHAY, 1962-

SCANDINAVIAN POLITICAL STUDIES, 15(4) (DEC 92), 307-328.

PETROLEUM POLICY IN BRITAIN AND NORHAY OFFERS AN OPPORTUMITY TO COMPARE POLICY FORMATION, STABILITY, AND TRANSFORMATION ON A CROSS-NATIONAL BASIS. THIS STUOY EXPLAINS WHY BRITISH AND NORHEGIAN OFFICIALS DECIDED TO INTERVENE IN THE NORTH SEA. WHY OFFSHORE POLICY IN THE TWO COUNTRIES WENT THROUGH PERIODS OF STABILITY AND CHANGE, AND WHY THEY ADOPTED SIMILAR OFFSHORE SYSTEMS IN THE 1960'S $1970 ' S$ BUT OIVERGED MARKEDLY IN THE 1980'S. THE AUTHOR
DEVELOPS AN EXPLANATORY FRAMEWORK USING INSIGHTS FROM STATEDEVELOPS AN EXPLANATORY FRAMEWORK USING INSIGHTS FROM STATEMODELS OF POLICY-MAKING. THE FRAMEHORK IDENTIFIES THREE 
DECISION-MAKING CONTEXTS IN WHICH PETROLEUM POLICY-MAKERS OPERATE SIMULTANEOUSLY: AN OIL CONTEXT, A DOMESTIC POLITICAL CONTEXT, AND AN INTERNATIONAL CONTEXT. EACH CONTEXT ESTABLISHES OBJECTIVES FOR POLICY-MAKERS, INDICATES AN ACCEPTABLE DEGREE OF GOVERNMENT INTERVENTION, AND NARROWS POL ICY OPTIONS. RATIONAL DECISION-MAKING WITHIN EACH CONTEXT, HOWEYER, MAY YIELD CONFLICTING RESULTS. THESE MUST BE HORKED OUT THROUGH INTRASTATE AND/OR STATE-SOCIETY BARGAINING.

06792 NELSON, B.J.

THE ROLE OF SEX AND GENDER IN COMPARATIVE POLITICAL ANALYSIS: INDIVIDUALS, INSTITUTIONS, AND REGIMES

AMERICAN POLITICAL SCIENCE REVIEW, 86(2) (JUN 92), 491-502.

THE AUTHOR DISCUSSES THE VARIOUS PERSPECTIVES ON THE

POL ITICAL ROLE OF WOMEN FOUND IN SIX RECENTLY-PUBLISHED

BOOKS ON WOMEN, GENDER, AND THE POL ITICAL ECONOMY. THE DISCUSS THE ROLE OF THE NOHEN'S MOVEMENT IN TRANSITION
POLITICS IN BRAZIL, WOMEN IN TAIHANESE POLITICS, WOMEN'S POLITICS IN BRAZIL, WOMEN IN TAIHANESE POLITICS, WOMEN'S
ISSUES IN INTERNATIONAL DEVELOPMENT PROGRAMS, AUSTRALIAN ISSUES IN INTERNATIONAL DEVELOPMENT PROGRAMS, AUSTRAL
FEMINIST INTERVENTIONS, AND WOMEN AND SOCIAL PROTEST.

06793 NELSON, D.

EUROPE'S UNSTABLE EAST

FOREIGN POLICY (82) (SPR 91) 137-158.

CONTRARY TO EARLY AND MORE HOPEFUL JUDGEMENTS ABOUT EUROPE'S FUTURE, RECENT ANALYSES ARE FRAUGHT WITH DIRE PREDICTIONS. SOME OF THE PROBLEMS AND CHALLENGES A CHANGING EASTERN EUROPE WILL FACE INCLUDE: HETEROGENEITY, ESPECIALLY ETHNONATIONALISM; ACTIVE OPPOSITION TO THE NOMENKLATURE AND SECRET POLICE; QUESTIONABLE LOYALTY AMONG SENIOR MILITARY OFFICERS AND AN UNCERTAIN RELATIONSHIP BETWEEN CIVIL AND MILITARY AUTHORITY; APATHY AMONG UNEMPLOYED WORKERS DEMOBILIZED TROOPS, AND OTHERS; "ANTI-POLITICS" POLITICS-THE MIX OF ANGER AND PURPOSEFUL APATHY TOWARD ALL POLITICIANS; AND EXTERNAL CONFLICTS AND THREATS BETHEEN GERMANY AND POLAND, POLAND AND BYELORUSSIA, THE UKRAINE AND LITHUANIA, ALBANIA AND YUGOSLAVIA, BULGARIA AND YUGOSLAVIA, GREECE AND YUGOSLAVIA, GREECE AND ALBANIA, THE SOVIET UNION AMD ROMANIA, BULGARIA AND TURKEY, AND BULGARIA AND ROMANIA.

06794 NELSON, D.

IMSECURITY AFTER COMMUNISM AND THE ROMANIAN CASE MEDITERRANEAN QUARTERLY: A JOURNAL OF GLOBAL ISSUES, 3(1) (WIN 92), 60-77.

ROMANIA, TO A MUCH MORE COMPLETE EXTENT THAN ELSEWHERE IN THE FORMER SOVIET BLOC, WAS DESPOILED AN EXHAUSTED BY THE SEVERITY OF CEAUSESCU'S DICTATORSHIP AND BY THE CULTURAL. POL ITICAL AND SOCIOECONOMIC COSTS ROMANIA INCURRED FROM SUCH POLITICAL AND SOCIOECONOMIC COSTS ROMANIA INCURRED FROM SUCH TYRANNY. NOW, THE NATION FACES ETHNIC TENSION ARISING CONFLICT WITH AN ENLARGED, WELL-ARMED SERBIA, CONFLICT WITH AN INDEPENDENT UKRAINE GOVERNED BY THE RIGHT-WING AN INDEPENDENT UKRAINE GOVERNED BY THE RIGHT-WING NATIONALISM OF RUKA, ANO OANGERS OF MASS MIGRATION GENERATED BY TURMOIL IN THE FORMER SOVIET UNION. IN ADOITION, ROMANIA CONFRONTS A MULTITUDE OF INTERNAL THREATS FROM THE FOLL DANGERS: ETHNONATIONALISM, THE POLITICAL STRAINS OF MARKETIZATION, THE RESISTANCE OF AN OLD NOMENKLATURA TO CHANGE, UNCERTAIN CIVILIAN AUTHORITY OVER MILITARY AND SECURITY FORCES, AND WIDESPREAD SUSPICION AND APATHY OF CITIZENS TOWARD POLITICIANS AND GOVERNMENT OF ANY KIND. MANAGEMENT OF THESE PROBLEMS WILL REQUIRE CONSIDERABLE DIPLOMATIC AND POLITICAL SKILL, GROUNDED IN A MATIONAL CONSENSUS ABOUT FUNDAMENTAL ISSUES. ROMANI ANS WILL HAVE TO BE HELPED FAR MORE, HOWEVER, BY WESTERN DEMOCRACIES THAT UNDERSTAND THE RELATIONSHIP' BETHEEN THE NATION'S SECURITY AND THAT OF POST-COMHUNIST EUROPE.

06795 NELSON, D.

SNATCHING DEFEAT FROM THE JAWS OF VISTORY

BULLETIN OF THE ATOMIC SCIENTISTS, 48(8) (OCT 92), 24-28. THE HELSINKI SUMMIT IN JULY HAS ACCOMPANIED BY UNCERTAINTY OF SUCCESS. THIS ARIICLE EXPLORES WESTERN EUROPEAN VIOLENCE AGAINST IMMIGRANTS, THE MAASTRICHT TREATY, THE U.S. ROLE IN EUROPE, AND NATO'S DELEGATING THE ROLE OF THE EURO-ARMY. IT ARGUES THAT HAVING SO RECENTLY DECLARED ITSELF THE COLD WAR VICTOR, THE WEST SEEMS DISINCLINED TO MAKE THE NECESSARY PREPARATIONS FOR THE TWENTY-FIRST CENTURY. IT CONCLUDES THAT WE MAY SEE MORE WORST-CASE SCENARIOS IN BESSARABIA, KOSOVO, MACEDONIA, THE CAUCASUS, THE CRIMEA AND ELSEWHERE.

06796 NELSON, J.

SOCIAL WELFARE AND THE MARKET ECONOMY

SCIENCE AND SOCIETY, 56(4) (WIN 92), 815-828.

THIS PAPER REVIEWS THREE ASPECTS OF THE PRIVATIZTION ARGUMENT, COMPETITIVE MARKETS, RATIONALITY, AND COST ARGUMENT; COMPETITIVE MARKETS, RATIONALITY, AND COST REDUCTION. IN EACH CASE, THE RESEARCH LITERATURE SUGGESTS OBSTACLES AND CONSTRAINTS TO APPLYIMG MARKET NORMS TO SOCIAL WELFARE. THE PAPER CONCLUDES BY QUESTIONING A CENTRAL CLAIM
OF ECONOMIC THEORY: THAT FREE MARKETS AND PRIVATE FIRMS ARE OF ECONOMIC THEORY: THAT FREE MARKETS AND PRIVATE FIRMS PRODUCING AND DISTRIBUTING ALL GOODS AND SERVICES.
06797 MELSON, K.S.

U.S. -VIETNAMESE NORMALIZATION

ASIAN AFFAIRS, AN AMERICAN REVIEW, 19(1) (SPR 92), 49-60. OBSERVERS OF VIETNAM SEE THE 1990 'S AS A TURNING POINT FOR THE COUNTRY AS IT DEALS WITH THE COLLAPSE OF COMMUNISM AND THE NEW INTERNATIONAL SHIFTS OF POWER. IN LIGHT OF THE CHANGING GLOBAL ORDER, IT IS TIME FOR THE UNITED STATES TO SERIOUSLY PURSUE THE RESTORATION OF DIPLOMATIC AND ECONOMIC RELATIONS WITH VIETNAM. NORMALIZATION OF RELATIONS WOULD ALLOW THE RESUMPTION OF MUTUALLY-BENEFICIAL ECONOMIC ACTIVITY AND WOULD OFFER THE UNITED STATES AN OPPORTUNITY TO PARTICIPATE IN A NEW BALANCE OF POWER IN THE REGION.

06798 MELSON, M.K. A CRITICAL ANALYSIS OF THE ACTION FOR BETTER CHILD CARE SERVICES

WOMEN AND POLITICS, 12(3) (1992), 1-25.

THE AUTHOR TRACES THE DEVELOPMENT OF THE ACT FOR BETTER CHILD CARE SERVICES (ABC). SHE ARGUES THAT THE MODIFICATION OF THIS PROPOSAL THROUGH THE LEGISLATIVE PROCESS AND THE STRATEGIES THAT PRODUCED THESE MODIFICATIONS CREATED A PIECE OF LEGISLATION THAT HAS AN UNEVENT IMPACT ON WOMEN WITH
RESPECT TO CHILD-CARE NEEDS. IN PARTICULAR, THE AUTHOR FOCUSES ON THE RECIPIENTS OF BENEFITS, THE MANNER IN WHICH FOCUSES ON THE RECIPIENTS OF BENEFITS, THE MANNER IN
THE DISTRIBUTION OF BENEFITS WAS IMPLEMENTED, AND THE THE DISTRIBUTION OF BENEFITS WAS IMPLEMENTED, AND THE IMPLICATIONS OHILD CARE.

06799 NENGOING, L.

KOREAM PEMIUSULA MOVES FURTHER TOWARDS PEACE

BEIJING REVIEH, 35(5-6) (FEB 92), 15.

ON JAKUARY 7,1992 , THE DEMOCRATIC PEOPLE'S REPUBLIC OF KOREA ANMOUNCED THAT IT WOULD SIGN A NUCLEAR SAFEGUARD AGREEMENT AND ACCEPT MUCLEAR INSPECTIONS IN ACCORDANCE WITH I.A.E.A. POLICIES. ON THE SAME DAY, SOUTH KOREA DECLARED THAT IT WOULD CANCEL ITS ANMUAL MILITARY MANOEUVRES WITH THE UNITED STATES.

06800 NENGOING, L.

PROGRESS IN INTER-KOREAN RELATIONS

BEI JING REVIEN, 35 (32) (AUG 92), 14-15.

IN JULY 1992, THE DEPUTY PRIME MINISTER OF THE

DEMOCRATIC PEOPLE'S REPUBLIC OF KOREA, KIM DAL HYON, VISITED SOUTH KOREA TO SPEAK HITH PRESIDENT ROH TAE HOO AND OTHER LEADERS. MOST OF THE DISCUSSION FOCUSED ON THE PROSPECTS FOR INCREASED ECONOMIC TIES BETWEEN THE TWO KOREAS.

06801 NETANYAMU, $B$.

TERRORISM: AN OVERVIEH

GLOBAL AFFAIRS, 6(1) (WIN 91), 74-86.

THIS ARTICLE ADORESSES FOUR OUESTIONS RELATING TO

TERRORISH. (1) WHY IS TERRORISM SIGNIFICANT FOR ISRAEL? (2) TERRORISH.
WHAT IS TERRORISH? (3) WHO IS CARRYING IT OUT? (4) WHAT IS WHAT IS TERRORISM? (3) WHO IS CARRYING IT OUT? (4) WHAT IS TO BE DONE ABDUT IT? THE AUTHOR DISTINGUISHES TERRORISM THE TRAGED

06802 NEU, C.H.; ETHREDGE, J.

COMMUNITY-SENSIBLE GOVERNANCE: THE EMERGING POLITICAL REAL ITY OF THE $215 T$ TENTURY

NATIONAL CIVIC REVIEW, 80(4) (FAL 91), 381-392

A NEW "CIVIL WAR" IS RAGIMG IN THE UNITED STATES THAT WILL REDEFINE WHERE THE POWER RESIDES TO SHAPE AND REALIZE THE DESTINIES OF COMMUNITIES. ALL LEVELS OF GOVERNMENT, ESPECIALLY STATE AND LOCAL, MUST RESPECT LOCAL AUTONOMY AND HORK TOGETHER TO ADORESS THE CHALLENGES FACED BY LOCALITIES COMHUNITY-SENSIBLE GOVERNANCE CAN BE THE MEANS BY WHICH U.S COMMUNITIES AND THE NATION AS A WHOLE EMBARK UPON AN UNCERTAIN, BUT EXCITING, FUTURE.

06803 NEUHOUSER, $K$.

DEMOCRATIC STABILITY IN VENEZUELA: ELITE CONSENSUS OR CLASS COMPROMISE?

AMERICAN SOCIOLOGICAL REVIEN, 57(1) (FEB 92), 117-135. ALTHOUGH AN ELITE FRAMEWORK IS OFTEN USED TO EXPLAIM DEMOCRATIC STABILITY IN POST-1958 VENEZUELA, A CLASSCOMPROMISE MODEL IS MORE USEFUL, NOT ONLY FOR UNDERSTANDING THE VENEZUELAN CASE BUT ALSO FOR EXPLAINING THE VARIATION IN REGIME OUTCOMES ACROSS REGIONS OF THE CAPITALIST WORLD AND WITHIN THE PERIPHERY. TO CONTRAST THE UTILITY OF THE THO MODELS, THE AUTHOR SUMMARIZES VENEZUELA'S POLITICAL HISTORY SINCE 1945. TO DEMONSTRATE THE GREATER USEFULNESS OF THE CLASS-COMPROMISE MODEL, HE COMPARES VENEZUELA TO TWO CDUNTRIES IN WHICH DEMOCRATIC REGIMES WERE DESTABILIZED-BRAZIL IN 1964 AND CHILE IN 1973. DEMOCRATIC STABILITY OCCURS WHEN STATE MANAGERS ARE ABLE TO BALANCE CAPITAL ACCUMULATION AND CONSUMPTION POLICIES. DEMOCRATIC

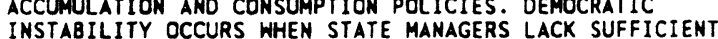
INSTABILITY OCCURS WHEN STATE MANAGERS LACK SUFFICIENT RESOURCES TO SATISFY THE CONSUMPTION DEMANDS OF A MOBILIZED WORKING CLASS HITH

06804 NEUMAN, E.

BUSH AND IRAQ: CRIME OR BLUNDER? 
INSIGHT, 8(49) (DEC 92), 6-12, 32-34

DEFEATED PRESIDENTS MAY FADE AWAY, BUT THEIR SCANDALS LINGER. PROBES CONTINUE INTO THE BUSH ADMINISTRATION'S DEALINGS WITH SADDAM HUSSEIN BEFORE THE PERSIAN GULF WAR. THIS ARTICLE STATES THAT THE KEY IS TO FIND OUT WHETHER AIO TO IRAQ WAS THE RESULT OF BAD POLICY OR ILLEGAL ACTIVITY.

06805 NEUMAN, E.

CLINTON ON THE EDUCATION FENCE

INSIGHT, 8(46) (NOV 92), 6-9; 30-33.

CRITICS WHO SAY THE RATIONAL EDUCATION ASSOCIATION (NEA) IS BENT ON PRESERVING THE STATUS OUO WORRY THAT THE INFLUENCE OF THE MATION'S LARGEST LABOR UNION ON ITS ENDORSED CANDIDATE, BILL CLINTON, WILL DOOM ANY CHANGES OF ENDORSED CANDIDATE, BILL CLINTON, WILL DOOM ANY CHANGES OF MEANINGFUL SCHODL REFROM SHOULD THE DEMOCRAT BE ELECT LD PRESIDENT. IN RECENT YEARS THE NEA AS GROWN INTO THE LARGEST AABUAL BUDGET OF MORE THAN S164 MILIION. THE NEA HAS ANNUAL BUDGET OF MORE THAN S164 MILLION. THE NEA SUPPORTED DEMOCRATIC CANDIDATES IN THE PAST FOUR PRESIDENTIAL ELECTION AND IN NUMEROUS STATE AND CONGRESSIONAL ELECTIONS. OPPONENTS ARGUE THAT THE BECOME MORE A
ORGANIZATION.

06806 NEUMAN, E.

MOVING THE LINE BETHEEN CHURCH AND STATE

INSIGHT, 8(20) (MAY 92), 14-16;34-38

WHERE DOES AN INDIVIDUAL'S RIGHT TO PRACTICE RELIGION END AND THE GOVERNMENT'S RIGHT TO RESTRICT ILLEGAL BEHAVIOR BEGIN? THE SUPREME COURT HAS RULED THAT STATES CAN UPHOLD THEIR LAWS EVEN IF THOSE LAWS PROHIBIT CERTAIN RELIGIOUS PRACTICES. RELIGIDUS GROUPS, LIBERAL AND CONSERVATIVE, HAVE ASKED CONGRESS TO LIMIT SUCH DISCRETION. THE ABORTION DISPUTE HAS LED TO COMPETING BILLS. THE ARTICLE CONLUDES

THAT THERE AREN'T ANY EASY ANSWERS.

06807 NEUMAN, E.

THE JUDICIAL REVOLUTION THAT WASN'T

INSIGHT, $8(30)$ (JUL 92 ) $14-16$.

WITH THE CONFIRMATION OF CLARENCE THOMAS TO THE SUPREME WITH THE CONFIRMATION OF CLARENCE THOMAS TO THE SUPREME COURT, THIS WAS SUPPOSED TO BE THE YEAR OF THE CONSERVATIVE COURT. BUT GIDOINESS ON THE RIGHT WAS SHORT - LIVED, TO THE THE AUTHOR EXPLORES THE QUESTION OF IF IT WASN'T A SOLID REHNQUIST MAJORITY, HOWEVER, HHAT WAS IT?

06808 NEUMAN, E.

THE NEW POLITICS OF WELFARE

INSIGHT, 8(13) (MAR 92), 6-11; 34-37

HITH TAXPAYERS INCREASINGLY COME TO REGARD HELFARE AS A SHAKEDOWN, THE WELFARE SYSTEM IS UNDERGOING MORE AND MORE OF A SHAKE-UP. DEFICIT-RIDDEN STATES, SAYING TRADITIONAL WELFARE HAS DONE LITTLE EXCEPT PROMOTE DEPENDENCY, ARE INTRODUCING REFORMS RANGING FROM DISCOURAGING HAVING CHILDREN OR ENCOURAGING MARRIAGE TO LIMITING BENEFITS FOR NEW RESIDENTS. THAT NEW POLICIES OF MARYLAND, CONNECTICUT, NEW JERSEY AND CALIFORNIA ARE EXPLORED. A CONSENSUS BETWEEM REPUBLICAN AND DEMOCRAT, RIGHT AND LEFT, IS FORMING BEHIND THE PUSH FOR REFORM.

06809 NEUMAN, E.

YEAR OF THE WOMAN OR JUST ANOTHER YEAR?

INSIGHT, 8(27) (SEP 92), 10-11, 30-32.

THE 1992 ELECTION IS SUPPOSED TO BE "THE YEAR OF THE WOMAN." PUNDITS SAY THAT THE GENDER GAP HAS WIDENED DUE TO TRIALS. THE INTEREST IN WOMEN'S ISSUES HAS PRODUCED A LARGERTHAN-USUAL CROP OF FEMALE CANDIDATES AND A SUGGESTION THAT THAN-USUAL CROP OF FEMALE CANDIDATES AND A SUGGESTION THAT
WOMEN MAY CAST THE DECIDING VOTES FOR PRESIDENT. BUT THAT MAY NOT BE THE CASE.

06810 NEUMANA, $H$.

ETERNAL AND TEMPORAL ENEMIES: CARL SCHMITT'S POLITICAL ETERNAL AML

POLITICAL COMMUNICATION, 9 (4) (1992), 279-284.

CARL SCHMITT HAS DEMONSTRATEO THAT ATHEISM IS THE HORSE CRIME, IF ANYTHING IS CRIMINAL. IF THERE IS NO GOD, NOTHING IS RIGHT OR WRONG, GOOD OR BAD. HITHOUT THEOLOGY, THERE IS NO MORALITY AND WITHOUT MORALITY, NO POLITICS. ANY NATION, QR POLITICAL FACTION, ADVOCATING LEGAL SAFEGUARDS FOR POLITICAL. POL ITICAL TOLERATION OF ATHEISM IS FRAUD OR POLITICAL.

06811 NEUMANH, $R$

THE PEACE PROCESS ON THE KNIFE'S EDGE

MIDDLE EAST INSIGHT O(2) (SEP Q1)

NEVER BEFORE IN THE TORTUROUS HISTORY OF ARAB-ISRAELI RELATIONS HAVE THE PROSPECTS FOR PEACE, AT LEAST FOR A CREDIBLE BEGINNING, BEEN BETTER. AND NEVER BEFORE HAS THE DANGER OF MISSTEP AHD FAILURE BEEN GREATER. THE PREEMINENCE OF THE UNITED STATES IN WORLD POLITICS (AND IN THE MIDOLE EAST AS SO POWERFULLY ASSERTED BY THE DESTRUCTION OF IRAQ'S MILITARY MIGHT) HAS CASUED SHIFTS TOWARDS A MORE MODERATE
POSITION ON THE PART OF ALL MIDOLE EAST PLAYERS, MOST NOTABLY SYRIA. HOWEVER, THE INTRANSIGENCE OF THE ISRAELIS, AS EVIDENCED BY THIER CONTINUED CREATION OF NEW SETTLEMENTS IN THE OCCUPIED TERRITORIES, THREATENS TO DESTORY EVEN THE BEST PLANS FOR PEACE. ONLY THE PURSUIT OF A PRUDENT, YET FIRM COURSE OF ENCOURAGEMENT BY THE UNITED STATES WILL AVERT TOTAL FAILURE OF THE PEACE PROCESS.

06812 NEUMANN, $R$.

1992, A YEAR OF STALEMATE IN THE PEACE PROCESS? MIDOLE EAST POLICY, 1(2) (1992), 47-56.

THIS ARTICLE FOCUSES ON THE BROAD AND PROBABLE ALTERNATIVES FACING THE UNITED STATES AND OTHER PARTIES IN REGARD TO THE DIFFERENCE BETWEEN THE PALESTINIAN AND ISRAELI AUTONOMY PLANS, U.S. POLICY CLASHES WITH ISRAEL, ESPECIALLY
REGARDING THE \$10-BILLION LOAN GUARANTEES. ITS EMPHASIS WILL REGARDING THE \$10-BILLION LOAN GUARANTEES. ITS EMPHASIS WILL
BE ON "POLITICS" RATHER THAM "POLICY, "EVEN THOUGH THE TWO ARE INYARIBLE LINKED IN ALL PRACTICAL DISCUSSIONS OF THE PEACE PROCESS.

06813 NEWBURG, J.A. ANATOMY OF A HOUSING PROGRAM: URBAN HOMESTEADING IN THEORY AND PRACTICE

JOURNAL OF LAH \& POLITICS, VIII(4) (SUM 92), 731-780. THE AUTHOR EXAMINES URBAN HOMESTEADING POLICY AT THE NATIONAL AND LOCAL LEVELS, FOCUSING ON PHILADELPHIA AS A CASE STUDY. HE REVIEWS THE HISTORY AND THE SOCIAL AND ECONOMIC THEORY OF URBAN HOMESTEADING. HE OUTLIMES THE FEDERAL AND LOCAL STATUTORY AND REGULATORY FRAMEWORK UNDER WHICH URBAN HOMESTEADING IS ADMINISTERED. HE REVIEWS THE ACCUMULATED EMPIRICAL DATA ON THE PERFORMANCE OF THE PROGRAM NATIONALLY AND IN PHILADELPHIA. FINALLY, HE EXPLORES THE ALMOST TWO DECADES OF IMPLEMENTATION.

06814 NEWLAND, C.

FAITHFUL EXECUTION OF THE LAW AND EMPOWERING PUBLIC CONFIDENCE

PRESIDENTIAL STUDIES QUARTERLY, XXI(4) (FAL 91), 673-686.

THIS ARTICLE ARGUES THAT CONSTITUTIONAL DISCIPLINES THAT EMPOWER GOVERNMENT GENERALLY AND THUS SUSTAIN PRESIDENTIAL AUTHORITY IN PARTICULAR REMAIN SERIOUSLY ERODED IN THREE RESPECTS: THE CULTURE OF A RULE OF LAW HITHIN GOVERNMENT AND RESPECTS: THE CULTURE OF A RULE OF LAW HITHIN GOVERNMENT
IN SOCIETY GENERALLY IS GRAVELY WEAKENED; INSTITUTIONAL IN SOCIETY GENERALLY IS GRAVELY WEAKENED; INSTITUTIONAL
STRUCTURES AND PROCESSES, PARTICULARLY THE SYSTEM OF SHARED STRUCTURES AND PROCESSES, PARTICULARLY THE SYSTEM OF SHARE
POWERS BETWEEN CONGRESS AND THE PRESIDENT AND RESPECTED POWERS BETWEEN CONGRESS AND THE PRESIDENT AND RESPECTED POLITICAL PRACTICES THAT ARE DISCIPLINED BY CIVIC DUTY AND PUBLIC SERVICE VALUES ARE OBSCURED BY POLITICS OF SPECIAL PUBLIC SERVICE VALUES ARE OBSCURED BY POLITICS OF SPECIAL INTERESTS AND THE PURSUIT OF PERSONAL GAIN. THE ARTICLE CONCLUDES THAT URGENT, SUSTAINED EFFORTS ARE REQUIRED TO RESTORE THESE THREE ESSENTIAL DISCIPLINES OF POPULAR SELF GOVERNANCE AND CONSTITUTIONAL GOVERNMENT: A RULE OF
INSTITUTIONAL DISCIPLINES; AND RESPONSIBLE POLITICS.

06815 NEWMAN, D.; HERMANN, T. A COMPARATIVE STUDY OF GUSH EMUMIM AND PEACE NOH MIDOLE EASTERN STUDIES, 28 (3) (JUL 92), 509-530.

EVALUATING THE RELATIVE SUCCESS OR FAILURE OF A SOCIAL MOVEMENT IS A CRITICAL PROBLEM IN ASSESSING THE CONTEXTUAL RELEVANCE OF EXTRA-PARLIAMENTARISM. VALUE, PARTICIPATION AND POWER ORIENTATIONS FORM THE BASIS OF THE ANALYSIS AND COMPARISON OF THE THO MAJOR EXTRA-PARLIMENTARY MOVEMENTS, GUSH EMUNIM (GE) AND PEACE NOW (PN), TO HAVE EMERGED IN ISRAEL DURING THE 1970S. THIS STUDY DEMONSTRATES THE INHERENT INTERRELATEDNESS BETWEEN RESPECTIVE VALUE, PARTICIPATION AND POWER ORIENTATIONS AND SUGGESTS THAT IT IS THE NATURE OF THE POWER ORIENTATIONS WHICH DETERMINES THE ULTIMATE SUCCESS OF EXTRA-PARLIAMENTARY MOVEMENTS.

06816 NEWMAN, E.

WILL IT HURT?

INSIGHT, 8(6) (APR 92), 6-11; 34; 36.

WHEN A CHILD IS VACCIINATED. AS THE LAW REQUIRES IN MOST STATES, CERTAIN RISKS ARISE. SOMETIMES AN INFANT'S REACTION TO A VACCINE GOES TRAGICALLY AWRY. NOT ONLY HAVE CONCERNS TO A VACCINE GOES TRAGICALLY AWRY. NOT ONLY HAVE CONCE
OVER SUCH A RESULT SPAWNED A FEDERAL VACCINE INJURY COMPENSATION PROGRAM, WHOSE CRITERIA ARE UNDER REVIEN, BUT COMPENSATION PROGRAM, WHOSE CRITERIA ARE UNDER REVIEW, BUT
NOW THEY MAY BE LEADING TO A TROUBLING PASS IN THE BATTLE NOW THEY MAY BE LEADING TO A TROUBLING PASS IN THE BATTL
AGAINST CHILDHOOD DISEASE. CRITICS SAY NEW NATIONALLY

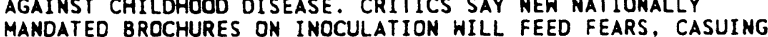
MANDATED BROCHURES ON INOCULATION WILL FEED FEARS, CASUING
PARENTS TO REJECT YACCINES, WHICH SAVE THOUSANDS OF LIVES.

06817 NEWPORT, F.; GALLUP, G. JR.

AMERICANS CONVINCED ECONOMY WILL NOT IMPROVE SOON GALLUP POLL MONTHLY, (315) (DEC 91), 42-48.

ACCORDING TO A GALLUP POLL CONDUCTED IN LATE 1991 AMERICANS ARE DEEPLY PESSIMISTIC ABOUT DOMESTIC ECONOMIC CONDITIONS AND DO NOT EXPECT THE RECESSION TO END QUICKLY. HOWEVER, A MAJORITY OF AMERICANS DO EXPECT THEIR PERSONAL

FINANCIAL SITUATION TO IMPROVE OVER THE NEXT YEAR.

06818 NEWPORT, F.: GALLUP, A.

DAVID DUKE WELL-KNOWN BUT VIEHED UNFAVORABLY 
GALLUP POLL MONTHLY (313) (OCT 91), 55-56.

APPROXIMATELY 6O\% OF AMERICAMS HAYE HEARD OR READ ABOUT DAVID DUKE. THE FORMER KU KLUX KLAN LEADER WHO IS A

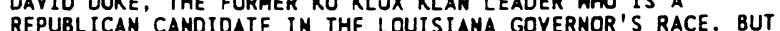
ONLY 10\% OF AMERICANS SAY THEY HAVE POSITIVE FEELINGS TOWARD DUKE, WHILE 66\% EXPRESS NEGATIVE FEELINGS TOWARD HIM.

06819 NEWPORT, $F$

1992 PRESIDENTIAL CAMPAIGN: AUGUST

GALLUP POLL MONTHLY, (323) (AUG 92), 2-24.

THE AUGUST 1992 POLLING OF THE U.S. PRESIDENTIAL

CAMPAIGN COVERS THE FOLLOWING TOPICS: WOMEN VOTERS KEY TO

DEMOCRATIC TICKET'S CHANCES; ABORTION; BUSH RATINGS; CLINTON

RATINGS; IRAQ ACTION; AND DEMOCRATIC PARTY GAINS AMONG

YOUNGER, BETTER EDUCATED VOTERS.

06820 NEWPORT, $F$

1992 PRESIDENTIAL CAMPAIGN: JULY

GALLUP POLL MONTHLY, (322) (JUL 92), 15-44.

THE JULY 1992 POLLIING OF THE U.S. PRESIDENTIAL CAMPAIGN

COVERS THE FOLLOWING TOPICS: CLING'S IMAGE, PEROT'S IMAGE;

THE DEMOCRAT CONVENTION: QUAYLE'S IMAGE; CLINTON'S MOMENTUM

GOING INTO CONVENTION; AND, THE REPUBLICAN CONVENTION.

06821 NEHPORT, $F$

1992 PRÉSIDENTIAL CAMPAIGN: OCTOBER

GALLUP POLL MONTHLY (325) (OCT 92), 2-25.

THE OCTOBER POLLING OF THE U.S. PRESIDENTIAL ELECTION

COVERS THE FOLLOWING TOPICS: CLINTON'S LEAD ANO PEROT'S RE-

ENTRY; VOTER ANGER; THE PRESIDENTIAL DEBATES; CLINTON'S

HONESTY; CONGRESS, BUSH'S IMPRESSION; AND SWING VOTERS.

06822 NEWSON, M.

SPACE, TIME AND POLLUTION CONTROL: GEOGRAPHICAL PRINCIPLES IN UK PUBLIC POLICY

AREA, 23(1) (MAR 91), 5-10.

THE AUTHOR ARGUES THAT OFFICIAL AGENCIES ARE NOH

STRUGGLING TO INTROOUCE EXPLICIT GEOGRAPHICAL ELEMENTS TO

POLLUTION CONTROL DEVICES--AN EXAMPLE BEING THE CONCEPT OF PROTECTION ZONES INTRODUCED TO RIVER POLLUTION CONTROL. THE PRESENT AND POTENTIAL ROLE OF ACADEMIC GEOGRAPHY AS A

DISCIPLINARY STRENGTH IN POLLUTION CONTROL IS DESCRIBED.

WAYS WHICH POLLUTION CONTROL POLICY IN THE UK HAS SHOWN A

OISTINCT GEOGRAPHICAL TENDENCY ARE EXPLORED.

06823 NEWTON, K.; VALLES, J.M.

IMTRODUCTION: POLITIICAL SCIENCE IN HESTERN EUROPE, 19601990

EUROPEAN

THE AUTHOR OFFERS AN OVERVIEW OF THE DEVELOPMENT OF THE

OISCIPLINE OF POLITICAL SCIENCE IN HESTERN EUROPE,

SCANDINAVIA, AND GREAT BRITAIN FROM 1960 TO 1990.

06824 NEWTON, $K$.

THE EUROPEAN CONSORTIUM FOR POLITICAL RESEARCH

EUROPEAN JOURNAL OF POLITICAL RESEARCH, 20(3-4) (DEC 91), $445-458$.

THE AUTHOR LOOKS AT THE EUROPEAN CONSORTIUM FOR

POL ITICAL RESEARCH, FOCUSING ON ITS GOALS, ACTIVITIES,

ORGANIZATION, MEMBERSHIP, PUBLICATIONS, AND STANDING GROUPS.

06825 NEYROUD, $P$.

MULTI-AGENCY APPROACHES TO RACIAL HARASSMENT: THE LESSONS

OF IMPLEMENTING THE RACIAL ATTACKS GROUP REPORT

NEW COMMUNITY, 18(4) (JUL 92), 567-578.

THE RACIAL ATTACKS GROUP (RAG) REPORT WAS PUBLISHED IN

1989 AS AN INTERDEPARTMENTAL CIRCULAR URGING AGENCIES TO

WORK TOGETHER TO TACKLE RACIAL HARASSMENT. THIS PAPER

SUMMARIZES THE MAJOR FINDINGS OF A PILOT MULTI-AGENCY

PROJECT IN HAMPSHIRE. THE ACHIEVEMENTS IN THE FIRST 18 MONTHS OF THE PROJECT ARE COMPARED TO THE RAG REPORT IN ORDER TO EVALUATE THE HAMPSHIRE MODEL. THREE OF THE FOUR MAIN BENEFITS OF MULTI-AGENCY COOPERATION ADVANCED BY RAG HAVE BEEN AT LEAST PARTIALLY ACHIEVED IN HAMPSHIRE. ALTHOUGH THERE HAS BEEN DIFFICULTY SECURING THE INYOLVEMENT OF BLACK AND ETHNIC MINORITY GROUPS, MULTI-AGENCY APPROACHES TO

TACKLING RACIAL HARASSMENT, PATTERNED ON RAG, OFFER SOME SUBSTANTIAL EXTRA BENEFITS NOT AVAILABLE TO AGENCIES WORKING SEPARATELY.

06826 NGUGI, $M$.

CRUCIBLE OF YOLATILITY

WEST AFRICA, 75(3887) (MAR 92), 450

THE QUESTION THAT IS UPPERMOST IN THE MIMDS OF MANY SOMAL RUTONALS, LATEST ROUND OF WHICH BEGUN LAST NOVEMBER IS: WILL THE PEACE THAT THE UNITED NATIONS IS NOW BROKERING IN SOMALIA HOLD? THE ESCALATION OF WAR SO SOON AFTER THE OUSTING OF FORMER DICTATOR BARRE IN JANUARY OF 1991 DEFIED THE PROSPECTS FOR A MUCH NEEDED PEACE AROUSED BY HIS DEPARTURE. THE BITTER HAR HAS CLAIMED OVER AN ESTIMATED 30,000 LIVES AND INJURED

THOUSANDS OF OTHERS, AND FORCED CLOSE TO ONE MILLION TO TAKE REFUGE IN NEIGHBORING COUNTRIES.
06827 NGUGI M.

LEARNING TO MULTI-PARTY

LEARNING TO MULTI-PARTY
WEST AFRICA, (3879) (JAN 92), 106

IN DECEMBER 1991, KENYA'S' CONSTIITUTION WAS AMENDED TO PERMIT THE EXISTENCE OF A MULTI PARTY SYSTEM. NO SOONER WAS THE CONSTITUTION AMENDED THAN A MAJOR REALIGNMENT OF POL ITICAL FORCES BEGAN AT EXTRAORDINARY COST TO THE RULING PALIT PARTY.

06828 NICE, D.

PEAK PRESIDENTIAL APPROVAL FROM FRANKLIN ROOSEVELT TO RONALD REAGAN

PRESIDENTIAL STUDIES QUARTERLY, 22(1) (WIN 92), 119-126. THE HIGHEST GALLUP APPROVAL RATINGS FOR U.S. PRESIDENTS FROM FRANKLIN ROOSEVELT TO RONALD REAGAN ARE POSITIVELY ASSOCIATED WITH THE PROPORTION OF THE PUBLIC IDENTIFYING WITH THE PRESIDENT'S PARTY AND NEGATIVELY RELATED TO THE PRDPORTION OF INDEPENDENTS IN THE POPULATION. VOTER TURNOUT, WAR, AND THE UNEMPLOYMENT RATE DURING THE PRESIDENT'S FIRT YEAR ARE UNRELATED TO PEAK APPROVAL. THE PAPER CONCLUDES THAT THE IMPORTANCE OF ECONOMIC GROWTH AS A PREDICTOR SEEMS TO HAVE BEEN OVERRRATED.

06829 NICE, D.C

INTERSTATE AND INTERGOVERMMENTAL FACTORS AFFECTING THE CONDITIONS OF RURAL BRIDGES

PUBL IUS: THE JOURMAL OF FEDERALISM, 22(4) (FAL 92), 1-14. MAYY OF THE MATION'S RUPAL HIGHAY BRIDGES ARE TRUCTURALLY DEFICIENT, FUNCTIONALLY INADEQUATE, OR BOTH, STRUCTURALLY DEFICIENT, FUNCTIONALLY INADEOUATE, OR BOTH CONSTRUCTION AND MAINTENANCE APPEARS TO BE A FACTOR. RURAL BRIDGES ARE ESPECIALLY LIKELY TO BE IN POOR CONDITION IN STATES WHERE THE FEDERAL GOVERMMENT PLAYS A SMALL ROLE IN THE HIGHWY PROGRAM, WHERE LOCAL GOVERNMENTS PLAY A LARGE ROLE IN HIGHWAY FINANCING, AND WHERE THE CHIEF STATE TRANSPORTATION AGENCY IS A HIGHHAY DEPARTMENT RATHER THAN A DEPARTMENT OF TRANSPORTATION.

06830 NICE, D.C

THE STATES AND THE DEATH PENALTY

WESTERN POLITICAL QUARTERLY, 45(4) (DEC 92), 1037-1048.

IN THE 1970'S A COMBINATION OF SUPREME COURT RULINGS AND THE SALIENCE OF THE CRIME PROBLEM GAVE THE AMERICAN STATES AN OPPORTUNITY TO REVISE THEIR DEATH PENALTY LANS. ANALYSIS OF BOTH FORMAL POLICY PROVISIONS AND THE APPLICATION OF THOSE POLICIES REVEALS THAT DEATH PENALTY DECISIONS ARE CLOSELY LINKED TO THE CLIMATE OF PUBLIC OPINON AND THE RATE OF MURDERS AND NON-NEGLIGENT HOMICIDES.

06831 NICHOLS, R.

A RIOT OF AN ELECTION: TURMOIL IN THE USA

ARENA, $9(100)(1992), 155-163$.

THE L.A. CIVIL RIOTT AND THE ELECTORAL REBELLION ILLUMINATE ONE ANOTHER. BOTH ARE RESPONSES TO THE PROBLEMS THE ESTABLISHED SYSTEM IS NOT HANDLING. BOTH POINT UP THE THE ESTABLISHED SYSTEM IS NOT HANDLING. BOTH POINT UP THE PLIGHT OF POLITICAL ACTION IN CONTEMPROARY AMERICA. THIS ARTICLE EXPLORES THE UNUSUALLY UNPOPULAR MAJOR PRESIDENT CONTENDERS AND THEIR STANCES. IT SUGGESTS THAT THE L.A. SENSELESS NOR CRIMINAL. THEY HAD A POLITICAL CHARACTER AND SENSELESS NOR CRIMINAL. THEY HAD A POL ITICAL CHARACTER
APPEAR TO BE MUCH OF A PIECE WITH THOSE OF THE 19905

06832 NICKSON, R.

DEMOCRATISATION AND THE GROWTH OF COMMUNISM IN NEPAL: A PERUVIAN SCENARIO IN THE MAKING?

JOURNAL OF COMMONWEALTH AND COMPARATIVE POLITICS, 30(3) (NOV 92 ), 358-386.

THIS ARTICLE TRACES THE HISTORY OF THE COMWUNIST MOVEMENT IN NEPAL, ITS GROWTH AND DIVISION DURING THE LONG STRUGGLE AGAINST ROYAL POWER, AND ITS CONSOLIDATION DURING THE 'DEMOCRACY MOVEMENT'. IT' EXAMINES THE PHENOMENON OF MAOISM IN NAPEL AND TRACES ITS LINKS HITH PERU AND INVESTIGATES WHETHER MAOIST PARTIES ARE CAPABLE OF GENERATING IN NEPAL THE KIND OF UNEXPECTED AND DRAMATIC IMPACT WHICH THEIR COUNTERPART HAS HAD ON THE PERUVIAN POLITICAL SYSTEM.

06833 NICOLAY, J.

A CONTENT ANALYSIS OF "FROM SOUTH AFRICA": NONTRADITIONAL LITERATURE IN THE TEACHING OF MINORITY POLITICS

PS: POLITICAL SCIENCE AND POLITICS, XXV(2) (JUN 92),

228-230.

THE AUTHOR EXPLAINS hOW HE USED "FROM SOUTH AFRICA," AN

ANTHOLOGY BY TAYLOR AND BANE TO HELP STUDENTS IN HIS

MINORITY POLITICS COURSE DEYELOP AN APPRECIATION OF THE

MINORITY POLITICS COUR

06834 NICOLSON, $J$.

THE LAST HARRUMPH

NEW REPUBLIC 206(16) (APR 92), 16-17.

FORMER PRIME MINISTER MARGARET THATCHER IS PLAYING A

MINOR ROLE IN THE 1992 ELECTION CAMPAIGM AMD IS SUPPORTING

JOHN MAJOR AND THE TORY PARTY IN A RATHER SUBDUED, QUALIFIED 
MANNER.

06835 NIEKERK, $P$.

THE SOUTH AFRICAN COMMUNIST PARTY

SOUTH AFRICA FOUNDATION REVIEW, 17(11) (NOV 91), 6.

IN MOST QUARTERS, THE FALL OF THE COMMUNIST PARTY OF THE SOVIET UNION WAS SEEN AS THE DEATH KNELL FOR WORLD COMMUNISM -- EXCEPT IN SOUTH AFRICA. ON 4 DECEMBER 1991 MEMBERS OF THE SOUTH AFRICAN COMMUNIST PARTY WILL BE DEBATING A NEW MANIFESTO AND RATIFYING THEIR CONSTITUTION AT THE FIRST LEGAL PARTY CONFERENCE INSIDE THE COUNTRY SINCE 1950. HOW THE PARTY FARES IN THE FUTURE DEPENDS IN PART UPON HOW IT IS ABLE TO EXPLAIN ITS PAST, AND ADJUST TO A RADICALLY CHANGED POL ITICAL CLIMATE, LOCALLY AS HELL AS INTERNATIONALLY.

06836 NIEMI, R.; WINSKY, L.

THE PERSISTENCE OF PARTISAN REDISTRICTING EFFECTS IN CONGRESSIONAL ELECTIONS IN THE 1970 S AND 1980 S

CONGRESSIONAL ELECTIONS IN THE 1970S AND 1980S
THE JOURNAL OF POLITICS, 54 (2) (MAY 92), 565-572.

BY CALCULATING RELATIVE VOTE AND SEAT GAINS BEFORE AND AFTER THE 1980S, REDISTRICTING, ABRAMOWITZ (1983) FOUND THAT PARTISAN CONTROL OF REDISTRICTING INFLUENCED THE 1982 CONGRESSIONAL ELECTIONS. THE AUTHORS FIRST EXTEND ABRAMOWITZ'S ANALYSIS TO 1970-1972, WITH RESULTS THAT ARE EQUALLY INDICATIVE OF PARTISAN ADVANTAGE. THEY THEN INQUIRE WHETHER THESE EFFECTS ARE LONG-LASTING, FINDING THAT THE INITIAL PARTISAN ADVANTAGE TYPIC
BUT THAT IT DOES SO GRADUALLY

06837 NIEMI, R.G.; FRANKLIN, M.N.; HHITTEN, G

CONSTITUENCY CHARACTERISTICS, INDIVIDUAL CHARACTERISTICS, AND TACTICAL VOTING IN THE 1987 BRITISH GENERAL ELECTION BRITISH JOURMAL OF POLITICAL SCIENCE, 22(2) (APR 92), 229-254.

THE AUTHORS ARGUE THAT ABOUT ONE IN EVERY SIX VOTERS HAD TACTICAL CONSIDERATIONS IN MIND WHEN DECIDING HOW TO VOTE IN GREAT BRITAIN'S 1987 GENERAL ELECTION, ALTHOUGH TACTICAL CONSIDERATIONS MAY NOT HAVE BEEN THE ONLY CRITERIA DETERMINING HOW THEY VOTED.

06838 NIEMI, R.G.; CRAIG, S.C.; MATTEI, F. MEASURING INTERNAL POLITICAL EFFICACY IN THE 1988 NATIONAL ELECTION STUDY

AMERICAN POLITICAL SCIENCE REVIEW, 85(4) (DEC 91),

1407-1413.

POLITICAL EFFICACY HAS BEEN STUDIED EXTENSIVELY SINCE THE 1950'S, BUT ANALYSTS HAVE NEVER BEEN FULLY SATISFIED WITH ITS MEASUREMENT. AFTER CONSIDERABLE TESTING, FOUR NEW QUESTIONS TAPPING INTERNAL POLITICAL EFFICACY WERE ADDED TO THES IONS NAPPING INTERNAL POLITICAL EFFICACY WERE ADDED THE 1988 NATIONAL ELECTION STUDY. THIS ESSAY ARGUES THAT INTER - ITEM CORRELATIONS AMONG THESE QUESTIONS INDICATE HIGH FACTOR AMALYSIS INDICATE THAT THESE ITEMS MEASURE A SINGLE FACTOR ANALYSIS INDICATE THAT THESE ITEMS MEASURE A SINGLE CONCEPT DISTINCT FROM EXTERNAL EFFICACY AND POLITICAL TRUST,
THAT THE MEASUREMENT MODEL IS ROBUST ACROSS MAJOR SUBGROUPS, THAT THE MEASUREMENT MODEL IS ROBUST ACROSS MAJOR SUBGROUPS, AND THAT THE OVERALL SCALE IS EXTERNALLY VALID AND PROVIDES A GOOD DISTRIBUTION OF EFFICACY SCORES ACROSS THE POPULATION
FURTHER, THE RESULTS OF AN ORDER EXPERIMENT IN THE SURVEY SUGGEST THAT RESPONSES ARE UNAFFECTED BY MODE OF PRESENTATION. IN SHORT, THE FOUR NEW QUESTIONS CONSTITUTE THE MOST SATISFACTORY MEASURE OF INTERHAL POLITICAL EFFICACY TO DATE.

06839 NIES, H.

RESEARCH AND THE LOCAL PLANNING OF SERVICES FOR ELDERLY PEOPLE: AN INTERACTIVE APPROACH

POLICY AND POLITICS, 20(1) (JAN 92), 1-13.

THE ASSESSMENT OF NEED AND THE VESTED INTERESTS OF POWERFUL ACTORS CONSTITUTE THO MAJOR PROBLEMS IN THE LOCAL PLANNING OF SERVICES FOR ELDERLY CITIZENS. IN THIS PAPER, THE CONTRIBUTION OF APPLIED RESEARCH TO THE PLANNING PROCESS IS EXPLORED BY MEANS OF A CASE STUDY OF CARE DELIVERY TO LONG-TERM ELDERLY PATIENTS.

06840 NIESSEN, J.

EUROPEAM COMMUNITY LEGISLATION AMD INTERGOVERMMEMTAL COOPERATION ON MIGRATION

INTERNATIONAL MIGRATION REVIEW, XXVI (2) (SUM 92), 676-684. THIS ARTICLE EXAMINES EUROPEAN COMMUNITY LEGISLATION REGARDING MIGRATION. ISSUES CONSIDERED INCLUDE FREE MOVEMENT, RESIDENCE, ADMISSION, THIRD-COUNTRY NATIONALS, SOCIAL POLICIES, HEALTH SAFETY ASSOCIATION AND COLS, SOCIAL AGREEMENTS, EDUCATION, AND POLICIES REGARDING DISCRIMINATION AND RACISM. THE ARTICLE ALSO EXAMINES THE CONFLICTS BETHEEN MEMBER STATES AND THE COMMUNITY WHICH ARISE FROM THE FACT

THAT THE EC IS AN UNEASY MIXTURE OF INTERNATIONAL AND SUPRANATIONAL COOPERATION. IMPLICATIONS OF THESE CONFLICTS FOR MIGRATION POLICY ARE DISCUSSED.

06841 NIKOLAEY, R.

THE BULGARIAN PRESIDENTIAL ELECTIONS

RFE/RL RESEARCH REPORT, 1(6) (FEB 92), 11-16.

PRESIDENT ZHELYU ZHELEY, HHO WAS ELECTEO BY THE

PARLIAMENT IN AUGUST 1990, WON BULGARIA'S FIRST-EVER OIRECT
PRESIDENTIAL ELECTIONS IN JANUARY 1992. ZHELEV AND HIS RUNAING MATE, BLAGA DIMITROVA, HERE SUCCESSFUL IN THE SECOND ROUND OF VOTING, WINNING BY A SHALL MARGIN OVER THE SOCIALIST-BACKED TEAM OF VELKO VALKANOV AND RUMEN VODENICHAROV. GEORGES GANCHEV, CONSIDERED AN OUTSIDER BY SOME, SUPRISINGLY FINISHED THIRD. ALTHOUGH THE PRESIDENT HAS ONLY LIMITED POWERS, ZELEV IS EXPECTED TO PLAY AN IMPORTANT ROLE IN DOMESTIC POLITICS AND IN FOREIGN RELATIONS.

06842 NIKOLAEV, $R$

UNION AND DISUNION AMONG BULGARIA'S AGRARIAN PARTIES

RFE/RL RESEARCH REPORT, 1(12) (MAR 92), 1-6.

DUE TO THEIR POOR SHOWINGS IN THE OCTOBER 1991 NATIONAL ELECTIONS, THE BULGARIAN AGRARIAN NATIONAL UNION-UNITED AND THE BULGARIAN AGRARIAN NATIONAL UNION-NIKOLA PETKOY ARE CONSIDERING A NEW EFFORT TO UNITE, EVEN THOUGH SEVERAL CONSIDERING A NEH EFFORT TO UNITE, EVEN THOUGH SEVERAL PREVIOUS ATTEMPTS HAVE FAILED AND THE TWO PARTIES ARE
SUFFERING FROM SERIOUS INTERNAL DIVISIONS. BOTH PARTIES HAVE SUFFERING FROM SERIOUS INTERNAL DIVISIONS. BOTH PARTIES HAVE HAD DIFFICULTY ATTRACTING YOUNG SUPPORTERS AND ARE HEADED BY
ELDERLY MEN TO TEND TO LOOK BACK RATHER THAN TO THE FUTURE.

06843 NIKOLAJEH, $Y$.

TRANSITIONAL ECONOMIES

FUTURES, 24(7) (SEP 92), 635-652

THE EMERGENCE OF A NEW PROBLEMATIQUE--TRANSITIONAL ECONOMIES--THAT CANNOT BE HANDLED WITHIN TRADITIONAL PARADIGMS AND MODELS IS LINKED TO THE DIFFICULT TRANSFORMATION OF EASTERN EUROPE AND THE FORMER SOVIET UNION TO A WESTERN-STYLE MARKET ECONOMY. THE CASE OF THE FORMER EAST GERMANY STANDS OUT. SEVERAL PHASES OF SUCH TRANSFORMATION ARE ENVISAGED: INTRODUCTION OF BASIC PRINCIPLES OF THE MARKET ECDNOMY, BUILDING OF INFRASTRUCTUAL, FINANCIAL, ADMINISTRATIVE AND LEGAL PRECONDITIONS FOR THE EFFICIENT RUNNING OF SCALE ECONOMIES, BRINGING ABOUT THE SHIFT TO SOCIALLY ORIENTED AND ECONOLOGICALLY SUSTAINABLE ECONOMIC PERFORMANCE. HE TRANSFORMATION NEEDS HELP FROM THE WEST.

06844 NIKSCH, L.

DEALING HITH NORTH KOREA ON THE NUCLEAR HEAPONS THRESHOLD KOREAN JOURNAL OF DEFENSE ANALYSIS, IV(1) (SUM 92), 67-84. THO DEVELOPMENTS RELATED TO NORTH KOREA'S APPARENT NUCLEAR WEAPONS PROGRAM LIKELY WILL COME TO A HEAD IN JUNE AND JULY 1992. FIRST, NEGOTIATIONS OVER OUTSIDE INSPECTIONS OF SUSPECTED NORTH KOREAN NUCLEAR WEAPONS FACILITIES WILL PROBABLY CLARIFY THE EXIENT TO WHICH NORTH KOREA WILL ALLOW PROBABLY CLARIFY THE EXIENT TO WHICH NORTH KOREA WILL ALLOH
INSPECTIONS. SECOND, NORTH KOREA'S PLUTONIUM REPROCESSING INSPECTIONS. SECOND, NORTH KOREA'S PLUTONIUM REPROCESSING
PLANT COULD BECOME OPERATIONAL BY THE SUMMMER OF 1992. THIS PLANT COULD BECOME OPERATIONAL BY THE SUMMMER OF 1992. THIS
WOULD BE A MAJOR STEP TOWARDS A NUCLEAR WEAPONS PRODUCTION CPABILITY. THIS ARTICLE DISCUSSES INTERNATIONAL PRESSURES, CPABILITY. THIS ARTICLE DISCUSSES INTERNATIONAL PRESSURES, INCLUOING SANT IONS, WHICH ARE BEING EXERTED ON NORTH KOREA NUCLEAR WEAPONS CAPABILITIES.

06845 NILLER, R.H.

VIETNAM: FOLLY, QUAGMIRE, OR INEVITABILITY? STUDIES IN CONFLICT AND TERRORISM, 15(2) (APR 92), 99-124.

THIS ARTICLE TRACES THE POLICY CHOICES THAT SUCCESSIVE AMERICAN PRESIDENTS FACED REGARDING VIETNAM IN THE CDNTEXT OF HORLD WAR II AND THE ENSUING COLD WAR. IT DESCRIBES THE CHOICES MADE AS "MAINSTREAM" POLITICAL DECISIONS AT THE TIME, DESPITE THE DEEPENING AND ULTIMATELY UNSUCCESSFUL ENGAGEMENT INTO WHICH THOSE DECISIONS LED THE UNITED STATES. FINALLY, IT NOTES THE ULTIMATE IRONY THAT, ALTHOUGH U.S. POLICIES LED TO DEFEAT IN VIETNAM, THEY ACHIEVED THEIR LARGER OBJECTIVE OF ENSURING THAT THE REST OF SOUTHEAST ASIA REMAINED OUT OF COMMUNIST ORBIT, POLITICALLY STABLE AND ECONOMICALLY DYNAMIC.

06846 NIMER, B.

TERRORISM AND SOUTHERN AFRICA

TERRORISH, 13(6) (NOV 90), 447-454.

THIS ARTICLE FOCUSES ON THE ACTIVITIES OF THE AFRICAN NATIONAL CONGRESS (ANC) AS THEY MAY BE RELEVANT TO TERRORISM. ANC ACTIVITIES RAISE ALL THE MAJOR OUESTIONS ABOUT TERRORISH: THE MEANING OF THE TERM ITSELF; HOW TO VIEW THE POLITICIZED USE OF TERRORISM BOTH BY THOSE WHO CHARGE IT AND THOSE WHO DENY ITS APPLICABILITY TO THEMSELVES; STATESUPPORTED TERRORISM: AND STATE TERRORISM, AGAINST WHICH THE PUTATIVE TERRORIST ORGANIZATION CLAIMS TO ENGAGE AT MOST IN PUTATIVE TERRORIST ORGANIZATION CLAIMS TO ENGAGE AT MOST IN
COUNTERTERRORISM. THE AUTHOR ILLUSTRATES THE RELEVANCE OF COUNTERTERRORISM. THE AUTHOR ILLUSTRATES THE RELEVANCE
ANC ACTIVITIES TO TERRORISM WITH SPECIFIC EVENTS AND ANC ACTIVITIE
ACTIVITIES.

06847 NIMETZ, $M$.

UNITED STATES INTERESTS AND ETHNIC CONFLICTS

MEDITERRANEAN QUARTERLY: A JOURNAL OF GLOBAL ISSUES, $3(4)$ (FAL 92), 10-20.

THE UNITED STATES HAS GREAT DIFFICULTIES DEVELOPING WELLCONCEIVED PROGRAMS TO DEAL WITH ETHNIC DISPUTES. AS THESE ISSUES CONTINUE TO CONFRONT, AMERICAN POLICYMAKERS WILL BE CONFRONTED AGAIN AND AGAIN WITH LOCALIZED ISSUES THAT RAISE PROFOUND AND FUNOAMENTAL ISSUES. THIS ARTICLE OUTLINES A
PLAN TO DEAL WITH THESE ISSUES AS THEY ARISE--ISSUES THAT 
THE AUTHOR CALLS THE NEW TRIBALISM IN INTERNATIONAL AFFAIRS AND OFFERS SIX BROAD PRINCIPLES TO BE APPLIED TO THEM.

06848 NIMO, $K$

BREAKING A TRADITION

WEST AFRICA, (3908) (AUG 92), 1346-1347

GHANA'S CIVIL SERVANTS HAVE TRADITIONALLY BEEN

DISTINGUISHED BY UNOBTRUSIVE DOCILITY AND TAMENESS. BUT THIS IMAGE IS BEING SHED AS THE BUREAUCRATS ADOPT A NEW, MILITANT POSTURE. RECENTLY THE CIVIL SERVANTS HAVE BEEN STAGING PUBLIC DEMONSTRATIONS, PROTESTING THEIR LOW SALARIES ANO POOR WORKING CONDITIONS, MUCH TO THE ALARM OF GOVERNMENT LEADERS

06849 MINCIC, M.

A SENSIBLE PUBLIC: NEW PERSPECTIVES ON POPULAR OPINION AND FOREIGN POLICY

JOURMAL OF CONFLICT RESOLUTION, 36(4) (DEC 92), 772-789. FOUR BOOKS ARE REVIEWED IN THIS ARTICLE WHICH SHARE A CONVICTION THAT MANY IMPORTANT INFLUENCES ON THE INTERMATIONAL BEHAYIOR OF MATIONS FLOW FROM HITHIN THEM, THAT PUBLIC OPINION IS A SIGNIFICANT SUCH INFLUENCE AND THAT, AS A GENERAL RULE, POPULAR PREFERENCES ARE SENSIBLY RELATED TO THE SOUND CONDUCT OF FOREIGN POLICY. A CONCEPTION OF TO THE SOUND CONDUCT OF FOREIGN POLICY. A CONCEPTION RATIONALITY AS REASONABLENESS IS ONE OF THIS BOOY OF LITERATURE'S CONTRIBUTIONS; ANOTHER IS THE INSIGHT IT POVERMMENT INTERESTS, AND MEDIA VIEHS. AT THE SAME TIME, THIS ARTICLE SUGGESTS WAYS IN WHICH THE STUDY OF PUBLIC THIS ARTICLE SUGGESTS WAYS IN WHICH THE STUDY OF PUBLI THEORETICAL DIRECTIONS.

06850 NIMDI, $B$.

STATE INTERVENTION, CONTRADICTIONS AND AGRICULTURAL STAGNATION IN TANZANIA--CASHEW NUT VS. CHARCOAL PRODUCTION PUBLIC ADMINISTRATION AND DEVELOPMENT, 11(2) (MAR 91), 127-134

THE ARTICLE FIRST DESCRIBES TANZANIAN DEVELOPMENT IDEOLOGY AND MAIN ECONOMIC ACTIVITIES. IT EXPLAINS ECONOMIC DECLINE AND GIVES A BRIEF DESCRIPIION OF RUFIJI DISTRICT. THE NEXT SECTION EXAMINES THE DYNAMICS OF STATE-PEASANTCOMMERCIAL CLASS RELATIONSHIP IN RUFI JI DISTRICT WITHIN THE WIDER CONTEXT. THERE IS A NUMBER OF BROAD THEORETICAL LINES OF REASONING THAT HAVE COM TO PREDOMINATE IN CONTEMPORARY DEBATE ON THE ORIGINS AND GENESIS OF THE AFRICAN AGRICULTURAL CRISIS AND TANZANIA IN PARTICULAR. THIS PAPER SEEKS TO SHOW THAT THE MOTION OF CRISIS MUST BE SUB CAREFUL, SPECIFIC, AND HISTORICALLY SENSITIVE ANALYSIS.

06851 NIOU, E.; ORDESHOOK, P.

A GAME THEORETIC ANALYSIS OF THE REPUBLIC OF CHINA'S A GAME THEORETIC ANALYSIS

INTERNATIONAL POLITICAL SCIENCE REVIEN, 13(1) (JAN 92), 59-80.

GAME THEORY IS USED TO UNDERSTAMD THE REPUBLIC OF CHINA'S EVOLVING ELECTORAL INSTITUTIONS ANO PROCESSES. THE AUTHORS EXAMINE THE TYPES OF ISSUES THAT OPPOSITION PARTIES ARE MOST LIKELY TO USE IN CHALLENGING KMT RULE. THEY ARGUE THAT THE ROC OUGHT TO BE ESPECIALLY SENSTIVE TO RIKER'S CONCLUSION THAT EVOLVING DEMOCRACIES SHOULD DEVOTE SPECIAL ATTENTION TO DEVELOPING INSTITUTIONAL STRUCTURES SUCH AS BICAMERALISM AND STAGGERED TERMS OF OFFICE. THEY ARGUE THAT THE FORM OF ELECTORAL COMPETITION IS A FUNCTION OF THE EXTENT TO WHICH VOTERS PERCEIVE ELECTORAL COMPETITION IN TERMS OF INDIVIDUAL CANDIDATE CHARACTERISTICS VERSUS PARTY LABELS. FINALLY, THEY EXAMINE THE CIRCUMSTANCE UNDER WHICH THE NATURE OF THE ISSUES THAT CONCERN AN ELECTORATE DETERMINES THE FORM OF COMPETITION IN DEMOCRACIES CHARACTERIZED BY A SINGLE DOMINANT PARTY.

06852 NISAN, M.

ZIONIST DIALECTICS AND PALESTINIAN PARADOXES

JOURMAL OF THEORETICAL POLITICS, 4(4) (OCT 92), 435-441.

THE COMPLEXITY AND NUANCES OF ISRAEL I RULE OVER THE

AREAS OF JUDEA-SAMARIA AND THE GAZA STRIP SINCE 1967 HAVE BEEN LARGELY IGNORED BY MOST SCHOLARS AND COMHENTATORS. IT SEEMS THAT ISRAEL HAS BEEN UNABLE TO CONVEY THE FACT OF A JEWISH-PALESTINIAN VIRTUAL TRADE-OFF IN THEIR PROBLEMATIC RELATIONSHIP FOR THOSE EXAMINING THE PROCESSES AND INFLUENCES FROM THE STATE-BUILDING ENTERPRISE BEYOND ISRAEL'S GREEN LINE 8ORDER. ALSO ABSENT FROM ADEQUATE RECOGNITION AND PERCEPTION IN THIS RESPECT IS THE EXIGENCY RECOGNITIDN AND PERCEPTION IN THIS RESPECT IS THE EXIGENCY OF THE MIDDLE EAST POLITICAL ENVIRONMENT AND ITS RELEVANCE
FOR THE ISRAELI CASE. THE STATE-BUILDING EXPANSIVE ISRAELI FOR THE ISRAELI CASE. THE STATE-BUILDING EXPANSIVE ISRAELI
EFFORT CONTAINS WITHIN IT THE POWER TO DETERMINE THE OUTCOME OF THE ISRAELI-PALESTINIAN COMPETITION, HHEN ALL IS SAID AND DONE.

06853 NISHIMURA, S.

US AND JAPAN AS PARTMERS

FAR EASTERN ECONOMIC REVIEH, 155(30) (JUL 92), 13

THE END OF THE COLD WAR AND THE RESULTANT SHIFT IN U.S. MILITARY STRATEGY AHAY FROM CONTAINING THE ERSTWHILE SOVIET UNION HAVE CAUSED THE U.S. - JAPAN RELATIONSHIP TO BE
RECONSIDERED. THIS ARTICLE ARGUES THAT JAPAN WILL STILL BE USEFUL TO THE UNITED STATES BY FUNCTIONING AS A HOST-NATION, ALLOWING THE U.S. TO OUICKLY AND EFFECTIVELY RESPOND TO REGIONAL CONFLICTS IN ASIA. JAPAN WILL SURELY TAKE ON MORE OF THE BURDEN OF DEFENDING ITS OWN TERRITORY AND PROTECTING ITS INTERESTS AROUND THE PACIFIC RIM, BUT CALLS FOR AN AUTONOMOUS JAPANESE DEFENSE CAPABILITY ARE NAIVELY PREMATURE. IN SHORT, U.S. -JAPANESE MILITARY COOPERATION SHOULD AND WILL CONTINUE IN THE NEAR FUTURE.

06854 NIVOLA, P.S

MINDING THEIR BUSINESS: REFLECTIONS ON REGULATING UNFAIR TRADE

BROOKIMGS REVIEW, 10(4) (FAL 92), 36-41

MOST U.S. LAWMAKERS ARE NOT ANXIOUS TO RESTORE OUTMODED PROTECTIONISM. POLITICIANS KNOW WHAT A MAJORITY OF AMERICANS SUSPECT: THE COUNTRY'S ABILITY TO COMPETE ECONOMICALLY DEPENDS MORE ON MAINTAINING INTERMAL FITNESS THAN ON PROTESTING EXTERNAL CONDITIONS.

06855 NIXON, R.

IS AMERICA A EUROPEAN POHER?

NATIONAL REVIEW, XLIV(4) (MAR 92), 26-37

THE END OF THE COLD WAR COULD SEE THE END OF THE WESTERN ALLIANCE. SINCE THIS WOULD ISOLATE AMERICA AND DESTABILIZE

ALLIANCE. SINCE THIS WOULD ISOLATE AMERICA AND DESTABILIZE
EUROPE, RICHARD NIXON CONSIDERS HOW BEST TO SECURE THE PEACE.

EUROPE, RICHARD NIXON CONSIDERS HOW BEST TO SECURE THE

RICHARD NIXON. COPYRIGHT 1992 BY EAST-WEST RESEARCH.

06856 NOCK, C.J.

EQUAL FREEDOM AND UNEQUAL PROPERTY: A CRITIQUE OF NOZICK'S LIBERTARIAN CASE

CANADIAN JOURNAL OF POLITICAL SCIENCE, XXV(4) (DEC 92), 677-696.

ROBERT NOZICK HAS ARGUED THAT INVIOLABLE CAPITALIST PROPERTY RIGHTS ARE A NECESSARY COROLLARY OF THE FREE SOCIETY. THIS VIEW IS GROUNDED IN HIS COMMITMENT TO THE CLASSICAL LIBERAL PRINCIPLE OF EQUAL LIBERTY. THIS PAPER TESTS THE INTERNAL COHERENCE OF NOZICK'S PERSPECTIVE WITH REFERENCE TO THE DEMANDS SET BY THIS PRINCIPLE. IT IS ARGU THAT HIS LAISSEZ-FAIRE PROPOSALS CANNOT SATISFY THESE ECONOMIC ARRANGEMENTS THAT COULD RESPOND TO THE DILEMMAS POSED BY THE EQUAL LIBERTY PRINCIPLE, THE SUGGESTION BEING THAT A PARTICIPATORY DEMOCRATIC FRAMEWORK WOULD PROMOTE A RESPONSE SUPERIOR TO NOZICK'S.

06857 MODIA, G.; AVINERI, S.; FUKUYAMA, F. NATIONALISM AND DEMOCRACY
JOURMAL OF DEMOCRACY, 3(4) (OCT 92), 3-31. IN THIS ESSAY, GHIA NODIA ASKS IF NATIONALISM AND IN THIS ESSAY, GHIA NODIA ASKS IF NATIONALISM AND
DEMOCRACY ARE TWO SEPARATE ENTITIES OR IF, IN FACT, DEMOCRACY ARE TWO SEPARATE ENTITIES OR IF, IN FACT, "LIBERAL DEMOCRACY." HE SUGGESTS THAT THE IDEA OF NATIONALISH IS IMPOSSIBLE-INDEED UNTHINKABLE--WITHOUT THE NATIONALISH IS IMPOSSIBLE--INDEED UNTHINKABLE--WITHOUT THE IDEA OF DEMOCRACY AND THAT DEMOCRACY NEVER EXISTS NITHOUT NATIONALISH. THE THO ARE JOINED IN A SORT OF COMPLICATED MARRIAGE, UNABLE TO LIVE WITHOUT EACH OTHER, BUT COEXISTING IN AN ALMOST PERMANENT STATE OF TENSION. DIVORCE MIGHT SEEM THE LOGICAL SOLUTION TO A HESTERN LIBERAL HORRIFIED BY THE TWENTIETH CENTURY'S EXPERIENCE OF EUROPEAN NATIONALISH, BUT THIS OPTION IS NOTHING MORE THAN WISHFUL THINKING WHEN REAL POLITICAL FORCES ARE TAKEN INTO ACCOUNT. AFTER NODIA CONCLUDES HIS ESSAY, FRANCIS FUKUYAMA AND SHLOMO AVINERI COMMENT ON HIS ARGUMENTS.

06858 NOEL, E

REFLECTIONS ON THE MAASTRICHT TREATY

GOVERNMENT AND OPPOSITION, 27 (2) (SPR 92), 148-157. THE CONCLUSIONS REACHED AT THE MEETING OF THE EUROPEAN COUNCIL IN MAASTRICHT IN DECEMBER 1991 REGARDING ECONOMIC MONETARY, AND POLITICAL UNION FORM AN IMPRESSIVE AND COMPLEX WHOLE, IN WHICH UNDERTAKINGS OF MAJOR IMPORTANCE COEXIST WITH MORE TIMID ONES. IN THIS ARTICLE, THE AUTHOR EXAMINES SOME OF THE MORE SIGNIFICANT PROVISIONS OF THE MAASTRICHT AGREEMENT.

06859 NOELLE-MILLS, M.

HAITI: THE COUP AND THE REFUGEE CRISIS

TRANSAFRICA FORUM $9(1)$ (SPR 92 )

THE MOST RECENT CRISIS IN HAITI RESUITIMG FROM THE COUP OF SEPTEMBER 30, 1991, HAS HAD HORRIFIC EFFECTS FOR THE ISLAND-NATION AND ITS' SIX MILLION INHABITANTS. THE COUNTRY ISLAND-NATION AND ITS SIX MILLION INHABITANTS. THE COUNTRY IS EXPERIENCING POLITICAL CHAOS, SOCIOECONOMIC OISLOCATION, VIOLENT REPRISALS, AND MASS EXODUS. HAITI'S TRIBULATIONS ARE TURNED AWAY THOUSANDS OF HAITIAN REFUGEES.

06860 NOGUCHI, M.G.

THE RISE OF THE HOUSEHIFE ACTIVIST

JAPAN QUARTERLY, XXXIX(3) (JUL 92), 339-352.

ENVIRONMENTAL MOVEMENT ON A TV PROGRAM OR IN THE PRINTED MEDIA IS A MIDDLE-AGED HOMAN WHO CALLS HERSELF A "HOUSEWIFE. 
"IN THIS ARTICLE, THE AUTHOR PROFILES SIX FEMALE LEADERS OF GRASSRDOTS ENVIRONMENTAL GROUPS IN JAPAN.

06861 NOLAN, C.

THE LÁST HURRAH OF CONSERVATIVE ISOLATIONISM: EISENHOWER, CONGRESS, AND THE BRICKER AMENOMENT

PRESIDENTIAL STUDIES QUARTERLY, XXII(2) (SPR 92), 337-350. ON 14 SEPTEMBER, 1951, REPUBLICAN SENATOR JOHN BRICKER OF OHIO INTRODUCED A PROPOSED CONSTITUTIONAL AMENDMENT AIMED AT LIMITING PRESIDENTIAL TREATY-MAKING POHER. THE RESOLUTION SEVERELY THREATENED PRESIDENTIAL AUTHORITY AND AMERICA'S NEW INTERNATIONALIST ROLE IN FOREIGN AFFAIRS. IT WAS STRONGLY RESISTED BY PRESIDENT EISENHOWER. THIS ARTICLE EXAMINES THE UNDERLYING MOTIVATIONS OF THE BRICKER AMENDMENT'S BACKERS. UNDERLYING MOTIVATIONS OF THE BRICKER AMENDMENT'S BAC IT CONCLUDES THAT ISOLATIONISM HAS THE AMENDNENT'S
MAINSPRING OF SUPPORT. ALTHOUGH SOME CONSERVATIVES DID MAINSPRING OF SUPPORT. ALTHOUGH SOME CONSERVATIVES DID
INDEED OBJECT TO UN INVOLVEMENT WITH HUMAN RIGHTS, SUCH UN INDEED OBJECT TO UN INVOLVEMENT WITH HUMAN RIGHTS, SUCH UN FUNDAMENTAL, ISOLATIONIST ASSAULT ON THE PRESIDENCY. IN FUNDAMENTAL, ISOLATIONIST ASSAULT ON THE PRESIDENCY. IN SHORT, THE AMENDMENT, WHICH FAILED BY A NARR
CONSERVATIVE ISOLATIONISM'S "LAST HURRAH."

06862 NOLTE, N.

EUROPE IN GLOBAL SOCIETY TO THE THENTIETH CENTURY INTERNATIONAL SOCIAL SCIENCE JOURNAL, 131(131) (FEB 92), 23-40.

WHAT EUROPE "IS" IS EXPLORED IN THIS ARTICLE FROM A "ONE WORLD" PERSPECTIVE. TO EXPLAIN THE WHOLE STORY THE AUTHOR LOOKS AT THE SETTING AS A WHOLE AND MAKES TWO POINTS; 1) CAPITALISM AND THE EUROPEAN WORLD SYSTEM CANNOT BE CONSIDERED TO BE IDENTICAL AND, 2 ) THE FUNCTIONS DIFFERENT NATIONS HAD FOR EACH OTHER WERE NOT ONLY IMPORTANT IN THE ECONOMY, BUT ALSO IN SOCIAL AND POLITICAL INSTITUTIONS, MILITARY PONERS, AND IDEAS AND RELIGION. THIS STUDY BEGINS IN MEDIEVAL TIMES AND SPEAKS ABOUT ALL THE CONTEXTS IN WHICH HUMAN LABOR IS MANIFESTED. FURTHER, SINCE THE MOST CONSPICUDUS FEATURE OF THE HISTORY OF EUROPE IN GLOBAL SOCIETY IS EUROPEAN EXPANSION. THIS IS THE ORGANIZING CONCEPT.

06863 NOLUTSHUNGU, 5 .

AFRICA IN A WORLD OF DEMOCRACIES: INTERPRETATION ANO AFRICA IN

JOURNAL OF COMMONHEALTH AND COMPARATIVE POLITICS, 30(3) (NOV 92 ), 316-334.

WHATEVER MAY BE THE IMPORTANCE OF THE OPENING FOR DEMOCRACY IN WORLD POLITICS AND HHATEYER IS MADE OF THE REGIMES AND MOVEMENTS SAID TO BE DEMOCRATISING, THE PROBLEMS AS WELL AS THE APPEALS OF DEMOCRACY REMAIN HHAT THEY ALWAYS WERE. IF NO ONE CAN SET HIS FACE AGAINST DEMOCRACY IT IS, NEVERTHELESS, TRUE THAT BOTH ITS WORTH AND THE THING ITSELF ARE MATTERS OF DEBATE, APPROACHED FROM ALL SIDES WITH RESERVATIONS AND QUALIFICATION. THIS ARTICLE EXPLORES THE JUSTIFICATION OF DEMOCRACY. IT ARGUES THAT THAT IT WILL ALWAYS BE SENSIBLE FOR AFRICANS TO SEEK TO ESTABLISH THE CONDITIONS THAT WOULD ENABLE THEM TO CHOOSE THE GOVERNMENTS
UNDER WHICH THEY LIVE AND TO ACQUIRE THE MEANS TO EXERCISE GREATER CONTROL OVER THEIR POLICIES AND DECISIONS.

06864 NONAN, $N$

THO SOLUTIONS TO THE ZHENSKII VOPROS IN RUSSIA AND THE USSR--KOLLONTAI AND KRUPSKAIA: A COMPARISON

WOMEN AND POLITICS, 11(3) (1991), 77-100.

IN THIS ARTICLE THE AUTHOR PRESENTS AN OVERVIEH OF THE MAJOR SOLUTIONS TO THE "WOMAN'S QUESTION," ADVOCATED BY MARXIST WOMEN, IN PRE-REVOLUTIONARY RUSSIA. THE ARTICLE SETS THE DIALOGUE ON THE "WOMAN'S QUESTION," AGAINST THE BACKDROP OF THE REVOLUT IONARY AGENDA, ON THE ONE HAND, AND THE REFORMIST FEMINIST MOVEMENT OF THE EARLY 2OTH CENTURY, ON THE OTHER.

06865 NONMENMACHER, G.

A NEH CHAPTER IN THE RELATIONSHIP BETHEEN AMERICA AND GERMANY

GERMAN TRIBUNE, (1495) (DEC 91), 5

ALTHOUGH THE UNITED STATES AND GERMANY HAVE NEVER ENJOYED THE "SPECIAL RELATIONSHIP" THAT BRITAIN AND AMERICA HAVE HAD, THE AMERICANS HAVE LOOKED ON DEMOCRACY IN THE FEDERAL REPUBLIC OF GERMANY AS THEIR FOSTER CHILD. THEY HAVE FOLLOWED WEST GERMANY'S PROGRESS WITH PRIDE, AND, AT TIMES, WITH THE ANXIETY OF A COMPETITOR AS IT GREW INTD A MAJOR ECONOMIC POWER AND HORLD CHAMPION EXPORTER. THAT WAS PARTLY ECONOMIC POWER AMD WORLD CHAMPION EXPORTER. THAT WAS WHY AMERICA, IN CONTRAST WITH A NUMBER OF GERMANY'S NEIGHBORS IN EUROPE, MADE NO ATTEMPT TO OELAY REUNIFICATION AND EVENTUALLY ACCEPTED IT WITHOUT RESERVATIONS. HOWEVER, A NEW CHAPTER IN U.S. -GERMAN RELATIONS HAS ARRIVED AS AMERICA BECOMES EVER MORE INWARO LOOKING AND EXPECTS GERMANY TO ASSUME A ROLE IN EUROPE AND THE WORLD WHICH REFLECTS GERMANY'S ECONOMIC CLOUT. AMERICAN OISAPPOINTMENT WITH THE RELATIVE LACK OF GERMAN SUPPORT FOR THE ANTI-IRAQ COALITION MAY BE ONLY THE FIRST OF A SERIES OF DISAGREEMENTS ANO CONFLICTS OVER THE FUTURE ROLE OF THE THO STATES.
06866 NONNENMACHER, G AFTER 50 YEARS THE UNITED NATIONS NEEDS REFORMING GERMAN TRIBUNE, 31(1531) (SEP 92), 2

THAT SINCE THE END OF THE EAST-WEST CONFLICT THERE HAS BEEN NO VETO IN THE UNITED NATIONS HELPS TO ILLUSTRATE THE TRANSFOMATION EXPERIENCED BY THE UN. THE ABILITY OF THE UNITED NATIONS TO TAKE ACTION HAS IMPROVED SINCE THE END OF THE COLD WAR AND ITS SERVICE HAS BEEN ENLISTED TO AN INCREASING EXTENT. HOWEVER, THE ORGANIZATION IS THE EXPRESSION OF THE DISTRIBUTION OF POWER IN THE WORLD IN THE YEAR 1945. THIS ARTICLE SUGGESTS THAT IT NOW REQUIRES TOTAL REFORM IN ORDER TO MAINTAIN ITS LEGITIMACY IN A CHANGED HORLD ALMOST 50 YEARS AFTER IS FOUNDATION. IT ARGUES THAT THERE IS A GREAT RISK THAT, AFTER A REFORM, THE LIMITED ABILITY TO ACT ASSOCIATED WITH THE END OF THE COLD HAR WILL LOOK LIKE AN HISTORICAL INTERMEZZO.

06867 NONNENMACHER, G.

CHANGING PERSPECTIVES ABOUT GERMANY'S NEW STATUS GERMAN TRIBUNE, (1501) (JAN 92) 1 -2.

BONN POLITICIANS ARE NOT ALONE IN HAVING DIFFICULTIES WITH UNITED GERMANY'S CHANGING STATUS AND GREATER RESONSIBILITY IN THE WORLD; GERMANY'S NEIGHBORS AND PARTNERS ARE ALSO HAVING OIFFICULTY IN SAYING, WITHOUT ENTANGLING THEMSELVES IN CONTRADICTIONS, WHAT THEY EXPECT OR REQUIRE OF GERMAN POLICY. THIS UNCERTAINTY IS ILLUSTRATED BY THE CRITICISM OF GERMANY'S "HOLDING BACK" OF ITS SUPPORT DURING THE GULF CRISIS AND THE LATER CRITICISM OF GERMANY FOR TAKING THE LEAD IN RECOGNIZING THE SOVEREIGNTY OF CROATIA AND SLOVENIA. DESPITE REPEATED GERMAN ASSURANCES OF POLICY CONTINUITY, MANY QUESTION GERMANY'S COMMITMENT TO NATO AND THE EUROPEAN COMMUNITY. THESE DOUBTS ARE THE RESULT OF PRESUMED INEVITABILITIES OF EUROPEAN HISTORY AND GEOGRAPHY AND ARE BASED ON EXPECTATIONS THAT A GERMANY FREED FROM THE TRAUMA OF DIVISION AND WITH ITS SOVEREIGNTY FULLY RESTORED WILL BE STAKING A CLAIM TO GREAT POWER STATUS IN KEEPING WITH ITS ECONOMIC CLOUT.

06868 NONNENMACHER, G.

EASTERN EUROPE REACHES FOR SECURITY, PROSPERITY GERMAN TRIBUNE, (1505) (FEB 92), 1.

THE INSTITUTIONS OF WESTERN EUROPE SET UP DURING THE COLD WAR--IN RATHER OVERSIMPLIFIED TERMS, NATO FOR SECURITY AND THE EUROPEAN COMMUNITY FOR PROSPERITY--HAVE BECOME POLES AN ATTRACTION FOR EASTERN EUROPE. FOLLOWING THE COLLAPSE OF OF ATTRACTION FOR EASTERN EUROPE. FOLLOWING THE COLLAPSE OF
COMMUNIST RULE, SECURITY AND PROSPERITY IS PRECISELY WHAT COMMUNIST RULE, SECURITY AND PROSPERITY IS PRECISELY WHAT THE GOVERNMENTS AND PEOPLES OF EASTERN AND CENTRAL EUROPE WANT. TO EXCLUDE THE REFORMED NATIONS OF EASTERN EUROPE FROM THESE STRUCTURES HOULD BE UNJUSTIFIED. HOWEVER, IT IS IN THE INTEREST OF THE OLD WEST AND THE NEW EAST TO MOVE TOHARDS
INTEGRATION STEP BY STEP. THE WHOLESALE ACCEPTANCE OF INTEGRATION STEP BY STEP. THE WHOLESALE ACCEPTANCE OF
EASTERN EUROPE INTO NATO AND THE EC COULD DESTROY BOTH OF EASTERN EUROPE INTO
THE ORGANIZATIONS

06869 NONNENMACHER, G

EUROPE STILL SEEKING ITS POINTS OF REFERENCE GERMAN TRIBUNE, (1513) (MAY 92), 1-2.

THE CHANGES THAT HAVE SHEPT THROUGH THE WORLD-MOST NOTABLY THE COLLAPSE OF THE SOVIET UNION AND THE REVOLUTIONS IN EASTERN EUROPE--CONFRONT EUROPE WITH TWO STARKLY DIFFERENT CHOICES. SOME ADVOCATE THAT WESTERN EUROPE FOLLOH THE LEAD OF THE EAST ON A COURSE OF "RENATIONALIZATION," A RETURN TO THE TRADITIONAL NATION-STATE SYSTEM. OTHERS CALL FOR FURTHER INTEGRATION AND COOPERATION. THIS ARTICLE SIDES WITH THE PROPONENTS OF INTEGRATION. IT ARGUES THAT THE COMPETITION WHICH WOULD INEVITABLY ACCOMPANY

RENATIONALIZATION WOULD BE DAMAGING TO ALL PARTIES INVOLVED. ONLY FURTHER COMMITMENT TO COOPERATION AND EXPANSION OF EXISTING STRUCTURES (I.E. THE EC, NATO, CSCE, AND EUROPEAN COUNCIL) WILL AVERT THE ETHNIC RIVALRIES, BORDER DISPUTES, AND CHAOS WHICH CONFRONT EUROPE.

06870 NONHENMACHER, G.

EUROPEAN COMMUNITY WRESTLES WITH MAASTRICHT AND SIZE OF BUDGET

GERMAN TRIBUNE, 31(1543) (DEC 92), 1-2.

THE EDINBURGH EC SUMMIT THIS MONTH WILL BE DOMINATED BY THE CONTROVERSIAL BUDGET. BRITAIN, WHICH HOLDS THE THE CONTROVERSIAL BUDGET. BRITAIN, WHICH HOLOS THE
PRESIDENCY, WANTS SPENDING TO BE HELD WELL BELOH THE LEVEL
PLANNED BY THE PRESIDENT OF THE EUROPEAN COMMISSION. THAT PLANNED BY THE PRESIDENT OF THE EUROPEAN COMMISSION.
WOULD MEAN LESS MONEY FOR THE POORER EC COUNTRIES.

06871 NONNENMACHER, G.

EUROPEAN SECURITY ARCHITECTURE IS SEEN IN DRESDEN AS A EUROPEAN SECURITY ARC

GERMAN TRIBUNE, (1516) (MAY 92) 4-5.

THIS ARTICLE DISCUSSES THE VARIOUS CHALLENGES FACING THE DIFFERENT SECURITY STRUCTURES IN WESTERN EUROPE. THE NORTH ATLANTIC THREATY ORGANIZATION (NATO) IS FACING THE FUNDAMENTAL PROBLEM OF THE LOSS OF ITS RAISON D'ETRE: THE SOVIET UNION. MANY ARE QUESTIONING THE CONTINUED NEED FOR THE ORGANIZATION. THE LARGER CONFERENCE ON SECURITY AND COOPERATION IN EUROPE (CSCE) HAS DECLARED ITSELF IN FAVOR OF PEACE, DEMOCRACY AND HUMAN RIGHTS. HOWEVER, SEYERAL 
SIGNATORIES ARE GUILTY OF VIOLATIONS OF THESE IDEALS AND THERE IS LITTLE PROYISION FOR ENFORCEMENT WITHIN THE CSCE. THE EUROPEAN COMMUNITY (EC) HAS DECLARED ITS INTENTIONS TO CONTINUE ECONOMIC AND POLITICAL INTEGRATION AND TO PURSUE COMMON SECURITY OBJECTIVES. HOWEVER, THE EC'S INABILITY TO FORGE A COMMON POL ICY WITH REGARDS TO THE CONFLICT IN YUGOSLAVIA CASTS SERIOUS DOUBT ON THE EC'S ABILITY TO RESOLVE CONFLICTS OR ENSURE PEACE IN ANY VENUE. THE OVERALL TREND IN EUROPE IS TOWARD A COMBINING OF SECURITY AND ECONOMIC INTERESTS. WITHOUT THE LOOMING THREAT OF THE USSR, THE OVERRIDING COMMON INTEREST IN SECURITY IS DIMINISHING AND VARIOUS STATES AND ORGANIZATIONS ARE PURSUING THEIR INDIVIDAL POLICIES WITH REGARDS TO SECURITY AND THE VACUUM LEFT IN THE USSR'S HAKE.

06872 NONNENMACHER, G.

FRENCH REFERENDUM HOLDS LESSONS FOR GOVERNMENTS

GERMAN TRIBUNE, (1533) (SEP 92), 1.

DESPITE THE WAFER-THIN MAJORITY IN FAVOR OF MAASTRICHT, THERE CAN BE NO DOUBT ABOUT THE IMMEDIATE OUTCOME OF THE FRENCH REFERENDUM ON EUROPEAN UNIDN. THERE IS NOW A

GRARANTEE THAT THE MAASTRICHT PROCESS CAN GO AHEAD. BUT THE GUARANTEE THAT THE MAASTRICHT PROCESS CAN GO AHEAD. BUT
FINAL SHAPE OF EUROPEAN UNION IS UNCERTAIN. THE GERMAN FINAL SHAPE OF EUROPEAN UNION IS UNCERTAIN. THE GERMAN GOVERMMENT HAS REPEATEDLY STRESSED THAT ITS GOAL IS EUROPEAN MEMBERS DON'T SHARE THAT VISION.

06873 NONNENMACHER, G

MATO TO REMAIN AS EUROPE'S PRINCIPAL DEFENCE BULHARK GERMAN TRIBUNE, (1493) (NOV 91), 1-2.

NATO SECRETARY-GENERAL MANFRED HORNER SAYS THE DECISIONS TAKEN AT THE NORTH ATLANTIC PACT'S MEETING IN ROME OPEN UP A NEW CHAPTER. KEY FEATURES, THE SETTING UP OF A RAPID DEPLOYMENT FORCE AND THE NUCLEUS OF A MULTI-NATIONAL FORCE, WERE DECIDED ON EARLIER IN THE YEAR AND WERE PUBLICLY KMOWH IN ADVANCE. PRESIDENT BUSH ANTICIPATED THE MAIN MILITARY MOVE IN SEPTEMBER WITH HIS NUCLEAR DISARMAMENT INITIATIVE, WHICH IN MID-OCTOBER WAS ADOPTED AS PACT POLICY. SOME HAVE ARGUED FOR THE EXTENSION OF NATO TO INCLUDE EASTERN EUROPE; OTHERS HAVE CALLED FOR THE REDUCTION OF THE ORGANIZATIONAL TIES ESPECIALLY VIS-A-VIS THE UNITED STATES. ALTHOUGH THE CHANGES ADOPTED IN ROME MAY BE CONSIDERED AS SIGNIFICANT THE UNDERLYING FOUNDATION OF NATO, THE FIRM LINKS ACROSS' THE ATLANTIC, REMAIN INDISPENSABLE FOR POLITICAL STABILITY IN EUROPE.

06874 NORBU, $D$.

CHINA'S POLICY TOHARD ITS MINORITY MATIONALITIES IN THE CHINATS

CHINA REPORT, 27(3) (JUL 91), 219-234.

THE ORIGINS OF CHINESE COMMUNIST POLICY TOWARDS MONORITY MATIONALITIES IN THE PEOPLE'S REPUBLIC OF CHINA ARE TRACED NATIONALITIES IN THE PEOPLE'S REPUBLIC OF CHINA ARE TRACED BACK TO THE FORMATIVE PERIOD PRIOR TO 1949 AS REFLECTED ECONOMIC IMPERATIVES IMPEL BEIJING TO CONTINUE BASICALLY THE ECONOMIC IMPERATIVES IMPEL BEI JING TO CONTINUE BASICALLY THE
SAME TENENTS OF NATIONALITY POLICY WITH MINOR MOOIFICATIONS. SAME TENENTS OF NATIONALITY POLICY WITH MINOR MOOIFICATIONS. THIS ARTICLE DOES FORSEE SOME CHANGES IN THE ECONOMIC AND
CULTURAL SPHERES BUT HARDLY ANY IN THE POLITICAL DOMAIN.

06875 NORDBY, J.

DEMOCRATIC MONGOLIA, 1991: PROBLEMS AND PROSPECTS JOURNAL OF COMMUNIST STUDIES, 8(1) (MAR 92), 175-179. IN DECEMBER 1989, A DEMOCRATIC MOVEMENT LED BY YOUNG UNIVERSITY LECTURERS, JOURNAL ISTS, AND LAMAS EMERGED IN ULAN
BATOR. IN LESS THAN THO YEARS, THIS MOVEMENT HAS WROUGHT PROFOUND CHANGES IN THE COUNTRY'S POLITICAL, ECONOMIC, ANO SOCIAL LIFE. NEVERTHELESS, MONGOL IA FACES MONUMENTAL PROBLEMS, ESPECIALLY IN IMPROVING ITS ECONOMIC PROSPECTS.

06876 MORDEN, E.

RIGHT BEHIND YOU SCARLETT

AMERICAN SPECTATOR, 24(8) (AUG 91), 14-16

THIS ARTICLE CONTRASTS THE PREVAILING VIEHS OF AMERICAN AND ISRAELIS ON THE ISSUE OF ALLOWING WOMEN INTO COMBAT SITUATIONS. A GRONING MOVEMENT IN AMERICA CALLS FOR EQUAL TREATMENT OF WOMEN, EVEN IF IT MEANS SENDING SOME OF THEM HOME IN BOOY BAGS DURING TIMES OF HAR. ISRAEL, ON THE OTHER HAND, DRAFTS NEARLY SIXTY PERCENT OF GIRLS AFTER THEIR HIGH SCHOOL GRADUATION. HOWEVER, WOMEN ARE GENERALLY KEPT OUT OF COMBAT SITUATIONS AND AWAY FROM THE FRONT LINES--A TASK NONE TOO SIMPLE IN A COUNTRY WHERE THE DISTINCTION BETWEEN FRONT AND REAR LINES IS QUITE HAZY. THE BOTTOM LINE IS THAT THE AND REAR LINES IS QUITE HAZY. THE BOTTOM LINE IS THAT THE AVERAGE ISRAELI WOULD ARGUE THAT A COUNTRY THAT SENDS ITS HOMEN INTO BATTLE OUT
HORTH FIGHTING FOR.

06877 NORGAARD, 0

THE POLITICAL ECONOMY OF TRANSITION IN POST-SOCIALIST SYSTEMS: THE CASE OF THE BALTIC STATES

SCANDINAVIAN POLITICAL STUDIES, 15(1) (MAR 92), 41-60.

THE NATURE OF THE FAILED SOCIALIST SYSTEMS CALLS FOR COMPREHENSIVE TRANSITION, AND THE TRANSITION TO DEMOCRACY CANNOT BE TREATED AS SEPARATE FROM THE TRANSITION TO A MARKET ECONOMY AND NATIONAL INDEPENDENCE. THE CRITICAL PART
OF THE TRANSITION IS THE ECONOMIC REFORM INASMUCH AS THE INSTITUTIONS OF THE PLANMED ECONOMY ARE THE MAJOR POWER BASE FOR THE CONSERVATIVE ELITES. TO BE SUCCESSFUL. THE ECONOMIC TRANSITION MUST COMMAND POLITICAL SUPPORT, ACHIEVE SOCIAL ACCEPTANCE OF THE DISTRIBUTIONAL CONSEQUENCES, AND BE COMPATIBLE WITH DEMOCRATIC INSTITUTIONS. IN THE BALTIC STATES, THERE IS WIDESPREAD SUPPORT FOR THE TRANSITION TO A MARKET ECONOMY AND, THUS FAR, THE DEMOCRATICALLY-ELECTED GOVERNMENTS HAVE BEEN FAIRLY ACTIVE IN ESTABLISHING A LEGAL FRAMENORK FOR TRANSITION BUT APPEAR UNABLE TO IMPLEMENT THE NECESSARY STABILIZATION POLICY. THE REFORMS HAVE PRODUCED STRONG SOCIAL PROTESTS, AND THE GOVERNMENTS HAVE BEEN UNDER PRESSURE TO MAINTAIN SOCIAL GUARANTEES DURING THE TRANSITION. THE NON-BALTIC MINORITIES IN PART ICULAR DEFENO PREVIOUS SOCIAL PRIVILEGES AND ARE DISTRESSED BY THEIR UNCERTAIN STATUS. THEREFORE, THE ULTIMATE OUTCOME OF POL ITICAL AND

ECONOMIC TRANSITION IN THE BALTIC STATES REMAINS IN DOUBT.

06878 NORMAND, $R$.

QUEBEC AND CANADA: IS DIVORCE THE FINAL ANSWER?

CANADIAN PARLIAMENTARY REVIEW, (WIN 91), 2-4.

THIS ARTICLE EXAMINES POTENTIAL FUTURÉS FOR CANADA'S FEDERATION FOLLOWING THE DEMISE OF THE MEECH LAKE

CONSTITUTIONAL ACCORO. IT SOUNDS OUT OPINION IN WESTERM

CONSTITUTIONAL ACCORD. IT SOUNDS OUT OPINION IN WESTERN

CANADA, "ENGLISH" CANADA, AND QUEBEC. IT OUTLINES VARI OUS POSSIBLE SCENARIOS: THE STATUS QUO; A RENEWED FEDERAL

NEP CONSTION AND INDEPENDENCE FOR OUEBEC. IT CONCLUDES THAT THE LAST TWO POSSIBILITIES ARE THE MOST LIKELY.

06879 NORPOTH, H.; BUCHANAN, B.

WANTED: THE EDUCATION PRESIDENT

PUBLIC OPINION QUARTERLY (CHICAGO), 56(1) (SPR 92), 87-99.
THE STRATEGY OF AMBIGUITY COUNSELS CANDIDATES TO TAKE SOME POLICY POSITIONS IN THE TRADITIONAL TERRITORY OF THE OPPOSING PARTY. IN 1988, BOTH PRESIDENTIAL CANDIDATES TOOK SOME POSITIONS OF THAT KIND: GEORGE BUSH WITH PROMISES ON JOBS AND EDUCATION AND MICHAEL DUKAKIS ON DEFENSE. THIS ARTICLE ANALYZES (1) HOW AWARE VOTERS WERE OF THESE INCIDENTS OF ISSUE TRESPASSING, (2) WHETHER ATTENTION TO THE CAMPAIGN HELPED VOTERS BECOME MORE AHARE, AND (3) THE ELECTORAL PAYOFF OF THE STRATEGY. THE FINDINGS RAISE SERIOUS DOUBTS ABDUT THE YALUE OF ISSUE TRESPASSING. VOTERS TEND TO RELY TOO MUCH ON PARTY STEREOTYPES TO NOTICE ATTEMPTS TO INVADE THE OTHER PARTY'S TRADITIONAL TERRITORY AND INVADE THE OTHER PARTY'S TRADITIONAL TERRITORY, AND TENDENCY IN THO OF THE THREE INSTANCES EXAMINED FROM THE 1988 CAMPAIGN.

06880 NOROUIST, $G$.

MANMING THE LIFEBOATS
NATIONAL REVIEH, XLIV (20) (OCT 92), 26-28.

THE MOST PROMISING DEVELOPMEMT FOR GEORGE BUSH'S

PRESIDENTIAL CAMPAIGH HAS BEEN THE RECENT BRITISH INVASIONS: THREE WAVES OF KEY CAMPAIGN ADVISORS TO PRIME MIMISTER JOHM MAJOR HAVE SWEPT THROUGH WASHINGTON, BRIEFING AND EXHORTING REPUBLICAN CAMPAIGN OFFICIALS AND WHITE HOUSE STAFFERS THEIR MESSAGE OFFERS BOTH HOPE AND A SERIOUS STRATEGY. THIS ARTICLE SUGGESTS THAT IN POLITICS, AS IN WAR, THE RULES CHANGE WITH EACH GO-ROUND. GEORGE BUSH JUST MIGHT SAVE HIS PRESIDENCY IF HE LEARNS AND APPLIES THE LESSONS OF JOHN MAJOR.

06881 NORQUIST, G.

THE COMING CLINTON DYNASTY

AMERICAN SPECTATOR, 25(11) (NOV 92), 24-27

CONSERVATIVES WHO THINK THE CLINTON ADMINISTRATION WILL

BE A SHORT INTERREGNUM ARE MAKING A DISASTROUS MISTAKE.

SINCE HATERGATE, DEMOCRATS HAVE LEARNED TO DEAL BEHIND THE

SCENES TO ENSURE THEIR RE-ELECTION, WITH OR WITHOUT POPULAR

SUPPORT. BILL CLINTON WATCHED JIMHY CARTER CHAMPION THE

LIBERAL AGENDA AND GET SHEPT FROM THE WHITE HOUSE IN 1980.

HE WILL NOT ALLOW THAT TO HAPPEN TO HIM. HE HILL USE THE

POWER AND FINANCES OF THE STATE TO BUILD AN IMPREGNABLE

FORTRESS. AND HE WILL CHEERFULLY USE THE GOVERMMENT TO

KNEECAP HIS CRITICS AND RIVALS.

06882 NORRIS, P.; LOVENDUSKI, J.; VALLANCE, E.

DO CANDIDATES MAKE A DIFFERENCE? GENDER, RACE, IDEOLOGY AND INCUMBENCY

PARLIAMENTARY AFFAIRS, 45(4) (OCT 92), 496-517.

THE KEY OUEST

PARLIAMENTARY CANDIDATES EXPERIENCE ANY ELECTORAL BENEFITS

(IN TERMS OF INCLMBENCY) OR PENALTIES (IN TERMS OF RACE,

GENDER AND IDEOLOGY). IF SO, HOW MUCH? THE ARTICLE EXPLORES: WHETHER CANDIDATES REALLY MATTER FOR VOTES IN THE GENERAL ELECTION. ARE YOTERS BIASED AGAINST ETHMIC MINORITY

CANDIDATES; AND WHETHER THE LEFT LOST LABOUR SUPPORT IN 1987. IT QUESTIONS WHETHER THE GENERALLY ACCEPTED PERSPECTIVE-THAT MOST STUDIES HAVE A FOUND A MODEST INCUMBENCE EFFECT-IS TRUE OR NOT.

06883 NORRIS, $P$

GENDER DIFFERENCES IN POLITICAL PARTICIPATION IN BRITAIN: 
TRAOITIONAL, RADICAL ANO REVISIONIST MODELS

GOVERNMENT AND OPPOSITION, 26(1) (1991), 56-74.

THIS PAPER CRITICALLY RE-EXAMINES THE TRADITIONAL,

RADICAL, AND REVISIONIST PERSPECTIVES ABOUT THE EXTENT AND NATURE OF GENDER DIFFERENCES IN POLITICAL PARTICIPATION IN LIGHT OF TRENDS IN BRITAIN. THE EVIDENCE FOR THE ANALYSIS IS DERIVED FORM THE BRITISH ELECTION STUDIES (1964-87) AND THE BRITISH SOCIAL ATTITUDES SURVEY (1986). THE PAPER CONSIDERS HOW FAR GENDER DIFFERENCES HAVE CHANGED IN BRITAIM MODES OF PARTICIPATION: VOTING TURNOUT, CAMPAIGN PARTICIPATION, CONTACT ACTIVITY, AND COMMUNAL PARTICIPATION. IT IS ARGUED THAT THE TRADITIONAL PERSPECTIVE IS NO LONGER ADEQUATE AS THE GENDER GAP IN VOTING, CONTACT, AND CAMPAIGN ACTIVITY IS MINIMAL IN RECENT YEARS. IT IS FURTHER ARGUED THAT AVAILABLE EVIDENCE THROWS DOUBT ON THE RADICAL THESIS AND THAT, ON BALANCE, THE REVISIONIST CASE SEEMS MORE POF

PARTICIPATION AND THE IMPLICATION OF THESE DEVELOPMENTS.

06884 NORRIS, $P$

THE 1992 U.S. PRIMARIES: IF IT AIN'T BROKE DON'T FIX IT PARLIAMENTARY AFFAIRS, 45(3) (JUL 92), 428-436.

THIS ESSAY RECONSIDERS THE CRITICISMS DIRECTED AGAINST U. S. PRIMARY ELECTIONS IN LIGHT OF THE 1992 RESULTS. IT OUTLINES THE KEY EVENTS IN THE DEMOCRATIC AND REPUBLICAN CAMPAIGNS, ANALYZES THE RESULTS OF THE PROCESS FROM IOWA TO MICHIGAN, AND REFLECTS ON WHAT 1992 REVEALS ABOUT THE NATURE OF THE NOMINATION PROCESS. IT CONCLUDES THAT, AL THOUGH THE PRIMARY PROCESS IS OPEN TO SOME VALID COMPLAINTS, MANY

OBJECTIONS ARE EITHER MISDIRECTED OR EXAGGERATED. ON BALANCE, THE PROCESS WORKS-- NOT PERFECTLY, BUT PROBABLY AS WELL AS ANY OF THE PROPOSED ALTERNATIVES.

06885 NORTH, T

THE KIM JONG-II SUCCESSION PROBLEM IN THE CONTEXT OF THE NORTH KOREAN POLITICAL STRUCTURE

KOREA \& WORLD AFFAIRS, 16(1) (SPR 92), 40-67. SINCE THE ESTABLISHMENT OF THE DEMOCRATIC PEOPLE'S REPUBLIC OF KOREA, THE COUNTRY HAS KNOWN THE RULE OF ONLY ONE MAN, KIM IL-SUNG, WHO EXPECTS THAT HIS SON, KIM JONG-IL, WIL MAN, KIM IL-SUNG, WHO EXPECTS THAT HIS SON, KIM JONG-IL, WILL ASSUME POWER HHEN HE DIES. BUT EXAMPLES OF DYNASTIC
SUCCESSION ARE RARE IN MODERN DICTATORSHIPS AND UNHEARD OF SUCCESSION ARE RARE IN MODERN OICTATORSHIPS AND UNHEARD OF
IN THE COMMUNIST WORLD. IN THIS ESSAY, THE AUTHOR ENUMERATES IN THE COMMUNIST WORLD. IN THIS ESSAY, THE AUTHOR ENUMERATES POSSIBLE SOURCES OF OPPOSITION TO KIM JONG-IL'S SUCCESSION WHILE STUDYING HIS PERSONAL HISTORY IN ORDER TO LEARN WHAT KIND OF RULER HE WOULD BE. THE AUTHOR ALSO COMPARES THE SITUATION IN NORTH KOREA WITH THE FACTORS THAT LED TO THE
ANTI-GOVERNMENT MOVEMENTS IN EASTERN EUROPE, ASKING WHETHER POLITICAL UPHEAVAL IS INEVITABLE IN NORTH KOREA.

06886 NORTHCUTT, S.S.

AN ANALYSIS OF BUSH'S HAR SPEECH

INTERNATIONAL SOCIAL SCIENCE REVIEN, 67(3) (SUM 92),

123-129

ON AUGUST 8,1990 , PRESIDENT GEORGE BUSH DELIVERED A MAJOR FOREIGN POLICY SPEECH IN RESPONSE TO THE OUTBREAK OF THE GULF CRISIS. IN THIS ARTICLE, THE AUTHOR ANALYZES THE MAJOR COMPONENTS OF THAT SPEECH--ITS CLAIMS, EVIDENCE, AND WARRANTS--IN KEEPING WITH TOULMIN'S MODEL. SHE ALSO EXAMINES THE SPEECH'S POL ITICAL CONTENT, ESPECIALLY IN THEORETICAL TERMS. SHE ARGUES THAT THIS EXAMPLE OF PRESIDENTIAL WAR RHETORIC WAS BASED ON POLITICAL REALISM, A CENTRAL PARADIGM FAVORED BY AMERICAN POLICY-MAKERS AND SCHOLARS IN THE MIDDLE AND LATTER YEARS OF THE 2OTH CENTURY.

06887 NORTON, A.R.

BREAKING THROUGH THE WALL OF FEAR IN THE ARAB HORLD CURRENT HISTORY, 91(561) (JAN 92), 37-41.

THE MOST SIGNIFICANT RESULT OF THE PERSIAN GULF WAR MAY BE THAT THE "WALL OF FEAR" SEPARATING ARAB CITIZENS FROM THEIR AUTOCRATIC RULERS HAS BEEN BREACHED. THE UNITED STATES AND ITS ALLIES IN THE ANTI-IRAQ COALITION MAY HAVE UNLEASED WHIRLWINDS OF CHANGE THAT WILL ENGENDER PROFOUND INSTABILITY IN THE ARAB WORLD. WHILE THE GREAT POWERS APPLAUD PARTICIPATION AND EXALT DEMOCRACY, THEY LOATHE INSTABILITY; YET THE ACHIEVEMENT OF GREATER PARTICIPATION AND DEMOCRATIZATION WITHOUT ACCOMPANYING INSTABILITY IS DIFFICULT TO IMAGINE.

06888 NOSENKO, $V$

IRAQ'S AGGRESSION AGAINST KUWAIT IN THE CONTEXT OF NORTHIRAQ'S AGGRESSION

MEDITERRANEAN OUARTERLY: A JOURMAL OF GLOBAL ISSUES, 3(2) (SPR 92) 96-105.

IRAQ'S INYASION OF KUHAIT ON 2 AUGUST 1990 CAME AS A SURPROSE FOR BOTH THE MIDDLE EAST COUNTRIES AND THE HORLD COMMUNITY AS A WHOLE. IT IS NOW CLEAR THAT THE AGGRESSIVENESS OF THE IRAOI REGIME AND ITS READINESS FOR A NEW, LARGE-SCALE PROVOCATION WERE UNDERESTIMATED. AFTER THE END OF THE COLD WAR AND UP TO THE TIME OF THE IRAOI AGGRESSION. THE SUPERPOWERS KEPT THEMSELVES SOMEWHAT ALOOF FROM THE THIRD WORLD'S PROBLEMS. THIS ARTICLE EXAMINES THE
POSSIBLE TO AVOID CHALLENGES TO TO HEST IN THE FUTURE. IT CONCLUDES THAT THE ROLE THE THIRD WORLD IS GOING TO PLAY ON THE INTERNATIONAL SCENE DEPENDS GREATLY ON WHAT ASSISTANCE THE REST OF THE WORLD COMMUNITY WILL PROVIDE AS IT STRUGGLES THROUGH THE PRESENT PHASE.

06889 NOVAK, $M$

THE LONGTIME DEMOCRAT BLUES

NATIONAL REVIEH, XLIV(14) (JUL 92), 24-27

THIS ARTICLE CHARACTERIZES THE DEMOCRATIC PARTY AS BEIMG POPULATED BY INTELLIGENT, CARING PEOPLE WHO GET TOGETHER EVERY FOUR YEARS TO NOMINATE A CANDIDATE FOR PRESIDENT THAT CANMDT BE ELECTED. THE PROBLEM IS THAT THE DEMOCRATS HAVE SHIFTED THEIR EMPHASIS FROM THE COMMON PEOPLE TO THE CULTURAL ELITE AND TO SPECIAL INTERST GROUPS. FURTHERMORE, CULTURAL ELITE AND TO SPECIAL INTERST GROUPS. FURTHERMORE, ALIGN ITSELF WITH THE NEHEST, FLIMSIEST DOCTRINES OF THE ALIGN ITSELF WITH THE NEWEST, FLIMSIEST DOCTRINES OF ELECTORAL FAILURE IN PRESIDENTIAL ELECTIONS.

06890 NOVAK, $R$.

THE TROUBLE WITH CLINTOM

AMERICAN SPECTATOR, 25 (6) (JUN 92), 18-22

IN A ERA OF DEEP PUBLIC CYNICISM AND ANGER ABOUT GOVERNMENT, TO BE CARICATURED AS SOMEONE WHO CANNOT GIVE A STRAIGHT ANSWER IS DEVASTATING TO ANY CANDIDATE. ON THE SURFACE, ARKANSAS GOVERNOR, BILL CLINTON SEEMS TO BE A DESIGNER DEMOCRATIC CANDIDATE. HOWEVER, IN POLL AFTER POLL, MORE THAN HALF THE VOTERS SAY THEY DO NOT TRUST OR BELIEVE CLINTON. THIS ARTICLE SEEKS TO UNDERSTAND THE TROUBLE WITH CLINTON BY LOOKING AT HIS RESPONSE TO THE SIMPLE MATTER OF BUILDING SUBMARINES IN CONNECTICUT. IT CONCLUDES THAT CLINTON'S VIGOR AND INTELLIGENCE ARE UNDERCUT BY A LACK OF DISCIPLINE THAT ALWAYS LEADS HIM TO SEEK THE EASY WAY OUT.

06891 NDVE, A.

IDEOLOGY, PLANNING, AND THE MARKET

CRITICAL REVIEW, 5(4) (FAL 91), 559-572.

PAUL CRAIG ROBERTS HAS ATTRIBUTED THE EXCESSES OF WAR COMMUNISH, THE RESISTANCE TO MARKET-TYPE REFORMS, ANO THE RETENTION UNTIL VERY RECENTLY OF ADMINISTERED MATERIAL ALLOCATION IN THE SOVIET UNION TO MARXIST IDEOLOGY, AND IN ALLOCATION IN THE SOVIET UNION TO MARXIST IDEOLOGY, AND IN
PARTICULAR TO MARX'S VIEWS ON THE LINK BETHEEN MARKETS AND PARTICULAR TO MARX'S VIEWS ON THE LINK BETHEEN MARKETS AND
"ALIENATION." HOWEYER, WAR COMMUNISM HAS DUE IN SOME PART "ALIENATION." HOWEVER, WAR COMMUNISM HAS DUE IN SOME PART AHE INTERESTS OF THE RULING STRATUM THAT DELAYED THE MUCHTHE INTERESTS OF THE RULING STRATUM THAT DELAYED THE MUCH PROBLEMS IN RECONCILING SOCIALIST IDEAS WITH EFFICIENCY AND ENTREPRENEURSHIP AND LANGE'S ATTEMPT TO DEFINE A SORT OF NEOCLASSICAL SOCIALISM WAS UNSATISFACTORY. HOWEVER, IT DOES NOT FOLLOW THAT THE ONLY ALTER
IS UNTRAMALLLD LAISSEZ-FAIRE.

06892 NOVICKI, M.A.

A LESSON IN DEMOCRACY

AFRICA REPORT, 37(1) (JAN 92), 13-17.

THE RECENT ELECTION IN ZAMBIA WAS A LESSON FOR AFRICA IN HOW TO CONOUCT FREE AND FAIR ELECTIONS AND IN THE PEACEFUL TRANSFER OF POWER. THE INVOLVEMENT OF FOREIGN AND LOCAL ELECTION OBSERVERS, AS WELL AS THE DEDICATION AND COMMITMENT OF THE ZAMBIAN PEOPLE, ENSURED THAT THE PROCESS TOHARD A MULTI-PARTY SYSTEM WOULD NOT BE DERAILED. ZAMBIA OFFERS A NEW MODEL IN CIVIC RESPONSIBILITY AND PARTICIPATION FOR OTHER AFRICAN STATES TO EMULATE.

06893 NOVICKI, M.A.

A NEW AGENDA FOR THE OAU: SALIM AHMED SALIM AFRICA REPORT, 37 (3) (MAY 92), 36-39.

IN THIS INTERVIEW, THE SECRETARY-GENERAL OF THE ORGANIZATION FOR AFRICAN UNITY OUTLINES HIS ADMINISTRATION'S AGENDA FOR THE 1990'S, WHICH INCLUDES ADDRESSING ISSUES OF ECONOMIC INTEGRATION, CONFLICT RESOLUTION, AND THE MANAGEMENT OF POLITICAL CHANGE.

06894 NOVICKI, M.A.

BABACAR NDIAYE: AFRICA'S PREMIER BANKER

AFRICA REPORT, 37(1) (JAN 92), 39-41.

BABACAR NDIAYE, THE PRESIDÉNT OF THE AFRICAN DEVELOPMENT BANK, SEES LIMITLESS POSSIBILITIES FOR AFRICA'S ECONOMIES, WITH' A WHOLE NEW REALM OF MARKETS FOR AFRICA'S EXPORTS IN EASTERN EUROPE AND THE AFRICAN PRIVATE SECTOR AS THE ENGINE EASTERN EUROPE AND THE AFRICAN PRIVATE SECTOR AS THE ENGINE LAST DECADE, NDIAYE ARGUES THAT FOCUSING ON ITS HEAVY DEBT LAST DECADE, NDIAYE ARGUES THAT FOCUSING ON ITS HEAVY DEBT AFRICA--GENERATING NEW INFLOHS OF RESOURCES.

06895 NOWNES, A.

PRIMARIES, GENERAL ELECTIONS, AND VOTER TURNOUT: A MULTINOMIAL LOGIT MODEL OF THE DECISION TO VOTE AMERICAN POLITICS QUARTERLY, 20(2) (APR 92), 205-226.

A MULTINOMIAL LOGIT MOOEL IS USED IN THIS ARTICLE IN TESTING WHETHER OR NOT THE SAME PROCESS IS AT WORK IN DETERMINING BOTH PRIMARY AND GENERAL ELECTION TURNOUT. THE ADVANTAGE OF THIS METHODOLOGY IS THAT IT ALLOHS THE 
INCORPORATION OF PRIMARY AND GENERAL ELECTION VOTING INTO THE SAME MODEL. THE RESULTS INDICATE THAT A VARIETY OF SHORTTERM AND LONG-TERM FACTORS INFLUENCE THE DECISION TO VOTE. IT APPEARS THAT THE SAME PROCESS IS AT HORK IN DETERMINING BOTH PRIMARY AND GENERAL ELECTION TURNOUT.

06896 NOWOTNY, K.; PEACH, J.

CHANGES IN ENERGY CONSUMPTION, 1970-1989, AND ENERGY POLICY IN THE UNITED STATES

JOURNAL OF ECONOMIC ISSUES, 26(1) (MAR 92), 183-196.

THE NEED FOR THE CONTINUING U.S. DEPENDENCY ON ENERGY FROM UNSTABLE AND UNDEPENDABLE AREAS OF THE HORLD AND IN ORDER TO DETERMINE THE EXTENT TO WHICH OUR CONTINUING USE OF FOSSIL FUEL AND THE CONCOMMITTANT PRODUCTION OF CARBON DIOXIDE IS ECONOMICALLY DEFENSIBLE IN LIGHT OF THE DANGERS OF GREENHOUSE WARMING ARE EACH EXAMINED. THIS ARTICLE DISCUSSES THE NATURE OF THE CHANGES IN ENERGY CONSUMPTION IN THE UNITED STATES DURING THE 1970-1989 PERIOD. IT ALSO EXPLORES ENERGY PRICES, ENERGY PROBLEMS, ENERGY OPTIONS, AND POTENTIALLY USEFUL POLICIES FOR AN ENERGY STRATEGY.

06897 NOHROJEE, B.

TAYLOR LAUNCHES OFFENSIVE ON LIBERIAN CAPITAL

AFRICA REPORT, $37(6)$ (NOV 92), 5.

INTENSE FIGHTING ERUPTED ON THE OUTSKIRTS OF MONROVIA ON OCTOBER 17, 1992, THREATENING THE LIBERIAN PEACE PROCESS. THE FIGHTING WAS INITIATED BY CHARLES TAYLOR'S NATIONAL THE FIGHTING WAS INITIATED BY CHARLES TAYLOR'S NATIONAL PATRIOTIC FRONT OF LIBERIA (NPFL) IN AN APPARENT ATTEMPT TO OUST LIBERIA'S INTERIM GOVERNMENT, WHICH IS BEING
BY ECOMOG, THE WESTERN AFRICAN PEACEKEEPING FORCE.

06898 NSEREKO, D.D

RELIGIOUS LIBERTY AND THE LAH IN BOTSWANA

JOURNAL OF CHURCH \& STATE, 34(4) (FAL 92), 843-862.

BOTSHANA'S LEGAL SYSTEM IS BASED ON ROMAN-DUTCH LAW, AMD ITS CONSTITUTION EMBODIES A BILL OF RIGHTS THAT ENUMERATES THE FUNDAMENTAL RIGHTS AND FREEDOMS OF THE INDIVIDUAL. IN THIS ESSAY, THE AUTHOR FOCUSES ON THE CONCEPT OF RELIGIOUS FREEDOM IN BOTSWANA'S LAW.

06899 NSOULI, S.; CORNELIUS, P.; GEORGIOU, A. STRIVING FOR CURRENCY CONVERTIBILITY IN NORTH AFRICA FINANCE AND DEVELOPMENT, 29(4) (DEC 92), 44-47.

CURRENCY CONVERTIBILITY IS CENTRAL TO THE MANDATE OF THE IMF BECAUSE ITS ARTICLES OF AGREEMENT CALL FOR "THE ELIMIMATION OF FOREIGN EXCHANGE RESTRICTIONS WHICH HAMPER THE GROWTH OF WORLD TRADE." MEMBERS ACCEPTING THE OBLIGATIONS OF ARTICLE VIII UNDERTAKE, AMONG OTHER THINGS, TO REFRAIN FROM IMPOSING RESTRICTIONS ON THE MAKING OF TO REFRAIN FROM IMPOSING RESTRICTIONS ON THE MAK
PAYMENTS AND TRANSFERS FOR CURRENT INTERNATIONAL PAYMENTS AND TRANSFERS FOR CURRENT INTERNATIONAL
TRANSACTIONS. AS OF SEPTEMBER 1992, 72 OF MORE THAN 170 TRANSACTIONS. AS OF SEPTEMBER 1992, 72 OF MORE THAN 170
MEMBER COUNTRIES HAD ACCEPTED THESE OBLIGATIONS, BUT ONLY MEMBER COUNTRIES HAD ACCEPTED THESE OBLIGATIONS, BUT ONLY THREE AFRICAN COUNTRIES HAD DONE SO. THE EXPERIENCE OF ALGERIA, MOROCCO, AND TUNISIA ILLUSTRATES THE COMPLEX AND TIME-CONSUMING ADJUSTMENT POL ICIES AND ECONOMIC REFORMS
MUST BE IMPLEMENTED TO ESTABLISH, MAINTAIN, AND REAP THE MUST BE IMPLEMENTED TO ESTABLISH, MAII
BENEFITS OF CURRENT CONVERTIBILITY.

06900 NURMI, H.

AN ASSESSMENT OF VOTING SYSTEM SIMULATIONS PUBLIC CHOICE, 73(4) (1992), 459-488.

IN APPLYING THE RESULTS OF THE SOCIAL CHOICE THEORY TO VOTING PROCEDURES, THE QUESTION ARISES AS TO HOW OFTEN THE VARIOUS ANOMALIES CAN BE EXPECTED TO OCCUR. COMPUTER SIMULATIONS AND PROBABILITY MODELING ARE COMMON APPROACHES TO ADORESS THIS PROBLEM. THIS ARTICLE IS AN ATTEMPT TO FIND OUT THE ROBUSTNESS OF THE SO-CALLED IMPARTIAL CULTURE ASSUMPIION. FOR THIS PURPOSE, FIRST A MAJOR PERTUBATION OF THE IMPARTIAL CULTURE ASSUMPTION IS CONSIDERED AND, THEREAFTER, THE AUTHORS FOCUS ON A FEW MINOR MODIFICATIONS OF THE ASSUMPTION. THEY CONCLUDE THE ARTICLE WITH AN OBSERYATION OF THE LARGER CONTEXT OF THE PAPER.

06901 NUSSEIBEH, S.

AFTER MADRID, HHAT? A PALESTINIAN PERSPECTIYE MIDDLE EAST INSIGHT, 8(3) (1992), 9-12.

THO APPRAOCHES TO NEGOTIATING A SETTLEMENT BETWEEM ISRAEL AND THE PALESTINIANS ARE DESCRIBED. THIS ARTICLE SUGGESTS THAT THESE TWO APPRACHES WILL CLASH OVER SPECIFIC CRITICAL ISSUES WHOSE RESOLUTION IN ONE MANNER OR ANOTHER WILL DETERMINE THE DIRECTION THE INTERIM ARRANGEMENT WILL TAKE. IF PALESTINIANS EXPECT UNITED NATIONS SECURITY COUNCIL TAKE. IF PALESTINIANS EXPECT UNITED NATIONS SECURITY COUNCIL
RESOLUTION 242 TO MEAN AN END TO THE OCCUPATION, AND ISRAE! RESOLUTION 242 TO MEAN AN END TO THE OCCUPATION, AND ISRAE! EXPRECTS IT TO MEAN NO TERRITORIAL COMPROMISES IN THE WEST
BANK AT ALL. WHILE THE U.S. INVITES THE TWO SIDES SIMPLY TO BANK AT ALL, WHILE THE U.S. INVITES THE THO SIDES SIMPLY TO NEGOTAITE ON THEIR RESPECTIVE INTERPRETATIONS, THEN IT IS
UNLIKELY THAT A COMPROMISE WILL BE REACHED AT ALL. THE WORLD UNLIKELY THAT A COMPROMISE WILL BE REACHED AT ALL. THE WORLD MAKE NOT TAKE KINDLY TO THE PALESTINIANS IF THEY REFUSE
NEGOTIATE, BUT IT CANMOT FAIL TO SYMPATHIZE WITH THEM IF NEGOTIATE, BUT IT CANMOT FAIL TO SYMPATHIZE WITH
THEY INSIST ON THEIR BASIC RIGHTS OF FREEDOM AND THEY INSIST ON THEIR BASIC
INDEPENDENCE AS A PEOPLE.

06902 NUTTING, A.

THE CORE ISSUE OF A NEW WORLD ORDER
MIDOLE EAST INTERMATIONAL, (395) (MAR 91), 21

HHILE WINNING A WAR AGAINST IRAO SEEMED A RELATIVELY EASY TASK FOR THE WEST, WINNING THE PEACE AND IMPLEMENTING A NEW WORLD ORDER MAY PROVE TO BE MORE DIFFICULT. WHATEVER SECURITY ARRANGEMENTS THE VICTORS MAY SEEK TO CREATE IN THE GULF REGION. THE DANGERS OF A BACKLASH OF ARAB NATIONALISM AND MUSLIM FUNDAMENTALISM WILL MORE THAN JUST A POSSIBILITY IF AT THE SAME TIME NOTHING IS DONE TO BRING ABOUT A JUST SETTLEMENT FOR THE PALESTINIANS. THIS HAS BEEN AND, UNTIL IT IS RESOLVED, WILL ALWAYS BE THE CORE ISSUE OF THE MIDDLE EAST.

06903 NWAGBOSO, M.

BABANGIOA'S INDEL IBLE IMPRINT

WEST AFRICA, (3901) (JUN 92), 1044.

THE AUTHOR REYIEWS THE TENURE OF NIGERIAN PRESIDENT UNITY.

06904 NHAGBOSO, M.

THO TRANSITIONS IN PROGRESS

WEST AFRICA, (3877) (JAN 92), 16.

WEST AFRICA, (3877) (JAN 92), 16 .

FOR TRANSITION FROM MILITARY RULE TO DEMOCRACY.

06905 NHOLISE, 0

BLACKS IN THE DIASPORA: A CASE OF NEGLECTED CATALYSTS IN

THE ACHIEVEMENT OF NIGERIA'S FOREIGN POLICY GOALS

JOURNAL OF BLACK STUDIES, 23 (1) (SEP 92), 117-134.

THE HISTORY OF FOREIGN RELATIONS BETWEEN EUROPE AND AFRICA IN THE FOUR CENTURIES BEFORE COLONIZATION IS THE HISTORY OF SLAVERY AND VIOLENCE, LINKING UP WITH THE STORY OF AFRICANS IN THE DIASPORA TOOAY. THIS ARTICLE EXAMINES THE MATURE OF THE RELATIONSHIP BETWEEN NIGERIA, AFRICA'S LEADING NATION, AND AFRICAN PEOPLE IN THE DIASPORA, TO SEE THE EXTENT TO WHICH BOTH SIDES HAVE BEEN WORKING FOR EACH OTHER'S UPLIFTMENT. IT AIMS TO THROW LIGHTS ON THE EXTENT TO WHICH AFRICANS IN THE DIASPORA CONTRIBUTE TO THE ACHIEVEMENT OF NIGERIA'S FOREIGN POLICY GOALS AND TO GIVE INSIGHT INTO THE CONDITION OF AFRICAN PEOPLE IN THE DIASPORA TODAY, AS WELL AS THE FACTORS BEHIND THAT CONDITION.

06906 NYE, J.S. JR.

(89) (HIN 93), 96-115

A U.S.-JAPANESE TRADE WAR COULD DESTROY THE MULTILATERAL

TRADING SYSTEM, AND AN INSECURE JAPAN COULD SPARK AN ARMS

RACE IN EAST ASIA. YET THE UNITED STATES HAS NO COHERENT JAPANESE STRATEGY, AND THE GOVERMMENT IS POORLY ORGANIZED FOR DEALING WITH JAPAN. RECENT U.S. POLICY TOWARD JAPAN HAS OFTEN BEEN DOMINATED BY TRADE POLITICS AND SECTORAL INTERESTS SEEKING PROTECTION FROM JAPANESE PRODUCTS. BUT INTERESTS SEEKING PROTECTION FRDM JAPANESE PRODUCTS. BUT TRADE POLICY IS ONLY ONE PART OF FOREIGN POLICY, AND A STRATEGY TO ADVANCE THE LONG-TERM INTERESTS OF THE AMERICAN PEOPLE MUST GO BEYOND PROTECTING JOBS. IN THE ABSENCE OF A LARGER VISION, THE JAPANESE-AMERICAN RELATIONSHIP HILL BE SHAPED BY A COMBINATION OF INERTIA AND TRADE DISPUTES. THE TIME HAS COME FOR AMERI
JAPAN'S RISING POWER.

06907 NYE, J.S. JR.

WHAT NEW WORLD ORDER?

FOREIGN AFFAIRS, 71(2) (SPR 92), 83-96

THE AUTHOR DISCUSSES THE PROSPECTS FOR A NEH WORLD ORDER AND OUTLINES VARIOUS FORMS THAT SUCH AN ORDER MIGHT TAKE, INCLUDING A RETURN TO BIPOLARITY, MULTIPOLARITY, THE EMERGENCE OF THREE POWERFUL ECONOMIC BLOCS, AND UNIPOLAR HEGEMONY.

06908 NYE, M.; BULLOCK, C., III

CIVIL RIGHTS SUPPORT: A COMPARISON OF SOUTHERN AND BORDER STATE REPRESENTATIVES

LEGISLATIVE STUDIES OUARTERLY, 17(1) (FEB 92), 81-94.

THE SUPPORT FOR CIYIL RIGHTS BILLS AMONG MEMBERS OF THE U.S. HOUSE FROM SOUTHERN AND BORDER STATES OVER A 20-YEAR PERIOD IS EXAMINED. OVER TIME, THE DISTINCTIVENESS OF THE DEEP SOUTH FROM THE RIM SOUTH HAS LARGELY ERODED. THE DEEP SOUTH CONTINUES TO BE MORE CONSERVATIVE ON CIVIL RIGHTS THAN MOST LEGISLATIVE SESSIONS, PARTY IS A SIGNIFICANT PREDICTOR.

06909 NYIKA, T.

GABORONE DECLARATION

WEST AFRICA, (3908) (AUG 92), 1350-1351.

AL THOUGH, THE PEACE NEGOTIATIONS BETWEEN RENAMO AMD

FREL IMO HAVE BEEN PROCEEDING SLOWLY, RENAHO LEADER AFONSO

KHLAKAMA'S DECLARATIOH THAT HE IS "TIRED" OF THE BLOODY

CIVIL WAR HAS BROUGHT NEW HOPE FOR A POLITICAL SOLUTION.

06910 NYIKA, T.

REDEFINING ECONOMIC ROLE

WEST AFRICA, 75(3885) (MAR 92), 375

AS ECONOMIC BLOCS INCREASINGLY BECOME FASHIONABLE IN A

WORLD OF INCREASING STIFF COMPETITION. THE MERGING OF THE 
PREFERENTIAL TRADE AREA (PTA) FOR EASTERN AND SOUTHERN AFRICA AND THE SOUTHERN AFRICA DEVELOPMENT CO-ORDINATING CONFERENCE ECONOMIC GROUPS IS ON THE CARDS. SUCH A POWERFUL ECONOMIC BLOC WOULD IN THE FUTURE STRENGTHEN ECONOMIC TIES WITH ECOWAS AND THE ARAB MAGREB UNION TO CONSOLIDATE AN AFRICA ECONOMIC COMMUNITY (AEC), AS AGREED DURING LAST YEARS OAU HEADS OF STATE AND GOVERNMENT SUMMIT IN ABUJA, NIGERIA. ONCE WELCOMED IN THE SPIRIT OF EQUAL TRADE AND ECONOMIC DEVELOPMENT BY SADCC/PTA SOUTH AFRICA HOULD BE PERSUADED BY NECESSITY TO DISSOLVE SACU, AND A NEW MEMORANDUM OF AGREEMENT WOULD BE DESIGNED FOR THE ENTIRE REGION.

06911 NYIKA, T.

THREATS TO STABILITY

WEST AFRICA, (3901) (JUN 92$), 1055$

THE FRONTLINE STATES NOW HAVE A NEW THREAT ON THE

HORIZON: BORDER DISPUTES. BOTSWANA AND NAMIBIA ARE ARGUING OVER THE CHOBE RIVER ISL TO BOTH COUNTRIES. THERE ARE FEARS OF ADOITIONAL DISPUTES IN THE REGION UNLESS THE ORGANIZATION OF AFRICAN UNITY PRINCIPLE OF RESPECTING COLONIALLY-DEMARCATED BORDERS IS UPHELD.

06912 NYIKA, T.

WILL THE PEACE HOLD?

WEST AFRICA, (3926) (DEC 92), 2146

ON OCTOBER 4, 1992, PRESIDENT JOAQUIM CHISSANO AND RENAMO LEADER AFONSO DHLAKAMA SIGNED A HISTORIC ACCORD TO BRING PEACE TO MOZAMBIQUE, WHICH HAS BEEN RAVAGED BY 16 YEARS OF CIVIL WAR. IT WILL TAKE A FULL GENERATION TO HEAL THE SCARS INFLICTED ON THE POPULATION AND MANY YEARS OF MASSIVE FOREIGN AID TO REBUILD THE COUNTRY. BUT MANY MOZAMBICANS FEAR THAT THE WARRING FACTIONS WILL CONTINUE FIGHTING, DESTROYING THE FRAGILE PROSPECTS FOR PEACE.

06913 NYIRO, A.

THE LEADING BODIES OF THE PARTY IN THE MIRROR OF THEIR RESOLUTIONS

JOURNAL OF COMAUNIST STUDIES, 8(3) (SEP 92), 62-75.

THE LEADING ORGANS OF THE HUNGARIAN SOCIALIST WORKERS'

PARTY AND THE COMMUNIST STATE--THE POLITBURO, THE CENTRAL

COMMITTEE AND THE STANDING COMMISSIONS-DIVIDED FUNCTIONS

AMONG THEMSELVES IN A HIERARCHY. THIS HIERARCHY IS

AMONG THEMSELVES IN A HIERARCHY. THIS HIERARCHY IS

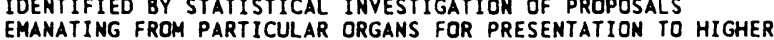

BOOIES, SOME OF WHICH CLEARLY EN JOYED THE POWER OF DECISIOM

BOOIES, SOME OF WHICH CLEARLY ENJOYED THE POWER OF

06914 NYONG'O, P.

AFRICA: THE FAILURE OF ONE-PARTY RULE

JOURNAL OF DEMOCRACY $3(1)$ (JAH 92)

AFTER INDEPENDENCE, AFRICAN NATIONALISTS ADVOCATED ONEPARTY RULE FOR A VARIETY OF REASONS: THE SINGLE PARTY WOULD PROMOTE NATIONAL UNITY; PEOPLE'S EFFORTS WOULD BE DIRECTED TOWARD NATION BUILDING, NOT DISSIPATED IN FRUITLESS POLITICKING; GIVEN THE POPULAR CONSENSUS THAT THE GOVERMMENT SHOULD MAINLY CONCERN ITSELF WITH DEVELOPMENT, PARTY POLITICS WOULD BE UNNECESSARY; AND WHATEVER DIFFERENCES MIGHT EMERGE COULD BE FREELY SETTLED UNDER THE SINGLE-PARTY REGIME, FOR DEMOCRACY WOULD BE PRACTICED AND HUMAN RIGHTS RESPECTED. THE RECORD, HOWEVER, SHOWS THAT SINGLE-PARTY REGIMES, INCLUDING NYERERE'S IN TANZANIA, GENERALLY FAILED TO LIVE UP TO THESE PROMISES. COUNTRIES WHERE SINGLE PARTIES HAVE REIGNED SUPREME FOR MOST OF THE POST-INDEPENDENCE PERIOD CANMOT CLAIM TO BE ANY MORE UNIFIED THAN OTHER MULTIPARTY STATES. NOR CAN ANY ONE-PARTY REGIME IN AFRICA BOAST OF ITS DEMOCRATIC PRACTICES OR GOOD RECORD ON HUMAN RIGHTS.

06915 O'BEIRNE, K.

MATIONAL REYIEH, XLIV(23) (NOY 92), 32-33.

THIS ARTICLE DISCUSSES SOME OF THE REASONS THAT BUSH LOST THE 1992 PRESIDENTAL ELECTION. THE AUTHOR STATES THAT "BUSH CONSISTENTLY PREFERRED HIS ENEMIES' ADV

06916 O'BRIEN, C.

THE FUTURE OF 'THE WEST'

NATIONAL INTEREST, 30(30) (WIN 92), 3-10.

THE EUROPEAN FEDERALIST PROJECT WAS FLAWED FROM THE BEGINNING, BECAUSE THE EUROPEAN STATES ARE NOT STATES IN THE AMERICAN SENSE; HITH THE EXCEPTION OF BELGIUM. THE EUROPEAN STATES ARE ALL NATION-STATES. THIS ARTICLE SUGGESTS THAT YOU CANHOT FEDERATE NATIONS, AND WHEN YOU SERIOUSLY TRY TO DO SO, YOU AROUSE MATIONAL ISM, AND WHEN YOU SERIOUSLY TRY TO DO SO, YOU AROUSE NATIONALISM AS IN THE CASE OF MAASTRICHT. THE ARTICLE EXPLORES THE END OF GERMAN DEFERENCE AND OF FRENCH PRETENSION. IT OFFER PARALLELS AND DIFFERENCES TO 1914 AND DEFINES THE SHRINKING HEST. IT CONCLUDES THAT THERE IS STILL A HEST, BUT IT IS SMALLER THAN THE SCOPE OF
COMHONLY ASSOCIATED WITH IT WOULD SUGGEST.

06917 O'BRIEN, P.; PIGMAN, G

FREE TRADE, BRITISH HEGEMONY AND INTERNATIONAL ECONOMIC ORDER IN THE NINETEENTH CENTURY
REVIEN OF INTERNATIONAL STUDIES, $18(2)$ (APR 92), 89-114. THE THEORY THAT THE INTERNATIONAL ECONOMY FUNCTIONED EFFECTIVELY FOR A CENTURY DOWN TO 1914 BECAUSE GREAT BRITAIN PROVIDED THE PUBLIC GOODS REOUIRED FOR THE SMOOTH OPERATION OF THE LIBERAL INTERNATIONAL ORDER HAS BECOME A TEXTBOOK GENERALIZATION. THIS HISTORY ANO ANALYSIS NOT ONLY QUESTIONES THIS NOTION, BUT ALSO ILLUSTRATES HOW BRITAIN OFTEN SQUANDERED THE STRUCTURAL POWER IT POSSESSED THROUGH POLICY CHOICES THAT UNDERMINED ITS HEGEMONIC POSITION. THE FOCUS OF THIS ARTICLE IS ON TARIFFS. IN THE NINETEEN CENTURY, GOVERMMENT INVOLVEMENT IN THE ECONOMIES OF STATES WAS
GROWING, BUT TARIFFS WERE STILL THE MOST OPENLY POLITICIZED ARENA OF INTERNATIONAL ECONOMIC POLICY, BOTH IN TERMS OF ARENA OF INTERNATIONAL ECONOMIC POLICY, BOTH
DOMESTIC POLICY AND INTERSTATE RELATIONS.

06918 O'BRIEN, $P$.

GERMAN-POLISH MIGRATION: THE ELUSIVE SEARCH FOR A GERMAN MATION-STATE

INTERNATIONAL MIGRATION REVIEW, XXVI(2) (SUM 92), 373-387. THIS ARTICLE EXAMINES PAST AND PRESENT MIGRATIONS TO GERMANY FROM THE PERSPECTIVE OF NATION-STATE FORMATION. MUCH OF MODERN GERMAN HISTORY HAS BEEN CHARACTERIZED BY REPEATED (AND FAILED) ATTEMPTS TO ESTABLISH AND SUSTAIN A STRONG, INDEPENDENT NATION-STATE LIKE FRANCE OR BRITAIN. BUT EACH ATTEMPT, INCLUDING THE RECENT REUNIFICATION, HAS FORCED GERMANY' TO ABSORB LARGE NUMBERS OF NON-GERMANS EITHER AS A RESULT OF EXPANDING BORDERS AND ANNEXATIONS AND/OR THE APPEAL AND LABOR NEEDS OF A ROBUST ECONOMY. FOCUSING ON THE MANY EXPERIENCES WITH THE POLISH MINORITY (RANGING FROM THE EIGHTEENTH CENTURY TO THE PRESENT), THIS ESSAY SUGGESTS THAT GERMANS HAVE NEVER DISCOVERED AN ACCEPTABLE AND HORKABLE APPROACH FOR DEALING WITH LARGE NON-GERMAN MINORITIES IN THE GERMAN NATION-STATE. RATHER, DIFFERENT REGIMES AT DIFFERENT TIMES HAVE VACILLATED BETWEEN AN EXCLUSIVE APPROACH FOUNDED ON NATIONALIST PRINCIPLES AND PRACTICES AND AN INCLUSIVE ONE BASED ON LIBERAL PRINCIPLES AND PRACTICES. IN THE CURRENT MIGRATION CRISIS, BROUGHT ON BY THE RAISING OF THE IRON CURTAIN, BOTH APPROACHES, DESPITE THE CONTRADICTIONS BETWEEN THEM, ARE BEING EMPLOYED TO DETERMINE WHO SHOULD AND WHO SHOULD NOT BE PERMITTED TO IMMIGRATE TO THE "NEH" GERMANY THE CONFUSION OVER THE THO APPROACHES PRODUCES NOT ONLY A CONFUSED IMMIGRATION POLICY, BUT ALSO REFLECTS A DEEP-SEAT CONFUSION OVER THE DEFINITION OF THE NEW GER
IDENTITY OF THE NEWLY UNIFIED GERMAN NATION.

06919 O'CONNOR, C.

GERMANY'S INTEGRATION DILEMMA

EUROPE, (304) (MAR 91) 23-24.

GERMANY IS NOW HOME TO A LARGE NUMBER OF IMMIGRANTS COMING FROM TURKEY, VIETNAM, CUBA, MOZAMBIQUE, ANGOLA, ALBANIA, ROMANIA, POLAND, AND BULGARIA-AS WELL AS LARGE GROUPS OF EUROPE AND THE SOVIET UNION, AND HAS OVERHHELMED THE GERMAN GOVERNMENT AND TRIGGERED SHARP SOCIAL TENSIONS AND RACISM--PARTICULARLY IN EASTERN GERMANY, WHERE UNEMPLOYMENT IS SEVERE.

$06920 O^{\prime}$ CONNOR, K.

THE EFFECTS OF THE THOMAS APPOINTMENT TO THE SUPREME COURT PS: POLITICAL SCIENCE AND POLITICS, $X X V(3)$ (SEP 92), 492-495.

THE AUTHOR DISCUSSES CLARENCE THOMAS' LEGAL

QUALIFICATIONS AND THE LIKELY IMPACT OF HIS APPOINTMENT TO THE U.S. SUPREME COURT.

06921 O'DONOVAN, I.

MANAGEMENT AND CHANGE IN NORTHERN NIGERIAN LOCAL GOVERMMENT PUBLIC ADMINISTRATION AND DEVELOPMENT, 12(4) (OCT 92). 355-371.

IN NIGERIA THE ELECTION OF CHAIRMAN AND COUNCILLORS AT THE LOCAL GOVERNMENT LEVEL HAS BEEN THE FIRST STEP IN THE RETURN TO CIVILIAN RULE IN A STABLE POLITY. IT IS ENVISAGED THAT LOCAL POL ITICIANS AND ADMINISTRATORS HILL WORK TOGETHER TO MOBILIZE LOCAL ACTION FOR URBAN AND RURAL DEVELOPMENT. THIS PAPER CONCENTRATES ON THE CONSEQUENCES OF THIS POLICY FOR THE MANAGEMENT OF LOCAL GOVERHMENT IN NORTHERN NIGERIA. THE RESOURCE AND MANAGEMENT ISSUES FOR LOCAL GOVERNMENT ARE DISCUSSED UNDER THE FOLLOWING HEADINGS: FINANCE, NATURAL

06922 O'LEARY, B.

PUBLIC OPINION AND NORTHERN IRISH FUTURES

POL IIICAL OUARTERLY (THE) 63(2) (APR 92) 142-170.

SEASONED SCEPTICS APPEAR TO HAVE SOLID GROUNDS FOR BELIEVING THAT NEITHER GREATER EUROPEAN INTEGRATION NOR A PROSPECTIVE CHANGE OF BRITISH GOVERNMENT WILL HAVE ANY IMPACT UPON RESOLYING NORTHER IRELAND. HOHEVER, THERE ARE SOME REASONS FOR SUGGESTING THAT PERCEPTIONS OF THE MOST DESIRABLE AND FEASIBLE HAYS OF RESOLVING THE CONFLICT ARE CHANGING THROUGHOUT THE ISLANDS OF THE BRITISH AND IRISH ARCHIPELAGO. POLLS DEMONSTRATE THAT PUBLIC OPINION IN GREAT BRITAIN AND THE REPUBLIC STRONGLY FAYORS A MAJOR ROLE FOR THE IRISH GOVERNEMNT IN THE FUTURE OF NORTHERN IRELAND, BUT OPINION WITHIN NORTHERN IRELAND REMAINS SHARPLY POLARIZED OVER THE REGION'S BRITISH AND IRISH DIMENSIONS. 
06923 O'LESSKER, K

DEMAGOGUING THE DEFICIT

AMERICAN SPECTATOR 25(12) (DEC 92), 54-56.

ENTI ILEMENTS NOW ACCOUNT FOR HALF THE TOTAL FEDERAL BUDGET, UP FROM ONE-TENTH THIRTY YEARS AGO. CONSERVATIVES WHO CALL FOR A REDUCTION IN BENEFITS MUST OFFER A MORE COMPELLING RATIONALE THAN LUMPING SOCIAL SECURITY IN WITH ALL OTHER ENTITLEMENTS, OR LABELING IT "WELFARE" FOR IT'S IMPORTANT TO DISTINGUISH BETWEEN TYPES OF ENTITLEMENTS. MEDICARE, DISABILITY, ANO SOCIAL SECURITY MAKE UP HALF OF ALL ENTITLEMENTS AND PAY THEIR OWN WAY THROUGH DEDICATED PAYROLL TAXES. AN IMPORTANT QUESTION IS WHETHER ANY FEDERAL EXPENDITURES (OTHER THAN INTEREST ON THE DEBT) OUGHT TO BE FUNDED OUTSIDE NORMAL APPROPRIATIONS.

06924 O'LOONEY, J.

FRACTURED DECISION MAKING: SUNSHINE LANS AND THE COLLIDING ROLES OF MEDIA AND GOVERMMENT

NATIONAL CIVIC REVIEW, 81(1) (WIN 92), 43-56.

THE ADVENT OF OPEN-MEETINGS LAHS COMBINED WITH CHANGES

IN THE STYLE AND NATURE OF POLITICAL NEWS REPORTING HAVE

IN THE STYLE AND NATURE OF POLITICAL NEWS REPORTING HAVE

TRANSFORMED ELECTED OFFICIALS AND THE MEDIA INTO OPEN
ANTAGONISTS IN THE POL ICY-MAKING PROCESS, PARTICULARLY

ANTAGONISTS IN THE POL ICY-MAKING PROCESS, PARTICULARLY
DURING TIMES OF CONTROVERSY OR CONFLICT. ALTERNATIVE DISPUTE

RESOLUTION TECHNIOUES--INVOLVING POLICY MAKERS, DISPUTANTS, AND REPRESENTATIVES OF THE PRESS--HOLD PROMISE FOR IMPROVING AND REPRESENTATIVES OF THE
GOVERMMENT-MEDIA RELATIONS.

06925 O'MANIQUE, J.

DEVELOPMENT, HUMAN RIGHTS AND LAH

HUMAN RIGHTS QUARTERLY, 14(3) (AUG 92), 383-408.

THIS PAPER EXPLORES THE FOUNDATIONS OF POSITIVE LAH WITHIN THE CONTEXT OF HUMAN RIGHTS AND DEVELOPMENT. POSITIVIST THEORIES OF RIGHTS AND LAW HAVE FILLED MUCH OF THE VACUUM LEFT BY THE REJECTION OF DIVINE LAW AND NATURAL LAN AS FOUNDATIONS FOR HUMAN RIGHTS AND POSITIVE LAH. IN GENERAL, POSITIVISTS SEE LAW AS A COERCIVE ORDER CREATED BY HUMAN COMMUNITIES TO PROTECT PEOPLE FROM ONE ANOTHER, AND RIGHTS AS ENTITLEMENTS GRANTED BY LAW. MORALITY IS NOT AN INTEGRAL PART OF THE VIEW AND THERE ARE NO UNIVERSAL BASES OR CRITERIA FOR LAW OR RIGHTS. THERE ARE, HOWEVER, SOME CURRENT CONTRASTING VIENS--SO-CALLED WORLD ORDER VIEWSHIICH ARE REMINISCENT OF THE OPTIMISTIC AND HOLISTIC CHARACTER OF THE EARLIER NATURAL LAW THEORIES. THEY INTEGRATE MORALITY, HUMAN RIGHTS AND LAW MORE INTIMATELY, AND GO SOME WAY IM' PROYIDING AL OF THEM WITH IN UNIVERSAL FOUNDATION. THE PAPER EXPLORES THIS QUESTION OF FOUNDATIONS FROM THE PERSPECTIVE OF DEVELOPMENT AND EVOLUTION RATHER THAN FROM A LEGAL PERSPECTIVE.

06926 O'MANIQUE, J.

HUMAN RIGHTS AND DEVELOPMENT

HUMAN RIGHTS QUARTERLY 14 (1) (FEB 92), 78-103.

THE CONCEPTS OF HUMAN RIGHTS AND DEVELOPMENT ARE EXPANDING AND CONVERGING. THIS PAPER EXPLORES THESE CONCEPTS, PRESENTS A WAY OF LOOKING AT THEM HHICH FURTHERS THEIR EXPANSION AND INTEGRATION, AND DISCUSSES SOME OF THE THEORETICAL CONSEQUENCES OF THIS INTEGRATION. THE HOBBESIAN VIEW IS A PICTURE OF ONLY THE NEGATIVE SIDE OF NATURE. THE AUTHOR PREFERS THE MORE POSITIVE PICTURE PRESENTED BY MODERN THEORIES OF EVOLUTION. HIS PRIMARY OBJECTIVE IS TO EXPLORE CONCEPTS IN THE CONTEXT OF HUMAN DEVELOPMENT AS A CONTINUATION OF THE EVOLUTIONARY PROCESS.

06927 O'NEIL, D.

IRISH NATIONALISM AND ROMAN CATHOLICISM: THE REVOLUTIONARY EXPERIENCE OF PATRICK PEARSE (1979-1916), HORACE PLUNKET (1854-1932) AMD JAMES COMNOLLY (1868-1916)

CANADIAN REVIEW OF STUDIES IN NATIONALISM, XIX(1) (1992),

59-78.

THIS STUDY EXAMINES HOW THREE IRISH REVOLUTIONARY-PERIOD LEADERS-PATRICK PEARSE, HORACE PLUNKETT, AND JAMES CONNOLLY REACTED TO THE ROMAN CATHOL IC RELIGIOUS HERITAGE OF TURN-OFTHE-CENTURY IRELAND. UNLIKE MANY OF THE CONVENTIONAL STUDIES, IT CONCENTRATES ON THE IDEAS OF THE THREE PARTICIPANTS. IT EXPLORES HOW THEY PERCEIVED THE ROMAN CATHOL IC RELIGION, HOH THEY RELATED IT TO THEIR POLITICAL COMMITMENT, AND WHAT ADAPTATIONS THEY MADE OF IT.

06928 O'NEIL, R.M.

FIRST AMENDMENT ISSUES IN S. 100
JOURNAL OF LAW \& POLITICS, VIII (2) (WIN 92), 277-282.

THE AUTHOR CONSIDERS S. 100, A HYPOTHETICAL BILL THAT HOULD REFORM THE U.S. PRESIDENTIAL ELECTION PROCESS. HE FOCUSES ON HOW THE PROPOSED LEGISLATION WOULD AFFECT THE MEDIA, THE CANDIDATES, AND GOVERNMENTAL AGENCIES

06929 O'NEILL, B.

DETERRENCE THEORY DISCUSSION: ARE GAME MODELS OF DETERRENCE BIASSED TOHARDS ARMS-BUILDING? WAGNER ON RATIONALITY AND MISPERCEPTION

JOURNAL OF THEORETICAL POLITICS, 4(4) (OCT 92), 459-477.

R. HARRISON WAGNER HAS SHOWN HOW SOME SCHOLARS HAVE
DRAHN A FALSE OPPOSITION BETWEEN GAME THEORY AND PSYCHOLOGY OR THE CASE STUDY APPROACH, MISCONSTRUED THE PREMISES OF GAME THEORY, AND IMPOSED STANDARDS ON IT THAT THEIR OHM APPROACHES WOULD NOT MEET. IN THIS ESSAY, THE AUTHOR EXAMINES THE CRITICS' WORK, STUDYING GAME MODELS WITHIN THEIR OWN TERMS. HE ARGUES THAT PROBLEMS ARISE NOT FROM GAME THEORY ITSELF BUT FROM RECENT MODELLING APPROACHES. THUS, THE REMEDIES LIE IN AVOIDING ASSUMPTIONS THAT ALLOW ONLY MILITARY STEPS TO DETERRENCE, BROADENING THE SET OF SOLUTION CONCEPTS USED, AND PAYING ATTENTION TO THE INFORMATION COLLECTED BY EMPIRICALLY-ORIENTED SECURITY SCHOLARS.

06930 O'NEILL, B.; KASS, I.

THE PERSIAN GULF WAR: A POLITICAL-MILITARY ASSESSMENT COMPARATIVE STRATEGY, 11(2) (1992), 213-240.

THE PERSIAN GULF WAR MIGHT ALREADY BE THE MOT OVERANALYED CONFLICT IN HISTORY. THIS ESSAY, THEREFOR, FOCUSES ON POLITICAL AND MILITARY ISSUES THAT HAVE BEEN LARGELY ECLIPSED BY THE MORE DAZZLING ASPECTS OF DESERT STORM. THE OBJECTIVE IS TO PROVIDE A CLEARER PERSPECTIVE ON THE DYNAMICS OF THE WAR--ITS CAUSES, CONDUCT, AND THE DYNAMICS OF THE WAR--ITS CAUSES, CONDUCT, AND TERMINATION--AS WELL AS TO SET THE FRAMEHORK FOR A REGIONAL AND GLOBAL OUTCOMES.

06931 O'NEILL, D.M.; O'NEILL, J.

AFFIRMATIVE ACTION IN THE LABOR MARKET ANNALS OF THE AMERICAN ACADEMY OF POLITICAL AND SOCIAL SCIENCE, (523) (SEP 92), 88-103.

ONE OF THE MOST CONTROVERSIAL TOOLS OF FEDERAL ANTIDISCRIMINATION POLICY IN EMPLOYMENT IS THE AFFIRMATIVE ACTION PROGRAM CONOUCTED BY THE OFFICE OF FEDERAL CONTRACT COMPLIANCE PROGRAMS (OFCCP). THE OFCCP REQUIRES FIRMS HOLDING FEDERAL GOVERMMENT CONTRACTS TO SET NUMERICAL HIRING GOALS FOR MINORITIES AND WOMEN. FIRMS THAT FAIL TO MEET THEIR TARGETS FACE THE THREAT OF CONTRACT CANCELLATION. THE SETTING OF HIRING GOALS REQUIRES ESTIMATION OF AVAILABLE POOLS OF QUALIFIED MINORITIES AND WOMEN, WHICH IN PRACTICE CANMOT BE DONE WITH ANY PRECISION. STUDIES SHOH NO CLEAR POSITIVE LINK BETWEEN GAINS IN MINORITY EARNINGS AND THE AFFIRMATIVE ACTION EFFORTS OF THE OFCCP. CURRENT EARMINGS OIFFERENTIALS BETWEEN BLACKS AND WHITES APPEAR TO BE MORE CLOSELY TIED TO OIFFERENCES IN WORK-RELATED SKILLS THAN TO LABOR MARKET DISCRIMINATION. THE GROWING PREMIUM ON SKILL IN SCHOOL ING OF BLACKS AND OTHER MINORITIES SUFFERING

EDUCATIONAL DEFICIENCIES.

06932 O'REILLY, J.

CAMPAIGN ISSUES: WOMEN

COLAMPAIG ISSUES: WOMEN

THE AUTHOR LOOKS AT THE' ROLE OF WOMEN IN THE 1992 U.S. NATIONAL ELECTION CAMPAIGNS.

06933 O'ROURKE, P

IN DEFENSE OF DEFENSE

AMERICAN SPECTATOR, 24(5) (MAY 91), 17-20.

THE COLLAPSE OF HARD-LINE REGIMES IN EASTERN EUROPE AND THE DECLINE IN U.S. - SOVIET TENSIONS HAVE LED MANY TO SERIOUSLY QUESTION THE NEED FOR CONTINUED SPENDING ON DEFENSE AT CURRENT LEVELS. THIS ARTICLE CONSIDERS THE PERFORMANCE OF U.S. ARMED FORCES IN OPERATION JUST CAUSE (IN PANAMA) AND THE DEFENSE ESTABLI SHMENT IN GENERAL AND CONCLUDES THAT CONTINUED SPENDING IS JUSTIFIED (THE ARTICLE WAR WRITTEN BEFORE DESERT STORM). THE AUTHOR ARGUES THAT SPENDING CUTS HILL MERELY BE COUNTERBALANCED BY INCREASED SPENDING IN OTHER AREAS, THEREBY YIELDING NO BUDGET BENEFITS. THE ARTICLE CONCLUDES THAT U.S. MILITARY SPENOING IS THE BEST (ANO CHEAPEST) LIFE INSURANCE THE TAXPAYER CAN BUY.

06934 O' SULLIVAN, J.

THE GOOFY POLITICS OF GEDRGE BUSH

NATIONAL REVIEW, XLIV(2) (FEB 92), 26-33.

THIS ARTICLE ARGUES THE PRESIDENT GEORGE BUSH HAS CONSISTENTLY FAILED TO RECOGNIZE POLITICAL OPPORTUNITIES HHEN THEY PRESENTED THEMSELVES. HE DREW BACK ALMOST INSTINCTIVELY FROM POL ITICAL VICTORIES ON QUOTAS AND TAXES. HE COULD NOT MAKE SENSE OF THE NEW WORLD ORDER EXCEPT IN TERMS OF THE OLD. HE DID NOT SEE THAT HE COULD PRESIDE OVER A HISTORIC SHIFT AWAY FROM THE LIBERAL HEGEMONY IN U.S POLITICS BY THE SIMPLE EXPEDIENT OF DOING NOTHING. HIS REACTION ON ALL OF THESE OCCASIONS HAS BEEN TO COMPROMISE REACTION ON ALL OF THESE OCCASIONS HAS BEEN TO COMPROMISE
HITH THE DEMOCRATIC LEADERSHIP IN ORDER TO SAVE IT FROM HITH THE DEMOCRATI
OUTRIGHT DEFEAT.

06935 O'SULLIVAN, J. WHY BUSH LOST

XLIV (23) (NOY 92), 30-34

GEORGE BUSH NEVER REALIZED THE HE WON AS REAGAN'S HEIR IN 1988, SO HE SPENT THE NEXT FOUR YEARS DISMANTLING THE REAGAN COALITION. THIS ARTICLE STATES THAT IS THE REASON CLINTON HON THE ELECTION. MANY OF BUSH'S POLICY CHANGES ARE DISCUSSED IN THE ARTICLE. 
06936 OAKES, G.; GROSSMAN, A.

MANAGING NUCLEAR TERROR: THE GENESIS OF AMERICAN CIVIL DEFENSE STRATEGY

INTERNATIONAL JOURNAL OF POLITICS, CULTURE AND SOCIETY,

5(3) (SPR 92), 361-404

THIS IS A STUDY OF THE FIRST ATTEMPTS TO ARTICULATE AND CONTROL THE AMERICAN EXPERIENCE OF THE ATOMIC BOMB IN THE

EARLY YEARS OF THE COLD WAR. SECTION II EXAMIMES THE

INTERPRETATION OF NUCLEAR TERROR THAT CIVIL DEFEMSE

THEORISTS PIACES ON THE PUBLIC REACTION TO THE ATOMIC BOMB THEORISTS SLACES ON THE PUBLIC REACTI CN YO THE ATOMIC BOMB

EARLY COLD WAR NATIONAL SECURITY POLICY. SECION III ANALYZES EARLY COLD WAR NATIONAL SECURITY POLICY. SECION III ANALYZES
CERTAIN ASPECTS OF THE STRATEGY THAT CIVIL DEFENSE THEORISTS CERTAIN ASPECTS OF THE STRATEGY THAT CIVIL DEFENSE THEORISTS DEVELOPED IN LIGHT OF THIS INTERPRETATION. IT PRESENTS A CONCEPTION OF NUCLEAR REALITY WHICH WAS THE BASIS OF A
SYSTEM OF EMOTION MANAGEMENT THAT REPLACED TERROR OF ATOMIC SYSTEM OF EMOTION MANAGEMENT THAT REPLACED TERROR OF ATOMIC ATTACK WITH THE

06937 OBERFELD, K.E.

THE SINGLE ISSUE IS CHARACTER

INSIGHT, 8(27) (SEP 92), 40 .

WHEN VOTERS ELECT A PRESIDENT, THEY TEND, IN THE

SOLITUDE OF THE VOTING BOOTH, TO CONSIDER JUST ONE QUESTION: WHOM DO I TRUST? THAT'S PRECISELY WHY ALL THE ISSUE-ORIENTED PROGNOSTICATIONS USUALLY PROVE HRONG OR ONLY BY HAPPENSTANCE CORRESPOND WITH THE REAL CHOICE VOTERS MAKE. THUS, THE EMPHASIS IN THE 1992 ELECTION IS ON THE CHARACTERS OF GEORGE BUSH AND BILL CLINTON.

06938 OBERST, R.C

A WAR WITHOUT WINMERS IN SRI LANKA

CURRENT HISTORY, 91(563) (MAR 92) $128-131$.

PRESIDENT RANASINGHE PREMADASA'S GOVERNMENT HAS BEEN

UNABLE TO HALT THE GUERRILLA WAR FOR AN INDEPENDENT TAMIL

NATION IN NORTH AND EAST SRI LANKA. THE FIGHTING HAS

PREVENTED HIS GOVERNMENT FROM FOCUSING ON ECONOMIC
DEVELOPMENT, AND MUCH OF THE NATIONAL BUDGET IS BEING USED

DEVELOPMENT, AND MUCH OF THE NATIONAL BUDGET IS BEING

TO MAINTAIN THE MILITARY MACHINE NEEDED TO FIGHT THE

LIBERATION TIGERS OF TAMIL EELAM (LTTE). THE FUTURE OF SRI

LANKA DEPENDS ON THE WILLINGNESS OF THE GOVERNMENT AND THE

LITE TO END

06939 OBOLER, $S$

THE POLITICS OF LABELING: LATINO/ACULTURAL IDENTIES OF

THE POLITICS OF

SELF AND OTHERS
LATIN AMERICAN PERSPECTIVES, $19(75)$ (FAL 92), 18-36

SOME OF THE INTERMALIZED OTHERS WITHIN AND AGAINST WHICH

THE LATINO/A SELF IS ASSERTED IN THE UNITED STATES IS

FOCUSED ON IN ORDER TO SUGGEST (1) THAT CLASS AND RACE

BACKGROUND AND VALUES SHAPE THE MEANING AND SOCIAL VALUE

INDIVIDUALS ATTRIBUTE TO THE TERMS THEY ADOPT TO DEFINE BOTH

SELF AND OTHER AND (2) THAT, AT LEAST IN THE PRESENT

CONJUNCTURE, BOTH SELF AND OTHER ARE FUNDAMENTAL TO THE

FORMATION OF THE ETHOS OF THE LATINO-A EHTHNIC GROUP IN THE

UNITED STATES. THE AUTHOR EXPLORES THE SELF/OTHER DICHOTOMY

THROUGH AN ANALYSIS OF INTERYIENS WITH MIDOLE- AND WORKING-

CLASS LATINOS CURRENTLY LIVING AND WORKING IN NEW YORK CITY.

06940 OBRMAN, J.

AFTER THE SPLIT: CHALLENGES FOR CZECH FOREIGN POLICY

RFE/RL RESEARCH REPORT, 1(45) (NOV 92), 26-31.

SLOVAKIA BEGAN FORMULATING ITS FOREIGN-POLICY OBJECTIVES

VERY SOON AFTER THE TOPPLING OF THE CZECHOSLOVAK COMMUNIST

REGIME. BUT THE CZECH REPUBLIC, ASSUMING THAT THE

CZECHOSLOVAK STATE WOULD CONTINUE TO EXIST, FAILED FOR A

TIME TO CONSIDER ITS OWN FOREIGN-POLICY PRIORITIES. RECENTLY,

IT FORMULATED A SET OF FOREIGN-POLICY GOALS THAT ESTABLISH

AS WELL AS ITS INTEGRATION INTO THE INTERNATIONAL COMMUNITY.

06941 OBRMAN, J.

ALEXANOER DUBCEK, SYMBOL OF THE PRAGUE SPRING, HAS DIED

RFE/RL RESEARCH REPORT, 1 (45) (NOV 92), 12-14.

ON NOYEMBER ? ON NOVEMBER 7, 1992, ALEXANDER DUBCEK, THE FORMER FIRST SECRETARY OF THE COMMUNIST PARTY OF CZECHOSLOVAKIA AND ONE FROM INJURIES SUF BERE IN A CAR ACCIDENT. IN THE SHORT-LIVED FROM INJURIES SUFFERED IN A CAR ACCIDENT. IN THE SHORT-LIVED REFORM PERIOD OF THE PRAGUE SPRING, DUBCEK CAME TO SYMBOL

06942 OBRMAN, J.

CZECHOSLOYAKIA: STAGE SET FOR DISINTEGRATION?

RELEL RESEARCH : STAGE SET FOR DISINTEGRATION?

AFTER SEVERAL INCONCLUSIVE ROUNDS OF TALKS BETWEEN THE

WINNERS OF THE JUNE 1992 CZECHOSLOVAK ELECTIONS, THE LEADER

OF THE CZECH-BASED CIVIC DEMOCRATIC PARTY, VACLAV KLAUS, AND

THE LEADER OF THE MOVEMENT FOR A DEMOCRATIC SLOVAKIA,

VLADIMIR MECIAR, AGREED ON A FIXED TIMETABLE TO DEAL WITH

THE COUNTRY'S CONSTITUTIONAL CRISIS. ALTHOUGH LEADINC

POLITICIANS ARGUED THAT THE FATE OF CZECHOSLOVAKIA HAD NOT

BEEN SEALED IN THE TALKS, THE AGREEMENTS HAVE SET IN MOTION

A PROCESS OF DISINTEGRATION THAT CAN HARDLY BE STOPPED
UNLESS ONE OF THE THO SIDES DECIDES TO ALTER ITS POSITION FUNDAMENTALLY.

06943 OBRMAN, J.; PEHE, J.

CZECHOSLOVAKIA'S NEW GOVERMMENTS

RFE/RL RESEARCH REPORT, 1(29) (JUL 92), 1-8.

IN MID-1992, CZECHOSLOVAKIA'S NEW FEDERAL GOVERNMENT AND THE CZECH REPUBLICAN GOVERMMENT WERE SWORN IN. BOTH THE STRUCTURE AND THE COMPOSITION OF THE GOVERMMENTS SIGNAL A SHI.FT OF POWER FROM THE FEDERAL TO THE REPUBLICAN LEVEL. MOREOVER, THE AGREEMENT BETHEEN THE TWO WINNERS OF THE ELECTIONS, VACLAY KLAUS AND VLADIMIR MECIAR, ON CREATING A DRAMATICALLY STREAMLINED AND IDEOLOGICALLY HETEROGENEOUS FEDERAL GOVERNMENT IS A STRONG INDICATION THAT THE FEDERAL GOVERMMENT WILL HAVE ONLY A LIMITED MANDATE AND TENURE. GOVERMMENT WILL HAVE ONLY A LIMITED MANDATE AND TENURE. NATIONAL COUNCIL IS RELATIVELY SOLID NOW, IT MAY FACE SOME NATIONAL COUNCIL IS RELATIYEL
DIFFICULTIES IN THE FUTURE.

06944 OBRMAN, J.

DUBCEK JOINS THE SOCIAL DEMOCRATS IN SLOVAKIA

RFE/RL RESEARCH REPORT, 1(14) (APR 92), 16-19.

ALEXANDER DUBCEK, THE BEST-KNOWN SYMBOL OF THE PRAGUE SPRING AND CURRENTLY THE CHAIRMAN OF THE CZECHOSLOVAK FEDERAL ASSEMBLY, HAS DECIDED TO JOIN THE SOCIAL DEMOCRATIC PARTY IN SLOVAKIA. IT IS UNCLEAR WHAT IMPACT THIS DECISION WILL HAVE ON THE POLITICAL LANDSCAPE IN THE SLOVAK REPUBLIC, AND THE CLAIMS THAT DUBCEK'S STEP WILL STRENGTHEN PROFEDERAL FORCES MAY BE SOMEWHAT PREMATURE.

06945 OBRMAN, J.

MOSCOW REVEALS DOCUMENTS ON 1968 INVASION OF CZECHOSLOVAKIA

RFE/RL RESEARCH REPORT, 1(37) (SEP 92), 16-19.

ALMOST 24 YEARS AFTER SOVIET-LED ARMIES PUT A VIOLENT

END TO THE PRAGUE SPRING REFORM MOVEMENT, DOCUMENTS RELEASED

IN MOSCOW HAVE CONFIRMED THE SUSPICION THAT SEVERAL SENIOR OFFICIALS OF THE CZECHOSLOVAK COMMUNIST PARTY WERE INVOL VED

IN PREPARATIONS FOR THE INVASION.

06946 OBRMAN, J.

PRESIDENT HAVEL'S DIMINISHING POLITICAL INFLUENCE

RFE/RL RESEARCH REPORT, 1 (11) (MAR 92), 18-23.

TWO YEARS AFTER THE VELVET REVOLUTION, CZECHOSLOVAK PRESIDENT VACLAV HAVEL REMAINS THE SINGLE MOST POPULAR CZECHOSLOVAK POLITICIAN. HOWEVER, HIS ABILITY TO TRANSFORM THIS POPULARITY INTO POLITICAL INFLUENCE HAS BEEN GRADUALLY DIMINISHING. CURRENTLY, THE PRESIDENCY SEEMS TO BE MORE ISOLATED THAN AT ANY POINT SINCE THE FALL OF THE COMMUNIST REGINE, AND THE CONTINUING PROCESS OF STRENGTHENING THE PARLIAMENTARY DEMOCRACY IS LIKELY TO REDUCE THE ROLE OF THE PRESIDENTI IAL OFFICE EVEN FURTH

06947 OBRMAN, J.

ROUNDTABLE: RELATIONS HITH THE CZECH REPUBLIC AND HUNGARY RFE/RL RESEARCH REPORT, 1(49) (DEC 92), 33-42.

AT A ROUNDTABLE ON SLOVAKIA'S FUTURE FOREIGN POLICY, SLOVAK FOREIGN MINISTRY OFFICIALS STRESSED THAT THEIR COUNTRY WOULD BE WESTERN-ORIENTED. THE CONTROVERSIAL GABCIKOVO-NAGYMAROS HYDROELECTRIC PLANT PROJECT ON THE DANUBE AND THE TREATMENT OF MINORITIES WERE IDENTIFIED AS THE MOST IMPORTANT POINTS OF CONTENTION BETWEEN SLOVAKIA AND HUNGARY. DURING THE DISCUSSION, BOTH SIDES MADE IT CLEAR THAT COMPROMISES COULD BE FOUND. A GOOD RELATIONSHIP WITH SLOVAKIA IS ALSO AMONG THE PRIORITIES OF CZECH FOREIGN POLICY.

06948 OBRMAN, J.

RUSSIA AND CZECHOSLOVAKIA SIGN FRIENDSHIP TREATY

RFE/RL RESEARCH REPORT, 1(19) (MAY 92), 17-21.

ON APRIL 1, 1992, A' FRIENDSHIP AND COOPERATION TREATY BETHEEN THE CZECH AND SLOVAK FEDERAL REPUBLIC AND THE RUSSIAN FEDERATION WAS SIGNED BY PRESIDENTS VACLAV HAVEL AND BORIS YELTSIN. IT REPLACED THE 1991 CZECHOSLOVAK-SOVIET TREATY, WHICH WAS INITIALED BUT NEVER RATIFIED DUE TO THE DISINTEGRATION OF THE USSR. THE THO COUNTRIES HAVE ALSO DISINTEGRATION OF THE USSR. THE THO COUNTRIES HAVE ALSO RESOL VED THE LONG DISPUTE OVER COMPENSATION FOR THE DAMAGE
CAUSED BY SOVIET TROOPS STATIONED IN CZECHOSLOVAKIA FOR MORE THAN TWO DECADES. WHILE THESE HISTORIC AGREEMENTS ATTRACTED
LITTLE INTEREST AMONG THE CZECHOSLOVAK PEOPLE, CRITICS SAY LITTLE INTEREST AMONG THE CZECHOSLOVAK PEOPLE,

CZECHOSLOVAKIA. IN ANY EVENT. THE AGREEMENTS MAY SERVE AS CZECHOSLOVAKIA. IN ANY EVENT, THE AGREEMENTS MAY SERVE AS MODELS FOR CZECHOSLOVAK TREATIES WITH OTHER FORMER SOVIET WITH OTHER FORMER SOVIET SATELLITES.

06949 OBRMAN, J.

SLOVAK POLITICIAN ACCUSED OF SECRET POLICE TIES RFE/RL RESEARCH REPORT, 1(15) (APR 92), 13-17

A SLOVAK PARLIAMENTARY COMMITTEE HAS ACCUSED VLADIMIR MECIAR, SLOVAKIA'S FORMER PRIME MINISTER AND MINISTER OF INTERNAL AFFAIRS, OF COLLABORATION WITH THE ILL-REPUTED COMMUNIST STATE SECURITY. EVEN MORE SERIOUS ARE CHARGES THAT HE ABUSED HIS POSTCOMMUNIST GOVERNMENT POSITIONS TO COVER UP 
HIS PAST, PROTECT AND PROMOTE HIS FRIENDS, AND DESTROY THE CAREERS OF HIS FOES. THE OUTCOME AND LONG-TERM IMPACT OF THE SCANDAL ARE HARD TO PREDICT; BUT THERE ARE INDICATIONS THAT THE REPORT COULD BACKFIRE BECAUSE MECIAR AND HIS ALLIES ARE ANTI-SLOVAK PLOT ORCHESTRATED BY FEDERAL OFFICIALS.

06950 OBRMAN, J.

SLOVAKIA DECLARES SOVEREIGNTY; PRESIDENT HAVEL RESIGNS RFE/RL RESEARCH REPORT, 1(31) (JUL 92), 25-29.

ON JULY 17, 1992, THE SLOVAK NATIONAL COUNCIL ADOPTED THE SLOVAK REPUBLIC'S DECLARATION OF SOVEREIGNTY. WHILE THE INITIATORS OF THE DECLARATION EMPHASIZED THAT IT WAS ONLY A SYMBOLIC MOVE WITH NO LEGAL CONSEQUENCES, IT WAS HIDELY SEEN AS ANOTHER STEP TOWARD THE DISINTEGRATION OF CZECHOSLOVAKIA. WITHIN MINUTES OF THE ADOPTION, PRESIDENT VACLAV HAVEL ANMOUNCED HIS DECISION TO RESIGN. HAVEL EXPLAINED THAT HE COULD NO LONGER INFLUENCE DEVELOPMENTS IN THE COUNTRY AND THAT HE WOULD NOT PRESIDE OVER THE DISMANTLING OF CZECHOSLOVAKIA. HIS DECISION IS LIKELY TO ACCELERATE THE BREAKUP OF THE COUNTRY, BECAUSE HAVEL REPRESENTED THE LAST REMAINING LINK BETWEEN THE TWO REPUBLICS.

06951 OBRMAN, J.

THE CZECHOSLOVAK ARMED FORCES: THE REFORM CONTINUES THE CZECHOSLOVAK ARMED FORCES: THE REFORM COM
RFE/RL RESEARCH REPORT, $1(6)$ (FEB 92), 48-54.

THE REFORM OF THE CZECHOSLOVAK ARMED FORCES IS AMONG THE POSTCOMMUNIST GOVERMMENT'S PRIORITIES. THE DEFENSE MINISTRY HAS ISSUED AMBITIOUS PLANS FOR PROFESSIONALIZATION OF THE MILITARY AND IS TRYING TO COUNTER THE WIDESPREAD LACK OF SYMPATHY FOR THE ARMY. HOWEVER, BUDGETARY RESTRAINTS AND ETHNIC TENSION MAKE IT UNLIKELY THAT THE MILITARY'S PROBLEMS WILL BE SOLVED IN THE NEAR FUTURE.

06952 OBRMAN, $J$.

UNCERTAIN PROSPECTS FOR INDEPENDENT SLOVAKIA

RFE/RL RESEARCH REPORT, $1(49)$ (DEC 92 ), 43-48.

SLOVAKIA'S IMAGE AS A POTENTIAL SOURCE OF REGIONAL

INSTABILITY AND THE RELATIVELY POOR INTERNATIONAL REPUTATION OF ITS LEADERSHIP ARE LIKELY TO BE STUMBLING BLOCKS IN THE NEWLY-INDEPENDENT STATE'S RELATIONS WITH THE OUTSIDE WORLD. IN FACT, THERE ARE JUSTIFIED FEARS THAT SLOVAKIA MIGHT SOON BE RELEGATED TO THE RANKS OF POSTCOMMUNIST EUROPE'S SECONDRELUCTAMTLY TOWARD DEMOCRACY AND A MARKET ECONOMY.

06953 0DD, W.

RETHINKING REVOLUTIONS: THE COLD WAR IN THE THIRD WORLD JOURNAL OF PEACE RESEARCH 29 (4) (NOV 92) $435-464$.

THIS ARTICLE CRIIQUES RECENT RESEARCH ON THE FOREIGN

POLICIES ON LATE 2OTH-CENTURY REVOLUTIONARY MOVEMENTS, AND

POLICIES ON LATE 2OTH-CENTURY REVOLUTIONARY MOVEMENTS, AND
ATTEMPTS TO IDENTIFY SOME BASIC ELEMENTS IN THE IDEOLDGY AND ATTEMPTS TO IDENTIFY SOME BASIC ELEMENTS IN THE IDEOLDGY AND
ORGANIZATION OF THESE POLICIES. THE AUTHOR FINDS THE SEARCH ORGANIZATION OF THESE POLICIES. THE AUTHOR FINDS THE SEARCH FOREIGN POLICY PRACTICE OF REVOLUTIONARIES, AND SEEKS TO FOREIGN POLICY PRACTICE OF REVOLUTIONARIES, AND SEEKS TO ANALYZE HOW GREAT POWER INTERESTS AND LOCAL REVOLUTIONAY ASPIRATIONS INTERPLAYED IN DIFFERENT CASES. IN CONCLUSION, THE AUTHOR LOOKS AT HOW THE COLD WAR INTERNAT IONAL SYSTEM INFLUENCED THE CHANCES FOR REVOLUTIONARY SUCCESS, AND FINDS THAT THE CHARACTER OF THE SOVIET-AMERICAN CONFLICT IN MANY COUNTRIES ENHANCED THE POTENTIAL FOR REVOLUTION BY MAKING I IMPOSSIBLE FOR ESTABLISHED REGIMES TO MONOPOLIZE FOREIGN SUPPORT.

06954 ODEH, A.A.

THO CAPITALS IN AN UNDIVIDED JERUSALEM

FOREIGN AFFAIRS, 71(2) (SPR 92), 183-188.

THE AUTHOR OFFERS A SOLUTION TO THE PROBLEM OF JERUSALEM,

BASED UPON AN EXAMINATION OF THE HISTORY OF THE CONFLICT AND A DIAGNOSIS OF THE COMPETING CLAIMS.

06955 ODOM, H.E.

SOVIET POLITICS AND AFTER: OLD AND NEW CONCEPTS

WORLD POLITICS, 45(1) (OCT 92), 66-98.

THE TOTALITARIAN MODEL WAS THE BEST ANALYTIC CONCEPT FOR STUDYING SOVIET POLITICS BECAUSE IT OFFERED CLEAR EMPIRICAL REFERENTS, PROVIDED A YARDSTICK FOR MEASURING CHANGE, AND COULD BE ADAPTED TO EXPLAIN THE NATURE OF CHANGE.

ALTERNATIVE MODELS EMPHASIZING PLURALISM ENCOURAGED THE IMPRESSION THAT POLITICAL DEVELOPMENT WAS OCCURRING WHEN IT WAS ACTUALLY POL ITICAL DECAY. ALTHOUGH THE STUDY OF THE SOVIET SUCCESSOR STATES MUST NOW BE BROUGHT WITHIN A MORE GENERAL APPROACH TO COMPARATIVE POL BROUGHT WITHIN A MORE TOTALATARIAN MODEL RETAINS UTIL ITY FOR UNDERSTANDING THE TOTALITARIAN MODEL RETAINS UTILITY FOR

06956 OFFERMAN-ZUCKERBERG, J.

POLITICS AND PSYCHOLOGY: CONTEMPORARY PSYCHODYNAMIC

PLENUM PRESS, 1991,313

WRITTEN TO ADORESS A NUMBER OF CONTEMPORARY THEMES WITHIN THE CHANGING POLITICAL CLIMATE, "POLITICS AND PSYCHOLOGY" EXAMINES HOW THE INTEGRATION AND APPLICATION OF PSYCHOLOGICAL CONCEPTS CAN BROADEN OUR UNDERSTANDING OF
POLITICS AND HISTORY. NINTEEEN ESSAYS--INCLUDING ACADEMIC, CLINICAL AND RESEARCH-ORIENTED PAPERS AND PERSONAL COMMENTARIES-DISCUSS THE MEDIA'S ROLE IN THE POLITICAL ARENA PSYCHIC VULNERABILITIES OF NATIONAL LEADERS AND THEIR POLITICAL REPERCUSSIONS, THE ROLE OF SOCIETAL FORCES IN

CHILDHOOD DEVELOPMENT, AND VARIOUS OTHER PSYCHOSOCIAL
CDMPONENTS BEHIND THE MAKING OF HAR AND KEEPING OF PEACE.

06957 OFFNER, $P$.

WORK-FA

NEW REPUBLIC, 207 (27) (DEC 92), 13-15.

THE AUTHOR EXAMINES THE OBJECTIVES AND RESULTS OF THE FAMILY SUPPORT ACT OF 1988 AND DISCUSSES PRESIDENT-ELECT BILL CLINTON'S POTENTIAL POLICY REGARDING WELFARE REFORM.

06958 OFORI, R.

VERDICT ON ASSEMBLIES

WEST AFRICA, (3881) (FEB 92), 181-182.

GHANA'S GOVERNMENT INTRODUCED DISTRICT ASSEMBLIES FOUR

YEARS AGO, IN ORDER TO GIVE POWER TO THE PEOPLE AT THE

GRASSROOTS LEVEL AND REVERSE DECADES OF CENTRAL GOVERNMENT

CONTROL. BUT SOME OF GHANA'S CITIZENS SAY THAT ALL POLITICAL

POWER STILL RESIDES IN ACCRA AND THAT LITTLE HAS CHANGED FOR

POWER STILL RESIDES IN ACCRA

06959 OGASAWARA, T.

LEADERS AREN 'T LEADING

JAPAN TIMES (NEEKLY IMTERMATIONAL EDITION), 32(13) (MAR

92 ) 10.

LEADERS AREN'T LEADING, AND PERHAPS MORE FRIGHTENING STILL, DON'T SEEM TO BE LOOKING AT THE BIG PICTURE, THE ISSUES THAT LIE BEHIND THE PROBLEMS OF THE DAY. JAPAN AND THE UNITED STATES NEED TO CONCENTRATE ON THE WEB OF RELATIONSHIPS BETWEEN THEM AND APPRECIATE THE NUANCES. THESE THO COUNTRIES HAVE BEEN THE LARGEST BENEFICIARIES OF THE OPEN TRADING SYSTEM, AND JAPAN PROBABLY HAS THE MOST TO LOSE IF THE RULES ARE CHANGED. THERE HAVE BEEN INEQUITIES IN THE RELATIONSHIP THAT TAKE THEIR MOST VISIBLE FORM IN TRADE IMBALANCES

06960 OGASAHARA, T.

THE PRESSURE OF POLITICS

JAPAN TIMES (HEEKLY INTERNATIONAL EDITION), 32(5) (FEB 92), 10.

THE SUMMIT BETWEEN U.S. PRESIDENT GEORGE BUSH AND JAPANESE PRIME MINISTER KIICHI MIYAZAWA WAS MARRED BY THE OVEREMPHASIS ON TRADE ISSUES. FACING AN ELECTION AT HOME, BUSH CHOSE TO PLAY POL ITICS BY FOCUSIMG OM TRADE AMD BY INCLUDING U.S. BUSINESS EXECUTIVES IN HIS ENTOURAGE. DESPITE INCLUDING U.S. BUSINESS EXECUTIVES IN HIS ENTOURAGE. DESPITE INCLUDING THE TOKYO DECLARATION AND THE GLOBAL ACTION PLAM
FOR COOPERATION AND COORDINATION IN THE POST-COLD WAR ERA.

06961 OGUNBANHO, $S$.

THE UNITED NATIONS DISARMAMENT TRAINING FOR DIPLOMATES : HOPES FOR THE FUTURE

BULLETIN OF PEACE PROPOSALS, 22(1) (1991), 49-54.

THE STUDY OF THE UN DISARMAMENT TRAINING PROGRAM FOR DIPLOMATES IS THE SUBJECT OF THIS ARTICLE. FIRST, THE DEVELOPMENT OF THE STUDY OF DISARMAMENT IS DESCRIBED. THEN THE PROGRAM ITSELF IS EXAMINED. THE PROGRAM INCLUDES NINE WEEKS OF DAILY MEETINGS IN GENEVA, A ONE-WEEK STUDY VISIT TO HIROSHIMA AND NAGASAKI, AND INDIVIDUAL INDEPENDENT RESEARCH PROJECTS.

06962 DGUNBANHO, $S$.

THE UNITED NATIONS DISARMAMENT TRAINING FOR DIPLOMATS: HOPES FOR THE FUTUR

BULLETIN OF PEACE PROPOSALS, 22(1) (MAR 91), 49-54. IN 1989, UNITED NATIONS DISARMAMENT TRAINING FOR DIPLOMATS CELEBRATED ITS TENTH ANHIVERSARY. THE VARIOUS REASONS WHICH HAD INSPIRED ITS CREATION A DECADE AGO BY THE UN GENERAL ASSEMBLY ARE EXAMINED IN THIS ARTICLE WHICH ALSO OFFERS AND EVALUATION OF THE EFFECTIVENESS AND IMPACT OF THE TRAINING PROGRAM. WHILE IT IS ASSUMED THAT THE TRAINING PROGRAM WILL CONTINUE ALONG CURRENTLY ESTABLISHED LINES, SUGGESTIONS ARE OFFERED WHICH MIGHT BE CONSIDERED IN CONNECTION WITH FUTURE DEVELOPMENTS.

$06963 \mathrm{OH}, \mathrm{K}$.

MAKING PEACE OH THE KOREAN PENINSULA: A LONG MARCH YET TO START

KOREAN JOURMAL OF DEFENSE ANALYSIS, IV(1) (SUM 92), $167-190$.

THE CONFRONTATION ON THE KOREAN PENINSULA IS A NATURAL COMSEO PURSUED SINCE THE BEGINNING OF THE KOREAN WAR. THE RECENTLY CONCLUDED BASIC AGREEMENT AND JOINT NUCLEAR-FREE DECLARATION WERE AT FIRST HAILED AS CONCRETE EVIDENCE OF THE NORTH'S RENOUNCEMENT OF ITS REVOLUTIONARY STRATEGY AND ACCEPTANCE OF PEACEFUL COEXISTENCE. SUCH PRECIPITANT EXPECTATION SEEMS NOW TOTALLY BETRAYED BY AN EVASIVE ATTITUDE IN IMPLEMENTING THE INTER-KOREAN AGREEMENTS. THIS MAY BE WELL-CALCULATED NORTH 
KOREAN STRATEGY, BUT IT IS NOT EASY TO SEE HOH THEY WEIGH BENEFITS AND COSTS OF THIS PRESENT COURSE.

06964 OHKI, E.

TALKS WITH JAPANESE LEADERS WERE SATISFACTORY: JIANG JAPAN TIMES (WEEKLY INTERNATIONAL EDITION), 32 (16) (APR 92), 3.

FOLLOWING AN OFFICIAL VISIT TO JAPAN IN APRIL 1992, JIANG ZEMIN, SECRETARY GENERAL OF THE CHINESE COMMUNIST PARTY, EXPRESSED SATISFACTION. ALTHOUGH JIANG AND HIS HOSTS COULD NOT REACH AGREEMENT ON ALL MATTERS, HE FELT THAT THE RESULTS.

06965 OHMAE, $K$.

BUSH HAS A BIG JOB TO DO FIRST ON DOMESTIC FRONT JAPAN TIMES (WEEKLY INTERNATIONAL EDITION), 32(3) (JAN 92), JAPAN

ALTHOUGH U.S. PRESIDENT BUSH HAS BLAMED JAPANESE IMPORTS FOR MAMY OF HIS ECONOMY'S PROBLEMS, AN EXAMINATION OF THE FACTS REVEALS THAT THIS IS NOT THE CASE. AT MOST, JAPANESE IMPORTS ARE RESPONSIBLE FOR ONLY 4.6\% OF TOTAL U.S UNEMPLOYMENT. FOREIGN INVESTMENT BY JAPANESE COMPANIES HAS CREATED MORE JOBS IN THE USA THAN ALL THE BIG AMERICAN COMPANIES COMBINED IN THE PAST FEH YEARS. MOREOVER, JAPAN IS SECOND ONLY TO CANADA IN IMPORTATION OF U.S. GOODS, DESPITE BUSH'S ACCUSATIONS THAT IT IS A CLOSED MARKET.

06966 OI, J.C.

FISCAL REFORM AND THE ECONOMIC FOUNDATIONS OF LOCAL STATE CORPORATISM IN CHINA

WORLD POLITICS, 45(1) (OCT 92), 99-126.

IN THE $1980^{\prime} S$, FISCAL REFORM IN CHINA PROVIDED

LOCALITIES WITH STRONG INCENTIVES AND A HEIGHTENED CAPACITY TO PURSUE INDUSTRIAL GROWTH. LOCAL GOVERMMENTS RESPONDED VIGOROUSLY TO ECONOMIC REFORM, MANAGING RURAL COLLECTIVEOWNED ENTERPRISES AS DIVERSIFIED CORPORATIONS, WITH LOCAL OFFICIALS PERFORMING THE ROLE OF A BOARD OF DIRECTORS. THIS ESSAY ANALYZES THE INCENTIVES THAT LED TO THE DEVELOPMENT OF THIS FORM OF LOCAL STATE CORPORATISM AND RAPID RURAL INDUSTRIALIZATION. IT ALSO DESCRIBES THE WAYS IN WHICH LOCAL GOVERMMENTS COORDINATED ECONOMIC ACT REVENUES FROM INDUSTRIAL PRODUCTION. THESE DEVELOPMENTS SHOW THAT LOCAL GOVERNMENT INVOL VEMENT IN THE ECONOMY DOES NOT THAT LOCAL GOVERNMENT INVOLVEMENT IN THE ECONOMY
NECESSARILY DECLINE HITH THE EXPANSION OF MARKET

NECESSARILY DECLINE HITH THE EXPANSION OF MARKET
COORDINATION AND OFFER A SUCCESSFUL MODEL OF REFORM THAT

SERVES AS A COUNTERPOINT TO PRIVATIZATIOM PROPOSALS.

06967 OI W.Y.

WORK FOR AMERICANS WITH DISABILITIES

AMNALS OF THE AMERICAN ACADEMY OF POLITICAL AND SOCIAL SCIENCE, (523) (SEP 92) 159-174.

THE AMERICANS WITH DISABILITIES ACT IS INTENDED TO IMPROVE THE PLIGHT OF THE DISABLED BY MANDATING EQUAL EMPLOYMENT RIGHTS--A RIGHTS APPROACH THAT HAS WORKED WELL FOR RACE AND GENDER BUT WILL NOT DO FOR THE TASK AT HAND BECAUSE PEOPLE WITH DISABILITIES DO NOT CONSTITUTE AN IDENTIFIABLE MINORITY. THEY MOVE INTO AND OUT OF THE STATE OF BEING DISABLED AND EXHIBIT DIFFERENT DEGREES OF LIMITATION AND DIFFERENT LIFE EXPECTATIONS. THE AIM OF ELIMINATING LABOR MARKET DISCRIMINATION IS IMPORTANT, BUT EQUAL ACCESS TO JOBS AND PUBLIC PLACES WILL NOT SIGNIFICANTLY IMPROVE THE WELL-BEING OF DISABLED PERSONS UNLESS IT IS INTEGRATED INTO A LARGER DISABILITY POLICY PROGRAM INCLUDING REHABILITATION, MEDICAL CARE, AND INCOME TRANSFERS.

06968 OKANIA, K.

SOGLO STRIKES BACK

WEST AFRICA, (3914) (SEP 92), 1607

FOR MONTHS, TRADE UNIONS, OPPOSITION PARTIES, AND THE PRESS HAVE ATTACHED PRESIDENT NICEPHORE SOGLO AND HIS WIFE. IN A LIVE, NATIONALLY-TELEYISED PRESS CONFERENCE HE RECENTLY DEFENDED HIMSELF AND GAVE HIS VIEH OF THE STATE OF AFFAIRS IN BENIN. DISMISSING MOST OF THE CRITICISM AS "HOLLOW," HE OUTLI IMED FOUR CHALLENGES FACING HIS GOVERMMENT, INCLUDING REBUILDING THE ECONOMY AND INVESTIGATING CHARGES OF CORRUPTION AGAINST OFFICIALS OF THE DEFUNCT KEREKDU ADMINISTRATION.

06969 OKANLA, $K$.

RETURA' OF. THE OLD DEMOH

WEST AFRICA, (3918) (OCT 92), 1773

REPORTS OF GROWING SOCIAL TENSION IN NORTHERN BENIN HAVE BEEN CIRCULATIMG SINCE THE MORTHERNERS BELIEYE THAT THEIR REGION HAS HISTORICALLY BEEM DOMINATED AND DENIGRATED BY THE SOUTH AMD THAT THIS DOMINATED AND DENIGRATED BY THE SOUTH AND THAT THIS INEQUAL ITY IS CONTINUING TODAY. THEY HAVE PRESENTED DEMANDING THE RELEASE OF NORTHERNERS WHOM THEY BELIEVE ARE DEMANDING THE RELEASE
POLITICAL PRISONERS.

06970 OKANLA, K.

TIP OF THE ICEBERG?
WEST AFRICA, 75(3909) (AUG 92), 1389.

MALI-BORN SORCERER MOHAMED AMADOU CISSE AND NINE OTHER DEFENDANTS OF BENINOIS CITIZENSHIP REAPPEARED IN COURT IN COTONOU ON JULY 31. THE CHARGES INCLUDED FRADULENT TRANSFERS OF PUBLIC FUNDS, ABETTING VARIOUS FINANCIAL CRIMES AND ABUSING STATE AUTHORITY. A WEEK AFTER THE TRIAL MOVED INTO HIGH GEAR, THERE WERE INDICATIONS THAT THE PUBLIC HAS ONLY BEEN SEEING THE TIP OF THE ICEBERG, OR, APPROPRIATELY THE TREE THAT OVERSHAOWS THE RAIN FOREST. THE TEN DEFENDANTS NOW IN COURT ARE DEFINITELY NOT THE ONLY ONES WHO WRECKED THE COUNTRY.

06971 OKEDARA, J.T.; OKEDARA, C.A.

MOTHER-TONGUE' LITERACY, IM NIGERIA

ANNALS OF THE AMERICAN ACADEMY OF POLITICAL AND SOCIAL

SCIENCE, (520) (MAR 92), 91-102.

THE IMPORTANCE OF MOTHER-TONGUE LITERACY CANNOT BE OVEREMPHASIZED. REGRETTABLY CONTEMPORARY LANGUAGE LITERACY IN NIGERIA IS FRAUGHT WITH CONSTRAINTS, SUCH AS THE LACK OF ORTHOGRAPHY FOR A LARGE NUMBER OF NIGERIAN LANGUAGES. THE PROSPECTS FOR MASS LITERACY IN NIGERIA ARE NOT ENCOURAGING, UNLESS THE FEDERAL GOVERMMENT DIRECTS ITS EFFORTS TOWARDS DEVELOPING ORTHOGRAPHY AND LITERATURE IN THE UNHRITTEN INDIGENOUS LANGUAGES. MOREOVER, THERE IS A NEED TO CLARIFY, IN TERMS OF POLICY, WHAT IT MEANS TO BE LITERATE LOCALLY, REGIONALLY, AND NATIONALLY. THE NEWLY-ESTABLISHED COMMISSION FOR ADULT AND NON-FORMAL EDUCATION HAS BEEN CHARGED WITH DEVELOPING LANGUAGE POLICY FOR AN ADULT LITERACY PROGRAM IN NIGERIA. IT IS HOPED THAT THE COMMISSION WILL SOON PROVIDE A REALISTIC SOLUTION TO THE PROBLEM AND THAT NIGERIA WILL

BECOME A MODEL FOR OTHER COUNTRIES IN SIMILAR CIRCUMSTANCES.

06972 OKERE,

THE PRESS AND FOREIGN POLICY IN NIGERIA

ROUND TABLE, 321(321) (JAN 92), 61-72.

THE BEST OF NIGERIAN PRESS COVERAGE, ANALYSIS,

INTERPRETATION AND PRESENTATION OF FOREIGN POLICY NEWS

IMPROVED MARKEDLY IN THE 1980S. IT IS TO BE HOPED THAT THIS

TREND MAY CONTINUE IN THE 1990S. ON THE WHOLE, NIGERIAM

FOREIGN POLICY HAS NOT BEEN WEL

SINCE INDEPENDENCE BY EITHER DOMESTIC OR FOREIGN NEWSPAPERS,

THOUGH THERE HAVE BEEN A FEW NOTABLE EXCEPTIONS. THIS

ARTICLE CONCLUDES THAT INTELLIGENT OISCUSSION AND REALIST

ARTICLE CONCLUDES THAT INTELLIGENT OISCUSSION AND REALIST

APPRAISAL OF THE SUBSTANCE OF
ON AN ACCURATE AND ABLE PRESS.

06973 OKIGBO, C

HORSERACE AND ISSUES IN MIGERIAN ELECTIONS

JOURNAL OF BLACK STUDIES, $22(3)$ (MAR 92), 349-365.

THE TRUE YALUE OF THE ELECTION STORY IS PERHAPS THE

YICARIOUS ENTERTAINMENT IT PROVIDES IN THE SENSE OF SPORTS-

LIKE COVERAGE AND NOT THE INFORMATION ON ISSUES. MUCH OF THE BENEFITS OF MEDIA CONTENT IS LUDENIC. IN ORDER TO

EMPIRICALLY DETERMINE THE PATTERN OF PRESS COVERAGE OF NIGERIA'S 1979 AND 1983 ELECTIONS, IH LIGHT OF PLAY THEORY, THIS PAPER REPORTS ON A CONTENT ANALYSIS OF TWO NATIONAL NEWSPAPERS. THE CONCLUSION DRAHN IS THAT POLITICAL COMMUNICATION IS PLAYFUL. THE PAPER QUESTIONS WHETHER I SHOULD BE SO, AND ASKS WHAT THE IMPLICATIONS OF THE PLAYFUL NATURE OF POLIITICAL COMHUNICATION FROM THE POINT OF VIEN OF MEDIA EFFECTS ON VOTERS ARE.

06974 OKITA, S.

JAPAN'S ROLE IN ASIA-PACIFIC COOPERATION

ANHALS OF THE AMERICAN ACADEMY OF POLITICAL AND SOCIAL

SCIENCE, (513) (JAN 91), 25-37.

THE ASIA-PACIFIC COUNTRIES ACHIEVED RAPID ECONOMIC GROWTH WITH THE FLYING-GOOSE MODEL IN THE 1980'S--GROWTH BUTTRESSED BY EXPORT-ORIENTED DEVELOPMENT STRATEGIES AND THE POLICY CULTURE. WHILE JAPAN AND THE OTHER ASIA-PACIFIC COUNTRIES STILL HAVE STRONG GROWTH POTENTIAL. MANY PROBLEMS REMAIN, INCLUDING TRADE IMBALANCES WITH THE UNITED STATES AND THE RISE OF U.S. PROTECTIONISM, THE ASIA-PACIFIC ECDNOMIES' VULNERABILITY, AND THE NEED TO CONSOL IDATE THE INFRASTRUCTURE FOR GROWTH. IT IS IMPERATIVE THAT JAPAM CONTRIBUTE TO THE DEVELOPMENT OF THE REGION BHAT JAPAN CONTRIBUTE TO THE DEVELOPMENT OF THE REGION BY RESPONDING EFFECTIVELY TO THESE ISSUES AND THAT IT STRENGTHEN THE INTERNATIONAL TRADING ARRANGEMENTS BY PROMOT ING ASIA-PACIFIC COOPERATION PREMISED ON OPENNESS. GIVEN THE REGION'S GREAT INTERNAL DIVERSITY, ASIA-PACIFIC ECONOMIC COOPERATION COULD
SERVE AS A MODEL FOR INTERNATIONAL ECONOMIC COORDINATION.

06975 OKOLICSANYI, $K$.

HUNGARY: ANTALL'S GOVERNMENT PROVES LESS THAN GREEN

HUNGARY: ANTALL'S GOVERAMENT PROVES LESS THAN
RFE/RL RESEARCH REPORT, 1 (33) (AUG 92), 65-69.

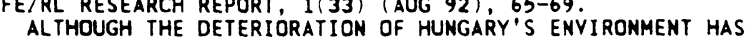
SLOWED DOWN SINCE FREE ELECTIONS WERE HELD IN 1990. THIS IS A RESULT OF THE SIGNIFICANT ECONOMIC DOWNTURN, RATHER THAN EFFECTIVE GOVERMMENT ENVIRONMENTAL POLICY.

06976 OKOLICSANYI, $K$.

HUNGARY: THE NONEXISTENT LONG-TERM ECONOMIC PLAM

RFE/RL RESEARCH REPORT, 1 (3) (JAN 92), 35-37.

HUNGARY IS ATTEMPTING TO MOVE FROM A CENTRALLY-PLANHED 
TO A MARKET ECONOMY WITHOUT ANY SPECIFIC MEDIUM- OR LONGTERM ECONOMIC PLAN LEADERS BELIEVE THERE IS NO NEED FOR CENTRAL MACROECONOMIC PLAN, SINCE THE DEVELOPED HESTERN COUNTRIES PROVIDE A CLEAR EXAMPLE THAT CAN BE FOLLOWED. ONLY THE GOVERMMENT'S KUPA PROGRAM COMES CLOSE TO BE A PLAN, BUT IT IS ACTUALLY A COLLECTION OF OESIRABLE TARGETS RATHER THAN A REAL ECONOMIC PROGRAM.

06977 OKOLICSANYI, K.

NEW HUNGARIAN BANK LANS MAINTAIN POLITICAL INFLUENCE RFE/RL RESEARCH REPORT, 1(8) (FEB 92), 41-45.

IN 1991 THE HUNGARIAN PARLIAMENT ADOPTED TWO BANKING REFORM LAWS: ONE REGULATING THE OPERATIONS OF THE NATIONAL BANK OF HUNGARY AND THE SECOND DESIGNED TO REFORM THE OPERATIONS OF THE COUNTRY'S OTHER FINANCIAL INSTITUTIONS. THE FINAL VERSION OF THE LAWS GAVE THE GOVERNMENT A SIGNIFICANT DEGREE OF CONTROL OVER BANKING OPERATIONS. DESPITE THE LAHS' SHORTCOMINGS, THEY SHOULD, IN TIME, BRING THE COUNTRY'S BANKING SYSTEM AND FINANCIAL INSTITUTIOMS MORE IN LINE WITH INTERNATIONAL, ESPECIALLY WESTERN, STANDARDS.

06978 OKOLICSANYI, $K$.

SLOVAK-HUNGARIAN TENSION: BRATISLAVA DIVERTS THE DANUBE RFE/RL RESEARCH REPORT, 1 (49) (DEC 92), 49-54

ON OCTOBER 24, 1992, SLOVAKIA BEGAN DIVERTING WATER FRO THE DANUBE FOR ITS GABCIKOVO HYDROELECTRIC DAM SYSTEM. THE MOVE CAME AFTER HEIGHTENED DIPLOMATIC ACTIVITY AMOMG BRAT ISLAYA, PRAGUE, AND BUDAPEST. HUNGARY SUFFERED A MAJOR FOREIGN-POLICY DEFEAT IHEN IT APPEALED, WITHOUT SUCCESS, TO THE INTERNATIONAL COMMUNITY TO STOP THE SLOVAK ACTION. IN THE END, NEGOTIATIONS MEDIATED BY THE EUROPEAN COMMUNITY CONVINCED THE PARTIES THAT A FURTHER ESCALATION OF THE CONFLICT WOULD HARM THEIR CHANCES OF JOINING THE E.C.

06979 OKOL ICSANYI, $K$.

THE HUNGARIAN BUDGET DEFICI

RFE/RL RESEARCH REPORT, 1(29) (JUL 92), 53-55.

HUNGARY HAS UNABLE TO REVERSE ITS ECONOMIC DECLINE IN THE FIRST FIVE MONTHS OF 1992. ALTHOUGH THE 1992 BUDGET ASSUMES THAT THE GROSS NATIONAL PRODUCT WILL GROW BY 1-2\%, THE DOWNTURM IN THE ECONOHY PRODUCED A RECORD BUDGET DEFICIT IN MAY 1992. THE MAIN REASON FOR THE DOWNTURM WAS THE DRASTIC INCREASE IN THE NUMBER OF BANKRUPTCIES FOLLOWING THE PASSAGE OF ACCOUNTIMG AMD BANKRUPTCY LAWS. THE GOVERNMENT IS NOW FACED WITH THE DILEMMA OF EITHER ALLOWING ADDITIONAL BANKRUPTCIES (WHICH COULD MEAN AN EVEN LARGER BUDGET DEFICIT AND GREATER POLITICAL PRESSURE) OR MAINTAINING ITS PRESENT REFORM COURSE. IF IT CHOOSES THE LATTER, IT SEEMS UNLIKELY THAT THE POLITICAL PAYOFFS WILL BE FORTHCDMING IN THE MEAR THAT THE
FUTURE.

06980 OKOLICSANYI, $K$.

TWO NEW HUNGARIAN LAWS TIGHTEN ECONOMIC DISCIPLIME TWO NEW HUNGARIAN LAWS TIGHTEN ECONOMIC DISCIP

TWD PIECES OF LEGISI ATION PASSED IN 1991 THAT ATTRACTED LITTLE NOTICE WILL BEGIN TO HAVE AN EFFECT ON HUNGARY'S ECONOMY IN 1992. THE ACCOUNTING LAW WILL TIGHTEN AND REGULATE THE REPORTING OF ACCOUNTS, AND THE NEW BANKRUPTCY LAW WILL FORCE DEBT-RIDDEN FIRMS TO FILE FOR BANKRUPTCY. IF THE TWO LAWS ARE ENFORCED, THEY WILL LEAD TO MAJOR LAYOFFS AND THE DISAPPEARANCE OF MANY FIRMS.

06981 OKPALA, A.

THE NIGERIAN ECONOMIC DEVELOPMENT UNDER SAP

SCANDINAVIAN JOURNAL OF DEVELOPMENT ALTERNATIVES, $11(3)$

(SEP 92), 119-126.

LIKE MOST AFRICA, NIGERIA FACES A FORMIDABLE CHALLENGE IN TRYING TO IMPROVE THE LIVING STANOARDS AND QUALITY OF LIFE OF ITS PEOPLE. THE ECONOMIC CONDITION CONTINUES TO DETERIORATE DUE TO THE EXISTENCE OF A RAPIDLY GROWING POPULATION, WITH A LABOR FORCE THAT IS IN-ADEQUATELY TRAINED. THIS ARTICLE DISCUSSES THE POLICY FRAMEWORK OF THE NIGERIAM STRUCTURAL ADJUSTMENT PROGRAM (SAP) AND THE ECONOMY AFTER SAP RESPECTIYELY. IT CONCLUDES THAT POLICY MAKERS MUST PAY INCREASED ATTENTION TO IMPROVING HUMAN AND INSTITUTIONAL CAPABILITIES BY PROMOTING A QUALITY AND MORE EXTENSIVE EDUCATION AND HEALTH CARE.

06982 OKSA, J.

REGIONAL AND LOCAL RESPONSES TO RESTRUCTURING IN PERIPHERAL RURAL AREAS IM FIMLAND

URBAN STUDIES, 29(6) (AUG 92) 991-1002. NATIONAL "POLICY PROJECTS" WITH DIFFERENT RURAL IMPACTS: THE SETTLEMENT PROJECT, THE PROJECT OF THE INDUSTRIAL WELFARE STATE. AND THE EMERGING NEH RURAL POL ICY. THIS PAPER FOCUSES STATE, AND THE EMERGING NEH RURAL POL ICY. THIS PAPER FOCUSES DURING THE FIRST PERIOD. THE EARLIER FORMS OF RURAL ECONOMY DURING THE FIRST PERIOD, THE EARLIER FORMS OF RURAL COLLAPSED AND RURAL COMMUNITIES FOLLOWED DIVERSIFIED
DEVELOPMENT PATHS. THE STATE SUPPORTED INDUSTRIALIZATION OF RURAL AREAS (REGIONAL POLICIES), RATIONALIZATION OF AGRICULTURE (STRUCTURAL POLICIES AND PRICE SUBSIDIES), AND WELFARE SERVICES. RURAL RESIDENTS RESPONDED BY MIGRATING, BY SUPPORTING POLITICAL PROTEST PARTIES, AND BY ORGANIZING INTO
VILLAGE COMMITTEES. DURING THE SECOND PERIOD, HHICH IS STILL GOING ON, NEW SOCIAL GROUPS HAVE BEEN EXPRESSING THEIR CONFLICTING INTERESTS REGARDING THE COUNTRYSIDE. THE STATE IS TRYING TO CREATE THE NEN RURAL POLICY TO CHANNEL THE FUNDS AND EXPERTS FROM EARLIER AGRICULTURAL PROJECTS INTO MORE COMPREHENSIVE RURAL DEVELOPMENT WORK.

06983 OLA-DAVIES, G.

"WE WANT CHANGE"

WEST AFRICA, 75(3924) (NOV 92), 2058.

MAITRE ABDOULAYE WADE HAS RESIGNED AS MINISTER OF STATE

IN SENEGAL TO EMBARK ONCE AGAIN ON A CAMPAIGN FOR THE

PRESIDENTIAL ELECTION IN FEBRUARY 1993. THIS REPORT

DISCUSSES WADE'S FEELINGS ABOUT HIS SERVICE IN THE

GOVERNMENT OF PRESIDENT DIOUF AND WHETHER OR NOT HE THINKS

HE HAS LOST SUPPORT BECAUSE OF THIS SERVICE. HE DISCUSSES

THE NEW ELECTORAL CODE, THE CALL FOR INTERNATIONAL OBSERVERS

AND HUMAN RIGHTS ABUSE.

06984 OLA-DAVIES, G.

DACKO RE-EMERGES

WEST AFRICA, (3917) (OCT 92), 1708

FORMER PRESIDENT DAVID DACKO HAS RETURNED TO THE CENTRAL AFRICAN REPUBLIC'S POLITICAL SCENE AND WILL RUN AS AN

INDEPENDENT CANDIDATE IN THE OCTOBER 1992 PRESIDENTIAL ELECTION.

06985 OLA-DAVIES, G.

GUINEA'S DIFFICULT TRANSITION

WEST AFRICA (3913) (SEP 92) 1558-1559

SINCE THE OPENING UP OF GUINEA'S POLITICAL SYSTEM IN 1992, MANY UNDERGROUND POLITICAL PARTIES HAVE SURFACED. THE MAJOR PARTIES ARE GENERAL LANSANA CONTE'S UNITY AND PROGRESS PARTY, MOMODOU BAH'S UNION FOR A NEW REPUBLIC, SIRADIOU DIALLO'S PARTI DE RENOUVEAU ET DU PROGRES, AND ALPHA CONDE'S GUINEA PEOPLE'S RALLY.

06986 OLA-DAVIES, $G$.

MATTERS OF CREDIBILITY

WEST AFRICA, (3905) ( JUL 92), 1212-1213.

IN SENEGAL, PRESIDENT ABDOU DIOUF HAS TRIED TO QUIET DISSENT BY INYITING MAJOR OPPOSITION LEADERS AND PARTIES TO JOIN HIS GOVERNMENT. IN THIS INTERVIEH, ABDDULAYE BATHILY OF
THE DEMOCRATIC LEAGUE/WORKERS PARTY MOVEMENT EXPLAINS WHY HIS PARTY REFUSED DIOUF'S INYITATION.

06987 OLA-DAVIES, G.

SETTLING THE POLEMICS

WEST AFRICA, (3894) (MAY 92), 758.

BARELY THO WEEKS BEFORE CONGO'S MAY 1992 GENERAL

ELECTION, THO OF THE KEY PLAYERS--PRIME MINISTER ANDRE

MILONGO AND OPPOSITION LEADER PASCAL LISSOUBA--WERE IN

FRANCE, PRESUMABLY TO LOOK FOR SUPPORT AMONG FRENCH LEADERS,

WHOSE ROLE IN CONGOLESE POLITICS IS SIGNIFICANT.

06988 OLA-DAVIES, G.

SPREADING THE US IDEAL

WEST AFRICA, 75(3887) (MAR 92), 460

THE ATMOSPHERE WAS STRAINED WHEN THE US ASSISTANT SECRETARY OF STATE FOR AFRICAN AFFAIRS VISTED THE PRESIDENT OF ZAIRE. THERE EXISTS A DEEPSEATED MUTUAL DISTRUST BETWEEN WASHINGTON AND PRESIDENT MOBUTU. THE AMERICANS ARE SAYING THAT THE NATIONAL CONFERENCE SHOULD BE RECONVENED; THAT THE RESTRICTIONS ON IT SHOULD BE LIFTED: THAT A CONVENIENT TIMETABLE BE SET UP AND A NEW PRIME MINISTER NAMED. THE US ACKNOWLEDGED THAT THE NATIONAL CONFERENCE IS NOT A PANACEA FOR ZAIRE'S POLITICAL PROBLEMS, BUT SAID THAT IT HAD BECOME A SYMBOL FOR DEMOCRATIC CHANGE IN THE COUNTRY.

06989 OLA-DAVIES, G. STRANGE HAPPENINGS

WEST AFRICA, (3895) (MAY 92), 791

THE AUTHOR RECALLS THE 1967 IMPOSITION OF MARTIAL LAW IN SIERRA LEONE BY BRIGADIER DAVID LANSANA AND THE 1968 MUTINY BY JUNIOR MILITARY OFFICERS, HICH LED TO THE FORMATION THE ANTI-CORRUPTION REVOLUTIONARY MOVEMENT.

06990 OLASKY, M.

MESS IN MIAMI

NATIONAL REVIEW, XLIV(11) (JUN 92), 25-26.

THIS ARTICLE BRIEFLY REPORTS ON' THE ANNUAL CONFERENCE OF THE COUNCIL OF FOUNDATIONS--A TRADE ASSOCIATION OF 1,309

FOUNDATIOINS AND CORPORATE GIVING PROGRAMS. WHICH TOGETHER FOUNDATIOINS AND CORPORATE GIVING PROGRAKS, WHICH TOGETHER CONTROL SOME \$74 BILLION IN ASSETS AND MAKE MORE THAN S4 BILLION WORTH OF GRANTS EACH YEAR. THE AUTHOR IS HIGHLY "CRITICAL OF THE COUNCIL, ESPECIALLY FOR ITS DECISION TO "CONVINCE" THE MAYOR OF HOST CIAL MIAMI BEACH TO GIVE AN "APPROPRIATE TRIBUTE" TO AFRICAN NATIONAL CONGRESS LEADER NELSON MANDELA. THE GESTURE SATISFIED THE POLITICAL LEFT, BUT ANGERED MANY HISPANICS IN THE CITY.

06991 OLCOTT, M.

CENTRAL ASIA'S POST-EMPIRE POLITICS

ORBIS, 36(2) (SPR 92), 253-268. 
ECONOMIC DIFFICULTIES HAVE TRANSLATED INTO POLITICAL PROBLEMS IN THE CENTRAL ASIAN REPUBLICS. THE BUREAUCRATS FROM MOSCOW NO LONGER SERVING AS SCAPEGOATS, CENTRAL ASIA'S LEADERS HAVE FOUND THEMSELVES THE FOCUS OF ANGER BY AN INDIGNANT PUBLIC. CONSEQUENTLY, ENORMOUS POLITICAL CHANGES ARE TAKT ARE TAKING PLACE WITHIN THE LEADERSHIP OF IS ESSENTIAL IM UNDERSTANDING THE NATURE OF THESE CHANGES IS ESSENTIAL IN DETERMINING CENTRAL ASIA'S FUTURE ROLE IN WORLD AFFAIRS.

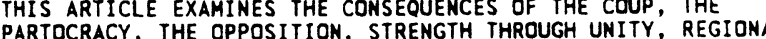
PARTOCRACY, THE OPPOSITION, STRENGTH THROUGH UNITY, REGIONAL NEIGHBORS, AND FOREIGN INTERESTS. IT CONCLUOES THAT EVENT IN CENTRAL ASIA DO NOT DIRECTLY THREATEN U.S. SECURITY INTERESTS BUT IN THE LONG RUN, A SHIFT IN THE GEOPOL STRATEGIC BALANCE IN SOUTH ASIA AND THE MIDDLE EAST.

06992 OLCOTT, M.

THE SOVIET (DIS)UNION

FOREIGN POLICY, (82) (SPR 91), 118-136.

SOVIET PRESIDENT MIKHAIL GORBACHEV'S INEXPERIENCE WITH NATIONALITY RELATIONS HAS COST HIM DEARLY. IT HAS UNDERMINED HIS AUTHORITY, COST HIM THE SUPPORT OF CLOSE POLITICAL ALLIES, CRIPPLED HIS REFORM PROGRAMS, RESULTED IN THE DEATHS OF WHAT SOME ESTIMATE TO BE MORE THAN A THOUSAND CITIZENS, AND COULD WELL LEAD TO THE BLOODY DISSOLUTION OF THE COUNTRY HE IS SEEKING TO PRESERVE. THIS ARTICLE CHRONICLES THE GROWING SEPARATISM AND NATIONALISH IN MANY OF THE SOVIET REPUBLICS AND GORBACHEV'S OFTEN FUMBLING ATTEMPTS TO SUPPRESS THEM.

06993 OLCOTT, M.B.

CENTRAL ASIA'S CATAPULT TO INDEPENDENCE

FOREIGN AFFAIRS, 71 (3) (SUM 92), 108-130

THE FIRST-ORDER CHALLENGE NOW FACING THE CENTRAL ASIAN STATES IS TO EMERGE FROM POL ITICAL OBSCURITY AND ECONOMIC STATES IS TO EMERGE FROM POLITICAL OBSCURT ANTLY ACCEPTED ISOLATION. THE CENTRAL ASIANS HAVE RELUCTANTLY ACCEPTED NATIONHOOD, WHICH CARRIES WITH IT ENORMOUS BURDENS-PREPARED AND WHICH EVEN THE MOST ABLE TRIED TO AVOID.

06994 OLIVAS, M.

THE POLITICAL ECONOMY OF IMMIGRATION, INTELLECTUAL PROPERTY, AND RACIAL HARASSMENT: CASE STUDIES OF THE IMPLEMENTATION OF LEGAL CHANGE ON CAMPUS

JOURNAL OF HIGHER EDUCATION, 63(5) (SEP 92), 570-598. THIS ARTICLE ASKS HOH INSTITUTIONS ABSORB LEGAL REQUIREMENTS AND HOW THEY ARE CHANGED AS A RESULT. THE AUTHOR SUGGESTS A PRELIMINARY FRAMENORK FOR MEASURING THE EFFECT OF LEGAL CHANGES UPON COLLEGES, USING IMPLEMENTATION THEORY LITERATURE TO EXAMINE IMMIGRATION, INTELLECTUAL PROPERTY, AND RACIAL HARASSMENT. EACH IS DISCUSSED AND CONTRASTED FOR ITS FIT HITHIN THE THEORETICAL. FRAMEWORK. FIMALLY, THE THEORETICAL SIGNIFICANCE AND POLICY IMPLICATIONS ARE EXAMINED.

06995 OLIVEN, E.

STUDENT ACTIVISM IN THE UKRAINIAN INDEPENDENCE MOVEMENT MICHIGAN JOURNAL OF POLITICAL SCIENCE, 14 (HIN 91), 18-57. HISTORICALLY DURING PERIOD OF DRAMATIC UPHEAVAL, STUDENTS HAVE OFंTEN BEEN FOUND TO BE IN THE FOREFRONT OF THOSE DEMANDING CHANGES. THIS THESIS STUDIES THE UKRAINIAN STUDENT MOYEMENT IN THE SPRING OF 1991 PART ONE OF THE ESSAY PROVIDES RELEVANT SETS OF THEORETICAL AND HISTORICAL ESSAY PROVIDES RELEVANT SETS OF THEORETICAL AND HISTORICAL BACKGROUND INFORMATION ON THE TOPIC OF UKRAINIAN STUD ACTIVISM. THE SECOND SECTION IS THE PRESENTATION AND
INTERPRETATION OF DATA. THE FINAL PORTION OF THIS WORK INTERPRETATION OF DATA. THE FINAL PORTION OF THIS WORK COMPARES THE NATURE AND EXTENT OF UKRIANIAN STUDENT ACTIVISH TO THOSE FOUND ELSEWHERE. DATA FROM THIS PROJECT IS USED THELP EXPLAIN

06996 OLIVER, D.

WRITTEN CONSTITUTIONS: PRINCIPLES AND PROBLEMS PARL DEBATES ABOUT THE REFORM OF THE CONSTITUTION OF THE UNITED KINGDOM HAVE PASSED THROUGH A NUMBER OF PHASES IN THE LAST THIRTY YEARS OR SO. EARLIER, THE EMPHASIS WAS ON THE NEED TO MAKE THE LEGISLATIVE PROCESS MORE EFFICIENT. THESE PRESSURES LED TO THE INTRODUCTION OF THE CROSSMAN REFORMS WHICH ESTABLISHED A SYSTEM OF SUBJECT-RELATED SELECT COMMITTEES. THESE WERE ALSO REFORMED TO THE LEGISLATIVE PROCEDURES OF THE COMMONS. THIS ARTICLE EXPLORES HOW THREE CONSTITUTIONS HAVE COME INTO EXISTENCE AND THE PRINCIPAL CHANGES TO THE PRESENT SYSTEM THAT THEY PROPOSE. IT ALSO EXPLORES COMPLEX QUESTIONS THAT ARISE WHEN INDULGING IN CONSTI TUT ION-MAKI NG.

06997 OLIVIER, $N$.

ANC CONSTITUTIONAL PROPOSALS AND STATE REACTION SOUTH AFRICA INTERMATIONAL, 22(2) (OCT 91) 55-64. SOUTH AFRICA'S RULING NATIONAL PARTY'S CALL FOR A NEH CONSTITUTION HAS AROUSED MUCH SPECULATION THROUGHOUT THE NATION. THIS ARTICLE EXAMINES THE CONSTITUTIONAL PROPOSALS OF THE AFRICAN NATIONAL CONGRESS (ANC) IN DETAIL, OUTLINING
AREAS OF AGREEMENT OR DISAGREEMENT HITH THE GOVERMMENT. A PERHAPS SURPRISING DEGREE OF CONSENSUS ON MANY BROAD AREAS OF CONSTITUTIONAL PRINCIPLE BETWEEN THESE TWO POLITICAL ACTORS EMERGES, CONSIDERING THAT FORMAL NEGOTIATIONS HAVE YET TO OFFICIALLY BEGIN. NONETHELESS, THERE ARE SOME KEY POINTS OF DEPARTURE IN CRITICAL AREAS SUCH AS DEVOLUTION OF

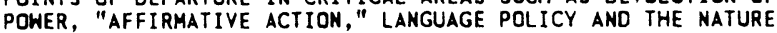
OF THE EXECUTIVE.

06998 OLLMAN, B. (ED.); BIRMBAUM, J. (ED.)

THE UNITED STATES CONSTITUTION--200 YEARS OF ANTI-

FEDERALIST, ABOLITIONIST, FEMINIST, MUCKRACKING,

PRDGRESSIVE, AND ESPECIALLY SOCIALIST CRITICISM

NEW YORK UNIVERSITY PRESS, 1991, 332

THIS VOLUME CONTAINS MAJOR WRITINGS ON THE CONSTITUTION FROM SIX CRITICAL TRADITIONS. IT OUTLINES THE MAIN EVENTS AND PROBLEMS THAT LED UP TO AND CONTRIBUTED TO THE CALLING AND PROBLEMS THAT LED UP TO AND CONTRIBUTED TO THE CALLING OF THE CONSTITUT IONAL CONVENTION IN 1787; CONCENTRATES ON WHAT ACTUALLY HAPPENED AT THE CONVENTION; DEALS WITH THE TWOHUNDRED YEAR HISTORY OF INTERPRETATIONS AND AMENDMENTS THAT FOLLOHED; AND OFFERS A NUMBER OF IDEAS THAT SHOULD PR
HELPFUL IN CONSTRUCTING THE ADEOUATE THEORY OF THE CONSTITUTION THAT STILL ELUDES US.

06999 OLOWO, B

BABANGIDA'S CARROT AND STICK

WEST AFRICA, (3898) (JUN 92), 914-915.

ON MAY 24, 1992, IN A NATIONHIDE BROADCAST, PRESIDENT IBRAHIM BABANGIDA SPOKE ABOUT THE ORIGINS OF THE VIOLENCE THAT HAD ENGULFED HIS COUNTRY AND EXPLAINED HOW HIS GOVERMMENT HAD REACTED AND WOULD RESPOND IN THE FUTURE TO A CONTINUATION OF THE CIVIL DISTURBANCES.

07000 OLOWO, B.

CRAVING THE CAKE

HEST AFRICA, (3914) (SEP 92), 1604-1605

DESPITE OFFICIAL GOVERNMENT STATEMENTS THAT NEH STATES

WILL NOT BE CREATED WITHIN NIGERIA, THE MEDIA CONTINUES TO

CALL FOR THE CREATION OF MORE STATES. THE PRIMARY REASON

BEHIND THE DEMAND FOR NEW STATES IS DESIRE TO CONTROL LOCAL DEVELOPMENT.

07001 OLOWO, 8 .

INTRA-PARTY SOUABBLES

WEST AFRICA (3884) (FEB 92), 320-321

AS NIGERIA PREPARES FOR ITS 1992 ELECTIONS, THE NATIONAL REPUBLIC CONYENTION (NRC) AND THE SOCIAL DEMOCRATIC PARTY (SDP) ARE MIRED IN LEADERSHIP TUSSLES THAT COULD AFFECT THEIR FORTUNES AT THE POLLS. IN THE NRC, DISSATISFIED BUT HIGHLY-PLACED PARTY MEMBERS ARE CALLING FOR THE OUSTER OF CHAIRMAN TOM IKIMI. MEANWHILE, THE SDP'S POOR SHOWING IN THE 1991 GOVERNORSHIP ELECTIONS HAS LED TO CALLS FOR THE REMOVAL OF CHAIRMAN ALHAJI BABA GANA KINGIBE.

07002 OLOWO, B MONETARY POLICY CHANGE

WEST AFRICA, (3879) (JAN 92), 112.

THE NIGERIAN GOVERNMENT HAS PLEDGED TO EASE ITS HOLD ON MONETARY POLICY BY ADOPTING "INDIRECT CONTROL." IT HAS ALSO RELEASED THE 1992 MONETARY AND POLICY GUIDELINES DESCRIBING THE MECHANISM FOR ACHIEVING THE OBJECTIVES OF ITS INDIRECT APPROACH, WHICH WILL BE PREMISED ON THE OPEN MARKET MODEL. UNDER THE INDIRECT APPROACH, THE GOVERMMENT'S MAIN GOALS WILL BE TO ERADICATE THE EXCESS LIQUIDITY IN THE BANKING SYSTEM AND OTHER INADEQUACIES, WHICH HAVE BEEN THE CAUSE OF PRESISTENT GOVERNMENT DEFICITS.

07003 OLOWO, B

SELF-SERVING AND ILL-TIMED?

HEST AFRICA, (3880) (JAN 92), 144.

IN NIGERIA, SOME OLDER POLITICIANS HAVE CALLED FOR A

MATIOMAL COMSENSUS GOVERMMENT BUT PRESIDENT IBRAHIM

BABANGIDA HAS SAID THAT HIS OWN TRANSITION PROGRAM NEGATES

THE NEED FOR A NATIONAL CONSENSUS GOVERMMENT. MOREOVER, THE

TWO POLITICAL PARTIES THAT WOULD RUN A CONSENSUS GOVERNMENT

HAVE REACTED NEGATIVELY TO THE IDEA.

07004 OLOWO, B.

SETTLING DOWN

WEST AFRICA, (3880) (JAN 92), 144-145

NIGERIA'S NEWLY-ELECTED STATE GOVERNORS AND LEGISLATORS

ARE OUICKLY LEARNING HOW DIFFICULT THEIR JOBS WILL BE. THEY ARE QUICKLY LEARNING HOW DIFFICULT THE RAVE LIMITED

RESOURCES AND THAT THEIR CAMPAIGN PROMISES MAY BE DIFFICULT, OR EVEN IMPOSSIBLE, TO KEEP.

07005 OLOWO, B

SHARING THE CAKE

WEST AFRICA, (3910) (AUG 92), 1434-1435.

THE AUTHOR EXPLAINS HOW NIGERIA ALLOCATES PUBLIC REVENUE FOR BOTH THE CAPITAL AND RECURRENT EXPENDITURES OF THE THREE TIERS OF ITS GOVERHMENT. 
07006 OLPADWALA, P.; GOLDSMITH, W.W.

THE SUSTAINABILITY OF PRIVILEGE: REFLECTIONS ON THE ENVIRONMENT, THE THIRD WORLD CITY, AND POVERTY

WORLD DEVELOPMENT, 20(4) (APR 92), 627-640.

IN MANY COUNTRIES, URBANIZATION, ENVIRONMENTAL PROBLEMS, AND POVERTY HAVE INCREASED DRAMATICALLY OVER THE PAST QUARTER-CENTURY. IN THIS PAPER, THE AUTHORS EXAMINE THESE THREE PHENOMENA, USING CONCEPTS OF SOCIAL CLASS TO MAKE CONNECTIONS. THIS APPROACH STRESSES THE HUMAN ELEMENT OVER MATTERS OF NATURE OR INANIMATE TECHNOLOGY. BY DISAGGREGATING SOCIETY INTO COMPETING GROUPS, IT REVEALS ENVIRONMENTAL PROBLEMS TO BE ESSENTIALLY THOSE OF PEOPLE AND SOCIAL AND POLIT ICAL ORGANIZATION, NOT OF NATURE AND TECHNOLOGY. THUS, ENVIRONMENTAL IMPROVEMENT IN THE LARGE CITIES OF THE THIRD WORLD WILL REQUIRE SOCIAL CHANGE.

07007 OLSEN, E.

A NEW AMERICAN STRATEGY IN ASIA?

ASIAN SURVEY, 31(12) (DEC 91), 1139-1154.

AMERICAN STRATEGY IN ASIA IS ON THE VERGE OF BEING

TRANSFORMED BY LARGER GLOBAL TRENDS. WASHINGTON NOW PLANS

FOR UNCERTAIN REGIONAL CONTIMGENCIES. THIS APPROACH IS

ACCOMPANIED BY NEW CONCEPTS OF RECALIBRATED BASE FORCES FOR VARIOUS REGIONS OF THE HORLO. ASIAN REACTIONS AND THE END OF ASIA'S COLD WAR ARE ASSESSED IN THIS ARTICLE. IT CONCLUDES THAT APPLYING NEN U.S. NATIONAL SECURITY STRATEGY TO ASIA AS AVOIDED BY AMERICANS FOR ARCHAIC, COLD-WAR VINTAGE REASONS.

07008 OLSEN, E.

TARGET JAPAN AS AMERICA'S ECONOMIC FOE

ORBIS, 36(4) (FAL 92), 491-504.

AFTER THE COLD WAR, JAPAN PURSUES THE FRUITS OF VICTORY, WHILE THE UNITED STATES REMAINS HOBBLED BY A COLD WAR MINDSET. THE UNITED STATES FACED PROBLEMS LINKED TO JAPAN'S EVOLVING ROLE IN WORLD AFFIARS. THIS ARTICLE EXPLORES SEVERAL OF THESE PROBLEMS AND CONCLUDES THAT THE U.S. CANHOT SOLVE ITS DOMESTIC PROBLEMS AT THE EXPENSE OF FOREIGM COMPETITORS AND MUST COME TO GRIPS WITH THE SCOPE OF ITS ECONOMIC COMPETITION AND IN THE WAYS IN WHICH ITS COMPETITIORS HAMPER THE UNITED STATE'S ABILITY TO ENHANCE DOMESTIC PRODUCTIVITY.

07009 OLSEN, J.

MODERNIZATION PROGRAMS IN PERSPECTIVE: INSTITUTIONAL ANALYSIS OF ORGANIZATIONAL CHANGE

GOVERNANCE, 4 (2) (APR 91$), 125-149$.

THIS ARTICLE EXPLORES THE POSSIBLE VALUE OF ORGANIZATION THEORY FOR THE STUDY OF COMPREHENSIVE ADMINISTRATION REFORM. THEORY FOR THE STUDY OF COMPREHENSIVE ADMINISTRATION REFORM. AN ATTEMPT IS MADE TO SPECIFY HOW MODERNIZATION EFFORTS MAY BE AFFECTED BY PROPERTIES OF EXISTING INSTITUTIONS. IT IS AN INSTRUMENTAL VIEW OF ORGANIIZATIONAL DECISION-MAKING AND AN INSTRUMENTAL VIEW OF ORGANIZATIONAL DECISION-MAKING
CHANGE. AN INSTITUTIONAL PERSPECTIVE IS THEN OUTLINED.

07010 OLSON, A.G.

EIGHTEENTH-CENTURY COLONIAL LEGISLATURES AND THEIR CONSTITUENTS

JOURNAL OF AMERICAN HISTORY, 79(2) (SEP 92), 543-567.

THE AUTHOR FOCUSES ON THE RELATIONSHIPS OF 18 TH-CENTURY ASSEMBLIES HITH THEIR CONSTITUENTS AND THE CHANGES IN THOSE RELATIONSHIPS OVER TIME. SHE STUDIES THREE VERY DISSIMILAR COLONIAL LEGISLATURES: THE VIRGINIA HOUSE OF BURGESSES, THE

07011 OLSON, $P$

THE U.S. HUMAN RIGHTS PROGRAM IN SOUTH AFRICA, 1986-1989 HUMAN RIGHTS QUARTERLY, 13(1) (FEB 91), 24-65.

SINCE MID-1986, THE U.S. AGENCY FOR INTERMATIONAL DEVELOPMENT (AID) HAS CONOUCTED A MAJOR PROGRAM TO DEFEND HUMAN RIGHTS AND PROMOTE DEMOCRATIC DEVELOPMENT IN SOUTH AFRICA. WHILE NEITHER THE FIRST NOR THE ONLY U.S. GOVERNMENT PROGRAM OF THIS NATURE IN RECENT YEARS, THE REMARKABLE RECENT DEVELOPMENTS IN SOUTH AFRICA AND A NUMBER OF SPECIFIC FEATURES MAKE THIS PROGRAM AN ESPECIALLY INSTRUCTIVE ONE. THIS ARTICLE DESCRIBES THE ORIGINS OF THE PROGRAM AND MAJOR CONCEPTUAL AND OPERATIONAL ISSUES ARISING IN ITS IMPLEMENTATION IN THE FIELD, AND CONCLUOES BY OFFERING A PRELIMINARY ASSESSMENT OF ITS EFFECTIVENESS AND SOME LESSONS IT MAY OFFER FOR SUCH PROGRAMS IN THE FUTURE.

07012 OLSON, R.

TURKEY AND IRAO: TOWARDS NORMALIZATION?

MIDDLE EAST INTERNATIONAL, (431) (AUG 92), 19.

LESS THAN TWO YEARS AFTER THE INYASION OF KUWAIT, RECENT PRESS REPORTS INDICATE THAT TURKEY WOULD LIKE TO BEGIN THE PROCESS OF NORMALIZING RELATIONS WITH IRAO. THIS IS DESPITE THE FACT THAT TURKEY WAS ONE OF THE MOST ENTHUSI ISTIC OF THOSE COUNTRIES HHICH SUPPORTED THE WAR AGAINST IRAQ. THE MAIN REASON FOR THIS CHANGE OF HEART IS CLEAR: THE GULF WAR INCREASE IN THE ACTIVITIES OF THE KURDISH NATIONAL MOVEMENT IN TURKEY. THE KURDISH PROBLEM, BOTH WITHIN AND BEYOND
FOREIGN POLICY CONCERN OF THE TURKISH GOVERNMENT. TURKEY HAS NOW COME TO REALIZE THAT THE EFFORT AND EXPENSE OF TRYING TO DESTROY THE KURDISH NATIONALISTS AT HOME AND AT THE SAME TIME CONTROL THOSE IN IRAQ IS BEYOND ITS FINANCIAL, DIPLOMATIC AND POLITICAL RESOURCES, EVEN IF IT POSSESSED THE REQUISITE MILITARY POWER.

07013 OLTAY, E.

A PROFILE OF ISTVAN CSURKA

RFE/RL RESEARCH REPORT, 1(40) (OCT 92), 26-29.

AN EXAMINATION OF THE LIFE AND POLITICAL ESSAYS OF ISTVAN CSURKA SHOWS A CONTINUITY OF THOUGHT BETHEEN HIS EARL IER WRITINGS AND HIS LATEST TRACT, WHICH HAS CAUSED A POLITICAL STORM IN HUNGARY. CSURKA'S WRITINGS HAVE CONSISTENTLY FOCUSED ON THE PRESERVATION OF HUNGARIAN IDENT ITY, THE ELEVATION OF THE "LOWER STRATA" OF SOCIETY, AND THE "THIRD ROAD" FOR HUNGARY, REPRESENTED BY THE REJECTION OF CAPITALISM AND WESTERN POLITICAL MOOELS. THE ANTI-SEMITIC VIEWS EXPRESSED IN CSURKA'S LATEST ESSAY ARE ALSO FAMILIAR THEMES IN HIS WORK.

07014 OLTAY, E.

HUNGARIAN CIVIC GROUPS ADJUST TO DEMOCRACY

RFE/RL RESEARCH REPORT AL 32 ) (AUG 92) $18-20$

HUNGARIAN CIVIC ASSOCIATIONS MADE A DRAMATIC RECOVERY IN THE LATE $1980^{\prime} S$ AND PLAYED AN ACTIVE PART IN SECURING DEMOCRATIC CHANGES. THESE ASSOCIATIONS ARE NOH FULLY PROTECTED BY THE LAW, AND THEIR NUMBER HAS REACHED A POSTWAR PEAK OF MORE THAN 10,000. MANY GROUPS ESTABLISHED IN OPPOSITION TO THE COMHUNIST REGIME ARE NOW EXAMINING THEIR ROLE IN A PARLIAMENTARY DEMOCRACY. RELATIONS AMONG ASSOCIATIONS ARE OFTEN STRAINED AS NEW ONES ARE FORMED AND OLD ONES SEEK TO ADJUST TO THE CONDITIONS OF POLITICAL PLURALISM.

07015 OLTAY, E.

HUNGARIAN CULTURE IN "NO-MAN'S LAND"

RFE/RL RESEARCH REPORT, 1(9) (FEB 92), 60-63.

THE STATE'S WITHDRAWAL FROM THE CULTURAL SPHERE HAS

BROUGHT A SUBSTANTIAL REDUCTION IN FUNDING, CREATING SERIOUS FINANCIAL DIFFICULTIES FOR HUNGARY'S ARTISTS AND CULTURAL INST ITUTIONS. CULTURAL EXPERTS AND ECONOMISTS ARGUE THAT A NEH SYSTEM OF SPONSORSHIP SHOULD BE ESTABLISHED IN WHICH STATE FINANCING IS AUGMENTED BY PRIVATE SPONSORSHIP AND ARTISTS DETERMINE HOW STATE FUNDS ARE DISTRIBUTED. THE PROBLEMS OF CREATING SUCH A SYSTEM REFLECT THE CULTURAL COMMUNITY'S PERSISTENT DISTRUST OF THE STATE AND
DIFFICULTIES OF ADJUSTING TO THE NEW CONDITIONS.

07016 OLTAY, E.

HUNGARIAN DEMOCRATIC FORUM RENT BY DISPUTE OVER EXTREMISM RFE/RL RESEARCH REPORT, 1 (47) (NOV 92), 22-25.

THE LARGEST PARTY IN HUNGARY'S GOVERNING COALITION, THE HUNGARIAN DEMOCRATIC FORUM, IS RENT BY A DISPUTE OVER THE ANTI-SEMITIC VIEWS OF ITS DEPUTY CHAIRMAN ISTVAN CSURKA. POL ITICAL EXTREMISM IS IRRECONCILABLE WITH THE PARTY'S CENTRIST IMAGE AND WITH THE BASIC VALUES OF ITS THREE MAJOR WINGS: THE POPULIST-NATIONAL, THE CHRISTIAN-DEMOCRATIC, AND THE NATIDNAL-LIBERAL. THUS FAR, THE NATIONAL-LIBERAL WING HAS BEEN THE MOST OUTSPOKEN IN CONDEMNING CSURKA'S VIEWS, BUT MODERATES FROM ALL THREE WINGS WILL HAVE TO SPEAK UP' AT THE COMING PARTY CONGRESS IN ORDER TO DEFEND THE PARTY'S CENTRIST CHARACTER AND RETAIN THE SUPPORT OF THE MODERATE PUBLIC. THE PARTY WILL NEED TO TAKE AN UNAMBIGUOUS STANCE ON CSURKA'S VIEWS IF IT IS TD END THE CURRENT DISPUTE AND AVERT A POSSIBLE SPLIT IN ITS RANKS.

\section{OLTAY, E.}

RFE/RL RESEARCH REPORT, 1 (39) (OCT 92), 39-43.

TWO YEARS AFTER THE MULTIPARTY ELECTIONS, THE HUNGARIAN MEDIA ARE NO LONGER THE MOUTHPIECE OF A ONE-PARTY POLITICAL SYSTEM AND FACE A NEH SET OF CHALLENGES. THE PRESS, WHICH IS THE MOST PRIVATIZED OF ALL HUNGARIAN BUSINESS ACTIVITIES, IS STRUGGLING TO SURVIVE UNDER MARKET CONDITIONS. THE PRIVATIZATION OF RADID AND TELEVISION, BY CONTRAST, HAS STALLED DUE TO SERIOUS DISPUTES BETWEEN THE GOVERNMENT AND THE OPPOSITION, EACH ACCUSING THE OTHER OF SEEKING TO CONTROL BROADCASTING. CAUGHT IN THE MIDDLE OF A POLITICAL STRUGGLE. THESE THO INSTITUTIONS ARE FINDING THAT THEIR INDEPENDENCE AND CREDIBILITY ARE BEING UNDERMINED.

07018 OLTAY, E.

HUNGARY

RFE/RL RESEARCH REPORT, 1(27) (JUL 92), 16-24. SINCE THE 1990 ELECTIONS HUNGARY HAS ERECTED SOME OF THE BASIC PILLARS OF A STATE BUILT ON THE RULE OF LAW. THE SEPARATION OF THE THREE BRANCHES OF GOVERMMENT HAS BEEN ACHIEVED TO A LARGE EXTENT, AND THE PARLIAMENT HAS BEEN SUCCESSFUL IN USING ITS EXCLUSIVE CONSTITUTIONAL RIGHT TO FRAME LAWS. HOWEYER, VARYING INTERPRETATIONS OF AMBIGUOUS CONSTITUTIONAL PROVISIONS AND LEGISLATION HAVE OFTEN PROOUCED TENSIONS BETHEEN VARIOUS OFFICES AND INSTITUTIONS. THE CONSTITUTIONAL COURT HAS COME TO PLAY A MAJOR ROLE IN 
SHAPING HUNGARY'S LEGAL AND INSTITUTIONAL SYSTEM BY ACTING AS THE FINAL ARBITER ON ISSUES RANGING FROM DISPUTES OVER CONSTITUTIONAL JURISDICTION TO SOCIAL PROBLEMS.

07019 OLTAY, E.

HUNGARY IS ILL-PREPARED FOR RISING DRUG ABUSE

RFE/RL RESEARCH REPORT, 1(33) (AUG 92), 62-64.

IN THE PAST TWO YEARS, HUNGARY HAS BECOME A MAJOR TRANSIT COUNTRY FOR DRUG TRAFFICKERS, PARTLY BECAUSE IT LACKS THE MEANS TO FIGHT THE SPREAD OF DRUG TRAFFICKING AND ABUSE. HUNGARIAN CUSTOMS OFFICIALS AND POLICE HAVE NEITHER THE SPECIALIZED TRAINING NOR THE PROPER EQUIPMENT FOR DRUG DETECTION. MOREOYER, HUNGARY'S HEALTH CARE SYSTEM LACKS THE PERSONNEL AND MEDICAL FACILITIES TO TREAT DRUG ADOICTS. THE GOVERNMENT, WHICH HAS ONLY RECENTLY TAKEN STEPS TO IMPLEMEN A COMPREHENSIVE ANTI-DRUG PROGRAM, IS SEEKING THE HELP OF THE CHURCH AND OTHER NONGOVERMMENTAL
WITH THE GROWING NUMBER OF ADDICTS.

07020 OLTAY, E.

MINORITIES AS STUMBLING BLOCK IN RELATIONS WITH NEIGHBORS

RFE/RL RESEARCH REPORT, 1(19) (MAY 92), 26-33.
THE ISSUE OF THE RIGHTS OF HUNGARIAN MINORITIES ABROAD

PLAYS A CENTRAL ROLE IN HUNGARY'S RELATIONS WITH ITS

NEIGHBORS. DUE TO CONCERN ABOUT THE ETHNIC SITUATION,

HUNGARY HAS PROPOSED THE CREATION OF AN INSTITUT IONAL

FRAMENORK FOR THE PROTECTION OF MINORITY RIGHTS. WHILE THERE

THUS FAR, THE ONLY COUNTRY WILLING TO EXPAND SUBSTANTIALLY

THES FAR, THE ONLY COUNTRY WILLING OF ITS ETHNIC HUNGARIANS--RELATIONS WITH ROMANIA,

THE RIGHTS OF ITS ETHNIC HUNGARIANS--RELATIONS WITH ROMANIA,
CZECHOSLOVAKIA, AND SERBIA REMAIN STRAINED. THE CONTROVERY

CZECHOSLOVAKIA, AND SERBIA REMAIN STRAINED. THE CONTROVERY

ILLUMINATES MUTUAL SUSPICIONS HITH DEEP HISTORICAL ROOTS

07021 OLTAY, E.

MINORITY RIGHTS STILL AN ISSUE IN HUMGARIAN-ROMANIAN

RELATIONS

RFE/RL RESEARCH REPORT, 1(12) (MAR 92), 16-20.

THE RIGHTS OF THE HUNGARIAN MINORITY IN ROMANIA CONTINUE TO BE THE MAIN STUMBLING BLOCK IN HUNGARIAN-ROMANIAN RELATIONS. ROMANIA MAINTAINS THAT THE MINORITY ISSUE IS A PURELY INTERHAL AFFAIR AND THAT THERE ARE NO PROBLEMS IN ITS TREATMENT OF MINORITIES. HUNGARY, HOWEVER, HAS ACCORDED THE ISSUE A CENTRAL ROLE IN INTERSTATE RELATIONS AND HAS TURNED TO INTERNATIONAL FORUMS FOR SUPPORT. HUNGARY IS ALSO SEEKING TO HAVE THE CONCEPT OF COLLECTIVE RIGHTS CODIFIED IN INTERNATIONAL DOCUMENTS. AGAINST THE BACKGROUND OF REPEATED ROWS OVER THE MINORITY ISSUE AND ROMANIAN CHARGES OF HUNGARIAN IRREDENTISM. THE CHANCES OF REACHING AN UNDERSTANDING BETWEEN THE TWO SIDES LOOK AS SLIM AS EVER.

07022 OLTAY, E.

OPPOSITION PARTIES IN THE PARLIAMENT

RFE/RL RESEARCH REPORT, 1 (48) (DEC 92), 40-43.

HUNGARY'S THO LIBERAL OPPOSITION PARTIES, THE ALLIANCE OF FREE DEMOCRATS AND THE ALLIANCE OF YOUNG DEMOCRATS, AND THE OPPOSITION HUNGARIAN SOCIALIST PARTY, THE SUCCESSOR TO THE COMMUYIST PARTY ARE FIMDIMG IT DIFFICULT TO FULFILL THE COMMUNIST PARTY, ARE FINDING IT DIFFICUL COMPAIN THAT THEIR ROLE IN PARLIAMENT. THE THREE PARTIES COMPLAIN THAT THEIR PROPOSALS ARE EITHER IGNORED OR VOTED DOWN BY THE PARLIAMENTARY MAJORITY. BUT THE OPPOSITION PARTIES ARE THEMSELVES UNDECIDED ABOUT THEIR PROPER ROLE ANO ARE FREQUENTLY TOO DIVIDED TO COOPERATE. THE FREE DEHOCRATS AND THE YOUNG DEMOCRATS VIEH EACH OTHER AS RIVALS AND REJECT CLOSER COOPERATION WITH THE SOCIALISTS, FEARING THAT THEY WILL DISCREDIT THEMSELVES IN THE EYES OF THE PUBLIC. WHIL THE OPPOSITION PARTIES DEPICT THEMSELVES AS ALTERNATIVE GOVERNING PARTIE

07023 OLUGBADE, K.

THE MIGERIAY STATE AND THE OUEST FOR A STABLE POLITY COMPARATIVE POLITICS, 24(3) (APR 92), 293-316.

THROUGHOUT THE POSTCOLONIAL ERA, NIGERIA HAS SEARCHED FOR A STABLE POL ITY. DURING THIS ARDUOUS SEARCH IT HAS FOR A STABLE POLITY. DURING THIS ARDUOUS SEARCH IT HAS PARL IAMENTARY, DEMOCRATIC PRESIDENTIAL, AND MILITARY. SINCE INDEPENDENCE, MILITARY GOVERMMENTS HAVE RULED NIGERIA FOR THENTY OF THIRTY YEARS, AND THE POLITICAL SYSTEM HAS BEEM VERY UNSTABLE. POLITICAL PRACTITIONERS--CIYILIAN AND MILITARY--AND SCHOLARS HAVE ATTEMPTED TO EXPLAIN THIS INSTABILITY. THE PURPOSE OF THIS PAPER IS TO JOIN THE
ONGOING DEBATE ON THE NATION'S QUEST FOR A STABLE POLITY IN THE THIRD REPUBLIC. THE AUTHOR ADVOCATES INSTITUTIONAL REFORM, OR "REINSTITUTIONALIZATION," THROUGH SOME FORM OF CONSTITUTIONAL ENGINEERING AND/OR REDESIGN AS THE PATH TO GREATER STABILITY.

07024 OMAAR, $R$.

DIMINISHING PROSPECTS

WEST AFRICA, (3881) (FEB 92), 182-183.

THE SAYAGERY OF THE BATTLE FOR MOGADISHU HAS LEFT

SOMALIS STUMNED AND GROPING FOR HAYS TO HELP THEIR COUNTRY.

ELDERS ARE REGARDED AS THE ONLY SOMALIAN SOCIAL GROUP WITH
THE AUTHORITY TO PROMOTE THE SEARCH FOR PEACEFUL DIALOGUE. SIAD BARRE. THE DEPOSED OICTATOR, HAD SOUGHT TO UNDERMINE TRADITIONAL COMMUNAL AUTHORITY THROUGH A POLICY OF CORRUPTING, IMPRISONING, KILLING, OR EXILING ELDERS. FORTUNATELY, SOME ELDERS SURVIVED AND THE COMMUNITY'S RESPECT FOR THEM REMAINS INTACT. BUT THEY CANNOT BROKER AN ACCORD ALONE; THEY HILL NEED THE SUPPORT OF THE

INTERNATIONAL COMMUNITY.

07025 OMAAR, $R$.

SOMALIA: AT WAR WITH ITSELF

SOMALIA: AT WAR WITH ITSELF
CURRENT HISTORY $91(565)$ (MAY 92), 230-234

IN MOYEMBER 1991, FULL-SCALE CIVIL WAR BROKE OUT IN SOMALIA, MAKING IT A BLOODY BATTLEGROUND. THE WESTERN MEDIA SOMALIA, MAKING IT A BLOODY BATTLEGROUND. THE WESTERN MEDIA
HAS PORTRAYED THE SOMALIAN WAR AS A CLAN CONFLICT, IGNORING HAS PORTRAYED THE SOMALIAN WAR AS A CLAN CONFLICT, IGNO THE COMPLEX REALITY THAT IT IS ALSO AN INTENSE POWER STRUGGLE BETWEEN TWO AMBIITIOUS LEADERS (INTERIM PRESIDENT MOHAMMED ALI MAHDI AND GENERAL MOHAMMED FARRAH AIDID) AND A STRUGGLE FOR BASIC RESOURCES, INCLUDING FOOO, BY GROUPS OF IMPOVERISHED BUT HEAVILY ARMED CITIZE
WILL BE REQUIRED TO END THE FIGHTING.

07026 OMAAR, $R$

SOMALIA'S NIGHTMARE

WEST AFRICA, 75(3909) (AUG 92), 1382-1383.

DESCRIBING SOMALIA AS "THE WORST HUMAN TRAGEDY IN THE WORLO" IS IN DANGER OF BECOMG A CLICHE. UNFORTUNATELY, FORCE OF REPETITION IS NOT GALVANIZING THE WORLD INTO AVERTING AN EVEN GREATER CATASTROPHE. THIS ARTICLE EXPLORES THE AMBITIONS OF TWO MEN, GENERAL AIDID AND PRESIDENT MAHDI BOTH OF WHOM HAVE SHOWN THEMSELVES WILLING TO DESTROY THEIR NATION IN AN EFFORT TO SECURE ABSOLUTE POWER. HUNDREDS OF THOUSANDS OF SOMALIANS HAVE BEEN FORCED TO ABANDON THEIR HOMES IN RURAL AREAS OF THE SOUTH AND ARE POURING INTO URBAN AREAS IN SEARCH OF FOOD. THE HUGE IMFLUX INTO MOGADISHU IS A STARK STATEMENT ABOUT THE DESPERATION INSIDE THE REST OF THE COUNTRY. NEALY THREE MILLION ARE DISPLACED.

07027 OMARA-OTUNNU, A.

THE STRUGGLE FOR DEMOCRACY IN UGAMDA

JOURNAL OF MODERN AFRICAN STUDIES, 30(3) (SEP 92), 443-463.

JOURNAL OF MODERN AFRICAN STUDIES, 30(3) (SEP 92), 443-463. POLITICAL ELITE AND THEIR ENJOYMENT BY THE CITIZENRY HAS REMDERED PROBLEMATIC THE SUBSTANTIVE MEANING OF ANY RENDERED PROBLEMATIC THE SUBSTANTIVE MEANING OF ANY PARTICIPATORY SYSTEM OF GOVERNMENT, AND ITS REALIZATION ON IN MANY COUNTRIES. THIS ARTICLE OUTLINES THE VARIOUS HISTORICAL FACTORS THAT HAVE MADE DEMOCRACY OF PART REVELANCE TO AFRICA, AND THEN EXAMINES SOME OF THE PRONOUNCEMENTS AND ACTIONS OF THE NATIONAL RESISTANCE ARMY THE RHETORIC AND PRACTICE OF DEMOCRACY IN UGANDA.

07028 OMESTAD, $T$. WHY BUSH LOST FOREIGN POLICY, (89) (WIN 93), 70-81

IMMEDIATELY' AFTER DESERT STORM, GEORGE BUSH'S REELECTION SEEMED CERTAIN. HIS FOREIGN POLICY EXPERTISE SEEMED TO INSURE HIS VICTORY, BUT IRONICALLY IT DID LITTLE TO HELP HIM AT THE POLLS. THE GLOBAL TRANSFORMATION FOR WHICH BUSH TOOK CREDIT LIMITED THE POL ITICAL BENEFITS OF FOREIGN POLICY ISSUES. AFTER HOPEFULLY PROCLAIMING A NEW HORLD ORDER, BUSH HAD ACTED AS THOUGH SOME INVISIBLE HAND HOULD CONSTRUCT IT FOR HIM. THE ADMINISTRATION'S INTELLECTUAL EXHAUSTION PREVENTED IT FROM GETTING ON WITH ITS BASIC TASK: INTEGRATING DOMESTIC RENEWAL WITH AN ACTIVE FOREIGN POLICY AND MAKING EACH PRIORITY WORK FOR THE OTHER. FINALLY, THE AND MAKING EACH PRIORITY WORK FOR THE OTHER. FINALLY, THE GLORY OF BUSH'S SHINING MOMENT, VICTORY OVER IRAQ, FADED
LIKE A DESERT MIRAGE. IN ITS AFTERMATH CAM SERIOUS DOUBTS LIKE A DESERT MIRAGE. IN ITS AFTERMATH CAM
ABOUT JUOGMENT AND HIS CREDIBILITY.

07029 OMI, M.; DOMHOFF, G.

OMI, M.; DOMHOFF, G. SHIFTING THE BLAME: RADI

CRITICAL SOCIOLOGY 18(3) (FAL 92), 77-98.

IN THE POST-CIVIL RIGHTS ERA, CRITICS ON THE RIGHT HAVE INOICATED LIBERAL SOCIAL POLICIES FOR EXACERBATING THE VERY INDICATED LIBERAL SOCIAL POLTY THEY PURPORT TO ALLEVIATE. IN PROBLEMS OF RACISM AND POVERTY THEY PURPORT TO ALLEVIATE. IN VASTLY DISTINCT WAYS, THE FAR RIGHT AND NEOCONSERVATISM ATTEMPTED TO RESHAPE POPULAR CONCEPTIONS AND SCHOLARLY
WISDOM ABOUT RACE AND RACIAL EQUALITY. THEY HAVE TARGETED WISOOM ABOUT RACE AND RACIAL EQUALITY. THEY HAVE TARGETED THE LIBERAL STATE OF THE 1960 S AND 1970 S AS THE CAUSE OF A NEH RACIALLY UNJUST ORDER AND FUELED THE RESENTMENT OF WHITE AMERICANS TO LIBERAL SOCIAL POLICY. DESPITE THE ASCENDANCE OF THE FAR RIGHT AND NEOCONSERVATISM IN THE 1980S, THE REAGAN-BUSH YEARS HAVE NOT WITNESSED THE CONSOLIDATION OF A NEW COMMON SENSE WITH RESPECT TO RACE AND RACIAL POLICY. IN THE WAKE OF THE RIOTS IN LOS ANGELES AND
AN OPENING FOR A RENEWED DEBATE IS APPARENT.

07030 OMO-BARE, I

ECONOMIC DEVELOPMENT IN NIGERIA: AN EXAMINATION OF PUBLIC POLICY UNDER MILITARY AND CIVILIAN LED REGIMES

SCANDINAVIAN JOURNAL OF DEVELOPMENT ALTERNATIVES, 11(3)

(SEP 92), 91-110. 
THE PRINCIPAL CONCERM OF THIS STUDY IS TO ASSESS THE INFLUENCE OF MILITARY AND CIVILIAN REGIMES ON PUBLIC POLICY IN NIGERIA. THE KEY OUESTION UNDERLYING THIS ARTICLE IS: DOES IT MAKE ANY DIFFERENCE FOR A COUNTRY TO BE GOVERNED BY A MILITARY OR CIVILIAN GOVERMMENT? SOME RESEARCH INDICATE THAT REGIME TYPE DOES HAVE POLICY IMPLICATIONS, HHILE OTHERS SUGGEST THAT IT DOES NOT. TO DETERMINE THE LINKAGE (IF ANY) BETHEEN REGIME TYPE AND PUBLIC POLICY THIS ESSAY PROVIDES CRITICAL ANALYSIS OF THE IMPACT OF REGIME TYPE ON PUBLIC POLICY WITH A CASE STUDY OF REGIME PERFORMANCE ON INDUSTRIAL DEVELOPMENT IN NIGERIA/ THE PICTURE THAT EMERGES FROM THIS ANALYSIS SUGGESTS THAT MILITARY AND CIVILIAN REGIME SIN NIGERIA ARE INDISTINGUISHABLE IN TERMS OF ECONOMIC POLICY OUTPUTS AND OUTCOMES. FOR THE MAJORITY OF AFRICAN COUNTRIES, THE MILITARY COUP HAS BECOME SO FREQUENT AS TO CONSTITUTE A ROUTINE AND ANTICIPATED MEANS OF CHANGING TOP POLITICAL LEADERSHIP. COUPS IN NIGERIA HAVE AFFECTED REGIME CHANGE MUCH MORE FREQUENTLY THAN HAVE ELECTIONS AND OTHER FORMS OF CONSTITUTIONALLY SANCTIONED METHOOS OF CHANGE. THUS, REFERRING TO NIGERIA, ITS FORMER PRESIDENT SHEHU SHAGARI PROCLAIMED: "IN THIS COUNTRY THERE ARE, IN THE END, ONLY THO PARTIES, THE CIVILIANS AND THE SOLDIERS."

07031 OMOLO, L.

NO HOME FOR THE OAU?

MEW AFRICAN, (287) (AUG 91), 18.

THE 27TH' ORGANIZATION OF AFRICAN UNITY (OAU) SUMMIT ENDED IN THE NEW NIGERIAN FEDERAL CAPITAL, ABUJA, WITHOUT FINDING A NEH HOME FOR THE OAU SECRETARIAT. SEVERAL COUNTRIES HAD VOLUNTEERED TO HOST THE OAU AFTER ETHIOPIAN PEOPLE'S REVOLUTIONARY DEMOCRATIC FRONT REBELS TOOK THE TRADITIOHAL OAU HEADQUARTERS OF ADDIS ABABA. ASIDE FROM ITS FAILURE TO FIND A NEH HOME, THE MOST IMPORTANT ISSUE DISCUSSED AT THE CONFERENCE WAS THE CHANGES IN SOUTH AFRICA. MODERATE AFRICAN STATES CALLED FOR A LESSENING OF ECONOMIC SANCTIONS AGAINST SOUTH AFRICA IN RECOGNITION OF F.W. DE KLERK'S REFORMS. HOHEYER. THE HARD-LINE MAJORITY INSISTED ON MAINTAINING SANCTIONS AND HON OUT IN THE END.

07032 ONEAL $F$

THE PROVOCATIVE PUBLIC SECTOR: DOMESTIC POLITICAL PROTEST AND PUBLIC SECTOR GROWTH IN THE OECD, 1965-1982

PUBLIC CHOICE, 70(1) (APR 91), 51-69.

THIS ARTICLE EXAMINES THE RELATIONSHIP OF FISCAL

EXPANSION AND DOMESTIC POLITICAL PROTEST IN THE INDUSTRIAL

DEMOCRACIES OF THE ORGANIZATION FOR ECONOMIC COOPERATION AND

DEYELOPMEMT (OECD) THE CENTRAL THEORY ADVANCED IS THAT WHEN

DEVELOPMENT (OECD) THE CENTRAL THEORY ADVANCED IS THAT WHEM

ECONOMIC SCARCITY LIMITS CITIZENS ACCEPTANCE OF CONTINUED

PUBLIC SECTOR EXPANSION, AND WHEN CITIZENS PERCEIVE THEIR

CONTROL OVER PUBLIC SECTOR GROWTH TO BE OUTHEIGHED BY OTHER INFLUENCES IN THE POLICY-MAKING PROCESS, THEN THE PROPENSITY RESULTING ULTIMATELY IN AN INCREASED INCIDENCE OF PROTE THE STUDY FINDS THAT PUBLIC SECTOR GROHTH EMERGES AS A SIGNIFICANT FACTOR POSITIVEL AFFECTING PROTEST, 'R INIL RELATED TO AVERAGE PROTEST.

07033 ONILE-ERE, T.

THE RAWLINGS EQUATION

WEST AFRICA, (3900) (JUM 92), 1008-1009.

IT IS VERY PROBABLE THAT THE PNDC WILL FORM A PARTY TO CONTEST THE UPCOMING ELECTIONS AND THAT PNDC CHAIRMAM RAWL INGS WILL BE A PRESIDENTIAL CANDIDATE. BY VOHING TO BE A ONE-TERM PRESIDENT, RAWLINGS HOPES TO PROVIDE A DEGREE OF CONT INUINTY IN THE TRANSITION TO CONSTITUT IONAL GOVERMMENT WHILE SIMULTANEOUSLY OFFERING THE PROSPECT OF GRADUAL CHANGE AND INCREASED ACCOUNTABILITY.

07034 OPELLO JR.,.

PORTUGUESE' REGIONALISM IN THE TRANSITION FROM THE "ESTADO NOVO" TO THE SINGLE MARKET

REGIONAL POLITICS \& POLICY, 2(1,2) (SPR 92), 162-187 THE PURPOSE OF THIS ARTICLE IS TO REPORT THE RESULTS OF

RESEARCH CARRIED OUT ON SUB-NATIONAL GOVERNMENT IN PORTUGAL AND THE ROLE THAT IT CAN PLAY IN ACCELERATING THE TRANSITION TO THE INTERNAL MARKET. IT BEGINS HITH A DISCUSSION OF PORTUGUESE REGIONALISM BEFORE AND AFTER 25 APRIL 1976. THE RESULTS OF SURVEYS ARE PRESENTED IN THO SECTIONS. THE ARTICLE CONCLUDES WITH AN ANALYSIS OF THE POLICY AREAS LOCAL OFFICIALS AND PRIVATE INTEREST GROUP LEADERS WOULD SUPPORT AS PART OF FUTURE COMMUMITY IMTER-REGIOMAL IMITIATIVES AMD CO-OPERATIVE PROGRAMS.

07035 OPLATKA, A.; HOTTINGER, A.; KAHL, J.; SCHMID, U. DISMAMTI IMG THE SOYIET, EMPIRE SWISS REVIEW OF WORLD AFFAIRS, 41(10) (JAN 92), 6-13. AUTHORS REPORT ON POL ITICAL CONDITIONS IN CENTRAL ASIA, AUTHORS REPORT ON POLITICAL CONDI
ARMENIA, GEORGIA, AND MONGOLIA.

07036 OPLATKA, A.

RUSSIA'S RETREAT FROM HORLD AFFAIRS

SHISS REVIEH OF HORLD AFFAIRS, 42(7) (OCT 92), 4-5.
ONLY A YEAR AFTER THE ATTEMPTED COUP OF AUGUST 1991, RUSSIA FINDS ITSELF CONFINED TO TERRITORIAL BORDERS MUCH LIKE THOSE IN FORCE WHEN PETER THE GREAT CAME TO POWER THREE CENTURIES AGO. THUS FAR, THE RUSSIANS SEEM RESIGNED TO THEIR NEH STATUS. MANY ACCUSATIONS COULD BE HURLED AT THE RUSSIAN NEW STATUS. MANY ACCUSATIONS COULD BE HURLED AT THE RUSSIA LEADERSHIP AROUND PRESIDENT YELISIN BUT NOT--AT LEAST THE TIME BEING--THAT IT IS PURSUING A COUF

07037 ORDESHOOK, $P$.

A POLITICAL THEORY PRIMER

ROUTLEDGE, 1992,324

"A POLITICAL THEORY PRIMER" IS DESIGNED AS AN

INTRODUCTORY COURSE FOR STUDENTS IN THE APPLICATION OF GAME THEORY TO MODELING POL ITICAL PROCESSES. EXAMINING THE PHENOMENA THAT POWER POLITICAL MACHINERIES-ELECTIONS, LEGISTLATIVE AND COMMITTEE PROCESSES, AND INTERNATIONAL CONFLICT, THE BOOK ATTEMPTS TO ANSWER FUNDAMENTAL QUESTIONS ABOUT THEIR NATURE AND FUNCTION. THE STUDENT WHO COMPLETES A COURSE AROUND THIS TEXT WILL BE EQUIPPED TO READ NEARLY ALL OF THE PROFESSIONAL LITERATURE THAT MAKES USE OF GAMETHEORETIC AMALYSIS.

07038 ORIORDAN, T.

STABILITY AND TRANSFORMATION IN ENVIRONMENTAL GOVERMMENT POLITICAL QUARTERLY (THE), 62(2) (APR 91), 167-185.

THIS ARTICLE IS BASED ON THE PREMISE THAT BRITISH SOCIAL ALUES ARE MORE ENDURING THAN POLITICAL TRENDS. THE AUTHOR VALUES ARE MORE ENDURING THAN POLITICAL TRENDS.

CITES STUOIES THAT SHOW SOCIAL CONCERNS HAVE NOT
SUBSTANTIALLY CHANGED DESPITE A DECADE OF THATCHERISM. HE SUBSTANTIALLY CHANGED DESPITE A DECADE OF THATCHERISM. HE
FURTHER ARGUES THAT THE UNCHANGED VALUES INCLUDE CARING, FURTHER ARGUES THAT THE UNCHANGED VALUES INCLUDE CARING, SHARING, AND SACRIFICING WITH A VIEH TO ENSURING A GREATER GLOBAL GOOD. THE REAL CHANGE HAS OCCURRED NOT IN VALUES BUT FURTHER THAT GLOBAL GOOD.

07039 ORKIN, M.

\$DEMOCRACY KNOWS NO COLOUR': RATIONALES FOR GUERRILLA INVOL VEMENT AMONG BLACK SOUTH AFRICANS

JOURNAL OF SOUTHERN AFRICAN STUDIES, 18(3) (SEP 92), 642-669.

THE ARMED STRUGGLE WHICH THE MILTARY WING (MK) OF THE AFRICAN MATIONAL CONGRESS, IS TOLD FROM THE PRESPECTIVE OF COMPARING THREE BLACK SOUTH AFRICANS' ACCOUNTS--ONE FROM EACH OF THE THREE DECADES OF MK'S STRUGGLE--OF THE CIRCUMSTANCES ANO MOTIVATION THROUGH WHICH THEY CHOSE TO BECOME GUERRILLAS. THESE MEN WERE INTERVI EHD HITH THE PURPOSE OF PREPARING EXPERT WRITTEN EVIDENCE TO BE PRESENTED IN COURT ON THEIR BEHALF IN MITIGATION OF SENTENCE. THIS ARTICLE BEGINS HITH THEIR SOCIO-HISTORICAL BACKGROUND AND CONTINUES ON WITH THEIR PHILOSOPHIES. THE NARRATIVES SPEAK LARGELY FOR THEMSELVES.

07040 ORLANS, H.

AFFIRMATIVE ACTION IN HIGHER EDUCATION

ANMALS OF THE AMERICAN ACADEMY OF POLITICAL AND SOCIAL SCIENCE, (523) (SEP 92), 144-158.

SCIENCE, (523) (SEP 92), 144-158.
AFFIRMATIVE ACTION IN HIGHER EDUCATION HAS SOUGHT TO ANCREASE THE NUMBER OF FEMALE AND MINORITY STUDENTS AND INCREASE THE NUMBER OF FEMALE AND MINORITY STUDENTS AND
FACULTY IN MOST EDUCATIONAL FI ELDS, LEVELS, AND RANKS. VACULTY BEGAN IN THE 1960'S, BEFORE THE GOVERNMENT IMPOSED FACULTY BEGAN IN THE $1960^{\prime}$ ' , BEFORE THE GOVERNMENT IMPOSED ELABORATE REQUIREMENTS TO PROMOTE THE EMPLOYMENT OF WOMEN AND MINORITY FACULTY. WOMEN'S GROUPS PRESSING TO CHANGE ADMISSION AND EMPLOYMENT PRACTICES HAVE MADE FAR GREATER GAINS THAN BLACKS. ASIANS HAVE ALSO MADE SIGNIFICANT GAINS AS GRADUATE STUDENTS, FACULY, ARO RESEARCH STTUS OF BLACKS SCIENCES AND ENGINEERING. THE TROUBLESOME STATUS OF BLACK IN HIGHER EDUCATION REFLECTS, IN SHALL PART, THE BLACK

STUDENTS PREFERENCE FOR THE PROFESSIONS OVER GRADUATE SCHOOL AND ACADEMIC LIFE; IN LARGER PAR
THE IMPACT OF SLUM LIFE AND SCHOOLS.

07041 ORNSTEIN, M.

ASPECTS OF THE POLITICAL AND PERSON SOCIOLOGY OF AIDS: KNOHLEDGE, POLICY ATTITUDES, AND RISK

CANADIAN REVIEH OF SOCIOLOGY AND ANTHROPOLOGY, 29(3) (AUG 92), 243-265.

BASED ON RESEARCH INTO CANADIAN PUBLIC OPINION REGARDING AIDS. THE AUTHOR LOOKS AT THE RELATIONSHIP BETWEEN KNOWLEGE AND ATTITUDES ABOUT HIV-INFECTED INDIVIDUALS. STUDYING ATTITUDES ABOUT AIDS OFFERS IMPORTANT INSIGHTS ABOUT CANADIANS' SUPPORT FOR CIVIL LIBERTIES AND ABOUT PUBLIC POL. ICY MAKING INVOL VING AIDS. THE AUTHOR DESCRIBES A MODEL OF THE DETERMINANTS OF AND INTERRELATIONS BETHEEN ABOUT AIDS AND HIV INFECTION, ATTITUDES CONCERNING GOVERNMENT POLICIES FOR DEALING WITH AIDS, AND THE PREVALENCE OF BEHAVIOR THAT INVOLVES RISK OF HIV INFECTI
A HOSTILE CLIMATE OF PUBLIC OPINION DISCOURAGES POLICY A HOSTILE CLIMATE OF PUBLIC OPINION DISCOURAGES POLICY MAKERS FROM SUPPORTING EFFORTS TO DEAL WITH THE EPIDEMIC AND
PREYENTS INOIYIDUALS FROM RECOGNIZING WHEN THEY ARE AT RISK.

07042 ORNSTEIN, N.J.

FOREIGN POLICY AND THE 1992 ELECTION 
FOREIGN AFFAIRS, 71(3) (SUM 92), 1-16

IT SEEMS LIKELY THAT THE 1992 U.S. PRESIDENTIAL ELECTION WILL FOCUS ON DOMESTIC ISSUES, BUT FOREIGN POLICY WILL NOT BE COMPLETELY ABSENT. IN THIS ESSAY, THE AUTHOR DISCUSSES WHAT ROLE FOREIGN POLICY WILL PLAY, WHO WILL BENEFI POLITICALLY, ANO HOW THIS MIGHT AFFECT AMERICA'S ROLE IN THE POST-COLD HAR WORLD.

07043 ORR, D.

AFTER THE ELECTIONS

WEST AFRICA, (3917) (OCT 92), 1716.

AFTER NEARLY THREE DECADES OF MATIONAL AND CIVIL CONFLICT, ANGOLA HAS FINALLY MADE THE TRANSITION TO DEMOCRACY. DURING THE LAST TWO DAYS OF SEPTEMBER 1992, THE AND PARLIAMENTARY ELECTIONS. THE RUL ING POPULAR MOVEMENT FOR THE LIBERATION OF ANGOLA (MPLA) HON A SUBSTANTIAL VICTORY THE LIBERATION OF ANGOLA (MPLA) WON A SUBSTANTIAL INDEPENDENCE OF ANGOLA (UNITA).

07044 ORTTUNG, R.W.

ST. PETERSBURG: ECONOMIC REFORM AND DEMOCRATIC INSTITUTIONS RFE/RL RESEARCH REPORT, 1(16) (APR 92), 13-17.

SINCE IT CAME TO POWER IN THE SPRING OF 1990, THE ST. PETERSBURG CITY GOVERNMENT HAS HAD CONSIDERABLE OIFFICULTY CARRYING OUT EFFECTIVE ECONOMIC REFORM. ITS PROBLEMS ARE A DIRECT RESULT OF THE POOR DELINEATION OF POWERS AMONG THE CITY'S INSTITUTIONS. WHILE ANATOLII SOBCHAK, THE MAYOR AND CHAIRMAN OF THE SOVIET, FAVORS A STRONG EXECUTIVE AND A CONCENTRATION OF POWER' IN ORDER TO EXPEDITE THE IMPLEMENTATION OF POLICY, THE DEPUTIES PERCEIVE THE CONCENTRATION OF POWER AS UNDEMOCRATIC AND PREFER A MORE COLLECTIVE APPROACH TO DECISION-MAKING. THESE DIFFERING VIEWS HAVE BEEN THE CAUSE OF CONSIDERABLE TENSION. THE REORGANIZATION OF THE CITY GOVERNMENT, WITH THE CREATION OF THE OFFICE OF MAYOR, HAS FAILED TO ADDRESS THIS PROBLEM ADEQUATELY.

07045 ORZECHOWSKI, W.

REAGANOMICS AND THE USE OF COLLECTIVE REBATES

PUBLIC CHOICE, 69(3) (MAR 91), 311-322.

TO A LARGE EXTENT THE LITERATURE ON GOVERMMEMT GROWTH AND REGULATION CASTS A PESSIMISTIC SHADOW. THE LITERATURE IS CAREFUL TO ENUMERATE THE MEANS BY WHICH SPECIAL INTEREST CAREYUL HAYE USED TE THE MEANS BY WHICH SPECIAL INTEREST ENHANCING SPENDING PROBLEMS AND REGULATIONS. IN ADDITION THE GENERAL IMPRESSION IS THAT IT IS VERY DIFFICULT TO "TURM THE GENERAL IMPRESSION IS THAT IT IS VERY DIFFICULT TO "TURM BACK THE TIDE. THIS PAPER ARGUES THAT COLLECTIVE REBATES ARE AN EFFECTIVE WAY TO REDUCE GOVERNMENT INTERVENTION. A COLLECTIVE REBATE IS A RELATIVELY LARGE AND TANGIBLE BENEFIT TO COMPENSATE CITIZENS FOR THE LOSS OF GOVERMMENT SPENDING TO COMPENSATE CITIZENS
GROHTH OR REGULATIONS.

07046 OSAGHAE, E.E.

THE STATUS OF STATE GOVERMMENTS IN NIGERIAN FEDERALISM PUBLIUS: THE JOURNAL OF FEDERALISM, 22(3) (SUM 92),

$181-200$

NIGERIAN STATES HAVE EXPERIENCED UNPRECEDENTED REDUCTIONS IN THEIR POWERS AND HAVE ALMOST COMPLETELY LOST THEIR AUTONOMY. THE ENTRENCHMENT OF LOCAL GOVERMMENT AUTONOMY AND THE LOSS OF SOME STATE POWERS TO LOCAL AUTHORITIES, THE REDUCTION OF THE STATES' FINANCIAL PONERS AND THEIR SHARE OF THE FEDERAL ACCOUNT, AND THE HIGHLYCENTRALIZED THO-PARTY SYSTEM HAVE, HITHIM THE FRAMEWORK OF STRUCTURAL ECONDMIC ADJUSTMENT AND THE TRANSITION TO CIVIL RULE, HORSENED THE POSITIION OF THE STATE GOVERMMENTS. HOWEYER, WITH THE ESTABL I SHMENT OF CIVILIAN GOVERNANCE IN THE STATES AND THE RETURN OF CONSTITUTIONAL RULE IN JANUARY 1993, THE STATE GOVERMHENTS MAY BEGIN TO REASSERT THEIR AUTONOMY.

07047 OSBAND, $K$.

ECONOMIC CRISIS IN A SHORTAGE ECONOMY

JOURNAL OF POLITICAL ECONOMY, $100(4)$ (AUG 92), 673-690.

IT IS NOT UNUSUAL FOR REFORMING SOCIALIST ÉCONOMIES TO RELAX WAGE CONTROLS WITHOUT HARDENING BUDGET CONSTRAINTS ON ENTERPRISES OR FREEING THE PRICES OF CONSUMER GOODS. THIS POLICY CAN BE DANGEROUSLY DESTABILIZING. HHILE HIGHER WAGES PERMIT WORKERS TO PURCHASE MORE OF SOME GOOOS, THEY ALSO TEND TO EXACERBATE SHORTAGES AND TO BREED WASTE AND CORRUPTION. BEYOND A CERTAIN LEVEL, ECONOMY-WIDE WAGE HIKES WILL HORSEN HORKER WELFARE. THIS IS TRUE WHETHER DEFICIT WILL WORSEN WORKER HELFARE. THIS IS TRUE WHETHER DEFICIT GOODS ARE STRICTLY RATIONED, ARE SOLD RANDOMLY AT OFFICTAL

"INSIDERS" ONLY AT BLACK-MARKET PRICES.

07048 OSBORN, A.

JOHN MAJOR: CLARK KEMT OR SUPERMAN?

EUROPE, (317) (JUN 92), 27

THIS ARTICLE BRIEFLY EXAMINES GREAT BRITAIN'S PRIME MINISTER JOHN MAJOR, HIS LIFE, POLITICAL EXPERIENCE AND BELIEFS. OFTEN CHARACTERIZED AS BEING PAINFULLY ORDINARY,
ORDINARINESS IN ORDER TO RISE THROUGH THE RANKS OF THE CONSERVATIVE PARTY AND SUCCESSFULLY WIN A NATIONAL ELECTION. HIS SPEECHES REVEAL HIS PRIMARY AMBITIONS: TO ELIMINATE RACISM, SNOBBERY, PRIVILEGE AND CLASS, AND TO MAKE THE UNITEO KIMGDOM a NATION "AT EASE WITH ITSELF."

07049 OSBORNE, J.A.

ICENSING WITHOUT LAW: LEGALIZED GAMBLING IN BRITISH COLUMBIA

CANADIAN PUBLIC ADMINISTRATION, 35(1) (SPR 92), 56-74. OVER THE PAST TWO DECADES, BRITISH COLUMBIA HAS

EXPERIENCED THE RAPID GROWTH OF LEGAL PUBLIC GAMING, WHICH MUST BE LICENSED OR CONDUCTED BY THE PROVINCE. THUS, A NEW SPHERE OF PROVINCIAL PUBLIC POLICY HAS BEEN CREATED. THIS PAPER STUDIES THE EMERGENCE OF THIS POLICY IN BRITISH CAPER STUOIES THE EMERGENCE OF THIS POLICY IN BRITISH ADMINISTER IT. THE RECOGNIZED INDICES OF ADMINISTRATIVE LAH-ADMINISTER IT. THE RECOGNIZED INOICES OF ADMINISTRATIVE LAH-
STATUTORY AUTHORITY, STRUCTURE, FUNCTION, DISCRETION, AND REMEDIES--ARE APPLIED, SUBJECTING THIS AREA OF PUBLIC ADMINISTRATION TO CRITICAL SCRUTINY. IT IS CLEAR THAT THE LICENSING OF LOTTERY SCHEMES IN BRITISH COLUMBIA IS CONDUCTED BY AN ADMINISTRATIVE AGENCY THAT IS NOT A
STATUTORY CREATION AND USES LICENSING TOOLS THAT ARE DEVOID OF STATUTORY AUTHORITY. THIS IS, IN EFFECT, LICENSING WITHOUT LAW. THERE IS A DUTY TO MAKE LAW IN SUCH A SITUATION, IN ORDER TO MINIMIZE UNFETTERED DISCRETIONARY POWERS.

07050 OSBORNE, $P$

MODERNITY IS A QUALITATIVE, NOT A CHRONOLOGICAL, CATEGORY NEW LEFT REVIEW, (192) (MAR 92), 65-84.

THE AUTHOR ENDEAVORS TO EXCAVATE THE MANY-LAYERED MEANINGS OF THE MODERN AND TO ADVANCE THE VIEN THAT MODERNITY ITSELF SHOULD BE UNDERSTOOD AS A QUALITATIVE, RATHER THAN A CHRONOLOGICAL, CATEGORY. HE ARGUES THAT BOTH MARSHALL BERMAN AND PERRY ANDERSON HAVE PLACED TDO MUCH RELIANCE ON A CONCEPTUALIZATION OF UNEVEN CAPITALIST DEVELOPMENT AS CAPITALIST MODERNIZATION. WHILE ANDERSON HAS ALSO FAILED TO SEE THAT MODERNITY IS THE CHARACTERISTIC JUXTAPOSITION OF UNEVENNESS AND SIMULTANEITY.

07051 OSLA, K

LEADERSHIP AND FOLLOHSHIP: NIGERIA'S PROBLEMS OF GOVERMANCE SCANDINAVIAN JOURNAL OF DEVELOPMENT ALTERNATIVES, $11(3)$ (SEP 92), 175-194.

FOR THREE DECADES, NIGERIA HAS BEEN POLITICALLY INDEPENDENT. THIS PAPER CENTERS ON THEORIES OF LEADERSHIP INOEPENDENT. THIS PAPER CENTERS ON THEORIES OF LEADERSH
AND FOLLOWERSHIP. ITS PREMISE IS THAT FOR DEMOCRACY TO MATURE AND SURVIVE IN NIGERIA, EFFECTIVE LEADERSHIP AND INFORMED FOLLOWERSHIP MUST BE IN PLACE. AN ANALYSIS OF POLLRME FOLLOWERSHIP MUST BE IN PLACE. AN ANALYSIS OF POLITICAL LEADERSHIP AND FOLLOWERSHIP OFFERS A CLEARER
UNDERSTANDING OF THE FACTORS THT HOULD CONTRIBUTE TOWARDS AN EVOLUTION OF A WORKABLE DEMOCRATIC SYSEM AND IS PRESENTED.

07052 OSHAN, $S$.

SABAH STATE ELECTIONS: IMPLICATIONS FOR MALAYSIAN UNITY ASIAN SURVEY, 32(4) (APR 92), 380-391.

"SABAH'S RIGHTS" HAVE FAR-REACHING IMPLICATIONS FOR NATIONAL INTEGRATION AND UNITY IN MALAYSIA. AS THE ELECTIONS OF 1990 REVEALED, SABAH WANTS TO MAINTAIN CERTAIN RIGHTS EVEN IF THIS UPSETS THE BALANCE OF STATE-FEDERAL RELATIONS, AND IT BECOMES CLEAR THAT IT WILL BE MORE DIFFICULT TO WORK TOWARD NATIOMAL UNITY. IN THIS ARTICLE, THE AUTHOR DISCUSSES THE MAJOR ISSUES THAT CONCERN SABAHANS AND THEIR IMPACT ON THE STATE'S POLITICS AND RELATIONS WITH THE CENTER. THE BACKGROUND AND THE PARTI BESATU SABAH POSITION; SABAHFEDERAL RELATIONS; AND IMPLICATIONS OF THE 1990 ELECTIONS ARE EACH REVIEWED.

07053 OSTAS, D.

INSTITUTIONAL REFORM IN EAST-CENTRAL EUROPE: HUNGARIAN AND POLISH CONTRACT LAH

JOURNAL OF ECONOMIC ISSUES, 26 (2) (JUN 92), 513-524.

EAST-CENTRAL EUROPE IS AWASH IN LEGAL REFORMS. THIS ARTICLE IDENTIFIES AND CRITIQUES THE CHANGES IN CONTRACT LAW CURRENTLY UNDERHAY IN HUNGARY AND POLAND. SOURCES INCLUDE ENGLISH TRANSLATIONS OF THE RELEVANT CONTRACT CODES, BOTH PRIOR TO AND FOLLOWING THE CURRENT REFDRMS. IN ADOITION, THE ARTICLE DRAWS UPON INTERVIEWS WITH HUNGARIAN AND POLISH LAWYERS ACADEMICS, ENTREPRENEURS, AND GOVERNMENT OFFICIALS CONDUCTED DURING THE AUTHOR'S JULY 1991 VISIT TO BUDAPEST AND WARSAH. IT CLOSES HITH AN ANALYSIS OF THE TOUGH POLICY AND WARSAH. IT CLOSES WITH AN ANALYSIS OF THE TOU

07054 OSTERMAN, $P$.

NEW LESSONS FOR STATE TRAINING

RECENTLY THERE HAS BEEN A SURGE OF INTEREST IN TRAINING POLICY, GENERATED LARGELY BY CONCERNS ABOUT THE UNITED STATES: INTERNATIONAL COMPETITIVENESS. OFFICIALS ARE CONCERNED WITH A HIDE RANGE OF ISSUES, INCLUDING SCHOOL REFORM AND SCHOOL-TO-HORK TRANSITION. THIS PAPER FOCUSES ON ONE ASPECT OF THE CURRENT DISCUSSION, THE EFFORT TO IMPROVE THE SKILLS OF ADULT WORKERS BY CREATING EMPLOYER-CENTERED PUBLIC TRAINING PROGRAMS. WHILE THESE PROGRAMS ARE 
POLITICALLY POPULAR, THERE ARE DISADVANTAGES TO THIS APPROACH, INCLUDING THE DANGER THAT LOH-INCOME AND UNEMPLOYED WORKERS WILL FALL THROUGH THE GAPS. THE AUTHOR DISCUSSES THE PROS AND CONS OF VARIOUS TRAINING MODELS THAT STATE GOVERNMENTS MAY ADOPT.

07055 OSTROM, E.

COMMUNITY AND THE ENDOGENOUS SOLUTION OF COMMONS PROBLEMS JOURMAL OF THEORETICAL POLITICS, 4(3) (JUL 92), 343-351.

THE AUTHOR DISCUSSES FOUR QUESTIONS ABOUT THE CONCEPT OF COMMUNITY: (1) IS COMMUNITY IMPORTANT FOR THE SOLUTION OF COMMON-POOL RESOURCE (CPR) PROBLEMS? (2) IS COMMUNITY SUFFICIENT FOR THE SOLUTION OF CPR PROBLEMS? (3) IS COMMUNITY NECESSARY FOR THE SOLUTION OF CPR PROBLEMS? (4) ARE SOLUTIONS TO CPR PROBLEMS ROBUST OVER THE LONG TERM WI THOUT ENFORCERS?

07056 OSTROM, E.; GARDNER, R.; HALKER, J. COVENANTS WITH AND HITHOUT A SHORD: SELF-GOVERHANCE IS POSSIBLE

AMERICAN POLITICAL SCIENCE REVIEH, 86(2) (JUN 92), 404-417. CONTEMPORARY POL ITICAL THEORY OFTEN ASSUMES THATT INDIVIDUALS CANNOT MAKE CREDIBLE COMMITMENTS WHERE

SUBSTANTIAL TEMPTATIONS EXIST TO BREAK THEM UNLESS SUCH COMMITMENTS ARE ENFORCED BY AN EXTERMAL AGENT. ONE SUCH SITUATION MAY OCCUR IN RELATION TO COMMON POOL RESOURCES WHICH ARE NATURAL OR MAN-MADE RESOURCES WHOSE YIELD IS SUBTRACTABLE AND HHOSE EXCLUSION IS NONTRIVIAL (BUT NOT NECESSARILY IMPOSSIBLE). EXAMPLES INCLUDE FISHERIES, FORESTS, GRAZING RANGES, IRRIGATION SYSTEMS, AND GROUNDWATER BASINS. EMPIRICAL EVIDENCE, HOWEVER, SUGGESTS THAT APPROPRIATORS IN COMMON POOL RESOURCES DEVELOP CREDIBLE COMMITMENTS IN MANY CASES WITHOUT RELYING ON EXTERMAL AUTHORITIES. THE AUTHORS PRESENT FINDINGS FROM A SERIES OF EXPERIMENTS EXPLORING (1) COVENANTS ALONE (BOTH ONE-SHOT AMD REPEATED COMHUNICATION OPPORTUNITIES); (2) SHORDS ALONE (REPEATED OPPORTUNITIES TO SANCTION EACH OTHER); AND (3) COVENANTS COMBINED WITH AN INTERNAL SHORD (ONE-SHOT COMMUNICATION FOLLOWED BY REPEATED OPPORTUNITIES TO SANCTION EACH OTHER).

07057 OSHALD, D.J.

J.S. MILL'S A PRIORI DEDUCTIVE METHODOLOGY: A CASE STUDY IN POST-MODERN PHILOSOPHY OF SCIENCE

REVIEW OF SOCIAL ECONOHY, 48(2) (SUM 90), 172-197.

THE PURPOSE OF THIS ARTICLE IS TO SHOW THAT JOHN STUART MILL'S PHILOSOPHY OF SCIENCE PROVIDES SUPPORTING EVIDENCE FOR THE INTERPRETATION OF SCIENCE HELD BY CONTEMPORARY OR FOR THE INTERPRETATION OF SCIENCE HELD BY CONTEMPORARY OR
POST-MODERN PHILOSOPHY OF SCIENCE. IN ADDITION. THE ARTICLE POST-MODERN PHILOSOPHY OF SCIENCE. IN ADDITION, THE ART
ADORESSES SOME CONFLICTING INTERPRETATIONS OF MILL'S ADDRESSES SOME CONFLICTIN
PHILOSOPHY OF SCIENCE.

07058 OTAYEK, $R$.

THE DEMOCRATIC RECTIFICATION IN BURKINA FASO JOURNAL OF COMMUNIST STUDIES, 8 (2) (JUM 92), 82-104. BURKINA FASO WAS THE FIRST FRANCOPHONE AFRICAN STATE TO INITIATE POL ITICAL AND ECONOHIC REFORMS. WIDESPREAD DISENCHANTMENT HITH THE FAILURES AND PRIVATIONS OF THE SANAKARA REGIME FORCED THE FRONT POPULAIRE OF BLAISE COMPAORE TO PROMOTE A "OEMOCRATIC OPENING." HOWEVER, CAMPAORE'S COMMITMENT TO OEMOCRACY IS QUESTIONABLE. HE FIRST USED REFORM TO LEGITIMIZE HIS REGIME. WHICH HAD MURDERED ITS WAY TO POWER IN 1987, AND HAS SUBSEQUENTLY SOUGHT TO STRENGTHEN HIS PERSONAL HOLD OVER THE COUNTRY BY CREATING A NEW POLITICAL PARTY AND WINNING THE PRESIDENTIAL ELECTION OF DECEMBER 1991, HICH WAS BOYCOTTED BY THE OPPOSITION. ALTHOUGH THERE HAS BEEN A RETREAT FROM STATE CAPITALISM AND A SHIFT TO THE PRIVATE SECTOR, GOVERMMENT VIOLENCE TOWARDS ITS OPPONENTS, A FRAGMENTED OPPOSITION, AND DOUBTS ABOUT CONTINUED FRENCH PRESSURE FOR REFORM MAKE FOR AN UNCERTAIN DEMOCRACY IN BURKINA FASO. ON THE POSITIVE SIDE, THE COUNTRY HAS A VIGOROUS HISTORY OF OPPOSING DEPOTISM, WHICH DERIVES IN PART FROM A WELL-ORGANIZED TRADE UNION MOVEMENT, AND, PERHAPS MORE IMPORTANTLY, FROM THE STRUCTURES OF MOSSI TRADITIONAL SOCIETY.

07059 OTIS, P.

POLITICAL AND MILITARY CONSIDERATIONS OF THE KURDISH CASE, 1991: A HINDOW OF OPPORTUNITY?

SMALL WARS \& INSURGENCIES, 2 (1) (APR 91), 61-90.

THE KURDS PRESENT A PARTICULAR PROBLEM FOR THE STATES OF THE MIDOLE EAST. THEY PROVIDE THE WORLD WITH AN ARCHETYPAL TEST OF THE VALIDITY OF MODERN STATEHOOD. THIS ARTICLE TEST OF THE VALIDITY OF MODERN STATEHOOD. THIS ARTICLE ARGUES THAT WHILE THE PROBLEMS OF THE KURDS HAVE LONG BEEN
RELEGATED TO THE BOTTOM OF WORLD CONCERNS IT MAY NOW BE TIME RELEGATED TO THE BOTTOH OF WORLD CONCERNS IT MAY NOW BE TIME
TO TAKE ANOTHER LOOK AT THEM. IT EXPLORES THEIR HISTORY. TO TAKE ANOTHER LOOK AT THEM. IT EXPLORES THEIR HISTORY,
CULTURE, POLITICAL THEORY AND PRACTICE, AND CONTEMPORARY CULTURE, POLITICAL THEORY AND PRACTICE, AND CONTEMPORARY
POLITICAL AND MILTARY GOALS. CONCLUDING WITH A POLITICAL AND POL ITICAL AND MILTARY GOALS. CONCLUDING WITH A POLITICAL AND
MILITARY ASSESSMENT IT SUGGESTS THAT SUPPORT FOR THE KURDISH CAUSE BY ANY OTHER STATE IN THE REGION IS UNLIKELY UNLESS THAT STATE HAVE THE BACKING OF OTHER REGIONAL POWERS AND IT IS TO THEIR ADVANTAGE.

07060 OTITE, A.

THE RULING ELITE AND THE ROLE OF GOVERNMENT IN MIGERIAN
POLITICAL ECONOMY

SCANDINAVIAN JOURNAL OF DEVELOPMENT ALTERNATIVES, 1113 (SEP 92), 111-118.

THIS PAPER IS CONCERNED WITH THE TASK OF LOOKING CRITICALLY AT NIGERIA'S LEADERSHIP STRUCTURE AND CHANGES ACROSS TIME; AND TO SOME EXTENT USE THIS TO PROGNOSTICATE INTO WHAT TO EXPECT IN THE LEADERSHIP-STRUCTURE, COME 1992. THIS IS USED TO A LARGE EXTENT TO VERIFY THE ROLE OF GOVERMMENT IN THE DEVELOPMENT OF THE POLITICAL ECONOMY OF THE COUNTRY. IN PURSUIT OF THIS, IT LOOKS AT THE "CIRCULATING ELITES THEORY" AND SUBSTANTIATES WHETHERE THERE IS A CIRCULATING ELITE CLASS OR RECYCLING ELITE CLASS IN NIGERIA, AND FINALLY, THE EFFECT OF THIS ON THE FUTURE OF NIGERIAN POLITICAL ECONOMY.

07061 OTSUKA, J.

THE YEM'S NEW ROLE

FAR EASTERN ECONOMIC REVIEN, 155(1) (JAN 92), 44. THIS ARTICLE ARGUES THAT THE WORLD IS FACING THE POSSIBILITY OF A SEVERE SHORTAGE OF FUNDS, AND JAPAN NEEDS TO PLAY A BIGGER PART IN RELIEVING THE PRESSURE ON INTERNATIONAL LIQUIDITY. THE MATTER HAS BECOME MORE URGENT AS A RESULT OF THE BREAK-UP OF THE SOVIET UNION AND THE RAPID LIBERALIZATION OF EASTERN EUROPE. THE ARTICLE CONCLUDES THAT THE EURO-INTERBANK MARKET, THE MAIN CHANNEL FOR PRIVATE INTERNATIONAL CAPITAL MOVEMENTS, HILL SOON EXPERIENCE A SHARP LIQUIDITY CRUNCH. FOR THIS TO BE AVOIDED, JAPAN WILL HAVE TO STRENGTHEN ITS ABILITY TO SUPPLY INTERNATIONAL LIOUIDITY. FOR GEOGRAPHICAL AND HISTORICAL REASONS, JAPAN HAS A CLEAR RESPONSIBILITY TO SUPPLY CAPITAL TO DEVELOPING EAST ASIA. ON THIS SCORE, THERE ARE GOOD REASONS TO THINK THAT JAPAN AND THE REST OF EAST ASIA WILL
INCREASINGLY COMPLEMENT EACH OTHER IN TERMS OF FLOW OF CAPITAL WITHIN THE REGION.

07062 OTTATI, V.C.; RIGGLE, E.; STEENBERGEN, M.R.

THE COGNITIVE AND AFFECTIVE COMPONENTS OF POLITICAL ATTITUDES: MEASURING THE DETERMINANTS OF CANDIDATE EVALUATIONS

POLITICAL BEHAVIOR, 14(4) (DEC 92), 423-442.

PAST RESEARCH SUGGESTS THAT BELIEFS AND EMOTIONS OPERATE AS PARTIALLY DISTINCT DETERMINANTS OF POLITICAL ATTITUDES. IN ADOITION, WILE POSITIVE AND NEGATIVE BELIEFS ABOUT A IN ADOITION, WILE POSITIVE AND NEGATIVE BELIEFS ABOUT A NEGATIVE EMOTIONS HAVE BEEN DEMONSTRATED TO BE RELATIVELY NEGATIVE EMOTIONS HAVE BEEN DEMONSTRATED TO BE RELATIVELY
INDEPENDENT. IN THIS PAST RESEARCH, BELIEFS AND EMOTIONS INDEPENDENT. IN THIS PAST RESEARCH, BELIEFS AND EMOT IONS
HAVE BEEN ASSESSED WITH DIFFERENT MEASURES. YET CURRENT HAVE BEEN ASSESSED WITH DIFFERENT MEASURES. YET CURRENT
MODELS OF SURVEY RESPONDING SUGGEST THAT RESPONSES TO SURVEY ITEMS ARE OFTEN INFLUENCED BY THE MANNER IN WHICH THE RESEARCHER POSES THE QUESTIONS. AS SUCH, IT IS NOT CLEAR WHETHER THE UNIQUENESS OF THESE BELIEF AND EMOTION MEASURES REFLECTS A VALID DIFFERENCE BETWEEN TWO UNDERLYING CONSTRUCTS OR MERELY AN ARTIFACTUAL DIFFERENCE INDUCED BY DIFFERING METHODS OF MEASUREMENT. IN THIS STUDY, BELIEFS AND EMOTIONS ARE SHOWN TO OPERATE AS PARTIALLY UNIQUE PREDICTORS OF CANDIDATE EVALUATION EVEN HWEN EMPLOYING CORRESPONDING METHODS OF MEASUREMENT. THE INDEPENDENCE OF POSITIVE AND NEGATIVE EMOTION, HOWEVER, ONLY ARISES WHEN EMPLOYING A DICHOTOMOUS MEASURE. WHEN EMPLOYIMG ORDINAL MEASURES, POSITIVE AND NEGATIVE EMOTIONS CONTAIN A SUBSTANTIAL COMPONENT OF BIPOLARITY.

07063 OTTAHAY, M.

MEDIATIÓN IN A TRANSITIONAL CONFLICT: ERITREA ANMALS OF THE AMERICAN ACADEMY OF POLITICAL AND SOCIAL SCIENCE, (518) (NOV 91), 69-81.

AFTER 30 YEARS OF HAR, THE CONFLICT BETHEEN THE ETHIOPIAN GOVERNMENT AND THE ERITREAN NATIONALISTS WAS FURTHER THAN EVER FROM A SOLUTION. LIBERATION MOVEMENTS HAD BEEN ORGANIZED IN OTHER AREAS OF THE COUNTRY MOST NOTABLY IN TIGRE, WHERE THE TIGREAN PEOPLE'S LIBERATION FRONT HAD WON MAJOR VICTORIES. WHAT HAD STARTED AS A BILATERAL CONFLICT BETHEEN THE GOVERMMENT AND THE ERITREAN NATIONALISTS THUS ENTERED A PHASE OF TRANSITION TO A MUL ILATERAL CONFLICT. THIS MADE THE PROSPECT OF NEGOTIATED SOLUTION MORE REMOTE. BY DEFINITION, MANY OF THE CONDITIONS NECESSARY FOR SUCCESSFUL NEGOTIATIONS ARE ABSENT IN TRANSITIONAL CONFLICTS, MOST NOTABLY A MUTUALLY-HURTING

IN TRANSITIONAL CONFLICTS, MOST NOTABLY A MUTUALLY
STALEMATE AND THE EXISTENCE OF VALID SPOKESMEN.

07064 OTTAWAY, M.

NATIONALISM UNBOUND: THE HORN OF AFRICA REVISITED SAIS REVIEH, 12(2) (SUM 92), 111-128.

NATIONALISM HAS BEEN CENTRAL TO THE POLITICS OF THE HORN, BUT IT HAS HAD VERY DIFFERENT MEANINGS AND DIFFERENT IMPLICATIONS IN EACH COUNTRY. THO QUESTIONS ARE RAISED ABOUT THESE NATIONALISMS. FIRST, IS THERE AN INEVITABLE PROGRESSION FROM COUNTRY-WIDE NATIONALISM TO ETHNIC NATIONALISM, AND FINALLY TO EVER MORE LOCAL CLAIMS, UNTIL THE SOMALI SITUATION IS DUPLICATED ELSEHWERE? AND SECOND, IS THE HORN A UNIQUE CASE IN AFRICA, OR IS THE TRIUMPH OF NATIONALISM THERE JUST A PRELUDE TO WHAT MAY HAPPEN IN THE REST OF THE CONTINENT? 
07065 OTTE, T.

CONTINUITY AND CHANGE: NATO'S ROLE AFTER THE COLD WAR ARMS CONTROL, 13(2) (SEP 92), 234-251

THE END OF THE COLD WAR HAS BROUGHT ABOUT A FUNDAMENTAL CHANGE IN THE POLITICAL AND SECURITY ENVIRONMENT OF THE WESTERN ALLIANCE. ONLY WITH THE EASTERN AND CENTRAL EUROPEAN REVOLUTIONS OF 1989 DID BOTH SECURITY DIMENSIONS COME BACK ON TO NATO'S POLITICAL AGENDA; AND SECURITY CONCEPT FOR THE $1990 S$ AND BEYOND HAS AGAIN TO EMBRACE THE CREATION OF A STABLE POLITICAL ORDER AND PROTECTION FROM POTENTIAL MILITARY CONFLICTS. THE REAL PROBLEM TO BE ADORESSED BY NATO IS HOW NATO WILL HAVE TO RESPOND TO THE CHALLENGES OF THE IS HOW NATO WILL HAVE TO RESPOND TO THE CHALLENGES OF THE
NEW ERA AND WHAT ROLE IT IS TO PLAY IN THE PROCESS OF CHANGE NEW ERA AND WHAT ROLE IT IS TO PLAY IN THE PROCESS OF CHANGE
WITHIN AND OUTSIDE THE TREATY AREA. THIS PAPER DISCRIBES THE WITHIN AND OUTSIDE THE TREATY AREA. THIS PAPER DISCRIBES NEW CHALLENGES AND SECURITY RISKS AND ANALYZES NATO'

07066 OTTENBERG, M.A.

OPERATIONAL IMPLICATIONS OF MIDDLE EAST BALLISTIC MISSILE PROLIFERATION

DEFENSE ANALYSIS, 7(1) (MAR 91), 3-20

THE AUTHOR ARGUES THAT SURFACE-TO-SURFACE BALLISTIC MISSILES (SSMS) MAY NOT PROVIDE THE COMBAT EDGE THAT HAS BEEN ADVERTISED FOR THESE HEAPONS, AND THAT OPERATIONAL IMPLICATIONS LIMIT SSM USEFULNESS' FOR COMBAT. THIS ARTICLE ADORESSES THESE AND RELATED ISSUES BY EXAMINING SYRIAN SSM CAPABILITIES DURING FUTURE ARAB-ISRAELI HOSTILITIES. IT ESTIMATES LIKELY TARGET SETS, DETERMINES SYRIAN SSM CAPABILITIES, DISCUSSES EXPECTED ISRAELI COUNTERMEASURES, AND PRESENTS A NET ASSESSMENT ON THE UTILITY OF THESE HEAPONS IN SELECTED CDMBAT OPERATIONS. THE ARTICLE CONCLUDES WITH SEVERAL GENERAL OBSERVATIONS CONCERNING CURRENT SSM CAPABILITIES, ISRAELI ATBM EFFORTS, AND SSM

ANTIPROL IFERATION EFFORTS.

07067 OTTOSEN, R.

THE MEDIA AND THE GULF WAR REPORTING: ADVERTISING FOR THE ARMS INDUSTRY?

BULLETIN OF PEACE PROPOSALS, 23(1) (MAR 92), 71-84.

THIS ARTICLE ARGUES THAT THE STRUCTURAL FRAMEHORK THAT SURROUNDED MASS MEDIIA NEWS-REPORTING OF THE 1991 GULF WAR SURROUNDED MASS MEDIA NEWS-REPORTING OF THE 1991 GULF WAR
MAKES IT MORE CORRECT TO TALK ABOUT CONTROLLED MILITARY MAKES IT MORE CORRECT TO TALK ABOUT CONTROLLED MILITARY COMHUNICATION THAN TRADITIONAL NEHS REPORTING. THE AUTHOR
ARGUES THAT THE UNITED STATES PRACTICED MILITARY CENSORSHIP ARGUES THAT THE UNITED STATES PRACTICED MILITARY CENSORSH NOT ONLY TO ENSURE VICTORY IN THE GULF WAR BUT ALSO TO
IMPROVE THE IMAGE OF THE MILITARY BY CREATING THE MYTH OF IMPROVE THE IMAGE OF THE MILITARY BY CREATING THE MYTH OF A "CLEAN AND HUMANE WARFARE" THROUGH THE PROPAGANDA MYTH "SMART BOMBS." IN THIS PERSPECTIVE, TV CDVERAGE HAD A SPINOFF EFFE
INDUSTRY.

07068 OTUATHAIL, G.; AGNEW, J.

GEOPOLITICS ANO DISCOURSE: PRACTICAL GEOPOLITICAL REASONING IN AMERICAN FOREIGN POLICY

POLITICAL GEOGRAPHY QUARTERLY, 11(2) (MAR 92), 190-204. THIS PAPER ARGUES FOR THE RE-CONCEPTUALIZATION OF GEOPOLITICS USING THE CONCEPT OF DISCOURSE. FOUR THESES EXPLICATING RE-CONCEPTUALIZATION ARE OUTLINED INCLUDING THE DISTINCTION BETWEEN FORMAL AND PRACTICAL GEOPOLITICS. THESE ARGUMENTS ARE ILLUSTRATED BY A GENERAL DISCUSSION OF PRACTICAL GEOPOL ITICAL REASONING IN U.S. FOREIGN POLICY. GEOPOLITICAL REASONING, IT IS CONCLUDED, IRONICALLY WORKS BY BEING ANTI-GEOPOLITICAL.

07069 OTUNNU, 0.

EMERGING TRENDS IN THE NEW WORLD SITUATION

ROUND TABLE, 324(324) (OCT 92), 401-410

THE AUTHOR PROPOSES TO TOUCH ON A FEW ELEMENTS, A FEH FACTORS, AND, A FEW CHALLENGES, WHICH IN HIS VIEW,

CHARACTERIZES THE EMERGING HORLD SITUATION IN ITS

WHICH IT REPRESENTS. HE EXPLORES: SOVEREIGNTY; MOUNTING

WHICH IT REPRESENTS. HE EXPLORES: SOVEREIGNTY; MOUNTING

COLLECTIVE SECURITY; U.S. POWER; THE MEREGING GLOBAL AGENDA;

COLLECTIVE SECUR
AND, SOLIDARITY.

07070 OUDENAREN, J.

EUROPEAN INTEGRATION AS SEEN FROM THE UNITED STATES
INTERNATIONAL SOCIAL SCIENCE JOURNAL, 131(131) (FEB 92), INTERNATIO

AS 1992 APPROACHES, THE UNITED STATES IS VIEHING THE PROGRESS OF EUROPEAN ECONOMIC AND POLITICAL INTEGRATION WITH A MIXTURE OF SUPPORT AMD APPREHENSION. HOWEVER, THERE HAS ALWAYS BEEN A CERTAIN AMBIVALENCE ON THE AMERICAN SIDE ABOUT EUROPEAN UNITY, PARTICULARLY WHEN IT HAS TAKEN UNFORESEE
AND UNINTENDED (BY THE UNITED STATES) DIRECTIONS AND AND UNINTENDED (BY THE UNITED STATES) DIRECTIONS AND TODAY, US POLICY-MAKERS LOOK TO A STRONGER AND MORE UNITED EUROPE TO TAKE THE LEAD IN HELPING THE NEW DEMOCRACIES IN CENTRAL AND EASTERN EUROPE TO ACHIEVE ECONOMIC AND POLITICAL STABILITY, TO ANCHOR A UNITED GERMANY IN A BROADER FRAMEWORK THAT WILL PREVENT A POTENTIALLY DANGERIOUS RENATIONALIZATION OF GERMAN SECURITY POLICY, AND FOR HELP IN DEALING WITH THE DAUNTING ECONOMIC, POLITICAL, AND SECURITY CHALLENGES IN THE
THIRD WORLD.

07071 OUGAARD, M.

THE U.S. STATE IN THE NEW GLOBAL CONTEX

COOPERATION \& CONFLICT: NORDIC JOURNAL OF INTERMATIONAL POLITICS, $27(2)$ (JUN 92), 131-162.

THE AUTHOR CONSIDERS SOME DEEP TRANSFORMATIONAL TRENDS MARKING THE GLOBAL SOCIAL FORMATION AND DISCUSSES THE QUESTIONS THEY POSE FOR THE ROLE OF THE NATION-STATE. HE FOCUSES ON ECONOMIC INTERNATIONAL IZATION,

INTERNATIONALIZATION OF CIVIL SOCIETY, AND THE EVOLUTION OF THE INTERNATIONAL POLITICAL SUPERSTRUCTURE. ONE OF THE QUESTIONS CONCERNING THE ROLE OF THE STATE IS WHETHER AND QUESTIONS CONCERNING THE ROLE OF THE STATE IS WHETHER AND
HOW IT CONTRIBUTES TO THESE PROCESSES. THE AUTHOR ALSO HOW IT CONTRIBUTES TO THESE PROCESSES. THE AUTHOR ALSO
EXAMINES THE U.S. STATE IN THIS PERSPECTIVE FOCUSING ON GATT EXAMINES THE U.S. STATE IN THIS PERSPECTIVE FOCUSING ON
AND ECONOMIC POLICY COORDINATION. HE CONCLUDES THAT IT

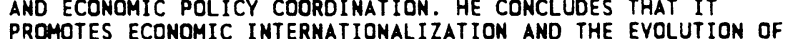
PROHOTES ECONOMIC INTERNATIONALIZATION AND THE EVOLUTION OF SELECTIVE MANNER, DEFENDING HARD CORES OF NATIONAL SELECTIVE MA
SOVEREIGNTY.

07072 OUTSHOORN, J. WOMEN AND POLITICS IN THE NETHERLANDS: A REVIEW OF THE LITERATURE EUROPEAN JOURNAL OF POLITICAL RESEARCH, 21(4) (JUN 92), 453-468

THIS SURVEY DISCUSSES THE LITERATURE ON WOMEN AND POLITICS IN THE NETHERLANDS UNDER FIVE HEADINGS. IT BEGINS WITH AN EXAMINATION OF THE FEH STUDIES PRODUCED BEFORE THE RISE OF SECOND-WAVE FEMINISM AND WOMEN'S STUDIES. THEN IT DISCUSSES THE NEW LITERATURE IN THREE MAJOR SUBFIELDS: POLITICAL BEHAVIOR, INCLUDING HOMEN'S ORGANIZATIONS; ISSUES AND PUBLIC POLICY; AND POLITICAL THEORY. THE AUTHOR USED THREE CRITERIA IN SELECTING THE LITERATURE: IT CONTAINS NEW EMPIRICAL FINDINGS: IT CRITIQUES EXISTING THEORY; OR IT RECONSTRUCTS KEY CONCEPTS.

07073 OVERBY, L.M.; HENSCHEN, 8.M.; STRAUSS, J.; HALSH, M.H. COURT ING CONSTITUENTS? AN ANALYSIS OF THE SENATE CONFIRMATION VOTE ON JUSTICE CLARENCE THOMAS AMERICAN POLITICAL SCIENCE REVIEW, 86(4) (DEC 92 ), AMERICAN 1006 .

THE INCREASING PUBLIC ATTENTION PAID TO SUPREME COURT NOMINATIONS HAS ELEVATED THE SALIENCE OF SENATE CONFIRMATION BATTLES, RAISING INTERESTING QUESTIONS ABOUT THE IMPACT OF THE AUTHORS EXPLORE THIS RELATIONSHIP USING A LOGISTICAL THE AUTHORS EXPLORE THIS RELATIONSHIP USING A LOGISTICAL REGRESSION MODEL TO EXAMINE THE IMPACTS OF AFRICAN-AMERICAM CONSTITUENCY SIZE AND THE PROXIMITY OF REELECTION ON THE ROLL CALL BEHAVIOR OF SENATORS ON THE CLARENCE THOMAS
CONFIRMATION VOTE. THEIR ANALYSES INDICATE THAT THESE CONFIRMATION VOTE. THEIR ANALYSES INDICATE THAT THESE
FACTORS WERE BOTH STATISTICALLY AND SUBSTANTIVELY FACTORS WERE BOTH STATISTICALLY
SIGNIFICANT IN THE THOMAS CASE.

07074 OVERY, R.J. AIR POWER ANO THE ORIGINS OF DETERRENCE THEORY BEFORE 1939 JOURNAL OF STRATEGIC STUDIES, 15(1) (MAR 92), 73-101. THE ROOTS OF THE MODERN THEORY OF DETERRENCE ARE TO BE FOUND IN THE EVOLUTION OF STRATEGIC AIR POWER BEFORE WORLD WAR II. AIR POWER THEORY AND FORCE STRUCTURE BEFORE 1939 SHOW STRONG LINES OF CONTINUITY WITH THE POST-WAR WORLD. INDEED, MANY UNDERLYING ASSUMPTION AND MODES OF THOUGHT IN DETERRENCE THEORY CAN BE TRACED BACK TO THE INTER-WAR ERA. MANY CENTRAL ARGUMENTS IN CONTEMPORARY DETERRENCE THEORY HAVE THEIR SOURCE IN SIMILAR 1930'S ARGUMENTS ABOUT FIRSTSTRIKE CAPABILITY. BUT A FULL-FLEDGED DETERRENCE THEORY DID NOT EXIST BEFORE WORLD WAR II, BECAUSE THE DEVELOPMENT OF THE THEORY HAS BEEN A SLOH, INCREMENTAL PROCESS, BOUND UP CLOSELY HITH TECHMOLOGICAL CHANGE, POLITICAL RECEPTIVITY, AND COMBAT EXPERIENCE.

07075 OHUSU, $M$.

DEMOCRACY AND AFRICA: A VIEW FROM THE VILLAGE JOURNAL OF MODERN AFRICAN STUDIES, 30(3) (SEP 92), 369-396. THIS IS AH EXPLAMATIOY OF HHAT IT HAS IM EX-COIOMIAL HEST AFRICAN SOCIETIES THAT PRODUCES POL ITICAL INSTABIL WEST AFRICAN SOCIETIES THAT PROOUCES POLITICAL INSTABILITY AND SUPPORTED AUTHORITARIAN AND MILITARY ORDER, AND WHAT HAD TO HAPPEN TO MAKE LIBERAL DEMOCRACY POSSIBLE. THE ARTICLE EXPLORES THE EXISTENCE OF THO RELATED BUT OFTEN CONFUSED SET OF PROBLEMS; THE PRACTICAL ISSUES WHICH ARISE FROM THE EFFORTS MADE TO IMPOSE FOREIGN POLITICAL MODELS ON SOCIETIES WITH A DIFFERENT HISTORY AND UNIQUE COMBINATION OF INDIGENOUS TRADITIONS, ECONOMIC CONDITIONS, AND EXTERNAL CONSTRAINTS; AND, THE THEORETICAL QUESTIONS WHICH RELATE TO THE METHODS, AIMS, AND PROCESSES OF LIBERALI
DEMOCRATIZATION IN THIRD-HORLD COUNTRIES.

07076 OYE, K.A. ECONOMIC DISCRIMINATION AND POLITICAL EXCHANGE--HORLD POLITICAL ECONOMY IN THE 1930 S AND 1980 S PRINCETON UNIVERSITY PRESS, 1992, 256

THE AUTHOR OF THIS WORK SHOWS HOW ECONOMIC DISCRIMINATION CAN FOSTER INTERMATIONAL ECONOMIC OPENNESS BY FACILITATING POLITICAL EXCHANGE. PREFERENTIAL POLICIES 
BENEFIT THE PARTIES TO AGREEMENTS AT THE EXPENSE OF THIRD PARTIES. THE AUTHOR DEMONSTRATES THAT THE EXPECTED BENEFITS OF INCLUSION AND THE EXPECTED COST OF EXCLUSION PLAY A PIVOTAL ROLE IN BROADENING ANTI-PROTECTIONIST DOMESTIC COALITIONS AND IN DRANING THIRD NATIONS INTO LIBERALIZING INTERNATIONAL NEGOTIATIONS. IN HIS VIEH, EXPLICIT ECONOMIC DISCRIMINATION IN THE 1930 S SLOWED AND ULTIMATELY REVERSED THE MOVEMENT TOWARD ECONOMIC CLOSURE, AND DISCRIMINATORY ARRANGEMENTS UNDER SUPER 301 , CANADI AN-AMERICAN FREE TRADE AND THE EUROPEAN CDMHUNITY SI INGLE INTEGRATED MARKET REDUCED BARRIERS TO INTERNATIONAL MOVEMENTS OF GOODS AND CAPITAL IN THE 1980S.

07077 OZEROV, M.

IS A COMMONHEALTH OF NATIONS POSSIBLE IN THE USSR? ROUND TABLE, 321 (321) (JAN 92), 19-22.

SOVIET PROSPECTS FOR BECOMIMG A COMMONWEALTH ARE EXAMINED. COMMONWEALTH MACHINERY IS EXPLORED AS WELL AS THE PROBLEMS AND POTENTIAL THAT THE USSR MAY COME TO EXPECT. THE AUTHOR REPORTS ON HIS RESEARCH ON THIS SUBJECT AND CONCLUDES WITH A QUOTE FROM A COMHONWEALTH HEADS OF GOVERNMENT MEETING IN 1991--" WE CANHOT, AND SHOULD NOT, SIMPLY LOOK ON WHILE IN $1991--"$ HE CANHOT, AND SHOULD NOT, SIMPLY LOOK ON WHILE
PEOPLES WHO HAVE LIBERATED THEMSELVES FROM TOTALITARIANISM PEOPLES WHO HAVE LIBERATED
FIGHT FOR A BETTER LIFE."

07078 OZERSKY, J.

THE ENLIGHTENMENT THEOLOGY OF POLITICAL CORRECTNESS TIKKUN, 6(4) ( JUL 91), 35-39

THIS ARTICLE EXAMINES THE PHENOMENON OF MULTICULTURALISH AND ITS ENFORCEMENT ARM, POLITICAL CORRECTNESS (PC). IT ARGUES THAT THE PC MOVEMENT SETS OUT TO CHANGE THE WORLD ON TRANSCENDENT MORAL GROUNDS, AND IN DOING SO, ITS ALIGNMENT WITH PRACTICAL, PIECEMEAL, WORLDLY AIMS SHOULD BE UNDERSTOOD FOR WHAT IT IS. PC IS AN ENLIGHTENMENT THEOLOGY; RELIGIOUS IN ITS MODES OF DISCOURSE, AND RELIGIOUS IN ITS WORLDVIEW. UNFORTUNATELY, THE IDEAL PERSON OF PC WOULD BE WITHOUT MALICE, WITHOUT JUDGHENT, WITHOUT BIAS, WITHOUT FORMATIVE ROLE MODELS OF ONE OR THE OTHER SEX: IN SHORT, WITHOUT ANY INDIVIDUAL PERSONALITY AT ALL.

07079 OZUYE, 0

BLACK SEA ECONOMIC COOPERATION

MEDITERRANEAN QUARTERLY: A JOURNAL OF GLOBAL ISSUES, 3(3) (SUM 92), 48-54.

POLITICAL AND ECONOMIC CHANGES IN THE BLACK SEA REGION HAVE BROUGHT TURKISH PRESIDENT TURGUT OZAL'S VISION OF ECONOMIC AND POLITICAL COOPERATION IN THE REGION CLOSER TO FUL.FILMENT. THE DIVISIONS ANO CONFRONTATIONS THAT WERE SO FULFILMENT THE DIVISIONS AND CONFRONTATIONS THAT WERE SO
COMMON IN THE PAST--LARGELY A RESULT OF THE COLD WAR--ARE COMMON IN THE PAST--LARGELY A RESULT OF THE COLD WAR--ARE
BEING REPLACED BY AN UNDERSTANDING OF PEACE AND DIALOGUE. BEING REPLACED BY AN UNDERSTANDING OF PEACE AND DIALOGUE.
THE EMERGENCE OF COMMONLY SHARED VALUES, SUCH AS DEMOCRACY, THE EMERGENCE OF COMMONLY SHARED VALUES, SUCH AS DEMOCRACY, HUMAN RIGHTS, AND FREE ENTERPRISE, HAS CREATED FAVORABLEC CONDITIONS FOR ALL NATIONS TO EMBARK UPON NEH FORMS OF OF COMPLEX FACTORS--REVOLUTIONARY PROGRESS IN COMHUNICATIONS OF COMPLEX FACTORS--REVOLUTIONARY PROGRESS IN COMHUN AND INFORMATION TECHNOLOGIES; INCREASED MOBILITY OF INDIVIDUALS, GOOOS, SERVICES, AND CAPITAL; DIFFUSION OF MODERN TECHNOLOGY; AND THE GLOBALIZATION OF MARKETS RESULTED IN AN INTERDEPENENCE POSITIED AS THE MOST SIGNIFICANT DEVELOPMENT OF THE LAST DECADE. GIVEN THES CONDITIONS, TURKEY PUT FORTH THE BLACK SEA ECONOMIC COOPERATION PROJECT HITH A VIEH TO DEVELOPING AMD DIVERSIFYING EXISTING ECONOMIC RELATIONS AMONG THE BLACK SEA COUNTRIES BY MAKING EFFICIENT USE OF THE ADVANTAGES ARISING FROM THEIR GEOGRAPHICAL PROXIMITY, THEIR TRADITIONAL TIES, AND THE COMPLIMENTARY NATURE OF THEIR ECONOMIES.

07080 PAARLBERG, R.; LIPTON, M.

CHANGING MISSIONS AT THE WORLD BANK

NORLD POLICY JOURNAL, VIII(3) (SUM 91), 475-498.

NOT MANY YEARS AGO, THE hORLD BANK DEDICATED A SIZABLE

PORTION OF ITS RESOURCES TO THE TASK OF AGRICULTURE AND

RURAL DEVELOPMENT IN POOR COUNTRIES. UNDER THE PRESIDENCY OF ROBERT S. MCNAMARA (1968 TO 1981), THE BANK BOLDLY REDEFINED ITSELF AS A NEH CHAMPION OF THE POOR AND DEVOTED SIGNIFICANT PORTION OF ITS RAPIDLY GRDWING LOAN BUDGET TO AGRICULTURAL AND RURAL DEVELOPMENT PROJECTS. SINCE 1980 , HOHEVER. THE BANK HAS BEEN TAKING ON NEW PROBLEMS WHICH HAVE DIVERTED ITS ATTENTION--AND RESOURCES--AWAY FROM ITS EARLIER COMMITMENT TO AGRICUL TURAL AND RURAL DEVELOPMENT. THIS ARTICLE SEEKS TO EXPLAIN THE REASONS BEHIND THIS UNFORTUNATE SHIFT IN THE WORLD BANK'S ORIENTATION. THE AUTHORS ALSO SHOW HOH THE BANK'S SHIFT HAS HAD FAR-REACHING CDNSEOUENCES, FOR THE BANK NOT ONLY DISBURSES MONEY BUT, BY WAY OF EXAMPLE, THE BANK NOT ONLY DISBURSES MONEY

07081 PAARLBERG, R.

HOW AGRICUL TURE BLOCKED THE URUGUAY ROUND

SAIS REVIEW, $12(1)($ WIN 92), 27-42.

THE REASONS FOR THE FIVE YEARS OF SLUGGISH PROGRESS IN THE URUGUAY ROUND OF GATT MEGOTIATIONS HAS BEEN "AGRICULTURE. "EVER SINCE THE ROUND bEgAN, THE U.S. AND THE EC HAVE OISAGREED OVER HOW MUCH TO REDUCE SUBSIDIES TO THEIR AGRICUL TURAL PROOUCERS. RECENTLY, THESE DIFFERENCES HAVE
BEEN NARROWED. THIS ARTICLE EXPLORES U.S. FARM POLICY FRUSTRATION AT HOME, PRESUMED ADVANTAGES FROM INTERNATIONALIZING THE REFORM PROCESS, AND EARLY RESISTANCE TO THE U.S. REFORM PLAN. IT CONCLUDES THAT THE AGRICULTURAL REFORM AGREEMENT THAT MAY EVENTUALLY EMERGE FROM THE URUGUAY ROUND WILL BE QUITE DIFFERENT FROH THE SORT OF AGREEMENT CONTEMPLATED BY U.S. TRADE OFFICIALS WHEN THE ROUND BEGAN IN 1986.

07082 PACELLE, R. JR.; BAHN, L. SUPREME' COURT AUTHORITY IN THE JUDICIARY: A STUDY OF REMANDS

AMERICAN POLITICS QUARTERLY, 20(2) (APR 92), 169-191. IN THE RELATIONSHIP BETWEEN THE SUPREME COURT AND LONER COURTS, ONE IMPORTANT ISSUE IS THE EXTENT TO WHICH LOWER COURT JUDGES RECOGNIZE AND RESPOND TO THE SUPREME COURT'S AUTHORITY. THIS ARTICLE EXPLORES THE COURT'S AUTHORITY THROUGH A STUDY OF CASES REMENDED BY THE COURT DURING THE 1965-74 TERMS. THE RELATIONSHIP BETHEEN THE OUTCOMES OF CASES IN THE LOWER COURTS AFTER SUPREME COURT REMANDS AND SEVERAL CONDITIONS THAT SEEM LIKELY TO AFFECT THE STRENGTH OF THE COURT'S AUTHORITY ARE EXAMINED. THE STATISTICAL RESULTS INDICATE THAT MOST OF THESE CONDITIONS HAVE A SIGNIFICANT IMPACT ON OUTCOMES. MORE BROADLY, THESE RESULTS SIGNIFICANT IMPACT ON OUTCOMES. MORE BROADLY, THESE RESULTS PROVIDE EVIDENCE THAT THE COURT'S AUTHORITY IS A SIGNIFICANT
FORCE IN SHAPING THE BEHAVIOR OF JUOGES IN THE LOWER COURTS.

07083 PACHON, H.; DESIPIO, L.

LATINO ELECTED OFFICIALS IN THE 1990'S

PS: POLITICAL SCIENCE AND POLITICS, XXV(2) (JUN 92), 212-217.

THE AUTHORS EXAMINE ONE FACET OF THE EXPANDING LATINO POL ITICAL CLOUT--THE GROHING NUMBER OF HISPANICS ELECTED TO OFFICE AT ALL LEVELS OF GOVERNMENT IN THE UNITED STATES.

07084 PACK, J.R. BIDS, DIDS, SIDS, SADS: PRIVATE GOVERNMENTS IN URBAN AMERICA

BROOKINGS REVIEW, 10(4) (FAL 92), 18-21

IN MANY CITIES, THERE IS A TREND TOWARD "PRIVATE

GOVERMMENTS" MADE UP OF DOWNTOWN PROPERTY OHNERS AND THEIR TENANTS, WHO CANNOT GET FROM THEIR MUNICIPAL GOVERMMENT THE SERVICES THEY CONSIDER ESSENTIAL TO REMAIN IN BUSINESS. KNOWN AS BUSINESS IMPROVEMENT DISTRICTS (BIDS), DOWNTOWN IMPROVEMENT DISTRICTS (DIDS), SPECIAL IMPROVEMENT DISTRI (SIDS), OR SPECIAL ASSESSMENT DISTRICTS (SADS), THESE MAINTAIN THE VALUE OF THEIR PROPERTIES AND BUSINESSES BY IMPROVING LOCAL PUBLIC SERVICES BEYOND WHAT THE CITY CAN PROVIDE.

07085 PACK, J.R.

YOU RIDE I'LL PAY: SOCIAL BENEFITS AND TRANSIT SUBSIDIES BROOKINGS REVIEH, $10(3)$ (SUM 92), 48-51.

IN ARGUING AGAINST PUBLIC SUBSIDIES FOR MASS TRANSIT, IT IS ANGUING AGAINST PUBLIC SUBSIDIES FOR MASS TRANSIT, I BENEFICIARIES OF MASS TRANSIT. SOCIETY AS A WHOLE BENEFITS BECAUSE THERE ARE FEWER CARS ON THE ROADS, FEWER TRAFFIC ACCIDENTS, LESS AIR POLLUTION, AND FEWER PARKING GARAGES. BUT THE QUESTION IS HOW THE BENEFITS AND THE SUBSIDIE COMPARE. IF THE SOCIAL BENEFITS DERIVED FROM PUBLIC TRANSPORTATION ARE DEMONSTRABLY SMALLER THAN THE SUBSIDY, IT MAY BE TIME TO REALLOCATE RESOURCES AHAY FROM TRANSIT SUBSIDIES.

07086 PADDOCK, J.

EXTENT OF NATIONALIZATION OF REPUBLICAN POLICY POSITIONS IN THE POST-NEW DEAL ERA

SOCIAL SCIENCE QUARTERLY, 72(1) (MAR 91), 163-171 THIS STUDY EXAMINES THE DEGREE OF INTRAPARTY INTEGRATION IN REPUBLICAN POLICY POSITIONS DURING A PERIOD ON HHICH THE REPUBL ICAN NATIONAL COMMITTEE HAS INCREASINGLY NATIONALIZING PARTY AFFAIRS THROUGH THE PROVISION OF SERVICES AND MONEY TO STATE AND LOCAL CANDIDATES AND ORGANIZATIONS. MATIONAL AND STATE REPUBLICAN PLATFORMS FROM THE PERIOD 1956-80 ARE CONTENT ANALYZED. THE RESULTS SUGGEST THAT THE GOP MAINTAINED IT TRADITIONALLY DECENTRALIZED STRUCTURE DURING A PERIOD IN WHICH THERE WAS A NATIOMALIZATION OF OTHER PARTY FUNCTIONS.

07087 PADDOCK, J.

INTER-PARTY IDEOLOGICAL DIFFERENCES IN ELEVEN STATE INTER-PARTY IDEOLOGIC

WESTERN POLITICAL QUARTERLY, 45(3) (SEP 92), 751-761.

THE AUTHOR PROBES INTER-PARTY IDEOLOGICAL DIFFERENCES AMONG 11 STATE PARTIES BETHEEN 1956 AND 1980: A PERIOD OF INCREASING IDEOLOGICAL POLARIZATION IN THE NATIONAL PARTY ORGANIZATIONS. THE CENTRAL OUESTION IS WHETHER STATE ORGANIZATIONS, LIKE THE NATIONAL PARTIES, MOVED AHAY FROM PRAGMATIC CENTRISM AMD TOMA ORIENTATION. HE ANALYZES DEMOCRATIC AND REPUBLICAN PLATFORMS FROM 11 STATES ON THE BASIS OF A FIVE-POINT SCALE MEASURING IDEOLOGICAL DIRECTION. THE RESULTS SHOW SOME MOVEMENT TOWARD GREATER INTER-PARTY IDEOLOGICAL DIFFERENCES. ALTHOUGH THE 
STATE PARTIES HARDLY BECAME POLARIZED, THE EVIDENCE SUGGESTS THAT BEGINNING IN 1964 THEY MOVED IN THE DIRECTION OF TAKING MORE IDEOLOGICALLY-DISTINCT POSITIONS.

07088 PAE, $S$.

KOREA: LEADING THE THIRD WORLD IN DEMOCRATIZATION

ASIAN AFFAIRS, AN AMERICAN REVIEW, 19(2) (SUM 92), 80-96.

DEMOCRATIZATION HAS BEEN STUDIED BY MANY STUDENTS OF COMPARATIVE POLITICS. THIS ARTICLE HAS THREE OBJECTIVES. THE FIRST IS TO EXAMINE MA JOR EMPIRICAL RESEARCH UNDERTAKEN ON THE BASIS OF A ONE-TIME STATIC, CROSS-NATIONAL COMPARATIVE APPROACH AND TO IDENTIFY MAJOR METHODOLOGICAL SHORTCOMINGS. THE SECOND OBJECTIVE IS TO TEST THE THEORY THAT ECONOMIC DEVELOPMENT IS A PREREQUISITE FOR A STABLE DEMOCRACY. THE THIRD OBJECTIVE IS TO DETERMINE WHETHER KOREA IS LEADING THIRD WORLD IN DEMOCRATIZATION. IT CONCLUDES THAT THOUGH KDREA BELATEDLY STARTED DEMOCRATIZING, IT HAS ALREADY
UP WITH AND SURPASSED THE MOST RAPIDLY DEMOCRATIZING DEVELOPING COUNTRIES.

07089 PAEHLKE, R.; TORGERSON, D.

TOXIC WASTE AS PUBLIC BUSINESS

CANADIAN PUBLIC ADMINISTRATION, 35(3) (FAL 92), 339-362.

THAT THERE IS SOME PUBLIC RESPONSIBILITY FOR TOXIC WASTE MANAGEMENT IS WIDELY TAKEN FOR GRANTED, BUT THERE IS CONTROYERSY OVER WHETHER A PUBLIC CORPORATION SHOULD ASSUME PRIMARY RESPONSIBILITY. PROPOSALS FOR A PUBLIC CORPORATION TO ASSUME SUCH RESPONSIBILITY HAVE BEEN ADVANCED IN CANADA AT THE PROYINCIAL LEYEL, WITH WIDELY VARYING RESULTS BY COMPARING THREE CASES-BRITISH COLUMBIA ALBERTA, AND COMPARING THREE CASES-BRITISH COLUMBIA, ALBERA, AND DEBATE AND OUESTION THE PREVAILING MODE OF PROBLEM DEFINITION, IN ORDER TO PROPOSE A CONTRASTING APPROACH TO DEFINITION, IN ORDER TO
PUBLIC RESPONSIBILITY.

07090 PAGANO, M.; BOWMAN, A.; KINCAID, J.

THE STATE OF AMERICAN FEDERALISM, 1990-1991

PUBLIUS: THE JOURNAL OF FEDERALISM, 21(3) (SUM 91), 1-26. AN ANALYSIS OF FEDERAL-STATE RELATIONS IN THE UNITED STATES TODAY REVEALS THE RISE OF A "COERCIVE FEDERALISM," WHICH COMBINES FEDERAL MANDATES AND PREEMPTIONS WITH TAXCOSTS TO STATE AND LOCAL GOVERMMENTS. SOME OBSERVERS HAVE DESCRIBED THIS DEVELOPMENT AS "PERMISSIVE FEDERALISM"; YET, THE FEDERAL GOVERNMENT HAS BECOME LESS, NOT MORE PERMISSIV
NEVERTHELESS, THE CUMULATIVE EFFECTS OF STATE AND LOCAL GOVERNMENT REFORM. THE REAGAN-BUSH NEW FEDERALISM, THE FEDERAL BUDGET DEFICIT, AND THE CHANGING VIEWS OF THE SUPREME COURT MAY SIGNAL THE EMERGENCE OF A NEW BALANCE OF POHER IN THE FEDERAL SYSTEM. STATE AND LOCAL REVENUES GREW FASTER THAN THE FEDERAL REVENUES IN THE 1980S, AND THE FEDERAL GOVERNMENT LOST MUCH OF ITS LUSTER AS A CENTER OF PROGRESSIVE INNOVATION. INCREASINGLY, THE STATES HAVE BECOME VIEWED AS CENTERS OF INMOVATION AND EXPERIMENTATION.

07091 PAIK, J.

NECESSITY AND TASKS FOR MORE ACTIVE POLICY OF PEACEFUL COEXISTENCE AND COOPERATION

KOREA \& WORLD AFFAIRS, 16(4) (WIN 92), 638-653. THE AUTHOR DFISCUSSES THE BEST LONG-TERM POL ICY OPTIONS FOR SOUTH KOREA AS IT ENDEAVORS TO INSURE PEACE ON THE KOREAN PENINSULA AND ULTIMATELY ACHIEVE REUNIFICATION WITH KOREAN PENIN
THE NORTH.

07092 PAINE, C.; COCHRAN, T.

SO LITTLE' TIME SO MANY WEAPONS, SO MUCH TO DO BUL LITTLE TIME, SO MANY WEAPONS, SO MUCH TO DO BULLETIN OF THE ATOMIC SCIENTISTS, $48(1)$ (JAN 92 ), $12-16$.
THE BUSH ADMINISTRATION'S MESSAGES ON THE DESTRUCTION OF NUCLEAR HARHEADS HAYE BEEN DECIDEDLY MIXED. ON THE ONE HAND, NUCLEAR WARHEADS HAVE BEEN DECIDEDLY MIXED. ON THE ONE HAND, THE WAY FOR THE DESTRUCTION OF A SIGNIFICANT NUMBER OF THE WAY FOR THE DESTRUCTION OF A SIGNIFICANT NUMBER OF NUCLEAR WEAPONS. BUT SINCE THE PRESIDENT'S SEPTEMBER INITIATIVES AND GORBACHEV'S POSITIVE RESPONSE TO THEM, ADMINISTRATION POLICY ON NUCLEAR WARHEAD AND FISSILE
MATERIAL ARMS CONTROL MEASURES HAS BEEN IN LIMBO. NO CLEAR POTIERIAL ARMS CONTROL MEASURES HAS BEEN THE DEFENSE AND POLICY DIRECTION HAS EMERGED, EVEN AR THE OVIET UNION SEEK U. NUCLEAR ENERGY MINISTRIES OF THE FORMER SOVIET UNION SEEK
S. ASSISTANCE TO STORE AND DISHANTLE SOME 15,000 NUCLEAR S. ASSISTAM

07093 PAINTER, M. INTERGOVERNMENTAL RELATIONS IN CANADA: AN INSTITUTIONAL ANALYSIS

CANADIAN JOURNAL OF POLITICAL SCIENCE, XXIV(2) (JUN 91), 269-288.

FROM RECENT DEBATES ABOUT THE PERFORMANCE OF THE CAMADIAN FEDERAL SYSTEM, TWO IMAGES OF PROCESSES OF INTERGOVERNMENTAL RELATIONS CAN BE EXTRACTED: A "COMPETIIIVE" AND "COLLABORATIVE" IMAGE. DIFFERIMG PROPOSITIONS ABOUT THE EFFECTS ON PROCESSES AND OUTCOMES OF THE FRAMEWORK OF RULES AND INSTITUTIONS OF INTERGOVERMMENTAL RELATIONS ARE EMBODIED IN THESE CONTRASTING IMAGES. ELINOR OSTROM'S FRAMEHORK FOR INSTITUTIONAL ANALYSIS IS APPLIED TO THE INVESTIGATION OF THESE EFFECTS. USING FRITZ SCHARPF'S analysis of the "PATHOLOGICAL" EFFECTS OF a SPECIFIC SET OF COLLABORATIVE ARRANGEMENTS IN WEST GERMANY AS POINTS OF DEPARTURE AND CONTRAST, THE HORKING RULES UNDERLYING CANADIAN INTERGOVERMMENTAL RELATIONS ARE ELABORATED. THE AUTHOR CONCLUDES THAT A COMPETITIVE DYNAMIC UNDERPINS A HIGH DEGREE OF FLEXIBILITY IN THESE ARRANGEMENTS. PROPOSALS TO IMPLEMENT A MORE COLLABORATIVE SET OF ARRANGEMENTS THROUGH CONSTITUTIONAL REFORM ARE CRITICALLY EVALUATED IN THIS LIGHT, AND THE AUTHOR MAKES SUGGESTIONS ABOUT THE COURSE CONSTITUTIONAL REFORM MIGHT TAKE FOLLOWING THE FAILURE TO ADOPT THE MEECH LAKE ACCORD.

07094 PAISLEY, E.

KEYS TO REFORM

FAR EASTERH ECONOMIC REYIEW, 155(66) (JUL 92), 34-35. SOUTH KOREA'S FINANCIAL SYSTEM, LONG IN NEED OF REPAIR, IS SET FOR WIDE-RANGING LIBERALIZATION AS THE FINANCE MINISTRY BENDS TO INCREASING PRESSURE. IN A MOVE THAT DISTINGUISHES THE PRESENT PROMISES OF REFORM FROM PREVIOUS ONES, THE MINISTRY HAS SET A DETAILED TIMETABLE FOR LIBERALIZATION. IT IS ALSO NEGOTIATING A WORLD BANK LOAN TO UPGRADE ITS FINANCIAL-SERVICES SECTOR.

07095 PAISLEY, E.; BAUM, J.; KAYE, L.

RISKS AND RÉWARDS

FAR EASTERN ECONOMIC REVIEN, 155(35) (SEP 92), 8-9.

THE 24 AUGUST ARRIVAL IN BEIJING OF SOUTH KOREAN FOREIGN MINISTER LEE SANG-OCK AND THE SUBSEQUENT SIGNING OF A NORMALIZATION AGREEMENT WITH CHINA MAKRED AN HISTORIC TURN IN MODERN ASIA. SOME 42 YEARS AFTER HUNDREDS OF THOUSANDS OF
CHINESE TROOPS POURED ACROSS THE YALU RIVER TO FIGHT THE U.S. -BACKED SOUTH KOREAN REGIME, THIS CHAPTER OF THE COLD WAR WAS FINALLY CLOSED. FOR SOUTH KOREAN PRESIDENT ROH TAE WOO IT WAS A CROWNING MOMENT FOR HIS "NORDPOLITIK," WHICH COULD NOT ONLY LEAD THE HAY TO PEACE ON THE PENINSULA BUT ALSO MAKE THE NORTHEAST ASIAN REGION AN ECONOMIC POWERHOUSE. MAKE THE NORTHEAST ASIAN REGION AN ECONOMIC POWERHOUSE.
ROH'S OPTIMISM, HOWEVER, IS UNLIKELY TO BE SHARED BY TAIWAN ROH'S OPTIMISM, HOWEVER, IS UNLIKELY TO BE SHARED BY TAIWAN RESPECTIVE LONG-STANDING ALLIES IN SEOUL AND BEIJING. IN RESPECTIVE LONG-STANDING ALLIES IN SEOUL AND BEI JING. IN
ADDITION, SOME KOREAN CRITICS OF ROH'S NORTHERN POLICY ARGUE ADDITION, SOME KOREAN CRITICS OF ROH'S NORTHERN POLICY ARGUE
THAT THE NORMALIZATION OF TIES WITH CHINA WILL ONLY FURTHER THAT THE NORMALIZATION OF TIES WITH CHINA WILL ONLY FURTHER
NORTH KOREA'S DESPERATION AND MAY LEAD TO A NEW CONFLICT ON NORTH KOREA'S
THE PENINSULA.

07096 PAISLEY, E.

RUSSIAN ROULETTE

FAR EASTERN ECONOMIC REVIEW, 155(23) (JUN 92), 38-39.

WHEN SOUTH KOREA OFFERED A

BILLION TO THE SOVIET UNION IN JANUARY 1991, IT WAS REGARDED BY ITS CRITICS AS A BLIND BET ON THE SURVIVIAL OF MIKHAIL GORBACHEV. ACCORDING TO THE PACKAGE, THE USSR WAS TO RECEIVE USSI BILLION IN COMMERCIAL BANK LOANS, AND USS2 BILLION IN TRADE CREDITS FOR MERCHANDISE, PLANTS, AND EQUIPMENT. NOW GORBACHEV IS GONE AND AN INTEREST PAYMENT ON THE LOAN IS IN DEFAULT. SEOUL IS FACED WITH THE DILEMMA OF HOW TO DEAL WITH THE SITUATION. IF IT CONTINUES TO DISBURSE $\$ 1.5$ BILLION IN
UNUSED CREDITS TO AN UNRELIABLE DEBTOR, THE RULING GOVERNMENT OFFICIALS COULD BE CALLED TO TASK IN THE NEXT ELECTION. FAILURE TO CONTINUE WITH THE LOAN, HOWEVER, MAY DAMAGE FUTURE ECONOMIC TIES WITH RUSSIA AND WILL LIKELY REDUCE SEOUL'S LEVERAGE WITH NORTH KOREA.

07097 PAISLEY, E.

SEOUL AS SUITOR

FAR EASTERN ECONOMIC REVIEW, 155 (31) (AUG 92), 44-45. NORTH KOREAN PRESIDENT KIM IL-SUNG APPEARS TO HAVE ADROITLY ADAPTED HIS TACTICS FROM A POSITION OF BEING
POLITICALLY ISOLATED TO BEING ECONOMICALLY COURTED. JUST AS PE USED TO PLAY OFF THE FORMER SOVIET UNION AND CHINA HE USED TO PLAY OFF THE FORMER SOVIET UNION AND CHINA
AGAINST EACH OTHER, NOW HE APPEARS TO BE USING ECONOMIC LEVERAGE AGAINST BOTH SOUTH KDREA AND JAPAN. THE BAIT IS MORTH'S NATURAL RESOURCES AND CHEAP LABOR. IN THE LATEST ROUND OF ECONOMIC AND POLITICAL DIPLOMACY, THE NORTH KOREAM DEPUTY PREMIER KIM DAL-HYON SECURED SOUTH KOREAN APPROYA FOR A TEAM OF SOUTH KOREAN BUSINESSMEN AND GOVERNMENT
EXPERTS TO TRAVEL TO THE NORTH AND EXPLORE THE FEASIBILITY EXPERTS TO TRAVEL TO THE NORTH AND EXPLORE THE FEASIBIL
OF INVESTING THERE. THE SOUTH KOREAN INITIATIVE, WHICH
PREVIOUSLY HAS DECLARED TO BE DEPENDENT ON PYONGYANG PREVIOUSLY WAS DECLARED TO BE DEPENDENT ON PYONGYANG AGREEING TO BILATERAL NUCLEAR INSPECTIONS, WAS NOT
WITH ANY CORRESPONDING CONCESSION BY NORTH KOREA.

07098 PAIXAO, P.; FIGUEIREDO, S.

MUSTERING AY ARMY FOR AL OF EUROPE

WORLD PRESS REYIEH, $39(8)$ (AUG 92), 13.

SINCE ATTEMPTS TO CREATE A EUROPEAN DEFENSE INDEPENDENT OF THE ATLANTIC ALLIANCE WERE SOUASHED, THE PARIS-BONN AXIS HAS BEEN WORKING TO CREATE WHAT IS DESCRIBED AS "THE EMBRYO OF FUTURE EUROPEAN ARMED FORCES." THE EUROPEAN COMMUNITY AND ITS AMERICAN ALLY ARE WORKING TO DEFINE THE ROLES THAT WILL FALL TO NATO AND THE HESTERN EUROPEAN UNION UNDER THE NEW CIRCUMSTANCES. THE DEBATE BETWEEN THE PRO-ATLANTIC AND PROEUROPEAN SCHOOLS OF THOUGHT SEEMS TO BE DRAHING TO A CLOSE. WITHIN THREE YEARS, APPROXIMATELY 40,000 FRENCH ANO GERMAN 
TOWARD FEWER TROOPS WITH GREATER SPECIALIZATION AND MORE SOPHISTICATED EQUIPMENT.

07099 PAKENDORF, H.

EQUALITY YS. FREEDOM

SOUTH AFRICA FOUNDATION REVIEN, 18(8) (AUG 92), 1-2. UNLESS A NEW POLITICAL AND ECONOMIC DISPENSATIION ACHIEVES A BALANCE BETWEEN EQUALITY AND FREEDOM IN SOUTH AFRICA, THERE IS A STRONG LIKELIHOOD OF A RESURGENCE OF RACISM.

07100 PAL, I.

WOMEN AND ISLAM IN PAKISTAN

MIDOLE EASTERN STUDIES, 26(4) (OCT 90), 449-464.

THIS ARTICLE CONSIDERS THE ROLE THAT WOMEN CAN PLAY IN THE ECONOMIC DEVELOPMENT OF THE ISLAMIC REPUBLIC OF PAKISTAK, THE ESSENTIAL THEME IS THAT THE MORAL, RELIGIOUS, AND SOCIAL PRONOUNCEMENTS OF THE OURAN HAVE A SOCIAL-HISTORICAL CONTEXT. THE INTERPRETATION OF THE QURANIC LAW CONSISTS OF A MOYEMEMT FROM THE PRESENT SITUATIOM TO THE OURANIC IMES AND BACK TO THE PRESENT. THIS PAPER EXAMINES THE QUESTION OF PURDAH (THE PRACTICE OF SECLUDING WOMEN) AND DISCUSSES THE PURDAH (THE PRACTICE OF SECLUDING WOMEN) AND DISCUSSES THE ISLAMIC VIEH OF FAMILY LIFE. IT ALSO REVIEWS SOME RECENT MEASURES TAKEN BY THE ZIA-UL HAQ GOVERMMENT TO ISLAMICIZE
THE LAWS OF PAKISTAN. IT CONCLUDES WITH SOME CDMMENTS ON THE THE LAWS OF PAKISTAN. IT CONCLUDES WITH SOME COMMENTS ON THE QUESTION FOR THE FUTURE OF WOMEN'S RIGHTS IN THE COUNTRY.

07101 PALAVEEY, C. SECURITY IN THE BALKANS AT THE NEW PAN-EUROPEAN INSTITUTIONS

PEACE AND THE SCIENCES, \& (DEC 91), 59-62.

THIS PAPER ABOUT SECURITY IN THE BALKANS AND THE NEW PANEUROPEAN INSTITUTIONS ANALYZES THE MAIN FACTORS AND TENDENCIES WHICH ARE CLOSELY CONNECTED WITH THE SECURITY OF THE REGION. SECURITY IS NOT CONSIDERED ONLY FROM A MILITARY POINT OF VIEW, BUT RATHER AS A COMPLEX STATE OF AFFAIRS, WIICH THE RESULTS OF THE RECIPROCAL ACTION OF ECONOMIC, POLITICAL, SOCIAL, ETHNIC, ECOLOGICAL AND HUMANITARIAN FACTORS AND TENDENCIES. IT DOES NOT INTEND TO UNDERTAKE HISTORICAL REFLECTIONS, OR TO DRAH A UNIVERSAL AND COMPLETE PICTURE OF THE SOCIAL AND SOCIOCULTURAL SITUATION.

07102 PALAVERSICH, D.

THE THIRD BALKAN WAR?

ARENA, (96) (SPR 91), 22-24.

ETHNIC MAKE-UP OF YUgoslavia IS SUCH THAT IT IS ALMOST INEVITABLE THAT, GIVEN THE RECENT SHARP ECONOMIC DOWNTURNS AND THE LONG-STANDING ETHNIC RIVALRIES, THE POLITICAL AND MILITARY SITUATION WILL BECOME INCREASIMGLY MORE COMPLEX AND MORE BLOODY. ARMED CONFLICT BETHEEN SERBIA AND CROATIA HAS THE POTENTIA TO ESCALATE INTO A LARGER WAR, ESPECIALLY IF IT SPREADS TO BOSNIA AND HERCEGOVINA. THIS WOULD INTRODUCE NEW ACTORS AND MAKE ANY SOLUTION TO THE CONFLICT MUCH MORE OIFFICULTT TO ACHIEVE. UTLIMATELY, THE TONG-TERM STABILITY OF THE BALKANS MAY ONLY BE ACHIEVED THROUGH THE INTEGRATI
EUROPEAN COMMUNITY.

07103 PALAZZOLO, D.J.

MAJORITY PARTY LEADERSHIP AND BUDGET POLICY MAKING IN THE HOUSE OF REPRESENTATIVES

CONGRESS AND THE PRESIDENCY, 19(2) (FAL 92), 157-174.
DURING THE 1980 'S BUDGET POLICY DOMINATED THE CONGRESSIONAL AGENDA AND THE SPEAKER OF THE HOUSE OF REPRESENTATIVES BECAME MORE INVOLVED IN FORMULATING THE PRIORITIES OF THE MAJORITY PARTY--A TASK TRADITIONALLY LEFT UP TO COMHITTEES. THIS PAPER TRACES THE DEVELOPMENT OF THE SPEAKER'S ROLE IN FORMULATING BUDGET PRIORITIES BY ASSESSING CHANGES IN THE SPEAKER'S RELATIONSHIP WITH THE HOUSE BUDGET COMMITTEE. IT PROBES THE CONDITIONS UNDER HHICH THE SPEAKER BECAME A MORE ACTIVE PARTICIPANT IN BUDGET POLICY MAKING AND DISCUSSES THE INDIYIDUAL QUALITIES THAT DEFINE EACH SPEAKER'S STYLE, FOCUSING ON THOMAS P. "TIP" O'NEILL JR. AND JAMES WRIGHT. BOTH O'NEILL AND WRIGHT OPERATED UNDER SIMILAR CONDITIONS--DIVIDED GOVERNMENT, LARGE DEFICITS, AND HIGH LEVELS OF PARTY UNITY--WHICH ENHANCED THE SPEAKER'S ROLE IN POLICY MAKING. BUT THEY EXERCISED DIFFERENT LEADERSHIP STYLES, AND THE DIFFERENCES WERE BASED PARTLY ON THO INDIVIDUAL FACTORS: POLICY EXPERTISE AND CONCEPTION OF LEADERSHIP.

07104 PALLEY, H.A.

SOCIAL POLICY AND THE ELDERLY IN SOUTH KOREA: CONFUCIANISM, SOCIAL POLICY AND THE ELDERLY IN

ASIAN SURVEY, XXXII ( 9 ) (SEP 92) 787-801.

THIS ARTICLE EXAMINES THE REPUBLIC OF KOREA'S

INTENTIONAL GOVERNMENTAL STRATEGY NOT TO DEVELOP

SUPPORTING SOCIAL INFRASTRUCTURE OR A MODERN HELFARE STATE

PACKAGE OF SOCIAL SERVICES AKD INCOME POLICIES AMD PROGRAMS THAT WOULD ASSIST THE ELDERLY AND THEIR INFORMAL CAREGIVERS. IT EXAMINES THE REASONS FOR THE LACK OF GOVERNMENT ACTION IM THE FACE OF INCREASING IMPERATIVES OF DEMOGRAPHY, AS WELL AS
MOOERNIZATION AND URBANIZATION. ANOTHER PROBLEM THAT DOES NOT SEEM TO BE ADEQUATELY ADDRESSED BY CURRENT SOCIAL POLICIES IS THE EROSION OF STATUS OF THE ELDERLY IN KOREA POLICIES IS THE EROSION OF STATUS OF THE ELDERLY IN KOREA FOSTERING "CONFUCIANISM" AND FAMILY RESPONSIBILITIES APPEAR FOSTERING "CONFUCIANISH" AND FAMILY RESPONSIBILITIES APPEAR TO BE DISINGENUOUS. THE REAL MOTIVE BEHIND THE GOVERNMENT'S INACTION IS THE POLITICAL-ECONOMIC DRIVE OF LOW INCOME TAXES AND LOW TAXES ON EQUITY TRANSACTIONS COMBINED HITH SUBS AND INCENTIVES TO ENCOURAGE EXPORTS AND A SUBSTANTIAL COMI TMENT TO THE MILITARY BUDGET WHICH LEAVES FEW RESOURCES
AVAILABLE FOR NECESSARY SERVICES FOR THE DISABLED AND THE ELDERLY.

07105 PALLEY, M.L.; PALLEY, H.A.

THE THOMAS APPOINTMENT: DEFEATS AND VICTORIES FOR WOMEN PS: POLITICAL SCIENCE AND POLITICS, $X X V(3)$ (SEP 92), 43-476.

CLARENCE THOMAS' APPOINTMENT TO THE U.S. SUPREME COURT IS A STORY OF RACIAL POLITICS ENMESHED WITH GENOER POLITICS AND THE CONSERVATIVE SOCIAL AGENDA OF THE REAGAN-BUSH ADMINISTRATIONS. IN THIS ARTICLE, THE AUTHORS LOOK AT THE CONFIRMATION PROCESS AND AT THE SIGNIFICANCE OF THOMAS' APPOINTMENT FOR WOMEN.

07106 PALLEY, M.L

HOMEN'S RIGHTS AS HUMAN RIGHTS: AM INTERMATIONAL PERSPECTIVE

ANNALS OF THE AMERICAN ACADEMY OF POLITICAL AND SOCIAL

SCIENCE, (515) (MAY 91), 163-178.

EXPLOITATION OF FEMALE LABOR AS WELL AS MORE GENERAL ISSUES OF GENDER EQUITY HAVE EMERGED AS UNIVERSAL CONCERNS IN THE PAST DECADE. IN ADDITION, HOMEN OFTEN FACE PROBLEMS OF SEXUAL EXPLOITATION. IN MOST SOCIETIES WOMEN'S MOVEMENTS HAVE BEEN ORGANIZED TO ADDRESS THESE PROBLEMS AND TO DEMAND MORE EQUITABLE CONDITIONS FOR NOMEN. THE SOCIAL AND POL ITICAL RESPONSES OF BOTH MEN AND WOMEN TO THESE MOVEMENTS HAVE BEEN CULTURALLY CONSTRAINED. THERE ARE AS MANY PERSPECTIVES AND APPROACHES TO RESOLVING GENDER INEQUITIES AS THERE ARE SOCIETIES. IN THIS ESSAY, ILLUSTRATIONS ARE DRAWN FROM A CROSS SECTION OF SOCIETIES TO DEMONSTRATE SEVERAL ASSUMPTIONS REGARDING WOMEN'S RIGHTS AND WOMEN'S MOVEMENTS. THE CONSTRAINTS IMPOSED BY BEHAVIORAL CULTURE THAT AFFECT ISSUE DEVELOPMENT AND CHANGE MECHANISMS ARE CONSIDERED IN THE CONTEXT OF UNIVERSAL CALLS FOR GENDER EQUITY AND AN END TO THE EXPLOITATION OF FEMALE LABOR AND SEXUALITY.

07107 PALM, T.

THE SUURUPI PROGRAM: ESTONIAN ECONOMIC POLICY FOR THE TRANSITION

JOURNAL OF BALTIC STUDIES, 23(3) (FAL 92), 283-298.

A CONFERENCE OF SEVERAL DOZEN ECONOMISTS, GOVERNMENT OFFICIALS AND OTHER INVITED PARTICIPANTS CONVENED IN ESTONIA IN THE FALL OF 1991. THE FIRST WEEK OF SESSIONS WAS INTENDED IN THE FALL OF 1991. THE FIRST WEEK OF SESSIONS WAS TO GENERATE ECONOMIC POLICY PROPOSALS TO GUIDE THE DEVELOPMENT OF THE COUNTRY FOR THE COMING HALF DECADE

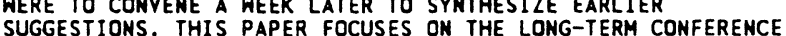
SUGEESTIVES.

07108 PALMER, G.

NEW WAYS TO MAKE INTERMATIONAL ENVIRONMENTAL LAW AMERICAN JOURHAL OF INTERNATIONAL LAH, 86(2) (APR 92), 259-283.

THE PURPOSE OF THIS PAPER IS TO PROPOSE NEW WAYS TO MAKE INTERNATIONAL ENVIRONMENTAL LAW. THE EXISTING METHODS ARE SLOH, CUMBERSOME, EXPENSIVE, UNCOORDINATED, AND UNCERTAIN. SOMETHING BETTER MUST BE FOUND IF THE ENVIRONMENTAL CHALLENGES THE WORLD FACES ARE TO BE MET SUCCESSFULLY. NEARLY THENTY YEARS AFTER THE STOCKHOLM DECLARATION, THE WORLD STILL LACKS THE INSTITUTIONAL AND LEGAL MECHANISMS TO DEAL EFFECTIVELY HITH TRANSBOUNDARY AND BIOSPHERIC ENVIRONMENTAL DEGRADATION. THE 1992 UNITED NATIONS CONFERENCE ON ENVIRONMENT AND DEVELOPMENT WILL PRESENT AN OPPORTUNITY TO MAKE PROGRESS. UNFORTUNATELY, THE SITUATION IN LATE 1991 SUGGESTS THAT THERE IS NO POLITICAL WILL TO MAKE THE HARD DECISIONS. THE NEED FOR TAKING BOLD STEPS IS OBVIOUS DUE TO THE FORMIDABLE NATURE OF THE ENVIRONMENTAL ISSUES; THE CONOITION OF INTERMATIONAL ORGANIZATION RELATING TO THE ENYIRONMENT, PARTICULARLY THE UNITED NATIONS SYSTEM; AND THE METHODS CURRENTLY USED TO MAKE INTERNATIONAL ENVIRONMENTAL LAH.

07109 PALMER, $N$

LOVE OF GLORY AND THE COMMON GOOD: ASPECTS OF POLITICAL THOUGHT OF THYCYDIDES

ROWAN AND LITTLEFIELD, $1992,188$.

THE RELATIONSHIP BETWEEN PERICLEAN DEMOCRACY AND THE DECLINE IN ATHENIAM POL ITICAL LIFE THAT FOLLOWED THE DEATH OF PERICULES IS CLEARLY DEFINED. MICHAEL PALMER ELABORATES UPON THE VIEWS OF THUCYDIDES, WHO SAH THE SUBSEQUENT TYRANNICAL RULE OF ALCIBIADES AND THE ACCOMPANYING DISINTEGRATION OF ATHENIAN POLITICAL LIFE AS A LOGICAL CONSEQUENCE OF THE DEFECTS IN THE SPEECHES AND DEEDS THAT 
PERICLES USED TO INSPIRE THE ATHENIAN PEOPLE. THE AUTHOR SHOWS THAT THUCYDIDES WAS A POLITICAL THINKER OF THE FIRST RANK HHO DESERVES THE SAME CAREFUL STUDY aCCORDED TO PLATO AND ARISTOTLE.

07110 PANCER, S.; BIOSVERT S.; HUNSBERGER, B.; PRATT, M.; RUTH,

POLITICAL ROLES AND THE COMPLEXITY OF POLITICAL RHETORIC POL ITICAL PSYCHOLOGY, 13(1) (MAR 92), 31-44.

THE COMPLELXITY OF POLITICAL RHETORIC OF POLITICIANS IN A POLICY-MAKING AND OPPOSITION ROLE IS EXAMINED. SPEECHES BY MEMBERS OF THE GOVERNMENT AND OPPOSITION PARTIES IN THE CANADIAN HOUSE OF COMMONS FROM 1948 TO 1988 WERE SCORED IN TERMS OF THEIR INTEGRATIVE COMPLEXITY. RESULTS INDICATED THAT INDIVIDUALS IN A POLICY-MAKING ROLE MADE SPEECHES THAT WERE MORE COMPLEX THAN THOSE MADE BY INDIVIDUALS IN AN OPPOSITION ROLE. THE COMPLEXITY OF GOVERNMENT AND OPPOSITION RHETORIC WAS RELATED TO HOW MUCH TIME HAD PASSED SINCE THE LAST ELECTION. RESULTS ARE DISCUSSED IN RELATION TO THE DIFFERENTIAL ACCOUNTABILITY OF THOSE IN A POLICY-MAKING AND OPPOSITION ROLE.

07111 PANDEY, D.

SAARC AND THE DEVELOPMENT OF SOUTH ASIA: A NEPALESE PERSPECTIVE

SOUTH ASIA JOURNAL, 5(1) (JUL 92), 45-64.

MANY NEPAL IS LIKE TO BELIEVE THAT THE IDEA OF SOUTH ASIAN REGIONAL COOPERATION CAME FROM KING BIRENDRA. THIS ARTICLE ATTEMPTS TO VIEW THIS MORE OBJECTIVELY-AND SYMBOL ICALLY--AS A CONCRETE EXAMPLE OF THE ASPIRATIONS FOR REGIONAL COOPERATION AT THE PEOPLES' LEVEL. IT DISCUSSES WHERE NEPAL HAS COME AND WHERE IT SHOULD BE HEADING FOR THE REALIZATION OF REGIONAL COOPERATION. IT ARGUES THAT THOSE IN REALTH ASIA HAVE NO ALTERNATIVE TO STRENGTHENING SAARC AS AN SOUTH ASIA HAVE NO ALTERNATIVE TO STRENGTHENING SAARC AS AN INSTRUMENT OF BETTER INTEGRATING THEIR ECONOMIES FOR SPE
DEVELOPMENT IN THEIR REGION. A CASE IS MADE THAT SUCH DEVELOPMENT IN THEIR REGION. A CASE IS MADE THAT SUCH
INTEGRATION IS POSSIBLE ONLY IF THE SPECIFIC NEEDS AND INTEGRATION IS POSSIBLE ONLY IF THE SPECIFIC NEEDS AMD PROBELMS OF THE SMALLER COUNTRIES IN THE REGION ARE
RECOGNIZED BY THE BIGGER AND MORE DEVELOPED PARTNERS.

07112 PANGESTU, $M$.

THE ROLE OF THE PRIVATE SECTOR IN INDONESIA: DEREGULATION AND PRIVATIZATION

INDONESIAN OUARTERLY, 19(1) (WIN 91), 27-51.

THIS ARTICLE DISCUSSES THE ROLE OF THE PRIVATE SECTOR IN INDONESIA AS THE ECONOMY HAS BECOME LESS DOMINATED BY STATEOWHED ENTERPRISES AND MORE PRIVATIZED AND DEREGULATED. THE AUTHOR ARGUES THAT THE MOVE TOWARD PRIVATIZATION IS NOW AT THE FORMULATION STAGE AND WILL BE A GRADUAL PROCESS IM OF THE CONCEPTUAL, POLITICAL, AND PRACTICAL PROBLEMS ASSOCIATED WITH THE PROCESS. THE EFFECTS OF THE AVAILABILITY OF OIL REVENUES IN THE 19705 AND 1980 S IS INVESTIGATED.

07113 PANITCH, L.

BEYOND COMMUNISM AND SOCIAL DEMOCRACY

STUDIES IN POLITICAL ECONOMY: A SOCIALIST REVIEH, (38)

(SUM 92), $139-154$. COMMUNISM" AND THE LOSS OF SOCIALIST COMMITMENT IN WESTERN SOCIAL DEMOCRACY FROM THE STANDPOINT OF A MEMBER OF THE 1960 S GENERATION. HE ARGUES THAT THE '60S GENERATION'S SOCIALISM WAS DEF INED IN SPITE OF, AND AGAINST BOTH

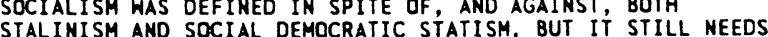
STALINISM AND SOCIAL DEMOCRATIC STATISM, BUT IT STILL NEEDS TO REMIND ITSELF OF THE HISTORICALLY SPECIFIC CONDITIONS THAT PRODUCED THESE THO EARLY THENTIETH CENTURY EXPRESSIONS OF THE SOCIALIST IDEA. THE AUTHOR ARGUES THAT THE DEMOCRAT AND LIBERATORY PRACTICES AND INSTITUTONS OEVELOPED BY THE LEFT SINCE THE 1960 S ARE VALID EXPRESSIONS OF THE SOCIALIST IDEAL FOR THE CURRENT TIMES, AS WELL AS A NECESSARY STA

07114 PANITCH, L.

HOW OUR DEMOCRACY COULD HORK

HOW OUR DEMOCRACY COULD HORK

THE DEMOCRATIC CHANGES THAT HAVE TAKEN PLACE IN EASTERM EUROPE HAVE MOT SIGNIFICANTLY INCREASED THE CONFIDENCE OF EUROPE HAVE NOT SIGNIFICANTLY INCREASED THE CONFIOENCE OF "DANADIANS IN THE FREE MARKET SYSTEM. THIS ARTICLE EXAMI YEARNING FOR. THE FACT THAT YOTERS IN ONTARIO REJECTED ALL YEARNING FOR. THE FACT THAT VOTERS IN ONTARIO REJECTED ALL CONVENTIONAL MOOES OF POLITIICS AND ADMINISTRATION IS A SIGN POINIS DESIRE. THIS NEW SYSTEM HILL REQUIRE A PLURALITY OF POINTS OF ACCESS TO ELECTED REPRESENTATIVES, A CONSIDERABLE ATTENUATION OF SECRECY, AND THE ENCOURAGING AND FACILITATING OF THE ORGANIZATION OF COMMUNITIES OF IDENTITY AND INTEREST. THE SUCCESS OF THIS "DEMOCRACY MOVEMENT" DEPENDS ON THE PARTICIPATION OF CITIZENS IN DECISIONMAKING

07115 PANITCH, L.

THE NDP IN POWER: ILLUSION AND REALITY

STUDIES IN POLITICAL ECONOMY: A SOCIALIST REVIEN, 37(1)

(SPR 92), 173-188.

THE AUTHOR SUGGESTS THAT THE BOOK "SOCIAL DEMOCRACY WITHOUT ILLUSIONS" MIGHT BE WELL TIMED GIVEN THE CURRENT
POLITICAL CONTEXT. HE ALSO SUGgests THAT THE MAIN "IllLUSION" THAT THE BOOK FOSTERS IS THAT IT ACTUALLY HAS A REALISTIC STRATEGY FOR A SOCIAL DEMOCRATIC ALTERMATIVE TO CAPITALIST SOCIETY, ON THE OTHER HAND, HE STATES THAT THE DOCUMENT, "PUTTING PEOPLE FIRST," OFFERS MORE DATA AND EXPLANATION OF THE WAY IN WHICH INDIVIDUAL ECONOMIES HAVE BECOME MUCH LESS SELF-CONFIDENT AND SELF-SUFFICENT THAN IN THE WHOLE OF "SOCIAL DEMOCRACY WITHOUT ILLUSIONS." HE CONCLUDES THAT ONLY WITH MOBILIZATIONAL CAPACITY CAN A GOVERNMENT MAKE ITS WILL EFFECTIVE.

07116 PAPADAKIS, E.

PUBLIC OPINION, PUBLIC POLICY AND THE WELFARE STATE POLITICAL STUDIES, XL(1) (MAR 92), 212-237.

A RECURRING PROBLEM IN POLITICAL ANALYSIS IS TO LINK PUBLIC OPINION TO PUBLIC POLICY. THE BURGEONING LITERATURE ON PUBLIC OPINION AND THE CRISIS OF THE WELFARE STATE HAS FAILED TO PROVIDE A CONSISTENT ACCOUNT OF HHAT ASPECTS OF POLICY MIGHT BE DRIVEN BY PUBLIC DEMAND OR VICE VERSA. THE INTERPRETATIONS OF SURVEY DATA ARE EITHER MISLEADING

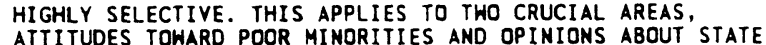
ATTITUDES TOWARD POOR MINORITIES AND OPINIONS ABOUT AND PRIVATE WELFARE. IN ORDER TO PROVIDE A BETTER UNDERSTANDING OF THE PROBLEMS OF LINKING POLICY AND OPINION AND TO OFFER SOME GUIDING PRINCIPLES FOR RESEARCH IN THIS AREAS, THIS PAPER ATTEMPTS TO CLARIFY SOME OF THESE DIFFICULTIES.

07117 PAPAGEORGIOU, F.; VERNEY, S. REGIONAL PLANMING AND THE INTEGRATED MEDITERRANEAN PROGRAMMES IN GREECE

REGIONAL POLITICS \& POLICY, 2(1,2) (SPR 92), 139-161. THIS ARTICLE, BASED ON DATA GATHERED IN 1989 IS AN INTERIM REPORT ON THE TIMID DECENTRALIZATION PROCESS WHICH THE IMPS AND THE RDPS APPEAR TO HAVE STIHULATED IN GREECE. IT SUGGESTS THAT AS SUCH REGIONAL PROGRAMS PROGRESS, THEY WILL BEGIN TO ACQUIRE THEIR OWN MOMENTUM, WITH THE OPERATIONAL NEEDS OF AN EFFICIENT PLANHING AND IMPLEMENTATION PROCESS BRINGING ABOUT A GRADUAL SILENT IMPLEMENTATION PROCESS BRINGING ABOUT A GRADUAL SILENT REVOLUTION IN CENTER-PERIPHERY RELATIONS. ITS BASIC
CONCLUSION POINTS TO THE NEED FOR SIGNIFICANT POLITICAL CONCLUSION POINTS TO THE NEED FOR SIGNIFICANT POLITICA CHANGE IF THE GREEK REGION IS EVER TO BECOME REALLY
MEANINGFUL AS AN EFFECTIVE PLANNING ANO DEVELOPMENT UNIT.

07118 PAPENDIECK, H.

ZAMBIANS ARE OFFERED HARDSHIP ON THE PATH TO A NEH DEAL GERMAN TRIBUNE, (1493) (NOV 91) 2 .

THE ELECTION OF TRADE UNION LEADER FREDERICK CHILUBA AS ZAMBIA'S PRESIDENT BELIES THE WIDESPREAD BELIEF THAT AFRICA IS DOONED TO REMAIN FOREVER POOR, HUNGRY AND BACKWARD, AT THE MERCY OF GREEDY LOCAL ELITES AND. HARD-BARGAINING FOREIGNERS. THE PEACEFUL TRANSITION FROM KENNETH KAUNDA, A PROMISING SIGN FOR DEMOCRACY ON THE AFRICAN CONTINENT. ALTHOUGH ZAMBIANS ARE PRAGMATICALLY LOOKING AT THE IMMENSE PROBLEMS THE COUNTRY STILL FACES, THE FACT THAT THE WINDS OF EUROPE ARE NOW REACHING AFRICA IS TAKEN AS A GOOD PORTENT.

07119 PAPPE, I.

OVERT CONFLICT TO TACIT ALLIANCE: ANGLD-ISRAELI RELATIONS $1948-51$

MIDDLE EASTERN STUDIES, 26(4) (OCT 90), 561-581.

IN LESS THAN TWO YEARS ISRAEL AND BRITAIN MOVED FROM A SITUATION IN WHICH THE BOTH HAD BEEN ON THE BRINK OF WAR TO ONE IN WHICH THEY WERE SERIOUSLY CONSIDERING A TREATY OF ALLIANCE. THIS ARTICLE EXAMINES THE EVENTS THAT LED TO THIS DRAMATIC. THOUT-FACE OYER THE YEARS 1948-51. KEY FACTOR IN THE THE CHANGE WAS ISRAELI SUPPORT FOR THE WEST IN THE KOREAN CRISIS AND THE BRITISH DESIRE TO KEEP ISRAEL IN THE WESTE
CAMP AS THE DIVISION BETHEEN EAST AND WEST BECAME MORE EVIDENT.

07120 PAREDES, $C$.

DEMOCRACY AND REFORM IN THE AMERICAS

BROOKINGS REVIEH, 10(3) (SUM 92), 53

THE EXPERIENCE OF THE $1980^{\circ} \mathrm{S}$ 'RAISED QUESTIONS ABOUT WHETHER DEMOCRACY AND ECONOMIC REFORM CAN COEXIST IN LATIN WHETHER DEMOCRACY AND ECONOMIC REFORM CAN COEXIST IN LATIN
AMERICA. IN FACT, THEY CAN. THE STABILITY OF ECONOMIC POLICY AMERICA. IN FACT, THEY CAN. THE STABILITY OF ECONOMIC POL IN COLOMBIA SINCE THE MID-1960' S AND THE DRAMATIC, FARREMOCRACY AND MARKET-ORIENTED REFORM ARE COMPATIBLE.

07121 PAREKH, B.

THE CULTURAL PARTICULARITY OF LIBERAL DEMOCRACY

POLITICAL STUDIES, 40 (1992), 160-175.

LIBERAL DEMOCRACY IS LIBERALIZED DEMOCRACY: THAT IS, DEMOCRACY DEFINED AND STRUCTURED WITHIN THE LIMITS SET BY LIBERALISM. THE PAPER OUTLINES THE CONSTITUTIVE FEATURES OF LIBERALISM AND SHOWS HOW THEY DETERMINED THE FORM AND CONTENT OF DEMOCRACY AND GAVE RISE TO LIBERAL DEMOCRACY AS WE KNOW IT TODAY. IT THEN GOES ON TO ARGUE THAT LIBERAL DEMOCRACY IS SPECIFIC TO A PARTICULAR CULTURAL CONTEXT AND 
TO CULTURAL RELATIVISM AS IT IS POSSIBLE TO FORMULATE UNIYERSAL PRINCIPLES THAT EYERY GOOD GOVERNMENT SHOULD RESPECT. THE PAPER OFFERS ONE WAY OF RECONCILING UNIVERSALISM AND CULTURAL DIVERSITY.

07122 PAREKH, B.

THE POVERTY OF INOIAN POLITICAL THEORY

HISTORY OF POLITICAL THOUGHT, 13(3) (FAL 92), 535-650. THIS PAPER CONCENTRATES ON POST-INDEPENDENCE INDIA AND EXPLORES WHY A FREE SOCIETY HITH A TRADITION OF PHILOSOPHICAL INQUIRY HAS NOT DEVELOPED MUCH ORIGINAL POLITICAL THEORY. THE FIRST PART OF THE PAPER OUTLINES SOME OF THE PROBLEMS EXPERIENCED BY POST-INDEPENDENCE INDIA AND THE SECOND SHOWS THAT THEY REMAIN POORLY THEORIZED. THE FINAL PART EXPLORES SOME OF THE LIKELY EXPLANATIONS OF THIS NEGLECT.

07123 PARENTI, M.

MEDIA DISTORTION AND THE GULF WAR PROTEST

POLITICAL AFFAIRS, LXX(4) (APR 91), 13-15.

THE HUNDREDS OF THOUSANDS OF INDIVIDUALS IN AMERICA AND AROUND THE WORL WHO TOOK TO THE STREETS TO PROTEST THE WAR IN THE MIDOLE EAST PROVIDED YET ANOTHER OCCASION TO OBSERVE HOW THE CORPORATE-OWNED MEDIA MISREPRESENT MASS DISSIDENCE. HOH THE CORPORATE-OWNED MEDIA MISREPRESENT MASS DISSIDENCE. UNDERCOUNTING, TRIVIALIZING AND MARGINALIZING, SHOWING FAVORITISM FOR PRO-WAR ADVOCATES, AND DENYING CONTENT.

07124 PARIS, S

AMERICA SEEN ON TELEVISION

NEH POLITICS, IV(1) (SUM 92 ) 22-26.

THIS ARTICLE EXAMINES THE TELEVISION COVERAGE OF THE CLARENCE THOMAS HEARINGS AND THE MIKE TYSON RAPE TRIAL AS REPRESENTATIVE EXAMPLES OF HOW AFRICAN-AMERICANS ARE OFTEN PROTRAYED IN THE UNITED STATES. BLACK AMERICANS ON THE AMERICA OF TV ARE MOST OFTEN IN THE NEWS AS HAVING INDIVIDUAL PROBLEMS HHICH ARE, PARADOXICALLY, MUNDANE AND SHOCKING. THE THOMAS MEARINGS BOTH ACKNOWLEDGED THAT SEXUAL HARASSMENT IS ENDEMIC TO AMERICAN SOCIETY, AND DENIED IT BY TREATING THE CHARGE AGAINST THOMAS AS A SCANDAL BOUMD TO ROCK THE NATION. SIMILARLY, THE EMPHASIS ON MIKE TYSON'S TROUBLED CHILDHDOD MADE HIS ACTIONS SEEM INCREDIBLY ABERRANT WHEREAS IN REALITY MEN RAPE WOMEN AT THE RATE OF ONE A
MINUTE. TV CULTURE COVERS THIS BIAS IN A MASK OF OBJECTIVITY THAT CONSIDERS BOTH SIDES OF AN ISSUE, BUT FAILS TO REVEAL UNDERLYING AGENDAS.

07125 PARK, A.

GLOBAL SECURITY, GLASNOST AND THE RETREAT DIVIDEND GOVERMMENT AND OPPOSITION 26(1) (1991) 75-85.

THIS ARTICLE ADDRESSES VARIOUS QUESTIONS PERTAINING TO GLOBAL SECURITY GLASNOST AND INTERPRETATION OF THE RESULTS GLOBAL SECURITY, GLASNOST, AND INTERPRETATION OF THE RESULTS OF THE END OF THE COLD WAR. SPECIFIC ISSUES CONSIDERED WHAT IS GLASNOST? WHAT ARE THE MAIN FEATURES OF ITS DEVELOPMENT IN 1985-90? WHAT IS THE PLACE OF GLASNOST CONTEXT OF THE MAIN POLITICAL DIVIOENDS OF THE SOVIET LEADERSHIP? WHAT ARE THE LIMITS OF THE RETREAT FROM ORTHODOX COMHUNIST POSITIONS? WHAT IS THE PROSPECT OF GLASNOST IN THE LIGHT OF THE MAIN SCENARIOS OF THE USSR'S FUTURE? HOW IS GLASNOST RELATED TO GLOBAL SECURITY?

07126 PARK, A.

GORBACHEV ANO THE ROLE OF PERSONALITY IN HISTORY STUDIES IN COMPARATIVE COMMUNISM, 25(1) (MAR 92), 31-46. ANY GENERAL ASSESSMENT OF GORBACHEV'S ROLE DEPENDS ON THE COMPETING SYSTEMS OF POLITICAL VALUES AND THE AUTHOR ARGUES THAT THERE ARE LOTS OF REASONS TO BE HIGHLY SKEPTICAL ABOUT THE ABILITY TO REACH THE TRUTH. THAT A LEADER LIKE GORBACHEY WAS PROBABLY MECESSARY TO UNLEASH THE SOVIET REVOLUTION, BUT THAT SINCE THEN HIS ROLE HAS DIMISHED IS POSTULATED', GORBACHEY'S ROLE IN THE SOVIET REVOLUTION HAS MORE ESSENTIAL IN 1985 THAN IN 1991. THE ARTICLE CONCLUDES THAT IT IS NOT LIKELY THAT THERE WILL EVER BE A CONSENSUS ABOUT HOW POSITIVE OR NEGATIVE WAS GORBACHEV'S GENERAL ROLE IN HISTORY.

07127 PARK, A.

THE POST-SOVIET SYSTEM OF STATES

BULLETIN OF PEACE PROPOSALS, 23(1) (MAR 92), 11-16. THIS ARTICLE CONCEPTUALIZES SOME FEATURES OF THE USSR'S DEVELOPMENT FROM THE SPRING TO THE AUTUMN OF 1991. IT EXAMINES THE EVENTS OF THIS PERIOD BOTH AS THE CULMINATION OF PROCESSES BEGAN IN 1985 WITH THE REFORMS OF MIKHAIL GORBACHEV AND AS THE "THIRD SYSTEMIC IMPERIAL CRISIS" IN GORBACHEV AND AS THE "THIRD SYSTEMIC IMPERIAL CRISIS" IN CHRONICLES THE END OF THE COLD CIVIL WAR, THE FORMATION OF CHRONICLES THE END OF THE COLD CIVIL WAR, THE FORMATION OF A NEW UNION TREATY, THE ELECTION OF BORIS YELTSIN, AND THE ATTEMPTED COUP AGAINST GORBACHEV. IT PREDICTS THAT THE ECONOMIC ANARCHY AND CRISIS IN MANY OF THE POST-SOVIET REPUBLICS WILL SOONER OR LATER AGAIN LEAD TO SOME FORM OF POLITICAL CRACKDOWN.

07128 PARK, K. ; LEE, S

CHANGES AND PROSPECTS IN INTER-KOREAN RELATIONS
ASIAN SURVEY, 22(5) (MAY 92), 429-447.

CONSIDERING THAT KOREA IS MOSTLY AN ETHNICALLY

HOMOGENEOUS MATION. THE INITIATION OF A NATIONAL MOVEMENT TOWARD REUNIFICATION HAS TO BE VIEWED AS A NATURAL COURSE OF ACTION. THE PURPOSE OF THIS PAPER IS TO EXAMINE INTER-KOREAN RELATIONS OVER THE YEARS AND ANALYZE THE FACTORS THAT HAVE CONTRIBUTED TO THEIR EVOLUTION. IT THEN ASSESS THE PROSPECTS FOR FUTURE RELATIONS. INTER-KOREAN RELATIONS ARE EXPECTED TO

07129 PARK, T.

ISSUES OF ARMS CONTROL BETHEEN THE THO KOREAS

ASIAN SURVEY, 32(4) (APR 92), 350-365.

ARMS CONTROL HAS BECOME A REALITY TODAY FROM WHICH THE TWO KOREAS WOULD FIND IT DIFFICULT TO ESCAPE. THIS ARTICLE ATTEMPTS TO PROVIDE AN OVERVIEN TO THE PROBLEM OF ARMS CONTROL AND DISARMAMENT ON THE KOREAN PENINSULA.

SPECIFICALLY, THE DISCUSSION BEGINS WITH THE IDENTIFICATION OF MAJOR NATIONAL SECURITY GOALS OF NORTH AND SOUTH KOREA AS THEY HOUL AFFECT FUTURE NEGOTIATIONS IN ARMS CONTROL THEM IT MOVES TO THOSE CRITICAL ISSUES THAT WILL DOMINATE THE AGENDA OF BILATERAL TALKS. FINALLY, IT PRESENTS SOME POLICY OPTIONS EACH KOREA MAY TAKE, ESPECIALLY AT THE INITIAL STAGE OPTIONS EACH KOREA MAY TAKE, ESPECIALLY AT THE INITIAL STAG OF ARMS CONTROL NEGOTIATIONS. ALSO INCLUDED IN THE ANALYSIS

ARE THE ROLES THAT THE SURROUNDING MAJOR POWERS

07130 PARKER, G.

THE DISTRIBUTION OF HONORARIA INCOME IN THE U.S. CONGRESS: WHO GETS RENTS IN LEGISLATURES AND WHY?

PUBLIC CHOICE, 73(2) (MAR 92), 167-182.

NOT ALL OF THE PAY OF LEGISLATORS OCCURS HITHIN THE

CONFINES OF THE FEDERAL BUDGET: MOST LEGISLATORS RECEIVE

"EXTRA" PAY. THE PURPOSE OF THIS ANALYSIS IS TO EXPLAIN THE DISTRIBUTION IN HONORARIUMS IN THE U.S. CONGRESS IN TERMS OF ECONOMIC THEORIES AND HYPOTHESES ABOUT RENT-SEEKING. SEVERAL HYPOTHESES ABOUT RENT-SEEKING ARE DISCUSSED IN TERMS OF THEIR IMPACT ON THE DEMAND AND SUPPLY OF RENTS. THE VARIABLES ARE OPERATIONALIZED AND ENTERED INTO OLS REGRESSION EQUATIONS EXPLAINING THE DISTRIBUTION OF HONORARIA INCOME IN THE HOUSE AND SENATE.

07131 PARKER, R.8.

THE JUNE HAR: WHOSE CONSPIRACY?

JOURMAL OF PALESTINE STUDIES, XXI(4) (SUM 92), 5-21. CONSPIRACY THEORIES ABOUT THE JUNE 1967 WAR ABOUNO. IN THIS ARTICLE, THE AUTHOR SUMMARIZES SOME OF THE MAJOR CONSPIRACY THEORIES HE EXPIORES THE MOT IVES AND ROLES OF THE SYRIANS. THE EGYPTIANS, THE SOVIETS, THE AMERICANS, AND THE ISRAELIS.

07132 PARSONS, A.

THE UN CHAPTER AND INTERNATIONAL INTERVENTION IN IRAQ MIDDLE EAST INTERNATIONAL, (398) (APR 91), 20-21.

THIS ARTICLE CONSIDERS THE JUSTIFICATION GIVEN FOR NONINTERVENTION IN IRAO AS SADDAH HUSSEIN REPRESSES THE KURDISH AND SHI' ITE REBELLIONS. IT CONSIDERS ARTICLE 2 (7) OF THE UN CHARTER AND CONCLUDES THAT THERE IS NO REASON WHY THE UN SHOULD NOT INTERVENE TO PREVENT SADDAM FROM CONTINUING THE MASSACRE ARABS AND KURDS AND TO FORCE THEM TO FLEE HIS PERSECUTION. THE SECURITY COUNCIL HAS EVERY RIGHT TO ADOPT MEASURES, INCLUDING THE USE OF FORCE, TO PREVENT FURTHER OPPRESSION, TO ENABLE THE REFUGEES TO RETURN OR TO REMAIN IN THEIR COUNTRY IN SAFETY, AND TO ENSURE THAT THERE IS NO PERSECUTION OF THE TENS OF THOUSANDS OF IRAQIS IN THE SOUTH WHO HAVE TAKEN REFUGE IN THE AMERICAN OCCUPIES ZONE SHORTLY TO BE HANDED OVER TO A SMALL UN MONITORING FORCE.

07133 PASCD, X.: SOURBES, I

US AND SOVIET POLICY FOR LONG-TERM HUMAN EXPLORATION OF SPACE: A EUROPEAN ASSESSMENT

SPACE POLICY, 73 (AUG 91), 207-220.

THE POSSIBILITY OF A RENEHAL OF MANMED EXPLORATION MISSIONS IN OUTER SPACE EXISTS IN BOTH THE USA AND USSR --
BUT IN VERY DIFFERENT CONTEXTS. THE AUTHORS OF THIS ARTICLE ANALYZE THE REASONS FOR PAST MISSIONS AND EXAMINE THE DEBATE SURROUNDING THE SPACE EXPLORATION INITIATIVE IN THE USA AND MARS 94 AND 98 MISSIONS IN THE USSR.

07134 PASCU, M.

INTEGRATION AND DISINTEGRATION IN EUROPE

PEACE AND THE SCIENCES, 3 (SEP 91), 16.

EUROPE IS AT AN IMPORTANT CROSSROAD. ON THE ONE HAND, THE HESTERN STRUCTURES ARE STILL IN PLACE, PROMISING THE WESTERN STRUCTURES ARE STILL IN PLACE, PROMISING
CONSOLIDATION, WHILE THE EASTERN ONES ARE FACING DISMANTLING. CONSOLIDATION, WHILE THE EASTERN ONES ARE FACING DISMANTLING
THIS IS BECAUSE THE FIRST WERE BUILT ON A SOLID BASE OF THIS IS BECAUSE THE FIRST WERE BUILT ON A SOLID BASE OF BUILT IN THE SOVIET INTEREST TO HOLD ITS NEH ALLIES AND BUILT IN THE SOVIET INTEREST TO HOLD ITS NEH ALLIES AND PARTNERS TOGETHER. THEREFORE, WHEN THAT INTEREST COULD BE MAINTAINED ANY LONGER, THE EASTERN MULTINATIONAL
STRUCTURES WERE CONFRONTED WITH DISSOLUTION. THIS ARTICLE STRUCTURES HERE CONFRONTED WITH DISSOLUTION. THIS ART
DISCUSSES INTEGRATION AND DISINTEGRATION IN EUROPE. 
07135 PASHA, H.A.

MAXIMUM LOT SIZE ZONING IN DEVELOPING COUNTRIES

URBAN STUDIES, $29(7)$ (OCT 92), 1173-1181.

THE AUTHOR IDENTIFIES THE PRINCIPAL MOTIVATIONS FOR RESORTING TO LAND RATIONING IN THE FORM OF MAXIMUM LOT SIZE ZONING IN DEVELOPING COUNTRIES. HE ANALYZES THE CONSEQUENCES OF SUCH REGULATION ON UTILITY LEVELS, LAND VALUES, AND METROPOLITAN AREA WITHIN THE SPATIAL, GENERAL EQUILIBRIUM FRAMEWORK OF A SEMI-CLOSED CITY WITH TWO INCDME GROUPS, THE RICH AND THE POOR. HE ARGUES THAT THE REALIZATION OF THE ANTICIPATED BENEFITS FROM THE REGULATION DEPENDS UPON THE FEATURES OF THE PARTICULAR CITY WHERE SUCH LEGISLATION IS CONTEMPLATED, ESPECIALLY IN TERMS OF THE PATTERN OF INTRAURBAN LOCATION OF THE THO INCOME GROUPS.

07136 PASHA, M.K.

SECURITY AS HEGEMONYL NATIONAL SECURITY AND THE POLITICS OF INTEGRATION IN INDIA ANO PAKISTAN; ASSOCIATION FOR ASIAN STUDIES 1992 ANNUAL MEETING

ASSOCIATION FOR ASIAN STUDIES, $1992,136$.

NATIONAL SECURITY IN BOTH INDIA AND PAKISTAN HAS BEEN VIEWED AS THE PRIVILEGED DOMAIN OF THE STATE IN HER EXTERNAL VIEWED AS THE PRIVILEGED DOMAIN OF THE STATE IN HER EXTERNAL RELATIONS, BUT THE DISCOURSE ON "NATIONAL SECURITY" HAS NOT USUALLY BEEN SEEN AS A PROJECT OF ESTABLISHING HEGEMONY
CIVIL SOCIETY. THIS PAPER APPROACHES THE QUESTION OF CIVIL SOCIETY. THIS PAPER APPROACHES THE QUESTION OF
NATIONAL SECURITY AS A HEGEMONIC PROJECT AND EXAMINES THE IMPLICATIONS FOR DOMESTIC POLITICS IN INDIA AND PAKISTAN. THE WORKING HYPOTHESIS IS THAT THERE IS AN INVERSE RELATIONSHIP BETWEEN NATIONAL SECURITY-AS-HEGEMONY AND MATIONAL INTEGRATION. THE LATTER IS A PRODUCT OF A GENUINE ACKNOWLEDGMENT OF THE CLAIMS OF CIVIL SOCIETY, RATHER THAN THE RESULT OF STATE DOMINATION OF CIVIL SOCIETY. BY DENYING THE CLAIMS OF CIVIL SOCIETY--EXPRESSED EITHER IN PLURAL ISM OR CULTURAL CONSCIOUSNESS OF ETHNIC GROUPS-THE CONFLATION OF NATIONAL SECURITY WITH NATIONAL INTEGRATION IS LIKELY TO YIELD POLITICAL INSTABILITY AND THE DELIGIMATION OF THE STATE. REAL HEGEMONY CAN EMANATE MAINLY FROM CIVIL SOCIETY, NOT THE STATE. THE HISTORICAL EXPERIENCE, ESPECIALLY THAT OF RECENT POLITICAL DEVELOPMENTS IN SOUTH ASIA, SUGGESTS A PARTIAL EROSION OF STATE CAPACITY. ACCENTUATED LARGELY BY A NARROWLY CONCEIVED NOTION OF HEGEMONY.

07137 PASOUR, JR., E.

ECONOMISTS AND PUBLIC POLICY: CHICAGO POLITICAL ECONOMY VERSUS CONVENTIONAL VIEHS

PUBLIC CHOICE, 74(2) (1992), 153-168.

THE PURPOSE OF THIS PAPER IS TO CONTRAST THE
THE

CONVENTIONAL AND CHICAGO POLITICAL ECONOMY (CPE) VIEWS OF

THE COLLECTIVE CHOICE PROCESS AND TO DESCRIBE THE

THE COLLECTIVE CHOICE PROCESS AND TO DESCRIBE THE IMPLICATIONS FOR THE ROLE OF THE ECONOMIST IN PUBLIC POL ICY ANALYSIS. THE U.S. SUGAR PROGRAM IS USED AS A CASE STU CONTRASTING THE IMPLICATIONS OF CPE AND CONVENTIONAL APPROACHES. THE ANALYSIS STRESSES THE IMPORTANCE OF THE
EQUILIBRIUM ASSUMPTION IN CPE AND SHOWS WHY THE CPE RESULT EQUILIBRIUM ASSUMPTION IN CPE AND SHOWS WHY THE CPE RESUL DOES NOT IMPLY THAT ECONOMIC EDUCATION IS HORTHLESS. THE
ARGUMENT IS THAT UNCERTAINTY, COSTLY INFORMATION, AND PERVERSE INCENTIVES IMPLY IMPERFECT COORDINATION, PROVIDING SCOPE FOR POTENTIAL IMPROVEMENT IN THE POLITY AND,

CONSEQUENTLY, A BENEFICIAL ROLE FOR THE ECONOMIST.

07138 PASTOR, M. : HISE, C.

PERUVIAN ECONOMIC POLICY IN THE 1980S: FROM ORTHODOXY TO HETERODOXY AND BACK

LATIN AMERICAN RESEARCH REVIEW, 27(2) (1992), 83-118.

LOOKING BACK OVER PATTERNS OF ECONOMIC ADJUSTMENT AND STRUCTURAL REFORM IN LATIN AMERICA SINCE THE DEBT CRISIS BEGAN IN 1982, THO BROAD TRENDS STAND OUT. THE FIRST IS THE DRAMATIC FLUCTUATION IN MACROECONOMIC POLICY BETHEEN THE ORTHODOX PROGRAMS TRADITIONALLY ADVDCATED BY THE IMF. THE SECOND TREND IS THE INABILITY OF STATES TO FOLLOH THROUGH COHERENTLY ON ANY GIVEN POLICY COURSE. THIS ARTICLE EXAMINES THE TWO THEMES OF POLICY FLUCTUATIONS AND INCONSISTENCIES A

07139 PASTOR, R.

PREEMPTING REVOLUTIONS: THE BOUMDARIES OF U.S. INFLUENCE INTERNATIONAL SECURITY, 15(4) (SPR 91), 54-86.

THE FOCUS OF THIS ARTICLE IS ON SUCCESSION CRISES, IN WHICH A DECLINING DICTATOR, WHO HAD BEEN FRIENDLY TO THE U.S BUT RUTHLESS TO HIS OWN PEOPLE, FACES A BROADLY-BASED NATIONAL MOVEMENT TO UNSEAT HIM. THE ESSENCE OF THE CHALLENGE FOR THE U.S. IS NOT HOW TO DEAL WITH THE REVOLUTIONARIES, BUT RATHER HOW TO PERSUADE OR COERCE THE DECLINING DICTATOR TO YIELD POHER IN SUCH A HAY THAT THE DECLINING DICTATOR TO YIELD POWER IN SUCH A WAY THAT THE
SUCCESSOR IS LEAST LIKELY TO BE ANTI-AMERICAN AND MOST SUCCESSOR IS LEAST LIKELY TO BE ANTI-AMERICAN AND MOS
LIKELY TO BE DEMOCRATIC. THE ARTICLE DISTINGUISHES SUCCESSION CRISES FROM OTHER U.S. FOREIGN POLICY CHALLENGES
STE SUCH AS REVOLUTIONS. IT THEN ANALYZES EIGHT CASES WITH DIFFERENT OUTCOMES, AND SEEKS EXPLANATIONS FOR WHY A REVOLUTION OCCURS OR IS PREEMPTED, HHY U.S. POLICIES HAVE TENDED TO LOOK SIMILAR IN APPARENTLY DIFFERENT CIRCUMSTANCES, AND WHAT LESSONS CAN BE DRAWM FOR DEALING WITH SIMILAR CRISES IN THE FUTURE.
07140 PASTOR, R.A.

THE LATIN AMERICAN OPIION

FOREIGN POLICY, (88) (FAL 92), 107-125.

IN 1992, U.S. POLICY TOHARD LATIN AMERICA SEEMS

INCOHERENT AND EXHAUSTED--OR PERHAPS JUST SUSPENDED FOR THE PRESIDENTIAL ELECTION. WHAT IS NEEDED IS A NEW, ENERGIZED APPROACH THAT HOULD NEGOTIATE GENERAL PRINCIPLES, ENSURE THE SECURITY OF INDIVIDUAL COUNTRIES AND THE REGION, GUARANTEE DEMOCRACY AND DEFEND HUMAN RIGHTS, AND PROMOTE ECONOMIC DEVELOPMENT AND AN IMPROVED OUALITY OF LIFE FOR ALL THE PEOPLES OF THE HEMISPHERE.

07141 PATAKI, J.

DEALIMG WITH HUNGARIAN COMMUNISTS' CRIMES

RFE/RL RESEARCH REPORT, $1(9)$ (FEB 92), 21-24.

ON NOVEMBER 4, 1991, THE HUNGARIAN PARLIAMENT PASSED A LAW SUSPENDING THE STATUTE OF LIMITATIONS FOR ALL CRIMES OF MURDER, TREASON, AND AGGRAVATED ASSAULT LEADING TO THE VICTIM'S DEATH THAT WERE COMMITTED DURING THE PAST 45 YEAR BUT, FOR POLITICAL REASONS, HERE NOT PROSECUTED. NOT BUT, FOR POLITICAL REASONS, HERE NOT PROSECUTED. NOT EVERYONE IS IN FAVOR OF THE LAH BECAUSE SOME PEOPLE FEAR
THAT IT WILL PRODUCE A POLITICAL WITCH-HUNT. OTHERS BELIEVE THAT IT WILL PRODUCE A POL ITICAL WITCH-HUNT. OTHERS BELIEVE SO HUNGARY'S PRESIDENT HAS REFERRED IT TO THE CONSTITUTIONAL
COURT.

07142 PATAKI, J.

HUNGARIANS DISSATISFIED WITH POLITICAL CHANGES

RFE/RL RESEARCH REPORT, 1(44) (NOV 92), 66-70.

ACCORDING TO A PUBLIC OPINION SURVEY, A LARGE MAJORITY OF THE HUNGARIAN POPULATION IS DISAPPOINTED WITH THE POLITICAL AND ECONOMIC CHANGES AND BLAMES THE GOVERMMENT AND THE GOVERNING PARTIES FOR THE SITUATION. TWO OF THE LARGEST POLITICAL PARTIES CURRENTLY REPRESENTED IN THE PARLIAMENT SEEM TO HAVE LOST A LARGE PERCENTAGE OF THEIR SUPPORTERS SINCE THE 1990 NATIONAL ELECTIONS. THE FINDINGS HIGHLIGHT THE APPARENT FRAGILITY OF HUNGARIAN POL ITICAL PARTIES, WHICH COULD HAVE AN ADVERSE EFFECT ON THE MAKEUP OF THE NEXT GOVERNMENT AND PARLIAMENT. SOME REFORM COMMUNIST LEADERS SEEM TO HAVE RETAINED THE CONFIDENCE OF THE VOTERS, ALTHOUGH THE HUNGARIAN SOCIALIST PARTY ITSELF DOES NOT SEEM TO HAVE

07143 PATAKI, J.

HUNGARY MAKES SLOW BUT STEADY PROGRESS

HUNGARY MAKES SLOW BUT STEADY PROGRESS
RFE/RL RESEARCH REPORT, $1(1)($ JAN 92$), 87-90$.

AT THE CLOSE OF 1991, HUNGARY HAD A FUNCTIONING

GOVERNMENT, PARLIAMENT, AND LEGAL SYSTEM AND HAD MADE CONSIDERABLE PROGRESS IN ESTABLISHING A MARKET ECONOMY. NEVERTHELESS, IT WAS OBVIOUS THAT TRANSFORMING THE ECONOMY WOULD BE A LENGTHY PROCESS AND THAT A REAL RECOVERY COULD NOT BE EXPECTED IN THE NEAR TERM. THE YEAR 1991 ALSO REVEALED THAT TRANSFORMING THE POLITICAL MENTALITY OF THE POPULATION WOULD BE AS DIFFICULT AS RESTRUCTURING THE
ECONOMY.

07144 PATAKI, J.

HUNGARY: YOUNG DEMOCRATS PREPARE FOR 1994 ELECTIONS RFE/RL RESEARCH REPORT, 1(12) (MAR 92), 7-11. THE CONGRESS OF THE ALLIANCE OF YOUNG DEMOCRATS IN FEBRUARY 1992 WAS A FIRST STEP TOWARD PREPARING THE PARTY FOR THE NATIONAL ELECTIONS SCHEDULED FOR 1994. ACCORDING TO VARIOUS OPINION POLLS, THE PARTY HAS BEEN GAINING SUPPORT AT AN UNPRECEDENTED RATE SINCE THE 1990 NATIONAL ELECTIONS AND COULD PLAY AN IMPORTANT ROLE IN THE FUTURE. THE PARTY'S SUCCESS MAY BE AT LEAST PARTLY DUE TO ITS FAVORABLE PRESS COVERAGE, WHICH HAS NOT FOCUSED ON THE DIFFERENCES OF OPINION AMONG PARTY MEMBERS NOR ANALYZED THE PROBLEMS THAT COULD ARISE IF A PARTY WHOSE MEMBERS ARE PREDOMINANTLY YOUNGER THAN 35 YEARS WERE TO COME TO POWER.

07145 PATAKI, J.

HUNGARY'S FREE DEMOCRATS ELECT NEW LEADERSHIP RFE/RL RESEARCH REPORT, 1 (50) (DEC 92), 41-44. THE ALLIANCE OF FREE DEMOCRATS, THE LARGEST OPPOSITION PARTY IN THE HUNGARIAN PARLIAMENT, HAS A NEW CHAIRMAN: 46YEAR-OLD IVAN PETO. ELECTED AT THE ALLIANCE'S ANMUAL CONFERENCE IN NOVEMBER 1992, PETO REPLACED PETER TOLGYESSY, WHO FAILED TO RETAIN THE SUPPORT OF THE PARTY'S FOUNDERS. ALTHOUGH TOLGYESSY PLEDGED TO SUPPORT PETO, THUS AVOIDIMG AN OPEN SPLIT, THE THO POLITICIANS HAVE CONTRASTING LEADERSHIP OPEN SPLIT, THE THO POLITICIANS HAVE CONTRASTING LEAD
STYLES AND SEEM TO SUBSCRIBE TO SOMEWHAT DIFFERENT IDEOLOGIES AS WELL. WHILE TOLGYESSY REFUSED TO COOPERATE IDEOLOGIES AS WELL. WHILE TOLGYESSY REFUSED TO COOPERATE WITH THE HUNGARIAN SOCIALIST PARTY, PETO DOES NOT RULE OUT LEADERSHIP THE PARTY COULD SHIFT TOWARD THE POLITICAL LEFT.
L L THE

07146 PATAKI, J.

INCREASING INTOLERANCE OF FOREIGNERS

RFE/RL RESEARCH REPORT, 1(19) (MAY 92), 34-38, DUE TO THE RECENT CHANGES IN EASTERN EUROPE, MANY REFUGEES AND ILLEGAL ALIENS HAVE FLED TO HUNGARY. IN GENERAL, HUNGARIANS HAVE BEEN TOLERANT OF THE POLITICAL REFUGEES FROM YUGOSLAYIA. HOWEVER, OHING TO THE INCREASING NUMBER OF 
ILLEGAL IMHIGRANTS WITH ALIEN CULTURES, RACIAL INTOLERANCE IS ON THE RISE SOME HUNGARIAN OFFICIALS ARGUE THAT A NEW, COMPREHENSIVE LAH ON IMMIGRATION IS NEEDED TO CURB THE INFLUX OF ILLEGAL ALIENS AND TO PREVENT LARGE-SCALE MIGRATION FROM THE EAST TO HUNGARY AS ECONOMIC AND POLITICAL CONDITIONS DETERIORATE IN ROMANIA AND SOME AREAS OF THE FORMER SOVIET UNION.

07147 PATAKI, J.

ISTVAN CSURKA'S TRACT: SUMMARY AND REACTIONS

RFE/RL RESEARCH REPORT, 1(40) (OCT 92), 15-22.

A TRACT PUBLISHED BY ISTVAN CSURKA, A VICE PRESIDENT OF THE RULING HUNGARIAN DEMOCRATIC FORUM, HAS CAUSED A STORM IN HUNGARIAN POLITICS. CSURKA ASSERTS THAT, RATHER THAN PURSUING A COHERENT STRATEGY AIMED AT DEFEATING THE FORMER NOMENKLATURA AND DEFENDING "HUNGARIAN VALUES," THE FORUM HAS BEEN MERELY IMPROVISING. HE CALLS ON PRIME MINISTER JOZSEF ANTALL TO DESIGMATE AMD TRAIM A SUCCESSOR. HE ALSO ATTACXS THE NOMEMKIATURA FOR HAYIMG RETAINED THEIR POWER AND HEALTH AND ACCUSES THE TO DO SO. THE ANTI-SEMITIC--SOME EVEN SAY HATIONAL SOCIALIST -OVERTONES OF THE ESSAY HAVE BEEN STRONGLY CRITICIZED BY LIBERALS WITHIN CSURKA'S OWM PARTY AND OTHER LEADERS, AS WELL AS BY THE DOMESTIC AND INTERNATIONAL MEDIA.

07148 PATAKI, J.

POLITICAL BATTLE IN HUNGARY OVER BROADCASTING DISMISSALS RFE RL RESEARCH REPORT I(30) (JUI 92$)$ 26-30

THE GOVERNMENT AND THE OPPOSIIION PARTIES HAVE INVOLVED THE HUNGARIAN CONSTITUTIONAL COURT IN THEIR FIGHT OVER THE BROADCASTING MEDIA. THE COURT ISSUED A RULING THAT LIMITS PRESIDENT ARPAD GONCZ'S PONER OVER APPOINTMENTS AND OISMISSALS AT HUNGARIAN RADIO AND TELEVISION; ALTHOUGH THE COURT DISMISSED AS UNCONSTITUTIONAL A DECREE USED BY THE GOVERNMENT TO SUPERVISE BROADCASTING, IT WILL PERMIT THE DECREE TO REMAIN OPERATIONAL UNTIL NOVEMBER 30, 1992, THE DEADLINE SET BY THE COURT FOR THE PASSAGE OF A MEW MEDIA LAW.

07149 PATAKI, J.

REFORM OF THE HUNGARIAN HEALTH-CARE SYSTEM

RFE/RL RESEARCH REPORT, 1(6) (FEB 92) 59-62.

HUNGARY'S HEALTH-CARE SYSTEM IS BADLY IN NEED OF COMPREHENSIVE REFORM, BUT THE HAPHAZARD WAY IN WHICH CHANGES ARE BEING INTRODUCED IS CAUSING CONFUSION AND CONCERN AMOMG DOCTORS AND PATIENTS ALIKE. THE INTERESTS OF PHYSICIANS WHD HAVE SECURE POSITIONS AND SUPPLEMENT THEIR INCOMES BY ACCEPTING TIPS FROM THEIR PATIENTS ARE ENDANGERED BY THESE CHANGES. INDEED, THE GOVERNMENT HAS ONLY NOW BEGUN TO TACKLE THE REFORM OF THE HEALTH-CARE SYSTEM BECAUSE OF EXTENSIVE LOBB REFORM OF THE HEALTH-CARE SYSTEM BECAUSE OF EXTENS
LOCTORS OPPOSED TO CHANGES IN THIS SECTOR.

07150 PATAKI, J.

ROLE OF SMALLHOLDERS' PARTY IN HUNGARY'S COALITION DRMENT

RFE/RL RESEARCH REPORT, 1(14) (APR 92), 20-23.

IN FEBRUARY 1992 THE CHAIRMAN OF THE INDEPENDENT SMALLHOLDERS' PARTY, JOZSEF TORGYAN, ANMOUNCED THAT HIS PARTY HAS LEAVING HUNGARY'S COALITION GOVERNMENT. THE DECISION WAS REACHED AFTER A POWER STRUGGLE LASTING ALMOST TWO YEARS BETHEEN TORGYAN AND PRIME MINISTER JOZSEF ANTALL, WHO HAD MADE IT VERY HARD FOR THE PARTY TO EXERT ANY INFLUENCE WITHIN THE COALITION. HOWEVER, OWING TO INFIGHTING WITHIN THE SMALLHOLDERS' PARTY, ONLY A SMALL NUMBER OF ITS DEPUTIES ACTUALLY LEFT THE COALITION WITH TORGYAN; THE MAJORITY CONTINUE TO SUPPORT THE GOVERNMENT, SO THE COALITION IS NOT EXPECTED TO FALL APART.

07151 PATAKI, J.

WILL THE GOVERNING COALITION SURVIVE?

RFE/RL RESEARCH REPORT, 1 (48) (DEC 92), 36-39.

THE FUNCTIONING OF THE HUMGARIAN PARLIAMENT HAS BEEN RELATIVELY UMAFFECTED BY THE POLITICAL STORMS CREATED BY SOME MEMBERS OF THE RULING COALITION. THE LACK OF A COHERENT COMMON PRDGRAM OR STRATEGY HAS CAUSED DIFFERENCES TO EMERGE BOTH AMONG THE PARTIES FORMING THE COALITION ANO HITHIN INOIVIDUAL PARTIES. BUT, THUS FAR, THIS HAS NOT LED TO A BREAKUP OF THE COALITION. INSIDE PARL IAMENT THE COALIIION PARTIES HAVE CONTINUED TO ACT AS A UNIFIED BLOC, ENSURING PASSAGE FOR MOST DRAFT LAWS SUBMITTED BY THE GOVERNMENT. THE PARLI IAMENTARY CONSEQUENCES OF A POSSIBLE BREAKUP OF THE RULING HUNGARIAN DEMOCRATIC FORUM ARE DIFFICULT TO PREDICT, BECAUSE ALL THE DEPUTIES HAVE A YESTED INTEREST IN THE SURVIVAL OF THE PRESENT PARLIAMENT FOR ITS FULL FOUR-YEAR SURVIVA

07152 PATEL, S.J.

IN TRIBUTE TO THE GOLDEN AGE OF THE SOUTH'S DEVELOPMENT WORLD DEVELOPMENT, 20(5) (MAY 92), 767-777

MANY COUNTRIES' IN THE SOUTH ARE EXPERIENCING DEEP CRISES AND DESPAIR. THERE IS DANGER OF FORGETTING ALTOGETHER THE SOUTH'S SPECTACULAR ECONOMIC AND SOCIAL SPRINT FOR TWO GENERATIONS SINCE 1950. IN THE PAST THERE HAS NO PARALLEL TO THIS UPSURGE--IN TERMS OF ITS PACE, SIZE, OR SPREAD; OR THE SHEER NUMBERS OF PEOPLE AND COUNTRIES INVOLVED; OR THE
LENGTH OF TIME. THIS ESSAY PINPOINTS THE MAJOR LANDMARKS OF IHIS MONUMENTAL TRANSFORMATION AGAINST THE BACKGROUND OF THE NORTH'S ADVANCE IN THE 19TH CENTURY AND POST-1950 NORTH S ADVANCE IN THE 19TH CENTURY AND POST-19SO TERCEPTIONS OF DEVELOPMENT ECONONICS. IT PAYS TRIBUTE TO THE TRANSFORMATION IN THE HOPE THAT THE LESSONS STILL TO BE DISTILLLD FROM IT WILL FORGE FUTURE STRATEGIES TO BUILD UPON THE SOUTH'S STRENGTHS AND OVERCOME ITS WEAKNESSES.

07153 PATEMAN, C.; HIRSCHMANN, N.J.

POLITICAL OBLIGATION, FREEDOM, AND FEMINIS

AMERICAN POLITICAL SCIENCE REVIEW, 86(1) (MAR 92), 179-188.

HOW SHOULD FEMINIST THEORISTS APPROACH THE ANALYSIS OF POLITICAL OBLIGATION AND FREEDOM? NANCY J. HIRSCHMANN HAS PROPOSED A FUNDAMENTAL RECONSTRUCTION OF THE RELEVANT CONCEPTS. IN THIS DIALOGUE, CAROLE PATEMAN AGREES THAT LIBERAL OBLIGATION THEORY INADEQUATELY TREATS THE COERCION OF WOMEN AND OTHER GROUPS UNDER THE GUISE OF YOLUNTARY OBLIGATIONS, BUT SHE ARGUES THAT HIRSCHMANN GOES TOO FAR, PARTICULARLY IN REJECTING THE PRIORITY OF FREEDOM. IN RESPONSE, HIRSCHMANN EXPLAINS THEIR DISAGREEMENTS AND HER OWN APPROACH.

07154 PATEMAN, $R$

INTELLIGENCE AGENCIES IN AFRICA: A PRELIMINARY ASSESSMENT JOURMAL OF MODERM AFRICAN STUDIES, 30(4) (DEC 92), 569-586. JOURNAL OF MODERN AFRICAN STUDIES, $30(4)$ (DEC 92 ), 569 ESTABLISHED SOME FORM OF STATE-SECURITY APPARATUS, IN MANY ESTABLISHED SOME FORM OF STATE-SECURITY APPARATUS, IN MANY CASES HITH CONSIDERABLE ASSISTANCE FROM FOREIGN ALLIES. IN ADDITION TO COLLECTING INTELLIGENCE AND INFLUENCING FOREIGN MECHANISMS FOR INFLUENCING THE INTERNAL POLITICAL AFFAIRS OF AFRICAN NATIONS.

07155 PATERSON, P.; BROWN, A. ; MCCRONE, D.

CONSTITUTIONAL CRISIS: THE CAUSES AND CONSEQUENCES OF THE 1992 SCOTTISH GENERAL ELECTION RESULT

PARLIAMENTARY AFFAIRS, 45(4) (OCT 92), 627-639.

THE 1992 ELECTION RESULT IN SCOTLAND SURPRISED MANY PEOPLE, NOT THE LEAST THE SCOTTISH CONSERVATIVES. THIS ARTICLE SETS THE 1992 RESULT IN THE CONTEXT OF SHORT-TERM DEVELOPMENTS SINCE 1987 AND ALSO LONGER-TERM CHANGES SINCE THE MID-THENTIETH CENTURY. IT CONCLUDES THAT THE CONSTITUTIONAL CRISIS THAT WAS FORESHADOWED BY THE 1987 RESULT IS, DESPITE THE MOMENTARY RELIEF FOR THE CONSERVATIVES IN 1992, LIKELY TO EMERGE IN EVEN MORE ACUTE FORM WELL BEFORE THE NEXT GENERAL ELECTION. THE MAIN DIFFERENCE FROM 1987 WILL BE THAT THE CRISIS HILL AFFECT LABOUR AS MUCH AS THE CONSERVATIYES.

07156 PATOMAKI, $\mathrm{H}$

FROM MORMATIVE UTOPIAS TO POLITICAL DIALECTICS: 8EYOND A DRCONSTRUCTION OF THE BROWN-HOFFMAN DEBATE

MILLENNIUM, 21(1) (SPR 92), 53-76.

THE AUTHOR DISCUSSES THE MORMATIVE THEORY OF

INTERMATIONAL RELATIONS, ARGUING THAT THE DEBATE BETWEEN

STATE-CENTRISM AND COSMOPOLITANISM RESTS ON WEAK FOUNDATI INS. HE USES A DECONSTRUCTION OF A RECENT EXCHANGE BETHEEN CHRIS BROWN AND MARK HOFFMAN TO ARGUE THAT EACH OF THE COMPETING VIEWS IS BASED EITHER ON ITS OPPOSITION TO THE OTHER OR ON TRANSCENDENTAL ASSUMPTIONS. TO OVERCOME THIS PROBLEM, HE PROPOSES AN ALTERNATIVE DIALOGICAL MORAL EPISTEMOLOGY THAT HAS MORE RELEVANCE FOR PRACTICAL POLITICS.

07157 PATRAS, J.; VIEUX, S

THE CHILEAN "ECONOMIC MIRACLE": AN EMPIRICAL CRITIQUE CRITICAL SOCIOLOGY, 17(2) (SUM 90), 57-72.

THE PINOCHET REGIME IN CHILE HAS CLAIMED NUMEROUS ECONOMIC ACHIEVEMENTS, INCLUDING VIGOROUS GRONTH, INTELLIGENT AND INMOVATIVE MANAGEMENT OF DEBT AND POVERTY, AND AN EXEMPLARY APPROACH TO PRIVATIZATION. THIS PAPER EXAMINES EMPIRICALLY THE HISTORICAL RECORD OF THE PINOCHET REGIME IN EACH OF THESE AREAS. IT CONCLUDES THAT THE CLAIMS OF THE REgIME CANNOT BE SUSTAINED. THE NEO-LIBERAL POLICIES OF THE POST-PINOCHET AYLWIN GOVERNMENT ARE DESCRIBED, TOGETHER WITH THE INSTITUTIONAL CONTEXT IN WHICH THESE POLICIES ARE BEGIN CARRIED OUT. AYLWIN NEO-LIBERALISM IS LIKELY TO PRODUCE ECONOMIC AND SOCIAL OUTCOMES SIMILAR TO THOSE OF THE PINOCHET REGIME. THE POL ITICAL CONSEQUENCES OF THIS COURSE ARE BRIEFLY EXPLORED.

07158 PATTERSON, H.; ROULSTON, C.

THE SAMDINISTAS IN OPPOSITION

JOURMAL OF CDMMUNIST STUDIES, 8(4) (DEC 92), 227-250

SINCE THE FSLN'S ELECTORAL DEFEAT IN 1990, IT HAS BEEN INVOLVED IN A PROCESS OF INTERNAL DEBATE AND ATTEMPTED INVOLVED IN A PROCESS OF INTERNAL DEBATE AND ATTEMPTED
RENOVATION. IT HAS ALSO HAD TO DEVELOP AN EFFECTIVE STRATEGY OF OPPOSITION IN RADICALLY DIFFERENT DOMESTIC AND OF OPPOSITION IN RADICALLY DIFFERENT DOMESTIC AND
INTERNATIONAL CIRCUMSTANCES. THE LEADERSHIP'S STRATEGY OF "CONCERTACION" WITH THE GOVERNMENT HAS ANMOYED THE MORE RADICAL SECTIONS OF THE PARTY. THE COMMITMENT TO RENOVATION AND INTERMAL DEMOCRATIZATION HAS BEEN CRITICIZED IN LIGHT OF THE OUTCOME OF ITS FIRST CONGRESS IN JULY 1991. DIVISIONS WHILE DISILLUSION AND APATHY HAVE BECOME WIDESPREAD AMONG 
THE PARTY'S RANK AND FILE.

07159 PATTERSON, K.D.; MAGLEBY, D.B.

PUBLIC SUPPORT FOR CONGRESS

PUBLIC OPINION QUARTERLY (CHICAGO), 56(4) (WIN 92), 539-551.

THE AUTHORS EXPLAIN THE SHORT- AND LONG-TERM FACTORS THAT INFLUENCE THE PUBLIC'S OPINION OF CONGRESS AND IDENTIFY TRENDS IN PUBLIC SUPPORT FOR THE LEGISLATIVE BODY.

07160 PATTERSON, M; GRUBB, M

THE INTERMATIONAL POLITICS OF CLIMATE CHANGE

INTERNATIONAL AFFAIRS, 68(2) (APR 92), 293-310.

THE SIGNING OF A CONVENTION WHICH WOULD BEGIN TO TACKLE THE THREAT OF HUMAN INDUCED CLIMATE CHANGE IS EXPECTED TO BE THE THREAT OF HUMAN INDUCED CLIMATE CHANGE IS EXPECTED TO BE AND DEVELOPMENT. NEGOTIATIONS TO DATE HAVE ALREADY REVEALED ANO DEVELOPMENT. NEGOTIATIONS TO DATE HAVE ALREADY REVEALED SERIOUS DIVISIDNS OF INTEREST, OF WHICH THOSE DIVIDING NOR BEST PROSPECTS FOR BUILDING AN EFFECTIVE LONG-TERM REGIME BEST PROSPECTS FOR BUILDING AN EFFECTIVE LONG-TERM REGIME
WILL ARISE FROM SEEKING TO DEVELOP NON-TRADITIONAL ALLIANCES ACROSS THE NORTH-SOUTH DIVIDE, SO AS TO FORM A CENTRAL COALITION THAT MORE RELUCTANT STATES WILL ULTIMATELY HAVE TO ACCEPT. THE CONVENTION TO BE SIGNED AT RIO WILL NOT SOLVE THE GREENHOUSE PROBLEM, BUT IT COULD FORM THE BASIS FOR NEGOTIATIONS THAT CAN START EFFECTIVELY TO ADDRESS IT.

07161 PATTERSON, S.C. ; QUINLAN, S.V.; RIPLEY, R.B.

CITIZENS' ORIENTATIONS TOWARD LEGISLATURES: CONGRESS AND THE STATE LEGISLATURE

WESTERM POLITICAL QUARTERLY, 45(2) (JUN 92), 315-338.

IN DEMOCRATIC SOCIETIES, CONSENT MAY REST AS MUCH UPON CITIZENS' SUPPORTIVE ORIENTATIONS AS UPON THE SATISFACTION OF POLICY DEMANDS. THE AUTHORS EXAMINE CITIZEN SUPPORT FOR CONGRESS AND THE STATE LEGISLATURE IN OHIO AND THEN SEEK TO ESTABLISH THE BASIS FOR VARIATIONS IN CITIZENS' SUPPORTIVE ORIENTATIONS. THEIR DATA DERIVE FROM INTERVIEWS WITH A SAMPLE OF OHIOANS, WHO WERE ASKED "HOW STRONGLY DO YOU AEGISLATURE! IS HANDLING ITS JOB?" THE AUTHORS CONSTRUCT AN ANALYTICAL MODEL OF LEGISLATIVE SUPPORT AND ESTIMATE THE ANALYTICAL MODEL OF LEGISLATIVE SUPPORT AND ESTIMATE THE
EFFECTS OF INDEPENDENT VARIABLES, USING THE SURVEY DATA.

07162 PAUL-SHAHEEN, $P$.

OVERLOOKED CONNECTIONS: POLICY DEVELOPMENT AND OVERLOOKED CONNECTIONS: POLICY DEVELOPMEM

JOURNAL OF HEALTH POLITICS, POLICY AND LAW, 15(4) (WIN 90),

INCREASED PUBLIC DEMAND FOR HEALTH SERVICES, COMBINED WITH FISCAL AND OPERATING RESTRAINTS, HAS LED TO THE NEED FOR PROGRAMS THE TWILL OPERATE EFFICIENTLY AND EFFECTIVELY TO ACHIEVE THEIR OBJECTIVES. ESTABLISHING SUCH PROGRAMS REQUIRES AN UNDERSTANDING OF THE FACTORS THAT CONTRIBUTE TO THEIR DEVELOPMENT AND IMPLEMENTATION. THIS IN TURN REQUIRES A GREATER UNDERSTANDING OF THE POLICY FORMULATION AND POLICY IMPLEMENTATION PROCESSES. THIS PAPER USES A CASE STUDY OF MICHIGAN'S STATE/LOCAL COST SHARING PROGRAM TO EXPLORE HOW POLICY FORMULATION LINKS TO AND INFLUENCES IMPLEMENTATIONS IT CONSIDERS THE INTERACTION BETWEEN THE ADMINISTRATIVE AND POLITICAL PROCESSES AND HOW THEY ARE AFFECTED BY SHIFTING POWER RELATIONS, CONSTITUENCIES, AND THE ENVIRONMENT, AND HOW IN TURN THESE AFFECT PROGRAM LEADERSHIP AND OPERATING POLICIES. THE PAPER DEVELOPS A MODEL AS A FRAMEWORK FOR MONITORING THE COURSE OF THE PROGRAM THROUGH THE POLICY CYCLE AND RECOMMENDS THAT THE POLICY PROCESS BE CONSIDERED AS DYNAMIC, INTERACTIVE, AND EVDLUTIMARY. THE CASE STUDY APPROACH ALLOWS FOR A GREATER UNDERSTANDING OF THE PHASES OF THE PROCESS, THEIR INTERACTION, AND THEIR IMPACT ON SPECIFIC POL ICY OUTCOMES.

07163 PAUL, D.B.

EUGENIC ANXIETIES, SOCIAL REALITIES, AND POLITICAL CHOICES SOCIAL RESEARCH, 59(3) (FAL 92), 663

THE AUTHOR DISCUSSES THE CURRENT CONTROVERSY OVER EUGENICS AND THE HUMAN GENOME INITIATIVE. SHE CONCLUDES THAT THERE ARE ISSUES IN SCIENCE, PARTICULARLY WHEN PROFIT IS INVOLVED, THAT MUST BE ADDRESSED BY DEMOCRATIC, SOCIALLYCONSCIOUS GOVERNMENTS. CURRENT HORK IN GENETICS WILL FORCE WHICH MAY BE GOVERNED AS MUCH BY POLITICS AS SCIENCE.

07164 PAUL, S.

ACCOUNTABILITY IN PUBLIC SERVICES: EXIT, VOICE, AND CONTROL WORLD DEVELOPMENT, $20(7)$ (JUL 92 ) 1047-1060

THE AUTHOR ARGUES THAT THE POSITIVE IMPACT OF PUBLIC ACCOUNTABILITY ON PUBLIC SERVICE PERFORMANCE AND GOVERNANCE IN GENERAL CAN BE AUGMENTED BY MOVING AHAY FROM AN EXCLUSIVE RELIANCE ON CONTROL MECHANISMS, SUCH AS HIERARCHICAL MONI TORING AND USE OF ORGANIZATIONAL INCENTIVES, TO A SYSTEM THAT USES "EXIT" OR "VOICE" MECHANISMS IN CONJUNCTION WITH CONTROL. WHETHER THE PUBLIC WILL RESORT TO EXIT OR VOICE WILL DEPEND ON THE RELATIVE COSTS ASSOCIATED WITH THESE OPTIONS AND THE EXPECTED VALUE TO THEM OF THE PERFORMANCE
PUBLIC SERVICES CAN BE CATEGORIZED IN TERMS OF THE EXIT AND VOICE POTENTIAL THEY AFFORD THE PUBLIC BY REFERENCE TO CERTAIN BARRIERS AKD CHARACTERISTICS. THIS PAPER PROVIDES A FRAMEHORK FOR ANALYSIS OF THE FEATURES AND BARRIERS OF PUBLIC SERVICES AND OF THE PUBLICS INVOLVED THAT CAN BE USED TO PREDICT THE POTENTIAL FOR THE USE OF EXIT AND VOICE IN SPECIFIC SERVICE CONTEXTS.

07165 PAUL, T.V.

INFLUENCE THROUGH ARMS TRANSFERS: LESSONS FROM THE U.S.PAKISTANI RELATIONSHIP

ASIAN SURYEY, XXXII (12) (DEC 92), 1078-1092.

ARMS TRANSFER IS A MULTIDIMENSIONAL PROCESS INVOLVING COMPLEX SETS OF RELATIONSHIPS, INTERESTS, AND OUTCOMES.

POLITICAL OR DIPLOMATIC INFLUENCE IS ONE OF THE MANY MOTIVES BEHIND ARMS TRANSFERS FROM SUPPLIER STATES TO DEVELOPING COUNTRIES. DURING THE COLD WAR ERA, ARMS SUPPLY WAS

IMPORTANT TOOL FOR CREATING DEPENDENCIES, PATRON-CLIENT TIES, IMPOR ALL IANCE RELATIONSHIPS. THE SUPERPOWERS BEHAVED UNDER A AND ALLI IANCE RELATIONSHIPS. THE SUPERPOWERS BEHAVED UNDER A
GENERALLY HELD, THOUGH NOT YET FULLY TESTED BELIEF THAT THE GENERALLY HELD, THOUGH NOT YET FULLY TESTED BELI

SUPPLY OF ARMS SERVED AS A MAJOR INSTRUMENT FOR
INTERNATIONAL INFLUENCE, OFTEN BENEFITTING THE STRATEGIC AND INTERNATIONAL INFLUENCE, OFTEN BENEFITTING THE STRATEGIC AND
POLITICAL INTERESTS OF THE SUPPLIER. THIS ARTICLE ATTEMPTS TO TEST THE LINKAGE BETWEEN ARMS AND INFLUENCE BY LDOKING AT THE RECORD OF THE U.S. ARMS TRANSFER RELATIONSHIP WITH PAKISTAN DURING 1979-91. THO CENTRAL QUESTIONS ARE: DID THE U.S. SUCCEED IN BUILDING A PATRON-CLIENT RELATIONSHIP WITH PAKISTAN AND TO HHAT EXTENT DID THE ARMS SUPPLY PROVIDE THE U.S. WITH TANGIBLE INFLUENCE ON OUTCOMES IN SPECIFIC ISSUE AREAS SUCH AS NUCLEAR NON-PROLIFERATION? IT CONCLUDES THAT THE U.S. WAS MODESTLY SUCCESSFUL IN ATTAINING POLITICAL AND DIPLOMATIC INFLUENCE ON PAKISTAN THROUGH ARMS TRANSFERS. HOWEVER, IF A CLIENT STATE IS OF CONSIDERABLE STRATEGIC IMPORTANCE, AS WAS THE CASE IN PAKISTAN, THE PATRON STATE IS UNLIKELY TO BE ABLE TO INFLUENCE THE CLIENT STATE IN IMPORTANT AREAS SUCH AS SECURITY (I.E. THE U.S. WAS UNABLE TO PREVENT PAKISTAN'S ACQUISITION OF NUCLEAR WEAPONS).

07166 PAUSEWANG, $S$

A UN CONVENTION TO WARD OFF COUP D'ETAT?

BULLETIN OF PEACE PROPOSALS, 23(1) (MAR 92), 67-70.

IN INTERNATIONAL RELATIONS THERE IS A GROWING READINESS IN INTERNATIONAL RELATIONS THERE IS A GROHING READINESS
TO CONDEMH COUPS D'ETAT AS A MATTER OF PRINCIPLE BASED ON TO CONDEMH COUPS D'ETAT AS A MATTER OF PRINCIPLE BASED ON INTERNATIONAL AND HUMAN RIGHTS. THE WIDESPREAD CRITICISM OF THE ATTEMPTED COUP IN THE SOVIET UNION OF AUGUST 1991 INTERMATIONAL TREND. THIS ARTICLE ARGUES THAT THE TIME HAS INTERNATIONAL TREND. THIS ARTICLE ARGUES THAT THE TIME

COME TO TAKE THE STEP FRDM MORAL CONDEMNATION IN WORD, TOWARDS INTERNATIONAL ACTION WHICH CAN DETER FUTURE COUP
MAKERS. THE ARTICLE SUGGESTS THAT THE UNITED NATIONS SHOULD MAKERS. THE ARTICLE SUGGESTS THAT THE UNITED NATIONS USE THE CURRENT FAVORABLE PUBLIC CONCERN TO DECLARE,
OFFICIALLY, THAT MILITARY COUPS AND OTHER FORMS OF VIOLENT OFFICIALLY, THAT MILITARY COUPS AND
USURPATION OF POWER ARE ILLEGAL.

07167 PAVLISCHEK, K.J

JOHN COURTHEY MURRAY, CIVIL RELIGION, AND THE PROBLEM OF POLITICAL NEUTRALITY

JOURNAL OF CHURCH \& STATE, 34(4) (FAL 92), 729-750.

THE AUTHOR DISCUSSES THE WORK OF THE JESUIT THEOLOGIAN JOHN COURTNEY MURRAY AND MICHAEL J. SCHUCK'S ANALYSIS OF MURRAY'S IMPACT ON CATHOLICISM AND AMERICAN POLITICAL THOUGHT. HE FOCUSES ON THE QUESTION OF WHETHER MURRAY HAS TO SOME DEGREE CAPITULATED TO AMERICAN CIVIL RELIGION.

07168 PAHSAT, C.

EMOTIONAL, POLITICALLY-CHARGED FIGHT OVER IVORY EXPOSES PACT'S WEAKNESS

JAPAN TIMES (HEEKLY INTERNATIOMAL EDITIOM), 32(12) (MAR

92) 14 .

THE CLASH OVER THE IVORY TRADE HAS CALLED INTO QUESTION THE CONVENTION ON INTERNATIONAL TRADE IN ENDANGERED SPECIES (CITES) MECHANISM AND THE RIGHT OF EACH STATE TO SET ITS OWN WILDLIFE POLICY. DUE TO OVERWHELMING OPPOSITION, ZIMBABWE, BOTSWANA, MAMIBIA, MALAHI, AND SOUTH AFRICA HAVE WITHDRAWN THEIR PROPOSAL TO REPLACE THE CURRENT COMPULSORY THEIR PROPOSAL TO REPLACE THE CURRENT COMPUL SORY
INTERNATIONAL BAN ON THE IVORY TRADE HITH A VOLUNTARY BAN. OPPONENTS SAID THAT VOLUNTARY BAN WOULD HAVE DOOMED ELEPHANT

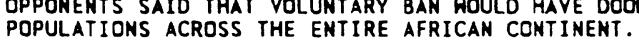

07169 PAXTON, $M$.

ETHNIC AINU'S FIRST DIET CANDIDATE

ETHNIC AINU'S FIRST DIET CANDIDATE
JAPAN TIMES (WEEKLY INTERNATIONAL EDITION), 32(16) (APR 92), 14 .

AUTHOR PROFILES SHIGERU KAYANO, THE FIRST ETHNIC AINU TO RUN FOR ANY NATIONAL PUBLIC OFFICE IN JAPAN. KAYANO WAS CHOSEN AS A CANDIDATE BECAUSE HE HAS WORKED VIGOROUSLY FOR THE PRESERVATION OF AINU CULTURE AND HAS EXTENSIVE KNOWLEDGE OF AINU ETHNICITY.

07170 PAYIN, E.

THE TRAGEDY OF THE MESKHESTIAN TURKS

CULTURAL SURYIVAL QUARTERLY, 16(1) (WIN 92), 36-37.

THE REPRESSION AND INJUSTICES SUFFERED BY THE MESKHETIAN 
TURKS DURING THE SOVIET ERA ARE CONTINUING TODAY IN INDEPENDENT GEORGIA. MOREOVER, THE MESKHESTIAN TURKS ARE NOW FLEEING FROM UZBEKISTAN, DUE TO VIOLENCE AGAINST THEM LED BY UZBEK EXTREMISTS.

07171 PAYNE, A. MANLEY'S LEGACY HEMISPHERE, 4(3) (SUM 92), 20-21

IN 1989, EIGHT YEARS AFTER HAVING BEEN SOUNDLY DEFEATED IN HIS FIRST REELECTION BID, MICHAEL MANLEY RETURNED TO OFFICE AS JAMAICA'S PRIME MINISTER. DUBBED THE "NEW MANLEY," HE DISPLAYED A NEW POLITICAL STYLE AND PURSUED A DIFFERENT AGENDA. THE KEY ISSUE IN EVALUATING THE NEW MANLEY IS NOT SO MUCH HIS ALTERED POLITICAL STYLE (WHICH MAY SIMPLY HAVE REFLECTED TACTICAL JUDGMENTS) OR EVEN HIS IDEOLOGICAL BELIEFS ( WHICH MAY HAVE CHANGED LESS THAN HAS BEEN GENERALLY ASSUMED) BUT HIS ACTUAL MANAGEMENT OF THE JAMAICAN POL ITICAL ECONOMY. HERE THERE IS UNEQUIVOCAL EVIDENCE OF A NEW MANLEY AT WORK. HIS NEW APPROACH DEVELOPED HALTINGLY, WITH MANLEY AND HIS GOVERNMENT PERHAPS HAVING BEEN DRAGGED ALONG BY EVENTS RATHER THAN CONFIDENTLY CHARTING A NOVEL COURSE. NEVERTHELESS, THE CUMULATIVE RESULT IS SIGNIFICANT.

07172 PAYNE, A.; SUTTON, $P$.

THE COMMONWEALTH CARIBBEAN IN THE NEW WORLD ORDER: BETWEEN THE COMMONHEALTH CARIBBEAM

JOURNAL OF INTERAMERICAN STUDIES AND WORLD AFFAIRS, $34(4)$

(HIN 92$)$, 39-76.

THE SUPPOSED EMERGENCE OF A NEW WORLD ORDER HAS QUICKLY BECDME ONE OF THE CLICHES OF THE 1990S. THE PARADOX OF THE NEW WORLD ORDER IS THAT THE STATES IN THE SYSTEM ARE RIVALS AND ALLIES AT THE SAME TIME. THIS ARTICLE EXAMINES THE FORGOTTEN DIMENSION OF THE NEH HORLD ORDER DEBATE WHICH
CONCERMS THE ROLE OF DEVELOPING COUNTRIES WITHIN THIS NEW GLOBAL POLITICAL ECONOMY. IT EXAMINES THE ROLE THAT BOTH EUROPE AND NORTH AMERICA PLAY HITH THE CARRIBEAN IN THIS RESPECT. IT CONCLUDES THAT THE PROCESS MUST CONTINUE AND BE PURSUED WITH ALL URGENCY, FOR THE NEW WORLD ORDER IS NO PLACE FOR SMALL ISLANDS TO DRIFT ALONE AND RUDDERLESS.

07173 PAYNE, A.

THE INTERNATIONAL POLITICS OF THE GLENEAGLES AGREEMENT ROUND TABLE, (320) (OCT 91), 417-430.

ONE FEATURE OF COMMONHEAITH POL ICY TOHAROS SOUTH AFRICA HICH HAS NEVER BEEN SUBJECT TO ADEOUATE SCRUTINY IS THAT RELATING TO SPORT-- NAMELY. THE COMMONWEALTH STATEMENT ON RELATTHE TD IN SPORT ISSUED AT THE TIME OF THE LONDON SUMMIT

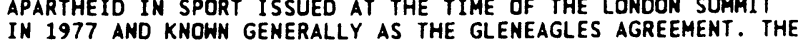
GLENEAGLES STATEMENT IS AN IMPORTANT PART OF MODERN GLENEAGLES STATEMENT IS AN IMPORTANT PART OF MODERN COMMONWEALTH HISTORY AND NEEDS TO BE SET PROPERLY WITHIN
THAT CONTEXT. BUT IT ALSO CONSTITUTES A NEGLECTED FEATURE OF THAT CONTEXT. BUT IT ALSO CONSTITUTES A NEGLECTED FEATURE THE WIDER SPORTS BOYCOTT OF SOUTH AFRICA AND A REVEALING ILLUSTRATION OF THE ACTION OF AN INTERNATIONAL ORGANIZATION EXPLORES ALL OF THESE FACETS OF THE AGREEMENT.

07174 PAYME, D.W. HOT CONTEST IN NEW YORK FREEDOM REVIEW, 23(5) (SEP 92), 16-18

IN NEW YORK CITY'S $12 T H$ CONGRESSIONAL DISTRICT, INCUMBENT U.S. REPRESENTATIVE STEPHEN J. SOLARZ IS RUNNING AGAINST FOUR LATINO CANDIDATES IN THE 1992 DEMOCRATIC PRIMARY ELECTION. WHATEVER THE OUTCOME, THIS RACE WILL HAVE CITY-WIDE REPERCUSSIONS. MOREOVER, ON A NATIONAL LEVEL, IT IS CERTAIN TO FUEL THE DEBATE OVER MINORITY REPRESENTATION IN A UNITED STATES BEING REINVENTED BY A NEW WAVE OF IMMIGRANTS.

\section{PAYNE, D.W.}

LATIN AMERICAN DEMOCRACY: IN SEARCH OF THE RULE OF LAH FREEDOM REVIEW, 23(1) (JAN 92), 48-50.

ALTHOUGH MOST LATIN AMERICAN POPULACES CAN CHOOSE THEIR GOVERMMENTS THROUGH THE BALLOT BOX, THE BASIS OF RULE IN ALL BUT A FEH COUNTRIES REMAINS POWER, NOT LAH. IN GENERAL LATIN AMERICAN POLITICS ARE STILL DOMINATED BY TRADITIONAL ELITES WHO OPERATE WITH IMPUNITY IN A CULTURE OF ENTRENCHED CORRUPTION, HHILE MOST PEOPLE CONTINUE TO STRUGGLE FOR SURVIVAL AMID POVERTY AND UNCHECKED POLITICAL AND CRIMINAL VIOLENCE. THE OUESTION IS WHETHER THE DEMOCRATIC

DETERMINATION OF THE MAJDRITY CAN OVERCOME THE AUTHORITARIAM STRUCTURES THAT BLOCK THE PATH TO TRULY REPRESENTATIVE GOVERNMENT.

07176 PAYNE, D.W.

PERU: FU WIMORI BREAKS THE LAH

FREEDOM REVIEW, 23(4) (JUL 92), 8-11.

ON APRIL 5, 1992, PRESIDENT ALBERTO FUJIMORI, BACKED BY THE MILITARY, DISSOL VED CONGRESS AND ASSUMED VIRTUAL DICTATORIAL CONTROL OVER PERU. SOUNDING THE REFRAIN OF MANY LATIN STRONGMEN BEFORE HIM, FUJIMORI CLAIMS HE IS NOT A DICTATOR, THAT HE IS MERELY RESPONDING TO THE DEMANDS OF THE PEOPLE. AND, IN FACT, HIS ACTIONS HERE MET WITH A LARGE MEASURE OF POPULAR SUPPORT. BUT MOST LATIN AMERICAN
DICTATORS HAVE BEEN HAILED AS SAVIORS BY SIGNIFICANT
PORTIONS OF THEIR POPULATIONS--IN THE BEGINNING.

07177 PAYME, J.

ELECTIONS AND GOVERNMENT SPENDING

PUBLIC CHOICE, 7O(1) (APR 91), 71-82.

IT IS WIDELY BELIEVED THAT ELECTORAL PRESSURES CAUSE LEGISLATORS TO FAVOR GOVERNMENT SPENDING PROGRAMS. THIS "ELECTORAL THEORY OF SPENDING" IS SHOWN TO ENCOMPASS TWO CORE HYPOTHESES: (1) THE ELECTORAL CONSEQUENCES HYPOTHESIS, WHICH STATES THAT SUPPORT FDR SPENDING PROGRAMS IMPROVES THE REPRESENTATIVE'S ELECTORAL SHOWING; AND (2) THE LEGISLATOR INSECURITY HYPOTHESIS, HHICH STATES THAT GREATER ELECTORAL INSECURITY LEADS REPRESENTATIVES TO BE MORE IN FAVOR OF SPENDING PROGRAMS. A TEST OF THESE IDEAS USING SPENDING SCORES FOR U.S. REPRESENTATIVES IN 1986 FINDS THAT NEITHER HYPOTHESIS IS SUPPORTED BY THE DATA.

07178 PAYNE, J.L.

UNHAPPY RETURNS: THE $\$ 600$ BILLION TAX RIP-OFF

POLICY REVIEW, (59) (WIN 92), 18-24.

MANY EVALUATORS OF FEDERAL PROGRAMS ASSUME THAT THE COST OF RAISING TAX REVENUES IS TRIVIAL BECAUSE THE BUDGETS OF THE INTERNAL REVENUE SERVICE AND THE UNITS OF THE JUSTICE AND TREASURY DEPARTMENTS THAT ASSIST TAX COLLECTION ADDED UP TO ONLY \$6 BILLION IN 1990. THIS LEADS MANY PEOPLE TO ENDORSE CERTAIN GOVERMMENT SPENDING PROGRAMS ON THE GRDUNDS ENDORSE CERTAIN GOVERNMENT SPENDING PROGRAMS ON THE GROUNDS
THAT THE GOVERNMENT'S FUND-RAISING SYSTEM IS MORE EFFICIENT THAT THE GOVERNMENT'S FUND-RAISING SYSTEM IS MORE EFFICIENT
THAN A VOLUNTARY ARRANGEMENT COULD BE. THE FALLACY OF THIS THAN A VOLUNTARY ARRANGEMENT COULD BE. THE FALLACY OF THIS
CONCLUSION IS THAT VIRTUALLY ALL COSTS OF OPERATING THE U.S.
TAX SYSTEM ARE DISPLACED ONTO THE PRIVATE SECTOR. THEY DO TAX SYSTEM ARE DISPLACED ONTO THE PRIVATE SECTOR. THEY DO
NOT APPEAR IN THE FEDERAL BUDGET AND ARE APPROXIMATELY 100 NOT APPEAR IN THE FEDERAL BUDGET AND ARE APPROXIMATELY 100 PRIVATE-SECTOR COSTS TOTAL 65 PERCENT OF TAX REVENUE.

07179 PAYNE, K.B.

DETERRENCE AND U.S. STRATEGIC FORCE REQUIREMENTS AFTER THE COLD HAR

COMPARATIVE STRATEGY, 11(3) (JUL 92), 269-282.

THE DEMISE OF THE USSR AND THE PLANHED REDUCTION OF STRATEGIC OFFENSIVE FORCES HAVE LED MANY TO CONCLUDE THAT EFFECTIVE DETERRENCE WILL BE LESS BURDENSOME IN THE FUTURE. THAT MAY BE CORRECT FINANCIALLY - IN THE SENSE THAT THE U.S. STRATEGIC OFFENSIVE NUCLEAR FORCE STRUCTURE NECESSARY TO SUPPORT DETERRENCE HILL PROBABLY NOT NEED TO BE AS ROBUST IN THE FUTURE AS IT IS NOW. HOWEVER, CREATING AN EFFECTIVE POLICY OF DETERRENCE IN THE POST-COLD WAR PERIOD HILL BE MORE CHALLENGING INTELLECTUALLY, AND THE ROLES THAT DETERRENCE MUST PLAY WILL BE MORE DEMANDING AS THE U.S. MILITARY WITHDRAWAL FROM ABROAD AND THE PROL IFERATION OF WEAPONS CONTINUE APACE. THE TRADITIONAL U.S.-SOVIET MODEL OF DETERRENCE ESTABLISHED DURING THE COLD WAR WILL BE INADEQUATE AS THE UNITED STATES CONFRONTS A POTENTIALLY DIVERSE SET OF UNFAMILIAR OPPONENTS. STANDARD ASSUMPTIONS ABOUT THE GOALS, VALUES, AND CHARACTER OF THE LIKELY ABOUT THE GOALS, VALUES, AND CHARACTER OF THE LIKELY
OPPONENT WILL NO LONGER BE APPROPRIATE, AND AN EFFECTIVE OPPONENT WILL NO LONGER BE APPROPRIATE, AND AN EFFECTIVE
POLICY OF DETERRENCE WILL HAVE TO BE TAILORED TO SPECIFIC AND UNIOUE CRISES. IN THIS EMERGING CONTEXT, POLICIES OF AND UNIQUE CRISES. IN THIS EMERGING CONTEXT, POLICIES OF DETERRENCE HILL BE LESS RELIABLE IN GENERAL, AND ACT DEFENSES HILL BE ESSENTIAL. IT WILL BE IMPORTANT TO ESTABLISH THE MOST EFFECTIVE DETERRENT POSSIBLE; THIS WILL
NECESSITATE MUCH GREATER FAMILIARITY WITH NUMEROUS POTENTIAL NECESSITATE MUCH GREATER FAMILIARITY WITH NUMEROUS REGIONAL AGGRESSORS AND AN UNP
FLEXIBILITY IN FORCE PLANMING.

07180 PAYNE, K.B.; STANLEY, W.; VLAHOS, L.

YELTSIN'S GLOBAL SHIELD

POLICY REVIEW, (62) (FAL 92), 78-81

IN JANUARY' 1992 RUSSIAN PRESIDENT BORIS YELTSIN COMPLETELY REWROTE THE TERMS OF THE DEBATE OVER THE STRATEGIC DEFENSE INITIATIVE (SDI) BY PROPOSING A GLOBAL PROTECTION SYSTEM TO DEFEND AGAINST LIMITED MISSILE STRIKES. YELTSIN'S PROPOSAL CONVERGES NICELY WITH THE DIRECTION U.S. PRESIDENT GEORGE BUSH TOOK REGARDING SDI IN 1991-TOWARD A GLOBAL CAPABILITY TO DEFEND AGAINST SMALL-SCALE MISSILE ATTACK. EVEN MORE IMPORTANTLY, THE RUSSIAN PRESIDENT'S INITIATIVE MEANS THAT RUSSIA NOW OFFICIALLY SUPPORTS CDOPERATION WITH THE UNITED STATES ON MISSILE DEFENSES.

07181 PAYNE, $R$.

THE WEST EUROPEAM ALLIES, THE THIRD WORLD, AND U.S. FOREIGN POLICY

GREENHOOD PRESS, 1991, 282

THE RECENT AND ONGOING CRISES IN THE MIDOLE EAST, THE PERSIAN GULF, CENTRAL AMERICA, AND SOUTHERN AFRICA HAVE BEEN AND CONTINUE' TO BE APPROACHED IN VERY DIFFERENT WAYS BY THE AN TED STATES AND ITS EUROPEAN ALLIES. THIS BOOK PROVIDES A COMPREHENSIVE ANALYSIS OF THE UNDERLYING TENSIONS, AS WELL COMPREHENSIVE ANALYSIS OF THE UNDERLYING TENSIONS, AS WELL
AS COOPERATION, BETHEEN THE U.S. AND NATO COUNTRIES IN OUTAS CODPERATION, BETWEEN THE U.S. AND NATO COUNTRIES IN OUTOF-AREA CONFLICTS. THE BOOK MAINTAINS THAT THE U.S. MUST ADAPT ITS FOREIGN POLICY TO A NEH INTERNATIONAL ORDER, CONFRONTATIONALISM IN THE THIRD WORLD. 
07182 PEARSON, M.

BREAKING THE BONDS OF "ORGANIZED DEPENDENCE": MANAGERS IN CHINA'S FOREIGN SECTOR

STUDIES IN COMPARATIVE COMMUNISM, 25(1) (MAR 92), 57-78. AUTHORITY RELATIONS IN POST-REVOLUTIONARY CHINESE STATE ENTERPRIZES HAVE BEEN CHARACTERIZED BY PERSONALISTIC NETHORKS DOMINATED BY REPRESENTATIVES OF THE PARTY-STATE. PARTY CADRE-MANAGERS HAVE WIELDED BROAD DISCRETIONARY AUTHORITY OVER EMPLOYEES, CONTROLLED SUCH CRUCIAL DECISIONS AS PROMOTIONS, JOB MOBILITY, AND THE DISTRIBUTION OF BONUSES ANO MATERIAL BENEFITS. THIS ARTICLE ARGUES THAT CHINESE MANAGERS ARE MORE DEPENDENT UPON THEIR RELATIONSHIPS WITH THESE CADRE-MANAGERS THAN ARE WORKERS IN OTHER SOCIALIST COUNTRIES. IT CONCLUDES THAT THROUGH THESE RELATIONSHIPS, EMPLOYEES ARE BOUND TO THE STATE ENTERPRISE AND, IN TURN, TO EMPLOYEES ARE BOUND TO THE

07183 PEC, S.S.

THE 1940'S SOVIETIZATION OF POLAND: A HISTORIOGRAPHIC APPRAISAL

EAST EUROPEAN QUARTERLY, XXVI(1) (SPR 92), 109-122.

THE MAJOR WORKS ON THE HISTORY OF THE SOVIETIZATION OF POLAND DURING THE 1940'S CAN BE DIVIDED INTO THREE

INTERPRETATIONS: THE TRADITIONAL WESTERN, THE MARXIST, AND THE RECENT WESTERN. EACH INTERPRETATION ADORESSES THE NATURE OF THE CONFLICT, ITS TIMING, THE OUTCOME OF NEGOTIATIONS, AND THE RESPONSIBILITY FOR THE SOVIETIZATION OF POLAND. THE ARGUMENTS PRESENTED BY EACH POINT OF VIEW COLLIDE OR COINCIDE WITH ONE OTHER, DEPENDING ON THE ISSUE.

07184 PECK, J.: BEZOLD, C.
HEALTH CARE AND AIDS

ANNALS OF THE AMERICAN ACADEMY OF POLITICAL AND SOCIAL

SCIENCE, 522 (JUL 92), 130-139.

MANY POWERFUL FORCES ARE POISED TO TRANSFORM THE INDUSTRIALIZED HEALTH CARE STRUCTURE OF THE 2OTH CENTURY, AND AIDS MAY ACT AS EITHER A CATALYST OR AN AMPLIFIER FOR THESE FORCES. FOR EXAMPLE, AIDS COULO SHAMP LOCAL RESOURCES AND THEREBY HELP TRIGGER NATIONAL REFORM IN A HEALTH CARE SYSTEM THAT HAS ALREADY LOST PUBLIC CONFIDENCE. AIDS CAN ALSO HASTEN THE PARADIGM SHIFT THAT IS OCCURRING THROUGHOUT HEALTH CARE. MANY OF THE CHOICES SOCIETY WILL CONFRONT WHEN DEALING WITH AIDS CARRY IMPLICATIONS BEYOND HEALTH CARE. DEALING WITH AIOS CARRY IMPLICATIONS BEYOND HEALTH CARE.
INFORMATION ABOUT WHO HAS THE DISEASE, FOR EXAMPLE, ALREADY 作 FUTURE INFORMATION SYSTEMS COULD MAKE DISCRIMINATION BASED POSIIVE INDIYIDUALS; YET THESE SYSTEMS ALSO OFFER THE HOPE POSITIVE INDIVIDUALS; YET THESE SYSTEMS ALSO OFFER THE HOPE OF ACCELERATED PROGRESS AGAINST AIDS AND OTHER MAJOR HEALTH THREATS. THE POLICY CHOICES THAT DEFINE SOCIETY'S RESPO TO AIDS CAN BEST BE MADE IN THE CONTEXI OF A CLEARLYARTICULATED VIS

07185 PECK, J.

TECS AND THE LOCAL POLITICS DF TRAINING

POLITICAL GEOGRAPHY QUARTERLY, 11(4) (JUL 92), 335-354. THIS PAPER DESCIBES THE BRITISH GOVERMMENT'S TRAINING AND ENTERPRISE COUNCILS (TECS) INITIATIVE, DRAWING OUT SOME OF THE POLITICAL AND ECONOMIC IMPLICATIONS OF ITS INTRODUCTION AND SPECULATING UPON ITS FUTURE DEYELOPMENT. THROUGH THE TEC INITIATIVE, CLOSE TO 3 BILLION (POUNDS STERLING) OF PUBLIC FUNDS AND OVER 5000 CIVIL SERVICE JOBS HAVE BEEN TRANSFERRED FROM THE PUBLIC TO THE PRIVATE SPHERE, AS THE GOVERMMENT HANDS OVER "OWMERSHIP" OF THE TRAINING AMD ENTERPRISE SYSTEM TO EMPLOYERS. TECS, AS PRIVATE COMPANIES CHARGED WITH THE RESPONSIBILITY FOR THE DELIVERY OF PUBLICLY FUNDED EMPLOYMENT PROGRAMS ARE CHARACTERIZED AS "POSTCORPORAT IST" POLITICAL STRUCTURES--STATE-CAPITAL COAL ITIONS IN WHICH THE LABOR MOVEMENT HAS BEEN PURPOSEFULLY MARGINALIZED. THIS IS A STRATEGY NOT WITHOUT RISK FOR THE CONSERYATIVE GOVERNMENT BECAUSE IN THE EMPLOYER-DOMINATED TECS IT HAS CREATED A POWERFUL AND TO A CERTAIN EXTENT UNPREDICTABLE POL ITICAL LOBBY THE PAPER ARGUES THAT THE POTENTIAL POLITICAL VOLATILITY OF TECS IS ROOTED IN PART TO THEIR SUSCEPTIBILITY TO LOCAL POLITICAL INFLUENCES.

07186 PECK, R.

JOINT YENTURES--JAPANESE-AMERICAN EDUCATION PARTMERSHIPS CHANGE, 23(2) (MAR 91), 47-50.

THE NUMBER OF JAPANESE-AMERICAN JOINT EDUCATION PROJECTS HAS INCREASED IN RECENT YEARS. IN MANY CASES, THE JAPANESE APPROACH A FINANCIALLY-AILING SMALL LIBERAL ARTS COLLEGE AND BASICALLY OFFER TO BUY THE COLLGE IN RETURM FOR PERMISSION BASICALLY OFFER TO BUY THE COLLEGE IN RETURN FOR PERMISSION USUALIY HAPPY MERGER OF SATISFACTION OF FINANCIAL DEMANDS AND AN INCREASE IN GLOBAL CULTURAL AWARENESS AND CREATIVITY IN JAPAN. PROBLEMS AND IMPLICATIONS OF THIS TREND ABOUND IN JAPAN. PROBLEMS AND IMPLICATIONS OF THIS TREND ABOUND, DEMANDS OF A TEMPORAL MARKETPLACE AND THE CAUSE OF GLOBAL CIVILIZATION, MANY SEE THE FUTURE AS BRIGHT.

07187 PECKHAM, J.R.S.

ALBANIANS IN GREEK CLOTHING
WORLD TODAY, 48(4) (APR 92), 58-59.

THE PROBLEMS THAT COME WITH INCREASED MIGRATION ARE ONES THAT THE EUROPEAN COMMUNITY AS A WHOLE MUST GRAPPLE WITH. MEANWHILE, INDIVIDUAL COUNTRIES, LIKE GREECE, ARE STRUGGLING TO COPE WITH THE INFLUX OF REFUGEES FROM COUNTRIES LIKE ALBANIA.

07188 PECORELLA, R.F

COMMUNITY POHER IN THE POSTREFORM ERA

M. E. SHARPE, $1993,240$.

THIS BOOK EXAMINES COMMUNITY POLITICS IN THE 1990S BY FOCUSING ON NEW YORK CITY'S COMMUNITY BOARD SYSTEM. THE BOOK SUGGESTS THAT ALTHOUGH THE RADICAL DEMANDS FOR COMMUNITY CONTROL WHICH AROSE IN THE 1960 S WERE NEVER FULLY REALIZED, CITIES LIKE NEW YORK. THE BOOK ANALYZES THE EFFECTS OF THIS RECENT RE-EMERGENCE OF COMMUNITY POWER ON POLITICS IN NEW YORK. THE ANALYSIS FOCUSES ON NEH YORK'S COMMUNITY BOARDS BECAUSE THEY ARE AMONG THE MOST DEFINITIVE EXAMPLES OF BECAUSE THEY ARE AMONG THE MOST DEFINITIVE EXAMPLES OF SYSTEM WAS ADOPTED AS PART OF THE CITY CHARTER REFORMS OF 1975 AND WAS STRENGTHENED BY THE CHARTER REVISIONS OF 1989 1975 AND WAS STRENGTHENED BY THE CHARTER REVISIONS OF 1989 THE BOARDS WERE ALLOCATED ADVISORY RESPONSIBILITIES OVER LAND-USE PLANNING, BUDGET PRIORITIES, AND SERVICE MONITORING WITHIN THEIR COMMUNITY DISTRICTS. THE BOOK'S EARLY CHAPTERS PRESENT THE THEORETICAL AND HISTORICAL CONTEXT WITHIN WHICH THE LATTER CHAPTERS
ON CITY POLITICS.

07189 PEDEN, E.

PRODUCTIVITY IN THE UNITED STATES AND ITS RELATIONSHIP TO GOVERNMENT ACTIVITY: AN ANALYSIS OF 57 YEARS, 1929-1986

PUBLIC CHOICE, 69(2) (FEB 91), 153-174

UNDER THE CLASSICAL SUPPLY-SIDE PARADIGM OF PRODUCTIVITY GROUTH, RAISING GOVERMMENT ECONOMIC ABOVE RUDIMENTARY LEVELS INTEGRATES MARKETS AND PROVIDES USEFUL PUBLIC GOODS WHICH ENHANCE GROWTH. BEYOND SOME POINT HOWEVER, INCREASING GOVERNMENT ACTIVITY DISCOURAGES GROWTH THROUGH TAX DISINCENTIVES AND BY REWARDING DEPENDENCE ON GOVERMMENT EXPENDITURES. DEFINING GOVERMMENT ECONOMIC ACTIVITY TO BE EXPENDITURES. DEFINING GOVERNMENT ECONOMIC ACTIVITY TO BE GOVERMMENT EXPENDITURES AS A PERCENTAGE OF GNP, THIS STUDY
LOOKS FIRST AT DATA FROM THE PERIOD 1889-1986 AND SHOWS THAT LOOKS FIRST AT DATA FROM THE PERIOD 1889-1986 AND SHOWS THAT THE U.S. ECONOMY HAS EXPERIENCED WHAT IS PREDICTED BY THE
SUPPLY-SIDE PARADIGH. IN ADDITION, THE STUDY PRESENTS AN SUPPLY-SIDE PARADIGA. IN ADOITION, THE STUDY PRESENTS AN
ECONOMETRIC ANALYSIS OF GOVERNMENT'S EFFECTS ON PRODUCTIVITY ECONOMETRIC ANALYSIS OF GOVERNMENT'S EFFECTS ON PRODUC I

FOR THE PERIOD $1929-1986$ USING A STANDARD NEOCLASSICAL
GROWTH MODEL. THIS ANALYSIS VALIDATES THE CLASSICAL SUPPLYGROWTH MODEL. THIS ANALYSIS VALIDATES THE CLASSICAL SUPPLY SIDE PARADIGM AND SHOWS THAT MAXIMUM PRODUCTIVITY GROWTH GNP, FAR LESS THAN THE 35\% WHICH EXISTED IN 1986.

07190 PEDERSEN, $K$

THOUGHTS ON INTERNATIONAL SPACE COOPERATION AND INTERESTS IN THE POST-COLD WAR WORLD

SPACE POLICY, 8(3) (AUG 92), 205-220.

THERE IS NO DOUBT THAT THE END OF THE COLD WAR HAS MADE INTERNATIONAL COOPERATION IN SPACE ENDEAVORS MORE FEASIBLE AND ATTRACTIVE TO THE UNITED STATES. HOWEVER, THE LOSS OF A MAIN ENEMY AND THE REPLACEMENT OF POLITICAL-MILITARY RIVALRY BY SHARPENED ECONOMIC COMPETITIVENESS AMONG FORMER ALLIES CAN BE EXPECTED TO INTRODUCE A COUNTERVAILING ELEMENT OF CAUTION INTO U.S. POLICY MAKING. THIS ARTICLE CONSIDERS HOW THE TRADITIONAL PRINCIPLES AND PRACTICES GOVERNING THE UNITED STATES' APPROACH TO INTERNATIONAL COOPERATION IN SPACE.

07191 PEDERSEN, T.

POL ITICAL CHANGE IN THE EUROPEAN COMMUNITY: THE SINGLE EUROPEAN ACT AS A CASE OF SYSTEM TRANSFORMATIOM COOPERATION \& CONFLICT: NORDIC JOURNAL OF INTERMATIONAL POLITICS, 27(1) (MAR 92), 7-44.

THE AUTHOR CONTRIBUTES TO THE NEW PLURALISTIC DEBATE ON INTEGRATION THEORY FOCUSING ON THE PROBLEM OF POLITICAL CHANGE IN INTEGRATION SYSTEMS. VIEWING THE EUROPEAN COMHUNITY (EC) AS A POLITICAL SYSTEM, HE ELABORATES ON LIMDBERG AND SCHEINGOLO'S OBSERYATIOHS IN "EUROPE'S WH POLITY" REGARDING PATTERNS OF POLITICAL CHANGE IN THE EC. HE SUGGESTS A WIDER SET OF CATEGORIES OF POLITICAL CHANGE, SUGGESTS A WIDER SET OF CATEGORIES OF POL ITICAL CHANGE, OISTINGUISHING BETWEEN THE NATURE OF INTEGRATIOM
(DIRECTED/UNDIRECTED) AND THE DEGREE OF CHANGE (DIRECTED/UNDIRECTED) AND THE DEGREE OF CHANGE
(MARGINAL/INCREMENTAL/DRAMATIC). HE ALSO CONSIDERS IN DETAIL (MARGINAL/INCREMENTAL/DRAMATIC). HE ALSO CONSIDERS IN THE CATEGORY OF SYSTEM TRANSFORMATION, STRESSING THE
IMPORTANCE OF THE INTERNATIONAL ENYIRONMENT IN EXPLAINING IMPORTANCE OF THE INTERNATIONAL ENVIRONMENT IN EXPLAINING SUCH TRANSFORMATIONS. FINALLY, HE EXAMINES THE EXTENT TO
WHICH THE ADOPTION OF THE SINGLE EUROPEAN ACT CAN BE SAID TO WHICH THE ADOPTION OF THE SINGLE EUROPEAN
HAYE CONSTITUTED A SYSTEM TRANSFORMATION.

07192 PEEK, J.

JAPAN AND THE INTERNATIONAL BILL OF RIGHTS

JOURNAL OF NORTHEAST ASIAN STUDIES, $X(3)$ (FAL 91), 3-15

POINTS OF CONFLICT BETWEEN THE OPERATIVE LAN AND SOCIAL

PRACTICES OF JAPAN, AND KEY UN HUMAN RIGHTS DOCUMENTS ARE

EXAMINED. DIFFERENCES ARE FOUND TO BE MORE FREQUENT AND 
FUNDAMENTAL IN TERMS OF ECONOMIC THAN POLITICAL RIGHTS. THE GENERAL RESPONSE OF THE JAPANESE GOVERMMENT TO THESE DIFFERENCES HAS BEEN A DEFENSE OF PREVAILING PRACTICES. THE POSITIONS TAKEN BY THE GOVERNMENT ARE AT TIMES AT ODDS WITH THOSE OF SIGNIFICANT SEGMENTS OF THE JAPANESE PUBLIC. MANY OF THE MOST DISADVANTAGED OF THE GOVERNMENT'S OPPONENTS HAVE TURNED TO THE UN FOR ASSISTANCE IN GAINING RECOGNITION OF THEIR BASIC RIGHTS.

07193 PEEK, J.

JAPAN, THE UNITED MATIONS AND HUMAN RIGHTS

ASIAN SURVEY, XXXIII(3) (MAR 92), 217-229.

THIS DISCUSSION ON JAPAN AND HUMAN RIGHTS STATES THAT, IN A VERY REAL SENSE, U.N. HUMAN RIGHTS ACTIVITIES HAVE HAD AS MUCH IF NOT MORE IMPACT ON JAPAN THAN JAPAN HAS HAD OH THE EFFORTS OF THE ORGANIZATION TO PROMOTE AND PROTECT HUMAN RIGHTS. THIS IS BECAUSE JAPAN OPERATES ON THE BASIS OF A VERY LIMITED VIEW OF THE ROLE OF ANY MULTILATERAL ORGANIZATION. IT STATES THAT JAPAN'S FOREIGN POLICY WILL CONTINUE TO BE UMILATERERAL AND DEFENSIVE IN NATURE UNTIL THERE IS A GREATER ACCEPTANCE AMONG JAPAN'S POLITICAL ELITE OF THE PRACTICAL NECESSITY OF CREATING AN INTERNATIONAL OF THE PRACTICAL NECESSITY OF CREATING AN INTERNATIONAL
SYSTEM BASED ON A CORE SET OF UNIVERSAL NORMS. THE FIRST SYSTEM BASED ON A CORE SET OF UNIVERSAL NORMS. THE FIRST
STEP IN THIS PROCESS MUST BE A RECOGHITION THAT JAPANESE STEP IN THIS PROCESS MUST BE A RECOGNITION THAT JAPANESE
CLAIMS OF BEING UNIQUE ARE IN THE LONG RUN SELF-DESTRUCTIVE; CLAIMS OF BEING UNIQUE ARE IN THE LONG RUN SELF-DESTRUCTIVE;
JAPAN'S FUTURE LIES IN EMPHASIZING HUMAN COMMONALITIES NOT JAPAN'S FUTURE
DIFFERENCES.

07194 PEELE, G.

THE CONSTRAINED PRESIDENCY OF GEORGE BUSH CURRENT HISTORY, 91 (564) (APR 92), 151-155.

TWO FEATURES' STAND OUT IN THE RECORD OF THE BUSH ADMINISTRATION'S FIRST TERM. THE FIRST IS A DEGREE OF CAUTION AND PRAGMATISM IN POL ICYMAKING THAT HAS PRECLUDED DISASTER BUT AT THE SAME TIME HAS NOT ENCOURAGED BOLD INITIATIVES. THE SECOND IS A CURIOUS INCAPACITY TO STATE WHAT EITHER THE PRESIDENT HIMSELF OR HIS PRESIDENCY STANDS FOR OR TO IMPART A CLEAR SENSE OF DIRECTION TO AMERICAN POLICY. THE CAUTIOUS PRAGMATISM OF THE BUSH PRESIDENCY HAS PERHAPS BEEN MOST EVIDENT IN HIS HANDLING OF FOREIGN AND DEFENSE POLICIES, BUT BUSH HAS ALSO ADOPTED A HIGHLY REACTIVE, RATHER THAN AN ASSERTIVE, STRATEGY ON DOMESTIC ISSUES.

07195 PEFFLEY, M.; HURHITZ, J.

INTERNATIONAL EVENTS AND FOREIGN POLICY BELIEFS: PUBLIC RESPONSE TO CHANGING SOVIET-U.S. RELATIONS AMERICAN JOURNAL OF POLITICAL SCIENCE, 36(2) (MAY 92), 431-461.

HOW DO CITIZENS RESPOND TO DRAMATIC FOREIGH POLICY EVENTS, SUCH AS THE RECENT CHANGES IN SOVIET-U.S. RELATIONS, WHEN A TRADITIONAL FOE EXHIBITS STRONG SIGNS OF CONCILIATORY BEHAVIOR? USING PANEL DATA COLLECTED BEFORE AND AFTER THE NUCLEAR ARHS SUMMITS OF 1987 AND 1988, THE AUTHORS OF THIS CHANGING IMAGES OF THE SOVIET UNION. HAVING SHOWN IN A PRIOR CROSS-SECTIONAL STUDY THAT SOVIET IMAGES CONSTRAIN POLICY CROSS-SECTIONAL STUDY THAT SOVIET IMAGES CONSTRAIN POLICY
ATTITUDES IN A STATIC SENSE, THE CURRENT PANEL STUDY FINDS LITTLE EVIDENCE OF WHAT CONVERSE (1964) LABELED DYNAMIC CONSTRAINT, IN THAT SOFTENING PERCEPTIONS OF THE SOVIET UNION APPEARED TO PRECIPITATE MORE "DOVISH" POL ICY ATITTUDES. THIS STUDY ALSO EXTENDS EARLIER WORK ON ENEMY IMAGES IN FINDING THAT SOME PEOPLE ARE MORE RESISTANT TO CHANGE THAN
OTHERS, NOTABLY POLITICAL EXPERTS HITH EXTREMELY NEGATIVE (I E. "BAD FAITH") INITIAL IMAGES.

07196 PEHE, J.

CHECHOSLOVAK FEDERAL ASSEMBLY ADOPTS ELECTORAL LAH RFE/RL RESEARCH REPORT, 1 (7) (FEB 92), 27-30 ON JANUARY 29, 1992, THE FEDERAL ASSEMBLY REJECTED AN ELECTORAL BILL PROPOSED BY PRESIDENT VACLAV HAVEL AND ADOPTED INSTEAD A LAW DRAFTED BY A PARLIAMENTARY GROUP. THE NEW LAH, WHICH WILL BE APPLIED TO THE JUNE 1992 PARLIAMENTARY ELECTIONS, IS AN AMENDED VERSION OF THE 1990 ELECTORAL LAW AND IS BASED PRIMARILY ON A SYSTEM OF PROPORTIONAL REPRESENTATION. IT IS HOPED THAT THE LAH WILL PREVENT THE PARLIAMENT FROM BECOMING TOO FRAGEMENTED AND WILL STRENGTHEN THE COUNTRY'S PARTY-BASED POLITICAL SYSTEM.

07197 PEHE, J.

CZECH-SLOVAK CONFLICT THREATENS STATE UNITY

RFE/RL RESEARCH REPORT, 1 (1) (JAN 92) 83-86.

IN 1991, CZECHOSLOVAKIA CONTINUED ITS EFFORTS TOWARD POL IT 1991, CZECHOSLOVAKIA CONT INUED ITS EFFORTS TOWARD POLITICAL AND ECONOMIC TRANSFORMATION. THE SINGLE MOST IMPORTANT POLITICAL DEVELOPMENT HAS THE INTENSIFICATION OF SLOVAKIAN DEMANDS FOR FULL INDEPENDENCE OR, AT LEAST, MORE POLITICAL AND ECONOMIC AUTONOMY. IN THE SECOND HALF OF THE
YEAR, CZECHOSLOVAK POLITICS WERE ALMOST COMPLETELY DOMINATED BY THE DISPUTES BETHEEN CZECH AND SLOVAK LEADERS OVER THE COUNTRY'S FUTURE CONSTITUTIONAL SYSTEM. AT THE END OF 1991 , THE CONTINUED EXISTENCE OF CZECHOSLOVAKIA AS A SINGLE FEDERAL STATE SEEMED TO BE SERIOUSLY THREATENED.
07198 PEHE, J.

CZECHOSLOVAK PARLIAMENT VOTES TO DISSOLVE FEDERATION RFE/RL RESEARCH REPORT, $1(48$ ) (DEC 92 ) 1-5.

ON NOVEMBER 25, 1992, THE CZECHOSLOVAK FEDERAL ASSEMBLY VOTED TO DISSOLVE THE CZECHOSLOVAK FEDERATION ON JANUARY 1 , 1993. THE LAW WAS PASSED ON THE THIRD ATTEMPT; PREVIOUSLY THE OPPOSITION HAD INSISTED THAT CZECHOSLOVAKIA COULD BE DISSOLVED ONLY ON THE BASIS OF A REFERENDUM. UNDER THE LAW, THE CZECH AND SLOVAK REPUBLICS WILL BE THE SUCCESSORS TO THE FEDERATION AND, EVEN BEFORE THE DISSOLUTION OF CZECHOSLOVAKIA, WILL HAVE THE RIGHT TO CONCLUDE INTERNATIONAL TREATIES AND ADOPT LAWS NEEDED FOR THEIR INDEPENDENT EXISTENCE. EARLIER THE FEDERAL ASSEMBLY HAD APPROVED A LAN ON THE DIVISION OF THE FEDERATION'S ASSETS BETWEEN THE THO REPUBLICS. IN ADOITION, THE REPUBLICAN GOVERMMENTS HAVE CONCLUDED MORE THAN 30 AGREEMENTS THAT WILL GOVERN RELATIONS BETWEEN THE INDEPENDENT CZECH AND SLOVAK STATES.

07199 PEHE, J.

CZECHOSLOVAKIA

RFE/RL RESEARCH REPORT, 1(39) (OCT 92), 34-38,

SINCE 1989 THE MEDIA IN CZECHOSLOVAKIA HAVE BEEN RADICALLY TRANSFORMED. SEVERAL NEW, PRIYATELY-OHNED NEHSPAPERS AMD MAGAZINES HAVE SPRUNG UP AND THE PARTICIPATION OF FOREIGN CAPITAL IN FIMANCING THE PRINT AND BROADCASTING MEDIA HAS BEEN STEADILY GROWING. TELEVISION AND BROADCASTING MEDIA HAS BEEN STEADILY GRONING. TELEVISION AND MINUS SIDE. THE CZECH-SLOVAK CONFLICT HAS BEEN RESPONSIBLE FOR DEEPENING THE DIVISIONS BETWEEN THE CZECH AND SLOVAK FOR DEEPENING THE DIVISIONS BETWEEN THE CZECH AND SLOVAK MEDIA, WHILE THE DAYS OF THE FEDERAL MEDIA INSTITUTIONS
APPEAR TO BE NUMBERED. IN THE CZECH REPUBLIC, JOURNALISTS APPEAR TO BE NUMBERED. IN THE CZECH REPUBLIC, JOURNALISTS
HAVE BEEN FREE OF GOVERMMENT INTERFERENCE, BUT IN SLOVAKIA THE NEW GOVERNMENT HAS ATTEMPTED TO MUZZLE THE MEDIA. IN BOTH REPUBLICS, JOURNALISTIC STANDARDS ARE STILL LOW.

07200 PEHE, J.

CZECHOSLOYAKIA

RFE/RL RESEARCH REPORT, 1(27) (JUL 92), 10-15.

ONE OF THE TOP PRIORITIES OF CZECHOSLOVAKIA'S NEH DEMOCRATIC REGIME IS BUILDING A STATE BASED ON THE RULE OF LAH, A CONCEPT THAT HAS SPARKED INTENSE THEORETICAL AMD POLITICAL DISCUSSION. IMPORTANT CONCRETE STEPS, SUCH AS THE ADOPTION OF HUMAN RIGHTS LAWS AND THE REBUILOING OF THE JUDICIARY, HAVE BEEN TAKEN. HOWEVER, LAWMAKERS HAVE FAILED TO ADOPT NEN REPUBLICAN AND FEDERAL' CONSTITUTIONS AND HAVE IMPLEMENTED MEASURES TO DEAL WITH COLLABORATORS WITH THE FORMER REGIME THAT FLOUT SOME BASIC PRINCIPLES OF THE CONCEPT OF THE RULE OF LAH. THE CONTINUING CIECH-SLOVAK CONCEPT OF THE RULE OF LAH. THE CONTINUING CZECH-SLOVAK
CONFLICT IS CAUSING A DEGREE OF LEGAL INSECURITY AMONG CONFLICT IS CAUSING A DEGREE OF LEGAL INSECURITY AMONG
CITIZENS AND IS THEREBY HINDERING THE PROCESS OF BUILDING A CITIZENS AND IS THEREBY HINDERI

07201 PEHE, J.

CZECHOSLOVAKIA: PARTIES REGISTER FOR ELECTIONS RFE/RL RESEARCH REPORT, 1(18) (MAY 92), 20-25.

IN JUNE 1992 CZECHOSLOVAKIA HILL HOLD GENERAL ELECTIONS, THE SECOND SINCE THE FALL OF COMMUNISM. POLITICAL GROUPS THAT HAVE QUALIFIED TO REGISTER FOR THE ELECTIONS WILL COMPETE FOR SEATS IN THE FEDERAL ASSEMBLY, THE CZECH NATIONAL COUNCIL, AND THE SLOVAK NATIONAL' COUNCIL. IN ALL, 40 PARTIES, MOVEMENTS, AND COALITIONS WILL COMPETE FOR REPRESENTATION IN AT LEAST ONE OF THE THREE PARLIAMENTS. ABDUT HALF OF THE REGISTERED PARTIES ARE ALREADY REPRESENTED IN AT LEAST ONE OF THE LEGISLATURES. MOST OF THE OTHER GROUPS ARE NEW ANO ARE NOT WELL-KNOWN.

07202 PEHE, J.

CZECHOSLOVAKIA'S CHANGING POLITICAL SPECTRUM

RFE/RL RESEARCH REPORT, 1(5) (JAM 92), 1-7

SINCE THE PARLIAMENTARY ELECTIONS IN JUNE 1990 THE POL ITICAL MOVEMENTS THAT LED THE 1989 "VELVET REVOLUTION" HAVE DISINTEGRATED AND BEEN REPLACED BY POLITICAL PARTIES WITH MORE DISTINCTIVE POLITICAL PHILOSOPHIES. NOH THE MAJORITY OF POLITICAL PARTIES IN THE CZECH REBUBLIC CAN BE DESCRIBED AS HAVING A DISTINCTIVE LEFTIST, CENTRIST, OR RIGHTIST ORIENTATION. IN SLOVAKIA THE DIVISION OF THE POLIIICAL SPECTRUM IS BLURRED, BECAUSE SOME MAJOR PARTIES HAVE A NATIONALIST AGENDA BUT VACILLATE BETHEEN RIGHTIST AND LEFTIST VIEWS ON SOME ISSUES.

07203 PEHE, J.

CZECHS AND SLOVAKS DEFIME POSTDIVORCE RELATIONS

CZECHS AND SLOVAKS DEFINE POSTDIVORCE RELAT
RFE/RL RESEARCH REPORT, 1 (45) (NOV 92 ) 7-11.

AMID THE CONTINUING' PARALYSIS OF DECISION-MAKING AT THE FEDERAL LEVEL CZECH PRIME MINISTER YACLAV KLAUS AND SLOVAK PRIME MINISTER VIADIMIR MECIAR SIGNED AGREEMENTS ON OCTOBER 29, 1992, DEFINING RELATIONS BETWEEN THE CZECH AND SLOVAK REPUBLICS AFTER THE DISSOLUTION OF CZECHOSLOVAKIA ON JANUARY 1, 1993. THE AGREEMENTS, IF APPROVED BY THE REPUBLICAN PARLIAMENTS, WILL PROVIDE FOR THE ESTABL ISHMENT OF A CUSTOMS UNION AND THE CONTINUED USE OF THE COMMON CURRENCY, AT LEAST FOR THE TIME BEING. THE THO PRIME MINISTERS ALSO PREPARED A DRAFT LAH PROVIDING FOR THE ABOLITION OF THE CZECHOSLOVAK 
FEDERATION

07204 PEHE, J.

CZECHS AND SLDVAKS PREPARE TO PART

RFE/RL RESEARCH REPORT, 1(37) (SEP 92), 12-15

ON JANUARY 1, 1992, CZECHOSLOVAKIA WILL SPLIT INTO THO INDEPENDENT STATES IF THE POLITICAL AGREEMENTS OF JULY 22 AND AUGUST 26 BETWEEN CZECH PRIME MINISTER VACLAY KLAUS AND SLOVAK PRIME MINISTER VLADIMIR MECIAR ARE HONORED. BUT IT IS STILL NOT CLEAR HOW THE COUNTRY WILL BE DIVIDED. BOTH KLAUS AND MECIAR HOULD LIKE THE FEDERAL ASSEMBLY TO ADOPT A LAW ON DISSOLVING THE FEDERATION, BUT THERE IS STRONG OPPOSITION TO THE SPLIT IN THE FEDERAL BODY. MEANHHILE, THE SLOVAK

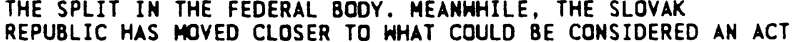
REPUBLIC HAS MOVED CLOSER TO WHAT COULD BE CONSIDERED AN ACT OF SECESSION BY ADOPTING THE SO-CALLED "FULL CONSTITUTION,
THEREBY CASTING DOUBT ON THE CONTINUING FORCE OF FEDERAL THEREBY CASTING DOUBT ON THE CONTIMUI
LAWS AND INSTITUTIONS IN SLOVAKIA.

07205 PEHE, J.

SCENARIOS FOR DISINTEGRATION

RFE/RL RESEARCH REPORT, 1(31) (JUL 92) 30-33

THE DISINTEGRATION OF CZECHOSLOVAKIA INTO TWO STATES APPEARS VIRTUALLY INEVITABLE. THERE ARE SEVERAL SCENARIOS FOR THE SPLIT, RANGING FROM CONSTITUTIONAL SOLUTIONS TO SOLUTIONS THAT WOULD BYPASS THE CURRENT CONSTITUTION. HHILE SOME OF THE COUNTRY'S LEADING POLITICIANS ARGUE THAT THE FUTURE OF THE COUNTRY MUST BE DECIDED IN A REFERENDUM, OTHERS HAVE SUGGESTED THAT THE BREAKUP OF CZECHOSLOVAKIA COULD OCCUR WITHOUT ONE.

07206 PEHE, J.

SLOVAK NATIONALISM SPLITS CHRISTIAN DEMOCRATIC RANKS RFE/RL RESEARCH REPORT, 1(13) (MAR 92), 13-16.

IN SLOVAKIA, THE RULING CHRISTIAN DEMOCRATIC MOVEMENT SPLIT INTO TWO GROUPS AT THE BEGINNING OF MARCH 1992. THE SPLIT WAS THE RESULT OF ACCELERATING DISAGREEMENT BETHEEN AN INCREASINGLY NATIONALIST WING OF THE PARTY LED BY JAN KLEPAC, THE DEPUTY CHAIRMAN OF THE SLOVAK PARLIAMENT, AND THE MODERATE FOLLOWERS OF JAN CARNOGURSKY, THE SLOVAK PRIME MINISTER AND PARTY LEADER. THE SPLIT HAS STRENGTHENED NATIONALIST FORCES IN THE SLOVAK NATIONAL COUNCIL AND INCREASED THEIR CHANCES FOR A VICTORY I

07207 PEHE, J.

THE NEH SLOVAK GOVERMMENT AND PARLIAMENT

RFE/RL RESEARCH REPORT, $1(28)$ (JUL 92), 32-36.

ON JUNE 23, 1992, THE NEW SLOVAK NATIONAL COUNCIL (THE REPUBLICAN PARLIAMENT) CONVENED; THE NEXT DAY, A NEW SLOVAK GOVERMMENT WAS FORMED. BOTH BDDI I S OF GOVERMMENT ARE DOMINATED BY LEFT-OF-CENTER NATIONALIST FORCES. FOLLOWING THE LATEST DEVELOPMENTS IN CZECHOSLOVAKIA, HHICH SUGGEST THAT THE COUNTRY WILL SOON SPLIT INTO TWO STATES, BOTH THE COUNCIL AND THE GOVERNMENT WILL PLAY A MUCH MORE IMPORTANT ROLE IN SLOVAKIA THAN THEY DID IN THE PAST.

07208 PEHE, J.

THE REFERENDUM CONTROVERSY IN CZECHOSLOVAKIA

RFE/RL RESEARCH REPORT, $1(43)$ (OCT 92), 35-38

VIRTUALLY ALL RECENT PUBLIC OPINION POLLS TAKEN IN

CZECHOSLOVAKIA INDICATE THAT A MAJORITY OF CZECHS AND

SLOVAKS WOULD PREFER TO PRESERVE THE COMMON STATE.

NEVERTHELESS, THE SPLIT WILL ALMOST CERTAINLY OCCUR AND THE PEOPLE HILL NOT BE GIVEN A CHANCE TO VOTE ON THE ISSUE IN A REFERENDUM, DESPITE THE IMPACT THAT THE BREAKUP WILL HAVE ON THEIR LIVES. THE RULING PARTIES IN BOTH REPUBLICS ARE OPPOSED TO A REFERENDUM AND HAVE ENOUGH POWER TO BLOCK IT. THEY HAVE BEEN CRITICIZED BY THE OPPOSITION PARTIES MOST OF WHICH ARE DEMAMDING A REFEREMOUM UMOEMOCRATIC AS THE BEHAYIOR OF THE RULING PARTIES MAY SEEM, A REFERENDUM WOULD NOT PROVIDE AN UNAMBIGUOUS AMSWER TO THE OUESTION OF CZECHOSLOVAKIA'S FUTURE. IN FACT, IT WOULD PROBABLY ONLY PROLONG THE DECISION-MAKING PARALYSIS, WHILE THE CAMPAIGH PRECEDING A REFERENDUM MIGHT ESCALATE INTO AN OPEN CONFLICT BETWEEN CZECHS AND SLOVAKS.

07209 PEHE, J.

THE VELVET FAREWELL

FREEDOM REVIEW, 23(6) (NOY 92), 16-20

THE CZECH-SLOVAK STATE HAS OFTEN BEEN DESCRIBED AS AN UNHAPPY MARRIAGE AND THE DISSOLUTIOH OF THE COUNTRY AS A DIVORCE. THE FORCES BEHIND THE CZECHOSLOVAKIAN DIVORCE ARE COMPELIING AND AS DIFFICULT TO RESIST AS THE MORE VIOLENT COMP YISIBLE ONES DT WORK IN OTHER PARTS OF EASTER EUROPE. AND VISIBLE ONES AT WORK IN OTHER PARTS OF EASTERN EUROPE. THEY ARE RELATED, ABOVE ALL,
AND MEMORIES OF COEXISTENCE.

07210 PEHE, J. (ED.); BROWN, J.F.; JOHNSON, A.R.; ROYEN, C.; VALENTA, J.

CZECHOSLOVAKIA IN A NEW INTERNATIONAL CONTEX

RFE/RL RESEARCH REPORT, 1(16) (APR 92), 23-32.

SIMCE THE FALL OF THE COMMUNIST REGIME, CZECHOSLOVAKIA

HAS DEVELOPED NEW FOREIGN AND SECURITY POLICIES. DESPITE

SOME NOTABLE FOREIGN-POLICY SUCCESSES, CZECHOSLOVAKIA'S
POSITION IN INTERNATIONAL AFFAIRS IS PRECARIOUS, OWING TO CONTINUING CONFLICTS BETHEEN THE CZECH AND SLOVAK REPUBLICS OVER THE FUTURE CONSTITUTIONAL FRAMEWORK OF THE COUNTRY. ONE OF THE MOST PRESSING TASKS FACING CZECHOSLOVAKIA AS A SINGLE FEDERAL STATE CONSISTING OF TWO REPUBLICS IS TO DEFINE A COMMON NATIONAL INTEREST BASED ON THE SPECIFIC NATIONAL INTERESTS OF THE CZECHS AMD THE SLOVAKS.

07211 PEI, M.

SOCIETAL TAKEOVER IN CHINA AND THE USSR

JOURNAL OF DEMOCRACY, 3(1) (JAN 92) 108-118.

THE PAST DECADE HAS WITNESSED ATTEMPTS, GENERATED INITIALLY FROM WITIH THE CENTERS OF POHER, TO REFORM COMMUNIST RULE IN BOTH CHINA AND THE SOVIET UNIDN. THE APPARENT OUTCOME HAS DIFFERED ORAMATICALLY ACROSS THE THO APPARENT OUTCOME HAS DIFFERED DRAMATICALLY ACROSS THE TWO
CASES: THE COMMUNIST PARTY OF THE SOVIET UNION HAS BEEN DRIVEN FROM POHER BY THE YERY FORCES UNLEASHED BY REFORM, WHILE ITS CHINESE COUNTERPART SUCCEEDED IN BRUTALLY WHILE ITS CHINESE COUNTERPART SUCCEEDED IN BRUTALLY CAREFUL ANALYSIS REVEALS NOT ONLY MANY SIMILARITIES IN THE CAREFUL ANALYSIS REVEALS NOT ONLY MANY SIMILARITIES IN THE WAY THE PROCESS OF REFORM UNFOLDED IN THE THO COUNTRIES, BUT ALSO A MUCH MORE COMPLEX SITUATION WITH REGARD TO THEIR FUTURE PROSPECTS FOR DEMOCRACY. DESPITE THE POLITICAL REPRESSION THAT HAS REIGNED IN CHINA SINCE THE TIANANMEN SQUARE MASSACRE OF 1989, THE LIBERALIZATION OF THE COUNTRY'S ECDNOMY HAS PROCEEDED APACE. IN THE FORMER SOVIET UNION, BY CONTRAST, EVEN A SEISMIC POLITICAL CHANGE HAS NOT YET PRODUCED THE MOVEMENT TOHARD A MARKET ECONOMY THAT IS ESSENTIAL FOR THE SUCCESSFUL CONSOLIDATION OF DEMOCRACY.

07212 PEILIN, L.

CHINA IN A PERIOO OF SOCIAL TRANSFORMATION

INTERNATIONAL SOCIAL SCIENCE JOURNAL, (133) (AUG 92),

433-444.

CHINA'S REFORM PRACTICE OVER THE PAST DECADE GOES WELL BEYOND THE STANDARD THEORIES. THIS ARTICLE EXAMINES THE UNIQUE CHARACTERISTICS OF CHINA'S TRANSFORMATION FROM A SELFSUFFICIENT AND SEMI-SUFFICIENT PRODUCT ECONOMY TO A PLANNED COMMODITY ECONOMY. IT SHOWS HOT THE TRANSFORMATION OF SOCIAL STRUCTURES WAS CARRIED OUT WITH THE TRANSFORMATION OF THE ECONOMIC SYSTEM, WHILE THE WHOLE SOCIAL TRANSFORMATION PROCESS SHOWED A TENDENCY TO SPREAD FROM RURAL TO URBAN AREAS.

07213 PEILIN, $X$.

RAMOS WINS CONFIDENCE AND FACES TOUGH TASKS

BEI JING REVIEW, 35(45) (NOV 92), 16.

SINCE BECOMING PRESIDENT OF THE PHILIPPINES ON JUNE 30 , 1992. FIDEL RAMOS HAS MADE POLITICAL STABILITY AND ECONOMIC RECOVERY HIS MAJOR PRIORITIES. HE HAS DIRECTED HIS EFFORTS TOWARDS RESTORING PEACE AND ORDER, RESUSCITATING THE AILING ECONONY, PROTECTING THE ENVIRONMENT, ERADICATING GRAFT AND CORRUPTION, AND EMPONERING THE POOR.

07214 PELCHAT, C.

MANAGING PUBlic funds: "BaCKBENCHERs" and the CONTROL of SPENDING

PARLIAMENTARIAN, LXXIII(2) (APR 92), 95-97.

THE AUTHOR EXPLAINS HOW THE QUEBEC NATIONAL ASSEMBLY

FORMULATES THE PROVINCIAL BUDGET AND HOW IT HAS DEVELOPED A NEW MECHANISM TO ADD MORE PARLIAMENTARY CONTROLS OVER PUBLIC SPENDING.

07215 PELED, $Y$

BURCKHARDT'S LIBERAL-CONSERVATISH

HISTORY OF POLITICAL THOUGHT, 13(3) (FAL 92), 487-512.

RECENT SCHOLARSHIP HAS DEMONSTRATED THAT SWISS HISTORIAN JACOB BURCXHARDT DID INDEED THINK AND WRITE ABOUT POLITICS. THE RELATIONSHIP BETHEEN JACOB BURCKHARDT THE POLITICALLY ASTUTE CULTURAL HISTORIAN AND A BURCKHARDIAN POLITICAL PHILOSOPHY IS EXPLORED IN THIS ARTICLE. LIBERALCONSERVATIVES SEEK TO SAFEGUARD INDIVIDUALITY AND FREEDOM HITHOUT FORSAKING TRADITION AND WITHOUT DISREGARDING THE ACCUMULATED WISDOM OF PAST GENERATIONS AND CIYIIIZATIONS THE ARTICLE ARGUES THAT THIS PHILOSOPHICAL POSITION--THE LIBERAL-CONSERYATIVE ONE--BEST DESCRIBES JACOB BURCKHARDT'S POLITICAL THINKING.

07216 PELED, Y.

ETHNIC DEMOCRACY AND THE LEGAL CONSTRUCTION OF CITIZENSHIP: ARAB CITIZENS OF THE JEWISH STATE

AMERICAN POLITICAL SCIENCE REVIEH, 86(2) (JUN 92), 432-443. THE CITIZENSHIP STATUS OF ISRAEL'S ARAB CITIZENS IS THE THE CITIZENSHIP STATUS OF ISRAEL'S ARAB CITIZENS
KEY TO THE STATE'S ABILITY TO FUNCTIOM AS AN ETHNIC

DEMOCRACY-DTHAT IS A POLITICAL SYSTEM COMBINING DEMOCRATIC DEMOCRACY-THAT IS, A POLITICAL SYSTEM COMBINING DEMOCRATIC CONFLUENCE OF REPUBLICANISM AND ETHMONATIONALISM WITH LIBERALISM, AS PRINCIPLES OF LEGITIMATION, HAS PRODUCED THO TYPES OF CITIZENSHIP: REPUBLICAN FOR JEWS AND LIBERAL FOR ARABS. THUS, ARAB CITIZENS CAN ENJOY CIVIL AND POLITICAL ARAB CITIZENSHIP STATUS, WHILE MUCH MORE RESTRICTED THAN THE JEWISH, HAS BOTH INDUCED AND ENABLED ARABS TO CONDUCT THEIR POLITICAL STRUGGLES HITHIN THE FRAMEWORK OF THE LAW, IN 
SHARP CONTRAST TO THE NONCITIZEN ARABS OF THE OCCUPIED TERRITORIES. THUS, IT MAY SERVE AS A MODEL FOR OTHER DOMIMANT ETHNIC GROUPS SEEKING TO MAINTAIN BOTH THEIR DOMINANCE AND A DEMOCRATIC SYSTEM OF GOVERNMENT.

07217 PELISSERO, J.P.; MORGAN, D.R. TARGETING INTERGOVERNMENTAL AID TO LOCAL SCHOOLS: AM ANALYSIS OF FEDERAL AND STATE EFFORTS

HESTERN POLITICAL QUARTERLY, 45(4) (DEC 92), 985-1000. CONVENTIONAL ECONOMIC THEORY SUGGESTS THAT THE NATIONAL GOVERMMENT SHOULD BE MORE EFFECTIVE THAN THE STATES IN EFFECTUATING REDISTRIBUTIVE POLICIES. IN THIS PAPER, THE AUTHORS COMPARE NATIONAL ANO STATE EFFORTS TO TARGET INTERGOVERNMENTAL AID TO MORE THAN 13,600 INDEPENDENT SCHOOL OISTRICTS IN 44 STATES. THEY FIND LITTLE EVIDENCE THAT FEDERAL AIO TO SCHOOLS IS TARGETED TO SOCIOECONOMIC OR FISCAL NEED. HHILE MOST STATE ASSISTANCE TO LOCAL SCHOOLS IS ENROLLMENT-DRIVEN, A POOLED ANALYSIS SHOHS THAT STATES ARE DOING A BETTER JOB OF TARGETING THAN THE FEDERAL GOVERMMENT. SEPARATE ANALYSES OF INDIVIDUAL STATES SHOW THAT TARGETING TO NEEDIER SCHOOL DISTRICTS IS A SIGNIFICANT FEATURE OF A NUMBER OF STATE AID SYSTEMS.

07218 PELLETIER, R.; TEMBLAY, $M$ LES FEMMES SONT-ELLES CANDIDATES DANS DES CIRCONSCRITIONS PERDUES D' CAMADIAN JOURAL 249-268.

IT IS STATED THAT HOMEN MORE OFTEN THEN MEN ARE CANDIDATES IN CONSTITUENCIES WHERE DEFEAT IS EXPECTED. THIS CANDIDATES IN CONSTITUENCIES WHERE DEFEAT IS EXPECTED POPUI THE QUEBEC EXBERAL PARTY AND THE PARTI QUEBECOIS DURING THE THE QUEBEC LIBERAL PARTY AND THE PARTI QUEBECOTS DURI POLITICAL PARTIES HILL HAVE TO COLLABORATE IF MORE WOMEN ARE TO BECOME MEMBERS OF THE NATIONAL ASSEMBLY.

07219 PEMPEL, T.J.

BUREAUCRACY IN JAPAN

PS: POLITICAL SCIENCE AND POLITICS, XXV(1) (MAR 92), 19-24.

JAPAN PROVIDES AN EXCELLENT CASE STUDY OF A NON-WESTERN, BUT HIGHLY MODERN, MATIONAL BUREAUCRACY. BECAUSE OF THE CENTRAL ROLE THAT JAPANESE BUREAUCRACY HAS PLAYED IN PLANNING AND IMPLEMENTING MANY MAJOR CHANGES IN JAPAN, IT IS A GOOD EXAMPLE OF BUREAUCRACY AS PLANMER AND AGENT OF CHANGE. BECAUSE THE JAPANESE BUREAUCRACY HAS BEEN SO CLOSELY LINKED TO POL ITICAL LEADERSHIP IT PRDVIDES AN IMPORTANT CONTRAST TO COUNTRIES WHERE BUREAUCRATS AND POLITICIANS ARE PRESUMED TO HAVE SEPARATE AND ANTAGONISTIC ROLES. BECAUSE JAPAN HAS LIMITED THE SIZE OF ITS GOVERMMENTAL BUREAUCRACY, THE JAPANESE CASE PROVIDES AN EXCELLENT COUNTER-CASE TO JAPANESE CASE PROVIDES AN EXCELLENT COUNTER-CASE TO
PRESUMPTIONS THAT BUREAUCRATIC EXPANSION IS INEVITABLE. PRESUMPTIONS THAT BUREAUCRATIC EXPANSION IS INEVITABLE. BECAUSE THE JAPANESE BUREAUCRACY HAS EXPERIENCED SEVERAL CONSCIOUS HISTORICAL REFORMULATIONS, INCLUDING IMITATIO THE PRUSSIAN MODEL AND SYSTEMATIC REFORM BY AMERICAN INTERACTION OF COMPETING BUREAUCRATIC TRADITIONS.

07220 PEMPEL, T.J. JAPANESE DEMOCRACY AND POLITICAL CULTURE: A COMPARATIVE PERSPECTIVE

PS: POLITICAL SCIENCE AND POLITICS, XXV(1) (MAR 92), 5-12. THE AUTHOR DISCUSSES THE CONMOTATIONS OF THE TERM "DEMOCRACY" AND EXPLAINS WHY JAPAN IS AN EXCELLENT CASE FOR THE COMPARATIVE STUDY OF THE CONNECTIONS BETWEEN DEMOCRACY AND CULTURE.

07221 PEMPEL, T.J.

POLITICAL PARTIES AND REPRESENTATION: THE CASE OF JAPAN

PS: POL ITICAL SCIENCE AND POLITICS, XXV(1) (MAR 92), 13-18. THE AUTHOR LOOKS AT THE HISTORY OF JAPAN'S POL ITICAL SYSTEM AND HOW IT PRESENTLY OPERATES UNDER THE LIBERAL 1955.

07222 PENG, L.

CHINA'S ECONOMY IN THE 1990 'S

BEI JING REVIEW, 35(7) (FEB 92), 15-17.

ON JANUARY 30,1992 , CHINESE PREMIER LI PENG ADDRESSED THE ANNUAL MEETING OF THE WORLD ECONOMIC FORUM. HE BRIEFLY SUMMARIZED CHINA'S CURRENT ECONOMIC SITUATION AND DISCUSSED ITS PLANS FOR FUTURE DEYELOPMENT.

07223 PENG, L.

CHINESE VIEHS ON A NEH WORLD ORDER

BEI JING REVIEW, 35(7) (FEB 92) 12-14.

CHINESE PREMIER LI PENG ADORESSED A SUMMIT MEETING OF THE UNITED NATIONS SECURITY COUNCIL ON JANUARY 31, 1992, AT THE UNITED NATIONS SECURITY COUNCIL ON JANUARY 31 , 1992, A VIEWS ON THE NEW WORLD ORDER AND CALLED FOR A MORE ACTIVE U. N. ROLE IN MAINTAINING WORLD PEACE.

07224 PENG, L.

FOR AN EFFECTIVE INTERMATIONAL COOPERATION
BEI JING REVIEN, 35(25) (JUN 92), 11-13.

IN JUNE 1992 LI PENG, PREMIER OF THE STATE COUNCIL OF THE PEOPLE'S REPUBLIC OF CHINA, ADDRESSED THE SUMMIT MEETIMG OF THE UNITED NATIONS CONFERENCE ON ENVIRONMENT AND DEVELOPMENT. HE STATED THAT ENVIRONMENTAL PROTECTION AND ECONOMIC DEVELOPMENT ARE IMPORTANT TO THE FUTURE OF MANKIND AND AFFECT EACH COUNTRY EACH NATION AND EACH INDIVIDUAL. AND AFFECT EACH COUNTRY, EACH NATION, AND EACH INDIVIDUAL. PHEREFORE, SOL PROBLEMS REQUIRES EXTENSIVE AND EFFECTIVE INTERNATIONAL PROBLEMS REQUIT
COOPERATION.

07225 PENG, Y.

PRIVATIZATION IN EASTERN EUROPEAN COUNTRIES

EAST EUROPEAH QUARTERLY XXVI (4) (HIN 92), 471-484.

THE AUTHOR EXPLAINS THE IMPORTANCE AND' INEVITABILITY OF PRIVATIZATIOH IN EASTERN EUROPE. HE DISCUSSES THE NECESSITY, BACKGROUND, DIFFICULTIIES, PROCESS, AND PROBLEMS OF PRIVATIZATION IN THE EAST EUROPEAN CONTEXT.

07226 PENNER, R.G. THE BUDGET DEFICIT: POLITICAL MONSTER BORN OF POLITICAL PETS

JOURMAL OF LAW \& POLITICS, IX(1) (FAL 92), 137-146.

MUCH OF THE FUTURE CONFLICT OVER REDUCING THE FEDERAL BUDGET DEFICIT WILL FOCUS ON FUNDING FOR THE ELDERLY PARTICULARLY IN ENTITLEMENT PROGRAMS. WILE ENTITLEMENTS AND INTEREST PAYMENTS ON THE DEBT ACCOUNTED FOR ONLY ONE-THIRD OF FEDERAL SPENDING DURING THE 1950'S, THESE THO CATEGORIES WILL ACCOUNT FOR THO-THIRDS IN 1992. MEANHHILE, THE POL ITICAL DESIRE TO CONTROL THE DEFICIT WILL PROBABLY BE POLI A LACKING. ALTHOUGH THE ECONOMIC HARM INFLICE DOL ITICAL COST OF RESTRAINING THE DEFICIT THROUGH SPENDING CUTS AND TAX RESTRAINING THE DEFICIT THROUGH SPENDING CUTS AND TAX 199 INCREASES WOULD BE FELT IMMEDIATELY. NEVERTHELESS, THE 1992 ELECTIONS MAY PRESENT A GOOD OPPORTUNITY FOR CHANGE, BECAUS THERE WILL BE A LARGE TURN-OVER IN CONGRESSIONAL MEMBERSH AND THE

07227 PENROSE, E.T. ECONOMIC LIBERALIZATION: OPENMESS AND INTEGRATION--BUT WHAT KIND?

DEVELOPMENT POLICY REVIEN, 10(3) (SEP 92), 237-254. INTEGRATION INTO THE WORLD ECONOMY IS,' APPARENTLY IN ALL INNOCENCE, URGED IN THE NAME OF "LIBERALIZATION," DESPITE THE FACT THAT THE INTERNATIONAL ECONOMY IS NOT PARTICULARLY LIBERAL. ALTHOUGH THIS ECONOMY CLEARLY REVOLVES AROUND MARKETS AND CONSUMER DEMAND, BOTH OF THESE ARE AS OFTEN MANIPULATED AS THEY ARE "FREE." INTEGRATION INTO THIS ECONOMY REQUIRES THE ACCEPTANCE OF MANAGERIAL CAPITALISM IN ONE FORM OR ANOTHER AND, IN MANY WAYS, INVOLVES A DEGREE OF SUBJECTION TO THE DECISIONS OF VERY POWERFUL PRIVATE HIERARCHIES. THIS IS NOT NECESSARILY AN UNACCEPTABLE COURSE OF ACTION, BUT IT DOES CAST CONSIDERABLE DOUBT ON THE NOTION THAT MATIONAL GOALS MAY IN THEMSELVES HAVE AN IMPORTANT ROLE IN THE DEVELOPMENT OF A COUNTRY'S ECONOMIC WELFARE AND ON THE ECONOMIC VALIDITY OF COUNTRY-CENTERED ASPIRATIONS. THE ASSUMPTION THAT INTEGRATION IS AN IMPORTANT ASPECT OF ECOMOMIC LIBERALIZATION FOR DEVELOPING COUNTRIES REQUIRES ECONOMIC LIBERALIZATIO

07228 PERALTA, G.A.

GUATEMALA'S MILITARY TRANSITION

HEMISPHERE, $4(3)$ (SUM 92 ), 39-41. HAS OVERTHROWN IN A MILITARY COUP, AND A PROCESS OF WAS OVERTHROWN IN A MILITARY COUP, AND A PR IS WHY DID SOME DEMOCRATIC TRANSITION BEGAN. THE QUESTION IS WHY DID DEMOCRATIC PATH? THE REASON WAS THE EMERGENCE OF AN ALTERNATIVE TO REPRESSION AS A STR

07229 PERCY-SMITH, J.

AUDITING SOCIAL NEEDS

POLICY AND POLITICS, 20(1) ( JAN 92), 29-34.

THE IDEA OF SOCIAL AUDITING HAS ÁTTRACTED CONSIDERABLE ATTENTION IN RECENT YEARS. THIS PAPER OUTLINES A MODEL OF SOCIAL AUOIT THAT REVOLVES AROUND THE CONCEPT OF SOCIAL NEEDS AS BOTH A BASIS FOR POLICY FORMULATION AND A CRITERION FOR POLICY EVALUATION. THE AUTHOR PRESENTS THE ARGUMENTS FAVORING REGULAR SOCIAL AUDITS, DESCRIBES THE PROCESSES INVOLVED IN CONDUCTING A SOCIAL AUDIT, AND OUTLINES A PRACTICAL EXAMPLE OF AN AUDIT OF HEALTH AND WELFARE NEEDS. WHILE THE AUDITING OF SOCIAL NEEDS IS NOT HITHOUT ITS DIFFICULTIES, IT IS A VITAL COMPONENT IN THE POLICY PROCESS.

07230 PERCY, S.: HAHKINS, B. FURTHER TESTS OF INOIVIDUAL-LEVEL PROPOSITIONS FROM THE TIEBOUT MODEL

THE JOU ALOF POLITICS, 54(4) (NOV 92), 1149-1157. THE JOURNAL OF POLITICS, 54(4) (NOV 92), 1149-1157.

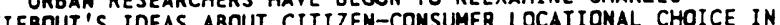
TIEBOUT'S IDEAS ABOUT CITIZEN-CONSUMER LOCATIONAL CHO METROPOLITAN AREAS. THE AUTHORS, AMONG OTHERS, HAVE 
TIEBOUT'S THESIS USING INDIVIDUAL-LEVEL EXPLORATION OF TIEBOUT PROPOSITIONS BY PRESENTING RELEVANT INDIVIDUAL-LEVEL DATA AND CRITICALLY ASSESSING RECENT WORK IN THE FIELD.

07231 PEREK, L.

SPACE DEBRIS AND THE WORLD ECONOMY

SPACE POLICY, $7(1)$ (FEB 91), 9-12.

IN THE EARLY YEARS OF SPACE FLIGHT THE UNITED NATIONS RAPIDLY DEVELOPED THE PRINCIPLES WHICH NOW GOVERN OUTER SPACE ACT IVITIES. IN CONTRAST, INTERNATIONAL AGENCIES DURING THE 1980 S PROVED RELUCTANT TO CONFRONT THE ESCALATING PROBLEM FOR FEAR OF THE LIKELY EXPENSE OF REMEDIAL ACTION. THIS ARTICLE EXAMINES THE PROBLEM AND CONCLUDES THAT ALL THE NECESSARY MEASURES NEED NOT BE EXPENSIVE, AND EVEN THE MOST UNPALATABLE WOULD BE COST EFFECTIVE IN THE LONG RUN. HOWEVER, UNPALATABLE WOULD BE COST EFFECTIVE IN THE LONG RUN. HOWEV
CONCERTED ACTION IS URGENTLY REQUIRED BEFORE THE PROBLEM CONCERTED ACTION IS URGENTLY REQUIRED BEFORE THE PROBL
BECOMES UNMANAGEABLE. THE ARTICLE ARGUES FOR IMMEDIATE BECOMES UNMANAGEABLE. THE ARTICLE ARGUES FOR IMMEDIATE
INTERNATIONAL DISCUSSION INITIATED THROUGH THE COMMITTEE ON INTERNATIONAL DISCUSSION INITIATED

07232 PERERA, J.

LET THE U.S. TAKE THE LEAD

MIDDLE EAST INTERNATIONAL, (396) (MAR 91), 8

WHEN SOVIET OFFICIALS CAN SPARE TIME AND ENERGY FROM THEIR IMCREASINGLY COMPLEX DOMESTIC SITUATION. THEY ARE USING WHAT LEVERAGE THEY HAVE TO PROMOTE THE IDEA THAT PEACE HILL COME ONLY AFTER A SETTLEMENT OF THE ARAB-ISRAELI CONFLICT WITH ARAB, WESTERN AND ISRAELI LEADERS. WHILE SUPPORTING THEIR LONG-HELD IDEA OF AN INTERNATIONAL CONFERENCE TO DECIDE THE ISSUE, THE SOVIETS HAVE DECLARED THEIR WILLINGNESS TO SUPPORT MOST ANY U.S. PLAN THAT GIVES THE PALESTINIANS ANYTHING FROM AUTONOMY TO AN INDEPENDENT STATE.

07233 PERERA, J.

MOSCOW'S FEAR OF PRECEDENTS

MIDDLE EAST INTERNATIONAL (398) (APR 91) 9

MOSCOW'S RELATIVE SILENCE OVER RECENT DEVELOPMENTS IN IRAO REFLECTS THE DILEMMA POLICY MAKERS ARE FACING AS THE PLIGHT OF THE KURDS HORSENS. WHILE THE SOVIET PRESS, LIKE THE WESTERN MEDIA, HAS BEEN EXPRESSING HORROR AT THE SITUATION, THE EMBARRASSMENT IN GOVERMMENT CIRCLES IS ALMOST PAINFUL. WHILE THE MASS SLAUGHTER OF A PEOPLE, 10,000 OF WHOM LIVE INSIDE THE USSR CANNOT BE IGNORED. THE IMPLICATIONS OF U.S. OR INTERNATIONAL INTERVENTION AND THE POSSIBLE DISINTEGRATION OF NORTHERN IRAQ ARE CAUSING SOME POSSIBLE DISINTEGRATION OF NORTHERN IRAQ ARE CAUSING SOME
DISMAY IN MOSCOW. AND THIS IN S ECHOED BY THE OFFICIAL MEDIA. DISMAY IN MOSCOW. AND THIS IN S ECHOED BY THE OFFICIAL MEDI MANY ARE SENSITIVE TO THE PARALLELS THAT MIGHT BE ORA
BETHEEN THE SITUATION IN IRAQ AND ANY NUMBER OF THE BETWEEN THE SITUATION IN IRAQ AND
MINORITIES IN THE SOVIET UMION.

07234 PERERA, J.

RELATIONS UNSCATHED

RELATIONS UNSCATHED
MIDOLE EAST INTERNATIONAL, (395) (MAR 91), 15-16.

THE OVERHHELMING REACTION TO THE END OF THE GULF WAR AMONG SOVIET POLICY-MAKERS IS PROFOUND RELIEF--RELIEF THAT THE CONFLICT DID NOT DRAG ON OR SPREAD TO INVOLVE OTHER STATES, BUT MOST OF ALL THAT RELATIONS WITH WASHINGTON HAVE SURVIVED THE ORDEAL MORE OR LESS UNSCATHED. SOVIET POLICY MAKERS NOW HOPE TO MOVE ON TO OTHER ISSUES IN THE REGION INCLUDING REGIONAL SECURITY, ARMS CONTROL, AND THE RESOLUTION OF THE ARAB-ISRAELI QUESTION. MEANHHILE, EVEN THOUGH HOSTILITIES HAVE ENDED, SOVIET LEADERS WILL FACE CONTINUED PRESSURE FROM HARD=LINERS AS A RESULT OF THE CONFLICT. THE EXTREMELY POOR SHOWING OF SOVIET MILITARY EQUIPMENT IN IRAQ'S HANDS CLEARLY CAME AS A GREAT SHOCK TO THE MILITARY. THIS HAS GIVEN THEM THE GREATEST LEVER YET TO REVERSE THE DEFENSE CUTS ALREADY MADE AND THOSE PLANNED FOR THE FUTURE.

07235 PERERA,

RUSSIA'S ÓTHER PRIORITIES

MIDDLE EAST INTERNATIONAL (418) (FEB 92) 7

WHILE RUSSIAN OFFICIALS DESCRIBED THE MIDDLE EAST PEACE TALKS IN MOSCOW AS A "DIPLOMATIC SUCCESS" AND PAID LIP SERVICE TO PALESTIHIAN RIGHTS TO SELF-DETERMINATION, IT BECAME EVIDENT TO MOST OBSERVERS THAT RUSSIA'S MIDOLE EAST POLICY HAD BECOME LITTLE MORE THAN AN EXTENSION OF WASHINGTON'S. RUSSIA'S REAL PRIORITIES INCLUDE THE WIDER PROBLEM OF NUCLEAR DISARMAMENT AND RUSSIA'S NEED FOR INTERNATIONAL ECONOMIC SUPPORT. PRESIDENT BORIS YELTSIN'S ABSENCE FROM THE MOSCOW MEETING WAS A CLEAR SIGNAL OF RUSSIA'S PREOCCUPATION WITH OTHER ISSUES.

07236 PERERA, J.

WHAT THE UN'S NUCLEAR INSPECTORS HAVE FOUND IN IRAO

MIDDLE EAST INTERNATIONAL, (431) (AUG 92), 18-19.

THIS ARTICLE RECOUNTS A YEAR'S WORTH OF EFFORTS OF THE

UNITED NATIONS NUCLEAR WEAPONS INSPECTION TEAM IN IRAQ. THE INSPECTORS INITIALLY BEGAM AT THE TUWAITHA NUCLEAR RESEARCH FACILITY, A COMPLEX WHOSE EXISTENCE WAS PREVIOUSLY ADMITTED IN ACCORDANCE WITH NON-PROLIFERATION TREATY (NPT) GUIDELINES. HOWEVER, WITHIN A YEAR THE TEAM DISCOVERED 22 SEPARATE FACILITIES COVERING ALMOST THE ENTIRE FUEL CYCLE
FROM URANIUM MINING TO PLUTONIUM PRODUCTIOM. SIX OF THESE, MAINLY IN NORTHERN IRAQ, WERE CONCERNED WITH URANIUM PRODUCTION AND PROCESSING; 11 WERE INVOLVED IN URANIUM ENRICHMENT AND FIVE WERE RELATED TO THE WEAPONS PROGRAM. IRAQI DELAYING TACTICS AND HOSTILITY MADE IT CLEAR THAT THE MILITARY ESTABLISHMENT IN IRAQ STILL HOPES TO RETAIN AT LEAST SOME NUCLEAR FACILITIES. THE UN TEAM IS CONVINCED THAT A LONG-TERM CONTINUOUS MONITORING IS REQUIRED TO ENSURE THAT IRAQ DOES NOT GAIN A WEAPONS CAPABILITY IN THE FUTURE.

07237 PERES, Y.; YUCHTMAN-YAAR, E.

TRENDS IN ISRAELI DEMOCRACY: THE PUBLIC'S YIEW

LYNNE RIENNER PUBLISHERS, $1992,59$.

DEMOCRACY, MORE THAN ANY OTHER FORM OF GOVERNMENT,

DEPENDS FOR ITS SURVIVAL ON PUBLIC SUPPORT. CAN THAT SUPPORT BE SUSTAINED DURING PERIOOS OF INTERNAL OR EXTERNAL CRISIS, WHICH OFTEN ENGENDER DISAPPOINTMENT IN THE INSTITUTIONS OF GOVERNMENT? SEEKING TO ANSWER THAT QUESTION. THIS BOOK EXAMINES THE ATTACHMENT TO DEMOCRATIC VALUES AND

INSTITUTIONS IN ISRAEL, A COUNTRY EXPERI ENCING ONGOING INTERNAL AND EXTERNAL TENSIONS. THE AUTHORS INVESTIGATE A NUMBER OF RELEVANT ISSUES, DRAWING ON A SERIES OF PUBLIC OPINION SURVEYS CONOUCTED IN 1987 THROUGH EARLY 1991. THEY ALSO DISCUSS THE FAIRLY PREDICTABLE IMPACT OF FOUR YEARS OF INTIFADA ON ISRAELI DEMOCRATIC ATTITUDES, ON CONTRACT TO THE SURPRISING REACTION TO THE GULF WAR AND THE IRAQI MISSILE ATTACKS.

07238 PERETZ, D.

ISRAEL SINCE THE PERSIAN GULF WAR

CURRENT HISTORY, 91(561) (JAN 92), 17-21.

DURING THE GULF WAR, ISRAEL'S RESTRAINT IN THE FACE OF

IRAQI ATTEMPTS TO TERRORIZE AND PROVOKE THE SHAMIR

GOVERMMENT HAS HIDELY PRAISED IN THE UNITED STATES. BUT AMERICAN GRATITUDE FOR THIS RESTRAINT HAS NOT TRANSLATED INTO TANGIBLE REWARDS FOR THE ISRAELIS OR INTO AMERICAN WILLINGNESS TO SUPPORT ISRAEL'S POSITION AS IT FACES ITS ARAB NEIGHBORS AT THE PEACE TABLE.

07239 PERETZ, D.

THE MIDDLE EAST: WAR AND ITS AFTERMATH

FREEDOM REVIEN, 23(1) (JAN 92), 44-47.

THE GULF WAR AND ITS AFTERMÁTH DOMINATED NEARLY EVERY

POLITICAL DEVELOPMENT IN THE MIDDLE EAST DURING 1991. ALL

MIDEAST NATIONS WERE INVOLVED EITHER AS PARTICIPANTS OR

THROUG THE ECONOMIC IMPACT ON THE REGION. ALTHOUGH THE

UNITED STATES HAD VEHEMENTLY DENIED THAT THERE WAS ANY

LINKAGE BETHEEN THE GULF CRISIS AND THE ARAB-ISRAELI

CONFLEN

OCTOBER 1991.

07240 PERETZ, J.H.

EQUITY UNDER AND STATE RESPONSES TO THE SUPERFUND

AMENDMENTS AND REAUTHORIZATION ACT OF 1986

POLICY SCIENCES, 25(2) (MAY 92), 191-209.

A DIFFICULT PROBLEM FACING STATES WITH SIGNIFICANT COMMERCIAL HAZARDOUS WASTE TREATMENT AND DISPOSAL CAPACITY IS THE INFLOW OF HASTE INTO THE STATE FOR DISPOSAL. THE STATES HITH COMMERCIAL CAPACITY ALLEGE THAT OTHER STATES ARE RELUCTANT TO AGGRESSIVELY PURSUE SITING FACILITIES AND, IN FACT, MAY BE IMPEDING DEVELOPMENT THROUGH RESTRICTIVE SITING PROVISIONS. LIKEWISE, CAPACITY STATES ARE FRUSTRATED WITH THE ENVIRONMENTAL PROTECTION AGENCY FOR ITS PERCEIVED INACTION IN REVIEWING STATE SITING STANDARDS. CAPACITY STATES HOPED THAT THE EQUITY ISSUE HOULD BE ELEVATED TO FEDERAL DEBATE THROUGH SECTION $104(\mathrm{~K})$ OF THE SUPERFUND AMENDMENTS AND REAUTHORIZATION ACT OF 1986. IN THIS PAPER, THE AUTHOR EXAMINES EQUITY ISSUES AND REVIEWS HAZARDOUS WASTE MANAGEMENT IN A FEDERALISM CONTEXT TO DEFINE THE RELATIONSHIP BETWEEN THE EPA AND THE STATES, FOCUING ON THE DIFFERENT ROLES THE EPA AND THE STATE PERCEIVED FOR ONE ANOTHER DURING IMPLEMENTATION OF SECTION $104(\mathrm{~K})$.

07241 PERETZ, M.

THE OTHER AL

NEW REPUBLIC, 207(17) (OCT 92), 19-20, 22

THE AUTHOR PROFILES TENNESSÉE SENATOR AL GORE JR., BILL CLINTON'S RUNNING MATE ON THE DEMOCRATIC TICKET IN THE 1992 PRESIDENTIAL ELECTION CAMPAIGN.

07242 PEREZ-STABLE, M.

CHARTING CUBA' S COURSE

HEMISPHERE, 4 (2) (WIN 92), 11-12.

DUE TO THE COLLAPSE OF MANY OF THEIR COMMUNIST ALLIES

CUBAN SOCIALISM IS NO LONGER YIABLE. WHATEVER FORM A MARKET

ECONOMY MAY ASSUME IN CUBA, ITS POINTS OF DEPARTURE WILL BE

DICTATED BY THE PRE-1959 HISTORICAL REALITIES OF THE

ISLAND'S LEVEL OF DEVELOPMENT AS WELL AS THE POST-1959

LEGACIES OF THE REVOLUTION.

07243 PEREZ, A.

HISTORICAL CHANGE AND ADMINISTRATIVE STATE: AN ANALYSIS OF

THE THEORETICAL FOUNDATIONS OF PUBLIC ADMINISTRATION

INTERNATIONAL JOURHAL OF PUBLIC ADMINISTRATION, $16(2)$ 
(1992), 261-293.

THIS ARTICLE OFFERS AN EXPLANATION FOR THE THEORETICAL UNDERDEVELOPMENT OF PUBLIC ADMINISTRATION. IT ARGUES THAT PUBLIC AOMINISTRATION STUDIES THE RELATIONS AMONG ELEMENTS OF THE ADMINSTRATIVE STATE AND BETHEEN THE ADMINISTRATIVE STATE AND ITS ENVIRONMENT DISSOCIATED FROM TIME. THE AHISTORICAL ORIENTATION OF THE DISCIPLINE HAS DRASTICALLY REDUCED ITS CAPACITY FOR THEORY BUILDING.

07244 PEREZ, A.

THE FSLN AFTER THE DEBACLE: THE STRUGGLE FOR THE DEFINITION OF SANDIMISMO

JOURMAL OF INTERAMERICAN STUDIES AND WORLD AFFAIRS, 34(1) (SPR 92 ), $111-140$.

THE SOURCES OF DISUNITY AND THE PROPSECTS FOR FSLM UNITY IN NICAROGUA IN THE FUTURE ARE EXAMINED. THIS ARTICLE LAYS OUT A BASIC CONCEPTUAL FRAMEWORK WITH WHICH TO ANALYZE THE ISSUE OF UNITY/DISUNITY IN POLITICAL ORGANIZATION. IT
REVIEHS THE INSTITUTIONAL DEVELOPMENT OF THE FSLN UP TO THE REVIEHS THE INSTITUTIONAL DEVELDPMENT OF THE FSLN UP TO THE
TIME OF THE 1990 ELECTIONS. IT THEN UTILIZES THIS REVIEN TO TIME OF THE 1990 ELECTIONS. IT THEN UTILIZES THIS REVIEN TO
ANALYZE THE POLITICAL AND IDEOLOGICAL DEBATE THAT EMERGED ANALYZE THE POLITICAL AND IDEOLOGICAL DEBATE THAT EMERGED
WITH THE FSLN IN THE HAKE OF THEIR DEFEAT IN THAT ELECTION. WITH THE FSLN IN THE WAKE OF THEIR DEFEAT IN THAT ELECTION.
THE FIRST PARTY CONGRESS IS ASSESSED IN TERMS OF ITS

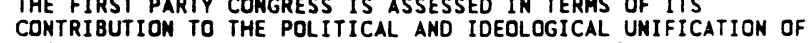
CONTRIBUTION TO THE POL ITICAL AND IDEOLOGICAL UNIFICATION
THE FSLN. THE CONCLUSION ANALYZES THE PROPSECTS FOR UNITY AND/OR DISUNITY WITHIN THE SANDINISTA PARTY.

07245 PERL, $R$

UNITED STATES ANDEAN DRUG POLICY: BACKGROUND AND ISSUES FOR DECISIOMMAKERS

JOURNAL OF INTERAMERICAN STUDIES AND WORLD AFFAIRS, 34(3)

(FAL 92), 13-36.

PRESIDENT BUSH HAS OUTLINED A COMPREHENSIVE DRUG CONTROL STRATEGY WITH BOTH NATIONAL AND INTERNATIONAL DIMENSIONS. THE STRATEGY HAS FOCUSED ON REDUCING BOTH THE DEMAND AND SUPPLY OF ILLICIT DRUGS. TREATMENT, PREVENTION/EDUCATION, RESEARCH, LAW ENFORCEMENT, AND INTERNATIONAL EFFORTS ARE MAJOR COMPONENTS OF THE STRATEGY. THIS ARTICLE EXPLORES THE ELEMENTS OF ANDEAN INITIATIVE AND OFFERS AN EVALUATION OF STRATEGY PROGRESS AND EFFECTIVENESS. IT CONCLUDES BY EXPLORING THE ISSUES FOR DECISIONMAKERS.

07246 PERLO, $V$.

RACISM = SUPERPROFITS

POLITICAL AFFAIRS, 71(2) (FEB 92), 1-6.

FEARING THAT APPEALS TO RACIST' PREJUDICES THROUGH INFLAMMATORY MISINFORMATION WILL AGAIN BE A MAIN WEAPON OF REACTION IN THE U.S. PRESIDENTIAL ELECTIONS, THE AUTHOR OF THIS ARTICLE SEEKS TO REFUTE THE NOTION THAT BLACKS AND HISPANICS ARE "WELFARE LOAFERS." THE REALITY IS THAT AFRICAM AMERICANS AND HISPANICS, WHO DO NEED MORE GOVERMMENT ASSISTANCE BECAUSE THEY ARE MOST VICTIMIZED BY CAPITALIST EXPLOITATIOM AMD IMPOVERISHMENT, GET LESS. THE ARTICLE EXAMINES THIS DISCRIMINATION IN THE ARENAS OF TRANSFER PAYMENTS, EDUCATION, CIVIL RIGHTS, AND GENERAL LEVELS OF PAYMENTS, EDUCATION, CIVIL RIGHTS, AND GENERAL LEVELS OF
INCOME. THE AUTHOR CONCLUDES THAT IT IS TO THE SHORT-TERM INCOME. THE AUTHOR CONCLUDES THAT IT IS TO THE SHORT-TERM
BENEFIT OF THE AMERICAN CAPITALISTS TO KEEP MINORITIES BENEFIT OF THE AMERICAN CAPITALISTS TO KEEP MINORIT
REPRESSED. OVERCOMING SUCH DISCRIMINATION IS THE REPRESSED. OVERCOMING SUCH DISCRIMINATION IS THE
RESPONSIBILITY OF ALL AMERICANS, AFRICAN-AMERICAN, HISPANIC, ASIAN AND WHITE.

07247 PERLO, $V$.

THE ECONOMIC AND POLITICAL CRISIS IN THE USSR POLITICAL AFFAIRS, LXX(8) (AUG 91), 10-18.

THE ECONOMIC CRISIS IN THE SOVIET UNION INTERACTS HITH AN ACUTE POLITICAL CRISIS: THE THREATENED BREAKUP OF THE UNION INTO SEPARATE REPUBLICS; THE DESTRUCTION OF THE SYSTEM OF PLANNED ECONOMY; THE SPREAD OF CAPITALIST PROPERTY RELATIONS: A MARKET DETERIORATION IN THE INTERMATIONAL INFLUENCE OF THE USSR; AND A WEAKENING OF ITS MILITARY SECURITY. IN 1985, WITH THE ACCESSION OF MIKHAIL GORBACHEV TO POLITICAL LEADERSHIP. THE POLICY KNOWN AS "PERESTROIKA" WAS INITIATED. BUT THERE HAVE REALLY BEEN THO PERESTROIKAS. IN ITS FIRST STAGE, THROUGH MOST OF 1988, IT HAS A PROGRAM TO MODERNIZE AND MAKE MORE FLEXIBLE, TO DEMOCRATIZE THE SOCIALIST SYSTEM. SINCE THE SECOND STAGE BECAME DOMINANT IN 1989, PERESTROIKA HAD BECOME A PROGRAM THREATENIMG TO DESTROY SOCIALISM AND IMPOSE CAPITALISM. THE LACK OF CONTINUITY BETWEEN THE TWO PHASES OR TYPES OF PERESTROIKA IS LARGELY RESPONSIBLE FOR THE ECONOHIC CRISIS IN THE SOVIET UNION.

07248 PERLOFF, R.M.

PSYCHOLOGICAL DYNAMICS OF POLITICAL ADVERTISING EFFECTS POLITICAL COMNUNICATION AND PERSUASION, $8(4)(1991)$ POLITICAL

THE AUTHOR STUDIES THE EFFECTS OF POLITICAL ADVERTISING BY EXAMINING THE PSYCHOLOGICAL DYNAMICS OF POLITICAL ADS. HE EXPLORES THE IMPLICATIONS OF CONTEMPORARY PERSUASION THEORIES--PARTICULARLY THOSE FOCUSING ON SOURCE, MESSAGE, PROCESS-BASED, CHANNEL, AND RECEIVER FACTORS. IN ADDITION, HE EXAMINES ELITE PERCEPTIONS OF POLITICAL ADVERTISING, FOCUSING ON THE BELIEFS OF PROFESSIONAL CONSULTANTS AND
PERCEPTIONS OF POLITICAL AD CONTENT AND EFFECTS, HAS MAILED TO A RANDOM NATIONAL SAMPLE OF CONSULTANTS AND JOURNALISTS. THE RESULTS REVEAL THAT THESE TWO GROUPS DIFFER

SIGNIFICANTLY IN THEIR PERCEPTIONS OF THE ADS.

07249 PERMUT, D.L.; VERDON, J.P. PROTECTING THE AMERICAN TRADITION OF WRITE-IN VOTING AFTER BURDICK $V$. TAKUSHI JOURHAL OF LAW \& POLITICS, IX(1) (FAL 92), 185-222. THE TRADITION OF WRITE-IN VOTING HAS BEEN THREATENED BY THE SUPREME COURT'S DECISION IN BURDICK V. TAKUSHI. THE UNITED STATES' HIGHEST COURT RULED THAT THE STATE OF HAHAII'S PROHIBITION ON WRITE-IN VOTING DID NOT UNREASONABLY INFRINGE UPON ITS CITIZENS' FIRST AND FOURTEENTH AMENDMENT RIGHTS. IN REVERSING SEVERAL LOWER COURT DECISIONS THAT HAD INVALIOATED HRITE-IN VOTING RESTRICTIONS ON FIRST AMENDMENT GROUNDS, THE COURT MADE IT CLEAR THAT THE FEDERAL CONSTITUTION OFFERS FEH OBSTACLES TO OTHER STATES WISHING TO RESTRICT WRITE-IN VOTING. AFTER THE BURDICK DECISION, ALL
WRITE-IN VOTING RESTRICTIONS ARE PRESUMPTIVELY VALID, AS WRITE-IN VOT ING RESTRICTIONS ARE PRESUMPTIVELY VALID, AS
LONG AS THE STATE DOES NOT UNREASONABLY RESTRICT A POLITICAL LONG AS THE STATE DOES NOT UNREASONABLY RESTRICT A POL ITICAL
CANDIDATE'S EFFORTS TO HAVE HIS OR HER NAME PRINTED ON THE CANDIDATE'S EFFORT

07250 PEROTTI, R.

IRCA'S ANTIDISCRIMINATION PROVISIONS: WHAT WENT WRONG? INTERNATIONAL MIGRATION REVIEW, 26(3) (FAL 92), 732-753. AFTER NEGOTIATING FOR FIFTEEN YEARS, WHY COULDN'T CONGRESS BUILD INTO ITS MAJOR ILLEGAL IMMIGRATIOAN BILL ADEQUATE SAFEGUARDS AGAINST NEW NATIONAL ORIGIN AND CITIZENSHIP DI SCRIMINAT ION? ONE ANSWER LIES IN THE PROCESS
THROUGH WHICH CONGRESS AND INTEREST GROUP ADVOCATES NEGOTIATED IRCA'S VERIFICATION AND REDRESS PROVISIONS, THE BILL'S MAIN PROTECTIONS AGAINST DISCRIMINATION. THIS ESSAY CONCLUDES THAT, ALTHOUGH IT WAS FORESEEN THAT OISCRIMINATION PROBLEMS MIGHT' ARISE FROM IRCA'S "EXISTING DOCUMENTS" VERIFICATION PROVISIONS, MEMEBERS OF CONGRESS STILL AGREED ON THESE PROVISIONS TO AVOID DIFFICULT POLITICAL QUESTIONS. RESTRICTIONISTS AND LIBERALS MUST ENGAGE IN A DIALOGUE AIMED AT DEVELOPING VERIFICATION PROVISIONS THAT WILL NOT BE DISCRIMINATORY.

07251 PERRY, C.M.

THEATER MISSILE THREATS AND DEFENSIVE OPTIONS IN THE 1990'S ANNALS OF THE AMERICAN ACADEMY OF POLITICAL AND SOCIAL SCIENCE, (517) (SEP 91), 66-79.

THE SUCCESS OF THE PATRIOT ANTI-MISSILE SYSTEM IN THE 1991 PERSIAN GULF WAR PLACED THE NEED FOR IMPROVED THEATER MISSILE DEFENSES HIGH ON THE PROCUREMENT AGENDAS OF THE MISSILE DEFENSES HIGH ON THE PROCUREMENT AGENDAS OF THE
UNITED STATES AND ITS MAJOR ALLIES. THE NEED FOR MORE UNITED STATES AND ITS MAJOR ALLIES. THE NEED FOR MORE
EFFECTIVE FOLLOW-ONS TO EXISTING PATRIOT SYSTEMS, MOREOVER, EFFECTIVE FOLLOW-ONS TO EXISTING PATRIOT SYSTEMS, MOREOY WILL BE RENDERED ALL THE MORE COMPELLING BY EXPECTED
ADVANCES IN THE QUALITY AND QUANTITY OF THEATER MISSILE ADVANCES IN THE QUALITY AND QUANTITY OF THEATER MISSILE
FORCES FIELDED BY REGIONAL POHERS-SUCH AS SYRIA, IRAN

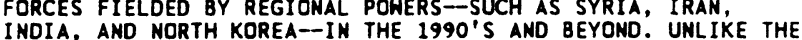
INDIA, AND NORTH KOREA-IN THE 1990'S AND BEYOND. UNL IKE IRAOI SCUDS IN DESERT STORM, NEXT-GENERATION THEATER MISSILES--ARMED WITH IMPROVED GUIDANCE AND MORE LETHAL WARHEADS--HILL PRESENT A CREDIBLE THREAT TO VITAL
ASSETS AS HELL AS POPULATION CENTERS. HENCE, NEW ASSETS AS WELL AS POPULATION CENTERS. HENCE, NEW TECHNOLOGIES FOR ACTIVE MISSILE DEFENSE WILL BECOME
INCREASINGLY IMPORTANT TO THE EFFECTIVE PROTECTION OF U.S. ALLIES AND FORWARD-DEPLOYED FORCES.

07252 PERRY, D.; KELLER, L.

PUBLIC ADMIMISTRATION AT THE LOCAL LEVEL: DEFINITION, THEORY, AND CONTEXT; MANAGING LOCAL GOVERNMENT--PUBLIC ADMINISTRATION IN PRACTICE

SAGE PUBLICATIONS, $1991,3-30$.

THIS CHAPTER BÉgINS WITH A DISCUSSION OF THE "PAST, PLACE AND INSTITUTIONAL IMAGE" OF LOCAL ADMINISTRATION AS A "SOCIAL EVENT." A THEORETICAL SKETCH OF THE BROADER URBAN POLITICAL ECONOHY IS NECESSARY TO FRAME THE HUMAN AGENCY OF LOCAL POLITICAL MANAGEMENT. THE CHAPTER THEN IDENTIFIES THE VARIOUS COMPONENTS OF LOCAL PUBLIC MANAGEMENT AS PRACTICES EMBEDDED IN THE BROADER URBAN SOCIETY. AN ORGANIZATIONAL THEORY PERSPECTIVE IS USED TO OUTLINE AND PLACE WITHIN THE LARGER SYSTEM THE PRACTICES OF LOCAL MANAGEMENT WITHIN THE PUBLIC AGENCY OF HHAT DETRACTORS CALL THE "BUREAUCRACY." THE CHAPTER CONCLUDES WITH A BRIEF REVIEW OF THE GENERAL APPROACH OF THE BOOK: GROUNDING PUBLIC ADMINISTRATION AT THE LOCAL LEVEL IN TERMS OF ITS POLITICAL-ECONOMIC CONTEXT AND

LOCAL LEVEL IN TERMS OF ITS POL

07253 PERRY, D.M.

BULGARIA: A NEW CONSTITUTION AND FREE ELECTIONS RFE/RL RESEARCH REPORT, 1(1) (JAN 92), 78-82.

THE YEAR 1991 BEGAN' WITH BULGARIA'S FIRST MULTI-PARTY COALITION GOVERMMENT SETTLING IN WHILE THE NATIONAL PARL IAMENT DEPUTIES HERE EMBROILED IN INTERPARTY STRIFE. THE RESULT WAS LITTLE LEGISLATION BUT MUCH ANIMOSITY. BY MIDYEAR, THE LONG-AWAITED CONSTITUTION WAS PROHULGATED, THOUGH NOT WITHOUT BEING SERIOUSLY CONTESTED BY THOSE HHO FELT IT FAYORED THE BULGARIAN SOCIALIST PARTY. ELECTIONS FOLLOWED IN OCTOBER, BRINGING A UNION OF DEMOCRATIC FORCES GOVERMMENT TO 
POWER. THE YEAR WAS MARRED BY THE RESURGENCE OF ETHNOCENTRIC NATIONALISM DIRECTED AGAINST ETHNIC TURKS BY A SMALL BUT VOCAL SEGMENT OF SOCIETY.

07254 PERRY, D.M

REPUBLIC OF MACEDONIA

RFE/RL RESEARCH REPORT, 1(39) (OCT 92), 44-46.

SINCE THE REPUBLIC OF MACEDONIA DECLARED INDEPENDENCE FROM YUGOSLAVIA IN NOVEMBER 1991. THE STATUS OF THE MEDIA HAS NOT CHANGED RADICALLY. THERE HAS BEEN NO SUCCESSFUL PRIVATIZAIION IN ANY SPHERE, AND MEDIA GROHTH REMAINS VERY SLUGGISH DUE TO THE ECONOMIC CRISIS GRIPPING THE LAND.

07255 PERRY, D.M

THE REPUBLIC OF MACEDONIA AND THE OOOS FOR SURVIVAL RFE/RL RESEARCH REPORT, 1 (46) (NOV 91), 12-19.

THE REPUBLIC OF MACEDONIA IS CONFRONTING EXTERNAL AND INTERNAL DANGERS THAT THREATEN THE EXISTENCE OF THE NEW STATE. ECONOMIC WOES RESULTING FROM GREEK PRESSURE ON THE EUROPEAN COMMUNITY AND THE USA NOT TO EXTEND RECOGNITION TO MACEDONIA, FROM MACEDONIA'S ADHERENCE TO U.N. SANCTIONS AGAINST SERBIA, AND FROM A GREEK ENERGY BLOCKADE MAY CAUSE EXISTING FRICTION BETWEEN ETHNIC MACEDONIANS AND ETHNIC ALBANIANS TO TURN INTO OPEN CONFRONTATION. EVEN IF THIS DOES NOT HAPPEN, MACEDONIA FACES THE PROSPECT OF BEING DRAWN INTO A CIVIL WAR IN KOSOVO SHOULD THE SITUATION THERE GET OUT OF CONTROL. SUCH A DEVELOPMENT COULD, IN TURN, TRIGGER A CIVIL WAR IN MACEDONIA.

07256 PERRY, G.L

SHOULD WE CUT TAXES?

BROOKINGS REVIEW, 10(1) (WIN 92), 53.

THE UNITED STATES' ANEMIC ECONOMIC RECOVERY HAS LED POLITICIANS FROM BOTH PARTIES TO CALL FOR TAX CUTS. HOHEYER, FOR A MIXTURE OF REASONS, MOST ECONOMISTS OPPOSE TAX FOR A MIXTURE OF REASONS, MOST ECONOMISTS OPPOSE TAX

07257 PERRY, $H$

THE REPUBLICAN AGENDA FOR US POLICY TOWARD THE WESTERN THE REPUBLICAN AGENDA FOR

JOURNAL OF INTERAMERICAN STUDIES AND WORLD AFFAIRS, 34(2) (SUM 92), 19-28.

THE PURPOSE OF THIS ESSAY IS TO OUTLINE THE LATIN AMERICAN AGENDA OF THE REPUBLICAN PARTY FOR THE 1990S. IT SUGGESTS THAT THE UNDERLYING CHALLENGE IS THE NEED TO FORM A BROAD, BIPARTISAN BASE OF SUPPORT THAT RECOGNIZES THE CRUCIAL OPPORTUNITY THAT THE WESTERN HEMISPHERE NOW OFFERS TO THE UNITED STATES. THE GENERAL LIMES OF STRATEGY ARE OUTLINED IN THE ENTERPRISE FOR THE AMERICANS INITIATIVE. THESE IDEAS STAND IN NEED OF SUPPORT
COMMUNITY AND THE PUBLIC AT LARGE.

07258 PERSAUD, B

EUROPE AND THE CHALLENGE OF GLOBAL CHANGE

ROUND TABLE, (320) (OCT 91), 437-444.

REGIONAL INTEGRATION ON THE BASIS OF THE EUROPEAN COMMUNITY (EC) HAS BEEN ONE OF THE MOST EXCITING GLOBAL DEVELOPMENTS SINCE HORLD WAR II. THE MOMENTUM IT HAS GAINED IN RECENT YEARS THROUGH THE SPEEDED-UP PROGRESS OF ESTABL ISHING A SINGLE MARKET AND THROUGH ITS EVER WIDENING SCOPE HAS ADDED TO ITS SIGNIFICANCE BUT THIS PROGRESS HAS NOT LED TO ADEQUATE ATTENTION TO FURTHERING EUROPE'S GLOBAL INTERESTS AND RESPONSIBILITIES. THE FAILURE ARISES FROM BOTH THE LIMITED PROGRESS IN DEVELOPING COMMON EXTERNAL RELATIONS AND THE LIMITED USE MADE OF THE SCDPE FOR COMMON ACTION ON CRITICAL GLOBAL ISSUES. THIS ARTICLE ARGUES THAT GLOBAL MANAGEMENT IS SEVERELY INADEQUATE, AND THE THE EC HAS SPECIAL ADVANATAGES TO CONTRIBUTE TO ITS IMPROVEMENT. SOME SPECIAL AOVANATAGES TO CONTRIBUTE TO ITS IMPROVEMENT. SOME
OF THESE ARISE FROM THE INTEGRATION PROCESS ITSELF IN TERMS
OF BOTH THE VALUABLE EXPERIENCE IT PROVIDED IN INTERHATIONAL CDOPERATION MECHANISMS AND THE INCREASING STRENGTH OF THE COMPERATION

07259 PERSAUD, $Y$. DEVELOPING COUNTRIES CAN COMPETE IN INTERMATIONAL CAPITAL MARKETS

ROUND TABLE, 323(323) (JUL 92), 359-362

TOUND TABLE, $323(323)$ (JUL 92 ), 359-362. BECOMING FIERCER. LARGE-SCALE ADOPTION OF MARKET SYSTEMS BY BECOMING FIERCER. LARGE-SCALE ADOPTION OF MARKET SYSTEMS CROM SHOWING RESILIENCE. DEVELOPING COUNTRIES ARE GENERALLY IN A SHOWING RESILIENCE. DEVELOPING COUNTRIES ARE GENERALLY IN A BETTER POSITION TO MAKE PROGRESS ON POLICY AND INSTITUIONAL REFORM THAT WILL KEEP THEM AHEAD OF THE GAME. THIS ARTICL
EXPLORES THE POLICY AND INSTITUTIONAL CHANGES THAT HILL EXPLORES THE POLICY AND INST

07260 PERTHES, $Y$.

SYRIA'S' PARLIAMENTARY ELECTIONS: REMODELING ASAD'S POLITICAL BASE

MIDDLE EAST REPORT, 22(1) (JAN 92), 15-19.

ON MAY 22 AND 23, 1990, SYRIAN VOTERS WERE CALLED TO THE POLLS TO ELECT A NEW PARL. IAMENT SYRIA'S MEDIA CELEBRATED
ACHIEVE INCREASED POPULAR PARTICIPATION IN THE ADMINISTRATION OF THE COUNTRY'S AFFAIRS. THESE ELECTIONS, WHILE HARDLY "DEMOCRATIZATION" MIGHT INDICATE A GRADUAL REMODELING OF THE POLITICAL STRUCTURE AND THE SOCIOPOLITICAL BASE THAT ASAD RELIES ON. THE ELECTIONS ALSO REPRESENT THE DESIRE OF SOCIAL GROUPS HITHERTO NOT REPRESENTED IN THE INSTITUTIONS OF THE BA'THIST STATE TO MAKE THEIR VOICES HEARD FROM WITHIN THE SYSTEM.

07261 PETEET, J.; HARLOW, 8. GENDER AND POLITICAL CHANGE

MIDDLE EAST REPORT, 21 (6) (NOV 91), 4-8

MIDDLE EASTERN WOMEN HAVE BEEN RAISING THEIR VOICES AND ORGANIZING FOR EMANCIPATION AND SOCIAL REFORM SINCE THE BEGINNING OF THIS CENTURY. IN THE INTERVENING DECADES, MUCH HAS CHANGED IN THEIR LIVES. THERE IS GREATER ACCESS TO HAS CHANGED IN THEIR LIVES. THERE IS GREATER ACCESS TO EDUCATION AND EMPLOYMENT, AND IN MANY COUNTRIES WOMEN HAVE THE RIGHT TO VOTE. IN SOHE COUNTRIES, LAWS GOVERNING FAMILY AND PERSONAL STATUS HAVE ALTERED PATTERNS AND EXPE

OF FAMILY LIFE. CHANGE HAS BEEN UNEVEN, VARYING
SIGNIFICANTLY ACCORDING TO THE SOCIAL CLASS, LOCATION AND SIGNIFICANTLY ACCORDING TO THE SOCIAL CLASS, LOCATION AND SHOULD CONTROL WOMEN'S LIVES, IN THE FAMILY AND IN SOCIETY AT LARGE.

\section{PETER, L.}

THE ARISTOCRACY, THE GENTRY, AND THEIR PARLIAMENTARY TRADITION IN NINETEENTH-CENTURY HUNGARY

SLAVONIC AND EAST EUROPEAN REVIEH, 70(1) (JAN 92), 77-110. FROM THE MIDDLE AGES UNTIL RECENTLY, THE ARISTOCRACY AND THE GENTRY LANDOWNERS DOMINATED HUNGARIAN SOCIETY. THESE TWO GROUPS, THE CATHOLIC TITLED ARISTOCRACY AND THE PARTLY PROTESTANT WELL-TO-DO PROVINCIAL GENTRY, FORMED THE LANDOWNING ELITE. EACH GROUP POSSESSED INDEPENDENT SOCIAL POWER WHILE, ARGUABLY, NO OTHER SOCIAL GROUP DID SO ENDURINGLY ON A WIDE SCALE. THE ELITE'S POWER WAS ROOTED IN THE NOBLE OWNERSHIP OF THE LAND, BASED ON ROYAL DONATION, IN EXEMPTIONS, IMMUNITIES, AND OTHER PRIVILEGES; IN THE EXEMPTIONS, IMMUNITIES, AND OTHER PRIVILEGES ; IN THE
MAINTENANCE OF SERFDOM, WHICH ENABLED THE ELITE TO BE MAINTENANCE OF SERFDOM, WHICH ENABLED THE ELITE TO BE
MASTERS OVER THE BULK OF THE POPULATION AS A HORKFORCE; AND MASTERS OVER THE BULK OF THE POPULATION AS A HORKFORCE;
IN THE POLITICAL INSTITUTIONS AT THEIR DISPOSAL. IN THIS IN THE POLITICAL INSTITUTIONS AT THEIR DISPOSAL. IN THIS
ESSAY, THE AUTHOR EXAMINES THE ARISTOCRACY, THE GENTRY, AND ESSAY, THE AUTHOR EXAMINES THE ARISTOCRACY, THE GENTRY
THE PARLIAMENTARY TRADITION IN $19 T H$-CENTURY HUNGARY.

07263 PETERS, B.G

THE POLICY PROCESS : AN INSTITUTIONALIST PERSPECTIVE CANADIAN PUBLIC ADMINISTRATION, 35 (2) (SUM 92), 160-180. THE STAGES MOOEL OF THE POLICY PROCESS CONSTITUTES THE THE PUCH OF POLITICAL SCIENCE AND PUBLIC ADMINISTRATION. THAT MODEL HAS PERFORMED A NUMBER OF IMPORTANT TASKS FOR THESE DISCIPLINES BUT ALSO CONTAINS A NUMBER OF FUNDAMENTAL WEAKNESSES, INCLUDING ITS ASSUMPTIONS CONCERHING LINEARITY AND THE TEMPORAL ORDERING OF THE STAGES AND THE DIFFICULTY OF THE
MODEL IN COPING WITH POLICY CHANGE. FURTHER, OUTCOMES OF THE STAGES MODEL TEND TO BE DETERMINED BY THE ENYIRONMENT OF POLITICS, RATHER THAN BY THE ACTORS AND INSTITUTIONS WITHIN GOVERNMENT. THE ANALYSIS IN THIS PAPER ATTEMPTS TO RESTORE INSTITUTIONS, INCLUDING THE PUBLIC BUREAUCRACY, TO A MORE APPROPRIATE CENTRAL POSITION IN THE FORMULATION AND DETERMINATION OF POLICY CHOICES. THE USE OF INSTITUTIONAL ANALYSIS NOT ONLY REFLECTS MORE CLEARLY THE COMPLEX REALITY OF POLICY-MAKING AND THE INTERACTION OF ORGANIZATIONS HITHIN THE PUBLIC SECTOR, BUT IT RESTORES VALUE CONCERNS TO A CENTRAL PLACE IN THE ANALYSIS AND INTERPRETATION OF PUBLIC POLICY.

07264 PETERS, $C$.

THE RIGHT PRIORITIES FOR THE NINETIES

THINGTON MONTHLY, 23(1,2) (JAN 91), 13.

THIS ARTICLE ARGUES THAT THE GULF CRISIS, ALTHOUGH IMPORTANT, IS NOT THE ONLY ISSUE DESERVING OF U.S. ATTENTION. IT OUTLINES SEVERAL OTHER ISSUES THAT WILL SUFFER FROM THE OIVERTING EFFECTS OF FOREIGN POLICY IN THE GULF. THEY INCLUDE: THE ECONOMIC COMPETITION OF JAPAN AND GERMANY; THE INCLUDE: THE ECONOMIC COMPETITION OF JAPAN AND GERMANY;
ENORMOUS BUDGET DEFICIT; THE NEED FOR A CONSCIENCE IN ENORMOUS BUDGET DEFICIT; THE NEED FOR A CONSCIENCE IM CAPITALISM; AND THE DIVERSION OF AMERICA'S BEST AND BRIGHTEST INTO MORALLY MARGINAL OR POSITIVELY HARMFUL ACTIVITIES TI

07265 PETERS, C. (ED.)

COLLATERAL DAMAGE--THE NEH HORLD ORDER AT HOME AND ABROAD SOUTH END PRESS, 1991, 250.

WRITTEN DURING AND AFTER THE PERSIAN GULF WAR, THIS COLLECTION OF ESSAYS OFFERS A COMPREHENSIVE PICTURE OF THE UNITED STATES ASAY POL ICEMAN IN THE NEH HORLD ORDER, AND EXAMINES OPPRESSION AND THE MISUSE OF POHER IN ALL ITS MANIFESTATIONS AS THE KEY TO UNDERSTANDING BOTH THE SHORTAND LONG-TERM CRISES AT HOME AND ABROAD. SOME QUESTIONS ADORESSED IN THE BOOK ARE: WHAT ARE THE DOMESTIC COSTS AND CONSEQUENCES OF BEING THE HORLD'S MILITARY MIGHT? WHAT DOES THE U.S. ROLE IN THE PERSIAN GULF CRISIS REVEAL ABOUT POSTCOLD WAR INTERNATIONAL CONFIGURATIONS OF POWER? HOW IS 
RACISM USED TO JUSTIFY U.S. FOREIGN POLICY? WHAT WILL BE THE SOCIAL AND POL ITICAL FALL-OUT IN THE MIDDLE EAST? WHAT ARE THE HUMAN AND ENVIRONMENTAL CONSEQUENCES TO SUCH MASSIVE DESTRUCTION? WHAT ARE THE RELATIONSHIPS BETHEEN PATRIARCHY, RACISH, AND MILITARISM? HOW SHOULD THE U.S. MOVEMENT FOR PEACE AND JUSTICE RESPOND TO THIS CRISIS ABROAD
ONGOING STRUGGLES AGAINST OPPRESSION AT HOME?

07266 PETERS, G.

GOVERMMENT REORGANIZATION: A THEORETICAL ANALYSIS INTERNATIONAL POLITICAL SCIENCE REVIEW, 13(2) (APR 92), 199-218.

REORGANIZATION IS ONE OF THE MOST COMMON ACTIVITIES OF GOVERNMENT, BUT IT IS NOT ADEQUATELY UNDERSTOOD. THIS ARTICLE APPLIES THREE BROAD APPROACHES IN ADMINISTRATIVE THEORY--PURPOSIVE ACTION, ENVIRONMENTAL DETERMINISM, AND INSTI TUTIONALISM--TO THE' STUDY OF REFORM IN INDUSTRIALIZED DEMOCRACIES. EACH OF THESE THREE BROAD APPROACHES IS FURTHER DEMOCRACIES. EACH OF THESE THREE BROAD APPROACHES IS
DIVIDED INTO A NUMBER OF MORE SPECIFIC APPROACHES. THE ARTICLE EVALUATES ALL THE AVAILABLE APPROACHES, AND ENDS BY ARTICLE EVALUATES ALL THE AVAILABLE APPROACHES,
ARGUING IN FAVOR OF THE INSTITUTIONAL APPROACH.

07267 PETERSON, J.

PUBLIC POLICY AND THE ECONOMIC STATUS OF WOMEN IN THE UNITED STATES

JOURNAL OF ECONOMIC ISSUES, 26(2) (JUN 92), 441-448. THE CONTRADICTORY NATURE OF STATE ACTION IS OF CRITICAL IMPORTANCE IN DISCUSSIONS OF PUBLIC POLICY AFFECTING THE STATUS OF NOMEN. THIS ARTICLE ARGUES THAT THIS CONTRADICTORY RELATIONSHIP BETHEEN WOMEN AND THE STATE IS ROOTED IN THE CONCEPTION OF PUBLIC AND PRIVATE THAT HAVE GROUNDED TRADITIONAL THEORIES OF THE ECONOMY AND OF WOMEN'S PLACE IN SOCIETY. THE PAPER FOCUSES ON THE ROLE OF PUBLIC-PRIVATE DISTINCTIONS IN THE DEVELOPMENT OF AMERICAN SOCIAL HELFARE POLICY. IT IS ARGUED THAT BY IGNORING THE ROLE OF TRADITIONAL GENDER IDEOLOGY IN THE DEVELOPMNET OF U.S. WELFARE POLICY, MANY ANALYSTS MISS THE SOURCE OF THE CONTRADICTIONS AND TENSIONS THAT CONTINUE TO FRUSTRATE THE PROCESS OF WELFARE REFORM.

07268 PETERSON, M.A.

THE PRESIDENCY AND ORGANIZED INTERESTS: HHITE HOUSE PATTERNS OF INTEREST GROUP LIAISOM

AMERICAN POLITICAL SCIENCE REVIEH, 86(3) (SEP 92), 612-625.

THE AUTHOR INVESTIGATES THE NATURE OF THE RELATIONSHIPS BETHEEN NATIONAL MEMBERSHIP ORGANIZATIONS AND THE PRESIDENCY, AS WELL AS THE REASONS THE RELATIONSHIPS VARY BOTH ACROSS ADMINISTRATIONS AND WITHIN A SINGLE PRESIDENT'S EXECUTIVE ADMINISTRATIONS AND WITHIN A SINGLE PRESIDENT'S EXECUT OFFICE. BASED ON PRESIDENTIAL STRATEGIC INTERESTS AND CHOICES ILLUMINATED FOR SEVERAL ADMINISTRATIONS THROUGH INTERVIEWS WITH WHITE HOUSE OFFICIALS, HE IDENTIFIES FOUR BUILDING, DUTREACH, AND LEGITIMIZATION. HE THEN EMPIRICALLY BUILDING, OUTREACH, AND LEGITIMIZATION. HE THEN EMPIRICALLY EVALUATES THESE APPRDACHES FOR THE REAGAN WHITE HOUSE, USING INTERVIENS WITH REAGAN'S STAFF AND THE RESPONSES OF SEVE HUNDRED INTEREST GROUP LEADERS TO SURVEYS OF NATIONAL
VOLUNTARY ASSOCIATIONS. LIKE THE CARTER ADHINISTRATION AFTER VOLUNTARY ASSOCIATIONS. LIKE THE CARTER ADMINISTRATION AFTER ITS FIRST YEAR, THE REAGAN WHITE HOUSE INITIALLY EMPHA "LIAISON AS GOVERNING PARTY" BUILT ON EXCLUSIVE AND PROGRAMMATIC TIES TO GROUPS. A LESS ACTIVIST LEGISLATIVE
AGENDA AND NEW CIRCUMSTANCES LATER SHIFTED THE EMPHASIS OF THE REAGAN AND BUSH ADMINISTRATIONS TO OTHER FORMS OF INTEREST GROUP LIAISON.

07269 PETERSON, M.J.

TRANSNATIONAL ACTIVITY, INTERNATIONAL SOCIETY, AND WORLD POLITICS

MILLENNIUM, 21(1) (SPR 92), 371-388.

THE SIGNIFICANCE OF TRANSHATIONAL ACTIVITY CAN BE UNDERSTOOD BEST THROUGH A CONCEPT OF INTERNATIONAL CIVIL SOCIETY RESULTING FROM LINKS AMONG SOCIETAL ACTORS IN THE WORLD'S VARIOUS NATIONAL CIVIL SOCIETIES. THIS CONCEPT POSITS A GLOBAL PUBLIC SPACE SHARED BY STATES AND TRANSMATIONALLY-LINKED SOCIETAL ACTORS THAT NEED AND SEEK TO INFLUENCE EACH OTHER.

07270 PETERSON, P.E. AN IMMODEST PROPOSAL

DAEDALUS, 121(4) (FAL 92), 151-174.

BECAUSE THE POLITICAL CLOUT OF SENIOR CITIZENS OUTWEIGHS THE POLITICAL INFLUENCE OF CHILDREN, AMERICAN SOCIAL POLICY HAS DONE MORE TO ERADICATE POVERTY AMONG THE ELDERLY THAN AHONG CHILDREN. WHILE POVERTY RATES FOR THOSE OVER AGE 65 AHONG CHILDREN. WHILE POVERTY RATES FOR THOSE OVER AGE 65 HAS FALLEN, THE NUMBER OF CHILDREN LIVING IN POVERTY HAS EXPENDITURES ON PROGRAMS FOR THE ELDERLY VERSUS SPENDING FOR CHILDREN REVEALS A MAJOR CAUSE OF THESE TRENDS.

07271 PETERSON, S.

CHURCH PARTICIPATION AND POLITICAL PARTICIPATION: THE SPILLOVER EFFECT

AMERICAN POLITICS QUARTERLY, 20(1) (JAN 92), 123-139. THE SPILLOVER EFFECT POSTULATES THAT PARTICIPATION IN
POLITICAL ORIENTATIONS AND BEHAVIOR. DATA FROM THE 1987 NORC GENERAL SOCIAL SURVEY ARE USED TO TEST THESE EXPECTATIONS WITH RESPECT TO PARTICIPATION IN RELIGIOUS ORGANIZATIONS. WITH MORE CONSERVATISM AMD SOMEWHAT GREATER POLITICIZATION, WITH MORE CONSERVATISM AND SOMEHHAT GREATER POLITICIZAT
ALTHOUGH THERE ARE SOME VARIATIONS BY RACE, SEX, AND ALTHOUGH THERE
DENOMINATION.

07272 PETERSON, $V$.

GENDERED' STATES: FEMINIST (RE)VISIONS OF INTERNATIONAL RELATIONS THEORY

LYMNE RIENNER PUBLISHERS, 1992, 224

WHILE INTERNATIONAL RELATIONS THEORISTS ARE INCREASINGLY CRITICAL OF NEOREALIST ASSUMPTIONS ABOUT THE STATE AND THE INTERNATIONAL SYSTEM, FEW HAVE EXPLORED THE GENDERED CONSTRUCTION OF THE STATE AND ITS IMPLICATIONS FOR INTERNATIONAL RELATIONS. THIS BOOK EXPLORES HOW CORE CONCEPTS OF POLITICAL AND INTERNATIONAL THEORY--THE STATE, SOVEREIGNTY, POWER--ARE REFRAMED THROUGH FEMINIST LENSES. TAKING SERIOUSLY THE QUESTION "WHAT DIFFERENCE DOES GENDER MAKE? " THE AUTHORS ILLUMINATE NEW DIRECTIONS IN

MAKE? " THE AUTHORS ILLUMINATE NEW DIRECTIONS IN
INTERNATIONAL RELATIONS BY HIGHLIGHTING THE ROLE OF GENDER INTERNATIONAL RELATIONS BY HIGHLIGHTING THE ROLE OF GENDER AND ITS RELATED NATIONS OF SECURITY, AUTHONOMY, AND IDENTITY.

07273 PETERSON, V.S.

TRANSGRESSING BOUNDARIES: THEORIES OF KMOHLEDGE, GENDER, AND INTERNATIONAL RELATIONS

MILLENNIUM, 21 (2) ( SUM 92), 183-208

POST-POSITIVIST AND FEMINIST CRITIQUES HAVE IMPORTANT CONTRIBUTIONS TO MAKE TO THE STUDY OF INTERNATIONAL

RELATIONS. FEMINISH'S RECOGNITION OF THE GENDERED NATURE OF POSITIVIST DICHOTOMISING PRACTICES ADOS A SIGNIFICANT

DIMENSION TO THE POST-POSITIVIST CRITIQUE.

07274 PETERSON, H.C.

TRANSFER SPENDIMG, TAXES, AND THE AMERICAN WELFARE STATE

KLUWER ACADEMIC PUBLISHERS, 1991, 176

THIS EXAMINATION OF TAXES AND WELFARE BEGINS WITH A BRIEF DESCRIPTION OF THE DEVELOPMENT OF THE HELFARE STATE FROM ITS BEGINNINGS WITH THE BEVERAGE REPORT AND THE CREATION OF SOCIAL INSURANCE IN GREAT BRITAIN, AND ITS EVOLUTION AND IMPLEMENTATION IN THE UNITED STATES, RESULTING IN THE CURRENT WELFARE SYSTEM. IT CHRONICLES THE GROWTH OF THE PUBLIC ASSISTANCE COMPONENT OF U.S. WELFARE SPENDING IT EXPLAINS HOW GOVERNMENTS SPEND TAX REVENUES EITHER TO PURCHASE GOOOS AND SERVICES OR TO TRANSFER FROM ONE GROUP TO PNOTHER TO ACHIEVE ANY NUMBER OF SOCIAL OBJECTIVES. IT SHOWS ANOTHER TO ACHIEVE ANY NUMBER OF SOCIAL OBJECTIVES. IT SHOH THAT TWO-THIRDS OF GOVERNMENT SPENDING ARE TRANSFERS AND THUS REDISTRIBUTIONAL IN CHARACTER. IT CONCLUDES THAT THE
UNITED STATES HAS A THREE-TIERED WELFARE SYSTEM THAT IS MUCH UNITED STATES HAS A THREE-TI IERED WELLARE SYSTEM THAT
MORE COMPREHENSIVE THAN THE CLASSICAL WELFARE STATE MORE COMPREHENSIVE THAN THE CLASSICAL WELFARE STATE ENVISAGED IN THE BEVERAGE REPORT OR THE PRE-1965 WELLARE
SYSTEM IN THE UNITED STATES. IT ALSO COMMENTS OM THE EFFECTS SYSTEM IN THE UNITED STATES. IT ALSO COMMENTS ON THE EFFECTS SOCIAL SECURITY.

07275 PETRACCA, M.P.; JUMP, D.

FROM COAST TO COAST: THE TERM-LIMITATION EXPRESS NATIONAL CIVIC REVIEH, 81(3) (SUM 92), 352-364.

THE TERM-LIMITATION MOVEMENT CURRENTLY HAS A SIMGLE REFORM AIM, ALBEIT MOTIVATED BY MANY DIFFERENT REASONS SHOULD THE MOVEMENT FALL FLAT IN THE NOVEMBER 1992 ELECTIONS, ITS LEADERS MIGHT BE INSPIRED TO THINK ABOUT A MORE COMPREHENSIVE AGENDA FOR REFORMING THE POLITICAL PROCESS.

07276 PETRAKOS, G.C.

URBAN CONCENTRATION AND AGgLOMERATION ECONOMIES: REEXAMINING THE RELATIONSHIP

URBAN STUDIES, 29(8) (DEC 92), 1219-1230.

USING A SAMPLE OF 49 COUNTRIES AND TWO-STAGE LEAST SQUARES ESTIMATORS. THE AUTHOR STUOIES THE EFFECT OF URBAN COMCENTRATION ON ECONOMIC GROHTH. EVIDENCE IS PROVIDED THAT EXTERMAL AGGLOMERATION ECONOMIES IN THE LARGEST CITIES HAVE BEEN EXHAUSTED, EVEN THOUGH THE PROCESS OF CONCENTRATION CONTINUES TO HAVE A POSITIVE IMPACT ON OUTPUT. HOWEVER, THIS EFFECT IS ATTRIBUTABLE TO INTERNAL ADJUSTMENTS CAUSED BY CONCENTRATION IN FACTOR INTENSITY AND MARGINAL FACTOR PRODUCTIVITY IN THE PRODUCTION ACTIVITIES OF URBAN AREAS. THE RESULTS SUGGEST THAT A MEANINGFUL POLICY AIMING TO ALLEVIATE THE SOCIAL COSTS OF CONCENTRATION IN OVERPOPULATED ALLEVIATE THE SOCIAL COSTS OF CONCENTRATION IN OVERPOPULATED METROPOL ISES, WITHOUT REDUCING THE OVERALL EFFICIENCY OF THE
ECONOMY, SHOULD FOLLOW A LONG-TERM STRATEGY OF DEVELOPING ECONOMY, SHOULD FOLLOW A LONG-TERM STRATEGY OF DEVELOPING SHALLER CITIES IN THE PERIPHERY AND FAVORING THE OPERATION OF SMALLER-

07277 PETRAS, J.

EAST GERMANY: CONQUEST, PILLAGE AND DISINTEGRATION JOURNAL OF CONTEMPORARY ASIA, 22 (3) (1992), 340-359. THIS ARTICLE EXAMIMES THE DETERIORATING ECOMOMIC CONDITIONS IN THE FORMER EAST GERMANY. IT ARGUES THAT EAST GERMANY'S "DEMOCRATIC REVOLUTION" AND THE SUBSEQUENT UNIFICATION HITH WEST GERMANY WERE THE RESULT OF A LONG-TERM 
WESTERN PLAN TO SUBVERT SOCIALISM AND ANHEX EAST GERMAN TERRITORY. NOW THAT THE WEST IS VICTORIOUS, THEY DO LITTLE TO ALLEVIATE THE SUFFERING OF THE ONCE-PROSPEROUS EAST GERMANS. THE ARTICLE CONCLUDES THAT ONE CAN ASK WHETHER THE ALTERNATIVE OF STEADY GROWTH, WITHIN A FRAMEWORK OF DEMOCRATIC PLANNING AND SELECTIVE MARKET CHANGES AND A DEMOCRATIC POL ITICAL SYSTEM MIGHT NOT HAVE BETTER SERVED THE EAST GERMANS IN THE PLACE OF THE HUGE LOSSES AND MASS DISLOCATION THAT THEY ARE CURRENTLY SUFFERING WITH THE ANHEXATION POLICY. THEREFORE, PRONOUNCEMENTS ON THE "DEATH OF COMMUNISM" ARE PREMATURE.

07278 PETRAS, J.; VIEUX, S.

MYTHS AND REALITIES: LATIN AMERICA'S FREE MARKETS INTERNATIONAL JOURMAL OF HEALTH SERVICES, $22(4)(1992)$ 611-617.

THE AUTHORS SURVEY THE SOCIOECONOMIC PERFORMANCE OF LATIN AMERICA FROM 1981 TO 1991. THEY EXAMINE THREE MYTHS PROMOTED IN THE U.S. MEDIA CONCERNING THE CAUSES AND CONSEQUENCES OF "THE LOST DECADE" AND THE PROSPECTS FOR THE FUTURE: (1) POPULIST AND STATIST POLICIES AND REGIMES ARE TO BLAME FOR ECONOMIC AND SOCIAL REGRESSION IN THE 1980'S; (2) AT THE END OF THE DECADE THE ADOPTION OF FREE MARKET POLICIES CAUSED THE LATIN AMERICAN ECONOMIES TO "TURM AROUND"; (3) A NEW CONSENSUS EMBRACING NEOL IBERAL RULERS AND WORKING PEOPLE HAS EMERGED IN SUPPORT OF NEOLIBERAL POLICIES.

07279 PETRI, T.E.; ELY, $B$

REAL TAXPAYER PROTECTION

POLICY REVIEW, (60) (SPR 92), 25-29.

AS THE SAVINGS AND LOAN CRISIS HAS DEMONSTRATED, THE

PRESENT SYSTEM OF FEDERAL DEPOSIT INSURANCE IS UNSOUND. THE UNITED STATES MUST REPLACE FEDERAL DEPOSIT INSURANCE WITH A NEW FORM OF PROTECTION FOR DEPOSITORS AND TAXPAYERS.

07280 PETROCIK, J.R.

AN ALGORITHM FOR ESTIMATING TURNOUT AS A GUIDE TO PREDICTING ELECTIONS

PUBLIC OPINION OUARTERLY (CHICAGO), 55(4) (WIN 91),

643-647.

PREDICTING TURNOUT IS NOT THE ONLY SOURCE OF ERROR IN PREELECTION POLLS, BUT IT DISPLAYS ONE OF THE LARGEST CORRELATIONS WITH ACCURACY. IN THIS ESSAY, THE AUTHOR OFFERS AN ALGORITHM FOR ESTIMATING TURMOUT AS A GUIDE TO PREDICTING AL ALGORITHM FOR

07281 PETROYA, D.; KANEY, K.

BULGARIA BETWEEM THE RED AND THE BLUE

NEW POLITICS, 13(1) (SUM 92), 88-102

WEW POLITICS, 13(1) (SUM 92), 88-102.

BULGARIA HAS BEEN EXPERIENCING TWO YEARS OF "PERMANENT

REVOLUTION." OBSERVERS NOTE THE HIGH DEGREE OF POLITICAL

POLARIZATION; SOCIETY IS DIVIDED INTO TWO NEARLY EQUAL
HOSTILE PARTS ENGAGED IN IDEOLOGICAL BATTLE. THE MOST RECENT

HOSTILE PARTS ENGAGED IN IDEOLOGICAL BATTLE. THE MOST RECEMT

MANIFESTATION OF THIS BATTLE WAS THE OCTOBER 1991 ELECTION,

(UDF) RECEIVED 34.36 PERCENT OF THE VOTE FOLLOWED CLOSELY BY

THE HEIR OF THE FORMER COMMUNIST PARTY, THE BULGARIAN

SOCIALIST PARTY (BSP), WHICH GARNERED 33.14 PERCENT OF THE

VOTE. IN THE PASSIONATE CLASHES OF POSITIONS AND INTERESTS

SOME SEE THE NEW SYMPTOMS OF THE BIRTH OF MODERN POLITICS;

OTHERS SENSE THE DANGER THAT A NEW AUTHORITARIANISM IS

REPLACING "COMMUNISM."

07282 PETTIFER, J.

ALBANIA: A CHALLENGE FOR EUROPE

WORLD TODAY 48(6) (JUN 92) 95-97.

THE OVERHHELMING VICTORY OF SALI BERISHA AND THE

DEMOCRATIC PARTY IN ALBANIA'S MARCH 22, 1992, ELECTION HAS

BEEN WIDELY HAILED AS THE FINAL VICTORY OF THE PEOPLE OVER COMMUNISM AND THE ONE-PARTY STATE. THE SOCIALIST PARTY SECURED ONLY A MODEST PORTION OF THE VOTES AND SEEMS DOOMED TO A PERIOD OF REORGANIZATION. ALBANIA'S NEW DIRECTION WIL PRESENT CHALLENGES FOR REST OF EUROPE, WHICH MUST REORIENT ITS FOREIGN POLICIES TO DEAL WITH BOTH NEW LEADERS AND OLD PROBLEMS, SUCH AS ALBANIA'S POVERTY.

07283 PETTIFER, J.

GREECE: INTO THE BALKAN CRISIS

WORLD TODAY, 48(11) (NOY 92) 194-195.

THE CENTRAL QUESTION FACING THE MITSOTAKIS GOVERMMENT IS HOW TO RECONCILE GREECE'S ECONOMIC DEPENDENCE ON

INTERNATIONAL BODIES, ESPECIALLY THE EUROPEAN COMMUNITY

WITH AN INCREASINGLY NATIONALISTIC AND INDEPENDENT FOREIGM

WITH AN INCREASINGLY NATIONALISTIC AND INDEPEND
POLICY BASED ON A CLOSE ALLIANCE WITH SERBIA.

07284 PETTIFER, J.

THE NEW MACEDONIAN QUESTION

INTERNATIONAL AFFAIRS 68(3) (JUL 92), 475-485.

THE AUTHOR EXPLORES THE NEH DIMENSIONS OF THE MACEDONIAM QUESTION, COMPARING THE GOALS OF THE NEW SKOPJE REGIME WITH THE ASPIRATIONS OF TRADITIONAL MACEDONIAN NATIONALISM. HE ARGUES THAT EXTREME ECONOMIC INSTABILITY WILL BE THE CENTRAL FEATURE OF THE NEW MACEDONIAN STATE. HE ALSO OUTLINES THE CURRENT POSITIONS OF THE MAJOR REGIONAL PROTAGONISTS AND
DISCUSSES THE ROLE OF THE EUROPEAN COMMUNITY AS A

REPLACEMENT FOR THE GREAT POWERS OF THE PAST.

07285 PFALTZGRAFF, R.L. JR.

GERMANY AND THE U.S.: THE NEW EUROPEAN ORDER

FREEDOM REVIEW, 23(6) (NOV 92), 28-31.

THE AUTHOR DISCUSSES THE NEW DIRECTIONS U.S. FOREIGN POLICY TOWARD GERMANY SHOULD TAKE IN THE POST-COLD WAR EUROPEAN SECURITY SETTING.

07286 PFALTZGRAFF, R.L. JR.

THE EMERGING GLOBAL SECURITY ENVIRONMENT

ANMALS OF THE AMERICAN ACADEMY OF POLITICAL AND SOCIAL

SCIENCE, (517) (SEP 91), 10-24.

THE GLOBAL SECURITY ENVIRONMENT OF THE 1990'S IS FAR MORE COMPLEX THAN IN ANY PREYIOUS ERA. BEFORE THE END OF THE DECADE, SEVERAL ADDI I IONAL STATES WILL HAVE ACQUIRED
FORMIDABLE MILITARY ARSENALS WITH WEAPONS OF INCREASING RANGE, ACCURACY, AND DESTRUCTIVENESS FOR THE CONDUCT OF HIGHRANGE, ACCURACY, AND DESTRUCTIVENESS FOR THE CONDUCT OF

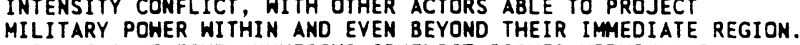

MILITARY POWER WITHIN AND EVEN BEYOND THEIR IMTEDIATE BETWEEN EXISTING STATES--SOME BASED ON THE REYIVAL OF HISTORICAL ANIMOSITIES AND OTHERS OF MORE RECENT ORIGIN-WILL FUEL THE POTENTIAL FOR INSTABILITY, INCLUDING THE POSSIBILITY OF CIVIL WAR FOUGHT WITH NUCLEAR WEAPONS. THEREFORE, THE UNITED STATES HILL FACE A CONT INUING NEED TO DEVELOP DOCTRINES, TECHNOLOGIES, AND FORCE STRUCTURES FOR AN UNFOLDING SECURITY ENYIRONMENT CHARACTERIZED BY DRAMATIC CHANGE, INSTABILITY, AND MULTIPOLARITY.

07287 PFALTZGRAFF, R.L. JR

THE KOREAN-AMERICAN RELATIONSHIP IN A NEN WORLD ORDER KOREAN JOURNAL OF OEFENSE ANALYSIS, 3(2) (WIN 91), 143-162.

EMERGING TRENDS IN THE KOREAN-AMERICAN RELATIONSHIP ARE EXPLORED IN THE CONTEXT OF MAJOR POHER RELATIONS AND NORTHEAST ASIA. THE PLACE OF THE ROK IN THE EVOLVING ORDER IN RELATION TO DEFENSE AND TRADE IS EXAMINED AS WELL AS THE POSSIBILITIES OF NORTH KOREA EMERGING AS A NUCLEAR STATE. THE INITIAL THEME OF THIS ARTICLE IS THAT WHATEVER THE DISCERNIBLE TRENOS THAT FURNISH A USEFUL POINT OF DEPARTURE FOR PROJECTIONS ABOUT THE EMERGING KOREAN-AMERICAN RELATIONSHIP IN A NEW WORLD ORDER, UNCERTAINTIES ABOUND.

07288 PFALTZGRAFF, R.L. JR.

THE USSR AND EASTERN EUROPE: THE UNCERTAIN ROAD TO REFORM FREEDOM REVIEW, 23(1) (JAN 92), 29-31, 34-36.

IN 1991. THERE WAS SIGNIFICANT PROGRESS IN ESTABLISHING POLITICAL AND LEGAL SYSTEMS THAT RESPECT AND PROTECT FUNDAMENTAL HUMAN RIGHTS IN THE SOVIET UNION AND EASTERN EUROPE. BUT THE CHANGE WAS PRODUCED BY A TURBULENT PROCESS OF REFORM, WHICH CARRIES WITH IT A HIGH RISK OF POTENTIAL REVERSAL. THE RISE OF NATIONALISM AND A YEARNING FOR POLITICAL FREEDOM AMONG THE MANY PEOPLES LIVING IN THE REGIONS HAVE BEEN INSTRUMENTAL IN PRODUCING THE POLITICAL AND ECONOMIC REFORMS. BUT SOME STATES--INCLUDING BULGARIA, ROMANIA, ALBANIA, ANO VARIOUS PARTS OF YUGOSLAVIA AND THE USSR--STILL HAVE A LONG WAY TO GO ON THE PATH TO DEMOCRATIC REFORM. IN MANY CASES, FORMER COMMUNIST PARTY ELITES AND THE BENEFICIARIES OF THE PARTY-STATE ADMINISTRATIVE-COMMAND STRUCTURE REMAIN IN OR CLOSE TO POWER.

07289 PHAM, H.

THE FALL OF HANOI

NATIONAL REVIEN, III(2) (FEB 91), 40-43.

THIS ARTICLE CONSIDERS THE FAILING FORTUNES OF THE COMINUNIST REGIME IN VIETNAM. IT ARGUES THAT SOME SIXTEEN YEARS AFTER THE WITHDRAWAL OF U.S. FORCE FROM SAIGON, THE PENDULUM IS SWINGING BACK IN FAVOR OF THE VIETNAMESE' PEOPLE. AFTER A CENTURY OF COLONIALISM, CIVIL WAR, AND COMMUNIST OPPRESSION, THERE IS PEACE, PROSPERITY, AMO FREEDOM ON THE VIETHAMESE HORIZON. HOWEVER, IF AMERICA ACTS TOO SWIFTLY BY LIFTING ITS TRADE EMBARGO, THE TOTTERING COMMUNIST REGIME MAY BE GIVEN AN UNTIMELY BOOST AND A MEW LEASE ON LIFE.

07290 PHELAN, S.

INTIMATE DISTANCE: THE DISLOCATION OF NATURE IN MODERNITY WESTERN POLITICAL QUARTERLY, 45(2) (JUN 92), 385-402.

THIS PAPER PROBES THE AMBIGUITY OF THE IDEA OF NATURE IN MODERN WESTERN POLITICAL THOUGHT AND PROPOSES A POSSIBLE CONCEPTUALIZATION OF NATURE THAT ACCOUNTS FOR THIS NECESSARY CONCEPTUALIZATION OF NATURE THAT ACCOUNTS FOR THIS NECE BETWEEN NATURE AND HISTORY. IS NATURE SOMETHING OUTSIDE OF BETWEEN NATURE AND HISTORY. IS NATURE SOMETHING OUTSIDE OF
OR PRECEDING HISTORY, OR IS IT HISTORICAL IN ITS ESSENCE? OR PRECEDING HISTORY, OR IS IT HISTORICAL IN ITS ESSENCE? THESE QUESTIONS HAVE DOGGED POLITICAL PHILOSOPHY FOR TWO
CENTURIES. EXAMINATION OF THE AMBIGUOUS FUNCTION OF "NATURE" CENTURIES. EXAMINATION OF THE AMBIGUOUS FUNCTION OF "NATURE" IN THE HORK OF ROUSSEAU AND NIETZSCHE ALLOWS US TO BETTER MATURE AND HISTORY IN POL ITICAL THEORY AS WELL AS IN NATURE AND HISTORY IN POLITICAL THEORY AS WELL AS IN POLITICAL ARGUMENT AND STRATEGY. THE AUTHOR ARGUES FOR BUT NEVER SIMPLY "THERE" TO RETRIEVE OR TO GUIDE MAN'S ACTIONS. 
07291 PHILIP, G

VENEZUELAN DEMOCRACY AND THE COUP ATTEMPT OF FEBRUARY 1992 COYERMMENT AND OPPOSITION, 27(4) (FAL 92), 455-469.

THE AUTHOR LOOKS AT THE ATTEMPT TO OVERTHROW VENEZUELA'S GOVERMMENT IN FEBRUARY 1992 AND ITS SIGNIFICANCE FOR BOTH VENEZUELA'S DEMOCRACY AND OTHER DEMOCRATIC GOVERMMENTS IN LATIN AMERICA.

07292

MUST FEMINISTS GIVE UP ON LIBERAL DEMOCRACY?

POLITICAL STUDIES, 40 (1992), 68-82.

FEMINISTS HAVE TAKEN ISSUE WITH LIBERAL DEMOCRACY ON A NUMBER OF COUNTS, INCLUDING THE CONDITIONS NECESSARY TO ACHIEVE POLITICAL EQUALITY AND THE IMPORTANCE TO BE ATTACHED TO POLITICAL PARTICIPATION. THIS PAPER CONSIDERS ISSUES CURRENTLY RAISED UNDER THE RUBIC OF CITIZENSHIP, EARLIER AND CONTINUING ARGUMENTS FOR A MORE ACTIVELY PARTICIPATORY DEMOCRACY, AND OUESTIONS ASSOCIATED WITH REPRESENTING SOCIAL HETEROGENEITY AND GROUP DIFFERENCE. THE ARGUMENT THROUGHOUT IS THAT WHLE LIBERAL DEMOCRACY HAS SIGNALLY FAILED TO ADORESS THESE FAILINGS IN TERMS OF GIVING UP ON LIBERAL DEMOCRACY.

07293 PHILLIPS, D.: KARN, $Y$

RACE AND HOUSING IN A PROPERTY-OWNING DEMOCRACY NEH COMMUNITY, 18 (3) (APR 92), 355-369.

THE $1980^{\circ}$ ' ' WITMESSED A SIGNIFICANT RESTRUCTURING OF HOUSING TENURE AND WIDESPREAD GOVERNMENT SUPPORT FOR THE IDEOLOGY OF HOME OWNERSHIP IN GREAT BRITAIN. THIS PAPER EXAMINES THE IMPLICATIONS OF MARKET TRENDS FOR ETHNIC MINORITIES AND LOOKS AT THE CHANGING STRATEGIES OF ETHNICMINORITY HOUSING PURCHASERS. A COMPLEX PICTURE OF GAINS AND LOSSES EMERGES

07294 PHILLIPS, D.

TERRORISH AND SECURITY IN THE CARIBBEAN: THE 1976 CUBANA DISASTER OFF BARBADOS

TERRORISH, 14(4) (1991), 209-220.

THE CUBANA AIRLINE CRASH IS EXAMINED IN THE LIGHT OF POLITICAL TERRORISM IN THE CARIBBEAN. THIS RESEARCH ENDEAVOR ANALYZES THE ACTIVITIES OF THE TERRORISTS AND DETERMINES THE CATEGORY WITHIN WHICH THE CUBANA AIRLINE DISASTER FALLS HITHIN MICKOLUS TYPOLOGY. IN ADDITON. THE MOT IVATION OF THE TERRORISTS AS WELL AS LIMITED ASPECTS OF SOME OF THE LEGAL ISSUES THAT AROSE WITH REGARD TO THE CUBANA CRASH ARE DISCUSSED. FINALLY, THERE IS SOME ATTEMPT TO DETERMINE THE EFFECTS OF THE CUBANA DISASTER ON THE CARIBBEAN AND ON BARBADOS IN PARTICULAR. IT CONCLUDES THAT THE MOTIVATION BHAT UNDERLAY THE ACTION OF THE ANTI-CASTRO TERRORISTS HAS THAT UNDERLAY THE ACTION OF THE ANTI -CASTRO TERRORISTS WAS TO FORCE A REALIGNMENT IN THE RELATIONSHI

07295 PHILLIPS, P.

FUNCTIONAL RIGHTS: PRIVATE, PUBLIC AND COLLECTIVE PROPERTY FUNCTIONAL RIGHTS: PRIVATE, PUBLIC AND COLLECTIVE PROP
STUDIES IN POLITICAL ECONOMY: A SOCIALIST REVIEW, (38) STUDIES IN POLITIC

CONT), 61-84

CONTRARY TO SOME RECENT OPINION, THIS PAPER VIEWS

PROPERTY NOT AS A UNIDIMENSIONAL THING, BUT A COMPLEX OF RIGHTS AND FUNCTIONS. THE PAPER DELINEATES DIFFERENT FORMS OF PROPERTY AND THEIR IMPLICATIONS FOR THE DEBATE ON POLICIES FOR "FEASIBLE SOCIALISM." IT ALSO DIFFERENTIATES AMONG THE SEVERAL ELEMENTS OF PROPERTY RIGHTS WITH RESPECT TO THEIR FUNCTION, AND HOW THE ALLOCATION OF THESE FUNCTIONS RELATES TO SOCIALIST OR SOCIAL DEMOCRATIC GOALS. IT THEN RELATES THE ELEMENTS OF PROPERTY RIGHTS TO TYPES OF PROPERTY. FINALLY, IT SUGGESTS A FRAMEHORK FOR THE ALLOCATION OF ELEMENTS OF PROPERTY RIGHTS THAT MIGHT SATISFY THE DEMOCRATIC SOCIALIST GOALS OF EFFICIENCY, SUSTAINABLE GROWTH, AND EQUITY, NOT ONLY IN TERMS OF MATERIAL REWARD, BUT WITH RESPECT TO THE DISTRIBUTION OF ECONOMIC, POLITICAL AND SOCIAL POWER.

\section{PHILLIPS, R.}

SOVIET MILITARY DEBATE ON THE INITIAL PERIOD OF HAR: CHARACTERISTICS AMO IMPLICATIONS

JOURNAL OF SOVIET MILITARY STUDIES, 4(1) (MAR 91), 30-61.

IN THE PAST SEVERAL YEARS, ESPECIALLY IN 1988, SOVIET MILITARY JOURNALS HAVE DISPLAYED AN UNUSUALLY HIGH LEVEL OF ATTENTION TO THE INITIAL PERIOD OF WAR. THIS STUDY OF THE CURRENT DISCUSSION HAS THO PURPOSES. FIRST, IT EXAMINES THE CHARACTERISTICS AND IMPORTANT STRATEGIC FACTORS BROUGHT OUT CHARACTERISTICS AND IMPORTANT STRATEGIC FACTORS BROUGH IN THE SOVIET WORKS. SECOND, IT ADDRESSES CAUSES AND
IMPLICATIONS. IT CONCLUDES THAT THE CURRENT SOVIET IMPLICATIONS. IT CONCLUDES THAT THE CURRENT SOVIET
DISCUSSION OF THE INITIAL PERIOD OF HAR IS CLEARLY LINKED TO DISCUSSION OF THE INITIAL PERIOD OF WAR IS CLEARLY LINKED THE RECOGNITION OF A NEW AND RAPID REVOLUTION IN MILITARY AFFAIRS, OCCURRING PRIMARILY AT THE CONVENTIONAL LEVEL.
FURTHERMORE, A MAJOR FACTOR IN CHANGING MILITARY SCIENCE AND FURTHERMORE, A MAJOR FACTOR IN CHANGING MILITARY SC
MILITARY ART IS SOVIET MILITARY THREAT PERCEPTIONS.

07297 PHYNE, J.

CHANGES FROM COMPLIANCE TO DETERRENCE AMONG FEDERAL

FISHERY OFFICERS: AN ATYPICAL CASE OF REGULATORY POLICING? CANADIAN REVIEN OF SOCIOLOGY AND ANTHROPOLOGY, 29(4) (NOV
$92), 524-534$

DF REGLATORY OFFICIALS HAVE SHOWN THAT THERE IS A PREFERENCE FOR COMPLIANCE OVER DETERRENCE IN THE REGULATORY PROCESS. HOWEVER, FISHERY OFFICERS BASED IN THE NEWFOUNDLAND IN-SHORE FISHERY APPEAR TO BE AN ANOMALY. WHILE THEY ARE REGULATORY OFFICIALS, THEIR ROLE HAS SHIFTED FROM THE USE OF COMPL IANCE TO THE USE OF DETERRENCE. THIS SHI CAN BE EXPLAINED IN TERMS OF THE ROLE OF THE STATE IN RESTRUCTURING CANADA'S IN-SHORE FISHERIES. GIVEN THIS CASE, THE COMMON DISTINCTION BETWEEN REGULATORY OFFICIALS ENGAGED IN COMPLIANCE AND THE PUBLIC POL ICE ENGAGED IN DETERRENCE, FROM THE SOCIO-LEGAL LITERATURE, SHOULD
GRANTED AND NEEDS TO BE RE-EXAMINED.

07298 PIACHALD, D.

REVITALISING SOCIAL POLICY

POLITICAL QUARTERLY (THE), 62(2) (APR 91), 204-224.

THIS ARTICLE DESCRIBES WHAT IS CONTENDED TO BE THE

FAILURE AND FUTILITY OF THE THATCHERITE ATTEMPT TO INTRODUCE A NEW RIGHT SOCIAL POLICY. THEN THE CHALLENGES OF REVITALIZING SOCIAL SERVICES AND OF TACKLING POVERTY ARE OISCUSSED. FINALLY, THE CASE IS ARGUED FOR A BROADER SOCIAL STRATEGY IHAT INTEGRATES SOCIAL AND ECONOMIC POLICY AND HILL ASSERT SOCIETY.

07299 PICHON, F.J. AGRICUITURAL SETTLEMENT AND ECOLOGICAL CRISIS IN THE AGRICULTURAL SETTLEMENT AND ECOLOGICAL CRISIS IN THE ECUADORIAN AH

POLICY STUDIES JOURNAL, 20(4) (WIN 92), 662-678.

THE AUTHOR DISCUSSES STRUCTURAL FACTORS IN ECUADOR'S POLICY ENVIRONMENT THAT ARE INFLUENTIAL IN THE PROCESS OF THE OCCUPATION OF AMAZONIA BY AGRICULTURAL COLONISTS AND THE EMERGING LAND SETTLEMENT PATTERNS IN THE REGION. THESE FACTORS ARE FUNDAMENTALLY CONCERNED WITH (A) NATIONAL SOVEREIGNTY INTERESTS OVER REMOTE. PERIPHERAL TERRITORIES CHARACTERI ZED BY LOW POPULATION DENSITY AND ILL-DEFINED LAN OWNERSHIP, (B) THE REDUCTION OF DEMOGRAPHIC AND SOCIAL PRESSURES IN OTHER REGIONS OF THE COUNTRY, AND (C) THE EXTENSION OF THE AGRICULTURAL FRONTIER. FOR ECDNOMIC AND GEOPOL ITICAL REASONS, THE ECUADORIAN STATE IS LIKELY TO SUPPORTED BY LEGISLATION TO ALLOW THE OCCUPATION OF THE AMAZON REGION. CONSEOUENTLY, AS MIGRANTS CONTINUE TO FLOH INTO THE EASILY DEGRADABLE AREAS OF THE AMAZON AMD HITHOUT INCREASED POPULATION-CARRYING CAPACITY DUTSIDE THE AMAZON, SOME CONYERSION OF THE RAINFOREST OF EASTERN ECUADOR TO OTHER USES IS CERTAIN TO CONTINUE. A MORE DETAILED MICROLEVEL UMDERSTANDING OF THE INTERRELATIONSHIP AMONG FACTORS INFLUENCING LANO-USE DECISIONS BY SETTLER FARMERS IS NEEDED TO FIND POLICY-ENTRY POINTS.

07300 PICHT, H.: STUVEN, V.

EXPROPRIATION OF FOREIGN DIRECT INVESTMENTS: EMPIRICAL EXPROPRIATION OF FOREIGN

PUBLIC CHOICE, 69(2) (FEB 91), 19-38.

THE LIMITED ACCESS TO INTERNATIONAL CREDIT OF LESS DEVELOPED COUNTRIES (LDCS) SUGGESTS THAT FOREIGN DIRECT INYESTMENT (FDI) MAY PLAY A LARGER ROLE IN THE FUTURE. IN INVESTMENT (FDI I MAY PLAY A LARGER ROLE IN THE FUTURE. IN THIS ANALYSIS THO HYPOTHESIS ON GOVERNMENT BEHAVIOR WITH
RESPECT TO FOREIGN CAPITAL INFLOWS ARE TESTED. BOTH
HYPOTHESIS ARE BUILT UPON THE ASSUMPTION THAT GOVERMMENTS HYPOTHESIS ARE BUILT UPON THE ASSUMPTION THAT GOVERMMENTS BENEFIT CALCULUS. THE ANALYSIS TRIES TO IDENTIFY WHICH CALCULUS GOVERNS THE BEHAVIOR OF THE LDCS TOWARDS FDI. VARIOUS ECONOMIC AND POLITICAL FACTORS ARE CONSIDERED THAT REPRESENT THE COSTS AND BENEFITS FROM EXPROPRIATIONS TO EXPLAINS SELECTIVE AND UNSPECIFIC EXPROPRIATION PATTERNS AS SUGGESTED BY THE PUBLIC-INTEREST AND POLIT-ECONOMIC HYPOTHESES.

07301 PICHUGIN, B

ECONOMIC CRISIS--EASTERN EUROPE AND THE FORMER SOVIET UNION SECURITY DIALOGUE, 23(4) (DEC 92), 97-108.

WITH THE END OF THE COLD WAR FOREIGN ECONOMIC RELATIONS BECAME A PRIORITY SECTOR OF REFORMS IN ALL EASTERN EUROPEAN COUNTRIES. THE WEST BECAME THE MODEL FOR FUTURE DEVELOPMENT. THE REORIENTATION WAS STARTED IN CONDITIONS OF DEEPENING CRISIS IN THE EASTERN EUROPEAN COUNTRIES DOMESTIC ECONOMIES. THERE WAS DRAMATIC FALL IN NATIONAL IMCOME, INDUSTRIAL PRODUCTION, AND INCREASING UNEMPLOYMENT. EQUAL AND MUTUALLY ADYANTAGEOUS COOPERATION BETWEEN EASTERN EUROPE, RUSSIA AND OTHER CIS STATES COULD SPEED UP ECONOMIC STABILIZATION AMD RECOYERY ACCELERATE REFORMS AMD IMPROVE THE MATERIAL BASIS RECOVERY, ACCELERATE REFORMS
FOR THEIR FRIENDLY RELATIONS.

07302 PICK, 0

EASTERN EUROPE II: CZECHOSLOVAKIA'S DIVISIONS

WORLD TODAY, 48(5) (MAY 92), 83-85.

AS CZECHOSIOYAKIA PREPARES FOR ITS 1992 ELECTIONS, IT IS POLITICALLY FRAGMENTED. MORE THAN 120 POLITICAL PARTIES AND GROUPINGS HAVE SPRUNG UP TO CONFUSE THE VOTER, WHILE THE CAMPAIGN HAS FAILED TO PROOUCE CLEAR-CUT POLITICAL PROFILES 
THAT MIGHT POLARIZE VOTER ATTITUDES TOWARD THE MAJOR PARTIES AMONG THE IMPORTANT CAMPAIGN ISSUES ARE RELATIONS WITH GERMANY AND THE STATE OF THE ECONOMY.

07303 PICKEL, A.

JUMP-STARTING A MARKET ECONOMY: A CRITIQUE OF THE RADICAL STRATEGY FOR ECONOMIC REFORM IN LIGHT OF THE EAST GERMAN EXPERIENCE

STUDIES IN COMPARATIVE COMMUNISM, 25(2) (JUN 92), 177-192. THAT THE RADICAL STRATEGY IN EAST GERMANY HAS FAILED IN CRUCIAL RESPECTS IS ARGUED. RAPID AND COMPREHENSIVE REFORM HAS NOT CREATED THE CONDITIONS FOR SELF-SUSTAINED ECONOMIC DEVELOPMENT AS HAD BEEN EXPECTED. THIS ANALYSIS IDENTIFIES THE MAJOR THEORETICAL PROBLEMS IN THE EAST GERMAN RADIAL THE MAJOR THEORETICAL PROBLEMS IN THE EAST GERMAN
STRATEGY AND SHOWS HOW THEY ARE ROOTED IN A NARROW STRATEGY AND SHOWS HOW THEY ARE ROOTED IN A NARROH
CONCEPTION OF THE PRDBLEM OF TRANSITION. IT SKETCHES AN CONCEPTION OF THE PRDBLEM OF TRANSITION. IT SKETCHES AN ALTERNATIVE, BROADER CONCEPTION AND PROPOSES TH
ARGUMENTS IN SUPPORT OF GRADUALIST STRATEGY.

07304 PIECIAK, $W$.

THE MEH THREAT OF THE FAR RIGHT

WORLD PRESS REVIEW, 39(5) (MAY 92), 22-24.

IN WESTERN EUROPE, RADICAL RIGHT-WING POPULIST PARTIES HAVE BECOME THE MOST SERIOUS THREAT TO STABLE DEMOCRACIES. THEY HAVE BROUGHT AN ELEMENT OF UNPREDICTABILITY TO THE POLITICAL SCENE IN MANY COUNTRIES, INCLUDING FRANCE, AUSTRIA, BELGIUM, AND SWEDEN. ALTHOUGH THESE GROUPS HAVE DIFFERENT PROGRAMS, STRUCTURES, AND ORIGINS, THEY EXPLOIT SIMILAR SITUATIONS AND THEIR XENOPHOBIC APPEALS ARE WINNING OVER THE DISAFFECTED THROUGHOUT WESTERH EUROPE.

07305 PIEL, D.

EUROMONEY: HOW MUCH MARKET, HOW MUCH POLITICS?

GERMAN TRIBUNE, (1536) (OCT 92), 7

EUROPEAN ECONOMIC AND MONETARY POLICY IS CONFRONTED WITH A SERIOUS CRISIS THAT IS NOT JUST ABOUT ECONOMIC IMBALANCES BETWEEN MEMBER STATES OR CURRENCIES BUT HAS MORE OF AN INTELLECTUAL CHARACTER: THERE IS NOT ENOUGH UNDERSTANDING AMONG THE POLITICAL AND ECONOMIC LEADERS IN EUROPE FOR WHERE THE RULES OF A MARKET ECONOMY SHOULD TAKE PRECEDENCE AMD WHERE THEY SHOULD BE SUBORDINATED TO POLITICAL CONSTRAINTS.

07306 PIERCE, R.; ROCHON, T.

CONSTANCY OF LEGISLATIVE PERCEPTIONS OF CONSTITUENCY CONSTANCY OF LEGISLATIVE PERCEPTIONS OF CONSTITUENCY COMPARATIVE POLITICAL STUDIES, 23(4) (JAN 91), 478-496.

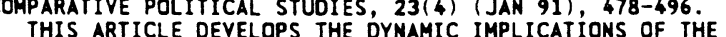

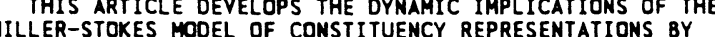
MILLER-STOKES MODEL OF CONSTITUENCY REPRESENTATIONS BY EXPLORING THE EXTENT TO WHICH THERE HAS CONSTANCY BETWEEN THO "GENERATIONS" OF FRENCH SOCIALIST PARTY CANDIDATES FOR THE NATIONAL ASSEMBLY FORM THE SAME CONSTITUENCIES, IN THEIR PERCEPTIONS OF THE OPINIONS OF THEIR CONSTITUENTS. DERIVE FROM PERSONAL INTERVIEWS CONDUCTED WITH THE CANDIDATES SHORTLY AFTER THE LEGISLATIVE ELECTIONS OF 1967 AND 1978. THE PHENOMENA DISCUSSED INCLUDE THE RELATIONSHIP BETWEEN CONSTANCY OF CANDIDATE PERCEPTIONS AND ACCURACY OF
CANDIDATE PERCEPTIONS. THE AUTHORS ALSO EXAMINE THE EXTENT CANDIDATE PERCEPTIONS. THE AUTHORS ALSO EXAMINE THE EXTENT
TO WHICH THE CANDIDATES BASE THEIR PERCEPTIONS OF DISTRICT TO WHICH THE CANDIDATES BASE THEIR PERCEPTIONS OF DISTRICT
OPINION ON THE POLITICAL COMPOSITION OF THEIR CONSTITUENCIES. THAT PRACTICE HAS DAUNTING IMPLICATIONS BOTH FOR THE COMPARATIVE STUDY OF REPRESENTATION AND FOR THE REPRESENTATIVE PROCESS ITSELF.

07307 PIERCE, R.

TOWARD THE FORMATION OF A PARTISAN ALIGMMENT IN FRANCE

POLITICAL BEHAVIOR, 14(4) (DEC 92), 443-469

THE AUTHOR STUDIES THE BASIC PARTISAN ALIGNMENT IN

FRANCE BETHEEM 1958 AMD 1988. DURING THAT PERIOD THE INCIDENCE OF PARTY IDENTIFICATION ROSE FROM ABNORMALIY LOW TO NORMAL LEVELS AND THE COMPOS ITION OF THE AL IGNMENT EVOLVED FROM INDETERMINACY. THROUGH A LEFT-RIGHT STAND-OFF, TO SOCIALIST PARTY PREDOMINAMCE. HE EXAMINES HOW A PARTISAM ALIGMMENT IS CREATED AND TRACES THE PROCESS, WITH SPECIAL REFERENCE TO THE INCIDENCE OF PARTY IDENTIFICATION AND THE COMPOSITION OF THE ALIGNMENT BY AGE IN 1988. HE ALSO INCLUDES A COMPARISON BETWEEN FRANCE IN 1968 AND THE UNITED STATES IN 1932. HE UNDERSCORES THE FRAGILITY OF THE 1988 ALIGNMENT BECAUSE IT IS COMPARATIVELY NEW AND SHAPED MAINLY BY THE PARTISAN IDENTIFICATIONS OF YOUNGER CITIZENS, MAKING IT VULNERABLE TO ANY WEAKENING OF THE CONDITIONS THAT HELPED CREATE IT.

07308 PIERRE, J. ORGANIZED CAPITAL AND LOCAL POLITICS: LOCAL BUSINESS
ORGANIZATIONS, PUBLIC-PRIVATE COMMITTEES, AND LOCAL ORGANIZATIONS, PUBLIC-1

GOVERNMENT IN SWEDEN
URBAN AFFAIRS QUARTERLY 28(2) (DEC 92) 236-257.

URBAN AFFAIRS QUARTERLY, 28(2) (DEC 92), 236-257.

MANY ANALYSES OF URBAN POLITICAL ECONOMY TEND TO

OVERLOOK THE SIGNIFICANCE OF LOCAL BUSINESS ORGANIZATIONS
AND PUBLIC-PRIVATE COMMITTEES IN THE URBAN POLITICAL PROCESS THIS PAPER EXAMINES THE ROLES OF LOCAL BUSINESS

ORGANIZATIONS AND JOINT COMMITTEES IN SWEDISH MUNICIPALITIES.

THE AUTHOR CONCLUDES THAT POLITICAL STABILITY IS MORE

IMPORTANT THAN THE IDEOLOGICAL ORIENTATION OF THE LOCAL
POLITICAL ELITE IN THE CREATION OF JOINT COMMITTEES. BUSINESS INFLUENCE ON LOCAL POLITICS IS CONTINGENT ON THE INSTITUTIONALIZED FORMS OF PUBLIC-PRIVATE INTERACTION. BUSINESS DEMANDS ON LOCAL POLITICS COVER ALMOST ALL URBAN SERVICE SECTORS, AND SWEDISH LOCAL AUTHORITIES HAVE LARGELY RESPONDED TO THESE DEMANDS.

07309 PIERRE, J.; WIDFELDT, A.

SWEDEN JDURNAL OF POLITICAL RESEARCH, 22(4) (DEC 92),

519-526.

THE AUTHORS REPORT THE RESULTS OF SHEDEN'S 1991

PARLIAMENTARY ELECTIONS AND SUMMARIZE MAJOR ISSUES IN

SWEDISH DOMESTIC POLITICS.

07310 PIERSON, C.

DEMOCRACY, MARKETS AND CAPITAL: ARE THERE NECESSARY

ECONOMIC LIMITS TO DEMOCRACY?

POLITICAL STUDIES, 40 (1992), 83-98.

THIS ARTICLE REVIEWS THE NEO-LIBERAL CASE FOR ECONOMIC LIMITS TO DEMOCRACY, ASSESSES THE COUNTERPOSED ARGUMENT OF SOCIALISTS AND SOCIAL DEMOCRATS AND CONSIDERS WHY THE LATTERS' PRACTICAL EXPERIENCE IN \$DEMOCRATIZING ECONOMIC LIFE' HAS BEEN SO UNSATISFACTORY. THE SECOND HALF OF THE PAPER CONSIDERS THE CLAIM THAT SOME FORM OF "MARKET SOCIALISM" CAN OVERCOME THESE LIMITATIONS. WHILE THE MARKET SOCIALISTS HAVE SOME SUCCESS IN UNDERMINING THE CLAIMS OF THE NEOLIBERALS, THERE ARE ACUTE DIFFICULTIES IN TRANSFORMING THEIR AGENDA FOR ECONOMIC DEMOCRACY INTO A PRACTICABLE POLITICS. AT THE SAME TIME, IT IS SUGGESTED THAT WHILE THERE MAY INDEED BE SOME ECONOMIC LIMITS TO DEMOCRACY, WE ARE STILL VERY FAR FROM REACHING THEM.

07311 PIETERSE, J.N. (ED.)

EMANCIPATIONS, MODERN AND POSTMODERN

SAGE PUBLICATIONS, 1992, 328.

THESE ESSAYS SUGGEST THAT THE TERM EMANCIPATION IS BEING INCREASINGLY USED TO REFLECT THE LIMITATIONS OF CLASS ANALYSIS IN THE FACE OF COLLECTIVE ACTIONS THAT DO NOT SIGNIFY CLASS. THE EDITOR PROPOSES THAT IT MIGHT ALSO REFLECT THE LIMITATIONS OF POSTMODERN DISCOURSE WHICH TEND TO BLUR DIFFERENT TYPES OF COLLECTIVE ACTION. THE BOOK FOCUSES ON MARXISM AND POST-MARXISM, DEMOCRACY, SOCIAL FOCUSES ON MARXISM AND POST-MARXISM, DEMOCRACY, SOCIAL
MOVEMENTS, FEMINISM, AND DEVELOPMENT THEORY. IT PORTRAYS MOVEMENTS, FEMINISM, AND DEVELOPMENT THEORY. IT PORTRAYS
EMANCIPATION AS A CONCEPT WHICH CAN EMBRACE SOCIAL MOVEMENTS, LIBERATION, PARTICIPATION, AND EMPOWERMENT.

07312 PIJAHKA, K.D.; MUSHKATEL, A.H

PUBLIC OPPOSITION TO THE SITING OF THE HIGH-LEVEL NUCLEAR WASTE REPOSITORY. THE IMPORTANCE OF TRUST

POLICY STUDIES REYIEW 1O(4) (WIN Q2) 180-194.

THE AUTHORS EXAMINE SEVERAL DIMENSIONS OF PUBLIC OPPOSITION TO THE PROPOSED SITING OF THE U.S. HIGH-LEVEL NUCLEAR HASTE REPOSITORY AT YUCCA MOUNTAIN. IN ORDER TO PROVIDE A CONTEXT FOR THE PUBLIC'S VIEWS OF THE REPOSITORY IN METROPOLITAN CLARK COUNTY, GOVERMMENTAL STUDIES OF THE REPOSITORY SITING PROCESS AND ELEMENTS OF THE NUCLEAR WASTE POLICY ACT ARE ANALYZED. THIS ANALYSIS SUGGESTS THAT ONE POTENTIALLY KEY COMPONENT OF THE PUBLIC'S OPPOSITION TO THE SITING, AS WELL AS THEIR PERCEPTIONS OF THE RISKS ASSOCIATED WITH THE FACILITY, MAY BE THE RESULT OF A LACK OF TRUST IN THE DEPARTMENT OF ENERGY. EMPIRICAL ANALYSIS OF SURVEY DATA COLLECTED IN NEVADA IN 1988 CONFIRMS THE STRONG RELATIONSHI

07313 PIJIPERS, A.

THE TREATY OF MAASTRICHT AND EUROPEAN FOREIGN POLICY JERUSALEM JOURNAL OF INTERNATIONAL RELATIONS, $14(2)$ (JUM 92) $13-34$.

THE TREATY OF MAASTRICHT WILL PROBABLY BOOST THE ASPIRATIONS OF THE EUROPEAN COMMUNITY TO PLAY A SALIENT ROLE IN HORLD AFFAIRS. PERHAPS MOST SIGNIFICANTLY, THE TREATY HAS BROKEN WITH THE OLD EC TABDO ON DEFENSE BY SPEAKING OF PRODECURE FOR THE FOREIGN AND SECURITY AREAS.

07314 PIKA, J.A.; THOMAS, N.C.

THE PRESIDENCY SINCE MID-CENTURY

CONGRESS AND THE PRESIDENCY, 19(1) (SPR 92), 29-46.

MANY SCHOLARS AND OBSERVERS CLAIM THAT THE U.S.

PRESIDENCY AND THE POLITICAL ENVIRONMENT IN WHICH PRESIDENTS OPERATE HAVE BEEN TRANSFORMED IN THE SECOND HALF OF THE 2OTH CENTURY. THE STARTING POINT FOR EXAMINING THESE CLAIMS IS RICHARD NEUSTADT'S CLASSIC ASSESSMENT OF THE PRESIDENCY AT RICHARD NEUSTADT'S CLASSIC ASSESSMENT OF THE PRESIDENCY AT PRESIDENT'S INTENSIFIED RELATIONSHIP WITH THE PUBLIC, THE SOPRESIDENT'S INTENSIFIED RELATIONSHIP WITH THE PUBLIC, CALLED "POST-MODERN" PRESIDENCY, AND LEADERSHIP UNDER CONDITIONS OF DIVIDED GOVERNMENT. FAR FROM BEING A RONALD REAGAN'S EXPERIENCE IN OFFICE REPRESENTS A
CONTINUATIDN OF EXISTING TRENDS WITH ONLY LIMITED IMPACT ON CONTINUATION OF EXISTING TRENDS WITH ONLY LIMITED IMPACT ON THE INSTITUTION AND THE CONDUCT OF ITS OCCUPANTS. NEITHER NEUSTADT MOR HIS CRITICS HAVE DEVISED AN ANSWER FOR HOH
PRESIDENTS CAN CLOSE THE GAP BETWEEN PERFORMANCE AND EXPECTATIONS. 
07315 PIKE, D.

VIETNAM IN 1991. THE TURNIMG POINT

ASIAN SURYEY, XXXIII(1) (JAN 92), 74-81.

THE YEAR 1991 WAS A SEMINAL ONE FOR VIETNAM--A YEAR IM WHICH THE NATION: FINALLY DIVESTED ITSELF OF THE CAMBODIAN MILLSTONE, ENDED ITS DECADE-LONG COLD WAR WITH CHINA, ENTRENCHED AND MADE THE IDEA OF A MARKET ECONOMY IDEOLOGICALLY CORRECT, SERIOUSLY EMBARKED ON THE COMPLEX TASK OF REPLACING GOVERNMENT BY PARTY FIAT WITH GOVERMMENT BY CODIFIED RULE OF LAH, AND BEGAN THE TENTATIVE PROCESS OF RELEGATING THE VIETNAM WAR TO THE HISTORY BOOKS. THE ARTICLE STATES THAT VIETNAM MADE MORE ECONOMIC, SOCIAL, AND DIPLOMATIC PROGRESS IN 1991 THAN IN THE 15 YEARS FOLLOWING THE END OF THE WAR. IT HAS, OF COURSE, MUCH FURTHER TO $G O$.

07316 PIKE, J.; BOLKCOM, C.

GLOBAL PROTECTION AGAINST LIMITED STRIKES: AN UNMECESSARY AND UNWORKABLE SYSTEM

SPACE POLICY, 73 (AUG 91), 179-183.

SINCE THE THREAT OF NUCLEAR CONFLICT HITH THE USSR HAS RECEDED, THE U.S. STRATEGIC DEFENSE INITIATIVE HAS

METAMORPHOSED INTO THE GLOBAL PROTECTION AGAINST LIMITED STRIKES (GPALS) SYSTEM. BUT A DISPASSIONATE ANALYSIS SHOWS THAT GPALS WOULD NOT WORK AGAINST THE THREATS ADDUCED TO JUSTIFY ITS CREATION, NOR DO THE TREATS THEMSELVES REALLY EXIST. THERE IS NO NEED FOR THE SYSTEM OTHER THAN POLITICAL EXIST. THERE IS NO NEED FOR THE SYSTEM OTHER THAN POLITICAL EXPEDIENCY. A FAR BETTER GUARANTEE OF THE USA'S NATIONAL SECURITY LIES IN UPDATING THE ABM TREATY TOGETHER WITH A MODEST PROGRAM OF RESEARCH INTO SPACE-BASED STRATEGIC
DEFENSE.

07317 PIKKERT, P

CHRISTAIN ZIONISM: EVANGELICAL SCHIZOPHRENIA

IDDLE EAST INTERNATIONAL 439 (DEC 92) 19-20.

THE SCHIZOPHRENIC ATTITUDE OF MUCH OF THE NORTH AMERICAN EVANGELICAL RIGHT WING IS, AFTER THE JEWISH LOBBY, ONE OF THE MOST PONERFUL FORCES PREVENTING U.S. ADMINISTRATIONS FROM APPROACHING THE MIDDLE EAST PROBLEM EVENHANDEDLY. CHRISTIAN ZIONISM IS A CENTRAL POINT IN THE EVANGELICAL RIGHT'S PLATFORM. THIS ARTICLE EXPLORES THE CHRISTIAN ZIONIST'S HISTORICAL HANG-UPS AND DOCTRINAL ERROR AND EXAMINES A CHANGE IN ATTITUDES.

07318 PILAT, J.

THE EMERGING EUROPEAM ARMS CONTROL ARENA

ARMS CONTROL, 12 (3) (DEC 91), 51-59.

ARMS CONTROL IS CERTAIN TO CONTINUE TO BE AN IMPORTANT FEATURE OF EUROPEAN SECURITY. NOT EVERYTHING ON THE OLD AGENDA MAY BE CONSIDERED AS COMPLETED, ESPECIALLY IF THERE ARE DIFFICULTIES IN FULLY IMPLEMENTING THE CONVENTIONAL ARE DIFFICULTIES IN FULLY IMPLEMENTING THE CONVENTIONAL
FORCES IN EUROPE TREATY (CFE). THE SEARCH FOR A NEW ARMS CONTROL AGENDA TO FURTHER SECURITY AND STABILTIY WILL BE OF DYMAMIC WORLD WITH NEHEY-EMERGING THREATS, AMONG MORE OF A DYMAMIC WORLD HITH NEWLY-EMERGING THREATS, AMONG MORE PART ICIPANTS WITH A GREAT DIVERSITY OF INTERESTS, WILL FAR MORE DIFFICULT THAN PREVIOUSLY WAS THE CASE. THIS
ARTICLE CONCLUDES THAT IF THE GOAL IS SECURITY AND STABILTIY ARTICLE CONCLUDES THAT IF THE GOAL IS SECURITY AND STABI
IN EUROPE, THE PROMOTION OF OPENNESS AND TRANSPARENCY IN EUROPE, THE PROMOTION OF OPENNESS AND TRANSPARENCY THROUGH MULTIPLE ENDEAVOURS, RATHER THAN THROUGH FURTHER QUANITIATIVE LIMITATIONS ON CONVENTIONAL FORCES,
DESERVE THE HIGHEST PRIORITY BY POLICY MAKERS.

07319 PILON, J.G

ROMANIA'S STUBBORN DEMOCRATS

FREEDOM REVIEW, 23(6) (NOV 92), 24-25

THE AUTHOR REVIENS THE POLITICAL SITUATION IN ROMANIA PRECEDING THE FALL 1992 GENERAL ELECTIONS

07320 PINCH, P.

ORDINARY PLACES?: THE SOCIAL RELATIONS OF THE LOCAL STATE IN TWO EM4-CORRIDOR' TOWNS

POLITICAL GEOGRAPHY QUARTERLY, 11(5) (SEP 92), 485-500.

RECENT NEO-MARXIST ATTEMPTS TO COMSTRUCT A GENERAL

THEORY OF THE LOCAL STATE HAVE FOCUSED ON HOW THE UNEVEN SPATIAL DEVELOPMENT OF SOCIAL RELATIONS HITHIN CAPITALIST SOCIETIES UNDERPINS LOCAL POLITICAL AND POLICY CONTRASTS. IN BRITAIN, EMPIRICAL APPLICATIONS OF THESE THEORIES HAVE CONCENTRATED ON LOCALITIES HITH DISTINCTIVE POLITICAL HISTORIES--MOST MOTABLY PLACES HHERE RADICAL SOCIALISH CONSCIOUSNESS AND POL ICY HAVE COME INTO DIRECT CONFRONTATION WITH CENTRAL GOVERNMENT. BY EXAMINING THE SOCIAL RELATIONS IN AND ABOUT LOCAL GOVERHMENT IN TWO TOWNS IN BRITAIN'S \&M4 IN AND ABOUT LOCAL GOVERMMENT IN THO TOWNS IN BRITAIN'S LOCALITIES WHICH ARE SOCIALLY AND OCCUPATIONALLY

LOCALITIES WHICH ARE SOCIALLY AND OCCUPATIONALLY
HETEROGNEIOUS AND HAVE UNREMARKABLE POLITICAL HISTORIES.

07321 PINDER, J.

THE FUTURE OF THE EUROPEAN COMMUNITY: A STRATEGY FOR ENLARGEMEN

GOVERNMENT AND OPPOSITION, 27 (4) (FAL 92), 414-432.

THE AUTHOR LOOKS AT THE PROSPECTS FOR ENLARGING THE EUROPEAN COMMUNITY MEMBERSHIP IN LIGHT OF THE DANISH, FRENCH, AND BRITISH RESPONSES TO THE TREATY OF MAASTRICHT.
07322 PINDERHUGHES, D.M.

DIVISIONS IN THE CIVIL RIGHTS COMMUNITY

PS: POLITICAL SCIENCE AND POLITICS, XXV(3) (SEP 92), 485-487.

AFTER 10 YEARS OF PRESSURE PRIMARILY DUE TO THE SHIFT IN CIVIL RIGHTS POLICY DURING THE REAGAN-BUSH ADMINISTRATIONS, THE BLACK CIVIL RIGHTS COALITION IS SHOWING SEVERE SIGNS OF STRESS. IT IS SPLIT AND IN DISARRAY ON THE POLICY FRONT AS DISAGREEMENTS OVER LEGISLATION, INCLUDING THE CIVIL RIGHTS BILLS OF 1990 AND 1991, AND THE CLARENCE THOMAS NOMINATION SHOW.

07323 PINES, 8.

A PRIMER FOR CONSERVATIVES

NATIONAL INTEREST, (23) (SPR 91), 61-68.

THIS ARTICLE OUTLINES TEN CONSERVATIVE PRINCIPLES FOR $U$. S. FOREIGN POLICY; THEY ARE DESIGNED TO FILL THE VACUUM LEFT BY GEORGE BUSH'S LARGELY AD HOC APPROACH TO FOREIGN POLICY. THEY ARE: FOREIGN POLICY IS DOMESTIC POLICY; MORALITY SHOULD NOT DRIVE FOREIGN POLICY; AMBITIOUS FOREIGN POLICY POSES DOMESTIC DANGERS: DEAL WITH WORLD REALITY; SPECIFIC POLICIES DOMESTIC DANGERS; DEAL WITH WORLD REALITY; SPECIFIC POLICIES
FOR SPECIFIC PROBLEMS SHOULD REPLACE GLOBAL FOREIGN POLICY; FOR SPECIFIC PROBLEMS SHOULD REPLACE GLOBAL FOREIGN POLICY
RANK THE THREATS TO AMERICA (SOVIET MISSILES, THIRD WORLD RANK THE THREATS TO AMERICA (SOVIET MISSILES, THIRD WORLD MISSILES, THREATS TO FREEDOM OF THE SEAS, DOMINATIONS OF EUROPE BY A HOSTILE POWER, DOMINATION OF EAST ASIA BY A AMD ABROAD): MEXICO, RUSSIA, ISRAEL JAPAN, AND CHINA MERIT AND ABROAD) : MEXICO, RUSSIA, ISRAEL, JAPAN, AND CHINA MERIT NDECIAL TREATMENT; EXPAND OPPORTONITES ORER AMERICANS; GIVE NO NATION OR ORGANIZATION A VETO OVER AMERICAN

07324 PINES, B.Y.

THE GREAT POTOMAC EARTHQUAKE: AMERICA'S MEW BARGAIN WITH HASHINGTON

POLICY REVIEH, (62) (FAL 92), 18-23.

THE 1992 U.S. PRESIDENTIAL RACE IS TURHING OUT TO BE ONE OF THE CLOSEST IN RECENT HISTORY, AND THE CONGRESSIONAL

ELECTION CAMPAIGNS ARE PROMISING MAJOR CHANGES IN WASHINGTON. THE APPARENT CAUSES INCLUDE THE SPONTANEOUS MOBILIZATION OF H. ROSS PEROT'S LEGIONS, DISSATISFIED HITH REPUBLICANS AND DEMOCRATS ALIKE, AND PUBLIC DISAPPROVAL OF CONGRESS. BUT LIKE ALL MAJOR EARTHQUAKES, THE UNDERLYING CAUSE IS A SHIFT OF SUBTERRANEAN GEOLOGICAL PLATES. HAT IS SLIDING AHAY IS THE COLD HAR BEDROCK UPON WHICH MUCH OF AMERICA'S POST-WORLD WAR II POLITICS HAS RESTED.

07325 PINES, B.Y. (ED.) ; EDWARDS, L.; FAIRBANKS, C.H. JR.; IKLE, F.C.; KEMBLE, P.; PAYNE, K.B.; PFALTZGRAFF, R.L. JR.; ROSENBLATT, P.R.

MAKING THE WORLD SAFE FOR AMERICA

POLICY REVIEH, (61) (SUM 92), 50-69.

IN APRIL 1992, THE CONSERVATIVE HERITAGE FOUNDATION PUBLISHED A REPORT ENTITLED "MAKING THE HORLD SAFE FOR AMERICA: A U.S. FOREIGN POLICY BLUEPRINT " THIS ARTICLE
INCLUDES A SLIGHTLY ABRIDGED VERSION OF THIS REPORT ALONG WITH COMMENTS BY SEVEN FOREIGN POLICY SPECIALISTS.

07326 PING, G.

KNOT IN US-CUBA RELATIONS REMAINS TIED

BEI JING REVIEH, 35(36) (SEP 92), 14-16.

SINCE THE END OF THE COLD WAR, STRAINED RELATIONS BETWEEN THE UNITED STATES AND ITS CLOSEST COMHUNIST NEIGHBOR, CUBA, HAVE NOT BEEN EASED IN THE SLIGHTEST DEGREE. ON THE CONTRARY, IT SEEMS THAT US-CUBAN RELATIONS HAVE FURTHER DETERIORATED. THIS ARTICLE SUGGESTS THAT THE MOST CRUCIAL REASON THE UNITED STATES IS RELUCTANT TO MOVE FORHARD IN IMPROVING ITS TIES HITH CUBA IS THAT THE U.S. GOVERNMENT DOES NOT THINK THE CUBAN GOVERMMENT'S SYSTEM OF RULE ARE IN LINE WITH U.S. PRINCIPLES OF DEMOCRACY AND HUMAN RIGHTS.

07327 PING, X.: ZHIXING, L.

BAKER'S VISIT FUELS PEACE PROCESS

BEIJING REVIEH, 35(32) (AUG 92), 13-14

IN JULY 1992, U.S. SECRETARY OF STATE JAMES BAKER VISITED THE MIDDLE EAST TO TALK WITH THE LEADERS OF ISRAEL, EGYPT, JORDAN, SYRIA, LEBANON, AND SAUDI ARABIA AND WITH REPRESENTATIVES OF THE PALESTINIANS. MEANWHILE, ISRAELI PRIME MINISTER ITZHAK RABIN AND EGYPTIAN PRESIDENT HUSNI MUBARAK MET FOR TALKS AIMED AT BREAKING THE IMPASSE IN THE PEACE PROCESS.

07328 PING, $X$.

TALKS ON PALESTINIAN SELF-RULE STALL

BEIJING REVIEH, 35(12) (MAR 92), 14 .

ARABS AND ISRAELIS, ON THE FOURTH ROUND OF THEIR PEACE TALKS HICH ENDED IN HASHINGTON ON MARCH 4 ACHIEYED MO PROGRESS. HOWEVER, THE PALESTINIAN-ISRAELI' TALKS ON PALESTINIAN SELF-GOVERMMENT IN THE ISRAELI-OCCUPIED TERRI TORIES ATTRACTED HORLDWIDE ATTENTION. THIS ARTICLE DETAILS THE PLAN WHICH STATES THE IDEAS AND STEPS FOR SELFGOVERNMENT IN THE OCCUPIED TERRITORIES. THE PRESENT ISRAELI ATTITUDE HAS NOT ONLY EMBARRASSED THE UNITED STATES AND EGYPT, BUT IT HAS ALSO MADE THE FUTURE OF THE PALESTINIAN- 
ISRAELI TALKS NOT TOO ENCOURAGING.

07329 PINKELE, $C$

PLUS CA CHANGE: THE INTERACTION BETHEEN THE LEGAL SYSTEM AND POLITICAL CHANGE IN FRANCOIST SPAIH

INTERNATIONAL POLITICAL SCIENCE REVIEH, 13(3) (JUL 92), 269-284.

LAH AND POLITICS ARE PIECES OF THE SAME CLOTH. INDEED, MANY ARE PREDISPOSED TO BELIEVE IN MANY INSTANCES THAT IN AUTHORITARIAN POLITICAL SYSTEMS, LIKE SPAIN UNDER FRANCO, LAH AND LEGAL SYSTEM ELITES ARE FUNDAMENTALLY IRRELEYANT' ACTORS, EXCEPT AS PAWNS OF THOSE IN COMMAND. THIS ARTICLE ARGUES THAT THE LAW AND LEGAL SYSTEM ELITES HERE IMPORTANT POLITICAL ACTORS DURING THE TRANSITION FROM AUTHORITARIAK TO NON-AUTHORITARIAN POLITICS UNDER FRANCO AND THAT THE SPANISH CASE PROVIDES US WITH A ROUGH MAP TOWARD OUR
OF SYSTEM CHANGES IN OTHER ARENAS AS WELL.

07330 PINKERTON, J.

NEW PARADIGMS, OLD PRINCIPLES

NATIONAL REVIEW, XLIII(1) (JAN 91), 37-42.

THIS ARTICLE EXAMINES THE LEGACY OF RONALD REAGAN AND HIS FELLOW CONSERVATIVES, AND SEEKS TO GAIN LESSONS FOR FUTURE POLITICIANS AND POLICYMAKERS. IT CONCLUDES THAT THE CONTEMPORARY CONSERVATIVE MOVEMENT CAN BENEFIT FROM THE SWEEPING POLITICAL AND TECHNOLOGICAL CHANGES OF THE 1980 S IF THEY ABSORB THO LESSONS: FIRST. THE AMERICAN PEOPLE DO NOT LIKE TAXES. SECOND, THEY DO WANT A "KINDER, GENTLER" AMERICA. IT PROPOSES A "PARADIGM SHIFT" FROM AN OLD PARADIGM THAT SEES GOVERNMENTS AS CENTRALIZED BUREAUCRACIES SOLVING PROBLEMS BY SPENDING MORE MONEY, TO A NEW PARADIGM THAT TAKES AN ENTREPRNEURIAL APPROACH TO GOVERNMENT, EMPHASIZING RESULTS, BREAKING UP THE MONOPOLY BUREAUCRACIES, OFFERING CHOICE AND EMPOWERMENT, RELYING ON MARKET FORCES, SAVING MONEY AND SAVING PEOPLE AT THE SAME TIME.

07331 PINSKER, $S$.

AMERICA'S CONSPIRATORIAL IMAGINATION

VIRGINIA QUARTERLY REVIEW, 6814) (FAL 92), 605-625.

SANFORD PINSKER OBSERVES AT THE OUTSET OF HIS

EXAMIMATION OF AMERICA'S CONSPIRATORAIL IMAGINATION THAT NO

ONE DOUBTS THAT CONSPIRACY THEORY IS A SURE-FIRE MONEYMAKER.

ONE DOUBTS THAT CONSPIRACY THEORY IS A SURE-FIRE MONEYMAKER.
FOR THOSE WHO SPECIALIZE IN NEW INSTALLMENTS OF "HHO SHOT

FOR THOSE WHO SPECIALIZE IN NEW INSTALLMENTS OF "HHO SHOT

JFK", CONSPIRACY-SPINNING IS A GROWTH INDUSTRY AND TH
BOOM 'TIME. IN THIS ARTICLE HE FOCUSES ON THREE LARGE

BOOM TIME. IN THIS ARTICLE HE FOCUSES ON THREE LARGE
CULTURAL CONVULSIONS AND SUGGESTS HOW THEY HAVE BECOME

CULTURAL CONVULSIONS AND SUGGESTS HOW THEY HAVE BECOME

INEXTRICABLY ENTANGLED HITH THE AMERICAN IMAGAINATION. HE

THEN CONSIDERS THE MOTHER OF CONTE
THEORY --THE KENNEDY ASSASSINATION.

07332 PINTO, D.

THE GREAT EUROPEAN SEA CHANGE

DAEDALUS, 121(4) (FAL 92), 129-150.

THE TRANS-ATLANTIC RELÁTIONS THAT GOVERNED THE POSTWAR

PERIOD, BASED ON A COMMON ENEMY AND A WEAKER EUROPE LEARNING

ITS DEMOCRATIC LESSONS FROM A MORE EXPERIENCED AMERICA, HAVE EFFECTIVELY ENDED. THE NEW RELATIONS THAT HILL EMERGE WILL BE BASED ON A GREATER SENSE OF EQUALITY. FOR THAT TO HAPPEN, EACH SIDE OF THE ATLANTIC MUST HAVE A BETTER SENSE OF ITS STRENGTHS AND WEAKNESSES, TOGETHER WITH GREATER RESPECT FOR ITS HISTORIC PARTNER. IN THE INTERIM, NO HARM HILL COME IF TRANS-ATLANTIC RELATIONS ARE TEMPORARILY PLACED ON THE BACK BURNER.

07333 PION-BERLIN, $D$.

MILITARY AUTONOMY AND EMERGING DEMOCRACIES IN SOUTH AMERICA COMPARATIVE POLITICS, 25(1) (OCT 92), 83-102.

ESCHEWING SWEEPING GENERALIZATIONS ABOUT MILITARY

AUTONOMY IN SOUTH AMERICA, THE AUTHOR EXPLORES CRITICAL

VARIATIONS IN THE DEGREE TO WHICH THE MILITARY IS WILLING

AND ABLE TO DEFEND ITS PERCEIVED PEROGATIVES UNDER

DEMOCRATIC RULE. THERE IS A CEILING ABOVE WHICH THE ARMED

FORCES CAMMOT OR PREFER NOT TO GO AND BELOH WHICH THEY

DESIRE TO EXTEND THEIR INFLUENCE WITHIN THE DEMOCRATIC ORDER.

THE EXTENT VARIES ACCORDING TO COUNTRY AND ISSUE AREA. THE

ARMED FORCES HAVE EXERTED MORE LEVERAGE OVER DEMOCRATIC

ARMED FORCES HAVE EXERTED MORE LEVERAGE OVER DEMOCRATIC
GOVERNMENTS IN BRAZIL AND CHILE IHAN IN PERU, URUGUAY, AND

GOVERNMENTS IN BRAZIL AND CHILE THAN IN PERU, URUGUAY
ARGENTINA. LEVELS OF MILITARY AUTONOMY ARE HIGHER FOR

ARGENTINA. LEVELS OF MILITARY AUTONOMY ARE HIGHER FOR
INTERNAL PROFESSIONAL FUNCTIONS THAN FOR FUNCTIONS IN EITHER

INTERNAL PROFESSIONAL FUNCTIONS THAN FOR FUNCTIONS IN EITHER
THE GRAY ZONE BETHEEN PROFESSIONAL AND POLITICAL SPHERES OF

INFLUENCE OR THE POLITICAL SPHERE ITSELF.

07334 PIOTROWSKI, J.L.

SDI AND MISSILE PROLIFERATION

SDI AND MISSILE PROLIFERATION

THIS ARTICLE EXAMINES THE ROLE OF THE STRATEGIC DEFENSE

INITIATIVE (SDI) IN THE AREA OF MISSILE PROLIFERATION. THE TOPIC IS ADDRESSED WITHIN THE CONTEXT OF THE IRAN-IRAO WAR AND THE GULF WAR. THE USE OF BALLISTIC MISSILES IN THE IRAMIRAQ WAR IS DESCRIBED, AS WELL AS THE USE OF SCUD MISSILES BY IRAQ TO ISRAEL IN THE GULF HAR.

07335 PIPER, $N$

BLAME FOR GATT TRADE-TALKS CRISIS LIES WITH EUROPEAN
COMMUNITY

GERMAN TRIBUNE, 31(1541) (NOV 92), 1-2.

COMPARISONS WITH THE EARLY 193OS ARE BECOMING

COMMONPLACE. IT ISN'T JUST THE RIGHT-WING EXTREMIST MOBS IN THE STREETS. IN THE ECONOMY, COMPARISONS ARE MADE WITH FRIGHTENING FREQUENCY WITH 1929, THE YEAR IN WHICH THE GREAT DEPRESSION BEGAN. BECAUSE OF THE THREAT OF A TRADE WAR BETWEEN THE UNITED STATES AND EUROPE, ECONOMISTS ARE SOUNOING THE ALARM. BLAME FOR THE CRISIS LIES WHOLLY WITH THE EUROPEAN COMMUNITY, WITH THE FRENCH GOVERMMENT AS CHIEF CULPRIT.

07336 PIPER, $N$.

ECONOMIC SUMMIT DECIDES TO SHELVE THE PROBLEM AGAIN GERMAN TRIBUNE, (1524) (JUL 92), 6-7.

AT THE MUNICH SUMMIT THE 92 ) 6 6-7.

INDUSTRIALIZED NATIONS SPOKE MUCH ABOUT THE NEED TO COMPLETE

INDUSTRIALIZED NATIONS SPOKE MUCH ABOUT THE NEED TO COMPLET ON TARIFFS AND TRADE (GATT). AMD WHILE AGREEMENT HAS BEEN REACHED ON A HOST OF ISSUES INCLUDING INTELLECTUAL PROPERTY REACHED ON A HOST OF ISSUES INCLUDING INTELLECTUAL PROPERTY AND TEXTILE QUOTAS, THE KEY STICXING POINT, AGRICUL TURE, FREE TRADE ADVOCATES SUCH AS THE UNITED STATES, ARGENTINA, AUSTRALIA AND NEW ZEALAND CALL FOR THE END TO AS MANY AGRICULTURAL SUBSIDIES AS POSSIBLE. THE EUROPEAN COMMUNITY REGARDS SUBSIDIES AS NECESSARY FOR THE SURYIVAL OF COMMUNITY FARMERS AND HAS REFUSED TO GIVE IN TO THE DEMANDS OF THE FREE TRADE PROPONENTS. THE GAP BETWEEN THE RHETORIC AND POLICY OF THE INDUSTRIALIZED NATIONS IS BECOMING

INCREASINGLY APPARENT. THE CONSEQUENCES OF FAILING TO

COMPLETE THE GATT ROUND INCLUDE ECONOMIC DOWNTURNS,

PROTECTIONISM AND POLITICAL INSTABILITY.

07337 PIPES, $D$.

THE TARBABIES OF AMERICAN POLITICS

NATIONAL REVIEW, XLIV(22) (NOV 92), 40; 42;

TARBABY-LIKE, TROUBLES HITH THE ISLAMIC REPUBLIC KEEP

STICKING. IRAN AND IRAQ BREED U.S. SCANDALS EVEN FASTER THAN

THEY DO INTERNATIONAL CRISES. AFTER A RECITAL OF U.S.

INTERACTIONS WITH THESE COUNTRIES, THE AUTHOR SUGGESTS THAT AMERICAN POLICY IN THE PERSION GULF REGION IS THE SHAPE OF THE FUTURE. THEY TYPIFY THE BALANCE-OF-POWER POLICES WHICH CHARACTERIZE POLITICS IN A NON-COLD-HAR WORLD. THE MORE CHARACTERIZE POLITICS IN A NON-COLD-WAR WORLD. THE MORE
QUICKLY AMERICANS ACCEPT THE PATTERN, THE BETTER THEIR

QUICKLY AMERICANS ACCEPT THE PATTERN, THE
COUNTRY'S FOREIGN POLICY WILL FUNCTION.

07338 PIPES, $D$

WHAT KIMD OF PEACE?

NATIONAL INTEREST, (23) (SPR 91), 8-13.

WHILE THE U.S. STRATEGY DESIGNED TO COUNTER IRAQ'S

INVASION OF KUWAIT HAS OBVIOUSLY SUCCESSFUL, THERE SEEMS TO BE LITTLE IN THE WAY OF A U.S. POLICY DESIGNED TO "WIN THE PEACE." THIS ARTICLE CDNSIDERS THIS CHALLENGE, AND OUTLINES POTENTIAL U.S. OBJECTIVE AND POLICIES. IT ARGUES THAT THE OVERRIDING AMERICAN INTEREST IN THE GULF IS STABILITY. ONCE
STABILITY IS ACHIEVED, OTHER DESIRABLE GOALS SUCH AS LOW OIL STABILITY IS ACHIEVED, OTHER DESIRABLE GOALS SUCH AS LOW OIL DEMOCRATIC ELECTIONS CAN BE ADDRESSED. U.S. POLICY SHOULD, THEREFORE, BE GEARED TOWARDS THE ACHIEVEMENT OF TERRITORIAL INTEGRITY IN IRAQ; AS MODERATE AND NON-BELLICOSE A

GOVERNMENT IN BAGHOAD AS POSSIBLE; A BALANCE BETHEEN IRAQI AND IRANIAN POWER; THE AL-SABAH DYNASTY'S RETURN TO KUWAIT; AND THE FUTURE SECURITY OF KUWAIT, SAUDI ARABIA, AND THE OTHER PER-CAPITA INCOME GIANTS.

07339 PIRO, T.

PARLIAMENT, POLITICS, AND PLURALISM IN JORDAN: DEMOCRATIC TRENDS AT A DIFFICULT TIME

MIDDLE EAST INSIGHT, VIII (6) (JUL 92), 39-44.
THE POLITICAL CHANGE IN JORDAN HAS BEEN MORE

EVOLUT IONARY THAN REVOLUTIONARY. ALTHOUGH JORDAN IS NOT

ABOUT TO BECOME A MADI SONIAN MOOEL OF POLITICAL DEMOCRACY,

CERTAIN POLITICAL AND SOCIAL CHANGES SINCE THE LATE 1980's

WARRANT A CLOSER ANALYSIS. JORDAN'S BEHAVIOR DURING THE GULF

WAR COUPLED WITH RECENT POLITICAL AND ECONOMIC TRENDS

DEMONSTRATE THAT THE POLITICAL CONTOURS OF KING HUSSEIN'S

REIGN ARE UNDERGOING CHANGE.

07340 PISANO, J.G

AFTER THE RIOTS: MULTI-CULTURALISM IN LOS ANGELES

NATIONAL CIVIC REVIEW, 81(3) (SUM 92), 313-318.

AMONG THE ROOTS OF' THE LOS ANGELES RIOTS IS A

SUBURBANIZATION PROCESS THAT HAS ISOLATED INNER-CITY

POPULATIONS AND ENCOURAGED UNDERINVESTMENT IN URBAN

EDUCATIONAL AND COMMUNITY INSTITUTIONS. GREATER UNITY AMONG

METROPOL ITAN COMMUNITIES AND THEIR RESIDENTS IS ONE KEY TO THE URBAN FUTURE.

07341 PISANO, $V$.

GENESIS, RISE, AND DECLINE OF ITALIAN TERRORISM: THE OPERATIONAL DIMENSION

CONFLICT, 10(3) (1990), 227-238.

THIS ARTICLE EXAMINES THE STRUCTURE OF ITALY'S TERRORIST

GROUPS, AS WELL AS LAW ENFORCEMENT'S RESPONSE TO THE 
DYNAMICS OF TERRORISM IN ITALY. IT FOCUSES ON THE OPERATIONAL DIMENSIOH OF THE ITAL IAN TERRORIST PHENOMENON BY REVIEWING THE STRUCTURE AND TACTICS OF THE PRINCIPAL TERRORIST GROUPS AND THE COUNTERMEASURES ADOPTED BY THE ORGANS OF GOVERNMENT AND THE SECURITY AGENCIES.

07342 PITNEY J. JR.

WHO LOVES THE GUVS?

REASON, 24(3) ( JUL 92), 44-45

WHEN BILL CLINTON AND JERRY BROWN OUTLASTED SEVERAL

OTHER CONTENDERS FOR THE DEMOCRATIC PRESIDENTIAL NOMINATION, THEY CONFIRMED TWO THINGS. FIRST, IT PAYS FOR CANDIDATES TO TALK ABOUT NEH IDEAS, AND SECOND, GOVERNORS HAVE ONCE AGAIN BECOME MAJOR PLAYERS IN PRESIDENTIAL POLITICS. GOVERNORS HAVE SEEN AN INCREASE IN THEIR REELCTION RATES FROM 70 PERCENT TO 75 PERCENT. THE EXPANSION OF STATE GOVERMMENT PROVIDED GOVERNORS WITH MUMEROUS OCCASIONS TO PROMOTE THEIR INHOVATIVE POLICES AND GREATER OPPORTUNITIES TO WIN EXPOSURE AND POLITICAL CONTACTS BEYOND THEIR STATES' BORDERS. THIS ARTICLE EXPLORES THIS PHENONEMA AS WELL AS THE FLIP SIDE OF GOVERNOR POPULARITY. IT SUGGESTS THAT A NEW KIND OF PRESIDENTAIL CONTENDER WOULD BE A GOVERNOR WHO ACHIEVES PRESIDENTAIL CONTENDER WOULD BE A GOVERNOR WHO ACHIEVES
PROMINENCE BY MAKING GOVERMMENT BETTER INSTEAD OF BIGGER.

07343 PITTARD, F.L.

SYSTEMATIC APPROACH TO FUNCTIONAL CONSOLIDATION AND MERGER NATIONAL CIVIC REVIEH, 81(4) (FAL 92), 488-499

SERVICE INEFFICIENCY AND DUPLICATION OF EFFORT AND INVESTMENT DRAMATIZE THE DOWN-SIDE OF SUBURBANIZATION. FIRE PROTECTION IS AN AREA THAT DEMONSTRATES THE POTENTIAL OF
REGIONAL COOPERATION IN PROVIDING AN ESSENTIAL SERVICE.

07344 PITTINGER, J.

"GARCIA" AND THE POLITICAL SAFEguardS OF FEDERALISM: IS THERE A BETTER SOLUTION TO THE CONUNDRUM OF THE TENTH AMENDMENT?

UBLIUS: THE JOURMAL OF FEDERALISM, 22(1) (HIN 92), 1-20.

IN GARCIA V. SAN ANTONIO METROPOLITAN TRANSIT AUTHORITY JUSTICE HARRY BLACKMAN HELD THAT THE TENTH AMENDEMENT DOES NOT PREVENT THE CONGRESS FROM SUBJECTING STATE AND LOCAL GOVERMMENTS TO THE PROVISIONS OF THE FAIR LABOR STANDARDS ACT. THIS ARTICLE EXAMINES THE INTELLECTUAL FOUNDATIONS OF THE POLITICAL SAFEGUARDS OF FEDERALISM AND FINDS THEM ADEOUATE. IT THEN SURVEYS THE POST-GARCIA SCHOLARSHIP TO ASCERTAIN WHETHER AN ALTERNATIVE THEORY OF THE TENTH AMENDMENT HAS EMERGED.

07345 PITTS, J.

\section{TWILIGHT ZONE}

NEH REPUBLIC, 207(11-12) (SEP 92), 25, 28

IN 1982, MARYLAND BECAME ONE OF THE FIRST STATES TO EXPERIMENT WITH ESTABLISHING ENTERPRISE ZONES AS A WAY OF REVITALIZING INNER CITIES AND PUTTING PEOPLE BACK TO WORK. REVITALIZING INNER CITIES AND PUTTING PEOPLE BACK TO WORK. BOTH MARYLAND AND BALTIMORE HAVE OFFERED SUBSTANTIAL TAX BREAKS TO ENTICE BUSINESSES TO LOCATE IN PARK CIRCLE, AN
ENTERPRISE ZONE IN BALTIMORE. BUT AFTER A DECADE, THE ZONE HAS HAD NO TANGIBLE EFFECT ON THE NEIGHBORHOOD AROUND IT.

07346 PIVEN, $F$.

REFORMING THE WELFARE STATE

SOCIALIST REVIEH, 22(3) (JUL 92), 69-82,

THE AUTHOR ATTEMPTS TO ANSWER THE QUESTION: AS WE EMERGE FROM A LONG PERIOD OF UNRELENTING, RARELY CHALLENGED ASSAULTS ON THE POLICIES OF THE WELFARE STATE, WHAT SHOULD A LEFT GROWN UNACCUSTOMED TO AGITATING FOR SOCIAL PROGRAMS NOW BE LOOKING TO ACHIEVE? HE EXAMINES; THE SILENCE ON THE LEFT; THE BEAURACRACY MYTH; UNIVERSAL PROGRAMS; AND HELFARE.

07367 PIZZANITA, A.

MAURITANIA'S FOREIGN POLICY: THE SEARCH FOR PROTECTION JOURNAL OF MODERN AFRICAN STUDIES, 30(2) (JUN 92), 281-304. AFTER AN HISTORICAL REVIEH OF THE MAURITANIA'S POLITY AND EXTERMAL ENVIRONMENT, THIS ARTICLE ATTEMPTS TO ANALYZE THE REGIME'S RELATIONS WITH CERTAIN AFRICAN AND MIDDLE EASTERN STATES, WITH SPECIAL REFERENCE TO THREE CRISES DURING THE PAST DECADE WHICH HAVE EXPOSED, AT LEAST TO SOME EXTENT, THE CONTINUING ROLE OF DOMESTIC POLITICAL ATTITUDES IN FOREIGN POLICY AUGHENTS: THE HESTERN SAHARA WAR, HHICH INVOLVED MAURITANIA BETWEEN 1975-1979; THE DISPUTE WITH SENEGAL DURING 1989-90: AND THE GUIF CONFLICT CAUSED BY IRAO'S INVASION ON KUHAIT IN AUGUST 1990.

07348 PLANAS, J.

WHY DOES CASTRO SURVIVE?

MORLD AFFAIRS, 154 (3) (WIN 92), 87-93.

THE OUESTION, "WHY DOES CASTRO SURYIVE?" HAS DRAHH CONSIDERABLE POLITIICAL INTEREST FOLLOWING THE COLLAPSE OF MARXIST-LENINIST SOCIALISM IN EASTERN EUROPE. ANALYZING WHY CASTRO HAS NOT YET FALLEN CAN BE HELPFUL TO THE EXTENT THAT IT DRAHS ATTENTION TO THE INTERPLAY BETWEEN THE INNER WORKINGS OF THE CURRENT CUBAN SYSTEM, THE IMPACT OF WORLD ATTI TUDES AND BEHAVIOR TOWARD CUBA, AND CASTRO'S CONTINUED ABILITY TO REMAIN IN POWER. THIS ARTICLE SUGGESTS THAT EXTERMAL OPPOSTION IS SUFFOCATING THE EFFECTS OF THE CRISIS
BROUGHT ABOUT BY THE SOVIET REFORMS BY CREATING AN ARTIFICIAL SENSE OF HOPE THAT THE NIGHTMARE WILL DISAPPEAR ON ITS OWN WHILE PROVIDING SUPPORTERS OF THE REGIME WITH THE S THEIR ONLY ALTERNATIVE.

07349 PLANT, S.; WELLS, 8 .

FOOD: WHAT COMMONWEALTH PARLIAMENTS CAN DO IN FURTHERING FOOD PRODUCTION, MARKETING, AND CONSUMPTION

PARLIAMENTARIAN, LXXIII (1) (JAN 92), 22-23.

COMMONHEALTH PARLIAMENTS COULD IMPROVE FOOD PRODUCTION, MARKETING, AND DISTRIBUTION IN POORER COUNTRIES BY PROMOTINC EXCHANGES BETWEEN COMMONHEALTH STATES. FOR EXAMPLE, FOOD PRODUCTION COULD BE INCREASED BY DISSEMINATION OF IRRIGATION TECHNOLOGY AND THE ESTABLISHMENT OF A DATA BANK ON RESEARCH AND TECHMOLOGICAL ADVANCES IN AGRICULTURE.

07350 PLANTICD, R.C.

A PROPERTY RIGHTS STRATEGY FOR PROTECTING THE ENVIRONMENT : A COMMENT ON STROUP AND GOOOMAN

HARVARD JOURNAL OF LAM AND PUBLIC POLICY, 15(2) (SPR 92), 455-466.

FOR YEARS, THE DOMINANT POLITICAL VIEH HAS BEEN THAT PROPERTY RIGHTS AND THE ENVIRONMENT ARE NECESSARILY AT WAR WITH EACH OTHER: PROTECTING ONE IS CERTAIN TO COMPROMISE THE OTHER. AS COMMAND AND CONTROL APPROACHES TO REGULATING THE ENVIRONMENT HAVE DEVELOPED OVER THE PAST QUARTER-CENTURY, BEEN WAGED IN HETLANDS, IN NEIGHBORHOODS, ON BEACHES, AND IN OTHER THEATERS. TO SAVE THE ENVIRONMENT, SO THE ARGUMENT GOES, RIGHTS TO USE PRIVATE PROPERTY MUST BE LIMITED. THUS, MANY U.S. INSTITUTIONS OF ENVIRONHENTAL PROTECTION HAVE BEEN DESIGNED TO LIMIT PRIVATE PROPERTY RIGHTS. IN THIS PAPER, THE AUTHOR EXAMINES THE VALIDITY OF THIS PERSPECTIVE.

07351 PLASSER, F.; GRAUSGRUBER, A.; ULRAM, P. ELECTORAL COMPETITION IN AUSTRIA

WEST EUROPEAN POLITICS, 15(1) (JAN 92), 16-45.

THIS ARTICLE COMHENCES BY SKETCHING OUT THE SUBCULTURAL UNDERP INNING OF AUSTRIA'S CONSOCIATIONAL SYSTEM, NAMELY, THE SO-CALLED LAGER. BY REFERENCE TO A WEALTH OF EMPIRICAL DATA IT THEN IDENTIFIES PROCESSES, SUCH AS THE DECLINE OF LAGER MENTALITY, BY WHICH AUSTRIA'S ENCAPSULATED SUBCULTURES HAVE BEEN ERODED. ATTENTION IS THEN GIVEN TO THE IMPLICATIONS OF
THESE ONGOING DEVELOPMENTS FOR THE PREVIOUS HYPERSTABILITY OF AUSTRIAN ELECTORAL BEHAVIOR AND EXPLANATIONS ARE OFFERED OF AUSTRIAN ELECTORAL BEHAVIOR AND EXPLANATIONS ARE OFFERED
AS TO HOW AND WHY AUSTRIA'S ELECTORATE HAS OF LATE BECOME AS TO HOW AND WHY AUSTRIA'S ELECTORATE HAS OF LATE BECOME
INCREASINGLY YOLATILE. BY DETAILED ANALYSIS OF THE 1990 INCREASINGLY VOLATILE. BY DETAILED ANALYSIS OF THE 1990
GENERAL ELECTION THE AUTHORS FIRST DEMONSTRATE THE DECLINING GENERAL ELECTION THE AUTHORS FIRST DEMONSTRATE THE DECLINING
SALIENCE OF TRADITIONAL DETERMINANTS OF VOTING BEHAVIOR. SALIENCE OF TRADITIONAL DETERMINANTS OF VOTING BEHAVIOR.
SECOND, THEY IDENTIFY EIGHT NEW "CLUSTERS" OR "SEGMENTS" OF SECOND, THEY IDENTIFY EIGHT NEN "CLUSTERS" OR "SEGMENTS" OF
VOTERS WHICH MAY CONSTITUTE THE BASES FOR RESTRUCTURING OF PATERS WHICH MAY CONSTITUTE THE BASES FOR RESTRUCTURING OF OF THE AUSTRIAN PARTY SYSTEM.

07352 PLATT, G.; POOLE, K.T.; ROSENTHAL, H.

DIRECTIONAL AND EUCLIDEAN THEORIES OF VOTIMG BEHAYIOR: A LEGISLATIVE COMPARISON

LEGISLATIVE STUDIES QUARTERLY, XVII(4) (NOV 92), 561-572. RECENT RESEARCH BY RABINOWITZ AND MACDONALD CLAIMS THAT VOTING BEHAVIOR IS BETTER EXPLAINED BY A DIRECTIONAL MODEL THAN BY A TRADITIONAL PROXIMITY OR EUCLIDEAN MODEL. IN THIS PAPER, THE AUTHORS COMPARE DIRECTIONAL AND EUCLIDEAN MODELS USING CONGRESSIONAL ROLL-CALL VOTING DATA. FOR THESE

RELATIVELY WELL-INFORMED VOTERS. THE AUTHORS UNAMBIGUOUSLY REJECT THE DIRECT IONAL MODEL IN FAVOR OF THE TRADITIONAL EUCL IDEAN SPATIAL MODEL AND CONCLUDE THAT CONGRESSIONAL
VOTING CAN BE VERY ACCURATELY REPRESENTED BY THE EUCLIDEAN MODEL.

07353 PLAUT, S. PORK IN ISRAEL

NATIONAL INTEREST, 28 (SUM 92), 73-80.

ISRAEL'S PROBLEM--AT ONCE ECONOMIC AND STRATEGIC--IS THAT ITS ECONOMY HAS GROWM VERY LITTLE OVER THE PAST TWENTY YEARS. THE LACK OF GROWTH IN ISRAELI PRODUCTIVITY HAS PLACED LIMITS AND PRESSURES ON MILITARY EXPEDITURE WHICH IN FACT HAS BEEN REDUCED CONTINUOUSLY IN REAL TERMS FOR SEVERAL YEARS. THIS PAPER ARUGES THAT ECONOMIC GROWTH IS IMPORTANT FOR ISREAL FOR STRATEGIC REASONS AS WELL AS SOCIAL ONES. IT EXPLORES THE CONSEQUENCES AND CAUSES OF: STAGHATION;

EXPLORES THE CONSEQUENCES AND CAUSES OF : STAGNATION;
POL ITICISM: PROTECTION; AND, AMERICAN POLICY. IT SUGGESTS POL ITICISM: PROTECTION; AND, AMERICAN POLICY. IT SUGGESTS THAT AMERICAN AID COULD SERVE
DIRECTION OF ECONOMIC HEALTH

07354 PLEASE, $S$.

BEYOND STRUCTURAL ADJUSTMENT IN AFRICA

DEVELOPMENT POLICY REVIEW, $10(3)$ (SEP 92), 289-308,

THE AUTHOR LOOKS AT THE ACHIEVEMENTS AKD FAILURES OF STRUCTURAL ADJUSTMENT PROGRAMS IN AFRICA. HE STATES THAT AFRICAN COUNTRIES MUST EMBRACE SHORT-TERM DISCIPLINED MACRODEMAND MANAGEMENT; MEDIUM-TERM STRUCTURAL ADJUSTMENT WITH EMPHASIS ON UTILIZING PRODUCTIVE CAPACITY MORE EFFICIENTLY 
IN TECHNICAL, ECONOMIC, AND SOCIAL TERMS; AND LONG-TERM STRUCTURAL TRANSFORMATION OF THE ECONOMY WITH AN EMPHASIS ON CHANGING TECHNOLOGIES, IMPROVING EDUCATIONAL AND HEALTH STANDARDS, EXTENDING INFRASTRUCTURE, AND STRENGTHENING INSTITUTIONS.

07355 PLETENIK, 8.; COOPER, P.J. ADMINISTRATION AT THE CUSP OF SCIENCE: THE CASE OF RECOMBINANT DNA

ADMINISTRATION AND SOCIETY, 24(2) (AUG 92), 132-162. THE AUTHORS CONSIDER THE PROBLEMS FACED BY JUDGES IN LAH ANO POLICY DISPUTES INVOLVING COMPLEX SCIENTIFIC AND AND POLICY DISPUTES INVOLVING COMPLEX SCIENTIFIC AND TECHNOLOGICAL ISSUES. THEY EXAMINE THE HISTORICAL
DEVELOPMENT OF GOVERNMENT INVOL VEMENT IN REGULATING DEVELLPMENT OF GOVERNMENT INVOLVEMENT IN REGULATING
RECOMBINANT DNA RESEARCH, FOCUSING ON THE CASE OF FOUNDATION RECOMBINANT DNA RESEARCH, FOCUSING ON THE CASE OF FOUNDATION
ON ECONOMIC TRENDS $Y$. HECKLER. ALTHOUGH EFFORTS HERE MADE TO ON ECONOMIC TRENDS $Y$. HECKLER. ALTHOUGH EFFORTS HERE MADE TO
HANDLE THIS CASE IN TERMS OF HARROWLY-DEFINED LEGAL ISSUES, HANDLE THIS CASE IN TERMS OF NARROWLY OEFINED LEGAL ISSUES
CASES LIKE THIS PRODUCE AN INEVITABLE MIXTURE OF LEGAL, CASES LIKE THIS PRODUCE AN INEVITABLE MIXTURE OF LEGAL,
SCIENTIFIC, AND POLICY ISSUES. THE AUTHORS CONSIDER THE IMPLICATIONS OF THIS BLENDING OF ISSUES FOR THE STUDY OF CONTROVERSIES INVOLVING LAH, SCIENCE, AND ADMINISTRATION.

07356 PLETKA, D.

A TUG-OF-WAR FOR ISLAM POWER

INSIGHT, 8(8) (FEB 92), 14-16; 35

THE BREAKUP OF THE SOVIET UNION HAS LED TO A STRUGGLE BETWEEN TURKEY AND IRAN TO GAIN THE UPPER HAND WITH MILLIONS OF MUSLIMS. AT STAKE ARE NATURAL RESOURCES, NUCLEAR TECHNOLOGY, SHEER NUMBERS OF PEOPLE AND POHER. IT IS A BATTLE OF EAST VERSUS WEST, OF THEOCRACY VERSUS DEMOCRACY. THE TURKS HAVE WON THE OPENING BATTLES BUT THE WAR IS FAR FROM OVER. A PROFESSOR OF URALIC AND ALTAIC STUDIES SUGGESTS THAT THEY DON'T WANT TO GO TO THE KORAN AND TRY TO DECIDE WHAT KIND OF SOCIETY TO HAVE, BUT AS A SYMBOL, ISLAM'S AS

POPULAR AS APPLE PIE AND MOTHERHODD IN THE UNITED STATES.

07357 PLETKA, D.

AMERICA'S FIRST SECOND COMING

INSIGHT, 8(1) (JAN 92), 4-9.

UNITED STATES ISOLATIONISM IS GAINING UNPRECEDENTED SUPPORT DRAWING PROPONENTS FROM MAHY THROUGHOUT THE

POLITICAL SPECTRUM. THE NEW AMERICA FIRST MOVEMENT HAS MANY POLITICAL SPECTRUM. THE NEW AMERICA FIRST MOVEMENT HAS MANY ROOTS, FROM THE VICTORY OVER COMMUNISM TO A CHANCE TO DEFE
THE PRESIDENT. HISTORY HOLDS LESSONS ABOUT THE ECONOMIC THE PRESIDENT. HISTORY HOLDS LESSONS ABOUT THE ECONOMIC CONSEOUENCES OF RELINQUISHING A ROLE IN THE WORLD. THIS ARTICLE CONTENDS THAT IS ONLY ONLY IN COMPARISON WITH THE FABPEARS TO BE IN DECLINE BUT, BE THAT AS IT MAY, BOOSTERISM APPEARS TO BE IN

07358 PLETKA, D.

ARAB AGAINST ARAB

INSIGHT, 7 (6) (FEB 91), 16-17.

WHILE MANY ARABS DECRY U.S. INVOLVEMENT IN THE GULF WAR, THE EGYPTIANS, SAUDIS, AND SYRIANS REMAIN ARRAYED WITH UNITED STATES AGAINST THEIR FELLOW ARABS IN IRAQ. THEIR SUPPORT HAS GIVEN ARAB POLITICIANS AND DEMAGOGUES A HOT ISSUE TO POUNCE ON AND EXACERBATE THE TENSION IN ALREADY STRAINED INTERNAL RELATIONS. HOWEVER, THUS FAR THERE HAS BEEN NO REVOLT, NO MASS UPRISING, AND NO ATTEMPT TO OVERTHROW AMERICA'S MINIONS IN THESE COUNTRIES.

07359 PLETKA, D

ARAB PROTECTORS

INSIGHT, 7(13) (APR 91), 14-15.

ON 6 MARCH 1991 REPRESENTATIVES FROM THE GULF CDOPERATION COUNCIL-DAUDI ARABIA, BAHRAIN, OATAR, THE UNITED ARAB EMIRATES, KUWAIT, OMAN--AND SYRIA AND EGYPT SAT DOWN IN THE SYRIAN CAPITAL AND SIGNED A SECURITY PACT. THE EGYPTIAN TROOPS TO BE BASED IN THE PERSIAN GULF TO PROTECT THE EMIRS, SHEIKHS, AND KINGS OF THE REGION FROM THE IRAQIS, IRANIANS, OR ANYONE ELSE BENT ON ALTERING THE STATUS QUO--IN RETURN FOR \$14 BILLION A YEAR. WHILE THE PACT SEEMS TO BE A GOOO START ON A REGIONAL SECURITY SYSTEM, THE VIRTUAL

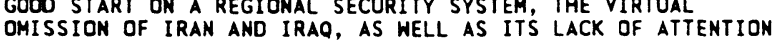
OMISION OF IRAN AND IRAQ, AS WELL AS ITS LACK OF ATTENTION BEFORE THE DAMASCUS DECLARATION CAN BE VIABLE.

07360 PLETKA, D.

$$
\text { PLETKA, D. }
$$

INSIGHT 7 (4) (JAN 91), 31.

SWEDEN WAS LONG THOUGHT OF AS A MODEL OF INDEPENDENT THINKING. AN ARCHETYPE OF THE BLISSFUL UNION OF CAPITALISM AND SOCIALISM, AND A STAUNCH NEUTRALIST. HOWEVER, AFTER CENTURIES OF NEUTRALITY, SHEDEN IS RELUCTANTLY JOINING THE EUROPEAN COMMUNITY IN HOPES OF REVIVING ITS FALTERING ECONOMY. ITS PROGRESSIVE, AND SOME HOULD SAY EXCESSIVE,
SOCIAL PROGRAMS HAVE PAINTED THE COUNTRY INTO A FINANCIAL CORNER.

07361 PLETKA, $D$.

MAK INC

INSIGHT, 7(15) (APR 91), 26-28.
AFTER SIDING WITH U.S. -LED FORCES, SYRIA CAME OUT OF THE PERSIAN GULF WAR \$3 BILLION RICHER AND WITH MUCH MORE POPULARITY. BUT TO KEEP SYRIA'S NEW FOUND FRIENDS AND AMERICA HAPPY, PRESIDENT HAFEZ AL-ASSAD FINDS HIMSELF IN THE UNCOMFORTABLE POSITION OF HAVING TO TALK PEACE WITH ISRAEL, WHICH IS ALSO UNDER PRESSURE TO TALK. STILL, NEITHER SEEMS TO BE WILLING TO PAY THE PRICE OF PEACE WITH EACH OTHER.

07362 PLETKA, D.

ON THE SIDELINES

INSIGHT, $7(5)$ (FEB 91), 15-16

THE GULF CRISIS HAS DEMOTED IRAN TO THE STATUS OF THE LESSER OF TWO EVILS IN THE MIDDLE EAST. IRAN SEEMS CONTENT TO ACCEPT THIS STATUS AND REMAIN ON THE SIDELINES OF THE CONFLICT BETWEEN IRAO AND MOST OF THE REST OF THE HORLD. BY REMAINING IDEAL. IRAN CAN WATCH ITS FORMER ENEMY DEMORALIZED AND NEUTRALIZED AS A REGIONAL POWER; IT CAN WATCH AS SADDAM AND NEUTRALIZED AS A REGIONAL POWER; IT CAN WATCH AS SADDAM HUSSEIN BATTLES THE FORCES THAT CHAMPIONED HIM IN HIS WAR ON IRAN; AND IT CAN CONSOLIOATE ECONOMIC TIES WITH FUNDAMENTALISM THAT IRAN REPRESENTS. IRAN HAS ALREADY BEGUN REPAIRING RELATIONS WITH THE INTERNATIONAL COMMUNITY--TIES NECESSARY FOR THE ECONOMI
POWER IT CLAIMS TO BE.

07363 PLETKA, D. POPULAR AND VULNERABLE INSIGHT, 7(4) (JAN 91), 28-29.

ONCE' THOUGHT TO BE THE MIDDLE EAST'S MOST MODERATE MONARCH, JORDAN'S KING HUSSEIN SEEMS TO HAVE FORSWORN POPULARITY ABROAD IN FAVOR OF POPULARITY AT HOME. HE HAS RALLIED HIS PEOPLE BEHIND HIM AS NEVER BEFORE BY THE EXPEDIENT OF SUPPORTING IRAQ IN ITS WAR WITH THE WORLD. HOWEVER, SOME OBSERVERS SEE HUSSEIN LOSING HIS GRIP ON THE REINS OF POWER. THE PALESTINIANS AND ISLAMIC FUNDAMENTALISTS ARE RESPONSIBLE FOR JORDANIAN POLICY, AT THE EXPENSE OF THE KING AND THE ECONOMY. HOWEVER THE GULF CRISIS ENDS, JORDAN IS LIKELY TO EMERGE A LOSER.

07364 PLETKA, D.

THE ALLIES

INSIGHT 7 (5) (FEB 91), 12-14.

EVER' SINCE PRESIDENT BUSH BEGAN ENLISTING SUPPORT FOR A MULTINATIONAL COALITION TO FORCE IRAQ OUT OF KUWAIT, THERE MULTINATIONAL CDALITION TO FORCE IRAQ OUT OF KUWAIT, THERE DAVE BEEN DOUBTS ABOUT WHETHER IT WOULD HOLD UP. NOW THAT DESERT STORM HAS BEGUN IN EARNEST, AND THE COALITION SEEMS THE BANDHAGON. HOWEVER, SOME ALLIED PARTNERS ARE STILL QUESTIONABLE--NOT FOR THEIR LACK OF BELIEF IN THE EFFORT'S QUESTIONABLE--NOT FOR THEIR LACK OF BELIEF IN THE EFFORT'S GUCCES, BUT FOR THEIR OWH AGENDAS. NOTABLE AMONG THE LATT

07365 PLETKA, D.

THE PAST WEIGHTS HEAVILY

INSIGHT, $7(9)$ (MAR 91), 8-12.

WESTERNERS CONFUSED BY THE ACTIONS OF SOME ARAB LEADERS WOULD DO WELL TO STUDY HISTORY, FOR IN THE MIDDLE EAST THE PAST PERVADES THE PRESENT. MUSLIM LEADERS LONG TO RIGHT THE WRONGS OF THE 2OTH CENTURY--AND TO RELIVE THE GLORIES OF LONG AGO. FROM THE DOMINATION OF THE OTTOMAN EMPIRE TO THE SIX-DAY WAR, PERCEIVED INJUSTICES OF THE PAST FUEL THE FIRE OF TODAY'S HARRIORS. MANY IN THE ARAB WORLD BLAME THE WEST FOR THE CURRENT TURMOIL AND POINT TO THE CREATION OF ISRAEL AS PROOF THAT THE WEST IS OUT TO DESTROY ISLAM.

07366 PLETKA, D.

UNDER THE IRON FIST: INSIDE ASSAD'S SYRIA

INSIGHT, 7(31) (AUG 91), 28-31.

SYRIA'S HAFEZ AL-ASSAD HAS MANAGED, IN THE SPACE OF LESS THAN THREE YEARS, TO IMPROVE RELATIONS WITH THE WEST WHILE AT THE SAME TIME REMAINING A SPONSOR OF INTERNATIONAL TERRORISM, A STOCKPILER OF ARMS RIVALED ONLY BY IRAQ'S SADDAM HUSSEIN AND THE IMPERIAL CONTROLLER OF NEIGHBORING LEBANON. UNOPPOSED AT HOME, ASSAD HAS PROVEN TO BE A MASTER FENCE-STRADOLER AND A OIPLOMAT PAR EXCELLENCE. HIS MOST SUPPORTING SUPPORTING A PEACE PROCESS DESIGNED TO SOLVE THE ARABISRAELI DISPUTE. CRITICS ARE QUICK TO POINT OUT THAT ASSAD
CONTINUES TO CONDONE THE VIOLATION OF BASIC HUMAN RIGHTS AND CONTINUES TO CONDONE THE VIOLATION OF BASIC HUMAN RIGHTS

THAT SYRIA GOT ON THE PEACE BANDWAGON ONLY
CLEAR THAT ISRAEL WOULD REJECT THE PROCESS.

07367 PLETKA, D.

WHO RULES THE ARABS?

INSIGHT, 6(52) (JAN 91), 22-23.

ALTHOUGH FREEDOM HAS BEEN DANGLED BEFORE THE POPULACE OF THE ARAB WORLD, OUT OF A GROUP OF MORE THAN TWENTY NATIONS NOT ONE HAS EMERGED AS A TRUE DEMOCRACY. THE WEALTHY SHEIKDOMS AND POVERTY-STRICKEN DICTATORSHIPS REMAIN POLITICALLY RETROGRADE. RECENT EVENTS HAVE BROUGHT NEH PROMISE, BUT HISTORY CASTS DOUBT ON THEIR VERACITY.

07368 PLIATZKY, L.

QUANGOS AND AGENCIES 
PUBLIC ADMINISTRATION (LONDON), 70(4) (WIN 92), 555-563. AUTONOMOUS NONGOVERMMENTAL ORGANIZATIONS THAT HAVE A ROLE IN AUTONOMOUS NONGOVERNMENTAL ORGANIZATIONS THAT HAVE A ROLE THE PROCESSES OF GOVERNMENT IN THE UNITED KINGDOM NOT GOVERMMENT OEPARTMENTS OR PART OF A GOVERNMENT DEPARTMENT. QUANGOS INCLUDE THREE TYPES OF BODIES: (1) EXECUTIVE BODIES THAT FUNCTION ON THE FRINGES OF CENTRAL
GOVERNMENT AND ARE, IN MOST CASES, ESTABLISHED BY A SPECIFIC GOVERNMENT AND ARE, IN MOST CASES, ESTABLISHED BY A SPECIF
ACT OF PARLIAMENT; (2) ADVISORY BODIES; AND (3) TRIBUNALS.

07369 PLOSS, I.; RUBINSTEIN, J. WATER FOR' PEACE NEH REPUBLIC, 207(11-12) (SEP 92), 20-22.

WATER IS LIKELY TO BE A MAJOR FACTOR IN WHETHER THE MIDEAST EXPERIENCES WAR OR PEACE IN THE FUTURE BECAUSE ISRAEL'S HATER CONSUMPTION EXCEEDS NATURAL REPLACEMENT.

07370 PLOURDE, A.

THE NEP MEETS THE FTA

CANADIAN PUBLIC POLICY--ANALYSE DE POLITIQUES, XVII(1)

(MAR 91) $14-24$

A MUMBER OF PROPONENTS AND OPPONENTS OF THE CANADA-U.S. FREE-TRADE AGGREEMENT (FTA) HAVE ARGUED THAT IT PRECLUDES THE ADOPTION OF ANOTHER NATIONAL ENERGY PROGRAM (NEP). THIS PAPER EXAMINES THE KEY PROVISIONS OF THE NEP IN THE LIGHT OF THE ERENGY-RELATED MEASURES IN THE FTA. IT IS ARGUED THAT THE ERENGY-RELATED MEASURES IN THE FTA. IT IS ARGUED THAT SOME OF THE MOST CONTROVERSIAL MEASURES OF THE NEP (E.G.ं
PRICE CONTROLS, PRODUCTION TAXES, SOME OF THE DISCRIMINATORY PRICE CONTROLS, PRODUCTION TAXES, SOME OF THE DISCRIMIMA ASPECTS OF THE PETROLEUM INCENT IVES PROGRAM) WOULD BE
ALLOWED UNDER THE FTA. OTHER MEASURES (E.G., EXPORT TAXES, ALE ASPECTS OF THE PETROLEUM INCENTIVES PROGRAM THAT OISCRIMINATED ACCORDING TO NATIONALITY OF INVESTOR), HOWEVER, HOULD INDEED BE PROHIBITED UNDER THE FTA.

07371 PLUCHINSKY, $D$

ACADEMIC RESEARCH ON EUROPEAN TERRORIST DEVELOPMENTS ; PLEAS FROM A GOVERNHENT TERRORISM ANALYST

STUDIES IN CONFLICT AND TERRORISM, 1 (1992), 13-24.

THIS ARTICLE EXAMINES THE STATE OF ACADEMIC RESERARCH ON TERRORIST DEVELOPMENTS IN EUROPE. IT ARGUES THAT MORE RESEARCH ARTICLES SHOULD BE AIMED AT THE TERRORISH ANALYST RATHER THAN THE POLICYMAKER. SEVERAL SUGGESTED RESEARCH TOPICS ARE PRESENTED AND AN EXAMINATION OF PROPAGAMDA OUTLETS USED BY EUROPEAN FIGHTING COMMUNIST ORGANIZATIONS IS OFFERED. A PROJECTION IS MADE OF AN INCREASE IN ETHNIC, NEOCOMHUNIST, AND MIDDLE EASTERN TERROISM IN EASTERN EUROPE AND THE FORMER SOVIET UNION. A PLEA IS MADE FOR MORE INTERACTION BETWEEN U.S. GOVERNMENT TERRORISM ANALYSTS AND ACADEMIC BETWEEN U.S. GOVERMMENT TERRORISM ANALYS
RESEARCHERS CONCERNED WITH TERRORISM.

07372 PLUCHINSKY, D.A.; ALEXANDER, Y. (ED.)

AN ORGANIZATIONAL AND OPERATIONAL ANALYSIS OF GERMANY'S AN ORGANIZATIONAL AND OPERATIONAL ANALYSIS OF GERMANY'S RED ARMY FACTION TERRORIST GROUP

BRASSEY'S (US), 1992, 43-92.

THE AUTHOR PROVIDES BRIEF ORGANIZATIONAL AND OPERATIONAL PROFILES OF THE RED ARMY FACTION (RAF)-ONE OF EUROPE'S MOST ENOURING, NOTORIOUS, AND DANGEROUS TERRORIST GROUPS-FOCUSING ON THE DEVELOPMENT AND ACTIVITIES OF THE RAF'S COMMANDO LEVEL. HE INCLUDES AN ANNOTATED CHRONOLOGY OF
SIGNIFICANT RAF COMMANOO-LEVEL OPERATIONS FROM 1972 THROUGH 1991.

07373 PLUCHINSKY, D.A.; ALEXANDER, Y. (ED.) MIDOLE EASTERN TERRORIST ACTIVITY IN WESTERN EUROPE IN THE 1980'S: A DECADE OF VIOLENCE; EUROPEAN TERRORISM: TODAY AND TOMORROH

BRASSEY'S (US), $1992,1-42$.

THE AUTHOR PROVIDES AN OVERVIEN OF MIDDLE EASTERN TERRORIST ACTIVITIES IN WESTERN EUROPE DURING THE 1980'S. HE EXPLAINS WHY MIDOLE EASTERN TERRORISTS ARE ATTRACTED TO WESTERN EUROPE, WAT STATES AND GROUPS ARE RESPONSIBLE FOR THE VIOLENCE, THE LOCATION AND TARGETS OF THE INCIDENTS, AND THE STATED OR SUSPECTED MOTIVES. HE ALSO LOOKS AT INCIDENTS OIRECTED AT U.S. TARGETS, SUCH AS EMBASSIES, IN WESTERM EUROPE.

07374 PLUTZER, E.

PREFERENCES IN FAMILY POLITICS: WOMEN'S CONSCIOUSNESS OR FAMILY CONTEXT?

POLITICAL GEOGRAPHY QUARTERLY, 10(2) (APR 91), 162-173. THIS PAPER CHALLENGES THE PREVAILING VIEHS'THAT HOMEN'S SUPPORT OF FEMINISM IS PRIMARILY A FUNCTION OF PERSONAL SUPPORT OF FEMINISM IS PRIMARILY A FUNCTION OF PERSONAL EXPERIENCES WHICH RESULT IN A TRANSFORMATION OF POLITICAL
CONSCIOUSNESS. RATHER INTERESTS DERIVING FROM FAMILY CONTEXT CONSCIOUSNESS. RATHER INTERESTS DERIVING FROM FAMILY CONTEXT GREATER EXPLANATORY POWER BECAUSE IT GENERALIZED EASILY TO GREATER EXPLANATORY POWER BECAUSE IT GENERALIZED EASILY TO THE STUDY OF MEN;S ATTITUDES AS WELL. AN EMPIRICAL TEST CONFIRMS THE USEFULNESS OF THE APPROACH IN EXPLAINING
SUPPORT OF FEMINIST GOALS IN A SAMPLE OF AMERICAN MEN AND WOMEN. THE PAPER CONCLUDES HITH A DISCUSSION OF THE PARTICULAR SOCIAL OR PSYCHOLOGICAL MECHANISMS WHICH ARE MOST LIKELY TO UNDERLINE THE EMPIRICAL RESULTS.
07375 PODBIELSKI, P

WHENCE SECURITY? POLISH DEFENSE AND SECURITY AFTER THE HARSAW PACT

JOURNAL OF SOVIET MILITARY STUDIES, 5(1) (MAR 92), 97-114. POLAND IS REDEFINING ITS SECURITY OBJECTIVES. IT WANTS TO BE AN ACTIVE MEMBER OF THE EUROPEAN COMMUNITY. THIS ARTICLE IDENTIFIES THE DIRECTION OF CHANGES, SOME COMPLEMENTING PREVIOUS REFORMS, OTHERS REPRESENTING A SIGNIFICANT BREAK WITH THE PAST WITHIN POLAND'S DEFENSE ESTABLISHMENT. IT EXPLORES THE TRANSITION FROM

TOTALITARANISM TO DEMOCRACY, DEFENSE REFORMS, MILITARY EDUCATION, AND THE FACTORS INHIBITING CHANGE. THE CONCLUSION DRAWN IS THAT ECONOMIC AND POLITICAL REFORMS ALONG WITH THE CHANGES DESCRIBED ARE CRUCIAL TO LAYING THE FOUNDATION FOR A DEMOCARTIC TRADITION.

07376 POOEH, E.

THE COLD WAR IN THE MIDDLE EAST: THE WESTERN QUEST FOR A REGIONAL DEFENSE ORGANIZATION, 1945-1953

ORIENT, 33(2) (JUN 92), 265-278.

THIS ARTICLE ATTEMPTS TO DESCRIBE WESTERN INITIATIVES AND ARAB RESPONSES TOWARDS THE CONCEPT OF A MIDDLE EASTERN DEFENSE ORGANIZATION BETWEEN THE YEARS 1945 AND 1953. BRITAIN AND THE UNITED STATES SOUGHT TO ESTABLISH A SECURITY ORGANIZATION UNDER THEIR COMMAND AGAINST THE SOVIET MENACE. THE WESTERN SCHEMES WERE UNDERMINED BY EGYPT'S RESOLUTE REFUSAL TO PARTICIPATE IN A WESTERN-LED PACT BEFORE THE COMPLETION OF BRITISH WITHORAWAL FROM EGYPTIAN SOIL. THE WEST UNHITTINGLY HUMILIATED ARAB STATES AND MOST ARAB LEADERS INSISTED THAT THE DEFENSE OF THE AREA SHOULD BE
UNDERTAKEN BY THE LOCAL INHABITANTS. THE IMPORTANCE OF THESE UNDERTAKEN BY THE LOCAL INHABITANTS. THE IMPORTANCE OF THES
ABORTIVE ATTEMPTS WAS IN LAYING THE FOUNDATIONS FOR THE ABORTIVE ATTEMPTS WAS IN LAYING THE FOUR
FORMATION OF A REGIONAL DEFENSE PACT.

07377 PODES. S.

POLYBIUS AND HIS THEORY OF "ANACYCLOSIS": PROBEMS OF NOT JUST ANCIENT POLITICL THEORY

HISTORY OF POLITICAL THOUGHT, 12(4) (WIN 91), 577-588.

THE AUTHOR IS INTERESTED IN PURSUING THE FOLLONING

QUESTIONS HHICH DO NOT APPEAR TO HAVE BEEN PUT TO THE TEXT

OF POLYBIUS THUS FAR. (1) HOW IS THE MACRO-MACRO LINK PRECISELY TO BE UNDERSTOOD IN POLYBIUS' THEORY OF ANACYCLOSIS? (2) DOES POLYBIUS SUCCEED IN SOLYING THE SPECIAL PROBLEMS THAT RESULT FROM HIS ANSWER TO (1)? THESE QUESTIONS LEAD TO A COMPARATIVE ANALYSIS WHEREBY POLYBIUS' ADRIDGED VERSION IS RANGED AGAINST HIS DETAILED VERSION. THE AUTHOR CONCLUDES THAT APPLYIMG HIS RESEARCH PROGRAM TO THE ANALYSIS OF CONSTITUTIONAL CHANGES MAY PROVE HIGHLY FRUITFUL AND EVEN SUCCEED IN REHABILITATING POLYBIUS' THEORY OF ANACYCLOSIS AT LEAST FOR SINGLE LINKS OF THE GENETIC ANACYCLOSIS AT LEAST
EXPLANATORY CHAIN.

07378 PODHORETZ, J.

THE GROWING OF GEORGE BUSH

MATIOMAL REYIEH, XLIV(21) (NOY 92) 48-51.

THE AUTHOR EXPLAINS WHY GEORGE BUSH CHOSE TRUST AS HIS MAIN THEME FOR THE 1992 PRESIDENTIAL ELECTION CAMPAIGN AND SPECULATES ON HOW A SECOND BUSH ADMINISTRATION WOULD DIFFER FROM THE FIRST.

07379 PODHORETZ, N.

BUCHANAN AND THE CONSERVATIVE CRACKUP

COMMENTARY, 93(5) (MAY 92), 30-34.

UP UNTIL THE RESULTS OF' THE MICHIGAN AND ILLINOIS PRIMARIES IN MARCH, PATRICK J. BUSHANAN WAS REPRESENTED ALMOST EVERYHHERE AS A VERY SUCCESSFUL PROTEST CANDIDATE. HOWEVER, A CAREFUL LOOK AT THE PRIMARY RESULTS REVEALS THAT BUCHANAN ACTUALLY PERFORMED POORLY EVEN WHEN HE WAS THOUGHT TO HAVE DONE WELL. THIS ARTICLE CONCLUDES THAT BUCHANAN'S APPEAL TO REPUBLICAN VOTERS IN GENERAL IS VERY STRICTLY LIMITED. BUT THE NEWS IS WORSE WHEN HIS APPEAL TO CONSERVATIVES IS CONSIDERED. IT ALSO CONCLUDES THAT THE BAD NEWS ABOUT THE BUCHANAN CANDIDACY IS NOT BAD NEWS JUST FOR CONSERVATIVES, AND THAT THE FIGHT NOH BEGINING FOR THE SOUL OF THE CONSERVATIVE MOVEMENT MATTERS A GREAT DEAL FOR EVERYONE ELSE AS HELL.

07380 PODHORTZ, N. AMERICA ÁND ISRAEL: AN OMINOUS CHANGE

COMMENTARY, 93(1) (JAN 92), 21-25.

HAS THERE BEEN A CHANGE IN AMERICAM POLICY TOWARD ISRAEL SINCE THE BUSH ADMINISTRATION TOOK OFFICE? ACCORDING TO THE LINE COMING OUT OF WASHINGTON, NO SUBSTANTIVE CHANGE HAS LINE COMING OUT OF WASHINGTON, NO SUBSTANTIVE CHANGE HAS TAKEN PLACE AT ALL. OFFICIAL STATEMENTS CLAIM THAT THE
UNITED STATES IS STILL COMMITTED TO THE SAME GOALS IT HAS UNITED STATES IS STILL COMMITTED TO THE SAME GOALS IT HAS
ALWAYS PURSUED. NOW, HOWEYER. THE BUSH ADMINISTRATION HAS MOVED WITH UNPRECEDENTED DETERMINATION AND SKILL TO TAKE MOVED WITH UNPRECEDENTED OETERMINATION AND SKILL TO TAKE ADVANTAGE OF IT. THIS ARTICLE EXPLORES THIS CONTROV

CONCLUDES THAT TO FORCE ISRAEL TO HITHDRAH FROM THE
TERRITORIES IN FAVOR OF A NEW PALESTINIAN STATE HOULD BE TERRI TORIES IN FAVOR OF A NEW PALESTINIAN STATE WOULD BE
TANTAMOUNT TO PLACING IT IN MORTAL DANGER AND THAT THAT IS SOMETHING THE AMERICAN PEOPLE WOULD NOT WISH TO DO 
07381 POE, S.

HUMAN RIGHTS AND ECONOMIC AID ALLOCATION UNDER RONALD REAGAN AND JIMMY CARTER

AMERICAN JOURNAL OF POLITICAL SCIENCE, 36(16) (FEB 92), 147-167.

IN THIS STUDY, THE AUTHOR TRIES TO RESOLVE THE HUMAM RIGHTS CONTROVERSY BY SOLVING THE PROBLEMS IDENTIFIED WITH THE CINGRANELLI AND PASOUARELLO STUDY. THE ARTICLE FOCUSES ON AID ALLOCATION TO WESTERN HEMISPHERE COUNTRIES AND TO A SAMPLE OF COUNTRIES FROM AROUND THE WORLD, UNDER BOTH THE CARTER AND THE REAGAN PRESIDENCIES. THE RESULTS INDICATE THAT HUMAN RIGHTS CONSIDERATIONS WERE IMPORTANT IN DETERMINING THE OUTCOMES OF U.S. BILATERAL ECONOMIC AID DECISIONS UNDER BOTH ADMINISTRATIONS AS THEY PERTAIN TO THE DECISIONS UNDER BOTH ADMINISTRATIONS AS THEY PERTAIN TO THE
WESTERN HEMISPHERE REGION AND TO THE WORLD'S NATIONS IN GESTERN

07382 POGREBIN, L.

BEYOND MITZAYIM: EGYPT, ISRAEL, ANO MIDOLE EAST PEACE TIKKUN, 7(6) (NOV 92), 34-38.

EGYPT IS NEVER IRRELEVANT TO THE ARAB HORLD OR THE STATE OF ISRAEL. ESPECIALLY NOW THAT PRIME MINISTER YITZHAK RABIN HAS JUMP-STARTED THE PEACE PROCESS, FRIENDS OF ISRAEL OWE IT TO THEMSELVES TO DECOOE EGYPT'S BEHIND-THE-SCENES ROLE AT THE TALKS AND EXPLORE HER POTENTIAL AS A MEDIATOR WHOSE EFFORTS MIGHT BENEFIT ISRAELI INTERESTS. THIS ARTICLE ASKS WHAT EGYPT'S STAKE IS IN THE PROCESS AND WHAT SHE CAN BE EXPECTED TO ACCOMPLISH.

07383 POGREBIN, L.

SHOULD PROGRESSIVES SUPPORT BILL CLINTON?

TIKKUN, 7(4) (JUL 92), 29-32.

THE AUTHOR OF THIS ARTICLE SEES THE 1992 PRESIDENTIAL ELECTION AS A GOLDEN OPPORTUNITY FOR PROGRESSIVE FORCES TO PUT DIVISIVE AND SELF DESTRUCTIVE POLITICS OF PURISM BEHIND THEM. THE CLINTON CAMPAIGN IS HERALDED AS THE ANSWER TO PROGRESSIVE AIMS AND THE AUTHOR STATES THAT THEY MUST GET INVOLVED, RAISE MONEY, AND GATHER BEHIND THE DEMOCRATIC CANDIDATE.

07384 POGUNTKE, T.

BETWEEN IDEDLOGY AND EMPIRICAL RESEARCH: THE LITERATURE ON THE GERMAN GREEN PARTY

EUROPEAN JOURNAL OF POLITICAL RESEARCH, 21(4) (JUN 92), 337-356.

THE AUTHOR STUDIES THE LITERATURE ON THE GERMAN GREEN PARTY, FOCUSING ON SUCH ASPECTS AS THE FORMATIVE PHASE OF THE MOVEMENT, GREEN PROGRAMMATIC ORIENTATIONS AND FACTIONALISH, THE GREEN SOCIAL BASES, THE PARTY ORGANIZATION,
AND THE PARTY'S LOCATION IN PARTY THEORY.

07385 POGUNTKE, T. GERMANY

EUROPEAN JOURNAL OF POLITICAL RESEARCH, 22(4) (DEC 92 ), 409-416.

THE AUTHOR GIVES POLITICAL DATA FOR GERMANY IN 1991 , INCLUDING THE COMPOSITION OF LAND GOVERMMENTS AND PARTY VOTING STRENGTH IN THE BUNDESRAT.

07386 POGUNTKE, T

UNCONVENTIONAL PARTICIPATION IN PARTY POLITICS: THE EXPERIENCE OF THE GERMAN GREENS

POLITICAL STUDIES, XL (2) (JUN 92), 239-254.

THE GERMAN GREEN PARTY, WHICH IS ONE OF THE MOST SUCCESSFUL GREEN PARTIES IN WESTERN EUROPE, HAS NOT ONLY BEEN EFFICIENT IN CHANGING THE POLITICAL AGENDA OF THE FEDERAL REPUBLIC. IT HAS ALSO CHALLENGED THE CONVENTIONAL WAY OF ORGANIZIMG PARTY POLITICS BY INTITUTIOMAL IZING A SERIES OF ORGANIZATIONAL PRINCIPLES THAT ARE INSPIRED BY THE IDEALS OF GRASS-ROOTS DEMOCRACY. HOHEVER, DESPITE THE IDEALS OF GRASS-ROOTS DEMOCRACY. HOWEVER, DESPITE THE SYPATHIZERS, THE PARTY HAS FAILED TO ATTRACT SUFFICIENTLY LARGE NUMBERS OF ACTIVE PARTY MEMBERS. THE GREENS ARE CAUGHT LARGE NUMBERS OF ACTIVE PARTY MEMBERS. THE GREENS ARE CAUGHT IN A DILEMMA, BECAUSE THEY APPEAL TO THOSE SEGMENTS OF WEST GERMAN SOCIETY WHERE "MON-PARTISANS" ARE MOST NUMEROUS. THIS
UNDERMINES THE FUNCTIONING, AND HENCE THE CREDIBILITY, OF GREEN GRASS-ROOTS DEMOCRACY.

07387 POIRIER, F.

A FRENCH REPUBLICAN VIEW

PARLIAMENTARY AFFAIRS, 45(4) (OCT 92), 669-682.

IT IS DIFFICULT TO' INQUIRE INTO THE DIFFERENCES THAT EXISTS BETWEEN POLITICAL SYSTEMS AND AVOID BOTH UNOERPLAYING THEM OR INFLATING THEM. ANY POLITICAL SYSTEM IS NOT FOUNDED THEM OR INFLATING THEM. ANY POLITICAL SYSTEM IS NOT FOUNDED INTERMAL LOGIC DELIVERING BASICALLY THE SAME GOODS AS IN INTERNAL LOGIC DELIVERING BASICALLY THE SAME GOODS AS IN NEIGHBDRING NATIONS. THIS ARTICLE EXPLORES ASPECTS OF THE ENGLISH AND FRENCH EXPERIENCE, ELECTORAL RITUALS, POLITICAL
PARTIES, AND DEMOCRACY. IT CONCLUDES THAT THOSE HO STUDY FRANCE AMD BRITAIN SENSE THAT THE THO COUNTRIES ARE

RESHAPING THEMSELVES BY BORROWING FROM EACH OTHER.

07388 POKORNY, D.

EFFICIENCY AND JUSTICE IN THE INDUSTRIAL WORLD---VOLUME I:
THE FAILURE OF THE SOVIET EXPERIMENT

M. E. SHARPE, 1993, 400.

IN THE LAST YEARS OF THE SOVIET UNION, WITH REMARKABLE SUDDENNESS, IT BECAME COMMONPLACE TO OBSERVE THAT WHAT THE COUNTRY NEEDED WAS A FREE MARKET, PRIVATE PROPERTY, AND INTEGRATION INTO THE GLOBAL ECONOMY. THIS BOOK CONSIDERS WHY THIS CONSCIOUSNESS AROSE WHEN IT DID. IT ARGUES THAT THE TIME HAS COME TO REFLECT ON WHAT THE EPOCHAL EVENTS OF OUR ERA TEACH ABOUT LARGER QUESTIONS--THE RELATIONSHIP BETWEEN ECONOMY AND SOCIETY, CULTURE AND MARKET. THE AUTHOR CONSIDERS THESE QUESTIONS AND REVISITS THE IDEAS OF CLASSIC AND CONTEMPORARY PHILOSOPHERS IN THE LIGHT OF THE FAILURE OF THE SOVIET ORDER AND THE EXIGENCIES OF POST-SOVIET THE SOVIET ORDER AND THE EXIGENCIES OF POST-SOVIET
TRANSFORMATION. THE AUTHOR ARGUES THAT INTEGRATION IN A POSTTRANSFORMATION. THE AUTHOR ARGUES THAT INTEGRATION IN A POST
INDUSTRIAL GLOBAL ECONOMY ENTAILS PROFOUND CHANGES IN THE INDUSTRIAL GLOBAL ECONOMY ENTAILS PROFOUND CHANGES IN THE
DOMAIN OF PROPERTY RIGHTS, A REDEFIMITION OF THE RELATION DOMAIN OF PROPERTY RIGHTS, A REDEFIMITION OF THE RELATION
BETWEEN EQUITY AND EFFICIENCY, AND A REGROUPING OF NATIONAL BETWEEN EQUITY AND EFFICIENCY, AND A REGROUPING OF NATIONA
CONSCIOUSNESS. THIS VOLUME EXAMINES THE IMPLICATIONS OF THESE DEMANDS FOR POST-SOVIET SOCIETIES.

07389 POLLAK, L.H.

THE LIMITLESS HORIZONS OF BROWN $V$. BOARD OF EDUCATION FORDHAM LAW REVIEW, LXI(1) (OCT 92), 19-22.

THE AUTHOR DISCUSSES THE IMPACT OF BROWN $V$. BOARD OF EDUCATION ON SUPREME COURT JURISPRUDENCE. HE BEGINS BY SUMMARIZING MORGAN V. VIRGINIA, AN IMPORTANT SUPREME COURT DECISION THAT FORESHADOWED THE HOLDING IN BROWN. HE ALSO ASSESSES BROWN'S IMPACT ON FIRST AMENDMENT JURISPRUDENCE AND INTERNATIONAL LAW.

07390 POLNER, M.

THE THREAT OF PEACE

COMMONWEAL, CXIX(9) (MAY 92), 16, 18-19.

FOR DEFENSE CONTRACTORS, THE END OF THE COLD WAR WILL GRADUALLY BRING AN END TO THE SYSTEM UNDER WHICH THEY OPERATED WITH ALMOST NO MARKET COMPETITION, WITH GUARANTEED PROFITS, AND LITTLE CONCERN FOR COST CONTAINMENT,

MANUFACTURED PRODUCTS WITH LITTLE OR NO ECONOMIC UTILITY

THAT WERE SELDOM PUT TO USE. EARNED FABULOUS SUMS. AMD CREATED MANY JOBS. UNDER THE CUTBACKS THAT ARE SURE TO COME, MANY MILITARY BASES AND AIRFIELDS WILL BE CLOSED OVER THE NEXT FIVE OR SIX YEARS, AND COMMUNITIES CONDITIONED TO LIVING OFF MILITARY PAYCHECKS MAY FIND THEMSELVES IN TROUBLE. A HALF-MILLION TROOPS WILL BE DISCHARGED FROM THE MILITARY BY 1996, INCLUDING MANY MINORITY SOLDIERS WHO SAH MILITARY SERVICE AS A SOURCE OF STABLE EMPLOYMENT AND SECURE FUTURES. AND WHAT THE FEDERAL GOVERMMENT'S RESPONSE SHOULD BE.

07391 POLNER, M. WILL JOBS GO SOUTH? COMMONWEAL, CXIX(18) (OCT 92), 5-6.

THE NORTH AMERICAN FREE TRADE AGREEMENT (NAFTA) THREATENS THE JOBS OF HUNDREDS OF THOUSANDS OF AMERICAN WORKERS WHILE IT GRANTS UNELECTED GOVERMMENT BUREAUCRATS IN CANADA, MEXICO, AND THE UNITED STATES THE RIGHT TO OVERRIDE ANY FEDERAL OR STATE LAH THEY DEEM INCOMPATIBLE WITH THE TREATY. ESSENTIALLY, NAFTA IS A MULTI-NATIONAL CORPORATION'S ANTI-UNION AND ANTI-ENVIRONMENTALIST DREAM PACT BECAUSE THESE VAST INTERNATIONAL FIRMS WILL BE ABLE TO MINIMIZE THEIR COSTS AND MAXIMIZE THEIR PROFITS AS THEY MOVE FROM COUNTRY-TO-COUNTRY IN SEARCH OF LOWER TAXES AND CHEAPER LABOR, IMPOTENT UNIONS, AND COOPERATIVE THIRD-WORLD POLITICIANS.

07392 POLOMKA, P.

EAST ASIAN SECURITY IN A CHANGING WORLD: JAPAN'S SEARCH FOR A "THIRD WAY"

KOREAM JOURNAL OF DEFENSE ANALYSIS, IY(2) (WIN 92), 71-94. THE RAPIDLY CHANGING GEOPOL ITICAL AND ECOMOMIC CONDITIONS IN THE HORLD HAVE CAUSED JAPAN TO RETHINK ITS FOREIGN POL ICY SOME IN JAPAN ARE SEARCHING FOR A "THIRD WAY" BETWEEN THE MERCHANT STATE THAT JAPAN HAS BEEN, AND THE "NORMAL" POL ITICAL-MILITARY POHER OF CONTEMPORARY TIMES. IN SHORT, JAPAN IS SEARCHING FOR ACCEPTANCE AS A NORMAL MEMBER SHORT, JAPAN IS SEARCHING FOR ACCEPTANCE AS A NORMAL MEM
OF THE INTERMATIONAL COMMUNITY, BUT ALSO AS ONE WHICH

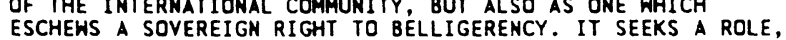
ESCHEWS A SOVEREIGN RIGHT TO BELLIGERENCY. IT SEEKS A ROL
ACCEPTABLE TO ITS PEOPLE, THAT SUSTAINS JAPAN'S DOMESTIC ACCEPTABLE TO ITS PEOPLE, THAT SUSTAINS JAPAN'S DOMEST
COHESION AND SAFEGUARDS ITS SECURITY, REASSURES ITS NEIGHBORS OF ITS PEACEFUL INTENTIONS, AND MAKES AN HONORABLE CONTRIBUTION TO THE INTERMATIONAL COMHON GOOD. THIS PAPER CONTRIBUTION TO THE INTERNATIONAL COMHON GOOD. THIS PAPER
EXAMINES WAYS IN WHICH THE UNITED STATES, ALONG WITH OTHER EXAMINES WAYS IN WHICH THE UNITED STATES, ALONG WITH OTHER
ASIAN POWERS--CHINA, RUSSIA, THE KOREAS--CAN SUPPORT JAPAN ASIAN POWERS--CHINA, RUSSIA, THE KOREAS--CAN SUPPORT JAPAN IN ITS SEARCH. IT CONCLUDES THAT A THO-PRONGED APPROACH NECESSARY: A NEW REGIONAL FORUM WHICH CAN IDENTIFY AND
ADORESS ISSUES OF COMMON SECURITY CONCERN; AND A RESHAPING ADORES ISSUES OF COMMON SECURITY CONCERN; AND A RESHAPING OF THE U.S.-JAPAN ALLIANCE INTO A MATURE RELATIONSHIP, BASED AUTONOMY IT NEEDS TO ASSUME A GREATER ROLE IN WORLD AFFAIRS.

07393 POMAR, M.

THE ROLE OF INFORMAL GROUPS AND INDEPENDENT ASSOCIATIONS

IN THE EVOLUTION OF CIVIL SOCIETY IN THE SOVIET UNION NATIONALITIES PAPERS, 18(2) (FAL 90), 50-55. 
THIS ARTICLE DISCUSSES FIRST THE CONDITION OR SITUATION OF INFORMAL GROUPS WITHIN THE SOVIET UNION AND, IN PARTICULAR, THE RUSSIAN GROUPS. THE SECOND PARI OF THE ARTICLE INVESTIGATES WHAT THESE INFDRMAL GROUT ABOUT THE DIRECTIONS OF SOVIET DEVELOPMENT.

07394 POMPER, G.

PARTY ORGANIZATION AND ELECTORAL SUCCESS

POLITY, XXIII(2) (WIN 90), 187-206.

AT ONE TIME, THE LITERATURE OF THE FIELD OF POLITICS ATTRIBUTED ALMOST UNBOUNDED POWER TO PARTY ORGANIZATIONS, PARTICULARLY THE DISTINCTIVE FORM OF PARTY ORGANIZATION KNOWN AS THE MACHINE. HOWEVER, RECENT WRITINGS HOTLY DISPUTE THIS VIEW. PART OF THE APPARENT CONTRADICTION MAY BE DUE TO
ACTUAL CHANGE IN THE STRENGTH OF THE PARTIES OVER TIME, BUT MUCH IS ALSO DUE TO A LACK OF CONSENSUS ON WHAT, SPECIFICALLY, CONSTITUTES A HEAL THY, FUNCTIONING PARTY. THIS ARTICLE EXPLORES SUCCESS, EXAMINES THE WAY IN WHICH THIS SUCCESS HAS BEEM MEASURED AMD SUGGESTS SOME DIFFERENT AMD USEFUL MEASURES OF PARTY SUCCESS.

07395 POMPER, G.M.

CONCEPTS OF POLITICAL PARTIES

JOURAAL OF THEORETICAL POLITICS (2) (APR 92) 143-159.

OURAL OF THEORETICAL POLITICS, 4(2) (APR 92), 143-159. THEIR RELATIONSHIP TO DEMOCRATIC PHILOSOPHY, WITH PRIMARY THEIR RELATIONSHIP TO DEMOCRATIC PHILOSOPHY, WITH PRIMARY ATTENTION TO NORMATIVE RATHER THAN EMPIRICAL MODELS. HE DEVELOPS THREE DICHOTOMOUS, ANALYTICAL DIMENSIONS: THE
PARTIES' ELITE OR MASS FOCUS, THE COLLECTIVE OR COALITIONAL GOALS, AND THE INSTRUMENTAL OR EXPRESSIVE MODE. COMBINING THESE DIMENSIONS PRODUCES EIGHT ABSTRACT PARTY CONCEPTS, EACH IDENTIFIED WITH PARTICULAR THEORISTS AND PRACTITIONERS. THESE CONCEPTS PORTRAY PARTY AS ONE OR MORE OF THE FOLLOWING GOVERNING CAUCUS, CAUSE ADVOCATE, IDEOLOGICAL COMMUNITY SOCIAL MOVEMENT, BUREAUCRATIC ORGANIZATION, RATIONAL TEAM OF OFFICE SEEKERS, URBAN MACHINE, AND PERSONAL COALITION. IN AN ANALYSIS OF DEMOCRATIC THEORY, PARALLEL DIMENSIONS ARE DEVELOPED: THE ACCESSIBILITY OF LEADERSHIP, VOTER GOALS, AND THE CHARACTER OF POPULAR PARTICIPATION. PARTICULAR KINDS OF PARTIES ARE ASSOCIATED WITH THESE DIFFERENT CONCEPTS OF DEMOCRACY AND WITH PARTICULAR FORMS OF GOVERNMENT.

07396 POND, E. GERMANY IN THE NEW EUROPE

FOREIGN AFFAIRS, 71(2) (SPR 92), 114-130.

GERMANY'S LIGHTNING UNIFICATION HAS BEEN A CATALYST FOR EUROPE. IT HAS GIVEN URGENCY TO WEST EUROPEAN INTEGRATION AS THE ONLY WAY TO PROVIDE NEIGHBORS WITH LEVERAGE OVER THE NEH GERMAN COLOSSUS. IT HAS COMBINED WITH PLANS FOR EUROPE 1992 TO REVIVE A OYNAMISM THAT THE CONTINENT HAD LOST TO THE USA TO REVIVE A DYNAMISM THAT THE CONTINENT HAD LOST TO THE
AND THE USSR. FURTHERMORE. IT HAS PAVED THE WAY FOR THE AND THE USSR. FURTHERMORE, IT HAS PAVED THE WAY FOR THE REENTRY OF EASTERN EUROPEAN INTO EUROPE PROPER, AND IT HAS
CLARIFIED THE EVENTUAL TERMS FOR ANY ENTRY INTO EUROPE BY CLARIFIED THE
THE RUSSIA.

07397 PONGSSUDHIRAK, J.

AVOID THE 18TH COUP

FAR EASTERN ECONOMIC REVIEH, 151(14) (APR 91), 18

THE 23 FEBRUARY COUP IN THAILAND HAS SEVERELY UNDERMINED ALL THAT HAD BEEN ACCOMPLISHED UNDER THE BANNER OF SO-CALLED THAI-STYLE DEMOCRACY, WHERE A PLURALISTIC POL ITICAL SYSTEM PRECARIOUSLY ACCOMMODATED THE INSTITUT IONAL INTERESTS OF THE MILITARY. AN ELECTED ASSEMBLY, A MONARCHY, A PROLIFERATING MIDOLE CLASS AND THE BUSINESS COMMUNITY. IF THE FUTURE GOVERMMENT IS TO REVERSE THE TREND OF CHANGING GOVERNMENT BY MILITARY COUPS, CONSTITUTIONAL REFORMS, IMMEDIATE GESTURES OF SINCERITY, AND EFFORTS TO DIVIDE AND CO-OPT THE MILITARY ARE REQUIRED:

07398 PONTUSSON, J.

AT THE END OF THE THIRD ROAD: SWEDISH SOCIAL DEMOCRACY IN CRISIS

POLITICS AND SOCIETY, 20(3) (SEP 92), 305-332.

IN 1991 THE SWEDISH SOCIAL DEMOCRATS SUFFERED AN UNPRECEDENTED ELECTORAL DEFEAT. AFTER DECADES OF SOCIAL DEMOCRATIC RULE, VOTERS BROUGHT IN A COALITION GOVERNMENT COMMITTED TO FAR-REACHING REFORMS OF THE WELFARE STATE. THIS ARTICLE FOCUSES ON A PARTICULAR DIMENSION OF THE CRISIS OF SHEDISH SOCIAL DEMOCRACY: THE FAILURE OF THE ECONOMIC RECOVERY STRATEGY PURSUED BY THE SOCIAL DEMOCRATS IN THE 1980S, COMMONLY KNOWN IN SWEDEN AS "THE THIRD ROAD." THERE CAN BE LITTLE DOUBT THAT ECONOMIC ISSUES WERE THE PRIMARY CONCERN OF VOTERS IN 1991. THIS ARTICLE ENTERTAINS TWO CONCERN OF VOTERS IN 1991. THIS ARTICLE ENTERTAINS THO DEMOCRATIC ECDNOMIC MANAGEMENT IN THE 1980S. THE FIRST INTERPRETATION HOLOS THAT THE SOCIAL DEMOCRATS MADE INTERPRETATION HOLDS THAT THE SOCIAL DEMOCRATS MADE STRATEGIC CHOICES THAT WEAKENED THE LABOR MOVEMENT, AND THUS UNDERMINED THEIR OWN POLITICAL BASE. THE THIRD ROAD FROM THE SOCIAL DEMOCRATS' TRADITIOHAL APPROACH TO MACROECONOMIC POLICY, THE REHN-MEIDNER MODEL, AND FAILED FOR REASONS THAT CONFORMED TO THE LOGIC OF THIS MODEL. THE SECDND INTERPRETATION HOLDS THAT THE FAILURE OF SOCIAL DEMOCRATIC ECONOMIC MANAGEMENT ULTIMATELY DERIVES FROM LONGTERM CHANGES IN THE STRUCTURE OF SWEDISH INDUSTRY AND THE
DYNAMICS OF INTERMATIONAL COMPETITION.

07399 POOL, J.

THE MULTILINGUAL ELECTION PROBLEM

JOURNAL OF THEORETICAL POLITICS, 4(1) (JAN 92), 31-52.

MUTLILINGUAL ELECTIONS MAY DEMOCRAT I CALLY ENFRANCHISE

LINGUISTIC MINORITIES OR MAY PROMOTE EXTREMIST

UNCOMPROMISING, CLIENTELISTIC, AND INEFFICIENT POLITICS. ONE THEORETICAL APPROACH TO THIS ISSUE EXTENDS EXISTING SPATIAL MODELS OF ELECTIONS, ALLOWING CANDIDATES TO STATE DIFFERENT POSITIONS IN DIFFERENT LANGUAGES AND ASSUMING THAT LANGUAGE BARRIERS GIVE VOTERS INCOMPLETE INFORMATION ABOUT THE POSITIONS STATED IN THEIR NON-NATIVE LANGUAGES. IN A SIMPLE MODEL OF MULTILINGUAL CAMPAIGNING, UNDER SOME CONDITIONS, CANDIDATES CAN STATE DIFFERENT POSITIONS IN DIFFERENT LANGUAGES SO THAT EVERY VOTER AGGREGATES THE POSITIONS INTO A PERCEPTION COINCIDING EXACTLY WITH THE VOTER'S OWN POSITION. TO DO THIS, CANDIDATES MUST CHOOSE POSITIONS MORE EXTREME THAN THE POSITIONS OF THE RESPECTIVE AUDIENCES. AS GROUPS GAIN MULTILINGUAL FLUENCY, CANDIDATE EXTREMISM FURTHER INCREASES. EXTREMISM IS VOTE-MAXIMIZING UNLESS FURTHER INCREASES. EXTREMISM IS VOTE-MAXIMIZING VOTERS SUFFICIENTLY PENAL IZE INCONSISTENCY. WHEN
INCONSISTENCY IS IMPORTANT ENOUGH, CANDIDATES CONSISTENTLY INCONSISTENCY IS IMPORTANT ENOUGH, CANDIDATES CONSISTENTLY
TAKE THE POSITION OF THE LARGER GROUP IN THO-GROUP ELECTIONS TAKE THE POSITION OF THE LARGER GROUP IN THO-GROUP ELECT AND OF THE II

07400 POOLE, R.W. JR.

DEREGULATION: FINISHING THE JO

NATIONAL REVIEW, XLIV(21) (NOV 92), 25-29.

FOURTEEN YEARS AFTER AIRLINE DEREGULATION BEGAN IN THE UNITED STATES, IT HAS MORE CRITICS THAN SUPPORTERS. EVEN SOME CONSERVATIVES HAVE ADVOCATED RE-REGULATING THE AIRLINES. BUT THE ANSWER IS NOT TO ABANDON DEREGULATION; IT IS TIME TO FINISH WHAT CONGRESS STARTED.

07401 POORSOLTAN, $K$.

CHINA DEBATES CAPITALISM

CONTEMPORARY REVIEW, 261(1518) (JUL 92), 1-12.

CHINA, LONG BEFORE THE SOVIET UNION AND THE EASTERN EUROPEAN COUNTRIES, INITIATED ITS OWN VERSION OF PERESTROIKA. THE PURPOSE OF THIS CHANGE WAS USING ECONOMIC AND LEGAL MEANS TO CONTROL THE ECONOAY INDIRECTLY, WHICH WAS A GREAT DEPARTURE FROM CONTROLLING THE ECONOMY THROUGH ADMINISTRATIVE DIRECTIVES. AT THE END OF 1991, CHINA HAD ACCUMULAIED 13 YEARS OF EXPERIENCE. DURING THOSE YEARS A GREAT NUMBER OF POLICIES WENT INTO EFFECT. THE RESULTS CAME TO BE A BITERSHEET LEGACY. THE LESSONS LEARNED FROM THIS TO BE A BITTERSWEET LEGACY. THE LESSONS LEARNED FROM THIS EXPERIENCE ARE EYE OPENING FOR BOTH SOCIALIST

07402 POPE, $H$

AZERBAIJAN--THE FRONT WINS THROUGH

MIDDLE EAST INTERNATIONAL, (427) (JUN 92), 12-13.

THE RELENTLESS MARCH TO POWER IN AZERBAI JAN OF THE PROTURKISH POPULAR FRONT ENTERED ITS FINAL STAGE WITH AM ELECTION FOR A NEW PRESIDENT ON 7 JUNE. FRONT LEADER ABDULFEZ ELCHIBEY SEEMS ON COURSE TO WIN WITH ABOUT 60 PERCENT OF THE VOTE. THE GRADUAL COLLAPSE OF SOVIET POWER IN THIS REMOTE CAUCASUS STATE OF SEVEN MILLION HAS TAKEN AN ERRATIC AND OFTEN BLOODY COURSE. THE FRONT HAS OFTEN SPLINTERED AND WEAKEKED BUT ITS MEMBERS HAVE NEVER WAVERED IN THEIR STRUGGLE FOR AN INDEPENDENT AZERBAI JAN. IF ELCHIBEY'S WIN IS CONFIRMED, HE PROMISES HUMAN RIGHTS, DEMOCRACY, RESPECT FOR LAH AND NEW PARLIAMENTARY AND LOCAL ELECTIONS. THE NEW ASSEMBLY WILL BE CHARGED WITH DRAWING UP A NEW CONSTITUTION FOR THE COUNTRY. INTERNATIONALLY HE WILL TAKE AZERBAIJAN DUT OF ITS PARTICIPATION IN THE COMMONWEALTH OF INDEPENDENT STATES. HE WILL ALSO PRESS FOR CLOSER RELATIONS WITH TURKEY AND THE UNITED STATES, INCLUDING, IF POSSIBLE, A NEW DEFENSE RELATIONSHIP.

07403 POPE, $\mathrm{H}$

GOLDEN FUTURE?

MIDDLE EAST INTERNATIONAL, (395) (MAR 91), 19.

PRESIDENT TURGUT OZAL'S PROMISES OF A GOLDEN FUTURE FOR TURKEY AFTER THE GULF CRISIS ARE ABOUT TO FALL DUE, BUT WHILE THERE IS HOPE FOR THE ECONOMY, THERE IS LITTLE SIGN YET THAT HIS MUCH-VAUNTED REGIONAL ROLE IS GOING TO AMOUNT TO VERY MUCH. TURKEY'S NAME HAS BEEN OMINOUSLY ABSENT FROM MUCH SCENARIO SPECULATION NOT DIRECTLY AIMED IN ANKARA'S MUCH SCENARIO SPECULATION NOT DIRECTLY AIMED IN ANKARA'S
DIRECTION. TURKEY SEEMS TO FALL BETWEEN THO CAMPS: AN EGYPTDIRECTION. TURKEY SEEMS TO FALL BETHEEN THO CAMPS: AN EGYPT
SYRIA-GCC FRONT ON THE ONE HAND AND A NEW EUROPE-DOMINATED SYRIA-GCC FRONT ON THE ONE HAND AND A NEW EUROPE-DOMINATED NATO ON THE OTHER. THAT MAY LEAVE ANKARA WITH NO CHOI ALLIANCES WITH THE UNITED STATES.

07404 POPE, $H$

HEAT ON THE PKK

MIDDLE EAST INTERNATIONAL, (379) (APR 91), 6-7.

IN RESPONSE TO SADDAM HUSSEIN'S HARSH MILITARY OFFENSIVE, TENS OF THOUSANDS OF KURDS WERE PRESSING AGAINST THE IRAQI TURKISH BORDER, BEGGING TO BE LET IN. IT WAS A TRAGIC REVERSAL FOR THE KURDS AND PROBABLY SOUNDED THE DEATH KNELL 
FOR TURKISH PRESIDENT TURGUT OZAL'S NEH POLICY OF KURDISH LIBERALIZATION, ALREADY ONLY HALF-HEARTEDLY IMPLEMENTED IN A COUNTRY A WHERE THE TURKISH REPUBLICAN ESTABLISHMENT FEELS DEEPLY THREATENED BY EVEN A WHIFF OF CONCESSION. TURKEY'S SEPARATIST GUERRILLAS, THE KURDISH WORKERS PARTY (PKK) ARE ALSO FEELING THE HEAT AS THEY LOSE SUPPORTERS IN MILITARY CONFLICTS AND FACTIONAL SOUABBLES.

07405 POPE, H.

IRAQI KURDISTAN: ONSLAUGHT AGAINST THE PKK

MIDOLE EAST INTERNATIONAL, 436 (OCT 92) 11-12.

THE IRAQI KURDS' ONSLAUGHT AGAINST THE KURDISTAN HORKER

PARTY (PKK) CONTINUED IN NORTHERN IRAQ, WEAKENING BUT

PARTY (PKK) CONTINUED IN NORTHERN IRAQ, WEAKENING BUT
APPARENTLY NOT YET BREAKING THE BACK OF THE PKK'S HARDENED

AUERRILLAS. THE PKK HAVE BUILT THEMSELVES INTO A MAJOR FORCE

GUERRILLAS. THE PKK HAVE BUIL THE PAST 18 MONTHS, HITTING AN ARMAMENTS JACKPOT IN

NORTHERN IRAO AFTER THE GULF WAR AND SETTING UP BASES IN

NORTHERN IRAQ AFTER THE GULF WAR AND SETTING UP BASES IN REMOTE MOUNTAIN BORDER REGIONS WHERE THE IRAQI KURDS DID NOT
HAVE THE STRENGTH TO INTERFERE. THIS REPORT DETAILS SEVERAL HAVE THE STRENGTH TO INTERFERE. THIS REPORT DETAILS SEVERAL REASD
PKK.

07406 POPE, H.

THE KURDS--ALLIES LEAVE, FIGHTING RESUMES

MIDDLE EAST INTERNATIONAL, (405) (JUL 91), 10-11.

THE WESTERN ALLIES WITHOREH THEIR LAST'PERMANENT FORCES FROM NORTHERN IRAO ON 15 JULY, PROUD OF THEIR ACCOMPLISHMENTS IN THE KURDISH EMERGENCY BUT LEAVING BEHIND THEM A RAGED END OF UNCERTAINTY AND FEARS OF VIOLENCE. ONE OUTBREAK OF VIOLENCE CLOSE TO THE IRANIAN BORDER LEFT AT LEAST DOZENS DEAD AND MORE WOUNDED. DISPUTES BETHEEN THE WESTERN ALLIES AND TURKEY HAYE HAMPERED THE ESTABLISHMENT OF CLEAR CONDITIONS FOR AMY FUTURE INTERVENTION IN THE KURDS' BEHALF. MANY KURDS STILL DEEPLY FEAR THE EVENTUAL RETURN OF SADDAM'S GOVERMMENT.

07407 POPE, H.

TURKEY-ALL EYES ON THE CAUCASUS

MIDDLE EAST INTERNATIONAL, (421) (MAR 92), 9-10.

A HUGE EARTHQUAKE IN TURKEY ON 13 MARCH LEFT SOME 370 PEOPLE DEAD. THE DISASTER AVERTED (FOR THE MOMENT AT LEAST) TURKISH ATTENTION AWAY FROM TWO CONFLICTS: THE FIGHTING TURKISH ATTENTION AWAY FROM TWO CONFLICTS: THE FIGHTING
BETHEEN ARMENIA AND AZERBAIJAN OVER THE ENCLAVE OF NAGORNYBETHEEN ARMENIA AND AZERBAI JAN OVER THE ENCLAVE OF NAGORNY-
KARABAKH, AND GROWIHG CLASHES BETWEEN KURDS AND THE TURKISH KARABAKH, AND GROWING CLASHES BETWEEN KURDS AND THE TURKISH MILITARY IN SOUTH-EAST TURKEY. BEFORE THE EARTHQUAKE POPULAR
PRESSURE TO CONYINCE THE GOVERMMENT TO TAKE MILITARY ACTION PRESSURE TO CONVINCE THE GOVERNMENT TO TAKE MILITARY ACTION AGAINST BOTH THE ARMENIANS AND THE KURDS WAS RESISTED BY PRESSURE WOULD SOON BE TOO STRONG TO RESIST.

07408 POPE, H.

TURKEY-MISSION TO CENTRAL ASIA

MIDDLE EAST INTERNATIONAL, (425) (MAY 92), 11-12

A WEEK-LONG TOUR OF CENTRAL ASIA AND AZERBAIJAN BY TURKISH PRIME MINISTER SULEYMAN DEMIREL IN EARLY MAY HAS MARKED THE HIGH POINT OF TURKEY'S ATTEMPTS TO JOIN IN SPIRIT AT LEAST THE SIX NATIONS OF THE WORLD HHOSE 100 MILLION PEOPLE SPEAK A TURKIC LANGUAGE. THE VISIT SHOWS THAT TURKS FEEL A GENUINE MISSION TO HELP THEIR LONG-LOST CENTRAL ASIAN COUSINS. DURING HIS TOUR, DEMIREL PLEDGED ABOUT \$1.2-BILLION WORTH OF AID. ABOUT \$600-MILLION WAS OFFERED IN SOFT LOANS FOR WHEAT AND SUGAR AND \$600-MILLION IN TURKISH EXIMBANK EXPORT GUARANTEES WHOSE USE WILL BE AGREED BY JUNE FOR IMPORTS FROM TURKEY, CONSTRUCTION AND INVESTMENT. WHILE ECONOMIC TIES ARE BEGINNING TO BE FORMED BETWEEN TURKEY AND CENTRAL ASIA, POLITICAL COOPERATION IS HAMPERED BY THE TO BE THE SPIRITUAL LEADER OF THE ISLAMIC REPUBLICS.

07409 POPE, H.

TURKEY--TREADING SOFTLY ON ARMENIA

MIDOLE EAST INTERNATIONAL, (426) (MAY 92), 13-14 TURKEY HAS FINALLY BEGUN TO GARNER SOME FRUIT FROM ITS DIPLOMATIC CAMPAIGN TO BLOCK ARMENIA'S ADVANCES IN THE CAUCASUS, ALTHOUGH STILL BARELY ENOUGH TO STAY GROWING PRESSURE' AT HOME TO THREATEN MILITARY INTERVENTION. SHARP STATEMENTS FROM NATO AND THE COUNCIL FOR SECURITY AND COOPERATION IN EUROPE (CSCE) HAVE CALLED FOR ARMENIA'S WITHDRAWAL TO INTERNATIONAL BOUNDARIES. HOWEVER, HOPES OF WITHDRAWAL TO INTERNATIONAL BOUNDARIES. HOWEVER, HOPES OF
ENDING FOUR YEARS OF THE WORST CONFLICT TO ACCOMPANY THE ENDING FOUR YEARS OF THE HORST CONFLICT TO ACCOMPANY
BREAK-UP OF THE SOVIET UNION MAY STILL BE PREMATURE, BREAK-UP OF THE SOVIET UNION MAY STILL BE PREMATURE,

ESPECIALLY SINCE THERE IS LITTLE S
COMPROMISE FROM THE ARMENIAN CAMP.

07410 POPE, H.

TURKEY-TRIAL OF STRENGTH WITH THE PKK

MIDOLE EAST INTERMATONAL (422) (APR 92), 10-11. CONFUSION AND WORRY ARE DIVIDING THE TURKS AFTER AN UNPRECEDENTED BOUT OF BLOODSHED DURING THE LATEST AND MOST POWERFUL SHOW OF KURDISH NATIONALISM DURING NAWRUZ, THE KURDISH NEW YEAR. TURKEY'S NATO ALLIES ARE ALSO DIVIDED ON THEIR RESPONSE TO THE NAWRUZ FIGHTING, DURING WHICH ABOUT 70 PEOPLE DIED, MOSTLY KURDISH CIVILIANS CAUGHT IN THE CROSSFIRE BETHEEN SECURITY FORCES AND THE KURDISH PEOPLE'S
PARTY (PKK) GUERRILLAS. GERMANY LED A GROUP OF EUROPEAN STATES THAT CONDEMNED TURKEY AND BLOCKED ARMS SUPPLIES BRITAIN, SPAIN AND THE NETHERLANDS KEPT THEIR OWN COUNSEL, WHILE THE U.S. STOOD SOUARELY BEHIND TURKEY. THE FIGHTING WAS AN INDICATION OF THE GROHING NUMBERS AND APPEAL OF THE PKK, WHICH HAS CURRENTLY BECOME THE PRINCIPAL REPRESENTATIVE OF THE RISING NATIONAL CONSCIOUSNESS OF THE KURDS. THE PKK CAN ALREADY CLAIM THAT IT IS RESPONSIBLE FOR FORCING TURKEY'S RECOGHITION OF THE KURDISH PROBLEM AFTER 70 YEARS IN WHICH IT WAS DENIED AND THEIR LANGUAGE BANNED. NOW, HITH 3,000 ARMED GUERRILLAS IN SOUTHEAST TURKEY AND WIDESPREAD SUPPORT AMONG KURDS ACROSS THE COUNTRY. THE PKK POSES A SUPPORT AMONG KURDS ACROSS THE COUNTRY, THE PKK POSES A USING CURRENT POLICIES.

07411 POPE, H.

TURKEY, IRAO AND THE KURDS--BACK TO THE OLD ALLIANCE?

MIDDLE EAST INTERHATIONAL, (430) (JUL 92), 14.

TURKEY, A PASSIVE BUT IMPORTANT ALLY IN THE ANTI-IRAO COALITION DURING THE GULF CRISIS, NOW HAS A DIFFERENT GOVERNMENT AND NEW POLICIES DRIVEN BY AN INCREASING FEAR OF THE KURDISH ENTITY THAT HAS EMERGED IN NORTHERN IRAQ. THERE IS NO QUESTION THAT TURKEY'S FOREIGN MINISTRY AND MILITARY HAWKS ARE ONCE AGAIN ASCENDANT, INFLUENCING PRIME MINISTER SULEYMAN DEMIREL WITH A HARDLINE VIEW OF THE NEED TO RENEW THE TRADITIONAL REGIONAL ALLIANCES AS SADOAM HUSSEIN LOOKS MORE FIRMLY ENTRENCHED IN BAGHDAD. THE TENTATIVE OVERTURES MADE TOWARDS THE KURDS BY PRESIDENT TURGUT OZAL HAVE BEEN REPLACED WITH A POLICY OF GRANTING THE MILITARY A FREE HAND IN VIOLENTLY REPRESSING ANY KURDISH MOVEMENTS IN TURKEY. AS OF JULY 1992, NEARLY 1,000 PEOPLE HAVE BEEN KILLED IN CONFLICTS BETWEEN THE TURKISH MILITARY AND KURDISH GROUPS. THE PLIGHT OF THE KURDS IS HORSENED BY IRAQ'S GROWING RESISTANCE TO UNITED NATIONS RELIEF EFFORTS. THERE ARE GROWING DOUBTS ABOUT THE SURVIVAL PROSPECT OF THE KURDS AS THEY FACE ANOTHER WINTER OF DOUBLE BLOCKADE: BAGHDAD'S STRANGLEHOLD INSIDE IRAO AND THE OFFICIAL UN SANCTIONS FROM WITHOUT.

07412 POPE, H.

TURKEY, SYRIA AND IRAN: COMBINING AGAINST THE KURDS

MIDDLE EAST INTERNATIONAL, 438(438) (NOV 92), 11-12. GLOSSING OVER THEIR OLD RIVALRIES, TURKEY, IRAN, AND SYRIA HAVE SAID THEY WILL COOPERATE AGAINST KURDISH SELFDETERMINIATION IN NORTHERN IRAO IN A STATEMENT MADE AFTER AN UNUSUAL MEETING IN THE TURKISH CAPITAL. THE STRONGEST STATEMENT CALLED THE EMERGENCE DF A FEDERAL STATE OF KURDISTAN IN NORTHERN IRAQ CHAOTIC WITHOUT RESPONSIBLE GOVERNMENT, AND A THREAT TO ALL THREE COUNTRIES' NATIONAL GOVERNMENT, AND A THREAT TO ALL THREE COUNTRIES NATIONAL SECURITY, TURKEY, SYRIA, IRAN, AND IRAQ ALL HAVE LARGE NORTHERN IRAQI KURDS' SUCCESS IN SELF-GOVERMMENT.

07413 POPE, H.

TURKEY: DIGGING INTO IRAQ

MIDOLE EAST INTERNATIONAL, (437) (NOV 92), 4.

AT LEAST 15,000 TURKISH TROOPS HAVE ADVANCED INTO NORTHERN IRAQ, CLEARING A WIDE AREA THAT DIPLOMATS SAY MAY TURN INTO A "SECURITY ZONE" LIKE ISRAEL ESTABLISHED IN SOUTH LEBANON. HOWEVER, SOME TURKISH OFFICIALS MAINTAIN THAT THE OFFENSIVE, WHICH STARTED IN MID-OCTOBER 1992, IS A HIT-ANDRUN RAID THAT WILL BE TERMINATED WHEN TROOPS SUPPORTING THE REBEL KURDISTAN HORKERS' PARTY (PKK) ARE WIPED OUT.

NEVERTHELESS, THE TURKISH ARMED FORCES ARE MAKING WINTER PREPARATIONS AND MOST TURKISH LEADERS SEE THE SECURITY ZONE AS AN OPEN OPTION.

07414 POPE, H.

TURKEY: STRIKING OUT

MIDDLE EAST INTERNATIONAL, 439 (DEC 92 ), 11-12.
TURKEY IS STRIKING OUT ON ITS OWN, SOMETIMES ENCOURAGED

BY THE U.S. BUT SOMETIMES NOT EVEN IMFORMING IT STAUNCH

SUPPORTERS IN WASHINGTON IN ADVANCE OF ITS MOVES. EXCEPT FOR RUSSIA AND ITS OWN KURDISH REBELLION, TURKEY IS THE STRONGEST AND BEST ORGANIZED STATE IN THE REGION, AND IS ALSO AT ITS GEOGRAPHIC AND HISTORICAL CENTER. TURKEY STARTED THESE BILATERAL REGIONAL INITIATIVES SOME TIME AGO WITH THE IDEA FOR A BLACK SEA ECONOMIC ZONE. IT HOPES THAT BY PLAYING THE ROLE OF MIDDLE MAN BETHEEN MUSLIMS AND CHRISTIANS IT WILL ACQUIRE AN ENHANCED STATUS AND SOMEHOW SECURE GREATER STABILITY IN WHAT ITS ARMED FORCES CHIEF SECURE GREATER STABILITY IN WHAT ITS ARMED FORCES CHIEF
RECENTLY DESCRIBED AS THE CENTER OF A GREAT DEAL OF RISK.

07415 POPE, $H$.

TURKEY'S INTOL ERABLE BURDEM

MIDDLE EAST INTERNATIONAL, (398) (APR 91) 4-5

THE WAVE OF KURDISH REFUGEES ON TURKEY'S BORDER PRESENTS TURKEY WITH A DIFFICULT DILEMMA. TURKEY HAS MAINTAINED ITS REFUSAL TO COUNTENANCE A MASS INFLUX OF REFUGEES DOWN FROM THE DREADFUL HIGH MOUNTAIN BORDER CAMPS TO THE MORE READILY ACCESSIBLE PLAINS. IT KNOWS THAT IT CANNOT CARE PROPERLY FOR HALF A MILLION REFUGEES, MORE THAN HALF OF THEM CHILDREN, AND DOES NOT BELIEVE INTERNATIDNAL PLEDGES OF AID WILL LAST
LONG OF THE REFUGEES ARE EVER BROUGHT INTO TURKEY AND THE 
CRISIS DIES AWAY. IN THIS TURKEY IS SUPPORTED BY THE U.S. AND OTHER MAJOR ALLIANCE POWERS, AND THERE IS LITTLE PRESSURE ON ANKARA TO ABANDON ITS POLICY. ON THE OTHER HAND, THE SUFFERING IN THE REFUCEE CAMPS IS APPALLING AND TURKEY IS CONSCIOUS OF THE POSSIBILITY OF CRITICISM FROM ITS ALLIES IF THE KURDS ARE ALLOWED TO DIE.

07416 POPE, $\mathrm{H}$.

U-TURN ON THE KURDS

MIDDLE EAST INTERNATIONAL, (396) (MAR 91), 13-14.

THE THE ASTONISHMENT OF HIS WESTERN ALLIES AND EVEN HIS

OWN FOREIGN MINISTRY, TURKEY'S PRESIDENT TURGUT OZAL HAS

REVERSED SIXTY YEARS OF REPUBLICAN POLICY AND STARTED TO

DEAL WITH KURDS AS KURDS. DOMESTIC OPPOSITION FROM RIGHT-

WING POLITICAL GROUPS AND FROM THE MILITARY IS LIKELY TO

SLOW ANY MAJOR REFORMS WHICH MIGHT FOLLOW OZAL'S

ANMOUNCEMENT OF HIS DESIRE FOR KURDISH FRIENDSHIP. POSSIBLE

REASONS FOR OZAL'S SUDDEN CHANGE RANGE FROM A DESIRE TO

DISTRACT ANY FEELING OF PAN-KURDISH EXCITEMENT IN TURKEY, TO

A NEED TO SECURE FUTURE OIL INTERESTS IN NORTHERN IRAQ.

07417 POPPER, F.

THINKING GLOBALLY, ACTING REGIONALLY

TECHNOLOGY REYIEH, ACTING REGIONALLY

DESPITE AMERICANS' PROFESSED AVERSION TO GOVERNMENT

INTERVENTION, STATES AND COMMUNITIES ARE PRACTICING EVER INTERVENTION, STATES AND COMMUNITIES ARE PRACTICING EVER
MORE AGGRESSIVE FORMS OF REGIONAL PLANHING, WITH POSITIVE EFFECTS ON ENVIRONMENTAL. QUALITY AND ECONOMIC GRONTH. THIS ARTICLE EXPLORES WAYS IN WHICH REGIONAL LAND-USE PLANNING CAN CURE MANY ENVIRONMENTAL AND ECONOMIC ILLS. IT FINDS THAT MOST OF THE NATION'S REGIONAL LAND-USE PLANNING IS RARELY RECDGNIZED FOR WHAT IT IS. TO GAIN SUPPORT AND EVENTUAL PASSAGE, MOST PLANNING LAHS MUST TRAVEL UNDER THE COVER OF ENVIRONMENTAL LEGISLATION. BECAUSE A RAPIDLY GROWING MAJORITY OF THE POPULATION LIVES IN SUBURBS, NEW REGIONAL AGENCIES ARE DESPERATELY NEEDED TO CONTAIN SPRAWL, PROTECT FARML AND, AND CONTROL POLLUTION.

07418 PORTANIERO, J.

FOUNDATIONS OF A NEW POLITICS

REPORT ON THE AMERICAS, 25(5) (MAY 92) 17-20.

TODAY'S CRISIS CHALLENGES THE LEFT TO INVENT A NEH

POLITICAL CULTURE WITH NEW FORMS OF COLLECTIVE ACTION, WHICH IN TURN COULD LEAD THEM TO NEW MODES OF UNDERSTANDING. THIS ARTICLE ANALYZES THE PAST DECADES IN LATIN AMERICA AND SUGGESTS THAT THE GENERAL PICTURE IN LATIN AMERICAN TODAY IS TRAGIC. THE DECADE OF THE 1990 S HOLDS OUT TO THESE FRAGILE DEMOCRACIES THE ENORMOUS CHALLENGE OF OVERCOMING THE CRISIS DEMOCRACIES THE ENORMOUS CHALLENGE OF OVERCOMING THE CRISIS
AND OF FINDING A WAY TO FIT INTO A WORLD OF FLUX. THE AUTHOR AND OF FINDING A HAY TO FIT INTO A WORLD OF FLUX. THE AUTY
SUGGESTS THAT THE DEMOCRATIC LEFT SHOULD PROMOTE A NEW SUGGESTS THAT THE DEMOCRATIC LEFT SHOULD PROMOTE A NEW BOUND BY THE LOGIC OF EITHER THE MARKET OR THE STATE.

07419 PORTER, B.

A COUMTRY INSTEAD OF A CAUSE: RUSSIAN FOREIGN POLICY IN THE POST SOVIET ERA

WASHINGTON QUARTERLY, 15(3) (SUM 92), 41-56.

THIS ARTICLE EXAMINES HOW RUSSIAN FOREIGN POLICY WILL DIFFER FROM SOVIET FOREIGN POLICY. IT OUTLINES SOURCES OF CHANGE IN RUSSIAN FOREIGN POLICY INCLUDING THE ABANDONMENT OF IDEOLOGY, THE IMPACT OF INTERNAL REFORM ON INTERNATIONAL BEHAVIOR, THE IMPLICATIONS OF A DECENTRALIZED COMMONWEALTH, AND THE IMPLICATIONS OF A SETTLEMENT OF TENSIONS WITH EUROPE
THE AUTHOR ALSO CONSIDERS SOURCES OF CONTINUITY IN RUSSIAN FOREIGN POLICY--HISTORICAL, INSTITUTIONAL AND BUREAUCRATIC. THE ARTICLE CONCLUDES THAT THERE IS A POSITIVE ROLE THE WES (NOTABLY THE UNITED STATES) CAN PLAY IN AIDING RUSSIA: BRINGNING ABOUT CHANGE THROUGH A WEB OF COOPERATIVE ECONOMIC AND POLITICAL LINKS BETHEEN THE WEST AND RUSSIA.

07420 PORTER, B.

THE COMING RESURGENCE OF RUSSIA

SAIS REVIEW, (23) (SPR 91) 14-23.

DESPITE THE POTENTIAL OF A BREAKUP OF THE SOVIET UNION, THE MOST LIKELY PROGNOSIS FOR RUSSIA'S FUTURE IS NOT ITS RETREAT FROM THE HORLD SCENE, BUT ITS RESURGENCE BOTH AS A GLOBAL POHER AND AS A CONTINUING OBSTACLE TO WESTERN INTERESTS. THIS ARTICLE EXAMINES THE GEOGRAPHY, CULTURE, AND RESOURCES OF RUSSIA AS WELL AS THE PROSPECTS FOR RUSSIA'S FUTURE. IT CONCLUDES THAT BY THE YEAR 2000 WE ARE LIKELY TO SEE A RESURGENCE OF RUSSIAN MILITARY POWER IN BOTH RELATIVE AND ACTUAL TERMS. FOR THE REGIME THAT GOVERNS RUSSIA AT THE AND ACTUAL TERMS. FOR THE REGIME THAT GOVERNS RUSSIA AT
TURN OF THE CENTURY WILL NOT MERELY INHERIT THE EXISTING TURN OF THE CENTURY WILL NOT MERELY INHERIT THE EXISTING SOVIET MILITARY ESTABLISHMENT, IT WILL ACTIVELY BUILD ON THAT FOUNDATION TO ENSURE RUSSIA'S PLACE AS THE PREDOMINANT
POWER IN EUROPE AND THE MILITARY EQUAL OF THE UNITED STATES.

07421 PORTEUS, $H$.

CONTROLLING ARMS EXPORTS

ARMS CONTROL, 12(2) (SEP 91), 231-240

FOR PROPONENTS OF ARMS CONTROL, THE MELTING AWAY OF THE SOVIET THREAT HAS LEFT IN ITS HAKE A PUZZLING RANGE OF

QUESTIONS WHICH HAD PREVIOUSLY LAIN DORMANT. EXPORT CONTROLS HILL NOW HAVE TO BE VIEWED FROM A RADICALLY ALTERED ANGLE.
NOW, WESTERN NATIONS ARE FACED BY A COLLECTION OF STATES WHO ARE WILLING TO SPEND TIME AND MONEY TO ACQUIRE WEAPONS OF MASS DESTRUCTION. NUCLEAR, BIOLOGICAL AND CHEMICAL WEAPONS AND BALLISTIC MISSILES ARE PERCEIVED AS AN ESSENTIAL CURRENCY OF POHER. A NEH APPROACH MUST BE DEVISED TO CONTROL THE SPREAD OF TECHNOLOGY TO THE MIDOLE EAST. THIS PAPER EXAMINES WHAT THE RESPONSE TO THIS CHALLENGE HAS BEEN FROM THE WESTERN NATIONS, WITH AN EYE TO TERRITORY THAT REMAINS UNCHARTERED AND THE PITFALLS THAT LIE AHEAD.

07422 PORTNOY, B.

THE THEORY AND PRACTICE OF ALLIANCE COHESION: EXAMINING THE NATO PARADOX

MICHIGAN JOURMAL OF POLITICAL SCIENCE, 14 (WIN 91), 58-114.

AT ISSUE IN THIS ESSAY IS COOPERATION AMONG NATIONS IN ALLIANCE. ITS PRIMARY PURPOSE IS TO SHOW THAT COOPERATION AMONG ALLIED NATIONS IS MOST LIKELY WHEN ALLIES SIMILARLY PERCEIVE A THREAT TO THEIR INTERESTS, AND SIMILARLY VALUE THAT WHICH IS BEING THREATENED. IT ARGUES THAT THE UNITY AND DISCORD EXHIBITED IN SPECIFIC CASES WAS CONDITIONED BY DISCORD EXHIBITED IN SPECIFIC CASES WAS CONDITIONED BY
DIVERGENT THREAT PERCEPTIONS, STAKES, AND VULNERABILITIES. DIVERGENT THREAT PERCEPTIONS, STAKES, AND VULMERABILITIES.
IT HELPS TO DEMONSTRATE THE LIMITS OF NATO'S SCOPE AND IT HELPS TO DEMONSTRATE THE LIMITS OF NATO'S SCOPE AND EFECTIVENESS. IT CONCLUDES THAT ON THE WHOLE, THE FURTHER
THE DEBATE IN NATO STRAYED FROM EURDPEAN SECURITY ISSUES, THE DEBATE IN NATO STRAYED FROM EUROPEAN SECURITY ISSUES, THE LESS INST ITUTIONAL MECHANISMS THERE WERE TO HANDLE
DEBATE, AND THE MORE DIFFICULT COOPEPRATION BECAME.

07423 PORTUGALI, J.

JEWISH SETTLEMENT IN THE OCCUPIED TERRITORIES: ISRAEL'S SETTLEMENT STRUCTURE AND THE PALESTINIANS

POL ITICAL GEOGRAPHY QUARTERLY, 10(1) (JAN 91), 26-53.

POST 1967 JEWISH SETTLEMENT ACTIVITIES IN THE OCCUPIED TERRITORIES ARE DESCRIBED INT HE LIGHT OF THE HISTORICAL DEVELOPMENT OF THE ZIONIST SETTLEMENT PROCESS, AMD IN THE LIGHT OF DATE FROM A FIELD SURVEY CONDUCTED IN AUGUST 1985. THE PAPER CONSIDERS THE IMPLICATIONS OF THESE SETTLEMENT ACTIVITIES FOR ISRAEL'S SETTLEMENT STRUCTURE AS A WHOLE, FOR THE SOCIAL GEOGRAPHY OF ISRAELI PALESTINIAN RELATIONS, AND FOR PERVIOUS ATTEMPTS TO BUILD A THEORETICAL FRAMEWORK FOR A STUDY ON THE ISRAELI-PALESTINIAN ISSUE.

07424 POSTMAN, D.

HE'S BACK AGAIM

NEW REPUBLIC, 206(14) (APR 92), 10-11.

FORMER PRESIDENT RICHARD NIXON HAS BEEN QUOTED FREQUENTLY IN THE PRESS BECAUSE HE HAS CRITICIZED THE BUSH ADMINISTRATION FOR NOT OFFERING ENOUGH OF THE RIGHT KIND OF ADMINISTRATION FOR NOT OFFERING ENOUGH OF THE RIGHT KIND OF FOREIGN AID TO RUSSIA AND PRESIDENT BORIS YELTSIN. IN THIS
ARTICLE, THE AUTHOR LOOKS AT HOW NIXON "LEAKED" THE STORY TO ARTICLE, THE AUTHOR LOOKS AT HOW NIXON
THE PRESS IN ORDER TO MAKE HEADLINES.

07425 POSTREL, V.I.

REASON, $24(7)$ (DEC 92 ), 4-5.

THE MOST DANGEROUS OF BILL CLINTON'S ECONOMIC PROPOSALS IS ALSO THE MOST OBSCURE--AND, SEEMINGLY, THE MOST SENSIBLE. CLINTON WANTS TO REQUIRE ALL EMPLOYERS TO SPEND AT LEAST 1. 5\% OF PAYROLL ON FORMAL WORKER TRAINING. THOSE WHO SPEND LESS WOULD HAVE TO PAY A SPECIAL TAX INTO A GOVERMMENT TRAINING FUND. CLINTON'S PLAN SUFFERS FROM THE CENTRAL FALLACY OF PROGRESSIVISM: THE DRIVE TO TURN GOOD IDEAS INTO COERCION AND, IN THE PROCESS, TO LOSE ANY CONNECTION WITH THE SUBTLETIES OF REAL-WORLD PROBLEMS.

07426 POTTER, $W$.

THE NEW SUPPLIERS

ORBIS, 36(2) (SPR 92), 199-210.

MANY ANALYSTS FEAR THAT AN INFLUX OF NEW NUCLEAR

SUPPLIERS WILL ERODE THE EXISTING SYSTEM OF EXPORT

RESTRAINTS AND UNDERMINE NONPROL IFERATION EFFORTS. THE EMERGING NUCLEAR SUPPLIERS PROJECT (ENSP), LAUNCHED IN 1985. ANALYZED EXPORT BEHAVIOR OF FIFTEEN STATES. THIS ARTICLE PRESENTS THE MORE SIGNIFICANT PROJECT FINDINGS, ALONG WITH A DISCUSSION OF HOW RECENT CHANGES IN SOVIET NUCLEAR EXPORT BEHAVIOR MAY UNDERMINE INTERNATIONAL EFFORTS TO ENCOURAGE NUCLEAR EXPORT RESTRAINT ON THE PART OF NEW SUPPLIERS.

07427 POTTERS, J.; VANHINDEN, $F$

LOBBYING AND ASYMMETRIC INFORMATION

PUBLIC CHOICE, 74(3) (OCT 92), 269-292.

INFORMATIONAL LOBBYING--THE USE BY INTEREST GROUPS OF THEIR EXPERTISE OR PRIVATE INFORMATION ON MATTERS OF IMPORTANCE FOR POLICYMAKERS IN AN ATTEMPT TO PERSUADE THEM TO IMPLEMENT PARTICULAR POLICIES--IS OFTEN REGARDED AS AN IMPORTANT MEANS OF INFLUENCE. THIS PAPER ANALYZES THIS PHENOMENON IN A GAME SETTING WHERE THE INTEREST GROUP IS ASSUMED TO HAVE PRIVATE INFORMATION THAT IS RELEVANT TO THE POL ICYMAKER WHILE, ON THE OTHER HAND, THE POLICYMAKER IS ASSUMED TO BE FULLY AWARE OF THE STRATEGIC INCENTIVES OF THE INTEREST GROUP TO REPORT, MISREPORT, OR CONCEAL ITS PRIVATE INFORMATION. IN A SETTING OF PARTIALLY-CONFLICTING INTERESTS, A RATIONALE FOR INFORMATIONAL LOBBYING CAN ONLY EXIST IF MESSAGES BEAR A COST TO THE INTEREST GROUP AND IF THE GROUP'S PREFERENCES CARRY INFORMATION IN THE "RIGHT 
DIRECTION." FURTHERMORE, IT IS NOT THE CONTENT OF THE MESSAGE AS SUCH BUT THE CHARACTERISTICS OF THE INTEREST GROUP THAT INDUCES POTENTIAL CHANGES IN THE POLICYMAKER'S BEHAVIOR.

07428 POTTINGER, B.

THE YEAR AHEAD

THIS ARTICLE OUTLINES WHAT THE FUTURE MAY HOLD FOR SOUTH AFRICA. IT ARGUES THAT THREE THINGS CAN BE EXPECTED FROM 1992: SOME CONVERGENCE ON POLICIES, COMPROMISE ON PROCEDURES AND INCREASING INTER-PARTY FISSURES AND FRICTION. BOTH MAJOR PARTIES ARE COMING INTO INCREASING AGREEMENT ON THE IDEA OF DECENTRALIZATION OF POWER AND THE NEED FOR AN INTERIM GOVERNMENT IN SOME FORM. AN IMPORTANT AREA OF COMPROMISE DEALS WITH THE ROLE OF MINORITIES, WHETHER RACIAL, CULTURAL DEALS WITH THE ROLE OF MINORITIES, WHETHER RACIAL, CULTURAL
OR RELIGIOUS. THE FIERCEST DEBATE WILL FOCUS ON THE

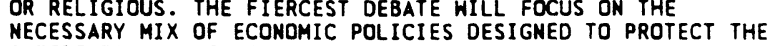
NECESSARY MIX OF ECONOMIC POLICIES DESIGNED TO PROTECT THE
INTERESTS OF THE WEALTH-GENERATING SECTOR OF THE COUNTRY WHILE MOVING TO REDRESS THE HISTORIC INEQUALITIES OF THE WHILE MOVING TO REDRESS THE HISTORIC INEQUALITIES OF THE PAST. UNFORTUNATELY, POL ITICAL VIOLENCE IS LIKELY TO
CONTINUE AS SOME PARTIES BECOME INCREASINGLY MARGINALIZED. HOWEVER, MUCH OF THE SO-CALLED POLITICAL VIOLENCE IS NOTHING SO MUCH AS LOCAL GROUPS (POLICE, CRIMINAL, POLITICAL AND KINSHIP) FOLLOWING BY VIOLENT MEANS THEIR OWM AGENDAS IN A SUDDENLY CONFUSED, LIBERATED POLITICAL ENVIRONMENT.

07429 POUDYAL, S.R.

ECONOMIC INTEGRATION AMONG SAARC NATIONS

SOUTH ASIA JOURNAL, 5(2) (OCT 91), 121-130.

FIVE YEARS HAVE PASSED SINCE THE SOUTH ASIAN ASSOCIATION FOR REGIONAL COOPERATION (SAARC) COMPRISING BANGLADESH, BHUTAN, SRI LANKA, INDIA, THE MALDIVES, NEPAL AND PAKISTAN WAS CONCEIVED AND ALL MEMBERS HAVE SHOWN CONCERN TO PROMOTE ECONOMIC COOPERATION AMONG THEMSELVES. THIS PAPER SEEKS TO EXPLORE THE PROSPECTS AND PROBLEMS OF ECONOMIC INTEGRATION AMONG SAARC NATIONS. WHILE THE DISCUSSION IS RATHER GENERAL FOR LACK OF RELEVANT DATA. IT PROVIDES SOME ANALYTICAL INSIGHTS INTO THE BASIC ISSUES INVOLVED IN THE PROCESS OF ECONOMIC INTEGRATION OF THE SAARC NATIONS. IT ARGUES THAT THE ELIMINATION OF TARIFFS ON INTER-REGIONAL TRADE THROUGH THE FORMATION OF A CUSTOMS UNION OF THE SEVEN SOUTH ASIAN COUNTRIES HOULD NOT RESULT IN SIGNIFICANT SHORT TERM GAINS TO THE MEMBER COUNTRIES. BEFORE REAL GAINS FROM INTEGRATION CAN BE REALIZED, EXTENSIVE STUDY OF
COMPLIMENTARITIES MUST BE CONDUCTED.

07430 POULTON, H.

RISING ETHNIC TENSION IN VOJVODINA

RFE/RL RESEARCH REPORT IN (50) (DEC 92), 21-27.

TENSION IS RISING IN THE SERBIAN PROVINCE OF VOJVOOINA BECAUSE IT HAS BEEN STRIPPED OF THE AUTONOMOUS STATUS IT HAD EN JOYED SINCE 1974 AND BECAUSE OF FACTORS PRODUCED BY THE CONTINUING CIVIL WAR--PRIMARILY RESISTANCE TO THE MILITARY DRAFT BY ETHNIC HUNGARIANS UNWILLING TO FIGHT FOR A GREATER SERBIA AND AN INFLUX OF PREDOMINANTLY SERBIAN REFUGEES FROM BOSNIA AND HERZEGOVINA AND CROATIA. IN RETURN FOR SUPPORTING THE REGIME OF SLOBODAN MILOSEVIC, THE REFUGEES APPEAR TO HAVE BEEN GIVEN A FREE HAND TO UTILIZE PRESSURE, INCLUDING VIOLENCE, TO DRIVE THE CROATIAN, HUNGARY, AND SLOVAK RESIDENTS OF VOJVODINA FROM THEIR HOMES AND NEIGHBORHOODS, A SITUATION THAT HAS FURTHER UPSET THE HISTORICALLY-DELICATE ETHNIC BALANCE OF THE REGION.

07431 POURGERAMI, A.

AUTHORITARIAN VERSUS NONAUTHORITARIAN APPROACHES TO ECONOMIC DEVELOPMENT: UPDATE AND ADDITIONAL EVIDENCE

PUBLIC CHOICE, 74(3) (OCT 92), 365-377.

THE AUTHOR UPDATES DICK'S DATA SET AND EXPAMDS THE SAMPLE SIZE TO PROBE THE LINK BETHEEN ECONOMIC GRONTH AND POLITICAL COMPETITIVENESS. HE ALSO EXAMINES THE RELATIONSHIP BETHEEN ECONOMIC DEVELOPMENT, WHICH IS VIEWED AS AN OVERALL IMPROVEMENT IN THE QUALITY OF HUMAN LIFE, AND POLITICAL DEMOCRACY. IN ADDITION, HE ANALYZES THE INTERRELATIONSHIPS BETHEEN POL ITICAL DEMOCRACY AND SUCH FUMDAMENTAL COMCEPTS OF HUMAN LIFE AS FREEDOM AND HUMAN RIGHTS TO PRESENT A COMPREHENSIVE SCENARIO FOR THE COMPLEMENTARITY BETHEEN ECONOMIC DEVELOPMENT AND POLITICAL DEMOCRACY.

07432 POYALL, M.

ACTION FOR WOMEN IN BRITAIN

ANMALS OF THE AMERICAN ACADEMY OF POLITICAL AND SOCIAL SCIENCE, (523) (SEP 92), 175-185

EMPLOYERS' PROGRAMS TO IMPROVE WOMEN'S OPPORTUNITIES IN BRITAIN STARTED IN THE LATE 1970'S AFTER EQUAL PAY, SEX DISCRIMINATION, AND RACE RELATIONS LEGISLATION HAD' BEEN PASSED, HHIE EOUAL OPPORTUMITY IS NOW OM MOST EMPLOYERS' AGENDAS, ACTIVITY IS LIMITED TO A SMALL NUMBER OF WELL-KNOWM ORGANIZATIONS WHOSE PROGRAMS OFTEN LACK SPECIFIC TARGETS. ACTION PROGRAMS FOR WOMEN IN BRITAIN ARE MORE COMMON THAN THOSE FOR ETHNIC MINORITIES, DESPITE PARALLEL LEGISLATION. EQUAL OPPORTUNITY EMPLOYERS ARE NOW INITIATING ACTION PROGRAMS FOR PERSONS WITH DISABILITIES, THOUGH THEY ARE NOT COVERED BY ANTIDISCRIMINATION LEGISLATION. RESULTS ARE
AWAITED FROM THE STRONG RELIGIOUS ANTIDISCRIMINATION LEGISLATION IN NORTHERN IRELAND AND FROM EUROPEAN ECONOMIC COMMUNITY ATTEMPTS TO STRENGTHEN LEGISLATION TO ASSIST WOMEN.

07433 POHELL, D.

IRAQ--APPEAL AGAINST SANCTIONS

MIDDLE EAST INTERNATIONAL, (412) (NOY 91), 13-14,

FRESH EVIDENCE OF AN EPIDEMIC OF WATER-BORNE DISEASES AND NATIONHIDE MALMUTRITION AMONG IRAQI CHILDREN LOOKS SET TO RENEH PRESSURE FOR EASING OF ECONOMIC SANCTIONS. FOUR TIMES AS MANY IRAQI CHILOREN ARE DYING TODAY AS BEFORE THE GULF CRISIS, 900,000 ARE MALNOURISHED AND OVER 100,000 AT GULF CRISIS, 900,000 ARE MALNOURISHED AND OVER 100,000 AT
IMMEDIATE RISK OF STARVATION, ACCORDING TO A REPORT BY AN 87IMMEDIATE RISK OF STARVATION, ACCORDING TO A REPORT BY AN 87
MEMBER INTERNATIONAL TEAM OF EXPERTS. FOOD AND MEDICINE ARE MEMBER INTERNATIONAL TEAM OF EXPERTS. FOOD AND MEDICINE ARE ALLOWED INTO IRAQ--THOUGH WIDESPREAD SHORTAGES ARE REPORTED. BUT MACHINERY TO DRIVE POHER STATIONS AND WATER PURIFICATION PLANTS IS STILL SUBJECT TO UN SANCTIONS COMMITTEE APPROVAL. SANCTIONS COMMITTEE OF THE UN SECURITY COUNCIL. MANY BELIEVE THAT SANCTIONS WILL REMAIN IN FORCE AS LONG AS SADDAM THAT SANCTIONS WILL REMAIN
HUSSEIN REMAINS IN POWER.

07434 POWELL, R. ABSOLUTE AND RELATIVE GAINS IN INTERNATIONAL RELATIONS THEORY

AMERICAN POLITICAL SCIENCE REVIEW, 85(4) (DEC 91), 1303-1320.

THE PROBLEM OF ABSOLUTE AND RELATIVE GAINS DIVIDES NEOL IBERAL INSTITUTIOHALISM AND STRUCTURAL REALISM. THE FORMER ASSUMES STATES FOCUS PRIMARILY ON THEIR ABSOLUTE GAINS AND EMPHASIZES THE PROSPECTS FOR COOPERATION. THE LATTER SUPPOSES STATES ARE LARGELY CONCERNED WITH RELATIVE GAINS AND EMPHASIZES THE PROSPECTS FOR CONFLICT. EXISTING WORK IN INTERNATIONAL RELATIONS THEORY GENERALLY TRACES THE DIFFERENCES BETHEEN THESE THO THEORITES TO DIFFERENT ASSUMPTIONS ABOUT STATES' PREFERENCES. USING A SIMPLE GAMETHEDRETIC MODEL. THIS ESSAY OFFERS A REFORMULATION OF THE PROBLEM OF ABSOLUTE AND RELATIVE GAINS THAT LINKS CHANGES IN THE STATES' BEHAVIOR, THE FEASIBILITY OF COOPERATION, AND ESPECIALLY THE STATES' CONCERN FOR RELATIVE, VERSUS ABSOLUTE, GAINS EXPLICITLY TO CHANGES IN THE CONSTRAINTS FACING THE STATES. MANY OF THE DIFFERENCES BETWEEN NEOLIBERAL INSTITUTIONALISM AND STRUCTURAL REALISM APPEAR AS SPECIAL INSTI IUTIONALISM AN

07435 POWER, J.

\$INDIVIDUALISM IS THE ANTITHESIS OF INDIRECT RULE': \$INDIVIDUALISM IS THE ANTITHESIS OF INDIRECT RULE' MALAWI

MALAWI
INTERNATIONAL JOURNAL OF PUBLIC ADMINISTRATION, 15(7) (1992), 317-348.

THE INTRODUCTION OF COOPERATIVES AND INDIRECT RULE TO COLONIAL MALAHI DURING THE 1930 S WAS PART OF AN EXERCISE IN IMPERIAL SOCIAL ENGINEERING DESIGNED TO THWART CLASS FORMATION. IN THE 3OS OFFICIALS BELIEVED THAT, IN ADOITION TO ECONOMIC BENEFITS, INDIRECT RULE, AND LATER, COOPERATIVES, WOULD PAY POLITICAL DIVIDENDS: INDIRECT RULE, BY ENHANCING RURAL ADHINISTRATION, AND COOPERATIVES, BY DIVERTING THE POLITICAL ENERGIES OF THE AFRICAN PETIT BOURGEOISIE INTO
COLLECTIVE ECONOMIC ENDEAVOUR. YET NEITHER INDIRECT RULE NOR COOPERATIVES WERE ABLE TO IMPEDE THE PROCESS OF CLASS FORMATION.

07436 PRADETTO, A

TRANSFORMATION IN EASTERN EUROPE, INTERNATIONAL

COOPERATION, AND THE GERMAN POSITION

STUDIES IN COMPARATIVE COMHUNISM, 25(1) (MAR 92), 23-30. THE CONTEXT OF THE TRANSFORMATION GOING ON IN THE CENTRAL AND EASTERN PART OF EUROPE IS ANALYZED. THE THESE PARTS OF ERS ON THE CONDITIONS OF THE INTEGRATION OF ENABLES SOME PROGRESS TOWARDS THE NECESSARY INTERNAL ECONOMIC AND POL ITICAL REFORMS. THESE CONDITIONS ARE ANALYZED UNDER THE ASPECTS OF HOW WESTERN COUNTRIES ACT AND REACT AND HOW EASTERM COUNTRIES BEHAVE. THE ROLE OF GERMANY AND THE EFFECTS OF GERMAN UMIFICATION ON THE PROCESSES AND INTENTIONS MENTIONED ARE DESCRIBED AND ANALYZED.

07437 PRAGER, J.

IS PRIVATIZATION A PANACEA FOR LDCS? MARKET FAILURE VERSUS PUBLIC SECTOR FAILURE

JOURNAL OF DEVELOPING AREAS, 26(3) (APR 92), 301-323.

THE PURPOSE OF THIS PAPER IS TO ANALYZE THE ISSUE OF PRIVATIZATION FROM THE VIEWPOINT OF EFFICIENCY, THE ABILITY TO MAXIMIZE PRODUCTION WITH A GIVEN STOCK OF RESOURCES. IT BEGINS WITH A BRIEF ANALYSIS OF MARKET FAILURE AND OTHER MOTIVES FOR GOVERNMENT INTERVENTION IN PRODUCTION. IT PLACES THE BLAME FOR PUBLIC SECTOR INEFFICIENCY ON THE ABSENCE OF EFFICIENCY-PROMOTING INCENTIVES, WITH PARTICULAR ATTENTION PAID TO (A) THE PRESENCE OF MULTIPLE AND CONFLICTING GOALS, (B) THE LACK OF MANAGEMENT INDEPENDENCE, (C) AN INAPPROPRIATE REWARD STRUCTURE, AND (D) INCENTIVES EVEN ENCOURAGING INEFFICIENCY. THE PAPER RETURNS TO THE PRIVATE SECTOR TO DEMONSTRATE THAT SUCH DISINCENTIVES ARE LESS 
COMMON THERE.

07438 PRAKASH, $S$.

CHINA'S IDEOLOGICAL PERCEPTION OF THE THIRD WORLD CHINA REPORT, $27(3)$ (JUL 91), 197-218 IT IS CLAIMED THAT WE HAVE REACHED THE END OF IDEOLOGY. THE QUESTION THIS PAPER SETS OUT TO ANSWER IN THE CASE OF THE PEOPLE'S REPUBLIC OF CHIMA IS WHETHER THIS CLAIM COULD BE APPLIED TO IT AFTER 1949 AND IN THE PRESENT SITUATION. CHINA'S REVOLUTIONARY IDEOLOGY AS APPLIED TO THE THIRD HORLD WAS PREVIOUSLY A HANDMAIDEN TO ITS OUEST FOR INTERNATIONAL POLITICAL LEGITIMACY AND STRATEGIC SECURITY AND NOW IT WILL BE THE MEANS FOR SEARCHING OUT ADDITIONAL MARKETS FOR CHINA'S EXPORTS AND SOURCES OF RAW MATERIALS SUPPLY, GIVEN THE REQUIREMENT OF FUNCTIONING WITHIM A MULTIPOLAR INTERNATIONAL SYSTEM. CHINA'S PRESENT APPROACH OF USING ITS INTERNATIONAL RELATIONS TO PROMOTE PEACE AND ECONOMIC DEVELOPMENT IS DERIVED FROM CHINA'S ASSESSMENT THAT THE BUILDING OF A SOCIALIST ECONOMY AND POLITY WILL BE A PROTRACTED PROCESS AND WUST TAKE PLACE ON A NATIONAL BASIS WITH THE HELP OF AND IN CORRDINATION WITH OTHER DEYELOPED AND THIRD WORLD COUNTRIES.

07439 PRATORIUS, $J$

EARTH SUMMIT: IT IS UP TO THE INDUSTRIALIZED NATIONS GERMAN TRIBUNE, (1519) (JUN 92), 1,3

THE UNITED NATIONS "EARTH SUMMIT IN RIO DE JANERIO IS THE LARGEST INTERHATIONAL CONFERENCE EVER HELD. HHILE THE PURPOSE OF THE SUMMIT, TO ACHIEVE AGREEMENTS ON REDUCING POLLUTION, ENERGY CONSUMPTION, AND OTHER FORMS OF ENVIRONMENTAL DEGRADATION, IS LAUDABLE, THE WAY IN WHICH MOST OF THE HORLD'S POLITICIANS ARE APPROACHING THE PROBLEM IS NOT. MANY, LED BY U.S. PRESIDENT GEORGE BUSH AND EUROPEAN LEADERS, SEEM DETERMINED NOT TO SACRIFICE NATIONAL ECONOMIC WANTS AND NEEDS TO THE GREATER GLOBAL GOOD. THE DEVELOPING NATIONS, EAGER TO "CATCH UP" WITH THE INDUSTRIALIZED HORLD, ARE EQUALLY RETICENT TO TAKE MEASURES THAT MIGHT SLOW GROWTH OR DEVELOPMENT.

07440 PRATT, C.B.

EDITORIALS IN NATIONAL DEVELOPMENT: PERCEPTIONS OF NIGERIAN JOURMAL ISTS

POLITICAL COMHUNICATION AND PERSUASION, 8(4) (1991), 221-232.

THIS STUDY AMALYZES THE SELF-REPORTED PERCEPTIONS OF THE ROLE OF EDITORIALS IN NATIONAL DEVELOPMENT FOR A PURPOSIVE SAMPLE OF 348 FULL-TIME, SALARIED NIGERIAN JOURNALISTS WORKING FOR NINE PRIVATE OR GOVERHMENT-OWNED NATIONAL NEWSPAPERS. ON SEVEN-STATEMENT COMPARISONS OF THE ROLE OF EDITORIALS IN NATIONAL DEVELOPMENT, GOVERNMENT JOURNALISTS PERCEIVED THEIR EDITORIALS AS MORE SUPPORTIVE OF THE GOVERMMENT THAN DID PRIVATE JOURNAL ISTS--A RESULT LARGELY GOVERMMENT THAN DID PRIVATE JOURNAL ISTS--A RESULT LARGELY
REFLECTIVE OF GOVERNMENT NEHSPAPERS' PERSUASIVE ROLE ON REFLECTIVE OF GOVERNMENT NEHSPAPERS' PERSUASIVE ROLE ON
BEHALF OF GOVERNMENT AGENCIES. HOWEVER, OWNERSHIP OF BEHALF OF GOVERNMENT AGENCIES. HOWEVER, OWNERSHIP NEWSPAPERS IS NOT A PARTICULARLY STRONG FACTOR IN JOURNALISTS' PERCEPTIONS OF THE ROLE OF EDITORIALS IN
DEVELOPMENT. BECAUSE THIS STUDY INDICATES THAT NEWSPAPER DEVELOPMENT. BECAUSE THIS STUDY INDICATES THAT NEWSPAPER
OWNERSHIP IS OCCASIONALLY NOT A FACTOR IN THE PERCEPTION OF OWNERSHIP IS OCCASIONALLY NOT A FACTOR IN THE PERCEPTION
THE ROLE OF EDITORIALS IN DEVELOPMENT, IT OUESTIONS THE IMPLICATIONS OF THE SIMPLE, TRADITIONAL DISTINCTION BETWEEN GOVERNMENT AND PRIVATE NEHSPAPERS FOR NATIONAL DEVELOPMENT IN SUB-SAHARAN AFRICA.

07441 PRAVDA, A. (ED.)

THE END OF THE OUTER EMPIRE--SOVIET UNION/EAST EUROPEAN RELATIONS IN TRANSITION, 1985-1990

SAGE PUBLICATIONS, 1992, 256.

THIS VOLUME CONSIDERS THE POLITICAL AND ECONOMIC

RAMIFICATIONS OF THE DISINTEGRATION OF THE IRON CURTAIN FOR THE FORMER SOVIET UNION'S ALLIES. IT COMPREHENSIVELY EXAMINES THE RELATIONSHIPS BETHEEN THE SOVIET UNION AND HER NEIGHBORS, FOCUSING PARTICULARLY ON THE GORBACHEY PERIOD (1985-1989). THE VOLUME'S ANALYSIS REFLECTS BOTH THE INCREASING DIVERSITY OF DEVELOPMENT AS HELL AS THE REMARKABLE PACE OF CHANGE IN RELATIONS.

07442 PRAVDA, A. (ED.); EYAL, J.; HNIZDO, B.; PARTOS, A.;

SANFORD, G.; SMITH, A. RELATIONS IN TRANSITION, 1985-1990

SAGE PUBLICATIONS, 1992, 238.

THE DISAPPEARANCE OF COMMUNIST RULE IN EASTERM EUROPE WAS THE RESULT OF LONG-TERM DECAY AND COLLAPSE FROM WITHIN, WAS THE RESUL OF LONG-TERM DECAY AND COLLAPSE FROM WITHIN, THE SOVIET UNION DURING THE SECOND HALF OF THE POLICY PERESTROIKA AND FOREIGN POLICY REFORM MEANT THAT THE SOVIET UNION'S EMPIRE WAS SCRUTINIZED ON A FAR STRICTER COSTBENEFIT BASIS AND SUBORDINATED TO THE HIGHER PRIORITIES OF DOMESTIC REFORM AND DETENTE IN EUROPE. THIS STUDY SHOWS HOW MIKHAIL GORBACHEV LOST CONTROL OVER HIS OWN POLICY, OPENING THE WAY TO FAR FASTER AND MORE REVOLUTIONARY CHANGE THAN HE HAD ENVISIONED.
07443 PREEG, E. THE U.S. LEADERSHIP ROLE IN WORLD TRADE: PAST, PRESENT, AND FUTURE

WASHINGTON QUARTERLY, 15(2) (SPR 92), 81-92. THE FUTURE OF AN INTERNATIONAL TRADING SYSTEM BASED ON PRINCIPLES OF FAIRNESS AND OPENNESS IS VERY MUCH IN DOUBT AS IT CONFRONTS GROWING PRESSURES OF REGIONALISH, TECHNOLOGICAL INNOVATION, AND A CHANGING GEOPOL ITICAL ENVIRONMENT. WHETHER THE TRADING SYSTEM CAN SURVIVE THE CURRENT STORM DEPENDS VERY MUCH ON THE CONTINUED COMMITMENT OF THE UNITED STATES TO LEADERSHIP OF THE SYSTEM EVEN AS U.S. POHER DIMINISHES THIS ARTICLE DISCUSSES THE U.S. LEADERSHIP ROLE IN WORLD TRADE: PAST, PRESENT, AND FUTURE.

07444 PREMDAS, R.; STEEVES, J VANUATU: THE 1991 ELECTIONS AND THE EMERGENCE OF A NEH ORDER

ROUND TABLE, 323(323) ( JUL 92), 339-358.

IN ORDER TO UNDERSTAND THE MEANING OF THE 1991 ELECTIONS IN VAUATU, THIS ARTICLE REVIEWS THE MODERN BICULTURAL

STRUCTURE OF THE VANUATU STATE WHICH IS LARGELY DERIVED FROM STRUCTURE OF THE VANUATU STATE HHICH IS LARGELY DERIVED FROM
ITS COLONIAL HISTORY. IT ALSO PRESENTS A BACKGROUND TO THE ITS COLONIAL HISTORY. IT ALSO PRESENTS A BACKGROUND TO THE
INTERVAL FACTIONAL FEUDS WITHIN THE YANUA'AKU PATI SINCE INTERVAL FACTIONAL FEUDS WITHIN THE VANUA AKU PATI SINCE ANIS CAME TO DOMINATE THE DIRECT ION OF CONTEMPORARY POL AND LED DIRECTLY TO THE OVERTHROW OF LINI. IT OFFERS CONSTITUTIONAL AND POLITICAL
EXPLORES THE CAMPAIGN ISSUES.

07445 PRESSER, S.; TRAUGOTT, M.

LITTLE WHITE LIES AND SOCIAL SCIENCE MODELS: CORRELATED RESPONSE ERRORS IN A PANEL STUDY OF VOTING

PUBLIC OPINION QUARTERLY (CHICAGO), 56(1) (SPR 92), 77-86.

ONE INTERPRETATION FOR THE COMMON SURVEY FINDING THAT

THE BACKGROUND CHARACTERISTICS OF VOTE OYERREPORTERS

RESEMBLE THOSE OF ACTUAL VOTERS IS THAT MISREPORTERS USUALLY VOTE. THIS HYPOTHESIS- THAT MISREPORTERS REGULARLY VOTED IN EARLIER ELECTIONS--IS TESTED HITH DATA FROM THE 1972, 1974, AND 1976 MICHIGAN ELECTION PANEL AND RECEIVES NO SUPPORT. THE 1972 AND 1974 VALIDATED TURNOUT OF THE 1976 MISREPORTERS WAS VERY LOW. MOREOVER, MISREPORTING HAS A FAIRLY STABLE RESPONDENT CHARACTERISTIC: MISREPORTING ABOUT AN ELECTION IN ONE INTERVIEW WAS CORRELATED WITH MISREPORTING ABOUT THE REMAINING ELECTIONS IN EACH OF THE OTHER TWO INTERVIEWS. A COMPARISON OF REGRESSIONS PREDICTING TURNOUT USING THE VALIDATED REPORTS VERSUS THE SELF-REPORTS SHOWS THAT THE CORRELATES OF VOTING. FOR EXAMPLE, CONTROLLING FOR THREE OTHER VARIABLES, EDUCATION WAS RELATED TO SELF-REPORTED VOTING BUT NOT TO VALIDATED VOTING. HERE, AS WELL AS IN SURVEYS OF OTHER SOCIALLY DESIRABLE OR UNDESIRABLE ISSUES, SURVEYS OF OTHER SOCIALLY-DESIRABLE OR UNDESIRABLE ISSUES,
RESPONDENT SELF-REPORTS MAY BIAS SURVEY DATA IN FAVOR OF RESPONDENT SELLF-REPORTS MAY BIAS
COMMONSENSE MODELS OF THE WORLD.

07446 PRESSER, S.; BLAIR, J.; TRIPLETT, T. SURVEY SPONSORSHIP, RESPONSE RATES, AND RESPONSE EFFECTS SOCIAL SCIENCE QUARTERLY, 73(3) (SEP' 92), 699-702 AN EXPERIMENTAL COMPARISON OF UNIVERSITY VERSUS NEWSPAPER SPONSORSHIP IN A RANDOM DIGIT DIAL TELEPHONE SURVEY PROOUCED NO SIGNIFICANT RESPONSE RATE DIFFERENCE, BUT A CLEAR DIFFERENCE IN RESPONSE OISTRIBUTIONS ON ONE ISSUE. THE AUTHORS HYPOTHESIZE THAT THE LATTER RESULT WAS DUE TO THE CONJUNCTION OF TWO FACTORS: THE NEWSPAPER HAD TAKEN A MANY RESPONDENTS PROBABLY HAD NOT FORMED A CRYSTALLIIED OPINION.

07447 PRESSMAN, $S$.

THE \$1000 QUESTION: A TAX CREDIT TO END CHILD POVERTY? CHALLENGE, 35(1) ( JAN 92), 49-52.

THE NATIONAL COMMISSION ON CHILDREN, CHAIRED BY SEMATOR JOHN D. ROCKEFELLER IV, HAS RECOMMENDED THAT A $\$ 1000$ REFUNDABLE TAX CREDIT PER CHILD BE GIVEN TO AMERICAN FAMILIES TO HELP REDUCE POVERTY IN THE UNITED STATES.

07448 PRESTAGE, J.L.

PRESTAGE, J.L. ANNALS OF THE AMERICAN ACADEMY OF POLITICAL AHD SOCIAL SCIENCE, (514) (MAR 91), 88-103.

AFRICAN AMERICAN WOMEN, POLITICAL ACTIVISTS FOR THEIR ENTIRE HISTORY ON THE AMERICAN CONTINENT BUT LONG DENIED THE ENTIRE HISTORY ON THE AMERICAN CONTINENT BUT LONG
RIGHT TO VOTE AND HOLD OFFICE, HAVE RESORTED TO RIGHT TO VOTE AND HOLD OFFICE, HAVE RESORTED TO
NONTRADITIONAL POLITICS. AS VICTIMS OF RACIAL AND SEXUAL NONTRADITIONAL POLITICS. AS VICTIMS OF RACIAL AND SEXUAL
DISCRIMINATION. THESE WOMEN HAVE BEEN ACTIVE IN BOTH THE DISCRIMINATION, THESE WOMEN HAVE BEEN ACTIVE IN BOTH THE
AFRICAN AMERICAN LIBERATION MOVEMENT AMD THE WOMEN'S AFRICAN AMERICAN LIBERATION MOVEMENT AMD THE HOMEN'S
MOVEMENT. ALONG THE HAY, THEY DEVELOPED A RICH ARRAY OF INMOVATIVE ALTERNATIVES TO THE TRADITIONAL POLITICAL ACTIVITIES FROM WHICH THEY WERE EXCLUDED. AFTER THE 1965 VOTING RIGHTS ACT, NONTRADITIONAL ACTIVITIES BEGAN TO GIVE HAY TO MORE TRADITIIONAL ONES. CURRENTLY, BLACK WOMEN ARE THE PRIME USERS OF THE BALLOT, HOLD A HIGHER PERCENTAGE OF THEIR RACE'S ELECTIVE OFFICES THAN DO WHITE WOMEN, ARE HIGHLY SUPPORTIVE OF WOMEN'S ISSUES, AND AS OFFICEHOLDERS EXHIBIT HIGHER LEVELS OF NOMEN'S ORGANIZATION MEMBERSHIP THAN DO WHITE WOMEN. 
07449 PRESTOHITZ, C BEYOND LAISSEZ FAIRE FOREIGN POLICY, (87) (SUM 92), 67-87. THIS ARTICLE ARGUES THAT CONTINUED ADHERENCE TO LAISSEZ FAIRE ECONOMIC POLICIES WILL BE DETRIMENTAL TO AMERICA'S FUTURE. THE AUTHOR PROPOSES A NEH STRATEGY WHICH RECOGNIZES THE IMPORTANT FACT THAT WHAT AMERICA MAKES MATTERS AMD WHICH CALLS FOR AN EXPLICIT, HIGH-PRIORITY COMMITMENT TO AMERICAN LEADERSHIP IN IMPORTANT INDUSTRIES AND TECHNOLOGIES. SUCH A PROGRAM IS BASED ON SEVEN ELEMENTS: IMPLEMENT A MACROECONOMIC POLICY THAT AIMS TO DOUBLE U.S. RATES OF CAPITAL FOPMATIOH AND INVESTMEMT. ESTABLISH POLICIES TO OPTIMIZE THE STRUCTURE OF THE U.S. ECONOMY; BUILD A TWENTYFIRST FIRST CENTURY INFRASTRUCTURE; ESTABLISH AN EDUCATIONAL EXTENSION SERVICE; REORIENT INVESTMENT PRIORITIES TO EMPHASIZE THE LONG TERM; CREATE A NATIONAL HEALTH CARE
PROGRAM TO CONTAIN COSTS AND FREE RESOURCES FOR PRODUCTIVE INVESTMENTS; AND ENCOURAGE CERTAIN TYPES OF FOREIGN INVESTMENTS:
INVESTMENT.

07450 PRESTRE, $P$.

ADAPTING TO TURBULENCE: THE UNITED STATES AND THE TRANSFORMATIONS OF NATO, 1989-199

ETUDES INTERNAT IONALES, 23 (1) (MAR 92), 57-76.

THE END OF THE COLD WAR HAS FREED EASTERN EUROPE FROM THE SOVIET UNION AND WESTERN EUROPE FROM THE UNITED STATES THIS ARTICLE EXPLORES HOW THE AMERICANS HAVE ATTEMPTED TO ADAPT TO THESE NEW UNCERTAINTIES BY REDEFINING THE THREAT AND BY SEEKING A NEW POLITICAL AND MILITARY IDENTITY FOR NATO. THE INDIVIDUAL, SOCIETAL, AND EXTERNAL VARIABLES THAT MAY EXPLAIN HOW STRATEGIES OF ADAPTATION ARE CHOSEN ARE THEN IDENTIFIED. THE TURBULENCE OF THE SYSTEM ACCENTUATES AN APPROACH OF REACTING TO EVENTS AND PRESERVING THE STATUS QUO, AN APPROACH WHICH LEAVES NATO AT THE MERCY OF GERMAN OBJECTIVES IN EUROPE WITHOUT RESOLVING THE ISSUE OF EUROPEAN SECURITY.

07451 PREVOST, J.

LA THEORIE ANARCHO-CAPITALISTE DE L'ETAT: UNE CRITIQUE METHODOLDGIOUE

CANADIAN JOURNAL OF POLITICAL SCIENCE, $X X V(4)$ (DEC 92), 737-756.

THE AUTHOR STUDIES THE CONCEPTION OF THE STATE DEFENDED
THE BY LIBERTARIAN MURRAY N. ROTHBARD, WHO IS THE FOREMOST ADVOCATE AND THEORETICIAN OF ANARCHO-CAPITALISH. HIS PURPOSE IS TO SHOW THAT ROTHBARD'S THESES REGARDING THE NATURE, IS TO SHOW THAT ROTHBARD'S THESES REGARDING THE NATURE, METHODOLOGICAL PRESCRIPTIONS AND THE FUNDAMENTAL AXIOMS THAT METHODOLOGICAL PRESCRIPTIONS AND THE FUNDAMENTAL AXIOMS THA THEORY. IN FACT, NEITHER THE DEFINITION OF HUMAN ACTION AS THEORY. IN FACT, NEITHER THE DEFINITION OF HUMAN ACTION AS END-GOVERNED, NOR METHODOLOGICAL INOIVIDUALISM, NOR THE CONCEPT OF DEMONSTRATED PREFERENCE CAN BE RECONCILED
EXPLANATIONS IN HHICH CONSPIRACY, MANIPULATION, AND EXPLANATIONS IN WHICH CONSPIRACY, MANIPULAT
INYOLUNTARY IGNORANCE PLAY A DECISIVE PART.

07452 PREYOST, R.

CLERGY MALPRACTICE AFTER OREGON V. SMITH

JOURNAL OF CHURCH \& STATE, 34(2) (SPR 92), 279-301

THE AUTHOR DISCUSSES THE ISSUE OF STATE REGLUATION OF PASTORAL, OR SPIRITUAL, COUNSELING-FOCUSING ON THE CONSTITUTIONAL QUESTIONS SURROUNDING STATE REGULATION OF COUNSEL ING BY THE CLERGY. THE ISSUE INVOLVES BOTH THE ESTABLISHMENT AND FREE EXERCISE CLAUSES OF THE FIRST AMENDMENT. THE STATE REGULATES MATTERS OF HEALTH AND SAFETY, WHICH INCLUDES REGULATING AND LICENSING COUNSELORS. INSOFAR AS THE STATE TRIES TO REGULATE COUNSELING, IT IS MOTIVATED TO REGULATE RELIGIOUS COUNSELING. THIS HILL LEAD TO AN INEVITABLE CLASH BETHEEN THE STATE'S RIGHT TO ORDER THE LIFE OF THE COMMUNITY AND THE RELIGIOUS BELIEVER'S RIGHT TO EXERCISE HIS OR HER RELIGIOUS BELIEFS FREELY.

07453 PRICE, D.

OUR POLITICAL CONDITION

PS: POLITICAL SCIENCE AND POLITICS, 25(4) (DEC 92), 679-683.

THE AUTHOR SUGGESTS THAT THE RESPONSE OF ELECTED U.S. OFFICIALS HAS OFTEN BEEN INADEQUATE TO THE NEEDS OF THE COUNTRY. HE ARGUES THAT A REALISTIC PROGRAM TO ADORESS THE NATION'S NEEDS MUST GO BEYOND SPECIFIC POLICY INITIATIVES TO ADDRESS THE CONDITIONS OF EFFECTIVE ACTION. ALSO, THAT THE PRESENT DIFFICULTIES RUN MUCH MORE DEEPLY THAN HAVING A DEMOCRAT PRESIDENT, AND REOUIRES MAJOR ALTERATIONS IN THE DEMOCRAT PRESIDENT, AND REQUIRES MAJOR ALTERATIONS IN THE
WAY AMERICANS CONCEIVE OF--AND PRACTICE-D CITIZENSHIP AND WAY AMERICANS
LEADERSHIP.

07454 PRICE, D.

PACIFUSION: MAKING PEACE PERMANENT THROUGH THE FUSION OF PACIFUSION: MAKINC VITAL INTERESTS
PEACE AND THE SCIENCES, 3 (SEP 91), 26-30

POST-WAR FRANCD-GERMAN RELATIONS CHANGED THE WHOLE CONCEPT OF WEST EUROPEAN POLITICS. THE EUROPEAN COMMUNITY, AS A NEH POLITICAL ACTOR GIVING A NEW DIRECTION TO WORLD
POLITIICS, HAS CREATED A HIGH LEVEL OF SATISFACTION AMONG THE
CORE STATES OF THE EUROPEAN COMMUNITY. TAKING THE CASE OF GERMANY AND FRANCE, THE COMHUNITY'S "AXIS", WHAT LESSONS CAN BE DRAWN FOR CREATING STABLE RELATIONSHIPS IN THE WHOLE OF EUROPE? THE ANSWERS ARE DISCUSSED IN THIS ARTICLE.

07455 PRICE, D.C.

REFORMERS, REVOLUTIONARIES AND SECRET SOCIETIES: PROTOPOPULISM AMONG THE LATE CH'ING ELITE; ASSOCIATION FOR ASIAN STUDIES 1992 ANNUAL MEETING

ASSOCIATION FOR ASIAN STUDIES, 1992, 37-38.

MODERN CHINA'S PEASANT REVOLUTION POSED FOR HER

REVOLUTIONARIES THE QUESTION OF THE ROLE OF THE COMMON

PEOPLE, AND FOR MARXIST REVOLUTIONARIES, THE QUESTION OF THE PROPER ROLE OF THE PEASANTS AND THEIR LEADERS, AS HELL AS THE NATURE OF A COMMUNIST-LED REVOLUTION. THIS PANEL ADDRESSES ITSELF TO THE INTERPLAY OF IDEAS AND EXPERIENCE IN ADDRESSES ITSELF TO THE INTERPLAY OF IDEAS AND EXPERIENCE IN EVOLVING ELITE ATTITUDES TOWARD COMMONERS. ISSUES EXAMINED INCLUDE THE EMERGENCE OF A QUALIFIED POPULIST STRAIN IN THE LATE CH'ING, THE CATEGORIES USED BY THE EARLIEST COMMUNIS PEASANT ORGANIZERS TO EVALUATE THEIR CONSTITUTENTS AND TO YENATUCT THE IMAGE OF A "MODEL" "PEASANT REVOLUTIONARY, YENAN-ERA PROPAGANDA EFFORTS "BY "STREET PLAY" DRAMATISTS, AND THE CONSTRUCTION OF THE "PEASANTRY" AS A CATEGORY OF 2OTH-CENTURY CHINESE DISCOURSE.

07456 PRICE, J

TEACHERS; DRESS CODE

INSIGHT, 7(8) (FEB 19), 20.

PHILADELPHIA'S DECISION TO ENFORCE A 96-YEAR-OLD STATE LAW THAT PROHIBITS TEACHERS FROM WEARING RELIGIOUS CLOTHING AND EMBLEMS IN THE CLASSROOM HAS CREATED A STIR. RELIGIOUS AND LEGAL GROUPS SAY THE MEASURE IS UNCONSTITUTIONAL AND FEAR THAT OTHER SCHOOL SYSTEMS MAY FOLLOH SUIT. THEY YOH TO CONTINUE CHALLENGING THE LAN IN COURT.

07457 PRICE, V.; HSU, M.

PUBLIC OPINION ABOUT AIDS POLICIES

PUBLIC OPINION QUARTERLY (CHICACO), 56(1) (SPR 92), 29-52.

IN AN EFFORT TO BETTER UNDERSTAND THE COGNITIVE AND

ATTITUDINAL FACTORS UNDERLYING PUBLIC OPINION ON AIDS-

RELATED ISSUES, THE AUTHORS PROPOSE AND EMPIRICALLY TEST

MODEL OF THE RELATIONSHIPS AMONG (1) KNOWLEDGE OF HIV TRANSMISSION, SPECIFICALLY THE MISINFORMATION THAT AIDS CAN BE TRANSHITTED EASILY THROUGH CASUAL CONTACT WITH HIVINFECTED PERSONS; (2) ATTITUDES TOWARD HOMOSEXUALS, THE MOST PROMINENT OF THE SOCIAL GROUPS PRESENTLY AFFECTED BY THE AIDS CRISIS; AND (3) SUPPORT FOR RESTRICTIVE PUBLIC POLICIES AIMED AT HIV-INFECTED PERSONS. DATA FROM THO SURVEYS CONDUCTEO IN 1985 ANO 1987 PROVIOE EVIOENCE THAT MISINFORMATION ABOUT AIDS TRANSMISSION AND NEGATIVE ATTITUDES TOHARD HOMOSEXUALS ARE STRONG PREDICTORS OF SUPPORT FOR STRINGENT RESTRICTIONS OF PERSONS WITH AIDS. THE FINDINGS ALSO SUGGEST THAT SEVERAL BACKGROUND FACTORS--IN PARTICULAR, EDUCATION AND POLITICAL LIBERALISM--MAY PLAY DECISIVE ROLES IN INFLUENCING LEVELS OF SUPPORT FOR RESTRICTING THOSE INFECTED WITH THE AIDS VIRUS.

07458 PRIDHAM, G.; VERNEY S.

THE COALITIONS OF 1989-90 IN GREECE: INTER-PARTY RELATIONS AND DEMOCRATIC CONSOLIDATION

WEST EUROPEAN POLITICS, 14(4) (OCT 91), 42-69

THE GREEK COALITIONS OF 1989-90 WERE SIGNIFICANT AS A DEPARTURE IN GREEK POL ITICS. COALITIONS ARE AS SUCH ALMOST UNKNOWN IN POSTWAR GREECE, AND ONE-PARTY GOVERNMENT HAS BEEN THE RULE SINCE 1974. DRAWING ON LESSONS FROM COALITION THEORY, THE FORMATION AND MAINTENANCE OF THESE TWO GOVERMMENTS ARE DISCUSSED. HHILE THEIR POLICY ACHIEVEMENTS WERE LIMITED, THE GOVERNMENTS OF 89-90 ALLOWED GREECE TO OVERCOME CRISIS AND SCANDALS AND MADE WAY FOR A SECOND ALTERNATION IN POHER. ON BALANCE THEY ARE LIKEIY TO HAYE CONTRIBUTED TO THE ONGOING PROCESS OF DEMOCRATIC CONSOLIDATION IN GREECE.

07459 PRIES, K.

EAST GERMANS HAYE YET TO LEARN TOLERANCE

GERMAN TRIBUNE, 1487 (OCT 91), 3, 5.

HOSTILITY TOWARDS FOREIGNERS IN GERMANY HAS REACHED A NEW DIMENSION. THIS TIME THE CENTER OF VIOLENCE WAS THE TOWH

OF HOYERSHERDA IN NORTHERN SAXONY. THERE WERE ALSO REPORTS OF ATTACKS IN THIENDORF AND FRETAL NEAR DESDEN AND IN HOSTELS NEAR HANOVER AND FREIBURG. DESPITE A LARGE POLICE CONTINGENT, 120 RIGHT-WING EXTREMISTS IN HOYERSWERDA TRIED CONTINGENT, 120 RIGHT-WING EXTREMISTS IN HOYERSHERDA TRI TO STORM AN ASYLUM HOSTEL. FIVE PEOPLE, INCLUDING THO JOURNALISTS WERE INJURED. ACCORDING TO EYEWITNESS REPORTS, CHEERING THEM ON OUTSIDE THE HOSTEL.

07460 PRILLELTENSKY, I PSYCHOLOGY IN' INDUSTRY: ORIGINS AND SOCIOPOLITICAL IMPLICATIONS

CRITICAL SOCIOLOGY, 17(2) (SUM 90), 73-92.

IN SPITE OF THE NUMEROUS SOCIOPOLITICAL IMPLICATIONS INVOLVED IN THE PRACTICE OF INDUSTRIAL/ORGANIZATIONAL (I/O) PSYCHOLOGY, SOCIAL SCIENTISTS WORKING IN INDUSTRIES HAVE 
BEEN OPERATING UNDER THE ERRONEOUS ASSUMPTION THAT THEY ARE MERELY PROVIDING AN APOLITICAL SERVICE THAT WILL IMPACT FAVORABLY ON EMPLOYERS AMD EMPLOYEES ALIKE. THE MAIM ARGUMENT ADYANCED IN THIS PAPER IS THAT WHILE I/O PSYCHOLOGY IS POTENTIALLY CAPABLE OF SERVING THE NEEDS OF WORKERS, IT IS USED PRIMARILY TO PROTECT THE INTERESTS OF MANAGERS AND OWNERS. THIS ARTICLE EXPOSES THE IDEOLOGICAL UNDERPINNINGS OF I/O PSYCHOLOGY AND THE PRACTICAL WAYS WHEREBY IT CONTRIBUTES TO UPHOLD THE IMDUSTRIAL STATUS QUO. ETHICAL DILEMMAS FACING SOCIAL SCIENTISTS IN THE WORKPLACE AND METHODS WHEREBY THEY CAN CHALLENGE - RATHER THAN RATIFY THE INDUSTRIAL STATUS QUO ARE ALSO DISCUSSED.

07461 PRIMORAC, M.

OUT OF THE RUBBLE

NATIONAL REVIEN, XLIV(18) (SEP 92), 46, 48

IN PURSUING ITS "ETHNIC CLEANSING" POLICY, THE SERBS ARE DELIBERATELY TERRORIZING NON-SERBIAN POPULATIONS AND INFLICTING MORE DAMAGE THAN WAS DONE IN WORLD WAR II. THE NAZI-LIKE CAMPAIGN INCLUDES DEATH CAMPS, SUMMARY EXECUTIONS, AND THE CREATION OF MILLIONS OF REFUGEES. QUICK HESTERN ACTION COULD WESTERN POWERS HAVE NOT TAKEN THE NECESSARY STEPS.

07462 PRITCHARD, A.

CHAMGES IN ELECTORAL STRUCTURES AND THE SUCCESS OF WOMEN CHANGES IN ELECTORAL STRUCTURES A

SOCIAL SCIENCE QUARTERLY, 73(1) (MAR 92), 62-70.

IN THE 1982 ELECTION, CHANGES IN ELECTORAL RULES AND STRUCTURES, COMBINED WITH RECRUITING EFFORTS BY WOMEN'S ORGANIZATIONS, CONTRIBUTED TO AN UMUSUAL INCREASE IN THE PROPORTION OF WOMEN LEGISLATORS SERVING IN THE FLORIDA HOUSE OF LEGISLATURE. ALL SENATORS, RATHER THAN THE USUAL ONE-HALF, WERE ELECTED. HOMEN CANDIDATES ALSO BENEFITED FROM CHANGES IN DECISION MAKING BY ELECTORAL ELITES. MORE HOUSE INCUMBENTS RETIRED, AND THE PROPORTION OF HOMEN CANOIDATES FOR BOTH HOUSE AMD SEMATE SEATS INCREASED.

07463 PRITCHARD, A.

STRATEGIC CONSIDERATIONS IN THE DECISION TO CHALLENGE A STATE LEGISLATIVE INCUMBENT

LEGISLATIVE STUDIES QUARTERLY, XVII(3) (AUG 92), 381-394,

THE AUTHOR SEEKS TO EXPLAIN WHY SOME LEGISLATIVE INCUMBENTS ATTRACT CHALLENGERS HHILE OTHERS DO NOT BY ANALYZING DECISIONS TO CHALLENGE IN RACES FOR THE FLORIDA HOUSE OF REPRESENTATIVES BETHEEN 1972 AND 1980. ALTHOUGH SHE FINDS LITTLE EVIDENCE OF STRATEGIC DECISION-MAKING AMONG CHALLENGERS IN PRIMARY ELECTIOMS INCUMBENTS HHO APPEAR TO CHA VULNERABLE ARE MORE IKELY TO' BE CHALLENGED IN GEMERAL ELECTIONS. CONDITIONS THAT ARE LESS DIRECTLY UNDER AN ELECTIONS. CONDITIONS THAT ARE LESS DIRECTLY UNDER AN
INCUMBENT'S INFLUENCE ARE MDRE LIKELY TO INFLUENCE DECISIONS INCUMBENT'S IMF

07464 PROUSIS, T.C.

ALEKSAMDR STURDZA: RUSSIAN CONSERVATIVE RESPONSE TO THE GREEK REVOLUTION

EAST EUROPEAN QUARTERLY, XXVI(3) (FAL 92 ), 309-344.

ALEKSANDR STURDZA DESCRIBED HIMSELF AS' "AN ORTHODOX CHRISTIAN, GREEK BY DESCENT, AND A LOYAL AND DEDICATED SERVANT" OF THE RUSSIAN EMPEROR. AS A GOVERNMENT OFFICIAL, TRANSLATOR, AND PUBLICIST, STURDZA BECAME AN ARDENT DEFENDER OF ORTHODOXY AND OF RUSSIA'S PROECTION OF CO-RELIGIONISTS IN THE GREEK EAST. ALONG WITH HIS SERVICE IN THE RUSSIAN MINISTRIES OF FOREIGN AFFAIRS AND PUBLIC EDUCATION, STUROZA PARTICIPATED IN RELIGIOUS AND POLITICAL DEBATES, WINNING A DESERVED REPUTATION AS A METTERNICHEAN CONSERVATIVE AND A PROPONENT OF UNFETTERED AUTOCRACY. THE ONE EXCEPTION TO

STURDZA'S CONSERVATISM HAS HIS SUPPORT OF THE GREEK NATIONAL CAUSE AND HIS PRO-HELLENIC ACTIVITY IN RUSSIA AND WESTERN EUROPE. AN EXAMINATION OF STURDZA'S RESPONSE TO THE GREEK REVOLUTION SHEDS LIGHT ON THE COMPLEXITY OF HIS CONSERVATIVE SOCIAL AMD POLITICAL BELIEFS. IT ALSO SERVES AS A REMINDER OF THE BROADER RAMIFICATIONS OF "THE EASTERN QUESTION" OF WHO OR WHAT WOULD REPLACE THE DECLINING OTTOMAN EMPIRE IN THE STRATEGIC REGION OF THE EASTERN MEDITERRANEAN AND THE BALKANS.

07465 PROVOPOULOS, G. ; ZAMBARAS, A.

TESTING FOR CAUSALITY BETWEEN GOVERNMENT SPENDING AND TAXATION

PUBLIC CHOICE, 68(1-3) (JAN 91), 277-282.

IN THE PAST FEW YEARS THE PUBLIC SECTOR DEFICIT IN GREECE HAS REACHED ALARMING HIGH LEVELS. IN VIEN OF THE VARIOUS HYPOTHESES BETWEEN GOVERMMENT SPENDING AND REVENUES, VARIOUS HYPOTHESES BETHEEN GOVERNMENT SPENDING AND REVENUES THE AUTHORS OF THIS PAPER TEST FOR CAUSALITY BETHEEN THESE STUDY SUPPORT THE YIEH THAT THE LARGE DEFICITS OF THE GREEK STUDY SUPPORT THE VIEH THAT THE LARGE DEFICITS OF THE GREEX PUBLIC SECTOR ARE MAINLY DUE TO FAST GROWING EXPENDITURES. THIS IMPLIES THAT MEASURES TO CURTAIL THE LATER SHOULD
COMPRISE THE LARGEST PART OF ANY POLICY AIMING AT CONTAINING COMPRISE THE LARGEST PART OF ANY POLICY AIMING AT CONTA THE DEFICIT. HOWEVER, A POLICY AIMING AT BROADENING THE TAX BASE MIGHT ALSO BE FRUITFUL AS THE RESULTS INDICATE THAT MORE TAX REVENUES DO NOT LEAD TO INCREASED SPENDING.
07466 PRUDEN, $W$

QUAYLE BOMBSHELL IS LESSON FOR BUSH

INSIGHT, $8(45)$ (NOV 92$), 17-18$

THE AUTHOR COMMENTS ON THE 1992 CAMPAIGN DEBATE BETHEEM VICE-PRESIDENTIAL CANDIDATES DAN QUAYLE, AL GORE, AND JIM STOCKDALE.

07467 PRYBYLA, J

CHINA'S ECONOMIC DYNAMOS

CURRENT HISTORY, 91(566) (SEP 92) 262-267.

THE AUTHOR DISCUSSES CHINA'S RECENT ATTEMPTS TO REFORM ITS ECONOMIC POLICY, TO ESTABLISH SPECIAL ECONOMIC ZONES, AND TO ATTRACT MORE FOREIGN INVESTMENT.

07468 PRYDE, I KYRGYZSTAN: SECULARISM VS. ISLAM HORLD TODAY, 48(11) (NOV 92), 208-211.

THE AUTHOR DESCRIBES THE ETHNIC COMPOSITON OF KYRGYZSTAN AND EXPLAINS WHY THUS FAR THE FORMER SOVIET REPUBLIC HAS BEEN LESS PRONE TO ETHNIC VIOLENCE THAN SOME OF ITS NEIGHBORS.

07469 PRZEWORSKI, A.

COULD WE FEED EVERYONE? THE IRRATIONALITY OF CAPITALISM AND THE INFEASIBILITY OF SOCIALISM

POLIIICS AMD SOCIETY 19(1) (MAR 91), 1-38.

THIS ARTICLE EXAMINES THE QUESTIONS: IS THE SOCIAL ORGANIZATION OF OUR ECONOMIC SYSTEMS THE REASON HE UNDERUTILIZE THE PRODUCTIVE POTENTIAL; DOES THE FAILURE OF SOCIALISM INVALIDATE THE SOCIALIST CRITIOUE OF THE IRRATIONALITY OF CAPITALISM; AND CAN EITHER SYSTEM BE REFORMED TO ASSURE THE MATERIAL WELFARE FOR EVERYONE? TO STUDY THESE OUESTIONS, THE AUTHOR BEGINS BY STATING DEFINITIONS AND CLARIFYING THE LOGICAL STRUCTURE OF THE PROBLEM. THEN HE REVIEWS VARIOUS CRITIQUES OF CAPITALISM AND SOCIALISM CONCERNING: BLUEPRINTS; THE FEASIBILITY OF THESE
BLUEPRINTS; REALITIES; AND REFORMABILITY OF THE REALITIES.

07470 PRZEHORSKI, A.

THE NEOLIBERAL FALLACY

JOURNAL OF DEMOCRACY, 3(3) (JUL 92), 45-59.

SEVERAL COUNTRIES, IN EASTERN EUROPE AND ELSEWHERE, HAVE RECENTLY BEGUN THE GREATEST IDEOLOGICALLY INSPIRED EXPERIMENT SINCE THE DAYS OF STALIN. THE ECONOMIC TRANSFORMATIONS ENVISAGED IN THESE COUNTRIES IMPLEMENT AN INTELLECTUAL BLUEPRINT, A BLUEPRINT DRAWN UP WITHIN THE WALLS OF AMERICAN ACADEMIA AND SHAPED BY INTERNATIONAL FINANCIAL INSTITUTIONS. THIS ARTICLE ARGUES THAT THIS NEOLIBERAL IDEOLOGY IS NO MORE THAN A MIXTURE OF EVIDENCE, ARGUMENT FROM FIRST PRINCIPLES, SELF-INTEREST ANO WISHFUL THINKING. THE AUTHOR CAUTIONS AGAINST THE DANGERS OF EXCESSIVE IDEOLOGICAL ZEAL. HE CONCLUDES LITTLE IS KNOWN EXCESSIVE IDEDLOGICAL ZEAL. HE CONCLUOES LITLE IS KNOWN ABOUT MARKETS AND DEMOCRACIES, AND WHAT LITTLE
DOES NOT SUPPORT ANY IDEOLOGICAL BLUEPRINTS

07471 PUCHALA, F.

POLAND AND EUROPEAN SECURITY

RUSI JOURNAL, 137 (1) (FEB 92), 15-18.

THE DESTRUCTION OF THE BERL IN HALL INITIATED THE PRDCESS OF GERMAN UNIFICATION AMD SOYIET FORCES ARE BEING HITHDRAWH FROM EASTERM EUROPE. COUNTRIES OF THIS REGION-DOLAMD AMONG THEM- HAYE THEM--HAVE, FOR THE FIRST TIME FOR MEALY HALF A CENTURY, TO DEFINE THEIR CONCEPT OF SECURITY. THIS ARTICLE LOOKS AT SECURITY OPTIONS FACING POLAND AND OUTLINES THE AIMS OF POLISH SECURITY POL ICY AS THE FORGING OF CLOSER LINKS WITH

07472 PUDDINGTON, A.

CLARENCE THOMAS AND THE BLACKS

COMMENTARY, $93(2)$ (FEB 92), 28-33.

THE APPOINTMENT OF CLARENCE THOMAS TO THE SUPREME COURT MAY WELL MARK AN IMPORTANT MOMENT IN THE DEBATE OVER RACIAL POLICY IN AMERICA. IT MAY BRING THE US NEARER TO A

RESOLUTION OF THE OFTEN BITTER ARGUMENTS OVER THE STRATEGIES FOR BLACK ECONOMIC ADVANTAGE, THE DEGREE TO WHICH RACISM IS RESPONSIBLE FOR BLACK-WHITE INEOUALITY, AND THE PROPER ROLE OF RACE IN GOVERNMENT SOCIAL POLICY. AT THIS TIME IT SEEMS EVIDENT THAT AN INCREASING NUMBER OF BLACKS ARE MOVING BEYOND THE AFFIRMATIVE-ACTION CONTROVERSY, WHICH THEY SEE AS INCREASINGLY IRRELEVANT TO THE FUTURE OF THEIR RACE, AND PAYING RENEHED ATTENTION TO THE CRISIS OF THE BLACK URBAN POOR. AMECDOTAL EVIDENCE INDICATES THAT THIS MOVEMENT IS GROHING. THE SUPPORT THOMAS RECEIVED FROM THE MAJORITY OF BLACK AMERICANS, ALONG WITH THE GROWING COMPETITION OF IDEAS BLACK AMERICANS, ALONG HITH THE GRONING COMPETITION OF IDEAS OVER THE FUTURE OF RACE RELATIONS, TOGETHER SUGGEST THAT A PROCESS MAY BE UNDER WAY WHICH WILL FINALLY POINT AMER
THE DIRECTION OF A SOLUTION TO ITS LONGSTANDING RACIAL THE DIRECT

07473 PUDOINGTON, A.

DENYING THE TERROR FAMINE

MATIOMAL REYIEH XLIV( 10$)$ (MAY 92) 33-36.

THE 1933 UKRAINIAN FAMINE ESCAPED SERIDUS SCHOLARLY INQUIRY FOR OVER FIFTY YEARS. WHILE THE MAJORITY OF SCHOLARS 
WHO HAVE SINCE STUDIED THE SUBJECT AGREE THAT THE FAMINE KILLED MILLIONS AND WAS ENGINEERED BY STALIN FOR FUNDAMENTALLY POLITICAL REASONS, A SEGMENT OF SOVIETOLOGY HARSHLY ATTACKS THE GENERAL VIEW. THEY ARGUE THAT THE EXTENT OF THE FAMINE IS VASTLY OVERSTATED AND THAT THE CULPRITS WERE NOT STALIN AND HIS FOLLOWERS BUT RATHER THE "KULAKS" OR WEALTHY PEASANTS. THEY ALSO POINT TO THE UKRAINE'S DARK PAST OF ANTI-SEMITISM AND NAZI COLLABORATION AND ARGUE THAT CONSTANT HARPING ON THE FAMINE IS AN ATTEMPT BY UKRAINIAN NATIONALISTS TO DEFLECT ATTENTION ANAY FROM THEIR OWN EVILS. THIS ARTICLE ASSESSES THESE ARGUMENTS AND FINDS THEM WOEFULLY WANTING.

07474 PUDOINGTON, A.

IS WHITE RACISM THE PROBLEM?

WHITE RACISM HAS BEEN SUGGESTED AS THE CAUSE FOR THE LASTEST RIOTS IN LOS ANGELES. THIS TIME THE FOCUS OF THE CHARGES WAS THE POLICE DEPARTMENT. THE CRIMINAL-JUSTICE CHARGES WAS THE POLICE DEPARTMENT, THE CRIMINAL-JUSTICE

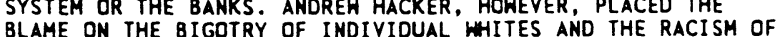
BLAME ON THE BIGOTRY OF INDIVIDUAL IHITES AND THE RACISM OF AMERICAN INSTITUTIONS. HE USES RACISM THE WAY MARZISTS USE CLASS OPPRESSION, AS A READY-MADE EXPLANATION FOR ALL SOCIAL
PHENOMENA. THIS ARTICLE SEEKS TO REFUTE HACKER'S THESIS AND ARGUMENTS AND SUGGESTS THAT AFTER LOS ANGELES, AMERICA HAS A CLEAR CHOICE IN ITS APPROACH TO RACIAL DIVISION. IT COULD FOLLOH ANDREH HACKER OR COULD BEGIN PAYING HEED TO PEOPLE, BOTH BLACK AND WHITE, WHO HAVE NEW THOUGHTS ABOUT REACHING THE UNDERCLASS.

07475 PUDDINGTON, A.

THE QUESTION OF BLACK LEADERSHIP

COMMENTARY 91 (1)

THE QUESTION OF BLACK LEADERSHIP HAS BEEN PLACED IN SHARP FOCUS BY A RECENT SERIES OF UNSETTLING AND SOMETIMES UGLY INCIDENTS INCLUDING THE TRIAL OF WASHINGTON MAYOR MARION BARRY, THE CENTRAL PARK JOGGER TRIAL, THE BOYCOTT OF MARION BARRY, THE CENTRAL PARK JOGGER TRIAL, THE BOYCOIT OF OF BLACK CHICAGO CONGRESSMAN GUS SAVAGE, AND THE REEMERGENCE OF LOUIS FARRAKHAN. ALTHOUGH DIFFERING IN SOME RESPECTS, OF LOUIS FARRAKHAN. ALTHOUGH DIFFERING IN SOME RESPECTS, THESE CASES CONTAIN A NUMBER OF COMMON FEATURES. FIRST, AHILE THE INCIDENTS AND INDIVIDUALS ARE ROUT INELY DESCRIBED AS CONTROVERSIAL, THERE IS VERY LIT DAMNING THE EVIDENCE, MANY BLACKS CLING TO THE NOTION THAT BARRY, SAVAGE,
FARRAKHAN, THE JOGGER DEFENDANTS, AND OTHERS ARE THE VICTIMS FARRAKHAN, THE JOGGER DEFENDANTS, AND OTHERS ARE THE VIC

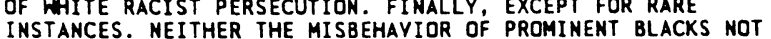
INSTANCES. NEITHER THE MISBEHAVIOR OF PROMINENT BLACKS NOT THE EXTREME OR PARANOID VIEHS OF THEIR SUPPORTERS HAVE DRA
REBLUES FROM MAINSTREAM FIGURES IN THE BLACK COMMUNITY.

07476 PUGH, M.C.

UNILATERAL NUCLEAR DISARMAMENT AT SEA

ARMS CONTROL, 13(1) (APR 92), 108-120.

THE AUTHOR DISCUSSES THE RATIONALE FOR NUCLEAR DISARMAMENT AT SEA, CONSIDERS THE POLITICAL ISSUES INVOLVED IN VERIFICATION, AND ASSESSES THE VERIFICATION OPTIONS. VERIFICATION OF NONSTRATEGIC NAVAL NUCLEAR WEAPONS HAS ALWAYS BEEN PROBLEMATIC BECAUSE OF THE DUAL CAPABILITY OF DELIVERY SYSTEMS AND THE MIXING OF CONYENTIONAL AND NUCLEAR WARHEADS ON NAVAL PLATFORMS. IN GENERAL, NAVAL

ESTABLISHMENTS HAVE ALSO TRADITIONALLY PERCEIVED A SECURITY REOUIREMENT FOR YESSELS TO BE INSPECTION-FREE. UNLIATERAL DISARMAMENT MAY APPEAR TO BYPASS THIS OBSTACLE ON THE PRINCIPLE THAT, IF SOMETHING HAS BEEN REMOVED, ITS PRESENCE NEED NOT BE CHECKED AND CONFIDENCE IN DECLARATIONS CAN BE ASSUMED. ACCORDING TO THIS VIEH, VERIFICATION WOULD BE A LUXURY. ALTHOUGH UNILATERALISM MAY OBVIATE THE REQUIREMENT FOR WATER-TIGHT VERIFICATION, A CONFIDENCE-BUILDING VERIFICATION REGIME HOULD SERYE IMPORTANT POLIIICAL PURPOSES AND ENHANCE NAVAL COOPERATION IN THE POST-COLD WAR WORLD.

07477 PUHL, D.

AN INTERNATIONAL POLICE FORCE IS BADLY NEEDED

GERMAN TRIBUNE, (1515) (MAY 92), 2

UN PEACEKEEPING TROOPS ARE NOW STATIONED IN IRAO, CROATIA, CAMBODIA, AND ELSEWHERE. NEVER BEFORE HAS THE CROATIA, CAMBODIA, AND ELSEWHERE. NEVER BEFORE HAS THE PROTECT THE TRANSITION TO A PEACEFUL DEVELOPMENT; NEVER PROTECT THE TRANSITION TO A PEACEFUL DEVELOPMENT; EXTENSIYELY ESTABL ISHMENT OF A PERMANENT UN POLICE FORCE. HOWEVER, IT IS ESTABLISHMENT OF A PERMANENT UN POLLICE FORCE. HOWEVER, IT IS MUCH WILL DEPEND ON THE CONSTRUCTIVE COOPERATION OF THE BIG PONERS AND THE MEDIUM-SIZED POWERS SUCH AS GERMANY, JAPAN, PONERS AND THE MEDIUM-SIZED POWERS
INDIA, NIGERIA, BRAZIL AND MEXICO.

07478 PUHL, D.

DEFENSE AND THE WESTERN EUROPEAN UNION

GERMAN TRIBUNE, (1477) (JUL 91), 5

THE SECRETARY-GENERAL OF THE WESTERN EUROPEAN UNIOM (WEU), WILLEM VAN EEKELEN, HAS SUGGESTED THAT THE DEFENSE STATES SHOULD SEND SEVERAL HUNDRED SOLDIERS TO YUGOSLAVIA TO
SUPERVISE THE CEASEFIRE AGREED ON IN PRINCIPLE BETWEEN THE CIVIL WAR PARTIES FOLLOWING EUROPEAN COMUUNITY MEDIATION. THIS BOLD PROPOSAL HAS PROMPTED SERIDUS DEBATE ON THE ROLE OF THE WEU, AND ON HOW THE ORGANIZATION SHOULD COOPERATE WITH OR INTERACT WITH OTHER ORGANIZATIONS INCLUDING NATO. WEU OFFICIALS STATE THAT THEIR ROLE WILL BE TO INTERVENE IN AREAS THAT NATO AND THE COUNCIL ON SECURITY ANO COOPERATION IN EUROPE (CSCE) ARE UNABLE OR UNHILLING TO MEDDLE WITH. HOWEVER, SOME NATO OFFICIALS SEE THE WEU POSTURING AS REDUNDANT AND DIVISIVE.

07479 PULZER, P.

NOTES ON RECENT ELECTIONS: THE AUSTRIAN PRESIDENTIAL ELECTION OF 1992

ELECTORAL STUDIES, 11(4) (DEC 92), 347-351.

THE ELECTION TO CHOOSE A SUCCESSOR TO KURT WALDHEIM WAS INTENDED TO BE LOH-KEY. FOLLOWING THE POLARIZATION CREATED BY THE 1986 ELECTION CAMPAIGN AND THE EMBARRASSMENTS OF WALDHEIM'S TERM, THERE WAS A GENERAL DESIRE WITHIN AUSTRIA'S POLITICAL ELITE' TO REESTABLISH DOMESTIC CONSENSUS AND OBJECTIVES WERE ATTAINED WHILE OTHERS HERE NOT.

07480 PUNNETT, R.

THE ALTERNATIVE VOTE RE-VISITED

ELECTORAL STUDIES, 10(4) (DEC 91), 281-298.

IN THE RENEWED ELECTORAL REFORM DEBATE, RELATIVELY LITTLE ATTENTION HAS BEEN DEVOTED TO THE ALTERNATIVE VOTE (THAT SYSTEM OF ELECTION WHICH REQUIRES THE VOTER TO RANK THE CANDIDATES IN ORDER OF PREFERENCE, AND WHICH TAKES THE VOTER'S LOWER PREFERENCES INTO CONSIDERATION IF THE COUNTING OF THE FIRST PREFERENCES FAILS TO PRODUCE A CANDIDATE WITH AN OVERALL MAJORITY). ELECTORAL REFORM RE-EMERGED IN THE $1980 S$ AS A SIGNIFICANT ISSUE IN BRITISH POLITICS. SINCE 1987 GROWING CONCERN OVER THE CONSERVATIVE'S ELECTORAL DOMINANCE HAS PROMPTED RENEWED INTEREST IN ELECTORAL PACTS BETWEEN OUTOF-OFFICE PARTIES, AND THUS IN ELECTORAL SYSTEMS WHICH MIGHT FACILITATE SUCH PACTS. THE 1990 LABOUR CONFERENCE

RECOMMENDED THAT THE PARTY CONSIDER THE CREATION OF A

SPEAKERS' CONFERENCE TO EXAMINE THE WHOLE ISSUE OF ELECTORAL REFORM.

07481 PUNTASEN, A.; PUNYASAVATSUT, C.; SIRIPRACHAI, S. POLITICAL ECONOMY OF EUCALYPTUS: BUSINESS, BUREAUCRACY AMD THE THAI GOVERNMENT

JOURNAL OF CONTEMPORARY ASIA, 22(2) (1992), 187-206.

THIS ARTICLE SEEKS TO EXPI IN HOW EUCALYPTUS HAS BEEN

INTRODUAED BY THAIAND'S ROYAL FOREST DEPARTMENT (RFD) UNDER THE GUISE OF A REFORESTATION PROGRAM. IT EXPLORES THE HIDDEN AGENDA BEHIND THE RFD'S ACTIONS. IT ALSO SEEKS TO DETERMINE AHETHER THE ARGUMENT OF REFORESTATION IS ONLY USED TO REDIRECT ATTENTION AWAY FROM ENVIRONMENTAL CONCERNS AND WHETHER THERE ARE ANY BUSINESS INTERESTS INVOLVED IN THE INTROOUCTION OF THE TREE. THE EUCALYPTUS IS USED AS A CASE STUDY OF ECONOMIC INTEREST WHICH MAY EXPLAIN THE REACTION OF THE THAI GOVERMMENT AND ITS BUREAUCRACY IN RESPONSE TO SHORTTERM POLITCO-ECONOMIC GAIN FOR THOSE INVOLVED. IT CONCLUDES THAT THE GOVERNMENT'S REACTIONS MAY BRING ABOUT ECOLOGICAL

07482 PURCELL, S.K.

COLLAPSING CUBA

FOREIGN AFFAIRS, 71(1) (1992), 130-145

IT IS ONLY A MATTER OF TIME BEFORE CUBAN COMMUNISM COLLAPSES. TINKERING WITH THE DESIGN OF CUBA'S OUTMODED COMMUNIST SYSTEM MAY POSTPONE CASTRO'S DAY OF RECKONING, BUT FUNDAMENTAL ECONOMIC AND POLITICAL CHANGES ARE INCREASINGLY UNAVOIDABLE. THE MOST INTERESTING QUESTION IS WHETHER CUBA WILL BE ABLE TO AVOID VIOLENCE AND EXPERIENCE A PEACEFUL
TRANSITION FROM COMMUNIST DICTATORSHIP TO REPRESENTATIVE DEMOCRACY.

07483 PURCELL, S.K. MEXICO'S NEW ECONOMIC VITALITY

CURRENT HISTORY, 91(562) (FEB 92) 54-58.

TODAY MEXICO' IS CONSIDERED AN ECONOMIC SUCCESS STORY, WITH ONE OF THE MOST OPEN ECONOMIES IN THE WORLD.

"SAL IMASTROIKA" MAS REFOPMED THE MEXICAN ECONOMY, REDUCED "SALINASTROIKA" HAS REFORMED THE MEXICAN ECONOMY, REDUCED
TRADE BARRIERS, MANAGED THE FOREIGN DEBT CRISIS, AND REDUCED GOVERMMENT INVOLVEMENT IN THE ECONOMY. ALTHOUGH POLITICAL
REFORM HAS NOT BEEN PURSUED AS AGGRESSIVELY, SOME PROGRESS REFORM HAS NOT BEEN PURSUED AS AGGRESSIVELY, SOME PRDG
HAS BEEN MADE IN DISMANTLING MEXICO'S AUTHORITARIAN HAS BEEN MADE IN DISMAN
POLITICAL STRUCTURES

07484 PURCELL, S.K.

RISKY BUSINESS? THE CUBAN DEMOCRACY ACT OF 1992 HEMISPHERE, 4(3) (SUM 92), 6-7

U.S. CONGRESSMAN ROBERT TORICELLI HAS PROPOSED THE CUBAN DEMOCRACY ACT OF 1992 AS A MEANS OF PROMOTING A PEACEFUL TRANSITION TO DEMOCRACY IN CUBA. THE PROPOSAL INCLUDES A NUMBER OF INCENTIVES FOR INDIVIDUALS AND GROUPS PROMOTING DEMOCRATIC CHANGE IN CUBA ALONG WITH SANCTIONS AGAINST THE GOVERMMENT OF FIDEL CASTRO. SOME OF THE BILL'S INCENTIVES AND SANCTIONS HAVE ALREADY BEEN TRIED HITHOUT MUCH SUCCESS. 
MOREOVER, TORICELLI'S MEASURES COULD HAVE NEGATIVE REPERCUSSIONS IN OTHER LATIN AMERICAN COUNTRIES.

07485 PURCELL, S.K. (ED.); IMMERMAN, R.M. (ED.) JAPAN AND LATIN AMERICA IN THE NEW GLOBAL ORDER LYNNE RIENNER, 1992, 163

AS LATIN AMERICA EMERGES FROM THE "LOST DECADE" OF THE 1980 S INTO THE "GROWTH DECADE" OF THE 1990S, JAPAN IS REASSESSING ITS RELATIONSHIP WITH THE REGION. WITH ITS LARGE AND DEVELOPING MARKETS AND ITS RICH RESOURCE BASE, LATIN AMERICA WILL LOOK INCREASINGLY ATTRACTIVE TO JAPAN, ASSUMING IT CONTINUES TO STABILIZE ANO RESTRUCTURE ITS ECONOMIES. THE MOMENT IS ALSO RIGHT FOR ACTIVE COLLABORATION BETHEEN JAPAN AND THE UNITED STATES IN LATIN AMERICA, AND THE UNITED STATES HAS ENCOURAGED JAPAN'S INCREASED ECONOMIC AID TO THE REGION. THIS BOOK EXPLORES THE POTENTIAL FOR CONFLICT AND COOPERATION IN THE EMERGING JAPAN-LATIN AMERICA-U.S. RELATIONSHIP, HIGHLIGHTING THE CASES OF BRAZIL AND MEXICO. THE BOOK ADDRESSES CRITICAL ISSUES AND OFFERS POLICY RECOMMENDATIONS TO HELP ENSURE MUTUALLY BENEFICIAL RELATIONS NOW AND IN THE YEARS TO COME.

07486 PUTHAM, R.D. ; LEONARDI, R.; MANETTI, R. MAKING DEMOCRACY WORK--CIVIC TRADITION IN MOOERN ITALY PRINCETON UNIVERSITY PRESS, $1992,288$.

IN A WORLD ALIVE WITH NEW HOPE FOR DEMOCRATIZATION BUT WARY OF GOVERNMENT FAILURE, THIS BOOK OFFERS EMPIRICAL EVIDENCE FOR THE IMPORTANCE OF "CIVIC CDMMUNITY" IN DEVELOPING SUCCESSFUL INSTITUTIONS. TAKING ADVANTAGE OF A UNIQUE EXPERIMENT BEGUN IN 1970 WHEN ITALY CREATED NEW GOVERMMENTS FOR EACH OF ITS REGIONS--WHICH VARY GREATLY FROM THE STANDPOINT OF WEALTH, SOCIAL STRUCTURE AND POLITICAL LEANINGS--THE AUTHORS SPENT THO DECADES ANALYZING THE EFFICACY OF THESE GOVERMMENTS IN SUCH FIELDS AS AGRICULTURE, HOUSING, AND HEALTH SERVICES. THEIR FIMDINGS INDICATE THAT THE REGIONS WHICH ENJOY EFFECTIVE GOVERNMENT IN THE $1990 \mathrm{~S}$ HAVE INHERITED A LEGACY OF CIVIC ENGAGEMENT THAT CAN BE TRACED BACK TO THE EARLY MIDDLE AGES. THE AUTHORS ILLUMINATE PATTERNS OF ASSOCIATIONISH, TRUST, AND COOPERATION THAT FACILITATE GOOD GOVERMANCE AND ECONOMIC PROSPERITY.

07487 QIANG, $Z$.

CHINA AND THE GENEVA CONFERENCE OF 1954

CHINA QUARTERLY, (129) (MAR 92), 103-122.

MUCH HAS BEEN WRITTEN ABOUT THE ROLE OF THE WESTERN

POWERS AT THE GENEVA CONFERENCE OF 1954, BUT DISCUSSIONS ON

CHINA'S POLICY TOWARD THE EVENT REMAIN LIMITED. IN THE LAST

FEW YEARS, MANY CHINESE MATERIALS THAT SHED LIGHT ON

BEIJING'S ROLE IN THE SETTLEMENT OF THE INDOCHINA ISSUE HAVE BEIJING'S ROLE IN THE SETTLEMENT OF THE INDOCHINA ISSUE HAV
BECOME AVAILABLE. BASED ON THESE SOURCES AND ON WESTERN BECOME AVAILABLE. BASED ON THESE SOURCES AND ON WESTERN
DOCUMENTS, THE AUTHOR EXAMINES CHINA'S PREPARATION FOR AND DOCUMENTS, THE AUTHOR EXAMINES CHINA'S PREPARATION FOR A
PERFORMANCE DURING THE CONFERENCE AHD DISCUSSES CHINA'S PERFORMANCE DURING THE CONFERENCE AND DISC
RELATIONS WITH THE MAJOR PONERS AT GENEVA.

07488 OICHEN, 0.

AN INDEPENDENT FOREIGN POLICY OF PEACE

BEIJING REVIEW, 35(12) (MAR 92), 13-15.

QIAN QICHEN, STATE COUNCILOR AND FOREIGN MINISTER OF THE PEOPLE'S REPUBLIC OF CHINA, MADE A SPEECH AT THE GERMAN ASSOCIATION FOR FOREIGN POLICY ON MARCH 12, 1992. THIS ARTICLE CONTAINS EXCERPTS OF HIS SPEECH TITLED "CHINA'S FOREIGN POLICY." AFTER A BRIEF DESCRIPTION OF THE WORLD SITUATION OICHEN DETAILS FIVE BASIC POINTS OF CHINA'S FOREIGN POLICY AND ADOS THAT CHINA CONTRIBUTES TO WORLD PEACE AND SUPPORTS THE INTER-KOREAN DIALOGUE AND WORKED ON SETTLING THE CAMBOOIAN CONFLICT.

07489 QICHEN, $Q$.

ASIA, CHINA, AND AUSTRALIA

BEIJING REVIEW, 35(27) (JUL 92), 14-18

CHINESE FOREIGN MINISTER QIAN OICHEN ADORESSED THE ASIAAUSTRALIA INSTITUTE ON JUNE 19, 1992. HE EMPHASIZED THAT CHINA IS AN IMPORTANT ELEMENT IN MAINTAINING PEACE AND STABILITY IN THE ASIA-PACIFIC REGION. HE REFUTED THE VIEH THAT CHIMESE SOCIALISM HILL COLLAPSE IN THE WAKE OF THE DISINTEGRATION OF THE SOVIET UNION, AND HE CALLED FOR CLOSE COOPERATION BETHEEN CHINA AND AUSTRALIA.

07490 QICHEN, $Q$.

CHINA'S REFORM AND OPENING-UP AND SINO-BRITISH RELATIONS

BEIJING REVIEW, 35(12) (MAR 92), 10-12

THIS ARTICLE OFFERS DETAILED EXCERPTS FROM A SPEECH MADE BY QIAN OICHEN, STATE COUNCILLOR AND FOREIGN MINISTER OF THE BY QIAN QICHEN, STATE COUNCILLOR AND FOREIGN MINISTER PEOPLE'S REPUBLIC OF CHINA, AT THE ROYAL INSTITUTE OF INTERNATIONAL AFFAIRS IN LONDON ON MARCH 9, 1992. QICHEN
DETAILS RAPID ECONOMIC GRONTH AND STEPPING UP THE REFORM. HE DETAILS RAPID ECONOMIC GROWTH ANO STEPPING UP THE REFORM. HE
SUGGESTS THAT THROUGH THEY CANHOT YET CLAIM TO BE AFFLUENT, THEY HAVE NONETHELESS BASICALLY SOLVED THE PROBLEM OF PROVIDING ADEQUATE FOOO ANO CLOTHING FOR THE 1.1. BILLION CHINESE PEOPLE AND THAT THEIR MARKET IS BRISK, COMMODITIES ARE ABUNDANT, AND PRICES STABLE.

07491 QICHEN, Q.

NAM TO PLAY STRONG ROLE ON HORLD STAGE
BEI JING REVIEW, 35 (37) (SEP 92), 13-14.

IN THIS ADORESS TO THE 1OTH SUMHIT CONFERENCE OF THE HEADS OF STATE OR GOVERMMENT OF THE NONALIGNED MOVEMENT, CHINESE FOREIGN MINISTER QIAN QICHEN DISCUSSES THE PRESENT INTERNATIONAL SITUATION AND THE ROLE OF THE MONALIGNED COUNTRIES IN PRESERVING WORLD STABILITY AND PEACE. HE STATES THAT THE BASIC PURPOSES AND PRINCIPLES OF THE NONALIGNED MOVEMENT ARE STILL HIGHLY RELEYANT AND THAT NAM HAS AN IMPORTANT INTERNATIONAL ROLE AS A FORUM FOR DEVELOPING NATIONS AND A FORCE TO BE RECKONED WITH.

07492 QICHEN, $Q$.

QIAN CALLS FOR FURTHER ECONOMIC COOPERATION AMONG ASIAPACIFIC NATIONS

BEIJING REVIEH, 35(38) (SEP 92), 13-15.

AT THE FOURTH MINISTERIAL MEETING OF THE ASIA-PACIFIC ECONOMIC COOPERATION (APEC) GROUP IN SEPTEMBER 1992, CHINA'S FOREIGN MINISTER QIAN QICHEN REVIEWED THE RECENT ECONOMIC AND POLITICAL PROGRESS IN THE ASIA-PACIFIC REGION. HE STATED AND POL ITICAL PROGRESS IN THE ASIA-PACIFIC REGION. HE STATED THAT IMPROVED RELATIONS AMONG THE ASIA-PACIFIC NATION
HELPED PROMOTE PEACE AND STABILITY, PROVIDING A GOOD HELPED PROMOTE PEACE AND STABILITY, PROVIDING A GOOD
ENYIRONMENT FOR REGIONAL ECONOMIC DEVELOPMENT THEN HE ENVIRONMENT FOR REGIONAL ECONOMIC DEVELOPMENT. THEN HE
CALLED FOR CONTINUED ECONOMIC COOPERATION AMONG APEC MEMBERS.

07493 OICHEN, 0

QIAN ON REgIONAL DISARMAMENT AND SECURITY BEI JING REVIEH, 35(35) (AUG 92), 13-16.

CHINESE STATE COUNCILOR AND FOREIGN MINISTER QIAN QICHEN RECENTLY PUT FORWARD A FIVE-POINT OUTLINE ON REGIONAL OISARMAMENT AND SECURITY. QIAN SAID THAT THE ASIA-PACIFIC REGION OCCUPIES AN IMPORTANT POSITION IN AND HAS A

SIGNIFICANT INFLUENCE ON THE WORLD. HE PREDICTED THAT THE 2IST CENTURY WILL OFFER GREAT OPPORTUNITIES AND CHALLENGES FOR THE REGION.

\section{OICHEN, $Q$.}

HORLD ENTERS NEW PHASE OF DEVELOPMENT

BEIJING REVIEW, 35(40) (OCT 92), 12-16.

IN A SPEECH BEFORE THE UNITED NATIONS ON SEPTEMBER 23,

1992, CHINA'S MINISTER OF FOREIGN AFFAIRS OIAN OICHEN

EXPLAINED HIS COUNTRY'S OFFICIAL VIEH OF THE NEH

INTERNATIONAL ORDER. HE STATED THAT FORCE SHOULD NOT BE USED,

EVEN AS A LAST RESORT, TO SETTLE INTERNATIONAL PROBLEMS.

THE FUNDAMENTAL SOLUTION TO TODAY'S ETHNIC WARS LIES IN A

RECONCILIATION OF THE VARIOUS ETHNIC GROUPS THROUGH PEACEFUL

NEGOTIATIONS AND DIALOGUES ON AN EQUAL FOOTING. THE NEW

INTERMATIONAL ORDER SHOULD BE BASED ON THE PRINCIPLES OF

INTERNATIONAL ORDER SHOULD BE BASED ON THE PRINCIPLES OF

MUTUAL RESPECT FOR SOVEREIGNTY AND TERRITORIAL INTEGRITY,
MUTUAL NON-AGGRESSION, NON-INTERFERENCE IN ANOTHER COUNTRY'S

DOMESTIC AFFAIRS, EQUALITY, MUTUAL BENEFIT, AND PEACEFUL
COEXISTENCE.

07495 OIHHUA, $P$.

NO LONGER FOES, BUT STILL VIGILANT

BEIJING REVIEN, 35(21) (MAY 25), 14-15

THIS YEAR'S U.S. -RUSISIAN RELATIONS ARE CHARACTERIZED BY FREQUENT EXCHANGE OF VISITS BY HIGH-RANKING U.S. AND RUSSIAK OFFICIALS, HHICH HAS PROMOTED THE DEVELOPMENT OF THEIR CLAIMED PARTNERSHIP. PRESENT U.S.-RUSSIAN RELATIONS ARE BASED ON MUTURAL NEED. ON THE PART OF THE UNITED STATES, IT WANTS TO INTEGRATE RUSSIA INTO THE WESTERN WORLD TO SERVE ITS STRATEGIC PURPOSE. FOR THE RUSSIA'S PART, IT BADLY NEEDS U.S. AID.

07496 OIHUA, $P$

FRANCE, U.S. DIFFER ON EUROPEAN DEFENSE

BEIJING REVIEW, 35(2) (JAN 92), 16-17.

THE 13TH SUMMIT OF THE NORTH ATLANTIC TREATY

ORGANIZATION (NATO) EXPANDED THE POLITICAL FUNCTIONS OF THAT ORGANIZATION AND REAFFIRMED ITS LEADERSHIP ON EUROPEAN DEFENSE MATTER. HOWEVER, A RIFT HAS APPARENT, ESPECIALLY BETHEEN THE UNITED STATES AND FRANCE. ONE OF THE MAJOR AREAS OF DISAGREEMENT IS WHO WILL DOMINATE EUROPE'S FUTURE

SECURITY STRUCTURE-MATO OR THE EUROPEAN COMMUMITY?

07497 QIN, S.

HIGH-TECH INDUSTRIALIZATION IN CHIMA: AN ANALYSIS OF THE CURRENT STATUS

ASIAN SURVEY, XXXII(12) (DEC 92), 1124-1136.

CONFRONTED WITH THE CHALLENGE OF THE NEH TECHMOLOGICAL REVOLUTION IN THE WORLD. CHINA IS MAKING AN EFFORT TO CATCH UP WITH WORLD DEVELOPMENTS AND NARROW THE GAP BETWEEN IT AND ADVANCED FOREIGN COUNTRIES IN CERTAIN AREAS THAT VITALLY AFFECT FUTURE DEVELOPMENTS IN SCIENCE, TECHNOLOGY, AND THE ECONOMY AND MAKE USE OF THE ADVANTAGES DERIVED. CHINA HAS DRAWN UP THO NATIONAL PLANS: THE HIGH-TECH RESEARCH AND DEVELOPMENT PROGRAM IN 1987 AND THE TORCH PROGRAM IN 1988. HOWEVER, THERE ARE PROBLEMS THAT IMPEDE THE DEVELOPMENT OF HIGH-TECH INDUSTRIES, FOR INSTANCE, THE DIFFICULTY IN TRANSFERRING HIGH-TECH R\&D RESEARCH RESULTS INTO PRODUCTION. THIS ARTICLE ANALYZES THE STATUS, POLICIES, AND PROBLEMS OF HIGH-TECH INDUSTRIALIZATION IN CHINA, AND RAISES SOME QUESTIONS ABOUT LEARNING FROM THE SUCCESSFUL EXPERIENCE OF FOREIGN COUNTRIES. 
07498 QINGCHANG, $Z$.

BILL CLINTON WINS PRESIDENTIAL ELECTION

BEI JING REVIEW, 35 (46) (NOV 92), 14-15.

THE AUTHOR ENDEAYORS TO EXPLAIN WHY GOVERNOR BILL CLINTON DEFEATED INCUMBENT PRESIDENT GEORGE BUSH IN THE 1992 U.S. PRESIDENTIAL ELECTION. HE STATES THAT VOTERS HAD LOST CONFIDENCE IN BUSH'S ABILITY TO MANAGE THE ECONOMY, THAT CLINTON DEFTLY ADAPTED TO THE VOTERS' MOOD BY PRESENTING HIMSELF AS THE CANDIDATE OF CHANGE, AND THAT BUSH WAS WEAKENED BY CHALLENGES FROM ROSS PEROT AND PAT BUCHANAN.

07499 QINGCHANG, $Z$.

ECONOMY ON THE RIGHT PATH

BEI JING REVIEW, 35(44) (NOV 92), 11.

BEI JING REVIEW, 35 (44) (NOV 92), 11 . TURKEY SEEKS TO IMPROVE THE QUALITY OF LIFE FOR ITS PEOPLE, TURKEY SEEKS TO IMPROVE THE QUALITY OF LIFE FOR ITS PEOP

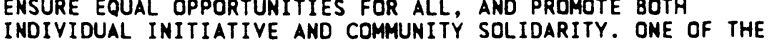
INDIVIDUAL INITIATIVE AND COMMUNITY SOLIDARITY. ONE OF GOYERMMENT'S SHARE AND INFLUENCE IN THE ECONOMY WHILE GOVERNMENT'S SHARE AND INFLUENCE IN THE ECONOMY WHIL

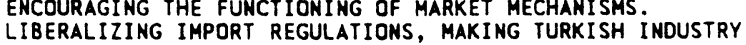
MORE COMPETITIVE, AND ATTRACTING FOREIGN CAPITAL ARE ALSO IMPORTANT OBJECTIVES.

07500 QINGCHANG, $Z$.

ISRAELI PRESIDENT TO VISIT CHINA

BEI JING REVIEN, 35 (51) (DEC 21), 10-11.

THE AUTHOR REVIEWS THE PROGRESS DURING THE FIRST YEAR OF DIPLOMATIC CONTACTS BETWEEN ISRAEL AND COMMUNIST CHINA, WHICH ESTABLISHED BILATERAL RELATIONS AT THE BEGINNING OF 1992.

07501 QINGCHANG, $Z$. MASS STRIKE IN SOUTH AFRICA

BEIJING REVIEW, 35(34) (AUG 92), 31-32.

ON AUGUST 3, 1992, THE AFRICAN NATIONAL CONGRESS AND ITS ALLIES LAUNCHED A TWO-DAY GENERAL STRIKE. LATER, STRIKERS MARCHED TO GOVERNMENT HEADOUARTERS IN PRETORIA TO PROTEST THE WHITE LEADERSHIP'S INTRANSIGENCE IN THE DEADLOCKED NEGOT IATIONS ON DISMANTLING APARTHEID AND INTRODUCING DEMOCRATIC REFORMS.

07502 QIMGCHANG, $Z$.

RE JUVEMATION OF PAKISTAN'S ECONOMY

BEI JNG REYIEH $35(42)$ (OCT 22$)$

SINCE COMING TO POWER IN 1990 PAKISTANI PRIME MINISTER MOHAMMAD NAHAZ SHARIF HAS INTRODUCED FUNDAMENTAL ECONOMIC REFORMS AIMED AT REDUCING RELIANCE ON FOREIGN AID AND DEVELOPING A VIGOROUS, EFFECTIVE, AND COMPETITIVE ECONOMY. THESE REFORMS HAVE BEGUN TO PAY OFF IN THE FORM OF MORE EXPORTS, HIGHER PRODUCTION, AND INCREASED FOREIGN INVESTMENT.

07503 QINGCHANG, $Z$.

RISING TO THE CHALLENGE

BEIJING REVIEW, 35(17) (APR 92), 14-16.

THE 48TH SESSION OF THE U.N. SOCIAL AND ECONOMIC COMMISSION FOR ASIA AND THE PACIFIC WAS HELD IN BEIJING IN APRIL 1992. THE PARTICIPANTS LAID A SOLID FOUNDATION FOR FURTHER COOPERATION IN THE AREAS OF INDUSTRY, SCIENCE, TECHNOLOGY, ENERGY, AND TRANSPORTATION.

07504 QINGCHANG, $Z$. WORLD REACTIONS TO LOS ANGELES RIOTING

BEI JING REYIEW, 35(20) (MAY 92) 13-14.

THE VIOLENT' INCIDENTS IN LOS ANGELES ONCE AGAIN PROVES THAT REACIAL DISCRIMINATION AND VIOLATIONS OF HUMAN RIGHTS EXIST IN THE UNITED STATES. IRONICALLY, IN RECENT YEARS SOME PEOPLE IN THE UNITED STATES HAVE POSED AS THE GUARDIANS OF HUMAN RIGHTS AND HAVE USED THE HUMAN RIGHTS ISSUE TO INTERFERE IN THE INTERNAL AFFAIRS OF OTHER COUNTRIES. MATURALLY THE LOS AMGELES RIOTING HAS DRAHM STROMG REACTIONS FROM MANY COUNTRIES OF THE WORLD, INCLUDING INDIA, IRAN, JORDAN, JAPAN, SOUTH KOREA, CANADA. THE CARIBBEAN, FRANCE, RUSSIA, GERMANY AND ITALY.

07505 OINGCHANG, $Z$.

IOTH NAM SUMMIT ACHIEVEMENTS

BEI JING REVIEW, $35(38)$ (SEP 92), 17

ON NOVEMBER 6 , 1992 , THE 10TH SUMMIT MEETING OF THE NONALIGNED MOVEMENT (NAM) CLOSED, AFTER OUTLINING ITS FUTURE NONALIGNED MOVEMENT (NAM) CLOSED, AFTER OUTLINING ITS MISSION AND FUNCTIONS IN A FINAL DOCUMENT AND IN "THE JAKARTA MESSAGE. THE MESSAGE STATED THAT THE NEW WORLD MATER MS' CHARTER AND MUST BE DEDICATED TO PEACE AND JUSTICE NATIONS' CHARTER AND MUST BE DEDICATED TO PEACE AND JUSTICE, SECURITY, DEVELOPMENT, DEMOCRACY, AND THE
AND FREEDOMS OF INDIVIDUALS AND NATIONS.

07506 QINGSHAN, T.

THE MAKING OF U.S. CHINA POLICY: FROM NORMALIZATION TO THE POST-COLD WAR ERA

LYNNE RIENAER PUBLISHERS, $1992,178$.

FOCUSING ON FOUR CASE STUDIES (THE TAIWAN RELATIONS ACT,

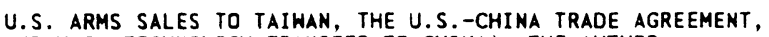
AND U.S. TECHNOLOGY TRANSFER TO CHINA), THE AUTHOR EXPHASIZES THE NECESSARY LINKAGE BETHEEN STRATEGIC INTERESTS AND GOVERNMENT PROCESS IN FOREIGN POLICYMAKING. HIS EXAMINATION OF THE VARIANCE IN U.S. CHINA POLICY EXPLAINS WHY SOME POLICIES REFLECTED THE CONVERGENCE OF STRATEGIC INTERESTS AND INTERGOVERNMENTAL POLITICS, WHILE OTHERS DID NOT.

07507 QIZHEN, $Z$.

CHINA'S FOREIGN POLICY AND CHINA-US RELATIONS

BEIJING REVIEH, 35(12) (MAR 92), 31-33.

CHINA HAS ALWAYS HELD THAT DIFFERENCES IM IDEOLOGIES AND SOCIAL SYSTEMS SHOULD NOT STAND IN THE WAY OF ESTABLISHING STATE-TO-STATE RELATIONS. THEREFORE, IT ATTACHES IMPORTANCE TO THE DEVELOPMENT OF FRIENDLY RELATIONS AND COOPERATION TO THE DEVELOPMENT OF FRIENDLY RELATIONS AND COOPERATION WITH ALL WESTERN DEVELOPED COUNTRIES ON THE BASIS OF THE
FIVE PRINCIPLES OF PEACEFUL COEXISTENCE. IN THE PAST YEAR FIVE PRINCIPLES OF PEACEFUL COEXISTENCE. IN THE PAST YEAR CHINA HAS RESTORED NORMAL RELATIONS WITH JAPAN AND HAS SEEN ITS RELATIONS WITH THE EUROPEAN COMMUNITY COUNTRIES GET BACK UNITED STATES.

07508 QUADAGNO, J.

SOCIAL MOVEMENTS AND STATE TRANSFORMATION: LABOR UNIONS AND RACIAL CONFLICT IN THE WAR ON POVERTY

AMERICAN SOCIOLOGICAL REVIEW, 57(5) (OCT 92), 616-634.

THE AUTHOR ANALYZES THE HISTORICAL DEVELOPMENT OF JOB TRAINING PROGRAMS ENACTED DURING THE WAR ON POVERTY COMBINING INSIGHTS FROM POHER RESOURCE THEORY, MASS TURMOIL THEORY, AND THE POLITY-CENTERED APPROACH, SHE DEVELOPS A "STATE TRANSFORMATION" THEORY. STATE TRANSFORMATION THEORY MOVES BEYOND THE TRADITIONAL FOCUS OF SOCIAL MOVEMENT THEORIES ON HOW THE STATE SHAPES THE OUTCOME OF SOCIAL PROTEST TO CONSIDER HOW SOCIAL MOVEMENTS AFFECT THE PROCESS OF STATE FORMATION. SHE DUTLINES STATE TRANSFORMATIONS THAT OCCURRED WITHIN THE CONTEXT OF CONFLICT BETWEEN CIVIL RIGHTS ACTIVISTS AND ORGANIZED LABOR OVER THE DEFINITION OF ECONOMIC JUSTICE. EVIDENCE INDICATES THAT DEEP STRUCTURAL CHANGE OCCURRED WITHIN THE STATE AND SUGGESTS THAT THIS TRANSFORMATION WAS LEGITIMATED BY IDEOLOGICAL CLAIMS THAT REDEFINED DEMOCRATIC RIGHTS.

07509 QUADE, $Q$

DON'T FIX IT--TOO MUCH

DON'T FIX IT--TOO MUCH
POLITICAL QUARTERLY (THE), 63(2) (APR 92), 186-196.

POLITICAL QUARTERLY (THE), 63 (2) (APR 92), 186-196.
MR. QUADE URGES THE BRITISH TO REFLECT ON THE FACT THAT THEY NOW HAVE A POL ITICAL ARRANGEMENT HHICH DECENTLY APPROXIMATES THE WAY RATIONAL PEOPLE ACTUALLY LIVE THEIR APPROXIMATES THE WAY RAT IONAL PEOPLE ACTUALLY. HIS HOPE IS LIVES, BEFORE OPTING FOR MORE RADICAL CHANGES. HIS HOPE IS FRUSTRATING RECMMES BRITISH REFORM PROPONENTS HOULD FULLY FRUSTRATING CHANGES, BRITISH REFORM PROPONENTS WOULD FULLY ACCEPT THE OBLIGATION TO IDENTIFY, DESCRIBE, AND DEF SUPERIOR MINORTY-RULE ALTERNATIVES; AND WOULD LOOK
RIGOROUSLY AT THE IMPLICATIONS OF SUCH CHANGES, WHICH CAN BE RIGOROUSLY AT THE IMPLICATIONS OF SUCH CHANGES
SEEN CONCRETLY WORKED OUT IN OTHER SYSTEMS.

07510 QUADE, Q.L.

THE CATHOLIC CHURCH: MILITANT OR PACIFIST?

FREEDOM REVIEW, $23(4)$ (JUL 92 ), 44-46.
THE AUTHOR ANALYZES THE ROMAN CATHOLIC CHURCH'S VIEHS ON WAR AS ARTICULATED IN "LA CIVILITA CATTOLICA."

07511 QUANSAH, E.

SPORT OF UNITY?

WEST AFRICA, (3884) (FEB 92), 330.

IN 1960, HHEN GHANA ATTAINED REPUBLICAN STATUS, SOCCER WAS STRUGGLING FOR RECOGNITION, SUPPORTERS AND POLITICIANS CALLED FOR A REORGANIZATION OF THE TEAM TO REFLECT THE COUNTRY'S LEADING ROLE IN AFRICAN NATIONALISM. ACCORDINGLY, THE TEAM BECAME A SYMBOL OF THE RISING SPIRIT OF BLACK AFRICA. MANY OTHER AFRICAN COUNTRIES FOLLOWED THE GHANAIAN EXAMPLE AND NAMED THEIR NATIONAL TEAMS TO REFLECT NATIONAL ASPIRATIOHS THUS SOCCER HAS BECOME MORE THAM A GAME IM AFRICA. IT IS ONE ARENA WHERE AFRICA CAN STAND ON EQUAL TERMS WITH THE REST OF THE WORLD, AND AFRICAN NATIONS CAN BE PROUD OF THEIR TEAMS.

07512 QUANSHENG, $Z$.

DOMESTIC FACTORS OF CHINESE FOREIGN POLICY: FROM VERTICAL TO HORI ZONTAL AUTHORITARIANISM

ANMALS OF THE AMERICAN ACADEMY OF POLITICAL AND SOCIAL ANHALS OF THE AMERICAN ACADEMY

FOREIGN POLICY DECISION-MAKING IN CHINA IS NO LONGER THE DOMAIN OF A PARAMOUNT LEADER ACTING THROUGH A VERTICAL DOMAIN OF A PARAMOUNT LEADER ACTING THROUGH A VERTICAL COMMAND CHANMEL WITH A FUNDAMENTALLY-UNIFIED POLICY. FOREIG BASES COORDINATED AT THE CENTER, WITH MULTIPLE COMMAND BASES COORDINATED AT THE CENTER, WITH MULTIPLE COMMAND CHANNELS REFLECTING DIFFERENT INTERESTS AND POLICIES. BUREAUCRATIC INTERESTS, AGENDAS OF POLICY ISSUES, LOCAL-
CENTRAL AUTHORITY RELATIONS, INTELLECTUAL AND THINK-TANK CENTRAL AUTHORITY RELATIONS, INTELLECTUAL AND THINK-TANK
INFLUENCES, AND THE DOMESTIC POLITICAL-ECONOMIC ENVIRONMENT DIFFERENTIALLY AFFECT POLICY INPUT AND OUTPUT. THE CHANGE FROM VERTICAL TO HORIZONTAL AUTHORITARIANISH PARALLELS THAT 
WHICH OCCURRED IN SOUTH KOREA AND TAIWAN, BUT WHETHER IT WILL EVOLVE TOWARD DEMOCRATIC PLURALISM REMAINS TO BE SEEN.

07513 QUANYU, $Y$.

THE RIGHT TO SUBSISTENCE NOT TO BE SHUNNED

BEIJING REVIEN, 35(2) (JAN 92), 13

ALTHOUGH AMERICANS OFTEN CRITICIZE CHINA'S HUMAN RIGHTS RECORD AND THE VALUE CHINA PLACES ON THE RIGHT OF

SUBSISTENCE, THE HUMAN RIGHTS SITUATION IN THE UNITED STATES

IS FAR NORSE THAN THAT IN CHINA. IN THE UNITED STATES THE

COMMON PERSON'S RIGHT TO SUBSISTENCE HAS BEEN SERIOUSLY

JEOPARDIZED AND ENCROACHED UPON, AS IS EVIDENT FROM THE HIGH

CRIME RATE AND THE LARGE NUMBERS OF HOMELESS INDIVIDUALS.

07514 QUAYE, R.

THE POLITICAL ECONOMY OF HEALTH AND MEDICAL CARE: THE GHANAIAN EXPERIENCE

SCANDINAVIAN JOURNAL OF DEVELOPMENT ALTERNATIVES, XI(1)

(MAR 92), 5-26.

THE AUTHOR EXAMINES HEALTH AND MEDICAL CARE IN GHANA FROM A DEPENDENCY MODE OF ANALYSIS. HE REJECTS THE DOMINANT CUL TUROLOGICAL HEALTH AND SICKNESS PERSPECTIVE, WHICH FOCUSES ON CULTURAL PRACTICES, BELIEFS, CUSTOMS, AND TRADITIONAL VALUES AS THE ONLY EXPLANATORY VARIABLE FOR UNDERSTANDING THE HEALTH NEEDS OF GHANAIANS. INSTEAD, HE OFF LOCATING GHANA'S HEALTH PROBLEMS HITHIN THE GLOBAL BY LOCATING GHANA'S HEALTH PROBLEMS WITHIN THE GLOBAL ECONOMIC STRUCTURE. GHANA 'S DEPENOENT PERIPHERAL STANOING HAS CREATED A SERIDUS BOTTLENECK FOR THE ECONOMY. GHANA IS DEPENDENT UPON OUTSIDE SOURCES FOR MANUFACTURED GOODS, MUST EXPORT PRIMARY PRODUCTS FOR FOREIGN EXCHANGE, AND IS SADDLED WITH A CRIPPLING BURDEN OF FOREIGN DEBT. GHANA HAS BLINOLY FOLLOWED THE WESTERN MODEL OF HEALTH CARE HITH NO ATTEMPT TO ADORESS THE UNIQUE HEALTH NEEDS OF ITS POPULATION. THE AUTHOR CALLS FOR AN EXPANDED STATE ROLE IN HEALTH CARE AND FOR THE INTEGRATION OF TRADITIONAL AND WESTERN MEDICAL SYSTEMS.

07515 QUIGLEY, M.

PEACE HITHOUT HIROSHIMA: SECRET ACTION AT THE VATICAN IM THE SPRING OF 1945

MADI SON BOOKS, 1991,187

BASED ON DOCUMENTS RECENTLY DECLASSIFIED BY THE UNITED STATES AND JAPAN, THE AUTHDR, FORMERLY AN O.S.S. AGENT UNDER THE THE O.S.S. DIRECTOR GENERAL WILLIAM J. DONOVAN, RECOUNTS THE TRUE STORY OF A PLAN FOR PEACE WHICH SUCCEEDED IN OPENING COMMUNICATIONS WITH TOKYO IN THE SPRING OF 1945. WITH THE HELP OF A YATICAN DIPLOMAT, A JAPANESE PRIEST, AND THE JAPANESE AMBASSADOR TO THE HOLY' SEE, TALKS WERE THE JAPANESE AMBASSADOR TO THE HOLY SEE, TALKS WERE INITIATED, BUT PLANS WERE SIDETRACKED AND PEACE WAS NOT
ACHIEVED UNTIL AFTER THE BOMBINGS OF HIRSHIMA AND NAGASAKI. ACHIEVED UNTIL AFTER THE BOMBINGS OF HIRSHIMA AND NAGASAKI. PEACE WAS POSSIBLE IN LATE JUNE OR EARLY JULY OF 1945. HHY OFFERED AFTER THE BOMBINGS OF HIROSHIMA AND HAGASAKI REMAINS OFFERED AFTER

07516 QUIGLEY,P.

RETHINKING RESISTANCE: ENVIRONMENTALISM, LITERATURE, AND POSTRUCTURAL THEORY

ENVIRONMENTAL ETHICS, 14(4) (WIN 92), 291-306.

THIS ARTICLE ARGUES THAT WITH THE ADVENT OF

POSTSTRUCTURALISH, TRADITIONAL THEORIES OF REPRESENTATION, TRUTH, AND RESISTANCE HAVE BEEN SERIOUSLY BROUGHT INTO QUESTION. REFERENCES TO THE "NATURAL" AND THE "WILD" CANMOT ESCAPE THE POSTSTRUCTURAL ATTACK AGAINST FOUMDATIONAL CONCEPTS AND THE CONSTITUTING CHARACTER OF HUMAN-CENTERED LANGUAGE. IT EXPLORES THE HAYS IN WHICH ENVIRONMENTAL MOVEMENTS AND LITERARY EXPRESSION HAVE TENDED TO POSIT PREIDEOLOGICAL ESSENCES, THEREBY REPLICATING PATTERNS OF POWER AND AUTHORITY. IT ALSO POINTS OUT HOH ENVIRONMENTALISM MIGHT BE RESHAPED IN THE LIGHT OF POSTSTRUCTURALISM TO CHALLENGE POWER WITHOUT REFERENCE TO AUTHORITY.

07517 QUIJANO, A.; WALLERSTEIN, I.

AMERICANITY AS A CONCEPT, OR THE AMERICAS IN THE MODERM WORLD-SYSTEM

INTERNATIONAL SOCIAL SCIENCE JOURNAL, 143(143) (NOV 92), 549-558

THE AMERICAS AS A GEOSOCIAL CONSTRUCT WERE BORN IN THE SIXTEENTH CENTURY. THE CREATION OF THIS GEOSOCIAL ENTITY IS EXPLORED AS THE CONSTITUTIVE ACT OF THE MODERN HORLD-SYSTEM. EXPLORED AS THE CONSTITUTIVE ACT OF THE MODERN WORL THIS ARTICLE SUGGESTS THAT THE AMERICAS WERE NOT
INCORPORATED INTO AN ALREADY EXISTING CAPITALIST WORLDINCORPORATED INTO AN ALREADY EXISTIMG CAPITALIST HORLD ECONOMY BUT RATHER THAT THERE COULD NOT HAVE BEEN A AND ITS AFFECTS UPON THE AMERICAS IS EXAMINED.

07518 OUINE, R.E.

SPENDING CONTROLS: FINANCIAL RESPONSIBILITY IN THE DEMOCRATIC PROCESS

PARLIAMENTARIAN, LXXIII (2) (APR 92), 98-100.

THE AUTHOR DISCUSSES THE PROBLEM OF CONTROLLING PUBLIC SPENDING AND EXPLAINS HOW THE PARL IAMENT ON THE ISLE OF MAN APPROACHES ITS FINANCIAL RESPONSIBILITIES.
07519 OUINLAN, M.

BRITISH DEFENCE PLANMING IN A CHANGING WORLD

WORLD TODAY, 48(8-9) (AUG 92), 160-162.

THE AUTHOR DISCUSSES THE HAYS IN WHICH GREAT BRITAIN'S BASIC IDEAS ABOUT DEFENSE SHOULD CHANGE IN LIGHT OF THE DRAMATIC DEYELOPMENTS IN INTERNATIONAL RELATIONS OVER THE PAST FEW YEARS.

07520 QUINA-JUDGE, P.

FACTS ON FILE

NEW REPUBLIC, 206(26) (JUN 92), 16-17

THE YELTSIN ADMINISTRATION IS HORKING THROUGH "THE SPECIAL FILE" OF SECRET COMMUNIST DOCUMENTS, PREPARING TO RELEASE A SELECTION OF THE MATERIAL. THE FILE CONTAINS INFORMATION ON A WIDE VARIETY OF UNSAVORY DEALINGS, FROM SOVIET SUPPORT OF TERRORISTS TO LINKS WITH THE EXTREME NATIONALIST VLADIMIR ZHIRINOVSKY. THE YELTSIN REGIME IS MOTIVATED BY A DESIRE TO DESTROY THE COMMUNIST PARTY AND EXPOSE GORBACHEV ONCE AND FOR ALL. YELTSIN IS CONVINCED THAT THE PARTY COULD YET PROVIDE A POWERFUL BASE FOR AH AUTHORITARIAN MOVEMENT THAT WOULD TRY TO RESTORE THE OLD REGIME. AND HE IS OBSESSED WITH THE IDEA THAT GORBACHEY MIGHT SOMEHOH MAKE A COMEBACK.

07521 QUINN-JUDGE, P.

REVENGE TRAGEDY

NEW REPUBLIC, 206(14) (APR 92), 11-12.

THE ARMENIANS HO LIVE IM KARABAKH HAVE DECLARED

THEMSELVES INDEPENDENT FROM AZERBAIJAN, WHICH HAS CONTROLLED THE AREA SINCE 1923. DUE TO THE GROWING ETHMIC TENSION, THE AZERBAI JANI MINORITY POPULATION HAS DROPPED DRAMATICALLY IN THE LAST FOUR YEARS. NOW THE ARMENIANS ARE PREPARIMG TO LAUNCH AN OFFENSIVE AGAINST SHUSHA. THE LAST AZERBAIJANI STRONGHOLD IN KARABAKH, AND AT LEAST ONE CITY IN AZERBAI JAN PROPER. THE HORLD COMMUNITY IS BELATEDLY SCRAMBLING TO FIND A SOLUTION TO THE CONFLICT BEFORE IT SPILLS OVER INTO THE REST OF THE CAUCASUS AND PERHAPS CENTRAL ASIA, TOO. DESPITE THE BEST INTENTIONS OF THE UNITED NATIONS, THE ISLAMIC CONFERENCE, THE CSCE, IRAN, AND TURKEY, THE CHANCES FOR A COMPROMISE SOLUTION TO THE HAR LOOK DESPERATELY REMOTE.

07522 QUINN-JUDGE, $P$.

SPOOKED

NEW REPUBLIC, 206(11) (MAR 92), 18-19.

THERE IS A DEEP GAP BETWEEN THEORY AMD REALITY REGARDING

THE STATE SECURITY APPARATUS IN POST-TOTALITARIAN RUSSIA.

THE THEORY IS THAT THE KGB HAS BEEN BROKEN UP, THAT IT IS

HEMORRHAGING SECRET FILES, THAT ITS FOREIGN INTELLIGENCE

HEMORRHAGING SECRET FILES, THAT ITS FOREIGN INTELLIGENCE OPERATION HAS COLLAPSED, AND THAT ITS REMAINING STAFFERS

FRIENDLY, SLIGHTLY WISTFUL EUNUCHS. IN FACT, THE KGB IS ALIVE AND WELL. IN ALL PROBABILITY, IT IS NON GROWING AGAIN, RATHER THAN SHRINKING. MOST CHANGES HAVE BEEN COSMETIC, AND PAST.

07523 QUINN-JUDGE, S.; RASHID, A.

A FOOT IN THE DOOR

FAR EASTERN ECONOMIC REVIEN, 155(1) (JAN 92), 20.

THE RUSH IS ON TO GET A FOOTHOLD IN THE NEW MARKETS OPENING UP IN THE CENTRAL ASIAN REPUBLICS. WITH THE RIGIDLY CENTRALIZED STRUCTURES OF THE FORMER SOVIET UNION WITHERING AWAY AND TRADITIONAL SOURCES OF IMPORTS FROM EASTERN EUROPE DRYING UP, MANY ASIAN STATES THAT ONCE STAYED ALOOF FROM RUSSIAN AND CENTRAL ASIAN MARKETS ARE POSITIONING THEMSELVES TO TAKE ADVANTAGE OF NEW OPPORTUNITIES. ASIAN STATES THAT ARE SEEKING GREATER ECONOMIC AND TRADE TIES WITH THE NEWLY INDEPENDENT REPUBLICS INCLUDE: INDIA, VIETMAM (LONG-TIME TRADING PARTNERS WITH THE USSR), PAKISTAN, TURKEY, SOUTH KOREA, TAIWAN, BANGLADESH, THAILAND, AND SINGAPORE.

07524 QUINM-JUDGE, S.

GRIM LEGACY

FAR EASTERN ECONOMIC REVIEW, 154(52) (JAN 92), 20.

THE FIVE SOVIET ASIAN REPUBLICS HILL BE OBLIGED TO CARRY OUT RAPID ECONOMIC REFORMS IF THEY CONFIRM THEIR IMITIAL DECISION TO JOIN THE NEN COMMONWEALTH OF INDEPENDENT STATES (CIS)-BUT THIS IS FAR FROM AN EASY PROCESS. PREDICTIONS OF FUTURE DIFFICULTIES ARE ESPECIALLY APPLICABLE TO UZBEKISTAN, THE MOST POPULOUS OF THE CENTRAL ASIAN REPUBLICS WITH 20 MILLION PEOPLE. WHICH IS WITHHOLOING A FIMAL DECISION ON MILLION PEOPLE, WHICH IS WITHHOLDING A FINAL DECISION JOINING THE COMMONHEALTH UNT IL AFTER ITS PRESIDENTIAL
ELECTION. MANY UZBEKS WOULD AGREE THAT THEIR NOW SOVEREIGN ELECTION. MANY UZBEKS WOULD AGREE THAT THEIR NOW
STATE FACES SEVERE PROBLEMS INCLUDING WIDESPREAD STATE FACES SEVERE PROBLEMS INCLUDING WIDESPREAD LEAVING UZBEKISTAN, ECOLOGICAL DEVASTATION, AND AM LEAVING UZBEKISTAN, ECOLOGICAL DEVASTATION, AND AN UNHILLINGNESS OF SOME

07525 QUINH-JUDGE, S

HOBBLED BY OLD HABITS

FAR EASTERN ECONOMIC REVIEH, 155(10) (MAR 92), 16.

ECONOMIC REFORMS IN RUSSIA'S PACIFIC PROVINCES ARE BEINC HELD UP BY THE OBSTRUCTIONIST TACTICS OF FORMER COMMUNISTS 
ENTRENCHED WITHIN PROVINCIAL ADMINISTRATIONS SUCH AS SAKHALIN'S. WITH WOULD-BE REFORMERS SUCH AS SAKHALIN'S VALENTIN FYORODOV PARALYZED AND DISCREDITED, THE INITIAL ENTHUSIASM OF THE PEOPLE IS GIVING WAY TO CYNICISM AND EVEN TO CALLS FOR AN AUTONOMOUS REPUBLIC.

07526 QUINN-JUDGE, $S$.

LENIN'S ROAD BENDS

FAR EASTERN ECONOMIC REVIEW, 151(28) (JUL 91), 17-18. THE SOVIET UNION MAY BE PRESERVING "CORRECT" DIPLOMATIC RELATIONS WITH THE HARD-LINE NORTH KOREAN GOVERNMENT, BUT ITS 437,000 CITIZENS OF KOREAN ORIGIN ARE NOT. THESE' DESCENDANTS OF FARMERS WHO FLED DROUGHT AND THE JAPANESE ANNEXATION IN 1910, AND REFUGEES OF THE FAILED UPRISING AGAINST JAPAN IN 1919, WERE ONCE ONE OF THE COUNTRY'S MORE AGAINST JAPAN IN 1919, WERE ONCE ONE OF THE COUNTRY'S MORE DOCILE MINORITIES. NOW THEY APPEAR TO BE SHAKING OFF THE SHACKLES OF COMHUNIST ORTHODOXY WITH REMARKABLE EASE. THE SUDDEN THAW IN SOVIET-SOUTH KOREAN RELATIONS THAT BEGAM
THE 1988 SEOUL OLYMPICS HAS THRUST THE SOVIET UNION'S THE 1988 SEOUL OLYMPICS HAS THRUST THE SOVIET UNION'S KOREANS INTO A NEW POSITION OF RESPECT. THE NEW LAWS PRIVATIZATION AND ENTERPRISE MAY SOON
CONTINGENT OF KOREAN ENTREPRENEURS.

07527 QUINN-JUDGE, S

MARKET FORCES

FAR EASTERN ECONOMIC REVIEW, 155(6) (FEB 92), 22.

THE REMNANTS OF RUSSIA'S' VIETHAM LOBBY APPEAR TO BE WINNING A DEBATE ON THE WISDOM OF CONTINUING TIES WITH THEIR INDOCHINESE ALLY. A RUSSIAN SPOKESMAN RECENTLY INDICATED THAT THE BASIC DIRECTION OF SOVIET POLICY IN INDOCHINA WOULD BE CONTINUED BY THE RUSSIAN FEDERATION, DESPITE THE TEMPORARY FALL-OFF IN TRADING TIES CAUSED BY THE UPHEAVALS OF ECONOMIC REFORM. THE RUSSIANS MAKE NO SECRET OF THE FACT THAT THEIR CONTINUING ECONOMIC INTEREST IS LARGELY BASED ON HOPES OF CARVING OUT A ROLE FOR THEMSELVES IN SOUTHEAST ASIAN MARKETS VIA THREE-HAY PROJECTS WITH VIETNAM AND OTHER COUNTRIES IN INDOCHINA.

07528 QUINN-JUDGE, S.

PEASANT'S PROGRESS

FAR EASTERN ECONOMIC REVIEW, 153(31) (AUG 91), 15-18.

KAZAKHSTAN PRESIDENT NURSULTAN NAZARBAYEY, THE 51 -YEAROLO SON OF A KAZAHK PEASANT, IS PERHAPS THE FIRST SOVIET ASIAN LEADER TO TRANSCEND THE ROLE OF LOCAL CHIEFTAIN. HIS ASIAN LEADER TO TRANSCEND THE ROLE OF LOCAL CHIEFTAIN. HIS WE HAS BECOME AMONG THE FAVORED CANDIDATES TO BECOME THE HE HAS BECOME AMONG THE FAVORED CANDIDATES TO BECOME THE HIS NAME FORHARD AS A CONTEMDER FOR THE SOVIET PRESIDENCY WHEN POPULAR ELECTIOMS ARE HELD. AS THE LEADER OF RESOURCEWHEN POPULAR ELECTIONS ARE HELD. AS THE LEADER OF RESOURCERICH REPUBLIC, STRATEGICALLY LOCATED BETHEEN WESTERN CHINA
AND EUROPE, NAZARBAYEY HAS AN AUTOMATIC CLAIM TO POWER. BUT AND EUROPE, NAZARBAYEV HAS AN AUTOMATIC CLAIM TO POWER IT IS HIS UNIQUE POLITICAL COURSE, SKILLFULLY PLOTTED BETWEEN SOVIET PRESIDENT MIKHAIL GORBACHEV'S CENTRIST PATH AND NATIONALIST DEMANDS FOR REPUBLICAN AUTO
MADE HIM A REAL FORCE IN SOVIET POLITICS.

07529 OUINH-JUDGE, S.

STICKING TOGETHER

FAR EASTERN ECONOMIC REVIEW, 154(52) (JAN 92), 19 A DECISION BY THE PRESIDENTS OF THE FIVE SOVIET ASIAN REPUBLICS ON 13 DECEMBER, 1991, TO JOIN THE NEW COMMONWEALTH OF INDEPENDENT STATES (CIS) WAS A RELIEF TO THOSE HHO FEARED THE SOVIET UNION COULD SPLIT INTO SEPARATE SLAVIC AND ISLAMIC OR TURKESTAN AXES. BUT THERE STILL APPEARS TO BE CONFUSION AMONG THE COMMONHEALTH'S FOUNDERS ABOUT ITS RAISON D'ETRE. IN BOTH KAZAKHSTAN AND RUSSIA THE ASIAN REPUBLICS' CAUTIOUS DECISION WAS GREETED WITH RELIEF. THE 40\% OF KAZAKHSTAN'S POPULATION WHO ARE SLAVIC HAVE NO INTEREST IN BEING STRANDED OUTSIDE A SLAVIC GROUPING, WHILE THOSE RUSSIANS WHO UNDERSTAND THEIR TERRITORY'S COMPLEX ETHNIC MAKE-UP SEE THE DANGER IN SL IGHIING THEIR ASIAN AND MUSLIM PEOPLES BY FORMING AN EXCLUSIVELY EUROPEAN UNION.

07530 QUINN, D.; SHAPIRO, R.

ECONOMIC GROHTH STRATEGIES: THE EFFECTS OF IDEOLOGICAL PARTISANSHIP ON INTEREST RATES AND BUSINESS TAXATION IN THE UNITED STATES

AMERICAN JOURNAL OF POLITICAL SCIENCE, 35(3) (AUG 91), 656-687.

THE AUTHORS OF THIS ARTICLE REFORMULATE THE PARTISANSHIP THESIS IN LIGHT OF RECENT CLAIMS LEVELLED AGAINST IT. THE REFORMULATED VERSION, IDEOLOGICAL PARTISANSHIP, IS BASED UPON THE THEORY THAT, IDEOLOGICAL PARTISANSHIP, IS BASED FOLLOW FROM THE DIFFERENT USE OF POL ICY INSTRUMENTS. OWING FOLLOW FROM THE DIFFERENT USE OF POLICY INSTRUMENTS. ONINC TO THEIR ROLE AS DETERMINANTS OF INVESTMENT AND INTEREST RATES, BUSINESS TAXATION RATES, AND THE REDISTRIBUTION IF THE TAX BURDEN BETHEEN CAPITAL GAINS AND EARNED INCOME ARE EXAMINED. THE AUTHORS AOVANCE MODELS TAKE INTO ACCOUNT OTHER VIEWS OF POLITICS BESIDES THE
PARTISAN ONE, AND TEST FOR POLITICAL INFLUENCES. THEY FIND THAT THE UNITED STATES IS CHARACTERIZED BY VERY PRONOUNCED PARTISAN DIFFERENCES IN NATIONAL ECDNOMIC POLICY WITH DEMOCRATIC ADMINISTRATIONS SEEKIMG TO PROMOTE GROWTH THROUGH A CONSUMPTION DRIVEN STRATEGY, WHILE REPUBLICAN
ADMINISTRATIONS PROMOTE AN INVESTMENT DRIVEN STRATEGY.

07531 QUIRK, P.J.

EVALUATING CONGRESSIONAL REFORM: DEREGULATION REVISITED JOURNAL OF POLICY ANALYSIS AND MANAGEMENT, 10(3) (1991), 407-425.

AN EVALUATION OF THE CHANGES IN CONGRESS'S STRUCTURE THAT OCCURRED IN THE 1970 S REQUIRES ATTENTION TO THREE DIMENSIONS OF ITS PERFORMANCE AS A POLICYMAKING INSTITUTION: REPRESENTATION OF INTERESTS, DELIBERATION, AND CONFLICT RESOLUTION. CONSIDERED THIS WAY. THE CHANGES SEEM TO HAVE ENHANCED SOME ASPECTS OF CONGRESSIONAL CAPACITY (ESPECIALLY
THE REPRESENTATION OF BROADLY-BASED INTERESTS) BUT TO HAVE DIMINISHED OTHERS (ESPECIALLY DELIBERATION AND CONFLICT RESOLUTION ON ISSUES THAT ARE SALIENT TO MASS RESOLUTION ON ISSUES THAT ARE SALIENT TO MASS
CONSTITUENCIES). THE RESULTING STRENGTHS AND WEAKNESSES HELP CONSTITUENCIES). THE RESULTING STRENGTHS AND WEAKNESSES
TO EXPLAIN DIFFERENCES IN CONGRESSIONAL PERFORMANCE ON TO EXPLAIN DIFFERENCES IN CONGRESSIONAL PERFORMANCE ON
TRUCKING DEREGULATION AND NATURAL GAS DEREGULATION IN THE TRUCKING DEREGULATION AND NATURAL GAS DEREGULATION IN
LATE 1970 S AND EARLY 1980 S. TO SOME DEGREE, THEY HAVE LATE $1970 S$ AND EARLY 1980S. TO SOME DEGREE, THEY HAVE ALTERED THE OPPORTUNITIES, STRATEGIC CONSIDERATIONS, AND CENTRAL SKILLS FOR POLICY
CONGRESSIONAL DECISIONS.

07532 RA, J.O.; CHUNG, E.S.

POLITICAL INSTITUTIONALIZATION OF LABOR IN KOREA ASIAN AFFAIRS, AN AMERICAN REVIEH, 18(4) (WIN 92), 228-239. KOREAN LABOR HAS PLAYED A VITAL, IF UNWITTING, ROLE IN SHAPING THE ECONOMY AND POLITICS OF THE NATION. GIVEN THE THEORETICAL IMPORT OF LABOR'S PLACE IN AN UNSETTLED DEMOCRACY, THE CENTRAL ISSUE IS HOW LABOR'S INVOLVEMENT IN POLITICS BECOMES, IF INDEED IT DOES, ULTIMATELY INSTITUTIONALIZED AS PART OF A CONTINUOUS AND STABLE SYSTEM OF GOVERNANCE. ONE WAY OF TACKLING THE ISSUE IS TO BEGIN BY DEFINING THE CHARACTERISTICS OF THE KOREAN LABOR POLITICAL MOVEMENT BY USING TERMS BORROHED FROM ITS U.S. COUNTERPART. THIS INCLUDES DELINEATING THE AMERICAN MODEL AND PRESENTING AN ABBREVIATED, BARE-BONES DESCRIPTION OF KOREAN LABOR IN POLITICS, WITH A VIEW TOWARD POSING RESEARCH QUESTIONS FOR THE FUTURE.

07533 RAAB, C.D.

TAKING NETWORKS SERIOUSLY: EDUCATION POLICY IN BRITAIN EUROPEAN JOURNAL OF POLITICAL RESEARCH, 21(1-2) (FEB 92) 69-90.

THIS PAPER ARGUES AGAINST THE MERELY METAPHORICAL USE OF THIS PAPER ARGUES AGAINST THE MERELY METAPHORICAL
CONCEPTS SUCH AS "NETHORK" IN THE ANALYSIS OF POLICY CONCEPTS SUCH AS "NETHORK" IN THE ANALYSIS OF POLICY PROCESSES THAT INYOLVE RELATIONSHIPS BETHEEN GOV

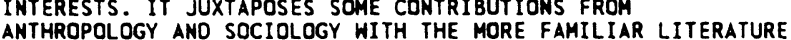
ANTHROPOLOGY AND SOCIOLOGY WITH THE MORE FAMILIAR LITERATURE OF POL ITICAL SCIENCE AND POLICY STUDIES. IT CONSIDERS THE QUESTION OF NORMS, UPON WHICH AN ANALYSIS OF NETHORKS HAS SOME BEARING. NEXT, IT FOCUSES UPON THE UNDERSTANDING OF HUMAN AGENCY AND TRUST AS A MICRO-ANALYTIC STRATEGY FOR RESEARCH ON MESO-LEVEL INTERACTIONS, OR "NETHORKING." IN
LIGHT OF THIS, IT THEN LOOKS AT THE EDUCATIONAL POLICY LIGHT OF THIS, IT THEN LOOKS AT THE EDUCATIONAL POLICY
PROCESS IN BRITAIN, WITH PARTICULAR REFERENCE TO SCOTLANO, AS SEEN IN RECENT LITERATURE. IT ENDS BY DISCUSSING THE CHANGING EDUCATIONAL "PARTNERSHIP" IN BRITAIN, CONSTRUING THIS CONCEPT AS ONE THAT SERVES ACTORS AS WELL AS OBSERVERS AND THAT HAS AFFINITIES WITH OTHER ANALYSES OF POLICY NETWORKS.

07534 RABANAL, C.R.

THE ROOTS OF PERU'S DETERIORATION

HEMISPHERE, 5(1) (FAL 92), 2-3.

PERU REPRESENTS AN EXTREME EXAMPLE OF THE GENERAL DETERIORATION OCCURRING IN LATIN AMERICA. CONTEMPORARY PERU IS IN THE SECOND DECADE OF AN INTERNAL WAR THAT BEGAN IN THE SOUTHERN ANDES BUT NOW ENCOMPASSES VIRTUALLY THE ENTIRE COUNTRY. IT HAS BECOME A TERRIFYING WORLD IN WHICH EXTREME POVERTY IS INTERHOVEN WITH BOTH PREINDUSTRIAL AND POSTINDUSTRIAL FORMS OF VIOLENCE. BECAUSE PERUVIAN SOCIETY IS MULTI-ETHNIC AND MULTICULTURAL, ITS MEMBERS LIVE WITHIN A RIGIDLY-DEFIMED HIERARCHY OF SOCIAL STRATA HITH MINIMAL AMD HIGHLY DISTORTED CHANNELS OF INTERSTRATUM COMMUMICATIOM. PERUVIAN SOCIETY'S COMBINATION OF HETEROGENEITY AND RIGIDITY PERMITS THE COEXISTENCE OF CERTAIN DEMOCRATIC FREEDOMS WITH A LARGE-SCALE DIRTY WAR, IN WHICH NEARLY ALL THE DEAD AND MISSING BELONG TO THE MESTIZO AND INDIAN POPULATIONS THAT CONSTITUTE THE LOW END OF THE SOCIOECONOMIC HIERARCHY. THIS CONSTITUTE THE LOW END OF THE SOCIOECONOMIC HIERARCHY. THIS
PROFOUND DETERIORATION OF PERUVIAN SOCIETY IS ROOTED IN THE PROFOUND DETERIORATION OF PERUVIAN SOCIETY IS RRO
STRUCTURE AND CULTURE OF PRE-COLUMBIAN SOCIETY.

07535 RABE, B.

BEYOND THE NIMBY SYNDROME IN HAZARDOUS WASTE FACILITY

SITING: THE ALBERTAN BREAKTHROUGH AND THE PROSPECTS FOR COOPERATION IN CAMADA AND THE UNITED STATES GOVERNANCE, 4(2) (APR 91), 184-206.

THE PROSPECTS FOR AGREEMENTS IN THE SITIMG OF HAZARDOUS WASTE FACILITIES IN CANADA AND THE UNITED STATES WOULD APPEAR BLEAK GIVEN THE REPEATED FAILURES OF THE PAST DECADE. A VARIETY OF PROVINCIAL AND STATE SITING APPROACHES HAVE BEEN ATTEMPTED, ONLY TO BE THWARTED REGULARLY BY LOCAL OPPOSITION. THE MOST FAR-REACHING EXCEPTIONAL CASE INVOLVES 
THE SITING OF A COMPREHENSIVE HAZARDOUS WASTE DISPOSAL FACILITY IN ALBERTA, CANADA IN THE MID-1980S. THE ALBERTA APPROACH TO SITING DIFFERED MARKEDLY FROM THOSE OF OTHER PROVINCES AND STATES AND IN MANY RESPECTS MET THE CONDITIONS MECESSARY FOR POLICY COOPERATION SPECIFIED BY THE MATURING IMSTITUTIONALIST AND GAME THEORETIC LITERATURES ON THIS TOPIC. THE ALBERTA SITING AGREEMENT HAS ALREADY DEMONSTRATED SHORTCOMINGS IN THE IMPLEMENTATION PHASE AND MAY NOT BE EASILY TRANSPLANTED TO OTHER SUBNATIONAL UNITS OF GOVERNMENT. NONETHELESS, IT SUGGESTS THAT THE NOT-IN-MY-BACK-YARD SYNDROME SO FAMILIAR IN HAZARDOUS WASTE FACILITY SITING NEED NOT BE AN INEVITABILITY AND THAT CAREFUL ATTENTION TO KEY ASPECTS OF SITING OPLICY MAY FACILITATE COOPERATION.

07536 RABIE, M.

ARAB-ISRAELI PEACE: A NEW VISION FOR A TRANSFORMED MIDDLE EAST

AMERICAN-ARAB AFFAIRS, (36) (SPR 91) 73-86.

THIS PAPER PROVIDES AN OUTLINE FOR A NEW PROPOSAL TO DEAL WITH THE ARAB-ISRAELI CONFLICT AND ADDRESS THE BASIC NEEDS AND ASPIRATIONS OF BOTH ISRAELIS AND PALESTINIANS

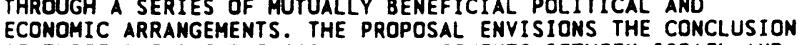
OF THREE DIFFERENT TYPES OF ARRANGEMENTS BETWEEN ISRAEL AND OF THREE DIFFERENT TYPES OF ARRANGEMENTS BETWEEN ISRAEL
ITS PALESTINIAN AND OTHER ARAB ADVERSARIES: AN ISRAELIITS PALESTINIAN AND OTHER ARAB ADVERSARIES: AN ISRAELI-
PALESTINIAN ARRANGEMENT TO SETTLE HISTORICAL AND MORAL PALESTINIAN ARRANGEMENT TO SETTLE HISTORICAL AND MORAL
CLAIMS AND TO SATISFY NATIONAL AND POLITICAL RIGHTS AND CLAIMS AND TO SATISFY NATIONAL AND POLITICAL RIGHTS AND
ASPIRATIONS FOR PALESTINIANS AND ISRAELIS ALIKE; AN ISRAELIASPIRATIONS FOR PALESTINIANS AND ISRAELIS ALIKE; AN ISRAELI-
JORDANIAN-PALESTINIAN ARRANGEMENT TO ADORESS ISSUES RELATED JORDANIAN-PALESTINIAN ARRANGEMENT TO ADORESS ISSUES RELATED TO SECURITY, NATIONAL SOVEREIGNTY AND ECONOMIC COOPERATION; AND, AN ARAB-ISRAELI ARRANGEMENT TO SETTLE OTHER POLITICAL, SECURITY, AND TERRITDRIAL ISSUES, NAMELY THE ISRAELI-SY

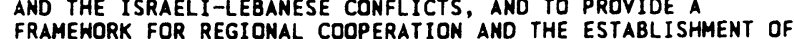
FRAMENORK FOR REGIONAL COOPERATION AND THE
A MIDDLE EAST ECONOMIC COMMUNITY (MEEC).

07537 RABIE, M.

THE POLITICS AND ECONOMICS OF OI

MIDDLE EAST POLICY, 1(1) (1992), 97-106

THE OIL PROOUCING AND THE OIL CONSUMING COUNTRIES HAVE COMPELLING REASONS TO WORK TOGETHER TO CONSTRUCT A MUTUALLY ACCEPTABLE SYSTEM OF OF PRODUCTION ANO PRICING TO MEET SHORTTERM NEEDS AND SERVE LONG-TERM INTERESTS OF PRODUCERS AND CONSUMERS ALIKE. A PROPOSED PLAN TO RECONCILE THE INTERESTS OF PRODUCERS AND CONSUMERS COULD BE CALLED THE INTERNATIONALIZATION OF OIL. THIS PLAN IS MEANT TO ADDRESS THE GRIEVANCES OF BOTH PARTIES AND FACILITATE THE PROTECTION OF MUTUAL INTERESTS AS RELATED TO THE SECURITY OF SUPPLIES AND THE STABILITY OF PRICES. THIS ARTICLE EXPLORES THE INTERNATIONALIZATION OF OIL AND THE REGIONALIZATION OF ARAB INTERNATIONALIZATION OF OIL AND THE REGIONALIZATION OF ARAB AND THE INTELLECT TO ACHIEVE SUCH A GOAL AND THAT IT IS TIME AND THE

07538 RABIE, $M$.

THE U.S.-PLO DIALOGUE: THE SWEDISH CONNECTION JOURMAL OF PALESTINE STUDIES, XXI(4) (SUM 92), 54-66. ON DECEMBER 14, 1988. THE UNITED STATES ANMOUNCED ITS DECISION TO START' 1988 , THE WTISU THE PALESTINE LIBERATION ORGANIZATION (PLO), REVERSING A BAND THAT HAD BEEN IN EFFECT SINCE 1975. THIS DIALOGUE WAS THE RESULT OF THO SEPARATE INITIATIVES, ONE IN THE UNITED STATES AND ONE IN SHEDEN, THAT INTERSECTED AT A CRUCIAL MOMENT. THIS PAPER CONCENTRATES ON THE SWEDISH INITIATIVE, INCLUDING THE ROLE PLAYED BY A SMALL GROUP OF JEWISH-AMERICANS WHO WERE ALSO WORKING TOWARDS ARAB-ISRAELI PEACE.

07539 RABKIN, R.

THE AYLHIN GOVERMMENT AND \$TUTELARY' DEMOCRACY: A CONCEPT IN SEARCH OF A CASE?

JOURNAL OF INTERAMERICAN STUDIES AND HORLD AFFAIRS, $34(4$ (WIN 92), 119-194.

THE GOVERMMENT OF CHILE MAY BE BETTER UNDERSTOOD UNDER THE TRADITIONAL RUBRIC OF "UNCONSOLIDATED," OR "POLITICIZED, " DEMOCRACY. THIS ARTICLE EXAMINES THE CONCEPTUAL MODEL OF TUTELARY DEMOCRACY IN THE LITERATURE ON LATIN AMERICAN POLITICS AND EXPLAINS WHY, GIVEN CHILE'S DEMOCRATIC TRADITIONS AND SPECIFIC HISTORICAL EXPERIENCES, THE DECISION OF CIVILIAN POLITICAL ACTORS TO PURSUE A TRANSITION WITHOUT CONSTITUTIONAL RUPTURE REPRESENTS A CONSCIOUS, WELL-REASONED STRATEGY. IT ALSO DESCRIBES HOW CHRISTIAN DEMOCRATIC PREDOMINANCE WITHIN THE GOVERNING COALITION HAS AFFECTED CIVIL-MILITARY RELATIONS, ESPECIALLY IN REGARD TO PAST HUMAN CIVIL-MILITARY RELATIONS, ESPECIALLY IN REGARD TO PAST HUMAN
RIGHTS ABUSES. SPECIAL ATTENTION IS PAID TO THE POLITICAL RIGHTS ABUSES. SPECIAL ATTENTION IS PAID TO THE POLIITICAL DYNAMICS THAT WERE INVOLVED IN REDUCING THE PREROGATIVES THE MILITARY. THE BROAER POLITICAL IMPLICATIONS OF THE AYLWIN GOVERNMENT'S STRATETGY OF HANDLING CIVILIAN-MILITARY RELATIONS FOR
IS ANALYZED.

07540 RABOY, M. (ED.); DAGENIAS, B. (ED.)

MEDIA, CRISIS AND DEMOCRACY--MASS COMMUNICATION AND THE DISRUPTION OF SOCIAL ORDER

SAGE PUBLICATIONS, 1992, 224.
IN MODERN STATES, THE SMOOTH FUNCTIONING OF DEMOCRATIC POLITICS IS INEXTRICABLY TIED TO THE ROLE OF THE MEDIA IN THE CREATION AND DISSEMINATION OF INFORMATION, IMAGES AND IDEAS. UTILIZING A NUMBER OF DIFFERENT CONTEXTS, THIS BOOK EXPLORES THE WAYS IN WHICH CRISES SERVE TO HIGHLIGHT THE PROBLEMATIC ISSUES OF MEDIA PERFORMANCE IN DEMOCRATIC STATES.
THE BOOK ALSO EXAMINES THE RELATIONSHIP BETWEEN COMMUNICATION AND CIVIL SOCIETY. THE RELATIONSHIP BETWEEN THE MEDIA AND CRISIS IS EXAMINED IN CASE STUDIES OF THE PERSIAN GULF WAR, POLAND, EASTERN EUROPE, TABLOID NEWS, TELEVISION, MEDIA
MUMBER OF OTHERS.

07541 RACZ, B.

THE HUNGARIAN PARLIAMENT'S RISE AND CHALLENGES

RFE/RL RESEARCH REPORT, 1(7) (FEB 92), 22-26.

A NEW HUNGARIAM PARLIAMENT WAS ELECTED IN THE SPRING OF 1990. ITS MAIN TASK WAS TO IMPLEMENT POLITICAL AND ECONOMIC TRANSFORMATION, BUT IT HAS HAD MIXED RESULTS. ALTHOUGH THE PARLIAMENT HAS PASSED NUMEROUS LAWS--INCLUDING SOME CONTROVERSIAL ONES, THEY HAVE BEEN CONCERNED HITH MINOR MATTERS, TO THE DETRIMENT OF IMPORTANT ECONOMIC ISSUES. DEFICIENCIES IN THE PARLIAMENT'S PROCEDURAL RULES AND ITS INFRASTRUCTURE HAVE HAMPERED ITS EFFICIENCY. ITS WORK HAS ALSO BEEN MARKED BY DIVISIONS INDUCED BY CLASHES BETHEEN DIFFERENT POLITICAL SUBCULTURES.

07542 RACZYNSKI, D.

SOCIAL POLICY AND ECONOMIC CHANGE IN CHILE, 1974-1985: THE SOCIAL POLICY AND

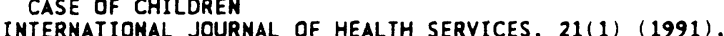
$17-48$

TAKING THE CASE OF CHILE IN THE PERIOD 1974-85, THIS ARTICLE EXAMINES THE IMPACT OF ECONOMIC CONDITIONS AND SOCIAL POLICIES ON POOR HOUSEHOLDS, AND ESPECIALLY ON CHILDREN. THE STUDY STARTS WITH AN ANALYSIS OF THE NATURE OF THE ECONOMIC POLICIES IMPLEMENTED IN CHILE DURIMG 1974-85 AND THEIR EFFECTS ON INCOME DISTRIBUTION AND ON THE MATERIAL LIVING CONDITIONS OF POOR HOUSEHOLDS. IT THEN LOOKS INTO THE SOCIAL POLICIES, GOVERNMENT EXPENDITURE, AND THE MAIN PROGRAMS DIRECTED TOWARD POOR HOUSEHOLDS AND CHILDREN, AS WELL AS AT THE CHANGES IN CHILD WELFARE THAT FOLLOWED. FROM THIS MACROSOCIAL LEVEL THE STUDY DIVERTS TO THE HOUSEHOLD LEVEL AND DESCRIBES BASED ON SEVERAL IN-DEPTH STUDIES OF SMALL SAMPLES OF HOUSEHOLDS IN THE SANTIAGO METROPOLITAN AREA DURING THE YEARS 1982-85, THE DAILY EXPERIENCES OF POOR HOUSEHOLDS-THEIR DETERIORATING ECONOMIC CONDITIONS AND THE BEHAVIORS ADOPTED TO STRETCH SCARCE RESOURCES TO SATISFY BASIC NEEDS. THE FINAL PART DRAHS SOME LESSONS FROM THE CHILEAN CASE.

07543 RADCLIFF, B.

MAJORITY RULE AND IMPOSSIBILITY THEOREMS SOCIAL SCIENCE QUARTERLY, 73(3) (SEP 92), 511-522.

MOST DISCUSSIONS OF THE IMPLICATIONS OF THE VOTER'S PARADOX FOR THE THEORETICAL INTEGRITY OF MAJORITY RULE HAVE PARADED WITH (A) THAT THE PROBLEM REPRESENTS A LETHAL.

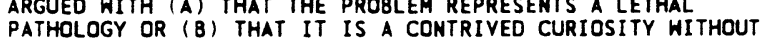
PATHOLOGY OR (B) THAT IT IS A CONTRIVED CURIOSITY WITHOC
RELEYANCE TO THE REAL WORLD. THIS PAPER ASSUMES THAT CYCLICAL MAJORITIES ARE BOTH REAL AND RELEYANT, BUT

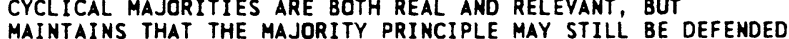
MAINTAINS THAT THE MAJORITY PRINCIPLE MAY STILL BE ON PROCEDURAL
PERSPECTIVES.

07544 RADCLIFF, B.

THE GENERAL WILL AND SOCIAL CHOICE THEORY REVIEH OF POLITICS, 54 (1) (WIN 92), 34-49.

THE CONCEPT OF THE GENERAL WILL HAS BEEN CRITICIZED AS BEING EITHER TYRANNICAL OR EMPIRICALLY UNATTAINABLE. FROM A SOCIAL CHOICE PERSPECTIVE, RIKER AND OTHERS HAVE MERGED THE SUBSTANCE OF BOTH PERSPECTIVES. THE NEW ARGUMENT MAINTAINS THAT ARROW'S THEOREM AND SIMILAR IMPOSSIBILITY RESULTS IMPLY THAT THE GENERAL WILL IS BOTH DANGEROUS AND INTELLECTUALLY ABSURD. WHILE NOT DENYING THE RELEVANCE OF THE COLLECTIVE CHOICE LITERATURE, THE AUTHOR OF THIS ESSAY ARGUES THAT SUCH APOCALYPTIC CONCLUSIONS ARE PREMATURE.

07545 RADCLIFF, $B$

THE WELFARE STATE, TURNOUT, AND THE ECONOMY: A COMPARATIVE ANALYSIS

AMERICAN POLITICAL SCIENCE REVIEN, 86(2) (JUN 92), 444-456. THE ECONOMIC-VOTING LITERATURE IS VOLUAINOUS, BUT COMPARATIVELY LITTLE ATTENTION HAS BEEN GIVEN TO THE QUESTION OF HOW--OR WHETHER--THE ECONOMY AFFECTS TURNOUT. IN QUESTION BY COMPARING NATIONAL ELECTIONS IN 29 COUNTRIES. USING TIME SERIES DATA, HIS INITIAL FINDINGS ARE REPLICATED BY A CASE STUDY OF
AMERICAN PRESIDENTIAL AND MIDTERM ELECTIONS SINCE 1896. HE AMERICAN PRESIDENTIAL AND MIDTERM ELECTIONS SINCE 1896. HE
ARGUES THAT THE EFFECT OF ECONOMIC ADVERSITY DEPENDS UPON ARGUES THAT THE EFFECT OF ECONOMIC ADVERSITY DEPENDS UPON IS NONLINEAR, SO THAT MOBILIZATION OCCURS AT EITHER EXTREME IS NONLINEAR, SO THAT MOBILIZATION OCCURS AT EITHER EXTR
WHILE WITHDRAWAL OCCURS IN THE MIDOLE RANGE. THE AUTHOR WHILE WITHDRAHAL OCCURS IN THE MIDDLE RANGE. THE AUTHOR DISCUSSES THE IMPORTANCE TO DEMOCRATIC THEORY,
ELECTIONS, AND THE POLITICS OF WELFARE POLICY. 
07546 RADELET, $S$. REFORM WITHOUT REVOLT: THE POLITICAL ECONOMY OF ECONOMIC REFORM IN THE GAMBIA

WORLD DEYELOPMENT, 20(8) (AUG 92), 1087-1099.

GAMBIA'S ECONOMIC RECOVERY PROGRAM DIFFERED FROM MOST ADJUSTMENT PROGRAMS IN SUB-SAHARAN AFRICA BECAUSE THE ECONOMY QUICKLY RECOVERED AND BECAUSE THE GOVERNMENT IMPLEMENTED THE REFORMS WITH REMARKABLY LITTLE PUBLIC OPPOSITION. THIS PAPER EXAMINES THE POLITICS OF REFORM IN GAMBIA, FOCUSING ON GOVERNMENT DECISIONS REGARDING REFORM AND SUBSEQUENT PUBLIC REACTIONS. THE ANALYSIS HIGHLIGHTS THE IMPORTANCE OF GAMBIA'S DEMOCRATIC POLITICAL TRADITIONS, THE RURAL POLITICAL POWER BASE, THE RELATIONSHIP WITH RURAL POLITICAL POWER BASE, THE RELATIONSHIP WITH
NEIGHBORING SENEGAL, WEAK OPPOSITIION GROUPS, STRONG NEIGHBORING SENEGAL, WEAK OPPOSITION GROUPS, STRONG
LEADERSHIP, AND LUCKY BREAKS. GAMBIA PROVIDES AN EXAMPLE OF LEADERSHIP, AND LUCKY BREAKS. GAMBIA PROVIDES AN EXAMPLE OF
A DEMOCRACY THAT SUCCESSFULLY IMPLEMENTED A STRONG REFORM PROGRAM PRECEDING A NATIDNAL ELECTION.

07547 RADIN, B.A.

RURAL OEVELOPMENT COUNCILS: AN INTERGOVERMMENTAL COORDINATION EXPERIMENT

PUBLIUS: THE JOURNAL OF FEDERALISM, 22(3) (SUM 92), 111-128.

IN 1990, THE FEDERAL GOVERMMENT ESTABLISHED EIGHT PILOT STATE RURAL DEVELOPMENT COUNCILS TO COORDINATE RURA DEVELOPMENT EFFORTS AMONG FEDERAL DEPARTMENTS AND AGENCIES AND TO ESTABLISH COLLABORATIVE RELATIONS WITH STATES, LOCAL GOVERNMENTS, AND THE PRIVATE SECTOR. IN THE FIRST YEAR OF OPERATION, THESE COUNCILS PROVIDED A MECHANISM FOR THE PARTICIPATING STATES TO DEFINE THE RURAL ISSUES RELEVANT TO THEIR SETTINGS AND TO WORK TOWARD THE ACCOMPL ISHMENT OF SPECIFIC GOALS. IN ADDITION, THE PROCESS ALLOWED FEDERAL OFFICIALS TO UTILIZE THE OISCRETION AVAILABLE IN THE SYSTEM AGENDAS OR EXPECTATIONS SURROUNDED THE INITIATIVE: SUBSTANTIVE, POLITICAL, AND PROCESS APPROACHES. ALTHOUGH IT IS TOO EALRY TO DETERMINE THE EXTENT TO WHICH THE COUNCILS HAVE MET THESE EXPECTATIONS, THE EXPERIMENT PROVIDES PRELIMINARY EVIDENCE OF THE SCOPE OF FEDERAL ABILITY TO STIMULATE CHANGE WITHIN A STATE AS WELL AS THE ECONOMIC AND POLITICAL FORCES THAT CONSTRAIN IT.

07548 RADO, E.

HUNGARY ONE YEAR ON

HUNGARY ONE YEAR ON
CONTEMPORARY REVIEW, 259(1506) (JUL 91), 1-3

A YEAR AFTER THE FIRST FREE ELECTION IN OVER 40 YEARS FINDS HUNGARY'S PARLIAMENT SEEMINGLY MORE PREOCCUPIED WITH FINDS HUNGARY'S PARLIAMENT SEEMINGLY MORE PREOCCUPIED HOW TO RETURN TO THE STATUS QUD BEFORE 1948, WHEN THE COMMUNISTS TOOK POWER, THAN WITH HON BEST TO GO FORHA

1992. HOWEVER, THE PASSING AND IMPLEMENTATION OF A COMPENSATION LAH--A FIMAL PEACE TREATY WITH THE GHOSTS OF THE PAST-IIS A PRECONDITION FOR MAKING REAL PROGRESS WITH PRIVITIZATION OF INDUSTRY AND COMMERCE. HHETHER HUNGARY HILL BE ABLE TO IMPLEMENT ITS AMBITIOUS ECONOMIC PLAN TO PRODUCE A BALANCED BUDGET, BRIMG INFLATION UNDER CONTROL, CONVERTIBILITY BY 1994, WILL LARGELY DEPEND ON THE COALITION GOVERMMENT'S ABILITY AND WILLINGNESS TO REACH COMPROMISE AND CONSENSUS.

07549 RADOSH, R

RED HILLS OF AFRICA

AMERICAN SPECTATOR, 25(9) (SEP 92), 44-47.

IN THE NEW SOUTH AFRICA, THE FORMERLY UNDERGROUND COMMUNIST PARTY (SACP) HAS BECOME LEGAL AND IS IN THE MIDST OF A RECRUITING DRIVE. CALLING FOR A "NEW TERRAIN OF STRUGGLE," THE SACP LEADERS ACCUSE THE ANC OF FAILING TO APARTHEID AND OF ACCEPTING UNNECESSARY COMPROMISES.

07550 RADU, M.

CAN FUJIMORI SAYE PERU?

BULLETIN OF THE ATOMIC SCIENTISTS, 48(6) (JUL 92), 16-21. ON 5 APRIL, 1992, PERUVIAN PRESIDENT ALBERTO FUंJIMORI SUSPENDED THE CONSTITUTION, DISSOLVED THE ELECTED CONGRESS, PURGED MUCH OF THE JUDICIARY, AND WITH MILITARY BACKING ASSUMED COMPLETE POWER. FUJIMORI CLAIMED HIS HAND HAD BEEN FORCED BY THE JUDICIARY'S CORRUPT ION AMD INEFFICIENCY BEE FORCED BY THE JUDICIARY'S CORRUPTION AND INEFFICIENCY, AND OF ISSUES, INACTION, AND INCOMPETENCE. WHILE MANY HAVE BEEN OF ISSUES, INACTION, AND INCOMPETENCE. HHILE MANY HAVE CRITICAL OF FUJIMORI'S "ANTI-DEMOCRATIC" MEASURES, THE
UNDERLYING TRUTH IS THAT FUJIMORI DID NOT KILL DEMOCRACY; HE UNDERLYING TRUTH IS THAT FUJIMORI DID NOT KILL DEMOCRACY; $H$ REMOVED A DEMOCRATIC MASK FROM A CORRUPT SYSTEM. THE LARGE DEGREE OF POPULAR SUPPORT THAT FUJIMORI STILL ENJOYS IS EVIDENCE THAT HIS MEASURES, ALTHOUGH DRASTIC, WERE NEEDED.
WHAT IS ALSO NEEDED IS THE AID AND SUPPORT, NOT CENSURE, OF WHAT IS ALSO NEEDED IS THE AID

07551 RAE, $\mathrm{N}$

THE DEMOCRATS' "SOUTHERN PROBLEM" IN PRESIDENTIAL POLITICS PRESIDENTIAL STUOIES QUARTERLY, 22(1) (WIN 92), 135-152. SINCE 1964. THE DEMOCRATIC PARTY HAS BEEN PERSISTENTLY WEAK IN PRESIDENTIAL ELECTIONS IN THE SOUTH, WHILE
CONTINUING TO DOMINATE MOST ELECTIONS FOR LOWER LEVEL OFFICES. THIS PAPER EXPLAINS THE PARTY'S FAILURES IN PRESIDENTIAL POLITICS IN TERMS OF STRUCTURAL CHANGES IN THE DEMOCRATS' PRESIDENTIAL MOMINATING PROCESS WHICH HAVE UNDERMINED THE POSITION OF THE SOUTH HITHIN THE NATIONAL PARTY. THE PROCESS AS IT NOW OPERATES IS ALMOST GUARANTEED TO PRODUCE DEMOCRATIC PRESIDENTIAL NOMINEES WHO ARE UNACCEPTABLE TO THE OVERHHELMING MAJORITY OF WHITE SOUTHERMERS. THE PAPER CONCLUDES THAT ONLY A SEVERE NATIOMAL RECESSION CAN PROBABLY REVIVE THE PRESIDENTIAL DEMOCRATIC PARTY IN THE REGION.

07552 RAE, N.C.

CLASS AND CULTURE: AMERICAN POLITICAL CLEAVAGES IN THE THENTIETH CENTURY

WESTERN POLITICAL QUARTERLY, 45(3) (SEP 92), 629-650.

FOR MOST OF U.S. HISTORY, POLITICAL CLEAVAGES HAVE BEEN BASED ON CUL TURAL CONFLICTS RATHER THAN THE SOCIOECONOMIC CLASS CONFLICTS CHARACTERISTIC OF THE NEW DEAL ERA. THIS PAPER ARGUES THAT THE 1932-1952 PERIOD WAS AN ABBERATION AND THAT, SINCE 1952, U.S. PRESIDENTIAL POLITICS HAS ONCE AGAIM REFLECTED CULTURAL AS OPPOSED TO CLASS DIVISIONS. CULTURA CONFLICTS OVER NONMATERIAL, ETHICAL QUESTIONS ARE MORE
DIFFICULT TO RESOLVE THAN SOCIOECONOMIC ISSUES, BUT IN THE DIFFICULT TO RESOLVE THAN SOCIOECONOMIC ISSUES, BUT IN THE PRE-NEW DEAL PERIDD POWERFUL PARTY ORGANIZATIONS PARTIALLY
MEDIATED THESE CLEAVAGES. IN THE MODERN ERA, THE EROSION OF MEDIATED THESE CLEAVAGES. IN THE MODERN ERA, THE EROSION OF LEAD TO A DEGREE OF SOCIAL POLARIZATION THAT MIGHT THREATEN THE STABILITY OF THE POLITICAL SYSTEM AS A WHOLE.

07553 RAFFALOVICH, L.E.; LEICHT, K.T.; WALLACE, M. MACROECONOMIC STRUCTURE AND LABOR'S SHARE OF INCOME: UNITED STATES, 1950 TO 1980

AMERICAN SOCIOLOGICAL REVIEN, 57(2) (APR 92), 243-258.

THE AUTHORS TEST SEVERAL HYPOTHESES DERIVED FROM MARXIST CRISIS THEORIES REGARDING THE IMPACT OF MACROECONOMIC PERFORMANCE ON THE DISTRIBUTION OF INCOME BETWEEN LABOR AND CAPITAL IN THE UNITED STATES FROM 1950 TO 1980. USING ANNUAL DATA ON COMPENSATION, PROFITS, AND EMPLOYMENT, THEY ESTIMATE THE SHORT-TERM EFFECIS OF CYCLICAL VARIATIONS' IN

UNEMPLOYMENT, INFLATION, GRONTH, AND CAPACITY UTILIZATION ON LABOR'S INCOME SHARE. WITH AN ADOITIVE DECOMPOSITION OF

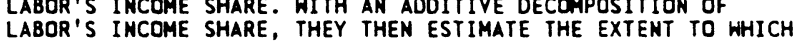
LABOR'S INCOME SHARE, THEY THEN ESTIMATE THE EXTENT TO
THE OBSERVED EFFECTS CAN BE ATTRIBUTED TO CHANGES IN THE OBSERVED EFFECTS CAN BE ATTRIBUTED TO CHANGES IN COMPENSATION, OUTPUT, AND EMPLOYMENT. THEY FIND LITTLE
SUPPORT FOR THE HYPOTHESIS THAT TIGHT LABOR MARKETS INCREASE SUPPORT FOR THE HYPOTHESIS THAT TIGHT LABOR MARKETS INCREASE OF LABOR. THE HYPOTHESIS THAT LABOR COMPENSATION LAGS BEHIND PROFIIS OVER THE BUSINESS CYCLE IS SUPPORTED. THE RESULTS, THEREFORE, FAVOR THE "REALIZATION FAILURE" RATHER THAN THE "RESERVE ARMY" THEORY OF CYCLICAL CRISIS.

07554 RAFSHOON, G.M. ROSS PEROT IS NO JOHM AMDERSON

BROOKINGS REVIEW, 10(3) (SUM 92), 54

THE AUTHOR LOOKS AT COMPARISONS BETHEEN H. ROSS PEROT, A POTENTIAL THIRD-PARTY CANDIDATE IN THE 1992 PRESIDENTIAL ELECTION, AND JOHN ANDERSON, A THIRD-PARTY CANDIDATE IN 1980

07555 RAGAN, $M$.

CHANGES AFOOT

INSIGHT, $7(7)$ (FEB 91), 26.

NO MATTER WHO FINS THE 19 FEBRUARY 1991 ELECTION. THE POWERFUL LOS ANGELES COUNTRY BOARO OF SUPERVISORS WILL GET ITS FIRST HISPANIC MEMBER IN 115 YEARS. SUPPORTED BY A FEDERAL COURT ACTION, HISPANIC RIGHTS GROUPS SEE THE ELECTION AS ONLY THE BEGINNING OF THEIR POLITICAL OUEST: TO ACHIEVE REPRESENTATION PROPORTIONAL TO THEIR CONSIDERABLE NUMBERS. THE GAP BETWEEN POPULACE AND REPRESENTATION IS ESPECIALLY EVIDENT IN LOS ANGELES WHERE HISPANICS MAKE UP ONE-THIRD OF THE COUNTY'S 8.8 MILLION RESIDENTS.

07556 RAGAN, $M$.

THE DALEY DYNASTY

INSIGHT, $7(9)$ (MAR 91), 22-23.

MAJOR RICHARD M. DALEY LOOKS UNSTOPPABLE IN CHICAGO'S FEBRUARY 26 DEMOCRATIC PRIMARY. HE HAS BUILT A COALITION OF MINORITIES AND LIBERALS, AS WELL AS THE WHITE ETHNICS WHO SUPPORTED HIS FATHER. CHALLENGER DANNY DAVIS HAS BEEN UNABLE TO RALLY ALACK VOTING BLOC, DIVIDED SINCE THE DEATH OF HAROLD WASHINGTON.

07557 RAHR, A.

A RUSSIAN PARADOX: DEMOCRATS SUPPORT EMERGENCY POWERS RFE/RL RESEARCH REPORT, 1 (48) (DEC 92), 13-19.

PRESIDENT BORIS YELTSIN'S SPECIAL POWERS GRANTED TO HIM BY THE LEGISLATORS FOR A PERIOD OF ONE YEAR ARE DUE TO EXPIRE AT THE DECEMBER 1992 SESSION OF THE CONGRESS OF PEOPLE'S DEPUTIES, BUT HE DOES NOT WANT TO RELINQUISH THEM. TO RETAIN THESE POHERS, WHICH HE CONSIDERS NECESS THROUGH REFORM, HE MAY INTROOUCE A TYPE OF DIRECT MANY SENIOR POLITICIANS FROM THE REFORMIST CAMP ARE URGING YELTSIN TO IMPOSE EMERGENCY RULE, ARGUING THAT THIS IS THE 
onLY haY To save RUSSIA.

07558 RAHR, A.

CHALLENGES TO YELTSIN'S GOVERMMENT

RFE/RL RESEARCH REPORT, $1(9)$ (FEB 92), 1-5

THE REFORMIST GOVERMMENT OF PRESIDENT BORIS YELTSIN AND

FIRST DEPUTY PRIME MINISTER GENHADII BURBULIS HAS COME UNDER ATTACK FROM ALL SIDES, PARTICULARLY FROM SUPREME SOVIET CHAIRMAN RUSLAN KHASBULATOV AND VICE PRESIDENT ALEKSANDR RUTSKDI. YELTSIN HAS NEUTRALIZED RUTSKOI BY GIVING HIM THE AGRICULTURE PORTFOLIO. BUT, IF THE ECONOMIC SITUATION OETERIORATES FURTHER, YELTSIN MAY BE TEMPTED TO REPLACE HIS PRESENT GOVERNMENT WITH A MORE AUTHORITARIAN ONE THAT COULD INCLUDE RUTSKOI IN A MORE INFLUENTIAL ROLE.

07559 RAHR, A.

EL'TSIN ECLIPSES GORBACHEV AS HARD-LINE COUP FAILS RFE/RL RESEARCH REPORT, 1(1) (JAN 92), 9-11.

IN 1991, RUSSIAN LEADER BORIS EL'TSIN RELEGATED SOVIET PRESIDENT MIKHAIL GORBACHEV TO THE SIDELINES OF THE POLITICAL ARENA AND REPLACED HIM AS THE CHIEF REFORMER, CONCLUDING A STRUGGLE OVER POWER AND IDEOLOGY THAT BEGAN IN 1987. ALTHOUGH EL'TSIN CONTINUED TO PAY LIP SERVICE TO THE IDEA OF PRESERVING THE SOVIET UNION IN SOME FORM, HIS POLICIES WERE ACTUALLY DIRECTED TOWARD ELIMINATING CENTRAL SOVIET INSTITUTIONS, DEPRIVING GORBACHEV OF ALL BUT CEREMONIAL DUTIES, AND TRANSFERRING DECISION-MAKING POWER TO THE EXECUTIVE OFFICES OF THE RUSSIAN FEDERATION. THE AGREEMENT ON ESTABLISHING THE COMMONWEALTH OF INDEPENDENT STATES HAS BROUGHT EL'TSIN VERY CLOSE TO ATTAINING ALL HIS GOALS.

07560 RAHR, A.

GORBACHEV UNDER INVESTIGATION

RFE/RL RESEARCH REPORT, I(7) (FEB 92), 35-38

MIKHAIL GORBACHEV, HAVING TO SOME DEGREE RECOVERED FROM THE HUMILIATION OF HIS FORCED RESIGNATION AND HAVING EMBARKED ON A MEN CAREER AS HEAD OF A RESEARCH FOUNDATION, MAY SOON FACE LEGAL ACTION FOR ALLEGED PRIOR KNOHLEDGE OF CRIMINAL ACTS COMMITTED BY THE FORMER COMMUNIST PARTY OF THE SOVIET UNION AND FOR TOLERANCE OF KGB ACTIONS AGAINST DEMOCRATS. IF HE IS EXONERATED, A NUMBER OF POWERFUL ALLIES SEE A POLITICAL FUTURE FOR HIM IN THE COMMONWEALTH OF INDEPENDENT STATES.

07561 RAHR, A.

LIBERAL-CENTRIST COALITION TAKES OVER IN RUSSIA

RFE/RL RESEARCH REPORT, 1(29) (JUL 92), 22-25.

A REGROUPING OF FORCES HAS TAKEN PLACE IN THE RUSSIAN LEADERSHIP THAT MAY EVENTUALLY SLOW DOWN THE REFORM PROCESS. HOWEVER, IN VIEW OF THE EMERGING POWERFUL NATIONAL-BOL SHEVIK OPPOSITION, PRESIDENT BORIS YELTSIN'S NEW ALLIANCE WITH THE "OPPOSITION, PRESIDENT BORIS YELTSIN'S NEN ALLIANCE WITH THE STABILIZE THE POLITICAL AND SOCIAL POWER BASE OF THE STABILIZE THE

07562 RAHR, A.

MOSCOW ONE YEAR AFTER THE ATTEMPTED COUP RFE/RL RESEARCH REPORT, 1(33) (AUG 92), 1-4.

THE PRESENT POLITICAL SITUATION IN RUSSIA RESEMBLES THE ONE THAT EXISTED IN THE SOVIET UNION SHORTLY BEFORE THE PUTSCH IN AUGUST 1991. SOME OBSERVERS WARN THAT THE NEWLYCREATED RUSSIAN SECURI TY COUNCIL MAY TURN OUT TO BE A NEW VERSION OF THE EMERGENCY COMMITTEE FORMED BY THE AUGUST PLOTTERS. IN GENERAL, A SHIFT TO THE RIGHT IS EVIDENT IN RUSSIAN POLITICS.

07563 RAHR, A.

THE KGB SURVIVES UNDER YELTSIN'S HING RFE/RL RESEARCH REPORT, 1(13) (MAR 92), 1-4.

RUSSIAN PRESIDENT BORIS YELTSIN HAS INCORPORATED THE CENTRAL KGB APPARATUS INTO THE NEWLY-CREATED RUSSIAM MINISTRY OF SECURITY WITHOUT DISMANTLING THE OLD STRUCTURES. IN THE ABSENCE OF PROPER DEMOCRATIC CONTROL OVER THE SECURITY ORGANS, THE KGB COULD STILL PRESENT A THREAT TO THE DEMOCRATIZATION PROCESS IN RUSSIA AND THE OTHER MEMBERS OF THE COMMONHEALTH OF INDEPENDENT STATES.

07564 RAHR, A.

UPCOMING CONGRESS WILL TEST YELTSIN'S LOYALTY TO DEMOCRATS RFE/RL RESEARCH REPORT, 1 (38) (SEP 92 ), 7-11.

RUSSIAN PRESIDENT BORIS YELTSIN IS BEING PRESSURED BY PARLIAMENTARY SPEAKER RUSLAN KHASBULATOY AND BY THE CIVIC PARLIAMENTARY SPEAKER RUSLAN KHASBULATOV AND BY THE UNION, A COALITION OF INDUSTRIALISTS AND THE FORMER NOMENKLATURA, TO SLOW THE PACE OF ECONOMIC AND POLITICAL IN PERSONMEL APPOINTMENTS, HE HAS RETAINED LEADING REFORMERS, IN PERSONNEL APPOINTMENTS, HE HAS RETAINED LEADING REFORMERS SUCH AS EGOR GAIDAR AND ANDREI KOZYREV, AND HAS NOT HALTED THE REFORM PROCESS. BUT EVENTS AT THE CONGRESS OF PEOPLE'S DEPUTIES WILL BE THE TRUE TEST OF WHETHER HE WILL CONTINUE TO DEFEND HIS GOVERMMENT ANO ITS AGENDA
07565 RAHR, A.

HINMERS AND LOSERS OF THE RUSSIAN CONGRESS

RFE/RL RESEARCH REPORT, 1 (18) (MAY 92) 1-7

RUSSIAN PRESIDENT BORIS YELTSIN HAS' SURVIVED A STRONG ATTACK ON HIS RADICAL REFORM PROGRAM BY THE CONGRESS OF PEOPLE'S DEPUTIES. YELTSIN'S CONCEPT OF A PRESIDENTIAL REPUBLIC SEEMS TO HAVE WON OVER THE IDEA OF A PARLIAMENTARY
REPUBLIC, WHICH HAD BEEN FAVORED BY THE CONGRESSIONAL PRESIDIUM. THE VICTORY WILL GIVE YELTSIN NEW OPPORTUNITIES TO STRENGTHEN HIS PRESIDENTIAL POWERS. MEANWHILE, VICE PRESIDENT ALEKSANDR RUTSKOI REMAINS A KEY PLAYER' IN APPEASING THE INCREASINGLY INFLUENTIAL NATIONAL-PATRIOTIC FORCES IN RUSSIA.

07566 RAHR, A.

YELTSIN FACES NEW POLITICAL CHALLENGES

RFE/RL RESEARCH REPORT, 1(42) (OCT 92), 1-5.

RUSSIAN PRESIDENT BORIS YELTSIN IS UNDER SIEGE FROM ALL SIDES. THE CIVIC UNIDN IS DEMANDING A BIGGER ROLE IN GOVERNMENT DECISION-MAKING; LOCAL LEADERS ARE CALLING FOR MORE AUTONOMY FROM MOSCOW; AND LEADERS OF THE CENTRAL ASIAN STATES ARE ASKING HIM NOT' TO ABANDON THEM ECONOMICALLY AND TO SUPPORT THE ESTABLISHMENT OF CLOSE TIES BETHEEN RUSSIA AND THEIR STATES.

07567 RAI, S.; MALYSHEVA, M.; PHIZACKLEA, A.; PILKINGTON, H. FEMINISM AND BOLSHEVISM: TWO WORLDS, TWO IDEOLOGIES; WOMEN IN THE FACE OF CHANGE: THE SOYIET UNION, EASTERM EUROPE AND CHINA

ATLEDGE, 1992, 186-199.

THE HISTORY OF BOLSHEVISM HAS BEEN SUBSTANTIALLY REINTERPRETED AND THE PATH TO SOCIALISH RE-EVALUATED. THIS CHAPTER RE-EVALUATES BOLSHEVIK IDEOLOGY THROUGH THE PRISM OF FEMINISM. IT OFFERS A RECONSIDERATION OF THE HISTORY OF THE PRE-REVOLUTIONARY RUSSIAN HOMEN'S MOVEMENT, INCLUDING AN ASSESSMENT OF ITS LEVEL AND FORM OF DEVELOPMENT HITHIN THE BROADER SPECTRUM OF NINETEENTH-CENTURY EUROPEAN HOMEN'S MOVEMENTS. THE IMPACT OF BOL SHEVISM ON THE WOMEN'S MOVEMENT AND THE EXPERIENCE OF RUSSIAN WOMEN UNDER SOVIET RULE ARE CONSIDERED.

07568 RAI, S.; JUNZUO, Z.; PHIZACKLEA, A.; PILKINGTON, $H$. GENDER AND POLITICAL PARTICIPATION IN RURAL CHINA; WOMEN IN THE FACE OF CHANGE: THE SOVIET UNION, EASTERN EUROPE AND CHINA

ROUTLEDGE, $1992,41-56$

THE ROLE AND' STATUS OF RURAL CHINESE WOMEN IN THE PRESENT DEVELOPMENTAL PROCESS ARE FAIRLY COMPLEX HITH REGARD TO THEIR ECONOMIC POLITICAL AND SOCIAL PARTICIPATION. THIS CHAPTER FOCUSES ON A COMPARATIVE EXAMINATION OF RURAL HOMEN'S POLITICAL PARTICIPATION DURING TWO MAJOR INSTITUTIONAL PHASES OF AGRICULTURAL PRODUCTION. WITHIN THIS INSTITUTIONAL PHASES OF AGRICULTURAL PRODUCTION. WITHIN THIS OF CHINESE RURAL WOMEN.

07569 RAI, S.; PHIZACKLEA, A.; PILKINGTON, H.; RIMASHEVSKAIA, N. PERESTROIKA AND THE STATUS OF WOMEN IN THE SOVIET UNION, WOMEN IN THE FACE OF CHANGE: THE SOVIET UNION, EASTERM EUROPE AND CHINA

ROUTLEDGE, 1992, 11-19.

THE RADICAL CHANGES WHICH HAVE OCCURRED IN ALL SPHERES OF SOCIAL LIFE IN THE USSR AS A RESULT OF THE TRANSITION TO A MARKET ECONOMY RAISE A NUMBER OF QUESTIONS ABOUT THEIR IMPACT ON WOMEN AND THEIR IMPL ICATIONS FOR SOCIAL POLICY. THIS CHAPTER ADDRESSES SOME OF THESE QUESTIONS, PARTICULARLY THOSE WHICH RELATE TO TRENDS IN WOMEN'S EMPLOYMENT. IT SUGGESTS THAT THE SITUATION DEMANDS SPECIAL MEASURES FOR THE SOCIAL PROTECTION OF WOMEN AND ALSO A NEED TO CHANGE THE CURRENT STEREOTYPES OF APPROPRIATE GENDER ROLES IN THE FAMILY AND SOCIETY AS A WHOLE.

07570 RAI, S.; DAVIN, D.; PHIZACKLEA, A.; PILKINGTON, H. POPULATION POLICY AMD REFORM: THE SOVIET UNION, EASTERN EUROPE AND CHINA; NOMEN IN THE FACE OF CHANGE: THE SOVIET UNION, EASTERN EUROPE AND CHINA

ROUTLEDGE, 1992, 79-104.

FOR A HOMAN, EFFECTIVE CONTROL OVER HER OWN FERTILITY IS A PREREQUISITE FOR ACHIEVING CHOICE IN OTHER AREAS OF HER LIFE AND FOR PLAYING A FULL ROLE IN SOCIETY. THE AUTHOR EXAMINES THE EFFECTS OF THE ECONOMIC, POLITICAL AND SOCIAL REFORMS INTRODUCED IN THE 1980 S IN CHINA, THE SOVIET UNION, EAST GERMANY, POLAND, HUNGARY, CZECHOSLOVAKIA AND ROMANIA ON EAST GERMANY, POLAND, HUNGARY, CZECHOSLOVAKIA AND ROMAH THE AVAILABILITY OF BIRTH CONTROL WHICH INCLUDES BOTH
CONTRACEPTION AND ABORTION. A REVIEH OF STATE POLICIES ON CONTRACEPTION AND ABORTION. A REVIEH OF STATE POLICIES ON DEVELOPED MAINLY IN RESPONSE TO SPECIFIC NATIONAL DEVELOPED MAINLY IN RESPONSE TO SPECIFIC NATIONAL
CIRCUMSTANCES, HITH IDEOLOGY INCREASINGLY A MINOR FACTOR.

07571 RAI, S.; KONSTANTINOVA, V.; PHIZACKLEA, A.; PILKINGTON, H. THE NOMEN'S MOVEMENT IN THE USSR: A MYTH OR A REAL CHALLENGE?; WOMEN IN THE FACE OF CHANGE: THE SOVIET UNION, EASTERN EUROPE AND CHINA

ROUTLEDGE, $1992,200-217$

THE EMERGENCE OF THE DEVELOPING INDEPENDENT WOMEN'S 
MOVEMENT IN THE USSR IN THE PERESTROIKA PERIOD, AMD THE DIFFICULTIES THAT THEY FACE AFTER THREE GENERATIONS OF ONE PARTY DOMINATION ARE EXPLAINED. THIS CHAPTER CONSIDERS THE CURRENT OFFICIAL STRUCTURES FOR THE REPRESENTATION OF WOMEN, THEIR INADEQUACIES, AND HOW WOMEN'S ISSUES HAVE BEEN LEFT OFF THE AGENDA OF THE NEW CITIZEN'S ASSOCIATIONS CURRENTLY EMERGING IN THE USSR. IT CONSIDERS THE NEW INFORMAL WOMEN'S MOVEMENT AND REPORTS ON THE FIRST INDEPENDENT WOMEN'S FORUM, WHICH WAS HELD IN APRIL 1991 AND SPECULATES ABOUT THE FUTURE OF THE WOMEN'S MOVEMENT IN THE USSR.

07572 RAI, S.; PHIZACKLEA, A.; PILKINGTON, H.; PINE, F UNEVEN BURDENS: WOMEN IN RURAL POLAND; WOMEN IN THE FACE OF CHANGE: THE SOVIET UNION, EASTERN EUROPE AND CHINA ROUTLEDGE, 1992, 57-78.

WOMEN HAVE OFTEN BEEN DESCRIBED AS BEARING THE DOUBLE BURDEN OF DOMESTIC RESPONSIBLITY AND WAGED EMPLOYMENT IN CONTEMPORARY POLISH SOCIETY. FOR MANY RURAL HOMEN, THE CONTEMPORARY POLISH SOCIETY. FOR MANY RURAL HOMEN, THE
BURDEN APPEARS TO BE NOT DOUBLE BUT TRIPLE OR GREATER, BURDEN APPEARS TO BE NOT DOUBLE BUT TRIPLE OR GREATER,
EXTENDING TO AGRICULTURAL LABOR AS WELL AS DOMESTIC AND EXTENDING TO AGRICULTURAL LABOR AS WELL AS DOMESTIC AND WAGED WORK. THIS ARTICLE ATTEMPTS TO EXAMINE THE WAYS IN WHICH WOMEN'S LIVES IN ONE AREA OF RURAL POLAND WERE SHAPED DURING THE SOCIALIST PERIOD, NOT IN TERMS OF STATE POLICY, CONCLUDES THAT WOMEN'S WORK IS ECONOMICALLY AND CULTURALLY CONCLUDES THAT WOMEN'S WORK IS ECONOMICALLY AND CULTURALLY
UNDERVALUED IN RELATION TO THAT OF MEN AND THAT THEY ARE UNDERVALUED IN RELATION TO THAT OF MEN AND THAT THEY ARE
SUBJECT TO A SERIES OF GENDER-LINKED CONSTRAINTS WHICH THE SUBJECT TO A SERIES OF GENDER-LINKED CONSTRAINTS WHICH LIKELY TO CARRY OVER INTO THE MARKET ECONOMY.

07573 RAI, S.; PHIZACKLEA, A.; PILKINGTON, H.

WATERING ANOTHER MAN'S GARDEN : GENDER, EMPLOYMNET AND EDUCATIONAL REFORMS IN CHINA; WOMEN IN THE FACE OF CHANGE: THE SOVIET UNION, EASTERN EUROPE AND CHINA

ROUTLEDGE, 1992 , 20-39.

THE 1980 S SAH TREMENDOUS CHANGES IN THE ECONOMIC AND POLITICAL ETHOS OF CHINA. FOR CHINESE WOMEN THE CHANGED AGENDA HAS HAD PARTICULAR CONSEQUENCE. IN THIS PAPER, THE AUTHOR EXPLORES SOME OF THESE AND THEIR HIDER IMPLICATIONS IN THE CONTEXT OF EDUCATION AND EMPLOYMENT POLICIES FOR CHINESE WOMEN IN THE 1980S. SHE ARGUES THAT THE STATE, BY LOOSENING ITS CONTROL OVER THE ECONOMIC SPHERE, AND SIGNIFICATNLY DILUTING THE RADICAL SOCIO-POLITICAL RHETORIC SF EOUALITY, AND BY GIVING LEGITIMACY TO MARKET RELATIONS IN OF EQUALITY, AND BY GIVING LEGITIMACY TO MARKET RELATIONS IM CIVIL SOCIETY, CONTINUES
OPPRESSION OF THE WOMEN.

07574 RAI, S.; PHIZACKLEA, A.; PILKINGTON, H. HOMEN IN THE FACE OF CHANGE: THE SOVIET UNION, EASTERN EUROPE AND CHINA

ROUTLEDGE, 1992, 227

MUCH HAS BEEN WRITTEN IN THE PAST FEW YEARS ABOUT

POLITICAL AND ECONOMIC CHANGES IN THE SOVIET UNION, EASTERN EUROPE AND CHINA. WHAT IS SELDOM MENTIONED IS HOH CHANGE AFFECTS THE MILLIONS OF WOMEN WHO LIVE IN THESE SOCIETIES. THIS BOOK REDRESSED THE IMBALANCE BY PRESENTING ORIGINAL AND THREE SITES FOR EXAMINATION ARE IDENTIFIED. THE FIRST IS A GENDERED ANALYSIS OF THE PROGRAMS OF ECONOMIC AND POLITICAL RESTRUCTURING AND THE INTERACTION BETWEEN SOCIAL POLICY AND CHANGE. THE SECOND IS THE WAY IN WHICH IMAGES OF WOMEN HAVE BEEN CONSTRUCTED, AND THE BOOK EXAMINES WHETHER THESE, AND
WOMEN'S SELF-IMAGES ARE CHANGING AS THE PATERNALISTIC STATE IS ROLLED BACK. THE THIRD AREA CONSIDERED IS WOMEN'S EXPERIENCE OF REFORM AND WHETHER THIS EXPERIENCE IS DEVELOPNG INTO A WOMEN'S CONSCIOUSNESS. THE BOOK REVEALS THE SEPARATE AND CRITICAL WOMEN'S YOICE WHICH IS RE-EMERGING IN THESE SOCIETIES.

07575 RAIS, R. 8.

AFGHANISTAN AFTER THE SOVIET WITHDRAWAL

CURRENT HISTORY 91 (563) (MAR 92) 123-127.

THE AUTHOR DISCUSSES HOH THE WITHDRAWAL OF SOVIET TROOPS HAS AFFECTED NAJIBULLAH'S REGIME AND THE AFGHANISTAN CONFLICT IN GENERAL. HE WARNS THAT THE POLITICAL AND POLITICAL SETTLEMENT ACCEPTABLE TO AT LEAST THE MAJORITY OF THE FACTIONS CAN BE REACHED AND WIDELY-REPRESENTATIVE TRANSITIONAL ARRANGEMENTS ARE PUT IN PLACE.

07576 RAKE, A.

SOMAL IA--REBUILDING A NATIOH

SEW AFRICAN, (282) (MAR 91) 14

AFTER THENTY-ONE YEARS OF MISRULE BY SIYAD BARRE THE SOMALI PEOPLE FACE A HUGE TASK OF NATYON BUILDING. THE SOMALI PEOPLE FACE A HUGE TASK OF NATYON BUILDING. THE ECONOMY HAS BEEN RUINED, THE SOCIAL FABRIC DESTROYED AND LARGE PARTS OF MOHADISHU, THE CAPITAL, AND THE NORTH HAYE BEEN REDUCED TO RUBBLE. THE NEW MEN IN POWER HAVE THE DAUNTING TASK OF RECREATING AN ATMOSPHERE OF TRUST AND REBUILDING THE NATION FROM SCRATCH. INTERIM PRESIDENT ALI
MAHDI MUHAMMAD HAS PROMISED FREE ELECTIONS AND HAS ASKED FOR INTERNATIONAL AID AND ASSISTANCE.
07577 RAKE, E.

SOUTH AFRICA'S ANC CHOSES ITS NEW LEADERS NEW AFRICAN, (287) (AUG 91), 33

IN SOUTH AFRICA, A RECENT CONFERENCE OF THE AFRICAN NATIONAL CONGRESS (ANC) HAS LEFT THE PARTY WITH A CLEAR COMMAND STRUCTURE AND NELSON MANDELA OFFICIALLY IN CHARGE. THE ANC ELECTIONS THIS TIME WERE MORE DEMOCRATIC THAN EVER BEFORE. THE ELECTION OF CYRIL RAMAPHOSA TO THE POSITION OF SECRETARY GENERAL SYMBOLIZES THE RISING GENERATION WHICH IS HAVING AN INCREASINGLY LARGE SAY IN ANC MATTERS.

07578 RAKODI, C.

HOUSING MARKETS IN THIRD WORLD CITIES: RESEARCH AND POLICY INTO THE 1990'S

WORLD DEVELOPMENT, 20(1) (JAN 92), 39-55.

THE AUTHOR REVIEWS ANALYSES OF URBAN HOUSING MARKETS IN ORDER TO SUGGEST DIRECTIONS FOR RESEARCH AND POLICY IN THE NEXT DECADE. SHE CONTRASTS THE NEOCLASSICAL APPROACH TO HOUSING ECONOMICS WITH A POLITICAL ECONOMY FRAMEWORK, WITH HOUSING ECONOMICS WITH A POLITICAL ECONOMY FRAMEWORK,
RESPECT TO THE PRODUCTION OR SUPPLY OF HOUSING AND RESPECT TO THE PRODUCTION OR SUPPLY OF HOUSING AND

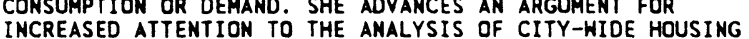
MARKETS, USING INSIGHTS FROM BOTH THEORETICAL APPROACHES, AND FOR RESEARCH INTO PROCESSES OF EXCHANGE. SUCH ANALYSES AND FOR RESEARCH INTO PROCESSES OF EXCHANGE. SUCH ANALYSES SHOULD FORM THE BASIS FOR POLICIES THAT FOCUS NEITHER ON FROM WIDER HOUSING MARKET PROCESSES NOR ON HOUSING OUTPUT TARGETS BUT PRIMARILY ON ENSURING THE PROVISION OF ESSENTIAL INPUTS.

07579 RAKOVE, J.N.

JAMES MADISON AND THE BILL OF RIGHTS: A BROADER CONTEXT PRESIDENTIAL STUDIES QUARTERLY, XXII(4) (FAL 92), 667-677.

THE AUTHOR STUOIES THE EVOLUTION OF JAMES MADISON'S THOUGHT REGARDING THE BILL OF RIGHTS. MADISON, THE AUTHOR OF THE FIRST TEN AMENDMENTS TO THE U.S. CONSTITUTION, WAS DRIVEN BY POLITICAL EXPEDIENCY BUT HE WAS ALSO CONCERNED WITH THREATS TO REPUBLICAN PRINCIPLES. HE REALIZED THAT LEGISLATIVE POWER COULD BECOME OPPRESSIVE AND THAT IT WAS NECESSARY TO PROTECT INDIVIDUALS AND MINORITIES FROM THE SELF-INTERESTS OF POPULAR MAJORITIES ACTING THROUGH THE GOVERMMENT. ALTHOUGH HE HAS SOMEWHAT RELUCTANT AT FIRST, MADISON CAME TO SHARE THOMAS JEFFERSON'S VIEH THAT THE MADISON CAME TO SHARE THOMAS JEFFERSON'S VIEH THAT THE
PEOPLE NEEDED A BILL OF RIGHTS TO PROTECT THEM AGAINST GOVERMMENT.

07580 RAMAGA, P.V

THE BASES OF MINORITY IDENTITY

HUMAN RIGHTS QUARTERLY, 14(3) (AUG 92), 409-428.

HITH THE INTRODUCTION OF THE INTERNATIONAL COVENANT ON CIVIL AND POLITICAL RIGHTS (ICCPR), THE UNITED NATIONS BEGAN TO PROVIDE FOR FULL PROTECTION OF MINORITY RIGHTS. A UNIVERSAL MINORITY REGIME HAS INTRODUCED IN ARTICLE 27 OF THE ICCPR. THIS ARTICLE DISCUSSES THE MEANING OF GROUP IDENTITIES UNDER ARTICLE 27 AND ASSESSES ITS IMPLICATIONS FOR MINORITY PROTECTION. THE ARTICLE USES THE PRINCIPLES AND PRACTICES OF THE LEAGUE OF NATIONS SYSTEM AND THE PREPARATORY WORK, THE SUBSTANCE AND CONCLUSIONS, AND THE SUBSEQUENT PRACTICES OF STATES UNDER THE ICCPR TO ILLUMINATE AND EXPLAIN THE DEVELOPMENT OF MINORITY IDENTITY CONCEPTS. BECAUSE MINORITY PROTECTION IS VIEWED AS AN ALLOWANCE FOR DIVERSITY, AND NOT NECESSARILY THE ATTAINMENT THEREOF, IT ACTS AS A TEXTUAL GUARD AGAINST ACTUAL AND LIKELY VICTIMI ZATION.

07581 RAMAMURTI, R.

THE IMPACT OF PRIVATIZATION ON THE LATIN AMERICAN DEBT PROBLEM

JOURNAL OF INTERAMERICAN STUDIES AND WORLD AFFAIRS, 34(2) ( SUM 92), 93-126.

THE EXTENT TO WHICH STATE-OWNED ENTERPRISES (SOES) WERE RESPONSIBLE FOR CREATING THE LATIN AMERICAN DEBT PROBLEM IS EXPLORED, AS WELL AS THE EXTENT TO WHICH THE PRESENT PRIVATIZATION OF THOSE ENTERPRISES MAY HELP TO RESOLVE THAT PROBLEM. THIS ARTICLE SUGGESTS THAT PRIVATIZATION CAN PLAY A PART IN SOLVING THE DEBT CRISIS AND RESTORING GROWTH, BUT DOWN THE ROAD IF NOT USED CAREFULLY.

07582 RAMAN, A.S

RAJIV GANDHI: THE END OF AN ERA

CONTEMPORARY REVIEH, 259(1506) (JUL 91), 4-6,

THE ASSASSINATION OF RAJIV GANDHI MARKS THE END OF AN ERA IN INDIAN POLITICS. THE OVER ONE-HUNDRED-YEARS OLD ERA IN INDIAN POLITICS. THE OVER ONE-HUNDRED-YEARS OLD INDIAN NATIONAL CONGRESS, NOW KNOWN AS THE CONGRESS

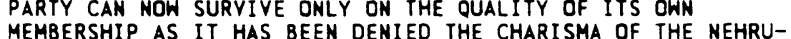
MEMBERSHIP AS IT HAS BEEN DENI ED THE CHARISMA OF THE NEHRU-
GANDHI DYNASTY. WHILE CERTAINLY NOT FREE OF FAULTS AND FLAWS, RAJIV GANDHI--WHO ENTERED POLITICS ONLY RELUCTANTLY--WILL LIKELY BE REMEMBERED FOR HIS FORWARD-LOOKING WORLDVIEW AND HIS MODERNIZATION PROGRAMS WHICH ATTEMPTED TO BRING
TO THE LEVEL OF OTHER INDUSTRIALIZED DEMOCRACIES. 
07583 RAMAN, S.

TECHNOLOGY OR POLITICS?

JOURHAL OF PEACE RESEARCH, 29(3) (AUG 92), 345-352.

IN "INVENTING ACCURACY," DONALD MACKENŻIE REFUTES THE BELIEF THAT THE SO-CALLED "ARMS RACE" IS CAUSED BY AN INHERENT TECHNOLOGICAL IMPERATIVE. BASED ON MORE THAN 140 INTERVIEWS WITH POLITICIANS AND ENGINEERS INVOLVED IN THE $U$. S. NUCLEAR PROGRAH, THE AUTHOR UNRAVELS THE OPEN-ENDEDNESS OF TECHNICAL OEVELOPMENT. THE ACHIEVEMENT OF HIGH ACCURACY IN NUCLEAR MISSILES IS BELIEVED TO HAVE BROUGHT ABOUT THE SHIFT FROM COUNTER-CITY TO COUNTER-FORCE STRATEGY. THE AUTHOR SHOWS THAT THIS LINEAR MODEL OF TECHNOLOGY INFLUENCING POLITICS OVERLOOKS BOTH TECHNICAL UNCERTAINTY AND THE POLITICAL SHAPING OF TECHNOLOGY. DRAHING ON THE SOCIAL CONSTRUCTION OF TECHNOLOGY (SCOT) APPROACH, HE DEMONSTRATES THE CONVENTIONALITY OF KNOWLEDGE CLAIMS AND ARGUES THAT DETERMINISM ONLY PARALYZES ACTION TOWARD CHANGE. HOWEVER, THERE ARE STILL BARRIERS TO LARGE-SCALE CHANGE WITHIN THE BUREAUCRATIC POLITICS OF TECHNOLOGY; HENCE, THIS HORK NEEDS TO BE RELATED TO BROADER POLITICAL ISSUES IN PEACE RESEARCH.

07584 RAMBANAPASI, $C$.

DECENTRALIZATION AND RECENTRALIZATION IM THE HISTORICAL

DECENTRALIZATION AND RECENTRALIZATION IN THE HISTORICA INTERMATIONAL JOURNAL LF PUBL

(1992). 1493-1526.

THE 1493-1526.

THE OF THIS PAPER IS THAT HITHIN THE CONTEXT OF ZIMBABWE, THERE HAS BEEN A MAJOR DESCREPANCY BETWEEN THE LARGELY TERRITORIAL GOALS OR ENDS TO BE ACHIEVED BY POST COLONIAL LOCAL GOVERNMENT TRANSFORMATION AND ITS CONTINUING FUNCTIONAL ORGANIZATION INHERITED FROM COLONIALISM. THIS CONTRADICTION IS DESCRIBED IN THE TITLE AS DECENTRALIZATION AND RECENTRALIZATION.

07585 RAMESH, $M$.

SOCIAL SECURITY IN SINGAPORE: REDRAHING THE PUBLIC-PRIVATE BOUNDARY

ASIAN SURVEY, XXXII (12) (DEC 92), 1093-1108.

THIS ARTICLE EXAMINES SINGAPORE'S SOCIAL SECURITY PROGRAMS AND ASSESSES THE EXTENT TO WHICH THEY ADDRESS THE NEEDS OF THE SOCIETY'S WEAKER SECTIONS. IT FIRST DESCRIBES SINGAPORE'S STATUTORY SOCIAL SECURITY PROGRAMS, HIGHLIGHTING THEIR MAIN STRENGTHS AND DEFICIENCIES. IT THEN DISCUSSES RECENT DEVELOPMENTS AND DEMONSTRATES THAT CURRENT REFORMS ARE DIRECTED NOT AT EXPANDING STATUTORY SOCIAL SECURITY BUT AT PRIVATIZING IT BY PROMOTING THE ROLE OF THE FAMILY AT PRIVATY COMMUNITY, AND MARKET. IT THEN ARGUES THAT WHILE PROMOTING
THE PRIVATE SECTOR HAS SOME ADVANTAGES, IT IS ALSO SERIOUSLY THE PRIVATE SECTOR HAS SOME ADVANTAGES, IT IS ALSO
LIMITED WITH RESPECT TO ADEOUACY, EQUITY, AND EVEN

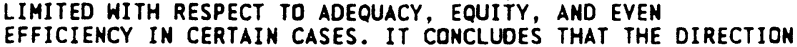
EFFICIENCY IN CERTAIN CASES. IT CONCLUDES THAT THE DIRECTION IN WHICH THE SINGAPORE GOVERNMENT IS MOVING IS UNLIKELY TO LEAD TO SUFFICIEN
OF THE SOCIETY.

07586 RAMET, $S$

BALKIN PLURALISM AND ITS ENEMIES

ORBIS, 36(4) (FAL 92), 547-564.

WITHIN POSTCOMMUNIST EASTERN EUROPE, THE NORTHERN REGION HAS GENERALLY FARED BETTER THAN THE BALKANS IN EFFORTS TO ESTABLISH DEMOCRATIC SOCIETIES. THIS ARTICLE EXPLORES WHY THIS IS THE CASE AND THE SPECIFIC OBSTACLES THAT THE BALKAN STATES FACE IN THEIR TRANSITION TO DEMOCRACY? IT EXAMINES WHETHER THESE OBSTACLES ARE SURMOUNTABLE AND IF SO, UNDER WHAT CONDITIONS. IN CONCLUSION IT EXAMINES HOW WASHINGTON CAN ASSIST THE BALKAN STATES IN CREATING DEMOCRATIC SOCIETIES.

07587 RAMET, S.P

THE BREAKUP OF YUGOSLAYIA

GLOBAL AFFAIRS, 6(2) (SPR 91), 93-110

THE AUTHOR ARGUES THAT YUGOSLAVIA IS SLIDING TOWARD FRAGMENTATION AND THAT CIVIL WAR COULD ENSUE AT ANY TIME. SPECIFIC QUESTIONS ADDRESSED IN THE ARTICLE ARE: HOW AND WHY DID YUGOSLAVIA REACH THIS POINT? WHOSE INTERESTS ARE SERVED BY THE DETERIORATION OF THE POLITICAL FABRIC? WHAT ARE THE LIKELY EFFECTS OF CIVIL HAR--IF AND WHEN IT DOES TAKE PLACE? AN ANALYSIS OF THE POLITICAL TENSION IS GIVEN.

07588 RAMET, S.P.

WAR IM THE BALKANS

FOREIGN AFFAIRS.71(4) (FAL 92), 79-98.

WESTERN OFFICIALS AND PUBLICATIONS CIRCULATE MYTHS THAT PERPETUATE MISUNDERSTAMDINGS ABOUT THE NATURE OF THE YUGOS LAY YUGOSLAV WAR AND RENDER ANY EFFECTIVE COUNTERMEASURES THE CONFLICT BETHEEN SERBS AND CROATS IS CENTURIES OLD; IT IS PRIMARILY A RELIGIOUS WAR; NO ONE ANTICIPATED THE WAR AND, SINCE BOTH CROATIAN AND SERBIAN GOVERNMENTS ARE REPRESSIVE, THEY MUST SHARE NEAR-EQUAL BLAME FOR THE WAR. ALTHOUGH NONE OF THESE MYTHS IS TRUE, EACH HAS GAINED A CERTAIN CURRENCY. WHAT IS TRUE IS THE SERIOUS DANGER THAT THE CONFLICT WILL SPREAD TO KOSOVO AND MACEDONIA, DRAHING IN ALBANIA, GREECE, BULGARIA, AND TURKEY. IF THAT EVENTUALITY
IS NOT AVERTED, THE DAMAGE TO WEST EUROPEAN AMD AMERICAM INTERESTS WILL RISE CONSIDERABLY. THE LONGER HESTERN LEADERS POSTPONE MILITARY ACTION, THE HIGHER THE STAKES WILL BECOME. MOREOVER, IF NEIGHBORING COUNTRIES ARE DRAWN INTO THE CONFLICT, THEIR ECONOMIES WILL BE FURTHER STRAINED AND THE DEMOCRATIZATION PROCESS UNDERWAY IN ALBANIA AND BULGARIA WILL BECOME EVEN MORE TENUOUS.

07589 RAMPHAL, S.

GLOBALISM AND MEANINGFUL PEACE: A NEH WORLD ORDER ROOTED IN INTERNATIONAL COMHUNITY

SECURITY DIALOGUE, 23(3) (SEP 92), 81-88

THE CHALLENGE IS TO MAKE THE POST COLD WAR ERA NOT ONE OF DOMINION, BUT TO ENSURE DEMOCRACY IN THE GLOBAL SYSTEM. A STRENGTHENED SYSTEM OF GLOBAL GOVERNANCE IS NEEDED, WITH THE UN AS ITS HEADQUARTERS. GLOBAL LAW ENFORCMENT ARRANGEMENTS MUST BE BACKED BY A GLOBAL EMERGENCY SYSTEM THAT ENABLES SWIFT INTERNATIONAL, PREVENTATIVE ACTION AND ESTABLISHED TRIPHIRES FOR WOULD-BE-AGGRESSORS. THE UN SECURITY COUNCIL MUST ACCEPT 'DEVELOPMENT' AS PART OF ITS MANDATE OF ENSURING PEACE AND SECURITY.

07590 RAMPHAL, S.

GLOBALISM AND MEANINGFUL PEACE: A NEW HORLD ORDER ROOTED GLOBALISM AND MEANINGFUL PEAC

MEDITERRANEAN OUARTERLY: A JOURNAL OF GLOBAL ISSUES, $3(2)$ (SPR 92), 8-16.

A NATIONAL SOCIETY CANMOT BE AT PEACE IF POWER,

PRIVILEGE, AND PROSPERITY ARE THE PREROGATIVES OF' ONLY A FEW, WITH DEPRIVATION, DEGRADATION, AND DISPAIR THE LOT OF MANY. THE AUTHOR OF THIS PRESENATION SUGGESTS THAT THE SECURITY COUNCIL ACCEPT DEVELOPMENT AS AN INTEGRAL PART OF ITS MANADATE OF ENSURING PEACE AND SECURITY. HE CONCLUDES THAT IT IS IN FREEING OURSELVES FROM THE ILLUSION THAT PEACE MEANS THE ABSENCE OF WAR HHERE THE MAIN DIFFICULTY LIES; AND, THAT THE OBJECTIVE OF MANKIND SHOULD BE TO PURSUE CONFLICT RESOLUTION AND THE ENLARGEMENT OF PEACE AND SECURITY IN THE
FULL MEANING OF THOSE CONCEPTS FOR ALL THE WORLD'S PEOPLE.

07591 RAMSBOTHAM, D.

MILITARY REALITIES--RECONSTRUCTION, REDEPLOYMENT, RESETTLEMENT

RUSI JOURNAL, 137(4) (AUG 92), 7-10.

IN THIS ARTICLE, THE AUTHOR EXAMINES THE CHALLENGES, AND SOME OF THE SOLUTIONS, FACING AN ARMY LACKING A SINGLE TANGIBLE ENEMY AFTER THE END OF THE COLD WAR, AND WITH THE ADDED PROBLEMS OF REORGANIZATION AND REDUNDANCY IMPOSED UPON IT AT A TIME OF ECONOMIC RECESSION.

07592 RAMSDEN, J.

HISTORY JOURNALS FOR POLITICAL SCIENTISTS

POL ITICAL STUDIES XI (3) (SEP 92) 554-560

THE LAST OUARTER-CENTURY HAS SEEN AN EXPLOSION IN THE NUMBER OF HISTORY JOURNALS PUBL ISHED IN BRITAIN, BUT THERE HAS BEEN LITTLE ATTEMPT TO CAPITALIZE ON THE CLOSER WORKING RELATIONSHIP BETWEEN HISTORIANS AND POLITICAL SCIENTISTS, ALTHOUGH SOME INTERDISCIPLINARY JOURNALS DO EXIST.

07593 RAPOPORT, A.

DETERRENCE THEORY DISCUSSION: COMMENTS ON 'RATIONALITY AND MISPERCEPTIONS IN DETERRENCE THEORY

JOURNAL OF THEORET ICAL POLITICS, $4(4)$ (OCT 92), 479-484.
THE AUTHOR DISCUSSES GAME THEORY AND ITS APPLICATIONS FOCUSING ON "RATIONALITY AND MISPERCEPTIONS IN DETERRENCE THEORY" BY R. HARRISON WAGNER.

07594 RAPP, C.

THE CRISIS OF REASON IN CONTEMPORARY THOUGHT: SOME

REFLECTIONS ON THE ARGUMENTS OF POSTMODERNISM

CRITICAL REVIEW, 5(2) (SPR 91), 261-290.

MANY RECENT THINKERS IMAGINE THAT A NEW WAY OF LIFE, OR A NEW KIND OF THINKING, IS BEGINNING TO UNFOLD ON THE BASIS OF THE DISCOVERY THAT REASON IS AN OUTMODED CONCEPT AND THAT THE PROJECTS OF WESTERN PHILOSOPHY ARE NOH DEFUNCT. POSTMOOERNIST THINKERS, IN PARTICULAR, HAVE TRIED TO DESCRIBE THE HAY THINGS LOOK FROM A POST-PHILOSOPHICAL, POST RATIONAL POINT OF VIEW. THE EFFORT TO ESTABLISH A POSTPHILOSOPHICAL, POST-REATIONAL HAY OF LOOKING AT THINGS INVOLVES AN UNWITTING EXERCISE OF THE RATIONAL POWER TO CONCEIVE OF A SITUATION IN TERMS OF THE RELATIVE DISPOSTION OF ITS ELEMENTS. THIS ARTICLE ARGUES THAT THE THEMES AND IDEAS OF POST-PHILOSOPHY CAN BE SHOWN TO HAVE ORIGNATED IDEAS OF POST-PHILOSOPHY CAN BE SHOWN TO HAVE ORIGNATED WITHIN THE TWO GRAND NARRATIVES OF MODERN PHIL
EMANCIPATORY AND THE SPECULATIVE NARRATIVES

07595 RARAMAGA, P.

RELATIYITY OF THE MINORITY CONCEPT

HUMAN RIGHTS QUARTERLY, 14(1) (FEB 92), 104-119.

MIMORITY ISSUES CONTINUE TO BE A SUBJECT OF CONTROVERSY, MORE SO WITH THE RECENT POLITICAL CHANGES IN EASTERN EUROPE THAT HAVE REKINDLED MINORITY ASPIRATIONS. THIS IS THE FIRST OF THREE ARTICLES EXPLORING THE UNDERSTANDING OF MINORITES IN HISTORICAL AND CONTEMPORARY CONTEXTS. THIS ARTICLE DEALS WITH THE CORE OF THE MINORITY CONCEPT--THE STRUCTURE OF 
GROUP RELATIONS, WITHOUT WHICH MINORITIES CANHOT EXIST. IT EXPLORES THE NUMERICAL FACTOR, AND GEOGRAPHICAL, JURISOICTIONAL, SOCIAL, SOCIO-ECONOMIC CONTEXTS ANO THEN RECONCILS THEM.

07596 RASHID, A.

CALL OF CHAUVINISM

FAR EASTERN ECONOMIC REVIEW, 155(1) (JAN 92), 15

THE BREAKUP OF THE SOVIET UMION HAS LEFT THE IEADERSHIP OF THE CENTRAL ASIAN REPUBLICS TO DEAL WITH A TANGLED WEB OF ETHNIC RIVALRIES AND TENSIONS WITHOUT SUPPORT FROM A STRONG CENTER IN MOSCOW OR THE SOVIET ARMED FORCES TO MAINTAIN LAH AND ORDER. INCREASING FEARS FOR THE FUTURE AMONG THE POWERFUL RUSSIAN MINORITY IN THE REGION AND SUSPICIONS ABOUT POWERFUL RUSSIAN MINORITY IN THE REGION AND SUSPICIONS ABOUT THE REPUBLICS. THE TRAGEDY IS THAT INTER-ETHNIC PROBLEMS ARE ESPECIALLY ACUTE IN REPUBLICS LIKE KAZAKHSTAN AND KIRGYZSTAN, ESPECIALLY ACUTE IN REPUBLICS LIKE KAZAKHSTAN AND KIRGYZSTAN, MARKET HAVE TAKEN PLACE. THE LEADERS OF THE CENTRAL ASIAN MARKET HAVE TAKEN PLACE. THE LEADERS OF THE CENTRAL ASIAN REPUBLICS WILL HAVE TO ACQUIRE SOME NATIONALIST RHETORIC IN ORDER TO MAINTAIN LOCAL MORALE, BUT AT THE SAME TIME ENSURE THAT IT DOES NOT GET OUT OF HAND--A DIFFICULT BALANCE ACT AT
THE BEST OF TIMES AND MUCH MORE OF A PROBLEM WHEN THE SHOPS THE BEST OF

07597 RASHID, A.

CAUGHT IN A CLEFT

FAR EASTERN ECONOMIC REVIEW, 155(46) (NOV 92), 23-24. WITH THE BATTLE LINES OF CIVIL WAR IN NEIGHBORING TAJIKISTAN ALREADY DRAWN, CENTRAL ASIA'S NEXT FLASH POINT IS LIKELY TO BE IN UZBEKISTAN'S FERGHANA VALLEY--WHERE A COMBINATION OF LOOMING ECONOMIC COLLAPSE AND GROWING ISLAMIC FUNDAMENTALISM ARE THREATENING THE SURVIVAL OF PRESIDENT ISLAM KARIMOV'S GOVERMMENT. UZBEKISTAN, ALREADY RAVAGED BY ECONOMIC PROBLEMS, GROWING UZBEK NAT IONALISM AND AN EXDOUS OF RUSSIAN SETTLERS, SEEMS ILL-PREPARED TO TAKE ON THE SAUDI ARABIAN-BACKED FUMDAMENTALISTS WHO ARE, ACCORDING TO THE CLAIMS OF SENIOR UZBEK OFFICALS, CREATING A SECRET ARMY. THE VAST MAJORITY OF PEOPLE IN CENTRAL ASIA ARE SUNHI MUSLIMS OF THE HANNAFI SECT AND HAVE LITTLE KNOWLEDGE OR EXPERIENCE OF THE FUNDAMENTALIST TIDE THAT HAS SHEPT THROUGH ISLAMIC THE FUNDAMENTALIST TIDE THAT HAS SHEPT THROUGH ISLAMIC
COMMUNITIES FRDM NORTH AFRICA TO INDIA. THE FUTURE OF KARIMOV'S REGIME NOW DEPENDS ON HOH QUICKLY IT IS ABLE TO IMPLEMENT ECONOMIC REFORMS, ESPECIALLY IN THE FERGHANA VALLEY.

07598 RASHID, A.

FORCED TO FLEE

FAR EASTERY ECONOMIC PEYIEW, 155(45) (NOY 92), 24-26.

THE REPUBLICS OF CENTRAL ASIA ARE EXPERIENCING A MASS MIGRATION OF PEOPLE--OF BOTH ASIAN AND EUROPEAN DESCENT-WHICH HAS NOT BEEN WITNESSED SINCE STALIN'S TIME. TENS OF THOUSANDS ARE FLEEING THEIR HOMES TO ESCAPE CIVIL WAR, THE GROWTH OF ISLAMIC FUNDAMENTALISM, ECONOMIC HARDSHIP, AND ETHNIC DISCRIMINATION. IN TAJIKISTAN, THE LARGEST ETHNIC GROUPS TO LEAVE ARE THOSE OF EUROPEAN DESCENT: RUSSIANS, GERMANS, AND UKRAINIANS. AT LEAST 100,000 RUSSIANS AND OTHERS HAVE FLED TAJIKISTAN FOR RUSSIA LAST YEAR, WHILE AT LEAST 250,000 MORE HAVE LEFT OVER THE PAST THREE YEARS. IN NEIGHBORING UZBEKISTAN, THE RISE IN ISLAMIC FUNDAMENTALISM HAS PROMPTED NEARLY A MILLION RUSSIANS TO LEAVE SINCE 1985 WITH 25\% OF THEM GOING IN THE PAST 12 MONTHS. NO GOVERNMENT IN CENTRAL ASIA HAS YET ATTEMPTED TO FORMULATE GENUINELY FAIR ETHNIC POLICIES THAT DO NOT DISCRIMINATE AGAINST MINORITIES. INDEED, LEADERS IN UZBEKISTAN, TAJIKISTAN AND TURKMENISTAN ARE RELYING INCREASINGLY ON APPEALS TO LOCAL NATIONALISM--NOT ONLY TO RETAIN THEIR GRIP ON POWER BUT ALSO TO CONTAIN THE NATIONALISM BEING ESPOUSED BY OPPOSITION PARTIES.

07599 RASHID, A.

HEROES OLD AND NEH

FAR EASTERN ECONOMIC REVIEW, 155(47) (NOV 92), 39-41.

ACROSS CENTRAL ASIA, THE UZBEKS AND TAJIKS, THE KAZAKHS AND KIRGYZ--THE HEIRS OF THE MONGOLS, TURKS AND PERSIANS WHO CONQUERED THE WORLD MANY TIMES OVER-ARE REDISCOVERING A HEROIC PAST THAT COMMUNISM TRIED BUT CLEARLY FAILED TO DESTROY. A MASSIVE CULTURAL REVIVAL IS UNDER WAY IN WHICH HISTORY IS BEING REWRITTEN, ISLAM IS RE-EMERGING, AND HEROES HISTORY IS BEING REWRITTEN, ISLAM IS RE-EMERGING, AND HEROES
OF THE PAST ARE BECOMING KNOWN TO A NEW GENERATION OF YOUTH. IRONICALLY, EVEN OLD COMMUNISTS ARE BEING RESURRECTED AS IRONICALLY, EVEN OLD COMMUNISTS ARE BEING RESURRECTED AS
NATIONALIST LEADERS IF THEY FELL VICTIM TO STALIN'S PURGES NATIONALIST LEADERS IF THEY FELL VICTIM TO STALIN'S PURGES
OR DEFIED MOSCOW ON SOME ISSUES. THE REVIVAL OF ANCIENT OR DEFIED MOSCOW ON SOME ISSUES. THE REVIVAL OF ANCIENT WIDER DEBATE OF WHAT THESE FIVE NEW NATION-STATES STAND FOR. HIDER DEBATE OF WHAT THESE FIVE NEW NATION-STATES STAND FOR. STILL IN POHER ACROSS THE ENTIRE REGION, A NEW POL ITICAL BATTLE IS BEING FOUGHT BETWEEN ISLAMIC FUNDAMENTALISTS ON BATTLE IS BEING FOUGHT BETWEEN ISLAMIC FUNDAMENTALISTS ON
THE ONE HAND AND SECULAR NATIONALISTS ON THE OTHER. LIBERAL THE ONE HAND AND SECULAR NATIONALISTS ON THE OT
DEMOCRATS OCCUPY A HEAK POSITION IN THE MIDOLE.

07600 RASHID, A.; ALI, S.

PEACE HITH' PITFALL

FAR EASTERN ECONOMIC REVIEW, 156(18) (MAY 92), 10-12.
AFGHANISTAN SEEMED ON THE BRINK OF AN ETHNIC WAR AS RIVAL MUJAHIDEEN GROUPS ENTERED ITS CAPITAL, KABUL, ON 25-26 APRIL FOLLOWING THE COLLAPSE OF THE MOSCON-BACKED NAJIBULLAH REGIME. PAKISTANI MEDIATION, HOWEVER, LED TO A CEASE-FIRE AND AN AGREEMENT BETWEEN THE MAIN GROUPS ON HOW TO FORM A PROVISIONAL GOVERMMENT. THE FUTURE DEPENDS ON WHETHER PROMINENT MUJAHIDEEN LEADERS SUCH AS TAJIK COMMANDER AHMED SHAH MASUD AND PASHTUN FUNDAMENTALIST GULBUDDIN HEKMATYAR COOPERATE WITH EACH OTHER ENOUGH TO MAKE THE GOVERNMENT WORK. IF NOT, THE GOVERNMENT COULD WELL DISINTEGRATE ON TRIBAL LINES.

07601 RASHID, A.

PICKING UP THE PIECES

FAR EASTERN ECONOMIC REVIEH, 155 (1) (JAN 92), 13-15.

MIKHAIL GORBACHEV'S CHRISTMAS DAY RESIGNATION AND THE FORMAL BREAK-UP OF THE SOVIET UNION A DAY LATER HAVE CREATED A VACUUM WHICH THE SUCCESSOR COMMONWEALTH OF INDEPENDENT STATES (CIS) WILL FIND EXTREMELY HARD TO FILL. ABROAD, MEDIA HEADLINES HAVE FOCUSED ON WHO WILL CONTROL THE TRIGGER OF THE VAST STRATEGIC NUCLEAR ARSENAL OF THE FORMER COMMUNIST SUPERPOWER AND THE FATE OF TENS OF THOUSANDS OF TACTICAL NUCLEAR WEAPONS SPREAD ACROSS THE FORMER SOVIET UNION. BUT THE MOST URGENT CONCERNS OF RUSSIAN PRESIDENT BORIS YELTSIN, HIS SLAVIC BRETHEREN IN UKRAINE AND BYELORUS, AND THE CENTRAL ASIANS RELATE MAINLY TO ECONOMY, LAW AND ORDER, AND ETHNIC AND RELIGIOUS RIVALRIES WITH THE FORMER SOVIET EMPIRE. THE SOVIET DISINTEGRATION HAS GIVEN THE CENTRAL ASIAN REPUBLICS A DRAMATIC DEGREE OF INDEPENDENCE THAT THEY ARE RELUCTANT TO HAVE AND ARE TOTALLY UNPREPARED TO DEAL WITH. HOWEVER, IF THE CENTRAL ASIANS MEET THE IMMEDIATE CHALLENGE OF INDEPENDENCE, THEY HAVE GREAT LONG-TERM POTENTIAL FOR ECONOMIC PROGRESS.

07602 RASHID, A.

PULLS AND PRESSURES

FAR EASTERN ECONOMIC REVIEW, 155(13) (APR 92), 18.

IN A MOVE THAT COULD BOOST PEACE EFFORTS IN AFGHANISTAN, PRESIDENT NAJIBULLAH DECLARED ON 19 MARCH THAT HE WILL RESIGN ONCE AN INTERIM GOVERNMENT TAKES OVER IN KABUL. EVEN AS HIS ANNOUNCEMENT WAS BEING WELCOMED IN DIPLOMATIC CIRCLES, RECENT BATTLEFIELD DEVELOPMENTS POSED NEW THREATS TO PEACE. RECENT BATTLEFIELD DEVELOPMENTS POSED NEW THREATS TO PEACE.
LONG-STANDING FEARS ABOUT THE FRAGMENTATION OF THE COUNTRY LONG-STANDING FEARS ABOUT THE FRAGMENTATION OF THE COUNTR
INCREASED AFTER UZBEK AND TAJIK MILITIAS TOOK OVER THE INCREASED AFTER UZBEK AND TAJIK MILITIAS TOOK OVER THE
STRATEGIC NORTHERN CITY OF MAZAR-I-SHARIF AND KILLED DOZENS STRATEGIC NORTHERN CITY OF MAZAR-I-SHARIF AND KILLED DOZENS
OF SOLDIERS BELONGING TO THE MAJORITY PASHTUN ETHNIC GROUP OF SOLDIERS BELONGING TO THE MAJORITY PASHTUN ETHNIC GRO
NAJIBULLAH'S DECLARATION WILL HELP THE UNITED NATIONS NAJIBULLAH'S DECLARATION WILL HELP THE UNITED NATIONS
PERSUADE THE REJECTIONIST MUJAHIDEEN FACTIONS TO ATTEND A PERSUADE THE REJECTIONIST MUJAHIDEEN FACTIONS TO ATTEND A GATHERING OF ALL AFGHAN GROUPS IN EUROPE IN APRIL, WHICH
WILL BEGIN THE PROCESS OF SETTING UP AN INTERIM GOVERNMENT.

07603 RASHID, A.

REVIVAL OF SUFISM

FAR EASTERN ECONOMIC REVIEW, 155(50) (DEC 92), 32-33.

AT THE HEIGHT OF THE COLD WAR, WESTERN ACADEMICS

MAINTAINED THAT DESPITE STALIN'S HARSH CAMPAIGN TO WIPE OUT ISLAM, INCLUDING A CLOUSRE OF MOSOUES AND A BAN ON CARRYING OUT ISLAMIC MARRIAGES AND FUNERALS, SUFISM, THE MYSTICAL TREND OF ISLAM, WAS KEEPING ISLAM ALIVE IN CENTRAL ASIA. NOW, WITH THE FALL OF THE COMMUNISTS, IT IS THRIVING. HOWEVER, SUFISM NOW FACES A DIRECT THREAT FROM THE SECTARIANISM THÁT IS BEING IMPORTED AT BREATHTAKING SPEED FROM THE DIVIDED MUSLIM WORLD TO THE SOUTH. HOWEVER, THE REVIVAL OF SUFISM AND ITS TOLERANCE FOR OTHER MODES OF RELIGION AND THOUGHT ARE AN INDICATION OF HOW DEEPLY-ROOTED THE NON-

FUNOAMENTALIST TRADITION OF ISLAM IS IN THE REGION AND BODES WELL FOR THIS MYSTICAL TREND OF ISLAM IN THE FUTURE.

07604 RASHID, A.

RASHID, A.ं. FURACE

FAR EASTERN ECONOMIC REVIEW, 155(44) (NOV 92), 18-20.

THE SHIFT COLLAPSE OF AN ATTEMPT BY TAJIKISTAN'S COMMUNIST OLD GUARD TO REINSTATE DEPOSED PRESIDENT TAKHMON NABIVEV MAY HAVE PREVENTED MUCH HEAVIER BLOODSHED THAN THE 150 OR MORE PEOPLE THOUGHT TO HAVE BEEN KILLED DURING THE THREE-DAY CRISIS. BUT THE REBELS' DECISION TO HITHDRAW FROM KEY BUILDINGS IN THE TAJIKISTAN CAPITAL, DUSHANBE, IN RETURN FOR A TOKEN AGREEMENT TO HAVE PARLIAMENT RECONSIDER THEIR CASE, DOES NOT MEAN THAT THE COUNTRY IS ANY CLOSER TO PEACE. RATHER, THE EPISODE SUGGESTS YET ANOTHER STANDOFF BETWEEN
THE FORMER COMMUNISTS AND THE ISLAMIC FUNDAMENTALISTS WHO THE FORMER COMMUNISTS AND THE ISLAMIC FUNDAMENTALISTS
FORM ONE OF THE THO MOST POWERFUL GROUPS WITHIN THE FORM ONE OF THE TWO MOST POWERFUL GROUPS WITHIN THE
OPPOSITION ALLIANCE IN THE THREE-MONTH OLD STRUGGLE FOR OPPOSITION ALLIANCE IN THE THREE-MONTH OLD STRUGGLE FOR
TAJIKISTAN. OFFERS OF PEACEKEEPING INTERVENTION BY THE TAJIKISTAN. OFFERS OF PEACEKEEPING INTERVENTION BY THE
COMMONWEALTH OF INDEPENDENT STATES (CIS) ARE UNHEEDED AS ALL COMMONWEALTH OF INDEPENDENT STATES (CIS) ARE UNHEEDED AS ALL ORGANIZING THEIR OWN MILITIAS IN PREPARATION FOR THE NEXT ORGANI ZING THEIR QHN
ROUND OF FIGHTING.

07605 RASHID, A.

THE TAJIK TIME BOMB

FAR EASTERN ECONOMIC REVIEH, 155(41) (OCT 92), 22.

AS HUNDREDS OF PEOPLE DIED IN FIERCE CLASHES BETWEEN

RIVAL GROUPS IN TAJIKISTAN IN SEPTEMBER, SENIOR RUSSIAN 
OFFICIALS FEARED THE CIVIL WAR COULD ENGULF THE WHOLE OF CENTRAL ASIA. ALTHOUGH MOSCOW RECENTLY SENT 2,000 TROOPS TO THE TAJIK CAPITAL OF DUSHANBE, IT APPEARS HELPLESS IN TRYING TO BRING THE CONFLICT TO AN END. MOSCOW SEES THE TAJIKISTAM SITUATION AS A THREAT TO RUSSIA'S NATIONAL SECURITY. THE RISK OF THE CONFLICT SPREADING TO OTHER CENTRAL ASIAN REPUBLICS IS THE WORST FEAR, BUT THE FOREIGN MINISTRY IS ALSO CONCERNED AT THE GROWING INVOLVEMENT OF IRAN AND AFGHANISTAN WITH THE DIFFERENT TAJIK FACTIONS. IN DUSHANBE THERE IS NO EFFECTIVE GOVERNMENT AS ACTING PRESIDENT AKBARARSHO ISKANDAROV HAS ADMITTED THAT HE IS UNABLE TO PUT AN END TO THE FIGHTING. GOVERNMENT CONTROL SOUTH OF THE CAPITAL HAS CEASED TO EXIST TO THE EXTENT THAT OFFICIALS ARE INCAPABLE OF EVEN GIVING RELIABLE CASUALTY FIGURES.

07606 RASHID, A.

UNDER THE GUN

FAR EASTERN ECONOMIC REVIEW, 151(28) (JUL 91), 22. JUST AS PRIME MINISTER NAWAZ APPEARED TO BE CONSOLIDATING HIS GRIP ON POWER, PUNJAB--PAKISTAN'S MOST POPULOUS AND POLITICALLY IMPORTANT PROVINCE--HAS BEEN POPULOUS AND POLITICALLY IMPORTANT PROVINCE--HAS BEEN JOINING THE VIOLENT RANKS OF THE THREE OTHER PROVINCES, WAVE OF PANIC HAS SPREAD AMONG THE POPULATIOM AND SHARIF'S RAVE OF PANIC HAS SPREAD AMONG THE POPULATION AND SHARIF'S REGIME APPEARS TO BE IN A STATE OF SIEGE. SOME ANALYSTS
OFFICIALS BLAME THE PROXY WAR BETWEEN INDIA AND PAKISTAN OFFICIALS BLAME THE PROXY WAR BETWEEN INDIA AND PAKISTAN
OVER KASHMIR AND PUNJAB FOR THE VIOLENCE. OTHERS BELIEVE THAT THE MASSACRES COULD BE THE WORK OF ANTI-SHARIF POLITICAL ELEMENTS, WHO WOULD LIKE TO SEE THE COLLAPSE OF HIS GOVERMMENT AND THE IMPOSITION OF MARITAL LAH. THE LAHAND-ORDER CRISIS IS COMPLEMENTED BY A SHARP RISE IN PRICES WHICH HAS FUELED PUBLIC ANGER.

07607 RASHISH, P DIPLOMATIC RECOGNITION EUROPE, (311) (NOV 91), 15-16

DIPLOMATIC RECOGNITION IS NOW CONSIDERED TO BE

POLITICAL ACT, NOT A LEGAL ONE, UNDER INTERMATIONAL LAH AND IS A BILATERAL MATTER BETWEEN TWO STATES. THAT RECOGNITION CAN BE USED AS AN INSTRUMENT OF FOREIGN POLICY IS BORNE OUT BY RECENT EVENTS IN THE CASE OF THE BALTIC STATES. THE EUROPEAN COMMUNITY, EAGER TO PLAY A LEAD ROLE IN EASTERN EUROPE, TOOK THE RISK OF RECOGNIZING THE BALTICS BEFORE ITS SUPERPOWER ALLY THE UNITED STATES DID. THE EC HOPED TO CREATE AN EARLY RESERVOIR OF GOODWILL WITH THE NEW CREATE AN EARLY RESERVOIR OF GOODWILL WITH THE NEH
GOVERNMENTS IN ESTONIA, LATVIA, AND LITHUANIA. THE BUSH GOVERMMENTS IN ESTONIA, LATVIA, AND LITHUANIA. THE BUSH
ADMINISTRATION, RELUCTANT TO RATTLE THE ALREADY SHAKY ADMINISTRATION, RELUCTANT TO RATTLE THE ALREADY SHAKY
FOUNDATIONS OF PRESIDENT GORBACHEY'S RULE. WAITED UNTIL IT FOUNDATIONS OF PRESIDENT GORBACHEV'S RULE, WAITED UNTIL IT
WAS CLEAR THAT THE SOVIET GOVERNMENT ITSELF WAS LIKELY TO WAS CLEAR THAT THE SOVIET GOVERNMENT ITSE
GRANT THE BALTIC STATES THEIR FREEDOM.

07608 RASMUSSEN, T.H.

NOT IN MY BACKYARD: THE POLITICS OF SITING PRISONS, LANDF ILLS, AND INCINERATORS

STATE AND LOCAL GOVERMMENT REVIEW, 24(3) (FAL 92), 128-133. PROPOSALS TO BUILD PRISONS, LANDFILLS, AND INCINERATORS OFTEN GENERATE INTENSE NOT-IN-MY-BACKYARD (NIMBY) OPPOSITION AMONG POTENTIAL NEIGHBORS. THIS ARTICLE HYPOTHESIZES THAT NIMBY OPPOSITION IS LIKELY TO BE WEAK WHEN PERCEIVED RISK ASSOCIATED WITH A PROJECT IS LOW, ECONOMIC BENEFIT TO THE COMMUNITY IS LARGE, AND THE POPULATION DENSITY OF THE COMMUNITY IS LOW. DATA ARE DERIVED FROM ACCOUNTS IN "THE NEW YORK TIMES" OF 33 PRISON AND WASTE DISPOSAL PROJECT DECISIONS FROM 1987 TO 1990. IN GENERAL, NIMBY OPPOSITION IS WEAKEST FOR LESS RISKY PROJECTS THAT BRING SUBSTANTIAL ECONOMIC COMPENSATION TO THE HOST COMMUNITY.

07609 RATCLIFFE, P.

RENEWAL, REGENERATION, AND RACE: ISSUES IN URBAN POLICY NEW COMMUNITY, 18(3) (APR 92), 387-400.

THE AUTHOR' EVALUATES THE IMPACT OF URBAN POLICY ON BRITAIN'S INMER CITIES AND, SPECIFICALLY, ON THE VARIOUS COMMUNITIES LIVING HITHIN THEM. HE SUGGESTS THAT POLICIES NEED TO ADDRESS THE ISSUE OF RACIAL INEQUALITY DIRECTLY, RATHER THAN RELYING ON TRICKLE-DOWN EFFECTS FROM CONVENTIONAL ECONOMIC REGENERATION MODELS. HE HIGHLIGHTS PRDBLEMS HITH CURRENT URBAN RENEWAL SERVICE DELIVERY POLICIES AND PROPOSES SOME IMPROVEMENTS.

07610 RATH, J.: GROENENDIJK, K.; PENHINX, R. THE RECOGNITION AND INSTI IUTIONALIZATION OF ISLAM IN BELGIUM, GREAT BRITAIN, AND THE NETHERLANDS NEH COMHUNITY, 18 (1) (OCT 91) 101-114. THE HISTORICALLY SPECIFIC LAWS AND REGULATIONS HITH REGARD TO RELIGIOUS GROUPS IN BELGIUM RELAIN AND THE REGARD TO RELIGIOUS GROUPS IN BELGIUM, BRITAIN, AND THE NETHERLANDS PROVOKE DIFFERENT POL ITICAL REACTIONS TO THE
PRESENCE OF MUSLIMS. THESE LANS AND REGULATIONS ALSO AFFECT, PRESENCE OF MUSLIMS. THESE LAKS AND REGULATIONS ALSO AFFECT, TO SOME EXTENT. THE IDEOLOGICAL REPRESENTATIONS OF ISLAM. SUPPRESS "UNDESIRABLE" MUSLIM BEHAVIOR. BUT OTHER LAWS HAVE BEEN CHANGED OR CIRCUAVENTED TO ENABLE MUSLIMS TO INSTI TUTIONALIZE. THE IDEOLOGICAL REPRESENTATION OF ISLAM DOES NOT NECESSARILY DEPEND ON RELIGIOUS CHARACTERISTICS BUT MAY ALSO TURN ON ETHNIC OR SOCIO-CULTURAL FACTORS.
07611 RATHJENS, G.; MILLER, M. NUCLEAR PROL IFERATION AFTER THE COLO HAR NUCLEAR PROLIFERATION AFTER THE COLD HAR TECHNOLOGY REVIEW, 94(6) (AUG 91), 24-32

WITH THE WANING OF CONFLICT BETWEEN THE SUPERPOWERS POLICIES OF DENIAL OF TECHNOLOGY CAN NO LONGER STEM THE SPREAD OF NUCLEAR WEAPONS. THIS ARTICLE EXAMINES THE INCREASING THREAT OF NUCLEAR PROLIFERATION. IT OUTLINES TROUBLED REGIONS WHICH COULD BECOME HEAVILY PROLIFERATED INCLUDING THE MIDOLE EAST AND SOUTH ASIA. IT CONCLUDES THAT MORE ATTENTION SHOULD BE FOCUSED ON WHAT CAN BE DONE TO REDUCE MOTIVATIONS TO ACQUIRE NUCLEAR HEAPONS, NOT MERELY ON WITHHOLDING VITAL TECHNOLOGY.

07612 RATHMELL, A.

TERRORISM IN THE MIDDLE EAST: DEFEATED OR RESURGENT? RUSI JOURNAL, $137(5)$ (OCT 92), 66-70.

THE QUESTION: HAS THE THREAT OF MIDOLE-EASTERN TERRORISM, SO PREYALENT FOR THE LAST THENTY YEARS, REALLY RECEDED IN THE WAKE OF THE END OF THE COLD HAR AND GULF CONFLICT? THE AUTHOR DISCUSSES HOW THE GENERAL PATTERNS OF TERRORISM REFLECT THE NUANCES OF INTERNATIONAL RELATIONS, YET REMAIN SPECIFIC TO THEIR POLITICAL CONTEXTS AND THEN OUTLINES THE MAIN FACTORS DETERMINING THE POTENTIAL SHAPE OF TERRORIS
ACTIVITY IN THE FUTURE.

07613 RATHWELL, T.

SELF-GOVERNING HOSPITALS IN A PUBLIC FUMDED HEALTH CARE SYSTEM: NHS TRUSTS IN BRITAIN AND INDEPENDENT HOSPITALS IN CANADA

POLICY AND POLITICS, 20(4) (OCT 92), 319-330.

THE BRITISH NATIONAL HEALTH SERVICE (NHS) IS UNDERGOING A PERIOD OF RADICAL REFORM. ONE OF THE MOST IMPORTANT AND FUNDAMENTAL CHANGES IS THE RIGHT FOR HOSPITALS AND OTHER PROVIDER UNITS TO APPLY FOR SELF-GOVERNING STATUS. SELFGOVERNING HOSPITALS ARE A NEW PHENOMENON IN BRITAIN AND THERE IS LITTLE UNDERSTANDING OR EVIDENCE OF HOW THE POLICY CHANGE HILL IMPACT ON HEALTH SERVICES DELIVERY. THIS PAPER EXPLORES THE LIKELY DEVELOPMENT OF THE BRITISH SELFGOVERNING HOSPITAL FROM THE PERSPECTIVE OF THE HOSPITAL IM THE CANADIAN HEALTH SYSTEM. CANADA HAS A COMPREHENSIVE, GOVERNMENT-FUNDED AND REGULATED SYSTEM OF HEALTH CARE, FREE AT THE POINT OF DELIVERY AND AVAILABLE TO ALL CITIZENS, BUT ITS HOSPITALS OPERATE AS AUTONOMOUS INSTITUTIONS WITHIN THE OVERALL STRUCTURE.

07614 RATTINGER H. DEMOGRAPHY AND FEDERAL ELECTIONS IN GERMANY 1953-1990--AND BEYOND

ELECTORAL STUDIES, 11 (3) (SEP 92), 223-248.

IN RECENT YEARS GROWING DIFFERENCES IN VOTING BETWEEN OLDER ANO YOUNGER VOTERS HAVE BEEN OBSERVED IN GERMANY. COHORT ANALYTIC TECHNIQUES ARE USED HERE TO BREAK UP SUCH DIFFERENCES INTO THOSE THAT REFLECT EITHER LIFE CYCLE OR GENERATIONAL EFFECTS ON TURNOUT AND THE VOTE. THE DATA BASE IS A UNIQUE SET OF OFFICIAL STATISTICS THAT HAS BEEN COLLECTED IN GERMANY SINCE 1953 BY MARKING A RANDOM SAMPLE OF BALLOTS ACCORDING TO SEX AND AGE OF VOTERS. THE ANALYSIS SHOWS THAT BOTH LIFE CYCLE AND COHORT FACTORS HAVE HAD A SIGNIFICANT AND SYSTEMATIC IMPACT ON TURNOUT AND THE PROBABILITY OF A YOTE FOR EACH PARTY. IT ALSO DEMONSTRATED THAT THE GROWING POLARIZATIN BY AGE OF THE VOTE FOR SOME PARTIES PRIMARILY REFLECTS GENERATIONAL DISPARITIES, NOT AN INCREASED IMPORTANCE OF THE LIFE CYCLE.

07615 RAUCH, J. SUPPLY-SIDE DEMOCRAT

NEW REPUBLIC, 207(14) (SEP 92), 23, 26-27.

FOR ANYONE WHO CARES ABOUT BILL CLINTON OR HIS PARTY,

CLINTONOMICS CREATES A PAINFUL DILEMMA. ON SOME ISSUES,

NOTABLY RACE AND VALUES, CLINTON LOOKS LIKE THE RIGHT MAN.

BUT THEN THERE'S HIS ECONOMIC PROGRAM, HITH ITS RICH LAROING OF SHAM AND EVASION. IT REPRESENTS THE TRIUMPH OF THE SUPPLYSIDE MOVEMENT IN THE DEMOCRATIC PARTY.

07616 RAVENHILL, J.

WHEN WEAKNESS IS STRENGTH: THE LOME IV NEGOTIATIONS; EUROPE AND AFRICA: THE NEH PHASE

LYNAE RIENHER PUBLISHERS, 1992, 41-62.

THE RENEWAL OF THE LOME CONVENTION IN 1989 MAINTAINED A PATTERM OF NEGOTIATIONS THAT WAS CHARACTERISTIC NOT ONLY OF PREVIOUS LOME TALKS BUT WAS ALSO OBSERYED IN ITS PREVIOUS LOME TALKS BUT WAS ALSO OBSERVED IN ITS PREDECCESSORS. THE MOST IMPORTANT NEGOTIATIONS CONTINUED TO OCCUR WITHIN THE EUROPEAN COMMUNITY, IN PARTICULAR BETWEEN THE MEMEBER STATES AT THE COUNCIL OF MINISTERS LEVEL. WITH LITTLE PROPSECT OF SIGNIFICANT REYERSAL OF AFRICA'S ECONOMIC DECLINE IN THE COMING DECADE, AND NEW OPPORTUNITIES FOR THE EC OPENING UP IN EASTERN EUROPE, THE ACP STATES ARE LIKELY TO CONTINUE TO DECLINE IN SIGNIFICANCE AS ECONOMIC PARTNERS
FOR WESERN EUROPE. THE THIRD DECADE OF THE LOME RELATIONSIP WILL ALMOST CERTAINLY BE FOCUSED ON THE AID RELATIONSHIP.

07617 RAYMOND, P.

THE AMERICAN VOTER IN A NONPARTISAN, URBAN ELECTION 
AMERICAN POLITICS QUARTERLY, 20(2) (APR 92), 247-260. THIS STUDY ANAYZES INDIVIDUAL-LEVEL DATA TO TEST A MULTIVARIATE MODEL OF VOTING BEHAVIOR ON A NONPARTISAN URBAN ELECTION. A TELEPHONE SURVEY OF VOTERS PARTICPATING IN LEXINGTON, KENTUCKY'S 1985 NOMPARTISAN CITY COUNCIL RACES IDENTIFIED THE DETERMINANTS OF THE VOTE. VOTERS' PERCEPTIONS OF OFFICE SEEKERS WERE SHAPED THROUGH CONTACTS WITH FRIENDS AND NEIGHBORS, VOLUNTEERS, AND CAMPAIGN LITERATURE, ONCE DTHER YARIABLES WERE CONTROLLED, NEHSPAPER ENDORSEMENTS HAD NEITHER A DIRECT NOR INDIRECT EFFECT ON THE VOTING DECISION.

07618 RAYMAULD, A.; VIDAL, J.

SMOKERS' BURDEN ON SOCIETY: MYTH AND REALITY IN CANADA CAMOKERS BURDEN ON SOCIETY: MYTH AND REALITY IN CANADA 92), 300-317.

SUPPLEMENTARY COSTS RELATED TO SMOKING ARE ESTIMATED IN THIS PAPER, BUT SINCE FUTURE HEALTH COST REDUCTIONS ARE LESS THE NET EXTERNAL COSTS GENERATED DO NOT EXCEED 207 MILLION. THESE COSTS GIVE RISE TO TRANSFERS, BUT THESE IN TURN ARE MORE THAN COMPENSTATED BY OTHER TRANSFERS SUCH AS TAXES PAID BY SMOKERS AND REDUCTIONS IN PENSION BENEFITS WHICH LEAD TO A NET FLOW OVERALL OF 3 MILLION DOLLARS IN FAVOR OF NON-
SMOKERS. THE DIRECTION OF THIS CONCLUSION REMAINS UNCHANGED.

07619 RAYNER, L.

HONG KONG--PROSPECTS FOR DEMOCRACY

ROUND TABLE, 322(322) (APR 92), 229-236

THE 1984 JOINT DECLARATION BY BRITAIN AND CHINA THAT THE COLONY OF HONG KONG WOULD REVERT TO CHINESE SOVEREIGNTY ON 30 JUNE 1997 CREATED MANY OBVIOUS PROBLEMS. THE BIGGEST PROBLEM BEING THE NEED TO DEVISE A SYSTEM OF GOVERNMENT FOR HONG KONG THAT WOULD SIT WELL WITH ITS FUTURE MARXIST MASTERS IN BEIJING. THIS ARTICLE STUDIES: THE MOVES TOWARDS THE 1984 DECLARATION; ECONOMIC SUCCESS; AND, TRANSITIONS TO DEMOCRACY. IT CONCLUDES THAT IF DEMOCRACY HAS ANY ROLE TO PLAY, THEN THE BEST BRAINS ON THE SUBJECT MUST MEET TO DEVISE A FORMULA WHICH SUITS HONG KONG'S PRACTICAL NEED, ITS PEOPLE'S ASPIRATIONS AND CHINA'S SOVEREIGN RIGHTS.

07620 RAYSIDE, D.; LINDQUIST, E.

AIDS ACTIVISM AMD THE STATE IN CANADA

AIDS ACTIVISM AND THE STATE IN CANADA
STUDIES IN POLITICAL ECONOMY: A SOCIALIST REVIEW, 39(39)

STUDIES IN POLIT

THIS ANALYSIS LOOKS AT THE GROWTH OF AIDS GROUPS IN TORONTO, VANCOUVER, AND MONTREAL, AS HELL AS AT THE EMERGENCE OF MAT, AND MONTREAL, AS WELL AS AT THE BACKGROUND IS PROVIDED ON THE AIDS CRISIS, ON THE POLIITICAL AGENDA OF ACTIVIST GROUPS, AND ON SOME OF THE CHANGES IN STATE POLICY TOWARDS AIDS THAT SUCH ACTIYISM HAS PROVOKED. THE THEORETICAL ARGUMENTS OVER THE FACTORS MITIGATING AGAINST AND FAVORING COMMUNITY ACTIVIST INFLUENCE ARE PRESENTED.

07621 RAYSIDE, D.

HOMOPOHOBIA. CLASS AND PARTY IN ENGLAND

CANADIAN JOURNAL OF POLITICAL SCIENCE, 35(1) (MAR 92), 121-150.

INSTITUTIONALIZED HOMOPHOBIA IN ENGLAND HAS BEEN INTENSIFIED OVER THE LAST DECADE, LINKED TO CONCERNS ABOUT PERMISSIVENESS SO PROMINENT WITHIN THE LOWER MIDDLE CLASSES SO COURTED BY THE MODERN CONSERVATIVE PARTY. HOHEVER, ANTIGAY NORMS HAVE BEEN EMBEDDED IN WORKING-CLASS AND MIDDLECLASS CULTURES. MORALISTIC CRUSADES AGAINST HOMOSEXUALITY HAVE BEEN COMMON AND ARE STILL INFORCED BY THE POLICE, THE COURTS, AND ESPECIALLY THE TABLOID PRESS. OPPOSITION HAS BEEN ROUSED HITHIN LABOUR PARTY AND LIBERAL DEMOCRATIC CIRCLES, BUT OFTEN RELUCTANTLY, AND FRAMED BY A LIMITED FORM OF TDLERANCE.

07622 REAMSBOTTOM, $B$.

IS LABOUR FINISHED?

FREEDOM REVIEW, 23(4) (JUL 92), 19-21.

THE AUTHOR LOOKS AT THE RESULTS OF GREAT BRITAIN'S 1992 GENERAL ELECTION AND SPECULATES ABOUT THE FUTURE OF THE LABOUR PARTY.

07623 REARDON, D.

PUPPETS AND FREEDOM IN CZECHOSLOVAKIA

FREEMAN, 42(2) (FEB 92), 73-74.

THE TENTACLES OF TOTALITARIAM GOVERMMENT EXTENDED DEEP

INTO SOCIETY IN THE DECADES THAT PASSED AFTER THE CDMMUNISTS

INTO SOCIETY IN THE DECADES THAT PASSED AFTER THE COMMUNISTS
SEIZED POWER IN 1948 IN CZECHOSLOVAKIA. THE EXPERIENCES OF

SEIZED POWER IN 1948 IN CZECHOSLOVAKIA. THE EXPERIENCES OF

ALICIA SOUCKOVA IN HER DREAM OF STARTING HER OHN BUSINESS

IN HER COUNTRY. THROUGH HER STRUGGLE TO SELL PUPPETS, THIS IN HER COUNTRY. THROUGH HER STRUGGLE TO SELL PUPPETS, THIS ARTICLE TRACE
WITH FREEDOM.

07624 REBELO, $S$

LONG-RUNG POLICY ANALYSIS AND LONG-RUN GROWTH

JOURNAL OF POL ITICAL ECONOMY, 99(3) (JUN 91), 500-521.

THE WIDE CROSS-COUNTRY DISPARITY IN RATES OF ECONOMIC GROWTH IS THE MOST PUZZLING FEATURE OF THE DEVELOPMEN PROCESS. THIS PAPER DESCRIBES A CLASS OF MODELS IN WHICH
THIS HETEROGENEITY IN GROWTH EXPERIENCES CAN BE THE RESULT OF CROSS-COUNTRY DIFFERENCES IN GOVERNMENT POLICY. THESE DIFFERENCES CAN ALSO CREATE INCENTIVES OF LABOR MIGRATION FROM SLOW-GROWING TO FAST-GROWING COUNTRIES. IN THE MODELS CONSIDERED, GROWTH IS ENDOGENOUS DESPITE THE ABSENCE OF INCREASING RETURNS BECAUSE THERE IS A "CORE" OF CAPITAL GOODS THAT CAN BE PRDDUCED WITHOUT THE DIRECT OR INDIRECT CONTRIBUTION OF FACTORS THAT CANNOT BE ACCUMULATED, SUCH AS LAND.

07625 RECLIFT, M.R.

A FRAMEWORK FOR IMPROVING ENVIRONMENTAL MANAGEMENT: BEYOND THE MARKET MECHANISM

WORLD DEVELOPMENT, 20(2) (FEB 92), 255-259.

ECONOMISTS HAVÉ BEGUN TO EXAMINE THE POTENTIAL OF MARKET ECONOMISTS HAVE BEGUN TO EXAMINE THE POTENTIAL OF MARKET
AND FISCAL POLICY INTERVENTIONS FOR IMPROVING ENVIRONMENTAL AND FISCAL POLICY INTERVENTIONS FOR IMPROVING ENVIRONMENTAL
MANAGEMENT AMONG SMALL FARMERS. THESE APPROACHES CAN BE MANAGEMENT AMONG SMALL FARMERS. THESE APPROACHES CAN BE CRIPPY SIDE OF THE EOUATION. MOST INTERVENTIONS EMPHASIZE SUPPY SIDE OF THE EQUATION. MOST INTERVENTIONS EMPHASIZE INSTITUTIONS AND POLICIES RATHER THAN THE STRATEGIES AND CHOICES OF THE RURAL POOR. IMPORTANT MOVES TO IMPROVE
RESOURCE ACCOUNTING AND TO REMOVE DISINCENTIVES TO BETTER ENVIRONMENTAL MANAGEMENT WILL HAVE UNPREDICTABLE EFFECTS IF THE PERSPECTIVES OF MOST ENVIRONMENTAL MANAGERS ARE NOT CONSIDERED ON THE DEMAND SIDE OF THE EQUATION.

07626 RECORD, J. WHY THE AIR WAR WORKED

ARMED FORCES JOURNAL INTERNATIONAL, (APR 91), 44-45.

THIS ARTICLE SEEKS TO DETERMINE THE REASONS WHY THE AIR WAR AGAINST IRAO WAS SO OVERHHELMINGLY SUCCESSFUL. REASONS DISCUSSED INCLUDE: THE CONDITIONS FOR AN AIR CAMPAIGN WERE CLOSER TO THE IDEAL THAN ANY PREVIOUS CAMPAIGN; THE COALITION FORCES HAD A FIVE-MONTH PLANNING PERIOD BEFORE THE OUTBREAK OF HOSTILITIES; THE CHARACTER OF IRAQ'S MILITARY MACHINE AND SUPPORTING ECONOMY WAS ESPECIALLY VULNERABLE TO AIR ASSUALT; THE WEATHER AND CLIMATIC CONDITIONS HERE CONDUCTIVE TO AIR POWER SUCCESS; THE IRAQI RESPONSE WAS FRAGMENTED OR NON-EXISTENT; AND THE CAMPAIGN WAS SUPERBLY PLANNED.

07627 RECTOR, R. REQUIEM FOR THE WAR ON POVERTY

REQUI EM FOR THE WAR ON POVERTY
POLICY REVIEW, (61) (SUM 92), 40-46.

POLICY REVIEW, (61) (SUM 92), 40-46. THE HAR ON POVERTY HAS
DESPITE SUBSTANTIAL EXPENDITURES, THE FAILED. THE PROBLEM WITH THE WELFARE STATE IS NOT THE LEVEL OF SPENDING; IT IS THAT MEARLY ALL OF THE EXPENDITURES PROMOTE SELF-DESTRUCTIVE BEHAVIOR AMONG THE POOR. IN ORDER TO UNDERSTAND THE PROBLEM, IT IS NECESSARY TO DISTINGUISH BETWEEN TWO TYPES OF POVERTY: MATERIAL AND BEHAVIORAL. "MATERIAL POVERTY" MEANS HAVING A FAMILY INCOME BELOW THE BREAKDOWN IN THE VALUES AND CONDUCT THAT LEAD TO THE FORMATION OF HEALTHY FAMILIES, STABLE PERSONALITIES, AND SELF-SUFFICIENCY. BEHAVIORAL POVERTY IS A CLUSTER OF SOCIAL PATHOLOGIES, INCLUDING DEPENDENCY AND EROOED WORK ETHIC, LACK OF EDUCATIONAL ACHIEVEMENT, INABILITY OR UNWILLINGNESS TO CONTROL ONE'S CHILDREN, INCREASED SINGLE PARENTHOOD AND

ILLEGITIMACY, CRIMINAL ACTIVITY, AND DRUG AND ALCOHOL ABUSE.

07628 REDDING, $K$.

FAILED POPULISM: MOVEMENT-PARTY DISJUNCTURE IN NORTH CAROL INA, 1890 TO 1900

AMERICAN SOCIOLOGICAL REVIEW, 57(3) (JUN 92), 340-352.

THE AUTHOR EXAMINES THE RELATIONSHIP BETHEEN SOCIAL

MOVEMENTS AND POLITICAL PARTIES THROUGH THE STUDY OF

POPULISM IN NORTH CAROLINA IN THE LATE 19TH CENTURY. HE USES COUNTY-LEVEL DATA ON NORTH CAROLINA FARMERS' ALLIANCE MEMBERSHIP AND PEOPLE'S PARTY VOTES TO TEST THEORIES ON THE
SOCIAL-STRUCTURAL BASES OF THE THO ORGANIZATIONS AND TO GAUGE THE RELATIONSHIP BETWEEN THEM. THE RESULTS INDICATE A STRIKING DISJUNCTURE BETHEEN ALLIANCE MEMBERSHIP AND PEOPLE'S PARTY SUPPORT AND SUGGEST A NEW INTERPRETATION OF THE DEFEAT OF POPULISM. THE RESULTS ALSO PROVIDE THE BASIS FOR ANALYSIS OF THE DIFFERENT ORGANIZATIONAL AND

FOR ANALYSIS OF THE DIFFERENT ORGANI ZATIONAL AND
MOBILIZATION PROCESSES OF MOVEMENTS AND PARTIES.

07629 REDING, A.

BOLSTERING DEMOCRACY IN THE AMERICAS

HORLD POLICY JOURNAL, IX(3) (SUM 92), 401-416.

THIS ARTICLE EXAMINES HAYS IN WHICH THE UNITED STATES CAN FOSTER THE DEVELOPMENT OF DEMOCRACY IN LATIN AMERICA. IT CAN FOSTER THE DEVELOPMENT OF DEMOCRACY IN LATIN AMERICA. IT
ARGUES THAT CURRENT TRADE RELATIONS ARE CREATING A OE FACTO ARGUES THAT CURRENT TRADE RELATIONS ARE CREATING A DE FACTO
GENERAL GOVERNMENT IN THE AMERICAS. THEREFORE, THE UNITED GENERAL GOVERNMENT IN THE AMERICAS. THEREFORE, THE UNITED STATES SHOULD RATIFY THE AMERICAN CONVENTION ON HUMAN RIGHTS AND MAKE IT EFFECTIVE BY JOINING THE INTER-AMERICAN COURT. DOING SO HILL SET A PAN-AMERICAN STANDARD THAT WILL HELP ENSURE THAT THE EMERGING HEMISPHERIC TRADE SYSTEM SERVES TO IMPROVE THE OVERALL QUALITY OF LIFE FOR ALL AMERICANS. WITH FULL-COST PRICING TO INTERNALIZE SOCIAL AND ECOLOGICAL
OF PRODUCTION, AND A REGIONAL DEVELOPMENT BANK TO HELP EQUALIZE OPPORTUNITY, COMPETITION CAN BE HARNESSED FOR PROSPERITY WITH SOCIAL JUSTICE AND ECOLOGICAL SANITY. TO THESE ENDS, THE DISCUSSION OF THE FORMATION OF AN AMERICAN 
PARLIAMENT MUST BEGIN. SUCH A PARLIAMENT WILL REPRESENT THE PEOPLES OF THE AMERICAS IN THE DESIGH OF COMMON ECONOMIC, SOCIAL, AND ENVIRONMENTAL POLICIES.

07630 REDING, A.

PROPORTIONAL REPRESENATATION AND AMERICAN DEMOCRACY PEACE \& DEMOCRACY NEWS, $11(2)$ (WIN 92), 3-5

UNITED STATES CITIZENS ARE ASSURED OF REPRESENTATION BY TERRITORY, BUT NOT BY POLITICAL OUTLOOK. THIS ARTICLE ARGUES THAT PROPORTIONAL REPRESENTATION IS A MUST IF THE UNITED STATES IS TO BECOME A TRULY REPRESENATATIVE DEMOCRACY. THE IDEAS BEHIND ONE PERSON, ONE VOTE IS THAT ALL CITIZENS HAVE AN EQUAL RIGHT TO INFLUENCE IN A DEMOCRACY. WE ARE ALL EQUALLY SUBJECT TO TAXATION, AND THAT GIVES US A RIGHT TO EQUAL REPRESENTATION. THE AUTHOR SUGGESTS THAT IT IS TIME TO FORM A BROAD-BASED CITIZENS' MOVEMENT TO RENEH THE CRY

07631 REDMAN, B.J. STRANGE BEDFELLOHS: LUBAVITCHER HASIDIM AND CONSERVATIVE CHRISTIANS

JOURNAL OF CHURCH \& STATE, 34(3) (SUM 92), 521-548.

RECENT YEARS HAVE SEEN THE POLITICAL ALLIANCE OF THE CONSERYATIVE CHRISTIANS AND LUBAVITCHER HASIDIM ON ISSUES CONCERNING THE SEPARATION OF CHURCH AND STATE. THIS ALLIANCE HAS BEEN MOST STRIKING WITH RESPECT TO THE PLACING OF RELIGIOUS SYMBOLS ON PUBLIC PROPERTY, SUCH AS THE USE OF CRECHES TO DECDRATE PUBLIC BUILDINGS AT CHRISTMAS OR THE MENORAH AT CHANUKA. IN CONTRAST TO OTHER JEWISH GROUPS, LUBAVITCHER HASIDIM ALSO FAVORS A MOMENT OF SILENCE FOR PRAYER IN PUBLIC SCHOOLS--A CAUSE DEAR TO THE HEARTS OF CONSERVATIVE CHRISTIANS.

07632 REED, K.S.

CRIMINAL ANTI-PROFIT STATUTES AMD THE FIRST AMENDMENT: SIMON AND SCHUSTER INC. V. NEH YORK CRIME VICTIMS BOARD HARVARD JOURNAL OF LAW AND PUBLIC POLICY, 15(3) (SUM 92). 1060-1069.

IN SIMON AND SCHUSTER INC. V. NEW YORK CRIME VICTIMS BOARD, THE UNITED STATES SUPREME COURT STUCK DOWN SECTION 632-A (THE SO-CALLED "SON OF SAM LAW") OF NEW YORK'S EXECUTIVE LAW. WHICH HAD OPERATED TO SEIZE AND HOLD ANY REVENUE A CRIMINAL RECEIVED FROM THE COMMERCIAL DEPICTION OF HIS CRIMES UNTIL THE CRIMINAL'S VICTIMS HAD A CHANCE TO CLAIM COMPENSATION FOR THEIR INJURIES.

07633 REED, W. : SCHANSBERG, D.

THE BEHAVIOR OF CONGRESSIONAL TENURE OVER TIME: 1953-1991 PUBLIC CHOICE, 73(2) (MAR 92), 183-204.

THE BEHAVIOR OF AVERAGE LENGTH OF TENURE FOR COHORTS OF S. RESPRESENTATIVES WHO ENTERED OFFICE FROM 1953-1989 ARE .S. RESPRESENTATIVES WHO ENTERED OFFICE FROM 1953-1989 ARE
STUDIED IN THIS PAPER. USING A NEW METHODOLOGY, IT ADDRESSES STUDIED IN THIS PAPER. USING A NEW METHODOLOGY, IT ADDRESSES STAY IN OFFICE NOW COMPARED TO TWENTY YEARS AGO? IF AN STAY IN OFFICE NOW COMPARED TO TWENTY YEARS AGO? IF AN INCREASE IN TENURE HAS OCCURRED, WHEN DID IT BEGIN? ARE REELECTION OUTCOMES OR VOLUNTARY DEPARTURES THE PRIMARY DETERMINANTS OF CHANGES IN CONGRESSIONAL TENURE OVER TIME? THE RESULTS OF THIS STUDY ARE THEN APPLIED TO A
HYPOTHESES CONCERNING POSSIBLE CAUSES OF LONGER HYPOTHESES CONCERNING
CONGRESSIONAL STAYS.

07634 REEDER, R.J.; ROBINSON, K.L.

ENTERPRISE ZONES

POL ICY STUDIES JOURNAL, 20(2) (1992), 264-275.

THE ENTERPRISE ZONE' (EZ) IS A RELATIVELY NEW ECONOMIC DEVELOPMENT STRATEGY THAT PROVIDES INCENTIVES TO BUSINESSES INVESTING IN DESIGNATED DISTRESSED AREAS. AT THE END OF THE $1980^{\circ} \mathrm{S}, 38 \mathrm{U}$.S. STATES HAD EZ PROGRAMS. WITH ABOUT HALF OF THE STATE-DESIGNATED EZ'S IN RURAL AREAS. IN THIS ESSAY, THE AUTHORS USE STATE EXPERIENCE WITH EZ'S TO EXAMINE THE THEORETICAL AND EMPIRICAL SUPPORT FOR USING EZ'S TO CREATE JOBS AND OTHER BENEFITS IN DISTRESSED RURAL AREAS. THEY FOCUS ON TWO QUESTIONS: HOW EFFECTIVE ARE STATE EZ'S IN GENERAL? HOH EFFECTIVE ARE RURAL EZ'S IN PARTICULAR?

07635 REES, J.

COMAUNISTS MAY RULE IN THE THIRD WORLD

ORBIS, 36(4) (FAL 92), 565-580.

THREE PARTICULARLY Y FLURISHING MARXIST-LENINIST

MOVEMENTS IN THE THIRD WORLD ARE THE SENDERA LUMINOSO OF

PERU: THE AFRICAN NATIONAL COMGRESS OF SOUTH AFRICA: AND THE PERU; THE AFRICAN NATTONAL CONGRESS OF SOUTH LFRICA; AND THE PARTIA KARTIA KURDISTAN OF SOUTHEASTERN TURKEY. THIS ARTICLE SUGGESTS THAT ALL THREE OF THESE MARXIST-LENINIST MOVEMENTS REASONABLE CHANCE OF ACHIEVING STATE POWER BY THE END OF THIS DECADE. IT EXPLORES PERU'S VULNERABILITY, COMMUNISM IN SOUTH AFRICA, AND TURKEY'S KURDS. IT CONCLUDES THAT IT WOULD BE INACCURATE TO MAINTAIN THAT THE UTOPIAN

07636 REES, $J$

HAWKE LIES HOUNDED

FAR EASTERN ECONOMIC REVIEW, 151(24) (JUN 91), 10-11.

UNLESS HE GOES QUIETLY, AUSTRALIA'S LABOR PRIME MINISTER BOB haHKE MAY HAVE TO FACE ANOTHER CHALLENGE TO HIS
LEADERSHIP WITHIN MONTHS. A RECENT NO-CONFIDENCE CHALLENGE MOUNTED BY HAWKE'S DEPUTY AND TREASURER FOR EIGHT YEARS, MOUNTED BY HAWKE'S OEPUTY AND TREA URER FOR ETGHT YEARS, PAUL KEATING, WAS OVERCOME IN PARL IAMENT, BUT HAWKE'S LEADERSHIP HAS BEEN DESTABILIZED BY THE STRUGGLE AND IS WIOE
OPEN TO A SECOND KEATING ATTACK. EVENTS LEADING UP TO THE OPEN TO A SECOND KEATING ATTACK. EVENTS LEADING UP TO THE
CHALLENGE DEALT A SERIOUS BLOW TO HAHKE'S STANDING IN CHALLENGE DEALT A SERIOUS BLOW TO HAHKE' S STANDING IN PARLIAMENT AND THE NATION. PARTICULARLY DAMAGING WAS THE REVELATION THAT HE MISLED THE AUSTRALIAN ELECTORATE OVER THE LEADERSHIP IN THE 1990 ELECTION. MANY INFLUENTIAL MEMBERS
THE LABOR PARTY ARE ATTEMPTING TO PERSUADE HAWKE TO STEP THE LABOR PARTY ARE ATTEMPTING TO PERSUADE HAKTE TO CONFLICTS.

07637 REES, J. OVER THE HILL

FAR EASTERN ECONOMIC REVIEW, 151(28) (JUL 91), 20. THE CENTENARY OF AUSTRALIA'S LABOR PARTY FOUND PRIME MINISTER BOB HAWKE SURVIVING TWO FURTHER TESTS OF HIS LEADERSHIP ONLY AT A HUGE COST TO THE STANDING OF HIS GOVERNMENT AND HIS ALREADY DIMINISHED PERSONAL CREOIBILITY. A CENTENARY CONFERENCE OF THE LABOR PARTY OFFERED NO SOLUTIONS FOR THE NATION'S 10 PERCENT UNEMPLOYED OR THE PROBLEM OF AUSTRALIA'S ASI30 BILLION FOREIGN DEBT. THE PARTY THAT WAS BORM OF YISION AND PROMISE FOR ORDINARY PEOPLE IS NOW LOSING MEMBERS ACROSS THE NATION. HOWEVER, THE KEY OPPOSITION LEADER, JOHN HEWSON, HAS FAILED TO' CAPITALIZE ON THE SITUATION, AND HAWKE CONTINUES TO ENJOY HIGH LEVELS OF PERSONAL POPULARITY.

07638 REES, $M$.

NEW REPUBLIC, 206(23) (JUN 92), 30-31.

THE AUTHOR LOOKS AT THE UNCOMFORTABLE PREDICAMENT OF HOMOSEXUALS WHO ARE CONSERVATIVE AND WANT TO BE ACTIVE IN REPUBLICAN PARTY POLITICS.

07639 REESE, L.

ECONOMIC DEVELOPMENT STRATEGIES IN ONTARIO: A COMPARATIVE PERSPECTIVE

AMERICAN REVIEW OF CANADIAN STUDIES, 22(2) (SUM 92),

215-234

THIS PAPER PROVIDES A COMPARATIVE ANALYSIS OF ECONOMIC DEVELOPMENT POLICY BETWEEN CANADIAN AND U.S. CITIES. LOCAL POLICIES AND THE ATTITUDES OF ECONDMIC-DEVELOPMENT POLICYMAKERS IN THE PROVINCE OF ONTARIO IS EXAMINED AND SOME CONCLUSIONS OFFERED AS TO THE SIMILARITIES ANO DIFFERENCES IN ECONOMIC DEVELOPMENT POLICY, PARTICULARLY WITH CITIES IN THE STATE OF MICHIGAN. A BRIEF SUMMARY OF THE COMPARATIVE LITERATURE IN URBAN ECONOMIC DEVELOPMENT IS PRESENTED, FOL OWED BY A DESCRIPTION OF PRACTICES IN THE PROVINCE OF ONTARIO BASED ON FACE-TO-FACE INTERYIEWS WITH OFFICIALS IN THREE MAJOR CITIES.

07640 REESE, L.A.

LOCAL ECONOMIC DEVELOPMENT PRACTICES IN ONTARIO

LOCAL ECONOMIC DEVELOPMENT PRACTICES IN ONTARIO
CANADIAN PUBLIC ADMINISTRATION, 35 (2) ( SUM 92), 237-249.

CANADIAN PUBLIC ADMINISTRATIN, 35 (2) (SUM AUTHOR DISCUSSES URBAN ECONOMIC DEVELOPMENT ISSUES, FHE AUTHOR DISCUSSES URBAN ECONOMIC DEVELOPMENT ISSUES, ONTARIO.

07641 REGENS, J.L.: LAUTH, T.P. TRES IN STATE IMDEBTEDNESS, 1950-1989 PUBLIC ADMINISTRATION REVIEW, 52(2) (MAR 92), 157-161. UBLIC ADMINISTRATION REVIEW, $52(2)$ (MAR 92 ' 1950 THROUGH 1989 THEIR FINDINGS INDICATE THAT STATES RELY MORE ON LONG-TERM THAN SHORT-TERM DEBT AND THAT THERE WAS A MORE ON LONG-TERM THAN SHORT-TERM DEBT AND THAT THERE WAS A DRAMATIC SHIFT DURING THAT PERIOD FROM REL ANCE ON GENERALOBLIGATION DEBT TO NONGUARANTEED DEBT. THE INCREASE IN LONGTERM INDEBTEDNESS WAS RELATIVELY GRADUAL WHEN MEASURED IN CONSTANT DOLLARS. WILE THE ROLE OF STATE INDEBTEDNESS AS A PROPORTION OF TOTAL STATE REVENUES INCREASED FROM 44 PERC
IN 1950 TO 50 PERCENT IN 1989 . THE AMOUNT OF THAT DEBT DERIVED FROM LONG-TERM NONGUARANTEED LOANS GREH SIGNIFICANTLY, FROM SLIGHTLY OVER 7 PERCENT OF STATE REVENUES IN 1950 TO NEARLY 40 PERCENT IN 1989

07642 REGENS, J.L.; ELLIOTT, E.

POLITICAL AND ECONOMIC INFLUENCES ON PRIVATE-SECTOR POLLUTION CONTROL COSTS

WESTERN POLITICAL QUARTERLY, 45(1) (MAR 92), 113-124. DRAHING UPON PREVIOUS STUDIES THAT HAVE ASSESSED THE IMPACT OF POLITICAL AND ECONOMIC FACTORS ON MACROECONOMIC PERFORMANCE AS HELL AS REGULATORY POLICYMAKING, THIS RESEARCH EXAMINES THE MAGNITUDE AS WELL AS THE DIRECTION OF THOSE INFLUNCES OM PRIVATE-SECTOR POLLUTION CONTROL COSTS IN THE UNITED STATES. THE ANALYSIS DEMONSTRATES THAT IN THE UNITED STATES. THE ANALYSIS DEMONSTRATES TI DDMINISTRATION, DEMOCRATIC CONGRESSIONAL STRENGTH, AND THE ADMINISTRATION, DEMOCRATIC CONGRESSIONAL STRENGTH, AND THE ENVIRONMENTAL PROTECTION AGENCY'S ABATEMENT AND ENFORCEMENT OUTLAYS ARE IMPORTANT PREDICTORS OF THE COMP

07643 REHNOUIST, W.H. WHY A BILL OF RIGHTS IS NOT ENOUGH 
HILSON QUARTERLY, XVI(2) (SPR 92), 111-117. AS IMPORTANT AS GUARANTEES OF RIGHTS ARE IN PROTECTING INDIVIDUAL FREEDOM, A BILL OF RIGHTS IS MEANINGLESS WITHOUT AN INDEPENDENT JUDICIARY TO INTERPRET AND SAFEGUARD INDIVIDUAL LIBERTIES.

07644 REICH, B.; DROPKIN, N.; HURMSER, M. THE IMPACT OF THE SOVIET JEHISH VOTE ON THE ISRAELI KNESSET ELECTION

MIDDLE EAST INSIGHT, VIII(4) (MAR 92), 48-55

THE CURRENT WAVE OF JEHISH IMMIGRATION FROM THE FORMER SOVIET UNION TO ISRAEL IS DIFFERENT FROM ITS PREDECESSORS IN VIRTUALLY ALL RESPECTS. THIS ARTICLE EXAMINES THE POLITICAL VIRTUALLY ALL RESPECTS. THIS ARTICLE EXAMINES THE POL
ROLES OF THESE NEW IMMIGRANTS (OL IM) IN THE ISRAEL I ROLES OF THESE NEW IMMIGRANTS (OL IM) IN THE ISRAELI
POLITICAL SYSTEM. IT CONCLUDES THAT THE RECENT SOVIET POLIIICAL SYSTEM. IT CONCLUDES THAT THE RECENT SOVIET
IMMIGRANTS WILL HAVE A POTENTIALLY SIGNIFICANT EFFECT AS EARLY AS THE 1992 ELECTION AND ESPECIALLY ON SUCH ISSUES AS EARLY AS THE 1992 ELECTION AND ESPECIALLY ON SUCH ISSUES AS THE NEXT GOVERMMENT. ONE SPECIFIC CONCLUSION IS THAT THE LABOR PARTY WILL PROBABLY FIND IT INCREASINGLY DIFFICULT TO FORM ISRAEL'S NEXT COALITION GOVERNMENT.

07645 REICH, J.

INTELLIGENTSIA AND CLASS POWER IN EASTERN EUROPE AUSSEN POLITIK, 43(4) (1992), 315-324.

THE COLLAPSE OF THE SOCIALIST SYSTEM IN EUROPE IN 1989 WILL BE A FOCUS OF INTEREST FOR HISTORIANS FOR MANY YEARS TO COME. JENS REICH OUTLINES HIS VIEWS ON THE ROLE OF THE INTELLIGENTSIA IN AND AT THE END OF THE SOCIALIST SYSTEM, ITS SITUATION AND ITS PROBLEMS SINCE THEN, AND ITS TASKS FOLLOWING SOCIALISM. THEORIES ON THE END OF SOCIAL CLASS POWER ARE EXPLORED.

07646 REICH, M.R.; BOWONDER, B. ENVIRONMENTAL POLICY IN INDIA: STRATEGIES FOR BETTER IMPLEMENTATION

POLICY STUDIES JOURNAL, 20(4) (WIN 92), 643-661. THE AUTHORS REVIEW THE SIGNIFICANT CHANGES INDIA HAS ACHIEVED IN ENVIRONMENTAL POLICY IN THE PAST DECADE, ESPECIALLY IN TERMS OF REGULATORY PROCEDURES AND ORGAKIZATIONAL STRUCTURE. DESPITE THESE CHANGES, ERVIRONMENTAL QUALITY HAS CONTINUED TO DETERIORATE, LARGELY ENVIRONMENTAL QUALITY HAS CONTINUED TO DETERIORATE, LARGELY
BECAUSE A WIDE GAP PERSISTS BETWEEN POLICY INTENT AND THE ACTUAL ACHIEVEMENT AND BECAUSE MAJOR PROBLEMS HAVE NOT RECEIVED SERIOUS ATTENTION. THE AUTHORS IDENTIFY MAJOR OBSTACLES TO THE IMPLEMENTATION OF INDIAN ENVIRONMENTAL POLICY, WITH PARTICULAR ATIENTION TO POLICY DESIGN, POLICY ANALYSIS, AND SETTING STANDARDS. THEY IDENTIFY POLITICAL PRD IMPLEMENTATION AND PROPOSE STRATEGIES TO IMPROVE AND IMPLEMENTAT
IMPLEMENTATION.

07647 REICH, R.B.

A BUDGET CURE-AL

NEW REPUBLIC, 206 (9) (MAR 92), 20, 22-23.

THE AUTHOR OFFERS SOME SUGGESTIONS FOR REFORMING THE U.S. NATIONAL BUDGET PROCESS.

07648 REICH, R.B.

CLINTONOMICS 101

NEW REPUBLIC, 207(10) (AUG 92), 23-25, 28.

ON JUNE 23, 1992, GOVERNOR BILL CLINTON UNVEILED THE ECONOMIC PLAN HE HILL PURSUE IF HE IS ELECTED PRESIDENT. ON JULY 23, PRESIDENT GEORGE BUSH REITERATED THE ECONOMIC PLAN HE HAD PROPOSED IN HIS STATE OF THE UNION ADDRESS. THE CONTRAST COULD NOT BE SHARPER. THE CENTERPIECE OF THE CLINTON PLAN IS A MAJOR INCREASE IN PUBLIC INVESTMENT IN EDUCATION, TRAINING, AND INFRASTRUCTURE. THE PRESIDENT'S PLAN CONTAINS TAX CREDITS AND INCENTIVES, BUT IT'S CENTERPIECE IS A CUT IN THE CAPITAL GAINS TAX.

07649 REID, H.J.

PARLIAMENT AND THE EXECUTIVE

CANADIAN PARL IAMENTARY REVIEH, (WIN 91), 10-11.

THIS ARTICLE BRIEFLY OUTLINES SOME DIFFERENCES IN THE TYPICAL LEGISLATOR AND EXECUTIVE OFFICIAL IN CANADA. FIRST, THE EXECUTIVE OFFICIAL WORKS FULL TIME ON MATIONAL ISSUES, WHILE THE LEGISLATOR SPENDS A GREAT DEAL OF TIME HITH THE LOCAL CONSTITUENCY. SECOND, LEGISLATORS TEND TO BE THEIR OWH WORST ENEMIES BY FIGHTING THEIR ELECTION BATTLES OVER AND OVER AGAIN IN THE LEGISLATURE. THIRD, THE KIND OF PEOPLE WHO OVER AGAIN IN THE LEGISLATURE. THIRD, THE KIND OF PEOPLE WH JOIN THE LEGISLATURE ARE NOT EXPERTS. FOURTH, THE CHANGIN NATURE OF SOCIETY AND THE INCREASING NUMBER OF OUTSIDE FORCES WITH SIGNIFICANT INFLUENCE MOVE MANY ISSUES BEYOND THE CAPABILITIES OF GOVERMMENTS AND LEGISLATURES. FINALLY, LEGISLATORS

07650 REID, P.: CLAYTON, S.

RACISM AND SEXISM AT WORK

SOCIAL JUSTICE RESEARCH, 5(3) (SEP 92), 249-268.

THIS ARTICLE REVIEHS THE DIFFERENCES RESULTING FROM DEFINITIONS OF RACE AND GENDER, AS WELL AS THOSE DIFFERENCES STEMMING FROM HISTORICAL, LEGAL, AND DEMOGRRAPHIC FACTORS.
IN PARTICULAR, IT FOCUSES ON THE INTERACTIVE EFFECTS OF RACISM AND SEXISM IN THE EXPERIENCE OF WOMEN OF COLOR. THE ASSUMPTION THAT AFFIRMATIVE ACTION OPERATES EQUIVALENTLY FOR ALL RACIAL ANO GENDER GROUPS IS EXAMINED AND SOME DIRCTIONS FOR FURTHER RESEARCH ARE OFFERED.

07651 REID, $W$.

CHANGING NOTIONS OF PUBLIC ACCOUNTABILITY

PUBLIC ADMINISTRATION, 70(1) (SPR 92), 81-88.

THOSE MATTERS IN RELATION TO THE CHANGING STRUCTURES OF GOVERNMENT DEPARTMENTS AND THE HEALTH SERVICE; AND THE

INCREASING POWER AND PERVASIVENESS OF FINANCIAL AND QUALITY AUDIT ARE DEALT WITH IN THIS ARTICLE. IT COMMENTS ON SOME RECENT DEVELOPMENTS AND CHANGES OBSERVED IN PUBLIC STRUCTURES AND ACCOUNTABILTIY. IT EMPHASIZES THE NEED FOR PUBLIC ADMINISTRATORS TO IMPROVE THEIR COMHUNICATION SKILLS, PUBLIC ADMINISTRATORS TO IMPROVE THEIR COMHUNICATION SKILLS,
TO LISTEN TO THE PUBLIC, TO MINIMIZE DELAY, TO GIVE REASONS TO LISTEN TO THE PUBLIC, TO MINIMIZE DELAY, TO GIVE REASONS
FOR THEIR ACTIONS, TO BE RESPONSIVE TO AUDIT, TO CONCEDE FOR THEIR ACTIONS, TO BE RESPONSIVE TO AUDIT, TO CONCEDE
THAT APPEALS ON DECISIONS ARE OPENLY FAIRER WHEN DECIDED BY THAT APPEALS ON DECISIONS ARE OPENLY FAIRER WHEN DECIDED BY RESPONSIBLITIES, AND, TO SET AND EXPLAIN THEIR AIMS AND OBJECTIVES.

07652 REID, W.K.

PUBLIC MANAGEMENT: CHANGING NOTIONS OF PUBLIC ACCOUNTABILITY

PUBLIC ADMINISTRATION (LONDON), 70(1) (SPR 92), 81-87 THE AUTHOR TRACES THE EVOLUTION OF CHANGING NOTIONS OF PUBLIC ACCOUNTABILITY IN GREAT BRITAIN AS REFLECTED IN LEGISLATION AND OTHER GOVERNMENT ACTIVITIES.

07653 REIERSON, K.; WEISSBRODT, D.

THE FORTY-THIRD SESSION OF THE UN SUB-COMMISSION ON PREVENTION OF DISCRIMINATION AND PROTECTION OF MINORITIES: THE SUB-COMMISSION UNDER SCRUTINY

HUMAN RIGHTS QUARTERLY, 14(2) (MAY 92), 232-277.

THE THENTY-SIX MEMBERS OF THE UN SUB-COMMISSION ON PREVENTION OF DISCRIMINATION AND PROTECTION OF MINORITIES CONVENED FOR THE SUB-COMMISSION'S FORTY-THIRD SESSION DURING AUGUST 1991 IN GENEVA. THE SUB-COMMISSION CONDUCTED THIS SESSION IN AN ATMOSPHERE OF SELF-EXAMINATION, PROMPTED BY INCREASING CRITICISM OF THIS METHOD OF WORK BY ITS PARENT BODY. THIS ARTICLE DISCUSSES THE ACCOMPLISHMENTS OF THE FORTY-THIRD SESSION OF THE SUB-COMMISSION, INCLUDING FORTY-THIRD SESSION OF THE SUB-COMMISSION, INCLUDING
RESOLUTIONS REGARDING HUMAN RIGHTS, PRE-SESSIONAL WORKING RESOLUTIONS REGARDING HUMAN RIGHTS, PRE-SESSIONAL WORKING GROUPS ON CONTEMPORARY FORMS OF SLAVERY AND ON INDIGEN
PEOPLES, REFORM OF THE SUB-COMMISSION'S WORK, AND NEW PEOPLES, REF
INITIATIVES.

07654 REINGOLD, 8

CONCEPTS OF REPRESENTATION AMONG FEMALE AND MALE STATE LEGISLATOR

LEGISLATIVE STUDIES QUARTERLY, XVII(4) (NOV 92), 509-538. ARE FEMALE LEGISLATORS MORE LIKELY THAN MALE LEGISLATORS TO ACTIVELY REPRESENT WOMEN AND WOMEN'S CONCERNS? THE AUTHOR TAKES AN ATTITUDINAL APPROACH TO THIS QUESTION, FOCUSING ON LEGISLATORS' PREDISPOSITIONS THAT MAY OR MAY NOT LEAD TO ACTIVE REPRESENTATION OF WOMEN. USING DATA GATHERED PRIMARILY FROM INTERVIENS WITH CALIFORNIA AND ARIZONA STATE LEGISLATORS, SHE FINDS THAT FEMALE LEGISLATORS ARE MORE LIKELY THAN THEIR MALE COUNTERPARTS TO THINK OF THEMSELVES AS REPRESENTATIVES OF HOMEN AND TO CONSIDER WOMEN AN IMPORTANT CONSTITUENCY GROUP WITH PARTICULAR POL ITICAL CONCERNS. FEMALE LEGISLATORS ALSO TEND TO BELIEVE THAT, BECAUSE OF THEIR GENDER, THEY ARE UNIQUELY QUALIFIED TO, RESPONSIBLE FOR, REPRESENTING WOMEN'S CONCERNS. MORE IMPORTANTLY, THEY ARE MORE LIKELY TO ACCEPT THIS NOTION THAN THEIR MALE COLLEAGUES ARE TO REJECT IT. FINALLY, INTERSTATE DIFFERENCES IN THESE ATTITUDES SUGGEST THAT THE ENTIRE ISSUE DIFFERENCES IN THESE ATTITUDES SUGGEST THAT THE ENTIRE ISSUE
OF POLITICAL REPRESENTATION OF WOMEN IS MORE SALIENT IN THE CALIFORNIA LEGISLATURE THAN IN ARIZONA.

07655 REINHARDT, C.

A DEFENCE MINISTER WITH AN UMMILITARY BEARING

GERMAN TRIBUNE, (1533) (SEP 92), 4.

THE AUTHOR PROFILES VOLKER RUHE, WHO BECAME GERMANY'S

MINISTER OF DEFENSE IN APRIL 1992 AND HAS VOWED TO

RESTRUCTURE THE BUNDESHEHR. RUHE IS YERY INTERESTED IN

GERMAN FOREIGH
KLAUS KINKEL.

07656 REIMHARDT, U.

DEVELOPMENT AGENCIES AND REgIONAL POLICY: THE CASE OF THE SCOTTISH DEVELOPMENT AGENCY

REGIONAL POLITICS \& POLICY, 2(3) (FAL 92), 1-26.

A CENTRAL OBJECTIVE OF REGIONAL POLICIES IN EUROPE HAS BEEN TO REDISTRIBUTE ECONOMIC ACTIVITY FROM PROSPEROUS TO DISADVANTAGED AREAS. THE AIM OF THIS ARTICLE IS TO ANALYZE THE DEVELOPMENT OF THE SCOTTISH DEVELOPMENT AGENCY (SDA) AS AN EXAMPLE OF THE DEVELOPMENT-AGENCY APPROACH TO REGIONAL INDUSTRIAL POLICY, AND THUS ITS CENTRAL CONCERN IS TO ESTABLISH TO WHAT EXTENT THE ORGANIZATIONAL ANO STRATEGIC ADVANTAGES GENERALLY ATTRIBUTED TO THIS PARTICULAR INSTITUIONAL SET-UP--OPERATIONAL FREEDOM AND INDIGENOUS 
FOCUS--EVENTUALLY MATERIALIZED IN THE SCOTTISH CASE. AN ANALYTICAL FRAMEHORK IS PROPOSED AND THEN THE INSTITUIONAL ENVIRONMENT OF THE SOA AND THE DEVELPMENT OF ITS MAJOR POLICY PROGRAMS ARE EXAMINED. WHETHER OR NOT THE SDA HAS BEEN A MODEL AGENCY IS REASSESED.

07657 REINHARDT, U.

THE UNITED STATES: BREAKTHROUGH ANO WASTE

JOURNAL OF HEALTH POLITICS, POLICY AND LAW, 17(4) (WIN 92), 37-666.

THE HEALTH SYSTEM OF THE UNITED STATES IS IN A

PARADOXICAL POSITION. AT ITS BEST, THE SYSTEM IS A MAGHET FOR THOSE SEEKING THE LATEST TECHNICAL BREAKTHROUGHS. IT CAN OFFER THAT EXCELLENCE BECAUSE THERE HAVE NEVER BEEN EFFECTIVE FINANCIAL CONSTRAINTS ON THE IMAGINATION; THE SYSTEM HAS BECOME A MAJOR ECONOMIC FRONTIER, AT WHICH PROFESSIONAL AND OTHER ENTREPRENEURS SUCCESSFULLY SEEK THEIR FORTUNE. AT THE SAME TIME, THE SYSTEM IS LEAVING INCREASING NUMBER OF AMERICANS FRUSTRATED AND DISILLUSIONED. IT IS BESET BY EXCESS CAP FRUSTRATED AND DISILLUSIONED. IT IS EXPENSIVE, AND OFTEN BESTOWS UNHECESSARY HEALTH SERVICES YET ONLY THE EXPERTS ARE AHARE OF THESE FLAWS;MOST AMERICANS YET ONLY THE EXPERTS ARE AHARE OF THESE FLAWS; MOST AMERI STILL EXPRESS HIGH SATISFACTION WITH THE QUALITY OF THE
SERVICES THEY RECEIVE FROM THEIR DOCTORS AND HOSPITALS. THE PUBLIC'S MAJOR MISGIVINGS ARISE OVER THE AHKHARD AND INEQUITABLE WAY IN WHICH AMERICAN HEALTH CARE IS FINANCED. THE TYPICAL PRIVATE HEALTH INSURANCE POLICY, FOR EXAMPLE, IS TIED TO A PARTICULAR JOB. IF THE JOB IS LOST, SO IS THE HEALTH INSURANCE. FURTHERMORE, THESE POLICIES ARE PRICED ON ACTUARIALLY "FAIR" PRINCIPLES, SO SICK INDIVIDUALS ARE FORCED TO PAY HIGHER INSURANCE PREMIUMS THAN RELATIVELY HEALTHY ONES AND CHRONICALLY ILL PERSONS OFTEN CANNOT OBTAIN HEALTH INSURANCE COVERAGE AT ANY PRICE. ALTHOUGH THERE ARE PUBLIC PROGRAMS TO CATCH MANY PERSONS NOT PRIVATELY INSURED, THE COVERAGE TENDS TO BE INSUFFICIENTLY EXTENSIVE AND DEEP. SOME 35 MILLION AMERICANS, MOSTLY POOR, HAVE NO HEALTH INSURANCE WHATSOEVER. UNFORTUNATELY, AT THIS TIME THERE IS NO POLITICAL FORCE IN THE UNITED STATES STRONG ENOUGH TO REFORM THE AMERICAN HEALTH SYSTEM TOWARD GREATER SOCIAL EOUITY AND ECONOMIC EFFICIENCY, WHEREAS THERE ARE NUMEROUS GROUPS POWERFUL ENOUGH TO BLOCK WHATEYER REFORM MIGHT HARM THEIR OWN NARROW ECONOMIC INTERESTS.

FROM

07658 REINICKE, W.H.

ARMS SALES ABROAD: EUROPEAN COMMUNITY EXPORT CONTROLS BEYOND 1992

BROOKINGS REVIEW, 10 (3) (SUM 92), 22-25.

HISTORICALLY THE ISSUE OF ARMS EXPORTS HAS BEEN THE PROVINCE OF EUROPE'S NATIONAL GOVERNMENTS. NOW, AS THE EUROPEAN COMMUNITY NEARS COMPLETION OF ITS AMBITIOUS SINGLE MARKET PROGRAM IT FACES THE POL IT ICALLY-SENSITIVE TASK OF MARKET PROGRAM, IT FACES THE POLITICALLY-SENSITIVE TASK OF
DEVELOPING A COMMUNITY-WIDE POL ICY GOVERNING THE EXPORT OF ARMS AND MILITARY-RELATED GOODS AND TECHNOLOGIES.

07659 REISCH, A.A.

HUNGARIAN ETHNIC PARTIES PREPARE FOR CZECHOSLOVAK ELECTIONS RFE/RL RESEARCH REPORT, 1(18) (MAY 92), 26-32.

IN CZECHOSLOVAKIA'S' FIRST POSTCOMMUNIST PARL IAMENTARY ELECTIONS IN JUNE 1990, THE POLITICAL GROUPS REPRESENTING THE COUNTRY'S HUNGARIAN NATIONAL MINORITY GAINED SEATS IN BOTH THE FEDERAL ASSEMBLY AND THE SLOVAK PARLIAMENT. THE 1992 NATIONAL ELECTIONS WILL BE CRUCIAL FOR CZECHOSLOVAKIA'S MINORITIES, ESPECIALLY IN THE SLOVAK REPUBLIC, WHERE THE VOTE COULD LEAD TO A CHANGE IN SLOVAKIA'S DOMESTIC AND INTERNATIONAL STATUS AND TO A BREAKUP OF THE PRESENT CZECHSLOVAK FEDERATION. A STRICTER ELECTORAL LAW HAS PROMPTED THREE OF THE FOUR HUNGARIAN PARTIES TO FORM A COALITION TO MAXIMIZE THEIR CHANCES OF RETAINING PARLIAMENTARY REPRESENTATION.

07660 REISCH, A.A.

HUNGARIAN SOCIALIST PARTY LOOKS AHEAD

RFE/RL RESEARCH REPORT, 1(28) (JUL 92), 20-25.

THE HUNGARIAN SOCIALIST PARTY HELD ITS THIRD NATIONAL CONGRESS IN MAY 1992 TO OUTLINE ITS PROGRAM AND CHART ITS COURSE UNTIL THE 1994 NATIONAL ELECTIONS. CHAIRMAN GYULA HORN SHARPLY CRITICIZED THE POLICIES AND PERFORMANCE OF THE CENTER-RIGHT COALITION GOVERNMENT AND EXPRESSED READINESS TO ESTABLISH LINKS WITH HUNGARY'S LIBERAL OPPOSITION PARTIES. THE SOCIALIST PARTY, WHICH DESCRIBES ITSELF AS SOCIAL

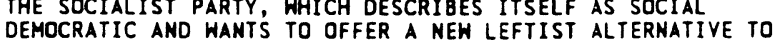
DEMOCRATIC AND WANTS TO OFFER A NEW LEFTIST ALTERNATIVE TO VOTERS, HAS MADE SOME GAINS IN POPULARITY IN THE PAST YEAR. BUT IT WUST STILL RESOLVE ITS INTERMAL PROBLEMS AND FACE THE BASIC QUESTION OF WHA
HUNGARIAN POLITICS.

07661 REISCH, A.A.

HUNGARIAN-GERMAN TREATY CEMENTS CLOSE RELATIONS RFE/RL RESEARCH REPORT, 1(10) (MAR 92), 26-31.

ON FEBRUARY 6, 1992, HUNGARY AND GERMANY SIGNED A COOPERATION TREATY OPENING A NEW CHAPTER IN THE ALREADY GOOD RELATIONS BETHEEN THE THO COUNTRIES. IN THE TEN-YEAR TREATY, WHICH COVERS A WHOLE RANGE OF AREAS OF COOPERATION, GERMANY
PLEDGES TO HELP HUNGARY BECOME A FULL-MEMBER OF THE EUROPEAN COMMUNITY AMD ACHIEVE ITS TRANSITION TO A MARKET ECONOMY. THE TREATY UNDERLINES NOT ONLY BONN'S CLOSE RELATIONS WITH BUDAPEST BUT ALSO ITS HEAVY INVOLVEMENT IN EAST CENTRAL EUROPE AND ITS INTENTION TO PROMOTE POLITICAL STABILITY AND ECONOMIC RECOVERY THERE.

07662 REISCH, A.A.

MECIAR AND SLOVAKIA'S HUNGARIAN MINORITY

RFE/RL RESEARCH REPORT, 1(43) (OCT 92), 13-20.

THE JUNE 1992 ELECTORAL VICTORY OF VLADIMIR MECIAR'S MOVEMENT FOR A DEMOCRATIC SLOVAKIA RADICALLY ALTERED THE COMPOSITION OF THE SLOVAK NATIONAL COUNCIL. THE COUNCIL'S ADOPTION OF MECIAR'S NEH GOVERMMENT PROGRAM, OF A DECLARATION OF SLOVAK SOVEREIGNTY, AND OF A NEN SLOVAK CONSTITUTION WERE ALL MARKED BY CLASHES BETWEEN MECIAR'S PARTY AMD DEPUTIES OF THE ETHNIC HUNGARIAN PARTIES, WHO PROTESTED THAT NONE OF THESE DOCUMENTS PROVIDED ADEQUATE GUARANTEES OF MINORITY RIGHTS. MECIAR SAID THAT THE ETHNIC DEPUTIES DID NOT REPRESENT THE MAGYAR MINORITY AND ACCUSED THEM OF MAKIMG UMREALISTIC DEMANDS. THE MIMORITY'S SITUAT THEM OF MAKING UNREALISTIC DEMANOS. THE MINORITY'S SITUATION IS COMPLICATED BY THE OIFFICULTIES OF OVERCOMING CONTENTIOUS
ISSUES BETHEEN HUNGARY AND SOON-TO-BE INDEPENDENT SLOVAKIA.

07663 REISCH, A.A.

ROUNDTABLE: HUNGARY'S PARLIAMENT IN TRANSITION

RFE/RL RESEARCH REPORT 1(48) (DEC 92) 27-35.

DURING THE FIRST TWO YEARS OF ITS EXISTENCE, HUNGARY'S DEMOCRATIC PARLIAMENT HAS PASSED MANY LAHS, ALTHOUGH NOT NECESSARILY THE MOST ESSENTIAL ONES. THE PARTIES AND DEPUTIES ARE UNDERGOING A PROTRACTED LEARNING PROCESS, WHICH HAS BEEN COMPLICATED BY DIFFERENCES BETWEEN THE RULING COALITION AND THE OPPOSITION, BY PARTY FACTIONALISM, AND BY THE POLITICIZATION OF THE ISSUES. NEVERTHELESS, THE HUNGARIAN PARLIAMENT HAS PROVIDED POLITICAL STABILITY AND IS LIKELY TO COMPLETE ITS FOUR-YEAR TERM.

07664 REISCH, A.A.

THE DIFFICULT SEARCH FOR A HUNGARIAN-SLOVAK ACCORD

RFE/RL RESEARCH REPORT, 1(42) (OCT 92), 24-31.

THREE MONTHS BEFORE THE SCHEDULED DISSOLUTION OF CZECHOSLOVAKIA, HUNGARY AND SLOVAKIA HAVE BEGUN TO BUILD A NEW RELATIONSHIP. BUT, AS SLOVAK PRIME MINISTER VLADIMIR MECIAR'S IMCONCLUSIVE VISIT TO HUNGARY PROVED. REACHING AGREEMENT ON SUCH CONTENTIOUS ISSUES AS THE TREATMENT OF THE MAGYAR MIMORITY IN SLOVAKIA AND THE SLOVAK MINORITY IN HUNGARY AND THE FATE OF THE HUNGARIAN-CZECHOSLOVAK DAM AND POWERPLANT ON THE DANUBE WILL BE A LONG, ARDUOUS PROCESS. DESPITE STRONG NATIONALIST SENTIMENT IN SLOVAKIA. MANY DESPITE STRONG NATIONALIST SENTIMENT IN SLOVAKIA,

HUNGARIANS AND SLOVAKS HOPE THAT, THROUGH PATIENT
NEGOTIATIONS, BUDAPEST AND BRATISLAVA CAN EVENTUALLY ACHIEVE NEGOTIATIONS, BUDAPEST AND BRATISLAVA CAN EVENTUALLY A NEW ACCORD THAT

07665 REISCH, A.A.

TRANSCARPATHIA AND ITS NEIGHBORS

RFE/RL RESEARCH REPORT, 1(7) (FEB 92), 43-47

IN A DECEMBER 1991 REFERENDUM ON AUTONOMOUS STATUS FOR THE TRANSCARPATHIAN OBLAST OF WESTERN UKRAINE, 78\% OF THE VOTERS WERE IN FAVOR OF THE PROPOSED CHANGE. THE LOCAL POPULATION ALSO SUPPORTS THE CREATION OF A SPECIAL ECONOMIC, FREE TRADE ZONE IN THE TERRITORY. SINCE THE OBLAST BORDERS ON CZECHOSLOVAKIA, HUNGARY, AND ROMANIA AND IS HOME TO HUNGARIAN, ROMANIAN, AND SLOVAK MINORITIES, THESE THREE

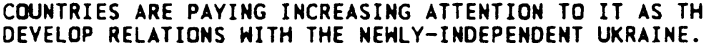

07666 REISCH, A.A.

TRANSCARPATHIA'S HUNGARIAN MIMORITY AND THE AUTONOMY ISSUE RFE/RL RESEARCH REPORT, 1(6) (FEB 92), 17-23.

ON DECEMBER 1, 1991, THE POPULATION OF THE

TRANSCARPATHIAN OBLAST NOT ONLY ENDORSED THE FULL

IMDEPENDENCE OF UKRAINE BUT ALSO VOTED IN FAVOR OF GRANTING THE OBLAST "SPECIAL SELF-GOVERNING ADMINISTRATIVE STATUS"-THAT IS, AUTONOMY HITHIN UKRAINE. MOREOVER, BEREGSZASZ RAION, HERE ALMOST HALF OF THE OBLAST'S ETHNIC HUNGARIAN MINORITY LIVES, VOTED FOR THE CREATION OF A MAGYAR "MATIONAL DISTRICT." THE ISSUE OF RUTHENIAN AND HUMGARIAN AUTONOMY AND THE RESURGENCE OF UKRAINIAN NATIONALISM HAVE GIVEN RISE TO PROBLEMS BETWEEN THE REGION'S MANY NATIONALITIES AND UKRAINE'S VICTORIOUS DEMOCRATIC FORCES.

07667 REISMAN, W. ; BAKER, J.

REGULATING COVERT ACTION--PRACTICES, CONTEXTS, AND REGULATING COVERT ACTION--PRACTICES, CONTEXTS, AND
POLICIES OF COVERT COERCION ABROAD IN INTERNATIONAL AND POLICIES OF COVI

YALE UMIYERISITY PRESS, $1992,256$.

COVERT ACTIYITY HAS ALHAYS BEEM A SIGNIFICANT ELEMENT OF INTERMAT ACIIVITY HAS ALWAYS BEEN A SIGNIFICANT ELEMENT OF INTERNATIONAL POLITICS. WHEN IT HAS SERVED THEIR INTERESTS, GOVERNMENTS HAVE SECRETLY DISSEMINATED PROPAGANDA IN OTHER COUNTRIES, MANIPULATED THE ECONOMIES OF THESE COUNTRIES, AND
ABETTED THE COUPS AGAINST THEIR LEADERS. THIS BOOK IS THE
FIRST TO ASSESS THE LAHFULNESS OF COVERT ACTION UNDER WATIONAL AND INTERNATIONAL LAW AND TO FACE THE IMPLICATIONS 
FOR DEMOCRATIC STATES POSED BY COVERT OPERATIONS. THE AUTHORS IDENTIFY DIFFERENT TYPES OF COVERT ACTIONS AND DISCUSS A VARIETY OF CASES THAT INCLUDE THE TRUJILLO ASSASSINATION IN 1961, THE "RAINBOW WARRIOR" INCIDENT IN 1985. AND THE RAID ON LIBYA IN 1986.

07668 REISSMULLER, J.

CARE NEEDED' IN HANDLING LINKS WITH RUSSIA

GERMAN TRIBUNE, 31(1537) (OCT 92), 2.

THE KOHL/KIMKEL GOVERMMENT HAS GOOD REASON TO TREAT

RUSSIA WITH CARE. THE MOSCOW EMPIRE MAY NO LONGER BE A WORLD

POWER, BUT ONE DAY IT WILL BE ONCE AGAIN. ALL GERMANS WHO

HAVE DEALINGS WITH RUSSIA SHOULD RESPECT RUSSIAN PRIDE. IRRESPECTIVE OF HIS FAILINGS, YELTSIN IS A STROKE OF LUCK FOR GERMANY AND FOR THE ENTIRE FREE COMMUNITY OF STATES. THE GORBACHOV CULT FOSTERED IN THE WEST, IN GERMANY TOO, WHICH YELTSIN IN RUSSIA, IS NOT A SIGN OF JUDICIOUSNESS.

07669 REITSMA, H.; DE HAAN, L.

MORTHERN TOGO AND THE WORLD ECONOMY

POLITICAL GEOGRAPHY QUARTERLY, 11 (5) (SEP 92), 475-484

DOES THE HORLD ECONOMY ENCOMPASS THE REMOTE CORNERS OF THE THIRD WORLD? IF IT DOES, WHEN DID THESE AREAS BECOME INCORPORATED INTO THE WORLD ECONOMY? WHEREAS BY 1919 TOGO HAD HARDLY ANY ECONOMIC CONTACTS WITH THE OUTSIDE HORLD, THE IMPACT HHICH THE GREAT DEPRESSION HAD ON IT SERVES AS EVIDENCE THAT ONLY 10 YEARS LATER THIS RURAL PERIPHERY HAD LOST PART OF ITS FORMER ISOLATED, SELF-SUFFICIENT EXISTENCE. SINCE THEN, CAPITALIST PENETRATION HAS MADE FURTHER INROADS INTO THE AREA. TODAY'S HORLD ECONOMY DOES APPEAR TO BE ONE GLOBE-SPANNING, INTERDEPENDENT SYSTEM.

07670 REMER, C.

HUMANISM, LIBERATION \& THE SKEPTICAL CASE FOR RELIGIOUS TOLERATION

POLITY, 25(1) (FAL 92), 21-44.

LIBERALS HAVE DEVELOPED A DEFENSE OF TOLERATION THAT IS VALUE-NEUTRAL AND RIGHTS-BASED. THIS ARTICLE OFFERS AN ALTERNATIVE THEORY OF TOLERATION WHICH REJECTS THE LIBERALS' ALTERNATIVE THEORY OF TOLERATION WHICH RE ASSUMPTIONS. IN CONTRAST TO THE RADICAL SKEPTICISM OF LEBERALS, THE HUMANISTS ADOPT THE MITIGATED SKEPTICISM OF THE ACADEMIC SKETPTICS. IN WHICH SOME DOGMATIC AND ETHICAL TRUTHS COULD BE ASCERTAINED, AT LEAST WITH PROBABILTIY INSTEAD OF EMPHASIZING THE INDIVIDUAL'S ASSERTION OF RIGHTS AGAINST THE COMAUITY,

07671 REMER, G.

HOBBES, THE RHETORICAL TRADITION, AND TOLERATION REVIEH OF POLITICS, 54 (1) (WIN 92), 5-33.

SCHOLARS DISAGREE ABOUT WHETHER OR NOT THERE WAS A BREAK BETWEEN HOBBES'S EARLIER, HUMANISTIC PERIOD AND HIS LATER, SCIENTIFIC PERIOD. THIS ESSAY CONTENDS THAT, HHEN JUDGED ON THE EPISTEMOLOGICAL LEVEL, HOBBES BROKE WITH HIS HUMANIST PAST BY EXCHANGING THE PROBABILITY OF THE HUMANISTS' RHETORICAL EPISTEMOLOGY FOR THE CERTAINTY OF SCIENTIFIC KNOWLEDGE. HOBBES BELIEVED THAT ONLY CERTAINTY COULD SHIELD AGAINST THE ANARCHY OF CIVIL WAR. HIS REJECTION OF THE HUMANISTS' EPISTEMOLOGY HAD PRACTICAL CONSEQUENCES FOR THE ISSUE OF RELIGIOUS TOLERATION. THE HUMANISTS TURNED TO CONSENSUS AS THE CRITERION OF TRUTH. BY RELYING ON CONSENSUS, THE HUMANISTS WERE ABLE TO REDUCE THE AREA OF INTOLERANCE: ONLY THOSE BELIEFS ON WHICH THERE EXISTED A BROAD-BASED AGREEMENT OF THE CHRISTIAN FAITHFUL WERE VIEWED AS ESSENTIAL. HOBBES'S REJECTION OF THE HUMANISTS' EPISTEMOLOGY, WHICH INCLUDED THEIR CONCEPT OF CONSENSUS, ALSO ENTAILED HIS REJECTION OF THEIR PARTICULAR DEFENSE OF TOLERATION. NEVERTHELESS, SINCE HOBBESIAN POL ITICAL THEORY IS, IN PRINCIPLE, NEUTRAL ON THE QUESTION OF TOLERATION, THERE
NOTHING IN THE LOGIC OF HOBBES'S ARGUMENT THAT HOULD
PRECLUDE SOVEREIGN'S PRUDENTIAL ASSESSMENT OF EXISTING CIRCUMSTANCES.

07672 REN, S.

DORLD: CHALLENGES, OPPORTUNITIES

BEI JING REVIEW, 35(1) (JAN 92), 10-12.

WITH THE WORLD SITUATION DRASTICALLY CHANGING, THE THIRD WORLD COUNTRIES FACE CHALLEMGES AND OPPORTUNITIES IN THE $1990^{\prime} S$. IF THESE CDUNTRIES CAN SEIZE THE OPPORTUNITIES TO DEVELOP THEIR NATIONAL ECONOMIES AND STRENGTHEN SOUTH-SOUTH COOPERATION WHIL PROMOTING NORTH-SOUTH DIALOGUE. THEY WILL SURELY BECOME A MAJOR FORCE IN THE INTERNATIONAL ARENA.

07673 RENGGER, N.J.

A CITY WHICH SUSTAINS ALL THINGS? COMMUNITARIANISM,

INTERNATIONAL SOCIETY, AND LEGITIMACY

MILLENNIUM, 21(1) (SPR 92), 353-370.

THE IDEA OF INTERNATIONAL SOCIETY AS DEVELOPED BY BULL, WIGHT, AND WATSON CANNOT BEAR THE INTELLECTUAL WEIGHT THEY HISH TO PUT ON IT. IT CAN NEITHER ADD VERY MUCH TO THE EXPLANATION OR UNDERSTANDING OF WORLD POLITICS NOR CAN IT SERVE AS A USEFUL NORMATIVE GUIDE TO ACTION IN HORLD POLITICS. A PRIMARY REASON FOR THIS IS THE COMHUNITARIAN
LIBERAL FORM THE ARGUMENT TAKES--A FORM UNABLE TO PROVIDE IT WITH THE CONCEPTUAL RESOURCES NECESSARY FOR SUCH A TASK. AS A RESULT, REFLEXIVE THINKING ABOUT WORLD POLITICS MUST DEVELOP DIFFERENT STRATEGIES TO EXAMINE AND EVALUATE THE CONTEMPORARY SITUATION.

07674 RENGGER, N.J. ARMS CON

ARMS CONTROL, 13(1) (APR 92), 32-57.

THE AUTHOR CONSIDERS THE PROSPECTS FOR ARMS CONTROL IN THE CHANGING WORLD ENVIRONMENT AND SUGGESTS THAT THE FOCUS OF ARMS CONTROL POLICIES MUST BE COORDINATED WITH POLICIES THAT ADORESS THE WIDER OUESTIONS OF INTERNATIONAL SOCIETY AND INTERNATIONAL ORDER IF THEY ARE TO ACHIEVE ANYTHING AND INTERNATIONAL ORDER IF THEY ARE TO ACHIEVE ANYTHING
SIGNIFICANT. HE OISCUSSES HEDLEY BULL'S CONTRIBUTION TO ARMS SIGNIFICANT. HE DISCUSSES HEDLEY BULL'S CONTRIBUTION TO ARMS
CONTROL THEORY, ESPECIALLY BULL'S LINKAGE OF ARMS CONTROL CONTROL THEORY, ESPECIALLY BULL'S LINKAGE OF ARMS CON
WITH INTERNATIONAL SOCIETY AND INTERNATIONAL ORDER

07675 RENGGER, N.J. NO TIME LIKE THE PRESENT? POSTMODERNISM AND POLITICAL THEORY

POLITICAL STUDIES, XL(3) (SEP 92), 561-570.

THE AUTHOR DOES NOT ENDEAVOR TO OFFER AN EXHAUSTIVE CATEGORIZATION OF ALL FORMS OF POSTMODERNISM, BUT HE DOES OFFER AN INTERPRETATION AND CRITIQUE OF POSTMODERN POLITICAL THEORY.

07676 RENOLDS, A.

TIME FOR TERM LIMITS

NATIONAL REVIEW, XLIV(7) (APR 92), 43-44.

THE POLITICAL MARKET, UNLIKE ECONOMIC MARKETS, SUFFERS FROM TOTAL ABSENCE OF CONSUMER PROTECTION. THERE ARE NO GUARANTEES. THE MARKET IS FURTHER DISTORTED BY POOR CONSUMER INFORMATION. THIS ARTICLE STATES THAT TO ENSURE THAT TAXPAYER'S MONEY IS WELL SPENT, TERM LIMITS MUST BE IMPOSED ON MEMBERS OF CONGRESS.

07677 RENSHAW, E.; TRAHAN, E.

A NOTE ON THE ELECTORATE'S MOST PREFERRED INFLATION RATE PUBLIC CHOICE, 70(1) (APR 91), 95-98.

THIS ARTICLE SEEKS TO DETERMINE THE ELECTORATE'S "MOST THIS ARTICLE SEEKS TO DETERMINE THE ELECTORATE'S "MOST
PREFERRED" INFLATION RATE. THIS IS DEFINED AS THAT ATE HHICH HIL MAXIMI ZE THE CHANCE OF AN INCUMBENT POL ITICAL PARTY WILL MAXIMIZE THE CHANCE OF AN INCUMBENT POLITICAL

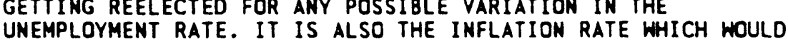
PRESUMABLY PREVAIL IN A DEMOCRATIC SOCIETY IF UNEMPLOYMENT PRESUMABLY PREVAIL IN A DEMOCRATIC SOCIETY IF UNEMPLOYMEMT PREFERRED INFLATION RATE IS 2.84 PERCENT AND IS ASSOCIATED PREFERRED INFLATION RATE IS 2.84 PERCENT AND IS ASSOCIATED WITH A MAXI
PERCENT.

07678 RENSHON, S. THE PSYCHOLOTY OF GOOD JUDGMENT: A PRELIMINARY MODEL WITH SOME APPLICATIONS TO THE GULF WAR POLITICAL PSYCHOLOGY, 13(3) (SEP 92), 477-496.

PROCEDUARL MODELS OF HIGH-QUALITY DECISION-MAKING FOCUS ON PROCESS RATHER THAN DYNAMICS AND OUTCOMES. THIS PAPER PRESENTS A PRELIMINARY MODEL OF GOOD JUDGMENT WHICH EXAMINES THE PSYCHOLOGICAL FACTORS, BOTH CHARACTEROLOGICAL AND COGNITIVE, WHICH ALLOH A LEADER TO MADE EFFECTIVE USE OF PROCEDURES. THE MODEL OF GOOD JUDGMENTS IS LINKED WITH A THEORY OF LEADERSHIP EFFECTIVENESS AND SOME LIMITED ASPECTS OF THE MODEL IN RELATIONS TO THE DECISION OF SADDAM HUSSEIN TO INVADE KUWAIT AND OF GEORGE BUSH TO OPPOSE HIM ARE EXAMINED.

07679 RESHAUR, $K$. CONCEPTS OF SOLIDARITY IN THE POLITICAL THEORY OF HAMMAH ARENDT

CANADIAN JOURNAL OF POLITICAL SCIENCE, XXY(4) (DEC 92), 723-736.

THIS ESSAY haS THO OBJECTIVES: (1) TO DISTINGUISH AND EXPLICATE FOUR CONCEPTS OF SOLIDARITY THAT ARE FOUND IN THE WRITINGS OF HANNAH ARENDT AND (2) TO SHOW HOW ARENDT'S RESPECT FOR FACTS AND SUSPICION OF SENTIMENTALITY PUBLICLY DISPLAYED ARE JUSTIFIED. THE FIRST CONCEPT OF SOLIDARITY IS EXCLUSIVE SOLIDARITY; IT IS LIMITED TO THOSE WHO ARE EXCLUSIVE SOLIDARITY; IT IS LIMITED TO THOSE WHO ARE SUFFERING FROM EXPLOITATION OR OPPRESSION. THE SECOND
CONCEPT OF SOLIDARITY IS INCLUSIVE; IT INCLUDES THOSE WHO CONCEPT OF SOLIDARITY IS INCLUSIVE; IT INCLUDES THOSE WHO
SUFFER BUT CAN ALSO ACCOMMODATE THOSE WHO MAKE COMMON CAUSE SUFFER BUT CAN ALSO ACCOMMODATE THOSE WHO MAKE COMMON CAUSE
WITH THEM. THIS IS THE ONLY KIND OF SOLIDARITY THAT ARENDT WITH THEM. THIS IS THE ONLY KIND OF SOLIDARITY THAT ARENOT SPECIFICALLY ANALYZES. A THIRD CONCEPT OF SOL IDARITY IS
UNIVERSAL; ITS PROXIMATE CONSTITUENT PARTS ARE THE DIFFERENT UNIVERSAL; ITS PROXIMATE CONSTITUENT PARTS ARE THE DIFFERENT "PEOPLES" WHO COLLECTIVELY MAKE UP MANKIND. FINALLY, THERE IS NATURAL SOL IDARITY, BUT
INADEQUATE AND CONFUSED.

07680 RESICH, A.A.

HUNGARIAN FOREIGN MINISTRY COMPLETES REORGANIZATION RFE/RL RESEARCH REPORT, 1 (13) (MAR 92), 34-40.

AFTER AN INITIAL REORGANIZATION IN THE SUMMER OF 1990 , HUNGARY'S FOREIGN MINISTRY WAS STREAMLINED AGAIN AT THE END 
TO INTERNATIONAL POLITICAL CHANGES AND MAKE ITS OPERATIONS MORE EFFECTIVE. DURING THE PROCESS, TWO DEPUTY STATE SECRETARIES ANO THE MINISTRY'S STATE SECRETARY FOR ADMINISTRATION RESIGNED. ALL THREE WERE PART OF THE MINISTRY'S OLD APPARATUS, MOST OF HHOSE MEMBERS HAYE DEMONSTRATED THEIR ABILITY TO WORK WITH THE NEH PERSONNEL HIRED AFTER HUNGARY'S DEMOCRATIC GOVERNMENT TOOK OFFICE IN MAY 1990.

07681 RESNICK, P.

TOWARD A CANADA-QUEBEC UNION

MCGILL-QUEEN'S UNIVERSITY PRESS, 1991, 119

THIS BOOK OFFERS A PROPOSAL FOR A NEW CONFIGURATION OF CANADA'S TWO FOUNDING NATIONS: THE ESTABLISHMENT OF SEPARATE PARLIAMENTS AND GOVERMMENTS IN ENGL ISH CANADA AND QUEBEC, TO BE LINKED BY A NEW INSTITUTIONAL ARRANGEMENT CALLED THE CANADA-QUEBEC UNION. THE BOOK ALSO DEALS WITH TWO VITALLY IMPORTANT OUESTIONS OF MINORITY RIGHTS AND THE THREAT, FOR ALL OF CANADA, OF AMERICANIZATION.

07682 REUS-SMITH, C.

REALIST AND RESISTANCE UTOPIAS: COMMUNITY, SECURITY, AND POLITICAL ACTION IN THE NEH EUROPE

MILLENNIUM, 21(1) (SPR 92), 1-28

THE VIEWS OF EAST EUROPEAN DISSIDENTS AND WEST EUROPEAK PEACE ACTIVISTS HAVE BEEN LARGELY EXCLUDED FROM THE MAINSTREAM SCHOLARLY DEBATE ABOUT THE FUTURE OF EUROPEAN SECURITY. MAINSTREAM SCHOLARS HAVE INVOKED THE REALIST/IDEALIST OICHTOMY TO OISMISS THE WORK OF RESISTANCE WRITERS, BUT UNDERLYING THIS DICHTOMY IS A FALSE DISTINCTION BETWEEN THE "REALISTIC" AND THE "UTOPIAN." BOTH REALIST aND IDEALIST THEORIES HAVE UTOPIAN DIMENSIONS. THE MAINSTREAM INTERNATIONAL SECURITY DEBATE SHOULD BE BROADENED TO ENCOMPASS THE INSIGHTS OF RESISTANCE WRITERS.

07683 REUTER, $P$.

HAWKS ASCENDANT: THE PRIMITIVE TREND OF AMERICAN DRUG POLICY

DAEDALUS, $121(3)$ ( SUM 92), 15-52

THE AUTHOR DESCRIBES THREE BROAD POSITIONS ON ORUG CONTROL POL ICY: THE HAWKS, THE DOVES, AND THE OWLS. THE HAWKS FAVOR HARSH PUNISHYENT FOR DRUG USERS AMD STRICT LAH ENFORCEMENT IS THE ONLY SOLUTION TO THE DRUG PROBLEM. THE DOVES ARGUE THAT MOST OF THE EVILS ASSOCIATED WITH DRUGS ARISE FROM PROHIBITIONS AND THE ENFORCEMENT OF THOSE PROHIBITIONS. THE OWLS ARGUE THAT DRUG ENFORCEMENT EFFORTS HAVE FAILED AND THAT REDUCING THE NATION'S DRUG EFFORTS HAVE FAILED AND THAT REDUCING THE NATION'S DRUG
PROBLEM REQUIRES A CHANGE IN SPENDING PRIORITIES, GIVING PROBLEM REQUIRES A CHANGE IN SPENDING PRIORITIES, GIVING
MORE MONEY TO PREVENTION AND DRUG TREATMENT PROGRAMS. THE AUTHOR ENDEAVORS TO EXPLAIN WHY THE HAWKS HAVE TAKEN CONTROL AUTHOR ENDEAVORS TO EXPLAIN WHY THE HAWKS HAVE TAKEN CONTROL OF U.S. DRUG POLICY AND HOW THE HAWKISH APPROACH HAS HARMED
AMERICAN SOCIETY THROUGH "EXCESSIVE PUNITIVENESS."

07684 REUTER, P.; RONFELDT, $D$.

OEST FOR INTEGRITY: THE MEXICAN-US DRUG ISSUE IN THE 1980 S JOURNAL OF INTERAMERICAN STUDIES AND WORLD AFFAIRS, $34(3)$ (FAL 92), 89-154.

THE FLOW OF DRUGS FROM MEXICO TO THE UNITED STATES HAS BEEN A SOURCE OF TROUBLE IN US-MEXICAN RELATIONS FOR AT LEAST TWO DECADES. THIS STUDY ANALYZES THE INTERACTION OF THE TWO COUNTRIES WITH RESPECT TO DRUGS. IT BEGINS BY DEVELOPING ESTIMATES OF THE VALUE ADDED IN MARI JUANA AND OPIUM/HERION PRODUCTION IN MEXICO. IT THEN EXAMINES THE POLITICAL SETTING OF DRUG PRODUCTION AND TRAFFICKING. THE EMERGENCE OF A NEW MEXICAN NATIONAL SECUIRTY APPARATUS AND DOCTRINE ARE EXAMINED.

07685 REUTER, $P$.

THE LIMITS AND CONSEQUENCES OF U.S. FOREIGN DRUG CONTROL EFFORTS

ANMALS OF THE AMERICAN ACADEMY OF POLITICAL AND SOCIAL SCIENCE, 521 (MAY 92), 151-162.

EFFORTS TO REDUCE COCAIME PRODUCTION AND EXPORTS FROM THE ANDEAN REGION CONTINUE TO BE AN IMPORTANT COMPONENT OF S. DRUG CONTROL EFFORTS. THIS ARTICLE PRESENTS A SIMPLE ECONOMIC ANALYSIS OF THE EFFECTS OF MAJOR SOURCE-COUMTRY CONTROL PROGRAMS: ERADICATION, CROP SUBSTITUTION, AND REFINERY DESTRUCTION. WHEN THE STRUCTURE OF PRICES IN THE COCAINE INDUSTRY AND THE ABILITY OF FARMERS AND REFINERS TO MAKE BEHAVIORAL ADAPTATIONS ARE TAKEN INTO ACCOUNT, NONE OF MAKE BEHAVIORAL ADAPTATIONS ARE TAKEN INTO ACCOUNT, NONE OF COCAINE TO THE UNITED STATES. DESPITE THE CONTINUED FAILURE OF THE PROGRAMS AND THE ANALYTIC ARGUMENTS AGAINST THEM THEY CONTINUE TO FLOURISH BUDGETARIIY; THEY ARE PROTECTED BY THEY CONTINUE TO FLOURISH BUDGETARILY; THEY ARE PROTECTED THE RHETORICAL CLAIMS OF THE PAST, THE NEED TO APPEAR TQ HAVE A COMPLETE PORTFOLIO OF PROGRAMS.
MOMENTUM OF DRUG CONTROL EXPEMDITURES.

07686 REVEL, J.

FROM THE ONE, MANY: THE MULTICULTURALIST THREAT FREEDOM REVIEW, 23(5) (SEP 92), 34-36.

ALTHOUGH "MULLTICUL TURALISM" IS THE RAGE TODAY, AMERICAN EDUCATION HAS ONCE DRIVEN BY AN ASSIMILATIONIST IDEAL BASED ON THE CONVICTION THAT PEOPLES FROM OIVERSE RELIGIOUS,
CULTURAL, AND ETHNIC BACKGROUNDS COULD BE WELDED INTO A SINGLE NATION SHARING A SINGLE CULTURE BASED ON DEMOCRATIC LIBERAL VALUES.

07687 REVEL, 0.

STRUCTURE OF COUNTERTERRORISH PLANNING AND OPERATIONS IN THE UNITED STATES

TERRORISH, 14(3) (1991), 135-144.

THE FBI IS COMMITTED TO A PROGRAM OF INTENSIVE

INVESTIGATIVE ACTIVITY TO SUCCESSFULLY COUNTER THE VIOLENT INTENTIONS OF TERRDRIST ORGANIZATIONS IN THE UNITED STATES. ALTHOUGH THE ARREST, PROSECUTION, AND INCARCERATION OF KEY LEADERSHIP ELEMENTS OF VARIOUS TERRORIST ORGANIZATIONS

COUPLED WITH SUCCESSFUL PREVENTIVE MEASURES, HAS

SIGNIFICANTLY CONTRIBUTED TO THE DECLINE IN THE NUMBER OF

TERRORIST INCIDENTS COMMITTED IN THE UNITED STATES, IT HOULD BE INCORRECT TO CONCLUDE FROM THESE SUCCESSES THAT THE PERNICIOUS THREAT OF TERRORISM IN THE UNITED STATES HAS BEEM ERADICATED. MORE PROPERLY, THE REDUCTION IN TERORIST ERADICATED. MORE PROPERLY, THE REDUCTION IN TERORIST
INCIDENTS IN THE UNITED STATES CLOSELY CORRESPONDS TO THE INCIDENTS IN THE UNITED STATES CLOSELY CORRESPONDS TO THE
FBI'S AND ASSOCIATED LAW ENFORCEMENT AGENCIES' ACCELERATION FBI'S AND ASSOCIATED LAW ENFORCEMENT AGENCIES ACCELERAT OF AN ALL-OUT COUNTERTERRORI SM EFFORT, WHICH HAS BEEN ENHANCED COUNTERTERRORISM TRAINING, AND MORE EFFICIENT USE OF AN INCREASINGLY EFFECTIVE INTELLIGENCE BASE.

07688 REYNOLDS, A.

FLAT CHANCE

NEW REPUBLIC, 206(16) (APR 92), 14-16.

THE AUTHOR ANALYZES FORMER CALIFORNIA GOVERNOR JERRY BROWN'S FLAT-TAX PROPOSAL, WHICH IS DESIGNED TO ENCOURAGE EFFORT AND INVESTMENT WHILE ELIMINATING COMPLEXITY AND AMBIGUITY.

07689 REYNOLOS, A.; HOROWITZ, C.F.; MACKENZIE, R.B.; NISKANEN, W.; ROBERTS, P.C.; SAMUEL, P.; TURE, N.B.; YAGO, G. THE REAL REAGAN RECORD

NATIONAL REVIEH, XLIV(17) (AUG 92), 25-40, 42-62.

THE AUTHORS ENDEAVOR TO ASSESS THE ECONOMIC RECORD OF PRESIDENT RONALD REAGAN. THEY CONSIDER SUCH FACTORS AS INCOME DISTRIBUTION, THE EFFECT OF DEBT AND INFLATION DN THE ECONOMY, THE BUDGET DEFICIT, THE SAVINGS AND LOAN CRISIS, AND SOCIAL POLICY.

07690 REYNOLDS, H.B.

AFFIRMATIVE ACTION AND ITS NEGATIVE REPERCUSSIONS ANMALS OF THE AMERICAN ACADEMY OF POLITICAL AND SOCIAL SCIENCE, (523) (SEP 92), 38-49.

(

WHETHER PREFEREN A SET-ASIDE, A GOAL-AND-TIMETABLE, OR AFFIRMATIVE ACTION, THE CONSEQUENCE IS THE SAME. FAVORING CERTAIN INDIVIDUALS DUE TO RACE, GENDER, RELIGION, OR NATIONAL ORIGIN INESCAPABLY MEANS THAT INDIVIDUALS NOT SIMILARLY ENDOWED ARE DISFAVORED FOR THE MOST OFFENSIVE OF REASONS. TO PRETEND SUCH ACT ION IS AFFIRMATIVE--OR THAT SUCH DISCRIMINATION IS BENIGN--MOCKS THE VALIANT STRUGGLE FOR EQUAL OPPORTUNITY THAT HAS DEFINED AMERICA'S DOMESTIC AGENDA FOR THE LAST FOUR DECADES. THE NATION LOST SIGHT OF THIS FUNDAMENTAL TRUTH DURING THE 1970'S AND PERMITTED GOVERMMENT TO FASHION AFFIRMATIVE ACTION POLICIES THAT MADE RACE, GENDER, AND NATIONALITY THE FINAL ARBITER OF EMPLOYMENT, STUDENT ADMISSIONS, AND CONTRACT DECISIONS. IT TOOK A SERIES OF SUPREME COURT RULINGS IN THE LATE 1980'S TO RIGHT THAT WRONG AND RESTORE THE EQUALITY IDEA THAT THE COURT HAD EARLIER ARTICULATED IN BROWN V. BOARD OF EDUCATION.

07691 RHEE, S.

INTER-KOREAN RELATIONS IN THE 21ST CENTURY

KOREA \& WORLD AFFAIRS, 16(1) (SPR 92) 68-81

THE AUTHOR PAINTS A SCENARIO FOR FUTURE RELATIONS BETHEEN NORTH AND SOUTH KOREA. THEN HE PRESENTS THE LOGIC AND ARGUMENTS THAT SUPPORT THIS SCENARIO.

07692 RHODES, J.M.

ON VOEGELIN: HIS COLLECTED WORKS AND HIS SIGNIFICANCE REVIEW OF POLITICS, 54(4) (FAL 92), 621-647.

LOUISIANA STATE UNIVERSITY PRESS HAS COMMITTED ITSELF TO PUBLISHING 34 VOLUMES OF ERIC VOEGELIN'S COLLECTED WORKS. IN PUBLISHING 34 VOLUMES OF ERIC VOEGELIN'S COLLECTED WORKS. IN THIS ARTICLE, THE AUTHOR OUTLINES THE SCOPE OF THE PROJECT
AHD DISCUSSES SOME OF THE MAJOR THEMES IN VOEGELIN'S WORK.

07693 RHODES, M.

RELIGIOUS BELIEVERS IN RUSSIA

RFE/RL RESEARCH REPORT, 1(14) (APR 92), 60-64

A SURVEY OF RUSSIANS CONDUCTED IN SEPTEMBER 1991 SUGGESTS THAT THE CHURCH HAS CONSIDERABLE SUPPORT AMONG THE RUSSIAN POPULATION. A LARGE PERCENTAGE (41\%) OF THE RESPONDENTS CONSIDERED THEMSELVES TO BE RELIGIOUS BELIEVERS, AND A MAJORITY OF NONBELIEVERS FELT THE CHURCH HAS A POSITIVE VALUE FOR RUSSIAN SOCIETY. ON ALMOST ALL POLITICAL AND SOCIAL ISSUES, THE RELIGIOUS BELIEVERS HAD MORE CONSERVATIVE ATTITUDES, INCLUDING A STRONG DESIRE FOR ORDER AND STABILITY, THAN DID THE NONBELIEVERS. A MAJORITY OF THE RELIGIOUS BELIEVERS WERE WOMEN WITH RURAL TIES, ALTHOUGH 
THERE IS ALSO EVIDENCE OF A CONSIDERABLE POPULATION OF YOUNG URBAH BELIEVERS WHO ARE YOUNGER, BETTER EDUCATED, AKD MORE LIBERAL THAN THEIR RURAL COUNTERPARTS.

\section{RHODES, $M$}

THE COUP IN RETROSPECT: VIEWS FROM THE RUSSIAN HEARTLAND RFE/RL RESEARCH REPORT, 1(29) (JUL 92), 66-72.

IN A SURVEY CONDUCTED IN VORONEZH OBLAST IN FEBRUARY 1992, MORE THAN 40\% OF THE INTERVIEWEES SAID THAT, IN RETROSPECT, THEY WOULD NOT HAVE SUPPORTED THE COUP ATTEMPT IN AUGUST 1991 EVEN IF THE LEADERS HAD BEEN ABLE TO DELIVER IN AUGUST 1991 EVEN IF THE LEADERS HAD BEEN ABLE TO DELIVER THE SOCIAL IMPROVEMENTS THEY PRDMISED. SLIGHTLY MORE THAN
ONE-QUARTER OF THE RESPONDENTS SAID THAT SUCH IMPROVEMENTS WOULD HAVE JUSTIFIED THE COUP, WHILE A THIRD REMAINED WOULD HAVE
UNDECIDED.

07695 RHODES, R.A.W.; MARSH, D.

NEW DIRECTIONS IN THE STUDY OF POLICY METWORKS EUROPEAN JOURNAL OF POLITICAL RESEARCH, 21(1-2) (FEB 92), 181-205.

THIS PAPER SUMMARIZES RECENT THEORETICAL DISCUSSIONS IN BRITAIN OF THE CONCEPTS OF POLICY COMMUNITIES AND POLICY NETWORKS. SECONDLY, IT PRESENTS A TYPOLOGY OF POLICY NETWORKS BASED UPON BOTH THESE RECENT THEDRETICAL DISCUSSIONS AND A SERIES OF CASE STUDIES OF NETWORKS IN ACTION WITHIN THE BRITISH GOVERNMENT. THIRDLY, IT ADDRESSES A SERIES OF CRUCIAL QUESTIONS ABOUT THE UTILITY OF THE POLICY NETWORKS' APPROACH. FINALLY, IT IDENTIFIES SOME NEH DIRECTIONS FOR FUTURE RESEARCH. IT DRAWS UPON THREE MAJOR SOURCES OF EMPIRICAL AND THEORETICAL WORK: THE ECONOMIC AND SOCIAL RESEARCH COUNCIL (ESRC) RESEARCH INITIATIVE INTO THE RELATIONSHIP BETWEEN CENTRAL AND LOCAL GOVERNMENTS IN GREAT BRITAIN, THE ESRC RESEARCH INITIATIVE INTO THE RELATIONS BETWEEN GOVERNMENT AND INDUSTRY, AND THE NUFFIELD FOUNDATION'S WORKSHOP ON THE COMPARISON OF POLICY NETWORKS IN THE BRITISH GOVERMMENT.

07696 RICCIARDI, J.

THE MILITARY'S HAKE-UP CALL

REPORT ON THE AMERICAS, 26(1) (JUL 92), 7-9.

POPULAR SUPPORT FOR THE FEBRUARY COUP ATTEMPT EVINCED THE DEPTH OF PUBLIC DISENCHANTMENT WITH A CORRUPT AND SELF-
SERVING POLITICAL ELITE. VENEZUELA HARDLY SEEMED A LIKELY SERVING POLITI CAL ELITE. VENEZUELA HARDLY SEEMED A LIKELY
CANDIDATE FOR A COUP. THE COUNTRY IS SOUTH AMERICA'S OLDEST CANDIDATE FOR A COUP. THE COUNTRY IS SOUTH AMERICA'S OLDEST DEMOCRACY--WITH 34 YEARS OF UNINTERRUPTED CONSTI YUTIONAL RULE. HOWEVER, THE COUP ATTEMPT RUDELY AHAKENED VENEZUELA'S LEADERS TO THE OIRE ECONOMIC AND POLITICAL CRISES UNDERLYING THE STATISTICS OF ECONOMIC PERFORMANCE. THIS AUTHOR PREDICTS THAT IN THE EVENT OF ANOTHER COUP ATTEMPT, VENEZUELA'S DEEPLY DIVIDED MILITARY MAY NOT BE ON HAND TO SAVE THE PRESIDENT.

07697 RICE, C.

THE MILITARY UNDER DEMOCRACY

JOURNAL OF DEMOCRACY, 3(2) (APR 92), 27-42

THE STATES THAT HAVE FREED THEMSELVES FROM SOVIET RULE ARE NOW FACING AN ARRAY OF URGENT AND LIFE-THREATENING PROBLEMS. IF DEMOCRACY IS TO TAKE ROOT AND THRIVE IN EASTERN EUROPE AND THE FORMER USSR, THE NEW POST COMMUNIST REGIMES MUST REFORM BANKRUPT ECONOMIES, REDISTRIBUTE POLITICAL POWER, AND DEVISE A NEW SOCIAL CONTRACT THAT IS BASED ON SELF RELI IANCE RATHER THAN STATE SUBSIDY AND CONTROL. MOREOVER, THEY MUST ACCOMPLISH THESE TASKS THROUGH INSTITUTIONS THAT ARE STILL UNTESTED. THE AUTHOR EXPLORES THE NEW NORMATIVE AND INSTITUTIONAL FOUNDATIONS FOR THE SEPARATION OF THE MILTARY FROM POLITICS THAT THE SUCCESSOR STATES MUST BEGIN TO LAY. SHE SUGGESTS THAT STABLE CIVIL-MILITARY RELATIONS WILL BE ACHIEVED WHEN THE ARMY BEL IEVES THAT THE SEPARATIDN

07698 RICE, E.M.

PUBLIC ADMINISTRATION IN POST-SOCIALIST EASTERN EUROPE PUBLIC ADMINISTRATIDN REVIEW, 52 (2) (MAR 92), 116-124. PUBLIC ADMINISTRA IDN REVIEW, $52(2)$ (MAR 92), 116-124. PUBLIC ADHINISTRATIONS OF EAST EUROPEAN COUNTRIES INTO THE POST-SOCIALIST ERA. HE DISCUSSES THE NEED FOR REFORM BASED POST-SOCIALIST ERA. HE DISCUSSES THE NEED FOR

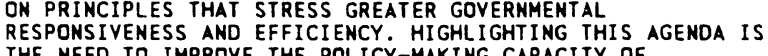
THE NEED TO IMPROVE THE POLICY-MAKING CAPACITY OF
GOVERMMENTS AND A NUMBER OF STEPS TO CHANGE THE GENERAL ROLE GOVERMMENTS AND A NUMBER OF STEPS TO CHANGE THE GENERAL
OF GOVERNMENT IN EAST EUROPEAN SOCIETIES. THE AUTHOR'S OF GOVERNMENT IN EAST EUROPEAN SOCIETIES. THE AUTHOR'S RECOMMENDATIONS INCLUDE THE TRANSFORMATION OF GOVERNMENT INTO A SERVANT OF THE PEOPLE, GREATER DECENTRALIZATION, GOVERMMENT SYSTEMS, AND MAJOR REFORMS OF BOTH THE PUBLIC FINANCE AND CIVIL SERVICE SYSTEMS.

07699 RICE, M.F.

JUSTIFYING STATE AND LOCAL GOVERMMENT SET-ASIDE PROGRAMS

THROUGH DISPARITY STUDIES IN THE POST-CROSON ERA

PUBLIC ADMINISTRATION REVIEN, $52(5)$ (SEP 92), 482-490.

SEEKING EVIDENCE OF CURRENT AND PAST DISCRIMINATION TO OF JURISDICTIONS HAVE HIRED OUTSIDE EXPERTS TO ANALYZE LOCAL
AND REGIONAL DISPARITIES IN THE AWARDING OF GOVERNMENT CONTRACTS. THE AUTHOR DESCRIBES THE CONTENTS OF A TYPICAL STUDY AND USES EXAMPLES FROM ATLANTA, MILHAUKEE, TALLAHASSEE, AND HILLSBOROUGH COUNTY, FLORIDA. HE PROVIDES A DETAILED METHODOLOGICAL CRITIQUE OF A LOUISIANA DISPARITY STUDY THAT FOUND NO EVIDENCE OF DISCRIMINATION IN THE AWARDING OF PUBLIC WORKS CONTRACTS. HE CONCLUDES THAT DISPARITY STUDIES, IF PROPERLY DONE, CAN PRODUCE EFFECTIVE SET-ASIDE PROGRAMS.

07700 RICH, J.; HULBUT D.

FREE TRADE WITH MEXICD: WHATS IN IT FOR TEXAS?

LYNDON B. JOHNSON SCHOOL OF PUBLIC AFFAIRS, 1992, 64.

THE U.S. -MEXICAN POLICY STUDIES PROGRAM INCORPORATES A WIDE RANGE OF RESEARCH INTO BINATIONAL POLICY ISSUES. AMONG THESE ARE RESEARCH PROJECTS ON THE U.S. - MEXICAN TRADE RELATIONSHIP, INCLUDING: THE LABOR AND ENVIRONMENTAL IMPACTS OF A FREE-TRADE AGREEMENT; OPPOSITION GOVERNMENTS IN MEXICO AND THEIR IMPACT BOTH ON THE BORDER REGION AND ON THE BINATIONAL RELATIONSHIP; AND A VARIETY OF STUDIES INVESTIGATING THE EFFECTS OF INDUSTRIAL INTEGRATION ON THE U. S.-MEXICAN BORDER REGION. THIS PUBLICATION SPECIFICALLY ADDRESSES NAFTA AND THE LINK TO TEXAS; MANUFACTURING AND AGRICULTURE; THE BORDER ECONOMY; IMPACT ON LABOR; AND POLICY RECOMMENDATIONS.

07701 RICH, J.

PLANNING THE BORDER'S fUTURE: THE MEXICAN-U.S. INTEGRATED BORDER ENVIRONMENTAL PLAN

U.S.-MEXICAN POLICY STDIES PROGRAM, 1992, 48.

THIS ANALYSIS BEGINS WITH A BRIEF HISTORY OF THE ECONOMIC TRENDS THAT LED TO CREATION OF THE INTEGRATED ENVIRONMENTAL PLAN FOR THE MEXICD-U.S. BORDER AREA. A SECOND SECTION ANALYZES THE MEXICAN AND U.S. BORDER COMMUNITY RESPONSE TO THE FIRST PUBLICLY RELEASED DRAFT OF THIS PLAN IN AUGUST 1991. THE FINAL SECTION DESCUSSES THE REVISED VERSION OF THE PLAN AND WHETHER THESE MODIFICATIONS ADEQUATELY ADDRESS THE CONCERNS OF BORDER COMMUNITIES AFFECTED BY THE PLAN.

07702 RICH, R.

RINHOLD NEBUR AND THE ETHNICS OF REALISM IN INTERNATIONAL RINHOLD NEBIDNS

RELATIONS
HISTORY OF POLITICAL THOUGHT, 13(2) (SUM 92), 281-298.

THE DEVELOPMENT OF REINHOLD NIEBUHR'S THINKING ON THE REALIST OUTLOOK IN INTERMATIONAL RELATIONS AND HIS ATTEMPT TO LINK THIS AS FAR AS POSSIBLE TO ETHICAL GOALS IN WORLD AFFAIRS IS ASSESSED IN THIS PAPER. IT EXAMINES IN PARTICULAR NEIBUHR'S RELEVANCE TO CONTEMPORARY DEBATE BY FOCUSING ON NIEBUHR'S WRITINGS DURING AND AFTER THE SECOND WORLD WAR. THE PAPER ARGUES THAT IT WOULD BE INCORRECT TO PERCEIVE NIEBUHR AS SIMPLY A FIGURE DEFINED BY THE COLD WAR. THE
EARLY RADICALISM OF THE INTER-WAR YEARS LEFT AN IMPORTANT LEGACY OF CONCERN FOR SOCIAL AND ECONOMIC JUSTICE THAT MAKES HIM A FIGURE OF CONTINUING INTEREST.

07703 RICH, $V$. AFRICA'S 'NEW WIND OF CHANGE' WORLD TODAY, 48(7) (JUL 92), 116-119.

SOME OBSERVERS SUGGEST THAT THE WORLD IS WITNESSING THE DEMISE OF THE AUTHORITARIAN MODEL OF POLITICS THAT HAS UNDERPINNED MOST AFRICAN STATES SINCE INDEPENDENCE. BUT OTHERS ARE QUICK TO POINT OUT THAT THE EMERGENCE OF MORE DEMOCRATIC FORMS OF GOVERNMENT IS PATCHY ACROSS THE CONTINENT. SOME REGIMES ARE RESISTING PRO-DEMOCRACY PRESSURES FROM BOTH LOCAL ACTIVISTS AND AID DONORS. ELSEWHERE THE POLITICAL CHANGES HAVE YET TO BE CONSOLIDATED AND DEMOCRATIC REGIMES LEGITIMIZED. DEMOCRATIC PRESSURES ARE AND DEMOCRATIC REGIMES LEGITIMIZED. DEMOCRATIC PRESSURES ARE DEFLECT THE DEMANDS OF THE PRIMARILY URBAN-BASED, PROCREDITS AGAINST ONE ANOTHER.

07704 RICH, V. THE GREAT SOVIET DIVORCE

WORLD TODAY, 48(2) (FEB 92), 19-20.

THE AUTHOR LOOKS AT SOME' OF THE ISSUES FACING THE NEN COMMONWEALTH OF INDEPENDENT STATES, INCLUDING THE FUTURE OF COMMONWEALTH OF INDEPENDENT STATES, INCLUDING THE FUTURE
THE SOVIET SPACE PROGRAM, SOVIET NUCLEAR WEAPONS, AND THE SOVIET SPACE PROC
ECONOMIC PROBLEMS.

07705 RICHARDS, D

DO CANADIAN'S WANT ZERO INFLATION? SOME EVIDENCE FROM A DO CANADIAN'S WANT ZERO INFLATION?
MODEL WITH SOPHISTICATED VOTERS CANADIAN PUBLIC POLICY--AKALYSE DE POLITIQUES, 18(4) (DEC $92), 413-424$

THIS PAPER USES A SOPHISTICATED VOTER MODEL TO INFER THE PREFERENCES OF THE CANADIAN PUBLIC REGARDING MACROECONOMIC POLICY AND, MORE SPECIFICALLY, THE OPTIMAL RATE OF INFLATION. USING PUBLIC OPINION DATA, THE AUTHOR ESTIMATES THAT THE PREFERRED INFLATION RATE OF THE CANADIAN ELECTORATE IS IN THE ORDER OF 7 TO 8 PER CENT. HE ALSO FINDS THAT VOTER SUPPORT FOR THE INCUMBENT FEDERAL PARTY IS SIGNIFICANTLY RELATED BOTH TO THAT PARTY'S ABILITY TO LIMIT FLUCTUATIONS IN REAL GDP AND ITS ABILITY TO MAINTAIN INFLATION CLOSE TO 
THE PREFERRED INFLATION RATE.

07706 RICHARDSON, J.; MALONEY, W.; RUDIG, W. THE DYNAMICS OF POLICY CHANGE: LOBBYING AND WATER PRIVATIZATION

PBLIC ADMINISTRATION, 70(2) (SUM 92), 157-176. THE PRIVATIZATION OF THE WATER INDUSTRY WAS ONE OF THE MOST CONTROVERSIAL AND TURBULENT PRIVATIZATIONS OF THE 1980S. THE GOVERNMENT UNDERTOOK THE PROJECT SOMEWHAT RELUCTANTLY, THEN THE FIRST PLANS HAD TO BE HITHORAHN, BUT EVENTUALLY, THE PRIVATIZATION OF THE INDUSTRY WS SUCCESSFULLY COMPLETED IN 1989. IN THIS ARTICLE, THE AUTHORS SET OUT TO PROVIDE A THOROUGH ACCOUNT OF THE PROCESS OF PRIVATIZING HATER, BASED ON PRIMARY SOURCES AND EXHAUSTIVE INTERVIEWS. IN DOING SO, THE AUTHORS IDENTIFY SOME MAJOR PROBLEMS OF ESTABLISHED THEORIES OF BRITISH POLICY MAKING: THE PROCESS OF WATER PRIVATIZATION CLEARLY DOES NOT CONFORM TO ANY SINGLE MODEL OF POLICY MAKING. INSTEAD, INDIVIDUAL 'EPI SODES' OF THE POLICY PROCESS CONFORM TO DIFFERENT MODELS. ARGUING THAT EXISTING THEORIES OF BRITISH POLICY MAKING MAY HAVE FOCUSED TOO NARROWLY ON ROUTINE DECISION-MAKING PROCESSES, WE TOO NARROWLY ON ROUTINE DECISION-MAKING PROCESSES, WE
PROPOSE THAT A THEORY OF THE TRANSFORMATION OF POLICY PROPOSE THAT A THEORY OF THE TRANSFORMATION OF POLICY
COMMUNITIES IS REOUIRED TO UMDERSTAND THE DYNAMICS OF RADICAL POLICY CHANGE IN BRITAIN.

07707 RICHARDSON, J.T.; DEWITT, J. CHRISTIAN SCIENCE SPIRITÚL HEALING, THE LAW, AND PUBLIC OPINION

JOURNAL OF CHURCH \& STATE, 34(3) (SUM 92), 549-562.

UNTIL RECENTLY MOST STATES TOLERATED OR ACCOMMODATED THE CHRISTIAN SCIENCE BELIEF IN SPIRITUAL HEALING, ALLOWING PARENTS TO CHOOSE FAITH HEALING IN LIEU OF CONVENTIONAL
MEDICINE FOR THEIR CHILDREN. IN THE 1960 's, A SHIFT IN FAVOR OF AN INCREASING GOVERMMENTAL ROLE IN PROTECTING CHILDREN BEGAN TO EMERGE, ANO THE RESULT WAS A CHANGE IN FEDERAL POLICY. FEDERAL CHILD ABUSE REGULATIONS ADOPTED IN 1983 EXPLICITLY DEFINED FAILURE TO PROVIDE MEDICAL CARE AS CHILD NEGLECT AND FURTHER STATED THAT GOVERNMENTAL ACTION OVERRIDING PARENTAL JUDGMENT HOULD BE NECESSARY "WHENEVER THE CHILD'S HEALTH REQUIRED IT." IN THIS ESSAY, THE AUTHOR EXAMINES THE NEW FEDERAL POLICY ANO SEVEN CASES WHEN CHRISTIAN SCIENTIST PARENTS CHOSE SPIRITUAL HEALING INSTEAD OF CONVENTIONAL TREATMENT FOR THEIR SICK CHILDREN.

07708 RICHARDSON, N.

"TRADE BLOCS" IN THE NEW WORLD ORDER AND IMPLICATIONS FOR THE MIDOLE EAST

JERUSALEM JOURNAL OF INTERNATIONAL RELATIONS, 14(2) (JUN 92), 103-113.

THE WORLD TRADE SYSTEM ESTABLISHED UNDER THE GATT IS LIKELY TO SURVIVE THE TENSIONS CURRENTLY ENGENDERED BY FALTERING TRADE RULES. FTAS ARE LIKEIY TO EXPAND, BUT WITHOUT THE CONCOMITANT, EXCESSIVE PROTECTIONISM THAT SOME EXPECT. IN THE MIDDLE EAST. THE GULF OIL EXPORTERS WILL PROBABLY NOT BE SUBSTANTIALLY AFFECTED BY THESE TRENDS; THE MAGHREB COUNTRIES MAY BE HARMED BY TRADE WARS IN THE NORTH, WHEREAS ISRAEL MAY HELL BENEFIT FROM THEM.

07709 RICHARDSON, R.C. III

THE FUTURE OF THE NORTH ATLANTIC TREATY ORGANIZATION JOURNAL OF SOCIAL. POLITICAL AND ECONOMIC STUDIES, 16(4) (WIN 91), 387-399

THE AUTHOR REVIEWS THE PROSPECTS FOR CHANGES IN NATO DUE TO THE REDUCED THREAT FROM EASTERN EUROPE AND THE FORMER SOVIET UNION.

07710 RICHARDSON, R.J.

FREE TRADE: WHY DID IT HAPPEN?

CANADIAN REVIEH OF SOCIOLOGY AND ANTHROPOLOGY, 29(3) (AUG 92), 307-328.

WHEN BRIAN MURONEY CAMPAIGNED FOR THE LEADERSHIP OF THE PROGRESSIVE CONSERVATIVE PARTY IN 1983, HE DENOUNCED FREE TRADE. SHORTLY AFTERWARD, HE REVERSED HIS POSITION AND INITIATED THE NEGOTIATIONS THAT PRODUCED THE FREE TRADE AGREEMENT BETHEEN CANADA AND THE UNITED STATES. ALTHOUGH MORE CANADIANS OPPOSED THIS AGREEMENT THAN SUPPORTED IT, THE PROGRESSIVE CONSERVATIVES WON THE 1988 ELECTION AND IMPLEMENTED THE FREE TRADE AGREEMENT. THIS PAPER DOCUMENTS A SIGNIFICANT CONCENTRATION AND INTEGRATION OF ECONOMIC OWNERSHIP AMD RELATES THESE DEVELOPMENTS TO THE THEORY OF FINANCE CAPITAL TO DEMONSTRATE THE INCREASING STRENGTH OF THE CANADIAN CAPITALIST CLASS OVER THE PAST DECADE. IT ALSO THE CANADIAN CAPITALIST CLASS OVER THE PAST DECADE. IT ALSO
DOCUMENTS THE HEAKENING OF CANADA'S SUBORDINATE CLASSES. DOCUMENTS THE HEAKENING OF CANADA'S SUBORDINATE CLASSES.
THESE THIN DEVELOPMENTS EXPLAIN THE ACTIONS OF THE CANADIAM THESE THIN DEVELOPMENTS EXPLAIN THE ACTIONS OF THE CANADIA STATE. COMPARI SONS OF CANADIAN STATE POLICY BETWEEN THE 1970 'S AND THE PRESENT AND OF THE CANADA-USA TRADE AGREEMEN
WITH THE EUROPEAN ECONOMIC UNION SUPPORT THIS EXPLANATION.

07711 RICHTER, A.

RUSSIA'S HEAKNESS IS ALSO THE STRENGTH OF YELTSIN GERMAN TRIBUNE, (1524) (JUL 92), 2-3.

AT THE MUNICH SUMMIT, THE HORLD'S SEVEN LEADING

INDUSTRIALIZED NATIONS (G7) ARGUED THAT RUSSIA'S BORIS

YELTSIN IS IN AN EXTREMELY PRECARIOUS POSITION. THE G7,
FIRST AND FOREMOST THE UNITED STATES, HAD THE CHOICE OF EITHER PROPPIMG UP THE INHERITOR OF GORBACHEV'S ESTATE THROUGH EXTENSIVE FIMANCIAL AND ECONOMIC AID OR RUNNING THE RISK OF A NEW COUP IN RUSSIA WITH SHOCK WAVES FOR ALL OTHER CIS STATES. THE CHOICE WAS MADE AND YELTSIN RETURNED TO RUSSIA WITH PROMISES OF AN AID PACKAGE WHICH GORBACHEV COULD ONLY DREAM OF AT THE LONDON SUMMIT A YEAR AGO. THE INTERNATIONAL MONETARY FUND AND THE WORLD BANK ARE TO IMMEDIATELY PROVIDE \$1 BILLION TO RUSSIA, HITH \$3 BILLION MORE TO FOLLOW IN OCTOBER (IF MOSCOW STAYS THE REFORM COURSE). THE RISK OF RUSSIA'S COLLAPSE ALSO WELDED TOGETHER THE SUMMITEERS IN MUNICH WHEN OTHER ISSUES WERE UNDER OISCUSSION. AGREEMENT WAS REACHED (OR APPROACHED) ON ISSUES SUCH AS NUCLEAR POWER PLANT SAFETY, AGRICULTURAL SUBSIDIES, AND FREE TRADE.

07712 RIDDELL-OIXON, E.

TO SIGN OR NOT TO SIGN THE LAH OF THE SEA CONVENTION: GOVERNMENTAL POLITICS IN THE UNITED KINGDOM AND CANADA JOURNAL OF COMMONWEALTH AND COMPARATIVE POLITICS, XXIX(2) ( JUL 91 ), 212-233.

THIS STUDY COMPARES AND CONTRASTS THE PROCESSES BY WHICH BRITISH AND CANADIAN POLICIES WERE FORHULATED FIRST FOR THE UNITED NATIONS THIRD CONFERENCE ON THE LAW OF THE SEA (UNCLOS III 1973-82) AND THEN FOR THE 1982 DECISION ON SIGNING. IN THE CANADIAN CASE. THE PROCEDURE FOR THE LATTER DECISION WAS LARGELY A CONTINUATION OF PAST PATTERNS OF DECISIONHAKING. IN THE UNITED KINGOOM, HOWEVER, THE PROCESS CHANGED FROM ONE CENTERED ON WHITEHALL TO ONE INVOLVING A MUCH WIDER RANGE OF ACTORS, EACH COMPETING TO CONVINCE THE SENIOR CABINET MEMBERS WHO WOULD MAKE THE DECISION, OF THE SUPERIORITY OF HIS OR HER ARGUMENT. THE ARTICLE ALSO IDENTIFIES KEY GOVERNMENTAL AND NON-GOVERNMENTAL ACTORS, AND EXAMINES THEIR RESPECTIVE PRIORITIES, AND SUCCESSES IN INFLUENCING POLICY.

07713 RIDDELL, J.B.

THINGS FALL APART AGAIN: STRUCTURAL ADJUSTMENT PROGRAMS IN SUB-SAHARAN AFRICA

JOURNAL OF MODERN AFRICAN STUDIES, 30(1) (MAR 92), 53-68. THE AUTHOR EXPLAINS HOW THE INTERNATIONAL MONETARY FUND HAS IMPOSED CONDITIONS IN SUB-SAHARAN AFRICA AS INTEGRAL AFFECT NOT ONTYCTURAL ADJUSTMENT PROGRAMS (SAP'S) THAT AFFECT NOT ONLY THE LIVES OF ALL THE INHABITANTS BUT ALSO THE SPECIFICS OF SAP'S DIFFER, FOUR BASIC ELEMENTS ARE ALWAYS PRESENT: CURRENCY DEVALUATION, THE REMOVAL/REDUCTION OF THE STATE FROM THE HORKINGS OF THE ECDNOMY, THE OF THE STATE FROM THE WORKINGS OF THE ECDNOMY, THE ELIMINATION OF SUBSIDIES IN AN ATTEMPT TO REDUCE
EXPENDITURES, AND TRADE LIBERALIZATION. SAP'S ALTER THE EXPENDITURES, AND TRADE LIBERALIZATION. SAP'S ALTER THE
COUNTRIES IN FUNDAMENTAL WAYS BECAUSE THEY IMPACT THE COUNTRIES IN FUMDAMENTAL WAYS BECAUSE THEY IMPACT THE
ORGANIZATION OF THE STATE, THE ENVIRONMENT, THE FOOD SUPPLY, ORGANIZATION OF THE STATE, THE ENVIRONMENT, THE FOOD SUPPLY,
THE MEANING OF DEVELOPMENT, AND URBAN-RURAL INTERACTIONS.

07714 RIDOELL, P.

IVES AFTER 1992

POLITICAL QUARTERLY (THE), 63(4) (OCT 93), 422-431.

THE DIRECTION OF THE CONSERVATIVE PARTY IS LESS CLEAR THAN IT HAS BEEN SINCE THE LATE 1970 S WHEN MARGARET THATCHER TOOK CONTROL. THE TORIES ARE NOW CLEARLY A POST-THATCHERITE PARTY, SINCE MANY OF THE POLICIES PURSUED DURING THE $1980 \mathrm{~S}$ REFLECTED TRADITIONAL CONSERVATIVE THEMES. THIS ARTICLE ARGUES THAT IT IS WRONG TO SEE THE CONSERVATIVE PARTY IN SUGGESTS THAT THE PARTY' IS BEST VIEHED AS AN ORGANISH, DEVELOPING AND CHANGING OVER TIMES.

07715 RIEDINGER, J.M.

EVERYDAY RESISTANCE TO REDISTRIBUTIVE REFORM: AGRARIAN REFORM IN THE PHILIPPINES; ASSOCIATION FOR ASIAN STUDIES 1992 AMNUAL MEETING

ASSOCIATION FOR ASIAN STUDIES, 1992, 149.

AGRARIAN REFORM POL ICY HAS BEEN CENTRAL TO THE RECENT DEBATE OVER POLITICAL AND SOCIAL CHANGE IN THE PHILIPPINES. THIS PAPER FOCUSES ON ELITE RESISTANCE TO REDISTRIBUTIVE AGRARIAN REFORM AND FINDS THAT PRESIDENT AQUINO AND REGIONAL ELITES SHARED RHETORICAL STRATEGIES TO LIMIT THE SCOPE AND DIRECTION OF REFORM. TO DO SO THEY CONCENTRATED ON CERTAIN CRITICAL ISSUES WHICH LEGITIMIZED THE ABANDONMENT OF IMPORTAMT ELEMENTS OF REFORM AMD DISEMPOHERED RURAL IMPORTANT ELEMENTS OF REFORM AND DISEMPOHERED RURAL PXPERIENCE SUGGESTS THAT NON-REVOLUTIONARY PROCESSES OF REGIME TRANSITION AND POLITICAL LIBERALIZATION ARE UNLIKELY, REGIME TRANSITION AND POLITICAL LIBERALIZATION ARE UNLIKELY
IN AND OF THEMSELVES, TO FOSTER SIGMIFICANT REDISTRIBUTIVE IN AND OF THEMSELVES, TO FOSTER SIGMIFICANT REDISTRIBUTIVE ECONOMIC REFORM. THE OBSTACLES CONFRONTING PROPONENTS OF AGRARIAN REFORM ARE PARTICULARLY ACUTE IN THE PHILIPPINES, WHERE DEMOCRATIC INSTITUTIONS ARE SUPERIMPOSED ON HISTORIC AND CONTINUING PATTERNS OF FRAGMENTED SOCIAL CONTE
ACUTE DISPARITIES IN LAND OWNERSHIP AND WEALTH.

07716 RIEDMILLER, J.

AID FOR THE EX-SOVIET STATES: A QUESTION OF INTERVENTION MASSIVE, (1501) (JAN 92), 1-2.

THE MASSIVE AMOUNTS OF GERMAN FOREIGN AID SENT TO THE 
SOVIET UNION WERE DESIGNED TO HELP PRESIDENT GORBACHEV AND HIS REFORM POL ICIES, TO PAY FOR GERMAN REUNIFICATION, TO FINANCE THE WITHDRAHAL OF SOVIET TROOPS FROM EASTERN GERMANY, AND TO GAIN A FOOTHOLD IN A FUTURE MARKET. AT A RECENT INTERNATIONAL CONFERENCE ON AID FOR THE EX-SOVIET REPUBLICS, THE GERMAN AID PROGRAM WAS CRITICIZED FOR ENABLING GORBACHEY TO AVOID MORE RADICAL REFORMS AND FOR KEEPING THE DECREPIT SOVIET SYSTEM GOING LONGER THAN WAS NECESSARY. WHILE THE ROLE OF GERMAN AID IN THE SOVIET DISSOLUTION IS CERTAINLY DEBATABLE ISSUE, PARTICIPANTS IN THE CONFERENCE SEEMED MORE UNIFIED ON THE NEED FOR THE PROPER APPLICATION OF AID TO THE COMMONWEALTH OF INDEPENDENT STATES (CIS). EMPHASIS IS NOW BEING PLACED ON "HELPING THE REPUBLICS HELP THEMSELVES" WITH BEING PLACED ON "HELPING THE REPUBL ICS HELP THEMSELVES
PROGRAMS DESIGNED TO SAFEGUARD AND REPAIR TRANSPORT AND PROGRAMS DESIGNED TO SAF
DISTRIBUTION FACILITIES.

07717 RIEDMILLER, J.

LECH WALESÁ IN GERMANY: A POLE WITH A EUROPEAN OUTLOOK GERMAN TRIBUNE, (1510) (APR 92), 1-2.

THE VISIT OF POLISH PRESIDENT LECH WALESA TO GERMANY, THE FIRST OFFICIAL VISIT A POLISH HEAD OF STATE HAS EVER PAID TO THE FEDERAL REPUBLIC, HIGHLIGHTS BOTH POLAND'S TROUBLES AND WALESA'S WESTHARD-LOOKING ATTITUDE. WALESA
OFTEN RAISED THE SUBJECT OF POVERTY AND POLITICAL DISORDER OFTEN RAISED THE SUBJECT OF POVERTY AND POLITICAL DISORDER COMING FROM THE POST-SOVIET REPUBLICS ON POLAND'S EASTERM
BORDER. FURTHERMORE, HIGH UNEMPLOYMENT RATES AND ECONOMIC TROUBLES IN POLAND INCREASE THE RISK OF INSTABILITY. HALESA IS CONVINCED THAT ONLY INCLUSION OF POLAND IN WESTERN EUROPEAN SECURITY AND ECONOMIC STRUCTURES WILL AVERT POLITICAL AND ECONOMIC CRISIS AND A POSSIBLE RETURN TO AUTHORITARIANISM IN POLAND.

07718 RIEDMILLER, J.

RUSSIAN PATIENCE FADES, YELTSIN UNDER PRESSURE

GERMAN TRIBUNE, (1508) (MAR 92), 2, 5.

BORIS YELTSIN'S POLITICAL FUTURE IS ADDRESSED SKEPIICALLY IN BOTH RUSSIA AND AMERICA. THE RUSSIAN PRESIDENT HAS DEREGULATED THE PRICES OF BASIC FOODS, WHICH ARE NOW ALMOST BEYOND THE REACH OF MORE AND MORE PEOPLE. THERE ARE MANY SIGNS THAT THE PEOPLE'S DAYS OF PASSIVE ENDURANCE OF HARDSHIP ARE DRAHING TO A CLOSE. ONE OF THE MOST STRIKING IS THAT THE OPPOSITION HAVE JOINED FORCES, FROM THE COMMUNIST LEFT TO THE CHAUVANIST RIGHT. THEY CALL FROM THE COMMUNIST LEFT TO THE CHAUVANIST RIGHT. THEY CALL THEMSELVES THE UNITED OPPOSITION. THEIR JOINT AIM IS TO FORCE PRESIDENT YELTSIN TO EITHER RETRACT OR RES

MIXED BAG OF POLITICAL ADVENTURERS AND ROMANTICS,

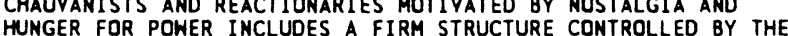
POWER ELITE OF OLD. PERHAPS THE ONLY WAY TO AVERT THE POWER ELITE OF OLD. PERHAPS THE ONLY WAY TO AVERT THE GROWING DISORDER IS MASSIVE FOREIGN AID TO THE TUNE OF GRARLY \$2O BILLION A YEAR. SUCH AN AID POLICY WOULD LAY THE GROUNDWORK FOR ENSURING THAT RUSSIA
CHAOS NOR POSES A THREAT TO OTHERS.

07719 RIEDMILLER, J

YUGOSLAV FACTIONS SEEK OUTSIDE HELP FOR DIFFERING REASONS GERMAN TRIBUNE, (1494) (NOV 91), 2

THE SERBIANS AND CROATIANS ARE NOW CALLING FOR UNITED NATIONS TROOPS. AFTER FOUR MONTHS OF CIVIL WAR THE LEADERS OF BOTH SIDES SEEM TO HAVE REALIZED THAT MORE BLOODSHED WILL NO LONGER SERVE THEIR RESPECTIVE CAUSES. BUT THEIR REASONS DIFFER HIDELY IN OTHER RESPECTS. THE CROATIANS HAVE LONG WANTED TO HAVE PEACEKEEPING FORCES IN THE COMBAT AREA; THEY WERE WILLING ALMOST FROM THE OUTSET TO MEET THE EUROPEAN COMMUNITY'S DEMAND FOR THE WARRING PARTIES TO AGREE TO THIS, THE SERBIANS, BY CONTRAST, HAVE CALLED FOR UN INTERVENTION ONLY RECENTLY. THEY ARE MOTIVATED BY THE HOPE THAT A UN RESPONSE TO THEIR "URGENT" REQUEST HILL INCREASE THE LEGITIMACY OF THE SERBIAN DOMINATED CENTRAL GOVERNMENT OF YUGOSLAVIA AND THAT SERBIA'S TERRITORIAL INCURSIONS INTO CROATIA WILL ALSO BE RECOGNIZED. THE OUESTION OF BORDERS AMD AUTONOMY IS A THORNY ONE. THE UNITED NATIONS, THE USA AND THE EUROPEAN COMMUNITY HAVE ALI WRESTLED WITH THE ISSUE WITH LITTLE CONSENSUS ON THE PROPER COURSE OF ACTION.

07720 RIELLY, J.

PUBLIC OPINION: THE PULSE OF THE ' 905

FOREIGN POLICY, (82) (SPR 91), 79-96.

THIS ARTICLE REPORTS ON THE LATEST QUADRENNIAL SURVEY OF THE AMERICAN PUBLIC AND OF ELITE OPINION MAKES SPONSORED BY THE CHICAGO COUNCIL ON FOREIGN RELATIONS. THE MOST IMPORTANT GENERAL CONCLUSIONS ARE THAT THE MOOD OF THE AMERICAN PUBLIC GENERAL CONCLUSIONS ARE THAT THE MOOD OF THE AMERICAN PUDL
AND ITS LEADERS HAS SHIFTED. THE COLD WAR AND THE U.S.SOVIET COMPETITION ARE PASSING FROM CENTER STAGE, AND A NEH AGE OF GLOBAL ECONOMIC COMPETITION HAS EMERGED. AMERICANS AGE OF GLOBAL ECONOMIC COMPETITION HAS EMERGED. AMERICANS MILITARY PREEMINENCE, BUT WITH A GROWING SENSE OF ECONOMIC VULNERABILITY. THE ARTICLE PRESENTS AMERICAN PUBLIC OPINION ON THE BEST ROLE OF AMERICA IN THE FUTURE, ON AMERICA'S PERCEIVED INTERESTS, AND ITS CHIEF COMPETITORS.

07721 RIESELBACK, L.

PURPOSIVE POLITICIANS MEET THE INSTITUTIONAL CONGRESS: A REVIEW ESSAY
LEGISLATIVE STUDIES QUARTERLY, 17(1) (FEB 92), 95-112. THIS ESSAY EXAMINES SIX SEEMINGLY DIVERSE BOOKS THAT HAVE IN COMMON THE USE OF FORMAL THEORY TO EXPLAIN LEGISLATIVE BEHAVIOR. THE AUTHOR EVALUATES THEIR INDIVIDUAL CONTRIBUTIONS ON A RANGE OF DIMENSIONS AND USES THEM TO MEASURE THE CONTRIBUTION OF ECONOMIC MODELS TO THE STUDY OF LEGISLATURES. HE SUGGESTS THAT COLLECTIVELY, THE BOOKS TESTIFY TO THE CONTINUING CREATIVITY AND VITALITY OF LEGISLATIVE STUDIES, TO THE CONTINUING CAPACITY OF CONGRESS TO FASCINATE SCHOLARS AND THAT THEY SHOULD REDUCE THE FRUSTRATION INHERENT IN THE ATTEMPT TO EXPLAIN AND PREDICT THE WORKING OF CONGRESS.

07722 RIESSMAN, F.; BAY, T.

THE POLITICS OF SELF-HELP

SOCIAL POLICY, 23(2) (FAL 92), 27-31.

THE TREND OF SELF-HELP GROUPS EMPOWERING INDIVIDUALS AND LEADING TO POLITICAL ACTIVISM CAN BE SEEN IN THE WOMEN'S MOVEMENT WHICH BEGAM IN THE 1960'S WITH SMALL. CONSCIOUSNESS-RAISING GROUPS AND GRADUALLY EMERGED AS A FULLFLEDGED SOCIAL AND POLITICAL MOVEMENT. A SIMILAR EVOLUTION HAS OCCURRED WITH THE DISABLED RIGHTS MOVEMENT AND THE GAY
RIGHTS CAUSE. ALL OF THESE MOVEMENTS BEGAN BY ESTABLISHING A SHARED SENSE OF IDENTITY, WITH THE SELF-HELP PHASE FUNCTIONING AS A CRITICAL STEP IN LEVERAGING THEM TO LARGER SOCIAL INVOL VEMENT AND POLITICAL ACTION. THUS, IN SOME INSTANCES, SELF-HELP SERVES AS A STAGE IN THE PROCESS OF POL ITICAL ENGAGEMENT.

07723 RIGGIN, L.J.C.; GRASSO, P.G.; WESTCOTT, M.L. A FRAMEWORK FOR EVALUATING HOUSING AND COMMUNITY DEVELOPMENT PARTNERSHIP PROJECTS

PUBLIC ADMINISTRATION REVIEW, 52(1) (JAN 92), 40-46. THE AUTHORS ARE CONCERMED WITH THE QUESTION OF WHETHER PUBLIC-PRIVATE PARTNERSHIPS CAN BE EFFECTIVELY EVALUATED. THEY LOOK AT AN EFFORT BY THE GENERAL ACCOUNTING OFFICE TO DEAL WITH THE UNIQUE CHALLENGES POSED BY HOUSING AND COMHUNITY DEVELOPMENT PROGRAMS THAT MAKE CONSIDERABLE USE OF THESE PARTNERSHIPS. THEY DISCUSS THE MAJOR OBSTACLES TO ASSESSING THE PARTNERSHIPS AND PROVIDE A FRAMEWORK BASED ON NINE CRITERIA REFLECTING THREE STANDARDS: NEEDS, PROCESS, AND OUTCOMES.

07724 RIGGLE, E.

COGMITIVE STRATEGIES AND CAMDIDATE EVALUATIONS AMERICAN POLITICS OUARTERLY, 20(2) (APR 92), 227-246. DECADES OF VOTING BEHAVIOR STUDIES HVE FOUND PARTY AFFILIATION, ISSUE STANOS, AND IDEOLOGY, AND CANDIDATE IMAGE TO BE MAJOR FACTORS INFLUENCING VOTER EVALUATIONS OF CANDIDATES. THE RELATIVE IMPORTANCE OF THESE CRITERIA MAY DEPEND ON THE CONTEXT IN WHICH THE INFORMATION PROCESSING ABOUT THE CANDIDATE OCCURS. IN THIS STUDY AN EXPERIMENTALLY DESIGNED SURVEY IS USED TO CHANGE THE CONTEXT OF THE JUDGMENT TASK FROM AN ABSOLUTE JUDGMENT OF ONE CANDIDATE TO A COMPARISION JUDGMENT OF THO CANDIDATES. THE RESULTS SHOW THAT SUBJECTS CHANGED FROM A DISCRETE INFORMATION PROCESSING STRATEGY WHEN JUDGING ONE CANDIDATE TO A HEURISTIC PROCESSING STRATEGY WHEN JUDGING TWO CNADIDATES. THE
IMPLICATIONS FOR CITIZEN EVALUATIONS OF POLITICAL CANDIDATES ARE DISCUSSED.

07725 RIGGLE, E.D.; KUKLINSKI, J.; OTTATI, V.C.; SCHWARZ, N.;

WYER, R.S. NON-STEREOTYPIC INFORMATION

POLITICAL BEHAVIOR, 14(1) (MAR 92), 67-87.

THE AUTHORS SUMMARIZE THREE EXPERIMENTS USED TO EVALUATE THE ROLE OF STEREOTYPIC AND NON-STEREOTYPIC CRITERIA IN JUDGMENTS OF POLITICAL CANDIDATES. THE EFFECTS OF PHYSICAL ATTRACTIVENESS, POLITICAL PARTY, AND STANDS ON SPECIFIC POL ITICAL CANDIDATES WERE EXAMINED TO EVALUATE THREE HYPOTHESES ABOUT STEREDTYPE AND ATTRIBUTE USE. IN THE ABSENCE OF OTHER INFORMATION, CANDIDATES' PHYSICAL ABSENCE DF OTHER INFORMATION, CANDIDATES PHYYICAL ATTRACTIVENESS HAD A SUBSTANTIAL IMPACT ON SUBJECTS
EVALUATIONS OF THEM AND INFERENCES OF BOTH THEIR PERSONAL EVALUATIONS OF THEM AND INFERENCES OF BOTH THEIR PERSONAL
QUALITIES AND THEIR POLITICAL IDEOLOGY. HOWEVER, WHEN OTHER QUALITIES AND THEIR POLITICAL IDEOLLGY. HOWEVER, WHEN OTHE INFORMATION ABOUT THE CANDIDATES PARTY MEMBERSHIP AND
STANDS ON SPECIFIC ISSUES WAS AVAILABLE, THE CANDIDATES' STANDS ON SPECIFIC ISSUES WAS AVAILABLE, THE CANDIDATES'
ATTRACTIVENESS HAD NO EFFECT ON THE EVALUATIONS OF THEM. ATTRACTIVENESS HAD NO EFFECT ON THE EVALUATIONS OF THEM.
WHEN SUBJECTS MADE JUDGMENTS OF ONLY ONE CANDIDATE, SUBJECTS WHEN SUBJECTS MADE JUDGMENTS OF ONLY ONE CANDIDATE, SUBJECTS
RELIED EXCLUSIVELY ON THE CANDIDATE'S VOTING RECORD. WHEN SUBJECTS WERE ASKED TO MAKE COMPARATIVE JUDGMENTS OF TWO SUBJECTS WERE ASKED TO MAKE COMPARATIVE JUDGMENTS OF TWO PARTY MEMBERSHIP AND NOT ON THEIR RESPECTIVE VOTING RECORDS.

07726 RIGOULOT, $P$.

REUNIFICATION: FROM LIP SERVICE TO REALITY FREEDOM REVIEW, 23(3) (MAY 92), 22-23.

NORTH AND SOUTH KOREAN LEADERS ARE OBLIGED BY TRADITION TO REFER TO THEIR DESIRE TO SEE THEIR COUNTRY ONCE AGAIN UNITED; BUT WHAT THEY HAVE IN MIND IS NOT THE SAME COUNTRY NOR THE SAME UNIFICATION PROCESS. IN THE SOUTH, NO ONE 
ELECTIONS. THE NORTH ENVISIONS A CONFEDERATION THAT WOULD LEAVE THE PRESENT REGIMES IN PLACE. YET THINGS ARE HAPPENING ON BOTH SIDES OF THE DEMILITARIZED ZONE AND EVEN INSIDE THE MORTH AND SOUTH AT A LEVEL NEVER SEEN SINCE 1953.

07727 RIKER, $H$.

THE JUSTIFICATION OF BICAMERALISM

INTERNATIONAL POLITICAL SCIENCE REVIEW, 13(1) (JAN 92), 101-116.

THE MAIN DISADVANTAGE OF UNICAMERAL LEGISLATURES

OPERATING BY SIMPLE MAJORITY RULE IS THAT, WHEN POLITICS IS THO-DIMENSIONAL, THEY ALLOW THE ADOPTION OF OUT-OF-

EOUILIBRIUM POLICIES. SINCE IN SUCH CASES A MAJORITY OPPOSED EQUILIBRIUM POLICIES. SINCE IN SUCH CASES A MAJORITY OPPO TO WHAT A MAJORITY HAS ADOPTED, THE RESULT IS MAJORITY
TYRANHY. TO MINIMIZE SUCH TYRANHY, IT IS NECESSARY TO DELAY TYRANHY. TO MINIMIZE SUCH TYRANNY, IT IS NECESSARY TO DEL
ACTION UNTIL A TRUE MAJORITY IN SOCIETY IS ARRIVED AT. ACTION UNTIL A TRUE MAJORITY IN SOCIETY IS ARRIVED AT. ALLOWS FOR SIMPLE MAJORITY RULE WHEN POLITICS IS ONE-

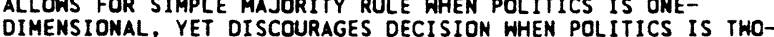
DIMENSIONAL,

07728 RILEY, K.

DEADLY EXPORT

INSIGHT, 7(11) (MAR 91), 36

AMERICAN INDUSTRY IS ANXIOUSLY AWAITING NEH COMMERCE DEPARTMENT RULES CURBING THE EXPORT OF CHEMICALS AND EQUIPMENT THAT CAN BE USED TO MAKE CHEMICAL WEAPONS. IT FEARS THE RULES, WICH WILL MAKE HUNDREDS OF U.S. COMPANIES SUBJECT TO EXPORT CONTROL LAHS FOR THE FIRST TIME, WILL BE FAR TOO RESTRICTIVE. THE CONTROVERSY UNDERSCORES THE DIFFICULTY OF CONTAINING THE SPREAD OF CHEMICAL WEAPONS.

07729 RIMANELLI, M.; ALEXANDER, Y. (ED.); PLUCHINSKY, D.A. (ED.) FOREIGN COMRADES IN ARMS: ITALIAN TERRORISH AND INTERNATIONAL TIES (1968-1991); EUROPEAN TERRORISM: TODAY AND TOMORROH

BRASSEY'S (US), 1992, 127-180.

THE AUTHOR STUDIES ASPECTS OF TERRORISM IN ITALY INCLUDING THE IDEOLOGIES AND EVOLUTION OF ITALIAN TERRORISM,

THE TACTICS OF NEO-NAZI AND RED TERRORIST GROUPS, AND THE

CONNECTIONS BETWEEN ITALIAN TERRORISTS, TRANSNATIONAL

CONNECTIONS BETWEEN ITALIAN TERRO
TERRORISM, AND FOREIGN STATES.

07730 RIMANELLI, M.

THE RATIONALE, EVOLUTION, AND FUTURE OF ARMS CONTROL COMPARATIVE STRATEGY, $11(3$ ) (JUL 92), 307-329.

ARMS CONTROL IS A SOPHISTICATED, TECHHICAL TOOL OF MODERN DIPLOMACY AND NATIONAL SECURITY. AS SUCH, IT HAS PLAYED A KEY ROLE IN MAINTAINING NATIONAL SECURITY WHILE PROMOTING COOPERATION DURING CRUCIAL PERIODS OF RADICAL INTERNATIONAL CHANGE AND TENSION. YET ARMS CONTROL'S SUCCESS IN FOSTERING INTERNATIONAL ACCEPTANCE OF WEAPONS NONPROLIFERATION AND DEEP ARMS REDUCTIONS HAS BEEN GREATEST WHEN THE PACE OF INTERNATIONAL CHANGE HAS LED THE WORLD NOT INTO OPEN WARFARE BUT, THANKS TO THE NUCLEAR BALANCE OF TERROR, INTO INTERMITTENT PERIODS OF DETENTE AND MUTUALLYACCEPTABLE COOPERATION BETHEEN TRADITIONALLY HOSTILE BLOCKS. THE COLLAPSE OF COMMUNISM AND THE END OF THE COLD WAR ON WESTERN TERMS, AS WELL AS THE PARALLEL BOOST IN ARMS CONTROL ACCORDS TO CODIFY THIS NEW POLITICO-MILITARY BALANCE, HAVE

ASSURED THAT THIS LATEST PHASE OF DETENTE WILL LAST
INDEFINITELY WHILE THE EAST STRUGGLES TO MERGE WITH THE WEST.

07731 RIORDAN, R.

THE POLITICS OF THE EASTERN CAPE

SOUTH AFRICA FOUNDATION REVIEW, 16(11) (NOV 90), 3.

THIS ARTICLE EXAMINES THE POL ITICAL GROUPING' 3 .

MOVEMENTS IN SOUTH AFRICA'S EASTERN CAPE TERRITORY. HHITE POLITICS BASICALLY REFLECT NATIONAL AVERAGES WITH THE RULING NATIONAL PARTY DOMINATING THE CONSERVATIVES AND THE DEMOCRATS. "COLOURED POLITICS," LONG DOMINATED BY THE LABOUR PARTY IS NOW CHARACTERIZED BY CONSIDERABLE SUPPORT FOR THE AFRICAN NATIONAL CONGRESS/UNITED DEMOCRATIC FRONT COALITIOH. HOW THE NEWLY LEGALIZED AND DEALS HITH THEIR LOYAL CONSTITUENCIES IN THE AREA WILL HAVE A GREAT IMPACT ON THE FUTURE POLITICS OF SOUTH AFRICA.

07732 RIP, M.; FONTANELLA, J.

A WINDOW OF THE ARAB-ISRAELI YOM KIPPUR WAR OF 1973: A WINDOW OF THE ARAB-ISRAELI YOM KIPPUR WAR OF 1973: INTELLIGENCE AND NATIONAL SECURITY, 6(1) (JAN 91), 15-89. IT IS THE AIM OF THIS STUDY TO: OUTLINE PHOTORECONNAISSANCE ACTIVITIES BY UNITED STATES AND SOVIET HIGHALTITUDE AIRCRAFT AND SATELLITES DURING A NUMBER OF PROMINENT COMFLICTS BEFORE THE 1973 ARAB-ISRAELI HAR, AS WELL AS TO PROVIDE AN OVERVIEW OF WHAT IS KNOWN ABOUT THE CHARACTERISTICS ANO CAPABILITIES OF SUCH MILITARY REMOTE SENSIMG PLATFORMS AT THAT TIME; REVIEW SOVIET SATELLITE DEPLOYMENTS AND, FOR THE FIRST TIME, ANALYZE THE USE OF U.S PHOTO-RECONNAISSANCE SATELLITES DURING THE WAR; ADORESS THE IMPORTANT HISTORICAL FEATURE OF HOW BOTH THE EARLIER SIX-DAY WAR AMD THE 1973 CONFLICT HAVE ARGUABLY PROVIDED THE MOS IMPETUS FOR, AND DETERMINISTIC EFFECT ON, RUSSIAN AND
AMERICAN RECONNAISSANCE SATELLITE DEVELOPMENT; AND CONSIDER THE REQUIREMENTS FOR SATELLITE PHOTO-INTELLIGENCE THAT WERE DECIDED UPON DURING THIS PERIOD, THE LONG
WHICH ARE BEING EXPERIENCED TO THIS DAY.

07733 RIPLEY, R.; MAURER, L.; PATTERSON, S.; QUINLAN, S. CONSTITUENTS' EVALUATIONS OF U.S. HOUSE MEMBERS

AMERICAN POLITICS QUARTERLY, 20(4) (OCT 92), 442-456.

THIS ANALYSIS DRAWS ON PREVIDUS RESEARCH' TO CONSTRUCT AND TEST A MODEL ON CONSTITUENT EVALUATION. THE DATA COME FROM INTERVIEHS CONDUCTED IN 1988 WITH 1,013 OHIOANS, WHO WERE ASKED TO EYALUTE THEIR MEMBER OF THE U.S. HOUSE, OF REPRESEHTATIVES. THE AMALYSIS RELIES ON ORDINARY LEAST SOUARES REGRESSION. THE RESULTS UNDERSCORE THE POWERFUL ROLE OF PARTISANSHIP IN THE NEXUS OF CONSTITUENTS AND THEIR OF PARTISANSHIP IN

07734 RISKIN, 8.

BEHIND THE FREE TRADE MASK

POLITICAL AFFAIRS, LXX(8) (AUG 91), 19-22

THE DEVELOPMENT OF FREE TRADE BLOCS THROUGHOUT THE WORLD IS TO THE BENEFIT OF TRANSNATIONAL SUPER COMPANIES. WITH OPERATION LOCATIONS IN EACH BLOC, THEY ARE POISED TO PRODUCE THEIR GOODS WHERE LABOR IS CHEAPEST, WHERE LABOR IS UNORGANIZED, AMD WERE IT IS WITHOUT IMPORTANT FRINGE BENEFITS, SOCIAL AND LEGAL RIGHTS AND WON THROUGH YEARS OF STRUGGLE. WITHOUT GLOBAL ORGANIZATION, LABOR WILL CONTINUE ABOUT CORPORATE PROFITS THAN INDIVIDUAL NEEDS.

07735 RITTERBAND, C.E.

HUMAN RIGHTS AND NONINTERVENTION

SWISS REVIEH OF WORLD AFFAIRS, 41(3) (JUN 91), 6-7. THE TRAGIC CIRCUMSTANCES OF IRAQI KURDS REVIVED AN OLD CONTROVERSY IN THE REALM OF INTERNATIONAL LAH: THE DISPUTE BETWEEN THE SOVEREIGNTY OF NATION-STATES AND THE RIGHTS OF THE PEOPLE WHO INHABIT THEM, OR, THE CONFLICT BETWEEN THE. PRINCIPLE OF NONINTERVENTION IN THE INTERNAL AFFAIRS OF NATIONS AND THE PRINCIPLE OF PROTECTING HUMAN RIGHTS. THE VIEWS OF GOVERMMENTS REMAIN WIDELY DIVERGENT. WHILE THE USA AND BRITAIN CAME OUT STRONGLY ON THE SIDE OF NONINTERVENTION AND BRITAIN CAME OUT STRONGLY ON THE SIDE OF NONINTERVENT DURING THE EARLY DAYS OF THE KURDISH REFUGEE CRISIS, THE GERMAN GOVERNMENT STATED UNEQUIVOCALLY THAT INTERMA
LAW HAS EVOL VED TO QUITE A DIFFERENT LEVEL WHERE

LAW HAS EVOLVED TO QUITE A DIFFERENT
HUMANITARIAN CONCERNS ARE INVOLVED.

07736 RITTERBAND, C.E.

NEW CRITICISH OF BRITAIN'S ROYAL FAMILY

SWISS REVIEN OF WORLD AFFAIRS, 42(1) (APR 92), 26-27.

THE PERIOD LEADING UP TO THE 4OTH ANNIVERSARY OF QUEEN ELIZABETH II'S CORONATION BROUGHT NEW PUBLIC CRITICISM OF BRITAIN'S ROYAL FAMILY. THE ALLEGEDLY UNRULY BEHAVIOR OF THE QUEEN'S DAUGHTERS-IN-LAW AND WHAT IS PERCEIVED AS THE ELITIST CONCERNS OF PRINCE CHARLES AROUSE LITTLE SYMPATHY AMONG BRITONS. IN ADDITION, THE QUEEN'S EXEMPTION FROM INCOME TAX HAS AGAIN BECOME A SUBJECT FOR PUBLIC DISCUSSION.

07737 RITTERBAND, C.E.

NO REST FOR NORTHERN IRELAND

SWISS REVIEW OF WORLD AFFAIRS, 41(11) (FEB 92), 20-22.

IN 1991, AFTER THE COLLAPSE OF THE POLITICAL TALKS IN NORTHERN IRELAND, THE VIOLENCE AND COUNTER-VIOLENCE INTENSIFIED. DESPITE AN EXTERNAL FACADE OF NORMAL URBAN LIFE, THE SITUATION IN BELFAST REMAINS EXPLOSIVE, WITH LITTLE HOPE FOR A RESUMPTION OF POLITICAL DIALOGUE UNTIL AFTER BRITAIN'S 1992 PARLIAMENTARY ELECTIONS.

07738 RIVLIN, A.M.

A NEW VISION OF AMERICAN FEDERALISM

PUBLIC ADMINISTRATION REVIEW, 52(4) (JUL 92), 315-320.

THE AUTHOR CALLS FOR A NEW VISION OF FEDERALISM THAT

PROVIDES A CLEARER DISTINCTION AMONG THE RESPONSIBILITIES OF STATE AND MATIONAL GOVERMMENTS. SHE EMPHASIZES THREE MAJOR DIMENSIONS OF THE NEW VISION: A FEDERAL GOVERNMENT EMPHASIS ON SOCIAL INSURANCE RESPONSIBILITIES; THE STATES' ASSUMPTION OF EDUCATION, INFRASTRUCTURE, AND OTHER PRODUCTIVITY AGENDA ITEMS; AND A NEH SYSTEM OF COMMON SHARED TAXES.

07739 RIVLIN, A.M.

REVIVING THE AMERICAN DREAM

BROOKINGS REVIEH, 10(3) (SUM 92), 5

THE UNITED STATES NEEDS A NEW DIVISION OF THE DOMESTIC RESPONSIBILITIES OF GOVERMMENT. THE FEDERAL GOVERNMENT SHOULD CONTINUE TO DO WHAT IT RAS PROVED IT CAN DO WELL: STRENGTHEN THE NATION'S SOCIAL INSURANCE SYSTEM. IT SHOULD TAKE ON THE TASK OF CONTROLLING THE GROWTH OF HEALTH CARE COSTS AND ENSURING THAT EVERYONE HAS HEALTH INSURANCE. BUT AMD ECONOMIC DEVELOPMENT TO THE STATES, WHICH ARE BETTER SUITED TO MANAGE THEM.

07740 RIZVI, G.

GANDHI AND NEHRU: AN ENDURING LEGACY

ROUND TABLE, 323(323) (JUL 92 ), 363-368. 
THE CLASH BETWEEN IMPERIALISM AND NATIONALISM THREW UP LEGENDARY AND CHARISMATIC LEADERS WHO LED THE INDIAN REVOL AGAINST WESTERN DOMINANCE AND TOOK THEIR PEOPLE TO FREEDOM. THE REPUTATIONS OF MAHATMA GANDHI AND JAWAHARLAL NEHRU HAVE ONLY BEEN ENHANCED BY THE PASSAGE OF TIME. THEY WERE COLOSSI IN EVERY SENSE OF THE WORD; THEY LED YARIED AND EVENTFUL LIVES AND LEFT DEEP IMPRINTS ON SO MANY DIFFERENT FACETS THAT IS IS NOT EASY TO ENCOMPASS THEIR LIVES AND PHILOSOPHIES IN SINGLE VOLUME BIOGRAPHIES. THIS ARTICLE REVIEWS THE RESPECTIVE BIOGRAPHIES OF THESE TWO MEN BY JUDITH BROWN AND SARVEPALLI GOPAL.

07741 ROBBINS, C.A.

DATELINE HASHINGTON: CUBAN-AMERICAN CLOUT

FOREIGN POLICY, (88) (FAL 92), 162-182.

HIGH-PRESSURE DOMESTIC POLITICS IS THE KEY TO

UNDERSTANDING PRESIDENT GEORGE BUSH'S POSITION ON CUBA. THE

WHITE HOUSE DOES NOT WANT TO OFFEND ITS LONG-TIME SUPPORTERS, THE CUBAN AMERICAN NATIONAL FOUNDATION, ESPECIALLY IN AN ELECTION YEAR. THE FOUNDATION AND ITS CHAIRMAN VEHEMENTLY OPPOSE ANY CHANGE IN U.S. POLICY THAT DOES NOT PUNISH AND ISOLATE CASTRO EVEN MORE. THEY BELIEVE THAT DIALOGUE WITH CASTRO WOULD BE TANTAMOUNT TO SLEEPING WITH THE ENEMY AMD ANYONE WHO SUGGESTS IT MUST BE EITHER A TRAITOR OR A COMMUNIST DUPE. IN THE FACE OF SUCH PASSION AND CLOUT, THE BUSH ADMINISTRATION HAS DECIDED TO LEAVE CUBAN POLICY AS IT IS.

07742 ROBBINS, J.; CARPENTER, T.; KOSKO, B.; HEIDENBAUM, M. ARMS WRESTLING

REASON, 24(5) (OCT 92 ), 38-45.

NEW DIRECTIDNS FOR THE U.S. MILITARY ARE DESCRIBED IN FIVE SHORT ARTICLES IN THE AREA OF ARMS FOR THE SECURITY OF THE UNITED STATES. "WHAT TO BUY AND WHY" "BEYOND INTERVENTION", "HASTE MAKES WASTE", "INVESTMENT IN HIGHER MACHINE IO", AND "DEFENSE TRUST BUSTING" ARE THE TITLES OF OF PAPERS BY FIVE DIFFERENT AUTHORS. THESE ARTICLES SUGGEST THAT THE U.S. STRATEGIC GOALS DURING THE COLD WAR WERE REACTIVE; THAT DRAMATIC CHANGES IN THE INTERNATIONAL POLIIICAL AND MILITARY ENYIRONMENT CREATE BOTH THE OPPORTUNITY AND THE NEED FOR THE UNITED STATES TO ADOPT A NEW SECURITY STRATEGY; THAT EVENTS SINCE 1989 REINFORCE THE NEED FOR A NEW LOOK BY THE UNITED STATES IN SETTING NATIONAL DEFENSE STRATEGY: THAT MOST MONEY FOR WEAPONS GOES TO DEFENSE STRATEGY; THAT MOST MONEY FOR WEAPONS GOES TO DEVELOP THEM; AND, THAT THE END OF THE STRUGGLE FOR HEGEMONY IN EUROPE WILL BE ENJOYED BY A GERMANY DEFEATED IN BOTH IS IRONIC BUT

07743 ROBERT, A.R.

SCOTLAND UNITED YS. WESTMINSTER UNION: SCOTTISH

INDEPENDENCE DEFEATED

FREEDOM REVIEW, 23(4) (JUL 92), 19-21.

THE AUTHOR DISCUSSES HOW THE CONSERVATIVE VICTORY IN GREAT BRITAIN'S 1992 GENERAL ELECTION WILL AFFECT THE FUTURE OF SCOTLAND.

07744 ROBERT, $K$.

ARGENTINA: WHERE YOUTH IS A CRIME

REPORT ON THE AMERICAS, 36(3) (DEC 92), 12-15.

WHILE RULING OFFICIALS DISTANCE THEMSELVES FROM THE FRAY, A DISTURBING PATTERN OF POLICE VIOLENCE AGAINST YOUNG PEOPLE PLAGUES ARGENTINA. THE REASONS WHY YOUNG PEOPLE ARE SO OFTEN THE VICTIMS OF A PARALLEL "JUSTICE" SYSTEM ARE EXPLORED AND SEVERAL SPECIFIC CASES OF YOUTHS BEING KILLLD WHILE IN POLICE CUSTODY ARE DETAILED. CITIZENS ARE DEMANDING THAT THE JUSTICE DEPARTMENT UNDERGO THE SAME KINDS OF REFORMS AS HAVE BEEN ACHIEVED IN THE EXECUTIVE BRANCH AND IN CONGRESS.

07745 ROBERTS, B.

ARMS CONTROL AND THE END OF THE COLD WAR

WASHINGTON OUARTERLY, 15(4) (FAL 92) 39-56.

DOES ARMS CONTROL HAVE AN IMPORTANT ROLE TO PLAY IN THIS NEW ERA? THIS ARTICLE OFFERS A SPECULATIVE ANALYSIS. II REVIEWS THE THREE FOCAL POINTS OF U.S. ARMS-CONTROL POLICY IN THE DECADE AHEAD: THE CONTINUING EAST-WEST AGENDA, THE MULTILATERAL OR GLOBAL AGENDA, AND REGIONAL MEASURES'. IT THEN GOES ON TO DISCUSS THE THO PRINCIPAL DETERMINANTS OF THE IMPACT ARMS CONTROL WILL HAVE ON THE MANAGEMENT OF INTERNATIONAL CONFLICT: THE ABILITY TO SIGN AND IMPLEMENT EFFECTIVE COMPLIANCE MECHANIMS AND THE PROPENSITY TO SEEK NEGOTIATED MEASURE. IT CONCLUDES THAT ARMS CONTROL WILL NEGOTIATED MEASURE. IT CONCLUDES THAT ARMS CONTROL WILL
CONT INUE TO BE A PROMINENT U.S. POLICY INSTRUMENT, BUT NOT CONT INUE TO
AS BEFORE.

07746 ROBERTS, D.

CAMBODIA: PROBLEMS OF A U.N.-BROKERED PEACE

WORLD TODAY, 4817 ) (JUL 92), 129-132.

THE SIGNING OF THE CAMBODIAN PEACE AGREEMENT ON OCTOBER 23, 1991, ENDED A HAR THAT HAD BEEN FOUGHT FOR 12 LONG YEARS. IT MARKED THE START OF A PERIDD OF EXTERNAL AID FOR RECONSTRUCTION AND MODERNIZATION THAT BEEN DENIED CAMBODIA DURING THE VIETNAMESE OCCUPATION. BUT CAMBODIA, AND THOSE
WHO DEIGN TO HELP IT, FACE A MULTIPLICITY OF PROBLEMS THAT ARE ALREADY BEGINNING TO UNRAVEL THE LOOSELY SPUN THREADS OF THE DELICATE PEACE. IF THESE ISSUES ARE NOT QUICKLY

CONFRONTED, BOTH THE PEACE AND THE ECONOMIC DEVELOPMENT THAT CAMBODIA DESPERATELY NEEDS AND RICHLY DESERVES MAY BECOME AS ELUSIVE AS THEY HERE DURING THE POL POT ERA.

07747 ROBERTS, G.K.

RIGHT-WING RADICALISM IN THE NEW GERMANY

PARLIAMENTARY AFFAIRS, 45(3) (JUL 92), 327-344.

TO UNDERSTAND THE RECENT UPSURGE IN EXTREME RIGHT-WING POLITICAL ACTIVITY IN GERMANY, IT IS ESSENTIAL TO KNOW THE HISTORICAL BACKGROUND. IN THIS ESSAY, THE AUTHOR LOOKS AT RADICAL RIGHT-WING GROUPS IN THE FEDERAL REPUBLIC FROM 1949 TO 1989 AND AT THE RADICAL RIGHT-HING MOVEMENT SINCE THE REUNIFICATION OF GERMANY IN 1989.

07748 ROBERTS, H.

THE ALGERIAN STATE AND THE CHALLENGE OF DEMOCRACY GOVERMMENT AND OPPOSITION, $27(4)$ (FAL 92), 433-454. THE AUTHOR PROVIDES A HISTORICAL PERSPECTIVE ON THE POLITICAL TURMOIL THAT HAS PLAGUED ALGERIA FOR THE PAST SEVERAL YEARS.

07749 ROBERTS, J.

SEIGNORAGE AND RESOURCE MOBILIZATION IN SOCIALIST ETHIOPIA DEVELOPMENT POLICY REVIEW, 10 (3) (SEP 92), 271-288.

THE AUTHOR BEGINS WITH A BRIEF SKETCH OF ETHIOPIA's MACRO-ECONOMIC FEATURES AND ECONOMIC DEVELOPMENTS SINCE THE EARLY 1980'S. HE THEN EXAMINES MONETARY TRENDS AND RATIOS AND THEIR RELATIONSHIP TO FISCAL PERFORMANCE. HE DISCUSSES THE WORKINGS OF THE BANKING AND CREDIT SYSTEM, INTEREST RATES, AND BANKING SECTOR ADVANCES. HE OFFERS A SOMENHAT SPECULATIVE EXPLANATION OF FALLING INCOME VELOCITY OF CIRCULATION IN ETHIOPIA, TAKING INTO ACCOUNT THE PROBABLE FINANCING PATTERNS OF THE REBEL FORCES' WAR EFFORT. FINALLY, HE ANALYZES HOW LIBERALIZATION OF THE FINANCIAL SECTOR IN TERMS OF INTEREST RATES AND CREDIT ALLOCATION-OCCCURRING IN THE CONTEXT OF A WIDER LIBERALIZATION OF INVESTMENT DECISIONS AND PRICES--IS LIKELY TO AFFECT MONETARY BEHAVIOR AND THE PARAMETERS OF FISCAL PLANHING.

07750 ROBERTS, N.C.

PUBLIC ENTREPRENEURSHIP AND INNOVATION

POLICY STUDIES REVIEW, 11 (1) (SPR 92), 55-74.

THE AUTHOR PRESENTS A CONCEPTUAL FRAMEWORK OF PUBLIC ENTREPRENEURSHIP, WHICH IS DEFINED AS "THE GENERATION OF A NOVEL OR INNOVATIVE IDEA AND THE DESIGN AND IMPLEMENTATION OF THE INMOYATIVE IDEA INTO PUBLIC SECTOR PRACTICE." SHE USES THE CONCEPTUAL FRAMEWORK TO DISTINGUISH BETWEEN PUBLIC ENTREPRENEURS AND OTHER ACTORS IN THE POLICY PROCESS AND TO
CLARIFY THE DIFFERENCES BETHEEN POLICY, POLITICAL, EXECUTIVE, AND BUREAUCRATIC ENTREPRENEURS. TAKING A FUNCTIONALIST PERSPECTIVE, SHE DIFFERENTIATES BETWEEN INDIVIDUAL AND COLLECTIVE ENTREPRENEURSHIP ANO GENERATES PROPOSITI
MOVE CLOSER TO A THEORY OF PUBLIC ENTREPRENEURSHIP.

07751 ROBERTS, $P$

ECONOMIC DOMINOES

NATIONAL REVIEH, XLIV(23) (NOV 92), 37-42

MANY FACTORS CONTRIBUTED TO GEORGE BUSH'S DEFEAT, BUT POLLS REPORT THAT THE ECONOMY PLAYED THE BIGGEST ROLE. IN THE BUSH PRESIDENCY WAS DESTROYED BY ECONOMIC DOMINOES TOPPLED BY THE TAX REFORM ACT OF 1986. IRONICALLY, THIS DISASTROUS LEGISLATION WAS THE WORK OF BUSH ADVISORS JAMES A. BAKER AND RICHARD DARMAN, WHO WERE RUNHING THE TREASURY DEPARTMENT AT THAT TIME.

07752 ROBERTS, $P$

HOH TO HRECK AN ECONOMY

NATIONAL REVIEN, XLIV(4) (MAR 92), 32-33.

THE CURRENT ECONOMIC STAGNATION, NOW THREE YEARS OLD, HAS ITS ORIGINS IN THE CHARGE THAT THE REAGAN TAX CUT OF 1981 WOULD FUEL INFLATION. EXPECTING A WORSENIMG OF THE INFLATION OF THE 1970S, MANY INVESTORS SOUGHT REFUGE IN REAL ESTATE, A TIME-PROVEN INFLATION HEDGE. BY 1986 IT HAS APPARENT THAT INFLATION HAD COLLAPSED, AND MANY REAL ESTATE INVESTMENTS THAT HAD RELIED ON INFLATION TO MAKE THE GOOD WERE TURNING SOUR. JUST AT THE MOMENT WHEN A MAJOR PILLAR OF $U$.S. WEALTH AND THE COLLATERAL BEHIND HUNDREDS OF BILLIONS OF DOLLARS IN LOANS HAS IN LINE FOR A SHAKE OUT, THE FEDERAL GOVERNMENT ENACTED THE 1986 TAX REFORM ACT. THE REAL-ESTATE GOVERNMENT ENACTED THE 1986 TAX REFORM ACT. THE REAL-ESTAT
PROVISIONS IN THE ACT HOULD HAVE DESTROYED REAL-ESTATE PROVISIONS IN THE ACT HOULD HAVE DESTROYED REAL-ESTATE INVESTMENTS IN SOUNDER SHAPE THAN MANY HELD AT THE TIME. FOR THE LONG HAUL THE CAPITAL GAINS TAX RATE HAS RAISED BY FORTY PERCENT, SODN LARGE MUMBERS OF S\&LS AND BANKS WERE FORTY PERCENT. SODN LARGE NUMBERS OF S\&LS AND BANKS WERE COLLAPSING, FORCING TAXPAYERS TO PICX UP THE MULTI-HUNDREDBILLION DOLLAR TAB FOR DEPOSIT INSURANCE. BY DESTROYING THE ABILITY OF THE FINANCIAL SYSTEM TD FINANCE INVESTMENT, THE ECONOMY'S ABILITY TO CONTINUE GROWING. 
07753 ROBERTS, $P$ WHAT EYERYONE "KNOWS" ABOUT REAGAMOMICS COMMENTARY, 91 (2) (FEB 91), 25-30.

WHAT EVERYONE "KNOWS" ABOUT REAGANOMICS IS THAT II FAILED. AS THE ALMOST UNIVERSALLY ACCEPTED STORY GOES, THE REAGAN ADMINISTRATION MADE A FORECAST THAT ITS TAX CUTS WOULD PAY FOR THEMSELVES. INSTEAD THEY PRODUCED SURGING BUDGET DEFICITS WHICH SADDLED THE U.S. WITH MASSIVE DEBTS, THIS ARTICLE ARGUES THAT WHAT EVERYONE "KNOWS" ABOUT REAGANONICS LACKS ANY BASIS IN FACT. IN PARTICULAR, THE REAGAN ADMINISTRATION DID NOT PREDICT THAT THE TAX CUTS WOULD BE SELF-FINANCING. IT PREDICTED THE EXACT OPPOSITE-THAT EVERY DOLLAR OF TAX CUT MOULD LOSE A DOLLAR OF REVENUE. THE ECONOMISTS AND THE JOURNALISTS HAVE SIMPLY IGNORED THE FACTS AND LAUNCHED A CRUSADE TO DRIVE OUT THE DEVIL OF REAGANOMICS, HHICH HAD BEEN GUILTY OF DOING WHAT THEY SAID COULD NEYER BE DONE--CREATING 20 MILLION NEH JOBS WITHOUT CAUSING AN INCREASE IN INFLATION. FURTHERMORE, THE BUSH ADMINISTRATION HAS AGREED TO RAISE TAXES AND LOWER INTEREST RATES. THE COMBIMATION OF HIGH TAXES AND EASY MONEY IS THE RATES. THE COMBINATION OF HIGH TAXES AND EASY MONEY IS THE
SAME POL ICY MIX THAT EVENTUALLY PRODUCED THE STAGFLATION OF SAME POLICY MIX THAT EVENTUALLY PRODUCED THE STAGFLATION OF THE 1970 S FROM WHICH

07754 ROBERTS, $R$.

GOVERNMENT SUBSIDIES TO PRIVATE SPENDING ON PUBLIC GOODS PUBLIC CHOICE, 74 (2) (1992) 133-152.

THIS PAPER EXAMINES HOW THE SIZE OF AN EFFICIENT SUBSIDY VARIES WITH THE AMOUNT OF FREERIDING AND THE PRESENCE OF DISTORTING TAXATION. THE ANALYSIS DISTINGUISHES BEWEEN TRADITIONAL PUBLIC GOODS SUCH AS NATIONAL DEFENSE AND WHAT THE AUTHOR CALLS TRANSFER PUBLIC GOODS, WHERE MEMERS OF SOCIETY CARE ABOUT THE CONSUMPTON OF A PARTICULAR GROUP IN SOCIETY SUCH AS THE POOR. HE GENERALIZED THE SAMUELSON RESULTS TO DERIVE CONDITIONS FOR EFFICIENCY IN PROVIDING TRANSFER PUBLIC GOODS.

07755 ROBERTS, R.N.; DOSS, M.T. JR.

PUBLIC SERVICE AND PRIVATE HOSPITALITY: A CASE STUDY IN FEDERAL CONFLICT-OF-INTEREST REFORM

PUBLIC ADMINISTRATION REVIEW, 52(3) (MAY 92), 260-270. THE EMPHASIS ON EXTERNAL RESTRAINTS IN GOVERNHENT ETHICS HAS NOT BEEN EFFECTIVE IN PROMOTING PUBLIC TRUST OF GOVERNMENT. THE CASE OF FEDERAL GIFT ACCEPTANCE AND RELATED REGULATIONS IS AN EXCELLENT EXAMPLE. REFLECTING THE INCREASING RELIANCE ON EXTERMAL CONTROLS, GIFT-ACCEPTANCE INCREASING RELIANCE ON EXTERNAL CONTROLS, GIFT-ACCEPTANCE YEARS. THE RESULT HAS BEEN AN OVER-CONCERN WITH LEGALISTIC TRUST OR CONFIDENCE. MODERN CONFLICT OF INTEREST REGULATIONS DEAL MORE WITH ORGANIZATIONAL CREDIBILITY THAN WITH PERSONAL INTEGRITY, AND GREATER EFFORT IS DEVOTED TO MAINTAINING THE POLITICAL SYMBO

07756 ROBERTS, $S$

A LAND DIVIDED

CULTURAL SURVIVAL QUARTERLY, 16(1) (WIN 92), 45-48.

IN THE SOUTHEASTERN REGION OF THE FORMER' SOVIET EMPIRE THE BORDER WITH CHINA DIVIDES TWO CUL TURALLY-SIMILAR ISLAMIC REGIONS THAT TOGETHER ENCOMPASS MORE THAN TWO MILLION SOUARE MILES. FOR THE FIRST TIME IN DECADES, THE POLITICAL SITUATION OFFERS SOME HOPE FOR A REBIRTH OF TRADITIONAL CULTURAL AND ECONOMIC CONTACT ACROSS THIS CENTRAL ASIAN BORDER. INDEPENDENCE MAY EVEN EVENTUALLY MEAN THE OISAPPEARANCE OF THIS BORDER. HOHEVER, DECADES OF SEPARATION AND ISOLATION HAVE ALREADY DONE MUCH DAMAGE TO THE REGION'S CUL TURE, WHICH MAY PRECLUDE EITHER A UNION OF CENTRAL ASIA'S TWO HALVES OR A RENAISSANCE OF ITS CULTURE.

07757 ROBERTS, S

PLAYING PACHINKO AS JAPAN CHURNS

NEW LEADER, LXXIII(15) (NOV 91) 6-7.

CRACKS ARE BEGINNING TO APPEAR IN THE ONCE SEEMIMGLY INVINCIBLE JAPANESE MONOLITH. JAPAN IS CURRENTLY CONSUMED BY A SERIOUS OF DEBATES ABOUT ITS MATIONAL IDENTITY AND IMAGE. THE PRESSURE FROM THE UNITED STATES AND ELSEWHERE TO ASSUME A LARGER INTERNATIONAL ROLE CONFLICTS WITH DEEP-SEATED MISTRUST OF AROUSED MILITARY INSTINCTS AND THE GUILT AND HORROR OF WORLD WAR II WHICH LEFT MILLIONS DEAD. SELF-DOUBT ALSO PLAGUES THE DOMESTIC FRONT AS INVESTORS WAIT FOR THE "BLSO PLAGUES THE DOMESTIC FRONT AS INVESTORS WAIT FOR THE COMMON JAPANESE CITIZEN--OVERHORKED AND UNDERPAID--BEGINS TO COMMON JAPANESE CITIZEN--OVERHORKED AND UNDERPAID--BEGINS TO QUESTION WHETHER THE NATION'S UNPARALLELED ECONOMIC SUCCESS INCREASED POWER OF WOMEN'S GROUPS, MAY OFFER SOME SOLUTIONS, INCREASED POWER OF WOMEN S GROUPS, MAY OFFER SOME SOLUTIONS, BUT THE SPE

07758 ROBERTS, $W$

THE LIFE AND DEATH OF INTEGRATION IN YUGOSLAVIA MEDITERRANEAN QUARTERLY: A JOURNAL OF GLOBAL ISSUES, 312 (SPR 92$), 34-43$
YUGOSLAVIA AS IT EXISTED BETHEEN 1919 AND 1941 AND BETWEEN 1945 AND 1991 IS MO MORE. DEMOCRATIC GERMANY MAY HAVE ACHIEVED IN 1991 WHAT TOTALITARIAN GERMANY FAILED TO ACCOMPLISH DURING THE SECOND WORLD WAR. HISTORY DOES NOT SUPPORT THE ARGUHENT THAT YUGOSLAVIA WAS NEVER VIABLE AND THAT IT DESERVED TO BE PARTITIONED. AFTER A BRIEF ANALYSIS OF THE SITUATION THIS ARTICLE CONCLUDES THAT PRESENTLY IN YUGOSLAVIA THE MOST NATIONALISTIC ELEMENTS ARE CONTROLLING THE AGENDA. HOWEVER, IT CAN BE EXPECTED THAT ECONOMIC EXIGENCIES WILL TAKE OVER AND PERHAPS COOLER HEADS HILL EMERGE.

07759 ROBERTSON, A.H.; MERRILLS, J.G.

HUMAN RIGHTS IN' THE WORLD

MANCHESTER UNIVERSITY PRESS, 1989, 314.

THIS BOOK PROVIDES AN OVERVIEN OF A NEW BRANCH OF INTERNATIONAL LAH: HUMAN RIGHTS LAH. IT OUTLINES THE WORK OF THE UNITED NATIONS IN THE FIELD OF CIVIL AND POLITICAL RIGHTS AND ECONOMIC, SOCIAL AND CULTURAL RIGHTS. IT DESCRIBES THE STRUCTURE AND FUNCTION OF EACH OF THE REGIONAL SYSTEMS OF HUMAY RIGHTS, REYIEWS THE ACTIYITIES OF SPECIALIZD AGENCIES AMD COMSIDERS THE RELEYANT ASPECTS OF HUMANITARIAN LAH. SUBSTANTIALLY REWRITTEN, THIS NEW EDITION DEALS HITH MANY CURRENT DEVELOPMENTS AND INCLUDES AN DEALS WITH MANY CURRENT DEVELOPMENTS AND INCLUDES AN
ANALYSIS OF THE AFRICAN CHARTER ON HUMAN AND PEOPLE'S RIGHTS, ANALYSIS OF THE AFRICAN CHARTER ON HUMAN AND PEOPLE'S A DISCUSSION OF THE RECENT WORK OF THE HUMAN RIGHTS ACCOUNT OF THE LATEST CASE LAH OF THE EUROPEAN AND INTERAMERICAN COURTS OF HUMAN RIGHTS.

07760 ROBERTSON, A.H.; MERRILLS, J.G. INTERNATIONAL CONCERN WITH HUMAN RIGHTS; HUMAN RIGHTS IN THE WORLD

MANCHESTER UNIVERSITY PRESS, 1989, 1-22

THIS CHAPTER EXAMINES AND CHRONICLES THE INCREASE OF INTERNATIONAL CONCERN FOR HUMAN RIGHTS. IT OUTLINES VARIOUS HUMAN RIGHTS TRADITIONS INCLUDING WESTERN LIBERAL, UNIVERSAL, SOCIALIST, AND TRADITIONS IN THE DEVELOPING HORLD. IT ALSO EXAMINES THE FIRST INTERMATIONAL MEASURES FOR THE PROTECTION OF HUMAN RIGHTS INCLUDING THE ABOLITION OF SLAVERY, THE PROTECTION OF MINORITIES, AND HUMANITARIAN LAW.

07761 ROBERTSON, A.H.; MERRILLS, J.G.

INTERNATIONAL HUMAN RIGHTS LAW TOOAY AND TOMORROW; HUMAN RIGHTS IN THE WORLD

MANCHESTER UNIVERSITY PRESS, 1989, 286-305.

THIS CONCLUDING CHAPTER SUMMARIZES RECENT DEVELOPMENTS IN HUMAN RIGHTS LAN AND ASSESSES BOTH THE CURRENT POSITION AND FUTURE OF HUMAN RIGHTS LAW. IT EXAMINES THE GROWTH, AND FUTURE OF HUMAN RIGHTS LAW. IT EXAMINES THE GROWTH,
REALITY, AND POLITICS OF HUMAN RIGHTS LAW AND THE THEORY OF REALITY, AND POLITICS OF HUMAN RIGHTS LAW AND THE THEORY OF
HUMAN RIGHTS. IT CONCLUDES THAT THE MOUNTING PRESSURE OF PUBLIC OPINION IN THE YEARS TO COME WILL CONTINUE TO HAVE AN PUBLIC OPINION IN THE YEARS TO COME WILL CONTINUE EFFECT IN PERSUADING OR SHAMING GOVERMMENTS WHICH
SYSTEMATICALLY VIOLATE HUMAN RIGHTS TO IMPROVE THEIR SYSTEMATICAI
BEHAVIOR.

07762 ROBERTSON, D.B.

POLITICAL CONFLICT AND LESSON-DRAWINC

JOURNAL OF PUBLIC POLICY, 2(1) (JAN 91), 55-78.

POLITICAL ADVERSARIES HAVE REASON AND OPPORTUNITY TO USE FOREIGN LESSONS TO GAIN ADVANTAGE IN POLITICAL CONFLICTS. POLITICAL FACTORS STRONGLY AFFECT THE WAY PUBLIC POLICY LESSONS ARE DRAHN AND TRANSFORMED INTO PUBLIC POLICY. POLITICAL OPPONENTS CONTEST THE VALUE, PRACTICALITY, AND TRANSFERABILITY OF POLICY INITIATIVES IN ORDER TO BIAS THE OUTCOME. THE PAPER HYPOTHESIZES THAT (1) THE POL ITICIZATION OF LESSON-DRAHING INDUCES ISSUE EXPERTS TO EMPHASIZE THE DESCRIPTIVE AND TECHNICAL ASPECTS OF PROGRAMS: (2) GIVES AN INCENTIVE TO ADVOCATES OF CHANGE TO USE LESSONS TO ADVANCE THEIR POSITION DURING THE AGENDA-SETTING PROCESS; AND (3) GIVES OPPONENTS OF CHANGE AN INCENTIVE TO DRAN COUNTERBALANCING NEGATIVE LESSONS FROM FOREIGN EXPERIENCE WHEN A PROPOSED LESSON REACHES THE POINT WHERE ADOPTION IS ENTIRELY POSSIBLE. THE 1988 CONGRESSIONAL DEBATE OVER MANDATORY PLANT CLOSING PRENOTIFICATION PROVIDES EVIDENCE SUPPORTING HYPOTHESES. THE PAPER FURTHER HYPOTHESIZES: $(4)$ MOST POLITIES HILL NOT ADOPT BOTH CONSERVATIVE AND LIBERAL PROGRAMS EVEN WHEN THEORETICALLY THEY COULD DO SO; AND (5) THE DEGREE TO WHICH A POPULATION OF POLITIES ADOPT A PARTICULAR LESSOM HILL BE A FUNCTION OF THE PROGRAM'S ECONOMIC AND POL ITICAL FEASIBILITY. THE DIFFUSION OF LABOR MARKET AND INCOME MAINTENANCE POL ICIES ACROSS THE AMERICAN MARKET AND INCOME MAINTENANCE POLICIES

07763 ROBERTSON, D.S

SCOTTISH HOME IMPROVEMENT POLICY, 1945-1975: COMING TO TERMS WITH THE TENEMENT

URBAN STUDIES, 29(7) (OCT 92), 115-1136.

THIS PAPER TRACES THE DEVELOPMENT OF HOME IMPROVEMENT POLICY IN SCOTLAND, ILLUSTRATING HOW THE TRADITIONAL TENEMENT HOUSING FORM FOR A LONG TIME HINDERED AND THEN EVENTUALLY SHAPED THIS POLICY. TENEMENT HOUSING WAS A CONSTRAINT ON THE PROMOTION OF HOME IMPROVEMENT POLICY DUE TO A VARIETY OF TECHNICAL AND ADMINISTRATIVE FACTORS. IT WAS, 
HOWEVER, THE POLITICAL PREJUDICE AGAINST LANDLORDS AND THE SOCIAL ATTITUDES ABOUT TENEMENT HOUSING THAT PROVED TO BE THE MOST DIFFICULT TO OVERCOME. THE PAPER STUDIES A NUMBER OF INFLUENTIAL POLICY REPORTS THAT ADVOCATED THE ADOPTION OF HOME IMPROVEMENT AND HOW THEY EVENTUALLY WERE INCORPORATED INTO LEGISLATION. THE CENTRAL ROLE OF THE GLASGOW GOVERMMENT IN FRAMING THIS POLICY APPROACH IS ILLUSTRATED.

07764 ROBERTSON, $H$.

TRUDEAU'S LEGACY

CANADIAM FORUM, LXIX(797) (MAR 91), 5

LIBERAL PRIME MINISTER PIERRE TRUDEAU LEFT CANADA A LEGACY OF BILINGUALISM, DIVISION AND DIALECTICAL BLUNTNESS. LEGACY OF BILINGUALISM, DIVISION AND DIALECTICAL BLUN
CANADA'S CURRENT PRIME MINISTER, BRIAN MULRONEY, IS UNINTENTIONALIY CREATING A LEGACY OF MEARLY UMANIMOUS HATRED UNINTENTIONALLY CREATE MINISTER, BRIAN MULRONEY, IS OF THE GOVERMMENT AMONG CANADIANS. WHILE UNABLE TO TOPPLE BENEFICIAL SIDE EFFECT: THE UNIFICATION OF CANADA.

07765 ROBINSON, D.L.

THE COMPARATIVE STUDY OF CONSTITUTIONS: SUGGESTIONS FOR ORGANIZING THE INQUIRY

PS: POLITICAL SCIENCE AND POLITICS, XXV(2) (JUN 92), 272-280.

THE AUTHOR DISCUSSES THE SIGNIFICANCE OF THE UNITED STATES CONSTITUTION AND OFFERS SOME SUGGESTIONS FOR ORGANIZING A COMPARATIVE COURSE OF STUDY ON CONSTITUTIONS.

07766 ROBINSON, J.; PAXMAN, D.

TECHNOLOGICAL, ECONOMIC, AND POLITICAL FEASIBILITY IN OSHA'S AIR CONTAMINANTS STANDARD

JOURNAL OF HEALTH POLITICS, POLICY AND LAW, 16(1) (SPR 91), $1-18$.

IN 1989, AFTER ALMOST THO DECADES OF SUBSTANCE-BYSUBSTANCE STANDARD SETTING, THE OCCUPATIONAL SAFETY AND HEALTH ADMINISTRATION (OSHA) PROMULGATED ITS AIR CONTAMINANTS STANDARD, IMPOSING NEW EXPOSURE LIMITS FOR 376 TOXIC SUBSTANCES ENCOUNTERED IN U.S. INDUSTRY. IN MARKETED CONTRAST TO EARLIER REGULATIONS, THE AIR CONTAMINANTS CONTRAST TO EARLIER REGULATIONS, THE AIR CONTAMINANTS
STANDARD HAS GENERATED RELATIVELY LITTLE INDUSTRY OPPOSITION. STANDARD HAS GENERATED RELATIVELY LITTLE INOUSTRY OPPOS
THIS PAPER ANALYZES THE STANDARD IN THE CONTEXT OF THE THIS PAPER ANALYZES THE STANDARD IN THE CONTEXT
TWENTY-YEAR DEBATE OVER THE APPROPRIATE ROLE FOR TWENTY-YEAR DEBATE OVER THE APPROPRIATE ROLE FOR
TECHNOLOGICAL FEASIBILITY AND ECONOMIC COMPLIANCE COSTS IN TECHNOLOGICAL FEASIBILITY AND ECONOMIC COMPLIANCE COSTS IN OCCUPATIONAL HEALTH POL ICY. THE POL ITICAL FEASIBILITY OF THE NEW STANDARD IS TRACED TO OSHA'S ABANDONMENT OF "TE FORCING" IN FAVOR OF RELIANCE ON "OFF-THE-SHELF" TECHNOLOGIES ALREADY IN USE IN MAJOR FIRMS. WHILE IMPORTANT AS AN EMBODIMENT OF OSHA'S NEW "GENERIC" APPROACH TO REGULATION, THE AIR CONTAMINANTS STANDARD CANNOT SERVE AS A MODEL FOR FUTURE OCCUPATIONAL HEALTH POLICY, DUE RELIANCE ON INFORMAL, CLOSED-DOOR MECHANISMS FOR ESTABLISH

07767 ROBINSON, J.B.

RISKS, PREDICTIONS, AND OTHER OPTICAL ILLUSIONS

RETHINKING THE USE OF SCIENCE IN SOCIAL DECISION-MAKING POLICY SCIENCES, 25(3) (AUG 92), 237-254.

THE AUTHOR EXAMINES RISK ANALYSIS AND LONG-TERM ENERGY DEMAND FORECASTING, THO EXAMPLES OF WHAT HAS BEEN CALLED "MANDATED SCIENCE," WITH A VIEW TOWARD DISENTANGLING THE IMPLICIT ASSUMPTIONS UNDERLYING THEIR USE IN PUBLIC POLICY DEBATES AND THE POLICY PROCESS. IN BOTH FIELDS, THERE HAS VIEWS OF THE ROLE AND STATUS OF MANDATED SCIENCE IN INFORMING DECISION-MAKING. THIS CHALLENGE HAS LED TO THE REFORMULATION OF SOME OF THE ATTRIBUTES OF THE STANDARD VIEW, WITHOUT HOWEVER CAUSING CHANGES IN THE UNDERLYING VIEW OF THE NATURE OF THE PROBLEM OR THE ROLE OF SCIENCE IN PRINCIPLE. A DEEPER CRITIQUE SUGGESTS THAT MANDATED SCIENCE IS INHERENTLY VALUE-LADEN, PRODUCING CONCLUSIONS THAT ARE TURN REFLECT UNDERLYING VALUES. THUS, A SHARP SEPARATION OF SCIENCE AND POLICY IS UNTENABLE AND AMOUNTS TO A HIDDEN POLICY BIAS IN FAVOR OF THE BUSINESS-AS-USUAL POLICIES POLICY BIAS IN FAVOR OF THE BUSINESS-AS-USUAL POLICIES
SUPPORTED BY CONVENTIONAL SCIENCE. THERE IS A NEED FOR A NEW SUPPORTED BY CONVENTIONAL SCIENCE. THERE IS A NEED FOR A NEW
CONCEPT OF SCIENCE-ONE THAT IS MORE INTEGRATED INTO THE CONCEPT OF SCIENCE--ONE THAT IS MORE INTEGRATED INTO THE
POLICY CONTEXT, MORE CONTEXTUAL AND OPENLY VALUE-LADEN, LESS POLICY CONTEXT, MORE CONTEXTUAL AND OPENLY VALUE-LADEN, LES
ORIENTED TO MASTERY OVER NATURAL AND SOCIAL PROCESSES, AND ORIENTED TO MASTERY OVER NATURAL AND SOCIA
MORE ACCESSIBLE TO THE PUBLIC AT LARGE.

07768 ROBINSON, L.

WHY CENTRAL AMERICA IS STILL NOT DEMOCRATIC

WHY CENTRAL AMERICA IS STILL NOT

THE ENDING OF WARS AND HOLDING OF ELECTIONS ARE ONLY THE PREREQUISITES FOR BUILDING SOLID, FUNCTIONING DEMOCRATIC SYSTEMS IN CENTRAL AMERICA. THE IMMEDIATE CHALLENGE FOR EACH COUNTRY OF THE REGION DIFFERS, SINCE EACH IS AT A DIFFERENT POINT ON THE ROAD TO DEMOCRACY. THIS ARTICLE EXPLORES THE EXPERIENCE OF THREE COUNTRIES--NICARAGUA, EL SALVADOR, AND HONDURAS. A DISCUSSION OF THE SUCCESS AND OR FAILURE OF U.S. POLICY IN CENTRAL AMERICA
DEMOCRACY IN THAT REGION.
07769 ROBINSON, R.

U.S. AFRICAN POLICY: BUILDING A DEMOCRATIC PEACE TRANSAFRICA FORUM, $9(2)$ (SUM 92), 39-46.

THE END OF THE COLD WAR HAS REMOVED THE FUMDAMENTAL CORNERSTONE THAT MOTIVATED U.S. POLICY TOWARD AFRICA. NO NEH POLICY RATIONALE HAS YET BEEN FULLY ARTICULATED, ALTHOUGH THE BUSH ADMINISTRATION HAS TALKED OF BUILDING A NEW WORLD ORDER FOUNDED ON RESPECT FOR HUMAN RIGHTS, THE ESTABLISHMENT OF A DEMOCRATIC PEACE BASED ON POLITICAL AND ECONOMIC
FREEDOM, AND THE PEACEFUL RESOLUTION OF DISPUTES. THE ENORMOUS RAMIFICATIONS OF THE DEMISE OF THE COLD WAR ARE ENORMOUS RAMIFICATIONS OF THE DEMISE OF THE COLD WAR ARE
PARTICULARLY POIGNANT FOR SUB-SAHARAN AFRICA. IN THE ABSENCE OF A WELL-DEFINED POL ICY RATIONALE FOR ENGAGEMENT IN AFRICA,
THE USA MIGHT BEGIN A PROCESS OF GRADUAL DISENGAGEMENT FROM THE USA MIGHT

07770 ROBINSON, T.

DOMESTIC AND INTERNATIONAL TRENDS IN ASIAN SECURITY: IMPLICATIONS FOR AMERICAN DEFENSE POLICY

KOREAN JOURNAL OF DEFENSE ANALYSIS, IV(1) (SUM 92), 29-146.

THE EFFECTS OF THE TRANSFORMATION OF THE INTERNATIONAL SYSTEM, FOLLOWING THE SPECTACULAR EVENTS OF 1989-1991, HAVE REVERBERATED THROUGHOUT ASIA. THERE ARE EMERGING TRENDS AND FORCES ON THE DOMESTIC AS WELL AS INTERNATIONAL LEVELS, LEADING TOWARDS THE FORMATION OF A NEW ASIAN SECURITY SYSTEM. WHAT SIZE, CHARACTERISTIC, AND COSTS THIS NEW SECURITY SYSTEM WILL ASSUME, AND THE CONSEQUENCES FOR AMERICAN SECURITY POLICY IN ASIA, ARE EXAMINED IN THIS PAPER. PART II ADORESSES THE DOMESTIC TRENDS TOWARDS, AND INTEGRATION OF, MODERNIZATION AND REVOLUTION IN POST-COLD WAR ASIA.

07771 ROBINSON, $W$.

PUTTING ITS OWN PEOPLE LAST

ARENA MAGAZINE, (1) (OCT 92), 23-25.

THE BOOM AND SLUMP CYCLE AND ITS ATTENDANT HUMAN MISERY

IS HOH THE CAPITALIST ECONOMY WORKS SUGGESTS WAYNE ROBINSON.

HE DEFINES NEW ZEALAND'S DECLINE AS ONE OF INSUFFICIENT

INTEGRATION WITH THE WORLD MARKET, WHICH HAS RESULTED OVER

THE PAST EIGHT YEARS IN SUPREME IMPORTANCE BEING GIVEN TO

THE PAST EIGHT YEARS IN SUPREME IMPORTANCE BEING GIVEN TO
THE WISHES OF THE COUNTRY'S INTERNATIONAL CREDITORS. THE

THE WISHES OF THE COUNTRY'S INTERNATIONAL CREDITORS.
BOLGER GOVERNMENT HAS REACTED STRONGLY AGAINST THE

BOLGER GOVERNMENT HAS REACTED STRONGLY AGAINST THE
SUGGESTION THAT THE STRUCTURAL CONSEOUENCES OF ITS FREE

SUGGESTION THAT THE STRUCTURAL CONSEQUENCES OF ITS FREE
MARKET POLICIES ARE SOCIAL DISINTEGRATION AND VIOLENCE, AND

CONTINUES TO PUT THE INTERESTS OF ITS OWN PEOPLE LAST.

07772 ROBISON, G.

SUDAN: A CAUSE FOR CONCERN

HORLD TODAY, 48(4) (APR 92), 61-64.

THE AUTHOR LOOKS AT THE REGIME OF SUDANESE PRESIDENT

LIEUTENANT-GENERAL OMAR HASSAN AL-BASHIR, WHO CAME TO POWER VIA A COUP IN 1989.

07773 ROBISON, $O$

THE PRESIDENTIAL ELECTION AND AMERICAN FOREIGN POLICY

WORLD TODAY, 48(7) (JUL 92), 119-122.

THE AUTHOR LOOKS AT THE ROLE OF FOREIGN POLICY IN THE

1992 U.S. PRESIDENTIAL ELECTION CAMPAIGN.

07774 ROCA, J.

CHANGES IN THE RANKS OF SPANISH COMMUNISM, 1991-92

JOURMAL OF COMMUNIST STUDIES, 8(3) (SEP 92), 140-144.

SPANISH COMMUNISM HAS BEEN TRYING TO ADAPT ITS FORMS TO

THE CHANGES THAT HAVE TAKEN PLACE WITHIN THE MACROCOSM OF

COMMUNISM IN THE WORLD. THERE HAVE BEEN IMPORTANT MUTATIONS AMONG THE POLITICAL FORCES OF SPANISH COMMUNISM OVER A VERY SHORT PERIOD OF TIME. THIS ARTICLE EXAMINES THE CHANGES WITHIN MODERATE COMMUNISM, CHANGES WITH RADICAL COMMUNISM,

AND NEW FORMS OF POLITICAL IDENTITY.

07775 ROCCA, J.

CORRUPIION AND ITS SHADOW: AN ANTHROPOLOGICAL VIEW OF CORRUPTION IN CHINA

CHINA QUARTERLY, (130) (JUN 92 ), 402-416.

THERE HAS BEEN LITTLE SYSTEMÁTIC RESEARCH ON CORRUPTION

IN CHINA. MOST ANALYSES ONLY REVIEW VARIOUS CASES OF

IN CHINA. MOST ANALYSES ONLY REVIEH VARIOUS CASES OF

CORRUPTION AND COMMENT ON THE RETROGRADE ASPECT OF THE
CHINESE STATE. WORK OF THIS NATURE TENDS TO BE TOO STATIC,

CHINESE STATE. WORK OF THIS NATURE TENDS TO BE TOO STATIC,

OF POLITICS, AND TOO SUPERFICIAL, CONCENTRATING ON ANECDOTAL

OF POLITICS, AND TOO SUPERFICIAL, CONCENTRATING ON ANECDOTAL

ASPECTS OF CORRUPTION. AS A RESULT, ONE COULD QUITE SIMPLY

WHICH WOULD BE BOTH RATIONAL AND EFFICIENT, ALTHOUGH WITHOUT WHICH WOULD BE BOTH RATIONAL AND EFFICIENT, ALTHOUGH WITHOUT EXPLAINING HOW THIS SHOULD COME ABOUT. IN THIS PAPER, THE AUTHOR REASSESSES THE CAUSES AND NATURE OF THE PHENOMENON CORRUPTION IN CHINA, IN LIGHT OF WORKS DEALING WITH THE
SHIFTING ROLE OF THE STATE IN SOCIETIES UNDERGOING CHANGE.

07776 ROCHA, R.D.

INFLATION AND STABILIZATION IN YUGOSLAVIA

CONTEMPORARY POLICY ISSUES, $X(4)$ (OCT 92), 21-38.

THE AUTHOR OUTLINES THE MAIN CAUSES OF' THE ACCELERATION

OF INFLATION IN YUGOSLAVIA DURING THE 1980'S AND DESCRIBES

YUGOSLAVIA'S LAST ATTEMPT AT STABILIZATION IN 1990. YUGOSLAV 
INFLATION SHARED COMMON ELEMENTS WITH INFLATION IN OTHER HIGHLY-INDEBTED COUNTRIES, DESPITE APPEARANCES TO THE CONTRARY. YUGOSLAVIA FAILED TO MAKE INTERNAL ADJUSTMENTS TO MATCH A LARGE TRANSFER TO RESOURCES ABROAD, RESULTING IN A LARGE INTERNAL REDISTRIBUTION TO REAL RESOURCES THROUGH INFLATION. BUT THESE INTERNAL CONDITIONS WERE NOT TRANSPARENT. INSTEAD OF AN OPEN FISCAL DEFICIT, COMPLEX INTERACTIONS TOOK PLACE AMONG ENTERPRISES, BANKS, AND THE CENTRAL BANK, INVOLVING THE CENTRAL BANK'S ABSORPTION AND SERVICING OF A LARGE STOCK OF FOREIGN EXCHANGE LIABILITIES. FAILURE TO CORRECT HIDDEN LOSSES IN THE ECONOMY WAS THE MAIM REASON THAT SERIOUS STABILIZATION ATTEMPTS FAILED OURING THE $1980^{\prime} S$. THE 1990 PROGRAM HAS THE FIRST TO RECOGNIZE THE EXISTENCE OF THOSE HIDOEN LOSSES AND THE NEED FOR A FISCAL CORRECTION.

07777 ROCHELEAU, B.

INFORMATION MANAGEMENT IN THE PUBLIC SECTOR: TAMING THE COMPUTER FOR PUBLIC MANAGERS

PUBLIC ADMINISTRATION REVIEW, 52(4) (JUL 92), 398-400

THE AUTHOR REVIEWS FOUR RECENTLY-PUBLISHED BOOKS ON THE

ROLE OF COMPUTERS IN THE PUBLIC SECTOR.

07778 ROCK, M.

PUBLIC SECTOR MARKETING AMD PRODUCTION ASSISTANCE TO SOUTH KOREA'S MANUFACTURING EXPORTERS: DID IT MAKE A DIFFERENCE? DEVELOPMENT POLICY REVIEH, 10(4) (DEC 92), 339-358.

TO CLARIFY THE IMPACT OF PUBLICLY PROVIOED SERVICES ON EXPORT PERFORMANCE, THIS ARTICLE OFFERS A DETAILED CASE STUDY OF SOUTH KOREA'S PUBLIC SECTOR EXPORT SERVICES PROGRAM DURING THE EARLY STAGES OF THE COUNTRY'S EXPORT EXPANSION. THE EARLY STAGE OF EXPORT EXPANSION IS FOCUSED ON, BECAUSE THE NEED FOR PRODUCTION AND MARKETING ASSISTANCE IS LIKELY TO BE GREATEST DURING THIS PERIDO. SOUTH KOREA WAS CHOSEN FOR STUDY BECAUSE ITS PUBLIC SECTOR EXPORT SERVICES ASSISTANCE HAS OFFERED IN TANDEM WITH A LUCRATIVE EXPORT INCENTIVE SYSTEM. THE ARTICLE EXAMINES THE GOVERNMENT'S PRODUCTION AND MARKETING ASSISTANCE HITH THE CONTEXT OF THE OVERALL EXPORT PROGRAM. IT PROVIDES EVIDENCE ON THE SOURCES OF EXPORT SERVICES USED BY KOREAN EXPORTERS OF MANUFACTURES. IT CONCLUDES BY DRAWING IMPLICATIONS FROM SOUTH KOREA'S EXPERIENCE OF PUBLIC SECTOR INTERVENTION FOR POSSIBLE WIDER APPLICATION.

07779 ROCKWELL, L.

SOME DOMESTIC LOWLIGHTS OF THE BUSH ADMINISTRATION

NATIONAL REVIEH, XLIV(23) (NOV 92), 38-39.

THIS ARTICLE DEMONSTRATES THAT IHE REPUDIATION OF

CONSERVATISH WAS THE ANIMATING PRINCIPLE OF THE PRESIDENT'S

DOMESTIC POLICY. IT STATES THAT WHENEYER A PRESSURE GROUP

RAISED ITS VOICE, LIBERTY AND PROPERTY RIGHTS WERE DEEMED

EXPENDABLE.

07780 RODAN, G.

SINGAPORE'S LEADERSHIP TRANSITION: EROSION OR REFINEMENT OF AUTHORITARTAM RULE?

BULLETIN OF CONCERNED ASIAN SCHOLARS, 24(1) (JAN 92), 3-18. THE NEW LEADERSHIP TRANSITION IN SINGAPORE HAS BEEN

COMPLETED UNDER ECONOMIC AND SOCIAL CONDITIONS THAT POSE NEH CHALLEGES TO THE PEOPLE'S ACTION PARTY'S (PAP) OBJECTIVE OF RETAINING ABSOLUTE POLITICAL SUPREMACY. THE PAP IS TRYING OUT A THO PRONG STRATEGY WHICH CONSISTS OF THE PARTY'S ENJOYING A SIGNIFICANT CAPACITY TO DEFINE THE LIMITS OF POLITICAL PARTICIPATION AND DISSENT, AND ALSO THE ABILITY TO ENFORCE THE CLOSURE OF GENUINE PLURALISM THROUGH A SERIES OF REPRESSIVE MEASURES. THE BULK OF THIS PAPER IS DEDICATED TO OUTLINING THIS TWO-PRONGED STRATEGY AS A WAY OF UNDERSTANDING THE SIGNIFICANCE OF THE LEADERSHIP TRANSITION FOR THE PROSPECTS OF POLITICAL LIBERALIZTION IN SINGAPORE.

07781 RODENBECK, $M$.

ARABS RESIGNED BUT ANGRY OVER LIBYA SANCTIONS

MIDOLE EAST INTERMATIOMAL (424) (MAY 92 ) 3

IN THE FORTNIGHT SINCE THE UNITED NATIONS IMPOSED SANCTIONS ON LIBYA, LITTLE HAS CHANGED TO RAISE EXPECTATIONS OF A PEACEABLE OUTCOME TO THE LOCKERBIE AFFAIR. FEW OBSERVERS SEE HOW THE MILD PUNISHMENT OF AN AIR AND ARMS EMBARGO CAN ALTER LIBYAN DECISIONMAKING, OR HOW IMPOSING MORE SEVERE PENALTIES CAN FAIL TO IGNITE THE VERY PAN-ARAB RAGE THAT SADOAM HUSSEIN ONLY HALF SUCCEEDED IN TAPPING AFTER HIS INVASION OF KUWAIT. IN LIBYA-AS AROUND THE ARAB WORLD--THE IMPOSITION OF SANCTIONS ON 15 APRIL HAS GREETED BY RESIGNATION AND ANGER. MANY ACCUSED THE HEST OF ONCE AGAIN ENGAGING IN A DOUBLE STANDARD. HOHEVER SOME LIBYANS SEEMED NOT DISPLEASED TO SEE THE QADHAFI RAGIME DISCOMFITED.

07782 RODENBECK, M.

CALM AND CONCILIATORY

MIDOLE EAST INTERNATIONAL, (397) (APR 91), 14-15.

IN A FEEBLE SHOH OF POST-WAR UNITY, REPRESENTATIVE FROM ALL 21 ARAB COUNTRIES GATHERED IN CAIRO FOR THE FIRST

REGULAR ARAB LEAGUE MEETING SINCE THE OUTBREAK OF THE GULF

CRISIS. DESPITE THE FACT THAT THE BRIEF SESSION ENDED WITH A

PREARRANGED MOTION TO ADJOURN UNTIL MAY AND WAS DELIBERATELY
STRIPPED OF DEBATE, THE FACT THAT IT WAS HELD AT ALL WAS CONSIDERED AN ACHIEVEMENT IN LIGHT OF THE INTENSE ANIMOSITIES GENERATED BY IRAQ'S INVASION OF KUWAIT.

07783 RODENBECK, $M$.

EGYPT AND LIBYA--DISMAYED BY THE WEST

MIDOLE EAST INTERNATIONAL, (421) (MAR 92), 7-8,

EGYPIIAN DIPLOMATS ARE GETTING USED TO DIFFICULT

SITUATIONS. TRYING TO RECONCILE STRONG TIES WITH THE WEST WITH SYMPATHY FOR ARAB REGIMES SEEN AS HOSTILE TO WESTERN INTERESTS CAN BE DEMORALIZING. YET ANOTHER UGLY ARAB-WESTERN CLASH-THE EFFORT TO STOP NORTH KOREA FROM SUPPLYING MISSILES TO SYRIA--ADDED TO THE CONFLICT OVER LIBYAN RESPONSIBILITY FOR THE LOCKERBIE AND UTA BOMBINGS, HAS FURTHER COMPLICATED EGYPT'S SELF-APPOINTED ROLE AS EXECUTOR OF THE VISION FOR REGIONAL HARMONY THAT WAS BRIEFLY SHARED AT THE END OF THE GULF WAR. ANY WESTERN ATTEMPT TO USE FORCE AGAINST LIBYA TO PUNISH IT FOR ITS ROLE IN THE TERRORIST ACTIVITES WOULD BE VERY DANGEROUS TO THE EGYPTIAN GOVERMMENT.

07784 RODENBECK, M.

EGYPT-ORACONIAN POWERS
MIDOLE EAST INTERNATIONAL, (430) (JUL 92), 11-12.

WORRIED BY AN UPSURGE IN VIOLENCE BY ISLAMIC MILITANTS, THE EGYPTIAN STATE HAS JUST ARMED ITSELF HITH NEW ANTITERRORISM LEGISLATION. THE CHANGES IN THE PENAL CODE ADO DRACONIAN POWERS TO AN ALREADY WIDE-RANGING ARSENAL OF REPRESSION AT A TIME WHEN HUMAN RIGHTS GROUPS HAVE EXPRESSED GROWING ALARM ABOUT ABUSES. THE IDEA OF INTRODUCING MORE PRECISE LEGISLATION DIRECTED AGAINST RELIGIOUS VIOLENCE HAD. WIDE INITIAL PUBLIC SUPPORT, BUT DEBATE IN THE 454-MEMBER ASSEMBLY REVEALED THAT EVEN MEMBERS OF THE RULING NATIONAL DEMOCRATIC PARTY HAD RESERVATIONS ABOUT THE LAWS. IT WAS WIDELY BELIEVED THAT THE NEW PROPOSALS WOULD REPLACE THE DECADE-OLD EMERGENCY LAWS, HHICH, AMONG OTHER THINGS, FORBID UNLICENSED PUBLIC GATHERINGS AND ALLOW FOR OETENTION WITHOUT TRIAL FOR UP TO 60 DAYS. INSTEAD, THE LAWS SUPPLEMENT A RANGE OF EXTRAORDINARY POWERS, INCLUDING THE EMERGENCY LAWS, THAT GIVE THE GOVERMMENT NEARLY UNLIMITED MEANS OF CONTROL. IN RECENT MONTHS HUMAN RIGHTS GROUPS HAVE REPORTED IN DETAIL ON HIDESPREAD USE OF TORTURE BY THE MINISTRY OF INTERIOR'S STATE INVESTIGATION BRANCH. THE NEH MEASURES ARE LIKELY TO OPEN EGYPT TO EVEN MORE SEVERE CRITICISM.

07785 RODENBECK, $M$.

EGYPT--THE STRUGGLE AGAINST POLITICAL ISLAM

MIDDLE EAST INTERNATIONAL, (428) (JUN 92), 5-6.

THE MURDER OF AN OUTSPOKEN SECULARIST AND A FLARE-UP OF KILIING IN THE HOT-BLOODED SOUTH HAVE RAISED FEARS THAT THE STRUGGLE BETWEEN POLITICAL ISLAM AND THE EGYPTIAN

ESTABLISHMENT HAS TAKEN ON A NEW, MORE DANGEROUS DIMENSION. THE DEVELOPMENTS HAVE HARDENED ATTITUDES ON BOTH SIDES, THE DEVELOPMENTS HAVE HARDENED ATTITUDES ON BOTH SIDES,
AUGURING A SUMMER OF CONFLICT AND RECRIMINATION. THE KILLING OF FARAG FOOA. 47 -YEAR OLD WRITER AND POLITICIAN WHOSE SATIRICAL JIBES AGAINST POLITICAL ISLAM HAVE LONG OUTRAGED ITS ADVOCATES, INSPIRED A FLOOD OF COMMENTARY THAT REVEALED JUST HOW POLARIZED THE EGYPTIAN POLITICAL SCENE HAS BECOME. FEW EGYPTIAN SECULARISTS AGREED WITH ALL OF FODA'S METHODS AND OPINIONS. HIS LOUD PRAISE FOR PEACE WITH ISRAEL AND ABRASIVE, UNSOPHISTICATED ATIACKS ON ISLAMIZATION WERE FELT BY MANY TO DAMAGE THEIR CAUSE. BUT HIS DEATH APPEARED TO HAYE SHOCKED MUCH OF EGYPT'S INTELLIGENTSIA INTO FEELING THAT THE ONLY SIDES TO BE TAKEN NOW ARE SECULAR VERSUS RELIGIOUS.

07786 RODENBECK, M.

PUSHING THE PEACE PROCESS

MIDOLE EAST INTERNATIONAL, (395) (MAR 91), 17.

BY ALL ACCOUNTS, THE PERSIAN GULF WAR WAS A GOOD WAR FOR EGYPT. EGYPTIAN FORCES FOUGHT WELL, LOSING ONLY NINE KILLED OUT OF 35,000 TRDOPS AT THE FRONT. EGYPT HAS WON RESPECT FROM EAST AND WEST AND SECURED A PIVOTAL POSITION IN REGIONAL DEALINGS. ITS ECONOMIC FUTURE IS BRIGHTER DUE TO DEBT FORGIVENESS OF THE U.S. AND OTHER MEMBERS OF THE COALITION AND TO GOVERMMENT REFORMS. HITH THIS NEW FOUND CONFIDENCE, EGYPT IS FORGING AHEAD ON A MIDEAST AGENDA BASED ON REGIONAL DISARMAMENT, A MORE INSTITUTIONALIZED TRANSFER OF OIL WEALTH TO POORER STATES AND OF MILITARY POWER TO WEAKER STATES, MUTUAL ARAB-ISRAELI RECOGNITION, AND GREATER ECONOMIC INTERDEPENDENCE.

07787 RODENBECK, M,

QADHAFI AND THE HEST: ARAB FEARS OF CONFRONTATION MIDDLE EAST INTERNATIONAL (422) (APR 92) 5-6.

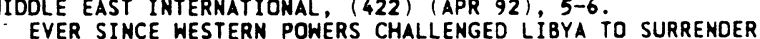
SUSPECTS IN THE LOCKERBIE AND NIGER AIRLINE ATRDCITIES EXPECTATIONS OF HOH THE AFFAIR WILL END HAVE OSCILATED FROM GLOOM TO HOPE AND BACK AGAIN. BUT DESPITE THE SEEMING POLARIZATION OF POSITIONS SINCE THE DISPUTE ERUPTED IN NOVEMBER 1991, BOTH SIDES HAVE LARGELY REFRAINED FROM PROVOCATION, AND BOTH HAVE TURNED TO INTERNATIONAL INSTITUTIONS TO BACK THEIR CLAIMS. SINCE LIBYA HAS NOT REJECTED THE IDEA OF A TRIAL, THE OISPUTE BOILS DOWN TO A SIMPLE CONFLICT OVER JURISDICTION. 
07788 RODENBECK, M.

QADHAFI SEEKS A LAST-MINUTE COMPROMISE

MIDDLE EAST INTERNAT IONAL, (423) (APR 92), 4-5

THE WEEK OF 10-17 APRIL, 1992, IS EXPECTED TO DETERMINE

IBYA'S FATE IM THE LOCKERBIE AFFIAR JUST 24 HOURS BEFORE

THE SANCTIONS IMPOSED BY THE UNITED NATIONS SECURITY COUNCIL AGAINST LIBYA ARE DUE TO COME INTO FORCE. THE HORLO COURT IS SCHEDULED TO RULE WHETHER LIBYA CAN LEGITIMATELY CONTINUE TO SCHEDULED TO RULE WHETHER LIBYA CAN LEGI OMATEL THE THO SUSPECTED AIRI NE BOMBERS FOR TRIAL IN THE UNITED STATES OR BUSPECTED AIRLINE BOMBERS FOR TRIAL IN THE UNITED STATES BRITAIN. AS THE 15 APRIL SANCT IONS DEADLINE APPROACHED, AN OFFER TO SEND THE TWO HANTED MEN TO MALTA, A NEUTRAL PARTY, WHICH WOULD HOLD THEM PENDING THE WORLD COURT' DECISION WAS SEEN AS TOO LITTLE TOO LATE. IN TRIPOLI DEMONSTRATORS ATTACKED DIPLOMATIC MISSIONS OF COUNTRIES THAT HAD VOTED FOR SANCTIONS. THE VENEZUELAN EMBASSY WAS HRECKED, AND RUSSIAN VEHICLES AND PROPERTY WERE STONED. LIBYA'S COLONEL QADHAFI SPOKE OF A "NEW GLOBAL CONFLICT BETHEEN CHRISTIANITY AND ISLAM" AND DEMANDED SUPPORT AGAINST THE "NEW CRUSADERS."

07789 RODENBECK, M.

RELIEF IN CAIRO

MIDDLE EAST INTERNATIONAL, (429) (JUL 92), 7

EGYPTIANS HEAVED A COLLECTIVE SIGH OF RELIEF AT THE OUTCOME OF ISRAEL'S NATIONAL ELECTIONS. IT WAS NOT SO MUCH AN UNRESERVED HELCOME FOR RABIN'S VICTORY AS THE FEELING OF WAKING FROM A NIGHTMARE. EGYPTIANS SEEM TO HAVE DISCOVERED THE TRUE DEPTH OF THEIR LOATHING FOR YITZHAK SHAMIR ONLY WITH HIS DEFEAT. EGYPT WILL BE PROBING A WARMING UP OF RELATIONS WITH ISRAEL THAT UNDER LIKUD HAD PRACTICALLY RELATIONS WITH ISRAEL THAT UNDER LIKUD HAD PRACTICALLY

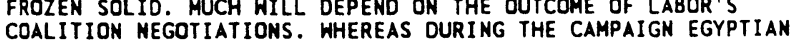
COALITION NEGOTIATIONS. WHEREAS DURING THE CAMPAIGN EGYPTIAN DIPLOMACY MAINTAINED A CAREFUL SILENCE SO AS TO NOT GIVE EXPANSIVE ON THE PROSPECTS FOR PEACE.

07790 RODENBECK, M.

SUDAN--ALL OUT FOR A MILITARY SITUATION

MIDDLE EAST INTERMATIOMAL (422) (APR 921, 13-14.

THE FIVE-PRONGED SPRING OFFENSIVE AGAINST SOUTHERN

REBELS BEING WAGED BY THE SUDANESE ARMY HAS EMERGED AS THE MOST SERIOUS ESCALATION OF THE SUDANESE CIVIL WAR SINCE THE SUDAN PEOPLE'S LIBERATION ARMY (SPLA) LAUNCHED ITS INSURGENCY NINE YEARS AGO. ACCURATE CASUALTY STATISTICS AND BATTLEFIELD INFORMATION ARE UNAVAILABLE, BUT BOTH SPLA AND GOVERMMENT SOURCES CONFIRM ARMY ADVANCES IN A CAMPAIGN THAT SEEMS TO AIM AT IMPOSING A MILITARY SOLUTION TO THE CONFLICT. SEVERAL FACTORS HAVE ENCOURAGED THE FUNDAMENTALIST GOVERMMENT OF GENERAL OMAR AL-BASHIR TO PUSH FOR VICTORY AT THIS STAGE. CHINESE AND IRANIAN ARMS HAVE STRENGTHENED THE ILL-EQUIPPED ARMY. THE 80,000-MAN FORCE HAS ALSO BEEN BEEFED UP WITH THE RECRUITMENT OF A SO-CALLED POPULAR DEFNSE ARMY MODELED ON IRAN'S REVOLUTIONARY GUARDS. AN ETHNIC AND FACTIONAL SPLIT HAS MEANWHILE HEAKENED THE SPLA. THE SUDANESE GOVERNMENT HAS ALSO LAUNCHED A POLITICAL OFFENSIVE AGAINST THE REBELS, SEEKING COOPERATION FROM NEIGHBORS IN ISOLATING THE SPI A AND SEEKING MORAL SUPPORT FROM ISLAMIC ALLIES IN THE BATTLE AGAINST THE "NAZARENES AND JEHS" IN SOUTHERN SUDAN.

07791 RODENBECK, M.

MIDDLE EAST INTERNATIONAL, (398) (APR 91), 17.
ENCIRCLED BY A ZONE OF WAR, HUNGER AND POL ITICAL TURMOIL, ENCIRCLED BY A ZONE OF WAR, HUNGER AND POL ITICAL TURY
EGYPTIANS SEEM TO HAVE LOST INTEREST IN THE REGION'S EGYPTIANS SEEM TO HAVE LOST INTEREST IN THE REGION'S
BOTTOMLESS STRUGGLES. WHILE REGIONAL EVENTS HAVE BEEN KIND BOTTOMLESS STRUGGLES. HHILE REGIONAL EVENTS HAVE BEEN KI TO EGYPT'S FORTUNES--THE DESTRUCTION OF ITS ONLY SERIOUS ARAB RIVAL, THE SLASHING OF ITS EXTERNAL DEBT, AND THE
OPENING UP' OF GULF STATE COFFERS TO EGYPT-MOST EGYPTIANS OPENIMG UP OF GULF STATE COFFERS TO EGYPT--MOST EGYPTIANS THESE IS THE IMF-SPONSORED REFORM AGREEMENTS WHICH SOME FEAR WILL RESUIT IN A BOUT OF HYPER-INFLATION.

07792 RODGERS, D.T.

REPUBLICAMISM: THE CAREER OF A CONCEPT

JOURNAL OF AMERICAN HISTORY, 79(1) (JUN 92 ), 11-38.
THE CONCEPT OF REPUBLICANISM GAINED NEW PROMINENCE IN THE 1980'S. AL THOUGH THE TERM "REPUBLICANISM" WAS NOT UNK SCORES OF OTHERS IN THE HISTORICAL VOCABULARY. FIRST GIVEN FORMAL ANALYTIC AND CONCEPTUAL IDENTITY IN A

HISTORIOGRAPHICAL ESSAY BY ROBERT SHALHOPE IN 1972, WITHIN A DECADE IT HAD VAULTED INTO THE EYE OF SCHOLARLY DEBATE OVER U.S. REVOLUTIONARY AND EARLY NATIONAL POLITICS--AND SOON THEREAFTER INTO 19TH-CENTURY HISTORIDGRAPHY AS WELL. BY 1985 IT HAD BECOME "THE MOST PROTEAN" CONCEPT IN ANTEBELLUM CULTURAL HISTORY. BY 1990, IT WAS EVERYWHERE AND ORGANIZING EVERYTHING, BUT PERCEPTIBLY THINNING OUT, LIKE A NOVA ENTERING ITS RED GIANT PHASE.
07793 RODGERS, J.R POVERTY AND CHOICE OF MARITAL STATUS: A SELF-SELECTION MODEL

POPULATION RESEARCH AND POLICY REVIEW, 10(1) (1991), 67-88.

OVER THE LAST FEW DECADES IN THE UNITED STATES, THE POVERTY RATE FOR FEMALE-HEADED FAMILIES HAS BEEN ABOUT FIVE TIMES THE POVERTY RATE FOR OTHER FAMILY TYPES. THIS PAPER ADDRESSES THE QUESTION OF WHY, IN GENERAL, FEMALE-HEADED FAMILIES ARE SO MUCH POORER THAN OTHER FAMILIES. RECOGNIZING THAT INDIVIDUALS CHOOSE THEIR OWN MARITAL STATUS, A SELFSELECTION MODEL IS USED TO IDENTIFY THE FACTORS WHICH SELECTION MODEL IS USED TO IDENTIFY THE FACTORS WHICH
DETERMINE THE POVERTY RATES FOR MARRIED-COUPLE FAMILIES, DETERMINE THE POVERTY RATES FOR MARRIED-COUPLE FAMILIES,
FAMILIES HEADED BY FEMALES WITH NO HUSBAND PRESENT, AND

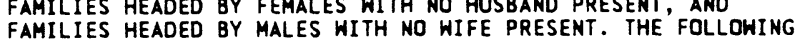
FAMILIES HEADED BY MALES WITH NO WIFE PRESENT. THE FOLLOWING CONTROL VARIABLES ARE FOUND TO BE IMPORTANT DETERMINANTS POVERTY FOR ALL THREE FAMILY TYPES: EDUCATION OF FAMILY FAMILY HEAD; GEOGRAPHICAL LOCATION, SIZE AND COMPOSITION OF FAMILY HEAD; GEOGRAPHICAL LOCATION, SIZE AND COMPOSITION FAMILIES ARE FOUND TO BE LESS POOR THAN FEMALE-HEADED FAMILIES MAINLY BECAUSE THE MARGINAL EFFECTS OF THE CONTROL VARIABLES, AND TO A LESSER EXTENT THE MEAN LEVELS OF THE CONTROL VARIABLES, FAVOR THE FORMER THO TYPES OF FAMILIES OVER FEMALE-HEADED FAMILIES.

07794 RODGERS, P.H.; MANRIQUE, C.

THE DILEMMA OF TEACHING POLITICAL SCIENCE RESEARCH METHODS HOW MUCH COMPUTERS? HOW MUCH STATISTICS? HOW MUCH METHODS? PS: POLITICAL SCIENCE AND POLITICS, XXV(2) (JUN 92), 234-236

THE EMERGENCE OF COMPUTERS AS A TEACHING AND LEARNING TOOL HAS RAISED QUESTIONS ABOUT THEIR USE IN POLITICAL SCIENCE COURSES. POLITICAL SCIENCE TEACHERS AND STUDENTS FACE A THREE-PRONGED PROBLEM: HOW TO BALANCE CONTENT, STATISTICS, AND COMPUTING TO CREATE THE BEST POSSIBLE LEARNING EXPERIENCE.

07795 RODGERS, R.; HUNTER, J.E. A FOUNDÁTION OF GOOD MANAGEMENT PRACTICE IN GOVERNMENT: MANAGEMENT BY OBJECTIVES

PUALIC ADMINISTRATION REVIEW, 52(1) (JAN 92), 27-39.

THE AUTHORS EXPLAIN THE RESULTS OF A META-ANALYSIS OF 70 STUOIES OF MANAGEMENT-BY-OBJECTIVES (MBO) ADOPTIONS IN THE PUBLIC AMD PRIVATE SECTORS. THEY FIND THAT MBO HAS HAD A POSITIVE IMPACT ON PRODUCTIVITY IN ALL THE PUBLIC SECTOR AGENCIES STUDIED. THE GREATEST GAINS WERE GENERATED IN AGENCIES STUDIED. THE GREATEST GAINS WERE GENERATED IN AGENCIES WHERE TOP MANAGEMENT WAS HI GHLY COMMITIED TO THE APPROACH. MBO HAS BEEN AS EFFECTIVE
IT HAS BEEN IN THE PRIVATE SECTOR.

07796 RDDMAN, $P$.

GRIMLINS IN CLINTONLAND

NATIONAL REVIEW, XLIV (25) (DEC 92), 16-17

MORE THAN MOST PRESIDENTS-ELECT, BILL CLINTON IS

DEFINING THE WHOLE DIRECTION OF HIS ADMINISTRATION BY HIS PERSONNEL SELECTIONS. EVERY PERSON CHOSEN DISAPPOINTS HALF A DOZEN OTHERS--PLUS THE CONSTITUENCIES THEY REPRESENT. THIS ARTICLE EXPLORES WHETHER CLINTON HILL BE A NEW AND DIFFERHET DEMOCRAT, CLEAVING TO THE CENTER, OR A TRADITIONAL LIBERAL, BEHOLDEN' TO THE PARTY'S IDEOLOGICAL CORE. IT PREDICTS WHICH MIND.

07797 RODMAN, $P$.

ISLAM AND DEMOCRACY

NATIONAL REVIEW, XLIV(9) (MAY 92), 28-29.

MORE THAN A DOZEN YEARS AFTER THE IRANIAN REVOLUTION, IT IS NOW CLEAR THAT ISLAMIC FUNDAMENTALISM IS RAPIDLY SPREADING. THIS ARTICLE STATES THE BUSH ADMINISTRATION'S POINT OF VIEH AS: WE SHOULD BE PREPARED TO HAVE WHATEVER POINT OF VIEH AS: WE SHOULD BE PREPARED T HATE WHATEVER
KIND OF RELATIONSHIP WITH ISLAMIC FORCES THAT THEY ARE
PREPARED TO HAVE WITH US. AND SECONDLY, WE CANNOT AVOID TAKING THEIR IDEOLOGY SERIOUSLY.

07798 RODMAN, $S$.

RIRST TEST FOR DEMOCRACY

NATIONAL REVIEW, III(2) (FEB 91), 24,26

FATHER JEAN-BERTRAND ARISTIDE, THE 37 -YEAR-OLD PRIEST WHO WON AN OVERHHELLING VICTORY IN THE FREE AND FAIR WHO WON AN OVERHHELMING VICTORY IN THE FREE AND FAIR
PRESIDENTIAL ELECTION OF DECEMBER 16, 1990 , WILL, AFTER ALL,
BE INAUGURATED ON FEBRUARY 71991 THANKS TO THE ARMY'S UE INAUGURATED ON FEBRUAR 7 1991 UNPRECEDENTED TURNING BACK OF GERARD LAFONTANT'S ATTEMPTED ABRAHAM, ARE PLAYING A ROLE UNIQUE IN HAITI'S VIOLENT HISTORY: DEFENDERS OF DEMOCRACY. ARISTIDE NOW HAS THE DIFFICULT TASI
AND POLITY.

07799 RODRICK, S

BUSHIES AND THE CLINTONITES: MUZZLED

NEH REPUBLIC, $207(20)$ (NOV 92), 14,16

THE AUTHOR COMPARES THE TACTICS USED BY BUSH AND CLINTON STAFFERS TO STIFLE DISSENSION AT RALLIES. SOME CITIZENS HAVE COMPLAINED THAT THE SECRET SERVICE DETAIL PROTECTING 
PRESIDENT BUSH HAS OVERSTEPPED ITS BOUNDS BY STIFLING POLITICAL PROTEST IN THE NAME OF SECURITY.

07800 RODRIGUEZ, J.

AFRO-CDLOMBIA DENIED

REPORT ON THE AMERICAS, 25(4) (FEB 92), 28-33.

COLOMBIA'S NEH CONSTITUTION GRANTS SPECIAL "ETHMIC RIGHTS" TO THE 2\% OF THE POPULATION THAT IS INDIAN, BUT DENIES THESE TO THE 10\% TO 30\% THAT IS BLACK--A SYMPTOM OF WIDESPREAD DENIAL OF THE NATION'S OIVERSITY. THIS STEMS FROM THE ENDURING LEGACY OF SOCIO-RACIAL CASTES PREDOMINANT IN THE SPANISH COLONIES. THE RACIAL NOMENCLATURE MAY HAYE DISAPPEARED, BUT THE DISCRIMIMATORY CONDUCT ASSOCIATED WITH IT HAS NOT. THE AUTHOR IS SADOENED THAT AN OPPORTUNITY HAS BEEN LOST TO BROADEN THE PARAMETERS OF THE INDIGENOUS MOVEMENT SO THAT IT COULD BENEFIT PEOPLES, WHO, FOLLOWING MHE INDIANS' EXAMPLE, TODAY STRUGGLE FOR THEIR OWN ETHNIC THE IND
RIGHTS.

07801 RODRIK, D.

CONCEPTUAL ISSUES IN THE DESIGN OF TRADE POLICY FOR INDUSTRIALIZATION

HORLD DEVELOPMENT, 20(3) (MAR 92), 309-320.

STARTING FROM FIRST PRINCIPLES, HHAT KIND OF A CASE CAN BE MADE FOR AN INDUSTRY-ORIENTED IRADE POLICY AND WHAT HOULD SUCH A POL ICY LOOK LIKE? THE ANSWER LIES IN AN EXPLICIT CONSIDERATION OF SPECIFIC MARKET FAILURES AND EXTERNALITIES THAT, IN THE ABSENCE OF CORRECTIVE POLICIES, MAY LEAVE INDUSTRY IN COMMAND OF A SOCIALLY-SUBOPTIMAL SHARE OF THE ECONOMY'S RESOURCES. THIS PAPER CONSIDERS SUCH MARKET FAILURES AND THE ROLE THAT TRADE POLICY CAN PLAY IN ADDRESSING THEM. SPECIAL ATTENTION IS PAID TO THE FOLLOWING: THE APPROPRIATE LEVEL OF PROTECTION; PRICE VERSUS NONPRICE MEASURES: THE ROLE OF TARGETING, SELECTIVITY, AND UNIFORMITY THE STABILITY OF INCENTIVES OVER TIME; AND THE QUALITATIVE ASPECTS OF TRADE REGIMES.

07802 ROEBROEK, J.

THE CONTRADICTORY ENTITY OF SOCIAL SOLIDARITY AND WELFARE STATE EVOLUTION

ACTA SOCIOLOGICA, 35(1) (1992), 63-70.

"THE POLITICS OF SOCIAL SOLIDARITY" BY PETER BALDWIN IS A NEXT STEP TOWARDS A MORE PRDFOUND UNDERSTANDING OF HESTERM WELFARE STATES, OF THEIR HISTORICAL EVOLUTION, THEIR PRESENT MANIFESTATION, AND THEIR FUTURE IMAGES. BALDWIN SUGGESTS MANIFESTATION, AND THEIR FUTURE IMAGES. BALDHIN SUGGES

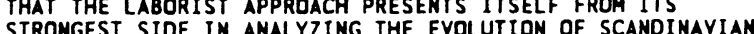
STRONGEST SIDE IN ANALYZING THE EVOLUTION OF SCANDINAVIAN
WELFARE STATES FROM THE 1930 S ONHARDS AND FOR BRITAIN DURING WELFARE STATES FROH THE $1930 S$ ONHARDS AND FOR BRITAIN DURIMG THE BEVERIDGE ERA, BUT REVEALS SHORTCOMINGS IN A CASE MORE DETAILED AND NUANCED ANALYSIS FOR MORE COMPLEX SOCIAL AND POL ITICAL SURROUNDING OF HELFARE STATE EVOLUTION. IT IS FROM THIS CRITIQUE ON WELFRARE STATE ANALYSES MORE IN GENERAL AND THE LABORIST APPROACH MORE SPECIFICALLY THAT BALDWIN SETS
OUT HIS OWN COURSE TOWARDS AN EXPLANATION OF WELFARE STATE OUT HIS OWN COURSE TOWARDS AN EXPLA
EVOLUTION IN WESTERN DEMOCRACIES.

07803 ROELOFS, H.

CITIZEN SCHOLARS, SCHOLARLY CITIZENS: A WORKING TRIBUTE TO CRHISTIAN BAY

NEW POLITICAL SCIENCE, 23 (FAL 92), 51-62.

THE POLES OF CHRISTIAN BAY'S THOUGHT WERE A CONCERN TO ILLUMINATE PHILOSOPHICALLY THE DEMOCRATIC IDEAL, AND ALSO, A MEED TO EXPOSE THE ILLUSIONS AND SHAMS OF THE SO-CALLED DEMOCRACY AMERICANS EXPERIENCE IN THEIR EVERYDAY LIVES. THIS ARTICLE FOCUSES ON ONE ASPECT OF THE GENERAL DEBATE ABOUT DEMOCRATIC IDEALS AND ASKS THE FOLLOWING QUESTIONS: IS IT POSSIBLE IN THE CONTEXT OF THEM TO BE A CITIZEN SCHOLAR? IS THERE A SPECIAL PLACE IN THE DEMOCRATIC VISION FOR THE INTENSELY COMMITTED SCHOLARLY CITIZEN? CHRISTIAN BAY AMSHERED THESE OUESTIONS IN THE AFFIRMATIVE AND THIS PAPER CONCURS WITH HIS ANSHERS, BUT ON ITS OWN TERMS AND HITH ITS OWN EMPHASES.

07804 ROELOFS, H.

THE PROPHETIC PRESIDENT: CHARISMA IN THE AMERICAN POLITICAL TRADITION

POLITY, 25(1) (FAL 92), 1-20.

PRESIDENTIAL LEADERSHIP IS COMMONLY ASSOCIATED WITH THE TERM "CHARISMA." THIS ARTICLE CLARIFIES THE CONCEPT OF CHARISMA BY DRAWING UPON A BIBLICAL PARADIGM OF LEADERSHIP IN WHICH AMERICAN POLITICAL CULTURE HAS BEEN STEEPED. IN WHICH AMERICAN POLITICAL CUL TURE HAS BEEN STEEPED,
PRESIDENTS, THE AUTHOR CONTENDS, ARE CALLED TO BE "CHARISMATIC HEROES" WHO BY THEIR "PROPHETIC" WORDS "CONGREGATE" THE PEOPLE AS A "COVENANTED" PRESENCE IN
"HISTORY." ALL OF THESE hORDS ARE TECHWICAL TERMS WITH "HISTORY." ALL OF THESE HORDS ARE TECHMICAL TERMS WITH STIPULATED MEANINGS, AND TOGETHER THEY MAKE EXPLICIT
THAT IS AT ONCE DISTINCTIVE AND CREATIVE OF NATIONAL SOLIDARITY, IDENTITY, AND LEGITIMACY. SO CONCEIVED, THE AUTHOR CONCLUDES, THE PRESIDENT'S ROLE AS "TRIBUNE OF THE PEOPLE" IS THE MOST IMPORTANT AND POWERFUL IN AMERICAN POLITICS BUT ALSO DANGEROUSLY AND INHERENTLY UNSTABLE.

07805 ROELOFS, J.

FOUNDATIONS AND POLITICAL SCIENCE
NEW POLITICAL SCIENCE, 23 (FAL 92), 3-28.

THE CAUCUS FOR NEW POLITICAL SCIENCE WAS FOUNDED IN 1967 TO OPPOSE CURRENT TRENDS IN POLITICAL SCIENCE, ESPECIALLY ITS LACK OF ATTENTION TO THE VIETHAM WAR AND MASS PROTEST
MOVEMENTS. A MAJOR ITEM ON THE ORGINAL AGENDA WAS FOUNDATION MOVEMENTS. A MAJOR ITEM ON THE ORGINAL AGENDA WAS FOUNDA INFLUENCE ON CHOICE OF RESEARCH TOPIC, AND FOUNDATION ARTICLE IS DIRECTLY A RESULT OF THE DISCUSSION HELD AT THE INITIAL MEETING. IT CONCLUDES THAT COLLECTIVE THINKING IS NEEDED ON WHAT RESEARCH IS NECESSARY TO PROMOTE DESIRED SOCIAL CHANGE, STARTING WITH THE UNFULFILLED LIBERAL GOALS, SUCH AS PEACEFUL RESOLUTION OF DISPUTES, ELIMINATION OF POVERTY, AND BASIC HUMAN RIGHTS.

07806 ROEMER, J.E.

CAN THERE BE SOCIALISM AFTER COMMUNISH?

POLITICS AND SOCIETY, 20(3) (SEP 92) 261-276.

THIS ARTICLE ARGUES THAT THE ECONOMIC FAILURES OF THE COMMUNIST MODEL CAN BE TRACED TO THE CONJUNCTON OF THREE OF ITS CHARACTERISTICS. PUBLIC OHNERSHIP OF FIRMS. THE

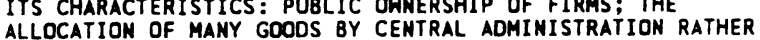
ALLOCATION OF MANY GOODS BY CENTRAL ADMINISTRATION RATHER
THAN BY MARKETS, AND POLITICAL DICTATORSHIP. THE ARTICLE THAN BY MARKETS, AND POLITICAL DICTATORSHIP. THE ARTICLE SEEKS TO REDEFINE SOCIALISM NOT AS A SYSTEM IN WHICH THERE
IS, SIMPLY, PUBLIC OWNERSHIP, BUT AS A SYSTEM IN WHICH THERE IS, SIMPLY, PUBLIC OHNERSHIP, BUT AS A SYSTEM IN WHICH ARE INSTITUT IONAL GUARANTEES THAT AGGREGATE PROFITS ARE
DISTRIBUTED MORE OR LESS EQUALLY IN THE POPULATION. SUCH A DISTRIBUTED MORE OR LESS EQUALLY IN THE POPULATION. SUCH A SYSTEM WOULD ALLOW FOR MARKET FORCES TO DEAL WITH PROBLEMS, OF INEFFICIENCY AND WITH "PRINCIPAL-AGENT" PROBLEMS-
THAT WERE FUNDAMENTAL IN THE FAILURE OF COMMUNISM.

07807 ROGERS, A.; WOOOWARD, J.A. ASSESSING STATE POPULATION PROJECTIONS HITH TRANSPARENT MULTIREGIONAL DEMOGRAPHIC MODELS POPULATION RESEARCH AND POLICY REVIEW, 10(1) (1991), 1-26. POPULATION PROJECTION MODELS THAT ARE CONCEPTUALLY SIMPLE ENOUGH TO BE CALLED TRANSPARENT MAY BE USED TO CHECK THE VALIDITY OF PROJECTIONS GENERATED BY "BLACK BOX" MODELS WHOSE BEHAVIOR MAY BE SOMEHATAT SHROUDED IN MYSTERY. THIS PAPER ADOPTS A MULTIREGIONAL DEMOGRAPHIC MOOEL TO ILLUSTRATE HOW SUCH A VALIDATION PROCEDURE MIGHT BE CARRIED OUT ON STATE POPULATION PROJECTIONS PRODUCED BY THE U.S. BUREAU OF THE CENSUS IN 1988.

07808 ROGERS, C. 8.

NEH MEMBER SOCIALIZATION IN THE HOUSE OF REPRESENTATIVES CONGRESS AND THE PRESIDENCY, 19(1) (SPR 92), 47-63.

CURRENT SOCIALIZATION OF' FRESHMEN MEMBERS OF THE HOUSE OF REPRESENTATIVES REFLECTS THE ENTREPRENEURIAL CULTURE OF THAT ORGANIZATION. THE ORIENTATION PROGRAMS CENTRAL TO SOCIALIZATION FACILITATE THE ENTREPRENEURIAL ENTERPRISE OF SOCIALIZATION FACILITATE THE ENTREPRENEURIAL ENTERPRISE OF
EXISTING MEMBERS AS MUCH AS THEY TEACH NEW MEMBERS "THE EXISTING MEMBERS AS MUCH AS THEY TEACH NEW MEMBERS "THE ROPES." THE MESSAGES COMMUNICATED TO NEW MEMBERS ENCOURAGE
INDIVIDUAL ENTERPRISE ON THEIR PART. LITTLE IS LEFT OF THE LEARN ABOUT THE WAYS OF THE INSTITUTION BEFORE STRIKING OUT LEARN ABOUT THE WAYS OF THE INSTITUTION BEFORE STRIKING OUT ON THEIR OWM. RATHER, NEW MEMBERS ARE ENCOURAGED TO ACTIVELY PURSUE THEIR OWN SELF-INTERESTS ANO TO BE AHARE OF TH IMPORTANCE TO SUCH AN EXTENT THAT IT DECREASES
EFFECTIVENESS OF THE HOUSE AS AN ORGANIZATION.

07809 ROGERS, L.; SHELBY, B.

THE ROYAL FAHILY REPAYS A DEBT

WORLD PRESS REVIEH, 39(12) (DEC 92), 21-22.

IN THIS INTERVIEW, A LEADING KUWAITI OPPOSITION JOURMALIST DISCUSSES THE POL ITICAL CHANGES THAT HAVE OCCURRED IN KUWAIT SINCE THE END OF THE GULF CRISIS AND THE RETURN OF THE ROYAL FAMILY.

07810 ROGERS, $R$.

THE FUTURE OF REFUGEE FLOWS AND POLICIES

INTERNATIONAL MIGRATION REVIEW, 26(4) (WIN 92 ), 1112-1143.

THE NUMBER OF FORCED MIGRANTS-RECOGNIZED REFUGEES,

PERSONS IN "REFUGEELIKE" SITUATIONS, AND INTERNALLY

DISPLACED-IS ESTIMATED TODAY TO EXCEED 40 MILLION. THE CHANGED INTERNATIONAL CLIMATE OF THE 1990S (A RENEWED EMPHASIS ON HUMAN RIGHTS; BROADER CONCEPTS OF NATIONAL SECURITY; AND THE PROFOUND POL ITICAL CHANGES IN EASTERN EUROPE ANO THE FORMER SOVIET UNION) HAS SHIFTED THE FOCUS OF ORIGIN. THERE IS TODAY A GREATER WILLINGNESS TO INTERVENE OF ORIGIN: THERE IS TODAY A GREATER WILLINGWESS TO INTERVENE IN OTHER COUNTRIES AFFAIRS EITHER TO AVERT INTERNALLY NEW FLOWS OF FOCUSED MIGRANTS OR TO ASSIST INTERNALLY
DISPLACED POPULATIONS, AND THERE IS THE EXPECTATION OF LARGEDISPLACED POPULATIONS, AND THERE IS THE EXPECTATION OF LARGESCALE VOLUNTARY RETURNS OF REFUGEES IN ASYLUM. THIS ARTICLE DISCUSSES THESE AND OTHER POLICY ISSUES CONCERNI
MIGRATION IN THIS MEH INTERNATIONAL ENVIRONMENT.

07811 ROGOV, S.

INTERMATIONAL SECURITY AND THE COLLAPSE OF THE SOVIET UNION HASHINGTON QUARTERLY, 15(2) (SPR 92), 15-32.

WITH THE PASSING OF THE COLD WAR, POL ICYMAKERS AND PUNDITS IN THE CAPITALS OF THE WEST HAVE BEGUN TO MAKE PLANS FOR A FUTURE IN WHICH THE LONG-STANDING DILEMAAS OF SECURITY HAVE BEEN SET TO REST. THIS ARTICLE STATES THAT THE 
INTERESTS OF THE UNITED STATES AND THE USSR'S SUCCESSORS DO NOT CLASH; IN FACT, THEY FACE MANY COMMON CHALLENGES IN THE NEW MULTIPOLAR WORLD. THIS IS BOUND TO CHANGE THEIR STRATEGIC INTERACTION. THIS ARTICLE CONCLUDES THAT THE WEST GENERALLY HAS FAILED TO APPRECIATE THE PRECARIOUS FUTURE OF THE ERSTWHILE UNION AND THE NUMBEROUS AND SEVERE IMPLICATIONS OF A OISINTEGRATION OF ALL ELEMENTS OF CENTRAL AUTHORITY.

07812 ROH, T.; BOWRING, P.; CLIFFORD, M.; SHIM, J.

PRESIDENT PINS HIS HOPES ON MOSCOW AND PEKING
(M-17

THIS ARTICLE CONTAINS EXCERPTS FROM AN INTERVIEH WITH

SOUTH KOREAN PRESIDENT ROH TAE WOO. TOPICS DISCUSSED INCLUDE:

ROH'S MEETING WITH MIKHAIL GORBACHEV; STOPPING THE THREAT

OF A NORTH KOREAN NUCLEAR CAPABILITY; SOUTH KOREA'S

APPLICATION FOR MEMBERSHIP TO THE UN AND THE POSSIBILITY OF

A CHINESE VETO; FUTURE RELATIONS WITH NORTH KOREA BOTH

BEFORE AND AFTER THE DEATH OF KIM IL SUNG; ROH'S SUCC
TO THE KDREAN PRESIDENCY; AND REFORM OF SOUTH KOREA'S

POLITICAL SYSTEM.

07813 ROHATYN, F.G.

THE NEED FOR A NEW DOMESTIC ORDER

JOURNAL OF STATE GOVERMMENT, 65(4) (FAL 92), 27-33.

HITH THE EMERGENCE OF A NEW WORLD ORDER, THE CHOICES

FACING PUBLIC POL ICY MAKERS HAVE CHANGED DRAMATICALLY. TO

DEAL HITH THE NATIONAL DEBT AND THE NATIONAL DEFICIT, NEW

PRIORITIES MUST BE ESTABLISHED--PRIORITIES THAT PROTECT THE

LONG-TERM VIABILITY OF THE UNITED STATES IN AN INCREASINGLY

COMPETITIVE GLOBAL ENVIRONMENT.

07814 ROHR, J.A.

FRENCH CONSTITUTIONALISM AND THE ADMINISTRATIVE STATE: A COMPARATIVE TEXTUAL STUDY

ADMINISTRATION AND SOCIETY, 24(2) (AUG 92), 224-258.

THE AUTHOR EXAMINES THE RELATIONSHIPS BETWEEN

CONSTITUTIONALISH AND PUBLIC ADMINISTRATION THROUGH A

COMPARATIVE TEXTUAL ANALYSIS OF THE CONSTITUTIONS OF THE

FIFTH FRENCH REPUBLIC AND THE UNITED STATES. PARTICULAR

EMPHASIS IS PLACED ON THE EXCEPTIONAL POWERS OF THE

PRESIDENTS OF THE TWO COUNTRIES, THE INFLUENCE OF THE

EXECUTIVE POWER ON THE RESPECTIVE LEGISLATIVE PROCESSES, AND

THE PRACTICAL SIGNIFICANCE OF THE DIVIDED EXECUTIVE POWER IN

THE PRACTICAL SIGNIFICANCE OF THE OIVIDED EXECUTIVE POWER IM
FRANCE COMPARED TO THE FORMALLY UNIFI IED AMERICAN EXECUTIVE.

FRANCE COMPARED TO THE FORMALLY UNIFIED AMERICAN EXECUTIVE.
THESE DIVERSE COMPARISONS ARE UNIFIED BY THE THEME OF HOH

THESE DIVERSE COMPARISONS ARE UNIFIED BY THE THEME OF HOH
THE CONSTITUTIONAL TRADITIONS IN THE THO COUNTRIES BOTH

THE CONSTITUTIONAL TRADITIONS IN THE THO COUNTRIES
PROMOTE AND INHIBIT THE CAPACITY FOR ACTION OF THE

PROMOTE AND INHIBIT THE

07815 ROLLE, D.

A QUESTION OF SECURITY: SMALL STATES SEEK TO REDUCE THEIR VULNERABILITY

PARLIAMENTARIAN, LXXIII(3) (JUL 92), 181-184.

RECENT TRENDS IN INTERNATIONAL AFFAIRS HAVE LED TO

QUESTIONS ABOUT THE VIABILITY OF SMALL STATES AND THEIR

VULNERABILITY TO INVASIONS. IN THE BAHAMAS, LEADERSHIP

MAINTAINS A STRONG COMMITMENT TO CARIBBEAN REGIONALISM AND

LOOKS TO THE BRITISH COMMONWEALTH TO HELP SECURE GLOBAL

RESPECT FOR THE INTERESTS OF SMALL STATES.

07816 ROLLINS, E.

ADVICE FOR MR. BUSH

NATIONAL REVIEW, XLIV(7) (APR 92), 38-41.

IN ADORESSING THE 1992 PRESIDENTIAL CAMPAIGN, SHOULD THE

CAMPAIGN THEME BE SADDAM HUSSEIN, THE HOUSE BANK, OR

GENNIFER FLOWERS? IN THIS ARTICLE, EDWARD J. ROLLINS,

MANAGER OF THE 1984 REAGAN LANDSLIDE, TELLS PRESIDENT BUSH

HOW TO WIN NOT JUST THE ELECTION, BUT THE ELECTORATE.

ROLLINS STATES THAT THE ELECTION WILL BELONG TO THE

POLITICAL PARTY THAT DOES THE BETTER JOB OF APPEALING TO

RESTLESS VOTERS WHO HAVE BEEN TRANSMITTING UNRELENTING

SIGNALS THAT THEIR ALLEGIANCE IS UP FOR GRABS IN 1992.

07817 ROLLO, J.M.C.

REFORM OF THE CAP: THE BEGINNING OF THE END OR THE END OF THE BEGINMING?

WORLD TODAY, 48 (1) ( JAN 92), 4-7.

THE AUTHOR BRIEFLY EXPLAINS THE PURPOSE, METHODS, AMD EFFECTS OF THE COMMON AGRICULTURAL POLICY (CAP) BEFORE DISCUSSING THE NEED FOR REFORM, THE LATEST PACKAGE OF REFORM DISCUSSING THE NEED FOR REFORM, THE LATEST PACKAGE OF
PROPOSALS, AND THE POTENTIAL IMPACT OF REFORM. HE ALSO PROPOSALS, AND THE POTENTIAL IMPACT OF REFORM. HE ALSO
CONSIDERS THE IMPLICATIONS OF THE CAP FOR THE REST OF THE CONSIDERS THE IMPLICATIONS OF THE CAP FOR THE REST
HORLD, FOCUSING ON EASTERN EUROPE AND GATT MEMBERS.

07818 ROMANO, $R$.

A GUIDE TO TAKEOVERS: THEORY, EVIDENCE, AND REGULATION YALE JOURNAL ON REGULATION, 9 (i) (WIN 92), 119-180.

THE 1980'S HITNESSED AN EXPLOSION OF ACTIVITY IN THE FIELD OF CORPORATE TAKEOVERS, WHICH EVENTUALLY PRODUCED INCREASED REGULATION OF THESE TRANSACTIONS. THESE EVENTS PROMPTED EXTENSIVE STUDY INTO THE CAUSES FOR TAKEOVERS AND THE EFFECTS OF REGULATION. THIS PAPER SURVEYS AND ANALYZ
REGULATORY REGIMES MAKE THE MOST SENSE IN LIGHT OF THE EMPIRICAL EVIDENCE. ALTHOUGH NO SINGLE THEORY CAN EXPLAIN ALL TAKEOVERS, THE EVIDENCE IS MOST CONSISTENT WITH EXPLANATIONS OF TAKEOVERS AS EVENTS THAT MAXIMIZE VALUES FOR TARGET-FIRM SHAREHOLDERS AND ENHANCE SOCIAL EFFICIENCY. HOWEVER, ECONOMIC LEARNING AND PUBLIC POLICY HAVE NOT ADEQUATELY REFLECTED THIS. INFLUENCED BY UNSUBSTANTIATED FEARS AND SPECULATION ABOUT THE IMPACT OF TAKEOVERS ON THIRD PARTIES, REGULATION IN THE UNITED STATES HAS TENDED TO THWART AND BURDEN TAKEOVERS AS IF THEY WERE NON-VALUEMAXIMIZING WEALTH TRANSFERS. AN INFORMED READING OF THE LITERATURE SUGGESTS THAT MUCH OF THE EXISTING REGULATORY APPARATUS IS UNWARRANTED.

07819 ROMBERG, A.; BOUTON, M.

THE U.S. AND ASIA IN 1991

ASIAN SURVEY XXXII (1) (JAN 92), $1-10$.

THE UNITED STATES BEGAN THE YEAR 1991 WITH ITS ASIAN

POLICY IN A STATE SOMEWHERE BETHEEN DISREPAIR AND NEGLECT.

YET IT HAD STRONG INTERESTS IN THE REGION. ALTHOUGH THE GULF WAR VICTORY AND COLLAPSE OF THE PRINCIPAL SETTER OF THE INTERNATIONAL POLITICAL AGENDA, THE U.S. MADE IT CLEAR IT WAS NOT ONLY WILLING TO SHARE RESPONSIBILITIES, IT INSISTED ON DOING

07820 ROMM, J.

LAID WASTE BY WEAPONS LUST

BULLETIN OF THE ATOMIC SCIENTISTS, 48(8) (OCT 92), 14-23.

IN THE 1980S, THE PENTAGON STARTED DEVELOPING A NEW GENERATION OF WEAPONS--WITH A TRILLION DOLLAR PRICE TAG. THIS ARTICLE SUGGESTS THAT AS BUDGETS DECLINE, THE PENTAGON MUST FACE FACTS; GLITZY NEW WEAPONS WILL MEAN FEWER TROOPS, FEWER SPARE PARTS, AND INADEQUATE MAINTENANCE. IT ALSO SUGGESTS THAT THERE WILL BE NO PEACE DIVIDEND ANO THAT THE UNITED STATES SEEMS POISED TO RETURN TO HOLLOW FORCES--SHORTCHANGING READINESS AND SUSTAINABILITY.

07821 ROMMETVEDT, $\mathrm{H}$.

THE NORHEGIAN STORTING: THE CENTRAL ASSEMBLY OF THE PERIPHERY

SCANDINAVIAN POLITICAL STUDIES, 15(2) (JUN 92), 79-97. DESPITE THE GENERAL VIEN THAT STATE-BUILDING IN WESTERN EUROPE IS CHARACTERIZED BY THE DOMINATION OF A STRONG CENTER OVER WEAK PERIPHERIES, THE INFLUENCE OF THE NORWEGIAN OVER WEAK PERIPHERIES, THE INFLUENCE OF THE NORWEGIAN
PERIPHERY IS OUITE SUBSTANTIAL. THE AIM OF THIS PAPER IS TO PERIPHERY IS QUITE SUBSTANTIAL. THE AIM OF THIS PAPER IS TO
PRESENT A NUANCED PICTURED OF CENTRE-PERIPHERY RELATIONS IN PRESENT A NUANCED PICTURED OF CENTRE-PERIPHERY RE NORHEGIAN POLITICS. IT TAKES A CLOSER LOOK AT THE
REPRESENTATION OF THE PERIPHERY IN THE NORHEGIAN PARLIAMENT REPRESENTATION OF THE PERIPHERY IN THE NORHEGIAN PARLIAMENT ACTIVITIES OF THE MP'S.

07822 ROMNEY, P.

THE NATURE AND SCOPE OF PROVINCIAL AUTONOMY: OLIVER MOWAT, THE OUEBEC RESOLUTIONS AND THE CONSTRUCTION OF THE "BRITISH NORTH AMERICA ACT"

CANADIAN JOURNAL OF POLITICAL SCIENCE, 35(1) (MAR 92), 3-28.

IN THE 1930S, THE JUDICIAL COMMITTEE OF THE PRIVY COUNCIL WAS CRITICIZED FOR ALLEGEDLY PERVERTING THE MEANING OF THE BRITISH NORTH AMERICA ACT (BNA) AND THE INTENTIONS OF ITS FRAMERS. WHILE THE CLAIMS RESTED ON A LEGALLY HETERODOX CONCEPTION OF COLONIAL CONSTITUTIONAL STATUS, THE BNA ACT GAVE LEGAL EFFECT TO THAT CONCEPTION AS APPLIED TO FEDERALPROVINCIAL RELATIONS. THIS ALLOWED OLIVER MOWAT TO DO WHAT EARLIER REFORM LEADERS COULD NOT HAVE DONE: ENFORCE THE LOCAL CLAIMS IN COURT.

07823 RONCEK, D.W.

LEARNIMG MORE FROM TOBIT COEFFICIENTS: EXTENDING A COMPARATIVE ANALYSIS OF POLITICAL PROTEST

AMERICAN SOCIOLOGICAL REVIEW, 57(4) (AUG 92), 503-507. USING WALTON AND RAGIN'S TOBIT ANALYSIS OF AUSTERITY PROTESTS IN DEBTOR NATIONS, THE AUTHOR SHOWS THAT TOBIT COEFFICIENTS CAN BE DECOMPOSED INTO TWO EFFECTS: (1) AN EFFECT REPRESENTING AN INCREASE IN THE SEVERITY OF PROTESTS IN CDUNTRIES THAT HAVE EXPERIENCED PROTESTS AND (2) AN EFFECT REPRESENT ING A CHANGE IN THE PROBABILITY OF EXPERIENCING AN AUSTERITY PROTEST IN COUNTRIES THAT RECORDED NO PREVIOUS PROTESTS.

07824 ROMGGUANG, S.

CHINA HILL CONTINUE ITS ROLE, VETERAM DIPLOMAT SAYS

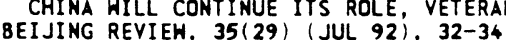

IING REVIEN, $35(29)$ (JUL 92 ), 32-34.
SINCE THE DISINTEGRATION OF THE SOVIET BLOC, SOME PEOPLE SINCE THE DISINTEGRATION OF THE SOVIET BLOC, SOME PEOPLE
THINK COMMUNIST CHINA HAS BECOME AN IRRELEVANT FACTOR IN INTERNATIONAL AFFAIRS, BUT THIS IS NOT TRUE. CHINA'S FUNDAMENTAL STRENGTHS, IN SCIENCE ECONOMIC POLICY, AND SOCIAL DEVELOPMENT WILL ENABLE IT TO CONTINUE PLAYING A ROLE AND TO BE INCREASINGLY POWERFUL IN WORLD AFFAIRS.

07825 RONGXIA, L.

ECONOMIC RECTIFICATION MEETS ITS GOALS

BEIJING REVIEN, 35(1) (JAN 92), 16-19, 21-22. 
OVER THE LAST THREE YEARS, CHINA'S ECONOMIC

RECTIFICATION POLICY HAS SUCCESSFULLY CONTROLLED INFLATION AND ELIMINATED THE ADVERSE EFFECTS OF AN OVERHEATED ECONOMY. IT HAS ALSO STABILIZED THE MARKET AND STIMULATED INITIAL CHANGES IN CHINA'S INDUSTRIAL STRUCTURE, PROVIDING FAVORABLE CONDITIONS FOR RAPID REFORM IN THE NEAR FUTURE.

07826 RONNAS, $P$.

ROMANIA: AILING STATE FIRMS MAY CREATE A ROADBLOCX RFE/RL RESEARCH REPORT, 1(17) (APR 92), 85-90.

THUS FAR, THE PROGRESS OF PRIVATIZATION IN ROMANIA HAS BEEN MIXED. THE SALE OF STATE ENTERPRISE ASSETS HAS RECENTLY BEGUN, AND THE FIRST PILOT SALES OF ENTIRE ENTERPRISES ARE EXPECTED SOON. HOWEVER, THE INEFFICIENCY AND POOR PROSPECTS OF MANY STATE FIRMS AND THE FAILURE TO MAKE ENTERPRISES GENUINELY AUTONOMOUS AND ACCOUNTABLE FOR THEIR PERFORMANCE HAVE PUT THE IMPLEMENTATION OF THE AMBITIOUS PRIVATIZATION PROGRAM IN DOUBT. ALTHOUGH PRIVATE ENTREPRENEURSHIP HAS DEVELOPED RAPIDLY SINCE MID-1991, MOST NEW VENTURES ARE SMALL AND CONCENTRATED IN THE SERVICE SECTOR. OFFICIAL ATTITUDES TOHARD THIS SECTOR SEEM TO HAVE BECOME MORE SUPPORTIVE LATELY.

07827 ROOD, S.

NON-GOVERMMENT ORGANIZATIONS AND THE 1992 PHILIPPINE ELECTIONS; ASSOCIATION FOR ASIAN STUDIES 1992 ANMUAL ELECTIONS:

MEETING
ASSOCIATION FOR ASIAN STUDIES, 1992, 149-150.

PHILIPPINE POLITICAL BEHAVIOR, ESPECIALLY DURING ELECTIONS, HAS BEEN VIEWED WITHIN A PATRON-CLIENT NETWORK. HOWEVER, THIS FOCUS ON ELECTORAL ACTIVITY BETHEEN POLITICIAN AND VOTER TENDS TO EXCLUDE OTHER FORMS OF POLITCIAL PARTICIPATION. THERE ARE OTHER USES OF "DEMOCRATIC SPACE" IN THE COURSE OF EVERYDAY POLITICS. FURTHERMORE, MODERNIZATION ATTENUATES PATRON-CLIENT TIES, RAISING THE QUESTION OF WHAT BASIC CITIZENS USE FOR ELECTORAL CHOICE. NON-GOVERMMENT ORGANIZATIONS (NGOS) CAN BE CENTRAL TO ADDRESSING SUCH TOPICS IN TWO WAYS. SOME CONTEMPORARY NGOS WHICH FOCUS ON PEOPLE EMPOWERMENT HAVE INTERPRETED THEIR MANDATE AS EXTENDING BEYOND COMMUNITY AFFAIRS TO ELECTORAL PARTICIPATION, AND HORK TO DO BOTH RESEARCH AND EDUCATION TOWARDS "GENERATING AN ELECTORAL BLOCK THAT CAM SIGNIFICANTLY INFLUENCE THE ELECTIONS FOR NATIONAL POSITIONS AND IN CERTAIN SPECIFIC LOCALITIES." A LARGER CLASS OF NGOS DISDAIN SUCH DIRECT INVOLVEMENT IN A PROCESS WHICH THEY FEEL SYSTEMATICALLY DISENFRANCHISES GRASS ROOTS ORGANIZATIONS. YET EVEN THEY OPERATE IN A CONTEXT WHICH THEIR CLIENTELE YET EVEN THEY OPERATE IN A CONTEXT WHICH THEIR CLIENTE
TAKES SERIOUSLY. THUS, THEY ARE NOT FREE TO ISOLATE TAKES SERIOUSLY. THUS, THEY ARE NOT FREE TO ISOLATE
THEMSELVES TOTALLY FROM ELECTIONS, BUT MUST DECIDE ON HOW TO THEMSELVES TOTALLY FROM ELECTIONS, BUT MUST DECIDE ON
RELATE TO THE ELECTORAL ARENA. THIS PAPER REPORTS ON RELATE TO THE ELECTORAL ARENA. THIS PAPER REPORTS ON RESEARCH INTO THE INTERACTION BETHEEN NGOS AND ELECTIONS,
USING DATA REGARDING BOTH VARIETIES OF NGO TO DOCUMENT THESE USING DATA REGARDING BOTH VARIETIES OF NGO TO DOCUMENT
ASSERTIONS. IMPLICATIONS FOR THE FUTURE OF PHILIPPINE POLITICS ARE THEN DRAWH.

07828 ROOD, $S$.

PERSPECTIVES ON THE ELECTORAL BEHAVIOR OF BAGUIO CITY (PHILIPPINES) VOTERS IN A TRANSITION ERA

JOURNAL OF SOUTHEAST ASIAN STUOIES, 22(1) (MAR 91), 86-108.

USING SURVEY EVIDENCE, THE AUTHOR ANALYZES THE ELECTORAL BEHAVIOR OF BAGUIO CITY VOTERS DURING TWO YEARS BEGINNING WITH THE 1986 PRESIDENTIAL ELECTION CONTEST BETWEEN FERDIMAND MARCOS AND CORAZON AOUINO. HE EMPHASIZES THE IMPORTANCE OF POLITICAL VARIABLES, AS OPPOSED TO SOCIOECONOMIC ONES, IN UNDERSTANDING THE ELECTORATE. HE EXPLORES THE EFFECTS OF TWO TYPES OF ISSUES, CHARACTER AND POLICY AND DISCUSSES TWO FACTORS, ETHNICITY AND PATRON-CLIENTELISM, THAT ARE ESPECIALLY IMPORTANT BECAUSE THEY INVOL VE POSSIBLE LINKS BETWEEN THE SOCIO-ECONOMIC AND POLITICAL SPHERES.

07829 ROOS, J.; SCHEMMER, B.

CONGRESS WANTS COMPREHENSIVE REPORTS ON GULF WAR ARMED FORCES JOURNAL INTERMATIOMAL (MAY 91), 30

LITTLE NOTICED IN ITS SUPPLEMENTAL BUDGET AUTHORIZATION AND PERSONNEL BENEFITS ACT FOR THE PERSIAN GULF CONFLICT, SIGNED INTO LAW ON APRIL SIXTH, CONGRESS HAS ASKED THE PENTAGON FOR ONE OF THE MOST COMPREHENSIVE AFTER-ACTION REPORTS EVER TO BECOME PUBLIC. THE "LESSONS LEARNED" REPORT WILL ADDRESS A THOUSAND-HORD LIST OF 45 ISSUES, INCLUDING BOTH "ACCOMPLISHMENTS AND SHORTCOMINGS" ON TOPICS RANGING FROM "THE MILITARY STRATEGY OF THE MULTINATIONAL COALITION" TO THE "EFFECTIVENESS OF THE RESERVE COMPONENTS" AND THE DEPLOYMENT, AS WELL AS THEIR POST-ACTIVATION TRAINING.

07830 ROOS, J.; SCHEMMER, B.

DESERT STORM BARES" "ROUNDOUT FLAW" BUT VALIDATES ARMY MODERNIZATION GOALS

ARMED FORCES JOURNAL INTERNATIONAL, (APR 91), 14,35.

WHILE THE NUMBER ONE LESSON LEARNED FROM OPERATIOI DESERT STORM WAS THAT "THE DOCTRINE OF OVERHHELMING FORCE" WORKED, OTHER LESSONS--SOME POSITIVE, SOME NEGATIVE--WERE ALSO LEARNED. A KEY FLAW IN THE U.S. OPERATIONS WAS THE LACK OF READINESS ON THE PART OF NATIONAL GUARD "ROUNDOUT"
BRIGADES, HHICH ARE DESIGNED TO AUGMENT THO ACTIVE BRIGADES IN ARMY COMBAT DIVISIONS. ALTHOUGH THREE ROUNDOUT BRIGADES WERE ACTIVATED, NONE WERE CONSIDERED READY FOR COMBAT, EVEN
AFTER INTENSIVE PREDEPLOYMENT TRAINING. ON THE POSITIVE SIDE, AFTER INTENSIVE PREDEPLOYMENT TRAINING. ON THE POSITI
MANY OF THE ARMED FORCES HIGH TECH WEAPONS PERFORMED MANY OF THE ARMED FORCES HIGH TECH WEAPONS PERFORMED
SUPERBLY. THESE INCLUDE THE JOINT SURVEILLANCE AND TARGET ATTACK RADAR SYSTEM. THE APACHE HELICOPTER AND THE M-1 TANK.

07831 ROOS, J.

DOO REVERSES EXHIBITIONS POLICY: "GEE-WHIZ" LINEUP hEADS FOR PARIS SHOW

ARMED FORCES JOURMAL INTERMATIONAL, (MAY 91), 12.

THE JUNE PARIS AIR SHOW WILL SHOWCASE THE MOST

IMPRESSIVE LINEUP OF U.S. AEROSPACE TECHNOLOGIES EVER

DISPLAYED IN PUBLIC--THANKS, IN PART, TO A REVERSAL OF THE PENTAGON'S HANDS OFF POLICY REGARDING DEFENSE EXHIBITIONS. PENTAGON SUPPORT FOR THE PARIS GATHERIMG MEANS THE U.S. SERVICES WILL ALLOW AIRCRAFT AND OTHER SYSTEMS FROM THEIR INVENTORIES TO PARTICIPATE IN THE EVENT. WHILE THIS IS ESSENTIALLY WHAT IS DONE BY MOST OTHER NATIONS AT

ESSENTIALLY WHAT IS DONE BY MOST OTHER NATIONS AT
INTERNATIONAL EXHIBITIONS, IT IS A SIGNIFICANT REVERSAL OF $U$. INTERNATIONAL EXHIBITIONS, IT IS A SIGNIFICANT REVERSAL
S. POLICY ESTABLISHED DURING THE CARTER ADMINISTRATION. S. POLICY ESTABLISHED DURING THE CARTER ADMINISTRATION.
EXPECTED TO BE DISPLAYED AT THE SHOH ARE THE FIITA (STEALTH EXPECTED TO BE DISPLAYED AT THE SHOH ARE THE F117A (STEALTH
FIGHTER). THE PATRIOT MISSILE LAUNCHER, AND OTHER TOP U.S. FIGHTER ), THE PATRIOT
WEAPONS AND SYSTEMS.

07832 ROOS, J.

NATO SHIFTS TOHARD CRISIS MANAGEMENT; EUROPEANS CONSIDER REGIONAL ALLIANCE

ARMED FORCES JOURNAL INTERNATIONAL, (APR 91), 34

NATO LEADERS ARE GINGERLY CRAFTING A NEW FRAMEWORK FOR THE WEST'S FOREMOST MILITARY ALLIANCE--A FUTURE COALITION BALANCED AGAINST THE REALITIES OF A DIMINISHED SOVIET THREAT IN CENTRAL EUROPE, YET SENSITIVE TO THE POLITICAL EXPECTATIONS OF EUROPEAN MEMBER NATIONS. CLEARLY, HOWEVER, NATO HAS REACHED A CRITICAL JUNCTURE. JUST AS ALL NATO HATIONS WITH FORCES NOW STATIONED IN GERMANY ARE FINE-TUNING PLANS TO EITHER GREATLY REDUCE, OR ELIMINATE, THOSE CONTINGENTS, A GROWING CHORUS AMONG EUROPEAN ALLIANCE MEMBERS IS SUGGESTING IT IS TIME FOR A STRICTLY EUROPEAN SECURITY COUNTERPART TO NATO.

07833 ROOS, J. CONFLICT

ARMED FORCES JOURNAL INTERMATIONAL, (APR 91), 32 ONE OF THE GULF WAR'S FIRST "CASUALTIES"--AT LEAST FROM THE COMMERCIAL PERSPECTIVE--WAS SPOT'S "OPEN SKIES, OPEN ACCESS" POLICY. THE POLICY OF THE FRENCH JOINT COMMERCIALACCESS POL ICY. THE POLICY OF THE FRENCH JOINT COMMERCIAL-
GOVERNMENT VENTURE WAS THAT IMAGERY OF ANY NATION WOULD BE GOVERNMENT VENTURE WAS THAT IMAGERY OF ANY NATION WOULD BE COLLECTED WITHOUT PERMISSION, AND MADE AVAILABLE TO ANYONE DE, SPOT IMAGE SUSPENDED ANY DELIVERY OF DATA OR IMAGES TO ON, SPOT IMAGE SUSPENDED ANY DELIVERY OF DATA OR IMAGES TO IRAQ OR ANY OTHER COUNTY FRANCE SUSPECTED MIGHT TRANSFER THE PHOTOS TO IRAQ. SOME ANALYSTS SUSPECT THAT THE SOVIET UNION
SHOWED SOME SATELLITE IMAGES TO IRAQ, PROBABLY WITH THE

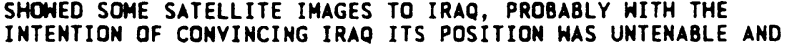
INTENTION OF CONVINCINC
SHOULD BE ABANDONED.

07834 ROOTES, C.A.

THE NEW POLITICS AND THE NEW SOCIAL MOVEMENTS

EUROPEAN JOURNAL OF POLITICAL RESEARCH, $22(2$ ) (AUG 92 ),

171-191.

CENTRAL TO WESTERN EUROPE'S "NEW POLITICS" IS THE INCREASED SALIENCE OF NONHATERIAL ISSUES AND A HEIGHTENED CONCERN HITH PARTICIPATION. "NEW SOCIAL MOVEMENTS" AND "NEW POLITICS" PARTIES ARE CONTINGENT MANIFESTATIONS OF THE NEH POLITICS, WHICH IS ALSO REVEALED IN CHANGED ORIENTATIONS TOWARD ESTABLISHED POLITICAL PARTIES. IN MOST RESPECTS, THE BRITISH APPEAR NO LESS WELL-DISPOSED TOWARD THE NEW POLITICS THAN THEIR EUROPEAN NEIGHBORS. YET BRITAIN IS DISTINGUISHED BY THE ABSENCE OF EITHER A RADICAL ECOLOGICAL MOVEMENT OR A SUCCESSFUL NEH POLITICS PARTY. BRITISH EXCEPTIONALISM IS EXPLAINED BY INSTITUTIONAL ARRANGEMENTS THAT PUSH THE ENVIRONMENTAL MOVEMENT TOWARD INTEGRATION RATHER THAN OPPOSITION ANO AN ELECTORAL SYSTEM THAT POLARIZES POLITICAL COMPETITION AND INHIBITS THE DEVELOPMENT OF NEW PARTIES. ONE CONSEQUENCE IS THE PRESERVATION OF THE LABOR PARTY AS A BENEFICIARY OF, AND VEHICLE FOR, THE EXPRESSION OF MUCH POLITICAL DISSENT. AS A RESULT, IN BRITAIN THE NEH POLITIC
IS COMBINED WITH THE OLD POLITICS TO AN UNUSUAL DEGRE.

07835 ROPER, J.H.

MARK MORGAN AND LAUREL HILL: PERSONAL CAPITALISM

MARK MORGAN AND LAUREL HILL: PERSONAL CAPITALISM
INTERNATIONAL SOCIAL SCIENCE REVIEN, 67(2) (SPR 92), 62-75. THERE HAS BEEN MUCH DEBATE AMONG SCHOLARS ABOUT THE NATURE OF INDUSTRIAL DEVELOPMENT IN THE SOUTHERN UNITED STATES IN THE ERA BETWEEN THE CIVIL WAR AND WORLD WAR I. SOME INSIST THAT THE CIVIL WAR CREATED A SECOND AMERICAN REVOLUTION THAT BROUGHT NEW PEOPLE TO ECONOMIC POWER IN THE THE POSTBELLUM INDUSTRIAL DEVELOPMENT WAS PRESIDED OVER BY THE SAME KIND OF AGRARIAN LEADERS WHO DOMINATED THE REGION BEFORE 1865. A CASE STUDY OF ONE INDUSTRIAL LEADER IN NORTH 
CAROLINA SUGGESTS THAT THE BEST MODEL TO EXPLAIN SUCH PATTERNS OF DEVELOPMENT IS ALEKSANDR GERSCHENKRON'S DEPICTION OF A "BACKWARD" LAND RESPONDING TO CHALLENGES FROM "FORWARD-LOOKING" TRADING PARTNERS.

07836 ROPP, S.C.

EXPLAINING THE LONG-TERM MAINTENANCE OF A MILITARY REGIME: PANAMA BEFORE THE U.S. INYASION

WORLD POLITICS, 44(2) (JAN 92), 210-234.

BEFORE THE U.S. INVASION OF 1989 , PANAMA EXPERIENCED ONE OF THE LONGEST PERIODS OF MILITARY RULE IN THE MODERN HISTORY OF LATIN AMERICA. WHILE NUMEROUS AUTHORITARIAN MILITARY REGIMES EMERGED IN THE REGION DURING THE 1960'S AND ESTABLISHED A RELATIVELY HIGH DEGREE OF AUTONOMY FROM BOTH DOMESTIC AND INTERNATIONAL ACTORS, ONLY THOSE IN PANAMA, PARAGUAY, AND CHILE SURVIVED UNTIL THE LATE 1980'S. OF THESE PARAGUAY, AND CHILE SURVIVED UNTIL THE LATE 1980'S. OF THREE, ONLY PANAMA'S ENDED THROUGH THE APPLICATION OF
EXTERNAL MILITARY FORCE. THE LONG-TERM MAINTENANCE OF EXTERNAL MILITARY FORCE. THE LONG-TERM MAINTENANCE OF
PANAMA'S MILITARY AUTHORITARIAN REGIME WAS DUE IN LARGE PART PANAMA'S MILITARY AUTHORITARIAN REGIME WAS DUE IN LARGE PART TO ITS ABILITY TO ACQUIRE SUBSTANTIAL AMOUNTS OF FOREIGN CAPITAL. DURING THE 1970'S, SUCH CAPITAL WAS PREFERENTIALLY OBTAINED FRDM THE INTERNATIONAL BANKING COMMUNITY. DURING THE 1980 'S, IT WAS OBTAINED THROUGH ILLICIT ACTIVITIES
VARIOUS KINDS, INCLUDING PARTICIPATION IN THE GROWING VARIOUS KINDS, INCLUDING
INTERNATIONAL DRUG TRADE.

07837 ROS, J.

FREE TRADE OR COMMON CAPITAL MARKET? NOTES ON MEXICO-US ECONOMIC INTEGRATION AND CURRENT NAFTA NEGOTIATIONS JOURNAL OF INTERAMERICAN STUDIES AND WORLD AFFAIRS, 34(2) (SUM 92), 53-92.

THE KEY ISSUES INVOLVED IN UNDERSTANDING CURRENT TRADE NEGOT IATIONS BETWEEN MEXICD AND THE UNITED STATES ARE ADDRESSED. THIS ARTICLE EXAMINES MEXICO'S REFORM OF ITS EXTERNAL SECTOR SINCE THE MID-1980S, ITS INITIAL EFFORTS, AND THE DYNAMICS OF THE REFORM PROCESS WHICH WERE TO LEAD TO THE FREE TRADE AGREEMENT INITIATIVE. IT THEN FOCUSES ON THE LIKELY ECONOMIC EFFECTS OF NAFTA AND REVIEHS THE BODY OR RECENT RESEARCH ON THE SUJECT. THE FINDINGS OF THIS RESEARCH FORM THE BASIS FOR A CRITIQUE WHICH IS OFFERED.

07838 ROSARIO, L.

WOMEN IN A DOUBLE BIND

FAR EASTERN ECONOMIC REVIEW, 155(38) (SEP 92), 40-41. WHILE IT IS TRUE THAT JAPANESE WOMEN HAVE COME A LONG WAY IN THE PAST DECADE THEY ARE STILL AT A DISTINCT DISADVANTAGE IN THE WORKPLACE. SOME OF THE PROBLEMS OF WORKING WOMEN IN JAPAN ARE TO BE FOUND IN OTHER CONSERVATIVE, MALE-ORIENTED SOCIETIES. OTHERS, HOWEVER, ARE A RESULT OF JAPAN S PECULIAR CORPORATE CULTURE, WHICH REQUIRES EMPLOYEES TO BE TOTALLY COMMITTED TO THEIR WORK, EVEN AT THE EXPENSE OF THEIR PRIVATE LIVES. ANOTHER MAJOR OBSTACLE IS THE WEAK INFRASTRCUTURE SUPPORT FOR WORKING WOMEN SUCH AS CHILD CARE, IN A RICH NATION WELL KNOWN FOR ITS POVERTY IN SOCIAL STOCX THE DILEMMA FACED BY JAPANESE WOMEN IS ALSO A FUNCTION OF
THE RIGID STRUCTURE OF JAPANESE SOCIETY, WHERE ROLES ARE SHARPLY DEFINED FOR MEN AS WELL AS WOMEN. THE TRADITIONAL DIVISION OF LABOR HAS NOT BEEN MODIFIED TO REFLECT SUCH MODERN CONCEPTS AS EQUALITY OF THE SEXES. FEH JAPANESE MEN ARE READY TO HELP OUT AT THE HOME OR IN CARING FOR THEIR CHILDREN. WORKING WOMEN THEREFORE END UP WITH TWO JOBS, ONE IN THE WORKPLACE AND ANOTHER AT HOME. PROVISIONS FOR MATERNAL AND CHILD-CARE LEAVE AND OTHER WELFARE THAT WILL

HELP WOMEN TO KEEP THEIR JOBS AS WELL AS THEIR FAMILIES ARE
STILL A RARITY. CHILD-CARE CENTERS ARE GROSSLY INSUFFICIENT.

07839 ROSDIL, D.

THE CONTEXT OF RADICAL POPULISM IN U.S. CITIES: A COMPARATIVE ANALYSIS

JOURNAL OF URBAN AFFAIRS, 13/1) (1991) 77-96.

DURING THE 1980S, URBAN SCHOLARS DETECTED A TENDENCY IN CERTAIN U.S. CITIES, CALLED PROGRESSIVE, TO MAKE INVESTMENT IN HOUSING AND OFFICE SPACE SOCIALLY ACCOUNTABLE. THIS PAPER COMPARES FIVE PROGRESSIVE CITIES TO THREE BOOSTER CITIES WHICH CONTINUE TO PROMOTE UMIMITED GROHTH. IT EMPLOYS CULTURAL ANALYSIS TO INTERPRET THESE EXCEPTIONS TO THE LOGIC OF GROWTH POLITICS. IT ARGUES THAT THE DIFFUSION OF HIGHER EDUCATION, CHANGING GENDER ROLES, THE REPLACEMENT OF EDUCATION, CHANGING GENDER ROLES, THE REPLACEMENT OF
TRADITIONAL RELIGIOUS FAITH WITH SECULAR OR NON-WESTERN BELIEFS, THE GROWTH OF NON-TRADITIONAL HOUSEHOLD

ARRANGEMENTS, AND THE RISING IMPORTANCE OF HUMAN SERVICE ARRANGEMENTS, AND THE RISING IMPORTANCE OF HUMAN SERVICE
EMPLOYMENT COMBINE TO GENERATE COUNTERCUL TURAL ENCLAVES IN EMPLOYMENT COMBINE TO GENERATE COUNTERCULTURAL ENCLAVES
URBAN AREAS. THESE ADVERSARIAL SUBCULTURES REJECT THE URBAN AREAS. THESE ADVERSARI AL SUBCUL TURES REJECT THE
DOMINANT CULITURE'S EMPHASIS ON GROWTH PROMOTION IN FAVOR OF MORE SOCIALLY RESPONSIBLE POLICY OUTCOMES.

07840 ROSE, GARY

CONMECTICUT POLITICS AT THE CROSSROADS

UNIVERSITY PRESS OF AMERICA, 1991 122 .

THE DECLINE OF POLITICAL PARTIES IN THE STATE OF CONNECTICUT IS DOCUMENTED. THE AUTHOR PRESENTS EXTENSIVE DESCRIPTIONS OF STATEHIDE POLITICAL TRENDS, TAPS THE PERCEPTIONS OF STATE LAWMAKERS REGARDING THE CURRENT CONDITION AND INFLUENCE OF PARTY ORGANIZATION, AND PROVIDES
THE RESULT OF DETAILED INTERVIEWS WITH SEASONED POLITICIANS TO DEMONSTRATE THAT POLITICAL PARTIES IN CONHECTICUT HAVE DECLINED IN THEIR CAPACITY TO STRUCTURE THE COURSE OF STATE POLITICS. THE TEXT SERVES AS A SHORT SUPPLEMENTAL WORK FOR INTRODUCTORY COURSES ON AMERICAN POLITICS, POLITICAL PARTIES, AND STATE AND LOCAL GOVERNMENT.

07841 ROSE, J.A.E.

GOOD-BYE TO SHORTSIGHTEDNESS

JOURNAL OF STATE GOVERNMENT, 65(2) (APR 92), 47-49. KENTUCKY RECENTLY ADOPTED A NEW PROGRAM THAT WILL PREDICT THE LONG-RANGE CONSEQUENCES OF STATE ACTION, MAKING IT ONE OF THE FEW STATES TO INCORPORATE FORESIGHT INTO GOVERNMENT POLICY-MAKING. USING ENVIRONMENTAL SCANNING TECHNIQUES TO ASSESS CHANGE, PLANNERS HOPE TO PAINT A TECHNIQUES TO ASSESS CHANGE, PLANNERS HOPE TO PAINT BROADER PICTURE OF WHERE THE STATE IS HEADED AND TC
ANTICIPATE PROBLEMS BEFORE THEY BECOME CRITICAL.

07842 ROSE, P.

WHAT FUTURE FOR THE LABOUR PARTY?

CONTEMPORARY REVIEH, 261(1521) (OCT 92), 179-184.

THE TRANSFORMATION OF LABOUR FROM THE PARTY OF THE PRODUCER TO THE PARTY OF THE CONSUMER AT A TIME WHEN NUMBERS EMPLOYED IN PRODUCTION ARE DECREASING STEADILY IS NOT ONLY A MORAL BUT A PRACTICAL CHOICE IF LABOUR IS TO SURVIVE IN THE NEXT CENTURY. THIS ARTICLE ANALYZES THE FUTURE OF THE PARTY AND IS PESSIMISTIC ABOUT THE POSSIBILITY OF A VICTORIOUS PARTY OF THE CENTRE-LEFT IN BRITAIN BEFORE THE TURN OF THE CENTURY. IT SUGGESTS THAT RATHER THAN LABOUR'S MARCHING FORWARD WHILE LOOKING TO ITS RELATIVELY RECENT PAST, IT BROADER COALITION IN ORDER TO UNDERSTAND THE FUTURE.

07843 ROSE, R.

ESCAPING FROM ABSOLUTE DISSATISFACTION: A TRIAL-AND-ERROR MODEL OF CHANGE IN EASTERN EUROPE

JOURNAL OF THEORETICAL POLITICS, 4(4) (OCT 92), 371-393. THE AUTHOR OUTLINES ALTERNATIVE SCENARIOS FOR THE FUTURE OF EASTERN EUROPE. THE LESS PROBABLE SCENARIOS ARE AN UNINTERRUPTED TRANSITION TO A MARKET DEMOCRACY OR THE RETURN OF AN AUTHORITARIAN NON-MARKET SYSTEM. THE MORE LIKELY SCENARIOS ARE PROGRESS BY TRIAL AND ERROR (MISINTERPRETED BY MANY WESTERNERS AS EVIDENCE OF INSTABILITY BUT IN ACTUALITY MOVING TOWARD MARKET DEMOCRACY), AN AUTHORITARIAN TAKEOVER, MOR A SEQUENCE IN WHICH DEMOCRATIC FAILINGS MAY LEAD TO OR A SEQUENCE IN WHICH DEMOCRATIC FAILINGS MAY LEAD TO A
TEMPORARY LAPSE INTO AUTHORITARIANISM, FOLLOWED BY A RETURN TEMPORARY LAPSE
TO DEMOCRACY.

07844 ROSE, R.; FALCONER, P.

INDIVIDUAL TASTE OR COLLECTIVE DECISION? PUBLIC POLICY ON SCHOOL MEALS

JOURNAL OF SOCIAL POLICY, 21(3) (JUL 92), 349-371.

IN GREAT BRITAIN, SOME PUPILS ARE CHARGED FOR SCHOOL MEALS WHILE OTHERS ARE NOT. THIS SITUATION REJECTS TWO TYPES OF UNIVERSALISTIC PRINCIPLES: ALLOCATING PRIVATE BENEFITS BY THE MARKET AND PROVIDING MERIT GOODS COLLECTIVELY FREE OF CHARGE. IN THIS PAPER, THE AUTHORS EXAMINE, EMPIRICALLY AND CONCEPTUALLY, THE CHANGING MEANING OF SCHOOL MEALS; THE DEMAND AND SUPPLY OF SCHOOL MEALS AND THE ALLOCATION OF PUBLIC SUBSIDIES TO NON-NEEDY CHILDREN; AND THE CONFLICTING GOALS OF NUTRITIONISTS, EGALITARIANS, REDISTRIBUTIONISTS, MANAGERS, PARENTS, AND CHILDREN. THEY ALSO CONSIDER POLITICAL CONSTRAINTS ON RATIONALIZING THE PROGRAM IN THE NAME OF UNIVERSALISTIC PRINCIPLES. THESE CONSTRAINTS INCLUDE THE INHER I TANCE OF COMMITMENTS FROM PREVIOUS GOVERNMENTS, COLLECTIVE RESPONSIBILITY OF SPENDING AND TREASURY MINISTERS INTRA-PARTY DIVISIONS BETWEEN FRONTBENCH AND BACKBENCH MP'S ; AND LOH POLITICAL SALIENCE OF CHARGING AS AN ISSUE.

07845 ROSE, R.

LONG-TERM STRUCTURAL CHANGE OR CYCLICAL 1992 ELECTION IN DYNAMIC PERSPECTIVE

PARLIAMENTARY AFFAIRS, 45(4) (OCT 92), 451-465.

VIEWED FROM CLOSE UP, THE CONSERVATIVE VICTORY IN THE 1992 ELECTION WAS A SURPRISE. HOWEVER FROM A LOMG-TERM PERSPECTIVE THERE IS NOTHING SURPRISING IN THE CONSERVATIVES WINNING AGAIN, FOR THE STRUCTURAL TRENDS IN BRITISH SOCIETY HAVE BEEN ERODING THE LABOUR VOTE WHILE LABOUR WAS WINNING ELECTIONS. THIS ARTICLE EXPLORES WHAT A NORMAL VOTE IS FOR A PARTY AND OFFERS A PERSPECTIVE FOR THE 1992 ELECTION. IT ADDRESSES THE IMPLICATIONS OF A FRACTIONATED PARTY SYSTEM AND OFFERS A REVIEH OF SPECULATION REGARDING IT.

07846 ROSE, R.; THOMPSON, R.

THE PRESIDENT IN A CHANGING INTERNATIONAL SYSTEM PRESIDENTIAL STUDIES QUARTERLY, XXI (4) (FAL 91), 751-770. THIS ARTICLE EXAMINES THE CHANGES IN THE INTERNATIONAL SYSTEM THAT AFFECT THE IMPERATIVES OF THE PRESIDENCY TODAY. IT PRESENTS THE CONVENTIONAL VIEN OF THE PRESIDENCY: A PRESIDENT HAS A BETTER CHANCE OF INFLUENCING EVENTS ABROAD THAN AT HOME. IT THEN SHOWS HOW THIS ASSUMPTION, APPROPRIATE TO AN ERA OF AMERICAN HEGEMONY, IS NO LONGER VALID IN AN ERA OF GLOBAL INTERDEPENDENCE IN SECURITY AND ECONOMIC AFFAIRS, IN WHICH OTHER NATIONS HAVE THE CAPACITY TO EXCHANGE 
INFLUENCE WITH THE WHITE HOUSE. SINCE THIS INCREASES THE SUBSTANTIAL PROBLEMS THAT THE PRESIDENT HAS IN JUGGLING CONCERNS WITH CONGRESS AND PUBLIC OPINION, THE ARTICLE ALSO CONSIDERS ALTERNATIVE RESPONSES: COMPARTMENTALIZATION, TAKING CHARGE THROUGH POSITIVE INTEGRATION AND/OR BEING CAUGHT IN THE MIDOLE THROUGH NEGATIVE INTEGRATION. THE CONCLUSION ASSESSES HOW AMERICA'S GROWING INTERDEPENDENCE MEANS THAT A PRESIDENT DOES NOT HAVE TO BE A WORLD LEADER;
INSTEAD, HE MAY BE VULNERABLE, ISOLATED OR A GLOBAL FAILURE.

07847 ROSE, S.; BROUWER, S.

THE EXPORT OF FUNDAMENTALIST AMERICANS, : U.S. EVANGELICAL EDUCATION IN GUATEMALA

LATIN AMERICAN PERSPECTIVES, 17(4) (FAL 90), 42-56.

THIS ARTICLE EXAMINES THE DRAMATIC INCREASE IN THE

SPREAD OF U.S. EVANGELICAL EDUCATION IN GUATEMALA. IT AMALYZES THE GROWTH OF U.S. -SPONSORED EDUCATIONAL MATERIALS AND PRACTICES WHICH AMOUNT TO THE "INCREASING CULTURAL EXPRESSION OF U.S. IMPERIALIST VALUES." ONE REASONS FOR SUCH DRAMATIC GROWTH IS THAT THE RULING CLASSES OF GUATEMALA HAVE EITHER HELCOMED OR TOLERATED RELIGIOUS PRACTICES WHICH

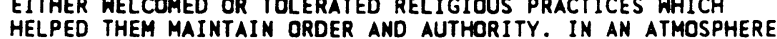
HELPED THEM MAINTAIN ORDER AND AUTHORI TY. IN AN ATMOSPHERE
OF POPULAR UNREST AND ECONOMIC CHAOS, WHEN CERTAIN TRENDS OF POPULAR UNREST AND ECONOMIC CHAOS, WHEN CERTAIN TRENDS
WITHIN CATHOL ICISM ARE PROMOTING THE THEOLOGY OF LIBERATION, WITHIN CATHOL ICISM ARE PROMOTING THE THEOLOGY OF LIBERATION,
BOTH CAPITALIST AMD MILITARY OBJECTIVES ARE FURTHERED BY A BOTH CAPITALIST AMD MILITARY OBJECTIVES ARE FURTHERED BY A
CONSERYATIVE PROTESTAMT IDEDLOGY WHICH STRESSES INDIVIDUAL CONSERVATIVE PROTESTANT IDEDLOGY WHICH STRESSES INDIVIDUAL
SALVATION RATHER THAN GROUP SOLIDARITY AND OISCIPLINED WORK SALVATION RATHER THAN GROUP
UNDER SANCTIONED AUTHORITY.

07848 ROSECRANCE, $R$.

A NEW CONCERT OF POWERS

FOREIGN AFFAIRS, 71(2) (SPR 92), 64-82.

THE BREAKUP OF THE SOVIET UMION, THE LIBERATION OF EASTERN EURDPE, THE GULF WAR, AND THE RAPPROCHEMENT BETHEEN THE USA AND RUSSIA HAVE GIVEN THE HORLD A NEH CONCERT OF POWERS. FIVE GREAT POHER BASES NOW CONTROL THE ORGANIZATION OF THE WORLD ORDER: THE UNITED STATES, RUSSIA, THE EUROPEAH COMMUNITY, JAPAN, AND CHINA. THE PRESENT SITUATION IS BOTH URGENT AND PRECARIOUS. MHILE PAST CONCERTS LINGERED ON FOR SOME YEARS, THEY FAILED TO CONTROL EVENTS AFTER ABOUT A DECADE. IF THE NEH POST-COLD WAR SYSTEM BEGAN IN 1989, THE WORLD HAS ABOUT SEVEN TO TEN YEARS TO MAKE IT WORKABLE AND LASTING. IF THIS NEW SYSTEM IS NOT FIRMLY ESTABLISHED WITHIN THAT PERIOD. THE HORLD ORDER MAY AGAIN LAPSE INTO A BALANCE OF POWER OR AN UNHORKABLE MULTIPOLAR DETERRENCE BY THE YEAR 2000.

07849 ROSEFIELDE, S.

GORBACHEV'S TRANSITION PLAN: STRATEGY FOR DISASTER

GLOBAL AFFAIRS, $6(2)$ (SPR 91), 1-21.

THIS PAPER EXAMINES THE PROSPECTS FOR SUCCESSFUL ECONOMIC AND POLITICAL TRANSITION ACCORDING TO THE "CONSENSUS" PLAN CHOSEN BY GORBACHEY AND APPROVED BY THE SUPREME SOVIET IN OCTOBER 1990. IT DEMONSTRATES THAT GORBACHEV'S STRATEGY, WICH IS ESSENTIALLY A LENGTHENED VERSION OF THE PROGRAM DEVISED IN AUGUST 1990 BY HIS FORMER PRESIDENTI IAL ADVISOR, WILL FAIL BECAUSE SHOCK THERAPY CANNOT REVIVE A MARKET THAT DOES NOT EXIST, AND WILL ONLY SERVE TO UNDERMINE GORBACHEV'S LEGITIMACY BY FURTHER DESTABILIZING AN ECONOMY ALREADY IN A STATE OF CRISIS.

07850 ROSEN, J.

CAMPAIGN ISSUES: DISCOURSE

COLUMBIA JOURNALISM REVIEW, 31(4) (NOV 92), 34-35

THE AUTHOR EXAMINES THE ROLE OF THE MEDIA IN POLITICAL CAMPAIGNS AND LOOKS AT SOME INCIDENTS IN THE $1992 \mathrm{U} . \mathrm{S}$ PRESIDENTIAL ELECTION CAMPAIGN.

07851 ROSEN, J.

COURT' TEST

NEH REPUBLIC, 207(14) (SEP 92), 15-16, 18.

IF BILL CLINTON IS ELECTED PRESIDENT, HE HILL BE THE FIRST DEMOCRAT IN 25 YEARS TO APPOINT A JUSTICE TO THE SUPREME COURT. WITH 2-4 SEATS AT HIS DISPOSAL, CLINTON COULD TRANSFORM THE COURT. INSTEAD OF COUNTERING THE CONSERVATIVE ACTIVISM OF THE REPUBLICAN JUSTICES BY RESURRECTING THE LIBERAL ACTIVISM OF THE WARREN ERA, CLINTON COULD RETURN A MORE INSPIRING VISION: A LIBERAL COMMITMENT TO JUOICIAL RESTRAINT. HE COULD BREAK THE INTELLECTUAL GRIDLOCK OF THE PAST QUARTER-CENTURY, IN WHICH REPUBLICANS HAVE BETRAYED THEIR STRICT CONSTRUCTIONIST PRINCIPLES AND DEMOCRATS HAVE FOUGHT TO PRESERVE ACTIVIST PRECEDENTS. BUT THERE ARE FOUGHT TO PRESERVE ACTIVIST PRECEDENTS. BUT THERE ARE SEVERAL REASONS TO FEAR THAT CLINTON HAS NOT YET MADE A MIGHT BE NO LESS POLITICAL THAN GEORGE BUSH'S.

07852 ROSEN, J.

NEVER MIND

NEW REPUBLIC, 207(13) (SEP 92), 18, 20-22.

THE AUTHOR ASSESSES ASSOCIATE JUSTICE CLARENCE THOMAS FIRST YEAR OF SERVICE ON THE U.S. SUPREME COURT.

07853 ROSEN, J.

NO CONTENT; THE PRESS, POLITICS, ANO PUBLIC PHILOSOPHY
TIKKUN, 7(3) (MAY 92), 11-14; 77-80.

SOME OF THE MATION'S BIGGEST MEHS ORGANIZATIONS.

CONYINCED THAT SOMETHING WAS WRONG WITH POLITICS AND STIRRED BY THE SENSE THAT THEY BEAR PART OF THE BLAME, VOWED TO CHANGE THE WAY THEY COVERED THE 1992 PRESIDENTIIAL CAMPAIGN. HAD THEY SUCCEEDED, IT COULD HAVE PUT THE PRESS ON A COLLISION COURSE WITH THE CANDIDATES AMD MARKED THE FIRST MAJOR CHANGE IN POL ITICAL JOURNALISM IN DECADES. THIS ARTICLE EXPLORES WHY AFTER MAKING THIS COMMITTMENT THE PRESS COULDN'T KEEPS ITS PROMISE TO PULL ITSELF OUT OF THE TABLOID MUCK OF SO-CALLED CHARACTER ISSUES. AFTER INVESTIGATING THE ISSUES, THIS ARTICLE ASKS: IF A FREE PRESS CAN FIND NO VIRTUE IN PROMOTING A POLITICS WITH MEANING, THEN WHAT IS THE MEANING OF PROMOTING THE VIRTUE OF A FREE PRESS?

07854 ROSEN, J.

IV AS ALIBI: A RESPONSE TO MICHAEL SCHUDSON

TIKKUN, 6(1) (MAR 91), 52-54,87.

THIS ARTICLE RESPONOS TO THE CLAIMS OF MICHAEL SCHUDSON

THAT THE POHER OF TELEVISION TO INFLUENCE POLITICS IS

SOMENHAT OVERRATED. THIS ARTICLE ARGUES THAT TELEVISION'S

POHER LIES IN ITS TEMPORARY CLAIM ON THE AUDIENCE'S

POWER LIES IN ITS TEMPORARY CLAIM ON THE AUDIENCE'S
ATTENTION. BY DOMINATING THE MOMENT (EVEN WITH WEAK RESULTS), ATTENTION. BY DOMINATING THE MOMENT (EVEN WITH WEAK
TV OCCUPIES PUBLIC TIME AND TAKES UP PUBLIC SPACE.

TV OCCUPIES PUBLIC TIME AND TAKES UP PUBLIC SPACE.

MEANHHILE, POLITICS PROCEEDS, REGARDLESS OF WHETHER ITS TRUE

CONCERNS ARE COMMUNICATED. TV CREATES A "NO-STICK" POLITICAL
ENVIRONMENT, DOMINATED BY THE WEAK EFFECTS OF ITS SPECTACLE.

07855 ROSEN, M.E.

THE UNITED STATES NAVAL BLOCKADE OF IRAQ: A FOREIGN POLICY AND INTERNATIONAL ANALYSIS

INTERMATIONAL JOURNAL OF PUBLIC ADMINISTRATION, 14(5)

(1991), 955-1031.

THE CURRENT PERSIAN GULF CRISIS MAY SIGNAL A NEW PERIOD

IN HUMAN HISTORY IN WHICH THE UNITED NATIONS IS VIEWED AS

THE FORUM OF FIRST RESORT FOR THE RESOLUTION OF

INTERNATIONAL HARMS AND DISPUTES. THIS ESSAY DEALS WITH THE

EVENTS LEADING UP TO THE IRAQI INVASION OF KUWAIT, THE STEP-

BY-STEP REACTION BY THE U.S. GOVERNMENT, THE IMPOSITION OF

THE U.S. NAVY BLOCKADE OF KUHAITI SHIPPING, AND THE LEGAL

JUSTIFICATION FOR THE INTRODUCTION OF FORCES. IT ALSO

EXAMINES THE HISTORY OF NAVAL BLOCKADES BEFORE AND AFTER THE 1945 UN CHARTER.

07856 ROSEN, S. (ED.); ZOU, G. (ED.)

PROGRAMS OF CHINA'S ECONOMIC SYSTEM REFORM, 1979-1987 (I)

CHINESE LAW AND GOVERMMENT, 25 (2) (SUM 92), 3-80.

THIS OVERVIEW OF CHINA'S ECONOMIC REFORMS FROM 1979 TO

1987 INCLUDES OFFICIAL POLICY STATEMENTS AND PAPERS, SUCH AS

"OUTLINE OF THE REPORT ON ECONOMIC SYSTEM REFORM DURING THE

SIXTH FIVE-YEAR PLAN PERIOD AND FOR THE YEAR 1983" AND

"COMPREHENSIVE OUTLINE OF THE REPORT ON THE PLAN FOR

ECONOMIC SYSTEM REFORM (FEBRUARY 14, 1984)."

07857 ROSEN, S. (ED.): ZUD, G. (ED.)

PROGRAMS OF CHINA'S ECONOMIC SYSTEM REFORM, 1979-1988 (II) CHINESE LAH AND GOVERNMENT, 25 (3) (FAL 92), 2-95.

THIS VOLUME INCLUDES THE FOLLOWING DOCUMENTS RELEVANT TO CHIMA'S ECONOMIC TRANSFORMATION: OUTLINE OF A REPORT ON THE STUDIES FOR AN OVERALL ECONOMIC SYSTEM REFORM (JULY 2, 1985); PRELIMINARY 1986 PLAN FOR ECONOMIC SYSTEM REFORM (NOVEMBER 26, 1985); THE PLAN FOR IMPLEMENTING THE ECONOMIC SYSTEM

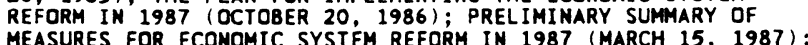
MEASURES FOR ECONOMIC SYSTEM REFORM IN 1987 (MARCH 15, 1987) AND PRELIMINARY PLAN FOR DEEPENING ECONOMIC
IN 1988 (DRAFT FOR SOLICITATION OF OPINIONS).

07858 ROSENAU, J.

THE MEH GLOBAL ORDER: UNDERPINNINGS AND OUTCOMES ETUDES INTERMATIONALES, 23(1) (MAR 92), 9-36.

THE NEW HOLRD ORDER IS DEPICTED IN TERMS OF THREE BASIC PARAMETERS THAT BIND THE GLOBAL SYSTEM. AT THE MICRO LEVEL THE ANALYTIC SKILLS OF INDIVIDUALS ARE CONCEIVED TO HAVE UNDEGONE EXTENSIVE EXPANSION. AT THE MICRO LEVEL THE TRANSFORMATIOM INVOLVES THE BIFURCATION OF WORLD POLITICS INTO A STATE-CENTRIC WORLD AND A MULTI-CENTRIC WORLD. AT THE MACRO-MICRO LEVEL, TRANSFORMATION IS SEEN TO HAVE OCCURRED IN AUTHORITY RELATIONS. THE EMERGENT GLOBAL ORDER IS VIEWED AS ENCOURAGING THE INSTITUTIONALIZATION OF THE TENSIONS, THE OUTCOME OF HHICH IS READILY DISCERNIBLE IN PRESENTDAY

RELATIONS AMONG THE STATES.

07859 ROSENAU, J.

THE UNITED NATIONS IN A TURBULENT HORLD

LYMNE RIENNER PUBLISHERS, 1992, 87

JAMES ROSENAU'S SPECULATION ABOUT THE EMERGING PROSPECTS FOR THE UNITED NATIONS INCLUDE A DEFINITION OF THE PROBLEM, THEN A DESCRIPTION OF THE TURBULENCE IN WORLD POLITICS. HIS MODEL OF GLOBAL TURBELENCE SUGGESTS THE EMERGENGE OF A SERIES OF POWER GAPS THAT MAY HELL BE FILLED BY THE UNITED NATIONS IN THE YEARS AHEAD. THE ANALYSIS HIGHLIGHTS THE PROBABILITY THAT, FAR FROM BEING ENGULFED BY CHANGE, THE UN AS A PRODUCT AND AN AGENT OF CHANGE IS EXPLORED AND 
POLICY-ORIENTED SUGGESTIONS ARE OFFERED AS WAYS TO HELP CHANGE COME ABOUT

07860 ROSENAU, J.N.

THE RELOCATION OF AUTHORITY IN A SHRINKING WORLD COMPARATIVE POLITICS, 24(3) (APR 92), 253-272.

DEVELOPMENTS IN MANY COUNTRIES ILLUSTRATE THE GLOBAL PROCESS WHEREBY AUTHORITY IS UNDERGOING RELOCATION IN TWO DIRECTIONS: UPWARD TOWARD TRANSNATIONAL ORGANIZATIONS AND DIRECTIONS: UPWARD TOWARD TRANSNATIONAL ORGANIZATIONS AND DOWNWARD TOWARD SUBNATIONAL GROUPS. THE RESULT IS THAT AMD RESOL VE MAJOR ISSUES CONFROMTING THEIR SOCIETIES. IN AND RESOL.VE MAJOR ISSUES CONFRONING THEIR SOCIE PROCESS THIS PAPER, THE AUTHOR SEEKS TO ILLUMINATE THTS PROCE THROUGH AN ANALYSIS OF THE NATURE OF AUTHORITY, AN EXPLORATION OF THE SKILL REVDLUTION THAT IS ALTERING THE CAPACITY OF CITIZENS TO ENGAGE IN COLLECTIVE ACTION, AND A
STUDY OF THE DYNAMICS WHEREBY SPONTANEITY MARKS MUCH OF THE COLLECTIVE ACTION THAT IS TRANSFORMING WORLD POLITICS.

07861 ROSENAU, P.

POST-MODERNISM AND THE SOCIAL SCIENCES: INSIGHTS, INROADS, AND INTRUSIONS

PRINCETON UNIVERISTY PRESS, 1992, 229

THE SPREAD OF POST-MODERNISM THROUGH DIFFERENT ACADEMIC FIELDS IN THE UNITED STATES HAS LED TO A CRISIS IN CONVENTIONAL INTELLECTUAL THOUGHT. IN ADDRESSING THE ISSUES, PAULINE ROSENAU EXAMINES, EXPLAINS AND CLARIFIES THE MAIN DIMENSIONS OF THE POST-MODERN CHALLENGES TO MODERN SOCIAL SCIENCES AND JUDGES HOW POST-MODERNIST IDEAS ARE APPLIED TO DIFFERENT ACADEMIC DISCIPLINES. SHE DIVIDES POST-MODERNISM INTO THO BROAD CATEGORIES: THE SKEPTICAL AND THE AFFIRMATIVE. SHE EXAMINES WHY AND HOW BOTH SKEPTIC AND AFFIRMATIVE POSTMODERNISTS CHALLENGE THE FOUNDATIONS OF MODERN SOCIAL SCIENCES.

07862 ROSENAU, W.: FLANAGAN, L.H.

BLOOD OF THE CONDOR: THE GENOCIDAL TALONS OF PERU'S SHINING PATH

POLICY REYIEW, (59) (WIN 92), 82-85.

FOR THE PAST DECADE. THE UNITED STATES HAS LARGELY IGNORED A TOTALITARIAN, KHMER ROUGE-LIKE MOVEMENT IN ITS OWM HEMISPHERE. IN PERU, SENDERO LUMINOSO (THE SHINING PATH), A RADICAL ORTHODOX MAOIST INSURGENCY, IS WAGING A GUERRILLA WAR OF UNPARALLELED BRUTALITY. ALTHOUGH THE SHINING PATH
CAUSES ENORMOUS NUMBERS OF DEATH AND SIGNIFICANT DESTRUCTION, CAUSES ENORMOUS NUMBERS OF DEATH AND SIGNIFICANT DESTRUCTION, POWER IN PERU. NEVERTHELESS, SENDERO IS THREATENING PERU'S FRAGILE DEMOCRATIC INSTITUTIONS AND DRIVING THE COUNTRY DEEPER INTO ECONOMIC AND SOCIAL CHAOS. IF THE INSURGENCY REMAINS STRONG, IT COULD GENERATE THOUSANDS OF REFUGEES AND THREATEN THE STABILITY OF OTHER ANDEAN COUNTRIES. PERU MUST SOLVE ITS OWN PROBLEMS. BUT THE UNITED STATES AND OTHER COUNTRIES IN THE HEMISPHERE HAVE A RESPONSIBILITY AND AN INTEREST IN SEEING THE SHINING PATH BROUGHT UNDER CONTROL. MODEST AMOUNTS OF U.S. FUNDS AND ADVICE COULD HELP THE EFFECTIVELY.

07863 ROSENBERG, G.

THE HOLLOH HOPE--CAN COURTS BRING ABOUT SOCIAL CHANGE? UNIVSERITY OF CHICAGO PRESS, $1991,424$.

LIBERALS HAVE ACCLAIMED, AND CONSERYATIVES DECRIED, RELIANCE ON COURTS AS TOOLS FOR CHANGE. BUT WHILE THE DEBATE RAGES OVER WHETHER THE COURTS SHOULD BE PLAYING SUCH A ROLE, THIS BOOK POSES A FAR MORE FUNDAMENTAL QUESTION: CAN COURTS THIS BOOK POSES A FAR MORE FUNDAMENTAL QUESTION: CAN COURT DEGREE AND UNDER WHAT CONDITIONS? THE AUTHOR PRESENTS AN OVERWHELMING CASE THAT EFFORTS TO USE THE COURTS TO GENERAT SIGNIFICANT REFORMS IN CIVIL

07864 ROSENBERG, G.N.

JUDICIAL INDEPENDENCE AND THE REALITY OF POLITICAL POWER JUDICIAL INDEPENDENCE AND THE REALITY OF

REVIEW OF POLITICS, 54 (3) ( SUM 92 ) $369-398$. TO MAKE DECISIONS IN THE SHORT TERM WITHOUT REGARD FOR THE PREFERENCES OF OFF THE SHORT TERM HITHO EXAMINES THE PREFERENCES OF OFFICEOLUR, CONDITIONS UNDER WHICH JUDICIAL INDEPENDENCE IS, AND IS NOT, LIKELY TO BE FOUND. HE IDENTIFIES NINE PERIODS OF INTENS CONGRESSIONAL HOSTILITY TO THE SUPREME COURT AND CHARTS COURT REACTIONS ALONG A CONTINUUM FROM PURE INDEPENDENCE TOTAL SUBSERVIENCE. EXAMINATION OF THE HISTORICAL RECORD HIGHLIGHTS FIVE KEY FACTORS RELATED TO INDEPENDENCE AND SHOWS THAT JUDICIAL INDEPENDENCE EXISTED ONLY IN THREE OF THE PERIODS. IN THE REMAINING PERIODS, THE COURT EITHER REFRAINED FROM HEARING CERTAIN CASES, ISSUED OPINIONS MDRE IN LINE WITH CONGRESSIONAL PREFERENCES, OR REVERSED ITSELF. THE AUTHOR REJECTS THE HYPOTHESIS OF JUDICIAL INDEPENDENCE, CONCLUDING THAT IN TIMES OF CONGRESSIONAL OPPOSITION TO THE CONDITIONS.

07865 ROSENBERG, J.

CUBA'S FREE-MARKET EXPERIMENT: LOS MERCADOS LIBRES
CAMPESINOS, 1980-1986

LATIN AMERICAN RESEARCH REVIEW, 27(3) (1992), 51-90. WHY DID CUBAN GOVERMMENT OFFICIALS OPPOSED IN PRINCIPLE TO DECENTRALIZATION AGREE TO PRIVATIZE A VITAL ECONOMIC ACTIVITY? AND, WHY IN SPITE OF A GENERALLY FAVORABLE RECEPTION BY CONSUMERS AND FARMERS WERE THE MARKETS TERMINATED IN 1986? TO ANSWER THESE QUESTIONS, THIS ARTICLE WILL EXAMINE THE POLITICAL FACTORS INVOLVED IN THE DECISIONS TO OPEN THE MLCS IN 1980, TO RESTRICT THEIR OPERATION IN 1983. AND TO END THEM IN 1986.

07866 ROSENBERG, J.; PERLSTADT, H.: PMILLIPS, $W$. POLITICS, FEMINISM AND WOMEN'S PROFESSIONAL ORIENTATIONS: POLITICS, FEM STUDY OF WOMEN LAWYERS WOMEN AND POLITICS, $10(4)(1990), 19-48$.

THE PURPOSE OF THIS STUDY WAS' TO CONSTRUCT A TYPOLOGY OF PROFESSIONAL ORIENTATIONS OF WOMEN LAWYERS BASED ON THEIR POL ITICAL IDENTITY, PROFESSIONAL INTERESTS AND PATTERNS OF INSTITUTIONAL PARTICIPATION. USING FACTOR AND CLUSTER ANALYSIS, FOUR ORIENTATIONS WERE IDENTIFIED. VARIATIONS ON INSTRUMENTAL-MARKET AND FEMINIST THEMES ARE AT THE CORE OF THE ORIENTATIONS, AND EACH IS RELATED TO THE BROADER POLITICAL IDENTITIES OF THE WOMEN AND TO THE TYPES OF ACTION THEY RECOMMEND AS EFFECTIVE MEANS OF CORRECTING SEX-BASED
INEQUITIES IN THE PROFESSION. WHEREAS THE MAJORITY OF LAWYERS ADOPT ONE OF THESE PERSPECTIVES IN RELATIVELY UNDILUTED FORM, THE ORIENTATIONS OF TWO SMALL LEADERSHIP GROUPS ARE MORE COMPLEX. ALTHOUGH SCHOLARS BELIEVE THAT LEADERSHIP GROUPS ARE MORE COMPLEX. ALTHOUGH SCHOLARS BELIEVE THAT THE ENTRY OF WOMEN WILL HAVE IMPORTANT EFFECTS ON LEGAL PRACTICE AND DISCOURSE, THE RESULTS OF THIS STUDY, INDICATING DIVERSITY OF ORIENTATION AMONG WOMEN, SUGGEST THAT THE REALIZATION OF THIS EXPECTATION IS CONTINGENT ON A VARIETY OF FACTORS.

07867 ROSENBERG, J

RATIONALITY AND THE POLITICAL BUSINESS CYCLE: THE CASE OF LOCAL GOVERNMENT

PUBLIC CHOICE, 73(1) (JAN 92), 71-82

TRADITIONAL MODELS OF POLITICAL BEHAVIOR ARE BASED ON THE ASSUMPTION THAT THE OBJECTIVE HHICH DETERMINES POLICY THE MAXIMIZATION OF THE PROBABILITY OF RE-ELECTION. THIS ASSUMPTION IS COMMON IN THE LITERATURE OF PUBLIC CHOICE IN
GENERAL AND IN THE THEORY OF POLITICAL BUSINESS CYCLES IN GENERAL AND IN THE THEORY OF POLITICAL BUSINESS CYCLES IN
PARTICULAR. BASED ON THIS ASSUMPTION IT IS ARGUED THAT THERE PARTICULAR. BASED ON THIS ASSUMPTION IT IS ARGUED THAT THERE IS AN INHERENT ASYMMETRY IN THE TIME PATTERN OF EXPENDIT VOTERS WILL BE ADOPTED BEFORE AN ELECTION, WITH THE LESS PLEASANT CONSEQUENCES OF SUCH POLICIES BEING DEFERRED TO TH POST-ELECTION PERIDD. THIS ARTICLE ARGUES THAT THIS THEORY IS BASED ON THO IMPLICIT ASSUMPTIONS OF DOUBTFUL VALIDITY:
MYOPIC VOTERS WHOSE TIME HORIZON IS TOO SHORT TO ENCOMPASS THE COMPLETE POLITICALLY MANIPULATED POLICY CYCLE; AND IRRATIONAL VOTERS WHO CANNOT PERCEIVE THE SYSTEMIC RELATIONSHIP BETWEEN POLICY DECISIONS AND THE TIMING OF ELECTIONS. THE PAPER VIEWS VOTERS AS NEITHER MYOPIC NOR IRRATIONAL, AND RECOGNIZES THAT FOR INCUMBENTS THERE IS LIFE AFTER ELECTION EVEN IF OUSTED. WITH UNCERTAINTY ABOUT THE OUTCOME OF THE ELECTION, THERE IS NO NEED TO ASSUME MYOPIC BEHAVIOR OR IRRATIONALITY OF VOTERS IN ORDER TO GET A POLITICAL BUSINESS CYCLE AS AN OPTIMAL POLICY.

07868 ROSENBERG, J.

SECRET ORIGINS OF THE STATE: THE STRUCTURAL BASIS OF "RAISON D' ETAT"

REVIEW OF INTERNATIONAL STUDIES, 18(2) (APR 92), 131-160. THE ITALIAN CITY-STATE SYSTEM OCCUPIES A SPECIAL PLACE IN THE CANON OF ORTHODOX INTERNATIONAL RELATIONS. THAT HISTORICAL TERRAIN OFTEN REGARDED AS THE STRONGHOLD OF REALISM IS ACTUALLY THE SITE OF ITS MOST SPECTACULAR FAILURES IS ARGUED. THE ARGUMENT IS SET OUT IN THE FOLLOWING MANNER. FIRST, THE EARLY DEVELOPMENT OF THE ITALIAN CITY-STATE SYSTEM IS BREIFLY REVIEWED. THE NEX SECTION RECALLS MARX'S DISCUSSION OF THE STRUCTURAL
CONDITIONS OF THE RISE OF SUCH A PPURELY POLITICAL STATE'; AND THE PAPER THEN TURNS TO CONSIDER HOW THESE CONDITIONS AND THE PAPER THEN TURNS TO CONSIDER HOW THESE CDNDIT CAME TO OBTAIN IN THE ITALIAN CASE--THROUGH PROCESSES
EXTENDING DEEP INTO THE FEUDAL HORLD SURROUNDING THE CITY EXTENDING DEEP INTO THE FEUDAL WORLD SURROUNDING THE CITY
STATES. THE PERSPECTIVES USED TO EXPLORE THE PREMODERN CASES STATES. THE PERSPECTIVES USED TO EXPLORE THE PREMODERN CAS
ARE TURNED ON THE MODERN INTERNATIONAL SYSTEM ITSELF IN ARE TURNED ON THE MODERN INTERNATIONAL SYSTEM ITSELF IM ORDER TO

07869 ROSENBERG, M.

YOUNG EXECS EXHORTED TO TACKLE HORLD ISSUES JAPAN TIMES (WEEKLY INTERMATIONAL EDITION), 32(13) (MAR 92), 17

YOUNG JAPANESE, AMERICAN, AND EUROPEAN BUSINESSPEOPLE MUST BYPASS GOVERMMENT AND OIRECTLY FORGE ALLIANCES TO SOLVE THE WORLO'S PRESSING PROBLEMS, ACCORDING TO JUNYA YOSHIDA, VICE PRESIDENT OF THE JUNIOR CHAMBER INTERNATIONAL. RELATIONS BETWEEN THE USA AND JAPAN HAVE BEEN FOULED BY MISUNDERSTANDINGS THAT HAVE CAUSED THEM TO DETERIORATE FURTHER THAN AT ANY TIME SINCE HORLD WAR II. SUCH 
MISUNDERSTANDINGS MUST BE ACTIVELY COMBATTED FOR THE GOOD OF BOTH COUNTRIES AND THE WORLD.

07870 ROSENBERG, M.M. ; JEDWAB, J.

INSTITUTIONAL COMPLETENESS, ETHNIC ORGANIZATIONAL STYLE, AND THE ROLE OF THE STATE: THE JEWISH, ITALIAN, AND GREEK COMMUNITIES OF MONTREAL

CANADIAN REVIEH OF SOCIOLOGY AND ANTHROPOLOGY, 29(3) (AUG 92 ), 266-287

THE AUTHORS EXAMINE THE RELATIONSHIP BETWEEN AN ETHNIC COMMUNITY'S ORGANIZATIONAL STYLE AND THE POLICIES. REGULATIONS, AND ACTIONS IMPLEMENTED BY THE STATE, FOCUSING ON MONTREAL'S THREE LARGEST AND OLDEST ETHNOCUL TURAL MINORITIES-JEWS, ITALIANS, AND GREEKS. IN EACH CASE, THEY DETAIL THE SPECIFIC LINKAGES AMONG (1) ETHNIC GROUP CHARACTERISTICS, (2) THE DEVELOPMENT OF ETHNIC ORGANIZATIONAL STRUCTURES, AND (3) THE ROLE OF THE QUEBEC STATE. FOR EACH GROUP. THEY DISCUSS SOME CRUCIAL FACTORS THAT EITHER FACILITATED OR INHIBITED INSTITUTIONAL DEVELOPMENT IN THE ETHMIC COMMUNITY AND THE RESULTING ORGANIZATIONAL STYLE THAT HAS COME TO CHARACTERIZE THAT ORGANIZATIONAL STYLE THAT HAS COME TO CHARACTERIZE THAT COMMUNITY. THEN THEY STUDY THE EVOLUTION OF EDUCATIONAL STRUCTURES WITHIN EACH COMMUNITY BECAUSE EDUCATION IS THE SECTOR THAT BEST DISPLAYS THE UNEVEN IMPACT OF THE ROLE OF THE STATE. FINALLY, THEY DISCUSS WHAT THE QUEBEC STATE HAS THREE COMMUN ITIES AND THE STATE. IN THIS NEW RELATIONSHIP. THEE COMUNITIES AND THE STATE. IN THIS NEW RELATIONSHIP, EXCHANGE FOR COMPLIANCE WITH STAIE POLICY, IN PARTICULAR THE EXCHANGE FOR COMPLIANCE WITH STATE POLICY, IN PARTICULAR
"FRANCISIZATION" OF COMHUNITY INSTITUTIONS AND PRACTICES.

07871 ROSENBERG, T

LATIN AMERICA'S MAGICAL LIBERALISM

WILSON QUARTERLY, XVI(4) (FAL 92), 58-74

DESPITE BEING BORN UNDER THE BANNER OF "LIBERALISM," THE NATIONS OF LATIN AMERICA HAVE BEEN PLAGUED BY AUTHORITARIAN RULERS, CORRUPTION, AND ECONOMIES DOMINATED BY PRIVILEGE. TODAY, AS A RESURGENT FAITH IN CONSTITUTIONAL DEMOCRACY AND FREE MARKETS SWEEPS THE WORLD, MANY LATIN AMERICAN LEADERS AND INTELLECTUALS ARE TRYING TO MAKE THEIR HATIONS LIBERAL IN FACT AS WELL AS IN NAME, BUT SUCCESS IS ANYTHING BUT ASSURED.

07872 ROSENBERG, T. WOMEN AND' THE LAH

HEMI SPHERE, 5(1) (FAL 92), 20-23

IN A REGIONAL CONTEXT OF STRUGGLES FOR DEMOCRACY AND HUMAN RIGHTS, THE LATIN AMERICAN WOMEN'S MOVEMENT IS GAINING MOMENTUM. NEYERTHELESS, WOMEN'S MOST BASIC RIGHTS STILL REMAIN LARGELY UNPROTECTED IN LATIN AMERICA, BOTH IN THE LAW REMAIN LARGELY UNPROTECTED IN LATIN AMERICA, BOTH IN AND IN EVERYDAY LIFE. WHILE FEMINISTS HAVE REGISTERED ADJUSTMENT HAVE BEEN A SOURCE OF PROFOUND NEW SETBACKS.

07873 ROSENBERGER, C.; DE CANDOLE, R.

AFTER VELVET, IRON

NATIONAL REVIEW, XLIV(13) (JUL 92), 22-24.

CZECHOSLOVAKIA'S FIRST GENUINE MULTI-PARTY ELECTIONS ON JUNE 5-6 1992 CONFIRM EVERY FEDERALIST'S WORST FEARS: THE TWO REPUBLICS ARE HEADING IN OPPOSITE AND IRRECONCILABLE DIRECTIONS. FREE-MARKET REFORM PARTIES TRIUMPHED IN THE CZECH LANDS AND WERE ELIMINATED BY THE NATIONALIST LEFT IN SLOVAKIA. THIS ARTICLE OISCUSSES THE INTERNATIONAL REACTIONS AND STATES THAT A COUNTER-COUNTER-REVOLUTION IS TAKING PLACE IN CZECHOSLOVAKIA.

07874 ROSENBERGER, L.

ECONOMIC TRANSITION IN EASTERN EUROPE: PAYING THE PRICE FOR FREEDOM

EAST EUROPEAN QUARTERLY, XXVI(3) (FAL 92), 261-278.

THE AUTHOR ARGUES THAT THE TRANSITION PROCESS HAS MANY ELEMENTS, SUCH AS INSTITUTION BUILDING ANO ATTITUDINAL

CHANGES, THAT SIMPLY DO NOT LEMD THEMSELVES TO RAPID

TRANSITION WHILE OTHERS, SUCH AS PRIVATIZATION OF STATE ENTERPRISES, MUST OCCUR RELATIVELY QUICKLY IF A FREE MARKETORIENTED ECONOHY IS TO BE A REALITY. IN ANY DISCUSSION OF THE SPEED AND SEQUENCING OF ECONOMIC REFORMS, THE TRANSITIONAL COSTS OF MOVING FROM SOCIALISM TO CAPITALISH MUST BE ADORESSED. THESE TRANSITIONAL COSTS DEPEND UPON THE EXPECTATIONS OF THE EAST EUROPEAMS AND THE CREDIBILITY OF THE TRAYSITIOM POL ICY ITSELF UMFORTUMATELY THE UMREALISTIC THE TRANSITION POLICY ITSELF. UNFORTUNATELY, THE UNREALISTIC EXPECTATIONS OF THE EAST EUROPEAN PEOPLE REGARDING THE EASE AND LENGTH OF THE TRANSITION IS UNDERMINING THE CREDIBILITY OF GOVERMMENT TRANSITION POLICY IN A NUMBER OF EAST EUROPEAN CAPITALS. THE EUPHORIC CONSENSUS THAT SUPPORTED A DASH TO THE FREE MARKET IS FADING AND CALLS FOR A SLOWER TRANSITION TO THE FREE MARKET ARE GROHING, BOTH WITHIN GOVERNMENTS AMD AMONG OPPOSITICN GROUPS. EASTERN EUROPE'S ONLY HOPE OF ACHI EVING PROSPERITY SOON DEPENDS ON HOH POLITICALLY DEAF
AND DETERMINED THE REGION'S REFORM LEADERS ARE OVER THE NEXT YEAR OR TWO.

07875 ROSENBLOOM, D.H.

PUBLIC ADMINISTRATIVE LIABILITY FOR CONSTITUTIONAL TORTS,
THE REHNOUIST COURT, AND PUBLIC ADMINISTRATION ADMINISTRATION AND SOCIETY, 24(2) (AUG 92) 115-131. UMDER THE BURGER SUPREME COURT, PUBLIC ADMINISTRATIVE LIABILITY FOR VIOLATION OF THE INDIVIDUAL'S CONSTITUTIONAL RIGHTS INCREASED DRAMATICALLY. THEREFORE, PUBLIC ADMINISTRATORS WERE WELL ADVISED TO DEVELOP KNOWLEDGE OF THE CONSTITUTIONAL LAH PERTAINING TO THEIR JOBS AND TO INCORPORATE CONSTITUTIONAL VALUES AND REQUIREMENTS INTO THEIR OFFICIAL ACTIONS. AN ANALYSIS OF PUBLIC-SECTOR LIABILITY DECISIONS BY THE REHNQUIST COURT THROUGH 1990 INDICATES THAT IT HAS TAKEN AN INCREMENTAL APPROACH TO DEALING HITH THE ISSUES POSED AND HAS NEITHER STAKED OUT A MARKEDLY NEH DIRECTION NOR ATTEMPTED A ROLLBACK TO PREBURGER DECISIONS.

07876 ROSENTHAL, P.

JACKED IN: FORDISM, CYBERPUNK, MARXISM

SOCIALIST REYIEH, 21(1) (JAM 91) 79-104.

PHILOSOPHERS AND POLITICAL THEORISTS ARE QUICK TO

DECLARE THAT SOCIETY IS UNDERGOING A TRANSFORMATION AWAY

FROM INDUSTRIALISM. HOWEVER, THE PHRASES "POSTMODERMISM",

FROM INDUSTRIALISM. "HOWEVER, THE PHRASES "POSTMODER
"POSTINDUSTRIALISM," OR "POST-FORDISH" ARE NOT VERY

IMFORMATIVE ABOUT WHAT KIND OF SOCIETY LOOM AHEAD. THIS

ARTICLE ARGUES THAT SOME OF THE BETTER WRITINGS OF CYBERPUNK,

ART ICLE ARGUES THAT SOME OF THE BETTER WRITINGS OF CYBERPUNK,
A POPULAR SCIENCE FICTION GENRE, SHED SOME LIGHT ON WHERE A POPULAR SCIENCE FICTION GENRE, SHED SOME LIGHT ON WHERE CONTRASTS THEM WITH SOME OF THE MORE "SERIOUS" WRITINGS OF MARX AND OTHER THEORISTS.

07877 ROSS, G.

AFTER MAASTRICHT: HARD CHOICES FOR EUROPE

WORLD POLICY JOURNAL, IX(3) (SUM 92), 487-514.

THE MOVEMENT TOWARDS EUROPEAN INTEGRATION HAS COME UP AGAINST SEVERAL COUNTERVAILING MOVEMENTS, MANY OF HHICH FLOW FROM UNFORESEEN SOURCES. THE COLLAPSE OF THE SOVIET EMPIRE, GERMAN UNIFICATION, THE FRACTIONING OF YUGOSLAVIA, AND HEIGHTENED INTEREST IN EUROPEAN COMMUNITY (EC) MEMBERSHIP AMONG COUNTRIES OUTSIDE OF THE CURRENT THELVE HAVE ALL CHALLENGED THE ASSUMPTIONS UPON HHICH THE EC WAS FOUNDED. FEARING FOR THE FUTURE, EUROPEAN LEADERS MET IN MASSTRICHT, NETHERLANDS IN DECEMBER 1991 TO RETHINK THE ISSUES OF INTEGRATION MORE LUCIDLY. THIS ARTICLE EXAMINES THE INTEGRATION PROCESS, THE EFFECTS OF THE MAASTRICHT SUMMIT AND AGREEMENTS, AND THE POSSIBLE FUTURES OF EUROPE. IT ARGUES THAT MAASTRICHT HAS OPENED A NEW PERIOD OF QUESTIONING, PERHAPS OF CRISIS, WILE ALSO REVEALING SOME OF THE EC'S TRAGIC FLAWS. CONCERNS FOR THE LOSS OF NATIONAL THE EC'S TRAGIC FLAHS. CONCERNS FOR THE LOSS OF NATIONAL
SOVEREIGNTY, REFLECTED MOST RECENTLY IN THE DANISH REJECTION
OF MAASTRICHT IN OF MAASTRICHT IN A RECENT REFERENDUM, HAVE RESURFACED IN
VARIOUS MEMBER STATES. THE ARTICLE CONCLUDES THAT THE HEROIC VARIOUS MEMBER STATES. THE ARTICLE CONCLUDES THAT THE HEROIC 1985 IS OVER. THE EC'S POST-1985 STRATEGIES SUCCEEDED 1985 IS OVER. THE EC'S POST-1985 STRATEGIES SUCCEEDED PROCESS HAS BEEN INCREASINGLY FRAUGHT WITH OBSTACLE AND PROCESS HAS

07878 ROSS, G.

CONFRONTING THE NEW EUROPE

NEW LEFT REVIEW, (191) (JAN 92), 49-68.

THE AUTHOR RECONSTRUCTS THE PATH OF MAASTRICHT AND ASSESSES ITS OUTCOME. HE EXPLAINS HOW JACQUES DELORS AND LORD COCKFIELD STRUCK UP AN UNL IKELY ALLIANCE IN PREPARINC THE GROUND FOR 1992. WHILE MAASTRICHT NOTCHED UP ANOTHER MILESTONE ON THE ROCKY ROAD TO EUROPEAN UNIFICATION, THE BRITISH GOVERMMENT HELPED TO SABOTAGE THE MODEST NEH MEASURES THAT WERE PROPOSED TO REGULATE CONDITIONS OF EMPLOYMENT. THE HEADS OF GOVERNMENT FOUND IT EASIER TO AGREE ON DEFLATIONARY CONTROLS THAN TO ADDRESS THE LOOMING DANGERS OF GENERALIZED RECESSION. REGARDLESS OF THEIR INTENTIONS THEIR IRRESPONSIBLE AND PROVOCATIVE ACTIONS ARE LIKELY TO ENCOURAGE SOCIAL UNREST AND MORE CONCERTED TRADE-UNION RESISTANCE IN THE FUTURE.

07879 ROSS, G.

PARTY DECLINING AND CHANGING PARTY SYSTEMS: FRANCE AND THE FRENCH COMMUNIST PARTY

COMPARATIVE POLITICS, 25(1) (OCT 92), 43-62.

MAJDR DEYELOPMENTS IN PARTY SYSTEMS ARE OFTEN EXPLAINED BY PARALLEL DEVELOPMENTS IN THE ENVIRONMENTS IN WHICH PARTIES FUNCTION. THE FRENCH PARTY SYSTEM CHANGED IN BASIC WAYS IN THE $1980^{\circ}$ 'S-THE MOST IMPORTANT ELEMENT PROBABLY WAYS IN THE 1980 S-THE MOST IMPORTANT ELEMENT PROBABLY BEING THE ABRUPT DECLINE OF THE FRENCH COM UNIST TRICH DECLINED MORE RAPIDLY AND DIFFERENTLY THAN TRADITIONAL WORKING CLASS PARTIES IN OTHER COUNTRIES WITH SIMILARLY UNFAVORABLE ENVIRONMENTS. THE CPF ACTED INEFFECTIVELY AS A STRATEGIC ACTOR, AND ITS INEFFECTIVENESS WAS A FUNCTION LARGELY OF THE FORMAL AND INFORMAL STRUCTURE OF ITS INTERMAL LIFE. THE COMPLEXITY OF THE CPF'S ORGANIZATION FIRST DRAMATICALLY CONSTRAINED AND THEN PARALYZED ITS ABILITY TO RESPOND ADEQUATELY TO ITS CHANGING ENYIROMMENT. ANY THEORY OF PARTY SYSTEM CHANGE SHOULD INCLUDE THE NOTION OF PARTIES AS ORGANIZATIONALLYCONSTRAINED STRATEGIC ACTORS THAT SHAPE THE UNFOLDING ENYIRONMENTS TO WHICH THEY MUST SIMULTANEOUSLY RESPOND. 
07880 ROSS, J.I.

RESEARCH NOTE: CONTEMPORARY RADICAL RIGHT-HING VIOLENCE IN CANADA: A QUANTITATIVE ANALYSIS

TERRORISM AND POLITICAL VIOLENCE, 4(3) (FAL 92), 72-101. THE AUTHOR USES AN EVENTS DATA METHODOLOGY TO SHOW THE DYNAMICS OF RADICAL RIGHT-WING VIOLENCE IN CANADA OVER THE LAST THREE DECADES. HE THEN MAPS OUT THE ATTRIBUTES OF THIS PARTICULAR TYPE OF YIOLENCE AND, WHERE POSSIBLE, SPECIFIES ITS CORRELATES.

07881 ROSS, L.

THE POLITICS OF ENVIRONMENTAL POLICY IN THE PEOPLE'S REPUBLIC OF CHINA

POLICY STUDIES JOURNAL, 20(4) (WIN 92), 628-642.

THE PEOPLE'S REPUBL IC OF CHINA HAS MADE SUBSTANTIAL PROGRESS IN DEYELOPING ENYIRONMENTAL LEGISLATION AND COMPLEMENTARY REGULATORY STRUCTURE. THESE GAINS ARE DIRECTLY RELATED TO THE ECONOMIC REFORMS AND OPENING TO THE OUTSIDE WORLD THAT BEGAN IN THE 1970's, WHICH INTRODUCED A GREATER EMPHASIS ON EFFICIENCY AND MORE AWARENESS OF THE COSTS ASSOCIATED WITH POLLUTION AND ENVIRONMENTAL DEGRADATION. HOWEVER, THE ECONOMIC GROWTH AND DEVOLUTION OF POWER UNLEASHED BY THE REFORMS HAVE ALSO CREATED NEW ENVIRONMENTAL STRESSES AND TO SOME EXTENT REDUCED THE REGULATORY CAPABILITY OF GOVERNMENTAL AUTHORITIES. AS A RESULT, SOME ENVIRONMENTAL STRESSES ARE INCREASING EVEN AS PROGRESS IS MADE ON OTHER FRONTS. POLITICAL PARTICIPATION IS RESTRICTED AND ENVIRONMENTAL ISSUES ONLY OCCASIONALLY ACQUIRE POLITICAL SALIENCE. HOWEVER, INTERNATIONAL PRESSURE ON CHINA TO CONFIRM TO INTERNATIONAL ENVIRONMENTAL NORMS IS LIKELY TO INCREASE, WHICH WILL PROBABLY AFFECT DOMESTIC POLICY MAKING.

07882 ROSS, $M$.

TELEVISION NEHS AND CANDIDATE FORTUNES IN PRESIDENTIAL NOMINATION CAMPAIGNS: THE CASE OF 198

AMERICAN POLITICS QUARTERLY, 20(1) (JAN 92), 54-68. THIS ARTICLE EXAMINES HOW THREE POTENTIAL EFFECTS OF TELEVISION NEWS AFFECT PUBLIC PERCEPTION OF CANDIDATES. DATA TELEVISION NEWS AFFECT PUBLIC PERCEPTION OF CANDIDATES. DATA CANDIDATE DURING THE 1984 DEMOCRATIC PRIMARY CAMPAIGN AND CANDIDATE DURING THE 1984 DEMOCRATIC PRIMARY CAMPASGM MONITORING SURVEY. THE ANALYSIS PROVIDES SUPPORT FOR THE MONITORING SURVEY. THE ANALYSIS PROVIDES SUPPORT FOR THE TONE EFFECTS ON THE MASS PUBLIC'S ASSESSMENT OF A CANDIDATE'S ATTRACTIVENESS; PEOPLE'S WILLINGNESS TO VOTE FOR A CANDIDATE; AND JUDGMENTS ABOUT A CANDIDATE'S LIKELIHOOD OF GARMERING THE NOMINATION. TELEVISION COVERAGE OF CANDIDATES MATTERS BUT IN DIFFERENT WAYS AND TO DIFFERENT DEGREES ACROSS CANDIDATES. FINALLY, THERE IS EVIDENCE FOR THE POWER

OF STRONG INDIRECT MEDIA EFFECTS, A TESTIMONY TO THE RAPID
DIFFUSION OF MEDIA MESSAGES INTO' THE WIDER POLITICAL CULTURE.

07883 ROSS, R.

CHINA AND the Cambodian peace process: the value of COERCIVE DIPLOMACY

ASIAK SURVEY, 31(12) (DEC 91), 1170-1185.

SINCE YIETNAM'S INVASION AND OCCUPATION OF CAMBODIA IN DECEMBER 1978, CHINA HAS CONSISTENTLY PURSUED THREE INTERRELATED OBJECTIVES FOR INDOCHINA. IT SOUGHT A REDUCTION OF THE SOVIET PRESENCE IN THE REGION, IT SOUGHT VIETNAMESE WITHDRAWAL FROM CAMBODIA. IT INSISTED ON THE DISSOLUTION OF THE HENG SAMRIN/HUN SEN GOVERNMENT. BEI JING'S ROLE IN THE CAMBODIAN CONFLICT UNDERSCORES THE CHINESE LEADERSHIP'S DETERMINATION TO ACHIEVE CHINA'S SECURITY AND POLITICAL DBJECTIVES IM INDOCHIMA REGARDLESS OF THE COST TO THE OBJECTIVES IN INDOCHINA, REGARDLESS OF THE COST

CIVILIAN POPULATION IN THE INDOCHINESE COUNTRIES. ABILITY TO ENFORCE ITS DEMANDS.

07884 ROSS, R.S.

CHIMA AND POST-CAMBODIA SOUTHEAST ASIA: COPING HITH SUCCESS ANMALS OF THE AMERICAN ACADEMY OF POLITICAL AND SOCIAL SCIENCE, 519 ( JAN 92), 52-66.

THROUGHOUT THE 1980'S CHIHA'S ASIA POLICY FOCUSED OM ENDING VIETNAMESE EXPANSIONISM IN CAMBODIA. BECAUSE

ENDING VIETNAMESE EXPANSIONISM IN CAMBODIA. BECAUSE BEIJING'S OBJECTIVE COINCIDED WITH THE INTERESTS OF THE NONCOMAHUNIST SOUTHEAST ASIAN STATES, IT WAS RELATIVELY EASY HOWEVER, THE VERY SUCCESS OF CHINESE DIPLOMACY IN THE 1980'S HOWEVER, THE VERY SUCCESS OF CHINESE DIPLOMACY IN THE 1980 ' HAS NNDERMINED BEIJING'S ABILITY TO MAINTAIN ITS REGIONAL INFLUENCE IN THE $1990^{\prime} S$. NOW THAT THE STRATEGIC ASPECTS THE CAMBODIA ISSUE HAVE BEEN RESOLVED, THE REGION IS CONCENTRATING ON ECONOMIC ISSUES, BUT CHINA HAS LITTLE ECONOMIC INFLUENCE IN SOUTHEAST ASIA AND THUS IS LIKELY TO BE EXCLUDED FROM THE MOST SIGNIFICANT REGIONAL NEGOTIATIONS. IN THIS CDNTEXT, CHINA'S MILITARY CAPABILITIES COULD ASSUME HEIGHTENED SALIENCE, STIMULATING INCREASED SUSPICIONS OF CHINESE INTENTIONS AND FURTHER UNDERMINING BEI JING'S EFFORT TO FOSTER A PEACEFUL ENVIRONMENT IN WHICH TO MO
07885 ROSS, R.S.

CHINA LEARNS TO COMPROMISE: CHANGE IN U.S.-CHINA RELATIONS 1982-1984

CHINA QUARTERLY, (128) (DEC 91), 742-773.

CHANGE IN U.S.-CHINA RELATIONS BETWEEN 1982 AND 1984 REFLECTED A COMBINATION OF BILATERAL AND MULTILATERAL DYNAMICS IN WHICH WASHINGTON'S CHINA POLICY EVOLVED IN THE CONTEXT OF CHANGING SUPERPOWER RELATIONS. WHEN CHINESE LEADERS RECOGNIZED THE SIGNIFICANT CHANGES TAKING PLACE IN THE GLOBAL BALANCE AND THEIR IMPLICATIONS FOR CHINESE LEVERAGE IN U.S.-CHINA NEGOTIATIONS, THEY UNDERSTOOD THAT THE U.S. WILLINGNESS TO INCUR THE COSTS OF CONTINUING TENSION REFLECTED AMERICAN RESOLVE RATHER THAN AN ATTEMPT BLUFF CHINA INTO MAKING UNNECESSARY CONCESSIONS. THEY THEN RECOGNIZED THE NECESSITY FOR POLICY ADJUSTMENT. U.S. - CHINA TENSION WAS REQUIRED FOR THIS CHANGE, BECAUSE IT REFLECTED AND LEARNING PROCESS IN WHICH OLD ASSUMPTIONS WERE

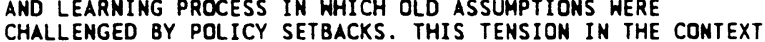
OF CHANGING INDICES OF U.S. INTENTION ULTIMATELY PERSUADED OF CHANGING INDICES OF U.S. INTENTION ULTIMATELY PERSUAD
CHINESE LEADERS TO COMPROMISE AND ACCEPT WASHINGTON'S CHINESE LEAOERS TO COMPROMISE AND ACCEPT WASHINGTON'

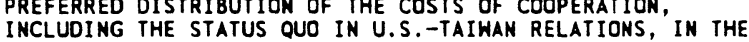
INTEREST OF STRATEGIC COOPERATION.

07886 ROSSABI, M. MONGOLIA: A NEH OPENING? CURRENT HISTORY, $91(566)$ (SEP 92), 278-283.

IN 1990 MONGOL I A BECAME THE FIRST ASIAN NATION TO RENOUNCE COMMUNISM. UNFORTUNATELY, THE 1990 FREE ELECTIONS WERE FOLLOWED BY A STRINGENT ECONOMIC REFORM PROGRAM THAT HAS LEFT MONGOLIANS UNETHUSIASTIC ABOUT THE WORKINGS OF DEMOCRACY. STILL, THE NEW SENSE OF NATIONHOOD HAS GIVEN THE MONGOLS A DRAMATIC AFFIRMATION OF THEIR ETHNIC IDENTITY.

07887 ROST, J.

LEADERSHIP FOR THE TWENTY-FIRST CENTURY

PRAEGER, $1991,220$.

THIS EXAMINATION OF LEADERSHIP STUDIES MAKES TWO MAJOR POINTS. FIRST, THERE IS A LACK OF A SINGLE, WIDELY ACCEPTED DEFINITION OF "LEADERSHIP." THIS EVASION HAS ENFEEBLED THE ENTIRE STUOY OF THE SUBJECT. SECOND, A NEW CONCEPTION OF LEADERSHIP SHOULD BE UNIVERSALLY ADOPTED BOTH TO END ONCE AND FOR ALL THE SLOPPINESS THAT HAS CHARACTERIZED LEADERSHIP STUDIES AND TO BEGIN THE POST-INDUSTRIAL ERA WITH A PARADIGH OF LEADERSHIP PARTICULARLY SUITABLE FOR IT. THIS DEFINITION OF LEADERSHIP IS: "AN INFLUENCE RELATIONSHIP AMONG LEADERS AND FOLLOWERS WHO INTEND REAL CHANGES THAT REFLECT THEIR MUTUAL PURPOSES." FOUR KEY ELEMENTS ARE PRESUMED: THE RELATIONSHIP IS BASED ON INFLUENCE; LEADERS AND FOLLOWERS
ARE THE PEOPLE IN THIS RELATIONSHIP; LEADERS AND FOLLOWERS INTEND REAL CHANGES; AND LEADERS AND FOLLOHERS DEVELOP MUTUAL PURPOSES.

07888 ROSTOW, E.

U.S. FOREIGN POLICY AFTER THE SOVIET COLLAPSE SAIS REVIEW, $12(2)$ (SUM 92), 1-21.

THE MAJOR POWERS AGAIN HAVE A NEW OPPORTUNITY TO COOPERATE IN CONSOLIDATING AND MANAGING PEACE. THIS ARTICLE EXPLORES WHETHER THE POWERS WILL FAIL TO ACHIEVE AND MAINTAIN PEACE, AS THEY DID TWICE BEFORE IN THIS CENTURY. IT SUGGESTS THAT THERE IS NO OBJECTIVE REASON FOR THEM TO FAIL THIS TIME. THEY POSSESS ALL THE RESOURCES REQUIRED FOR THE TASK. IT ALSO ASKS WHTHER THEY POSESSS THE INSIGHT, DISCIPLINE, UNITY, AND WILL WITHOUT WHICH THEIR WEALTH AND POWER WILL PROVE UNAVAILING. AFTER A THOROUGH ANALYSIS OF THESE IDEAS, THE AUTHOR CONCLUDES THAT MANKIND IS NOT LIKELY TO SOON ACHIEVE AND SUSTAIN PEACE WITHOUT HAR TO ENFORCE ITS RULES.

07889 ROSTOW, E.V. COLD SHOULDER

NEW REPUBLIC, 206(15) (APR 92), 12, 14-15

THE AUTHOR LOOKS AT THE BUSH ADMINISTRATION'S POLICY TOWARD AIDING RUSSIA AND THE OTHER FORMER SOVIET REPUBLICS.

07890 ROTBLAT, J

TOWARDS' A NUCLEAR WEAPON-FREE WORLD: SOCIETAL VERIFICATION SECURITY DIALOGUE, 23(4) (DEC 92), 51-62.

THE FEASIBILITY OF A WORLD FREE OF NUCLEAR WEAPONS DEPENDS LARGELY ON EFFECTIVE VERIFICATION. SUCH A REGIME WOULD HAVE TO BE NEARLY 100\% EFFECTIVE. FURTHER INTENSIVE WOULD HAVE TO BE NEARLY $100 \%$ EFFECTIVE. FURTHER INTENSIV TECHNOLOGICAL VERIFICATION. IN PARALLEL WITH THIS, THERE IS NEED TO EVOLVE A SYSTEM OF SOCIETAL VERIFICATION IN WHICH ALL MEMBERS OF THE COMMUNITY WOULD HAVE AN ACTIVE ROLE TO PLAY. ACHIEVING LEGISLATION WOULD MEAN THE UNDERWRITING OF AN AGREEMEN

07891 ROTHBART, T

SPREAD OF NUCLEAR WEAPONS A HEADACHE FOR MATO

GERMAN TRIBUNE, 1498 (JAN 92) 4 .

THE UNCONTROLLED PROLIFERATION OF WEAPONS OF MASS 
DESTRUCTION AND SPREAD OF HEAPON TECHMOLOGY THROUGH A BRAIN DRAIN OF NUCLEAR SCIENTISTS IS ONE OF NATO'S BIGGEST HORRIES. THIS ARTICLE IS A COPY OF AN INTERVIEW WITH THE ORGANIZATION'S SECRETARY-GENERAL, MANFRED WORNER. NATO'S
ROLE IN WORLD AFFAIRS, EUROPE IN PARTICULAR, IS DISCUSSED.

07892 ROTHCHILD, D.; HARTZELL, C.

GREAT- AND MEDIUM-POWER MEDIATIONS: ANGOLA

ANNALS OF THE AMERICAN ACADEMY OF POLITICAL AND SOCIAL SCIENCE, (518) (NOV 91), 39-57.

TWO TYPES OF CONFLICT SITUATIONS EXISTED CONCURRENTLY IN ANGOLA: CONFLICT IN THE INTERSTATE REALM AND CONFLICT IN THE INTRASTATE REALM. IN THIS ESSAY, THE CONFLICT MANAGEMENT PROCESSES ARE ANALYZED BY DEALING SEPARATELY WITH THESE TWO REALMS OF MEDIATORY ACTIVITY. AFTER AN EXAMINATION OF THE ORIGINS OF INTERSTATE ANO INTRASTATE TENSIONS. THE DIFFERENT MEDIATION PROCESSES AND THEIR APPARENT CONSEQUENCES ARE COMPARED. THE GREAT- AND MEDIUM-POWER MEDIATORS ARE DIFFERENTIATED IN TERMS OF THEIR STATUS, DETERMINATION, AND THE RESOURCES THEY WERE ABLE TO BRING TO BEAR ON THE VARIOUS OISPUTING PARTIES. THE ZAIRIAN AND PORTUGUESE MEDIATION PROCESSES ARE THEN ANALYZED IN TERMS OF THE CHANGE OVER TIME PROCESSES ARE THEN ANALYZED IN TERMS OF THE CHANGE OVER TIME
IN THE INCENTIVES INFLUENCING THE PREFERENCES OF THE VARIOUS IN THE INCENTIVES INFLUENCING THE PREFERENCES OF THE VARIOUS
ACTORS. IN THE CONCLUDING SECTION, AN ATTEMPT IS MADE TO ACTORS. IN THE CONCLUDING SECTION, AN ATTEMPT IS MADE
LINK THE SHIFT IN ACTOR INCENTIVES AND THE MEDIATORS' LINK THE SHIFT IN ACTOR INCENTIVES AND THE MEDI ATORS
RESOURCES, ABILITIES, AND MOTIVATIONS TO MOVES TOHARD A RESOURCES, ABILITIES, AND MOTIVATIONS
SETTLEMENT OF EACH CONFLICT SITUATION.

07893 ROTHFELD, C.

FEDERALISM IN A CONSERYATIVE SUPREME COURT PUBLIUS: THE JOURNAL OF FEDERALISM, 22(3) (SUM 92), 21-32. AFTER YEARS OF MAINTAINING A BALANCE ON QUESTIONS OF FEDERALISH, THE SUPREME COURT'S VIEHS ON THE FEDERAL-STATE RELATIONSHIP HAVE UNDERGONE A TRANSFORMATION DUE TO THE RECENT CHANGE IN THE COURT'S COMPOSITION. THE NEW CONSERVATIVE MAJORITY HAS PROVED WILLING TO PROTECT THE STATES FROM DIRECT REGULATION BY THE FEDERAL GOVERNMENT IN ALMOST ALL CIRCUMSTANCES. HOWEVER, IT REMAINS UNCLEAR WHETHER THE COURT WILL GIVE INCREASED PROTECTION TO STATE REGULATORY EFFORTS--AND WHETHER THE COURT'S NEW MEMBERS WILL BE WILLING TO RESPECT THE AUTONOMY OF STATES THAT ARE EXERCISING THEIR AUTHORITY IN AN ACTIVIST, AND TRADITIONALLY LIBERAL, MANNER.

07894 ROTHL, R

THE IMPACT OF DECREASED DEFENSE SPENDING ON EMPLOYMENT IN THE UNITED STATES

ARMED FORCES AND SOCIETY, 18(3) (SPR 92), 383-406

FOLLOHING THE MANY POLITICAL CHANGES IN EASTERN EUROPE IN 1989 AND THE 1990S. THE FEELING IN THE UNITED STATES WAS THAT THE COLD WAR WAS FINALLY OVER. THE COMBINED EFFECT OF MORE FAVORABLE SECURITY DEVELPMENTS AND BUDGET DIFFICULTIES HAVE RASIED QUESTIONS ABOUT THE IMPACT OF DECREASES IN HAVE RASIED QUESTIONS ABOUT THE IMPACT OF DECREASES IN AT THE PEACE DIVIDEND AND POSSIBLE DEFICIT REDUCTION WAS SOON DAMPENED BY PREDICTIONS OF INCREASED UNEMPLOYMENT IN DEFENSE INDUSTRIES AND THEIR LOCALITIES. THIS ARTICLE FOCUSES ON THE EMPLOYMENT IMPACTS OF DECREASED DEFENSE SPENDING IN THE UNITED STATES.

07895 ROTHMAN, J.

CONFLICT RESEARCH AND RESOLUTION : CYPRUS

ANNALS OF THE AMERICAN ACADEMY OF POLITICAL AND SOCIAL SCIENCE, (518) (NOV 91), 95-108.

PROTRACTED ETHNIC CONFLICTS POSE A MAJOR CHALLENGE TO FORGING A MORE PEACEFUL WORLD ORDER IN THE WANING YEARS OF THE TWENTIETH CENTURY. THE SERIOUS AND FRESH ATTENTION GIVEN TO THESE CONFLICTS MAY ALSO PROVIDE VALUABLE CONCEPTUAL AND PRACTICAL TOOLS FOR CONFLICT MANAGEMENT. IN THIS ARTICLE, THE AUTHOR DESCRIBES A METHODOLOGY USED FOR CONFLICT RESOLUTION TRAINING AND INTERVENTION IN THE CONTEXT OF PROTRACTED ETHNIC CONFLICTS AND APPLIES IT TO THE CYPRUS THAT IT MIGHT BE FRUITFUL IF PARTIES IN CONFLICT, OR EXAMINATIONS OF CONFLICT, WERE ABLE TO SYSTEMATICALLY DEVELOP A VARIETY OF DIFFERENT WAYS OF ANALYZING THE CONFLICT AND POSING SOLUTIONS TO IT. THE AUTHOR SUGGESTS THREE DIFFERENT LENSES FOR CONFLICT ANALYSIS AND MANAGEMENT : ADVERSARIAL, REFLEXIVE, AND INTEGRATIVE.

07896 ROTHMAN, J.

FROM CONFRONTATION TO COOPERATION--RESOLVIMG ETHMIC AND REGIONAL CONFLICT

REGIONAL CONFLICT

AS THE TWENTIETH CENTURY NEARS ITS END, THE GLOBAL ARENA PRESENTS A PARADOX OF SIMULTANEOUS UNITY AND FRAGMENTATIOM. ON THE ONE HAND, AN INTERNATIONAL INDEPENDENCE PREVAILS. MODERN COMMUNICATION LINKS PEOPLE THROUGHOUT THE GLOBE. YET, AT THE SAME TIME, A GREATER SEPARATIST NATIONALISM IS BREWING, ONE THAT ASSERTS ETHNIC IDENTITY AND DEMANDS INDEPENDENCE AND STATEHOOO. THIS BOOK EXPLORES THIS PROBLEM AND OFFERS CONSTRUCTIVE DIRECTION FOR CONFLICT RESOLUTION. IT EXAMINES MODERN JEWISH AND PALESTINIAN NATIONALISH AS A
CASE STUDY AND THEN APPLIES ITS METHODOLOGY TO VARIOUS OTHER
CASES IN THE MIDDLE EAST.

07897 ROTHMAN, J. INTRODUCTION: PRENEGOTIATION AS A MERGING OF THEORY AND PRACTICE

JERUSALEM JOURNAL OF INTERNATIONAL RELATIONS, 13(1) (MAR 91), $1-6$

BEFORE NEGOTIATIONS ARE POLITICALLY POSSIBLE, A GREAT DEAL OF PREPARATORY HORK--OFTEN UNOFFICIAL AND ALWAYS OUT OF PUBLIC SCRUTINY--IS CLEARLY NECESSARY. ART ICULATING OVERT AND HIDDEN CONFLICT ISSUES, AGREEING ON PARTICIPANTS, AGREEING ON AGENDAS, STRUCTURING DISCUSSIONS, AMD EVEN ANTICIPATING ASPECTS OF POSSIBLE SOLUTIONS CONSTITUTE MECESSARY PRENEGOTIATION EFFORTS ON THE PATH TO INITIATING FORMAL NEGOTIATION. BASED ON A GENERAL BODY OF EMERGING CONFLICT RESOLUTION THEORY AND A NEW APPROACH TO INTERNATIONAL NEGOTIATION KNOWN AS TRACK-THO DIPLOMACY, AN EMERGING SUBDISCIPL INE OF PRENEGOTIATION IS INCREASINGLY GAINING ATTENTION AMONG THEORISTS AND PRACTITIONERS.

07898 ROTHMAN, $J$.

NEGOTIATION AS CONSOLIDATION: PRENEGOTIATION IN THE NEGOTIATION AS CONSOLIDATION:

ISRAELI-PALESTINIAN CONFLICT
JERUSALEM JOURNAL OF INTERNATIONAL RELATIONS, 13(1) (MAR

JERUSALEM JOUR

THIS ARTICLE DISCUSSES THE IMPORTANCE OF PRENEGOTIATION AND OUTLINES VARIOUS WAYS OF CONCEPTUALIZING IT. THE ARTICLE OFFERS A LARGELY PRESCRIPTIVE MOOEL OF PRENEGOTIATION AND
ILLUSTRATES IT WITH A CASE STUDY OF THE ISRAELI-PALESTINIAN ILLUSTRATES
CONFLICT.

07899 ROTHMAN, J

THE ART' AND SCIENCE OF GETTING TO THE TABLE: A REPORT ON A TWO-MONTH TRAINING SEMIMAR IN PRENEGOTIATION FOR OIPLOMATS JERUSALEM JOURNAL OF INTERNATIONAL RELATIONS, 13(1) (MAR 91), 96-123.

THIS ARTICLE DESCRIBES HOH THE MODEL OF PRENEGOTIATION-FRAMING, INVENTING, STRUCTURING--SERVED AS THE BASIS OF A SEMINAR FOR MID-LEVEL DIPLOMATS. THE THEORY BEHIND EACH OF THE NINE TRAINING SESSIONS, AND THE PRACTICAL EXERCISES THAT THE DIPLOMATES ENGAGED IN TO GAIN HANDS-ON EXPERIENCE IN PRENEGOTIATION APPLICATIONS, ARE REVIEWS AND DESCRIBED. THE SEMINAR WAS DESIGNED TO BRIDGE GAPS BETWEEN THEORY AND PRACTICE. THE AUTHOR HOPES THAT IT "WILL PROVIDE USEFUL FOUNDATIONS FOR FURTHER EXPLORATION AND OEVELOPMENT."

07900 ROTHMAN, J.

THE HUMAN DIMENSION IN ISRAEL I-PALESTINIAN MEGOTIATIONS JERUSALEM JOURNAL OF INTERMATIONAL RELATIONS, 14(3) (SEP $92), 69-81$.

OYER THE BETTER PART OF A YEAR, ISRAELIS AND

PALESTIMIANS HAVE ENGAGED IN US-SPONSORED NEGOTIATIONS ALTHOUGH SIGNIFICANT IN THAT THEY ARE OCCURRING, SUBSTANTIVE PROGRESS HAS NOT YET BEEN ACHIEVED. THIS ARTICLE SUGGESTS THAT BY STEPPING BACK FROM FORMAL NEGOTIATIONS AND ENGAGING IN SYSTEMATIC TRACK-THO DIPLOMACY, THE PARTIES COULD COOPERATIVELY RESTRUCTURE THE AGENDA FOR THE NEGOTATIONS WITH A NEW EMPHASIS ON THE HUMAN DIMENSION OF THE CONFLIC AND THUS ENHANCE THE LIKELIHOOD OF SUCCESSFUL OUTCOMES.

07901 ROTHSTEIN, B.

EXPLAINING SWEDISH CORPORATISM: THE FORMATIVE MOVEMENT

SCANDINAVIAN POLITICAL STUDIES, 15(3) (SEP 92), 173-191.

THE AUTHOR ADDRESSES THE OUESTION OF HOW TO EXPLAIN

MAJOR INTENTIONAL CHANGE IN NATIONAL POLITICAL SYSTEMS

WHICH ARE USUALLY SO TIGHTLY STRUCTURED THAT THE PROSPECTS

OF ACTORS INTRODUCING SUCH CHANGES ARE VERY SMALL. HE ARGUES

THAT SUCH CHANGES CAN OCCUR ONLY DURING CERTAIN PERIODS OF

CRISIS; IT IS ONLY DURING SUCH FORMATIVE MOMENTS THAT

POLITICAL ACTORS CAN CHANGE THE INSTITUTIONAL PARAMETERS OR

tHe nature of tHe "Game." he extends this aRgument In an

ATTEMPT TO EXPLAIN WHY SWEDEN'S POLITICAL SYSTEM BECAME

HIGHLY CORPORATIST. FROM A RATIONALISTIC APPROACH,

COLLECTIVE ACTION--I.E., WHY INDIVIDUALS JOIN AND SUPPORT

INTEREST ORGANIZATIONS--IS DIFFICULT TO EXPLAIN. SO THE

AUTHOR OFFERS AN INSTITUTIOMAL EXPLANATION. HE SHOWS HOH

CENTRALLY-PLACED POLITICIANS IN SHEDEN DURING THE $1930^{\prime} \mathrm{S}$, BY CHANGING THE PAYOFFS, COULD SOLVE THE FREE-RIDER PROBLEM FOR BOIH FARMERS' AND WORKERS' INTEREST ORGANIZATIONS. CONTRARY TO EARLIER STUDIES, HIS AMALYSIS SHOHS THAT THE BREAKTHROUG TO EARLIER STUDIES, HIS ANALYSIS SHOWS THAT THE BREAKTHROUGH OF CORPORATIST PRINCIPLES IN SHEDISH POLITICS OCCURRED UNDER A LIBERAL GOVERNMENT STRONGLY SUPPORTED BY THE CONSERVA

PARTY. THE TRADITIONAL CONNECTION BETWEEN THE SOCIAL
DEMOCRATS AND THE CORPORATIST NATURE OF SHEDISH POLITICS IS

DEMOCRATS AND THE CORPORATIST NATURE OF SHEDISH POLITICS

THUS QUESTIONED AND THE 1933 ALLIANCE BETHEEN THE SOCIAL
DEMOCRATS AND THE FARMERS' LEAGUE IS GIVEN A NEH EXPLANATION.

07902 ROTHSTEIN, $B$.

SOCIAL JUSTICE AND STATE CAPACITY

POLITICS AND SOCIETY, 20(1) (MAR 92), 101-126.

AFTER THE COLLAPSE OF THE SOVIET UNION AND THE

DEMOCRATIC REYOLUTIONS IN EASTERN EUROPE, THE QUESTION IS,

VERY IDEA OF IMPROVING DISTRIBUTIVE JUSTICE THROUGH RATIONAL 
ADMINISTRATION AND STATE INTERVENTION IN THE ECONOMY HAS CDME INTO SERIOUS DOUBT. THE ARGUMENT IN THIS ARTICLE IS THAT BOTH THE EVENTS IN EASTERN EUROPE AND THE REVIVAL OF
NORMATIVE POLITICAL THEORY CALLS FOR PROFOUND RETHINKING ABOUT THE QUESTION OF STATE CAPACITY.

07903 ROUNDS, T.A.

TAX HARMONIZATION AND TAX COMPETITION: CONTRASTING VIEWS AND POLICY ISSUES IN THREE FEDERAL COUNTRIES

PUBLIUS: THE JOURNAL OF FEDERALISM, 22(4) (FAL 92), 91-120. THE AUTHOR CONTRASTS ATTITUDES TOWARD TAX COMPETITION AND TAX HARMONIZATION IN AUSTRALIA, CANADA, AND THE UNITED STATES. DESPITE STRONG ARGUMENTS ON EACH SIDE, COMPETITION AND HARMONI IATION ARE NOT NECESSARILY CONFLICTING GOALS

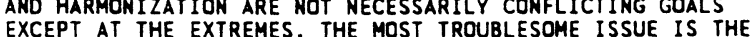
TRADE-OFF BETHEEN PROMOTING EFFICIENCY IN THE PUBLIC SECTOR TRADE-OFF BETWEEN PROMOTING EFFICIENCY IN THE PUBLIC AND IN THE PRIVATE SECTOR. DUE TO THE DIFFICULTY OF
MEASURING AND COMPARING EFFICIENCY IN BOTH SECTORS, THIS

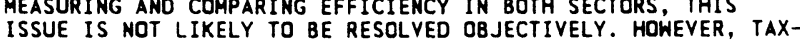
ISSUE IS NOT LIKELY TO BE RESOLVED OBJECTIVELY. HOW BASE HARMONIZATION APPEARS TO BE THE BEST COMPROMISE IM
PURSUING BOTH GOALS. SOME FUNDAMENTAL PROBLEMS REMAIN PURSUING BOTH GOALS. SOME FUNOAMENTAL MICRO-LEVEL COMPETITION AND ADDRESSING ENVIRONMENTAL AND REDISTRIBUTIVE CONCERNS IN REGIONAL AND LOCAL ARENAS. IMPROVED INTERGOVERNMENTAL COOPERATION AND EXPERIMENTATION ARE VIEWED AS THE KEY TO RESOLVING THESE ISSUES.

07904 ROURKE, F.C

RESPONSIVENESS AND NEUTRAL COMPETENCE IN AMERICAN BUREAUCRACY

PUBLIC ADMINISTRATION REVIEW, 52(6) (NOV 92), 539-546. RECENT YEARS HAVE SEEN A GROHING INCLINATION TO QUESTION HHETHER THE TERM "NEUTRAL COMPETENCE" ANY LONGER DESCRIBES EITHER THE ROLE THAT ADMINISTRATORS NOH PLAY IN NATIONAL POLICY-MAKING OR THE PRINCIPAL IDEA ABOUT WHICH THAT ROLE SHOULD BE ORGANIZED. THE PRESSURES FOR GREATER POLITICAL
RESPONSIVENESS FROM THE WHITE HOUSE AND CONGRESS, COUPLED WITH THE EMERGENCE OF ACCESSIBLE OUTSIDE EXPERTISE, THREATEN WITH THE EMERGENCE OF ACCESSIBLE OUTSIDE EXPERTISE

TO DIMINISH THE IMPORTANCE OF NEUTRAL COMPETENCE
SIGNIFICANTLY. THIS ESSAY PROVIDES A HISTORICAL OVERVIEW OF

SIGNIFICANTLY. THIS ESSAY PROVIDES A HISTORICAL OV
THIS TREND AND HARNS OF ITS NEGATIVE CONSEQUENCES.

07905 ROURKE, J.; HISKES, R.; ZIRAKZADEH, C.

DIRECT DEMOCRACY AND INTERNATIONAL POLITICS: DECIDING INTERNATIONAL ISSUES THROUGH REFEREMDUMS

LYNNE RIENNER PUBLISHERS, 1992, 202.

THE REPRESENTATIVE FORM OF DEMOCRACY THAT PREVAILS TODAY MAY NOT BE THE ULTIMATE FORM OF DEMOCRATIC GOVERNANCE. THIS BDOK EXAMINES THE GROWTH, USE, AND IMPACT OF INTERHATIONALISSUE REFERENDUMS AND DISCUSSES CURRENT DEBATES OVER THE PROMISE AND PERILS OF DIRECT DEMOCRACY. COMPARING MORE THAN TWENTY INTERNTIONAL-ISSUE REFERENDUMS, THE AUTHORS EXPLORES THE POLITICAL CONTEXTS THAT GIVE RISE TO REFERENDUMS, THE DYNAMICS OF RHETORIC OF REFERENDUM CAMPAIGNS, INFLUENCES ON VOTERS' PARTICIPATION AND DECISIONS, AND THE' EFFECT OF REFERENDUMS ON NATIONAL FOREIGN-POLICY TRADITIONS. THEY OFFER BOTH EMPIRICAL AND NORMATIVE CONCLUSIONS.

07906 ROURKE, T.R.; COCHRAN, C.E.

THE COMHON GOOD AND ECONOMIC JUSTICE: REFLECTIONS ON THE THOUGHT OF YVES R. SIMOH

REVIEW OF POLITICS, 54(2) (SPR 92), 231-252.

THE AUTHORS EXPIORE THE ISSUE OF ECONOMIC LIFE WITHIM THE THEORETICAL TRADITION OF THE COMMON GOOD. TO CLARIFY THE IMPLICATIONS OF THE THEORY OF THE COMMON GOOD FOR ECONOMICS, THEY EXAMINE THE ECONOMIC PHILOSOPHY OF YVES R. SIMON. AFTER CLARIFYING THE MEANING OF SIMON'S CONCEPTION OF THE COMMON GOOD, THEY STUDY THE IMPLICATIONS OF THE COMMON GOOD FOR SIMON'S ECONOMIC THOUGHT. THEY ARGUE THAT, FOR SIMON, THE SIMON'S ECONOMIC THOUGHT. THEY ARGUE THAT, FOR SIMON,
ECONOMIC SYSTEM IS A COMMON GOOD THAT UNDERGRIDS THE' ECONOMIC SYSTEM IS A COMMON GOOD THAT UNDERGRIDS THE TRADITIONAL THOMISTIC IMPERATIVE THAT THE USE OF GOODS
COMMON. THEN THEY ANALYZE SOME OF THE DIFFICULTIES THAT COMMON. THEN THEY ANALYZE SOME OF THE DIFFICULTIES THAT
SIMON'S THOUGHT PRESENTS FOR MARKET ECONOMICS AND USE SIMON'S THOUGHT TO SUGGEST SOLUTIONS. IN THIS CONTEXT, THE SIMON'S THOUGHT TO SUGGEST SOLUTIONS. IN THIS CONTEXT, THE
ROLES OF AUTHORITY AND VIRTUE (PARTICULARLY PRUDENCE) ARE ROLES OF

07907 ROUTLEDGE, $P$. PUTTING POLITIICS IN ITS PLACE: BALIAPAL, INDIA, AS A

POLITICAL GEOGRAPHY, 11 (6) (NOV 92), 588-611.

CONTEMPORARY SOCIAL MOVEMENT RESÉ PRIMARILY ON THE GOALS, ORGANIZATION, AND SUCCESS OF PARTICUIAR STRUGGLES, PAYING INSUFFICIENT ATIENTION TO HOW MOVEMENT CHARACTER AND AGENCY ARE MEDIATED BY PLACE. THIS PAPER EXPLORES THIS THEME HITHIN THE CONTEXT OF CONTEMPORARY INDIAN SOCIETY, WHICH HAS SEEN THE RECENT EMERGENCE OF PLACESPECIFIC, AUTONOMOUS SOCIAL MOVEMENTS. THE AUTHOR ALSO CONSIDERS THE INTERPLAY BETWEEN PROCESSES OF DOMINATION AND RESISTANCE WITHIN INDIAN CIVIL SOCIETY.

07908 RONE, M.

WHOSE INTERESTS WERE AT STAKE?--WHO HAS AT THE TABLE? NEGOTIATION JOURNAL, 8(1) (JAN 92), 21-24.
MOST ARTICLES ANALYZING THE GULF WAR FROM A NEGOTIATION PERSPECTIVE WILL BE WRITTEN BY KNOWLEDGEABLE COLLEAGUES WO KNOW THE GULF REGION AND WHOSE EXPERTISE LIES IN THE AREA OF WORLD PEACE. SUCH ANALYSIS IS SORELY NEEDED. THIS SHORT NOTE, BY CONTRAST, IS PERHAPS IMPRACTICAL. IT SPEAKS MAINLY OF THE INTERESTS OF INDIVIDUALS AS INDIVIDUALS. THE AUTHOR ASKS: COULD WE HAVE GOTTEN MORE OF THE INTERESTED PARTIES TO THE TABLE? WHO GAINED? WHO PAID THE PRICE? WHAT OPTIONS DID INDIVIDUALS HAVE?

07909 ROWLAND, J.

ALGERIA--FIS BREATHES ITS LAST

MIDDLE EAST INTERNATIONAL, (424) (MAY 92), 14-15

SEVEN OPPOSITION PARTIES IN ALGERIA HAVE LAUNCHED WHAT

SEVEN OPPOSITION PARTIES IN ALGERIA HAVE LAUNCHED WHAT
IS PROBABLY THE MOST SERIOUS CHALLENGE YET TO THE COUNTRY'S IS PROBABLY THE MOST SERIOUS CHALLENGE YET TO THE COUNTR PARTIES ACCUSED THE AUTHORITIES OF HANTING TO ELIMINATE ALL FORMS OF DEMOCRATIC EXPRESSION, AND CALLED FOR A WIDERANGING NATIONAL DIALOGUE, TO INCLUDE ALL POLITICAL GROUPINGS, AND AN IMMEDIATE RELAUNCHING OF THE ELECTORAL PROCESS. THE CRITICISM IS ALL THE MORE SERIOUS SINCE, UNTIL PROCESS. THE CRITICISM IS ALL THE MORE SERTOUS SIMC THE PARTIES HAVE GIVEN THEIR SUPPORT TO THE AUTHORITIES' ATTEMPTS TO TACKLE ALGERIA'S MANY ECONOMIC AND SOCIAL PROBLEMS. THE PUBLICATION OF THE STATEMENT COINCIDES WITH THE LAST STAGE OF THE LEGAL BATTLE AIMED AT OUTLAWING THE COUNTRY'S MAIN OPPOSITION PARTY, THE ISLAMIC SALVATION FRONT (FIS). AS IF IN ANTICIPATION OF BEING BANNED, THE FIS CALLED ON ITS SUPPORTERS ON 22 APRIL TO TAKE UP ARMS AGAINST THE AUTHORITIES.

07910 ROWLAND, J.

ALGERIA: CAPITAL UNDER CURFEH

MIDDLE EAST INTERMATIONAL, 440(440) (DEC 92), 11.

RECENTLY ALGERIA'S MILITARY-BACKED AUTHORITIES HAYE STEPPED UP THEIR FIGHT AGAINST ISLAMIC FUNDAMENTALISTS WITH THE IMPOSITION OF A CURFEH IN AND AROUND THE CAPITAL. ALMOST 300 COUNCILS CONTROLLED BY THE ISLAMIC SALVATION FRONT HAVE BEEN DISSOLVED AND MANY LOCAL CDUNCILLORS ARRESTED. THE FUNDAMENTALISTS HAVE WAGED A GUERRILLA WAR AGAINST THE
AUTHORITES SINCE THE BEGINNING OF THE YEAR, WHEN THE ARMY AUTHORITES SINCE THE BEGINNING OF THE YEAR, WHEN THE ARMY
INTERVENED TO CALL OFF GENERAL ELECTIONS. A NATIONWIDE STATE INTERVENED TO CALL OFF GENERAL ELECTIONS. A NATIONWIDE STAT
OF EMERGENCY WAS DECLARED IN FEBRUARY AND SINCE THEN MORE OF EMERGENCY WAS DECLARED IN FEBRUARY AND SINCE THEN MORE
THAN 250 MEMBERS OF THE SECURITY FORCES HAVE BEEN KILLED IN THAN 250 MEMBERS OF THE SECURITY FORC
ATTACKS BY ARMED ISLAMIC MILITANTS.

07911 ROWLAND, J.; KIELMAS, M.; SHERMAN, S.

LIBYA: SIGMAL TO THE WEST--QUADHAFI'S EMPTY OIL OFFER MIDOLE EAST INTERNATIONAL, 439 (DEC 92), 12-13.

IN A CLEAR SIGNAL TO THE WEST THAT IT WANTS TO RESOLVE THE LOCKERBIE CRISIS, LIBYA HAS APPOINTED A NEW FOREIGN MINISTER. BRITIAN WOULD LIKE TO SEE SANCTIONS AGAINST LIBYA LIFTED RATHER THAN TIGHTENED. THE LIBYAN LEADER'S OFFER TO SHARE HALF OF HIS COUNTRY'S OIL REVENUES WITH LIBYAN NATIONALS WHO OPT TO LEAVE THE COUNTRY IS BEING INTERPRETED AS A SIGN THAT HE EXPECTS THE UN TO IMPOSE AN OIL IMBARGO WHEN THE PRESENT SANCTIONS ARE REVIEWED BY THE UN SECURITY CDUNTIL IN DECEMBER.

07912 ROHLAND, J.

MOROCCO--A YES FOR THE KING

MIDOLE EAST INTERNATIONAL, (433) (SEP 92), 16-17

MOROCCANS HAVE VOTED OVERWHELMINGLY IN FAVOR OF A NEW CONSTITUTION, UNDER WHICH KING HASSAN DELEGATES A FEW OF HIS CONSIDERABLE POWERS TO THE GOVERNMENT AND THE PARLIAMENT. ACCORDING TO THE OFFICIAL RESULTS. THE TURN-OUT FOR THE REFERENDUM ON 4 SEPTEMBER WAS 97 PEERCENT, AND MORE THAN 99 PERCENT OF THE ELECTORATE GAVE THEIR APPROVAL TO THE CONSTITUTIONAL REFORMS. UNDER THE NEW CONSTITUTION, THE GOVERMMENT IS MADE MORE ACCOUNTABLE TO PARL IAMENT, AND THE GOVERMMENT IS MADE MORE ACCOUNTABLE TO PARL IAMENT, AND
PRIME MINISTER IS GIVEN NEW RESPONSIBILITIES. BUT KING PRIME MINISTER IS GIVEN NEW RESPONSIBILITIES. BUT KING
HASSAN REMAINS FIRMLY IN CONTROL OF THE COUNTRY'S AFFAIRS. HASSAN REMAINS FIRMLY IN CONTROL OF THE COUNTRY'S AFFAIRS.
THE CONSTITUTIONAL REFERENDUM PAVES THE WAY FOR LOCAL AND GENERAL ELECTIONS IN MOROCCO LATER THIS YEAR.

07913 ROWLAND, J.

MOROCCO: ELECTION RESULTS DENOUNCED

MIDOLE EAST INTERNATIONAL, 436 (OCT 92), 10

MOROCCAN OPPOSTION PARTIES HAVE DENOUNCED THE RESULTS OF THE LOCAL ELECTIONS WHICH TOOK PLACE ON 16 OCTOBER, COMPLAINING OF CORRUPT ION AND FRAUD. THE THE ELECTIONS WERE DUE TWO YEARS AGO, BUT THEY WERE POSTPONED TO GIVE THE UN SAHARA. AS PART OF ITS ATTEMPTS TO BREAK THE DEADLOCK SAHARA. AS PART OF ITS ATTEMPTS TO BREAK THE DEADLOCK BETHEEN MOROCCO AND POLISARIO OVER WHO SHOULD BE ALLONEO TO VOTE, THE UN HAS PROP
BE HELD IN GENEVA.

07914 ROWLAND, J.

STATE OF EMERGENCY

MIDDLE EAST INTERNATIONAL, (419) (FEB 92), 9

HAVING ARRESTED MOST OF THE LEADERS OF' THE ISLAMIC SALVATION FRONT (FIS) ON 9 FEBRUARY, ALGERIA'S MILITARYBACXED AUTHORITIES DECLARED A STATE OF EMERGENCY, ENABLING THEM TO ROUND UP AS MANY AS 6,000 PARTY SUPPORTERS. THE 
STATE OF EMERGENCY, WHICH IS DUE TO LAST FOR A YEAR, WAS IMPOSED FOLLOWING A SERIES OF CLASHES ACROSS THE COUNTRY BETWEEN THE SECURITY FORCES AND FUMDAMENTALIST SYMPATHIZERS. HHILE THE FIS HAS REMAINED DEFIANT, IT IS APPARENT THAT THE HEAVY-HANDED GOVERMMENT REPRESSION IS BEGINNING TO TAKE ITS TOLL: A PLANNED 14 FEBRUARY "NATIONAL PEACEFUL MARCH" WAS CANCELLED DUE TO AN OVERWHELMING SHOW OF MILITARY STRENGTH BY THE GOVERNMENT. SOME EVIDENCE INDICATES THAT THE FIS, FINDING ITSELF UNABLE TO TAKE POWER THROUGH ELECTIONS, HILL RETURN TO UNDERGROUND ACTIVITIES.

07915 ROWLAND, J.

THE MAGHREB: PAPERING OVER THE CRACKS

MIDOLE EAST INTERMATIONAL, 438(438) (NOV 92), 15

THE FIVE STATES OF THE ARAB MAGHREB UNION APPEAR TO BE NO NEARER TO AGREEMENT ON CLOSER POLITICAL AND ECONOMIC UNION AFTER THEIR SUMMIT MEETING IN NOVEMBER. THE UNION WAS FORMED IN 1989 WHEN THE FIVE COUNTRIES COMMITTED THEMSELVES TO BUILDING A SINGLE MARKET ALONG THE LINES OF THE EUROPEAN COMMUNITY AND FORGING CLOSER POLITICAL LINKS. THREE YEARS LATER THE UNION IS FALTERING. THE FINAL DECLARATION MADE AT LATER THE UNION IS FALTERING. THE FINAL DECLARATION MADE
THE SUMMIT APPEARED TO BE LITTLE MORE THAN AN ATTEMPT TO THE SUMMIT APPEARED TO BE LITTLE
PAPER OVER THE DEEPENING CRACKS.

07916 ROWLAND, J.

THE TUAREG REBELLION

AFRICA REPORT, 37(4) (JUL 92), 43-45

IN 1990, THE BERBER-SPEAKING TUAREGS OF NORTHERN MALI REBELLED AGAINST THE GOVERNMENT, STAGING SMALL-SCALE ATTACKS ON OFFICIAL TARGETS. THE VIOLENCE ESCALATED, WITH MALIAN SOLDIERS MASSACRING ENTIRE TUAREG VILLAGES. MANY TUAREGS HAVE SINCE FLED MALI, INCLUDING APPROXIMATELY 35,000 WHO HAVE SOUGHT REFUGE IN MAURITANIA. A TENUOUS CEASE-FIRE WAS SIGNED IN APRIL 1992, BUT IT WILL TAKE POLITICAL GOODWILL ON BOTH SIDES TO INDUCE THE TUAREG REFUGEES TO RETURN HOME.

07917 ROWLAND, J.

TUNISIA: MORE REPRESSIVE THAN EVER

AFRICA REPORT, $37(5)$ (SEP 92), 50-51.

ANXIOUS TO AVOID THE EXPLOSION OF ISLAMIC FUMDAMENTALISM EXPERIENCED IN NEIGHBORING ALGERIA, THE TUNISIAN GOVERMMENT HAS INITIATED LEGAL ACTION AGAINST' 300 INDIVIDUALS, ALL OF WHOM ARE MEMBERS OR SUPPORTERS OF ENMAHDA, A BANNED ISLAMIC PARTY. THE CHARGES INCLUDE PLOTTING TO OVERTHROW THE GOVERMMENT AND BELONGING TO THE COMMANDOS OF SACRIFICE, A CLANDESTINE PARAMILITARY GROUP.

07918 ROWLAND, R.; TODD, B.

WHERE YOU STAND DEPENDS ON WHO SITS: PLATFORM PROMISES AND JUDICIAL GATEKEEPING IN THE FEDERAL DISTRICT COURTS

THE JOURNAL OF POLITICS, 53(1) (FEB 91), 174-185.

A BURGEONING BODY OF' RESEARCH HAS IDENTIFIED A

PERSISTENT LINK BETHEEN THE POLITICS OF FEDERAL JUOICIAL

APPOINTMENTS AND PATTERNS OF JUDICIAL JUDGEMENT. THIS PAPER FOCUSES ON PROCEDURAL DISPUTES OVER HHO HAS STANDING TO SUE IN FEDERAL TRIAL COURTS. THE AUTHORS FIND THAT, DESPITE THEIR PLATFORM-BASED COMMITMENT TO "JUDICIAL RESTRAINT," REAGAN APPOINTEES ARE MUCH LESS LIKELY THAN NIXON OR CARTER APPOINTEES TO DENY DISPUTED STANDING TO "UNDERDOG" CLAIM HOWEVER, WHEN THE CLAIMANT IS AN "UNDERDOG" CLAIMING
STANDING TO SUE CORPORATE OR GOVERMHENTAL DEFENDANTS, REAGAN APPOINTEES ARE TWICE AS LIKELY AS NIXON APPOINTEES AND FOUR TIMES AS LIKELY AS CARTER APPOINTEES TO DENY ACCESS.

07919 ROWLANDS, I.

THE INTERMATIONAL POLITICS OF ENVIRONMENT AND DEVELOPMENT: THE POST-U.N.C.E.D. AGENDA

MILLENMIUM, $21(2$ ) (SUM 92), 209-234

IN THIS DISCUSSION OF ENVIRONMENTAL AND DEVELOPMENT POLITICS AFTER THE RIO CONFERENCE, THE AUTHOR EXAMINES THE ISSUES (CLIMATE CHANGE, BIO-DIVERSITY, PROTECTION OF FORESTS, AND THE FINANCING OF ENVIRONMENTAL PROTECTION IN THE DEVELOPING WORLD) AMD THE ACTORS (NGO'S, CORPORATIONS, AMD STATES) THAT WILL BE CENTRAL TO THE ONGOING DEBATE. THEN HE CONSIDERS THE IMPLICATIONS OF INTERNATIONAL ENVIRONMENTAL POLITICS IN UNDERSTANDING INTERNATIONAL RELATIONS.

07920 ROWLEY, A.

A BIGGER STICK

FAR EASTERN ECONOMIC REVIEN, 155(3) (JAN 92), 45-46.

THE RECENT SPECTACLE OF JAPAN BENDING OVER BACKHARDS TO BOOST IMPORTS FROM AILING U.S. INDUSTRIES COULD ONLY BE REST IMPORTS FROM AILING U.S. INDUSTRIES COULD ONLY BE RETHEEN EAST ASIA AND JAPAN AS GREATER THAN THATE IMBTLLANCE BETWEEN EAST ASIA AND JAPAN IS GREATER THAN THAT BETWEEN THE
$U . S$. AND JAPAN. IN THE FIRST ELEYEN MONTHS OF 1991 J JAPAN'S COS. AND JAPAN. IN THE FIRST ELEVEN MONTHS OF 1991, JAPAN'S COMBINED U.S.\$35.7 BILLION TRADE SURPLUS WITH SOUTH KOREA, TAINAN, HONG KONG AND SINGAPORE EXCEEDED THAT HITH THE U. BY US\$1.7 BILLION. JAPAN APPEARS TO REGARD ITS WIDENING TRADE GAP WITH THE REGION AS JUSTIFIABLE FOR STRUCTURAL REASONS, INCLUDING THE FACT THAT A HIGH PROPORTION OF EAST ASIAN IMPORTS FROM JAPAN ARE CAPITAL GOODS. JAPAN'S COMBINED, WHILE THE GAP WITH THE U.S. HAS NARROWED.
07921 ROWLEY, A.

A PARTNERSHIP OF EQUALS

FAR EASTERN ECONOHIC REVIEW, 151(25) (JUN 91), 58-60. THE DESIRE TO BE ACCEPTED IN EUROPE AS CUI POLITICAL EQUALS RUNS DEEP IN EUROPE AS CULTURAL AND CONTINUING EFFORTS BY TOKYO TO DEEPEN OFFICIAL DIALOGUE WITH EUROPEAN NATIONS. TO ALL INTENTS AND PURPOSES, THIS MEANS IMPROVING RELATIONS WITH THE EC IN BRUSSELS. TOKYO'S EFFORTS TO ENTER INTO A BROADER AND MORE MATURE DIALOGUE WITH THE EC CULMINATED IN FORMER PRIME MINISTER NOBORU TAKESHITA'S SPEECH IN LONDON DURING 1988 WHEN HE CALLED FOR A NEW "THREEPILLAR" RELATIONSHIP AMONG THE U.S., JAPAN, AND EUROPE. THESE EFFORTS ARE BEARING FRUIT AS EVIDENCED BY THE MOVES TOWARDS ALLOWING TOKYO TO ENJOY THE SAME KING OF "SUMMIT DIPLOMACY WHICH TAKES PLACE ANNUALLY BETHEEN THE U.S. PRESIDENT AND LEADERS OF THE EC.

07922 ROWLEY, A.

AFFLUENCE WITH INFLUENCE

FAR EASTERN ECONOMIC REVIEN, 151(25) (JUN 91), 41-44. JAPAN HAS REACHED A TURNING POINT WHEN IT IS NO LONGER ABLE TO REGARD ITSELF AS AN HONORARY WESTERN COUNTRY SHARING THE PRIVILEGES BUT FEH OF THE RESPONSIBILITIES OF THE POSTWAR INTERNATIONAL ORDER. FOR BETTER OR WORSE, THE GULF WAR CHANGED THE OLD ORDER OY CATALYZING A PROCESS WHICH HAD ALREADY BEGUN. WHETHER IT IS A QUESTION OF LANGUAGE, CULTURAL OR GEOGRAPHIC UNCERTAINTY, UNCOMPETITIVE SALARIES IN OVERSEAS INSTITUTIONS--OR SIMPLY THE FACT THAT JAPANESE FEEL MORE COMFORTABLE IN THEIR OWN RELATIVELY AFFLUENT SOCIETY--THE PRESSURES ON THEM TO JOIN THE WIDER WORLD ARE BOUND TO INCREASE. HOWEVER, WITHOUT POLITICAL REFORMS AND INSPIRED LEADERSHIP, OR AT LEAST RESORT TO CHAMPIONING A FORM OF ASIAN REGIONALISM LESS DEMANDING THAT THE CHALLENGES OF INTERNATIONALISM. THE IMPLICATIONS FOR GLOBAL PROSPERITY AND STABILITY WOULD NOT BE PROMISING.

07923 ROWLEY, A.

ARMOUR UNMESHED

FAR EASTERN ECONOMIC REVIEW, 155(16) (APR 92), 56-57. TOKYO'S STOCKMARKET CRASH IS BEGINNING TO SHAKE THE FOUNDATIONS OF JAPAN INC. AS SHARE PRICES DECLINE, THERE IS AN INCREASING RISK THAT THE MESH OF CROSS-HOLDINGS HHICH SUPPORTS CORPORATE JAPAM WILL START TO UMRAVEL. IN THE LONGER RUN, THE CRISIS MAY SPUR THE EMERGENCE OF A NEH AMD STRONGER FINANCIAL AND BUSINESS SYSTEM. BUT THE TRANSITION COULD BE A PAINFUL ONE. THIS ARTICLE CHARTS THE FACTORS THAT COULD BE A PAINFUL ONE. THIS ARTICLE CHARTS THE FACTORS HAVE CAUSED THE MARKET'S FALL AND DESCRIBES THE LIKELY CONSEQUENCES FOR JAPAN'
FINANCIAL INSTITUTIONS.

07924 ROWLEY, A.

EASE UP JAPAM

FAR EASTERN ECONOMIC REVIEW, 155(31) (AUG 92), 52-55. IN JAPAN, "KYOSEI" IS A WORD THAT IS LIKELY TO BE HEARD HITH INCREASING FREQUENCY IN THE FUTURE. LITERALLY TRANSLATED AS "SYMBIDSIS" OR "LIVING TOGETHER," THE TERM HAS TAKEN ON LARGER CONMOTATIONS IN A WIDE-RANGING DEBATE THAT COULD CHANGE THE WAY JAPAN DOES BUSINESS AT HOME AND OVERSEAS. AMONG THE LARGER ISSUES IN THE DEBATE IS JAPAN'S LONG-STANDING DESIRE TO MAKE ITS CITIZENS' QUALITY OF LIFE MATCH THEIR ECONOMIC SUCCESS. COUPLED WITH THIS IS A HARDEREDGED EXAMINATION OF HOW JAPAN CAN AVOID DESTROYING ITS ECONOMIC COMPETITORS, OR FORCING THEM INTO PROTECTIONISM. AMONG THE COUNTRY'S POL ICYMAKING ELITE, THE "KYOSEI" DEBATE IS ALSO A RESPONSE TO THE NOTION THAT JAPAN HAS STOPPED PLAYING ECONOMIC CATCH-UP
MAGNANIMITY OF A VICTOR.

07925 ROWLEY, A.; DELFS, R.

KAIFU'S ALBATROSS

FAR EASTERN ECONOMIC REVIEW, 153(31) (AUG 91), 8-9. SCANOALS EMBROILING JAPAN'S LEADING SECURITIES HOUSES AND THE FINANCE MINISTRY HAVE SPREAD INTO THE POLITICAL ESTABLISHMENT WHERE THEY THREATEN TO UNDERMINE THE CREDIBILITY OF PRIME MINISTER TOSHIKI KAIFU'S "CLEAN" GOVERMMENT. SUSPICIONS OF AN ATTEMPTED POLITICAL COVER-UP ARE GROWING, FOLLOWING ATTEMPTS TO FEND OFF A FULL PARLIAMENTARY INOUIRY AND DEBATE WHICH SOME SUGGEST COULO REYEAL UNPALATABLE FACTS ABOUT PAYMENTS TO POLITICIANS FROM SECURITIES HOUSES AND BUSINESS CORPORATIONS. JAPANESE PRESS SECURITIES HOUSES AND BUSINESS CORPORATIONS. JAPANESE PRES COMPANY OFFICIALS WERE INTENDED TO PREVENT THE SCANDAL FROM COMPANY OFFICIALS WERE INTENDED TO PREVENT THE SCANDAL FROM SPREADING TO POLITICAL CIRCLES. ACROSS JAPAN, MORE THAN 100 PUBLIC BODIES AHD LDCAL GOVERNMENTS HAVE EXPRESSED THEIR WITH THE "BIG FOUR" BROKERS.

07926 ROWLEY, A.

MENTAL BLOC

FAR EASTERN ECONOMIC REVIEW, 151(23) (JUN 91), 19.

JAPAN AND THE EUROPEAN COMMUNITY (EC) ARE ABOUT TO ENTER INTO WHAT TOKYO HOPES WILL BE A MORE ROUNDED AND MATURE RELATIONSHIP HICH WILL EMBRACE POLITICAL AND SECURITY CONSULTATIONS AS WELL AS ECONOMIC COOPERATION. BUT BRUSSELS 
STILL SEEMS UNABLE TO ACCEPT JAPAN AS A FULL MEMBER OF THE INTERNATIONAL COMMUNITY. A NEW ARRANGEMENT WILL INSTITUTIONALIZE ANNUAL CONSULTATIONS AMONG THE JAPANESE PRIME MINISTER, THE PRESIDENT OF THE EC COMMISSION AND THE CHAIRMAN OF THE EC COUNCIL OF MINISTERS. HOWEVER, DESPITE THIS CHANGE, THE EC SEEMS DETERMINED TO EMPHASIZE ECONOMIC
ISSUES AT THE EXPENSE OF JAPAN'S WORRIES ABOUT POLITICAL AMD ISSUES AT THE EXPEN
SECURITY MATTERS

07927 ROWLEY, A.

THE ART OF SAYING "SORRY"

FAR EASTERN ECONOMIC REVIEW, 151(27) (JUL 91), 54.

THE RITUAL ACT BY JAPANESE POLITICAL AND BUSINESS

LEADERS OF "TAKING RESPONSIBILITY" FOR SCANDALOUS ACTIONS

CLOSE TO THEM USUALLY OBSCURES THE REAL REASON FOR THE SELFSACRIFICE. THE SIMULTANEOUS RESIGNATION OF THE PRESIDENTS OF NOMURA AND NIKKO SECURITIES IS NO EXCEPTION. BOTH THE MA JOR SECURITIES HOUSES ADMIT TO DEALING WITH A GANGLAND BOSS IN A MANNER WHICH DOES LITTLE FOR THEIR PROFESSIOMAL REPUTATIOM. HOWEYER BOTH ARE ALSO IMPLICATED IN THE ACT OF COMPEMSATING FAVORED STOCK MARKET CRASH. SOME ARGUE THAT THE ACT OF RESIGNATION STOCK MARKET CRASH. SOME ARGUE THAT THE ACT OF RESIGNATION
IS AN EXERCISE DESIGNED TO DRAH A SMOKESCREEN OVER THE TRUE IS AN EXERCISE DESIGNED TO DRAH A SMOKESCREEN OVER THE TRUE
SIZE OF THE EFFECTIVE GUARANTEES OF MINIMUM RETURNS: NOMURA SIZE OF THE EFFECTIVE GUARANTEES OF MINIMUM RETURNS; NOMURA
AND NIKKO ARE PUTTING THEIR CLIENTS ON NOTICE THAT SUCH AND NIKKO ARE PUTTING THEIR CLIENTS ON NOTICE THAT SUCH GUARANTEES WILL NOT BE OFFICIALLY TOLERATED LET ALONG
HONORED. THE ONLY LONG-TERM SOLUTION TO THESE ABUSES IS GREATER PUBLIC ACCOUNTABILITY, BASED ON RESPECT FOR GREATER PUBLIC ACCOUN
INDIVIDUAL RIGHTS.

07928 ROWLEY, A.

THE ASIA CARD

FAR EASTERN ECONOMIC REVIEH, 155(5) (FEB 92), 50 THIS ARTICLE ARGUES THAT' JAPAN HAS MADE A' STRATEGIC BLUNDER IN COMMITTING SO MUCH OF ITS FOREIGN DIRECT INVESTMENT TO THE WEST AT THE EXPENSE OF ASIA. IN THE FORTY YEARS UP TO 1990, JAPAN POURED DIRECT INVESTMENT WORTH US\$136 BILLION (44\% OF THE TOTAL) INTO NORTH AMERICA. WHILE LATIN AMERICA ABSORED A FURTHER 13\%. EUROPE TOOK 19\% OF THE TOTAL DURING THIS TIME, WHILE THE WHOLE OF ASIA RECIEVED JUST 15\%. NOW, AS REGIONAL TRADE BLOCS EMERGE, JAPAN WILL BE
HARD PRESSED TO MAINTAIN ITS INVESTMENTS. JAPANESE COMPANIES ARE BEGINNING TO SHIFT THE FOCUS OF THEIR INVESTMENT ATTENTION TO ASIA AND TO ASEAN IN PARTICULAR. THIS MIGHT IMPLY THAT JAPANESE INVESTMENT IN ASIA WOULD QUICKLY CATCH UP WITH THAT OF THE UNITED STATES. BUT THE ABSOLUTE SIZE OF THE GAP IS STILL LARGE AND, IN ANY CASE, JAPAN'S OVERALL INVESTMENT FLOWS ARE SHRINKING. EVEN IF ASIA AS A WHOLE IS TO GET THE LION'S SHARE OF FUTURE INVESTMENT, THE NEED TO FINANCE EXISTING COMMITTMENTS TO THE EUROPEAN COMMUNITY PLUS THE FORMIDABLE COST OF MAINTAINING AND POSSIBLY EXPANDING INVESTMENTS ELSEHHERE WILL PRE-EMPT MUCH OF THE SCOPE FOR A MASSIVE DRIVE IN ASIA.

07929 ROWLEY, A.

WI NDOW OF OPPORTUNITY

FAR EASTERN ECONOMIC REVIEW, 155(1) (JAN 92) 34-35

THE FUTURE OF THE 108-MAIION GENERAL AGREEMENT ON

TARIFFS AND TRADE (GATT), WHICH HAS PROVIDED THE FRAMEWORK

FOR A MASSIVE EXPANSION OF WORLD TRADE OVER THE PAST 30

YEARS, HANGS IN A VERY DELICATE BALANCE. A STALEMATE OVER

DISMANTLING THE PROTECTION OF TRADE IN AGRICULTURAL GOODS

APPEARS TO BE THE MAIN THREAT TO ATTEMPTS BY GATT'S DIRECTORGENERAL, ARTHUR DUNKEL, TO PUSH MEMBERS INTO A CONCLUSION OF THE FIVE-YEAR-OLD URUGUAY ROUND OF TALKS ON TRADE LIBERALIZATION. A COMPROMISE DRAFT WRITTEN BY DUNKEL CONTAINS A WEALTH OF NON-AGRICULTURAL MEASURES WHICH WOULD HELP ENSURE THAT WESTERN MARKTES REMAIN OPEN IN THE 19905 TO EAST ASIAN MANUFACTURED GOODS. MOST ASIAN NATIONS WOULD SUPPORT THE DUNKEL DRAFT EVEN WITHOUT MAJOR CONCESSIONS ON AGRICULTURAL ACCESS. ESPECIALLY ENTICING IS THE PROVISION WHICH EFFECTIVELY OUTLAWS THE RESORT TO BILATERAL WEAPONS SUCH AS SECTION 301 OF THE U.S. TRADE ACT. HHICH PROVIDES FOR RETALIATION AGIANST OTHER NATIONS DEEMED TO BE PLAYING UNFAIRLY ON TRADE.

07930 ROXBOROUGH, I.

INFLATION AND SOCIAL PACTS IN BRAZIL AND MEXICO

JOURNAL OF LATIN AMERICAN STUDIES, 24(3) (OCT 92), 639-664.

THE AUTHOR EXAMINES THE POLITICS OF INFLATION IN LATIM

AMERICA, FOCUSING ON BRAZIL AND MEXICO. HE ALSO LOOKS AT THE AND ITS DISASTROUS CONSEOUENCES FOR THE PEOPLE OF LATIM AMERICA.

07931 ROY, D.

THE HIDDEN ECONOMY OF EGYPT

MIDOLE EASTERN STUDIES, 28 (4) (OCT 92), 689-711.

A HIDDEN ECONOMY IN EGYPT HAS BEEN A FEATURE OF THIS

CENTRALLY-PLANMED STATE FOR SEYERAL DECADES. THE MAIM

COMPONENTS OF THE HIDOEN ECONOMY REPRESENT ECONOMIC ACTIVITY

THAT IS MOSTLY UNREPORTED AND RECORDED, BUT NEVERTHELESS THE EFFECTS OF WHICH ARE NOT AND RECORDED, BUT NEVERTHELESS EFFECTS OF WHICH ARE NOT ENTIRELY INVISIBLE. THIS ARTICLE
SUGGESTS THAT THE ACTIONS OF ANY ONE COMPONENT CANNOT OFTEN
BE ISOLATED FROM THOSE OF THE OTHERS AND DESCRIBES THE CHARACTERISTICS OF EACH ON A SEPARATE BASIS. IT EXAMINES THE BLACK MARKET, THE INFORMAL MARKET, AND THE UNREPORTED ECONOMY. IT THEN MEASURES HIDDEN ECONOMIC ACTIVITY AND PROVIDES AN ANALYSIS AND THE GENERAL IMPLICATIONS OF THE HIDDEN ECONOMY.

07932 ROZELL, M.

LOCAL $V$. NATIONAL PRESS ASSESSMENTS OF VIRGINIA'S 1989 GUBERNATORIAL CAMPAIGN

POLITY, 29(1) (FAL 91), 69-90.

THE 1989 VIRGINIA GUBERNATORIAL CAMPAIGN WAS COVERED EXTENSIVELY BY BOTH LOCAL AND NATIONAL PRESS. COVERAGE FOCUSES ON DOUGLAS WILDER'S ATTEMPT TO BECOME THE NATION'S FIRST ELECTED BLACK GOVERNOR AND ON THE ISSUE OF ABORTION. USING CONTENT ANALYSIS, THIS ARTICLE ASSESSES PRESS REPORTS AND FINDS A DISTURBING PATTERN OF ONE-SIDED COVERAGE. IT CONCLUDES THAT A REVIEW OF THE PRESS COVERAGE OF THIS

CONCLUDES THAT A REVIEW OF THE PRESS COVERAGE OF THIS
ELECTION PROVIDES INSIGHT INTD HOW NEWS JUDGEMENTS ARRIVED

ELECTION PROVIDES INSIGHT INTO HOW NEWS JUDGEMENTS ARRIVED
AT OVER THE COVERAGE OF A CAMPAIGN LED MANY REPORTERS AWAY

ATOM ACHIEVING THE GOAL OF BEING OBJECTIVE.

07933 ROZELL, M.

PRESIDENT NIXON'S CONCEPTION OF EXECUTIVE PRIVILEGE:

DEFINING THE SCOPE AND LIMITS OF EXECUTIVE BRANCH SECRECY PRESIDENTIAL STUDIES QUARTERLY, XXII (2) (SPR 92), 323-336.

THE NIXON PRESIDENCY IS REMEMBERED MOST FOR ITS INVOLVEMENT IN ONE OF THE GREAT CONSTITUTIONAL CRISES OF AMERICAN HISTORY. THIS PAPER FOCUSES ON A CENTRAL ISSUE OF THAT CRISIS: THE SCOPE AND LIMITS OF EXECUTIVE PRIVILEGE IN THE SEPARATION OF POWERS SYSTEM. THE AUTHOR IDENTIFIES AND DISCUSSES PRESIDENT NIXON'S CONCEPTION OF EXECUTIVE PRIVILEGE. HE COMPARES PRESIDENT NIXON'S CONTRIBUTION TO THE UNDERSTANDING OF THE DOCTRINE OF EXECUTIVE PRIVILEGE TO TRADITIONAL CONCEPTIONS OF THAT DOCTRINE FOUND IN AMERICAN POLITICAL THOUGHT, PRACTICE AND CONSTITUTIONAL HISTORY. THE AUTHOR ARGUES THAT ALTHOUGH THE DOCTRINE OF EXECUTIVE PRIVILEGE HAS LEGAL AND HISTORICAL BASES IN THE SEPARATION OF POWERS SYSTEM, PRESIDENT NIXON'S CONCEPTION OF THAT DOCTRINE IS TOO BROAD AND LACKS LEGAL OR HISTORICAL FOUNDATION. FURTHERMORE, WHEREAS THE ADOPTION OF THE NIXON STANDARD HOULD UNDERMINE THE DELICATE BALANCE OF POWER BETWEEN THE BRANCHES OF GOVERNMENT, ONE SHOULD NOT GENERALIZE FROM THE NIXON CASE THAT ALL CLAIMS OF EXECUTIVE PRIVILEGE ARE BASELESS.

07934 ROZMAN, G.

JAPAN'S RESPONSE TO THE GORBACHEV ERA, 1985-1991

PRINCETON UNIVERSITY PRESS, 1992, 370.

GORBACHEV'S TRANSFORMATION OF BOTH SOVIET SOCIALISM AND THE COLD HAR WORLD ATMOSPHERE KINDLED A FAR-REACHING DEBATE IN JAPAN. WOULD JAPAN AT LAST FREE ITSELF OF ITS SECONDARY POSTWAR STANDING? WOULD A NEW SOVIET SYSTEM AND WORLD ORDER SOON BE ESTABLISHED? THIS BOOK ARGUES THAT JAPANESE PERCEPTIONS OF THE SOVIET UNION ARE DISTINCTIVE AND ARE HELPFUL FOR UNDERSTANDING WHAT WILL BECOME AN INFLUENTIAL WORLDVIEW. FOCUSING ON DIVERSE OPINION LEADERS AND THE RELATIONSHIP BETWEEN THE JAPANESE MEDIA, POLICY-MAKING, AND PUBLIC OPINION, THE AUTHOR SHOWS HOW LONG-STANDING NEGATIVE IMAGES OF SOVIET SOCIALISH AND MILITARISM HAVE BEEN RECONSIDERED SINCE THE MID-1980S. HIS ANALYSIS TREATS BURNING ISSUES SUCH AS THE NORTHERN TERRITORIES DISPUTE, THE SOVIET COMMITMENT TO REFORM, AND THE SOVIET-AMERICAN RELATIONSHIP. IT ALSO SHEDS LIGHT ON JAPANESE VIEWS OF

07935 ROZMAN, G. (ED.); SATO, S.; SEGAL, G.

REFORMING COMMUNISM--COMMON CAUSES AND REGIONAL VARIATIONS JOHNS HOPKINS UNIVERSITY PRESS, $1992,304$.

BY THE LATE $1980 S$ COMMUNISM HAD BEGUN TO CRUMBLE IN THE SOVIET UNION AND EASTERN EUROPE. YET TODAY, THE FATE OF COMMUNISM THROUGHOUT THE WORLD IS FAR FROM CERTAIM AS FORMER COMMUNIST NATIONS CONTINUE TO UNDERGO DRAMATIC CHANGE IN THE 1990S, IT IS BECOMING APPARENT THAT THE ROAD AHAY FROM COMHUNISM IS NOT A SMOOTH PATH FROM MARXISM TO CAPITALISH BUT ONE THAT MAY LEAD TO DIFFEREMT AND OUITE UNEXPECTED DESTINATIONS. THIS WORK TAKES A CLOSE LOOK AT THE LONG-TERM FORCES OF CHANGE AND REFORM IN COMMUNIST COUNTRIES. IT PRESENTS TWO COMPARATIVE APPROACHES TO ANALYZING THE TRANSFORMATION OF COMMUNISH. THE FIRST APPROACH IS REGIONAL, STRESSING THE COMMONALITIES AND DIFFERENCES THAT EXIST AMONG COMMUNIST NATIONS AND STATES IN THE SOVIET UNION, EASTERN EUROPE, CHINA, AND ASIA. OTHER CHAPTERS USE A TOPICAL APPROACH TO EXPLORE THE CAUSES AND PATTERN OF TRANSFORMATION.

07936 RUBENSTEIN, D.

PALESTIMIAN FRUSTRATION AND THE ROAD TO BAGHDAD

PALESTINIAN FRUSTRATION AND

WHILE SOME TEN YEARS AGO PALESTINIANS HERE AT THE FOREFRONT OF THOSE WHO CRITICIZED IRAQ'S WAR WITH IRAN, THE STRIDENT SUPPORT FOR SADOAM HUSSEIN AMONG PALESTINIANS IN THE CURRENT CRISIS IS UBIQUITOUS. THIS ARTICLE EXAMINES THE EVENTS THE EVENTS AND CHANGES THAT LED TO THE PALESTINIANS'
SUPPORT FOR SADDAM HUSSEIN IN THE GULF CRISIS. IT CONCLUDES 
THAT IN THE DECADE SINCE THE INITIAL CENSURE OF IRAQ, MUCH HAS CHANGED FOR THE PALESTINIANS: A LONG A PAINFUL WAR IN LEBANON; A POLITICAL ALLIANCE WITH JORDAN, THE INTIFADA AND COLLABORATION WITH EGYPT; RECOGNITION OF THAT STATE OF ISRAEL AND MOVES TOWARD A NEGOTIATED SETTLEMENT; AND FINALLY, DEEP DISAPPOINTMENT WITH THE POLITICAL APPROACH. THE EMBRACE OF SADOAM HUSSEIN BY PALESTINIANS IS MORE THE RESULT OF A FRUSTRATED MASS THAT FEELS NO OTHER CHOICE THAN A CONSCIOUS DECISION OF THE RULING ELITE.

07937 RUBENSTEIN, R.E.

THE LOS ANGELES RIOTS: CAUSES AND CURES

NATIONAL CIVIC REVIEN, 81(3) (SUM 92), 319-325.

GIVEN THE CONDITIONS PRESENT IN LOS ANGELES AND OTHER U. S. INNER CITIES--ECONOMIC DISPARITY, PHYSICAL ISOLATION, FAILED SOCIAL SERVICES AND EDUCATIONAL SYSTEMS, AND GENERAL HOPELESSNESS--THE MORE APPROPRIATE QUESTION TO ASK REGARDING URBAN UNREST MAY BE "WHY DON'T RIOTS ERUPT MORE OFTEN?" DESPERATELY NEEDED ARE NEH FORUMS FOR THE RESOLUTION OF CONFLICTS AND RESTRUCTURING OF FAILED SYSTEMS.

07938 RUBIN, I.S. BUDGET REFORM AND POLITICAL REFORM: CONCLUSIONS FROM SIX BUDGET

PUBLIC ADMINISTRATION REVIEW, 52(5) (SEP 92), 454-466.

THE AUTHOR LOOKS AT THE ADOPTION OF NEH AND INNOVATIVE BUDGETING TECHNIOUES IN SIX MAJOR CITIES OVER THE PAST TWO DECADES. THE REFORMED SYSTEMS EVOLVED IN DIFFERENT WAYS IN EACH JURISOICTION. ALTHOUGH ENVIRONMENTAL THREATS WERE INFLUENTIAL. THE AUTHOR DID NOT FIND A DIRECT ONE-TO-ONE LINK BETWEEN SUCH THREATS AND REFORM. CATEGORIZING THE CITIES BY DEGREE OF POLITICAL REFORM, SHE FINDS THAT THE MOST-REFORMED JURISDICTIONS HERE LIKELY TO ADOPT BUDGET REFORMS MORE QUICKLY THAN OTHER CITIES, ALTHOUGH THE INMOVATIONS EVENTUALLY SPREAD TO THOSE CLASSIFIED AS INTERMEDIATE- AND LEAST-REFORMED CITIES. THE LEVEL OF POLITICAL REFORM ALSO DETERMINED THE MOTIVATION BEHIND THE ADOPTION OF NEW BUDGETING APPROACHES, WITH THE MOST-REFORMED GOVERMMENTS DEMONSTRATING A WILLINGNESS TO TRY SOMETHING NEW AND THE LEAST-REFORMED JURISDICTIONS EMBRACING THOSE INMOVATIONS THAT HOULD ENHANCE CONTROL OVER DEPARTMENTAL OPERATIONS. BUDGET REFORMS HAVE A WIDESPREAD IMPACT OVER TIME, AND THEIR ADOPTION IS NOT MERELY SYMBOLIC.

07939 RUBINFIEN, E. HOLDING THE EMPIRE TOGETHER

NATIONAL REVIEW, III(2) (FEB 91), 21-22

ON 11 JANUARY, SOVIET TROOPS STORMED THE LITHUANIAN CAPITAL OF VILNIUS AND ENDED, FOR THE TIME BEING, ANY HOPES CAPITAL OF VILNIUS AND ENDED, FOR THE TIME BEING, ANY HOPES
OF LITHUANIAN INDEPENDENCE. THE CLASH WAS THE LATEST IN A OF LITHUANIAN INDEPENDENCE. THE CLASH WAS THE LATEST IN A CLASH OF VIEWS BETWEEN LITHUANIA'S DEMOCRATICALLY-ELECTED GOVERNMENT AND THE SOVIET CENTRAL GOVERMMENT OVER THE FUTURE
OF THE BALTIC STATES, SEIZED BY THE SOVIETS IN 1940. THE DF THE BALTIC STATES, SEIZED BY THE SOVIETS IN 1940 . THE
KREMLIN'S HARD-LINE POLICY CARRIES DANGEROUS CONSEQUENCES. KREMLIN'S HARD-LINE POLICY CARRIES DANGEROUS CONSEQUENCES.
IT POLARIZES SOVEREIGNTY-MINDED REPUBLICS AND THE CENTRAL IT POLARIZES SOVERE IGNTY-MINDED REPUBLICS AND THE
GOVERMMENT EVEN FURTHER. IT HAS ALSO LED TO UTTER DISILLUSIONMENT AMONG GORBACHEV'S REFORMIST ALLIES.

07940 RUBINFIEN, E.

IN SEARCH OF A FOREIGN POLICY

NAT IONAL REVIEW, XLIV(14) ( JUL 92), 19-20.

RUSSIAN PRESIDENT BORIS YELTSIN HAS BEEN PURSUING A FOREIGN POLICY THAT IS UNABASHEDLY PRO-WESTERN. FOR RUSSIAN REFORMERS, THE INTEGRATION INTO INSTITUTIONS SUCH AS THE IMF AND EVEN NATO IS THE BEST GUARANTEE AGAINST A RESURGENCE OF RUSSIAN TOTALITARIANISM. HOWEVER, SOME ARGUE THAT YELTSIN'S PRE-OCCUPATION WITH THE WEST COMES AT THE EXPENSE OF MORE PRESSING FOREIGN POLICY PROBLEMS CLOSER TO HOME. RUSSIA HAS YET TO PURSUE A COHERENT POLICY WITH REGARDS TO ITS RELATIONS WITH THE OTHER FORMER SOVIET REPUBLICS AND WITH REGARDS TO CONFLICTS IN GEORGIA, MODOLVA AND NAGORNYKARABAKH. MANY ARE CALLING UPON' YELTSIN TO RECOGNIZE GEOPOLITICAL REALITY: RUSSIA IS A EURASIAN, NOT A EUROPEAN, STATE.

07941 RUBINFIEN, E. RUSSIA MEÉTS THE MARKET

NATIONAL REVIEN, XLIV(4) (MAR 92), 33-35.

SO FAR, RUSSIAN PRESIDENT BORIS YELTSIN IS STANOING FIRM. THE HARSH ECONOMIC MEASURES THAT HAVE DRIVEN PRICES UP MORE THAN THREE TIMES OVERNIGHT HAVE NOT BROUGHT MASSES INTO THE STREETS. THE MOOD IN MOSCON IS ONE OF HATCHFULNESS. BUT STREETS. THE MOOD IN MOSCOW IS ONE OF WATCHFULNESS. BUT YELTSIN WOULD DO WELL TO REST UP AND GATHER HIS STRENGTH ROUGHER TIMES IN APRIL. REMAINING CONTROLLED PRICES ON
STAPLES AND ENERGY ARE DUE TO BE LIBERALIZED THEN. YELTSIM STAPLES AND ENERGY ARE DUE TO BE LIBERALIZED THEN. YELTSIN
FACES SIGNIFICANTLY DIFFERENT CHALLENGES BECAUSE HE IS NO FACES SIGNIFICANTLY DIFFERENT CHALLENGES BECAUSE HE IS NO
LONGER THE OPPOSITION UNDERDOG. NOW HE IS HELD RESPONSIBLE LONGER THE OPPOSITION UNDERDOG. NOW HE IS HELD RESPONSIBLE FOR DETERIORATING CONDITIONS. IN OPPOSITION TO YELTSIN ANO
HIS REFORMS, SCATTERED GROUPS OF NATIONALISTS HAVE STARTED HIS REFORMS, SCATTERED GROUPS OF NATIONALISTS HAVE STARTED VARIETY OF CONSERVATIVE PARTIES ARE UNITING AROUND THE IDEA OF RECLAIMING LOST TERRITORY AND REBUILOING A GREAT RUSSIA.
07942 RUBINFIEN, E.

RUSSIA'S IDENTITY CRISIS

NATIONAL REVIEW, XLIV(9) (MAY 92), 19-22.

SEVEN DECADES OF SOVIET COMMUNIST DICTATORSHIP ON TOP OF CENTURIES OF CZARIST AUTOCRACY HAVE NOT CREATED A FERTILE SOIL FOR A FREE-MARKET ECONOMY AND WESTERN DEMOCRACY IN RUSSIA. THIS ARTICLE DISCUSSES THE PROBLEMS RUSSIA IS ENCOUNTERING AS IT ATTEMPTS TO BRIDGE THE GAP BETHEEN COMMUNISM AND DEMOCRACY.

07943 RUBINFIEN, E.; SNEIDER, D.

YELTSIN'S UNFINISHED REVOLUTION

MATIONAL REVIEW, XLIV(24) (DEC 92), 21-22; 24.

PRESIDENT YELTSIN CONFRONTS YET ANOTHER CONFLICT IN A SEEMINGLY ENDLESS SERIES OF CHALLENGES TO HIS RULE ON DECEMBER 1, WHEN THE CONGRESS OF PEDPLE'S DEPUTIES CONVENES ITS WINTER SESSION. ALL OF THE CRISES ULTIMATELY STEM FROM THE UNFINISHED CHARACTER OF THE SECOND RUSSIAN REVOLUTION-THAT IS, FROM MR. YELTSIN'S FAILURE TO CREATE A POST-SOVIET POLITICAL SYSTEM. ALONGSIDE PRACTICAL CONSIDERATIONS, MR. YELTSIN'S HESITATION IS ALSO A PRODUCT OF HIS TENDENCY TO RELY ON HIS PERSONAL STRENGTH TO GET WHAT HE WANTS. THIS RELY ON HIS PERSONAL STRENGTH TO GET WHAT HE WANTS. THIS ART ICLE SUGGESTS THAT YELTSIN IS CONFIDENT THAT HE CAN
AHAY FROM THIS CONGRESS WITH MOST OF WHAT HE WANTS.

07944 RUBINOFF, A.

GOA'S ATTAINMENT OF STATEHOOD

ASIAN SURVEY, $22(5)$ (MAY 92 ), 471-487

AFTER NEW DELHI'S MILITARY FORCES TERRITORIALLY INTEGRATED THE FORMER PORTUGUESE POSSESSIONS ON THE INDIAM SUBCONTINENT IN 1961. THE QUESTION OF THE FUTURE STATUS OF GOA, DAMAN, AND DIU REMAINED UNRESOLVED. DESPITE ASSURANCES FROM CENTRAL GOVERNMENT LEADERS THAT THE REGION'S UNIQUE CULTURAL INTEGRITY WOULD BE RESPECTED, THE NEIGHBORING STATES EMBARKED UPON A CAMPAIGN TO ABSORB THE TINY ENCLAVES. THIS ARTICLE EXPLORES THE CAMPAIGN FOR STATEHOOD--A CONDITION THAT WAS LINKED TO POLITICAL INTEGRATION WHEN GOA BECAME INDIA'S 25TH STATE.

07945 RUBINSTEIN, A.

IN SEARCH OF A FOREIGN POLICY

SOCIETY, 29(6) (SEP 92) 9-14.

IN THE 1990S THE U.S. FINDS ITSELF AT A WATERSHED. THE DISAPPEARANCE OF A DEFINING IDEOLOGICAL ENEMY, COMBINED WITH HARD TIMES AT HOME, HAS SPAHNED A NEW ISOLATIONIST IMPULSE. THIS ARTICLE OBSERVES THAT TENSION BETWEEN ISOLATIONISTS AND INTERNATIONALISTS IS AS OLD AS THE REPUBLIC; THAT CALLS FOR HEFTIER PEACE DIVIDENDS COULD WREAK HAVOC WITH ORDERLY FORCE REDUCTIONS; AND THAT RUSSIA'S CURRENT TIME OF TROUBLES IS A REDUCTIONS; AND THAT RUSSIA'S CURRENT TIME OF TROUB CONCLUDES THAT AMERICAN FOREIGN POLICY IS AT A CROSSROADS. CONCLUDES THAT AMERICAN FOREIGN POLICY IS AT A CROSSROADS.
CHOICES NEED TO BE MADE, THE CONSEOUENCES OF WHICH FOR THE CHOICES NEED TO BE MADE, THE CONSEQUENCE
FUTURE OF THE U.S. COULD BE MOMENTOUS

07946 RUBINSTEIN, D.

FROM HOPE TO UMCERTAINTY

TIKKUN, 7(2) (MAR 92), 21-23; 86-88

PALESTINIANS LOOKED TO THE MADRID NEGOTIATIONS HITH THE HOPE THAT INTERNATIONAL ATTENTION WOULD WIN THEM BOTH PEACE AND SELF-DETERMINATION. DISALLUSIONMENT FOLLOWED WHEN ISRAEL REMAINED INTRANSIGENT IN ITS REFUSAL TO EXCHANGE LAND FOR PEACE. HOWEVER, SOME HOPE REMAINS FOR THE PALESTINIANS WHO SEE NO OTHER ALTERNATIVE TO THE TALKS. PALESTINIAN SUPPORTERS OF A NEGOTIATED SETILEMENT HAVE TO RESIST THE FORCES ON BOTH SIDES OF THE CONFLICT POISED TO LEAD THEM INTO FRUSTRATION AND DESPAIR.

07947 RUDIG, H.

GREEN PARTY POLITICS AROUND THE WORLD

ENVIRONMENT, 33(8) (OCT 91), 6-9, 25-31

GREEN POLITICAL PARTIES HAVE BEEN ESTABLISHED IN MANY COUNTRIES DURING THE LAST 20 YEARS, YET VERY FEH HAVE EXPERIENCED SIGNIFICANT ELECTORAL SUCCESS. HERE, THE AUTHOR DISCUSSES THE DEVELOPMENT OF GREEN PARTIES, IDENTIFIES THE FACTORS BEHIND THEIR SPORADIC SUCCESSES AND RECURRING DEFEATS, AND EVALUATES THE ABILITY OF THE GREENS TO ATTRACT VOTERS, GIVEN THE GROWING ENVIRONMENTAL ZEAL OF MANY MAJOR POLITICAL PARTIES.

\section{RUDMAN, H.B.}

REFLECTION

JOURNAL OF LAW \& POLITICS, IX(1) (FAL 92) 121-126.

THE AUTHOR. WHO IS A UNITED STATES SENATOR, LAMENTS LOST OPPORTUNITIES TO CONTROL THE FEDERAL BUDGET DEFICIT. HE OPPORTUNITIES TO CONTROL THE FEDERAL BUDGET DEFICIT. HE NOTES THAT POL ITICAL CANDIDATES RARELY DISCUSS THE TOUGH
SOLUTIONS REOUIRED FOR CUTTING THE DEFICIT AND INSTEAD SPEAK SOLUTIONS REQUIRED FOR CUTTING THE DEFICIT AND INSTEAD SPEAK IN TERMS OF SYMBOLS OR PLATITUDES. THE DEFICIT PROBLEM IS DIFFICULT THAT EVEN IF DOMESTIC DISCRETIONARY AND FOREIGN AID WERE ELIMINATED, THE DEFICIT HOULD REMAIN. THE AUTHOR
CALLS FOR RESTRAINING GROWTH IN SPENDING, PARTICULARLY IN ENTITLEMENTS, AND/OR RAISING TAXES TO BRING THE BUDGET BACK UNDER CONTROL. 
07949 RUDNER, $M$.

EUROPEAN COMMUNITY DEVELOPOMENT ASSISTANCE TO ASIA:

POLICIES, PROGRAMS AND PERFORMANCE

MODERN ASIAN STUDIES, 26(1) (FEB 92), 1-30.

THE EUROPEAN COMMUNITY DIFFERS IN STRUCTURE, PURPOSE AND ROLE COMPARED TO OTHER, MORE FAMILIAR ORGANIZATIONS WHO ARE DONORS OF INTERNATIONAL DEVELOPMENT ASSISTANCE. THE COMMUNITY CONSTITUTES A SUPRA-EUROPEAN GOVERNMENTAL AUTHORITY IN THE MAKING. THIS ARTICLE EXPLORES THE EVOLUTION OF EEC AID POLICIES AND PROGRAMS AND THE FLOW OF ITS DEVELOPMENT ASSISTANCE TO ASIA. THE ROLE OF EEC AID TO ASIA IS STUDIED AND THE CHALLENGES TO EUROPEAN COMMUNITY STRATEGY TOWARDS ASIA ARE ENUMERATED. THE CONCLUSION IS DRAWN THAT A REORIENTATION OF EUROPEAN COMMUNITY POLICIES MORE IN FAVOR OF GREATER RECIPROCITY IN TRADE. INVESTMENT AND CDMMERCIAL

RELATIONS WITH THE DEVELOPING COUNTRIES OF ASIA IS REQUIRED.

07950 RUDOLF, $P$.

NON-PROL IFERATION AND INTERNATIONAL EXPORT CONTROL AUSSEN POLITIK, $42(4)$ (1991) 390-401

THE PROLIFERATION OF WEAPONS OF MASS DESTRUCTION AND LONG-RANGE DELIVERY SYSTEMS IN THE "THIRD WORLD" IS INCREASINGLY BECOMING A FOCUS OF THE INTERNATIONAL SECURITY DISCUSSION. THE LATEST EXPERIENCE WITH THE IRAQI ARMS ACOUISITION POLICY FORCED WESTERN INDUSTRIAL NATIONS TO RETHINK THEIR PREVIOUS EXPORT POLICIES. HOWEVER, TIGHTER NATIONAL RESTRICTIONS ON THE TRANSFER OF GOODS AND TECHNOLOGIES TO THE THIRD WORLD ARE ONLY EFFECTIVE AND SUSTAINABLE IN THE LONG RUN AGAINST ECONOMIC OPPOSITION IF ALL SUPPLIERS COMMIT THEMSLEVES TO A COMMON EXPORT CONTROL POLICY. THIS REQUIRES THE EXTENSION OF MULTILATERAL COORDINATION AND COOPERATION. THIS ARTICLE CONSIDERS HOW INTERNATIONAL EXPORT CONTROL COOPERATION HAS FARED SO FAR. IT OUTLINES THE PROBLEMS WHICH HAVE OVERSHADOWED

MULTILATERAL COOPERATION, AND CONSIDERS WAYS IN WHICH COOPERATION MIGHT BE EXTENDED AND IMPROVED. ITS EMPHASIS IS ON "DUAL USE" TECHNOLOGY.

07951 RUEHL, L.

ARMS CONTROL AFTER EAST-WEST CONFRONTATION

AUSSEN POLITIK, 43(4) (1992), 343-351.

DURING THE COLD WAR THE MAIN CONCERN OF THE WEST WAS ITS EFFORT TO DEFUSE THE ASPECT OF EXISTING TENSION THROUGH

PROGRESS IN ARMS CONTROL. AFTER THE FORMER USSR COMPLETED

THE TRANSITION TO COOPERATION WITH THE WESTERN COUNTRIES,

SITUATIONAL REOUIREMENT CHANGED. THIS ARTICLE OUTLINES THE

DEVELOPMENTS SINCE THE NEGOTIUTION AND SIGNING OF THE

STRATEGIC ARMS REDUCTION TALKS TREATY.

07952 RUELAND, J.

EUROPE--A MODEL FOR ASIA?

AUSSEN POLITIK, 43(4) (1992), 392-401

THE NEED FOR TRANSNATIONAL COOPERATION HAS BECOME

INCREASINGLY EVIDENT DURING THE POST-WAR ERA. WESTERN EUROPE

LED THE WAY WITH REGARD TO OVERCOMING NATION-STATE ISOLATION.

INTERNATIONAL ATTENTION HAS MAINLY CONCENTRATED ON THE

ASSOCIATED PROCESSES OF CONVERGENCE. ELSEWHERE THERE ALSO

HAVE BEEN ANALOGOUS EFFORTS WHICH COULD BE EQUALLY

SIGNIFICANT IN THE FUTURE. THIS APPLIES IN PARTICULAR TO INTEGRATION EFFORTS IN THE BOOMING ECONOMIC SOUTHEAST ASIAN REGION. THESE EFFORTS ARE THE FOCUS OF THIS STUDY.

07953 RUESCHEMEYER, M. (ED.)

WOMEN IN THE POLITICS OF POST-COMMUNIST EASTERN EUROPE

M. E. SHARPE, 1993, 288.

DURING THE COMMUNIST ERA IN EASTERN EUROPE, WOMEN HAD FORMAL MAMDATED PARTICIPATION AT LEAST IN MIDOLE-LEVEL POLITICAL POSITIONS IN MOST CDUNTRIES, AND TYPICALLY, HOMEN HAD JOBS OUTSIDE THE HOME. DESPITE NUMEROUS PROBLEMS WITH RESPECT TO THE DIVISION OF LABOR WITHIN THE HOUSEHOLD AND EQUALITY AT THE WORKPLACE AND IN POLITICAL LIFE, WOMEN DID ENJOY A CERTAIN STANDING AND OPPORTUNITIES IN SOCIETY. TODAY, HOWEVER, THE SOCIAL UPHEAVALS OF THE POST-COMMUNIST ERA, THE EARLY STAGES OF TRAMSITION TO MARKET ECONOMY THE COLLAPSE OF SOCIALIST STATE SERVICES, AND THE INTRODUCTION OF COMPETITIVE ELECTTS OFFECT ON HOMEM AND OFT TH THT EFFECT IS SPECIAL HARDSHIP EFFECT ON WOMEN, AND OFTEN THAT EFFECT IS SPECIAL HARDSHIP. IN EXAMINING THIS DILEMMA, THE PRESENT VOLUME FOCUSES ON THE ROLE OF HOMEN IN THE POLITICAL LIFE OF EASTERN EUROPE IT ANALYZES THE OFTEN MUTED VOICE OF WOMEN IN THE NEH POLITICAL PARTIES, THE UNION, AND THE RELIGIOUS INSTITUTIONS OF THE REGION, AND THE STRATEGIES THAT WOMEN ARE DEVELOPING TO INFLUENCE POLICYMAKING, PARTICULARLY IN THE
EMPLOYMENT, SOCIAL SERVICES, AND HEALTH POLICY.

07954 RUGGIE, $J$.

MULTILATERALISM: THE ANATOMY OF AN INSTITUTION INTERMATIONAL ORGANIZATION, 46 (3) (SUM 92), 561-598.

A CORE FEATURE OF THE INTERMATIONAL INSTITUTIONAL ORDER IS ITS MULTILATERAL FORM. THIS ARTICLE RECOVERS ITS PRINCIPLED MEANINGS FROM HISTORICAL PRACTICE, SHOWS HOH AND WHY THESE PRINCIPLED MEANINGS HAVE COME TO BE INSTITUTIONALIZED, AND SUGGESTS WHY MULTILATERALISM MAY CONTINUE TO PLAY A SIGNIFICANT ROLE TODAY EVEN AS SOME OF
THE POSTWAR CONDITIONS THAT GAVE RISE TO IT HAVE CHANGED.

07955 RUGGIE, $M$.

THE PARADOX OF LIBERAL INTERVENTION: HEALTH POLICY AND THE AMERICAN WELFARE STATE

AMERICAN JOURNAL OF SOCIOLOGY, 97 (4) (JAN 92), 919-944. MEDICARE AND MEDICAID ARE TYPICAL EXAMPLES OF LIBERAL INTERVENTIONISM. BEFORE 1980, THE U.S. GOVERNMENT ASSISTED OUTLAYS. DUE TO SKYROCKETING HEALTH CARE COSTS, THE GOVERNMENT HAS BECDME MORE INVOLVED IN REGULATING THE ACTIVITIES OF BOTH HOSPITALS AND PHYSICIANS. THE VEHICLE OF THIS CHANGE IN STATE INTERVENTION IS THE DIAGNOSTIC RELATED GROUP, OR DRG, SYSTEM OF PROSPECTIVE PAYMENT TO HOSPITALS ADOPTED IN 1983. DRG'S ENHANCE THE CAPACITY OF THE STATE TO GOVERN THE HEALTH CARE SYSTEM AS A WHOLE AND TO MANAGE ITS FACTORS OF PRODUCTION. THIS STEP-BY-STEP GROWTH OF FACTORS OF PRODUCTION. THIS STEP-BY-STEP GROWTH OF ENDORSES PRIVATE ENTERPRISE AND MARKETPLACE RATE SETTING CAN BE TERMED "THE PARADOX OF LIBERAL INTERVENTION."
BET

07956 RUHL, L.

BONN DEALS WITH THE REALITY OF RUSSIA

GERMAN TRIBUNE, (1495) (DEC 91), 2

BORIS YELTSIN'S VISIT TO BONN SYMBOLIZED RUSSIA'S

RECOGNITION AS A POWER IN ITS OWN RIGHT IN THE INTERNATIONAL COMMUNITY AND AS A WEAKENED BUT ONGOING EUROPEAN POWER WITH A FUTURE. SINCE THE EVENTS THAT SHOOK MOSCOW IN THE SUMMER OF 1991, A DISTINCTION HAS HAD TO BE DRAWN BETWEEN RUSSIA AND THE FORMALLY STILL EXISTING SOVIET UNION IN THE PROCESS OF TRANSFORMATION TO A LOOSE CONFEDERATION OF SOVEREIGN STATES WITH RUSSIA AS ITS NUCLEUS AND THE OTHER SEVEN MEMBERS. RUSSIA IS RETURNING TO THE INTERNATIONAL ARENA AS A SEPARATE ENTITY. YELTSIN EMBODIES THE RUSSIAN STATE AND RUSSIAN NATIONAL FEELING IN ALL ITS AMBIVALENCE AS A RUSSIAN FEDERATION COMPRISING OVER 140 ETHNIC GROUPS WITHIN RUSSIA. OVER 80 PERCENT OF THE UNION'S NATURAL RESOURCES, INCLUDING OIL AND NATURAL GAS, IS ON FEDERATION TERRITORY, AND MR. YELTSIN CLAIMS CONTROL OVER THEM AS HEAD OF THE' GOVERNMENT. HIS IMCREASED STATURE HAS CAUSED THE GEPMAY GOYERMMENT TO CONSIDER HIM TO BE A FORCE TO BE RECKONED WITH.

07957 RUHL, L.

CSCE METHODS UNSUITED TO CONTAINING CRISES

GERMAN TRIBUNE, 31(1538) (OCT 92), 2 .

MOVEMBER IS THE TIME TO ASSESS CSCE POLICY. THE MAIN PROBLEM IS THAT CONFLICT CAUSES HAVE SHIFTED FROM RELATIONS BETHEEN STATES, FOR WHICH THE CSCE WAS SET UP, TO DOMESTIC CLASHES WHICH CROSS BORDERS AND CREATE FRESH SECURITY RISKS FOR ALL EUROPE. CONFLICTS

07958 RUHL, L.

GERMANY'S FUTURE "ANCHORED IN WESTERN ALLIANCE" GERMAN TRIBUNE, 1500 (JAN 92), 2-3.

GERMANY'S REUNIFICATION WITHIN THE CONTRACTUAL FRAMEHORK OF THE ATLANTIC ALLIANCE, UNDER THE UMBRELLA OF THE ASSISTANCE CLAUSE OF THE 1949 ALLIANCE TREATY, IS THE FIRST AND MOST IMPORTANT PREREQUISITE FOR THE GUARANTEED EXISTENCE OF GERMANY AND ITS IMMEDIATE NEIGHBORS IN CENTRAL AND NORTHWEST EUROPE. THIS ARTICLE DISCUSSES UNITED GERMANY'S PLACE IN INTERNATIONAL RELATIONS. IT DISCUSSES THE VEIWS OF NATO ON THE SUBJECT.

07959 RUHL, L.

MAASTRICHT PLEBISCITE: EVEN A YES WOULD CAUSE UNDERTINTIES GERMAN TRIBUNE, 31(1531) (SEP 92), 1-2.

IT IS THE COINCIDENCE OF A REFEREMDUM ON THE MAASTRICHT TREATY, WHICH IS CONSTITUTIONALLY NOT ESSENTIAL, WHICH HAS LED TO A CRITICAL SITUATION FOR THE EUROPEAN UNIFICATION-JUST AS MAASTRICHT ITSELF HAS THE OVERHASTY REACTION TO GERMANY UNIFICATION AND UPHEAVELS IN EUROPE. THE CONFLICT BETHEEN NATIONAL INTERESTS IN IHIS SITUATION HAS YET TO BE RESOLYED. THIS ART ICLE SUGGESTS THAT SIMCE 1989 HESTERM EUROPE'S POLITICAL CLASS ON THE WHOLE HAS DEMONSTRATED ITS LACK OF HISTORICAL UNDERSTANDING. ITS INABIIITY TO THINK IN STRATEGIC TERMS AND ITS LOSS OF A SENSE OF REALITY IN YIEW STRATEGIC TERMS AND ITS LOSS OF A SENSE OF REALITY IN VIEN OF THE DISINTEGRATION OF THE RUSSIAN SOVIET EMPIRE WITH AN EPOCH-MAKING UPHEAVAL OF THE GEOPOL ITICAL STRUCTURE
EUROPEAN CONTINENTS AND ALSO IN VIEW OF THE BLOODY DISSOLUTION OF YUGOSLAVIA. THE ARTICLE CONCLUDES THAT DISSOLUTION OF YUGOSLAVIA. THE ARTICLE CONCLUDES THA
GERMANY NOW NEEDS TO BRING ITS OWH HOUSE IN ORDER.

$07960^{\circ}$ RUHL, L.

UKRAINE ALTERS HORLD'S NUCLEAR EQUATION GERMAN TRIBUNE (1496) (DEC 91 ) 2 .

THE DISSOLUTION OF THE SOVIET UNION RAISES THE PROBLEM OF SOVIET MUCL EAR HEAPONS AND INTERMATIONAL SECURITY AND ARMS CONTROL. ALL FIVE BRANCHES OF THE SOVIET ARMED FORCES HAVE MUCLEAR WEAPONS IN VARIOUS AMOUNTS. AS LONG AS SOVIET NUCLEAR WEAPONS ARE IN THE UKRAINE, ITS DECLARATION OF INDEPENDENCE MAKES IT THE WORLD'S THIRD OR FOURTH LARGEST NUCLEAR POWER, AHEAD OF FRANCE AND BRITAIN. 162 STRATEGIC 
MISSILE SYSTEMS AND 120 STRATEGIC BOMBERS ARE LOCATED IN THE UKRAINE THE MAJOR FACTORS HICH WILL DETERMINE THE STABIL ITY AMD CONTROL OF NUCLEAR WEAPONS IN THE REGION ARE: THE EFFECTIVENESS OF CENTRAL POLITICAL AND MILITARY CONTROL: THE NATURE AND EXTENT OF THE INVOLVEMENT OF THE FOUR REPUBLICS OF RUSSIA, THE UKRAINE, BELORUSSIA, AND KAZAKHSTAN THE EFFECTIVENESS OF ADMINISTRATION AND CONTROL BY THE KGB OF THE SOVIET UNION; THE PERMISSION OF INTERNATIDNAL CONTROLS AND ON-THE-SPOT INVESTIGATIONS; AND THE GUARANTEE THAT ALL SUCCESSOR STATES OF THE SOVIET UNION STRICTLY OBSERVE AND APPLY THE 1969 GENEVA NONPROL IFERATION TREATY, THE 1988 INF TREATY, AND THE 1991 START TREATY.

07961 RUHLE, H.

EUROPEAN ALTERNATIVE tO NATO FORCE IS STILL "A HAREBRAINED STRATEGIC NOTION"

GERMAN TRIBUNE, 1487 (OCT 91), 5.

THE AUTHOR OF THIS ARTICLE, HANS RUHLE, WAS FOR SEVERAL YEARS HEAD OF PLANNING AT THE DEFENSE MINISTRY IN BONN, GERMANY. RUHLE DISCUSSES THE POSSIBILITY OF A EUROPEAN ATERNATIVE TO NATO FORCE. A NUMBER OF POLITICIANS AND JOURNALISTS, GERMANS INCLUDED, HAVE PUBLICLY RAISED THE JOURNALISTS, GERMANS INCLUDED, HAVE PUBLICLY RAISED THE
POSSIBILITY OF SENDING IN A EUROPEAN RAPID REACTION FORCE.

07962 RUMMEL, R. (ED.)

TOHARD POL ITICAL UNION. PLANHING A COMMON FOREIGN AND SECURITY POLICY IN THE EUROPEAN COMNL

MOMOS VERLAGSGESELLSCHAFT, 1992,362

THIS BOOK DEALS HITH THE CURRENT STATE OF THE ENVISAGED DEVELOPMENTS OF A COMMON FOREIGN AND SECURITY POLICY IN THE EUROPEAN COMMUNITY (EC). VARIOUS AUTHORS CONDUCT ANALYSES AND ASSESSMENTS IN FOUR AREAS: FORTHCOMING TASKS OF A FOREIGN AND SECURITY POLICY OF THE EUROPEAN UNION; INTERNAL ORGANIZATION ANO EXTERNAL ACTION RADIUS OF PREVIOUS EXTERNAL RELATIONS OF THE EC AND WITHIN THE FRAMEWORK OF EUROPEAN POLITICAL COOPERATATION; ASSESSMENT OF THE INITIATED FORMATION OF THE UNION BY NEIGHBORING STATES IN INTERNATIONAL PARTNERS; AND ALTERNATIVE CONCEPTS AND DEVELOPMENTAL VARIANTS FOR POLITICAL UNION.

07963 RUPERT, J.

DATELINE TASHKENT: POST-SOVIET CENTRAL ASIA

FOREIGN POLICY, (87) (SUM 92), 175-195.

THIS ARTICLE EXAMINES THE FOREIGN POLICY CHALLENGES PRESENTED BY THE ARRIVIAL OF POST-SOVIET CENTRAL ASIAN REPUBLICS ON THE INTERNATIONAL SCENE. IT BRIEFLY OUTLINES DEFINING CHARACTERISTICS OF UZBEKISTAN, KAZAKSTAN, KYRGYZSTAN, TURKMENISTAN, AND TAJIKISTAN. IT THEN ARGUES THAT PROMINENT AMERICAN PERCEPTIONS ABOUT THE REGION, MOST THAT PROMINENT AMERICAN PERCEPTA ONS ABOUT THE REGION, MOST NOTABLY THAT IT IS A HOTBED OF ISLAMIC FUNDAMENTALISH, ARE FLAWED. THE ARTICLE ARGUES FOR INCREASED AMERICAN ATTENTION AND ECONOMIC REFORM IN CENTRAL ASIA.

07964 RUPNIK, J.

CZECH REPUBLIC, 207(8-9) (AUG 92), 15-16.

WITH THE RESIGNATION OF PRESIDENT VACLAY HAVEL ON JULY 17, 1992, MOST OBSERVERS ASSUMED THAT CZECHOSLOVAKIA HAD BEGUN THE PROCESS OF CENTRIFUGAL COLLAPSE AND DIVISION INTO THO STATES. ON THE CONTRARY, THIS WAS THE BEGINNING OF A PROCESS OF PRAGMATIC BARGAINING, THE CONCLUSION OF WHICH IS BY NO MEANS CERTAIN.

07965 RUSCIANO, F.L.

RETHINKING THE GENDER GAP: THE CASE OF WEST GERMAN

ELECTIONS, 1949-1987

(APR 92), 335-357.

TWO COMMON ASSUMPTIONS REGARDING THE "GENDER GAP" IN VOTING ARE THAT SIGNIFICANT DIFFERENCES IN MALE AND FEMALE VOTING PATTERNS STEM FROM CHANGES IN FEMALE PERCEPTIONS OF THEIR POLITICAL ROLES AND IN A GREATER HILLINGNESS TO RENDER POL ITICAL JUOGMENTS. AN EXAMINATION OF WEST GERMAN FEDERAL ELECTIONS BETHEEN 1949 AND 1987, FOCUSING ON THE 1972 ELECTION, CHALLENGES THESE ASSUMPTIONS. IN THE WEST GERMAN CASE, HOMEN CLAIMED A MORE VISIBLE ROLE IN POLITICS, BECAME MORE LIKELY TO RENDER POLITICAL JUDGMENTS, AND THEREBY CLOSED A PREYIDUSLY EXISTING GENDER GAP IN VOTING. THE MECHANISMS FOR THIS CHANGE ARE STUDIED USING DATA ON FEMALE EYALUATIONS OF THEIR POL ITICAL ROLES POLITICAL PARTIES AMD EVALUATIONS OF THEIR POLITICAL ROLES, POLITICAL PARTIES, AND CANDIOATES. OF CHANGES IN WOMEN'S STATUS TN THE HOME, HORK FORCE, AND

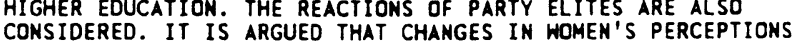
CONSIDERED. IT IS ARGUED THAT CHANGES IN WOMEN'S PERCEPT POL POLITICAL AGENDA TO CLOSE THE GENDER GAP. GENDER GAP THEORY POLITICAL BEHAVIOR.

07966 RUSH, M.

THE VARIABILITY OF PARTISANSHIP AND TURNOUT: IMPLICATIONS FOR GERRYMANDERING ANALYSIS AND REPRESENTATION THEORY AMERICAN POLITICS QUARTERLY, 20(1) (JAN 92), 99-122.

RESEARCH ON THE IMPACT OF REDISTRICTING ON THE
REPRESENTATIONAL OPPORTUNITY OF POLITICAL GROUPS IS FREQUENTLY GROUMDED ON THE ASSUMPTION THAT A GROUP'S "FAIR REPRESENTATION" CAN BE EASILY DETERMINED. IN THIS ARTICLE, THE AUTHOR TAKES ISSUE WITH THIS ASSUMPTION AND SHOWS THAT BECAUSE PARTISAN BEHAVIOR IS OUITE SENSITIVE TO CHANGES IN THE ELECTORAL ENVIRONMENT THE PARTISAN PROFILE AND THEREFORE, THE FAIR REPRESENTATION OF A GIVEN CONSTITUENCY IS QUITE DIFFICULT TO DETERMINE. AS A RESULT, THEORIES OF REPRESENTATION AS HELL AS THE CONCEPT OF ITS DENIAL BY GERRYMANDER MUST BE RECONSIDERED.

07967 RUSONIK, A.

ISRAELI DEFENSE DOCTRINE AND US MIDDLE EAST DIPLOMACY: FROM SUEZ TO THE LOAN GUARANTEES/SETTLEMENTS DISPUTE JERUSALEM JOURNAL OF INTERNATIONAL RELATIONS, 14(3) (SEP 92), 44-68.

WITH THE DEFEAT OF THE AMERICAN JEHISH LOBBY IN THE LOAN GUARANTEES DISPUTE AND THE APPARENT OBSOLESCENCE OF ISRAEL'S ROLE AS A US STRATEGIC SURROGATE AFTER THE SOVIET COLLAPSE, STRONG EVIDENCE OF CONTINUED US SUPPORT FOR ISRAEL'S MILITARY ADVANTAGE EVEN AMID SHARP DIPLOMATIC CONFLICT DEMANDS A NEW EXPLANATORY APPROACH TO US-ISRAELI RELATIONS. BASED ON DECLASSIFIED US GOVERMMENT DOCUMENTS, THIS ARTICLE BASED ON DECLASSIFIED US GOVERMMENT DOCUMENTS, THIS ARTICLE ENLISTS ALLIANCE THEORY TO ARGUE THAT A FUNDAMENTAL AND
CONSTANT GOAL IN AMERICAN SUPPORT OF ISRAEL'S CONVENTIONAL CONSTANT GOAL IN AMERICAN SUPPORT OF ISRAEL'S CONVENTIONAL
DETERRENT IS THE RELAXATION OF ISRAELI PREEMPTIVE TENDENCES OETERRENT IS THE RELAXATION OF ISRAELI PREEMPTIVE TENDENCES
AND NUCLEAR AMBITIONS THAT JEOPARDIZE US INTERESTS IN THE AND NUCLEAR AR NORLD.

07968 RUSSELL, M.; COLGLAZIER, E.; TONN, B.

THE U.S. HAZARDOUS WASTE LEGACY

ENVIRONMENT, 34(6) ( JUL 92), 12-15.

AT BEST GUESS, THE TOTAL' COST OF CLEANING UP U.S.

HAZARDOUS HASTE SITES WILL REACH MORE THAN S750 BILLION. A CHANGE IN POLICY, HOWEVER, TOWARD EITHER MORE CONTAINMENT OR MORE DESTRUCTION OF WASTES, COULD SIGNIFICANTLY REDUCE OR INCREASE THIS ESTIMATE. THEREFORE, THE PROGRESS OF CURRENT REMEDIATION EFFORTS MUST BE REASSESSED TO ENSURE THAT CLEANUP CONTINUES EFFICIENTLY INTO THE FUTURE.

07969 RUSSELL, P.

CAN THE CANADIANS BE A SOVEREIGN PEOPLE?

CANADIAN JOURNAL OF POLITICAL SCIENCE, 29(4) (DEC 91), 691-710.

NO COUNTRY HAS BEEN ENGAGED IN MACRO-CONSTITUTIONAL POLITICS SO INTENSIVELY FOR SO LONG AS CANDA. WHEN CONSTITUTIONAL POLITICS IS AT THE MACRO LEVEL. THE CONSTITUTIONAL QUESTION TENDS TO DHARF ALL OTHER ISSUES. EXCEPT FOR A FEW SHORT INTERVALS CANADA HAS BEEN ENGAGED IN CONSTITUTIONAL POLITICS SINCE THE MID-1960S. THIS ARTICLE CONCLUDES THAT AS CANADIANS ENTER THE FINAL ROUND OF MACROSONSTITUTIONAL POLITICS, THEY WILL FIND OUT WHETHER THEY SONSTITUTIONAL POLITICS, THEY WILL FIND OUT WHETHER THEY
SHARE ENOUGH IN COMMON TO CONSTITUTE THEMSELVES A SINGLE SHARE ENOUGH IN COH
SOVEREIGM PEOPLE.

07970 RUSSETT, B. : ANTHOLIS, $W$.

DO DEMOĆRACIES WITH EACH OTHER? EYIDENCE FROM THE PELOPONMESIAN WAR

JOURMAL OF PEACE RESEARCH, 29(4) (NOY 92), 415-534.

THE PROPOSITIDN THAT DEMOCRACIES RARELY FIGHT EACH OTHER IN THE MODERN INTERNATIONAL SYSTEM IS INCREASINGLY ACCEPTED, AND OF GREAT IMPORTANCE TO THEORY AND PRACTICE. YET THE REASONS BEHIND THIS PHENOMENON, AND HENCE EXPECTATIONS AS TO HOW IT MAY OPERATE UNDER OTHER CONDITIONS, ARE STILL NOT WELL UNDERSTOOD. THIS ARTICLE SYSTEMATICALLY COMPILES INFORMATION ON WARS AND TYPES OF POLITICAL SYSTEMS IN THE WORLD OF ANCIENT GREEK CITY-STATES, AND ASKS WHEN AND WHY DEMOCRACIES FOUGHT EACH OTHER. A QUANTATIVE ANALYSIS OF HARFIGHTING PATTERMS IS INCONCLUSIVE, BUT CONTEXTUAL EXAMINATION OF ACTS AND PERCEPTIONS AS REPORTED IN ANCIENT SOURCES ILLUMINATES THE MOTIVATIONS. DESPITE PROMINENT EXCEPTIONS, A NORM AGAINST FIGHTING OTHER DEMOCRACIES WAS EMERGING AND HAD SOME EFFECT.

07971 RUSSO, J.: CORBIN, B.

A SYSTEM OF INTERPRETATION: CATHOLIC SOCIAL TEACHING AND AMERICAN UNIONISH

CONFLICT, 11(4) (1991), 237-266.

THIS ARTICLE IS ABOUT THO SOCIAL INSTITUTIONS WHICH HAVE EXPERIENCED CONFLICTS WITHIN THEIR OWN RESPECTIVE

ORGANIZATIONS REGARDING THEIR POLICY TOWARD THE OTHER ORGANIZATION AND HAYE EXPERIENCED CONFLICTS BETHEEN THEM REGARDING COMMON PROBLEMS. THE HISTORICAL AND ON-GOING POLITICAL RELATIONSHIP BETWEEN THE U.S. CATHOLIC CHURCH AND AMERICAN UNIONS ARE DISCUSSED BY ANALYZING THE THEORETICAL AMERICAN UNIONS ARE DISCUSSED BY ANALYZING THE THEORETICAL FOUNDATION OF THAT RELATIONSHIP. SEVERAL CASE STUDIES THAT HIGHLIGHT VARIOUS ASPECTS
ALLIANCES ARE PRESENTED.

07972 RUST, $M$

A CAP ON LAHMAKERS' TERMS

INSIGHT, 8(48) (NOV 92), 6-11

THIS ARTICLE STATES THAT THE "THROW THE RASCALS OUT" CLARION MAY HAVE FALLEN ON MOSTLY DEAF EARS WHEN IT CAM TO 
RETURNING INCUMBENTS TO OFFICE, BUT IT RANG LOUD AND CLEAR FOR BACKERS OF TERM-LIMIT BALLOT MEASURES IN 14 STATES, ALL OF WHICH PASSED. THESE ACTIVISTS SAY IT'S THE BEGINNING OF THE END FOR CONGRESS'S SUFFOCATING SENIORITY

07973 RUST, M.

GAY RIGHTS IN BOTTOM OF NINTH

INS I GHT, 8(45) ( NOV 92), 10-13, 34-37

ON NOVEMBER 3,1992 , OREGONIANS WILL VOTE ON MEASURE 9 WHICH WOULD OFFICIALLY DISCOURAGE HOMOSEXUALITY AND PREYENT THE GOVERNMENT FROM PROMOTING IT VOTERS ON BOTH SIDES OF THE ISSUE AGREE THAT INDIVIDUAL RIGHTS ARE AT STAKE. SUPPORTERS SAY THE GOVERMMENT NEEDS TO RESPECT THEIR MORAL CODE, WHILE OPPONENTS SAY GAYS ARE BEING MADE A SCAPEGOAT.

07974 RUST, $M$

POLITICS' GREAT DIVIDE

INSIGHT, 8(34) (AUG 92), 14-16;39.

AS DEMOCRATS AND REPUBLICANS PREPARE FOR THE FALL CAMPAIGN THE SUBJECT OF ABDRT PREPARE FOR THE FALL CONTINUES TO SPLIT BOTH PARTIES. MEMBERS HHO DON'T TOE THE PARTY LINE HAVE FOUND THEIR POLITICAL HOUSES INHOSPITABLE. FORMER ALLIES SEE THE DISSENTERS NOT AS PROPHETS BUT AS HERETICS, FOR WHOM A PURGE RATHER THAN A PLATFORM IS THE PROPER RESPONSE. BOTH SIDES DO AGREE THAT THE HOSTILITIES WILL NOT END SOON.

07975 RUST, M.

STILL FIGHTING THE CIVIL WAR

INSIGHT, 8(31) (AUG 92), 14-16

THE NEO-CONFEDERATES ARE CONSERVATIVES WHO REJECT

LINCOLN. THEY BELIEVE IN CONTINUING THE FIGHT FOR STATES' RIGHTS AND AGAINST GAOVERNMENT-ENFORCED EOUALITY. NOT ALL ARE PARTISANS OF THE SOUTH OR OPPONENTS OF THE FEDERAL SYSTEM, BUT THEY ALL SHARE THE VIEW THAT ABRAHAM LINCOLN'S BELIEF' IN EQUALITY IS INCOMPATIBLE WITH TRUE CONSERVATISM. THEY ARE MOVING TO A PARTICULAR AMERICAN TREND THAT EMPHASIZES STATES' RIGHTS, LIMITED GOYERMMENT--EVEM CHEAP GOVERNMENT. OUITE SIMILAR TO THE DEMOCRATIC PARTY UP TO 1932

07976 RUST, M.

THE ELITES VERSUS THE PEOPLE'S CHOICE

INSIGHT $8(40)$ (OCT 92 ) $12-13 ; 38-39$.

THE BUZZWARD IN POLITICS THIS YEAR IS "ELITE," WITH EACH PARTY USING IT TO ATTACK THE OTHER. TWO POLITICAL OBSERVERS PART COME FROM DIFFERENT IDEO THER. TWO POLITICAL OBSERVERS THO THINGS: THE SOCIAL HIERARCHY EXISTS AND GIVING THE PEOPLE WHAT THEY WANT HILL REQUIRE LOOKING BEYOND MERE PEOPLE WHAT THEY WAM
INCOME STATISTICS.

07977 RUST, $M$

TRASHING WASTE IN GOVERMMENT

INSIGHT, 8(43) (OCT 92), 14-16;36.

POLITICIANS HAVE HAD A LOT TO SAY LATELY ABOUT COMBATING WASTE AND ABUSE IN FEDERAL SPDENDING, BUT HOW MUCH OF IT IS POSTURING, ASKS THIS ARTICLE. A LOT, IT DECIDES, BUT EFFORT BY GROUPS SUCH AS CITIZENS AGAINST GOVERMMENT WASTE AND SOME LAWMAKERS GENUINELY COMMITTED TO DEFICIT REDUCTION COULO TURN THE TIDE.

07978 RUST, M.

VOTING'S NEW RACIAL BOUNDARIES

INSIGHT, 8(27) (SEP 92), 14-16, 38 .

THE REDISTRICTING THÁT OCCURS EYERY 10 YEARS DUE TO

POPULATION SHIFTS RECORDED BY THE CENSUS HAS PRODUCED SOME

STRANGE BEDFELLOWS IN 1992. THE REPUBLICAN PARTY HAS ALLIED

ITSELF WITH THE CIVIL RIGHTS ESTABL ISHMENT IN A BID TO
DILUTE DEMOCRATIC VOTING STRENGTH. BLACKS AND HISPANICS HOPE

TO USE NEWLY-REDRAWN DISTRICTS TO BOOST THEIR RANKS IN

CONGRESS.

07979 RUSTIN, M.

CITIZENSHIP AND CHARTER 88

NEW LEFT REVIEW, (191) (JAN 92), 37-42.

THE AUTHOR IS A MEMBER OF THE ORGANIZING COUNCIL OF CHARTER 88, WHICH OVER THE PAST THREE YEARS HAS FOCUSED MUCH PUBLIC DISCUSSION ON QUESTIONS OF DEMOCRATIC RIGHTS AND PROCEDURES. IN THIS ESSAY, HE MAKES A CASE FOR BROADENING PROCEDURES. IN THIS ESSAY, HE MAKES A CASE FOR BROADENING RIGHTS AND THE EUROPEAN DIMENSION.

07980 RUTHERFORD, $M$.

BRITAIN: A YERY DOMESTIC ELECTION

BRITAIN: A VERY DOMESTIC ELECTION

THE RESUITS OF BRITAIN'S APRII 1992 GENERAL ELECTIONS SURPRISED THE POL STERS. THE CONSERVATIVE PARTY WON ALMOST 43\% OF THE VOTES, WITH LABOUR TAKING 35\%. ALTHOUGH THE LIBERAL DEMOCRATS BENEFITTED FROM THE LEADERSHIP OF PADDY ASHDOWN, THEY CLAIMED ONLY $18 \%$ OF THE VOTES.

07981 RUTLEDGE, J.

HOH TO INCREASE UNEMPLOYMENT

NATIONAL REVIEW, XLIV(22) (NOV 92), 46.
CLINTONOMICS IS A RADICAL DEPARTURE FROM TRADITIONAL DEMOCRATIC THINKING. CLINTON IS THE FIRST DEMOCRATIC CANDIDATE SINCE THE 1930 S WHOSE ECONOMIC PROGRAM IS NOT BASED ON KEYMESIAN DEMAND MANAGEMENT. CLINTON'S POLICIES RELY ON THE DARK SIDE OF SUPPLY-SIDE THINKING. THEY ATTEMPT TO MANIPULATE MARKET PRICES IN ORDER TO ENGINEER A SOCIAL OR ECONOMIC OUTCOME THE PRIVATE MARKET WOULD NOT OTHERWISE PRODUCE. THIS ARTICLE ARGUES THAT CLINTON'S POLICIES ARE

07982 RUTTAN, V.W.

AN EMERGING VISION OF GLOBAL FUTURES

CHALLENGE, 35(3) (MAY 92), 51-52.

THE SINGLE MOST IMPORTANT OBJECTIVE OF U.S. FOREIGN ECONOMIC COOPERATION IN THE NEXT FIVE YEARS SHOULD BE TO ECONOMIC COOPERATION IN THE NEXT FIVE YEARS SHOULD BE TO
ACHIEVE A SUCCESSFUL TRANSITION OF THE RUSSIAN AND EAST ACHIEVE A SUCCESSFUL TRANSITION OF THE RUSSIAN ANO EAST TO LIBERAL POLITIES.

07983 RUTTAN, V.W.

WHAT HAPPENED TO POLITICAL DEVELOPMENT?

ECONOMIC DEVELOPMENT AND CULTURAL CHANGE, 39(2) (JAN 91), 265-293.

THIS ARTICLE REPRESENTS AN ATTEMPT TO ASSESS WHAT DEVELOPMENT ECONOMISTS COULD LEARN FROM THEORY AND RESEARCH IN THE FIELD OF POLITICAL DEVELOPMENT TO ADVANCE KNOWLEDGE AND THEORY IN THE FIELD OF ECONOMIC DEVELOPMENT. THE AUTHOR REVIEWS THE CONTRIBUTIONS OF SEVERAL DEVELOPMENT ECONOMISTS WHO HAVE ATTEMPTED TO GIVE EXPLICIT ATTENTION TO POLITICAL PRECONDITIONS OR CONDITIONS FOR ECONOMIC DEVELOPMENT. THE AUTHOR THEN REVIEWS THE EVOLUTION OF THOUGHT IN THE FIELD OF POLITICAL DEVELOPMENT. FINALLY, THE ARTICLE CONCLUDES WITH A DISCUSSIDN OF THE CENTRAL PROBLEM OF THE GROWTH OF POLITICAL POWER AND ITS RELATIONSHIP TO ECONOMIC GROWTH.

07984 RYAN, D.; BRIDGEMAN, G.

JUDGING THE ROLES OF LEGISLATION, EDUCATION AND OFFSETTING BEHAVIOUR IN SEAT BELT USE: A SURVEY AND NEH EVIDENCE FROM ALBERTA

CANADIAN PUBLIC POLICY--ANALYSE DE POLITIQUES, 188(1) (MAR $92), 27-46$.

IN THE CONTEXT OF A MODEL THAT ALLOWS FOR DRIVER BEHAVIOURAL RESPONSES, THE AUTHORS SURVEY THE EYIDENCE CONCERNING THE EFFECTS OF EDUCATION PROGRAMS AND LEGISLATION IN PROMOTING SEAT BELT USE, AND INCLUDE SOME NEW EMPIRICAL IN PROMOTING SEAT BEL USE, AND INCLUDE SOME NEW EMPIRICAL FINDINGS BASED ON A SURVEY UNDERTAKEN IN ALBERTA PRIOR TO SUCH USE BECOMING AANDATEYY. THEY CONCLUDE THAT EFFECTIVE DRIVER EDUCATION PROGRAMS MUST BE DESIGNED IN A HAY THAT ALLONS DRIVERS TO GAIN EXPERIENCE AND DEVELOP THE HABIT OF WEARING SEAT BELTS. PARADOXICALLY, MANDATORY SEAT BELT USE LEGISLATION MAY BE ONE OF THE MOST EFFECTIVE MEANS FOR PROVIOING DRIVERS WITH THE OPPORTUNITY FOR DEVELOPING THESE
HABITS.

07985 RYAN, J.

LITERACY RESEARCH, POLICY, AND PRACTICE: THE ELUSIVE TRIANGLE

ANNALS OF THE AMERICAN ACADEMY OF POLITICAL AND SOCIAL SCIENCE, (520) (MAR 92), 36-41.

THE AUTHOR EXPLORES THE INTERRELATIONSHIPS BETHEEN LITERACY RESEARCH, PUBLIC POLICY, AND PRACTICE. HE CONTENDS THAT THESE THREE SPHERES OF ACTIVITY, WHICH IN PRINCIPLE SHOULD BE CLOSELY RELATED AND MUTUALLY SUPPORTIVE, HAVE DEVELOPED INDEPENDENTLY AND REMAIN SEPARATED BY MUTUAL MISUNDERSTANDINGS. IN DEVELOPING NATIONS, INTERNATIONALLYSANCTIONED POLICY OBJECTIVES AND EXTERNALLY-FUNDED RESEARCH HAVE OFTEN RESULTED IN RESEARCH ENDEAVORS THAT FAIL TO ILLUMINATE PREVAILING REALITIES AND IN POLICY GOALS OUT OF TOUCH HITH ACTUAL POSSIBILITIES. THE AUTHOR NOTES THE TOUCH WITH ACTUAL POSSIBILITIES. THE AUTHOR NOTES THE INCREASING EFFORTS IN BOTH INDUSTRIALIZED AMD DEVELOPING COUNTRIES TO ENSURE CLOSER LINKAGES BETWEEN RESEARCH, POLICY FORMULATION, AND PRACTICE.

07986 RYAN, J.E.

THE SURVEY 1992

FREEDOM REVIEW, 23(1) (JAN 92), 7-11, 13,-24. THE AUTHOR EXPLAINS THE GUIDELINES FOR THE FREEDOM HOUSE'S ANNUAL "COMPARATIVE SURVEY OF FREEDOM" AND PRESENTS HOUSE'S ANNUAL "COMPARATIVE SURVEY OF FREEDOM" AND
THE RESULTS OF THE 1991 SURVEY. IN 1991, THE WORLD EXPERIENCED RADICAL POLITICAL MOVEMENT, REFLECTED IN CHANGED EXPERIENCED RADICAL POLITICAL MOVEMENT, REFLECTED IN CHANGED RATINGS FOR 54 COUNTRIES. THIRTY-EIGHT COUNTRIES IMPROVED
THEIR HUMAN RIGHTS SITUATIONS, WHILE DIMINISHED HUMAN RIGHTS THEIR HUMAN RIGHTS SITUATIONS, WHILE DIMINISHED HUMAN R
WERE OBSERVED IN 16 COUNTRIES. IN ADDITION, 23 NATIONS WERE OBSERVED IN 16 COUNTRIES. IN ADDITIDN, 23 NATIONS
IMPROVED THEIR STANDING IN THE "FREE," "PARTLY FREE," OR

"NOT FREE" CATEGORIES WHILE ONLY SIX LOST GROUND.

07987 RYAN, R.

ARE THERE NO LIMITS TO FEDERAL REGULATORY POWER? FREEMAN, 42(12) (DEC 92 ), 469-470.

THIS ARTICLE EXPLORES WHETHER OR NOT THE FEDERAL GOVERMMENT OF LIMITED AND ENUMERATED POHERS REALLY COULD MAKE A FEDERAL CASE OF HOW ONE CHOOSES TO KILL BUGS IN THEIR OWN KITCHEN. THE AUTHOR, A LAHYER, RESEARCHED THIS QUESTION 
AND DISCOVERD THAT EVEN HITHOUT SUCH SPECIFIC ENUMERATED POWER, CONGRESS HAS INDEED ENACTED AN ELABORATE REGULATORY SCHEME FOR PESTICIDES, CALLED THE FEDERAL INSECTICIDE, FUNGICIDE, ANO RODENTICIDE ACT. HE EXPLORES HOH KITCHEN USE OF A BUG SPRAY CONSTITUTES INTERSTATE COMMERCE.

07988 RYEN, D.

THE STATE AGENDA FOR THE COMING YEARS

JOURNAL OF STATE GOVERNMENT, 65(2) (APR 92), 53-57.

THE MID-1990'S PROMISE TO BE EXTREMELY CHALLENGING YEARS AS STATE LEADERS AND INSTITUTIONS STRUGGLE TO BRING ACCOUNTABILITY AND PREDICTABILITY BACK INTO THEIR POLITICAL SYSTEMS. FACED WITH CONTINUING BUDGET TROUBLES, INCREASING DEMANDS FOR SERVICES, AND A SHIFT OF RESPONSIBILTY FROM THE FEDERAL - TO THE STATE-LEVEL, THE U.S. STATES WILL BE HAROPRESSED TO SATISFY CONSTITUENT NEEDS OR IMPROVE STATE SERVICES. HOWEVER, THE TOUGH TIMES MAY PRODUCE LONG-TERM IMPROVEMENTS IN STATE GOVERMMENT AS ADMINISTRATORS STREAMLINE AGEMCIES REDUNDANT PROGRAMS, AND STATE LEADERS GENERALLY SEEK NEH AND COST EFFECTIVE SOLUTIONS TO SOCIAL AND ECONOMIC PROBLEMS.

07989 RYSTAD, G.

IMMIGRATION HISTORY AND THE FUTURE OF INTERNATIONAL MIGRATION

INTERNATIONAL MIGRATION REVIEW, 26(4) (WIN 92), 1168-1199. INTERNATIONAL MIGRATION MUST BE UNDERSTOOD AS A PERMANENT PHENOMENON RATHER THAN AS A TEMPORARY MOVEMENT. IN THIS ARTICLE, THE AUTHOR PROCEEDS FROM THE PREMISE THAT IN APPRECIATING THE RELATION BETHEEN THE PAST AND THE PRESENT, WE MAY BE ABLE TO DRAH ON "LESSONS OF THE PAST" TO MODIFY OUR DEFINITION AND PERCEPTION OF CURRENT PROBLEMS AND TO ANALYZE POSSIBLE POLICIES AND DECISIONS. THE ARTICLE IS DIVIDED INTO SEVERAL SECTIONS, HISTORICAL CHANGES HITHIN MIGRATION PATTERNS INCLUDING DIFFERENT CATEGORIES OF MIGRANTS, VARIOUS PHASES HITHIN THE MIGRATION PROCESS IN RECENT HISTORY, THEORETICAL CONSIDERATIONS IN ANALYSIS, DISTINCT TYPES OF IMWIGRATION POLICIES PURSUED BY VARIOUS STATES, AND CURRENT AND POSSIBLE FUTURE TRENDS.

07990 SA'ADAH, A.

FORGIVING WITHOUT FORGETTING: POLITICAL RECONCILIATION AND DEMOCRATIC CITIZENSHIP

FRENCH POLITICS AND SOCIETY, 10(3) (SUM 92), 94-113. WHEN THE FIRST REPUBLIC WAS OECLARED ON SEPTEMBER 21 ,

1792, FRANCE WAS AT WAR; THE KING HAD JUST BEEN OVERTHROHN: AND SOON THE TERROR HOULD BEGIH. THE JACOBIN REPUBLIC'S ANO SOON THE TERROR HOULD BEGIN. THE JACOBIN REPUBLIC'S LEGACY HAS ALWAYS BEEN A DIFFICULT ONE, AND IT WAS MOST THE AUTHOR CONSIDERS THE IMPLICATIONS OF A POLITICAL IN THE FALL OF 1974 BUT WAS NEVER IMPLEMENTED. CENTRAL TO IN THE FALL OF 1974 BUT WAS NEVER IMPLEMENTED. CENTRAL THE ABANDONED STRATEGY, WHICH WAS CHAMPIONED BY ROBERT LINDET, WAS A POLICY OF NATIONAL RECDNCILIATION. LINDET ARGUED THAT CONSTITUT IONAL GOVERNMENT WOULD REMAIN BEYOND REACH UNLESS THE FRENCH WERE WILLING TO FORGIVE AND FORC
POLITICAL ACTS COMMITTED DURING EARLIER PHASES OF THE POLITICAL
REVOLUTION.

07991 SAAD, L.

AMERICANS FIND THEIR DEMOCRACY TARNISHED

GALLUP POLL MONTHLY (316) (JAN 92) 14-15.

A RECENT POLL FOUND THAT AMERICANS' SATISFACTION WITH THE WAY DEMOCRACY HORKS WAS SHAKEN IN THE LAST HALF OF 1991. AS THE RECESSION DRAGS ON, MOST AMERICANS ARE DISSATISFIED WITH THE CURRENT EFFECTIVENESS OF U.S. DEMDCRACY, FEEL DIMINISHED PRIDE, AND HAVE LESS CONFIDENCE IN U.S

TECHNOLOGY. MOST FIMD PROSPECTS FOR THE FUTURE BLEAK AND HAVE LITTLE CONFIDENCE THAT THE SYSTEM CAN IMPROVE THE LIVES OF AMERICA'S UNDERCLASS. THE POOR FEEL THE MOST ALIENATED FROM THE POLITICAL SYSTEM, AND FEWER THAN 38 PERCENT OF AMERICANS WITH INCOMES UNDER \$20,000 PER YEAR SAY THEY ARE SATISIFIED WITH THE WAY DEMOCRACY IS WORKING.

07992 SAAD, L.

AMERICANS OPPOSE A WEINBERGER PARDON

GALLUP POLL MONTHLY, (326) (NOY 92), 22-27.

THIS ARTICLE REPORTS THAT, BASED ON A PUBLIC OPINION POLL. AMERICANS OVERHHELMINGLY BELIEVE THAT PRESIDENT GEORGE BUSH SHOULD NOT PARDON FORMER DEFENSE SECRETARY CASPAR WEINBERGER FOR HIS ALLEGED INVOLVEMENT IN THE IRAN-CONTRA WEINBERGER FOR HIS ALLEGED INVOL VEMENT IN THE IRAN-CONTRA
AFFAIR. IT ALSO INCLUDES CHARTS OF IRENDS IN BUSH'S APPROVAL AFFAIR. IT ALSO INCLUDES CHARTS OF TRENDS I
RATINGS FROM JANUARY 1989 TO NOVEMBER 1992.

07993 SAAD, L.

BUSH STANCE ON ENYIRONMENT UNPOPULAR

GALLUP POLL MONTHLY, (321) (JUN 92), 24-25.

A PUBLIC OPINION POLL SUGGESTS THAT PRESIDENT GEORGE BUSH IS LOSING THE PUBLIC RELATIONS BATTLE OVER HIS ENVIRONMENTAL POLICIES. BUSH'S STATED PRIORITY OF PLACING AMERICAN JOBS BEFORE INTERNATIONAL ENVIRONMENTAL ACCORDS PLUS WIDESPREAD CRITICISM FROM THE ENVIRONMENTAL COMHUNITY APPEAR TO HAVE DAMAGED THE PRESIDENT'S IMAGE. BUSH'S APPROVAL RATINGS ON ENVIRONMENTAL ISSUES HAVE FALLED SHARPLY
IN THE FIRST HALF OF 1992.

07994 SAAD, L.

BUSH TAX VETO UMPOPULAR WITH DEMOCRATS, INDEPENDENTS GALLUP POLL MONTHLY, (318) (MAR 92), 46

PRESIDENT GEORGE' BUSH'S SHIFT VETO OF A TAX BILL SPONSORED BY CONGRESSIONAL DEMOCRATS STIRRED PREDICTABLY PARTISAN RESPONSES AMONG THE PUBLIC, ACCORDING TO A PUBLIC OPINION POLL. REPUBLICANS APPROVED OF BUSH'S VETO WHILE DEMOCRATS OVERHHELMINGLY DISAPPROVED. OVERALL, ONLY THREE IN TEN AMERICANS APPROVED OF BUSH'S VETO WHILE 44 PERCENT FELT THAT HE SHOULD HAVE SIGNED THE BILL, WHICH WOULD HAVE GIVEN TAX CUTS TO MIDOLE-INCOME WAGE EARNERS AND RAISED TAXES ON THOSE WITH HIGHER INCOMES.

07995 SAAD, L.

OPERATION RESTORE HOPE GETS PUBLIC'S BLESSING

GALLUP POLL MONTHLY, 327 (DEC 92), 18-20.

ACCORDING TO A GALLUP POLL CONDUCTED IN DECEMBER 1992, A LARGE MAJORITY OF AMERICANS APPROVE OF THE DECISION TO SEND J.S. TROOPS ON A HUMANITARIAN MISSION TO FEED THE STARVING

IN SOMALIA, BUT ONLY 31 PERCENT FAVOR EXPANDI

07996 SAAD, 1

PUBLIC SKEPTICAL CONGRESS WILL MEET PRESIDENT'S DEADLINE ON ECONOMY

GALLUP POLL MONTHLY, (317) (FEB 92), 11

WHILE PRESIDENT GEDRGE BUSH WAITS FOR CONGRESSIONAL

DEMOCRATS TO PASS HIS ECONOMIC PACKAGE, THE AMERICAN PUBLIC ISN'T HOLDING ITS COLLECTIVE BREATH. ALREADY PESSIMISTIC

ABOUT THE FUTURE OF THE U.S. ECONOMY AND THEIR OWN PERSONAL

FINANCES, AMERICANS ARE SKEPTICAL THAT CONGRESS HILL PRODUCE AN ECONOMIC LEGISLATION PACKAGE BY MARCH 20,1992 , THE
DEADLINE SET BY BUSH IN HIS STATE OF THE UNION ADDRESS.

07997 SAAD, L.

THE JURY IS OUT ON CLINTON'S MANDATE FOR CHANGE

GALLUP POLL MONTHLY, (326) (NOY 92), 19-21.

THE AUTHOR REPORTS THE RESULTS OF PUBLIC OPINION POLLS

REGARDING PRESIDENT-ELECT BILL CLINTON'S PROMISES TO RAISE

TAXES ON THE RICH, MANDATE FAMILY LEAVE, AND REMOVE ABORTION

COUNSELING RESTRICTIONS AT FEDERALLY-FUNDED CLINICS.

07998 SAAD, L.

SAAD, L.

GALLUP POLL MONTHLY, (316) (JAN 92), 10-11.

POLITICAL PARTY IDENTIFICATION AMONG AMERICANS SHOWED NO

SIGNIFICANT CHANGE IN 1991, ACCORDING TO A GALLUP POLL. IN

SIGNIFICANT CHANGE IN 1991, ACCORDING TO A GALLUP POLL.

1991, THE NUMBER OF AMERICANS IDENTIFYIMG THEMSELVES AS

DEMOCRATS ROSE ONE PERCENT WHILE THE NUMBER OF PEOPLE
CALLING THEMSELVES "REPUBLICANS" DECLINED BY THO PERCENT,

CALLING THEMSELVES "REPUBLICANS" DECLINED BY THO PERCE

COMPARED TO 1990. GALLUP'S ANNUAL ANALYSIS OF PARTY

IDENTIFICATION SHOWS THAT REPUBLICANS AND DEMOCRATS HAVE BEEN HOVERING AROUND
SINCE THE MID-1980'S

07999 SAAR, A.: JOE, L.

POLLING, UNDER THE GUN: POLITICAL ATTITUDES IN ESTONIA, SURVEYED AT THE HEIGHT OF THE SOVIET COUP ATTEMPT, AUGUST 1991

PUBLIC OPINION QUARTERLY (CHICAGO), 56(4) (HIN 92),

519-523.

ON AUGUST 19, 1991, THE EIGHT-MEMBER COMMITTEE FOR THE SOVIET COUP D'ETAT DECLARED ITSELF IN POWER OVER THE ENTIRE SOVIET UNION. THE NEXT DAY, THE ESTONIAN SUPREME COUNCIL DECLARED INDEPENDENCE. THAT SAME DAY, AS TAMKS WERE APPROACHING TALLINN, THE CAPITAL CITY, SOVIET SPECIAL FORCES PARATROOPERS WERE LANDING AT THE MUNICIPAL AIRPORT. ON THE THIRD DAY OF THE COUP, THE SAAR POLL OF THE MASS

COMHUNICATION RESEARCH AND INFORMATION CENTER CONDUCTED PHONE INTERVIENS OF ESTONIANS. THE INTENT IN DOING INTERVIEWS DURING THE HEIGHT OF THE TENSIONS, WHEN IT WAS UNCERTAIN WHICH DIRECTION EVENTS HOULD GO, HAS TO LEARN WHETHER IN A CRISIS SITUATION PUBLIC SUPPORT HAS LEANING TOWARD THE INVADING FORCES OR THE ESTONIAN GOVERNMENT.

08000 SABBAT-SWIDLICKA, A.

POLAND

RFE/RL RESEARCH REPORT, 1(39) (OCT 92), 47-52

THREE YEARS AFTER THE COLLAPSE OF COMHUNISH, THE POLISH MEDIA ARE STILL IN A STATE OF CONFUSION. ALTHOUGH THE PRESS MEDIA ARE STILL IN A STATE OF CONFUSION. ALTHOUGH THE PRES MARKET IS BEGINNING TO STABILIZE, THE FORMER COM GAINED AN UNFAIR ADVANTAGE IN THE DISTRIBUTION OF
PUBLICATIONS WHEN THE PARTY'S PRESS EMPIRE HAS DISSOLVED,
CAUSING MUCH RESENTMENT. THE DEYELOPMENT OF RADIO AND TELEVISION IS HAMPERED BY THE LACK OF VITAL NEH LEGISLATION TELEVISION IS HAMPERED BY THE LACK OF VITAL NEW LEGISLATIO
THAT WOULD DEFINE THE STATUS AND STRUCTURE OF THE STATE BROADCAST MEDIA AND ESTABLISH A LEGAL BASIS FOR PRIVATE BROADCASTERS. MEANIHILE, THE PROLONGED UNCERTAINTY OF THE TRANSITION PERIOD, EXACERBATED BY BOTH GOVERNMENT AND OPPOSITION ATTEMPIS TO INFLUENCE THE SHAPE OF TELEVISION, HAS PRODUCED INCONSISTENT PERSONNEL AND ORGANIZATIONAL 
STANDARDS. UNIMPEDED BY ANY CENSORSHIP, THE MEDIA AS A WHOLE IS ABLE TO PRESENT THE FULL SPECTRUM OF POLITICAL AND CULTURAL VIEWS; UNFORTUNATELY, THIS FREEDOM IS ALL TOO OFTEN ABUSED BY INDIVIDUALS WHO ARE NOT ACCUSTOMED TO HAVING TO TAKE PUBLIC RESPONSIBILITY FOR THEIR STATEMENTS.

OBO01 SABBAT-SWIDLICKA, A.

POLAND

RFE/RL RESEARCH REPORT, 1(27) (JUL 92), 25-33.

AFTER THE COLLAPSE OF COMMUNISH, POLAND'S NEW LEADERS ACCEPTED THE PRINCIPLE THAT THE POLISH STATE AND ALL ITS INSTITUTIONS SHOULD BE BASED ON THE RULE OF LAW. TODAY, NO INDIVIDUAL, PARTY, OR AGENCY STANDS ABOVE THE LAN; ALL

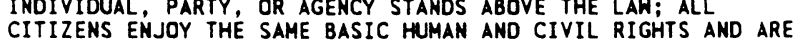
CITIZENS ENJOY THE SAME BASIC HUMAN AND CIVIL RIGHTS AND ARE EQUAL BEFORE THE LAH; MOREOVER, THE STATE ITSELF IS SUBJECT TOES NOT FULLY SATISFY PUBLIC PERCEPTIONS OF FAIRNESS AND DOES NOT FULLY SATISFY PUBLIC PERCEPTIONS OF FAIRNESS AND JUSTICE. THE LEGAL INFRASTRUCTURE IS NOT ALWAYS EQUAL TO THE IMPEDE LEGAL AND INSTITUTIONAL REFORM. THE STATE'S IMPEDE LEGAL AND INSTITUTIONAL REFORM. THE STATE'S RESTRICTED FINANCIAL, PERSONNEL, AND ADMINISTRATIVE
POTENTIAL MAKES IT HARDER STILL FOR THE RULE OF LAW TO TAKE PERMANENT ROOT IN POLISH DAILY LIFE.

08002 SABBAT-SHIDLICKA, A.

POLAND INVESTIGATES RADICAL FARMERS' UNION

RFE/RL RESEARCH REPORT, 1 (38) (SEP 92), 19-25.

THE RADICAL SELF-DEFENSE FARMERS' UNION IS BEING

INVESTIGATED BY THE PROSECUTOR'S OFFICE FOR A NUMBER OF

LEGAL VIOLATIONS. IN THE EIGHT MONTHS SINCE ITS FOUNDING,

OSTENSIBLY TO REPRESENT THE INTERESTS OF INSOLVENT FARMERS,

THE UNION HAS ORGANIZED A SIT-IN, ROAD BLOCKADES, AND A

MARCH ON WARSAW. IT HAS ALSO SPAWNED A POLITICAL PARTY

DEDICATED TO SEIZING POLITICAL POWER. ITS RHETORIC AND RADICALISM EXPLOIT THE VERY DIRE STRAITS THAT MANY OF POLAND'S FARMERS ARE EXPERIENCING DUE TO THE SHIFT TO A MARKET ECONOMY. ITS UNHILLINGNESS TO COOPERATE WITH THE
MINISTRY OF AGRICULTURE AND THE LESS RADICAL FARMERS' UNIONS SUGGESTS THAT IT HAS AN INTEREST IN DESTABILIZING THE POLITICAL SITUATION.

08003 SABBAT-SWIDLICKA, A.

POLAND: WEAK GOVERMMENT, FRACTIOUS SEJM, ISOLATED PRESIDENT RFE/RL RESEARCH REPORT, 1(15) (APR 92), 1-7.

THE POLISH GOVERMMENT'S PARLIAMENTARY BASE OF SUPPORT HAS BECOME VERY TENUOUS. ATTEMPTS TO BROADEN THE COALITION OR FIND ALTERNATIVES TO IT HAVE BEEN HAMPERED BY DEEP REPRESENTED IN THE SEJM AS WELL AS INTERNAL PROBLEMS WITHIN THE TWO MAJOR POST-SOLIDARITY PARTIES. PRESIDENT WALESA'S ROLE HAS DIMINISHED BUT HE HAS CONTINUED TO TRY TO INFLUENCE POLITICS IN HIS OWN UNIQUE WAY.

08004 SABBAT-SWIDLICKA, A.

POLAND'S TWO CAMPS SPECIFY TERMS FOR GRAND COALITION RFE/RL RESEARCH REPORT, 1 (18) (MAY 92), 14-19.

IN POLAND, THE TEN PARTIES OFFICIALLY INVOLVED IN THE ATTEMPT TO SÉCURE A BROADER BASE OF PARLIAMENTARY SUPPORT FOR THE GOVERNMENT OF PRIME MINISTER JAN OLSZEWSKI HAVE MET ON A NUMBER OF OCCASIONS, BUT THEY DO NOT SEEM TO HAVE MADE ANY REAL PROGRESS. IN AN ATTEMPT TO FOCUS THE NEGOTIATIONS ON SPECIFIC ISSUES, THE LEADER OF THE DEMOCRATIC UNION, TADEUSZ MAZOWIECKI, HAS FORMULATED THE PRINCIPLES AND GOALS FOR A GRAND COALITION GOVERNMENT. THE PARTIES SUPPORTING THE GOVERMMENT HAVE REACTED BY DRAHING UP THEIR OWM LIST OF CONDITIONS. BOTH DOCUMENTS HAVE BEEN ACCEPTED AS THE BASIS FOR FURTHER DISCUSSION.

08005 SABBAT-SHIDLICKA, A.

POLITICAL TURMOII OVERSHADOWS SOLIDARITY'S CONGRESS

RFE/RL RESEARCH REPORT, 1 (28) (JUL 92), 16-19.

IN POLAND THE SOLIDARITY UNION IS STRUGGLING TO RESOLVE

THE INHERENT CONTRADICTION BETWEEN ITS DESIRE TO ESTABLISH

ITSELF AS A PROFESSIONAL LABOR UNION AND ITS SENSE OF

RESPONSIBILITY FOR THE SUCCESS OF POLITICAL AND ECONOMIC

REFORMS BEGUN IN ITS NAME ALMOST THREE YEARS AGO. IN 1991, THE GROUP EXPERIENCED A DECLINE IN ITS INFLUENCE DESPITE ITS MODERATE SUCCESS IN THE PARLIAMENTARY ELECTIONS. IN JUNE MODERATE SUCCESS IN THE PARLIAMENTARY ELECTIONS. IN JUNE
1992 THE UNION'S FOURTH CONGRESS OCCURRED JUST AS THE 1992 THE UNION'S FOURTH CONGRESS OCCURRED JUST AS
COUNTRY WAS THROWN INTO TURMOIL BY THE RELEASE OF COUNTRY WAS THROWN INTO TURMOIL BY THE RELEASE OF
INFORMATION FROM SECRET POLICE FILES AND THE SEJM'S VOTE OF INFORMATION FROM SECRET POLICE FILES AND THE SEJM'S VOT
NO CONFIDENCE IN THE GOVERNMENT OF JAN OLSZEWSKI. THE NO CONFIDENCE IN THE GOVERNMENT OF JAN OLSZEWSKI. THE
DELEGATES' EVIDENT SUPPORT FOR OLSZEWSKI AND THEIR CRITICAL DELEGATES' EVIDENT SUPPORT FOR OLSZEWSKI AND THEIR CRITICAL ATTITUDE TOWARD PRESIDENT LECH WALESA, THEIR FORMER LEADER, SHOWS THAT THE COUNTRY'S UNSTABLE POLITICAL AND ECOMOM SITUATION HAS LED TO POLITICAL RADICALIZATION AMONG
SOLIDARITY'S FRUSTRATED UNIONISTS. BUT MARIAN KRZAKLEWSKI, SOLIDARITY'S FRUSTRATED UNIONISTS. BUT MARIAN KRZAKLEWSKI,
WHO WAS REELECTED TO A SECOND TERM AS SOLIDARITY'S CHAIRMAN, BELIEVES THAT THE UNION CAN PLAY A MEDIATING ROLE IN THE CURRENT POLITICAL CRISIS.

08006 SABBAT-SWIDLICKA, A.

PROBLEMS OF POLAND'S STATE SECURITY OFFICE

RFE/RL RESEARCH REPORT, $1(9)$ (FEB 92), $15-20$.
MANY POLES ARE DOUBTFUL IF THE STATE SECURITY OFFICE OFFICIALS, MANY OF WHOM SERVED IN THE FORMER COMMUNIST-RUN SECRET POLICE, CAN REALLY BE TRUSTED TO SAFEGUARD THE FLEDGLING DEMOCRACY AND RESPOND ADEQUATELY TO THE NEW DANGERS FACING POLAND.

08007 SABBAT-SHIDLICKA, A.

SUMMER STRIKES: FIRST TEST FOR NEW POLISH GOVERNMENT

RFE/RL RESEARCH REPORT, 1(34) (AUG 92), 8-14.
POLAND IS EXPERIENCING A WAVE OF STRIKES THAT STARTED AS LOCAL LABOR ACTIONS BUT ARE NOW BEGINNING TO ESCALATE INTO A NATIONWIDE SWELL AS RADICAL AND POSTCOMMUNIST UNION LEADERS TRY TO TAKE CONTROL OF THE PROTESTS AND GIVE THEM A POL ITICAL CONTEXT. THUS FAR, HANNA SUCHOCKA'S GOVERMMENT HAS REFUSED TO COMPROMISE ON ITS POSITION THAT THE CONFLICTS REFUSED TO COMPROMISE ON ITS POSITION THAT THE CONFLICTS THAT THE GOVERHMENT IS NOT A PARTY TO THE CONFLICT. THE THAT THE GOVERMMENT IS NOT A PARTY TO THE CONFLICT. THE SPEEDING UP PRIVATIZATION, AND ON DEVISING A NEW FRAMENORK SPEEDING UP PRIVATIZATION, AND ON DEVISING A NEW FRAMENORK FOR LABOR RELATIONS IN THE HOPE OF ALLEVIATING SOME OF THE SYSTEMIC PROBLEMS PLAGUING THE POLISH ECONOMY AND AFFECTINC THE EMPLOYEES OF STATE-OWNED ENTERPRISES. THE MODERATE
LEADERSHIP OF THE SOLIDARITY UNION, WHICH ACCEPTS THE NEED FOR SYSTEMIC REFORMS, IS OPPOSED TO THE STRIKES AND WANTS TO PRESSURE THE GOVERNMENT THROUGH NEGOTIATIONS.

08008 SABROSKY, A.

A WAR UNHON: THE US FIGHT AGAINST DRUG TRAFFICKING SMALL WARS \& INSURGENCIES, 2(1) (APR 91), 8-11.

THREE SCHOOLS OF THOUGHT HAD EMERGED BY 1989 ON THE SUBJECT OF THE WAR AGAINST DRUGS. THIS ARTICLE DETAILS THESE APPROACHES AND SUGGESTS THAT ALL THREE APPROACHES HAD BEEN TRIED OVER THE YEARS BY A HOST OF AMERICAN GOVERNMENTAL AND PRIVATE AGENCIES AND ORGANIZATIONS AT LOCAL, STATE AND NATIONAL LEVELS. THE WAR ON DRUGS HAS BECOME A SUBJECT OF CONTROVERSY AND DEBATE AND THE OUTCOME IS STILL TO BE DETERMINED. IT CONCLUDES THAT THE ADMINISTRATION SHOULD REFLECT ON THE CONSEOUENCES OF NOT WINNING THIS PARTICULAR HAR, AND ACT BEFORE IT BECOMES TOO LATE FOR THE US EVEN TO HOPE FOR ANYTHING BETTER THAN A PYRRHIC VICTORY INDISTINGUISHABLE FROM DEFEAT.

08009 SABROSKY, A.

PANAMA 1989: DEPOSING A DICTATOR

SMALL WARS \& INSURGENCIES, 1 (3) (DEC 90), 303-306.

THE US MILITARY INTERVENTION IN PANAMA IN DECEMBER 1989 MARKED PRESIDENT BUSH'S ENTRY INTO THE WORLD OF GUNBOAT DIPLOMACY AND THE END OF THE REGIME OF GENERAL MANUEL NORIEGA, THE ERSTWHILE DICTATOR OF PANAMA. THE OVERALL RESPONSE TO THE US INTERVENTION IN PANAMA TELLS SOMETHING ABOUT THE USE OF FORCE BY THE UNITED STATES IN THE THIRD
WORLD IN GENERAL, AND IN CENTRAL AMERICA IN PARTICULAR. IF WORLD IN GENERAL, AND IN CENTRAL AMERICA IN PART ICULAR. IF
THE OPERATION HAD LINGERED ON, BECOMING A CENTRAL AMERICAN THE OPERATION HAD LINGERED ON, BECOMING A CENTRAL AMERICAM EQUIVALENT OF BEIRUT OR VIETNAM AS SOME AMERICAN PLANNERS
FEARED BEFOREHAND, THE CONSEQUENCES OF UNILATERALISM FOR THE UNITED STATES COULD BE GREAT INDEED.

08010 SACCO, G

ITALY' AFTER COMMUNISH

WASHINGTON QUARTERLY, 15(3) (SUM 92), 25-40.

IN ITALY THERE IS A GROWING SENSATION THAT THE

UNDERLYING STABILITY OF THE COUNTRY'S POLITICAL SYSTEM IS BEGINNING TO CRACK. IN ORDER TO FOSTER UNDERSTANDING OF THE EXCEPTIONAL NATURE OF RECENT ITALIAN POLITICAL EVENTS, THIS ARTICLE CONSIDERS THE EVOLUTION OF POST-WAR ITALY AGAINST THE BACKGROUND OF THE TUMULIOUS CHANGES THAT HAVE OCCURRED ON THE INTERNATIONAL SCENE IN THE PAST TWO YEARS AND THAT CULMINATED IN THE IDEOLOGICAL BANKRUPTCY OF SOCIALISH. ITALY'S CURRENT CRISIS IS CLOSELY LINKED TO THESE EVENTS. THE IMPENDING CHAOS AND NATIONAL FRAGMENTATION IN THE FORMER COMAUNIST EMPIRE COULD SPREAD INTO THE WEST.

08011 SACHS, A.

"WATCH OUT--THERE'S a CONSTITUTION ABOUT"

SOUTH AFRICA INTERNATIONAL, 22(4) (APR 92), 184-189.

IT IS REMARKABLE THAT SO MUCH AGREEMENT ON FUNDAMENTAL CONSTITUTIONAL PRINCIPLES EMERGED BETWEEN THE ANC AND THE RULING NATIONAL PARTY EVEN BEFORE FORMAL NEGOTIATIONS BEGAN RULING NATIONAL PARTY EVEN BEFORE FORMAL NEGOTIATIONS BEGAN
IN DECEMBER 1991. NEVERTHELESS, WHILE THE AGREEMENTS IN
PRINCIPLE ARE IMPORTANT, THE DISAGREEMENTS IN DETAIL CANNOT PRINCIPLE ARE IMPORTANT, THE DISAGREEMENTS IN DETAIL CANNOI
BE IGNORED. IN THIS ARTICLE PROFESSOR ALBIE SACHS, IN THE BE IGNORED. IN THIS ARTICLE PROFESSOR ALBIE SACHS, IN THE FORM OF A DEBATE WITH THE VENERATED LIBERAL, THE LATE
WENTZEL, FOCUSES ON THESE DISAGREEMENTS IN DETAIL-OIN WENTZEL, FOCUSES ON THESE DISAGREEMENTS IN DETAIL--IN
PARTICULAR. THE ANC'S VIEW ON FEDERALISM, REDISTRIBUTION, PARTICULAR, THE ANC'S VIEN ON FEDERALISM, REDISTRIBUTION,
AFFIRMATIVE ACTION AND SO-CALLED SECOND AND THIRD GENERATION AFFIRMATIVE ACTION AND SO-CALLED SECOND AND THIRD GENERAT
RIGHTS--SUCH AS THE RIGHT TO EMPLOYMENT. A PROVOCATIVE RIGHTS--SUCH AS THE RIGHT TO EMPLOYMENT. A PROVOCATIVE AND THOSE PREVALENT WITHIN THE ANC, EMERGES FROM THE ADDRESS.

08012 SACHS, J.

HOME ALONE THO

NEW REPUBLIC, 207(26) (DEC 92), 23-25.

THE GREATEST FOREIGN POLICY BLUNDER OF THE BUSH 
ADMINISTRATION HAS BEEN ITS NEGLECT OF RUSSIA'S NEEDS SINCE THE COLLAPSE OF THE SOVIET UNION. AMERICAN, JAPANESE, AND EUROPEAN STINGINESS HAS MADE PRESIDENT BORIS YELTSIN'S TASK VASTLY MORE DIFFICULT AND HAS STRENGTHENED THE HAND OF THE HARD-LINERS, WHO ARE TRYING TO REVERSE THE ECONOMIC REFORMS. DESPITE THE WEST'S LARGE STAKE IN THE SUCCESS OF RUSSIA'S REFORMS, ACTUAL WESTERN SUPPORT HAS BEEN MINISCULE. IN FACT, THE CONTRAST BETWEEN HIGH-SOUNDING RHETORIC AND LITTLE REAL SUPPORT HAS HAO AN ENORMOUSLY CORROSIVE EFFECT ON RUSSIAN POLITICS.

\section{SADOHSKI, $Y$}

SANDSTROM WITH A SILVER LINING?

BROOKINGS REYIEW, 10(3) (SUM 92), 6-11.

THERE IS A GRONIMG DEBATE IN THE ARAB NORLD ABOUT MILITARY SPENDING. THE DEBATE HAS BEEN TRIGGERED NOT BY A REDUCTION OF HOSTILITIES OR A SUDDEN OUTBREAK OF PACIFISM BUT BY COLD ECONOMIC LOGIC. DECLINIMG OIL PRICES,

OVERPOPULATION, ECONOMIC MISMANAGEMENT, AND FOREIGN POLICY ADVENTURISM HAVE COMBINED TO WREAK HAVOC ON THE ARAB ECONOMIES. THE GULF WAR AGGRAVATED THIS TREND, EVEN FOR THOSE STATES THAT SUFFERED MINIMAL PHYSICAL DAMAGE. ECONOMICALLY EXHAUSTED, MANY ARABS ARE SEARCHING FOR CHEAPER ECOYS OF MEETING THEIR MATIONAL SECURITY NEEDS. THE RESULT IS THE MOST PROMISING SETIING FOR REGIONAL ARMS CONTROL TALKS IN 40 YEARS.

08014 SADONSKI, Y.

SCUDS VS. BUTTER: THE POLITICAL ECONOMY OF ARMS CONTROL IN THE ARAB HORLD

MIDDLE EAST REPORT, 22(4) (JUL 92), 2-13.

CONTRARY TO THE COMMON WISDOM IN WASHINGTON, MOST ARABS ARE POOR, RATIONAL, AND INTERESTED IN ARMS CONTROL.

DECLINING OIL PRICES, RISING POPULATION, ECONOMIC

MISMANAGEMENT AND FOREIGN POLICY ADVENTURISH HAVE WREAKED HAVOC WITH THE ECONOMIES OF THE MIDDLE EAST, WHILE LOCAL ARMS RACES HAVE STEADILY RAISED THE PRICE OF PROVIDING FOR NATIONAL DEFENSE. CAUGHT BETHEEN THESE SCISSORING FORCES, MIDDLE EAST COUNTRIES ARE FINDING IT MORE DIFFICULT TO SUSTAIN THEIR MILITARY BUDGETS. ECONOMIC AND POLITICAL PRESSURE ARE PUSHING MANY COUNTRIES TO DIVERT FUNDS FROM MILITARY TO CIVILIAN INVESTMENTS.

D8015 SAEMALA, F.J.

PARLIAMENTARY COMMITTEES: BUILDING A NEH PARLIAMENTARY TRADITION IN THE SOLOMON ISLANDS

PARLIAMENTARIAN, LXXIII (2) (APR 92), 85-86.

THE AUTHOR DESCRIBES THE COMMITTEE SYSTEM EMPLOYED BY

THE PARLIAMENT OF THE SOLOMON ISLANDS.

08016 SAENZ, E.

INTERREGIONAL MIGRATION PATTERNS OF CHICANOS: THE CORE, PERIPHERY, AND FRONTIER

SOCIAL SCIENCE QUARTERLY, 72(1) (MAR 91), 135-148.

THE INTERNAL MIGRATION PATTERNS OF CHICANOS HAVE BEEN AN OVERLOOKED TOPIC. THIS STUDY USES DATA FROM THE 1980 PUBLIC USE MICRODATA SAMPLE TO EXAMINE THE 1975-80 INTERREGIONAL MIGRATION FLOWS OF CHICANOS BETHEEN FOUR REGIONS: (1) CORE
(SOUTHWEST): (2) NORTHWEST PERIPHERY; (3) MIDWEST PERIPHERY; (SOUTHWEST); ( 2 ) NORTHWEST PERIPHERY; ( 3 ) MIDWEST PERIPH
AND (4) FRONTIER. THE CORE EXPERIENCED A NET OUTFLOW OF CHICANOS TO THE NORTHWEST PERIPHERY. HOWEVER, AMONG THE CHICANO CORE OUTMIGRANTS, FRONTIER MIGRANTS ARE THE MOST SELECTIVE SOCIOECONOMICALLY.

OBO17 SAFFORD, F.

THE PROBLEM OF POLITICAL ORDER IN EARLY REPUBLICAN SPANISH AMERICA

JOURNAL OF LATIN AMERICAN STUDIES, 24 (1992), 83-98.

THE PERSISTENT INSTABILITY AND OISORDER OF SPANISH AMERICAN POL ITIES IN THE POST-INDEPENDENCE PERIOD HAS UNDOUBTEDLY ONE OF THE MOST PERPLEXING CONCERNS OF SPANISH AMERICAN ELITES IN THE 19TH CENTURY, AND IT HAS REMAINED A SUBJECT OF DEBATE AMONG 2OTH-CENTURY SCHOLARS. IHIS PAPER OUTLINES SEVERAL GENERAL APPROACHES TO THE PROBLEM AMONG 20TH-CENTURY INTERPRETERS, COMPARES CONTEMPORARY 19THCENTURY ANALYSES WITH THE SALIENT 2OTH-CENTURY YIEWS, AMD OFFERS A CRITICAL COMMENTARY ON THE VARIOUS 2OTH-CENTURY ANALYTICAL FRAMEHORKS.

08018 SAFI, L.

NATIONALISM AND THE MULTINATIONAL STATE

AMERICAN JOURNAL OF ISLAMIC SOCIAL SCIENCES, 9(3) (FAL 92), AMERICAN

THE AUTHOR TRACES THE ORIGIN AND DEVELOPMENT OF THE CONCEPT OF NATIONALISM, UNDERSCORES IT DEFECTS, AND POINTS CONCEPT OF NATIONALISM, UNDERSCORES IT DEFECTS, AND POINTS OUT SOME OF ITS DEVASTATING CONSEQUENCES, ESPECIALLY IN REGIONS RICH IN ETHNIC AND RELIGIOUS MINORITIES. HE ARGUES THAT NATIONALISM IS A EUROPEAN PHENOMENON INVENTED BY GERM INTELLECTUALS AND EMPLOYED BY PRUSSIA IN ORDER TO BRING
ABOUT A UNITED GERMAN STATE. A NATIONAL GOVERNMENT TENDS TO ABOUT A UNITED GERMAN STATE. A NATIONAL GOVERMMENT TENDS TO
SUPPRESS MINORITY GROUPS AND IS, THEREFORE, INAPPROPRIATE TO SOCIETIES WITH HETEROGENOUS AND OIVERSE POPULATIONS. THE AUTHOR CONCLUDES BY DISCUSSING THE MODEL OF COMHUNAL PLURALISM THAT FLOURISHED UNDER THE "KHILAFAH" SYSTEM.
08019 SAFRAN, $H$.

LANGUAGE, IDEOLOGY, AND STATE-BUILDING: A COMPARISON OF POLICIES IN FRANCE, ISRAEL. AND THE SOVIET UNIOM INTERNATIONAL POLITICAL SCIENCE REVIEN, 13(4) (OCT 92), $397-414$

THE AUTHOR COMPARES THE RELATIONSHIP BETWEEN DOMINANT POL ITICAL IDEOLOGIES AND LANGUAGE POL ICIES--JACOBINISM AND FRENCH: ZIONISM AND HEBREW: AND SOCIALISM-COMMUNISH AND RUSSIAN--AND ANALYZES THE USE OF SUPERORDINATE LANGUAGES AS STATE-BUILDING INSTRUMENTS. HE EXAMINES THE POLICIES PURSUED AND THE POLI ITICAL RATIONALES INVOKED BY FRANCE TO SUPPRESS BRETON AND OTHER PERIPHERAL LANGUAGES; BY ISRAEL TO DISCOURAGE THE USE OF YIDDISH; AND BY THE SOVIET UNION TO UNDERMINE OR SOVIETIZE MON-SLAVIC LANGUAGES. FINALLY, HE ASKS WHETHER ALTERNATIVE APPROACHES WERE FEASIBLE AND WHETHER THESE POLICIES HAVE SERVED OR SHOULD SERVE AS MOOELS FOR OTHER COUNTRIES.

08020 SAFRIET, B.J.

HEALTH CARE DOLLARS AND REGULATORY SENSE: THE ROLE OF ADVANCED-PRACTICE NURSING

YALE JOURNAL ON REGULATION, $9(2)$ (SUM 92), 417-488.

THE U.S. HEALTH CARE SYSTEM HAS BEEN CRITICIZED FOR PROVIDING TOO LITTLE CARE, TOO LATE, FOR TOO FEW PEOPLE, AT TOO HIGH A COST. THESE PROBLEMS CALL FOR A FUNDAMENTAL TOO HIGH A COST. THESE PROBLEMS CALL FOR A FUNDAMENTAL
RESTRUCTURING OF EXISTING HEALTH CARE DELIVERY METHODS AND RESTRUCTURING OF EXISTING HEALTH CARE DELIVERY METHODS AMD
MORE EFFECTIVE UTILIZATION OF ALL HEALTH CARE PERSONNEL. MORE EFFECTIVE UTILIZATION OF ALL HEALTH CARE PERSONNEL.
ADVANCED-PRACTICE MURSES HAVE DEMONSTRATED THAT THEY CAN ADVANCED-PRACTICE NURSES HAVE DEMONSTRATED THAT THEY CAN PROVIDE COST-EFFECTIVE, HIGH-QUALITY PRIMARY CARE FOR

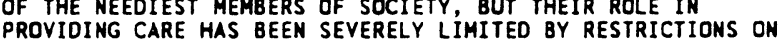
PROVIDING CARE HAS BEEN SEVERELY LIMITED BY RESTRICT THEIR SCOPE OF PRACTICE, PRESCRIPTIVE AUTHORITY, AND
ELIGIBILITY FOR REIMBURSEMENT. IMHEDIATE LEGISLATIVE REFORM IS NEEDED TO REDUCE THE RESTRICTIONS THAT CURRENTLY CONSTRAIN ADVANCED-PRACTICE NURSES, ESPECIALL
PRACTITIONERS AND CERTIFIED NURSE-MIDWIVES.

08021 SAGAN, E.

THE POLITICS OF THE IMPOSSIBLE: OR, WHATEVER HAPPENED TO EVOLUT IONARY THEORY?

SOCIAL RESEARCH, 59(4) (WIN 92), 739-758.

BASED ON MARXIST EVOLUTIOHARY THEORY, THE AUTHOR ARGUES

THAT THE SOVIET UNION WAS ULTIMATELY DOOMED TO COLLAPSE

BECAUSE THE BOL SHEVIK REVOLUTION ATTEMPTED TO PRECLUDE TWO

STAGES OF SOCIAL EVOLUTION.

08022 SAGIV, $D$.

JUDGE ASHMAHI AND MILITANT ISLAM IN EOYPT

MIDOLE EASTERN STUDIES, 28(3) (JUL 92), 531-546. JUDGE ASHMAKI'S BOOK, "POLITICAL ISLAM", SERVES AS A GENERIC WORK WHICH EXPRESSES BOTH THE CONCERN OF INTELLECTUALS OVER EXTREMIST ISLAMIC TRENDS AND THE INTELLECTUALS OVER EXTREMIST ISLAMIC TRENDS AND THE
ARGUMENTS THEY USE AGAINST THEM. BOTH THE BOOK AND THE ARGUMENTS THEY USE AGAINST THEM. BOTH THE BOOK AND THE REACTION TO IT REFLECT THE SITUATION AND SERVE AS A MODEL FOR THE CONTROVERSY RANGING WITHIN EGYPTIAN SOCIETY. THE VARIOUS ISLAMIC CURRENTS WHICH ADVOCATE IMPLEMENTATION OF SITUATION SERVE AS A BACKGROUND FOR THEIR ACTIVITIES. SITUATION SERVE AS A BACKGROUND FOR THEIR ACTIVITIES.
FURTHER RESEARCH NEEDS TO BE DONE IN ORDER TO ASSESS THE EXTENT OF THE PHENOMENON AND EVALUATE JUST WHERE EGYPTIAN SOCIETY IS HEADING.

08023 SAHN, D.E.

PUBLIC EXPENDITURES IN SUB-SAHARAN AFRICA DURING A PERIOD OF ECDNOMIC REFORM

WORLD DEVELOPMENT, 20(5) (MAY 92), 673-693 PUBLIC EXPENDITURE RESTRAINT IS THE MOST DIRECT MEANS OF REDUCING BALANCE-OF-PAYMENTS ANO BUDGET DEFICITS AND CONSEQUENTLY, IS A KEY ASPECT OF MACROECONOMIC ADJUSTMENT PROGRAMS. THERE WAS A STEADY INCREASE IN TOTAL CENTRAL GOVERMMENT AND SOCIAL SERVICES SPENDING DURING 1977-1989 IN SUB-SAHARAN AFRICA, BUT THE GROWTH IN POPULATION CONTRIBUTED TO AN OVERALL EROSION IN PER CAPITA EXPENDITURES. HHILE TOTAL GOVERNMENT EXPENDITURES AS A SHARE OF GDP HAVE BEEN STABLE DURING THE PAST DECADE, THEY HAVE DECLINED NET OF INTEREST REPAYMENTS, WHICH REPRESENT AN INCREASINGLY LARGE SHARE OF TOTAL SPENDING. AN ANALYSIS OF SPENDIMG IN THE THREE YEARS BEFORE AND AFTER DONOR-FIMANCED ADJUSTMENT PROGRAMS BEGAN REVEALS ND PATTERN OF INCREASE OR DECREASE IN REAL LEVELS OF TOTAL AND SOCIAL SECTOR EXPENDITURES, OR IN SOCIAL SECTOR SPENDING AS A SHARE OF THE TOTAL EXPENDITURES. ELASTICITIES OF HEALTH AND EDUCATION SPENDING HITH RESPECT TO GDP WERE FOUND TO BE GREATER THAN UNITY IN RECENT YEARS, TO GDP WERE FOUND TO BE GREATER THAN UNITY IN RECENT YEARS
INDICATING THAT AS COUNTRIES DEVELOP, SOCIAL SPENDING WILL INDICATING THAT AS COUNTRIES DEVEL
CONSTITUTE A LARGER SHARE OF GDP.

08024 SAICH, T. (ED.): YANG, B.

THE RISE TO POWER OF THE CHINESE COMMUNIST PARTY-DOCUMENTS AND ANALYSIS

M. E. SHARPE, 1993,1500

THIS WORK SYSTEMATICALLY PRESENTS FOR THE FIRST TIME IN ANY WESTERN LANGUAGE ALL THE KEY DOCUMENTS COVERING THE RISE TO PONER OF THE CHINESE COMMUNIST MOVEMENT. THE DOCUMENTS 
SHOW HOW THE CHINESE COMMUNIST PARTY INTERPRETED THE REVOLUTION IN WHICH IT PLAYED A KEY ROLE, HOW IT DEVISED POLICIES TO MEET CHANGING CIRCUMSTANCES, AND HOW THESE WERE COMMUNICATED TO BOTH PARTY MEMBERS AND THE PUBLIC AT LARGE. THE MATERIALS PERMIT FOR THE FIRST TIME IN FORTY YEARS A COMPREHENSIVE REAPPRAISAL OF THE RISE TO POWER OF THE CHINESE COMMUNIST MOVEMENT. THEY PROVIDE A COMPLEX PICTURE OF THE PARTY'S POLICIES AND ITS RELATIONSHIP TO DIFFERENT SOCIAL FORCES IN THE COUNTRYSIDE AND CITIES, SHED NEW LIGHT ON THE DEVELOPMENT OF THE CCP AS AN ORGANIZATION AND ITS INTERNAL DIVERSITY, AND DEMONSTRATE HOW MAO ZEDONG

SKILLFULLY OUTMANUEVERED HIS OPPONENTS TO RULE THE PARTY.

08025 SAID, A.

ISLAMIC FUMDAMENTALISM AND THE WEST

MEDITERRANEAN OUARTERLY: A JOURNAL OF GLOBAL ISSUES, $3(4)$

(FAL 92 ), 21-36.

ISLAMIC FUNDAMENTALISM IS A DEFENSIVE SOCIAL AND

POLITICAL MOVEMENT A REACTION TO WESTERNIZATION AHD MODERNIZATION. THIS ARTICLE SUGGESTS THAT THE UNITED STATES IS NOT OFFERING MUSLIMS A LONG-RANGE VISION OF THE FUTURE, NOR ARE THE GOVERNMENTS OF THE ISLAMIC WORLD ANY MORE FORTHCOMING IN THIS RESPECT. IT EXPLORES THE WEST AND ISLAMFROM RIYALRY TO REVIVAL, THE NEED FOR DIALOGUE BETWEEN THE WEST AND ISLAM, AND THE PARADOX OF POLITICS AND DEVELOPMENT IN ISLAM. IT CONCLUDES THAT THE CHALLENGE FOR MUSLIMS IS HOW
TO DEVELOP THE ISLAMIC HORLD THROUGH ITS OWN TRADIIONS, NOT TO DEVELOP THE ISLAMIC HORLD THROUGH
THROUGH HESTERN SECULAR IDEOLOGIES.

08026 SAID, K.

CAUGHT BETHEEN THE WEST AND IRAN

WORLD PRESS REVIEW, 39(7) (JUL 92), 14.

TO ACQUIRE AN IN-DEPTH UNDERSTANDING OF THE STRUGGL BETWEEN TURKEY AND IRAN OVER THE FORMER SOVIET REPUBLICS OF CENTRAL ASIA, ONE MUST CONSIDER THE AMERICAN FACTOR. THE WEST, PARTICULARLY THE UNITED STATES, WANTS TO IMPOSE HEGEMONY AND TO INTEGRATE THESE REPUBLICS INTO THE NEW WORLD ORDER THAT THE USA INSISTS ON DOMINATING. THE MESSAGES BEING SENT BY IRAN AND TURKEY REVOLVE AROUND A MAJOR ISSUE FOR THE SENT BY IRAN AND TURKEY REVOLVE AROUND A MAJOR ISSUE FOR THE
REPUBLICS: THE SEARCH FOR AN IDENTITY THROUGH WHICH THEY CAN REPUBLICS: THE SEARCH FOR AN IDENTITY THROUGH WHICH THEY
ASSERT THEMSELVES NATIONALLY AND INTERNATIONALLY. IRAN ASSERT THEMSELVES NATIONALLY AND INTERNATIONALLY. IRAN
ADVOCATES AN IDENTITY THAT HOULD AFFIRM THE REPUBLICS' ADVOCATES AN IDENTITY THAT HOULD AFFIRM THE REPUBLICS
INDEPENDENCE AND REJECT ANY NEW MASTERS. MEANHHILE, TURKEY INDEPENDENCE AND REJECT ANY NEW MASTERS. MEANHHILE, TURKEY
POSES ITSELF AS A MODEL OF SECULAR DEMOCRACY WITH ISLAMIC POSES ITSELF AS A MODEL OF SECULAR DEMOCRACY WITH ISLAMIC
PRINCIPLES PURSUING THE FREE MARKET AND RESPECTING HUMAN RIGHTS.

08027 SAIKAL, A.

AFGHAMISTAN: A NEW APPROACH

JOURNAL OF DEMOCRACY, 3(2) (APR 92), 95-104.

AFGHANISTAN IS IN THE MIDST OF THE MOST CRITICAL

TRANSFORMATION IN ITS MODERN HISTORY. IT IS TODAY A HIGHLY FRAGMENTED, DISJOINED, AND FACTIONALIZED COUNTRY. MO MATTER WHAT REGIME RULES IN KABUL, REPAIRING THE DAMAGE DONE TO THE COUNTRY SINCE 1979 WILL IN ALL LIKELIHOOD REQUIRE THE ENERGY AND SKILLS OF SEVERAL GENERATIONS. THIS ARTICLE EXPLORES THO KEY FACTORS WHICH HAVE LONG CONDITIONED THE POLITICAL DEYELOPMENT OF AFGHANISTAN. THE FIRST IS THE HETEROGENEIOUS NATURE OF THE COUNTRY AND THE SECOND IS AFGHAN SOCIETY'S ANCIENT AND COMPLEX ISLAMIC HERITAGE. IT CONCLUDES THAT IF A SETTLEMENT IS NOT REACHED, THEN AFGHANISTAN HILL MOST LIKELY

REMAIN MIRED IN BLOODSHED, AND WILL CONTINUE TO BE A MAJOR
SOURCE OF REGIONAL INSTABILITY IN THE POST-COLD WAR ERA.

08028 SAIKAL, A.

U.S. STRATEGY IN THE PERSIAN GULF: A RECIPE FOR INSECURITY WORLD POLICY JOURNAL, IX(3) (SUM 92), 515-532.

SINCE THE GULF WAR, THE BUSH ADMINISTRATION HAS BEEN TRYING TO PLACE WHAT MIGHT BE CALLED A UNIPOLAR SECURITY SYSTEM IN THE PERSIAN GULF. UNDER THIS SYSTEM THE UNITED STATES, AS THE SOLE SUPERPOWER, WILL GUARANTEE THE SECURITY OF ITS GULF ALLIES IN EXCHANGE' FOR THEIR POLITICAL, FINANCIAL, AND INFRASTRUCTURAL SUPPORT. THIS SYSTEM IS ATTRACTIVE TO U.S. POL ICYMAKERS BECAUSE IT SEEMS TO BE A NOVEL WAY TO MEET A NUMBER OF LONG-STANDING POLICY GOALS IN EFFECTIVE IN PREVENTING CONFLICT AND BRINGING STABILITY TO
THE GULF REGION IN THE LONG TERM. A BETTER ALTERNATIVE WOULD THE GULF REGION IN THE LONG TERM. A BETTER ALTERNATIVE WOULD
BE A COMPREHENSIVE COLLECTIVE SECURITY ARRANGEMENT IN WHICH BE A COMPREHENSIVE COLLECTIVE SECURITY ARRANGEMENT IN
ALL OF THE REGION'S STATES WOULD HAVE THE OPTION OF ALL OF THE REG
PARTICIPATING.

08029 SAINSBURY, D.

THE 1991 SHEDISH ELECTION: PROTEST, FRAGMENTATION, AND A SHIFT TO THE RIGHT

HEST EUROPEAN POLITICS, 15(2) (APR 92), 160-166.

THE SEPTEMBER 1991 ELECTION IN SHEDEN RESULTED IN A DRAMATIC RIGHTHARD SHIFT IN THE ELECTORATE AND THE RESIGNATION OF THE SOCIAL DEMOCRATIC GOVERNMENT AFTER NINE YEARS IN OFFICE. ALL THE PARTIES IN PARL I AMENT, EXCEPT FOR THE CONSERVATIVES SUFFERED LOSSES. THE HINNERS WERE THE PARTIES ON THE RIGHT. THIS ARTICLE EXPLORES THE EVENTS BETWEEN THE ELECTIONS AND THE CAMPAIGN, AND THE NEW NONSOCIALIST GOVERNMENT. BECAUSE OF EXISTING DIFFICULTIES MOST
OBSERVERS WOULD BE SURPRISED IF THE GOVERNMENT SURVIVES UNTIL THE NEXT REGULAR ELECTION IN 1994.

08030 SAINT-GERMAIN, M.; MORGAN, M.

equality: Costa RICAN hOMEN DEMAND "THE REAL THING" WOMEN AND POLITICS, 11(3) (1991), 23-76.

LITTLE HAS BEEN WRITTEN ABOUT WOMEN'S STRUGGLES FOR POLITICAL EQUALITY IN CENTRAL AMERICAN COUNTRIES. THIS ARTICLE FOCUSES ON ONE SUCH PROPOSAL PUT BEFORE THE COSTA RICAN NATIONAL LEGISLATURE IN 1988, CALLED "THE LAH OF REAL EOUAL ITY FOR WOMEN " TRACING THE PROGRESS OF THIS PROPOSAL REYEALS THE ATTITUDES AMD BELIEFS OF ELITES ABOUT PROPEN THE REVEALS THE ATTITUDES AND BELIEFS OF ELITES ABOUT WOMEN, THE POWER OF STATE ACTORS TO INFLUENCE GENDER RELATIONS, AND THE IDEDLOGY OF POLITICAL DISCOURSE IN COSTA RICA. THE ARTI DISCRIBES THE UNIQUE FACTORS THAT GAVE RISE TO THIS
PROPOSAL AT THIS TIME IN COSTA RICAN HISTORY AND ANAYLZE PROPOSAL AT THIS TIME IN COSTA RICAN HISTORY AND ANAYLZE
WHAT THIS CASE STUDY CAN ADD TO OUR UNDERSTANDING OF THE ROLE OF THE STATE IN GENDER RELATIONS.

08031 SAKALA, C.

THE DEVELOPMENT OF NATIONAL MEDICAL CARE PROGRAMS IN THE UNITED KINGDOM AND CANADA: APPLICABILITY TO CURRENT CONDITIONS IN THE UNITED STATES

JOURNAL OF HEALTH POLITICS, POLICY AND LAW, 15(4) (WIN 90), 709-754.

AFTER A HIATUS IN THE EARLY TO MID-1980S, A GROWINC NUMBER OF POL ICY LEADER, POLICY ORGANIZATIONS, AND CITIZEN GROUPS ARE ADVOCATING PROGRAMS THAT ENSURE BASIC MEDICAL CARE FOR ALL. THIS PAPER EXAMINES THE DEVELOPMENT OF NATIONAL PROGRAMS IN THE UNITED KINGDOM AND CANADA AND ADORESSES TWO QUESTIONS: FIRST, WHAT FACTORS WERE CRITICAL TO THE ESTABLISHMENT OF THE BRITISH NATIONAL HEALTH SERVICE AND THE CANADIAN HOSPITAL AND PHYSICIAN INSURANCE PROGRAMS : SECOND, HOW APPLICABLE ARE THOSE FACTORS TO CURRENT

CONDITIONS IN THE U.S.? THE PAPER SHOWS THAT THE U.S., WHILE DIFFERING MANY PARTICULARS, PRESENTS SEVERAL PARALLELS TO THE U.K. AND CANADA. IT ARGUES THAT THE CURRENT ENVIRONMENT IN THE U.S. OFFERS THE NATION THE OPPORTUNITY TO DEVELOP AT STATE OR LOCAL LEVELS GOVERMMENT-SPONSORED PROGRAMS THAT GUARANTEE BASIC MEDICAL BENEFITS TO ALL.

08032 SAKATA, $H$.

OUCHI UPBEAT ON DSP'S FUTURE CLOUT

JAPAN TIMES (WEEKLY INTERNATIONAL EDITION), 32(18) (MAY

$92), 4$.

DEMOCRATIC SOCIALIST PARTY (DSP) CHAIRMAN KEIGO OUCHI EXPECTS HIS PARTY TO PLAY AN IMPORTANT ROLE IN THE JAPANESE DIET AFTER THE JULY 1992 ELECTIONS, BECAUSE HE PREDICTS THAT THE RULING LIBERAL DEMOCRATIC PARTY HILL NO LONGER BE ABLE
TO FORGE A MAJORITY IN THE UPPER HOUSE WITHOUT DSP SUPPORT.

08033 SAKATA, $H$.

PARTY MEMBERS SAY PULLOUT THREATENS HOKKAIDO CITIES JAPAN TIMES (WEEKLY INTERNATIONAL EDITION), $32(14)$ (APR 92) 7 .

THE SOCIAL DEMOCRATIC PARTY OF JAPAN (SDPJ) APPEARS TO BE OIVIDED OVER THE DEFENSE AGENCY'S PLAN TO REDUCE THE NUMBER OF GROUND SELF-DEFENSE FORCE (GSDF) PERSONNEL STATIONED IN HOKKAIDO. SDPJ MEMBERS OF THE LOCAL ASSEMBLIES IN THE HOKKAIDO MUNICIPALITIES OF NAYORO, RUMOI, KUCHAN, AND TAKIGAWAY HAVE VOICED THEIR OPPOSITION TO GSDF REDUCTIONS BECAUSE THEY WOULD MEAN A LOSS TO THE LOCAL ECONOMIES. MEANWHILE, THE SDPJ CENTRAL LEADERSHIP HAS ENDORSED A DISARMAMENT POLICY BUT DENIES THAT THERE IS A CONFLIC BETWEEN ITS POLICY AND THE LOCAL SDPJ'S OBJECTIONS TO REDUCING THE SIZE OF THE GSDF.

08034 SAKOLSKY, R.

TOWARD THE CREATION OF A DEMOCRATIC CULTURAL POLICY: A COMPARATIVE ANALYSIS OF THE ALLIANCE FOR CULTURAL

DEMOCRACY (U.S.) AND ANOTHER STANDARD (U.K.)

NEW POLITICAL SCIENCE, (20) (SUM 91), 81-96.

TO EXAMINE ART HITHIN A CULTURAL DEMOCRACY PARADIGM INVOLVES AN EXPLORATION OF THE IDEOLOGICAL AND CULTURAL UNDERPINNINGS OF ART. LOOKING BEYOND THE NARROWNESS OF THE ART WORLD FRAMEWORK, THE MODEL OF CULTURAL DEMOCRACY ENTAILS AN ANALYSIS OF BOTH THE DOMINANT CULTURE AND COUNTERAN ANALYSIS OF BOTH THE DOMINANT CULTURE AND COUNTER-
HEGEMONIC FORMS OF CULTURAL INSURGENCY. THIS ARTICLE SEEKS HEGEMONIC FORMS OF CULTURAL INSURGENCY. THIS ARTICLE SEEH
TO USE THE APPROACH OF CULTURAL DEMOCRACY IN ORDER TO TO USE THE APPROACH OF CULTURAL DEMOCRACY IN ORDER TO
EXAMINE THE CONNECTIONS BETWEEN CULTURE AND RESISTANCE IN A EXAMINE THE CONNECTIONS BETWEEN CULTURE AND RESISTANCE IN
WAY THAT ILLUMINATES BOTH THE OPPOSITIONAL AND GENERATIVE WAY THAT ILLUMINATES BOTH THE OPPOSITIONAL AND GENERATIVE
FORMS TAKEN BY THAT RESISTANCE AND THEIR RELATIONSHIP TO FORMS TAKEN BY THAT RESISTANCE AND THEIR RELATIONSHIP TO CULTURAL POLICY. EXAMPLES FROM THE UNITED STATES (NATIONAL
ENDOWMENT FOR THE ARTS) AND GREAT BRITAIN ARE DISCUSSED AND ENDOWMENT
CDMPARED.

08035 SALEH, H.

ERITREA EMERGES FROM AFRICA'S LONGEST WAR MIDDLE EAST INTERNATIONAL, (427) (JUN 92) 19-20. AFTER EMERGING ON 21 MAY 1991 FROM WHAT HAS OFTEN BEEN DESCRIBED AS THE LONGEST HAR IN AFRICA, ERITREA CAN BOAST THAT IT IS THE MOST STABLE COUNTRY IN THE REGION. WITH SOMALIA, SUDAN, DJIBOUTI AND ETHIOPIA IN THE GRIP OF CIVIL WAR AND ETHNIC STRIFE, ERITREA IS NOW THE ONLY COUNTRY AT 
PEACE IN THE HORN OF AFRICA. ERITREANS ARE STILL ELATED OVER THE EMD OF THEIR 30-YEAR HAR OF INDEPENDENCE FROM ETHIOPIA. THEIR NEW GOVERMMENT, SET UP BY THE FORMER SEPARATIST REBEL ORGANIZATION, THE ERITREAN PEOPLE'S LIBERATION FRONT (EPLF),
CONTINUES TO RIDE HIGH ON A WAVE OF POPULAR SUPPORT. ERITREA CONTINUES TO RIDE HIGH ON A WAVE OF POPULAR SUPPORT GOVERNING IN A PROVISIONAL CAPACITY PENDING A PLEBISCITE ON INDEPENDENCE TO BE HELD UNDER UN AUSPICES IN APRIL 1993. EPLF OFFICIALS SAY A WAITING PERIOD IS NECESSARY FOR THE NEH REGIME IN ETHIOPIA TO STABILIZE. THE ETHIOPIAN PEOPLE'S REVOLUTIONARY DEMOCRATIC FRONT (EPRDF). NOW IN POWER IN ADDIS ABABA, IS A FORMER REBEL ORGANIZATION WITH STRONG TIES TO THE EPLF. INTERNATIONAL RECOGNITION OF ERITREA'S

SOVEREIGNTY HILL NOT COME UNTIL AFTER THE PLEBISCITE. BUT

UNTIL THEN, ERITREA IS INDEPENDENT IN EVERYTHING BUT NAME.

08036 SALERNO, R.A.

THEORY AND ACTION IN WIRTH'S "URBANISM"

INTERMATIONAL SOCIAL SCIENCE REVIEW, 67(2) (SPR 92), 51-59.

LOUIS WIRTH'S ABILITY TO CONMECT SOCIAL THEORY TO HUMAN ACTION PLACED HIM IN AN ELITE GROUP OF SCHOLAR-ACTIVISTS.

THIS PAPER EXAMINES THE PERSONAL INFLUENCES AND SOCIAL ISSUES THAT LED WIRTH TO WRITE "URBANISM AS A WAY OF LIFE" IN 1938. THE AUTHOR SUGGESTS THAT WIRTH'S PAPER WAS AN OUTGROWTH OF HIS LIFE-LONG EFFORTS TO LINK SOCIAL THEORY TO PUBLIC POLICY AND HIS WORK WITH THE NATIONAL RESOURCES PLANNING 8OARO'S URBANISM COMMITTEE. IT WAS LARGELY THROUGH WIRTH'S HORK THAT CITIES BECAME A FOCUS OF ATTENTION FOR
SOCIOLOGISTS AMD SOCIAL PLANNERS.

08037 SALES, $P$

PHILLIPINES: A VALLEY OF LOST DREAMS

ARENA, 98 (1992), 40-46.

THOUSANDS OF TRIBAL PEOPLE IN THE HILLY, FORRESTED AREAS OF THE PHILIPPINES HAVE BEEN PUT TO FLIGHT BY AFP OPERATIONS AGAINST THE BAGONG HUKBO BAYAN (OR NEW PEOPLE'S ARMY). IN LATE 1990 OFFICIAL SOURCES REPORTED A CHANGE IN THE RESPONSE OF RURAL SETTLEMENTS TO MILITARY OPERATIONS. IN PARTICULAR. PEOPLE WERE CHOOSING--OFTEN AT GREAT RISK--TO REMAIN IN SITU DURING AFP ACTIVITIES. A MAJOR DETERMINANT IN REGARD TO THIS BRAVE DECISION TO STAY AND FACE THE RATH OF THE SOLDIERS WAS THE EXPERIENCE OF THE EVACUATION CENTERS THEMSELVES WHICH WERE INADEQUATE. THE PEOPLE CONTINUE TO SUFFER BECAUSE OF THE STRATEGIC SIGNIFICANCE OF THEIR AREA. THE AUSTRALIAN AUTHOR OF THIS ARTICLE SUGGESTS THAT AUSTRALIANS SHOULD MAKE A MORE HONEST ANO THOUGHTUL APPRAISAL OF THE SITUATION IN THE PHILIPPINES, RECOGNIZING THE POTENTIALLY EXPLOSIVE SIGNIFICANCE OF' THE COUNTRY AND ITS PROBLEMS.

08038 SALLOUM, H.

CAN TOURISM SAVE CUBA'S COMMUNIST SYSTEM?

CONTEMPORARY REVIEW, 261(1520) (SEP 92), 130-135.

CUBA HAS BEEN STRIVING HARD SINCE THE COLLAPSE OF THE SOVIET UNION TO COPE WITH HORRENDOUS ECONOMIC DIFFICULTIES SUCH AS SHORTAGES OF OIL AND MOST OTHER ESSENTIALS, BUT THE PLANNED TOURIST PROJECTS HAVE NOT BEEN HALTED OR EVEN DELAYED. IN ITS NUMEROUS RESORTS, THE CUBAN GOVERNMENT IS DOING ITS UTMOST TO MAKE SURE TOURISM WILL BRING IN MORE AND MORE OF THE WORLD'S FINANCIAL CONTROLLER--THE AMERICAN DOLLAR. THE AUTHOR EXPLORES HOW THE NEH TOURISM POLICY IS
AFFECTING ALL PARTS OF THE COUNTRY. HE CONCLUDES THAT, AS IM EASTERM EUROPE, COMMUNISM IN CUBA COULD CDME CRASHING DOWM WITH A VENGEANCE IF THE RUSH TO TOURISM FAILS.

08039 SALLOUM, H.

THE DEMOCRATIC FUTURE FOR YEMEN

CONTEMPORARY REVIEH, 261(1522) (NOV 92), 236-239.

THE DEMOCRATIZATION OF YEMEN SEEMS TO BE ON A PATH OF NO RETURN. THE COUNTRY HAS COME VERY FAR IN THE LAST THIRTY YEARS AND CONTINUES TO PROGRESS. THIS ARTICLE EXAMINES PROGRESS IN POLITICAL PARTIES, WOMEN'S RIGHTS, SCHOOLING, MEDICINE, AND THE ROAD SYSTEM. PRESENT CHALLENGES AND POSSIBLE SOLUTIONS ARE PRESENTED.

08040 SALMON, T.

TESTING TIMES FOR EUROPEAN POLITICAL COOPERATION: THE GULF AND YUGOSLAVIA, 1900-1992

INTERNATIONAL AFFAIRS, 68(2) (APR 92), 233-254.

DURING THE PAST TWENTY YEARS EUROPEAM POL ITICAL

COOPERATION HS EVINCED A MIXED RECORD OF SUCCESS AND FAILURE ON CONSENSUS AMONG EUROPEAN COMMUNITY MEMBERS. A "REFLEX" OF COOPERATION HAS BEEN ESTABL ISHED ON SECOND-ORDER ISSUES. THE COOPERATION HAS BEEN ESTABLISHED ON SECONO-ORDER ISSUES. AUTHOR OF THIS ARTICLE EXPLORES THE TENSION BETWEEN IMPORETANCE NAMELY THE GUL AND YUGOSLAY OF MAJOR IMPORATANCE, NAMELY THE GULF AND YUGOSLAVIA, AND CONCLUDES THAT PERCEPT
PREVAILED.

08041 SALOP, J.

REDUCING POVERTY: SPREADING THE MORO

FINANCE AND DEVELOPMENT, 29 (4) (DEC 92 ), 2-4.

IN KEEPING WITH ITS RENEWED EMPHASIS ON ELIMINATING POVERTY, THE WORLD BANK HAS ISSUED TWO PUBLICATIONS TO DISSEMINATE INFORMATION ABOUT THE POLICIES AND PRACTICES
THAT WORK BEST. THE MESSAGE IS CLEAR: COUNTRIES SHOULD INVEST IN BASIC SOCIAL SERVICES, PROMOTE EFFICIENT AND INVEST IN BASIC SOCIAL SERVICES, PROMOTE EFFICIENT AND PREJUDICE THE POOR'S INTERESTS.

08042 SALPETER, E.

AFTER THE ELECTIONS--TEST TIME FOR ISRAEL'S MODERATES NEW LEADER, LXXV(9) (JUL 92 ), 5-7.

THE PEACEFUL SETTLEMENT OF A POTENTIALLY VIOLENT SITUATION INVOLVING SIX WANTED TERRORISTS, THOUSANDS OF PALESTINIAN STUDENTS, AND ISRAELI SECURITY FORCES WAS A BOON FOR THE NEW LABOR-LED GOVERMMENT OF YITZCHAK RABIN. THE REALIZATION OF A MUTUAL INTEREST IN FINDING A PEACEFUL RESOLUTION TO THE CRISIS APPEARS TO BODE WELL FOR TALKS ON PALESTINIAN AUTONOMY. HOWEVER, A CLOSE LOOK AT THE ISRAEL'S 23 JUNE GENERAL ELECTION, HHILE ENCOURAGING OPTIMISM, SUGGESTS THAT TOO MUCH SHOULD NOT BE EXPECTED TOO SOON. RABIN AND LABOR'S VICTORY WAS DRAMATIC, BUT IT HAS NOT SUFFICIENTLY DEEP TO OVERCOME THE FUNDAMENTAL WEAKNESS OF THE COUNTRY'S POLITICS: UNDER ITS PROPORTIONAL REPRESENTATION SYSTEM, NO PARTY HAS EVER OBTAINED A MAJORITY IN THE 120-SEAT PARLIAMENT. STILL, FEH DOUBT THAT ONE IMMEDIATE EFFECT OF THE LABOR VICTORY HAS BEEN TO IMPROVE THE CLIMATE FOR THE PEACE PROCESS.

08043 SALPETER, E.

AFTER THE FALL OF SADDAM

NEH LEADER, LXXIV(2) (JAH 91), 3-4.

THE GULF WAR HAS SIGNIFICANTLY CHANGED THE FACE OF POL ITICS, BOTH IN THE MIDEAST REGION AND IN THE HORLD. THE CAUSE OF ARAB - ISRAELI PEACE WAS HURT BY THE PLO'S SUPPORT FOR SADDAM HUSSEIN. THE CHEERS OF THE PALESTIMIANS AS SCUDS FLEW OVER TEL AVIV WILL LIKELY DIMINISH ISRAEL'S WILLINGNESS TO NEGOTIATE. VIEWED FROM A WIDER, INTERNATIONAL PERSPECTIVE, THE WAR ILLUMINATED THREE CHANGES: THE INCREASING AHARENESS THAT EVEN INFERIOR OR SHALL COUNTRIES CAN WIELD SIGNIFICANT MILITARY POWER (I.E. IRAQ'S CHEMICAL AND NUCLEAR CAPABILITY); THE WEAKENED CONDITION OF THE SOVIET UNION WHICH HAS MADE AMERICA THE SOLE EFFECTIVE "POL ICEMAN OF THE WORLD"; AND THE CONTINUED TROUBLE THAT THE MIDDLE EAST REGION WILL CAUSE, A CONDITION THAT WILL SOW DISCORD AMONG DEMOCRATIC FRIENDS AND BE EXPLOITED IN COMMUNIST POHER PLAYS.

08044 SALPETER, E

LABOR CLOSES RANKS IN ISRAEL

NEW LEADER, LXXV(5) (APR 92), 3-4.

ISRAEL'S LABOR PARTY HAS SEVERAL REASONS TO BE CONFIDENT ABOUT ITS CHANCES IN THE FORTHCOMING GENERAL ELECTION. LABOR ADOPTED A PRIMARY SYSTEM FOR PICKING A CHAIRMAN AND FOR DRANING UP A LIST OF KNESSET (PARLIAMENT) CANDIDATES, AN DRAWING UP A LIST OF KNESSET (PARLIAMENT) CANDIDATES, AN UNPRECEDENTED MOVE IN ISRAEL. PARTY LEADER SHIMON PERES--
BRANDED BY THE RULING LIKUD PARTY AS A DOVE--WAS REPLACED BY BRANDED BY THE RULING LIKUD PARTY AS A DOVE-WAS REPLACED BY
YITCHAK RABIN--FORMER PRIME MINISTER, DEFENSE MINISTER, AND YITCHAK RABIN--FORMER PRIME MINISTER, DEFENSE MINISTER, AND
ARMED FORCES CHIEF OF STAFF. IN ADDITION, DISUNITY AMONG THE ARMED FORCES CHIEF OF STAFF. IN ADDITION, DISUNITY AMONG

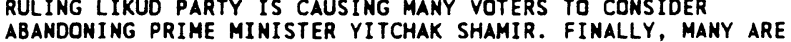
ABANDONING PRIME MINISTER YITCHAK SHAMIR. FINALLY, MANY ARE BEGINNING TO SEE THE WISDOM IN LABOR'S TWO-TIERED VIEH OF THE ISSUE OF PEACE WITH THE ARABS. LABOR ARGUES THAT THE ABSENCE OF PEACE IS PREVENTING ISRAEL'S LINKAGE WITH
MULTINATIONAL COMPANIES AND ITS INTEGRATION INTO THE MULTINATIONAL COMPANIES ANO ITS INTEGRATION INTO THE
INTERNATIONAL ECONOMY. AND, IN THE LONG RUN, WITHOUT A INTERNATIONAL ECONOMY. AND, IN THE LONG RUN, WITHOUT A
REASONABLE SETTLEMENT ISRAEL WILL FIND ITSELF FIGHTING PERHAPS THE BLOODIEST WAR YET WITH THE ARABS.

08045 SALPETER, E.

RABIN'S SYRIA CARD

NEW LEADER, LXXV(13) (OCT 92), 8-10.

DURING PRIME MINISTER YITZCHAK RABIN'S ELECTION CAMPAIGN LAST SUMMER, HE STRESSED THE PRIORITY OF THE PALESTINE QUESTION IN THE ISRAELI-ARAB NEGOTIONS, BOTH BECAUSE OF ITS CENTRALITY TO PEACE AND BECAUSE GRANTING AUTONOMY DOES NOT REQUIRE MAKING THE BIG STEPS AN OVERALL SETTLEMENT WILL INEVITABLY ENTAIL. SINCE THEN, THE ISRAELI DELGATION HAS SHIFTED ITS FOCUS TO THE TALKS WITH THE SYRIANS AND EXPRESSED A READINESS TO DISCUSS TERRITORAL DIMENSION. THIS ARTICLE SUGGESTS THAT RABIN'S MAIN REASONS FOR SHITCHING ATTENTION TO THE SYRIANS HERE BASED ON REGIONAL CONSIDERATIONS. IT CONCLUDES THAT IN PLAYING THE SYRIAN CARD RABIN IS TELLING DAMASCUS THAT UNLESS IT BECOMES MORE FLEXIBLE, HIS SPACE FOR COMPROMISE MAY SOON BE EXHAUSTED.

08046 SALPETER, E.

THE BACKDROP TO ISRAEL'S ELECTIONS

NEW LEADER, LXXV(1) (JAN 92 ) $8-9$

WEW LEADER, LXXV(1) (JAN 92 ), 8 -9. IN THE MONTH BEFORE THO TINY FAR RIGHT PARTIES UNHAPPY WITH THE MIDEAST PEACE PROCESS QUIT PRIME MINISTER SHAMIR'S LIKUD COALITION, AND THIS PRECIPITATED THE
ELECTIONS SCHEDULED ID BE HELD ON 23 JUNE, PUBLIC ETHICS IN ELECTIONS SCHEDULED TO BE HELD ON 23 JUNE, PUBLIC ETHICS
ISRAEL REACHED A LOW POINT. TAXPAYERS' MONEY WAS BEING ISRAEL REACHED A LOH POINT. TAXPAYERS SPENT IN A VAIN EFFORT TO ASSURE THE CONTINUED SUPPORT OF THE MINOR COALITION PARTHERS. THE MAYOR OF JERUSALEM FELT COMPELLED TO JOIN DEMONSTRATIONS AGAINST GOVERNMENT-SUPPORTED JEWISH FANATICS TAKING OVER HOUSES IN ARAB NEIGHBORHOODS. THE ATTORNEY GENERAL REFUSED TO DEFEND 
ACTIONS BY THE MINISTRY OF HOUSING. THE SUPREME COURT HAD TO ORDER THE SPEAKER OF THE KNESSET, A LIKUD FAITHFUL, TO KEEP HIS WORD TO THE OPPOSITION. RECENT PROPOSALS DESIGNED TO REFORM THE POLITICAL SYSTEM IN ORDER TO AYOID FUTURE OEADLOCKS HAVE BEEN RESISTED BY SHAMIR AND THE LIKUD PARTY.

08047 SALPETER, E.

WHY ISRAEL IS UNEASY ABOUT MADRID

MEW LEADER, LXXIV (11) (OCT 91) 5-7

AT FIRST GLANCE IT APPEARS THAT IN THE TERMS FOR THE INTERMATIONAL PEACE CONFERENCE IN MADRID THERE WAS MORE EROSION OF THE PALESTINIANS' ORIGINAL POSITIONS THAN OF ISRAEL'S. YET IN ADDITION TO GIVING IN ON AN INTERNATIONAL CONFERENCE ALTOGETHER, AS WELL AS ON EUROPEAN COMMUNITY PARTICIPATION AND A UN OBSERVER, ISRAEL MADE THO OTHER CONCESSIONS: IT WENT ALONG WITH NOT HAVING THE INVITATIONS SPECIFICALLY MENTION PEACE TREATIES AS THE AIM OF THE TALKS AND IT DID NOT WALK OUT UPON LEARNING THAT PRESIDENT AL-ASSAD WAS REFUSING TO HAVE SYRIA TAKE PART IN THE MULTILATERAL PHASE OF THE CONFERENCE UNTIL ISRAEL WITHDREH TO ITS PRE-1967 BORDERS. ISRAEL INCREASINGLY FEELS THAT ITS CONTROL OF THE PEACE PROCESS IS BEING GRADUALLY DIMINI

08048 SALSMAN, $R$

BANKING WITHOUT THE "TOO-BIG-TO-FAIL" DOCTRINE

FREEMAN, 42(11) (NOV 92), 426-431.

SINCE THE FAILURE OF CONTINENTAL ILLINOIS IN 1984, THE U. S. GOVERMMENT HAS PURSUED A DELIBERATE POLICY OF BAILING OUT LARGE COMMERCIAL BAHKS DEEMED "TOO-BIG-TO-FAIL." THE MAIN THEME OF THIS ARTICLE ON U.S. BANKING HISTORY IS THAT CENTRAL BANKING IS DETRIMENTAL BOTH TO SOUND MONEY AND SAFE CENTRAL BANKING IS DETRIMENTAL BOTH TO SOUND MONEY AND SAFE BANK ING. THE MEASURES OF BANKING SYSTEM STRENGTH HAVE EBB AND FLOWED CYCLICALLY OVER THE PAST EIGHT DECADES. THE
AUTHOR, HOWEYER, HAS IDENTIFED AN UNDENIABLY PRONOUNCED

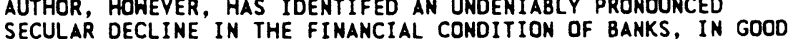
SECULAR DECLINE IN THE FINANCIAL CONDITION OF BANKS, IN CENTRAL BANKING AS SUCH.

08049 SALT, J.

THE FUTURE OF INTERNATIONAL LABOR MIGRATION

INTERNATIONAL MIGRATION REVIEH, 26(4) (WIN 92), 1077-1111. THE ARTICLE REVIEWS THE NATURE OF INTERNATIONAL LABOR MIGRATION TODAY AND THE ECONOMIC AND POLITICAL RATIONALE FOR ITS OCCURRENCE. IT SUGGESTS THAT WILE THE DEVELOPED ECONOMICS WILL CONTINUE TO ATTRACT AND EXCHANGE HIGHLY SKILLED LABOR, THEY WILL HAVE LITTLE NEED FOR MASS IMMIGRATION BY THOSE WITH LOW SKILL LEVELS. IN CONTRAST POORER COUNTRIES WITH RAPID POPULATION GROWTH AND LOW LIVING STANDARDS WILL ENCOURAGE EMIGRATION, EXCEPT BY THE HIGHLY SKILLED. ONE CONSEQUENCE WILL BE MORE ILLEGAL IMMIGRATION. GEOGRAPHICAL PATTERNS WILL CONTINUE TO BE DOMINATED BY A SET OF MACROREGIONAL NETWORKS, AMONG WHICH THE ASIA-PACIFIC REGION IS THE MOST RECENTLY DEVELOPED. CHINA AND THE FORMER SOVIET UNION (AS SENDERS) AND JAPAN (AS RECEIVER) CONSTITUTE THE MAIN ENIGMAS.

08050 SALTZSTEIN, G.

BUREAUCRATIC RESPONSIVENESS: CONCEPTUAL ISSUES AND CURRENT RESEARCH

JOURNAL OF PUBLIC ADMINISTRATION RESEARCH AND THEORY, 2(1)

(JAN 92) 29-62.

DRAWING UPON RELEVANT LITERATURE, THIS ASSAY EXAMINES THE CONCEPT OF BUREAUCRATIC RESPONSIYNESS AND ATTEMPTS TO

DELINEATE (1) THE MAJOR BOUNDARIES OF THE CONCEPT, (2) THE

DELINEATE (1) THE MAJOR BOUNDARIES OF THE CONCEPT, (2)

YARIIPAL THEORETICAL AND METHODOLGICAL LIMITATIONS OF

THUS FAR OVERLOOKED OR INADEQUATELY ADORESSED.

O8051 SAMAD, P.; BAKAR, D.

MALAYSIA-PHILIPPINES RELATIONS: THE ISSUE OF SABAH ASIAN SURVEY, $22(6)$ (JUN 92), 554-567.

THE PATTER OF RELATIONS BETHEEN MALAYSIA AND THE THE PATTERN OF RELATIONS BETWEEN MALAYSIA AND THE
PHILLIPINES IN THE CONTEXT OF THE SABAH DISPUTE IS DESCRIBED AND EXPLAINED IN THIS ARTICLE. THE SIGNIFICANT OF VARIOUS AND EXPLAINED IN THIS ARTICLE. THE SIGNIFICANT OF VARIOUS IN ORDER TO UNDERSTAND HOW CRISES DEVELOPED. THE PAPER ALSO EXAMINES THE PROSPECTS FOR BISES DEVELCPED. THE PAPER ALSO TWO CDUNTRIES, CONSIDERING THE OPTIONS AND INTERESTS OF BOTH TWO COUNTRI
PARTIES.

08052 SAMAD, Y

BOOK BURNING AND RACE RELATIONS: POLITICAL MOBILIZATION OF BRADFORD MUSLIMS

NEW COMMUNITY, 18(4) (JUL 92), 507-519.

IN GREAT BRITAIN, THE INTERNATIONAL CAMPAIGN AGAINST SALMAN RUSHDIE'S "THE SATANIC VERSES" PRODUCED A PARTICULARLY VIGOROUS REACTION AMONG PAKISTANI MUSLIMS IM BRADFORD. THE MILITANCY OF THE BRADFORD MUSLIMS MUST BE EXPLAINED IN PART BY THE STRUCTURAL EXPERIENCES THEY UNDERWENT IN THE 1980'S. IT IS ONLY BY COMING TO GRIPS HITH THE SPECIFICITY OF THE RACE DISCOURSE THAT IT BECOMES UNDERSTANDABLE WHY IENSION CONTINUED IN BRADFORD AFTER THE RUSHDIE AFFAIR HAD DIED DOWN ELSEWHERE IN THE WORLD. THE
BRADFORD MUSLIMS' INDIGNANT DEFIANCE OF "THE ESTABLISHMENT" GAVE THEM NOTORIETY AND PERHAPS JUSTIFIED THE CLAIM THAT BRITAIN WAS WITNESSING THE EMERGENCE OF MUSLIM POLITICS WITHIN ITS BORDERS.

08053 SAMARDZIC, S

GOVERNMENT AND OPPOSITION IN SERBIA IN PEACE AND WAR

EAST EUROPEAN REPORTER, 5(1) (JAN 92), 12-13.

THIS ARTICLE CONSIDERS HOW MUCH REAL SUPPORT IN SERBIA THERE IS FOR THE POLICIES OF LEADER SLOBODAN MILOSEYIC. IT ALSO CONSIDERS, GIVEM CONDITIONS FOR MULTI-PARTY PLURAIISH ALSO CONSIDERS, GIVEN CONOITIONS FOR MULTI-PARY PLURALISM BETER THAN IN SOME PARTS OF YUGOSLAVIA--NOT TO MENTION A DEMOCRATIC TRADITION GOING BACK INTO THE LAST CENTURY-WHY SERBIA IS THE LAST COUNTRY IN CENTRAL AND EASTERN EUROPE STILL TO BE RULED BY A SOCIALIST PARTY. IT CONCLUDES THAT THE SUCCESS OF MILOSEVIC IS LARGELY DUE TO HIS SKILL IN
USURPING AND MANIPULATING THE SERBIAN POLITICAL AGENDA (AS USURPING AND MANIPULATING THE SERBIAN POLITICAL AGENDA (AS
WELL AS TO THE USUAL TECHNIQUES OF ONE-PARTY RULE), THOUGH WELL AS TO THE USUAL TECHNIQUES OF ONE-PARTY RULE),

08054 SAMATAR, A.I

DESTRUCTION OF STATE AND SOCIETY IN SOMALIA: BEYOND THE TRIBAL CONVENTION

JOURNAL OF MODERN AFRICAN STUDIES, 30(4) (DEC 92), 625-642. THE AUTHOR PROVIDES BOTH A SUMMARY OF AND COMMENTARY ON THE SCHOLARLY LITERATURE ABOUT THE ORIGINS AND NATURE OF THE COLLAPSE OF THE SOMALI STATE AND THE SUBSEQUENT COMPLETE BREAKDOWN OF CIVIL ORDER. THE CENTRALITY OF KINSHIP IN UNDERSTANDING CONTEMPORARY SOMALI POLITICS AND ITS TENDENCY TOWARDS FRAGMENTATION AND ANARCHY HAS BEEN STRESSED BY A NUMBER OF SCHOLARS. ALTHOUGH OTHER SCHOLARS ACKNOWLEDGE THE IMPORTANCE OF CULTURE IN APPRECIATING THE CONTOURS OF RECENT DEVELOPMENTS, THEY MAINTAIN THAT THE SIGNIFICANCE OF TRADITIONAL RELATIONS HAS BEEN CHANGED ALMOST BEYOND RECOGNITION BY EVOLVING INTERACTIONS. HENCE, IT IS NECESSARY TO UMRAVEL THE DYNAMICS OF POLITICAL AND ECONOMIC PROCESSES THAT CDNDITION THE STRUCTURE OF SOCIAL RELATIONS IN COMMUNITY AT A PARTICULAR HISTORICAL JUNCTURE.

08055 SAMPLE, Y.A. RESOURCE PLANMING AND BUDGETING FOR NATIONAL FOREST MANAGEMENT

PUBL IC ADMINISTRATION REVIEW, 52(4) (JUL 92), 339-347. CAN AGENCIES ADAPT THE HYBRID PLANNING AND BUDGETING SYSTEMS CREATED DURING THE $1960^{\prime} S$ AND 1970 'S TO TODAY'S SYEDS FOR COST EFFICIENCY AND CONGRESSIONAL ACCOUNTABILITY? NEEDS FOR COST EFFICIENCY AND CONGRESSIONAL ACCOUNTABILITY? USING THE CASE OF THE NATIONAL FOREST SYSTEM, THE AUTEGRATION DEMONSTRATES THAT AGENCY EFFORTS TO IMPROVE THE INTEGRATION OF PLANNING AND BUDGETARY PROCESSES CAN ACCOMPLISH $U$. STH OBJECTIVES. AFTER PROVIDING A DESCRIPTION OF THE U.S. FOREST
SERVICE'S EFFORTS, HE CALLS FOR CONGRESSIONAL ACTION THAT WILL PROMOTE COST EFFICIENCY AND ACCOUNTABILITY.

08056 SAMUEL, P.

WHO WILL REgULATE THE REgULATORS?

NATIONAL REVIEW, XLIV(21) (NOV 92), 38, 40, 42

THE AUTHOR RECOUNTS AN EPISODE WHEN THE ENVIRONMENTAL PROTECTION AGENCY. THE FOOD AND DRUG ADMINISTRATION, AND THE FEDERAL TRADE COMMISSION BECAME INVOLVED IN THE REGULATION OF SPORICIDIN, A GERMICIDE WIDELY USED IN CLINICS ANO HOSPITALS. HE ARGUES THAT THESE AGENCIES, WHICH ARE SUPPOSEDLY DEDICATED TO SERVING PUBLIC HEALTH, ARE ACTUALLY ENDANGERING IT BY SPREADING DISINFORMATION, DISRUPTING THE SUPPLY OF DISINFECTANTS, AND THREATENING THE ECONOMIC VIABILITY OF COMPANIES THAT MANUFACTURE THEM.

08057 SAMUELS, G.

RUSSIA SLIPS INTO THE SOVIET SEAT

NEW LEADER, LXXV(2) (FEB 92), 5-7.

WITH THE OVERTHROW OF THE SOVIET UNION AND ITS RULING COMMUNIST PARTY, RUSSIA, THE LARGEST REPUBLIC (TOOAY CALLED THE RUSSIAN FEDERATION), HAS WITHOUT DEBATE OR A VOTE SIMPLY TAKEN OVER--"INHERITED"--THE USSR'S SEAT IN THE 15-NATION UN TAKEN OVER--"INHERITED"--THE USSR'S SEAT IN THE 15-NATION UY
SECURITY COUNCIL. THE MOVE, ENGINEERED BY RUSSIAN PRESIDENT BORIS N. YELTSIN, WAS QUIETLY ENCOURAGED BY WASHINGTON AND ACCEPTED BY OTHER PERMANENT MEMBERS. THE MOVE CAME AT THE VERY TIME PRESSURE WAS BUILDING TO ENLARGE THE SECURI TY COUNCIL TO REFLECT THE CHANGING CHARACTER OF THE UN'S MEMBERSHIP. JAPAN AND GERMANY HAVE BEEN PRESSING FOR PERMANENT SEATS AS WORLD POWERS; AND LARGE DEVELOPING
COUNTRIES SUCH AS NIGERIA, INDIA AND BRAZIL FEEL THEY ARE NO COUNTRIES SUCH AS NIGERIA, INDIA AND BRAZIL FEEL THEY ARE
LESS DESERVING. THE SPEED WITH WHICH RUSSIA WAS ACCEPTED LESS DESERVING. THE SPEED WITH WHICH RUSSIA WAS ACCEPTED INTO THE SECURITY COUNCIL IS AN INDICATION OF THE FIVE
PERMANENT MEMBERS' DESIRE TO AVOID CHANGE TO THEIR POWERFUL POSITIONS.

08058 SAMUELS, G.

SECOND CHANCE FOR THE UNITED NATIONS

NEW LEADER, LXXV(11) (SEP 92), 3-5.

SOME UN DIPLOMATS ARE BEGINNING TO QUESTION WHETHER THE ASSEMBLY'S ROLE IN THE POST-COLD WAR ERA SHOULD NOT SOMEHOW BE EXPANDED. UNDER THE PROVISIONS OF THE CHARTER IT MAY DISCUSS... CONSIDER... MAKE RECOMMENDATIONS, BUT THE 15-NATION SECURITY COUNCIL HAS PRIMARY RESPONSIBLITY FOR PEACE AND 
SECURITY. A SAMPLING OF DELEGATES REVEALS THAT FEELINGS ABOUT THE PROSPECTS FOR CHANGE RANGE FROM DOWNRIGHT PESSIMISM TO GUARDED OPTIMISM. THE SECRETARY GENERAL WARNS THAT THERE IS A NEED TO ENSURE THAT THE LESSONS OF THE PAST FOUR DECADES ARE LEARNED AND THAT THE ERRORS ARE NOT REPEATED.

08059 SAMUELS, M.A.

CREATING A BANANA FORTRESS

HEMISPHERE, 5(1) (FAL 92), 38-39.

SINCE 1990 THE EUROPEAN COMMUNITY (EC) HAS BEEN

STRUGGLING WITH THE TASK OF UNIFYING THE SEVEN DIFFERENT BANANA IMPORT POLICIES THAT CURRENTLY EXIST AMONG ITS MEMBER STATES. IT IS A TASK COMPLICATED BY INTERNATIONAL

COMMITMENTS, EMOTIONAL ATTACHMENTS TO FORMER COLONIES, ANO A VARIETY OF CONFLICTING ECONOMIC INTERESTS. UNFORTUNATELY THE EC COMHISSION HAS CHOSEN A PATH THAT JUSTIFIES FEARS THAT THE EC MIGHT PRODUCE A FORTRESS EUROPE. UNLESS THE

COIMISSION'S PROPOSED POLICY IS CHANGED. THE LOSERS WILL BE THE BANANA GRONERS AND THE ECONOMIES OF THE BANANA-PRODUCING COUNTRIES OF LATIN AMERICA.

08060 SAMUYLOV, S.; BLANK, S.

THE GORBACHEY PRESIDENCY: ON THE WAY TO DICTATORSHIP? PRESIDENTIAL STUDIES OUARTERLY, XXII (2) (SPR 92), 239-260. THIS ARTICLE ARGUES THAT ONE OF THE MAJOR WEAKNESSES OF THE GORBACHEY PRESIDENCY, THAT HAD BEEN ESTABLISHED AFTER A FAILURE OF SOMETHING LIKE PARLIAMENTARIANISM ON THE ALLUNION LEVEL, HAS HIS COLLEGIATE STYLE OF POLITICAL

LEADERSHIP. GORBACHEV PROVED TO BE UNABLE TO USE HIS WIDE EXECUTIVE POWERS, INCLUDING EMERGENCY ONES, TO FULFILL HIS CONSTITUTIONAL DUTIES. FINALLY, AS A RESULT OF THIS FAILURE AND GROWING SEPARATIST MOVEMENTS THROUGHOUT THE SOVIET UNION, A MIXED SYSTEM, PRESIDENTIAL AT THE TOP AND ESSENTIALLY PARLIAMENTARY AT THE BOTTOM, APPEARED. THE ARTICLE ARGUES THAT THE NEW SYSTEM PROVED UNABLE TO CURB THE ECONOMIC DOWNTURN AND WAS WEAK ENOUGH TO ENCOURAGE THE AUGUST 1991 COUP ATTEMPT AGAINST GORBACHEY.

08061 SANCTON, A.

CANADA AS A HIGHLY URBANIZED NATION: NEW IMPLICATIONS FOR GOVERNMENT

CANADIAN PUBLIC ADMINISTRATION, 35(3) (FAL 92), 281-298. ALTHOUGH CANADA IS A HIGHLY-URBANIZED NATION, MANY IMPORTANT PRINCIPLES RELATING TO ITS GOVERNANCE SEEM TO BE BASED ON THE ASSUMPTION THAT URBANIZATION NEED NOT BE FULLY RECOGNIZED. BUT THIS ASSUMPIION IS NOW BEING QUESTIONED, CAUSING SUBSTANTIAL PROBLEMS AT ALL LEVELS OF GOVERNMENT. CAUSING SUBSTANTIAL PROBLEMS AT ALL LEVELS OF GOVERNMENT. PROVISIONS OF THE CANADIAN CHARTER OF RIGHTS AND FREEDOMS ARE NOW BEING EMPLOYED TO CHALLENGE ELECTORAL SYSTEMS THAT
GIVE SPECIAL TREATMENT TO NON-URBAN AREAS. AS MORE CANADIANS GIVE SPECIAL TREATMENT TO NON-URBAN AREAS. AS MORE CANADIANS LIVE IN MAJOR METROPOLITAN AREAS, PROBLEMS WITH ORGANIZING GREATER TORONTO AREA. EVEN WHEN METROPOL ITAN AREAS HAVE GREATER TORONTO AREA. EVEN WHEN METROPOLITAN AREAS HAVE REORGANIZED METROPOLITAN STRUCTURES, SUCH STRUCTURES ARE RARELY ABLE TO DEAL WITH SUCH ISSUES AS TRANSIT, HATER SUPPLY AND SEWAGE, AND GARBAGE DISPOSAL. IT IS TIME TO RECONCEPTUALIZE PROVINCIAL GOVERNMENTS AS INSTITUTIONS PRIMARILY CONCERNED WITH THE MAJOR ISSUES OF URBAN LIFE. THEN LOCAL CITY AND TOWN GOVERNMENTS WOULD HAVE A CRUCIAL ROLE IN DELIVERING SERVICES AND EXPRESSING LOCAL OPINION.

08062 SANDERS, A.

MONGOLIA'S NEW CONSTITUTION: BLUEPRINT FOR DEMOCRACY ASIAN SURVEY, $22(6)$ (JUN 92 ), 506-520

WITH THE ADOPTION OF ITS NEN CONSTITUTION, MONGOLIA HAS TAKEN THE TRANSITION FROM A COMMUNIST-TYPE ONE-PARTY RULE TO A GOVERNMENT COMBINING THE TRADITIONS OF STATEHOOD AND PARLIAMENTARY RULE. THIS ARTICLE REVIEWS PREVIOUS CONSTITUTIONS IN MONGOLIA FROM 1924 TO 1960, AND THEM OUTLINES THE NEW CONSTITUTION. IT ALSO EXPLORES SOME GRAY AREAS WHERE DIFFICULTIES OF INTERPRETATION MAY ARISE DURING IMPLEMENTATION.

08063 SANDERS, A.

VICTORY: HOW A PROGRESSIVE DEMOCRATIC PARTY CAN WIM AND GOVERN

M. E. SHARPE, 1992, 208.

THIS BOOK ADORESSES A SERIES OF CONTEMPORARY PHENOMENA.

GLARING SOCIAL NEEDS IN AMERICA GO UNMET. RACE RELATIONS

DETERIORATE. ENVIRONMENTAL CDNCERNS GROW. INCOME INEOUALITY

DETERIORATE. ENVIRONMENTAL CDNCERNS GROW. INCOME INEQUALITY
WIDENS. EVIDENCE MOUNTS OF PUBLIC DISTRUST OF GOVERNMENT ANO WIDENS. EVIDENCE MOUNTS OF PUBLIC DISTRUST OF GOVERMMENT AND ALIENATION FROM THE POLITICAL PROCESS. MEANHHILE, AND NOT UNRELATEDLY, THE DEMOCRATIC PARTY HAS LOST FIVE OF THE SIX PRESIDENTIAL ELECTIONS HELD BETHEEN 1968 AND 1988 . THE AUTH THAT THE PUBLIC DOES SUPPORT PROGRESSIVE POLICIES. HE SHOW THAT THE PUBLIC DOES SUPPORT PROGRESSIVE POLICIES. HE DEMONSTRATES THAT A PROGRESSIVE AGENDA IS THE BEST HAY TO IMPROVE TO DEMOCRATIC PARTY'S PRESIDENTIAL CHANCES. HE OUTLINES, STATE BY STATE, AN ELECTORAL STRATEGY THE PARTY SHOULD FOLLOW. HE ALSO SHOWS HOW A TOUGH-MINDED PROGRESSIVE AGENDA HILL, OVER THE LONG TERM, ENABLE THE DEMOCRATIC PARTY
TO RECONMECT PEOPLE HITH THEIR GOVERMMENT AND BY SO DOING REINVIGORATE THE AMERICAN POLITICAL SYSTEM.
08064 SANDERS, $D$.

GOVERNMENT POPULARITY AND THE NEXT GENERAL ELECTION POLITICAL QUARTERLY (THE), 62(2) (APR 91), 235-261. THIS PAPER IS CONCERNED WITH THE OUTCOME OF THE NEXT GENERAL ELECTION IN THE UK. IT SEEKS TO ESTABLISH WHAT JOHN MAJOR AND NORMAN LAMONT NEED TO ACHIEVE ON THE DOMESTIC ECONOMIC FRONT TO RESOLVE BRITAIN'S ECONOMIC DIFFICULTIES
AND THEREBY ENSURE THE CONSERVATIVES' REELECTION. THE FIRST SECTION REVIENS THE MAIN ECONOMIC PROBLEMS THAT HAVE CONFRONTED THE GOVERNHENT SIMCE 1989. SECTION 2 DISCUSSES THE GENERAL EVIDENCE WHICH RELATES VARIATIONS IN GOVERMMENT POPULARITY TO CHANGES IN THE MACRO-ECONOMY AND SHOWS HOW THIS EVIDENCE CAN BE USED TO MODEL BOTH PAST AND FUTURE MOVEMENTS IN POPULARITY. SECTION 3 EXAMINES THE POTENTIAL ROLE OF THE "THIRD PARTY" VOTE AND ITS INFLUENCE ON THE TARGET VOTE SHARE. THE FINAL SECTION ADDRESSES THE QUESTION AS TO WHETHER MR. LAMONT IS LIKELY TO BE ABLE TO CREATE THE RIGHT SET OF ECONOMIC CIRCUMSTANCES IN TIME FOR THE CONSERVATIVE PARTY TO HAVE A STRONG CHANCE OF WINNING THE NEXT GENERAL ELECTION.

08065 SANDERS, $H$.

BUILDING THE CONVENTION CITY: POLITICS, FINANCE, AND BUILDING THE CONVENTION CITY: POLI

JOURNAL OF URBAN AFFAIRS, 14(2) (1992), 135-160.

THE DEVELOPMENT OF CONVENTION CENTERS HAS EMERGED AS AN INCREASINLY COMMON STRATEGY FOR URBAN ECONOMIC DEVELOPMENT. THE RESULT HAS BEEN AN EXPLOSION OF PUBLIC INVESTMENT IN CONVENTION AND TOURIST FACILITIES, EVEN IN FACE OF FINANCIAL PROBLEMS FOR MANY COMMUNITIES. THE RECENT SUSTAINED SPENDING ON CONVENTION FACILITIES IS FOOTED IN A RESTRUCTURING OF LOCAL FISCAL POLITICS WITH INVESTMENT DECISION EFFECTIVELY REMOVED FROM PUBLIC REVIEW AND CONTROL. INVESTMENT IN CONVENTION CENTERS AND OTHER PUBLIC PROJECTS IS NOW SUSTAINED BY NONELECTED COALITIONS WITH NARROW SPENDING GOALS.

08066 SANDERS, J.H.

THE PROSPECTS FOR "DEMOCRATIC ENGAGEMENT"

WORLD POLICY JOURNAL, IX(3) (SUM 92), 367-388.

AMERICAN POL ICYMAKERS OF NEARLY ALL PERSUASIONS SEEM

COMMITTED TO FOSTERING THE SPREAD OF DEMOCRACY THROUGHOUT

THE WORLD. THIS ARTICLE CONSIDERS THE CHALLENGES FACING SUCH A POLICY OF "DEMOCRATIC ENGAGEMENT." IT EXAMINES THE COMPATIBILITY OF DEMOCRATIC POLITICS AND LAISSEZ-FAIRE ECONOMICS. IT ALSO EXAMINES THE UTILITY OF CONTINUED ADHERENCE TO THE REALIST POWER POLITICS PARADIGM, AS WELL AS AHE "NEED" FOR CONTINUED U.S. HEGEMONY AS A PRECONDITION TO THE "NEED" FOR CONTINUED U.S. HEGEMONY AS A PRECONDIT
PEACE AND ORDER. IT CONCLUDES THAT THE UNITED STATES, PEACE AND ORDER. IT CONCLUDES THAT THE UNITED STATES,
THROUGH DEMOCRATIC ENGAGEMENT, CAN PLAY A MAJOR ROLE IN THE THROUGH DEMOCRATIC ENGAGEMENT, CAN PLAY A MAJOR ROLE IN THE
EVOLUTION OF HORLD ORDER, BUT' IT WILL HAVE TO BEGIN BY EVOLUTION OF HORLD ORDER, BUT IT WILL HAVE TO BEGIN BY
PUTTING THE ERA OF REALIST POHER POLITICS AND LAISSEZ-FAIRE PUTTING THE ERA OF REALIST POHER POLITICS AND LAISSEZ-FAIRE
LIBERALISM BEHIND IT-A NEGLIGIBLE SACRIFICE INDEED FOR LIBERALISM BEHIND IT--A NEGL IGIBLE SACRIFICE INDEED FOR
INVESTMENT IN PEACE AND FOR DEMOCRACY AT HOME AND ABROAD.

08067 SANDERSON, $S$

MEXICAN PUBLLIC SECTOR FOOD POLICY UNDER AGRICULTURAL TRADE LIBERALIZATION

POLICY STUDIES JOURNAL, 20(3) (1992), 431-446

MEXICO HAS ENJOYED ONE OF THE THIRD HORLD'S MOST SUCCESSFUL FOOD PRODUCTION SYSTEMS, BASED ON A COMPLEX PATTERN OF PUBLIC SECTOR INTERVENTION. HOWEVER, SINCE 1982 , THE PUBLIC SECTOR HAS WITHDRAWN IN A REMARKABLY STEADFAST TRADE LIBERALIZATION. THIS PAPER IDENTIFIES THE KEY' ELEMENTS OF THAT PROCESS AND THEIR LIKELY IMPACT ON THE TRADITIONAL POL ITICAL GOALS OF FOOD SECURITY, PROGRESSIVE SOCIAL POLICY IN THE COUNTRYSIDE, AND EXTERNAL' SECTOR DEPENDENCE. PRIVATIZATION AND TRADE LIBERALIZATION LEAVE POOR FARMERS VULNERABLE BUT UNDOUBTEDLY OFFER FISCAL GAINS TO THE STATE AND BENEFITS TO URBAN CONSUMERS, ESPECIALLY IN LIGHT OF REDUCED SUBSIDIES.

08068 SANDHOLTZ, $W$.

HIGH-TECH EUROPE--THE POLITICS OF INTERMATIONAL COOPERATION UNIVERSITY OF CALIFORNIA PRESS, 1992, 320.

GOVERMMENTS HAVE RECOGNIZED FOR DECADES THE DYNAMIC ROLE PLAYED BY MICROELECTRONICS, COMPUTERS, AND

TELECOMMUNICATIONS IN THE MODERN ECONOAY. ALTHOUGH EUROPE'S DEFICIENCIES IN THESE CRUCIAL SECTORS HAD LONG BEEN

ACKNOWLEDGED IT WAS MOT UNTIL THE 1980S THAT EUROPEAN

ACKNOWLEGED, IT WAS NOT UNTIL THE 1980 THAT EUROPEAN NATIONS BEGAN COLLABORATING INDUSTRIES. THEIR COLLABORATION GIVES RISE TO MANY OUESTIONS. INDUSTRIES. THEIR COLLABORATION GIVES RISE TO MANY QUESTIONS. DATE RATHER THAN IN THE 1960 S OR 705 ? AND HOH IS IT DATE RATHER THAN IN THE 1960 S OR 7OS? AND HOW IS IT SENSITIVE AREAS? THESE QUESTIONS POINT TO FUNDAMENTAL ISSUES IN THE AREAS OF INTERNATIONAL COOPERATION, INTERNATIONAL IN THE AREAS OF INTERNATIONAL COOPERATION, INTER, AND TECHNOLOGY POLICY. THIS BOOK EXAMINES THE BREAKDOWN OF THE HALLS BETHEEN INTERMATIONAL COOPERATION ON TECHNOLOGICAL ISSUES. 
08069 SANDI, A.

RESTORING CIVIL SOCIETIES IN CENTRAL AND EASTERN EUROPE FUTURES, 24(2) (MAR 92), 110-117

THE STURUCTURES PROVIDED BY CIVIL SOCIETIES BECOME AN ESSENTIAL ELEMENT IN ADVANCING DEMOCRACY BY FACILITATING PEOPLE'S PARTICIPATION. THIS ARTICLE EXPLORES THE LEVELLED SOCIETIES INHERITED BY CENTRAL AND EASTERN EUROPEAN COUNTRIES FROM THEIR FORMER TOTALITARIAN REGIMES HHICH ARE NOW UNDERGOING AN ATOMIZATION PROCESS. RESTORING CIVIL SOCIETIES IS FACING SEYERAL PROBLEMS AND IS DELAYED BY THE SOCIETIES IS FACING SEVERAL PROBLEMS AND IS DELAYED
SLOW FULFILMENT OF A NUMBER OF PREQUESITES. HESTERM SLOW FULFILMENT OF A NUMBER OF PREQUESITES. HESTER COUNT IRES MAY COOPERATE THROUGH THE CHANNELS OF
INTERNATIONAL NETWORKS, IN ACCELERATING THE PROCESS IN INTERRAL IONAL NESTERN EUROPE.

08070 SANDLER, T.

AFTER THE COLD WAR, SECURE THE GLOBAL COMMONS AFTER THE COLD WAR, SECURE THE
CHALLENGE, 35(4) (JUL 92), 16-23

THE ISSUE OF HOW NATIONS MANAGE THE GLOBAL COMMONS SUBSUMES A CRUCIAL CLASS OF ECONOMIC PROBLEMS FOR THE 1990'S AND BEYOND--PROBLEMS INVOLVING RESOURCES THAT TRANSCEND BORDERS AND ARE OWNED IN COMMON BY THE PRESENT AND FUTURE GENERATIONS OF ALL NATIONS. THE DESTRUCTION OF NATURAL RESOURCES, WATER, AND AIR THREATENS THE HORLD'S SECURITY AS MUCH AS MUCLEAR WEAPONS. POLICY FOR GROWTH AND DEVELOPMENT MUST BEGIN TO INTEGRATE EFFORTS TO SUSTAIN THE GLOBAL COMMONS.

08071 SAMDSCHNEIDER, E.

GERMANY--A MODEL FOR CHINESE UNIFICATION?

AUSSEN POLITIK, 43(1) (1992), 92-101.

THE ERA OF POST-WAR POLITICS HAS COME TO AN END IN THE WAKE OF EVENTS IN CENTRAL AND EASTERN EUROPE, THE WORLDWIDE CRISIS OF MARXISM-LENINISM, AND THE COLLAPSE OF COMMUNIST SYSTEMS SINCE 1989. A NEW EPOCH OF INTERNATIONAL RELATIONS HAS BEGUN. ONE OF THE CHARACTERISTIC FEATURES OF THE POLITICS OF EAST-WEST CONFRONTATION WAS THE PHENOMENON OF POLITICS OF EAST-WEST CONFRONTATION WAS THE PHENOMENON OF NATIONS DIVIDED BETWEEN THO CAMPS: GERMANY, KOREA, VIETNAM AND CHINA. EVEN THOUGH THE DIVISION OF CHINA CAN BE VIEWED AS THE OUTCOME OF DOMESTIC STRIFE, THE FACT REMAINS THAT, BY THE BEGINNING OF THE KOREAN HAR AT THE LATEST, BOTH CHINESE
STATES HAD BECOME FRONTLINE STATES IN THE EAST-WEST CONFLICT. FOLLOWING ROUGHLY 40 YEARS OF OFFICIAL NON-RELATIONS, MAINLAND CHINA AND TAINAN HAVE DEVELOPED A DYNAMIC MAINLAND CHINA AND TAIWAN HAVE DEYEI

08072 SANG-WOD, R.

NORTH KOREA IN 1991: STRUGGLE TO SAVE CHUCH'E AMID SIGNS OF CHANGE

ASIAN SURVEY, XXXII(1) (JAN 92), 56-64.

THE SIGNS OF CHANGE IN NORTH KOREA ARE OISCUSSED IN THIS ARTICLE. THERE IS AN INDICATION OF NORTH KOREA'S INTENTION TO EMULATE THE CHINESE VERSION OF PERESTROIKA--INTRODUCTION OF A MARKET-ORIENTED ECONOMY UNDER THE STRONG GUIDANCE OF AN AUTHORITARIAN GOVERNMENT RUN BY ONE PARTY. ALSO DISCUSSED ARE: THE ECONOMY, FOREIGN POLICY, AND INTER-KOREAN RELATIONS.

08073 SANGMPAM, S.N.

THE OVERPOLITICIZED STATE AND DEMOCRATIZATION: A THEORETICAL MODEL

COMPARATIVE POLITICS, 24(4) (JUL 92), 401-417

THE REPLACEMENT OF AUTHORITARIAN RULE BY COMPETITIVE RULE IN MANY THIRD WORLD COUNTRIES HAS REKINDLED THE DEBATE OYER DEMOCRATIZATION. THIS ESSAY ARGUES THAT THE DEBATE FAILS TO ADDRESS THE STRUCTURAL COMPLICITY BETWEEN AUTHORITARIAN AND COMPETITIVE RULE. IN CONTRADISTINCTION TO THE LIBERAL DEMOCRATIC STATE, THE THIRD WORLD STATE IS THE LIBERAL DEMOCRATIC STATE, THE THIRD WORLD STATE IS CHARACTERIZED BY THE OMINPRESENCE OF OPEN POLITICAL COERCIDN,
AN EFFECT OF A TRIPLE DIVERGENCE IN SOCIETY. BY DEFINITION, OPENOCRATIC RULE. THE OMNIPRESENCE OF OPEN POLITICAL COERCION DEMOCRATIC RULE. THE OMNIPRESENCE OF OPEN POLITICA
MAKES COMPETITIVE RULE IN THE THIRD WORLD ALMOST

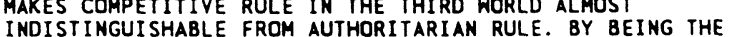
INDISIINGUISHABLE FROM AUTHORITARIAN RULE. BY BEING THE SOURCE OF COMPLICITY BETHEEN AUTHORITARIAN AND COMPETITIVE
RULE, THE OVERPOLITICIZED STATE IS LIKELY TO FRUSTRATE THE RULE, THE OVERPOLITICIZED STATE IS LIKELY TO FRUST DSMOCRATIZATION. STRATEGIES OF DEMOCRATIZATION CAN BE DEMOCRATIZATION. STRATEGIES OF DEMOCRATIZATION CAN BE
SUCCESSFUL ONLY IF ONE WRESTLES FIRST WITH THE THEORETICAL ISSUES SURROUNDING THE OVERPOLITICIZED STATE.

08074 SANJIAN, G.S.

A FUZZY' SET MODEL OF NATO DECISION-MAKING: THE CASE OF SHORT-RANGE NUCLEAR FORCES IN EUROPE

JOUR - RANGE NUCLEAR FORCES IN EUROPE 21, 271-285.

THE AUTHOR DEVELOPS A FUZZY-SET MODEL OF GROUP DECISIONMAKING AND APPLIES IT TO THE 1989 DEBATE BETWEEN THE NATO STATES OVER WHETHER TO MODERNIZE THE ALLIANCE'S SHORT-RANG NUCLEAR MISSILES OR NEGOTIATE A FORCE REDUCTION AGREEMENT WITH THE WARSAH TREATY ORGANIZATION (WTO). FROM AMONG FOUR DISCERNIBLE COURSES OF ACTION--(1) MODERNIZE, (2) NEGOTIATE, (3) MODERNIZE AND NEGOTIATE, (4) NEITHER MODERNIZE NOR NEGOT IATE--THE ALL I ANCE AGREED TO NEGOTIATE WITH THE WTO. "FUZZY." FIRST, HE DETERMINES THE 16 NATO ALLIES' INDIVIDUAL
PREFERENCE ORDERINGS OF THE FOUR ALTERNATIVES VIA A CONTENT ANALYSIS OF THEIR DISCUSSIONS. HE USES THESE PREFERENCE ORDERINGS TO DEFINE A FUZZY GROUP PREFERENCE RELATION DESCRIBING THE EXTENT TO WHICH EACH ALTERNATIVE WAS PREFERRED TO THE OTHERS BY THE ENTIRE ALLIANCE. FROM THE FUZZY GROUP RELATIONS, HE DERIVES NATO'S OPTIMAL PREFERENCE ORDERING AS HELL AS THE ORGANIZATION'S FUZZY LEVEL OF AGREEMENT FOR THAT ORDERING. ANALYSIS REVEALS THAT THE GROUP'S OPTIMAL PREFERENCE ORDERING WAS THE REVERSE OF THE UNITED STATES' AT THE OUTSET OF THE SUMMIT BUT IDENTICAL TO GERMANY'S PREFERENCE ORDERING. THE AUTHOR DISCUSSES THE IMPLICATIONS OF THIS FOR FUTURE NATO DECISIONS.

08075 SANTOPIETRO, G. : SHABMAN, L.

CAN PRIVATIZATIOON BE INEFFICIENT? THE CASE OF THE

JOURNAL OF ECONOMIC ISSUES, 26(2) (JUN 92), 407-420.

THE EFFICIENCY OF PRIVATE PROPERTY OVER ALTERNATIVE PROPERTY RIGHTS STRUCTURES HAS BEEN A CENTRAL FOCUS OF NATURAL RESOURCE ECONOMICS. THE FIRST OBJECTIVE OF THIS PAPER IS TO OFFER A FRAMEWORK FOR CONSISTENTLY DEFINING
DIFFERENTIATING AMONG PROPERTY RIGHTS STRUCTURES THAT DIFFERENTIATING AMONG PROPERTY RIGHTS STRUCTURES THAT
EXPANDS UPON THE CURRENT LITERATURE. THE SECOND OBJECTIVE IS EXPANDS UPON THE CURRENT LITERATURE. THE SECOND OBJECT
TO PROVIDE A CASE STUDY OF THE OYSTER FISHERY OF THE CHESAPEAKE BAY IN ORDER TO REEXAMINE THE CONVENTIONAL FISHERIES ECONOMICS THEORY AND POLICY PRESCRIPTIONS THAT EMPHASIZE THE ECONOMIC SUPERIORITY OF PRIVATE PROPERTY RIGHTS.

08076 SAPERSTEIN, A.

ALLIANCE BUILDING VERSUS INDEPENDENT ACTION: A NONLINEAR MODELING APPROACH TO COMPARATIVE INTERNATIONAL STABILITY JOURNAL OF CONFLICT RESOLUTION, 36(3) (SEP 92), 518-545. AN IMPORTANT INTERNATIONAL SECURITY QUESTION IS WHETHER NATIONS IN AN ANARCHIC COMPETITIVE WORLD SYSTEM ARE MORE
LIKELY TO ENSURE THEIR SECURITY BY PURSUING POLICIES OF COMPLETE INDEPENDENCE OR OF ALLIANCE BUILDING. THE QUESTION IS ADDRESSED USING THE PARADIGM THAT STRONG CHAOS IN AN ARMSRACE MODEL IS EQUIVALENT TO CRISIS INSTABILITY AND WAR IN THE INTERNATIONAL SYSTEM BEING MODELED. NONLINEAR RECURSION THE INTERNATIONAL SYSTEM BEING MODELED. NONLINEAR RECUR RELATIONS MODELS OF COMPETITIVE ARMS PROCUREMENT ARE
CONSTRUCTED FOR INDEPENDENT ARMING AND FOR ALLIANCE BUILDING CONSTRUCTED FOR INDEPENDENT ARMING AND FOR ALLIANCE BUILDING
POLICIES IN A WORLD SYSTEM OF THREE SYMMETRIC NATIONS. THE POLICIES IN A WORLD SYSTEM OF THREE SYMMETRIC NATIONS.
RESULTS ARE THAT ALLIANCE BUILDING ALWAYS PRESERVED A RESULTS ARE THAT ALLIANCE BUILDING ALWAYS PRESERVED A PEACEFUL HORLD FROM PERTURBATIONS IN THE RELATIONSHIPS COURSES OF ACTION MAY ALLOW SUCH PERTURBATIONS TO BUILD UP TO STRONG CHAOS AND PRESUMABLY HAR.

08077 SAPIRE, H.

POLITICS AND PROTEST IN SHACK SETTLEMENTS OF THE PRETORIAWITHATERSRAND-VEREENIGING REGION, SOUTH AFRICA, 1980-1990 JOURNAL OF SOUTHERN AFRICAN STUDIES, $18(3)$ (SEP 92), 670-697

THIS STUDY OF THE RECENT HISTORY OF SQUATTERS IN THE PWV RIGION SUGGESTS SOME OF THE REASONS FOR THE RAPIDITY WITH WHICH SOUATTERS COULD BE MOBILIZED BY CAMPAIGNING POLITICIANS PRIDR TO VIOLENCE. THIS ARTICLE EXPLORES THE EMERGENCE OF SHACK SETTLEMENTS IN THE PWV REGION IN THE 1980S. THE SOCIAL COMPOSITION OF SHACK SETTLEMENTS, THE RISE AND FALL OF RESIDENTS COMMITTEES IN FREE-STANDING SETTLEMENTS, AND SQUATTER ORGANIZATIONS AND POLITICAL STRUGGLE.

08078 SAPIRO, $Y$.

FEMINISM: GEMERATION LATER

ANNALS OF THE AMERICAN ACADEMY OF POLITICAL AND SOCIAL SCIENCE, (514) (MAR 91), 10-22.

THE AUTHOR REPORTS ON INVESTIGATIONS BY POLITICAL

PSYCHOLOGISTS THAT REVEAL SOME OF THE CHANGES IN PUBLIC OPINION, GENDER CONSCIOUSNESS, AND GENDER IDEOLOGY THAT HAVE OCCURRED SINCE THE BEGINNING OF THE WOMEN'S MOVEMENT. OCCURRED SINCE THE BEGINNING OF THE WOMEN'S MOVEMENT. ALTHOUGH THERE IS MORE GENERAL ACCEPTANCE OF EQUALITY
BETWEEN THE SEXES, EVEN YOUNG PEOPLE STILL SHOW SOME BETWEEN THE SEXES, EVEN YOUNG PEOPLE STILL SHOW SOME
ADHERENCE TO TRADITIONAL DIVISIONS OF ROLES AND TRADITIONAL ADHERENCE TO TRADITIONAL DIVISIONS OF ROLES AND TRADITIONAL
GENDER IDEOLOGY STILL PLAYS A PART IN MAINTAINING INEQUALITY. GENDER IDEOLOGY STILL PLAYS A PART IN MAINTAINING INEQUAL
NEVERTHELESS, THERE IS WIDESPREAD SUPPORT FOR A WOMEN'S NEVERTHELESS, THERE IS WIDESPREA
MOVEMENT, ESPECIALLY AMONG WOMEN.

08079 SARBAUGH, T.J.

IRISH AMERICA AT THE CROSSROADS: A NEW BEGINNING OR THE IRISH AMERICA AT THE CROSSROADS: A NEW BEGINNING OR THE
LAST GASP OF IRISH IMMIGRATION IN THE TWENTY-FIRST CENTURY? MIGRATION WORLD, 19 (3) (1991), 4-8

THIS PAPER INVESTIGATES THE INCREASE IN IRISH IMMIGRATION DURING THE 1980 S AS AN INDICATION OF FUTURE TRENDS. HISTORICAL OVERVIEW OF IRISH IMMIGRATION TO THE UNITED STATES IS FIRST PROVIDED. THE MODERN IRISH IMMIGRANT IS DESCRIBED AS BEING, TYPICALLY, EDUCATED, WELL-OFF, AND UPWARDLY MOBILE, HAVING LEFT A NATION WITH BLEAK ECONOMIC PROSPECTS. AMERICAN IMMIGRATION POLICY IS SURVEYED AND THE EFFECTS OF THIS POLICY ON IRISH IMMIGRATION TRENDS ARE ANALYZED. EFFORTS TO REMOVE RESTRICTIONS ON THE IMMIGRATION OF IRISH AND OTHER EUROPEANS TO AMERICA ARE OUTLINED. IT IS PREDICTED, HOWEVER, THAT THE TRADITION OF IRISH IMMIGRATION 
IS ENDING ON THE EVE OF THE THENTY-FIRST CENTURY. FACTORS LIKELY TO CONTRIBUTE TO THIS INCLUDE THE STRUCTURE OF AMERICAN IMMIGRATION LAW, THE ATTRACTIVENESS OF EUROPE AS THE RESULT OF ITS 1992 ECONOMIC UNIFICATION, AND THE CONTINUED IMMIGRATION OF ASIANS AND LATIN AMERICANS TO THE UNITED STATES IN NUMBERS GREATLY EXCEEDING EUROPEAN IMIMI GRANTS.

08080 SARDAR, Z.; DAVIES, M.

THE FUTURE OF EASTEN EUROPE: LESSONS FROM THE THIRD WORLD FUTURES, 24(2) (MAR 92), 150-157.

EASTERN EUROPEAN STATES ARE IN A SIMILAR POSITION TO THIRD WORLD COUNTRIES JUST AFTER THEIR INDEPENDENCE. THREE MAIN PARALLELS ARE IDENTIFIED AND ONE MAJOR DIFFERENCE IS DESCRIBED. EASTERN EUROPE CAN LAY LEGITIMATE CLAIMS TO BE PART OF THE DOMINANT EUROPEAN CIVILIZATION. GIVEN THE STRONG PARALLELS, EASTERN EUROPE IS SET TO FOLLOW THE CLASSICAL PATTERNS OF THIRD WORLD UNDERDEVELOPMENT. AS SUCH, EASTERN EUROPEAN COUNTRIES SHOULD JOIN HANDS WITH THIRD HORLD STATES TO SET AN AGENDA FOR GENUINE STRUCTURAL CHANGES IN THE GLOBAL ECONOMIC SYSTEM.

08081 SARVER, F.

FIGHT BACK | INSURE THE CHILDREN: RECOGNIZING AND ADORESSING SUBSTANCE ABUSE AMONG YOUTH

NATIONAL CIVIC REVIEW, 81(2) (SPR 91), 132-136.

THE CITY OF LITTLE ROCK, IN CONCERT WITH COMMUNITY PARTNERS, HAS LAUNCHED A COST-EFFECTIVE, SINGLE-PAYER IMSURANCE PLAN TO ASSURE ACCESS TO SUBSTANCE ABUSE TREATMENT FOR ITS ENTIRE PUBLIC SCHOOL POPULATION.

08082 SASS, $T$.

CONSTITUTIONAL CHOICE IN REPRESENTATIVE DEMOCRACIES PUBLIC CHOICE, 74(4) (1992), 405-524.

WHILE MUCH HAS BEEN WRITTEN ABOUT THE DECISIONS MADE WITHIN REPRESENTATIVE DEHOCRACIES, RELATIVELY LITTLE ATTENTION HAS BEEN PAID TO THE INITIAL CHOICE OF THE RULES THAT DETERMINE HOW THOSE DECISIONS ARE MADE. THERE HAS BEEN NO EMPIRICAL INVESTIGATION MADE OF THE INITIAL CHOICE OF CONSTITUT IONAL VARIABLES IN A REPRESENTATIVE DEMOCRACY. THE AUTHOR SEEKS TO FILL THIS VOID BY STUDYING THE RULES ADOPTED BY THE PRIVATE REPRESENTATIVE GOVERMMENTS OF CONDOMINIUM HOMEOWNER ASSOCIATIONS. HE FOCUSES ON PRIVATE VOTING ORGANIZATIONS BECAUSE THE MAXIMAND IS MORE CLEARLY DEFINED IN PRIVATE VOTING GROUPS. HE CONCLUDES THAT THE GREATER THE PROTECTION HHICH WILL BE AFFORDED MINORITY INTERESTS.

08083 SASSEN, 5.

WHY MIGRATION?

REPORT ON THE AMERICAS, 26(1) (JUL 92), 14-19

FOREIGN INVESTMENT, LONG TOUTED AS THE BEST WAY TO KEEP PEOPLE FROM EMIGRATING, ACTUALLY HAS THE OPPOSITE EFFECT. THE U.S. ECONOHY MEANHHILE REOUIRES EVER-CHEAPER LABOR AT HOME. THIS REPORT FOCUSES ON IMMIGRATION, AND ON THE DEEP AMBIVALENCE OF U.S. IMMIGRATION POLICY WHICH HAS IDEOLOGICAL ROOTS. NATIVISM IS BACK WITH THE COMPLAINT THAT WE HAVE LOST CONTROL OF OUR BORDERS, CHIEFLY WITH MEXICO. THIS ARTICLE SUGGESTS THAT PERHAPS WE NEED NEH WAYS TO THINK ABOUT THE PROCESS OF IMMIGRATION. UNTIL POL ICYMAKERS ABANDON THE MOTION THAT IMMIGRATION CONTROL IS A POLICE MATTER, ATTEMPTS TO STEM THE FLOOD WILL CONTINUE TO FAIL.

08084 SASSER, J.

THE DAWMING NEW WORLD ORDER: CHALLENGES AND OPPORTUNITIES MIDOLE EAST INSIGHT, VII(5) (MAY 92), 4-6

SENATOR JAMES SASSER DISCUSSES THE CHALLENGES FACING THE UNITED STATES AS THE COLD HAR ENDS AND THE UNCERTAIN "NEW WORLO ORDER" BEGINS. IN THE POLITICAL ARENA, FLEXIBILITY AND PATIENCE ARE REQUIRED AS REGIMES ATTEMPT TO ESTABLISH OVERNIGHT WHAT THE WEST DEVELOPED THROUGH THO HUNDRED YEARS OF TRIAL AND ERROR. THE INTERIM PERIOD MAY BE FILLED WITH DISORDER AND EVEN WAR, BUT THE COMPETITION FOR FAVORABLE DIPLOMATIC AND COMMERCIAL RELATIONS WITH EASTERN EUROPE AND THE FORMER SOVIET UNION WILL BE HON BY THOSE COUNTRIES THAT MAINTAIN A CONSISTENT PRESENCE AND PATIENTLY WORK THROUGH THE PERIOD OF CHANGE HITH THEM. THE ECONOMIC CHALLENGES POSED BY THE CHANGING INTERNATIONAL SCENE WILL ALSO REQUIRE FLEXIBILITY AND PATIENCE. THE REWARDS, HOHEVER, MAY BE WELL HORTH THE WAIT.

08085 SASSOON, D.

CHANGE IN THE SOCIALIST WORLD AMD EUROPEAN INTEGRATION SOCIALISM AND DEMOCRACY, (12) (JAN 91) 19-26.

TCIALISA AND DEMOCRACY, (12) (JAN 91), 19-26. THE PROBLEMS IT HAS HAD PARTICULARIY IN THE LAST TEN YEARS. THE PROBLEMS IT HAS HAD, PARTICULARLY IN THE LAST TEN YEARS THE MAJOR EXPLANATION FOR THE WELL-KNOWN "CRISIS OF SOCIALISM" HAS THAT A STAGE HAD BEEN REACHED WHEN SOCIALIST POLICIES COULD NO LONGER BE FOLLOWED WITHIN THE CONSTRAINTS OF THE EUROPEAN NATION-STATE. SOCIALISTS COULD WIN ELECTIONS BUT ONCE THEY HERE ELECTED THEY WERE SOUEEZED BY THE CONSTRAINTS OF INTERNATIONAL CAPITALISM. THE AUTHOR CALLS FOR UNIFICATION AND REFORM NOT ON A NATIONAL LEVEL, BUT ON A EUROPEAN OR EVEN PLANETARY LEVEL.
08086 SATHYAMURTHY, T.Y.

THE IMDIAN STATE IN THE CONTEXT OF SOCIAL CHANGE; ASSOCIATION FOR ASIAN STUDIES 1992 ANMUAL MEETING ASSOCIATION FOR ASIAN STUDIES 1992 ANNUAL
ASSOCIATION FOR ASIAN STUDIES, 1992,129

ASSOCIATION FOR ASIAN STUDIES, $1992,129$. THIS PAPER CHARACTERIZES THE EVOLUTION OF THE INDIAN
STATE SINCE 1947. IT EXAMINES WIDE-RANGING CHANGES IN THE SPHERES OF POLITICAL ECONONY, GOVERMMENT POLICIES DEVELOPMENT PRIORITIES, INTERNATIONAL RELATIONS, CIVILSOCIAL RELATIONS, GENDER AND CLASS POL ITICS, THE CHANGING ROLE OF VIOLENCE' IN THE RELATIONSHIP BETWEEN THE STATE STRUCTURES AS THEY HAVE DEVELOPED AND POLITICAL FORCES ACTING FROM WITHOUT THEIR FORMAL INSTITUTIONAL UNITS. THE SUBJECTS EXPLORED IN THIS WEB OF INTERCONNECTED ISSUES AND THEMES INCLUDE A DISCUSSION OF DEMOCRATIC STRUCTURES; PATRIARCHY; SPECIFIC STRANDS OF LITERATURE RELATING TO THE STATE; RIGHTS-HUMAN, CIVIL AND DEMOCRATIC; VIOLENCE; PLANNING INDUSTRIAL. TECHNOLOGICAL AND POPULATION POLICIES AND INDIA'S CHANGING INTERNATIONAL ROLE.

08087 SATLOFF, $R$.

A MADRID POST-MORTEM
MIDOLE EAST INSIGHT, 8(3) (1992), 4-8.

FOR ALL ITS HISTROINICS, REAL HISTORY WAS MADE AT THE MADRID CONFERENCE ON ARAB-ISRAELI PEACE. THIS ESSAY EXAMINES HHAT LESSONS CAM BE DRAHN BOTH FROM WHAT WAS AND NOT SAID DURING THE PEACE CONFERENCE AS WELL AS FROM ACTIONS AND INACTION BY VARIOUS CONFERENCE PARTICIPANTS AND OBSERVERS. AMERICAN POTENTENCY AND SOVIET FRAILTY, AS HELL AS, ISRAEL MODERATION AND PALESTINIAN PRAGMATISM, SYRIAN ISOLATION, LEBANESE POWERLESSNESS, JORDANIAN GUMPTION, EGYPTIAN AMBIVALENCE, SAUDI ASSERTIVENESS AND EUROPEAN RELEVANCE ARE EACH EXPLORED.

08088 SATO, K.

JAPAN'S RESOURCE IMPORTS

ANMALS OF THE AMERICAN ACADEMY OF POLITICAL AND SOCIAL SCIENCE, (513) (JAN 91), 76-89.

AS A RESOURCE-POOR COUNTRY, JAPAN DEPENDS GREATLY ON IMPORTS OF RESOURCE GOOOS-FOODS, FUELS, AND CRUDE MATERIALS-TO KEEP ITS ECONOMY RUNNING. THIS DEPENDENCE HAS INCREASED OVER TIME, MAKING JAPAN VULMERABLE TO SUPPLY SHOCKS. AT THE SAME TIME, DEMAND SHOCKS EMANATING FROM JAPAN'S DOMESTIC ECONOMY HAVE COME TO EXERT A GREATER INFLUENCE ON THE HORLD ECONOMY. BECAUSE JAPAN EXPORTS MANUFACTURED GOODS AND IMPORTS LARGELY RESOURCE GOODS, ITS BILATERAL TRADE BALANCE HAS A SURPLUS HITH INDUSTRIAL IZED ECONOMIES AMD A DEFICIT HASH PRIMARY-PRODUCIMG COUUTRIES EVEM HHEM JAPAY'S TRADE WITH PRIMARY HRDHCIND COUNTRIZES ECEN WHEN JAPAN'S TRADE IS GLOBALLY BALANCED. THIS TRADE STRUCTURE GIVES RISE TO TRADE
FRICTIONS, ESPECIALLY HITH THE UNITED STATES. UNLESS THE FRICTIONS, ESPECIALLY HITH THE UNITED STATES. UNLESS THE STRUCTURE IS ALTERED FUNDAMENTALLY, JAPAN WILL FIND IT
INCREASINGLY DIFFICULT TO FIT ITSELF INTO THE WORLD ECONOMY.

08089 SATO, T

PROTESTS GREET RESUMPTION OF SOUTH AFRICAN TIES

JAPAN TIMES (HEEKLY INTERMATIONAL EDITION), 32(4) (JAN 92), 3.

ON JANUARY 14, 1992, DEMONSTRATORS PICKETED THE JAPANESE FOREIGN MINISTRY' TO PROTEST THE GOVERMMENT'S RESUMPTION OF FULL DIPLOMATIC RELATIONS WITH SOUTH AFRICA. THE PROTESTORS ALSO EXPRESSED OPPOSITION TO SOUTH AFRICAN PRESIDENT F.H. DEKLERK'S PROPOSED VISIT TO JAPAN.

08090 SATTER, D.

MOSCOW' BELIEVES IN TEARS

NATIONAL REVIEH, XLIII (7) (APR 91), 30-34.

FOOD SHORTAGES IN THE SOVIET UNION ARE NOTHING NEW, BUT IN THE SIXTH YEAR OF PERESTROIKA. THE CONDITIONS IN MOSCOW ARE THE HORST SINCE THE END OF THE WAR. THE FEELING PREVAILS THAT THE COUNTRY IS ON THE VERGE OF A CATASTROPHE AND THAT, IF LIVING STANDARDS DON'T IMPROVE SOON, THE REVOLUTION FROM ABOVE LAUNCHED BY GORBACHEV MAY BE REPLACED BY A REVOLUTION FROM BELOW. THE RESTIVE MASSES MAY FIND IN BORIS YELTSIN A RALLYING POINT WITH WHICH TO TOPPLE THE HAPLESS CENTRAL GOVERMMENT. MANY OBSERVERS SEE ONLY THO POSSIBLE FUTURES: A ASSUMPTION OF POWER BY YELTSIN IN A BLOODLESS COUP, OR A VIOLENT CRACKDOWN BY THE ARMY AND KGB--WITH DISASTROUS LONG TERM CONSEQUENCES.

08091 SATTLER, H.

PREMIER OF EASTERN LAND LOSES CONFIDENCE OF PARTY, RESIGNS GERMAN TRIBUNE, (1475) (JUL 91) 3

THE CDU (CHRISTIAN DEMOCRAT)' PREMIER OF ONE OF THE NEH THE CDU (CHRISTIAN DEMOCRAT) PREMIER OF ONE OF THE NEH
LANDER (PROVINCES) IN THE FORMER EAST GERMANY HAS RESIGNED LANDER (PROVINCES) IN THE FORMER EAST GERMANY HAS RESIGN
AFTER ALLEGATIONS OF MALPRACTICE. GERD GIES, OF SAXONYAFTER ALLEGATIONS OF MALPRACTICE. GERD GIES, OF SAXONYANHALT IS BEING REPLACED BY WERNER MUNICH. THIS MEANS A WESTERNER IS TAKING OVER FOR AN EASTERNER. IT ALSO MEANS THAT A PROFESSIONAL HAS REPLACED AN AMATEUR. THE CHAMG UNOERSCORES THE CATASTROPHIC LACK OF COMPETENT AND
UNBURDENED EXECUTIVE MANPOWER IN THE EAST, A CONDITION WHICH COULD BECOME A REAL TRAGEDY IF NOT RECTIFIED.

08092 SATZ, D.

MARKETS IN WOMEN'S REPRODUCTIVE LABOR 
PHILOSOPHY AND PUBLIC AFFAIRS, 21(2) (SPR 92), 107-131. RECENTLY, AMERICAN SOCIETY HAS BEGUN TO EXPERIMENT HITH MARKETS IN WOMEN'S REPRODUCTIVE LABOR. THE AIM OF THIS ARTICLE IS TO CRTICIZE SEVERAL POPULAR WAYS OF DEFENDING THE SYMMETRY THESIS AND TO OFFER AN ALTERNATIVE DEFENSE. THE ANALYSIS THASIS AMD TO OFFER AN ALTERMATIVE DEFENSE, THE CRITICIZES THE ARGUMENTS AGAINST THE COMMODIFICATION OF WOMEN'S REPRODUCITVE LABOR THAT TURN ON THE ASSUMPTION THAT
REPRODUCTIVE LABOR IS A SPECIAL FORM OF LABOR. IN THE SECOND PHESIS THAT APPEAL TO NORM OF PARENTAL LOVE. THE THIRD PART THESIS THAT APPEAL TO NORM OF PARENTAL LOVE. THE THIRD OF THE ART ICLE EXAMINES AN ARGUMENT THAT STRESSES THE POTENTIAL NEGATIVE CONSEQUENCES OF CONTRACT PREGNANCY FOR CHILDREN. AND THE FOURTH PART ARGUES THAT THE ASYMMETRY THESIS IS TRUE BUT THAT
PROPERLY UNDERSTOOD.

08093 SAUTMAN, B.

SIRENS OF THE STRONGMAN: NEO-AUTHORITARIANISM IN RECENT CHINESE POLITICAL THEORY

CHINA QUARTERLY, (129) (MAR 92), 72-102.

PRIOR TO THE TIANANMEN SQUARE VIOLENCE OF 1989, HIGHLY-

PLACED CHINESE INTELLECTUALS DEBATED THE THEORY OF NEDAUTHORITARIANISM--A DOCTRINE REFLECTING THE POLICY PRESCRIPTIONS OF PRE-REVOLUTIONARY CHINESE LEADERS AND CONTEMPORARY THIRD WORLD STRONGMEN. TODAY NEO-

AUTHORITARIAMISM CONTINUES TO BE DISCUSSED BY EXILED INTELLECTUALS AND STUDENTS AS AN ALTERNATIVE TO DEMANDS FOR THE IMMEDIATE IMPLEMENTATION OF LIBERAL DEMOCRACY IN CHINA. IN ORDER TO GAUGE THE IMPL ICATIONS OF THE NEO-AUTHORITARIAN POTENTIAL FOR THE FUTURE OF CHINESE POLITICS, THIS PAPER REVIEWS THE DEBATE DURING THE FIRST FIVE MONTHS OF 1989. THE REVIEWS THE DEBATE DURING THE FIRST FIVE HONTS OF 1989. THE AUO-AUTHORITARIAN REGIME IN CHINA IN LIGHT OF THE CHARACTERISTICS OF EAST ASIAN AUTHORITARIAN REGIMES AND RECENT ATTEMPTS AT STRENGTHENING AUTHORITY IN ORDER TO AUTHORITARIANISM IS A POSSIBLE BRIDGE BETWEEN CONFLICTING AUTHORITARIANISH IS A POSSIBLE BRIDGE BETWEEN CONFLICTING POLITICAL AND INTELLECTUAL ELITES AND THUS MAY BE MORE LIMITED REFORMISH OF THE CURRENT CCP LEADERS OR THE RADICAL REFORMISM OF MANY CHINESE INTELLECTUALS.

08094 SAVAGE, J.D.

THOMAS JEFFERSON'S BALANCED BUDGET AMENDMENT

DURNAL OF LAW \& POLITICS, IX(1) (FAL 92), 1-8

A RE-EXAMINATION OF THOMAS JEFFERSON'S' POSITION ON BALANCING THE FEDERAL BUDGET IS INSTRUCTIVE IN APPRECIATING THE COMPLEXITIES OF THE ISSUE. ALTHOUGH JEFFERSON WAS NOT MASTER OF THE INTRICACIES OF PUBLIC FINANCE, BALANCING THE FEDERAL BUDGET CLEARLY PLAYED A CENTRAL ROLE IN HIS PHILOSOPHY OF GOVERMMENT. SOME OF JEFFERSON'S CONCERNS WERE PECULIAR TO HIS ERA, BUT OTHERS ARE DIRECTLY RELEVANT TO MODERN PROBLEMS.

08095 SAVAS, E.S.

PRIVATIZATION IN POST-SOCIALIST COUNTRIES

PUBLIC ADMINISTRATION REVIEN, 52(6) (NOV 92), 573-581.

THE AUTHOR OFFERS AN OVERVIEH OF THE EXPERIENCE OF POSTSOCIALIST EUROPEAN COUNTRIES HITH PRIVATIZATION, NOTING THE WIDE RANGE OF PRIVATIZING STRATEGIES AND SOME OF THE KEY PROBLEMS. HE PAYS PARTICULAR ATTENTION TO ISSUES SURROUNDING THE DETERMINATION OF OWNERSHIP. THE VALUATION OF STATE-OWNED ENTERPRISES, HOW TO "SELL" THE BUSINESSES, AND THE ATTITUDES ENTERPRISES, HOW TO "SELL" THE BUSINESSES, AND THE ATTI TUDES OF MANY
FORCES.

08096 SAVITCH, H.V.; THOMAS, J.C.

BIG CITY POL IUICS IN TRANSITION

SAGE PUBLICATIONS, 1991,262

THIS BOOK EXAMINES THE FUMDAMENTAL CHANGES THAT ARE SHAPING AMERICA'S BIG CITIES AND WHICH ARE MAKING THEM SHAPING AMERICA S BIG CITIES AND WHICH ARE MAKING THEM PAST. IT COMPILES ANALYSES OF THIRTEEN INDIVIDUAL CITIES: BOSTON, PHILADELPHIA, CHICAGO DETROIT, ST. LOUIS, ATLANTA, BOSTON, PHILADELPHIA, CHICAGO, DETROIT, ST. LOUIS, AT
MIAMI, NEW ORLEANS, DENVER, HOUSTON, LOS ANGELES, SAN MIAMI, NEW ORLEANS, DENVER, HOUSTON, LOS ANGELES, SAN PARADOXICAL CHANGES BY OUTLINING A SERIES OF DEVELOPMENTS PARADOXICAL CHANGES BY OUTLINING A SERIES OF DEVELOPHEH REBUILDING OF LOCAL ECONOMIES, AND THE OUEST FOR CENTRAL REBUILDING OF LOCAL ECONOMIES,
AUTHORITY AMID HYPERPLURALISM.

08097 SAVITCH, H.V.; THOMAS, J.C.

CONCLUSION: END OF THE MILLENHIUM BIG CITY POLITICS; BIG CITY POLITICS IN TRANSITION

SAGE PUBLICATIONS, 1991, 235-251.

THIS CHAPTER SUMMARIZES THE LESSONS THAT CAN BE LEARNED FROM THE BOOK'S ANALYSIS OF THIRTEEN BIG CITIES. AMERICAN CITIES HAVE AT ONCE BECOME MORE IMPORTANT AS CENTERS OF THE NATION'S POST-INDUSTRIAL MIGHT, YET MORE DISPENSABLE BECAUSE OF SUBURBAN ALTERMATIVES. BIG CITY MAYORS HAVE BECOME MORE IMPORTANT AS PUBLIC LEADERS, YET THEY ARE LESS ABLE TO LEAD DIYIDED CITIES THIRTY YEARS AGD THE WORDS "URBAN CRISIS" LED THE MATIOH'S POLITICAL AGEMDA. AS URBAN PROBLEMS HAYE
BECOME MORE SEVERE, THEY SEEM TO HAVE DISAPPEARED FROM THE PUBLIC MIND. THE EXPLANATION OF THESE PARADOXES HINGES ON A SERIES OF DEVELOPMENTS: THE GRONTH OF THE EXOGENOUS CITY; THE REBUILDING OF LOCAL ECONOMIES; THE METAMORPHOSIS OF THE URBAN CRISIS; THE CONTINUING SIGNIFICANCE OF RACE ANO ETHNICITY; AND THE QUEST FOR CENTRAL AUTHORITY AMID HYPERPLURALISM.

08098 SAVITSKII, V.M. ASPECTS OF JUDICIAL REFORM IN THE USSR COEXISTENCE, 28(1) (MAR 91), 119-132. THIS ARTICLE DESCRIBES THE SOVIET UNION'S EFFORTS TO FASHION A RULE-OF-LAW STATE THAT GIVES EFFECT TO THE THEORY SEPARATION OF POWERS--LEGISLATIVE, EXECUTIVE, AND JUDICIAL. STEPS IN THIS PROCESS THAT MUST BE UNDERTAKEN FOR IT TO BE ACHIEVED ARE OUTLINED. THE NATURE OF SUCH REFORM IN THAT

08099 SAWA, T.

A NEW ROAD TO SUSTAINABLE DEVELOPMENT JAPAN TIMES (WEEKLY INTERNATIONAL EDITION), 32(12) (MAR 92), 11

THERE IS A GROHING AWARENESS THAT ENVIRONMENTAL PROBLEMS ARE GLOBAL PROBLEMS AND THAT HHAT IS BEST FOR THE ENVIRONMENT OFTEN CLASHES WITH THE DESIRE FOR GREATER ECONOMIC AND INDUSTRIAL DEVELOPMENT. IN THIS ARTICLE, THE AUTHOR SUGGESTS SEVERAL STEPS TO ENVIRONMENTALLY-FRIENDLY, SUSTAINABLE DEVELOPMENT.

08100 SAWICKY, M.

WHAT'S NEWP? A GUIDING THEORY OF THE NEW RIGHT SOCIAL POLICY, 22(3) (WIN 92), 7-18.

THE NEW PARADIGM (NEWP) IS AN UNWHOLESOME PHILOSOPHY ORIVING THE PROGRAMS AND RHETORIC OF A SIGNIFICANT FACTION OF THE NEW RIGHT. NEWP HOULD FACILITATE THE INDI SCRIMINATE ELIMINATION OF FEDERAL AND STATE DOMESTIC PROGRAMS AND THE GENERAL REDUCTION OF NON-MILITARY PUBLIC SPENDING. THE INVENTORS OF NEWP HAVE DISGUISED THIS FAMILIAR CONSERVATIVE GOAL BY AVOIDING A FORTHRIGHT DENIAL OF THE BENEFITS OF GOAL BY AVOIDING A FORTHRIGHT DENIAL OF THE BENEFITS OF SOCIAL PROGRAMS. INSTEAD NEWP ASSURES THE

08101 SAXENA, K.K. MAINTAINING DECORUM IN THE MIDST OF HEATED DEBATE: THE SPEAKER IN NAURU

PARLIAMENTARIAN, LXXIII(2) (APR 92), 132-134.

NAURU, AN ISLAND IN THE PACIFIC THAT WAS FORMERLY A U.N. TRUST IERRITORY, HAS A UNICAMERAL PARLIAMENT THAT GENERALLY FUMCT IONS ON THE WESTMINSTER MODEL ALTHOUGH SOME IMPORTANT CHANGES HAVE BEEN MADE IN ITS PROCEDURES. THE PARLIAMENT ELECTS ONE OF ITS MEMBERS TO BE SPEAKER. NAURU'S PARLIAMENTARY SPEAKER RESEMBLES HIS COUNTERPARTS IN OTHER COUNTRIES IN SOME RESPECTS BUT IS UNIQUE BECAUSE HE HAS MORE POWERS AND RESPONSIBILITIES THAN IS GENERALLY THE CASE.

08102 SAYIGH, Y.

FROM OBSCURITY TO LEADERSHIP: THE PALESTINIAN GUERILLAS AND THE 1967 WAR

MIDDLE EAST INTERMATIONAL, (427) (JUN 92), 17-18 THIS ARTICLE CONSIDERS THE ORGINS OF THE PALSTINIAN NATIONALIST MOVEMENT. IT ARGUES THAT THE PALESTINIAN ENTITY AS IT EXISTS TODAY--THE PLO, WITH ITS REPRESENTATIVE CHARACTER AND ITS POLITICAL AND INSTITUTIONAL EXPERIENCE-WAS BORN IN THE JUNE 1967 WAR. MORE PRECISELY STILL, IT OWES MUCH OF ITS INFLUENCE AND FORM TO THE SIX-MONTH PERIOD IMMEDIATELY FOLLONING THAT HAR. IN THAT TIME, THE PALESTINIAN GUERRILLA GROUPS THAT WERE SUBSEQUENTLY TO TAKE COMMAND OF THE PLO THREW EVERYTHING THEY HAD INTO ORGANIZING AN ARMED INSURRECTION IN THE NEWLY-OCCUPIED WEST BANK. THE AN ARMED INSURRECTION IN THE NEWLY-OCCUPIED WEST BANK. THE ISRAELIS QUICKLY DEFEATED THIS ATTEMPT, BUT IT HAD ALREADY SET IN MOTION THE PROCESS THAT WAS TO TURN THE RENASCENT
PALESTINIAN NATIONAL MOVEMENT INTO A "PARTNER IN THE ARAB PALESTINIAN NATIONAL MOVEMENT INTO A "PARTNER IN THE ARAB
REGIONAL SYSTEM WHICH FRON THE FIRST DAYS OF ITS JOINING HAD AN EFFECT ON THE INTERACTION OF THE ARAB SYSTEM THAT WAS FAR AN EFFECT ON THE INTERACTION OF

08103 SAYIGH, Y,

ISRAEL'S PLAM FOR PALESTIME

MIDDLE EAST INTERNATIONAL, 440(440) (DEC 92), 16-17.

THE ISRAELI PROPOSED MODEL FOR PALESTINIAN "INTERIM SELFGOVERNMENT" IS IN STARK VIOLATION OF THE TERMS OF REFERENCE OF THE MAORID PROCESS OF UN SECURITY COUNCIL RESOLUTIONS, AND EVEN OF PREVIOUS ISRAELI COMMITMENTS UNDER THE CAMP DAVID ACCORDS TO HITHDRAHL AKD PALESTINIAN AUTONOMY. THIS ARTICLE IDENTIFIES THE CORE ISSUES CURRENTLY UNDER ISRAELI PALESTINIAN NEGOTIATION BY SYSTEMATICALLY COMPARING ANO INTEGRATING WHAT SUBSTANCE HAS APPEARED IN PUBLIC SO FAR HITH THE DETAIL
OF $1979-1982$.

08104 SAYIGH, Y.

PALESTINIAN REPRESENTATION: TIME FOR A PLO INITIATIVE

MIDDLE EAST INTERNATIONAL, (396) (MAR 91), 19-20.

HITH THE END OF THE SECOND GULF WAR, ATTENTION IS 
FOCUSING ON RESOLVING THE PALESTINIAN PROBLEM WITH IMMEDIATE FOCUS ON THE ISSUE OF PALESTINIAN REPRESENTATION. THE U.S. AND ISRAEL MAINTAIN THEIR HARD-LINE STANCE OF REJECTING THE PLO AS A NEGOTIATOR. WESTERN EUROPE AND THE ARAB STATES OF THE ANTI-IRAQ COALITION VACILLATE BETHEEN THE U.S.-ISRAELI REJECTIONISM AND THE MORE SPECIFIC OBJECTION TO DEALING WITH YASSER ARAFAT. THE CHALLENGE FACING THE PLO NOW IS TO CREATE A CREDIBLE PALESTINIAN ELECTION PLAN BASED ON EITHER A REFERENDUM OR PARLIAMENTARY ELECTIONS.

08105 SAYIGH, Y.

REVERSING THE NUCLEAR ARMS RACE IN THE MIDDLE EAST

MIDOLE EAST REPORT, 22 (4) (JUL 92 ), 13-23.

THE MIDDLE EAST' HAS ENTERED THE NUCLEAR AGE, STATES THIS ARTICLE. THE CURRENT STRATEGIC BALANCE IN THE MIDDLE EAST IS IN TRANSITION AS THE REGION SEEKS A NEW EQUILIBRIUM, AN EQUILIBRIUM WHICH HAS BEEN IN CONSTANT FLUX OVER THE PAST THREE DECADES. THE QUESTION NOW, IN THE AFTERMATH OF THE SECOND GULF HAR, IS TO ASSESS THE IMPACT OF NONCONVENTIONAL WEAPONS ON THE REGION. (NONCONVENTIONAL WEAPONS, OR WEAPONS OF MASS DESTRUCTION, REFER PRIMARILY TO NUCLEAR, BIOLOGICAL OF MASS DESTRUCTION, REFER PRIMARILY TO NUCLEAR, B
AND CHEMICAL ARMS, AND BALLISTIC MISSILE SYSTEMS.)

08106 SAYIGH, Y.

WHY IRAQ COULD NOT WIM

MIDOLE EAST INTERNATIONAL, (395) (MAR 91), 5-6.

THE GULF WAR CONSTITUTED PERHAPS THE MOST DEVASTATING DEFEAT OF AN ARAB ARMY IN RECENT HISTORY. ALTHOUGH THERE ARE A PLETHORA OF EXPLANATIONS FOR IRAO'S DEMISE, SEVERAL ON THE STRATEGIC LEVEL STAND OUT: THE IRAOI'S APPEAR TO HAVE SERIOUSLY MISJUDGED THE FULL IMPACT OF ALLIED MILITARY POWER-IN THE AIR ESPECIALLY; ALL WEAPONS OR TACTICS USED BY THE ANTI-IRAO COALITION HERE EXTENSIVELY DISCUSSED BY THE EASTERN MEDIA, BUT WERE APPARENTLY NO CONSIDERED BY IRAQI PLANNERS: THE' COMMAND SYSTEM, DOMINATED BY SADDAM HUSSEIN, WAS PRONE TO SELF-DELUSION AND THE MAGNIFICATION OF ERRORS. IN THE CONDUCT OF ANY CONFLICT, WHAT MATTERS IS ON LEADERS CONCEPTUALIZE ITS NATURE AND ANTICIPATE ITS COURSE, ON THE BASIS OF THEIR SPECIFIC UMDERSTAMDING AND EXPECTATIONS WITH REGARD TO THE CAPABILITIES OF BOTH FRIEND AND FOE, WHETHER MILITARY, ECONOMIC, OR POLITICAL.

08107 SAYLE, M.

HHO'S ON FIRST?

FAR EASTERN ECONOMIC REVIEN, 155(25) (JUN 92), 26-28. MIT ECONOMIST LESTER THUROW HAS RECENTLY PÜBLISHED A BOOK IN WHICH HE ANALYZES THE CURRENT AND FUTURE STATE OF THE WORLD ECONOMY. HE ARGUES THAT THE HORLD IS MARCHING TOWARD ECONOMIC HAR. THE COLD WAR IS OVER, LEAVING THREE TOWARD ECONOMIC WAR. THE COLD WAR IS OVER, LEAVING THREE
"ECONOMIC SUPERPOWERS," THE UNITED STATES, JAPAN, AND EUROPE,
CENTERED OM GERMANY, COMPETIMG FOR WORLO DOMINANCE. THUROW CENTERED ON GERMANY, COMPETING FOR WORLD DOMINANCE. THUROH PREDICTS EUROPE HILL ASCEND TO PREEMINENCE. HE NOTES THAT THE EUOPEAN COMMUNITY CURRENTLY ENJOYS A MARKET OF 380 MILLION AND, HITH THE ADDITION OF CENTRAL AND EASTERN EUROPE, COULD GROH INTO AN INTEGRATED ECONOMY OF 850 TO 900 MILLION. MANY EUROPEANS ARE TECHNICALLY EDUCATED, DILLIGENT, AND EAGER TO GET RICH. SECOND ON THE HORLD ECONOMIC TOTEM POLE WILL BE JAPAN. THE INDUSTRIAL COORDINATION OF THE MINISTRY OF INTERNATIONAL TRADE (MITI), THE WILLINGNESS OF THE JAPANESE WORKER TO ENDURE LONG HOURS AND SAVE LARGE CHUNKS OF INCDME, AND A GROWING NUMBER OF ROBOTS ALL EQUIP JAPAN TO BE HIGHLY COMPETITIVE IN THE YEARS TO COME. THE UNITED STATES, ON THE OTHER HAND IS FACED WITH THE PROSPECT OF CONTINUED DECLINE. THUROW ARGUES THAT SHORT-SIGHTED SELFINTEREST, AN INORDINATE LONGING FOR PERSONAL WEALTH, AN UNWILLINGNESS TO SAVE, AND A FAILING EDUCATION SYSTEM
CRIPPLE AMERICA'S ABILITY TO COMPETE IN THE GLOBAL ECONOMY. HIS SOLUTION IS INDUSTRIAL POLICY. HE CONCLUDES THAT THE UNITED STATES SHOULD BE WILLING TO MATCH FOREIGN INDUSTRIAL
POLICIES "DOLLAR FOR DOLLAR."

08108 SCALAPINO, R.

MATIONAL POLITICAL INSTITUTIONS AND LEADERSHIP IN ASIA WASHINGTON QUARTERLY, 15(4) (FAL 92), 157-172.

CRITICAL DIFFEREMCES EXIST BETHEEM ASIAM AND HESTERN TRADITIONS THAT HAVE CONSEQUENCES FOR THE POLITICAL INSTITUTIONS ESTABLISHED IN ASIA SINCE HORLD HAR II, ALMOST ALL OF WHICH WERE PATTERNED AFTER WESTERN MODELS. THIS ARTICLE ANALYZING THE MANNER IN WICH THESE DIFFERENCES HAVE AFFECTED THE CONTEMPORARY POLITICAL INSTITUTIONS OF ASIA'S NATION-STATES. THE SECOND FOCUS OF THIS ESSAY IS LEADERSHIP WATION-STATES. THE SECOND FOCUS OF THIS ESSAY IS LEADERSHI WHICH IS DEFINED AS THE CAPACITY TO INFLUENCE THE THOUGHTS
AND BEHAVIOR OF OTHERS. THE ARTICLE EXPLORES THE LENINIST AND BEHAVIOR OF OTHERS. THE ARTICLE EXPLORES THE LENI
STATE, ASIAN DEMOCRACIES, AND LEADERSHIP FACTORS. IT STATE, ASIAN DEMOCRACIES, AND LEADERSHIP FACTORS. IT SUPRANATIONAL ECONONIC AND POLITICAL INSTITUTION-BUILDING.

08109 SCALINGI, P.

U.S. INTELLIGENCE IN AN AGE OF UNCERTAINTY: REFOCUSING TO MEET THE CHALLENGE

WASHINGTON QUARTERLY, 15(1) (WIN 92), 147-156

WILL THE BUSINESS' OF SPIES PASS AHAY HITH THE SOVIET

THREAT? SHOULD IT? THE PROPER ROLE OF THE U.S. INTELLIGENCE

COMHUNITY IN A PAST-COLD WAR WORLD IS EMERGING AS A SUBJECT
OF SHARP DISPUTE AND AS A FOCAL POINT OF THE DEBATE ABOUT GEOSTRATEGY AND GEOECONOMICS. THIS ESSAY ANALYZES THE REORMS LIKELY TO BE IMPLEMENTED DURING THE NEXT BUDGET CYCLE. I CONCLUOES THAT WITHOUT A FORHARD-LOOKING INDIVIDUAL TO RESHAPE THE COMMUNITY FOR THE FUTURE, U.S. INTELLIGENCE WILL REMAIN POORLY PREPARED TO MEET THE CHALLENGES OF THE $1990 \mathrm{~S}$ AND BEYOND.

08110 SCAMMON, R.M.

INTERNATIONAL ELECTION NOTES

WORLD AFFAIRS, 154 (2) (FAL 91), 81-83.

THE AUTHOR REPORTS THE RESULTS OF FALL 1991 ELECTIONS IN

SHITZERLAND, CANADA, BELGIUM, SHEDEN, AND UNITED KINGDOM.

08111 SCANDIZZO, P.L.

JOURNAL OF POLICY MODELING, 14(5) (OCT 92), 561-582.

THE AUTHOR DEVELOPS AN AHALYTICAL FRAMEHORK

EXAMINING THE ISSUES OF TRADE LIBERALIZATION AND SECTOR

PRICES IN THE CONTEXT OF INTERNATIONAL FACTOR MOVEMENT.

PIRST, HE DESCRIBES THE MAIN PROBLEMS THAT ARISE IN THE

FIRST, HE DESCRIBES THE MAIN PROBLEMS THAT ARISE IN THE
ATTEMPT TO MEASURE THE EFFECTS OF TRADE LIBERALIZATION WHEN

ATTEMPT TO MEASURE THE EFFECTS OF TRADE LIBERALIZATION
FACTORS ARE OR HAVE BEEN INTERHATIONALLY MOBILE. AFTER

FACTORS ARE OR HAVE BEEN INTERMATIONALLY MOBILE. AFTER
EXAMINING SOME OF THE RESULTS OBTAINED HITH PARTIAL AND

EXAMINING SOME OF THE RESULTS OBTAINED WITH PARTIAL AND
GENERAL EQUILIBRIUM MODELS, HE ANALYZES THE PREDICTABLE

GENERAL EQUILIBRIUM MODELS, HE ANALYZES THE PREDICTABLE
EFFECTS OF LIBERALIZING TRADE UNDER A VARIETY OF MARKET

CONDITIONS ON THE BASIS OF A GENERAL EOUILIBRIUM MODEL OF

CONDITIONS ON THE BASIS OF A GENERAL EOU
MORTH-SOUTH TRADE AND FACTOR MOVEMENT.

08112 SCANIAN, J.

THE CURIOUS CASE OF AFFIRMATIVE ACTION FOR WOMEN

SOCIETY, 29( 2) (JAN 92), 36-41.

OMLY' ON RARE OCCASIONS HAVE THE COURTS GIVEN ATTENTION

TO THE QUESTION WHETHER THE CONSTITUTIONAL ANALYSIS OF

GENDER PREFERENCES SHOULD BE DIFFERENT FROM THE ANALYSIS OF

RACIAL PREFERENCES. THE APPROACH WHEREBY GENDER PREFERENCES

ARE AUTOMATICALLY UPHELD IF RACIAL REPRERENCES ARE UPHELD IS

PLAUSIBLE ONLY SO LONG AS THE FOCUS IS SOLELY UPON THE LONER

LEVEL OF SCRUTINY THAT HAS HISTORICALLY BEEN APPLIED TO

GENDER CLASSIFICATIONS. THIS ARTICLE EXPLORES EMPLOYMENT

QUOTAS, THE FEMINIZATION OF POVERTY, SUPREME COURT ACTIONS,

AND CONGRESSIONAL ACTION. IT CONCLUDES THAT AS THE LAH

PRESENTLY STANDS. THERE COULD STILL BE MUCH ROOM FOR

AFFIRMATIVE ACTION FOR WOMEN WHEN AFFIRMATIVE ACTION FOR

MINORITIES HAS BEEN ENTIRELY PROHIBITED.

08113 SCAPERLANDA, A.

THE EUROPEAN COMMUNITY AND MULTINATIONAL ENTERPRISES:

LESSONS IN THE SOCIAL CONTROL OF INDUSTRY

JOURNAL OF ECONOMIC ISSUES, 26(2) (JUN 92), 421-432.

WITH THE RISING DOMINANCE OF MULTINATIOHAL ENTERPRISE (MNE) IN THE POST-WORLD WAR II ERA, THE CALL FOR PUBLIC, SOCIAL CONTROL OF INDUSTRY HAS TAKEN ON AN INTERNATIONAL SOCIAL CONTROL OF INDUSTRY HAS TAKEN ON AN INTERNATIONAL DIMENSION. IN THIS PAPER, THE AUTHOR EXAMINES SELECTED POLICIES THAT WILL AFFECT INTRA-EC MNES TOHARD THE END OF
ANSWERING THE OUESTION: WILL EC POLICIES, AIMED TO EXERT ANSWERING THE QUESTION: WILL EC POLICIES, AIMED TO EXERT CONTROL OVER MHS FORCE ENOUGH HARMONIZATION OF NATIONAL POLICIES AMD/OR SUPERCEDE NATIONAL POLICY SO THAT THE RESULTS OF THE COMMUNITY'S POLICIES PROVIDE AN EMBRYONIC INSTITUT IONAL FRAMEWORK FOR EXERTING INTERNATIONAL SOCIAL
CONTROL OVER MNES? IN ORDER TO UNDERSTAND THE CONTEXT WITHIN WHICH EC INSTITUTIONAL DEVELOPMENTS ARE TAKING PLACE, THE AUTHOR SURVEYS THE TECHNOLOGICAL FORCES THAT UNDERPIN THE EVOLVING ECONOMIC, SOCIAL, AND POLITICAL ENVIRONMENT IN THE EUROPEAN COMHUNITY.

08114 SCHAEFER, M.

THE FEDERAL RESEARCH PUZZLE: MAKING THE PIECES FIT ENVIRONMENT, $33(9)$ (NOV 91), 16-20, 38-42.

A NUMBER OF U.S. FEDERAL AGENCIES AND DEPARTMENTS SHARE THE RESPONSIBILITY FOR ENVIRONMENTAL RESEARCH. BUT NEW CONCERNS NOW FACING THE UNITED STATES, SUCH AS GLOBAL CLIMATE CHANGE, RAISE QUESTIONS ABOUT THE ABILITY OF THIS DECENTRALIZED STRUCTURE TO PROVIDE CLEAR SCIENTIFIC INFORMATION TO POLICYMAKERS.

08115 SCHANTZ, H.

THE EROSION OF SECTIONALISM IN PRESIDENTAIL ELECTIONS POLITY, 24(3) (SPR 92), 355-378.

THIS ARTICLE EXAMINES THE V.O. KEY AND E. E.

SCHATTSCHNEIDER ASSERTIONS OF THE EROSING OF SECTIONALISM AND A GROWING NATIONAL IZATION IN PRESIDENTIAL BALLOTING BY ANALYZING REGIONAL VOTING PATTERNS FROM 1888 TO 1988. ANALYZING REGIONAL VOIING PATTERNS FROM 1888 TO 1988. FOCUSING ON REGIONAL DEVIATIONS FROM THE NATIONAL VOTE REGIONAL SHINGS AWAY FROM NAT IONAL TRENDS. THE AUTHOR CONCLUDES THAT THERE HAS BEEN AN EROSION OF SECTIONALI
PRESIDENTAIL VOTING, A DECLINE IN BOTH THE REGIONAL PRESIDENTAIL VOTING, A DECLINE IN BOTH THE REGIO
DISPERSION OF THE VOTE AND THE VOTING SHINGS.

08116 SCHARLAU, B.A.; PHILIPS, D. MOT THE END OF GERMAN LEFT-HING TERRORISM TERRORISM AND POLITICAL VIOLENCE, 4(3) (FAL 92), 107-116. ON APRIL 10, 1992, THE GERMAN RED ARMY FACTION ISSUED A COMMUNIQUE OFFERING A CEASEFIRE. THIS COMMUNIQUE MAY PRESENT 

AN OPPORTUNITY TO MOVE CLOSER TO A SIGNIFICANT REDUCTION IN
LEFTIST TERRORISH IN THE FEDERAL REPUBLIC OF GERMANY, BUT IT IS UNLIKELY TO BE THE END OF LEFTIST GERMAN TERRORISM.

08117 SCHATTEN, F

LIMITED CHAHGE IN GHANA

SWISS REVIEW OF WORLD AFFAIRS, 42(4) (JUL 92), 26-27.

GHANA'S TENTATIVE ECONOMIC REFORMS, WHICH HAVE BEEN MUCH

PRAISED BY THE IMF ANO WORLD BANK, APPEAR ON CLOSE

EXAMINATIOY TO BE IMADEQUATE THE ECOMOMIC PROGRAMS OF THE

RAWL INGS REGIME ARE CHANGING LITTLE FOR MOST OF THE POPULACE.

ALSO QUESTIONABLE ARE THE EFFECTS OF THE THREE-STEP

REDEMOCRATIZATION PLAN, WHICH BEGAN WITH A CONSTITUTIONAL

REDEMOCRATIZATION PLAN, WHICH BEGAN WITH A CONSTITUTIONAL
REFERENDUM IN APRIL 1992 AND IS SCHEDULED TO CULMINATE WITH

PRESIDENTIAL AND PARLIAMENTARY ELECTIONS IN LATE 1993.

08118 SCHATZ, R, RISKE, S

INTERNATIONAL REACTIONS TO THE THREAT OF NUCLEAR WAR: THE

RISE AND FALL OF CONCERN IN THE EIGHTIES

POLITICAL PSYCHOLOGY, 13(1) (MAR 92), 1-30

THE THREAT OF NUCLEAR WAR WAS A SUBSTANTIAL CONCERN

DURING THE 1980 S IN THE UNITED STATES, EUROPE AND THE SOVIET UNION. THIS ARTICLE REVIEWS POLL DATA AND PSYCHOLOGICAL LITERATURE INVESTIGATING REACTIONS TO THE NUCLEAR THREAT IN THESE THREE AREAS OF THE WORLD. IT DOCUMENTS THE TRENDS IN LIKELIHOOD ESTIMATES, CONCERN, AND POLICY PREFERENCES DURING THE LAST DECADE AND EXAMINES FACTORS THAT MAY ACCOUNT FOR THESE TREMDS. THE REACTIONS OF THE DIFFERENT NATIONS ARE COMPARED. THE REACTIONS OISPLAYED A SIMILAR PATTERN OVER TIME. ALSO DISCUSSED ARE METHODOLOGICAL ISSUES, THE POTENTIAL OF PSYCHOLOGY TO EFFECT POLITICAL CHANGE, AND THE POSSIBLE FUTURE RISE IN CONCERN ABOUT NUCLEAR HAR.

08119 SCHECHLA,J.

PLANAING THE END OF EXISTENCE

MIDOLE EAST POLICY, 1 (2) (1992), 106-119.

THE CURRENT NEGOTIIATIONS FOR' PEACE BETHEEN ISRAEL AND

ITS NEIGHBORS ARE SQUARELY FOCUSED ON LAND AND JEHISH

ITS NEIGHBORS ARE SQUARELY FOCUSED ON LAND AND JEWISH

PETTLEMENTS IN THE OCCUPIED PALESTINIAN TERRITORIES. THE

PALESTINIAN AND OTHER ARAB DELEGATIONS, ECHOED BY THE
OF MANY GOVERNMENTS, HAVE CALLED FOR ISRAEL TO END ITS

OF MANY GOVERNMENTS, HAVE CALLED FOR ISRAEL TO END ITS
SETTLEMENTS AND CONFISCATION OF OCCUPIED LANDS AS THE

SETTLEMENTS AND CONFISCATION OF OCCUPIED LANDS AS THE

CONFLICT'S ESSENTIAL ELEMENT IS THE STRUGGLE OVER THE LAND

CONFLICT'S ESSENTIAL ELE
OF HISTORIC PALESTINE.

08120 SCHECTER, K.

SOVIET SOCIALIZED MEDICINE AND THE RIGHT TO HEALTH CARE IN A CHANGING SOVIET UNION

HUMAN RIGHTS QUARTERLY, 14(2) (MAY 92), 206-215.

THE PERCEPTION OF HEALTH CARE AS A BASIC HUMAN RIGHT IS

A RELATIVELY RECENT DEVELOPMENT, AND THE CONCEPT OF THE

STATE PROVIDING FREE COMPREHENSIVE HEALTH CARE TO ALL ITS

CITIZENS IS NEW TO THIS CENTURY. THE SOVIET UNION WAS THE

FIRST COUNTRY TO EXPERIMENT WITH A FULLY SOCIALIZED HEALTH

CARE SYSTEM AND TO PROVIDE COMPREHENSIVE HEALTH CARE TO ALL

OF ITS CITIZENS AS A BASIC HUMAN RIGHT. UNFORTUNATELY,

HEALTH CARE IS INADEQUATE IN THE FORMER SOVIET UNION, AND

THE INITIAL GOALS REMAIN UNREALIZED. A BRIEF EXAMINATION OF

THE HISTORICAL DEVELPMENT OF SOVIET HEALTH CARE HELPS TO

ILLUMINATE THE PROBLEM OF THE DETERIORATION OF THE SYSTEM

TOOAY. THIS ARTICLE THEN OFFERS THREE MAIN EXPLANATIONS FOR

THE DISINTEGRATION OF THE SOVIET HEALTH CARE SYSTEM. IT

CONCLUDES THAT THERE ARE DIFFICULT TRADE-OFFS THAT EVERY

POLITICAL SYSTEM MUST FACE; THAT EACH APPROACH HAS BOTH

ADVANTAGES AND DISADVANTAGES: AND THAT THE BASIS FOR EACH

SOCIETY'S HEALTH CARE SYSTEM EVOLVES FROM ITS FOUNDING

VALUES AND PRIORITIES.

08121 SCHEFFLER, $S$.

RESPONSIBILITY, REACTIVE ATTITUDES AND LIBERALISM IN PHILOSOPHY AND' POLITIICS

PHILOSOPHY AND PUBLIC AFFAIRS, 21(4) (FAL 92), 299-323.

HISTORY WILL RECORD, THAT DURING THE 1980S, LIBERAL ISM
CAME UNDER ATTACX IN THE UNITED STATES. IT IS ARGUED IN THIS

CAME UNDER ATTACX IN THE UNITED STATES. IT IS ARGUED IN THIS

ARTICLE THAT THE REASON VARIOUS LIBERAL PROGRAMS MAY APPEAR
INCOMPATIBLE WITH ORDINARY THINKING ABOUT RESPONSIBLITY IS

INCOMPATIBLE WITH ORDINARY THINKING ABOUT RESPONSIBLITY IS
THAT THEY ASSIGH IMPORTANT BENEFITS AND BURDENS ON THE BASIS

THAT THEY ASSIGN IMPORTANT BENEFITS AND BURDENS ON THE BAS
OF CONSIDERATIONS OTHER THAN INDIVIDUAL DESERT. IT ALSO

OF CONSIDERATIONS OTHER THAN INDIVIDUAL DESERT. IT ALSO
ARGUES THAT NONE OF THE PROMINENT CONTEMPORARY VERSIONS OF

ARGUES THAT NONE OF THE PROMINENT CONTEMPORARY VERSIONS

PHILOSOPHICAL LIBERALISM ASSIGNS A SIGNIFICANT ROLE TO
DESERT AT THE LEVEL OF FUNDAMENTAL PRINCIPLE. THIS SUGGESTS

DESERT AT THE LEVEL OF FUNDAMENTAL PRINCIPLE. THIS SUGGES

THAT, FAR FROM HELPING POLITICAL LIBERALS TO REBUT

CHARGE OF INCOMPATIBILITY WITH ORDINARY NOTIONS OF
RESPONSIBLITY, COMTEMPORARY PHILOSOPHICAL LIBERALISM MAY

ITSELF BE VULAERABLE TO SUCH A CHARGE.

08122 SCHEINMAN, L.

NUCLEAR SAFEGUARDS AND NON-PROLIFERATION IN A CHANGING WORLD ORDER

SECURITY DIALOGUE, 23(4) (DEC 92), 37-50.

SAFEGUARDS ARE ONLY ONE PART OF A REGIME OF NORMS, RULES,

INSTITUTIONS AND PROCEDURES DEVELOPED TO PREVENT THE SPREAD OF NUCLEAR WEAPONS. THESE SAFEGUARDS HAVE BECOME
INCREASINGLY CRITICAL IN NATIONAL ASSESSMENTS OF THE NONPROL IFERATION REGIME IN THE POST-COLD WAR ERA, PARTICULARLY AFTER THE DISCOVERY OF A MAJOR CLANDESTINE NUCLEAR PROGRAM IN IRAQ. WHAT HAPPENED IN IRAQ WAS NOT A BREAKDOWN OF SAFEGUARDS ON DECLARED MATERIAL BUT A CIRCUMVENTING OF THE SYSTEM AS DESIGNED, AND OF THE REGIME AS A WHOLE. THE IRAOI AFFARIS ALTERED POL ITICAL EXPECTATIONS REGARDING THE BREADTH OF SAFEGUARDS. NOW EXPECTATIONS EXTEND TO PROVIDING ASSURANCES THAT NO UNDECLARED MATERIAL AND FACILTIES EXIST IN STATES THAT HAVE RATIFIED THE NPT. TO MEET SUCH EXPECTATIONS, RESOURCES, AUTHORITY AND POLITICAL SUPPORT MUST BE PROVIDED TO THE IMPLEMENTING INSTITUTIONS. SPECIAL MUST BE PROVIDED TO THE IMPLEMENTING INSTITUTIONS. SPECIAL
INSPECTIONS, SECURING COMPLIANCE AND NUCLEAR TRANSPARENCY INSPECTIONS, SECURING COMPLIANCE AND
ARE ISSUES ANALYZED IN THIS ARTICLE.

08123 SCHENK, C.; BERNARD, E.

SOCIAL UNIÓNISM: SOCIAL POLICY, 23(1) (SUM 92), 38-46.

IN RECENT YEARS U.S. LABOR HAS SEEN A SIGNIFICANT ROLLING BACK OF ITS RIGHTS. WHILE CANADIAN UNIONIZATION RATES HAVE CONTINUED TO GROW, THE ONCE-POWERFUL U.S. LABOR MOVEMENT HAS SEEN ITS INFLUENCE DECLINE, THE ORGANIZATION RATE TUMBLE, AND AVERAGE LIVING STANDARDS FOR WORKERS FALL. IN MANY CANADIAN JURISDICTIONS, LABOR HAS WON IMPORTAN INNOVATIVE LABOR-LAW REFORMS AND RIGHTS FOR WORKERS UNIONISTS IN THE UNITED STATES HAVE BEGUN TO USE CANADIAN LABOR LAWS, THOUGH FAR FROM IDEAL, AS EXAMPLES OF MOOEST REFORMS THAT WOULD BRING A SEMBLANCE OF FAIRNESS TO U.S. INDUSTRIAL RELATIONS.

08124 SCHERER, $P$

STATE CRITCIZED FOR HANDLING OF VIOLENCE AGAINST FOREIGNERS GERMAN TRIBUNE, 31(1534) (OCT 92), 5 .

GERMANY'S HANDLING OF THE VIOLENCE AGAINST FOREIGNERS HAS COME UNDER HEAVY CRITICISM FROM THE NEW HEAD OF THE GERMAN JEWISH COMMUNITY. IGNATZ BUBIS SAYS POLICE INVESTIGATIONS HAVE BEEN HESITANT; EFFORTS BY THE GERMAN STATE TO CLAMP DOWN ON THE VIOLENCE HAVE BEEN UNSATISFACTORY. AT THE TIME OF THE ATTACKS IN HOYERSHERDA. IN EASTERM GERMANY LAST YEAR, HE SAID THIS WAS A CLEAR CASE OF ATTEMPTED MURDER. THE VICTIMS HAD BEEN MERELY EVACUATED AND ATE OFFENDERS NOT ARRESTED. BUBIS' FATHER, BROTHER AND THE OFFENDERS NOT ARRESTED. BUBIS FATHER, BROTHE
SISTER WERE KILLED IN NAZI CONCENTRATION CAMPS.

08125 SCHERER, $P$.

STOP BRIBERY AND CORRUPTION, SAYS PUBLIC PROSECUTOR GERMAN TRIBUNE, 1487 (OCT 91), 8.

THE GERMAN CIVIL SERVICE IS WELL ON THE WAY TO FALLING INTO DISCREDIT, STATES THIS ARTICLE. FOR DECADES PUBLIC OFFICIALS IN THE FEDERAL REPUBLIC OF GERMANY HAD A REPUTATIONS FOR BEING MODELS OF PROPRIETY AND LOYALTY TO THEIR EMPLOYER, THE STATE. BUT THIS REPUTATION HAS TAKEN A NASTY KNOCK, WITH TOO MANY CASES HAVING COME TO LIGHT IN WHICH CORRUPT OFFICIALS HAVE BEEN TAKEN TO COURT.

08126 SCHEYE, E.

PSYCHOLOGICAL NOTES ON CENTRAL EUROPE 1989 AND BEYOND POLITICAL PSYCHOLOGY, 12(2) (JUN 91), 331-344.

INTERVIEWS CONDUCTED IN CENTRAL EUROPE IN THE SUMMER AND FALL OF 1990 SUGGEST THAT MANY CENTRAL EUROPEAN CITIZENS EXPERIENCED PRE-1989 SOVIET-COMMUNIST HEGEMONY IN TERMS OF A TRUE/PRIVATE VERSUS A FALSE/PUBLIC SELF SPLIT. THE CENTRAL EUROPEAN SELF WAS SPLIT ALONG THREE DISTINCT AND SEPARATE DIMENSIONS: (1) NATIONAL-INTERNATIONAL; (2) CIVIL SOCIETYGOVERNMENT; (3) INTRAPSYCHICALLY. AN EXAMINATION OF THE CENTRAL EUROPEAN PSYCHIC STRUCTURE MAY BE HELPFUL IN ANALYZING FUTURE POL ITICAL DEYELOPMENTS IN THE REGION.

08127 SCHIAVONE, G.

COOPERATION

CACE AND THE SCIENCES, 3 (SEP 91), 12-15.

TO THE ENDING OF THE DIVISION IN TWO HALVES, WHICH HAD COME TO BE ACCEPTED AS A PERMANENT FEATURE OF THE EUROPEAN SCENE, MAKES THE PROSPECTS OF A EUROPE-WIDE ECONOMIC COOPERATION
MATTER OF PROFOUND RELEVANCE ON BOTH SIDES OF THE ATLANTIC MATTER OF PROFOUND RELEVANCE ON BOTH SIDES OF THE ATLANT AND THE PACIFIC. THE ECONOMIC AND INSTITUTIONAL SHAPE OF
EUROPE IN THE LAST DECADE OF THIS CENTURY WILL BE A DECISIVE EUROPE IN THE LAST DECADE OF THIS CENTURY WILL BE A DECISIVE FACTOR IN DETERMINING WHETHER THE WORLD WILL FRAGMENT INTO NUMBER OF MUTUALLY OPPOSED PROTECTIONIST TRADING BLOCS, OR WHETHER A NEW SYSTEM WILL EMERGE AIMED AT PRESERVING AND ARTICLE DISCUSSES THE PROSPECTS OF INSTITUTIONALIZATION OF ARTICLE DISCUSSES THE PROSPECTS OF

08128 SCHIER, $S$. DEFICITS WITHOUT END: FISCAL RETHINKING AND BUDGET FAILURE IN CONGRESS

POLITICAL SCIENCE, 107(3) (FAL 92), 411-433.

AN EXAMINATION OF THE POLITICAL ECONOMY OF LEGISLATORS SHOW THEIR FISCAL CONCERNS FLOH NATURALLY FROM THE DUTIES OF THEIR JOBS. DEFICITS PERSIST BECAUSE ACCURATE REPRESENTATION CAN LEAD ITS MERITS TO DUBIOUS POLICY. THIS ARTICLE SUGGESTS THAT THE FISCAL LIMITS OF CONGRESS ARE SET BY THE IDEA OF 
ITS MEMBERS. IDENTIFY THE LIMITS AND YOU HAVE IDENTIFIED INSTITUTIONAL CAPACITY.

08129 SCHIERUP, C.

THE POST-COMMUNIST ENIGMA: ETHNIC MOBILIZATION IN YUGOSLAVIA

NEW COMMUNITY, 18(1) (OCT 91), 115-131.

ETHNIC-NATIONALIST MOBILIZATION IS THE DOMINANT

POLITICAL FACTOR OF THE YUGOSLAV CRISIS. NEW POST-COMMUNIST

POPULAR MOVEMENTS AND POLITICAL PARTIES ARE CONFRONTED WITH

OILEMMAS SIMILAR TO THOSE FACED BY THE DETHRONED SOCIALIST

REGIMES, IN A SITUATION WHERE RADICAL ECONOMIC REFORMS ARE

CAUSING IMPOVERISHMENT, INDUSTRIAL CLOSURES, AND INCREASED UNEMPLOYMENT. THOSE WHO SEE A STARK CONTRAST BETHEEN A DEMOCRATIC, LIBERAL YUGOSLAVIAN NORTH AND A DESPOTIC, STILL COMMUNIST SOUTH ARE MISTAKEN. EVEN RULING POST-COMMUNIST POLITICAL COALITIONS IN SLOVENIA AND CROATIA FACE THE DANGER OF LAPSING INTO A NEW TYPE OF TOTAL ITARIANISM, WITH INCALCULABLE HUMAN CONSEQUENCES.

08130 SCHIESSER, $W$.

LOOKING TOWARD THE EARTH SUMMIT

SWISS REVIEW OF WORLD AFFAIRS, 42(1) (APR 92), 4-5.

PREPARATIONS ARE UNDERHAY FOR THE UNITED MATIONS' CONFERENCE ON THE ENVIRONMENT AND DEVELOPMENT, WHICH IS INTENDED TO INAUGURATE THE TRANSITION TO ECOLOGICALLYSUSTAINABLE DEVELOPMENT ON A GLOBAL SCALE. THE CENTERPIECE OF THE CONFERENCE, WHICH WILL BE HELD IN JUNE 1992 IN RIO DE JANEIRO, WILL BE THE SIGNING OF THE EARTH CHARTER, A SOLEMN DECLARATION OF HUMANITY'S RIGHTS AND OBLIGATIONS REGARDING THE ENVIRONMENT.

08131 SCHIESSER, $W$

THE ROCKY ROAD TO SUSTAINABLE DEVELOPMENT

SHISS REVIEW OF WORLD AFFAIRS, 42(4) (JUL 92), 6-8.

A POLICY AIMED AT SUSTAINABILITY, AT CHANGE WITHOUT OVERLOADING THE EARTH'S ECOSYSTEM, NEEDS TO EXAMINE THE QUESTION OF WHAT PREREQUISITES MUST BE FULFILLED IN ORDER FOR MANKIND TO PURSUE A PATH LEADING OUT OF THE ECOLOGICAL DANGER ZONE INTO WHICH DEMOGRAPHIC AND ECONOMIC EXPANSION HAS BROUGHT IT. IN THE LONG TERM DEVELOPMENT CAN BE TRULY SUSTAINABLE ONLY BY STRICTLY LIMITING CONSUMPTION TO RENEHABLE RESOURCES--THAT IS, TO "INTEREST" THAT CAN BE GLEANED WITHOUT DIMINISHING THE HORLD'S NATURAL "CAPITAL " THE REAL CHALLENGE IS TO USE RENEHABLE RESOURCES IN SUCH A HAY THAT THEIR SOURCES DO NOT DRY UP AND TO BRING HAY THAT THEIR SOURCES DO NOT DRY UP AND TO BRING
CONSUMPTION OF NONRENEWABLE RESOURCES UNDER QUALITATIVE AND CONSUMPTION OF NONRENEWABLE RESOURCES UNDER QUALITATIVE QUANTITATIVE CONTROL TO THE POINT HHERE NO UNR
PROBLEMS ARE GENERATED, EVEN IN THE LONG TERM.

08132 SCHIFF, $Z$.

THE MIDOLE EAST TIMETABLES

MIDDLE EAST INSIGHT, VIIII6) ( JUL 92), 3-4.

IN THE MIDOLE EAST PEACE PROCESS, A NUMBER OF TIMETABLES ARE CONVERGING. THE ISRAELIS AND ARABS HAVE THEIR TIMETABLES AS DOES THE UNITED STATES. THE RESULT IS THAT THE WINDOH OF
OPPORTUNITY MAY BE LESS OPEN THAN GENERALLY ASSUMED.

08133 SCHIFTER, $R$.

HAVE THE DEMOCRATS REALLY CHANGED?--A DEBATE: YES COMMENTARY, $94(3)$ (SEP 92 ), 23-26.

THERE HAS BEEN MUCH TALK OF A POSSIBLE MOVE TOHARD SUPPORT OF THE CLINTON-GORE TICKET BY MANY SO-CALLED REAGAN DEMOCRATS AND NEOCONSERVATIVE INTELLECTUALS HO HAVE BECOME INCREASINGLY UNHAPPY WITH THE BUSH ADMINISTRATION. SOME HAVE MADE THE MOVE WHILE OTHERS REMAIN UNCONVINCED THAT THE DEMOCRATIC PARTY HAS REALLY FREED ITSELF FROM THE LEFTISI FORCES WHOSE ACCESSION TO POWER IN 1972 DROVE THEM OUT. RICHARD SCHIFTER EXPLAINS WHY HE BELIEVES THAT GOVERMOR CLINTON HAS EARNED THE RENEHED BACKING OF THE TRADITIONAL DEMOCRATIC CONSTITUENCY.

08134 SCHILL, M.H.

THE FEDERAL ROLE IN REDUCING REGULATORY BARRIERS TO AFFORDABLE HOUSING IN THE SUBURBS

JOURNAL OF LAH \& POLITICS YIII(4) (SUM 92), 703-730. THE ADYISORY COMMISSIOM ON REGULATORY BARRIERS TO AFFORDABLE HOUSING HAS ISSUED A REPORT WHICH CONCLUDES THAT SUBURBS HAVE ERECTED REGULATORY BARRIERS TO HOUSING FOR LOWAND MODERATE-INCOME HOUSEHOLDS AND RECOMMENDS A SERIES OF ACTIONS TO RELAX THESE RESTRICTIONS. IF THE COMMISSION'S PROPOSALS ARE ADOPTED, THE FEDERAL GOVERMMENT WILL, FOR THE PROPOSALS ARE ADOPTED, THE FEDERAL GOVERMMENT WILL,
FIRST TIME, TAKE AN ACTIVE ROLE IN POLICING LAND USE FIRST TIME, TAKE AN ACTIVE ROLE IN POLICING LAND USE REGULATIONS--TRADITIONALLY A FUNCTION OF LOCAL GOVERMMEM
IN THIS PAPER, THE AUTHOR SUMMARIZES THE COMMISSION'S IN THIS PAPER, THE AUTHOR SUMMARIZES THE COMMISSION'S
FINDINGS AND RECOMMENDATIONS. HE SHOWS THAT, UNDER CURRENT FINDINGS AND RECOMNENOATIONS. HE SHOWS THAT, UNDER CURR DOCTRINE, ANY CONSTRAINTS ON THE ABILITY OF CONGRESS
LIMIT OR ELIMINATE RESTRICTIVE LAND-USE PRACTICES ARE POLITICAL RATHER THAN LEGAL. HE PRESENTS A JUSTIFICATION FOR THE COMMISSION'S RECOMMENDATION THAT THE FEDERAL GOVERNMENT TAKE A MORE ACTIVE ROLE IN POLICING LOCAL LAND-USE DECISIONS FINALLY, HE EXPLAINS WHY THE COMMISSION IS CORRECT IN

ASSUMING THAT MEMBERS OF CONGRESS WOULD BE MORE HILLING THAM STATE LEGISLATORS TO RESTRAIN THE EXCLUSIONARY PRACTICES OF
SUBURBAN MUNICIPALITIES.

08135 SCHILLINGER, E.; PORTER, C.

GLASNOST AND THE TRANSFORMATION OF THE MOSCOW NEWS

JOURNAL OF COMMUNICATION, 41(2) (SPR 91), 125-149.

THIS STUDY SEEKS TO EXPLORE QUANTITATIVELY AND

QUALITATIVELY THE NATURE OF THE CHANGE THAT HAS TAKEN PLACE IN THE MOSCOW NEWS. THE UNUSUAL FOUNDING OF THE PAPER AS AN ENGLISH-LANGUAGE NEWSPAPER BY AN AMERICAN JOURMALIST AND ITS SUBSEQUENT CDOPTATION BY SOVIET AUTHORITY PROVIDES THE STARTING POINT FOR QUALITATIVE ANALYSIS. THE AUTHORS THEN EVALUATE THE SIGKIFICANCE OF OBSERVED CHANGES IN THE PAPER'S MISSION, INTENDED AUDIENCE, AND DISTRIBUTION WITHIN THE CONTEXT OF ITS HISTORY. THE AUTHORS SEEK TO CHARACTERIZE MOSCOW NEWS OVER THE YEARS AS IT RESPONDED TO THE JOURNALISTIC AGENDA OF EACH POLITICAL ERA. THEY CONCLUDE BY JOURNALISTIC AGENDA OF EACH POLITICAL ERA. THEY CONCLUDE
FOCUSING ON THE IMPACT OF THE PAPER'S PIONEERING EDITOR, FOCUSING ON THE IMPACT OF THE PAPER'S PIONEERING EDITOR,
YEGOR YAKOVLEV, ON THE NEWSPAPER'S TRANSFORMATION AND ON ITS YEGOR YAKOVLEV, ON THE NEWSPAPER'S TRANSFOR
POSITION IN THE NATIONAL PRESS OF THE USSR.

08136 SCHLEMMER, L.

NEH REPUBLIC, 207 (6) (AUG 92), 20, 22

POLITICAL SLAUGHTER HAS BECOME' COMMONPLACE IN SOUTH

AFRICA. SINCE THE BEGINNING OF 1985, MORE THAN 11,000 PEOPLE HAVE BEEN KILLED IN SUCH VIOLENCE.

08137 SCHLEMMER, L.

BUSINESS WITH ARMS AND LEGS

SOUTH AFRICA FOUNDATION REVIEH, 17(11) (NOV 91), 4-5. IN SOUTH AFRICA DURING THE APARTHEID ERA BUSINESS WAS SELDOM DIRECTLY PENAL IZED; RATHER IT WAS CONSTRAINED, REGULATED AND ITS OPERATING TERRAIN ERODED. A BEWILDERING ARRAY OF FORMS OF ADMINISTRATIVE MANIPULATION, REGULATION, TAXATION AND POLITICAL EXPERIMENTATION DISTORTED ITS INTERMAL ECONOMICS AND ITS MARKETS. WITHIN A MUSCULAR ENVIRONMENT. THE BUSINESS LOBBY, DESPITE ITS PUBLIC ARTICULATION, IS FRAGHENTED AND EXHIBITS LITTLE INSTITUTIONAL CAPACITY TO ACHIEVE INDEPENDENT ACCESS TO POLITICAL CONSTITUENCIES.

08138 SCHLEMMER, L. MORE HASTE LESS SPEED--IS SOUTH AFRICA'S TRANSITION GOING TOO FAST?

SOUTH AFRICA FOUNDATION REVIEW, 19(6) (JUN 92), 4-5

SOUTH AFRICA FOUNDATION REVIEW, $19(6)$ (JUN 92$)$ (4-5.
THE NEAR COLLAPSE OF MULTI-PARTY NEGOTIATIONS IN CODESA II. FOLLOWING THE FAILURE OF THE WORKING GROUP ON CONSTITUTIONAL ISSUES TO REACH AGREEMENT, HAS EVOKED A FEAST OF RECRIMINATIONS AND SOME POINTED QUESTIONS. ONE OF THE CRITICAL QUESTIONS IS WHETHER OR NOT EXPECTATIONS OF PRITICAL QUESTIONS IS WHETHER OR NOT EXPE HITHIN CODESA AND IN THE COUNTRY AT LARGE, WERE NOT TOO HIGH. QUESTIONS HAVE ALSO BEEN RAISED ABOUT' THE PACE OF NEGOTIATIONS INCLUDING HHETHER OR NOT MUCH MORE TIME SHOULD HAVE BEEN ALLOWED FOR NEGOTIATIONS AND DECISIONS ABOUT THE LIMITS OF MAJORITY POHER IN THE CENTRAL

CONSTITUTION ITSELF. IN A MANIFESTLY DIVIDED SOCIETY, WITH VAST NUMERICAL IMBALANCES IN BOTH CULTURAL AND MATERIAL INTERESTS, THE SCOPE OF MAJORITY-BASED POWER IS THE CRITICAL ISSUE. THERE IS INCREASING EVIDENCE THAT A MAJORITY OF SOUTH AFRICANS, BLACK AND WHITE, ARE CONCERNED HITH THE PACE OF NEGOTIATIONS AND WANT THE PROCESS TO PROCEED ON A MORE CAUTIOUS PACE.

08139 SCHLEMER,

NATIONAL PARTY CONSTITUTIONAL PROPOSALS

SOUTH AFRICA INTERNATIONAL, 22(2) (OCT 91), 65-70.

SOUTH AFRICA'S NATIONAL PARTY CONSTITUTIONAL PROPOSALS HAVE AT THEIR CORE AN ATTEMPT TO EOUALIZE "THE POWER OF A MAJORITY PARTY AND MINORITY PARTIES." THE ALL-PARTY EXECUTIVE. THE SECOND CHAMBER OF PARL IAMENT, AND THE DEVOLUTION OF POWERS TO REGIONAL AND LOCAL AUTHORITIES ALL BEAR THIS OUT. BUT IN A COUNTRY WHERE THE MAJORITY IS LIKELY TO BE PERMANENT, SUCH AN ARRAY OF CHECKS AND BALANCES MAY NOT IN FACT BE AS "UNDEMOCRATIC" AS SOME OBSERVERS CLAIM.

08140 SCHLEMMER, L.

THE BLACK UNEMPLOYED--A THREAT TO STABILITY?

SOUTH AFRICA FOUNDATION REVIEW, 18(12) (DEC 92), 1-3. UNEMPLOYMENT IS A SERIOUS PROBLEM HITH GRAVE HUMAN,

POLITICAL AND ECONOMIC IMPLICATIONS. THIS ARTICLE SUGGESTS THAT IT SHOULD BE A MAJOR CONSIDERATION IN THE DEVELOPMENT OF ECONOMIC AND WELFARE POLICIES FOR THE FUTURE. IN ORDER TO KNOW HOW TO APPROACH THE ISSUE OF UNEMPLOYMENT IT IS NECESSARY TO DEFINE THE NATURE OF THE PROBLEM MORE ACCURATELY THAN IS THE CASE IN THE GENERAL POLICY DEBATE IN SOUTH AFRICA. THE ARTICLE ARGUES THAT THE THREAT MAY NOT BE AS SERIOUS AS MANY OBSERVERS FEAR.

08141 SCHLEMMER, L.

VIOLENCE--WHAT IS TO BE DONE?

SOUTH AFRICA INTERNATIONAL, $23(2)$ (OCT 92), 60-65.

AN INVESTIGATION OF THE VIOLENCE THAT HRACKS SOUTH

AFRICA REVEALS THAT NO ONE PARTY IS SOLELY TO BLAME. NOT CAN

IT ALL BE ASCRIBED TO A THIRD FORCE. THE SOLUTIONS TO THE 
VIOLENCE LIE WITH THE COMMUNITY-BASED POLICING, THE COMMITMENT TO AMD THE ACTIVE INTERVENTION OF POLITICAL LEADERS IN LOCAL DISPUTES, AND BALANCED MEDIA COVERAGE. ONLY WHEN THESE OPTIONS ARE EXAUSTED CAN ONE CONTEMPLATE THE LAST RESORT: A STATE OF EMERGENCY; OVERSEEN BY AN IMPARTIAL TRIBUNAL WITH POWERS OF DETENTION.

08142 SCHLESINGER, J.

THE TRANSATLANTIC PARTNERSHIP: AN AMERICAN VIEW BROOKINGS REVIEH, 10(3) (SUM 92), 14-21.

THE COLLAPSE OF COMMUNISM MUST ULTIMATELY MEAN A REDUCED ROLE AND LESSENED INFLUENCE FOR THE UNITED STATES IN EUROPE. AMERICANS WILL BE INCLINED TO REMINISCE ABOUT THE GLORY OF AMERICANS WILL BE INCLINED TO REMINISCE ABOUT THE GLORY
COLD WAR DAYS AND WILL BE SLOW TO ACKNOWLEDGE AMERICA'S COLD WAR DAYS AND WILL BE SLOW TO ACKNOWLEDGE AMERICA'S DIMINISHED STATUS. EUROPEANS, UNDERSTANDABLY DELIGHTED RECOGNIZE THESE CHANGES IN THE U.S. ROLE, BUT FOR REASONS OF RECOGNIZE THESE CHANGES IN THE U.S. ROLE, BUT FOR REASONS OF GRATITUDE, DIPLOMACY, OR TACTICS HILL BE DISINCLINED TO STRESS SO FUNDAMENTAL A CHANGE IN THEIR RELATIONS WITH THEIR AMERICAN ALLIES. HOWEVER, TIME AND THE UNFOLDING OF EVENTS WILL MAKE THAT CHANGE INCREASINGLY EVIDENT.

08143 SCHLESINGER, J.A.

POLITICAL PARTIES AND THE WINNING OF OFFICE

UNIVERSITY OF MICHIGAN PRESS, 1991, 248.

THIS BOOK CONSIDERS THE PHENOMENON OF THE POLITICAL

PARTY IN AMERICA. WHILE THERE IS EVIDENCE--NON-VOTING, NON-

IDENTIFICATION, SPLIT-TICKET VOTING, AND THE REDUCED ROLE OF

PARTIES AND POLITICIANS IN THE NOMINATING PROCESS--TO SUPPORT THE NOTION THAT POLITICAL PARTIES ARE IN DECLINE, THERE IS A GREAT DEAL OF EQUALLY COMPELLING EVIDENCE WHICH INDICATES THAT PARTIES ARE AT LEAST HOLDING THEIR OWN AND PROBABLY ARE GROWING STRONGER. THE BOOK CONSIDERS THIS PARADOX AND SEEKS TO EXPLAIN IT THE AUTHOR ENDORSES THE DOWNSIAN DEFINITION OF PARTY: "A TEAM SEEKING TO CONTROL THE GOVERNING APPARATUS BY GAINING OFFICE IN A DULY CONSTITUTED PART OF THIS TEAM EFFORT TO WIN CONTROL OF ELECTIVE OFFICE. PART OF THIS TEAM EFFORT TO WIN CONTROL OF ELECTIVE HE CONSIDERS POLITICAL AMBITION AND THE STRUCTURE OF
ELECTORAL COMPETITION, WITH EMPHASIS ON ITS PRESIDENTIAL ELECTORAL COMPETITION, WITH EMPHASIS ON ITS PRESIDENTIAL
COMPONENT. HE CONCLUDES THAT PARTISAN IDENTIFICATION IS A COMPONENT. HE CONCLUDES THAT PARTISAN IDENT IFICATION IS
POOR IMDICATOR OF THE STRENGTH OR WEAKNESS OF PARTISAN POOR INDICATOR OF THE STRENGTH OR WEAKNESS OF PART

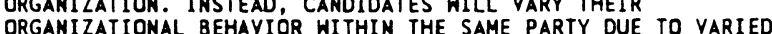
COMPETITIVE CONDITIONS.

08144 SCHLESINGER, M. ; DORWART, R.A.

FALLING BETHEEN THE CRACKS: FAILING NATIONAL STRATEGIES FOR THE TREATMENT OF SUBSTANCE ABUS

DAEDALUS, 121(3) (SUM 92), 195-238

A FUMDAMENTAL STRATEGIC ERROR UNDERLIES U.S. DRUG CONTROL POLICY: THE ATTEMPT TO STRUCTURE THE DRUG TREATMENT SYSTEM ALONG THE PLURALISTIC LINES COMMON TO MOST HEALTH AND HUMAN SERVICES IN THE UNITED STATES. IN THIS PAPER, THE AUTHORS TRACE THE HISTORICAL DEVELOPMENT OF THIS HETEROGENEITY. THEY DOCUMENT HOW, AS ARRANGEMENTS FOR TREATING DRUG ABUSE AND FINANCING THAT TREATMENT GREW MORE COMPLEX, POLICYMAKERS LOST SIGHT OF PORTIONS OF THE TREATMENT SYSTEM. THEN THEY SHOW HOW POLICIES BASED ON THIS LIMITED UNDERSTANDING MISS SOME OF THE MOST DYNAMIC ASPECTS OF THE SYSTEM, ASPECTS THAT CAN UNDERMINE THE EFFECTIVENESS OF POLICIES INTENDED TO EXPAND CAPACITY FOR PARTICULAR GROUPS OF DRUG ABUSERS. FINALLY, THEY OFFER A VERY DIFFERENT STRATEGIC APPROACH. THIS NEW STRATEGY MOVES POLICYMAKING AWAY FROM THE TRADITIONAL MEDICAL OR CRIMINAL JUSTICE MODELS TOWARD WHAT COULD BE TERMED A "PUBL IC HEALTH" OR "PUBLIC UTILITY" MOOEL. IT WOULD REDEFINE WHAT IS EXPECTED FROM A DRUG TREATMENT SYSTEM AS WELL AS HOW POLICYMAKERS SHOULD GUIDE THE PERFORMANCE OF THAT SYSTEM.

08145 SCHLIEPHAKE, $K$.

WATER IN THE ARAB GULF REGION--NATURAL POTENTIAL AND FACTOR OF CRISIS

ORIENT, 33(2) (JUN 92), 227-243.

REGIONAL CONFLICTS STEM FROM FIGHTS FOR SCARCE NATURAL RESOURCES IN AN IMPOVERISHED GEOGRAPHICAL SETTING. THE ARABS GULF REGION IS ONE OF THE DRIEST AREAS IN THE WORLD AND INCAPABLE OF NOURISHING EVEN PARTS OF ITS CURRENT POPULATION. IN THE FUTURE WATER WILL HAVE TO BE HARVESTED AND USED IN IHE MOST ECONOMIC WAY, RENOUNCING FOOD SELF-SUFFICIENCY AND THE MOST ECONOMIC WAY, RENOUNCING FOOD SELF-SUFFICIENCY AND CHARGING THE CUSTOMERS AT LEAST A REASONABLE PART OF THE OF THE BASE OF AUTARKY FOR THE DIFFERENT STATES.

08146 SCHMID, $U$.

GROWING PAINS: RUSSIA SUFFERS AS THE OLD ORDER LINGERS WORLD PRESS REVIEW, 39(11) (NOV 92), 9-10.

SEVEN DECADES OF SOVIET LAHLESSNESS HAVE INFLICTED WOUNDS ON RUSSIAN SOCIETY THAT WILL NOT HEAL QUICKLY AND ARE IMPEDING THE TRANSITION TO DEMOCRACY. THE LAST VESTIGES OF THE PERVASIVE INFLUENCE OF THE COMMUNIST PARTY AND LEADERS ARE HARD TO ERADICATE.
08147 SCHMID, U.

MOSCON'S IRANSITION TO DEMOCRACY AND THE MARKET

SWISS REVIEW OF HORLD AFFAIRS, 42(4) (JUL 92), 9-11.

ALTHOUGH COMMUNISM AND THE SOVIET STATE HAVE BARELY BEEN LAID TO REST, RUSSIA IS EXPECTED TO QUICKLY BECOME A WESTERNSTYLE DEMOCRACY. THE RESISTANCE THAT GORBACHEV PERMITTED BROUGHT YELTSIN TO POWER, AND THERE IS MUCH TALK OF THE FREE MARKET, OF PRIVATIZATION, AND LAND REFORM. DESPITE ALL THIS, THE OLD ORDER STILL PREVAILS IN RUSSIA, DOMINATING ITS POLITICAL, ECONOMIC, AND SOCIAL LIFE--AND ABOVE ALL. THE THOUGHTS AND FEELINGS OF THE RUSSIAN PEOPLE.

08148 SCHMID, $U$.

PLUS CA CHANGE: THE RUSSian bUREAUCRACY AND THE KGB SWISS REVIEW OF WORLD AFFAIRS, 42(1) (APR 92), 6-8.

THE SHRINKING OF THE CENTRAL BUREAUCRACY THAT RUSSIA INHERITED FROM THE SOVIET UNION HAS BEEN PURELY COSMETIC. NO ONE HAS BEEN FIRED; EMPLOYEES WHOSE POSITIONS HAVE BEEN ELIMINATED ARE BEING GIVEN NEW JOBS IN ONE OF THE COUNTLESS, NOMINALLY-INDEPENDENT MINISTERIAL ENTERPRISES. THERE IS STILL ENORMOUS RESISTANCE, AMONG THE BUREAUCRATS AND THE PEOPLE, TO EVEN A PARTIAL DISENGAGEMENT OF GOVERMMENT. THE KGB HAS NOT BEEN DISSOLVED BUT SIMPLY SPLIT UP. ITS MOST
IMPORTANT SECTIONS REMAIN INTACT, WITH THE SAME PERSONNEL. COMBINED WITH THE RUSSIAN SECRET SERVICE. THE KGB CONTINUES TO OPERATE EXTRALEGALLY, WITH NO PARLIAMENTARY CONTROLS, AND THE RUSSIAN EXECUTIVE LACKS THE POWER TO RESTRUCTURE OR EVEN REIN IN THE ORGANIZATION.

08149 SCHMID, U.

RUDE AHAKENING ON THE NEVA

SHISS REVIEW OF WORLD AFFAIRS, 42(3) (JUN 92), 9-11.

THE OPTIMISH THAT GRIPPED ST. PETERSBURG IN 1991 HAS EVAPORATED. THE HOPES ONCE INVESTED IN THE CREATION OF A SPECIAL ECONOMIC ZONE HAVE, THUS FAR, NOT BEEN REALIZED. RUSSIA'S NATIONAL PARLIAMENT HAS BEEN SLOW TO ISSUE SPECIAL PERMITS, AND THERE IS A GROWING SENSE THAT MOSCOW DOES NOT WANT ST. PETERSBURG TO PURSUE ITS OWN SEPARATE COURSE. AT THE SAME TIME, THE LONGED-FOR TRANSFORMATION TO LIBERAL DEMOCRACY HAS PROCEEDED NO FARTHER THAN IT HAS IN THE REST DEMOCRACY HAS PROCEEDED ND FARTHER THAN IT HAS IN THE REST OF RUSSIA. THE STAGNATION IS DUE NOT SO MUCH TO A DETERMINATION AMONG THE NEW POLITICAL ELITE AS TO
OBSTRUCTIONISM BY OFFICIALS, BOTH LOCALLY AMD AHONG THE OBSTRUCTIONISM BY OFFICIALS, BOTH LOCALLY AMO AHONG THE
LOCAL CENTRAL BUREAUCRACY IN MOSCOW, WHICH CONTINUES TO LOCAL CENTRAL BUREA

08150 SCHMIDHAUSER, J.

LEGAL IMPERIALISM: ITS ENOURING IMPACT ON COLANIAL AND POST-COLONIAL JUDICIAL SYSTEMS

INTERNATIONAL POLITICAL SCIENCE REVIEW, 13(3) (JUL 92 ), 320-334.

THIS ARTICLE EXAMINES THE EXPANSION OF SEVERAL MAJOR FAMILIES OF LAW AS A CONCOMITANT OF MILITARY CONQUEST, COLONIAL AGGRANOIZEMENT, AND?OR ECONOMIC PENETRATION--THE ATTRIBUTES OF LEGAL IMPERIAL ISM--AND SOME OF THE LONG-TERM CDNSEQUENCES OF THESE HISTORICAL PATTERNS. THE FAMILIES INVESTIGATED ARE THE ANGLO-AMERICAN COMMON LAW, ROMANISTIC MORDIC, GERMANIC, SOCIALISTIC, AND ISLAMIC.

08151 SCHMIDHUBER, $P$.

A CHANGING EUROPE IN A GLOBAL ECONOMY AUSSEN POLITIK, 43(3) (JUL 92), 211-219.

THE END OF EAST-WEST CONFRONTATION IN THE WAKE OF THE CHANGES WHICH HAVE OCCURRED IN EASTERN EUROPE SINCE 1989 HAS RESHAPED THE EUROPEAN CONTINENT. THIS IS PARTICULARLY TRUE IN ECONOMIC TERMS. THE FORMER SYSTEM-INDUCED ISOLATION OF THE EAST HAS BEEN SUCCEEDED BY EFFORTS ON THE PART OF EASTERN STATES TO INTEGRATE AS RAPIDLY AND AS EXTENSIVELY AS POSSIBLE INTO THE WESTERN WORLD IN ORDER TO SHARE THE POSSIBLE INTO THE WESTERN WORLD IN ORDER TO SHARE THE
FREEDOM, STABILITY AND PROSPERITY OF THE HESTERN PEOPLES. TREEDM, STABILITY AND PROSPERITY OF THE HESTERM PEOPLES POLITICAL, SOCIAL AND ECONOMIC RUIN LEFT BEHIND BY SOCIALISM HAS TURNED THE EASTERN COUNTRIES INTO A POVERTY ZONE HHICH CANMOT SIMPLY BE INTEGRATED INTO THE WEST. THIS PROBLEM CREATES NEW TENSION AND A NEW DANGER ON THE EUROPEAN CONTINENT.

08152 SCHMIDT, A.

LEGAL FOUNDATIONS OF THE MARKET: IMPLICATIONS FOR THE FERMERLY SOCIALIST COUNTRIES OF EASTERN EUROPE AND AFRICA JOURNAL OF ECONOMIC ISSUES, 26(3) (SEP 92), 707-732. IN THE FORMERLY SOCIAL COUNTIRES IN EASTERN EUROPE AND AFRICA THERE IS A MICROINSTITUTIONAL FOUNDATION OF THE AFRICA THERE IS A MICROINSTITUTIONAL FOUNDATION OF THE MARKET THAT NEEDS ATTENTION. THIS ARTICLE OFFERS A BRIEF REVIEW OF INSTITUTIONAL THEORY, A BIT OF HISTORY, AND A FEW IS ACCEPTED WHOLLY BY NEW MARKET ECONOMIES, HE MUST BE CLEAR IS ACCEPTED WHOLLY BY NEW MARKET ECONOMIES, WE MUST BE CLEAR ON WHERE WE CAME FROM. FOUR AREAS ARE REVIEWED: 1) OIRECT GOVERNMENT INVESTMENTS; 2 ) LANS DETERMINING HHAT IS A COST AND TO WHOM; 3) COMMERCIAL LAW; AND 4) LAW OF NEGOTIABLE INSTRUMENTS. IT CONCLUDES THAT POLICYMAKERS IN AFRICA AND EASTERN EUROPE WILL MISS A UNIQUE OPPORTUNITY IF THEY FAIL EFFICIENCY FOLLOWS FROM THE RIGHTS AT THE STARTING POINT. 
08153 SCHMIDT, C.

THE ABMORMALLY UNPOPULAR GEROGE BUSH: GROUP-FANTASIES IM THE ELECTION YEAR 1992

JORNAL OF PSYCHOHISTORY, 20(2) (FAL 92), 229-242. THE POPULARITY OF GEROGE BUSH HAS DROPPED FROM AI APPROVAL RATING OF $91 \%$ TO A MERE 30\%, AND REPRESENTS THE FASTED DROP IN PRESIDENTIAL POPULARITY IN THE HISTORY OF POLL-TAKING IN THE UNITED STATES. THE AUTHOR ADDRESSES THE PSYCHOHISTORICAL REASONS FOR THIS DRASTIC CHANGE, AND TOGETHER WITH A BRIEF OVERVIEH OF THE GROUP-FANTASIES CURRENTLY AFOOT IN AMERICA, INTERPRETS THE UNCONSCIOUS DECISIONS THAT THE GROUP HAVE MADE, AND HOW THEY MAY DETERMINE THE LIKELY OUTCOME OF THE NOVEMBER 1992 ELECTIONS.

08154 SCHMIDT, G.

BEYOND THE CONVENTIONAL HISDOM: USAID PROJECTS INTERORGANIZATIONAL LINKAGES, AND INSTITUTIONAL REFORM IN PERU

JOURNAL OF DEVELOPING AREAS, 26(4) (JUL 92), 431-456.

FROM 1983 TO 1987 THE UNITED STATES AGENCY FOR INTERMATIONAL OEVELOPMENT (USAID) PROVIDED SUPPORT TO SEVERAL NATIONAL-LEVEL ORGANIZATIONS IN PERU. THIS ARTICLE PROVIDES AN OVERVIEH OF THE RECENT LITERATURE ON INTERORGANIZATIONAL LINKAGES AND DECENTRALIZATION. IT THEM GIVES GENERAL BACKGROUND ON THE PERUVI AN IISI TUT IONAL CONTEXT, AND EXAMINES THE CONSTRAINTS FACED BY DEPARTMENTAL DEVELOPMENT CORPORATIONS (CORDES). IT THEN DESCRIBES THE THO USAID PROJECTS THAT COLLABORATED WITH CORPORATIONS. THE ORGANIZATIONAL NETHORK ESTABLISHED BY THE THO PROJECTS ARE SUMMARIZED AND HOH INTERORGANIZAT IONAL LINAGES WERE ALSO USED FOR THE UNCONVENTIONAL OBJECTIVE OF INSTITUIONAL REFORM IS ANALYZED.

08155 SCHMIDT, $H$.

THE SEARCH FOR GLOBAL ORDER: THE PROBLEMS OF SURVIVAL SECURITY DIALOGUE, 23(3) (SEP 92), 41-56.

THIS REPORT FROM THE INTER-ACTION COUNCIL SUGGESTS THAT NUCLEAR HEAPONS SHOULD BE ELMINATED AMD THAT THE POPULATION EXPLOSION NEEDS TO BE ADDRESSED IN REGIONAL RATHER THAM GLOBAL TERMS. DEPENDENCE ON GULF OIL HILL INCREASE DRAMATICALLY. IT CALLS FOR AN APOLLO-TYPE INTERNATIONAL PROGRAM TO DEVELOP NON-POLLUTING ENERGY SOURCES. THE UN WILL HAVE TO BE MADE MORE EFFECTIVE. THE SECURITY COUNCIL REFLECTS A BYGONE ORDER AND MUST BE RESTRUCTURED.

08156 SCHMIDT, $M$.

POL ITICAL SOMSEQUENCES OF GERMAN UNIFICATION

WEST EUROPEAN POLITICS, 15 (4) (OCT 92), 1 (15.

THE 'BIG BAHG' APPROACH TO GERMAN UNIFICATION POSES SEVERAL PROBLEMS FOR THE FEDERAL REPUBLIC AFFECTING THE GOVERNAMCE STRUCTURE AND THE NATURE OF PUBLIC POLICY. FOUR QUESTIONS REQUIRE PARTICULAR ATTENTION: HOH CAN THE POLFCTS OF UNIFICATION? HOW FAR WIL THE COSTS MECESSITATE EFFECTS OF UNIFICATION? HOH FAR HILL THE COSTS MECE BASIC CHANGES IN ECONOMIC AND SOCIAL POLICY? WILL
UNIFICATION BRING ABOUT A FUNDAMENTAL SHIFT IN GERMAN'S UNIFICATION BRING ABOUT A FUNDAMENTAL SHIFT IN GERMAN'S FOREIGN POL ICY ROLE? A GENERAL CONCLUSION IS THAT THE EFFECTS OF THE UPHEAVALS ARE LESS LIKELY TO MAKE THE FEDERAL IN ITS BECOMING JUST LIKE OTHER INDUSTRIAL DEMOCRACIES.

08157 SCHMIDTZ, D.

THE LIMITS OF GOVERMMENT

HESTVIEH PRESS, 1991,197

THIS BOOK EXAMINES VARIOUS ASPECTS OF THE PUBLIC GOODS ARGUMENT. IT EXAMINES A HOST OF RELATED ISSUES INCLUDING HOH GOVERMMENTS MIGHT BE JUSTIFIED (OR NOT JUSTIFIED), THE ORIGIN OF THE RIGHT TO PROPERTY, THE RIGHT TO PUNISH, AMD THE MORALITY OF RECIPROCITY. THE AUTHOR OFFERS SUPPORT FROM EXPERIMENTAL ECONOMICS. EMPHASIS IS PLACED ON "MUTUAL ASSURANCE CONTRACTS" IN WHICH SIGMERS ARE ASKED TO PLEDGE A CONTRIBUTION TOHARDS PUBLIC GOODS PRODUCTION, CONDITIONAL UPON OTHERS' PLEDGES AS WELL. SUCH CONTRACTS ARE NOT VULNERABLE TO TRADITIONAL FREE-RIDING BEHAVIOR, BECAUSE A PERSON DOES NOT HAVE TO PAY HIS OR HER PLEDGE IF OTHERS DO NOT DO SO.

08158 SCHMITT-BECK, R

A MYTH INSTI TUTIONALIZED: THEORY AND RESEARCH ON NEH SOCIAL MOVEMENTS IM GERMANY

EUROPEAN JOURMAL OF POLIIICAL RESEARCH, 21(4) (JUN 92),

357-384.

THE AUTHOR OFFERS A BRIEF CHRONOLOGICAL OVERVIEH OF THE NEW SOCIAL MOVEMENTS (NSM'S) IN GERMANY AND DIRECTS ATTENTION TO CASE STUDIES OF THE VARIOUS MOVEMENTS. THEN HE ATEAMIMES THE LITERATURE OM NSM'S UMDER THO BROAD HEADINGS: EXAMINES THE LITERATURE ON NSM'S UMDER THO BROAD HEADINGS: (1) THE ATTEMPTS TO OEVELOP SOME THEORETICAL UNDE
OF NSM'S AND (2) THE EMPIRICAL RESEARCH OM THE OF NSM'S AND (2) THE EMPIRICAL RESEARCH ON THE CHARACTERISTICS OF THE NSM'S AND THEIR SUPPORTERS. FINALLY,
HE OFFERS SOME REFLECTIONS ABOUT THE EXPLANATORY SCOPE AND EMPIRICAL FOUNDATIONS OF THE VARIOUS THEORETICAL APPROACHES.
08159 SCHMITT M.

THE JUDICIAL AND NON-JUDICIAL PUNISHMENT SYSTEMS OF THE SOVIET ARMED FORCES

JOURMAL OF SOVIET MILITARY STUDIES, 4(1) (MAR 91), 87-123. CURRENT SOVIET REFORMS ARE AFFECTING NOT ONLY THE CIVILIAN JUDICIAL SYSTEM, BUT ALSO THE SYSTEM OF MILITARY JUSTICE. AT THE SAME TIME, THE CURRENT UMREST IN THE SOVIET UNION HAS INFECTED THE MILITARY, PLACING INCREASED DEMANDS ON THE ORGANS RESPONSIBLE FOR MAINTENANCE OF OISCIPLINE. THIS ARTICLE IS DES IGHED TO PROVIDE THE READER HITH A BASIC UNDERSTANDING OF THE STRUCTURE AND FUNCTIONS OF SOVIET MILITARY JUSTICE--BOTH NON-JUDICIAL AND JUDICIAL. IT ALSO EXAMINES THE PROBLEMS AND PRESSURES CURRENTLY FACED BY MILITARY AUTHORITIES. IT CONCLUDES THAT THE SOVIET ARMED FORCES ARE ENCOUNTERING SEVERE DISCIPLINARY PROBLEMS. THE KEY CHALLENGE FOR THE SOVIETS IS TO AVOID THE TEMPTATION TO RESORT TO SHORT-TERM SOLUTIONS AND, INSTEAD, RELY ON THEIR LEGAL SYSTEM AS THE BEST METHOD FOR MAINTAINING DISCIPLINE.

08160 SCHMITT, U.

GENSCHER DISCOVERS SOME COMMON GROUND IN JAPAN

GERMAN TRIBUAE (1504) (FEB 92) 16.6

FOR SIX YEARS, AN INCOMPREHENSIBLYY AND INEXCUSABLY LONG PERIOD, GERMANY'S FOREIGN MINISTER, HANS-DIETRICH GENSCHER, OID NOT FEEL IT NECESSARY TO YISIT' JAPAN FOR TALKS. THE PROBLEM WAS THAT THERE WERE NO PROBLEMS GERMAY-SAPAMESE RELATIONS HERE OF A BORING. TRIAMGULAR NATURE, MEDIATED BY THE UNITED STATES. GENSCHER HAS NOW BEEM TO JAPAN. DURING HIS VISIT, HE PRAISED JAPAN'S HILLINGNESS TO TAKE ON A NEW ROLE IN WORLD POLITICS; HE AGREED ON CONSUL TATIONS EVERY SIX
MONTHS; HE HELPED UNDERSTANDING FOR THE NEW EXTENSIVE "VANCOUVER TO VLADIVOSTOK" SLOGAN; AND HE CLAIMED THAT HIS VISIT WAS TIMED AT THE BEST POSSIBLE MOMENT. HHILE IN JAPAN, HE ALSO CAMPAIGNED FOR JAPAMESE INVESTMENT IN THE FORMER EAST GERMANY. HE CALLED FOR APPROPRIATE JAPANESE LOANS FOR RUSSIA, BUT DIPLOMATICALLY AVOIDED PRESSURING JAPAN ON THE THORNY KURIL ISLANDS DISPUTE.

08161 SCHMUCKLE, G.

KEEPING THE PEACE HITHOUT THE WEAPONS

MORLD PRESS REVIEW, 39(5) (MAY 92), 16-18.

THE AUTHOR DISCUSSES THE PRESENT STATUS OF THE FORMER

SOVIET UNION'S NUCLEAR HEAPONS ANO THE FUTURE OF MUCLEAR

WEAPONS IN THE INTERNATIONAL SECURITY SYSTEM.

08162 SCHMULTS, R.

HILL LEADERS PLOT FRESHMAY ORIEMTATION

INSIGHT, 8(48) (NOV 92), 12-13.

WITH THE BIGGEST FRESHMAN CLASS IN MEARLY 20 YEARS,

CONGRESS APPEARS PRIMED FOR A POWER STRUGGLE. MOST INCOMING

REPRESENTATIVES AIM TO END BUSINESS AS USUAL: IN THEIR HAY

IS AN OLD GUARD WITH A LOT OF WAYS TO HOLD OF REFORMS.

08163 SCHNECK, S.; MCHILLIAMS, H.C.; WINTHROP, D.

POLITY FORUM: ALEXIS DE TOCQUEVILLE

POLITY, XXV(2) (WIN 92), 283-314.

THIS FORUM FOCUSES ON TRADITIONAL VERSUS NEH

INTERPRETATIONS OF ALEXIS DE TOCQUEVILLE'S "DEMOCRACY IN

AMERICA." STEPHEN SCHNECK ARGUES THAT THE NEH READINGS

INOICATE THAT TOCQUEVILLE ULTIMATELY DID NOT LOCATE

SOVEREIGNTY IN THE MODERN INDIVIDUAL SUBJECT AND, THUS, THE

FOUNDATION FOR LEGITIMATE GOVERMMENT MUST BE FOUND ELSEWHERE-

-RAISING THE QUESTION OF "WHERE?" SCHMECK CONTENDS THAT

THERE ARE TWO PLAUSIBLE LOCATIONS FOR POLITICAL SOVEREIGNTY,

WHICH MEANS THAT THERE ARE TWO NEW INTERPRETATIONS OF

"DEMOCRACY IN AMERICA." WHILE SHARING MUCH IN THEIR IMPLICIT

CRITICISM OF THE OLD LIBERAL READING. THE TWO NEH

INTERPRETATIONS DIFFER SIGNIFICANTLY ON THE LOCATION OF

SOVEREIGNTY AND, ACCORDINGLY, EACH SUGGESTS A DIFFERENT

LESSON FOR DEMOCRACY. H. CAREY MCHILLIAMS AND DELBA WINTHROP

COMMENT ON SCHNECK'S ARGUMENT.

08164 SCHNEIDER, M.: TESKE, P

TOWARD A THEORY OF.THE POLITICAL ENTREPRENEUR: EYIDENCE FROM LOCAL GOVERMMENT

AMERICAN POLITICAL SCIENCE REVIEW, 86(3) (SEP 92), 737-747. POLITICAL ENTREPRENEURS ARE INDIVIDUALS HO CHANGE THE DIRECTION AND FLOW OF POLITICS. IN THIS RESEARCH NOTE, THE AUTHORS SYNTHESIZE ASPECTS OF AN ECONOMIC APPROACH TO ENTREPRENEURSHIP WITH CONCEPTS USED IN POLITICAL SCIENCE. THEN THEY TIE THESE THEORETICAL OBSERVATIONS TO THE THEN THEY TIE THESE THEORETICAL OBSERVATIONS TO THE
EMERGENCE OF ENTREPRENEURS IN LOCAL GOVERNMENTS AND TEST EMERGENCE OF ENTREPRENEURS IN LOCAL GOVERNMENTS AND TEST
COMPONENTS OF THEIR THEORY USIMG OBSERVATIONS FROH A LARGE COMPONENTS OF THEIR THEORY USING OBSERVATIONS FROM A LARGE
SET OF SUBURBAN MUNICIPAL GOVERNMENTS. EMPIRICALLY, THEY SET OF SUBURBAN MUNICIPAL GOVERMMENTS. EMPIRICALLY. THEY
IDENTIFY SEVERAL CONDITIONS--ESPECIALLY SLACK BUDGETARY IDENTIFY SEVERAL CONDITIONS--ESPECIALLY SLACK BUDGETARY RESOURCES THAT THE POL ITICAL ENTREPRENEUR CAN REALLOCATE--
THAT AFFECT THE PROBABILITY THAT AN ENTREPRENEUR HILL EMERGE THAT AFFECT THE PROBABILITY THAT AN ENTREPRENEUR WILL
IN A LOCAL GOVERMMENT. THE PROBABILITY FOR FINDING AN ENTREPRENEUR IN LOCAL GOVERNMENT IS A FUNCTION OF THE DIFFICULTY OF OVERCOMING COLLECTIVE ACTION PROBLEMS IN A COMMUNITY.

08165 SCHNEIDER, M

UNDERMINING THE GROWTH MACHINE: THE MISSING LINK BETHEEN 
LOCAL ECONOMIC DEVELOPMENT AND FISCAL PAYOFFS

THE JOURMAL OF POL ITICS, 54(1) (FEB 92) 214-320. WHILE THE GROWTH MACHINE IS UMDOUBTEDLY STILL AMONG THE MOST POTENT FORCES IN LOCAL POLITICS, IN MANY COMMUNITIES RESIDENTIAL SUPPORT FOR PRO-GROWTH POLICIES HAS BEEN REPLACED BY STRONG OPPOSITION. USING A SAMPLE OF APPROXIMATELY SEVEN HUNDRED SUBURBAN MUNICIPALITIES, THE APPROXIMATELY SEVEN HUNDRED SUBURBAN MUNICIPALITIES, THE
AUTHOR SHOWS THAT THE FLOW OF FISCAL BENEFITS TO COMHUNITIES FROM ECONOMIC DEVELOPMENT HAS SLONED DURING THE LAST 15 YEARS. GIVEN THE MOUNTING COSTS OF GROWTH AND THE INCREASING COSTS OF PRO-GROWTH POLITICS, THE LACK OF SIGNIFICANT FISCAL
PAYOFFS HELPS EXPLAIN GROWING DISAFFECTION WITH THE GROWTH MACHINE AND THE RISE OF THE ANTIGROWTH MOVEMENT.

08166 SCHNEIDER, R.; GANDILLOT, T.; GILSON, M.; SCHLOSSER, F. WHAT WILL HAPPEN IF FRANCE SAYS "NO"?

WORLD PRESS REVIEW, 39(8) (AUG 92), 11-13.

THE AUTHORS PAINT A SCENARIO FOR THE COLLAPSE OF THE EUROPEAN COMMUNITY, WITH DIRE CONSEQUENCES FOR THE ENTIRE WESTERN WORLD, IF FRENCH VOTERS REJECT THE MAASTRICHT TREATY.

08167 SCHMEIDER, S.K.

GOVERNMENTAL RESPONSE TO DISASTERS: THE CONFLICT BETHEEN BUREAUCRATIC PROCEDURES AND EMERGENT MORMS

PUBLIC ADMINISTRATION REVIEW, 52(2) (MAR 92), 135-145. TO UNDERSTAND WHY SOME GOVERNMENT EFFORTS AT DISASTER RELIEF ARE MORE SUCCESSFUL THAN OTHERS, THE AUTHOR FOCUSES ON THE GAP BETWEEN WHAT GOVERNMENTS ARE PREPARED TO DO IN EMERGENCY MANAGEMENT SITUATIONS (BUREAUCRATIC NORMS) AND WHAT DISASTER VICTIMS EXPECT (EMERGENT NORMS). SHE APPLIES THIS APPROACH TO FIVE CASE STUOIES OF RECENT DISASTERS ILLUSTRATING THE RANGE FROM EMERGENCY MANAGEMENT SUCCESS TO FAILURE. SHE CRITICIZES THE MEDIA'S TENDENCY TO BLAME GOVERNMENT FOR PROGRAM FAILURES AND STRESSES THE NEED FOR GOVERMMENT AGENCIES TO STICK WITH STANDARD OPERATING PROCEDURES AND THE PRE-ESTABLISHED DIVISION OF LABOR AMONG LEVELS OF GOVERNMENT.

08168 SCHNEIDER, $V$.

THE STRUCTURE OF POLICY NETWORKS: A COMPARISON OF THE "THE STRUCTURE OF POLICY NETHORKS: A COMPARISON OF THE "CHEMICAL CONTROLS"

EUROPEAN JOURNAL OF POLITICAL RESEARCH, 21(1-2) (FEB 92), EUROPEAN

THE AUTHOR CONCENTRATES ON THE STRUCTURAL EFFECTS OF POLICY NETHORKS. AFTER A CONCEPTUAL DISCUSSION OF SOME FUNCT IONAL IMPLICATIONS OF FORMAL NETHORK STRUCTURES, HE FOCUSES ON AN EMPIRICAL DESCRIPTION AND STRUCTURAL MAPPING OF POLICY NETWORKS IN TWO GERMAN POLICY DOMAINS. EMPHAS
LAID ON THE PARTICULAR PROPERTIES OF DIFFERENT NETHORK LAID ON THE PARTICULAR PROPERTIES OF DIFFERENT NETHOF
STRUCTURES AMONG WHICH PLURALISM, CORPORATISM, AND CLIENTELISM ARE UNDERSTOOD AS IDEAL TYPES.

08169 SCHOENFELD, G.

UNDERWATERGATE

NEW REPUBLIC, 206 (17) (APR 92), 20-21

THE AUTHOR REPORTS ON A SOVIET MUCLEAR POHER ACCIDENT THAT OCCURRED ON CHAZHMA BAY NEAR THE VILLAGE OF SHKOTOVO ON AUGUST 10, 1985, BUT WAS NOT REVEALED UNTIL RECENTLY.

08170 SCHOFIELD, P.

PROTECTING THE ENVIRONMENT IN CENTRAL EUROPE

CONTEMPORARY REVIEW, 261(1521) (OCT 92), 189-201.

NEW ATTITUES FOR THE ENVIRONMENT ARE BEING DEVELOPED IN THE CENTRAL EUROPEAN THREE (CET). THERE IS A GROWING FEELING THAT THERE SHOULD BE A COUNCIL OF EUROPEAN ENVIRONHENT MINISTERS, RESPONSIBLE FOR OVERSEEING THE EVALUATION OF MINISTERS, RESPONSIBLE FOR OVERSEEING THE EVALUATION OF
ENVIRONMENTAL IMPACTS, SETTING TARGETS AND PRIORITIES,
BUILDING AND MONITORING AN INFORMATION SYSTEM, STRENGTHENING BUILDING AND MONITORING AN INFORMATION SYSTEM, STRENGIHENING
ENVIRONMENTAL LAH AND BOOSTING ENVIRONMENTAL EDUCATION. IT ENVIRONMENTAL LAH AND BOOSTING ENVIRONMENTAL EDUCATION. IT
IS TAKING LONGER FOR THE ENVIRONMENTALISTS TO REORGANIZE AND IS TAKING LONGER FOR THE ENVIRONMENTALISTS TO REORGANI ZE
TO ATTRACT OUTSIDE HELP THAN IT IS FOR THE FINANCIAL AND TO ATTRACT OUTSIDE HELP THAN IT IS FOR THE FINANCIAL AND
ECONOMIC ORGANIZATIONS WITHIN CET. ENVIRONMENTAL EDUCATION ECONOMIC ORGANIZATIONS WITHIN CET. ENVIRONMENTAL EDUCATION AT ALL LEVELS IS
OF THE SITUATION.

08171 SCHOFIELD, R.

THE IRAQ-KUWAIT BOUNDARY: A PROBLEM OUTSTANDING

IIDDIE EAST INTERMATIONAL: (398) (APR 91) 21-22

IN ACCEPTING TERMS FOR A GULF CEASE-FIRE LAID DOWN IN UN RESOLUTION 687 WHICH WAS PASSED ON 3 APRIL. IRAO HAS COMMITTED ITSELF TO RESPECT THE INVIOLABILITY OF THE IRAOKUWAIT BORDER. THERE IS A CLEAR DANGER IN ASSUMING THAT IRAO'S CLAIMS TO KUWAIT TERRITORY WIL DISAPPEAR WITH A RESOLUTION OF THE CURRENT CRISIS AND THE REMOVAL OF SADDAM HUSSEIN, IF AND WHEN THIS OCCURS. IN SHORT, THIS IN UNLIKELY, PRINCIPALLY BECAUSE IRAQI CLAIMS TO KUWAITI TERRITORY HAVE BEEN PURSUED WITH REMARKABLE CONSISTENCY OVER THE LAST HALFCENTURY THROUGH PERIODS OF MONARCHY AND REVOLUTIONARY RULE ALIKE.

08172 SCHOLTZ, L.

SOUTH AFRICA AND THE WEST

SOUTH AFRICA FOUNDATION REVIEW, 18 (12) (DEC 92), 6-7.
AN ARGUEMENT IS MADE FOR THE NEW SOUTH AFRICA TO CONTINUE ITS TRAOITIONAL POLICY OF BEING A DEPENDABLE ALLY OF THE WEST, RATHER THAN FOCUSING ON AFRICA OR BECOMING A NONALIGNED STATE. THE PURPOSE OF THIS ARTICLE IS TO SUGGEST THAT SOUTH AFRICA'S OBJECTIVE INTERESTS HOULD NOT BE SERVED BY SUCH A POLICY CHANGE. THE ARTICLE EXPLORES THE NEEDS OF SOUTH AFRICA AND SUGGESTS PRACTICAL ALTERNATIVES. IT LOOKS AT THE DIFFERENT PARTS OF THE WORLD AND HOW THE COUNTRY'
FOREIGN POLICY COULD CONTRIBUTE TO THE PROMOTION OF ITS INTERESTS.

08173 SCHOLZ, R.

FEDERAL NATURE OF THE NEW EUROPE NEEDS LEGAL UNDERPINNING GERMAN TRIBUNE, (1525) (JUL 92), 3.

THE TREATY OF MAASTRICHT DOES NOT SIMPLY EXTEND THE EUROPEAN COMMUNITY AS AN "ORGANIZATION OF ECONOMIC POLICY EXPEDIENCE." IT REFLECTS THE WILL TO ESTABLISH A EUROPEAN POLITICAL UNION. AN ASPECT WHICH ALSO HAS FAR-REACHING

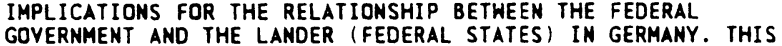
GOVERNMENT AND THE LANDER (FEDERAL STATES) IN GERMANY. THIS
ARTICLE ARGUES THAT THE EUROPE OF THE FUTURE SHOULD NOT BE A SUPRANATIONAL CENTRALIST STATE, BUT MUST HAVE A FEDERALIST STRUCTURE IN WHICH THE INTERNAL FEDERAL ORGANIZATION OF INDIVIDUAL STATES IS RETAINED. EUROPEAN UNIFICATION CANNOT MEAN THAT A UNITARY OR CENTRALIST-STATE STRUCTURE IS PRESCRIBED FOR A FEDERAL STATE SUCH AS GERMANY. INSTEAD, THE EMERGENT EUROPEAN CONSTITUTIONAL ORDER SHOULD NOT AFFECT INTERNAL FEDERAL STRUCTURES.

08174 SCHONFELD, R.

GERMANY II: PRIVATISING THE EAST

HORLD TODAY, 48(8-9) (AUG 92), 152-155.

THE TRANSFORMATION AND PRIVATIZATION OF THE EAST GERMAN ECONOMY HAS TURNED OUT TO BE MORE COMPLICATED THAN WEST GERMANS EXPECTED WHEN THEY SO ENTHUSIASTICALLY EMBRACED REUNIFICATIOH.

08175 SCHONSEE, R.; LEDERER, G.

THE GENTLE REVOLUTIOM

POLIIICAL PSYCHOLOGY, 12 (2) (JUN 91) 309-330.

IN THE TOTALITARIAN STRUCTURE OF THE GDR, THE POLITICAL IN THE TOTALITARIAN STRUCTURE OF THE GDR, THE POLITICAL

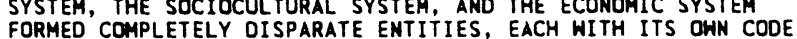
FORMED COMPLETELY DISPARATE ENTITIES, EACH WITH ITS OWN CODE A SYNTHESIS OF THE SOCIAL IDENTITY OF THE INDIVIDUAL. A SYNTHESIS OF THE SOCIAL IDENTITY OF THE INDIVIDUAL. INSTEAD, UNINTEGRATED ROLE SET EXISTED SIDE BY SIDE AND INDIVIDUALS SWITCHED FROM ONE ROLE TO THE OTHER ICOLLECTIVE SCHI ZOPHRENIA). THE INITIAL GOAL OF THE REVOLUTION WAS THE REGAINING OF THE BASIC TRUE FREE SPEECH, OF THE FREEDOM OF DISCUSSION HITHIN AND BETWEEN THE BOUNDARIES OF THE VARIOUS
GOR SYSTEMS. HOWEVER, IN A SEARCH FOR LEADERSHIP, THE GERMAN GDR SYSTEMS. HOWEVER, IN A SEARCH FOR LEADERSHIP, THE GERMAM MOVEMENT CONTINUED AS A "REVOLUTION FROM ABOVE." THE PEOPLE ACCEPTED THE LEADERSHIP OF THE WEST GERMANY POLITICAL PARTIES WITHOUT EVER ACHIEVING TRUE COMMUNICATION. THIS SOCIAL PSYCHOLOGICAL SITUATION WAS EXPERIENCED AS TRAUMATIC AND GAVE RISE TO A WIDESPREAD FEELING OF PARALYSIS PAIRED WITH ANXIETY AND FEAR.

08176 SCHOONMAKER, S.

STATE AUTOMOMY AND STRUCTURAL CONSTRAINTS: SOFTWARE WARS IN BRAZIL

CRITICAL SOCIOLOGY, 19(1) (1992), 3-18.

IN 1987, THE BRAZILIAN GOVERMMENT'S DECISION TO DENY ICENSING OF MICROSOFT'S MS-DOS OPERATING SYSTEM LED TO THE IMPOSITION OF U.S. TRADE SANCTIONS. THIS ARTICLE EXAMINES THE IMPLICATIONS OF THE MS-DOS CASE FOR UNDERSTANDING THE ROLE OF THE STATE IN NEWLY INDUSTRIALIZING COUNTRIES AND IT RELATIONSHIP TO LOCAL AND FOREIGN CAPITAL. IT ASSESSES THE RELATIONSHIP TO LOCAL AND FOREIGN CAPIITAL. IT ASSESSES RELEVANCE OF DEPENDENCY THEORY, IDENTIFYING ITS MAJOR
CONTRIBUTION AS THE ANALYSIS OF THE STRUCTURAL CONDITIONS CONAT AFFECT THE PROSPECTS FOR STATE ACTION. BRAZIL;S POSITION OF TRADE DEPENDENCY CREATED A CONVERGENCE OF INTERESTS BETWEEN LOCAL EXPORTERS AND THE U.S. GOV INFORMATICS POLICY.

08177 SCHOPPA, R. REVLUTIONARY CHANGE IN A CHINESE COUNTY, 19001950

JOURNAL OF ASIAN STUDIES, 51(4) (NOV 92), 770-797.

IN ITS EXPLORATION OF' THE SOURCES AMD DIRECTION OF CHANGE IN XIAOSHAN COUNTRY, THIS ESSAY EXAMINES THE SIGNIF TN XIAOF THE MATURA AND SOCIAL CONTEXTS FOR REVOLUTIONRY CHANGE. IT ADDRESSES THESE QUESTIONS: ARE THERE RELATIONSHIPS BETHEEN CONTEXT AND THE SHAPE OF COUNTY POLITICAL AND SOCIAL CHANGE AND, IF SO, WHAT FORM DO THEY TAKE? WHTHIN A SPECIFIC CONTEXT, WHICH CUL TURAL STRUCTURE AND VALUES SEEM MOST SIGNIFICANT? BEYOND CONTEXT, WHAT FORCES AND DYNAMICS BEST EXPLAIN SUCH CHANGE: SINCE THE AGENCY AND STIMULUS FOR CHANGE ARE KEYS TO UNDERSTAM STRUCTURES OF CHANGE IN THE HALF CENTURY? 
08178 SCHORR 0.

BUSH BEHILDERED AMD DISMAYED

NEW LEADER, LXXIV (13) (DEC 91), 3-4.

FORMER ATTORNEY GENERAL DICK THORNBURGH LOST TO SENATOR HARRIS WOFFORD IN PENNSYLVANIA, AND DAVID DUKE LOST TO FORMER GOVERNOR EDIWN W. EDWARDS IN LOUISIANA. BUT, IN NATIONAL TERMS, THE BIG LOSER WAS PRESIDENT GEORGE' BUSH AND GOVERNMENT IN GENERAL, WILE THE BIG WINNER WAS CLASS AND RACE POLARIZATION. THE ELECTIONS REVEALED AN AMERICA SORELY TROUBLED BY ECONOMIC INSECURITY VENTING ITS FEARS IN ANGER AGAINST BOTH THE RULING CLASS AND THE UNDERCLASS.

UNFORTUNATELY, BUSH'S RESPONSE HAS BEEN A NEW ROUND OF CONGRESS BASHING ACCOMPANIED WITH HINTS OF A NEW ECONOMIC POLICY IN JANUARY.

08179 SCHORR, D.

BUSH'S BUCHANAN JITTERS

NEW LEADER, LXXV(2) (FEB 92), 3.

THE PRESIDENTIAL ELECTION CAMPAIGN HAS SIGNIFICANCE NOT JUST FOR THE NEXT FOUR YEARS, BUT ALSO FOR HOW THE NATION IS UST FOR THE NEXT FOUR YEARS, BUT ALSO FOR HON THE NATION GEORGE BUSH, MOT FAMOUS FOR HARBORING MANY CORE CONVICTIONS, HAS BEEN COMING UNDER INCREASING PRESSURE TO TAILOR GOVERNMENT POLICY AND ACTIONS TO PERCEIVED POLITICAL NEED. GOVERNMENT POLICY AND ACTIONS TO PERCEIVED POLITICAL NEED.
FOR THE PRESENT, THAT MEANS MAINLY TRYING TO OFFSET THE FOR THE PRESENT, THAT MEANS MAINLY TRYING TO OFFSET THE APPEAL OF PATRICK BUCHANAN TO THE CONSERVAT IVE BASE BUSH INHERITED FROM RONALD REAGAN. BUSH'S MOVES TO APPEASE THE CONSERVATIVE CAMP INCLUDE THE FIRING OF JOHN E. FROHNMAYER, CHAIRMAN OF THE NATIONAL ENDOWMENT FOR THE ARTS; RESCINDING OF A BUDGET PROPOSAL THAT WOULD HAVE REQUIRED CHURCHES
REPORT CONTRIBUTIONS OF MORE THAN S500 TO THE INTERNAL REPORT CONTRIBUTIONS OF MORE THAN \$500 TO THE INTERNAL
REVENUE SERVICE; AND THE CANCELLING OF A TENTATIVE MOVE TO OPEN SEVERAL UNDERUSED VETERANS' HOSPITALS TO NONVETERANS. IN AOOITION, FROM THE DEPORTATION OF HAITIAN REFUGEES TO THE RELUCTANCE TO PROVIDE LARGE-SCALE AID TO HELP BAIL OUT THE FORMER SOVIET REPUBLICS, THE IMPACT OF BUCHANAN'S "AMERICA FIRST" RHETORIC HAS BEEN VISIBLE.

08180 SCHORR, $D$.

ON THE WAY TO WAR

NEH LEADER, LXXIV(1) (JAN 91), 3-5.

NOTED COLUMNIST DAMIEL SCHORR RECOUNTS THE LAST MONTHS AND DAYS OF AMERICA'S COUNTDOWN TO THE 15 JANUARY DEADLINE FOR SADDAM HUSSEIN'S WITHDRAHAL FROM KUWATI. HE CONSIDERS THE LAST-MINUTE NEGOTIATIONS, THE TELEVISION DIPLOMACY, AND THE BEHIND-THE-SCENES POLITICAL WRANGLING THAT OSTENSIBLY GAVE PEACE A CHANCE, BUT LEFT NO ALTERNATIVE FOR GEORGE BUSH GAVE PEACE A CHANCE, BUT LEFT NO ALTERNATIVE FOR GEORGE BUSH
BUT WAR. THE HORLDWIDE ATTENTION ON THE MIDEAST OBSCURED BUT WAR. THE HORLDWIDE ATTENTION ON THE MIDEAST OBSCURED IMPORTANT EVENTS IN OTHER PARTS OF THE HORLD
CONSOLIDATION OF POWER BY SOVIET HARD-LINERS.

08181 SCHORR, $D$.

PEROT'S NIXON PATTERN

NEW LEADER, LXXY(8) (JUN 92), 3-4.

THIS ARTICLE COMPARES UNDECLARED PRESIDENTIAL CANDIDIATE ROSS PEROT TO RICHARD NIXON. THE AUTHOR FIMDS A SIMILARITY WITH MIXON IN PEROT'S EVIDENT NEED TO CONTROL HIS ENVIRONMENT AND HIS PENCHANT FOR LASHING OUT AT THOSE WHO CROSS HIM. BOTH NIXON AND PEROT ARE TALENTED, COMPULSIVE MEN AND ARE VERY MUCH HANDLERS OF THEIR OWN DESTINIES. BOTH HAVE USED BOOKS TO BURNISH THEIR IMAGES. SUCH SIMILARITIES ARE FOREBODING, GIVEN THE FACT THAT NIXON'S COMPULSIVE NEED TO CONTROL HIS ENVIRONMENT AND TO "GET THE GOODS" ON HIS ENEMIES LED TO WATERGATE.

08182 SCHORR, D.

THE HORROR OF BOSNIA

NEW LEADER, LXXV(10) (AUG 92), 3

SLOBODAN MILOSEVIC,

IN THE NAME OF "ETHNIC CLEANSING" haVE PUT BOSNIANS AMD

CROATS IN CONCENTRATION CAMPS OR SHIPPED THEM AWAY IN SEALED BOX CARS. ONLY BELATEDLY HAS THE U.S. STATE DEPARTMENT CONFIRMED THE EXISTENCE OF THESE CAMPS, WHILE INDICATING THAT NO ACTION HAS PLANHED BEYOND VERBAL CONDEMMATION. DANIEL SCHOOR SUGGESTS THAT THIS LACK OF ACTION IS PROMPTED BY POLITICAL INTERESTS IN AN ELECTION YEAR AND THAT THE WORLD HAS GROHN MUCH SMALLER THAN IT WAS IN 1938.

08183 SCHORR, D.

THE PRESIDENT ON A TIGHTROPE

NEW LEADER, LXXV(1) (JAN 92), 3-4.

NEVER IN THE PAST DID A PRESIDENT STAKE SO MUCH OF HIS FUTURE ON A STATE OF THE UNION ADORESS AS GEORGE BUSH. FACED HITH A CONTINUING RECESSION, A TROUBLESOME IRAO AND EVERDITH A CONTINUING RECESSION, A TROUBLESOME IRAQ, AND EVERDECLINING POPULARITY POLLS, BUSH SOMEHOH GOT HIMSELF INTO THE POSITION OF STANDING ON A TIGHTROPE, SWAYING IN THE WIND, AND INVITING PEOPLE TO HOLD THEIR BREATHS WHILE HE PREPA FOR HIS DEATH-DEFYING ORATORICAL LEAP. IN REALITY, THE
ADORESS TURNED OUT TO BE ANTI-CLIMATIC--MORE A REPUBLICAN ADDRESS TURNED OUT TO BE ANTI-CLIMATIC--MORE A REPUBLICAN UNITY DOCUMENT THAN AN OUTLINE OF AN ELECTION CAMPAIG PLATFORM. BOTH IN RHETORIC AND RECOMMENDATIONS, THE CONSERVATIVES IN CONGRESS AND IN NEH HAMPSHIRE THAN TO WIN BACK DISAFFECTED WORKING-CLASS VOTERS.
08184 SCHORR, D.

WASHINGTON NOTEBOOK: BUSH'S UPHILL CAMPAIGN NEW LEADER, LXXV(12) (SEP 92), 3-5.

UNDER THE MANAGEMENT OF JAMES A. BAKER III, PRESIDENT BUSH'S RE-ELECTION CAMPAIGN HAS DISPLAYED NOT' SO MUCH A FIRM HAND AT THE RUDDER AS THE TENDENCY TO ENGAGE IN EXPERIMENTAL TACKING. ONE AFTER ANOTHER, CAMPAIGN THEMES HAVE BEEN TRIED AND DISCARDED.

08185 SCHORR, $N$.

FOSTER CARE AND THE POLITICS OF COMPASSION

TIKKUN, $7(3)$ (MAY 92), 19-22; 80-82.

THIS ARTICLE CHARGES THAT THE LIBERAL STATE HAS MISUSED CHILD-PROTECTIVE AGENCIES, ENFORCING CLASS PREJUDICES AND WRECKING MANY WORKING-CLASS AND POOR FAMILIES. HAVING DEFINED THE PRIMARY PROBLEM AS BAD PARENTING. THE STATE IS FREE TO INTERVENE WITHOUT RESTRAINT IN ITS CLIENTS' DAILY LIVES BY REMOVING CHILDREN FROM THEIR PARENTS WITH MINIMAL INVESTIGATION AND LITTLE RESPECT FOR LEGAL PROCEDURES-BEFORE EXPLORING AVENUES FOR KEEPING THE FAMILY TOGETHER. THE SOLUTION TO THIS PROBLEM, IT IS SUGGESTED, IS THAT THE FOCUS MUST BE NOT ON INDIVIDUAL CHANGE--IDEALLY THAT FOLLOHS INSTITUTIONS THAT CAN ADDRESS THEIR NEEDS FOR SUPPORT,

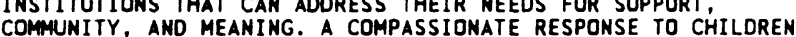
MUST INCLUDE AN EOUALLY COMPASSIONATE RESPONSE TO THEIR MUST INCLC
PARENTS.

08186 SCHORTMAN, E.; URBAN, P.

RESOURCES, POWER, AND INTERREGIONAL INTERACTION PLENUM PRESS, 1992, 259

THE CHOICE OF WORLD SYSTEMS, POLITICAL IDEOLOGY, AND WARFARE AS THE INTERACTION PERSPECTIVES REPRESENTED IN THIS BOOK IS DETERMINED BY THE EDITOR'S IMPRESSION THAT THESE VIEWPOINTS CURRENTLY DOMINATE ARCHAEOLOGICAL DISCUSSIONS OF INTERSOCIETAL CONTACT PROCESSES. THE BOOK IS ORGANIZED INTO PARTS CONTAINING THE CHAPTERS THAT ARE DEVOTED TO EACH OF THESE VIEWPOINTS. AN INTRODUCTORY CHAPTER INVESTIGATES HISTORICAL PATTERNS IN ARCHAEOLOGICAL CONSIDERATIONS OF INTERACTION PROCESSES. THE CONCLUDING CHAPTER DRAWS TOGETHER THEMES FROM THE PRECEDING CHAPTERS AND OFFERS SOME SUGGESTIONS FOR THE CONSTRUCTION OF A COHERENT PARADIGM THROUGH WICH ANCIENT INTERACTIONS PATTERNS AND THEIR RELATIONS TO SOCIOPOLITICAL CHANGE MIGHT BE INVESTIGATED.

08187 SCHRAEDER, P.J.

BUREAUCRATIC INFLUENCE IN THE U.S. -ZAIRIAN SPECIAL RELATIONSHIP

TRANSAFRICA FORUM, $9(3)$ (FAL 92), 31-56.

POST-COLD WAR AMERICAN POLICIES TOWARD AFRICA HAVE NOT BEEN MARKED BY A SIGNIFICANT CHANGE INDICATIVE OF A NEW ERA BEEN MARKED BY A SIGNIFICANT CHANGE INOICATIVE OF A NEW ERA POLICIES. AMERICAN FOREIGN POLICY TOWARD AFRICA HAS BEEN POLICIES. AMERICAN FOREIGN POLICY TOHARD AFRICA HAS BEEN CHARACTER IED BY A HIGH DEGREE OF BUREAUCRATIC INFLU BUREAUCRATIC INCREMENTALISM-DTHT MAKES IT VERY DIFFICULT TO BUREAUCRATIC INCREMENTALISM--THAT MAKES IT VERY DI CHANGE POLICY EVEN IN THE ALTERED POST-COLD WAR INTERNATIONAL SYSTEM. THE EVOLUTION OF U.S. FOREIGN POLICY TOHARD ZAIRE OFFERS A GOOD CASE STUDY OF BUREAUCRATIC INFLUENCE IN THIS AREA.

08188 SCHRAG, D.

RECONSTRUCTING REASON IN THE AFTERMATH DF DECONSTRUCTION CRIIICAL REVIEW, 5(2) (SPR 91), 247-260

THOMAS MCCARTHY HAS PROVIDED A CRITIOUE OF THE

DECONSTRUCTIONIST TURN IN RECENT PHILOSOPHY AND HAS OUTLINED A PROGRAM OF RECONSTRUCTION IN ITS AFTERMATH. HIS DESIGN IS NOT SIMPLY AN APPROPRIATION AND DEFENSE OF HABERMAS. HE PROVIDES A CRITICAL REFORMULATION OF THE HABERMASIAN POSITION, USING HABERMAS AGAINST HIMSELF. THE AUTHOR OF THIS ARTICLE DISTANCES HIMSELF FARTHER THAM DOES MCCARTHY FROM THE CRITERIOLOGICAL CONCEPT OF RATIONALITY THAT WAS PROPOSED BY KANT AND WHICH CONTINUES TO INFORM HABERMAS'S REQUIREMENT FOR THE GROUNDING OF VALIDITY CLAIMS. HE PROPOSES A NEN APPROACH TO THE RESOURCES OF REASON ALONG THE LINES OF WHAT HE HAS COME TO CALL THE DYNAMICS OF TRANSVERSAL RATIONALITY.

08189 SCHRAM, A.J.H.C.

RATIONAL CHOICE MODELS OF INDIVIDUAL POLITICAL BEHAVIOUR IN THE METHERL AMDS

EUROPEAN JOURNAL OF POLITICAL RESEARCH, 21(4) (JUN 92), 423-452.

THE AUTHOR OFFERS A SURVEY OF PAPERS, WRITTEN IN DUTCH OR IN ENGLISH ABOUT THE NETHERLANDS, IN A SUBFIELD OF RATIONAL CHOICE THEORY--INDIVIDUAL CHOICE IN THE POLITICAL SPHERE. HE DISCUSSES DUTCH CONTRIBUTIONS TO THEORIES OF THE BEHAVIOUR OF BUREAUCRATS, POLITICIANS. AND VOTERS; STUDIES CONCERNING INDIVIDUAL PARTICIPATION IN COLLECTIVE ACTION; AND POLITICO-ECONOMIC MODELS COVERING VARIOUS ASPECTS OF INDIVIDUAL BEHAVIOUR IN THE POLITICAL SPHERE.

08190 SCHRAM, S

POST-ACTIVISTIC POLICY ANALYSIS \& THE FAMILY SUPPORT ACT 
OF 1988: SYMBOLS AT THE EXPENSE OF SUBSTANCE

POLITY, 24(4) (SUM 92), 633-656.

THE FAMILY SUPPORT ACT OF 1988 REPRESENTS AN EXAMPLE OF THE CONTRADICTORY SYMBOLISM OF WELFARE UNDERCUTTING SUBSTANTIVE BENEFITS. THIS ARTICLE, USING POST-POSITIVISTIC ANALYSIS. EXPLORES THE CONTRADICTORY CHARACTER OF RECENT REVISIONS IN WELFARE POLICY. THE AUTHOR CONCLUDES THAT THESE CHANGES FULFILL SYMBOLIC PURPOSES, OFTEN AT THE EXPENSE OF CHANGES FUL FILL SYMBOLIC PURPOSES,
THE PEOPLE SERVED BY THE PROGRAM.

08191 SCHRAMM, F.; SCHLESE, M

FROM SOL TDARITY TO COOPERATION: THE GERMAN CASE FUTURES, $24(2)$ (MAR 92), 173-178.

THE SPECIAL PROBLEMS IN THE RELATIONSHIP BETWEEN EAST AMD WEST GERMANS IS DEALT WITH. THE AUTHORS DISCUSS THE CONDIT BETWEEN THE THO COUNTRIES. ACCORDING TO THEIR OBSERVATIONS, A LAGGED ALOFFNESS OF THE EAST GERMANS TOWARD WEST GERMANY PLAYS A CENTRAL ROLE AT PRESENT. IT IS EXPLAINED BY A NECESSARY, NEH-IOENTITY-FINDING PROCESS THAT THEY ARE UNDERGOING AND RENDERS HOPES FOR A OUICK MENTAL GERMAN UNIFICATION PREMATURE.

08192 SCHREYER, U.

POST-NEHRU INDIA LOOKS TO THE HEST AND MARKET ECONOMICS GERMAN TRIBUNE, 1487 (OCT 91), 2

THIS ARTICLE DISCUSSES THE POSSIBILITY OF A MARKET ECONOMY REPLACING CENTRALLY MANAGED ECONOMY IN INDIA. THE NATION. WHICH USED TO BE MORE OR LESS UNCOUPLED FROM THE WORLD MARKET, MUST NOW OPEN UP TO EUROPE EVEN MORE THAN IN THE PAST. ONE IMPORTANTANT STEP IN THIS DIRECTION HAS ALREADY BEEN TAKEN. FOREIGN FIRMS ARE NOW ENTITLED TO HOLD A MAJORITY SHAREHOLDING IN INDIAN JOINT VENTURES.

08193 SCHRIRE, R.

THE ECONOMIC DEBATE AND THE POLITICS OF UNREASON SOUTH AFRICA INTERNATIONAL, $23(2)$ (OCT 92), $71-77$ THE ECONOMIC DEBATE IN SOUTH AFRICA HAS LARGELY MOVED
SOUTH AFRICA INTERNATIONAL, $23(2)$ (OCT 92 ), $11-77$. AHAY FROM ISSUES OF PRINCIPLE TOWARDS ISSUES OF DETAIL. IT IS CLEAR THAT ECONOMIC GROWTH IS THE KEY ELEMENT IN IS CLEAR THAT ECONOMIC GROWTH IS THE KEY ELEMENT IN REDISTRIBUTION. WHAT IS NEEDED IS A MULTIDIMENSIONAL
STRATEGY, FOCUSING ON A RANGE OF REDISTRIBUTIVE MECHANISMS STRATEGY, FOCUSING ON A RANGE OF REDISTRIBUT IVE MECHANISMS

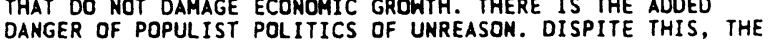
OANGER OF POPULIST POLITICS OF UNREASON. DISPITE THIS, THE CDMBINING A WAR AGAINST POVERTY WITH A RANGE OF MICRO-POLICY
REMEDIES COULD SATISFY BOTH POLITICAL AND ECONOMIC CRITERIA REMEDIES COULD SATISFY BOTH POLIT
IN A POST-APARTHEID SOUTH AFRICA.

08194 SCHRODER, B.

EASTERN HEO-NAZIS SHAPE THEIR OWM DESTINY

GERMAN TRIBUNE, (1533) (SEP 92), 14-15.

IF ENERGETIC STEPS ABOUT NOT' TAKEN TO CURB NEO-NAZISM, GERMANY IS LIKELY TO BECOME THE EUROPEAN NATION MOST HOSTILE TO FOREIGNERS. THIS COULD HAVE ECONOMIC AS WELL AS POLITICAL CONSEOUENCES; JAPANESE FIRMS ARE ALREADY RELUCTANT TO INVEST IN EASTERN GERMANY BECAUSE THE SECURITY OF THEIR EMPLOYEES CANMOT BE GUARANTEED. THE ONLY WAY TO TAKE THE WIND OUT OF THE NEO-NAZI SAILS IS TO GIVE IMMIGRATION A LEGAL BASIS. IF
POLITICIANS SIMPLY TAKE UP THE AGITATION AND THE SLOGANS OF THE BARROOMS, ALL THEY WILL DO IS MAKE THE ULTRA-RIGHT RESPECTABLE. THE CONSTITUTIONAL STATE MUST NOT ALLOW ITSELF TO BE BLACKMAILED BY TERRORISTS.

08195 SCHRODER, D.

THE EC MARCHES ON AT A LESS-THAN-GLORIOUS JUNCTURE GERMAN TRIBUNE, (1496) (DEC 91), 2-3.

THE EUROPEAN COMMUNITY IS TRYING TO TAKE THE GREATEST STEP FORWARD SINCE IT WAS FOUNDED AT A TIME WHEN EUROPE IS NOT AT ONE OF ITS HIGH POINTS. IN THE FIGHTING BETWEEN SERBIA AND CROATIA THE COMMUNITY HAS SHOWN ITSELF TO BE A PAPER TIGER, UNABLE TO END A WAR IN ITS OWN BACKYARD. THE COLLAPSE OF COMMUNISM HAS CHANGED THE WORLD. EUROPE IS NO LONGER DIVIDED BUT THE WORLD IS UNABLE TO COME TO TERMS WITH IT. THE THIRD WORLD IS UNABLE TO COPE WITH ITS PROBLEMS, PROBLEMS FOR WHICH EUROPE IS PARTLY TO BLAME, BUT THE COMHUNITY CHOOSES TO IGNORE THEM. IN ADDITION, EUROPEANS ARE INCREASINGLY COMING TO ADOPT A FORTRESS MENTALITY. GIVEN THESE DAUNTING PROBLEMS, IT IS LITTLE WONDER THAT LEADERS OF EC NATIONS HAVE REDUCED THEIR EXPECTATIONS OF WHAT WILL BE ACCOMPLISHED AT THEIR APPROACHING SUMMIT. DISAGREEMENTS OVER A COMMON EUROPEAN CURRENCY AND OVER FUTURE SECURITY AMD PROGRESS THAT HAS ALREADY BEEN MADE.

08196 SCHRODER, D.

UN NEEDS DEPUTIES WITH STAR, NOT MORALISERS

GERMAN TRIBUNE, (1526) (JUL 92), 1

UNTIL RECENTLY, THE TWO SUPERPOWERS WERE RELIED UPON AS NORLD POLICE. NOW, THE SOVIET UNION NO LONGER EXISTS, AND THE UNITED STATES IS A HORLD POLICE OFFICER ON CRUTCHES-COMPLETELY UNSUITED FOR CONFLICTS WHICH, SUCH AS THE FRATRICIDAL HAR IN YUGOSLAVIA, DO NOT AFFECT THEIR INTERESTS OTHER NATIONS MUST HAVE AN EVEN GREATER INTEREST IN ENABL ING INTERMATIONAL ORGANIZATIONS TO ASSUME THIS POLICING
ROLE AND TAKING ON THE TASK OF SETTLING CONFLICTS AND PROMOTING PEACE. THE INTERNATIONAL ORDER WHICH HAS EMERGED FOLLOWING THE END OF THE COLD WAR LEAVES THE MEDIUM SIZED POWERS, WHICH INCLUDE GERMANY, WITH NO OPTION BUT TO ASSUME MORE RESPONSIBILITY. THEREFORE, A CONSTITUTIONAL AMENDMENT AND A CORRESPONDING PREPARATION OF THE GERMAN ARMY IS VITAL.

08197 SCHROEDER, D.

ADAM SMITH ON FEUDALISM, COMMERCE AND SLAVERY

ADAM SMITH ON FEUDAL ISM, COMMERCE AND SLAVERY
HISTORY OF POLITICAL THOUGHT, 13(2) (SUM 92), 219-242.

THE INFLUENCE OF THE MATERIALIST INTERPRETATION OF ADAM SMITH'S TREATMENT OF HISTORY HAS BEEN WEAKEN BY WRITERS WHO HAVE OB JECTED TO THE NARROHING OF THE SCOPE FOR AN INDEPENDENT POL ITICAL AND JURISPRUDENTIAL SPHERE. THE AUTHOR ARGUES THAT THE READING OF SHITH WHICH ATTRIBUTES TO HIM A THEORY OF THE TRANSITION FROM FEUDALISM TO CAPITALISM, AND THE IMPLICATIONS WHICH FOLLOH FROM IT, ARE UNFOUNDED. ${ }^{H}$ CHALLENGES THREE KEY ASPECTS OF THE INTERPRETATION AND
EXAMINES THE MARXIAN INTERPRETATION, COMMERCE, AND LIBERTY.

08198 SCHROEDER, D.

POLITICAL PARTIES DRAW CLOSER ON EMOTIVE ISSUE OF ASYLUM GERMAN TRIBUNE, (1480) (AUG 91), 1-2.

THE PRESENCE OF SOME $113,000^{\circ}$ ASYLUM APPLICATIONS IN GERMANY IN 1991 HAS CAUSED GROWING DEBATE OVER THE FUTURE OF ARTICLE 16 OF GERMANY'S BASIC LAW, WHICH DEALS WITH THE LAW OF ASYLUM. GERMANY'S BORDERS WITH EASTERN EUROPE ARE NOW OPEN, AND, UNDER PRESSURE FROM THE PROBLEM AND THEIR VOTERS, THE CHRISTIAN AND SOCIAL DEMOCRATS ARE STARTING TO COME TOGETHER ON THE SUBJECT. THE PROBLEM IS NO LONGER MAINLY A MATTER OF POLITICAL ASYLUM. MORE THAN EVER IT HAS BECOME ONE OF A MIGRATION OF PEOPLES FROM THE POOR TO THE RICH PARTS OF THE HORLD. IN THIS TENSE SITUATION, ARTICLE 16 OF BASIC LAW, WHICH GRANTS PEOPLE POLITICALLY PERSECUTED THE RIGHT OF ASYLUM, IS IN SERIOUS DANGER. IT IS GROWING INCREASINGLY DIFFICULT TO SEPARATE FROM THE GROWING NUMBER OF ASYLUM APPLICANTS THE BONA FIDE POLITICAL CASES, WHO ACCOUNT FOR AN ESTIMATED 10 PERCENT OF THE TOTAL.

08199 SCHROEDER, $K$.

WESTERN FINANCIAL ASSISTANCE FOR REFORMS IN EASTERN EUROPE: CONDITIONS AND RISKS

AUSSEN POLITIK, 42(4) (1991), 326-343.

THE ELIMINATION OF THE PLANNED ECONOMY SYSTEM AND THE MOVE TOWARDS A MARKET ECONOMY CONFRONTS THE SOVIET UNION AND COUNTRIES IN EASTERN EUROPE WITH UNIQUE ADJUSTMENT PROBLEMS. IN AN EFFORT TO REDUCE THE DIFFICULTIES AND SHORTEN THE ADJUSTMENT PERIOD THESE COUNTRIES CALL FOR FRESH FINANCIAL
ASSISTANCE FROM THE WEST IN THE FORM OF EXTENSIVE CREDIT ASSISTANCE FROM THE WEST IN THE FORM OF EXTENSIVE CREDIT PROGRAMS. THIS ARTICLE EXAMINES THE CORRELATIONS WHICH EXIST BETHEEN EXTERNAL DEBT AND CREDIT STANDING ON THE

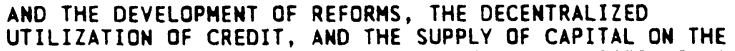
OTHER. ATTENTION ALSO' FOCUSES ON THE GROWING DIFFERENCES BETWEEN REFORMING COUNTRIES AS WELL AS ON THE CERTAINTIES REGARDING THE DURATION OF THE REFORM PHASE IN TERMS OF CREDIT AND DEBT POLICY REQUIREMENTS. IT ARGUES THAT THE REFORMING COUNTRIES ARE THREATENED BY A NEW OVERINDEBTEDNESS: DEBT SERVICING IS GROWING FASTER THAN EXPORTING CAPABILITIES; A NEW LENDING POLICY MUST BE DEVELOPED TO AVOID DEBT PROBLEMS OF A LATIN AMERICAN DIMENSION; AND GREATER IMPORTANCE MUST BE ATTACHED TO THE TRANSFER OF REAL CAPITAL THROUGH OIRECT INVESTMENTS THAN TO BORROWING.

08200 SCHROGL, K.

"SPACE BENEFITS"--A NEH ASPECT OF GLOBAL POLITICS

AUSSEN POLITIK, 42(4) (1991), 373-382.

WHEREAS THE SPACE POWERS--A CLUB CONSISTING OF THE INDIA. AND BRAZIL AS CANDIDATES WITH THE GREATEST CHANCE OF INDIA, AND BRAZIL AS CANDIDATES WITH THE GREATEST CHANCE OF AUTONOMY--REAP SUBSTANTIAL REWARDS FROM THE DEVELOPMENT OF SPACE TECHNOLOGIES, THERE IS A GROWING IMPRESSION AMONG THE MAJORITY OF DEVELOPING COUNTRIES THAT THEY ARE NOT RECEIVING THEIR FAIR SHARE OF THE BENEFITS OF CIVIL SPACE ACTIVITIES THE HOPES TO MAKE GREAT DEVELOPMENT LEAPS FORHARD HITH HELP OF COMNUNICATION, DIRECT BROADCASTING AND REMOTE
SENSING SATELLITES IN THE FIELDS OF INFRASTRUCTURE,

SENSING SATELLITES IN THE FIELDS OF INFRASTRUCTURE,
EDUCATION, FARMING AND THE EXPLOITATION OF MINERAL RESOURCES EDUCATION, FARMING AND THE EXPLOITATION OF MINERAL RESOURCES
FELL THROUGH BECAUSE OF THE LACK OF FUNDS TO CONSTRUCT THEIR FELL THROUGH BECAUSE OF THE LACK OF FUNDS TO CONSTRUCT THEIR OWN SATELLITES, HIRE SATELLITE LINKS OR PURCHASE DATA. THE
THIRD WORLD FEELS DEBARRED FROM THE USE OF OUTER SPACE. THIS THIRD WORLD FEELS DEBARRED FROM THE USE OF OUTER SPACE. THIS
SENSE OF BEING DISADVANTAGED AND DISCRIMINATED HAS NOW FOUND SENSE OF BEING DISADVANTAGED AND DISCRIMINATED HAS NOW FOUMC
ITSELF IN THE CATCHWORD "SPACE BENEFITS." THIS MOVEMENT ITSELF IN THE CATCHWORD "SPACE BENEFITS." THIS MOVEMENT TECHNOLOGY HAS GAINED COHERENCE AND MOMENTUM IN RECENT YEARS

08201 SCHROTH, R.A.

U.N. SANCTIONS IN IRAO

COMMONHEAL, CXIX (15) (SEP 92), 4-6

THE AUTHOR COMPARES THE JUSTICE AND EFFECTIVENESS OF INTERNATIONAL ECONOMIC SANCTIONS AGAINST SOUTH AFRICA WITH THE U.N./U.S. SANCTIONS AGAINST IRAO. HE DRAWS THREE CONCLUSIONS REGARDING IRAQ: (1) THERE IS LITTLE EVIDENCE 
THAT THE IRAQI PEOPLE PERCEIVE SADDAM, RATHER THAN THE USA OR THE UNITED NATIONS, AS THE SOURCE OF THEIR PAIN. THE IRAQI MAJORITY IS WILLING TO ADAPT TO THE HARDSHIPS CAUSED BY SANCTIONS. (2) THE IRAQI ELITE IS NOT SHAMED BY INTERNATIONAL DISAPPROVAL. SADDAM'S FAMILY AND HIS SUPPORTERS ARE GETTING RICH ON THE SHUGGLING AND BUSINESS OPPORTUNITIES CREATED BY SANCTIONS. (3) THE BUSH ADMINISTRATION ARGUED BEFORE OPERATION DESERT STORM THAT THE GOALS OF ITS "JUST HAR" TO LIBERATE KUWAIT COULO NOT BE ACHIEVED BY SANCTIONS ALONE. BY FAILING TO PURSUE IRAQ'S ARMY TO THE GATES TO BAGHDAD AND TO GIVE MILITARY SUPPORT TO THE KURD AND SHIITE REBELLIONS, WICH IT HAD IRRESPONSIBLY INVITED, THE BUSH ADMINISTRATION SIGNALED THAT IT PREFERRED A STABLE IRAQ GOVERHED BY SADDAM HUSSEIM TO A DISMEMBERED COUNTRY CONTROLLED BY KURDS AND IRAN-BACKED SHIITES.

08202 SCHROTT, P.R.; LANOUE, D.J.

HOW TO HIN A TELEVISED DEBATE: CAMDIDATE STRATEGIES AND YOTER RESPONSE IN GERMANY 1972-1987

BRITISH JOURNAL OF POLITICAL SCIENCE, 22(4) (OCT 92), 45-467

THE AUTHORS aNALYZE THE STRATEgIES CHOSEN bY CANDIDATES IN TELEVISED DEBATES AMD VOTER RESPONSES TO THOSE TACTICS. BASED ON GERMAN ELECTION CAMPAIGM DEBATES SINCE 1972 , THEY IDENTIFY A NUMBER OF DIFFERENT DEBATING STRATEGIES AND THE STRATEGIC CHOICES MADE BY EACH PARTY LEADER. EMPLOYING AGGREGATE-LEVEL DATA, THEY USE REGRESSION MODELS TO DETERMINE WHETHER OR NOT THE DEBATERS' STRATEGIES INFLUENCED VOTERS ' EVALUATIONS OF WHO WON AND WHO LOST EACH ENCOUNTER. THEY REPORT THREE MAJOR FINDINGS: (1) POSITIVE, NONATTACKING DEBATING STYLES GENERATE THE MOST FAVORABLE PUBLIC EVALUATIONS; (2) VOTERS ARE MOST ATTENTIVE TO CANDIDATES OISCUSSIONS OF THE PARTIES' AND GOVERNMENT'S RECORD RATHER THAN THEIR DISCUSSIONS OF INDIVIDUAL PERSONALITIES; AND (3) IN SOME CASES, THESE EFFECTS EXCEED THOSE OF PARTY IDENTIFICATION.

08203 SCHUBERT, D.

THE MISSED CHANCE: SOME COMMENTS ON THE RISE AND FALL OF THE RESEARCH ON EASTERM EUROPE IN THE GERMAN DEMOCRATIC REPUBLIC IN THE 1980'S

STUDIES IN COMPARATIVE COMMUNISM, XXV(3) (SEP 92), 303-310. THE AUTHOR REFLECTS ON THE STATUS OF RESEARCH ON EASTERM EUROPE IN THE GERMAN DEMOCRATIC REPUBLIC IN THE 1980's. HIS COMMENTS ARE BASED ON HIS EXPERIENCES AS SOMEONE WHO PARTICIPATED IN THIS RESEARCH AND WAS AFFECTED BY THE PARTICIPATED IN THIS RESEARCH AND WAS AFFECTED BY THE
DEVELOPMENTS AND DECISIONS THAT IMPINGED ON IT. HIS COMMENTS DEVELOPMENTS AND DECISIONS THAT IMPINGED ON IT. HIS COMMENTS
CONCERN THE OFFICIAL RESEARCH GUIDED BY THE SOZIALISTISCHE CONCERN THE OFFICIAL RESEARCH GUIDED BY THE SOZIALISTISCHE
EINHEITSPARTEI DEUTSCHLANDS AND CONDUCTED AT STATE RESEARCH EINHEITSPARTE
INSTI TUTES.

08204 SCHUDSON, M.

TROUT OR HAMBURGER; POLITICS AND TELEMYTHOLOGY

TROUT OR HAMBURGER; POLITICS AND

IKKUN, 6(1) (MAR 91), 47-51,86-87.
THIS ARTICLE EXAMINES THE CONTINUED "TELEMYTHOLOGY": A SET OF WIDELY CIRCULATED STORIES ABOUT THE DANGEROUS POHERS OF TELEVISION, HITH RESPECT TO POLITICS, THERE ARE THREE KEY ELEMENTS OF THAT MYTHOLOGY: KENNEDY DEFEATED NIXON IN 1960 BECAUSE HE PRESENTED A MORE ATTRACTIVE IMAGE IN THE FIRST TELEVISION DEBATE; TELEVISION'S GRAPHIC PORTRAYAL OF THE WAR IN VIETNAM SICKENED ANO HORRIFIED AMERICAN VIEHERS, WHO WERE LED BY HARD PHOTOGRAPHIC REALITY TO OPPOSE THE WAR; AND THE UNPRECEDENTED POPULARITY OF PRESIDENT REAGAN HAS NO RATIONAL EXPLANATION BUT CAN BE ACCOUNTED FOR ONLY BY THE PONER OF A SKILLED ACTOR MANIPULATING A VISUAL MEDIUM. THIS ARTICLE REEXAMINES THESE AND OTHER CLAIMS AND CONCLUDES THAT TELEVISION'S POWER IS OVERSTATED AT BEST. IT IS MORE THE BELIEF IN TELEVISION POWER AMONG THE PRESS THAT MAKES IT A INFLUENTIAL FORCE. THAN TELEVISION'S DIRECT EFFECT ON THE AUDIENCE.

08205 SCHUDSON, M.

HATERGATE: A STUDY IN MYTHOLOGY

COLUMBIA JOURNALISM REVIEW, 31(1) (MAY 92), 28-33.

IN THE 20 YEARS SINCE THE HATERGATE SCANDAL IT HAS BECOME A MAJOR MYTH OF MODERN JOURNALISM. BUT IT IS A MYTH THAT MUST BE SERIOUSLY CHALLENGED ON THREE POINTS: (1) DID THE PRESS AS AN INSTITUTION ACT COURAGEOUSLY TO KEEP POWER IN CHECK? (2) WAS THE PRESS UNAIDED IN ITS BATTLE AGAINST THE EVILS OF WATERGATE? OR WAS IT BUT ONE INSTITUTION AND ONE SET OF INDIVIDUALS AMONG MANY, INCLUDING CONGRESS AND THE COURTS, WHO MADE EQUALLY IMPORTANT CONTRIBUTIONS? (3) THE COURTS, WHO MADE EQUALLY IMPORTANT CONTRIBUTIONS? ( 3 ) ONLY BY ITS SENSE OF RESPONSIBILITY TO THE PUBLIC WELFARE?

08206 SCHUL ENBURG, 1.

GERMANY: SOLIDARITY AT A PRICE

JOURAAL OF HEALTH POLITICS, POLICY AND LAH, 17(4) (WIN 92), 715-738.

THE HEALTH CARE SYSTEM OF THE FEDERAL REPUBLIC OF GERMANY RELIES ON THE PRIVATE SECTOR FOR THE FINANCING DELIVERY, AND PAYMENT OF CARE. HOWEVER, THE PRIVATE SECTOR IS REGULATED BY THE GOVERNMENT TO ENSURE THAT BROAD SOCIETAL INTERESTS ARE BEING FULFILLED. THE SYSTEM HAS MANAGED TO
ACHIEVE COMPREHENSIYE COVERAGE AND EQUAL ACCESS FOR ALL CITIZENS, FREEDOM OF CHOICE FOR PATIENTS, HIGH-QUALITY SUCCESS IS A COMBINATION OF DECENTRALIZED POWER AND DECISION MAKING AND THE ESTABLISHMENT OF AN EFFECTIVE NEGOTIATION SYSTEM THAT TAKES PLACE AT FEDERAL, STATE, AND LOCAL LEVELS. THE SYSTEM SUFFERS FROM SOME PROBLEMS, HOWEVER, WHICH WILL HAVE TO BE ADDRESSED: THE PRESENT STRUCTURING OF HOSPITAL AND AMBULATORY CARE RESULTS IN EXCESSIVELY LONG LENGTHS OF STAY IN HOSPITAL; DRUGS ARE OVERPRESCRIBED; THE SUPPLY OF HEALTH PROFESSIONALS DOES NDT MEET THE COUNTRY;S NEEDS; MORE NURSING HOMES ARE NEEDED; AND EASTERN GERMANY MUST BE FULLY INTEGRATED INTO THE SYSTEM.

08207 SCHULL, J.

WHAT IS IDEOLOGY? THEORETICAL PROBLEMS AND LESSONS FROM SOVIET-TYPE SOCIETIES

POLITICAL STUDIES, XL (4) (DEC 92), 728-742.

THE ARTICLE CONTRASTS TWO APPROACHES TO IDEOLOGY WHICH VIEW IT, RESPECTIVELY, AS A BELIEF SYSTEM AND AS A FORM OF DISCOURSE, AND ARGUES FOR THE SECONO. VIEWING IDEOLOGY AS A BELIEF SYSTEM INVOLVES UNWARRANTED ASSUMPTIONS ABOUT THE AMD REDUES ITS CAUSAL POWER TO ITS CONTRNENT AN IDEOLOGY AND REDUCES ITS CAUSAL PONER TO ITS CONTINGENT CAPACITY TO CONDITION BELIEFS. VIEWING IDEOLOGY AS A DISCOURSE ENABLES A MORE ADEQUATE ACCOUNT OF THE DIVERSITY OF BELIEFS AMONG MEMBERS OF AN IDEOLOGICAL MOVEMENT AND ALSO LOCATES ITS CAUSAL POHER AT THE LEVEL OF SOCIAL CONVENTIONS RATHER THAN INDIVIDUAL PSYCHOLOGY. THE POWER OF IDEOLOGY IS BASED ON RESPECT, NOT FAITH. THIS THEORETICAL DISCUSSION IS LINED WITH THE CASE OF SOVIET-TYPE SOCIETIES, SERVING AS THE BASIS FOR A REINTERPRETATION OF IDEOLOGY'S ROLE IN THE MAINTENANCE AND MORE RECENT DECLINE OF THESE POLITICAL SYSTEMS.

08208 SCHULTZ, D.

AUSTRIA IN THE INTERMATIONAL ARENA: NEUTRALITY, EUROPEAN INTEGRATION AND CONSOCIATIONALISH

WEST EUROPEAN POLITICS, 15(1) (JAN 92), 173-200. THIS ARTICLE DISCUSSES THE RELATIONSHIP BETHEEN AUSTRIA'S INTERNATIONAL ENVIRONMENT AND ITS DISTINCTIVE PATTERN OF CENTRAL IZED, CO-OPERATIVE POLITICS DOMINATED BY THE POLITICAL PARTIES AND THE MAJOR INTEREST GROUPS. THROUGH AN EXAMINATION OF AUSTRIA'S NEUTRALITY AND INTEGRATION POLICIES, THE AUTHOR SUGGESTS THAT EXTERNAL FACTORS--AND PARTICULARLY AUSTRIA'S LOCATION ON A FAULTLINE OF THE COLD WAR--WERE INSTRUMENTAL IN THE DEVELOPMENT OF CONSOCIATIONAL PAR-TERE INSTRUMENTAL IN THE DEVELOPMENT OF CONSOCIAT POLICY. REDUCED EAST-WEST TENSIONS AND FURTHER INTEGRATION POLICY. REDUCED EAST-WEST TENSIONS AND FURTHER INTEGRATION POLICY OPIIONS, BUT WILL ALSO PROMOTE THE DECLINE OF CONSOCIATIONALISM BY REDUCING THE SOCIAL COHESIVENESS ON WHICH IT IS BASED.

08209 SCHULTZE, C.L.

THE ECONOWY: THREE PROBLEMS, NOT ONE BROOKINGS REVIEW, 10 (2) (SPR 92), 5

THE UNITED STATES' STALLED ECONOMIC RECOVERY IS A SERIOUS SETBACK, BUT IT IS ACTUALLY LESS SERIDUS THAN TWO OTHER LONGER-TERM PROBLEMS. THE FIRST PROBLEM IS SLUGGISH GROWTH IN NATIONAL PRODUCTIVITY, REAL HAGES, AND FAMILY INCOME. THE SECOND PROBLEM IS UNEOUAL INCOME DISTRIBUTION BECAUSE THE BURDEN OF SLOW ECONOMIC GRONTH IS NOT BEING SHARED EQUALLY. WHILE THE WEALTHY HAVE BEEN DOING OUITE WELL, MOST AMERICAN FAMILIES ARE LOSING GROUND OR RUNNING HARD JUST TO STAY IN PLACE.

08210 SCHULZ, 5 .

THE UNITY AND DISUNITY OF AN EVER-CHANGING EUROPE GERMAN TRIBUNE, (1524) (JUL 92), 5, 14

THIS ARTICLE BRIEFLY EXAMINES THE CHANGES IN BORDERS AND ALIGNMENTS AMONG THE NATIONS OF EUROPE DURING THE PAST CENTURY. IT THEN RECOUNTS THE GROWING MOVEMENT TOWARDS UNIFICATION AND INTEGRATION IN WESTERN EUROPE AND THE MORE RECENT INCREASE IN FORCES MOVING TOWARDS BREAK-UP AMD CONFLICT IN EASTERN EUROPE. IT ARGUES THAT WHILE UNITY IN EUROPE IS A POL ITICAL AND ECONOMIC NECESSITY, UNIFICATION AND INTEGRATION MUST COME ONLY AT A PACE WHICH WILL ALLOH THE NEWLY-FREED MATIONS OF EAST EUROPE TO DEYELOP A HEALTHY SENSE OF NATIONAL IDENTITY.

08211 SCHUMAN, H. RIEGER,

HISTORICAL ANALOGIES, GENERATIONAL EFFECTS, AND ATTITUDES TOWARD HAR

AMERICAY SOCIOLOGICAL REYIEW, 57 (3) (JUN 92), 315-326,

DURING THE PERSIAN GULF CRISIS, DEBATE IN THE USA OVER INITIATING WAR HITH IRAQ OFTEN REVOLVED AROUND THO ANALOGIES FROM THE PAST--WORLD WAR II AND THE VIETNAM HAR--WITH THE PARTICIPANTS' VIEWS BEING COLORED BY THE EXPERIENCE OF THEIR GENERATION. ALONG WITH THREE OTHER THEORETICAL CONDITIONS THIS DEBATE PROVIDES AN UNUSUAL OPPORTUNITY TO DEVELOP AND ASSESS IMPORTANT IMPLICATIONS OF MANMHEIM'S THEORY OF GENERATIONAL EFFECTS. NATIONAL DATA GATHERED BEFORE AND HAD A SIGNIFICANT EFFECT ON WHICH ANALOGY WAS CHOSEN AS MORE 
RELEVANT AND THAT THE CHOSEN ANALOGY HAD, IN TURN, A STRONG RELATION TO SUPPORT FOR OR OPPOSITION TO' THE WAR. ' HOWEVER, THE TRANSLATION OF GENERAT IONAL EXPERIENCE INTO FINAL SUPPORT OR OPPOSITION IS WEAK, AND
REASONS FOR THIS WEAK CORRELATION.

08212 SCHUTT, R.; GARRETT, G.

RESPONDING TO THE HOMELESS: POLICY AND PRACTICE

PLENUM PRESS, 1992, 258.

A PRESPECTIVE ON THE PROBLEM OF HOMELESSNESS IS DERIVED FROM THE AUTHORS' SHARED EXPERIENCE WITH RESEARCHERS,

ACADEMICS, STUDENTS, PROVIDERS, POLICYMAKERS, AND HOMELESS

PERSONS THEMSELVES. SCHUTT AND GARRETT TAKE THE READER INTO

THE SHELTERS AND ACQUAINT HIM OR HER WITH THE PHILOSOPHICAL AND PRACTICAL DILEMMAS FACING LINE HORKERS AS WELL AS POLICYMAKERS. THIS VOLUME INCLUDES CLEAR DESCRIPTIONS OF THE POLICYMAKERS. THIS VOLUME INCLUDES CLEAR DESCRIPTIONS OF
PROCESS OF COUNSELING AND CASE MANAGEMENT FORM HOMELESS PROCESS OF COUNSELING AND CASE MANAGEMENT FORM HOMELESS INDIVIDUALS. IT ALSO INCLUDES CURRENT RESEARCH FINDINGS,
PROGRAMS DESCRIPTIONS, CASE STUDIES, AND VIGNETTES. THE AUTHORS DRAH UPOH HISTORY, EXPERIENCES, AND EMPIRICAL DATA TO PRODUCE A REFERENCE WORK THAT WILL HAVE PRACTICAL TO PRODUCE A
APPLICATION.

08213 SCHWARTZ, D.C.; BARTELT, D.W.; FERLAUTO, R.; HOFFMAN, D.N.; LISTOKIN, $D$.

A NEW URBAN HOUSING POLICY FOR THE 1990'

JOURNAL OF URBAN AFFAIRS, $14(3-4)(1992), 239-262$.

THE AUTHORS OUTLINE A PLAN FOR FEDERAL INVESTMENT IN U.S. CITIES. THEY INCLUDE SPECIFIC PROPOSALS FOR CREATION OF A NATIONAL HOUSING INVESTMENT CORPORATION TO PROVIDE EQUITY FOR HOME OWNERSHIP PROJECT DEVELOPMENT; NEW LAWS TO ENCOURAGE PENSION-FUND INVESTMENT IN URBAH HOUSING AND ENCOURAGE EMPLOYER-ASSISTED HOUSING; ENHANCED RENTAL CORPORATIONS: A NATIONAL LAW TO COMBAT HOMELESSNESS; A NEW TRANSITIONAL HOUSING PROGRAM FOR THE HOMELESS; AND HOUSINGWITH-NEEDED-SERVICES PROGRAMS FOR THE ELDERLY, HANDICAPPED, ANO HOMELESS. THE AUTHORS EXPLAIN HOW URBAN GOVERMMENTS COULD BETTER ENFORCE PROPERTY MAINTENANCE CODES, TAKE OVER ABANDONED PROPERTY, ADOPT PLANNING PROCESSES THAT ENHANCE HOUSING AFFORDABILITY, ENCOURAGE HISTORIC PRESERVATION, AND INVEST ADOITIONAL CITY FUNDS IN HOUSING.

08214 SCHWARTZ, J.; GRIFFITH, J.; WOOD, L.

THE IMPACT OF MILITARY LIFE ON SPOUSE LABOR FORCE OUTCOMES

ARMED FORCES AND SOCIETY, 17(3) (SPR 91), 385-408,

THIS ARTICLE FOCUSES ON THE IMPACT OF ARMY LIFE ON

SPOUSE (WIFE) EMPLOYMENT OUTCOMES. SPOUSE EMPLOYMENT IS THOUGHT TO BE AN IMPORTANT DETERMINANT OF A SOLDIER'S COMMITMENT TO THE ARMY, JOB PERFORMANCE, AND REENLISTMENT DECISION. USING 1985 INDIVIDUAL-LEVEL DEPARTMENT OF DEFENSE SURVEY DATA, THE AUTHORS EXAMINE THE UNDERLYING DETERMINANTS OF ARMY HIVES LABOR FORCE PARTICIPATION, EMPLOYMENT, LEVE OF EMPLOYMENT, AND UNDEREMPLOYMENT, WITH A FOCUS ON THE POLECT OF ON-POST SPOUSE EMPLOYMENT PROGRAMS AND OTHER ARMY POLICIES ON THESE OUTCOMES. THE RESULTS SUGGEST THAT SPOUSE
EMPLOYMENT PROGRAMS, EDUCATION, LENGTH OF TIME SPENT AT THE EMPLOYMENT PROGRAMS, EDUCATION, LENGTH OF TIME SPENT SAME LOCATION, AND A CONTINENTAL U.S. LOCATION HAVE A OUTCOMES.

08215 SCHHARTZ, J.T

AMERICA'S ECONOMIC-TECHNOLOGICAL AGENDA FOR THE 1990'S DAEDALUS, 121(1) (WIN 92), 139-165.

SOME 'LEADING MEMBERS OF THE UNITED STATES' TECHNOLOGICAL COMMUNITY ARE CONCERNED ABOUT THE IMPAIRMENT OF U.S.

TECHNICAL, INDUSTRIAL, AND FINANCIAL COMPETITIVENESS. THEY BELIEVE THAT THE TRADE DEFICIT HAS THE POTENTIAL TO UNDERMINE THE USA'S INTERNATIONAL ROLE, DEFENSIBILITY, DEMOCRATIC STABILITY, AMD EVEN INDEPENOENCE IF NOT BROUGHT UNDER CONTROL. BUT CLASSICALLY-MINDED ECONOMISTS TEND TO VIEW U.S. ECONOMIC FIGURES HITH EQUANIMITY, SEEING IN THEM LITTLE MORE THAN ANOTHER TEMPORARY AND READILY REVERSIBLE. ALBEIT LARGE-SCALE, MOVEMENT IN A PERPETUALLY SHIFTING WORLD TRADE BALANCE. TO MANY IN DEFENSE AND INDUSTRIAL CIRCLES, THESE SAME FIGURES TELL A FEARSOME TALE OF ABRUPT NATIOMAL DECLINE THAT THREATENS TO BECOME IRREVERSIBLE. THEIR VIEH REFLECTS AN ANGUISHED DICHOTOMY. ON THE ONE HAND, THEY SEE A SELF-CONFIDENT SOCIETY THAT POSSESSES GREAT MILITARY FORCE AS WELL AS POLITICAL, CULTURAL, AND MORAL INFLUENCE WORLDWIDE. AT THE SAME TIME, THEY FEAR THAT, DUE TO A WORLDWIDE. AT THE SAME TIME, THEY FEAR THAT, DUE TO A DEFECTIVE SENSE OF NATIONAL SELF-INTEREST, ECONOMICIDEOLOGICAL FIXATIONS, OVERCONSUMPTION, AND UNCHECXED CONGRESSIONAL REGIONALISM, U.S. SOCIETY MAY LOOSE ITS
PREEMINENCE AND ALLOW OUTSIDERS TO GAIN CONTROL OVER KEY PREEMINENCE AND ALLOW OUTSIDERS TO GAIN CONTROL
SECTORS OF ITS ECONOAY AND NATIONAL DESTINY.

08216 SCHHARZ, A.

CHARISMASTIC ENIGMA

FAR EASTERN ECONOMIC REVIEW, 155(45) (NOV 92), 34-36. THIS ARTICLE EXAMINES THE RISE TO POWER, THE IDEDLOGY, AND THE FUTURE OF ABDURRAHMAN WAHID, THE LEADER OF THE LARGEST MUSLIM ORGANIZATION IN INDONESIA, THE HORLD'S
LARGEST MUSLIM COUNTRY. HE LEADS THE NAHOLATUL ULAMA (NU),
AN ORGANIZATION HHOSE NAME MEANS "THE RISE OF THE RELIGIOUS TEACHERS." IT IS A TRADITIONAL, CONSERVATIVE, RURAL-BASED SOCIO-CULTURAL ORGANIZATION OF SOME 25-30 MILLION MUSLIM INDONESIANS. BUT WAHID HIMSELF IS MODERN IN OUTLOOK, LIBERAL IN APPROACH, AND VERY MUCH AN URBAN INTELLECTUAL. HE ESPOUSES MODERATION, INDIVIDUALISM, AND DEMOCRACY IN AN AUTHORITARIAN COUNTRY WHERE ISLAMIC FUNDAMENTALISM BECOMES EVER MORE POWERFUL. THE BELIEFS OF NU MEMBERS MIX FREELY WITH NON-MUSLIM BELEIFS, WITH JAYANESE MYSTICISM AMD WITH REMNANTS OF THE HINDU CULLTURE THAT PREDATE THE ARRIVAL OF ISLAM IN JAVA.

08217 SCHWARZ, A.

DEATH HARRANT

FAR EASTERN ECONOMIC REVIEW, 151(24) (JUN 91), 13.

THREE DAYS OF OFTEN CONTENTIOUS TALKS THAT ENDED ON 4

JUNE FAILED TO BRIDGE FUNDAMENTAL DIFFERENCES BETWEEN RIVAL CAMBODIAN FACTIONS ON HOW TO BRING PEACE TO THE WAR-TORN COUNTRY. SOME HOPE FOR PROGRESS FLICKERED ON THE FIRST DAY OF THE TALKS WHEN HEN SUN AND PRINCE NORODOM SIHANOUK, TITULAR HEAD OF THE RESISTANCE COALITION, AGREED ON A
FORMULA FOR LEADING THE SUPREME NATIONAL COUNCIL (SNC), A 12FORMULA FOR LEADING THE SUPREME NATIONAL COUNCIL ISNC
MEMBER BODY EOUALLY SPLIT BETWEEN PHNOM PENH AND IHE MEMBER BODY EQUALLY SPLIT BETWEEN PHNOM PENH AND THE
RESISTANCE. CAMBODIANS AGREE THAT THE NATION'S SOVEREIGNTY RESTS WITH THE SNC. BUT THE KHMER ROUGE, WHO ARE HELD RESPONSIBLE FOR THE DEATHS OF AS MANY AS ONE MILLOM CAMBODIANS DURING THEIR 1975-79 RULE, QUICKLY SCUTTLED THE PLAN. THE END RESULT IS A DEADLOCK WHICH WILL BE BROKEN ONLY BY A SHOW OF MUCH MORE FLEXIBILITY ON THE PART OF ALL THE CAMBODIAN FACTIONS.

08218 SCHWARZ, A.

DOUBLE-EDGED SWORD

FAR EASTERN ECONOMIC REVIEW, 155(10) (MAR 92), 10.

AN INDONESIAN MILITARY COMMISSION HAS DISCIPLINED SIX SENIOR OFFICERS AND SAID EIGHT OTHERS SOLDIERS WOULD BE COURT-MARTIALED FOR THEIR ROLE IN THE KILLING OF AT LEAST FIFTY YOUTHS IN EAST TIMOR ON 12 NOVEMBER 1991. WHILE THE COMMISSION'S REPORT IS LIKELY TO DAMPEN INTERMATIONAL CRITICISM OF INDONESIA'S HANDLING OF THE TIMOR KILLINGS, THE VERDICTS HAVE ALSO TRIGGERED UNEASE AMONG THE MILITARY.' IN ADDITION, WESTERN DIPLOMATS AND HUMAN-RIGHTS ORGANIZATIONS ADOI ITION, WESTERN DIPLOMATS AND HUMAN-RIGHTS ORGANIZATIONS
SAY THEY ARE WORRIED BY SIGNS THAT THE ARMY IS PREPARING TO SAY THEY ARE WORRIED BY SIGNS THAT THE ARMY IS PREPARING
CLOSE EAST TIMOR TO FOREIGN JOURNALISTS AND TOURISTS TO CLOSE EAST TIMOR TO FOREIGN JOURNALIS
PRELUDE A RENEWED MILITARY CRACKDOWN.

08219 SCHWARZ, A.; WISE, P.

MADOENING SILENCE
FAR EASTERN ECONOMIC REVIEH, 155(4) (JAN 92), 11. INDONESIA'S RELATIONS WITH THE EUROPEAN COMMUNITY ARE BEING STRAINED BY THE COMPUNITY'S LACK OF RESPONSE TO INDONESIAN EFFORTS TO AMELIORATE HUMAN RIGHTS ABUSES IN EAST TIMOR, THE PORTUGUESE COLONY JAKARTA ANNEXED IN 1976. INDONESIAN AND EUROPEAN DIPLOMATS BLAME THE INACTION ON PORTUGAL, HHICH ASSUMED THE EC PRESIDENCY ON 1 JANUARY AND IS DETERMINED NOT TO LET THE EAST TIMOR ISSUE FADE AWAY. MANY GOVERNHENTS GIVE JAKARTA HIGH MARKS FOR TAKING POLITICALLY DIFFICULT STEPS TO DISCIPLINE THE ARMY. BUT THE EC'S REFUSAL TO ACKNOWLEDGE THIS IS CAUSING ILL-WILL AMONG MANY IN THE FOREIGN POLICY ESTABLISHMENT AND DOES NOT HELP THOSE IN THE GOVERNMENT PUSHING FOR MORE SENSITIVITY ON HUMAN RIGHTS ISSUES.

08220 SCHWARZ, A.

PAUSE FÓR MEW GROWTH

FAR EASTERN ECONOMIC REVIEW, 151(16) (APR 91), 33-35.

SEVERAL STRONG YEARS OF ECONOMIC GROWTH HAS TRANSFORMED INDONESIA'S NATIONAL MOOD FROM DEEP-SEATED ANXIETY TO CAUTIOUS OPTIMISM. A WHOLESALE OVERHAUL OF ECONOMIC POLICY IN THE MID TO LATE 19805 PRODUCED UNEXPECTEDLY ROBUST GROWTH IN 1988-90. BY DISMANTLING LAYERS OF SUFFOCATING REGULATIONS AND ALLOHING THE PRIVATE SECTOR TO EMERGE AS THE MAIN ENGINE OF GROWTH, THE GOVERNMENT WAS LEFT WITH AN ECONOMY FAR MORE INSULATED FROM THE VAGARIES OF INTERNATIONAL OIL PRICES. BUT SUCCESS BREEDS ITS OWH PROBLEMS. INDONESIA'S PHYSICAL INFRASTRUCTURE IS REELING FROM THE HIGHER DEMANDS PUT ON IT. THE COUNTRY'S LEGAL AND EDUCATIONAL SYSTEMS ARE FALLING EVEN FUE COUNTRY'S LEGAL AND EDUCATIONAL SYSTEMS ARE FALLING EVEN PRIVATELY HELD WEALTH HAS BROUGHT TO THE FOREFRONT ETHNIC AND REGIONAL RIVALRIES AND CHALLENGED THE NATION'S RELIGIOUS AND REGIONAL RIVALRIES AND CHALLENGED THE NATION'S RELIGIOUS
UNDERPINNINGS. INDONESIA MIST CONFRONT THESE ISSUES BEFORE MOVING ON TO THE NEXT STAGE OF GROWTH.

08221 SCHWARZ, A.

PRESSURES OF HORK

FAR EASTERN ECONOMIC REYIEW, 151(25) (JUN 91), 14-16.

GROWING DISSATISFACTION AMONG INDONESIA'S WORKERS, THE CENTRAL IF OFTEN OVERLOOKED ACTORS IN THE COUNTRY'S FOURYEAR, EXPORT-LED ECONOMIC BOOM, IS BEGINNING TO TAKE ON A MORE STRIDENT TONE AND POSE BOTH A POLITICAL AND ECONOMIC CHALLENGE FOR THE GOVERMMENT, LOCAL BUSINESS, AND FORE INVESTORS. AN UPSURGE IN STRIKES, HORK STOPPAGES AND INCREASING. ANALYSTS ARGUE THAT COMPLAINTS OF LOW WAGES AND 
POOR WORKING CONDITIONS HAVE SOWN THE SEEDS OF A MORE RADICALIZED MOVEMENT. THE GOVERMMENT--STILL REGARDING UNIONS AS COMMUNIST-INSPIRED BOOIES MORE INTERESTED IN POLITICS THAN PROTECTING WORKERS--HAS DECLARED ITS DETERMINATION TO
PREVENT ORGANIZED LABOR FROM EITHER DISTURBING THE CONTINUED FLOW OF FOREIGN INVESTMENT OR FROM BECOMING A POLITICAL FORCE IN ITS OWN RIGHT.

08222 SCHWARZ, A.; VATIKIOTIS, M.

SEE YOU IN RIO

FAR EASTERN ECONOMIC REVIEW, 156(22) (JUN 92), 60-61. BEHIND THE DEBATES THAT HILL TAKE PLACE IN RIO ARE TWO VERY DIFFERENT VIEWS OF THE WORLD--DIFFERENCES NEATLY CAPTURED BY THE LANGUAGE OF THE THO MAIN CAMPS. AMONG INDUSTRIALIZED NATIONS (THE NORTH), THE BUZZWORD IS CONSERVATION. PRESSED BY LOBBY GROUPS AND WORR IED CITIZENS, THE NORTH WANTS TO REVERSE THE POISONING OF LAND AND OCEANS AND LIMIT THE INDUSTRIAL EMISSIONS AND FOREST-CLEARANCE THAT ARE ALTERING THE EARTH'S ATMOSPHERE AND CLIMATE. BUT FOR THE POORER NATIONS (THE SOUTH), THE FOCUS IS ON "SUSTAINABLE DEVELOPMENT." THEY FEAR THAT ENVIRONMENTAL PROTECTIONS, DEVELOPMENT." THEY FEAR THAT ENVIRONMENTAL PROTECTIONS,
HRONGLY APPLIIED, WILL HOLD BACK THEIR EFFORTS TO MAINTAIN ECONOMIC GROWTH. THEY FEAR THAT CONSTRAINTS COULD TRAP THE SOUTH EVER MORE FIRMLY IN THE CYCLE OF POVERTY, THAT IS ULTIMATELY THE REAL DESTROYER OF THE ENVIRONMENT. IN RIO, THEREFORE, THE SOUTH HOPES TO MAKE A DEAL: AGREEMENT TO NEH
ENVIRONMENTAL PROTECTION MEASURES IN RETURN FOR NOTHING LESS ENVIRONMENTAL PROTECTION MEASURES IN RETURN FOR NOTHING LESS
THAN A TRANSFORMATION OF THE WORLD'S ECONOMIC AND TRADING THAN A
SYSTEM.

08223 SCHWARZ, A.

STRAINS OF GROWTH

FAR EASTERN ECONOMIC REVIEW, 155(13) (APR 92), 33.

INDONESIA IS STRUGGLING MIGHTILY TO SYNCHRONIZE THE DIFFERENT PARTS OF ITS CHANGING ECONOMY. USING BOTH MONETARY AND FISCAL MEASURES, POLICYMAKERS ARE TRYING TO PUT THE ECONOMY ON A MORE EVEN KEEL AND REDRESS THE IMBALANCES CREATED BY UNEXPECTEDLY RAPID GROWTH IN 1989-90. BUT BEHIND THE MACROECONOMIC STATISTICS LIES A MORE HORRYING PICTURE. SOME AREAS OF THE ECONOMY--LIKE BANKING--HAVE GROWN TOO FAST, WHILE OTHERS--LIKE AGRICULUTRE--HAVE LAGGED. ECONOMISTS AND INVESTORS SAY THE GOVERMMENT MUST CONTINUE HITH, AND ACCELERATE, THE PROCESS OF REFORMING THE ECONOMY IF CONSOLIDATION INTO ONE OF LONG-TERM SUSTAINED GRONTH. A FURTHER CONCERN IS HOW LONG IMDONESIA WILL BE ABLE TO PRESS AHEAD WITH A MODERN, EXPORT-ORIENTED ECONOMY WITHOUT A CONCOMITANT RELAXATION OF POLITICAL RULES.

08224 SCHWARZ, A.

SUHARTO'S DILEMMA

FAR EASTERH ECONOMIC REVIEW, 154(52) (JAN 92), 9-10.

THE INDONESIAN GOVERMMENT, REELING UNDER AH INTERNATIONAL UPROAR OVER THE FATAL SHOOTING OF TIMORESE YOUTHS ON 12 NOVEMBER 1991, IS IN A DILEMMA. PRESIDENT SUHARTO MUST SOON ANNOUNCE WHETHER A GOVERNMENT SPONSORED INQUIRY INTO THE KILLINGS HAS CORROBORATED THE OFFICIAL BUT WIDELY CONTRADICTED ACCOUNT OF THE INCIDENT OR HAS DEVIATED FROM IT. THE INVESTIGATION TEAM COULD ENDORSE THE OFFICIAL LINE--THAT INDONESIAN SOLDIERS FIRED IN SELF-DEFENSE ON AN UNRULY MOB OF INDEPENOENCE-SEEKING DEMONSTRATORS IN EAST TIMOR, KILLING 19 AND WOUNDING 89. THIS APPROACH WILL ALMOST CERTAINLY DISRUPT RELATIONS HITH SEVERAL WESTERN COUNTRIES AND JEOPARDIZE AID AND INVESTMENT FLONS. ON THE OTHER HAND, IF THE TEAM'S REPORT IS CLOSER TO EYEWITNESS ACCOUNTS--THA THE ARMY OPENED FIRE UNPROVOKED ON UNARMED DEMONSTRATORS, KILLING AS MANY AS 100--IT WOULD APPEASE WESTERN OBSERYERS BUT IT COULD ALSO SET OFF A MATIONALIST BACKLASH, DEMORALIZE THE ARMED FORCES AND POSSIBLY COMPLICATE SUHARTO'S AMBITIONS TO SEEK ANOTHER TERM AS PRESIDENT.

08225 SCHWARZ, A.

TILTING AT WIMDMILLS

FAR EASTERN ECONOMIC REVIEW, 155(14) (APR 92), 10-11.

INDONESIA HAS REJECTED ALL AID FROM THE NETHERLANDS AND DISBANDED THE 24-YEAR-OLD INTER-GOVERMMENTAL GROUP ON INDONESIA (IGGI), A 14-MEMBER AID CONSORTIUM CHAIRED BY THE DUTCH WHICH PROVIDES GRANTS AND CHEAP LOANS TO THE COUNTRY. THE MOVE REPRESENTS INDONESIA'S STRONGEST MOVE TO DATE AGAINST ATTEMPTS BY WESTERN DONORS TO LINK HUMAN RIGHTS CONCERNS AND OTHER CONDITIONS TO AID. INDONESIA'S MOVE IS UNLIKELY TO HAVE SERIOUS ECONOMIC IMPLICATIONS. WHILE CONTINUED FLOWS OF AID ARE CRITICAL TO THE COUNTRY'S SHORTTERM PROSPERITY, JAKARTA'S DECISION TO DISSOLVE IGGI SHOULD TERM PROSPERITY, JAKARTA'S DECISION TO DISSOLVE IGGI SHOULD
NOT HAVE A MATERIAL IMPACT ON FUTURE AID COMMITMENTS. THE ROT HAVE A MATERIAL IMPACT ON FUTURE AID COMMITMENTS. THE REJECTION OF DUTCH AID MAY WELL PROVE TO BE A POLITICAL WHICH MUST CONTEND PARL IAMENTARY ELECTIONS ON 9 JUNE. SOME WHICH MUST CONTEND PARL IAMENTARY ELECTIONS ON 9 JUNE. SOME
SAY THAT A DOSE OF DUTCH-BASHING WILL HELP HIS NATIONALIST SAY THAT A DOS
CREDENTIALS.

08226 SCHWARZ, G

AID INSTEAD OF TRADE

SHISS REYIEW OF WORLD AFFAIRS, 41(10) (JAN 92), 4-5.
IN DECEMBER 1990, THE FOREIGN MINISTERS OF THE EUROPEAN COMMISSION GAVE THE GREEN LIGHT FOR NEGOTIATING TREATIES OF ASSOCIATION WITH POLAND, HUNGARY, AND CZECHOSLOVAKIA. THE NEGOTIATIONS WERE INTENDED TO BIND THE THREE REFORM-MINDED, FORMER EAST BLOC STATES MORE CLOSELY TO THE WEST AND TO HELP THEM ALONG THE ROAD TO A MARKET ECONOMY BY CREATING CONDITIONS FOR FREE, OR NEARLY FREE, TRADE. BUT PROGRESS ON THE LATTER GOAL HAS PROVED DIFFICULT. THE NEGOTIATIONS WERE SCHEDULED TO BE COMPLETED BY LATE OCTOBER 1991, BUT THERE HERE DELAYS AND THE AGREEMENTS WERE NOT DRAFTED UNTIL A MONTH LATER. THE TREATIES HILL GO INTO EFFECT ON MARCH 1 1992, ON AN INTERIM BASIS. THE EXPERIENCE DEMONSTRATES ONCE AGAIN WHAT A TOUGH TIME THE WESTERN INDUSTRIAL NATIONS HAVE WITH FREE TRADE.

08227 SCHHARZ, G.

GERMANY AS A MAGHIFYING GLASS

SHISS REVIEH OF WORLD AFFAIRS, 42(9) (DEC 92), 24-25.

IN THEIR RUSH TOWARD REUNIFICATION, GERMAN LEADERS APPARENTLY UNDERESTIMATED THE ENORMITY OF THE TASK. BRINGING THE EAST GERMAN ECONOMY UP TO PAR IS PROVIMG TO $B E$ THE EAST GERMAN ECONOMY

08228 SCHWEDLER, J.

EARLY ELECTIONS IN THE WEST BANK AND GAZA

MIDDLE EAST INSIGHT, VIII(6) (JUL 92), 5-9

THE OUESTION OF ELECTIONS IN THE WEST BANK AND GAZA CANMOT BE FULLY EXAMINED WITHOUT EXPLORING THE LARGER ISSUES STALLING THE NEGOTIATIONS AND PLAGUING THE PEACE PROCESS. THERE IS A SURPRISING LACK OF DEBATE ON THE POTENTIAL FO EARLY ELECTIONS TO PROPEL THE DIALOGUE OVER OUTSTANDING ISSUES. VIENING ELECTIONS ONLY AS A RESULT OF PEACEFUL, NEGOTIATED SETTLEMENT IGNORES THE POTENTIAL FOR EARLY ELECTIONS TO SERVE AS AN IMPETUS RATHER THAN A CONSEQUENCE.
IN SPITE OF THE FUNDAMENTAL DIFFERENCES BETWEEN THE PALESTINIAN AND ISRAELIS APPROACHES TO THE PEACE PROCESS, THERE MAY BE SUFFICIENT COMMON GROUND TO PROCEED WITH ELECTIONS IN THE OCCUPIED TERRITORIES BEFORE THE PEACE PROCESS REACHES CLOSURE.

08229 SCHWEIGLER, G.

STRATEGIC ASPECTS OF A UNITED GERMANY

JERUSALEM JOURNAL OF INTERNATIONAL RELATIONS, 14(2) (JUN $92)$, 68-89.

THE UNIFICATION OF GERMANY PROVIDED FOR BOTH STABILITY AND THE POSSIBILITY OF CHANGE IN REGARD TO GERMANY'S STRATEGIC SITUATION. STABILITY WAS ACHIEVED THROUGH THE UNIFICATION PROCESS ITSELF, WHICH SAN THE ESTABLISHMENT OF A WEST GERMANY WRIT LARGE. EXTERNAL AGREEMENT TO UNIFICATION WEST GERMANY WRIT LARGE. EXTERNAL AGREEMENT TO UNI HAS OBTAINED THROUGH THE ACCEPTANCE OF CONSTRAINTS
PERTAINING TO GERMANY'S BORDERS AND ITS MILITARY STRENGTH. PERTAINING TO GERMANY'S BORDERS AND ITS MILITARY STRENGTH.
CHANGE WILL BECOME NECESSARY AS GERMANY HAS TO FACE NEW CHANGE WILL BECOME NECESSARY AS GERMANY HAS TO FACE NEW RESPONSIBLITIES IN A DRASTICALLY CHANGED EUROPE; BUT THE
MAJOR ASPECT OF A UNITED GERMANY HILL BE STABILITY IN CHANGE.

08230 SCHWELLER, R.L. DOMESTIC STRUCTURE AND PREVENTIVE WAR: ARE DEMOCRACIES MORE PACIFIC?

HORLD POLITICS, 44(2) (JAN 92), 235-269.

REALISTS HAVE LONG VIEWED UNEVEN RATES OF GROWTH AMONG STATES AS A MAJOR CAUSE OF HARS. ACCORDING TO THE STRICT LOGIC OF REALPOLITIK, A DECLINING DOMINANT POWER SHOULD LAUNCH A PREVENTIVE WAR AGAINST A RISING CHALLENGER AS A PRUDENT LONG-TERM SECURITY STRATEGY. BUT, HISTORICALLY, POWER SHIFTS HAVE ONLY SOMETIMES RESULTED IN WAR. ALTHOUGH PREVENTIVE WAR HAS BEEN THE PREFERRED RESPONSE OF DECLINING AUTHORITARIAN LEADERS, NO DEMOCRACY HAS EVER INITIATED SUCH A WAR. INSTEAD, DEPENDING ON THE REGIME TYPE OF THE RISING CHALLENGER, DEMOCRATIC STATES HAVE CHOSEN ACCOMMODATION, DEFENSIVE ALLIANCES, OR INTERNAL BALANCING TO SOLVE THE PROBLEM OF IMPENDING DECLINE. IN ADDITION TO ESTABLISHING THE CORRELATION BETWEEN PREVENTIVE HAR AND AUTHORITARIAN REGIMES AND EXPLAINING HHY DEMOCRATIC STATES SHUN THIS OPTION, THIS ESSAY (1) DEYELOPS A MOOEL BASED ON DOMESTIC STRUCTURES OF THE LEADER AMD CHALLENGER THAT PREDICTS WHICH STRATEGY HILL BE EMPLOYED BY A DECLINING DOMINANT POHER AND (2) TESTS IT AGAINST HISTORICAL SURVEY DATA AND SEVERAL INDEPTH CASE STUDIES.

08231 SCHWENMINGER, S.R.

REINVIGORATING THE GLOBAL ECONOMY

WORLD POLICY JOURNAL, IX(3) (SUM 92), 429-448.

THE CURRENT CRISIS IN THE WORLD ECONOMY REFLECTS AN UNFINISHED TRANSITION IN THE HORLD ECONOMIC ORDER--FROM A URILATERAL TO A MULTILATERAL ORDER--THAT IS AS POTENTIALLY SIGNIFICANT FOR WORLO PEACE AS THE END OF THE COLD HAR ITSELF. THIS ARTICLE OUTLINES MEASURES THE UNITED STATES CAN TAKE TO REINVIGORATE THE GLOBAL ECONOMY AND FACILITATE THE TRANSITION TO A MULTILATERAL ORDER. THESE MEASURES INCLUDE: HORK WITH THE INTERNATIONAL MONETARY FUND (IMF) TO SUP
ONETIME ISSUE OF SPECIAL DRANING RIGHTS BY THE IMF: ENCOURAGE THE WORLD BANK TO EXPAND AND FRONTLOAD ITS LENDING OVER THE NEXT YEAR; BEGIN AN INITIATIVE TO EXPAND CURRENT DEBT RELIEF EFFORTS TO INCLUDE MULTILATERAL DEBT FORGIVENESS 
AND ENCOURAGE A SLOWER TRANSITION TO A MARKET ECONOMY IN EASTERN EUROPE AND THE FORMER SOVIET UNION.

08232 SCIOLI, F.P. JR.; CAMPBELL, J.E.

NSF FUNDING OPPORTUNITIES FOR POL ITICAL SCIENCE RESEARCH PS: POLITICAL SCIENCE AND POLITICS, XXV(2) (JUN 92), 259-261.

THERE ARE THO REASONS TO BE OPTIMISTIC ABOUT FUTURE NSF FUNDING FOR POLITICAL SCIENCE RESEARCH AND TO ENCOURAGE POL ITICAL SCIENTISTS TO SEEK NSF SUPPORT. THE FIRST IS THAT THE POLITICAL SCIENCE PROGRAM AT NSF HAS DONE OUITE WELL OVER THE LAST FEW YEARS. THE SECOND IS THAT THERE ARE OVER THE LAST FEW YEARS. THE SECOND IS THAT THERE ARE
OPPORTUNITIES FOR FUNDING AT NSF THAT POLITICAL SCIENTISTS OPPORTUNITIES FOR FUNDING AT NSF THAT POLITICAL SCIENTISTS HAVE YET TO EXPLOIT FULLY-DERHAPS BECAUSE THEY ARE

08233 SCIORTINO, G.

IMMIGRATION INTO EUROPE AND PUBLIC POLICY: DO STOPS REALLY

NEW COMMUNITY, 18(1) (OCT 91), 89-99.

USING ITALY AS A CASE STUDY, THE AUTHOR ASKS WHETHER ATTEMPTS TO STOP IMMIGRATION CAN EVER BE EFFECTIVE. HE ALSO LOOKS AT HOW STRICT IMMIGRATION CONTROLS AFFECT MIGRAN MINORITIES ALREADY LIVING IN A COUNTRY.

08234 SCOBELL, A.

WHY THE' PEOPLE'S ARMY FIRED ON THE PEOPLE: THE CHINESE MILITARY AND TIANANMEN

ARMED FORCES AND SOCIETY, 18(2) (WIN 92), 193-214.

THE PEOPLE'S LIBERATION ARMY (PLA) PLAYED THE DECISIVE

ROLE IN CRUSHING THE 1989 STUDENT PRODEMOCRACY MOVEMENTS IN THE PEOPLE'S REPUBLIC OF CHINA. THIS ARTICLE EXPLORES THE ACTUAL PROCESS BY WHICH THE PLA BECAME INVOLVED IN THE CRISIS WHICH LED TO THE OPEN FIRE ON CRONDS AND SUCCEEDED IN ENDING THE DEMONSTARTIONS AT A COST OF HUNDREDS OF DEATHS AND THOUSANDS OF INJURIES. THE ARTICLE SUGGESTS THAT THE PLA'S INVOL VMENT IN THE INCIDENT HAS RESULTED IN A MARKED DECLINE IN PUBLIC PRESTIGE AND A DROP IN MORALE. IT CONCLUDES THAT THERE IS A GOOD LIKELIHOOD OF AN EVENTUAL ARMY-PARTY SPLIT.

08235 SCOTT, J.T.

THE THEODICY OF THE "SECOND DISCOURSE": THE PURE STATE OF NATURE AND ROUSSEAU'S POLITICAL THOUGHT

AMERICAN POLITICAL SCIENCE REVIEH, 86(3) (SEP 92), 696-711.

SINCE ROUSSEAU SCIENCE REVIEH, 86(3) (SEP 92), 696-71. SINCE ROUSSEAU, AND PERHAPS BECAUSE OF HIM, POLITICAL THEORY HAS OFTEN BEEN CHARACTERIZED BY A OISJUNCTION BETWEEN CONSIDERATIONS OF HUMAN NATURE AND QUESTIONS OF JUSTICE AND LAH. REEXAMINING THE "SECOND DISCOURSE" AS A THEODICY FORCES SCHOLARS TO RETHINK HOW THE ESSENTIAL QUESTIONS OF POLITICAL THEORY ARE RELATED JUST WHERE THEY SEEM TO BECOME SEPARATED. THE CORE OF THE THEOOICY IS ROUSSEAU'S VIEW THAT MEN ARE, BY
NATURE, PHYSICAL BEINGS EMBEDDED UNPROBLEMATICALLY IN NATURENATURE, PHYSICAL BEINGS EMBEDDED UNPROBLEMATICALLY IN NAT -GOOD, OR ORDERED, BEINGS IN A GOOD, OR ORDERED, WHOLE. AS A JURIDICAL DOCTRINE SEEMINGLY SEPARATED FROM HIS UNDERSTANDING OF HUMAN NATURE AND HISTORY, HIS POLITICAL THOUGHT IS FOUNDED UPON HIS PORTRAIT OF MAN'S EXISTENCE IN THE PURE STATE OF NATURE. THIS PORTRAIT SERVES AS A POSITIVE FORMAL MODEL TO ENABLE MAN TO REMAKE HIS CORRUPTED EXISTENCE THROUGH THE LEGITIMATE STATE-ITSELF MODELED BY ROUSSEAU ON THE DIVINE OR NATURAL WHOLE.

08236 SCOTT, L.

SPIRIT OF THE AGE OR GHOST FROM THE PAST? LABOUR AND NUCLEAR DISARMAMENT IN THE 1990S

POLITICAL QUARTERLY (THE), 62(2) (APR 91), 193-203.

THIS PAPER EXAMINES THE LABOUR PARTY'S NEW APPROACH TO

UNILATERAL NUCLEAR DISARMAMENT, AND IN PARTICULAR THE POLICY

ON BRITISH STRATEGIC NUCLEAR WEAPONS. IT ANALYZES THE

COMMITMENT TO EL IMINATE POLARIS AND TRIDENT THROUGH

STRATEGIC ARMS NEGOTIATIONS, THE MILITARY ROLE OF THE

BRITISH TRIDENT AMD WHETHER AMBIGUITIES IN POL ICY CALL INTO

DROU T THE POL

DISARMAMENT. IT ARGUES THAT HILE IT IS RIGHT TO PLACE

THOUGHT NEEDS TO BE GIVEN TO WHAT CAN BE ACHIEVED BY THIS

POLICY.

08237 SCOTT, L.

TARGETING TRIDENT IN ARMS MEGOTIATIONS

ARMS CONTROL, 12(1) (MAY 91),82-93.

THE AIM OF THIS ARTICLE IS TO EXAMINE HHETHER AND HOW THE BRITISH "TRIDENT" FORCE SHOULD BE INCLUDED IN START -2 NEGOTIATIONS, AMD WHAT THIS MIGHT ACHIEVE. IT EXPLORES BRITAIN'S GROWING STRATEGIC NECLEAR CAPABIL ITY ARGUMENTS FOR BRITISH PARTICIPATION IN STRATEGIC ARMS TALLS, A BRITISH ROLE IN ENHANCING STRATEGIC STABILITY, TRADING TRIDENT, AND IMPLICATIONS FOR BRITISH NUCLEAR STRATEGY. IT CONCLUDES THAT WHETHER BRITAIN WILL NEED NUCLEAR WEAPONS AT ALL IN THE NEXT CENTURY IS A QUESTION THAT GOES WELL BEYOND THIS ARTICLE.

08238 SCOTT, M.

WAR AND MEMORY
FAR EASTERN ECONOMIC REVIEW, 155(15) (APR 92), 36-38.

THE PEOPLE OF CAMBBODIA, FACING A FRAGILE PEACE AND AN UNCERTAIN FUTURE, ARE BEING FORCED TO COME TO GRIPS WITH THE LEGACY (AND THE CONTINUED EXISTENCE) OF POL POT AND THE KHMER ROUGE. THE GOVERNMENT-SPONSORED HISTORY EMPHASIZES POL POT'S GENOCIDAL POLICIES WITHOUT EXAMINING THE CONTEXT OR CAUSES OF THE TRAGEDY. SOME CAMBODIANS, NOTABLY UNIVERSITY STUDENTS, ARE BEGINMING TO CAL FOR AM EXAMIMATION OF THE COMPLEX HISTORICAL LANDSCAPE THAT GAVE RISE TO THE KHMER ROUGE--FRENCH COL VIETNAM WAR, U.S. BOMBS, AND THE NURTURING OF AN AGGRIEVED, ANGRY NATIONALISM WHICH WAS WELDED TO A COMMUNIST AGENDA FOR CREATING A NEW SOCIETY. THIS STRUGGLE OVER THE PAST, OVER CREATING A NEW SOCIETY. THIS STRUGGLE OVER THE PAST, OVER
WHAT WILL BE THE COLLECTIVE MEMORY OF THE KHMER ROUGE PERIOD WHAT WILL BE THE COLLECTIVE MEMORY OF THE KHMER ROUG
IS ONE OF THE MOST IMPORTANT SUBTEXTS OF CAMBODIA'S IS ONE OF THE
REAHAKENING.

08239 SCONCROFT, B.

EISENHOWER AND A FOREIGN POLICY AGENDA

PRESIDENTIAL STUDIES QUARTERLY, XXIII(3) (SUM 92), 451-454. THE AUTHOR DISCUSSES THE CHALLENGES, OPPORTUNITIES, AND RESPONSIBILITIES OF U.S. FOREIGN POLICY IN THE EISENHOWER ERA AND TODAY. IN THE FORMER PERIOD, THE USA WAS DESCENDING FROM THE OPTIMISM AND HOPE ENGENDERED BY THE END OF WORLD WAR II AND HAD ENTERED THE CONFRONTATION OF THE COLD WAR. TODAY THE SITUATION IS REVERSED FROM CONFRONTATION TO OPTIMISM AND HOPE. STILL, THE USA TODAY NEEDS THE CHARACTERISTICS OF EISENHOWER'S LEADERSHIP, WHICH EMPHASIZED THAT AMERICA MUST NOT WITHDRAW FROM THE WORLD BUT MUST MAINTAIN ITS INTERNATIONAL LEADERSHIP.

08240 SCULLY, G.; SLOTTJE, D.

RANKING ECONOMIC LIBERTY ACROSS COUNTRIES

PUBLIC CHOICE, 69(2) (FEB 91), 121-152.

THE PURPOSE OF THIS PAPER IS TO CONSTRUCT SOME AGGREGATE INDEXES OF ECONOMIC LIBERTY AND TO OEMONSTRATE HOW RELATIVE RANKINGS OF LIBERTY BETWEEN COUNTRIES WILL VARY, CONTINGENT ON HOW RELATIVE INFORMATION ABOUT LIBERTY, FROM INDIVIDUAL LIBERTY INDICATORS, IS AGGREGATED AND WEIGHTED. THE PAPER PROVIDES A SENSITIVITY ANALYSIS DEMONSTRATING HOW HORLD RANKINGS OF LIBERTY VARY AS THE WAY THE INFORMATION IS RUMMARIZED.

08241 SCULLY, G.

RENT-SEEKING IN U.S. GOVERNMENT BUDGETS, 1900-88 PUBLIC CHOICE, 70(1) (APR 91), 99-106.

THIS ARTICLE CALCULATES A MEASURE OF HASTE FROM THE COMPETITIVE RENT-SEEKING ACTIVITY OF SPECIAL INTEREST GROUPS IN FEDERAL, STATE, AND LOCAL BUDGETS OVER THE PERIOD 1900-88. THIS PERIOD IN U.S. FISCAL HISTORY IS CHARACTERIZED BY CONSTITUTIONAL CHANGES THAT HAVE MADE FOR MORE TRANSPARENCY IN GOVERMMENTAL FISCAL ACTIVITIES AND FOR GREATER DIFFUSION OF TAXES. AS A RESULT, OPPORTUNITIES FOR RENT-SEEKING
THROUGH BUDGETARY REALLOCATIONS ROSE IN THE UNITED STATES

08242 SCULLY, L.

CIVIL WRONGS

NATIONAL REVIEW, XLIV(10) (MAY 92), 22-28.

OF ALL THE WARREN COURT'S LANDMARK DECISIONS, NONE DID

MORE THAN MAPP $\checkmark$. OHIO TO CHANGE THE BALANCE OF AMERICAN

CRIMINAL LAW--IN FAVOR OF THE CRIMINALS. THIS ARTICLE ARGUES THAT THE "CASE WAS A COUNTERFEIT PASSED OFF BY THE ACLU." THE MAPP V. OHIO RULING APPLIED THE EXCLUSIONARY RULE--ИHICH BARS THE USE OF EVIDENCE SAID TO HAVE BEEN ILLEGALLY OBTAINED--TO STATE COURT PROCEEDINGS. THE ARTICLE REEXAMINES THE CASE AND CONCLUDES THAT THE EXISTENCE OF A SEARCH WARRANT (A KEY ELEMENT IN THE CASE) HAS MEVER CHALLENGED IN THE ORIGINAL TRIAL.

08243 SEARING, D.D.

ROLES, RULES, AND RATIONALITY IN THE NEW INSTITUTIONALISH AMERICAN POLITICAL SCIENCE REVIEH, 85(4) (DEC 91), 1239-1260.

THE AUTHOR ENDEAVORS TO REINVIGORATE THE STUDY OF POLITICIANS' ROLES BY SHOWING HOW MOTIVATIONAL ROLE THEORY CAN BE USED TO EXAMINE THE IMPACT OF GOALS AND INCENTIVES UPON BEHAVIOR AND THEREBY INTEGRATE ECONOMIC AND SOCIOLOGICAL PERSPECTIVES. HE ADDRESSES THREE REASONS FOR THE RECENT NEGLECT OF POLITICIANS' ROLES--CHANGES IN

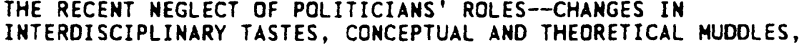
INTERDISCIPLINARY TASTES, CONCEPTUAL AND THEORETICAL MUDDLES,
AND FAILURE TO DEMONSTRATE CONSEQUENCES FOR BEHAVIOR--AND AND FAILURE TO DEMONSTRATE CONSEQUENCES FOR BEHAVIOR--AND
FINDS THEM UNCONVINCING. HE ARGUES THAT THE MOST PROMISING FINDS THEM UNCONVINCING. HE ARGUES THAT THE MOST PROM
FRAMENORK FOR THE NEW INSTITUTIONALISM IS ONE THAT FRAMEWORK FOR THE NEW INSTI ITUTIONALISM IS ONE THAT INCORPORATES BOTH FORMAL AND INFORMAL INSTITUTIONAL IMCORPORATES, RATHER THAN EXCLUDES, POLITICAL BEHAVIOR.

08244 SEARS, A.

AIDS AND THE HEALTH OF NATIONS: THE CONTRADICTIONS OF PUBLIC HEALTH

CRITICAL SOCIOLOGY, 18(2) (SUM 91), 31-50.

THE PUBLIC HEALTH RESPONSE TO AIDS HAS GENERALLY REFLECTED A "HEALTH FROM ABOVE" PERSPECTIVE THAT CASTS THE STATE AS THE KEY ACTOR IN PROTECTING THE HEALTH OF THE 
COMAUNITY. THIS CONSTRUCTION OF AIDS HAS BEEN CHALLENGED BY ACTIVISTS EMERGING LARGELY FROM THE LESBIAN AND GAY MOVEMENT. THIS CHALLENGE PRESENTS GLIMPSES, IN AN INCIPIENT FORM, OF POLITICS OF "MEALTH FROM BELOW" THAT LOCATES THE STRUGGLE FOR HEALTH AS PART OF THE FIGHT FOR CONTROL OVER OUR BODIES DEBATES ABOUT ANONYMOUS TESTING FOR HIV ANTIBODIES.

08245 SEARS, D. ; FUNK, C.

GRADUATE EDUCATION IN POLITICAL PSYCHOLOGY

OLITICAL PSYCHOLOGY, 12 (2) (JUN 91), 345-362.

DATA ARE PRESENTED FROM A SURVEY OF GRADUATE COURSES AND GRADUATE TRAINING PROGRAMS IN POLITICAL PSYCHOLOGY IN THE UNITED STATES AND CANADA. COURSES LABELED "POLITICAL PSYCHOLOGY" ARE OF RELATIVELY RECENT VINTAGE AND ARE OFFERED MOST OFTEN IN POL ITICAL SCIENCE DEPARTMENTS. THEY GEMERALLY DO NOT COVER THE ENTIRE FIELD, BUT FOCUS ON ONE OF THREE MAJOR AREAS: MASS POLITICAL BEHAVIOR, PERSONALITY AND POLITICS, OR THE PSYCHOLOGY OF INTERNATIONAL RELATIONS. MOST MAJOR POL ITICAL SCIENCE DEPARTMENTS NOW OFFER COURSES IN MAJOR POLITICAL SCIENCE DEPARTMENTS NOW OFFER COURSES IM
POLITICAL PSYCHOLOGY, THOUGH A CRITICAL MASS OF FACULTY POLITICAL PSYCHOLOGY, THOUGH A CRITICAL MASS OF FACULTY
EXISTS IN ONLY ABOUT' 14 UNIVERSITIES. SEVEN FORMALIZED EXISTS IN ONLY ABOUT 14 UNIVERSITIES. SEVEN FORMALIZED
DOCTORAL TRAINING PROGRAMS EXIST WITH MULTIPLE COURSES AND DOCTORAL TRAINING PROGRAMS EXIST WITH MULTIPLE COURSES AND
FACULTY, MOST QUITE RECENT IN ORIGIN AND MOST ARE DISTINCTLY FACULTY, MOST QUITE RECENT IN ORIGIN AND MOST ARE DISTINCTLY
INTERDISCIPLIMARY. DOCTORAL STUDIES IN POLITICAL SCIENCE OR INTERDISCIPLIMARY. DOCTORAL STUDIES IN POLITICAL SCIENCE OR
PSYCHOLOGY CAN SPECIALIZE IN POLITICAL PSYCHOLOGY, BUT NO PSYCHOLOGY CAN SPECIALIZE IN POLITICAL PSYCHOLOGY, BUT NO
FREE-STANDING INTERDISCIPLINARY DEGREE PROGRAMS CURRENTLY FREE-STA
EXIST.

08246 SEBENIUS, J.

CHALLENGING CONVENTIONAL EXPLANATIONS OF INTERNATIONAL COOPERATION: NEGOTIATION ANALYSIS AND THE CASE OF EPISTEMIC COMMUNITIES

INTERNATIONAL ORGANIZATION, 46(1) (WIN 92), 323-366 ANALYSES OF INTERNATIONAL POLICY COOPERATION ARE OFTEN MARKED BY ANALYTIC AND EMPIRICAL CONFUSION. THIS ARTICLE DESCRIBES THE EMERGING NEGOTIATION-ANALYTIC APPROACH AND ARGUES THAT IT PROVIDES A USEFUL FRAMEWORK WITHIN WHICH CONCEPTUAL PROBLEMS CAN BE AVOIDED AND EXPLANATORY POWER CAN BE ENHANCED. FROM A NEGOTIATION-ANALYTIC PERSPECTIVE, IT ARGUES, EPISTEMIC COMMUNITIES CAN BE VIEWED AS DISTINCTIVE DE FACTO NATURAL COALITIONS OF BELIEVERS WHOSE MAIN INTEREST LIES IN EXPANDING TO BECOME WINNING COALITIONS CAPABLE OF ENSURING THE ADOPTION OF SPECIFIC POLICY PROJECTS. THE ARTICLE CONCLUDES THAT THE EFFECTS OF SHARED BELIEFS AND OF POLICY CONFLICT CAN BE READILY INCORPORATED INTO THE NEGOTIATION-ANALYTIC MODEL OF BARGAINING, THEREBY GIVING NEGOTIATION-ANALYTIC MODEL OF BARGAINING, THEREBY GIV
RISE TO MORE PRECISELY DRAWN OBSERVATIONS ABOUT THE RISE TO MORE PRECISELY DRAWN OBSERVATIONS ABOUT THE
CONDITIONS UNDER WHICH BELIEVERS WILL HAVE THE STRONGEST CONDITIONS UNDER WHICH BELIEVERS WILL HAVE THE STRONG POSSIBLE TO IMPROVE POLICY PRESCRIPTIONS IN THE ACTUAL OR POSSIBLE TO IMPROVE POLICY PRESCRIPTIONS IN
POTENTIAL PRESENCE OF EPISTEMIC COMMUNITIES

08247 SEBENIUS, $J$.

DESIGNING NEgOTIATIONS TOWARD A NEW REGIME: THE CASE OF GLOBAL WARMING

INTERNATIONAL SECURITY, 15(4) (SPR 91), 110-148.

POPULAR AND SCIENTIFIC CONCERN HAS BEEN RISING ABOUT THE POSSIBILITY THAT HUMAN ACTIVITIES WILL RESULT IN DAMAGING GLOBAL CLIMATE CHANGE. AT PRESENT, THERE IS NO INTERNATIONAL REGIME TO ADDRESS GLOBAL CLIMATE CHANGE, BUT IMPENDING NEGOTIATIONS TOWARD WORLDWIDE AGREEMENT' TO RESTRICT DAMAGING ACTIVITIES MAY CONSTITUTE THE BEGINNING OF ONE. TWO CONDITIONS FOR THE FUNDAMENTAL TASK ARE: THAT EACH MEMBER OF THE COALITION SEE ENOUGH GAIN IN THE REGIME, RELATIVE TO THE ALTERNATIVES, TO ADHERE, AND THAT POTENTIAL AND ACTUAL "BLOCKING" COALITIONS OF INTERESTS OPPOSED TO THE REGIME ARE PREVENTED FROM FORMING OR ARE NEUTRALIZED. THIS ARTICLE DRAWS ON CONCEPTS FROM THE FIELD OF "NEGOTIATION ANALYSIS" TO ORGANIZE THE KEY OUESTIONS OF NEGOTIATION DESIGN WHOSE ANSWERS WILL INFLUENCE HOW AND WHETHER THESE THO CONDITIONS WILL BE MET.

08248 SEDGHI, H,

THE PERSIAN GULF WAR: THE NEN INTERNATIONAL ORDER OF DISORDER?

NEW POLITICAL SCIENCE, 21-22 (SPR 92), 61-68.

TO ESTABLISH THAT THE UNITED STATE'S EMPIRE IS WELL AND ALIVE MILITARILY IS THE INTENT OF THE AUTHOR. HAMIDEH SEDGHI PRESENTS AN INTERPRETATION OF THE NEW WORLD ORDER WITHIN THE CONTEXT OF PAX-AMERICANA. BY DRAWING ON THE U.S. - LED INYATSION OF IRAO THE CDNCERN IS WITH THE NEH GIOBAL INVATSION OF IRAQ THE CONCERN IS WITH THE NEH GLOBAL
DIVISION OF POWER BASED ON THE EROSION OF EAST/WEST DIVISION OF POHER BASED ON THE EROSION OF EAST/WEST CONFION. ALSO ADORESSED IS THE PERSIAN GULF WAR IN VIEH OF TENSION. ALSO ADDRESSED IS THE PERSIAN GULF WAR IN VIEN OF
THE DECLINING ECONOMIC POSITION OF THE U.S. VIS-A-VIS JAPAM THE DECLINING

08249 SEEGERS, A.

CURRENT TRENDS IN SOUTH AFRICA'S SECURITY ESTABLISHMENT ARMED FORCES AND SOCIETY, 18(2) (WIN 92), 159-174.

THREE SECURITY TRENDS IN A TRANSITIONAL SOUTH AFRICA ARE

ASSESSED: THE ROLE OF THE POLICE, THE MILITARY'S RELATIONS

TO STATE POHER, AND HHAT HAS NOT HAPPENED. ALTHOUGH THE
MILITARY'S CONFIDENCE REMAINS HIGH, ITS GRIP ON STATE POWER HAS BEEM WEAKENED. THAT THE CAUSES OF TRENDS NOW COINCIDE WITH A NEW POLITICAL WILL, HAS CONVINCED MANY SOUTH AFRICANS THAT MINORITY RULE WILL END SOON. CIVILIAN LEADERSHIP HAS FAILED TO ACT FULLY ON EVIDENCE OF SCANDALOUS BEHAVIOR BY MEMBERS AND UNITS OF THE SECURITY ESTABLISHMENT. ALTHOUGH IT
COULD BE ARGUED THAT THIS FAILURE IS EXPLAINED BY THE FEAR COULD BE ARGUED THAT THIS FAILURE IS EXPLAINED BY THE FEAR THAT THE TRANSITION TO MAJORITY RULE WILL BE RUINED AT THE DEMOCRACY IN THE LONG RUN.

08250 SEEGERS, A.

SA'S SECURITY FORCES

SOUTH AFRICA FOUNDATION REVIEW, 1818) (AUG 92), 3.

SINCE FEBRUARY 1990, THE SOUTH AFRICAN DEFENCE FORCE

(SADF) AND THE SOUTH AFRICAN POLICE (SAP) HAVE BEEN AT THE

CENTER OF THE REFORM PROCESS IN SOUTH AFRICA. FEW OTHER

STATE INSTITUTIONS HAVE COME UNDER AS MUCH PRESSURE. BOTH

INSTITUTIONS BEAR THE IMPRINT OF PAST PRACTICES AND POLICIES

BUT MUST NOW OPERATE UNDER NEW RULES. WHAT HAS ONCE REQUIRED OR INDULGED IS INCREASINGLY EXPOSED, CRITICIZED, AND UNPROTECTED.

08251 SEEKINGS, J

\$TRAILING BEHIND THE MASSES': THE UNITED DEMOCRATIC FRONT AND TOWNSHIP POLITICS IN THE PRETORIA-HITHATERSRAND-VAAL REGION, 1983-84

JOURNAL OF SOUTHERN AFRICAN STUDIES, 18(1) (MAR 92),

THE FORMATION OF THE UNITED DEMOCRATIC FRONT (UDF) IN SOUTH AFRICA IN MID-1983 WAS FOLLOHED IN 1984 BY AN ESCALATION OF TOWNSHIP PROTESTS, ESPECIALLY IN THE PRETORIAWITHATERSRAND-VAAL REGION. THIS ARTICLE ARGUES THAT DURING THE PERIOD FROM 1983 TO EARLY 1985 THE UDF HAD ONLY AN INDIRECT IMPACT ON TOWNSHIP POLITICS IN THIS REGION. THE UDF'S LACK OF DIRECT INVOLVEMENT IS ATTRIBUTED TO THE INITIAL CHARACTER OF THE UDF AS AN ORGANIZATION FORMED TO TAKE UP NATIONAL POLITICAL ISSUES WHICH IMMEDIATELY AND PRIMARILY AFFECTED COLOURED AMD INDIAN AREAS, WHEREAS THE ESCALATING TOWNSHIP PROTESTS PRIMARILY CONCERNED LOCAL ISSUES IN AFRICAN TOWNSHIPS.

08252 SEEKINS, $D$.

JAPAN'S' AID RELATIONS WITH MILITARY REGIMES IN BURMA, 19621991

ASIAN SURVEY, XXXII(3) (MAR 92), 245-262.

BECAUSE OF CONSTUTIONAL LIMITATIONS ON THE USE OF MILITARY FORCE, OFFICIAL DEVELOPMENT ASSISTANCE HASE BECOME MILITARY FORCE, OFFICIAL DEVELOPMENT ASSISTANCE HASE BECOME THE JAPANESE GOVERMMENT'S PRINCIPAL MEANS OF EXERTING IT
INFLUENCE ABROAD. BURMA REPRESENTS AND INTERESTING CASE STUDY OF JAPANESE AID POLICY IN ACTION. SINCE THE 1950S, STUDY OF JAPANESE AID POLICY IN ACTION. SINCE THE 1950S, ASSISTANCE. INITIALLY RELUCTANT TO ACCEPT LARGE AMDUNTS OF ASSISTANCE. INITIALL RELUCTANT TO ACCEPT LARGE AMDUNTS OF 1962 TO 1988, EVENTUALLY DEPENDED UPON IT TO PROP UP THE 1962 TO 1988 , EVENTL
TROUBLED ECONOMY

08253 SEEKS, $H$

CELEBRATING THE BEGINNING OF CHANGE

CULTURAL SURVIVAL QUARTERLY, 16(3) (FAL 92), 56-58.

CANADIAN INDIANS WANT THE GOVERMMENT TO PROTECT INDIAN RIGHTS AT HOME, JUST AS IT ADVOCATES HUMAN RIGHTS ABROAD. IN THIS INTERVIEN WITH CHIEF WILI SEEKS, ON OF THE HEREDITARY CHIEFS OF THE GITKSAN. A NATION OF ABOUT 6,000 INDIANS IN BRITISH COLUMBIA, CANADA, HE TELLS HOW IT HAPPENED THAT HE GOT INVOLVED WITH PROTESTING SPAIN'S 500 YEARS CELEBRATION AND HOW HE, AMONG OTHERS, BOARDED THE COLUMBUS EXPEDITION TO DEMAND AN APOLOGY. THE GOVERNMENT OF SPAIN AGREED TO APOLOGIZE AND TO FLY THE INDIAN'S FLAG AT EVERY PROT THEY ENTERED.

08254 SEETHAL, C.

RESTRUCTURING THE LOCAL STATE IN SOUTH AFRICA: REGIONAL SERVICES COUNCILS AND CRISIS RESOLUTION

POL ITICAL GEOGRAPHY QUARTERLY, 10(1) (JAN 91), 8-25. THIS PAPER FOCUSES ON THE CURRENT CRISIS IM SOUGHT AFRICA AND THE STATE;S ATTEMPT TO DEFUSE IT BY RESTRUCTURING THE LOCAL STATE. CENTRAL TO THE DISCUSSION ARE THE NEW METROPOLITAH REGIONAL SERYICES COUMCILS (RSCS)-FIRST ESTABL ISHED IN 1987. THE PAPER EXPLAINS THE RATIONALE TO INCORPORATE THE DISENFRANCHISED CONSERVATIVE BLACK MAJORITY AT THE LOCAL LEVEL OF DECISIONMAKING. IT ALSO ASSESSES THE AT THE LOCAL LEVEL OF DECISIONMAKING. IT ALSO ASSESSES THE THE LOWER TIERS OF GOVERNMENT. A BRIEF EXPLORATORY CASE THE LOWER TIERS OF GOVERNMENT. A BRIEF EXPLORATORY CASE STUDY IS MADE OF THE RESPONSE OF THE KWAZULU HOMELAND GOVERNMENT TO THE INTROOUCTION OF THE RSCS. THE PAPER UTILIZES POULANTZAS' DIALECTICAL STRUCTURAL VIEW OF THE STATE AND ITS APPARATUS IN EXPLICATING THE APARTHEID STATE IN DEALING HITH THE FUNDAMENTAL CONTRADICTIONS GIVING RISE TO THE CURRENT CRISIS IN SOUTH AFRICA IS ADDRESSED.

08255 SEGAL, G.

CHINA AND AFRICA 
ANNALS OF THE AMERICAN ACADEMY OF POLITICAL AND SOCIAL SCIENCE, 519 (JAN 92), 115-126.

IT IS HARD TO ARGUE THAT AFRICA MATTERS VERY MUCH TO CHINA. ALTHOUGH THE AFRICAN COUNTRIES CONSTITUTE ROUGHLY ONEQUARTER OF ALL U.N. MEMBERS AND ABOUT HALF OF ALL DEVELOPING STATES, THEY MATIER LITTLE IN THE OVERALL SCHEME OF CHINESE FOREIGM POLICY OBJECTIVES. TO BE SURE, THERE HAVE BEEN TIMES WHEN CHINA WAS LESS INTERESTED IN THE APPROVAL OF THE INTERNATIONAL COMMUNITY AND ITS RHETORICAL SUPPORT FOR AFRICAN CAUSES APPEARED TO SUGGEST THAT AFRICA WAS IMPORTANT TO CHINA. BUT THE RHETORIC ABOUT AFRICA HAS NOT BEEN SUPPORTED BY REAL INITIATIVES, ESPECIALLY SINCE THE LATE SUPPORTED BY REAL INITATIVES, ESPECIALLY SINCE THE LATE
1970 'S, WHEN CHINA BEGAN TO SEEK PROSPERITY THROUGH GREATER $1970 ' 5$, WHEN CHINA BEGAN TO SEEK PROSPERITY THROUGH GREATER
PARTICIPATION IN THE GLOBAL MARKET ECONOMY. AN EXAMINATION PARTICIPATION IN THE GLOBAL MARKET ECONOMY. AN EXAMINATION
OF THE RECORD CAN HELP IDENTIFY THE PRIORITIES OF CHINESE OF THE RECORD CAN HELP IDENTIFY THE PRIORITIES OF CHINESE FOREIGN POLICY AND SEPARATE THE
LOFTY RHETORIC REGARDING AFRICA.

08256 SEGAL, G.

CHINA AND THE DISINTEGRATION OF THE SOVIET UNION ASIAN SURVEY, XXXII (9) (SEP 92), 848-868.

MO SINGLE EXTERMAL EVENT HAS HAD AS MUCH IMPACT ON THE PEOPLE'S REPUBLIC OF CHINA AS THE DISINTEGRATION OF THE SOVIET UNION. THIS ARTICLE SETS OUT A RANGE OF ISSUES TO BE CONSIDERED AS CHINA REACTS TO THE BREAK-UP OF THE SOVIET UNION AND THE TRANSFORMATION OF THE HORLD FOLLOWING THE COLD WAR. IT CONSIDERS IMPLICATIONS FOR DOMESTIC POL ICY INCLUDING CHINA'S DRIVE TO "PUT PROSPERITY FIRST," TO "SECURE STABILITY," AND TO "RETHIMK SOVEREIGNTY." IT ALSO CONSIDERS IMPLICATIONS FOR EXTERNAL RELATIONS INCLUDING A REDUCED RUSSIAN THREAT AND GROWING THREATS IN CENTRAL ASIA. IT MAKES SOME GENERAL CONCLUS IONS ABOUT A NEW BALANCE OF POWER IN ASIA, AND CONCLUDES WITH AN EXAMINATION OF CHINA'S INCREASING REGIOMAL AND GLOBAL WEAPOMS TRANSFERS.

08257 SEGAL, G.

MANAGING NEW ARMS RACES IN THE ASIA/PACIFIC

HASHINGTON QUARTERLY, 15(3) (SUM 92), 83-102.

DESPITE A GLOBAL TREND TOWARDS REDUCED ARMS SALES AND

TRANSFERS, THERE IS EVIDENCE THAT THE ARMS RACE IS EXPANDING IN THE ASIA/PACIFIC REGION. IN 1991 THE REGION ACCOUNTED FOR 35 PERCENT OF ALL IMPORTS OF MAJOR WEAPONS, MORE THAN ANY OTHER REGION INCLUDING EUROPE. THIS ARTICLE ARGUES THAT THE POST-COLD WAR WORLD, THERE ARE GOOD REASONS TO BE
WORRIED ABOUT THE ARMS RACE IN BOTH EAST AND SOUTH ASIA. IT EXAMINES IN SOME DETAIL THE SUBREGIONAL PATTERNS OF THE ARMS TRADE AND THEN LOOKS AT WAYS IN WHICH THE COMMERCE CAN BE CONTROLLED. IT CONCLUDES THAT THE NATIONS OF THE DEVELOPED WORLD HAVE THE ABILITY TO CONTROL THE VAST MAJORITY OF WEAPONS EXPORTED INTO THE ASIAJPACIFIC REGION, BUT WILL NEED TO ENCOURAGE THE PRC TO COOPERATE IF COMPLETE SUCCESS IS TO
BE ATTAINED.

08258 SEGAL, G.

NORTH-EAST ASIA: COMMON SECURITY OR A LA CARTE?

INTERHATIONAL AFFAIRS, 67(4) (OCT 91), 755-812

THE REGIONAL BALANCES OF POWER AND' INTEREST IN NORTHEAST ASIA IS SURVEYED BY GERALD SEGAL WHO SEES IT AS A ZONE WITH NO SHARED SECURITY INTERESTS AND OLD HOSTILITIES INTACT-A ZONE IN SEARCH OF A REGIONAL IDENTITY. HOW TO CONSTRUCT THIS IS EXPLORED. SEGAL REPORTS ON A RECENT CANADIAN INITIATIVE, BUT ALSO, IN CASE A COMMON SECURITY APPROACH IS UNSUCCESSFUL, OUTLINES THE POSSIBILITIES FOR A MORE FLEXIBLE,

A LA CARTE APPROACH TO THE HIGHEST-RISK SECURITY ISSUES.

08259 SEGAL, G.

OPENING AND DIVIDING CHINA

WORLD TODAY, 48(5) (MAY 92), 77-80

THE COLLAPSE OF THE SOVIET EMPIRE RAISES QUESTIONS ABOUT THE FUTURE OF THE CHINESE EMPIRE. THERE ARE INCREASING SIGNS THAT, AS CHINA CONTINUES ITS ECONOMIC REFORMS ANO OPENING TO THE OUTSIDE WORLD, IT ALSO RUNS THE RISK OF FRAGMENTING. ALTHOUGH CHINA WILL NOT DISINTEGRATE IN THE SAME MANNER AS THE USSR, OPENNESS MAY LEAD TO IMPORTANT REGIONAL VARIATIONS, PERHAPS EVEN DE FACTO FEDERALISM OR INDEPENDENT POLICIES

FOR DIFFERENT PARTS OF CHINA.

08260 SEGAL, G.; PHIPPS, J.

WHY COMMUNIST ARMIES DEFEND THEIR PARTIES

ASIAN SURVEY, XXX(10) (OCT 90), 959-976.

EXPLAINING THE CONTRASTS IN THE BEHAVIOR OF COMMUNIST ARMIES REQUIRES A COMPLEX ANALYSIS OF THE PARTY AND ARMY AND THE RELATIONSHIP BETWEEN THEM. MANY OF THE CHALLENGES THAT THE RELATIONSHIP BETWEEN THEM. MANY OF THE CHALLENGES THA FACED THESE PARTIES AND ARMIES WERE ALSO PART OF BROADER SOCIAL CHANGES THAT COULD NOT BE SOLVED BY AN IMPROVEMENT IN CIVIL-MILITARY RELATIONS. THIS ARTICLE ATYEMPTS TO IDENTIFY E., CHINA) AND OTHERS DID NOT (I.E. EASTERN EUROPE). E., CHINA) AND OTHERS DID NOT (I. E., EASTERN EUROPE). TO POHER, WHETHER THE PARTY IS UNITED, WHETHER THE ARMY IS UNITED, AND WHETHER THERE ARE ANY OTHER INTERESTED AND/OR ARMED GROUPS.
08261 SEGAL, J.; CAMERON, C.; COVER, A. A SPATIAL MODEL OF ROLL CALL VOTING: SENATORS, CONSTITUENTS, PRESIDENTS, AND INTEREST GROUPS IN SUPREME COURT CONFIRMATIONS

AMERICAN JOURNAL OF POLITICAL SCIENCE, 36(16) (FEB 92), 96-121.

THIS ARTICLE TESTS A SPATIAL MODEL OF SUPREME COURT CONFIMATION VOTES THAT EXAMINES THE EFFECTS OF (1) THE IDEOLOGICAL DISTANCE BETWEEN SENATORS' CONSTITUENTS AND NOMINEES, (2) THE PERSONAL IDEOLOGIES OF SENATORS, (3) THE QUALIFICATIONS OF THE NOMINEE, (4) THE STRENGTH OF THE PRESIDENT, AND (5) THE MOBILIZATION FOR AND AGAINST NOMINEES BY INTEREST GROUPS. THE MODEL EXPLAINS $78 \%$ OF THE VARIANCES BY INTEREST, GROUPS. THE MODEL EXPLAINS $78 \%$ OF THE VARIANCES
IN SENATORS ' DECISIONS, PREDICTS $92 \%$ OF THE INDIVIDUAL IN SENATORS ' DECISIONS, PREDICTS $92 \%$ OF THE INDIVIDUAL
VOTES CORRECTLY, AND PREDICTS ALL OF THE AGGREGATE DUTCOMES VOTES CORRECI
CORRECTLY.

08262 SEGERSTROM, P.S.

INNOVATION, IMITATION, AND ECONOMIC GROWTH

JOURNAL OF POLITICAL ECONOMY, 99(4) (AUG 91), 807-827. THIS PAPER DEVELOPS A DYNAMIC GENERAL EQUILIBRIUM MOOEL OF ECONOMIC GROWTH. THE MODEL HAS A STEADY-STATE EQUILIBRIUM IN WHICH SOME FIRMS DEVOTE RESOURCES TO DISCOVERING QUALITATIVELY IMPROVED PRODUCTS AND OTHER FIRMS DEVOTE RESOURCES TO COPYING THESE PRODUCTS. RATES OF BOTH INNOVATION AND IMITATION ARE ENDOGENOUSLY DETERMINED ON THE BASIS OF THE OUTCOMES OF R\&D RACES BETHEEN FIRMS. INNOVATION SUBSIDIES ARE SHOWN TO UNAMBIGUOUSLY PROMOTE ECONOMIC GROWTH. WELFARE IS ENHANCED, HOWEVER, ONLY IF THE STEADY-STATE

08263 SEIDLITZ, $P$

NORTH KOREA LOSES OUT

GERMAN TRIBUNE, 31(1531) (SEP 92), 2

THE ROAD TO THE REUMIFICATION OF THE TWO KOREAS HAS BECOME SHORTER AND RAPPROCHEMENT BETHEEN SOUTH KOREA AND CHINA IS THE RESULT OF IMPROVED ECONOMIC RELATIDNS. THIS COULD ALSO LEAD TO A JAPANESE REASSESSMENT OF INVESTMENT POLICY IN CHINA WHICH IS A GIGANTIC MARKET FOR JAPANESE AND SOUTH KOREAN PRODUCTS. THIS ARTICLE ARGUES THAT THE LOSER IS NORTH KOREA WHOSE PEOPLE ARE FIGHTING AGAINST REUNIFICATION.

08264 SEIDMAN, R.B. JUSTIFYING LEGISLATION: A PRAGMATIC, INSTITUTIONALIST,
APPROACH TO THE MEMORANDUM OF LAW, LEGISLATIVE THEORY, AND PRACTICAL REASON

PRACTICAL REASON
HARVARD JOURNAL OF LEGISLATION, 29(1) (WIN 92), 1-78.

WHILE DECISION MAKING BY THE JUDICIARY IS CHARACTERIZED

BY FORMAL, WRITTEN OPINIONS AND THE INFLUENCE OF A

CONSIDERABLE BODY OF THEORY TO GUIDE THEIR CRITIQUE, THE LEGISLATIVE PROCESS ESSENTIALLY LACKS SUCH GUIDEPOSTS MOREOVER, POST-MODERNIST THEORY SUGGESTS THAT THE DISCRETIONARY VALUE CHOICES PERVADING THE LEGISLATIVE PROCESS SIMPLY DO NOT ADMIT OF OBJECTIVE, RATIONAL JUSTIFICATION. IN THIS ESSAY, THE AUTHOR TAKES THE PERSPECTIVE OF A LEGISLATIVE AIDE OR CONGRESSIONAL COMMITTEE STAFFER CHARGED WITH DRAFTING A BILL AND DESCRIBES THE ELEMENTS OF A THEORY OF LEGISLATION HELPFUL IN MAKING DRAFTING DECISIONS AND JUSTIFYING THEM IN AN ACCOMPANYING MEMORANDUM OF LAH. HE ARGUES THAT IT IS POSSIBLE RATIONALLY TO JUSTIFY AND CRITIQUE SUCH DECISIONS, EVEN WHERE THE DRAFTER AND THE CRITIC HOLD DIVERGENT PERSONAL AND POLITICAL VALUES.

08265 SEKAREY, A.

UKRAINE'S POLICY STRUCTURE

RFE/RL RESEARCH REPORT, 1(32) (AUG 92), 60-63. TO STRENGTHEN UKRAINE'S INDEPENDENCE, THE COUNTRY'S LEADERSHIP IS DEVOTING GREAT EFFORT TO FORIULATING AN NEW GOY PMIMG STRUCTURES AND FID KRAVCHUK HAS INSTITUTED SHARE HIS VIEWS. HOWEVER, THE ORGANIZATIONAL CHANGES AND THE GOVERMMENT'S IRRESOLUTENESS IN ENCOURAGING ENTERPRISE ARE HAMPERING THE ACTUAL IMPLEMENTATION OF MARKET REFORMS.

08266 SEKHAR, C.

INDIA'S SECURITY ENYIRONMENT: AN INDIA VIEW STUDIES IN CONFLICT AND TERRORISM, 15(4) (1992), 309-316. INDIA'S SECURITY CONCERNS SHOULD BE VIEWED ON A WIDER PERSPECTIVE RATHER THAN ONE LIMITED TO THE SOUTH ASIAH REGIONS. THREATS TO INDIA'S SECURITY ARE NOT ONLY LIMITED TO REGIONS. THREATS TO INDIA'S SECURITY ARE NOT ONLY LIMITED YO
PAKISTAN, BANGLADESH, SRI LANKA, AND BURMA. THREATS TO INDIA PAKISTAN, BANGLADESH, SRI LANKA, AND BURMA. THREATS
ALSD COME FROM CHINA AND PAKISTAN HITH THEIR NUCLEAR ALSO COME FROM CHINA AND PAKISTAN HITH THEIR NUCLEA CAPACITY. INDIA'S SECURITY IS ALSO THREATENED FROM INTERNATIONAL TURMOILS. THE INDO-U.S. RELATIONSHIP HAS THE HURDLES ARE NUCLEAR NONPROL IFERATION AND TRADE ISSUES.

08267 SEKI, S.

TOWARD U.S. -JAPANESE COOPERATION

BROOKINGS REVIEW, $10(2)$ (SPR 92), 53

BOTH THE UNITED STATES AND JAPAN MISSED AN IMPORTANT OPPORTUNITY TO IMPROVE BILATERAL RELATIONS DURING PRESIDENT BUSH'S VISIT TO TOKYO IN JANUARY 1992. THE LEADERS SHOULD 
HAVE DISCUSSED SUCH CRUCIAL QUESTIONS AS OPENING JAPAN'S RICE MARKET, REDUCING JAPANESE PROTECTIONISM, AND U.S. DOMESTIC ECONOMIC PROBLEMS. INSTEAD, BUSH'S DECISION TO TAKE AN ENTOURAGE OF U.S. BUSINESSMEN TO TOKYO DERAILED THE SUMMIT. A MEETING THAT COULD HAVE IMPROVED BILATERAL RELATIONS LED TO INCREASED FRUSTRATION AND DISRESPECTFUL, SELF-RIGHTEOUS PUBLIC EXCHANGES

08268 SEKULIC, $D$. NATIONALISM VERSUS DEMOCRACY: LEGACIES OF MARXISM INTERNATIONAL JOURNAL OF POLITICS, CULTURE AND SOCIETY, 6(1) (FAL 92), 113-132.

YUGOSLAVIA PRESENTS A PARADIGMATIC CASE OF EMERGING ETHNO-NATIONAL CONFLICTS IN POST-COMMUNIST EUROPE. THE AUTHOR EXAMINES THE ROLE OF COMMUNIST PARTY LEADERS IN THE DISINTEGRATION OF YUGOSLVIA INTO A CONGERIES OF REPUBLICS STRUGGLING OVER REFROM, DEMOCRACY AND ETHNO-NATIONAL STENTITY. HE EXAMINES THE TENSION AND ALLIANCE BETHEEN MARXIST AND NATIONALIST CLAIMS HISTORICALLY IN EUROPE BEFORE MARXIST AND NATIONALIST CLAIMS HISTORICALLY IN EUROPE BEFORE
TURNING TO THE 2OTH CENTURY CASE POSED BY YUGOSLAVIA AND ITS TURNING TO THE 2OTH CENTURY
POST-COMHUNIST REPUBLICS.

08269 SELA, A.

TRANSJORDAN, ISRAEL AND THE 1948 WAR: MYTH, HISTORIOGRAPHY

MIDDLE EASTERN STUDIES, 28(4) (OCT 92), 623-288.

A CENTRAL POLITICAL MYTH SPAWNED BY THE 1948 ARABISRAELI HAR CONCERNS THE SECRET AGREEMENT BETHEEN THE LEADERSHIP OF THE YISHUV AND THE ISRAELI GOVERMMENT ON THE ONE HAND, AND JORDAN'S KING ABDULLAH ON THE OTHER, REGARDING THE PARTITION OF PALESTINE. ACCORDING TO THIS MYTH OF COLLUSION, THE COURSE OF THE WAR ON THE EASTERN FRONT AND ITS POLITICAL OUTCOMES WERE DETERMINED BY THAT AGREEMENT. THE CENTRAL THESIS OF THIS ARTICLE IS THAT THE CONDITIONS AND BASIC ASSUMPTIONS THAT HAD CONSTITUTED THE FOUNDATIONS OF THE UNWRITTEN AGREEMENT BETWEEN ABDULLAH AND THE JEWISH AGENCY REGARDING THE PARTITION OF PALESTINE AS EARLY AS THE SUMMER OF 1946 WERE ALTERED SO SUBSTANTIVELY DURING THE UNMOFFICAL WAR AS TO RENDER THAT AGREEMENT ANTIOUATED AND IMPRACTICABLE. IT ARGUES THAT THE ARAB LEGION'S INTERVENTION IN JERUSALEM WAS NOT PLANNED IN ADVANCE BUT HAS FORCED ON IT BY ITS CIRCUMSTANCES.

08270 SELIGMAN, A.

TRUST AND THE MEAMING OF CIVIL SOCIETY

INTERNATIONAL JOURNAL OF POLITICS, CULTURE AND SOCIETY 6(1) (FAL 92), 5-22.

ADAM SELIGMAN EXAMINES THE LIMITS OF THE TERM CIVIL SOCIETY FOR EAST AND WEST IN RELATION TO THE EMERGING INTEREST IN THE INDIYIDUA IN RELATION TO THE EMERGING SWHD! CAN ACT ON HIS OR HER NEEDS AND DESIRES IN THE SOCIAL AND POLTICAL SPHERES. THIS IS IN THE ATTEMPT TO ARGUE A POSITION FOR CIVIL SOCIETY BY BORROWING FROM HABERMAS'S THEORY OF COMWNICATIVE RATIONALITY AND UNITING IT WITH CURRENT SOCIOLOGICAL INTEREST IN THE NEH SOCIAL MOVEMENTS. THE AUTHOR CONCENTRATES ON SOME OF THE MAJOR THEORETICAL AS
WELL AS PRACTICAL LACUNAE OF ARGUMENTS AS THEY RELATE TO THE WELL AS PRACTICAL LACUNAE OF ARGUMENTS AS THEY RELATE TO
ISSUE OF CIVIL SOCIETY AND THE DEFINING TERMS OF TRUST IN ISSUE OF CIVIL SOCIETY AND
MODERN WESTERN SOCIETIES.

08271 SELLE, P.; SVASAND, L.

MEMBERSHIP IN PARTY ORGANIZATION AND THE PROBLEM OF DECLINE OF PARTIES

COMPARATIVE POLITICAL STUDIES, 23(4) (JAN 91) 459-477.

THIS ARTICLE QUESTIONS ASSUMPTIONS IN THE LITERATURE DEALING WITH PARTY DECLINE. FIRST, EUROPEAH AGGREGATE MEMBERSHIP DATA DO NOT SUPPORT A GENERAL CONCLUSION OF PARTY DECLINE. SECOND, INDIVIDUAL-LEVEL DATA FOR NORHAY DEMONSTRATE THE COMPLEXITIES OF THE RELATIONSHIP BETWEEN MEMBERSHIP, PARTY IDENTIFICATION, ACTIVITY IN PARTIES, AND MEMBERSHIP STABILITY. THIRD, HE DISCUSS SOCIETAL CHANGES COMMONLY ASSOCIATED WITH PARTY DECLINE, SUCH AS THE RISE OD CORPORATISM, THE NEH POLITICAL MOVEMENTS, AND THE RISE OF THE ELECTRONIC MEDIA. THE AUTHORS ARGUE THAT THESE DEVELOPMENTS CHANGE THE STRUCTURAL POSITION OF PARTIES (EXTERNAL) AND THE RELATIONSHIP BETHEEN DIFFERENT LEVELS OF THE PARTY ORGANIZATION ITSELF (INTERNAL). WHILE SUCH DEVELOPMENTS MAY LEAD TO PARTY DECLINE, THEY ALSO GIVE PARTY ORGANIZATIONS NEW POLITICAL MANEUVERABILITY. FURTHERMORE, THE GROWTH OF NEW PARTIES, THE POLITICIZATION OF NEW ARENAS, AND THE NATIONALIZATIONS OF PARTY APPARATUSES COUNTERACT THE AND THE MATIONALIZATIONS OF PARTY APPARA
FACTORS ASSOCIATED HITH PARTY DECLINE.

08272 SELTH, A.

AUSTRALIAN DEFENSE CONTACTS WITH BURMA, 1945-1987 MODERN ASIAN STUDIES, 26(3) (JUL 92), 451-468.

THIS ARTICLE EXAMINES MILITARY AND DEFENSE RELATIONS BETWEEN BURMA AND AUSTRALIA FOLLOWING WORLD WAR II. IT CHRONICLES THE GRADUAL HARMING OF RELATIONS ANO COOPERATION BETWEEN THE TWO STATES AS EVIDENCED BY THE GROWING NUMBER OF BURMESE SOLDIERS WHO RECEIVED TRAINING IN AUSTRALIA (OR BY AUSTRALIAN OFFICERS IN BURMA). IT ALSO RECOUNTS THE DECLINE IN RELATIONS FOLLOWING NE WIN'S MILITARY COUP OF 1962. AUSTRALIA'S EARLY INTERST IN BURMA STEMHED PRIMARILY FROM
ITS GEOSTRATEGIC POSITION AT A TIME OF WIDESPREAD POLITICAL AND SOCIAL UNREST. TO AUSTRALIA'S STRATEGIC PLANNERS EFFORTS TO STRENGTHEN BURMA WOULD ASSIST IN THE DEFENSE OF AUSTRALIA ITSELF. AS BURMA'S INTERNAL SECURITY SITUATION IMPROVED, THE CHINESE THREAT DIMINISHED AND NE WIN'S XENOPHOBIC POL ICIES ISOLATED BURMA FROM THE REST OF THE REGION, SO BURMA'S STRATEGIC IMPORTANCE WANED. DEFENSE EXCHANGES FORMED ONLY A SMALL PART OF BILATERAL RELATIONS BETHEEN THE TWO STATES.

08273 SELTH, A.

POLITICALLY-MOTIVATED VIOLENCE IN THE SOUTHWEST PACIFIC TERRORI SH AND POLITICAL VIOLENCE, 4(3) (FAL 92), 51-63. OVER THE PAST 20 YEARS, THE SOUTHWEST PACIFIC HAS BEEN CHANGING AND THERE IS NOW CONSIDERABLE SCOPE FOR UNREST WITHIN THE STATES AND TERRITORIES OF THE REGION. SOME OF THESE TENSIONS HAVE ALREADY SPAWHED POLITICALLY-MOTIVATED VIOLENCE--FOR EXAMPLE, IN IRIAN JAYA, PAPUA NEW GUINEA, NEW CALEDONIA, AND FIJI. THOSE INCIDENTS THAT HAVE OCCURRED TO DATE HAVE STEMHED FROM LOCAL ISSUES AND HAVE BEEN DIRECTED AGAINST LOCAL TARGETS, BUT AN INCREASE IN TENSIONS COULD BRING THE PROSPECT OF INTERNATIONAL TERRORIST ACTIVITY. THERE IS THE POSSIBILITY OF INTERFERENCE FROM OUTSIDE
ELEMENTS SEEKING TO CAPITLIZE ON DOMESTIC UNREST AS PART OF ELEMENTS SEEKING

08274 SELYUNIN, $V$

THE COLLAPSE OF THE CONSUMER MARKET IN THE U.S.S.R. GLOBAL AFFAIRS, 6(2) (SPR 91), 22-43.

THIS ARTICLE EXAMINES THE GENERAL DISINTEGRATION OF THE SOVIET ECONOMY, WHICH THE AUTHOR ARGUES IS EVIDENCED BY THE COLLAPSE OF THE CONSUMER MARKET. HE DESCRIBES THE SITUATION AS STILL WORSENING. THE IMPORTANCE OF TRADE IS DISCUSSED IT'S ROLE IN ANY FUTURE RECOVERY IS PROJECTED.

08275 SEN, Y.; KOO, H.

INDUSTRIAL TRANSFORMATION AND PROLETARIANIZATION IN TAIWAN CRITICAL SOCIOLOGY, 19(1) (1992), 45-68.

THE RAPID IMDUSTRIALIZATION THAT HAS OCCURRED IN TAIWAN OVER THE PAST THREE DECADES HAS BEEN ACCOMPANIED BY AN EXTRAORDINARY SCALE AND PACE OF PROLETARIANIZATION. THIS PAPER ANALYZED THE PATTERN OF TAIWAN'S PROLETARIANIZATION AND EXAMINES THE DEMOGRAPHIC AND SOCIAL CHARACTERISTICS FEATURES OF TAIWAN'S INDUSTRIALIZATION ARE ITS FEATURES OF TAIWAN S INDUSTRIALIZATION ARE ITS PREDOMINANCE OF SMALL-SCALE ENTERPRISES. THIS HAS HELPED THE PREDOMINANCE OF SMALL-SCALE ENTERPRISES. THIS HAS HELPED FIRST GENERATION OF TAIWAN'S INDUSTRIAL WORKERS ADAPT SMOOTHLY TO INDUSTRIAL WORK BUT ALSO HAS RETARDED THE
DEVELOPMENT OF STRONG WORKER IDENTITY AND THE WORKING-CLASS DEVELOPMENT
MOVEMENT.

08276 SENAUER, B.; GARCIA, M.

DETERMINANTS'S OF THE' NUTRITION AND HEALTH STATUS OF DETERMINANTS OF THE NUTRITION AND HEALTH STATUS OF ECONOMIC DEVELOPMENT AND CULTURAL CHANGE, 39(2) (JAN91), ECONOMIC

PRESCHOOL CHILDREN ARE USUALLY CONSIDERED ONE OF THE GROUPS AT GREATEST NUTRITIONAL RISK. THIS ARTICLE OUTLINES A STUOY OF THE DETERMINANTS OF THE NUTRITION AND HEALTH STATUS OF PRESCHOOL CHILDREN IN DEVELDPING COUNTRIES. LONGITUDINAL DATA IS GATHERED FROM THREE RURAL PROVINCES IN THE PHILIPPINES. THE RESULTS ADD TO A GROWING LITERATURE CONCERNING THE EFFECTS OF SUCH FACTORS AS A CHILD'S BIRTH ORDER, WAGE RATES, THE PRICE OF THO MAJOR STAPLES, AND THE FOOD-PRICE SUBSIDY PROGRAM ON NUTRITION AND HEALTH AND ARE
IMPORTANT TO THE DESIGN OF PROGRAMS AND POLICIES TO REDUCE IMPORTANT TO THE DESIGN OF PROGRAMS AND POLICIES
MALNUTRITION AND IMPROVE THE HEALTH OF CHILDREN.

08277 SENIGALLIA, S.

AS ITALY GOES TO THE POLLS

NEW LEADER, LXXV(3) (MAR 92), 6-7.

AS ITALY GOES TO THE POLLS, IT FINDS ITSELF CONFRONTED WITH A MULTITUDE OF OF PARTY LOGOS AND CANDIDATES. THE PROLIFERATION OF MULTIFARIOUS GROUPS LARGELY PURSUING PRIVATE INTERESTS IS NOT EXTRAORDINARY IN A PERIOD OF WIDESPREAD FRUSTRATION AND DISSATISFACTION. IT IS ITALY'S PROPORTIONAL ELECTORAL SYSTEM, HOWEVER, THAT PROMPTS THEM TO ENTER THE POLITICAL ARENA. THE DISPERSION OF MILLION OF VOTES WILL HINDER THE MAIN PARTIES FROM FORMING A GOVERMMENT ABLE TO PERFORM ITS MISSION. THIS ARTICLE EXPLORES THE PARTIES, CANDIDATES AND ISSUES INVOLVED IN THIS ELECTION.

08278 SENIGALLIA, S. - AVOIDING THE OBYIOUS IN ITALY NEW LEADER, LXXIV(12) (NOV 91), 3-4. THIS ARTICLE ARGUES THAT ITALIANS ARE EXHIBITING AN UTTER UNWILLINGNESS TO ASSESS THE NEAR FUTURE OF THEIR COUNTRY AND TO BEGIN LIVING WITHIN THEIR MEANS. ECONOMISTS, INDUSTRIALISTS, LABOR LEADERS, AND FOREIGN OBSERVERS ARE BAFFLED BY THE WIDESPREAD FEEL ING OF BOOMING OPTIMISM AT THE VERY MOMENT WHEN ITALY APPEARS HEADED FOR BANKRUPTCY. THE MEMBERS OF THE EUROPEAN COMMUNITY HAVE REPEATEDLY WARNED ITALY ABOUT THE PLIGHT OF ITS ECONOMY, AND THE BALLOONING 
NATIONAL DEBT IS NOW OVER THE $\$ 1$ TRILLION MARK. NEVERTHELESS, FOREIGN FURS, DIAMONDS, AND WHISKEY CONTINUE TO BE IMPORTED IN GREATER QUANTITIES THAN ANYWHERE ELSE. THE SITUATION IS NOT HELPED BY AN ESPECIALLY FRAGMENTED COALITION GOVERNMENT WHICH OUT OF NECESSITY PLACES A PREMIUM ON COMPROMISE AND PROCRASTINATION.

08279 SENIGALLIA, S

FROM PEBBLES TO BRICKBATS IN ITALY

NEW LEADER, LXXIII (15) (NOY 91), 8-9.

AFTER FIVE-AND-A-HALF YEARS OF RELATIVE SILENCE AND AMONYMIIY ITALY'S PRESIDENT FRAMCESCO COSSIGA, HAS TURMED INTO A PROTAGONIST. THE USUALLY QUIET AND MILD-MANNERED COSSIGA HAS BECOME INCREASINGLY STRIDENT AND CRITICAL IN HIS COMPLAINTS ABOUT THE COUNTRY'S INEFFECTUAL EXECUTIVE AND SLUGGISH LEGISLATURE. THE LARGEST RECENT SPECTACLE WAS A CLASH BETWEEN COSSIGA AND THE LEADING OPPOSITION PARTY, THE COMMUNIST PARTY (PCI). COSSIGA RESPONDED TO PCI CRITICISM OF HIS POSSIBLE ROLE IN OPERATION GLADIO, A NATO-SPONSORED COVERT PROGRAM, WITH HIS OWN ACCUSATIONS OF "CYNICAL AND DIRTY SLANDER"' ON THE PART OF THE COMMUNISTS. THE INCREASING CONFLICT, WHILE NOT LIKELY TO SHAKE THE LONG-STANDING POLITICAL ALLIANCES IN ITALY, IS DESTINED TO KEEP POLITICS UNCERTAIN.

08280 SENIGALLIA, S.

ITALY'S GERMAN PROBLEM

NEW LEADER, LXXV(1) (JAN 92), 12-13.

WHILE SOME ITALIANS EXPRESSED CONCERN AND DISAPPOINTMENT

AT MARIO CUOMO'S DECISION NOT TO ENTER THE U.S. 1992

PRESIDENTIAL RACE. ITALY'S ATTENTION WAS FOR THE MOST PART,

DIRECTED ELSEWHERE. ONE MAJOR WORRY CONCERNS THE FUTURE OF

THE COMMONHEALTH OF INDEPENDENT STATES (CIS). ITALY HAS

PROMISED AID TO BORIS YELTSIN AND OTHER COMMONWEALTH LEADERS,

BUT UNCERTAINTY ABOUT CONDITIONS IN THE CIS IS LIKELY TO

CAUSE ITALY TO DRAG ITS FEET ON IMPLEMENTING AID PROGRAMS.

ITALY IS ALSO DISPLAYING GROWING CONCERN WITH THE

INCREASINGLY AGGRESSIVE AND AMBITIOUS BEHAVIOR OF GERMANY. WHILE ITALY WAS WILLING TO FOLLOW GERMANY'S LEAD IN RECOGNIZING THE INDEPENDENCE OF SLOVENIA AND CROATIA AND IN RAISING INTEREST RATES, IT DID SO GRUDGINGLY. THE RISE IN INTEREST RATES--A MOVE, DEEMED MECESSARY TO HARMONI ZE THE LIRA WITH OTHER EC CURRENCIES--COULD EXTEND ITALY'S ECONOMIC SLUMP.

08281 SENS, A.

CANADA, NATO, AND THE WIDENING ATLANTIC: CANADIAN DEFENCE POLICY IN THE 1990 S

CANADIAN DEFENCE QUARTERLY, 20(4) (FEB 91), 11-17 THIS ARTICLE DISCUSSES THE INCREASING DIVERGENCE OF SECURITY, POL ITICAL, AND ECONOMIC INTERESTS BETHEEN THE NORTH AMERICAN AND THE EUROPEAN PILLARS OF NATOR. THE ARTICLE ARGUES THAT IN ORDER TO BEST MEET THE CHALLENGE OF MANAGING SECURITY RELATIONS IN THE CONTEXT OF A HIDENING ATLANTIC, FUTURE CANADIAN SECURITY POLICY SHOULD RECOGNIZE AND ADAPT TO THE INEVITABLE DECLINE OF NATO'S VALUE TO CANADIAN FOREIGN POLICY INTERESTS AND PLACE MORE EMPHASIS ON NORTH AMERICAN AND GLOBAL CONTINGENCY SECURITY PRIORITIES. ALSO DISCUSSED ARE: THE CHANGING POLICY ENVIRONMENT, THE STRATEGIC SPLIT THE EROSION OF THE ATLANTIC COMMUNITY, THE RISE OF ECONOMIC COMPETITION, AND ENDURING REALITIES OF CANADIAN SECURITY POLICY.

08282 SENYAH, J.K.

FOOD, AFRICA, AND DEYELOPMENT

HEST AFRICA, (3905) (JUL 92), 1214

FOOD INADEQUACIES IN AFRICA MAY BE ATTRIBUTED TO TWO

MAIN CAUSES: NATURAL AND ARTIFICIAL. THE NATURAL CAUSES ARE

MAIN CAUSES: NATURAL AND ARTIFICIAL. THE NATURAL CAUSES ARE

ON THE OTHER HAND, ARE MAN-MADE AND CAN BE PREVENTED OR

STOPPED. ONE PROBLEM IS THE LARGE AMOUNT AFRICAN GOVERMMENTS

STOPPED. ONE PROBLEM IS THE LARGE AMOUNT AFRICAN GOVERMMENTS

FOOD PRODUCTION, INDUSTRY, HEALTH CARE, AND EDUCATION.

08283 SEPASGOSARIAN, $R$

THE 5OTH AMMIVERSARY OF THE ALLIED INVASIOM IN IRAN

ORIENT, 32 (1) (1991), 265-284.

THE 25TH OF AUGUST 1991 IS THE 5OTH ANNIVERSARY OF THE ALLIED INVASION IN IRAN. THIS DATE MARKS THE TURNING POINT IN THE HISTORY OF THE SECOND WORLD WAR. THE EVENTS OF THE FEN MONTHS PRIOR TO THE INVASION, TAKING ACCQUNT OF THE BASIC PRINCIPLES OF REZE SHAH'S FOREIGN POLICY IN THE POSSIBLITIES AS HELL AS THE LIMITS OF AN AUTONOMOUS IRANIAN POLICY. THIS PAPER FOCUSES ON DESCRIPTIONS OF THE EVENTS OF THE 25TH OF AUGUST 1941 IN IRANIAN HISTORIOGRAPHIC THE ACCORDING TO THE POLITICAL VIEH OF THE OBSERVER, IS STILL UNABLE TO CLARIFY THE REAL EXTENT TO WHICH REZE SHAH AND HIS MINISTERS COULD HAVE PREVENTED THE INVASION.

08284 SEPEHRI, A.

BALANCE OF PAYMENTS, OUTPUT, AND PRICES IN TANZANIA

WORLD DEVELOPMENT, 20 (2) (FEB 92), 289-302.
THIS PAPER STUDIES THE RELATIONSHIP BETWEEN CHANGES IN INTERNATIONAL RESERVES AND CHANGES IN OUTPUT, PRICES, AND MONETARY BALANCES IN TANZANIA. USING ANHUAL DATA FOR 1962-86, A SHORT-RUN MACROECONOMIC MODEL OF THE BALANCE OF PAYMENTS IS FORMULATED; OUTPUT AND PRICES ARE ENDOGENIZED, AND THE BEHAVIDRS OF THE MONETARY AND FISCAL AUTHORITIES ARE EXPLICITLY MODELED. THE ESTIMATION RESULTS ARE USED TO EXAMINE THE RELATIVE EFFECTIVENESS OF ALTERNATIVE POLICY INSTRUMENTS ON THE KEY MACROECONOMIC VARIABLES OF THE MODEL. INS MONETARY YARIABLES APPEAR TO HAVE PLAYED A RELATIVELY THE MONETARY VARIABLES APPEAR TO HAVE PLAYED A RELATIVELY
SIGNIFICANT ROLE IN THE DEVELOPMENT OF PRICES, BUT THEY WERE SIGNIFICANT ROLE IN THE DEVELOPMENT OF PRICES, BUT THEY WERE
ONLY MARGINALLY SIGNIFICANT IN THE PROCESS OF BALANCE-OFONLY MARGINALLY SIGNIFICANT IN THE PROCESS OF BALANCE-OFPAYMENTS ADJUSTMENT. THE SIMULATION RESULTS INDICATE THAT A
TRADEOFF EXISTED BETWEEN FASTER ECONOMIC GROWTH AND BETTER TRADEOFF EXISTED BETWEEN FASTER
BALANCE-OF-PAYMENTS PERFORMANCE.

08285 SERBIN, A.

VENEZUELA: REVERSAL OR RENEHAL?

HEMISPHERE, 4(3) (SUM 92), 24-27.

RISING POLITICAL PROTESTS AND VIOLENCE HAVE HAD LITTLE IMPACT ON PRESIDENT CARLOS ANDRES PEREZ OR THE POLITICA ELITE IN GENERAL. PEREZ AND OTHER POLITICAL LEADERS HAVE LOST TOUCH NOT ONLY WITH THE VAST MAJORITY OF VENEZUELANS BUT ALSO WITH THE RANK-AND-FILE OF THEIR OWN POL ITICAL PARTIES. WIDESPREAD, UNPUNISHED CORRUPTION HAS REINFORCED THE POLITICAL ALIENATION OF THE VENEZUELAN MAJORITY.

08286 SERFATY, A.

FOR ANOTHER KIND OF MOROCCD

MIDDLE EAST REPORT, 22(6) (NOV 92), 24-27.

THIS INTERVIEW WITH ABRAHAM SERFATY COVERS: CHANGES WHICH HAVE TAKEN PLACE IN MOROCCO OVER THE 17 YEARS HE WAS IN PRISON; RELIGION AND RELIGIOUS FUNDAMENTALISM; MOROCCO;S WELL BEING; KING HASSAN II ; WOMEN'S ISSUES; POLITICAL

PARTIES; REFORM: AND, THE ROLE OF FOREIGN PONERS.

08287 SERFATY, $S$

DEFINING MOMENTS

SAIS REVIEW, $12(2)$ ( SUM 92), 51-64.

THE QUESTION IS ASKED: "DOES THIS CENTURY THREATEN TO END AS IT BEGAN. AS IF NOTHING HAS BEEN LEARNED FROM THE WASTE OF THE COLD HAR AND FROM THE SAVAGERY OF TWO WORLD WARS? IN LATE 1990 , PRESIDENT BUSH DESCRIBED THE GULF CRISIS AS A "DEFINING MOMENT" FOR THE POST-COLD WAR ORDER AMERICANS SEEM TO FAVOR AN INTERNATIONAL ORDER THAT COULD BE MANAGED BY ALL ON BEHALF OF ALL. ON BOTH SIDES OF THE

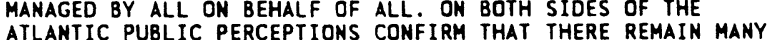
RISKS TO THE SECURITY OF ALL. ALSO, PUBL IC PERCEPTIONS SENSE RISKS TO THE SECURITY OF ALL. ALSO, PUBLIC PERCEPTIONS SENSE THAT THESE RISKS WILL BE BEST CONTROLLED TOETHER, RATHER THAN SEPARATELY; HENCE, THE HOPE OF THE DEFINING MOMENTS OF
THE 1990 S WILL BE SEIZED WITH THE SAME VISION AS THEY WERE FDUR DECADES AGO.

08288 SEROKA, J.

THE POLITICAL FUTURE OF YUGOSLAVIA: NATIONALISM AND THE CRITICAL YEARS, 1989-1991

CANADIAN REYIEH OF STUDIES IN NATIONALISM, XIX(1) (1992), 151-160.

YUGOSLAVIA'S BRIEF EXISTENCE AS A NATION-STATE HAS BEEN PUNCTUATED AND FORMED BY THE PATTERN OF THE RELATIONSHIPS OF EACH OF THE ETHNIC NATIONAL GROUPS IN THE COUNTRY TOWARDS EACH OTHER. AT THE HEART OF EACH POLITICAL COMPACT HAS BEEN YUGOSLAVIA'S POLICY TOWARDS INTERETHNIC RIVALRIES. NATIONALITY POLICY, IN EFFECT, HAS BEEN THE CENTRA POLITICAL ISSUE IN YUGOSLAYIA AND IT HAS BEEN ALTERNATINGLY THE CURSE AND THE SALVATION OF THE YUGOSLAV PEOPLES. TODAY, WE ARE WITNESSING THE BEGINNING OF ANOTHER SUCH CYCLE AND THE FORGING OF YET ANOTHER ETHNIC-BASED POLITICAL COMPACT IN YUGOSLAYIA. THIS ARTICLE EXPLORES THE CURRENT RENEGOTIATION YUGOSLAVIA. THIS ARTICLE EXPLORES THE CURRENT RENEGOTIATION OF THE NATIONAL COMPACT AS WELL AS THE CURSE OF ETHNIC=BASED THE YUGOSLAV STATE.

08289 SEROKA, J. (ED.); PAVLOVIC, V. (ED.)

THE TRAGEDY OF YUGOSLAVIA--THE FAILURE OF DEMOCRATIC TRANSFORMATION

M. E. SHARPE, 1992, 256.

M. E. SHARPE, 1992, 256. BEGINNING OF THIS DECADE DID NOT BRING WITH IT THE DEGINNING OF THIS DECADE DID NOT BRING WITH IT THE FROM CROATIA SERBIA. AND SLOVENIA EXAMINE THE JANUS FACE OF PLURALISM. THEIR CASE STUDIES OF ELECTORAL POLITICS IN THE PEPUBLICS AMD OF WHAT WERE THE COUNTRY'S INSTITUTIONS OF INTEGRAT AND OF WHA RERE THE COUNTR S INSTITUTIONS OF INTEGRATION--THE LEAGUE OF COMMUNISTS, THE MANAGERIAL AND THE ARMY--REVEAL HOW THE FAULT LINES OF POST-TITO

08290 SERRA, G.; COVER, A. THE ELECTORAL CONSEOUENCES OF PERQUISITE USE: THE CASEWORK CASE

LEGISLATIVE STUDIES QUARTERLY, 27(2) (MAY 92), 233-246. THIS STUDY BEGINS BY EXAMINING HOW CASEWORK AFFECTS INCUMBENT SALIENCY AND REPUTATION AMONG CONSTITUENTS. IT 
POSITIVE EVALUATION OF THE INCUMBENT AND INCREASES THE INCUMBENT'S SALIENCY AMONG CONSTITUENTS. THESE RESULTS ARE INCORPORATED INTO A MODEL USED TO PREDICT THE ELECTORAL CONSEQUENCES OF PERQUISITE USE. THE MODEL SUGGESTS THAT PERQUISITES HAVE MOST IMPACT IN CONSTITUENCES IN HHICH A RELATIVELY SMALL PROPORTION OF VOTERS IDENTIFY WITH INCUMBENT'S PARTY.

08291 SESHADRI, B.

THE ABERRATION OF HINDU FUNDAMENTALISM

CONTEMPORARY REVIEW, 261(1519) (AUG 92), 76-79.

OUTSIDE SCHOLARS HAVE NOTED THE APPEARANCE OF "HINDU FUNDAMENTAL ISM" IN INOIA. THIS ARTICLE EXAMINES THE PHENOMENON AND ITS IMPLICATIONS. THE AUTHOR ARGUES THAT THE TERM "FUNDAMENTALISM" CANNOT BE ACCURATELY APPLIED TO HINDUISH BECAUSE THE RELIGION HAS NO DOGMA, FUNDAMENTAL OR OTHERWISE. THEREFORE, THE SELF-STYLED FUMDAMENTALISTS ARE MERELY POI ITICAL OPPORTUMISTS WHO ARE TRYING TO HIM THE VOTES OF INDIA'S FLTES OF FLAMES OF RELIGIOUS AND CUL TURAL CONFLICT. THEIR IDEOLOGY
HAS NO BASIS IN ANY TRADITIONAL HINDU THOUGHT OR THEOLOGY.

08292 SESTANOVICH, S.

\section{OME MATION UMDER BORIS}

NEN REPUBLIC, 206(26) ( JUN 92), 20-23.

NATIOMALISSM IS A RALLYING PÓINT FOR BOTH LIBERALS AND CONSERVATIVES IN RUSSIA. A WESTERN-STYLE ORDER CAN TAKE HOLD IN RUSSIA ONLY IF ITS SUPPORTERS SHOW THAT THEY UNDERSTAND NATIONAL TRADITIONS, VALUES, AND PRIDE. RUSSIAN LIBERALS HOPE TO DEFINE THESE TRADITIONS IN THEIR OWN FASHION, EMPHASIZING CULTURAL PLURALISM, TOLERANCE, AND A PROUD--BUT NOT TOO BRISTLY--PATRIOTISM. THE EMERGING CONSERVATIVE OPPOSITION HAS OTHER IDEAS. CONSERVATIVES BELIEVE THAT NATIONALISM IS THEIR ISSUE AND THEIR MOST POTENT WEAPON FOR TOPPLING THE CURRENT GOVERNMENT. THEY CLAIM THAT LIBERAL REFORMERS HAVE TURNED A MIGHTY STATE INTO AN INTERNATIONAL CHARITY CASE AND ARE IMPORTING ECONOMIC AND POLITICAL INSTITUTIONS THAT HAVE NO BASIS IN RUSSIA'S PAST.

08293 SETH, S.

LENIN'S REFORMULATION OF MARXISM: THE COLONIAL QUESTION AS A MATIONAL QUESTION

HISTORY OF POLITICAL THOUGHT, XIII(1) (SPR 92), 99-128. MARXISM PROVED MORE INFLUENTIAL AND SUCCESSFUL IN THE FORMER COLONIAL AND SEMI-COLONIAL COUNTRIES OF THE EAST THAN IN THE BOURGEOIS SOCIETIES OF WESTERN EUROPE, DESPITE THE FACT THAT IN THE FORMER REGION THE NATIONAL QUESTION, ONE OF MARXISM'S GREAT THEORETICAL FAILINGS, WAS AN ISSUE OF MARXISM'S GREAT THEORETICAL FAILINGS, WAS AN ISSUE PRESSING POLITICAL IMPORTANCE. A MAJOR PART OF THE DEVELOPED AND REFORMULATED MARX'S THEORY. THE SEEDS OF BOTH DEVELOPEO AND REFORMULATED MARX'S THEORY. THE SEEDS OF BOTH THE SUCCESSFUL EXTENSION OF MARXISM TO THE UNDERDEVELOPED PARTS OF THE WORLD AND ITS FAILURE TO DEVELOP A THEORY UNDERTAKEN WITH THE THEORY OF IMPERIALISM.

08294 SEYMOUR, $C$.

A LOOK AT THE OTHER JAPAM

NEW LEADER, LXXIV (12) (NOV 91), 8-10

THIS ARTICLE RECOUNTS A TOUR OF SANYA, AN AREA OF TOKYO IN WHICH A LARGELY NEGLECTED UNDERCLASS LIVES. MOSTLY MIDDLEAGED, THESE WORKERS CONTRACT OUT THEIR LABOR ON AN INDEPENDENT BASIS. CONTRARY TO THE USUAL COMPANY ROUTE WITH ITS DEMANDS FOR INTENSE LOYALTY. CONDITIONS ARE POOR AND WORSENING AS MANY GROW TOO OLD FOR THE MANUAL LABOR PROJECTS AND RUN OUT OF MONEY. GOVERMMENT ATTEMPTS TO "CLEAN OUT" THE NEIGHBORHOOD OR CHANGE THE LIFESTYLE OF ITS PEOPLE HAVE FAILED.

\section{SHAATH, $N$.}

CHALLENGES OF 1992: THE PALESTIMIAH SITUATION

MIDOLE EAST POLICY, 1(1) (1992), 39-45.

AT THIS TIME, A NEW TYPE OF DIPLOMACY IS BEING CREATED-THE ISRAELI -PALESTINIAN CORRIDOR DIPLOMACY. IN ORDER TO UNDERSTAND THE COMPLEX PROCESS GOING ON NOW, THIS ARTICLE LOOKS BACK AT WHAT HAS BEEN TRIED BEFORE. IT DEFINES THE PALESTINE PROBLEM AS THE REAL ISSUE. THE FIRST SOLUTION TO THE PROBLEM THAT THE PALESTINIANS THOUGHT OF WAS THE AMERICAN SOLUTION: A HETEROGENOUS LAND OF MORE THAN ONE ETHNIC GROUP AND MORE THAN ONE RELIGIOUS GROUP LIVING IN ONE BIG COUNTRY UNDER THE PLURALIST DEMOCRATIC PRINCIPLE OF ONE BIG COUNTRY UNDER THE PLURALIST DEMOCRATIC PRINCIPLE
MAN, ONE VOTE. AT PRESENT THO BASIC FORMATS FOR THE MAN, ONE VOTE. AT PRESENT THO BASIC FORMATS FOR THE NEGOTIATING PROCESS ARE SUGGESTED--THE MULTINATIONAL

EXPLORED AS WELL AS AN EXPANDED ROLE FOR THE UNITED NATIONS.

08296 SHABSHINA, F.

THE KOREAN REALITY AMD KOREAN STUDIES IN THE USSR FAR EASTERN AFFAIRS, (3) (1990), 76-90.

THIS ARTICLE EXAMINES KOREAN STUDIES IN THE USSR, WHICH HAVE ONLY LATELY BECOME A SEPARATE BRANCH OF ORIENTAL STUDIES. THE GENERAL DEMOCRATIZATION OF SOVIET LIFE IS SEEN AS ALLOHING A TRUE ANALYSIS OF EVENTS IN KOREA. A NEH, MORE OBJECTIVE LOOK IS BEING TAKEN IN THE USSR OF THE TWO KOREAS
AND ISSUES RELATED TO THEIR PARTITION. THE FOUNDATIONS AND GOALS OF THE OPPOSING SYSTEMS IN NORTH AMD SOUTH KOREA ARE DISCUSSED.

08297 SHACKLETON, M.

THE EC'S BUDGET IN THE MOVE TO A SINGLE MARKET

SOCIALIST REVIEW, 21(1) (JAN 91), 94-114.

THIS ARTICLE CONSIDERS THE APPROACH OF 1992 AND THE SINGLE MARKET FROM THE PERSPECTIVE OF THE EUROPEAN COMMUNITY BUDGET. IT BEGINS BY RECALLING THE DISTINCTIVE

CHARACTERISTICS OF THAT BUDGET AND THE WAY IN WHICH ARGUMENT ABOUT IT DOMINATED THE EC AGENDA THROUGHOUT THE 1980 S UP UNTIL THE BRUSSELS EUROPEAN COUNCIL MEETIMG HELD BETWEEN 11 AND 13 FEBRUARY 1988. IT THEN CONSIDERS THE RELATIONSHIP BETWEEN THE DECISIONS TAKEN IN BRUSSELS AND THE HIDER ISSUE OF THE CREATION OF THE SINGLE MARKET. IN PARTICULAR, IT EXAMINES THE ISSUE OF RESOURCE AVAILABILITY AND ARGUES THAT THE BUDGETARY FRAMEWORK ESTABLISHED IN BRUSSELS SIGNIFICANTLY CONTRIBUTED TO MODIFYING THE EXTENT AND NATURE OF COMMUNITY POLICIES IN A WAY WHICH WILL CONTINUE TO BE FELT AFTER 1992.

08298 SHAFER, B.E. (ED.)

THE END OF REALIGNMENT? INTERPRETING AMERICAN ELECTORAL ERAS

THE UNIVERSITY OF WISCONSIN PRESS, 1991, 187

IN THIS VOLUME, FIVE SCHOLARS ATTACK AND DEFEND THE THEORY OF ELECTORAL REALIGNMENT. ONE AUTHOR ARGUES THAT ELECTORAL. REALIGMMENTS ARE NOT GOOD BREAK POINTS FOR THOSE WHO WISH TO DIVIDE ALL OF AMERICAN POLITICAL HISTORY INTO SEPARATE COMPONENTS. ANOTHER CONDEMNS REALIGMMENT AS A THEORY THAT HAS "SEDUCED DOZENS OF SCHOLARS TO DEVOTE THEIR ATTENTION TO IT, "ATTENTION WHICH COULD HAVE BEEN BETTER SPENT ON OTHER PURSUITS. A THIRD OFFERS AN ELECTORAL ORDER RATHER THAN A POLITICAL ERA OR A PARTY SYSTEM. HE ARGUES THAT ELECTORAL ERAS DIFFER FROM ONE ANOTHER IN TERMS OF THE ARRANGEMENT OF LINKAGES BETHEEN SOCIAL BASES, INTERMEDIARY ORGANIZATIONS SUCH AS PARTIES AND INTEREST GROUPS, AMD GOVERMMENT INSTITUTIONS. ANOTHER AUTHOR OFFERS A BRIEF CRITIQUE AND COMMENTARY ON THE FIRST THREE ESSAYS. HE ARGUES THAT ALL THREE AUTHORS HAVE ATTRIBUTED TOO MUCH TO THE REALIGNMENT PERSPECTIVE. THE FINAL AUTHOR DEFENDS REALIGNMENT THEORY, BUT ALSO USES THE NOTION OF "PUNCTUATED CHANGE" TO PRESENT A MODIFIED DEFINITION OF REALIGNMENT

08299 SHAFIR, G.

RELATIVE OVERDEVELOPMENT AND ALTERMATIVE PATHS OF NATIONALISM: A COMPARATIVE STUDY OF CATALONIA AND THE BALTIC REPUBLICS

JOURMAL OF BALTIC STUDIES, 23(2) (SUM 92), 105-120.

THE OF BALTIC STUDIES, $23(2)$ (SUM 92 ), 105-120. CONDITIONS THAT FACILITATE THE RISE AND DEFINES THE CHARACTER OF NATIONALISM IN REGIONS THAT CAN BOAST OF CHARACTER OF NATIONALISM IN REGIONS THAT CAN BOAST OF
"RELATIVE OVERDEVELOPMENT. "THIS IS DONE BY EXAMINING FOUR REGIONS THAT LAY AT OPPOSITE ENDS OF EUROPE: CATALONIA IN REGIONS THAT LAY AT OPPOSITE ENDS OF EUROPE: CATALONIA IN SPAIN AND THE REPUBLICS OF LATVIA, ESTONIA, AND LITHUA NATIONAL MOVEMENTS OF DIFFERENT DEGREES OF INTENSITY.

08300 SHAFIR, M.

"WAR OF THE ROSES" In ROMANIA'S MATIONAL SALVATION FRONT RFE/RL RESEARCH REPORT, 1(4) (JAN 92), 15-22.

FOLLOWING HIS DISMISSAL AS PRIME MINISTER, PETRE ROMAN OPENLY ATTACKED PRESIDENT ION ILIESCU, ACCUSING HIM OF HINDERING ROMANIA'S DEMOCRATIC TRANSFORMATION. ROMAN ALSO PLEDGED TO CHANGE THE NATIONAL SALVATION FRONT (NSF) INTO A GENUINELY DEMOCRATIC PARTY AND TO RID IT OF ALL "NOSTALGIC COMMUNISTS." THE THO RIVALS FOR THE LEADERSHIP OF THE NSF ARE ENGAGED IN A STRUGGLE FOR CONTROL OF THE PARTY APPARATUS, BUT THE NSF MAY OPT FOR A COMPROMISE SOLUTION IN ORDER TO ENSURE ITS SURVIVAL.

08301 SHAFIR, $M$.

ROMANIA

RFE/RL RESEARCH REPORT, 1(27) (JUL 92), 34-40.

PROGRESS HAS BEEN MADE IN ROMANIA TOWARD PASSING

LEGISLATION AIMED AT ESTABLISHING A STATE BASED ON THE RULE OF LAW. HOWEVER, THIS LEGISLATION HAS AT TIMES BEEN MARRED BY POTENTIALLY-DANGEROUS PROPOSALS. MOREOVER, THE IMPLEMENTATION OF LANS HAS BEEN DEFICIENT IN' SEVERAL RESPECTS, AND THERE REMAIN MANY QUESTIONS ABOUT THE INDEPENDENCE AND PROBITY OF THE JUDICIARY. HOWEVER. THE INDEPENDENCE AND PROBITY OF THE JUOICIARY. HOWEVER, THE
PUBLIC'S CONTRIBUTION TO ESTABLISHING THE RULE OF LAW HAS PUBLIC'S CONTRIBUTI

08302 SHAFIR, $M$

ROMANIA PREPARES FOR LOCAL ELECTIONS

RFE/RL RESEARCH REPORT, 1(5) (JAN 92), 18-23.

IN THE LOCAL ELECTIONS SCHEDULED FOR FEBRUARY 9, 1992, DIFFERENT VOTING SYSTEMS WILL BE EMPLOYED SIMULTANEOUSLY. IN THE RUN-UP TO THE ELECTIONS, AN ATTEMPT TO PASS A LAH PROVIDING FOR CAMPAIGN FINANCING FROM THE STATE BUDGET FAILED. THE OPPOSITION IS COMPLAINING THAT TELEVISION COVERAGE IS BIASED AND THAT IRREGULARITIES HAVE OCCURRED IN 
THE REgISTRATION OF CANDIDATES. SEVERAL PARTIES HAVE ENTERED INTO ALLIANCES AND WILL RUN ON JOINT LISTS.

\section{SHAFIR, M.}

ROMANIA: CONSTITUTION APPROVED IN REFERENDUM

RFE/RL RESEARCH REPORT, 1(2) (JAN 92), 50-55.

THE NEW ROMANIAN CONSTITUTION WAS APPROVED IN A

REFERENDUM ON DECEMBER 9, 1991. VIEWED FROM THE PERSPECTIVE OF DEMOCRATIC CONSTITUTIONAL THEORY AND COMPARED TO THE DRAFT CONSTITUTION PASSED IN JULY 1991, THE NEW VERSION IS AN IMPROVEMENT BECAUSE IT GUARANTEES MORE INDIVIDUAL RIGHTS, STRENGTHENS PARLIAMENTARY CONTROL OVER THE PRESIDENCY AND STRENGTHENS PARL I AMENTARY CONTROL OVER THE PRESIDENCY
EXECUT IVE BRANCH. AND GRANTS THE LEGISLATURE GREATER EXECUTIVE BRANCH, AND GRANTS THE LEGISLATURE GREATER
INDEPENDENCE FROM THE CONSTITUTIONAL COURT. THE REFERENDUM ITSELF WAS MARRED BY A LOW TURNOUT, AND JUST OVER HALF OF ITSELF WAS MARRED BY A LOW TURNOUT, AND JUST OVER CONSTITUTION.

08304 SHAFIR, M.

ROMANIA: INVESTIGATION INTO GOVERNMENT CORRUPTION RFE/RL RESEARCH REPORT, 1(8) (FEB 92), 31-36.

THE ESTABLISHMENT OF A PARLIAMENTARY COMMISSION TO INVESTIGATE POSSIBLE CORRUPTION AMONG AND MISMANAGEMENT BY MEMBERS OF FORMER PRIME MINISTER PETRE ROMAN'S GOVERNMENT WAS POLITICALLY MOTIVATED. THE COMMISSION'S FUNCTION IS TO ASSIST THE NATIONAL SALVATION FRONT FACTION THAT SUPPORTS PRESIDENT ION ILIESCU IN ITS STRUGGLE AGAINST THE FACTION HEADED BY ROMAN. NEVERTHELESS, THERE ARE INDICATIONS THAT SUSPICIONS OF CORRUPTION AND MISMANAGEMENT MAY NOT BE TOTALLY UNFOUNDED.

08305 SHAFIR, M.

ROMANIA: MAIN CANDIDATES IN THE PRESIDENTIAL ELECTIONS RFE/RL RESEARCH REPORT, 1(35) (SEP 92), 11-18. NO PRESIDENTIAL CANDIDATE IS LIKELY' TO BE VICTORIOUS IN THE FIRST ROUND OF ROMANIA'S ELECTIONS IN SEPTEMBER 1992. MOREOVER THE FADIMG POPULARITY OF IMCUMBENT PRESIDENT ION MOREOVER, THE FADING POPULARITY OF INCUMBENT PRESIDENT ION ILIESCU IS ENDANGERING HIS ELECTION ON THE SECOND BALLOT. THE NATIONAL SALVATION FRONT CANDIDATE, CAIUS DRAGOMIR,
APPEARS TO BE A GENUINE DEMOCRAT BUT SUFFERS FROM RELATIVE APPEARS TO BE A GENUINE DEMOCRAT BUT SUFFERS FROM REL
ANONYMITY-OAS DOES THE CANDIDATE OF THE DEMOCRATIC

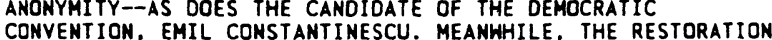
OF THE MONARCHY HAS BECOME A MAJOR ISSUE IN THE CAMPAIGN.

08306 SHAFIR, M.

ROMAMIA'S ELECTION CAMPAIGN: THE MAIM ISSUES

RFE/RL RESEARCH REPORT 1(36) (SEP 92) 29-31.

THE DOMINANT ISSUES IN ROMANIA'S 1992 GENERAL ELECTION ARE ECONOMIC REFORM, SOCIAL WELFARE, NATIONAL MINORITIES, WHETHER THE COUNTRY SHOULD BE A REPUBLIC OR A CONSTI TUT IONAL MONARCHY, "THE TRIAL OF COMMUNISM" AND THE FILES OF THE SECRET POLICE, AND FOREIGN POLICY, PARTICULARLY THE ISSUE OF UNION WITH MOLDOVA. WHILE THE MAJOR COMPETING PARTIES CLEARLY HAVE DIFFERENT POSITIONS ON MOST OF THESE ISSUES, THE RESULTS OF THE PARLIAMENTARY ELECTIONS WILL PROBABLY' BE INFLUENCED MORE BY THE PRESIDENTIAL ELECTION THAN BY THE PARTY PLATFORMS.

08307 SHAFIR, $M$.

ROMANIA'S ELECTIONS: MORE CHANGE THAN MEETS THE EYE RFE/RL RESEARCH REPORT, 1(44) (NOV 92), 1-9.

ROMANIA'S PRESIDENTIAL AND PARL IAMENTARY ELECTIONS GENERATED MORE CHANGE THAN IS APPARENT AT FIRST GLANCE. ALTHOUGH PRESIDENT ION ILIESCU WAS REELECTED WITH A SUBSTANTIALLY-REDUCED MAJORITY, HIS INFLUENCE MAY ACTUALLY GROW. THE PRO-CHANGE FORCES HAVE BEEN STRENGTHENED IN THE LEGISLATURE, BUT ANY COALITION SEEMS LIKELY TO BE PLAGUED BY INSTABILITY. THERE IS A REAL DANGER THAT THE EXECUTIVE WILL BECOME THE PRISONER OF THE "NATIONAL COMMUNISTS."

08308 SHAFIR, $M$.

ROMANIA'S ELECTIONS: WHY THE DEMOCRATIC CONVENTION LOST RFE/RL RESEARCH REPORT, 1(43) (OCT 92), 1-7. THE DEMOCRATIC CONVENTION OF ROMANIÁ DID NOT FARE AS WELL IN THE SEPTEMBER 1992 ELECTIONS AS THE PUBLIC OPINION POLLS HAD PREDICTED. THE MAJOR REASON FOR ITS RELATIVELY POOR SHOWING WAS ITS UNPROFESSIONAL ELECTION CAMPAIGN, WHICH FROM THE ELECTORATE'S POINT-OF-VIEH STRESSED THE WRONG FROM THE ELECTORATE'S POINT -OF-VI EN STRESSED THE WRONG

08309 SHAFIR, M.

ROMANIA'S NEW ELECTORAL LAHS

ROMANIA'S NEW ELECTORAL LAHS
RFE/RL RESEARCH REPORT, 1(36) (SEP 92), 24-28.

IN JULY 1992. THE ROMANIAN PARLIAMENT ADOPTED ELECTORAL LAWS TO GOVERM PRESIDENTIAL AND PARLIAMENTARY ELECTIONS. THESE REPLACE THE MARCH 1990 LAH AND WILL GOVERN THE NEXT GENERAL ELECTIONS IN THE FALL OF 1992. THE LAH ON PARLIAMENTARY ELECTIONS RETAINS THE SYSTEM OF PROPORTIONAL REPRESENTATION BUT ALSO CONTAINS NEW PROVISIONS DESIGNED TO PREVENT THE OVER-FRAGMENTATION OF THE LEGISLATURE. THE PARLIAMENT'S DECISION NOT TO FINANCE THE FALL ELECTIONS FROM THE STATE COFFERS COULD INVITE CORRUPTION. PUBLIC OPINION POLLS INDICATE THAT THE DEMOCRATIC CONVENTION IS LEADING OTHER PARTIES, BUT THE SERIOUS CAMPAIGNING HAS NOT YET BEGUN.
08310 SHAFIR, M.

ROMANIA'S NEW GOVERNMENT

RFE/RL RESEARCH REPORT, 1(47) (NOV 92), 11-16.

ROMANIA'S NEH REGIME IS A MINORITY GOVERNMENT COMPOSED OF INDEPENDENTS AND MEMBERS OF THE DEMOCRATIC NATIONAL SALVATION FRONT. PRIME MINISTER NICOLAE VACAROIU'S RECORD SHOWS HIM TO BE AN OPPONENT OF RAPID ECONOMIC AND POLITICAL REFORM. THE GOVERMMENT SEEMS TO CONSIST MOSTLY OF COMPETENT TECHNOCRASTS, BUT IT ALSO INCLUDES MEN WITH LINKS TO THE CEAUSESCU REGIME. FURTHERMORE, THERE IS A POSSIBILITY THAT IT WILL BE POLITICALLY-DOMINATED BY THE OPINIONS OF PRESIDENT ION ILIESCU.

08311 SHAFIR, M.

ROMANIA'S NEW INSTITUTIONS: THE CONSTITUTIONAL COURT RFE/RL RESEARCH REPORT, 1(42) (OCT 92 ) 47-50.

ROMANIA'S NEH LAW GOVERNING THE CONSTITUTIONAL COURT IS LARGELY CONSISTENT WITH DEMOCRATIC NORMS. ITS MAIM PROVISIONS CONCERN THE CONSTITUTIONALITY OF GOVERNMENT DECISIONS AND OF LAWS PASSED BY THE PARLIAMENT, THE CONSTITUTIONALITY OF THE RULES GOVERNING PARLIAMENT, AND THE CONDUCT OF POLITICAL PARTIES. POL ITICS PLAYS A LARGE PART IN THE APPOINTMENT OF JUDGES, BUT IT IS TOO SOON TO TELL WHETHER THIS WILL INFLUENCE THE COURT'S DECISIONS.

08312 SHAFIR, $M$.

ROMANIA'S TORTUOUS ROAD TO REFORH

RFE/RL RESEARCH REPORT, 1(1) (JAN 92), 96-99.

IN 1991, ROMANIA CONTINUED TO BE PLAGUED BY ECONOMIC

MALAISE AND SOCIAL UNREST, MOSTLY DUE TO THE ECONOMIC AND

POLITICAL TACTICS OF THE NATIONAL SALVATION FRONT GOVERNMENT.

08313 SHAFIR, M.

ROMANIAN LOCAL ELECTIONS HERALD NEH POLITICAL MAP RFE/RL RESEARCH REPORT, 1(11) (MAR 92), 24-31. NATIONAL SALVATION FRONT LOST MUCH OF ITS SUPPORT IN LARGE URBAN AREAS, WHERE THE DEMOCRATIC CONVENTION EMERGED AS VICTOR. THE RESULTS OF THE LOCAL COUNCIL ELECTIONS CLEARLY DEMONSTRATE THAT A MAJOR SHIFT IN ELECTORAL PREFERENCES HAS OCCURRED. COMPARED TO THE MAY 1990 GENERAL ELECTIONS SUPPORT FOR THE FRONT HAS NEARLY HALVED, HHILE THAT FOR THE

08314 SHAFIR, $M$.

THE MOVEMENT FOR ROMANIA: A PARTY OF 'RADICAL RETURN' RFE/RL RESEARCH REPORT, 1(29) (JUL 92), 16-21.

RFE/RL RESEARCH REPORT, 1 (29) (JUL 92), 16-21.
THE ADVERSARIES OF THE MOVEMENT FOR ROMANIA, A POLITICAL PARTY FORMED IN DECEMBER 1991, HAS ACCUSED IT OF AIMING TO REVIVE THE INTERWAR FASCIST IRON GUARD. AN EXAMINATION OF THE PARTY'S PROGRAM ALONE DOES NOT REVEAL WHETHER THIS IS INDEED THE CASE. BUT DECLARATIONS BY ITS LEADER, MARIAN MUNTEANU, AND REPORTED PRACTICES AT PARTY GATHERINGS WOULD SEEM TO PLACE IT FIRMLY IN THE RANKS OF THE RADICAL RIGHT.

08315 SHAH, S. ALLAHU AKBAR I (GOD IS THE GREATEST) THE POLITICAL IMPACT OF ISLAM

NUCLEAR TIMES, $9(2)$ (SUM 91), 21-23.

PERCEPTIONS AND ATTITUDES AMONG AMERICANS AMD OTHER WESTERNERS REGARDING ISLAM ARE EXAMINED, PARTICULARLY THE ASSOCIATION OF THIS RELIGION WITH FANATICISM, MILITANCE, INTOLERANCE, AND PATRIARCHY. THE INFLUENCE OF ISLAMIC MOVEMENTS IN THE MIDDLE EAST AND ELSEWHERE IN THE CONTEXT OF OPPOSITIONS TO GOVERNMENTS IS DISCUSSED. ISLAMIC GROUPS ARE COMPARED AND CONTRASTED WITH SECULAR POLITICAL GROUPS WITH REGARD TO LANGUAGE, SYMBOLISM, PURPORTED AUTHORITY, PLATFORMS, AND POPULLARITY. THE IMPACT OF THE GULF WAR ON ISLAMIC MOVEMENTS IS EVALUATED.

08316 SHAHAK, I. HOSTILITY AND COOPERATION

MIDOLE EAST INTERNATIONAL, (437) (NOV 92), 17-18 THE CURRENT NEGOTIATIONS BETWEEN ISRAEL AND SYRIA SHOULD BE SEEN AGAINST THE BACKGROUND OF THE INTRICATE CHARACTER OF THEIR RELATIONSHIP SINCE THE CEASE FIRE OF 1974. A REVIEW OF THEIR RELATIONSHIP SINCE THE CEASE FIRE OF 1974 . A REVIEN
THEIR RELATIONS REVEALS THAT ALL OPTIONS ARE OPEN BETWEEN THEIR RELATIONS REVEALS THAT ALL OPTI

08317 SHAHAK, I.

ISRAEL'S AGREEMENT WITH HIZBULLAH

MIDOLE EAST INTERNATIONAL, 440(440) (DEC 92), 17-18.

THE TACIT AGREEMENT WITH HIZBULLAH WHICH ISRAEL HAS BEEM DETERMINED TO ENFORCE HAVE BEEN BROKEN BY ISRAEL. ISREAL CLAIMS THAT ALL ITS OPERATIONS IN LEBANON HAVE BEEN EDUCATIONAL AND ALSO CLAIMS THE RIGHT TO EXERT THEM ON SYRIA. WHAT SEEMS TO BE HAPPENING NOW IS A STRECHING OF THE CONCEPT OF THE RULES OF THE GAME IN ORDER TO INCLUDE IN IT A REPETITION OF THE 1982 INVASION IN WHICH, HOWEVER, EITHER AN ATTACK ON SYRIA OR AN ULTIMATUM TO IT HILL PLAY A DOMINANT ROLE. 
08318 SHAHAK, I.

ISRAELI LAND SEIZURE IN THE OCCUPIED TERRITORIES MIDOLE EAST POLICY, 1(2) (1992), 96-105.

THE ISRAELI METHODS OF LAND SEIZURE IN THE OCCUPIED TERRITORIES CONSTITUTE A BURNING POLITICAL OUESTION, ESPECIALLY SINCE UNDER THE ISRAELI GOVERNMENT'S AUTONOMY PROPOSALS ALL SUCH LAND WILL NOT BE INCLUDED IN THE AREA IN WHICH PALESTINIANS WILL BE GRANTED A MODICUM OF SELF-RULE. THIS ARTICLE WILL DESCRIBE THE METHODS AND LEGAL JUSTIFICATIONS USED BY ISRAEL FOR LAND SEIZURE, COMCENTRATING ON THE ROLE OF THE PERSON WHO IS IN CHARGE OF SUCH OPERATIONS.

08319 SHAHAK, I.

NEH RESTRICTIONS ON ISRAEL'S PALESTINIAN WORKFORCE MIDOLE EAST INTERNATIONAL, (398) (APR 91), 23-24. A SERIES OF ISRAELI RESTRICTIONS ON THE ECONOMIC ACTIVITIES OF THE OCCUPIES TERRITORIES HAVE RESULTED IN A VAST NUMBER OF PALESTINIANS IN THE OCCUPIED TERRITORIES EARNING THEIR LIVELIHODD IN SIDE ISRAEL. THE EXACT NUMBER IS UNKNOHM BECAUSE THE BULK OF THAT WORKFORCE CONSISTED OF THE "UNAUTHORI ZED WORKERS," NAMELY THOSE WHD ENTERED ISRAEL AND FOUND EMPLOYMENT AND JOB OPPORTUNITIES BY THEIR OWN DEVICES. HOWEVER, RECENT ISRAELI POLICY IS AIMED AT THE COMPLETE

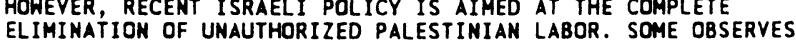
ELIMINATION OF UNAUTHORIZED PALESTINIAN LABOR. SOME OBSERVES IABOR OPPORTUNITIES FOR THE INFLUX OF SOVIET JEWS, AND TO INCREASE ISRAEL'S CONTROL OVER THE LIVELIHOOD OF THE INCREASE ISRAEL
PALESTINIANS.

08320 SHAHAK, I.

SETTLER OPPOSITION TO RABIN'S POLICIES

HIDOLE EAST POL ICY I(4) (1992)

IN VIEN OF THE FACT THAT THE OPPOSITION OF THE ISRAELI RELIGIOUS SETTLERS DID NOT SUCCEED IN SHAKING RABIN'S POSITION WITH THE ISRAELI PUBLIC WHILE THE GOLAN HEIGHTS SETTLERS ACHIEVED A MUCH GREATER SUCCESS, IT IS MECESSARY TO DISTINGUISH SHARPLY BETHEEN THE IDEOLOGIES OF THE THO GROUPS. THIS ARTICLE EXPLORES THE REAL ATTITIDE OF THE MAJORITY OF THE ISRAELI JEWS TO BOTH GROUPS OF SETTLERS AND TO THE OCCUPIED TERRITORIES THEMSELVES. IT CONCLUDES THAN RATHER THAN MOVING TOWARD PEACE RABIN WILL SIDE WITH ZIONISM.

08321 SHAHAK, I.

THE ISRAELI MYTH OF OMMISCIENCE: NUCLEAR DETERRENCE AND INTELLIGENCE

AMERICAN-ARAB AFFAIRS, (36) (SPR 91), 95-103.

THE DEBATES HELD IN ISRAEL DURING THE GULF WAR BROUGHT TO LIGHT SOME REMARKABLE REVELATIONS ABOUT PRE-WAR ISRAELI POLICIES. THIS ARTICLE DESCRIBES TWO SUCH REVELATIONS, THE POLICIES. THIS ARTICLE DESCRIBES TWO SUCH REVELATIONS, THE LEAST THREE ARAB STATES IN THE PAST, AND THE SECOND ABOUT THE REAL NATURE AND ES IN THE PAST, AND THE SECOND ABOU THE REAL NATURE AND CAPACITY OF THE ISRAELI INTELLIGENCE SERVICES. IT CONCLUDES THAT ISRAEL'S NUCLEAR RETALIATION STRATEGY, FOLLOWED FOR A NUMBER OF YEARS, FAILED DIS DURING THE GULF WAR. FURTHERMORE, ISRAEL'S VAUNTED INTELLIGENCE CAPABILITIES WAS SHOWN TO BE ERROR-PRONE AND INEFFICIENT. BOTH

08322 SHAHAK, I.

THE MUSAHI ASSASSINATION: A FORETELLING OF ISRAEL'S NEW POLICIES IN LEBANOM

WASHINGTON REPORT ON MIDDLE EAST AFFAIRS, XI(1) (JUN 92), $29,90$.

THE FEBRUARY 16, 1992 ASSASSINATION OF SHEIKH ABBAS MUSAWI HAS FOCUSED ATTENTION ON ISRAEL'S NEW MILITANT POLICY IN LEBANON. ONE OBJECTIYE OF THIS ISRAELI POLICY IS TO OFFSET THE EFFECTS OF THE MADRID CONFERENCE.

08323 SHAHAK, I.

U.S. EUPHORIA OVER RABIN'S VICTORY CAN BE DANGEROUS TO PEACE

HASHINGTON REPORT ON MIDDLE EAST AFFAIRS, XI(3) (AUG 92), 25.

THE ENTHUSIASM IN THE HALLS OF THE U.S. EXECUTIVE BRANCH THAT GREETED THE ELECTORAL TRIUMPH OF YITZHAK RABIN SUGGESTS A DANGEROUS EUPHORIA THAT MAY THREATEN PRESIDENT GEDRGE BUSH'S CHANCES FOR RE-ELECTION.

08324 SHAHIN, E.E.

ALGERIA: THE LIMITS TO DEMOCRACY

MIDOLE EAST INSIGHT, VIII (6) (JUL 92), 10-19.

THE ASSASSINATION OF PRESIDENT MOHAMED BOUDIAF IN JUNE 1992 MARKED A NEW PHASE IN ALGERIA'S ESCALATING POLIIICAL CRISIS. IT REFLECTED THE INTRA-ELITE CONFLICTS THAT HAVE SET THE COUNTRY ON A TREACHEROUS, UNCERTAIN PATH. ON JANUARY 11 , 1992, THE ALGERIAN MILITARY HAD STAGED A COUP TO BLOCK THE FREELY-ELECTED ISLAMIC SALVATION FRONT FROM COMING TO POWER. IRONICALLY, AND PERHAPS PREDICTABLY, IT WAS THE ARMY GENERALS AND THEIR ALLIANCE OF SO-CALLED "PRO-DEMOCRACY FORCES," NOT THE FIS, THAT VIOLATED THE CONSTITUTION, OUSTED
PRESIDENT CHADLI BENJEDID, SUPPRESSED HUMAN RIGHTS, AND DERAILED ALGERIA'S DEMOCRATIC PROCESS. THE SAME FORCES THAT
BANKRUPTED ALGERIA FOR 30 YEARS ARE NOW BACK TO RULE THE COUNTRY.

08325 SHAHIN, M.

A LOT ON ARAFAT'S MIND

MIDDLE EAST INTERNATIONAL, 438(438) (NOV 92), 6-7.

PLO OFFICIALS IN TUNIS HAVE BEEN KEEPING A CLOSE EYE ON THE PEACE TALKS AND THE PALESTINIAN LEADERSHIP HAD TO STEP INTO THE FAST LANE TO ENSURE ALTERATIONS WERE MADE TO THE WORDING OF THE JORDANIAN-ISRAELI DRAFT AGENDA FOR THE BILATERAL TALKS BEFORE PALESTINIAN CONCERNS WERE ONCE AGAIN OVERLOOKED. THE REFUGEE ISSUE HILL BE SETTLED ACCORDING TO EXISTING INTERNATIONAL LAH. THIS REPORT SUGGESTS THAT THERE ARE TWO SCHOOLS OF THOUGHT WITHIN THE PLO REGARDING THE ISSUES OF REFUGEES AND WATER-SHARING.

08326 SHAHIN, M.

BURST OF DIPLOMACY

MIDOLE EAST INTERNATIONAL, 439 (DEC 92), 7-8.

AFTER A THREE-DAY MEETING IN TUNIS AT WHICH PALESTINIAN NEGOTIATORS AND THE POL ITICAL LEADERSHIP AGREED TO CONTINUE WITH THE PEACE PROCESS DESPITE GROWING CRITICISM. THE WITH THE PEACE PROCESS DESPITE GROWING CRITICISM, THE WITH THE ISRAELIS PUTTING FORWARD A PLAN TO CANTONISE THE THAT THE PEACE TALKS, HAD MALESTINIANS COULD HARDLY CLAIM STALEMATE PROVOKED CALLS TO DELAY FURTHER DIALOGUE WITH THE ISRAELIS, AT LEAST UNTIL THE CLINTON ADMINISTRATION TAKES ISRAE
OVER.

08327 SHAHIN, M.

JORDAN: SET-BACK FOR THE KING'S VISION

MIDDLE EAST INTERNATIONAL, 440(440) (DEC 92), 10-11. IN JORDAN. POLITICAL ISSUES WHICH HAVE THREATENED TO UNDERMINE THE KING'S VISION OF DEMOCRACY APPEAR TO HAVE RUN AMOK, DESPITE APPEALS BY KING HUSSEIN. THE EXECUTIVE BRANCH HAS MOVED TO OUTLAW THE LEGALIZATION OF TWO POLITICAL PARTIES AND THE LOWER HOUSE OF PARLIMENT HAS MOVED TO SEVERELY CURB PRESS FREEDOMS. THE GOVERMMENT HAS ALSO BANNED THE OWNERSHIP OF MOST TYPES OF WEAPONS AND ORDERED THE LICENSING OF ALL OTHERS EARLIER THIS MONTH.

08328 SHAHIN, M.

JORDAN: THE KING'S PARDON

MIDDLE EAST INTERNATIONAL, 438(438) (NOV 92), 13-14. KING HUSSEIN ANNOUNCED A GENERAL AMNESTY FOR UP TO 1,000 PEOPLE HELD IN CUSTOOY FOR OR ACCUSED OF SECURITY-RELATED CRIMES. KING HUSSEIN HAS A LONG HISTORY OF PARDONING HIS POLITICAL OPPONENTS. EVEN HUSSEIN'S ADVERSARIES, OF WHICH POL ITICAL OPPONENTS. EVEN HUSSEIN'S ADVERSARIES, OF WHICH THERE ARE FEWER EACH YEAR, ADMIRE HIS ABILTIY TO RESTRAIN
THE AMOUNT OF FORCE USED AGAINST OPPONENTS. A RECENT CASE, THE AMOUNT OF FORCE USED AGAINST OPPONENTS. A RECENT CASE, HOWEVER, WAS MEANT AS A PUBLIC LESSON THAT ANYONE WHO IS ACCUSED OF SUBVERSION BY

08329 SHAHIN, $M$

PLO MORRIES OVER SYRIA

MIDDLE EAST INTERNATIONAL, (435) (OCT 92), 6-7.

AS ARAB PEACE NEGOTIATORS PREPARE THEMSELVES FOR ROUND SEVEN OF THE TALKS WITH THE ISRAELIS, SCHEDULED TO RESUME IN LATE OCTOBER, YASIR ARAFAT FACES INCREASING INTERNAL AND EXTERNAL PRESSURES TO CONSOLIDATE PALESTINIAN RANKS AND COME UP WITH A PROPOSAL ACCEPTABLE TO OPPOSITION GROUPS WITHIN THE PLO. ARAFAT'S MOST PUBLIC WORRY IS THE PROSPECT OF THE SYRIANS AGREEING TO SIGN A SEPARATE PEACE TREATY WITH THE ISRAEL IS. HOWEVER, DAMASCUS HAS REPEATEDLY DELCRAED ITS INTENTION THAT A FINAL MIDOLE EAST PEACE AGREEMENT BE "ALL INCLUSIVE." THE NEED TO QUELL INTERNAL UNREST IN THE PLO BECAME EVEN MORE IMPORTANT AFTER PRO-JORDANIAN PALESTINIAN OFFICIALS CAME TO AMMAN AT THE END OF SEPTEMBER. SOME PROARAFAT OBSERVERS ARE CONCERNED THAT JORDAN'S KING HUSSEIN, BY MEETING HITH ISRAELI ARAB NOTABLES AND PALESTINIAN DIGNITARIES, MAY HAVE UPSTAGED ARAFAT AND UNDERMINED HIS LEADERSHIP.

08330 SHAHIN, $M$

PLO--OPPOSITION TO THE TALKS

MIDDLE EAST INTERNATIONAL, (434) (SEP 92), 7-8.

TEN PALESTINIAN FACTIONS HAVE CALLED FOR AN ABRUPT TERMINATION OF PARTICIPATION IN THE PEACE PROCESS. IN WHAT IS TO DATE THE STRONGEST SHOW OF STRENGTH AGAINST THE ONGOING NEGOTIATIONS, THE SIX-POINT MEMORANDUM ISSUED IN DAMASCUS IN MID-SEPTEMBER WAS SIGNED BY FOUR GROUPS FROM DAMASCUS IN MID-SEPTEMBER WAS SIGNED BY FOUR GROUPS FROM
WITHIN THE PLO AND SIX ORGANIZATIONS OUTSIDE ITS UMBRELLA. WITHIN THE PLO AND SIX ORGANIZATIONS OUTSIDE ITS UMBRELLA. THE MEMORANDUM CALLED FOR AN IMMEDIATE END TO THE TALKS, DECLARED THAT THE NEGOI IATORS HAD NOT BEEN MANDATED TO SIGN ANY AGREEMENT, AND PLACED FULL RESPONSIBILITY ON THE PLO LEADERSHIP IF ANY PALESTINIAN RIGHTS WERE FORTIFIED. FEARS THAT A LESS THAN SATISFACTORY AGREEMENT OR A BREAKDOWN OF GROUPS HAVE ONLY INCREASED ANXIETIES AMONG PALESTINIAM SUPPORTERS OF THE TALKS. 
08331 SHAHIN, M.

SHALLOW VICTORY FOR ARAFAT

MIDDLE EAST INTERNATIONAL, 436 (OCT 92), 5-6.

WHAT APPEARED TO BE ANOTHER GO-AHEAD FOR PALESTINIAN NEGOTIATORS FOR THE SEVENTH ROUMD OF TALKS BY THE PALESTINE CENTRAL COMITTEE WHICH MET IN TUNIS IN OCTOBER, WAS IN REALITY A VERY SHALLOH VICTORY FOR THE POLICY MAKERS OF THE PLO EXECUTIVE COMMITTEE AMD CHAIRMAY ARAFAT THE PALESTINIAN OPPOSITION'S ANGER WITH THE LIMITED TERMS OF THE PALESTINIANISRAELI DIALOGUE HAS FURTHER INFLAMED LAST MONTH WHEN IT ISRAELI DIALOGUE WAS FURTHER INFLAMED LAST MONTH WHEN IT BECAME CLEAR THAT ISRAEL WAS INDEED CONSIDERING A LAND-FORPEACE DEAL WITH SYRIA. WHILE SYRIA AND ISRAEL HAVE SAID THAT SUCH A DEAL IS FAR

08332 SHAHIN, M.

THE KING LASHES OUT

MIDDLE EAST INTERNATIONAL, 49 (DEC 92) 3-4.

KING HUSSEIN APPEARED TO SACRIFICE TIES HITH KUWAIT IN NO UNCERTAIN TERMS WHEN HE LASHED OUT AT GULF ARABS IN GENERAL AND KUWAITIS IN PARTICULAR FOR THEIR BACKHARD AND TYRANNICAL WAYS AND QUESTIONED THEIR LEGITIMACY AS ARAB RULERS DURING AN ADDRESS TO GRADUATES OF ONE OF JORDAN'S MILITARY ACADEMIES ON NOVEMBER 23, 1992. KING HUSSEIN HAS GIVEN A CLEAR SIGN THAT EVEN IF HE TOLERATED JORDANIAN FINANCIAL, MILITARY, AND IDEOLOGICAL LINKS WITH SAUDI ARABIA AND IRAN IN THE PAST, HE NOW WANTS THEM CURTAILED.

08333 SHAHIN, M.

THE MULTILATERALS: THE THORNY ISSUE OF REFUGEES MIDDLE EAST INTERNATIONAL, (437) (NOV 92), 7-8

AMONG ALL THE ISSUES THE ISRAELIS AND PALESTINIANS ARE EXPECTED TO DISCUSS IN THE PEACE PROCESS, THE FUTURE OF PALESTINIAN REFUGEES IS SECOND IN IMPORTANCE ONLY TO THE FUTURE OF THE DISPUTED LAND ITSELF. BY CONSERVATIVE ESTIMATES, THERE ARE 2.5 MILLION PALESTINIAN REFUGEES WHO OFFICIALLY HAVE THE RIGHT OF RETURN OR COMPENSATION AS STIPULATED IN U.N. RESOLUTION 194.

08334 SHAIN, Y.; LINZ, J.

THE ROLE OF INTERIM GOVERNMENTS

JOURNAL OF DEMOCRACY 3(1) (JAN 92) 73-89.

THE PROBLEM OF WHO GOVERHS BETHEEN THE START OF A DEMOCRATIC TRANSITION AND THE ASSUMPTION OF POWER BY A FREELY ELECTED GOVERMMENT HAS BEEN A CENTRAL ONE IN MANY DEMOCRATIC REGIME CHANGES AROUND THE GLOBE, FROM EASTERM EUROPE TO THE PROTRACTED CONFLICTS IN CAMBODIA, AFGHANISTAN, AND SOUTH AFRICA. THIS ARTICLE EXAMINES THE ROLE OF INTERIM GOVERNMENTS IN DEMOCRATIC TRANSFORMATIONS. INTERIM GOVERNMENTS MAY AFFECT THE CONSTITUTIONAL FRAMEWORK AND THE NATURE OF THE FUTURE POLITICAL SYSTEM; THE DEGREE OF POLITICAL OPENNESS IN THE FUTURE DEMOCRACY, ITS RESPECT FOR HUMAN RIGHTS, AND ITS WILLINGNESS TO ERADICATE THE VESTIGES OF THE OLD REGIME; THE NATURE OF THE ECONOMY (CAPITALIST OR SOCIALIST); THE ROLE OF CERTAIN KEY INSTITUTIONS, ESPECIALLY THE ARMED FORCES, IN THE NEW SOCIETY; AND THE COUNTRY'S FUTURE INTERMATIONAL POSTURE AND ALLIANCES. YET ALL INTERIM ADMINISTRATIONS LACK A DEHOCRATIC MANDATE UNTIL FREE AND CONTESTED ELECTIONS ARE HELD AND A PROPERLY CHOSEN GOVERNMENT ASSUMES POHER.

08335 SHAMBAUGH, D.

CHECKS AND BALAMCES

FAR EASTERN ECONOMIC REVIEH, 155(45) (NOV 92), 23. A COMPREHENSIYE CHAMGIMG OF THE GUARD OCCURRED AT

CHINA'S RECENTLY CONCLUDED 14TH PARTY CONGRESS. NOT ONLY HAS

THERE A SIGNIFICANT DEGREE OF TURNOVER OF PERSONNEL IN THE

CENTRAL COMMITTEE AND THE RULING POLITBURO, THERE WERE ALSO

CETENSIVE CHANGES IN THE PARTY SECRETARIAT, DISCIPLINE

EXTENSIVE CHANGES IN THE PARTY SECRETARIAT, DISCIPLINE
INSPECTION COMMISSION AND CENTRAL MILITARY COMMISSION (CMC).

MANY SEE THE OUTCOME AT THE CONGRESS AS AN INDICATION OF
GROWING ACCEPTANCE OF DENG XIAOPING'S PROGRAM OF

LIBERALIZING THE ECONOMY WHILE MAINTAINING A FIRM GRIP ON

LIBERALIZING THE ECONOMY WHILE MAINTAINING A FIRM GRIP ON

POLITICAL POWER (A LA SINGAPORE OR TAIWAN). HOWEVER, CHINA

NATIONAL AGENDA IS NOT BEING SET IN PEKING BUT ACROSS
COUNTRY, WHERE MILLIONS OF CITIZENS ARE GRASPING THE

COUNTRY, WHERE MILLIONS OF CITIZENS ARE GRASPING THE

LEADERSHIP CAN DO IS TO WATCH PROCESSES THAT ARE

LEADERSHIP CAN DO IS TO WATCH PROCESSES THAT ARE
INCREASINGLY OUT OF THEIR CONTROL. AND IN SOME SMALL WAY

INCREASINGLY OUT OF THEIR CONTROL, AND IN SOME SMALL WAY

SACILITATE THE EVOLUTION TO A MARKET ECONOMY AND CIVIL

CONGRESS MAY LIE PRECISELY IN ITS IRRELEYANCE.

08336 SHAMBAUGH, D.

CHINA AND EUROPE

ANMALS OF THE AMERICAN ACADEMY OF POLITICAL AND SOCIAL

SCIENCE, 519 (JAN 92), 101-114.

RELATIONS BETHEEN CHINA AND EUROPE HAVE FLUCTUATED SINCE

1949. TO A SIGNIFICANT EXTENT, CHINA'S RELATIONS WITH BOTH

EASTERN AND WESTERN EUROPE HAVE BEEN A FUNCTION OF THE

BROADER PATTERN OF ITS RELATIONS WITH THE SOVIET UNION ANO

THE UNITED STATES. YET, IN BOTH EUROPEAN CASES, INDEPENDENT

FACTORS HAVE SERVED TO SUSTAIN OR STRAIN TIES. THIS ESSAY

TRACES THE COURSE AND DYNAMICS OF SINO-EUROPEAN
RELATIONSHIPS OVER THE PAST FOUR DECADES. TODAY, SINOEUROPEAN RELATIONS ARE BUSINESSLIKE YET FRAGILE--A FRAGILITY THAT THE RECEDING COLD WAR, THE FAILURE OF COMAUNISM IN EASTERN EUROPE, AND THE WEST EUROPEAN MARKET OF 1992 WILL INTENSIFY DURING THE FORESEEABLE FUTURE.

08337 SHAMBAUGH, $D$.

CHINA IN 1991: LIVING CAUTIOUSLY

ASIAN SURVEY, XXXII (1) (JAN 92), 19-32.

FOR BOTH STATE AND SOCIETY, 1991 WAS A YEAR OF CAUTION IN CHINA. THE SIEGE MENTALITY THAT HAS GRIPPED CHINA'S LEADERSHIP SINCE 1989 SHOWED NO SIGNS OF ABATEMENT. THE REGIMES ATTEMPTED RETURN TO QUASI-TOTALITARIAN RULE HAS MET WITH A COMBINATION OF PASSIVE RESISTANCE, FEIGNED COMPLIANCE, WITH A COMBINATION OF PASSIVE RESISTANCE, FEIGNED COMPLIANCE, DISCUSSES POLITICAL TRENDS, THE ECONOMY, SOCIETY, AND FOREIGN RELATIONS OF CHINA IN 1991.

08338 SHAMBAUGH, D.

REGAINING POLITICAL MOMENTUM: DENG STRIKES BACK CURRENT HISTORY, $91(566$ ) (SEP 92), 257-261.

THE AUTHOR LOOKS AT DENG XIAOPING'S RECENT REASSERTION OF HIS ROLE AS CHINA'S ELDER STATESMAN AND AT THE LEADERSHIP PROBLEMS AFFLICTING THE CHINESE POLITY.

08339 SHAMBAUGH, D. (ED.)

THE MAKING OF THE BIG LIE: CONTENT AND PROCESS IN THE CCP PROPAGANDA SYSTEM

CHINESE LAW AND GOVERNMENT, 25(1) (SPR 92), 3-86,

THIS ISSUE EXPLORES THE FORMULATION, SUBSTANCE, AND USE OF OFFICIAL PROPAGANDA IN COMMUNIST CHINA, FOCUSING ON THE REACTION TO THE TIANANMEN SQUARE UPRISING. THE CONTENTS INCLUDE A PROPAGANDA OUTLINE ON "THE NECESSITY OF GAINING A CLEAR UNDERSTANDING OF THE ESSENCE OF THE TURMOIL AND IMPOSING MARTIAL LAH," A SPEECH BY DENG XIAOPING TO A GROUP OF MILITARY OFFICERS IN JUNE 1989, LI PENG'S SPEECH AT A MEETING CALLED BY THE CCP CENTRAL COMHITTEE AND STATE NATIONAL CONFERENCE OF HEADS OF PROPAGANDA DEPARTMENTS IN JULY 1989 .

08340 SHAMSHUR, O.V.

UKRAINE IN THE CONTEXT OF NEW EUROPEAN MIGRATIONS INTERNATIONAL MIGRATION REVIEN, XXVI(2) (SUM 92), 258-268. LIKE OTHER SOVIET SUCCESSOR STATES, THE UKRAINE IS FACED BY MUL IPIE INTERMATIONAL MIGRATION-RELATED DILEMMAS AND OPPORTUNITIES. HOWEYER, APOCALYPTIC PREDICTIONS FORECASTING MASS EMIGRATION APPEAR UNHARRANTED. THE FUTURE CHARACTER OF UKRAINIAN EMIGRATION POLICIES IS DISCERNIBLE IN THE CATEGORY OF THOSE WHO TRAVEL FOR "PERSONAL REASONS," MOST OF WHOM ARE TOURISTS. MANY TOURISTS ARE LOOKING FOR WORK ABROAD BUSINESS TRIPS CONSTITUTE A SECOND CLASS OF OFTEN CONCEALED LABOR FORCE MOVEMENT. THE ECOLOGICAL EFFECTS OF THE CHERNOBYL DISASTER ALSO WILL BE A LONG-TERM FACTOR AFFECTING UKRAINIAN EMIGRATION.

08341 SHAMGQUAN, G. NEW OPERATING MECHANISM

BEI JING REVIEH, 35(24) (JUN 92), 18-24.

BEFORE THE YEAR 2000, IN ACCORDANCE WITH CHINA'S OVERALL GOAL OF ESTABLISHING A NEW "PLANNED COMMOOITY ECONOMIC SYSTEM" REGULATED BY A COMBINATION OF PLANNING AND MARKET FORCES, STATE-OWNED ENTERPRISES WILL CHANGE THEIR OPERATING MECHANISM AND BECOME INDEPENDENT, MARKET-ORIENTED ECONOMIC ENTITIES. THE FUNCTIONS AND FORM OF GOVERNMENT CONTROL OVER THE ECONOMY HILL CHANGE FROM DIRECT CONTROL OVER ENTERPRISES' PRODUCTION AND BUSINESS ACTIVITIES INTO A SYSTEM OF MACRO-ECONOMIC MANAGEMENT BASED ON INDIRECT REGULATION AND CONTROL.

08342 SHANKER, A. WHEN PRIVATE SCHOOLS ARE "PUBLIC": TAKING A PAGE FROM ORWELL'S BOOK

CHURCH AND STATE, 45(1) (JAN 92), 20

PRESIDENT BUSH AND SECRETARY OF EDUCATION ALEXANDER ARE NOT TACKLING THE TOUGH ISSUES FACING PUBLIC EDUCATION. RATHER, THEY ARE ENGAGING IN DOUBLESPEAK BY PROCLAIMING THAT RATHER, THEY ARE ENGAGING IN DOUBLESPEAK BY PROCLAIMING THAT
PRIVATE SCHOOLS ARE ACTUALLY PUBLIC AND ADVOCATING USING PRIVATE SCHOOLS ARE ACTUALLY PUBLIC AND ADVOCATING US
PUBLIC TAXES TO FUND THESE ERSTHHILE PRIVATE SCHOOLS.

08343 SHANKS, N.; SMITH, S.J.

BRITISH PUBLIC POLICY AND THE HEALTH OF HOMELESS PEOPLE POLICY AND POLITICS, 20(1) (JAN 92), 35-66.

IN GREAT BRITAIN, THERE IS GROWING CONCERM AMONG POLICY MAKERS AND THE PUBLIC ABOUT THE INCREASE IN HOMELESSNESS. THIS CONCERN IS HEIGHTENED BY EVIDENCE THAT HOMELESSNESS CARRIES HEALTH RISKS AND THAT HOMELESS PEOPLE OFTEN HAVE LIMITED ACCESS TO PRIMARY MEDICAL CARE. MOREOVER, THERE ARE
MANY VERY REAL WAYS IN WHICH HOMELESSNESS IS A PUBLIC HEALTH MANY VERY REAL WAYS IN WHICH HOMELESSNESS IS A PUBLIC HEALT
ISSUE AND A SOURCE OF HEALTH INEQUALITIES. NEVERTHELESS, THIS PAPER ARGUES THAT THE HEALTH PROFILE OF HOMELESS PEOPLE IS PRIMARILY A HOUSING ISSUE--ONE HHOSE URGENCY MAY BE COMPROMISED BY THE INCREASING TENDENCY TO "MEDICALISE" THE PROBLEM OF HOMELESSNESS AND HEALTH. 
08344 SHANOR, D.

BEYOND THE CZECH-SLOVAK BREAKUP

NEW LEADER, LXXV(11) (SEP 92), 6-7

NOW THAT A SPLIT BETWEEN THE REPUBLICS SEEMS IMMINENT, REGRET OVER THE DEMISE OF THE UNION IN CZECHSLOVAKIA IS TURNING INTO ANTICIPATION OF THE FRUITS OF INDEPENDENCE. THE CZECHS ARE LIKELY TO DO WELL IN THE NEW EUROPE BUT SLOVAKIA, THE INITIATOR OF THE SPLIT, WILL BE THE ONE TO SUFFER. THE SLIM HOPE OF AVERTING A BREAKUP APPEARS TO BE A REFERENDUM IN JANUARY. SHOULD THE DIVORCE TAKE PLACE, THE REPUBLICS CAN MAY OF THE GAINS MADE SINCE THE VELVET REVOLUTION NEARLY THREE YEARS AGO.

08345 SHAPIRO, A.; HENDT, A.

THE DIFFERENCE THAT REALISM MAKES: SOCIAL SCIENCE AND THE POLITICS OF CONSENT

POLITICS AND SOCIETY, 20(2) (JUM 92), 197-224.

TO ILLUSTRATE THE' DIFFERENCE THAT REALISM MAKES IN THE TO ILLUSTRATE THE DIFFERENCE THAT REALISM MAKES IN THE
CONDUCT OF THE HUMAN SCIENCES BY REFERENCE TO ARGUMENTS ABOUT THE NATURE OF CONSENT IS THE OBJECTIVE OF THIS ARTICE. IT BEGINS WITH A BRIEF DESCUSSION OF SOME OF THE PROBLEMS THAT STUDYING CONSENT PRESENTS TO SOCIAL SCIENTISTS. NEXT I ARGUES THAT LOGICAL EMPIRICISM HAS DEGENERATED IN PRACTICE INTO THO TRUNCATED FORMS, LOGICISM AND EMPIRICISM, AND SHOHS HOW THESE PLACE ARTIFICIAL CONSTRAINTS ON THE STUDY OF CONSENT. FINALLY. THE STUDY DF CONSENT IS DISCUSSED IN LIGHT OF A REALIST CONCEPTION OF SOCIAL SCIENCE.

08346 SHAPIRO, M.

THAT OBSCURE OBJECT OF VIOLENCE: LOGISTICS, DESIRE, WAR ALTERNATIVES, 17(4) (FAL 92), 453-478

A COMPLEMENTARY DIMENSION OF DEREALIZATION IS TREATED IN THIS ARTICLE. IT CONSIDERS THE PROCESS OF PRODUCING AN ABSTRACT ENMITY, AND RENDERS IT PECULIAR BY GOING BACK TO AN ANCIENT AND VERY DIFFERENT UNDERSTANDING OF WARFARE. THE ARTICLE STUDIES THE IDENTIFICATION OF FRIENDS AND FOES; OFFERS ONTOLOGICAL AND DISCURSIVE MEDIATIONS ON
DEREALIZATION; AND, EXAMINES THE "THIS/THAT" OBSCURE OBJECT OF DESIRE. IT CONCLUDES THAT "BEING IS SUPERIOR TO DOING. WHAT A NATION IS, IS ESSENTIAL. WHAT IT DOES CAN ONLY

08347 SHAPIRO, $R$

GET REAL

NEH REPUBLIC, 206 (7) (FEB 92), 11-12.

THE AUTHOR CRITIQUES PRESIDENT GEORGE BUSH'S STATE OF THE UNION ADDRESS OF JANUARY 28, 1992. HE ARGUES THAT THE SPEECH PROMISED A DESPERATE GIVE-AWAY OF MONEY BUSH DOESN'T HAVE TO ANYBOOY HHO VOTES. HE CONTENDS THAT IT REFLECTED THE TWO FAILED IDEOLOGIES OF THE 1980'S: REAGANISM AND BIGSPENDING LIBERALISM.

08348 SHARKANSKY, I.

GOVERNING A CITY THAT SOME WOULD INTERNATIONALIZE: THE CASE OF

JERUSALEM JOURNAL OF INTERMATIONAL RELATIONS, 14(1) (MAR 92), 16-32.

THE STATUS OF JERUSALEM IS HIGH ON ISRAEL'S LIST OF INTERNATIONAL ISSUES. PARTICIPANTS IN LOCAL DISPUTES ARE LIKELY TO HAVE FOREIGN SUPPORT, AND NATIONAL OFFICIALS OFTEN INTERVENE IN LOCAL MATTERS IN ORDER TO SHAPE THE COUNTRY'S
FOREIGN RELATIONS. AS A RESULT, INTERNATIONAL RELATIONS ARE EMBEDDED IN PROSAIC ISSUES OF MUNICIPAL ADMINISTRATION. THIS ARTICLE EXPLORES THE INTERNATIONAL FEATURE OF LOCAL

GOVERMMENT IN JERUSALEM; THE MANIFESTATIONS OF INTERNATIONAL TENSIONS IN LOCAL POLICYMAKING; AND JERUSALEM'S INTERNATION IMPORTANCE.

08349 SHARLET, $R$.

SOVIET CONSTITUTIONAL CRISIS

M.E. SHARPE, INC. $1992,250$.

MOVING FROM THE ADOPIION OF THE POST-STALIN CONSTITUTION OF 1977 THROUGH ITS SUBSEQUENT IMPLEMENTATION UNDER BREZHNEV THROUGH GORBACHEV, THE AUTHOR TRACES THE GRADUAL EVOLUTION OF A NASCENT CONSTI ITUTIONALISM IN THE ERSTWHLE USSR. HE DEMONSTRATES THE GRADUAL TRANSFORMATION OF LAH FROM AN INSTRUMENT OF COMMUNIST PARTY RULE INTO THE NEW RULES OF THE GAME FOR NONAUTHORITARIAN POLITICAL DEVELOPMENT. HE ARGUES THAT ONE OF GORBACHEV'S MOST DURABLE ACHIEVEMENTS MAY BE HIS THAT ONE OF GORBACHEV'S MOST DURABLE ACHIEVEMENTS MAY BE
REDEFINITION OF SOVIET POLITICS INTD A LEGAL IDIOM ALONG REDEFINITION OF SOVIET POLITICS INTO A LEGAL IDIOM ALONG WITH HIS RELOCATION OF POLICYMAKING FROM BEHIND THE CLOSED DOORS OF PARTY CONCLAVES INTO THE MORE OPEN, EMERGENT ARENA OF THE SOVEREIGN REPUBLICS AS SUCCESSORS TO THE FORMER USSR, OF THE SOVEREIGN REPUBLICS AS SUCCESSORS TO THE FORMER USSR

08350 SHARMA, D

INDIA'S LOPSIDED SCIENCE

BULLETIN OF THE ATOMIC SCIENTISTS, 47(4) (MAY 91), 32-36.

THE AUTHOR ARGUES THAT INDIAN SCIENCE, ALTHOUGH ONCE
INMOVATIVE, TODAY FAILS TO DELIVER SIGNIFICANT ADVANCES TO
THE SCIENTIFIC WORLD AT LARGE OR TO THE INDIAN PEOPLE. IT IS DESCRIBED AS HEAVILY SKEWED TOWARD NUCLEAR, MILITARY, AND SPACE RESEARCH. THE CAUSES OF INDIAN SCIENCE'S FAILURE TO BECOME A VECTOR FOR SOCIAL CHANGE ARE EXAMINED. THE AUTHOR PLACES THE BLAME LARGELY ON THO INDIVIDUALS: HOMI J. BHABHA AND JAHAHARLAL NEHRU. IT IS CONTENDED THAT THE CULT OF PERSONALITY THEY ALLOWED STIFLES INDIAN SCIENTIFIC ENDEAVOR. THE RELATIONSHIP BETWEEN THESE THO MEN, THEIR INFLUENCE ON THE SCIENTIFIC COMMUNITY, AND BHABHA'S' POLITICAL AND SCIENTIFIC ACTIVITIES ARE EXPLORED.

08351 SHARMA, P.D.; KUMAR, R.

LEGISLATORS IN AN INDIAN STATE: A STUOY IN SOCIAL CHARACTERISTICS

ASIAN SURVEY, XXXII(11) (NOV 92), 1000-1011.

THIS ARTICLE EXAMINES THE SOCIAL CHARACTERISTICS OF LEGISLATORS IN THE INDIAN STATE OF HARYANA. IT CONSIDERS THE DATA ON LEGISLATORS IN THO SUCCESSIVE ELECTIONS, 1987 AND 1991, TO THE HARYANA VIDHAN SABHA (LEGISLATIVE ASSEMBLY). IT ANALYZES THE SOCIAL ENVIRONMENT IN HARYANA, THE ROLE OF WOHEN, RELIGION, AND OF THE CASTE SYSTEM IN THE STATE'S POLITICS. IT CONCLUDES THAT VOTERS GENERALLY PLACE MORE POLITICS. IT CONCLUDES THAT VOTERS GENERALLY PLACE IMPORTANCE ON INOIVIDUALS THAN POLITICAL PARTIES.
FURTHERMORE, CASTE-BASED, MALE-DOMINATED POLITICS, FACTORS FURTHERMORE, CASTE-BASED, MALE-DOMINATED POLITICS,

OF RELIGION AND FAMILY, POLITICAL EXPERIENCE, AND
URBAN/RURAL CLEAVAGES ALL CONTINUE TO TO BE SIGNIFICANT

URBAN/RURAL CLEAVAGES ALL CONTINUE TO TO BE SIGNIFICAN
FACTORS INFLUENCING BOTH VOTERS AND POLITICAL PARTIES.

08352 SHARP, E.B.

AGENDA-SETTING AND POLICY RESULTS: LESSONS FROM THREE DRUG POLICY EPISOOES

POLICY STUDIES JOURNAL, 20(4) (WIN 92), 538-551.

THE AUTHOR FOCUSES ON THREE EPISODES OF U.S. POLICY

MAKING CONCERNING ILLICIT DRUGS DURING THE NIXOM

ADMINISTRATION, THE CARTER ADMINISTRATION, AND THE

CONTEMPORARY WAR ON DRUGS. DRAHING UPON EVIDENCE FROM

CONGRESSIONAL HEARINGS, THE GALLUP POLL, "THE READERS' GUIDE

TO PERIOOICAL LITERATURE," AND CONTENT ANALYSIS OF "THE NEH YORK TIMES INDEX," THE THREE EPISODES ARE CHARACTERIZED AS FITTING A MODEL OF AGENDA-SETTING BY COBB, ROSS, AND ROSS. THE AUTHOR ANALYZES THE LINKAGE BETWEEN THESE DIFFERENCES IN AGENDA-SETTING AND THE VERY DIFFERENT POLICY CONTENT OF EACH EPISODE. WHILE THE NIXON AND CARTER EPISODES EXEMPLIFY THE DYNAMICS OF MOBILIZATION AND INSIDE ACCESS AGENDA-SETTING RESPECTIVELY, THE CONTEMPORARY DRUG POL ICY EPISODE IS
ANOMALOUS. IT SUGGESTS THE NEED FOR AN EXTENSION OF THE COBB, ANOMALOUS. IT SUGGESTS THE NEED FOR AN EXTENSION OF THE COBB
ROSS, AND ROSS TYPOLOGY TO INCORPORATE A NEH, NETHORK TYPE OF AGENDA-SETTING.

08353 SHARP, G.

THE 'MOVEMENT' AND THE MOVEMENTS

ARENA MAGAZINE, 2 (DEC 92 ) 15-17.

ACCORDING TO THE AUTHOR, THE HISTORY OF BOB SAMTAMARIA'S 'MOVEMENT' TELIS MUCH ABOUT THE MATURE OF CONTEMPORARY POLITICS AND THE PROSPECTS FOR MORE RECENT SOCIAL MOVEMENTS AS A TIGHT-KNIT AMD DISCIPLINED ORGANIZATION. 'THE MOVEMENT AROSE WITHIN THE CONTEXT EMPHASIZING THE POLITICS OF INDIVDUAL CONSCIENCE WITHIN THE ESTABLISHED FRAMEWORK OF CATHOLIC PRACTICE. PRESENT WORKERS FACE A REDOUBLED PROBLEM. HOW CAN GOD LIVE WHEN THE CATEGORY OF HIS SUBJECTS IS BEING ERODED ON EVERY SIDE; HOW CAN ONE SPEAK OF A MORAL ORDER WHEN THE SPIRT OF AUTONOMY TAKES THE SPONTANEOUS FORM OF THE RADICAL DENIAL OF CONSTRAINT. THE AUTHOR HOPES THAT THE NEW EXPRESSIONS OF THE LAY APOSTALATE WILL FIND ANSWERS TO THESE DILEMMAS BECAUSE LIFE WITHIN THE POSTMODERN STATE WILL CERTAIMLY REQUIRE THEM.

08354 SHARP, J.

IF NOT NATO, WHO?

BULLETIN OF THE ATOMIC SCIENTISTS, 48(8) (OCT 92), 29-32. THE BALKIN WAR WILL RESHAPE EUROPE FAR MORE THAN HILL ANY OF THE BUREAUCRATIC STRUCTURES AND MECHANISMS THAT HAVE SPROUTED SINCE THE END OF THE COLD WAR. THE ONLY MILITARY FORCE THAT COULD HAVE STOPPED THE KILLING AND RESTORED ORDER IN BOSNIA-HERCEGOVINA WAS NATO UNDER U.S. COMAAND. TOO IMMENSE A TASK FOR U.N. PEACEKEEPING, THE SITUATION REQUIRED SERIOUS MILITARY INTERVENTION TO ENFORCE PEACE AND ESTABLISH RIGHTS FOR ALL MIKNORITIES. ALTHOUGH THE BALKINS MAY SEEMS A LONG WAY OFF TO THE AMERICANS, OTHER WESTERN GOVERNMENTS ARE UNLIKELY TO MOVE DECISIVELY HITHOUT THE UNITED STATES IN THE LEAD.

08355 SHARP, $M$.

TIDES OF CHANGE: THE HORLD ECONOMY AND EUROPE IN THE $1990 \mathrm{~S}$ INTERHATIONAL AFFAIRS, 68(1) (JAN 92), 17-36.

SOME OF THE FACTORS, PARTICULARLY THOSE RELATING TO TECHNOLOGY, THAT SEEM LIKELY TO IMPACK ON THE WORLD ECONOMY IN THE COURSE OF THE NEXT DECADE ARE TAKEN IN A BROADRANGING VIEW BY THIS SPECULATIVE ARTICLE. IT'S CONCERNS ARE WITH THE CONTINUITIES AND DISCONTINUITIES OF THE TIMES AND IT PROVIDES AN IMPRESSIONISTIC AND THOUGHT-PROVOKING SURVEY RATHER THAN TRYING TO PAINT IN FINE DETAIL. THE ESSAY HIGHLIGHTS A DIFFERENT ASPECT OF THE JAPANESE WAY OF
BUSINESS TO HHICH THE TITLE COOPERATIVE CAPITALISM IS GIVEN. 
08356 SHARP, R.L.

MANAGED TRADE DISTORTS FREE MARKETS

JAPAN TIMES (WEEKLY INTERHATIONAL EDITION), 32(14) (APR 92) 11 .

AONOR CONSIDERS THE PROBLEMS OF U.S. - JAPANESE TRADE AND THE VALIOITY OF CALLS FOR SOME FORM OF MANAGED TRADE

BETHEEN THE THO COUNTRIES.

08357 SHASTRI, A.

ELECTORAL COMPETITION AND MINORITY ALIENATION IN A

PLUALITY SYSTEM: SRI LANKA 1947-77

ELECTORAL STUDIES, 10(4) (DEC 91), 326-347.

THE LONG-TERM IMPACT THAT THE PLURALITY SYSTEM OF ELECTIONS HAD ON THE CONSOLIDATION OF POLITICAL ALIGHNMENTS AND CLEAVAGES IN SRI LANKA IN ITS POST-INDEPENDENT PERIOD IS AND CLEAVAGES IN SRI LANKA IN ITS POST-INDEPENDENT PERIOD ANALYZED. THIS STUOY FINDS THAT THE VERY SUCCESS OF THE PLURALITY SYSTEM IN ENCOURAGING POPULAR PARTICIPATION, BIPOLAR COMPETITION, POLITICAL COHESION AND STABILITY CONTRIBUTED TO ENGENDERING THEIR UNACCEPTABLE EXTREMES IN SRI LANKA'S RESOURCE-SCARCE CONTEXT. IN THE LONGER RUN, THE INCREASING RADICALIZATION OF THE ELECTORATE, ACUTE PARTY COMPETITION FOR CONTROL OF THE STATE, ETHNIC SECTARIANISM,
AND ABSOLUTE PARLIAMENTY MAJORITIES SERVED TO UNDERMINE THE DEMOCRATIC ASPECTS OF THE SYSTEM.

08358 SHASTRI, A.

SRI LANKA'S PROVINCIAL COUNCIL SYSTEM: A SOLUTION TO THE ETHNIC PROBLEM

ASIAN SURVEY, XXXII (8) (AUG 92), 723-743.

THE DEMAND FOR EFFECTIVE REGIONAL AUTONOMY HAS BEEN AT THE HEART OF THE STRUGGLE BY THE TAMIL MINORITY IN SRI LANKA TO ACQUIRE A POLITICAL STRUCTURE MORE SUITED TO ITS NEEDS. WHILE THE PUBLIC STANCE AND ACTIVITIES OF THE MOST MILITANT OF THE TAMIL YOUTH GROUPS, THE LIBERATION TIGERS OF TAMIL EELAM (LTTE) WHO FAVOR A SEPARATE STATE, HAS CAPTURED THE MOST INTERMATIOMAL ATTEMTIOM. THE DEBATE IN SRI LAMKA HAS RECENTLY BEEY FOCUSED OY A MARROHER OUESTION. HHETHER THE PROVIMCIAL COUNCIL (PC) SYSTEM OFFERS A VITALE SOLUTION TO PROVINCIAL COUNCIL (PC) SYSTEM OFFERS A VIABLE SOLUTION TO THE "ETHNIC PROBLEM" IN THE NORTH AND EAST OF THE ISLAND. THIS ARTICLE EXAMINES THE POTENTIAL THAT THE PC SYSTEM FOR RESOLVING THE CONFLICT BETWEEN THE ISLAND'S ETHNIC COMMUNITIES AND FOR MEETING THE CONCERNS OF THE TAMILS, BOTH IN TERMS OF THE SCOPE OF THE LEGAL PROVISIONS AND HOH THESE PROVISIONS HAVE BEEN IMPLEMENTED IN PRACTICE. IT IDENTIFIES THE PAC HAVE FUNCTIONED SO FAR AND WHAT ASPECTS OF THE THE PCS HAVE FUNCTIONED SO FAR AND WHAT ASPECTS OF THE

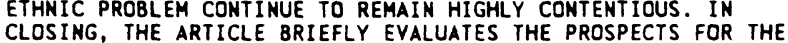
CLOSING, THE ARTICLE BRIEFLY EVALUA
SYSTEM IN THE FORESEEABLE FUTURE.

08359 SHASTRI, A.

THE PROVINCIAL COUNCIL SYSTEM IN SRI LANKA: A SOLUTION TO THE ETHNIC PROBLEM?; ASSOCIATION FOR ASIAN STUDIES 1992 ANNUAL REPORT

ASSOCIATION FOR ASIAN STUDIES, 1992, 134-135

THE ACUTE NEED FOR DECENTRALIZATION OF POWER IN SRI LANKA BECAME EVIDENT IN THE EIGHTIES IN THE FACE OF A VIOLENT MOVEMENT FOR A SEPARATE STATE LAUNCHED BY TAMIL YOUTH IN THE NORTHEAST OF THE ISLAND. AS AN OUTCOME OF THE INDO-SRI LANKAN ACCORD, A DEVOLUTION OF POWER WAS SOUGHT TO BE INSTITUTIONALIZED THROUGH THE PROYINCIAL COUNCIL SYSTEM IN NOVEMBER 1987. THE CHANGE HELD OUT THE POSSIBILITY FOR A RETURN TO PEACE AND STABILITY ON THE ISLAND. HOHEVER, IT ATTRACTED SIGNIFICANT CRITICISM FROM MILITANT SEGMENTS OF BOTH THE TAMIL AND THE SINHALESE COMMUNITIES. THIS PAPER ANALYZES THE MANNER IN WHICH THE NEW SYSTEM HAS BEEN INSTITUTIONALIZED AND HOW FAR IT SERVES TO SATISFY THE DEMANDS OF TAMIIS AND OTHER MINORITY GROUPS FOR DECENTRALIZATION AND OTHER MINORITY GROUPS FOR IN SUMMER 1991, AND RELIES ON BOTH ARCHIVAL RESEARCH AND INDEPTH INTERVIEWS. IT LOOKS AT THE WORKINGS OF CERTAIN PROVINCIAL COUNCILS IN DETAIL TO GAIN INSIGHTS INTO THE CONTRADICTORY PROCESSES AT HORK.

08360 SHAVIT, A.

ON GAZA BEACH

NEW POLITICS, 3(4) (WIN 92), 19-26.

THE AUTHOR. AN ISRAELI RESERVE SERVING AS GUARD AT THE PRISONS ON THE GAZA STRIP, DESCRIBES THE AFTERMATH OF THE INTIFADA, WHICH HAS DEPRIVED THE ISRAELIS THE MEANS OF THE POSSIBILITY OF AN ENLIGHTENED OCCUPATION. IT HAS FORCED THEM TO CHOOSE; TERRITORIES OR DECENCY. OCCUPATION OR FAIRNESS. HE PONOERS WHAT IS TO BE DONE BY ISRAELI CITIZENS WHO ARE
STRONGLY CONCERNED ABOUT THE DIRECTION THE COUNTRY HAS TAKEN IN THE OCCUPATION.

08361 SHAW, $B$.

BHUTAN IN 1991: "REFUGEES" AND "NGOLOPS"

ASIAN SURVEY, XXXII(2) (FEB 92 ) 184-188"

IN 1991 THE GOVERNMENT OF BHUTAN REINFORCED ITS

LONGSTANDING COMMITMENT TO MODERNIZATION BY IMPLEMENTING

PROGRAMS THAT ENCOURAGE DECENTRALIZATION IN DECISIONMAKING

AND IMPROVEMENT OF THE JUDICIAL SYSTEM. HOWEVER, THE MOST
GREVIOUS PROBLEM WHICH FACED BHUTAN IN 1991 WAS THE "ANTINATIONAL PROBLEM." AN INCREASING NUMBER OF NEPALESE SETTLERS ARE MOVING ACROSS THE POROUS INDIAN BORDER INTO BHUTAN. MANY SEE THEMSELVES NOT NECESSARILY AS SOJOURNERS, BUT AS MEMBERS OF AN EXTENDED NEPALESE COMMUNITY ON OTHERS' LAMO. AS A CONSEQUENCE, THEY HAVE STEPPED UP EFFORTS TO FORCE NATIVE TACTICS INCLUDE DEMONSTRATIONS, TERRORISM CONTYY THEIR COMPLAINING OF HUMAN RIGHTS VIOLATIONS BY' THE BHUTANESE GOVERMMENT. THE KING OF BHUTAN HAS PLEDGED TO ABDICATE IN THO YEARS IF A SOLUTION TO THIS PROBLEM IS NOT FOUND.

08362 SHAW, C.K.Y.

HEGEL'S THEDRY OF MODERN BUREAUCRACY

AMERICAN POLITICAL SCIENCE REYIEH, 86(2) (JUN 92), 381-389.

THE AUTHOR PRESENTS THREE MAJOR ARGUMENTS CONCERNING HEGEL'S THOUGHT ON BUREAUCRACY. FIRST, HEGEL'S THEORY OF BUREAUCRACY IS AS COMPREHENSIVE AS WEBER'S IDEAL TYPE OF BUREAUCRATIC ORGANIZATION. THE AUTHOR SUPPORTS THIS CONTENTION BY MAKING A SOCIOLOGICAL REFORMULATION OF HEGEL'S MODEL AND COMPARING IT HITH THE HEBERIAN PARADIGM. SECONDLY, HEGEL ADAPTS THE ARISTOTELIAN CATEGORY OF PRACTICAL JUDGMENT IN CHARACTERIZING THE BUREAUCRATIC ACTIVITY AS "SUBSUMPTION. " THIS CHARACTERIZATION IS CONTRARY TO THE DOMINANT VIEH THAT BUREAUCRACY EMBODIES MERE INSTRUMENTAL RATIONALITY AND SOLVES SOME DIFFICULTIES IN HEGEL'S POLITICAL THOUGHT. THIRDLY, HEGEL'S CONCEPTUALIZATION CAN CONTRIBUTE TO A
LIBERAL THEORY OF BUREAUCRACY THAT APPREHENDS MODERN POLITICAL REALITY MORE ADEQUATELY THAN THE SKEPTICISM OF CLASSICAL LIBERALS AND CONTEMPORARY LIBERTARIANS ABOUT BUREAUCRATIC ORGANIZATION.

08363 SHAW, $M$.

GLOBAL SOCIETY AND GLOBAL RESPONSIBILITY: THE THEORETICAL, HISTORICAL, AND POLITICAL LIMITS OF INTERNATIONAL SOCIETY MILLENNIUM, 21(1) (SPR 92), 421-434.

THE AUTHOR SUBJECTS THE CONCEPT OF "INTERNATIONAL

SOCIETY" TO A CRITICAL SOCIO-POLITICAL ANALYSIS. HE ARGUES THAT TO DESCRIBE THE CONSENSUAL TENDENCIES WITHIN THE INTERNATIONAL SYSTEM IN TERMS OF THE DEVELOPMENT OF
INTERMATIONAL SOCIETY IS TO ENGAGE IN A FALSE ABSTRACTION OF INTERMATIONAL SOCIETY IS TO ENGAGE IN A FALSE ABSTRACTION
INTERMATIONAL RELATIONS FROM SOCIAL RELATIONS IN GENERAL. INTERNATIONAL RELATIONS FROM SOCIAL RELATIONS IN GENERAL.
TENDENCIES TOWARDS NORMATIVE INTEGRATION IN INTER-STATE

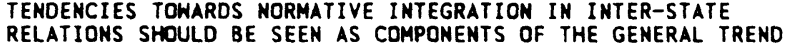
RELATIONS SHOULD BE SEEN AS COMPONENTS OF THE GENERAL TREND
TOWARDS GLOBALIZATION. THE CONCEPT OF GLOBAL SOCIETY RATHER TOWARDS GLOBALIZATION. THE CONCEPT OF GLOBAL SOCIETY RAT THAN INTERNATIONAL SOCIETY SHOULD BE AT THE CENTER OF THEORETICAL ENDEAVORS. THE LIMITATIONS OF THE INTERNATIONAL CRISES, WHICH IT FAILS TO UNDERSTAND ADEOUATELY, THEREBY CRISES, WHICH IT FAILS TO UNDE
LIMITING WESTERN RESPONSES.

08364 SHEAR, J.

CREATIVE BANKING

INSIGHT, $7(10)$ (MAR 91), 36-37.

INDICTMENTS SOON MAY REVEAL HOW SADDAM HUSSEIN'S THEORY OF AN ECONOMIC CONSPIRACY BELIEVED TO HAVE PUSHED HIM INTO THE INVASION OF KUWAIT, WAS OF HIS OWN DEVICE. APPARENTLY, HE REDIRECTED LOANS FROM THE U.S. BRANCH OF AN ITALIAN BANK TO HIS MILITARY, PROMPTING WASHINGTON TO CUT IRAQ'S EXPORT GUARANTEES.

08365 SHEAR, J.

POLITICS AS USUAL: A PARTY AFFAIR

INSIGHT, 7(42) (OCT 91), 26-27.

THREE HEEKS BEFORE THE SCHEDULED ELECTIONS IN JAPAN, PRIME MINISTER TOSHIKI KAIFU LOST HIS PARTY'S MANDATE AND DROPPED DUT OF THE RACE. HHILE KAIFU'S OUSTER WAS SOMETHING OF A SURPRISE, THE OUTCOME OF THE ELECTIONS IS NOT LIKELY TO CONTAIN ANYTHING NEH. THE POWERFUL FACTIONS WHICH CONTROL THE RULING LIBERAL DEMOCRATIC PARTY HAVE AN OVERHHELMIMG AMOUNT OF SAY IN WHO SUCCEEDS KAIFU. THE MOST LIKELY MANAZAWA CONTROLS THE THIRD LARGEST FACTION IN THE LDP. SOME MIYAZAHA CONTROLS THE THIRD LARGEST FACTION IN THE LDP. SOME
ARE ARGUING THAT THE JAPANESE POLITICAL SYSTEM HAS ATROPHIED ARE ARGUING THAT THE JAPANESE POLITICAL SYSTEM HAS ATROPH
AND SELDOM REFLECTS THE NEEDS OR DESIRES OF THE JAPANESE AND SELDOM REFLECTS THE NEEDS OR DESIRES OF THE JAPANESE
PEOPLE. THIS APPROACHING ELECTION WILL DO LITTLE TO CALM PEOPLE. THIS
THEIR FEARS.

08366 SHEAR, J.

TRADING PLACES

INSIGHT, $7(7)$ (FEB 91), 24-25

FOR THE FIRST TIME IN ITS 29-YEAR HISTORY, CONCERNS HAYE BEEN RAISED ABOUT POSSIBLE CONFLICT OF INTEREST AND INFLUENCE PEDOL ING AT THE UNITED STATE'S LEADING TRADE AGENCY, THE OFFICE OF THE U.S. TRADE REPRESENTATIVE. A REPORT' FROM THE CENTER FOR PUBLIC INTEGRITY, A WASHINGTONBASED INVESTIGATIVE ORGANIZATION, FOUMD FORMER HIGH OFFICIALS OF THE AGENCY LUCRATIVELY PLYING THE OTHER SIDE OF THE TRADE TABLE. THE REPORT FOUND THAT SINCE 1974, FORTYSEVEN PERCENT OF THE AGENCY'S TOP OFFICIALS OR THEIR FIRMS HAVE SIGNED ON AS FOREIGN AGENTS. PENDING LEGISLATION WILL
TRY TO TIGHTEN OUTDATED LAWS THAT HAVE ALLOWED FOREIGN FIRMS FREE ACCESS TO THOSE WHO SET U.S. TRADE POLICY. 
08367 SHEAR,

TRADING WITH KOREA

INSIGHT, 7(3) (JAN 91), 42-43.

AN ANTI-IMPORT CAMPAIGN INSPIRED BY THE SOUTH KOREAN GOVERMMENT HAS SPARKED AN ANGRY U.S. RESPONSE AND THREATENS TO IGNITE A MAJOR TRADE BATTLE. SOUTH KOREAN OFFICIALS ANXIOUS TO AVOID UNFAIR TRADER STATUS UNDER THE U.S. "SUPER 301" SECTION OF THE 1998 OMNIBUS TRADE BILL ARE APOLOGETIC AND ARE TRYING TO SMOOTH OVER STRAINED RELATIONS BETHEEN THE THO COUNTRIES.

08368 SHEAR, J. UNFINISHED BUSINESS

INS IGHT, 7(15) (APR 91), 34-35.

MIKHAIL GORBACHEV'S VISIT TO JAPAN IN APRIL WILL MARK

THE FIRST FOR THE SOVIET LEADER AND COULD END A LONG-

SIMMERING DISPUTE. JAPAN AND THE SOVIET UNION STILL HAVE NOT SIGNED A TREATY ENDING WORLD WAR II AND WON'T UNTIL THE VEXING ISSUE OF WHO OWNS SOME OF THE KURIL ISLANDS IS RESOLVED. RUMORS HAVE IT THAT JAPAN WILL PROVIDE THE SOVIETS HITH MUCH-NEEDED ECONOMIC AID IF THE SOVIETS AGREE TO RETURM THE KURILES TO JAPAN.

08369 SHEARMUR, J.

IN DEFENSE OF NEOLIBERALISM

IN DEFENSE OF NEOLIBERALISM

THIS ARTICLE RESPONDS TO RECENT CRITICISMS OF

NEOLIBERALISM. THREE TOPICS RECEIVE SPECIAL ATTENTION

MARKET IMPERFECTIONS AND ADAM SMITH'S "INVISIBLE HAND"; THE

POSITIVE ROLE OF THE STATE IN BRINGING ABOUT ECONOMIC

DEVELOPMENT (WITH SPECIFIC REFERENCE TO THE SWEDISH

EXPERIENCE); AND ISSUES OF PLURALISM AND SOCIAL

"EXPERIMENTS" THAT AFFECT THE LIVES OF ACTUAL HUMAN BEINGS. THE AUTHOR DEFENDS HIS PREFERENCE FOR REGIMES IN WHICH INDIVIDUAL FREEDOM, PROPERTY RIGHTS, AND THE RULE OF LAH ARE SECURED ON BEHALF OF ALL. THEREFORE, ME ARGUES FOR AN EASTERN EUROPEAN TRANSITION TO A REGIME THAT ERECTS BARRIERS AGAINST THE STATE.

08370 SHEARMUR, J.

THE SCOPE AND STATUS OF PRUDENTIAL LIBERALISH

REVIEW OF POLITICS, 54(2) (SPR 92), 211-230.

THE AUTHOR EXAMINES PRUDENTIAL LIBERALISM--THE ATTEMPT

TO DEVELOP CLASSICAL LIBERAL IDEAS UPON THE BASIS OF PURELY

PRUDENTIAL ARGUMENT. IT IS ARGUED, HITH PARTICULAR REFERENCE

TO JAN NARVESON, THAT THE UNIVERSALISM OF CLASSICAL

TO JAN NARVESON, THAT THE UNIVERSALISM OF CLASSICAL
LIBERALISM CANNOT BE SUSTAINED ON SUCH A BASIS. THIS

LIBERALISM CANNOT BE SUSTAINED ON SUCH A BASIS. THIS
CONFRONTS THE PROPONENTS OF PRUDENTIAL LIBERAL ISM WITH A

CONFRONTS THE PROPONENTS OF PRUDENTIAL LIBERAL ISH WITH A
PROBLEM: TO REJECT UNIVERSALISM WOULD REQUIRE A STRONGER

PROBLEM: TO REJECT UNIVERSAL ISM HOULD REQUIRE A STRONGER
CASE FOR REJECTING THE MORE ORDINARY IDEAS OF MORALITY THAN
HAS YET BEEN MADE; BUT IF UNIVERSALISM IS RESTORED BY

HAS YET BEEN MADE; BUT IF UNIVERSALISM IS RESTORED BY
RECOURSE TO NONPRUDENTIAL ARGUMENT, PRUDENT IALISM SEEMS

RECOURSE TO NONPRUDENT IAL ARGUMENT, PRUDENT IALISM SEEMS
INCOHERENT. IN EITHER CASE. THE DEFENSE OF THEIR POSITION INCOHERENT. IN EITHER CASE, THE DEFENSE OF THEIR POSIT AGAINST SUCH CRITICISMS WOULD SEEM TO LEAD PRUDENTIAL OFTEN ENGAGED AND REQUIRE THEM TO PARTICIPATE IN MORE OFTEN ENGAGED AND REQUIRE THEM TO PARI
TRADITIONAL PHILOSOPHICAL ARGUMENT.

08371 SHEEHAN, $R$

FEDERAL AGENCIES AND THE SUPREME COURT: AN ANALYSIS OF LITIGATION OUTCOMES, 1953-198

AMERICAN POLITICS QUARTERLY, 20(4) (OCT 92), 478-5.

THIS ARTICLE EXAMINES DIFFERENCES IN SUPPORT AMONC

FEDERAL AGENCIES APPEARING BEFORE THE SUPREME COURT. THE

AUTHOR REPORTS THAT THERE ARE SIGNIFICANT DIFFERENCES IN

LEVELS OF SUPPORT, AMONG THE AGENCIES, WHEN AGENCY TYPE AND

THE DIRECTIONALITY OF THE AGENCY'S DECISION OVER IS

CONTROLLED FOR. THE FINDINGS OF THE ANALYSIS INDICATE THAT THE SUPREME COURT IS MORE LIKELY TO SUPPORT AGENCIES THAT ARE INDEPENDENT IN NATURE AND PERFORM A QUASI-JUDICIAL ROLE IN THE BUREAUCRACY. THE CONCLUSION FROM THIS ANALYSIS IS THAT THE POLICY VALUES OF THE COURT HAVE A SIGNIFICANT IMPACT EVEN IN THE AREA OF AGENCY POLICY.

08372 SHEEHAM, R.S.

GOVERNMENTAL LITIGANTS, UNDERDOGS, AND CIVIL LIBERTIES: REASSESSMENT OF A TREND IN SUPREME COURT DECISIONMAKING WESTERN POLITICAL QUARTERLY, 45(1) (MAR 92), 27-40.

BASED ON THE FINDINGS OF EARLIER RESEARCH, THE AUTHOR HYPOTHESIZES THAT THE TREND TOHARD INCREASED SUPPORT FOR UNDERDOG LITIGANTS AGAINST GOVERNMENTAL LITIGANTS IN CIVIL UNDERDOG LITIGANTS AGAINST GOVERNMENTAL LITIGANTS IN CIVIL LIBERTIES CASES HAS CONTINUED IN RECENT YEARS. HOWEVER, HE FINDS THAT THERE HAS BEEN A REVERSAL IN THE TREND SINCE 1970 AND GOVERMMENTAL LITIGANTS ARE NOW WINNING SIGNIFICANT MORE OFTEN IN THE U.S. SUPREME COURT. THE CHANGE IN
DECISIONAL IRENDS SEEMS TO BE THE RESULT OF THE CHANGING IDEOLOGICAL COMPOSITION OF THE COURT AND THE SPECIAL
RELATIONSHIP OF THE FEDERAL GOVERHMENT TO THE COURT.

08373 SHEEHAN, R.S.; MISHLER, H.; SONGER, D.R. IDEOLOGY, STATUS, AND THE DIFFERENTIAL SUCCESS OF DIRECT PARTIES BEFORE THE SUPREME COURT

AMERICAN POLITICAL SCIENCE REVIEN, 86(2) (JUN 92) 464-474. A SUBSTANTIAL LITERATURE ON STATE AND LOWER FEDERAL
COURTS SUggests that the "haves" usually SUCCEed IN LITIGATION BECAUSE THEY POSSESS SUPERIOR RESOURCES AND REAP ADVANTAGES FROM THEIR REPEAT-PLAYER STATUS. THE AUTHORS INVESTIGATE THE SUCCESS OF 10 CATEGORIES OF LITIGANTS BEFORE THE WARREN, BURGER, AND REHNQUIST COURTS TO DETERMINE WHETHER THE RESOURCES OR EXPERIENCE OF LITIGANTS HAVE
EFFECTS ON SUPREME CDURT DECISIONS PARALLELING THOSE IN THE LOWER COURTS. WHILE DIFFERENT CATEGORIES OF LITIGANTS ARE FOUND TO HAVE VERY DIFFERENT RATES OF SUCCESS, THOSE DIFFERENCES DO NOT CONSISTENTLY FAVOR LITIGANTS WITH GREATER RESOURCES. A TIME SERIES ANALYSIS OF THE SUCCESS OF DIFFERENT CATEGORIES OF LITIGANTS SUGGESTS THAT THE CHANGING IDEOLOGICAL COMPLEXION OF THE COURT HAS A GREATER IMPACT ON THE SUCCESS OF LITIGANTS THAN DIFFERENCES IN RESOURCES AND EXPERIENCE.

08374 SHEEHY, A.

COMMONWEALTH EMERGES FROM A DISINTEGRATIMG USSR

RFE/RL RESEARCH REPORT, 1(1) (JAN 92), 5-8.

THE YEAR 1991 TO ALL INTENTS AND PURPOSES MARKED THE END OF THE USSR. IT WAS MIKHAIL GORBACHEV'S TRAGEDY THAT HE BECAME A VICTIM OF HIS OWN POLICIES, BECAUSE IT WAS HIS BECAME A VICTIM OF HIS OWN POLICIES, BECAUSE IT WAS HIS

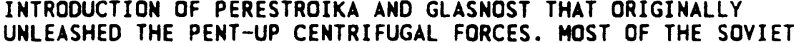
REPUBLICS HAVE INDICATED THAT THEY WILL FORM A NEH COMMONHEALTH OF INDEPENDENT STATES, BUT WHETHER OR NOT THIS ENTITY WILL BE VIABLE IN THE LONG, OR EVEN THE SHORT, TERM ENTITY WILL
IS DOUBTFUL.

08375 SHEEHY, A.

COMMONWEALTH OF INDEPENDENT STATES: AN UNEASY COMRPOMISE RFE/RL RESEARCH REPORT, 1 (2) (JAN 92), 1-5.

THE COMMONWEALTH OF' INDEPENDENT STÁTES BEGAN AS HASTILY-ARRIVED-AT COMRPOMISE. RUSSIA SAW IT AS A WAY OF PRESERVING SOME FORM OF UNION, WHEREAS UKRAINE REGARDED IT AS A NECESSARY TRANSITIONAL STAGE ON THE WAY TO COMPLETE DISSOCIATION FROM THE FORMER SOVIET UNION. BELARUS, KAZAKHSTAN, AND THE OTHER CENTRAL ASIAN REPUBLICS--WHICH HAD BEEN PREPARED TO SIGN THE NEH UNION TREATY--FOUND FULL IMDEPENDENCE THRUST UPON THEM WILLY-NILLY. ON THE OTHER HAND, THE VERY LOOSENESS OF THE CIS ARRANGEMENT MADE THE COMMONWEALTH PALATABLE TO INDEPENDENCE-MINDED ARMENIA AND MOLDAVIA. SERIOUS STRAINS HAVE ALREADY SURFACED BETWEEN RUSSIA AND UKRAINE IN THE CRUCIAL ECONOMIC AND MILITARY SPHERES.

08376 SHEEHY, A.

TATARSTAN ASSERTS ITS SOVEREIGNTY

RFE/RL RESEARCH REPORT, 1(14) (APR 92), 1-4.

IN A REFERENDUM ON MARCH 21, 1992, A MAJORITY OF THE CITIZENS OF TATARSTAN VOTED FOR THE REPUBLIC'S INDEPENDENCE IN DEFIANCE OF RUSSIAN PRESIDENT BORIS YELTSIN, THE RUSSIAN PARLIAMENT, AND THE RUSSIAN CONSTITUTIONAL COURT'S RULING THAT THE REFERENDUM WAS UNCONSTI TUTIONAL. TATARSTAM PRESIDENT MINTIMER SHAIMIEV HAS REFUSED TO SIGN THE RUSSIAN FEDERAL TREATY AND INSISTS THAT TATARSTAN'S RELATIONS WITH RUSSIA BE BASED ON A TREATY BETHEEN EOUALS. THE RUSSIAN LEADERSHIP FEARS THAT TATARSTAN'S ACTIONS COULD LEAD TO THE DISINTEGRATION OF THE RUSSIAN FEDERATION, BUT AT PRESENT THERE SEEMS TO BE LITTLE RUSSIA CAN DO ABOUT IT.

08377 SHEEHY, A.

THE CIS: A PROGRESS REPOR

RFE/RL RESEARCH REPORT, 1(38) (SEP 92), 1-6.

THE FIRST MONTHS OF' THE COMMONWEALTH OF INDEPENDEN STATES (CIS) WERE CHARACTERIZED BY A CONTINUATION OF THE CENTRIFUGAL TENDENCIES THAT HAD LED TO THE BREAKUP OF THE USSR. NON-RUSSIAN MEMBER STATES HOPED THAT THEY COULD STRENGTHEN THEIR NENFDUND INDEPENDENCE BY ESTABLISHING ECONOMIC AND OTHER LINKS WITH COUNTRIES OUTSIDE THE CIS. HOWEVER, IT HAS BECOME CLEAR THAT FOR THE TIME BEING TIES WITH RUSSIA REMAIN ALL-IMPORTANT. EVEN UKRAINE HAS FELT COMPELLED TO TAKE STEPS TO IMPROVE ITS RELATIONS HITH RUSSIA. AS A RESULT, THE DEMISE OF THE CIS NO LONGER SEEMS IMMINENT. NEVERTHELESS, IT REMAINS AN UNEASY COMPROMISE, WITH UKRAINE STILL RELUCTANT TO AGREE TO THE CREATION OF ANY STRUCTURES THAT WOULD GIVE IT TEETH.

08378 SHEEHY, A.

UNLOVED, ILL-FED INFANT FACES AN UNCERTIAN FUTURE

RFE/RL RESEARCH REPORT, 1 (8) (FEB 92), 1-3.

THO MONTHS INTO ITS' EXISTENCE. THE' COMMONHEALTH OF THO MONTHS INTO ITS EXISTENCE, THE COMMONHEALTH OF UNCLEAR. THE FORMER USSR REPUBLICS HAVE BEEN RECOGNIZED AS UNCLEAR. THE FORMER USSR REPUBLD COMMUNITY AND ARE BUSY ESTABLISHING TIES WITH FOREIGN COUNTRIES, BUT SO FAR THEY HAVE BEEN UNABLE TO AGREE AMONG THEMSELVES ON CRUCIAL HAVE BEEN UNABLE TO AGREE AMONG THEMS AND MILITARY ISSUES. THE CHIEF THREAT TO THE FUTURE OF THE COMMONWEALTH COMES FROM UKRAINE'S DETERMINATION TO ASSERT ITS INDEPENDENCE AND OPPOSE ANYTHING THAT IT SEES AS THE DIKTAT OF RUSSIA.

08379 SHEETS, R.G.; TING, $Y$. HORKER PERSPECTIVES ON THE PRIVATE FINANCING OF GOVERNMENT- 
SPONSORED DISLOCATED WORKER PROGRAMS

POLICY STUDIES REVIEW, 11(1) (SPR 92), 40-54.

BASED ON A SURVEY OF 1,555 EXPERIENCED WORKERS IN ILLINOIS, THIS STUDY ANALYZES WORKER PERSPECTIYES ON THE FINANCING RESPONSIBILITIES OF BUSINESSES, WORKERS, AND THE GOVERMMENT FOR DISLOCATED HORKER PROGRAMS THAT PROVIDE JOB SEARCH AND RETRAINIMG ASSISTANCE TO THE UMEMPLOYED. ACCORDING TO THE POO ASISTARCE TO THE UNEMPLOYED. FINANCING APPROACHES TO BE THE BEST AND LEAST POLARIZING FINANCING APPOACHES FINANCING ALTERNATIVE. IN CONTRAST, THE GOVERNMENT GRANT APPROACH IS EXTREMELY POLARI ZING WITH SIGNIFICANT SUPPORT BUT STRONG NEGATIVE REACTION AMONG HIGHER-INCDME, WHITE, COLLEGE-EDUCATED EMPLOYEES. SURPRISINGLY STRONG NEGATIVE REACTION IS ALSO FOUND AHONG LONER-INCDME, BLUE-COLLAR THE CONSERVATIVE ATTITUDES OF AMERICAN WORKERS TOWARD SOCIAL THE CONSERVATIVE
WELFARE PROGRAMS

08380 SHEFTER, $M$.

INSTITUTIONAL CONFLICT OVER PRESIDENTIAL APPOINTMENTS: THE CASE OF CLARENCE THOMAS

PS: POLITICAL SCIENCE AND POLITICS, 25(4) (DEC 92 ),

THE FIGHTS OVER THE CONFIMATION OF CLARENCE THOMAS FOR A SEAT ON THE U.S. SUPREME COURT WAS ANOTHER ROUND IN A STRUGGLE BETHEEN CONGRESS AND THE HHITE HOUSE FOR CONTROL OVER THE GOVERNMENT OF THE UNITED STATES. THIS ARTICLE EXPLORES THE BATTLES BETHEEN CONGRESS AND THE PRESIDENCY WHICH HAVE BECOME CENTRAL TO AMERICAN POLITICS IN RECENT YEARS. HE CONCLUDES THAT FUTURE ADMINISTRATIONS SHOULD BE DISCOURAGED FROM REPEATING THE TACTICS THAT HELPED SECURE THE CONFIRMATION OF CLARENCE THOMAS BUT THAT THE VERY SUCCESS DF THE EFFORT TO CONFIRM THOMAS MAY IEAD TO THE REPETITION OF THESE TACTICS.

08381 SHEHADEH, $R$

NEGOTIATING SELF-GOVERMMENT ARRANGEMENTS

JOURMAL OF PALESTINE STUDIES, XXI (4) (SUM 92), 22-31.

THE AUTHOR LOOKS AT THE PROBLEM OF NEGOTIATING SELF-

GOVERNMENT ARRANGEMENTS FOR THE PALESTINIANS IN THE OCCUPIED

TERRI TORIES. HE DISCUSSES THE ISSUES THAT WOULD BE INVOL VED

IN CREATING A SEPARATE ADMINISTRATION FOR THE PALESTINIANS.

08382 SHELBY, B.

OUR STRUGGLE IS JUST BEGINNING: SOUTH AFRICA MOVES FORWARO AFTER A CRITICAL REFERENDUM

WORLD PRESS REVIEW, 39(5) (MAY 92), 19-21.

IN THIS INTERVIEH, TWO SOUTH AFRICAN JOURNALISTS ANSWER QUESTIONS ABOUT THE NEGOTIATIONS BETWEEN THE DEKLERK GOVERNMENT AND THE AFRICAN NATIONAL CONGRESS, THE POLITICAL FUTURES OF NELSON MANDELA AND F.W. DEKLERK, THE WHITE GOVERMMENT'S ALLEGED "DOUBLE AGENDA," AND RELATED MATTERS.

08383 SHEMESH, $H$.

SOVIET-IRAQI RELATIONS, 1968-1988

LYNNE RIENMER PUBLISHERS, $1992,300$.

FROM THE BEGINNING OF THE BA'TH REGIME IN 1968 TO THE END OF THE IRAN-IRAO WAR IN 1988, IRAQ WAS THE SOVIET UNION'S MOST IMPORTANT ALLY IN THE MIDDLE EAST. THIS BOOK EXPLORES THE EVOLUTION OF THIS SOVIET-IRAQI RELATIONSHIP-ONE THAT MOSCOW OFTEN EXPLOITED--CONCENTRATING ON THE IMPACT OF THE 1969-1975 AND 1980-1988 IRAN-IRAQ CONFLICTS ON THE FLUCTUATIONS IN SOVIET-IRAQI TIES AND ALSO EXAMINING OTHER ISSUES RELEVANT TO THE ALLIANCE: THE IRAQI COMMUNIST PARTY, THE KURDISH PROBLEM, AND DEYELOPMENTS IN THE ARAB EAST, INCLUDING THE ARAB-ISRAELI DISPUTE.

08384 SHENG, $F$

OPENING UP AND MAKING USE OF CAPITALISM

BEIJING REVIEH, 35(12) (MAR 92), 18-20.

THE MODERN HISTORY OF CHINA HAS PROVEN THAT THE NATION

CAN ONLY TAKE THE SOCIALIST, NOT THE CAPITALIST, ROAD. THIS

CAN ONLY TAKE THE SOCIALIST, NOT THE CAPITALIST, ROAD. THIS

ARTICLE SUGGESTS, HOWEVER, THAT THE MODERN HISTORY OF THE

WORLD HAS ALSO SHOHN THAT ONLY WHEN ECONOMI CALLY BACKWARI

COUNTRIES CORRECTLY UTILIZE CAPITALISM AND CRITICALLY

ASSIMILATE USEFUL ASPECTS OF WESTERN CULTURE, WILL THEY

RESOLVE THIS CONTRADICTION.

08385 SHENG, $F$

PROSPECTS FOR MAIMLAMD-TAIHAN RELATIONS

BEIJING REYIEH, 35(17) (APR 92) 30-32

BEIJING REVIEW, 35(17) (APR 92), 30-32.
THERE ARE NEH SIGNS OF RECONCILIATION BETWEEN THE TWO THERE ARE NEW SIGNS OF RECONCILIATION BETWEEN THE TWO SIDES OF THE TAIHAN STRAITS. BOTH THE CHINESE COMHUNIST
PARTY AND THE KOUMINTANG HAVE DECLARED PUBLICLY THAT THERE IS BUT OME CHINA AND THAT THEY ARE OPPOSED TO TAIHAN'S INDEPENDENCE. MOREOVER, THE OVERWHELMING MAJORITY OF THE PEOPLE ON BOTH SIDES LOOK FORHARD TO AN EARLY REUNIFICATION OF THE MOTHERLAND.

08386 SHENG, M.M.

MAO, STALIN, AND THE FORMATION OF THE ANTI-JAPANESE UNITED FRONT : 1935-37

CHINA QUARTERLY, (129) (MAR 92), 149-170.
THE FORMATION OF THE ANTI-JAPANESE NATIONAL UNITED FRONT BETWEEN THE CHINESE COMMUNIST PARTY AND THE GUOMINDANG AND MOSCOW'S ROLE IN THE EFFORT HAVE ATTRACTED MUCH INTEREST. THE RECENT APPEARANCE OF WORKS BY JOHN GARVER AND KUI-KUONG SHUM HAVE ENRICHED KNOWLEDGE OF THE MOVEMENT. HOWEVER, THERE
ARE SOME IMPORTANT ISSUES THAT DEMAND FURTHER DISCUSSION AND SOME FACTUAL EVIDENCE THAT NEEDS MORE STUDY.

08387 SHENGWU, $Y$.

VESTIGES OF COLONIALIST IDEOLOGY: AN OBSTACLE TO THE HISTORY OF SINO-HESTERN RELATIONS

SOCIAL SCIENCES IN CHINA, XII(4) (NOV 91), 32-56.

ALTHOUGH THE WEST BOASTS A LARGE NUMBER OF ACADEMICALLYYALUABLE WORKS ON SINO-WESTERN RELATIONS, IN THE PAST, MANY VALUABLE WORKS ON SINO-WESTERN RELATIONS, IN THE PAST, MAMY
WESTERN SCHOLARS DISPLAYED COLONIALIST PREJUDICES. AFTER WESTERN SCHOLARS DISPLAYED COLONIALIST PREJUDICES. AFTER DRAMATICALIY, IN HESTERM ACADEMIC CIRCLES, BUT THEY HAVE NOT DRAMATICALLY IN WESTERN ACADEMIC CIRCLES, BUT THEY HAVE OISAPPEARED COMPLETELY. TYPICAL EXAMPLES OF COLONIALIST CAMBRIDGE HISTORY OF CHINA." SOME PASSAGES IN THESE TWO CAMBRIDGE HISTORY OF CHINA." SOME PASSAGES IN THESE THO TREATMENT OF WESTERN COUNTRIES AS ITS VASSALS, CLAIMING THAT BRITAIN WAS COMPELLED TO USE FORCE. OTHER PASSAGES INCORRECTLY DESCRIBE THE HESTERN POWERS' ACQUISITION OF TREATY RIGHTS AFTER THE OP IUM WAR AS "EXTENSIONS OF THE CHINESE TRADITION." STILL OTHERS DESCRIBE WESTERN AGGRESSION AS BRINGING CIVILIZATION TO CHINA. ALL THESE JUDGMENTS ENTAIL FALLACIOUS PROPOSITIONS AND DO NOT CONFORM TO THE FACTS. THESE VESTIGES OF COLONIALIST IDEOLOGY HINDER RESEARCH INTO SINO-WESTERN RELATIONS.

08388 SHEPHARD, A.

HENRY HOWARD AND THE LAWFUL REGIMENT OF WOMEN HISTORY OF POLITICAL THOUGHT, 12(4) (WIN 92), 589-604.

THE PUBLICATION OF JOHW KNOX'S "FIRST BLAST OF THE

TRUMPET" IN 1558 HAD ENGENDERED A RADICAL DEBATE ABOUT THE PUBLIC ROLE OF WOMEN AND THE NATURE OF FEMALE AUTHORITY AND PUBLIC ROLE OF WOMEN AND THE NATURE OF FEMALE AUTHORITY
OBEDIENCE. THIS ARTICLE CONCENTRATES ON HENRY HOWARD'S UNPUBLISHED CONTRIBUTION TO THE KNOX DEBATE. HOWARD'S
TREATISE IS EVIDENCE THAT AT LEAST SOME OF THE NOBILITY WERE TREATISE IS EVIDENCE THAT AT LEAST SOME OF THE NOBILITY WERE
PREPARED TO ACCEPT A GREATER PUBLIC ROLE FOR WOMEN IN ORDER PREPARED TO ACCEPT A GREATER PUBLIC ROLE FOR WOMEN IN ORDER
TO PRESERVE THE TRADITION OF INHERITED AUTHORITY. DESPITE TO PRESERVE THE TRADITION OF INHERITED AUTHORITY. DESPITE
HIS SOCIAL CONSERVATISM, HOWARD BELIEVED THAT WOMEN HAD AS MUCH RIGHT AS MEN, WITHIN THE LIMITS OF PRIMOGENITURE, TO INHERIT PROPERTY AND POWER, AND TO RECEIVE AN EDUCATION APPROPRIATE TO THE EXERCISE OF THAT POWER. THE RELATIVELY
HIGH NUMBER OF WELL-EDUCATED ARISTOCRATIC WOMEN IN SIXTEENTH HIGH NUMBER OF WELL-EDUCATED ARISTOCRATIC WOMEN IN SIXTEE CENTURY
BELIEF.

08389 SHEPHERO, A.

FANNING THE FLAMES

AFRICA REPORT, 37(5) (SEP 92), 57-60.

OVER THE LAST TWO YEARS, AN AVERAGE OF NINE PEOPLE PER DAY HAVE BEEN KILLED IN POLITICAL VIOLENCE IN SOUTH AFRICA. A HEARING IN LONDON CONCLUDED THAT THE DEKLERK GOVERNMENT IS
IMPLICITLY, IF NOT EXPLICITLY, RESPONSIBLE FOR THIS VIOLENCE, MUCH OF HHICH HAS BEEN BLAMED ON INKATHA-SPONSORED VIGILANTES ACTING WITH THE COLLUSION OF THE SECURITY FORCES. WHATEVER THE CAUSE, MOST ANALYSTS AGREE THAT EXTERMAL MONITORING OF THE POLICE AND THE JUSTICE SYSTEM WILL BE NEEDED TO HELP STOP THE VIOLENCE.

08390 SHEPHERD, A.

FROM ADJUSTMENT TO DEVELOPMENT: JAN PRONK

AFRICA REPORT, 37 (4) (JUL 92), 66-67

JAN PRONK, 'THE NETHERLANDS' MINISTER OF DEVELOPMENT AND COOPERATION,' IS AN ECONOMIST BEST KNOWN IN AFRICA FOR CHAMPITIN, IS AN ECONOMIST BEST KNOWN IN AFRICA FOR CHAMPIONING DEBT RELIEF PROPOSALS. HE HOSTED THE 1990
MAASTRICHT CONFERENCE THAT LED TO THE ESTABLISHMENT OF THE GLOBAL COALITION FOR AFRICA, WHICH AIMS TO FURTHER THE CONSENSUS-BUILDING PROCESS BETHEEN AFRICANS AND THEIR FOREIGN AID PARTMERS. PRONK BELIEVES THE HEST SHOULD WRITE OFF THE DEBT OF THE LEAST DEVELOPED COUNTRIES.

08391 SHEPHERD, A.

SHEPHERD, A. INEQUING DUT INEQUITIES

IRONING DUT INEQUITIES
AFRICA REPORT, $37(2)$ (MAR 92), 49-51

TRADE AND BANKING SANCTIONS HAVE TAKEN A HEAVY TOLL OM THE SOUTH AFRICAN ECONOMY, WHICH HAS LOST PERHAPS $\$ 40$

THE SOUTH AFRICAN ECONOMY, WHICH HAS LOST PERHAPS S

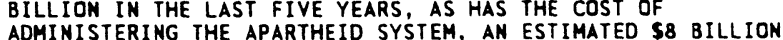
ADMINISTERING THE APARTHEID SYSTEM, AN ESTIMATED \$8 BIL ANNUALLY. A FUTURE NON-RACIAL GOVERNMENT, WHICH MUST RESTRUCTURE THE ECONOMY TO ELIMINATE ITS BUILT-IN INEQUIT
WILL AT THE SAME TIME HAVE TO INSTILL CONFIDENCE IN THE WILL AT THE SAME TIME HAVE TO INSTILL CONFI
BUSINESS AND FOREIGN INVESTOR COMMUNITIES.

08392 SHEPHERD, A

THE ECONOMICS OF DEMOCRACY

AFRICA REPORT, 37 (2) (MAR 92), 28-30

ALTHOUGH WESTERN DONOR-NATIONS HAVE LINKED ECONOMIC AID TO AFRICA WITH POLITICAL REFORM, THERE IS NO EVIDENCE THAT DEMOCRACY AUTOMATICALLY LEADS TO BETTER GOVERMMENT. IN FACT, SOME AUTOCRATIC GOVERNMENTS HAVE PROVED TO BE EFFICIENT AND 
MARKET-ORIENTED. THUS, DEMOCRACY MUST BE AN END IN ITSELF.

08393 SHEPHERD, A.

THE LOST DECADE

AFRICA REPORT, 37 (1) ( JAN 92), 36-38

FIVE YEARS AFTER THE ADOPTION OF THE UNITED NATIONS'

AMBITIOUS "PROGRAMME OF ACTION FOR AFRICAN ECONOMIC RECOVERY AND DEVELOPMENT," ECONOMIC AND SOCIAL CONDITIONS ARE ACTUALLY HORSE AND THE OUTLOOK FOR THE FUTURE IS GLOOMY. WHILE AFRICA HAS MADE PROGRESS TOWARD DEMOCRATIZATION, IT HAS NOT DONE ENOUGH TO LIBERALIZE ITS ECONOMIES. THE AFRICANS ARGUE THAT THE DONOR COMMUNITY RENEGED ON ITS COMMITMENT TO INCREASE FOREIGN AID, HITH NET INFLOWS

ACTUALLY DECLINING FIVE PERCENT BETWEEN 1986 AND 1990.

08394 SHEPHERD, A.

THE MORTGAGED CONTINENT

AFRICA REPORT, 37 (4) (JUL 92), 68-70

IN 1990, SUB-SAHARAN AFRICA'S DEBT WAS $\$ 272$ BILLION, OR

112 PERCENT OF GOP. THE INOUSTRIALIZED COUNTRIES ARE

INCREASINGLY FORGIVING CONCESSIONAL DEBT OWED BY THE POOREST COUNTRIES, AND OTHER DEBT RELIEF MEASURES HAVE BEEN APPLIED. BUT SOME OBSERVERS QUESTION WHETHER THIS IS ENOUGH AND ARGUE THAT BOLD EFFORTS ARE NEEDED TO REDUCE THE DEBT BURDEN AND YET GIVEN WESTERN CREDITORS THE LEVERAGE THEY DEMAND TO INDUCE ECONOMIC REFORM.

08395 SHEPHERD, A.

WAR OR PEACE?

AFRICA REPORT, 37 (3) (MAY 92), 40-42.

IN THE PAST THREE DECADES, 20 WARS HAVE BEEN FOUGHT ON THE AFRICAN CONTINENT, KILLING SEVEN MILLION PEOPLE, TURNING FIVE MILLION INTO REFUGEES, AND DAMAGING STRUGGLING ECONOMIES. HITH AFRICA'S BURGEONING DEMOCRACY MOVEMENT, THERE IS SOME HOPE THAT HARS MAY SOON BECDME A THING OF THE PAST; BUT AS ARMED CONFLICTS DRAG ON IN SOME COUNTRIES, THERE IS ALSO MUCH UNCERTAINTY AND SKEPTICISM.

08396 SHERMAN, A.

A NEW ALGERIAN HAR?

WORLD TOOAY, 48(3) (MAR 92), 37-38.

THE ALGERIAN CONFLICT, HICH STEMS FROM THE FUNDAMENTALIST CHALLENGE' POSED BY THE FRONT ISLAMIQUE DU SALUT (FIS) AND THE MILITARY RESPONSE TO IT, CAN BE EXPECTED TO DRAG ON FOR SOME TIME. THE COUNTRY'S POLITICO-MILITARY CLASS, WHICH SUPPORTS THE FRONT DE LA LIBERATION NATIONALE (FLN) AND HAS BEEN IN POHER FOR 30 YEARS, WILL NOT BE EASILY DISLOOGED AND HAS NO INTENTION OF GIVING UP WITHOUT A DISLODGED AND HAS NO INTENTION OF GIVING UP WITHOUT
STRUGGLE. IN THIS ARTICLE. THE AUTHOR LOOKS AT THE

STRUGGLE. IN THIS ARTICLE, THE AUTHOR LOOKS AT
HISTORICAL BACKGROUND TO THE PRESENT CONFLICT.

08397 SHERMAN, A.

MARKETS IN THE POST-COLD WAR ERA: CONTROLLED OR FREE? FREEMAN, 42(12) (DEC 92), 462-468.

A CAPITALIST REVOLUTION APPEARS UNDERWAY THROUGHOUT MUCH OF THE GLOBE. THOUGH ENTHUSIASM FOR THE FREE MARKET IS ONLY LUKEWARM AMONG SOME REGIMES, THE STUBBORN FACTS OF SOCIALISM'S DEMISE AND BANKRUPTCY - BOTH MORAL AND ECONOMIC-OF STATIST IDEOLOGY HAVE TAKEN THEIR TOLL. WHILE SENSIBLE LEADERS ACCEPT MATTER-OF-FACTLY THE NEED TO RESTRUCTURE RADICALLY THEIR STATE-STRANGLED ECONOMIES, THIS ARTICLE ARGUES THAT THE END OF COMMUNISM IN EUROPE DOES NOT INEVITABLY MEAN ECONOMIC FREEDOM AND THAT THERE IS MORE THAN ONE FORM OF SOCIALISH.

08398 SHERMAN, S

COUNTDOWN TO IRAQ'S DEFEAT

MIDOLE EAST INTERNATIONAL, (395) (MAR 91) 7

THIS ARTICLE CHRONICLES THE LAST FRANTIC ATTEMPTS TO

AVERT A FULL-SCALE GROUND WAR BETWEEN IRAQ AND THE ANTI-IRAQ

COALITION. IT BEGINS WITH SADOAM HUSSEIN'S "FEBRUARY 15

INITIATIVE," FOLLOWS THE PROGRESS (OR LACK THEREOF) OF THE

SOVIET PEACE PROPOSAL. THE U.S. ULTIMATUM ON 22 FEBRUARY,

THE GROUND OFFENSIVE, AND THE EVENTUAL CEASE-FIRE ON 28 FEBRUARY.

08399 SHERMAN, $S$.

GOING II' S' OWH WAY?

MIDDLE EAST INTERNATIONAL, (396) (MAR 91), 8

RECENT ACTIONS TAKEN BY THE BRITISH FOREIGN OFFICE INDICATE THAT THERE MAY BE CONSIDERABLE DIFFERENCES IN THE POST-WAR POLICIES TOWARDS THE MIDDLE EAST OF BRITAIN AND THE UNITED STATES. BRITISH DIPLOMATS VISITED JORDAN AND MET WITH IRAOI OPPOSITION TISH DIPLOMATS VISITED JORDAN AND MET WITH IHE U.S. SINCE THE HAR HOWEVER, BRITAIN'S GREATEST CONCERM HAS BEEN SECURING THE RELEASE OF THREE BRITONS HEST HOSTAGE HAS BEEN SECURING THE RELEASE OF THREE BRITONS HELD HOSTAGE IN LEBANON. DESPITE STRENUOUS DIPLOMATIC EFFOR
PROGRESS ON THE HOSTAGE ISSUE HAS BEEN MADE.

08400 SHERMAN, $S$

WHAT DID MAJOR KNOW?

MIDOLE EAST INTERNATIONAL, 438(438) (NOV 92), 4-5

WITH THE U.S. GOVERMMENT DEEPLY EMBARRASSED BY

INCREASING EVIDENCE OF A COVERT STRATEGY OF SUPPLYING ARMS
TO SADDAM HUSSEIN'S IRAQ, ITS BRITISH COUNTERPART FINDS ITSELF IN SIMILAR TROUBLE. BRITISH COMPANIES HAVE BEEN SELLING DEFENSE-RELATED ITEMS TO IRAQ OVER SEVERAL YEARS, WITH ONLY HALFHEARTED GOVERNMENT EFFORTS TO CONCEAL THIS. THIS ARTICLE EXAMINES THE MATRIX CHURCHILL CASE, THE SUPERGUN AFFAIR. AND THE HURRICANE OF INDIGNATION OVER THE
CHURCHILL CASE.

08401 SHERRILL, K.; BAILEY, R.; SOMERVILLE, C. WHAT POLITICAL SCIENCE IS MISSING BY NOT STUDYING AIDS PS: POLITICAL SCIENCE AND POLITICS, 25(4) (DEC 92),

88-693.

POLITICAL SCIENCE HAS BEEN SLOW TO ADDRESS THE POLITICAL AND POLICY ISSUES OF AIDS. BY DOWNPLAYING AIDS, IT HAS NOT ONLY ACQUIESCED IN TRIVIALIZING THIS DEADLY DISEASE AND IN MARGINALIZING GROUPS INITIALLY IDENTIFED WITH IT, BUT ALSO HAS SQUANDERED AN IMPORTANT OPPORTUNITY FOR ITSELF. THE AUTHOR SUGGESTS THAT POL ITICAL SCIENTISTS SHOULD MOT PASS UP AUTHOR SUGGESTS THAT POL ITICAL SCIENTISTS SHOULD NOT PASS
AN OPPORTUNITY TO EXAMINE A CASE CHARACTERIZED BY RAPIDLY AN OPPORTUNITY TO EXAMINE A CASE CHARACTERIZED BY RAPIDLY CHANGING EVENTS, SYMBOLIC RICHNESS, AND SHIFTING ALLIANCES ACROSS RACE, GENDER, SEXUAL ORIENTATION, CLASS, AND NATIONAL ACROSS RACE,
BOUNDARIES.

08402 SHERRY, G.

IRAQ'S FORGOTTEN MASS DEPORTATIONS

MIDOLE EAST INTERNATIONAL, 438(438) (NOV 92), 19-21.

IRAO PRACTICED ITS OWN VERSION OF ETHNIC CLEANSING AND THE BEST KNOWN VICTIMS ARE THE HUNDREDS OF THOUSAND OF KURDS WHO WERE EXECUTED, DISAPPEARED OR WERE FORCIBLY RESETTLED INSIDE IRAQ DURING THE ANFAL CAMPAIGN THAT BEGAN IN THE MID1980S. HOWEVER, YEARS BEFORE, IN A LESS BRUTAL BUT TRAMATIC PRECURSOR, THE GOVERMMENT WRECKED HAVOC ON THE LIVES OF SEVERAL HUMDRED THOUSAND IRAOI SHI'ITE FAMILIES-ARABS AND KURDS ALIKE--WHO WERE SUMMARILY DEPORTED TO IRAN FRAM BAGHDAD AND OTHER CITIES. TENS OF THOUSAMDS OF IRAO'S DEPORTED FAMILIES--SCATTERED ABROAD IN IRANIAN CITIES AND CAMPS, IN SYRIA AND IN WESTERN EUROPE--ARE STILL HAITING TO GO HOME, SECURE JUSTICE, AMD REBUILD THEIR LIVES.

08403 SHEVTSOVA, L.

POST-SOVIET EMIGRATION TODAY AND TOMORROW

INTERNATIONAL MIGRATION REVIEW, XXVI (2) (SUM 92), 241-257.

THIS ARTICLE DEALS WITH THE PROBLEMS OF POST-SOVIET

EMIGRATION. THE AUTHOR TRIES TO ANSWER THE OUESTION: WHAT

WILL THE POST-SOVIET EMIGRATION "CURVE" LOOK LIKE HITHIN THE NEXT FEW YEARS? ITS PEAK APPEARS MOST LIKELY TO BE REACHED IN 1993 AND 1994, WHEN THE NUMBER OF DEPARTURES MAY GO UP TO $1-1.5$ MILLION PEOPLE A YEAR. THIS MAY HAPPEN IF THE PRESENT UNFAVORABLE SOCIOECONOMIC CONDITIONS AND INSTABILITY CONTINUE TO EXIST AND IF TECHNICAL PROBLEMS RELATED TO EXIT ARRANGEMENTS ARE SOLVED, ONCE THE SITUATION RELATED TO EXIT ARRANGEMENTS ARE SOLVED, ONCE THE SITUATIDN NORMALIZES F
AND FOREMOST IN RUSSIA, THE SCOPE OF EMIGRATION MAY BE MAINTAINED AT A LEVEL OF 500,000 OF 600,000 PEOPLE PER ANMUM MAINTAINED AT A LEVEL OF 500,000 TO 600,000 PEOPLE PER ANMUM
WITHIN THE NEXT THO OR THREE YEARS AND THEN BEGIN TO DECLINE.

$08404 \mathrm{SHI}, \mathrm{Z}$.

CHINA, ISRAEL EXPAND EXCHANGES

BEIJING REVIEH, 35(20) (MAY 92), 10-11.

THE ESTABLISHMENT OF DIPLOMATIC RELATIONS BETHEEN CHINA AND ISRAEL LAST JANUARY HAS GIVEN A BIG PUSH TO THE ONGOING BILATERAL EXCHANGES AND OPENED MORE CHANMELS FOR THE FUTURE CO-OPERATION, WHICH IS EXPECTED TO INVOLVE ALL FIELDS OF ECONOMY, CULTURE, SCIENCE, AND TECHNOLOGY. TRADE YOLUME IS LIKELY TO DOUBLE THAT OF THE PREVIOUS YEAR. THAT FIGURE MAY BE MINISCULE COMPARED WITH THE TRADE VOLUMES BETWEEN CHINA AND OTHER COUNTRIES, BUT IT IS SIGNIFICANT FOR IT REPRESENTS A TENDENCY OF EXPANSION OF TRADE AND ECONOMIC RELATIONS.

08405 SHICHOR, Y

CHINA AND THE MIDDLE EAST SINCE TIAMAMMEN

ANMALS OF THE AMERICAN ACADEMY OF POLITICAL AND SOCIAL

SCIENCE, 519 ( JAN 92), 86-100.

BY THE LATE 1980'S, THE MIDDLE EAST HAD BECOME A SOLID BASE OF OPERATIONS FOR CHINA'S POLITICAL, ECONOMIC, AND MILITARY FOREIGN POLICY. AFTER THE TIANANMEN MASSACRE, THE SOLIDITY OF THIS BASE REMAINED UNSHAKEN WHILE CHINA TRIED TO BREAK THROUGH THE WESTERN-IMPOSED ISOLATION AND PAVE THE WAY FOR AN EVENTUAL INTERNATIONAL REHABILITATION. AFTER IRAO'S FOR AN EVENTUAL INTERNATIONAL REHABILITATION. AFTER IRAQ'S
VIOLENT ANNEXATION OF KUWAIT, CHINA USED THE PERSIAN GULF VIOLENT ANNEXATION OF KUWAIT, CHINA USED THE PERSIAN GULF
CRISIS TO RESTORE ITS POSITION AS A GREAT POWER HHOSE

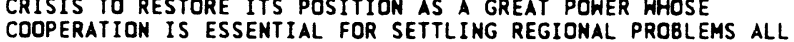
COOPERATION IS ESSENTIAL FOR SETTLING REGIONAL PROBLEMS ALL
OVER THE WORLD. SINCE THEN, CHINA'S STRAINED RELATIONS WITH THE WEST, IN GENERAL, AND HITH THE UNITED STATES, IN
PARTICULAR, HAVE SHOWN GRADUAL IMPROVEMENT. BY INSISTING ON PARTICULAR, HAVE SHOWN GRADUAL IMPROVEMENT. BY INSISTING ON
A PEACEFUL SOLUTION TO THE GULF CRISIS, CHINA MANAGED TO A PEACEFUL SOLUTION TO THE GULF CRISIS, CHINA MANAGED TO
MAINTAIN ITS IMAGE AS THE TRUE REPRESENTATIVE OF THE THIRD HORLD, WITH EASY ACCESS TO ALL PARTIES--FRIENDS AND FOES ALIKE.

08406 SHICHOR, $Y$.

CHINA'S DEFENCE IN A CHANGING HORLD

CHINA REPORT, 28 (2) (APR 92) 125-140.

WHILE THE WORLD IS MOVING TOWARD GREATER RELAXATION OF 
INTERNATIONAL TENSION, THE CHINESE REMAIN WORRIED BECAUSE OF NEW KINDS OF THREATS AND DIFFICULTIES THAT THEY HAVE NEVER ENCOUNTERED BEFORE. THE COLLAPSE OF THE SOVIET EMPIRE AND THE POWERFUL USE OF MILITARY FORCE BY THE UNITED STATES AND ITS ALLIES IN IRAQ DEMONSTRATE THE EXTENT OF CHANGES IN THE INTERNATIONAL SPHERE. IN ADDITION, THERE ARE DOMESTIC INTERNATIONAL SPHERE. IN ADDITION, THERE ARE DOMEST
THREATS: "PEACEFUL EVOLUTION" (AS MANIFESTED BY THE

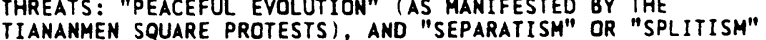
IIANANMEN SQUARE PROTESTS), AND "SEPARATISH" OR "SPLITISM" THREATS: TENSION ALONG THE BORDERS, INDEPENDENCE TENDENCIES THREATS: TENSION ALONG THE BORDERS, INDEPENDENCE TENDENCIES IN TAIWAN, UNREST IN HONG KONG, AND THE POSSIBLE EMERGENCE OF JAPAN AS A MILITARY POWER. TO DEAL WITH THESE THREATS ANO DIFFICULTIES BEI ING HAS ALREADY TAKEN STEPS TO STRENGTHEN ITS DEFENSE AND MILITARY SYSTEM. THE LONG YEARS OF REGARC MILITARY AND SECURITY MATTERS AS SECOI
MODERNIZATION APPEAR TO HAVE ENDED.

08407 SHIELL, T.

THE UNITY OF PLATO'S POLITICAL THOUGHT

HISTORY OF POLITICAL THOUGH, 12(3) (FAL 91), 377-390.

PLATO IS HIDELY RECOGNIZED AS ONE OF THE MOST INSIGHTFUL AND INFLUENTIAL POLITICAL THEORISTS IN WESTERN THOUGHT. STUDENTS CAN BE DIVIDED INTO THREE GROUPS--THE INCONSISTENCY READING GROUP, THE FULL CONSISTENCY READING GROUP AND THE WEAK CONSISTENCY READING GROUP. THIS ARTICLE DEFENDS A VERSION OF THE THIRD READING SINCE THE CASE IN ITS FAVOR HAS NOT BEEN ADEQUATELY STATED. IT PROVIDES A STRAIGHTFORHARD ARGUMENT BUILD UP FROM TEXTUAL EVIDENCE THAT OFFERS EXPLANATIONS OF HOW PLATO CAN PRESCRIBE DIFFERENT POLITICAL IDEALS AND INSTITUTIONS YET REMAIN CONSISTENT AND OF HOW THE TWO RIVAL READINGS GO WRONG. IT EXPLORES THE UNITY HITHIN

THE DIFFERENCES, AND THE DIFFERENCES WITHIN THE UNITY.

08408 SHIH, C.

PSYCHOLOGICAL SECURITY AND NATIONAL SECURITY: THE TAIWAN

FACTOR IN CHINA'S U.S. POLICY

JOURMAL OF SOCIAL, POLITICAL AND ECONOMIC STUDIES, $16(4)$ (WIN 91) 441-46?

FOREIGN POLICY BEHAVIOR ACTUALIZES, CONFIRMS, AND DRAMATIZES A STATE'S NATIONAL SELF-IMAGE AS PERCEIVED BY ITS DECISION-MAKERS. A SECURITY PROBLEM ARISES WHEN THE STAT DENIED ITS FAIR SHARE IN THE INTERNATIONAL STATUS QUO. THEREFORE, THE STATE RESPONDS TO PERCEIVED THREATS TO BOTH ITS PHYSICAL SECURITY AND ITS PSYCHOLOGICAL SECURITY. IN IMAGE IN FOREIGN POLICY FORMATION AND EXAMINES CHINA'S U.S POLICY IN THE POSTWAR PERIOD, EMPHASIZING THE ROLE OF TAIWAN. THROUGH TAIWAN, CHINESE LEADERS PERIODICALLY ANO SYMBOLICALLY DEMONSTRATE CHINA'S DEDICATION TO ITS NATIONAL IMAGE, FOR THE BENEFIT OF THE UNITED STATES. THE INTERNATIONAL SECURITY PROBLEM, RELATED TO TAIWAN IN SINOAMERICAN RELATIONS, IS A FUNCTION OF THE PERSONAL PSYCHOLOGICAL SECURITY PROBLEMS OF THE CHINESE LEADERSHIP.

08409 SHIINA, M.

AMERICAN FOREIGN POLICY. A JAPANESE VIEN

SAIS REVIEW, 12 (2) (SUM 92 ), 73-80.

IT IS SOMEHHAT DIFFICULT FOR A JAPANESE, AT THIS

PARTICULAR TIME, TO ASSERT THAT THE UNITED STATES SHOULD

REMAIN ENGAGED IN WORLO AFFAIRS AMD MAINTAIN ITS MILITARY

REMAIN ENGAGED IN WORLD AFFAIRS AND MATNTACH ITS MILITARY,

POLITICAL AND ECONOMIC PRESENCE ABROAD BECAUSE AMERICANS ARE

IS USEFUL FOR PLAYERS TO LISTEN TO HOW OUTSIDERS SEE THE

IS USEFUL FOR PLAYERS TO LISTEN TO HOW OUTSIDERS SEE THE

SITUATION. THIS ARTICLE PROVIDES A JAPANESE REVIEH OF THE

PRESENT INTERNATIONAL SITUATION AND DEMOCRACIES AT

DESCRIBES A NEW INTERNATIONAL FRAMEWORK, AMERICA'S

LEADERSHIP AND JAPAN'S ROLE. IT CONCLUDES THAT THIS IS A

TIME OF TRIAL FOR THE VITALITY OF THE INDUSTRIAL DEMOCRA

HISTORY, WE HAVE TO START OVER.

08410 SHIINA, M.

WHERE JAPAH CAN HELP

FAR EASTERN ECONOMIC REVIEH, 155 (5) (FEB 92), 15.

ON 16 OCTOBER 1991 , JAPAN WAS ELECTED TO SERVE ANOTHER TWO-YEAR TERM AS A NON-PERMANENT MEMBER OF THE UN SECURITY COUMCIL JAPAN'S RE-ELECTION SERVES TO HIGHLIGHT THE FACT COUNCIL. JAPAN'S RE-ELECTION SERVES TO HIGHLIGHT THE FACT THAT THERE ARE CONFLICTING VIEHS OVER THE DIRECTION THAT JAPAN'S FOREIGN POLICY SHOULD TAKE IN THE POST-COLD WAR ERA. SOME SEE THE NATION BECDMING MORE INTERNAT IONALLY MINDED, AND ARE EXPRESSING STRONG HOPES THAT JAPAN WILL BE ACCORDED PERMANENT MEMBERSHIP OF THE SECURITY COUNCIL. OTHERS SEE A CONTRARY TREND. ACCORDING TO THIS SECOND SCENARIO JAPAM GRADUALLY DOWMPLAY ITS TIES WITH THE UNITED STATES AND
BECOME LESS INHIBITED ABOUT USING ITS MILITARY CAPABILITIES AS A TOOL OF OIPLOMACY. THIS ARTICLE ARGUES THAT HHAT THE WORLD DESPERATELY NEEDS ARE NATIONS WITH THE RESOURCES AND TECHNOLOGY TO COPE WITH PROL IFERATING CHALLENGES. INCREASED INVESTMENT IN DEVELOPING COUNTRIES, INCREASED AID TO REBUILD SHATTERED INFRASTRUCTURES, AND INCREASED TRADE ARE EXTREMELY IMPORTANT TO ENSURE FUTURE PEACE AND PROSPERITY. IN THE ATTAIMMENT OF ALL THIS CONTINUED JAPAN-U.S. COOPERATION IS CRUCIAL.
08411 SHILLING, J.

TRADE POLICIES AND THE ENVIRONMENT

FINANCE AND DEVELOPMENT, 29(2) (JUN 92), 26-27.

THE RELATIONSHIP BETWEEN TRADE AND ENYIRONMENTAL

POLICIES HAS RECENTLY EMERGED AS A MAJOR TOPIC OF DEBATE. IN SOME CIRCLES, INTERNATIONAL TRADING RULES ARE SEEN AS A LIMIT ON THE ABILITY OF COUNTRIES TO PROTECT NATIONAL AND GLOBAL ENVIRONMENTAL RESOURCES. YET TRADE POL ICY ANALYSTS FORM OF PROTECTIONISM. FURTHER, DEVELOPING COUNTRIES WORRY FORM OF PROTECTIONISM. FURTHER, DEVELOPING COUNTRIES HORRY TORCE COMPLIANCE WITH NATIONAL AND INTERNATIONAL FORCE COMPLIANCE WITH NATIONAL ANO INTERNATIONAL CURRENT TRADING RULES AFFECT ENVIRONMENTAL POLICY ISSUES.

08412 SHILS, E.

THE VIRTUE OF CIVIL SOCIETY

GOVERMMENT AND OPPOSITION, 26(1) (1991), 3-20

THIS ARTICLE ADDRESSES A THEME OF MONTESOUIEU--THE ASSOCIATION BETWEEN VIRTUE (I.E., PUBLIC SPIRIT OR CIVILITY) AND REPUBLICAN GOVERNMENTS. THE ARTICLE INQUIRES INTO THE PLACE OF VIRTUE IN THE LIBERAL DEMOCRATIC ORDER. THE MEANING OF CIVIL SOCIETY IS EXAMINED, AND THE REVIVAL OF THE CONCEPT EXPLORED.

08413 SHIM, J.

AGAINST THE RULER

FAR EASTERN ECONOMIC REVIEH, 155(14) (APR 92), 21.

AFTER BADLY RATTLING SOUTH KOREA'S POLITICAL

ESTABLISHMENT IN THE 24 MARCH GENERAL ELECTION, CHUNG JU-

YUNG, THE 76-YEAR-OLD FOUNDER OF THE GIANT HYUNDAI

CONGLOMERATE, HAS INDICATED THAT HE MAY RUN FOR THE

PRESIDENCY IN DECEMBER'S ELECTION. CHUNG'S PRESIDENTIAL AMBITIONS--BASED ON THE SUCCESS OF HIS BARELY THO-MONTH-OLD UNIFICATION NATIONAL PARTY (UNP) WINNING 31 SEATS IN THE 299MEMBER PARL IAMENT--MAY YET BE TEMPERED BY HIS AGE AND COULD LEAD HIM TO MAKE A DEAL WITH A MORE CONVENTIONAL CANDIDATE. BY AY LAUNCHING A POLITCAL PARTY AND SUCCESSTULLY ESTABLISHING THAT SOUTH KOREA'S TRADITIONAL GOVERMMENT-BUSINESS

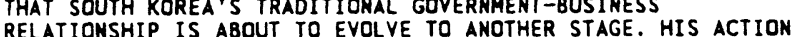
RELATIONSHIP IS ABOUT TO EVOLVE TO ANOTHER STAGE. HIS ACT ALSO THREATENS HALF A DOZEN PROFESSIONAL POLITICIANS WHO
HAVE MURSED PRESIDENTIAL AMBITIONS INCLUDING PERENHIAL ALSOHAVE NURSED PRESIDENTIAL AMBITIONS INCLUDING PERENMIAL ALSORANS SUCH AS KIM YOUNG SAM ANO CHIEF OPP

08414 SHIM, J.

CHEJU HONEYMOON

FAR EASTERH ECONOMIC REVIEW, 151(18) (MAY 91), 12-13.

IN SHARP CONTRAST TO HIS MUCH PUBLICIZED BUT ULTIMATELY FRUITLESS FOUR-DAY VISIT TO JAPAN, SOVIET LEADER MIKHAIL GORBACHEV'S OVERNIGHT STOP AT SOUTH KOREA'S CHEJU ISLAND-FOR THO MEETINGS WITH PRESIDENT ROH TAE WOO-WAS REMARKABLE FOR ITS GOODWILL AND OPTIMISH. GORBACHEY AND ROH TOUCHED ON A BROAD RANGE OF ISSUES, INCLUDING TRADE EXPANSION AND NEW SOVIET INITIATIVES FOR PEACE BETWEEN THE TWO KOREAS.

GORBACHEV'S ABRUPT OFFER TO SIGM A TREATY OF AMITY AND COOPERATION WITH SOUTH KOREA SEEMS INTENDED TO CONSOLIDATE THE NEH RELATIONSHIP, DESPITE THE STRAIN IT WOULD PLACE IN TIES HITH NORTH KOREA--WITH WHICH MOSCOH HAS HAD A SIMILAR TREATY HITH SINCE 1961.

08415 SHIM, J.

ENCOURAGE TEAM SPIRIT

FAR EASTERN ECONOMIC REVIEH, 155(2) (JAN 92) 13.

THE UNITED STATES AND SOUTH KOREA ANXIOUS TO COAX NORTH KOREA INTO OPENING ITS SECRETIVE NUCLEAR DEVELOPMENT FACI ITY TO INTERMATIONAL INSPECTION HAVE AGREED TO HOLD OFF THEIR ANNUAL JOINT MILITARY EXERCISE FOR 1992, ACCORDING TO AN OFFIAL ANMOUNCEMENT ON 7 JANUARY THEY IMDICATED TO AN OFFICIAL ANMOUNCEMENT ON 7 JANUARY. THEY INDICATED HOWEVER, THAT THE PLAN NOT TO HOLD THE MILITARY MANEUVERSCODE NAMED TEAM SPIRIT--APPLIED ONLY TO 1992 AND THAT THE EXERCISES COULD RESUME IF THE NORTH FAILED TO ACCEPT OUTS RECENT DRAMATIC IMPROVEMENT IN RELATIONS BETHEEN THE THO RECENT DRAMATIC IMPROVEMENT IN RELATIONS BETHEEN THE THO
KOREAS, INCLUDING TWO AGREEMENTS THEY SIGNED PLEDGING TO KOREAS, INCLUDING THO AGREEMENTS THEY SIGNED PLEDGING TO DESIST FROM WAR AND TO DENUCLEARIZE THE PENINSULA, AMD
FURTHER EXPECTED TO BOOST THE TREND TOWARDS DETENTE.

08416 SHIM, J.

GOODBYE TO ALL THAT

FAR EASTERN ECONOMIC REVIEN, 155(15) (APR 92), 18.

STUDENT OISSIDENTS WHO ONCE BATTLED RIOT POLIICE IN THE STREETS ARE TRADING BRICKS AND OTHER IMPROVISED MISSILES FOR SOBER SUITS AND SEATS IN THE NATIONAL PARLIAMENT. BUT WHILE VOTERS ARE PREPARED TO SUPPORT THIS NEW BREED OF POLITICIAN LINKED TO CENTRIST OPPOSITION GROUPS LIKE THE DEMOCRATIC PARTY (DP), THEY DRAH THE LINE AT ACCEPTING DISSIDENTSTURNED-CANDIDATES LINKED TO RADICAL LEFTWING GROUPS. THE EMERGENCE OF THE ERSTWHILE OEMONSTRATORS IN PARLIAMENT AFTER THE 24 MARCH GENERAL ELECTION IS EXPECTED TO HAYE A PROFOUND IMPACT ON THE GENERAL TEXTURE OF OPPOSITION POLITICS IN SOUTH KOREA. IT CONFIRMS THE PERCEPTION THAT DISSIDENTS ARE BECOMING INCREASINGLY IRRELEVANT AS A POLITICAL FORCE IN 
SOUTH KOREA AS THE COUNTRY MOVES SLOWLY TOHARDS A PLURALISTIC SOCIAL AND POLITICAL SYSTEM UNDER PRESIDENT ROH
TAE WOO.

08417 SHIM, J.

NO JOY FOR PARTIES

FAR EASTERN ECONOMIC REVIEN, 151(25) (JUN 91), 19-20.

SOUTH KOREA'S INDEPENDENT CANDIDATES ARE ENJOYING

SURGE IN POPULARITY AT THE EXPENSE OF THE ESTABLISHED

POLITICAL PARTIES AS THE COUNTRY PREPARES FOR POLLS ON 20 JUNE--FOR THE SECOND TIME IN THREE MONTHS--AND FOR MUNICIPAL AND PROVINCIAL ASSEMBLIES IN SIX MAJOR CITIES, INCLUDING SEOUL AND NINE PROVINCES. THE TREND DISMAYS THE RULING DEMOCRATIC LIBERAL PARTY (DLP) AS MUCH AS THE OPPOSITION NEH DEMOCRATIC PARTY (NDP) AS IT UNDERSCORES THE ELECTORATE'S DISENCHANTMENT WITH THE EXISTING POLITICAL ORDER. ACCORDING TO THE CENTRAL ELECTION MANAGEMENT COMMITTEE, 34 PERCENT OF THE REGISTERED CANDIDATES DO NOT BELONG TO THE ESTABLISHED PARTIES. THIS COMES AT A TME WHEN THE POPUILARITY RATES FOR THE DLP AND NDP ARE STEADILY DECLINING WITH VOTER ATTENTION FOCUSED ON PROBLEMS SUCH AS INFLATION, ENYIRONMENTAL FOCUSED ON PROBLEMS SUCH AS INFLATION,
DEGRADATION AND HORSENING URBAN CRIME.

08418 SHIM, J.

NO TO ROH DYNASTY

FAR EASTERN ECONOMIC REVIEW, 151(17) (APR 91), 16-17.

PRESIDENT ROH TAE HOO HAS RULED OUT ANY MIIITARY LEADER OF CLOSE RELATIYE FORM BECOMING SOUTH KOREA'S MEXT HEAD OF STATE WHEN HIS TERM OF OFFICE EXPIRES IN FEBRUARY 1993. IRONICALLY OME OF THE MAIN INDIRECT CAUSALITIES OF THIS IRONICALLY, ONE OF THE MAIN INDIRECT CAUSALITIES OF THIS CONTENDER WITH NEITHER MILITARY LINKS NOR FAMILY CONNECTIONS TO ROH--KIM YOUNG SAM--WHOSE MAIN CLAIM TO POLITICAL FAME HAS FOR LONG BEEN HIS YEARS OF OPPOSITION TO AUTHORITARIAN MILITARY RULE. ROH'S DECISION HAS APPARENTLY OPENED THE FIELD OF POSSIBILITY AS FACTIONS IN THE RULING DEMOCRATIC LIBERAL PARTY SCRAMBLE IN SEARCH OF POTENTIAL CANDIDATES AND TRY TO KEEP OLDER GENERATION POLITICIANS LIKE KIM YOUNG SAM FROM SEIZING POWER.

08419 SHIM, J.: YANG, S. OPENING DOORS

FAR EASTERN ECONOMIC REVIEH, 151(14) (APR 91), 11. THE U.S.-LED UN COMMAND A LEGACY FROM THE KOREAN WAR THAT STILL PROVIDES THE LEGAL BASIS FOR THE CONTINUED PRESENCE OF 42,000 U.S. TROOPS IN SOUTH KOREA, HAS TAKEN A MAJOR INITIATIVE TOWARDS NORTH KOREA BY APPOINTING A SOUTH KOREAN ARMY GENERAL AS CHIEF DELEGATE AT THE MILITARY ARMISTICE COMMISSION TALKS AT PANMUNJOM. THE APPOINTMENT OF ARMISTICE COMMISSION TALKS AT PANMUNJOM. THE APPOINTMEM ARMISTICE TALKS MARKS AN IMPORTANT TRANSITION IN THE U.S. ARMISIICE TALLS MARKS AN IMPORTANT TRANSITION IN THE U.S. POLICY OF TRANSFERRIMG MORE AUTHORITY AND RESPONSIBILITY IN THE DEFENSE OF SOUTH KOREA AGAINST THE NORTH. ANALYSIS POIN OUT THAT THE MOVE COINCIDES HITH Â NEED FOR NORTH KOREA RETHINK ITS DIPLOMATIC AND DEFENSE POSTURE. THE GULF WAR WEAKMESS OF SOVIET WEAPONS AGAINST MODERN WESTERN ARMS.

08420 SHIM, J.

PEACE FEVER

FAR EASTERN ECONOMIC REVIEW, 154(52) (JAN 92), 8-9. NEGOTIATING AGAINST A BACKGROUND OF RISING TENSION OVER THE NORTH'S REFUSAL TO ALLOW INTERNATIONAL INSPECTION OF ITS NUCLEAR FACILITIES, THE PRIME MINISTERS OF NORTH AND SOUTH KOREA HAVE PRODUCED WHAT BOTH SIDES HOPE IS THE NEXT BEST THING. A WIDE-RANGING NON-AGGRESSION AND RECONCILIATION PACT, SIGNED ON 13 DECEMBER AFTER THO HECTIC DAYS OF TALKS COMMITS THE TWO GOVERMMENTS TO THE FIRST SERIOUS ATTEMPT AT MORMALIZING BILATERAL RELATIONS SINCE THE PENINSULA HAS DIVIDED IN 1945. IN THEIR HASTE TO REACH AN AGREEMENT ON BILATERAL ISSUES, THE THO SIDES DECIDED TO RESERVE THE NUCLEAR PROBLEM FOR SEPARATE DISCUSSION AT A LATER MEETING. DOMESTIC PRESSURES IN BOTH MORTH AND SOUTH MAY HAVE SPEEDED UP THE AGREEMENT. NORTH KOREAN PRESIDENT KIM IL-SUNG FACED DEEPENING INTERNATIONAL ISOLATION AS A RESULT OF HIS UNCOMPROMISING POSITION ON THE NUCLEAR DEVELOPMENT PROJECT ON THE OTHER HAND, SOUTH KOREAN PRESIDENT ROH TAE-WOO HAS UNDER PRESSURE TO DEL IVER A SPECTACULAR ACCOMPLISHMENT BEFORE THE END OF HIS TERM IN FEBRUARY 1993.

08421 SHIM, J.

RELUCTANT CHOICE

FAR EASTERN ECONOMIC REVIEN, 151(23) (JUN 91), 15. MORTH KOREA'S SURPRISE ANNOUNCEMENT ON 28 MAY EXPRESSING ITS READINESS TO SEEK SEPARATE MEMBERSHIP IN THE UN MARKS A ITS REAOINESS TO SEEK SEPARATE MEMBERSHIP IN THE UN MARKS SINCE 1957 WHEN HE HENT ALONG WITH THE SOVIET PROPOSAL FOR PARALLEL MEMBERSHIP IN THE UN ALONG HITH SOUTH KOREA. PARALLEL MEMBERSHIP IN THE UN ALONG HITH SOUTH KOREA, PRESIDENT SIM IL SUNG IS ACCEPTING THE REALITY OF DIVISION ON THE PENINSULA. THE REVERSAL OF NORTH KOREA'S COMES IN THE HAKE OF CONTINUOUS SETBACKS ON THE INTERMATIONAL SCENE. IT FOLLOWS THE RECENT FAILURE BY KIM PENG TO VETO SEOUL'S APPLICATION AT THE UN SECURITY COUNCIL.
WHILE THE PRESENCE OF BOTH KOREAS IN THE UN IS LIKELY TO IMPROVE RELATIONS BETHEEN SOUTH KOREA AND CHINA, RELATIONS BETWEEN NORTH KOREA AND THE U.S. OR JAPAN STILL' FACE SIGNIFICANT OBSTACLES TO NORMALIZATION.

08422 SHIM, J.

ROH'S PRIORITIES

FAR EASTERN ECONOMIC REVIEW, 151(23) (JUN 91), 13 THE POLITICAL LIFE SPAN OF CABINET MEMBERS UNDER SOUTH KOREAN PRESIDENT ROH TAE WOO CAN BE SHORT, RUNNING TO AN AVERAGE OF 11 MONTHS PER MINISTER. GIVEN THAT RECORD, IT IS HARDLY SURPRISING THAT THE NEW GOVERNMENT LINE-UP ANNOUNCED ON 24 MAY--THE ELEVENTH SHAKE-UP SINCE ROH TOOK OFFICE IN DECEMBER 1987--IMPRESSED NEITHER STUDENT DEMONSTRATORS OR THE PARL IAMENTARY OPPOSITION. THE CHANGES--INCLUDING THE APPOINTMENT OF HARDLINE FORMER EDUCATION MINISTER, CHUNG WON SHIK, AS PRIME MINISTER, AMD FORMER PROSECUTOR-GENERAL KIM KI CHUN, WHO STRONGLY DISAPPROVES OF STUDENT ACTIVISM, AS JUSTICE MINSTER-SHOWS THAT ROH'S CONCERN IS ON THE ECONOMIC AND WELFARE SPHERES AS HELL AS LAW AND ORDER. BUT WHILE ROH PROMISED POLICIES TO ARREST THE INFLATIONARY SPIRAL AND STAMP OUT REAL ESTATE SPECULATION, HE GAVE LITTLE INDICATION OF HOW HE HOULD DEAL WITH THE ENTRENCHED PROBLEMS OF STUDENT RADICALISH OR POLICE REFORMS.

08423 SHIM, J.

ROH'S RESERYATIONS

FAR EASTERN ECONOMIC REVIEH, 155(3) (JAN 92), 10-11 ONE YEAR AWAY FROM THE END OF HIS TERM, SOUTH KOREA'S PRESIDENT ROH TAE WOO HAS GIVEN THE STRONGEST HINT YET THAT HE WILL BACK KIM YOUNG SAH, A FORMER OPPOSITION LEADER WHO IS NOW THE RULING DEMOCRATIC LIBERAL PARTY'S (DLP) EXECUTIVE CHAIRMAN, AS THE NEXT PRESIDENT. BUT ROH'S EXPRESSION OF SUPPORT FOR KIM AT A NEWS CONFERENCE ON 10 JANUARY FELL
SHORT OF THE FIRM COMHITMENT THAT HAD BEEN EXPECTED, AND IN EFFECT LEAVES THE NOMINATION TO BE SETTLED BY A NATIONAL CONVENTION OF THE DLP, TO BE HELD MOST PROBABLY IN MAY. INSTEAD OF CATEGORICALLY ENDORSING KIM, ROH SAID HE WANTED HIM TO FACE THE TEST OF AN OPEN AND FAIR CONTEST FOR THE LEADERSHIP. KIM NOW FACES AT LEAST THO SERIOUS RIVALS FOR THE DLP NOMINATION: PARTY CO-CHIRMAN PARK TAE JUNE AND FORMER PRIME MINISTER KIM JONG PIL.

08424 SHIM, J.

THE PACE QUICKNESS

FAR EASTERN ECONOMIC REVIEW, 153(31) (AUG 91), 22-23. AS NORTH AND SOUTH KOREA PREPARE FOR PARALLEL MEMBERSHIP IN THE UNITED MATIONS IN SEPTEMBER, ENDING DECADES OF WASTEFUL RIVALRY PROSPECTS ARE STEADILY IMPROYIMG FOR SEOUL'S DIPLOMATIC NORMALIZATION WITH A STAUNCH PYONGYANG SEOUL'S DIPLOMATIC NORMALIZATION WITH A STAUNCH PYONGYANG
SUPPORTER--CHINA. THE DEPARTURE FOR BEI JING ON 17 JULY BY SUPPORTER--CHINA. THE DEPARTURE FOR BEI JING ON 17 JULY BY
CHUNG JU YUNG, SOUTH KOREA'S MOST INFLUENTIAL BUSINESSMAN, CHUNG JU YUNG, SOUTH KOREA'S MOST INFLUENTIAL BUSINESSMAN LEADING A 66-STRONG DELEGATION, AMOUNTS TO YET ANOTHER
ATTEMPT BY THE BUSINESS ESTABLISHMENT TO SPEED UP THE ATTEMPT BY THE BUSINESS ESTABLISHMENT TO SPEED UP THE COUNTRIES THAT STILL STAND BY NORTH KOREA. SEOUL AND BEIJING COUNTRIES THAT STILL STAND BY NORTH KOREA. SEOUL AND BEIJING INVESTMENT PROTECTION AND THE AVOIDANCE OF DOUBLE TAXATION AS A PRECURSOR TO FURTHER NEGOTIATIONS AND TIES.

08425 SHIM, J.

THE PRICE OF UNITY

FAR EASTERN ECONOMIC REVIEN, 155(12) (MAR 92), 54-56. AS THE THO SIDES OF THE KOREAN PENINSULA EDGE TOWARDS UNIFICATION, PEOPLE ARE STARTING TO ESTIMATE THE COST OF MERGING THO SUCH DISSIMILAR ECONOMIES. FIGURES IN SEOUL RANGE FROM US\$200 BILLION TO MORE THAN US\$500 BILLION INVESTED OVER FIVE TO TEN YEARS. IF THE TRANSITION IS GRADUAL AND SMOOTH, IT WILL COST LESS. IF THE PROCESS IS ABRUPT, IT COULD BE ENORMOUSLY EXPENSIVE FOR BOTH THE NORTH AND THE SOUTH, NOT TO MENTION FOR NEIGHBORING COUNTRIES. WHILE BOTH KOREAS AGREE THAT A MERGER IS THE ULTIMATE GOAL, THE GAP IN DEVELOPMENT POSES SIGNIFICANT PROBLEMS. NORTH KOREA IS ABOUT THENTY YEARS BEHIND THE SOUTH'S LEVEL OF DEVELOPMENT, WITH A STANDARD OF LIVING ROUGHLY ONE-SIXTH THAT OF SOUTH KOREA. THE FORMER'S POLICY OF SELF-RELIANCE, OR JUCHE, HAS BEEN ACHIEVED, BUT AT THE COST OF MODERN TECHNOLOGY AND ECONOMIC WELL-BEING. ELECTRICITY IS IN SHORT SUPPLY AND FOOD SHORTFALLS HAVE FORCED CUTBACKS IN FOOD RATIONS. POL ICYMAKERS IN SEOUL FEAR THAT. IF THINGS GET CONSIDERABLY HORSE. HUGE NUMBERS OF NORTH KOREAN REFUGEES MIGHT HEAD SOUTH BY FOOT AND BY BOAT.

08426 SHIM, J.

TOO MANY KIMS

FAR EASTERN ECONOMIC REVIEH, 155(12) (MAR 92), 9. THE SOUTH KOREAN GOVERNMENT'S ECONOMIC FAILURES ARE PROYING TO BE POTENT WEAPONS IN THE HANDS OF OPPOSITION CANDIDATES AND INDEPENDENTS IN THE RUN-UP TO THE 24 MARCH ELECTION TO THE SINGLE-CHAMBER PARL IAMENT. THIS IS NOT ONLY FORCING THE RULING DEMOCRATIC LIBERAL PARTY (DLP) ON THE DEFENSIVE, BUT IS ALSO BEGINNING TO CAST A SHADOW ON THE AMBITIONS OF DLP EXECUTIVE CHAIRMAN KIM YOUNG-SAM IN THE
PRESIDENTIAL ELECTION SCHEDULED FOR DECEMBER. ON THE WHOLE, 
VOTER INTEREST IN THE DLP AND THE ONCE-CHIEF OPPOSITION DEMOCRATIC PARTY (DP) APPEARS TO HAVE COOLED AS A RESULT OF GROWING DISENCHANTMENT WITH KIM YOUNG-SAM AND OP LEADER KIM DAE-JUNG, THE PERENNIAL RIVALS FOR THE PRESIDENCY. THE GROWING APATHY FOR THE TWO KIMS HAS CREATED A DEMAND FOR NEH FACES, WHICH HYUMDAI FOUNDER CHUN JU-YUNG AND HIS NEWLY FORMED UNIFICATION NATIONAL PARTY (UNP) SEEM TO BE MEETING.

08427 SHIM, J.

TOO POOR FOR POLITIICS

FAR EASTERN ECONOMIC REVIEN, 153(32) (AUG 91), 11. WHEN SOUTH KOREAN PARL IAMENTARIAN LEE CHAN KOD RESIGNED FROM HIS SEAT "BECAUSE OF SHORTAGE OF MONEY," HE NOT ONLY STUNMED HIS OWN PARTY, THE OPPOSITION NEW DEMOCRATIC PARTY (NDP) BUT ALSO REFOCUSED NATIONAL ATTENTION ON THE (NDP), BUT ALSO REFOCUSED NATIONAL ATTENTION ON THE PERENNIAL PROBLEM OF POLITICAL FUNDING. WHAT ENHANCED THE IMPACT OF HIS RESIGNATION WAS THAT IT CAME AT A TIME WHEN SOUTH KOREA WAS REELING FROM A NUMBER OF CORRUPTION SCANDALS INVOLVING POLITICIANS. AT LEAST SIX MPS--FROM THE GOVERNMENT AND THE OPPOSITION--HAVE BEEN CONVICTED IN RECENT MONTHS ON CORRUPTION CHARGES, INCLU
BUSINESSMEN AND OTHERS.

08428 SHIM, J.

TROUNCED AT THE POLLS

FAR EASTERN ECONOMIC REVIEH, 155(13) (APR 92), 10-11. SOUTH KOREAN YOTERS DEALT A CRUSHING BLOH TO SOUTH KOREA'S RULING LIBERAL DEMOCRATIC PARTY (DLP) BY DENYING IT A MAJORITY IN THE 24 MARCH PARL IAMENTARY ELECTIONS. ANALYSTS ATTRIBUTE VOTER DISENCHANTMENT TO PRESIDENT ROH TAE WOO'S POLICIES WHICH HAVE RESULTED IN A SLUGGISH ECONOMY AND HIGH INFLATION. THE PEOPLE WERE ALSO INFLUENCED BY THE CEASELESS JOCKEYING AMONG DLP LEADERS FOR THE PARTY'S CANDIDACY IN THE PRESIDENTIAL ELECTION DUE BY THE END OF THE YEAR. OF THE CONTESTED 237 SEATS, THE DLP WON ONLY 115 . THE DEFEAT OF THE CONTESTED 237 SEATS, THE DLP WON ONLY 115 . THE DEFEAT
RULING PARTY WAS ALL THE MORE SIGNIFICANT BECAUSE THE STRONGHOLDS AND INDEPENDENTS SCORED STRONGLY ACROSS THE NATION.

08429 SHIM, J.

UNITY OF PURPOSE

FAR EASTERN ECONOMIC REVIEW, 155(1) (JAN 92), 10

THE SIGNING OF A HISTORIC DECLARATION INTENDED TO RID THE KOREAN PENINSUIA OF ALL NUCLEAR HEAPONS HAS REINFORCED PERCEPTIONS THAT PYONGYANG AND SEDUL ARE AT LAST MOVING INTO A PERIOD OF PEACE AND RECONCILIATION. THE DRAFT ACCORD REACHED ON 31 DECEMBER AFTER A MARATHON SEVEN-AND-A-HALF HOURS OF TALKS AT THE ARMISTICE BORDER COMPOUND OF PANMUNJOM COMES HOT ON THE HEELS OF A WIDE-RANGING NON-AGGRESSION AGREEMENT BETWEEN THE TWO SIDES EARLIER IN THE MONTH. BUT THE DECLARATION ON THE NUCLEAR ISSUE LOOKED MORE LIKE A STATEMENT OF PRINCIPLE THAN AN AGREEMENT WITH STRONG BINDING POWER. NEVERTHELESS, THE PROGRESS ON DENUCLEARIZATION LIFTS THE NORTH FROM THE NADIR OF INTERNATIONAL ISOLATION, PROVIDING FRESH IMPETUS TO ONGOING TALKS WITH JAPAN FOR ECONOMIC AID AND NORMALIZATION OF RELATIONS.

08430 SHIM, J.H.

IMPERFECT CHOICES

FAR EASTERN ECONOMIC REVIEW, 155(49) (DEC 92), 16-18. THE SOUTH KOREAN PRESIDENTIAL ELECTION COMES AT A TIME WHEN THE NATION'S 43 MILLION PEOPLE ARE PREPARING TO RESTRUCTURE THEIR ECONOMIC SOCIAL AND POLITICAL INSTITUTIONS. GIVEN THE MULTIPLE CHALLENGES THE COUNTRY FACES--RANGING FROM MARKET OPENINGS TO A PROBABLE COLLAPSE FACES--RANGING FROM MARKET OPENINGS TO A PROBABLE COLLAPSE OF THE KIM IL-SUNG REGIME IN NORTH KOREA HITHIN THE NEN
PRESIDENT'S FIVE-YEAR TERM--THE DECEMBER POLL IS BEING SEEN AS A WATERSHED IN SOUTH KDREA'S HISTORY. EIGHT CANDIDATES ARE IN THE RACE TO SUCCEED PRESIDENT ROH TAE WOO IN FEBRUARY 1993, BUT THE FIGHT IS MAINLY BETWEEN THE CANDIDATES OF THE RULING DEMOCRATIC LIBERAL PARTY (DLP) KIM YOUNG SAM, 65, THE OPPOSITION UNITED PEOPLE'S PARTY (UPP), BUSINESS TYCOON CHUNG JU YUNG, 77, AND THE MAIN OPPOSITION DEMOCRATIC PARTY (DP). KIM DAE CHUNG, 67. THE CAMPAIGN IS NO LONGER DOMINATED BY THE ISSUE OF DEMOCRACY BUT BY FEARS ABOUT SOUTH KOREA'S BY THE ISSUE OF DEMOCRACY BUT BY FEARS ABOUT SOUTH KOREA'S FLAGGING ECONOMY. PROVIDING MORE CAUSE FOR WORRY WAS THE GROWTH RATE WAS ONLY 3.1\%--THE LOWEST LEVEL IN 11 YEARS. GROWTH RATE WAS ONLY 3.1\%--THE LOWEST LEVEL IN 11 YEARS. WITH ABOUT 40\% OF THE VOTERS STILL UNDECIDED, IT IS A REMARKABLE RACE IN MANY RESPECTS. IT IS THE FIRST ELECTION SINCE 1963 IN WHICH THE GOVERNMENT CANDIDATE HAS NOT BEEN A MILITARY FIGURE. IT IS ALSO THE FIRST TIME A MAJO
FIGURE HAS STEPPED INTO THE PRESIDENTIAL ARENA.

08431 SHIM, J.H.

MASTERLY RETREAT

FAR EASTERN ECONOMIC REVIEW, 155 (39) (OCT 92), 18, 20

SOUTH KOREAN PRESIDENT ROH TAE HOO'S DECISION TO GIVE UP TH AND TO RESIGN AS THE PARTY'S HONORARY PRESIDENT JUST THREE MONTHS BEFORE THE MID-DECEMBER PRESIDENTIAL ELECTION CAME AS SUCH A SURPRISE THAT THE NEWS WAS AT FIRST MET WITH DISBELIEF. HITHIN DAYS OF HIS 18 SEPTEMBER ANNOUNCEMENT,
HOWEVER, IT BECAME CLEAR THAT THE MOVE HAS IMPLICATIONS NOT ONLY FOR ROH'S OWN LAME DUCK PRESIDENCY BUT ALSO FOR RELATIONS BETWEEN HIM AND THE RULING PARTY'S PRESIDENTIAL CANDIDATE, KIM YOUNG SAM. DESIRING TO BE VIEWED AS A REFORMIST CANDIDATE, KIM YOUNG SAM HAD BLASTED ROH FOR BEING AN IMPEDIMENT TO DEMOCRATIC REFORM. ROH RESPONDED TO THESE PRESSURE TACTICS BY LEAVING THE RULING PARTY ALTOGETHER AND BY AGREEING TO FORM A NEUTRAL CABINET INCLUDING MEMBERS DRAWM FROM THE OPPOSITIOH AMD FROM OUTSIDE POLITICS. IN DOING SO, HE WAS IN EFFECT TERMINATING HIS TWO-YEAR POLITICAL COLLABORATION WITH KIM. ROH'S ACTION APPEARS TO PAVE ALSO BEEN DESIGNED TO CEMENT HIS CLAIMS TO A PLACE IN HAVE ALSO BEEN DESIGNED TO CEMENT HIS CLAIMS TO A PLACE IN
HISTORY AS A PIONEER OF DEMOCRACY IN SOUTH KOREAN POLITICS. HISTORY AS A PIONEER OF DEMOCRACY IN SOUTH KOREAN POLITICS.
HOWEVER, THE MOVE ALSO THREATENS TO BREAK APART THE RULING HOWEVER, THE MOVE ALSO THREATENS TO BREAK APART THE RULING
PARTY AND MAY RUIN KIM YOUNG SAM'S CHANCES OF WINNING THE PARTY AND
ELECTION.

08432 SHIM, J.H.

MONEY IS POWER

FAR EASTERN ECONOMIC REVIEW, 155(30) (JUL 92), 22-23.

IN SOUTH KOREA, MORE OPEN AND INCREASINGLY FREQUENT ELECTIONS HAVE RAISED TO COST OF POLITICS AND FOCUSED ATTENTION ON THE ISSUE OF CORRUPTION AMONG LEGISLATORS. EVEN AFTER GETTING ELECTED, THE COST OF STAYING IN OFFICE IS HIGH AND HAS RESULTED IN CASES OF SITTING MEMBERS OF PARLIAMENT BEING TRIED FOR ILLEGAL FUND RAISING. THE CURRENT POLITICAL SYSTEM IS BIASED HEAVILY IN FAVOR OF THE RULING PARTY WITH MOST PRIVATE COMPANIES AVOIDING ANY OPEN LINKS TO THE OPPOSITION. WHILE RECENT REVELATIONS ABOUT PAYOFFS TO PAST AND PRESENT PRESIDENTS BY TYCOON CHUNG JU YUNG HAVE LED TO INCREASED CRITICISM OF THE CORRUPT SYSTEM, THERE IS LITTLE PROSPECT FOR CHANGE AT LEAST UNTIL AFTER THE DECEMBER ELECTIONS.

08433 SHIM, J.H.

SOUTHERN COMFORT

FAR EASTERN ECONOMIC REYIEH, 155(31) (AUG 92), 16-17. WHILE SEOUL OFFICIALS REFUSE TO GIVE EXACT FIGURES, OBSERVERS SAY THE NUMBER OF DEFECTIONS FROM NORTH KOREA INCREASED SIGNIFICANTLY SINCE 1989 . THE DOZENS WHO HAVE
ESCAPED TO THE SOUTH HHILE ABROAD INCLUDE STUDENTS, WORKERS, ESCAPE TO THE SOUTH WHILE ABROAD INCLUDE STUDENTS, WORKERS, TECHNICIANS AND EVEN A SENIOR DIPLOMAT. PROTRACTED UPHEAVALS
IN THE FORMER SOVIET EMPIRE HELPED WEAKEN PYONGYANG'S GRIP IN THE FORMER SOVIET EMPIRE HELPED WEAKEN PYONGYANG'S GRIP
ON ITS PEOPLE ABROAD, MAKING IT IMPOSSIBLE TO MAINTAIN THE ON ITS PEOPLE ABROAD, MAKING IT IMPOSSIBLE TO MAINTAIN KIND OF SURVEILLANCE AND CONTROL POSSIBLE WITH HOSTRELAXATION IN EASTERN EUROPE AND RUSSIA, MORE INFORMATION ON SOUTH KOREA IS NOW EASILY AVAILABLE--A PROCESS ACCELERATED SOUTH KOREA IS NOW EASILY AVAILABLE--A PROCESS ACCELERATED BY THE OPENING OF MORE SOUTH KOREAN EMBASSIES. ON THE KOREAM PENINSULA ITSELF, SEVERAL NORTHERN SOLDIERS ON DUTY IN THE DEMILITARIZED ZONE HAVE BRAVED THE MINEFIELDS ALONG THE
BORDER TO DEFECT. MANY SEE THE GROWING NUMBER OF DEFECTIONS AS A SURE SIGN THAT THE ISOLATED AND REPRESSIVE REGIME OF KIM IL-SUNG IS COMING TO AN END.

08434 SHIM, J.H.

SOUTHERM LURE

FAR EASTERN ECONOMIC REVIEN, 156 (18) (MAY 92), 24.

SOUTH KOREA IS MOVING RAPIDLY TO READJUST ITS

RELATIONSHIP WITH VIETHAM. THE SOUTH KOREAN FOREIGN MINISTRY ANNOUNCED ON 20 APRIL THAT SEOUL AND HANOI HILL EXCHANGE LIASON OFFICES IN JULY WITH THE UNDERSTANDING THAT THEY WILL LEAD TO EMBASSIES SOON. SINCE THE BEGINMING OF NORMALIZATION OF TIES BETWEEN THE TWO COUNTRUES, TWO-WAY TRADE HAS RISEN FROM A MEAGER US\$76 MILLION TO ABOUT US\$220 MILLION IN 1991. SEOUL'S STRONGER TIES WITH VIETNAM COULD DAMPEN SOUTH

KOREA'S ECONOMIC ATTRACTION TO CHINA. RECENT HIGH LEVEL TALKS BETWEEN PEKING AND SEOUL FAILED TO INJECT ANY URGENCY INTO THE SLOW TIMETABLE ON THE OPENING OF RELATIONS. ONE
STICKING POINT CONTINUES TO BE SOUTH KOREA'S CLOSE RELATIONS WITH TAIWAN AND THE EXTENSIVE (USS3 BILLION) AMOUNT OF TRADE BETWEEN THE THO.

08435 SHIMADA, H.

THE EMPLOYMENT OF FOREIGN LABOR IN JAPAN

ANNALS OF THE AMERICAN ACADEMY OF POLITICAL AND SOCIAL ANNALS OF THE AMERICAN ACADEMY OF
SCIENCE, (513) (JAN 91), $117-129$.

THE PROBLEMS OF FOREIGN LABOR IN JAPAN HAVE BECOME INCREASIMGLY SERIOUS ECONOMICALLY, POLITICALLY, AND SOCIALLY IN RECENT YEARS. IN RESPONSE TO LABOR SHORTAGES AND HIGH WAGES, LARGE NUMBERS OF FOREIGN WORKERS ARE ENTERING JAPAN WAGES, LARGE NUMBERS OF FOREIGN WORKERS ARE ENTERING JAPAN AND ILLEGALLY ENGAGING IN UNSKILLED WORK UNDER POOR WORKING CONDITIONS. THE AMENDED LAH OF IMMIGRATION CONTROL WENT INTO EFFECT IN JUNE 1990 , STRICTLY PROHIBITING THE ENTRANCE OF FOREIGNERS FOR UNAUTHORIZED WORK WHILE OPENING DOORS MORE WIDELY FOR HIGHLY-SKILLED AND KNOWLEDGEABLE WORKERS. THIS
PAPER DISCUSSES THE RECENT PENETRATION OF THE JAPANESE LABOR PAPER DISCUSSES THE RECENT PENETRATION OF THE JAPANESE LAB
MARKET BY FOREIGN WORKERS, THE POTENTIAL MERITS OF THIS MARKET BY FOREIGN WORKERS, THE POTENTIAL MERITS OF THIS DANGERS ASSOCIATED WITH THE SPONTANEOUS INFLUX OF FOREIGN WORKERS UNDER CURRENT INSTITUTIONAL AND SOCIAL CONDITIONS. THE AUTHOR ADVOCATES A WORK-AND-LEARN PROGRAM JOINTLY ADMINISTERED BY THE GOVERNMENT AND THE PRIVATE SECTOR AS A POLICY REMEDY TO MAXIMIZE THE MERITS AND MINIMIZE THE 
DEMERITS OF ACCEPTING FOREIGN WORKERS.

08436 SHIMIZU, S

CLARENCE RANDALL AND THE CONTROL OF SINO-JAPANESE TRADE JOURMAL OF AMERICAN AND CAMADIAN STUDIES, 7 (SPR 92), 7-74.

EISENHOWER REVISIONISM HAS PROVIDED A USEFUL CORRECTIVE TO THE EARLIEST LITERATURE OF DWIGHT EISENHOWER AS PRESIDENT. THERE IS, HOWEVER, A CONSPICUOUS ABSENCE IN THE REVISIONIST WORKS OF A MAJOR POLICY ADVOCACY ROLE PLAYED BY CLARENCE B. RANDALL, THE SPECIAL CONSULTANT TO THE PRESIDENT ON FOREIGN ECONOMIC POLICY. THE ADMINISTRATION'S POLICY TOWARDS SINOJAPANESE TRADE DURING THE CRUCIAL 1956-1957 YEARS WAS CLEARLY MOTIVATED BY AN ISOLATIONIST SCHOOL OF ALLIANCE MANAGEMENT, AND RANDALL'S EFFECTIVE POLICY ADVOCACY AS THE CFEP CHAIRMAN MADE HIM ONE OF THE MOST IMPORTANT ARCHITECTS OF U.S. POLICY TOWARDS SINO-JAPANESE TRADE IN THE 1950 S.
THIS ARTICLE EXPLORES THE HISTORY OF UNITED STATES-SINOJAPANESE TRADE POLICY AND EVALUATES THE CONTRIBUTIONS OF EISENHOWER, DULLES, AND RANDALL TO IT.

08437 SHIMKO, $K$.

REGAN ON THE SOVIET UNION AND THE NATURE OF INTERNATIONAL COMFLICT

POLITICAL PSYCHOLOGY, 13(3) (SEP 92), 3533-378.

THAT REAGAN POSSESSED A HARDLINE IMAGE OF THE SOVIET UNION, THOUGH WITH SOME DEVIATIONS THAT CHANGED LITTLE DURING HIS PRESIDENCY IS SUGGESTED. REAGAN HAD AN ESSENTIALLY LIBERAL, OPTIMISTIC VIEN OF POLITICAL CONFLICT AS STEMMING FROM MISUNDERSTANDING AND MISPERCEPTION. THE PRESENCE OF THESE OFTEN CONTRADICTORY BELIEF PATTERNS SUGGESTS THAT REAGAN IS BEST THOUGHT OF, AND UNDERSTOOD AS, AN "UNCOMMITTED THINKER" RATHER THAN AN IDEOLOGUE.

08438 SHIMKO, K.L.

REALISM, NEOREALISM, AND AMERICAN LIBERALISM

REVIEW OF POLITICS, 54 (2) (SPR 92), 281-301

NEOREALISM HAS RECENTLY BEEN PORTRAYED AS AN ATTEMPT TO SYSTEMATIZE THE INSIGHTS OF CLASSICAL REALISM IN ORDER TO PUT THEM ON A MORE SOLID THEORETICAL FOUNDATION. THIS ESSAY REJECTS THIS COMMON CHARACTERIZATION OF THE EMERGENCE OF NEOREALISM BY ARGUING THAT NEOREALISM CONSTITUTES A FUNDAMENTALLY DIFFERENT CONCEPTUALIZATION OF INTERNATIONAL POLITICS THAN THAT PROVIDED BY CLASSICAL REALISTS. NEOREALISH IS BEST UNDERSTOOD AS AN ALTERHATIVE TO CLASSICAL REOREALISH IS BEST UNDERSTOOD AS AN ALTERNATIVE TO CLASSICAL RTATES, WHERE NEOREALISM EMERGED AND THRIVES.

08439 SHIMOGAMA, M.

RUBLE ROUSERS

JAPAN TIMES (WEEKLY INTERNATIONAL EDITION), 32(18) (MAY 92), 12-13.

SINCE THE BREAKUP OF THE SOVIET UNION, ENTREPRENEURS AND GOVERNMENT OFFICIALS HAVE BEEN SCURRYING TO ESTABLISH A FREE MARKET IN RUSSIA'S FAR EAST BEFORE ITS AGING INFRASTRUCTURE COLLAPSES COMPLETELY. BECAUSE THE RUSSIAN GOVERNMENT IS SADOLED WITH A HUGE FINANCIAL DEFICIT, THE BURDEN OF IMPROVING THE INFRASTRUCTURE RESTS LARGELY WITH THE REGION'S INHABITANTS. FUNDS ARE SCARCE, AND THE GROPING SEARCH FOR ECONOMIC SELF-RELIANCE HAS ONLY JUST BEGUN.

08440 SHIN, J.

KOREA AND A NEW REGIONAL ORDER IN NORTHEAST ASIA BULLETIN OF PEACE PROPOSALS, 23(1) (MAR 92), 85-92 AFTER THE KOREAN WAR, THE KOREAN PENINSULA BECAME THE MOST HIGHLY MILITARIZED AREA IN THE WORLD. MANY GREAT POWERS, REGIONAL AND GLOBAL, TOOK SIDES IN SUPPORTING MILITARY AND ECONOMIC DEVELOPMENT ON THE NORTH AND SOUTH ENDS OF THE PENINSULA. HOWEVER, IN THE LATE 1980S, THE CONFRONTATIONAL STRUCTURE CENTERED ON KOREA BEGAN TO LOSE SOME OF ITS BIPOLARITY. THIS PAPER ILLUSTRATES SEVERAL PROMINENT CHANGES IN THE MAJOR POWERS' POLICIES TOWARDS THE TWO KOREAS AND INTER-KOREAN RELATIONS, AND EXAMINES THEIR IMPLICATIONS FOR THE SEARCH FOR A NEW REGIONAL ORDER IN NORTHEAST ASIA. GREAT POHERS EXAMINED INCLUDE THE SOVIET UNION, THE PEOPLE'S REPUBLIC OF CHINA, JAPAN AND THE UNITED STATES.

08441 SHINN, $T$.

SCIENCE, TOCQUEVILLE, AND THE STATE: THE ORGANIZATION OF KNOWLEDGE IN MODERN FRANCE

SOCIAL RESEARCH, 59 (3) (FAL 92) 533-566.

ALEXIS DE TOCQUEVILLE DREW ATTENTION TO A SUBTLE AND PERMANENT FEATURE OF FRENCH INSTITUTIONAL AND POLITICAL LIFEPRMAELY THE ROBUST AND IONG-LIVED CONALCI AND POLITICAL POLITICAL LEADERSHIP, A NUMBER OF EXTREMELY POWERFUL STATE BUREAUCRACIES, AND A FORM OF KNOWLEDGE THAT COMBINES HIGH SCIENCE AND TECHNOCRATIC CONTROL. THIS ESSAY FOCUSES ON THREE COMPONENTS OF THIS STATE-SCIENCE BOND: (1) SCIENCE HAS LONG CONSTITUTED ONE OF FRANCE'S MOST VISIBLE, VOCAL, AND INFLUENTIAL LOBBIES. FOR NEARLY THREE CENTURIES, FRANCE HAS BOASTED AN ELABORATE SYSTEM OF CIVILIAN AND MILITARY BUREAUCRACIES, WITH THE UPPER REACHES FILLED BY SCIENTISTS AND ENGINEERS TRAINED IN A CLUSTER OF EXCLUSIVE SCHOOLS
RECENT ALLIANCE BETHEEN SCIENCE AND THE STATE LIES IN THE NUMEROUS AGENCIES FOR RESEARCH ESTABLISHED SINCE HORLD WAR II. (2) SCIENTIFIC KNOWLEDGE OF A CERTAIN VARIETY HAS HISTORICALLY OCCUPIED A CENTRAL POSITION IN FRANCE' IDEOLOGY. DIPLOMAS FROM SELECT SCIENCE SCHOOLS HAVE FACILITATED UPWARD SOCIAL AND POLITICAL MOBILITY BY PROVIDING BOTH ACCESS TO THE INFLUENTIAL STATE BUREAUCRACIES AND SYMBOL IC PROOF OF INTELLECTUAL SUPERIORITY. (3) PROGRESS THOUGH THE EXPANSION AND REIGN OF SCIENCE WAS INITIALLY PROMISED BY THE POLITICAL LEFT IN THE NINETEENTH CENTURY; THIS PROMISE HAS BEEN RENEWED, MODIFIED, AND REINVIGORATED IN THE THENTIETH CENTURY.

08442 SHINOHARA, M.

JAPAN AS A WORLD ECONOMIC POWER

ANNALS OF THE AMERICAN ACADEMY OF POLITICAL AND SOCIAL SCIENCE, (513) ( JAN 91), 12-24.

THE AUTHOR QUESTIONS WHETHER JAPAN'S ECONOMIC SUCCESS WILL LAST OR WILL BE SHORT-LIVED. HE ANALYZES THE REASONS FOR THE RELATIVE ECONOMIC DECLINE OF THE UNITED STATES FROM SUCH PERSPECTIVES AS CHANGES IN THE COMPETITIVENESS OF MAJOR INDUSTRIES IN THE USA AND JAPAN, THE MISMANAGEMENT OF U.S. THE OVERVALUATION OF THE DOLLAR IN THE 1980's. THEREIN LIE A NUMBER OF LESSONS FOR JAPAN IN CHARTING ITS FUTURE COURSE OF NUMBER OF LES'S CURRENT-ACCOUNT SURPLUS HAS BEGUN TO DECLINE, ACTION. JAPAN'S CURRENT-ACCOUNT SURPLUS HAS BEGUN TO AND IT IS NO LONGER FEASIBLE TO CONCENTRATE ONLY ON AUGMENTING DOMESTIC DEHAND. FIRST, JAPAN MUST BE CONCERNED WITH THE BALANCE BETHEEN DOMEST IC DEMAND AND CURRENT-ACCOUNT
SURPLUS, SO AS TO FULFILL ITS INTERMATIONAL RESPONSIBILITIES THROUGH OVERSEAS ECONOMIC COOPERATION. SECONDLY, THE CONSIDERABLE SIZE OF JAPAN'S CURRENT-ACCOUNT SURPLUS NECESSITATES SOME KIND OF RULES OR PHILOSOPHY, ACCEPTABLE INTERNATIONALLY, TO SERVE AS A GUIDE IN REALLOCATING SOME OF THE SURPLUS BY REGION AND PURPOSE.

08443 SHIOZAKI, H.

THE CATHOLIC BACKGROUND OF COUGHLINISM AND MCCARTHYISM JOURNAL OF AMERICAN AND CANADIAN STUDIES, 7 (SPR 92), 23-46

THIS PAPER AIMS TO THROW NEW LIGHT UPON THE CATHOLIC ASPECTS OF COUGHLINISM AND MCCARTHYISM THAT HAVE NOT BEEN REFERRED TO MUCH IN STUDIES ABOUT THEM. FIRST, THEIR ACTIVITIES ARE CONSIDERED IN THE CONTEXT OF AN AMERICAN CATHOL ICISM THAT AMALGAMATED MOSTLY WITH CONSERVATIVE AND PATRIOT AMERICANISM. SECOND, THEIR POPULARITY PROPAGATED MARIAN CULTS, AND ALSO ANTICOMHUNISM. THIRD, THEIR SPREAD MARIAN CULTS, AND ALSO ANTICOMMUNISM. THIRD, THEIR SPR CANNOT BE EXPLAINED HITHOUT TRADITIONAL POPULISH OR
PROGRESSIVISM. FINALLY, FUTURE STUDIES CONCERNING THESE PROGRESSIVISM. FINALLY, FUTURE STUDIES CONCERNING THESE
TOPICS SHOULD AIM AT RE-EXAMINING THE ATTITUDES OF AMERICAN TOPICS SHOULD AIM AT RE-EXAMINING THE ATTITUDES OF AMERI BISHOPS OR CATHOLIC REFORMISTS TOHARDS COUGHLINISM AND
MCCARTHYISM WITH THE HELP OF RECENT AMERICAN THEOLOGY.

08444 SHIPAN, C.

INDIVIDUAL INCENTIVES AND INSTITUTIONAL IMPERATIVES: COMMITTEE JURISDICTION AND LONG-TERM HEALTH CARE AMERICAN JOURNAL OF POLITICAL SCIENCE, 36(4) (NOV 92), B77-895.

THIS PAPER FOCUSES ON THE DEGREE TO WHICH A LEGISLATOR'S INSTITUTIONAL POSITION ACCOUNTS FOR HIS OR HER WILLINGNESS TO PUNISH VIOLATIONS OF NORMS. THE CASE COMES FROM THE $1100 T H$ CONGRESS IN WHICH A RULE WAS PROPOSED THAT WOULD HAVE FORCED CONSIDERATION OF A LONG-TERM HEALTH CARE BILL WITHOUT FIRST GOING THROUGH THE COMMITTEES OF JURISDICTION AND HITHOUT FOLLOHING NORMAL DISCHARGE PROCEDURES. EMPIRICAL HITHOUT FOLLOHING NORMAL DISCHARGE PROCEDURES. EMPIRICAL
ANALYSIS OF THE FLOOR VOTE ON THE RULE SUGGESTS THAT MEMBERS
WERE NOT GUIDED IN THEIR VOTE BY THE FACT THAT PROCEDURAL NORMS HAD BEEN VIOLATED BUT RATHER VOTED BASED ON PERSONAL PREFERENCES. IN PARTICULAR, THE ANALYSIS DEMONSTRATES THAT THOSE MEMEBERS EXPECTED TO BE MOST LIKELY TO PUNISH THE VIOLATION DID NOT DO SO.

O8445 SHIRATORI, R. JAPAN

EUROPEAN JOURNAL OF POLITICAL RESEARCH, 22(4) (DEC 92), 461-468.

AS OF JANUARY 1, 1991. ALL MEMBERS OF PRIME MINISTER TOSHIKI KAIFU'S CABINET HERE MEMBERS OF THE LIBERAL

DEMOCRATIC PARTY.

08446 SHIRK, S.

"PLIRK, S. "PLAYING TO THE PROVINCES:"

STRATEGY OF ECONOMIC REFORM
STUDIES IN COMPARATIVE COMHUNISM, XXIII(3-4) (FAL 90), STUDIES

T27-258.

THIS PAPER DESCRIBES WHY FISCAL REFORM MADE SENSE IN THE CHINESE HISTORICAL CONTEXT AND GOES ON TO DESCRIBE THE EVOLUTION OF THE FISCAL SYSTEM OVER THE COURSE OF THE REFORM DECADE, SHOWING HOW IT REFLECTS THE POLITICAL VALUE OF PROVINCIAL OFFICIALS TO CENTRAL POLITICIANS. AFTER A BRIEF NOTE ON OTHER REFORM POLICIES AIMED AT ENHANCING THE POWER LOCALITIES, THE AUTHOR DISCUSSES THE CONSEQUENCES OF FISCAL DECENTRALIZATION. THE PAPER CONCLUDES BY SHOWING THAT THE POLITICAL LOGIC OF FISCAL GIVEAWAYS TO THE PROVINCES 

OVERPOWERED THE CENTRALIZING INSTINCTS OF LI PENG AND HIS
CONSERVATIVE PARTY ALLIES WHEN THEY CAME TO POWER IN 1988.

08447 SHIRLEY, M.

THE WHAT, WHY, AND HOW OF PRIVATIZATION: A WORLD BANK PERSPECTIVE

FORDHAM LAW REYIEW, LX(6) (MAY 92), 23-36.

THIS ARTICLE OUTLLINES PRIVATIZATION, DEFINING THE CONCEPT AND SUGGESTING WHY PRIVATIZATION SHOULD OCCUR AND HOW IT CAN BE BEST IMPLEMENTED. IT FIRST DEFINES PRIVATIZATION AS THE TRANSFER OF OWNERSHIP OF ASSETS TO THE PRIVATE SECTOR. IT THEN DISCUSSES WHY A GOVERMMENT SHOULD PRIVATE SECTOR. IT THEN DISCUSSES WHY A GOVERMMENT SHOULD
PRIVATIZE, AS OPPOSED TO WHY GOVERMMENTS OFTEN WANT TO PRIVATIZE, AS OPPOSED TO WHY GOVERMMENTS OFTEN WANT TO PRIVATIZE. FINALLY, THE ARTICLE DISSCUSSES VARIOUS STEPS
GOVERNMENTS SHOULD TAKE IN EFFECTUATING PRIVATIZTIONS.

08448 SHIVELY, $W$.

FROM DIFFERENTIAL ABSTENTION TO CONVERSION: A CHANGE IN ELECTORAL CHANGE, 1864-1988

AMERICAN JOURNAL OF POLITICAL SCIENCE, 36(2) (MAY 92), 309-330.

THIS ARTICLE USES A NEW INDEX OF CONVERSION TO EXAMINE THE NATURE OF CHANGE IN PRESIDENTIAL ELECTIONS SINCE 1864. A CHANGE IN THE NATURE OF CHANGE IS EVIDENT AROUND THE 1950 S AND 1960S; NET ELECTORAL CHANGE BEFORE THEN APPEARS TO HAVE BEEN PRIMARILY A RESULT OF DIFFERENTIAL ABSTENTION (A ABSTENSION ACROSS A PAIR OF ELECTIONS YIELDS A LARGER NET GAIN OR LOSS FOR ONE PARTY THAN FOR THE OTHER), WHILE ELECTORAL CHANGE AFTERHARD HAS BEEN PRIMARILY A RESULT OF CONVERSION (A PROCESS BY WHICH CITIZENS WHO VOTED FOR ONE PARTY AT AN ELECTION SHITCH TO ANOTHER PARTY AT THE NEXT ELECTION). THE AUTHOR HYPOTHESIZES THAT THIS SHIFT HAS DUE TO THE ADVENT OF TELEVISION, INVESTIGATIVE REPORTING, FACETO-FACE DEBATES, AND OTHER FACTORS THAT EASED THE FLOH OF INFORMATION AND MADE CANDIDATES MORE TANGIBLY ACCESSIBLE TO VOTERS. THE HYPOTHESIS IS TESTED BY COMPARISONS TO CONGRESSIONAL RACES, ANALYSIS OF THE RESPONSES OF WELL- AND LESS-INFORMED VOTERS AND COMPARISONS WITH CONGRESSIONAL AND LESS-INFORMED VOTERS AND COMPARISONS WITH CONGRESSI
MINMESOTA LEGISLATIVE RACES OVER THE SAME PERIOD.

08449 SHIYOU, $Z$.

FRESH IMPETUS FROM DENG'S MESSAGE

BEI JING REVIEW 35(15) (APR 92) 4-6.

DENG XIAOPING CONTINUES TO INSPIRE THE CHINESE PEOPLE TO VIGOROUSLY PURSUE REFORM AND OPENING TO THE OUTSIDE NORLD. DURING A TOUR OF SOUTHERM CHINA, DENG REPEATEDLY ENCOURAGED THE PEOPLE TO CONTINUE ON THE CHOSEN PATH AND TO BE BOLDER AND DARE TO EXPERIMENT IN PURSUING REFORM. HE SAID THAT THE CRITERIA FOR PURSUING A COURSE OF ACTION SHOULD BE WHETHER THE MOVE FACILITATES THE DEVELOPMENT OF SOCIALIST PRODUCTIVE FORCES, WHETHER IT HELPS INCREASE THE NATIONAL STRENGTH OF CHINESE SOCIALISM, AND WHETHER IT PRODUCES BETTER LIVING CONDITIONS.

08450 SHOCKET, P.A.; BROWN, C.; HEIGHBERGER, N.R. THE EFFECT OF VOTING TECHNOLOGY ON VOTING BEHAVIOR IN A SIMULATED MULTI-CANDIDATE CITY COUNCIL ELECTION: POLITICAL EXPERIMENT OF BALLOT TRANSPARENCY

WESTERN POLITICAL OUARTERLY, 45(2) (JUN 92), 521-539.

THE AUTHORS INVESTIGATED THE RELATIONSHIP BETHEEN VOTING BEHAVIOR AND BALLOT DESIGN AND CONSTRUCTION. THEY CONDUCTED AN EXPERIMENT TO TEST THE IMPACT OF THREE YOTING

TECHNOLOGIES (MANUAL--PAPER AND PENCIL, COMPUTERIZED PUMCH CARD, AND DIRECT RECORDING ELECTRONIC) ON VOTING BEHAVIOR OPERATIOMALIZED AS THE MUMBER OF YOTES CAST IN A SIMUATED MULTI-CAHDIDATE FIELO ELCT POL POLITICAL COMMERCIALS FOR 18 CANDIDATES, WERE ASKED TO CHOOSE UP TO NINE CANDIDATES, AND THEN RANDOMLY ASSIGNED
ONE OF THE THREE VOTING SYSTEMS. THE ANALYSES CONFIRMED THREE HYPOTHESES AT THE INDIVIDUAL LEVEL THAT HAD BEEN SO THE OTHER VOTING SYSTEMS, SUBJECTS USING THE COMPUTERIZED PUNCH-CARD SYSTEM LESS FREOUENTLY EXERCISED THE R FULL PUNCH-CARD SYSTEM LESS FREQUENTLY EXERCISED THEIR FULL
FRANCHISE BY VOTING FOR A COMPLETE SLATE OF CANDIDATES, MORE FREQUENTLY SPOILED BALLOTS BY

08451 SHOGREN, J.; BAIK, K.

FAYORITES AND UMDERDOGS: STRATEGIC BEHAVIOR IN AN EXPERIMENTAL CONTEST

PUBLIC CHOICE, 74 (2) (1992), 191-206.

CONFLICTS BETWEEN FAYORITES AND UNDERDOGS ARE EYERYDAY PHENOMENA. THIS ARTICLE EXAMINES THEIR STRATEGIC BEHAYIOR IN AN EXPERIMENTAL CONTEST AND FIND BEHAVIDR PARTIALIY

AN EXPERIMENTAL CONTEST AND FIND BEHAVIOR PARTIALLY CONSISTENT WITH PREDICTIONS. FAVORITES GIVEN A FIRST-MOVERADVANTAGE DO OVERCDMMMIT EFFORT RELATIVE TO NASH. UND OFTEN SELECT THE BEST RESPONSE EFFORT LEVEL GIVEN THE FAVORITE'S MOVE. OVERALL DISSIPATION OF THE PRIZE WAS
SIGNIFICANTLY HIGHER HITH THE STRATEGIC COMMITMENT RELATIVE TO NASH.

08452 SHORRIS, E.

LATIMOS: THE COMPLEXITY OF IDENTITY
REPORT ON THE AMERICAS, XXVI(2) (SEP 92), 19-26.

IN THE UNITED STATES, INTERESTS MAY GAIN INFLUENCE BUT ONLY FACTIONS, SUCH AS POLITICAL PARTIES AND MOVEMENTS, CAN TRULY TAKE POWER. THE PROBLEM FOR LATINOS, WHO DREAM OF POLITICAL INFLUENCE EQUAL TO THEIR NUMBERS, IS THAT THEY ARE A LARGE CONGERIES OF DIFFERENT, OFTEN COMPETING, INTERESTS. INTERESTS CAN BE BALANCED AGAINST ONE ANOTHER, EFFECTIVELY INTERESTS CAN BE BALANCED AGAINST ONE ANOTHER, EFFECTIVELY FACTION, HAVE BEEN AT EACH OTHER'S THROATS SINCE THE MEXICANAMERICAN WAR.

08453 SHOUP, $P$.

SERBIÁ ATं THE EDGE OF THE ABYSS

RFE/RL RESEARCH REPORT, 1(36) (SEP 92), 7-14

THE POLITICAL SITUATION IN SERBIA REMAINS DEADLOCKED FOLLONING THE IMPOSITION OF SANCTIONS AND OPPOSITIOM DEMONSTRATIONS AGAINST SLOBODAN MILOSEVIC'S REGIME. IT WOULD APPEAR THAT MILOSEVIC'S DAYS ARE NUMBERED. THE OPPOSITION HAS DEVELOPED A NUMBER OF STRATEGIES TO EFFECT THE TRANSITION TO THE POST-MILOSEVIC ERA. YET IT IS FAR FROM CLEAR WHETHER A DEMOCRATIZING TRANSITION AND THE LIFTING OF SANCTIONS WILL BE ACCOMPLISHED IN TIME TO AVERT A SOCIAL AND ECONOMIC COLLAPSE OR CIVIL WAR IN SERBIA.

08454 SHOUP, $P$

THE U.N. FORCE: A NEW ACTOR IN THE CROATIAN-SERBIAN CRISIS RFE/RL RESEARCH REPORT, 1(13) (MAR 92), 17-22.

IN FEBRUARY 1992 THE UNITED NATIONS SECURITY COUNCIL ADOPTED A RESOLUTION ESTABLISHING THE U.N. PROTECTION FORCE FOR DEPLOYMENT IN THE BORDER REGIONS OF CROATIA. ITS TASK WILL BE TO OVERSEE THE DEMILITARIZATION OF THE AREAS WHERE FIGHTING HAS BEEN RAGING AND TO EASE ETHNIC TENSION,

ALLOWING THE E.C.-SPONSORED SEARCH FOR A POL ITICAL DUTIES ARE PARAMOUYT. IT WIU AL SO HAVE A ROLE TO PLAY IM PEACEMAKING, SUCH AS ASSISTING IN THE NORMALIZATION OF INTERETHNIC RELATIONS AND THE RETURN OF REFUGEES. DESPITE PREDICTIONS THAT THE U.N. OPERATION WILL LAST WELL BEYOND ITS ONE-YEAR MANDATE, THERE ARE FACTORS MILITATING AGAINST ITS ONE-YEAR MANDATE, THERE ARE FACTORS MILITATING AGAI
AN EXTENDED U.N. PRESENCE IN CROATIA. THUS, THE U.N. AN EXTENDED U.N. PRESENCE IN CROATIA. THUS, THE U.N.
SECURITY COUNCIL HILL BE UNDER PRESSURE TO JOIN THE EUROPEAN SECURITY COUNCIL WILL BE UNDER PRESSURE TO JOIN THE EURO
COMMUNITY IN SEEKING A RAPID SETTLEMENT OF THE CRISIS.

08455 SHRYBMAN, S.

THE COSTS OF ECONOMIC INTEGRATION: TRADING AHAY THE ENVIRONMENT

HORLD POLICY JOURNAL, 9 (1) (WIN 91), 93-110.

FOR THE FIRST TIME IN THE HISTORY OF TRADE NEGOTIATIONS, GOVERMMENTS ARE HAVING TO RESPOND TO CONCERNS ABOUT THE ENVIRONMENTAL CONSEQUENCES OF TRADE POLICY OBJECTIVES. THESE CONCERNS REFLECT GROWING RECOGNITION THAT CURRENT ATTEMPTS TO REVISE THE RULES GOVERNING REGIONAL AND GLOBAL TRADE THREATEN ENVIRONMENTAL PROTECTION EFFORTS WORLDWIDE. THIS ARTICLE SUGGESTS THAT BY FAILING TO ADEQUATELY COMPREHEND AND SATISFACTORILY ADDRESS THE ENVIRONMENT IMPLICATIONS OF PRESENT TRADE NEGOTIATIONS, NATIONAL GOVERMMENTS ARE UNDERMINING THE PROSPECTS OF MEETING PRESSING ECOLOGICAL CHALLENGES. IT EXPLORES THE RELATIONSHIP BETWEEN THE ENVIRONMENT, THE ECONOMY, AND TRADE AND EXAMINES MEANS TO SUSTAIN THE ECOSYSTEM.

08456 SHTROMAS, A.

HOW POLITICAL ARE THE SOCIAL MOVEMENTS IN THE BALTIC REPUBLICS?

NATIONALITIES PAPERS, 18 (2) (FAL 90), 15-21.

THIS ARTICLE DISCUSSES THE HISTORY AND CAUSES OF THE

NATIONALIST MOVEMENTS IN THE BALTIC STATES. THE SOCIAL, POLITICAL, AND SPIRITUAL RELATIONSHIP BETHEEN THE BALTIC STATES AND THE USSR IS EXAMINED. THE BACKGRDUND AND
ACTIIVITIES OF PRO-INDEPENDENCE DISSIDENT GROUPS ARE LOOKED AT.

08457 SHUBANE, $K$

SOUTH AFRICA: A NEW GOVERNMENT IN THE MAKING?

CURRENT HISTORY, 91(565) (MAY 92), 202-207.

SOUTH AFRICA'S GOVERNING NATIONAL PARTY SEEMS TO BE VERY

CONCERNED WITH PRESERVING ITS OWN POWER IN THE CURRENT

NEGOTIATIONS ON FORMULATING A NEW CONSTITUTION AND

ESTABL ISHING A NONRACIAL DEMOCRACY. MANY RADICAL BLACK

ESTABLISHING A NONRACIAL DEMOCRACY. MANY RADICAL BLACK
OPPONENTS OF THE GOVERMMENT BELIEVE THAT THE REGIME DOES NOT

OPPONENTS OF THE GOVERMMENT BELIEVE THAT THE REGIME DOES NOT
PLAN TO GIVE UP POWER COMPLETELY AND ALLOW THE FORMATION OF

PLAN TO GIVE UP POWER COMPLETELY AND ALLOH THE FDRMATION

AN UNFETTERED DEMOCRACY. THEY BELIEVE THE NATIDNAL PARTY

WILL USE ITS POWER TO STRUCTURE A TRANSITION THAT WILL

08458 SHUGART, M.

GUERRILLAS AND ELECTIONS: AN INSTITUTIONALIST PERSPECTIVE

ON THE COSTS OF CONFICT AND COMPETITION

INTERMATIONAL STUDIES OUARTERLY, 36(2) (JUN 92), 121-152

SETTLEMENTS OF GUERRILLA WARS THAT LEAD TO ELECTIONS OUT OF WHICH REBELS EMERGE AS "RELEVANT" PARTIES MAY BE UNDERSTOOD AS A PRODUCT OF CALCULATIONS OF THE COSTS OF CONTINUED CONFLICT VERSUS THE COSTS OF ELECTORAL COMPETITION FOR EACH SIDE. THE SEARCH FOR AN ELECTORAL EXIT FROM THE WAR 
MAY BE SPURRED BY AN INCREASE IN THE COSTS OF CONFLICT FOR ONE OR BOTH SIDES. SUCH AN INCREASE OFTEN STEMS FROM INTERNATIONAL PRESSURES ON THE PLAYERS. THE COSTS OF ELECTORAL COMPETITION MAY BE LOWERED BY INSTITUTIONAL REFORMS, FOR IT IS THE INSTITUTIONAL PARAMETERS THAT SHAPE THE PROSPECTS FOR SUCCESS IN ELECTIONS BY THE REBELS AS WELL AS OFFER GUARANTEES THAT NEITHER SIDE WILL DOMINATE THE OTHER.

08459 SHUGART, $M$

LEADERS, RANK AND FILE, AND CONSTITUENTS: ELECTORAL REFORM IN COLOMBIA AND VENEZUELA

ELECTORAL STUDIES, 11(1) (MAR 92), 21-45.

PRESSURES FOR ELECTORAL REFORM CAN BE EXPECTED IN CLOSEDLIST ELECTORAL SYSTEMS THAT CONCENTRATE POHER WITHIN THE HANDS OF PARTY LEADERSHIP, AS IN VENEZUELA, OR, AT THE OTHER EXTREME, IN THOSE WHICH ENCOURAGE INTRA-PARTY FACTIONS, AS IN COLOMBIA. REFORMS OCCUR WHEN RELATIONS AMONG PARTY LEADERS, RANK AND FILE, AND CONSTITUENTS BECOME SKEHED TO

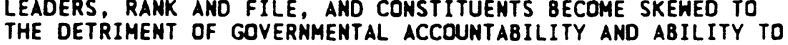
THE DETRIMENT OF GOVERNMENTAL ACCOUNTABILITY AND ABILITY TO
ADORESS SERIDUS PARTY PROBLEMS. REFORMS IN VENEZUELA INCLUDE ADDRESS SERIOUS PARTY PROBLEMS. REFORMS IN VENEZUEL
THE ADOPTION OF A SHISS-STYLE PANACHAGE SYSTEM FOR THE ADOPTION OF A SWISS-STYLE PANACHAGE SYSTEM FOR
MUNICIPALITIES AND A GERMAN-STYLE SYSTEM FOR THE CONGRESS, ALTHOUGH THE LATTER IS LIKELY TO FUNCTION DIFFERENTLY IN VENEZUELA'S PRESIDENTIAL SYSTEM THAN IN A PARLIAMENTARY SYSTEM. IN COLOMBIA, A CONSTITUT IONAL CONVENTION WAS ELECTED IN 1990 ON A BASIS OF NATIONWIDE REPRESENTATION IN ORDER TO CIRCUMVENT THE EXISTING CONGRESS AND IMPLEMENT REFORMS. EXPERIENCES OF THESE COUNTRIES OFFER LESSONS FOR OTHER DEVELOPING DEMOCRA
THE PHILIPPINES.

08460 SHUGART, M.S.

ELECTORAL REFORM IN SYSTEMS OF PROPORTIONAL REPRESENTATION EUROPEAN JOURNAL OF POLITICAL RESEARCH, 21(3) (APR 92), 207-224.

THE AUTHOR CONSIDERS THE QUESTION OF WHETHER ELECTORAL REFORM PRODUCES THE EFFECTS THAT WOULD BE EXPECTED ON THE BASIS OF WHICH FEATURES ARE MODIFIED. BASED ON THE LITERATURE ON ELECTORAL SYSTEMS, IT IS POSSIBLE TO PREDICT WHETHER A REFORM SHOULD PRODUCE A CONVERSIOY OF VOTES INTO SEATS MORE OR LESS PROPORTIONAL THAN THAT WHICH PRECEDED THE REFORM. AN EXAMINATION OF TEN CASES OF REFORM IN ISRAEL AND WESTERN EUROPE REVEAL THAT THOSE REFORMS PRODUCED THE WESTERN EUROPE REVEAL THAT THOSE REFORMS PRODUCED THE
EXPECTED RESULTS. HOWEVER, GRAPHICAL REPRESENTATION OF DATA EXPECTED RESULTS. HOWEVER, GRAPHICAL REPRESENTATION OF DATA
POOLED FROM ALL TEN CASES SUGGESTS THAT PARTY SYSTEMS HAVE POOLED FROM ALL TEN CASES SUGGESTS THAT PARTY SYSTEMS HAVE
THE ABILITY TO ADJUST AFTER JUST A FEW ELECTIONS, MAKING THE THE ABILITY TO ADJUST AFTER JUST A FEH ELECTIONS, MAKING THE
EFFECTS OF THE REFORM LESS IMPRESSIVE THAN WHEN IT WAS FIRST EFFECTS OF THE REFORM LESS IMPRESSIVE THAN WHEN IT WAS FI
ADOPTED. GRAPHICAL ANALYSIS ALSO REVEALS THAT CHANGES TO ADOPTED. GRAPHICAL ANALYSIS ALSO REVEALS THAT CHANGES TO PARTIES WAS ALREADY RISING, WHILE CHANGES TO LESS PARTIES WAS ALREADY RISING, WHILE CHANGES TO LESS PROPORTIONAL RULES (THAT HOULD TEND TO DECREASE THE NUMBER
OF "RELEVANT" PARTIES) OCCUR WHEN THE NUMBER OF PARTIES HAS OF "RELEVANT" PARTIES)
ALREAOY BEEN DECLINING.

08461 SHULL, S.

CONGRESSIONAL SUPPORT AND SUCCESS ON PRESIDENTS' CIVIL RIGHTS PROPOSAL

PRESIDENTIAL STUDIES QUARTERLY, XXI(4) (FAL 91), 705-716. THIS PAPER EXAMINES CONGRESSIONAL SUPPORT OF PRESIDENTS POSITIONS ON CIVIL RIGHTS VOTES AS WELL AS PRESIDENTS SUCCESS ON THEIR OWN LEGISLATIVE INITIATIVES. VARIATIONS IN PRESIDENTIAL SUPPORT AND SUCCESS ARE POSITED BY YEAR IN PRESIDENTIAL TERMS, INDIVIDUAL PRESIDENTS, AND PRESIDENTIAL PARTY. THE STUOY GOES BEYOND EARLIER RESEARCH BY EXAMINING THO SUBSETS OF LEGISLATIVE VOTES, AMENDMENTS AND KEY VOTES, ASSERTING THAT THEY SHOULD BE MORE CONTROVERSIAL (I.E. RECEIVE LESS SUPPORT FROM CONGRESS) THAN ALL VOTES IN CONGRESS. ADDITIONALLY, LEGISLATIVE VOTES ARE DIFFERENTIATED ACCORDING TO THE TARGET GROUPS AND SUB-ISSUE AREAS WITHIN CIVIL RIGHTS. ASSERTIVE IDEOLOGICAL PRESIDENTS GENERALLY FARE BETTER ON BOTH SUPPORT AND SUCCESS, BUT CONGRESS HAS MAINTAINED A DEGREE OF ASSERTIVENESS FOR ITSELF IN THE REALM OF CIVIL RIGHTS POLICY MAKING.

08462 SHULL, T.

THE ECOLOGISTS IN THE REgIONAL ELECTIONS: STRATEGIES BEHIND THE SPLIT

FRENCH POLITICS AND SOCIETY, 10(2) (SPR 92), 13-29.

WHILE FRANCE'S ECOLOGICAL POLITICAL PART' IES HAVE MADE INROADS INTO THE REGIONAL ASSEMBLIES, THEY HAVE STEADFASTLY INROADS INTO THE REGIONAL ASSEMBLIES, THEY HAVE STEADFASTLY REFUSED TO FORM AN ALLIANCE, FRUSTRATING THEIR OWN MEMBER
AND PUZZLING OUTSIDERS. "GENERATION ECOLOGIE" AND "LES AND PUZZLING OUTSIDERS. "GENERATION ECOLOGIE" AND "LES VERT
FOLLOWED DIVERGENT POLITICAL STRATEGIES FOR ALMOST A DECADE. FOLLOWED DIVERGENT POLITICAL STRATEGIES FOR ALMOST A DECADE. THEIR DIFFERENCES ARISE FROM CONTRASTING INTERPRETATIONS OF
THE NATURE AND GRAVITY OF ENVIRONMENTAL PROBLEMS. THE 1992 THE NATURE AND GRAVITY OF ENVIRONMENTAL PROBLEMS. THE 1992
REGIONAL ELECTICNS OFFERED INSIGHT INTO THEIR GOALS AND STRATEGIES.

08463 SHULTZ, R.

COMPELLENCE AND THE ROLE OF AIRPOHER AS A POLITICAL INSTRUMENT

COMPARATIVE STRATEGY, 11(1) (JAN 92), 15-28.
THIS STUDY SEEKS TO ADDRESS FOUR ISSUES CONCERNING AIR POWER AND THE USE OF FORCE IN THE AFTERMATH OF THE GULF WAR THESE INCLUDE: WHAT ARE THE CONTINUITIES AND DISCONTIMUITIES BETWEEN THE COLD WAR AND THE POST-COLD WAR INTERNATIONAL SECURITY ENVIRONMENT? WILL THE PREEMINENT U.S. STRATEGIC CONCEPT OF THE COLD WAR--DETERRENCE--REMAIN SO IN THE YEARS AHEAD OR WILL A DIFFERENT CONCEPT BE EQUALLY OR POSSIBLY MORE RELEVANT IN THIS NEW ENVIRONMENT? IS COMPELLENCE A MORE APPROPRIATE STRATEGIC CONCEPT FOR THE 1990S? CAN AIRPOWER, AS EMPLOYED STRATEGICALLY AND TACTICALLY IN THE GULF WAR, CONTRIBUTE TO THE ADROIT USE OF COMPELLENCE BY THE UNITED STATES AS A STRATEGIC CONCEPT?

08464 SHULTZ, R.H.

THE LOW-INTENSITY CONFLICT ENVIRONMENT OF THE 1990'S ANNALS OF THE AMERICAN ACADEMY OF POLITICAL AMD SOCIAL SCIENCE, (517) (SEP 91 ), $120-134$.

THE TERM "LOH-INTENSITY CONFLICT" (LIC) FIRST APPEARED IN THE LEXICON OF THE U.S. NATIONAL SECURITY COMMUNITY IN THE LATTER HALF OF THE 1970 's. DURING THE 1980'S, THE REAGAH ADMINISTRATION AND THE CONGRESS UNDERTOOK SEVERAL

INITIATIVES TO PREPARE THE UNITED STATES TO RESPOND TO VARIDUS TYPES OF LIC. FOLLOWING A BRIEF COMMENTARY ON THESE DEVELOPMENTS. THE AUTHOR ADDRESSES THREE INTERRELATED SUBJECTS: (1) THE CONCEPTUAL DEBATE SURROUNDING LIC AND ITS RELATIONSHIP TO THE AMERICAN APPROACH TO STRATEGY; (2) THE TYPES OF LIC THAT ARE LIKELY TO OCCUR IN THE $1990^{\prime} S$; AND (3)
THE IMPLICATIONS AND REQUIREMENTS FOR U.S. NATIONAL SECURITY POLICY.

08465 SHUMAN, $M$.

COURTS $V$. LOCAL FORIEGN POLICIES

FOREIGN POLICY, (86) (SPR 92), 158-177.

WHILE COMMUMITY-BASED DEMOCRACY HAS DRAMATICALLY

INCREASED IN MATIONS HORLDWIDE. THE UNITED STATES IS GOING AGAINST THIS WORLD TREND. ALARMED BY THE DRAMATIC GROWTH OF CITY, COUNTY AND STATE INVOLVEMENT IN FOREIGN POLICY. THREE UNITED STATES COURTS, WITH PRODDING FROM THE BUSH ADMINISTRATION, HAVE ASSERTED THAT THE FEDERAL GOVERMMENT HAS EXCLUSIVE JURISDICTION OVER ALL MATTERS AFFECTING INTERNATIONAL AFFAIRS. THESE PRONOUNCEMENTS BETRAY THE ORIGINAL INTENTIONS OF THE FOUNDING FATHERS AND THREATEN TO DEPRIVE THE NATION OF A RICH SOURCE OF INFORMATION,

EXPERTISE, AND INMOVATION.

08466 SHUNICHI, T.

THE LESSONS OF JAPAN'S BATTLE WITH POLLUTION

JAPAN QUARTERLY, XXXIX(3) (JUL 92 ), 321-327.

THE SUCCESSES OF THE ENVIRONMENTAL MOVEMENT IN JAPAM ATTEST TO THE IMPORTANCE OF DEMOCRATIC PRINCIPLES IN ARRESTING POLLUTION. THE HISTORY OF THE MOVEMENT AND THE SOCIAL CHANGES IN JAPAN SHOULD BE MADE PUBLIC KNOWLEDGE IN THE COUNTRIES THAT ARE NOW RUSHING TO FOLLOW IN JAPAN'S FOOTSTEPS ALONG THE PATH TO INDUSTRIAL IZATION. SPREADING
KNOWLEDGE OF ITS OWN EXPERIENCE IS JAPAN'S FIRST RESPONSIBILITY AND THE MOST IMPORTANT CONTRIBUTION IT CAN MAKE TO THE FORCES NOW POISED FOR THE NEXT ASSAULT IN THE BATTLE FOR ENVIRONMENTAL PROTECTION.

08467 SHUSTER, S.; TOLZ, V. MIKHAIL GORBACHEV INTERVIEWED IN MUNICH

RFE/RL RESEARCH REPORT, 1 (12) (MAR 92), 54-56.

IN THIS INTERVIEW, FORMER SOVIET PRESIDENT MIKHAIL GORBACHEV ANSWERS QUESTIONS ABOUT POLITICAL AND ECONOMIC PROSPECTS FOR RUSSIA AND THE COMMONHEALTH OF INDEPENDENT STATES. HE ALSO HARNS ABOUT GROWING RESTRICTIONS ON THE RUSSIAN MEDIA AND THAT POLITICAL UNREST MAY CREATE OPENINGS FOR REPRESSIVE LEADERS.

08468 SHUTE, J.

JEWS AMD LATINOS

TIKKUN, 7(6) (NOV 92), 47-48.

RE-ENVISIONING THE ETHNIC DIMENSION OF JEWISH POLITICS MEANS TRANSCENDING THE UNIVERALIST/PARTICULARIST DICHOTOMY THAT HAS DOMINATED ENLIGHTENED JEWISH DISCOURSE ABOUT THEIR PLACE IN THE HORLD SINCE THE EIGHTEENTH CENTURY. THE ENLIGHTENMENT'S VISION OF A UNIVERSAL HUMANITY GUIDED BY REASON TOWARD A HIGHER SOCIAL ORDER CAPTURED THE IMAGINATIOM OF MANY EMANCIPATED JEWS OF THE TIME, WHO FLED THEIR RELIGIOUS AND CUL TURAL PARTICULARITY IN SEARCH OF THIS MORE RELIGIOUS AND CUL TURAL PARTICULARITY IN SEARCH OF THIS MORE
UNIVERSAL IDENTITY. THIS ARTICLE DISCUSSES THIS ISSUE FOR UNIVERSAL IDENTITY.
JEHS AND LATINOS.

08469 SIBARY, S

DEVELOPING SUBNATIONAL RELATIONS: LEGAL ISSUES AND APPROACHES

SOCIAL SCIENCE JOURNAL, 29(4) (1992), 445-456

WITH INCREASING ECONOMIC INTEGRATION IN THE WORLD, THERE IS A NEED FOR EXPANDED RELATIONS BETWEEN THE NATIONS. THIS ARTICLE EXAMINES THE LEGAL POTENTIAL FOR SUBNATIONAL RELATIONS, THE RELATIONSHIP SUCH ARRANGEMENTS OR AGREEMENTS HAVE TO INTERNATIONAL LAH AND THE UTILITY OF A STATUE OR TREATY TO AUTHORIZE SUBNATIONAL AGREEMENTS. IT ALSO SUGGESTS THAT THE APPROACH DISCUSSED COULD BE A PRACTICAL PARADIGM 
FOR MORE EXTENSIVE RELATIONS BETWEEN PEOPLES OF THE WORLD.

08470 SIBRAA, K.W.

A HISTORIC VOTE: COMMONWEALTH OBSERVER MISSION TO THE ZAMBIAN ELECTIONS

PARLIAMENTARIAN, LXXIII(2) (APR 92), 90-94.

THE AUTHOR SUMMARIZES THE COURSE' OF EVENTS THAT LED TO ZAMBIA'S OCTOBER 1991 ELECTIONS AND DESCRIBES HIS

EXPERIENCES AS A MEMBER OF THE BRITISH COMMONWEALTH'S

OBSERVER MISSION, WHICH MONITORED THE ELECTIONS AND

OBSERVER MISSION, WHICH MONITORED THE ELECTI
CONCLUDED THAT THEY WERE "FREE AND FAIR."

08471 SICK, G.

OCTOBER SURPRISE

RANDOM HOUSE, 1991, 237

THIS BOOK ACCUSES THE 1980 REAGAN-BUSH CAMPAIGN OF

PLANNING TO SHIP ARMS TO IRAN YIA ISRAEL IN EXCHANGE FOR IRAN'S PROMISE TO DELAY THE RELEASE OF FIFTY-TWO AMERICAN HOSTAGES UNTIL AFTER THE 1980 U.S. PRESIDENTIAL ELECTION. THE AUTHOR ARGUES THAT THE REAGAN-BUSH TEAM INTENSELY FEARED THAT CARTER WOULD ACHIEVE AN "OCTOBER SURPRISE," A LAST MINUTE DEAL WITH IRAN TO SECURE THE RELEASE OF' THE U.S. HOSTAGES JUST BEFORE THE NOVEMBER ELECTION IN ORDER TO GARNER CARTER'S RE-ELECTION. THIS LED THE REPUBLICANS TO PLAN THEIR OWN DEAL. IN SHORT, THE REAGAN-BUSH CAMPAIGN PULLED OFF "NOTHING LESS THAN A POLITICAL COUP." THE AUTHOR'S CONSPIRACY THEORY RESTS ON HIS PREMISE THAT POWER TENDS TO CORRUPT POLITICANS AND THAT THE ONLY WAY SOCIETY CAN TRULY PROTECT DEMOCRACY IS FOR THE PUBLIC TO BE SKEPTICAL OF THOSE IN POWER.

08472 SIDAK, J.G.; SMITH, T.A. HHY DID PRESIDENT BUSH REPUDIATE THE INHERENT LINE-ITEM VETO?

JOURNAL OF LAW \& POLITICS, IX(1) (FAL 92), 39-60

THE AUTHORS ASK WHY PRESIDENT GEORGE BUSH FAILED TO USE THE CONSTITUTION'S INHERENT LINE-ITEM VETO. THEY REVIEW THE ARGUMENT THAT THE CONSTITUTION DOES ALLOW A PRESIDENTIAL LINE-ITEM VETO AND NOTE THAT BUSH REFUSED TO USE THIS VETO, LINE-ITEM VETO AND NOTE THAT BUSH REFUSED TO USE THIS VETO, DESPITE STRONG RECOMMENDATIONS THAT HE DO SO. THEY CONCCU
THAT BUSH CHOSE NOT TO USE THE VETO BECAUSE HE DID NOT THAT BUSH CHOSE NOT TO USE THE VETO BECAUSE HE DID NOT
CONSIDER CONTROLLING SPENDING IN THIS MANNER TO BE AN CONSIDER CONTROLLING SPENDING IN THIS MANNER TO BE AN
IMPORTANT PRIORITY OF HIS ADMINISTRATION. BUSH WAS CONCERMED IMPORTANT PRIORITY OF HIS ADMINISTRATION. BUSH WAS
NOT THAT HE WOULD FAIL IN HIS USE OF THE VETO BUT, PARADOXICALLY, THAT HE WOULD SUCCEED.

08473 SIDAWAY, J.

MOZAMBIQUE: DESTABILIZATION, STATE, SOCIETY AND SPACE POLITICAL GEOGRAPHY QUARTERLY, 11(3)' (MAY 92), 239-258. HOW THE STRATEGY OF NEIGHBORING SOUTH AFRICA HAS INTERACTED WITH THE POST-INDEPENDENCE POL ICY OF THE
MOZAMBICAN REGIME TO PRODUCE A SITUATION WHEREBY THE MOZAMBICAN STATES HAS BEEN UNABLE TO EXERT ITS SOVEREIGNTY THROUGHOUT ITS TERRITORY IS EXAMINED. THIS SITUATION HAS COME ABOUT THROUGH A COMPLEX COMBINATION OF EXTERNAL DESTABILIZATION AND INTERNAL RESISTANCE TO FRELIMO'S POLICY OF SOCIAL AND POLITICAL TRANSFORMATION. RECENT REFORMS IN MOZAMBIOUE HAVE SO FAR NOT BEEN ACCOMPANIED BY A SIGNIFICANT IMPROVEMENT IN THE ABILITY OF THE REGIME TO ASSERT ITS POWER THROUGHOUT THE COUNTRY. THE REFORMS HAVE GENERATED QUESTIONS REGARDING THE FUTURE PROSPECTS OF THE HITHERTO STABLE FRELIMO REGIME.

08474 SIDOIQUI, H.

THE SCRAMBLE FOR CENTRAL ASIA

WORLD PRESS REVIEW, 39(7) ( JUL 92), 9-10.

SINCE THE COLLAPSE OF THE SOVIET UNION, INTERNATIONAL

INTEREST IN KAZAKHSTAN, UZBEKISTAN, TAJIKISTAN, TURKMENISTAN, INTEREST IN KAZAKHSTAN, UZBEKISTAN, TAJIKISTAN, TURKMENIS AZERBAI JAN, AND KYRGYZSTAN HAS INCREASED, FOCUSING ON
POTENTIAL POL ITICAL AND ECONOMIC ALLIANCES. IRAN, TURKEY, SAUDI ARABIA, AND PAKISTAN ARE WOOING THE CENTRAL ASIAN REPUBLICS WHILE THE UNITED STATES AND OTHER WESTERN

REPUBLICS WHILE THE UNITED STATES AND OTHER WESTERN
COUNTRIES ARE INTERESTED IN THE REGION BUT LACK EXPERTISE IN

THE AREA.

08475 SIDLER, $P$.

INDONESIA'S EXPLOSIVE SOCIAL GAP

SWISS REVIEW OF WORLD AFFAIRS, 41(12) (MAR 92), 24-25.

TODAY INDONESIA CAN LOOK BACK ON THO YEARS OF
THS

BREATHTAKING ECDNOMIC GROWTH. HOWEVER, ONLY A SMALL MI NORITY

BREATHTAKING ECONOMIC GROWTH. HOWEVER, ONLY A SMALL MINORITY
HAS BENEFITTED FROM IT. IF THE POLITICAL STABILITY ACHIEVED

HAS BENEFITTED FROM IT. IF THE POLITICAL STABILITY ACHIEVED

UNDER THE QUARTER-CENTURY RULE OF PRESIDENT SUHARTO IS NOT

WEALTHY AND THE VAST MASSES OF THE POOR MUST BE REDUCED.

08476 SIEN, Y.C.

IRREVERSIBLE PROCESS

FREE CHINA REVIEW, 42(12) (DEC 92), 62-65.

AT PRESENT THERE ARE 58 PUBLIC MANUFACTURING ENTERPRISES

AND 45 PUBLIC SERVICE ENTERPRISES IN TAIHAN. LIKE PUBLIC

ENTERPRISES IN MANY OTHER COUNTRIES, THEY PLAYED A KEY ROLE

DURING EARLIER STAGES OF ECONOMIC GROWTH, BUT THEIR

IMPORTANCE HAS GRADUALLY DECLINED AS THE PRIVATE SECTOR HAS

GROWN AND THE ECONOMY HAS MATURED. LIBERALIZATION IS A
PREREQUISITE FOR FURTHER ECONOMIC DEVELOPMENT IN TAIWAN, AND THE PRIVATIZATION OF PUBLIC ENTERPRISES IS AN INTEGRAL PART OF THE PROCESS.

08477 SIGELMAN, L; ; TODD, J.S.

CLARENCE THOMAS, BLACK PLURALISM, AND CIVIL RIGHTS POLICY POLITICAL SCIENCE QUARTERLY, 107 (2) (SUM 92), 231-248. BECAUSE CLARENCE THOMAS VIENS ON CIVIL RIGHTS HAVE BEEN REPUDIATED BY MOST BLACK LEADERS, HIS NOMINATION TO THE INSIGHTS INTO CIVIL RIGHTS ISSUES AMONG BLACKS.

08478 SIGELMAN, L.; SIGELMAN, C.; WALKOSZ, 8.

THE PUBLIC AND THE PARADOX OF LEADERSHIP: AN EXPERIMENTAL ANALYSIS

AMERICAN JOURNAL OF POLITICAL SCIENCE, 36(2) (MAY 92),

IT IS COMMONPLACE FOR ELECTED OFFICIALS TO BE CRITICIZED FOR FAILING TO EXERCISE STRONG, INDEPENDENT LEADERSHIP AND ALSO FOR BEING UNRESPONSIVE TO THE HISHES OF THE PUBLIC. THIS STUOY PRESENTS AN EXPERIMENTAL ANALYSIS OF THE SOMETIMES CONTRADICTORY EXPECTATIONS THAT CITIZENS HAVE OF PUBLIC OFFICIALS. THE EXPERIMENTAL STIMULI DESCRIBE A DECISION-MAKING SITUATION IN WHICH AN OFFICEHOLDER MUST DECIDE HETHER TO ACT ON PERSONAL WISHES ON A CONTROVERSIAL MEASURE OR AS THE MAJORITY OF CONSTITUENTS WISH. SEVERAL ASPECTS OF THE SITUATION, INCLUDING THE OFFICIAL'S ULTIMATE DECISION, THE RATIONALE UNDERLYING THE DECISION, THE NATURE OF THE OFFICE, AND THE CHARACTER OF THE ISSUE, ARE MANIPULATED, AND THE CITIZEN'S LEVEL OF GENERALIZED TRUST IN POL ITICAL LEADERS IS ALSO TAKEN INTO ACCOUNT. ANALYSIS FOCUSES ON THE EXTENT TO HHICH THESE CONTEXTUAL FACTORS SHAPE EVALUATIONS OF THE OFFICIAL AND HIS OR HER ACTIONS AND PERCEPTIONS OF THE TYPICALITY OF THE OFFICIAL'S ACTIONS.

08479 SIGMUND, P.

CHRISTIANITY AND VIOLENCE: THE CASE OF LIBERATION THEOLOGY TERRORISM AND POLITICAL VIOLENCE, 34(4) (WIN 92), 80-99. UNDER POPE JOHN PAUL II, THE VATICAN HAS BEEN CRITICAL OF LIBERATION THEOLOGY'S BORROWINGS FROM MARXISM AND ITS IMPLIED ENDORSEMENT OF VIOLENCE, ALTHOUGH A MODERATE VERSION IMPLI IED ENDORSEMENT OF VIOLENCE, ALTHOUGH A MODERATE VERSION THAT STRESSES THE ORGANIZATION OF THE POOR INTO CHRISTIAN
BASE COMHUNITIES HAS BEEN MORE FAVORABLY RECEIVED. PARTLY AS BASE COMMUNITIES HAS BEEN MORE FAVORABLY RECEIVED. PARTLY AS
A RESULT OF VATICAN PRESSURE AND PARTLY AS A RESULT OF A A RESULT OF VATICAN PRESSURE AND PARTLY AS A RESULT OF A
GENERALIZED DISILLUSIONMENT OF THE LATIN AMERICAN LEFT WITH VIOLENCE AS A MEANS FOR SOCIAL CHANGE, LIBERATION VIOLENCE AS A MEANS FOR SOCIAL CHANGE, LIBERATION THEOLOGIANS TODAY HAVE MOVED AHAY FROM THEIR EARLIER DEMOCRACY THAT IS AWARE OF THE PREFERENTIAL OPTION FOR THE POOR.

08480 SIGUR, G

U.S. POLICY IN EAST ASIA AND THE PACIFIC: BUILDING ON THE PAST AND THE PRESENT FOR THE FUTUR

JOURNAL OF NORTHEAST ASIAN STUDIES, 1O(2) (SUM 92), 53-65.

IT IS ARGUED THAT U.S. POLICY IN THE ASIA-PACIFIC REGION HAS BEEN AND MUST CONTINUE TO BE BASED UPON FOUR FUNDAMENTAL PRINCIPLES: 1) GENUINE RESPECT FOR THE INTERESTS AND PREROGATIVES OF THE PEOPLES OF THE REGION; 2) SUPPORT FOR THE ESTABLISHMENT OF DEMOCRATIC INSTITUTIONS AND PROCESSES IN EAST ASIA AND THE PACIFIC: 3) THE EXPANSION OF TRADE AND INVESTMENT WITH BASIC RELIANCE ON THE MARKET FORCES OF COMPETITION AND FREE ENTERPRIZE; AND 4) RECOGNITION THAT PEACE AND STABILITY ARE BEST FACILITATED BY ADDRESSING SPECIFIC SOURCES OF REGIONAL TENSION.

08481 SIISIAINEN, $M$

SOCIAL MOVEMENTS, VOLUNTARY ASSOCIATIONS, AND CYCLES OF PROTEST IN FINLAND 1905-1991

SCANDINAYIAN POLIIICAL STUDIES, 15(1) (MAR 92), 21-40.

DURING THE 2OTH CENTURY, FINLAND HAS EXPERIENCED FIVE CYCLES OF PROTEST: 1905-1918, 1928-1932, 1944-48, 1966-1976, AND THE ONGOING CYCLE OF NEW SOCIAL MOVEMENTS THAT BEGAM AROUND THE END OF THE 1970'S. THIS PAPER OUTLINES THE DIFFERENCES AND SIMILARITIES IN THE FORMATION OF THESE CYCLES AGAINST THE BACKGROUND OF ANTECEDENT POL ITICAL
OPPORTUNITY STRUCTURES. THEN IT ADDRESSES THE QUESTION OF OPPORTUNITY STRUCTURES. THEN IT ADDRESSES THE QUESTION OF
THE RELATIONSHIP BETWEEN SOCIAL PROTEST MOVEMENTS AND FORMAL THE RELATIONSHIP BETWEEN SOCIAL PROTEST MOVEMENTS AND
VOLUNTARY ASSOCIATIONS. SOCIAL MOVEMENTS AND FORMAL VOLUNTARY ASSOCIATIONS. SOCIAL MOVEMENTS AND FORMAL
VOLUNTARY ASSOCIATIONS HAVE BEEN INTERACTIVE, MUTUALLY VOLUNTARY ASSOCIATIONS HAVE BEEN INTERACTIVE, MUTUALLY
REINFORCING WAYS OF REACTING TO DIFFERENT MANIFESTATIONS OF SOCIAL CRISIS. EXISTING FORMAL ASSOCIATIONS HAVE CREATED THE SOCIAL CRISIS. EXISTING FORMAL ASSOCIATIONS HAVE CREATED THE
PRECONDITIONS FOR THE OCCURRENCE OF PROTEST MOVEMENTS AND VICE YERSA; NEW YOLUNTARY ASSOCIATIONS HAYE BEEN BORN FROM VICE VERSA; NEW YOLUNTARY ASSOCIATIONS HAYE BEEN BORN FROM CYCLES OF PROTEST AND PROTEST MOVEMENTS. MOVEMENTS AND VOLUNTARY ASSOCIATIONS HAVE ALSO BEEN CENTRAL IN CREATING
PRESSURES FOR REFORMING STATE INSTITUTIONS AND THUS IN PRESSURES FOR REFORMING STATE INSTITUT
DEVELOPING THE FINHISH WELFARE STATE.

08482 SIKHOSAMA, M.; NZIMANDE, B.

CIVIL SOCIETY' AND DEMOCRACY

POLITICAL AFFAIRS, 71(3) (APR 92), 21-31.

THE CRISIS IN EASTERN EUROPE, THE FAILURE OF DEMOCRACY

IN AFRICA, AND IN SHADOW OF THE ABOVE THO. THE APPARENT 
"SUCCESS" AND "STABILITY" OF HESTERN BOURGEOIS DEMOCRACY HAVE ALL LED TO EXTENSIVE SOUL-SEARCHING AND DEBATE AMONGS SOCIALISTS AND MARXISTS ON HOW NATIONAL AND SOCIALIST DEMOCRACY CAN BE BROUGHT ABOUT IN THE CONTEMPORARY PERIOD. THESE DEBATES IN SOUTH AFRICA IN PARTICULAR, HAVE SOME UNDERLYING COMMON ASSUMPIIONS. SOME OF THESE ASSUMPTIONS ARE DISCUSSED IN THIS ARTICLE. AN UNCRITICAL REVIVAL OF AND TRUST IN THE CONCEPT OF "CIVIL SOCIETY" AS THE SOLUTION TO ESTABLISHING DEMOCRATIC REGIMES IS SAID TO BE A KEY FACTOR IN SOUTH AFRICAN THINKING.

08483 SIKORSKI, R. MY HUNDRED DAYS

NATIONAL REVIEW, XLIV(14) (JUL 92), 30-34.

THIS ARTICLE CHRONICLES THE EXPERIENCE OF THE AUTHOR AS POLAND'S DEPUTY DEFENSE MINISTER. WHILE THE AUTHOR WISHED TO CONCENTRATE ON TRANSFORMING AND MODERNIZING THE POL ISH ARMY AND ON INTEGRATING POLAND INTO WESTERN SECURITY STRUCTURES, HE FOUND HIMSELF IMMERSED IN INTERNECINE CONFLICTS HITH POLISH MILITARY INTELLIGENCE AND COUNTERINTELLIGENCE. THIS POLISH MILITARY INTELLIGENCE AND COUNTERINTELLIGENCE. THIS LAST BASTION OF COMMUNIST POWER IN POLAND IS DETERMINED TO HOLD ONTO THE REINS OF POWER AND HAS FOUND AN UNLIKELY ALLY
IN POLISH PRESIDENT LECH HALESA. THE FUTILITY OF THE CAUSE IN POLISH PRESIDENT LECH WALESA. THE FUTILITY OF THE CAUSE
RESULTED IN THE AUTHOR'S RESIGNATION. HE CONCLUDES THAT RESULTED IN THE AUTHOR'S RESIGNATION. HE CONCLUDES THAT STATES IN A TILT AHAY FROM THE WEST AND BACK TOWARDS AUTHORITARIANISM.

08484 SIKORSKI, R

NOTES FROM UNDERGROUND

MATIONAL REVIEW, XLIIII(7) (APR 91), 32-33.

MINERS IN THE SOVIET PROVINCE OF UKRAINE ARE ADAMANT IN THEIR STRIKES AND DEMANDS. THE CALL FOR THE RESIGNATION OF MIKHAIL GORBACHEV AND FOR RESPECT FOR UKRAIN'S SOVEREIGNTY. WHILE DETERMINED, THE MINERS HAVE NOT DEVELOPED THE SKILLS NECESSARY TO TOPPLE THE COMMUNISTS. HOWEVER, THEIR PERSISTENCE IS INDICATION OF A FAR GREATER MALAISE IN THE

SOVIET UNION--AN ILLNESS THAT NO REFORMS CAN CURE. IN THE
UKRAINE, THE BREAKUP OF THE SOVIET UNION SEEMS INEVITABLE.

08485 SIKORSKI, R.

ON THE BRINK OF CHAOS

NATIONAL REVIEH, XLIII(22) (DEC 91), 24-25.

IF EVER THE EVIL OF PROPORTIONAL REPRESENTATION NEEDED TO BE DEMONSTRATED, THEN THE POLISH ELECTIONS HAVE PROVEN THE CASE ONCE AND FOR ALL. THE FIRST DEMOCRATIC

THE CASE ONCE AND FOR ALL. THE FIRST DEMOCRATIC PARL IAMENTARY ELECTIONS FOR HALF A CENTURY SHOULD HAVE
A GREAT CELEBRATION OF THE VICTORY OVER COMHUNISM AND A A GREAT CELEBRATION OF THE VICTORY OVER COMHUNISM AND A
PRELUDE TO REBUILDING POLAND ON A DEMOCRATIC FOUNDATION. BUT,
LARGELY THROUGH THE TIMIDITY OF THE FORMER PRIME MINISTER, LARGELY THROUGH THE TIMIDITY OF THE FORHER PRIME MINISTER
TADEUSZ MAZOHIECKI, THE COMHUNIST-DOMINATED PARLIAMENT HAS TADEUSZ MAZOHIECKI, THE COMMUNIST-DOMINATED PARL IAMENT WAS NOT DISSOLVED AT THE MOST OPPORTUNE TIME--IN JANUARY 1990, WHEN THE POLISH COMMUNIST PARTY CEASED TO EXIST . INSTEAD THE FORMER COMMUNISTS AND THEIR ALLIES REMAINED IN PARLIAMENT-BLOCKING BILLS, OBSTRUCTING REFORM, AND ATTACKING THE HEROIC EFFORTS OF FINANCE MINISTER LESZEK BALCEROWICZ TO DRAG THE POLISH ECONOMY INTO FINANCIAL SANITY. AND THE COMMUNISTS HAVE LEFT POLAND ONE FINAL LEGACY. IN AN UNHOLY ALLIANCE WITH THE CATHOLIC FUNDAMENTALISTS, COMMUNIST MPS VOTED THROUGH PROPORTIONAL REPRESENTATION.

08486 SIKORSKI, R.

POLAND'S' ERHARD?

NATIONAL REVIEW, XLIV(21) (NOV 92), 23-24.

THE AUTHOR ASSESSES THE PROGRESS MADE DURING THE FIRST THREE YEARS OF POLAND'S AMBITIOUS ECONOMIC REFORM PROGRAM.

08487 SIKORSKY, $R$,

UKRAINE ON THE BRINK

NATIONAL REVIEW, XLIV(25) (DEC 92), 17-19

UKRAINE IS A TRIPWIRE FOR ANY RESURGENCE OF RUSSIAN EXPANSIONISM. IT IS THE ONE FORMER SOVIET REPUBLIC IN WHOSE LOSS EVEN RUSSIAN DEMOCRATS HAVE TROUBLE ACQUIESCING, LET ALONE THE SOVIET GENERALS WHO NOW SEEM TO BE RUNNING SECURITY POLICY IN THE KREMLIN. HERE A NEW, UNFRIENDLY REGIME TO COME TO POWER IN MOSCOW, ITS AGRESSION WOULD FIRST TURN AGAINST UKRAINE. WHILE THE WEST CANNOT SOLVE UKRAINE'S PROBLEMS FOR IT, IT INUST TREAT IT FAIRLY. IT IS IN NOBOOY'S INTEREST FOR THE HEST TO FURTHER A SENSE OF GRIEVANCE IN A VOLATILE COUNTRY ON THE BRINK OF DISASTER.

08488 SILK, L.

AIDING EASTERN EUROPE IN A CAPITAL-SHORT WORLD

SAIS REVIEW, 12 (1) (WIN 92), 1-10.

THE COUNTRIES OF EASTERN EUROPE AND THE FORMER SOVIET UNION OESPERATELY NEED MONEY FROM THE OUTSIDE HORLD AS THEY STRUGGLE TO GO CAPITALIST. THIS ARTICLE EXPLORES SOURCES FOR MONEY IN A HORLD THAT SEEMS TO BE SUFFERING FROM A SHORTAGE OF CAPITAL. IT STUDIES THE GLOBAL CREDIT CRUNCH, THE UNITINC OF EAST AND WEST EUROPE, AND THE POSSIBILITIES OF A MULTINATIONAL MARSHALL PLAN. IT CONCLUDES THAT MULTILATERAL EFFORTS BY THE UNITED STATES IS CRUCIAL IN ORDER TO RESCUE EASTERN EUROPE AND THE STATES OF THE FORMER SOVIET UNION FROM A DISASTER THAT COULD ENDANGER THE ENTIRE WORLD.
08489 SILLAH, $M$.

JUSTIFYING THE COUP

HEST AFRICA, (3897) (MAY 92), 879-880

THE AUTHOR LOOKS AT YARIOUS THEORIES ABOUT THE 1992 COUP IN SIERRA LEONE, INCLUDING THE SPECULATION THAT IT WAS ACTUALLY ORCHESTRATED BY GENERAL JOSEPH SAIDU MOMOH WHO AGREED TO BE OVERTHROWN IN RETURN FOR SAFE PASSAGE TO GUINEA AND IMMUNITY FROH PROSECUTION.

08490 SILLIMAN, G.S.

HUMAN RIGHTS UNDER THE MARCOS AND AQUIMO REGIMES ASSOCIATION FOR ASIAN STUDIES 1992 ANNUAL MEETING ASSOCIATION FOR ASIAN STUDIES, 1992, 150

A PATTERN OF HUMAN RIGHTS VIOLATIONS HAS CHARACTERIZED THE PHILIPPINES FOR THE PAST TWO DECADES, THIS DESPITE THE RESTORATION OF CONSTITUTIONAL GOVERNMENT. VIEWING MARCOS AS AUTHORITARIAN AND AQUIMO AS DEMOCRATIC, MANY OBSERVERS BELIEVED THAT THE REGIME CHANGE OF 1986 WOULD GIVE RISE TO A NEW SOCIAL ORDER IN WHICH THE RIGHTS OF CITIZENS WOULD BE RESPECTED. INDEED, DURING PRESIDENT AQUINO'S FIRST YEAR IN RESPECTED. INDEED, DURING PRESIDENT AQUINO'S FIRST YEAR
POWER, LEGAL AND INSTITUTIONAL CHANGES TO PROTECT HUMAN POWER, LEGAL AND INSTITUTIONAL CHANGES TO PROTECT HUMAN
RIGHTS WERE INTRODUCED. YET A NEW REGIME, NEW LAWS, AND NEW RIGHTS WERE INTRODUCED. YET A NEH REGIME, NEW LAWS, AND NEW
INSTI TUTIONS HAVE NOT ELIMINATED THE PROBLEM OF HUMAN RIGHTS INSTI IUTIONS HAVE NOT ELIMINATED THE PROBLEM OF HUMAN RIGHTS
ABUSE. THAT HUMAN RIGHTS VIOLATIONS CONTINUE TO BE A PROBLEM ABUSE. THAT HUMAN RIGHTS VIOLATIONS CONTINUE YO BE A PROB DISPARITIES OF PHILIPPINE SOCIETY GIVE RISE TO BOTH DEMANDS OISPARITIES OF PHILIPPINE SOCIETY GIVE RISE TO BOTH DEMANDS PROVIDES A SITUATIONAL CONTEXT, A CLIMATE OF OPINION, AND PROVIDES A SITUATIONAL CONTEXT, A CLIMATE OF OPINION, AND THE STATE LIMITS THE CURRENT GOVERNMENT'S ABILITY TO ACHIEVE ITS STATED GOAL OF PROMOTING HUMAN RIGHTS. FINALLY, VIOLENCE AND RITUALISM, DIMENSIONS OF PHILIPPINE CULTURE, UNDERMINE EFFORTS TO ALLEVIATE THE HUMAN RIGHTS PROBLEM.

08491 SILVA, E.

CAPITALIST REGIME LOYALTIES AND REDEMOCRATIZTION IN CHILE JOURNAL OF INTERAMERICAN STUDIES AND WORLD AFFAIRS, $34(4)$

(WIN 92 ), 39-76

CHILE' IS OFTEN PORTRAYED AS AN EXCEPTIONAL CASE AMONG RECENT TRANSITIONS FROM AUTHORITARIAN RULE. THIS ARTICLE ARGUES THAT ALTHOUGH FEAR OF RESURGENT SOCIALISM IS INDEED A MATTER OF CONCERN. THE THREAT FROH BELOW IS CONSIDERABLY WEAKER THAN TOUTED, ESPECIALLY AFTER THE TRANSFORMATION--OR RENOVATION-DF THE LEFT. IT SUGGESTS THAT HITHIN THE CONTEXT OF CHILE'S NEW POLITICAL INSTITUTIONS, A RECENT COMPROMISE FAVORS THE ECONOMIC INTERESTS OF CONSERVATIVE FORCES WHICH FAVERS THE ECONOMIC INTERESTS OF CDNSERVAT IVE FORCES WHIC ARE FURTHER STRENGTHENED BY THE FACT THAT THE COMPROMISE ENCOURAGED COLLABORATION BETWEEN GOVERMMENT AND THE PRIVATE
SECTOR IN ECONOMIC AND SOCIAL POLICYMAKING DURING THE AYLWIN SECTOR IN ECONOHI
ADMINISTRATION.

08492 SILVERSTEIN, J.

BURMA IN THE INTERNATIONAL PERSPECTIVE

ASIAN SURVEY, XXXII (10) (OCT 92), 951-963.

FOR FOUR YEARS BURMA'S RULING STATE LAW AND ORDER RESTORATION COUNCIL (SLORC) HAS BEEN IMPERYIOUS TO INTERNATIONAL CALLS FOR CHANGES IN ITS REPRESSIVE POLICIES. IT CONTINUES TO DECLARE THAT IT WILL ADHERE TO ITS OWH TIMETABLE OF CHANGE WITH REGARDS TO ENDING HUMAN RIGHTS ABUSES AND THE TRANSFER OF POHER TO A CIVILIAN GOVERNMENT HOWEVER, A SERIES OF STRONG RESOLUTIONS ADOPTED BY THE UNITED NATIONS SEEM TO HAVE CONVINCED THE SLORC TO ADOPT
SOME REFORMS. SINCE APRIL 1992 SEVERAL POLITICAL PRISONERS SOME REFORMS. SINCE APRIL 1992 SEVERAL POLITICAL PRISONERS
HAVE BEEN RELEASED, PERMISSION HAS BEEN GRANTED FOR FAMILY MEMBERS TO VISIT OPPOSITION LEADER AUNG SANG SUU KYI (WHO HAS BEEN UNDER HOUSE ARREST), PROMISES HAVE BEEN MADE TO HOLD A POLITICAL CONYENTION AND BEGIN THE PROCESS OF WRITING A NEW CONSTITUTION, AND THE MILITARY CAMPAIGN AGAINST BURMA'S KAREN MINORITY GROUP HAS BEEN HALTED. THIS ARTICLE EXAMINES THESE CHANGES AGAINST THE BACKGROUND OF SLORC'S POLICIES SINCE IT TOOK POWER IN A 1988 COUP D'ETAT. IT CONCLUDES THAT WHILE SLORC'S PREVIOUS INDIFFERENCE TO PROTESTS AND ACTIONS OF THE INTERNATIONAL COMMUNITY IS DIMINISHING, IT STILL HAS FAR TO GO IF IT IS TO PLACATE MOST OF ITS INTERNATIONAL CRITICS.

08493 SIMAI, $M$

HUNGARIAN PROBLEMS

GOVERNMENT AND OPPOSITION, 27(1) (WIN 92), 52-65

THE AUTHOR DISCUSSES SOME OF THE PROBLEMS FACING POSTCOMMUNIST HUNGARY. INCLUDING ITS ECONOMIC CRISIS, POLITICAL APATHY, AND THE ROLE OF "THE SILENT MAJORITY."

$08494^{\circ}$ SIMANDJUNTAK, D.S

COMCEMTRATIOM AMD CONGLOMERATION IN THE CONTEXT OF PROL IFERATING STRATEGIC ALLIANCES AMONG MULTINATIONALS INDONESIAN OUARTERLY 19(1) (WIN 91), 52-61.

THIS ARTICLE ADORESSES ISSUES OF CONCENTRATION OF RESOURCES AND POHER AND THEIR INTERNATIONAL ECONOMIC POLITICAL DYNAMICS. SECTION DNE DISCUSSES TYPES OF CONCENTRATION. SECTION THO CONTAINS AN ASSESSMENT OF THE LEVEL OF CONCENTRATION IN INDONESIA TODAY, IN SPITE OF THE SCARCITY OF FIRM-LEVEL DATA THAT MAKES THIS DISCUSSION 
QUALITATIVE RATHER THAN QUANTITATIVE. POSSIBLE SOURCES OF CONCENTRATION IN THE CONTEXT OF INDONESIA ARE CONSIDERED IN SECTION THREE. THE LAST SECTION EXPLORES ALTERMATIVE POLICIES ON WHICH A GOVERNMENT CAN RELY WHILE DEALING WITH ECONOMIC CONCENTRATION.

08495 SIMARD, $P$.

COMPETITION ELECTORALE ET PARTAGE DES POUVOIRS DANS UN ETAT FEDERAL

CANADIAN PUBLIC POLICY-ANALYSE DE POLITIQUES, XVII(4) (DEC 91), 409-416.

THE IMPACT OF ELECTORAL COMPETITION ON THE RELATIONS BETHEEN THE DIFFERENT LEVELS OF GOVERNMENT IN A FEDERAL STATE IS DISCUSSED IN THIS ARTICLE. IT EXAMINES THE STRATEGIES OF TWO LEVELS OF GOVERMMENT, NATION AND LOCAL, DURING A CONSTITUIONAL REVISIOM PROCESS ON THE NEW DIVISION OF POWERS. IT SHOWS HOW THE PERSPECTIVE OF A FUNDAMENTAL CHANGE IN THE DIVISION OF POWERS IN CANADA CAN SHAPE THE STRATEGY OF OPPOSING POLITICAL GROUPS. THE ANALYSIS SUGGESTS THAT, IN ORDER TO MINIMIZE RISKS OF ELECTORAL DEFEAT, THE CANADIAN FEDERAL GOVERNMENT COULD HAVE THE INCENTIVE TO ABANDON QUEBEC IN FAVOR DF
CITIZENS OUTSIDE QUEBEC.

08496 SIMCDCK. A.

ONE AND MANY--THE OFFICE OF SECRETARY OF STATE PUBLIC ADMINISTRATION, 70(4) (WIN 92), 535-554,

THIS ARTICLE SEEKS TO EXPLAIN THE NATURE OF THE OFFICE OF SECRETARY OF STATE IN THE UNITED KINGDOM, AND HOW THESE ARRANGEMENTS HAVE COME ABOUT. IT TRACES THE OFFICE FROM ITS MEDIAEVAL ORIGINS, AND FINDS THE EXPLANATION PARTLY IN THE DEVELOPMENT OF TUDOR GOVERMMENTS, AND PARTLY IN THE POLITICS OF THE EIGHTEENTH CENTURY. IT THEN TRACES THE MODERN DEVELOPMENT OF THIS DOCRINE AND SOME OF THE RAMIFICATIONS TO WHICH IT HAS GIVEN RISE.

08497 SIMES, $D$.

GORBACHEV'S TIME OF TROUBLES

FOREIGN POLICY, (82) (SPR 91), 97-117

THE SOVIET CRISIS GOES FAR BEYOND EMPTY SHELVES, A CRIME THE SOVIET CRISIS GOES FAR BEYOND EMPTY SHELVES, A CRIME
WAVE, RAMPANT CORRUPTION, INTER-ETHNIC VIOLENCE, AND THE WAVE, RAMPANT CORRUPTION, INTER-ETHNIC VIOLENCE, AND THE
PARALYZING STRUGGLE BETHEEN THE REMNANTS OF THE OLD ORDER PARALYZING STRUGGLE BETHEEN THE REMNANTS OF THE OLD ORD AND THE NEW POLITICAL FORCES. ALL THESE PROBLEMS ARE
SYMPTOMS OF THE OLD ORDER AND THE NEW POLITICAL FORCES. ALL SYMPTOMS OF THE OLD ORDER AND THE NEW POLITICAL FORCES. ALL THESE PROBLEMS ARE SYMP TOMS OF A MUCH DEEPER CRISIS: THE LEGITIMACY OF SOVIET POLITICAL INSTITUTIONS AND THE IDENTITY OF THE SOVIET PEOPLE. THE PARTY POLICE STATE IS IN SHAMBLES. PARTIALLY RESPONSIBLE AND PARTIALLY HELPLESS IN THE FACE OF
EVENTS IS PRESIDENT MIKHAIL GORBACHEV. HE WILL HAVE TO WALK EVENTS IS PRESIDENT MIKHAIL GORBACHEV. HE WILL HAVE AN INCREDIBLY FINE LINE BETHEEN RADICAL REFORM AND
CONSERVATIVE POWER RETENTION IN ORDER TO MAINTAIN THE CONSERVATIVE POWER RETENTION IN
SURVIVAL OF THE SOVIET UNION.

08498 SIMES, D.K.

AMERICA AND THE POST-SOVIET REPUBLICS

FOREIGN AFFAIRS, 71(3) (SUM 92), 73-89

WESTERN, AND PART ICULARLY U.S., ACTION OR INACTION HILL BE A CRUCIAL FACTOR DURING THE TRANSITION TO NEW POLITICAL, ECONOMIC, AND SECURITY ARRANGEMENTS IN THE FORMER SOVIET UNION. IN DEVELOPING AMERICAN APPROACHES TO THE FORMER SOVIET REPUBLICS, IT IS IMPORTANT TO UNDERSTAND THAT THE INDIVIDUAL STATES, RATHER THAN THE COMMONWEALTH OF INDEPENDENT STATES, WILL BE THE PRINCIPAL INTERLOCUTORS WITH WASHINGTON IN THE COMING YEARS.

08499 SIMHONS, A.B.; KEOHANE, K.

CANADIAN IMMIGRATION POLICY: STATE STRATEGIES AND THE QUEST FOR LEGITIMACY

CANADIAN REVIEW OF SOCIOLOGY AND ANTHROPOLOGY, 29(4) (NOY 92), 421-452.

IS BOTH POHERFUL AND VULNERABLE; THIS BOTH-AND FEATURE UNDERLIES CURRENT TRENDS IN CANADIAN IMMIGRATION POLICY. IN DEVELOPING IMMIGRATION POLICY, THE CANADIAN STATE ACTIVELY SEEKS TO GARNER SUPPORT FOR ITS OWN LEGITIMACY BY ACTIVELY SEEKS TO GARNER SUPPORT FOR ITS OWN LEGITIMACY BY
PURSUING MEASURES THAT HILL SHORE UP THE ECONOMY, AVOID PURSUING MEASURES THAT HILL SHORE UP THE ECONOMY, AVOID
PUBLIC CRITICISM, AND MEDIATE SOCIAL CONFLICT. THE STATE IS PUBLIC CRITICISM, AND MEDIATE SOCIAL CONFLICT. THE STATE
ENGAGED IN A HEGEMONIC PROJECT INVOLVING A PRD-ACTIVE ENGAGED IN A HEGEMONIC PROJECT INVOLVING A PRO-ACTIVE DIALOGUE TO GATHER INFORMATION, TO MONITOR SUPPORT AND OPPOSITION, AND TO ATTEMPT TO CONTROL DIVERSE INTEREST GROUPS. IN SUM, THE CANADIAN STATE IS IN CONTROL OF POLICY FIELD YET IS WARY OF POLITICAL FORCES THAT POTENTIALLY THREATEN ITS LEGITIMACY. NEW SOCIAL ACTORS-ETHNIC GROUPS, HUMANITARIAN ORGANIZATIONS, THE PROVINCES-HAVE COME TO PLAY A MORE PROMINENT ROLE WITHIN A FIELD DOMINATED BY THE FEDERAL STATE. TWO TRADITIONAL ACTORS, LABOR AND CAPITAL, HAVE MOVED TO LESS POLARIZED VIEWS. THE POL ICY ARENA IS SHIFTING AND PRONE TO BE UNSTABLE, AS THE KEY ACTORS, INCLUDING THE STATE, STRUGGLE TO COME TO TERMS WITH THE CHANGING GLOBAL CONTEXT.

08500 SIMMONS, J.

ECONOMIC THEORY OF OEMOCRACY: REVISED AND REVISITED

NEW POL ITICAL SCIENCE, 23 (FAL 92) 29-50.

THE FOCUS ON THE INDIVIDUAL AS THE SOURCE OF POLITICAL,
ECONOMIC AND MORAL VALUES HAS AN IMPORTANT ELEMENT IN THE SOCIAL DOCTRINES THAT DOMINATED HESTERN THOUGHT DURING THE EIGHTEENTH AND NENETEENTH CENTURES. IN THIS ARTICLE, THE AUTHOR FOCUSES ON THE EFFORTS BY SOCIAL CHOICE THEORISTS TO EXPLAIN PARTY COMPETITION THROUGH THE USE OF SOME VARIATION ON THE SPATIAL-MODEL THAT WAS FIRST DEVELOPED BY ANTHONY DOWNS. AFTER A BRIEF REVIEW OF THE LITERATURE ON SPATIAL MODELING, THE SUBSTANTIVE SECTIONS OF THIS PAPER ARE DEVOTED TO DEVELOPING AND DEFENDING AN ALTERNATIVE PARADIGH.

08501 SIMON, D.M.; MARRA, R.F.; OSTROM, C.W. JR.

THE PRESIDENT, REFERENDUM VOTING, AND SUBNATIONAL

ELECTIONS IN THE UNITED STATES

AMERICAN POLITICAL SCIENCE REVIEW, 85(4) (DEC 91),

1177-1192.

THIS RESEARCH IS DESIGNED TO GENERALIZE A REFERENDUM VOTING MODEL AND ASSESS ITS ABILITY TO ACCOUNT FOR THE AGGREGATE RESULTS OF ELECTIONS FOR THE HOUSE O

REPRESENTATIVES, THE SENATE, GOVERNORSHIPS, AND THE UPPER

AND LOWER CHAMBERS OF STATE LEGISLATURES. THE ANALYSIS SHOWS

THAT THESE RESULTS ARE INFLUENCED BY THE SAME SYSTEMATIC

SHORT- AND LONG-TERM FORCES. IN ADOITION TO THIS COMMON
REFERENDUM STRUCTURE, THE ANALYSIS REVEALS THAT THERE IS A

COMMON RESPONSE TO RANDOM SHOCKS, A SUBTLE FORM OF

INTERDEPENDENCE FOUND IN SYSTEMS OF SEEMINGLY UNRELATED REGRESSIONS.

08502 SIMON, G.

THE UKRAINE AND THE END OF THE SOVIET UNION

AUSSEN POLITIK, 43(1) (1992), 62-71.

BY AUTUMN 1991, THE PROCESS OF DISINTEGRATION IN THE ONCE SO UNITED AND SEEMINGLY MONOLITHIC SOVIET UNION HAD REACHED A STAGE WHICH MADE THE CONTINUATION OF ANY FURTHER COMMON BOND BETHEEN ITS REPUBLIC AND PEOPLES QUESTIONABLE. ONE OF THE MOST CRITICAL ASPECTS IS THE WILLINGNESS OF THE UKRAINIANS TO CONTINUE AND SUPPORT THE UNION. THE UKRAINIANS ARE NO LONGER WILLING TO DO WITHOUT NATIONAL AND STATE ARDEPENDENCE, AND IT IS NOT EVEN CERTAIN HHETHER THEY ARE WILLING TO MAKE COMMON ARRANGEMENTS WITH OTHER FORMER SOVIET WILLING TO MAKE COMMON ARRANGEMENTS WITH OTHER
REPUBLICS IN THE ECONOMIC AND SECURITY FIELDS.

08503 SIMPSON, $C$.

AFRICA REPORT, 37 (6) (NOV 92), 68-70.

IT IS NEARLY A YEAR BEYOND THE DATE THE UNITED NATIONS ORIGINALLY SET FOR A REFERENDUM ON SELF-DETERMINATION FOR THE PEOPLE OF THE HESTERN SAHARA. ALLHOUGH U.N. TROOPS CONTINUE TO MONITOR THE CEASEFIRE, VIRTUALLY NO PROGRESS HAS BEEN MADE. WHILE MOROCCO IS CONTENT TO WAIT, HOPING A REFERENDUM CAN BE AVOIDED, POLISARIO IS FRUSTRATED AT THE INACTION, ABLE ONLY TO PRESS THE U.N. AND THE WEST FOR PROGRESS ON THE PEACE PLAN.

08504 SIMPSON, C A TARNISHED PEACE WEST AFRICA, (3902) (JUN 92), 1082-1083.

THE UNITED NATIONS SPECIAL REPRESENTATIVE IN ANGOLA, MARGARET ANSTEE, RECENTLY EXPRESSED CONFIDENCE THAT THE COUNTRY WOULD BE ABLE TO PROCEED, AS PLANNED, WITH ELECTIONS IN SEPTEMBER 1992. HOWEVER, SHE ISSUED A GENTLE WARNING THAT VOTER REGISTRATION MUST BE SPEEDED UP AND THAT THE CONTINUING BARRAGE OF PROPAGANDA FROM BOTH THE GOVERMMENT AND UNITA COULD UNDERMINE THE CLIMATE OF CONFIDENCE AND STABILITY NECESSARY FOR FAIR ELECTIONS.

08505 SIMPSON, C.

BAMAKO BREAKTHROUGH

WEST AFRICA, (3893) (APR 92), 714.

THIRTEEN MONTHS AFTER MOUSSA TRAORE WAS DEPOSED, MALI IS

AWAITING THE ADVENT OF ITS THIRD REPUBLIC. LIEUTENANT-

COLONEL AMADOU TOUMANI TOURE, WHO LED THE COUP AGAINST

ALPHA OUMAR KONARE, A PUBLISHING MAGHATE AND FORMER

OPPOSITION LEADER.

08506 SIMPSON, $C$

BIYA HINS, BUT...

WEST AFRICA, (3886i (MAR 92), 411.

PRESIDENT PAUL BIYA'S CAMEROONIAN PEOPLE'S DEMOCRATIC

MOVEMENT HAS WON CAMEROON'S 1992 LEGISLATIVE ELECTIONS. THE
SOCIAL DEMOCRATIC FRONT, WHICH BOYCOTTED THE POLLS, HAS BEEN

SOCIAL DEMOCRATIC FRONT, WHICH BOYCOTTED THE POLLS, HAS BEEN

CONDEMNED BY OTHER OPPOSI

08507 SIMPSON, C.

CLAWING A WAY BACK

THE ECONOMIC CRISIS REMAINS CAMEROON'S MOST PRESSING PROBLEM. SINCE THE MID-1980'S CAMEROON'S ECONOMY HAS EXPERIENCED A DISASTROUS DECLINE, WHICH HAS BEEN A MAJOR FACTOR IN THE GROWTH OF OPPOSITION TO THE RULING CAMEROON PEOPLE'S DEMOCRATIC MOVEMENT. AT THE SAME TIME, THE POLITICAL TURBULENCE THAT HAS MARKED CAMEROON'S DIFFICULT TRAKSITION TO A MULTIPARTY SYSTEM HAS HAD A SIGNIFICANT 
NEGATIVE IMPACT ON THE ECONOMY.

08508 SIMPSON, $C$.

FRESH MAYHEH

HEST AFRICA, (3881) (FEB 92), 184

ZAIRE'S LATEST TRANSITIONAL GOVERMMENT ENJOYS LITTLE SUPPORT INSIDE OR OUTSIDE THE COUNTRY. AFTER A PERIOD OF RELATIVE CALM, VIOLENCE HAS FLARED ONCE MORE, AMD SECTIONS OF THE MILITARY ARE AGAIN RESTIVE. THE NATIONAL CONFERENCE PROVED TO BE A FIASCO, AND THE PRIME MINISTER'S DECISION TO SUSPEND THE CONFERENCE PROCEEDINGS ONLY MADE MATTERS WORSE.

08509 SIMPSON, $C$.

MAULED BY THE MILITARY

WEST AFRICA, (3880) (JAN 92), 148

THE AUTHOR DICUSSES THE POLITICAL TRANSITION PROCESS IN

CONGO, WHERE PEACEFUL CHANGE HAS BEEN DISRUPTED BY VIOLENCE.

08510 SIMPSON, C.

MINURSO MISGIVINGS

WEST AFRICA, (3885) (MAR 92), 374

THE UNITED NATIONS OPERATION IN WESTERN SAHARA (MINURSO) HAS COME UNDER FIERCE ATTACX IN WASHINGTON, DUE TO A REPORT COMMISSIONED BY THE U.S. SENATE COMMITTEE ON FOREIGN COMMISSIONED BY THE U.S. SENATE COMMITTEE ON FOREIGN RELATIONS. THE COMMITTEE'S CHAIRMAN HAS WARNED THAT
MINURSO'S CREDIBILITY IS BEING UNDERMINED AND THAT THIS, IM MINURSO'S CREDIBILITY IS BEING UNDERMINED AND THAT THIS, TURN, IS THREATENING THE UPCOMING REFERENDUM. SINCE THE CEASEFIRE, THE U.N. HAS BEEN ACCUSED OF, AT BEST, TURNI
BLIND EYE TO MOROCCD'S ATTEMPTS TO MOVE THE REFERENDUM GOALPOSTS AND, AT HORST, OF COLLABORATING WITH MOROCCO.

08511 SIMPSON, $C$ MINURSO MISIVINGS HEST AFRICA, 75(3885) (MAR 92), 374.

THE UN OPERATION IN WESTERN SAHARA HAS COME UNDER ATTACK IN WASHINGTON. THE U.S. HAS WARNED THAT MINURSO'S CREDITABILITY IS BEING UNDERMINED AND THIS IN TURN IS THREATENING A NEH REFERENDUM. POLISARIO HAS MADE NO SECRET OF ITS DISAPPOINTMENT WITH THE UN IN THE ORGANIZATION'S HANDLING OF THE WESTERM SAHARA BRIEF TO DATE. THE UN HAS BEEN ACCUSED OF TURNING A BLIND EYE TO MOROCCO'S ATTEMPTS AT MOVING THE REFERENDUM GOALPOSTS AND OF POSSIBLY

COLLABORATING IN THEM.

08512 SIMPSON, C

WEST AFRICA, (3895) (MAY 92), 796.

OPPOSITION LEADER NDEH NTUMAZAH HAS WARNED THAT, DESPITE THE CHANGES RECENTLY INTRODUCED INTO CAMEROON'S POLITICAL THE CHANGES RECENTLY INTRODUCED INTO CAMEROON'S POLITICAL SYSTEM, PRESIDENT PAUL BIYA IS STILL RUNMING THE COUNTRY AS A ONE-PARTY STATE. NTUMAZAH'S OWN UPC PARTY IS SPLIT INTO STRENGTHENING BIYA'S HAND.

08513 SIMPSON, $C$.

OULD TAYA OFF TARGET?

WEST AFRICA, (3881) (FEB 92), 184

NEITHER THE RESULT NOR THE REACTION TO MAURITANIA'S FIRST-EVER MULTIPARTY ELECTION ON JANUARY 24, 1992, CAME AS A GREAT SURPRISE. MAOUIYA OULD SID'AHMED TAYA EMERGED WITH 62.8\% OF THE VOTE, NEARLY DOUBLE THAT OF HIS CLOSEST RIVAL, AHMED OULD DADDAH. THE OPPOSITION CRIED FOUL; A CURFEW AND CRACKDOWN FOLLOWED.

08514 SIMPSON, $C$

POLISARIO'S CONCERHS

WEST AFRICA, (3919) (OCT 92), 1824

IN SEPTEMBER AND OCTOBER 1992, THERE WERE REPORTS OF RENEWED VIOLENCE IN SOUTHERN MOROCCO AND WESTERN SAHARA. POLISARIO ACCUSED THE MOROCCANS OF STARTING A NEW CAMPAIGM OF REPRESSION AGAINST THE SAHARAHI, BUT RABAT CLAIMED THAT THE VIOLENCE WAS MERELY SKIRMISHES BETWEEN LOCAL POLITICAL FACTIONS AND HAD NOTHING TO DO WITH SAHARAWI DEMANDS FOR SELF-DETERMINATION.

08515 SIMPSON, C. REFERENDUM REGRETS

WEST AFRICA, (3926) (DEC 92 ), 2147

MOHAMED ABDELAZIZ, PRESIDENT OF THE SAHARAWI ARAB DEMOCRATIC REPUBLIC AND SECRETARY-GENERAL OF POLISARIO, MAKES NO SECRET OF HIS FRUSTRATION AND DISAPPOINTMENTS DUE TO THE DELAYS IN SECURING THE REFERENDUM ON SELFTETERMINATION PROMISED BY MOROCCO AND THE UNITED NATIONS DETERMINATION PROMISED BY MOROCCD AND THE UNITED NATIONS NEVERTHELESS, HE IS ADAMANT THAT POLISARIO WILL STAY THE
COURSE AND THAT WESTERN SAHARA WILL BECOME AN INDEPENDENT STATE.

08516 SIMPSON, C.

RIOT AND RAMPAGE

WEST AFRICA, (3884) (FEB 92 ), 323.

ON FEBRUARY 18, 1992, A MARCH IN ABIDJAN CALLED BY THE

OPPOSITION IVOIRIAN POPULAR FRONT (FPI) DEGENERATED INTO

SCENES OF UNPRECEDENTED VIOLENCE. SECURITY FORCES ARRESTED

HUNDREDS OF DEMONSTRATORS, INCLUDING FPI LEADER LAURENT
GBAGBO.

08517 SIMPSON, $C$.

SAHARAN' SETBACKS

WEST AFRICA, (3878) (JAN 92), 70

JANUARY 1992 WAS SUPPOSED TO BE THE MONTH IN WHICH THE WESTERN SAHARA'S FUTURE WAS DECIDED ONCE AND FOR ALL. AFTER YEARS OF BITTER FIGHTING, THE SAHRAHI PEOPLE WERE TO CHOOSE : DID THEY WANT TO BE PART OF AN INDEPENDENT REPUBLIC OUTSIDE MOROCCO'S FRONTIERS OR DID THEY ACCEPT RULE FROM RABAT? VOTERS HERE TO DECIDE IN A U.N.-SUPERVISED REFERENDUM. BUT RELATIONS BETHEEN MOROCCO AND POLISARIO HAVE HIT A NEW LOH, AND THE REFERENDUM HAS BEEN POSTPONED UNTIL AUTUAM 1992 OR EVEN LATER

08518 SIMPSON, C.

STAND BY YOUR MAN

WEST AFRICA, (3882) (FEB 92), 243

THE AUTHOR DISCUSSES RECENT POLITICAL PROTESTS IN COTE D'IVOIRE

08519 SIMPSON, $C$.

TALES FROM TAYLORVILLE

WEST AFRICA, (3890) (APR 92), 581-582.

THE AUTHOR REPORTS ON THE CAMPAIGN OF JOHM TAYLOR, ONE

OF THE FEH BLACK CAMDIDATES IN GREAT BRITAIN'S 1992

PARLIAMENTARY ELECTIONS.

08520 SIMPSON, $C$

THE WAITING GAME

WEST AFRICA, (3920) (NOV 92), 1860-1861.

AL THOUGH' MOROCCO'S MONARCHY CONTINUES TO REAFFIRM ITS COMMITMENT TO HOLDING A REFERENDUM ON SELF-DETERMINATION IN HESTERN SAHARA UNDER U.N. AUSPICES, THE POLISARIO IS SKEPTICAL. THE SAHARAWIS HAVE LEARNED TO EXPECT THE WORST FROM RABAT. WHAT THEY FIND HARDER TO UNDERSTAND IS THE ATTITUDE OF THE INTERNATIONAL COMNUNITY, AND WESTERN GOVERNMENTS IN PARTICULAR, TOWARDS MOROCCO.

08521 SIMPSON, $C$.

THE WILDERMESS IN AMERICAN CAPITALISM: THE SACRALIZATION OF NATURE

INTERMATIONAL JOURNAL OF POLITICS, CULTURE AND SOCIETY, $5(4)$ (SUM 92), 555-576.

IN THE AREA OF NATURE AND URBAN REFORM, THE PRESERVATION OF PICTURESQUE NATURAL REGIONS CAME TO BE IDENTIFIED AS

REFORMIST IN AMERICAN SOCIETY, TAKEN UP BY THE MIDDLE

CLASSES AS PART OF THE GENERAL INTEREST OF SOCIETY. THIS

CLASSES AS PART OF THE GENERAL INTEREST OF SOCIETY. THIS
ARTICLE EXPLORES NATURE AND THE GUIDE IMAGE, TRAVEL WRITING

AND THE IMAGE OF SACRED WILDERNESS, AND THE BUREAUCRATIZING OF THE SACRED AND THE RATIONALIZATION OF NATURE. THE ARTI
CONCLLUDES THAT YEARS AFTER IT CEASED TO DESCRIBE ACTUAL CONCLUDES THAT YEAR S AFTER IT CEASED TO DESCRIBE ACTUAL PEOPLE, THE GUIDE IMAGE HAS BECOME A RECREATIONAL ANCHO FOR PERSONAL IOENTITY AND REGIONAL DEFINITION. IN THE STRUGGLE HITHIN HETEROGENEOUS SOCIETIES TO IMPOSE A COMMON PUBLIC POLICY, THE ADIRONDACK GUIDE REMINDS US THAT SHARPLY FOCUSED CULTURAL FIGURES ARE EFFECTIVE TOOLS.

08522 SIMPSON, C. WAITING AND WATCHING

WEST AFRICA, (3913) (SEP 92), 1569.

MOROCCO REMAINS, AT LEAST' IN PUBLIC, THOROUGHLY

COMPLACENT WHERE WESTERN SAHARA IS CONCERNED, KING HASSAN II HAS ENDORSED THE UNITED NATIONS' REFERENDUM PROPOSAL BUT DOES NOT SEEM TO PLACE ANY GREAT IMPORTANCE ON IT. MEANWHILE, POLISARIO IS HAITING FOR THE UNITED NATIONS TO TAKE THE LEAD, BUT ITS MISSION FOR REFERENDUM IN WESTERN SAHARA IS WELL BEHIND SCHEDULE AND THERE IS NO FIRM TIMETABLE FOR THE REFERENDUM

08523 SIMPSON, $C$.

YEAR OF THE CONFERENCES

WEST AFRICA, (3877) (JAN 92), 15

ALL IS NOT SWEETNESS AND LIGHT IN MALI'S NEW DEMOCRACY, THE YEAR 1991 ENDED WITH A NEW PEACE AGREEMENT BETHEEN THE GOVERMMENT AND TAUREG REPRESENTATIVES, BUT IT REMAIMS TO BE SEEN WHETHER THIS HILL PROVE ANY MORE SUCCESSFUL THAN THE TAMANRASSET AGREEMENT SIGNED AT THE BEGINMING OF 1991 IN 1991 IN COMGO DEMIS SASSOU-MGUESSO REMAINED PRESIDENT BUT MUCH IN CONCO, DENIS SASSOU NGUESSO REMAINED PRESIDENT BUT HEADED BY ANDRE MILONGO.

08524 SIMPSON, G.R

BANK ROBBER

NEW REPUBLIC 206(12) (MAR 92), 15-16

DAVID PAUI, THE FORMER CEO OF CENTRUST SAVINGS BANK, HEADED AN S\&L THAT WAS ALLOWED TO OPERATE FOR THO YEARS AFTER IT SHOUL HAVE BEEM CLOSED PAUI HAS A MAJOR

FUNDRAISER FOR THE DEMOCRATIC PARTY AND HAS ALSO INVOLVED

WITH THE ROGUE BANK OF CREDIT AND COMMERCE INTERNATIONAL.

08525 SIMPSON, J.

NUCLEAR CAPABILITIES, MILITARY SECURITY AND THE KOREAN 
PENINSULA: A THREE-TIERED PERSPECTIVE FROM EUROPE KOREAN JOURNAL OF DEFENSE ANALYSIS, IV (2) (WIN 92), 11-32. THIS PAPER ARGUES THAT SECURITY CHALLENGES POSED BY THE KOREAN PENINSULA AT THREE LEVELS: BILATERAL WITHIN THE PENINSULA, REGIONAL, AND GLOBAL. IT OFFERS AN ANALYSIS OF THE MAIN NUCLEAR ISSUES CONFRONTING THE STATES IN NORTHEAST ASIA. THESE INCLUDE: THE IMPACT OF THE CHANGED U.S.USSR/RUSSIAN RELATIONSHIP; THE REGIONAL NUCLEAR ENERGY CONTEXT; NORTH KOREA'S NUCLEAR PROGRAM; AND NEGOTIATIONS ON NORTH KOREA'S NUCLEAR CAPABILITIES. IT THEN CONISDERS POTENTIAL BILATERAL NUCLEAR NON-PROL I FERATION ARRANGEMENS ON THE KOREAN PENINSULA, REGIONAL NUCLEAR NON-PROLIFERATION ARRANGEMENTS IN NORTHEAST ASIA; AND THE GLOBAL NUCLEAR NONPROLIFERATION SYSTEM AND NORTHEAST ASIA. EACH OF THESE LEVELS REINFORCES THE OTHERS, AND TAKEN TOGETHER THEY OFFER A POTENTIAL FRAMEHORK FOR SECURITY ON THE KOREAN PENINSULA INTO THE NEXT CENTURY.

08526 SIMS, $N$.

COMMONWEALTH RESERVATIONS TO THE 1925 GENEVA PROTOCOL, 1930-92

ROUND TABLE, 324(324) (OCT 92), 477-500.

THIS ARTICLE EXAMINES THE ORIGINAL RESERVATIONS TO THE GENEVA PROTOCOL IN THEIR 1930 CONTEXT, TRACES THEIR SUBSEQUENT HISTORY IN THE CONTEXT OF EVOLVING CBH DISARMAMENT TREATIES, AND ANALYZES THE REASONS FOR THEIR WITHDRAHAL OR MODIFICATION. IT ADDRESSES THE IMMINENT CONCLUSION OF A CHEMICAL WEAPONS CONVENTION WHICH WILL CALL INTO QUESTION THE PERTINENCE AND EVEN THE PERMISSIBILITY OF SUCH RESERVATIONS ARE ARE STILL ATTACHED TO STATES' ACCEPTANCE OF THE GENEYA PROTOCOL. IT QUESTIONS WHETHER THOSE RESERVATIONS SHOULD BE ABANDONED.

08527 SINCLAIR, B.

SENATE PROCESS, CONGRESSIONAL POLITICS, AND THE THOMAS NOMINATION

PS: POLITICAL SCIENCE AND POLITICS, XXV(3) (SEP 92), 477-480.

THE AUTHOR CONSIDERS CRITICISMS OF THE CONGRESSIONAL CONFIRMATION PROCESS STEMMING FROM THE JUDICIARY COMMITTEE HEARINGS ON CLARENCE THOMAS' APPOINTMENT TO THE U.S. SUPREME COURT. SHE ARGUES THAT STRUCTURAL CHANGES IN THE PROCESS CANNOT MAKE IT EASY OR PAINLESS. MOREOVER, MOST OF THE CANNOT MAKE IT EASY OR PAINLESS. MOREOVER,
PROPOSED REFORMS WOULD NOT HORK OR WOULD BE

COUNTERPRODUCTIVE.

08528 SINCLAIR, B.

THE EMERGENCE OF STRONG LEADERSHIP IN THE 1980 S HOUSE OF THE EMERGENCE OF

REPRESENTATIVES
THE JOURALL OF POLITICS, 54(3) (AUG 92), 657-684.

THROUGH A COMPARISOM OF FOUR CAREFUL IY SELECTED

CONGRESSES, THIS STUDY DEMONSTRATES THAT THE CURRENT HOUSE

CONGRESSES, THIS STUDY DEMONSTRATES THAT THE CURRENT HOUSE MAJORITY PARTY LEADERSHIP, WHEN COMPARED TO OTHER POST-WORLD WAR II LEADERSHIPS, IS MORE INVOLVED IN AND MORE DECISIVE ORGANIZING THE PARTY AND THE CHAMBER, SETTING THE HOUSE
AGENDA, AND AFFECTING LEGISLATIVE OUTCOMES. AN EXPLANATION AGENDA, AND AFFECTING LEGISLATIVE OUTCOMES. AN EXPLANATION
FOR THE EMERGENCE OF STRONG LEADERSHIP IS OFFERED AND TESTED THE AUTHOR ARGUES THAT DURING THE PERIOD UNDER STUDY THE COSTS AND BENEFITS TO MAJORITY PARTY MEMBERS OF STRONG LEADERSHIP CHANGED SIGNIFICANTLY. THE STUDY FINDS THAT THE LIKELIHOOD OF LEADERSHIP INVOLVEMENT IS GREATEST WHEN THE MEMBERS MOST NEED HELP AND THE COSTS ARE LOWEST, AND THAT LEADERSHIP INVOLVEMENT DOES INCREASE THE PROBABILITY OF LEGISLATIVE SUCCESS.

08529 SINGER, $D$.

STRUGGLING WITH ONE SUPERPOWER

PEACE \& DEMOCRACY NEWS, 6(1) (WIN 92), 31-34.

THE ROAD TO CAPITALISM IN EASTERN EUROPE IS UNCHARTED AND IT IS THEREFORE DIFFICULT TO FORESEE WHERE IT WILL ULTIMATELY LEAD. THIS ARTICLE EXPLORES THE ROLE OF SOYIET FOREIGN POLICY, HESTERN AID AND THE ROLE OF PROGRESSIVE MOVEMENTS. IT SUGGESTS THAT VAST PROJECTS ARE THE PRODUCT OF GREAT SOCIAL MOVEMENTS, BUT SOCIAL MOVEMENTS FIND IT HARD TO GROW WITHDUT THE VISION OF AN ALTERNATIVE.

08530 SINGER, M.

SRI LANKA IN 1990: THE ETHNIC STRIFE CONTINUES

ASIAN SURVEY, XXXI (2) (FEB 91), 140-145

POL ITICALLY, 1990 DID NOT PROVE TO BE THE YEAR IN WHICH PEACE RETURNED TO SRI LANKA AS PEOPLE HAD HOPED WHEN THE YEAR BEGAN. THE INDIAN PEACEKEEPING FORCE (IPKF) DIO LEAVE THE ISLAND, AND FOR SINHALESE IN THE SOUTH THERE HAS A SENSE OF RETURN TO NORMALCY. BUT AS THE YEAR ENDED, THE BOMBING IN THE NORTH CONTINUED AND THE SEPARATIST LIBERATION TIGERS OF THE NORTH CONTINUED AND THE SEPARATIST LIBERATION TIGERS OF TAMIL EELAM (LTTE) HAS

08531 SINGER, $M$

SRI LANKA IN 1991: SOME SURPRISIMG THISTS

ASIAN SURVEY, XXXII(2) (FEB 92), 168-174.

THO MAJOR EVENTS OCCURRED DURING 1991 THAT PROMISE TO HAVE MAJOR RAMIFICATIONS FOR SRI LANKAN POLITICAL AFFAIRS
FOR YEARS TO COME. THE FIRST OCCURRED IN INDIA IN MAY WHEN, IN THE MIDOLE OF GENERAL ELECTIONS, FORMER PRIME MINISTER RAJIV GANDHI WAS ASSASSINATED. INCREASINGLY, IN THE COURSE OF THE YEAR, EVIDENCE ACCUMULATED THAT THE LIBERATION TIGERS OF TAMIL EELAM (LTTE) WERE RESPONSIBILE. THE SECOND EVENT WAS THE UPHEAVAL IN SRI LANKA'S RULING UNITED NATIONAL PARTY (UNP) AND THE DEMAND FOR IMPEACHMENT OF PRESIDIENT PREMADASA. ON THE ECONOMIC FRONT. THE ECONOMY BEGAN TO RECOVER FROM INYESTMENT BEGAN TO MOVE IMTO THE ISS TOURISTS AMD

08532 SINGER, M.E.

POSSIBLE ALTERNATIVE SOLUTIONS TO THE TAMIL//SINHALESE ETHNIC CONFLICT IN SRI LANKA; ASSOCIATION FOR ASIAN STUDIES 1992 ANMUAL MEETING

STUDIES 1992 ANNUAL MEETING
ASSOCIATION FOR ASIAN STUDIES, 1992, 135.

SOCIATION FOR ASIAN STUDIES, $1992,135$.
THIS PAPER REVIEWS FIVE POTENTIAL SOLUTIONS TO SRI

LANKA'S ETHNIC CRISIS AND THE RELATED MILITARY CONFRONTATION.

FIRST, THERE IS THE POSSIBILITY OF CRUSHING THE LIBERATION

TIGERS OF TAMIL EELAM (LTTE) BY THE SRI LANKAN ARMY. IT

COULD BE ARGUED THAT THIS IS MORE POSSIBLE NOH THAN AT ANY TIME SINCE 1984-85, BUT IT IS NOT A LIKELY ALTERNATIVE. SECOND, THERE IS THE POSSIBILITY OF THE DECLARATION OF A DE FACTO AND DE JURE TAMIL EELAM IN THE NORTHERN PROVINCE BY THE LTTE. THIS IS LESS LIKELY NOW THAN ANY OTHER TIME SINCE 1983. THIRD, THERE MAY BE NO TOTAL VICTORY FOR THE SRI LANKAN FORCES, BUT A SLOW WHITTLING AWAY AT THEIR POWER. THIS IS WHAT IS HAPPENING NOW FOR ALL INTENTS AND PURPOSES. IT IS NOT A "FINAL SOLUTION" FOR THE GOVERNMENT BUT IT IS AN ACCEPTABLE AND LIKELY ONE. FOURTH, SOME SORT OF DEVOLUTION OF POWER TO THE NORTH AND EAST SEPARATELY MIGHT BE POSSIBLE, EITHER RECOGNIZED LTTE CONTROL OF THE NORTH OR CALLING FOR AN ELECTION IN BOTH PLACES. FIFTH, FEDERALISM COULD BE INTRODUCED THROUGHOUT THE ISLAND. THE FORMER DISTRICT DEVELOPMENT COUNCILS WERE AN OPPORTUNITY MISSED, AND PROVINCIAL COUNCIL DEVOLUTION MAY BE THE NEXT BEST OPPORTUNITY.

08533 SINGER, M.R.

SRI LANKA'S TAMIL-SINHALESE ETHNIC CONFLICT: ALTERNATIVE SOLUTIONS

ASIAN SURVEY, XXXII (8) (AUG 92), 712-722.

WARFARE BETHEEN THE TAMILS AND THE SI HHALESE IN SRI

LANKA HAS BEEN GOING ON, WITH VARYING DEGREES OF INTENSITY, SINCE THE LATE 1970S. THOUSANDS OF YOUNG FIGHTERS ON BOTH SIDES HAVE DIED IN THE PROCESS. THIS ARTICLE CONSIDERS THE OBSTACLES TO A RESOLUTION OF THE CONFLICT FROM BOTH

SINHALESE AND TAMIL PERSPECTIVES, EXAMINES THE FACTORS

PUSHING THE PARTIES TOWARD A SETTLEMENT AND THEN LOOKS AT ALTERNATIVE SOLUTIONS. AT THE EXTREME RIGHT OF A THEORET ICAL CONTINUUM IS A COMPLETELY UNITARY STATE, WHICH IS WHAT THE SINHALESE EXTREMISTS WANT SRI LANKA TO BE; AT THE EXTREME LEFT IS A TOTALLY INDEPENDENT TAMIL STATE. IN BETWEEN THERE EXISTS AN ALMOST ENDLESS VARIETY OF OPTIONS. THE ANALYSIS CONCLUDES THAT THE TWO EXTREMES ARE IRRECONCILABLE AND THAT NEI THER HAS THE POHER TO IMPOSE ITS DESIRED SOLUTIONS ON THE OTHER. IT IS INEVITABLE THAT EVENTUALLY THERE MUST BE SOME DEVOLUTION OF POWER TO A LEVEL OF GOVERMMENT BELOW THE CENTER, AND IT IS SUGGESTED THAT THE PARTIES RECOGNIZE AND
ACT ACCORDINGLY.

08534 SINGER, 0.

CONSTRUCTING THE ECONOMIC SPECTACLE: THE ROLE OF CURRENCY UNION IN THE GERMAN UNIFICATION PROCESS

JOURMAL OF ECONOMIC ISSUES, 26(4) (DEC 92), 1095-1116.

THE POLITICAL DYNAMICS OF UNIFICATION ARE DESCRIBED IN THIS ARTICLE WHICH ALSO ANALYZES PUBLIC DEBATES AND INTERPRETATIONS THAT CONTRIBUTED TO THE CONSTRUCTION OF THE ECONOMIC POLITICAL SPECTACLE OF GERMAN UNIFICTION. THE AUTHOR STUDIES DIES THE SPECIAL CASE OF SYSTEM TRANSFORMATION IN EAST GERMANY AND CONCLUDES THAT THE PROCESS OF GERMAN ECONOMICS, MONETARY, AND SOCIAL UNION WILL RAISE MANY QUESTIONS ABOUT THE ROLE OF ECONOMIC POLICY TO

INFLUENCE BOTH ECONOMIC AGGREGATES AND POLITICAL ACTIVITIES.

08535 SINGH, A.J.

HOW THE TIBETAN PROBLEM INFLUENCED CHINA'S FOREIGN RELATIONS

CHINA REPORT, 28(3) (JUL 92), 259-290.

THIS ARTICLE EXAMINES THE HISTORY OF RELATIONS BETWEEN CHINA AND TIBET AND ANALYZES THE IMPACT OF TIBET ON CHINA'S RELATIONS WITH OTHER STATES. IT OUTLINES CHINA'S TRADITIONAL TRIBUTARY SYSTEM AND EXAMINES CHALLENGES TO THIS SYSTEM THAT AROSE FROM WESTERN ATTEMPTS TO ESTABLISH RELATIONS WITH AROSE FROM WESTERN ATTEMPTS TO ESTABLISH RELATIONS WITH
TIBET AS AN INDEPENDENT ENTITY. IT THEN CHRONICLES CHANGES-TIBET AS AN INDEPENDENT ENTITY. IT THEN CHRONICLES CHANC
INTERNAL, REGIONAL AND GLOBAL--THAT AFFECTED CHINA'S INTERNAL, REGIONAL AND GLOBAL--THAT AFFECTED CHINA'S
RELATIONS WITH TIBET. IT HIGHLIGHTS SIGNIFICANT EVENTS RELATIONS WITH TIBET. IT HIGHLIGHTS SIGNIFICANT EVENTS
INCLUOING THE SINO-TIBETAN AGREEMENT OF 1951. THE 1954 SINOIMDIAN AGREEMENT, THE INCLUSION OF TIBET ON THE AGENDA OF THE UNITED NATIONS IN 1959, AND THE SINO-INDIAN HAR OF 1962. IT CONCLUDES BY EXAMINING THE IMPLICATIONS OF RECENT WORLD CHANGES--THE COLLAPSE OF THE SOVIET UNION AND THE ACCOMPANYING REDUCTION OF CHINA'S WORLD STATURE--ON THE "TIBET PROBLEM." 
08536 SINGH,

GOH'S POLITICAL TEST

FAR EASTERN ECONOMIC REVIEH, 155(9) (MAR 92), 15.

ON 17 AUGUST 1991--THO WEEKS BEFORE SINGAPORE'S GENERAL ELECTIONS AND WELL BEFORE NOMINATIONS WERE FILED--PRIME MINISTER GOH CHOK TONG ANNOUNCED THAT HE WOULD HOLD BYELECTIONS IN "12 TO 18 MONTHS TIME AFTER THE NEW GOVERMMENT HAS SETTLED DOWN." GOH IS NOW FACING A DIFFICULT DILEMMA CAUSED BY HIS PROMISE. IF HE CALLS FOR BY-ELECTIONS, HE WILL HAVE TO PERSUADE SOME SITTING MPS TO RESIGN AND WILL HAVE TO FACE THE POSSIBILITY OF OPPOSITION GAINS AND DILUTION OF THE RULING PEOPLE'S ACTION PARTY'S (PAP) 77-4 MAJORITY IN PARLIAMENT. HOWEVER, A DECISION NOT TO HOLD AN ELECTION COULD BE REAGRDED AS A LOSS OF FACE FOR HIM. ONE POSSIBLE COMPROMISE SOLUTION WOULD BE TO HOLD A BY-ELECTION FOR ONLY ONE SEAT. THE LONGER GOH WAITS, THE GREATER THE CHANCES OF MISTAKES BEING MADE AND CONTROVERSIAL POLICIES BEING INTRODUCED WHICH COULD COST THE PAP VALUABLE VOTES.

08537 SINGH, G.

THE PUNJAB ELECTIONS 1992: BREAKTHROUGH OR BREAKDOWM ASIAN SURVEY, XXXII (11) (NOV 92), 988-999.

FEW RECENT STATE ELECTIONS IN INDIA HAVE HAD AS MUCH SIGNIFICANCE AS THE PUNJAB POLL IN FEBRUARY 1992. PUNJAB HAS BEEN WRACKED BY ETHNIC VIOLENCE THAT HAS CLAIMED OVER 18,000 LIVES SINCE 1984, AND HAS WITNESSED THE RISE OF A POWERFUL SEPARATIST MOVEMENT FOR AN INDEPENDENT SIKH STATE. THE ELECTION HAS GENERALLY WELCOMED AS AN OPPORTUNITY TO UNLOCK THE INTRACTABLE "PUNJAB PROBLEM" THAT HAD BEDEVILED SUCCESSIVE INDIAN GOVERMMENTS. HOHEVER, THE ELECTION FAILED TO PROVIDE A CRITICAL TURNING POINT, AND ITS OUTCOME SEEMED MORE LIKELY TO PRECIPITATE A POLITICAL BREAKDOWN THAN A BREAKTHROUGH. THIS ARTICLE EXPLAINS WHY THE ELECTIONS PRODUCED THIS OUTCOHE AND WHY THE POLICY INITIATIVES UNDERTAKEN BY THE NEW CONGRESS-I GOVERNMENT HAVE BEEN SO UNSUCCESSFUL. IT THEN ANALYZES FUTURE PROSPECTS.

08538 SINGH, G.

THE PUNJAB PROBLEM IN THE 1990S: A POST-1984 ASSESSMENT JOURNAL OF COMMONHEALTH AND COMPARATIVE POLITICS, XXIX(2) (JUL 91), 175-191.

WHEN IN JUNE 1984 THE INDIAN ARMY ENTERED THE GOLDEN TEMPLE THE "PUNJAB PROBLEM," WHICH HAD BEEN SIMMERING SINCE THE EARLY 1980S, BECAME AN INTERNATIONAL MEDIA EVENT. THIS ARTICLE ADDRESSES THE ISSUES OF WHY THE VARIOUS

"INITIATIVES" HAVE FAILED TO PROVIDE A CRITICAL BREAKTHROUGH, "IND WHAT LESSONS DOES THE POST-1984 "PUNJAB PROBLEM" PROVIDE FOR ETHNIC CONFLICT MANAGEMENT IN SOUTH ASIA. ITS PROVIDE FOR ETHNIC CONFLICT MANAGEMENT IN SOUTH ASIA. ITS
CENTRAL ARGUMENT IS THAT DEFINITIONS OF THE "PUNJAB PROBLEM" CENTRAL ARGUMENT IS THAT DEFINITIONS OF THE "PUNJAB PROBLEM" AND THE POSSIBILITIES OF ITS RESOLUTION HAVE SIGNIFICANTLY THE RESPONSES THEY HAVE GENERATED AMONG THE SIKH COMHUNITY. THE RESPONSES THEY HAVE GENERATED AMONG THE SIKH COMHUNITY. ALTHOUGH OPPORTUNITIES FOR A NEGOTIATED SETTLEMENT STILL EXIST, THE EXPERIENCE OF THE LAST SEVEN YEARS WILL STRONGL INFLUENCE

08539 SINGH, M.

INDIA: SEARCHING FOR A CONSENSUS BY AMENDING THE CONSTITUTION?

GOVERNANCE, 5(3) ( JUL 92 ), 358-373.

TWO MAJOR THEMES HAVE DOMINATED THE DEBATE OVER INDIA'S CONSTITUTIONAL DESTINY SINCE THE 1980S: PARL IAMENTARY VERSUS PRESIDENTIAL GOVERNMENT AND FEDERALIZATION OF ITS PREDOMINANTLY PARLI IMENTARY SYSTEM. THIS ARTICLE SUGGESTS THAT INDIA HILL DO WELL TO CONTINUE WITH ITS PARL IAMENTARY FORM OF GOVERMMENT. THE IMPACT ON INDIA'S

PARLIAMENTARY/FEDERAL SYSTEM OF THE CHANGING NATURE OF THE PARTY SYSTEM AND PREMIERSHIP STYLES IS ANALYZED. PHASES OF THE PARTY SYSTEM EVOLUTION ARE IDENTIFIED AND THREE STYLES OF PRIME MINISTERIAL LEADERSHIP ARE DEL INEATED. THO

PARTICULARLY PROMISING AVENUES OF FEDERALIZATION THAT COMBINE RESPONSIBLE FEDERALISM HITH RESPONSIBLE PARLIAMENTRY GOVERNMENT ARE DETAILED.

08540 SINGH, M.

THE DILEMMA OF THE NEH INDIAN PARTY SYSTEM: TO GOVERM OR NOT TO GOVERN?

ASIAN SURVEY, 2(4) (APR 92), 303-317

IN THE POLIITICS OF COUNTRIES OF INDIA'S SIZE AND

DIVERSITY A CRUCIAL OUESTION CONCERNS THE OYERARCHING

FRAMEWORK OF POLITICAL AGGREGATION AND GOVERNANCE. THE PARTY

SYSTEM IN INDIA IS THE CENTRAL IDEOLOGICAL STRUCTURE

SYSTEM IN INDIA IS THE CENTRAL IDEOLOGICAL STRUCTURE
STRADOLING THE CIVIL SOCIETY AND THE STATE. IN 1989, INOIA

STRADOLING THE CIVIL SOCIETY AND THE STATE. IN 1989, INDIA

FACED THE PROSPECT OF A FRACTIONALI IED MULTIPARTY SYSTE
THIS ARTICLE EXAMINES THE MAJOR ELEMENTS OF THE NEW PARLIAMENTARY PARTY SYSTEM HHICH GENERALLY CONFORMED TO THE MODEL OF POLARIZED PLURALISM WHICH HAS A STRONG FEDERAL OR REGIONAL AXIS IN THE PARTY SYSTEM. IT EXPLORES PARTIES AND MASS MOVEMENTS, INDIA IN
PARTY SYSTEM AS A WHOLE.
08541 SINGH, R.D.

GOVERMMENT-INTRODUCED PRICE DISTORTIONS AND GROWTH:

GOVIDENCE FROM TWENTY-NINE DEVELOPING COUNTRIES

EVIDENCE FROM TWENTY-NINE DEVELOPING
PUBLIC CHOICE, 73(1) (JAN 92), 83-100.

THIS STUDY ELABORATES ON PREVIOUS WORLD BANK ATTEMPTS TO EXAMINE STATE ECONOMIC POLICIES THAT PRODUCE MARKET DISTORTIONS AND THE EFFECT OF SUCH DISTORTIONS ON ECONOMIC GROWTH. IT EVALUATES THE GROWTH RELATIONSHIPS BY ESTIMATING AND ANALYZING THE EFFECTS OF PRICE DISTORTIONS ON: THE NATIONS' GDP GROWTH RATE; THE PER CAPITA GDP GROWTH RATE; AND THE NATIONS' INDUSTRIAL OUTPUT RATE. IT SAMPLES TWENTYNINE DEVELOPING COUNTRIES OVER THE PERIOD 1970-1980. THE RESULTS OF THE STATISTICAL ANALYSES SHOW WITHOUT ANY AMBIGUITY THAT PRICE DISTORTIONS HAVE HAD STRONGLY DETERRENT EFFECTS ON NATIONS' ECONOMIC GROWTH.

08542 SINGLETON, S.; TAYLOR, M. COMMON PROPERTY, COLLECTIVE ACTION, AND COMMUNITY JOURNAL OF THEORETICAL POLITICS, 4(3) (JUL 92), 309-324. THE AUTHORS INVESTIGATE WHY SOME GROUPS OF USERS OF COMMON PROPERTY ARE ABLE TO RESOLVE THEIR COLLECTIVE ACTION PROBLEMS BY THEMSELVES WHILE OTHERS ARE NOT. THEY ARGUE THAT PROBLEMS BY THEMSELVES WHILE OTHERS ARE NOT. THEY ARGUE THAT
A GROUP POSSESSES THE CAPACITIES FOR A WHOLLY ENDOGENOUS A GROUP POSSESSES THE CAPACITIES FOR A HHOLLY ENDOGENOUS MUTUALY VULNERABLE ACTORS. FOR AN INITIAL TEST, THEY REMUTUALLY VULNERABLE ACTORS. FOR AN INITIAL TEST, THEY REANALYZE THE CASES STUDIED BY ELINOR OSTROM IN "GOVERNING THE
COMMONS," IN WHICH THE CENTRAL ROLE OF COMMUNITY IS OBSCURED.

08543 SINHA, D. V.P. SINGH, ChandRa SHEKHAR, and "NOWHERE POLITICS" IN INDIA

ASIAN SURVEY, XXXI(7) (JUL 91), 598-612.

THIS ARTICLE DRAWS A BALANCE SHEET OF WHAT IS NOW REGARDED AS ONE OF THE MOST FASCINATING PERIDOS OF INDIAN POLITICS: NOVEMBER 1989 TO MARCH 1991. THE ARTICLE FOCUSES ON V.P. SINGH AND CHANDRA SHEKHAR DURING THEIR TENURES AS PRIME MINISTER WITH THE 1989 ELECTION AS A BACKDROP. THE ARTICLE WEAVES AND ANALYZES VARIOUS COMPLEXITIES PERTAINING TO THE RESPECTIVE METHODS OF CONFLICT-SOLVING OF THE TWO LEADERS. SINGH'S TACTICAL METHOD OF CONFLICT MANAGEMENT IS BASED ON THE PREMISE THAT POLITICS RAISES ITS UGLY HEAD WHEREVER CONFLICTS OR COMPETING OPTIONS ARE FOUND. THEREFORE, HE PLACED A PREMIUM ON THE MANAGEMENT OF THE CONTRADICTIONS WHICH ARE INHERENT IN ALL CONFLICTS. IN CONTRAST, CHANDRA SHEKHAR'S METHOD HAS PREMISED ON THE DIRECT AND FORTHRIGHT CONFRONTATION OF PROBLEMS.

08544 SINKKONEN, S.; HANNINEN-SALMELIN, E. WOMEN IN PUBL IC ADMINISTRATION IN FINLAND WOMEN IN PUBLIC ADMINISTRATION IN FINLA
WOMEN AND POLITICS, $1(4)(1991), 69-84$.

THE CURRENT REPRESENTATION OF HOMEN IN THE FINNISH POLITICAL SYSTEM AND IN PUBLIC ADHIMISTRATION IS DISCUSSED IN THIS ARTICLE. THE OVERALL PICTURE OF HOMEN'S PLACE IS ONE IN WHICH WOMEN DOMINATE THE LOHER LEVEL OFFICES AS WELL AS OFFICES IN CERTAIN FIELDS HITHIN THE STATE AND MUNICIPAL ADMINISTRATION, HITH ONLY A FEH TOKEN LEADERSHIP POSITIONS AT THE DEPARTMENT HEAD LEVEL AND ABOVE IN NATIONAL BOARDS AND MINISTRIES. WOMEN ARE POORLY REPRESENTED IN THE HIGHER ADMINISTRATIVE POSITIONS DESPITE THE FACT THAT WOMEN ARE WELL REPRESENTED IN THE POOL FROM WHICH PERSONS ARE RECRUITED FOR HIGHER POSITIONS.

08545 SINOPOLI, R.

LIBERALISM AND POLITICAL ALLEGIANCE IN ANTI-FEDERALIST POLITICAL THOUGH

PUBLIUS: THE JOURNAL OF FEDERALISM, 22(2) (SPR 92),

123-140.

THIS ARTICLE EXAMINES THE VIEHS OF ALLEGIAMCE OFFERED BY MAJOR ANTI-FEDERALISTS AND THE POLITICAL PSYCHOLOGY ON WHICH THEY ARE BASED. IT CONCLUDES THAT ANTI'FEDERALIST POLITICAL PSYCHOLOGY IS FLAWED LEAVING THE CONSIITUTION'S OPPONENTS VULNERABLE TO CHARGES THAT SOUND FUNCTIONING AND DURABILITY OF GOVERMMENT, RATHER THAN SIZE, ARE SUFFICIENT TO GENERATE CIVIC ALLEGIANCE. THE ANTI-FEDERALISTS' POSTIONS ON ALLEGIANCE ARE GROUNDED IN LIBERAL FIRST PRINCIPLES OF GOVERNMENT. THE ARGUMENTS OFFERED ARE NOT THOSE ONE WOULD EXPECT IF THE ANTI-FEDERALISTS ADHERED STRONGLY TO THE TENETS OF CIVIC HUMANISM.

08546 SISLIN, J.

REVOLUTION BETRAYED? ROMANIA AND THE NATIONAL SALVATION REVOLT

STUDIES IN COMPARATIVE COMMUNISM, 29(4) (DEC 91), 395-412.

THE REYOLUTION OF DECEMBER A WATERSHED IN THE HISTORY OF ROMANIA. MARKING BOTH THE END OF THE REIGN OF NICOLAE CEAUSESCU AND THE BEGINNING OF A NEW AND UNCERTAIN ERA. A YEAR HAS PASSED SINCE THE NATIONAL SALVATION FRONT (NSF) TOOK THE HELM IN ROMANIA AND MADE AMBITIOUS PLEDGES. THIS ARTICLE ASKS TO HHAT EXTENT THEY HAVE SUCCEEDED AND HOW FAR HAS THE NSF MOVED ROMANIA TOWARDS DEMOCRACY AND AWAY FROM THE CEAUSESCU LEGAGY? THE ACCOMPLISHMENTS OF ROMANIA'S NEIGHBORS, WHICH WERE MADE OVER A SIMILAR TIME PERIOD, SUGGEST THAT IT' IS NOT TOO EARLY TO LOOK AT THE FRONT'S RECORD TO DETERMINE HHETHER ROMANIA IS 
BEING LED TO DEMOCRACY, AUTHORITARIANISM, OR COLLAPSE.

08547 SISSON, R.; MAJMUNDAR, M.

INDIA IN 1990: POLITICAL POLARIZATION

ASIAN SURVEY XXXI(2) (FEB 91), 103-112.

THIS ARTICLE EXAMINES EVENTS IN INDIA IN 1990. IT LOOSELY GROUPS THEM UNDER THREE BASIC CATEGORIES: THE MATTER OF NATIONAL GOVERNANCE; INTEGRATION VERSUS SEPARATISH; AND POLT POLARIZATION WAS THE DOMINANT MOTIF IN INDIAN POLITICS. THE YEAR COMMENCED WITH A NEH PRIME MINISTER AND ENDED WITH ANOTHER AT THE HELM. IT BEGAN WITH A SENSE THAT POLITICAL COALITIONS WERE WORKABLE AND STABLE BUT ENDED WITH THAT POSSIBILITY IN DOUBT. IT BEGAN WITH AN EXPECTATION THAT COMNUAL TENSIONS WOULD BE CONTAINED, IF NOT REDUCED, BUT WITNESSES AN INCREASE IN COMMUNAL VIOLENCE BETWEEN HINDU,
MUSLIM, AND SIKH.

08548 SITARSKI, C

CONCEPTUAL ISSUES IN THE STUDY OF CENTRALIZATION AND INFORMATION TECHNOLOGY

CANADIAN PUBLIC ADMINISTRATION, 34(4) (WIN 91), 641-663. THE VIEH THAT THE USE OF ADVANCED TECHNOLOGY BY BUREAUCRACIES WILL DEPRIVE LOCAL ACTORS OF THEIR POLICYMAKING AUTONOMY HAS BEEN THE FOUNDATION FOR A SUBSTANTIAL BODY OF LITERATURE ON INFORMATION TECHNOLOGY ANO ORGANIZATIONAL CHANGE. BUT THE RELIANCE OF PAST RESEARCH ON ANECDOTAL OR CASE DATA CASTS DOUBT ON THE THEORETICAL AND EMPIRICAL SOUNDNESS OF THIS PROPOSITION. FINDINGS HAVE CONTRIBUTED FEW RELIABLE GENERALIZATIONS ABOUT THE WAYS IN WHICH THE LOCUS OF AUTHORITY BETHEEN A GOVERNMENT AGENCY AND ITS FIELD SERVICE SHIFTS. THIS PAPER OFFERS A REVISED APPROACH TO CHARACTERIZING AN ADMINISTRATIVE SYSTEM AS MOVING TOWARDS CENTRALIZATION OVER TIME. ASSUMPTIONS ABOUT THE NATURE AND DIRECTION OF CASUAL INFLUENCE FOR CONCEPTUALIZING CENTRALIZATION AS A DYNAMIC PROCESS ARE EXPLORED. AN ISSUE-CENTERED APPROACH AND PROCESS ORIENTATION ARE PROPOSED TO ASSESS CHANGES TO THE RELATIVE DISTRIBUTION ARE PROPOSED TO ASSESS CHANGES TO THE RELATIVE DISTRIBUTION OF POWER BETWEEN FIELD AND HEADQUARTERS. AN ACKNOWLEDGMENT
AND UNDERSTANDING OF THESE REFINEMENTS SERVE AS A BASIS FOR FUTURE EMPIRICAL RESEARCH.

08549 SITTON, J.

CITIZENS AND CLASSES: POLITICAL ISOLATION AND CLASS FORMATION

CRITICAL SOCIOLOGY, 17 (2) (SUM 90), 3-34.

CONTRARY TO FREQUENTLY EXPRESSED HOPES AND EXPECTATIONS, THERE IS A RECURRING ARGUMENT BY SOME THEORISTS IN THE MARXIAN TRADITION THAT THE TYPICAL STRUCTURES AND PROCESSES OF CAPITALIST DEMOCRACY ACTIVELY OBSTRUCT THE POLITICAL ORGANIZATION OF WORKERS AS A CLASS. THIS ESSAY BRINGS TOGETHER VARIOUS ASPECTS OF THIS ARGUMENT, ESPECIALLY AS DEVELOPED IN THE WORKS OF LUKACS, PASHUKANIS, POULANTZAS, PRZEWORSKI, AND KATZNELSON. THE THESIS ULTIMATELY CALLS INTO QUESTION THE SENSE IN WHICH "CLASSES" EXIST UNDER CONDITIONS OF CAPITALIST DEMOCRACY, THE USEFULNESS OF FOCUSING ON "CLASS FORMATION" AS A VEHICLE FOR SOCIALIST THEORY, AND THE ELECTORAL ROAD TO SOCIALISM IN GENERAL.

08550 SIU-KAI, L.

COLONIAL RULE, TRANSFER OF SOVEREIGNTY AND THE PROBLEM OF POLITICAL LEADERS IN HONG KONG

JOURNAL OF COMMONWEALTH AND COMPARATIVE POLITICS, 30(2)

(JUL 92 ), 223-242.

ACCORDING TO AN AGREEMENT BETHEEN BRITAIN AND CHINA,

CHINA WILL RESTORE SOVEREIGNTY OVER HONG KONG IN 1997. CHINA PROMISES HONG KONG A HIGH DEGREE OF SELF-GOOVERNMENT AND \$HONG KONG PEOPLE RUL ING HONG KONG'. NEVERTHELESS, WITH ABOUT FIVE YEARS REMAINING, HONG KONG IS STILL IN SEARCH OF AN ORGANIZED GROUP OF POLITICAL LEADERS HHO CAN BE TRUSTED BY THE PEOPLE OF HONG KONG AND THE THO GOVERNMENTS TO MAKE THE ARRANGEMENTS STIPULATED IN THE SINO-BRITISH AGR
WORK. IN THE PAPER. THE HISTORICAL AND STRUCTURAL WORK. IN THE PAPER, THE HISTORICAL AND STRUCTURAL
CONSTRAINTS ARE THE FOCUS OF ANALYSIS, THOUGH DATA FROM CONSTRAINTS ARE THE FOCUS OF ANALYSIS, THOUGH DATA FROM
QUESTIONMAIRE SURVEYS CONDUCTED BY THE AUTHOR AND OTHERS ARE ALSO USED TO SUBSTANTIATE THE MAJOR ARGUMENTS.

08551 SKAK, M.

POSTCOMMUNIST FOREIGN POLICIES: INITIAL OBSERVATIONS COOPERATION \& CONFLICT: NORDIC JOURNAL OF INTERNATIONAL POLITICS, 27 (3) (SEP 92), 277-300.

THE AUTHOR DESCRIBES THE GEMERAL FRAMEWORK OF THE EMERGING POST-COMMUMIST FOREIGN POLICIES IN EASTERN EUROPE AND OFFERS CASE STUDIES OF POLAND, CZECHOSLOVAKIA, HUNGARY, AND OFFERS CASE STUDIES OF POLAND, CZECHOSLO AAKIA, HUNGARY, WITHIN THE FRAMEWORK OF TRANSITION POLITICS--THE REINTEGRATION INTO THE INTERNATIONAL POLITICAL, ECONOMIC, AND SECURITY STRUCTURE. FOREIGN POLICY HAS AN AFFECTIVE DIMENSION BECAUSE OF ITS ROLE IN NATION- AND STATE-BUILDING. DANGER LIES IN THE COMPETING NATIONALISMS AND REINTEGRATION PROCESSES AS WELL AS IN THE POTENTIAL OF NATIONALISH AS AN ANTI-HESTERN DISCOURSE. THE CASE STUDIES POINT TO BOTH CONTINUITIES AND CHANGE AND TO IDIOGRAPHIC AND NOMOTHETIC PATTERMS. THE CONCLUSION HIGHLIGHTS THE SIGNIFICANCE OF
REGIONALISM AS A MEANS TOHARDS OVERCOMING REVISIONIST ORIENTATIONS AND THE WESTERM OPTION OF INFLUENCING THE DYNAMICS OF POST-COMMUNIST TRANSITION POLITICS.

08552 SKALABAN, A.

INTERSTATE COMPETITION AND STATE STRATEgIES TO DEREgULATE INTERSTATE BANKING 1982-1988

THE JOURNAL OF POLITICS, 54(3) (AUG 92), 793-809.

STATE STRATEGIES TO DEREGULATE INTERSTATE BANKING ARE EXPLORED IN THIS STUDY. THE DETERMINATION OF MARKET EXPANSIVENESS IS TESTED. INTERSTATE COMPETITION AND ECONOMIC CRISIS ARE FOUND TO BE SIGNIFICANT INFLUENCES ON THE DETERMINATION OF MARKET EXPANSIVENESS. THESE RESULTS ARE DETERMINATION OF MARKET EXPANSIVENESS. THESE RESULTS ARE WITH OTHER STUDIES OF POLICY OUTCOMES.

08553 SKED, A.

MYTHS OF EUROPEAN UNITY

NATIONAL INTEREST, (22) (WIN 91), 67-73.

THIS ARTICLE EXAMINES SEVERAL MYTHS ESPOUSED BY THE PROPONENTS OF EUROPEAN FEDERALISM. THEY INCLUDE; THE "EUROPEAN IDEAL" TRANSCENDS NATIONALISM, ITS AIM IS TO BRING NATIONS TOGETHER AND PREVENT WAR FROM BREAKING OUT AGAIN IN EUROPE; EUROPE IS NOT ONLY A GEOGRAPHICAL NOTION, BUT A CULTURAL UNITY FROM A SHARED HISTORICAL EXPERIENCE; EUROPE HAS THE RIGHT TO STAND IN THE CENTER OF WORLD AFFAIRS; THE CREATION OF EUROPEAN UNITY SINCE 1945 HAS BEEN THE WORK OF A NUMBER OF GREAT IDEALISTS, HEADED BY JEAN MONNET; AND EUROPE WILL NEVER BE ABLE TO PLAY ITS TRUE ROLE IN WORLD AFFAIRS UNLESS IT IS UNITED. THIS ARTICLE EXAMINES AND DEBUNKS THESE MYTHS.

08554 SKERRY, P.

ANMALS OF ETHNICITY: E PLURIBUS HISPANIC?

WILSON QUARTERLY, XVI(3) (SUM 92), 62-73.

FROM MIAMI'S CALLE OCHO TO THE LOS ANGELES BARRIOS, HISPANICS HAVE ESTABLISHED A VIVID PRESENCE IN U.S. CULTURE, AND THEY ARE BEGINNING TO PLAY A MORE IMPORTANT ROLE IN U.S. POLITICS. ALTHOUGH MEXICANS, PUERTO RICANS, CUBANS, AND OTHERS ARE NOW EIGHT PERCENT OF THE U.S. POPULATION, THEY OTHERS ARE NOW EIGHT PERCENT OF THE U.S. POPULATION, THEY ARE STILL GROPING FOR A COLLECTIVE HISPANIC IDENTITY. THEIR
FUTURE, AND THAT OF THE UNITED STATES, WILL BE STRONGLY INFLUENCED BY WHETHER THEY EMERGE AS A RACIAL MINORITY, AN ETHMIC GROUP, OR SOME COMBINATION OF THE TWO.

08555 SKIDELSKY, L.

THE NEW EUROPEAN ORDER

SAIS REVIEH, 12(1) (WIN 92), 101-124.

THE BRITISH HAVE FAVORED' "WIDENING" THE COMHUNITY TO INCLUDE AT LEAST SOME OF THE MEWLY INDEPENDENT COUNTRIES OF EASTERN EUROPE, WHICH MEANS HALTING, OR SLOWING DOWN, POLITICAL "DEEPENING." GREAT BRITIAN'S PREDILECTION IN FAVOR OF HIDENING REFLECTS A LONG-STANDING OPPOSITION TO POLITICAL UNIFICATION. THIS DEBATE IN BRITAIN HAS BEEN DAMAGING FOR THE RULING CONSERVATIVE PARTY AND WOULD HAVE BEEN EQUALLY SO FOR THE LABOUR PARTY, HAD IT BEEN IN POWER. NO AGREEMENT EXISTS IN BRITAIN ON CARRYING THE EUROPEAN PROJECT MUCH FURTHER THAN IT HAS ALREADY GONE. IF THE DOMINANT MEMBERS OF THE EC INSIST ON GOING FURTHER OR FASTER DOWN THE ROAD OF POLITICAL UNIFICATION THAN IS ACCEPTABLE TO THE BRITISH, A MULTITRACK, OR MULTISPEED, EUROPEAN COMMUNITY SEEMS INEVITABLE.

08556 SKINNER, C.

FREE TRADE WITH MEXICD

NEW POLITICS, 3(4) (HIN 92), 78-86

IN MEXICO AND THE U.S. . THE PUBLIC DEBATE OVER THE FREE TRADE AND INVESTMENT ACCORD (FTA) HAS BEEN DOMINATED BY EXTRAYAGANT CLAIMS OF ECONOMIC GAIN AND INJURY. FTA OPPONENTS ON BOTH SIDES OF THE BORDER FEAR DEINDUSTRIALIZATION, UNFAIR IMPORT COMPETITION, ANO A LOSS OF ECONOMIC SOVEREIGNTY. THIS ARTICLE SUGGESTS THAT BOTH YEA AND NAY-SAYERS SEEM TO EXAGGERATE THE FTA'S IMMEDIATE ECDNOMIC EFFECTS. IN FACT. THE PACT IS APT TO STREMGTHEM ECONOMIC EFFECTS. IN FACT, THE PACT IS APT TO STRENGTHEN COUNTRIES; AGAINST CERTAIN LABOR-INTENSIVE MANUFACTURING IN COUNTRIES; AGAINST CERTAIN LABOR-INTENSIVE MANUFACTURIN LIBERALIZING MEASURES ARE PHASED IN OVER A TEN TO FIFTEEN YIBERALIZING

08557 SKLAR, R.L.; STREGE, M.

FIMDING PEACE THROUGH DEMOCRACY IN SAHELIAN AFRICA CURRENT HISTORY, 91 (565) (MAY 92), 224-229

IHE SAHELIAN COUNTRIES IN WEST AFRICA HAVE TRADITIONALLY BEEN PLAGUED BY ETHNIC TURMOIL AND MILITARY GOVERMMENTS. BUT IN 1991, SEVERAL SMOLDERING WARS IN THE SAHELIAN REGION APPEAR TO HAVE BEEN MITIGATED BY CONCILIATORY ATTITUDES POLITICAL DEMOCRACY, OFFERING NEW HOPE FOR THIS SCARRED AREA.

08558 SKOGSTAD, G.

THE STATE, ORGANIZED INTERESTS AND CANADIAN AGRICULTURAL

TRADE POLICY: THE IMPACT OF INSTITUTIONS

CANADIAN JOURNAL OF POLITICAL SCIENCE, XXV(2) (JUN 92), 
319-348

THIS ARTICLE EXAMINES THE CANADA-UNITED STATES FREE TRADE AGREEMENT (FTA) WITH THE OBJECTIVE OF EXPLAINING THE INCLUSION OF AGRICULTURE IN THE FTA, THE NEGOTIATION PROCESS SURROUUNDING THE FTA AND THE OUTCOMES WITH RESPECT TO AGRICULTURAL COMMODITIES. IT DEPARTS FROM BOTH THE SYSTEMIC AND STATE-CENTERED MODELS WHICH HAVE DOMINATED CANADIAN FOREIGN ECONOMIC POLICY TO ARGUE THAT, WHILE DEVELOPMENTS IN THE INTERNATIONAL TRADING SYSTEM ARE IMPORTANT FACTORS IN EXPLAINING CANADA'S DECISION TO PURSUE THE FTA, THE NEGOTIATION PROCESS AND OUTCOMES OF THE FTA ARE IMPORTANTLY ACCOUNTED FOR IN TERMS OF DOMESTIC INSTITUTIONS:

SPECIFICALLY, STATE-SOCIETAL LINKAGES IN COMBINATION WITH FEDERAAL STRUCTURES. EVIOENCE THAT THE AUTONOMY AND CAPACITY OF NATIONAL TRADE OFFICIALS WAS REGARDING AGRICULTURALO COMMOOITIES REOUIRES A RE-FORMULATION OF FOREIGN ECOMOMIC POL ICY-MAKING THAT LINKS IT TO THE DOMESTIC INSTITUTIOMAL CONTEXT HITHIN THE IN COMBINATION WITH DURABLE STATE-GROUP POLICY NETHORKS, ARE IMPORTANT FACTORS.

08559 SKOLNICK J.H.

RETHINKING THE DRUG PROBLEM

DAEDALUS, 121 (3) (SUM 92), 133-160.

THE DRUG PROBLEM HAS TWO FACETS: ONE IS ABUSE OF AND ADDICTION TO BOTH LEGAL AND ILLEGAL DRUGS; THE SECOND IS THE CRIME AND VIOLENCE CONNECTED TO ILLEGAL DRUG USE AND SALES. THE BUSH ADMINISTRATION'S MOVES TO EXPAND LAN ENFORCEMENT IN AN UNPRECEDENTED WAY HAS HAD LITTLE IMPACT ON EITHER OF THESE PROBLEMS--EXCEPT TO WORSEN STREET VIOLENCE--BECAUSE IT IGNORE OR DOES NOT APPRECIATE THE IMPERATIVES DRIVING PEOPLE TO USE AND SELL ILLEGAL DRUGS; IT UNDERESTIMATES THE PROBLEMS FACED BY LAN ENFORCEMENT OFFICIALS IN CONTROLLING THE USE AND DISTRIBUTION OF DRUGS; AND IT IGNORES THE SOCIAL AND ECONOMIC UNDERPINMINGS OF DRUG USE AND MARKETING. THE UNITED STATES NEEDS A SHARP REVERSAL IN THINKING ABOUT DRUGS, FROM A PERSPECTIVE CENTERED ON MORAL FAILURE TO A BROADER AND MORE COMPLEX ETIOLOGY HIGHLIGHTING PUBLIC HEALTH AND UNDERLYING SOCIAL ISSUES. THE MILITARISTIC APPROACH IS PROGRAMHED TO FAIL BECAUSE PERSISTENT DILEMMAS AND PARADOXES UNDERMINE THE CAPACITY OF LAH ENFORCEMENT OFFICERS TO SOL VE THE DRUG PROBLEM.

08560 SLACK, J.D

AIDS AND THE POLITICAL SCIENCE CLASSROOM

PS: POLITICAL SCIENCE AND POLITICS, XXV(1) (MAR 92), 78-80. DESPITE THE POLITICAL AND GOVERMMENTAL ISSUES INVOLVED

IN DEALING WITH THE AIDS EPIDEMIC, LITTLE TIME IS CURRENTLY IN DEALING HITH THE AIDS EPIDEMIC, LITTLE TIME IS CURRENTLY ARTICLE, THE AUTHOR OFFERS A COURSE OUTLINE FOR STUDYING THE ARTICLE, THE AUTHOR OFFERS A COURSE OUTLINE FOR
POLITICAL AND BUREAUCRATIC RAMIFICATIONS OF AIDS.

08561 SLACK, J.D.

RESPONOING TO THE GLOBAL EPIDEMIC OF AIDS: CULTURAL AND POLITICAL CHALLENGES FACING GOVERNMENTS

POLICY STUOIES JOURNAL, 2O(1) (1992), 124-134.

THE AUTHOR EXPLORES HOW CULTURAL AND POLITICAL NORMS HELP SHAPE THE GOVERNMENTAL RESPONSE TO THE AIDS EPIDEMIC. IN DOING SO, HE POSES THO OUESTIONS: HOW DO NATIONAL VALUES AFFECT THE WAY IN WHICH AIDS IS DEFINED AND UNDERSTOOD? HOW DOES THE CULTURAL-POL ITICAL DEFINITION OF AIDS IMPACT GOVERNMENT'S ABILITY TO TAKE RESPONSIBLE ACTION AND LEADERSHIP IN ADORESSING THE IMPLICATIONS OF THIS CRISIS? HE EXAMINES THE RESPONSE TO AIDS IN THO CULTURALLY AND POLITICALLY DIVERSE SETTINGS--THE UNITED STATES AND THE PEOPLE'S REPUBLIC OF CHINA.

08562 SLACK, J.D.

THE PUBLIC ADMINISTRATION OF AIDS

PUBLIC ADMINISTRATION REVIEW, 52(1) (JAN 92), 77-81.

AIDS DID NOT JUST HAPPEN IN THE UNITED STATES; IT HAS ALLOHED TO HAPPEN BY INSTITUTIONS THAT FAILED TO PERFORM THEIR APPROPRIATE TASKS TO SAFEGUARD THE PUBLIC HEALTH. MUCH CAN BE LEARNED ABOUT THE PUBLIC SERVICE BY EXAMINING THE EVOLUTION OF THE AIDS CRISIS.

08563 SLATER, R. (ED.); DORR, S. (ED.); SCHUTZ, B. (ED.) GLOBAL TRANSFORMATIOM AMD THE THIRD WORLD

LYNNE RIENNER PUBLISHERS, $1992,315$.

THIS BOOK EXPLORES THE PHENOMENON OF GLOBAL

TRANSFORMATION IN THE CONTEXT OF THE THIRD WORLD, LOOKING TRANSFORMATION IN THE CONTEXT OF THE THIRD WORLD, LOOKING SPECIFICALLY AT THE PREFERENCE FOR MORE DEMOCRATIC POLITICAL
SYSTEMS, THE EMERGENCE OF A NEH INTERNATIONAL ECONOMIC ORDER, SYSTEMS, THE EMERGENCE OF A NEH INTERNATIONAL ECONOMIC ORDER, AND THE CHANGING FORMS OF CONFLICT, ITS MITIGATION, AND ITS
RESOLUTION. THE AUTHORS PROVIDE MAJOR THEORETICAL AMALYSES RESOLUTION. THE AUTHORS PROVIDE MAJOR THEORETICAL ANALYSES OF THESE THREE TRENDS, AS HELL
EXPLORE SPECIFIC DEVELOPMENTS.

08564 SLAY, B.

ECONOMIC REFORMERS FACE HIGH HURDLES

RFE/RL RESEARCH REPORT, 1 (1) (JAN 92), 100-104.

THE YEAR 1991 WAS NOT A GOOD ONE FOR THE EAST EUROPEAN ECONOMIES BECAUSE PRODUCTION DECLINED AND LIVING STANDARDS FELL FOR THE MAJORITY OF THE PEOPLE. NEVERTHELESS, POLAND,
HUNGARY, AND CZECHOSLOVAKIA MADE CONSIDERABLE PROGRESS IN TRANSFORMING SOCIALISM INTO CAPITALISM AND IN PURSUING ECONOMIC INTEGRATION HITH WESTERN EUROPE. THIS PROGRESS IM THE NORTHERN TIER CONTRASTED WITH DEVELOPMENTS IN ROMANIA, BULGARIA, AND ALBANIA, WHERE LESS AMBITIOUS REFORM EFFORTS WERE ACCDMPANIED BY GREATER ECONOMIC DISLOCATION. AS YUGOSLAVIA'S POLITICAL PROBLEMS WORSENED, THE COUNTRY ALSO SUFFERED ECONOMIC COLLAPSE.

08565 SLAY, B.

INTROOUCING NATIONAL CURRENCIES: CAUSES AND CONSEQUENCES

RFE/RL RESEARCH REPORT, 1(30) (JUL 92), 49-52.

THE DISSOLUTION OF MULTIETHNIC EMPIRES OR FEDERATIONS, SUCH AS THE USSR AND YUGOSLAVIA, IS BEING ACCOMPANIED BY THE INTRODUCTION OF NATIONAL CURRENCIES BY THE SUCCESSOR STATES. WHILE NATIONAL CURRENCIES BRING WITH THEM PROBLEMS OF THEIR OWN, THEY ALSO OFFER CERTAIN ADVANTAGES TO GOVERNMENTS STRUGGLING TO STABILIZE THE DOMESTIC ECONOMY AND EXTERNAL ECONOMIC RELATIONS.

08566 SLAY, B.

POLAMD: AN OVERVIEH

RFE/RL RESEARCH REPORT, 1(17) (APR 92), 15-21.

ALTHOUGH POLAND HAS BEEN OHE OF THE TRAILBLAZERS IN POSTCOMMUNIST PRIVATIZATION, NONE OF THE FOUR STAGES THROUGH WHICH POLISH PRIVATIZATION HAS PASSED SINCE THE LATE 1980'S HAS PRODUCED A PROGRAM BOTH ECONOMICALLY AND POLITICALLY VIABLE. WHILE THE PRIVATE SHARE OF ECONOMIC ACTIVITY IN POLAND HAS GROWN MARKEDLY SINCE 1989, MOST OF THIS HAS SECTOR, NOT TO ANY LARGE-SCALE TRANSFORMATION OF STATE-OWNED PROPERTY INTO PRIVATE PROPERTY.

08567 SLAY, B.

POLAND: THE RISE AND FALL OF THE BALCEROHICZ PLAN

RFE/RL RESEARCH REPORT, 1(5) (JAN 92), 40-47.

THE PROGRAM FOR ECONOMIC TRANSFORMATION INTRODUCED DURING 1990-91 BY FORMER DEPUTY PRIME MINISTER AND MINISTER OF FINANCE LESEK BALCEROHICZ MADE A DEEP IMPRESSION ON POLISH ECONOMIC AND POLITICAL LIFE. THE RECESSION AND THE BUGETARY CRISIS THAT THE NEW GOVERNMENT INHERITED FROM THE, BALCEROHICZ ERA HAVE NOT MADE PRIME MINISTER JAN OLSZEWSKI ' JOB ANY EASIER. HOWEVER, IT IS DIFFICULT TO IMAGINE WHERE POLAND WOULD BE TODAY WITHOUT THE BALCEROHICZ PLAN. UNDERSTANDING THE DILEMMAS IN WHICH OLSZEHSKI'S ECONOMIC TEAM NOW FINDS ITSELF REQUIRES AN ACCOUNTING OF THE COSTS TEAM NOW FINDS ITSELF REQUIRES AN ACCOUNTING OF THE
AND BENEFITS OF POLISH ECONOMIC DEVELOPMENT UNDER AND BENEFITS OF POLISH

08568 SLAY, B. TEDSTROM, J.

PRIVATIZÁTION IN THE POSTCOMMUNIST ECONOMIES: AN OVERVIEN RFE/RL RESEARCH REPORT, 1(17) (APR 92), 1-8.

PRIVATIZATION IS WIDELY REGARDED AS CENTRAL TO THE TRANSITION FROM STATE SOCIALISH TO MARKET CAPITALISM NOW UNDERHAY IN EASTERN EUROPE AND THE FORMER SOVIET UNION. MOREOVER, THE EMERGENCE OF A HEALTHY PRIVATE SECTOR IS SEEN AS A KEY BUILDING BLOCK UNDERPINNING THE DEVELOPMENT OF DEMOCRACY IN THE FORMER COMMUNIST COUNTRIES. IN THIS ARTICLE,
THE AUTHORS DISCUSS THE ROLE OF PRIVATIZATION IN THE ECONOMIC TRANSFORMATIONS AND HOH THE PROCESS IS PROGRESSING.

08569 SLAY, B.

ROUNDTABLE ON THE HUNGARIAN ECONOMY

RFE/RL RESEARCH REPORT, 1 (29) (JUL 92), 44-52

IN 1991 RELATIVELY LOH INFLATION AND A LARGE INFLUX OF FOREIGN CAPITAL MADE HUNGARY STAND OUT IN COMPARISON WITH THE OTHER COUNTRIES IN THE REGION. ON THE OTHER HAND, THE ABSENCE OF AN OVERALL PROGRAM FOR ECONOMIC TRANSITION AND WEAKNESSES IN THE PRIVATIZATION PROGRAM AND THE BANKING SYSTEM HAVE RAISED IMPORTANT QUESTIONS ABOUT THE HUNGARIAN ECONOMIC TRANSFORMATION. DOMESTIC POLITICAL UNCERTAINTY AND INSTABILITY IN NEIGHBORING COUNTRIES ALSO CAST LONG SHADOWS OVER HUMGARY'S ECONOMIC PROSPECTS.

08570 SLAY, B.

THE POL ISH ECONOMY: BETWEEN RECESSION AND RECOVERY RFE/RL RESEARCH REPORT, 1(36) (SEP 92), 49-57.

POLAND IS SHONING SIGNS OF A SUSTAINED RECOVERY FROM THE RECESSION THAT HAS PLAGUED EASTERN EUROPE SINCE 1989. ACCORDING TO OFFICIAL STATISTICS, DECLINES IN INDUSTRIAL ACCORDING TO OFFICIAL STATISTICS, DECLINES IN INDUSTRIAL
PRODUCTION AND CONSTRUCTION ACTIVITY HAVE BEEN HALTED; INFLATION IS CONTINUING TO FALL; AND A DRAMATIC TURNAROUND INFLATION IS CONTINUING TO FALL; ANO A DRAMATIC TURNAROL UNEMPLOYMENT IS CONTINUING TO GROW WHILE PRESSURES ON THE STEMPLOYMENT IS CONTINUING TO GROH WHILE PRESSURES ON THE STATE BUDGET AND THE BANKING SYSTEM, POLITICAL UNCERT

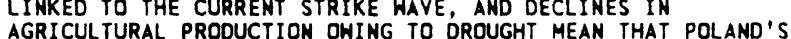
AGRICULTURAL PRODUCTION OWING TO DROUG
ECONOMIC PROSPECTS REMAIN UNCERTAIN.

08571 SLAY, B. (ED.)

ROUNDTABLE ON SYSTEMIC TRANSFORMATION

RFE/RL RESEARCH REPORT, 1(31) (JUL 92), 41-48.

(1) DOMINATED RECENT NEWS REPORTS ABOUT POLAND. THE FOIBLES OF 
POSTCOMMUNIST POLITICS HAVE NOT PREVENTED THE BEGINNINGS OF AN ECONOMIC RECOVERY FROM TAKING HOLD. WHETHER POLAND'S ECONOMIC TRANSITION CAN CONTINUE TO PROGRESS IN A DIFFICULT POLITICAL ENVIRONMENT REMAINS TO BE SEEN.

08572 SLAY, B. (ED.)

ROUNDTABLE: PROSPECTS FOR REFORM

RFE/RL RESEARCH REPORT, 1(12) (MAR 92), 23-30.

CZECHOSLOVAKIA HAS MADE SIGNIFICANT'PROGRESS IN THE TRANSITION FROM SOCIALISM TO CAPITALISM. PRICES HAVE BEEN LIBERALIZED, PRIVATIZATION HAS BEGUN, AND SURPLUSES HERE RECORDED ON THE BALANCES OF TRADE AND PAYMENTS IN 1991. ON THE OTHER HAND, MUCH OF THE MOST DIFFICULT WORK LIES AHEAD, AND UMCERTAINTY ABOUT PRIVATIZATION, TRADE WITH THE FORMER SOVIET UNION, AND SLOVAK SEPARATISM CASTS A LONG SHADOW OVER FUTURE ECONOMIC PROSPECTS

08573 SLIDER, D.

THE CIS: REPUBLICAN LEADERS CONFRONT LOCAL OPPOSITION RFE/RL RESEARCH REPORT, 1(10) (MAR 92), 7-11.

IN THE COMMONWEALTH OF INDEPENDENT STATES, RESISTANCE BY CONSERVATIVE LOCAL OFFICIALS TO REPUBLICAN REFORM PROGRAMS HAS LED REPUBLICAN PRESIDENTS TO SEEK NEW MECHANISMS FOR EXTENDING THEIR INFLUENCE INTO THE PROVINCES. THESE INCLUDE THE NOMINATION OF PERSONAL REPRESENTATIVES WHO MONITOR THE EXECUTION OF REPUBLICAN POLICY AT THE LOCAL LEVEL AND THE INTRODUCTION OF LEGISLATION ALLOWING THE PRESIDENT TO VETO APPOINTMENTS TO LOCAL EXECUTIVE POSTS. THESE CHANGES OCCURRED FIRST IN REPUBLICS WHERE NEW GOVERNMENTS MOVED TO COUNTER COMMUNIST PARTY DOMINATION OF LOCAL SOVIETS-PARTICULARLY IN GEORGIA, MOLDOVA, KYRGYZSTAN, AND RUSSIA. MORE RECENTLY, LEADERS OF OTHER REPUBLICS HAVE ADOPTED SIMILAR MEASURES.

08574 SLOAN, K.H.; BILOON, S CONSENT DECREES: POLIICIES UNDER PRESSURE JOURNAL OF STATE GOVERNMENT, 65(2) (APR 92), 41-46. A SERIES OF CONNECTICUT CASES ILLUSTRATES HOW FEDERAL A SERIES OF CONNECTICUT CASES ILLUSTRATES HOW FEDERAL
COURTS. THROUGH THE USE OF CONSENT DECREES, CAN FORCE COURTS, THROUGH THE USE OF CONSENT DECREES, CAN FORCE DECREES CAN IMPROYE CONDITIONS FOR CLIENTS OF STATE DECREES CAN IMPROVE CONDITIONS FOR CLIENTS OF STATE INSTITUTIONS, BUT THEY ALSO RAISE QUESTIONS RELATING TO ARGUE THAT STATE OFFICIALS SHOULD BE PREPARED TO ANALYZE THESE QUESTIONS PRIOR TO ENTERING INTO CONSENT DECREES.

08575 SMALL, M.; HOOVER, W.

GIVE PEACE A CHANCE: EXPLORING THE VIETMAM ANTIHAR MOVEMENT SYRACUSE STUDIES ON PEACE AND CONFLICT RESOLUTION, 1992. 272.

THIS BOOK EXAMINES HOW THE ACTIVITIES OF THE VIETNAM ANTIWAR MOVEMENT AFFECTED THE LIVES OF MOST AMERICANS. IT POINTS TO THE CONCLUSION "THAT NO ONE ORGANIZATION OR COALITION EVER CAPTURED THE LEADERSHIP OF THE AMORPHOUS GROUP OF MILLIONS OF AMERICAN FROM ALL SEGMENTS OF SOCIETY." THE AUTHORS RELY ON NEW PRIMARY MATERIAL AND ORAL HISTORIES TO EXPLORE NOT ONLY THE STRATEGIES AND TACTICS OF THE MOVEMENT, BUT ALSO THE MILTARY AND ANTIWAR ACTIVITIES, THE RELATIONSHIP BETWEEN WOMEN'S LIBERATION AND THE ANTIWAR
MOVEMENT, AND THE IMPACT OF THE MOVEMENT IN SCHOOLS AND UNIVERSITYS. IT PROBES INTO WHAT SORT OF PERSONALITIES MADE UP THE LEADERSHIP AND THE RANK AND FILE OF THE MOVEMENT AMD WHAT DIFFICULTIES THEY ENCOUNTERED IN TRYING TO BUILD

ORGANIZATIONS AND COALITIONS THAT HERE POLITICALLY EFFECTIVE.

08576 SMAREDON, B.

LIBERALISM, MARXISM AND THE CLASS CHARACTER OF RADICAL DEMOCRATIC CHANGE

STUDIES IN POLITICAL ECONOMY: A SOCIALIST REVIEW, $37(1)$ (SPR 92 ), 129-146.

THE TENDENCY OF THE RADICAL DEMOCRATIC THEORISTS TO STRESS CONTINUITY BETHEEN LIBERAL AND RADICAL DEMOCRACY IS EXAMINED. THE NEED TO INTEGRATE A DIVERSITY OF STRUGGLES EXAMINED. THE NEED TO INTEGRATE A DIVERSITY OF STRUGGLES INTO DEMOCRATIC CHANGES DOES NOT NEGATE THE FACT THAT OEMOCRACY. IN AN ERA OF GLOBAL CAPITAL. IT IS MORE IMPORTANT OEMOCRACY. IN AN ERA OF GLOBAL CAPITAL, IT IS MORE IMPOF RADICAL DEMOCRATIC EXPANSION AND THE UTOPIAN OUALITIES OF RADICAL DEMOCRATIC EXPANSION AND THE UTOPIAN QUALITIES OF ANY VISION WHICH CLAIMS THAT THE RADICAL OEMOCRATIC AGENDA DEMOCRATIC TRENDS.

08577 SMART, C.

AMID THE RUINS, ARMS MAKERS RAISE NEH THREATS ORBIS, 36(3) (SUM 92), 349-364.

THO SETS OF FORCES NOW SHAPE THE CONTINUING COLLAPSE OF SOVIET MILITARY INDUSTRIES. FIRST, EACH OF THE USSR'S SUCCESSOR STATES WILL DECIDE WHAT THREATENS ITS OWN BORDERS, AND WHAT IT NEEDS. SECONDLY, EACH STATE MUST DECIDE HOW ITS INDUSTRIES WILL BE RUN, ARRIVING AT SOME MIX OF GOVERNMENT PLANNING, MARKET FORCES, AND FOREIGN INVESTMENT AND TRADE. FOR THE HEST, THIS TRANSFORMATION PRESENTS DANGERS THAT CAM BE TURNED INTO OPPORTUNITIES. THIS ARTICLE SUGGESTS THAT A
COORDINATED PACKAGE OF INCENTIVES AND PENALITIES MAY HELP
MINIMIZE THE DAMAGE TO WESTERN INTERESTS ARISING FROM TWO PROBLEMS ASSOCIATED WITH A MILITARY-INDUSTRIAL BREAKDOWN IN THE EAST: MIGRATION STEMMING FROM MASS UNEMPLOYMENT, AND WEAPONS PROLIFERATION.

08578 SMEEDING, T.M.

WHY THE U.S. ANTI-POVERTY SYSTEM DOESN'T WORK VERY WELL CHALLENGE, 35(1) (JAN 92), 30-35.

TO UMDERSTAND HOH ANTI-POVERTY PROGRAMS AFFECT THE POOR IT IS VERY ILLUMINATING TO COMPARE THE EFFECT OF THE UNITED IT IS VERY ILLUMINATING TO COMPARE THE EFFECT OF THE UNITED STATES ' INCOME SECURITY POLICY WITH THE POLICIES OF OTHER MODERN NATIONS DURING THE 1980'S. IN RECENT YEARS, THE USA RATES. THE TAX AND TRANSFER SYSTEMS IN ALMOST ALL OTHER RATES. THE TAX AND TRANSFER SYSTEMS IN ALMOST ALL OTHER COMPARABLE NATIONS ARE BETTER SUITED THAN THE UNITED STATES'
TO FIGHT POVERTY AND PROMOTE CITIZENS' ECONOMIC INDEPENDENCE.

08579 SMIRNOV, A.; ERSHOV, E. PERESTROIKA: A CATASTROPHIC CHANGE OF ECONOMIC REFORM POLICY

JOURNAL OF CONFLICT RESOLUTION, 36(3) (SEP 92), 415-453. THE GENERAL SYSTEMS APPROACH HAS BEEN USED TO STUDY THE PROCESS OF SOVIET PERESTROIKA. A DRAMATIC CHANGE IN PUBLIC OPINION TOOK PLACE AND TO STUDY THE FACTORS THAT CAUSED THIS PROCESS, A NONLINEAR MODEL WAS DEVELOPED AND VERIFIED ON EMPIRICAL DATA. THE MOOEL HAS MADE IT POSSIBLE TO TRACE AND IDENTIFY VARIOUS STAGES OF PERESTROIKA AND TO COMPRISE DIFFERENT OUTCOMES OF A GROWING CONFLICT BETWEEN THE CENTRAL AND THE REPUBLICAN GOVERMMENTS THAT REACHED ITS CLIMAX IN AUGUST 1991, AFTER A CATASTROPHIC CHANGE IN PUBLIC SENTIMENT.

08580 SHITH, A.

NATIONAL IDENTITY AND THE IDEA OF EUROPEAN UNITY INTERNATIONAL AFFAIRS, 6811) (JAN 92), 55-76.

IS A GENUINE EUROPEAN IDENTITY POSSIBLE? WHY IS IT THAT WE ARE WITNESSING A REVIVAL OF NATIONALISM EVEN AS THE GLOBALIZING TRENDS OF POST-INDUSTRIAL SOCIETY BECOMES
CLEARER? THESE OUESTIONS ARE STUDIED IN THIS PAPER, WHICH CLEARER? THESE QUESTIONS ARE STUDIED IN THIS PAPER, WHICH
SUGGESTS THAT ESTABLISHED CULTURES ARE ESSENTIALLY

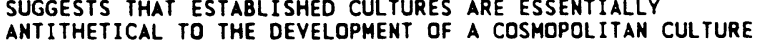
ANT ITHETICAL TO THE DEVELOPMENT OF A COSMOPOL ITAN CULTURE
WHICH POSES PROBLEMS FOR A EUROPEAN IDENTITY. IT CONCLUDES WHICH POSES PROBLEMS FOR A EUROPEAN IDENTITY. IT CONCLUDES
THAT IF THIS IS TO DO MORE THAN COEXIST WEAKLY ALONGSIDE THAT IF THIS IS TO DO MORE THAN COEXIST WEAKLY ALONGSIDE NATIONAL AND SUBNATIONAL IDENTITIES, IT MAY COME AT A
DANGEROUS PRICE--ONLY IF EUROPE DEFINES ITSELF EXCLUSIVELY DANGEROUS PRICE--ONLY IF EUROP
AGAINST OTHER WORLD ACTORS.

08581 SMITH, B.L.R. CRITICAL TECHNOLOGIES BROOKINGS REVIEW, 10(1) (WIN 92), 54

ALTHOUGH A STRONG TECHNOLOGICAL BASE IS CRITICAL TO BOTH AMERICA'S ECDNOMIC PERFORMANCE AND ITS NATIONAL SECURITY, SOME OBSERVERS BELIEVE THAT THE USA HAS FALLEN BEHIND, LOSING ITS TECHNOLOGICAL EDGE IN MANY INDUSTRIES. THE SUGGESTED CURE IS TO DEVELOP A LIST OF "CRITICAL TECHNOLOGIES" TO SPUR INNOVATIONS AND PROOUCT DEVELOPMENT AND TO SUPPORT THOSE TECHNOLOGIES UNTIL THEIR COMMERCIAL FEASIBILITY IS ESTABLI ISHED. THEN MARKET INCENTIVES WOULD TAKE OVER. ALTHOUGH THE CRITICAL TECHNOLOGIES IDEA HAS APPEAL, IT SKIRTS THE REAL ISSUES AND IS UNLIKELY TO PRODUCE THE DESIRED RESULTS.

08582 SMITH, C.; AZNAM, S.

FAR EASTERN ECONOMIC REVIEH, 155(37) (SEP 92), 10-11. WHEN THE LEADERS OF THE 108 NON-ALIGNED COUNTRIES MET IN THE INDONESIAN CAPITAL OF JAKARTA IN SEPTEMBER 1992 IT WAS CLEAR THAT THE NON-ALIGNED MOVEMENT (NAM) HAD COME A LONG WAY FROM ITS ORIGINAL OBJECTIVE FORGED IN THE EARLY YEARS OF THE COLD WAR. ALTHOUGH ASIA HAS BECOME A DOMINANT PLAYER IN THE POLITICS OF NAM, NOT ALL ASIAN LEADERS AGREE ON WHERE THE POLITICS OF MAM, NOT ALL ASIAN LEADERS AGREE ON WHERE
THE MOVEMENT SHOULD BE HEADED. WHILE PRESIDENT SUHARTO OF THE MOVEMENT SHOULD BE HEADED. WHILE PRESIDENT SUHARTO INDONESIA HOPED TO USE HIS CHAIRMANSHIP TO LAUNCH A CONSTRUCTIVE DEBATE ON ECONOMIC DEVELOPMENT WITH THE
INDUSTRIALIZED NORTH, MALAYSIAN PRIME MINISTER DATUK SERI INDUSTRIALIZED NORTH, MALAYSIAN PRIME MINISTER DATUK SERI
MAHATHIR MOHAMAD ADOPTED A RATHER CONFRONTATIONAL APPROACH. MAHATHIR MOHAMAD ADOPTED A RATHER CONFRONTATIONAL APPROACH.
MAHATHIR STRESSED THE THREAT TO DEVELOPING COUNTRIES OF A MAHATHIR STRESSED THE THREAT TO DEVELOPING COUNTRIES OF A
POST-COLD HAR UNIPOLAR HORLD AND CALLED FOR NAM MEMBERS TO POST-COLD WAR UNIPOLAR HORLD AND CALLED FOR NAM MEMBERS TO
PROTECT THEMSELVES FROM "WHAT AMOUNTS TO A REVIVAL OF THE PROTECT THEMSELVES FROM "WHAT AMOUNTS TO A REVIVAL OF THE OLD WESTERN COLONIALISM." OTHER ISSUES DEALT WITH AT THE
SUMMIT INCLUDE HARMONIZATION OF TREATMENT OF DEBTOR NATIONS, SUMMIT INCLUDE HARMONIZATION OF TREATMENT OF DEBTOR NATIONS
THE CONFLICT IN THE FORMER YUGOSLAVIA, AND THE FUTURE OF THE CONFLICT IN

08583 SMITH, C.

THE MILITARIZATION OF CIVIL SOCIETY IN GUATEMALA: ECONOMIC THE MILITARIZATION OF CIVIL SOCIETY IN GUA LATIN AMERICAN PERSPECTIVES, 17(4) (FAL 90), 8-41.

THIS ARTICLE INTRDDUCES AN ANALYSIS OF SOCIOECONOMIC CHANGES IN GUATEMALA'S INDIAN COMMUNITIES BY SITUATING THOSE CHANGES WITHIN A BROADER POLITICAL AND ECONOMIC CONTEXT-BOTH NATIONAL AND INTERNATIONAL. THE AUTHOR ARGUES THAT WHILE ECONOMIC CONTROL HAS REPLACED MILITARY COERCION AS THE GUATEMALAN STATE ERECTS A DEMOCRATIC VENEER FOR INTERHATIONAL CONSUMPTION, THE CURRENT PATTERN OF ECONOMIC 
RESTRUCTURING IN THE HIGHLANDS, WHETHER GUIDED DIRECTLY BY THE MILITARY, BY INTERNATIONAL FUNDING ORGANIZATIONS, OR BY THE MARKET, HAS BEEN EXTREMELY SUCCESSFUL IN REDUCING THE ECONOMIC AND POLITICAL AUTONOMY OF INDIAN COMMUNITIES, THE MAIN SOURCE OF RESISTANCE TO GUATEMALA'S MILITARY STATE. THIS PATTERN OF ECONOMIC RESTRUCTURING IMPLIES SIGNIFICAN CHANGES IN THE ROLE OF THE STATE AND MILITARY AND THEIR RELATIONSHIP TO EACH OTHER.

08584 SMITH, C.A.

THE IOWA CAUSCUSES AND SUPER TUESDAY PRIMARIES RECONSIDERED: HOW UNTENABLE HYPOTHESES ENHANCE THE CAMPAIGN MELODRAMA

PRESIDENTIAL STUDIES QUARTERLY, XXII(3) (SUM 92), 519-530. THE AUTHOR ASSESSES THE IMPORTANCE OF THE IOWA CAUCUSES AND THE SUPER TUESDAY PRIMARIES IN PRESIDENTIAL ELECTIONS. CONVENTIONAL WISDOM MAKES THE IOWA CAUCUSES A MAJOR PREDICTOR OF SUCCESS IN GAINING BOTH THE DEMOCRATIC AND REPUBLICAN NOMINATIONS AND CLAIMS THAT SUPER TUESDAY GIVES AN ADVANTAGE TO CONSERVATIVE DEMOCRATIC CANDIDATES. BUT THE FACTS ARE OTHERHISE. AND THE MYTHS ABOUT THE IOHA CAUCUSES FACTS ARE OTHERHISE, AND THE MYTHS ABOUT THE IOHA CAUCUSES
AND SUPER TUESDAY PRIMARIES HAVE BEEN CREATED BY JOURMALISTS.

08585 SMITH, D.

ANCHORING RUSSIA

RUSI JOURNAL, 137 ( 2 ) (APR 92 ), 30-34.

THE MOST SIGNIFICANT ASPECT OF THE BREAK UP OF THE SOVIET UNION IS THE EMERGENCE OF RUSSIA AS A NEW POWER ON BOTH THE INTERNATIONAL AND EUROPEAN SCENES. THE CHALLENGE NOW FACING THE WEST IS HOW TO INTEGRATE THIS UNKNOWN QUANTITY INTO NEW SECURITY STRUCTURES, TOGETHER WITH OTHER MEMBERS OF THE CDMMONWEALTH OF INDEPENDENT STATES (CIS), ANO HELP TO BUILD A SECURE, WESTERM-ORI ENTED AND ECONOMICALLY VIABLE RUSSIA. THIS ARTICLE CONSIDERS THE CHALLENGES ANO UNCERTAINTIES THAT ARE ASSOCIATED WITH THIS PROCESS. THEY INCLUDE THE POSSIBILITY OF WIDESPREAD ETHNIC AND NATIONALISTIC FIGHTING WITHIN RUSSIA, THE DISASTROUS ECONOMIC SITUATION, AND THE POTENTIAL FOR AUTHORITARIANISM TO REPLACE THE FLEDGLING DEMOCRACY.

08586 SMITH, D.

MODERNISM, HYPERLITERACY, AND THE COLONIZATION OF THE WORD ALTERNATIVES, $17(2)$ (SPR 92), 247-260

COMMON OPINION IS THAT THERE IS A CRISIS OF LITERACY IN

THE HEST. THIS PAPER TAKES UP THE QUESTION OF LITERACY

THROUGH A KIND OF GENEALOGICAL, PHENOMEMOLOGICAL

DECONSTRUCTIVE EXPLORATION OF CONTEXTS HITHIN WHICH ANY

DISCUSSION OF LITERACY TODAY MAY NEED TO BE LOCATED. THE

DISCUSSION OF LITERACY TODAY MAY NEED TO BE LOCATED.
AUTHOR SUGGESTS THAT THE VARIOUS CRISES OF LITERACY

AUTHOR SUGGESTS THAT THE VARIOUS CRISES OF LITERACY

CURRENTLY AT WORK FORCE A QUESTION ABOUT LITERACY ITSELF AS
A KIND OF CULTURAL ARTIFACT. HE IS LED TO AN UNDERSTANDING A KIND OF CUL TURAL ARTIFACT. HE IS LED TO AN UNDERSTAM OF LITERACY THAT HOLDS MUCH IN COMMON WITH MYSTICAL TRADITIONS FOCUSING ON SENSIBILITIES LIKE ATTUNEMENT AND
ATTENTION. HE CONCLUDES THAT READING THE HORLD, INSCRIBING ATTENTION. HE CONCLUDES THAT READING THE HORLD, INSCRIBING AND BEING PROFOUNDLY INSCRIBED BY IT, HAS MORE TO DO WITH DEEP ATTUNEMENT OR HEARING, AND
TO LIFE'S DEEPEST RESONANCES.

08587 SMITH, D.G

ELECTABILITY

FREEMAN, 42(10) (OCT 92 ), 390-391.

THE AUTHOR ARGUES THAT THE U.S. ECONOMIC SYSTEM WORKS

BEST WHEN LEFT ALONE. IT IS A SELF-GENERATING, ENERGY-

PRODUCING SYSTEM THAT RESISTS TAMPERING AND BRINGS INSTANT REWARDS WHEN IT IS ALLOWED TO RUN FREE. YET A POLITICIAN IS EXPECTED TO DO SOMETHING AND THIS INVARIABLY MEANS INJECTING HIMSELF INTO THE SYSTEM. WHETHER IT BE A FEDERAL PROGRAM TO FORCE EMPLOYERS TO PROVIDE MEDICAL INSURANCE OR A LOCAL ORDINANCE FORBIDDING SMOKING IN RESTAURANTS. THE POLITICIAN HAS TO MEDDLE IN ORDER TO CREATE AHD/OR MAINTAIN THE IMAGE OF VIGOR AND FARSIGHTEDNESS THAT IS ESSENTIAL TO ELECTABILITY.

08588 SMITH, D.G.

MICROCOSM: THE DECLINE OF U.S. COMPETITIVENESS

FREEMAN, 42(6) (JUN 92), 234-235.

THE AUTHOR ARGUES THAT INCREASED GOVERNMENT INTERVENTION HAS HAMPERED U.S. PRODUCTIVITY AND THAT THE PROLIFERATION OF GOVERMMENT REGULATIONS HAS LED TO THE DECLINE OF U.S.

COMPETITIVENESS.

08589 SMITH, D.L. (ED.); RAY, J.L. (ED.)

THE

M. E. SHARPE, $1992,240$.

THE COLLAPSE OF THE COMMUNIST REGIMES IN CENTRAL EUROPE THE DISINTEGRATION OF THE SOVIET UNION, AND THE UNIFICATION OF GERMANY HAVE BROUGHT AN END TO THE "POSTHAR ORDER" IN EUROPE. WHILE THESE CHANGES OFTEN GARMER MOST OF THE HEADLINES IN THE UNITED STATES, CHANGES NOW UNDER WAY WITHIN THE EUROPEAN COMMUNITY ARE LIKELY TO HAVE AT LEAST AS GREAT AN IMPACT ON THE FUTURE. WITH THE RATIFICATION OF THE SINGLE EUROPEAN ACT IN 1987, THE EUROPEAN COMMUNITY (EC) EMBARKED ON ITS MOST AMBITIOUS ATTEMPT TO DEEPEN THE LEVEL OF
PROJECT" REFERS TO THE PORTION OF THE 1987 SINGLE EUROPEAN ACT THAT COMMITS THE EC TO THE COMPLETION OF A SINGLE INTEGRATED MARKET BY 1992. THE PROJECT HAS BROUGHT ABOUT A DRAMATIC REVIVAL OF INTEREST IN THE EC. THIS BOOK'S CHAPTERS PROVIDE EVALUATIONS AND ESTIMATES OF THE FUTURE OF THE INTEGRATION PROCESS AND OF THE EC ITSELF. THE CONTRIBUTORS SHARE THO THEMES. THE FIRST IS THE VIEW OF THE INTEGRATION PROCESS AS A MULTI-LEVEL GAME. THE SECOND IS THE

CONSIDERATION OF THE CONSEQUENCES OF THE PROCESS.

08590 SMITH, F.

SAKHAROV AND SOLZHENITSYN: DISSIDENTS WITH A DIFFERENT HORLD VIEN

JOURNAL OF SOCIAL, POLITICAL AND ECONOMIC STUDIES, 16(4)

(WIN 91), 469-476

THO OF THE MOST FAMOUS DISSIDENTS OF THE SOVIET UMIONANDREY SAKHAROV AND ALEXANDER SOLZHENITSYN--CAME TO ADVOCATE DIFFERING APPROACHES TO REFORMING THE SOVIET UNION, PERHAPS

BECAUSE OF THEIR BACKGROUNDS AND THE COURSE OF THEIR LIVES.

08591 SMITH, G.

BRITAIN IN THE NEW EUROPE

FOREIGH AFFAIRS, 71(4) (FAL 92), 155-170.

FOREIGN AFFAIRS, 71(4) (FAL 92), 155-170.

COMMUNITY UNDER PRIME MINISTER JOHN MAJOR AND THE BRITISH

VISION OF THE FUTURE OF EUROPE.

08592 SMITH, G.A.

FAMILY AFFAIR: REPRESENTING A RURAL CONSTITUENCY

PARLIAMENTARIAN, LXXIII(3) (JUL 92), 189-190.

FAR FROM THE CAPITAL, BOTH GEOGRAPHICALLY AND CULTURALLY, THE FAMILY ISLANDS OF THE BAHAMAS PRESENT SOME INTERESTING PROBLEMS FOR THE CENTRAL GOVERNMENT. THE IMMEDIATE AFFAIRS OF THE FAMILY ISLANDS ARE ADMINISTERED BY COMMISSIONERS WHO ARE THE CHIEF GOVERNMENT AUTHORITY IN THE DISTRICT, ACTING as magistrates, paymasters, ahd revenue COLlectors.

08593 SMITH, J.

ENGAGEMENT: A NATIONAL STRATEGY FOR THE $1990 \mathrm{~S}$

COMPARATIVE STRATEGY, 11(4) (DEC 92), 463-474.

THE END OF THE COLD WAR CALLS FOR A MEW MATIONAL STRATEGY TO DEAL WITH THE CHALLENGES OF THE NEXT DECADE. AMERICAN NATIONAL STRATEGY MUST NOW BE INTEREST-BASED TO REPLACE A POLICY OF CONTAINMENT THAT WAS BASED ON BALANCE-OFPOWER CONSIDERATIONS. REGIONALLY ORIENTED, OUR NATIONAL STRATEGY MUST RECOGYIZE THE GRADUAL MOYE TOWARD REGIOMAL SECURITY SYSTEMS, ACCEPT A MYRIAD OF NON-TRADITIONAL THREATS, AND FOSTER GROWTH IN THE SUCH AREAS AS HUMAN RIGHTS.

AND FOSTER GROWTH IN THE SUCH AREAS AS HUMAN RIGHTS

FINALLY, THE UNITED STATES MUST MAINTAIN A CREDIBLE
CAPABILTIES-BASED MILITARY FORCE TO PROTECT THOSE INTERESTS CABROAD.

08594 SMITH, J.; KORMBERG, A.; NEVITTE, N MATIONAL IMAGES OF CANADA AND THE UNITED STATES: THEIR NATIONAL IMAGES OF CANADA AND THE STRUCTURE, COHERENCE AND MEANING
AMERICAN REVIEH OF CANADIAN STUDIES, 20(3) (FAL 90),

AMERICAN

IN THIS PAPER THE AUTHORS REPORT AN ANALYSIS OF RESPONSE FORM MEMBERS OF RANDOM SAMPLES IN THREE MEDIUM-SIZED CANADIAN CITIES TO SETS OF SEMANTIC DIFFERENTIAL ITEMS FOR BOTH CANADA AMD THE UNITED STARES. THEY REPORT ANALYSES THAT ADDRESS THE FOLLOWING QUESTIONS: DO ORDINARY CITIZENS OF CANADA SHARE A WELL-STRUCTURED CONCEPT OF THEIR COUNTRY; IF SO, IS THIS SAME STRUCTURED CONCEPT APPLI IED TO OTHER COUNTRIES AS WELL; IF THE ANSWERS TO BOTH PREYIOUS QUESTIONS ARE POSITIVE, DO THE IMAGES REPORTED DIFFER, AND IF SO, ARE THERE REASONABLE PATTERNS TO THESE DIFFERENCES; HOW ARE THESE IMAGES DISTRIBUTED IN SOCIAL SPACE; AND DO THE CONCEPTS IDENTIFIED REFER TO COUNTRIES, OR DO THEY HAVE OTHER REFERENTS?

08595 SMITH, J.; PAGNUCCO, R.

POLITICAL PROCESS AND THE 1989 CHINESE STUDENT MOVEMENT STUDIES IN CONFLICT AND TERRORISH, 15(3) (1992), 169-184. THIS ARTICLE ANALYZES THE 1989 CHINESE STUDENT MOVEMENT IN BEIJING USING THE POLITICAL PROCESS MODEL THAT WAS USED BY DOUG MCADAM (1982) IN HIS STUDY OF THE U.S. CIVIL RIGHTS MOVEMENT. DISCUSSING MCADAM'S THREE MAIN VARIABLES, THE AUTHORS PRESENT A CROSS MATIONAL APPLICATION OF THE MODEL. IN APPLYING MCADAM'S MODEL CROSSNATIONALLY, THE AUTHORS CALL FOR SOME MODIFICATIONS, BUT FIND ITS CENTRAL ELEMENTS TO BE FOR SOME MODIFICATIONS, BUT FIND ITS CENTRAL ELEMENTS TO BE ESSENTIALLY USEFUL IN EXPLAINING THE EMERGE
AND BASIC OUTCOMES OF THIS SOCIAL MOVEMENT.

08596 - SMITH, L.D.

THE PARTY PLATFORMS AS INSTITUTIONAL DISCOURSE: THE DEMOCRATS AND REPUBLICANS OF 1988

PRESIDENTIAL STUDIES OUARTERLY XXII(3) (SUM 92), 531-544.

FOCUSING ON THE 1988 REPUBLICAN AND DEMOCRATIC PLATFORMS THE AUTHOR EXAMINES THE DEVELOPMENT OF THESE CENTRAL PARTY DOCUMENTS. PARTY PLATFORMS REPRESENT A RECONCILIATION OF PRINCIPLES FOLLOWING THE DISINTEGRATING PROCESS OF THE STATE PRIMARIES AND CAUCUSES. IN 1988, THE DEMOCRATIC PLATFORM HAS "A LETTER TO THE AMERICAN PEOPLE" WHILE THE REPUBLICAN WAS 
ENCYCLOPEDIC IN CHARACTER.

08597 SMITH, M.

HISTORY IN THE PRESENT: CONTEMPORARY DEBATES ABOUT CAPITALISM

SCIENCE AND SOCIETY, 56(3) (FAL 92), 291-323. THREE WIDELY DISCUSSED CONTEMPORARY THEORIES ABOUT THE PLACE AND PROSPECTS OF WORKERS IN THE U.S. POLITICAL ECONOMY ARE CRITICIZED. THE REGULATION SCHOOL ERRONEDUSLY EXTENDS ARE CRITICIZED. THE REGULATION SCHOOL ERRONEDUSLY EXTENDS THE FORDIST ERA OF CORPORATE INOUSTRY PAST THE 19205 . THE
WORK OF VOWLES, GORDON, HEISSKOPF OBSCURES THE DEVELOPMENT SINCE THEN OF A CLASS STRUCTURE OF ACCUMULATION ONE-SIDELY SINCE THEN OF A CLASS STRUCTURE OF ACCUMULATION ONE-SIDELY WEIGHTED AGAINST A CORPORATE NORKING CLASS STILL ONLY
PROCESS OF FORMATION. BELL'S POST-INDUSTRIAL SOCIETY PROCESS OF FORMATION. BELL'S POST-INDUSTRIAL SOCIETY
OBSCURES THE CENTRAL ROLE OF SERVICE SECTOR GROWTH IN THE OBSCURES THE CENTRAL ROLE OF SERVICE SECTOR GROWTH IN THE
PRESENT-DAY EMERGENCE OF A MAJORITY CORPORATE WORKING CLASS. PRESENT-DAY EMERGENCE OF A MAJORITY CORPORATE WORKII
THESE DEVELOPEMTS, PARALLELED IN THE OTHER ADVANCED THESE DEVELOPEMTS, PARALLELED IN THE OTHER ADVANCED
CAPITALIST COUNTRIES, HAVE CREATED A WORKING CLASS WHICH WILL SOON, FOR THE FIRST TIME IN ITS HISTORY, HAVE THE CAPACITY TO INTERVENE DECISIVELY IN THE COURSE OF CAPITALIST
DEVELPMENT.

08598 SMITH, M.

REPLY' TO PROFESSOR LEBOVICS

INTERNATIONAL REVIEW OF SOCIAL HISTORY, 37(2) (1992), 252-254.

IN THIS REJOINOER TO HERMAN LEBOVICS, MICHAEL SMITH STATES HIS VIEW AS: THE RANGE OF GOVERMMENT POLICIES THAT WERE DETERMINED BY THE WARFARE BETWEEN THE INDUSTRIAL BOURGEOISIE AND THE INDUSTRIAL PROLETARIAT IN THE EARLY THIRD REPUBLIC WAS LIMITED AND THAT TARIFF POLICY WAS NOT AMONG THEM. HE SUGGESTS THAT CLASS ANALYSIS IS NOT THE ONLY WAY, MOR ALWAYS THE BEST WAY, TO ILLUMINATE WHAT WAS HAPPENING IN LATE NINETENHTH-CENTURY - FRANCE. SMITH DEFENDS HIS METHODS AND SUGGESTS THAT THE COLLECTIVE EFFORT TO ENDEAVORS.

08599 SMITH, M.

THE CANADIAN LABOR CONGRESS: FROM CONTINENTALISM TO ECONOMIC NATIONALISM

STUDIES IN POLITICAL ECONOMY: A SOCIALIST REYIEW, (38)

(SUM 92), 35-60

THE ENGLISH CANADIAN LABOR MOVEMENT, UNDER THE

LEADERSHIP OF THE CANADIAN LABOR CONGRESS (CLC), PLAYED AN IMPORTANT ROLE IN THE ANTI-FREE TRADE CAMPAIGN. THE POSITION OF THE CLC WAS EVIDENCE THAT IT HAD SHIFTED FROM BEING DEFENDER OF CONTINENTALISM TO A DEFENDER OF ECONOMIC NATIONALISM. THIS ARTICLE SEEKS TO EXPLAIN THIS SHIFT. IT OUTLINES THE CLC'S STRATEGIC POLICY OPTIONS AND DILEMMAS, AS WELL AS THE CLC'S POSITION ON TRADE AND INVESTMENT. I EXPLORES KEY MOMENTS IN THE CLC'S TRANSITIDN--THE 1968 PRICES AND INCOMES NEGOTIATIONS, THE 1975 IMPOSITION OF WAGE CONTROLS, AND THE CLC'S CONSULTATIVE STRATEGY VIS-A-VIS THE FEDERAL GOVERMMENT IN THE EARLY EIGHTIES. IT CONCLUDES THAT THE CLC'S SHIFT TO ECONOMIC MATIONALISM MUST BE TRACED TO THE PARTICULAR STRATEGIC DILEMMAS THAT FACED THE CONGRESS THROUGHOUT THE EIGHTIES.

08600 SMITH, M.

THE DEVIL YOU KNOW : THE UNITED STATES AND A CHANGING EUROPEAN COMMUNITY

INTERNATIONAL AFFAIRS, 68(1) (JAN 92), 103-120.

THIS IS AN ARTICLE ABOUT PERCEPTIONS IN THE US-EC

RELATIONSHIP. IT SURVEYS THE DEVELOPMENT AND DIFFERENTIATIOM OF U.S. IMAGES OF THE EC AMONG GOVERNMENT ELITES, CONGRESS, AND BUSINESS GROUPINGS SINCE THE 1950S. AS THE CONTEST OVER THE TERMS OF THE RELATIONSHIP SHARPENED, WITH EC DEPENDENCE IN A U.S.-DEFINED PARTNERSHIP GIVING WAY TO RIVALRY AND SOMETIMES ACUTE ANTOGONISM IN THE 1980 S AND 1990 S, IT TRACES THE SIMULTANEIOUS DEVELOPMENT OF CONTRADICTORY IMAGES OF THE EC.

08601 SMITH, M.

THE MELINE TARIFF AS SOCIAL PROTECTION: RHETORIC OR REALITY?

INTERNATIOMAL REVIEH OF SOCIAL HISTORY, 37(2) (1992),

230-243.

THE MELINE TARIFF OF 1982 IS TRADITIONALLY CREDITED WITH ENDING FRANCE'S EXPERIMENT IN FREE TRADE AND RETURNING THE COUNTRY TO A POLICY OF HIGH PROTECTION. SMITH AND LEBOVICS AGREE ON MUCH ABOUT THE TARIFF BUT PART COMPANY WHEN LEBOYICS SEES THE TARIFF AS AN EFFORT TO CONCILIATE LABOR. SMITH AND LEBOVICS BOTH SEE THE TARIFF AS A KEY INGREDIENT IN THE AND LEBOVICS BOTH SEE THE TARIFF AS A KEY INGREDIENT 18905 . THIS ARTICLE ATTEMPTS TO ANSWER THE OUESTION, WHICH 1890S. THIS ARTICLE ATTEMPTS TO ANSWER THE QUESTION, VIEW OF THE FRENCH PROTECTIONISTS' MOTIVES AND WHICH EXPLANATION OF THE ORIGINS OF THE MELINE TARIFF ARE MORE
JUSTIFIED? SMITH CONCLUDES THAT FRENCH INDUSTRIALISTS NEVER JUSTIFIED? SMITH CONCLUDES THAT FRENCH INDUSTRIALISTS NEVER SAH TARI
LABOR.

08602 SHITH, M.G. (ED.)

GLOBAL RIVALRY AND INTELLECTUAL PROPERTY
INSTITUTE FOR RESEARCH ON PUBLIC POLICY, 1991, 274.

THE PAPERS IN THIS VOLUME PROVIDE A CANADIAN PERSPECTIVE ON THE ISSUES SURROUNDING THE URUGUAY ROUMD OF GATT NEGOTIATIONS ON THE INTERNATIONAL HARMONIZATION OF RULES GOVERNING INTELLLCTUAL PROPERTY (PATENTS COPYRIGHTS AND TRADEMARKS). THE PAPERS STRESS THREE BASIC ISSUES. THE FIRST IS THE INCREASING KNOWLEDGE CDNTENT OF PRODUCTION AND TRADE AND THUS THE INCREASING IMPORTANCE OF INTELLECTUAL PROPERTY. THE SECDND IS THE DIVERGENCE OF VIEWS BETWEEN DEVELOPED AND DEVELOPING COUNTRIES REGARDING THE APPROPRIATE TREATMENT OF
INTELLECTUAL PROPERTY. THE THIRD IS THE GLOBAL ADVANTAGE OF INTELLECTUAL PROPERTY. THE THIRD IS THE GLOBAL ADVANT
A COMMON SET OF RULES APPLIED IN A NON-DISCRIMINATORY A COMMON
FASHIOH.

08603 SMITH, N.

MEDIATED POLITICS

MICHIGAN JOURNAL OF POLITICAL SCIENCE, 14 (WIN 91), $115-137$

THE PURPOSE OF ANY INQUIRY INTO THE ROLES AND EFECTS OF THE MASS MEDIA IN THE ELECTORAL PROCESS IS OFTEN GROUNDED IN THO CRITICAL ASSUMPTIONS: THE EMPIRICAL APPRECPTION THAT THE MASS MEDIA DO HAVE A SIGNIFICANT EFFECT IN DETERMINING A WINNER, AND THE NORMATIVE PRESUMPTION THAT THE MEDIA POSSESS A REPSONSILBITY TO EDUCATE THEIR AUDIENCE IN ORDER TO FOSTER A DEMOCRACY. THE PURPOSE OF THIS PAPER IS TO ANALYZE THE MASS MEDIA'S CONSTRUCTION OF A CERTAIN TYPE OF UNTRADITIONAL CANDIDATE AND TO EXPLORE THE IMPLICATIONS THIS MAY HAVE FOR THE STATE OF AMERICAN DEMOCRACY. IT ADDRESSES HOW AN IDEOLOGICAL MINORITY WAS CONSTRUCTED, AND ASSESSES HHETHER A SYSTEMATIC BAIS WAS PRESENT.

08604 SMITH, P.

ANDEAN ARMADEDOON: PERU ON THE BRINK

PEACE \& DEMOCRACY NEWS, 11 (2) (WIN 92), 29-34,

" BUT ITS

PROBLEMS ARE NOT UNIQUE IN THE REGION--ONLY MORE ADVANCED.

GIVEN CURRENT TRENDS IN LATIN AMERICA, PERU COULD WELL BE

THE FACE OF THE FUTURE. PRESIDENT FUJIMORI'S STUNNING DEFEAT

OF THE ESTABLISHED PARTIES OF THE LEFT, RIGHT AND CENTER

REFLECTED A POLITICAL SYSTEM OF POLITICAL PARTIES

INCREASINGLY SEPARATED FROM FROM THEIR POPULAR BASES.

HOWEVER, THE POPULIST PRESIDENT REVERSED HIMSELF ALMOST

OVERNIGHT. THE PRESIDENT'S SUDOEN UNILATERAL TURN TO THE IMF ROGRAM PUSHED BOTH APRA AND THE LEFT INTO OUTRIGHT

OPPOSTION IN THE LEGISLATURE AND LED TO THE UNRAVELING OF FUJIMORI'S PERSONAL ELECTORAL VEHICLE. THIS ARTICLE EXPLOES FUJIMOR'S AUTOGLOPE AND IMTERMATIDNAL RESPONSE TO THE COUP. THE IMPACT OF SENDERO LUMINOSO, AND THE DRUG TRADE UPON U.S. POLICY TOWARD PERU IS EXAMINED. THE ARTICLE CONCLUDES THAT PERU IS DOOMED TO CONTINUE A CYCLE OF VIOLENT UPHEAVAL UNTIL EITHER THE MILITARY OR THE MAOISTS ACHIEVE TOTAL VICTORY OR UNTIL THE COUNTRY COLLAPSES INTO ANARCHY.

08605 SMITH, P.

GRAPPLING WITH SHINING PATH

NEW POLITICS, 3(4) (HIN 92), 87-100.

IN PERU, THE GUERRILLA WAR EXISTS IN A CONTEXT OF ACUTE ECONOMIC, POLITICAL, ANO SOCIAL CRISIS FUELED BY THE WORST DEPRESSION IN THE COUNTRY'S HISTORY. AFTER ELEVEN YEARS, THE HIGH HOPES OF REFORMISTS HAVE TURNED TO DESPAIR AS THE DEMOCRATIC REGIME STAGGERS UNDER TWIN BURDENS OF ECONOMIC COLLAPSE AND ARMED REBELLION. AFTER EXAMINING THE SITUATION IN PERU, THE AUTHOR CONCLUDES THAT IS IS THE RESPONSIBLITY OF THE U.S. LEFT TO CHALLENGE THE ASSUMPTIONS OF NARCOTERRIORISM AND THE INTERNATIONAL HAR ON DRUGS AS PROMOTED BY THE BUSH ADMINISTRATION. THE STUGGLE FOR AN AUTHENTIC POPULAR DEMOCRACY EMBRACING SOCIAL JUSTICE IS THE ONLY SOCIALLY ACCEPTABLE ANO EFFECTIVE RESPONSE TO SHINING PATH.

08606 SMITH, P.

THE POLITICAL IMPACT OF FREE TRADE ON MEXICD JOURNAL OF INTERAMERICAN STUDIES AND HORLD AFFAIRS, 34(1) (SPR 92), 1-26.

CURRENT DEBATES OVER NORTH AMERICAN FREE TRADE FOCUS ALMOST EXCLUSIVELY ON ECONOMIC ISSUES. THERE IS MUCH LESS ATTENTION TO THE POLITICAL SIDE OF THIS OUESTION. THIS ARTICLE EXPLORES THE POLITICAL CONSEQUENCES OF FREE TRADE ARTICLE EXPLORES THE POLITICAL CONSEQUENCES OF FREE TRADE
AND ITS LONG-TERM IMPLICATIONS. IT WILL EXAMINE ALTERNATIVE AND ITS LONG-TERM IMPLICATIONS. IT WILL EXAMINE ALTERMA
SCENARIOS FOR THE POTENTIAL IMPACT THAT A FREE-TRADE SCENARIOS FOR THE POTENTIAL IMPACT THAT A FREE-TRADE
AGREEMENT MAY HAVE UPON THE MEXICAN POLITICAL SYSTEM. TO AGREEMENT MAY HAVE UPON THE MEXICAN POLITICAL SYSTEM. TO
THIS END, IT WILL OUTLINE CURRENT IDEAS THAT HAVE BEEN THIS END, IT WILL OUTLINE CURRENT IDEAS THAT HAVE BEEN
ADVANCED ON THE SUBJECT, TRY TO UNRAVEL THE LOGICAL PREMISES ADVANCED ON THE SUBJECT, TRY TO UNRAVEL THE LOGICAL PREMISES INHERENT IN EXISTING DEBATES, AND FOCUS ON PROBLEMS OF CAUSE
AND EFFECT. IT WILL ATTEMPT TO CLARIFY THE CONCEPTUAL TERMS AND EFFECT. IT WILL ATTEMPT TO CLARIFY THE CONCEPTUAL TERMS OF CUR

08607 SMITH, R.

INCOME GROWTH, GOVERMMENT SPENDING, AND HASTING ASSETS-ABLERTA'S OIL AND GAS

CANADIAN PUBLIC POLICY--ANALYSE DE POLITIQUES, 18(4) (DEC 92), 387-412

THIS PAPER DEYELOPS PHYSICAL AND MONETARY ACCOUNTS FOR 
THE OIL AND GAS SECTOR IN ALBERTA FROM 1963 THROUGH 1988. THESE ACCOUNTS ARE USED TO ADJUST ALBERTA'S GROSS DOMESTIC PRODUCT AND GROSS DOMESTIC INVESTMENT FOR CHANGES IN OIL AND GAS RESERVES. THE GAS AND OIL ACCOUNTS PERMIT COMPARISON OF PAST EXPENDITURES OF RESOURCE REVENUES WITH WHAT NOULD BE
SPENT UNDER A RULE OF THUMB SUCH AS ROBERT SOLOW'S SUGGESTION THAT ALLOWABLE CONSUMPTION BE INTEREST ON AN INITIAL PATRIMONY OF RESOURCE ENDOWMENT. SUCH A COMPARISON INDICATES THE PROVINCIAL GOVERNMENT MAY AND OVERSPENT AT TIMES; AT OTHER TIMES ITS POLICIES APPEAR TO HAVE BEEN QUITE CONSERVATIVE.

08608 SMITH, S.

THE FORTY YEARS' DETOUR: THE RESURGENCE OF NORMATIVE THEORY IN INTERNATIONAL RELATIONS

MILLENHIUM, 21(3) (WIN 92), 489-508.

THE AUTHOR RE-EXAMINES THE PLACE OF NORMATIVE THEORY IN INTERNATIONAL RELATIONS. AFTER TRACING THE HISTORY OF THE SUPPRESSION OF NORMATIVE CONCERN IN THE DISCIPLINE, HE LOOKS AT THE INTER-PARADIGM DEBATE, ARGUING THAT IT IS A AT THE INTER-PARADIGM DEBATE, ARGUING THAT IT IS A
CONSERVATIVE MOVE, STIFLING DEBATE BY APPEALING TO A CONSERVATIVE MOVE, STIFLING DEBATE BY APPEALING TO
MISLEADING NOTION OF KUHNIAN INCOMMENSURABILITY. HE MISLEADING NOTION OF KUHNIAN INCOMMENSURABILITY. HE
CONCLUDES BY OUTLINING THE DEBATE NOW FACING THE DISCIPLIME CONCLUOES BY OUTLINING THE
OF INTERNATIONAL RELATIONS.

08609 SMITH, S.K.; HERTMAN, D.A.

REDEFINING U.S. - WEST EUROPEAN RELATIONS IN THE 1990's: WEST EUROPEAN PUBLIC OPINION IN THE POST-COLD WAR ERA PS: POLITICAL SCIENCE AND POLITICS, XXV(2) (JUN 92), $188-195$.

AS EUROPEAN AND AMERICAN LEADERS SORT OUT THEIR NEW INTERNATIONAL RELATIONSHIPS, THE ATTITUDES OF EUROPEAN PUBLICS TOWARD THE UNITED STATES WILL PLAY A CRITICAL ROLE. USING MORE THAN 80 MULTI-COUNTRY SURVEYS CONDUCTED IN WESTERN EUROPE IN 1981-1991 ON BEHALF OF THE U.S. INFORMATION AGENCY, THIS ARTICLE ANALYZES WEST EUROPEAN PUBLIC ATTITUDES TOWARD THE USA, U.S. FOREIGN POLICY, AND ECONOMIC AND SECURITY RELATIONS BETHEEN THE UNITED STATES AND WESTERM EUROPE. SOME LONG-TERM TRENDS DRAHING ON MORE THAN 100 ADDITIONAL MULTI-COUNTRY SURVEYS FROM THE 1950'S, 1960'S, AND 1970'S ARE ALSO DISCUSSED.

08610 SMITH, T.

THE POLITICS OF THE BUDGET PROCESS: TRYING TO ANSWER THE HOWS AND WHYS

MICHIGAN JOURNAL OF POLITICAL SCIENCE, 15(15) (FAL 92), MICHIGAN

TOBIN SMITH EXPLORES THE FAILURE OF THE BUDGET PROCESS WHICH CREATED THE DEFICIT AND WHO IS TO BLAME. HIS ANALYSIS IS FORTIFIED WITH AN ESSENTIAL HISTORICAL OVERVIEW OF THE EVOLUTION OF THE BUDGET PROCESS. HE GOES ON TO EVALUATE YARIOUS PROPOSED SOLUTIONS TO THE BUDGET PROCESS NAMELY CONGRESSIONAL TERM LIMITATIONS. THE LINE-ITEM VETO, PLACING CONGRESSIONAL TERM LIMITATIONS, THE LINE-ITEM VETO, PLACING BUDGETARY RESPONSIBLITY SOLE
BALANCED BUDGET AMENDMENT.

08611 SMITH,

CASTRO: TO FALL OR NOT TO FALL?

SAIS REVIEH, 12(2) (SUM 92), 97-110

DETERIORATING ECONOMIC CONDITIONS WILL NOT NECESSARILY LEAD TO FIDAL CASTRO'S DEMISE UNLESS CUBANS ARE NILLING TO TAKE UP ARMS AGAINST THEIR LEADER. THERE IS NO SIGN THAT THEY ARE, OR WILL BE. THIS ARTICLE OFFERS AN EXPLORATION OF CASTRO'S ECONOMIC PROBLEMS AND CHANGES IN THE CUBAN ECONOMY. CUBA'S HOPES OF AVOIDING VIOLENCE AND U.S. INTERVENTION ARE STUDIED AS WELL AS WHAT U.S. POLICY SHOULD BE. IT CONCLUDES THAT IT WILL BE BEST TO ENCOURAGE A PEACEFUL TRANSITION.

08612 SMITH, H.

STATE, MARKET AND NEOLIBERALISM IN POST-TRANSITION ARGENTINA: THE MENEM EXPERIMENT

JOURNAL OF INTERAMERICAN STUDIES AND WORLD AFFAIRS, 3314 (WIN 92 ), 45-82.

THE THRUST OF THIS ANALYSIS SUGGESTS THAT THE STRUCTURAL REFORMS IMPLEMENTED BY ARGENTINA'S CIVILIAN GOVERMMENTS OF THE 1980S HAVE ACCELERATED THE IMPLANTING OF AN EXCLUSIONARY MODEL OF ACCUMULATION. THE FULL RAMIFICATIONS OF THIS MODEL ARE YET TO BE EXPLORED. NEVERTHELESS, NEOLIBERAL, MARKETORIENTED REFORMS HAVE ALREADY WROUGHT PROFOUND, IF NOT IRREYERSIBLE, CHANGES IN THE STATE, CIVIL SOCIETY, AND THE POL ITICAL ECONOMY. AT THIS POINT THERE IS A CONCERN THAT THE POLICIES AND DEVELOPMENTS DISCUSSED IN THIS ARTICLE MAY ALSO POLICIES AND DEVELOPMENTS DISCUSSED IN THIS ARTICLE MAY ALSO MEAN THAT THE EMERGING INSTITUTIONAL ORDER, WHILE DEMOCRA
HILL ALSO BE STRONGLY ELITIST AND SOCIALLY REGRESSIVE.

08613 SMITH, $W$.

U.S. NATIONAL SECURITY AFTER THE COLD WAR

WASHINGTON QUARTERLY, 15(4) (FAL 92), 23-34.

IF THE U.S. IS TO MAKE THE BEST USE OF NATIONAL

RESOURCES TO PROTECTS ITS INTERESTS AND CONTRIBUTE TO THE LARGER GOOD, IT MUST CAREFULLY DEBATE THE U.S. WORLD ROLE WHILE ALSO PRESERVING POLICY OPTIONS UNTIL THAT DEBATE HAS REACHED ITS CONCLUSION. THIS ARTICLE EXAMINES THE U.S. WORLD ROLE; CHARTING A NEW SECURITY PATH; U.S. MILITARY FORCES IN
THE POST-COLD WAR ERA; AND WHERE WE ARE NOW. IT CONCLUDES HOW TO HEDGE ITS SECURITY BETS AGAINST A VERY UNCERTAIN FUTURE BEFORE GOING FURTHER.

08614 SMITH, Z.A.

WATER AND FEDERALISM IN THE 1990'

PUBLIUS: THE JOURNAL OF FEDERALISM, 22(3) (SUM 92),

129-140.

THE AUTHOR SURVEYS CONTEMPORARY ISSUES IN

INTERGOVERMMENTAL RELATIONS AND WATER POLICY. FIRST, HE

EXAMINES THE RELATIONSHIP BETHEEN WATER, ENVIRONMENTAL

PROTECTION, AND FEDERALISM. THEN, HE DISCUSSES THE SHIFTING

FINANCIAL RESPONSIBILITY FOR WATER POLLUTION CONTROL FROM

THE FEDERAL TO STATE AND LOCAL GOVERNMENTS.

08615 SMITHSON, A.

CHEMICAL WEAPONS: THE END OF THE BEGIMNING

BULLETIN OF THE ATOMIC SCIENTISTS, 48(8) (OCT 92), 36-40

AFTER MORE THAN THREE CENTURIES OF FAILED ATTEMPTS AND A

FINAL NEGOTIATING MARATHON OF MORE THAN THREE DECADES, $A$

CHEMICAL HEAPONS CONVENTION HAS BEEN CONCLUDED AND WILL BE

SIGHED EARLY MEXT YEAR IN PARIS. THE CRITICS WILL WANT TO

SEND NEGOTIATORS BACK TO THE DRAHING BOARD IN SEARCH OF THE PERFECT AGREEMENT BUT THOSE LIVING UNDER THE THREAT OF CHEMICAL WEAPONS CANNOT BE EXPECTED TO HAIT WHILE

CHEMICAL WEAPONS CANNOT BE EXPECTED TO HAIT WHILE
NEGOTIATORS CHASE SOMETHING AS ILLUSORY AS PERFECTION. THIS NEGOTIATORS CHASE SOMETHING AS ILLUSORY AS PERFECTION. THIS ARTICLE ARGUES THAT THE TIME HAS COME TO CELEBRATE
OF A LONG TREK AND PREPARE FOR THE NEXT CHALLENGES.

08616 SMITHSON, A

OPEN SKIES READY FOR TAKEOFF

BULLETIN OF THE ATOMIC SCIENTISTS, 48(1) (JAN 92), 17-21. THE SOVIETS REJECTED OPEN SKIES IN 1955 AND GOT SPIED ON BY U-2 OVERFLIGHTS INSTEAD. SINCE THEN, AERIAL INSPECTIONS HAVE LEGITIMATELY AND EFFECTIVELY MONITORED ARMS CONTROL AND PEACE AGREEMENTS IN MIDEAST AND ELSEWHERE--AND "SPY" FLIGHTS WILL SOON BE LEGAL JUST ABOUT EVERYWHERE. AN OPEN SKIES AGREEMENT SEEMS LIKELY TO BE RATIFIED BY THE CONFERENCE ON SECURITY AND COOPERATION IN EUROPE (CSCE), POSSIBLY AT THE MARCH MEETING OF THE ORGANIZATION.

08617 SMOLANSKY, O.; SMOLANSKY, B.

THE USSR AND IRAQ--THE SOVIET QUEST FOR INFLUENCE DUKE UNIVERSITY PRESS, 1991,346

THIS BOOK IS AN ANALYSIS OF THE RELATIONSHIP BETHEEN THE USSR AND IRAQ. THE ANALYSIS TAKES THE FORM OF A DIPLOMATIC HISTORY OF THE RELATIONS BETHEEN THE THO NATIONS FROM 1968 HISTORY OF THE RELATIONS BETHEEN THE THO NATIONS FROM 1968
UNTIL 1988. HOWEVER, THE AUTHORS PLACE THEIR ANALYSIS WITHIN
A THEORETICAL FRAMEWORK EARLY ON, AND SET TO NOT ONLY SHED A THEORETICAL FRAMEWORK EARLY ON, AND SET TO NOT ONLY SH LIGHT ON THE SPECIFIC RELATIONSHIP, BUT ALSO TO EXPLORE VARIOUS PROPOSITIONS ABOUT "INFLUENCE RELATIONSHIPS" IN GENERAL. THE AUTHORS ATTEMPT TO PROVE FALSE THE GENERAL CONCEPTION THAT THE SOVIET-IRAQI PATRON-CLIENT RELATIONSHIP WAS ONE OF IRAQI DEPENDENCY, WITH MOSCOH EXERCISING GREAT INFLUENCE OVER IRAQ AND DICTATING ITS GENERAL FORM. THEY CONCLUDE THAT, IN REALITY, THE SOVIET UNION FAILED TO INFLUENCE IRAQ OTHER THAN IN SMALL DEGREES, AND IT HAS IRAQ WHICH DETERMINED THE RELATIONS, AND BEME
A MUCH GREATER DEGREE THAN DID MOSCON.

08618 SMOLLER, F.

WATERGATE REVISITED

PS: POLITICAL SCIENCE AND POLITICS, XXY(2) (JUN 92),

225-227.

THE AUTHOR OUTLINES A POLITICAL SCIENCE COURSE HE DEVELOPED FOCUSING ON THE HATERGATE SCANDAL OF 1972.

08619 SMYSER, H.R.

UNIFICATION GIVES GERMANY THE CHANCE OF TAKING ON THREE MAJOR WORLD TASKS

GERMAN TRIBUNE, (1533) (SEP 92), 5,7.

GERMAN UNIFICATION IS NOT THE END OF A ROAD; IT IS THE BEGINHING OF A NEW GERMAN ROLE IN HORLD AFFAIRS. GERMANY'S FIRST TASK IS TO SERVE AS A LINK BETWEEN HESTERN EUROPE AND THE ATLANTIC STATES AND TO ANCHOR HESTERN EUROPE. ITS SECOND TASK IS TO FORM A LINK BETHEEN THE ENTIRE WESTERN SYSTEM AND THE EAST AND TO HELP THE ALIENATED, DEPERSONALIZED VICTIMS OF LENINIST-STALINIST TYRANNY TO INTEGRATE INTO A PANEUROPEAN ANO GLOBAL SYSTEM. THIRDLY AND MOST IMPORTANTLY, IT MUST HELP TO REFORM THE GLOBAL SYSTEM TO BRING IT INTO LINE WITH THE NEW POWER ALIGNMENTS IN THE WORLD AND AND WITH WITH THE NEW POWER ALIGNMENTS IN
CHANGING SECURITY REOUIREMENTS.

08620 SMYTH, D.J.; TAYLOR, S.H.

WHY DO THE REPUBLICANS HIN THE WHITE HOUSE MORE OFTEN THAN THE DEMOCRATS?

PRESIDENTIAL STUDIES QUARTERLY, XXII(3) (SUM 92), 481-492. BEGINNING WITH 1952, THE REPUBLICAN PARTY HAS WON SEVEN OF 10 PRESIDENTIAL ELECTIONS. IN THIS ESSAY, THE AUTHORS CHALLENGE THE ACCEPTED VIEH THAT ATTRIBUTES' THIS REPUBLICAN SUCCESS "TO A COMBINATION OF PERSONALITY FACTORS, SUPERIOR CAMPAIGN STRATEGY, AD HOC POLITICAL EVENTS, AND PLAIN GOOD FORTUNE." INSTEAD, THEY ATTRIBUTE THE REPUBLICAN VICTORIES 
AND DEMOCRATIC DEFEATS TO THEIR DIFFERIMG MACROECONOMIC POLICIES. THEY CONTEND THAT THE DEMOCRATIC POLICIES ARE BASED ON REDUCING UNEMPLOYMENT AND THE REPUBLICAN ON CONTROLLING INFLATION. THEY ALSO ARGUE THAT THE DEMOCRATIC POLICIES ON UNEMPLOYMENT GOALS ARE SHORT-LIVED AND ARE FOLLOWED BY INCREASED INFLATION.

08621 SHIDAL, D.

INTERNATIONAL COOPERATION AMONG RELATIVE GAINS MAXIMIZERS INTERNATIONAL STUDIES QUARTERLY, 35(4) (DEC 91), 387-402. RELATIVE GAINS DO NOT INHIBIT COOPERATION TO NEARLY THE EXTENT SUGGESTED BY REALIST THEORISTS OF INTERNATIONAL RELATIONS. THE RELATIVE GAINS ARGUMENT POSITS THAT INTERNATIONAL CDOPERATION IS LIMITED BECAUSE STATES WORRY ABOUT HOW WELL THEY DO RELATIVE TO EACH OTHER RATHER THAK HOW WELL THEY DO THEMSELVES. THIS ARTICLE EXAMINES THIS PROPOSITION BY DEVELOPING AN ITERATED PRISONER' DILEMMA MODEL WHERE STATES ARE EXCLUSIVLY RELATIVE GAINS MAXIMIZERS.

08622 SNIDER, D.; GRANT, G.

THE FUTURE' OF CONYENTIONAL WARFARE AND U.S. MILITARY STRATEGY

WASHINGTON QUARTERLY, 15(1) (HIN 92), 203-228.

A DEBATE OVER THE FUTURE SECURITY POLICY OF THE UNITED STATES AND ITS ASSOCIATED MILTARY STRATEGY HAS BEEN EMERGING IN WASHINGTON. INITIALLY THE BUSH ADMINISTRATION HAS RELUCTANT TO ENTER THE DEBATE AND INSTEAD PROCEEDED PRAGMATICALLY HITH A FOREIGN AND SECURITY POLICY KNOWN AS POSTCONTAINMENT. THIS APPROACH EMPHASIZED DUAL TRACKS: DIPLOMATIC AND ECONOMIC INITIATIVES TO BRING ABOUT AND SUPPORT THE INDEPENDENCE, DEMOCRATIZATION, AND FUTURE VIABILITY OF THE EAST EUROPEAN COUNTRIES IN THE FACE OF AN INTERNALLY REFORMED SOVIET UNION; AND ARMS-CONTROL NEGOTIATIONS ON STRATEGIC ARMS REDUCTION AND CONYENTIOMAL FORCES IN EUROPE TO REDUCE AMD BALANCE THE MILITARY FORCES OF BOTH SUPERPOWER BLOCKS. AS HISTORY WILL SHOW, THE EVENTS THAT SWIFTLY FOLLOWED CANMOT BE ATTRIBUTED DIRECTLY TO U.S. POLICY. FOR THE PURPOSE OF THIS SURVEY, HOWEVER THESE EVENTS, AND THE SIGHIFICANT ROLE THE UNITED STATES PLAYED IN THEM, AND THE SIGNIFICANT ROLE THE UNITED STATES PLAYED IN THEM,
GREATLY EXPANDED THE BOUNDS OF THE DEBATE OVER THE FUTURE OF GREATLY EXPANDED THE BOUNDS OF THE DEBATE OVER THE FUTURE
CONVENTIONAL WARFARE AND THE APPROPRIATE U.S. ROLE AND CONVENTIONAL WARFARE AND THE APPROPRIATE U.S. ROLE AND
MILITARY STRATEGY FOR DEALING WITH IT. THIS PAPER EXPLORES THESE EVENTS AND THE ROLE THAT THE U.S. PLAYED IN THEM.

08623 SNITHONGSE, $K$

SOUTH-EAST ASIAN SECURITY ISSUES AND CONFIDENCE-BUILDING DISARMAMENT, XIV(3) (1991), 131-146.

SECURITY ISSUES IN THE SOUTHEAST ASIAN SUBREGION ARE BOTH DIVERSE AMD COMPLEX, INVOLVING SOME ISSUES THAT ARE BILATERAL AND SOME THAT ARE MULTILATERAL AS WELL AS SOME THAT RELATE BOTH TO STATES IN THE REGION AND TO EXTERNAL ACTORS. IN THIS ESSAY, THE AUTHOR ANALYZES THE SECURITY ISSUES RELEVAM

08624 SNOW, T

THE RACE CARD

NEW REPUBLIC, $207(24)$ (DEC 92), 17-18, 20.

GOVERNOR BILL CLINTON'S MISTAKES ON RACIAL ISSUES DURING THE 1992 PRESIDENTIAL CAMPAIGN GAVE THE REPUBLICAN PARTY AN OPPORTUNITY TO CLAIM CIVIL RIGHTS AS ITS OWN ISSUE.

UNFORTUNATELY, THE PARTY FAILED TO CAPITALIZE ON THE ISSUE.

08625 SNOWDEN, L.S.

THE IMPACT OF ASYLUM POLICY IN THE NETHERLANDS, FRANCE AND GERMANY

MIGRATION WORLD, 19(3) (1991) 14-18.

THIS PAPER EXAMINES THE POSITION OF ASYLUM SEEKERS:

PARTICULARLY THIRD WORLD CITIZENS AND ETHNIC MINORITIES,

DESIRING MIGRATION TO EUROPE. THE ASYLUM POLICIES OF THE

NETHERLANDS, FRANCE, AND WEST GERMANY ARE REVIEHED.

08626 SNYDER J., JR

COMMITTEE' POWER, STRUCTURE-INDUCED EQUILIBRIA, AND ROLL CALL VOTES

AMERICAN JOURNAL OF POLITICAL SCIENCE, 36(16) (FEB 92), $1-30$.

USING THE CONCEPT OF STRUCTURE-INDUCED EQUIILIBRIUM, THIS ESSAY DEVELOPS A SIMPLE BEHAVIORAL MODEL OF ROLL CALL
VOTING. THE MAIN RESULTS ARE (1) IF SOME COMMITTEES ARE VOTING. THE MAIN RESULTS ARE (1) IF SOME COMMITTEES ARE
PREFERENCE OUTLIERS RELATIVE TO THE LEGISLATURE AS A WHOLE, PREFERENCE OUTLIERS RELATIVE TO THE LEGISLATURE AS A THEN ROLL CALL DATA ARE LIKELY TO BE ARTIFICIALLY
UNIDIMENSIONAL. (2) THE UNIDIMENSIONAL BIAS PERSISTS EVEN AS UNIDIMENSIONAL. (2) THE UNIDIMENSIONAL BIAS PERSISTS EVEN THE DIMENSIONALITY OF THE POLICY SPACE BECOMES LARGE. (3)
EVEN IF COMMITTEES ARE PREFERENCE OUTLIERS, IT MAY BE EVEN IF COMMITTEES ARE PREFERENCE OUTLIERS, IT MAY BE IMPOSSIBLE

08627 SHYDER, J.

MUST THE U.S. DISEMGAGE?

NATIONAL REVIEH, XLIV(22) (NOV 92), 29-33

THE IMPULSE TO LEAVE FOREIGN AFFAIRS TO THE FOREIGNERS

HAS GAINED STRENGTH FROM THE SOVIET BREAKUP, SADDAM'S

SURVIVAL, AND THE U.S. ECONOMY. A NEH ROUND OF QUESTIONS HAS
BEGUN IN A VERY OLD DEBATE: SHOULD THE UNITED STATES CONTINUE TO DEPLOY MILITARY FORCES GLOBALLY? THIS ARTICLE SUGGESTS THAT SUPERPOWERS, IF THEY WISH TO INFLUENCE EYENTS TOWARD THE PROTECTION OF THEIR VITAL INTERESTS, CAN NEVER REALLY "COME HOME." THEY ARE CONDEMNED TO BALANCE A DOMESTIC AGENDA HITH FOREIGN COMMITMENTS.

08628 SNYDER, J.

NATIONALISM AND INSTABILITY IN THE FORMER SOVIET EMPIRE ARMS CONTROL, 12(3) (DEC 91), 6-16

OFTEN PEOPLE ACT POLITICALLY AS NATIONALISTS BECAUSE OF A REALISTIC ASSESSMENT OF THE COSTS AND BENEFITS OF THE OPTIONS AVAILABLE TO THEM. THE FIRST STEP IN CONTROLLING NATIONALISH IN THE FORMER SOVIET EMPIRE IS TO UNDERSTAND HOW IHOSE COSTS AND BENEFITS MIGHT BE INFLUENCED. THIS ARTICLE EXPLORES THE PROBLEM, THE CAUSES OF NATIONALISM, AND EXPLORES THE PROBLEM, THE CAUSES OF NATIONALISM, AND REASONABLE CHANCE THAT THE VIRULENCE OF NATIONALISMS CAN BE MITIGATED BY THE POLICIES OF OUTSIDE POWERS THAT AFFEC INCENTIVES. PROMOTING A STABLE SECURITY ENVIRONMENT, BUFFERING POPULATIONS FROM THE RIGORS OF ECONOMIC CHANGE, AND LINKING ECONOMIC AID TO THE BENIGN TREATMENT OF MINORITIES SHOULD HELP TO SERVE THESE ENDS.

08629 SNYDER, J.M. JR.

ARTIFICIAL EXTREMISM IN INTEREST-GROUP RATINGS

LEGISLATIVE STUDIES OUARTERLY, XVII(3) (AUG 92), 319-346. THE AUTHOR SHOWS THAT INTEREST-GROUP RATINGS BASED ON ROLL-CALL VOTING RECORDS TEND TO EXAGGERATE THE DEGREE OF EXTREMISM AND BIPOLARITY IN CONGRESS. THE SCORES ASSIGNED TO RELATIVELY MODERATE MEMBERS OF CONGRESS ARE TYPICALLY MORE EXTREME THAN THEIR TRUE POSITIONS. THE AUTHOR EXAMINES SOME OF THE IMPLICATIONS OF THIS BIAS FOR EMPIRICAL STUDIES THAT USE RATINGS.

08630 SHYDER, R.

EXPLAINING TRANSITIONS FROM NEOPATRIMONIAL DICTATORSHIPS COMPARATIVE POLITICS, 24 (4) (JUL 92), 379-399.

TRANSITIONS FROM NEOPATRIMONIAL DICTATORSHIPS MAY FOLLOW A YARIETY OF TRAJECTORIES: REVOLUTION, MILITARY COUP LEADING TO MILITARY DICTATORSHIP, OR NONREVOLUT IONARY TRANSITION TO CIVILIAN RULE. THIS PAPER EXAMINES THE NONREVOLUTIONARY TRANSITIONS OF THE PHILIPPINES, HAITI, PARAGUAY, AND ZAIRE ALONG WITH THE REVOLUTIONARY TRANSITIONS OF NICARAGUA, IRAN, AND CUBA. THREE VARIABLES ACCOUNT FOR THE VARIED TRANSITIONS FROM NEOPATRIMONIALISM: THE DEGREE OF MILITARY INSTITUTIONAL AUTONOMY, THE STRENGTH OF MODERATE OPPOSITION GROUPS, AMD THE STRENGTH OF REYOLUTIOMARIES. THREE CRITICAL

RELATIONSHIPS SHAPE THESE VARIABLES: THE RELATIONSHIPS BETWEEN THE RULER AND THE MILITARY, BETWEEN THE RULER AND DOMESTIC ELITES, AND BETWEEN DOMESTIC ACTORS AND FOREIGH POWERS. REVOLUTION IS LIKELY WHEN THE MILITARY LACKS AUTONOMY, REVOLUTIONARIES ARE STRONG, AND MODERATES ARE WEAK. A MILITARY COUP IS LIKELY WHEN REVOLUTIONARIES AND MODERATES ARE WEAK WHILE MILITARY AUTONOMY IS HIGH. STABILITY IS LIKELY WHEN REVOLUTIONARIES AND MODERATES ARE WEAK AND THE MILITARY LACKS AUTONOMY. DIRECT TRANSITION TO DEMOCRACY IS RARE BUT POSSIBLE WHEN MODERATES ARE STRONG AND MILITARY AUTONOMY IS HIGH.

08631 SO, A.: SUWARSONO

CLASS THEORY OR CLASS ANALYSIS? A REEXAMINATION OF MARX'S UNFINISHED CHAPTER ON CLASS

CRITICAL SOCIOLOGY, 17(2) (SUM 90), 35-56.

THIS PAPER ADOPIS AN IN-DEPTH APPROACH TO EXAMINE MARX'S USE OF THE TERM "CLASS" IN THO KEY HRITINGS, THE COMMUNIST MANIFESTO AND THE EIGHTEENTH BRUMAIRE OF LOUIS BONAPARTE. AFTER COMPARING THESE THO WORKS UNDER THE FOLLOWING HEADINGS - THE NUMBER OF CLASSES, THE LINKAGES BETHEEN ECONOMIC INTERESTS AND POLITICAL STRUGGLES, THE RELATIONSHIP BETWEEN CLASS AND STATE, THE IMPACT OF CLASS ON NONCLASS RELATIONS, AND THE DIRECTION DF CLASS STRUGGLE - THIS PAPER ARGUES THAT IN THE MANIFESTO MARX PRESENTS A STRUCTURAL "CLASS THEORY, CONSISTING OF A COHERENT SET OF TESTABLE PROPOSITIONS AND PREDICTIONS. HOHEVER, THIS PAPER ALSO CONTENDS THAT IN THE EIGHTEENTH BRUMAIRE, MARX DEVELOPS A DIFFERENT HISTORICAL CLASS ANALYSIS" THAT IS AN INTERPRETIVE SCHEME TO MAKE SENSE OF CHANGING POLITICAL EVENTS. IN THE CONCLUSION, THIS PAPER DISCUSSES HII

08632 SOBHAN, $R$.

CHANGING PATTERNS OF INTERDEPENDENCE: THE NEED FOR SYMMETRY IN MORTH-SOUTH ADJUSTMENT PROCESSES

ROUND TABLE 324(324) (OCT 92), 417-430.

THIS ARTICLE DISCUSSES THE CHANGING PATTERNS OF INTERDEPENDENCE BETHEEM THE DEVELOPING COUNTIRES (DCS), TERMED THE SOUTH, AND THE DEVELOPED MARKET ECONOMIES (DMES), TERMED AS THE NORTH. IT DISCUSSES THE CHANGING PATTERNS OF THE GLOBAL ECONOMY, THE PROBLEMS FACED BY THE DEVELOPING COUNTRIES IN HAVING TO ADJUST THEMSELVES TO A WORLD ECONOMY IN RECESSION, THE LACK OF SYMMETRY IN THE ADJUSTMENT PROCESS WITH THE DMCS MAKING LITTLE ATTEMPT TO ADJUST THEIR NATURE AND PROSPECTS OF BUILDING A MORE SYMMETRICAL PROCESS OF 
ADJUSTMENT WITHIN THE GLOBAL ECONOMY THROUGH A REACTIVATION OF THE NORTH-SOUTH DIALOGUE.

08633 SOCOR, $V$.

CREEPING PUTSCH IN EASTERN MOLDOVA

RFE/RL RESEARCH REPORT, 1(3) (JAN 92), 8-13.

ARMED DETACHMENTS OF THE "DNIESTER REPUBLIC," PROCLAIMED BY RUSSIAN COMMUNIST HOLDOUTS IN EASTERN MOLDOVA AND SUPPORTED BY THE SOVIET FOURTEENTH ARMY, ARE ATTEMPTING TO EXTEND THEIR CONTROL FROM THE RUSSIFIED CITIES INTO THE MOLDOVAN COUNTRYSIDE. MOLDOVANS CONSIDER THIS "CREEPING WHICH WAS SUPPORTED BY THE SAME LOCAL FORCES. THE USSR MINISTRY OF DEFENSE AND THE ARMED FORCES COMMAND OF THE COMMONHEALTH OF INDEPENDENT STATES HAVE REFUSED TO

DISCIPLINE THE FOURTEENTH ARMY. IN GENERAL, THE MOLDOVAN POLICE HAVE YIELDED TO SUPERIOR FORCE AND HAVE SUFFERED CASUALTIES IN SEVERAL ENCOUNTERS WITH DNIESTER DETACHMENTS. THE GOVERNMENT IN CHISNIAU HAS ADOPTED A POLICY OF CONCILIATION, SEEKING TO AVOID BLOODSHED AT ALMOST ANY COST, CONCILIATION, SEEKING TO AVOID BLOODSHED AT ALMOST ANY COST,
TO DEFUSE THE SITUATION BY POLITICAL MEANS, ANO TO PLAY FOR TIME.

08634 SOCOR, $V$

MOLDAYIA BUILDS A NEW STATE

RFE/RL RESEARCH REPORT, I (1) (JAN 92), 42-45.

IN 1991 MOLDAVIA CONTINUED TO DEVELOP THE INSTITUTIONAL FRAMENORK OF A DEMOCRATIC STATE AND TO DISMANTLE THE POLITICAL AND MILITARY MECHANISMS THAT HAD TIED IT TO THE USSR. THIS PROCESS ENTERED A DECISIVE STAGE WHEN MOLDAVIA PROCLAIMED ITS INDEPENDENCE ON AUGUST 27 AND BEGAN TO TAKE PRACTICAL STEPS TOWARD SECESSION. OWING TO THE FAILED COUP STAGED BY HARD-LINERS IN AUGUST, MOLDAVIAN INDEPENDENCE WAS PROCLAIMED SOONER THAN EXPECTED. BUT IT WAS A PREDICTABLE RESULT OF THE POLITICAL TRANSFORMATION BEGUN IN MOLDAVIA THREE YEARS EARLIER AND REINFORCED SINCE 1990 BY THE DECISIONS OF THE DEMOCRATICALLY-ELECTED PARLIAMENT AND ITS EXECUTIVE OFFICES. IN THE AFTERMATH OF THE COUP, MOLDAVIA'S LEADERS HURRIED TO EXPLOIT THE PARALYSIS OF ALL-UNION AND LOCAL COMMUNIST AND SECURITY INSTITUTIONS.

08635 SOCOR, $V$.

MOLDOVA

RFE/RL RESEARCH REPORT, 1(39) (OCT 92), 77-81.

MOLDOVA'S MEDIA ARE OWNED MOSTLY BY' THE STATE AND ARE OVERSEEN BY THE PARLIAMENT'S COMMISSION ON THE MASS MEDIA. ALTHOUGH FORMAL LEGAL GUARANTEES OF IMMUNITY FROM STATE ALTHOUGH FORMAL LEGAL GUARANTEES OF IMMUNITY FROM STA INTERFERENCE ARE NOT YET IN PLACE, THE MEDIA ARE NOT
EXPERIENCING SUCH INTERFERENCE AND ARE OPERATING FREELY. EXPERIENCING SUCH INTERFERENCE AND ARE OPERATING FREELY.
ADHERENTS OF THE OPPOSITION MOLDOVAN POPULAR FRONT MAKE UP A ADHERENTS OF THE OPPOSITION MOLDOVAN POPULAR FRONT MAKE UP RELATIVELY HIGH PROPORTION OF THE STAFFS OF THE GOVERNMENT MEDIA AND OFTEN CRITICIZE OFFICIAL POLICIES. JOURNALISTS AND WRITERS ENJOY CONSIDERABLE SOCIAL PRESTIGE AND ARE CRED WITH HAVING SUCCESSFULLY USED THE MEDIA TO SERVE THE MOVEMENT FOR NATIONAL EMANCIPATION. THE MOLDOVAN GOVERMM SPONSORS LIBERAL RUSSI IN-LANGUAGE NEWSPAPERS AND ALSO SUBSIDIZES PERIOOICALS AND RADIO AND TELEVISION PROGRAMS IM RUSSIAN, UKRAINIAN, GAGAUZ-TURKISH, AND BULGARIAN--MOSTLY RUN BY CULTURAL SOCIETIES AND COMMUNITY LEADERS. WHILE THE MOLDOVAN PRESS IS EXPERIENCING SEVERE ECONOMIC PROBLEMS, THE RUSSIAN-LANGUAGE COMMUNIST MEDIA SHOW VIGOR IN THE DNIE
REPUBLIC AND OTHER AREAS OF NONINDIGENOUS SETTLEMENT.

08636 SOCOR, $V$

MOLDOVA

REPORT ON THE USSR, 1(7) (FEB 92), 11-13

MOLDOVA'S DECISION TO JOIN THE CIS IS PARTLY

CONSEOUENCE OF THE REBUBLIC'S NEED TO TRADE ITS AGRICULTURAL PRODUCTS FOR FUEL AND RAW MATERIALS FROM RUSSIA AND OTHER FORMER SOVIET REBUBLICS. IT IS ALSO MOTIVATED BY THE DESIRE TO SAFEGUARD ITSELF AGAINST MILITARY PRESSURE HHILE USING THE FRAMEWORK OF THE CIS TO CREATE ITS OHN ARMY UTILIZING SOME OF THE CIS FORCES STATIONED IN MOLDOVA AS A BASE. CHISINAU'S PARTICIPATION IN CIS STRUCTURES AND ACCORDS HAS BEEN FAIRLY SELECTIVE SO FAR, USING THE "INTERESTED PARTY" ESCAPE CLAUSE IN A NUMBER OF INSTANCES. THE MOLDOVAN PARLIAMENT IS EXPECTED TO RATIFY THE CIS ACCORDS WITH CONDITIONS AND RESERVATIONS.

08637 SOCOR, $Y$

MOLDOVA'S NEH GOVERHMENT OF NATIOHAL CONSENSUS

RFE/RL RESEARCH REPORT, 1(47) (NOV 92) 5-10.

THE NEW MOLDOVAN GOVERMMENT HEADED BY ANDREI SANGHELI IS BASED ON THE CONCEPT OF A "NATIONAL CONSENSUS" CUTTING ACROSS ETHNIC AND PARTY LINES AND SEEKING TO ENSURE THE LONGTERM STABILITY OF THE STATE. THE LINCHPIN OF THE PROPOSED CONSENSUS IS THE CONSOL IDATION OF THE INDEPENDENT MOLDOVAM STATE AND ITS TERRITORIAL INTEGRITY--A PROPOSITION THAT APPEALS TO A GREAT MAJORITY OF THE POPULATION BECAUSE IT
WOULD RULE OUT BOTH UNIFICATION WITH ROMANIA AND ABSORPTION WOULD RULE OUT BOTH UNIFICATION WITH ROMANIA AND ABSORPTID RUSSIA. OTHER ELEMENTS OF THE CONSENSUS INCLUDE RECOGNITION OF BOTH THE NATIONAL CHARACTER OF THE MOLDOVAN STATE AND THE RIGHTS OF ETHNIC COMMUNITIES, INCLUDING FORMS OF
ADMINISTRATIVE AUTONOMY FOR THEM AND AGREEMENT ON ECONOMIC REFORMS CENTERED ON A PROGRAM OF PRIVATIZATION. THE GOYERMMENT'S POL ITICAL AND ETHNIC COMPOSITION REFLECTS THE BROADLY-BASED PRO-CONSENSUS MAJORITY THAT HAS TAKEN SHAPE IM THE PARL IAMENT AND IN SOCIETY AT LARGE. THE SLAVIC POPULATION ON THE RIGHT BANK OF THE DNIESTER APPEARS LOYAL TO MOLDOVA AND ITS POLITICAL REPRESENTATIVES LARGELY ADHER TO THE CONCEPT OF NATIONAL CONSENSUS; BUT POLITICAL AND INTER-ETHNIC STABILITY REMAINS UNDER THREAT FROM THE RUSSIAN INSURGENCY ON THE LEFT BANK.

08638 SOCOR, $V$.

OPINION POLLING IN MOLDOYA

RFE/RL RESEARCH REPORT, 1(13) (MAR 92), 60-63.

PUBLIC OPINION RESEARCH WAS INTRODUCED IN MOLDOVA IN 1991 AND IS BEING CONDUCTED BY THE NATIONAL INSTITUTE OF SOCIOLOGY (INSOC), WHICH IS DIRECTED BY A SMALL TEAM OF ROMANIAN SOCIOLOGISTS IN CHISINAU AND ASSISTED BY LOCAL NETWORKS IN THE FIELD. THIS ARTICLE SUMMARIZES THE INSOC'S WORKING METHODS AND REPORTS THE RESULTS OF POLLS ON THE POL I I PAL PRERENCES OF THE MOLDOYAN POPULATIS ON THE

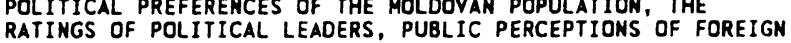
RATINGS OF POLITICAL LEADERS, PUBLIC PERCEPTIONS OF
COUNTRIES, AND ATTITUDES TOHARD INDEPENDENT MOLDOVAN COUNTRIES,
STATEHOOD.

08639 SOCOR, $V$.

RUSSIA'S FOURTEENTH ARMY AND THE INSURGENCY IN EASTERN MOI DOVA

RFE/RL RESEARCH REPORT, 1(36) (SEP 92), 41-48,

IN EASTERN MOLDOVA, RUSSIA'S 14TH ARMY HAS ENSURED THE RUSSIAN INSURGENTS' SUPERIORITY IN FIREPOWER AND LOGISTICS OVER THE NASCENT MOLDOVAN FORCES. ELEMENTS OF THE RUSSIAN ARMY HAVE ALSO JOINED THE INSURGENTS IN SUCCESSFUL OFFENSIVE OPERATIONS, GAINING TERRITORIES ON BOTH BANKS OF THE DNIESTER. RUSSIAN MILITARY AND POLITICAL LEADERS HAVE ADMITTED THAT THE ARMY HAS BEEN INVOL VED IN THE CONFLICT WHILE SEEKING TO JUSTIFY THAT INVOLVEMENT AND TO OBSCURE THE ISSUE OF POLITICAL RESPONSIBILITY FOR IT. THE QUESTION OF PRECISELY WHO HAS AUTHORIZED THE ARMY'S ACTIONS HAS PREOCCUPIED MANY OBSERVERS BUT IS ACADEMIC IN VIEW OF MOSCOW'S ASSENT TO THEM. MOSCOW IS CURRENTLY OFFERING TO SETTLE THE CONFLICT ON TERMS DESIGNED TO MAXIMIZE ITS POLITICAL AND MILITARY INFLUENCE IN MOLDOVA AND THE ADJACENT STRATEGIC REGION NONCONTIGUOUS TO RUSSIA.

08640 SOCOR, $V$.

RUSSIAN FORCES IN MOLDOVA

RFE/RL RESEARCH REPORT, 1 (34) (AUG 92), 38-43.

IN MOLDOVA, MOST OF' THE FORMER SOVIET TROOPS, WHICH WERE UNILATERALLY APPROPRIATED BY RUSSIA, ARE STATIONED ON THE LEFT BANK OF THE DNIESTER. THE BACKBONE OF THESE FORCES IS THE 14TH ARMY, MOSTLY RUSSIANS FROM THE RUSSIAN FEDERATION, THE 14TH ARMY, MOSTLY RUSSIANS FROM THE RUSSIAN FEDERATION,
SUPPLEMENTED BY THOUSANDS OF RESIDENT RUSSIAN RESERVISTS. SUPPLEMENTED BY THOUSANDS OF RESIDENT RUSSIAN RESERVISTS. THE RUSSIAN MILITARY PRESENCE HAS HAD A STRONG IMPACT ON
LEFT BANK'S SOCIAL STRUCTURE AND POLITICS. THE ARMY IS LEFT BANK'S SOCIAL STRUCTURE AND POLITICS. THE ARMY IS
TRYING TO RECRUIT SOLDIERS, AND IT HAS BEEN LENDING BOTH MEN TRYING TO RECRUIT SOLDIERS, AND IT HAS BEEN LENDING BOTH MEN
AND WEAPONS TO THE RUSSIAN INSURGENTS IN EASTERN MOLDOVA, AND WEAPONS TO THE RUSSIAN INSURGENTS IN EASTERN MOLDOVA, WHO ARE FIGHTING TO SECEDE. THE RUSSIAN MILITARY LEADERSHIP PORTRAYS ITS TROOPS AS LOCAL FORCES, IN ORDER TO COUNTER CALLS FOR THEIR HITHDRAWAL, AND IS ENCOURAGING THE FORMATIOH OF A DNIESTER REPUBLIC, WHICH
OUTPOST FOR THE RUSSIAN ARMY.

08641 SOCOR, $V$.

WHY MOLDOVA DOES NOT SEEK REUNIFICATION WITH ROMANIA RFE/RL RESEARCH REPORT, 1(5) (JAN 92), 27-33.

AT PRESENT MOLDOVANS OVERHMELMINGLY FAVOR INDEPENDENT STATEHOOD AS OPPOSED TO REUNIFICATION WITH ROMANIA. REASONS INCLUDE THE AMBIGUOUS LEGACY OF ROMANIAN RULE IN BESSARABIA, ECONOMIC DISINCENTIVES, A DESIRE TO SEE THE REPUBLIC GOVERNED BY MATIVE PERSONMEL, THE RESIDUAL APPEAL OF THE IDEA OF RECONSTITUTING "GREATER MOLDOVA," THE SETBACKS TO DEMOCRACY IN ROMANIA, AND CONCERN THAT REUNIFICATION WOULD LEAD TO "ROMANOPHOBIA," OR VIOLENCE AND SECESSION MOVEMENTS AMONG NONINDIGENOUS MINORITIES IN PARTS OF MOLDOVA. THE OPPOSITION MOLDOVAN POPULAR FRONT IS PRESSING FOR EARLY REUNIFICATION AND HAS LOST MUCH OF ITS POPULARITY AS A RESULT, HHILE PRESIDENT MIRCEA SNEGUR IS SEEKING A MEH POLITICAL CONSENSUS THAT WOULD ENCOMPASS NONINDIGENOUS GROUPS THAT SUPPORT MOLDOVA'S INDEPENDENCE. MOLDOVA BASES ITS RELATIONS WITH ROMANIA ON THE CONCEPT OF "TWO ROMANIAN INDEPENDENT STATES COOPERATING WITH EACH OTHER."

08642 SOLCHAMYK, R.

KRACHUV DEFINES UKRAINIAN-CIS RELATIONS

KRACHUV DEFINES UKRAINIAN-CIS RELATIONS
RFE/RL RESEARCH REPORT, 1(11) (MAR 92), 6-9

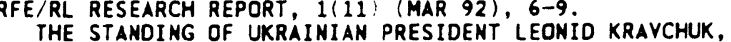
BOTH IN THE COMMONWEALTH OF INDEPENDENT STATES AND IN THE WEST, APPEARS TO BE GROWING AT THE EXPENSE OF HIS RUSSIAN COUNTERPART, BORIS YELTSIN. THE DISPUTES BETWEEN UKRAINE AND RUSSIA OVER POLITICAL, ECONOMIC, AND MILITARY ISSUES STEM FROM UKRAINE'S INSISTENCE THAT ITS INDEPENDENCE BE TAKEN SERIOUSLY BY RUSSIA AND THAT RUSSIA RECOGNIZE THAT IT CANNOT
COMPLETELY DOMINATE THE COMHONHEALTH. HOW THESE FUNDAMENTAL 
ISSUES ARE RESOLVED WILL DETERMINE TO A LARGE EXTENT HHETHER OR NOT THE COMMONWEALTH WILL SURVIVE.

08643 SOLCHANYK, R.

THE CRIMEAN IMBROGLIO: KIEV AND MOSCOH

RFE/RL RESEARCH REPORT, 1(40) (OCT 92), 6-10.

THE CRIMEAN QUESTION HAS PROVED TO BE A FORMIDABLE BARRIER TO THE ESTABLISHMENT OF NORMAL RELATIONS BETWEEN BARRIER TO THE ESTABLISHMENT OF NORMAL RELATONS DISPUTE OVER THE BLACK SEA FLEET, HAVE COMPLICATED THE ISSUE. RUSSIAN PRESIDENT BORIS YELTSIN AND HIS FOREIGN MINISTER HAVE SOUGHT TO DOWMPLAY THE PROBLEM, WITH LITTLE SUCCESS. HAVE SUSGHT TO DOWMPLAY THE PROBLEM, WITH LIA "ANNULLE" THE 195 THE RUSSIAN PARLIAMENT HAS OFFICIALL "ARAINE. THE KEY QUESTION NOW IS THE IMPACT OF AN IMPENDING CONFRONTATION, EXPECTED DURING THE FALL 1992 SESSION OF THE RUSSIAN PARLIAMENT, BETHEEN YELTSIN AND THE OPPOSITION ON RELATIONS BETWEEN KIÉV AND MOSCOW.

08644 SOLCHANYK, R.

THE CRIMEAN IMBROGLIO: KIEV AND SIMFEROPOL

RFE/RL RESEARCH REPORT, 1(33) (AUG 92) 13-16.

THE SEPARATIST MOVEMENT IN THE CRIMEA HAS BEEN ONE OF THE MOST VEXING POLITICAL ISSUES IN UKRAINE SINCE THE REPUBLIC DECLARED INDEPENDENCE. IN MAY 1992 THE CRIMEA PROCLAIMED ITS INDEPENDENCE TO PROTEST AN AUTONOMY LAW THAT WAS DEEMED UNSATISFACTORY IN SIMFEROPOL, BUT IT LATER BACKED AHAY FROM A HEAD-ON CONFRONTATION WITH KIEY AFTER A LENGTHY PROCESS OF NEGOTIATION THAT PRODUCED A NEW POHER-SHARING AGREEMENT BETWEEN THE TWO SIDES, THE CRIMEAN OUESTION RECEDED INTO THE BACKGROUND, BUT THE POTENTIAL FOR CONFLICT REMAINS.

08645 SOLCHANYK, R.

UKRAINE
RFE/RL RESEARCH REPORT, 1(7) (FEB 92), 1-5.

ALMOST AS SOON AS THE COMMONHEALTH OF INDEPENDENT STATES WAS CREATED IN DECEMBER 1991, OBSERVERS IN BOTH THE FORMER SOYIET UNION AND IN THE WEST EXPRESSED SERIOUS RESERVATIONS ABOUT ITS VIABILITY: NOT ONLY BECAUSE THE NEW BODY LACKED ABOUT ITS VIABILITY: NOT ONLY BECAUSE THE NEW BODY LACK STRUCTURES TO IMPLEMENT THE STATED INTENTIONS OF ITS FOUNDERS BUT ALSO BECAUSE IT SOON BECAME APPARENT THAT THE THO MAJOR PLAYERS, RUSSIA AND UKRAINE, ENTERTAINED SOMEWHAT DIFFERENT IDEAS ABOUT WHAT THE COMMONWEALTH SHOULD BE. THIS STEMMED LARGELY FROM THE HISTORICAL LEGACY OF THE RUSSIAMUKRAINIAN RELATIONSHIP, WHICH MILITATED AGA

08646 SOLCHANYK, $R$.

UKRAINE AND RUSSIA: THE POLITICS OF INDEPENDENCE

RFE/RL RESEARCH REPORT, 1(19) (MAY 92), 13-16.

WHILE UKRAINIAN INDEPENDENCE HAS ELIMINATED ONE SET OF

PROBLEMS ASSOCIATED WITH THE HEAVY HAND OF THE SOVIET

CENTRAL GOVERNMENT, IT HAS BROUGHT INTO FOCUS UKRAINE'S DIFFICULT RELATIONS WITH ANOTHER NEWLY-INDEPENDENT STATE, RUSSIA. THE POINT OF DEPARTURE FOR THE NORMALIZATION OF UKRAINIAN-RUSSIAN RELATIONS IS MOSCOW'S RECOGNITION OF UKRAINE AS A GENUI NELY INDEPENDENT STATE. RECENT DEVELOPMENTS SURRDUNDING THE CRIMEAN QUESTION AND THE DIVISION OF THE BLACK SEAT FLEET SUGGEST THAT THIS RECOGNITION ISSUE HAS YET TO BE FULLY RESOLVED. MEANHHILE, UKRAINE'S PERCEPTION OF RUSSIA AS A THREAT TO ITS SECURITY APPEARS TO BE COMING MORE CLEARLY INTO FOCUS AMD MAY HAVE BEARING ON IIS POLICY ON NUCLEAR ARMS.

08647 SOLCHANYK, R.

UKRAINE, THE (FORMER) CENTER, RUSSIA, AND "RUSSIA" STUDIES IN COMPARATIVE COMHUNISM, 25(1) (MAR 92), 31-46.

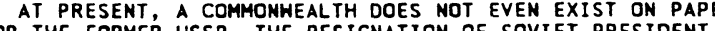
FOR THE FORMER USSR. THE RESIGNATION OF SOVIET PRESIDENT MIKHAIL GORBACHEY IN NO WAY SIGNIFIES THE DESTRUCTION OF THE CENTER, BUT THE TRANSFER OF THE IDEA OF CENTRAL POHER INTO OTHER HEADS. THE KEY ISSUE IS THE UKRAINIAN-RUSSIAM RELATIONSHIP, HHICH MEAHS THAT RUSSIA HAS YET TO COME TO TERMS WITH THE LOSS OF EMPIRE AND THAT UKRAINE CONTINUES TO PLAY A PRE-EMINENT ROLE IN THE SEARCH FOR RUSSIA'S IDENTITY. THIS ARTICLE EXPLORES THE UKRAINIAN-RUSSIAN NEXUS, PROBLEMS OF IDENTITY, AND HOH TO FORGE A MEH UKRAINIAN-RUSSIAN RELATIONSHIP.

08648 SOLCHANYK, $R$.

UKRAINE: FROM SOVEREIGNTY TO INDEPENDENCE

RFE/RL RESEARCH REPORT $1(1)$ (JAN 92) 35-38

THE IMMEDIATE CAUSE OF THE IRRETRIEYABLE COLLAPSE OF THE SOVIET UNION WAS THE REFERENDUM ON INDEPENDENCE HELD IN URRAINE ON DECEMBER 1, 1991 , WHICH YIELDED AN ASTOUNDING 90. $32 \%$ IN FAVOR OF THE REPUBLIC'S DECLARATION OF INDEPENDENCE. THE STRONGEST OPPOSITION TO UKRAINIAN INDEPENDENCE CAME FROM THE CENTRAL GOVERNMENT IN MOSCON AND ITS ALLIES IN URRAINE.

08649 SOLCHANYK, R.

UKRAINE: THE POLITICS OF ECONOMIC REFORM

RFE/RL RESEARCH REPORT 1(46) (NOY 91) 1-5.

ON SEPTEMBER 30,1992 , UKRAINIAN PRESIDENT LEONID
KRAVCHUK ANNOUNCED THE RETIREMENT OF VITOLO FOKIN, WHO HAD HEADED THE GOVERMMENT FOR THO YEARS. THE CAMPAIGN AGAINST FOKIN, WHICH WAS SPEARHEADED BY RUKH LEADER VYACHESLAY CHORNOYIL, HAD BEEN UNDERWAY SINCE THE BEGINNING OF THE YEAR. IT GAINED MOMENTUM IN THE SUMMER, WHEN PARLIAMENT PLACED THE QUESTION OF CONFIDENCE ON ITS AGENDA. AT THE SAME TIME, THE OPPOSITION JOINED FORCES TO TRY TO BRING DOWN FOKIN'S GOVERMMENT AND INITIATED AN ORGANIZED CAMPAIGN TO DISSOLVE THE PARL IAMENT. THE NEW CABINET OF MINISTERS IS HEADED BY
LEONID KUCHMA, A REPRESENTATIVE OF THE INDUSTRIALISTS' LOBBY, LEONID KUCHMA, A REPRESENTATIVE OF THE INDUSTRIALISTS' LOBBY
AND IS EXPECTED TO PROCEED WITH ECONOMIC REFORMS WITHOUT AND IS EXPECTED TO PROCEED W
RESORTING TO "SHOCK THERAPY."

08650 SOLCHANYK, $R$.

UKRAINIAN-RUSSIAN CONFRONTATION OVER THE CRIMEA RFE/RL RESEARCH REPORT, 1(8) (FEB 92), 26-30

THE QUESTION OF THE CRIMEA'S STATUS AS PART OF UKRAINE HAS BEEN RAISED BY THE RUSSIAN PARLIAMENT AND LINKED TO THE NO LESS CONTROVERSIAL PROBLEM OF WHO SHOULD INHERIT THE BLACK SEA FLEET. BOTH ISSUES SYMBOLIZE THE MUCH MORE FUNDAMENTAL AND DIFFICULT PROBLEM OF "READJUSTING" THE HISTORICAL RELATIONSHIP BETWEEN UKRAINE AND RUSSIA IN THE AFTERMATH OF THE COLLAPSE OF THE SOVIET SYSTEM. AT PRESENT, THE THO SIDES FIND THEMSELVES IN A DEADLOCK. IN THE MIDOLE OF THIS SEEMINGLY INTRACTABLE SITUATION ARE THE CRIMEANS, WHO OVERHHELMINGLY FAVOR SELF-DETERMINATION BUT ARE HAVING OIFFICULTY DEFINING THE PRECISE FORM IT SHOULD TAKE.

08651 SOLCHANYK, R.

UKRAINIAN-RUSSIAN SUMMIT AT DAGOMYS

RFE/RL RESEARCH REPORT, 1 ( 30 ) (JUL 92), 36-39.

IN JUNE 1992, THE TOP LEADERSHIP OF UKRAINE AND RUSSIA HAMMERED OUT AN AGREEMENT FOCUSING ON ECONOMIC ISSUES AND CALLING FOR THE CONCLUSION OF A NEW TREATY BETHEEN THE TWO STATES. THE CRIMEAN QUESTION WAS DELIBERATELY LEFT OFF THE AGENDA, THEREBY UNDERLINING RUSSIA'S WILLINGNESS TO CONCEDE THAT THIS IS AN INTERNAL UKRAINIAN MATTER. THE FACT THAT THE AGREEMENT COMES AT A TIME WHEN BOTH LEONID KRAVCHUK AND BORIS YELTSIN ARE FACED WITH GROWING POLITICAL OPPOSITION SUGGESTS THAT THE THO LEADERS HAVE COME TO REALIZE THAT
THEIR INTERESTS ARE BETTER SERVED BY CONSENSUS THAN CONFLICT.

08652 SOLIGAN, J

U.S. FORCES IN EUROPE: WHERE DO WE GO FROM HERE? COMPARATIVE STRATEGY, 11 (4) (DEC 92), 475-501.

THIS ARTICLE LOOKS AT ENDURING U.S. INTERESTS IN EUROPE, EMERGING CHALLENGES, STRATEGIC CHOICES, AND CRITERIA THE UNITED STATES SHOULD USE IF THE SECURITY ENVIRONMENT ALLOWS, OR REQUIRES, U.S. FORHARD-BASING IN EUROPE TO DROP BELOW THE ADMINISTRATION'S PROPOSED LEVEL OF 150,000. THE RECOMMENDATIONS ARE A BREAK FROM THE PAST. HOW SUCCESSFUL THE UNITED STATES IS IN ACHIEVING ITS GOALS WILL DEPEND LARGELY ON HOW WELL THE UNITED STATES MEETS ITS OWN DOMESTIC AND FOREIGN POLICY NEEDS, AND BY HOW WELL OTHER NATIONS PERCEIVE THE UNITED STATES HILL MEET THEIR FUTURE EXPECTATIONS AND REQUIREMENTS.

08653 SOLLARS, D.L.

ASSUMPTIONS AND CONSEQUENCES OF THE WAR ON DRUGS

POLICY STUDIES REVIEW, 11(1) (SPR 92), 26-39.

WHILE MOST POLITICIANS, POLICY MAKERS, AND POLICE AGENCIES CONTEND THAT LIMITING THE AVAILABILITY OF ILLICIT DRUGS WILL REDUCE DRUG USE AND LOWER THE RATES OF PROPERTY AND VIOLENT CRIME, THERE IS LITTLE THEORETICAL OR EMPIRICAL EVIDENCE TO SUPPORT THESE CLAIMS. IN FACT, IT IS POSSIBLE THAT PROPERTY AND VIOLENT CRIME COULD INCREASE AS MORE POLICE RESOURCES ARE ALLOCATED TO LIMITING DRUG TRADE. IN THIS PAPER, THE AUTHOR EVALUATES THE ASSUMPTIONS AND RESULTS OF THE WAR ON DRUGS, USING EVIDENCE FROM THE STATE OF
FLORIDA. THIS EVIDENCE SUGGESTS THAT THE STATED GOALS OF THE FLORIDA. THIS EVIDENCE SUGGESTS THAT THE STATED GOALS DRUG POLICY ARE NOT BEING MET AND THAT THERE ARE MANY UNINTENDED CONSEQUENCES. THE PAPER HAS THREE COMPONENTS: THE FIRST SURVEYS THE EFFECTS OF INCREASED EMPHASIS ON DRUG LAW ENFORCEMENT IN FLORIDA; THE SECOND CRITICALLY EVALUATES
MAJOR POL ICY ASSUMPTIONS: THE THIRD OFFERS ALTERNATIVE

MAJOR POL ICY ASSUMPTIONS; THE THIRD OFFERS ALTERNATI
STRATEGIES TO THE FLORIDA APPROACH TO DRUG POLICY.

08654 SOMERVILLE, $K$.

MALAWI STIRS

NORLD TODAY, 48(8-9) (AUG 92), 139-140.

MALAHI'S ROMAN CATHOLIC BISHOPS HAVE ISSUED A PASTORAL LETTER DENOUNCING THE POLICIES OF PRESIDENT NGWAZI DR. H. KAMUZU BANDA AND CALLING FOR GREATER POL ITICAL FREEDOM, RESPECT FOR HUMAN RIGHTS, AND SOCIAL AND ECONOMIC JUSTICE. UHACCUSTOHED TO POL ITICAL PAO SOCIAL AND ECONOMIC JUSTY CONTROLLED SYSTEM, SOME MALAKIANS HAVE REACTED WITH SHOCK TO THE SUDDEN OUTPOURING OF CRITICISM WHILE OTHERS HAVE BEEN GALVANIZED INTO ACTION.

08655 SOMERVILLE, $K$

ZAMBIA--ELECTION FEVER

NEW AFRICAN, (287) (AUG 91), 17.

DESPITE ZAMBIA'S KENMETH KAUMDA'S FAILURE TO SET THE

ELECTION DATE, BY THE END OF JUNE. THE COMPETITION BETWEEN 
THE PARTIES WAS BECOMING INCREASINGLY INTENSE AND HEATED. THE OPPOSITIOM MOVEMENT FOR MULTI-PARTY DEMOCRACY (MMD), WHICH HAS ALREADY ACCUSED THE RUL ING UNIP AND THE GOVERNMENT OF MANIPULATING THE PRESS TO ATTACK THE OPPOSITION, SAID THAT KAUNDA'S PARTY WAS CONTINUING TO USE GOVERMMENT FUNDS, VEHICLES AND RESOURCES TO RUN THE PARTY CAMPAIGN, AND, MORE OMINOUSLY, HAS SET UP A HIT SQUAD TO ELIMINATE OR MMD LEADERS. DESPITE THIS REPRESSION, MMD LEADERS
CONFIDENTLY SPEAK OF VICTORY AND OF COMPLETELY OVERHAULING THE NATION'S CONSTITUTION.

08656 SOMMA, M.

THE GENDER GAP AND ATTITUDES TOWARD ECONOMIC DEVELOPMENT STRATEGIES AMONG MIDWESTERN ADULTS

WOMEN AND POLITICS, 12 (2) (1992) 41-57.

DATA AND ANALYSIS ARE PRESENTÉD TO TEST THE ARGUMENT THAT POVERTY AND SOCIAL POSITION ACCOUNT FOR AN IMPORTANT DIFFERENCE BETHEEN THE POLITICAL ATTITUDES OF MEN AND WOMEN. THE OPENING OF THE GENDER GAP IN POLITICS COINCIDED HITH THE OPE OPENING OF THE GENDER GAP IN POLITICS COINCIDED WITH THE OPENIMG OF THE POVERTY GAP, AND GENDER POLINICS ARE AS MUCH ONE HYPOTHESIS IS THAT INCDME, GENDER, AND AGE COMBINE TO EXPLAIN VOTING IN THE 1988 PRESIDENTIAL ELECTION WHERE AGE EXPLAIN VOTING IN THE 1988 PRESIDENTIAL ELECTION WHERE ACE IS USED IN COMBINATION WITH INCOME AND GENDER TO REFLECT SOCIAL POST TION. A SECOND HYPOTHESES TESTS ATTITUDES ON ISSUES NOT APPARENTLY REFLECTING GENDER ASSOCIATION TO SEE WHETHER GENDER DIVISIONS EXIST. ATTITUDES TOWARD GOVERNMENT-
SUBSIDIZED ECONOMIC DEVELOPMENT STRATEGIES ARE USED AS THE SUBSIDIZED ECONOMIC DEVELOPMENT STRATEGI

08657 SOMMER, T.

A HORLD FREE OF NUCLEAR WEAPONS REMAINS DREAM GERMAN TRIBUNE, (1503) (FEB 92), 2

THE COLD WAR HAS BEEN OFFICIALLY CALLED OFF, COMMUNISH HAS COLLAPSED AND OLD FEARS OF THREAT IN EAST AND WEST HAVE DECLINED. DISARMAMENT HAS SUDDEMLY RETURNED TO THE FOREFRONT AND HAS BEEN ACCEPTED NOT ONLY AS POSSIBLE, BUT NECESSARY. MANY ARE HEARTENED BY THE UNILATERAL PROPOSALS FOR DISARMAMENT BY THE UNITED STATES AND THE SOVIET UNION AMD ITS SUCCESSOR, THE COMMONWEALTH OF INDEPENDENT STATES (CIS). HOWEVER, AS OF YET, NEITHER THE STRATEGIC ARMS REDUCTION TREATY (START) NOR THE CONVENTIONAL FORCE REDUCTION (CSE) TREATY HAVE BEEN RATIFIED. PROBLEMS OF IMPLEMENTATION, VERIFICATION, AND, MOST IMPORTANTLY (FOR RUSSIA), FINANCING THE DESTRUCTION OF WEAPONS STILL LOOM OVER THE DISARMAMENT PROCESS

08658 SOMMER, T.

LONG-TERH UN PRESENCE NEEDED IN THE HORN OF AFRICA LONG-TERH UN PRESENCE NEEDED IN THE HOR

THE UNITED STATES HAS DECIDED TO INTERVENE IN SOMALIA. WHERE THE AMERICANS HOLD BACK OR TURN AWAY, LITTLE OR MOTHING HAPPENS. THIS ARTICLE EXPLORES THE NEED FOR INTERVENTION IN BOSHIA. AMERICA SAYS THAT BOSNIA IS NOT "DOABLE" BUT THIS ARTICLE SUGGESTS THERE THERE EXISTS A WIDE RANGE OF MEASURES WHICH FALL BELOW MASSIVE INTERVENTION TO
TOPPLE SERBIA. THEY INCLUDE A TOTAL BLOCADE ENFORCEMENT; IF TOPPLE SERBIA. THEY INCLUDE A TOTAL BLOCADE ENFORCEMENT
NECESSARY, AIR RAIDS ON ART ILLERY POSITIONS, MILITARY NECESSARY, AIR RAIDS ON ARTILLERY POSITIONS, MILITARY AIRFIELDS, ARMAMENTS FACTORIES AND SUPPLY ROUTES; AND PRECAUTIONARY STATIONING OF PEACE TROOPS IN KOSOVO AND
MACEDONIA. THE AUTHOR WONDERS HOW LONG THE WESTERN WORLD WILL CONTINUE TO STAND IDLY BY.

08659 SOMMER, $T$.

THE PROCESS OF UNIFICATION MUST GO ON IN SPITE OF ALL THE DOUBTS

GERMAN TRIBUNE, 31(1534) (OCT 92), 2.

THE PROCESS OF EUROPEAN UNIFICATION MUST CONTINUE. DESPITE ALL THE UNCERTAINTIES, THERE ARE THREE MAIN REASONS IN ITS FAVOR: (1) THERE IS A CONSIDERABLE SEDIMENT OF NATIONALISM THROUGHOUT EUROPE: (2) A WESTERN EUROPEAN RELAPSE INTO THE NATION-STATE ISOLATIONISM WOULD BE A BAD OMEN FOR THE COUNTRIES OF CENTRAL AND EASTERN EUROPE: AND, (3) EUROPE'S ONLY CHANCE OF ASSERTING ITSELF IN THE DAHN UNION.

08660 SONDROL $P$

THE EMERGING NEW POLITICS OF LIBERALIZING PARAGUAY: SUSTAINED CIVIL-MILITARY CONTROL HITHOUT DEMOCRACY JOURNAL OF INTERAMERICAN STUDIES AND HORLD AFFAIRS, 34(2)

(SUM 92 ) 127-164.

PARAGUAY IS NOW EMERGIMG FROM ONE OF LATIN AMERICA'S MOST LONG-STANDING AUTHORITARIAN REGIMES. THIS ARTICLE LOOKS MOST LONG-STANDING AUTHORITARIAN REGIMES. THIS ARTICLE PRAETORIAN TRADITION HHICH HAS CHARACTERIZED PARAGUAY'S MORE RECENT HISTORY AND RULE BY STROESSNER. IT THEN DISCUSSES SOME OF THE FACTORS HHICH LED UP TO THE BREAKDOWN OF THIS SOME OF THE FACTORS WHICH LED UP TO THE BREAKDOWN OF THIS AUTHORITARIAN RLLE, CONDITIONING THE CURRENT TRANSITION PROCESS AND DIMMING PROSPECTS FOR THE EMERGENCE OF A TRULY IT MAY BE NECESSARY TO RETHINK CONVENTIONAL

AUTHORITARIAN/DEMOCRATIC DICHOTOMIES AND THAT ANY PARAGUAYAM DEMOCRACY LIKELY TO EMERGE FROM THIS PROCESS HILL PROBABLY
NOT CORRESPOND TO AMY US-TYPE, OR MORE COMMONLY ACCEPTED DEFINITION.

08661 SONDROL, P

THE PARAGuayan MILITARY IN TRANSITION AND THE EVOLUTION OF CIVIL-MILITARY RELATIONS

ARMED FORCES AND SOCIETY, 19(1) (FAL 92), 105-122.

THIS ARTICLE CHRONICLES THE PRAETORIAN TRADITION IN

PARAGUAY AND DOCUMENTS THE RECENT HISTORICAL RECORD

AFFECTING CIVIL-MILITARY TRENDS. IT THEN SHIFTS TO ANALYZE THE EVOLVING SCENARIO WITHIN PARAGUAY AND MAPS SEVERAL ALTERNATIVE TRANSITIONS EMERGING FROM THE CHARACTERISTICS OF THE STILL-UNFOLDING CIVIL-MILITARY RELATIONSHIP. THE DISCUSSION CONCLUDES WITH AN EXAMINATION OF THE MILTARY'S SIGNIFICANCE FOR POLITICAL STABILTIY AND THE PROSPECTS FOR DEMOCRACY IN PARAGUAY.

08662 SONG, Y.

MORTH KOREA'S NUCLEAR ISSUE

JOURNAL OF NORTHEAST ASIAN STUDIES, X(3) (FAL 91), 61-81. GIVEN THE UNPREDICTABLILITY OF NORTH KOREA'S LEADERSHIP, AND ITS CAPABILITY TO DEVELOP NUCLEAR WEAPONS, THE NORTH ADREAN NUCLEAR ISSUE HAS BECOME ONE OF THE MOST IMPORTANT KOREAN NUCLEAR ISSUE HAS BECOME ONE OF THE MOST IMPORTANT FOR THE UNITED STATES, JAPAN AND SOUTH KOREA. THIS ARTICLE GIVES SOME BACKGROUND IN NORTH KOREA S NUCLEAR HISTORY AND ON THE COUNTRY TO COMPLETELY RELINOUISH ITS NUCLEAR WEAPONS DEVELOPMENT.

08663 SONG, Y.S.

U.N. PEACE KEEPING OPERATIONS (PKO'S): THEIR PERSONALITIES AND PROSPECTS

KOREA \& WORLD AFFAIRS, 16(3) (FAL 92), 525-541. THIS PAPER REVIEWS THE HISTORY OF PEACEKEEPING OPERATIONS (PKO) AND BRIEFLY DETAILS THE ROLE OF PKO'S IN CAMBODIA THROUGH THE UNITED NATIONS TRANSITIONAL AUTHORITY IN CAMBODIA. IT ALSO ANALYZES JAPAN'S ATTITUDES AND ITS INTENTIONS TO EXPAND ITS INTERNATIONAL INFLUENCE BY PARTICIPATING IN PKO'S. FINALLY, SOUTH KOREA'S APPROACH TO PKO'S IS EXAMINED.

08664 SONGER, D.; HAIRE, S.

INTEGRATIMG ALTERNATIVE APPROACHES TO THE STUDY OF JUDICIAL VOTING: OBSCENITY CASES IN THE U.S. COURTS OF APPEALS

AMERICAN JOURNAL OF POLITICAL SCIENCE, 36(4) (NOV 92), 963-982.

THIS ANALYSIS BUILDS UPON PREVIOUS STUDIES THAT HAVE EXAMINED SEPARATELY THE EFFECTS OF POLITICAL ATTITUDES, CASE CHARACTERISTICS, NATURE OF THE PARTIES, CHANGING SUPREME COURT PRECEDENTS, AND DEFENSES RAISED BY LITIGANTS. TO

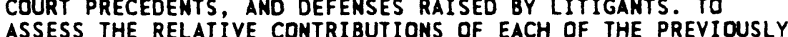
USED APPROACHES, AN INTEGRATED MULTIVARIATE MODEL WAS USED APPROACHES, AN INTEGRATED MULTIVARIATE MODEL WAS

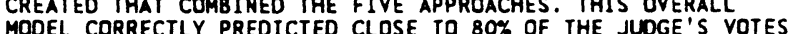
WITH A REDUCTION IN ERROR OF $46 \%$

08665 SONGER, D.; SHEEHAN, $R$.

WHO WINS ON APPEAL? UNDERDOGS AND UNDERDOGS IN THE UNITED STATES COURTS OF APPEAL

AMERICAN JOURNAL OF POLITICAL SCIENCE, 36(16) (FEB 92), 235-258.

THE CENTRAL FOCUS OF THIS INVESTIGATION IS THE EFFECT OF LITIGATION RESOURCES ON THE SUCCESS OF APPELLANTS APPEARING BEFORE THE UNITED STATES COURTS OF APPEALS. THE FINDINGS ARE THAT LITIGATION RESOURCES ARE MUCH MORE STRONGLY RELATED TO APPELLANT SUCCESS IN THE COURTS OF APPEALS THAN IN EITHER THE UNITED STATES OR STATE SUPREME COURTS. UPPERDOG LITIGANTS WIN MUCH MORE FREQUENTLY IN THE COURTS OF APPEALS IN BOTH PUBLISHED AND UNPUBLISHED DECISIONS OF THE COURTS OF APPEALS EVEN AFTER CONTROLS ARE INTRODUCED FOR PARTISAN AND REGIONAL EFFECTS AND THE DIFFERENCES AMONG TYPES OF CASES.

08666 SONGMIN, Z.; JIANG, L.

AFRICA CHALLENGED BY POLITICAL PLURALISM

BEIJING REVIEH, 35(30) (JUL 91), 13-16.

AFRICANS ARE BETTING ON POLITICAL PLURALISM TO CHANGE THE COURSE OF THEIR FUTURE. OVER THE PAST THREE YEARS, IN A TUMULTUOUS SEA CHANGE OF POLITICAL SYSTEMS, COUNTRY AFTER COUNTRY HAS BEGUN THE TRANSITION FROM ONE-PARTY OR MILITARY RULE TO MULTI-PARTY POLITICS.

08667 SONKO, K.N.M.

TIP OF AN ICEBERG?

WEST AFRICA (3899) (JUN 92), 960

THE $1980^{\prime}$ 'S SAH AN INCREASE IN THE TRAMSBOUNDARY OUMPING OF TOXIC WASTE IN WEST AFRICA BY HESTERN INDUSTRIALIZED ENTERPRISES. WEST AFRICA IS ATTRACTIVE FOR ILLEGAL DUMPING BECAUSE ITS CONTINUING ECONOMIC CRISIS AND NEED FOR FOREIGM EXCHAMGE MAKE SOME GOVERNMENTS AMENABLE TO IT.

08668 SONMEMAN, T.

OLD HATREDS IN NEW EUROPE: ROMA AFTER THE REVOLUTIONS 
NATIONAL REVIEW, XLIV(1) (JAN 92), 49-52; 93-94. EUROPE'S LONG-OSTRACIZED GYPSY POPULATION NOW FACES XENOPHOBIA AND PERSECUTION AT THE HANDS OF A NEH GENERATION OF EUROPEAN NATIONALISTS. GYPSIES, WHO PREFER THE NAME ROMA, HAVE BECOME CONYENIENT SCAPEGOATS FOR THE ECONOMIC AND POLITICAL ILLS OF EASTERN EUROPE. PARTICULARLY IN ROMANIA, WHERE THE GENERAL PUBLIC ALIKE STILL CASUALLY ACCEPT THE STABLE OF POPULAR LIBELS AGAINST THE ROMA. OVERT, DAILY SHOWS OF PREJUDICE HAVE SERVED TO INCITE VIOLENCE AGAINST THE ROMANI POPULATION. THIS ARTICLE EXPLORES THE SEPARATE LEGACIES OF TWO DIASPOARA CULTURES WHICH HAVE HAVE MADE IT DIFFICULT FOR THE ROMA TO RETAIN A STRONG SENSE OF CULTURAL UNITY. IT CONCLUDES THAT TO AVERT THE THREAT OF ANOTHE GENOCIDAL CATASTROPHE, JEWS AND ROMA MUST DRAW RENEWED COMPASSION AND STRENGTH FROM THEIR HISTORICAL BONDS, AND
UNITE TO RESIST VIGOROUSLY THE ANCIENT SPECTER OF PREJUDICE, UNITE TO

08669 SONNENFELDT, $H$.

FOREIGN POLICY FOR A POST-COLD WAR WORLD: A SECOND BUSH ADMINISTRATIOM

BROOKINGS REVIEW, 10(4) (FAL 92), 33, 35

PRESIDENT GEORGE BUSH AND HIS ASSOCIATES ARE COMMITTED INTERMATIONALISTS. THEY SEE THE EXTERNAL AND DOMESTIC PURPOSES OF THE UNITED STATES AS INTIMATELY CONNECTED. THEY ARE DETERMINED NOT TO REPEAT THE POST-WORLD WAR I ABDICATION FROM INTERNATIONAL ENGAGEMENT AND LEADERSHIP THAT A CONTRIBUTED TO THE DISASTERS THAT ENSUED. BUT THEY ALSO RECOGNIZE THAT THE COUNTRY'S INVOLVEMENTS ABROAD MUST BE SUSTAINABLE DOMESTICALLY.

08670 SONTHEIMER, $K$.

POWER PROBLEM MAKES A MIGHTY RETURN

GERMAN TRIBUNE, (1507) (MAR 92), 3.

THE NEW INTERNATIONAL POL ITICAL SITUATION FOLLOHING THE COLLAPSE OF THE SOVIET EMPIRE AND GERMAN REUNIFICATION HAS PRESENTED GERMANS WITH THE ISSUE OF WHAT TO DO WITH THEIR NEW-FOUND POHER. THIS ARTICLE ARGUES THAT GERMANS MUST REALIZE THAT IT IS IMPORTANT FOR GERMANY'S ROLE AND REALIZE THAT IT IS IMPORTANT FOR GERMANY'S ROLE AND THE SAME POL ITICAL OB JECTIVES OF PEACE AND UNDERSTANDING FOR THE SAME POLITICAL OBJECTIVES OF PEACE AND UNDERSTANDING FOR THE POWER THEY HAVE RECENTLY GAINED AS THOSE EMPLOYED IN THE
FORMER FEDERAL REPUBLIC OF GERMANY. PEACEFUL AND RESPONSIBLE FORMER FEDERAL REPUBLIC OF GERMANY. PEACEFUL AND RESPONSIBL
USE OF POWER WILL ALLAY THE FEARS OF GERMANY'S EUROPEAN USE OF POWER WILL ALLAY THE FEARS OF GERMANY'S EUROPEAN NEIGHBORS

08671 SOOD, $Y$.

LOW-INTENSITY CONFLICT: THE SOURCE OF THIRD-WORLD INSTABILITY

STUDIES IN CONFLICT AND TERRORISM, 15(4) (1992), 233-250. AS THE INTERNATIONAL SYSTEM ENTERS A NEH PHASE OF MATURITY THERE IS GROWING REALIZATION OF THE UNHINNABILITY OF NUCLEAR WAR. THE CURRENT INTERNATIONAL STRATEGIC ENVIRONMENT INDICATES THE EMERGING SIGNIFICANCE OF LOWINTENSITY CONFLICT (LIC). LIC MAY BE REFERRED TO AS THE WARFARE OF THE "WARFARE OF THE FUTURE." THIS ARTICLE EXAMINES THE EMERGING NATURE OF LOW-INTENSITY CONFLICT AND ITS IMPACT ON THE SOCIAL DEVELOPMENT OF THIRD-WORLD COUNTRIES SUCH AS INDIA.

08672 SORENSEN, A.

ON THE USEFULNESS OF CLASS ANALYSIS IN RESEARCH ON SOCIAL MOBILITY AND SOCIOECONOMIC INEOUALITY

ACTA SOCIOLOGICA, 34(2) (1991) 71-88.

THIS ARTICLE CRITICALLY DISCUSSES THE THO MAIN USES OF THE CONCEPT OF CLASS IN RECENT STRATIFICATION RESEARCH. THEY ARE JOHM GOLDTHORPE'S AMALYSIS OF SOCIAL MOBILITY FROM A ARE J CLASS FORMATION PERSPECTVE AND ERIK O. WRIGHT'S ANALYSIS INCOME INEQUALITY IN THE LABOR MARKET. THE ARTICLE ARGUES THAT THE MAIN PROBLEM WITH BOTH EFFORTS IS THE LACK OF A SATISFACTORY THEORY OF HOW CLASS GENERATES INEQUALITY WITHIN THE LABOR MARKET. THE LOGIC OF GODLTHORPE'S ARGUMENT ASSU THAT CLASS CAUSES INEQUALITY GENERATING SEPARATE CLASS
INTERESTS IN THE LABOR MARKET, BUT HE DOES NOT PROVIDE SUCH INTERESTS IN THE LABOR MARKET, BUT HE DOES NOT PROVIDE
A THEORY. WHILE WRIGHT DOES PROVIDE SUCH A THEORY, HIS SEVERAL CLASS SCHEMES EITHER PROVIDE EXPLANATIONS FOR INEQUALITY THAT CAN BE DERIVED FROM STANDARD INTERNAL LABOR MARKET THEORY THAT DOES NOT SATISFY THE REQUIREMENT OF CLASS THEORY; OR, THEY ARE BASED ON A CONCEPT OF EXPLOITATION THAT IS UNSATISFACTORY FOR THE IDENTIFICATION OF CLASS CATEGORI WITHIN THE LABOR MARKET. THE ARTICLE CONCLUDES THAT IT IS NOT CLEAR WHY MARXIST THEORY NEEDS A CLASS THEORY OF HON MEO-CLASSICAL ECDNOMIC THEORY SEEMS CONSISTENT WITH MARX'S OWN CONCEPTION OF THE CAPITALIST ECONOMY.

08673 SORENSEN, $D$

KANT AND PROCESSES OF DEMOCRATIZATION: CONSEQUENCES FOR NEOREALIST THOUGHT

JOURNAL OF PEACE RESEARCH, 29(4) (NOV 92), 397-414.

THE THEORETICAL FOUNDATION FOR EXPECTING PEACE TO FLOW FROM DEMOCRACY WAS SET FORTH BY IMMANUEL KANT. ACCORDING TO THE INTERPRETATION IN THIS ARTICLE, KANT'S NOTION OF A
PACIFIC UNION OF DEMOCRACIES RESTS ON THREE PILLARS. THIS PAPER ANALYSES EACH OF THE THREE CONDITIONS IN THE LIGHT OF RECENT PROCESSES OF DEMOCRATIZATION. IT CONCLUDES THAT THE EMERGENCE OF A GLOBAL PACIFIC UNION EMBRACING ALL THE NEW AND OLD DEMOCRACIES CANMOT BE TAKEN FOR GRANTED. IT ARGUES THAT IT IS POSSIBLE TO ACCEPT KANT'S VISION WITHOUT

REJECTING BASIC INSIGHTS OF NEOREALISM.

08674 SORENSEN, $R$.

FISCAL ILLUSIONS: NOTHING BUT ILLUSIONS? EUROPEAN JOURMAL OF POLITICAL RESEARCH, 22(3) (OCT 92), 279-305.

THE ARGUMENT THAT CITIZENS UNDERESTIMATE THE COSTS OF PROVIDING PUBLIC GOODS AND OVERESTIMATE THE BENEFITS OF GOVERMMENT PROGRAMS HAS RECEIVED HIDESPREAD ATTENTION AMONG SCHOLARS. ACCOROIMG TO THIS ARGUMENT THE MISINFORMED CITIZEN DEMANDS GREATER AMOUNTS OF PUBLIC GOOOS THAN A WELLINFORMED CITIZEN. DEMOCRATIC COMPETITION LEADS POLITICAL PARTIES TO ADJUST TO THE PERCEIVED DEMANDS OF THE VOTERS RATHER THAN TO THE ACTUAL INTERESTS OF THE ELECTORATE. THEREFORE. THE SUPPLY OF PUBLIC GOODS AND SERVICES TENDS TO BE GREATER THAN THE SOCIAL OPTIMUM. THIS PAPER ANALYZES A NATIONAL SURVEY FROM NORHAY THAT INDICATES A WIDESPREAD MISPERCEPTION OF GOVERNMENT COSTS, INCLUDING BOTH THE UNIT COSTS OF PARTICULAR SERVICES AND THE AGGREGATE COSTS OF THE PUBLIC SECTOR. HOWEVER, THE STUDY DOES NOT REVEALS A GENERAL UNDERESTIMATION OF COSTS. THE SURVEY IMPLIES THAT WHILE THE DEMAND FOR GOVERNMENT SERVICES DECLINES AS THE UNIT COST INCREASES, THE PRICE ELASTICITY OF GOVERNMENT SERVICES SEEMS TO BE SMALL. THE (MIS-) PERCEIVED TAX-PRICE SEEMS TO HAVE LITTLE IMPACT ON DEMAND COMPARED TO THE (MIS-) PERCEIVED COSTS LEVIED ON SOCIETY AS A HHOLE. EVEN IF PEOPLE DID UNDERRATE GOVERNMENT COSTS, THE IMPACT ON DEMAND WOULD BE MARGINAL. THUS, EMPIRICAL EVIDENCE PROVIDES LITTLE OR NO SUPPORT FOR THE HYPOTHESIS OF FISCAL ILLUSIONS.

08675 SORENSEN, T.C.

AMERICA'S FIRST POST-COLD WAR PRESIDENT

FOREIGN AFFAIRS, 71(4) (FAL 92), 13-30.

THE UNITED STATES' FIRST POST'-COLD WAR PRESIDENT WILL

FACE A WORLD OF BOTH UMMATCHED OPPORTUNITIES AND

UNPRECEDENTED OPACITY. UNDER PRESSURE TO CHOOSE A NEW COURSE

FOR THE COUNTRY, WITH THE GRAVEST CONSEQUENCES ATTENDANT

UPON THAT CHOICE, HE WILL BE STANDING AT A CROSSROADS,

LOOKING AT CONFLICTING SIGNPOSTS AND HOLDING OUTDATED MAPS.

08676 SORENSON, L.

madison on the meaning of the "general helfare," the

"PURPOSE" OF ENUMERATED PONERS, AMD THE "DEFINITION" OF CONST ITUT IONAL GOVERNMENT

PUBLIUS: THE JOURNAL OF FEDERALISM, 22(2) (SPR 92),

109-122.

ACCORDING TO JAMES MADISON, "THE MOST IMPORTANT AND FUNDAMENTAL QUESTION" HE EVER ADORESSED WAS THE MEANING OF AND RELATION BETWEEN THE GENERAL WELFARE CLAUSE AND THE ENUMERATION OF PARTICULAR POWERS. THE THESIS OF THIS ESSAY IS THAT MADISON ARGUED THAT THE CLAUSE WAS A SUBSTANTIVE GRANT OF POWER FOR THE GENERALLY STATED END AND THAT THE PRIMARY PURPOSE OF THE ENSUING ENUMERATION WAS TO DEFINE MORE PARTICULARLY THE ENDS ALLUDED TO BY THE PHRASE "GENERAL WELFARE." HENCE, THE MEANING OF THE GENERAL CONSTITUTIONAL GOVERMMENT IN THE AMERICAN FEDERAL SYSTEM IS A GOVERNMENT ORIENTED TO A LIMITED NUMBER OF LIMITED ENDS.

08677 SOUTHWELL, P.

RULES AS "UNSEEN PARTICIPANTS"

AMERICAN POLITICS OUARTERLY, 20(1) (JAN 92), 54-68,

THIS ARTICLE EVALUATES THE LIKELY CONSEQUENCES OF RECENT RULE CHANGES WITHIN THE DEMOCRATIC PARTY, SPECIFICALLY, THE DECISION TO REQUIRE PROPORTIONAL REPRESENTATION IN
PRIMARIES AND CAUCUSES AND TO REDUCE THE NUMBER OF SUIMARIES AND CAUCUSES AND TO REDUCE THE NUMBER OF PUPERDELEGATES. ANALYSIS OF STATEHIDE DATA FROM THE 1984 PRIMARIES AND CAUCUSES SHOWS THAT THE FRONT-RUNNER, WALTER MONDALE, WAS THE PRIME BENEFICIARY OF THE RULES DUE YO HIS MVRE THAN PROPORTIONAL SHARE OF DELEGATES WOM WIES MORE THAN PROPORTIONAL SHARE OF DELEGATES WON WITH A PLURALITY OF VOTES IN CAUCUSES AND PRIMARIES. THE COMBINED IMPACT OF THE ALLOCATION SYSTEM AND THE USE OF SUPERDELGATES IS SUCH THAT THE APPLICATION OF THE 1992 RULES TO THE
RACE COULD HAVE CHANGED THE OUTCOME OF THE DEMOCRATIC RACE COULD
NOMINATION.

08678 SOWELL, T.

HAVE THE DEMOCRATS REALLLY CHANGED?--A DEBATE: NO

COMMENTARY $94(3)$ (SEP 92$)$ 27-32.

THERE HAS BEEN MUCH TALK DF POSSIBLE MOVE TOWARO SUPPORT OF THE CLINTON-GORE TICKET BY MANY SO-CALLED REAGAN DEMOCRATS AND NEOCONSERVATIVE INTELLECTUALS WHO HAVE BECOME INCREASINGLY UNHAPPY WITH THE BUSH AOMINISTRATION. SOME HAVE ALREADY MADE THE MOVE WHILE OTHERS REMAIN UNCONVINCED THAT THE DEMOCRATIC PARTY HAS REALLY FREED ITSELF FROM THE LEFTIST FORCES WHOSE ACCESSION TO POWER IN 1972 DROVE THEM OUT IN THE FIRST PLACE. THOMAS SOHELL SUGGESTS THAT THE CHANGES IN THE DEMOCRATIC PARTY ARE NOTHING BUT A FORM OF 
ELECTION-YEAR CAMOUFLAGE AND HE MAKES THE CASE FOR SUPPORTING GEORGE BUSH.

08679 SPALDING, H.

THE THO LATIN-AMERICAN FOREIGN POLICIES OF THE U.S. LABOR MOVEMENT: AFL-CIO TOP BRASS VS. RANK-AND-FILE

SCIENCE AND SOCIETY, 56(4) (WIN 92), 421-439.

IN THE FOREIGN POLICY OF THE U.S. LABOR MOVEMENT IN LATIN AMERICA, TWO SETS OF POLICIES HAVE EMERGED IN THE PAST 30 YEARS. ONE IS ADVANCED BY AFL-CIO TOP BUREAUCRATS, OPERATING PRIMARILY THROUGH THE AMERICAN INSTITUTE FOR FREE LABOR DEVELOPMENT. THE INSTITUTE USUALLY ECHOES OFFICIAL U.S. PRONOUNCEMENTS. SINCE 1960 IT HAS TAKEN ACTIONS OFTEN DETRIMENTAL TO LATIN AMERICAN UNIONS AND WORKERS. ITS EFFORTS HAVE BEEN KEPT LARGELY SECRET FROM U.S. UNIONISTS AMD THE PUBLIC. MIDDLE LEVEL ORGANIZERS ALONG WITH THE RANKAND-FILE HAVE FASHIONED AN ALTERNATIVE POLICY WHICH SEEKS TO TRULY REPRESENT THE INTERESTS OF ALL WORKING PEOPLE NORTH AND SOUTH. BOTH SIDES ARE ENGAGED IN AN INCREASINGLY PUBLIC STRUGGLE TO MAKE THEIR POSITION THE ONE THAT REPRESENTS U.S. STRUGGLE
LABOR.

08680 SPARKS, $C$.

THE PRESS, THE MARKET, AND DEMOCRACY

JOURAL OF COMMUMICATION AND OEMOCRACY 36-51.

THE POST-STALINIST STATES IN EASTERN EUROPE WILL ALMOST CERTAINLY DEVELOP A NEWSPAPER PRESS THAT IS BASED ON THE MARKET. THESE DEVELOPMENTS POSE SOME PROBLEMS FOR THE FUTURE OF THE DEVELOPING DEMOCRATIC SYSTEMS. THIS PAPER EXAMINES THE DETAILED WORKINGS OF THE PRESS MARKET IN A SITUATIOH WHERE ADVERTISING REVENUE IS AN IMPORTANT ELEMENT IN NEHSPAPER FINANCES, USING EXAMPLES FROM BRITAIN. IT IS DEMONSTRATED THAT LEFT TO ITSELF THIS MARKET WILL STRATIFY INFORMATION PROVISION AND FAIL TO PROVIDE ALL CITIZENS WITH THE SAME QUALITY OF INFORMATION AND OPINION. IN PARTICULAR, OW-INCOME GROUPS WHO WANT ACCESS TO DETAILED PUBLIC INFORMATION WILL NOT BE CATERD TO. TO ALLEVIATE THESE PROBLEMS AND TO ASSIST IN THE DEVELOPMENT OF DEMOCRACY, IT IS ARGUED THAT THE RECONSTRUCTION OF PUBLIC COMMUMICATION IN EASTERN EUROPE MUST MAKE USE OF SUBSIDIES.

08681 SPECTOR, L.

THREATS IN THE MIDDLE EAST

ORBIS, 36(2) (SPR 92), 181-198.

LEONARD SPECTOR NOTES THE ACCELERATION OF EFFORTS BY CERTAIN MIDOLE EASTERN STATES TO DEVELOP NUCLEAR WEAPONS PROGRAMS. THE 1968 TREATY ON THE NON-PROLI IFERATION OF NUCLEAR HEAPONS HAS INEFFECTIVE IN RESTRAINING IRAQ'S QUEST NUCLEAR WEAPONS WAS INEFFECTIVE IN RESTRAINING IRAQ'S QUEST
FOR NUCLEAR ARHS, RAISING OUESTIONS ABOUT THE UTILITY OF THE FOR NUCLEAR ARMS, RAISING QUESTIONS ABOUT THE UTILITY OF THE
PACT AS A CURB ON PROLIFERATION ELSEHHERE IN THE REGION. BY PACT AS A CURB ON PROL IFERATION ELSEHHERE IN THE REGI

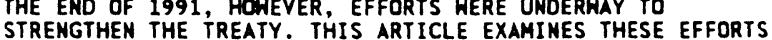
STRENGTHEN THE TREATY. THIS ARTICLE EXAMINES THESE EFFORTS AND CONCLUDES THAT WHATEVER ITS PAST FAILINGS, THE MEWLY NEXT WAVE OF NUCLEAR PROLIFERATION IN THE MIDOLE EAST.

08682 SPECTOR, L.S.

REPENTANT NUCLEAR PROLIFERANTS

FOREIGN POLICY, (88) (FAL 92), 21-37

WITH THE TREATY ON THE NONPROLIFERATION OF NUCLEAR WEAPONS (NPT) SUBJECT TO RENEWAL IN 1995 AND EXPECTATIONS FOR SLOWING PROLIFERATION SO HIGH, THE NEXT TWO YEARS HILL BE CRUCIAL FOR GLOBAL NONPROLIFERATION EFFORTS.

UNFORTUNATELY, IN MOST CASES, THE NETHORK OF INTERNATIONAL TREATIES, INSTIITUTIONS, EXPORT CONTROLS, AND NUCLEAR TRADE AGREEMENTS SIMPLY WILL NOT BE ENOUGH TO GUARANTEE THAT PENITENT PROL IFERANTS HAVE TRULY ABANDONED THEIR NUCLEAR AMBITIONS. TO CONFIRM THAT THOSE STATES HAVE GENUINELY ABANDONED NUCLEAR ARMS AND TO SECURE THEIR ABSTINENCE FOR THE LONG TERM, THE NEXT U.S. ADMINISTRATION MUST ACT SWIFTLY TO RESURRECT A FORGOTTEN PART OF THE NPT AND BRING THE CREDO OF STRICT VERIFICATION THAT IS BEING APPLIED IN IRAQ AND NORTH KOREA TO ALL STATES THAT TRESPASS NONPROLIFERATION NORMS.

08683 SPEGELE, R.D.

RICHARD ASHLEY'S DISCOURSE FOR INTERNATIONAL RELATIONS MILLENNIUM, 21(2) (SUM 92), 147-182.

THE WORK OF RICHARD ASHLEY, ONE OF THE MOST INFLUENTIAL POST-STRUCTURALIST THINKERS IN INTERNATIONAL RELATIONS, IS FLAWED IN SEYERAL HAYS. ASHLEY RELIES ON EXCESSIVE RHETORIC, FLAWED IN SEVERAL WAYS. ASHLEY RELIES ON EXCESSIVE RHETORIC, AND HIS UNDERSTANDING OF DERRIDA AND FOUCAUL IS INAC

RELTIIVISM, AND IRRATIDNALISM. IRONICALLY HE IS UNABLE TO

RELATIVISM, AND IRRATIONALISM. IRONICALLY, HE IS UNABLE ESCAPE THE STRAIT
STRONGLY CONDEMNS.

08684 SPEIRS, $M$

AGRARIAM CHANGE AND THE REVOLUTION IN BURKINA FASO AFRICAN AFFAIRS, 90(358) (JAN 91), 89-110,

THIS PAPER EXPLORES THE POLITICAL IMPLICATIONS OF THE AGRICULTURAL PRODUCTION AND FOCD SUPPLY CRISES IN BURKINO FASO, ONE OF THE LEAST DEVELOPED COUNTRIES IN THE SAHEL REGION OF WEST AFRICA. THE STUDY EMPHASIZES THE DIFFICULTIES
AND CONTRADICTIONS EMCOUNTERED IN "ECONOMIC MANAGEMENT" REFORMS THROUGH FOOD PRICE POLICIES AND AGRICULTURAL MARKETING STRATEGIES. THE BACKGROUNO OF THE 1983 REVOLUTION IS DESCRIBED, AND THEN AN OVERVIEH GIVEN OF THE MEASURES THAT HAVE BEEN INTRODUCED SINCE INDEPENDENCE TO MODERNIZE
THE AGRICULTURAL SECTOR AND IMPROVE MARKETING OF FOOD CROPS. THE AGRICULTURAL SECTOR AND IMPROVE MARKETING OF FOOD CROPS.
THE IMPLICATIONS OF THE 1983 REVOLUTION ARE NEXT EXPLORED, WITH PARTI CULAR REFERENCE TO THE CONFLICTING AND COMPLEMENTARY INTERESTS OF AGRICULTURAL PRODUCERS, TRADERS, URBAN HORKERS, AND MILITARY AND BUREAUCRATIC ELITES.

08685 SPENCE, J.E.

SOUTH AFRICA'S MANDATE FOR CHANGE

ORLD TODAY, 48(5) (MAY 92) 75-76.

IN THE MARCH 17, 1992, REFEREMDUM SOUTH AFRICANS OVERHHELMINGLY VOTED IN FAVOR OF CONTINUING THE NEGOTIATIONS THAT WILL EVENTUALLY PRDOUCE A NEW CONSTITUTION AND END APARTHEID. IN THIS ARTICLE, THE AUTHOR EXPLAINS THE REASONS UMDERLYING THE REFERENDUM RESULTS AND THE CONSEQUENCES OF THE VOTE.

08686 SPENCER, D.; SPENCER, H.; YANG, H CLOSING THE MEDIATION GAP: THE ETHIOPIA/ERITREA EXPERIENCE SECURITY DIALOGUE, 23(3) (SEP 92), 89-100.

THE 1989-90 MEDIATION EFFORTS OF THE INTERNATION NEGOTIATING NETHORK UNDER PRESIDENT CARTER, IN THE ETHIOPIA/ERTIRA CONFLICT ARE ANALYZED. FOUR PATHS ARE EXPLORED: ON THE RECORD DECISIONS; INFORMAL CONTACTS; JOINT WORKING GROUPS; AND ACADEMIC ANALYSIS. BARGAINING; SINGLE NEGOTIATED TEXT STRATEGY; JOINT PROBLEM-SOLVING, AND THE EMINENT PERSONS STRATEGY ARE FOUR STRATEGIES WHICH ARE PURSUED. THE FOLLOWING LESSONS ARE NOTED: DIRECT PARTICIPATION OF ALL MAJOR PARTIES IS CRUCIAL; THIRD PARTIES SHOULD REALIZE THAT THE PARTIES MAY HAVE HIDDEN AGENDAS; SOCIO-CULTURE DIFFERENCES ARE IMPORTANT; AND INCENTIVES CAN BE OFFERED TO REWARD PROGRESS.

08687 SPENCER, $M$

POLITICS BEYOND TURF: GRASSROOTS DEMOCRACY IN THE HELSINKI PROCESS

BULLETIN OF PEACE PROPOSALS, 22(4) (DEC 91), 427-436.

DEMOCRACY IS GENERALLY UNDERSTOOD TO MEAN RULE BY THE MAJORITY BUT AN EQUALLY IMPORTANT CONCERN OUGHT NEVER TO BE OMITTED FROM THE DEFINITION: THE PROTECTION OF THE RIGHTS OF MINORITIES FROM INFRINGEMENT BY THE MAJORITY. UNFORTUNATELY, THIS CONCEPT SEEMS TO BE INCREASINGLY IGNORED. AS A RESULT, A GROHING NUMBER OF SEPARATIST MOVEMENTS AMONG MINORITIES ARE EVIDENT. THIS ARTICLE PRESENTS SOME NEW STRUCTURES THAT WOULD ALLOW "CIVIL SOCIETY" TO TRANSCEND NATIONAL BORDERS, WOULD ALLOW "CIVIL SOCIETY" TO TRANSCEND NATIONAL BORDERS,
AND, THEREFORE, ENSURE THAT THE VOICE OF ALL CITIZENS OF THE AND, THEREFORE, ENSURE THAT THE VOICE OF ALL CITIZENS NORLD ARE HEARD IN INTERMATIONAL DECISIONS. IT PLACES EMPHASIS ON THE HELSINKI CITIZENS ASSEMBLY (HCA), AN SECURITY AND COOPERATION IN EUROPE (CSCE) AS A GRASSROOTS FORUM FOR ITS CITIZENS.

08688 SPENCER, S.I.; SPENCER, W.A. FEMALE dePUTIÉs aND CABiNet MEMBERS IN QUEBEC: PAST AND PRESENT

AMERICAN REVIEN OF CANADIAN STUDIES, 22(3) (FAL 92), 329-350.

BASED ON QUESTIONNAIRES AND PERSONAL INTERVIEWS WITH BOTH MEN AND WOMEN WHO HAVE SERVED AS PROVINCIAL OR FEDERAL DEPUTIES OR AS CABIMET MEMBERS, THE AUTHORS PROVIDE INFORMATION ABOUT WOMEN IN QUEBEC POLITICS, THE POLITICAL PREFERENCES OF THE POLITICIANS IN THE SURVEY, AND THEIR COMMITMENT TO THE ADVANCEMENT OF WOMEN.

08689 SPERLING, J.

GERMANY SECURITY POLICY AFTER THE COLD WAR: THE STRATEGY OF A CIVILIAN PONER IN AN UNCIVIL WORLD

ARMS CONTROL, 12(3) (DEC 91), 77-98.

THE CHANGES THAT HAVE TAKEN PLACE IN THE EUROPEAN STATE SYSTEM, PARTICULARLY THE UNSEEMLY AND HASTY DISINTEGRATION OF THE FORMER SOVIET UNION, AND THE PROSPECT OF AN UNWELCOMED AMERICAN RETREAT, DRIVEN BY FRUSTRATION WITH EUROPEAN DEMANDS EXACERBATED BY SEVERE DOMESTIC OISABILITIES, RAISE A NUMBER OF IMPORTANT OUESTIONS ABOUT GERMAN SECURITY POLICY IN THE POST-POSTHAR WORLD. THIS ARTICE EXPLORES THE FOLLOWING OUESTIONS: HOH DOES GERMANY DEFINE ITS SECURITY INTERESTS IN THIS WORLD? WHAT ARE THE ELEMENTS OF CONTINUITY AND CHANGE IN GERMAN SECURITY POLICY? WHAT INSTITUTIONS AND AND CHANGE IN GERMAN SECURITY POLICY? WHAT INSTITUTIONS AND
INSTITUTIONAL CONFIGURATION DO THE GERMANS FAVOR FOR THE
CONSTRUCTION OF A EUROPEAN SECURITY ORDER? WHAT ARE THE CONSTRUCTION OF A EUROPEAN SECURITY ORDER? WHAT ARE THE IMPLICATIONS OF THE CHANGED INTERNAIIONAL ENVIRONMENT FOR THE FUTURE OF THE GERMAN-AMERICAN RELAT SONSHIP? THE GERMAN RESPONSE TO THESE QUESTIONS FRAMES THE SECURITY DEBATE STABILITY OF THE FUTURE EUROPEAN SECURITY ORDER.

08690 SPETH, J.G. A POST-RID COMPACT

FOREIGN POLICY, (88) (FAL 92), 145-161

WHETHER THE UNITED STATES IS READY OR NOT, WORLD EVENTS 
ARE PRESSING FORWARD, DRIVEN BY POWERFUL CURRENTS OF CHANGE. ONE SUCH EVENT WAS THE 1992 EARTH SUMMIT IN RIO DE JANEIRO, WHERE THE OUTLINES OF THE NEW WORLD ORDER BECAME CLEAR. THE EARTH SUMMIT SUGGESTED THAT THE NEW AXIS OF WORLD AFFAIRS IS NOT EAST-WEST BUT NORTH-SOUTH. IF THE INDUSTRIALIZED COUNTRIES WANT MEANINGFUL ENVIRONMENTAL COOPERATION FROM THE COUNTRIES WANT MEANINGFUL ENVIRONMENTAL COOPERATION FROM THE
REST OF THE WORLD, THEY MUST PROPOSE A NORTH-SOUTH COMPACT.

08691 SPICKER, P.

EQUALITY VERSUS SOLIDARITY

GOVERNMENT AND OPPOSITION, 27(1) (WIN 92), 66-77.

IN FRANCE, THE PRINCIPIE OF "SOLIDARITY" HAS COME TO STAND FOR A JUSTIFICATION OF SOCIAL POLICY IN TERMS OF THE PROTECTION OF MUTUAL INTERESTS. IN THE LITERATURE OF SOCIAL POLICY, "SOLIDARITY" REFERS TO THE ESTABLISHMENT OF

COLLECTIVE ACTION AND RECOGNITION OF MUTUAL RESPONSIBILITY. THE PRINCIPLE IS OFTEN RELATED TO EGALITARI AN POLICIES; BUT THE PRESCRPTIONS OF SOLIDARITY MAY TEND IN A VERY DIFFEREN DIRECTION FROM THOSE THAT PURSUE EQUALITY. EQUALITY AND SOLIDARITY ARE NOT NECESSARILY INCOMPATIBLE OBJECTIVES, BUT AS COMMONLY UNDERSTOOD, THERE IS A TENSION BETWEEN THEM WHICH MEANS THAT EACH MIGHT UNDERMINE THE OTHER.

08692 SPIEGEL, S.

AMERICAN AND ISRAEL--HOW BAD IS IT?

NATIONAL INTEREST, (22) (WIN 91), 11-22.

EVEN BEFORE IRAO INVADED KUWAIT, THERE WAS A SENSE OF GROWING CRISIS IN THE U.S. -ISRAELI RELATIONSHIP. MANY WASHINGTON ANALYSTS WERE ARGUING THAT RELATIONS BETHEEN THE TWO COUNTRIES HOULD NECESSARILY DECLINE HITH THE END OF THE COLD WAR THIS ARTICLE CONSIDERS THE RELATIONSHIP BETHEEM THE TWO STATES FROM 1948 TO THE PRESENT. IT STRESSES THE

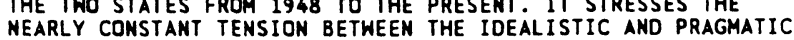
PHILOSOPHIES THAT CHARACTERIZE U.S. POLICY TOWARDS ISRAEL. PHILOSOPHIES THAT CHARACTERIZE U.S. POLICY TOWARDS ISRAEL. IT ARGUES THAT NHILE THE STRATEGIC IMPORTANCE OF ISRAEL AND THE MIDDLE EAST REGION HAS CHANGED LITTLE,
SUPPORT THAT ISRAEL ONCE ENJOYED IS WANING.

08693 SPIEGEL, S.L. (ED.); MARKS, J.

A HELSIMKI-TYPE PROCESS FOR THE MIDOLE EAST; THE ARABISRAELI SEARCH FOR PEACE

LYMUE RIEMMER PUBLISHERS $1992,71-80$.

THE AUTHOR DRAWS ON THE EXPERIENCE OF THE CONFERENCE OH SECURITY AND COOPERATION IN EUROPE (CSCE) TO DEMONSTRATE THAT THE FORMAT OF MEGOTIATIONS CAN AFFECT THEIR OUTCOME. WHILE RECOGNIZING THE VAST DIFFERENCES BETWEEN THE SITUATION IN EUROPE WHEN CSCE BEGAN IN THE MID-1970'S AND THAT IN THE MIDDLE EAST, HE SUGGESTS THAT THE CSCE'S WIDE SCOPE,

FLEXIBILITY, PROVISIONAL AGREEMENTS, EXTENSIVE PARTICIPATION, AND OPPORTUNITY FOR TRADE-OFFS BETWEEN ISSUES MAY SERVE AS A HORKABLE MODEL FOR THE ARAB-ISRAELI PEACE PROCESS

08694 SPIEGEL, S.L. (ED.); GAZIT, S.

AFTER THE GULF WAR: THE ARAB WORLD AND THE PEACE PROCESS: THE ARAB-ISRAELI SEARCH FOR PEACE

LYNNE RIENNER PUBLISHERS, 1992, 17-26.

UNDERLYING FORCES LEADING TO INSTABILITY IN THE MIDDLE EAST REMAIN IN PLACE, NOTWITHSTANDING RECENT EVENTS IN THE REGION. THE BASIC PROBLEMS HAVE LITTLE TO DO WITH ISRAEL BUT ARE DIRECTLY RELATED TO THE PHENOMENON OF INSTABILITY, WHICH IS CHARACTERISTIC OF ARAB COUNTRIES AND SOCIETY. IN THE AFTERMATH OF THE GULF HAR. THE NEEDS TO ATTAIN A REGIONAL BALANCE OF POWER DECREASE INTERMAL THREATS TO VARIOUS BALANCE OF POWER, DECREASE INTERNAL THREATS TO VARIOUS RETHEEN THE HAVES AND HAVE MOTS PEMAIM PRESSIMG FRICIION BETWEEN THE HAVES AND HAVE-NOTS REMAIN PRESSING. WHILE THE FULL IMPLICATIONS OF THE GULF WAR ARE NOT YET APPARENT, LEAST TWO OF THEM OPERATE TO ISRAEL'S ADVANTAGE. FIRST, SINCE IRAO IS NO LONGER A THREAT, THE ARABS HAVE NO REAL MILITARY OPTION. SECONDLY, THE PROVEN EFFECTIVENESS OF PRECISION-GUIDED MUNITIONS BENEFITS ISRAEL'S HIGHTTECH MILITARY. THUS, THE ARAB STATES HAVE WARILY ENTERED THE PEACE PROCESS, FEARING THAT ONE FUTURE EFFECT OF THE GULF WAR WILL BE INTENSIFIED D

08695 SPIEGEL, S.L. (ED.); GOLAN, G.

ARAB-ISRAELI PEACE MEGDTIATIONS: AM ISRAELI VIEH: THE ARABISRAEL I SEARCH FOR PEACE

LYNNE RIEMHER PUBLISHERS 1992, 37-48

THE AUTHOR LOKS AT THE CURREMT SHARP DIVISIONS WITHIN ISRAEL POL ITICS. THERE IS AN INCREASING RECOGNITION HITHIN ISRAEL THAT TRADE-OFFS MUST BE MADE. ISRAEL IS BEING FORCED TO CHOOSE BETHEEN ABSORPTION OF IMMIGRANTS AND CONTROL OVER THE TERRITORIES. A PARADOX EXISTS WHEN THE POSITIONS OF THE LIKUD AND THE PUBLIC ARE CONTRASTED: WHILE THE LIKUD IS NOT WILLING TO MAKE A DEAL ON THE WEST BANK FOR IDEOLOGICAL REASONS BUT IS OPEN TO COMPROMISE CONCERNING THE GOLAN HEIGHTS, THE ISRAEL PUBLIC'S CONCERN FOR SECURITY LEADS TO SOME WILLINGNESS TO COMPROMISE ON THE WEST BANK BUT GREAT RELUCTANCE TO GIVE UP ANY OF THE HEIGHTS. THE LABOR PARTY SEEKS TO GAIN AN ADVANTAGE FROM THIS PARADOX BY TAKING A HARDL INE STANCE ON THE HEIGHTS, FURTHER COMPLICATING AN ALREADY COMPLEX SITUATION.
08696 SPIEGEL, S.L. (ED.); TELHAMI, S. ISRAELI FOREIGN POLICY AFTER THE GULF WAR; THE ARABISRAELI SEARCH FOR PEACE

LYNNE RIENNER PUBLISHERS, 1992, 49-62.

BASED ON INTERVIEWS WITH ISRAELI POLITICIANS AND ANALYSTS, THE AUTHOR SUGGESTS THAT RECENT INTERNATIONAL EVENTS HAVE REINFORCED EXTANT POSITIONS AND STRATEGIES WITHIN ISRAEL. THE RESILIENCE OF THESE PREDISPOSITIONS AND DIVISIONS IN THE FACE OF INTERNATIONAL CHANGES ACCOUNTS FOR THE POLITICAL PARALYSIS THAT HAS CHARACTERIZED ISRAELI THE POLITICAL PARALYSIS THAT HAS CHARACTERI ZED ISRAELI
POLITICS. NEVERTHELESS. THE APPARENT WILLINGNESS OF THE POLITICS. NEVERTHELESS, THE APPARENT WILLINGNESS OF THE
ARABS TO CONSIDER PEACE. THE ECONOMIC COSTS OF ABSORBING ARABS TO CONSIDER PEACE, THE ECW THESE IMMIGRANTS WILL VOTE IN THE ISRAELI ELECTIONS, AND THE POSSIBILITY THAT ISRAELI ARABS WILL PLAY A LARGER POLITICAL ROLE HAVE GENERATED SOME FLUIDITY, OR AT LEAST UNCERTAINTY, IN THE DIRECTION ISRAEL FLUIDITY,

08697 SPIEGEL, S.L. (ED.); ABU-AMR, Z. PALESTINIAN-I SRAELI NEGOTIATIONS: A PALESTINIAN PERSPECTIVE; THE ARAB-ISRAELI SEARCH FOR PEACE LYNNE RIENNER PUBLISHERS, 1992, 27-36.

THE PALESTINIANS HAVE ENTERED THE PEACE PROCESS WITH, IF NOT ENTHUSIASM, AT LEAST THE RECOGNITION OF THEIR DIRE NEED FOR CHANGE IN ORDER TO AMELIORATE THEIR SUFFERING UNDER ISRAELI RULE. THIS IMPERATIVE ACCOUNTS FOR THE PALESTINIANS' WILLINGNESS TO COMPROMISE ON HITHERTO FUNDAMENTAL POSITIONS CONCERNING THE ROLE OF THE PALESTINIAN LIBERATION ORGANIZATION, THE INCLUSION OF PALESTINIANS FROM JERUSALEM AND OUTSIDE THE OCCUPIED TERRITORIES, AND A HALT TO NEW ISRAELI SETTLEMENTS. PREEXISTING DIVISIONS AMONG THE PALESTINIANS HAVE BEEN EXACERBATED BY THESE COMPROMISES, AND THE ABSENCE OF RECIPROCAL ISRAELI CONCESSIONS MAY UNDERMINE THE LEGITIMACY OF THE PALESTINIAN NEGOTIATORS AND ENDANGER THE PEACE PROCESS. WHILE THE PEACE PROCESS HAS THE POTENTIAL FOR GEMERATING POLICY SHIFTS THESE MAY BE EITHER POSITIVE OR NEGATIVE. OUTSIDE MEDIATORS, ESPECIALLY THE UNITED STATES, HAVE A RESPONSIBILITY TO ENSURE SUCCESS. THE ALTERNATIVE COUL A RESPONSIBILITY TO ENSURE SUCCESS. THE ALTERNATI COULD BE ESCALATING TENSIO
THREATEN REGIONAL PEACE.

08698 SPIEGEL, S.L. (ED.); ANANI, J.; CLAWSON, P.; FISHELSON, G. FOR ECOMOMIC COOPERATION IN THE

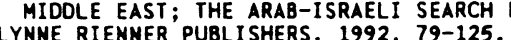

LYNNE RIENMER PUBLISHERS, 1992, 79-125. AMONG THE MANY CHANGES RESULTING FROM THE DEMISE OF THE
SOVIET UNION IS THE INCREASED EMPHASIS ON ECONOMICS, BOTH AS SOVIET UNION IS THE INCREASED EMPHASIS ON ECONOMICS, BOTH AS A SOURCE OF POLITICAL STABILITY AND AS A POTENTIAL ARENA FOR COOPERATION. IN THE MIDDLE EAST, DISCUSSION HAS BEGUN ON THE
USEFULNESS OF GREATER ECONOMIC COOPERATION. THE REGION IS MARKED BY DIFFERENT RESOURCE AND FACTOR ENDOWMENTS AND THUS HAS THE POTENTIAL FOR COOPERATION THAT WOULD FACILITATE EXTENSIVE GROWTH AND DEVELOPMENT. COOPERATION HOULD BENEFIT ALL SIDES, BUT IN RELATIVE TERMS THE POORER STATES WOULD BENEFIT MOST. IN THE PAST, COOPERATION HAS BEEN LIMITED BY POLITICAL IMPEDIMENTS, A PHENOMENON OBVIOUS IN THE HOSTILE RELATION BETWEEN ISRAEL AND THE ARABS BUT ALSO CRITICAL IN INTER-ARAB RELATIONS.

08699 SPIEGEL, S.L. (ED.): ALY, A.M.S.; DIAB, M.Z.; HELLER, M.A.: MULLER, H.; PLATT, A.

FOR ARMS CONTROL IN THE MIDOLE EAST; THE ARAB-ISRAELI SEARCH FOR PEACE

LYNNE RIENNER PUBLISHERS, $1992,127-179$

IN THIS SERIES OF ESSAYS, THE AUTHORS EXAMINE THE RELATIONSHIP BETWEEN ARHS CONTROL AND SECURITY IN THE MIDDLE EAST AND THE ROLE OF ARMS CONTROL IN THE RESOLUTION OF THE ARAB-ISRAELI CONFLICT. THEY ALSO OFFER A EUROPEAN PERSPECTIVE ON ARMS CONTROL IN THE MIDDLE EAST AND A
PROPOSED SECURITY REGIME FOR AN ARAB-ISRAELI SETTLEMENT

08700 SPIEGEL, S.L. (ED.)

THE ARAB-ISRAELI SEARCH FOR PEACE

LYNNE RIENNER PUBLISHERS, 1992, 199

THE ESSAYS IN THIS VOLUME EXAMINE THE CONTRIBUTIONS THAT REGIONAL PARTIES AND EXTERMAL ACTORS CAN MAKE TO CREATING CONDITIONS FAVORABLE TO PEACE IN THE MIDOLE EAST. THE BOOK IS DIYIDED BY SUBSTANTIVE AREAS, BEGIMNING HITH AM

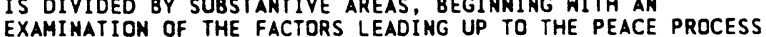
AND THE IMPORTANCE OF PROPERLY-STRUCTURED NEGOTIATIONS IN AACILITATING SUCCESSFUL CONFLICT RESOLUTION. THE SECOND PART FACILITATING SUCCESSFUL CONFLICT RENOL TON. THE SECOND PART FOCUSES ON THE POSSIBLE CONTRIBUTION OF ECDNOMIC COOPERATION IN SUSTAINING A SETTLEMENT. THE FINAL SECTION EXPLORES THE ISSUE OF ARMS CONTROL, FOR ONLY WHEN THE MIDEAST STAT SECURE WILL THER
ACCOMMODATION.

08701 SPIEGEL, S.L. (ED.): ZARTMAN, I.H.

THE NEGOTIATION PROCESS IN THE MIDOLE EAST; THE ARABISRAELI SEARCH FOR PEACE

LYNNE RIENNER PUBLISHERS, 1992, 63-70

THE AUTHOR ARGUES THAT PROSPECTS FOR PEACE IN THE MIDOLE EAST ARE NOT ESPECIALLY BRIGHT DUE TO THE LACK OF A "RIPE 
SIDES. HE EMPHASIZES THE POTENTIAL UTILITY OF "CARROTS AND STICXS" HELD BY BOTH REGIONAL AND EXTERNAL ACTORS--INCLUDING JEWISH, ARAB, AND CHRISTIAN COMMUNITIES IN THE UNITED STATES-IN MAKING CLEAR THE BENEFITS OF ACCOMMODATION AND THE COSTS OF DETERIORATION. REGARDING THE WEST BANK, HE SUGGESTS THERE IS A NEED TO GO BEYOND CONVENTIONAL CONCEPTS OF NEW AND LOOSER APPLICATIONS OF SOVEREIGNTY.

08702 SPINDLER, $Z$.

LIBERTY AND DEVELOPMENT: A FURTHER EMPIRICAL PERSPECTIVE PUBLIC CHOICE, 69(2) (FEB 91), 197-210.

THIS PAPER USES THE WRIGHT RATINGS OF ECONOMIC FREEDOM TO INVESTIGATE THE RELATIONSHIP BETWEEN ECONOMIC FREEDOM AND ECONOMIC DEVELOPMENT FOR MOST COUNTRIES IN THE WORLD. THIS RELATIONSHIP IS APPARENTLY STRONG AND DIRECT FOR SUCH ECONOMIC FREEDOMS AS FREEDOM OF PROPERTY AND FREEDOM OF MOYEMENT BUT INYERSE FOR FREEDOM OF ASSOCIATION. THESE FINDIMGS APPEAR TO BE INDEPENDENT OF THE TYPE OF ECONOMIC SYSTEM OR CIVIL LIBERTIES, AS MEASURED BY THE GASTIL RATINGS, SYSTEM OR CIVIL LIBERTIES, AS MEASURED BY THE GASTIL
WHICH HAVE THEIR OWN IMPORTANT EFFECTS ON ECONOMIC WHICH HAVE
DEVELOPMENT.

08703 SPINNER, J

CONSTRUCTING COMMUNITIES: EDMUND BURKE ON REVOLUTION POLITY XXIII (3) (SPR 11$)$ 395-422

WHY DID EDMUMD BURKE SUPPORT THE AMERICAN REVOLUTION BUT OPPOSE THE FRENCH? THE USUAL EXPLANATION LIES IN BURKE'S SUPPORT FOR TRADITION: THE AMERICANS WERE TRYING TO RESTORE THEIR TRADITIONAL RIGHTS, WHEREAS THE FRENCH BROKE RADICALLY WITH THE PAST. THIS ARTICLE FINDS THAT EXPLANATION INCOMPLETE. IT DOES NOT, THE AUTHOR ARGUES, EXPLAIN MANY OF THE APPARENT DISCREPANCIES IN BURKE'S WRITINGS ON THE THO REVOLUTIONS, AND HE LOOKS TO BURKE'S ACCOUNT OF COMMUNITIES

08704 SPINNEY, F.C.

UMCLE SAM'S BUDGET SHAMBLES

CHALLENGE, 35(3) (MAY 92), 9-12.

WITH THE U.S. ECONOMY CAREENING TOWARD A FINANCIAL

MELTDOWN, MOST OF THE CANDIDATES RUNMING FOR PRESIDENT AND BOTH PARTIES IN CONGRESS ARE SAYING THAT TAX CUTS WILL

STIMULATE THE ECONOMY AND RELIEVE THE HARDSHIPS AFFLICTIING THE MIDDLE CLASS. UNFORTUNATELY, THE POLITICALLY-EXPEDIENT IDEA OF CUTTING TAXES TO STIMULATE GROWTH WILL ONLY MAKE THE LONG-TERM PROGNOSIS WORSE. PAINFUL ADJUSTMENTS ARE BOTH NECESSARY AND INEVITABLE.

08705 SPOHN, C.: HORNEY, J. RPOPE LAW REFORM: A GRASSROOTS REVOLUTION AND ITS IMPACT PLENUM PRESS, 1992, 192.

TRACE THE EVOLUTION OF THE RAPE LAN REFORM MOYEMENT IN THE UNITED STATES AND ANALYZE THE IMPACT OF RAPE LAW REFORM IN SIX URBAN JURISDICTIONS: DETROIT, CHICAGO, LAW REFORM IN SIX URBAN JURISDICTIONS: DETROIT, CHICAGO, PHILADELPHIA, ATLANTA, HOUSTON, AND WASHINGTON, D.C.

DISCUSS CONTEXTUAL DIFFERENCES AND CASE-PROCESSING VARIATIONS IN DIFFERENT JURISOICTIONS, THE ATTITUDES OF RAPE LAH REFORM.

08706 SPOHN, $H$.

RELIGION AND WORKING-CLASS FORMATION IN IMPERIAL GERMANY $1871-1914$

POLITICS AND SOCIETY, 19(1) (MAR 91), 109-132.

UNTIL RECENTLY, RELIGION AND SECULARIZATION HAVE NOT BEEN MAJOR TOPICS EITHER WITHIN STUDIES OF LABOR HISTORY OF SPECIFIC NATIONS OR WITHIN COMPARATIVE HISTORICAL-

SOCIOLOGICAL APPROACHES TO WORKING-CLASS FORMATION. THIS ARTICLE ARGUES THAT HE RELIGIOUS COMPONENTS OF WORKING-CLASS FORMATION IN IMPERIAL GERMANY CONTRIBUTED TO THE FUNDAMENTAL POLITICAL DIVISIONS BETHEEN THE VARIOUS WORKING-CLASS CURRENTS. THIS HAD A CRUCIAL LONG-TERM IMPACT ON THE HISTORY OF WORKING-CLASS FORMATION IN TWENTIETH-CENTURY GERMANY.

08707 SPOTTS, S.E.

THE PRESIDENTIAL DEBATES ACT OF 1992

HARVARD JOURNAL OF LEGISLATION, 29(2) (SUM 92), 561-580.

THE AUTHOR LOOKS AT SOME OF THE PROBLEMS INHERENT IN THE 1988 PRESIDENTIAL CAMPAIGN DEBATES AND AT THE EFFORT TO IMPROVE THE CONTENT AND FORMAT OF FUTURE DEBATES, IN ORDER TO BETTER INFORM THE ELECTORATE.

08708 SPRINGBORG, R.

NO PEACE ABROAD - NO BREAD AT HOME

IHIS REPORT' ON THE AMERICAN HORD ORDER ARGUES THAT THE UNITED STATES ADMINISTRATION PUT FORWARD THE NEW WORLD ORDER TO PRE-EMPT A DISCOURSE OF PEACE. IT SUGGESTS THAT AFTER THE DEMISE OF THE SOVIET UNION A NEH SUBSTITUTE MENACE WAS FOUND IN THE FORM OF SADDAM HUSSEIN. IT CONCLUDES THAT PAX

AMERICANA IS LIKELY TO AFFLICT THE GLOBE UNTIL THE WRETCHED OF THE EARTH ONCE AGAIN MAKE THE HUGE SACRIFICE THAT WILL EMBOLDEN THE MORE TIMID FOLKS TO AT LEAST SPEAK UP AGAINST THE OUTRAGE.
08709 SOUIRE, $P$.

CHALLENGER PROFILE AND GUBERNATORIAL ELECTIONS

WESTERN POLITICAL OUARTERLY, 45(1) (MAR 92), 125-142. ALTHOUGH CHALLENGER PROFILE OR OUALITY IS AN IMPORTANT YARIABLE IN EXPLAINING LEGISLATIVE ELECTIONS, ITS UTILITY IN GUBERMATORIAL CAMPAIGHS HAS NOT BEEN EXPLORED. IN THIS PAPER, THE AUTHOR STUDIES CHALLENGER PROFILE IN GUBERNATORIAL CONTESTS, USING AGGREGATE DATA FOR ELECTIONS FROM 1977 TO 1989. HE SHOWS THAT THE DYNAMICS OF OPEN-SEAT CONTESTS DIFFER FROM THOSE HITH AN INCUMBENT RUNNING. HIGHER-PROFILE CANDIDATES RUN IN OPEN-SEAT CONTESTS THAN AGAINST INCUMBENTS, BUT PROFILE LEVEL EXERTS A STRONGER INFLUENCE IN INCUMBENT RACES. ECONOMIC CONDITIONS AFFECT CHALLENGER PROFILE IN RACES INVOLVING INCUMBENTS BUT NOT IN CAMPAIGNS FOR OPEN SEATS. ALTHOUGH CHALLENGER PROFILE IS CONSEQUENTIAL, THE STRENGTH OF A CANDIDATE'S PARTY IN THE STATE IS THE MOST IMPORTANT VARIABLE IN EXPLAINING THE RESULTS OF BOTH OPENSEAT AND INCUMBENT RACES.

08710 SQUIRE, $P$.

CHALLENGER QUALITY AND VOTING BEHAVIOR IN U.S. SENATE ELECTIONS

LEGISLATIVE STUDIES QUARTERLY, 27(2) (MAY 92), 247-264. A NUMBER OF STUDIES FIND THAT CHALLENGER QUALITY IS AN IMPORTANT VARIABLE IN EXPLAINING CONGRESSIONAL ELECTION OUTCOMES. THIS STUDY PROVIDES INDIVIDUAL-LEVEL EVIDENCE
SUPPORTING THIS CLAIM. IT DEVELOPS AND TESTS MEASURES OF TWO SUPPORTING THIS CLAIM. IT DEVELOPS AND TESTS MEASURES
ASPECTS OF CHALLENGER QUALITY, ONE BASED ON POLITICAL ASPECTS OF CHALLENGER QUALITY, ONE BASED ON POLITICAL
EXPERIENCE AND THE OTHER ON CAMPAIGN SKILLS. THE FINDINGS EXPERIENCE AND THE OTHER ON CAMPAIGN SKILLS. THE FINDINGS REAFFIRM THAT CANDID
ELECTION OUTCOMES

08711 SOUIRE, $P$.

LEGISLATIVE PROGESSIOMALIZATION AND MEMBERSHIP DIVERSITY IN STATE LEGISLATURES

LEGISLATIVE STUDIES QUARTERLY, 17(1) (FEB 92), 69-80. PERVERILL SQUIRE TESTS THE PROPOSITION THAT LEGISLATIVE PROGESSIONALIZATION INCREASES MEMBERSHIP DIVERSITY, DEFINED AS THE PROPORTIONS OF BLAKCS, WOMEN, AND VARIOUS OCCUPATIONAL GROUPS. USING A MEASURE OF PROFESSIONALIZATION BASED ON THE U.S. CONGRESS AS A BASELINE, HE FINDS THE MORE PROGESSIONAL LEGISLATURES HAVE MORE BLACKS AND FEWER WOMEN BUT THAT THEY LACK DIVERSITY BECAUSE THEY INCLUDE A LARGER PROPORTION OF MEMBERS WHO DEFINE THEIR OCCUPATION AS FULLTIME LEGISLATOR. HE CONCLUDES THAT FACTORS OTHER THAN PROFESSIONALIZATION LARGELY EXPLAIN THE PROPORTIONS OF PARTICULAR GROUPS.

08712 SQUIRE, $P$.

THE THEORY OF LEGISLATIVE INSTITUTIONALIZATION AND THE CALIFORNIA ASSEMBLY

THE JOURNAL OF POLITICS, 54(4) (NOV 92), 1026-1054. ANALYSIS OF OYERTIME CHAMGE IN LEGISLATURES IS A RARELY ATTEMPTED UNDERTAKING. THE AUTHOR ARGUES THAT THE PROCESS OF LEGISLATIYE INSTITUTIONAL IZATION IS DRIVEN BY THE

LEGISLATIVE INSTITUTIONALIZATION IS DRIVEN BY THE MEMBERSHIP'S CAREER GOALS. EXAMINATION OF DATA CDLLECTED ON THE CALIFORNIA ASSEMBLY PROOUCES IMPORTANT CONTRASTS WITH
THE HOUSE. EXAMINATION OF DATA REVEALS THAT THE ASSEMBLY HAS THE HOUSE. EXAMINATION OF DATA REVEALS THAT THE ASSEMBLY HAS INCREASED INTERNAL COMPLEXITY. IT FAILS TO EMPLOY SENIORITY AS THE MAIN RULE FOR THE DISTRIBUTION OF POSITIONS OF POWER. MORE DISCRETIONARY AND PARTICULARISTIC METHODS BETTER SERVE THE CAREER NEEDS OF THE ASSEMBLY MEMBERSHIP. THIS ANALYSI COMCEPT OF INSTITUTIONALIZATION.

08713 SRIDHARAN, E.

LEADERSHIP TIME HORIZONS IN INDIA: THE IMPACT ON ECONOMIC RESTRUCTURING

ASIAN SURVEY, 31 (12) (DEC 91), 1200-1213

THIS ARTICLE SEEKS TO EXPLORE THE RELATIONSHIP BETWEEN THE INSTITUTIONAL-PROCEDURAL FRAMEWORK AND THE POL ITICAL PROCESSES IN INDIA'S FEDERAL PARLIAMENTARY DEMOCRACY, ON THE ONE HAND, AND ON THE OTHER, THE TIME HORI ZONS OF POL ITICAL LEADERSHIPS AND THEIR CONSEQUENCES FOR THE DEVELOPMENT OF ECONOMIC POLICY. IT IS ARGUED THAT SEVERAL FEATURES OF THE SYSTEM IMPOSE A SHORT-TERM PERSPECTIVE ON GOVERMMENTS AT THE CENTER AND IN THE STATES, AND THAT THIS MILITATES AGAINST THE KINDS OF ECONOMIC POLICIES THAT HAVE SHORT-TERM POLITICAL COSTS BUT LONG-TERM BENEFITS, SUCH AS ECONOMIC RESTRUCTURING FOR COMPETITIVENESS. SOME OPTIONS FOR POLITICAL REFORMS THAT HOULD EXTEND THE TIME HORIZONS OF LEADERSHIPS BY LENDING A MODICUM OF SECURITY OF TENURE TO GOVERNMENTS ONCE ELECTED, WHILE LIMITING THEIR DISCRETIONARY POWERS TO CHECK THE MUSUSE OF SUCH SECURITY ARE EXPLORED IN THE CONTEXT OF THE PRESENT AND POSSIBLE FUTURE MINORITY OR THE CONTEXT OF THE PRESE

08714 SRIRAM, $K$

MARKETS AND STATES IN DEVELOPMENT: THE SEARCH CONTINUES FOR AN OPTIMAL MIX

SCANDINAYIAN JOURMAL OF DEVELOPMENT ALTERNATIVES, XI(1) (MAR 92), 41-52.

WHILE CURRENT THINKING ABOUT DEVELOPMENT CALLS FOR A 
BIGGER ROLE FOR MARKET FORCES, THE MARKETS IN DEVELOPING COUNTRIES ARE LESS DEVELOPED AND FRAGMENTED--SOMETIMES, EVEN NONEXISTENT. THUS, THE STATE MUST DEVELOP THE MARKET AND SOMETIMES SUBSTITUTE FOR IT. IT IS AN INTERESTING PARADOX THAT THE STATE MUST INTERVENE WITH THE AIM OF ULTIMATELY REDUCING ITS OWN ROLE IN THE FUNCTIONING OF THE NATION'S ECONOMY.

08715 SRIVASTAVA, R.S.

REGION, NATION, AND CLASS IN INDIA; ASSOCIATION FOR ASIAN STUDIES 1992 ANNUAL MEETING

STUDIES 1992 ANNUAL MEETING
ASSOCIAITON FOR ASIAN STUDIES, 1992, 129.

THIS PRESENTATION FOCUSES ON THE' PRINCIPAL WAYS IN WHICH THE THREE MAJOR SOCIAL CATEGORIES OF NATION, RELIGION AND THE THREE MAJOR SOCIAL CATEGORIES OF NATION, RELIGION
CLASS HAVE MESHED TOGETHER IN THE EVOLUTION OF INDIAN CLASS HAVE MESHED TOGETHER IN THE EVOLUTION OF INDIAN POLITICS SINCE 1947. THE ROOTS OF THE INTERCONNECTION
BETWEEN THESE THREE LEVELS OF POLITICAL ARTICULATION ARE BETWEEN THESE THREE LEVELS OF POLITICAL ARTICULATION ARE
LOCATED IN THE DIVERSE DISCOURSES THAT WERE GENERATED DURING LOCATED IN THE DIVERSE DISCOURSES THAT WERE GENERATED DUR
THE ANTI-COLONIAL NATIONALIST MOVEMENT. OF THESE, THE DISCOURSES DEVELOPED BY THE INDIAN NATIONAL CONGRESS, THE INDIAN COMMUNIST MOVEMENT, AND THE VOICES GIVEN TO THE SPECIFIC POLITICAL, SOCIAL, AND ECONOMIC ASPIRATIONS OF THE DIFFERENT COMMUNITIES (HINDU, MUSLIM, AND BACKHARD CASTES) CONSTITUTE THE MAJOR STRANDS. THE PUNJAB, THE MORTHEASTERM AND THE KASHMIR QUESTIONS; THE NEW PERSPECTIVES THAT HAVE SURFACED AS A RESULT OF AN ACTIVE HOMEN'S MOVMENT: THE TRANSMUTATION OF "CASTE" FROM AN IMMUTABLE GIVEN INTO NEH POLITICAL AND ECONOMIC CONFIGURATIONS GIVING RISE TO ACUTE TENSIONS: AND THE RISE OF COMMUNALISM ARE ALL INDICATIONS THAT EACH OF THE ABOVE-MENTIONED DISCOURSES HAVE BEEN SUBJECTED TO PRESSURE FROM SOCIAL FORCES NO LONGER WILLIMG TO SUBORDINATE THEIR SPECIFIC INTERESTS TO THE "NATIONAL" INTEREST.

08716 ST. JOHN, E.

A FRAMENORK FOR REEXAMINING STATE RESOURCE-MANAGEMENT STRATEGIES IN HIGHER ECUCATION

JOURNAL OF HIGHER EDUCATION, 62 (3) (MAY 91), 263-287.

SEVERE HIGHER EDUCATION, 62 (3) MAY 91), 263-287. MANY STATES TO REDUCE THEIR APPROPRIATIONS FOR PUBLIC HIGHER MANY STATES TO REDUCE THEIR APPROPRIATIONS FOR PUBLIC HIGHER
EDUCATION, A CONDITION THAT WILL APPARENTLY PERSIST IN THE EDUCATION, A CONDITION THAT WILL APPARENTLY PERSIST IN THE
$1990 S$. BASED ON AN EXAMINATION OF RECENT DEVELOPMENT IN 1990S. BASED ON AN EXAMINATION OF RECENT DEVELOPMENT IN THAT STATES CAM USE TO REEXAMINE THEIR RESOURCE-MANAGEMENT STRATEGIES IN HIGHER EDUCATION.

08717 ST. JOHN, R.

LIBYAN TERRORISM: THE CASE AGAINST GADDAFI

CONTEMPORARY REVIEW, 261 (1523) (DEC 92), 294-298.

IT IS PONDERED HHETHER GADDAFI WAS FREEDOM FIGHTER OR TERRORIST? PROPHET OR COMHON CRIMINAL? THE RECENTLY IMPOSED UNITED NATIONS SANCTIONS AGAINST LIBYA AGAIN FOCUS ATTENTION ON AN ISSUE WHICH HAS TROUBLED THE HORLD FOR MORE THAN THO
DECADES. THERE IS CONSIDERABLE REASON TO BELIEVE THE LIBYAN GOVERNMENT HAS BEEN A CONSISTENT SUPPORTER OF STATESPONSORED TERRORISM DURING THAT TIME. THIS ARTICLE CONCLUDES THAT THERE IS LITTLE EVIDENCE TODAY OF ANY REAL CHANGES IN THE POLICIES LIBYA HAS SINGLE-MINDEDLY PURSUED SINCE COMING TO POWER IN 1969.

08718 ST. JOHN, R.

THE FOREIGN POLICY OF PERU

LYNNE RIENNER PUBLISHERS, 1991, 269

SINCE PERU GAINED INDEPENDENCE IN 1824, ITS FOREIGN POLICY HAS BEEN SHAPED BY THE CONFLICTING DEMANDS OF INDEPENDENCE AND INTERDEPENDENCE. RONALD BRUCE ST JOHM SYSTEMATICALLY ANALYZES THE STRONG LINK BETWEEN THE EXTERNAL AND INTERNAL CONCERNS THAT DETERMINE PERUVIAN FOREIGN POLICY, DEMONSTRATING THAT DOMESTIC OBJECTIVES AND POLITICAL DEMONSTRATING THAT DOMESTIC OBJECTIVES AND POLITICAL
CONSIDERATIONS STRONGLY INFLUENCE MANY ASPECTS OF THE CONSIDERATIONS STRONGLY INFLUENCE MANY ASPECTS OF THE NATION'S INTERNATIONAL POSTURE. THIS BOOK STUDIES: THE
SEARCH FOR NATIONAL IDENTITY; RIVALRY IN THE PACIFIC; THE SEARCH FOR NATIONAL IDENTITY; RIVALRY IN THE PACIFIC; THE
WAR OF THE PACIFIC; POSTWAR RECONSTRUCTION AND REGENERATION; WAR OF THE PACIFIC; POSTWAR RECONSTRUCTION AND REG
AND NEH HORIZONS FOR THE FOREIGN POLICY OF PERU.

08719 STAAR, R.

THE RUSSIAN MILITARY IN A UNION OF SOVERIEGN STATES MEDITERRANEAH QUARTERLY: A JOURNAL OF GLOBAL ISSUES, $3(1)$ (WIN 92 )

THIS ARTICLE EXAMINES SEVERAL FACTORS WHICH ARE CRITICAL FOR UNDERSTANDING THE FUTURE OF THE RUSSIAN MILITARY IN A UNION OF SOVEREIGN STATES: THE 19-21 AUGUST 1991 ABORTIVE SERIOUS DISCUSSION ABOUT REFORM SHORTLY THEREAFTER; ATTEMPTS TO ADAPT MILITARY DOCTRINE IN THE CHANGING POLITICAL CONFIGURATION OF A UNION WITH AN UNCERTAIN FUTURE; THE
SEARCH FOR SAVINGS BY CONVERSION FROM MILITARY TO CIVILIAN SEARCH FOR SAVINGS BY CONVERSION FROM MILITARY TO CIVILIAA
PRODUCTION AND BY BUDGET CUTS; AND A POSSIBLE SCENARIO REGARDING FUTURE DEVELOPMENTS

08720 STABENOW, M.

SINGLE EUROPEAN MARKET BECKONS AS THE BARRIERS COME DOWN GERMAN TRIBUNE, (1505) (FEB 92)

THE SINGLE EUROPEAN MARKET IS SCHEDULED FOR COMPLETION
ON 31 DECEMBER 1992. HOWEVER, THE DATE BY NO MEANS MARKS THE BEGINHING OF A NEN ERA. MANY BORDER BARRIERS HAVE ALREADY BEEN REMOVED, AND THERE WILL STILL BE PLENTY OF OBSTACLES AT THE BEGINNING OF 1993. AT MOST BORDER CROSSINGS IN THE EUROPEAN COMMUNUITY ONLY THE MOST CONSCIENTIOUS CUSTOMS OFFICIALS STILL SEARCH THROUGH LUGGAGE. BORDER CONTROLS IN AIR TRAFFIC, HOWEVER, WILL STILL BE ALLOWED UNTIL 1995. THE FREE MOVEMENT OF CAPITAL HAS LONG SINCE BECOME REALITY AMONG MOST COMMUNITY STATES; IN THE SOUTH OF EUROPE, ON THE OTHER HAND, THE RESTRICTIONS IN THIS FIELD ARE ALLOWED TO REMAIN UNTIL THE END OF 1995. A BACKLOG OF OVER 50 PROPOSED CHANGES HAS YET TO BE ADOPTED. APART FROM THE REDUCTION OF STILL EXISTING RESTRICTIONS TO MARKET ACCESS, THE PREVENTION OF NEW TRADE BARRIERS, PARTICULARLY THROUGH DIFFERING ENVIRONMENTAL STIPULATIONS, IS ONE OF THE MAIN CHALLENGES.

08721 STACK, J.F. JR.

JUDICIAL POLICY-MAKING AND THE EVOLVING PROTECTION OF HUMAN RIGHTS: THE EUROPEAN COURT OF HUMAN RIGHTS IN

COMPARATIVE PERSPECTIVE
WEST EUROPEAN POLITICS, 15(3) (JUL 92), 137-155.

THIS IS A COMPARATIVE ANALYSIS OF THREE ATTEMPTS TO STRENGTHEN THE SUPRANATIONAL PROTECTION OF HUMAN RIGHTS IN AN INCREASINGLY TRANSNATIONAL WORLD. IT FOCUSES ON THE HUMAN RIGHTS COMMITTEE OF THE UNITED NATIONS, THE EUROPEAN COURT OF HUMAN RIGHTS, AND THE INTER-AMERICAN COURT OF HUMAN RIGHTS. THE RECENT DECISION BY THE INTER-AMERICAN COURT ON THE FORCED DISAPPEARANCE OF INDIVIDUALS BY STATE OR PARASTATE FORCES ILLUSTRATES THE IMPORTANT ROLE OF CROSSPOLLENIZATION FROM THE EUROPEAN COURT AND THE UNITED NATIONS. IT FURTHER DEMONSTRATES HOW JUDGES ON SUPRANATIONAL COURTS ATTEMPT TO MAKE LAW IN THE FACE OF UNCERTAIN GOVERNMENT COMPLIANCE.

08722 STADELMANN, B.

LAND CONSTITUTION PLEBISCITE WAS POLITICAL LITMUS TEST GERMAN TRIBUNE, (1521) (JUN 92), 4.

THE PEOPLE OF BRANDENBURG HERE THE FIRST IN THE NEH ANDER (FEDERAL STATES) OF EASTERN GERMANY TO DIRECTLY DECIDE IN A REFERENDUM ON WHETHER TO ACCEPT A DRAFT CHANGE TO THE LAND CONSTITUTION. BRANDENBURG IS THE ONLY LAND IN THE FORMER EAST GERMANY THAT IS GOVERNED BY THE SOCIAL THE FORMER EAST GERMANY THAT IS GOVERNED BY THE SOCIAL DEMOCRATIC PARTY (SPD). THEREFORE, THIS PLEBISCITE WAS REGARDED AS SOMETHING OF A VOTE OF CONFIDENCE FOR THE EMBATTLED SPD PREMIER, MANDRED STOLPE, WHO HAS BEEN UNDER INTENSE PRESSURE OVER THE EXTENT OF HIS CONNECTIONS STASI (FORMER EAST GERMAN SECRET POLICE). WHILE AN OVERWHELMING MAJORITY OF PARTICIPANTS IN THE VOTE FAVORED
THE DRAFT AND SOME 95 PERCENT SUPPORTED STOLPE. THE LOW THE DRAFT AND SOME 95 PERCENT SUPPORTED STOLPE, THE LOW
TURNOUT (LESS THAN 50 PERCENT) CAST SOME DOUBT ON THE ENTIRE PROCEEDINGS.

08723 STAFFORD, J.

WELCOME BUT WHY? RECENT CHANGES IN CANADIAN IMMIGRATION POLICY AMERICAN REVIEH OF CANADIAN STUDIES, 22(2) (SUM 92), 235-258

IN 1982, IMMIGRATION LEVELS IN CANADA HERE TO BE REDUCED.

IN 1986, PROJECTED FUTURE IMMIGRATION IN CANDADA WERE RAISED BY 10,000. THE PURPOSE OF THIS PAPER IS THREEFOLD: TO EXPLAIN THE REVERSAL IN GOVERMMENT POLICY; TO EXAMINE CRITICALLY THE VALIDITY OF THE ARGUMENTS SUPPORTING AN INCREASE IN IMMIGRATION; AND TO PROVIDE A FRAMEWORK HITHIN WHICH TO CARRY OUT DISCUSSION ON THE ADVANTAGES AND DISADVATAGES OF INCREASING IMMIGRATION LEVELS IN CANDA. IT BEGINS HITH A DESCRIPTION OF IMMIGRATION POLICY AS IT WAS APPL IED SINCE HORLD WAR II AND GOES ON TO EXAMIME CHANGES IN THE POLICY AND FACTORS BEHIND THESE CHANGES.

08724 STAHL, S.M.

RELIGIOUS PLURALISM AND THE WALL: SEPARATION PROTECTS EVERYONE'S RIGHTS

CHURCH AND STATE, 45(4) (APR 92), 19(91)-20(92).

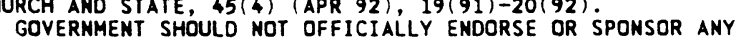
RELIGIOUS HOLIDAY OR ANY SACRED SYMBOL. RELIGION AND STATE MAKE INCOMPATIBLE MARRIAGE PARTNERS. THE HALL BETWEEN THEM MAKE INCOMPATIBLE MARRIAGE PARTNERS. THE HALL BETHEEN THEM
MUST REMAIN STURDY AND STRONG. ONCE A CRACK IN THAT WALL MUST REMAIN STURDY AND STRONG. ONCE A CRAC
APPEARS, ALL KINDS OF DANGERS CAN ERUPT.

08725 STALSETT, G.

RELIGIOM AND NATIONALISM

BULLETIN OF PEACE PROPOSALS, 23(1) (MAR 92), 3-10. THIS ARTICLE EXAMINES THE COMPLEX AND AMBI IGUOUS RELATIONSHIP BETWEEN NATIONALISM AND RELIGION IN EUROPE. NATIONAL IDENTITY HAS UNITED PEDPIE FOR THE GREATER GOOD AND HAS BROUGHT ABOUT PROGRESS ANO GROWTH: IT HAS ALSO BEEN THE DARK FORCE BEHIND HATRED AND GENOCIDE. RELIGION HAS SUSTAINED PEOPLE IN HOPE AND HITNESSED TO GOD'S LOVE FOR ALL HUMANKIND, BUT IT HAS ALSO BEEN USED TO DESTROY AND OPPRESS IN GOD'S NAME. THE ARTICLE SEEKS TO DETERMINE THE EXTENT TO WHICH THE COLLABORATION OF RELIGION AND NATIONALISM HAS ENABLED FULFILMENT OF LEGITIMATE ASPIRATIONS AND THE EXTENT TO WHICH THEY HAYE MANIPULATED EACH OTHER FOR THEIR OWM PARTICULAR ENDS. EMPHASIS IS ON CENTRAL AND EASTERN EUROPE 
WITH EXAMPLES FROM YUGOSLAVIA, POLAND, ROMANIA, THE BALTIC STATES, UKRAINE, AND GEORGIA.

08726 STANFORD, $K$

DISARMING THE HUNTER: IMPROVING ADMINISTRATIVE WRITING IN THE CLASSROOM

PS: POLITICAL SCIENCE AND POLITICS, 25(4) (DEC 92),

696-699.

THAT WRITING IS INSEPARABLE FROM THE PRACTICE OF

POLITICAL SCIENCE IS AN OBSERVATION THAT MAY BE EVEN MORE

PERTINENT TO THOSE STUDENTS WHO ENTER GRADUATE PROGRAMS IN PUBLIC ADMINISTRATION. THIS ARTICLE, WHILE CONCENTRATING ON WRITING WITHIN PUBLIC ADMINISTRATION GRADUATE PROGRAMS, SPEAKS TO ISSUES THAT CONCERN ALL TEACHERS WHOSE STUDENTS INTEND CAREERS IN PUBLIC SERVICE. IT EXPLORES HOW PUBLIC ADMINISTRATION FACULTIES CAN ADORESS THE TEACHING OF WRITING PROCESSES THAT RESULTS IN SUCCESSFUL PRODUCTS.

08727 STANFORD, K.A.

STATE BUDGET DELIBERATIONS: DO LEGISLATORS HAVE A STRATEGY? PUBLIC ADMINISTRATION REVIEW, 52(1) (JAN 92), 16-26.

THE AUTHOR STUDIES BUDGET HEARINGS IN THE' FLORIDA STATE LEGISLATURE TO DETERMINE IF LEGISLATIVE DELIBERATION OVER AGENCY BUDGET REQUESTS IS FOCUSED AND CALCULATIVE AND HHAT FACTORS DETERHINE THE FORM AND IMPACT OF THOSE DELIBERATIONS FOCUSING ON FOUR YEARS OF HEARINGS AND ANALYZING MORE THAN
12,000 OUESTIONS ASKED BY LEGISLATORS, SHE FINDS "A MORE 12,000 QUESTIONS ASKED BY LEGISLATORS, SHE FINDS SOPHISTICATED DECISION CALCULUS THAN SUGGESTED BY INCREMENTAL THEORY." HER FINDINGS INDICATE THAT THERE ARE
DISCERNIBLE PATTERNS IN THE LEGISLATIVE QUESTIONS REFLECTING DISCERNIBLE PATTERNS IN THE LEGISLATIVE QUESTIONS REFLECT DISTINCT ORIENTATIONS (CONTROL, MANAGEMENT, PLANNING AND FUNDING) TOHARD AGENCY BUDGETS. SHE ALSO FINDS THAT THO MISSIONS, AND TYPE OF AGENCY FUNDING SOURCES. THESE FINDINGS IMPLY THAT LEGISLATIVE PARTICIPATION IN THE BUDGETARY PROCESS IS MORE STRATEGIC THAN USUALLY ASSUMED.

08728 STANKEVICH, S

RUSSIA IN SEARCH OF ITSELF

NATIONAL INTEREST, 28 (SUM 92), 47-50.

SERGI STANKEVICH SUGGESTS THAT THE WORLD IS CHANGING RAPIDLY, AND NEH INTERSECTIONS OF INTERESTS AND NEH REGIONAL FDRMATIONS WITH AN INDEPENDENT ORIENTATION ARE EMERGING. ALL THIS IS AFFORDING RUSSIA OPPORTUNITIES TO OBTAIN PROPITIOUS GEOPOLITICAL POSITIONS IN KEY REGIONS, AND TO RANK, IN TIME, AMONG THE WORLD LEADERS. HE SEES RUSSIA'S MISSION IN THE HORLD IS TO INITIATE AND SUPPORT A MULTILATERAL DIALOGUE OF CURLD IS TO INITIATE AND SUPPORT A MULT TLATERAL DIALOGUE OF CULT EAST, CIVILIZATIONS, AND STATES. A COUNTRY IMBIBING WEST AND EAST, NORTH AND SOUTH, UNIQUE AND EXCLUSIVELY CAPABLE

08729 STANLEY, G.

WHITER CAMAOA?

POLITICAL OUARTERLY (THE), 63(3) (JUL 93) 329-340.

THIS ARTICLE EXPLORES HHAT IS HAPPENING IN CANADA. CANADIAN FEDERALISM IS IN CRISIS. IT IS TEMPTING TO FOCUS ON QUEBEC BUT THE TENSIONS AROUSED BY A FRACTIOUS QUEBEC ARE NOT THE CAUSE OF THE CRISIS CANADA FACES TODAY. THE ARTICLE SUGGESTS THAT QUEBEC INDEPENDENCE IS ONE POSSIBLE OUTCOME OF THE CURRENT CRISIS BUT IT IS ONLY ONE OF MANY AND, FOR MOST OF THOSE INVOLVED, WOULD BE AK UNINTENDED CONSEQUENCE, A RESULT OF THE MISHAHDLING OF THE FORCES AT HORK. IT ALSO SUGGESTS THAT A MORE LIKELY CONSEQUENCE IS THAT CANADA IS REORGANIZING ITSELF TO PLAY A MORE VIGOROUS ROLE IN A GLOE ECONOMY AMD THE MANAGEMENT OF NORTH AMERICA AS A WHOLE. CANADA SEEMS TO BE SUFFERING FROM A LACK OF LEADERSHIP AT TIME HEN ITS INSTITUT
NECESSARY ADJUSTMENTS.

08730 STANLEY, H.: NIEMI, R.

PARTISAMSHIP AND GROUP SUPPORT, 1952-1988

AMERICAN POLITICS QUARTERLY, 19(2) (APR 91), 189-210.

THE ARTICLE UPDATES THE AUTHORS' MULTIVARIATE ANALYSIS

OF GROUP SUPPORT FOR POLITICAL PARTIES THROUGH 1988 AND

EXPANDS IT TO NEH GROUPS, MIDTERM ELECTION YEARS, AMD

REPUBLICAN IDENTIFIERS. SHOWN IN OETAIL ARE THE CHANGES IN LONG-TERM COMPONENTS OF THE PARTY COALITION AMD THE PARTISAN TENDENCIES OF NEWLY PROMINENT GROUPS SUCH AS HISPANICS AMD RELIGIOUS FUNDAMENTALISTS. THERE ARE THREE GENERAL FINDINGS. FIRST, THE GREATEST MOVEMENT IS AHAY FROM THE NEW DEAL DEMOCRATIC COALITION BUT NOT INTO THE REPUBLICAN COALITION; DEMOCRATIC COALITION BUT NOT INTO THE REPUBLICAN COALITION:
REPUBLICANS HAVE YET TO FINAD A STRONG BASIS OF GROUP REPUBLICANS HAVE YET TO FINAD A STRONG BASIS OF GROUP SUPPORT. SECOND, AND OF MORE THEORETICAL IMPORT, IS THAT CHANGES IN PARTY SUPPORT OCCUR SLOWLY, SUGGESTING THAT GROUP REALIGNMENTS HAVE BEEN CHARACTERIZED BY SECULAR DECLINES AND ADVANCE RATHER THAN BY ABRUPT, "CRITICAL" ELECTIONS. FINALLL PARTIES AS ARE THE OLDER GROUPS, PERHAPS BOTH A CAUSE AND CONSEQUENCE OF THE PRESENT CANDIDATE-CENTERED PARTY SYSTEM.

08731 STANLEY, H.

SOUTHERN REPUBLICANS IN CONGRESS: HAVE THEY FALLEN AND

THEY CAN'T GET UP?

SOCIAL SCIENCE QUARTERLY, 73(1) (MAR 92), 136-140.
THIS ARTICLE EXAMINES THE ROLE THAT PRIMARY COMPETITION OR ITS LACK) HAS PLAYED IN THE "STALL" OF THE FORTUNES OF REPUBLICAN WOULD-BE LEGISLATORS IN THE SOUTH. IT CONCLLDES THAT A COMPETITIVE PRIMARY IS OFTEN A DIVISIIVE DETRIMENT TO WOULD-BE LEGISLATORS. FURTHERMORE, THE EXCEPTIONAL NATURE OF SOUTHERN POLITICS IS GRADUALLY CHANGING. IT CONCLUDES THAT THE FAILURE OF SOUTHERN REPUBLICANS IN CONVERTING PRESIDENTIAL-LEVEL POLITICAL APPEAL INTO MORE CONGRESSIONAL SEATS MUST BE EXPLAINED WITH A NATIONAL, NOT REGIONAL, SCOPE.

08732 STANLEY, J.

MARX, ENGELS AND THE ADMINISTRATION OF NATURE HISTORY OF POLITICAL THOUGHT, 12 (4) (WIN 92), 647-694. IN RECENT YEARS ATTEMPTS HAVE BEEN MADE BY A HOST OF WESTERN MARXISTS TO EMANCIPATE THE MASTER FROM

RESPONSIBILITY FOR VARIOUS UNSAVOURY DOCTRINES. THE AUTHOR ARGUES THAT THE CRITICS, DESPITE THEIR DIFFERENCES HAVE ALL BEEN UNCONVINCING IN THEIR ATTEMPTS TO SHOW CONSISTENT DISTINCTIONS AMONG THE TERMS IN THE MARXIAN TEXTS. A CAREFUL DISTINCTIONS AMONG THE TERMS IN THE MARXIAN TEXTS. A CARE
READING OF THE TEXTS, SHOWS A MARX WHO BASES A RELUCTANT
PROMETHEANISH ON AN AMBIGUOUS NATURALISM. NATURALISM WITH A SCIENCE OF MAN; WHO CONNECTS THAT SCIENCE NA PRAXIS AND PRAXIS TO THE ADMINISTERED DOMINATION OF NATURE. IF IT CAN BE SHOWN THAT MARX AND ENGELS SHARED SUCH NATURE. IF IT CAN BE SHOWN THAT MARX AND ENGELS SHARED SUCH

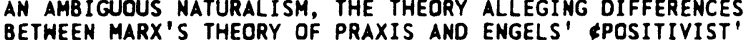
AUTHORITANIANISH WOULD BE UNJUSTIFIED.

08733 STANLEY, R.

CO-OPERATION AND CONTROL: THE NEW APPROACH TO MUCLEAR NONPROLIFERATION IN ARGENTINA AND BRAZIL

ARMS CONTROL, 13(2) (SEP 92), 191-213.

THE AGREEMENTS BETWEEN ARGENTINA AND BRAZIL MAY POINT TO PROMISING APPROACHES TO CURB THE SPREAD OF WEAPONS-USABL TECHNOLOGY. THIS ARTICLE ANALYSES THE AGREEMENT BETHEEN ARGENTINA AND BRAZIL, AND BETWEEN THESE TWO COUNTRIES AND CONTEXT IN WHICH TO GAUGE THE SIGNIFICANCE OF THIS DEVELOPMENT BY BRIEFLY DESCRIBING THEIR APPROACH THUS FAR TO NON-PROL IFERATION REGIMES. A SUMMARY OF THE DEVELOPMENT OF THEIR NUCLEAR PROGRAM ILLUSTRATES THAT BOTH COUNTRIES HAVE ACHIEVED MASTERY OF THE NUCLEAR FUEL-CYCLE. THE ARTICLE CONCLUDES WITH A DISCUSSION OF THE POTENTIAL MODEL FUNCTION OF THIS AGREEMENT FOR REGIONAL APPROACHES TO NUCLEAR NONPROLIFERATION.

08734 STANOVCIC, $V$.

PROBLEMS AND OPIIONS IN INSTITUTIONALIZING ETHNIC RELATIONS INTERNATIONAL POLITICAL SCIENCE REVIEW, $13(4)$ (OCT 92), 359-379.

THE AUTHOR DISCUSSES APPROACHES TO GOVERNING ETHNICALLYDIVIDED SOCIETIES, EXAMINING THE IMPACT OF SPECIFIC SOLUTIONS--SUCH AS GUARANTEES OF INDIVIDUAL OR COLLECTIVE RIGHTS, ETHMIC FEDERALISM, AND CONSOCIATIONALISM-ON ETHNIC GROUPS. HE EXPLORES THE RELATIONSHIP OF THESE APPROACHES TO SUCH CONCEPTS AS NATIOM-STATE, CONFEDERALISM, INTERNATIONAL GUARANTEES OF MINORITY RIGHTS, THE RIGHT OF SELFDETERMINATION, SECESSION, AND CULTURAL AUTONDMY. SOME FUNDAMENTAL ISSUES ASSOCIATED WITH DIFFERENT OPTIONS FOR GROUPS LIVING IN A DIASPORA AND FOR TERRITORIALLY CONCENTRATED MINORITIES ARE ANALYZED, AND ATTENTION IS DRAWN TO PARTICULARLY COMPLEX CASES WHERE GROUPS ARE MIXED OR WHERE ONE ETHNIC GROUP THAT MAY ITSELF BE A "MINORITY" ENCOMPASSES A SMALL GROUP THAT OTHERHISE BELONGS TO A "MAJORITY" WITHIN THE STATE. THE AUTHOR STUDIES THE EXPERIENCE OF YUGOSLAVIA AND OTHER COUNTRIES.

08735 STAR, A.

UNSETTLED

NEW REPUBLIC, 206(16) (APR 92), 17-18.

THE AUTHOR EXPLAINS THE CONTRADICTORY ISRAELI VIEWPOINTS REGARDING THE NEH SETTLEMENTS IN THE OCCUPIED TERRITORIES-WHY SOME ISRAELIS VIEW THEM AS OBSTACLES TO PEACE HHILE OTHERS BELIEVE THEY ARE OBSTACLES TO WAR.

08736 STARK, A.

CORPORATE ELECTORAL ACTIVITY, CONSTITUTIONAL DISCOURSE, AND CONCEPTIONS OF THE INDIVIDUAL

AMERICAN POLITICAL SCIENCE REVIEN, 86(3) (SEP 92), 626-637. THE AUTHOR ANALYZES THE DEEP STRUCTURE OF CONSTITTUTIONAL OISCOURSE IN ONE IMPORTANT AREA--THE LEGITIMACY OF PROHIBITIONS ON CORPORATE ELECTORAL ACTIVITY. HE SHOHS THAT PROHIBITIONS ON CORPORATE ELECTORAL ACTIVITY. HE SHOWS THAT THE CDNSTITUTIONAL ARGUMENTATION RECURRENTLY MOUNTED AGAINS
CORPORATE ELECTORAL ACTIVITY RESTS ON A PARTICULAR VERSION CORPORATE ELECTORAL ACTIVITY RESTS ON A PARTICULAR VERSION OF THE RADICALLY ENCUMBERED INDIVIDUAL AND THAT THE MAJOR CONSTITUTIONAL DEFENSES OF CORPORATE ELECTORAL ACTIVITY ASSUME A PART
INDIVIDUAL.

08737 STARK, A.

POLITICAL-DISCOURSE ANALYSIS AND THE debate OVER CANADA'S LOBBYING LEGISLATIOM

CANADIAN JOURNAL OF POLITICAL SCIENCE, XXY(3) (SEP 92), 513-534. 
RECENTLY, STUDENTS OF PUBLIC POLICY-MAKING IN NORTH AMERICA HAVE ADDED THE ANALYSIS OF POLITICAL DISCOURSE TO THE TOOLS OF THEIR TRADE. ACCORDING TO THE POLITICALDISCOURSE SCHOOL, THE EXTENT TO WHICH POLICY IDEAS GAIN ACCEPTABILITY CANNOT ALWAYS BE EXPLAINED RATIONALLY IN TERMS OF THEIR LOGICAL OR EMPIRICAL VALIDITY NOR INSTRUMENTALLY IN TERMS OF THE INTERESTS THEY SERVE. OFTEN, THEIR CAREERS MUST BE ACCOUNTED FOR, AT LEAST IN PART, BY A DETAILED EXPLORATION OF THEIR IDEOLOGICAL ASSUMPTIONS AND APPEAL AND THEIR RHETORICAL STRUCTURE AND PERSUASIVENESS. THIS PAPER PRESENTS A POLITICAL-DISCOURSE ANALYSIS OF THE 1985-88 DEBATE OVER CANADA'S BILL C-82, "AN ACT RESPECTIMG THE REGISTRATION OF LOBBYISTS." THAT DEBATE INVOLVED SOME OF CANADA'S MOST FACTUALLY-INFORMED AND INSTRUMENTALLY MOTIVATED POLICY ACTORS. NEVERTHELESS, THE PARTICIPANTS UNIFORMLY BASED THEIR ARGUMENTS ON BROAD ASSUMPTIONS UNSUBSTANTIATED BY EMPIRICAL ANALYSIS AND ADVANCED THOSE ARGUMENTS IN THE RHETORIC OF THE PUBLIC GOOD AND DEMOCRATIC
THEORY. THEORY.

08738 STARK, A.

PUBLIC SECTOR CONFLICT OF INTEREST AT THE FEDERAL LEVEL IN CANADA AND THE U.S.: DIFFERENCES IN UNDERSTANDING AND APPROACH

PUBLIC ADMINISTRATION REVIEN, 52(5) (SEP 92), 427-437. TO COMPARE THE CANADIAN AND U.S. APPROACHES TO CONFLICTOF-INTEREST LAWS, THE AUTHOR FOCUSES ON THREE ISSUES: EACH COUNTRY'S USE OF STATUTORY AND NONSTATUTORY MEANS FOR DEALI ING WITH CONFLICT-OF-INTEREST PROBLEMS; DIFFERENCES REGARDING QUESTIONS OF POST-EMPLOYMENT RULES; AND THE GENERAL ATTITUDE OF EACH NATION TOWARD THE INFLUENCE OF PRIVATE INTEREST IN THE JUDGMENTS OF PUBLIC SERVANTS. HE FINDS THAT MANY OF THE DIFFERENCES ARE ATTRIBUTABLE TO THE STRUCTURAL DISTINCTION BETHEEN THE U.S. SYSTEM BASED ON SEPARATION OF POWERS AND THE BRITISH-TYPE SYSTEM FOUND IN CANADA.

08739 STARK, L.

CHARACTER AND EXPERIENCE: PREDICTING PRESIDENTIAL PERFORMANCE

MICHIGAN JOURNAL OF POLITICAL SCIENCE, 13 (WIN 91), 69-84. JAMES DAVID BARBER ARGUES THAT A PRESIDENT'S CHARACTER' IS THE BEST PREDICTOR OF HIS PERFORMANCE IN THE WHITE HOUSE. THIS PAPER SUGGESTS THAT SOME OF THE DIFFICULTIES ASSOCIATED WITH BARBER'S APPRAOCH COULD BE MINIMIZED BY FUSING HIS WITH BARBER'S APPRAOCH COULD BE MINIMI ZED BY FUSING HIS
CHARACTER ANALYSIS WITH THE MORE TRADITIONAL EXPERIENCECHARACTER ANALYSIS WITH THE MORE TRADITIONAL EXPERIENCE-
BASED APPROACH TO PREDICTING PRESIDENTIAL PERFORMANCE. THE BASED APPROACH TO PREDICTING PRESIDENT IAL PERFORMANCE. THE
RESULT OF SUCH AN INTEGRATION HOULD BE A CHARACTER-TEMPERED RESULT OF SUCH AN INTEGRATION HOULD BE A CHARACTER-TEMPERED
ANALYSIS OF EXPERIENCE, AN APPROACH WHICH IS HINTED AT IN ANALYSIS OF EXPERIENCE, AN APPROACH WHICH IS HINTED AT IN
BOTH NEUSTADT'S AND BARBER'S WORK. AFTER DISCUSSING THE BOTH NEUSTADT'S AND BARBER'S WORK. AFTER DISCUSSING THE
IMPORTANCE OF STUDIES OF PRESIDENTIAL PERSONALITY GENERALLY, THIS PAPER EXAMINES SOME COMMON CRITICISMS OF BARBER' APPROACH AND PROVIDES AN OUTLINE OF THE POTENTIAL ADVANTAGES
OF CHARACTER-EXPERIENCE.

08740 STARK, L.

PREDICTING PRESIDENTIAL PERFORMANCE FROM CAMPAIGN CONDUCT: A CHARACTER ANALYSIS OF THE 1988 ELECTION PRESIDENTIAL STUDIES QUARTERLY, XXII(2) (SPR 92), 279-294. CHARACTER CLUES RELEVANT TO PREDICTING PRESIDENTIAL PERFORMANCE ARE OBSERVABLE AT EVERY STAGE OF A PRESIDENTIAL CAMPAIGN. LEADING CONTENDERS FOR THE 1988 REPUBLICAN AND DEMOCRATIC NOMINATIONS EXHIBITED PERSONAL ITY FEATURES WHICH DISADVANTAGED THEIR CANDIDACIES AND WOULD ALSO HAVE ENDANGERED THEIR PRESIDENCIES. AT THE MATIONAL CONVENTIONS, GEORGE BUSH AND MICHAEL DUKAKIS OFFERED GLIMPSES OF THEIR PRESIDENTIAL PERSONALITIES THROUGH THEIR YICE PRESIDENTIAL SELECTIONS AND ACCEPTANCE SPEECHES. WHEN THE TWO FACED EACH OTHER DURING THE GENERAL ELECTION, BUSH DISPLAYED A BETTER UNDERSTANDING OF THE NATURE OF THE PRESIDENCY AND APPEARED MORE CAPABLE OF FUNCTIONING SUCCESSFULLY IN IT. OVERALL, THE 1988 CAMPAIGN SUGGESTS HOW THE PRESIDENTIAL SELECTION SYSTEM CAN AND DOES PRODUCE VALUABLE INFORMATION FOR ASSESSING CANDIDATES' QUALIFICATIONS FOR THE WHITE HOUSE.

08741 STARKEY, B.A.

FOREIGN POLICY IN THE MUSLIM HORLD: A DIALOGUE BETHEEN STATE AND SOCIETY

POLITICAL COMMUNICATION, 9 (1) (1992), 31-45.

SOME WESTERN ELITES ARE CONCERNED ABOUT A POSSIBLE ISLAMIC CHALLENGE TO THE PREVAILING INTERNATIONAL ORDER. THIS PAPER EXPLORES THE VALIDITY OF THAT CONCERN BY LOOKING AT PATTERNS OF INTERACTION AND FOREIGN-POLICY CHANGE IN FOUR COUNTRIES IN THE MUSLIM WORLD (IRAN, EGYPT, ALGERIA, AND INDONESIA) AS WELL AS SOME DEVELOPMENTS IN THE LARGER MUSLIM WORLD. JUXTAPOSING SOCIAL CHANGE ON FOREIGN POLICY. THE AUTHOR POSTULATES THAT ECONOMIC REALISM IS THE DEFINITIVE FORCE IN THE INTERNATIONAL RELATIONS OF THESE STATES: FORCE IN THE INTERNATIONAL RELATIONS OF THESE STATES:
"MILITANT ISLAM" IS MORE A TOOL OF RADICAL DIPLOMACY THAN A MANIFESTATION OF TRANSWATIOMALISM. RADICAL DIPLOMACY THAN A THE MUSLIM HORLD DISPLAY A REGIONAL REGIME-STYLE ORIENTATION. DOMESTIC ISLAMIZATION IS FOUND TO BE A FORCE THAT, OVERALL, DOMESTIC ISLAMIZATION IS FOUND TO BE A FORCE THAT, RATIONALIZATION IN THE FOREIGN-POLICY REALM.
08742 STARR, $H$.

WHY DON'T DEMOCRACIES FIGHT ONE ANOTHER?: EVALUATING THE THEORY - FINDINGS FEEDBACK LOOP

JERUSALEM JOURNAL OF INTERNATIONAL RELATIONS, 14(4) (DEC $92), 41-59$

THIS ARTICLE DISCUSSES SOME OF THE MAJOR RESEARCH FINDINGS AND PRIMARY THEMES THAT HAVE EMERGED IN THE LITERATURE ON THE DEMOCRACY-WAR RELATIONSHIP. IT ASSESSES THE STRENGTHS AND WEAKNESSES OF CULTURE/NORMS,

STRUCTURE/CONSTRAINTS, AND EXPECTED-ULTILITY APPRAOCHES, AND SUGGESTS THAT A FULLER READING OF DEMOCRATIC THEORY AND A MORE COMPLETE UNDERSTANDING OF DEMOCRACY ARE NEEDED AS A BASIS FOR FURTHER DEVELOPING THEORIES OF HYY DEMOCRACIES DO BASIS FOR FURTHER DEV
NOT FIGHT EACH OTHER.

08743 STARR, J.

WATER WARS
FOREIGN POLICY, (82) (SPR 91), 17-36.

JORDAN, ISRAEL, CYPRUS, MALTA, AND THE COUNTRIES OF THE ARABIAN PENINSULA ARE SLIDING INTO THE PERILOUS ZONE WHERE ALL AVAILABLE FRESH SURFACE AND GROUNDWATER SUPPLIES WILL BE FULLY UTILIZED. ALGERIA, EGYPT, MOROCCO, AND TUNISIA FACE SIMILAR PROSPECTS IN 10 TO 20 YEARS. THIS ARTICLE CONSIDERS THE POLITICAL, ENVIRONMENTAL, AND ECONOMIC IMPLICATIONS OF THIS PROBLEM. IT EXAMINES THE CASES OF THE NILE RIVER AND TURKEY'S HATER PLANS. IT CONCLUDES THAT THE MIDDLE EAST AND NORTH AFRICA ARE FAILING TO CONFRONT OVERALL WATER SHORTAGES. THE CHALLENGES ARE TO MAKE WATER AVAILABLE AT ACCEPTABLE COSTS IN PLACES WHERE IT IS MOST NEEDED AND TO DRAMATICALLY IMPROVE THE MANAGEMENT OF EXISTING WATER RESOURCES.

08744 STARR, $P$

SOCIAL CATEGORIES AND CLAIMS IN THE LIBERAL STATE SOCIAL RESEARCH, 59(2) (SUM 92), 263-296.

OF THE MYRIAD DIFFERENCES AMONG PERSONS, ROLES, GROUPS, AND OTHER FORMATIONS IN COMPLEX SOCIETIES, ONLY A SMALL NUMBER ARE ACCEPTED AS LEGITIMATE CATEGORIES IN POLITICS, LAW, AND OFFICIAL STATISTICS. UNLIKE FOLK OR SCIENTIFIC CLASSIFICATIONS, OFFICIAL CLASSIFICATIONS (I.E., THE CATEGORIES ADOPTED OR APPROVED BY THE STATE AND' INCORPORATED CATEGORIES ADOP TED OR APPROVED BY THE STATE AND INCORPORAT
INTO LAH AND ADMINISTRATION) INVOLVE POLITICAL DECISIONS. INTO LAH AND ADMINISTRATION) INVOLVE POLITICAL DECISIONS.
EVERY STATE MUST DRAH LINES BETWEEN TYPES OF PEOPLE WHEN IT EVERY STATE MUST DRAH LINES BETWEEN TYPES OF PEOPLE WH
FORMULATES ITS CRIMINAL AND CIVIL LAWS, LEVIES TAXES, FORMULATES ITS CRIMINAL AND CIVIL LANS, LEVIES TAXES, ALLOCATES BENEFITS, REGULATES ECONOMIC TRANSACTIONS,
COLLECTS STATISTIISS, AND SETS RULES. SOCIAL CLASSIFICATION PRESENTS ESPECIALLY THORNY PROBLEMS FOR LIBERAL STATES, BECAUSE THE LIBERAL STATE DOES NOT, AS A GENERAL RULE, CLAIM ANY AUTHORITY TO DEFINE AND CONSTITUTE SOCIAL GROUPS. MOREOVER, IN ENFORCING JUSTICE AND ALLOCATING REWARDS, THE LIBERAL STATE, IN PRINCIPLE, TREATS PEOPLE AS INDIVIDUALS RATHER THAN AS MEMBERS OF A CLASS. NEVERTHELESS, LIKE ALL REGIMES, THE LIBERAL STATE CANNOT AVOID SHAPING SOCIAL GROUPS AND EMPLOYING CLASSIFICATIONS, GENERATING POLITICAL CONFL ICTS OVER THE CHOICE AND USE OF CATEGORIES. "SUSPECT CLASSIFICATIONS" PROVIDE ONE EXAMPLE OF POLITICAL INTERVENTION IN THE PREVAILING SOCIAL RULES OF CLASSIFICATION AND ILLUSTRATE THE ARGUMENT THAT THESE RULES ARE SHAPED POLITICALLY OVER LONG STRETCHES OF HISTORY.

08745 STARR, S.F.

PROSPECTS FOR STABLE DEMOCRACY IN RUSSIA

THE MERSHON CENTER, THE OHIO STATE UNIVERSITY, 1992, 25. THIS ESSAY ASSESSES THE PROSPECT FOR CIVIL SOCIETY IN RUSSIA OVER THE LONG TERM. THE PROSPECTS ARE EVALUATED ACCORDING TO CRITERIA WHICH INCLUDE FREEDOM OF ORGANIZATION, REGULAR ELECTIONS, RULE OF LAW, A FREE PRESS, A MARKET ECONOMY, AND AN INDEPENDENT JUDICIARY. THE OVERALL INQUIRY IS ORGANIZED AROUND SEVERAL OUESTIONS. THEY INCLUDE: DID RUSSIA'S PRE-COMMUNIST HERITAGE POSSESS ANY CHARACTERISTICS SUPPORTIVE OF DEMOCRATIZATION AND A CIVIL SOCIETY; WAS THIS LEGACY DESTROYED IN THE YEARS BEFORE 1985 , OR DID ANY NEW FACTORS THAT WERE SUPPORTIVE OF DEMOCRATIZATION APPEAR DURING THE SOVIET PERIDD; WHAT HAS, AND HAS NOT, BEEM ACCOMPLISHED IN THE AREA OF DEMOCRATIZATION NOT, BEEN SOCIETY SINCE 1985; AND, GIVEN THE PRESENT CORRELATION OF FORCES BETWEEN CONTINUITY AND CHANGE, WHAT ARE FUTURE PROSPECTS FOR DEMOCRATIZATION AND THE DEVELOPMENT OF CIVIL SOCIETY AND WHAT IMPLICATIONS DO THESE HAVE FOR U.S. -RUSSIAN
RELATIONS? IT CONCLUUES THAT, DESPITE SEVERAL DAUNTING RELATACLS, RUSSIA IS ON THE ROAD TO MORE PARTICIPATORY FORMS
OBSTACLES, OF RULE.

08746 STEARNS, $S$. BID TO IMPROVE TIES

WEST AFRICA, (3907) (AUG 92), 1309

CHARLES TAYLR RECENTLY SENT HIS MINISTER OF FOREIGN AFFAIRS TO WASHINGTON IN AN EFFORT TO IMPROVE RELATIONS WITH THE U.S. GOVERNMENT. THE MINISTER EXPLAINED NPRA PLANS FOR A POLITICAL SYSTEM INDEPENDENT OF INDIVIDUAL PERSONALITIES AND TRIED TO QUELL AMERICAN CONCERNS ABOUT THE TRAINING OF NPFL TROOPS IN LIBYA. 
08747 STEDMAN, S

BOTSWANA: THE POLITICAL ECOMOMY OF DEMOCRATIC DEYELOPMENT LYMNE RIENMER PUBL SHERS 1992 214.

AT A TIME WHEN ANALYSTS SPEAK DESPAIRINGLY OF A LOST DECADE OF ECONOMIC DEVELOPMENT IN AFRICA, BOTSHAMA STANDS OUT AS AN EXAMPLE OF SUCCESSFUL ECONOMIC PERFORMANCE. INDEED, BOTSWANA ATTAINED THE HIGHEST RATE OF ECONOMIC GROWTH IN THE WORLD DURING THE PERIOD 1965-1985; MOREOVER, IT DID SO
AS A MULTIPARTY LIBERAL DEMOCARACY, ALBEIT ONE DOMINATED BY ONE POLITICAL PARTY. THE AUTHORS OF THIS BOOK EXAMINE BOTSWANA'S PERFORMANCE TO DATE, SEEKING TO UNDERSTAND THE FACTORS THAT ACCOUNT FOR ITS EXCEPTIONAL STATUS AND INVESTIGATING PROBLEM AREAS THAT MIGHT ENDANGER ITS ACHIEVEMENTS. THEY CONCLUDE BY CONSIDERING BOTS

08748 STEEL, B.S.; LOVRICH, N.P.; STEIBER, B.; HARNER, R.L. POSTMATERIALIST VALUES AMD SUPPORT FOR FEMINISM AMONG CANADIAN AMD AMERICAN HOMEN AMD MEN

WESTERN POLITICAL QUARTERLY, 45(2) (JUN 92), 339-354.

SOME SCHOLARS ARGUE THAT POSTINDUSTRIAL SOCIETY HAS SOME SCHOLARS ARGUE THAT POSTINDUSTRIAL SOCIETY HAS
ALTERED INDIVIDUAL VALUE STRUCTURES SO THAT "HIGHER ORDER" ALTERED INDIVIDUAL VALUE STRUCTURES SO THAT "HIGHER ORDER"
NEEDS HAVE SUPPLANTED MORE FUNDAMENTAL SUBSISTENCE NEEDS AS NEEDS HAVE SUPPLANTED MORE FUNDAMENTAL SUBSISTENCE NEEDS AS THE PRIMARY MOTIVATIONAL SOURCES OF MUCH SOCIETAL

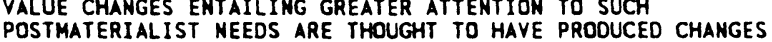
POSTMATERIALIST NEEDS ARE THOUGHT TO HAVE PRODUCED CHANGES
IN MANY TYPES OF PERSONAL ATTITUDES--ESPECIALLY THOSE
RELATED TO HOMEN'S STATUS IN SOCIETY. THIS STUDY EMPIRICALLY RELATED TO WOMEN'S STATUS IN SOCIETY. THIS ST EXAMINES THIS HYPOTHESIZED CONNECTION BETWEEN POSTMATERIALIST VALUE ORIENTATIONS AND SUPPORT FOR FEMINIST ATTITUDES IN CANADA AND THE UNITED STATES. FINDINGS SUGGEST THAT POSTMATERIALIST VALUES ARE INDEED ASSOCIATED WITH CONCERN FOR GENDER EQUITY AND THAT SUCH VALUES PLAY A SOMEWHAT DIFFERENT ROLE IN ATTITUDE STRUCTURES FOR MEN AND WOMEN IN THE UNITED STATES.

08749 STEEL, R.

LET THEM SINK

NEH REPUBLIC, 207(19) (NOV 92), 15-16.

THE EUROPEANS, QUITE HISELY, DID NOT INTERVENE IN THE AMERICAN CIVIL WAR, WHEN ONE PART OF THE NATION TRIED TO SECEDE FROM THE REST. THEY WAITED FOR THE AMERICANS TO RESOLVE THE CONFLICT, RECOGNIZING THAT ONLY THE AMERICANS COULD DO IT. EUROPEANS REMAIN SKEPTICAL ABOUT INTERVENTIONS IN CIVIL WARS, ESPECIALLY THOSE DESIGNED TO WARN DICTATORS EVERYHHERE THAT AGGRESSION CANNOT PROCEED WITHOUT RETRIBUTION. THEY KHOW THAT INTERVENTION HAS OFTEN FAILED IN THE PAST, AND AMERICANS SHOULD KNOW IT TOO FROM THEIR OWN UNFORTUNATE INTERVENTIONS IN VIETNAM AND SIMILAR CONFLICTS. UNFORTUNATE INTERVENTIONS IN VIETNAM AND SIMILAR CONFLICTS. FORMER YUGOSLAVIA ARE OFTEN THE SAME ONES WHO WERE MOST OPPOSED TO U.S. INVOLVEMENT IN VIETNAM.

08750 STEEL, R.

THE BOBBY GAP

NEW REPUBLIC, 206 (21) (MAY 92), 16-17.

THE AUTHOR CONTRASTS THE REACTIONS OF GOVERNOR BILL CLINTON AND PRESIDENT GEORGE BUSH TO THE LOS ANGELES RIOTS FOLLOWING THE RODNEY KING VERDICT WITH THOSE OF ROBER KENNEDY TO THE CRISES OF 1968.

08751 STEELE, G.

PRIVATE LAHYERS, PUBLIC LAH: ADMINISTRATIVE LAW IN THE MAKING

CANADIAN PUBLIC ADMINISTRATION, 35(1) (SPR 92), 1-21.

THE LAH OF PUBLIC ADMINISTRATION SUFFERS FROM A LACK OF CONCEPTUAL IDENTITY. ONE OF THE PRINCIPAL REASONS FOR THIS DEFICIENCY IS THE LIMITING NATURE OF ADMINISTRATIVE LAH THEORY, WIICH GENERALLY FAILS TO ADDRESS THE CONCERNS OF THE PRIVATE LAWYER DEALING WITH PUBLIC ADMINISTRATORS. WHAT IS NEEDED IS A MORE SOPHISTICATED UNDERSTANDING OF THE EVERYDAY INTERACTION OF LAWYERS AND ADMIMISTRATORS. THE AUTHOR PROPOSES AN ANALYTICAL SCHEME, BASED ON THE IDEA OF DECISIONMAKING AS TEXTUAL INTERPRETATION, BY WHICH THAT INTERACTION MIGHT BE BETTER UNDERSTOOO AND MORE USEFULLY STUDIED. HE ARGUES THAT THE ESSENTIAL SKILL OF ADMINISTRATIVE LAWYERS IS A FINE APPRECIATION OF HOW ADMINISTRATIVE DECISION-MAKERS DIFFER FROM JUDGES; THE GOOD ADMINISTRATIVE LAWYER UNDERSTANDS ADMINISTRATORS AND THE ADMINISTRATIVE PROCESS AND KMONS HOW TO TURN THAT KNOWLEDGE TO ADVANTAGE.

08752 STEER, A.

THE ENVIRONMENT FOR DEVELOPMENT

FINANCE AND DEVELOPMENT, 29(2) (JUN 92), 18-21.

HITHOUT ENVIRONMENTAL POLICIES, DEVELOPMENT WILL BE UNDERMINED. HITHOUT DEVELOPMENT, ENYIRONMENTAL PROTECTION WILL FAIL. WHILE THERE IS STRONG AGREEMENT AT THE CONCEPTUAL LEVEL ON THE NEED TO INTEGRATE POLICIES FOR DEVELOPMENT AND THE ENVIRONMENT, A LARGE GAP BETHEEN RHETORIC AND PRACTICE REMAINS. THIS ARTICLE DISCUSSES HOW BEST TO CLOSE THIS GAP. IT EXPLORES THE NATURE OF THE CHALLENGE, HOH TO BUILD ON THE POSITIVE LINKS AND HOW TO BREAK THE
COSTS OF SUSTAINABLE DEVELOPMENT.
08753 STEFANOY S.

WESTERN ECONOMIC SUPPORT FOR EASTERN EUROPE: A NEW APPROACH IS NEEDED

PEACE AND THE SCIENCES, 1(1) (1992), 7-12.

THE EAST EUROPEAN POPULATION HAS' COME TO KNOW THE NEW ECONOMIC ORDER FROM ITS NEGATIVE SIDE. THE QUESTION IS WHAT IS TO BE DONE IN ORDER TO MINIMIZE THE SOCIAL COSTS OF THE MARKET-ORIENTED REFORMS AND GUARANTEE THEIR REALIZATION. THIS ARTICLE PONDERS THE WAY IN WHICH THE SUPPORT FROM WESTERN COUNTRIES SHOULD BE ORGANIZED SO THAT IT COULD GIVE THE MAXIMUM IMPETUS POSSIBLE TO THE REFORM EFFORT. THE PLAN OFFERED REQUIRES SOME KIND OF A PERMANENTLY FUNCTIONING TRILATERAL, INTERGOVERMMENTAL ORGANIZATION IN HHICH THE
THREE MAIN ACTORS INVOLVED SHOULD BE PROPERLY REPRESENTED,

08754 STEGER, M.

A CAUTIOUS APPROACH: RACIST SPEECH AND THE FIRST AMENDMENT AT THE UNIVERSITY OF TEXAS

JOURNAL OF LAW \& POLITICS, VIII(3) (SPR 92), 609-648.

IN THE PAST DECADE, RACISH HAS BECOME ONE OF THE MOST PUBLICIZED AND POLITICIZED ISSUES ON AMERICA'S COLLEGE PUBLICIZED AND POLITICIZED ISSUES ON AMERICA S COLLEGE POLICIES INTENDED TO REDUCE OR DEAL WITH RACISM BY POLICIES INTENDED TO REDUCE OR DEAL WITH RACISH BY
REGULATING SPEECH IN SOME MANNER. THE ONE CONSISTENT STRAND REGULATING SPEECH IN SOME MANNER. THE ONE CONSISTENT STRAND
RUNNING THROUGH THE POLICIES ADDRESSING SPEECH ON CAMPUS IS RUNMING THROUGH THE POLICIES ADDRESSING SPEECH ON CAMPUS IS THAT THEY VIRTUALLY ALL VIOLATE THE FIRST AMENDMENT. THE
UMIVERSITY OF TEXAS HAS IMPLEMENTED A POLICY THAT REPRESENTS UNIVERSITY OF TEXAS HAS IMPLEMENTED A POLICY THAT REP

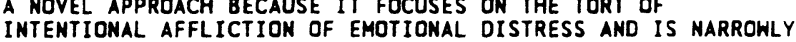
INTENTIONAL AFFLICTION OF EMOTIONAL DISTRESS AND IS
DRAWH AND APPLIED, IN ORDER TO AVOID FIRST AMENDMENT DRAWN AND APPLIED, IN ORDER TO AVOID FIRST AMENDMENT FIRST AMENDMENT PRINCIPLES IF APPLIED IN THE WRONG MANNER.

08755 STEIN, $H$

DEINDUSTRIALIZATION, ADJUSTMENT, THE HORLD BANK, AND THE IMF IN AFRICA

WORLD DEVELOPMENT, 20(1) (JAN 92), 83-95.

THE AUTHOR OUTLINES AND ANALYZES THE WORLD BANK/IMF MODEL OF INDUSTRIAL ADJUSTMENT. HE FINDS A NUMBER OF SERIOUS DEFICIENCIES IN THE MODEL, INCLUDING WEAKNESSES IN ITS METHODOLOGICAL FOUNDATION, INCONSISTENCIES IN THE COMPONENTS, AND IMPEDIMENTS LINKED TO STRUCTURE AND CLASS THAT WILL CONSTRAIN THE ADJUSTMENT PROCESS. OVERALL, THE HORLD BANK/IMF MODEL IS LIKELY TO DEINDUSTRIALIZE THE EXISTING MANUFACTURING BASE WITHOUT ENCOURAGING ANY SIGNIFICANT REPLACEMENT.

08756 STEIN, J

DETERRENCE AND COMPELLENCE IN THE GULF, 1990-91: A FAILED OR IMPOSSIBLE TASK?

INTERNATIOMAL SECURITY, 17(2) (FAL 92) 147-178.

THE QUESTION IS ASKED: WHETHER IF THE UNITED STATES HAD TRIED SERIOUSLY TO DETER IRAO BEFORE IT INVADED KUHAIT, DETERRENCE WOULD HAVE SUCCEEDED IN PREVENTING THE ATTACK. THE SECOND PUZZLE IS WHY COMPELLENCE FAILED. THE TWO FAILURES ARE INTERCONHECTED. THREE DIFFERENT EXPLANATIONS CAN BE ADVANCED FOR THE TWIN FAILURES. FIRST IS FAILURE OF THE UNITED STATES TO MOUNT AN EFFECTIVE STRATEGY OF DETERRENCE. SECOND IS THAT PERHAPS HUSSEIN SYSTEMATICALLY MISCALCULATED THE CAPABILITIES AND RESOLVE OF THE UNITED STATES. THE THIRD ARGUES THAT SADDAM HUSSEIN COULD NOT BE DETERRED. THIS ARTICLE COMPARES AMERICAN AND IRAOI ESTIMATES OF MILITARY AND POLITICAL CAPABILITIES MADE BEFORE THE WAR BEGAN. ON MOST DIMENSIONS, THERE ARE SURPRISING SIMILARITIES BETWEEN THE TWO SETS OF ESTIMATES. THIS SIMILARITY SUGGESTS THAT SADDAM'S ESTIMATES OF THE RELATIVE MILITARY AND POLITICAL BALANCE WERE NOT UNREASONABLE. THE CRITICAL DIFFERENCE WAS THE BROAD STRATEGIC JUDGMENT HE MADE EARLY IN THE PROCESS.

\section{STEIN, $K$.}

THE INTIFADA AND THE 1936-39 UPRISING: A COMPARISON

JOURAL OF PALESTIME STUDIES, XIX(4) (SUM 90), 64-85.

THIS ARTICLE COMPARES AND CONTRASTS THE ONGOING INTIFADA IN THE ISRAELI-OCCUPIED TERRITORIES AND A PALESTINIAN UPRISING THAT TOOK PLACE IN THE YEARS 1936-39. THE ARTICLE COMPARES FACETS OF THE TWO UPRISINGS INCLUDING PALESTINIAN LEADERSHIP: CHARACTER AND PARTICIPATION; THE ISLAMIC DIMENSION; AND DURATION AND EFFECTS. IT CONCLUDES WITH A BRIEF ANALYSIS OF SOME OF THE LESSONS THAT MIGHT BE LEARNED FROM THE EARLIER UPRISING.

08758 STEINBERG, D.

MOMARCHS AND MEM

FAR EASTERN ECONOMIC REVIEH, 155(28) (JUL 92), 26.

RECENTLY KING BHUMIBOL ADULYADEJ OF THAILAND HAS TWICE DEFTLY FORCED COMPROMISE TO DEFUSE CRISES IN THE HAKE OF THE MARCH GENERAL ELECTIONS. THE THAI KING HAS PLAYED THE ROLE OF THE MORAL ARBITER MANY TIMES IN THE PAST. IN THIS, THAILAND IS FORTUNATE. THE KING IS NOT ONLY THE HEAD OF STATE, BUT ALSO REVERED AS A SYMBOL OF NATIONAL UNITY AND OEFENDER OF THE BUDDHIST RELIGION. HOWEVER, IN SOME ASIAN COUNTRIES, MOST NOTABLY BURMA, THE LACK OF AN ACCEPTED SYMBOL OF AUTHORITY AND RESPECT EXACERBATES CRISES THAT THEY 
ARE ALREADY EXPERIENCING. IN THAILAND, THE KING IS THE SYMBOL OF NATIONAL UNITY. BURMA LACKS SUCH A SYMBOL. THERE IS NO RELIGIOUS OR SECULAR BURMESE FIGURE IN WHOM ABSOLUTE TRUST AND RESPECT RESIDES. THEREFORE, IN A BROAD SENSE, THE TRAGEDY OF BURMA IN BOTH ITS CIVILIAN AND MILITARY INCARMATIONS IS THAT IT HAS LACKED AN INSTITUTION OR IMDIVIDUALS WHO WERE ABOVE PARTISANSHIP, AND A NATIONAL SYMBOL THAT WOULD TURN THE TERRITORY OF THE STATE INTO A NATION WITH A COMMON SENSE OF IDENTITY.

08759 STEINBERG, D.

MYANMAR IN 1991: THE MIASMA IN BURMA

ASIAN SURVEY, XXXII (2) (FEB 92) 146-155.

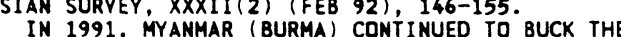
INTERNATIONAL TREND TOWARDS GREATER LIBERALIZATION AND DEMOCRATIZATION. THE RULING STATE LAH AND ORDER RESTORATION COUNCUL (SLORC) HAS NOT RELENTED IN ITS EFFORTS TO DENY THE NATIONAL LEAGUE FOR DEMOCRACY (NID) THE RUI ING POSITIDN IT NATIONAL LEAGUE FOR DEMOCRACY (NLD) THE RULING POSITION IT TON IN THE 1990 ELECTIONS. IN ADOITION, THE SLORC HAS BEGUN TO EMPHASIZE THE ISSUE OF BURMAN ETHNICITY--AT THE EXPENSE OF BURMA'S NUMEROUS MINORITY ETHNIC GROUPS. ON THE ECONOMIC FRONT, THE SLORC CONTINUES TO ALLOW FOREIGN INYESTMENT IN
HOPES OF GAINING MUCH NEEDED CAPITAL. HOWEVER, WHAT CAPITAL THAT IS ACQUIRED IS GENERALLY FUNNELED INTO AN AMBITIOUS MILITARY MODERNIZATION PROGRAM. MEANHHILE THE GENERAL POPULACE STRUGGLES TO BUY BASIC NECESSITIES WHOSE PRICES SKYROCKET DUE TO 60 PERCENT INFLATION. MYANMAR'S INTERMATIONAL RELATIONS WERE DUALISTIC: GENERALLY GOOD WITH NEIGHBORING STATES EXCEPT INDIA AND POOR RELATIONS WITH THE MAJOR INDUSTRIALIZED POWERS.

08760 STEINBERG, D.

ROUGH ROAD TO DEMOCRACY

FAR EASTERN ECONOMIC REVIEH, 153(32) (AUG 91), 18.

THIS SUMMER SOUTH KOREA CELEBRATES THE FOURTH

ANNIVERSARY OF ITS TRANSITION FROM AUTHORITARIAN RULE TO

POLITICAL PLURALISM--FROM THE FIFTH REPUBLIC TO THE SIXTH.

THIS POLITICAL CHANGE IS THE CULMINATION OF AN UNDERLYING

DEMOGRAPHIC TRANSFORMATION: AN EXPLOSIVE GROWTH IN

URBANIZATION. ALTHOUGH THE TRANSITION FROM AUTHORITARIANISM

TO PLURALISM IS IRREVERSIBLE. THE TRAHSITION TO DEMOCRACY--

INVOLVING CONCEPTS OF COMPROMISE, CONCILIATION, EQUALITY AND

INVOLVING CONCEPTS OF COMPROMISE, CONCILIATION, EQUALITY AND

IS AT A NEW POLITICAL STAGE NECESSITATES CHANGES IN THE

IS AT A NEW POLITICAL STAGE NECESSITATES CHANGES IN THE

TRADITIONAL POLITICAL CULTURE AND INSTI I UTIONS. ISSUES
CONSIDERED INCLUDE WHETHER THE PRESIDENT SHOULD BE DIRECTLY

ELECTED BY THE PEOPLE OR HHETHER A MODIFIED PRESIDENCY,

COUPLED HITH A PARLIAMENTARY SYSTEM, IS DESIRABLE. A NEW

GENERATION OF POLITICAL LEADERSHIP, BOTH IN THE GOVERNMENT

AND THE OPPOSITION, IS REQUIRED IF THE POLITICAL CULTURE IS
TO BE TRANSFORMED, AND SOUTH KOREA IS TO MOVE FROM PLURALISM TO BE TRANSFORY

08761 STEIMBRUNER, J.D

BUSINESS AS USUAL? THE REDESIGN OF NATIONAL SECURITY BRDOKINGS REVIEW, 10(3) (SUM 92), 12-15.

DURING THE COLD WAR, THE U.S. ECONOMY DEPENDED IN MANY

WAYS ON MILITARY SPENDING. NOW THAT THE THREAT FROM THE

SOVIET UNION HAS DIMINISHED, THE UNITED STATES MUST MAKE ADJUSTMENTS.

08762 STEINFELS, M.

AND THEY'RE OFF

COMMONWEAL, CXIX(3) (FEB 92), 3-4.

VOTERS IN NEW HAMPSHIRE ARE ABOUT TO KINK OFF THE 1992 PRESIDENTIAL ELECTION. THIS EDITORIAL DESCRIBES THE VARIOUS CANDIDATES IN BOTH MAJOR PARTIES WHO ARE SEEKING THE NOMINATION. IT DECLARES THAT WE LIVE IN FRACTIOUS TIMES, THAT WE ARE IN TROUBLE, AND YET WE SEEM BEREFT OF THE POLITICAL WILL NEEDED FOR THE TASK. IT ALSO SUGGESTS THAT A DECADE OF REAGANISM HAS LEFT THE NATION DEEPLY POLARIZED.

08763 STEINFELS, M.

ROE REDUX

COMMONWEAL, CXIX)(5) (MAR 92), 3-4.

BY OVERREACHING, IRELAND'S ATTORNEY GENERAL HAS HANDED THE PROCHOICE MOVEMENT A POTENT WEAPON WHICH WILL BE PUT TO IMMEDIATE USE IN THE UNITED STATES, EVEN THOUGH IN THE U.S. THE QUESTION IS NOT WHETHER THERE ARE ANY GROUNDS FOR "PERMITIING" ABORTION BUT RATHER THERE ARE ANY FOR

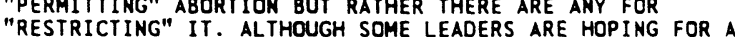
"RESISION THAT WIL OL OVERTHROW THE ROE $V$. WADE DECISION DECISION THAT WILL OVERTHROW THE ROE V. WADE DECISION
ALTOGETHER, THIS ARTICLE SUGGESTS THAT THE PANIC OF THE ALTOGETHER, THIS ARTICLE SUGG
PROCHOICERS IS UNAECESSARY.

08764 STEINFELS, M.

STATE OF THE WORLD

COMMONHEAL, CXIX(1) (JAN 92), 3-5.

FOREIGN POLICY BEGINS AT HOME. WHAT THE UNITED STATES SHOULD DO IN THE WORLD DEPENDS ON WHAT IT CAN DO AND THAT DEPENDS ON MANY FACTORS, FROM ECONOMIC STRENGTH TO POLITICAL WISDOM AND POLITICAL WILL. IF A THREAT SUCH AS SADDAM HUSSEIN'S AGAIN RISES, AND IS CREDIBLE, THE U.S. CAN COPE AGAIN. THIS EDITORIAL CONCLUDES THAT AS A MILITARY
SUPERPOWER, THE U.S. IS MORE OR LESS OUT OF A JOB, AND THAT IT OUTPACES ITS COMPETITORS ONLY IN THE SIZE OF ITS TRADE IMBALANCE.

08765 STEINFELS, M.O.

RIGHTS ' $R$ US: KIDS, HILLARY, AND THE LAW

COMMONWEAL, CXIX(9) (MAY 92), 4-5.

THE AUTHOR DISCUSSES THE CHILDREN'S RIGHTS MOVEMENT AND CHILDREN'S RIGHTS.

08766 STEINFELS, M.O.

SAFE, LEGAL, AND RARE: SLOGAN OR SUBSTANCE?

COMMONHEAL, CXIX(20) (NOV 92), 4-5.

THE PERILOUS CONDITION OF THE U.S. ECONOMY ENABLED BILL CLINTON TO RESURRECT THE DEMOCRATIC PARTY'S TRADITIONAL COALITION AND WIN THE 1992 PRESIDENTIAL ELECTION. HOWEVER, DESPITE CLINTON'S AVOWED INTENTION TO LEAVE NO ONE BEHIND, HE DID APPEAR TO TURN HIS BACK ON ANTI-ABORTION FORCES WHEN
HE DECLARED THAT ABORTION SHOULD BE "SAFE, LEGAL, AND RARE."

08767 STELZER, I

THE NEW PROTECTIONISH

NATIONAL REVIEW, XLIV(5) (MAR 92), 30-34.

ONLY TRADE BARRIERS CAN SAVE SOCIALISM, STATES THIS ARTICLE. FOR ONLY FREE TRADE STOPS THE GROWTH OF THE STATE AND OTHER LAZY CORPORATIONS. PROTECTIONISM SAVES JOBS AND INDUSTRIES IN THE SAME WAY THAT INFLATION SAVES SALARIES.

08768 STENBERG, $S$.

EVICTIONS IN THE WELFARE STATE--AN UNINTENDED CONSEQUENCE OF THE SHEDISH POLICY

ACTA SOCIOLOGICA, 34(2) (1991), 103-114.

DESPITE A REMARKABLE IMPROVEMENT IN THE GENERAL WELFARE OF THE SHEDISH POPULATION SIMCE THE SIXTIES, THE RATE OF HOUSING EVICTIONS HAS RAPIDLY INCREASED IN THE SAME PERIOD. THIS PAPER PRESENTS AN ANALYSIS OF FACTORS ASSOCIATED WITH THE GROWTH IN THE EVICTION RATE. THE MAIN HYPOTHESIS MODELS EVICTION RATE GROWTH AS THE UNINTENDED EFFECT IF SWEDISH HOUSING POLICY, OTHERWISE VIEWED AS HIGHLY SUCCESSFUL. THE AUTHOR ALSO SPECULATES ABOUT THE RELATIONSHIP BETWEEN HOMELESSNESS AND EVICTIONS, SUGGESTING THAT FOR SHEDEN THE FOMELESSNESS AND EVICTIONS, SUGGESTING THAT FOR SHEDEN EVICTION RATE AND THE PREVALENCE OF HOMELESSNESS ARE ASSOCIATED WITH A SMALL NUMBER OF HOMELESS INDIVIDUALS.

08769 STENSETH, D.

THE NEW RUSSIA, CIS AND THE FUTURE

SECURITY DIALOGUE, 23(3) (SEP 92), 19-26.

WITHIN THE CIS, DEMOCRACY REMAINS VUL NERABLE. THE KEY QUESTION AFTER THE DISSOLUTION OF THE SOVIET UNION IS HOW RUSSIA CAN ADAPT TO ITS SITUATION AS A CONTINENTAL POWER, SURROUNDED BY SMALL STATES THAT CUT IT OFF FROM THE OCEANS AND FROM CENTRAL/WESTERN EUROPE. THIS ARTICLE SUGGESTS THAT AN ACTIVE RUSSIAN FOREIGN POLICY IS NEEDED; THE CHALLENGE WILL TO BE TO AVOID THE SAME DEVELOPMENTS THAT LED TO THE DISSOLUTION OF THE SOVIET UNION.

08770 STEPANOV, $D$.

ILLIBERALISM IN THE OLD SOVIET UNION

FREEDOM REVIEW, 23(3) (MAY 92) 31-32.

THE AVERAGE SOVIET CITIZEN WHO VOTED FOR THE DEMOCRATS

AND DEMOCRATIC REFORMS DOES NOT GIVE A HOOT FOR DEMOCRACY OR HUMAN RIGHTS. MOST WERE MOTIVATED BY ECONOMIC REALITY: FOOD IS PLENTIFUL ANO CHEAP IN THE WEST. ONLY A SMALL PORTION OF THE SOVIET PEOPLE, MOSTLY THE INTELLIGENTSIA, WAS TRULY INTERESTED IN DEMOCRACY AND HUMAN RIGHTS. NOW, AFTER A YEAR OF HALTING STEPS TOWARD DEMOCRACY, MANY PEOPLE ARE STILL HUNGRY AND ARE BEGIMNING TO BELIEVE THAT TIMES WERE BETTER UNDER COMMUNISM.

08771 STEPASHIN, S

ON THE FUTURE DEFENSE POLICY OF RUSSIA

RUSI JOURNAL, $137(2)$ (APR 92), 35-37

THIS ARTICLE, WRITTEN BY THE CHAIRMAN OF THE RUSSIAN

SUPREME SOVIET COMMITTEE ON DEFENSE AND SECURITY AFFAIRS,

DISCUSSES THE FUTURE COURSE OF RUSSIA'S MILITARY FORCES. THE AUTHOR ARGUES THAT RUSSIA'S NEED FOR SECURITY IS AS REAL AND PRESSING AS ANY OTHER NATION'S. THEREFORE, THE WEST NEEDS TO BE PATIENT WITH RUSSIA AS IT GRADUALLY REDUCES ITS ARMED FORCES AND SEEKS TO ASSIMILATE THE SOLDIERS INTO THE CIVILIAN WORLD. FURTHERMORE, HE ARGUES THAT RUSSIA'S INTERESTS ARE BEST SERYED BY HER INVOLVEMENT IN THE NORTH ATLANTIC COOPERATION COUNCIL AND A GRADUAL EVOLUTION INTO NATO. HESTERN PATIENCE AND ASSISTANCE IN THIS GRADUAL AND DIFFICULT PROCESS IS REPEATEDLY REQUESTED.

08772 STEPHENS, $H$.

MARITIME' SECURITY IN THE UNITE STATES: LATENT THREATS AND LATENT VULNERABILITIES

TERRORISM ANO POLITICAL VIOLENCE, 2(4) (WIN 90), 554-573.

AMERICANS AND THEIR GOVERNMENT ARE SEEMINGLY UNCONCERNED ABOUT THE POSSIBILITY THAT MARITIME FACILITIES AND PERSONNEL MIGHT BE AT RISK TO ARMED VIOLENCE. NOT ONLY ARE CURRENT 
MARITIME SECURITY EFFORTS MINIMAL, THEY FEATURE A CURIOUS DICHOTOMY: ONE THRUST IS DIRECTED TOWARD OCCASIONAL ACTS OF TERRORISM, THE OTHER TOWARD COASTAL DEFENSE IN WARTIME. DESPITE A MANIFESTLY MORE INTERACTIVE WORLD MARKED BY THE READY AVAILABILITY OF POWERFUL, MOBILE WEAPONS, NO SERIOUS EFFORTS HAVE BEEN DIRECTED TOWARD PROTECTING MARITIME FACILITIES AND PERSONNEL IN THE UNITED STATES AGAINS SPECIAL OPERATIONS OR UNCONVENTIONAL WARFARE. THIS INDIFFERENCE REFLECTS THE PREVALENCE OF THE CLAUSEWITZIAN PARADIGM IN AMERICA'S ATTITUDE TOWARDS WAR AND THE COUNTRY'S HISTORICAL EXPERIENCE WITH COASTAL DEFENSE IN THE WARS OF THIS CENTURY. THE FRAGMENTED STRUCTURE OF CIVIL AND MILITARY PROTECTION AVAILABLE TO PROTECT PORTS AND OTHER FACILITIES SUGGESTS THAT PROTECTION COULD NOT BE QUICKLY UPGRADED IN THE FACE OF A RAPIDLY-DEVELOPING THREAT.

08773 STEPICK, A.

MIAMI: LOS CUBANOS HAN GANADOI

REPORT ON THE AMERICAS, XXVI (2) (SEP 92), 39-45.

THE AUTHOR LOOKS AT THE RISING POLITICAL POWER OF CUBAN-

AMERICANS IN MIAMI, FLORIDA.

08774 STERN, E.

INFORMATION MANAGEMENT AND THE WHISKEY ON THE ROCKS CRISIS COOPERATION \& CONFLICT: NORDIC JOURNAL OF INTERNATIONAL POLITICS, $27(1)$ (MAR 92), 45-96.

THE AUTHOR DEVELOPS AN ANALYTICAL FRAMEWORK IN ORDER TO INVESTIGATE THE ROLE OF INFORMATION IN CRISIS DECISIONMAKING. THREE THEORETICAL NODES (INFORMATION MANAGEMENT FUNCTIONS) EMERGE FROM A DISCUSSION DRAWING UPON EARLIER
CONTRIBUTIONS BY SCHOLARS SUCH AS SNYDER AND DIESING, GEORGE, CONTRIBUTIONS BY SCHOLARS SUCH AS SNYDER AND DIESING, GEORG
VERTZBERGER, AND JONSSON. "SEARCH" IS AN ACTOR-ORIENTED VERTZBERGER, AND JONSSON. "SEARCH" IS AN ACTOR-ORI
NODE FOCUSING ON THE COLLECTION OF DATA ABOUT THE NODE FOCUSING ON THE COLLECTION OF DATA ABOUT THE OPERATIONAL ENVIRONMENT. "PROCESSING" IS CONCEPTUALIZ TRANSFORMED INTO HIGHER-ORDER WORKING PROPOSITIONS ABOUT AN ACTOR OR A SITUATION. "COMMUNICATION" IS A DYADIC NODE IN WHICH THE DISTRIBUTION OF INFORMATION WITHIN AND THE CONVEYANCE OF MEANING BETWEEN STATE ACTORS ARE PROBLEMATIZED. THESE ANALYTICAL TOOLS ARE TESTED IN AN EMPIRICAL APPLICATION: SWEDISH DECISION-MAKING DURING THE "WHISKEY ON THE ROCKS" CRISIS OF 1981.

08775 STERN, E.; SUNDELIUS, B.

MANAGING ASYMMETRICAL CRISIS: SWEDEN, THE USSR, AND THE U137

INTERNATIONAL STUDIES QUARTERLY, 36(2) (JUN 92), 213-239. MUCH OF THE LEADING WORK ON INTERNATIONAL CRISIS SUFFERS FROM AN IMPLICIT BIAS FAVORING ANALYSIS OF CRISIS IN WHICH THE PROTAGONISTS ARE GREAT/SUPERPOWERS WITH ROUGHLY COMPARABLE LEVELS OF GROSS MILITARY CAPABILITIES. AS A COMPARABLE LEVELS OF GROSS MILITARY CAPABILITIES. AS A PRESCRIPTIONS DERIVED FROM THIS EXPERIENCE BASE CAN BE PRESCRIPTIONS DERIVED FROM THIS EXPERIENCE BASE CAN USEFULLY APPLIED TO CRISES CHARACTERIZED BY HIGHLY
ASYMMETRICAL GROSS MILITARY CAPABILITY STRUCTURES, I.E. ASYMMETRICAL GROSS MILITARY CAPABILITY STRUCRURES, SUPERPOWER VERSUS SMALL STATE. IN THIS PAPER, CENTRAL
PRESCRIPTIONS FROM THE CRISIS MANAGEMENT LITERATURE ARE PRESCRIPTIONS FROM THE CRISIS MANAGEMENT LITERATURE ARE
APPLIED TO THE 1981 U-137 ("WHISKEY ON THE ROCKS") CRISIS APPLIED TO THE 1981 U-137 UNISKEY ON THE ROCXS") CRISIS THIS CONCERN. THE ANALYSIS FOCUSES ON THE CRISIS MANAGEMENT PROBLEM FROM THE POINT OF VIEW OF THE SMALLER STATE. EMPIRICAL MANIFESTATIONS OF CAPABILITY ASYMMETRY ARE DISCUSSED AS ARE COMPENSATING ASYMMETRIES WHICH MAY MITIGATE A SEEMINGLY UNFAVORABLE MILITARY CAPABILITY STRUCTURE. TENTATIVE OBSERVATIONS OF A SMALL STATE "CRISIS MANAGEMENT STYLE" ARE SUBMITTED AS A PRELIMINARY KNOWLEDGE BASE FOR IMPROVING OUR UNDERSTANDING OF THE INCREASINGLY IMPORTANT ASYMMETRICAL CRISIS MANAGEMENT PROBLEMATIOUE.

08776 STERN, $M$

LYNDON JOHNSON AND RICHARD RUSSELL: INSTITUTIONS,

AMBITIONS, AND CIVIL RIGHTS

PRESIDENTIAL STUDIES QUARTERLY, XXI(4) (FAL 91), 687-704.

RICHARD RUSSELL WAS "SHOCKED AND EMBITTERED" AT THE

"COMPLETE SURRENDER" OF THE 1960 DEMOCRATIC PARTY PLATFORM

"TO THE NAACP AND THE OTHER EXTREME RADICALS AT LOS ANGELES. " HE BELIEVED THAT THE KENMEDY-JOHNSON TICKET PANDERED TO BLACK VOTERS BY ENDORSING ILLEGAL SIT-INS AND THE DESEGREGATION MOVEMENT. YET IN 1960 , FOR THS FIRST TIME SINCE 1936, RUSSELL CAMPAIGNED IN THE SOUTH FOR THE DEMOCRATIC TICKET. BY CAMPAIGNING FOR JOHNSON HE HELPED HOLD DEMOCRATIC TICKET. BY CAMPAIGNING FOR JOHNSON HE HELPED HOL JOHNSON-RUSSELL RELATIONSHIP HAD PROFOUND CONSEOUENCES FOR HATIONAL POL ITICS. THIS STUDY EXAMINES THE JOHNSON-RUSSEL NATIONAL POLITICS. THIS STUDY EXAMINES THE JOHNSON-RUSSELL RELATIONSHIP, AND HOW EACH MAN DEALT WITH THE CIVIL RICHT CONGRESSIONAL AND PRESIDENTIAL AMBITIONS.

08777 STERN, S.J.

PARADIGMS OF CONQUEST: HISTORY, HISTORIOGRAPHY, AND POLITICS

JOURNAL OF LATIN AMERICAN STUDIES, 24 (1992), 1-34

RECONFIGURATION OF WORLD MAGNITUDE. THE FUSION OF NATIVE
AMERICAN AND EUROPEAN HISTORIES INTO ONE HISTORY MARKED THE BEGINNING OF THE END OF ISOLATED STAGINGS OF HUMAN DRAMA. CONTINENTAL AND SUBCONTINENTAL PARAMETERS OF HUMAN ACTION, STRUGGLE, ACCOMPLISHMENT, AND FAILURE WOULD EXPAND INTO WORLD STAGE OF POWER AND WITNESS. AFTER 1492, EUROPEAN CIVILIZATION BEGAN ITS RISE TO A UNIQUE INTERCONTINENTAL AND EVEN GLOBAL ASCENDANCE AND EMBARKED UPON A TRANSITION TO CAPITALISM WHOSE ECONOMIC LINKAGES AND TRANSFORMATIONS CROSSED SEVERAL OCEANS AND CONTINENTS. FINALLY, WITHIN EUROPE ITSELF, THE HISTORICAL GEOGRAPHY AND CUL'TURAL

PREMISES OF WESTERN CIVILIZATION SHIFTED SHARPLY. AFTER 1492, THE CENTER OF GRAVITY SHIFTED TOHARDS A NORTH ATLANTIC AXIS AS THE CENTERS OF WESTERN ECONOMIC, POLITICAL, AND CULTURAL MIGHT MOVED TOWARDS WESTERN AND MORTHERN EUROPE AND,

EVENTUALLY, ACROSS THE NORTH ATLANTIC TO THE UNITED STATES.

08778 STERNTHAL, S

MOSCOW EXPLAINS THE BATTLE

INSIGHT, 7(8) (FEB 91), 28-29.

SINCE 1958 SOVIET MILITARY ADVISERS WERE INVOLVED AT ALL LEVELS OF IRAO'S MILITARY, FROM INTELLIGENCE ON DOWN. IRAQI LEVELS OF IRAQ'S MILITARY, FROM INTELLIGENCE ON DOWN. IRAQI
OFFICERS AND GENERALS WERE TRAINED IN MILITARY STRATEGY AND OFFICERS AND GENERALS WERE TRAINED IN MILITARY STRATEGY AND TACTICS AT THE PRESTIGIOUS VOROSHILOV MILITARY ACADEMY. MOST
OF IRAQ'S EQUIPMENT IS SOVIET-MADE-FROM ASSAULT RIFLES TO OF IRAQ'S EQUIPMENT IS SOVIET-MADE-FROM ASSAULT RIFLES TO
AIR DEFENSE MISSILES. THUS, THE SOVIETS FIND THEMSELVES IN A AIR DEFENSE MISSILES. THUS, THE SOVIETS FIND THEMSELVES
TICKLISH POSITION: HOW TO EXPLAIN THE PERFORMANCE, OR TICKLISH POSITION: HOW TO EXPLAIN THE PERFORMANCE, OR HAR.

08779 STERNTHAL, S.

RUBLE RECALL

INSIGHT, $7(7)$ (FEB 91), 34-35.

MIKHÁIL GORBACHEV'S ORDER TO PULL 50- AND 100-RUBLE

NOTES FROM CIRCULATION CREATED PANIC AMONG CITIZENS, WHO HAD LITTLE TIME TO SALVAGE WHATEVER SAVINGS THEY HAD. GORBACHEV SAID HE TOOK THE ACTION IN ORDER TO STEP UP THE STRUGGLE AGAINST SPECULATION, CORRUPTION, SHUGGLING, COUNTERFEITERS, UNEARNED INCOMES, AND TO NORMALIZE MONEY CIRCULATION AND THE CONSUMER MARKET. HIS CRITICS CALL THE DECREE A HALFHEARTED ATTEMPT TO CURB INFLATION WITHOUT REAL MARKET REFORMS. WHATEVER THE CASE, THE IMMEDIATE EFFECT OF THE DECREE WAS SHEER PANIC AMONG CITIZENS.

08780 STERNTHAL, $S$.

RUSSIANS ABROAD

INSIGHT, 7(5) (FEB 91), 23-25.

MOSCOW HAS REPEATEDLY CITED THE PROTECTION OF THE RUSSIAN MINORITY AS JUSTIFICATION FOR ITS MILITARY CRACKDOWN IN THE BALTIC STATES. HOHEVER, POLLS INDICATE THAT AT LEAST HALF OF RUSSIANS IN THE BALTICS SUPPORT THE INDEPENDENCE MOVEMENT. RUSSIAN RELIGIOUS IN LITHUANIA WERE OUICK TO DECRY THE KREMLIN'S USE OF VIOLENCE. THE END RESULT IS THAT THE
GOVERNMENT'S HEAVY-HANDED TACTICS ARE BASED ON EMPTY CLAIMS.

08781 STERNTHAL, $S$.

TEETERING?

INSIGHT, 7 (11) (MAR 91), 25-25.

ALBANIANS TOOK TO THE STREETS RECENTLY TO PROTEST STALINISH, WHICH MANY BLAME FOR THE NATION'S ISOLATION AND POVERTY. PRESIDENT RAMIZ ALIA HAS MADE SOME MODEST REFORMS, BUT MANY OBSERVERS SAY THAT THEY WILL NOT SATISFY A PEOPLE WHO HAVE WATCHED COMMUNIST GOVERNMENTS FALL IN THE REST OF EASTERN EUROPE. THERE IS PRESSURE FROM CONSERVATIVES AGAINST REFORM, BUT THE DRIVE FOR DEMOCRATIZATION AND CHANGE MAY PROVE TO BE STRONGER.

08782 STERNTHAL, S.

THE POWER' OF THE PEOPLE

INSIGHT, $7(36)$ (SEP 91), 18-20.

THE KREMLIN COUP PLOTTERS HAD INDICATIONS VERY EARLY AFTER THEIR ATTEMPT TO SEIZE POWER FROM MIKHAIL GORBACHEY THAT THERE WAS SOMETHING AMISS. THE SOVIET PEOPLE, LONG PERCEIVED AS PASSIVE AND OBEDIENT, REFLEXIVELY RESPONDING TO THE IRON HAND OF CENTRALIZED AUTHORITY, SURPRISED THE EIGHT APPARATCHIKS OF THE EMERGENCY STATE COMMITTEE BY NOT REACTING WITH THE DIFFERENCE AND SUBMISSION THAT THE OLD COMHUNISTS HAD EXPECTED. THE NEW SOVIET PEOPLE, ESPECIALLY THE YOUTH, ARE BETTER EDUCATED AND HAVE LESS FEAR THAN GENERATIONS PAST. GIVEN A TASTE OF GLASNOST, CITIZENS WEREN'T ABOUT TO REVERT TO OBEDIENCE AND APATHY. THEIR SUPPORT FOR BORIS YELTSIN AND THEIR RESISTANCE TO THE COUP WAS THE KEY FACTOR IN BRINGING IT'S DOWNFALL.

08783 STETSON, D.M

HOMEN'S'RIGHTS IN THE U.S.A. POLICY DEBATES AND GENDER ROLES

BRDOKS/COLE, 1991, 265

IN ADDRESSING THE RIGHTS OF WOMEN IN THE UNITED STATES, THIS BOOK EXAMINES THE HISTORICAL ROOTS OF WOMEN'S POSITION IN SOCIETY ALONG HITH VARIOUS FEMINIST RESPONSES TO IMPROVE THE STATUS OF HOMEN. THE AUTHOR ANALYZES LEGISLATIVE PROPOSALS, COURT DECISIONS, AND FEMINIST AGENDAS AS PROMOTING WOMEN'S RIGHTS BASED ON THE CONCEPT OF "DIFFERENCE,

" OR ALTERNATIVELY, THE CONCEPT OF EQUALITY. THE BOOK 
EXAMINES VARIOUS ISSUES INCLUDING THE CONSTITUTION, POLITICS, REPROOUCTION, EDUCATION, FAMILY, WORK, SEXUALITY, ANO ECONOMIC STATUS. THE AUTHOR POINTS OUT THE POWERFUL ROLE THAT LANGUAGE AND SYMBOLS PLAY IN DEFINING SOCIETY'S RESPONSE TO HOMEN'S ISSUES. THE AUTHOR ALSO EMPHASIZES THE INTERNAL SPLITS AMONG FEMINISTS.

08784 STEUERLE, E.

THE TAX DECADE: $1981-1990$

URBAN INSTITUTE PRESS, 1991, 175.

ONE OF THE KEY PLAYERS IN THE FORMULATION OF THE 1986 TAX REFORM ACT SURVEYS A DECADE OF U.S. FEDERAL TAX CHANGES UAPRECEDENTED IN HISTORY. THE AUTHOR INTERPRETS THE SUCCESSION OF TAX DEBATES DURING THE $1980 S$ AND OFFERS AN SUCCESSION OF TAX DEBATES DURING THE $1980 S$ AND OFFERS AN
INSIDER'S PERSPECTIVE ON THE TAX POLICIES OF THE REAGAN INSIDER'S PERSPECTIVE ON THE TAX POLICIES OF THE REAGAN
ADMINISTRATION. HE UNCOVERS THE FALSE MYTHS CREATED DURING ADMINISTRATION. HE UNCOVERS THE FALSE MYTHS CREATED DURT THE DECADE ABOUT TAX REFORM AND ITS CONSEQUENCES. HE FAILED, WHAT WAS LEFT UNFINISHED BY THE BUDGET AGREEMENT OF 1990, AND THE LESSONS TO BE LEARNED FROM. THE PAST ABOUT FUTURE TAX AND BUDGET REFORM PRIORITIES.

08785 STEUNENBERG, $B$.

COALITION THEORIES: EMPIRICAL EVIDENCE FOR DUTCH MUNICIPALITIIES

EUROPEAN JOURNAL OF POLITICAL RESEARCH, 22(3) (OCT 92), 245-278.

THE AUTHOR STUDIES COALITION FORMATION IN DUTCH MUNICIPALITIES. AFTER DISCUSSING THE MAIN FEATURES OF THE INSTITUTIONAL SETTING, HE DISCUSSES SEVERAL THEORIES, WHICH ARE CLASSIFIED AS SIZE-ORIENTED, POLICY-ORIENTED, OR ACTORORIENTED MODELS. A TEST STATISTIC IS PROPOSED TO DETERMINE THE PREDICTIVE POWER OF THESE MODELS. THE EMPIRICAL AMALYSIS SHOWS THAT STRATEGIC POSITIONS AS WELL AS SOME OF THE DISTINGUISHED PREFERENCES ARE IMPORTANT IN DUTCH MUNICIPALITIES. THE DOMINANT MINIMUM NUMBER PRINCIPLE YIELDS HIGHLY SIGNIFICANT RESULTS FOR COALITION FORMATIONS IN THE PERIOD 1978-1986.

08786 STEVENS, $C$.

THE EC AND THE POOR COUNTRIES IN THE $1990 \mathrm{~S}$

BULLETIN OF PEACE PROPOSALS, 23(2) (1992), 185-196.

THE PRESENT PATTERN OF THE EUROPEAN COMMUNITY'S

RELATIONS WITH THE POOR COUNTRIES OF THE SOUTH HAS DEVELOPED

FROM BILATERAL SETS OF POLICIES. THE ARGUMENT OF THIS ARTICLE IS THAT: RELATIONS WITH POOR COUNTRIES ARE FOUNOED IN A MIX OF POLITICO-ECONOHIC SELF-INTEREST AND MORALITY; THE EXISTING PATTERN NO LONGER REFLECTS EUROPEAN ECONOMIC INTERESTS; ALTHOUGH THE OLD PATTERN MIGHT HAVE CONTINUED UNDER THE WEIGHT OF GOVERNMENT INERTIA. THE SINGLE EUROPEAN MARKET, CHANGES IN EASTERN EUROPE AND THE GATT ROUND HILL
PROVOKE CHANGES; AND, THE NEW PATTERN WILL BE CREATED BY TWO PROVOKE CHANGES; AND, THE NEW PATTERN WILL BE CREATED SETS OF FORCES: THE CHANGES ASSOCIATED WITH THE SINGLE
EUROPEAN MARKET ARE LIKELY TO DOWHGRADE SOME IDCS, BUT THE HIGHER PROFILE GIVEN TO ISSUES SUCH A PUBLIC HEALTH MIGRATION AND THE ENVIRONMENT WILL ACT IN THE OPPOSITE DIRECTION IN SOME CASES.

08787 STEVENS, $R$.

CAN THE GOVERNMENT GOVERN? LESSONS FROM THE FORMATION OF THE VETERANS ADMINISTRATION

JOURNAL OF HEALTH POLITICS, POLICY AND LAH, 16(2) (SUM 91), 281-306.

THE FEDERAL HOSPITAL SYSTEM FOR VETERANS, ESTABLISHED IN THE AFTERMATH OF WORLD WAR I IN A CONTEXT OF

DECENTRALIZATION, PRIVATIZATION, AND REJECTION OF COMPULSORY HEALTH INSURANCE, SEEMS AN ANOMALY IN HEALTH CARE POLICY-

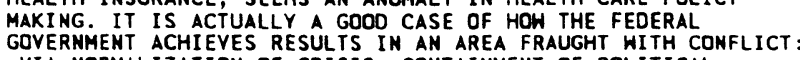
VIA NORMALIZATION OF CRISIS, CONTAINMENT OF POLITICAL DECISION MAKING, AND THE ASSOCIATION OF THE PROGRAM WITH PREVIOUSLY ACCEPTED GOALS (IN THIS INSTANCE, HORKERS' COMPENSATION). IN THE VETERANS ' CASE, POLITICAL JUDGMENTS WERE TRANSFORMED INTO SCIENTIFIC AND BUREAUCRATIC DECISIONS VIA THE PRAGMATIC USE OF EXPERTS. THE SYSTEM HORKED; THE FEDERAL GOVERNMENT GOVERMED.

08788 STEVER, J.

MODERNISM. ADMINISTRATION, AND THE POST-PROGRESSIVE ERA INTERNATIONAL JOURMAL OF PUBLIC ADMINISTRATION, 16(2) (1992), 237-260.

BEGINMING IN THE $1920 S$ A GROUP OF THEORISTS MADE A SIGNIFICANT DEPARTURE FROM PROGRESSIVE ADMINISTRATIVE THEORY. THESE POST-PROGRESSIVES ARGUED THAT ORGANIZATIONS MUST BE MORE THAN EFFICIENT PROOUCERS; THEY MUST BE INSTITUIONS WITHIN WHICH INDIVIDUALS CAN DEVELOP THEIR CREATIVE

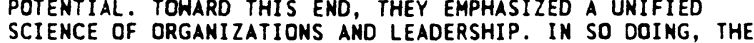
SCIENCE OF ORGANIZATIONS AND LEADERSHIP. IN SO DOING, THE POST-PROGRESSIVES BELIEVED THAT THEY WERE EXTENDING THE PROGRESSIVE SYNTHESIS BETWEEN EFFICIENCY AND HUMAN ORI ENTED ORGANIZATIONS RISKS NOT ONLY THE VIABILITY OF MODERI ORGANIZATIONS BUT THE COURSE OF MODERNITY AS WELL.
08789 STEVIS, D.

THE POLITICS OF GREEK ENYIRONMENTAL POLICY POLICY STUDIES JOURNAL, 20(4) (WIN 92), 695-709.

THIS ESSAY HAS THO GOALS: (1) TO PROVIDE AN ACCOUNT OF GREEK ENYIRONMENTAL POLICY FORMATION AND IMPLEMENTATION OVER THE PAST 20 YEARS AND (2) TO EXAMINE THE RELATIVE IMPACTS OF SPECIFIC POLITICAL FACTORS, AS CONTRASTED WITH AGGREGATE LEVELS OF SOCIOECONOMIC AND INSTI IUTIIONAL DEVELOPMENT. IN SHAPING ENYIROMMENTAL POLICY IN AN INDUSTRIALIZING COUNTRY. SUCH AS GREECE. CERTAIN ASPECTS OF STATE-SOCIETY RELATIONS SUCH AS GREECE. CERTAIN ASPECTS OF STATE-SOCIETY RELATIOH
AND OF THE INTRNAL ORGAIZATION OF THE GREEK STATE ARE AND OF THE INTERNAL ORGANIZATION OF THE GREEK STAT
FREOUENTY THE MAJOR REASONS BEHIND THE CDUNTRY'S FREOUENTLY THE MAJOR REASONS BEHIND THE COUNTRY'S
DIFFICULTIES IN FORMULATING IMPLEMENTABLE PREVENTIVE POLICY OIFFICULTIES IN FORMULATING IMPLEMENTABLE PREVENTI
AND IN IMPLEMENTING ADEQUATELY-CONSTRUCTED POLICY.

08790 STEWART, J.; WALSH, K.

THE MANAGEMENT OF PUBLIC SERVICES

PUBLIC ADMIMISTRATION $70(4)$ (WIM 92 )

THIS ARTICLE IDENTIFIES THE MAIN THEMES IN RECENT CHANGES IN PUBLIC SECTOR MANAGEMENT AND SHOWS THE EXTENT OF THE CHALLENGE TO PAST ORGANIZATIONAL ASSUMPTION. WHILE RECOGNIZING THE OBJECTIVES OF THE CHANGES COULD BRING BENEFITS IF REALIZED, IT ARGUES THAT THERE ARE A SERIES OF
ISSUES THAT ARE UNRESOLVE. THE LAMGUAGE OF CONSUMERISM, THE ISSUES THAT ARE UNRESOL VED. THE LAMGUAGE OF CONSUMERI
DEVELOPMENT OF GOVERMMENT BY CONTRACTS, THE FORM OF PERFORMANCE MANAGEMENT AND THE USE OF QUASI-MARKETS ARE SEEN AS CREATING PROBLEMS. THESE ARE SEEN AS DERIVING FROM AN ATTEMPT TO APPLY APPROACHES DRAWN FROM THE PRIVATE SECTOR TO THE PUBLIC DOMAIN. IT IS ARGUED THAT THEY NEED TO BE BALANCED BY APPROACHES THAT RECOGNIZE THE VALUES OF THE PUBLIC SECTOR.

08791 STEWART, M.; ACOCK, A.; CLARKE, H. ; KORMBERG, A. ARENAS AND ATTITUDES: A NOTE ON POLITICAL EFFICACY IN A FEDERAL SYSTEM

THE JOURNAL OF POLITICS, 54(1) (FEB 92), 173-196. POLITICAL EFFICACY AT THE NATIONAL ANO PROVINCIAL LEVELS OF THE CANADIAN FEDERAL SYSTEM USING 1983, 1984, AND 1988 SURVEY DATA IS INVESTIGATED. CONFIRMATORY FACTOR ANALYSES OF ALTERMATIVE MEASUREMENT MODELS REVEAL THAT EFFICACIOUS ALTERNATIVE MEASUREMENT MODELS REVEAL THAT EFF ICACIOUS
ATTI TUDES ARE STRUCTURED IN TERMS OF SEPARATE INTERMAL AND ATTITUDES ARE STRUCTURED IN TERMS OF SEPARATE INTERMAL AND
EXTERAL FACTORS AT THE TWO LEVELS OF GOVERMMENT. THE DEGREE EXTERNAL FACTORS AT THE THO LEVELS OF GOVERMMENT. THE DEGREE
OF ARTICULATION IN ATIITUDE STRUCTURE VARIES STRONGLY AND OF ARTICULATION IN ATTITUDE STRUCTURE VARIES STRONGLY AND
INVERSELY WITH REGIONAL DIFFERENCES IN THE SIMILARITY OF INVERSELY WITH REGIONAL DIFFERENCES IN
NATIONAL AND PROVINCIAL PARTY SYSTEMS.

08792 STEWART, M.; CLARKE, H. THE (UN IIMPORTANCE OF PARTY LEADERS: LEADER IMAGES AND. PARTY CHOICE IN THE 1987 BRITISH ELECIION THE JOURNAL OF POLITICS, 54(2) (MAY 92), 447-470. MOST RESEARCH HAS DEEMPHASIZED THE INFLUENCE OF LEADER IMAGES ON BRITISH VOTING. THIS PAPER USES THE 1987 BRITISH CAMPAIGN STUOY DATA TO INVESTIGATE THE STRUCTURE OF LEADER IMAGES AND THE DETERMINANTS OF ELECTORAL CHOICE. CONFIRMATORY FACTOR ANALYSES REVEAL TWO IMAGE DIMENSIONS-COMPETENCE AND RESPONSIVENESS. MULTIVARIATE ANALYSES SHOW THAT LEADER IMAGES HAD STRONG EFFECTS ON PARTY CHOICE.

08793 STEYN, J.

INVESTMENT IN HUMAN CAPITAL

SOUTH AFRICA INTERNATIOMAL, 22(3) (JAN 92), 137-139.

ALTHOUGH SOUTH AFRICA'S EXPENDITURE ON EDUCATION, AS A PERCENTAGE OF GDP, IS AS HIGH OR HIGHER THAN OTHER SIMILARLY DEVELOPING COUNTRIES, ITS EDUCATION SYSTEM IS IN CRISIS. GIVEN THIS CHALLENGE, THE SOUTH AFRICAN EDUCATION SYSTEM URGENT RECONSTUCTE STRATEG, BASED ON THE PRINCPLES OF WOULD BE A MATIONAL SCHOOL BUILDING PROGRAM, PROVIDING UNIVERSAL FREE AMD COMPUL SORY EDUCATION FOR' THE FIRST EIGHT UNIVERSAL FREE AND COMPULSORY EDUCATION FOR THE FIRST EIGHT
YEARS OF SCHOOL ING, THE ACHIEVEMENT OF PARITY OF PROVISION WITHIN A FINITE TIME-SCALE, AND FULL INVOLVEMENT OF ALL WITHIN A FINITE TIME-SCALE, AND FULL INVOLVEMET OF
EDUCATIONAL PLAYERS IN THE COUNTRY, VIA A FORUM FOR EDUCATIONAL RECONSTRUCTION.

08794 STIDHAM, R.; CARP, R.A.; SOMGER, D.R.; SURRATT, D. THE IMPACT OF MAJOR STRUCTURAL REFORM ON JUDICIAL DECISIONMAKING: A CASE STUOY OF THE U.S. FIFTH CIRCUIT WESTERN POLITICAL QUARTERLY, 45 (1) (MAR 92 ), $143-152$.
THIS NOTE EXPLORES THE EFFECT OF THE DIVISION OF THE U.S. FIFTH CIRCUIT, FOCUSING ON TWO BASIC QUESTIONS: DO FIFTH CIRCUIT, FOCUSING ON THO BASIC QUESTIONS: DO
STRUCTURAL CHANGES IN A CIRCUIT AFFET THE SUBSEQUENT STRUCTURAL CHANGES IN A CIRCUIT AFFECT THE SUBSEQUEMT
SUBSTANTIVE OUTPUT OF THE CIRCUIT'S JUOGES AND HOW SUBSTANTIVE OUTPUT OF THE CIRCUIT'S JUDGES AND HOW
SIGNIFICANT ARE SUCH OIFFERENCES COMPARED WITH THE KEY VARIABLE OF THE APPOINTING PRESIDENT? THE AUTHORS CONCLUDE AARIABLE OF THE APPOINTING PRESIDENT THE AUTHORS COHCLUDE SPLITING THE FIFTH CIRCUIT WOULD REVERSE OR HINDER GAINS SPLITTING THE FIFTH CIRCUIT WOULD REVERSE OR HINDER GAINS MADE BY THE OLD FIFTH CIRCUIT HERE UNFOUNOED. IN EXPLANATORY THEDRY, CHANGES IN THE STRUCTURE AND
ORGANIZATION OF THE FIFTH CIRCUIT DID NOT PRODUCE ANY SIGNIFICANT CHANGES IN THE SUBSTANTIVE OUTPUT OF THE APPELLATE AND OISTRICT COURTS. INSTEAD, THE EXTRA-JUDICIAL VARIABLES OF JUDGES' APPOINTING-PRESIDENT AND POLITICAL PARTY COMTAIN A GREATER DEGREE OF EXPLANATORY POHER. 
08795 STIEGER, C.

ALBANIA'S UMRESOLYED NATIOMAL QUESTION

SWISS REYIEW OF WORLD AFFAIRS, 42(2) (MAY 92), 23-24. THE POL IT WOR TRUCTURIMG OF YUGOSLAYIA AND THE RESULTANT CREATION OF MINI - STATES THREATENS FURTHER FRAGMENTATION FOR THE ALBANIANS LIVING IN THE SOUTHERN BALKANS. THE ALBANIANS OF KOSOVO ARE DETERMINED NOT TO REMAIN PART OF SERBIA: THIS COULD LEAD TO MORE ARMED CONFLICT AND DESTABILIZATION. ALL POLITICAL PARTIES IN ALBANIA ADVOCATE REUNIFICATION OF THEIR NATION, WHICH HAS BEEN DIVIDED SINCE THE BALKAN WARS OF 1912-13. AFTER THE DEMOCRATIC PARTY'S ELECTION VICTORY ON MARCH 22, 1992, THE HEAD OF THE PARTY ANNOUNCED THAT HE IS PREPARED TO GO BEYOND MERE VERBAL DECLARATIONS OF SOLIDARITY AND TAKE CONCRETE STEPS TO REUNITE ALL ALBANIANS.

08796 STILES, K.W.; MACDONALD, M.

AFTER CONSENSUS, WHAT? PERFORMANCE CRITERIA FOR THE U.N. IN THE POST-COLD WAR ERA

JOURMAL OF PEACE RESEARCH, 29(3) (AUG 92), 299-311.

COLD WAR STANDARDS FOR EVALUATING U.N. PERFORMANCE ARE OF LITTLE VALUE NOW, BUT THERE HAS BEEN LITTLE GENERAL OR THEORETICAL DISCUSSION OF ALTERNATIVE CRITERIA. IN AN EFFORT TO CLARIFY THE ISSUES, THE AUTHORS DERIVE FOUR DISTINCT PERFORMANCE CRITERIA EXTANT IN THE LITERATURE ON U.N. PERFORMANCE: (1) DECLARATIONS FOUND IN ORGANIC DOCUMENTS PERFORMANCE : (1) DECLARATIONS FOUND IN ORGANIC DOCUMENTS (CHARTER-BASED), (2) MEDIUH- AND SHORT-TERM OBJECTIVES ESTABLLISHED BY AGENCY OFFICIALS (OPERATIONAL), (3) PAS PERFORMANCE (TREND-BASED), AND (4) A SCENARIO FOLLOWING ELIMINATION OF THE AGENCY (ABSENCE-BASED). THEY DISCUSS THE STRENGTHS AND WEAKNESSES OF EACH CRITERIA AND CONCLUDE THAT A BLENDING OF THE OPERATIONAL AND TREND-BASED APPROACH OFFERS THE MOST PROMISING AVENUE FOR U.N. EVALUATION.

08797 STILLE, A.

BADFELLAS

NEW REPUBLIC, 207(7) (AUG 92), 12-13.

THE MASSIVE BRIBERY SCANDAL UNFOLDING IN MILAN PROMISES TO BE MORE THAN A PASSING PHENOMENON. ALREADY IT HAS SHAKEN ITALY'S RULING CLASS AND THREATENS TO OVERTURN THE PARTYDOMINATED SYSTEM THAT HAS RUN THE COUNTRY SINCE WORLD WAR II. THE INVESTIGATION. CALLED "OPERATION CLEAN HANDS," haS SHOWN BRIBE COLLECTION TO BE ONE OF THE MOST EFFICIENT AND ORGANIZED FUNCTIONS OF THE ITALIAN GOVERMMENT.

08798 STINSON, T.F.

SUBSIDIZING LOCAL ECONOMIC DEVELOPMENT THROUGH TAX INCREMENT FINANCING: COSTS IN NONMETRO COMMUNITIES IN SOUTHERN MINNESOTA

POLICY STUDIES JOURNAL, 20(2) (1992), 241-248.

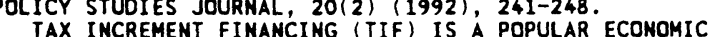
TAX INCREMENT FINANCING (TIF) IS A POPULAR ECONOMIC DEVELOPMENT TOOL IN MINNESOTA S NONMETRO COMMUNITIES. POCALITIES TO ESTABL ISH TAX INCREMENT DISTRICTS. THOSE LOCALITIES TO ESTABLISH TAX INCREMENT DISTRICTS. THOSE BY ISSUIMG BONOS BACKED BY INCREASES IN PROPERTY TAX

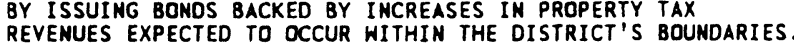
REVENUES EXPECTED TO OCCUR WITHIN THE DISTRICT'S BOUNDARIES. WHEN JUDGED SOLELY ON PHYSICAL EVIDENCE, TIF IS AN ECONOMIC
DEVELOPMENT STRATEGY FOR NONMETRO AREAS THAT APPEARS TO WORK. DEVELOPMENT STRATEG FOR NONMETRO AREAS THAT APPEARS TO WORK. SITE IMPROVEMENT, OR BUILDING. A MORE RELEVANT QUESTION IS WHETHER PHYSICAL COMPLETION OF A DEVELOPMENT PROJECT IS AN APPROPRIATE MEASURE OF SUCCESS. THE COMMUNITY IMPROVEMENT IS NOT ALWAYS WHAT ECONOMISTS CONSIDER ECONOHIC DEVELOPMENT.

08799 STIVERS, C.

TOWARD A FEMINIST PERSPECTIVE IN PUBLIC ADMINISTRATION THEORY

WOMEN AND POLITICS, 10(4) (1990), 49-66

THE FIELD OF PUBLIC ADMINISTRATION CURRENTLY LACKS A FEMINIST PERSPECTIVE, I.E., ONE THAT PRDBLEMATIZES HOMEN'S HISTORICAL EXCLUSION FROM PUBLIC ADMINISTRATION THEORY AND RAISES TOPICS AND QUESTIONS NEGLECTED AS A RESULT. FOUR IMPORTANT ISSUED ARE SUGGESTED AS AREAS WHERE A FEMINIST PERSPECTIVE MIGHT OFFER FRESH INSIGHTS: THE OUESTIOM OF ADMINISTRATIVE KNOWLEDGE; THE MODEL OF THE IDEAL PUBLIC SERVANT; THE MATURE OF ADMINISTRATIVE DISCRETION; AND THE DIMENSIONS OF THE ADMINISTRATIVE STATE.

08800 STOCK, L.; HUMPHRIES, R.

CODESA AND́ THE CONSERVATIVE PARTY

SOUTH AFRICA FOUNDATION REVIEW, 18(1, 2) (JAN 92), 9

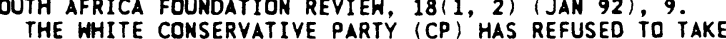
PART IN THE CONVENTION FOR A DEMOCRATIC SOUTH AFRICA PART IN THE CONVENTION FOR A DEMOCRATIC SOUTH AFRICA (CODESA). WHILE VARIOUS FACTIONS IN THE PARTY HAVE DIFFERING SOME HOPE TO WIN AN ELECTION DUE TO THEIR POSITION--THE PARTY, AS A WHOLE, RUNS THE RISK OF A SERIOUS SPLIT OR DE PARTY, AS A WHOLE, RUNS THE RISK OF A SERID
FACTO ACCEPTANCE OF BLACK MAJORITY RULE.

08801 STOCK, M.

PORTUGAL

EUROPEAN JOURNAL OF POLITICAL RESEARCH, 22(4) (DEC 92), 505-511.
THE AUTHOR SUMMARIZES THE RESULTS OF PORTUGAL'S 1991 PRESIDENTIAL AND PARLIAMENTARY ELECTIONS. SHE ALSO OUTLINES SOME OF THE MAJOR POLITICAL ISSUES FACING THE PORTUGUESE GOVERMMENT.

08802 STOCK, M.J.

POLITICAL SCIENCE IN PORTUGAL: THE IDEOLOGICAL OBSTACLES TO ITS INCIPIENT AUTONOMY

EUROPEAN JOURNAL OF POLITICAL RESEARCH, 20(3-4) (DEC 91), 425-430.

IN PORTUGAL POLITICAL SCIENCE WAS VERY SLOW TO ACHIEVE AUTONOMY AND DID NOT REALLY EMERGE UNTIL AFTER 1974 WHEN SOCIETY BECAME MORE OPEN, NEW EDUCATIONAL PROGRAMS WERE INTRODUCED, CERTAIN COURSES HERE RESTRUCTURED, AND NEW UNIVERSITIES WITH NEW DEGREES WERE CREATED. BUT POLITICAL SCIENCE STILL FAILED TO OVERCOME THE CONSTRAINTS OF LEGAL AND CONSTITUTIONAL STUDIES. THE DEPARTMENTAL STRUCTURE OF THE NEW UNIVERSITIES AND THE DEVELOPMENT OF THE SOCIAL SCIENCES, ESPECIALLY SOCIOLOGY, SEEM TO HAVE HAD SOME BENEFICIAL EFFECT ON POLITICAL SCIENCE BY ENCOURAGING NEW APPROACHES, BROADENING ITS CONCERNS, AND INTRODUCING NEW TOPICS FOR RESEARCH. BUT THESE SAME FACTORS HAVE LIMITED THE DISCIPLINE'S DEVELOPMENT, SINCE POLIIICAL SCIENCE TAKES
SECOND PLACE TO SOCIOLOGY IN THE CURRICULUM OF THE NEW SECOND PLACE TO SOCIOLLGY IN THE CURRICULUM OF THE NEW COURSES AND IS SUBJECTED TO SOCIOLOGICAL ASSUMPTIONS
REDUCE ALL POLITICAL PHENOMENA TO SOCIAL FACTORS.

08803 STOCKTON, $P$.

THE NEW GAME ON THE HILL: THE POLITICS OF ARMS CONTROL AND STRATEGIC FORCE MODERNIZATION

INTERNATIONAL SECURITY, 16(2) (FAL 91), 146-170.

THIS ARTICLE ARGUES THAT THE END OF' THE COLD WAR HAS CHANGED THE DOMESTIC POLITICS OF U.S. ARMS CONTROL AND STRATEGIC FORCE MODERNIZATION DECISIONS. GONE ARE THE DAYS WHEN SUPPORT FOR RATIFICATION OF A STRATEGIC ARMS CONTROL TREATY INVARIABLY BROUGHT WITH IT A HOST OF NEW STRATEGIC PROGRAMS. THE DECLINE OF THE SOVIET THREAT AND INCREASING PRESSURES TO CUT DEFENSE SPENDING HAVE MADE CDNGRESS RELUCTANT TO COMBINE ARMS CONTROL AND FORCE MODERNIZATION. THE START TREATY, HOWEVER, HAS BEEN BUILT ON THE ASSUMPTION THAT U.S. FORCES WILL HAVE TO BE RECONSIDERED.

08804 STOECKER, R.; SCHMIDBAUER, $M$ LOCAL

CRITICAL SOCIOLOGY, 18(3) (FAL 92), 99-124.

THIS PAPER DISCUSSES HOW TOLEDO CITY GOVERMMENT CHANGED FROM A MAYOR-WARD COUNCIL SYSTEM, TO A CITY MANAGER WITH A PROPORTIONAL REPRESENTATION COUNCIL SYSTEM, TO AN AT-LARGE COUNCIL MANAGER SYSTEM. THE AUTHORS DRAH FROM RESEARCH ON COUNCIL MANAGER SYSTEM. THE AUTHORS DRAN FROM RESEARCH ON THE STRUCTURAL LOCATION OF THE LOCAL STATE IN THE OVERALL STATE SYSTEM AND ITS ROLE IN CONTRADICTION MANAGEMENT,
CAPITALIST-LABOR STRUGGLE FOR CONTROL OF THE LOCAL STATE, CAPITALIST-LABOR STRUGGLE FOR CONTROL OF THE LOCAL STATE, AND THE EARLY 2OTH CENTURY MUNICIPAL REFORM MOVEMENT IN
UNITED STATES TO EXPLAIN THE OUTCOMES OF TOLEDO REFORM UNITED STATES TO EXPLAIN THE OUTCOMES OF TOLEDO REFORM STRUGGLES. THEIR RESEARCH SUPPORTS THE PROPOSITIONS THAT CAPITALISTS WILL ATTEMPT TO DEPOLITICIZE THE LOCAL STATE WHILE LABDR WILL ATTEMPT TO POLITICIZE THE LOCAL STATE. IT ALSO SHOWS THAT LABOR IS ABLE TO POLITICIZE THE LOCAL STRUCTURE
DIVIDED.

08805 STOJIC, E.; PAJOVIC, S

THE DANUBE' REGION IN THE PROCESS OF PAN-EUROPEAN INTEGRATION

PEACE AND THE SCIENCES, 3 (SEP 91), 41-44.

AFTER ENORMOUS CHANGES AND CIVILIZATION ADVANCEMENT, THE WORLD LIVES TODAY UNDER CONDITIONS OF DEEP INTERDEPENCENCE, BY MORE PONERFUL MANIFESTATION AND EXISTENCE OF POLITICAL AND OTHER PROCESSES ON REGIONAL LEVELS. THE IDEA OF PANEUROPEAN INTEGRATION ITSELF, INCLUDES ALSO THE CONFORMATION OF REGIONAL ACTIVITIES OF EUROPEANS. IN THE CONTEXT OF THE NECESSITY OF HARMONI ZATION OF REGIONAL ACTIVITIES WITH PANEUROPEAN ONES. THE MIDDLE PART OF THE CONTINENT SEEMS TO BE OF SPECIAL IMPORTANCE. THESE REGIONS HAVE TO BE FORMED ON THE BASIS OF NEW CRITERIA. INSTEAD OF MILITARY AND POLITICAL MEASURES OF THE PAST. THE NEH CRITERION SHOULD BE THE PRINCIPLE OF UTILIZING A NATURAL RESOURCE JOINTLY AND THE NECESSITY TO PROTECT IT. THE THEORETICAL AND PRACTICAL CONSIDERATIONS OF THIS ARE DISCUSSED IN THIS ARTICLE.

08806 STOKER, G.; WOLMAM, H.

DRAHING LESSONS FROM U.S. EXPERIENCE: AM ELECTED MAYOR FOR DRAWING LESSONS FROM U.S.

PUBLIC ADMINISTRATIOH, $70(2)$ (SUM 92), 241-268.

TAKING AS A STARTING POINT THE SUGGESTION THAT A USSTYLE ELECTED MAYORS MIGHT BE APPROPRIATE FOR BRITISH LOCAL GOVERMMENT THIS ARTICLE EXPLORES THE IMPLICATIONS OF SUCH A DEVELOPMENT. IT ANALYZES THE EXPERIENCE OF THE UNITED STATES ANO NOTES CRUCIAL DIFFERENCES BETWEEN THE LOCAL GOVERNMENT SYSTEMS OF BRITAIN AND THE UNITED STATES AND NOTES CRUCIAL DIFFERENCES BETWEEN THE LOCAL GOVERNMENT SYSTEMS OF BRITAIN AND THE UNITED STATES. THE ARTICLE DEMONSTRATES THE POTENTIAL OF PROSPECTIVE EVALUATION. 
08807 STOKER, L.

INTERESTS AND ETHICS IN POLITICS

AMERICAN POL ITICAL SCIENCE REYIEW, 86(2) (JUN 92), 369-380. THE AUTHOR EXAMINES THE PLACE OF SELF-INTEREST' IN POLITICAL LIFE AS GIVEN BY A CONCEPTION OF POLITICS THAT INYOKES ETHICS. THIS CONCEPTION PORTRAYS EACH CITIZEN AS AM INDIVIDUAL WITH UNIQUE HOPES AND DESIRES WHO IS AT THE SAME TIME JOINED WITH OTHERS-PART OF, AND CONTINUALLY GIVING TIME JOINED WITH OTHERS--PART OF, AND CONTINUALLY GIVING SHAPE TO, A SHARED SOCIAL AND POLITICAL LIFE. IT SEES IN POLITICAL DIVERSITY AND CONTROVERSY NOT JUST CONFLICTING INTERESTS BUT ALSO COMPETING CLAIMS ABOUT WHAT "WE" INDIVIDUALS LINKED TO PARTICULAR OTHERS THROUGH SOCIAL ROLES
AND RELATIONSHIPS AND TOGETHER FORMING A SINGLE CITIZENRY) AND RELATIONSHIPS AND TOGETHER FORMING A SINGLE CITIZENRY OUGHT TO DO OR SEEK. RESEARCH THAT SIMPLY ADOPTS A BROAD
CONCEPTION OF UTILITY OR INTEREST TO ADMIT NONSELFISH CDNCEPTION OF UTILITY OR INTEREST TO ADMIT NONSELFISH
PREFERENCES OR THAT EMPLOYS TYPOLOGIES CONTRASTING SELFINTERESTED WITH NON-SELF-INTERESTED MOTIVES HILL REVEAL NEITHER THE SIGNIFICANCE NOR THE LIMITS OF SELF-INTEREST IN THIS POLITICS. RATHER, SCHOLARS MUST EXPLORE HOW CITIZENS' INTERESTS ARE BOTH CHAMPIONED AND CHALLENGED BY THE UNDERSTANDINGS OF "GOOD" AND "RIGH" TO WHICH POLITICS GIVES VOICE.

08808 STOKES, 8. ORGANIZING TO TRADE

FOREIGN POLICY, (89) (WIN 93), 36-52.

BECAUSE EXPORTS OFTEN ACCOUNT FOR A SUBSTANTIAL MAJORITY OF THE UNITED STATES' ANNUAL ECONOMIC GROWTH AND INTERNATIONAL COMPETITION THREATENS THE SURVIVAL OF MAJOR SECTORS OF THE US ECOMOMY TRADE HAS BECOME AN INTRINSICALLY POL ITICAL ISSUE. IN THE RECENT PAST, AN ANEMIC INTRINSICALLY POLITICAL ISSUE. IN THE RECENT PAST, AN ANEMIC
U.S. TRADE REPRESENTATIVE AND A CONGRESS THAT WORKS AT CROSSU.S. TRADE REPRESENTATIVE AND A CONGRESS THAT WORKS AT CROSS
PURPOSES HITH THE ADMINISTRATION HAVE SOMETIMES SABOTAGED AMERICA'S SELF-INTEREST. OVER THE NEXT FEH YEARS, DECISIONS AMERICA'S SELF-INTEREST. OVER THE NEXT FEH YEARS, DECISIONS
ON THE REGULATION OF IMPORTS, THE PROMOTION OF EXPORTS, AND ON THE REGULATION OF IMPORTS, THE PROMOTION OF EXPORTS, AND
THE TYPE OF COOPERATION PERMITTED AMONG INDUSTRIES WILL HELP THE TYPE OF COOPERATION PERMITTED AMONG INDUSTRIES WILL HELP
SHAPE THE U.S. ECONOMY AND DETERMINE THE TYPES OF JOBS AND SHAPE THE U.S. ECONOMY AND DETERMINE THE TYPES OF JOBS AND
LIFESTYLES AYAILABLE TO AMERICANS. REORGANIZING TRADE--BY LIFESTYLES AVAILABLE TO AMERICANS. REORGANIZING TRADE--BY INSTITUTING AN ECONOMIC SECURITY COUNCIL, A DEPARTMENT OF
INTERMATIONAL TRADE AND INDUSTRY, ANO A CONGRESSIONAL TRADE OFFICE--WOULD PROVIDE THE MECHANISMS NEEDED FOR INTERMATIONAL COMPETITIVENESS.

08809 STOKES, $G$.

LESSONS OF THE EASTERN EUROPEAN REVOLUTIONS OF 1989 PROBLEMS OF COMMUNISH, XL(5) (SEP 91), 17-22.

THE BASIC LESSON OF 1989 IS THAT THE 2OTH CENTURY IS OVER: TWO OF THE THREE BASIC GENRES OF SOLUTIONS TO THE FUNDAMENTAL CHALLENGES OF THE PAST FEH HUNDRED YEARS-OTHE ANTI-RATIONALIST GENRE (TYPIFIED BY FASCISM) AND THE HYPERRATIONALIST GENRE (TYPIFIED BY COMMUNISM)--HAVE PROVEN TO BE POLITICAL, ECONOMIC, AND MORAL DEAD ENDS. BUT THIS DOES NOT MEAN THAT THE THIRD GENRE, PLURALISM, HAS ADEQUATELY SOLVED THE MODERN PROBLEMATIC; MAN HAS NOT LEARNED WHAT DOES WORK, AS SURELY AS HE HAS LEARNED WHAT DOES NOT WORK. IN ASSESSING THE VARIED DEVELOPMENTS IN THE POSTCOMMUNIST HORLD, MAN MUST TAKE INTO ACCOUNT MORAL AND CULTURAL FACTORS AS WELL AS THE ABILITIES OF INDIVIDUAL LEADERS.

08810 STOLA, $D$.

FORCED MIGRATION IN CENTRAL EUROPEAN HISTORY

INTERHATIONAL MIGRATION REVIEH, XXVI(2) (SUM 92), 324-341.

INTERNATIONAL MIGRATION REVIEW, XXVI (2) (SUM 92$), 324$
IN CENTRAL EUROPE, FORCED MIGRATIONS CONSTITUTE A CONSIDERABLE AND, IN SOME COUNTRIES, A MAJOR PART OF ALL
MIGRATORY MOVEMENTS IN MODERN HISTORY. THEY TAKE PLACE NOW MIGRATORY MOVEMENTS IN MODERN HISTORY. THEY TAKE PLACE NOH
AND WILL PROBABLY AFFECT THE FUTURE OF THE REGION, THIS AND WILL PROBABLY AFFECT THE FUTURE OF THE REGION, THIS
ARTICLE PRESENTS THE BASIC INFORMATION ON THE MAJOR CENTRAL ARTICLE PRESENTS THE BASIC INFORMATION ON THE MAJOR CENTRAL
EUROPEAN INVOLUNTARY MOVEMENTS OF THE LAST 200 YEARS. IT EMPHASIZES THE FIRST HALF OF THIS CENTURY, ESPECIALLY THE "BLACK DECADE" (1939-1949)--THE APOGEE OF FORCED MIGRATIONS. THE ARTICLE INDICATES SEVERAL FACTORS, KNOHN FROM THE PAST

MOVEMENTS, WHICH PERSIST OR RE-EMERGE IN TODAY'S
EUROPE AND MAY HAVE IMPACT ON FUTURE MIGRATIONS.

08811 STOLER, A.

SEXUAL AFFRONTS AND RACIAL FRONTIERS: EUROPEAN IDENTITIES AND THE CULTURAL POLIIICS OF EXCLUSION IN COLONIAL AND THE CULTURA

SOUTHEAST ASIA
COMPARATIVE STUDIES IN SOCIETY AND HISTORY, 34(3) (JUL 92) COMPARATIVE

514-550. COLONIAL CATEGORIES AND NATIONAL IDENTITIES AND WITH THOSE PEOPLE WHO AMBIGUOUSLY STRADDLED, CROSSED, AND THREATENED THESE IMPERIAL DIVIDES. IT BEGINS HITH A STORY ABOUT "METISSAGE" (INTERRACIAL UNIONS) AND THE SORTS OF PROGENCY TO WHICH IT GAVE RISE IN FRENCH INDOCHINA AT THE TURN OF THE CENTURY. IT IS A STORY WITH MULTIPLE VERSIONS ABOUT PEOPLE WHOSE CULTURAL SENSIBILITIES, PHYSICAL BEING, AND POLITICAL SENTIMENTS CALLED INTO OUESTION THE DISTINCTIONS OF DIFFERENCE HHICH MAINTAINED THE NEAT BOUMOARIES OF COLONIAL RULE. IT ALLOWS THE AUTHOR TO ADDRESS ONE OF THE TENSIONS OF EMPIRE WHICH IS THE RELATIONSHIP BETWEEN THE DISCDURSES OF INCLUSION, HUMANITARIANISM, AND EOUALITY WHICH INFORMED
LIBERAL POLICY AT THE TURN OF THE CENTURY AND THE EXCLUSIONARY, DISCRIMINATORY PRACTICES WHICH WERE REACTIVE TO, COEXISTENT WITH, AND PERHAPS INHERENT IN LIBERALISM ITSELF.

08812 STOLEROFF, A.

BETWEEN CORPORATION AND CLASS STRUGGLE: THE PORTUGUESE LABOUR MOVEMENT AND THE CAVACO SILVA GOVERNMENTS

WEST EUROPEAN POLITICS, 15(4) (OCT 92), 118-150. THIS ARTICLE LOOKS AT HOW THE CONJUNCTURE THAT BEGAN HITH THE ADVENT OF THE PSD MINORITY GOVERNMENT UNDER CAVACO HITH THE ADVENT OF THE PSD MINORITY GOVERNMENT UNDER CAVACO
SILVA IN 1985 RESULTED IN A DEFINITIVE DEMARCATION OF THE SILVA IN 1985 RESULTED IN A DEFINITIVE DEMARCATION OF
POSITIONS OF LABOR AND CAPITAL IN THE REDEMOCRATIZATION POSITIONS OF LABOR AND CAPITAL IN THE REDEMOCRATIZATIOH TENDENCY WITHIN PORTUGUES INDUSTRIAL RELATIONS. IT FOCUSES TENDENCY WITHIN PORTUGUES INDUSTRIAL RELATIONS. IT FOCUSES ON LABOR'S STRUGGLE AROUND ISSUES OF LABOR LAW REFORM AND WAGE AGREEMENTS FROM WITHIN AND FROM WITHOUT THE PERMANENT
COUNCIL FOR SOCIAL CONCERTATION, THE TRIPARTITE BODY FOR COUNCIL FOR SOCIAL CONCERTATION, THE TRIPARTITE BOOY FOR MACRO-ECONOMIC AND SOCIAL NEGOTIATION. THE ARTICLE ARGUES THAT LABOR SUFFERED A SERIOUS SETBACK AS A RESULT OF THIS
STRUGGLE AND THAT THIS SETBACK PROVIDED THE CLASS BASIS FOR THE EMERGENCE OF A HISTORICAL COMPROMISE ESTABLISHING A NEH PATTERN OF INDUSTRIAL RELATIONS IN PORTUGAL. IT THEN LOOKS AT THE SEQUELS OF THIS STRUGGLE TO DEMONSTRATE THE EFFECT THAT LABOR'S PREVIOUS DEFEAT HAS HAD UPON THE CONSOLIDATION OF TRI-PARTITE BARGAINING.

08813 STONE, $A$.

WHERE JUDICIAL POLITICS ARE LEGISLATIVE POLITICS: THE FRENCH CONSTITUTIONAL COUNCIL

WEST EUROPEAN POLITICS, 15(3) (JUL 92), 29-49.

JUDGES ON FRANCE'S ORDINARY AND ADMINISTRATIVE COURTS MAKE LAW AND POLICY BY INTERPRETING AND APPLYING STATUTES, BUT THE CONSTITUTIONAL COURT IS OVERTLY INVOLVED IN POLICYMAKING. THE COUNCIL SERVES AS A TYPE OF "THIRD" CHAMBER OF THE FRENCH PARL IAMENT, WHERE IT MAY ANNUL UNCONSTITUTIONAL
LEGISLATION, "CONSTITUTIONALIZE" VARIOUS LEGAL PRINCIPLES, LEGISLATION, "CONSTITUTIONALIZE" VARIOUS LEGAL PR
AND SOMETIMES EVEN PRESCRIBE THE PRECISE TERMS OF AND SOMETIMES EVEN PRESCRIBE THE PRECISE TERMS OF
LEGISLATION. THUS, THIS COURT-LIKE BODY PLAYS A SIGNIFICANT LEGISLATION. THUS, THIS COURT-LIKE BODY P
AND GROWING ROLE IN FRENCH POLICY-MAKING.

08814 STONE, C.D. "INSURING" AGAINST GLOBAL WARMING BEYOND RIO: "INSURING" AGAINST GLOBAL WARMING
AMERICAN JOURMAL OF INTERMATIONAL LAW, 86(3) (JUL 92 ) AMERICAN

THE AUTHOR DISCUSSES WHAT AN INTERNATIONAL CLIMATETHE AUTHOR DISCUSSES WHAT AN INTERNATIONAL CLIMATECHANGE CONVENTION SHOULD INCLUDE. HE CONSIDERS THE
SCIENTIFIC BACKGROUND TO THE GLOBAL WARMING PROBLEM, THE SCIENTIFIC BACKGROUND TO THE GLOBAL WARMING PROBLEM, THE
INTERNATIONAL PRECEDENTS AFFECTING ENVIRONMENTAL CONVENTIONS, MORTH-SOUTH CONFLICTS OVER ENVIRONMENTAL ISSUES, AND OTHER FACTORS THAT WILL AFFECT THE DRAFTING OF AN INTERNATIONAL AGREEMENT ON CLIMATE CHANGE.

08815 STONE, E.C. UNPROTECTED CONTENT PRESIDENTIAL STUDIES QUARTERLY, XXII(4) (FAL 92), 721-740. THE AUTHOR STUDIES THE QUESTION OF WHETHER, AND TO WHAT EXTENT, COMMERCIAL SPEECH IS PROTECTED BY THE FIRST AMENDMENT. THE ISSUE WAS NEVER REVIEWED BY THE SUPREME COURT UNTIL 1942, WHEN IT EXCLUDED COMMERCIAL SPEECH FROM A RECITATION OF FREE SPEECH GUARANTEES. THE COURT DID NOT RECONSIDER THE OUESTION UNTIL 1973, AND THEN IN 1976 IT DESCRIBED COMMERCIAL SPEECH AS A LESSER RIGHT THAN POLITICAL SPEECH. THE AUTHOR CONTENDS THAT THE DIFFERENTIATION BETHEEN COMMERCIAL SPEECH AND OTHER TYPES IS A FALSE ONE AND IS NOT SUPPORTED BY ANY PRINCIPLED ARGUMENT.

08816 STONE, M.

NATIONISM AND IDENTITY IN (FORMER) EAST GERMANY TIKKUN, $7(6)$ (NOV 92 ), 41-46.

THE RAMPAGE OF VIOLENCE IN THE FORMER YUGOSLAVIA AND IN SOMALIA, THE ETHNIC TENSIONS THROUGHOUT EASTERN EUROPE, THE SOMALIA, THE ETHNIC TENSIONS THROUGHOUT EASTERN EUROPE, AHD REEEMERGENCE OF NEO-NAZI ACTIVITY IN GERMANY, FRANCE,
OTHER WESTERN EUROPEAN COUNTRIES ARE BUT THE LATEST OTHER WESTERN EUROPEAN COUNTRIES ARE BUT THE LATEST
INDICATIONS THAT NATIONALISM AND ETHNIC PARTICULARISM WILL INDICATIONS THAT NATIONALISM AND ETHNIC PARTICULARISM WILL
BE CRITICAL FACTORS IN INTERNATIONAL POL ITICS OF THE POSTBE CRITICAL FACTORS IN INTERNATIONAL POL ITICS OF THE POST
COLD WAR ERA. THIS ARTICLE IS ON THE CONFLICT BETWEEN COLD WAR ERA. THIS ARTICLE IS ON THE CONFLICT BETWEEN
MATIONALISM AND INTERNATIONALISM. BETWEEN PARTICULARISM AND NATIONALISM AND INTERNATIONALISM, BETWEEN PARTICULARISM
UNIVERSALISM, IT EXAMINES HOW THESE TENSIONS ARE BEING UMIVERSALISM, IT EXAMINES HOW THESE TENSIONS ARE BEING
PLAYED OUT THE REALM OF THOUGHT AND IN THE REALM OF PLAYED OUT THE REALM OF
INTERNATIONAL POLITICS.

08817 STONE, $N$.

THE MARK OF HISTORY

NATIONAL INTEREST, 27 (SPR 92), 29-38

IN 1918 AT BREST-LITOVSK, THE GERMANS RECOGNIZED UKRAINIAN INDEPENDENCE. BY 1924 THE QUESTION BOILED DOWN TO THIS: HOW RUSSIAN WAS UKRAINE? THIS IS STILL A QUESTION TODAY, AS UKRAINE EMBARKS UPON AMOTHER PERIOD OF INDEPENDENCE. THIS ARTICLE EXPLORES THE POLISH IMPACT ON UKRAINE FROM THE FOURTEENTH TO THE TWENTIETH CENTURY. TODAY, THE GREAT PROBLEM FOR UKRAINE IS RELATIONS WITH RUSSIA. THE ESSAY ATTEMPTS TO SHOW VARIOUS THINGS FROM THE HISTORY OF 
UKRAINE HAVE HAD A VERY BAD TIME OF IT IN OUR CENTURY, BUT THEY DESERYE HELL OF THE MEXT.

08818 STONE, W.; ABRAMOWITZ, A.; RAPOPORT, R. CANDIDATE SUPPORT IN PRESIDENTIAL NOMINATION CAMPAIGNS: THE CASE OF IOHA IN 1984

THE JOURNAL OF POLITICS, 54(4) (NOV 92), 1074-1097. THREE EXPLANATIONS OF CANDIDATE CHOICE IN PRESIDENTIAL NOMINATION CAMPAIGNS ARE ANALYZED. THE EXPLANATIONS ARE TESTED ON SAMPLES OF DEMOCRATIC CAUCUS ATTENDERS AND STATE CONVENTION DELEGATES FORM IOWA IN 1984. THE EXPECTED UTILITY MODEL MOST SUCCESSFULLY PREDICTS CANDIDATE CHOICE IN BOTH SAMPLES. BOTH PREFERENCE AND CANDIDATE CHANGES MEASURES HAVE SIGNIFICANT INDEPENDENT EFFECTS ON CANDIDATE CHOICE. THE ANALYIS SUGGESTS THAT THE INTERESTS OF INDIVIUAL NOMINATION AS MANY CRITICS OF THE CONTEMPORARY PRDCESS BELIEVE.

08819 STONE, W. ; ATKESON, L.; RAPOPORT, R. TURNING ON OR TURNING OFF? MOBILIZATION AND DEMOBILIZATION EFFECTS OF PARTICIPATION IN PRESIDENTIAL NOMINATION CAMPAIGNS

AMERICAN JOURNAL OF POLITICAL SCIENCE, 36(3) (AUG 92) 665-691.

MUCH OF THE LITERATURE EMPHASIZES THE NEGATIVE EFFECTS OF PRESIDENTIAL NOMINATION CAMPAIGNS ON THE GENERAL ELECTION STAGE. STUDIES OF "DIVISIVE PRIMARIES" HAVE SUGGESTED THAT PRIMARIES UNDERMINE A PARTY'S CHANCES IN THE FALL CAMPAIGN, AND THE LITERATURE ON THE "CARRYOVER EFFECT" FINDS THAT SUPPORTERS OF NOMINATION-ROUND LOSERS ARE LESS LIKELY TO SUPPORT THEIR PARTY'S NOMINEE THAN THOSE WHO BACKED THE WINNER. THIS ARTICLE ARGUES THAT THIS LITERATURE HAS UNDERESTIMATED THE MOBILIZATION EFFECTS THAT RESULT FROM NOMINATION CAMPAIGNS. EMPLOYING DATA FROM STUDIES OF CAUCUS ATTENDERS IN 1984. THE AUTHORS FIND EVIDENCE OF A MOBILIZING EFFECT OF PARTICIPATION IN NOMINATION CAMPAIGNS. IN A PROPERLY SPECIFIED ANALYSIS, THE EVIDENCE FOR MOBILIZIING EFFECTS IS MUCH STRONGER THAN FOR DEMOBILIZATION. THAT IS, ACTIVITY FOR A NOMINATION CONTENDER INCREASES THE LEVEL OF PARTICIPATION FOR THE PARTY'S TICKET IN THE FALL CAMPAIGN. THE AUTHORS SUGGEST SOME WAYS THEIR FINDINGS CAN BE RECONCILED WITH THE LITERATURE, AND ARGUE THAT AN APPRECIATION OF THESE POSITIVE EFFECTS CAN MOTIVATE A REASSESSMENT OF THE CONTEMPORARY NOMINATION PROCESS.

08820 STONICH, S.C

STRUGGLING WITH HONDURAN POVERTY: THE ENVIRONMENTAL CONSEQUENCES OF NATURAL RESOURCE-BASED DEVELOPMENT AND RURAL TRANSFORMATIONS

WORLD DEVELOPMENT, 20(3) (MAR 92), 385-399.

EXPORT GROWTH THROUGH AGRICUL TURAL DIVERSIFICATION HAS EXPORT GROWTH THROUGH AGRICUL TURAL DIVERSIFICATION HAS SINCE WWII. THIS ARTICLE EXAMINES THE IMPACT OF THIS STRATEGY ON INEQUALITY, IMPOVERISHMENT, AND ENVIRONMENTAL DEGRADATION IN SOUTHERN HONDURAS. ANALYSIS CENTERS ON THE MEGRADATION IN SOUTHERN HONDURAS. ANALYSIS CENTERS ON TH CATTLE, AND THE SO CALLED "NONTRADITIONALS"--MOST SATTLE, AND THE SO CALLED "NONTRADITIONALS THE GULF OF FONSECA. THIS STUDY DEMONSTRATES THE SYSTEMIC INTERCONNECTIONS AMONG THE DYNAMICS OF AGRICULTURAL DEVELOPMENT, PATTERNS OF CAPITALIST ACCUMULATION, RURAL INEQUALITY AND IMPOVERISHMENT, AND PROBLEMS OF ENVIRONMENTAL DESTRUCIION. CONCLUSIONS POINT TO THE NEED FOR DEVELOPMENT POLICIES TO DIRECTLY ADDRESS THE EXTREMES OF WEALTH AND POVERTY IN ORDER TO REVERSE ENVIRONMENTAL DECLINE.

08821 STOREY, J.

OFFICIALS AIDS POLICIES ATTACKED BY VOLUNTEERS JAPAN TIMES (WEEKLY INTERNATIONAL EDITION), 32(13) (MAR $92), 9$.

JAPAN'S AIDS PREVENTION LAH REQUIRES THAT THE AGE, SEX, AND TRANSMISSION ROUTE OF ANYONE TESTING POSITIVE FOR THE HUMAN IMMUNODEFICIENCY VIRUS BE REPORTED TO AUTHORITIES. THE LEGISLATION ALSO STIPULATES THAT AUTHORITIES MUST RESPECT THE HUMAN RIGHTS OF THE INFECTED AND, THROUGH DISSEMINATION OF ACCURATE INFORMATION, ENSURE THAT THE PUBLIC DOES THE SAME. BUT CRITICS ARGUE THAT THE GOVERNMENT CLASSIFIES HIY CARRIERS INTO "GOOD" AND "BAD" CATEGORIES. "GOOD" CARRIERS ARE THOSE INFECTED BY CONTAMINATED BLOOD PRODUCTS. WHILE

"BAD" APPLIES TO THOSE INFECTED THROUGH SEXUAL CONTACT.

08822 STORK, J.

NEW ENEMIES FOR A NEW WORLD ORDER: FROM ARC OF CRISIS TO GLOBAL INTIFADA

MIDDLE EAST REPORT, 22(3) (MAY 92), 28-38.

THERE IS COMSIDERA 22(3) (MAY 92), 28-38. ADMINISTRATION SAW THE PERSIAN GULF WAR OF 1990-91 AS THE CONFLICT THAT COULD DEFINE A NEW POLITICO-MILITARY STRATEG FOR THE 1990S. THE WAR WITH IRAQ WOULD BE THE EMBLEMATIC CONTEST FOR THE POST-COLD WAR PERIOD. THIS ARTICLE SUGGESTS THAT HOW WE COME OF THIS WILL DETERMINE WHETHER WE CAN OR CANMOT STILL CALL ON FORCE TO ACHIEVE OUR GOALS ABROAD. IT STUDIES: YEAR ZERO; THREAT RECONSTRUCTION: IOEOLOGY

CONSTRUCTS; THE PARADIGM LOST; AND THE NEW WOLRD AURA. IT
CONCLUDES THAT THE ISLAMIC THREAT IS SERVING TO RATIONALIZE A STATUS QUD POLICY THAT MAY WELL CONTRIBUTE TO THE SORT OF MILITARY INTERVENTIOH.

08823 STRANAHAN, $P$.

STRANGE BEDFELLOWS: THE COMMUNIST PARTY AND SHANGHAI'S ELITE IN THE NATIONAL SALVATION MOVEMENT

CHINA QUARTERLY, (129) (MAR 92), 26-51.

DURING THE NATIONAL SALVATION MOVEMENT OF THE MID-1930's, THE SHANGHAI PARTY FORGED ITS MOST HORKABLE ALLIANCE NOT WITH THE PROLETARIAT BUT HITH PROGRESSIVES FROM THE CITY'S MIDOLE AND UPPER CLASSES. MAXING USE OF MULTI-CLASS PATRIOTISM, PARTY LEADERS ESTABLISHED A COOPERATIVE RELATIONSHIP WITH MEMBERS OF THE ELITE THAT BECAME A CRUCIAL ELEMENT OF CHINESE COMMUNIST PARTY RESISTANCE AGAINST JAPAN. THE RELATIONSHIP CONTINUED INTO THE POST-WAR YEARS AND CONTRIBUTED SIGNIFICANTLY TO THE COMMUNISTS' EASY TAKEOVER OF SHANGHAI IN 1949.

08824 STRANG, D.

GLOBAL PATTERNS OF DECOLONIZATION, 1500-1987

INTERNATIONAL STUDIES OUARTERLY, 35(4) (DEC 91), 429-454. THIS PAPER EXAMINES GLOBAL PATTERNS IN THE BREAKDOWN OF WESTERN OVERSEAS EMPIRES BETHEEN 1500 AND 1987. IT WESTERN OVERSEAS EMPIRES BETWEEN 1500 AND 1987. IT COUNTERPOSES THE IMPL ICATIONS OF WORLD ECONOMY, MARXIST, AND INSTITUTIONAL ARGUMENTS FOR THE TIMING OF DECOLONIZATION. NONPARAMETRIC ANALYSES INOICATE GREAT VARIATION IN THE RATE VARIATION OVER DEPENDENCY AGE. THIS SUGGESTS THAT THE PROCESSES PRODUCING DECOLONIZATION ARE PRIMARILY EXTERNAL RATHER THAN INTERNAL TO THE DEPENCENCY. THE PRESENCE OF A HEGEMONIC POWER, THE RISE OF AN ANTICOLONIAL POLITICAL DISCOURSE, AND DIFFUSION PROCESSES WITHIN AND ACROSS EMPIRES HELP TO EXPLAIN SHIFTS IN THE RATE OF DECOLONIZATION OVER HISTORICAL TIME.

08825 STRANGE, S.

STATES, FIRMS AND DIPLOMACY

INTERNATIONAL AFFAIRS, 68(1) (JAN 92), 1-16.

A NEW RESEARCH AGENT IN INTERNATIONAL RELATIONS IS PROPOSED BY SUSAN STRANGE AS SHE REPORTS ON HER RECENT WORK ON RELATIONS BETWEEN STATES AND FIRMS. SHE STUDIES FORMS AS ACTORS IN WORLD POLITICS AND OF STATE-FIRM AND FIRM-FIRM BARGAINING AS THO NEW DIMENSIONS TO DIPLOMACY. SHE ARGUES THAT GOVERNMENTS, LIKE ACADEMICS, MAKE WAKE UP TO THE ATTENTION TO THE INCREASING IMPORTANCE OF FIRMS.

08826 STRASSER, E.

STRASSER'S MANIFESTO

WEST AFRICA, 75(3909) (AUG 92), 1388.

CAPTAIN VALENTINE E. M. STRASSER MADE A STATEMENT ON AUGUST 6 TO MARK THE 1OOTH DAY OF THE APRIL 29 REVOLUTION. HE REPORTED ON THE OBJECTIVES OF HIS GOVERNMENT WHICH WERE TO BRING TO AN END THE REBEL WAR, TO GET THE BELEAGUERED ECONOMY OF THE COUNTRY ON A FIRM FOOTING, AND TO TAKE ALL MEASURES NECESSARY FOR THE RECOVERY OF ALL FINANCIAL RESOURCES LAWFULLY BELONGING TO THE GOVERNMENT, AND TO RELAUNCH THE DOMOCRATIC PROCESS ON A JUST, FAIR, AND LASTING BASIS. HE REPORTS ON THE DIPLOMATIC FRONT, THE ECONOMY, AND THE SOCIAL AND POLITICAL FRONTS.

08827 STRATMANH, T.

ARE CONTRIBUTORS RATIONAL? UNTANGLING STRATEGIES OF POLITICAL ACTION COMMITTEES

JOURNAL OF POLITICAL ECONOMY, 100(31) (JUN 92), 647-664. EMPIRICAL PUBLIC CHOICE LITERATURE AND CASUA OBSERVATION SUGGEST THAT THE BEHAVIOR OF POLITICAL ACTION COMMITTEES (PAC'S) IS REMARKABLY UNSOPHISTICATED--THAT PAC'S GIVE TO THOSE LEGISLATORS WHO WOULD SUPPORT THEIR INTERESTS ANYWAY. THUS, IT IS SUGGESTED THAT CONTRIBUTOR BEHAYIOR DEVIATES FROM RATIOMAL BEHAVIOR, WHICH IS A CORNERSTONE OF ECONOMIC ANALYSIS. IN THIS PAPER, THE AUTHOR ESTIMATES A SWITCHING REGRESSION MODEL THAT ALLOWS FOR STRATEGIES OF PAC'S TO VARY FOR DIFFERENT CONTRIBUTION RECIPIENTS. HE ANALYZES THE BEHAVIOR OF AGRICULTURAL PAC'S OVER THREE ELECTION CYCLES AND FINDS THAT CONTRIBUTOR BEHAVIOR IS MOT INCONSISTENT WITH RATIONAL BEHAVIOR. CONTRIBUTORS WHO ATTEMPT TO INFLUENCE THE VOTING BEHAVIOR OF CONGRESSMEN GIVE THE MOST MONEY TO LEGISLATORS WHOSE CONSTITUENCY INTEREST SUGGESTS THAT THEY ARE LIKELY TO BE UNDECIDED ON HOW TO VOTE SUGGESTS THAT THEY ARE LIKELY TO BE UNDECIDED ON HOW TO
AND PAC'S GIVE LESS MONEY TO LEGISLATORS WHO REPRESENT AND PAC'S GIVE LESS MONEY TO LEGISLATORS WHO REPRES DISTRICTS WITH LARGE FARM POPULATIONS BECAUSE THOSE
LEGISLATORS ARE LIKELY TO VOTE IN CONTRIBUTOR INTERESTS LEGISLATO

08828 STRAUBHAAR, J.; VISCASILLAS, G. CLASS, GENRE, AND THE REORGANIZATION OF TELEVISION PROGRAMMING IN THE DOMINICAN REPUBLIC

JOURNAL OF COMMUNICATION, 41(1) (WIN 91), 53-69. ALTHOUGH LATIN AMERICAN NATIONS CONTINUE TO DEPEND ON THE UNITED STATES, JAPAN, AND OTHER INDUSTRIALIZED NATIONS, PARTICULARLY FOR TECHNOLOGY AND ADVERTISING REVENUE, 
TELEYISION AS A CULTURAL INDUSTRY IN LATIN AMERICA HAS UNDERGONE CONSIDERABLE CHANGE. MANY OF THE RECENT DEVELOPMENT IN THE FLOW OF TELEVISION PROGRAMMING CAN BE EXPLAINED BY REFERENCE TO THE CONCEPT OF GENRE. THERE SEEM TO BE SPECIFIC AUDIENCES FOR REGIONAL GENRES IN LATIN AMERICAN, DIVIDED BY CLASS, AGE, AND SEX. TO EXAMINE THESE ISSUED, THE AUTHORS UNDERTOOK A SURVEY IN SANTO DOMINGO (DOMINICAN REPUBLIC) IN MARCH 1987. THEY FOUND THAT SOCIAL CLASS WAS SIGNIFICANTLY RELATED TO A PREFERENCE FOR PROGRAMS FROM OMLY OME PRODUCING COUMTRY--THE U.S. HOWEVER DESPITE ITS SMALL SIZE AMD LIMITED RESOURCES THE DOMINICAN REPUBLIC HAS BUILT UP A TELEYISION INDUSTRY WITH PROGRAMS THAT ATTRACT AND PLEASE IT VIEWERS.

08829 STRAUBHAAR, T.

ALLOCATIONAL AND DISTRIBUTIONAL ASPECTS OF FUTURE ALLOCATIONAL AND DISTRIBUTIONAL

INTERNATIONAL MIGRATION REVIEW, XXVI(2) (SUM 92), 462-483. THIS ARTICLE SHOWS THAT AN ANALYSIS OF THE IMPACTS OF IMMIGRANTS HAS TO BE DIVIDED INTO ALLOCATIONAL AND DISTRIBUTIONAL ASPECTS. FROM AN ALLOCATIONAL POINT OF VIEW, LIKE FREE TRADE IN GOODS, SERVICES AND CAPITAL, MIGRATION IS HELFARE-IMPROVING AS LOMG AS MARGINAL PROOUCTIVIIIIES OF LABOR ARE NOT EQUALIZED HORLDWIDE. FROM A DISTRIBUT IONAL
POINT OF VIEW, HOWEVER, THE IMMIGRATION SOCIETY HAS TO BEAR POINT OF VIEW, HOWEVER, THE IMMIGRATION SOCIETY HAS TO SOCIAL VALUES WITH THE NEW IMMIGRANTS. FREE IMMIGRATION WILL ONLY BE ALLOWED IF THE ALLOCATIONAL WELFARE GAINS EXCEED THE DISTRIBUTIONAL WELFARE LOSSES. ACCORDING TO THIS RULE OF THUMB, A GUIDELINE FOR AN EFFICIENT MIGRATION POLICY IS SKETCHED.

08830 STRAUCH, R.

NEW SELF-ASSURANCE EMERGES IN GERMANY'S FOREIGN POLICY

GERMAN TRIBUNE, 1500 (JAN 92 ), $1-2$.
THERE HAVE BEEN UNFRIENDLY' SOUMDS FROM NEIGHBORING EUROPEAN COUNTRIES AND FROH THE UNITED STATES BECAUSE GERMANY HAS PUT FORWARD ITS OWM OPINIONS ON SEYERAL OCCASIONS. SOME OF THE REMARKS HAVE BEEN PROVOKED BY FEAR OF TOO MUCH GERMAY STREMGTH, OTHERS BY UUCERTAINTY ABOUT GERMANY'S INTENTIONS. THE CAUSE OF A RESURGENCE OF GERMANY'S INTENTIONS. THE CAUSE OF A RESURGENCE OF
WIDESPREAD MISTRUST OF GERMAN POLICY IS FAR FROM CLEAR. THIS WIDESPREAD MISTRUST OF GERMAN POLICY IS FAR FROM CLEAR. THIS
ARTICLE DISCUSSES MANY OF THE REASONS WHY GERMAN HOME AND ARTICLE DISCUSSES MANY OF THE REASONS WHY GERMAM

08831 STREEK, B

COMMON SYMBOLS AND VALUES IN $S$. A.

SOUTH AFRICA FOUNDATION REVIEH, 18(8) (AUG 92), 6.

SHARED YALUES ARE AH ELUSIVE CONCEPT IM A COUNTRY HITH MANY CULTURES, BUT COMMON UNIFYING SYMBOLS ARE EMERGING IN SOUTH AFRICA DESPITE THE CODESA BREAKDOWN. THE EMERGENCE OF A NATIONAL IDENTITY BASED ON SHARED VALUES COULD EASE THE DIFFICULTIES OF POLITICAL TRANSITION. INDEED, IF THE NEW SOUTH AFRICA IS TO HAVE ANY REAL HOPE, IT IS VITAL THAT ITS FOUNDATIONS BE LAID ON THE BASIS OF SHARED VALUES AND COMMON SYMBOLS.

08832 STREEK, B.

THE RURAL VOTE--THE DECISIVE FACTOR?

SOUTH AFRICA FOUNDATION REVIEW, 17(11) (NOV 91), 1-2.

IN SOUTH AFRICA THE GOVERMMENT AND ANC EXPECTATIONS THAT THE PRETORIA/WITHATERSRAND/VEREEMIGING REGION HOULD DOMINATE THE NATION'S FIRST FREE ELECTIONS HAVE BEEN SHATTERED BY THE FINOING THAT NEARLY THO OUT OF EVERY FIVE VOTERS HILL COME FROM THE EASTERN CAPE AND NATAL REGIONS. THIS ARTICLE DISCUSSES THE UPCOMING ELECTIONS AND WHETHER OR NOT THE RURAL VOTE WILL BE THE DECISIVE FACTOR.

08833 STREIB, $G$.

APPLYING STRATEGIC DECISION MAKING IN LOCAL GOVERMMENT PUBLIC PRODUCTIVITY \& MANAGEMENT REVIEH, 15(3) (SPR 92), 341-354.

QUESTIONS ABOUT THE UTILITY OF STRATEGIC DECISION MAKING FOR LOCAL GOVERMMENT APPLICATIONS IS RAISED. THIS ARTICLE ARGUES THAT MANY LOCAL GOVERMMENTS CANMOT MAKE EFFECTIVE USE OF STRATEGIC DECISION-MAKING TECHNIQUES. SUPPORT FOR THIS $\checkmark I E W P O I N T$ IS DEVELOPED FROM AN ANALYSIS OF FOUR CRITICAL MANAGEMENT FUNCTIONS. THE AUTHOR ARGUES THAT LOCAL MANAGEMENT FUNCTIONS. THE AUTHOR ARGUES THAT LOCAL
GOVERMMENTS SHOULD NOT MAKE A LARGE INYESTMENT IN STRATEGIC DECISION MAKING UNLESS THEY ALREADY POSSESS A HIGH LEVEL OF MANAGEMENT SOPHISTICATION.

08834 STREIB, $G$. PROFESSIONAL SKILL AND SUPPORT FOR DEMOCRATIC PRINCIPLES: THE CASE

ADMINISTRATION AND SOCIETY, 24(1) (MAY 92), 22-40.

THIS STUDY EXAMINES THE IMPACT OF PROFESSIONAL SKILL ON CITIZEN PARTICIPATION AND RESPECT FOR POLITICAL LEADERSHIP AMONG LOCAL GOVERNMENT DEPARTMENT HEADS IN NORTHERN ILLINOIS. DATA WERE COLLECTED BY A MAILED SURVEY AND THE FINDING INDICATE THAT ALTHOUGH THE RESPONDENTS DISPLAYED SOME RESERYATIONS ABOUT INVASIVE CITIZEN PARTICIPATION AND THE IRRATIONALITY OF THE POLITICAL PROCESS, SUCH VIEHPOINTS WERE
NOT A FUNCTION OF INCREASED PROFESSIONAL SKILL. THE FINDINGS SUGGEST THAT WITHIN THE LOCAL GOVERNMENT ENIVRONMENT, PROCESSES ASSOCIATED WITH PROFESSIONALIZATION AND MUNICIPAL REFORM MAY BRING BENEFITS BEYOND INCREASED MANAGEMENT SKILL.

08835 STREIB, G.

STRATEGIC CAPACITY IN COUNCIL-MANAGER MUNICIPALITIES: EXPLORING LIMITS AND HORIZONS

INTERNATIONAL JOURNAL OF PUBLIC ADMINISTRATION, 15(9)

(1992), 1737-1755.

OVER THE PAST 10 YEARS INTEREST IN STRATEGIC DECISION MAKING HAS GROWN EXPOTENTIALLY. TO A GREAT EXTENT, SCHOLARS WHO HAVE DEALT WITH THIS TOPIC HAVE TAKEN A STRONG PRESCRIPTIVE TONE, SUGGESTING THAT THE TECHNIOUE IS SYNONYMOUS WITH SOUND MANAGEMENT PRACTICES. THIS STUDY ACCEPTS THE DESIRABILITY OF STRATEGIC DECISION MAKING BUT QUESTIONS THE FEASIBILITY. FINDINGS ARE PRESENTED FROM SURVEY OF CITY MANAGERS ANO MAYORS WHICH SUGGESTS THAT BARRIERS EXIST TO EFFECTIVE USE OF STRATEGIC DECISION MAKING IN PARTICULAR, THERE IS A NEED TO GAIN GREATER CONTROL OVER STRONGER CLIENT FOCUS AS A POSSIBLE REMEDY FOR THIS PROBLEM.

08836 STRICKLAND, R.A.; WHICKER, M.L.

COMPARING THE WILDER AND GANTT CAMPAIGNS: A MODEL FOR BLACK CANDIDATE SUCCESS IN STATEWIDE ELECTIONS

PS: POLITICAL SCIENCE AND POLITICS, XXV(2) (JUN 92), 204-212.

THE AUTHORS COMPARE THE PERFORMANCE OF BLACK CAMDIDATES IN THO RECENT STATEHIDE ELECTION CAMPAIGNS.

08837 STRICKLAND, R.A.; HHICKER, M.L. POL ITICAL AND SOCIOECONOMIC INDICATORS OF STATE RESTRICTIVENESS TOWARD ABORTION

POLICY STUDIES JOURMAL, 20(4) (WIN 92), 598-617. THE AUTHORS COMPARE THE RELATIVE IMPACTS OF POLITICAL AND SOCIOECONOMIC FACTORS ON STATE RESTRICTIVENESS TOWARD ABORTION DURING THE PRE-ROE, PRE-WEBSTER, AND POST-WEBSTER TIME FRAMES. THEY TEST THE VALUE OF CYCLE THEORY, WHICH POSITS THAT CONSERVATISM OR LIBERALISM ENHANCES THE ROLE OF POLITICAL VARIABLES IN SHAPING POLICY FORMATION DURING POLITICAL VARIABLES IN SHAPING POL ICY FORMATION DURING
SUCCEEDING EPOCHS, THUS CREATING A CYCLE WHERE CONSERVATISM
AND LIBERAL ISM ALTERNATE. THEY ALSO TEST THE EXPLANATORY ANO LIBERALISM ALTERNATE. THEY ALSO TEST THE EXPLANATORY ISSUES THAT CUT ACROSS PARTY LINES ACCENTUATE THE ROLE OF ISSUES THAT CUT APCRDSS PARTY LINES ACCENTUATE THE ROLE OF SOCIOECONOMIC VARIABLES IN SHAPING ISSUE EVOLUTION. THE RESULTS OF THIS ANALYSIS LEND SUPPORT TO BOTH CYCLE AND PUBLIC OPINION THEORIES, ALTHOUGH PUBLIC OPINION THEORY RECEIVES STRONGER SUPPORT. WHEN SOCIOECONOMIC INOEPENDENT VARIABLES ARE REGRESSED AGAINST THE DICHOTOMOUS MEASURE OF STATE RESTRICTIVENESS TOWARD ABORTION, THEY EXPLAIN MORE VARIANCE THAN POLITICAL INOEPENDENT VARIABLES. POLITICAL VARIABLES WERE MORE IMPORTANT IN THE CONSERVATIVE ERA (1989) THAN IN THE LIBERAL ERA (1972).

08838 STROBEL, $W$ CRACKDOWN BLUEPRIN INSIGHT, 7 (10) (MAR 91), 28

MOSCOW'S HARSH CRACKDOHM ON LITHUANIA HAS APPROVED AT THE HIGHEST LEVELS OF THE SOVIET COMMUNIST PARTY IN AUGUST 1990--FIVE MONTHS BEFORE SOVIET TROOPS STORMED A LITHUANIAN TELEVISION STATION, KILLING FIFTEEN. PARTY DOCUMENTS, PUBLISHED RECENTLY BY A MOSCOW NEWSPAPER AND NOW WIDELY CIRCULATED WITHIN THE BUSH ADMINISTRATION, OUTLINED A 10POINT PROGRAM FOR DEALING WITH THE RESTIVE REPUBLIC. THERE IS NO PROOF THAT MIKHAIL GORBACHEV KNOW OF THE PLAN, BUT THE NUMBER 2 PARTY MAN ENDORSED IT. ANALYSTS SAY IT IS UNLIKELY THAT HE WOULD NOT HAVE BEEN INFORMED.

08839 STROHM, C.

ROMANIA, A POTENTIALLY RICH COUNTRY IN NEED OF HELP GERMAN TRIBUNE, (1513) (MAY 92), 2.

OF ALL THE STATES IN EASTERN AMD SOUTHEASTERN EUROPE WHICH HAVE BEEN LIBERATED FROM COMMUNISM ROMANIA HAS SUFFERED ONE OF THE MOST DIFFICULT TRANSITIONS. IN THE THIRD YEAR AFTER THE CEAUCESCU ERA. THE LEGACY OF ONE OF THE WORST COMMUNIST DICTATORSHIPS STILL WEIGHS HEAVILY ON A PEOPLE WHICH HAS NOT EXPERIENCED "NORMAL" POLITICAL, ECONOMIC OR SOCIAL LIFE FOR OVER HALF A CENTURY. DESPITE UNCERTAINTIES SOCIAL LIFE FOR OVER HALF A CENTURY. DESPITE UNCERTAIN
ABOUT THE DEMOCRATIC CREDENTIALS OF ROMANIA'S RULING ABOUT THE DEMOCRATIC CREDENTIALS OF ROMANIA'S RULING
NATIONAL SALVATION FRONT, THE NATION MUST RECEIVE AID FROM NATIONAL SALVATION FRONT, THE NATION MUST RECEIVE AID FROM
THE WEST. IF NOT, ROMANIA'S VOLATILE MIX OF ETHNIC MINORITIES AND IT'S LEGACY OF VIOLENT REPRESSION PROMISE TO MINORITIES AND ITS LEGACY OF VIOLENT

08840 STROTHER, R

SALINAS AT MIDTERM

WATIONAL REVIEH, XLIV(2) (FEB 92), 20-21.

THREE YEARS AGO CARLOS SALINAS DE GORTARI WAS BEINC DENOUNCED AS A USURPER WHOSE CLAIM TO THE MEXICAN PRESIDENCY HAS BASED ON A BLATANT ELECTION FRAUD PERPETUATED BY HIS PARTIDO REVOLUCIONARIO INSTITUCIONAL (PRI). NOH, AT THE HALFWAY POINT IN HIS SIX-YEAR TERM HE HAS TURNED A SICK
ECONOMY AROUND, SUPPRESSED INFLATION, AND REVERSED THE 
PRINCIPAL SOCIALIST ERRORS OF HIS PREDECESSORS IN OFFICE, MAKING HIMSELF, IN THE PROCESS, THE MOST POPULAR MEXICAN PRESIDENT IN MANY YEARS. SALINAS HAS BEEN SUCCESSFUL IN TAKING ON POLITICALLY UNTOUCHABLE ISSUES IN MEXICO INCLLDING STEVEDORES' UNION IN VERACRUZ, THE "EJIDO" SYSTEM OF COLLECTIVE FARMING, AND THE CORRUPT PRI-RIGGED ELECTORAL SYSTEM.

08841 STROUP, R.L.; GOODMAN, S.L.

PROPERTY RIGHTS, ENVIRONMENTAL RESOURCES, AND THE FUTURE HARVARD JOURNAL OF LAW AND PUBLIC POLICY, 15(2) (SPR 92),
427-454.

THE AUTHORS ARGUE THAT THE PRIVATE SECTOR'S MARKETORIENTED DECISIONS WILL TEND TO ALLOCATE RESOURCES TO THEIR HIGHEST-VALUED USES ACROSS TIME, WHILE THE POLITICAL AND ADMINISTRATIVE DECISIONS MADE IN THE PUBLIC SECTOR HILL TEND TO ALLOCATE RESOURCES TO USES FOR WHICH CURRENT POL ITICAL SUPPORTERS EXERT THE STRONGEST IMMEDIATE PRESSURES. THEY COMPARE AND CONTRAST THE TIME HORIZONS REFLECTED IN COMPARE AND CONTRAST THE TIME HORIZONS REFLECTED IN
DECISIONS IN THREE AREAS IN HHICH BOTH PUBLIC AND PRIVATE DECISIONS IN THREE AREAS IN HHICH BOTH PUBLIC AND PRIVATE
DECISIONS ARE MADE: ASSETS TO PROVIDE PUBLIC SERVICES, DECISIONS ARE MADE: ASSETS TO PROVIDE PUBLIC SERVICES,
EMPLOYEE COMPENSATION AND FUNDING, AND ELECTRIC UTILITY EMPLOYEE COMP
REGULATION.

08842 STRYKER, J.D.; BAIRD, K.E

TRENDS IN AFRICAN AGRICULTURAL TRADE: CAUSES AND PROGNOSIS POLICY STUDIES JOURNAL, 20 (3) (1992), 414-430.

SUB-SAHARAN AGRICULTURE, HITH FEW EXCEPTIONS, HAS STAGNATED DESPITE OFFICIAL GOALS OF ACHIEVING SELFSUFFICIENCY AND INCREASING EXPORT EARNINGS. AFRICAN AGRICULTURE HAS SUFFERED DETERIORATING TERMS OF TRADE, INADEQUATE TECHNOLOGY AND INFRASTRUCTURE, AND POLICIES THAT SEVERELY DISCOURAGE AGRICULTURAL ENTERPRISE. IN SOME COUNTRIES STRUCTURAL ADJUSTMENT AND POLICY REFORM ARE UNDERHAY, AND THERE REMAINS GREAT POTENTIAL FOR AGRICULTURAL DEVELOPMENT DUE IN PART TO ABUNDANT LABOR AND ADVANTAGES IN NATURAL RESOURCES. IN THIS PAPER, THE AUTHORS SUGGEST A SPECIFIC SET OF INSTITUTIONAL

08843 STUBBS, $R$.

SUBREGIONAL SECURITY COOPERATION IN ASEAN: MILITARY AND ECONOMIC IMPERATIVES AND POLITICAL OBSTACLES

ASIAN SURVEY, $22(5)$ (MAY 92), 397-410.

THE ASEAN REGION HAS BEEN GREATLY INFLUENCED BY THE EVENTS OF THE END OF THE COLD HAR AND THE CRUMBLING OF THE SUPERPOWER RELATIONSHIP. WHILE RELATIONS WITHIN ASEAN ARE SUPERPOWER RELATIONSHIP. WHILE RELATIONS WITHIN ASEAN ARE
LIKELY TO BE STRAINED, THE NEW TRENDS WILL NOT NECESSARILY LIKELY TO BE STRAINED, THE NEW TRENDS WILL NOT NECESSARIL
PUT THE ASSOCIATION IN JEOPARDY. THIS ARTICLE EXPLORES PUT THE ASSOCIATION IN JEOPARDY. THIS ARTICLE EXPLORES
TRENDS IN REGIONAL SECURITY AND IN ECONOMIC ENVIRONMENT, AS TRENDS IN REGIONAL SECURITY AND IN ECONOMIC ENVIRONMENT, AS
HELL AS FORMS OF COOPERATION. THE OBSTACLES WHICH FACE ASEAN WELL AS FORMS OF COOPERATION. THE OBSTACLES WHICH FACE ASEAN
ARE DETAILED. A NUMBER OF POLITICAL CONSIDERATIONS WILL TEND ARE DETAILED. A NUMBER OF POLITICAL CONSIDERATIONS HILL TO PUT A DAMPER ON ANY MOVE TOWARD A FORMAL TRILATERAL SECURITY OR DEFENSE ARRANGEMENT. INFORMAL THREE-WAY
RELATIONS AMONG THE MILITARY AND INTELLIGENCE COMMUNITIES OF THE CORE COUNTRIES ARE LIKELY TO CONTINUE TO THRIVE.

08844 STUDLAR, D.; HELCH, S

THE PARTY SYSTEM AND THE REPRESENTATION OF WOMEN IN ENGLISH METROPOL ITAN BOROUGHS

ELECTORAL STUDIES, 11(1) (MAR 92), 62-69.

HOMEN NOW TOTAL TWENTY PERCENT OF LOCAL COUNCILLORS IM BRITAIN. THE VARIABILITY OF THE PROPORTIONS OF WOMEN IN DIFFERENT COUNCILS MAKE THEM USEFUL IN EXPLORING HYPOTHESES ABOUT FACTORS PROMOTING OR RETARDING WOMEN'S CANDIDATES AND VICTORIES. IN THIS PAPER, THE AUTHORS USE DATA ON CANDIDACIES FOR THE METROPOLITAN BOROUGH ELECTIONS OF MAY 1986 TO TEST A HYPOTHESIS THAT THE NATURE OF THE PARTY SYSTEM, IN PARTICULAR THE NUMBER OF PARTIES CONTESTING A SEAT, AFFECTS THE LIKELIHOOD OF WOMEN BEING ADOPTED AS CANDIDATES ANO BEING ELECTED IN SINGLE-MEMBER DISTRICT SYSTEMS.

08845 STULTZ, $N$.

EVOLUTION OF THE UNITED NATIONS ANTI-APARTHEID REGIME HUMAN RIGHTS OUARTERLY, 13(1) (FEB 91), 1-23.

FEN SUBJECTS HAVE BEEN MORE ENDURING BEFORE THE UMITED NATIONS THAN APARTHEID; THE TOPIC HAS BEEN KNOWN SINCE 1948. THE RESPONSE OF THE MEMBERS OF THE UNITED NATIONS TO APARTHEID HAS BEEN FAR DIFFERENT RECENTLY FROM WHAT IT WAS DURING THE UN'S EARLY YEARS. THIS ARTICLE ARGUES THAT A UM DURING THE UN S EARLY YEARS. THIS ARTICLE ARGUES THAT A UN HAS SUOSEQUENTLY EVOLVED IN IMPORTANT PARTICULARS. THE IDENT IDENTFY THOSE INDEPENOENT VARIABLES WITH WHICH IT APPEARS TO BE ASSOCIATED. IN PARTICULAR, THE AUTHOR SEEKS TO DETERMINE WHETHER THIS EVOLUTION OCCURRED GRADUALLY, OR WHETHER IT HAS BEEN CONTIMUOUS AND UNEVEN, A SERIES OF SUDDEN STEP-LIKE REACTIONS TO SPECIFIC OCCURRENCES, SUCH AS THE 1960 SHARPESVILLE MASSACRE.

08846 STUPAK, R. : HONE, T. NATIONAL SÉCURITY AND DOMESTIC POLICY-MAKING: THE
SIMILARITIES AND THE CRITICAL DIFFERENCES

INTERMATIONAL JOURMAL OF PUBLIC ADMINISTRATION, 15(7) INTERNATIONAL JOURMA

THIS ANALYSIS FOCUSES ON THE DISCUSSION OF WHETHER AND HOW NATIONAL SECURITY AND DOMESTIC POLICY-MAKING PROCESSES ARE SIMILAR AND/OR DIFFERENT. IT REMINDS PUBLIC ADMINISTRATORS OF THEIR RESPONSIBILITIES TO UNDERSTAND THE NATIONAL SECURITY ARENA IN ORDER TO DETECT BOTH THE UNIQUE FEATURES AS HELL AS THE BROADER GENERALIZATIONS ATTENDING THIS MICROCOSM OF PUBLIC POLICY-MAKING. PUBLIC

ADMINISTRATORS MUST MAKE CERTAIN THAT THIS LABORATORY OF PUBLIC POLICY IS RESEARCHED AND INVESTIGATED SO AS TO ENSURE THAT THE PROPER POLICY TRADE-OFFS ARE MADE IN THE 1990 .

08847 STURM, $P$

RISK OF CONFLICTS INCREASING AS ASIA BECOMES LESS STABLE GERMAN TRIBUNE, 31(1544) (DEC 92), 2.

MEMBERS OF ASEAN, THE ASSOCIATION OF SOUTH-EAST ASIAN NATIONS, ARE REACTING TO TRADE BLOCS THAT ARE EMERGING IN WESTERN EUROPE AND NORTH AMERICA HITH CLOSER ECOMOMIC COOPERATION, BUT THERE ARE NEW DEVELOPMENTS IN SECURITY POLICY, TOO. BECAUSE OF THE NUMEROUS SOURCES OF CONFLICT, HOPE FOR TOO. BECAUSE OF THE NUMEROUS SOURCES OF CONFLICT, HOPE FOR
A PEACEFUL FUTURE IN ASIA IS NOT PARTICULARLY STRONG. WHAT A PEACEFUL FUTURE IN ASIA IS NOT PARTICULARLY STRONG. WHAT
IS LACKING IN ASIA IS AN AUTHORITATIVE POWER ACCEPTED BY ALL IS LACKING IN ASIA IS AN AUTHORITATIVE POWER ACCEPTED BY ALL TOGETHER. THIS ARTICLE SUGGESTS THAT ONLY THE UNITED STATES, IF ANYONE, COULD ASSUME SUCH A ROLE.

08848 STURMER, M.

MIDOLE EAST AND ENERGY: THE DRUMMER IN THE ORIENT WILL BE HEARD AGAIN

GERMAN TRIBUNE, (1477) (JUL 91), 5

THE RECENT GULF CRISIS PROVIDES A STARK REMINDER OF HOW THE INTERESTS OF EUROPE ARE INTERTWINED WITH THE MIDDLE EAST. THE FACT THAT A LARGE PORTION OF THE WORLD'S OIL RESERVES ARE IN THIS POLITICALLY VOLATILE REGION DOES NOT BODE WELL FOR THE FUTURE. THE ARMS CONFIGURATION IN THE MIDDLE EAST, FAVORED BY LARGE AMOUNTS OF MONEY ON THE BUYER SIDE AND A LACK OF WISDOM AHONG SUPPLIERS, INCREASES THE INSTABILITY. WHILE THE EASING OF EAST-HEST TENSIONS ALLOWED THE SUPERPONERS TO ENGAGE IN ARMS CONTROL, SUCH MEASURES ARE UNLIKELY TO BE SUCCESSFUL IN THE MIDDLE EAST. POPULATION PRESSURES AND A GROWING NUMBER OF "ISLAMIC CRISES" ONLY INCREASE THE TENSION AND INSTABILITY.

08849 STURMER, M.

NUCLEAR RENUNCIATION REMAINS A PART OF GERMAN SECURITY GERMAN TRIBUNE, (1511) (APR 92), 1-2.

FOR REASONS' CONNECTED WITH THE PAST, PRUDENCE AND FOR REASONS CONNECTED WITH THE PAST, PRUDENCE AND

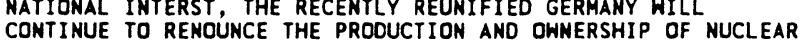
CONTINUE TO RENOUNCE THE PRODUCIION AND OWNERSHIP OF NUCLEAR WEAPONS. SIMPLY PUT, NUCLEAR ARMAMENT UNDER NATIONAL CONTRDL
COULD NOT IMPROVE MILITARY SECURITY, BUT WOULD FUNDAMENTALLY COULD NOT IMPROVE MILITARY SECURITY, BUT WOULD FUNDAMENTALLY AFFECT GERMANY'S MORAL, POLITICAL AND ECDNOMIC STATUS AND PULL THE EUROPEAN FRAMEWORK OFF ITS HINGES. THE COUNTRY EUROPEAN ALLIANCE ARE POLITICALLY INTERLINKED.

08850 STUTH, R.

GERMANY'S NEW ROLE IN A CHANGING EUROPE

AUSSEN POLITIK, 43(1) (1992), 22-32

THE EMERGENCE OF A LARGER GERMANY AS A RESULT OF GERMAN UNIFICATION AROUSED CONCERN, YET OCCASIONALLY HOPES, ABROAD
THAT IN FUTURE THE COUNTRY IN THE HEART OF EUROPE WILL EXERT MORE INFLUENCE AND PLAY A GREATER POLITICAL ROLE. THIS ARTICLE EXAMINES THE CHALLENGES FACING GERMANY, HOH IT WILL PROBABLY RESPOND, AND WHAT KIND OF GERMAN INFLUENCE WILL DEVELOP. ITS CONCLUSION IS THAT, IN VIEH OF NUMEROUS EXPECTATIONS, A SUBSTANTIAL EXTENT OF INFLUENCE, INDEED A LEADING ROLE, WILL FALL TO THE GERMANS. THIS NEW ROLE, HOWEVER, HILL NOT BE ASSUMED BY A GERMAN NATION-STATE, BUT BY A GERMANY WHICH INCREASINGLY RELINQUISHES CLASSIC SOVEREIGN RIGHTS AND INTEGRATES ITSELF INTO INTERNATIONAL COMAUNITIES (SUCH AS, IN PARTICULAR, THE EC AND NATO).

08851 STUTZLE, $N$.

A UNITED EUROPE: NEW STEPS TOHARDS AN OLD IDEA GERMAN TRIBUNE, (1496) (DEC 91), 1-2.

THE DECADES-OLD HISH FOR EUROPEAN UNIFICATION IS RAPIDLY MOVING TOWARDS FULFILLMENT. AS FAR AS IS HUMANLY CALCULABLE, WAR BETWEEN MEMBER-STATES OF THE EUROPEAN COMMUNITY IS NO LONGER CONCEIVABLE. WHAT IS MORE, THE COMMUNITY'S ECONOMIC LONGER CONCEIVABLE. WHAT IS MORE, THE COMMUNITY'S ECONOMIC
COOPERATION HAS BEEN SO SUCCESSFUL THAT FROM 1993 NOT ONLY COOPERATION HAS BEEN SO SUCCESSFUL THAT FROM 1993 NOT ONLY
THE EUROPEAN COMMUNITY BUT ALSO THE FORMER EFTA STATES ARE THE EUROPEAN COMMUNITY BUT ALSO THE FORMER EFTA STATES ARE ATTRACTION HAVE MADE THE CONCEPT OF NEUTRALITY SUPERFLUOUS AS SWEDEN, AUSTRIA, FINLAND, AND EVEN SHITZERLAND ARE CONSIDERING APPLICATION FOR MEMBERSHIP. IT IS NOW UP TO EUROPEAN COMMUNITY OFFICIALS TO TAKE THE NEXT STEPS TOWARDS UNITY INCLUDING MOVES TOWARD MONETARY UNION AND A COMMON SECURITY POLICY.

08852 STUTZLE, $W$.

FEW CERTAINTIES ON WHICH TO BUILD TOMORROW'S EUROPE 
GERMAN TRIBUNE, (1507) (MAR 92), 1, 3.

THE PEACEFUL CDLLAPSE OF THE SOVIET EMPIRE HAS BROUGHT EUROPE TO A COMPLETELY NEW STAGE OF DEVELOPMENT. WHILE THE NEWHESS OF THE CURRENT SITUATION IS BOUND TO CREATE UNCERTAINTY AMONG MANY EUROPEAN STATES, IT IS IMPORTANT FOR ALL TO REALIZE THAT OLD SOLUTIONS AND CONCEPTS NEED TO BE DISCARDED IN FAVOR OF FRESH NEW IDEAS. THE LONG-STANDING FEAR OF A POWERFUL GERMANY IS UNJUSTIFIED IN A NEW FEAR OF A POHERFUL GERMANY IS UNJUSTIFIED IN A NEW INTERDEPENDENT EUROPE IN WHICH GERMANY COULD NOT DISENTANGLE
ITSELF EVEN IF IT WANTED TO. EXTENSION OF PREVIOUS SECURITY ITSELF EVEN IF IT WANTED TO. EXTENSION OF PREVIOUS SECURI TY
STRUCTURES (I.E. NATO) TO EASTERN EUROPE IS SIMILARLY ILLSTRUCTURES (I. E. NATO) TO EASTERN EUROPE IS SIMILARLY ILL-
ADVISED. WHAT EUROPE NEEDS IS CONTINUED ECONOMIC INTEGRATION ADVISED. WHAT EUROPE NEEDS IS CONTINUED ECONOMIC INTEGRAT AND EVENTUAL POL ITICAL INTEGRATION. WHILE THE POTENTIAL
RISKS OF SUCH A PATH ARE REAL. THERE IS NO OTHER PEACEFUL COURSE.

08853 STUTZLE, $W$.

POST COLD WAR CHALLENGE IS TO FIND SOME NEH ANSWERS GERMAN TRIBUNE, 31(1542) (NOV 92), 1; 4

IT IS THAT IN THE TRANSITION FROM COLD WAR TO A NEW ERA AND IN VIEH OF PEACE BEING SO FRAGILE, GERMAN FOREIGN POLICY HAS LONG CEASED TO BE ABLE TO LIMIT ITSELF TO LOOKING AFTER THE NATIONAL INTEREST WITHIN A TRIED AND TRUSTED INTERNATIONAL FRAMEWORK. THE CIRCUMSTANCES OF THE NEH ERA THAT HAVE SO FAR COME TO LIGHT MAKE WAGES POLICY AND THE LAW OF ASYLUM KEYNOTES OF AN INTERNATIONALLY LINKED AND INTERDEPENDENT SECURITY POLICY. WHAT IS NEEDED NOW IS READINESS NOT TO NIP NEW QUESTIONS IN THE BUD WITH OLD PREJUDICES IF A RETHINK IS TO BE OF BENEFIT TO SOCIETY AS A HHOLE.

08854 STUTZLE, $H$.

QUESTION MARKS HANG OVER EUROPE IN THE NEW AGE GERMAN TRIBUNE, (1524) (JUL 92), 1.

SEVENTEEN YEARS AFTER THE HELSINKI FINAL ACT THE INTERMATIONAL COMMUNITY HAS BEEN NOTIFIED, IN THE 1992 DOCUMENT OF THE CONFERENCE ON SECURITY AND COOPERATION IN DOROPE (CSCE). THAT EUROPEANS AIM TO LOOK AFTER THEIR OWM PEACE AND SECURITY. LEAVE-TAKING OF THE OLD ORDER COULD HARDLY HAVE BEEN STATED MORE CLEARLY. THE DESIRE TO MOVE ON HARDLY HAVE BEEN STATED MORE CLEARLY. THE DESIRE TO MOYE CLEARLY EITHER. THE OUESTION THAT REMAINS TO BE ASKED IS WHETHER THE CONTINENT IS EQUIPPED TO HANDLE THE VICISSITUDES WHETHER THE CONTINENT IS EQUIPPED TO HANDLE THE VICISSITUDES OF LIFE--POLITICALLY, ECONOMICALLY, AND MILITARILY. ECONOM GOVERNMENT ARE BUT A FEH OF THE PROBLEMS FACING MANY GOVERNMENT ARE
EUROPEAN STATES.

08855 STUTZLE, $W$.

THE FUTURE OF EUROPE: IDENTIFYING THE DANGERS AND FINDING SOME CURES

GERMAN TRIBUNE, (1512) (APR 92), 2 .

A CONFERENCE OF EUROPEAN POLITICAL AND BUSINESS LEADERS IN GERMANY HIGHLIGHTED MANY OF THE UNCERTAINTIES FACING BOTH EAST AND WEST EUROPE. THE GENERAL TREND IN THE WEST IS
TOWARDS OVERCOMING THE NATION-STATE, INTEGRATING BOTH POLITICALLY AND ECONOMICALLY, ESTABLISHING A COMMON CURRENCY, AND COMBINING ARMED FORCES AND SECURITY STRUCTURES. IN CONTRAST, THE NEWLY INDEPENDENT STATES OF EASTERN EUROPE AND THE COMMONHEALTH OF INDEPENDENT STATES (CIS) ARE CLEARLY BENT ON RETAINING THEIR OWN SOVEREINGTY, MILITARY FORCES, ECONOMIC POLICIES, AND NATIONAL AND CULTURAL IDENTITY. THIS DICHOTOMY MAKES THE PROPOSED INTEGRATION OF EASTERN EUROPE INTO WESTERN ECONOMIC ANO POLITICAL STRUCTURES QUITE DIFFICULT. AT THE CONFERENCE GERMAN CHANCELLOR HELMUT KOHL ESTABL ISHED A SERIES OF GUIDEL INES FOR THE WEST IN THE DAYS ESTABLISHED A SERIES OF GUTE GERMAM CHAYCELLOR HELMUT KOHL AHEAD. UMED A SERIES OFFU GUIDELIMES FOR THE WEST IN THE DAYS EUROPEAN UNION SHOULD BE ENDOWED WITH POWER TO ACT AND MAKE DECISIONS. THE ALLIANCE WITH AMERICA MUST CONTINUE. ECONOM ORGANIZED AND CONTROLLED. AND, WHATEVER SHAPE THE EUROPEAN COMMUNITY MAY FINALLY TAKE, IT CANNOT EXTEND FURTHER EAST THAN THE BUG RIVER (I.E. NOT INTO THE CIS). WHEN ALL WAS
SAID AND DONE. THE GENERAL UNCERTAINTY ABOUT THE FUTURE SAID AND DOI

08856 SUALNIER, $R$.

CONSTRUCTIVE YEARS: THE U.S. ECONOMY UNDER EISENHOWER UNIVERSITY PRESS OF AMERICA, 1991, 266

THE CHAIRMAN OF PRESIDENT EISENHOHER'S COUNCIL OF ECONOMIC ADVISERS DURING THE PRESIDENT'S SECOND TERM OFFERS ECONOMIC ADVISERS DURING THE PRESIDENT'S SECOND TERM OFFERS AN AUTHORITATIVE ACCOUNT OF EISENHOHER'S ECONOMIC POL THE BOOK BEGINS WITH AN ACCOUNT OF THE POLITICAL AND ECDNOMIC PHILOSOPHY THAT MADE EISENHOHER AN ADVOCATE OF LIMITED, NON-INTERVENTIONIST GOVERMMENT AND COMPETI ITIVE,

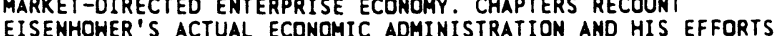
EISENHOWER'S ACTUAL ECONOMIC ADMINISTRATION AND HIS EFFORTS TO OBTAIN LEGISLATION ENABLING HIM TO INSTITUTE PROGRAMS
LINE WITH HIS PHILOSOPHY OF AMERICAN-STYLE INDIVIDUALISM.

08857 SUBRAHMANYAM, $S$

IRANIANS ABROAD: INTRA-ASIAN ELITE MIGRATION AND EARLY

MODERN STATE FORMATION

JOURNAL OF ASIAN STUDIES, 51(2) (MAY 92), 340-364.
ASIAN DIASPORA COMHUNITIES IS THE PRIMARY CONCERN OF THIS ARTICLE WHICH CONCENTRATES ON THE IRANIANS OF THE EARLY MODERN PERIOD. THE ARGUMENT IS THAT HE CANMOT UNDERSTAND THE TRADE OF THE IRANIANS IN THE INDIAN OCEAN USING THE NOTION OF THE DIASPORA. IT ARGUES THAT THE IRANIAN MODE OF OPERATION CHARACTERIZED A GREAT PART OF BOTH LONG-DISTANCE TRADE AND STATE FOMATION IN MANY PARTS OF ASIA IN THIS PERIOD. THE AUTHOR SKETCHES THE NATURE OF IRANIAN MIGRATION AND ITS EXTENT AND TIMING OVER THE FIFTEENTH, SIXTEENTH AND SEVENTEENTH CENTURIES.

08858 SUGIO, $N$.

DEVELOPING COUNTRIES TOLD TO PAY FOR CONSERYATION JAPAN TIMES (WEEKLY INTERNATIONAL EDITION), $32(17)$ (APR 92) 3

DEVELOPING NATIONS SHOULD CONTRIBUTE MOST OF THE MONEY MEEDED TO FUMD ENVIROMMENTAL PROTECTION AND DEVELOPMENT IN THEIR COUNTRIES, ACCORDING TO A DECLARATION ADOPTED BY "THE EMINENT PERSONS MEETING ON FINANCING GLOBAL ENVIRONMENT AND DEVELOPMENT." THE MEETING PARTICIPANTS INCLUDED FORMER U.S. PRESIDENT JIMMY CARTER, FORMER CHINESE FOREIGH MINISTER HUANG HUA, AND FORMER JAPANESE PRIME MINISTER NOBORU TAKESHITA; JAPAN WILL CONTRIBUTE SIGNIFICANTLY TO PROTECTING THE WORLD'S ENVIRONMENT BY CONTRIBUTING MONEY AND TRANSFERRING TECHNOLOGY, ACCORDING TO TAKESHITA.

08859 SUGIO, N.; WASHIO, A.

TURF WAR STALLS ENVIRONMENT ACCORD

JAPAN TIMES (WEEKLY INTERMATIONAL EDITION), 32(15) (APR 92), 14.

JAPAN'S ABILITY TO JOIN GLOBAL EFFORTS TO CONSERVE THE ENVIRONMENT WILL BE LIMITED IF JURISOICTIONAL STRIFE AMONG GOVERNMENT AGENCIES CONTINUES TO DELAY THE SIGNING OF A TREATY TO PREVENT WASTE DUMPING IN DEVELOPING COUNTRIES. THE ENVIRONMENT AGENCY AND "A LEAGUE" OF THE INTERMATIONAL TRADE AND INDUSTRY AND HEALTH AND WELFARE MINISTRIES CANNOT AGREE ON WHICH GOVERNMENT AGENCY SHOULD SEND A BILL TO THE DIET FOR ACCEDING TO THE CONVENTION. BECAUSE OF THIS TURF BATTLE, FOR ACCEDING TO THE CONVENTION. BECAUSE OF THIS TURF BATTL JAPAN HAS BEEN UNABLE TO SIGN "THE BASEL CONVENTION ON
CONTROL OF TRANSBOUNDARY MOVEMENTS OF HAZARDOUS WASTES AND THEIR DISPOSAL."

08860 SUH, M.

NORMALISATION AND UNIFICATION PROSPECTS IN KOREA AUSSEN POLITIK 43(3) (JUL 92), 256-266.

GERMAN UNIFICATION HAS ALSO' SET NEW STANDARDS FOR HANDLING THE PROBLEM OF A DIVIDED COUNTRY IN THOSE REGIONS IN WHICH THE SOCIALIST SYSTEM STILL EXISTS AND SYSTEMIC CONFRONTATION PERSISTS. AS OPPOSED TO VIETNAM IN 1975, GERMANY ACHIEVED ITS UNITY IN 1990 BY PEACEFUL MEANS: THE CRISIS OF THE SOCIALIST SYSTEM CHANGED IDEAS, EXPECTATIONS AND POSSIBILITIES ON BOTH SIDES. THIS IS PARTICULARLY CLEAR
IN DIVIDED KOREA, WHERE BOTH STATES HAVE MOVED TOWARDS A POLICY OF DETENTE, DIALOGUE AND CONTACT.

08861 SUKOSD, $M$.

JASZI AND UNIFYING EUROPE

EAST EUROPEAN REPORTER, 5(1) (JAN 92), 49.

MANY HAVE CONSIDERED THE IDEAL OF FEDERALISM REPRESENTED BY OSZKAR JASZI UTOPIAN. BUT THE IDEA THAT UNTIL NOW HAS ALWAYS BEEN FORCED INTO EXILE FROM EASTERN EUROPE IS TODAY BECOMING TOPICAL AGAIN. THIS TIME, IT DOES NOT STEM FROM INTELLECTUAL BITTERNESS, COMING ON THE HEELS OF REPRESSED REVOLUTIONS AND WORLD WARS, LOOKING TOWARDS A BEAUTIFUL UTOPIA; IT IS, RATHER, THE TANGIBLE NEARING REALITY OF THE EUROPEAN COMMUNITY THAT MAKES THE IDEA TIMELY. NOW IT IS NOT THE HUMANITY AND THE RATIOMAL ITY OF DANUBE BASIM PATRIOTISM, BUT THE REAL COMMERCIAL AND POL ITICAL INTEREST OF JOINING THE EUROPEAN COMHUNITY THAT HAS CAUSED THE IDEA OF DECADES, JASZI'S UTOPIA HAS BECOME A CLICHE OF REALPOLITIK.

08862 SULLIVAN, $D$.

BUREAUCRATIC POLITICS IN DEVELOPMENT ASSISTANCE: THE FAILURE OF AMERICAN AID IN EGYPT ADMINISTRATION AND SOCIETY, 23(1) (MAY 91), 29-53. THIS ARTICLE ANALYZES THE AMERICAM ECONOMIC AID PROGRAM IN EGYPT. THE FOCUS IS ON THE INTERBUREAUCRATIC STRUGGLES FACING USAID OFFICIALS, BOTH IN WASHINGTON AND IN CAIRO. THE FACING USAID OFFICIALS, BOTH IN WASHINGTON AND IN CAIRO. THE
PRIMARY HYPOTHESIS IS THAT SUCH STRUGGLS ARE SIGNIFICANT PRIMARY HYPOTHESIS IS THAT SUCH STRUGGLES ARE SIGNIFICANT IMPEDIMENTS TO FULFILLING THE ECONOMIC DEVELOPMENT GOALS OF THE U.S. AGENCY FOR INTERNATIONAL DEVELOPMENT (USAID). THIS EYIDENCE FOR HHY THE AID PROGRAM IN EGYPT HAS YET TO HAYE A MAJOR IMPACT ON EGYPIIAN DEVELOPMENT EFFORTS. GIVEN THE MAJOR IMPACT ON EGYPIIAN DEVELOPMENT EFFORTS. GIVEN THE POL. ITICAL REALITIES BEHIND ANY AID PROGRAM, ONE WAY TO IMPROVE THE AID DONATING PROCESS IS TO RESTRUCTURE THE PRINCIPAL AID AGENCY (USAID) AND RECONSTITUTE IT AS AN
INDEPENDENT AGENCY, BEYOND THE INFLUENCE OF CONGRESS, THE STATE DEPARTMENT, AND OTHER ORGANIZATIONS.

08863 SULLIVAN, J.

DEMOCRACY AND GLOBAL ECONOMIC GRONTH

WASHINGTON QUARTERLY, 15(2) (SPR 92), 175-186. 
THE COLLAPSE OF COMMUNISM IS BUT ONE PART OF THE MUCH BROADER MOVEMENT TOWARD DEMOCRACY AND FREE ENTERPRISE OF THE LATE THENTIETH CENTURY. YET THERE IS LITTLE UNDERSTANDING OF THE CONNECTION BETWEEN ECONOMIC AND POL ITICAL OPENING, OF THE STRATEGIES PURSUED BY DIFFERENT TYPES OF COUNTRIES TO SEQUENCE THESE OPENINGS, OF THE NEEDS OF COUNTRIES UNDERGOING DIFFERENT TYPES OF TRANSITIONS, AND THE IMPORTANC
OUTCOMES.

08864 SULLIVAN, J.; DIETZ, M.; FRIED, A.

PATRIOTISM, POLITICS, AND THE PRESIDENTIAL ELECTION OF 1988 AMERICAN JOURHAL OF POLITICAL SCIENCE, 36(16) (FEB 92), 200-234.

RECENT CIRCUMSTANTIAL AND JOURMALISTIC EVIDENCE SUGGESTS THAT THE PATRIOTISM ISSUE MAY HAVE HELPED GEORGE BUSH WIN THE 1988 ELECTION. WITHIN THE FRAMEWORK OF A HISTORICALCONCEPTUAL UNDERSTANDING OF PATRIOTISM, THE AUTHORS USED OMETHODOLOGY TO COLLECT DATA ON PATRIOTISM PERSPECTIVES FROM DIVERSE GROUPS OF CITIIENS AND USED THE RESULTS OF THESE STUDIES TO CONDUCT AN R-METHODOLOGY SURVEY OF A STUDIES TO CONDUCT AN R-METHODOLOGY SURVEY OF A
REPRESENTATIVE SAMPLE FROM THE COMMUNITY. RESULTS OF THE
SURVEY SHOW THAT PEOPLE WHO UMDERSTAMD PATRIOTISM

SURVEY SHOW THAT PEOPLE WHO UNDERSTAND PATRIOTIS

SYMBOLICALLY, EMOTIONALLY, OR INSTINCTIVELY WERE

PARTICULARLY SUSCEPTIBLE TO GEORGE BUSH'S RHETORICAL

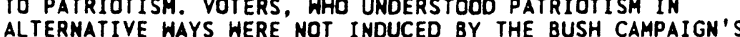

ALTERNATIVE WAYS WERE NOT INDUCED BY THE BUSH CAMPAIGN'S
RHETORICAL STRATEGY INTO VOTING FOR BUSH FOR PRESIDENT.

08865 SULLIVAN, J.

THE INTERPLAY BETWEEN ECONOMIC AND POLITICAL OPENING: THE SEQUENCE IN MEXICO

WASHINGTOM QUARTERLY, 15(2) (SPR 92), 187-204.

MEXICO'S ECONOMIC OPENING HAS BEEN BOLD IN ITS SPEED. THE UNITED STATES, STARTING AT THE LOW POINT OF ULTRA PROTECTIONISH OF 1930, TOOK ABOUT 40 YEARS TO ATTAIN AS MUCH IBERALIZATION AS MEXICO HAS ACHIEVED IN THE SIX YEARS SINCE IT ENTERED THE GENERAL AGREEMENT ON TARIFFS AND TRADE (GATT). MEXICD'S POLITICAL OPENING HAS BEEN TIMID BY CONTRAST. THE COUNTRY HAS FOLLOWED A NUANCED POLICY OF GRADUAL OPENING COMBINED HITH DELIBERATE DELAY. THIS ARTICLE DISCUSSES THE INTERPLAY BETHEEN ECONOMIC AND POL ITICAL OPENING.

08866 SULLIVAN, L.

BEYOND NOSTALGIA: NOTES ON BLACK STUDENT ACTIVISH SOCIALIST REVIEW, 20(4) (OCT 90), 21-28.

THIS ARTICLE CONSIDERS AFRICAN-AMERICAN STUDENT ACTIVISM AND POLITICS IN THE POST CIVIL RIGHTS ERA. WITH THE PASSAGE OF THE 1964 AND 1965 VOTING AND CIVIL RIGHTS LEGISLATION. OF THE 1964 AND 1965 VOTING AND CIVIL RIGHTS LEGISLAT
THE TRANSFORMATION OF AFRICAN-AMERICAN POLITICS FROM THE TRANSFORMATION OF AFRICAN-AMERICAN POLITICS FROM
PRIMARILY EXTRA-SYSTEMIC PROTEST TO ELECTORAL INCLUSION, THE REAGAN-BUSH ASSAULT ON SOCIAL WELFARE POLICIES, AND THE RESURGENCE OF RACIALLY MOTIVATED VIOLENCE ON U.S. COLLEGE CAMPUSES, AFRICAN-AMERICAN STUDENT ACTIVISM AND POLI

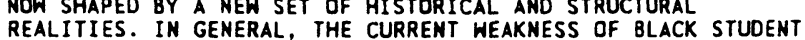
REALITIES. IN GENERAL, THE CURRENT WEAKNESS OF BLACK STUDENT THE LESSONS OF HISTORY, AND ALSO FROM A NOSTALGIA BASED ON AN UNPROOUCTIVE USE OF HISTORICAL KNOWLEDGE.

08867 SULLIVAN, R.

DISCARDING THE CHINA CARD

FOREIGN POLICY, (86) (SPR 92), 3-23

THIS ARTICLE ARGUES THAT THE UNITED STATES, LED BY THE BUSH ADMINISTRATION, CONTINUES TO CLING TO AN OUTDATED POLICY WITH REGARDS TO THE PEOPLE'S REPUBLIC OF CHINA. THE END OF THE COLD WAR AND THE DECLINE OF THE SOVIET THREAT REDUCE CHINA'S STRATEGIC IMPORTANCE TO THE UNITED STATES. THE BUSH ADMINISTRATION SEEMS TO BELIEVE THAT IT CAN SIMPLY PLUG IN NEW ISSUES--SUCH AS BILATERAL TRADE, THE PROLIFERATION OF MISSILE AND NUCLEAR WEAPONS TECHNOLOGIES, THE PEACE SETTLEMENT IN CAMBODIA, AND STABILITY ON THE KOREAN PENINSULA-TO REPLACE THE OLD ANTI-SOVIET EMPHASIS WHILE MAINTAINING THE OLD POL ICY PARADIGM. THE ARTICLE CONCLUDES THAT THE UNITED STATES SHOULD CEASE CODOLING CHINA.

INSTEAD IT SHOULD ACTIVELY PURSUE THE END OF THE COMMUNIST REGIME IN CHINA BY MAKING "LIFE AS UNCOMFORTABLE FOR THE CURRENT LEADERSHIP IN CHINA AS IT CAN."

08868 SULLIVAN, S.

HUNTING FOR A HERITAGE: POST-SOYIET YAKUTIYA

WORLD TODAY, 48(4) (APR 92), 56-58.

YAKUTIYA BECAME AN AUTONOMOUS REPUBLIC UNDER THE COMMUNIST NAT IONALITIES POLICY, WHICH ALLOWED NATIONAL
"AUTONOMY" AS LONG AS IT WAS UNDER PARTY (I.E. RUSSIAN) CONTROL. THE DISSIPATION OF THE SOYIET UNION HAS LEFT CONTROL. THE DISSIPATION OF THE SOVIET UNION HAS LEFT TERRITORY OF RUSSIA FREE TO EXPLORE NEH SELVES OR REDISCOVER TERRITORY OF
OLD ONES.

08869 SULLIVAN, $T$

THE BANK ACCOUNT PRESIDENCY: A NEW MEASURE AND EVIDENCE ON THE TEMPORAL PATH OF PRESIDENTIAL INFLUENC AMERICAN JOURNAL OF POLITICAL SCIENCE, 35(3) (AUG 91),
686-723.

USING HEADCOUNT DATA COVERING THE YEARS 1953-74 AND FOCUSING ON THE JOHNSON ADMINISTRATION $(1963-68)$ THE RESEARCH INVESTIGATES WHETHER OR NOT PRESIDENTS EXPERIENCE A "BANK ACCOUNT PRESIDENCY"; WHETHER THEY LOSE CONGRESSIONAL SUPPORT AND INFLUENCE OVER THEIR TENURE IN OFFICE. THIS PAPER APPLIES A NEW DATA SET AND DEFINES A USEFUL APPROXIMATION OF PRESIDENTIAL INFLUENCE CALLED PRESIDENTIAL SWAY. THE PAPER TESTS TWO EXPECTATIONS ABOUT THE "TEMPORAL PATH" OF INITIAL SUPPORT AND SWAY. THE PAPER ALSO TESTS FOUR CONJECTURES TO ACCOUNT FOR TEMPORAL PATHS. THE EVIDENCE SUGGESTS THAT PRESIDENT JOHNSON LOST INITIAL SUPPORT BUT MAINTAINED SWAY OVER HIS TENURE. THE RESEARCH THEN COMPARES THE JOHNSON EXPERIENCE WITH THAT OF THREE OTHER PRESIDENTS, FINDING NO SUPPORT FOR THE BANK ACCOUNT MODEL. IT FURTHER DEMONSTRATES THAT DYNAMIC FORCES LIKE THE PRESIDENT'S PRESTIGE, THE STATE OF THE ECONOMY, THE ORGANIZATION OF THE OPPOSITION, AND THE FOCUS OF THE ADMINISTRATION'S AGENDA HELP DETERMINE ITS TEMPORAL PATH.

08870 SULLUM, J.

THE LAH: GUN-SHY JUDGES

REASON, 23(1) (MAY 91), 47-49.

THE U.S. SUPREME COURT'S REFUSAL TO HEAR A RECENT GUNCONTROL CASE, FARMER V. HIGGINS, IS INDICATIVE OF ITS CONTROL CASE, FARMER V. HIGGINS, IS INDICATIVE OF ITS CONSIDERED A GUN-CONTROL CASE, OTHER THAN THOSE INVOLVING CONSIDERED A GUN-CONTROL CASE, OTHER THAN THOSE INVOLVING FELONS, IN MORE THAN 50 YEARS. MEANHHILE, CIRCUIT CDURTS LENDING CREDENCE TO THOSE WHO SAY IT NO LONGER EXISTS, IF IT EVER DID.

08871 SULLY, $M$ AUSTRIA: THE END OF AN ERA

HORLD TODAY, 48(8-9) (AUG 92), 143-144.

AUSTRIANS HAVE ELECTED THOMAS KLESTIL TO SUCCEED KURT WALDHEIM AS PRESIDENT. THE RESULT OF THE ELECTION WAS A SURPRISE TO MANY PUNDITS, WHO ARE FASCINATED BY KLESTIL'S CAMPAIGN AND ARE TRYING TO EXPLAIN THE SECRET OF HIS RAPID RISE FROM RELATIVE OBSCURITY TO THE PRESIDENCY.

08872 SUMSKY, $V$.

THE CITY AS POLITICAL ACTOR: MANILA, FEBRUARY 1986

ALTERNATIVES, 17(4) (FAL 92), 479-492.

CONCERNING THE FALL OF THE MARCOS REGIME, THIS ARTICLE EXAMINES HOW MASS NONVIOLENT ACTION COULD BE SO SUCCESSFUL IN A THIRD WORLD MEGAPOL IS OVERLOADED WITH SOCIAL PROBLEMS AND SEEMINGLY PROGRAMMED FOR A VIOLENT REVOLUTIONARY OUTBREAK. IT TAKES A CLOSER LOOK AT THE URBAN ENVIRONMENT IN WHICH THE EVENT OCCURRED, AND SEARCHES FOR SOME KIND OF CORRELATION BETWEEN THAT ENVIRONMENT AND THE ESSENCE OF THE EVENT. IT STUIDES LUNETA, ESDA, AND MENDIOLA. EACH OF WHICH EVENT. IT STUIDES LUNETA, ESDA, AND MENDIOLA, EACH OF WHICH
IS IMPOSSIBLE FOR A DWELLER OF THE CAPITAL TO IGNORE. IT IS IMPOSSIBLE FOR A DWELLER OF THE CAPITAL TO IGNORE. IT MANNER IN WHICH THE DICTATORSHIP WAS OVERTHROWN IS CRUCIAL.

08873 SUNDBERG, J.

FINLAND
EUROPEAN JOURNAL OF POLITICAL RESEARCH, 22(4) (DEC 92), 391-399.

THE AUTHOR SUMMARIZES THE RESULTS OF FINLAND'S 1991 PARLIAMENTARY ELECTIONS. HE ALSO BRIEFLY DISCUSSES FINLAND'S

08874 SUPELANO, A.

THE POLITICAL ECONOMY OF LATIN AMERICA: THE COLUMBIAN EXPERIENCE DURING THE 1980 S

JOURNAL OF ECONOMIC ISSUES, 26(3) (SEP 92), 845-864.

THE NEED FOR A NEH THEORETICAL FRAMEWORK INTRODUCES THIS ESSAY ON THE COLOMBIAN EXPERIENCE DURING THE 1980 S WHICH EXPLORES THE ECONOMIC POLICY IN LATIN AMERICA, THE COLOMBIAN EXPERIENCE, AND ECONOMY AND ECONOMIC POLICY IN THE 198OS. IT SUGGESTS THAT THE RECENT EXPERIENCE IN LATIN AMERICA SHOWS THAT MARKET FORCES DO NOT DIRECTLY PRODUCE IMDUSTRIALIZATION OR DEMOCRATIC GOVERHMENT. THE CHALLENGE TO THE LATIN AMERICAN EXPERIENCE IS FOR THEORISTS TO HELP TO CONSTRUCT A NEW ECONOMIC CULTURE AND TO PROPOSE REALISTIC SOLUTIONS SUITED TO THE CHANGING WORLD OF TODAY.

08875 SURYANARAYANA, P.S

TIME TO BREAK THE YALTA ORDER

WORLD PRESS REVIEH, 39(10) (OCT 92), 13-14

THE AUTHOR LOOKS AT THE UNITED MATIONS' ROLE IN THE NEW HORLD ORDER AND DISCUSSES SECRETARY - GENERAL BOUTROS BOUTROS

GHALI'S PROPOSAL FOR THE CREATION OF A PERMANENT U.N. PEACEKEEPING FORCE.

08876 SUSSMAN, L.R.

CENSORS RETREAT, EXCEPT IN THE GULF

FREEDOM REVIEH, 23(1) (JAN 92), 56-60.

OF 162 COUNTRIES EVALUATED IN 1991, 67 HAVE FREE NEWS MEDIA: 49 HAVE PARTIALLY FREE MEDIA; AND 46 DO NOT HAVE PRESS FREEDOM. IN 1991, AUTHORITARIANS YIELDED POWER RELUCTANTLY, OFTEN RENEGING ON PROMISES AND PUNISHING 
JOURNALISTS WHO TESTED THE PROMISED FREE SPEECH. ALONG WITH GREATER ACCESS TO NEWS SOURCES AND REDUCED CENSORSHIP OF REPORTS OFTEN CAME RENEWED HARASSMENT OF JOURNALISTS BY GOVERMMENTS AND NONGOVERNMENT TERRORISTS. MILITARY CENSORSHIP OF THE MEDIA WAS A PROBLEM DURING THE GULF WAR.

08877 SUTER, C.; STAMM, H.

COPING WITH GLOBAL DEBT CRISES: DEBT SETTLEMENTS, 1820 TO 1986

COMPARATIVE STUDIES IN SOCIETY AND HISTORY, 34(4) (OCT 92 ),

645-678.

THE SETTLEMENT OF THE EXTERNAL DEBT OF INSOLVENT

SOVEREIGN BORROWERS HAS BECOME ONE OF THE MOST IMPORTANT

ISSUES IN RELATIONS BETWEEN THE NORTH AND SOUTH SINCE THE

OUTBREAK OF THE GLOBAL DEBT CRISIS IN THE EARLY 1980S. THIS

ARTICLE ARGUES THAT QUICK AND EFFICIENT CRISIS MANAGEMENT,

THE CAPABILITY OF CREDITORS TO EXERT FAR-REACHING INFLUENCE

THE CAPABILIITY OF CREDITORS TO EXERT FAR-REACHING I
ON DEBT COUNTRIES AND TO ENFORCE HARD TERMS OF DEBT

ON DEBT COUNTRIES AND TO ENFORCE HARD TERMS OF DEBT
SETTLEMENTS AGAINST THE INTERESTS OF DEBTOR COUNTRIES,
DEPENDS UPON THE ESTABLISHMENT OF STRONG COOPERATIVE

DEPENDS UPON THE ESTABLISHMENT OF STRONG COOPERATIVE
NETHORKS AMONG CREDITORS. IT CONCLUDES THAT THE ELEMENTS OF

DEBT RELEASE HAVE TO BE CONSIDERABLY STRENGTHENED IN THE

DEBT RELEASE HAVE TO BE CONSIDERABLY STRENGTHENED IN THE
FUTURE, PARTICULARLY IF THE FEASIBILTIY OF DEBT INCREASE

FUTURE, PARTICULARLY
FURTHER DETERIORATES

08878 SUTER, $K$.

FRENCH NUCLEAR TESTING IN THE SOUTH PACIFIC

CONTEMPORARY REVIEW, 261(1520) (SEP 92), 126-129.

IN APRIL, FRANCE ANNOUNCED THE SUSPENSION FOR A YEAR OF ITS NUCLEAR TESTING IN THE SOUTH PACIFIC. THE DECISION HAS BEEN WELCOMED BY SOUTH PACIFIC NATIONS, AND PEACE AND ENVIRONMENT GROUPS. IT REPRESENTS ANOTHER TURNING POINT IN AN EVENTFUL SAGA WHICH HAS GONE ON FOR A QUARTER OF A CENTURY. AFTER REVIEWING THE HISTORY OF FRANCE'S NUCLEAR TESTING IN THE SOUTH PACIFIC, THIS ARTICLE SUGGESTS THAT IF TESTING HERE TO STOP PERMANENTLY AND FRANCE WERE TO RETAIN ITS COLONIES, IT HAS AN OPPORTUNITY TO DEVELOP CLOSE TIES WITH THE SURROUNDING NATIONS. IT COULD USE ITS FOREIGN AID, EDUCATION AND CULTURAL PROGRAMS TO CREATE A FRESH SET OF RELATIONSHIPS.

08879 SUTHERLAND, S.L.

THE AL-MASHAT AFFAIR: ADMINISTRATIVE ACCOUNTABILITY IN PARLIAMENTARY INSTITUTIONS

CANADIAN PUBLIC ADMINISTRATION, 34(4) (WIN 91), 573-603. THE AUTHOR USES THE CANADIAM GOVERMMENT'S HANDL ING OF THE AL-MASHAT AFFAIR IN MAY AND JUNE 1991 AS A CASE STUDY IN DIRECT ADMINISTRATIVE ACCOUNTABILITY. HE BEGINS WITH A DISCUSSION OF THE MAIN LINES OF POLITICAL CONTROL UNDER RESPONSIBLE GOVERNMENT. THIS LEADS TO THE FOLLOWING QUESTIONS ABOUT THE AL-MASHAT AFFAIR: WAS AN IMPORTANT QUESTIONS ABOUT THE AL-MASHAT AFFAIR: WAS AN IMPORTANT
MINISTER EFFECTIIVELY SHIELOED? WAS BLAME EVER ALLOCATED IN A MINISTER EFFECTIVELY SHIELDED? WAS BLAME EVER ALLOCAT
CONVINCING WAY? WERE THE CRITERIA OF NATURAL JUSTICE CDNVINCING WAY? WERE THE CRITERIA OF NATURAL JUSTICE
RESPECTED IN BOTH INTERNAL ACTIONS AND IN THE HOUSE OF RESPECTED IN BOTH INTERNAL ACTIONS AND IN THE HOUSE
COMMONS' STANDING COMMITTEE ON EXTERNAL AFFAIRS AND COMMONS' STANOING COMMITTEE ON EXTERNAL AFFAIRS AND
INTERATIIONAL TRADE? WERE DEMOCRATIC CONTROLS OVER POLITICAL INTERNATIONAL TRADE? WERE DEMOCRATIC CONTROLS OVER POLITICAL
AND ADMINISTRATIVE ACTION RESPECTED? HE CONCLUDES THAT THE AND ADMINISIRATIVE ACTION RESPECTED? HE CONCLUDES THAT THE GOVERNMENT'S STRATEGY TO DEFLECT ITS ACCOUNTABILITY ONTO A ON ALL THESE COUNTS AND SEVERAL MORE, AS WELL.

08880 SUTLEY, S.

THE REVITALIZATION OF UNITED STATES ATERRITORIAL INTERNATIONAL LOGIC: THE WORLD BEFORE AND AFTER THE 1989 INVASION OF PANAMA

CANADIAN JOURNAL OF POLITICAL SCIENCE, XXV(3) (SEP 92 ), 435-462.

THE AUTHOR SUGGESTS THE EXISTENCE OF THO RIVAL SOLUTIONS TO THE POLITICAL PROBLEM OF TERRITORIAL POSSESSION AND APPROPRIATION AMONG STATES. TAKING TERRITORIAL CONTROL AS THE ANALYTICAL STARTING POINT, HE EXAMINES THE EVOLUTION OVER THE LAST TWO CENTURIES OF TWO DIVERGENT SOLUTIONS TO THIS ISSUE. THE 19TH-CENTURY EUROPEAN RESPONSE OF SUPREME SOVEREIGNTY HITHIN THE CONTEXT OF A TRUE COMMUNITY OF STATES MAY BE CONTRASTED WITH THAT OF THE COMITY OF REPUBLICAN AMERICAN STATES SHARING A MORAL VISION AND, MORE RECENTLY, U. S. REFINEMENTS OF AN ATERRITORIAL LOGIC. THE U.S. INYASION OF PANAMA IN 1989 MAY BE UNOERSTOOD AS MARKING THE RESUMPTION OF THE HISTORICAL RIVALRY BETWEEN THESE THO LOGICS AND THE WIDENING OF THE APPLICATION OF U.S. STATE PRACTICES AND PRINCIPLES. TRACING THE EXPANSION OF THE AMERICAN LOGIC IN THIS WAY HELPS TO EXPLAIN THE GREATER FOCUS AMONG STATES ON PROBLEMS OF ECONOMIC PRODUCTION AND DISTRIBUTION AND THE LESSER FOCUS ON TERRITORIAL APPROPRIATION.

08881 SUTTER, R.G.

THE CRISIS IN U.S.-CHINA POLICY, 1991: THE ROLE OF CONGRESS JOURNAL OF NORTHEAST ASIAN STUDIES, $X(4)$ (WIN 92), 3-23. THE HISTORY OF U.S. GOVERNMENT DECISION-MAKING ON CHINA POLICY SINCE JUNE 1989 INCLUDES SEVERAL EPISODES HHEN PRESIDENT BUSH AND HIS SUPPORTERS IN THE EXECUTIVE AND LEGISLATIVE BRANCHES WERE CDNFRONTED BY LARGE NUMBERS OF LEGISLATIVE BRANCHES HERE CONFRONTED BY LARGE NUMBERS OF
CONGRESSIONAL MEMBERS CRITICAL OF HIS CHINA POLICY. IN 1991 ,
WHICH POSTED THE HIGHWATER MARK IN THE ONGOING U.S. POLICY DEBATE, THE DEBATE WENT THROUGH THREE DISTINCT STAGES, WITH THE CRISIS COMING DURING CRITICAL VOTES ON CONDITIONAL MFN LEGISLATION IN JULY 1991. AT YEAR'S END, ALL SIDES IN THE DEBATE ANTICIPATED CONTINUED STRONG CONGRESSIONAL CRITICISM OF CHINESE PRACTICES AND BUSH ADMINISTRATION POLICY, BUT CRITICS SEEMED UNABLE TO MAKE SUBSTANTIAL INROADS AMONG THOSE SENATORS WHO SUPPORTED THE BUSH ADMINISTRATION'S STANCE, ASSURING CONTINUED MFN TRADE TREATMENT FOR CHINA.

08882 SUTTERLIN, G.

GUYANA: 25 YEARS OF ONE-PARTY RULE

SWISS REVIEW OF WORLD AFFAIRS, 40(8) (NOV 90), 27-28.

THIS PAPER EXAMINES GUYANA'S CURRENT ECONOMIC AND

POLITICAL SITUATION. IT PRESENTS EVIDENCE TO SUPPORT THE

MCINTYRE REPORT'S DESCRIPTION OF GUYANA AS THE POOREST

COUNTRY IN THE WESTERN HEMISPHERE. THE HISTORY OF THE ONE-

COUNTRY IN THE WESTERN HEMISPHERE. THE HISTORY OF THE ONE-
PARTY RULE IN EFFECT SINCE THE 1950S, AND INDEPENDENCE FROM

PARTY RULE IN EFFECT SINCE THE 1950S, AND INDEPENDENCE
BRITAIN FROM 1966 ONHARD, ARE DESCRIBED. THE DIFFICULT

BRITAIN FROM 1966 ONHARD, ARE DESCRIBED. THE DIFFICUL
RELATIONSHIP AMONG THE NATION'S SIX ETHNIC GROUPS IS

RELATIONSHIP AMONG THE NATION'S SIX ETHNIC GROUPS IS
DISCUSSED, AND PREDICTIONS ARE MADE FOR AN IMMEDIATE FUTURE

DISCUSSED, AND PREDIC

08883 SUZUKI, M.

POLITICAL BUSINESS CYCLES IN THE PUBLIC MIND

AMERICAN POLITICAL SCIENCE REVIEW, 86(4) (DEC 92), 989-996.

NUMEROUS STUDIES HAVE SOUGHT TO DISCOVER POLITICAL

BUSINESS CYCLES IN MACROECONOMIC VARIABLES. ALTHOUGH VOTERS

SUBJECTIVE ECONOMIC EXPECTATIONS HAVE BEEN SHOWN TO

INFLUENCE THEIR ELECTORAL DECISIONS, NO PREVIOUS RESEARCH

HAS ATTEMPTED TO UNCOVER CYCLICAL PATTERNS IN CITIZENS

ECONOMIC EXPECTATIONS. USING SURVEY DATA, THE AUTHOR

ENDEAVORS TO DETERMINE WHETHER EXPECTATIONS SHIFT TO BENEFIT

THE INCUMBENT PRESIDENT'S ELECTORAL INTEREST. THE ANALYSES

SHOW THAT THE PERCENTAGE OF THE PUBLIC PREDICTIING AN

ECONOMIC UPTURN INCREASES BEFORE A PRESIDENTIAL ELECTION.

ONE EXPLANATION IS THAT VOTERS MIGHT EXTRAPOLATE CYCLICAL

EXPECTATIONS FROM MACROECONOMIC CONDITIONS THAT CONTAIN

ELECTION-DRIVEN CYCLES. YET THE ANALYSES SHOW THAT

ANTICIPATORY CYCLES APPEAR EVEN WHEN THE MACROECONOMIC

CONDITIONS ARE HELD CONSTANT. THE AUTHOR CONCLUDES BY

DRAWING AN EXPLANATION HITHOUT RECOURSE TO MACROECONOMIC

CYCLES.

08884 SUZUKI, $M$.

THE RATIONALITY OF ECONOMIC VOTING AND THE MACROECONOMIC REGIME

AMERICAN JOURNAL OF POLITICAL SCIENCE, 35(3) (AUG 91),

624-642.
SINCE VOTER RATIONALITY PLAYS A MAJOR ROLE IN THEORIES

OF POLITICAL ECONOMICS, IT IS IMPORTANT FOR POLITICAL

ANALYSTS TO INVESTIGATE THE EXTENT OF VOTER SOPHISTICATION.

A CONVENTIONAL STRATEGY FOR ADORESSING THIS QUESTION IS TO

DETERMINE WHAT DECISION RULE VOTERS APPEAR TO USE BY

ESTIMATING RIVAL POLITICAL SUPPORT MODELS THAT EMBODY

VARYING ASSUMPTIONS ABOUT VOTER RATIONALITY. HOWEVER, UNDER

SOME CIRCUMSTANCES, SUCH A STRATEGY MAY BE INCAPABLE' OF

IDENT IFYING THE DESCRIPTIVELY SUPERIOR MOOEL DUE TO AN
OBSERVATIONAL EOUIVALENCE PROBLEM. THE PAPER ESTIMATES THE

OBSERVATIONAL EQUIVALENCE PROBLEM. THE PAPER ESTIMATES

COMPETING POLITICAL SUPPORT MODELS UNDER ALTERNATIVE

MACROECONOMIC REGIMES AND FIMDS EVIC

08885 SVARA, $J$

COUNCIL AND ADMINISTRATOR PERSPECTIVES ON THE CITY

MANAGER'S ROLE

ADMINISTRATION AND SOCIETY, 23(2) (AUG 91), 227-246.

THE CONFLICT IN ROLE PERCEPIIONS HELD BY COUNCIL MEMBERS

AND CITY MANAGERS HAS BEEN REPORTED FREQUENTLY IN THE

LITERATURE ON URBAN POLITICS AMD AOMINISTRATION. IN THIS

VIEN. THE CITY MANAGER HAS EMERGED INTO A POLICY LEADERSHIP

ROLE BUT MUST CONFINE THAT LEADERSHIP TO SAFE AREAS BECAUSE

THE COUNCIL CONTINUES TO VIEW THE MANAGER AS AN

ADMINISTRATIVE TECHNICIAN. THIS THESIS NEEDS TO BE

REEXAMINED TO BETTER UNDERSTAND CITY MANAGERS AND THEIR

RELATIONSHIP TO ELECTED OFFICIALS. THE MANAGER'S POLICY ROLE

IS NOT NEW, AND A REVIEW OF EVIDENCE IN EXISTING STUDIES AS

WELL AS NEW SURVEYS DO NOT SUPPORT THE CONCLUSION THAT THE

COUNCIL AND MANAGER HAVE CONFLICTING DEFINITIONS OF THE

MANAGER'S ROLE. THERE IS SOME DIVERGENCE HHICH REFLECTS

DIFFERENCES IN VALUES AND BACKGROUND BETHEEN ELECTED

OFFICIALS AND PROFESSIONAL ADMINISTRATORS. THE GENERAL

CONGRUENCE OF ATTITUDES AND ACCEPTANCE OF THE MANAGER'S

POLICY ROLE, HOWEVER, INDICATES THAT THE CITY MANAGER CAN BE

A LEADER IN THE GOVERNMENTAL PROCESS.

08886 SVASAND, L.

NORHAY

EUROPEAN JOURNAL OF POLITICAL RESEARCH, 22(4) (DEC 92),

485-488.

THE AUTHOR LISTS THE MEMBERS OF PRIME MIMISTER GRO

HARLEM BRUNDTLAND'S CABINET AND SUMMARIZES SOME OF THE MAJOR

DOMESTIC POLITICAL ISSUES IN NORWAY. 
08887 SVASAND, L.; LINDSTROM, U. SLIDING TOWARDS E.C. MEMBERSHIP: MORHAY IN SCANDINAVIAN SLIDING TOHAR

GOVERNMENT AND OPPOSITION, 27 (3) (SUM 92), 330-344.

THE AUTHORS ADDRESS THE ISSUE OF NORWEGIAN MEMBERSHIP IN THE EUROPEAN COMMUNITY. THEY COMPARE NORWAY'S STANCE WITH THAT OF FINLAND AND SWEDEN, FOCUSING ON: (1) THE GEOPOLITICAL FACTORS AND (2) THE INTERPLAY OF THE E.C. ISSUE AND THE PARTY SYSTEM.

08888 SVEC, $M$.

CZECHOSLOVAKIA'S VELVET DIVORCE

CURRENT HISTORY, $91(568$ ) (NOV 92), 376-380.

THE AUTHOR REVIEHS THE PROGRESS CZECHOSLOVAKIA HAS MADE

TOWARD DEMOCRATIZATION SINCE THE FALL OF COMMUNISM AND PREDICTS THAT ITS DISSOLUTION INTO TWO STATES IS ALL BUT

INEVITABLE.

08889 SVIRSKY, G.

THE LONG RIDE TO SILWAM

TIKKUN, 7(2) (MAR 92), 25-27; 88-89.

THE LATEST ROUND OF EVICTIONS IN EAST JERUSALEM HAS

BROUGHT CONTEMPORARY ISRAEL'S MANY POLITICAL CONTRADICTIONS AND CONTESTED CULTURAL SYMBOLS INTO HIGH RELIEF. THE AUTHOR REPORTS ON HIS EMOTIONS, REFLECTIONS, AND THOUGHTS AS HE VISITS WITH MOUSSA ABASSI HHOSE HOME HAS NOW BEEN REDUCED TO THREE SMALL ROOMS SINCE THE SETTLERS HAVE TAKEN OVER THE LARGE PART OF THE HOUSE, MOUSSA HAS BEEN UNABLE TO FUNCTION SINCE THAT TRAUMMATIC NIGHT WHEM AT 3 A.M.. ISRAELI SOLDIERS EVICTED HIM, HIS WIFE, AND HIS SEVEN-YEAR-OLD SON FROM THE LARGE HOME THAT HE BELIEVED HE OWNED. MOUSSA HAS NOT BUILT TO BE A HERO ON THE FRONTLINE OF A SETTLERPALESTINIAN CONFLICT. THE AUTHOR IS UNABLE TO MAKE RESOLUTION OF ANY OF HIS EMOTIONS, REFLECTIONS OR THOUGHTS.

08890 SVITEK, I.

THE 1992 STATE BUDGETS IN CZECHOSLOVAKIA

RFE/RL RESEARCH REPORT, $1(9)$ (FEB 92), 34-37.

LAST YEAR'S DIVISION OF COMMON REVENUES AMONG THE

FEDERAL (35\%), CZECH (40\%), AND SLOVAK (25\%) REPUBLICS HAS BEEN SHOWN TO BE UNSUSTAINABLE IN 1992. AFTER A SERIES OF DIFFICULT NEGOTIATIONS. A COMPROMISE MORE FAVORABLE TO THE CZECH REPUBLIC HAS BEEN REACHED. IN ADOITION, THE FEDERAL GOVERNMENT WILL TRANSFER 5 BILLION KORUNY TO BOTH REPUBLICS BUDGETS. ALTHOUGH THE COMPROMISE BUDGET AGREEMENT HAS BEEN REVENUES WILL BE LARGE ENOUGH TO FULFILL THE EXPECTATIONS.

08891 SVVENSSON, P.: TOGEBY, L.

THE POLITICAL MOBILIZATION OF THE NEH MIDOLE CLASS IN THE POLITICAL MOBILIZATION OF THE

WEST EUROPEAN POLITICS, 14(4) (OCT 91), 149-168.

RECENT CHANGES IN POLITICAL PARTICIPATION IN DENMARK ARE ANALYZED. A DISTINCTION IS MADE BETHEEN THE MOBILIZATION AND THE SUPPLEMENTARY THEORY OF PARTICIPATION. APPLYING DATA FROM SAMPLES OF YOUNGER GENERATIONS FROM 1979 AND 1988, THIS ARTICLE SHOWS THAT A STRONG COLLECTIVE MOBILIZATION OF THE NEW MIDDLE CLASS OF WELL-EDUCATED PUBLIC SECTOR EMPLOYEES TOOK PLACE THROUGH GRASS-ROOTS ACTIVITIES DURING THE 1970. THIS CHANGED DURING THE 1980 S WHEN GRASS-ROOTS PARTICIPATION OF POLITICAL PARTICIPATION.

08892 SWAFFORD, D AWASH IN COFFEE

HEMISPHERE, 5(1) (FAL 92), 12-14

IN APRIL 1992 THE INTERNATIONAL COFFEE COUNCIL AGREED THAT A GLOBAL CONSENSUS EXISTS FOR THE NEGOTIATION OF A NEW INTERNATIONAL COFFEE AGREEMENT. DESPITE THE COUNCIL'S OPTIMISM, WORLD BANK ECONOMISTS AND OTHER OBSERVERS PREDICT THAT AN AGREEMENT SATISFYING THE ARRAY OF POLITICAL INTERESTS INVOLVED WILL NOT BE REACHED IN THE 1990'S. THE POL ITICAL FORCES AT PLAY IN THE COFFEE TRADE NEGOTIATIONS ARE VARIED BECAUSE THERE ARE BASIC DIFFERENCES OF INTEREST NOT ONLY BETHEEN PRODUCING COUNTRIES AND CONSUMING COUNTRIES BUT ALSO AMONG THE PRODUCERS THEMSELVES.

08893 SWAIN, C.M.

THE VOTING RIGHTS ACT: SOME UNINTENDED CONSEQUENCES BRDOKINGS REVIEH, 10(1) (WIN 92), 51.

ALTHOUGH THE VOTING RIGHTS ACT HAS CONTRIBUTED IMMENSELY TO POSITIVE CHANGE IN THE UNITED STATES, IT HAS HAD SEVERAL UNINTENDED CONSEOUENCES THAT MAY ACTUALLY IMPEDE PROGRESS UNINTENDED CONSEQUENCES THAT MAY ACTUALLY IMPEDE PROGRE TOHARD A COLOR-BLIND SOCIETY. ONE SUCH RESULT IS THE ANOTHER IS THE EMPHASIS ON CREATING "SAFE BLACK DISTRICTS," ANOTHER IS THE EMPHASIS ON CREATING "SAFE BLACK OISTRICTS, WHICH CONCENTRATE BLACK VOTERS IN ONE DISTRICT RATHER THAN SPREADING THEM OUT OVER SEVERAL DISTRICTS
TO INFLUENCE MORE THAN ONE REPRESENTATIVE.

08894 SWAIN, R.

"DEVELOPING" OR "DEVELOPED" COUNTRY STATUS--PROS AND CONS FOR SOUTH AFRICA

SOUTH AFRICA FOUNDATION REVIEH, 19(6) (JUN 92), 7-8.
TRADE AND AID PREFERENCES BETHEEN THE EUROPEAN COMMUNITY AMO A FUTURE SOUTH AFRICA WILL BE HIGHLY DEPENDENT ON SOUTH AFRICA'S CLASSIFICATION AS EITHER A DEVELOPED OR A DEVELOPING NATION. BOTH CLASSIFICATIONS HAYE ADVANTAGES. THERE EXISTS AN OPPORTUNITY FOR SOUTH AFRICA TO SEEK SOME SORT OF PREFERENTI IAL TRADE AGREEMENT WITH THE EUROPEAN COMMUNITY; A RANGE OF OPTIONS EXISTS BETWEEN ITS CURRENT DEVELOPED COUNTRY STATUS AND SEEKING DEVELOPING COUNTRY PRIVILEGES. THE OBVIOUS DRAWBACK TO SEEKING THE TRADE REGIMES APPLICABLE FOR "DEVELOPING STATUS" IS THE EFFECT THIS WILL HAVE ON THE BUSINESS SECTOR IN INTERNATIONAL CIRCLES. CONVERSELY, INCREASED AID TO THE NEW SOUTH AFRICA WILL HELP REDUCE THE POLITICAL VIOLENCE IN THE COUNTRY AND THEREFORE, ALONG WITH THE INTRODUCTION OF A CERTAIN POLITICAL STABILITY, THIS WILL ERODE ONE OF THE MAJOR STUMBLING BLOCKS TO FOREIGN DIRECT INVESTMENT.

08895 SWAIN, $R$.

THE EUROPEAN COMMUNITIES AND SOUTH AFRICA--NEW THREATS, NEH OPPORTUNITIES

SOUTH AFRICA INTERNATIONAL, 23(1) (JUL 92), 11-17.

IN ORDER TO POSITION ITSELF CORRECTLY TO MAKE THE BEST

USE OF THE OPPORTUNITY THE EC PRESENTS, SOUTH AFRICA WILL HAVE TO MOVE SHIFTLY AND CAREFULLY, AND MAKE SOME CRITICAL DECISIONS, SUCH AS WHETHER OR NOT TO JOIN THE LOME DECISIONS, SUCH AS WHETHER OR NOT TO JOIN THE LOME CONVENTION. IN ADDITION, IT WILL HAVE TO RETHINK ITS LOBBYING AND REPRESENTATION WITHIN THE EC, AND IT WILL NEED OF MINISTERS TO NEGOTIATE BENEFICIAL TRADE AND AID OF MINISTERS
AGREEMENTS

08896 SWAN, J.

CAMPAIGN ISSUES: JEMNIFER

COLUMBIA JOURNALISM REVIEW, 31(4) (NOV 92), 36-37

THE AUTHOR LOOKS AT THE SO-CALLED "CHARACTER" ISSUE IN THE 1992 U.S. PRESIDENTIAL CAMPAIGN, FOCUSING ON MEDIA COVER OF PRESIDENT GEORGE BUSH'S ALLEGED EXTRAMARITAL AFFAIR WITH HIS APPOINTMENTS SECRETARY, JENNIFER FITZGERALD.

08897 SWANK, D.

POLITICS AND THE STRUCTURAL DEPENDENCE OF THE STATE IN DEMOCRATIC CAPITALIST NATIONS

AMERICAN POLITICAL SCIENCE REVIEN, 86(1) (MAR 92), 38-54, THE AUTHOR EXPLORES EMPIRICALLY A CENTRAL CLAIM OF THE STRUCTURAL DEPENDENCE THESIS--THAT CAPITALISTS' ABILITY TO DISINVEST FUNDAMENTALLY CONDITIONS POLICY CHOICES IN DEMOCRATIC CAPITALIST SYSTEMS. UTILIZING TIME-SERIES DATA FOR 16 AFFLUENT DEMOCRACIES FROM 1965 TO 1984, HE FINDS THAT, INDEED, LOW RATES OF BUSINESS INVESTMENT ARE ASSOCIATED WITH REDUCTIONS IN CORPORATE TAX BURDENS AND THAT THESE REDUCTIONS ARE MORE PRONOUNCED IN PERIODS OF ECONOMIC STRESS. REDUCTIONS ARE MORE PRONOUNCED IN PERIODS OF ECONOMIC STRESS.
HOWEVER, HE ALSO FINDS THAT THE MAGNITUDE OF RESPONSIVENESS HOWEVER, HE ALSO FINDS THAT THE MAGNITUDE OF RESPONSIVENES
OF TAXATION TO LOW RATES OF INVESTMENT IS RELATIVELY SMALL OF TAXATION TO LOW RATES OF INVESTMENT IS RELATIVELY SMALL
AND THAT ANALYSES OF THE POLITICAL CONTEXT OF INVESTMENT AND AND THAT ANALYSES OF THE POLITICAL CONTEXT OF INVESTMEM

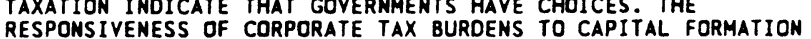
RESPONSIVENESS OF CORPORATE TAX BURDENS TO CAPITAL FORY

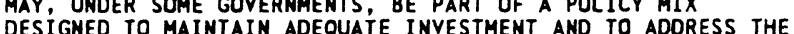
DESIGNED TO MAINTAIN ADEQUATE
DEMANDS OF CORE CONSTITUENCIES

08898 SWANN, R. A LOW-KEY AFFAIR IN LISBON MIDDLE EAST INTERNATIONAL, (412) (NOV 91), 12

THE OFFICIAL EURO-ARAB DIALOGUE AT THE GOVERMMENTAL LEVEL MAY BE DORMANT BUT ITS PARLIAMENTARY COUNTERPART IS THRIVING. THIS YEAR'S MEETING IN LISBON BETHEEN THE ARABINTER-PARLIAMENTARY UNION (AIPU) AND THE PARLIAMENTARY ASSOCIATION FOR EURO-ARAB COOPERATION (PAEAC) ATTRACTED MPS FROM 15 ARAB AND 14 EUROPEAN PARLIAMENTS AS WELL AS ISMAT ABD AL-MAGID, SECRETARY-GENERAL OF THE ARAB LEAGUE, AND ABEL MATUTES, EUROPEAN COMMISSIONER FOR NORTH-SOUTH AFFAIRS. AT THE MEETING THE PARLIAMENTARIANS EXPRESSED UNANIMOUS SUPPORT FOR ARAB PARTICIPATION IN THE MADRID PEACE CONFERENCE, "SEQUENTIAL AND COMPREHENSIVE" ARAB-ISRAELI NEGOTIAITONS, AND THE NEED TO LOOK PAST DIFFERENCES THAT AROSE DURING THE GULF HAR.

08899 SHANN, $R$.

FRANCE AND MOROCCO--THE DIOURI AFFAIR

MIDDLE EAST INTERMATIONAL, (405) (JUL 91) 13

FRENCH PRESIDENT MITTERAND MUST BE BITTERLY REGRETTING HIS DECISION TO ALLOW THE EXPULSION OF MOROCCAN OPPOSITION PERSOMALITY ABD AL-MOUMEN DIOURI AFTER EXACTLY THO-AMD-AHALF DAYS OF EXILE, DIOURI RETURNED TO FRANCE ON THE MORNING HALF DAYS OF EXILE, DIOURI RETURNED TO FRANCE ON THE MORMI
OF 1 JULY AMID SPECULATION OF MORE PROBLEMS FOR FRANCDOF 1 JULY AMID SPECULATION OF MORE PROBLEMS FOR FRANCDMOROCCAN RELATIONS. OBSERVERS NOTE THAT FRANCE PROBABLY EXPELLED DIOURI IN HOPES OF IMPROVING RELATIONS BETWEEN FRANCE AND MOROCCO; DIDURI'S CONSISTENT CRITICISH OF KING HASSAN'S REGIME AND HIS PUBLISHING OF BOOKS WHICH DENOUNCE THE REGIME MADE HIM AN UNPOPULAR FIGURE IN MOROCCO. HE WAS ALLOWED BACK INTO FRANCE AFT
EXPULSION TO BE UNJUSTIFIED. 
08900 SHANN, R.

FRANCE: THE SCAPEGOAT

MIDDLE EAST INTERNATIONAL, 417 (JAN 92), 7-8

AT THE MOMENT, FRANCE SEEMS TO PLAY THE ROLE OF SCAPEGOAT IN THE ALGERIAN CRISIS, AS SEEN FROM THE ALGERIAN POINT-OF-VIEH. FROM THE OUTSIDE, FRENCH POLICY CAN SEEM COMPLICATED, IF NOT CONTRADICTORY, IN ITS RELATIONSHIP WITH MAGHREB COUNTRIES, AND FOR THAT MATTER, ITS FORMER AFRICAN COLONIES. FRANCE'S OBJECTIVE IN ALGERIA IS TO PREVENT ANY LARGE-SCALE EXOOUS AND TO SECURE FINANCIAL INTERESTS.

08901 SWANN, $R$.

HOW INDEPENDENT A LINE?

MIDDLE EAST INTERNATIONAL, (397) (APR 91), 13

FRANCE'S PRESIDENT, FRANCOIS MITTERAND, EMPHASIZED THAT

ONLY AN ACTIVE PARTICIPATION IN THE GULF WAR COULD ENSURE

FRANCE A MAJOR ROLE IN THE POST-WAR SETTLEMENT. ALTHOUGH

FRENCH FORCES WERE SUCCESSFUL IN THE CONFLICT AND MITTERAND

ENJOYS HIGH POPULARITY RATINGS IT REMAINS UNCLEAR IF FRANCE

WILL PLAY A SIGNIFICANT ROLE IN POST-WAR NEGOTIATIONS. MOST

OF FRANCE'S PROPOSALS AND POINTS OF EMPHASIS HAVE BEEN

IGNORED BY THE U.S.

08902 SWANN, R.; KIDRON, $P$.

PLAYING WORLD STATESMAN: NOT A RESOUNDING SUCCESS

MIDDLE EAST INTERNATIONAL, 439 (DEC 92), 9-10.

AS DIFFICULTIES PILE UP FOR PRESIDENT MITTERRAND AT HOME,

HE CLEARLY ENJOYED PLAYING HIS WORLD STATEMAN ROLE DURING

VISIT TO ISRAEL AND JORDAN BETWEEN 15 AND 28 NOVEMBER.

HOWEVER, HIS STATE VISIT TO ISRAEL, LAUNCHED AND CONDUCTED

WITH TRADITIONAL POMP, NEVERTHELESS ENDED ON A TONE OF

BAFFLED FRUSTRATION ON BOTH SIDES. MITTERAND URGED ISRAEL TO

DEAL DIRECTLY WITH THE PLO. THE REPEAL OF THE NO MEETINGS

LAH IS A FOREGONE CONCLUSION.

08903 SWANN, $R$.

SOMALIA: BACK-STABBING AT HOME

MIDDLE EAST INTERNATIONAL, 440(440) (DEC 92), 8

FRANCE IS MAKING THE LARGEST NON-AMERICAN CONTRIBUTION

TO "OPERATION RESTORE HOPE" BUT DOES NOT SEEM TO BE REAPING

A COMMENSURATE RENARD. AS THE OPERATION SOUGHT TO BRING

PEACE TO SOMALIA, A SHARP LITTLE CIVIL WAR BROKE OUT HITHIN

THE FRENCH GOVERNMENT AND IT IS BY NO MEANS CERTAIN THAT THE

CONFLICT WILL TERMINATE WITHOUT MINISTERIAL BLOODLETTING. IT

ANYTHING GOES HRONG IN EITHER BOSNIA OR SOMALIA THERE WILL

BE A SCRAMBLE TO DISCLAIM RESPONSIBLITY AND BERNARD KOUCHNER

MAY FIND HIMSELF WITH DIFFICULTIES.

08904 SWANSON, G.

TECHNOLOGY TRANSFORMS THE TOWN MEETING

TECHNOLOGY TRANSFORMS THE TOWN MEETING

NATIONAL CIVIC REVIEH, 81(1) (WIN 92), 69.

LOCAL GOVERMMENTS TO MAKE NEH ENGLAND-STYLE TOWN MEETINGS

LOCAL GOVERMMENTS TO MAKE NEH ENGLAND-STYLE TOWN MEETINGS

POSSIBLE FOR THEIR COMMUNITIES. AMONG THE LOCALITIES

CONDUCTING ELECTRONIC TOWN MEETINGS ARE SAVANNAH, GEORGIA;

READING, PENNSYLVANIA; AND SANTA BARBARA, CALIFORNIA.

08905 SWARUP, H.; SIMHA, $N$

WOMEN IN PUBLIC ADMINISTRATION IN INDIA

HOMEN AND POLITICS, 1(4) (1991), 13-30.

INDIA IS THE SECOND BIGGEST COUNTRY IN TERMS OF FEMALE

POPULATION. HOWEYER, THE STATUS OF INDIAN WOMEN IN ALL

SPHERES OF THEIR LIVES, SOCIO-ECONOMIC, POLITICAL, AND

CULTURAL, HAS BEEN SECONDARY TO THE STATUS OF MALES. CHANGES

IN THE SOCIAL STRUCTURE, SUCH AS THE BREAKDOWN OF THE JOINT

FAMILY SYSTEM AND THE EMERGENCE OF NUCLEAR FAMILY UNITS,

CERTAIN DEGREE OF URBANIZATION, AND THE ENTRY OF MEN AND

WOMEN INTO THE SERVICE SEGMENT OF THE ECONOMY, HAVE HELPED

TO CHANGE THE LIVES OF A MINORITY OF INDIAN WOMEN. FOR THE

MAJORITY, LIFE HAS NOT CHANGED MUCH. THIS ARTICLE DISCUSSES

THE SITUATION OF INDIAN WOMEN IN PUBLIC ADMINISTRATION.

08906 SWIANIEWICZ, $P$.

THE POL ISH EXPERIENCE OF LOCAL DEMOCRACY: IS PROGRESS BEING MADE?

POLICY AND POLITICS, 20(2) (APR 92), 87-98.

THE AUTHOR EXAMINES THE STATUS OF POLISH LOCAL DEMOCRACY APPROXIMATELY ONE YEAR AFTER THE FIRST FREE LOCAL ELECTIONS. HE BEGINS BY DESCRIBING POLAND'S LOCAL GOVERMMENT MODEL UNDER THE COMHUNIST REGIME. THEN HE DISCUSSES THE

INTRODUCTION OF THE NEW SYSTEM AND ITS MAJOR FEATURES. HE COMPARES THE CHAMGES IN POLAND WITH THOSE IN THE REST OF EASTERN EUROPE, PARTICULARLY HUNGARY. FINALLY, HE DISCUSSES

THE INITIAL EXPERIENCES OF POLAND'S NEW LOCAL COUNCIIS.

08907 SWIECICKI, J.A.

SEVERING THE TIES THAT BIND: MOVING BEYOND DETERRENCE COMPARATIVE STRATEGY, 11 (3) (JUL 92), 283-306.

AN EXAMINATION OF, THE CONCEPTS COMPRISING DETERRENCE
AN AN EXAMINATION OF THE CONCEPTS COMPRISING DETERRENCE DOCTRINE AND STRATEGIC REALITY. DETERRENCE-AS-THEORY WAS NOT EFFECTIVE IN THE U.S.-SOVIET CONTEXT, AND THERE IS GROHING EVIDENCE THAT ATTEMPTS TO RESPOND TO TODAY'S STRATEGIC
REALITIES THROUGH THE SKEWED PRISM OF DETERRENCE THEORY HILL
ALSO NOT SUFFICE. HAVING ESTABLISHED THE INOPERABILITY OF SUCH CONCEPTS AS MUTUAL VULMERABILITY AND RATIONALITY, WHICH FORM THE BASIS OF STRATEGIC DOGMA, SEVERAL SCHOOLS OF THOUGHT ARE PROPOSING STRATEGIES TO REPLACE DETERRENCE. AFTER EXPLORING POSSIBLE ALTERNATIVES TO DETERRENCE, THE AUTHOR RECOMMENDS AN APPROACH THAT COMBINES STRATEGIC DEFENSE AND CRISIS PREVENTION MEASURES INTO A STRATEGY UPON WHICH THE UNITED STATES CAN RESTRUCTURE ITS THEORETICAL BASE, BRINGING IN THE PROCESS A YIABILTIY TO THE UEORETCAL BASE, DETERRENCE THEORY HAS NEVER PROVIDED.

08908 SWILLINGER, D.J.

REFLECTIONS ON FIFTEEN YEARS OF PRESIDENTIAL PUBLIC FINANCING

JOURMAL OF LAH POLITICS,

OURAL OF LAW \& POLITICS, VIII (2) (WIN 92), 339-344

CONDUCTED UNDER THE PUBLIC FINANCING PROVISIONS OF THE 1974

AMENDMENTS TO THE 1971 FEDERAL ELECTION CAMPAIGN ACT. IN

GENERAL, THE SYSTEM HAS WORKED SURPRISINGLY WELL FOR GENERAL ELECTION CANDIDATES BUT NOT NEARLY SO WELL FOR PRIMARY CANDIDATES. IT HAS ACCOMMODATED A RANGE OF CANDIDATES FROM INCUMBENT PRESIDENTS TO SUCH RELATIVE UNKNOWNS AS GOVERNOR JIMMY CARTER TO THIRD PARTY CANDIDATES. HOWEVER, THE STATUTORY SCHEME HAS CREATED A CUMBERSOME SYSTEM THAT IS DIFFICULT FOR THE FEDERAL ELECTION COMMISSION TO ADMINISTER AND DIFFICULT FOR THE CANDIDATES TO COMPLY WITH. MOREOVER, THE SCHEME HAS NOT ACHIEYED ONE OF ITS MAJOR OBJECTIVES, TO ALLEVIATE THE CANDIDATES' FUNDRAISING PROBLEMS. THE SYSTEM HAS ALSO CAUSED UNINTENDED POLITICAL CONSEQUENCES THAT MUST BE ADDRESSED.

08909 SHISS, J.E.

ADAPTING TOTAL QUALITY MANAGEMENT TO GOVERNMENT

PUBLIC ADMINISTRATION REVIEH, 52(4) (JUL 92), 356-362.

THE AUTHOR ARGUES THAT THE ORTHODOX FORM OF TOTAL

QUALITY MANAGEMENT (TQM) OUTLINED IN THE WORKS OF W. EDWARDS

DEMING AND OTHERS WILL NOT WORK WELL IN GOVERMMENTAL

AGENCIES. AMONG OTHER FACTORS LIMITING THE USEFULNESS OF TOM

IN PUBLIC SECTOR AGENCIES ARE THE EMPHASES ON PRODUCTS

RATHER THAN SERVICES, ON WELL-DEFINED CONSUMER GROUPS, ON

INPUTS AND PROCESSES RATHER THAN RESULTS, AND ON AN

INPUTS AND PROCESSES RATHER THAN RESULTS, AND ON AN

ORGANIZATIONAL CUL TURE HITH A SINGLE-MINDED PREOCCUPATION

COULD BE USEFUL IN THE PUBLIC SECTOR. ADOPTING MAJOR

COULD BE USEFUL IN THE PUBLIC SECTOR. ADOPTING MAJOR
FEATURES OF THE MORE ORTHODOX APPROACH, REFORM TOM HOULD

EMPHASIZE CLIENT FEEDBACK, PERFORMANCE MONITORING,

CONTINUOUS IMPROVEMENT, AND WORKER PARTICIPATION.'

08910 SHYMGEDOUW, $M$.

NATIONAL ELECTIONS IN BELGIUM: THE BREAKTHOUGH OF THE EXTREME RIGHT IN FLANDERS

REGIONAL POLITICS \& POLICY, 2(3) (FAL 92), 62-75

THE ELECTION RESULTS OF 24 NOVEMBER 1991 UNDERL INED THE FRAGMENTED AND FRAGMENTING NATURE OF THE BELGIAN POLITICAL SYSTEM. THIS ARTICLE EXAMINES TWO ASPECTS OF THE ELECTION RESULTS. FIRST, IT ANALYZES THE SOCIO-ECONOMIC

CHARACTERISTICS OF THE VB ELECTORATE. TO WHAT EXTENT DO FACTORS SUCH AS AGE, INCOME, GENDER, PROGESSIONAL STATUS, CHURCH ATTENDANCE AND LEVEL OF EDUCATION AFFECT THE CHOICE FOR THE VB? RELATED TO THIS IS THE QUESTION AS TO WHETHER THESE RESULTS MARK CONTINUITY OR CHANGE. ALSO THE ARTICLES TRIES TO SKETCH A THEORETICAL FRAMEWORK SO AS TO GAIN

INSIGHT INTO THE RISE OF THE VB IN THE $1980 \mathrm{~S}$.

08911 SYKES, C.

OPENING UP THE PUBLIC-SCHOOL GULAG

NATIONAL REVIEW, XLIV (14) (JUL 92), 17-18.

IF PRESIDENT BUSH WANTS A HINT OF JUST HOH POHERFUL AN ISSUE HE HAS IN SCHOOL CHOICE, HE NEED NOT LOOK ANY FARTHER THAN WISCONSIN. THE EFFORTS OF GOVERNDR TOMMY THOMPSON AND BROTHER BOB SMITH (AMONG OTHERS) TO ALLOW INNER-CITY STUDENTS A CHOICE BETWEN FAILING PUBLIC SCHOOLS AMD SUCCEEDING PRIVATE ONES (EVEN IF, LIKE BROTHER BOB'S MESSMER HIGH SCHOOL THEY ARE AFFIL IATED WITH A RELIGIOM HAYE BEEN PRAISED BY PARENTS AND STUDENTS. THEIR EFFORTS HAVE BEEN EOUALLY CRITICIZED BY THE LIBERAL EDUCATIONAL ESTABL ISHMENT WHO SEEMS MORE CONCERMED THAT STUDENTS ARE KEPT FREE OF CRUCIFIXES THAN WITH WHETHER THEY LEARN ANYTHING.

08912 SYKES, C.J.

THE NEXT BILL PROXMIRE?

NATIONAL REVIEW, XLIY(21) (NOV 92), 22-23.

THE AUTHOR LOOKS AT HISCONSIN'S' 1992 SENATORIAL CAMPAIGM BETWEEN REPUBLICAN INCUMBENT BOB KASTEN AND DEMOCRATIC

NEWCOMER RUSS FEINGOLD, HHO WON A LARGE UPSET YICTORY OVER

TWO BETTER-KNOWN, BETTER-FINANCED CANDIDATES IN HIS PARTY'S PRIMARY.

08913 SYLLA, R.

THE PROGRESSIVE ERA AND THE POLITICAL ECONOMY OF BIG GOVERMMENT

CRITICAL REVIEN, 5(4) (FAL 91), 531-557.

IN THE UNITED STATES, BIG GOVERMMENT WAS A CHILD OF THE

PROGRESSIVE ERA. MUCH RECENT HORK IN AMERICAN HISTORY, 
ESPECIALLY THAT OF THE "ORGANIZATIONAL" SCHOOL, SHOWS THAT BIG BUSINESS PLAYED AN ACTIVE, PERHAPS DOMINANT, ROLE IN THE
PROGRESSIVE ERA PUSH FOR BIG GOVERNMENT. THIS HORK UNDERCUTS PROGRESSIVE ERA PUSH FOR BIG GOVERMENT. THIS WORK UND
AN OLDER, LIBERAL INTERPRETATION EMPHASIZING CONFLICT BETWEEN BUSINESS AND GOVERMMENT. BUT WHY BIG BUSIMESS PUSHED FOR BIG GOVERMMENT IS STILL UNCLEAR. THIS PAPER ADVANCES THE HYPOTHESIS THAT THE PUSH RESULTED FROM A CONFLICT BETHEEM BIG BUSINESS AND STATE GOVERMMENT IN THE LATE IOTH CENTURY. AS THE POWER AND INFLUENCE OF BIG BUSINESS GREW, IT SAW BIG GOVERMMENT AT THE FEDERAL LEVEL AS THE SOLUTION TO MANY OF ITS PROBLEMS RESULTING FROM THE CONFLICT WITH STATE GOVERMMENT.

08914 SYLVAN, D.; THORSON, S. ONTOLOGIES, PROBLEM REPRESENTATION, AND tHE CUBAN MISSILE CRISIS

JOURNAL OF CONFLICT RESOLUTION, 36(4) (DEC 92), 709-732. PRDBLEM REPRESENTATION AND ONTOLOGY ARE INTRODUCED AS CONCEPTS CRITICAL TO UNDERSTANDING FOREIGN POLICY DECISION MAKING. THE ARTICLE EXPLICATES THESE CONCEPTS AND THEIR RELATIONSHIP AND FOCUSES ON SUCH ISSUES OF REPRESENTATION RATHER THAN VERIDICAL DESCRIPTIONS OF REALIYY THEREBY SHIFTING ATTENTION AHAY FROM CONCERM HITH MISPERCEPTION AND TOWARD ATTEMPTING TO UNDERSTAND HOW THESE REPRESENTATIONS ARE SOCIALLY CONSTRUCTED AND MODIFIED. IT IS ARGUED THAT THE CONFLICT RESOLUTION PROCESS CAN BE ENHANCED BY INCLUSION OF CONCERN WITH PROBLEM REPRESENTATION AND ONTOLOGY ALONG HITH TRADITIONAL TNTEREST IN OPIION SELCTION. THESE CONCEPTS ARE THEN RELATED TO DECISION MAKING IN THE CUBAN MISSILE CRISIS. BY FOCUSING ON ONTOLGIES AND PROBLEM REPRESENATIONS. THE NEH MODEL ILLUSTRATES AN APPROACH TO UNDERSTANDING AND REPRESENTING WHY SOME DECISION MAKERS ARE PREDISPOSED TO PARTICULAR OPTIONS OVER OTHERS.

08915 SYMMES, $P$.

THE LAST, BEST SEAT

AMERICAM SPECTATOR, 25(10) (OCT 92), $38,40$.

DUE TO THE 1990 CENSUS, MONTANA HAS LOST ONE OF ITS THO CONGRESSIONAL SEATS. THIS HAS PRODUCED A RACE BETWEEN TWO INCUMBENTS, SINCE NEITHER OF THE CURRENT REPRESENTATIVES WANTED TO QUIT. RON MARLENEE, AN EIGHT-TERM CONSERVATIVE REPUBLICAN, IS COMPETING AGAINST PAT WILLIAMS, A SEVEN-TERM LIBERAL DEMOCRAT. FOR YEARS, MARLENEE AND WILLIIAMS HAVE IN EFFECT CANCELLED EACH OTHER'S VOTES IN CONGRESS ON ISSUES RANGING FROM ABORION TO THE GULF HAR. THE NOVEMBER 1992 ELECTION WILL END THAT STALEMATE.

08916 SYPNOHICH, C.

THE FUTURE OF SOCIALIST LEGALITY: A REPLY TO HUNT NEW LEFT REVIEW, (193) (MAY 92), 80-88.

THE AUTHOR REPLIES TO ALAN HUNT'S CRITIQUE OF HER ARGUMENT IN "THE SOCIALIST CONCEPT OF LAW." SHE DEFENDS WHAT SHE SEES AS THE INDISPENSABLE CONTRIBUTION OF PHILOSOPHICAL JURISPRUDENCE TO A DEMOCRATIC SOCIALIST ORDER.

08917 SYROYEZHKIN, K.

THE ETHNOSOCIAL FACTOR OF DEVELOPMENT IN XINJIANG FAR EASTERN AFFAIRS, (3) (1990), 64-75.

THIS ARTICLE ARGUES THAT THE' ECONOMIC AMD POLITICAL SITUATION IN A REGION DEPEND IN PART ON THE ETHAIC STRUCTURE OF THE REGION'S POPULATION AND THE POLITICAL AND SOCIAL DEVELOPMENT OF THE ETHNOSES INHABITING THE REGION, THEIR
INYOLVEMENT IN SOCIAL PRODUCTION, ANO THEIR INFLUENCE ON ECONOMIC DEVELOPMENT AND POLITICAL DECISION-MAKING. ETHNOSOCIAL ASPECTS OF THE DEVELOPMENT OF MULTINATIONAL REGIONS ARE SEEN AS A KEY PROBLEM IN THE ANALYSIS OF ETHNIC RELATIONS AND THE NATIONAL QUESTION. IN THIS ARTICLE, THE XINJIANG-UIGHUR AUTONOMOUS REGION IN THE PEOPLE'S REPUBLIC OF CHINA IS USED AS AN EXAMPLE FOR ELABORATION OF THESE POPULATION.

08918 SZABO, $S$.

THE NEW GERMANY

JOURNAL OF DEMOCRACY, 3(1) (JAN 92), 97-107.

UNLIKE THE WESTERN THO-THIRDS OF GERMAMY THE EASTERM THIRD HAS NEVER SUSTAINED A SUCCESSFUL DEMOCRACY. THEREFORE, FAR FROM CLOSING THE "GERMAN QUESTION," THE UNIFICATION OF GERMANY HAS OPENED IT UP ONCE AGAIN. THIS ARTICLE ASSESSES THE PROSPECTS FOR DEMOCRACY IN THE FORMER GDR. IT LOOKS BACK ON THE REASONS BOTH FOR THE FAILURE ANO THE LATER SUCCESS OF DEMOCRACY IN GERMANY. IT EXAMINES GERMANY'S POL ITICAL DEMOCRACY IN GERMANY. IT EXAMINES GERMANY'S POL IIICAL
CULTURE. THE HISTORY OF ITS PARTY SYSTEM, AND THE VARIOUS CONSTITUT TOWAL AND ELECTORAL ARRATYMEMTS ADOPTED, AS WELL AS THE BROADER INTERNATIONAL CONTEXT.

08919 SZABO, S

THE UNITED STATES, GERMANY AND THE NEW HORLD ORDER ARMS CONTROL, 12(3) (DEC 91), 129-138.

AT ISSUE ONCE AGAIN IS THE KIND OF INTERNATIONAL ROLE AMERICA SHOULD PLAY IN A WORLD HHICH NO LONGER FACES THE SOVIET MILITARY, IDEOLOGICAL AND POLITICAL THREAT. THE KEY QUESTION IN THE DEBATE IS: SHOULD THE UNITED STATES CONTINUE TO PLAY THE KIND OF INTERNATIONAL ROLE IT HAS DONE DURING
THE COLD haR, AS THE LEADING GLOBAL POHER, OR RATHER SHOULD IT TURN MORE OF ITS ATTENTION TO DOMESTIC CONCERNS AND PLAY LESS ATTENTION TO AND HAVE A SMALLER ROLE IN INTERMATIONAL AFFAIRS, ESPECIALLY IN THE SECURITY AREA? THIS CHAPTER LDOKS AT HOW A NEW EUROPE FITS INTO THE BUSH ADMINISTRATION'S VIEM OF THE NEW WORLD ORDER AND THEN TURNS TO THE EXPECTIONS IN

08920 SZADADAT, I.; KELEMEN, G.

CAREER TYPES AND MOBILIZATION CHANHELS IN THE HUNGARIAN COMHUUIST PARTY, 1945-90

JOURAAL OF COMMUNIST STUOIES, 8(3) (SEP 92), 46-61. A STUDY OF THE CAREER ROUTES OF THOSE WHO REACHED THE POL ITBURO AND SECRETARIATE OF THE HUNGARIAN SOCIALIST HORKERS' PARTY FOCUSES ON THE POSITIONS OCCUPIED AND FUNCTIONS EXERCISED BY THOSE WHO REACHED THE COUNTRY'S POL ITICAL SUMMIT DURING FOUR DECADES OF COMHUNIST RULE. THIS ARTICLE BUILDS UP A PICTURE OF CAREER TYPES AND ROUTES TO
THE TOP, DRAWING DISTINCIIONS OVER TIME, AND PARTICULARLY AHE TOP, DRAHING DISTINCTIONS OVER TIME, AND PARTICULARLY
BETWEEN DIFFERET LEADERHIP ERAS. THIS ENABLES THE IDENTITY BETWEEN DIFFERENT LEADERSHP ERAS. THIS ENABLES THE IDENTITY
OF THE EXPERIENCE BROUGHT BY VARIOUS INDIVIDUALS TO THE TASK OF THE EXPERIEMTE
OF GOVERMMENT.

08921 SZAJKOHSKI, B.

THE ALBANIAN ELECTION OF 199

ELECTORAL STUDIES, 11(2) (JUM 92), 157-161.

THE FIRST MULTI-PARTY ELECTIONS IN ALBANIA SINCE THE COMMUNIST TAKE-OVER IN 1944, WERE HELD THROUGHOUT THE COUNTRY IN 1991. ALBANIA IS THE LAST NATION IN EASTERN EUROPE TO HOLD MULTI-PARTY ELECTIONS THUS LAYING A PARTIAL FOUNDATION FOR POLITICAL PLURALISM AND DEMOCRACY. FIVE PARTIES HAVE EMERGED AND TOOK PART IN THE ELECTIONS. THE ELECTIONS IDENTIFIED AND SHARPENED SOCIAL AND POLITICAL CLEAVAGES IN THE COUNTRY THAT THE COMHUNISTS IGNORED AND DENIED. THE AWP WAS FORCED INTO CONCESSION AFTER CONCESSION AND TO ACQUIESCE TO THE DEMOCRATIC PAFTY DEMANDS THAT FUNDAMENTALLY ALTERED THE NATURE AND STRUCTURE OF ALBANIAN POLITICS.

08922 SZAKADAT, I.; SZAKADAT, L.

INTERACTIONS' BETHEEN THE POLITBURO AND THE SECRETARIAT OF THE COMMUIST PARTY OF HUNGARY, 1945-89

JOURNAL OF COMHUNIST STUDIES, 8(3) (SEP 92), 27-45.

A STATISTICAL ANALYSIS OF THO DECISIVE, DIRECTING

POLITICAL BODIES--THE POLITBURO AND THE SECRETARIAT--OF THE

COMMUNIST PARTY OF HUNGARY BETWEEN 1945 AND 1990 IS

PRESENTED FOR THE FIRST TIME. THE AVAILABLE DATA REVEAL SIGMIFICANT DISTINCTIONS OVER TIME IN THE WAY DIFFERENT LEADERS MADE USE OF MEMBERHSHIP OF THESE THO BODIES. SUCH AN ANALYSIS HELPS TO IDENTIFY SOME CHARACTERISTICS OF THE SUCCESSIVE POLITICAL ERAS.

08923 SZAMUELY, $G$.

DESPREAD DEMOCRATS AND THE SICK OFFENSE

AMERICAN SPECTATOR, 24(7) (JUL 91), 15-17.

FORMER PRESIDENT CARTER AND ASSORTED CONGRESSMEN,

PUNDITS, AND NEWSPAPER EDITORIALISTS ARE CALLING ON THE HOUSE OF REPRESENTATIVE TO INVESTIGATE GARY SICK'S LATEST ALLEGATIONS THAT IN 1980 THE REAGAN CAMPAIGN TEAM CONSPIRED WITH THE KHOMEINI REGIME TO ENSURE THAT THE FIFTY-THO HOSTAGES SEIZED FROM THE U.S. EMBASSY IN TEHRAN THE PREVIOUS NOVEMBER WERE NOT RELEASED UNTIL AFTER THE ELECTIONS. THIS ARTICLE ARGUES THAT THE ALLEGATIONS ARE BASED SOLELY ON THE ACCUSATIONS OF PEOPLE OF DUBIOUS CREDIBILITY. FURTHERMORE, THERE IS VIRTUALLY NO DOCUMENTARY EVIDENCE SUPPORTING THE CLAIM. THE CONCLUSION IS THAT THIS IS SIMPLY AMOTHER DEMOCRAT PLOY TO DRAH ATTENTION AHAY FROM MORE SUBSTANTIVE ISSUES WHERE THE DEMOCRATS PERFORMED POORLY.

08924 SZOKE, L.

HUNGARIAN PERSPECTIVES ON EMIGRATION AND IMMIGRATION IN THE NEW EUROPEAN ARCHITECTURE

INTERMATIONAL MIGRATION REVIEW, XXVI(2) (SUM 92), 305-323. SINCE THE DOWNFALL OF THE DICTATORSHIP, HUNGARY'S APPROACH TO MIGRATION, TRADITIONALLY A LIBERAL ONE, IS NOW MAINLY SHAPED BY THE COUNTRY'S INTENTION TO BE REINTEGRATED INTO EUROPE AND TO HAVE ITS MIGRATION PRACTICE HARMONIZED WITH THAT OF THE WESTERN DEMOCRACIES. DECISIOEMARERS IN BUDAPEST SHOW NO GREAT CONCERM ABOUT EMIGRATION W INICH IS BUDAPEST SHOW NO GREAT CONCERM ABOUT EMIGRATION, HIICH IS EXPECTED TO REMAIN RELATIVELY INSIGNIFICANT. ATTENTION IS THEREFRE CONCENTRATED ON THE POSSIBILITY OF A MASSIVE
INFLUX OF IMMIGRANTS, ESPECIALLY FROM THE NEIGHBORING STATES. THIS COULD EASILY UNDERMINE HUNGARY'S POLITICAL STABILITY AND ECONOMIC DEVELOPMENT. THE QUESTION OF INTERNATIONAL MIGRATION CAN BE ADORESSED ONLY IN AN ALL-EUROPEAN FRAMEWORK. EXPERTS ARE CONVINCED THAT MIGRATORY PRESSURES ORIGINATING IN EASTERN AND CENTRAL EUROPE COULD BE CONSIDERABLY LIMITED BY MEASURES TAKEN TO GUARANTEE THE RIGHTS OF ETHNIC MINORITIES.

O8925 SZPIRO, $G$.

ISRAEL: SETTLERS YS. THE GOVERMMENT

SHISS REVIEH OF HORLD AFFAIRS $42(7)$ (OCT 92 ) 20. ALTHOUGH ISRAEL'S NEW LABOR GOVERMMENT HAS DECLARED 
KOKHAY YA'AKOY A STRATEGIC SETTLEMENT BECAUSE OF ITS PROXIMITY TO THE ISRAELI CAPITAL, CONSTRUCTION HAS BEEN STOPPED IN KOKHAV YA'AKOV AS WELL AS IN OTHER SETTLEMENTS ON THE WEST BANK. DESPITE THE GOVERMMENT'S ANNOUNCED POLICY, ISRAELI SETTLERS ON THE WEST BANK ARE OPTIMISTIC THAT

BUILDING WILL RESUME, SOONER OR LATER.

08926 SZYMANSKI, E. EXERCISES IN DEMOCRACY

WEST AFRICA, (3879) (JAN 92), 104

WEST AFRICA, (3879) (JAN 92), 104 .
WITH RAMPANT INFLATION, ARMY MUTINIES, RIOT-TORN

BUSINESSES, AND FREQUENT POL ITICAL VIOLENCE, ZAIRE IS

CHAOTIC AS IT WAITS FOR THE TERMS OF A TRANSITIONAL
GOVERMMENT TO BE HAMMERED OUT. THE UNION FOR DEMOCRATIC AND

GOVERMMENT TO BE HAMMERED OUT. THE UNION FOR DEMOCRATIC AND
SOCIAL PROGRESS (UDPS) IS THE MOST POPULAR AND POHERFUL OF

SOCIAL PROGRESS (UDPS) IS THE MOST POPULAR AND POWERFUL OF
THE OPPOSITION PARTIES. GILBERT MUNDELA-TSHIMANGA REPRESENTS

THE OPPOSITION PARTIES. GILBERT MUNDELA-TSHIMANGA REPRESENTS
THE UDPS IN THE UNITED STATES, WHERE HE LOBBIES FOR SUPPORT

THE UDPS IN THE UNIT
AND RAISES FUNDS.

08927 TABB, $W$.

VAMPIRE CAPITALISM

SOCIALIST REVIEW, 22(1) ( JAN 92), 81-94.

WILLIAM TABB SUGGESTS THAT WE ARE CURRENTLY WITNESSING A SUCCESSFUL NEW WORLD ORDER FOR THE U.S. RULING CLASS-A NEW WORLD ORDER THAT CAN BE CALLED VAMPIRE CAPITALISM. THE NAME IS MEANT TO CONVEY A STRATEGY OF GROWTH THROUGH

REDISTRIBUTION--A REDISTRIBUTION FROM EVERYONE IN THE WORLD TO THE U.S. RULING CLASS--BASED NOT ON THE PRODUCTIVE CAPACITIES OF THE UNITED STATES, BUT ON ITS MILITARY MUSCLE, AND ITS POLITICAL AND IDEOLOGICAL DOMINATION. AFTER AN EXPLORATION OF THIS THESIS HE CONCLUDES THAT BUSH'S BRAND OF CAPITALISM MAY MAKE THE NEO-LIBERAL AGENDA OF COMPETIVENESS THE BEST TICKET OUT.

08928 TABER, C.S.

POLI: AN EXPERT SYSTEM MODEL OF U.S. FOREIGN POLICY BELIEF SYSTEMS

AMERICAN POLITICAL SCIENCE REVIEH, 86(4) (DEC 92), 888-904.

ONE OF THE MOST FRUITFUL SYSTEMATIC APPROACHES TO THE STUDY OF FOREIGN POLICY VIEWS NATIONS AS INFORMATION PROCESSORS AND EXPLAINS FOREIGN POLICY AS A FUNCTION OF INFORMATION AND PROCESSING. MUCH OF SUCH PROCESSING DEPENDS INFORMATION AND PROCESSING. MUCH OF SUCH PROCESSING DEPENDS ON THE PRIOR BELIEFS OF DECISION MAKERS, BUT FOR A VARIETY OF REASONS THESE SYSTEMS OF PRIOR BELIEFS ARE VERY

TO ANALYZE USING "STANDARD" EMPIRICAL AND MODELING TECHNIQUES. COMPUTATIONAL MOOELING, INCLUDING EXPERT SYSTEM TECHNOLOGY, PROVIDES AN ALTERNATIVE METHODOLOGY THAT ALLOHS SUCH ANALYSIS. THE AUTHOR EXPLAINS POLICY ARGUER (POLI), AN EXPERT SYSTEM MODEL OF U.S. FOREIGN POLICY MAKING IN ASIA. POLI HAS BEEN VERY SUCCESSFUL IN REPRODUCING ACTUAL U.S. RESPONSES TO EVENTS IN ASIA FROM THE 1950'S. MORE IMPORTANTLY, POLI RECREATES POLICY DEBATE IN THE FORM OF THE ARGUMENTS AND COUNTER-ARGUMENTS USED TO JUSTIFY POLICY ALTERNATIVES. THE MODEL EXPLAINS FOREIGN POLICY OUTPUTS IN TERMS OF A COMPLETE PROCESS FROM FOREIGN POLICY BELIEFS, THROUGH DEBATE, TO CHOICE.

08929 TACCONI, L.; TISDELL, C.

RURAL DEVELOPMENT IN LDC'S: APPRAISAL, PARTICPATION AND SUSTAINABLITY

PUBLIC ADMINISTRATION AND DEVELOPMENT, 12(3) (AUG 92), 267-278.

EVIDENCE ON THE PERFORMANCE OF DEVELOPMENT PROJECTS SHOWS THAT SUSTAINABILITY IS SELDOM ACHIEVED. PROJECT SUSTAINABILITY IS INFLUENCED BY ECOLOGICAL, SOCIAL, POLITICAL, AND ECONOMIC SYSTEMS. THE PARTICIPATION APPROACH IS MORE SENSITIVE TO THE SOCIAL AND POLITICAL SYSTEMS THAN THE BLUEPRINT APPROACH. IT INVOLVES PEOPLE IN DECISIONMAKING AND SEES THE ACHIEVEMENT OF SUSTAINABLE PROJECTS AS THE RESULT OF PEOPLE'S EMPOWERMENT AND SELF-RELIANCE. UNDER CERTAIN CIRCUMSTANCES, THIS APPROACH CAN LEAD TO ENVIRONMENTALL UNSUSTAINABLE PROJECTS. SMALLER SCALE ENVIRONMENTALL UNSUSTAINABLE PROJECTS. SMALLER SCALE
PROJECTS TEND TO BRING ABOUT SUSTAINABILITY. PROBLEMS EXIST IN COMBINING THE BOTTOM-UP AND TOP-DOWN APPROACHES.

08930 TACTAQUIN, C.

WHAT RIGHTS FOR THE UMDOCUMENTED?

REPORT ON THE AMERICAS, 26(1) (JUL 92), 25-28.

UNDOCUMENTED IMMIGRANTS, A PERMANENT FEATURE OF THE U.S. UNDERCLASS, ARE THE MOST POWERLESS GROUP OF WORKERS IN THE UNDERCLASS, ARE THE MOST POWERLESS GROUP OF WORKERS IN UNITED STATES. AT THE SAME TIME, THE UNDOCUMENTED HAVE 8ECOME INCREASINGLY ADEPT AT DEFENDING THEIR RIGHTS BOTH IN THE WORKPLACE AND IN THE COMMUNITY AT LARGE. THE NUMBER OF LOCAL AND NATIONAL ORGANIZING EFFORTS TO PROTECT AND EXPAND THE RIGHTS OF THE UNDOCUMENTED HAVE SIGNIFICANTLY INCREASED OVER THE LAST TEN YEARS. MANY BELIEVE THAT NOTHING LESS
THE REPEAL OF EMPLOYER SANCTIONS HILL PREVENT FURTHER THE REPEAL OF EMPLOYER SAM
DETERIORATION OF RIGHTS

08931 TADAKI, J.M.

ARMACOST URGES JAPAN, UNITED STATES TO OUIT MUDSLINGING

JAPAN TIMES (WEEKLY INTERMATIONAL EDITION), 32(8) (FEB 92),

8.

MICHAEL ARMACOST, WASHINGTON'S AMBASSADOR TO TOKYO, SAYS
THAT JAPAN AND THE UNITED STATES SHOULD STOP HURLING ACCUSATIONS ACROSS THE PACIFIC. HE BELIEVES THAT BOTH COUNTRIES MUST RECOGNIZE THE EXTENT AND IMPORTANCE OF THEIR INTERDEPENDENCE.

08932 TAHI, M.

THE ARDUOUS DEMOCRATISATION PROCESS IN ALGERIA

JOURNAL OF MODERN AFRICAN STUDIES, 30(3) (SEP 92), 397-419. RIOTS IN 1988 IN ALGERIA CONVINCED ITS PRESIDENT, CHADLI BENJEDID, OF THE URGENT NECESSITY TO TRANSFORM THE $\dot{F} . L . N$. BENT AN ORGANIZATION THAT WOULD BE CAPABLE OF ACTING AS THE
INTO AN ARIVING FORCE OF "RENOVATION" IN ALGERIA. BECAUSE OF
DRIVII

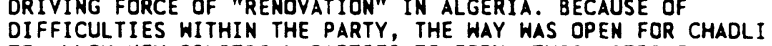
TO ALLOW NEW POLITICAL PARTIES TO FORM. THIS ARTICLE EXPLORES HIS THO-FOLD STRATEGY. TO ENLARGE THE BASIS OF SUPPORT FOR GOVERMMENT POLICIES BY BRINGING THE PARTIES INTO AN ALLIANCE WITH THE AUTHORITIES, AND TO CREATE A RIVAL BUT LIMITED SOURCE OF POWER THAT
OPPONENTS OF THE PRESIDENT.

08933 TAI, $M$

HOLDING THE LINE

FAR EASTERN ECONOMIC REVIEW, 151(26) (JUN 91), 23-25.

THE SOVIET MILITARY PRESENCE IN THE FAR EAST IS BEING CONVERTED FROM A SPRAWLING OFFENSIVE ARMY EQUIPPED WITH OFTEN AGING WEAPONRY AND WITH MANY UNDERMANHED UNITS TO A LEAN AND MEAN FORCE WHICH IS DEFENSE-ORIENTED BUY MAY ACTUALLY BE MORE ABLE TO INFLICT DAMAGE ON NEIGHBORS. HOWEVER, MOST OBSERVERS AGREE THAT THESE CHANGES ARE NOT AN INDICATION OF SOVIET PLANS FOR THE AGGRESSIVE USE OF MILITARY FORCE IN THE REGION. SEVERE DOMESTIC PROBLEMS AND A DESIRE TO END MILITARY CONFRONTATION WITH THE WEST HAVE TRANSFORMED THE SOVIET MILITARY THREAT FROM AN ACTIVE TO A PASSIVE DANGER FOR ASIAN DEFENSE PLANMERS.

08934 TAI, M.

DVICE THAN AID

FAR EASTERN ECONOMIC REVIEW, 151(23) (JUN 91), 15-16. CHINESE PREMIER LI PENG'S RECENT VISIT TO PYONGYANG
CY PIT UNDERLINES AN EMERGING GAP BETHEEN RHETORIC AND REALITY IN SINO-NORTH KOREAN RELATIONS. WHILE THE TRIP WAS OFFICIALLY HAILED AS A "COMPLETE SUCCESS," THERE APPARENTLY WAS HAILED AS A "COMPLETE SUCCESS," THERE APPARENTLY WAS
SUBSTANTIAL DISAGREEMENT BETWEEN THE THO COMMUNIST NEIGHBORS SUBSTANTIAL DISAGREEMENT BETWEEN THE THO COMMUNIST NEI
ON ISSUES RELATED TO SOUTH KOREA'S APPLICATION FOR UN MEMBERSHIP AND PEKING'S RELUCTANCE TO MEET PYONGYANG'S OEMANDS FOR MASSIVE ECONOMIC AND MILITARY ASSISTANCE. ADVICE SEEMS TO BE THE ONLY COMMODITY THAT THE CHINESE HAVE NOT HESITATED TO PROVIDE. THEY BASE THEIR UNWILLINGNESS TO PROVIDE FINANCIAL OR MATERIAL SUPPORT ON PYONGYANG'S REFUSAL TO REFORM ITS OUTDATED ECONOMY.

08935 TAI, $M$

MORTAL REMAINS

FAR EASTERN ECONOMIC REVIEW, 151(25) (JUN 91), 18-19.

A TWO-HEEK DELAY IN THE AMNOUNCEMENT OF THE DEATH OF JIANG QING, MAO ZADONG'S WIDOW AND THE LEADER OF THE GANG OF FOUR, SUGGESTS THAT CHINESE AUTHORITIES WERE UNSURE AS HOW TO HANDLE THE RAMIFICATIONS OF THE PASSING OF ONE OF MODERN CHINA'S MOST CONTROVERSIAL POLITICAL FIGURES. THE AUTHORITIES MAY HAVE FEARED THAT JIANG'S PASSING COULD BECOME A CATALYST IN SPARKING UNREST, MUCH AS THE DEATHS OF PROMINENT LEADERS IN THE PAST (E.G. ZHOU ENLAI AND HU YAOBANG), BROUGHT PEOPLE TO THE STREETS. WHILE THEIR FEARS OF UNREST PROVED TO BE UNFOUNDED, JIANG'S DEATH ALSO IS AN UNCOMFORTABLE REMINDER OF THE MORTALITY OF THE AGING RULING ELITE.

08936 TAI, M.

NEUTRAL RESPECT

FAR EASTERN ECONOMIC REVIEN, 151(30) (JUL 91), 16-17. WHEN THE SOVIET MILITARY WI THDRAWAL FROM MONGOL IA IS MILITARY UMBRELLA FOR THE FIRST TIME IN 70 YEARS. MONGOL IAN LEADERS ARE NOH HOPING TO SECURE A NEUTRALITY THAT HILL KEEP THEIR TWO GREAT NEIGHBORS, THE SOVIET UNION AND CHINA, AT A THEIR THO GREAT NEIGHBORS, THE SOVIET UNION AND CHINA, AT A
DISTANCE. THEY FACE DAUNTING OBSTACLES, HOWEVER, AS THE LANDDISTANCE. THEY FACE DAUNTING OBSTACLES, HOWEVER, AS THE
LOCKED AND THINLY POPULATED STATE IS DEPENDENT ON ITS LOCKED AND THINLY POPULATED STATE IS DEPENDENT ON ITS
NEIGHBORS FOR ACCESS TO THE SEA AS WELL AS FOR MUCH OF ITS NEIGHBORS FOR ACCESS TO THE SEA AS WELL AS FOR MUCH OF ITS
CRUCIAL IMPORTS. IN ADOITION, THE DIMINISHING MONGOLIAN CRUCIAL IMPORTS. IN ADOITION, THE DIMINISHING MONGOLIAN
MILITARY STILL FACES EXTERNAL THREATS IN THE FORM OF ETHNIC MILITARY STILL FACES EXTERNAL
UNREST IN THE SOVIET UNION.

08937 TAIB, D.; MAT, J.

ADMINISTRATIVE REFORMS IN MALAYSIA TOWARD ENHANCING PUBLIC ADMINISTRATIVE REFORY

GOVERNANCE, 5(4) (OCT 92), 423-437

THIS ARTICLE DESCRIBES CHANGES AND REFORM IN THE

MALAYSIAN CIVIL SERVICE THAT ARE ON-GOING PROCESSES. REFORM EFFORTS ARE GROUPED INTO THO PHASES: THE PERIOD OF RAPID ECONOMIC GROWTH IN THE 1960 S AND 1970 S WICH REQUIRED DEVELOPMENT ADMINISTRATION AND INSTITUTION BUILDING, AND THE PERIOD FROM 1985 TO THE PRESENT. THE ADMINISTRATIVE REFORM EXPERIENCES ARE UNIQUELY MALAYSIAN EFFORTS TO RESPOND TO THE MALAYSIAN SOCIO-POLITICAL ENVIRONMENT AND NEEDS. 
08938 TAIRA, $K$.

JAPAN, AN IMMINENT HEGEMON?

ANNALS OF THE AMERICAN ACADEMY OF POLITICAL AND SOCIAL SCIENCE, (513) (JAN 91), 151-163.

JAPAN HAS BEEN THRUST INTO A LEADING ROLE IN WORLD AFFAIRS BY ITS OWN ECONOMIC SUCCESS AND BY THE CONFLUENCE OF TWO POWERFUL GLOBAL TRENDS: (1) HEGEMONIC CYCLES THAT ANTICIPATE THE RISE OF A NEW HEGEMON AS A CONSEQUENCE OF THE RELATIVE DECLINE OF THE UNITED STATES AND (2) THE END OF HISTORY ITSELF, WHICH REVOLUTIONIZES THE MEANING OF HEGEMONY AND INTERMATIONAL ORDER. IN THIS ESSAY, THE AUTHOR EXAMINES JAPAN'S HEGEMONIC QUALIFICATIONS WITH RESPECT TO ECONOMIC RESOURCES FOR FINANCING HEGEMONY AND ITS ABILITY AND WILL TO LEAD THE WORLD. JAPANESE-STYLE HEGEMONY IS INFERRED FROM THE KMOWM CHARACTERISTICS OF GOVERNMENT-BUSINESS RELATIONS IN JAPAN AND IS EVALUATED IN THE CONTEXT OF U.S. - JAPANESE RELATIONS. THE AUTHOR ARGUES THAT THE PAX AMERICANA IS NOT DEAD AND THAT JAPAN FINDS IT MORE ADVANTAGEOUS TO FIT INTO MODIFIED AMERICAN HEGEMONY THAN TO GO IT ALONE BY REPLACING THE USA AS A NEW HEGEMON.

08939 TAKAHASHI, $K$.

BEHIND THE MYTH: SHIN KAMEMARU

JAPAN TIMES (WEEKLY INTERNATIONAL EDITION), 32(1) (JAN 92), 1,7 .

THE AUTHOR PROFILES SHIN KANEMARU, JAPAN'S FORMER DEPUTY PRIME MINISTER AND CHAIRMAN OF THE LIBERAL DEMOCRATIC PARTY'S LARGEST FACTION.

08940 TAKAHASHI, $K$.

WHAT YOU WANT IS NOT ALWAYS WHAT YOU GET FROM THE U.S. JAPAN TIMES (WEEKLY INTERNATIONAL EDITION), $32(10)$ (MAR $92), 8$.

U.S. PRESIDENT BUSH AND JAPANESE PRIME MINISTER MIYAZAMA HAVE AGREED ON AN ACTION PLAN TO CORRECT THE JAPANESE-U.S. TRADE IMBALANCE. THE PLAN CALLS FOR THE AMERICANS TO EXPOR 20,000 CARS PER YEAR TO JAPAN AND FOR THE JAPANESE TO BUY $\$ 19$ BILLION WORTH OF U.S. - MADE AUTO PARTS. UNFORTUNATELY, THE NATURAL IMPULSE OF AMERICAN POLITICAL AND BUSINESS LEADERS TO DEMAND THAT JAPAN DRAMATICALLY RECTIFY THE IMBALANCE IN AUTOMOTIVE TRADE WOULD APPEAR TO OPERATE IN DIRECT DEFIANCE OF WHAT JAPANESE CONSUMERS REALLY WANT TO BUY FROM THE UNITED STATES.

08941 TAKENISHI, A.; TAKENISHI, $M$

DOES COMMITMENT AFFECT THE MEANIMG OF FAIRNESS? COMMONALITY AMD STABILITY OF FAIRNESS CRITERIA IN A POLITICAL SETTING

SOCIAL JUSTICE RESEARCH, 5(4) (DEC 92), 415-429.

THIS STUDY EXPLORED POLITICAL FAIRNESS CRITERIA IN JAPAN: EXAMINING THEIR COMMONALITY AND STABILITY. RESPONDENTS WERE DIVIDED INTO THREE GROUPS ACCORDING TO THEIR COMMITMENT TO IHE INCUMBENT GOVERNMENT, AS MEASURED BY NEUTRALITY, TRUST, THE INCUMBENT GOVERNMENT, AS MEASURED BY NEUTRALITY, TRUST, AND RESPECT. REGRESSION ANALYSES REVEALED THAT PROCEDURAL TOTAL FAIRNESS OF THE CONSUMPTION TAX. CITIZENS' COMMITMENT AFFECTED FAIRNESS CRITERIA AND THEIR RELATIVE WEIGHTS. ANOTHER REGRESSION ANALYSIS WAS PERFORMED TO EXAMINE THE MEANING OF PROCEDURAL FAIRNESS. A COMPARISON HITH A PREVIOUS STUDY (TAKENISHI AND TAKENISHI, 1990) INDICATED THAT THE PROCEDURAL FAIRNESS CRITERIA REMAINED STABLE: HOHEVER, "VOICE" BECAME A CRITERION BECAUSE OF THE GOVERMMENT'S CAMPAIGN. RESULTS SUGGESTED THAN DEMOCRATIC ETHICALITY,
WHICH CONSISTS OF SOCIAL VALUES AND BELIEFS, WAS IMPORTANT.

08942 TAKESADA, H

KOREAN REUNIFICATION IN THE POST-COLD WAR ERA: A JAPANESE PERSPECTIVE

KOREAN JOURNAL OF DEFENSE AMALYSIS, IV(2) (WIN 92), 245-258.

THE END OF THE COLD WAR HAS USHERED IN AN ERA OF CHANGE AND CONFUSION. THIS ARTICLE EXAMINES, FROM JAPAN'S

PERSPECTIVE, THE POTENTIAL FOR UNIFICATION OF THE THO KOREAS. IT ARGUES THAT SOME PROGRESS HAS BEEN MADE IN THE NORTHSOUTH DIALOGUE; TALKS HAVE BEEN HELD BETHEEN PREMIERS OF THE TWO STATES AND TRADE HAS INCREASED SIGNIFICANTLY. HOWEVER, THE COUNTRIES SURROUMDING THE KOREAS HAVE SHOWM ATTITUDES THAT ARE APPARENTLY COUNTERPRODUCTIVE TO THE ADVANCING INTERKDREAN DIALOGUE. IN PERFORMING ITS FENCE-SITTING DIPLOMACY

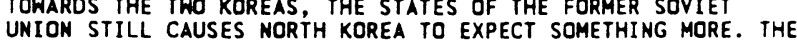
UNION STILL CAUSES NORTH KOREA TO EXPECT SOMETHING MORE. THE UNITED STATES HAS NOT BEEN QUITE SATISFIED NITH NORTH KOREA IN THEIR RELATIONS. CHINA HAS CONSIDERABLY IMPROVED ITS IN THEIR RELATIONS. CHINA HAS CONSIDERABLY IMPROVED ITS RELATIONS WITH NORTH KOREA OVER THE PAST TWO YEARS. EVEN
AFTER THE FORMAL ESTABLISHMENT OF ROK-PRC DIPLOMATIC TIES, CHINA'S POLICY TOWARDS THE KOREAN PENINSULA WILL REMAIN BASICALLY UNCHANGED. NORTH KOREA, IN TURN, HAS SHOWH EAGERNESS TO MAINTAIN ITS "JUCHE" SYSTEM, TAKING ADVANTAGE OF BEIJING'S SKILLFUL POLICY OF NON-INTERVENTION IN NORTH KOREAN INTERNAL AFFAIRS. FOR ITS PART, JAPAN CANNOT EASILY ESTABLISH FORMAL DIPLOMATIC TIES WITH NORTH KOREA BECAUSE THE NORTH-SOUTH RELATION HAS NOT SUFFICIENTLY STABILIZED.
$08943 \mathrm{TAL}, \mathrm{L}$

ON THE 8ANKS OF THE STORMY JORDAN: THE COMING MIDOLE EAST WATER CRISIS

CONTEMPORARY REVIEW, 260(1515) (APR 92), 169-174.

THE UNITED STATES HAS IDENTIFIED TEN PLACES IN THE WORLD WHERE WAR COULD BREAK OUT OVER SCARCE WATER RESOURCES. MOST WERE IN THE MIDOLE EAST WHERE WATER HAS REPLACED OIL AS THE
MOST IMPORTANT STRATEGIC RESOURCE. THIS ARTICLE EXPLORES THE REASONS WHY WATER IS SUCH A SENSITIVE ISSUE IN THE MIDDLE EAST, AS WELL AS NUMEROUS PLANS FOR THE INTEGRATED DEVELOPMENT OF THE JORDAN RIVER BASIN. IT CONCLUDES THAT UNTIL THERE IS A RESOLUTION OF THE PALESTINIAN PROBLEM AND COMPREHENSIVE PEACE TREATIES ARE SIGNED, THE WATER ISSUE WILL REMAIN A DESTABILIZING FACTOR IN MIDDLE EASTERN POLITICS.

08944 TALAVERA, A.F.

AN ILLUSION

JOURNAL OF DEMOCRACY, 3(3) (JUL 92), 111-117.

THIS ARTICLE CRITIQUES THE RECENT WRITINGS OF FRANCISCO WEFFORT AND FRANCIS FUKUYAMA ON THE FUTURE RELATIONSHIP BETWEEN CAPITALISM, SOCIALISM AND DEMOCRACY. THE AUTHOR
ARGUES THAT WEFFORT'S VISION OF A DEMOCRATIC, MARKETORIENTED SOCIALISM IS NOT DIFFERENT FROM WHAT DEMOCRATIC ORIENTED SOCIALISM IS NOT DIFFERENT FROM WHAT DEMOCRATIC COUNTRIES DEMOCRATIC SOCIALISM MIGHT MERELY MEAN A NEW TYPE OF MERCANTILISH ADVANCING UNDER THE BANNER OF EQUALITY. AS FOR FUKUYAMA'S ASSERTION THAT THE CURRENT TREND TOWARDS DEMOCRACY IS INEXORABLE AND INEVITABLE, THE AUTHOR ARGUES THAT THE ENSEMBLE OF BASIC LIBERAL DEMOCRATIC INSTITUTIONS COULD BETTER BE CONCEIVED IN KANTIAN, RATHER THAN IN HEGELIAN, TERMS. THUS THE STATE THAT EMBODIES FREEDOM SHOULD BE SEEN AS A TRANSCENDENTAL IDEAL RATHER THAN AS AN EMPIRICAL RESULT THAT HISTORY PREDICTABLY PROOUCES. THE AUTHOR CONCLUDES WITH SOME OBSERVATIONS ON THE CHILEAN TRANSITION TO OEMOCRACY. HE CONCLUDES THAT A COUNTRY'S PROSPERITY IS CLOSELY LINKED TO WIDESPREAD CONFIDENCE THAT ITS ELITES WILL MAKE RATIONAL DECISIONS. FURTHERMORE, CAPITALISM WAS NOT THE MOST IMPORTANT FACTOR IN BRINGING ABOUT CHILE'S TRANSITION TO DEMOCRACY; CULTURAL FACTORS AND POLITICAL DEVELOPMENTS AT THE NATIONAL AND INTERNATIONAL LEVELS WERE MORE IMPORTANT.

08945 TALBOTT, S.

CRY BLUES

FOREIGN AFFAIRS, 71(1) (1992), 53-69.

AT THE END OF THE GULF WAR, FOREIGN POLICY SEEMED TO BE GEORGE BUSH'S STRONG SUITE AND HIS TICKET TO REELECTION. BUT, AS EVENTS DEVELOPED IN 1992, THE ISSUES BECAME MORE AS EVENTS DEVELOPED IN 1992 , THE ISSUES
COMPLICATED AND THE OUTLOOK LESS CERTAIN.

08946 TAMARI, $S$

LEFT IN LIMBO: LENINIST HERITAGE AND ISLAMIST CHALLENGE MIDDLE EAST REPORT, 22 (6) (NOV 92) 16-21.

THE PEOPLE'S PARTY AND THE DEMOCRATIC FRONT HAVE RECONSTRUCTED THEMSELYES IN REACTIOH TO BOTH THE DEVELOPMENTS IN THE FORMER SOVIET BLOC AND THE INTIFADA. THE PREVAILING TENDENCY IN THE REFORMED PALESTINIAN LEFT IS A GLASTNOST TOWARDS ALL FORMER TABOOS. THIS ARTICLE EXPLORES CLASS, NATIONAL, AND FRONTIST POLITICS; CIVIL INTRUSIONS; THE LOSS OF A LEFT CONSENSUS; AND SOCIAL FREEDOMS. IT CONCLUDES THAT THE LEFT MUST STRUT
CULTURAL DOMAIN IN PUBLIC LIFE.

08947 TAMAS, G.M.

SOCIALISM, CAPITALISM, AND MODERNITY

JOURNAL OF DEMOCRACY, 3(3) (JUL 92), 60-74.

THIS ARTICLE ARGUES THAT THE PARALLELS BETWEEN WESTERN DEMOCRATIC AND EASTERN REVOLUTIONARY-DESPOTIC SOCIALISM ARE NUMEROUS ENOUGH TO JUSTIFY THE ASSERTION THAT SOCIALISM IS ONE OF THE MAIN STRATEGIES OF MODERNITY, INDEED, THE ONLY ONE WHICH IS (WAS) GLOBAL. FURTHERMORE, IT IS THE ONLY VARIANT OF MODERNITY THAT EAST AND WEST HAVE IN COMMON. HOWEVER, THE PUZZLE THAT THE COUNTRIES OF EASTERN EUROPE HAVE YET TO SOLVE IS WHETHER THEY WANT TO CONTINUE ON THE TRAJECTORY OF MOOERN DEVELOPMENT THAT SOCIALIST REVOLUTION AND CONOUEST STARTED, OR WHETHER THEY HANT TO TRY TO RESTORE SOME SORT OF FICTIONAL COMMUNITY ERECTED ON THE DOCTRINES OF ROUSSEAU AND DE MAISTRE. IT CONCLUDES THAT THE SITUATION IH EASTERN EUROPE HAS NOT ESSENTIALLY CHANGED SINCE THE EMERGENCE OF REVOLUTIONARY SOCIALISM. EAST EUROPEANS STILL DO NOT WANT TO ACCEPT THE "ALIENATED" INDIVIDUALISM AND DO NOT WANT TO ACCEPT THE "ALIENATED" INDIVIDUALISM AND
SOCIAL DIVERSITY OF LIBERAL CAPITALISM, BUT ARE UNHILLING TO SOCIAL DIVERSITY OF LIBERAL CAPITALISM, BUT ARE UNHILLING TO
RETURN TO THE KIND OF HARSH, TYRANMICAL, RULE THAT WOULD BE RETURN TO THE KIND OF HARSH, TYRAM

08948 TAMMERK, T.

SHAKING OFF THE SOVIET LEGACY

EAST EUROPEAN REPORTER, 5(1) (JAN 92), 40-41.

THE PROBLEM FACING ALL THREE BALTIC STATES NOW IS HOW TO TRANSLATE THE FORMAL INDEPENDENCE THEY REGAINED IN 1991 AFTER FIFTY YEARS OF SOVIET OCCUPATION INTO A DAY-TO-DAY EXISTENCE WORTHY OF THEIR HARD-WON STRUGGLE. FOR ESTONIA, 
THE MAIN DIFFICULTIES OF CEASING TO BE A COLONY ARE THREEFOLD. FIRST, THERE IS NEGOTIATING THE WITHDRAWAL OF HUGE NUMBERS OF FORMERLY SOVIET TROOPS STILL ON ESTONIAN TERRITORY, MADE MUCH HARDER BY THE VACUUM OF AUTHORITY IM THE NEW COMMONWEALTH. SECOND, THERE IS WINNING BACK FULL CONTROL OVER THE ECONOMY. THIRD, THERE IS BUILDING A UNITED, RESILIENT STATE OUT OF A NATIONALLY DIVIDED POPULATION.

08949 TAMMES, $R$.

THE UNITED STATES AND THE COLD WAR IN THE HIGH NORTH DARTMOUTH AND AD NOTAM, 1991, 384.

THIS MONOGRAPH SUMMARIZES AND SYNTHESIZES A WEALTH OF MATERIAL ABOUT THE BILATERAL SECURITY RELATIONSHIP BETWEEN

THE UNITED STATES AND ONE OF ITS SMALL ALLIES, NORWAY. IN IT, LEFT-WING CRITICS OF NORWEGIAY SECUR TY POS, NORWAY IN SOME OF THEIR SUSPICIONS CONFIRMED: THERE HAS INDEED FIMD SOME OF THEIR SUSPICIONS CONFIRMED: THERE WAS INDEED A STRONG COVERT ELEMENT OF DEFENSE COOPERATION BETWEEN THE UNITED STATES AND NORHAY AND IT DID INVDLVE NORHAY IN ELEMENTS OF U.S. STRATEGIC POLICY ONLY VERY INDIRECTLY RELATED TO THE DEFENSE OF NORHAY. ON THE OTHER HAND, THE CRITICS HAVE ERRED SIGNIFICANTLY IN THEIR BELIEF THAT THE STRATEGIC SIGNIFICANCE OF NORWAY TO U.S. INTERESTS HAS BEEN CDNSISTENTLY HIGH DURING THE POST-HAR PERIDD. AT TIMES, U.S. DECISIONMAKERS HAVE WRITTEN OFF NORWAY AS NON-DEFENDABLE, AT LEAST IN THE SHORT RUN. THE AUTHOR ALSO CONFIRMS THAT THE INTELLIGENCE RELATIONSHIP BETHEEN THE TWO COUNTRIES HAS BEEN THE MOST IMPORTANT AND CONSISTENT BILATERAL RELATIONSHIP BETWEEN THE THO COUNTRIES FOR MOST OF THE COLD WAR PERIOD.

08950 TANAKA, $N$

JAPAN MUST LEARN FROM HISTORY, ADAPT TO NEW AGE JAPAN TIMES (WEEKLY INTERNATIONAL EDITION), 32(1) (JAN 92), 9.

IN THE FUTURE, THE UNITED STATES WILL TURN INWARD AND ASSUME A SMALLER ROLE IN WORLD AFFAIRS AS IT ATTEMPTS TO DEAL WITH ITS OWN DOMESTIC PROBLEMS. MEANWHILE, JAPAN MUST TURN OUTWARD AND ASSUME A GREATER ROLE INTERNATIONALLY. JAPAN MUST LEARN FROM HISTORY AND CAREFULLY BUILD OPEN BECOMING INVOLVED IN WARS, AS THE UNITED STATES HAS.

08951 TANAKA, $R$.

AID TRAINEES FINALLY TO LEAVE NATIONALISTIC SCHOOL JAPAN TIMES (WEEKLY INTERNATIONAL EDITION), 32(10) (MAR 92), 15. GOVERNMENT-SPONSORED AGRICULTURAL AID WORKERS WILL BE PULLED OUT OF ONE OF THEIR TRAINING COLLEGES DUE TO CONTROYERSY OVER THE PRE-WWII -STYLE NATIONALISTIC INDOCTRINATION GIVEN BY THE SCHOOL. AFTER APRIL 1993, JAPAN OVERSEAS COOPERATION VOLUNTEERS WILL NO LONGER BE SENT TO A SCHOOL IN UCHIHARA THAT USES THE HINOMARU FLAG, THE KIMIGAYO NATIONAL ANTHEM, AND THE IMPERIAL RESCRIPT ON EDUCATION.

08952 TANDY, K.Q.; TANDY, A.

GOVERNMENT PERFORMANCE: DEVELOPING A QUALITY OF WORK-LIFE PROGRAM IN THE PUBLIC SECTOR

NATIONAL CIVIC REVIEW, 80(4) (FAL 91), 417-419.

THE PHRASE "QUALITY OF WORK LIFE" (QWL) IS BEING USED WITH INCREASING FREQUENCY TO DESCRIBE CERTAIN ENVIRONMENTAL AND HUMANISTIC VALUES NEGLECTED BY INDUSTRIALIZED SOCIETIES IN THE PURSUIT OF TECHNOLOGICAL ADVANCEMENT, INDUSTRIAL PROOUCTIVITY, AND ECONOMIC GROWTH. OWL PROGRAMS ENCOMPASS A WIDE VARIETY OF ORGANIZATIONAL IMPROVEMENT EFFORTS. THE COMMON ELEMENTS OF THESE PROGRAMS INCLUDE EFFORTS TO RESTRUCTURE MULTIPLE DIMENSIONS OF THE ORGANIZATION AND TO INSTITUTE A MECHANISM THAT INTROOUCES AND SUSTAINS CHANGE OYER TIME. IN PRACTICE, OWL PROGRAMS INCREASE EMPLOYEE PARTICIPATION IN A RANGE OF DECISIONS TO ENHANCE PROBLEM-
SOLVING, ENCOURAGE TEAMHORK, AND CREATE AN ATMOSPHERE OF MUTUAL RESPECT AMONG ALL EMPLOYEES.

08953 TANGRI, $R$.

THE POLITICS OF GOVERNMENT-BUSINESS RELATIONS IN GHANA JOURMAL OF MODERN AFRICAN STUDIES, 30(1) (MAR 92), 97-111.

IN 1983, GHANA'S RULING PROVISIONAL NATIONAL DEFENSE COUNCIL (PNDC) ADOPTED A FAR-REACHING ECONOMIC RECOVERY PROGRAM, INCLUDING MARKET-BASED REFORMS INTENDED TO STIMULATE DEVELOPMENT OF THE PRIVATE SECTOR AND LESSEN RELIANCE ON THE PUBLIC SECTOR. THUS FAR, THE ANTICIPATED CHANGES HAVE BEEN FAR LESS THAN EXPECTED, PARTLY BECAUSE ECONOMIC REFORMS DO NOT OPERATE IN A POLITICAL VACUUM AND PUBLIC-PRIVATE SECTOR RELATIONS ARE SHAPED BY A HOST OF DOMESTIC POLITICAL FACTORS. IN ORDER TO UNDERSTAND WHAT IS HAPPENING IN GHANA, IT IS NECESSARY TO EXAMINE THE POLITICS OF PRIVATE INVESTMENT AND THE ECONOMIC ROLE OF THE STATE UNDER THE PNDC. THE SUPPLY RESPONSES OF PRIVATE INVESTORS ARE CONDITIONED BY POLITICAL FACTORS AND THE STATE'S CHANGING DEVELOPMENTAL ROLE IS THE PRODUCT OF INTERNAL CONSTRAINTS AND CONFLICTS.

08954 TANHAM, $G$.

INDIAN STRATEGIC CULTURE

WASHI NGTON QUARTERLY, 15(1) (WIN 92), 129-146,

INDIA HAS GREAT AMBITIONS FOR A POSITION IN THE WORLD
BUT THEY HAVE NEVER BEEN CLEARLY ARTICULATED. THIS PAPER EXAMINES SOME OF THE FACTORS THAT HAVE HELPED SHAPE INDIAN STRATEGIS, BRIEFLY TOUCHES ON SOME ASPECTS OF THOSE STRATEGIES, AND EXAMINES SOME OF THE CHARACTERISTICS OF INDIAN STRATEGIC BEHAVIOR. IT CONCLUDES THAT INDIA'S STRATEGIC VISION WILL CLEARLY EXTEND FAR BEYOND THE SUBCONTINENT, BUT IT IS LIKELY TO FOCUS PRIMARILY ON THE REGION OF THE INDIAN OCEAN, ALTHOUGH NEVER COMPLETELY IGNORING WHAT IT SEES AS INDIA'S STATUS AS A WORLD NATION. THE FUTURE PROVIDES A GREAT CHALLENGE TO INDIA'S EMERGING STRATEGISTS.

08955 TANZI, $V$.

FISCAL POLICY AND ECONOMIC RECONSTRUCTION IN LATIN AMERICA WORLD DEVELOPMENT, 20(5) (MAY 92), 641-657.

THE AUTHOR SURVEYS THE FISCAL LANDSCAPE OF LATIN AMERICA, ANALYZING EXTERNAL AND DOMESTIC FACTORS THAT OVER THE YEARS ANALYZING EXTERNAL AND DOMESTIC FACTORS THAT OVER THE YEARS
HAVE LED TO THE DETERIORATION OF THE FISCAL ACCOUNTS. HE DISCUSSES THE DIFFICULTIES ENCOUNTERED IN PURSUING A SOUND FISCAL POLICY UNDER INFLATIONARY CONDITIONS. HE ALSO FISCAL POL ICY UNDER INFLATIONARY CONDITIONS. HE ALSO
EXAMINES ISSUES SUCH AS THE ROLE OF PUBLIC INVESTMENT AND THE CONNECTION BETWEEN EXTERNAL DEBT AND FISCAL POLICY. HE OFFERS GENERAL GUIDELINES FOR A FISCAL POLICY FOR THE ECONOMIC RECONSTRUCTION OF LATIN AMERICA.

08956 TAO, B.

THE KOREAN PENINSULA AND NORTHEAST ASIA

KOREA \& WORLD AFFAIRS, 16(4) (WIN 92), 685-694.

THE PAST THREE YEARS HAVE SEEN DRAMATIC INTERNATIONAL

POLITICAL CHANGES, WHICH HAVE IN TURN BEGUN TO PRODUCE

CHANGES IN INTER-KOREAN RELATIONS. IN THIS ARTICLE, THE

AUTHOR DISCUSSES THE PROSPECTS FOR A NEW ERA IN

INTERHATIONAL RELATIONS IN MORTHEAST ASIA AND THE ASIA-

PACIFIC REGION, FOCUSING ON HOW THE KOREAN COUNTRIES

INTERACT WITH THEIR NEIGHBORS.

08957 TAO, $H$.

SWEDEN'S U-TURN IN FOREIGN POLICY

BEI JING REVIEW, 35(46) (NOV 92), 15-16

IN OCTOBER 1991, SWEDEN FORMED A COALITION GOVERNMENT

WITH CARL BILDT AS PRIME MINISTER. THE COALITION HAS

REVAMPED SWEDEN'S FOREIGN POLICY BY DOWNPLAYING NEUTRALITY,

LONG A KEYSTONE OF SWEDISH INTERNATIONAL AFFAIRS, AMD

SEEKING MEMBERSHIP IN THE EUROPEAN COMMUNITY.

08958 TARAS, R.: ZERINQUE, M.

GRAND STRÁTEGY IN A POST-BIPOLAR WORLD: INTERPRETING THE

GRAND STRATEGY IN A POSI

FINAL SOVIET RESPONSE

THE FIRST OBJECTIVE OF THIS ESSAY IS TO EXPLORE THE ROLE

OF STRUCTURE AS AN INDIRECT INFLUENCE ON THE BEHAVIOUR OF

ITS CONSTITUENT ACTORS, IN THIS CASE, STATES. THE EFFECTS

ARE PRODUCED IS TWO WAYS: THROUGH SOCIALIZATION OF THE

ACTORS AND THROUGH COMPETITION AMONG THEM. EMPLOYING SYSTEMS

THEORY, THIS ESSAY SEEKS TO IDENTIFY A SOVIET GRAND STRATEGY

IN THE FINAL YEARS OF EXISTENCE IN THE USSR. IT CONSIDERS

THE ASSUMPTIONS AND LIMITIONS OF A SYSTEM APPROACH AND

CONNECTS SYSTEMS HITH GRAND STRATEGY AND LOOKS AT GRAND

STRATEGY IN A DIPLOMACY AND MILITARY DOCTRINE. IT SUGGESTS

THE MAIN CONTOURS OF A GOBACHEVIAN GRAND STRATEGY IN A POSTBIPOLAR SYSTEM.

08959 TARLETON, R.

WHAT REALLY HAPPENED TO THE STALIN LINE: PART

JOURNAL OF SOVIET MILITARY STUDIES, 5(2) (JUN 92), 187-219.

THE CONSTRUCTION, DISPOSITION, AND STRUCTURE OF THE

FRONTIER FORTIFICATIONS BUILT PRIOR TO 1939 AND THEIR ROLE

IN RED ARMY WAR PLANS DURING THE MID-TO-LATE 1930 S ARE EACH DESCRIBED IN THE FIRST PART OF THIS ARTICLE. THE SECONO PART THE STALIN LINE'S CONDITION IN MID-1941; IN ADOITION IT ANALYZES THE DECISION TO ABANDON THE ORIGINAL FORTIFICATIONS JUST AS WORK ON THOSE ON THE NEW BORDER WAS STARTING. IN REVIEWING THIS SET OF RELATED ISSUES, THE AUTHOR SEEKS TO SHED ADDITIONAL LIGHT ON STALIN'S INTENTIONS AND DECISIONS IN THE CRITICAL PERIOD BETHEEN THE OUTBREAK OF THE SECOND HORLD WAR AND THE JUNE 1941 NAZI INVASION.

08960 TARLING, $N$

AH-AH: BRITAIN AND THE BANDUNG CONFERENCE OF 1955 JOURNAL OF SOUTHEAST ASIAN STUDIES, 23(1) (MAR 92), 74-111. TO HISTORIANS OF SOUTHEAST ASIA, THE BANDUNG CONFERENCE OF 1955 IS ONE OF THE MOST STRIKING INTERNATIONAL INITIATIVES UNDERTAKEN BY NEWLY-INDEPENDENT INDONESIA, FOR HISTORIANS OF INDONESIA, IT MARKS THE EMPHASIS ON FOREIGN, AS OPPOSED TO DOMESTIC, POLICY THAT HAS ASSOCIATED WITH SUKARNO'S GROWING DOMINANCE. IO BIOGRAPHERS OF SUKARNO IT APPEARS TO BE BOTH A STRATEGIC DEVICE IN DOMESTIC POLITIICS AND A FARSIGHTED PERCEPTION OF A SHIFT IN INTERNATIONAL RELATIONS. TO STUDENTS OF INTERNATIONAL RELATIONS, IT DEMONSTRATES BOTH THE INFLUENCE AND THE LIMITS OF INDIA. MOREOVER, IT MARKS A SUCCESS FOR THE PEOPLE'S REPUBLIC OF ALREADY ASSOCIATED WITH GENEVA AND THE FIVE PRINCIPLES OF 
COEXISTENCE.

08961 TARR, G.A.

CONSTITUTIONAL THEORIES AND CONSTITUTIONAL RIGHTS: FEDERAL IST CONSIDERATIONS

PUBLIUS: THE JOURNAL OF FEDERALISM, 22(2) (SPR 92), 93-108. THIS ARTICLE EXAMINES THE CONTEMPORARY CONTROVERSY OVER CONSTITUTIONAL INTERPRETATION AND THE DIFFERIMG UNDERSTANDINGS OF CONSTITUTIONAL RIGHTS THAT UNDERLIE IT. THE AUTHOR FIRST CONSIDERS THE CHARACTER AND BASIS FOR INTERPRETIVISM, THAT IS, A JURISPRUDENCE THAT DELINEATES RIGHTS BY REFERENCE TO THE INTENT OF THE FOUNDER AND TO THE CONSTITUTIONAL TEXT. MEXT, THE AUTHOR REVIEWS THE NONINTERPRETIVIST ALTERNATIVE, FOCUSING ON RICHARD DHORKIN'S INFLUENTIAL ACCOUNT OF CONSTITUTIONAL RIGHTS. THE AUTHOR CONCLUDES THAT DESPITE ITS STRENGTHS, DHORKIN'S POSITION DOES JUSTICE NEITHER TO THE CONSTITUTIONAL TEXT NOR TO THE CONNECTION BETHEEN STRUCTURE AND RIGHTS IN THE UNITED STATES CONSTITUTION. CONSIDERING CONSTITUTIONAL THEORY FROM THE BROADER PERSPECTIVE OF STATE CONSTITUTIONALISM, THE AUTHOR CONCLUDES THAT ITS INSIGHTS ARE LIMITED TO THE U.S.

CONCLUDES THAT ITS INSIGHTS ARE LIMITED TO THE U.S. CONSTITUTIONAL THEORY.

08962 TARZI, S

AFGHANISTAN IN 1991: A GLIMMER OF HOPE

ASIAN SURVEY, XXXII(2) (FEB 92), 184-188.

WHILE THE CIVIL WAR RAGED ON IN AFGHANISTAN DURING 1991. THERE ARE SEVERAL REASONS TO HOPE THAT A END TO THE CONFLICT CAN BE FOUND SOON. THE GUERRILLA MUJAHIDEEN DEMONSTRATED A GROWING ABILITY TO FIGHT THE SOVIET-BACKED NAJIBULLAH REGIME ON A CONVENTIONAL LEVEL. HOWEVER, THE SCHISMS WITHIN THE RESISTANCE MOVEMENT HAVE, IF ANYTHING, GROWH MORE PRONOUNCED. THE MOST PROMISING SIGN IS THAT NEARLY ALL OF THE OUTSIDE FORCES WICH HAVE AN INTEREST IN THE AFGHAN CONFLICT-OTHE UNITED STATES, THE SOVIET UNION, SAUDI ARABIA, PAKISTAN, AND IRAN--ARE MOVING TOHAROS A CONSENSUS ON HOW THE CONFLICT SHOULD BE SETTLED. ESPECIALLY IMPORTANT IS THE US-SOVIET AGREEMENT TO TERMINATE THEIR SUPPLYING OF THE OPPOSING FORCES IN THE CONFLICT BY THE END OF THE YEAR. IN ADDITION, SAUDI ARABIA AND PAKISTAN ARE BOTH MOVING AWAY FROM THE MORE RADICAL DF THE MUJAHIDEEN GROUPS--MOST NOTABLY THAT OF HEKMATYAR. THE PEOPLE OF AFGHANISTAN CONTINUE TO SUFFER THE DEVASTATION OF HAR AS THE NUMBER OF REFUGEES AND CASUALTIES CONTINUES TO GROW.

08963 TASKER, R.

ASCENT OF ANGELS
FAR EASTERN ECONOMIC REVIEN, 155(38) (SEP 92), 12-13.

THE 13 SEPTEMBER THAI GENERAL ELECTION APPEARS TO HAVE

SIGNALLED A SIGNIFICANT CHANGE IN THAI POLITICS. THE OUTCOME REFLECTS THE WIDESPREAD PUBLIC AVERSION TO CONTINUED RULE BY THE THAI MILITARY, ESPECIALLY AFTER PRO-DEMOCRACY PROTESTERS WERE SHOT DOWN BY THE ARMY IN MAY. DEMOCRAT PARTY LEADER CHUAN LEEKPAI EMERGED AS THE PRIME MINISTER WITH THE SUPPORT OF A FOUR-PARTY COALITION. WITH THE DEMOCRAT PARTY AT ITS CORE, THE LOOSE PRO-DEMOCRACY COALITION SEEMS DESTINED TO TAKE OVER THE GOVERMMENT. HOWEVER, ITS MAJORITY IN PARLIAMENT IS DANGEROUSLY SMALL. THE COALITION HOPES TO CONTINUE THE ECONOMIC AND FISCAL LIBERATION BEGAN BY CARETAKER PRIME MINISTER ANAND, BUT MAY FACE DIFFICULTIES DUE TO THE FACT THAT IT MAY HAVE TO LURE ANOTHER MAJOR PARTY INTO THEIR CAMP TO ENSURE A WORKABLE PARL IAMENTARY MAJORITY.

08964 TASKER, $R$.

BAGMEN AND BRAS

FAR EASTERN ECONOMIC REVIEW, 155(30) (JUL 92) 8-9.

ANY HOPES AMONG THAIS STILL SMARTING FROM THE MAY BLOODSHED ON BANGKOK'S STREETS THAT THE 13 SEPTEMBER GENERAL ELECTION WILL MARK A NEW DEMOCRATIC DEPARTURE ARE BEING SEVERELY TESTED BY THO RECENT DEVELOPMENTS. FORMER PRIME MINISTER CHATICHAI CHOONHAVAN IS TRYING TO STAGE A COMEBACK, A DEPRESSING PRDSEPCT FOR PRO-DEMOCRATIC OPTIMISTS. AND SUPREME COMMANDER KASET ROJANMIN'S STATEMENT THAT ANOHTER MILITARY COUP AFTER THE ELECTION CANNOT BE RULED OUT CAPPED THE GENERAL FEELING THAT THE UPCOMING POLL MAY CHANGE NOTHING. CHATICHAI HAS TRIED TO PAINT HIS NEWLY CREATED CHART PATTANA PARTY AS A CENTRIST ENTITY--SITUATED BETHEEN THE OLD, PRO-MILITARY GROUPS AND THE OPPOSITION BACKED BY PRO-DEMOCRACY FORCES. BUT THE PARTY HAS MERELY PROVIDED A HAVEN FOR NUMEROUS DEFECTORS FROM PRO-MILITARY AND RIGHTWING GROUPS.

08965 TASKER, R.

BATTLE ON THE HOME FROMT

FAR EASTERN ECONOMIC REVIEH, 155(14) (APR 92), 12-13.

THE FIRST 527 THAI-BORDER CAMBODIAN REFUGEES TO BE TAKEN HOME BY THE UNITED NATIONS ON 30 MARCH ARE PROBABLY AMONC THE LUCKY ONES AT THE START OF A RUSHED PROGRAM WHICH AT BEST WILL BE A HAZARDOUS OPERATION. IRONICALLY, WHILE THEY WERE SUPPOSED TO BE VISIBLE SYMBOLS OF A UN-SPONSORED PEACE PROCESS IN THEIR COUNTRY, THEY RETURNED AS HOSTILITIES BETWEEN GOVERNMENT TROOPS AND KHMER ROUGE FORCES ESCALATED
THE UN IN ITS PROGRAM TO REPATRIATE ALL 370,000 REFUGEES BY THE END OF THE YEAR ARE: AYAILABILITY OF HABITABLE LAND, GIVEN THE FACT THAT MOST OF THE VACANT TRACTS ARE STILL STREWN WITH LANDMINES, AND THAT POTABLE WATER AND ACCESS ROADS ARE IN SHORT SUPPLY; COPING HITH THE RETURNEES MEDICAL
PROBLEMS, PARTICULARLY DRUG-RESISTANT MALARIA; AND GETTING PROBLEMS, PARTICULARLY DRUG-RESISTANT MALARIA; AND GETTING
ENOUGH DONATIONS TO SUPPORT THE USS116 MILLION PROGRAM, FOR WHICH ONLY ABOUT HALF HAS SO FAR BEEN PLEDGED.

08966 TASKER, $R$. COSY COMPROMISE

FAR EASTERN ECONOMIC REVIEH, 151(27) (JUL 91), 13.

AFTER TWO DAYS OF HISTORIC TALKS AMONG THE FOUR WARRING CAMBODIAN FACTIONS, MEETING FOR THE FIRST TIME AS A SUPREME NATIONAL COUNCIL (SNC), AN AGREEMENT WAS REACHED DECLARING AN UNLIMITED CEASEFIRE, A CUT-OFF OF ALL FOREIGN MILITARY SUPPLIES, AND A COMPLEX ARRANGEMENT ALLOWING THE SMC TO ESTABLISH A PERMANENT SEAT AS A "SUPER GOVERNMENT" IN PHNOM PENH. THE AGREEMENT APPEARED TO REFLECT A COMPROMISE BETWEEN PENH. THE AGREEMENT APPEARED TO REFLECT A COMPROMISE BETH
NORODOM SIHANOUK, AS THE NOMINAL HEAD OF THE TRIPARITE NORODOM SIHANOUK, AS THE NOMINAL HEAD OF THE TRIPARITE
RESISTANCE, AND THE VIETNAM-BACKED PNONH PENH REGIME OF RESISTANCE, AND THE VIETNAM-BACKED PNOMH PENH REGIME OF
PRIME MINISTER HUN SEN. THE KHMER ROUGE, A MEMBER OF THE PRIME MINISTER HUN SEN. THE KHMER ROUGE, A MEMBER OF THE
RESISTANCE COALITION, APPROVED THE AGREEMENT WITH RELUCTANCE. RESISTANCE COALITION, APPROVED THE AGREEMENT WITH RELUCTANCE
GROWING INTERNATIONAL PRESSURE FROM ALL MEMBERS OF THE UN SECURITY COUNCIL, INCLUDING ERSTWHILE KHMER ROUGE ALLY CHINA, IS THOUGHT TO HAY CHAMGE OF HEART.

08967 TASKER, R.

FACING UP TO SECURITY

FAR EASTERN ECONOMIC REVIEH, 155(31) (AUG 92), 8-9.

THE NEW MOOD OF THE ASSOCIATION OF SOUTH EAST ASIAN NATIONS (ASEAN) HAS MANIFESTED IN ITS ANNUAL FOREIGN MINISTERS' MEETING AND SUBSEQUENT TALKS WITH REGIONAL AND GLOBAL POWERS INCLUDING THE UNITED STATES, THE EUROPEAN COMMUNITY, JAPAN, RUSSIA, CHINA, AMD VIETHAM. WITH VIETNAM'S OCCUPATION OF CAMBODIA GONE AS A POLITICALLY UNIFYING FACTOR FOR THE BLOC, THE ASEAN MEETING FOCUSED TO AN UNPRECEDENTED EXTENT ON SECURITY IN THE SOUTH CHINA SEA, PARTICULARLY HITH REGARDS TO TERRITORIAL DISPUTES OVER THE SPRATLY ISLANDS. FOR THE FIRST TIME ALL SIX MEMBERS OPENLY CALLED ON THE UNITED STATES TO MAINTAIN A COMFORT ING MILITARY BALANCE IN ONLY REMAINING SUPERPOWER--WILL BE ABLE TO DEFUSE ANY POTENTIAL CONFLICT OVER THE POTENTIALLY OIL-RICH ISLAMDS, SOME OF WHICH ARE COVETED BY CHINA, VIETNAM, THE PHILIPPINES, MALAYSIA, AND BRUNEI. LEADERS OF ASEAN NATIONS WERE HAPPY MALAYSIA, AND BRUNEI. LEADERS OF ASEAN NATIONS WERE HAPPY
TO SEE THE HIGH DEGREE OF COOPERATION ON SECURITY ISSUES, TO SEE THE HIGH DEGREE OF COOPERATION ON SECURITY ISSUES,
BUT THEY ARE CONCERNED THAT THE GROUPING'S DYNAMIC RECORD OF BUT THEY ARE CONCERNED THAT THE GROUPING'S DYNAMIC RECORD OF
SUSTAINED ECONOMIC GROWTH OVER THE PAST DECADE IS PROVING A SUSTAINED ECONOMIC GROWTH OVER THE PAST DECADE IS PROVI
WORRIESOME FACTOR IN ITS DEALINGS WITH ITS WESTERN AND WORRIESOME FACTOR
REGIONAL ALLIES

08968 TASKER, R.; HANDLEY, P.

SACRED AND PROFANE
FAR EASTERN ECONOMIC REVIEN, 151(27) (JUL 91), 21-22.

BUDDHISH IN THAILAND IS UNDERGOING SUBTLE AND IMPORTANT CHANGES, BROUGHT ON LARGELY BY THE FAST-PACED ECONOMIC AND WESTERN-STYLE SOCIAL SHIFTS WHICH ARE ERODING TRADITIONAL SPIRITUAL AND CULTURAL MORES. THE CHANGES ARE PRIMARILY AN URBAN PHENOMENON, LEAVING THE STRONG TRADITIONAL ROLE OF MAINSTREAM RELIGION IN THE RURAL AREAS LARGELY UNAFFECTED. HOWEVER, WITH RAPID URBANIZATION AND THE SPREAD OF THE MASS UNLIKELY TO REMAIN ISOLATED FROM THESE TRENDS MUCH LONGER. THE INCREASINGLY VARIED, CONFUSING, AND OFTEN NEGATIVE ASPECTS OF BUDDHISM, THE "THIRD" PILLAR OF THAILAND'S STABILITY, ARE ERODING NATIONAL UNITY.

08969 TASKER, R.; HANDLEY, P.

SLOW AHEAD

FAR EASTERN ECONOMIC REVIEW, 151(29) (JUL 91), 31.

THAILAND'S POLITICAL AND ECONOMIC DEYELOPMENT REMAINS FULL OF AMOMALIES. DEMOCRACY IS THE GROWING CRY OF POLITICIANS, BUSINESSMEN AND EVEN MILITARY LEADERS, AS WELL AS THE ELECTORATE WHICH HAS TASTED A NEW DEGREE OF PLURALITY. YET THE COUNTRY IS PASSING THROUGH A TUNNEL IN WHICH THE MILITARY HOLD THE POLITICAL REINS OF POWER, WITH AN APPOINTED GOVERNMENT, AT LEAST NOMINALLY DOING THEIR BIDDING. THE COUNTRY'S CONTINUING ECONOMIC SUCCESS STORY IS THE ENVY OF HER NEIGHBORS, BUT THERE IS A DEPRESSING LOGJAH OF AFFORDABLE PROJECTS TO IMPROVE CREAKING INFRASTRUCTURE AND AFFDRDABLE PROJECTS TO IMPROVE CREAKING INFRASTRUCTURE
KEEP BANGKOK FROM TOTAL CHAOS. WHILE DEVELOPMENT--AND KEEP BANGKOK FROM TOTAL CHAOS. HHILE DEVELOPMENT--AND
PROSPERITY--ARE UNEVENLY SPREAD OVER THE COUNTRY, THE PROSPERITY--ARE UNEVENLY SPREAD OVER THE COUNTRY, THE
ECONOMY HAS CONTINUED TO SURGE AHEAD. HOWEVER, POLITICAL UNCERTAINTIES AND CORRUPTION PROVIDE CONTRADICTIONS WHICH UNCERTAINTIES AND CORRUPTION

08970 TASKER, R.; HANDLEY, P.

THE GOOO NEIGHBORS

FAR EASTERN ECONOMIC REVIEH, 151(29) (JUL 91), 36-42. WHILE THAILAND'S DOMESTIC POLITICAL SITUATION HAS CHANGED ORASTICALLY SINCE THE 23 FEBRUARY MILITARY COUP, THE THRUST OF ITS FOREIGN POLICY TOWARDS ITS NEIGHBORS HAS 
ALTERED ONLY SLIGHTLY UNDER THE NEW REGIME. OUSTED PRIME MINISTER CHATICHAI CHOONHAVAN'S POLICY OF TURNING INDOCHINA FROM "A BATTLEFIELD INTO A MARKETPLACE" REMAINS THE CORNERSTONE OF BANGKOK'S ATTITUDE TOWARDS INDOCHINA. NEW THAI FOREIGN MINISTER, ARSA SARASIN, HAS SUBTLY CORRECTED WHAT THE MILITARY CONSIDERED TO BE UNJUSTIFIED FAVORITISM TOWARDS VIETHAM. HOWEVER, THAILAND CONTINUES TO PROMOTE THE IDEA OF BANGKOK FUNCTIONING AS THE REGIONAL HUB FOR THOSE WANTING TO DO BUSINESS WITH INDOCHINA, AND HAS KEPT THE CHANNELS OPEN FOR THAI BUSINESSMEN TO BE AMONG THE FIRST TO
BENEFIT FROM OPENING DOORS IN VIETNAM, CAMBOOIA, AND LAOS.

08971 TASKER, $R$.

THE RINGMASTER RETURNS

FAR EASTERN ECONOMIC REVIEW, 155(25) (JUN 92), 8-9.

SHORTLY BEFORE THAI PRIME MINISTER-SELECT SOMBOON RAHONG WAS TO HAVE BEEN APPOINTED, THE MILITARY ESTABLISHMENT FIGURE'S NAME WAS REPLACED WITH THAT OF DIPLOMAT AND BUSINESSMAN ANAND PANYARACHUN. ANAND ENJOYS A WIDE DEGREE OF POPULAR ACCLAIM, BUT HE WILL HAVE HUGE, PERHAPS

INSURMOUNTABLE POLITICAL TASKS ON HIS HANDS DURING HIS BRIEF, SECOND-TIME PREMIERSHIP. HE WILL FUNCTION CHIEFLY AS AN ARBITER IN THE ELEMENTAL STRUGGLE BETWEEN THE FORCES OF OLD MILITARY ORDER AND NEW DEMOCRATIC ASPIRATIONS. THERE IS MUCH LEGAL SPECUALTION OVER HOW LONG ANAND WILL REMAIN IN POWER, DESPITE HIS STATEMENT THAT THE PERIOO WILL BE LIMITED TO THREE OR FOUR MONTHS. ONE MAJOR HURDLE WILL BE THE FACT THAT HE HAS TO SUBMIT CONSTITUTIONAL AMMENDMENTS TO THE KING WITHIN ONE MONTH OF HIS APPOINTMENT. IN THE CURRENT SITUATION, THERE ARE MANY THAIS WHO WOULD LIKE ANAND TO REMAIN IN POWER FOR AS LONG AS POSSIBLE. BUT IT IS UNLIKELY THAT HE WILL RISK POLITICAL CRITICISM BY EXTENDING HIS STAY BEYOND THE CONSTITUTIONAL LIMIT.

08972 TATE, $K$.

BLACK POLITICAL PARTICIPATION IN THE 1984 AND 1988 PRESIDENTIAL ELECTIONS

AMERICAN POLITICAL SCIENCE REVIEN, 85(4) (DEC 91), 1159-1176.

USING DATA FROM A LONGITUDINAL TELEPHONE SURVEY OF VOTING-ELIGIBLE BLACK AMERICANS, THE AUTHOR EXPLORES THE POLITICAL CONTEXT OF BLACK VOTER TURNOUT IN THE 1984 AND 1988 PRESIDENTIAL ELECTIONS AND REEXAMINES THE ATTITUDINAL AND DEMOGRAPHIC VARIABLES ASSOCIATED WITH BLACK ELECTORAL PARTICIPATION. JESSE JACKSON SUPPORTERS WERE MORE LIKELY TO VOTE IN THE 1984 PRESIDENTIAL ELECTION, AND BLACK OPPOSITION TO REAGAN WAS ALSO LINKED TO BLACK TURNOUT IN 1984. BUT BLACKS WHO PREFERRED JACKSON TO OTHER PRIMARY CONTENDERS IN THE 1988 PRIMARIES WERE LESS LIKELY TO VOTE IN THAT PRESIDENTIAL ELECTION. WHILE EDUCATION, POLITICAL INTEREST, PARTISANSHIP, AND AGE WERE GENERALLY ASSOCIATED WITH BLACK VOTER PARTICIPATION IN 1984 AND 1988, RACE IDENTIFICATION HAD A LESS CONSISTENT EFFECT. CHURCH MEMBERSHIP AND INVOLVEMENT IN BLACK POL ITICAL ORGANIZATIONS ARE COMMUNITYBASED ACTIVITIES THAT PROMOTE BLACK PARTICIPATION. THIS RESEARCH UNDERSCORES THE IMPORTANCE OF BOTH POLITICAL CONTEXT AND GROUP-BASED POLITICAL RESOURCES IN STIMULATING THE BLACK VOTE.

08973 TATE, $N$.

THE DEVELOPMENT OF COMPARATIVE JUDICIAL POLITICS PERSPECTIVES ON POLITICAL SCIENCE, 21(3) (SUM 92), 138-144. BOTH COMPARATIVE AND JUDICIAL POLITICS SCHOLARS WOULD BENEFIT BY INTEGRATING THE STUDY OF THE THO DISCIPLINES. THE FORMER WOULD BENEFIT BECAUSE THEY HAVE PERISTENTLY FAILED TO TREAT COURTS AS POLITICAL INSTITUTIONS HORTHY OF THE KIND OF TREAT COURTS AS POLITICAL INSTI TUTIONS HORTHY OF THE KIND OF BECAUSE THEY TOO OFTEN HAVE FAILED TO PUT COURTS INTO THE BECAUSE THEY TOO OFTEN HAVE FAILED TO PUT COURTS IN
COMPARATIVE POLITICAL CONTEXT THAT IS ESSENTIAL FOR COMPARATIVE POL ITICAL CONTEXT THAT IS ESSENTIAL FOR
DEVELOPING BROAD GENERALIZATIONS ABDUT COURTS, THEIR DEVELOPING BROAD GENERALIZATIONS ABDUT COURTS, THEIR
OPERATION, AND THEIR POLITICAL AND POLICY SIGNIFICANCE IN OPERATION, AND THEIR POLITICAL AND POLICY SIGNIFICANCE
SOCIETIES. THIS ARTICLE DISCUSSES THE DEVELOPMENT OF SOCIETIES. THIS ARTICLE DISCUSSES
CDMPARATIVE JUDICIAL POLITICS.

08974 TAXIN, G.P.

THE EIGHTH AMENDMENT IN SECTION 1983 CASES: HUDSON $V$. MCMILLAN HARVARD JOURNAL OF LAW AND PUBLIC POLICY, 15(3) (SUM 92), $1050-1060$.

IN HUDSON V. MCMILLAN, THE U.S. SUPREME COURT HELD THAT A PRISON GUARD VIOLATES THE EIGHTH AMENDMENT RIGHTS OF AM INMATE IF THE GUARD EXERTS FORCE "MALICIOUSLY AND SADISTICALLY TO CAUSE HARM, "EVEN IF THE INMATE IS NOT SERIOUSLY IN JURED. THIS EXCESSIVE FORCE TEST DIFFERS FROM THE TESTS EMPLOYED BY THE COURT IN OTHER PRISON CONDITION CASES IN TWO RESPECTS: THERE IS NO PREREQUISITE OF SERIOUS DEPRIVATION AND THE SUBJECTIVE COMPONENT--REQUIRING SADISTIC AND MALICIOUS INTENT RATHER THAN MERE INDIFFERENCE--IS HEIGHTENED. THIS DECISION CONSTITUTIONALLY SHIELDS INMATES FROM MINOR INJURIES AND, IN SO DOING, GREATLY EXPANDS THE SCOPE OF THE EIGHTH AMENDMENT.

08975 TAYLOR-HENLEY, S.; HUDSON, $P$

ABORIGINAL SELF-GOVERMMENT AND SOCIAL SERVICES: FIRST
NATIONS--PROVINCIAL RELATIONSHIPS CANADIAN PUBLIC POLICY--ANALYSE DE POLITIQUES, 188(1) (MAR $92), 13-26$.

RECEMT CHANGES IN THE CONTROL OF SOCIAL HELFARE SERVICES TO INDIAN PEOPLES ARE USED BY THIS PAPER IN A CASE STUDY APPROACH; MAMELY CHILD AND FAMILY SERVICES DELIVERED IN NORTHERN MANITOBA. THE AUTHORS IDENTIFY FOUR MODELS OF CONTROL AND FIND THE AMBIGUITY AND CONFUSION IN ROLES AND RELATIONSHIPS ARE INHERENT IN THE MANITOBA MODEL. SINCE THIS MODEL IS REPLICATED IN SEVERAL OTHER PROVINCES THIS IS SEEN AS A NATIONAL ISSUE. THE NEED FOR A PROVINCIAL POLICY WHIC ENDORSES INDIAN ASPIRATIONS FOR FULL CONTROL IS ARGUE
TOGETHER WITH ACTIVE ASSISTANCE IN IMPLEMENTATION.

08976 TAYLOR, A.

UAE AMD IRAN--IRREPARABLE DAMAGE?

MIDDLE EAST INTERMATIONAL, (434) (SEP 92), 12-13.

THE UNITED ARAB EMIRATES (UAE) WISHES TO MAINIAIN

RELATIONS WITH IRAN BUT WILL USE "ALL POSSIBLE MEANS" TO WIN BACK THREE STRATEGIC GULF ISLANDS RECENTLY OCCUPIED BY IRAN. BOTH COUNTRIES CLAIM TO HAVE DOCUMENTS WHICH PROVE THEIR OWNERSHIP OF THE ISLANDS AND THE UAE HAS CALLED FOR IRAN TO PRESENT THEM TO AN INTERNATIONAL FORUM RATHER THAN CLAIMING SOVEREIGNTY BY OCCUPATION. OPINIONS ARE DIVIDED ON THE PURPOSE OF IRAN'S ACTIONS. SOME SAY THAT IRAN SEIZED THE ISLANDS TO FORCE ITS GULF NEIGHBORS TO CUT OIL PRODUCTION, OTHERS FEEL THE ACTION WAS TAKEN PURELY FOR TERRITORIAL PURPOSES. ALTHOUGH THE IRANIAN GOVERMMENT HAS SAID IT WANTS TO RESOLVE THIS "MINOR ISSUE" IN A FRIENOLY ATMOSPHERE, THE WHOLE INCIDENT HAS ALL BUT DESTROYED THE GOODHILL IRAN HAD BUILT UP WITH THE GULF STATES SINCE IT CONDEMNED IRAQ'S INVASION OF KUWAIT. MANY ARAB STATES HAVE ALIGNED WITH THE UAE AND HAVE AFFIRMED THE UAE'S SOVEREIGNTY OVER ABU MUSA AND THE STRATEGICALLY PLACED GREATER AND LESSER TUNB.

08977 TAYLOR, A.J.

ISSUE NETHORKS AND THE RESTRUCTURING OF THE BRITISH AND WEST GERMAN COAL INDUSTRIES IN THE 1980'S

PUBLIC ADMINISTRATION (LONDON), 70(1) (SPR 92), 47-65. PUBLIC ADMINISTRATION (LONDON), 70 (1) (SPR 92), $47-65$.
THE AUTHOR USES POLICY NETWORK THEORY TO COMPARE THE POLITICS OF THE BRITISH AND WEST GERMAN COAL INDUSTRIES IN THE 1980'S. HE CONSIDERS THE REASONS WHY POL ICY IN BRITAIN WAS DIRECTED AT RESTRUCTURING AND IN WEST GERMANY A PRESERVING THE INDUSTRY'S EXISTING STRUCTURE. HE FOCUSES ON THE OYNAMICS OF NETWORK STABILITY AND CHANGE AND THE GROWING IMPORTANCE OF THE INTERNATIONAL DIMENSION IN DOMESTIC POLICY MAKING, A FACTOR OVERLOOKED BY NET WORK THEORY. HE CONTR AVOWEDLY COMMITTED TO FREE MARKETS, PURSUED VERY DIFFERENT POLICIES IN THE COAL INDUSTRY.

08978 TAYLOR, C.; GUTMANN, A.; ROCKEFELLER, S.C.; HALZER, M.; HOLF, S.

MULTICULITURALISM AND "THE POLITICS OF RECOGNITION" PRINCETON UNIVERSITY PRESS, 1992, 128.

CAN A DEMOCRATIC SOCIETY TREAT ALL ITS MEMBERS AS EQUALS AND ALSO RECOGNIZE THEIR SPECIFIC CULTURAL IDENTITIES? SHOULD IT TRY TO ENSURE THE SURVIVAL OF SPECIFIC CULTURAL GROUPS? IS POLITICAL RECOGNITION OF ETHNICITY OR GENDER ESSENTIAL TO A PERSON'S DIGNITY? THESE ARE SOME OF THE QUESTIONS AT THE HEART OF THE POLITICAL CONTROVERSY OVER MULTICULTURALISM AND RECOGNITION. THIS BOOK OFFERS AN ESSAY ON THIS SUBJECT WHICH SERVES AS A POINT OF DEPARTURE FOR COMMENTARY BY OTHER THINKERS. THE ESSAY COMPARES TWO COMPETING FORMS OF GOVERMMENT: ONE THAT PROTECTS NO PARTICULAR CULTURE BUT ENSURES THE RIGHTS AND WELFARE OF ALL ITS CITIZENS, AND ONE THAT NUTURES A PARTICULAR CULTURE YET PROTECTS THE BASIC RIGHTS AND WELFARE OF NONCONFORMING CITIZENS. THE COMMENTARIES FOCUS ON VARIOUS ASPECTS OF THIS ISSUE INCLUDING EDUCATION, SPEECH, FOREIGN CULTURES, AND A CULTURALLY NEUTRAL POLITICS.

08979 TAYLOR, $D$.

PAYLOR, D. ELECTIONS, AND DEMOCRACY IN PAKISTAM

JOURNAL OF CDMMONWEALTH AND COMPARATIVE POLITICS, 30(1)

(MAR 92), 96-115.

ALTHOUGH PAKISTAN HAS HAD FOUR NATIONAL ELECTIONS IN SIX

YEARS, THESE HAVE TAKEN PLACE AGAINST A BACKGROUND OF

PERVASIVE VIOLENCE AND A LACK OF COMMITMENT BY THE ELITE TO

THE SURVIVAL OF THE DEMOCRATIC PROCESS. THE INABLILITY OF THE POLITICAL SYSTEM TO PRODUCE A STABLE, DEMOCRATIC GOVERNMENT IS INDICATIVE OF AN UNDERLYING MALAISE. THE AUTHOR SUGGESTS THAT ANY PARTY-BASED GOVERNMENT IN PAKISTAN IS LIKELY TO BE CAUGHT BETHEEN THE POWERS OF LOCALIZED FACTIONS ON ONE HAND AND THE CONTROLLERS OF THE STATE

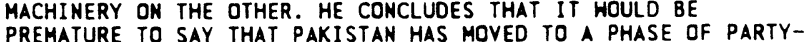
PREMATURE TO SAY THAT PAKISTAN HAS MOVED TO A PHASE OF PARTY ESTABLISHED TO BOLSTER A GOVERMMENT WITH A COHERENT PROGRAM OF ECONOMIC AND SOCIAL CHANGE.

08980 TAYLOR, D.W. AN INTERPRETIVE UNDERSTANDING OF THE IMPROVEMENT OF BUSINESS-GOVERNMENT RELATIONS 
CANADIAN PUBLIC ADMINISTRATION, 35(2) (SUM 92) 250-257. IM 1984, A SURVEY REVEALED THAT THERE WERE EXPLICIT DIFFERENCES IN OPINION BETWEEN BUSINESS AND GOVERNMENT LEADERS ABOUT THE GENERAL STATE OF THE BUSINESS-GOVERNMENT RELATIONSHIP IN CANADA. IN 1988, THIS RESEARCH HAS REPLICATED. THIS ESSAY REPORTS THE NEW SURVEY RESULTS REGARDING TWO QUESTIONS: RESPONDENT PERCEPTIONS OF THE STATUS OF BUSINESS-GOVERMMENT RELATIONS IN CANADA IN 1988 AND THE REASONS FOR ANY CHANGE IN THESE PERCEPTIONS SINCE 1984.

08981 TAYLOR, J.8.

THE SUPREME COURT AND POLITICAL ERAS: A PERSPECTIVE ON JUDICIAL POWER IN A DEMOCRATIC POLITY

REVIEW OF POLITICS, 54(3) (SUM 92), 345-368.

U.S. POLITICAL HISTORY IS OFTEN CONCEIVED AS A SERIES OF STABLE ERAS, CONTROLLED BY DOMINANT PARTY COALITIONS AND DEMARCATED BY REALIGNING ELECTIONS, MOST OFTEN IDENTIFIED AS THOSE OF 1828, 1860, 1896, AND 1932. SINCE THERE IS A LAG IN THE CORRESPONDING RECONSTITUTION OF THE SUPREME COURT, IT IS OFTEN DEEMED A COUNTER-MAJORITARIAN DRAG ON THE WORKINGS OF OFTEN DEEMED A COUNTER-MAJORITARIAN DRAG ON THE WORKINGS OF
ELECTORAL DEMOCRACY. AN EXAMINATION OF JUDICIAL REVIEN IN ELECTORAL DEMOCRACY. AN EXAMINATION OF JUDICIAL REVIEN IN
RELATION TO POLITICAL ERAS SHOWS THAT VIEN TO BE CORRECT ONLY IN THE NEW DEAL ERA. JUDICIAL REVIEW MOST COMMONLY OCCURS WITHIN ERAS RATHER THAN ACROSS THEM, WITH A RECONSTITUTED BY THE PREVAILING CDALITION NEGATING

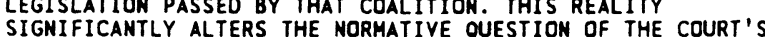
SIGNIFICANTLY ALTERS THE NORMATIVE QUESTION OF THE COURT ROLE IN A DEMOCRACY, AND IT RAISES QUESTIONS ABOUT THE CONCEPT OF STABLE ERAS. THE CURRENT TREND OF POLITICAL PARTY DEALIGNMENT CALLS INTO QUESTION
THE CRITICAL-ELECTIONS APPROACH.

08982 TAYLOR, M.

FORMAL VERSUS INFORMAL INCENTIVE STRUCTURES AND LEGISLATOR BEHAVIOR: EVIDENCE FROM COSTA RICA

THE JOURNAL OF POLITICS, 54(4) (NOV 92), 1054-1073.

THIS STUDY INVESTIGATES WHY LEGISLATORS PERFORM

CONSTITUENCY SERVICE IN A POLITICAL SYSTEM WHERE SUCH BEHAVIOR WOULD NOT BE PREDICTED BECAUSE OF A FORMAL ELECTORAL STRUCTURE THAT PROHIBITS REELECTION AND CHOOSES LEGISLATORS THROUGH PROPORTIONAL REPRESENTATION. IN COSTA RICA, PARTIES HAVE BEEN ABLE TO CAPITALIZE ON THE LIMITATIONS PLACED ON LEGISLATOR REELECTION AND USE IT TO THEIR ADVANTAGE FOR INDUCING REPRESENTATVIES TO ENGAGE IN CONSTITUENCY SERVICE. BECAUSE LEGISLATORS CANMOT BE REELECTED, IF THEY HANT TO PURSUE A FURTHER CAREER IN REELECTED, IF THEY WANT TO PURSUE A FURTHER CAREER IN
POLITICS THEY CURRY THE FAYOR OF THEIR PARTY. PART OF POLITICS THEY CURRY THE FAVOR OF THEIR PARTY. PART OF
EARNING PARTY FAVOR IS DELIVERING CONSTITUENCY SERVICE AND EARNING PARTY FAVOR IS DELIVE
PORK TO THEIR CONSTITUENTS.

08983 TAYLOR, P.

DOWN NEGOTIATION ROAD

NATIONAL REYIEH, XLIV (7) (APR 92), 22-24.

PRESIDENT F, H. DE KLERK'S CONYINCING WIN IN THE SOUTH AFRICAN REFERENDUM IS A RARE PIECE OF GDOD NEWS FOR THE COUNTRY. THE 2 TO 1 MARGIN OF VICTORY WAS GREATER THAN MOST PUNDITS HAD PREDICTED, AND IT LEAVES THE ROAD TO NEGOTIATED SETTLEMENT HIDE OPEN. YET THE RESULT RAISES THE QUESTION OF WHETHER THE VANQUI SHED RIGHT WING WILL NOH RESORT TO VIOLENCE IN ORDER TO SABOTAGE THE CONSTITUTIONAL TALKS AT THE COVENTION FOR A DEMCORATIC SOUTH AFRICA.

08984 TAYLOR, $P$.

IMPROVING POLITICAL DISCOURSE: A FIVE-MIMUTE FIX JOURNAL OF LAW \& POLITICS, VIII(2) (WIN 92), 283-290. THE PUBL IC NEEDS MORE POL ITICAL COMMUNICATION WITH PRESIDENTIAL CANDIDATES. HHAT IS NEEDED IS A NEW FORUM FOR COMMUNICATION ON TELEVISION-OONE THAT WOULD COMPETE HITH THE 30-SECDND SPOTS AND THE NINE-SECOND NEWS BITES, BUT IN A FORMAT PARTIAL TO WORDS OVER IMAGES, REASON OVER DEMAGOGUERY, AND SUBSTANCE OVER TRIVIA. SPECIFICALLY, EACH MAJOR CANDIDATE FOR PRESIDENT SHOULD BE GIVEN FIVE MINUTES OF FREE TIME ON ALTERNATING NIGHTS SIMULTAMEOUSLY ON EVERY TELEVISON AND RADIO STATION IN THE COUNTRY FOR THE FINAL FIVE WEEKS OF THE CAMPAIGN. IN RETURN FOR THE GRANT OF FREE TIME, EACH CANDIDATE WOULD AGREE TO ONE SIMPLE FORMAT RESTRICTION: HE OR SHE (OR HIS OR HER RUNNING MATE) WOULD HAVE TO APPEAR ON THE AIR FOR THE ENTIRE FIVE MINUTES--JUST THE CANDIDATE, TALKING INTO THE CAMERA, COMMUNICATING WITH THE VOTERS.

08985 TAYLOR, R.

THE ROAD TO RIO

EUROPE, (317) (JUN 92) 12-13

FOR MOST OF THE OELÉGATES AND OBSERVERS FROM 150 MATIONS WHO ARE GATHERING IN RIO DE JANERIO, THE UNITED NATIONS CONFERENCE ON ENVIRONMENT AND DEVELOPMENT IS THE SEMINAL MOMENT OF WHAT HAS BECOME THE CENTURY OF ENVIRONMENTAL AWARENESS. IF THE THO WEEKS IN BRAZIL GO AS PLANNED, WHAT IS TO EMERGE IS NOTHING LESS THAN A 21ST CENTURY CHARTER FOR ACCOMMODATING THE CONFLICTING DEMANDS THAT HUMAN ACTIVITY PLACES ON AN INCREASINGLY FRAGILE PLANET. HOWEVER, THE RETICENCE OF THE UNITED STATES TO SUPPORT MANY OF THE MORE FAR-REACHING PROPOSALS THREATENS TO DERAIL THE MOVE TOWARDS
GLOBAL COOPERATION ON THE ENVIRONMENT. PRESIDENT GEORGE BUSH IS SCHEDULED TO ATTEND THE SUMMIT FOR ONE OR TWO DAYS, BUT HAS REPEATEDLY STRESSED THE NEED FOR PROTECTIVE MEASURES
WHICH DO NOT CONFLICT WITH THE DEMANDS FOR ECONOMIC GROWTH

08986 TAYLOR, H.; MAZARR, M.

US-KOREAN SECURITY RELATIONS: POST-REUNIFICATION

KOREAN JOURMAL OF DEFENSE ANALYSIS, IV(1) (SUM 92), 147-166.

THIS PAPER EXAMINES THE FUTURE OF KOREA AND ITS SECURITY RELATIONS WITH THE UNITED STATES. UNIFICATION, IT CONTENDS, MAY BE APPROACHING FASTER THAN MANY HAVE BELIEVED. THIS PAPER EXAMINES THE TRANSITION, AND THE SECURITY ENVIRONMENT IN WHICH A UNIFIED KOREA WOULD FIND ITSELF, AND SKETCHES OUT A NUMBER OF POTENTIAL STRATEGIES BY WHICH KOREA COULD GUARANTEE ITS SECURITY. IT CONCLUDES THAT A UNIFIED KOREA WILL PROBABLY CONTINUE TO PREFER A SECURITY RELATIONSHIP WITH THE UNITED STATES TO ANY OTHER ULTIMATE SECURITY GUARANTEE.

08987 TAYLOR, W.L.; LISS, S.M. AFFIRMATIVE ACTION IN THE 1990'S: STAYING THE COURSE ANMALS OF THE AMERICAN ACADEMY OF POLITICAL AND SOCIAL SCIENCE, (523) (SEP 92 ), 30-37.

THE PHRASE "AFFIRMATIVE ACTION," hHILE CAPABLE OF FAIRLY MARROW DEFINITION, ALSO SERVES AS THE LINE THAT DIVIDES NARROW DEFINITION, ALSO SERVES AS THE LINE THAT DIVIDES
PEOPLE WHO HAVE STARKLY DIFFERENT VIENS ON ONE OF THE UNITED PEOPLE, WHO HAVE STARKLY DIFFERENT VIENS ON ONE OF THE UNITED PEOPLE OF COLOR. A CRITICAL OUESTION IS WHETHER AFFIRMATIVE PEOPLE OF COLOR. A CRITICAL QUESTION IS WHETHER AFFIRMATIVE ACTION POLICIES ARE EFFECTIVE--THAT IS, WHETHER THEY WORK IN CONJUNCTION WITH OTHER POL ICIES TO PROVIDE OPPORTUNITIES
EDUCATION AND ECONOMIC ADVANCEMENT THAT WERE PREVIOUSLY UNAVAILABLE. DATA DEMONSTRATE THE EFFECTIVENESS OF THESE POLICIES IN ENHANCING THE ECONOMIC STATUS OF MINORITIES. THE LEGAL STANDARDS GOVERNING AFFIRMATIVE ACTION DEMONSTRATE AN EFFORT TO BALANCE COMPETING INTERESTS IN ORDER TO MEET A TEST OF PRACTICAL FAIRNESS TO ALL PARTIES. HOWEVER, WITH THE RECENT CHANGES ON THE SUPREME COURT, IT SEEMS LIKELYY THAT THE LEGAL STANDARDS FOR ASSESSING THE VALIDITY OF AFFIRMATIVE ACTION WILL BE GUIDED INCREASINGLY BY IDEOLOGY RATHER THAN PRAGMATISM. WHILE AFFIRMATIVE ACTION IS UNDER SIEGE IN THE 1990'S, A RECOMMITMENT TO THE NATIONAL PROMISE OF RACIAL JUSTICE COULD YIELD TANGIBLE OPPORTUNITY FOR ALL.

08988 TE'AN, C.

MAJOR FACES HARD TASK FOR RE-ELECTION

BEIJING REVIEW, 35(8) (FEB 92), 16

BRITISH PRIME MINISTER, JOHN MAJOR, INDICATED RECENTLY THAT HE MIGHT HOLD GENERAL ELECTIONS BEFORE THE SCHEDULED DATE IN JUNE IN THE FACE OF A LINGERING RECESSION. THE DATE IN JUNE IN THE FACE OF A LINGERING RECESSION. THE PERSISTING ECONOMIC RECESSION POSES THE MOST SERIOUS
CHALLENGE TO MAJOR'S EFFORT TO BE RE-ELECTED PRIME MINISTER CHALLENGE TO MAJOR'S EFFORT TO BE RE-ELECTED PRIME MINISTER.
ALTHOUGH THE MEASURES HE HAS ADOPTED SINCE HE CAME TO OFFICE ALTHOUGH THE MEASURES HE HAS ADOPTED SINCE HE CAME TO OFFICE TO CHANGE SOME OF HIS PREDECESSOR'S UNPOPULAR DOMESTIC AND FOREIGN POLICIES ARE IMPRESSIVE, THIS ART
HE HAS TO OFFER MORE TO WIN THE VOTERS.

08989 TEAGUE, E.; HANSON, P.

NIKOLAI TRAVKIN ATTEMPTS PAINLESS ECONOMIC REFORM RFE/RL RESEARCH REPORT, 1 (38) (SEP 92), 39-44.

THUS FAR, EFFORTS TO INTRODUCE ECONOMIC REFORM AT THE LOCAL LEVEL IN RUSSIA HAVE YIELDED DISAPPOINTING RESULTS. NOW NIKOLAI TRAVKIN, ONE OF RUSSIA'S MOST PROMINENT POLITICIANS, IS CONDUCTING AN EXPERIMENT IN HIS NATIVE DISTRICT NEAR MOSCOW. TRAVKIN'S AMBITION IS TO SHOW THAT ECONOMIC REFORM CAN BE EFFECTED AT THE LOCAL LEVEL WHILE RETAINING THE POLITICAL SUPPORT OF THE POPULATION.

08990 TEAGUE, E.

RUSSIA'S INDUSTRIAL LOBBY TAKES THE OFFENSIVE

RFE/RL RESEARCH REPORT, 1 ( 32 ) (AUG 92), 1-6.

IN RECENT WEEKS, PAGES OF NEHSPRINT HAVE BEEN DEVOTED TO THE CAMPAIGN BEING HAGED BY THE MANAGERS OF RUSSIA'S STATEOWMED ENTERPRISES AGAINST THE GOVERMMENT'S ECONOMIC REFORMS THE INDUSTRIAL LOBBY IS CONDUCTING A HIGHLY SUCCESSFUL OFFENSIVE ON SEVERAL FRONTS. IT HAS ESTABLISHED ITS OWN POLITICAL PARTY AND MANAGED TO PLACE A NUMBER OF ITS REPRESENTATIVES IN CABINET POSTS; IT HAS ENTERED ALLIANCES WITH THE FORMERLY COMMUNIST-DOMINATED OFFICIAL TRADE UNIONS AND WITH RUSSIA'S PRIVATE BUSINESSMEN; AND IT HAS FORMED A COALITION WITH SEVERAL LARGER PARTIES AND GROUPS THAT SHOULD GIVE IT SOME PARLIAMENTARY MUSCLE. IN ADDITION, THE GIVE IT SOME PARL IAMENTARY MUSCLE. IN ADDITION, THE
INDUSTRIAL LOBBY HAS FORMULATED AN ALTERNATIVE ECONOMIC INDUSTRIAL LOBBY HAS FORMULATED AN ALTERNATIVE ECONOMIC
PROGRAM THAT IT HOPES TO SEE ADOPTED AS OFFICIAL POLICY. IT PROGRAM THAT IT HOPES TO SEE ADOPTED AS OFFICIAL POLICY. IT
IS BECDMING CLEAR THAT THE ISSUE OF PROPERTY RIGHTS LIES AT IS BECOMING CLEAR THAT THE ISSUE OF PROPERTY RIGHTS LIES THE CENTER OF THE DISPUTE BETWEE
RUSSIA'S REFORMIST GOVERNMENT.

08991 TEAGUE, E.

SPLITS IN THE RANKS OF RUSSIA'S RED DIRECTORS RFE/RL RESEARCH REPORT, 1(35) (SEP 92) 6-10.

RECENT DEVELOPMENTS' SUGGEST THAT RUSSIA'S INDUSTRIAL MANAGERS MAY BE LESS CAPABLE OF ACTING AS A COMERENT POLITICAL LOBBY THAN PREVIOUSLY THOUGHT. IN EARLY 1992, 
ARKADII VOLSKY'S RUSSIAN UNION OF INDUSTRIALISTS AND ENTREPRENEURS GAVE THE IMPRESSION OF A MIGHTY AND GROWING POLITICAL FORCE, PRESSING ALMOST IRRESISTIBLY FOR MORE CONSERVATIVE ECONOMIC POLICIES AND SOMETIMES ACTING IN ALLIANCE WITH OTHER GRDUPS IN THE CIVIC UNION. HOWEVER, IN AUGUST, IT BECAME CLEAR THAT THERE WERE A GREAT MANY SERIOUS DIVISIONS AMONG THE INDUSTRIALISTS THEMSELVES. THIS WAS ILLUSTRATED BY STRONG DISAGREEMENTS AMONG PARTICIPANTS AT THE ALL-RUSSIAN CONFERENCE OF MANUFACTURERS, AS WELL AS BY THE PUBLICATION OF A DRAFT PROGRAM FOR THE CIVIC UNION THAT WAS DISOWNED BY VOLSKY AND OTHERS AMONG HIS CIVIC UNION WAS DISOWNED BY VOLSKY AND OTHERS AMONG HIS CIVIC UNION
PARTNERS. SOME INDUSTRIAL MANAGERS ADVOCATE MORE RADICAL PARTNERS. SOME INDUSTRIAL MANAGERS ADVOCATE MORE RADICAL
REFORM THAN VOLSKY HAS ESPOUSED, WHILE ANOTHER CONTINGENT IS REFORM THAN VOLSKY HAS ESPOUSED, WHILE ANOTHER CONTINGENT IS
OPTING FOR A MORE REACTIONARY LINE THAT VOLSKY CANNOT EASILY OPTING FOR A MORE REACTIONARY LINE THAT VOLSKY CANNOT EASILY
EMBRACE IF HE IS TO MAINTAIN HIS CREDIBILITY AS A "CENTRIST."

08992 TEAGUE, E.; TOLZ, V.

THE CIVIC UNION: THE BIRTH OF A NEW OPPOSITION IN RUSSIA? RFE/RL RESEARCH REPORT, 1(30) (JUL 92), 1-11.

ALTHOUGH THE RECENT PAST HAS SEEN NUMBEROUS ATTEMPTS TO ESTABLISH A BLOC OF CENTRIST PARTIES SUPPORTING REFORM,

FIRST IN THE USSR AND THEN IN RUSSIA, ALL PROVED TO BE' SHORT LIVED. THE CREATION OF ANOTHER SUCH BLOC, THE CIVIC UNION, IN JUNE 1992 RESEMBLES PREVIOUS EXERCISES OF THIS KIND IN' SOME RESPECTS. HOWEVER, UNLIKE EARLIER CENTRIST BLOCS, THE CIVIC UNION IS NOT COMMITTED TO SUPPORTING THE ESTABLISHED GOVERNMENT BUT DESCRIBES ITSELF AS AN "OPPOSITION" GROUP. THE NEW BLOC HAS APPEARED ON THE SCENE AT A MOMENT WHEN EXTREMIST GROUPS ARE GROWING INCREASINGLY ASSERTIYE. PRESIDENT BORIS YELTSIN MAY TRY TO ENLIST THE MORE MODERATE CIVIC UNION AS A COUNTERHEIGHT TO THE RECENTLY-ESTABLISHED ALLIANCE BETWEEN HARD-LINE COMMUNISTS AND RUSSIAN NATIONALISTS.

08993 TEAGUE, E. (ED.)

IS EQUITY COMPATIBLE WITH EFFICIENCY?

RFE/RL RESEARCH REPORT, 1(17) (APR 92), 9-14.

VARIOUS APPROACHES HAVE BEEN SUGGESTED TO THE QUESTION

OF HOW THE PRIVATIZATION OF STATE PROPERTY SHOULD BE HANDLED

IN EASTERN EUROPE AND THE FORMER SOVIET UNION. SOME ARGUE

INAT, FOR EQUITY AND SPEED OF IMPLEMENTATION, STATE PROPERTY

SHOUID BE GIVEN AWAY TO THE POPULATION FREE OF CHARGE.

SHOULD BE GIVEN AWAY TO THE POPULATION FREE OF CHARGE.

EOUITABLE WAY OF DISPOSING OF THE NATIONAL WEALTH AND THAT

PQUPLE WILL YALUE PROPERTY ONLY IF THEY HAVE TO PAY

PEOPLE WILL VALUE PROPERTY ONLY IF THEY HAVE TO PAY A

REALISTIC PRICE FOR IT. STILL OTHERS ARGUE THAT THE MAIN POLICY ISSUES CANHOT USEFULLY BE REDUCED TO A QUESTION OF EQUITY VERSUS EFFICIENCY AND THAT THE MAIN QUESTION IS TO MOVE AHEAD MOST EXPEDITIOUSLY TO A MORE PRODUCTIVE ECONOMIC SYSTEM, WHICH WILL NECESSARILY INCORPORATE PRIVATE OWNERSHIP.

08994 TEDSTROM, J.

CIS: KIEV SUMMIT YIELDS FEW ECONOMIC RESULTS

RESEARCH REPORT, 1 (15) (APR 92) 26-28.

THE MARCH 1992 SUMMIT MEETING OF THE MEMBERS OF THE COMMONHEALTH OF INDEPENDENT STATES PRODUCED SOME PREDICTABLE AND SOME UNPREDICTABLE RESULTS. IMPORTANT PROGRESS HAS MADE ON THE ISSUE OF A UNIFIED SECURITY STRUCTURE, BUT ECNOMIC AGREEMENTS HERE MORE OR LESS EMPTY PROMISES TO EXAMINE ECONOMIC PRDBLEMS IN FURTHER DETAIL, AS HAD BEEN EXPECTED. SURPRISINGLY, RUSSIA PROVED TO BE THE SPOILER IN THE ECONOMIC NEGOTIATIONS, WHILE UKRAINE SIGNED EVERY ECONOMIC AGREEMENT WITHOUT RESERVATION.

08995 TEDSTROM, J.

ECONOMIC' CRISIS DEEPENS

RFE/RL RESEARCH REPORT, 1(1) (JAN 92), 22-26.

DURING 1991 THE ECONOMIC DETERIORATION OF THE SOVIET

UNION ACCELERATED. TRENDS SUGGEST THAT THE OUTLOOK FOR 1992

IS AT LEAST AS BLEAK. FOUR FUNDAMENTAL PROBLEMS CONTINUE TO DEFINE THE ECONOMICS OF THE REGION: AN ECONOMIC DEPRESSION THAT HAS CUT THE GNP BY ABOUT 12\%; BUDGETARY IMBALANCES THAT THAT HAS CUT THE GNP BY ABOUT 12\%; BUDGETARY IMBALANCES THAT
HAYE PRODUCED MACRO-INSTABILITY AND NEAR HYPERINFLATION; THE HAVE PRODUCED MACRO-INSTABILITY AND NEAR HYPERINFLATION; THE FAILURE TO ARTICULATE A COHERENT SET OF MEASURES AIMED AT
REFORMING AND REBUILDING ECONOMIC INSTITUTIONS AND POLICIES; REFORMING AND REBUILDING ECONOMIC INSTI IUTIONS AND POLIC
AND THE CONTINUING CONFUSION OVER THE NATURE OF THE NEH AND THE CONTINUING CONFUSION OVER THE NATURE OF THE

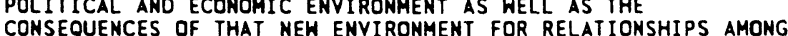

CONSEQUENCES OF THAT NEW ENVIRONM
THE VARIOUS REGIONAL ECONOMIES.

08996 TEDSTROM, J.

LEGISLATIVE MEASURES IN THE FORMER SOVIET REPUBLICS

LEGISLATIVE MEASURES IN THE FORMER SOVIET REPUE

THIS ARTICLE INCLUDES A LIST OF SELECTED LAHS AND OTHER

LEGISLATIVE AND EXECUTIVE ACTS PERTAINING TO THE REFORM OF

PROPERTY RIGHTS IN THE FORMER SOVIET REPUBLICS.

08997 TEDSTROM, J.

RUSSIA: PROGRESS REPORT ON INDUSTRIAL PRIVATIZATION

RFE/RL RESEARCH REPORT, 1 (17) (APR 92), 46-50.

PRIVATIZATION IS ONE OF THE MOST IMPORTANT--AND

CONTROYERSIAL--ASPECTS OF THE REFORM PROCESS IN THE FORMER

SOVIET REPUBLICS. IN RUSSIA, FEDERAL AND LOCAL LEADERS HAVE
MOUNTED A STRONG CAMPAIGN TO OVERCOME THE MANY SOCIAL, ECONOMIC, AHD POLITICAL OBSTACLES TO SUCCESSFUL PRIVATIZATION. SO FAR, THE RESULTS HAVE BEEN MEAGER, BUT THERE IS REASON TO BELIEVE THAT THE PROCESS WILL ACCELERATE IN THE COMING MONTHS.

08998 TEGHTSOONIAN, $K$.

INSTITUTIONS AND IDEOLOGY: SOURCES OF OPPOSTION TO FEDERAL REGULATION OF CHILD CARE SERVICES IN CANADA AND THE UNITED STATES

GOVERNANCE, 5(2) (APR 92), 197-223.

THE IMPACT OF FEDERAL POLITICAL ARRANGEMENTS AND CONSERVATIVE IDEOLOGY ON PROVISIONS FOR REGULATING CHILD CARE SERVICES EMBODIED IN THE MAJOR PROPOSALS FOR CHILD CARE LEGISLATION UNDER CONSIDERATION IN CANADA AND THE UNITED STATES DURING THE LATE 1980S IS EXPLORED. CONSERVATIVE PREFERENCES AND PRESSURES CONTRIBUTED TO THE EVENTUAL ADOPTION OF A NON-CENTRALIZED APPROACH IN BOTH COUNTRIES. FEDERALISM FACILITATED THIS EXPRESSION OF CONSERVATIVE IDEOLOGY BY PROVIDING SUPPORTERS OF A NON-CENTRALIZED
APPROACH WITH RESOURCES WITH WHICH TO PURSUE THEIR POLICY PREFERENCE, AND A POLITICAL RHETORIC WITH WHICH IT COULD BE JUSTIFIED.

08999 TEICHMAN, J.

THE MEXICAN STATE AND THE POLITICAL IMPLICATIONS OF ECONOMIC RESTRUCTURING

LATIN AMERICAN PERSPECTIVES, 19(2) (SPR 92), 88-104.

THE POLITICAL ECONOMY OF RESTRUCTURING IN MEXICO SPECIFICALLY DURING THE TUMULTUOUS YEARS OF THE ADMINISTRATION OF MIGUEL DE LA MADRID (1983-1988) IS EXAMINED. JUDITH TEICHMAN'S STARTING POINT IS THE STRUCTURALIST CONCEPT OF STATE ACTION. SHE IS INTERESTED IN DEFINING THE RELATIVE AUTOMOMY OF THE STATE, TRACING THE INTERACTION BETHEEN PARTICULAR ECONOMIC POLICIES, THE MANIFESTATIONS OF POPULAR REACTION, THE ADJUSTMENTS IN POLICY THAT THESE REACTIONS IN TURN CALLED FORTH, AND THE ROLE OF INTERNATIONAL PRESSURES. TO THIS END SHE DIVIDES THE DE LA MADRID ADMINISTRATION INTO THREE PERIODS AND ANALYZES EACH OF THEM.

09000 TEIXEIRA, R.A.

VOTER TURHOUT IN AMERICA

BROOKINGS REVIEW, 10(4) (FAL 92), 28-31.

VOTER TURNOUT' IN U.S. PRESIDENTIAL ELECTIONS HAS DECLINED ALMOST 13 PERCENTAGE POINTS SINCE 1960. IN THIS ARTICLE, THE AUTHOR DISPELLS SOME OF THE MYTHS ABDUT LOW TURNOUT, INCLUDING THE FOLLOWING: TURNOUT IS DECLINING BECAUSE THE POOR ARE DROPPING OUT OF POLITICS; TURNOUT IS DOWN BECAUSE PEOPLE HAVE BECOME SO CYNICAL ABOUT POLITICS; TURNOUT IS LOW BECAUSE VOTERS SEE NO DIFFERENCE BETWEEN THE DEMOCRATS AND THE REPUBLICANS.

09001 TEJA, R.

CRISIS, RECOVERY, AND TRANSFORMATION IN INDIA

FINANCE AND DEVELOPMENT, 29 (4) (DEC 92), 31-33.

JUDGED AGAINST THE RIGIDITIES OF ITS' PREVIOUS ECONOMIC REGIME, INDIA HAS COME A LONG WAY IN ITS ECONOMIC THINKING SINCE JULY 1991 HEN, FACED WITH A SEVERE BALANCE OF PAYMENTS CRISIS, THE GOVERMMENT LAUNCHED A SERIES OF IMFSUPPORTED MACROECONOMIC AND STRUCTURAL REFORMS. SIGNIFICANT POLICY CHANGES HAVE BEEN INTRODUCED, INCLUDING FISCAL AND MONETARY RESTRAINT, PARTIAL CONYERTIBILITY OF THE RUPEE, ABOLITION OF EXCESSIVE CONTROLS OVER INDUSTRIAL GROWTH, LIBERALIZED FOREIGN INVESTMENT NORMS, AND SIMPLIFIED IMPORT REGULATIONS. YET MUCH MORE NEEDS TO BE DONE TO SET IN MOTION A MAJOR RESTRUCTURING OF THE ECONOMY.

09002 TEJA, R.S.; BRACEWELL-MILNES, 8 .

THE CASE FÓR EARMARKED TAXES: GOVERMMENT SPENDING AND PUBLIC CHOICE

THE INSTITUTE OF ECONOMIC AFFAIRS, 1991, 103.

THIS BOOK CONSISTS OF THO SHORTER PAPERS, ONE BY EACH AUTHOR, WHICH ADORESS THE ISSUE OF TAX EARMARKING. BOTH AUTHORS OFFER A NUMBER OF ARGUMENTS FOR HOW TAX EARMARKING CAN BE EXPECTED TO IMPROVE EFFICIENCY IN COMPARISON TO CAN BE EXPECTED TO IMPROVE EFFICIENCY IN COMPARISON GENERAL FUND FINANCING. BOTH SEE ADVANTAGE IN THE
POSSIBILITY OF USING TAX EARMARKING TO BETTER CONNECT
BENEFITS RECEIVED FROM AND CONTRIBUTIONS MADE TO GOVERMMENT BENEFITS RECEIVED FROM AND CONTRIBUTIONS MADE TO GOVERMMENT
SERYICES. TAX EARMARKING IS SEEN AS IMPROVING ON GENERAL SERYICES. TAX EARMARKING IS SEEN AS IMPROVING ON GENERAL
FUND FINANCING BY PROVIDING INFORMATION ON THE COST OF FUND FINANCING BY PROVIDING INFORMATION ON THE COST OF
DIFFERENT GOVERNMENT ACTIVITIES AND THEREBY RATIONALIZING DIFFERENT GOVERNMENT ACTIVITIES AND THEREBY RATIONALIZING
DECISIONS ON THOSE ACTIVITES. ALSO, TAX EARMARKING IS SEEN DECISIONS ON THOSE ACTIVITES. ALSO, TAX EARMARKING IS SEEN IN WAYS THAT FACILITATE ADVANTAGEOUS POLITICAL EXCHANGES. IN WAYS THAT FACILITATE ADVANTAGEOUS POLITICAL EXCHANGES. AND PUT FORTH SOME WAYS OF EMPIOYING TAX EARMARKING, OR AND PUT FORTH SOME WAYS OF EMPLOYING TAX EARMARKING, OR
VARIATIONS OF EARMARKING, TO ADORESS PARTICULAR PROBLEMS.

09003 TELFORD, H.

THE POLITICAL ECONOMY OF PUNJAB: CREATING SPACE FOR SIKH MILITANCY

ASIAN SURVEY, XXXII(11) (NOV 92), 969-987.

OVER THE LAST DOZEN YEARS NO ISSUE HAS GRIPPED INDIAN 
POLITICS AS THOROUGHLY AS THE SIKH SEPARATIST MOVEMENT. THE CAMPAIGN FOR KHALISTAN, A SIKH STATE, HAS IGNITED MANY PASSIONS, PARALYZED POLICY MAKERS, CLAIMED THOUSANDS OF LIVES, AND LEFT SCHOLARS DISTRESSED AND GROPING FOR EXPLANATIONS. ALTHOUGH CHANGES IN THE INDIAN POLITICAL SYSTEM HAVE SERIDUSLY AFFECTED PUNJAB POLITICS, THIS ARTICLE FOCUSES ON THE INTERNAL DYNAMICS OF THE SIKH COMMUNITY. IT PAYS PARTICULAR ATTENTION TO THE SECULAR STRATEGY OF THE AKALI DAL MOVEMENT, WHICH CREATED SPACE FOR THE RISE OF SIKH MILITANCY. THE AUTHOR ARGUES THAT SIKH LEADER SANT JARNAIL SINGH BHINDRANHALE WAS A RATIONAL ACTOR AND THAT HIS SUPPORTERS WERE GENERATED OUT OF UNEOUAL DISTRIBUTION OF BENEFITS FROM THE GREEN REVOLUTION. THE AUTHOR ILLUSTRATES THE POLITICAL PRESSURE BHINDRANHALE PLACED ON THE AKALI DAL AND CONCLUDES WITH A BRIEF DISCUSSION OF THE POST-

BHINDRANWALE ERA.

09004 TELHAMI, $S$.

EVALUATING BARGAINING PERFORMANCE: THE CASE OF CAMP DAVID POLITICAL SCIENCE QUARTERLY, 107(4) (WIN 93), 629-654. THE AUTHOR ANALYZES HOW THE FORMS OF GOVERMMENT AND PERSONAL LEADERSHIP STYLES AFFECTED THE BARGAINING PERFORMANCE OF ISRAEL, EGYPT, AND THE UNITED STATES IN THE CAMP DAVID NEGOTIATIONS. HE THEN SHOWS THE RELEVANCE OF THESE FINDINGS FOR THE ARAB-ISRAELI NEGOTIATIONS IN THE THESE FINDINGS

09005 TELTSCHIK, H. MAJOR GERMAN POLITICAL PARTIES ARE BOTH IN THE DOLDRUMS GERMAN TRIBUNE, 1487 (OCT 91), 4

THE WRITER OF THIS ARTICLE', HORST TELTSCHIK, WAS FOR MANY YEARS HEAD OF FOREIGN POLICY AT THE CHANCELLOR'S OFFICE IN BONN, GERMANY, AND ONE OF HELMUT KOHL'S CLOSEST ADVISERS. THE ARTICLE DISCUSSES THE MAJOR GERMAN POLITICAL PARTIES, WHY THEY ARE IN A SLUMP SINCE GERMAN UNIFICATION, AND SOME OF THE OPTIONS FOR THE FUTURE.

09006 TEMPLE, C.

TERRORISM AND INTERNATIONAL LAW: TWO BARRIERS TO CONSENSUS CONFLICT, 10(3) (1990), 215-226.

MANY PROBLEMS EXIST IN THE EFFECTIVE CONSTRUCTION OF INTERNATIONAL LAW WHICH WOULD OBJECTIVELY PROHIBIT TERRORISM THE DIFFICULTY LIES IN STRICT DEFINITION AND CODIFICATION OF SPECIFIC ACTS OF TERRORISM. WHILE PROGRESS HAS BEEN MADE IN AREAS SUCH AS AERIAL AND MARITIME PIRACY, AS WELL AS HOSTAGE TAKING, EFFECTIVE OVERARCHING LEGISLATION REMAINS ELUSIVE. THIS SITUATION IS THE RESULT OF NUMEROUS PROBLEMS, ELUSIVE. THIS SITUATION IS THE RESULT OF NUMEROUS PROBLEMS,
TWO OF WHICH ARE THE DIFFERING DEFINITIONS AMONG GROUPS OF THO OF WHICH ARE THE DIFFERING DEFINITIONS AMONG GROUPS OF HE CONCEPT OF JUST HAR, AND THE REL IANCE IN THE MODERN
ON VIOLENCE AS A TOOL OF FOREIGN POLICY, ONLY CONTINUED ON VIOLENCE AS A TOOL OF FOREIGN POLICY, ONLY CONTINUED JUST WAR, AND A RETREAT FROM OFFENSIVE VIOLENCE AS POLICY, WILL HELP BREAK THE BARRIERS PROHIBITING THE CONSTRUCTION OF WILL HELP BREAK THE BARRIERS PROHIBITING
MORE EFFECTIVE INTERMATIONAL LEGISLATION.

09007 TERRIFF, T.

THE 'EARTH SUMMIT': ARE THERE ANY SECURITY IMPLICATIONS? ARMS CONTROL, 13(2) (SEP 92), 163-190

THE NOTION THAT ENVIRONMENTAL PROBLEMS ARE A SECURITY ISSUE IS CONTROVERSIAL. THE REASON FOR THE CONFLICT IN VIEWS IS THAT MANY ADVOCATE THAT THE TRADITIONAL REALIST, STATECENTERED APPROACH TO SECURITY IS INAPPROPRIATE, AND THAT A NEW VIEH OF INTERNATIONAL RELATIONS AND SECURITY IS NEEDED WHICH ACCOUNTS FOR THE GENERAL SECURITY, OR GENERAL PHYSICAL, SOCIAL, AND ECONOMIC WELL-BEING OF INDIVIDUALS. OTHERS ARGUE THAT SUCH AN ALL-ENCOMPASING APPROACH MAKES THE CONCEPT OF SECURITY SO AMORPHOUS THAT ITS LOSES INTELLECTUAL COHERENCE AND MAKE IT DIFFICULT TO FIND SOLUTIONS TO PARTICULAR PROBLEMS. THIS PAPER IS A BRIEF EXAMINATION OF SOME OF THE SIGNIFICANT IMPLICATIONS OF THE ENDING OF THE COLD WAR FOR THE CONCEPT OF SECURITY AND ALSO OF THE SECURITY ASPECTS AND IMPLICATIONS OF THREE ISSUES-PROTECTION OF FORESTS, GLOBAL CLIMATE CHANGE, AND MANAGEMENT OF FISH STOCKS--DEALT WITH BY THE UNCED.

09008 TERRILL, W.A.

THE MIDDLE EAST ARMS RACE AFTER DESERT STORH

MIDOLE EAST INSIGHT, VIII (6) (JUL 92), 45-53.

THE AUTHOR EXAMINES THE MILITARY BALANCE OF POWER IN THE MIDDLE EAST AFTER DESERT STORM, FOCUSING ON PRESIDENT BUSH'S PROPOSALS FOR THE REGION, CHANGES IN THE ARAB-ISRAELI

PROPOSALS FOR THE REGION, CHANGES IN THE ARAB-ISRAEL
BALANCE, AND THE DISTRIBUTION OF MILITARY HARDHARE.

09009 TERUKO, $S$

JAPAN'S INCONSISTENT APPROACH TO BURMA

JAPAN QUARTERLY XXXIX(1) (JAN 92) 17-27.

THE AUTHOR TRACES THE COURSE OF' JAPAN'S INCONSISTENT

POLICY REGARDING RELATIONS WITH AND FOREIGN AID TO BURMA.

09010 TESKE, P.

RENT-SEEKING IN THE DEREGULATORY ENVIRONMENT: STATE TELECOMMUNICATIONS

PUBLIC CHOICE, 68(1-3) (JAN 91), 235-244.

PROPONENTS OF RENT-SEEKING THEORIES ARGUE THAT FIRMS
PRESSURE AND REWARD POLITICIANS AND BUREAUCRATS TO PURSUE FAVORABLE POLICIES SO THEY CAN ACHIEVE HIGHER THAN NORMAL, MARKET RETURNS. IN AN ERA OF DEREGULATION, OFTEN HITH LOMG TRANSITION PERIODS TOHARD UNREGULATED COMPETITION, HOW DO FIRMS DEVELOP SPECIFIC POLITICAL STRATEGIES TO ACHIEVE SUCCESS IN RENT-SEEKING? DEREGULATION OF TELECDMMUNICATIONS AT THE STATE LEVEL ALLOWS COMPARISON OF THE STRATEGIES OF THE SEVEN FIRMS CREATED IN THE AT\&T DIVESTITURE IN MORE THAN ONE POLITICAL JURISDICTION. ONE FIRM, U S. WEST, HAS PURSUED THE MOST AGGRESSIVE POLITICAL STRATEGY. THIS PAPER ARGUES THAT U S WEST EXECUTIVES CORRECTLY PERCEIVED THAT THE POLITICAL ENVIRONMENT IN WHICH THEY OPERATED DIFFERED GREATLY FROM THAT IN THE REST OF THE COUNTRY ANO THAT A DIFFERENT DEREGULATORY STRATEGY WAS APPROPRIATE. THE FIRM EXPLOITED INSTITUTIONAL DIFFERENCES BY BYPASSING STATE REGULATORS AND GOING DIRECTLY TO STATE LEGISLATORS TO GET FAVORABLE POLICIES.

09011 TESKE, P.E.

STATE TELECOMMUNICATIONS POLICY IN THE 1980'S

POLICY STUDIES REVIEH, 11(1) (SPR 92), 118-125.

POLICY STUDIES REVIEN, 11(1) (SPR 92), 118-125.
THE ROLE OF THE STATE GOVERNMENT IN THE PROVISION OF TELECOMMUNICATIONS SERVICES COMBINES ASPECTS OF REGULATION, ECONOMIC DEVELOPMENT POLICY, TAX POLICY, AND GOVERNMENT PROCUREMENT. IN MANY STATES, THE GROWING REALIZATION THAT THE IMPLICATIONS OF DECISIONS ABOUT TELECOMMUNICATIONS ARE
NO LONGER NARROWLY CONFINED TO REGULATION HAS SPURRED THE ACTIVE INVOLVEMENT OF GOVERNORS AND LEGISLATORS.

09012 TESSITORE, A.

ARISTOTLE'S AMBIGUOUS ACCOUNT OF THE BEST LIFE POLITY, XXV(2) (WIN 92), 197-216

THE AUTHOR EXAMINES THE PROBLEMATIC RELATIONSHIP BETHEEN MORAL AND INTELLECTUAL VIRTUE IN "NICOMACHEAN ETHICS" BY EXPLORING ARISTOTLE'S CONCERN WITH THO DIFFERENT AUDIENCES: THOSE INCLINED TOWARD AN ACTIVE POLITICAL LIFE AND THOSE WHO ARE POTENTIAL PHILOSOPHERS. THE AUTHOR ARGUES THAT ATTENTIVENESS TO THE DUAL AUDIENCE OF "NICOMACHEAN ETHICS" RENDERS INTELLIGIBLE ARISTOTLE'S APPARENTLY INCONSISTENT TEACHING ON MORAL VIRTUE AS AN END IN ITSELF AND HIS FINAL EXALTATION OF THEORETICAL VIRTUE.

09013 TETHER, $P$.

RECRUITING CONSERVATIVE PARTY MEMBERS: A CHANGING ROLE FOR CENTRAL OFFICE

PARLIAMENTARY AFFAIRS, 44(1) (JAN 92), 20-32.

FROA ITS EARLIEST DAYS, THE BRITISH CONSERVATIVE CENTRAL OFFICE HAS BEEN INVOLVED IN MEMBERSHIP AND MEMBERSHIP-

RELATED ISSUED. ITS TRADITIONAL EXHORTATORY AND SERVICING RELATED ISSUED. ITS TRADITIONAL EXHORTATORY AND SERVICING
ROLE IS CHANGING AS A NUMBER OF DEVELOPMENTS IN THE 1980S ROLE IS CHANGING AS A NUMBER OF DEVELOPMENTS IN THE 1980 S
INCREASED CENTRAL OFFICE INVOLVEMENT IN MEMBERSHIP MATTERS INCREASED CENTRAL OFFICE INVOL VEMENT IN MEMBERSHIP MATTERS AND SUBTLY ALTERED CENTER-LOCAL RELATIONSHIPS. THIS ARTICLE CHARTS THESE DEVELOPMENTS. IT EXAMINES MEMBERSHIP LEVELS TRADITIONAL METHOOS BY WHICH CENTRAL OFFICE SEEKS TO HELP TRADI ITNAL METHOOS BY WHICH CENTRAL. THESE CONTINUE TO BE EMPLOYED, BUT WITH MORE VARIETY AND VIGOR AND GIVE THE CENTER AND ENHANCED, THOUGH STILL LARGELY INDIRECT, ROLE IN RECRUITMENT.

09014 TETLOCK, P.

GOOD JUDGGEETT IN INTERNATIONAL POLITICS: THREE

PSYCHOLOGICAL PRESPECTIVES

POLITICAL PSYCHOLOGY, 13(3) (SEP 92), 517-540.

THIS ARTICLE EXPLORES THREE DISTINCT PSYCHOLLOICAL PERSPECTIVES ON GODD JUDGMENT IN INTERNATIONAL POLITICS. ADVOCATES OF ONE PERSPECTIVE (SKEPTICS) ARGUE THAT GOOD JUDGMENT IS EXTREMELY RARE. ADVOCATES OF THE SECOND PERSPECTIVE (CONPLEXIFIERS) ARGUE THAT GOOD JUDGMENT IS CLOSELY LINKED TO THE ABILITY TO TRANSCEND COMMON COGNITIVE BIASES AND ERRORS THAT VITIATE MOST INTUITIVE PREDICTIONS. ADVOCATES OF THE THIRD PERSPECTIVE (SIMPLIFIERS OR FUNDAMENTALISTS) ARGUE THAT GOOO JUDGMENT IS CLOSELY LINKED TO THE ABILITY TO FOCUS ON A FEH BASIC PROCESSES. DRAHING ON THE RESULTS OF A PRELIMINARY STUDY OF EXPERTS' FORECASTS IN THREE POLICY DOMAINS THE AUTHOR ARGUES THAT EACH

PERSPECTIVE HAS COMPONENTS OF VALIDITY AMD THAT THE RESEARCH CHALLENGE IS TO IDENTIFY THE CONDITIONS UNDER WHICH EACH IS MOST USEFUL.

09015 TETREAULT, M.A.

KUWAIT: THE MORNIMG AFTER

CURRENT HISTORY, 91(561) (JAN 92), 6-10.

THE GULF CRISIS DIVIDED THE KUWAITIS INTO "INSIDERS," THOSE WHO ENDURED THE IRAOI INVASION AND OCCUPATION, AND "OUTSIDERS" "THOSE WHO FLED THE COUNTRY TO WATCH FROM SAFE HAVENS PERHAPS BECAUSE MOST MEMBERS OF THE GOVERMMENT WERE DUTSIDERS, INSIDER EXPERIENCES HAVE BEEN DEVALUED AND REPRESSED. UNLIKE THE PROGRESS IN RECONSTRUCTING KUWAIT'S PHYSICAL INFRASTRUCTURE, REPAIR OF THE POLITICAL COMMUNITY HAS BARELY BEGUN AND IT' IS DOUBTFUL HHETHER IT HILL MEET WITH THE SAME SUCCESS. 
09016 THAIN, C.; WRIGHT, M.

PLANNING AND CONTROLLING PUBLIC EXPENDITURE IN THE UK, PART I: THE TREASURY'S PUBLIC EXPENDITURE SURVEY

PUBLIC ADMINISTRATION, 70(1) (SPR 92), 3-24.

IN THE UNITED KINGDOM. THE TREAURY'S ANMUAL SURVEY OF PUBLIC EXPENDITURE IS THE CENTRAL ELEMENT IN PLANNING AND CONTROLLING PUBLIC EXPENDITURE. THIS ARTICLE EXAMINES AND EXPLAINS THE PROCESS OF PREPARING THE SURVEY, THROUGH THE MAIN STAGES FROM THE DECISIONS ABOUT THE SIZE OF TOTAL PUBLIC SPENDING IN THE CONTEXT OF THE GOVERMMENT'S PUBLIC SPENDING IN THE CONTEXT OF THE GOVERMMENT'S
MACROECONOMIC STRATEGY TO THE ANHOUNCEMENT IN THE AUTUMM MACROECONOMIC STRATEGY TO THE ANHOUNCEMENT IN THE AUTUMN
STATEMENT OF THE PLANMED TOTALS AND ALLOCATIONS FOR THE NEXT STATEMENT OF THE PLANNED TOTALS AND ALLOCATIONS FOR THE NEXT
THREE YEARS AND FINALLY TO THE PUBLICATION IN FEBRUARY OF THREE YEARS AND FINALLY TO THE PUBLICATION IN
THE DEPARTMENTAL PUBLIC EXPENDITURE CHAPTERS.

09017 THAIN, C.; WRIGHT, M.

PLANNING AND CONTROLLING PUBLIC EXPENDITURE IN THE UK, PART II THE EFFECTS AND EFFECTIVENESS OF THE SURVEY PUBLIC ADMINISTRATION, 70(2) (SUM 92), 193-224. PART I OF THIS ARTICLE EXAMINED AND EXPLAINED THE PROCESSES BY WHICH THE TREASURY PLANS AND CONTROLS PUBLIC EXPENDITURE THROUGH THE PUBLIC EXPENDITURE SURVEY. THE SECOND PART ANALYZES THE SURVEY'S EFFECTS AND EFFECTIVENESS THE SURVEY IS ASSESSED BY THE EXTENT TO WHICH THE PRINCIPAL FUNCTIONS OF PLANNING, ALLOCATING, CONTROLLING AND EVALUATING PUBLIC EXPENDITURE ARE ARTICULATE AND PERFORMED.

09018 THAKUR, R.

INDIA AFTER NONALIGNMENT

FOREIGN AFFAIRS, 71 (2) (SPR 92), 165-182

RECENT INTERNATIONAL CHANGES PRESENT INDIA WITH A STARK CHOICE. IT CAN PERSIST WITH AN INHARD-LOOKING POL ICY THAT MARGINALIZES THE COUMTRY AND LETS IT SLIOE INEXORABLY INTO INCREASING INTERNATIONAL IRRELEVANCE. OR IT CAN TAKE A HARD LOOK AT ITSELF AND AT THE FORMER DEVELOPING COUNTRIES THAT HAVE ACHIEYED SUCCESS THROUGH THEIR OWH EFFORTS RIES THAT HAVE ACHIEVED SUCCESS THROUGH THEIR OWN EFFORTS AND THEN CHART A RADICALLY NEW PASSAGE TO A BRIGHTER INDIA. INDIA
MUST CHOOSE BETWEEN THE COMFORTING FAMILIARITY OF THE OLD MUST CHOOSE BETWEEN THE COMFORTING FAMILIARITY OF THE ORDER WITH ITS COROLLARY OF ECONOMIC INCOHERENCE AHD
INTERNATIONAL INSIGNIFICANCE OR THE CHALLENGE OF EXPLOITING INTERNATIONAL INSIGNIFICANCE OR THE CHALLENGE OF
THE OPPORTUNITIES OFFERED BY THE NEW WORLD ORDER.

09019 THAKUR, R.

MORMALIZING SIMO-IMDIAN RELATIONS

PACIFALILING SINO-INOIAN RELATIONS

THIS ARTICLE DISCUSSES THE LEGACY OF THE BORDER DISPUTE BETWEEN CHINA AND IMDIA AND THE SHIFTING COURSE OF THEIR RELATIONS WITH THE SOVIET UNION AS A FACTOR IN THE BILATERAL SINO-INDIAN RELATIONS. IT ALSO EXAMINES THE PROBLEM OF TIBET AS AN ENDURING IRRITANT IN THE SINO-INDIAN RELATIONSHIP. THE EMPHASIS IS MAINLY ON THE 1980S.

09020 THANH, D.

BACK TO THE WORLD: RECENT CHANGES IN VIETNAMESE DOMESTIC AND FOREIGN POLICY

BULLETIN OF PEACE PROPOSALS, 22(1) (MAR 91), 25-30.

VIETNAM HAS RECENTLY TAKEN A NUMBER OF STEPS TOWAROS

REFORMING ITS ECONOMIC AND POLITICAL SYSTEM. THIS ARTICLE

CONSIDERS WHETHER IS WILL BE POSSIBLE FOR VIETNAM TO BREAK THE STATE OF ISOLATION IT HAS HAD SINCE 1979, AND IF IT CAN BECOME AS DYNAMIC IN THE ECONOMIC FIELD AS ITS NEIGHBORS. IT EXMINES HYY VIETMAM REMAINS BACKHARD ECONOMICALLY AND DIPLOMATICALLY. IT TAKES A BRIEF LOOK AT THE RECENT PAST AND CONCLUDES THAT EVERYTHING THAT THE INTERNATIONAL COMMUNITY CAN DO TO HELP VIETHAM SOLVE ITS DILEMMAS AND TO FACILITATE ITS TRANSITION TO A DYNAMIC ECONONY WOULD BE HARMLY WELCOMED IN VIETNAM.

09021 THAPA, B.

NEPAL IN 1991: A CONSOLIDATION OF DEMOCRATIC PLURALISM ASIAN SURVEY, XXXII(2) (FEB 92), 175-183.

THE YEAR I991 WILL LIKELY GO INTO THE ANMALS OF NEPALESE HISTORY AS A PERIOD OF CONSOLIDATION OF DEMOCRATIC

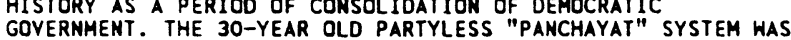
GOVERNMENT. THE 30-YEAR OLD PARTYLESS "PANCHAYAT" SYSTEM WAS REPLACED WITH A MULTIPARTY OEMOCRACY AND A NEW CONSTITUTION WAS CREATED THE PREVIOUS YEAR. CONSEQUENTLY, MAY 1991 SAH
THE FIRST MULTIPARTY PARLIAMENTARY ELECTION IN 32 YEARS. THE THE FIRST MULTIPARTY PARL I AMENTARY ELECTION IN 32 YEARS. THE
NEPALI CDNGRESS (NC), THE PARTY ELECTED TD POWER IN 1959, WAS ONCE AGAIN GIVE A MANDATE TO FORM THE GOVERMMENT. WHILE WAS ONCE AGAIN GIVE A MANDATE TO FORM THE GOVERMMENT. WHILE THE PEACEFUL NATURE OF THE ELECTION GIVES CREDENCE TO THOSE
WHO CLAIM DEMOCRACY IS EXPERIENCING A "SECOND DAWN" IN NEPAL, THE REAL CHALLENGE FACING THE NATION IS THE SOCIOECONOMIC CONE REAL CHALLENGE FACING THE NATION IS THE SOCIOECONOMIC CONDITION OF THE MAJORITY OF THE PEOPLE. IF DEMOCRACY IS

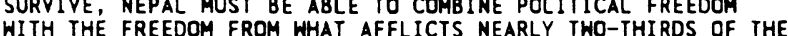
NEPALESE WHO LIVE BELOW THE OFFICIAL POVERTY LINE.

09022 THAXTON, R.

STATE MAKING AND STATE TERROR: THE FORMATION OF THE REVENUE POLICE AND THE ORIGINS OF COLLECTIVE PROTEST IM RURAL NORTH CHINE DURING THE REPUBLICAN PERIOD

THEORY AND SOCIETY, 19(3) (JUN 90), 335-376.

THIS ARTICLE REVIEWS THE SECOMDARY WESTERN LITERATURE ON THE CHINESE REVOLUTION, PARTICULARLY THAT OF THEDA SKOCPOL.
THE AUTHOR QUESTIONS THE BASIC PREMISES OF THE

REPRESENTATION THAT THE GENTRY CONTROLS AT THE EXTRA-VILLAGE LEVEL REDUCED THE LIKELIHOOD OF VILLAGE DWELLERS' COMING TOGETHER TO FORM A SIGNIFICANT PROTEST MOVEMENT. IT AIMS TO SHOW HOW THE "LOGIC OF STATEMAKING" PLAYED A PART IN MOYING CHINA'S RURAL PEOPLE TOWARD COLLECTIVE PROTEST IN THE PRE1949 PERIOD.

09023 THAYER, N.

BETHEEN THO FIRES

FAR EASTERN ECONOMIC REVIEW, 151 (17) (APR 91), 11-12.

IENS OF THOUSANDS OF CIVILIANS OF NORTHWEST CAMBODIA

FACE STARVATION OR FORCED DISPLACEMENT-PROBABLY INTO AREAS HELD BY THE KHMER ROUGE--AS A RESULT OF A U.S. DECISION TO SUSPEND AIR TO THE TWO NON-COMMUNIST FACTIONS OPPOSING THE HANOI-BACKED HUN SEN REGIME IN PHNOM PENH. THE U.S AID CUT HAS HAD NO EFFECT ON THE KHMER ROUGE, HWO CONTINUE TO RECEIVE LARGE AMOUNTS OF MILITARY AND OTHER AID FROM THEIR CHINESE BACKERS. MOST ANALYSTS AGREE THAT FURTHER DELAY IN GAINING ALL-AROUND ACCEPTANCE OF THE UN PEACE PLAN COULD RESULT IN THE DISINTEGRATION OF THE TWO NON-COMMUNIST FACTIONS, PITTING THE KHMER ROUGE ALONE AGAINST PHNOM PENH AND INCREASING THE LIKELIHOOD OF A PROLONGED MILITARY CONFLICT.

\section{THAYER, N.; AHANOHARA, S.}

CAMBODIA TAKES A BATH

FAR EASTERN ECONOMIC REVIEW, 155(41) (OCT 92), 56-57. THE AMOUNT OF RIEL BANKNOTES IN CIRCULATION IN CAMBODIA HAS INCREASED AS THE PHNOM PENH GOVERMMENT HAS RELEASED NEWLY PRINTED MONEY TO PAY ITS SOLDIERS AND CIVIL SERVANTS. THE RESULT HAS BEEN RAPIDLY RISING INFLATION AND GROHING SOCIAL UNREST, BOTH OF WHICH THREATEN TO PLAY INTO THE HANDS OF THE KHMER ROUGE. IN A DESPERATE ATTEMPT TO REDUCE INFLATION, THE UNITED NATIONS TRANSITIONAL AUTHORITY IN CAMBODIA (UNTAC) HAS TAKEN CONTROL OF THE NATIONAL BANK OF CAMBODIA, THE CENTRAL BANK. UNTAC INVOL VEMENT IN STABILIZING THE ECONOMY MAY MAKE IT EASIER TO CONTROL THE MONEY SUPPLY, BUT THE MOVE ENDANGERS CAMBODIA'S PROCESS OF POLITICAL RECONCILIATION. FEARING AN INCREASE IN SUPPORT FOR THE PHNOM RECONCILIATION. FEARING AN INCREASE IN SUPPORT FOR THE PHMOI
PENH GOVERMMENT, THE KHMER ROUGE IS LIKELY TO OPPOSE ANY PENH GOVERNMENT, THE KHMER ROUGE IS LIKELY TO OPPOSE ANY
MOVE THAT HILL LESSEN CAMBODIA'S ECONOMIC WOES. NEVERTHELESS MOVE THAT WILL LESSEN CAMBODIA'S ECONOMIC WOES. NEVERTHELESS ECONOMY FROM COLLAPSING.

09025 THAYER, N.

MAKING A KILLING

FAR EASTERN ECONOMIC REVIEW, 153(32) (AUG 91), 15

OBSERVERS HAVE BECOME INCREASINGLY ALARMED' IN RECENT WEEKS OVER THE GROWING LEVEL OF ANARCHY AND LANLESSNESS IN CAMBODIA, NOT LEAST BECAUSE OF ITS IMPLICATIONS FOR FUTURE SECURITY WHEN THE UN ASSUMES POLICE POWERS OUTLINED IN THE PEACE PLAN REACHED IN LATE JUNE. IN THE WAKE OF A DECLARED CEASE-FIRE THAT CAME INTO EFFECT FOLLOWING THE PEACE TALKS, HUNDREDS OF TROOPS HAVE DESERTED FROM ALL FOUR COMPETING FACTIONS AND ENTIRE MILITARY UNITS HAVE ROUTINELY ENGAGED IN MURDER, ROBBERY AND ORGANIZED RAIDS TO SEIZE VALUABLES FOR RESALE. THE OUTBREAK OF VIOLENCE REFLECTS A SENSE OF DESPERATION AT WHAT PEACE MAY MEAN FOR THE FACTIONAL ARMIES. ORDINARY SOLDIERS FROM ALL THE FACTIONS RECEIVE LITTLE OR NO PAY, AND GUERRILLA LEADERS SAY THERE IS WIDESPREAD FEAR SUPPORT THEIR FAMILIES.

09026 THAYER, N.

MURDEROUS INSTINCTS

FAR EASTERN ECONOMIC REVIEH, 155 (5) (FEB 92) 13.

THE ASSASSINATION OF AN OUTSPOKEN GOVERNMENT OFFICIAL HAS SHAKEN THE SURFACE CALM OF THE CAMBODIAN CAPITAL AND DENTED THE UN'S EFFORTS TO INDUCE A CHANGE IN HOW THE POLITICALLY RIVEN AND ECONOMICALLY SHATTERED COUNTRY IS RUN. TEA BUN LONG, A SENIOR OFFICIAL IN CHARGE OF RELIGIOUS AFFAIRS WHO IS KNOWN TO HAVE PUBLICLY CRITICIZED CORRUPTION AFFAIRS WHO IS KNOWN TO HAVE PUBLICLY CRITICIZED CORRUPTION
AMONG RUL ING PARTY CADRES IN RECENT MONTHS, WAS ABDUCTED BY AMONG RUL ING PARTY CADRES IN RECENT MONTHS, WAS ABDUCTED BY
MEN IN A MILITARY VEHICLE OUTSIDE HIS PHNOM PENH HOUSE ON 22 MEN IN A MILITARY VEHICLE OUTSIDE HIS PHNOM PENH HOUSE ON
JANUARY. GOVERNMENT SOURCES SAID HE HAS TAKEN OUTSIDE THE JANUARY. GOVERNMENT SOURCES SAID HE HAS TAKEN OUTSIDE THE
CITY AND SHOT DEAD BY HIS ABDUCTORS THE SAME NIGHT. SOME CITY AND SHOT DEAD BY HIS ABDUCTORS THE SAME NIGHT. SOME
DIPLOMATS BELIEYE THAT, DESPITE GUARANTEES OF BROAD FREEDOMS DIPLOMATS BELIEVE THAT, DESPITE GUARANTEES OF BROAD FREEDOMS
UNDER THE UN-BROKERED PEACE ACCORD, IT MAY BE IMPOSSIBLE TO UNDER THE UN-BROKERED PEACE ACCORD, IT MAY BE IMPOSSIBL
ORGANIZE FREE ELECTIONS WHILE THE GOVERHMENT'S CRITICS ORGANIZE FREE ELECTIONS WHILE THE GOVERMMENT'S CRITICS
CONTINUE TO BE THE TARGET OF INTIMIDATION. CAMBODIA'S RULING CONTINUE TO BE THE TARGET OF INTIMIDATION. CAMBODIA'S RULING SUPREME NATIONAL COUNCIL (SNC) HAS REPEATEDLY APPEALED TO THE UN TO DEPLOY ITS PEACEKEEPING FORCES AS SOON AS POSSIB SITUATION.

09027 THAYER, N.

PLUNDER OF THE STATE

FAR EASTERN ECONOMIC REVIEW, 155(1) (JAN 92), 11

RAMPANT OFFICIAL CORRUPTION AND AN ALARMING PONER VACUUM ARE THREATENING TO BRING THE FRAGILE CAMBODIAN PEACE PROCESS TO A HALT AND PLUNGE THE COUNTRY INTO ANARCHY. FEARS THAT THE COUNTRY IS BECOMING INCREASINGLY UNGOVERNABLE WERE BROUGHT INTO BLOODY FOCUS ON 21 DECEMBER WHEN POLICE OPENED 
FIRE ON CROWOS IN THE CAPITAL'S BUSINESS DISTRICT, LEAVING AT LEAST EIGHT DEAD AND SIXTEEN WOUNDED, AFTER FIVE DAYS OF ANTI-CORRUPTION DEMONSTRATIONS AND RIOTS BY STUDENTS, CIVIL SERVANTS AND WORKERS. HILE THE GOVERMMENT HAS CLOSED ALL UNIVERSITIES, BANNED DEMONSTRATIONS, IMPOSED A CURFEH AND SENT TROOPS ON TO THE STREETS OF THE CAPITAL SINCE THE 21 DECEMBER BLOODSHED, THE MOOD IN THE COUNTRY REMAINS VOLATILE.
OFFICIALS OF THE PHNOM PENH GOVERNMENT OF PRIME MINISTER HUN SEN HAVE BEEN ACCUSED OF EMBARKING ON AN EXTRAORDINARY ORGY OF CORRUPTION BY SELLING OFF STATE ASSETS AND POCKETING THE MONEY. MANY NOW CLAIM THAT THE ONLY WAY TO PREVENT A SLIDE INTO CHAOS IS THE RAPID DEPLOYMENT OF THE FULL UN PEACEKEEPING FORCE. IF THERE ARE ANY WINNERS IN THE DISORDER, IT IS THE KHMER ROUGE: THE FOCUS OF THE PEOPLE HAS SHIFTED FROM THEIR PAST MURDEROUS POLICIES TO THE CURRENT ECONOMIC AND POLITICAL PROBLEMS.

09028 THAYER, $N$.

THE WAR PARTY

FAR EASTERN ECONOMIC REVIEH, 155(25) (JUN 92), 12

THE FUTURE OF THE EIGHT-MONTH, UN-BROKERED CAHBODIAM PEACE ACCORD IS NOW IN JEOPARDY AS THE POWERFUL KHMER ROUGE GUERRILLA FACTION AND THE WORLD BODY BECOME INCREASINGLY LOCKED IN A CONFRONTATION THAT THREATENS TO WRECK THE FRAGILE AGREEMENT. THE KHMER ROUGE ACCUSES THE UM AMD "CERTAIN COUNTRIES" OF HAVING BETRAYED THE PEACE PLAN, OF REFUSING TO IMPLEMENT KEY ASPECTS OF THE PARIS ACCORDS AND OF USING THE MASSIVE UN OPERATION TO PROP UP THE VIETNAMESEINSTALLED GOVERNMENT IN PHNOM PENH. IN ADDITION TO MAKING DEMANDS THAT THE UN FINDS IT CANNOT MEET, THE KHMER ROUGE HAS SO FAR REFUSED UN PEACEKEEPERS ACCESS TO ITS CONTROL ZONES AND HAS STOPPED ATTENDING IMPORTANT MEETINGS RELATED TO IMPLEMENTING OTHER ASPECTS OF THE AGREEMENT. FURTHER KHMER ROUGE HEAD KHIEU SAMPHAN ANNOUNCED HE WOULD BOYCOTT AN IMPORTANT DONORS' MEETING IN TOKYO SCHEDULED FOR 20-22 JUNE ON FUNDING CAMBOIDA'S REHABILITATION.

09029 THAYER, $N$.

UNSETTLED LAND

FAR EASTERN ECONOMIC REVIEW, 155(8) (FEB 92), 22-24. THE LABORIOUSLY HON PEACE ACCORD SIGNED IN PARIS BY CAMBODIA'S WARRING FACTIONS IN OCTOBER 1991 THREATENS TO UNRAVEL UNLESS THE UNITED NATIONS CAN RAPIDLY DEPLOY ITS PROMISED PEACEKEEPING FORCE. HOWEVER, THE ARRIVAL OF THE UN FORCE IS CONTINGENT ON INTERNAL UN BUDGETARY AND BUREAUCRATIC CONSIDERATIONS. MEANHHILE, TENSION AND RIVALRIES, BOTH BETWEEN THE FACTIONS THAT FOUGHT THE 13-YEAR RIVALRIES, BOTH BETWEEN THE FACTIONS THAT FOUGHT THE 13-YEAR WAR AND WITHIN THE PRESENT GOVERNMENT, THREATEN TO RE-ERUPT COMBATANTS. FURTHER COMPL ICATEN CAN SEPARATE THE FORMER DEMOB IL S. FU AT LEAST 150,000 TROOPS FROM THE FACTION ARMIES AND RESETTLING SOME 350,000 REFUGEES. WHETHER THE UN FORCE CAN SUCCEED IN THIS AMBITIOUS MISSION HAS BECOME THE DEFINING ISSUE WITHIN CAMBODIAN POLITICS.

09030 THELEN, P.

MINISTER MOVES AT RIGHT MOMENT TO RAM THROUGH HIS HEALTH REFORMS

ERMAN TRIBUNE, (1536) (OCT 92), 6

IN THE PAST, GERMANY'S HEALTH-INSURANCE LOBBY HAS STYMIED EFFORTS TO REFORM THE COUNTRY'S HEALTH CARE SYSTEM. BUT THE UNPRECEDENTED MONEY PROBLEMS FACING THE HEALTH SYSTEM IN A DETERIORATING ECONOMIC SITUATION WITH THE STATE FINANCIALLY AGAINST THE WALL, PLUS NEW INSURANCE-PAYMENT LEVELS FOR HORKERS AT RECORD LEVELS, HAVE MADE THE POLITICAL PARTIES LESS SYMPATHETIC TO OBJECTIONS FROM THE HEALTHINSURANCE LOBBY AND HAVE MADE REFORM POSSIBLE.

09031 THEOHARIS, A.

FBI HIRETAPPING: A CASE STUDY OF BUREAUCRATIC AUTONOMY POLITICAL SCIENCE QUARTERLY, 107(1) (SPR 92), 101-122. UNDER SUCCESSIVE PRESIDENTS, THE FEDERAL BUREAU OF INVESTIGATION'S POWERS AND AUTONOMY INCREASED DUE TO THE METHOOS EMPLOYED AND AUTHORIZED BY THE CHIEF EXECUTIVESPARTICULARLY THEIR PREFERENCE FOR EXECUTIVE DIRECTIVES INSTEAD OF LAWS TO AUTHORIZE FBI ACTIVITIES AND THEIR INTEREST IN SECRECY TO MINIMIZE DISCOVERY OF THEIR AUTHORIZATION AND THE KIND OF INFORMATION THEY SOLICITED OR RECEIVED FROM THE FBI A REVIEN OF FBI HIRETAPPING POLICY AND USE ILLUSTRATES THIS PROCESS.

09032 THERBORN, G.

THE LIFE AND TIMES OF SOCIALISM

THE AUTHOR ENDEAVORS TO DRAW UP A GENERAL BALANCE SHEET OF THE COMMUNIST EXPERIENCE AND TO TAKE A BEARING ON THE HISTORICAL ACHIEVEMENTS AND VICISSITUDES OF THE HISTORIC LEFT. HE CITES EVIDENCE TO SHOW THAT GENUINE SOCIAL PROGRESS WAS SPONSORED BY COMMUNISM IN EASTERN EUROPE AND THE SOVIET UNION UP TO SOME TIME IN THE EARLY 1970'S. BUT HE FINDS THAT THE CLASSICAL RECIPES OF THE LEFT, WHETHER COMHUNIST OR SOCIAL DEMOCRATIC, HAVE BEEN OUTFLANKED IN A GLOBAL CONTEXT WHERE MARKETS RATHER THAN ENTERPRISES DOMINATE THE ORGANIZATION OF PRODUCTION. HOWEVER, HE ADVANCES REASONS TO
BELIEVE THAT THE GOALS OF THE LEFT CAN FIND A NEW RELEVANCE AND NEW DEFINITION IN A WORLD THAT IS MENACED BY THE FEVERISH AND RAPACIOUS LURCHES OF THE INDUSTRIAL CAPITALIST ORDER.

09033 THERIEN, J.

NATIONAL INTERESTS AND MULTILATERAL COOPERATION: CANADA AND DEVELOPMENT BANKS

ETUDES INTERNAT IONALES, 23(2) (JUN 92), 395-444.

HOW, IN KEEPING WITH THE OVERALL LOGIC OF ITS AID POLICY, CANADA'S PARTICIAPTION IN INTERNATIONAL FINANCIAL INSTITUTIONS HAS RESULTED FROM A MANY-SIDED CONFIGUARATION OF POLITICAL, DEVELOPMENTAL, AND ECONOMIC INTERESTS IS SHOWH IN THIS PAPER. THE PURPOSE OF THIS ARTICLE FINDS ITS JUSTIFICATION IN THE FACT THAT BY FOCUSING MAINLY ON BILATERAL ASSISTANCE PROGRAMS, THE LITERATURE ON CANADAIN AID HAS LARGLEY NEGLECTED THE STUDY OF THE MANY CHANNELS FOR DISTRIBUTING MULTILATERAL ASSISTANCE.

09034 THERKILDSEN, O.: SEMBOJA, J.

SHORT-TERM RESOURCE MOBILIZATION FOR RECURRENT FINANCING OF RURAL LOCAL GOVERMMENTS IN TANZANIA

HORLD DEVELOPMENT, 20 (8) (AUG 92), 1101-1113.

RURAL LOCAL GOVERNMENTS IN TANŻANIA FACE SERIOUS

OBSTACLES IN FINANCING THE OPERATION AND MAINTENANCE OF BASIC SERVICES. OVER THE PAST TWO DECADES, MACROECONOMIC IMBALANCES, PAST DEVELOPMENT POLICIES, AND INSTITUTIONAL PROBLEMS HAVE EXACERBATED THE LOCAL GOVERNMENTS' HOES. THE AUTHORS PROVIDE AN ESTIMATE OF THE ADDITIONAL FUNOS NEEDED FOR ADEQUATE FINANCING OF SALARY AND NON-SALARY RECURRENT EXPENDITURES. THEY ANALYZE THE SHORT-TERM POSSIBILITIES FOR RAISING THESE FUNDS DOMESTICALLY AT THE VILLAGE, DISTRICT, AND CENTRAL LEVELS. THEY IDENTIFY VARIOUS ECONOMIC, POLITICAL, AND INSTITUTIONAL CONSTRAINTS AND DISCUSS COMPETING CLAIMS ON PUBLIC SECTOR REVENUES. THEY CONCLUDE THAT, WITHOUT SHORT-TERM EXTERNAL ASSISTANCE FOR RECURRENT FINANCING OF LOCAL GOVERNMENTS, BASIC SERVICES ARE LIKELY TO DETERIORATE EVEN FURTHER.

09035 THIELEMANN, G.

MINORITY LEGISLATORS AND INSTITUTIONAL INFLUENCE SOCIAL SCIENCE JOURNAL, 29(4) (1992), 411-422.

ALTHOUGH THE FREQUENCY OF STUDIES ON BLACK AND MEXICANAMERICAN LEGISLATORS HAS INCREASED, LITTLE EMPHASIS IS GIVEN TO THE INSTITUTIONAL POLITICS WHICH IMPACT THESE GROUPS. THIS ANALYSIS COMPARES THE POLITICAL BEHAVIOR AND VIENS OF BLACKS, MEXICAN-AMERICANS AND AMGLOS IN THE ENVIRONMENTALLY STABLE SETTING OF THE TEXAS HOUSE AND FINDS THAT EVEN IN A SYSTEM THAT TREATS MINORITIES FAIRLY IN TERMS OF DISTRIBUTING INFLUENCE POSITIONS. MINORITY MEMBERS ARE MUCH MORE LIKELY TO FAVOR INSTITUTIONAL REFORMS. A MORE CAREFUL ANALYSIS OF THE ORGANIZATIONAL DYNAMICS OF THE TEXAS HOUSE REVEALS THAT MINORITIES ARE SUCCESSFUL ONLY AS A RESULT OF THE SPEAKER'S DESIRE TO ACCOMMODATE THEM AND THAT IN SPITE OF THIS ACCOMMODATION, MINORITY LEGISLATORS FAVOR INSTITUTIONAL RULES THAT GUARANTEE FAIR TREATMENT REGARDLESS OF THE SPEAKER'S HHIMS.

09036 THIELEMANN, G

PARTY DEVELOPMENT IN THE SOUTH: THE CASE FOR SOUTHERN EXCEPTIONAL ISM

SOCIAL SCIENCE QUARTERLY, 73 (1) (MAR 92), 141-143. SOUTHERN--PARTICULARLY REPUBLICAN-POL ITICS. CONTRARY TO SOME RECENT OPINION, THE ARTICLE MAINTAINS THAT SOUTHERN REPUBLICAN PARTIES REMAIN DISTINCT FROM BOTH SOUTHERM DEMOCRATIC PARTIES AND THOSE OF THE REST OF THE NATION. THIS UNIQUENESS LENDS INCREASED IMPORTANCE TO PRIMARY COMPETITION. THE TRUNCATED FORM OF REPUBLICAN PARTY DEVELOPMENT WHICH INTRODUCES CANDIDATES AND PLATFORMS IN GENERAL ELECTIONS RATHER THAN AT THE GRASS ROOTS LEVEL OF PRIMARY COMPETITION IS HARMFUL TO THE REPUBLICAN CAUSE IN THE SOUTH.

09037 THIELEMANN, G.

THE RISE AND STALL OF SOUTHERN REPUBLICANS IN CONGRESS SOCIAL SCIENCE QUARTERLY, 73(1) (MAR 92), 123-135. ONE OF THE MOST NOTED ELECTORAL SHIFTS IN RECENT AMERICAN POLITICS HAS BEEN THE SUCCESS OF THE REPUBLICAN PRESIDENTIAL MOMINEES IN THE SOUTH. ALONG WITH THESE HINS CAME HEIGHTENED EXPECTATIONS FOR SUCCESS AT OTHER ELECTORAL CAME HEIGHTENED EXPECTATIONS FOR SUCCESS AT OTHER ELECTORAL LEVELS. INCREASED REPUBLICAN SUCCESS HAS NOT OCCURRED AMONG PROPOSES AND TESTS A MODEL TO EXPLAIN REPUBLICAN STAGNATION PROPOSES AND TESTS A MODEL TO EXPLAIN REPUBLICAN STAGNATION IN THE REGION'S CONGRESSIONAL ELECTIONS BY EXPLORING THE EFFECTS OF INCUMBENCY, COATTAILS, AND
IN THE REGIONAL CONTEXT OF THE SOUTH.

09038 THIES, J.

GERMANY I: INTO TURBULENT WATERS

WORLD TODAY, 48(8-9) (AUG 92), 148-151.

GERMANY IS FACING A PERIOD OF DOMESTIC TURBULENCE AND, FOR THE TIME BEING, WILL REMAIN PREOCCUPIED WITH ITS POSTREUNIFICATION SITUATION, BOTH DOMESTICALLY AND IN TERMS OF ITS INTERNATIONAL ROLE. ALTHOUGH THIS WILL UNDOUBTEDLY 
CHANGE OVER THE NEXT FEW YEARS, THE COUNTRY HAS A LONG WAY TO GO BEFORE IT CAN ACQUIRE A SELF-CONFIDENT IDENTITY AND PLAY a REALLY ASSERTIVE ROLE IN EUROPE.

09039 THOMAS-SLAYTER, B.

CLASS, ETHNICITY, AND THE KENYAN STATE: CONTINUITY MOBILIZATION IN THE CONTEXT OF GLOBAL POLITICS INTERNATIONAL JOURNAL OF POLITICS, CULTURE AND SOCIETY, 4(3) (SPR 91), 301-322. THE KENYAN STATE IS TRAPPED BY NEARLY OVERHWELMING THE KENYAN STATE IS TRAPPED BY NEARLY OVERHELMING
ECONOMIC PRESSURES ARISING FROM ITS POSITION HITHIN THE ECONOMIC PRESSURES ARISING FROM ITS POSITION HITHIN THE
GLOBAL ECONOMY. MOREOVER, ITS POLITICAL SITUATION IS TENUOUS GLOBAL ECONOMY. MOREOVER, ITS POLITICAL SI TUATION IS TENUOUS HAVE BEEN IN A POSITION TO TAKE ADVANTAGE OF THE LARGESSE HAVE BEEN IN A POSITION TO TAKE ADVANTAGE OF THE LARGESSE THE KENYAN STATE DESPERATELY NEEDS TO MOBILIZE BOTH THE POLITICAL SUPPORT AND ECONOMIC RESOURCES OF THE RURAL PEOPLE. ON THE OTHER HAND, IT IS PREVENTED FROM FULLY UTILIZING THESE FORCES BY ITS OWN FRAGILITY AND FEARS OF LOSING CONTROL. ETHNICITY REMAINS THE MOST COMPELLING BASIS FOR COMMUNITY MOBILIZATION, AS WELL AS THE ENERGIZING FORCE WHICH THE STATE FEARS THE MOST.

09040 THOMAS, $B$.

CARRIBEAN BLACK POWER: FROM SLOGAN TO PRACTICAL POLITICS JOURNAL OF BLACK STUDIES, 22(3) (MAR 92), 392-410.

THIS ARTICLE ASSESSES THE EVOLUTION OF CARIBBEAN BLACK POWER FROM ITS CRUDEST FORM OF SLOGANEERING TO ITS TRANSFORMATION AS A WEAPON IN THE POLITICAL PROCESS. THE ANALYSIS BEGINS HITH A BRIEF ASSESSMENT OF NEW WORLDISM THROUGH BLACK POWER TO THE PARTICIPATION OF FORMER BLACK POWER ADVOCATES IN THE VERY POLITICS THAT THEY ONCE DEBUNKED. FIRST IT SHOWS THAT THE ADVOCATES OF THE 1960S HERE THE SUCCESSORS TO THE LEGACIES OF SPECIFIC PERSONS. AND SECOND, THE PECULIAR CONFIGUATATION OF THE CARIBBEAN DICTATED A COMPELLING SEARCH FOR AN APPROPRIATE IDEOLOGY TO PROPERLY ARTICULATE THE DEMANDS OF THE MULTIRACIAL SOCIETY.

09041 THOMAS, C.

HOW ISRAEL SAW IRAQ DURING THE GULF HAR

RUSI JOURNAL, 136(4) (WIN 91), 38-44.

DURING THE GULF HAR, IRAO BECAME ISRAEL'S MOST SERIOUS SECURITY CONCERN. HUSSEIN'S MISSILE ARSENAL WAS WELL KNOWN TO THE ISRAELIS AND THROUGHOUT THE CONFLICT ISRAELI INTELLIGENCE SOURCES WERE ABLE TO PROVIDE HIGH LEVELS OF INFORMATION ON IRAOI MOVEMENTS AND INTENTIONS. THE AUTHOR DISCUSSES THE PROGRESS OF THE CONFLICT, THE IRAQI MISSILE ATTACKS ON ISRAEL AND HOW ISRAEL MAINTAINED BOTH MISSILE AND FORCE MOVEMENTS. HE CONCLUDES THAT WITH SADDAM HUSSEIN'S RETENTION OF POWER, THE REGIONAL MILITARY BALANCE SEEMS TO HAVE TIPPED EVEN FURTHER AGAINST ISRAEL AMD MAY DRIVE HER INTO EVEN MORE HARDLINE POSITIONS IN ORDER TO MAINTAIN HER SECURITY.

09042 THOMAS, $D$.

THO PARTY POLITICS IN AMERIC

CONTEMPORARY REVIEW, 261(1520) (SEP 92), 117-121.

DURING CAMPAIGN 92 MANY AMERICANS SEEM TO BELIEVE THAT THE NATION IS ECONOMICALLY DECLINING AND A CHANGE IN POLITICAL LEADERSHIP IS MECESSARY. PRESIDENT BUSH HAS DECLINED IN POPULARITY AND HAS BECOME ONE OF THE FEH RECENT PRESIDENTS EVER TO ENCOUNTER SERIOUS INTRA-PARTY OPPOSITION. THE DEMOCRATIC PARTY CANDIDATE, BILL, CLINTON, SUFFERED FROM ADVERSE PUBLICTY RELECTING ON HIS CHARACTER WHICH SEEMED TO DIMISH THE CHALLENGE TO THE REPUBLICANS. A TEXAS BUSINESSMAN, ROSS PEROT HAD LAUNCHED A SERIOUS PRESIDENTIAL CAMPAIGN OUTSIDE THE TWO PARTY SYSTEM. HOWEVER, HE WITHDREW CLAIMING THAT HE DID NOT WANT TO CAUSE A CONSTITUTIONAL CRISIS. THIS THAT HE DID NOT WANT TO CAUSE A CONSTITUTIONAL CRISIS. THIS
ARTICLE CONCLUDES THAT IN SPITE OF THE PROBLEMS OF BUSH AND CLINTON IN CAMPAIGN 192 , ROSS PEROT'S HITHDRAWAL ENSURES THAT TWO-PARTY POLITICS REMAINS DOMINANT IN AMERICA.

09043 THOMAS, J.; HOXWORTH, D.

THE LIMITS' OF JUDICIAL DESEGREGATION REMEDIES AFTER THE LIMITS OF JUDIC

PUBLIUS: THE JOURNAL OF FEDERALISM, 21(3) (SUM 91) 93-108.

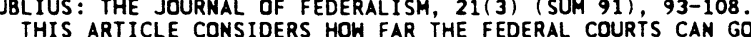
TO REMEDY UNCONSTITUTIONAL SEGREGATION. IN MISSOURI $V$.

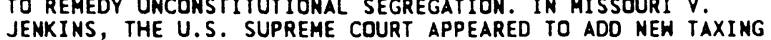
JENKINS, THE U.S. SUPREME COURT APPEARED TO ADD NEW TAXIMG POHERS TO THE EXISTING TOOLS AVAILABLE TO THE JUDICIARY. IT SAID, HOW IT WAS RECEIVED, AND MOST IMPORTANTLY, WHAT ITS IT SAID, HOH IT WAS RECEIVED, AND MOST IMPORTANTLY, WHAT IT "NONG-TERM SIGNIFICANCE MAY BE. THE AUTHORS ARGUE THAT THE "NEW" JUDICIAL TAXING AUTHORITY SANCTIONED IN THE DECISION MAY NOT PROVE NEARLY AS IMPORTANT AS FIRST ANTICIPATED. IN
THE LONG RUN, MISSOURI $V$. JENKINS MAY PROVE MOST SIGNIFICANT FOR THE QUESTIONS ABOUT DESEGREGATION RAISED BY JUSTICE ANTHONY KENNEDY IN A DISSENTING OPINION. THOSE QUESTIONS COULD PRESAGE A MORE SKEPTICAL COURT OUTLOOK ON SUBSTANTIVE SCHOOL DESEGREGATION REMEDIES, AT LEAST WHERE THOSE REMEDIES CALL FOR ADDITIONAL PUBLIC FUNDING, AS WELL AS GREATER COURT DEFERENCE TO THE OUTCOMES OF STATE-LOCAL POLITICAL PROCESSES.
09044 THOMAS, J.C.; SAVITCH, H.V. INTRODUCTION: BIG CITY POLITICS, THEN AND NOW; BIG CITY POLITICS IN TRANSITION

SAGE PUBLICATIONS, 1991, 1-13. THIS INTROOUCTORY CHAPTER CONSIDERS SEVERAL CHANGES THAT HAVE TAKEN PLACE IN AMERICAN BIG CITIES OVER THE PAST THREE DECADES. THE CHAPTER HIGHLIGHTS THE DEMOGRAPHICS AND
ECONOMIC BASE OF THE CITY; THE ROLE AND STRUCTURE OF CITY GOVERNMENT, INCLUDING INTERACTION WITH STATE HOUSES, SUBURBS, AND THE FEDERAL GOVERNMENT; AND THE CAST OF INTEREST GROUPS AND THE FEDERAL GOVERNMENT; AND THE CAST OF INTEREST GROUPS
AND POLITICAL INTELLECTUALS. CUTTING ACROSS THESE CONCERNS AND POLITICAL INTELLECTUALS. CUTTING ACROSS THESE CONCERNS IS A GENERAL INTEREST IN THE POL ITICAL CHARACTER OF THE
-THE COMPOSITION AND COHESION OF THE COALITIONS, GROUPS, -THE CDMPOSITION AND COHESION OF THE COALITIONS, GROUPS, DECISIONS.

09045 THOMAS, J.C.

THE TERM LIMITATIONS MOVEMENT IN U.S. CITIES

NATIONAL CIVIC REVIEW, 81(2) (SPR 91), 155-173.

WHILE THE MUNICIPAL TERM-LIMITS PHENOMENON IS A PERMUTATION OF THE STATE AND FEDERAL MOVEMENTS, IT EXHIBITS CERTAIN UNIQUE CHARACTERISTICS. WITH ITS MOMENTUM SHOWING NO SIGNS OF SLOWING, THE EXPERIENCE OF COMHUNITIES THAT HAVE ALREADY ADOPTED LIMITS HOLDS LESSONS FOR ELECTED OFFICIALS IN CITIES CONSIDERING SIMILAR INITIATIVES.

09046 THOMAS, R.G.C DEMOCRACY VERSUS SECURITY IN INDIA: THE CONSTITUTIONAL, POLITICAL AND MILITARY DEBATE; ASSOCIATION FOR ASIAM STUDIES 1992 ANNUAL MEETING

ASSOCIATION FOR ASIAN STUDIES, $1992,135-36$

THIS PAPER EXAMINES THE EROSION OF THE DEMOCRATIC PROCESS IN INDIA AS PROBLEMS OF EXTERNAL AND ESPECIALLY INTERNAL SECURITY INCREASE. THE STRESS ON THE INDIAN DEMOCRACY HAS BECOME CRITICAL WITH THE GROWTH OF SEPARATIST MOVEMENTS IN INDIAN PUNJAB AND KASHMIR AND THE INCREASING THREAT OF WAR WITH PAKISTAN. IN ADOITION, VIOLENT STRUGGLES IN ASSAM, NAGALAND AND TRIPURA CONTINUE TO PLACE A BURDEN ON IN ASSAM, NAGALAND AND TRIPURA CONTINUE TO PLACE A BURDEN ON THE INDIAN GOVERNMENT AS IT STRIVES TO FUNCTION WITHIN THE
SLOW AND RESTRICTED PROCEDURES PROVIDED BY THE PARLIAMENT SLOW AND RESTRICTED PROCEDURES PROVIDED BY THE PARLIAMENT
AND THE COURTS. THE CENTRAL QUESTION OF THE PAPER IS: SHOULD AND THE COURTS. THE CENTRAL QUESTION OF THE PAPER IS: THE URGENCY OR INTENSITY OF NATIONAL SECURITY ISSUES OVERRIDE DEMOCRATIC PROCESSES? IN INDIA, THE POL ITICAL
DEBATE IS ESSENTIALLY BETWEEN THOSE WHO BELIEVE IN "SECURITY DEBATE IS ESSENTIALLY BETWEEN THOSE WHO BELIEVE IN "SECU FIRST," AND THOSE WHO ADVOCATE "DEMOCRACY FIRST. "THE
VARIOUS ISSUES RAISED IN THIS DEBATE ARE EXAMINED AT THREE VARIOUS ISSUES RAISED IN THIS DEBATE ARE EXAMINED AT THREE
LEVELS: THE CONSTITUTIONAL, THE POLITICAL AND THE MILITARY.

09047 THOMAS, S.; GROFMAN, $B$. DETERMINANTS OF LEGISLATIVE SUCCESS IN HOUSE COMMITTEES PUBLIC CHOICE, 74(2) (1992), 233-244

THE FACTORS THAT ARE ASSOCIATED WITH WHETHER A BILL PASSES THE COMMITTEE STAGE IN THE U.S. HOUSE OF REPRESENTATIVES ARE EXAMINED. PROBIT RSULTS SHOW THAT A BILL IS MORE LIKELY TO PASS (1) IF THE SPONSOR CHAIRS THE COMMITTEE THAT CONSIDERS THE BILL; (2) THE HIGHER THE MUMBER OF DEMOCRATIC COSPONSORS WHO SIT ON THE COMMITTEE; (3) IF THE BILL HAS BIPARTISAN COSPONSORSHIP FROM MEMBERS WHO SIT ON THE COMMITTEE THAT CONSIDERS THE BILL. OTHER VARIABLES ARE NOT STATISTICALLY SIGNIFICANT.

09048 THOMAS, $S$.

THE EFFECTS OF RACE AND GENDER ON CONSTITUENCY SERVICE WESTERN POLITICAL QUARTERLY, 45(1) (MAR 92), 169-180.

09049 THOMAS, S.T.; ELLES, J.; MARTIN, D.

ASSESSING MEP INFLUENCE ON BRITISH E.C. POLICY GOVERMMENT AND OPPOSITION, 27 (1) (WIN 92 ), 3-26. IN GREAT BRITAIN, TORY MEMBERS OF THE EUROPEAN PARLIAMENT (MEP'S) ARE ORGANIZED AS THE EUROPEAN DEMOCRATIC GROUP. LABOUR MEP'S ARE THE EUROPEAN PARLIAMENTARY LABOUR GROUP. LABOUR MEP'S ARE THE EUROPEAN PARLIAMENTARY LABOUR
PARTY. EACH OF THESE GROUPS IS AUTONOMOUS OF ITS RESPECTIVE PARTY. EACH OF THESE GROUPS IS AUTONOMOUS OF ITS RESPECTIVE
PARLIAMENTARY PARTY AND ITS STRICTURES, ALTHOUGH THERE ARE PARL IAMENTARY PARTY AND ITS STRICTURES, ALTHOUGH THERE
SOME FORMAL TIES TO THE CENTRAL PARTY. SEVERAL FACTORS SOME FORMAL TIES TO THE CENTRAL PARTY. SEVERAL FACTORS SUGGEST THAT MEP'S SHOULD BE INCREASINGLY IMPORTANT IN
BRITISH POLITICS. HOHEVER, THEY DO NOT APPEAR TO BE SO. THIS BRITISH POLITICS. HOHEVER, THEY DO NOT APPEAR TO BE SO. THIS
STUDY ADDRESSES A NUMBER OF REASONS WHY BRITISH MEMBERS OF STUDY ADDRESSES A NUMBER OF REASONS WHY BRITISH MEMBERS OF
THE EUROPEAN PARLI AMENT CURRENTLY HAVE LITTLE INFLUENCE ON THE EUROPEAN PARL IAMENT CURRENTLY HAVE LITTLE INFLUENCE ON
BRITISH POLICY TOWARD THE EUROPEAN COMMUNITY AND CONCLUDES BRITISH POLICY TOWARD THE EUROPEAN COMMUNITY AND CONCLUDES
BY SUGGESTING THAT THE PROSPECTS FOR INCREASED INFLUENCE ARE BY SUGGESTING

09050 THOMPSON, A.

INFORMAL EMPIRE? AN EXPLORATION IN THE HISTORY OF ANGLOARGENT INE RELATIONS, $1810-1914$

JOURNAL OF LATIN AMERICAN STUDIES, 24(2) (MAY 92), 419-436. THE AUTHOR EXAMINES THE CONCEPT OF "INFORMAL IMPERIALISH" AND WHETHER IT CLARIFIES OR DISTORTS THE TRUE NATURE OF ARGENTINA'S RELATIONSHIP WITH BRITAIN FROM INDEPENDENCE UNTIL THE OUTBREAK OF WORLD HAR I.

09051 THOMPSON, B.

LIVING WITH A SUPREME COURT IN IRELAND 
PARLIAMENTARY AFFAIRS, 44(1) (JAN 92), 33-49.

THIS ARTICLE LOOKS AT SOME OF THE RECENT DECISIONS OF IRELAND'S SUPREME COURT IN ORDER TO EXAMINE THE RELATIONSHIP BETWEEN THE COURTS AND THE OTHER THO ORGANS OF GOVERNMENT IN IRELAND: LEGISLATURE AND EXECUTIVE. PARTICULAR FOCUS IS PLACED ON THE LIMITATIONS WHICH THE COURT CAN PLACE ON THOSE OTHER ORGANS.

09052 THOMPSON, D.F.

PARADOXES OF GOVERMMENT ETHICS

PUBLIC ADMINISTRATION REVIEH, 52(3) (MAY 92), 254-259.

THE AUTHOR DISCUSSES THE RESPONSIBILITIES OF GOVERNMENT ETHICS OFFICIALS. HE ARGUES THAT SUCH OFFICIALS NEED TO DO MORE THAN OVERSEE THE PAPERHORK ASSOCIATED WITH ETHICS LEGISLATION AND THE ENFORCEMENT OF SPECIFIC STANDARDS AND RULES. ETHICS OFFICIALS ALSO HAVE AN EDUCATIONAL
RESPONSBILITY TO REMIND OTHER PUBLIC SERVANTS OF THEIR FUNCTION IN AMERICAN DEMOCRACY. CARRYING OUT THIS EDUCATIONIN-DEMOCRACY IS DIFFICULT DUE TO THREE PARADOXES OR IN-DEMOCRACY IS DIFFICULT DUE TO THREE PARADOXES OR
MISCONCEPTIONS THAT IMPEDE THE WORK OF ETHICS OFFICIALS MISCONCEPTIONS THAT IMPEDE THE WORK OF ETHICS OFFICIALS:
MISCONCEPTIONS ABOUT THE IMPORTANCE OF ETHICAL ISSUES, THE MISCONCEPTIONS ABOUT THE IMPORTANCE OF ETHICAL ISSUES, THE
CONFLICT BETHEN PUBLIC AND PRIVATE ETHICAL BEHAVIOR, AND THE CONFLICT BETWEN PUBLIC AND PRIVATE ETHICAL BEHAVIOR,
IMPORTANCE OF APPEARANCES. THE MAJOR ROLE FOR ETHICS IMPORTANCE OF APPEARANCES. THE MAJOR ROLE FOR ETHICS VISIBLE EFFORT TO EDUCATE GOVERNMENT EMPLOYEES ABOUT THEIR VISIBLE EFFORT TO EDUCATE GOVE
DEMOCRATIC RESPONSIBILTIES.

09053 THOMPSON, F.

DEREGULATING DEFENSE ACQUISITIONS

POLITICAL SCIENCE QUARTERLY, 107 (4) (WIN 93), 727-750. THE AUTHOR GIVES AN OVERVIEW OF PROPOSALS' TO REFORM THE U.S. FEDERAL DEFENSE ACOUISITIONS PROCESS. HE ARGUES THAT, AS THE SIZE OF THE MILITARY IS REDUCED, FEWER DOLLARS WILL BE AVAILABLE FOR THE DEPARTMENT OF DEFENSE, SO THEY MUST BE SPENT MORE HISELY THAN IN THE PAST.

09054 THOMPSON, J.A.; CASSIE, $H$.

PARTY AND PAC CONTRIBUTIONS TO NORTH CAROLINA LEGISLATIVE CANDIDATES

LEGISLATIVE STUDIES QUARTERLY, XVII(3) (AUG 92), 409-416. THE AUTHORS INVESTIGATE THE SOURCES AND DISTRIBUTION OF CAMPAIGN FUNDS FOR STATE LEGISLATIVE CANDIDATES IN NORTH CAROLINA--A STATE CHARACTERIZED BY RELATIVELY STRONG INTEREST GROUPS AND WEAK POLITICAL PARTIES. CONSISTENT WITH PREVIOUS STUDIES, THEY FIND THAT POLITICAL ACTION COMMITTEES PREVIOUS STUDIES, THEY FIND THAT POL ITICAL ACTION COMMITTEES
CONTRIBUTE MORE MONEY AND A LARGER PROPORTION OF THEIR FUNDS CONTRIBUTE MORE MONEY AND A LARGER PROPORTION OF THEIR FUNDS
TO INCUMBENTS. IN ADOITION, PAC'S FAVOR LEGISLATIVE LEADERS. TO INCUMBENTS. IN ADOITION, PAC'S FAVOR LEGISLATIVE LEADERS.
CONVERSELY, THE STATE REPUBLICAN PARTY'S STRATEGY APPEARS TO CONVERSELY, THE STATE REPUBLICAN PARTY'S STRATEGY APPEARS TO
BE ONE OF FUNDING CHALLENGERS IN CLOSE RACES AND ASSISTING BE ONE OF FUNDING CHALLENGERS IN CLOSE

09055 THOMPSON, J.A.; FELTS, A.A. POLITICIANS AND PROFESSIONALS: THE INFLUENCE OF STATE AGENCY HEADS IN BUDGETARY SUCCESS

HESTERN POLITICAL QUARTERLY, 45(1) (MAR 92), 153-168. THIS PAPER CONTINUES RESEARCH UNDERTAKEN BY LAUTH AND THOMPSON IN THE MID-1980'S BY ANALYZING THE DIFFERENCES IN THE LEGISLATIVE BUDGETARY SUCCESS OF ELECTED AND APPOINTED AGENCY HEADS. SUPPORT FOR SHARKANSKY'S EARLY RESEARCH AND LAUTH'S IS REVEALED IN THE NEW DATA, BUT THE FINDINGS ARE ALSO CONSISTENT WITH THE INCREASING FOCUS UPON THE GOVERNOR AS THE CHIEF BUDGETARY OFFICER OF THE STATE. THE AUTHORS EXPLORE SEVERAL FACTORS, INCLUDING THE RELATIONSHIP BETHEEN GOVERNORS AND ELECTED OR APPOINTED AGENCY HEADS AS WELL AS THE DEGREE OF PROFESSIONALIZATION OF AGENCIES. THE FINDINGS INDICATE THAT APPOINTED HEADS MAY BE GAINING GROUND DUE TO PROFESSIONALIZATION AND EXECUTIVE CONSOL IDATION IN THE BUDGETARY PROCESS

09056 THOMPSON, K.L

SEALIFT TESTIMONY IRKS SOME ON HIL

ARMED FORCES JOURNAL INTERNATIONAL, (APR 91), 12

NAVY $V$. ADMIRAL FRANCIS $R$. DONOVAN TESTIFIED BEFORE THE HOUSE ARMED SERVICES' SUBCOMWITTEE ON SEAPOWER AND STRATEGIC AND CRITICAL MATERIALS ON 19 FEBRUARY ON THE SEALIFT SUPPORT PROVIDED TO OPERATIONS DESERT SHIELD AND DESERT STORM. SEALIFT SHORTFALLS REVEALED BY THE GULF WAR CAME AS NO
SURPRISE TO SUBCOMMITTEE MEMBERS. A MYRIAD OF PREVIOUS STUDIES HAD REACHED THE SAME CONCLUSIONS, PARTICULARLY THAT THE U.S. LACKS ADEQUATE SHIPPING TO TRANSPORT REQUIRED MILITARY EOUIPMENT OVERSEAS IN A SHORT TIME. MEMBERS OF CONGRESS WERE QUICK TORSAS IN A SHORT TIME. MEMBERS OF CONGRESS WERE QUICK TO CRITICIZE DONOVAN
FAILURE TO ACT ON THESE PREVIOUS STUDIES.

09057 THOMPSON, $P$. GREECE

EUROPE, (314) (MAR 92), 17-19.

AFTER YEARS OF COMPARATIVE PREDICTABILITY, GREECE'S RELATIONS WITH ITS THREE NORTHERN NEIGHBORS--ALBANIA YUGOSLAVIA AND BULGARIA--ARE UNCERTAIN, WHILE DIFFERENCES WITH TURKEY ARE AS ACUTE AS EVER. GREECE'S PRIME MINISTER, CONSTANTINE MITSOTAKIS, THEREFORE, TIED APPROVAL OF THE EUROPEAN COMHUNITY (EC) MAASTRICHT AGREEMENTS TO GREEK ADMISSION TO THE NINE-MEMBER WESTERN EUROPEAN UNION (WEU),
WHICH GREECE AND OTHERS WOULD LIKE TO BECOME THE COMMUNITY'S DEFENSE ARM. THE WEU DID OPEN ITS DOORS TO THE REMAINING EC MEMBER STATES BUT ALSO EMPHASIZED ITS NATO CONNECTIONS BY OFFERING "ASSOCIATE" STATUS TO NATO COUNTRIES NOT IN THE EC, INCLUDING TURKEY. SOME EC MEMBERS, NOTABLY BRITAIN, ARE UNHAPPY ABOUT THE APPARENTLY BINDING MILITARY COMMITMENT TO GREECE'S DEFENSE ENTAILED BY THE WEU CHARTER. ATHENS NOW SAYS THAT THE GREEK PARLIAMENT WILL RATIFY MAASTRICHT ONLY AFTER THE WEU NEGOTIATIONS ARE SATISFACTORILY CONCLUDED. AS A RESULT, GREECE FINDS ITSELF IN THE MAXIMALIST LOBBY ON MOST ASPECTS OF EUROPEAN UNION.

09058 THOMPSON, P.

YUGOSLAYIA: THE VIEW FROM GREECE

EUROPE, (314) (MAR 92), 31.

THIS ARTICLE EXAMINES THE CONFLICT IN YUGOSLAVIA FROM A GRREK PERSPECTIVE. TWO ISSUES MUST PREFACE ANY GREEK CONCERN ABOUT BALKAN TURBULENCE. FIRST, THE SQUABBLING NATIONALISMS THAT BLOODIED THE REGION AS THE OTTOMAN TURKS WITHDREN BEFORE WORLD WAR I. AND SECOND, THE CARE GREECE HAS GIVEN IM RECENT YEARS TO MAINTAINING STRONG TIES WITH BOTH YUGOSLAVIA AND BULGARIA, TO OFFSET CHRONIC STRAINS HITH TURKEY. WHILE AND BULGARIA, TO OFFSET CHRONIC STRAINS HITH TURKEY. WHILE AGAINST YUGOSLAVIA. IT HAS SHIED AHAY FROM RECOGNIZING THE INDEPENDENCE OF BREAKAHAY YUGOSLAV REPUBLICS, UNLESS THEY INDEPENDENCE OF BREAKAHAY YUGOSLAV REPUBLICS, UNLESS THEY MEET A STRINGENT "NO TERRI TORIAL CLAIMS" REQIREMENT GRE
APPREHENSIONS HITH REGARDS TO YUGOSLAVIA INCLUDE: THE POSSIBILITY OF A SOUTHHARD EXTENSION OF THE YUGOSLAV CONFLICT; THE OIRECT INVDLVEMENT OF BULGARIA; A FLOOD OF REFUGEES; AND ADDED IMPEDIMENTS ON LAND ROUTES TO CENTRAL EUROPE. BUT TURKEY'S DECLARED INTEREST IN THE MUSLIM POPULATIONS OF THE BALKANS MOST ALARMS ATHENS.

09059 THOMPSON, R.J.

CONTRASTING MODELS OF WHITE HOUSE STAFF ORGANIZATION: THE EISENHOWER, FORD, AND CARTER EXPERIENCES

CONGRESS AND THE PRESIDENCY, 19(2) (FAL 92), 113-136.

ANALYSTS OF THE PRESIDENCY AGREE THAT WHITE HOUSE STAFFS MAY BE ORGANIZED ALONG ONE DF THREE LINES: A COMPETITIVE MODEL, A HIERARCHICAL MODEL, OR A COLLEGIAL MODEL. THIS PAPER DETAILS THE INTERACTION PATTERNS OF THE EISENHOWER, FORD, AND CARTER SENIOR WHITE HOUSE STAFFS IN AN EMPIRICA TEST OF THE BASIC ASSUMPTIONS OF THESE MODELS OF STAFF ORGANIZATION. THE RESULTS OF THE ANALYSIS OF PRIVATE AND
GROUP MEETING ACCESS BY THE SENIOR STAFF WITH THE PRESIDENT GROUP MEETING ACCESS BY THE SENIOR STAFF WITH THE PRESIDENT
CLEARLY INDICATE THAT THESE MODELS DO NOT CAPTURE THE FULL CLEARLY INDICATE THAT THESE MODELS DO NOT CAPTURE THE FULL
RANGE OF STAFF INTERACTION AND THAT OTHER FACTORS NEED TO BE RANGE OF STAFF INTERACTION AND THAT OTHER FACTORS NEED TO TIVEN MORE SERIOUS CONSIDERATION

09060 THOMPSON, $W$

A REALIST RESPONSE TO THE APPEAL FOR PACIFISM PERSPECTIVES ON POLITICAL SCIENCE, 20(2) (SPR 91), 73-77. THIS ART ICLE EXAMINES PROFESSOR ROBERT L. HOLMES'S ATTEMPTS TO REVIVE THE ARGUMENT FOR PACIFISM IN THE NUCLEAR AGE. IT CONCENTRATES ON HOLMES'S ATTACKS ON REALISM AND REALIST POLICY. THIS ARTICLE CONCLUDES THAT REALISM IS NOT THE GLORIFICATION OF FORCE AND VIOLENCE; IT IS NOT THE ANTITHESIS OF MORALITY; AND THAT MORAL JUDGEMENT IS NOT EXHAUSTED IN THE MORAL PURPOSES AND GOALS OF A PARTICULAR NATION, EVEN THOUGH THROUGHOUT HISTORY NATIONS, AND MOST RECENTLY IRAQ, HAVE BEEN TEMPTED TO IDENTIFY THEIR MORAL ASPIRATIONS WITH UNIVERSAL MORAL PURPOSES.

09061 THOMPSON, H.; VESCERA, L. GROWTH HAVES, SYSTEMIC OPENMESS, AND PROTECTIONISM INTERNATIONAL ORGANIZATION, 46(2) (SPR 92), 493-592. ANALYSTS HAVE ARGUED THAT SYSTEMIC OPENMESS AND PROTECTIONISM CAN BE EXPLAINED IN TERMS OF HEGEMONIC STABILITY, IDEAS, SURPLUS CAPACITY, BUSINESS CYCLES, OR SHIFTS IN ELITE ORIENTATION. NONE OF THESE APPROACHES, HOWEVER, DEVELOPS AN APPRECIATION FOR THE FUNDAMENTAL EMPHASES TO BE RELATED TO ONE ANOTHER. THIS ARTICLE OFFERS POTENTIALLY INTEGRATIVE APPROACH FOCUSING ON TECHMOLOGICAL LEADERSHIP AND ON RECURRING GROWTH HAVES, HHICH ARE CHARACTERIZED IN ATTEMPT OF TECHNOLOGICAL FOLLOWERS TO CATCH UP. IT ARGUES THAT WHILE PROTECTIONISM IS GENERALLY MORE LIKELY TO OCCUR DURING WAVE DOWNTURNS, IT IS MORE INTENSE IN IHE CATCH-UP WAVE THAN IN THE ASCENT WAVE, SINCE COMPETITION THE CATCH-UP WAVE THAN IN THE ASCENT WAVE, SINCE COMPETI
FOR LEADERSHIP SUCCESSION IS MORE INTENSE AND THE GAP FOR LEADERSHIP SUCCESSION IS MORE INTENSE AND THE GAP
BETWEEN LEADERS AND FOLLOWERS IS NARROWER DURING THE CATCHBETWEEN LEA

09062 THOMPSON, H.C. WESTERN EUROPE: MORE FREEDOM--AND ITS PROBLEMS FREEDOM REVIEW, $23(1)$ (JAN 92), 51-55.

IN 1991, THE COUNTRIES OF HESTERN EUROPE APPLAUDED THE GREATER FREEDOM IN EASTERN EUROPE AND THE DISINTEGRATION OF THE SOVIET UNION. BUT THESE DEVELOPMENTS WERE NOT WITHOUT PROBLEMS, AS EVIDENCED BY THE CIVIL WAR IN YUGOSLAVIA AND THE EUROPEAN COMMUNITY'S FAILURE IN ITS PEACE-MAKING EFFORTS. FUTURE SECURITY OF EUROPE AND THE ROLE OF NATO AND THE 
UNITED STATES.

09063 THOMPSON, W.R

DEHIO, LONG CYCLES, AND THE GEO-HISTORICAL CONTEXT OF STRUCTURAL TRANSITION

WORLD POLITICS, 45(1) (OCT 92), 127-152.

LEADERSHIP LONG-CYCLE ANALYSES EMPHASIZE THE GLOBAL

POL ITICAL ECONOMY, SEA POWER, AND CYCLICAL RISE AND FALL OF MARITIME POWERS. LUDWIG DEHID'S INTERPRETATION OF EUROPEAN INTERNATIONAL POLITICS STRESSES REGIONAL POLITICS, LAND INTERNATIONAL POLITICS STRESSES REGIONAL POLITICS, LAND
POWER, AND THE CYCLICAL RISE AND FALL OF CONTINENTAL POWERS. POWER, AND THE CYCLICAL RISE AND FALL OF CONTINENTAL POHE
SINCE NEITHER FRAMEWORK TOTALLY IGNORES WHAT THE OTHER SINCE NEITHER FRAMEWORK TOTALLY IGNORES WHAT THE OTHER
ACCENTUATES, A MERGER OF THE TWO PERSPECTIVES IS OUITE ACCENTUATES, A MERGER OF THE TWO PERSPECTIVES IS OUITE FEASIBLE AND PRODUCES IMPROVED EXPLANATORY PONER. AS AN
ILLUSTRATION, SEVERAL OF DEHIO'S GENERALIZATIONS ABOUT THE ILLUSTRATION, SEVERAL OF DEHIO'S GENERALIZATIONS ABOUT THE
NATURE AND TIMING OF REGIONAL POWER CONCENTRATION ARE TESTED NATURE AND TIMING OF REGIONAL POHER CONCENTRATION ARE TESTED
FOR THE PERIOD $1494-1945$. THE RESULTS SUGGEST THAT PEAKS OF FOR THE PERIOD 1494-1945. THE RESULTS SUGGEST THAT
REGIONAL AND GLOBAL POWER CONCENTRATION ALTERNATE.

09064 THOMPSON, H.R.

SYSTEMIC LEADERSHIP AND GROWTH WAVES IN THE LONG RUN INTERNATIONAL STUDIES QUARTERLY, 36(1) (MAR 92), 25-48. HOHEVER ONE EVALUATES THE EVIDENCE FOR LONG ECONOMIC WAVES IN THE NINETEENTH AND TWENTIETH CENTURIES, THE QUESTION OF WHETHER LONG WAVES EXISTED PRIOR TO THE LATE EIGHTEENTH CENTURY REMAINS OPEN. THIS QUESTION IS AN IMPORTANT ONE FOR SUBSTANTIVE REASONS, BUT IT ALSO ADDRESSES ONE OF THE MAJOR GROUNDS FOR SKEPTICISM ABOUT LONG WAVES, NAMELY, THE SMALL NUMBER OF FLUCTUATIONS OSTENSIBLY EXPERIENCED TO DATE. EMPHASIZING THE CRITICAL ROLE OF SPECIFIC LEADING SECTORS FOR GROWTH, A COMMERICAL-PRODUCTION GROWTH SERIES FOR THE 1490S-1790S ERA THAT CAN BE LINKED TO SIMILAR DATA AVAILABLE FOR THE PAST THO HUNDRED YEARS IS DEVELOPED. THE PRE-NINETEENTH CENTURY SERIES IS CHARACTERIZED BY MORE FREQUENT FLUCTUATIONS THAN THE POSTNINETEENTH CENTURY DATA--AN OUTCOME ATTRIBUTED TO YARYIMG PATTERNS OF WARFARE AMD CHANGES IN THE NATURE OF LEADIMG PATTERNS OF WARFARE AND CHANGES IN THE NATURE OF LEADING SECTORS. YET AN IMPORTANT ELEMENT OF CONTINUITY OBSERVED OVER FIVE CENTURIES IS THE UPTURN ASSOCIATED WITH THE EMERGENCE OF A NEW LEAD ECONOMY. WHEN COMBINED WITH MORE CONTEMPORARY DATA, THE NEW SERIES PROVIDE A FIVE-CENTURY
BASIS FOR INVESTIGATING THE EVOLUTIONARY DYMAMICS AND IMPACTS OF LONG WAVES OF POLITICAL-ECONOMIC CHANGE.

09065 THOMSON, D.L.

COMPARATIVE POLICY TOWARDS CULTURAL ISOLATIONISTS IM CANADA AND NORHAY

INTERNATIONAL POLITICAL SCIENCE REVIEW, 13(4) (OCT 92), 433-449.

GROUPS THAT ISOLATE THEMSELVES FROM PARTICIPATION IN THE PROCESSES OF GOVERMMENT BECAUSE THEY DO NOT HISH TO BE INFLUENCED OR COOPTED ARE CALLED "CULTURAL ISOLATIONISTS." ALTHOUGH CULTURAL ISOLATIONISTS ARE SMALL IN NUMBER, THEY REGULARLY CDME INTO CDNFLICT WITH ESTABLISHED GOVERNMENTAL
POLICIES. WESTERN DEMOCRACIES SHOULD BE ABLE TO ACCOMMODATE THESE GROUPS, BUT THEY TEND TO IGNORE THE DEMANDS OF CULTURAL ISOLATIONISTS, EVEN WHILE THEY ARE RESPONSIVE TO OTHER INTEREST GROUPS. IN THIS PAPER. THE AUTHOR EXAMINES THE ISSUES INVOLVING THE AMISH AND HUTTERITES IN CANADA AND THE SAMI IN NORHAY. HE DISCUSSES THE STATE RESPONSES TO THESE GROUPS AND THE SIMILARITIES OF THESE CASES.

09066 THORBECKE, $W$.

SOCIAL SECURITY INVESTMENT POLICY AND CAPITAL FORMATION CONTEMPORARY POLICY ISSUES, $X(3)$ (JUL 92), 26-38.

RECENT LARGE SURPLUSES IN THE SOCIAL SECURITY TRUST FUND ACCOUNTS HAVE OFFERED THE POTENTIAL OF INCREASING OVERALL NATIONAL SAVING AND CAPITAL FORMATION. HOWEVER, POLITICIANS NATIONAL SAVING AND CAPITAL FORMATION. HOWEVER, POLI
HAVE USED THESE SURPLUSES TO INCREASE THE NON-SOCIAL HAYE USED THESE SURPLUSES TO INCREASE THE NON-SOCIAL ARGUES THAT INVESTING THE TRUST FUNDS IN PRIVATE ASSETS ARGUES THAT INVESTING THE TRUST FUNDS IN PRIVATE ASSETS COULD BRING INTO FOCUS THE MAGNITUDE OF THE NON-SOCIAL
SECURITY DEFICIT AND FORCE CONGRESS TO REDUCE IT. EVIDENCE INDICATES THAT THE TRADE DEFICIT, OUTPUT, AND MONETARY POLICY ARE SYSTEMATIC MACRO-ECONOMIC VARIABLES THAT AFFECT POLICY ARE SYSTEMATIC MACRO-ECONOMIC VARIABLES THAT AFFE
RELATIVE ASSET PRICES. THE EVIDENCE ALSO SUPPORTS THE RELATIVE ASSET PRICES. THE EVIDENCE ALSO SUPPORTS THE
ARGUMENTS OF NORDHAUS AND OTHERS THAT A CHAHGE IN TRUST FUND ARGUMENTS OF NORDHAUS AND OTHERS THAT A CHAHGE IN TRUST
INVESTMENT POLICY COULD LOWER THE TRADE DEFICIT, RAISE
OUTPUT, AND PRODUCE LOOSER MONETARY POLICY, THEREBY INCREASING CAPITAL FORMATION. INVESTING THE TRUST FUNDS IN INCREASING CAPITAL FORMATION. INVESTING THE TRUST FUNDS IN
PRIVATE ASSETS COULD INCREASE NATIONAL INVESTMENT AND GIVE PRIVATE ASSETS COULD INCREASE NATIONAL INVESTMENT AND GIVE THE BABY-BUST GENERATION MORE CAPITAL TO USE IN PRODUCING GOODS AND

09067 THORNE, $P$

ANDREW THORNE AND THE LIBERATION OF NORHAY

INTELLIGENCE AND NATIONAL SECURITY, $7(3)$ (JUL 92), 300-316. NORWAY WAS EXCLUDED FROM THE SURRENDER OF THE GERMAN ARMIES TO MONTGOMERY ON 5 MAY, 1945. IT HAS LEFT TO SIR ANDREH THORNE TO SECURE THE SURRENDER OF SOME 350,000 GERMANS WITH A BODY OF TROOPS THAT NEVER AMOUNTED TO MORE THAN 30,000 MEN. SINCE THIS TASK HAS OBVIOUSLY IMPOSSIBLE BY FORCE OF ARMS, HE HAD TO RELY ON HIS OWH POWERS OF
PERSUASION AND NEGOTIATION, BACKED BY THE FORTITUDE DECEPTION PLAN AND SUCH INTELLIGENCE ON CONDITIONS IN NORHAY AND THE MORALE OF THE GERMAN TROOPS THERE AS WAS AVAILABLE. ON THORNE'S 1951 REPORT OF THE LIBERATION OF NORWAY.

09068 THORNTON, T.P.

INDIA ADRIFT: THE SEARCH FOR MOORINGS IN A NEW WORLD ORDER ASIAN SURVEY, XXXII(12) (DEC 92), 1063-1077.

ALTHOUGH THE END OF THE COLD WAR HAS REDUCED TENSIONS ALL OVER THE GLOBE, FOR IMDIA, THE CHANGES WHICH HAVE TRANSFORMED INTERMATIONAL POLITICS THREATEN TO MAKE THE MOST POPULOUS NATION AND POWERFUL MILITARY FORCE IN SOUTH ASIA INCREASINGLY IRRELEVANT. THIS ARTICLE EXAMINES GLOBAL CHANGES--MOST NOTABLY THE COLLAPSE OF THE SOVIET UNION--AND REGIONAL CHANGES SUCH AS THE RISE OF ISLAM IN CENTRAL ASIA, AS WELL AS DOMESTIC PROBLEMS, ALL OF WHICH AFFECT INDIA'S POSITION IN THE WORLD. IT CONCLUDES THAT INDIA MUST ACT TO ASSERT ITS AUTONOHY AS AN INTERNATIONAL PLAYER; DEVELOP A FOREIGN POLICY THAT WILL PROVIDE THE RESOURCES AND MARKETS NECESSARY FOR ITS ECONOMIC DEVELOPMENT AND COMBAT TENDENCIES TOWARDS PROTECTIONISM; ADDRESS CREATIVELY A RANGE OF NEW ISSUES SUCH AS THE ENVRIONMENT, TERRORISM, AND NARCOTICS; ESTABLISH A FIRM REGIONAL BASE IN SOUTH ASIA THAT WILL ENHANCE ITS INTERNATIONAL IMAGE; AND, FIND A NEW WAY TO BECOME RELEVANT ON THE BROADER INTERNATIONAL SCENE
ESCAPE THE MARGINALIZATION THAT NOW LOOMS OVER IT.

09069 THORNTON, T.P.

REGIONAL ORGANIZATIONS IN CONFLICT MANAGEMENT ANNALS OF THE AMERICAN ACADEMY OF POLITICAL AND SOCIAL SCIENCE, (518) (NOV 91), 132-142.

THE END OF COLONIALISM AND THE DECLINE OF COLD WAR BIPOLARITY MEAN THAT THE UNITED STATES AND THE SOVIET UNION MUST FIND NEW WAYS OF RELATING TO A THIRD HORLD THAT IS GROWING INCREASINGLY INFLUENTIAL AND IS SEEKING WAYS TO BE THE MASTER OF ITS OWN DESTINY. THERE HAS BEEN A MARKED GROWTH IN REGIONAL ORGANIZATIONS WITHIN THE THIRD WORL DESIGNED TO DEAL WITH THE RELATED PROBLEMS OF SOLVING INTERNAL DISPUTES AND REDUCING THE ROLE OF OUTSIDE POWERS IN REGIONAL AFFAIRS. THESE ORGANIZATIONS HAVE MIXED RECORDS, AND SOME COULD POSE THREATS TO BROADER GLOBAL INTERESTS, INCLUDING THOSE OF THE USA AND THE USSR. NONETHELESS, THE TREND TOWARD REGIONALIZATION IS PERVASIVE, AND IN MANY CASES TEGIOMAL GROUPINGS CAN DEAL WITH PROBLEMS' THAT THE SUPERPOWERS NO LONGER CAN OR WANT TO HANDLE. MOSCOW AND WASHINGTON MUST JUDGE EACH CASE ON ITS OWN MERITS, BUT THEIR GENERAL APPROACH SHOULD BE TO LET REGIONAL GROUPINGS CARRY AS MUCH OF THE BURDEN AS POSSIBLE.

09070 THORSON, C.

LEGACY OF THE USSR CONSTITUTIONAL SUPERVISION COMMITTEE RFE/RL RESEARCH REPORT, 1(13) (MAR 92), 55-59.

THE USSR COMMITTEE FOR CONSTITUTIONAL SUPERVISION REPRESENTED THE FIRST REAL ATTEMPT TO ESTABLISH THE SUPREMACY OF LAW IN THE SOVIET UNION. ALTHOUGH IT HAD LIMITED AUTHORITY, THE COMMITTEE WAS INCREASINGLY SEEN AS AN ALTERNATIVE SOURCE OF POLITICAL POWER AND AS A POTENTIAL GUARANTOR OF HUMAN AND CIVIL RIGHTS. THE COMMITTEE'S INADEQUACY RESULTED FROM THE ILLEGITIMACY OF THE LAW IT WAS ENTRUSTED TO UPHOLD AND FROM THE FACT THAT ITS RULINGS HERE TREATED AS RECOMMENDATIONS AND AS SUCH WERE NOT BINDING ON THE GOVERNMENT. NEVERTHELESS, ON MORE THAN ONE OCCASION, THE COMMITTEE SUCCEEDED IN OVERTURHING LEGISLATION. THUS, ITS RECORD IS CERTAINLY RELEVANT FOR THE USSR'S FORMER REPUBLICS IN THEIR ATTEMPTS TO OVERCOME THE LEGACY OF THE COMMUNIST SYSTEM.

09071 THORSON, C.

MOSCOW: THE POLITICS OF REFORM IN ONE CITY

IN RUSSIAN POLITICS, THE SUCCESS OR FAILURE OF ECONOMIC

REFORM HAS BECOME A CRITICAL BAROMETER OF POLITICAL FORTUNES,

AND POWER STRUGGLES ARE BEING WAGED ON THE BASIS OF ECONOMIC ISSUES. IN MOSCOH, PRIVATIZATION IS THE CENTRAL BATTLEGROUND. THE UNSUCCESSFUL ATTEMPTS TO IMPLEMENT PRIVATIZATION IN MOSCOW ILLUSTRATE THE DIFFICULTIES OF PRIVATIZATION IN MOSCOW ILLUSTRATE THE DIFFICULTIES OF
LAUNCHING ECONOMIC REFORM AND THE QUANDRY OF HOW TO LAUNCHING ECONOMIC REFORM AND THE QUANDRY OF HOW TO DEMOCRATIZE AND RESTRUCTURE
MAINTAINING EFFECTIVENESS.

09072 THORSON, C.

RUSSIA
RFE/RL RESEARCH REPORT, 1(27) (JUL 92), 41-49.

OVERCOMING THE LEGACY OF THE COMMUNIST SYSTEM REQUIRES THAT THE RULE OF LAW BE ESTABLISHED IN RUSSIA. REFORM-MINDED POLITICAL LEADERS HAVE ADVOCATED THE CREATION OF A LAW-BASED STATE IN PRINCIPLE, BUT IN PRACTICE THERE HAS BEEN LITTLE ACTION. ALTHOUGH SOME LAHS HAVE BEEN ENACTED AND SOME INSTITUTIONAL CHANGES HAVE BEEN IMPLEMENTED, THESE MEASURES HAVE NOT BEEN FAR-REACHING ENOUGH. RECENT POLITICAL DEVELOPMENTS ALSO SUGGEST THAT THE GAP BETWEEN THEORY AND PRACTICE MAY BE WIDENING. 
09073 THORSON, $C$

THE FATE OF THE COMMUNIST PARTY IN RUSSIA

RFE R TESEA CHE COMHUNIST PARTY IN RUSSIA THE RUSSIAN CONSTITUTIONAL COURT IS' CURRENTLY EVALUATING THE LEGALITY OF THE COMMUNIST PARTY AS WELL AS THE CONSTITUT IONALITY OF PRESIDENT YELTSIN'S BAN ON IT. THE COURT HEARINGS, WHICH ARE STILL UNDERHAY, HAVE ALREADY SPARKED WIDESPREAD POLITICAL CONTROVERSY. THE DECISION, WHEN IT IS FINALLY MADE, IS LIKELY TO BE A COMPROMISE. NO MATTER HOW THE COURT RULES, THERE HILL BE SERIOUS CONSEQUENCES FOR THE POLITICAL STABILITY AND LEGAL FRAMEWORK OF THE RUSSIAM FEDERATION.

09074 THORSON, C. (ED.)

WEEKLY RECORD OF EVENTS: 14-27 DECEMBER 1991

RFE/RL RESEARCH REPORT, 1(2) (JAN 92), 56-70.

THE AUTHOR SUMMARIZESS MAJOR NEWS EVENTS IN THE SOVIET UNION AND EASTERN EUROPE DURING DECEMBER 14-27, 1991. SHE DISCUSSES THE DISSOLUTION OF THE USSR, GORBACHEV'S FINAL DAYS AS SOVIET PRESIDENT, AND THE EVOLUTION OF THE NEW COMMONHEALTH OF INDEPENDENT STATES.

09075 THORSON, C. (ED.)

WEEKLY RECORD OF EVENTS: 28 DECEMBER 1991-9 JANUARY 1992 WEEKLY RECORD OF EVENTS: 28 DECEMBER 1991-9

THE AUTHOR SUMMARIZES MAJOR NEHS EVENTS IN EASTERN EUROPE AND THE COMMONHEALTH OF INDEPENDENT STATES FROM DECEMBER 28, 1991, THROUGH JANUARY 9, 1992. SHE REPORTS ON THE COMMONHEALTH SUMHIT MEETING IN MINSK, THE ELECTION IN UZBEKISTAN, THE CEASEFIRE IN YUGOSLAVIA, AND THE CONFRONTATION BETWEEN GEORGIAN PRESIDENT GAMSAKHURDIA AND HIS OPPOSITION.

09076 THORSON, C. (ED.)

WEEKLY REVIEH: 10-16 JANUARY 1992

RFE/RL RESEARCH REPORT, 1(4) (JAN 92), 66-78

THE AUTHOR SUMMARIZES MAJOR NEWS EVENTS IN THE BALTIC STATES, EASTERN EUROPE, AND THE COMMONWEALTH OF INDEPENDENT STATES DURING THE WEEK OF JANUARY 10, 1992. SUBJECTS INCLUDE THE INCREASING TENSION BETWEEN UKRAINE AND RUSSIA, FORMER PRESIDENT GAMSAKHURDIA'S RETURN TO GEORGIA, THE CRISIS IN THE ESTONIAN GOVERMMENT, AND THE PRESIDENTIAL ELECTION IN BULGARIA.

09077 THORSON, C. (ED.)

WEEKLY REVIEH: 17-23 JANUARY 1992

RFE/RL RESEARCH REPORT, 1 (5) (JAN 92), 65-76,

THE EDITOR SUMMARIZES MAJOR NEWS STORIES IN EASTER

EUROPE AND THE COMMONWEALTH OF INDEPENDENT STATES DURING

EUROPE AND THE COMMONHEALTH OF INDEPENDENT STATES DURING
JANUARY 17-23, 1992. TOP ICS INCLUDE RELATIONS AMONG THE

YUGOSLAY REPUBLICS. PROTESTS OVER PRICE INCREASES IN THE CIS,

STUDENT PROTESTS IN TASHKENT. AND PEACE TALKS BETWEEN

GAMSAKHURDIA SUPPORTERS AND THE MILITARY COUNCIL IN GEORGIA.

09078 THRANERT, 0.

GERMANS BATTLE OVER BLUE HELMETS

BULLETIN OF THE ATOMIC SCIENTISTS, 48(8) (OCT 92), 33-35. IN THE AFTERMATH OF THE GULF CONFLICT, GERMANY SEES ITS MILITARY IN A NEH LIGHT. GERMAN ARMIES PROVIDED SUPPORT BUT NO GERMAN COMBAT TROOPS WENT TO THE GULF. GERMAN SOLDIERS WITH GUNS GIVE MANY EUROPEANS--INCLUDING GERMANS--THE CHILLS THE GOVERMMENT WANTS TO TAKE A GREATER LEADERSHIP ROLE--BUT MOST GERMANS DO NOT WANT TO SEE GERMAN TROOPS IN COMBAT. THIS ARTICLE EXPLORES WHAT THE NATURE OF GERMAN PARTICIPATION SHOULD BE AND WHETHER A UNIFIED AND POLITICAL MORE POWERFUL GERMANY SHOULD PARTICIPATE IN MILITARY ACTIONS AIMED AT STOPPING LOCALIZED ARMED CONFLICTS OUTSIDE THE NATO EREA?

09079 THUMER, G.

HUNGARIAN COMMUNISTS ASSESS NEW WORLD BALAMCE

POLITICAL AFFAIRS, 71(9) (SEP 92), 14-17.

THE BASIC TASK OF THE HUMGARIAN WORKERS PARTY IS DAY-TODAY POLITICAL ACTIVITY IN SAFEGUARDING WORKER'S INTERESTS AND MORE EFFECTIVELY CARRYING OUT THESE TASKS WITH THE GOAL OF THE PARTY GETTING INTO PARLIAMENT IN THE NEXT ELECTIONS. THIS ARTICLE STUDIES THE INTERNATIONAL SITUATION, CONFLICT IN EUROPE, FOREIGN POLICY, INTERNATIONAL ACTIVITIES, AND POLITICAL IDEOLOGY. IT REPORTS THAT THE WORKERS PARTY SUPPORTS BILATERAL CONTACTS INCLUDING MUTUAL ACTIONS AND INITIATIVES BY THE DIFFERENT LEFT-WING FORCES. IT CLAIMS THAT THE PARTY IS OPEN TO ANY INITIATIVE AND SUPPORTS THE ORGANIZATION OF AN IMTERNATIONAL MEETING OF THE WORKERS' ORGANIZATI
PARTIES.

09080 THURER, D.

THE EUROPEAN COMHUNITY BETWEEN ILLUSION AND REALITY SWISS REVIEN OF NORLD AFFAIRS, 42 (8) (NOV 92), 8-9.

ON DECEMBER 6, 1992, THE SHISS WILL VOTE ON WHETHER TO JOIN THE EUROPEAN ECONOMIC AREA, AND THERE WILL BE A REFERENDUM ON BRINGING THE EUROPEAN FREE TRADE ASSOCIATION INTO ASSOCIATE MEMBERSHIP WITH THE EUROPEAN COMHUNITY. IN DECISIONS FOR THE FUTURE OF SHITZERLAND AND WESTERN EUROPE.
09081 TIAN, L.

A DIARY OF TIBET'S DEMOCRATIC REFORM

BEIJING REVIEW, 35(34) (AUG 92), 23-27.

PRIOR TO 1959, A SERF SYSTEM AKIN TO SLAVERY REMAINED IN

PLACE IN TIBET, EVEN THOUGH THE REGION HAD BEEN PEACEFULLY

LIBERATED IN 1951. THE CHINESE COMMUNIST PARTY AND THE

IIBETAN PEOPLE, INCLUDING SOME PATRIOTIC INDIVIDUALS IN THE

UPPER STRATA, SPENT EIGHT YEARS ATTEMPTING TO PERSUADE THE

TIBETAN ELITE TO CHANGE THIS INHUMANE AND FEUDALISTIC SYSTEM. A HANDFUL OF REACTIONARY SERF-OWNERS STAGED AN ARMED REBELLION IN 1959, BUT THE RESULTS WERE FAR FROM WHAT THEY EXPECTED BECAUSE THE REBELLION HAS PROMPTLY CRUSHED AND THE PACE OF ABOL ISHING SERFDOM GREATLY ACCELERATED. AFTER SEVERAL MONTHS OF DEMOCRATIC REFORM, MILLIONS OF SERFS SAN THE END OF THE BITTER AND HUMILIATING SOCIAL SYSTEM AND BEGAN NEW LIVES IN WHICH THEY WERE ABLE TO ENJOY BASIC HUMAN RIGHTS FOR THE FIRST TIME.

09082 TICKTIN, H.H.

PERMANENT CHAOS WITHOUT A MARKET: THE

MONLATINAMERICANIZATION OF THE USSR

STUDIES IN COMPARATIVE COMMUNISM, XXV(3) (SEP 92), 242-256.

THE FORMER USSR AND ITS CONSTITUENT COUNTRIES ARE DOOMED TO A CHAOTIC INTERACTION BETWEEN MOVES TO THE MARKET AND RETREATS TO FORMS OF ORGANIZATION, ONCE CALLED "PLANNING." THE ONLY ALTERNATIVE PRESENTED BY THE ELITE IN THE VARIOUS REPUBLICS IS THAT OF THE MARKET. THE FUNDAMENTAL PROBLEM, HOWEVER, IS THAT PRIVATIZATION, THE INTRODUCTION OF MONEY, AND THE MOVE TO A CONVERTIBLE RUBLE CAN ONLY OCCUR IF SOVIET INDUSTRY IS LARGELY HIPED OUT. THAT IS WHY THE REAL ALTERNATIVE TODAY IS LATINAMERICANIZATION, WITH DE-

INDUSTRIALIZATION AND ITS ATTENDANT MASS UNEMPLOYMENT, COUPS, AND PERMANENT INSTABILITY. BUT SUCH AN ALTERMATIVE IS IMPOSSIBLE, FOR TWO REASONS. FIRSTLY, IT IS POLITICALLY IMPOSSIBLE TO DEFEAT THE WORKERS IN THE FORMER TERRITORIES OF THE USSR, EXCEPT IN PERIPHERAL AREAS. SECONDLY, THERE IS NO ECONOMIC METHOD OF TRANSITION TO CAPITALISM IN A PERIOD OF LATE STALINISM. IN SHORT, THERE HAS CDME INTO BEING, AND PERIOD AND THAT HAS ONLY THO ALTERMATIVES: SOCIALISM OR COLLAPSE.

09083 TIEFER, C.

THE FLAG-BURNING CONTROVERSY OF 1989-1990: CONGRESS' VALID ROLE IN CONSTITUTIONAL DIALOGUE

HARVARD JOURNAL OF LEGISLATION, 29(2) (SUM 92), 357-398.

THE AUTHOR ARGUES THAT CONGRESS' PERFORMANCE DURING THE FLAG-BURNING CONTROVERSY OF 1989-1990 DEMONSTRATED THE VALID ROLE THAT THE LEGISLATIVE BRANCH CAN PLAY IN PROMOTING THE UNDERSTANDING AND APPLICATION OF CONSTITUTIONAL VALUES. AFTER ANALYZING THE FLAG DEBATE IN CONGRESS AND THE MANNER IN WHICH IT WAS SHAPED BY CONGRESSIONAL PROCESSES AND CONGRESSIONAL LEADERS, HE ARGUES THAT THE FLAG DEBATE ILLUSTRATES THE IMPORTANT FUNCTION OF CONGRESS IN PRINCIPLE. FURTHERMORE, HE IS CRITICAL OF THE ARB ITRARY WAY IN WHICH THE U.S. SUPREME COURT SELECTED THE FLAG ISSUE FOR CONSIDERATION AND DISPOSITION IN TEXAS V. JOHNSON AND ARGUES THAT CONGRESS' SUPERIOR AGENDA-SETTING PROCESSES MAY IN FACT MAKE IT A MORE APPROPRIATE BODY FOR DECIDING WHEN CERTAIN CONSTITUTIONAL ISSUES SHOULD BE DEBATED AND RESOLVED.

09084 TIEJUN, C.

THE ARMY, THE PEASANTRY, AND CHIHA'S FUTURE

WORLD AFFAIRS, 154(4) (SPR 92), 160-167.

THE RELATIONSHIP BETWEEN THE CHINESE ARMY AND THE

PEASANTRY, AND THE PEASANTRY AND THE STATE, AS THEY HAVE CHANGED IN THE DECADE OF ECONOMIC REFORM ARE ANALYZED IN THIS ARTICLE. IN THE ANTICIPATED FULLSCALE PROCESS OF DEMOCRATI ZATION AND MARKET I ZATION THAT SHOULD FOLLOW THE DISAPPEARANCE OF THE AGING COMHUNIST LEADERSHIP-WHICH WILL NOT BE LONG IN COMING--THE CHINESE PEASANTRY IN GENERAL AND THE MILITARY IM PART ICULAR ARGUABLY WILL PLAY STABIL IZING ROLES IN THE RECONSTRUCTION. THE PEASANTRY AND THE ARMY ARE EACH EXAMINED IN DEPTH IM THE ARTICLE WHICH CONCLUDES THAT THERE ARE REASONABLE GROUNOS TO VIEW CHINA'S SOCIAL

TRANSFORMATION HITH A HIGH DEGREE OF OPTIMISM.

09085 TIERNEY, $W$.

NATIVE VOICE IN ACADEME

CHANGE, 23(2) (MAR 91), 36-39.

NATIVE AMERICANS FACE MANY CHALLENGES WHEN THEY GO TO COLLEGE, SOME PROBLEMS PARALLEL HHT CDUMTLESS OTHER STUDENTS FACE WHEM THEY ATTEND COLLEGE SUCH AS A LACK OF ACADEMIC PREPARAT ION OR A FEELING OF AWAY FROM HOME FOR THE FIRST TIME. OTHER PROBLEMS ARE UNIQUE TO INDIAN STUDENTS: NATIVE BELIEFS ABOUT SCIENCE THAT MIGHT CONFLICT WITH WHAT IS TAUGHT IN BIOLOGY CLASS, OR THE FEELING THAT ONE MUST RETURN HOME FOR SPECIFIC CEREMONIES EVEN IF IT MEANS A CLASS MUST BE MISSED OR AN EXAM SKIPPED. REGARDLESS OF THE CHALLENGES THAT AMERICAN INDIAN STUDENTS ENCOUNTER, EACH ISSUE IS ENVELOPED IN THE OFTEN-CONFLICTING CULTURES OF STUDENTS AND THEIR INSTITUTIONS. THE SOLUTIONS 
TO THE PROBLEMS NEED TO BE ADDRESSED AS SUCH.

09086 TIERSKY, R.

FRANCE IN THE NEH EUROPE

FOREIGN AFFAIRS, 71(2) (SPR 92), 131-146.

THE END OF THE COLD WAR AND THE UNIFICATION OF GERMANY HAVE CHANGED FRANCE'S INTERNATIONAL ROLE IN EUROPE. FRANCE MUST NOW REDEFINE ITS FOREIGN POLICY GOALS AND FIND ITS

RIGHTFUL PLACE IN EUROPEAN AFFAIRS.

09087 TIFFEN, M.; MORTIMORE, M.

ENVIRONMENT, POPULATION GROWTH AND PRODUCTIVITY IN KENYA: ENVIRONMENT, POPULATION GROWTH AND
A CASE STUDY OF MACHAKOS DISTRICT

DEVELOPMENT POL ICY REVIEH, 10(4) (DEC 92), 359-388.

A CASE STUDY OF MACHAKOS DISTRICT, KENYA, EXAMINING POPULATION GROWTH, AGRICULTURAL PRODUCTION AND ENVIRONMENTAL CONDITIONS OVER A RELATIVELY LONG PERIOD SHOWS THAT POPULATION INCREASE IS COMPATIBLE WITH ENVIRONMENTAL RECOVERY, PROVIDED THAT MARKET DEVELOPMENTS MAKE FARMING PROFITABLE. THIS STUDY SHOWS THE NEED FOR GOVERMMENT FACILITATION OF OEVELOPMENT BY FARMERS AND OTHER RURAL ENTREPRENEURS THOUGH POLICIES WHICH AID INFORMATION FLOWS
AND RAISES GATE PRICES AND THROUGH THE TYPES OF CONSULTATION AND RAISES GATE PRICES AND THROUGH THE TYPES OF CONSULTATI
THAT SECURE DIALOGUE BETHEEN LOCAL PEDPLE AND GOVERNMENT EXPERTS IN DIAGNOSING CONSTRAINTS AND IN REMOVING IMPEDIMENTS TO INNOVATION AND CHANGE. THE STUDY EXAMINES SEVERAL DANGER POINTS.

09088 TIFFIN, S.; OSOTIMEHIN, F INNOVATION OF NEW AND EMERGING TECHNOLOGY FOR INDUSTRIAL DEVELOPMENT IN AFRICA

JOURNAL OF ASIAN AND AFRICAN STUDIES, XXVII(I) (JAN 92), 94-113.

MOST COUNTRIES IN THE OECD SEE THE INMOVATION OF NEW AND EMERGING TECHNOLOGIES (NET) AS A KEY FACTOR SUPPORTING INOUSTRIAL COMPETITIVENESS. WHILE THEY INTENSIFY THEIR INVESTMENTS IN NET AND THE NEWLY INDUSTRIALIZING COUNTRIES SHOW REMARKABLE ABILITY TO FOLLOW SUIT, AFRICAN NATIONS ARE NOT INVOLVED AHD SEEM TO BE SLIPPING BACKWARDS IN TERMS OF NOT INVOLVED AHD SEEM TO BE SLIPPING BACKWARDS IN TERMS
THEIR ABILITY TO COPE WITH INDUSTRY AND TECHNOLOGY. THE THEIR ABILITY TO COPE WITH INDUSTRY AND TECHNOLOCY.
PREVAILING CURRENT OF OPINION IS THAT NET IS TOO PREVAILING CURRENT OF OPINION IS THAT NET IS TOO
SOPHISTICATED FOR MOST AFRICAN COUNTRIES AND THEY SHOULD SOPHISTICATED FOR MOST AFRICAN COUNTRIES AND THEY SHOULD
CONCENTRATE ON MASTERING SIMPLER TECHNOLOGIES FIRST. IN THIS CONCENTRATE ON MASTERING SIMPLER TECHNOLOGIES FIRST. IN
PAPER, IT IS ARGUED THAT AFRICAN COUNTRIES MUST INVOLVE THEMSELVES WITH NET AND CAN DO SO IN CERTAIN AREAS. THE PAPER IS BASED ON THE FIRST STATE OF AN OECD DEVELOPMENT PAPER IS BASED ON THE FIRST STATE OF AN OECD DEVY FOP CENTRERAGING THE RESEARCH, MANAGEMENT, INNOVATION

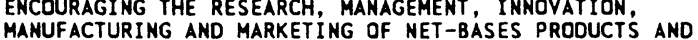
SERVICES IN THE NATURAL RESOURCE SECTOR OF SOUTHERN AFRICAN COUNTRIES. THE REPORT DEFINES NET IN A DEVELOPMENT CONTEXT, LAYS OUT THE IMPORTANCE OF INNOVATING NET IN AFRICA ANO INTRODUCES A STRATEGY FOCUSSING ON MARKET-DRIVEN

TECHNOLOGICAL INNOVATION AND DIFFUSION WHICH WILL BE TESTED IN THE ONGOING RESEARCH PROJECT.

09089 TIGLAO, R.

BACK TO THE FUTURE

FAR EASTERN ECONOMIC REVIEW, 151(18) (MAY 91), 44-46. POST-WAR RELATIONS BETHEEN THE PHILIPPINES AND JAPAM

WERE LARGELY CHARACTERIZED BY PHILIPPINE DISTRUST AND JAPANESE DISDAIN. BUT JAPANESE PRIME MINISTER TOSHIKI KAIFU'S SCHEDULED VISIT TO MANILA ON 4-5 MAY IS A SYMBOL OF CHANGING PERSPECTIVE. THE PHILIPPINES IS BEING NUDGED INTD JAPAN'S ECONOMIC EMBRACE BY A NUMBER OF FACTORS: THE DECLINE OF THE U.S. POLITICAL AND ECONOMIC ROLE IN THE COUNTRY THE NATION'S FRUSTRATIOY AT BEIMG PERENMIALLY BOGGED DOWM IN AN ECONOMIC QUAGMIRE, AND THE RISE OF A NEW GENERATION OF MORE OUTWARD LOOKING FILIPINO ENTREPRENEURS UNBURDENED BY HISTORICAL ANTIPATHIES. FOR JAPAN, ITS DOMESTIC BAOR SHORTAGE MAKES A STABLE PHILIPPINES ATTRACTIYE AS AM OFFSHORE BASE.

09090 TIGLAO, R.; TASKER, R.

FIDEL'S CHALLENGE

FAR EASTERN ECONOMIC REVIEH, 155(24) (JUN 92), 16-17.

THE 11 MAY ELECTION SHOWED PHILIPPINE DEMOCRACY AT ITS

THE 11 MAY ELECTION SHOWED PHILIPPINE DEMOCRACY AT ITS
BEST, BUT FIDEL RAMOS--THE RETIRED GENERAL WHO CAME FIRST

OUT OF SEVEN CANDIDATES IN THE PRESIDENTIAL POLL--LACKS A

STRONG POLITICAL BASE AND HAS BEEN SLOW TO ANMOUNCE POLICIES

STRONG POLITICAL BASE AND HAS BEEN SLOW TO ANNOUNCE POL
RAMOS HAS SPOKEN OF FORGING A "RAINBOW CDALITION" OF
DIFFERENT POLITICAL GROUPS, BUT HE WIL HAVE TO DEPEND

HEAVILY ON THE AUTHORITY AND THE POWER OF THE PRESIDENCY TO

GOVERA EFFECTIVELY.

09091 TIGLAO, R.

PAYMENT IN FULL

FAR EASTERN ECONOMIC REVIEW, 155(5) (FEB 92), 11-12.

PHILIPPINES' PRESIDENT CORAZON AQUINO'S ENDORSEMENT ON

25 JAMUARY OF FIDEL RAMOS AS HER CANDIDATE FOR THE

PRESIDENCY HAS CARVED OUT OF THE PRO-ADMINISTRATION CAMP A

NEW POLITICAL PARTY WITH THE FORMER DEFENSE SECRETARY AS ITS

STANDARD BEARER. ITS CORE CONSISTS OF POLITICIANS LED BY

AQUINO'S RELATIVES, PRINCIPALLY THE PRESIDENT'S UNCLE AND
HOUSE OF REPRESENTATIVES MAJORITY FLOOR LEADER FRANCISCO SUMULONG. BUT THE REAL STRENGTH OF THE AQUINO-RAMOS CAMP IS THAT IS EMERGING AS THE PREDOMINANTLY BIG-BUSINESS BACKED PARTY, WHILE AWKHARDLY TRYING TO APPEAR AS A GRASSROOTS AND MIDDLE-CLASS POPULAR MOVEMENT. AQUINO'S ENDORSEMENT OF RAMOS HAS PUZZLED MANY OBSERVERS, BUT MAY BE EXPLAINED BY THE OVERUSED CONCEPT OF "UTANG NA LOOB" (DEBT OF GRATITUDE) OFTEN CITED BY WESTERN SOCIDLOGISTS TO EXPLAIN THE WORKINGS OF PHILIPPINE SOCIETY. RAMOS IS WITHOUT DOUBT RESPONSIBLE FOR AOUINO'S SURVIVAL, BECAUSE OF HIS CRUCIAL REFUSAL TO JOIN AQUINO'S SURVIVAL, BECAUSE OF HIS CRUCIAL REFUSAL TO JOIN
THE COUP ATTEMPTS DURING HER SIX YEARS IN THE PRESIDENCY.

09092 TIGLAO, R.; TASKER, R.

POLITICS BYY NUMBERS

FAR EASTERN ECONOMIC REVIEW, 155(11) (MAR 92), 22-24.

THE RAPID ASCENT OF RAMOY MITRA FROM RELATIVE OBSCURITY TO LEADING CONTENDER IN THE PHILIPPINES, MAY PRESIDENTIAL ELECTION IS PRINCIPALLY DUE TO THE POWER OF THE LABAN NG DEMOKRAITKONG PILIPINO (LDP) POLIIICAL MACHINE BACKING HIS CANDIDACY. THE PARTY, WHICH SEEKS TO EMBRACE THE MIDDLE GROUND IN PHILIPPINES POLITICS, HAS LARGELY ESCHEHED IDEOLOGY IN FAVOR OF CREATING AN ORGANIZATION THAT NOW CONTROLS MANY OF THE COUNTRY'S LEVERS OF POHER. IN THIS RESPECT, THE LDP REPRESENTS THE PHILIPPINES' FIRST "MODERN" PARTY, UTILIZING BUSINESS METHODOLOGY, MARKET RESEARCH TECHNIOUES AND SOPHISTICATED COMPUTER ANALYSIS TO MOBILIZE ITS SUPPORTERS. HOWEVER, DESPITE THE TRAPPINGS OF DEMOCRACY, THE LDP ALSO HAS A MORE SECRETIVE SIDE BASED ON A CORE GROUP SAID TO ULTIMATELY SET THE PARTY'S AGENDA.

09093 TIGLAO, R.

POWER OF THE PURSE

FAR EASTERN ECONOMIC REVIEW, 155(7) (FEB 92), 16-17.

THE CAMPAIGN FOR THE MAY PRESIDENTIAL ELECTIONS IN THE PHILIPPINES IS TURNING OUT TO BE A THREE-WAY BATTLE BETHEEN HOUSE SPEAKER RAMON MITRA, FORMER DEFENSE SECRETARY FIDEL RAMOS, AND ONE-TIME MARCOS CRONY EDUARDO COJUANGCO, WHO FLED THE COUNTRY IN 1986 BUT HAS SINCE MADE A REMARKABLE POLITICAL COMEBACK. THE CONJUANGCO CAMPAIGN, WHICH AIMS TO POLITICAL COMEBACK. THE CONJUANGCO CAMPAIGN, WHICH AIMS TO MOBILIZE FORMER MARCOS-ERA POLITICAL BOSSES AND COCONUT FARMERS, APPEARS TO BE BASED ON THE NOTION THAT REAL POWER STILL RESIDES AT THE GRASSROOTS, RATHER THAN IN MANILA. BUT CONJUANGCO COULD STILL BE STOPPED, EITHER BY THE CATHOLIC CHURCH, DR BY THE BUSINESS ESTABLISHMENT WHICH BELIEVE REBUILDING HIS EMPIRE.

09094 TIGLAO, R.

SEEING THE LIGHT

FAR EASTERN ECONOMIC REVIEH, 155(35) (SEP 92), 33-37.

THE INAUGURATION OF FIDEL RAMOS AS PRESIDENT OF THE

PHILIPPINES GIVES HOPE TO THE BELEAGURED ISLAND NATION. THE LONG-TERM IMPACT OF THE PEACEFUL TRANSITION TO A NEW ADMINISTRATION ON 30 JUNE CANNOT BE UNDERESTIMATED. MUCH OF THE COUNTRY'S ECONOMIC TROUBLES HAVE BEEN GENERATED BY POLITICAL INSTABILITY. RAMOS HAS THE ADVANTAGE OF NOT HAVING TO WORRY ABOUT HOSTILITY FROM DISAFFECTED MILITARY ELEMENTS (HE HAS CLOSE TIES WITH THE MILITARY). IN ADDITION, HE NEED NOT FEAR AN ANGRY ELECTORATE (UNDER THE 1987 CONSTITUTION, HE CANMOT SEEK RE-ELECTION). THEREFORE, HE CAN PURSUE THE PAINFUL BUT NECESSARY ECONOMIC REFORMS THE COUNTRY SO BADLY NEEDS. TWO KEY REFORM PROGRAMS ARE REQUIRED: INCREASE STATE REVENUE SO THAT IT CAN UNDERTAKE THE INTERVENTIONS REQUIRED OF IT; AND FREE THE MARKET SO THAT THE FILIPINOS

COMPETITIVENESS AND CREATIVITY CAN BE TAKEN FULL ADVANTAGE OF. IF RAMOS IS EVEN MODERATELY SUCCESSFUL IN IMPLEMENTIMG THESE REFORMS, THERE IS A GOOD CHANCE THAT THE PHILIPPINES' ECONOMY--WHICH HAS SHOWN SURPRISING RESILIENCE IN THE FACE OF POLITICAL INSTABILITY, NATURAL DISASTERS ANO WORLD RECESSION--WILL PICK UP STEAM.

09095 TIKKU, M. K.; SCHWARZ, A.

ACCELERATED PROMOTION

FAR EASTERN ECONOMIC REVIEW, 155(7) (FEB 92), 12 THE MON-ALIGNED MOVEMENT' (NAM) MAY TAKE ON A NEH LEASE OF LIFE FOLLOWING INDONESIA'S INSTALLATION AS THE MOVEMENT'S DE FACTO LEADER. INDONESIA EFFECTIVELY BEGAN ITS TENURE AS THE NAM CHAIRMAN AT THE MOVEMENT'S 3-4 FEBRUARY MINISTERIAL MEETING. YUGOSLAVIA, THE PREVIOUS LEADER OF THE MOVEMENT, IS DISTRACTED BY INTERNAL TURMOIL AND ACKNOHLEDGED THAT IT IS IN NO POSITION TO ORGANIZE THE MEETINGS WHICH USUALLY PAVE
THE WAY FOR LEADERSHIP CHANGES. INDONESIA HOPES TO TURN THE THE WAY FOR LEADERSHIP CHANGES. INDONESIA HOPES TO TURN THE NAM INTO AN ORGANIZATION EMPHASIZING INTERNATIONAL ECONOMIC ISSUES AND TO MOVE AHAY FROM THE PRIMARILY POLITICAL, AND USUALLY CONFRONTATIONAL, STYLE OF THE PAST. THE VIEW FROM JAKARTA IS THAT THE MOVEMENT NEEDS A NEW BASIS NOW THAT THE COLD WAR HAS ENEDED. INDONESIA ALSO SEES A PRESSING NEED TO SOMEHOW MERGE THE G-77 GROUP OF THIRD WORLD
IS STRICTLY ECONOMIC IN FOCUS--WITH THE NAM.

09096 TILFORD, E.

SETUP: WHY AND HOW THE U.S. AIR FORCE LOST IN VIETNAM ARMED FORCES AND SOCIETY, 17(3) (SPR 91), 327-342.

IN TERMS OF RESOURCES ALLOCATED, THE VIETNAM WAR WAS 
PRIMARILY AN AIR WAR. APPROXIMATELY HALF OF THE S200 BILLION SPENT ON THE WAR SUPPORTED AERIAL OPERATION; 8 MILLION TONS OF BOMBS FELL AND OVER 8,500 AIRCRAFT WERE LOST BETWEEN 1961 AND 1975. FOR ALL THAT, WHILE AIR POWER WAS OCCASIONALLY PIVOTAL, IT WAS NEVER DECISIVE, AND AMERICA'S DEFEAT IN VIETNAM CAN BE CONSTRUED AS A DEFEAT FOR AIR POWER. THE
FAILURE OF AIR POWER RESULTED FROM DEFICIENCIES INHERENT IM DOCTRINE AND WEAKNESSES IN LEADERSHIP. FOR A VARIETY OF REASONS, THE AIR FORCE, WHICH DROPPED OVER 6 MILLION TONS OF BOMBS, HAS NOT FACED UP TO THE IMPLICATIONS OF ITS DEFEAT.

09097 TILLY, C.

FUTURES OF EUROPEAN STATES

SOCIAL RESEARCH, 59(4) (WIN 92), 705-718.

ACROSS THE EUROPEAN CONTINENT HHERE HUNDREDS OF GEOGRAPHICALLY-CONCENTRATED LINGUISTIC, RELIGIOUS, AND ETHNIC POPULATIONS HAVE SOME CLAIM TO DISTINCTMESS, THREE QUITE DIFFERENT FUTURES ARE POSSIBLE: (1) THE PROLIFERATION OF STATES MATCHING THE MORE BELLICOSE AND/OR DIPLOMATICALLY SUCCESSFUL OF THOSE POPULATIONS; (2) CONTINUATION OF THE LONG-TERM TREND TOWARD CONSOLIDATION INTO A DECREASING LONG-TERM TREND TOWARD CONSOLIDATION INTO A DECREASING NUMBER OF HOMOGENIZING STATES, THE LIMIT BEING A SINGLE
HOMOGENEOUS STATE (E.G., A VAST EUROPEAN COMHUNITY HAVING HOMOGENEOUS STATE (E.G., A VAST EUROPEAN COMHUNITY HAVING STATE-LIKE POWERS); (3) DETACHMENT OF THE PRINCIPLE OF CUL TURAL DISTINCTNESS FROM THAT OF STATEHOOD. EASTERN EUROPE SEEMS DESTINED TO FOLLOW THE FIRST COURSE FOR A TIME, WHILE
WESTERN EUROPE WILL PURSUE THE SECOND OVER THE NEXT FEW DECADES; BUT THE THIRD HILL PREVAIL OVER THE LONGER TERM.

09098 TILLY, C.

PRISONERS OF THE STATE

INTERNATIONAL SOCIAL SCIENCE JOURNAL, (133) (AUG 92), 329-342.

AS EUROPEANS UNCONSCIOUSLY SUBVERT THE STATE IN THE VERY ACT OF AFFIRMING ITS DESIRABILITY, COMPARATIVE-HISTORICAL SOCIOLOGISTS ARE UNHITTINGLY PERIPHERALIZING THE STATE WHILE ASSERTING ITS CENTRALITY. MANY INDICATORS POINT BEYOND THE CURRENT SPATE OF NATIONALISMS TONARD A GENERAL COLLAPSE OF THE LARGE, CONSOL IDATED, CENTRALIZED, SHARPLY BOUNDED STATE THAT BEGAN TO DOMINATE EUROPE IN THE EIGHTEENTH CENTURY AND BECAME THE MODEL FOR THE ENTIRE HORLD AFTER THE SECOND WORLD WAR. THIS ARTICLE EXPLORES THE MYTH OF THE CURTURALLY HOMOGENOUS NATION-STATE.

09099 TIMBERMAN, D.

PHILIPPINES IN 1990: ON SHAKY GROUND

ASIAN SURVEY, XXXI(2) (FEB 91), 153-163.

MANY, BUT NOT ALL OF THE PHILIPPINES; TROUBLES IN 1990 WERE EVERY KIND OF NATURAL DISASTER AS WELL AS BY NEGATIVE EXTERNAL DEVELOPMENTS SUCH AS THE DRAMATIC RISE IN WORLD OIL PRICES. THESE UNFORTUNATE OCCURRENCES WERE HEAPED ON A NATION STILL STRUGGLING TO INSTITUTIONALIZE DEMOCRACY, RESTRUCTURE ITS INEFFICIENT AND HEAVILY INDEBTED ECONOMY. RESTRUCTURE ITS INEFFICIENT AND HEAVILY INDEBTED ECONOMY, AND COME TO GRIPS WITH ITS SERIOUS SOCIOECONOMIC PROBLEMS. INFLICTED. SOME WERE CAUSED BY INADEQUATE OR INEFFECTIVE INFLICTED. SOME WERE CAUSED BY INADEQUATE OR INEFFECTIYE POLI ICAL LEADERSHIP; OTHERS NERE ATTRIBUTABLE TO THE UNWILLINGNESS OF MILITARY REBELS AND THEIR CIVILIAN SUPPORTERS TO RESPECT THE CONSTITUTION; STILL OTHERS WERE AND DEPARTMENTS OF GOVERMMENT; AND FINALLY, A NUMBER OF THE PROBLEMS HERE CAUSED BY POLITICALLY EXPEDIENT BUT ECONOMICALLY DAMAGING POLICY DECISIONS.

09100 TIMBERMAN, D.G.

THE PHILIPPINES AT THE POLLS

JOURNAL OF DEMOCRACY, 3(4) (OCT 92), 110-124.

THE PHILIPPINES' 1992 ELECTIONS WERE ESPECIALLY IMPORTANT FOR A NUMBER OF REASONS. IF THE ELECTIONS WENT WELL AND PRODUCED A CONSTITUTIONAL TRANSFER OF POWER, PUBLIC CONFIDENCE IN THE DEMOCRATIC SYSTEM WOULD GET A MUCH-NEEDED BOOST. CONVERSELY, A PROBLEM-RIDDEN OR DISPUTED ELECTION WOULD DAMAGE PUBLIC CONFIDENCE AND MIGHT EVEN BE USED BY THE MILITARY AS A PRETEXT FOR INTERVENTION. MOREOVER, THE ELECTIONS WERE A GENUINELY MULTI-PARTY CONTEST IN A COUNTRY THAT HISTORICALLY HAS HAD ONLY THO MAJOR PARTIES. IN ADDITION, THE 1992 NATIONAL AMD LOCAL ELECTIONS WERE SYNCHRONIZED, HHICH PRESENTED A LOGISTICAL CHALLENGE AND HAD A MAJOR IMPACT ON THE RESULTS OF THE PRESIDENTIAL RACE. FINALLY, BECAUSE THE UNITED STATES HAD AGREED TO WITHDRAH FROM ITS MILITARY BASES, THE ELECTIONS WERE THE FIRST IN MANY YEARS IN WHICH U.S.-PHILIPPINE RELATIONS WERE NOT A MAJOR ISSUE.

O9101 TIMMERMANN, H.

RUSSIAN FOREIGN POLICY UMDER YELTSIN: PRIORITY FOR INTEGRATION INTO THE COMMUNITY OF CIYILIZED STATES JOURNAL OF CDMMUNIST STUDIES, 8(4) (DEC 92), 163-185. RUSSIA IS IN THE PROCESS OF FORGING A NEH STATE STRUCTURE AND SEEKING A NEH IDENTITY. THIS IS REFLECTED IN ITS FOREIGN POLICY AND IN ITS RELATIONS WITH THE FORMER REPUBLICS OF THE USSR THAT ARE NOW PART OF THE COMHONWEALTH OF IMDEPENDENT STATES. RUSSIA STRIVES TO DOMINATE THE FORMER SOVIET REPUBLICS WHILE SEEING THE NEED FOR DIPLOMATIC
APPROACHES INYOLVING BILATERAL AND MULTILATERAL TREATIES, A APPROACHES INVOLVING BILATERAL AND MULTILATERAL TREA NEH REGIONAL COMMUNITY. AND THE DISMANTLING OF OLD
STRUCTURES. YELTSIN'S MAIN GOAL IS TO LINK RUSSIA WITH THE STRUCTURES. YELTSIN'S MAIN GOAL IS TO LINK RUSSIA WITH THE WEST, BROADLY DEFINED AS THE WHOLE ATLANTIC-EUROPEAN REGION AND JAPAN. THE OLD SOVIET POLICY OF DRIVING WEDGES BETWEEN THE ELEMENTS OF
OF FRIENDSHIP.

09102 TIMOTHY, B.

HHAT NEXT?

WEST AFRICA, (3896) (MAY 92), 840-841

NOW THAT THE NATIONAL PROVISIONAL RULING COUNCIL (NPRC) HAS OVERTHROWN THE CORRUPT REGIME OF JOSEPH MOMOH, IT MUST GET DOWN TO THE BUSINESS OF GOVERNING SIERRA LEONE. PUNISHING MOMOH'S CORRUPT OFFICIALS AND REVITALIZING THE ECONOMY SHOULD BE TOP PRIORITIES.

09103 TINBERGEN, J.

HOW TO ENHANCE POLITICAL WILL

BULLETIN OF PEACE PROPOSALS, 23(1) (MAR 92), 51-56.

THIS ARTICLE ARGUES THAT' THERE ARE A NUMBER OF YIABLE SOLUTIONS TO MANY OF THE HORLD'S MOST PRESSING PROBLEMS. WHAT IS LACKING IS THE POLITICAL WILL TO IMPLEMENT THESE

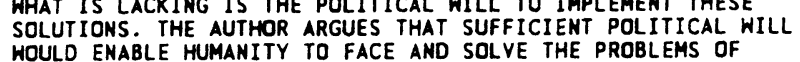
SECURITY, ENVIRONMENTAL PROTECTION, DEVELOPMENT AND

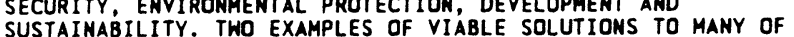
SUSTAINABILITY. TWO EXAMPLES OF VIABLE SOLUTIONS TO MANY
THESE PROBLEMS ARE THE EXPANSION OF THE UNITED NATIONS' THESE PROBLEMS ARE THE EXPANSION OF THE UNITED NATIONS
POWER TO INCLUDE A WORLD TREASURY AND A WORLD POLICE FORCE, POWER TO INCLUDE A WORLD TREASURY AND A WORLD POL ICE FORCE,
AND A MASSIVE INCREASE IN THE AMOUNT OF FOREIGN AID RENOERED AND A MASSIVE INCREASE IN THE AMOUNT OF FOREIGN AID RENDERED TO DEBT-RIDDEN UNDERDEVELOPED NATIONS. SUCH POLICIES ARE IN THE LONG-TERM INTEREST OF ALL THE NATIONS
REQUIRE ONLY POLITICAL WILL TO IMPLEMENT.

09104 TINDALE, S LEARNING TO LOVE THE MARKET: LABOUR AND THE EUROPEAN COMMUNITY

POLITICAL QUARTERLY (THE), 63(3) (JUL 93), 276-300. WITH THE PUBLICATION OF ITS "POLICY REVIEW" IN 1989 LABOR WAS MORE FIRMLY AND ENTHUSIASTICALLY PRO-EUROPEAN THAN AT ANY TIME IN ITS HISTORY. THE EC IS NOW SEEN EXPLICITY AS A FORUM WHICH CAN BE USED TO FURTHER LABOR'S REFORMIST SOCIAL DEMOCRATIC GOALS. THIS ARTICLE REPORTS ON THE TWO DISTINCT PHASES WHICH THE PARTY HAS EXPERIENCED TO REACH THIS POSITIVE EUROPEANISM. FOR THE MOST PART, THE EUROPEAN DIMENSION IS NOW A CENTRAL PART OF THE STRATEGY TO TRANSFORM BRITAIN.

09105 TIRELLI, P.

SIMPLE RULES FOR POLICY COORDINATION: AN EVALUATION OF ALTERNATIVE PROPOSALS

JOURNAL OF POLICY MODELING, 14(1) (FEB 92), 1-11.

THE AUTHOR COMPARES THO PROPOSALS FOR INTERNATIONAL POLICY COORDINATION THAT TAKE THE FORM OF SIMPLE RULES. IN POLICY COORDINATION THAT TAKE THE FORM OF SIMPLE RULES. THE FIRST RULE, FISCAL POL HO DOWN THE EXCHANGE RATE AT MONETARY POLICY IS USED TO HOLD DOWN THE EXCHANGE RATE AT
ITS "TARGET ZONE" LEVEL. IN THE SECOND RULE, MONETARY POLICY ITS "TARGET ZONE" LEVEL. IN THE SECOND RULE, MONETARY
CONTROLS INFLATION AND FISCAL POLICY IS ASSIGNED TO A CONTROLS INFLATION AND
FOREIGN WEALTH TARGET.

09106 TISMANEANU, $V . ;$ MIHAIES, M. INFAYY RESTORED: NATIONALISM IN ROMANIA EAST EUROPEAM REPORTER, 5(1) (JAN 92), 25-27.

ALTHOUGH NATIONALISM IS PERVASIVE IN ALL EAST EUROPEAN ALTHOUGH NATIONALISM IS PERVASIVE IN ALL EAST EUROPEAN
COUNTRIES ATTEMPTING TO ESCAPE FROM COMMUNISM TO LIBERAL COUNTRIES ATTEMPTING TO ESCAPE FROM COMMUNISM TO LIBERAL DEMOCRACY, IN ROMANIA IT IS PARTICULARLY CONSPICUOUS AND VIRULENT. IN ROMANIA, THE FORMER PROMOTERS OF CEAUCESCU'S IDEOLOGY OF NATIONAL COMMUNISM HAVE FOUND THEIR PLACE IN THE NEW REGIME AS EDITORS AND PUBLISHERS DISSEMINATING EXTREME XENOPHOBIA AND CHAUVINISM. WITH THE ISSUE OF THE HUNGARIAN MINORITY IN ROMANIA (WHICH IN DECEMBER VOTED OVERHHELMINGLY
AGAINST THE COUNTRY'S NEW CONSTITUTION) AND OF THE ROMANIANS IN EX-SOVIET MOLDAVIA (HHO CURRENTLY APPEAR TO VIEH REUNIFICATION WITH ROMANIA SKEPTICALLY) BOTH LIKELY TO FEATURE PROMINENTLY IN THE SCHEDULED 1992 ELECTIONS, THE QUESTION TO BE CONSIDERED IS THE EXTENT TO WHICH SUCH NATIONALISH NOW FINDS POLITICAL EXPRESSION.

09107 TISMANEANU, V.; CLAWSON, $P$

UPROOTING LENINISM, CULTIVATING LIBERTY

UNIVERSITY PRESS OF AMERICA, 1992, 104.

SINCE 1989 THE STATES OF EAST-CENTRAL EUROPE INCLUDING THE SOVIET UNION HAVE LABORED WITH THO HUGE TASKS: ELIMINATING THE POLITICAL-ECONOMIC INSTITUTIONS OF LENINISM, AND ESTABLISHING THE POLITICAL-ECDNOMIC INSTITUTIONS OF AND ESAL CAPITALISM. THIS COLLECTION OF ESSAYS EXAMINES THESE LIBERAL CAPITALISM. THIS COLLECTION OF ESSAYS EXAMINES THESE TASKS AND SUGGESTS HOW THE WEST CAN BEST ASSIST THE PEOP

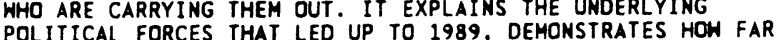
POLITICAL FORCES THAT LED UP TO 1989 , DEMONSTRATES HOH THE REGION HAS COME IN ESTABLISHING POLITICAL REGIMES, ANALYZES THE LOOMING POL ITICAL OBSTACLES TO THE CREATION OF
A FREE SOCIETY, AND OFFERS SUGGESTIONS FOR OVERCOMING THESE A FREE SOCIETY, AND OFFERS SUGGESTIONS FOR OVERCOMING THESE OBSTACLES. IT ALSO LOOKS AT THE CHALLENGE OF TRANSFORMING
SOCIALIST ECONOMICS INTO MARKET SYSTEMS, FOCUSING ESPECIALLY 
ON THE FORMER REPUBLICS OF THE SOVIET UNION, AND PAYING PARTICULAR ATTENTION TO THE IMPORTANCE OF ENCOURGAING NEW LEGAL FRAMEWORKS, NEW FIRMS, AND NEW ENTREPRENEURS.

09108 TITTERTON, M.

MANAGING THREATS TO WELFARE: THE SEARCH FOR A NEW PARADIGM OF WELFARE

JOURNAL OF SOCIAL POLICY, 21(1) (JAN 92), 1-23.

THE AUTHOR ARGUES THAT DOMINANT PARADIGMS IN THE STUDY OF SOCIAL WELFARE HAVE NEGLECTED THE ROLE OF CREATIVE HUMAN AGENCY IN RESPONDING DIFFERENTIALLY TO THREATS OF WELFARE ACROSS THE LIFESPAN. THIS IS DUE TO THE PREFERENCE FOR ACROSS THE LIFESPAN. THIS IS DUE TO THE PREFERENCE FOR INDIVIDUALS INTO HOMOGENEOUS GROUP INGS AND TO THE TENDENCY TO WORK WITH LIMITED MODELS OF VULNERABILITY AND HELPSEEKING. THESE PARADIGHS ARE FURTHER CHARACTERIZED BY A
PREOCCUPATION WITH PATHOLOGICAL VIEWS OF HEALTH AND WELFARE PREOCCUPATION WITH PATHOLOGICAL VIEWS OF HEALTH AND WELFARE
AND BY INADEOUATE CONCEPTUALIZATIONS OF MEDIATING FACTORS AND BY INADEQUATE CONCEPTUALIZATIONS OF MEDIATING FACTORS IS CALLED FOR, FOCUSING ON THE DIFFERENTIAL NATURE OF IS CALLED FOR, FOCUSING ON THE DIFFERENTIAL NATURE OF VULNERABILIITY AND RISK AMONG INDIVIDUALS AND THEIR
DIFFERENTIATED REACTIONS TO THREATS TO WELFARE. DIRECTIONS DIFFERENTIATED REACTIONS TO THREATS TO WELFARE. DIRECTIONS
FOR EMPICIAL RESEARCH WITHIN SUCH A PARADIGM ARE OUTLINED.

09109 TOBIN, R.

ENVIRONMENTAL PROTECTION AND THE NEN FEDERALISM: A LONGITUDINAL ANALYSIS OF STATE PERCEPTIONS

PUBLIUS: THE JOURNAL OF FEDERALISM, 22(1) (WIN 92), 93-108. SURVEYS OF THE DIRECTORS OF STATE AIR AND WATER OUALITY PROGRAMS IN 1979, 1985, AND 1990 ARE USED TO ASSESS THE DIRECTORS' (AND INDIRECTLY, THE STATES') REACTIONS TO THE NEH FEDERALISM OF THE 1980 S AND RELATED FEDERAL EFFORTS TO INCREASE THE ROLE OF THE STATES IN ENVIRONMENTAL

DECISIONMAKING. DESPITE THE FREQUENT CLAIMS THAT THE NEH FEDERALISM LED TO SIGNIFICANT IMPROVEMENTS IN STATE-FEDERAL RELATIONS IN THE ENVIRONMENTAL ARENA, THE SURYEY DATA SUGGEST THAT THESE RELATIONS HAVE CHANGED LITTLE SINCE 1979. THE ACTIONS OF THO PRESIDENTAL ADMINISTRATIONS HAVE HAD SOME EFFECTS, BUT IN SEVERAL INSTANCES, EARLY IMPROVEMENTS HAVE EVAPORATED.

09110 TODEV, $T$.

CAN THE COOPERATIVE MAKE THE TRANSITION TO MARKET ECONOMY CAN THE COOPERAT
LESS PAINFUL?

PEACE AND THE SCIENCES, 1(1) (SEP 92), 12-14.

THE PROCESS OF TRANSFORMATIOM TO A MARKET ECONOMY IN EASTERN EUROPE HILL BE A VERY PAINFUL ONE, FOR IT PRESUPPOSES A FUNDAMENTAL CHANGE OF ECONOMIC STRUCTURES. IN THIS CONTEXT, THE QUESTION OF PARAMOUNT IMPORTANCE ARISESWHETHER THE COOPERATIVE CAN DEVELOP WITHIN MARKET ECONOMY, INSPITE OF ITS ALMOST UTTERLY TARNISHED IMAGE AND WHETHER IT COULD THUS TAKE ON A NUMBER OF SOCIOECONOMIC FUNCTIONS MAKING THE TRANSITION TO MARKET ECONOMY LESS PAINFUL. ARGUMENTS ARE OFFERED WHICH FAVOR THE COOPERATIVE AS AN ADEQUATE FORM OF COPING WITH MANY TRANSITIONAL PROBLEMS DUE TO THE RADICAL CHANGE.

09111 TOGEBY, L.

THE NATURE OF DECLINING PARTY MEMBERSHIP IN DENMARK: CAUSES AND CONSEQUENCES

SCANDINAVIAN POLITICAL STUDIES, 15(1) (MAR 92), 1-19.

THIS PAPER ANALYZES DECLINING PARTY MEMBERSHIP IN

DENMARK IN LIGHT OF THE GENERAL DEVELOPMENT OF POLITICAL

PARTICIPATION IN THE 1970'S AND 1980'S. IT IS DEMONSTRATED

THAT THE DECLINE IN PARTY MEMBERSHIP WAS NOT RELATED TO THE GENERAL DECL INE IN POLITICAL PARTICIPATION. RATHER, IT WAS THE RESULT OF THREE DIFFERENT PROCESSES: (i) THE DECLINING NUMBER OF FARMERS, (2) THE WEAKENING OF LABOR ORGANIZATIONS, AND (3) THE POLITICAL MOBILIZATION OF THE NEW MIDDLE CLASS AND SOCIO-ECONOMIC. FURTHERMORE, THE DECLINING MEMBERSHIP AHREATENS THE PARTIES' TRADITIDHAL MOBILIZING AND SOCIALIZING FUNCTIONS AND THEREBY MAY INCREASE POLITICAL INEQUALITY IN DANISH SOCIETY.

09112 TOKES, $R$.

THE ANATOMY OF A PARTY-STATE: PRELIMINARY REFLECTIONS JOURNAL OF COMMUNIST STUDIES, 8(3) (SEP 92), 1-7.

THIS COMMENTARY ON THE FIRST RESULTS OF A YET-TO-BE

INAUGURATED INOUIRY INTO THE ANATOMY MOTOR FUNCTIONS

INAUGURATED INQUIRY INTO THE ANATOMY, MOTOR FUNCTIONS,

IMMUNE REACTIONS. SIGNALING MECHANISMS, HOMEOSTATIC SYSTEMS
AND CONGENITAL DEFECTS OF THE RECENTLY EXPIRES HUNGARIAN

AND CONGENITAL DEFECTS OF THE RECENTLY EXPIRES HUNGARIAN

PARTY-STATES MAKES THREE POINTS. FIRST, THAT THE EVIDENCE IS

INADEQUTE FOR A RECONSTRUCTION OF THE WORKINGS OF THE KADAR

REGIME IN HUNGARY. SECOND, THAT NO ONE HAS ANY INTEREST IM

FACING THE POLTICAL CONSEQUENCES OF A FULL AND PUBLISHED
POST-MORTEM OF THE OLD REGIME. THIRD, THERE ARE ONLY THO

POST-MORTEM OF THE OLD REGIME. THIRD, THERE ARE ONLY THO

GROUPS OF SCHOLARS--THE POLITICALLY UNCOMPROMISED YOUNG

HUNGARIAN SOCIAL SCIENTISTS AND THEIR WESTERN COLLEAGUES
WITH AN INTELLECTUAL STAKE IN PERFORMING A FULL SCAN OF THE COMMUNIST PARTY-STATE.

09113 TOLEDANO, B.C.

MIND YOUR MEMORABILIA
NATIONAL REVIEH, XLIV(15) (AUG 92), 32-34,

THE CAMPAIGN OF ROSS PEROT HAS DRAWM CRITICISM FROM SOME QUARTERS FOR BEING OUTSIDE THE "SYSTEM." THE SUPPORTERS OF PEROT WOULD EMPHATICALLY AGREE HITH SUCH AN ASSESSMENT. THEY ARGUE THAT THE TWO-PARTY SYSTEM HAS DEGENERATED INTO A TOOL TO MAINTAIN THE STATUS QUO. CONCURRENT HITH THAT FAILURE IS THE LOSS OF ANY REAL MEANING TO THE TERMS CONSERVATISM AND LIBERALISM. BOTH THE PARTIES AND THE PHILOSOPHIES ARE MORALLY AND INTELLECTUALLY BANKRUPT. PEROT MAY NOT HAVE ALL THE ANSWERS, BUT MANY ARE FLOCKING TO HIS CAUSE SOLELY BECAUSE HE IS NOT PART OF THE "SYSTEM."

09114 TOLEDANO, $S$.

PEACE BY STAGES

RUSI JOURMAL, 137 (3) (JUM 92), 15-18.

THIS ARTICLE OFFERS A "PEACE BY STAGES" PLAN FOR

RESOLYING THE ARAB-ISRAELI DISPUTE. THE BASIC COMPONENTS OF THE PROGRAM ARE: POLITICAL STALEMATE PROVIDES A SERIOUS THREAT TO THE STATE OF ISRAEL, TO PALESTINIANS AND TO ARAB COUNTRIES, AND COULD POSSIBLY PORTEND A NUCLEAR WAR; A PEACE AGREEMENT WITHOUT LONG-TERM PROVISIONS FOR SECURITY AND A PROCESS OF CONFIDENCE-BUILDING MEASURES, IS NO LESS A DANGER; AND THE PEACE AGREEMENT MUST BE MADE HITH BOTH THE ARAB STATES AND THE PALESTINIANS. THEREFORE, THE PLAN PROPOSES THAT THE GOVERNMENT OF ISRAEL COMMIT ITSELF TO VACATE, WITH MINOR MODIFICATIONS, THE WEST BANK AND GAZA STRIP AFTER FIVE YEARS, AND NOT OBJECT TO THE ESTABLISHMENT OF A PALESTINIAN STATE OR OF A PALESTINIAN-JORDANIAN CONFEDERATION IN THOSE VACATED TERRITORIES. IN RETURN FOR THIS ACTION, THE ARAB STATES WILL DECLARE A CESSATION OF THEIR HAR ON ISRAEL; THE PALESTINIANS WILL DECLARE AN END TO THE INTIFADA AND WILL RECOGNIZE ISRAEL'S RIGHT TO EXIST. AFTER THE INITIAL FIVE YEARS, A PEACE TREATY IS TO BE SIGNED BETWEEN THE TWO STATES AND FREE DEMOCRATIC ELECTIONS.

09115 TOLLEFSON, $\mathrm{H}$.

THE 1894 BRITISH TAKEOVER OF THE EGYPTIAN MINISTRY OF INTERIOR

MIDDLE EASTERN STUDIES, 26(4) (OCT 90), 547-560. AFTER THEIR OCCUPATION OF EGYPT IN 1882. THE BRITISH PREFERRED AN INDIRECT METHOD OF RULING. THIS METHOD OF "INFORMAL EMPIRE" ENABLED THEM TO CONTROL KEY POLICY DECISIONS THROUGH AGENTS AND ADVISERS WHILE STILL ALLOWING NATIVE MINISTRIES TO FUNCTION. IN 1894, LORD CROMER, BRITISH CONSUL-GENERAL IN EGYPT AND CHIEF REPRESENTATIVE OF BRITISH POWER IN THE COUNTRY, SUCCEEDED IN ESTABLISHING BRITISH CONTROL OVER THE MINISTRY OF INTERIOR. THIS ARTICLE SEEKS TO EXPLORE MORE FULLY THE BACKGROUND OF THE MINISTRY OF INTERIOR, ESPECIALLY THE ROLE OF THE POLICE QUESTION OR THE DEBATE OVER POLICE REFORMS, AND TO DELINEATE THE CONSEQUENCES OF THE TAKEOVER AND OF CONCOHITANT CHANGES

09116 TOLNAY, S.; BECK, E.; MASSEY, J.

BLACK COMPETITION AND WHITE VENGEANCE: LEGAL EXECUTION OF BLACKS AS SOCIAL CONTROL IN THE COTTON SOUTH 1890 TO 1929 SOCIAL SCIENCE QUARTERLY, 73(3) (SEP 92), 627-644.

DATA ON OVER 400 COUNTIES IN THE COTTON SOUTH FOR THE PERIODS 1890-1909 AND 1910-29 ARE USED TO EXAMINE THE UTILITY OF COMPETITION EXPLAMATIONS, PARTICULARLY BLALOCK'S THREAT HYPOTHESES, FOR EXPLAINING GEOGRAPHIC VARIATION IN THE FREQUENCY OF LEGAL BLACK EXECUTIONS. THE RELATIONSHIP BETWEEN BLACK POPULATION CONCENTRATION AND BLACK EXECUTIONS IS ASSESSED BEFORE AND AFTER INTRODUCING DIRECT MEASURES OF RACIAL COMPETITION. THE FINDINGS FOR THE EARLIER TIME PERIOD SUGGEST THAT ECONOMIC COMPETITION BETWEEN THE RACES HAD A SUBSTANTIAL INFLUENCE ON THE FREQUENCY OF BLACK EXECUTIONS WITHIN CDUNTIES. HOWEVER, A PERSISTENTLY STRONG RELATIONSHIP BETWEEN BLACK POPULATIONS CONCENTRATIONS AND EXECUTIONS BETHEEN BLACK POPULATIONS CONCENTRATIONS AND EXECUTIONS
INDICATES THE OPERATION OF SOCIAL FORCES NOT INCLUDED IN THE MODELS. THE EVIDENCE FROM THE EARLIER ANO LATER TIME PERIOOS COMBINED INDICATES THAT A REAL VARIATION IN THE PROPENSITY TO EXECUTE BLACKS HAS SHAPED BY BOTH ECONOMIC AND POLITICAL

09117 TOLOLYAN, K.

TERRORISM IN MODERN ARMENIAN POLITICAL CULTURE

TERRORISM AND POLITICAL VIOLENCE, 4(2) (SUM 92), 8-22.

IN THE PAST CENTURY, ARMENIAN POLITICAL CULTURE HAS BEEM SHAPED BY THE ARMENIAN REVOLUTIONARY FEDERATIDN (ARF), THE SHAPED BY THE ARMENIAN REVOLUTIONARY FEDERATIDN (ARF), THE
LARGEST NATIONALIST PARTY. BOTH THE ARF AND ITS MAJOR LARGEST NATIONALIST PARTY. BOTH THE ARF AND ITS MAJOR DIASPORAN OPPONENT, ASALA, HAVE USED OUTRIGHT TERRORISM AND
POLITICAL VIOLENCE WITH A VARIETY OF TARGETS, INTENTIONS, POLITICAL VIOLENCE WITH A VARIETY OF TARGETS, INTENTI
AUDIENCES, AND MEANINGS. THE VIOLENCE HAS OCCURRED AUDIENCES, AND MEANINGS. THE VIOLENCE HAS OCCURRED INTERMITTENTLY IN DIFFERENT LOCATIONS, BOTH IN ARMENIA A IN SOME 34 OTHER COUNTRIES. THE ROLE OF THESE ACTS IN SHAPING ARMENIAN POLITICAL CUL
CONTEXTS AND INTERPRETATIONS.

09118 TOLZ, V.

ACCESS TO KGB AND CPSU ARCHIVES IN RUSSIA

RFE/RL RESEARCH REPORT, 1(16) (APR 92), 1-7

THE RUSSIAN FEDERATION HAS NO LAH REGULATING PUBLIC ACCESS TO KGB FILES THAT CONTAIN THE NAMES OF SECRET POLICE 
AGENTS. ALTHOUGH THESE FILES ARE STILL CLASSIFIED AS "SECRET, "INFORMATION FROM THEM IS BEING LEAKED TO THE PRESS. SOME RUSSIANS ARE CALLING FOR THE ADOPTION OF A LAW THAT WOULD FORCE THE DISCLOSURE OF THE NAMES OF KGB AGENTS AND INFORMERS, ARGUING THAT THE SO-CALLED "OPERATIONAL" FILES OF THE KGB COULD BE USED TO MANIPULATE RUSSIAN POLITICIANS.

09119 TOLZ, V.; TEAGUE, E.

IS RUSSIA LIKELY TO TURN TO AUTHORITARIAN RULE?

RFE/RL RESEARCH REPORT, 1(4) (JAN 92), 1-8.

THERE HAS BEEN MUCH' SPECULATION THAT THE RUSSIAN

GOVERNMENT PRESENTLY HEADED BY A TEAM OF "DEMOCRATS" LED BY PRESIDENT BORIS YELTSIN MAY BE REPLACED BY AN AUTHORITARIAN, NATIONALIST ONE. MISTAKES BY YELTSIN'S REGIME AND RUSSIA'S CATASTROPHIC ECONOMIC SITUATION ADD PLAUSIBILITY TO SUCH SCENARIO. THE SPECTRUM FROM WHICH AN AUTHORITARIAN LEADERSHIP MIGHT SPRING RANGES FROM VIRULENTLY NATIONALIST GROUPS TO MORE MODERATE MOVEMENTS. AT THE SAME TIME, YELTSIN'S OWN GOVERNMENT HAS BEGUN TO DISPLAY INCREASINGLY AUTHORITARIAN TENDENCIES.

09120 TOLZ, $V$.

MINISTRY OF SECURITY OFFICIAL GIVES NEW FIGURES FOR STALIM'S VICTIMS

STALIN'S VICTIMS

AM OFFICIAL OF THE RUSSIAN MIMISTRY' OF SECURITY

(FORMERLY THE KGB) CLAIMS THAT, ACCORDING TO STATISTICS

FOUND IN THE AGENCY'S ARCHIVES', SEVEN MILLION PEOPLE WERE SENTENCED TO DEATH IN THE USSR IN THE DECADE FROM 1935 TO 1945. SIMILAR FIGURES HAVE BEEN SUGGESTED BY SOME WESTERN SCHOLARS, BUT THIS IS THE FIRST TIME SUCH A HIGH FIGURE HAS BEEN GIVEN BY A KGB OFFICIAL.

09121 TOLZ, $V$.

POLITICAL PARTIES IN RUSSIA

RFE/RL RESEARCH REPORT, 1(1) (JAN 92), 12-14.

THE MOST SIGNIFICANT DEVELOPMENT IN RUSSIAN POLITICS IN 1991 WAS THE DISSOLUTION OF THE LEADING BODIES OF THE CPSU AND THE RUSSIAN COMMUNIST PARTY IN THE AFTERMATH OF - THE ATTEMPTED COUP IN AUGUST. BUT THE DEFEAT OF THE COMMUNIST PARTY IN RUSSIA DID NOT TRANSLATE INTO A VICTORY FOR DEMOCRACY. POLITICAL ORGANIZATIONS OF DEMOCRATIC ORIENTATION FAILED TO FORM A WORKABLE COALITION AND CONTINUED TO BE TORN APART BY INTERHAL STRUGGLES.

09122 TOLZ, $V$.

RUSSIA

RFE/RL RESEARCH REPORT, 1(39) (OCT 92), 4-9.

UNDER MIKHAIL GORBACHEV THE RUSSIAM MEDIA FOUGHT AGAINST POLITICAL CENSORSHIP AND FOR MORE FREEDOM OF SPEECH. TODAY, POL ITICAL CENSORSHIP AND FOR MORE FREEDOM OF SPEECH. TODAY, INTERFERE IN THE MEDIA. THESE ISSUES HAVE LARGELY BEEN INTERFERE IN THE MEDIA, THESE ISSUES HAVE LARGELY BEEN
PUSHED ASIDE BY THE FINANCIAL WORRIES THAT INTENSIFIED WHEN PUSHED ASIDE BY THE FINANCIAL WORRIES THAT INTENSIFIED WHEN RUSSIA SPEEDED UP THE PACE OF ECONOMIC REFORMS. IN TODAY'S RUSSIA THE MEDIA'S IMPACT ON THE POPULATION IS MUCH WEAKER THAN IT WAS IN THE PERIOD OF PERESTROIKA. OPENMESS IN THE MEDIA IS NO LONGER A NOVELTY, AND THE RUSSIAN MEDIA IS
SUFFERING FROM AN IDENTITY CRISIS. MEANWHILE. THE RUSSIAN SUFFERING FROM AN IDENTITY CRISIS. MEANWHILE. THE RUSSIAN POLITICAL LEADERSHIP CONTINUES TO LIVE IN A HORLD
FROM THE MEDIA AS THAT OF THE OLD KREMLIN LEADERS.

09123 TOLZ, V.

RUSSIA: WESTERNIZERS CONTINUE TO CHALLENGE NATIONAL PATRIOTS

RFE/RL RESEARCH REPORT, 1(49) (DEC 92), 1-9.

LIBERAL AND CONSERVATIVE INTELLECTUÁLS ARE CURRENTLY DEBATIMG WHAT ROLE RUSSIA SHOULD ASSUME NOW THAT THE SOVIET UMION NO LONGER EXISTS. WHILE CRITICIZING THE RUSSIAN POLITICAL LEADERSHIP FOR BEING UNABLE TO DEFINE A NEW CONCEPT OF RUSSIAN STATEHOOD, BOTH GROUPS HAVE FOUND IT DIFFICULT TO DEFINE THE PROPER POST-SOVIET ROLE. THE LIBERALS HAVE NO LEGACY TO HELP THEM, SINCE THEIR PREDECESSORS IN THE 19TH AND EARLY 2OTH CENTURIES DID NOT QUESTION THE EXISTENCE OF THE EMPIRE. THE CONSERVATIVES, ON THE OTHER HAND, HAVE BORROWED MANY IDEAS FROM EARLIER RUSSIAM THINKERS BUT HAVE NOT ATTEMPTED TO ESTABLISH JUST HOW APPROPRIATE THESE IDEAS ARE FOR RUSSIA AT THE END OF THE 2OTH CENTURY.

09124 TOLZ, V.; TEAGUE, E.

RUSSIAN INTELLECTUALS ADJUST TO LOSS OF EMPIRE

RFE/RL RESEARCH REPORT, 1(8) (FEB 92), 4-8.

THE ESTABLISHMENT OF THE COMMONHEALTH OF INDEPENDENT STATES ELICITED A MIXED RECEPTION FROM RUSSIAN INTELLECTUALS. THE INITIAL REACTION OF MOST LIBERALS WAS HIGHLY POSITIVE, WITH RESERVATIONS EXPRESSED ONLY BY A FEW, WHILE STRONG DISAPPROVAL WAS VOICED BY "STATISTS" AND "NATIONAL PATRIOTS. " AS TIME PROGRESSED AND THE AMBIGUITIES UNDERLYING THE NEH ASSOCIATION BECAME INCREASINGLY CLEAR, LIBERAL CRITICISM BEGAN TO MOUNT. THERE IS NOW A STRIKING DEGREE OF AGREEMENT AMONG RUSSIAN INTELLECTUALS OF VARIOUS POLITICAL PERSUASIONS THAT THE DISINTEGRATION OF THE USSR HILL HAVE REGRETTABLE CONSEQUENCES FOR RUSSIA. MANY RUSSIAN LIBERALS SEEM TO BE
HAYING DIFFICULTY ADAPTING TO THE LOSS OF THE RUSSIAN EMPIRE.
09125 TOLZ, Y

THE FIRST ELECTIONS TO THE RUSSIAN ACADEMY OF SCIENCES RFE/RL RESEARCH REPORT 117) (FEB 92) 48-51.

THE FIRST ELECTIONS TO THE NEWLY-CREATED RUSSIAN ACADEMY OF SCIENCES RAISED DOUBTS ABOUT THE ABILITY OF THE NEW BODY TO AVOID A PROBLEM THAT PLAGUED THE USSR ACADEMY OF SCIENCES- NAMELY, DECISIONS AND ACTIONS WERE GOVERNED NOT BY SCIENTIFIC BUT BY POLITICAL CONSIDERATIONS. AS HAD BEEN THE CASE IN ITS ALL-UNION COUNTERPART, THE FIRST ELECTIONS TO THE RUSSIAN ACADEMY WERE CONTROLLED AND STRONGLY INFLUENCED BY THE GOVERNMENT AND STATE INSTITUTIONS OF THE RUSSIAN FEDERATION.

09126 TOLZ, V.

THE KATYN DOCUMENTS AND THE CPSU HEARINGS

RFE/RL RESEARCH REPORT, 1(44) (NOV 92), 27-33.

THE RUSSIAN LEADERSHIP IS USING DOCUMENTS FROM THE COMMUNIST PARTY ARCHIVES TO STRENGTHEN ITS CASE AGAINST THE CPSU IN CONSTITUTIONAL COURT HEARINGS. ONE SET OF DOCUMENTS CONCERNS THE MASSACRE OF 4000 POLISH OFFICERS IN KATYN CONCERNS THE MASSACRE OF 4000 POLISH OFFICERS IN KATYN
FOREST IN 1940. A COMPARISON OF STATEMENTS MADE BY RUSSIAN FOREST IN 1940. A COMPARISON OF STATEMENTS MADE BY RUSSIAN
OFFICIALS ABOUT THE CONTENT OF THE DOCUMENTS WITH THE TEXTS OFFICIALS ABOUT THE CONTENT OF THE DOCUMENTS WITH THE DISCREPANCIES, ESPECIALLY CONCERMING MIKHAIL GORBACHEV'S DISCREPANCIES, ESPECIALLY CONCERMING MIKHAIL GORBACHEV'S ROLE IN A COVER-UP OF THE "SMOKING GUN" EVIDENCE ON CONSTITUTIONAL COURT HAVE REPEATED THE PRESIDENTIAL VERSION UNCRITICALLY WITHOUT CHECKING ITS ACCURACY.

09127 TOLZ, $V$.

THE SOVIET MEDI

RFE/RL RESEARCH REPORT, 1(1) (JAN 92), 29-31

THE ATTEMPED COUP IN AUGUST 1991 WAS A HATERSHED AS FAR AS THE CENTRAL SOVIET AND THE RSFSR MEDIA HERE CONCERNED. EARLY 1991 HAS MARKED BY CENTRAL LEADERSHIP ATTEMPTS TO REIMPOSE POLITICAL CENSORSHIP OVER THE MASS MEDIA, ESPECIALLY TELEVISION, AND TO HAMPER THE DEVELOPMENT OF THE RSFSR'S OWM MEDIA NETHORK. IN THE AFTERMATH OF THE UNSUCCESSFUL COUP, THE SITUATION CHANGED DRAMATICALLY. JOURNALISTS CONCENTRATED ON MAKING THEIR OUTLETS COMPLETELY INDEPENDENT OF THE STATE, AND THE QUESTION OF HOW TO SURVIYE IN A MARKET ECONOMY ALSO GAINED IN IMPORTANCE.

09128 TOMARU, $H$.

LOST IN TRANSLATION: SDPJ DENIES ITS 'SOCIALIST' LABEL JAPAN TIMES (WEEKLY INTERNATIONAL EDITION), 32(11) (MAR 92 ), 4.

THE SOCIAL DEMOCRATIC PARTY OF JAPAN, THE COUNTRY'S LEADING OPPOSITION GROUP, IS IN THE MIDST OF AN IDENTITY CRISIS. AT ISSUE IS WHETHER THE PARTY SHOULD RETAIN ITS SOCIALIST IDEOLOGY OR BECOME A PARTY OF SOCIAL DEMOCRATS, IM SUBSTANCE AS WELL AS IN NAME.

09129 TOMASZCZUK, A.D.; JENSEN, J.E.

THE ADJUDICATORY ARM OF CONGRESS: THE GAO'S SIXTY-YEAR ROLE IN DECIDING GOVERNMENT CONTRACT BID PROTESTS COMES UNDER RENEWED ATTACK BY THE DEPARTMENT OF JUSTICE

HARVARD JOURMAL OF LEGISLATION, $29(2)$ (SUM 92), 399-428.

THE AUTHORS DESCRIBE THE EVOLUTION AND FORMALIZATION OF THE GENERAL ACCOUNTING OFFICE'S (GAO) ADJUDICATORY FUNCTION AND THE NATURE OF THE EXECUTIVE BRANCH'S GROWING RESISTANCE TO IT. THEN THEY DETAIL THE CONSTITUTIONAL AND PROCEDURAL POSTURE OF THE JUSTICE DEPARTMENT'S LATEST ATTACK ON THE GAO'S AUTHORITY TO ADJUDICATE GOVERNMENT CONTRACT BIDDING PROTESTS. THEY CONCLUDE WITH SOME SPECULATIONS ON THE MOTIVATIONS FUELING THIS INTER-BRANCH CLASH AND THE FUTURE OF THE GAO'S UNUSUAL ADJUDICATORY ROLE IN THE FEDERAL GOVERNMENT.

09130 TOMBINI, A.A.; NEWBOLD, P.

THE TIME-SERIES BEHAVIOR OF BRAZILIAN REAL GROSS DOMESTIC PROOUCT, 1947-87: AN ANALYSIS OF INTERVENTIONS

WORLD DEVELOPMENT, 20(2) (FEB 92), 283-288.

THE EVOLUTION OF BRAZILIAN REAL GROSS DOMESTIC PROOUCT IN THE POST-WORLD WAR II PERIOD HAS BEEN FAR FROM STABLE. SOME OF THIS INSTABILITY HAS ALMOST CERTAINLY BEEN DUE TO THE IMPACT OF EXTERHAL SHOCKS. IN THIS PAPER, THE AUTHORS EXAMINE THREE SHOCKS, OR INTERVENTIONS, THAT SEEM TO HAVE
HAD PARTICULARLY PRONOUNCED IMPACTS ON THE BRAZILIAN ECONOMY. HAD PARTICULARLY PRONOUNCED IMPACTS ON THE BRAZILIAN ECONOM THESE ARE THE POLITICAL UPHEAVALS AND ATTENDANT ECONOMIC
REFORMS OF THE EARLY 1960 'S AND THE OIL SHOCKS OF 1973 AND REFORMS OF THE EARLY 1960 'S AND THE OIL SHOCKS OF 1973 1979. THE AUTHORS BUILD A TIME-SERIES MODEL FOR ANMUAL
BRAZILIAN REAL GROSS DOMESTIC PRODUCT AND USE IT TO ESTIMATE BRAZILIAN REAL GROSS DOMESTIC PROD

09131 TOMMEL, I.

DECENTRALISATION OF REGIONAL DEVELOPMENT POLICIES IN THE NETHERLANOS--A NEW TYPE OF STATE INTERVENTION? WEST EUROPEAH POL

DURING THE PAST DECADE, REGIONAL DEVELOPMENT POLICIES IN THE NETHERLANDS HAVE BEEN DISMANTLED. AT THE SAME TIME, ECONOMIC DEVELOPMENT POL ICIES HAVE BEEN DECENTRALISED TO 
LOCAL INITIATIVES FOR IMPLEMENTING MARKET-ORIENTED AND MARKET-RELATED DEVELOPMENT STRATEGIES. IN THE LONG RUN, DECENTRALISATION OF ECONOMIC POLICIES RESULTS IN A NEN' TYPE OF REGULATION. THE KEYNESIAN MODEL OF REGULATION IS GRADUALLY BEING TRANSFORMED INTO A MORE MODERN MODEL, CHARACTERISED BY FLEXIBLE, FRAGMENTED, INDIRECT AND INVISIBLE MEASURES. THE RESULT IS A FUNDAMENTAL CHANGE IN THE RELATIONSHIP BETWEEN STATE AND ECONOMY.

09132 TONELSON, A.

AMERICA FIRST-DAST AND PRESENT

SOCIETY, 29(6) (SEP 92), 15-17.

THE AMERICA FIRST APPROACH HAS GROWN POPULAR ENOUGH TO TERRIFY MAINSTREAM FOREIGN POLICY EXPERTS BECAUSE THE HARDNOSED NATIONALISM AT ITS CORE IS SO NATURAL A FOREIGN POLICY POSTURE FOR A COUNTRY WITH POST-COLD WAR AMERICAN'S COMBINATION OF STRENGTHS AND HEAKNESSES. THIS ARTICLE LAMENTS THAT FRICTION AND CONFLICT ARE CONSIDERED TO BE THE LAMENTS THAT FRICTION AND CONFLICT ARE CONSIDERED TO BE THE NORM IN WORLD AFFAIRS AND SUGGESTS THAT MOST NATIONS PUT THEIR TRUS

09133 TONELSON, A.

PRUDENCE OR INERTIA? THE BUSH ADMINISTRATION'S FOREIGN POLICY

CURRENT HISTORY, 91(564) (APR 92), 145-150.

GEORGE BUSH TOUTS FOREIGN POLICY AS HIS STRONGEST SUIT, AND HE HAS HAD SOME UNDENIABLE SUCCESSES IN THAT AREA. NEVERTHELESS, HIS FOREIGN POLICY CONSERVATISM IS EXACTING CONSIDERABLE AND MOUNTING COSTS ON AMERICA. IT IS A CONSERVATISM LESS REASONED THAN FELT AND LESS A STRATEGY THEN AN IMPULSE. INDEED, BUSH'S INCESSANT, ALMOST RITUALISTIC INVOCATION OF COLD WAR IDEALS INDICATES THAT HIS CONSERVATISM IS BECOMING AN INTELLECTUAL CAGE.

09134 TONG, I.C.W.

A SPECIAL POLICY FOR SPECIAL PLACES? AN EVALUATION OF THE NOVA SCOTIA SPECIAL PLACES PROTECTION ACT

CANADIAN PUBLIC ADMINISTRATION, 35(4) (WIN 92), 549-557.

IN 1980 NOVA SCOTIA ENACTED THE SPECIAL PLACES

PROTECTION ACT TO PRESERVE SENSITIVE ECOLOGICAL AREAS. THIS ENVIRONMENTAL POLICY IS UNIQUE AMONG SIMILAR PROVINCIAL AND FEDERAL POLICIES BECAUSE IT IS ADMINISTERED BY THE NOVA

SCOTIA MUSEUM UNDER THE AEGIS OF THE DEPARTMENT OF EDUCATION. THIS PAPER ASSESSES THE EFFECTIVENESS OF THE SPECIAL PLACES PROTECTION ACT IN LIGHT OF ITS STATUTORY POWERS AND STRUCTURAL FACTORS. THE FIRST SECTION DESCRIBES THE ACT. THE STRUCTURAL FACTORS. THE FIRST SECTION DESCRIBES THE ACT. THE
FOLLOWING THREE SECTIONS EXAMINE THE ORIENTATION, SCIENTIFIC RESOURCES, AND DIFFUSION OF POLICY AIMS OF THE NOVA SCOTIA RESOURCES, AND DIFFUSION OF POLICY AIMS OF THE NOVA SCOTIA MUSEUM IN RELATION TO SPECIAL ECOLOGICAL PLACES. THE FIFTH SECTION CONSIDERS THE EFFECTS OF A COMPREHENSIVE MANAGEMENT
PLAN. FINALLY, THE PROVISION FOR SPECIAL PLACES DESIGNATION PLAN. FINALLY, THE PROVISION FOR SPECIAL PLACES DESIGNATI
ON PRIVATE LAND IS EXPLORED IN THE CONTEXT OF ECONOHIC ON PRIVATE
INCENTIVES.

09135 TONG, $S$.

WILL CHINA BE DEMOCRATIC

WORLD AFFAIRS, 154(4) (SPR 92), 139-154

AS HITH ALL OTHER CHANGES IN CHINA. THE REFORM POLICY HAS POSED MORE PROBLEMS THAN IT PROVIDED ANSWERS. THE CHINESE PEOPLE HAVE LOOKED TO POL ITICAL CHANGE AS HELL AS ECONOMIC CHANGE IN ORDER TO FULFILL THE PROMISE OF REFORM. THE CHINESE PEOPLE, WHO ARE IN A STATE OF POLITICAL CONFUSION, HANT DEMOCRACY. THE AUTHOR SUGGESTS THAT LOOKING AT CHINA AS A WHOLE, IT REMAINS QUITE UNCLEAR WHETHER, AFTER THE REGIME BREAKS DOWN, DEMOCRACY WILL BE INSTALLED. THERE ARE, HOWEVER, GROUNDS TO HOPE THAT THE AUGURIES FOR THE FUTURE ARE FAVORABLE TO A DEMOCRATIC CHINA.

09136 TOONEN, T.A.J.

EUROPE OF THE ADMINISTRATIONS: THE CHALLENGES OF 92 (AND BEYOND) PUBLIC ADMINISTRATION REVIEW, $52(2)$ (MAR 92 ), 108-115.
THE AUTHOR ENUMERATES FOUR CHALLENGES THAT EUROPEAN PUBLIC ADMINISTRATORS WILL FACE AS THE EUROPEAN COMHUNITY MOVES TOWARD GREATER INTEGRATION. IN ADDITION TO CONTENDING WITH THE CHALLENGE OF ADOPTING AND IMPLEMENTING COMHNITY POLICIES, THEY MUST DEAL WITH INSTITUTIONAL BARRIERS AND UNDERTAKE REFORMS THAT WILL ENABLE THEM TO FIT INTO THE NEH COMMUNITY FRAMEWORK. FUNCTIONAL PROBLEMS AND ISSUES RELATED TO PUBLIC MANAGEMENT ARE ALSO EMERGING AS SIGNIFICANT CHALLENGES. THE AUTHOR OFFERS AN OVERVIEW OF HOW PUBLIC ADMINISTRATORS AND GOVERMMENT OFFICIALS ARE ATTEMPTING TO COPE WITH THESE CHALLENGES THROUGH CO-PRODUCTION AND VARIOUS INSTITUTIONAL AND POLITICAL CHANGES.

09137 TORBAKOY, I.

THE STATISTS AND THE IDEOLOGY OF RUSSIAN IMPERIAL NATIONALISM

RFE/RL RESEARCH REPORT, 1(49) (DEC 92), 10-16.

THE DISINTEGRATION OF THE USSR AND THE COLLAPSE OF

COMMUNIST IDEOLOGY HAVE HAD A PROFOUND EFFECT ON THE RUSSIAN

PSYCHE. THE RESULT HAS BEEN A CRISIS OF IDENTITY AND A

CRISIS OF IDEDLOGY. AGAIN, AS MANY TIMES BEFORE IN RUSSIAN
HISTORY, THE ETERNAL "ACCURSED QUESTIONS" LOOM LARGE: WHO ARE WE? WHAT IS OUR PLACE IN THE WORLD? WHAT DO WE, OR SHOULD WE, BELIEVE IN? BORROWING WIDELY FROM THE THINKERS OF THE PAST, RUSSIA'S IMPERIAL NATIONALISTS ARE ADVOCATING A HIGHLY CONSERYATIVE, IF NOT REACTIONARY, IDEOLOGY THAT IN THE PRESENT PRECARIOUS POLITICAL AND ECONOMIC SITUATION HOLDS CONSIDERABLE APPEAL FOR SOME OF RUSSIA'S DISEMCHANTED MASSES. ITS ANTI-REFORMIST, CHAUVINISTIC, ANTI-HESTERN, AND ESSENTIALLY REVANCHIST NATURE MAKES IT A THREAT NOT ONLY TO RUSSIAN DEMOCRACY BUT ALSO TO RUSSIA'S NEIGHBORS AND TO THE WEST IN GENERAL.

09138 TORRES, L.

FREE TRADE

POLITICAL AFFAIRS, 71(9) (SEP 92), 11-13; 17

THE NAFTA AGREEMENT BRINGS TOGETHER THE LARGEST ECONOMIC TRADING GROUP THE WORLD HAS EVER KNOWN. THIS ARTICLE

SUGGESTS THAT THE COUNTRIES INVOLVED WILL NOT BE EQUAL

PARTNERS AND THAT FREE TRADE MEANS FREE TRADE DOMINATED BY $U$. S. IMPERIALISM. IT STUDIES THE GROWING OPPOSITION, TRENDS, JOBS, AND THE ROLE OF TRADE UNIONS. IT CONCLUDES THAT THE UNDERSTOOD IN ITS GLOBAL TERMS WHICH IS GLOBAL CLASS WAR.

09139 TORREY, E. F.

WHO GOES HOMELESS?

NATIONAL REVIEH, XLIII(15) (AUG 91), 34-36.

HOMELESSNESS IN AMERICA HAS EVOLVED FROM BEING A

HOMOGENOUS PROBLEM TO BEING A HETEROGENOUS CLUSTER OF

INTERRELATED PROBLEMS FOR WICH MANY OF THE SOLUTIONS ARE KNOWN. THIS ARTICLE CONSIDERS THE UNIQUE PROBLEMS AND POSSIBLE SOLUTIONS OF SEVERAL GROUPS OF HOMELESS INCLUOING THE MENTALLY ILL, ALCOHOL ICS AND DRUG ABUSERS, AND THE "DOWNON-MY-LUCK" GROUP OF HOMELESS.

09140 TOSHIHIRO, Y.

GUNNING FOR JAPAN'S PEACE CONSTITUTION

JAPAN QUARTERLY, XXXIX(2) (APR 92), 159-167.

FORTY YEARS AFTER IMPLEMENTATION OF THE JAPAN-U, $s$.

MUTUAL SECURITY TREATY, THE TREATY AND THE JAPANESE MILITARY ARE ON THE VERGE OF MAJOR QUALITATIVE CHANGES. THE FOCUS ON JAPAN-U.S. SECURITY IS SHIFTING TO ASIAN SECURITY AND EVEN WORLD SECURITY. JAPAN IS DEBATING WHETHER TO ALLOW ITS SELFDEFENSE FORCES TO JOIN UNITED NATIONS PEACEKEEPING

OPERATIONS, A MOVE THAT WOULD MEAN SENDING TROOPS OVERSEAS AND PERHAPS ALLONING THEM TO USE WEAPONS. THE PACIFISH ENSHRINED IN JAPAN'S CONSTITUTION HAS BEEN GRADUALLY EROOING ENSHRINED IN JAPAN'S CONSTITUTION HAS BEEN GRADU
AND IS NOH FACING ITS GREATEST THREAT TO DATE.

09141 TOSHIYUKI, T.

BEYOND THE MIMD-SET OF DETERRENCE TO GENUINE DISARMAMENT JAPAN QUARTERLY, XXXIX(3) (JUL 92), 290-302.

THE MEMBERS OF THE NUCLEAR PENTARCHY HOLD THE FIVE PERMANENT SEATS ON THE U.N. SECURITY COUNCIL. WHERE THEY CONTROL THE REAL POWER IN THE U.N. POLITICAL ARENA. THE FIVE'S ADHERENCE TO THE OUTDATED DOCTRINE OF DETERRENCE
MAKES THEM A KIND OF NUCLEAR HOLY ALLIANCE. NO DOUBT, THE MAKES THEM A KIND OF NUCLEAR HOLY ALLIANCE. NO DOUBT, THE ALLIANCE'S OBJECTIVE IS TO EXCLUSIVELY POSSESS AND DEVELOP NUCLEAR WEAPONS, SO AS TO PREVENT OTHER COUNTRIES FROH SO. ALTHOUGH NUCLEAR PROLIFERATION IS OBVIOUSLY VERY DANGEROUS AND SHOULD BE CONDEMNED, CONDEMNATION OF OTHER COUNTRIES CANMOT BE A SCREEN FOR THEIR OWN CULPABILITY. THE
HORLD MUST NOT EXCUSE THE PENTARCHY'S ATTEMPT TO LEGITIMIZE AN EXCLUSIVE RIGHT TO POSSESS NUCLEAR WEAPONS IN THE NAME OF DETERRENCE. FIRST, IT RUNS COUNTER TO THE HISTORICAL TREND TOWARD WORLD DEMOCRACY AND REVEALS UNJUSTIFIED DISCRIMINATION AMONG U.N. MEMBER NATIONS. SECONDLY, DETERRENCE IS NO LONGER A VIABLE CONCEPT. THE COLD WAR IS OVER, AND IT IS TIME TO MOVE BEYOND THE MIND-SET OF DETERRENCE TO GENUINE DISARMAMENT.

09142 TOTH, J.

DEMONIZIMG SADDAM HUSSEIN: MANUPULATING RACISM AS A PRELUDE TO WAR

NEW POLITICAL SCIENCE, 21-22 (SPR 92), 5-40.

THE DEMONIZING OF SADDAM HUSSEIN IS BUT A SMALL PART OF A WIDER AND DEEPR CAMPAIGN OF ANTI-ARAB RACISH ARGUES JAMES TOTH. THIS ARTICLE SUGGESTS THAT IN ORDER TO JUSTIFY A COUNTER VIOLENCE IN THE SIX MONTHS FOLLOWING THE AUGUST 2 MD IRAQI INVASION OF KUWAIT, U.S. GOVERNMENT PUBLICISTS OUTOISTANCED THEMSELVES IN CASTING THE IRAQI PRESIDENT IN THE MOST PERJORATIVE LIGHT POSSIBLE, THE ARTICLE CONCLUDES THAT SUCH GOVERNMENT-SPONSORED DEMONIZATION IS FREQUENTLY DIRECTED AGAINST LEADERS FROM UMFAMILIAR MIDOLE EAST

SOCIETIES IHEN MEDIA HENCHMEN GO UNCHALLENGED GY EITHER AREA SPECIALISTS OR EXPERIENCED LAYPEOPLE.

09143 TOUGAS, F.; BEATON, A.

WOMEN'S VIEHS ON AFFIRMATIVE ACTION: A NEH LOOK AT POMEN S VIEHS ON AFFIRHAT

SOCIAL JUSTICE RESEARCH, 5(3) (SEP 92), 239-248.

THE FIRST PART OF THIS PAPER SKETCHES A PROFILE OF HOMEN WHO ENDORSE AFFIRMATIVE ACTION, SHOWING THAT WOMEN WHO APPROVE OF AFFIRMATIVE ACTION IDENTIFY WITH A NONTRADITIONAL 
IMAGE OF WOMEN AND EXPERIENCE DISCONTENT WHEN PERCEIVING DISCRIMINATION ON THE BASIS OF SEX. THE IMPACT OF THE IMPLEMENTING PROCEDURE IS ALSO EXAMINED. RECENT STUDIES INDICATE AN ENDORSEMENT OF PREFERENT IAL TREATMENT POLICIES. THIS ARTICLE STUOIES THE FOLLOWING QUESTIONS: WHAT FACTORS TRIGGERED THIS CHANGE IN ATTITUDES? ARE THE MERIT PRINCIPLE AND PREFERENTIAL TREATMENT POLICIES TRULY INCOMPATIBLE? THE IMPLICATIONS OF THIS SHIFT IN ATTITUDES IS ADDRESSED.

09144 TOULOUSE, $C$.

THATCHERISM, CLASS POLITICS, AND URBAN DEVELOPMENT IN LONDON

CRITICAL SOCIOLOGY, 18(1) (SPR 91), 55-76

CLASS ANALYSIS IS USED TO EXPLORE THE POLITICS OF URBAN DEVELOPMENT IN LONDON IN THE 1980S. THIS PAPER SHOWS HOH THE THATCHER GOVERNMENT'S ECONOMIC AND URBAN POL ICIES HAD THE STRATEGIC EFFECT OF SHAPING ECONOMIC RESTRUCTURING IN THE CITY AND TRANSFORMING THE SOCIOLOGICAL BASES OF CLASS POLITICS. THE BROAD IMPACT OF THATCHERISM IN LONDON IS DISCUSSED, WITH PARTICULAR ATTENTION BEING PAID TO THE FINANCIAL DISTRCT AND THE DOCKLANDS. THE PAPER CONCLUDES
WITH A DISCUSSION OF THE STRUGGLE BETHEEN THE THATCHER WITH A DISCUSSION OF THE STRUGGLE BETHEEN THE THATCHER
GOVERMMENT AND THE LONDON LABOUR PARTY WHICH CULMINATED IN GOVERNMENT AND "THE

09145 TOVIAS, A.

THE EC'S CONTRIBUTION TO PEACE AND PROSPERITY IN THE MEDITERRANEAN AND THE MIDDLE EAST: SOME PROPOSALS JERUSALEM JOURNAL OF INTERMATIONAL RELATIONS, 14(2) (JUN 92), 123-132.

THE EC CANNOT HOPE TO SUCCEED ULTIMATELY AS AN ISLAND OF POLITICAL STABILITY AND ECONOMIC HELFARE IN AN OCEAN OF INSTABILITY AND DESTITUTION. ALTHOUGH THE EC'S INTERVENTION CAPABILITY IN FAVOR OF ITS MEDITERRANEAN PERIPHERY REMAINS STRONGEST IN THE REALM OF TRADE AND DEVELOPMENT ASSISTANCE THIS MAY NOT BE SUFFICIENT TO ANCHOR THESE COUNTRIES TO THE EC AND WORK TOWARD THEIR POLITICAL STABILZATION. THE LATTER COULD BE PROMOTED BY HAVING THE EC DECLARE PUBLICLY THAT THOSE COUNTRIES IN ITS EXTERNAL PERIPHERY THAT MAINTAIN A WESTERN-TYPE DEMOCRATIC REGIME WILL EVENTUALLY BE CONSIDERED AS POTENTIAL MEMBERS OF THE COMMUNITY. THIS MEANS GIVING PRIORITY TO THE GEOGRAPHY OF VALUES OVER THE CONVENTIONAL TERRITORIAL DEFINITION OF EUROPE.

09146 TRAPANS, J.A. (ED.)

CONFERENCE IN SALZBURG

RFE/RL RESEARCH REPORT, 1(49) (DEC 92), 17-27.

THE EDITOR REPORTS ON THE SALZBURG SEMINAR HELD IN OCTOBER 1992 TO DISCUSS SECURITY IN THE BALTIC REGION. THE OCTOBER 1992 TO DISCUSS SECURITY IN THE BALTIC REGION. THE
REPORT INCLUDES COMMENTS ON THE BALTIC REGION IN EAST-WEST REPORT INCLUDES COMMENTS ON THE BALTIC REGION IN EAST-WEST
RELATIONS, RUSSIA'S NEW SECURITY CONCEPT AND THE BALTIC AREA, RELATIONS, RUSSIA'S NEW SECURITY CONCEPT AND THE BALTIC
THE FUTURE AND SECURITY OF BALTIC GOVERNMENT, RUSSIA'S THE FUTURE AND SECURITY OF BALTIC GOVERNMENT, RUSSIA'S
VIENS ON THE BALTIC REGION AND SECURITY, INTERHATIONAL LAW VIENS ON THE BALTIC REGION AND SECURITY, INTERNATIONAL LAW
AND A EUROPEAN AGREEMENT ON BALTIC SECURITY, BALTIC DEFENSE AND A EUROPEAN AGREEMENT ON BALTIC SECURITY, BALTIC DEFENSE ATIITUDES TOWARD BALTIC SECURITY, AND THE GERMAN AND POLISH ATIITUDES TOWARD BALTIC SECURITY,
PERSPECTIVES ON THE BALTIC STATES.

09147 TRAUGOTT, M.W.; PRICE, $V$. EXIT POLLS IN THE 1989 VIRGINIA GUBERMATORIAL RACE: WHERE DID THEY GO WRONG?

PUBLIC OPINION QUARTERLY (CHICAGO), 56(2) (SUM 92),

245-253.

THE AUTHORS STUDY THE CIRCUMSTANCES SURROUNDING THE EXIT POLLS IN THE 1989 VIRGINIA GUBERMATORIAL RACE, WHICH PITTED DEMOCRAT L. DOUGLAS WILDER AGAINST REPUBLI ICAN J. MARSHALL THE MARGIN OF WILDER'S VICTORY.

09148 TRAXLER, F.

INTERESTS, POLITICS, AND EUROPEAN INTEGRATION: AUSTRIA'S POL ITICAL SYSTEM IN THE WAKE OF 1992

EUROPEAN JOURNAL OF POLITICAL RESEARCH, 22(2) (AUG 92), 193-217.

THE AUTHOR INVESTIGATES THE DETERMINANTS OF STATE ACTION, USING THE ROLE OF EUROPEAN INTEGRATION IN AUSTRIAN POLITICS AS A CASE STUDY. BASED ON AN ANALYSIS OF THE CONDITIONS AND PROCESS THAT LED TO AUSTRIA'S APPLICATION FOR EUROPEAN COMMUNITY MEMBERSHIP, HE ASSESSES THE EXPLANATORY POWER OF THE INSTRUMENTALIST AND STRUCTURALIST APPROACH TO STATE ACTION AND DRANS SOME CONCLUSIONS REGARDING STATE THEORY AND THE THEORY OF CORPORATISM.

09149 TREHUB, A.

HOUSING POLICY IN THE USSR/CIS: PERESTROIKA AND BEYOND HOUSING POLICY IN THE USSR/CIS: PERESTROIKA A
RFE/RL RESEARCH REPORT, $1(6)$ (FEB 92 ) 32-42

HOUSING IS ONE OF MANY INTRACTABLE' SOCIAL PROBLEMS FACING THE NEW LEADERS IN THE COMMONWEALTH OF INDEPENDENT STATES. CONSTRUCTION OF NEW HOUSING IN THE FORMER SOVIET UNION HAS BEEN STAGNANT OR EVEN DECLINING SINCE THE LATE 1980'S, AND THE BUILDING-MATERIALS INDUSTRY IS IN DISARRAY. FURTHERMORE, OLD HOUSING PROBLEMS HAVE BEEN COMPOUNDED BY OTHERS RESULTING FROM THE BREAKUP OF THE SOVIET UNION: MANY
MILITARY PERSONNEL DO NOT HAVE APARTMENTS AND ETHNIC STRIFE
IS CONTRIBUTING TO A GROHING REFUGEE POPULATION. ALTHOUGH FORMER SOVIET LEADER MIKHAIL GORBACHEV'S ATTEMPTS TO SOLVE THE HOUSING PROBLEM FAILED, HE DID ENCOURAGE NEW FORMS OF CONSTRUCTION AND OWNERSHIP. ONE OF THESE WAS THE PRIVATIZATION OF STATE HOUSING, WHICH BEGAN IN 1989 AND IS PROCEEDING UNDER THE STEWARDSHIP OF RUSSIAN PRESIDENT BORIS
YELTSIN AND THE LEADERS OF THE OTHER COMMONWEALTH REPUBLICS.

09150 TREISMAN, 0. KORRUPTSIA

NEW REPUBLIC, 206 (19) (MAY 92), 14, 16-17.

AS DEMOCRATIC FORMS INTERHEAVE WITH REMNANTS OF THE SOVIET STATE, A NEN BRAND OF POLITICS HAS BEEN EMERGING IN RUSSIA. DISGRACED OFFICIALS FROM THE OLD REGIME HAVE BECOME POWERS ONCE AGAIN, THANKS TO THEIR CONTACTS AND EXPERIENCE. AND NEWLY-ELECTED OFFICIALS ARE FINDING THAT THE BOUNDARY BETHEEN LEGITIMATE FORMS OF DEMOCRATIC PRESSURE AND THE PURSUIT OF CORRUPT ADVANTAGE IS POROUS INDEED. UNDER THE OLD COMMUNIST ORDER, BRIBES AND CONNECTIONS WERE ESSENTIAL LUBRICANTS, PROYIDING ACCESS TO SCARCE GOOOS. THAT'S STIL TRUE, BUT TODAY THE STAKES ARE HIGHER AND THE RULES OF PLAY ARE MUCH MORE FLUID AND DIFFICULT TO DIVINE.

09151 TREJO, S.J.

IMMIGRANT WELFARE RECIPIENCY: RECENT TRENDS AND FUTURE IMPLICATIONS

CONTEMPORARY POLICY ISSUES, $X(2)$ (APR 92), 44-53.

USING DATA FROM THE 1970 AND 1980 U.S. CENSUSES, THE AUTHOR IDENTIFIES RECENT TRENDS IN IMMIGRANT WELFARE RECIPIENCY. IMMIGRANT WELFARE USE INCREASED DURING THE 1970 'S, BOTH IN ABSOLUTE TERMS AND IN COMPARISON TO THE WELFARE USE OF NATIVES. A SMALL NUMBER OF SOURCE-COUNTRY
CHARACTERISTICS EXPLAIN MORE THAN TWO-THIRDS OF THE LARGE VARIATION IN WELFARE RECIPIENCY THAT EXISTS ACROSS NATIONALORIGIN GROUPS. MOREOVER, CHANGES IN THE AVERAGE SOURCECOUNTRY CHARACTERISTICS OF THE FOREIGN-BORN POPULATION BETWEEN 1970 AND 1980 CAN ACCOUNT FOR ALMOST ALL OF THE INCREASE IN IMMIGRANT WELFARE RECIPIENCY THAT OCCURRED OVER THE DECADE.

09152 TREMBLAY, G.; HARVEY, R.

A POLICY FAILURE OR THE REALIZATION OF A HIDDEN AGENDA? CANADIAN PUBLIC ADMINISTRATION, 35(4) (WIN 92), 558-566.

THE QUATRE-SAISONS TELEVISION NETWORK (TOS) WAS CREATED UNDER PRESSURE FROM CANADA'S FEDERAL DEPARTMENT OF COMMUNICATIONS. IN DECIDING THAT TOS WAS NEEDED, THE CANADIAN RADIO-TELEYISION AND TELECOMMUNICATIONS COMMISSION (CRTC) PURSUED THE FOLLOWING OBJECTIVES: COUNTERING FRAMCOPHOME YIEHER LOSS TO AMGLOPHOME STATIONS: IMCREASIMG FRANCOPHONE VIEHER LOSS TO ANGLOPHONE STATIONS; INCREASING THE AMOUNT OF CANADIAN CONTENT ON TELEVISION ; AND INCREASING
THE DIVERSITY OF MATERIAL AND CHOICES AVAILABLE TO FRANCOPHONE VIEWERS. DATA GATHERED OVER THE LAST THREE YEARS AS PART OF A RESEARCH PROJECT ON THE EVOLUTION OF MONTREAL'S TELEVISION INDUSTRY SUGGEST THAT THE EFFORT HAS FALLEN SHOR OF ITS GOALS. THE CREATION OF TQS HAS IN NO

09153 TREMBLAY, M.

QUAND LES FEMMES SE DISTINGUENT: FEMINISME ET REPRESENTATION POLIQUE AU QUEBEC

CANADIAN JOURNAL OF POLITICAL SCIENCE, 35(1) (MAR 92), 55-68.

THIS ARTICLE EXAMINES HOW QUEBEC POLITICIANS' SEX AND POLITICAL PARTY INFLUENCE THE ORIENTATION OF THEIR OPINIONS
THROUGH THREE THEMES: THE EVOLUTION OF WOMEN'S SOCIAL STATUS THROUGH THREE THEMES: THE EVOLUTION OF HOMEN'S SOCIAL STAT
ACTIONS OF THE FEMINIST MOVEMENT IN THIS SENSE; AND THE IDEA OF FEMALE LEGISLATORS REPRESENTING WOMEN. THE RESULTS OF A QUESTIONMAIRE SHOW THAT IF HOMEN AND MEN MANIFEST NO DIFFERENCES IN THEIR SUPPORT OF THE EVOLUTION OF HOMEN'S SOCIAL STATUS AND OF THE FEMINIST MOVEMENT, WOMEN ARE MORE INCLINED THAN MEN TO SUPPORT THE IDEA THAT WOMEN POLITICIANS SHOULD REPRESENT THE SPECIFIC INTEREST OF HOMEN. THE LIBERAL PARTY RESISTS THIS IDEA THE MOST AS WELL AS THE FEMINIST MOVEMENT IN GENERAL.

09154 TRENDLE, G.

LEBANON--STICKY START FOR SULH

MIDDLE EAST INTERNATIONAL, (426) (MAY 92), 7-8.

IT DID NOT TAKE LONG FOR RASHID SULH, APPOINTED

LEBANON'S NEW PRIME MINISTER BY PRESIDENT ELIAS HRAHI ON 13 MAY AFTER LENGTHY DISCUSSIONS IN THE SYRIAN CAPITAL, TO RUN INTO TROUBLE AFTER ANHOUNCING HIS 24-MAN MINISTERIAL CABINET. THE ANMOUNCEMENT OF THE CABINET, WHICH INCLUDES 16 OF THE THE ANMOUNCEMENT OF THE CABINET, WHICH INCLUDES 16 OF THE MINISTERS FROM THE OISCREDITED GOVERNMENT OF OMAR KARAMI WHICH RESIGNED ON 6 MAY IN THE WAKE OF CIVIL UNREST, BROL
ABOUT WIDESPREAD CRITICISM AND BOYCOTTS FROM ERSTWHILE ABOUT WIDESPREAD CRITICISM AND BOYCOTTS FROM ERSTWHILE GOVERMMENT SUPPORTERS. THE PRIME MINISTER NILL HAVE YET MORE PROBLEMS TO FACE IN THE NEAR FUTURE, ALL CONTENTIOUS ISSUES. THESE ARE THE PARLIAMENTARY ELECTIONS SET FOR THE SUMMER, THE REDEPLOYMENT OF SYRIAN FORCES TO THE BEQAA SCHEDLUED FOR SEPTEMBER; THE RETURN OF DISPLACED PERSONS; THE SEEMINGLY
IMPOSSIBLE TASK OF GETTING UN RESOLUTION 425 IMPLEMENTED; AND THE IMPLEMENTATION OF THE PLAN TO COLLECT ALL HEAPONS FROM THOSE MILITIAS THAT HAVE NOT YET BEEN COMPLETELY 
DISARMED, PARTICULARLY HIZBULLAH.

09155 TRENDLE, G.

LEBANON: DIRTY LITTLE WAR

MIDOLE EAST INTERNATIONAL, 436 (OCT 92), 10-11.

THE BITTER INTER-PALESTINIAN FEUD IN LEBANON BETWEEN MEMBERS OF YASI ARAFAT'S FATAH AND THE BREAK-AHAY FATAH REVOLUTIONARY COUNCIL (FRC)OF ABU NIDAL IS ONCE MORE ESCALATING, WITH 20 ASSASSINATIONS IN THE PAST THREE MONTHS. THE LONG-SIMMERING VENDETTA, BROUGHT BACK TO THE BOIL
APPARENTLY BY THE TWO GROUP'S DIFFERING POSITIONS ON THE APPARENTLY BY THE TWO GROUP'S DIFFERING POSITIONS ON THE CURRENT ARAB-I I RAELI PEACE NEGOTIATIONS, CLAIMED ITS LATEST
VICTIMS ON 17 OCTOBER WHEN TWO MILITARY OFFICERS OF THE FRC WERE SHOT DEAD. THE ABU NIDAL GROUP IS A GROUP OF AGENTS WHO WERE SHOT DEAD. THE ABU NIDAL GROUP IS A GROUP OF AGENTS WHO PHASE OF THE PEACE NEGOTIATIONS.

09156 TRENDLE, G.

LEBANON: HARIRI THE PANACAEA?

MIDDLE EAST INTERNATIONAL, (437) (NOV 92), 11-12.

THE PRINCIPAL TASK FACING LEBANON'S NEH GOVERNMENT HEADED BY RAFIO HARIRI IS TO RESCUE THE SUNKEN ECONOMY ANO INTEREST INVESTORS IN THE COUNTRY'S RECONSTRUCTION. COMMONLY PERCEIVED AS A MAN WHO WILL GIVE MORE THAN HE TAKES, THE LEBANESE SEE HARIRI AS A PANACAEA FOR ALL THEIR ECONOMIC ILLS.

09157 TRENDLE, $G$.

POPULAR FURY BRINGS DOWN LEBANON'S GOVERNHENT

MIDDLE EAST INTERMATIONAL (425) (MAY 92) 3-4.

FURY RETURNED TO BEIRUT AND OTHER LEBANESE CITIES ON 6

MAY WHEN DEMONSTRATORS, ON A TIDAL WAVE OF POPULAR

DISCONTENT, TOOK TO THE STREETS AND SHEPT AHAY THE

GOVERMMENT OF PRIME MINISTER OMAR KARAMI. IT WAS THE MOST

SERIOUS CIVIL UNREST IN LEBANON FOR TEN YEARS. KARAMI, WHO

THE PATH TO PEACE CA FAL 16 BUCKLED UMDER PRESSURE FROM THE

THE PATH TO PEACE, FINALLY BUCKLEO UNDER PRESSURE FROM THE

CONFEDERATION OF TRADE UNIONS (CTU) WHICH HAD CALLED FOR A
FOUR-DAY STRIKE TO PROTEST AT THE GOVERMMENT'S POOR HANDLING

FOUR-DAY STRIKE TO PROTEST AT THE GOVERMMENT'S POOR HANDLING
OF THE LATEST ECONOMIC CRISIS. THE IMMEDIATE CAUSES OF THE

OF THE LATEST ECONOMIC CRISIS. THE IMMEDIATE CAUSES OF

RIOTS WERE THE DEPRECIATION OF THE LEBANESE POUND WHICH
BEGAN AFTER THE CENTRAL BANK SUSPENDED ITS MARKET SUPPORT OF

BEGAN AFTER THE CENTRAL BANK SUSPENDED ITS MARKET SUPPORT OF

THE NATIONAL CURRENCY IN FEBRUARY, THE SUBSEQUENT RISE IN

THE COST OF LIVING, AND THE GOVERNMENT'S FAILURE TO STOP THE

ECONOMIC ROT. YET BASICALLY THE RIOTS WERE AN EXPRESSION
THE TOTAL LACK OF PUBLIC CONFIDENCE IN THE GOVERNMENT.

09158 TREVERTON, G.; BICKSLER, 8.

GERMANY AND THE NEW EUROPE

SOCIETY, 29(2) (JAN 92), 48-56

LESS THAN A YEAR AFTER THE OPENING OF THE BERLIN WALL, UNIFICATION BECAME A REALITY IN GERMANY. WITH UNIFICATION CAME THE QUESTION WHETHER THE WORLD CAN LIVE EASILY WITH THE NEW GERMANY. FOR THE FIRST TIME IN GERMAN HISTORY, UNITY WAS THE RESULT OF DEMOCRACY. THE TRANSITION INTD THE GERMANY OF TODAY IS EXPLORED HITH EMPHASIS ON ELECTIONS, DOMESTIC PREOCCUPATIONS, FOREIGN RELATIONS, MIGRATION, AND INTERMATIONAL TRADE. THE GULF AND THE GATT UNDERSCORE THE NEED FOR CONSTANT TENDING OF THE GERMANY-AMERICAN RELATIONSHIP.

09159 TREVERTON, G.F.

AMERICA, GERMANY, AND THE FUTURE OF EUROPE

PRINCETON UNIVERSITY PRESS, 1992, 248

THIS BOOK REVIEWS THE SIGNIFICANT EPISODES IN EUROPE'S HISTORY AFTER HORLD HAR II: THE DIVISION OF GERMANY THROUGH HALTING, HALF-INDIFFERENT STEPS; THE RECONSTRUCTIDN OF EUROPE THROUGH THE MARSHALL PLAN; THE CREATION OF NATO AND THE DECISION TO STATION AMERICAN TROOPS IN LARGE NUMBERS IN EUROPE; AND THE EPOCH-MAKING FRENCH BET, THE SCHUMAN PLAN AND THE BEGINNING OF EUROPEAN INTEGRATION. THE BOOK EMPHASIZES AMERICA'S PREOCCUPATION HITH EUROPE AMD THE DECISIVE EFFECT OF U.S. FOREIGN POLICY ON EUROPEAN SECURITY AND ECONOMIC ARRANGEMENTS DURING THE POSTHAR YEARS. IT ARGUES THAT ALTHOUGH EUROPE'S FUTURE IS UNCERTAIN, IT SHOULD ARGUES THAT ALTHOUGH EUROPE'S FUTURE IS UNCERTAIN, IT SHOULD BE HAPPIER THAN THE FROZEN STABILITY OF THE COLD WAR. THE
KIND OF INTERDEPENDENCE REFLECTED IN THE EUROPEAN CDMMUNITY SUGGESTS A FUTURE IN WHICH MILITARY ISSUES HILL RECEDE IN SUGGESTS A FUTURE IN WHICH MILITARY ISSUES HILL RECEDE IN LIKE THE CONFERENCE ON SECURITY AND COOPERAIION IN EUROPE (CSCE) CAN SERVE AS A FRAMEHORK FOR SECURITY. THERE WILL BE (CSCE), CAN SERVE AS A FRAMEWORK FOR SECURI TY. THERE WILL BE
A PLACE FOR AMERICA IN THIS FUTURE EUROPE, BUT IT WILL BE A A PLACE FOR AMERICA IN THIS
FAR LESS PROMINENT PLACE.

09160 TREVERTON, G.F.

THE NEW EUROPE

FOREIGN AFFAIRS, 71(1) (1992), 94-112

EUROPE REMAINS A FAR CRY FROM THE "EUROPE HHOLE AND FREE" ENVISIONED BY U.S. PRESIDENT GEORGE BUSH. FOR THE FORESEEABLE FUTURE, THE EASTWARD REACH OF THE EUROPEAN COMMUNITY WILL BE LIMITED BY THE BLOC'S WEST EUROPEAN PREOCCUPATIONS. NO ONE ON EITHER SIDE OF THE ATLANTIC REALLY KNOWS HOW TO RESHAPE THE AMERICAN CONNECTION TO EUROPE--OR
THAT THE UNITED STATES CLINGS TO NATO AS THE ONLY SERIOUS TRANS-ATLANTIC SECURITY CONNECTION, IT HAS BECOME EQUALLY APPARENT THAT NATO IS MISMATCHED HITH EUROPE'S FUTURE SECURITY PROBLEMS. MOREOVER, NATO IN ITS CURRENT FORM CANMOT SERVE AS THE BASIS FOR AMERICA'S FUTURE POLITICAL ROLE IN EUROPE.

09161 TREVERTON, G.F.

THE YEAR OF EUROPEAN (DIS)UNIFICATION

CURRENT HISTORY, 91 (568) (NOV 92), 353-358.

THE EUROPEAN UNITARY MARKET WILL BE IN PLACE IN 1993

BUT THE PLANS FOR FURTHER ECONOMIC AND POLITICAL INTEGRATION IN WESTERN EUROPE ARE ENCOUNTERING HIDESPREAD RESENTMENT, WHILE LINKS WITH THE EAST ARE EVEN MORE CONTROVERSIAL. THE IDEA OF A WHOLE AND UNDIVIDED EUROPE, WHICH ONCE SEEMED CH, MAY DISINTEGRATE IN T COLD WAR'S END.

09162 TREZISE, $P$

JAPAN'S PEACEKEEPING FORCES

BROOKINGS REVIEW, 10(4) (FAL 92), 56

ONE OF THE ENCOURAGING EVENTS ON THE INTERNATIONAL SCENE SINCE THE END OF THE COLD WAR HAS BEEN JAPAN'S DECISION TO ALLOW ITS SELF-DEFENSE FORCES TO JOIN UNITED NATIONS PEACEKEEPING ACTIVITIES. THE DECISION PROMISES THE U.N. ADOITIONAL, NEEDED MANPOHER AND SKILLS. IT MAY ALSO HELP ADVANCE JAPAN'S JUSTIFIABLE CLAIM TO A SECURITY COUNCIL SEAT.

09163 TRIFKOVIC, $S$.

THE FIRST YUGOSLAVIA AND ORIGINS OF CROATIAN SEPARATISM

EAST EUROPEAN QUARTERLY, XXVI (3) (FAL 92), 345-370.

THE AUTHOR DISCUSSES RECENT CALLS FOR CROATIAM

SEPARATISM IN LIGHT OF THE HISTORY OF CROATIA.

09164 TRIPATHI, $D$

AFGHANISTAN: THE LAST EPISODE?

WORLD TODAY, 48(1) (JAN 92) 10-12.

THE AUTHOR ANALYZES THE IMPACT OF THE AFGHAN FACTOR IN THE DEMISE OF THE SOVIET UNION AS THE COMMUNIST SUPERPOWER. HE DISCUSSES THE INVASION OF AFGHANISTAN AND THE INTERNATIONAL RESPONSE TO THE SOVIET OCCUPATION OF THE COUNTRY IN THE 1980'S. FINALLY, HE CONSIDERS THE IMPORTANCE OF SOVIET INVOLVEMENT IN AFGHANISTAN TO THE CENTRAL ASIANS.

09165 TRIPP, $L$

THE POLITICAL VIEWS OF BLACK STUDENTS DURING THE REAGAN ERA BLACK SCHOLAR, 22 (3) ( SUM 92), 45-52

THIS IS A STUDY OF THE POLITICAL VIENS AND ATTITUDES OF 739 AFRICAN-AMERICAN STUDIENTS WHO ATTENDED SOUTHERN ILLINOIS UNIVERSITY-CARBONDATE IN THE 1980S. THE PURPOSE OF THIS STUDY IS TO EXAMINE AND DESCRIBE THE CHANGES IN THEIR POLITICAL VIEHS AND ATTITUDES OVER THE LATTER HALF OF THE 1980S. TOPICS ADORESSED ARE: BLACK STUDENTS OF THE 1960S AND 1980S; THE AFRICAN AMERICAN COMMUNITY UNDER REAGANISH; THE IMPACT OF ECONOMIC STRUCTURAL TRENDS; POLITICAL GAINS AND COMUUNITY DECLINE; CULTURE CHANGES; STUDENT ACTIVISM; POL ITICAL INVOLVEMENT; PARTY PREFERENCE; BLACK NATIONALISM; EQUAL OPPORTUNITY VERSUS RACIAL QUOTAS; AND LIBERALISM VERSUS CONSERVATISM.

09166 TRITTEN, J.

THE SUPERPOWER WAR TERMINATION: THE MARITIME COMPONENT JOURNAL OF SOVIET MILITARY STUDIES, 4(1) (MAR 91), 1-29.

THE POLITICAL CHANGES IN THE SOVIET UNION AND THE RESULTING INSTABILITY OF THE SOVIET EMPIRE HAVE GIVEN RISE TO QUESTIONS ABOUT THE FUTURE OF THE EAST-WEST CONFLICT. THEY ALSO NECESSITATE CONSIDERATION OF WHETHER THE CATEGORY OF WAR TERMINATION IS A LEGITIMATE AREA FOR RESEARCH. THIS ARTICLE ARGUES THAT THE DANGER OF WAR STILL EXISTS, ALTHOUGH ARTICLE ARGUES THAT THE DANGER OF WAR STILL EXISTS, ALTHO
THE TYPE OF WAR CONSIDERED TO BE MOST LIKELY IS NOT OF NEARLY AS MUCH INTEREST AS IN PREVIOUS YEARS. THE ARTICLE LOOKS AT THE TYPES AND NATURE OF WAR ITSELF. IT THEN ATTEMPTS TO DEFINE ITS MARITIME COMPONENT AND THE ROLE THAT SEA SERYICES PLAY IN MARITIME COMPONENT AND THE ROLE THA SEA SERVICES PLAY IN WAR TERMINATION. IT CONCLUDES THAT WAR TERMINATION MIGHT BE MORE RAGGED IN THE MARITIME SECTOR DUE TO DEGRADATION OF COMMAND AND CONTROL THAT WOULD FOLLOH THE
BEGINMING OF HOSTILITIES. HOWEVER, IN THE CURRENT ATMOSPHERE BEGINNING OF HOSTILITIES. HOWEVER, IN THE CURRENT ATMOSP
OF UNCERTAINTY, NEGOTIATIONS DESIGNED TO REDUCE NAVAL OF UNCERTAINTY, NEGOTIATIONS

09167 TROMBLEY, $W$

GOLD RUSH

CHURCH AND STATE, 45(2) (FEB 92), $4(28)-6(30)$

SUPPORTERS

INITIATIVE THAT WOULD FUNMEL TAX FUNDS INTO VOUCHERS FOR PRIVATE AND PAROCHIAL SCHOOLS EXPECT TO PUT THE INITIATIVE ON THE CALIFORNIA BALLOT IN NOVEMBER 1992. THE PROPOSED CONSTITUTIONAL AMENDMENT HOULD REQUIRE THE STATE TO GIVE EVERY SCHOOL-AGE CHILD A $\$ 2,500$ SCHOLARSHIP TO ATTEND VIRTUALLY ANY PRIVATE OR CHURCH-RELATED SCHOOL HILLING TO ACCEPT HIM OR HER. EACH STUDENT WHO TRANSFERRED FROM A PUBLIC TO A PRIVATE SCHOOL WOULD REDUCE PUBLIC SCHOOL FUNDING BY $\$ 2,500$ 
09168 TROMP, H.

AFTER THE COLD WAR CONVERSION?

PEACE AND THE SCIENCES, 0 (DEC 91), 1-3

WITHIN THE FRAMEWORK OF THE INTERNATIONAL RESEARCH PROJECT "CONVERSION: NEW CHALLENGES AND EXPERIENCES", SPONSORED BY THE INTERNATIONAL INSTITUTE FOR PEACE (IIP), THE SECOND WORKSHOP "CONVERSION: NATIONAL CASE STUDIES" IS BEING ORGANIZED IN THE CAPITAL OF AUSTRIA AT THE END OF JANUARY 1992. THE PROCEEDINGS OF THIS CONFERENCE WILL $8 E$ PUBLISHED BY THE IIP. THIS ARTICLE IS DEVOTED MAINLY TO CONCEPTUAL APPROACHED TO CONVERSION.

09169 TROMP, $H$.

VERIFICATION AND CSBMS IN MILITARY R\&D: POSSIBILITIES AND CHALLENGES

PEACE AND THE SCIENCES, 1(1) (1992), 19-21.

SIX POINTS ARE MADE IN THIS REPORT: 1$)$ SECURITY IS DEFINED AS "MILITARY SECURITY"; 2 IDURING THE COLD WAR EVERYTHING WAS EASY TO UNDERSTAND AND THE RESULT WAS AN ARMS RACE; 3) PERESTROIKA HAS ALMOST IMMEDIATELY RESULTED IN A RESTRUCTURING OF INTERMATIONAL RELATIONS; 4 ) BECAUSE OF THE DESIRE FOR INDEPENDENCE, THE TRADITIONAL CONCEPT OF SECURITY HAS BEEN TURNED UPSIDE DOWN AND SEVERELY SHAKEN; 5) THE SIMULTANEOUS REVOLUTION IN INTERMATIONAL RELATIONS SIMULTANEOUS REVOLUTION IN INTERNATIONAL RELATIONS REINFORCED THE NEED TO REASSESS THE CONCEPT OF MILITARY THIS CENTURY IS SUDDENLY CONFRONTED WITH NEW CHALLENGES

09170 TROUT, B.T.

NAVAL ARMS CONTROL IN CONTEMPORARY SOVIET POLICY: THE CHALLENGE OF CONTROLLING NAVIES

DEFENSE ANALYSIS, 7(1) (MAR 91), 63-80.

THE GREATER PROMINENCE OF THE ISSUES OF NAVAL ARMS CONTROL IN U.S.-SOVIET SECURITY NEGOTIATIONS IS DISCUSSED. THE AUTHOR ARGUES THAT SOVIET INTEREST IN NAVAL ARMS CONTROL HAS RECENTLY INTENSIFIED. SOVIET MILITARY LEADERS AND A VARIETY OF SOVIET COMMENTATORS HAVE REGULARLY INCORPORATED NAVAL ISSUES INTO BOTH FORMAL AND INFORMAL DISCUSSIONS OF STRATEGIC POLICY AND ARHS LIMITATIONS. THIS ARTICLE EXAMINES THE PROPOSED SOVIET MEASURES, HHICH ADORESS THE TWO PRINCIPAL CATEGORIES OF NAVAL ARMS CONTROL: RESTRICTING NAVAL ACTIVITIES AMD OPERATIONS AND LIMITING THE SIZE OF ARMAMENT OF NAVAL FORCES.

09171 TROXEL, L.

BULGARIA'S GYPSIES: NUMERICALLY STRONG, POLITICALLY WEAK

RFE/RL RESEARCH REPORT, $1(10)$ (MAR 92), 58-61.

FOR YEARS, BULGARIA'S GYPSY POPULATION HAS ENDURED DISCRIMINATION AND PODR LIVING CONDITIONS. SINCE THE ADVENT OF DEMOCRATI ZATION IN 1989, A MUMBER OF GYPSY ORGANIIATIONS OF DEMOCRATIZATION IN 1989 , A NUMBER OF GYPSY ORGANI SITUATION. WITH A POTENTIAL CONSTITUENCY OF 400,000 TO ONE MILLION, THESE ORGANIZATIONS THEORETICALLY HAVE THE MILLION, THESE ORGANIZATIONS THEORETICALLY HAVE THE NUMERICAL STRENGTH TO PUT GYPSY INTERESTS ON THE POLITI
AGENDA. HOWEVER, BULGARIA'S GYPSY POPULATION REMAINS POLITICALLY WEAK OWING TO INTERNAL DIVISIONS AND A LOW LEVEL POLITICALLY WEAK OWING TO INT

09172 TROXEL, L.

SOCIALIST PERSISTENCE IN THE BULGARIAN ELECTIONS OF 1990-91 EAST EUROPEAN QUARTERLY, XXVI(4) (WIN 92), 407-430.

BULGARIA RE-ELECTED ITS FORMER COMMUNIST PARTY, NOH CALLED THE "BULGARIAN SOCIALIST PARTY" (BSP), TO A MAJORITY OF THE SEATS IN PARLIAMENT IN THE COUNTRY'S FIRST FREE ELECTIONS IN JUNE 1990. IN OCTOBER 1991, THE BSP WON ONLY ONE PERCENT LESS THAN THE MAIN OPPOSITION GROUP IN BULGARIA'S SECOND ROUND OF FREE ELECTIONS. A SUBSTANTIAL PORTION OF THE BULGARIAN ELECTORATE VOTED ON THE BASIS OF FEAR BECAUSE THE BSP ATTRIBUTED CERTAIN UNPOPULAR POLICIES TO THE OPPOSITION. THUS, THE BSP GAINED A SIGNIFICANT SHARE OF VOTES IN THE TWO ELECTIONS BY APPEALING TO "NEGATIVE

09173 TROY, D.E.

A DIFFERENCE OF OPINION

POLICY REVIEH, (61) (SUM 92), 27-33.

THE AUTHOR OISCUSSES THE CONTINUITY OF THE REAGAN-BUSH JUDICIAL APPOINTMENTS, QUESTIONS THE PERCEPTION THAT THE CURRENT U.S. SUPREME COURT IS CONSERVATIVE, AND ARGUES THAT LOWER COURT APPOINTMENTS ARE MORE INDICATIVE OF THE REAGANBUSH JUDICIAL PHILOSOPHY THAN THE SUPREME COURT.

09174 TRUBOWITZ, P.

SECTIONALISM AND AMERICAN FOREIGN POLICY: THE POLITICAL GEOGRAPHY OF CONSENSUS AND CONFLICT

INTERNATIONAL STUDIES QUARTERLY, 36(2) (JUN 92), 173-190. FOR OVER TWO DECADES AMERICAN FOREIGN POLICY HAS BEEN THE SUBJECT OF PROTRACTED CONFLICT. DEEP DIVISIONS EXIST OVER THE USES OF AMERICAN POWER. THIS STUDY ARGUES THAT THIS CONFLICT IS REGIONAL IN NATURE ANO IS PART OF A LARGER STRUGGLE OVER NATIONAL PRIORITIES BETWEEN THE NATION'S OLDEST AND NEWEST INDUSTRIALIZING REGIONS. USING CONGRESS AS A PROXY FOR THE NATIONAL POLITY, THE AUTHOR EMPLOYS A SPATIAL MODEL TO DESCRIBE AND ANALYZE THE REGIONAL BASES OF
LEGISLATIVE VOTING OVER FOREIGN POLICY. THE ARTICLE DEMONSTRATES THAT SINCE THE LATE 1960 S CONFLICTS OVER FOREIGN POLICY MATTERS HAVE PITTED THE "MANUFACTURING BELT" AGAINST THE "SUNBELT." THE AUTHOR ARGUES THAT THIS REGIONAL CONFLICT GOES A LONG WAY IN EXPLAINING THE DIFFICULTY AMERICA'S POLITICAL LEADERS HAVE EXPERIENCED IN ARTICULATING A VISION OF THE NATIONAL INTEREST THAT INSPIRES BROAD DOMESTIC SUPPORT.

09175 TSEDAIN, D.

TIBET: HUMAN RIGHTS AND CHINA'S SOVEREIGNTY

BEI JING REVIEW, 35(9) (MAR 92), 26-29.

NO AMOUNT OF LIES, HOWEVER CRAFTILY FABRICATED, CAN WHITEWASH THE HORRENDOUS HUMAN RIGHTS RECORD OF OLD TIBET, WHERE THE POLITICAL-RELIGIOUS RULERS DEPRIVED THE SERFS, WHO MADE UP THE OVERWHELMING MAJORITY OF THE TIBETAN POPULATION, OF THE MOST BASIC OF ALL HUMAN RIGHTS--THE RIGHT TO SUBSISTENCE. BEHIND THE FURORE ABOUT HUMAN RIGHTS IS A BID SUBSISTENCE. BEHIND THE FURORE ABOUT HUMAN RIGHTS IS A $B$ FOR TIBETAN
SOVEREIGNTY.

09176 TSUI, C.D. STRATEGIC OBJECTIVES OF CHINESE MILITARY INTERVENTION IN KOREA

KOREA \& WORLD AFFAIRS, 16(2) (SUM 92), 338-364.

THE PRIMARY POLITICAL OBJECTIVES OF CHINESE MILITARY INTERVENTION IN KOREA IN 1951-53 WERE TO "RESIST AMERICA AND AID KOREA, PROTECT THE HOMELAND, AND DEFEND THE COUNTRY." IN RECENT YEARS, CHINA HAS RELEASED MATERIALS ON THIS MILITARY INTERVENTION THAT SHED NEW LIGHT ON THE OPERATION, IN GENERAL, AND ITS STRATEGIC OBJECTIVES AND HOW THEY CHANGED OVER TIME, IN PARTICULAR. BASED ON THESE MATERIALS, THIS PAPER PRESENTS AN ACCOUNT OF THE CHINESE VIEN OF THIS INTERVENTION.

09177 TSUROKA, D.

SHITCH TO INDUSTRY

FAR EASTERN ECONOMIC REVIEW, 155(15) (APR 92), 45-46. JUST SIX YEARS AFTER A HARROWING FALL IN COMMODITIES PROCES WHICH MADE A SHAMBLES OF THE ECONOMY, MALAYSIA IS CONSOLIDATING ITS SWITCH TOWARDS INDUSTRY AND AHAY FROM PRIMARY RESOURCES. THE CUTTING EDGE FOR THIS SHIFT IN PRIORITIES, WHICH HAS MADE MALAYSIA ONE OF THE FASTEST PRIORITIES, WHICH HAS MADE MALAYSIA ONE OF THE FASTEST
GROWING ECONOMIES IN THE WORLD, HAS BEEN A SURGE IN FOREIGN GROWING ECONOMIES IN THE WORLD, HAS BEEN A SURGE IN FOREIG
MANUFACTURING INVESTMENTS WHICH HIT MS16 BILLION (US\$6.2 MANUFACTURING INVESTMENTS WHICH HIT MS16 BILLION (US\$6.2
BILLION) IN 1991. USING THE COMPARATIVE ADVANTAGE OF A CHEAP BUT EDUCATED HORKFORCE AND ABUNDANT LAND FOR DEVELOPMENT, MALAYSIA S GOVERMMENT GAVE CRITICAL MASS TO THE EQUATION BY OVERHAULING THE COUNTRY'S INVESTMENT RULES IN 1987 TO FAVOR FOREIGNERS. THE NATION'S POLITICAL STABILITY AND SUPERIOR INFRASTRUCTURE HAVE APPEALED ESPECIALLY YO JAPANESE AND TAIWANESE INVESTORS WHO ARE ALSO AWARE OF MALAYSIA'S SPECIAL TARIFF PRIVILEGES IN EXPORTING TO MAJOR MARKETS SUCH AS THE
UNITED STATES.

09178 TSURUMI, $Y$

CANADA DRAGGED INTO U.S. -JAPAN CONFLICT

JAPAN TIMES (WEEKLY INTERNATIONAL EDITION), 32(9) (MAR 92), 11.

HONDA CIVICS MADE IN CANADA HAVE BECOME THE LATEST TRADE HOSTAGES AS WASHINGTON CONTINUES TO BLAME ITS ECONOMIC AND POLITICAL PROBLEMS ON TOKYO. THE USA CONTENDS THAT THE CANADIAN-ASSEMBLED HONDAS DO NOT MEET THE 69 PERCENT "NORTH AMERICAN CONTENT" REGULATION. HHILE THE UNITED STATES ACCUSES JAPAN AND OTHER COUNTRIES OF BUREAUCRATIC STALLING OVER IMPORTS, IT IS IN FACT ONE OF THE GREATEST BUILDERS OF LEGAL AND BUREAUCRATIC BARRIERS TO IMPORTED PRODUCTS.

09179 TSURUMI, $Y$

CONFRONTING 'ASIAN BASHING' IN THE U $S$.

JAPAN TIMES (WEEKLY INTERMATIONAL EDITION), 32(15) (APR $92), 11$.

U.S. PRESIDENT GEORGE BUSH'S TRIP TO JAPAN IN JANUARY 1992 IGNITED WIDESPREAD ASIAN-BASHING IN HIS COUNTRY. HIS HIDDEN MESSAGE TO AMERICANS HAS THAT IT IS OKAY TO BLAME JAPANESE AND OTHER ASIANS FOR THE USA'S PROBLEMS. ONLY WHEN JAPAN DECIDES TO CONFRONT THE ASIAN-BASHERS AND STAND UP TO THE UNREASONABLE DEMANDS OF THE UNITED STATES CAN THE TWO MATIONS TRULY EXPLORE MUTUAL CDOPERATION.

09180 TSURUMI, $Y$

MENDING'U. S. -JAPANESE RELATIONS

JAPAN TIMES (WEEKLY INTERNATIONAL EDITION), 32(5) (FEB 92), JAPAN

THE AUTHOR DISCUSSES THE CLAIMS ANO COUNTERCLAIMS REGARDING U.S. -JAPANESE TRADE, HOW U.S. PRESIDENT GEORGE BUSH IS FAILING TO DEAL WITH THE REAL CRUX OF HIS COUNTRY'S ECONOMIC PROBLEMS, AND HOW JAPAN IS RESPONDING TO THE TRADE TENSIONS.

09181 TSUTSUI, S.

COST DIFERENTIAL AND WELFARE EFFECTS ON INTERVENTIONIST

TRADE POLICIES IN OLIGOPOLISTIC INTERNATIONAL TRADE JAPAN AND THE WORLD ECONOMY, 3(4) (APR 92), 331-340. 
THIS ARTICLE CONSIDERS THE SITUATION WHERE A FOREIGN FIRM PENETRATES A DOMESTIC MARKET AND A DOMESTIC GOVERNMENT IMPLEMENTS INTERVENTIONIST TRADE POLICIES TO PROTECT DOMESTIC PRODUCERS. IT INYESTIGATES THE IMPACT OF SUCH POLICIES ON WORLD WELFARE, WHICH IS DEFINED TO BE THE SUM OF DOMESTIC WELFARE AND FOREIGN WELFARE. AS REGARDS INTERYENTIONIST TRADE POLICIES, IT CONSIDERS NOT ONLY AN OUTPUT CEILING OR CAPACITY CONSTRAINT BUT ALSO TAXES ON THE FOREIGN FIRM AND SUBSIDIES ON THE DOMESIIIC FIRMS.

09182 TSYPKIN, M.

QUANTITY VERSUS QUALITY IN TODAY'S SOVIET NAVY JOURNAL OF SOVIET MILITARY STUDIES, 4(1) (MAR 91), 124-140. A RECENT CHANGE IN SOVIET MILITARY POLICY HAS BEEN A SHIFT FROM QUANTITY TO QUALITY. THIS CHANGE HAS A SPECIAL SIGNIFICANCE FOR THE SOVIET NAVY, WHICH IS IN THE PROCESS OF RIDOING ITSELF OF OLD "LOW-TECH" SHIPS AND OF ADOPTING SOME OF THE MOST ADVANCED PIECES OF NAVAL TECHNOLOGY BUILT ANYWHERE, HOWEVER, FLAWLESS HUMAN PERFORMANCE IS VITAL IN OPERATING COSTLY MODERN NAVAL TECHNOLOGY. THIS ARTICLE FOCUSES ON THE PROBLEMS THE SOVIETS HAVE IN PROVIDING GOOD MANPOWER, BOTH ENLISTED AND COMMISSIONED, AND RELIABLE TECHNOLOGY, FOR TODAY'S AND TOMORROW'S HIGH-TECH NAYY. IT EXPLORES ISSUES INCLUDING THE PROFESSIONAL SELF-ESTEEM OF COMMISSIONED OFFICERS, EDUCATION AND TRAINING, AND THE QUALITY OF CONSCRIPTS' IN THE NAYAL FORCES.

09183 TUCKER, $R$.

IS REALISM FINISHED"

NATIONAL INTEREST, 30(30) (WIN 92), 21-32

THE SCHOOL OF THOUGHT THAT HAS TRADITIONALLY CAST DOUBT ON THE ABILITY OF THE UNITED STATES--OR ANY COUNTRY--TO MAKE THE WORLD ANEW IS "REALISM." REALISM HAS BEEN ATTACKED FOR HUNDREDS OF YEARS, AND DESPITE RECURRENT ONSLAUGHTS FROM HUNDREDS OF YEARS, AND DESPITE RECURRENT ONSLAUGHTS
LIBERALS, MARXISTS, PACIFISTS, ENVIRONMENTALISTS, DECONSTRUCTIONISTS, AND OTHERS, IT PERSISTS AS THE DECONSTRUCTIONISTS, AND OTHERS, IT PERSISTS AS THE
FUNDAMENTAL METHOD OF ANALYZING WORLD POLITICS. THIS ARTICLE FUNDAMENTAL METHOD OF ANALYZING WORLD POLITIICS. THIS ARTICLE EXAMINES: THE CAUSES OF WAR: THE INTERNATIONAL SYSTEM; THE CHALLENGE FROM POL ITICAL AND ECONOMIC LIBERALISM; SOURCES OF OPTIMISM; THE PROBLEM OF PEACEFUL CHANGE; AND, MORALITY AND FOREIGN POLICY. AFTER THIS EXAMINATION IT CONCLUDES THAT THE UNITED STATES SHOULD RETURN TO SECURING AMERICAN POWER AND AND POLITICAL DEVELOPMENT ACROSS THE HORLD. IN THAT ORDER.

09184 TUCKER, $R$.

REALISM AND THE NEW CONSENSUS

NATIONAL INTEREST, $30(30)$ (WIN 92), 33-36.

THE AUTHOR OFFERS CONSIDERATIONS WHICH MAKE THE POINT THAT THERE ARE LIMITS TO THE UTILITY OF POLITICAL REALISM. HE SUGGESTS THAT IF REALISM DOES NOT EXPLAIN THE WHOLE OF INTERNATIONAL POLITICS AND FOREIGN POLICY IT STILL EXPLAINS A GREAT DEAL. EVEN MORE, IT ENCOURAGES AN OUTLOOK TOWARD FOREIGN POLICY THAT IS SORELY NEEDED IN A TIME OF TRIUMPHALISM AND UNBOUNDED OPTIMISM. HE CONCLUDES THAT IT IS DOUBTFUL THAT IT WILL GAIN THE HEARING THAT IT DESERVES.

09185 TUCKER, R.; HENDRICKSON, D.

THE IMPERIAL TEMPTATION: THE NEW WORLD ORDER AND AMERICA'S PURPOSE

COUNCIL ON FOREIGN RELATIONS PRESS, 1992, 240.

IN THIS CRITICAL ANALYSIS OF AMERICAN FOREIGN POLICY PRIORITIES, THE AUTHORS ARGUE THAT THE BUSH ADMINISTRATION, IN ITS ATTEMPTS TO ADORESS THE CHALLENGES POSED BY THE NEW GLOBAL REALITIES, HAS BETRAYED THE FUNDAMENTAL IDEALS ON WHICH THIS COUNTRY WAS FOUNDED. TAKING THE GULF WAR AS THEIR STARTING POINT. THEY DISSECT PRESIDENT BUSH'S VISION OF A NEH WORLD ORDER, EXPOSING ITS INCONSISTENCY WITH AMERICA'S TRADITIONAL DIPLOMATIC PRINCIPLES. BY USING FORCE TO RESOLVE THE GULF CRISIS AND THEN WALKING AHAY FROM THE RUIN CREATED
BY THE WAR, BUSH SUCCUMBED TO AN IMPERIAL TEMPTATION THAT

BY THE WAR, BUSH SUCCUMBED TO AN IMPERIAL TEMPTATION THAT
HAS SEDUCED AND CORRUPTED OTHER GREAT POWERS IN THE PAST.

09186 TUCKER, R.W.

THE PRÓTECTORATE

NEH REPUBLIC, 207 (7) (AUG 92), 19-20, 22-23.

IN THE SPRING OF 1992. THE BUSH ADMINISTRATION WAS

PURSUING FOREIGN POLICIES DESIGNED TO HASTEN THE DOWNFALL OF

PURSUING FOREIGN POLICIES DESIGNED TO HASTEN THE DOWN

SADDAM HUSSEIN IN IRAQ, MUA
YITZHAK SHAMIR IN ISRAEL.

09187 TUCKER, $H$

HOUSING. THE UMWELCOME WAGON ROLLS ON

REASON, 23(7) (DEC 91), 58-59.

HOUSIHG RESEARCHERS ESTIMATE THAT ZONING DELAYS AND BUILDING-CODE REQUIREMENTS ADD SOME $\$ 15,000$ TO $\$ 30,000$ TO THE PRICE OF A NEW HOME IN MANY PARTS OF THE COUNTRY. "STARTER HOMES"--SIMPLE, NO-FRILLS STRUCTURES THAT FIRSTTIME HOME BUYERS CAN AFFORD--ARE ALMOST IMPOSSIBLE TO BUILD IN EXPENSIVE SUBURBS. APARTMENTS ARE FOUGHT EVERYWHERE. MOBILE HOMES ARE RESTRICTED TO INDUSTRIAL ZONES--WHEN THEY ARE ALLOWED AT ALL. THE FEDERAL GOVERNMENT HAS RECOGNIZED THE PROBLEM BUT ITS PROPOSED SOLUTION, IRONICALLY, SEEMS TO BE MORE REGULATION. THE GREAT IRONY OF THE ZONING HARS IS
THAT PEOPLE WHO USE THE POWER OF THE GOVERNMENT TO PROTECT THEIR OWN INVESTMENTS HONESTLY BELIEVE THEY ARE DOING SO IN THE NAME OF PROPERTY RIGHTS. WHILE GUARDING HHAT THEY VIEW AS THEIR OHN PROPERTY RIGHTS, THEY REFUSE TO ACKNOWLEDGE THE PROPERTY RIGHTS OF OTHERS.

09188 TULCHIN, J.; BLAND, G.

ASSESSING THE TRANSITION TO DEMOCRACY; IS THERE A TRANSITION TO DEMOCRACY IN EL SALVADOR?

LYNNE RIENNER PUBLISHERS, 1991, 163-206.

THE AUTHOR APPLIES BROADLY TO EL SALYADOR'S DEMOCRATIC TRANSITION THEDRY DEVELOPED IN THE 1980S. THE CASE OF EL TRANSITION THEORY DEVELOPED IN THE 1980 S. THE CASE OF SALVADOR, HE ARGUES, DEMONSTRATES THAT STEPS TOWARD
DEMOCRATIZATION-DAN ELECTORAL PROCESS, A FREER PRESS, AND DEMOCRATIZATION-DAN ELECTORAL PROCESS, A FREER PRESS, AND
INCREASED POLITICAL PLURALISM--ARE SIGNIFICANT IN STARTING INCREASED POLITICAL PLURALISM--ARE SIGNIFICANT IN START
THE DEMOCRATIC TRANSITION. SOCIETAL ACCOMODATION IN THE DEMOCRATIC TRANSITION. SOCIETAL ACCOMODATION IN
INCREASING ACCEPTANCE OF THE POL ITICAL UNCERTAINTY THAT INCREASING ACCEPTANCE OF THE POLITICAL UNCERTAINTY THAT CHARACTERIZED DEMOCRACY WERE THE ESSENTIAL CRITERIA FOR DERO MAJOR ACTORS SUPPORTING THE ACCORDS AND IN LIGHT OF THE TRENDS EVIDENT THROUGHOUT SOCIETY, A FLEDGLING OFEMOCRACY, THE FIRST IN EL SALVADOR'S HISTORY, IS LIKELY TO BE ACHIEVED IN ROUGHLY TWO YEARS.

09189 TULCHIN, J.; BLAND, G.; MCAWARD, J. DISCUSSION; IS THERE A TRANSITION TO DEMOCRACY IN EL SAL VADOR?

LYNAE RIENNER PUBLISHERS, 1991, 63-68.

JOHN MCAWARD, AN ANALYST OF EL SAL VADOR AND U.S. POLICY FOR WELL OVER TEN YEARS, DISAGREES WITH GEORGE VICKER'S ASSESSMENT OF THE EFFICACY OF ELECTIONS IN EL SALYADOR. IN THE EARLY 1980S, ONE COULD OPPOSE THE U.S. POLICY OF SUPPORTING ELECTIONS, BUT TODAY THAT POLICY SHOULD BE VIEWED AS FARSIGHTED. THE VISION OF THIS POLICY CAN BE SEEN TODAY IN INCREASED POLITICAL PLURALISH AND IN THE IMPROVED BEHAVIOR OF THE MILITARY, ALTHOUGH THE 1989 KILLING OF THE JESUIT PRIESTS ILLUSTRATES THAT IT IS AN IMPERFECT PROCESS. THE RECENT ELECTIONS WERE NOT PERFECT, HE ARGUES; THE PROCESS CAN BE IMPROVED. DIFFICULT CHALLLENGES REMAIN, AND THE MOST IMPORTANT U.S. ROLE IS TO GIVE A STRONG SIGNAL TO THE MOST IMPORTANT U.S. ROLE IS TO GIVE A STRONG SIGNAL TO THE SALVADORAN MILITARY THAT A RESOLUTION OF THIS CONF
HAS TO COME NOW AND THAT BACKPEDALING IS UNACCEPTABLE.

09190 TULCHIN, J.; BLAND, G.; GIBB, T.

ELECTIONS AND THE ROAD TO PEACE; IS THERE A TRANSITION TO ELECTIONS AND THE ROAD TO

DEMOCRACY IN EL SALVADOR?
LYNNE RIENNER PUBLISHERS, 1991, 17-24.

TOM GIBB ARGUES THAT THE CONDUCT OF THE ELECTIONS IN EL SALVADOR RAISES A NUMBER OF CONCERNS. FIRST, THE REGISTRATION PROCESS IS OPEN TO ABUSE, ESPECIALLY IN THE COUNTRYSIDE. SECOND, AN EXTRARODINARY NUMBER OF NAMES WERE LOST FROM THE VOTING REGISTER WITHOUT EXPLANTION, SO TENS OF THOUSANDS OF PEOPLE WHO WERE REGISTERED WERE NOT ABLE TO VOTE. YET, THE ELECTION RESULTS PROBABLY REFLECTED BROADLY HOW THE PUBLIC ACTUALLY VOTED AND WERE HIGHLY FAVORABLE FOR THE PEACE PROCESS, LARGELY BECAUSE OF THE PARTICIPATION OF TWO PARTIES ON THE LEFT, WHOSE STRONG PERFORMANCE WAS THE SUPRISE OF THE ELECTION.

09191 TULCHIN, J.; ARNSON, C.; BLAND, G.

HUMAN RIGHTS, HAS THERE BEEN PROGESS?; IS THERE A

TRNASITION TO DEMOCRACY IN EL SALVADOR?

LYNNE RIENNER PUBLISHERS, $1991,85-94$.

THE PROGRESS, OR LACK THEROF, IN THE PROTECTION OF HUMAN RIGHTS IN EL SALVADOR IS TRACED. THE CRUCIAL ISSUE IS HOW TO PUT AN END TO HUMAN RIGHTS ATROCITIES AND IMPLEMENT THE INSTITUTIONAL CHANGES TO ENSURE THAT THEY ARE NOT REPEATED. EL SALVADOR HAS TRAVERSED A POLITICAL UNIVERSE SINCE APRIL 1991 HITH THE SIGNING OF A FINAL PEACE ACCORD. A REVIEW IS RELATE TO HUMAN RIGHTS, SUCH AS THE DISSOLUTION OF THE RELATE TO HUMAN RIGHTS, SUCH AS THE DISSOLUTION OF THE NOTORIOUS SECURITY FORCES. VIOLENCE IN EL SALVADOR IN THE COMING YEARS MAY EMERGE FROM GROUPS OPPOSED TO THE ACCORD OR, BECAUSE OF A LACK OF PROSECUTIDNS, FROM UNRPEPENTANT CRIMINALS EITHER WITHIN OR OUTSIDE THE MILITARY. THE FIRST TEST WILL BE THE TREATMENT AFFORDED

09192 TULCHIN, J.; BLANO, G.

IS THERE A TRANSITION TO DEMOCRACY IN EL SALVADOR? LYNNE RIENNER PUBLISHERS, 1992, 213.

THE TRANSITION TO DEMOCRACY IN EL SALVADOR IS A FRAGILE PROCESS RESULTING FROM A COMBINATION OF MANY ELEMENTS. THIS BOOK IS AN ATTEMPT TO CONSIDER EL SALVADOR AS A CASE OF THE TRANSITION TO DEMOCRACY IN LATIN AMERICA.. IT RECORDS LANDMARKS IN THE HISTORY OF EL SALVADOR AND OF CENTRAL AMERICA. IT RECORDS EVENTS THAT HAVE TAKEN PLACE ONLY RECENTLY AND ALSO PUTS THEM IN HISTORICAL AND THEORETICAL PERSPECTIVE. EL SALVADOR HAS RECEIVED A GREAT DEAL OF ATTENTION IN RECENT YEARS, BUT IT HAS NOT BEEN A FOCUS IN THE STUDY OF DEMOCRATIC TRANSITIONS. THE AUTHORS BELIEVE THAT THERE ARE MANY LESSONS TO BE LEARNED FROM THE COUNTRY'S EXPERIENCE. 
09193 TULCHIN, J.; BLAND, G.; DE SOTO, A. THE NEGOTIATIONS FOLLOWING THE NEW YORK AGREEMENT; IS THERE A TRANSITION TO DEMOCRACY IN EL SALVADOR? LYNNE REINNER PUBLISHERS, 1991, 139-148.

A DETAILED OUTLINE OF THE PEACE NEGOTIATIONS IS PROVIDED IN THIS CHAPTER WHICH ALSO EXAMINES THE PROSPECTS FOR A SETTLEMENT. FROM THE INITIAL INVOLVEMENT IN 1989 TO THE LATEST MAJOR ACCORD IN NEW YORK, THE AUTHOR EMPHASIZES, THE UNITED NATIDNS HAS OFFERED MANY IDEAS AND DONE A GREAT DEAL OF PERSUADING IN AN EFFORT TO BRING THE PARTIES TOGETHER ON CONTROVERSIAL POINTS. THE ASSUMPTION THAT THE COST OF THE TWO PARTIES RETURNING FROM NEH YORK EMPTY-HANDED WAS SO HIGH THAT THEY WERE VERY FLEXIBLE AND REACHED AGREEMENTS THAT WERE NOT POSSIBLE PREVIOUSLY.

09194 TULCHIN, J.; BLAND, G.; VICKERS, G. THE POLITICAL REALITY AFTER ELEVEN YEARS OF WAR; IS THERE A TRANSITION TO DEMOCRACY IN EL SALYADOR?

LYNHE RIENNER PUBLISHERS, 1991, 25-58.

THE ELECTORAL PROCCSS IN EL SALVADOR IS PLACED IN HISTORICAL PERSPECTIVE. THIS REVIEH OF THE SIX ELECTIONS HISTORICAL PERSPECTIVE. THIS REVIEH OF THE SIX ELECTIONS
BETWEEN 1982 AND 1989 DEOES NOT PROVIDE MUCH ROOM FOR BETWEEN 1982 AND 1989 DEOES NOT PROVIDE MUCH ROOM FOR
OPTIMISM. THE AUTHOR SEES THE PEACE NEGOTIATIONS GOING

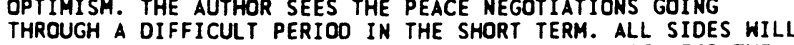
THROUGH A DIFFICULT PERIOO IN THE SHORT TERM. ALL SIDES WILL
HAVE TO SHED COMPLETELY THE ILLUSIONS OF THE PAST. FOR THE FAVE TO SHED COMPLETEL THAT MEANS DISCARDING THE BELIEF THAT DEMANDS FOR SOCIAL JUSTICE ARE THE RESULT OF COMMUNIST AGITATION. THE UNITED STATES MUST REALIZE THAT FORMAL MECHANISMS OF ELECTORAL DEMOCRACY CANMOT NECESSARILY BE EQUATED WITH DEMOCRATIC VALUES.

09195 TULCHIN, J.; ARONSON, B.; BLAND, G. THE ROLE OF US POLICY; is THERE a TRANSITION TO DEMOCRACY IN EL SALVADOR?

LYNNE TIENNER PUBLISHERS, 1991, 69-72.

BERNARD ARONSON EMPHASIZES THAT THE UNITED STATES FULLY AND UNEQUIVOCALLY SUPPORTS THE NEGOTIATING PROCESS WITH EL SALVADOR, BUT THAT THE UNITED STATES IS ALSO UNEQUIVAOCALLY COMMITTED TO THE DEFENSE OF THE SECURITY OF THE GOVERNMENT OF EL SALVADOR AND HOPES THAT THE COMMITMENT WILL NOT BE TESTED. THE UNITED STATES WOULD BE PLEASED TO USE ITS MILITARY ASSISTANCE TO SUPPORT A CEASE-FIRE AND THE REINTRODUCTION OF COMBATANTS FROM BOTH SIDES INTO CIVILIAN LIFE.

09196 TULCHIN, J.: BLAND, G.: MEZA, R. THE STATE OF THE ECONOMY: IS THERE A TRANSITION TO DEMOCRACY IN EL SALYADOR?

LYMNE RIENMER PUBLISHERS, 1991, 105-124.

SNE RIENNER PUBLIISHERS, 1991, 105-124.
SALVADORAN BUSINESSMAN ROBERTA MURRAY MEZA EXPRESSES AN SALVADORAN BUSINESSMAN ROBERTA MURRAY MEZA EXPRESSES AN
AIR OF OPTIMISM ABOUT THE STATE OF EL SALVADOR'S ECONOMY. HE AIR OF OPTIMISM ABOUT THE STATE OF EL SALVADOR'S ECONOMY. HE
ARGUES THAT THE PROGRESS IN THE PEACE NEGOTIATIONS IS BEING ARGUES THAT THE PROGRESS IN THE PEACE NEGOTIATIONS IS CRISTIANI'S MARKET-OREINTED POLICIES. THE OVERALL ECONOMIC CRISTIANI'S MARKET-OREINTED POLICIES, THE OVERALL ECONOMIC SITUATION HAS IMPROVED OVER THE PAST YEAR, BRINGING ABOUT INCREASED BUSINESS CONFIDENCE AND THE FIRST REAL STEPS
TOWARD EXONOMIC RECOVERY. REINTEGRATING TENS OF THOUSANDS OF COMBATANTS INTO CIVILIAN LIFE WILL BE A MAJOR CHALLENGE.

09197 TULCHIN, J.; BLAND, G.; GARCIA, J.

THE TANDA SYSTEM AND INSTITUTIONAL AUTONOMY; IS THERE A TRANSITION TO DEMOCRACY IN EL SALVADOR?

LYNNE RIENNER PUBLISHERS, 1991, 95-104

THE INSTITUTIONAL BASIS OF THE SALVADORAN ARMED FORCES, PARTICULARLY THE TANDA, OR CLASS ROTATION, SYSTEM OF PROMOTION IS ADDRESSED. THE AUTHOR ARGUES THAT MANY U.S. POLICYMAKERS AND HUMAN RIGHTS ADVOCATES CRITIZE THE TANDA SYSTEM FOR ITS EVILS. IT SHOULD, HOHEVER, BE VIEWED IN HISTORICAL CONTEXT AS A LARGELY' SUCCESSFUL EFFORT TO CREATE INTERNAL STABILITY IN THE MILITARY. THE CHAPTER HIGHLIGHTS THREE FACTORS: (1) THAT U.S. LEVERAGE OVER THE ARMY HAS DECREASED, (2) THAT COOPERATION BETHEEN THE ARMY AND THE GOVERMMENT HAS IMPROVED, AND
ARMED FORCES HAS IMCREASED.

09198 TULLOCK, G

RESEARCH NOTE: IS THERE A PARADOX OF VOTING? JOURNAL OF THEORETICAL POLITICS, 4(2) (APR 92), 225-230. THE PARADOX OF VOTING PRESENTED IN ARROW'S THEOREM HAS HARDLY ANY APPLICATION TO VOTING IN THE REAL WORLD. IN INTRODUCING HIS THEOREM, ARROH SAYS SPECIFICALLY THAT IT ODES NOT APPLY IN THOSE CASES IN WHICH INDIVIDUALS DO NOT DOES NOT APPLY IN THOSE CASES IN WHICH INDIVIDUALS DO NOT
VOTE ACCORDING TO THEIR ELEMENTARY PREFERENCES BUT ACCEPT

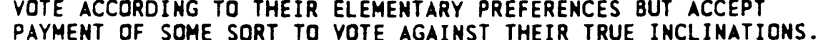
PAYMENT OF SOME SORT TO VOTE AGAINST THEIR TRUE INCLINATIONS.
SINCE LOG-ROLLING IS COMMON IN MOST DEMOCRATIC LEGISLATURES, THE THEOREM DOES MOT APPLY.

09199 TUMMALA, $K$

INDIA'S' FEDERALISM UNDER STRESS

ASIAN SURVEY, $22(6)$ ( JUN 92), 538-553.

TO GET A CLEAR PICTURE OF' INDIA'S FEDERALISM, ONE NEEDS TO UNDERSTAND THE SEVERAL REGIONAL, LINGUISTIC, AND RELIGIOUS DIVISIONS IN THE COUNTRY AND ANALYZE THE CONSTITUTIONAL DISTRIBUTION OF POWERS, DEVOLUTION OF
RESOURCES, ROLE OF GOVERNORS, EMERGENCY POHERS, THE DOMINANT PARTY THEME, PLANNING, ALL-INDIA SERVICES, THE

DECENTRALIZATION OF POWER SCHEME AND OTHER PROVISIONS AND PROCESSES. THIS ARTICLE CONFINES ITSELF TO AN EXAMINATION OF THO OF THESE FACETS AND THEIR NET IMPACT ON INDIAN

FEDERALISM: (1) THE USE (OR MISUSE) OF THE EXERCISE OF EMERGENCY POWERS, WITH PARTICULAR REFERENCE TO THE CASE OF TAMIL NADU, AND (2) THE DECENTRALIZATION SCHEME UNDER THE PANCHAYATI RAJ BILL OF 1989.

09200 TUNANDER, 0.

BUSH'S BRAVE NEW WORLD: A NEW WORLD ORDER--A NEW MILITARY STRATEGY

BULLETIN OF PEACE PROPOSALS, 22(4) (DEC 91), 355-368.

IN HIS SPEECH AT THE ASPEN INSTITUTE IN COLORADO ON 2 AUGUST 1990, U.S. PRESIDENT GEORGE BUSH REFERRED TO A NEW NATIONAL STRATEGY AND A NEW STRUCTURE FOR THE ARMED FORCES OF THE UNITED STATES. THIS NEW MATIONAL SECURITY STRATEGY THE SOVIET UNION AND EUROPE, AND THE DECISION TO MAKE A $25 \%$ CUT IN U.S. ARMED FORCES. ACCORDING TO BUSH'S ASPEN SPEECH, THE NEW HORLD ORDER DEMANDS MAJOR CHANGES IN THE PLANMING AND ORGANIZATION OF U.S. MILITARY POWER. THIS ARTICLE AUTLINES SOME OF THESE CHANGES IN MILITARY POLICY AND

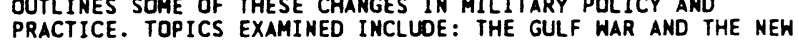
PRACTICE. TOPICS EXAMINED INCLUDE: THE GULF WAR AND THE NEW
WORLD ORDER; SHIFTING THE FOCUS FROM SUPERPOWER CONFLICT TO WORLD ORDER; SHIFTING THE FOCUS FROM SUPERPOWER CONFLICT
REGIONAL THIRD WORLD CONFLICTS: SHIFTING THE FOCUS FROM REGIONAL THIRD WORLD CONFLICTS: SHIFTING THE FOCUS FROM
IDEOLOGICAL CONFLICT TO ISSUES OF BORDERS, ETHNICITY AND IDEOLOGICAL CONFLICT TO ISSUES OF BORDERS, ETHNICITY AND GLOBAL AMBITIONS; THE UN AT CENTER STAGE; FROM A BIPOLAR TO GLOBAL AMBITIONS; THE UN AT CENTER STAGE; FROM A BIPOLAR TO A UNIPOLAR WORLD; TOHARDS A SHALLER BUT EVEN BETTER FORCE;
AND A U.S. INSTRUMENT TO DEAL WITH THE GERMAN AND JAPANESE AND A U.

09201 TUNANDER, 0.

THE TWO NORDENS: THE NORTH AND THE SOUTH, OR THE EAST AND THE WEST?

BULLETIN OF PEACE PROPOSALS, 22(1) (MAR 91), 55-64.

TO THE MORDIC COUNTRIES IN THE NORTH AND THE WEST, NAVAL ARMS CONTROL HAS BECOME A MAIN INSTRUMENT FOR EXTENDING THE DETENTE PROCESS AND THE JURIOICAL AND POLITICAL MEASURES OF THE EUROPEAN CONTINENT TO ELUSIVE MARITIME REGIONS. THIS ARTICLE EXPLORES THE STRATEGIC SIGNIFICANCE OF NORDEN AND ITS ATLANTIC AND EUROPEAN TIES. IT DISCUSSES THE THO NORDE AND THE EXTENSION OF EUROPE TO THE NORTHERN WATERS. COOPERATION TOGETHER WITH TODAY'S TENDENCY TOWARDS CIVILAIN COOPERATION WILL FAVOR THE CONTINENTALIZATION OF THESE MARITIME COUNTRIES.

09202 TUNG, D.D.

VIETHAM'S RENEWAL: INITIAL SUCCESSES AND EXPERIENCE FAR EASTERN AFFAIRS, (3) (1990), 3-20

THIS ARTICLE EXAMINES THE POLICY OF RENEWAL FORMULATED AT THE SIXTH CONGRESS OF THE COMNUNIST PARTY OF VIETNAM IN DECEMBER 1986 AND HOW THAT RENEWAL HAS PROCEEDED. THE AUTHOR ARGUES THAT A SOLUTION TO THE FOOD PROBLEM IS IN PROGRESS, ALTHOUGH THE PROBLEM HAS NOT YET BEEN COMPLETELY SOLVED. THE PROVISION OF THE POPULATION WITH CONSUMER GOOOS IS SEEN ANOTHER ACHIEVEMENT. POSITIVE CHANGES IN THE SPHERE OF PRICES ARE NOTED. CHANGES MADE IN THE ORGANIZATION OF THE
STRUCTURAL COMPONENTS OF THE POLITICAL SYSTEM ARE CONSIDERED TO MAKE IT MORE PRACTICAL AND EFFECTIVE.

09203 TURCHAK, T.

COOPERATION BETHEEN THE RSFSR AND CHINA: OPPORTUNITIES AND PROSPECTS

FAR EASTERN AFFAIRS, (3) (1990), 50-55.

THIS ARTICLE REPORTS ON A CONFERENCE OF SCIENTISTS AND EXPERTS ON PROMOTING CONTACTS BETHEEN THE RUSSIAN SOVIET FEDERATIVE SOCIALIST REPUBLIC (RSFSR) AND NORTHEASTERN CHINA HELD IN THE USSR IN DECEMBER 1989. THE ATTENDEES DISCUSSED PROBLEMS OF PROMOTING COOPERATION BETWEEN THE RSFSR, THE SOVIET UNION'S LARGEST REPUBLIC, AND THE PEOPLE'S REPUBLIC OF CHINA. THE CONFERENCE FOCUSED ON ISSUES OF TRADE, ECONOMIC, SCIENTIFIC, AND TECHNOLOGICAL RELATIONS BETHEEN THE RSFSR AND CHINA.

09204 TURNER, $F$

SOCIAL MOBILITY AMD POLITICAL ATTITUDES: COMPARATIVE PERSPECTIVES

TRANSACTION PUBLISHERS, 1991, 274.

DIFFERENT LEVELS OF' SOCIAL MOBILITY CHARACTERIZE NATIONS AROUND THE WORLD THIS YOLUME EXAMINES WHAT SORT OF IMPACT AROUND THE WORLD. H ON MASS POLITICS, AND, FROM WHAT SOURCES SOCIAL MOBILITY HAS ON MASS POLITICS, AND, FRO AND WHAT RESULTS. ITS SEEKS ANSWERS TO THIS INTERRELATIONSHIP BY GOING BEYOND THE NORMAL SOURCES IN
WESTERN EUROPE AND THE UNITED STATES, INTO STUDIES OF SIX WESTERN EUROPE AND THE UNITED STATES, INTO STUDIES OF SIX
EASTERN EUROPEAN NATIONS, AND SOCIAL MOBILITY EXPERIENCES IN EASTERN EUROPEAN NATIONS, AND SOCIAL MOBILITY EXPERIENCES
LATIN AMERICA AND AFRICA. THE BOOK PROVIDES A FUNDAMENTAL RETHINKING OF THE OLD LITERATURE ON MOBILITY AND POLITICS, AND A REASSESSMENT OF THE INTERPRETIVE SCHEMES BASED UPON' IT IN TERMS OF THE BROADER QUESTION OF HOW BASIC ISSUES IN THE SOCIAL SCIENCES SHOULD BE APPROACHED, THE DATA INDICATE THAT 
MUCH IS TO BE LEARNED FROM SUBJECTIING EVEN CHERISHED ASSUMPTIONS TO THE RIGORS OF SURVEY RESEARCH AND ANALYTICAL TECHNIQUES.

09205 TURNER, R.S. GROWTH POLITICS AND DOWNTOWN DEVELOPMENT: THE ECONOMIC IMPERATIVE IN SUNBELT CITIES

URBAN AFFAIRS QUARTERLY, 28(1) (SEP 92), 3-21. URBAN AREAS DOMINATED BY GROWTH DO NOT FOLLOW THE SAME PRO-GROWTH STRATEGIES FOR DEVELOPMENT. IN THIS COMPARATIVE STUDY, THE CHARACTERISTICS OF GROWTH POLITICS ARE EXAMINED, STUDY, THE CHARACTERISTICS OF GROWTH POLITICS ARE EXAMINED,
FOCUSING ON DOWNTOWN DEVELOPMENT STRATEGIES THAT AFFECT FOCUSING ON DOWNTOWN DEVELOPMENT STRATEGIES THAT AFFECT COMMERCIAL DEVELOPMENT AND NEIGHBORHOOD HOUSING. THE
DISTRIBUTION OF COSTS AND BENEFITS OF SUCH DEVELOPMENT TO DISTRIBUTION OF COSTS AND BENEFITS OF SUCH DEVELOPMENT
COMMERCIAL AND RESIDENTIAL SECTORS INDICATES DIFFERENT COMMERCIAL AND RESIDENTIAL SECTORS INDICATES DIFFERENT
PUBLIC/PRIVATE RELATIONSHIPS THAT CAN BE FOUND WITHIN GROWTH PUBLIIC/PRIV
POLITICS.

09206 TURNER, $S$

THE FUTURE OF THE U.S. NAYY IN THE MEDITERRANEAM MEDITERRANEAN QUARTERLY: A JOURNAL OF GLOBAL ISSUES, $3(1)$ WIN 92$), 35-48$

THIS ARTICLE EXAMINES THE RELEVANCE OF THE U.S. SIXTH FLEET IN THE MEDITERRANEAN. IT LOOKS AT THE MISSIONS THIS FLEET HAS FULFILLED SINCE ITS INCEPTION IN 1946. THE BASIC RATIONALE FOR THE FLEET WAS TO BE PREPARED, IN THE EVENT OF MAJOR WAR WITH THE SOVIET UNION, TO KEEP THE SEA LANES OPEN TO GREECE, TURKEY, AND EVEN ITALY, SO AS TO PROVIDE THEM WITH THE WHEREWITHAL TO DEFEND THEMSELVES. AFTER 1989 , HOWEVER, THE PROGRESSIVE DEMISE OF THE SOVIET UNION AND ITS MILITARY POWER IRREVOCABLY CHANGED THE MEDI IERRANEAN STRATEGY. THE SOVIETS HAVE WITHDRAWN THEIR FORMIDABLE MEDITERRANEAN SQUADRON, AND IT SEEMS DIFFICULT TO IMAGINE EITHER A SOVIET THRUST FROM EASTERH EUROPE INTO TURKISH THRACE, GREECE, OR ITALY, OR A MAJOR CLASH WITH THE SOVIETS AT SEA. HOWEVER, THE RECENT GULF WAR REINFORCES THE IMPORTANCE OF THE FLEET. THE NEW U.S. STRATEGY WILL BE A COMBINATION OF SECURING SEA AND AIR LINES OF COMMUNICATION TO THE MIDDLE EAST AND ENSURING THE ABILITY TO USE FORCE TO PROTECT U.S. INTERESTS ALL AROUND THE MEDITERRANEAN BASIN.

09207 TUSA, F.

WHY EC ' 92 WILL PLAY TO U.S., JAPANESE INTERESTS

ARED FORCES JOURNAL INTERNATIONAL, (APR 91), 40.

WHILE MANY IN THE UNITED STATES WORRY ABOUT THEIR RELATIONSHIP WITH EUROPE AFTER THE COMPLETION OF THE SINGLE EUROPEAN MARKET, SIR GEOFFREY PATTIE, A MEMBER OF THE BRITISH PARLIAMENT, ARGUES THAT 1992 WILL BRING INCREASED OPPORTUNITIES TO U.S. AND JAPANESE FIRMS. HE SPEAKS OUT AGAINST THE PROTECTIONIST TENDENCY OF THE U.S. GOVERNMENT AND CALLS FOR REFORM OF U.S. TECHNOLOGY TRANSFER LAWS. SUCH REFORMS ARE VITAL PRECONDITIONS TO DOING BUSIN
CHANGING WORLD ECONOMIC AND INDUSTRIAL SYSTEM.

09208 TUSA, J.

THE PROBLEMS OF FREEDOM AND RESPONSIBILITY IN BROADCASTING TERRORISM AND POLITICAL VIOLENCE, 2(4) (WIN 90), 544-553.

IN CONSIDERING FREEDOM AND RESPONSIBILITY IN

BROADCASTING, THIS ARTICLE ARGUES THAT BROADCASTERS ARE BOUND BY THEIR PROFESSIONAL RESPONSIBILITIES AS JOURNALISTS AND AS PEOPLE WHO WIELD INFLUENCE--NOT POWER--IN A CONFUSED AND AGITATED WORLD. THE FREEDOM THEY EXERCISE IS THE FREEDOM TO BE RESPONSIBLE. BEYOND THAT, THE DANGER OF THE CALLS FOR MORE RESPONSIBILITY IS THAT THEY ARE CODE-HORDS FOR SELFCENSORSHIP, FOR OBLIGING ACCOMMODATION HITH A GOVERNMENT OF THE DAY, FOR ACCEPTANCE OF THE PREVAILING CULTURE OF A GOVERNMENT OF THE DAY. IN DOING SO, THE ARTICLE SEEKS TO REFUTE THE SOMETIMES POSITIED DIVISION BETWEEN THE BROADCAST MEDIA AND THE WRITTEN WORD AND CONCLUDES THAT BOTH SHOULD OPERATE UNDER THE SAME ASSUMPTIONS AND SAME DUTY TO RESPONSIBILITY.

09209 TUSHNET, M.

PUBLIC LAW LITIGATION AND THE AMBIGUITIES OF BRONN FORDHAM LAW REVIEW, LXI(1) (OCT 92), 23-28.

THE AUTHOR POSITS THAT THE SUPREME COURT'S CONCERN FOR GRADUALLY IMPLEMENTING DESEGREGATION IN THE PUBLIC SCHOOLS IRONICALLY GAVE RISE TO PUBLIC LAH LITIGATION--AN AGGRESSIVE IRONICALLY GAVE RISE TO PUBLIC LAH LITIGATION--AN AGGRESSIVE
FORM OF JUDICIAL REVIEW. SPECIFICALLY, HE ARGUES THAT THE "ARM OF JUDICIAL REVIEW. SPECIFICALLY, HE ARGUES THAT THE "ALL DELIBERATE SPEED" STANDARD, WHICH SEPARATED THE FROM THE REMEDY, ENABLED THE COURTS TO BECOME A MORE
POWERFUL INSTITUTION IN SHAPING SOCIAL POLICY. HE ALSO POWERFUL INSTITUTION IN SHAPING SOCIAL POLICY. HE ALSO
PROVIDES INSIGHT INTO THE THOUGHT PROCESSES OF THE SUPREME COURT JUSTICES AT THE TIME OF THE BROWN DECISION.

09210 TVEDTEN, I

U.S. POLICY TOWARDS ANGOLA SINCE 1975 JOURNAL OF MODERN AFRICAN STUDIES, 30(1) (MAR 92), 31-52. THE AUTHOR RECOUNTS THE STORY OF U.S. INVOLVEMENT IN ANGOLA, BEGINNING IN 1975. HE ARGUES THAT THE CORE OF THE ANGOLAN PROBLEM HAS BEEN SOUTH AFRICA'S REGIONAL POLICY OF DESTABILIZATION AND THE INABILITY OF THE WEST-PARTICULARLY THE UNITED STATES--TO UMOERSTAND THE SOCIO-ECONOMIC AND POLITICAL REALITIES IN ANGOLA, DUE TO CONTINUING IDEOLOGICAL
MISCONCEPTIONS BY WESTERN LEADERS.

09211 TWERSKY, $D$.

JEWS FOR BILL

NEW REPUBLIC, 207(16) (OCT 92), 12-13.

POLLS INDICATE THAT PRESIDENT GEORGE BUSH WILL CAPTURE ONLY ABOUT 20 PERCENT OF THE JEWISH VOTE IN HIS 1992 REELECTION BID BECAUSE MANY U.S. JEWS PERCEIVE HIS MIDEAST POLICY AS BEING ANTI-ISRAEL. BILL CLINTON, ON THE OTHER HAND,

CAMPAIGN AND HAS BEEN VIGOROUSLY PURSUING IT.

09212 TWERSKY, $D$

THE ARAB-ISRAELI KNOT

NUCLEAR TIMES, 9 ( 2 ) (SUM 91), 19-20.

THE IMPACT OF THE PERSIAN GULF WAR ON THE IMPASSE

BETWEEN ARABS AND ISRAELIS OVER THE WEST BANK AND GAZA STRIP IS ASSESSED. AMERICAN DIPLOMATIC EFFORTS ARE SURVEYED. THE ROLES OF THE PLO, JORDAN, AND SYRIA IN THE NEGOTIATION
PROCESS ARE CONSIDERED, ALONG WITH ASSOCIATED PROBLEMS.

09213 TWINAM, J.

THE GULF COOPERATION COUNCIL SINCE THE GULF WAR: THE STATE OF THE STATES

MIDDLE EAST POLICY, 1(4) (1992), 96-115

THE EVENTS FROM AUGUST 1990 THROUGH DESERT STORM PROFOUNDLY AFFECTED THE ENIYRONMENT IN WHICH THE COUNCIL COUNTRIES SEEK TO SURVIVE AND PROSPER. THIS ARTICLE EXPLORES THE KEY QUESTION OF WHETHER THE GCC COUNTRIES HAVE BEEN JOLTED INTO A NEW ERA IN TERMS OF DOMESTIC, SOCIAL, AND POLITICAL DEVELOPMENT AND THEIR TIES WITH ONE ANOTHER AND THE WORLD BEYOND. IT CONCLUDES THAT FOR THE MOMENT REPRESENTATIVE DEMOCRACY SEEMS TO BE ALIVE AND WELL IN THE GCC COUNTRIES.

09214 THINE, $F$.

CITIZENSHIP: OPPORTUNITIES, RIGHTS, AND ROUTES TO WELFARE IN OLD AGE

JOURNAL OF SOCIAL POLICY, 21(2) (APR 92), 165-175.

URMAL OF SOCIAL POLICY, 21(2) (APR 92), 165-175.
BRITISH DEBATES ON CITIZENSHIP OFTEN START WITH AN

EXAMINATION OF THE WORK OF T.H. MARSHALL, AND THIS PAPER IS

NO EXCEPTION. THE AUTHOR ARGUES THAT MARSHALL CONFUSES

"RIGHTS" AND "OPPORTUNITIES" IN HIS CONCEPT OF CIVIL RIGHTS.

"RIGHTS" AND "OPPORTUNITIES" IN HIS CONCEPT OF CIVIL RIGHTS

THEN THE AUTHOR DEVELOPS HIS CRITIQUE IN TERMS OF TITMU

CONCEPT OF THE "SOCIAL DIVISION OF WELFARE SO AS TO DISTINGUISH DIFFERENT ROUTES TO WELFARE IN OLD AGE.

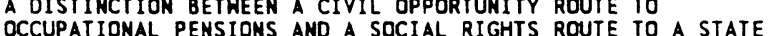
OCCUPATIONAL PENSIONS AND A SOCIAL RIGHTS ROUTE TO A EARNINGS-RELATED PENSION. HE THEN ELABORATES ON THIS DISTINCTION IN ORDER TO IDENTIFY SOME SOCIAL CLASS AND
GENDER DIMENSIONS OF CITIZENSHIP AND INEQUALITY IN OLD AGE FROM A LIFE-COURSE PERSPECTIVE.

09215 THISS, J.M.

CALIFORNIA HEALTHY CITIES PROJECT: PILOTING COMHUNITY-

BASED HEALTH PROMOTION STATEWIDE

NATIONAL CIVIC REVIEH, 81(2) (SPR 91), 105-114

GIVEN THE STEADILY-RISING COSTS OF MEDICAL CARE AND THE INCREASING RECOGNITION OF THE ROLE OF INDIVIDUAL

RESPONSIBILITY IN MAINTAINING PERSONAL HEALTH, THE CONCEPT OF THE HEALTHY CITY MAY BE AN IDEA WHOSE TIME HAS COME. THE COMMUNITY-BASED PROBLEM-SOLVING APPROACH BEING TRIES IN CALIFORNIA EMPHASIZED PREVENTION, AN EXPANSIVE DEFINITION OF "HEALTH," AND BROAD-BASED PARTICIPATION.

09216 TYLER, G.

HOH THE DEMOCRATS ARE DIFFERENT

NEW LEADER, LXXY(9) (JUL 92), 12-14.

SOME OBSERVERS DISMISS BILL CLINTON'S SIZABLE LEAD IN

THE POLLS, POINTING OUT THAT MICHAEL DUKAKIS ENJOYED A

SIMILAR LEAD IN 1988. HOWEVER, THERE ARE CRUCIAL

DISTINCTIONS BETWEEN 1988 AND 1992. FIRST AND FOREMOST IS

THAT THE ECONOMY WAS NOT IN RECESSION FOUR YEARS AGO. SECOND, GEORGE BUSH'S INABILITY TO OUST SADOAM HUSSEIN INCREASES GEORGE BUSH'S INABILITY TO OUST SADOAM HUSSEIN INCREASES
HIS "WIMP" IMAGE. THIRD, THE CLARENCE THOMAS CONTROVERSY HAS HIS "WIMP" IMAGE. THIRD, THE CLARENCE THOMAS CONTROVERSY HAS GALVANIZED THE WOMEN'S MOVEMENT--A CHANGE WHICH GENERALLY
FAVORS THE DEMOCRATS. FINALLY, UNLIKE DUKAKIS, CLINTON HAS FAVORS THE DEMOCRATS. FINALLY, UNL IKE DUKAKIS, CLINTON HAS
ELEVATED PRINCIPLES AND PROGRAM ABOVE PERSONA. HIS CALLS FOR ELEVATED PRINCIPLES AND PROGRAM ABOVE PERSONA. HIS CALLS FOR
TAX AND WAGE REFORM WILL LIKELY FIND RESONANCE IN MANY PARTS TAX AND WAGE REFORM WILL LIKELY FIND RESONANCE IN MANY PART
OF AMERICA. ALL OF THESE FACTORS COMBINE TO INCREASE THE OF AMERICA. ALL OF THESE FACTORS

09217 TYLER, G.

RUNBLINGS IN THE SRED ARMY'

NEH LEADER, LXXY(3) (MAR 92), 10-11.

YESTERDAY'S GLORIFIED RED' ARMY HAS BEEN THOROUGHLY BATTERED AND HUMILIATED SINCE THE COLLAPSE OF THE SOVIET STATE. RUSSIAN ANALYSTS WONDER AT THE MILITARY'S PATIENCE. FEW WOULD BE SURPRISED IF IT ENDORSED A CONSERVATIVE, HARDLINE GOVERMMENT BEFORE THE YEAR IS OUT. THIS ARTICLE SUGGESTS THAT THE DEMORALIZED, DIVIDED MILITARY, LACKING ANY FIRM COMMAND OR PURPOSE, IS A TICKING BOMB IN THE COMMONHEALTH. IT IS IMPOSSIBLE TO PRECISELY QUANTIFY WHAT IS NOW THE ARMED FORCES OF THE COMMONWEALTH OF INDEPENDENT 
STATES, AND CONTROL OF THE SOVIET NUCLEAR ARSENAL IS AS MUCH A POLITICAL AS A MILITARY ISSUE. THE VIEWS OF THE SENTIMENT THAT IS SHARED BY CONSERVATINVE RUSSIAN POLITICAL LEADERS, AS WELL AS THE RUSSIAN ORTHODOX CHRUCH.

09218 TYLER, G. SHADES OF 1932

NEW LEADER, LXXV(4) (MAR 92), 8-9.

IN MANY CRUCIAL RESPECTS THE ELECTION OF 1992 LOOKS LIKE A RERUN OF THE WATERSHED ELECTION OF 1932. THIS PAPER OFFERS AN EXPLORATION OF THE CURIOUS PHENOMENON AS A USEFUL STARTING POINT FOR A CITIZENRY EAGER TO RESCUE AN UNEASY AMERICA FROM ITS PRESENT ECONOMIC SLUMP AND POLITICAL CONFUSION. THE SIMILARITIES ARE ENCOURAGING AND AT THE SAME TIME SCARY. HHAT IS LACKING MONG THE MOVEMENTS THAT EXIST TODAY IS A UNIFYING THEME, AN IDEOLOGIC COMMON DENOMINATOR THAT WOULD JOIN PEOPLE IN A GRAND COALTION. WHETHER SUCH A COALITION OF PROGRESSIVE FORCES CAN BE PUT TOGETHER AND WHAT COALITION OF PROGRESSIVE FORCES CAN BE PUT TOGETHER AMD
THEIR PROGRAM SHOULD BE ARE QUESTIONS THAT ARE RAISED.

09219 TYLER, G.

STRAWS IN THE AMERICAN POLITICAL WINDS

NEW LEADER, LXXIV(15) (MOY 90) $10-12$.

THE ELECTION OF 1990 , THOUGHT BY SOME TO BE RATHER BLAND, MAY TURN OUT TO BE A HATERSHED FOR AMERICAN POLITICS. IN MAY TURN OUT TO BE A WATERSHED FOR AMERICAN POL ITICS. IN
THE NATIONAL LEGISLATIVE ELECTIONS, THE DEMOCRATIC PARTY MADE SIGNIFICANT GAINS, VIRTUALLY ENSURING A VETO-PROOF CONGRESS. IN THE STATE AND LOCAL ELECTIONS--WHICH WILL DETERMINE HOW VOTING DISTRICTS ARE REDRAWN--THE DEMOCRATS ALSO WON BIG. THE SHIFT AWAY FROM THE PARTY IN THE WHITE HOUSE IS EVIDENCE OF THO PHENOMENA: THE RETURN OF PEOPLE'S CONCERN TO THE PUBLIC (AS OPPOSED TO PRIVATE) INTEREST, AND GROWING VOTER FRUSTRATION ANO APATHY.

09220 TYLER, G.

THE CHANGING SHAPE OF OUR POLITICS

NEW LEADER, LXXY(11) (SEP 92 ), 14-15

THE YEAR 1992 HAS PROVIDED EVIDENCE THAT THE TIMES ARE CHANING--EVEN IF A MAJORITY OF THE ELECTORAL COLLEGE DOES NOT VOTE FOR A CHANGE AFTER NOVEMBER 3. THE GENERATIONAL SHIFT IS UNDER WAY IN AMERICAN POLITICS. POLLS INDICATE THAT THE 18--29 GENERATION WILL BE HEAVILY PRO-CLINTON. GIVEN THE DISCERNIBLE SHIFT IN THEIR ATTITUDE, THE NUMBER OF YOUNG DISCERNIBLE SHIFT IN THEIR ATTITUDE, THE NUMBER OF YOUNG
VOTERS GOING TO THE POLLS IN NOVEMBER SHOULD BE SURPRISINGLY VOTERS GOING TO THE POLLS IN NOVEMBER SHOULD BE SURPRISINGLY
HIGH. AMERICAN POLITICS ALSO IS UNDERGOING A GENDER CHANGE HIGH. AMERICAN POL ITICS ALSO IS UNDERGOING A GENDER CHANGE
AND THIS ELECTION YEAR PROMISES THE EMERGENCE OF A NEW SOUTH AND THIS ELECTION YEAR PROMISES THE EMERGENCE OF A NEN SOUTH
THAT IS NEITHER SOLDILY DEMOCRATIC NOR SOLIDLY REPUBLICAN. THAT IS NEITHER SOLDILY DEMOCRATIC NOR SOLIDLY REPUBLICAM
FINALLY, 1992 IS THE YEAR DISCONTENDED AMERICAN VOTERS FINALLY, 1992 IS THE YEAR DISCONTENDED AMERICAN VOTERS
DISPLAYED THEIR READINESS TO JOIM A THIRD PARTY MOVEMENT THROUGH ROSS PEROT. WHATEVER THE OUTCOME THESE CURRENTS WILL CONTUNIE TO RUN AND TO CARYE THE CONTOURS OF AMERICA'S CONTUNI

09221 TYLER, G

THE POLITICS OF CHANGE

NEW LEADER, LXXV(8) (JUN 92), 11-12.

ALL OF THE PRESIDENTIAL ASPIRANTS SEEM TO AGREE THAT "IT'S TIME FOR A CHANGE." NUMBERLESS MOVEMENTS AND "INTEREST GROUPS" ALSO SEEM COMMITTED TO FOSTERING CHANGE. THE PROBLEM IS THAT ALL THE CLAMOR FOR CHANGE LACKS A FOCUSING ELEMENT. THIS ARTICLE PROVIDES ONE: THE ECONOMY. IT DEMONSTRATES THAT A SOUND ECONOMY IS FUMDAMENTAL TO IMPROVEMENT IN A YAST ARRAY OF AREAS INCLUDING CRIME, EDUCATION, THE ENVIRONMENT, AND CIVIL RIGHTS.

09222 TYLER, G.

THE POWER OF ROSS PEROT

NEW LEADER, LXXV(6) (MAY 92), 12-14.

THIS ARTICLE EXAMINES THE UNPRECEDENTED APPEAL OF

UMDECLARED PRESIDENTIAL CANDIDATE H. ROSS PEROT. IT ARGUES

THAT THE APPEAL IS FOUND IN MONEY, MEDIA, AND MALAISE. PEROT HAS THE FUNDS (SOME S100 MILLION HAS BEEN PLEDGED TO THE CAMPAIGN) TO ORGANIZE, STAFF, AND ADVERTIZE A HUGE CAMPAIGM. THE FAR-REACHING AND DRAMATIC MATURE OF TODAY'S MASS MEDIA (MOST NOTABLY TELEVISION) IS WELL SUITED FOR PEROT. IN ADDITION, DISAFFECTION WITH THE ESTABLISHMENT ON THE PART OF A HIDE RANGE OF AMERICANS PLAYS INTO PEROT'S HANDS AS HE STYLES HIMSELF AN ANTI-ESTABLISHMENT CANDIDATE. IF PEROT MANAGES TO SECURE A LARGE PORTION OF THE POPULAR VOTE, IT IS POSSIBLE THAT NO SINGLE CANDIDATE WILL SECURE A MAJORITY OF POSSIBLE THAT NO SINGLE CANDIDATE WILL SECURE A MAJORITY
ELECTORAL COLLEGE VOTES. THIS WOULD SET OFF A BYZANTINE ELECTORAL COLLEGE VOTES. THIS NOULD SET OFF A BYZANTINE
SELECTION PROCESS, THE OUTCOME OF WHICH DEPENDS HEAVILY ON SELECTION PROCESS, THE OUTCOME OF WHICH
THE SENATE AND HOUSE OF REPRESENTATIVES.

09223 TYMER, J.

BEAT BUSH AND PEROT

POLITICAL AFFAIRS, 71(10) (OCT 92), 5-9; 35

THE COMMUNIST PARTY SEES THE U.S. 1992 ELECTION AS INVOLVING A CLASS CONFRONTATION. THIS ARTICLE LOOKS AT THE ELECTION FROM THE PERSPECTIVE OF HOW TO UTILIZE IT TO ADVANCE THE INTERESTS OF THE WORKING CLASS AND OPPRESSED. IT EXPLORES WHAT THE PARTY CAN DO TO ADVANCE THE AGENDA OF THE WORKING CLASS AND HOW IT CAN WIN ON THOSE ISSUES THAT
FAVORABLY AFFECT THE LIFE AND WELL BEING OF THE MAJORITY OF THE PEOPLE AND THE WORKING CLASS IN PARTICULAR.

09224 TYNER, J.

THIS YEAR'S ELECTION CHALLENGE

POLITICAL AFFAIRS, 71 (3) (APR 92), 1-9.

FOR THE PAST THENTY-FOUR YEARS IN THE UNITED STATES,

WORKING PEOPLE, ORGANIZED LABOR, THE RACIALLY OPPRESSED,

WOMEN, YOUTH AND SENIORS, HAVE HAD A CONSTANT DECLINE IN

LIVING STANDARD, QUALITY OF LIFE, ENVIRONMENT AND DEMOCRATIC RIGHTS, STATES THIS ARTICLE ABOUT PRESIDENTAL ELECTIONS. IT STATES THAT 1992 IS A PRESIDENTIAL ELECTION YEAR WITH A LARGE PART OF THE HOUSE, THIRTY-FIVE SENATE SEATS, THELVE GOVERNORSHIPS, AND HUNDREDS OF STATE AND LOCAL OFFICES IN CONTENTION. IF THE ANGER AND DISGUST OF THE PEOPLE ARE LINKED TO THE STRUGGLE AROUND THE ECONOMIC CRISIS AND FINDS EXPRESSION ON ELECTION DAY, GREAT POSITIVE CHANGES CAN OCCUR. THE ARTICLE DISCUSSES THE CANDIDATES, AND MAKES MANY THE ARTICLE DISCUSSES
SUGGESTIONS FOR CHANGE.

09225 TYNER, J

92 ELECTIONS AND AFTER: NEH PROBLEMS AND OPPORTUNITIES POLITICAL AFFAIRS, 71(12) (DEC 92), 1-8

THIS JOURNAL OF THE COMMUNIST PARTY EVALUATES THE 1992 ELECTIONS IN THE UNITED STATES. IT SUGGESTS THAT IN AN ELECTION, IT IS THE MOTION OF THE MAIN CONTENDING CLASS AND SOCIAL FORCES THAT HAS THE GREATEST INFLUENCE ON THE OUTCOME AND ON FUTURE DEVELOPMENTS. IT EXPLORES THE ECONOMY, HEALTH CARE, THE REPUBLICAN CONVENTION, THE ELECTION OF THE 1O3RD CONGRESS, THE MUTI-RACIAL WORKING CLASS, THE OVERWHELMING VOTE AGAINST BUSH, THE PEROT PHENOMENON, THE COMMUNIST

CANDIDATES, PRESSURING CLINTON, AND LEFTOVERS FROM BUSH.

09226 TYRELL, R.

PC PEOPLE

AMERICAN SPECTATOR, $24(5)$ (MAY 91), 8-9.
THIS EDITORIAL COMMENTS ON THE INCREASING EMPHASIS ON POLITICAL CORRECTNESS (PC) IN AMERICAN UNIVERSITIES. PC CAN BE DEFINES AS A CLUSTER OF BROADLY LEFT-WING ATTITUDES DESIGNED TO FOSTER TOLERANCE TOWARDS RACE, GENDER AND CLASS BUT WHICH SEEM, IN ORWELLIAN FASHION, TO DO THE OPPOSITE. EVEN AMERICAN LIBERALS ARE BEGINNING TO SENSE THAT PC CULTURE IS PROFOUNDLY ANTI-LIBERAL. THE REAL QUESTION IS: CULTURE IS PROFOUNDLY ANTI-LIBERAL. THE REAL QUESTION IS:
WILL ANYONE BE ABLE TO RESCUE THE UNIVERSITIES FROM PC'S WILL ANYONE BE ABLE TO RESCUE THE UNIVERSITIES FROM PC'S
ANTI-INTELLECTUAL RADICALS OF THE 1960S? THE AUTHOR SEES PC ANTI-INTELLECTUAL RADICALS OF THE 1960S? THE AUTHOR SEES
AS A VAST INFRINGEMENT ON THE HUMAN RIGHTS OF STUDENTS

09227 TYRRELL, R.E. JR.

DOUBLE TROUBLE

AMERICAN SPECTATOR, 25(10) (OCT 92), 12, 14

AMERICAN PRESIDENTIAL POLITICS IS INCREASINGLY A VAST DISPLAY OF MEANINGLESS. IN 1992, BOTH GEORGE BUSH AND BILL CLINTON HAVE MADE SATEMENTS THAT THEY KNOW ARE FALSE AND PROMISES THAT THEY KNOH THEY CANNOT KEEP. MEANHHILE, ROSS PEROT HINTS THAT HE BOTH IS AND IS NOT A CANDIDATE.

09228 U.S. DEPARTMENT OF STATE PATTERNS OF GLOBAL TERRORISM: 1990 TERRORI SM, 14(4) (1991), 253-278.

IN THIS APPENDIX, BACKGROUND INFORMATION OF THE MAJOR GROUPS DISCUSSED IN THIS REPORT OF "TERRORISM" IS OFFERED. THE DESCRIPTION, ACTIVITIES, STRENGTH, LOCATION AND AREA OF
OPERATION, AND SOURCES OF EXTERNAL AID ARE GIVEN. THE GROUPS ARE LISTED APHABETICALLY AND INCLUDE ABU NIDAL, BASQUE FATHERLAND AND LIBERTY, CNPZ, ELA, 15 MAY ORGANIZATION, JAPANESE RED ARMY, MANUEL RODIGUEZ PATRIOTIC FRONT, NATIONAL LIBERATION ARMY, PALESTINE LIBERATION FRONT, POPULAR FRONT FOR THE LIBERATION OF PALESTINE, RED BRIGADES, TERRA LLIURE, AND MAHY OTHERS.

09229 UDALOV, V.V.

THE CONCEPT OF BALANCE OF INTERESTS AND U.S.-SOVIET INTERACTION

ANMALS OF THE AMERICAN ACADEMY OF POLITICAL AND SOCIAL SCIENCE, (518) (

EFFECTIVE AND CONTIMUOUS SOVIET-AMERICAN COOPERATION IN HANDLING REGIONAL PROBLEMS IS HARDLY POSSIBLE WITHOUT A SHARED UNDERSTANDING OF CONFLICT IN GENERAL AND OPTIMUM WAYS FOR AFFECTING ITS DYNAMICS. MOST AMERICAN SCHOOLS OF FOR AFFECTING ITS DYNAMICS. MOST AMERICAN SCHOOLS OF
CONFLICT RESEARCH PROCEED FROM THE CONCEPT OF BALANCE OF CONFLICT RESEARCH PROCEED FROM THE CONCEPT OF BALANCE OF
POWER. SOVIET POLITICAL THINKING HAS SUGGESTED A COMPETING POWER. SOVIET POLITICAL THINKING HAS SUGGESTED A COMPETING APPROACH BASED ON THE CONCEPT OF BALANCE OF INTERESTS. THIS
CONCEPTUAL DEADLOCK CAN BE OVERCOME THROUGH AN ELABORATION CONCEPTUAL DEADLOCK CAN BE OVERCOME THROUGH AN ELABORATION OF WHAT PRECISELY IS MEANT BY BALANCE OF INTERESTS. SUCH AM ANALYSIS SHOWS THAT BALANCE OF INTERESTS IS VIRTUALLY AN EXTERNAL MANIFESTATION OF BALANCE OF POWER AND ITS CHARACTER
TYPICALLY DEPENDS ON THE LATTER'S TRANSFORMATION. IN BROADER TERMS, BALANCE OF INTERESTS MEANS AN EQUILIBRIUM BETWEEN ELEMENTS OF CONFRONTATION AND COOPERATION. THE CONCEPT OF BALANCE OF INTERESTS PROVES TO BE A LOT RICHER IN ITS IMPLICATIONS THAN RELIANCE ON PONER FLUCTUATIONS. SINCE IT JUSTIFIES A POSSIBILITY NOT ONLY OF A SETTLEMENT BUT ALSO OF RESOLUTION OF SOME CONFLICTS BY RECONSIDERING AND DRAHING APART INTERESTS THAT SEEMED TO BE MUTUALLY DENYING. 
09230 UDOGU, E.

UDOGU, E. NIGERIA'S THIRD REPUBLIC

SCANDINAVIAN JOURNAL OF DEVELOPMENT ALTERNATIVES, $11(3)$ (SEP 92), 5-30.

NIGERIA'S THREE DECADES OF INDEPENDENCE HAVE BEEN FRAUGHT WITH TURBULENCE AS A RESULT OF ECDNOMIC, SOCIAL AND FRAUGHT WITH TURBULENCE AS A RESULT OF ECONOMIC, SOCIAL AND
POLITICAL DISTEMPER. THIS PAPER IS AN ATTEMPT TO SUGGEST AND POLITICAL DISTEMPER. THIS PAPER IS AN ATTEMPT TO SUGGEST AND THE ISSUES OF PARTICIPATORY DEMOCRACY AND STABILITY IN NIGERIA IN 1992 AND AFTER. IT EXPLORES THE OPEN BALLOT NYSTEM. THE GOVERHING PROCESS, THE ROLE OF SCHOLARS

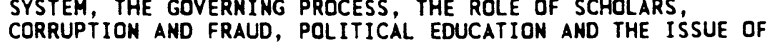
CORRUPTION AND FRAUD, POL ITICAL EDUCATION AND THE ISSUE OF DIARCHY. IT IS ARGUED THAT IN ORDER FOR DEMOCRACY TO BLOSSOM IN NIGERIA AND POLITICAL STABILITY TO BE SUSTAINED, IT
TAKE THE MUTUAL EFFORTS OF THE MILITARY AND CIVILIANS.

09231 UEDA, $T$.

LONELY LEADER HAS IDEAS FOR POLITICAL REFORM JAPAN TIMES (WEEKLY INTERNATIONAL EDITION), 32(17) (APR 92 ) 1,6

IN JAPAN'S BUSINESS hORLD RYUZABURO KAKU, CHAIRMAN OF CANON INC., IS PERHAPS THE MOST OUTSPOKEN AND LONELIEST CRITIC OF THE RULING LIBERAL DEMOCRATIC PARTY. IN THIS ARTICLE, THE AUTHOR EXAMINES SOME OF KAKU'S IDEAS FOR POLITICAL REFORM.

09232 UIBOPUU, $H$.

DEALING WITH MINORITIES: A BALTIC PERSPECTIVE

WORLD TODAY, 48(6) (JUN 92), 108-112.

THE SOVIÉT NATIONALITIES POLICY ATTEMPTED TO INTEGRATE

ETHNIC GROUPS BY RELOCATING LARGE NUMBERS OF PEOPLE AND

REPRESSING OR EVEN DESTROYING NATIONALITIES IN THEIR OWN

HOMELANDS. NOW THAT THE BALTIC STATES HAVE ACHIEVED

HOMELANDS. NOW THAT THE BALTIC STATES HAVE ACHIEVED

INDEPENDENCE, THEY MUST DEAL WITH A LARGE NON-BALTIC
POPULATION, PRIMARILY RUSSIANS WHO HAVE LIVED IN LITHUANIA,

POPULATION, PRIMARILY RUSSIANS HO HAVE LIVED IN LITHUANIA,
LATVIA, OR ESTONIA FOR UP TO THREE GENERATIONS BUT HAVE NOT

LATVIA, OR ESTONIA FOR UP TO THREE GENERATIONS BUT HAVE NOT
BEEN INTEGRATED INTO BALTIC SOCIETY. IN THIS ARTICLE, THE

BEEN INTEGRATED INTO BALTIC SOCIETY. IN THIS ARTICLE, THE
AUTHOR LOOKS AT THE HISTORY OF MINORITIES IN THE BALTIC

AUTHOR LOOKS AT THE HISTORY OF MINORITIES IN THE BALT
REPUBLICS, THE PRESENT CONSTITUTIONAL SITUATION, THE

RELEVANT STATUTORY LAH, AND THE OUESTION OF CITIZENSHIP FOR

RELEVANT STATU
MINORITIES.

09233 UKADIKE, $N$.

WESTERN FILM IMAGES OF AFRICA: GENERALOGY OF AN IDEDLOGICAL FORMATION

BLACK SCHOLAR, $21(2)$ (MAR 90), 30-48.

SINCE THE SIMULTANEOUS INVENTIONS OF THE MOTION PICTURE IN EUROPE AND AMERICA COINCIDED WITH THE HEIGHT OF EUROPEAM IMPERIALISM, IT IS NOT SURPRISING THAT FOR MANY YEARS THE DOMINANT IMAGE OF AFRICA SEEN ON WESTERN SCREENS WAS CONDESCENSION AND PATERNALISM. WESTERN FILMMAKERS BEGAN TO FILM IN AFRICA TAKING ADVANTAGE OF THE BEAUTY OF THE LANDSCAPE, THE SO-CALLED EXOTICISM OF ITS CUSTOMS, RELEGATING THE AFRICAN TO THE BACKGROUND, THIS ARTICLE EXPLORES THIS PHENOMENON FROM ITS ORIGINS TO THE PRESENT. IT ALSO PRESENTS A BRIEF OVERVIEW OF AFRICA'S RESPONSE TO WESTERN FILMMAKING.

09234 ULAM, A.B.

LOOKING AT THE PAST: THE UNRAVELING OF THE SOVIET UNION CURRENT HISTORY, 91(567) (OCT 92), 339-346.

IT WOULD BE NAIVE TO THINK THAT EVEN THE HISEST AND MOST FAR-SIGHTED REFORM POLICY COULD HAVE PREVENTED TROUBLE IN THE SOVIET UNION. STILL, WHEN THE TROUBLE CAME, IT MIGHT NOT HAVE BEEN AS FAR-REACHING AND SEEMINGLY INTRACTABLE IF GORBACHEV HAD BEEN MORE SENSITIVE TO THE PROBLEMS OF THE GORBACHEV HAD BEEN MORE SENSITIVE TO THE PROBLEMS OF THE
MULTINATIONAL STATE EMERGING FROM AUTOCRACY AND REPRESSION.
IN THE END, GORBACHEY FOUND HIMSELF IN THE POSITION OF THE SORCERER'S APPRENTICE: UNABLE TO STOP THE VERY FORCES HE HAD SORCERER'S
UNLEASHED.

09235 ULC, 0.

MO ÁID TO RUSSIA

NATIONAL INTEREST, 29 (FAL 92), 62-67

ANY REALISTIC ASSESSMENT OF THE LIKELY IMPACT OF ECONOMIC AID ON THE FORMER SOVIET UNION MUST TAKE A MEASURE ECONOMIC AID ON THE FORMER SOVIET UNION MUST TAKE A MEASURE IN THE DEVLOPING REGIONS OVER THE PAST FEW DECADES. BY IN THE DEVLOPING REGIONS OVER THE PAST FEN DECADES. BY COMPARISON WITH MOST DEVELOPING ECONOMIES, THE TASK OF RESTORING ECONOMIC HEALTH TO THE CIS STATES LOOKS TRULY IMPOSING. THIS ARTICLE PONDERS WHY THE DONOR COMMUNITY SHOULD BE EXPECTED TO SUCCEED IN THIS CHALLENGE WHEN IT HAS CONSPICUOUSLY FAILED IN MANY EASIER TESTS. IT SUGGESTS THAT THE ECONOMIC ASSISTANCE PROGRAMS NOH UNDER CONSIDERATION
THE WEST MAY NOT ONLY PROVE TO BE WASTEFUL, BUT MAY EVEN ULTIMATELY RETARD REFORM WORTHY OF THE NAME.

09236 ULLMANM, J.

BUILDING A PEACETIME ECONOMY

TECHMOLOGY REVIEW, 94(6) (AUG 91), 56-63.

IN THE DIFFICULT ECONOMIC CLIMATE THAT CAN BE EXPECTED

IN THE REST OF THE DECADE, THE RESOURCES TO STRENGTHEN U.S.
INDUSTRY CAN COME ONLY FROM THE MILITARY. MONEY RESCUED FROM DEFENSE SHOULD BE USED TO REBUILD U.S. INFRASTRUCTURE, MODERNIZE THE GROUND TRANSPORTATION SYSTEM, AND PROMOTE ENERGY RESEARCH AND DEVELOPMENT. INSTEAD OF MERE WORK RELIEF FOR A DIMINISHED MILITARY ESTABLISHMENT, CONVERSION MUST BE A CONCERTED EFFORT TO RESTORE THE NATION'S ECONOMIC HEALTH. THIS ARTICLE EXAMINES "WHO MUST CONVERT" (MILITARY BASES AND THEIR PERSONNEL, LARGE MILITARY CONTRACTORS, LARGE COMPANIES WITH MILITARY DIVISIONS, SMALL CONTRACTORS DOING SPECIALIZED WORK, AND FIRMS THAT ONLY SELL SOME OF THEIR USUAL PRODUCTS WORK, AND FIRMS THAT "NLY SELL SOME OF THEIR USUAL PRO
TO THE MILITARY) AND "HOW" (REDESIGNING FACILITIES,
RETRAINING STAFF,, AND SURVIVING ECONOMICALLY IN THE RETRAINING STA
TRANSITION).

09237 ULMER, J. OCCUPATIONAL SOCIALIZATION AND CYNICISM TOWARD PRISON ADMINISTRATION

SOCIAL SCIENCE JOURNAL, 29(4) (1992), 423-444.

CORRECTIONS OFFICERS OCCUPY A CRUCIIAL POSITION IN THE INSTITUTIONAL ORGANIZATION OF PRISONS, AND TRANSLATE THE POLICIES AND GOALS OF PRISON ADMINISTRATIONS INTO ACTION.
THIS STUDY FOCUSES ON THE FORMATION OF CYNICISM TOWARD PRISON ADMINISTRATION AND THE FACTORS THAT FOSTER OR INHIBIT IT. THE DATA SUGGEST THAT A SUBCULTURE OF CYNICAL OFFICERS MAY FORM AMONG FIRST-LINE OFFICERS DUE TO VARIATIONS IN OCCUPATION SOCIALIZATION PROCESSES. THREE CONCEPTUAL THEMES FROM SYMBOLIC INTERACTIONIST THEORIES OF OCCUPATIONAL SOCIALIZATION ARE PRESENTED THAT COULD LEAD TO IMPROVMENTS IN FUTURE RESEARCH ON CORRECTIONS OFFICERS.

09238 UMBACH, F.

CONTROL AND SECURITY OF NUCLEAR WEAPONS IN THE FORMER USSR AUSSEN POLITIK, 43(4) (1992), 362-372.

ONE OF THE MAIN RISKS TO INTERNATIONAL SECURITY IN THE FORMER SOVIET UNION IS THE GROWING DEFICIT OF CONTROL OVER THE TREMENDOUS NUCLEAR ARMS POTENTIAL LEFT BEHIND BY THE DEMISED COMMUNIST REGIME. THIS ANALYSIS SUGGESTS THE NEED TO REVISE THE WESTERN APPROACH TO THIS ISSUE. EXAMINED ARE: THE REVISE THE WESTERN APPROACH TO THIS ISSUE. EXAMINED ARE: THE
SECURITY OF SOVIET NUCLEAR WEAPONS; POSITIVE AND NEGATIVE SECURITY OF SOVIET NUCLEAR WEAPONS; POSITIVE AND NEGATIVE
CONTROL OF NUCLEAR POTENTIAL; SOVIET CONTROL STRUCTURES CONTROL OF NUCLEAR POTENTIAL; SOVIET CONTROL STRUCTURES
BEFORE THE AUGUST COUP IN 1991; AND THE LACK OF POLITICAL BEFORE THE AUGUST COUP IN 1991; AND THE LACK OF POLITICAL
CONTROL OVER NUCLEAR WEAPONS. THE ARTICLE CONCLUDES WITH AN CONTROL OVER NUCLEAR WEAPONS. THE ARTICLE CONCLUDES WITH AN
UNOFFICIAL AND ONCONVENTIONAL DEMAND FOR A WESTERN APPROACH TO THE ISSUE.

09239 UNDERDAL, A.

THE CONCEPT OF REGIME EFFECTIVENESS

COOPERATION \& CONFLICT: NORDIC JOURNAL OF INTERNATIONAL POLITICS, 27 (3) (SEP 92), 227-240.

TWO MAJOR OUESTIONS IN THE STUDY OF INTERNATIONAL COOPERATION ARE: (1) UNDER WHAT CONDITIONS IS SOME KIND OF COOPERATIVE ARRANGEMENT LIKELY TO BE ESTABLISHED? (2) UNDER WHICH CONDITIONS HILL THE ESTABLISHED ARRANGEMENT BE EFFECTIVE? ARGUING THAT GOOD REASONS CAN BE GIVEN FOR SHIFTING SOME RESEARCH EFFORTS FROM THE FORMER TO THE LATTER QUESTION AND THAT A FAIR AMOUNT OF CONCEPTUAL GROUNDWORK REMAINS TO BE DONE BEFORE REGIME EFFECTIVENESS CAN BE SYSTEMATICALLY STUDIED, THE AUTHOR BRIEFLY EXAMINES THREE QUESTIONS: (1) AGAINST HHICH STANDARD IS THIS OBJECT TO BE EVALUATED? (2) AGAINST WICH STANDARD IS THIS OBJECT TO BE EVALUATED? (3) WHAT KINDS OF MEASUREMENT OPERATIONS MUST BE PERFORMED IN ORDER TO ATTRIBUTE A CERTAIN SCORE OF

EFFECTIVENESS TO A CERTAIN ARRANGEMENT?

09240 UNGAR, $S$.

CIVIL, RELIIGION ARMS RACE

CANADIAN REVIEW OF SOCIOLOGY AND ANTHROPOLOGY, 28(4) (NOV 91), 503-525.

THIS PAPER EXAMINES THE INTERACTION BETWEEN CIVIL RELIGION AND POLITICS IN THE NUCLEAR ARMS RACE. IT ARGUES THAT THE BOMB POSED SPECIAL DIFFICULTIES TO AMERICAN VALUES, AND THAT THESE WERE OVERCOME BY SYBOLICALLY ALIGNING IT WI ELEMENTS OF AMERICAN CIVIL RELIGION. THE NUCLEAR MONOPOL WAS VIEWED AS A "SACRED TRUST" THE RESULT OF THE UNITED STATES UNIQUENESS AND PROOF OF ITS SPECIAL DESTINY OF THE UNITED STATES. AS THE CLAIM OF THE U.S. TO UNIQUENESS WAS UNDERMINED BEFORE THE WHOLE WORLD, THE NATION'S SPECIAL DESTINY WAS ASSOCIATED PARTICULARLY WITH ITS TECHNOLOGICAL SUPERIORITY. THE UPSHOT WAS THE PARADOXICAL DEVELOPMENT OF AN AMERICAN TECHNOCRACY, WHICH CONTRASTS SHARPLY
CANADIAN RESPONSES TO THE SOVIET NUCLEAR THREAT.

09241 URBAN, G.

THE AWAKENING

NATIONAL INTEREST, 27 (SPR 92), 39-47.

IT MAY WELL BE THAT OUR DISTAANT SUCCESSORS, CHRONICLING THE DECLINE AND FALL OF THE SOVIET EMPIRES, HILL SAY OF OUR AGE THAT THE HORLD'S RE-ORIENTATION TOWARD A SANER AND LESS WARLIKE ORDER HAD ITS ROOTS IN THE GREAT SEED-BEDS OF SLAVIC SUFFERING. THE LONG HESITATION OF THE WEST TO OFFER SUPPORT TO AND SHAPE SEPARATIST ASPIRATIONS IN THE FOREMR SOVIET UNION IS A WEAKENESS IN FOREIGN POLICY. LEADERS MUST REALIZE THAT IT IS OUR OWN SECURITY THAT DEMANDS THE STABILIZATION OF THE EX-SOVIET ECONOHY. 
09242 URBAN, J.

A DOOMSDAY SCENARIO FOR EUROPE

(ORLD PRESS REVIEW, 39(10) (OCT 92), 16-18

THE AUTHOR PAINTS A SCENARIO FOR A FUTURE CENTRAL

EUROPEAN CONFLAGRATION THAT COULD BE SPARKED BY THE DIVISION OF CZECHOSLOVAKIA INTO THO SEPARATE STATES. HE WARNS THAT, IF EUROPEAN DEMOCRACY IS TO SURVIVE AND PROSPER, IT MUST RECOGNIZE THE THREAT POSED BY THE INCREASING MOMENTUM OF NATIONALISM.

\section{URQUHART, B}

THE UNITED NATIONS IN 1992: PROBLEMS AND OPPORTUNITIES INTERNATIONAL AFFAIRS, 68(2) (APR 92), 311-319.

THIS ARTICLE DISCUSSES THE OPPORTUNITIES AKD CHALLENGES AS WELL THE PROBLEMS OF THE POST-COLD WAR WORLD. IT SUGGESTS THE MAGNITUDE AND URGENCY OF THESE PROBLEMS - - POLITICAL, ENVIRONMENTAL OR POPULATION-RELATED - - AND PROPOSES WAYS OF TACKLING THEM, ESPECIALLY THROUGH THE UPDATING AND STRENGTHENING OF THE UNITED NATIONS. IMPROVEMENTS IN THE STRENGTHENING OF THE UNITED NATIONS. IMPROVEMENTS IN THE UNITED NATIONS PEACE AND SECURITY SYSTEM AS WELL AS ITS
CAPACITY FOR DEALING WITH GLOBAL PROBLEMS ARE DISCUSSED AND CAPACITY FOR DEALING WITH GLOBAL PROBLEMS ARE DISCUSSED AND
THE AUTHOR STRESSES THE URGENT NEED FOR PROGRESS TOWARDS A THE AUTHOR STRESSES THE URGENT

09244 USEEM, M.

BUSINESS RESTRUCTURING, MANAGEMENT CONTROL, AND CORPORATE ORGANIZATION

THEORY ANO SOCIETY, $19(6)$ (DEC 90), 681-708

THIS ARTICLE EXAMINES SEVERAL INTERRELATED ISSUES IN CORPORATE RESTRUCTURING, MANAGEMENT CONTROL, AND CORPORATE ORGANIZATION. IT IS ARGUED THAT RESTRUCTURING SHOULD BE VIEWED AS PART OF A BROADER TRANSFORMATION IN THE ORGANIZATION OF CORPORATE OWNERSHIP AMD MANAGERIAL CONTROL. THE AUTHOR INDICATES THAT THE SCOPE OF RESTRUCTURING EXPANDED DURING THE MID- TO LATE-1980S, THAT IS AFFECTED A LARGE MUMBER OF MAJOR U.S. CORPORATIONS, AND THAT SUBSTANTIAL ORGANIZATIONAL CHANGE MAY BE INTRODUCED AS A BYPRODUCT OF THE RESTRUCTURING. FINALLY, IT IS ARGUED THAT THE TOP COMPANY MANAGEMENT HAS CONSIDERABLE DISCRETIONARY AUTHORITY IN DETERMINING COMPANY BEHAYIOR IN NOM-FINANCIAL AREAS AND THEREFORE ITS ROLE WILL BE CRITICAL IN SHAPING THE OUTCOME OF THE CURRENT WAVE OF RESTRUCTURING.

09245 USOWSKI, $P$.

INTELLIGENCE ESTIMATES ANO U.S POLICY TOWARD LAOS, 1960-63 INTELLIGENCE AND NATIONAL SECURITY, 6(2) (APR 91), 367-394. THE EXTENT TO WHICH EVEN THE FIRST-RATE INTELLIGENCE PRODUCT AFFECTS OR INFLUENCES POLICY VARIES AS

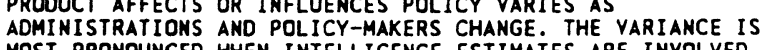
MOST PRONOUNCED WHEN INTELLIGENCE ESTIMATES ARE INVOLVED. THIS STUDY EXAMINES THE IMPACT OF THE CIA'S INTELLIGENCE ESTIMATES ON U.S. POLICY TOWARD THE ONGOING POLITICAL AND MILITARY UNREST IN LAOS DURING THE KENNEDY ADMINISTRATION. DURING THAT PERIOD, IT ANALYZES EACH ESTIMATE AND KEY POLICY DURING THAT PERIOD, IT ANALYZES EACH ESTIMATE AND KEY POL DECISION WITHIN THE OVERALL CONTEXT OF THE PRESIDENT' LAOTIAN POLICY OBJECTIVES IN ORDER TO REACH A BETTER
UNDERSTANDING OF INTELLIGENCE ESTIMATES AND THEIR ROLE IM SHAPING NATIONAL POLICY.

09246 UTAGAWA, R.

SIGNS OF CHANGE EMERGING IN JAPANESE DOMESTIC POLITICS JAPAN TIMES (HEEKLY INTERNATIONAL EDITION), $32(16)$ (APR $92), 9$.

AFTER THIRTY-FIVE YEARS OF LIBERAL DEMOCRATIC PARTY DOMINANCE, THE JAPANESE POLITICAL SYSTEM NEEDS A MAJOR OVERHAUL. THE DEFINING CHARACTERISTICS OF JAPANESE POLITICS-MOBOCRACY (EXCESS PUBLIC DEMANDS) AND LACK OF EFFECTIVE LEADERSHIP--MUST BE OVERCOME AND REPLACED HITH ORDERED DEMOCRACY HEADED BY INCORRUPTIBLE LEADERS.

09247 UVIN, P.

REGIME, SURPLUS, AND SELF-INTEREST: THE INTERMATIONAL POLITICS OF FOOD AID

INTERNATIONAL STUDIES QUARTERLY, 36(3) (SEP 92), 293-312. IT IS USUALLY ARGUED THAT FOOD AID DONATION IS MOTIVATED SOLELY BY THE ECONOMIC AND POLITICAL SELF-INTEREST OF THE DONOR, AND THAT IT IS EFFICIENT IN FURTHERING THESE INTERESTS. THIS ARTICLE ARGUES THAT BOTH THESE STATEMENTS ARE HRONG, AND GOES ON TO DEVELOP AM ALTERMATIVE INTERPRETATION CENTERIMG ON THE OPERATIONAL RELEVANCE OF DEVELOPMENTAL INTERNATIONL FOOD AID REGIME. FINALLY, THE DEVELOPMENTAL INTERNATIONL FOOD AID REGIME. FINALLY. THE STUDY OF INTERNATION RELATIONS ARE BRIEFLY DISCUSSED.

09248 UYS, $S$

CAN A DEMOCRATIC CONSTITUTION TAKE ROOT IN SA? SOUTH AFRICA INTERNATIONAL, 22(2) (OCT 91), 82-85. THIS ARTICLE ARGUES THAT THERE IS ALREADY CONSIDERABLE CONSENSUS BETHEEN THE NATIONAL PARTY AND THE AFRICAN NATIONAL CONGRESS ON THE PRINCIPLE OF AN INCLUSIVE, RATHER THAN A SIMPLE MAJORITARIAN CONSTITUTIONAL STRUCTURE FOR SOUTH AFRICA. THE EXPERIENCE OF THE NATIONAL PEACE
INITIATIVE, AND, IF IT TRANSPIRES, OF A SHARED INTERIM GOVERMMENT SHOUID FURTHER EMTRENCH THE FOUNDATIONS FOR DEMOCRACY IN SOUTH AFRICA. BUT THE CRITICAL FACTOR WILL NOT BE POLITICAL CONSENSUS, BUT A GRONING ECONOMY. ECONOMIC CONSENSUS ON RESTORING GROWTH IS AS VITAL, IF NOT MORE SO, THAN IS POLITICAL AGREEMENT.

09249 UYS, $S$

CAN A DEMOCRATIC CONSTITUTION TAKE ROOT IN SOUTH AFRICA? SOUTH AFRICA FOUNDATION REVIEW, 17 (10) (OCT 91), 1-3. THIS ARTICLE EXAMINES THE CHALLENGES AND PRESSURES THAT FACE NEGOTIATDRS WHO ARE TRYING TO HAMMER OUT A CONSTITUTION THAT WILL BE ACCEPTABLE TO SOUTH AFRICA'S BLACK MAJORITY AND ITS WHITE MINORITY. IT ADVOCATES POHER SHARING, AT LEAST IN THE TRANSITIONAL PHASE. A SHARED EXECUTIVE COULD BECOME A STABILIZING MECHANISM, BECAUSE GROUPS WOULD FEEL THAT THEIR INTERESTS WERE PROTECTED NOT ONLY BY RIGHTS ON PAPER, BUT BY ACTUAL REPRESENTATION IN GOVERNMENT BY THEIR OWN PEOPLE. IN ADOITION, THE MORE THE AFRICAN NATIONAL CONGRESS (ANC) AND OTHER MAJOR PLAYERS ARE DRAWM INTO THE TRANSITIOMAL PROCESS, THE DEEPER WILL BECOME THEIR VESTED INTEREST IN SEEING THAT IT SUCCEDS IT SUCCEEDS. FURTHERMORE, IF THE TRANSITION TO A DEMOCRATIC
SYSTEM IS TO TAKE PLACE. A SIMULTAENOUS REMOVAL OF OBSTACLES SYSTEM IS TO TAKE PLACE, A SIMULTAEM
TO ECONOMIC GROWTH MUST BE ENACTED.

09250 UYS, $S$.

THE ANC'S INTERNATIONAL STANDING

SOUTH AFRICA FOUNDATIOH REYIEW, 18(7) (JUL 92), 1-2.

THE SUPREME ADVANTAGE THE ANC ENJOYED OF OCCUPYING THE MORAL HIGH GROUND--FIGHTING A JUST WAR AGAINST AN UNJUST SYSTEM--IS FADING. THE MORE SOUTH AFRICA NORMALIZES, THE MORE BOTH THE ANC AND THE GOVERMMENT WILL BE JUDGED NOT ON THE PAST BUT ON PRESENT PERFORMANCE. ALTHOUGH THE ANC AND THE GOVERMMENT ARE INCREASINGLY BEING ASSESSED ON THEIR ECONOMIC BONA FIDES. THE WAY THAT BOTH RESPOND TO THE ENDEMIC VIOLENCE HILL BE CRITICAL TO THEIR INTERNATIONAL CREDIBILITY.

09251 VAISANEN, I.

CONFLICT AND COMSENSUS IN SOCIAL POL ICY DEVELOPMENT: A COMPARATIVE STUDY OF SOCIAL INSURANCE IN 18 OECD COUNTRIES, 1930-1985

EUROPEAN JOURNAL OF POLITICAL RESEARCH, 22(3) (OCT 92), 307-327.

IN THE STUDY OF WELFARE STATE DEVELOPMENT, DIVERGENT APPROACHES ASSIGN DIFFERING WEIGHTS TO CONSENSUS AMD CONFLICT AS WELL AS TO VARIOUS CAUSAL FACTORS BEHIND CHANGES IN SOCIAL POLICY. THIS PAPER MOVES BEYOND THE TRADITIONAL CONCENTRATION ON SOCIAL EXPENDITURES AND TESTS THE ROLE OF DIFFERENT CAUSAL FACTORS BY FOCUSING ON THE DEVELOPMENT OF SOCIAL RIGHTS IN THE AREAS OF WORKPLACE ACCIDENTS, SICKNESS, SOCIAL RIGHTS IN THE AREAS OF WORKPLACE ACCIDENTS,
AND UNEMPLOYMENT INSURANCE. HYPOTHESES DERIVED FROM

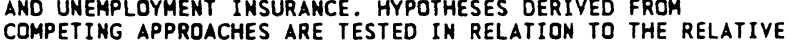
COMPETING APPROACHES ARE TESTED IN RELATION TO THE RELATIVE DEVELOPMENT OF SOCIAL RIGHTS IN THESE THREE POLICY AREAS
IN RELATION TO VARIATION IN SOCIAL RIGHTS IN ACCIDENT IN RELATIOM

09252 VALDES,

THE CURRENT SITUATION IN CUBA AND THE PROCESS OF CHANGE LATIN AMERICAN PERSPECTIVES, 18(2) (SPR 91), 10-17. THIS ARTICLE EXAMINES THE POLITICAL SITUÁTION IN CUBA AND THE IMPLICATIONS OF THE CHANGES TAKING PLACE IN EASTERN EUROPE, THE SOVIET UNION AND ELSEWHERE. ALTHOUGH CUBA IS UNDERGOING A PERIOD OF "RECTIFICATION" AND REFORM. THE AUTHOR ARGUES THAT CUBA'S PROGRAM IS INDEPENDENT OF PERESTROIKA OR THE CHANGES IN EASTERN EUROPE. REFORMS EMBARKED UPON INCLUDE INCREASED HEALTH CARE, CHILD CARE, BASIC FOOD PROGRAMS, AND TRANSPORTATION REFORM

09253 VALENCA, M.M. THE INEYITABLE CRISIS OF THE BRAZILIAN HOUSING FINANCE SYSTEM

URBAN STUDIES, 29(1) (FEB 92), 39-56.

THE AUTHOR SUMMARIZES THE MAJOR TRENDS THAT PRODUCED A CRISIS IN THE BRAZILIAN HOUSING FINANCE SYSTEM (SFH) DURING THE FIRST HALF OF THE 1980'S. HE ARGUES THAT THE CRISIS WAS INEVITABLE, DUE TO BOTH THE SFH'S ORIGINAL OPERATIONAL FORMAT AND SEVERAL INCONSISTENT MEASURES ADOPTED FOR

POLITICAL AND ECONOMIC EXPEDIENCY.

09254 VALENTINE, T.; DICKS, N.; MINETA, N.Y.; OLVER, J.;

THORNTON, R. PRO: SHOULD THE NATIONAL COMPETITIVENESS ACT BE APPROVED? CONGRESSIONAL DIGEST, $71(12$ ) (DEC 92) 302, 304, 306, 308,

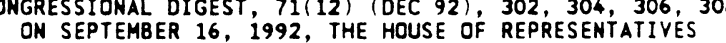
OEBATED H.R. 5232, THE NATIONAL COMPETITIVENESS ACT. THIS INA FAVOR OF THE BILL BY

CONGRESSMEN TIM VALENTINE, RAY THORNTON, JOHN OLVER, NORMAM $Y$. MINETA, AND NORM DICKS.

09255 VALLES, J.M.

POLITICAL SCIENCE IN SPAIN, 1960-1990: THE UNFIMISHED HISTORY OF ITS COMING OF AGE

EUROPEAN JOURNAL OF POLITICAL RESEARCH, 20(3-4) (DEC 91), 
431-444.

THE AUTHOR SUMMARIZES THE CIRCUMSTANCES THAT PREVENTED POLITICAL SCIENCE FROM DEVELOPING IN SPAIN AT THE SAME PACE AS IN OTHER WESTERN COUNTRIES. HE GIVES A DETAILED ACCOUNT OF HOW SPANISH POLITICAL SCIENCE EVOLVED AS A DISCIPLINE FROM 1960 TO 1990, TAKING 1975 AS THE DIVIDING POINT BETWEEN TWO DIFFERENT STAGES OF DEVELOPMENT BECAUSE THAT YEAR MARKED THE END OF FRANCD'S THE END OF FRANCO S LONG DICTATORSHIP AND THE BEGINNING OF MAJOR CHANGES IN THE POLITICAL SYSTEM. HE ALSO REVIEWS THE CHANGES IN THE ACADEMIC ORGANIZATION OF SPANISH POL ITICAL
SCIENCE, ITS RESEARCH CONTENT, AND ITS PERSONNEL RESOURCES

09256 VALLS-RUSSELL, $J$.

CONFRONTING COLLABORATION IN FRANCE

NEW LEADER, LXXY (8) (JUN 92) 9-11.

NEW LEADER, LXXV(8) (JUN 92), 9-11.

AGAINST PAUL TOUVIER, ONE OF THE LEADERS OF THE "MILICE," A

PARAMILITARY FORCE THAT WORKED CLOSELY HITH THE GESTAPO' IN MARSHAL PETAIN'S PRO-HITLER FRANCE. THE COURT'S ANMOUNCEMENT, WHICH COINCIDED WITH THE 5OTH ANNIVERSARY OF THE FIRST EXPULSION OF FRENCH JEWS TO NAZI EXTERMINATION CAMPS, WAS BITTERLY CRITICIZED BY THE FRENCH MEDIA. MANY SAH THE COURT'S DECISION AS EVIDENCE THAT THE FRENCH COURTS ARE INHERENTLY CONSERVATIVE, ONE STEP BEHIND THE REST OF SOCIETY, AND LENIENT HITH COLLABORATORS. OTHERS SAW THE DECISION AS AN INDICATION OF A LARGER UNDERLYING MALAISE: THE FRENCH
REFUSAL TO ACKNOHLEDGE THEIR ROLE IN THE ATROCITIES OF WORLD WAR II.

09257 VALLS-RUSSELL, J.

FRANCE'S SPREADING BLOOD SCANDAL

NEW LEADER, LXXXY (15) (NOY 92), 8-9.

IN FRANCE IT IS NOH EVIDENT THAT IN 1985 FRENCH HEALTH OFFICIALS ALLOWED THE DISTRIBUTION OF BLOOD KNOWN TO BE CONTAMINATED WITH THE HIV VIRUS. SINCE THEN, 300 HEMOPHILIACS WHO WERE TREATED WITH A CLOTING FACTOR FROM THE TAINTED SUPPLY AND 700 OTHER INDIVIDUALS WHO RECEIVED TRANFUSIONS IN THE COURSE OF OPERATIONS, HAVE DIED OF AIDS. TRANFUSIONS IN THE COURSE OF OPERATIONS, HAVE DIED OF AIDS.
MITTERAND HAS CALLED ON FRANCE'S PARLIAMENTARIANS TO CONVENE MITTERAND HAS CALLED ON FRANCE'S PARLIAMENTARIANS TO CONVENE
THE HIGH COURT OF JUSTICE, THE SOLE BODY EMPOWERED TO TRY THE HIGH COURT OF JUSTICE, THE SOLE BODY EMPOWERED TO TRY
GOVERHMENT MINISTERS. IT HAS BEEN REVEALED THAT THE HEALTH GOVERMMENT MINISTERS. IT HAS BEEN REVEALED THAT THE HEALTH
BUREAUCRACY'S FINANCIAL CONSIDERATIONS PREVAILED OVER ITS BUREAUCRACY'S FINANCIAL CONSIDERATIONS PREVAILED OVER ITS
CONCERN FOR HUMAN LIVES. COME MARCH, MANY VOTERS MAY WELL BE RELUCTANT TO AGAIN ENTRUST THE SOCIALIST PARTY WITH THEIR RELUCTA
FATE.

09258 VALLS-RUSSELL, J.

MARX AND MARCHAIS TOTTER IN FRANCE

NEW LEADER, LXXV(1) (JAN 92), 6-7.

THROUGHOUT THE POST-WAR PERIOD, FRENCH COMMUNISM FED ON THE CHAUVINIST, ANTI-AMERICAN MOOD THAT BECAME ALMOST A NATIONAL POLICY AFTER CHARLES DE GAULLE SEIZED POWER IN 1958. MARXISM APPEALED TO TRADE UNIONISTS, TEACHERS AND JOURNALISTS, WHO ADMIRED, ENVIED AND OESPISED THE UNITED STATES FOR ITS LARGER-THAN-LIFE SUCCESSES ON FILM SCREENS AND BATTLEFIELDS--UNTIL THE VIETHAM WAR PROVIDED THEM A STICK WITH WHICH TO BEAT AMERICA. IN THE LATE SEVENTIES, THE FRENCH COMMUNIST PARTY (PCF) OBTAINED 20.4 PERCENT OF THE VOTE IN THE PRESIDENTIAL ELECTION. HOWEVER, CHANGES HAVE SHEPT THROUGH EUROPE AND THE SOVIET UNION AND HAVE LEFT THE PCF AND ITS LEADER, GEORGES MARCHAIS, CLINGING TO OUTDATED IDEOLOGIES. THE PCF HAS LOST THE PUBLIC SUPPORT IT ONCE EN JOYED, GARNERING A MERE THREE PERCENT IN A RECENT POLL. NEVERTHELESS, MARCHAIS CONTINUES TO SPOUT A HARD LINE THAT FINDS INCREASINGLY FEW ADHERENTS.

09259 VALLS-RUSSELL, J.

NOT SUCH A WEE \OUI'

NEH LEADER, LXXV(13) (OCT 92 ), 13-14.

IN SPITE OF THE NARROW MARGIN WHICH APPROVED THE MAASTRICHT TREATY IN FRANCE THE VICTORY IS DECISIVE. SOME VIEW THE OUTCOME IN FRANCE AS A DEMONSTATION OF CONFIDENCE IN THE IDEAL OF A UNITED EUROPE. THE DRIVE TO DEFEAT MAASTRICHT HAS FOCUSED LARGELY ON NATIONALIST ASSERTIONS AND MAASTRICHT HAS FOCUSED LARGELY ON NATIONALIST ASSERTIONS
PHOBIA. THERE IS A FEELIING IN FRANCE THAT THE VOTERS ARE PHOBIA. THERE IS A FEEL ING IN FRANCE THAT THE VOTERS ARE
HOPING TO NUDGE THEIR MOST INFLUENTIAL POLITICIANS TOWARDS SOME KIND OF CONSENSUS (AS ON THE MAASTRICHT TTREATY) IN SOME KIND OF CONSENSUS (AS ON THE
ORDER TO TACKLE PRESSING PROBLEMS.

09260 VALLS-RUSSELL, J.

SHAKING UP THE FREMCH SOCIALISTS

SHAKING UP THE FRENCH SOCIALISTS

AFTER FRANCE'S RULING SOCIALIST PARTY SUFFERED DEYASTATING LOSSES IN THE 22 MARCH REGIONAL ELECTION, PRESIDENT FRANCOIS MITTERAND SAH THAT IT WAS TIME FOR A CHANGE. HIS SELECTION OF PIERRE BEREGOVOY AS PRIME MINISTER WAS PROBABLY THE BEST CHOICE POSSIBLE. BEREGOVOY, KNOWN FOR HIS HONESTY AND MODESTY, IMMEDIATELY LAUNCHED AN INTENSE ANTI-CORRUPTION CAMPAIGN AND PLEDGED TO TACKLE THE PROBLEMS WHICH PLAGUE VOTERS MOST: UNEMPLOYMENT, THE ENVIRONMENT, CRIME, AND ILLEGAL IMMIGRATION. WHILE THE NEW PRIME MINISTER HAS ONLY ELEVEN MONTHS TO WORK WITH BEFORE THE GENERAL, ELECTION, MANY FEEL THAT HE HILL REVIVE THE SOCIALISTS'
PRESIDENT JACQUES DELORS--TO TAKE OVER FROM MITTERAND.

09261 VAN DEN BULCK, J.

PILLARS AND POLITICS

HEST EUROPEAN POLITICS, 15(2) (APR 92), 35-55. THE BELGIAN POLITICAL SYSTEM IS USUALLY DESCRIBED AS PILLARISED. CAREFUL EXAMINATION DEMONSTRATES THAT IT ALSO SEEMS TO SHOW ALL THE CHARACTERISTICS OF NEO-CORPORATISM, EVEN MORE SO THAN COUNTRIES WHICH HAVE TRADITIONALLY BEEN SEEN AS HAVING STRONG NEO-CORPORATIST STRUCTURES. THIS ARTICLE ATTEMPTS TO EXPLAIN HOW BELGIAN PILLARISATION ARTICLE ATTEMPTS TO EXPLAIN HOW BELGIAN PILLARISATION
PROVIDES ALL OF THE PREREQUISITES FOR SUCCESSFUL NEOCORPORATISM IN POLICY SECTORS WHERE NEO-CORPORATISH USUALLY CORPORATISM IN POLICY SECTORS WHERE NEO-CORPORATISM USUALLY
CANMOT OCCUR. HOWEVER, IT IS ARGUED THAT NEO-CORPORATISM CANNOT OCCUR. HOHEVER, IT IS ARGUED THAT NEO-CORPORATISM CANNOT OFFER AN OVERALL EXPLANATION OF THE BELGIAN POLITICAL PROCESS. INSTEAD AN APPROACH IS CON
VARIOUS FORMS OF POLICY NETHORKS.

09262 VAN DEN HAAG, E.

WORSE THAN A CRIME

NATIONAL REVIEW, XLIV(1) (JAN 92), 48; 50-51.

RECENT REFORHS HAVE MADE CRIME VIRTUALLY RISK FREE

ERNEST VAN DEN HAAG CONSIDERS HOW TO MAKE JUSTICE SHIFT AND CERTAIN ONCE AGAIN. HE POINTS OUT THAT MINOR CRIMES HAVE BEEN EFFECTIVELY DECRIMINALI ZED. THE SYSTEM IS TOO BUSY WITH MAJOR ONES. PROSECUTORS ARE COMPELLED TO REDUCE CHARGES IF THE SYSTEM IS TO FUNCTION AT ALL. AFTER AN EXAMINATION OF THE SITUATION THE ARTICLE CONCLUDES THAT IF WE WANT TO DETER CRIME HE NEED MORE JUDGES, PROSECUTORS, AND PRISONS.

09263 VAN DUIN, $P$.

RACISM AND SOUTH AFRICAN BUILDING WORKERS, $1890-1940$ INTERNATIONAL REVIEW OF SOCIAL HISTORY, XXXVII (1) (1992), 59-90.

THIS ARTICLE DEALS HITH RACIAL ASPECTS OF THE LABOR MARKET AND LABOR RELATIONS IN SOUTH AFRICA'S BUILDING INDUSTRY, FOCUSING LARGELY, THOUGH NOT EXCLUSIVELY, ON
SKILLED BUILDING WORKERS ON THE WITHATERSRAND (SOUTHERN TRANSVAAL). DIFFERENT TRADE-UNION STRATEGIES ARE EXAMINED, AS PURSUED BY BUILDING TRADE UNIONS IN THE TRANSVAAL AS WELL AS PURSUED BY BUILDING TRADE UNIONS IN THE TRANSVAAL AS WELL
AS THE EASTERN CAPE AND NATAL, IN ORDER TO ADD A COMPARATIVE AS THE EASTERN CAPE AND NATAL, IN ORDER TO ADD A COMPARATIVE
OIMENSION. IN THE LATTER AREAS, SHORTLY AFTER WORLD WAR I, A DIMENSION. IN THE LATTER AREAS, SHORTLY AFTER WORLD WAR I,
WHITE-EXCLUSIONIST ORGANIZING POLICY WAS REPLACED IN SOME WHITE-EXCLUSIONIST ORGANIZING POLICY WAS REPLACED IN SOME
URBAN CENTERS BY A PRAGMATIC STRATEGY OF INCORPORATING "COLORED" ARTISANS (AFRICANS AND INDIANS CONTINUED TO BE "COLORED" ARTISANS (AFRICANS AND INDIANS CONTINUED EXCLUDED)' IN THE TRANSVAAL, ON THE OTHER HAND, THE RELATIY-INGRAINED RACISM ENSURED THE MAINTENANCE OF RACIALLYEXCLUSIVE TRADE UNIONISM IN THE BUILDING HISTORY.

09264 VAN REETH, G.; MADDERS, $K$

REFLECTIONS ON THE QUEST FOR INTERNATIONAL COOPERATION SPACE POLICY, 8(3) (AUG 92), 221-232

CHANGED POL ITICAL OBJECTIVES, STRAITENED ECONOMIC CIRCUMSTANCES AND AN ALTERED BALANCE OF CAPABILITY AND EXPERTISE IN SPACE ENDEAVORS HAVE TOGETHER PRODUCED MORE DISCUSSION OF THE NEED FOR INTERNATIONAL COOPERAITON THAN EVER BEFORE. HOWEVER, THE MEANING OF THE TERM HAS SUBTLY SHIFTED. INSISTING ON U.S. "LEADERSHIP" IS SELF-DEFEATING; WHAT IS INSTEAD FIRMLY DESIRED BY THE USA'S POLITICAL PARTNERS IS A BALANCED RELATIONSHIP IN WHICH EACH NATION MAKES AN IDENTIFIABLE CONTRIBUTION AND TAKES THE LEAD IN AT LEAST ONE OF A PACKAGE OF PROJECTS. IF THIS IS GOING TO HAPPEN, THERE MUST BE AN INTERNATIONAL FORUM OR FRAMEWORK IN WHICH PROJECTS CAN BE DISCUSSED AND AGREED. THIS IN TURN REQURIES INITIATIVE AT THE GOVERNMENTAL LEVEL.

09265 VAN ROSSZENDAAL, P.

THE EFFECT OF DOMINANT AND CENTRAL PARTIES ON CABINET COMPOSITION AND DURABILITY

LEGISLATIVE STUDIES QUARTERLY, 17(1) (FEB 92), 5-36. A TYPOLOGY OF PARLIAMENTARY GAMES ON THE BASIS OF THE COMBINED PRESENCE OR ABSENCE OF PARTIES THAT ARE DOMINANT AND CENTRAL PLAYERS IN THE GAME IS DEVELOPED. THE AUTHOR USES THE TYPOLOGY TO DERIVE PREDICTIONS WITH REGARD TO CABINET COMPOSITION AND DURABILITY AND TESTS THESE PREDICTIONS WITH DATA ON 382 CABINETS IN WESTERN MULTIPARTY DEMOCRACIES. THE RESULTS SHOW THAT THE APPROCAH DEVELOPED DEMOCRACIES. THE RESULTS SHOW THAT THE APPROCAH DEVELOPED HERE OFFERS A PROMISING PERSPECTIVE
CABINET COMPOSITION AND DURABILITY.

09266 VAN SCHENDEL, W.

THREE DELTAS--ACCUMULATION AND POVERTY IN RURAL BURMA, BENGAL AND SOUTH INDIA

SAGE PUBLICATIONS, 1991, 344.

TRADITIONALLY VIEHED AS A RESULT OF SCARCITY, THIS BOOK ASSERTS THAT POVERTY IS THE OUTCOME OF UNEOUAL RELATIONSHIPS BETHEEN GROUPS OF PEOPLE. RATHER THAN BELIEVING POVERTY IS A TEMPORARY STATE THAT HILL GRADUALLY DISAPPEAR, THE BOOK EXPLORES POVERTY AS AN INDISPENSABLE STRUCTURAL FEATURE OF THE SOCIETIES IN HHICH IT OCCURS. ACCORDINGLY, A SOLUTIOH MASS POVERTY MUST START FROM A PROPER UNDERSTANDING OF
SPECIFIC LOCAL RELATIONS AND HOW THEY ARE CONNECTED WITH RURAL CLASS CONFLICT, PROLETARIANIZATION, AGRARIAN 
CAPITALISM, STATE FORMATION, AND PATTERNS OF PERIPHERALIZATION.

09267 VAN STEENBERGEN, B.

TRANSITION FROM AUTHORITARIAN/TOTALITARIAN SYSTEMS: RECENT DEVELOPMENTS IN CENTRAL AND EASTERN EUROPE IN A

COMPARATIVE PERSPECTIVE

FUTURES, 24(2) (MAR 92), 158-166.

THE METHOD OF OF COMPARATIVE PROGNOSIS IS USED TO COMPARE THE TRANSITIONS FROM AN AUTHORITARIAN SYSTEM TO A DEMOCRATIC ONE IN THE COUNTRIES OF SOUTHERN EUROPE AND LATIN AMERICAN HITH THOSE OF CENTRAL/EASTERN EUROPE. THE AIM OF THIS EXERCISE IS TO SHOW WHAT THE COUNTRIES OF

CENTRAL/EASTERN EUROPE CAN LEARN FROM THE EXPERIENCES OF THE OTHER TWO REGIONS. WHAT ARE THE CHANCES, BUT ALSO WHAT ARE THE PITFALLS OF SUCH A RAPID TRANSITION TO DEMOCRACY ANO A MARKET ECONOMY? MUCH ATTENTION IS GIVEN HERE TO THE ROLE OF OUTSIDERS, AND ESPECIALLY TO THE USA AND THE EC COUNTRIES.

09268 VAN ZON, H.

ALTERMATIVE SCENARIOS FOR CENTRAL EUROPE

FUTURES, $24(5)$ (JUN 92 ), $471-482$.

IN THIS ARTICLE ALTERNATIVE SCENARIOS FOR CENTRAL EUROPE-HUNGARY, CZECHOSLOVAKIA AND POLAND--ARE DISCUSSED WITHIN A NATIONAL, AND AN INTERMATIONAL CONTEXT. IT IS SHOWN HOW THE VARIOUS DIMENSIONS OF CHANGE IN CEMTRAL EUROPE ARE CLOSELY INTERLINKED. THE SOLUTION OF THE MAJOR OUESTS THE REGION FACE, I.E. THE OUEST FOR ECONOMIC VIABILITY, THE QUEST FOR SOCIAL AND POLITICAL COHESION AND THE QUEST FOR A STABLE AND SECURE INTERHATIONAL ENVIRONMENT, OCCUR IN CONJUNCTION. IT IS ARGUED THAT THE COMPLETION OF THE VARIOUS TASKS EXHIBIT DIFFERENT TIMESCALES WHICH IN ITSELF MAY PROVOKE ADDITIONAL
PROBLEMS. MOREOVER, POTENTIAL SYNERGIES MAY EASILY TURN INTO SELF-DESTRUCTIVE DYNAMICS. BASED ON A COMPREHENSIVE ASSESSMENT OF THE PROBLEMS THE REGION FACES NOW AND MOST PROBABLY IN THE 15-20 YEARS TO COME, FIVE SCENARIOS ARE CONSTRUCTED WHICH HIGHLIGHT THE DRIVING FORCES THE REGION MAY FACE. DISTINGUISHED ARE THE LAISSEZ-FAIRE/CAPITALIST SCENARIOS, THE POPULIST-AUTHORITARIAN SCENARIO, THE LEANINGUPON-THE-WEST SCENARIO, THE SUSTAINABLE DEVELOPMENT SCENARIO, AND THE MUDOLING-ON SCENARIO.

09269 VAN ZYL SLABBERT, F.

DILEMMAS FOR DEMOCRACY IN SOUTH AFRICA

SOUTH AFRICA INTERNATIONAL, 23(1) (JUL 92), 4-10.

SOUTH AFRICA IS MOVING TOWARDS DEMOCRACY VIA A PROCESS DRIVEN BOTH BY PACTS AT LEADERSHIP LEVEL AND REFORM PRESSURES FROM BELOW. THERE IS NO GUARANTEE THAT A DEMOCRACY PRESSURES FROM BELOW. THERE IS NO GUARANTEE THAT A DEMOCRA
WILL IN FACT BE THE OUTCOME. ONE OF THE PROBLEMS IS THE WILL IN FACT BE THE OUTCOME. ONE OF THE PROBLEMS IS THE
DISAGREEMENT ABOUT WHAT DEMOCRACY ACTUALLY IS. THIS ARTICLE DISAGREEMENT ABOUT WHAT DEMOCRACY ACTUALLY IS. THIS ARTICLE
SUGGESTS THAT CERTAIN CONDITIONS WILL HAVE TO BE MET IN SUGGESTS THAT CERTAIN CONDITIONS WILL HAVE TO BE MET IN
ORDER FOR SOUTH AFRICA TO DEVELOP A CULTURE OF DEMOCRACY TO ORDER FOR SOUTH AFRICA
SUSTAIN A DEMOCRACY

09270 VANAGUNAS, S

THE USSR:' SOME THOUGHTS ON THE DELINE OF THE ULTIMATE ADMINISTRATIVE STATE

PUBLIC PRODUCTIVITY \& MANAGEMENT REVIEW, 15(3) (SPR 92). 281-288.

THE UNION OF SOVIET SOCIALIST REPUBLICS IS COMING APART. THOUGH THE FAILURE OF THE SOVIET POLITICAL ECONOMY IS ATTRIBUTABLE TO A VARITY OF COMPLEX FACTORS, IT IS APPARENT THAT TO A SUBSTANTIAL EXTENT THE USSR CAN BE CONSIDERED A CASE OF ADMINISTRATIVE FAILURE. SOVIET PUBLIC ADMINISTRATION BECAME INEPT AND INERT MAINLY BECAUSE OF IMPROPER AND EXCESSIVE POL ITICAL INTERFERENCE; LACK OF A RATIONAL PREDICTABLE LEGAL ENVIRONMENT; AND THE DEBILITATING EFFECTS OF PERVASIVE AND ENDEMIC CORRUPTION.

09271 VAMAIK, A.

REFLECTIONS ON COMMUNALISM AND NATIONALISM IN INDIA

NEW LEFT REVIEW, (196) (NOV 92), 43-64.
THE AUTHOR EXAMINES THE REASONS FOR THE PERSISTENCE OF COMMUNALIST SENTIMENT IN INDIA AND EXPLORES THE POSSIBILITIES FOR RESISTING IT. HE ARGUES THAT NEH DELHI'S OFFICIAL SECULARISH FAILS TO ACKNOWLEDGE EITHER THE USE OF RELIGIOUS APPEALS BY CONGRESS IN THE INDEPENDENCE STRUGGLE OR THE CRUCIAL ORIENTING ROLE OF RELIGIOUS IDENTITY IN INDIA TODAY. HE CAREFULLY CONSIDERS THE RELATIVIST ARGUMENTS OF THE ANTI-SECULARISTS, WHO ALLEGE THAT SECULARISM IS AN ALIEN IMPORT HITH NO PURCHASE ON INDIAN CONDITIONS BUT FINDS THEM TO BE EVEN MORE INADEQUATE TO A CRITICAL UNDERSTANDING OF TO BE EVEN MORE INADEQUATE TO A CRITICAL UNDERSTANDING OF
COMMUNALISM THAN OFFICIAL STATE SECULARISM. HE CONCLUDES COMMUNALISM THAN OFFICIAL STATE SECULARISM. HE CONCLUDES THAT HINDU COMMUNALISM IS VULNERABLE TO DEMOCRATIC AND CLASS BASED CHALLENGES BECAUSE IT THREATENS NOT ONLY THE COUNTRY'S 200 MILLION MUSLIMS BUT ALSO
ARE STIGMATIZED BY CASTE.

09272 VANBERG, V.J.; CONGLETON, R.D. RATIOMALITY MORALITY 'R.D. AMERICAN POLITICAL SCIENCE REVIEW, 86(2) (JUN 92), 418-431. THE AUTHORS EXPLORE THE MORALITY AND RATIONALITY ISSUE FROM AN AXELROD-TYPE PERSPECTIVE-THAT IS, IN TERMS OF RECURRENT-PRISONER'S-DILEMMA-TYPE GAMES AND BEHAVIORAL
STRATEGIES OR PROGRAMS FOR PLAYING THEM. THEY ARGUE THAT INTUITIVE NOTIONS OF RATIONALITY AND MORALITY CAN BE SHOWN TO BE MUTUALLY COMPATIBLE IF TWO ASSUMPTIONS ARE MADE: (1) MORALITY IS SPECIFIED AS A GENERAL BEHAVIORAL DISPOSITION PROGRAM WHOSE RATIONALITY IS DETERMINED IN COMPARISON TO ALTERNATIVE BEHAVIORAL PROGRAMS AND (2) THE RECURRENT GAME IS SPECIFIED AS A PRISONER'S DILEMMA GAME WITH AN EXIT OPTION. THEY PRESENT THE RESULTS OF A SIMULATION EXPERIMENT, SHOWING THAT A "MORAL PROGRAM" (ONE THAT NEVER DEFECTS BUT
EXITS IN RESPONSE TO AN OPPONENT'S DEFECTION) IS SUCCESSFUL EXITS IN RESPONSE TO AN OPPONENT'S DEFECTION) IS SUCCESSF IN COMPETITION WITH A
INCLUDING TIT FOR TAT.

09273 VANCLAY, F, ; LAWRENCE, G.

A BLUE-GREÉ POLITICS?

ARENA, 98 (1992), 10-14

A 1991 OUTBREAK OF ALGAL BLOOMS IN AUSTRALIA IS REPORTED TO HAVE KILLED HUNDREDS OF CATTLE AND SHEEP. THESE BLUEGREEN ALGAE ARE ALSO TOXIC TO HUMANS AND INFESTED WATER CANMOT BE TREATED BY BOILING. ANGAL BLOOMS POSE A SEVERE THREAT TO TOWN HATER SUPPLIES ANO TO THE HEALTH OF PEOPL SITUATION AND CONCLUDES THAT SO LONG AS RIVERS ARE VIEWED AS A NATURAL. WASTE AND RETICULATION SYSTEM RATHER THAN AS AN ESSENTIAL SOURCE. THERE WILL CONTUNIE TO BE WATER POLLUTION AND ALGAL BLOOMS.

09274 VANOERVEER, $P$.

AYODHYA AND SOMNATH: ETERNAL SHRINES, CONTESTED HISTORIES SOCIAL RESEARCH, 59(1) (SPR 92), 85-110

COMFL ICT OYER THE AYODHYA MOSOUE HAS LED TO YIOLENCE AND POLITICAL MANEUVERING AMONG INDIA'S HINDUS AND MUSLIMS, AS EACH RELIGION CLAIMS THE SAME HOLY SITE. IN 1984, THE VISHVA HINDU PARISHAD (VHP) BEGAN A CAMPAIGN TO REMOVE THE AYOOHYA MOSOUE FROM ITS PRESENT LOCATION, WHICH IS PURPORTED TO BE THE BIRTHPLACE OF THE HINDU GOD RAMA, AND TO REPLACE IT WITH A TEMPLE. THE VHP CLAIMS THAT THE MOSQUE, BUILT IN 1528, REPLACED A TEMPLE, WHICH HAD BEEN DEMOLISHED BY THE FIRS MUGHAL EMPEROR. POLITICALLY, THE VHP'S CAMPAIGN HAS BEEN CHAMPIONED BY THE BHARATIYA JANATA PARTY, WHICH HAS SUCCESSFULLY USED THE ISSUE TO GAIN MEMBERS AND VOTES AMONG THE HINDUS. THE DISPUTE OVER AYODHYA BROUGHT DOWN INDIA'S NATIONAL GOVERMMENT IN 1990 AND HAS ENDANGERED HINDU-MUSLIM RELATIONS MORE THAN ANY OTHER ISSUE SINCE PARTITION. IN PLEADING ITS CASE, THE VHP OFTEN CITES A PRECEDENT IN WHICH THE HINDU TEMPLE OF SOMANATHA WAS DESTROYED BY A MUSLIM RULER AND LATER RECONSTRUCTED. THE EMOTIONAL ISSUE SHOWS NO SIGNS OF A OUICK RESOLUTION, AND THE VIOLENCE IT INCITES IS LIKELY TO CONTINUE.

09275 VANGENT, A.

TURKEY EXTÉNDS A HELPING HAND

WORLD PRESS REVIEW, 39(7) (JUL 92), 12-13.

WORLD PRESS REVIEW, 39 (7) (JUL 92), 12-13.

THERE IS A NEH OPTIMISM IN ANKARA ABOUT THE
INTERMATIONAL ROLE OF TURKEY. AS THE COUNTRY SEEKS TO FORGE INTERNATIONAL ROLE OF TURKEY. AS THE COUNTRY SEEKS TO FORGE SOLID RELATIONS WITH THE NEWLY-INDEPENDENT CENTRAL ASI REPUBLICS, THERE IS HOPE THAT TURKEY MAY PROVIDE AN CENTRAL ASIAN REPUBLICS MORE TOWARD THAN THE WEST THAN THE MIDDLE EAST.

09276 VANGENT, A.

TURKEY'S CLAIM TO LEADERSHIP IN CENTRAL ASIA SWISS REVIEH OF WORLD AFFAIRS, 42(2) (MAY 92), 21-22. TURKEY, IRAN, AND PAKISTAN ARE COMPETING FOR POWER AND INFLUENCE IN THE ISLAMIC REPUBLICS OF THE FORMER SOVIET UNION. TURKEY IS MAKING SKILLFUL USE OF PROMISES TO THE MOSTLY-SECULAR CENTRAL ASIAN POWER ELITES TO HELP THEM LINK UP WITH HESTERN CIVILIZATION AND, AT THE SAME TIME, IS ASSURING THE HEST THAT IT WILL SERVE AS A BULLARK AGAINST ISLAMIC FUNDAMENTALISM. AS VISIONS OF A SINGLE HOMELAND FOR ALL TURKIC PEOPLES QUIETLY RESURFACE, TURKEY BELIEVES ITS CULTURAL LEADERSHIP OF ALL TURKIC-SPEAKING NATIONS IS INEVITABLE.

09277 VANGENT, A.

THO TURKISH TALES

SWISS REVIEW OF WORLD AFFAIRS, 42(7) (OCT 92), 6-8.

IN JULY 1992, TURKEY DEDICATED THE ATATURK DAM IN SOUTHEASTERN ANATOLIA. TECHNOLOGICALLY, POLITICALLY, AND ECONOMICALLY, IT IS THE LARGEST PROJECT EVER UNDERTAKEN BY THE REPUBLIC OF TURKEY; IT CONSTITUTES THE CORE OF THE COUNTRY'S AMBITIOUS SOUTHEAST ANATOLIA PROJECT, WHICH IS DESIGNED TO TRAMSFORM THE DRY REGION INTO A BREADBASKET HOWEVER, BECAUSE THE ATATURK DAM BLOCXS THE EUPHRATES RIVER, HOWEVER, BECAUSE THE ATATURK DAM BLE TGHBORING COUNTRIES DEPEND, IT THREATENS TO ON WHICH NEIGHBORING COUNTRIES OEPEND, IT 'S WATER RESOURCES. INTENSIFY THE DISPUTE OVER THE MIDDLE EAST'S WATER RESOURCES IN A TOTALLY DIFFERENT REALM, 1992 HAS WITNESSED A SPATE
ASSASSINATIONS OF TURKISH JOURNALISTS--ALL OF THEM EITHER ASSASSINATIONS OF TURKISH JOURNALISTS--ALL OF THEM EITHER KURDS OR REPORTERS INVESTIGATING GOVERMMENT INVOLVEMENT IN HUMAN RIGHTS VIOLATIONS AND THE TRAINING AND FINANCIN FUNDAMENTAL IST CONTRAS. PRIME MINISTER DEMIREL HAS CATEGOR ICALLY DENIED ANY GOVERNMENT INVOL YEMENT IN THE
MURDERS AND, IN THE NEXT BREATH, HAS CLAIMED THAT THE 
VICTIMS WERE NOT JOURNALISTS BUT "MILITANT IDEOLOGUES" IN DISGUISE.

09278 VANKOPPEN, P.J.

JUDICIAL POLICY-MAKING IN THE NETHERLANDS: THE CASE-BYCASE METHOD

WEST EUROPEAN POLITICS, 15(3) (JUL 92), 80-92.

THE DUTCH JUDICIARY, WHICH IS MODELED ON THE FRENCH,

PLACES A PREMIUM ON THE SEPARATION OF POWERS. ONE

MANIFESTATION OF THIS ADHERENCE TO THE STRICT SEPARATION OF

MANIFESTATION OF THIS ADHERENCE TO THE STRICT SEPARATION OF
POWERS IS THE PROHIBITION AGAINST JUDICIAL REVIEW. HOWEVER

POWERS IS THE PROHIBITION AGAINST JUDICIAL REVIEW. HOWEVER
SINCE EARLY IN THIS CENTURY, JUDGES IN THE ORDINARY COURTS SINCE EARLY IN THIS CENTURY, JUDGES IN THE ORDINARY COUR

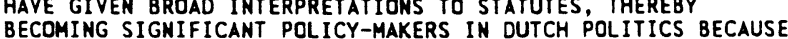
BECOMING SIGNIFICANT POLICY-MAKERS IN DUTCH POLITICS BECAUSE OF THE SYSTEM OF COALITION GOVERNMENTS. LAWS ARE DRAFTED
VAGUE TERMS, LEAVING INTERPRETATION TO THE COURTS, AND VAGUE TERMS, LEAVING INTERPRETATION TO THE COURTS, AND ISSUES ON WHICH THERE IS NO POSSIBILITY OF POLITICAL

09279 VANPRAAGH, D.

BULLETS AND BALLOTS IN ASIA

FREEDOM REVIEW, 23(5) (SEP 92), 9-12.

THE PAST YEAR HAS BEEN A TUMULTUOUS ONE FOR THAIS AND FILIPINOS. IN THAILAND. THOUSANDS OF PEOPLE CONFRONTED AND OVERCAME COMBAT TROOPS' THAT OPENED FIRE IN DEFENSE OF MILITARY BUREAUCRATS DESPERATELY TRYING TO PRESERVE THEIR POLITICAL DOMINATION. IN THE PHILIPPINES, VOTERS REJECTED TRADITIONAL POLITICIANS IN A POPULAR ELECTION. IF THESE TWO DISTINCTIVE SOCIETIES ARE ABLE TO STAY ON THE DEMOCRATIC ROAD, THEY WILL DEMONSTRATE IN DIFFERENT WAYS THAT POL ITICAL LIBERTY AND ECONOMIC OPPORTUNITY GO HAND-IN-HAND. IF THEY FAIL, IT WILL BE A SETBACK FOR ALL OF ASIA.

09280 VANWAARDEN, $F$.

DIMENSIONS AND TYPES OF POLICY NETHORKS

EUROPEAN JOURNAL OF POLITICAL RESEARCH, 21(1-2) (FEB 92),

29-52.

THIS PAPER OFFERS A REFINED, SYSTEMATIC CONCEPT OF STATEBUSINESS RELATIONS BASED ON THE "POLICY NETWORK" IDEA. THE MAJOR DIMENSIONS OF POLICY NETWORKS ARE PRESENTED AS (1) MAJOR DIMENSIONS OF POLICY NETWORKS ARE PRESENTED AS (1) STRUCTURE, (4) INSTITUTIONALIZATION, (5) RULES OF CONDUCT, (6) POWER RELATIONS, AND (7) ACTOR STRATEGIES. CERTAIN (6) POWER RELATIONS, AND (7) ACTOR STRATEGIES. CERTAIM POPULAR CONVENTIONAL POLICY-MAKING ARRANGEMENTS (E.G.'. SECTORAL CORPORATION, SPONSORED PLURALISM, CLIE
EXAMINED IN TERMS OF THE NETHORK DIMENSIONS.

09281 VANHAARDEN, $F$

THE HISTORICAL INSTITUTIONALIZATION OF TYPICAL NATIONAL PATTERNS IN POLICY NETWORKS BETWEEN STATE AND INDUSTRY EUROPEAN JOURNAL OF POLITICAL RESEARCH, $21(1-2)$ (FEB 92 ), 131-162.

USING EMPIRICAL EXAMPLES FROM THE UNITED STATES ANO THE NETHERLANDS, STATE-INDUSTRY POLICY NETWORKS ARE EXPLAINED BY NATIONALLY-SPECIFIC CHARACTERISTICS OF THE ACTORS INYOLVE: ORGANIZED SOCIETAL INTERESTS AND STATE AGENCIES. POLICY NETWORKS ARE SEEN AS THE PRODUCT OF DIFFERENT POLITICAL, ADMINISTRATIVE, AND CULTURAL INSTITUTIONS. THEIR HISTORICAL EMERGENCE IS DISCUSSED.

09282 VARGAS, $V$.

HOMEN: TRAGIC ENCOUNTERS WITH THE LEFT

REPORT ON THE AMERICAS, 25(5) (MAY 92), 30-34.

WOMEN IN LATIN AMERICA ARE FINDING THAT DESPITE THEIR YEARS OF INVOLVEMENT WITH THE PARTIES, THEY ARE UNABLE TO CHANGE IN ANY SUBSTANTIAL WAY THEIR AUTHORITARIAN AND EXCLUSIVE CHARACTER. THE AUTHOR RELATES THE CONFLICTIVE RELATIONSHIP BETHEEN WOMEN AND THE LEFT WHICH IS A STORY PROMOTING DEMOCRACY AS A WAY OF LIFE, NOT JUST A FORM OF GOVERNMENT. THE WOMEN'S MOVEMENT IS CHALLENGING THE INGRAINED AUTHORITARIAN TRADITIONS OF THE LEFT.

09283 VAROUFAKIS, $Y$

FREEDOM WITHIN REASON: FROM AXIOMS TO MARXIAN PRAXIS SCIENCE AND SOCIETY, 56 (4) (WIN 92), 440-466.

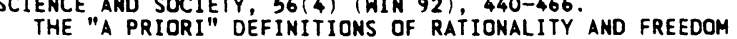
THAT PERMEATE ORTHODOX ECONOMICS IN PARTICULAR AND THE THAT PERMEATE ORTHODOX ECONOMICS IN PARTICULAR AND THE
LIBERAL DISCOURSE IN GENERAL HAVE IMPORTANT THEROETICAL LIBERAL DISCOURSE IN GENERAL HAVE IMPORTANT THEROETICAL
IMPLICATIONS. A HEGELIAN CRITIOUE OF AHISTORICAL APPROACHES IMPL ICATIONS. A HEGELIAN CRITIQUE OF AHISTORICAL APPROACHES
TO THE MEANING OF LIBERTY AND REASON REVEALS INSURMOUNTABLE PROBLEMS THAT THE AXIOMATIC APPROACH INFLICTS UPON GAME PROBLEMS THAT THE AXIOMATIC APPROACH INFLICTS UPON GAME THEORY, CONTRACTARIAN THEORIES OF JUSTICE AND RATIONAL CHOICE MARXISH. WHILE THE POSTMODERN CRITIQUE AND THE METHOD
OF DECONSTRUCTION ARE USEFUL, THE MEANING SOUGHT IS BEST OF DECONSTRUCTION ARE USEFUL, THE MEANING SOUGH
GLEANED THROUGH MARX'S CONCEPTION OF PRAXIS.

09284 VARVITSIOTES, I.

SECURITY IN THE MEDITERRANEAN AND THE BALKANS

MEDI IERRANEAN OUARTERLY: A JOURNAL OF GLOBAL ISSUES, 3(1)

WIN 92 ), 25-34.

THE BALKAN REGION IS BESET BY SECURITY THREATS OF BOTH AN EXTERNAL AND INTERNAL NATURE. EXTERNAL THREATS INCLUDE THE ARMED FORCES OF THE SOVIET UNION (OR ITS SUCCESSOR), AND
THE ARAB-ISRAEL CONFLICT, WHICH OPERATES AS A DESTABILIZING FACTOR ON THO FRONTS: SERVING AS A CATALYST FOR ARAB SOLIDARITY AGAINST ISRAEL, AND BECOMING A CAUSE OF INTRAARAB CONFLICTS. INTERNAL THREATS INCLUDE: ECONOMIC DEPRESSION IN BULGARIA THAT UNDERLIES THE COUNTRY'S PRONOUNCED POLITICAL INSTABILITY; SLOW AND PAINFUL DOMESTIC POLITICAL FERMENT IN ALBANIA, CHARACTERIZED BY THE REGIME'S DETERMINATION TO REPLACE OLD-FASHIONED STALINISM WITH MODERNDAY NATIONAL CHAUVINISM; GREEK-TURKISH DIFFERENCES THAT HAVE, DAY NATIONAL CHAUVINISM; GREEK-TURKISH DIFFERENCES THAT
AS THEIR ORIGIN, THE 1974 OCCUPATION BY FORCE OF THE AS THEIR ORIGIN, THE 1974 OCCUPATION BY FORCE OF THE
NORTHERN PART OF CYPRUS; AND TENSIONS IN YUGOSLAV-ALBANIAN NORTHERN PART OF CYPRUS; AND TENSIONS IN YUGOSLAY-ALBANIAN
RELATIONS THAT ARE GENERATED ESSENTIALLY BY MINORITY ISSUES. RELATIONS THAT ARE GENERATED ESSENTIALLY BY MINORITY ISSUES.
ALL OF THE THESE PROBLEMS CONSTITUTE FESTERING SOURCES OF ALL OF THE THESE PROBLEMS CONSTITUTE FESTERING SOURCES OF
INSTABILITY AND DISCERNIBLE RISKS FOR CROSS-BORDER CONFLICS INSTABILITY AND DISCERNIBLE RISKS FOR CROSS-BORDER CONFLICS
IN THE BALKANS. THE BEST POSSIBLE REMEDY FOR MANY OF THESE IN THE BALKANS. THE BEST POSSIBLE REMEDY FOR MANY OF THESE THREATS

09285 VASILEVA, D.

BULGARIAN TURKISH EMIGRATION AND RETURM

INTERNATIONAL MIGRATION REVIEW, XXVI (2) (SUM 92), 342-352.

THE HISTORY OF THE EMIGRATION OF BULGARIAN MUSLIM TURKS

TO TURKEY IS MORE THAN A CENTURY OLD. THE VIOLATION OF THE

HUMAN RIGHTS OF ETHNIC TURKS BY THE TOTALITARIAN REGIME DURING THE 1980 S RESULTED IN THE MOST MASSIVE AND UNPREDICTABLE MIGRATION WAVE EVER SEEN IN THAT HISTORY. THIS ARTICLE EXAMINES THE COMPLEXITY OF FACTORS AND MOTIVATIONS OF THE 1989 EMIGRATION WHICH INCLUDED ALMOST HALF OF THE ETHNIC TURKS LIVING IN BULGARIA AND CONSTITUTING UNTIL THAT TIME 9 PERCENT OF THE TOTAL POPULATION. THE AUTHOR CONSIDERS THE STRONG AND LONG-LASTING EFFECT OF THIS EMIGRATION-FOLLOHED BY THE SUBSEQUENT RETURN OF HALF OF THE EMIGRANTS AFTER THE FALL OF THE REGIME--BOTH ON BULGARIA'S ECONOMY AND ON THE POLITICAL LIFE OF THE SOCIETY. THE ARTICLE AIMS ALSO AT PROVIDING A BETTER UNDERSTANDING OF THE CHARACTER OF ETHNIC CONFLICTS IN POST-TOTALITARIAN EASTERN EUROPE.

09286 VASILLOPULOS, C.

FUMCTIONAL INTEGRATION AND THE MIDOLE EAST JOURNAL OF POLITICAL AND MILITARY SOCIOLOGY, 20(2) (WIM 92 ), $179-198$

FUNCTIONAL INTEGRATION, A COMBINATION OF POLITICAL ECONOMY AND MANAGEMENT THEORY, STRESSES THAT EFFECTIVENESS, DOING THE RIGHT THING, OFTEN IS MORE CRUCIAL THAN EFFICIENCY DOING CONVENTIONAL THINGS RIGHT. FUNCTIONAL INTEGRATION IS
THE ABILITY TO ACHIEVE EFFECTIVENESS AND CONTROL RIVALS THE ABILITY TO ACHIEVE EFFECTIVENESS AND CONTROL RIVALS INDIRECTLY BY DEFINING THE PLAYING FIELD AND THE RULLES OF THE GAME. AS THEY PURSUE EFFECTIVENESS, OFTEN IGNORING
CONVENTIONAL "EFFICIENCY," DOMINANT PONERS IMPART PERVERSE CONVENT IONAL "EFFICIENCY," DOMINANT POHERS IMPART PERVERSE
INCENTIVES TO RIVALS AND INDUCE THEM TO ADOPT THEIR TACTICS INCENTIVES TO RIVALS AND INDUCE THEM TO ADOPT THEIR AND STRATEGIES. IN A SENSE; HHEN THE DOMINANT POHERS
REDIRECT THEIR COMPETITORS, FOCUS ON HOW TO DO THINGS RIGHT INSTEAD OF WHAT IS THE RIGHT THING TO DO, THEY CONVERT THESE COMPETITORS INDIRECTLY INTO FUNCTIONAL SUBSIDIARIES AND STEER THEM INTO EFFICIENCY WITHOUT EFFECTIVENESS. IN TODAY;S EMERGING GLOBAL INTERDEPENDENCE, THE STRATEGY HAS WORLDWIDE IMPLICATIONS AND DESERT STORM IS ONLY ONE EXAMPLE OF THE POTENTIAL EFFECTS OF FUNCTIONAL INTEGRATION. THE PARADIGM COULD CONTRIBUTE TO THE DEBATE ON APPROPRIATE DEVELOPMENT AND REGIONAL SECURITY AND IDENTIFY FACTORS THAT AFFECT ECONOMIC AND POLITICAL BLOCKS.

09287 VATIKIOTIS, M.

A BIT MORE BACKBONE

FAR EASTERN ECONOMIC REVIEN, 153(31) (AUG 91), 10-11. UNDER PRESSURE TO SHARPEN THE ROLE OF THE ASSOCIATION OF SOUTHEAST ASIAN NATIONS (ASEAN), THE MINISTERS OF THE REGIONAL ORGANIZATION MET ON 19 JULY TO ESTABLISH THEIR RESOLVE TO ENHANCE ECONOMIC COOPERATION, STRENGTHEN INSTITUTIONAL SUPPORT AND RE-EXAMINE EXTERNAL TIES. THE FACT INSTITUTIONAL SUPPORT AND RE-EXAMINE EXTERNAL TIES. THE FACT
THAT THE SOVIET UNION AND CHINA HERE INVITED TO THE MEETING FOR THE FIRST TIME AND THAT SOUTH KOREA WAS ACCEPTED AS A FOR THE FIRST TIME AND THAT SOUTH KOREA WAS ACCEPTED AS A
FULL DIALOGUE PARTNER IS EVIDENCE OF ASEAN'S DESIRE TO ADAPT FULL DIALOGUE PARTHER IS EVIDENCE OF ASEAN'S DESIRE TO ADAP
TO GLOBAL CHANGES. HOWEVER, THE OPTIMISM OF THE PREVIOUS TO GLOBAL CHANGES. HOWEVER, THE OPTIMISM OF THE PREVIOUS YEAR HAS DECLINED AS THE GULF WAR, THE SOVIET UNION'S
DECLINE, THE BREAKDOWN OF INTERNATIONAL TRADE TALKS, AND THE ONSET OF GLOBAL ECONOMIC POLARIZATION PERSUADE ASEAM GOVERMMENTS OF A THREAT TO THEIR NEW-FOUND DYNAMISH AND

9288 VATIKIOTIS, $M$.

A CODE FOR THE ROYALS

FAR EASTERN ECONOMIC REVIEW, 155(10) (MAR 92), 8-9.

AFTER A PERIOD OF COMPARÁIIVE CALM FOLLOHING THE 1983 CONSTITUTIONAL CRISIS, MALAYSIA HAS BEEN GALVANIZED FOR ANOTHER DUEL BETHEEN THE MALAY POLITICAL ESTABLISHMENT AND THE MALAY SULTANS. IN WHAT SENIOR OFFICIALS OF THE RULING UNITED MALAYS NATIONAL ORGANIZATION (UNMO) DESCRIBED AS A
"HISTORIC" EVENT, A DELEGATION OF PARTY LEADERS MET SEVEN OF MALAYSIA'S NINE HEREDITARY RULERS ON 25 FEBRUARY AND PRESENTED A MEMORANDUM ALLEGING INTERFERENCE BY THE RULERS IN POLITICS AND BUSINESS. AMONG THE ALLEGATIONS RAISED BY UNMO IN THE MEMORANDUM HERE ALLEGED PRESSURE ON STATEGOVERNMENT OFFICIALS AND ATTEMPTS TO INFLUENCE THEIR 
APPOINTMENT; INVOL VEMENT IN BUSINESS AND GAMBLING; AND THE USE OF THE PRESS TO EXPOSE THEIR DIFFERENCES WITH CERTAIN OFFICIALS. FOLLOWING THE MEETING, UNMO LEADERS ANNOUNCED THAT THE RULERS HAD AGREED TO CONSIDER A WRITEN COOE GOVERNING THEIR CONDUCT. HOWEVER, SOURCES ON BOTH SIDES OF THE DEBATE INSIST THAT THIS IS NOT A MOVE TO PREPARE MALAYS FOR THE FUTURE REPLACEMENT OF THE MONARCHY AS THE HEAD OF STATE.

\section{VATIKIOTIS, M.}

ACTION AT LAST

FAR EASTERN ECONOMIC REVIEH, 155 (5) (FEB 92), 10-11. ASEAN LEADERS CONCLUDED THEIR FOURTH SUMMIT WITH A PLEDGE TO "MOVE TOWARDS A HIGHER PLANE" OF POLITICAL AND ECONOMIC COOPERATION. BREAKING AN OLD HABIT OF SHUNNING SPECIFIC PLANS OF ACTION, THE ASEAN HEADS OF GOVERNMENT 作 THEM TO CLOSER ECONOMIC COOPERATION AND A COMMITMENT TO SET UP AN ASEAN FREE TRADE AREA WITHIN 15 YEARS. RECOGNIZING THAT A PAST STUMBLING BLOCK HAS BEEN THE DIFFICULTY OF
ACHIEVING A FULL CONSENSUS ON HOW TO PROCEED, THE AGREEMENT ACHIEVING A FULL CONSENSUS ON HOW TO PROCEED, THE AGREEMENT
STATES THAT "THO OR MORE MEMBERS MAY PROCEED FIRST" WITH THE STATES THAT "THO OR MORE MEMBERS MAY PROCEED FIRST" WITH
IMPLEMENTATION OF COOPERATIVE MEASURES IF OTHER MEMBER IMPLEMENTATION OF COOPERATIVE MEASURES IF OTHER MEMBER STATES ARE NOT READY. THE TEXT OF THE AGREEMENT COVERS
COOPERATION IN TRADE, INDUSTRY, FINANCE AND BANKING, AS WELL COOPERATION IN TRADE, INDUSTRY, FINANCE AND BANKING, AS DEVELOPMENT OF SUB-REGIONAL GROWTH AREAS, BOTH WITHIN ASEAN DEVELOPMENT OF SUB-REGIONAL GROWTH AREAS, BOTH WITHIN ASEAN AND BETWEEN ASEAN AND NON-ASEAN STATES. THE ULTIMATE AIM IS
TO CREATE A SINGLE ASEAN MARKET COMPRISING SOME 330 MILLIOM TOOPLE AND A COMBINED GNP IN EXCESS OF US\$300 BILLION.
PEOPL

09290 VATIKIOTIS, $M$

AGAINST THE DODS

FAR EASTERM ECONOMIC REVIEW, 155(3) (JAN 92), 23-26.

IN PENINSULAR MALAYSIA'S' MORTHERN STATE OF KELANTAN, AN ISLAMIC STATE GOVERNMENT IS STRUGGLING TO FIND A PATH TO ISLAMIC RULE--AND ECONOMIC DEVELOPMENT. THE ATTEMPT IS BEING CLOSELY MONITORED BY NEIGHBORING COUNTRIES, INCLUDING THAILAND WHICH HAS HAD TROUBLE IN THE PAST WITH MUSLIMS IN ITS SOUTHERN PROVINCES. THE RULING PARTI ISLAM (PAS) HAS BEEN CAREFUL TO EXERCISE MODERATION IN ITS INTRODUCTION OF ISLAMIC PRINCIPLES AND IS TRYING TO ATTRACT FOREIGN INVESTMENT. EVEN SO THE STATE REMAINS FAR BEHIND MOST OF PENINSULAR MALAYSIA IN INCOME LEVELS AND INDUSTRIALIZATION. STATE OFFICIALS ADMIT THEY MAY HAVE TO RAISE TAXES IN 1992 , HHILE LOCALS COMPLAIN THEY ARE BEING ASKED TO PAY DUTIES AND RATES THEY CLAIM HERE NEVER LEVIED BEFORE.

09291 VATIKIOTIS, $M$.

APPLES OF DISCONTENT

FAR EASTERN ECONOMIC REVIEH, 155(14) (APR 92), 11.

OFFICIALS FROM BOTH THE UNITED STATES AND MALAYSIA TACITLY ACKNOWLEDGE THAT BILATERAL RELATIONS, NEYER TOO WARM AT THE BEST OF TIMES, ARE PRESENTLY FAR FROM PERFECT. THE AT THE BEST OF TIMES, ARE PRESENTLY FAR FROM PERFECT. THE FACT THAT MALAYSIAN PRIME MINISTER DATUK SERI MAHATHI MOHAMAD WAS "UNAVAILABLE" TO TAKE A CALL FROM U.S. PRESIDENT GEORGE BUSH WILE BUSH WAS IN SINGAPORE IN JANUARY COMBINES HITH MALAYSIA'S SUDDEN PREOCCUPATION WITH THE RED COLORING OF U.S. HASHINGTON STATE APPLES TO CREATE A STRANGE ATMOSPHERE OF TENSION. APPARENTLY, THE ROOT OF THE PROBLEM IS MAHATHIR'S PERCEPTION THAT THE UNITED STATES PLAYED A KEY ROLE IN PERSUADING ASIAN COUNTRIES NOT TO ACCEPT HIS PROPOSED EAST ASIA ECONOMIC CAUCUS (EAEC). HHICH ENVISAGED A GROUPING OF ASIAN COUNTRIES INCLUDING JAPAN. HOWEVER, MOST ANALYSTS ARGUE THAT THE IMPORTANCE OF THE UNITED STATES TO MALAYSIA IN TERMS OF TRADE AND INVESTMENT MAKES IT IMPROBABLE THAT MALAYSIA WILL PURSUE A FULL SCALE RIFT WITH THE UNITED STATES.

09292 VATIKIOTIS, M.

BRAVE NEH HORLD

FAR EASTERN ECONOMIC REVIEN, 155(4) (JAN 92), 19-20,

AS THE ASSOCIATION OF SOUTH EAST ASIAN MATIONS (ASEAN)

STRUGGLES TO FORGE MEANINGFUL COOPERATIOM AMONG ITS SIX

MEMBERS WHICH CLAIM COMMON VALUES AND SHARE SIMILAR LEVELS

OF DEVELOPMENT, THE FOUR REMAINING NATIONS OF SOUTHEAST ASIA-VIETNAM, LAOS, CAMBODIA, AND BURMA--WANT TO JOIN THE ORGANIZATION AND TURN A SUB-REGIONAL GROUPING INTO A REGIONAL BLOC. THE AMBITIOUS CALLS OF SOME FOR REGIOMAL ECONOMIC, POL ITICAL, AND MILITARY INTEGRATION AMONG THE TEN MATOMS, POLITICAL, AND MILITARY INTEGRATION AMONG THE DIFFERENCES OF OPINION ON SUCH ISSUES AMONG THE EXISTING DSEAN STATES.

09293 VATIKIOTIS, $M$

CREED FOR SURVIVAL

FAR EASTERN ECONOMIC REVIEH, 155(41) (OCT 92), 18. HASSANAL BOLKIAH CELEBRATED HIS 25TH YEAR AS THE SULTAN OF BRUNEI WITH A PROCESSION THROUGH STREETS LINED WITH THOUSANDS OF HIS SUBJECTS. PERHAPS BECAUSE BRUNEI IS GOVERNED BY A UNIQUELY PRESERVED ABSOLUTE MONARCHY, OBSERVERS EXPECTED THE SULTAN TO MAKE SOME CONCESSION TO THE MODERN POLITICAL AGE. INSTEAD, HE DECLARED BRUNEI'S LONG
HISTORY "HAS PROVEN THAT THE SYSTEM OF MONARCHY, WHICH WE
HAVE PRACTICED ALL ALONG, IS STRONG AND HAS BEEN SUCCESSFUL IN BRINGING BENEFITS TO THE PEOPLE." DUE TO THE SUSPENSIDM OF THE COUNTRY'S CONSTITUTION IN 1962 THE SULTAN HAS RULED THROUGH EMERGENCY DECREES SINCE HE ASCENDED THE THRONE IN 1967. HOWEVER, MODERN BRUNEI APPEARS TO BE FREE OF POPULAR POLITICAL URGES. SINCE 1990 THE SULTAN HAS MOVED TO CONSOLDATE DOMESTIC MUSLIM SUPPORT FOR THE MONARCHY WHILE PROMOTING BRUNEI AS AN INTERESTED PARTICIPANT IN WORLD AFFAIRS.

09294 VATIKIOTIS, M.; REES, J.

CULTURAL CRINGE

FAR EASTERN ECONOMIC REVIEH, 153(32) (AUG 91), 13-14. AN AUSTRALIAN INITIATIVE TO COOL A LONG SIMMERING ROW BETWEEN CANBERRA AND KUALA LUMPUR MOVED CLOSER TO RESOLUTION FOLLOWING THE RECENT VISIT OF AUSTRALIA'S FOREIGN MINISTER GARETH EVANS TO MALAYSIA. HOWEVER, WHILE EYANS' MID-JULY VISIT AS A SPECIAL ENVOY OF PRIME MINISTER BOB HAWKE DREW A CAUTIOUS WELCOME FROM SENIOR MALAYSIAN POLITICIANS, IT ALSO UNLEASHED A STREAM OF CRITICISM FROM THE AUSTRALIAN MEDIA. THE SOURING OF TIES APPEARS TO STEM FROM MALAYSIAN PRIME THE SOUR ING OF TIES APPEARS TO STEM FROM MALAYSIAN PRIM MINISTER DATUK SERI MAHATHIR MOHAMAD'S OBJECTION TO
AUSTRALIAN MEDIA PORTRAYALS OF MALAYSIA. THESE RANGE FROM AUSTRALIAN MEDIA PORTRAYALS OF MALAYSIA. THESE RANGE FROM POLICY TO A DRAMA SERIES SET IN A FICTITIOUS SOUTHEAST ASIAN COUNTRY WHICH MANY BELIEVE IS AT LEAST PARTLY MODELLED ON MALAYSIA. WHETHER THE EVANS MISSION ACCOMPLISHED ITS TASK MALAYSIA. WHETHER THE
REMAINS TO BE SEEN.

09295 VATIKIOTIS, $M$

DOUBLE BLOW
FAR EASTERN ECONOMIC REVIEN, 155(47) (NOV 92), 13 . THE RECENT ANNOUNCEMENT THAT BOTH OF SINGAPORE'S DEPUTY PRIME MINISTERS HAVE CANCER HAS THROHN THE NATION'S POLITICAL FUTURE INTO UNCERTAINTY. AS SOON AS NEWSPAPERS REPORTED THAT BOTH LEE HSIEN LOONG, 40, AND ONG TENG CHEONG, 56, WERE AFFLICTED WITH CANCER, SPECULATION BEGAN ABOUT SIMGAPORE'S FUTURE POLITICAL COMPLEXION. LEE, THE ELDEST SON OF FORMER PRIME MINISTER LEE KUAN YEW, IS PRE-EMINENT AMONG THE NATION'S NEW GENERATION OF LEADERS AND WAS HIDELY PERCEIVED AS THE ONE MOST LIKELY TO SUCCEED GOH CHOK TONG AS PRIME MINISTER. POLITICAL OBSERVERS SUGGEST THAT LEE'S ILLNESS HAS AN IMMEDIATE BEARING ON THE RUN-UP TO BYELECTIONS EXPECTED IN MARCH 1993. HIS INABILITY TO CAMPAIGN MAY HURT THE RULING PARTY. IN THE LONGER TERM, LEE'S ILLNESS RAISES QUESTIONS ABOUT POLITICAL SUCCESSION--AT LEAST UNTIL A CLEAN BILL OF HEALTH IS DECLARED. AN OBSERVATION MADE A CLEAN BILL OF HEALTH IS DECLARED. AN OBSERVATION MADE LEADERS OF MINISTERIAL CALIBER HAS SUDDENLY TAKEN ON A NEW URGENCY.

09296 VATIKIOTIS, M

EYE ON THE ISLANDS

FAR EASTERN ECONOMIC REVIEW, 151(27) (JUL 91), 19. ANOTHER ROUND OF TALKS AIMED AT SORTING OUT THE TANGLED WEB OF INTERESTS IM THE SOUTH CHINA SEA WIL BE HELD IN INDONESIA IN MID-JULY. THIS, THE SECOND WORKSHOP TO BE HELD SINCE JAKARTA LAUNCHED ITS SOUTH CHINA SEA INITIATIVE LAST YEAR, WILL BRING TOGETHER OFFICIALS FROM CHINA AND VIETMAM, AS WELL AS ASEAN COUNTRIES WITH COMPETING TERRITORIAL CLAIMS SOVEREIGNTY OVER ALL THE ISLANDS IN THE SOUTH CHINA SEA IS A SIGN OF PROGRESS. HOWEVER, THE CHINESE INS I STENCE THAT THE DISCUSSIONS ARE ONLY "AN EXCHANGE OF VIENS AMONG SCHOLARS" AND THE SUBTLE CRITICISM OF JAKARTA FOR EMPHASIZING VIETNAM'S PARTICIPATION AHEAD OF CHINA'S ARE BOTH SIGNS THAT CHINA IS STILL LESS THAN ENTHUSIASTIC ABOUT GRANTING CONCESSIONS IN THE SOUTH CHINA SEA.

09297 VATIKIOTIS, M.

NEEDED RENEWAL BRINGS ANXIETY

FAR EASTERN ECONOMIC REVIEH, 151(16) (APR 91), 35-36. THE APPROACH OF INDONESIA'S 1992 ELECTIONS FINDS THE REPRESENTATIVE ASSEMBLY, THE DPR, IN A QUIETLY CONFIDENT MOOD. HILE PLEASED HITH THE STEADY GROWTH AND FUTURE POTENTIAL OF THE NATION'S ECONOMY, SOME ECONOMISTS AND POLITICIANS ARE BEGINNING TO QUESTION THE ABILITY OF PRESIDENT SUHARTO'S NEW ORDER GOVERNMENT TO CONTINUE TO RULE IN THE PRAGMATIC AND BENEFICIAL FASHION IT HAS DONE IN THE PAST THO-AMD-A-HALF DECADES. FURTHERMORE, THE IMEYITABLE TRANSITIOM OF POHER THAT WIIL TAKE PLACE WHEM SUHARTO 70 TRANSITION OF POWER THAT WILL TAKE PLACE WHEN SUHARTO, 70, STEPS DOHN WORRIES MANY OBLLR TAKE PLACE WHEN SUHARTO MAY TAKE PLACE AT A TIME WHEN INDONESIA IS ALREADY FEELING
THE STRESSES OF THE SHIFT TOWARDS AN INDUSTRIALIZED ECONOMY THE STRESSES
AND SOCIETY.

09298 YATIKIOTIS, M.

PERMAMENT PRESENCE

FAR EASTERN ECOMOMIC REYIEH, 155(2) (JAN 92), 22 FACED WITH CONCERHS THAT THE U.S. PULLOUT FROM ITS PHILIPPINE BASES HOULD CREATE A POHER VACUUM IN SOUTHEAST ASIA, PRESIDENT GEORGE BUSH VISITED SINGAPORE ON 3-5 JANUARY ARMED WITH NEW INITIATIVES AIMED AT REASSURING U.S. ALLIES IN THE REGION THAT WASHINGTON HAS A COMMITMENT TO THEIR 
SECURITY AND PROSPERITY. SECURITY WAS HIGH ON THE AGENDA AS SINGAPORE HAS SPEARHEADED CONCERN ABOUT WASHINGTON'S REDUCED SECURITY COMMITMENT TO THE REGION IN THE WAKE OF THE MOVE SECURITY COMMITMENT TO THE REGION IN THE WAKE OF THE MOVE OUT OF THE PHILIPPINES. OF THE SIX ASEAN NATIONS, SINGAPORE
HAS ALSO PROVED THE MOST WILLING TO PLAY HOST TO REDEPLOYED HAS ALSO PROVED THE MOST WILLING TO PLAY HOST TO REDEPLOYED U.S. FORCES IN THE REGION. HOWEVER IT IS NOT YET CLEAR MILITARY SIGNIFICANCE SHOULD BE ATTACHED TO THE "NAVAL LOGISTIC FACILITY" THE TWO GOVERNMENTS HAVE AGREED IN
PRINCIPLE TO RELOCATE FROM SUBIC BAY IN THE PHILIPPINES TO PRINCIPLE TO RELOCATE FROM SUBIC BAY IN THE PHILIPPINES TO SINGAPORE. MANY FEAR THAT AN INCREASED U.S. PRESENCE IN SINGAPORE WILL

09299 VATIKIOTIS, $M$

POLE POSITION PLOYS

FAR EASTERN ECONOMIC REVIEW, 155(46) (NOV 92), 10-11. THE RACE TO BECOME THE NEXT PRIME MINISTER OF MALAYSIA HAS ALREADY BEGUN. NO ONE IS CHALLENGING THE LEADERSHIP OF DATUK SERI MAHATHIR MOHAMAD, WHO IS THE PRESIDENT OF THE RUL ING UNITED MALAYS NATIONAL ORGANIZATION (UNMO) AND BY VIRTUE OF THAT, PRIME MINISTER. BUT CRUCIAL PARTY ELECTIONS WILL BE HELD NEXT YEAR AND SOME SENIOR UMNO LEADERS MAY HAVE THEIR EYE ON THE POST OF DEPUTY PRESIDENT, HHO AUTOMATICALLY SUCCEEDS THE PRESIDENT UNDER THE PARTY CONSTI IUTION. THE BABA. MANY PREDICT MAHATHIR HILL SERVE AT LEAST ANOTHER TWOYEAR TERM AS PARTY CHIEF. HOWEVER, AS GHAFAR IS ALREADY 67, THE LONGER MAHATHIR STAYS ON THE MORE LIKELY IT IS THAT THE LONGER MAHATHYR STAYS ON THE MORE LIKELY IS ALS THAT GHAFAR WILL BE CHALLENGED BY YOUNGER PARTY LEADERS HAITING
IN THE WINGS. POISED TO MOUNT THE CHALLENGE ARE SENIOR VICEIN THE WINGS. POISED TO MOUNT THE CHALLENGE ARE SENIOR VICE
PRESIDENT DATUK SERI ANWAR IBRAHIM, VICE-PRESIDENT DATUK PRESIDENT DATUK SERI ANHAR IBRAHIM, VICE-PRESIDENT DATUK SERI SANUSI JUNID AND VICE-PRESIDENT DATUK ABDULLAH AHMAD BADAHI. MAHATHIR HAS DISPLAYED CONCERN ABOUT THE INFI IGHTING AND HAS PUBLICLY WARMED THAT IF PARTY OISUNITY CONTINUES, ONE OF THE

09300 VATIKIOTIS, M.; AWANOHARA, S.

POLITICAL CLEAN-UP

FAR EASTERN ECONOMIC REVIEH, 155(9) (MAR 92), 10-11.

THE ENVIRONMENT HAS EMERGED AS A KEY ISSUE WITHIN THE ASSOCIATION OF SOUTHEAST ASIAN NATIONS (ASEAN). MANY MEMBER STATES ARE TAKING THE INITIATIVE ON ENVIRONMENTAL ISSUES SO AS NOT TO BE PLACED ON THE DEFENSIVE BY DEVELOPED NATIONS AT THE UNITED NATIONS CONFERENCE ON THE ENVIRONMENT AND DEVELOPMENT (UNCED) SCHEDULED TO BE HELD IN BRAZIL IN JUNE. ASEAN STATES HAVE EXPRESSED CONCERNS ABOUT THE RIGHT TO DEVELOP AND EXPLOIT THEIR FORESTS ON A SUSTAINABLE BASIS; URGENT MEASURES TO COMBAT CLIMATIC CHANGE AIMED AT STEMMING THE EMISSION OF "GREENHOUSE GASSES" BY DEVELOPED COUNTRIES AND THE TRANSFER OF FUNDS AND TECHNOLOGY FROM THE DEYELOPED COUNTRIES TO ENCOURAGE ENVIRONMENTALLY-SOUND DEVELOPMENT. THE HIGH AND OFTEN STRIDENT PROFILES ADOPTED BY SINGAPORE AND MALAYSIA REFLECT THE FACT THAT ASEAN HAS EMERGED AS A REGION REPLETE WITH ENYIRONMENTAL ISSUES AND IS BECOMING INCREASINGLY YOCAL ABOUT DEFENDING ITSELF.

09301 VATIKIOTIS, M.

PRIMING FOR RIO

FAR EASTERN ECONOMIC REVIEN, 156(19) (MAY 92), 22 .
MALAYSIA'S PRIME MINISTER DATUK SERI MAHATHIR MOHAMAD SEIZED ANOTHER OPPORTUNITY TO PROJECT HIMSELF AS THE CHAMPION OF THE SOUTH AGAINST THE NORTH AT A CONFERENCE ON ENYIRONMENTAL PROBLEMS HELD IN KUALA LUMPUR ON 26-29 APRIL. ENVIRONMENTAL PROBLEMS HELD IN KUALA LUMPUR ON 26-29 APRIL. MALAYSIA CONYENED THE CONFERENCE, WHICH HAS ATTENDED BY REPRESENTATIVES FROM 55 CQUNTRIES, IN ORDER TONER A IN JUNE. WORLD AGENDA FOR THE EARTH SUMTIT IN RI ON FINANCE, MALAYSIA WHILE JAPAN LOOKS SET TO TAKE THE LEAD ON FINANCE, MALAYSIA IS SETTING THE RHETORICAL TONE ON BEHALF OF THE DEVELOPING COUNTRIES. A "KUALA LUMPUR DECLARATION" STRESSES THE L BETHEEN ENVIRONMENT AND DEVELOPMENT AND STATES THAT "DEVELOPMENT IS A FUNDAMENTAL RIGHT." IT REJECTS CONDITIONALITY AND CALLS ON DEVELOPED COUNTRIES TO THEIR CONSUMPTION AND PRODUCTION PATTERNS TOHARDS ENVIRONMENTALLY SOUND DEVELOPMENT. PRIME MINISTER MADE IT PLAIN THAT HE SEES THE SUMMIT AS PART OF A
CONTINUING EFFORT TO OVERCOME DECADES OF NEGLECT BY THE NORTH IN THE GROWTH AND DEVELOPMENT OF THE SOUTH.

09302 VATIKIOTIS, M.; BARTHOLOMEW, J.

RAIDERS DF RIAU

FAR EASTERN ECONOMIC REVIEW, 155(23) (JUL 92), 14-15. THERE IS A GROWING NUMBER OF INCIDENTS OF PIRACY ALONC THE PHILLIPS CHANNEL SOUTHWEST OF SINGAPORE. SOME H4 INCIDENTS HAVE BEEN REPORTED BETWEEN JANUARY AND MAY 1992. THE GROWTH IN PRIACY HAS RAISED FEARS IN SHIPPING CIRCLES THAT PIRACY IS NOW SO RAMPANT THAT IT THREATENS TO DISRUPM THE FLOH OF GOODS THROUGH THE MALACCA STRAIT. TRADING ASSOCIATIONS FRON SINGAPORE, HONG KONG AND LONDON HAVE ALL EXPRESSED CONCERN ABOUT THE INCREASE. THE CULPRITS SEEM USUALLY TO COME FROM A GROUP OF ISLANOS IN INDONESIA'S RIAU PROVINCE. UNLIKE MORE ORGANIZED PIRACY IN THE GULF OF THAILAND AND OFF THE PHILIPPINES WHERE HI JACKING SHIPS FOR THEIR CARGOES IS VIRTUALLY ROUTINE. THE PIRACY PREVAILING
AROUND THE MALACCA STRAIT AMOUNTS TO LITTLE MORE THAN BURGLARY AT SEA. ATTACKS OF THIS KIND MAY INYOLVE LESS FINANCIAL LOSS, BUT OCCUR WITH MORE FREQUENCY AND, THEREFORE, THREATEN GREATER DISRUPTION TO SHIPPING. SOME ALSO FEAR THAT A MAJOR OIL SPILL IS INEVITABLE IF THE PIRACY CONTINUES.

09303 VATIKIOTIS, M.

SENSE OF PURPOSE

FAR EASTERN ECONOMIC REVIEH, 151(25) (JUN 91), 24-28. THIS YEAR COULD SEE THE ASSOCIATION OF SOUTH EAST ASIAN MATIONS (ASEAN) ADOPT MEASURES WHICH WILL FUNDAMENTALLY CHANGE THE TEMPO OF THE SIX-NATION GROUP. FROM WITHIN ASEAN THERE ARE CALLS FOR MORE REALISTIC AND EFFECTIVE ECONOMIC COOPERATION, THE EXIENSION OF ASEAN MEMBERSHIP TO OTHER SOUTHEAST ASIAN STATES AND THE DISCRETE MOVING AWAY FROM
CLOSER DEFENSE COOPERATION. CREATED PRIMARILY IN RESPONSE TO CLOSER DEFENSE COOPERATION. CREATED PRIMARILY IN RESPONSE TO
THE COMMUNIST THREAT. THE ASSOCIATION OF BRUNEI, INDONESIA, THE COMMUNIST THREAT, THE ASSOCIATION OF BRUNEI, INDONESIA,
MALAYSIA, THE PHILIPPINES, SINGAPORE, AND THAILAND HAS BEEN MALAYSIA, THE PHILIPPINES, SINGAPORE, AND THAILAND HAS BEE
FORCED TO SEARCH FOR A NEW RAISON D'ETRE AS THE COMMUNIST THREAT SLOWLY FADES. THE ABSENCE OF A COMMON THREAT HAS REVEALED ECONOMIC, SECURITY, AND POLITICAL FISSURES WITHIN THE ASSOCIATION.

09304 VATIKIOTIS, M. THE DAP DILEMMA

FAR EASTERN ECONOMIC REVIEW, 155(9) (MAR 92), 24-26. MALAYSIA'S OPPOSITION DEMOCRATIC ACTION PARTY (DAP) MARKS A QUARTER CENTURY OF EXISTENCE NO NEARER ITS GOAL OF FORMING A GOVERNMENT, BUT CONTINUING A TRADITION OF PARLIAMENTARY OPPOSITION RARELY SEEN ANY MORE IN THE REGION. THE PARTY, BORN AMIOST THE POLARIZED ETHNIC AMD IDEOLOGICAL POLITICS OF PENINSULAR MALAYSIA IN 1966, STILL STRUGGLES TO PROPAGATE ITS LONG-CHERISHED PRINCIPLES OF RACIAL EQUALITY AND DEMOCRATIC SOCIALISM. BUT IN A REGION WHERE ECONOMIC AND DEMOCRATIC SOCIALISM. BUT, IN A REGION WHERE ECONOMIC PROSPERITY AND STABILITY HAVE BECOME ASSOCIATED HITH FIRM
GOVERNMENT AND MORE OR LESS UNQUESTIONED ONE-PARTY DOMINANCE, THE DAP IS INCREASINGLY SEEN AS SOMETHING OF A POL ITICAL MUSEUM PIECE. ITS ROLE AS AN INSTITUTIONALIZED OPPOSITION HAS BEEN PRAISED, BUT YOUNGER PARTY LEADERS ARE BEGINNING TO
QUESTION THE DAP'S IDEOLOGY AND ITS RELIANCE ON THE CHINESE QUESTION THE
COMMUNITY.

09305 VATIKIOTIS, M

TIME FOR DECISIONS

FAR EASTERN ECONOMIC REVIEN, 155 (2) (JAN 92), 23-24. THE FOURTH ASSOCIATION OF SOUTHEAST ASIAN NATIONS (ASEAN) SUMMIT IN SINGAPORE AT THE END OF JANUARY OFFERS A CHANCE FOR THE SIX MEMBER COUNTRIES TO TRANSFORM THE REGIONAL ASSOCIATION FROM A COMFORTABLE CLUB OF CONVENIENCE INTO AN EFFECTIVE FRAMEHORK FOR THE ARTICULATION OF COMMON ECONOMIC AND SECURITY CONCERNS. WHETHER THE HEADS OF GOVERNMENT FROM BRUNEI, INDONESIA, MALAYSIA, THE PHILIPPINES, SINGAPORE, AND THAILAND AGREE TO THIS TRANSFORMATION WHEN THEY GATHER ON 27 JANUARY DEPENDS ON THEIR WILLINGNESS TO TAKE TWO STEPS. FIRST, THEY MUST BEGIN FORGING ASEAN INTO A COMMON MARKET BY CREATING AN ASEAN FREE TRADE AREA. SECOND, THEY WILL HAVE TO BURY THEIR MISGIVINGS AND SET UP A CONCRETE FRAMEWORK FOR THE DISCUSSION OF REGIONAL SECURITY ISSUES.

09306 VAUGHAN, 0.

CHIEFTAINCY POLITICS AND SOCIAL RELATIONS IN NIGERIA JOURNAL OF COMMONHEALTH AND COMPARATIVE POLITICS, 29(3) (NOV 92 ), 308-326.

AN ATTEMPT IS MADE TO ANALYSE THE FORMATION AND THE COMPLEX CHARACTER OF COALITIONS IN POST-COLONIAL AFRICA BY EXAMINING THE ACTIVITIES OF CHIEFLY RULERS, WHO OPERATE LARGELY IN THE INFORMAL SECTOR OF NIGERIAN POLITICS AND SOCIETY. IT IS A STUDY OF MODERN PARAMOUNT CHIEFS WHO ARE VERY MUCH AN INTEGRAL PART OF A DYNAMIC CIVIL SOCIETY. WHILE THESE LEADERS OPERATE OUTSIDE THE PURVIEH OF THE STATE, THIS ARTICLE CONCLUDES THAT THEY RETAIN THE UNOUESTIONABLE ABILITY EITHER TO ACCOMMODATE AND OCCASIONALLY CONFRONT GOVERMMENT POLICIES, OR TO INHOVATE OUTSIDE THE NARROH CONFINES OF MODERN STRUCTURES.

09307 VAVRINA, $Y$

FROM POUGHKEEPSIE TO PEORIA TO THE PERSIAN GULF: A FOYICE'S ICDHS ODYSSEY

PS: POL ITICAL SCIENCE AND POLITICS, 25(4) (DEC 92), 700-702.

ICONS IS A HIGH TECH VERSION OF A "MODEL UNITED NATIONS, " HHICH CAN BE THOUGHTFULIY INTEGRATED INTO THE CLASSROOM. IT HAS THE ADVANTAGE OF ALLOWING GREATER NUMBERS OF STUDENTS FROM LITERALLY ALL OVER THE WORLD TO PARTIPCATE FOR GREATER LENGTHS OF TIME AND THE PARTICIPANTS CAN AVAIL THEMSELVES OF a FOREIGN LANGUAGE OPTION. THIS ARTICLE EXPLORES THE PHASES IN SETTING THE PROGRAM UP AND MAKING IT WORK.

09308 YEDDER, R.; GALLAWAY, L.

POLICY REVIEH, (62) (FAL 92), 24-30.

WHENEVER HIGH UNEMPLOYMENT PERSISTS FOR SEVERAL YEARS,

IT IS BECAUSE THE COSTS OF LABOR ARE RISING MORE RAPIDLY 
THAN ITS PROOUCTIVITY. A LOOK AT THE UNITED STATES' PAST PNS AND ECONOMIC POLICIES REVEALS THE VERACITY OF THIS STATEMENT. AND IT REMAINS TRUE IN 1992, WHEN THE MINIMUM WAGE AND UNEMPLOYMENT COMPENSATION POLICIES OF PRESIDENT GEORGE BUSH AND THE OEMOCRATIC MAJORITY IN CONGRESS HAVE PRICED MILLIONS OF AMERICANS OUT OF THE JOB MARKET.

09309 VEGA, B.

IF CASTRO SHOULD FALL

HEMISPHERE, 5(1) (FAL 92), 10-11.

THE AUTHOR SPECULATES ABDUT THE IMPACT THE FALL OF FIDEL CASTRO WOULD HAVE ON CUBAN TRADE AND FOREIGN RELATIONS WITH THE UNITED STATES AND THE DOMINICAN REPUBLIC.

09310 VEIDEL, A.

CHINA'S WORRY: WHEN WILL THE CRY FOR FREEDOM RING OUT AGAIN?

GERMAN TRIBUNE, 31(1538) (OCT 92), 2; 7.

THERE ARE NO SIGNS YET THAT THE NEXT COMMUNIST GIANT IS SET TO FOLLOW IN THE SOVIET UNION'S FOOTSTEPS AND COLLAPSE. IN CHINA, THE COMMUNIST PARTY IS STILL THE ONLY WELLIN CHINA, THE COMMUNIST PARTY IS STILL THE ONLY WELLORGANI ZED FORCE. HOHEVER, CHANGE AT THE ECONOMIC BASE IS
BOUND TO TRIGGER CHANGE OF THE POLITICAL SUPERSTRUCTURE. BOUND TO TRIGGER CHANGE OF THE POLITICAL SUPERSTRUCTURE. SOONER OR LATER THE CRY FOR FREEDOM WILL RESOUND AGAIN AS IT
DID ON TIENANMEN SOUARE IN 1989. THE ONLY QUESTION IS HOW LONG HILL IT BE BEFORE IT DOES SO.

09311 VEIT-WILSON, J.H. MUDDLE OR MENDACITY? THE BEVERIDGE COMMITTEE AND THE POVERTY LINE JOURNAL OF SOCIAL POLICY, 21(3) (JUL 92), 269-301.

IT IS OFTEN ASSUMED THAT THE BEVERIDGE COMMITTEE OF 1942 BASED ITS PROPOSALS FOR SOCIAL SECURITY SCALES ON A POVERTY LINE AT THE "HUMAN NEEDS" OR SOCIAL PARTICIPATION LEVEL BECAUSE OF ITS "PRINCIPLE OF ADEQUACY OF BENEFIT IN AMOUNT AND TIME." USING THE COMMITTEE'S HORKING PAPERS, THE AUTHOR DESCRIBES ITS DISCUSSIONS ABOUT THE IDEAS OF NEED AND MEASURES OF POVERTY TO BE USED. THE EVIDENCE SHOWS THAT THE COMMITTEE KNEW VERY WELL THAT ITS PROPOSED BENEFIT LEVELS WERE NOT ENOUGH FOR SOCIAL PARTICIPATION. BECAUSE IT CONSCIOUSLY IMPLEMENTED THE PRINCIPLES OF MINIMUM SUBSISTENCE AND LESS ELIGIBILITY IN THE FACE OF INADEQUATE HAGES THE PROPOSED SCALES HERE ARGUABLY MORE AUSTERE THAN EVEN ROHNTREE'S "PRIMARY POVERTY" STAMDARD HHICH BOTH HE AND BEVERIDGE ACKNOWLEDGED WAS NOT SUFFICIENT TO MEET HUMAN SOCIAL NEEDS. WHETHER MUDDLE OR MENDACITY, THIS MYSTIFICATION HAS HAD SERIOUS CONSEQUENCES FOR THE POOR IN MYSTIFICAT

09312 VEITA, K.T.

MANAGING THE TRANSITION

WEST AFRICA, (3888) (MAR 92), 502.

AS GHANA'S CONSULTATIVE ASSEMBiY MEARS THE END OF ITS DELIBERATIONS, THE FOCUS OF ATTENTION IS SHIFTING TO WHAT PROMISES TO BE THE MOST CONTENTIOUS ISSUE--THE TRANSITIONAL PROVISIONS OF THE NEH CONSTITUTION. ONE FACTION IS ARGUING THAT THE CONSTITUTION SHOULD CONTAIN NO TRANSITIONAL PROVISIONS. HOHEVER, THE MAJORITY AGREES THAT THE CONSTITUTION SHOULD INCLUDE TRANSITIONAL PROVISIONS BUT DISAGREES ON WHETHER THEY SHOULD INCLUDE INDEMNITY CLAUSES, AS IN THE 1974 CONSITUTION.

09313 VEITA, K.T. ROAD TO LASTING DEMOCRACY WEST AFRICA, (3883) (FEB 92), 283

IF GHANA'S FOURTH ATTEMPT' AT MULTI-PARTY DEMOCRACY IS TO ENDURE AND SUCCEED, GOVERNMENTS OF THE NEXT REPUBLIC MUST ADHERE STRICTLY TO' THE MATIONAL MOTTO OF "FREEDOM AND JUSTICE." ALL POLITICAL PARTIES MUST CLEARLY EVIDENCE INTRAAMD INTER-PARTY DEMOCRACY. THE PARTY LEADERS ESPECIALLY THOSE OF THE GOVERNING PARTY, MUST BE OPEN AND INVOLVE THE PEOPLE IN DECISION-MAKING. IN ADOITION, THE MASS OF THE POPULATION MUST PROVIDE STRONG SUPPORT FOR THEIR LEADERS.

09314 VENGROFF, R.; BELHAJ, M.; MDIAYE, M. THE NATURE OF MANAGERIAL WORK IN THE PUBLIC SECTOR: AN AFRICAN PERSPECTIVE

PUBLIC ADMINISTRATION AND DEVELOPMENT, 11(2) (MAR 91), 95-110.

MUCH OF THE MANAGEMENT DEVELOPMENT LITERATURE SINCE THE MID $70 S$ HAS DEALT WITH THE REPLICABILITY OF MINTZBERG'S PARTITION OF THE NATURE AND CONTENTS OF THE MANAGER'S ACTIVITIES IN DIVERSE WESTERN WORK SETTINGS, IN THE U.S PRIMARILY. FEH ATTEMPTS HAVE BEEN UNDERTAKEN TO TEST ARTICLE, THE AUTHORS ATTEMPT TO PARTIALLY FIL THIS GAP IN ARTICLE, THE AUTHORS ATTEMPT TO PARTIALLY FILL THIS GAP IN THE DEGREES TO WHICH THE MAKAGEMENT ROLES IDENTIFIED IN THE U.S. CAN BE APPLIED GENERICALLY TO THE PUBLIC SECTOR IN THE AFRICAN CONTEXT. THE FINDINGS INDICATE THAT PERCEPTIONS OF MANAGEMENT ROLES AT THE MACRO LEVEL ARE HIGHLY CONSISTENT
PRIMARILY FROM THE HISTORIC EXPERIENCE OF COLONIAL

ADMINISTRATION AND THE CONTINGENT MICRO LEVEL IMPACT ARE ALSO NOTED. THE IMPLICATIONS OF THESE FINDINGS FOR THE DESIGN AND IMPLEMENTATION OF MANAGEMENT TRAINING PROGRAMMES IN AFRICA ARE EXPLORED.

09315 VERFURTH, H.

UNLIKELY ALLIANCE PLANMED FOR THE GREENS

GERMAN TRIBUNE, (1517) (MAY 92), 3.

THE PROPOSED MERGER OF THE (WESTERN GERMAN) GREENS AND ALLIANCE 190, WHO REPRESENT CIVIL RIGHTS GROUPS IN THE EXGDR, SEEMS AT FIRST GLANCE TO BE PERFECTLY NORMAL TURN OF EVENTS. THE GREENS STILL SEE THEMSELVES AS A MELTING POT OF CIVIL RIGHTS MOVEMENTS AND GROUPS, WHILE ALLIANCE ' 90 WAS LAUNCHED BY CIVIL RIGHTS GROUPS THAT SPEARHEADED THE PEACEFUL REVOLUTION OF AUTUMN 1989 AND SPRING 1990. HOWEVER, THE THO PARTIES' VIEWS OF POLITICS ARE COMPLETELY DIFFERENT FROM EACH OTHER. THE ALTERNATIVE LEFT-WING CHARACTERISTICS OF THE GREENS, UNQUESTIONABLY A LEGACY OF THE 1968 STUDENT UPRISING GENERATION ARE FAR LESS MARKED AMONG ALLIANCE TO MEMBERS YEME THAT PANGE FROM MIDDLE-OF-THE-ROAD TO CONOED, WITH

THE ALLIANCE ' 90 ALSO SUPPORTS A FREE MARKET ECONOMY, WHILE THE GREENS ENTERTAIN SERIOUS DOUBTS ABOUT THE WESTERN THE GREENS ENTERT.

09316 VERHARDAKIS, G

INSIDE PERCEPTIONS OF PUBLIC POLICY MAKING IN FRANCE PRELIMINARY ANALYSIS

INTERNATIONAL JOURNAL OF PUBLIC ADMINISTRATION, $15(9)$

(1992), 1697-1735.

BASED ON INTERVIEWS IN PARIS WITH GOVERNMENT OFFICIALS FROM THE OFFICE DF THE PRESIDENCY, THE PRIME MINISTER'S CABINET, CABINETS OF FIVE IMPORTANT MINISTRIES, "GRAND CORPS" MEMBERS, AND LEADERS OF TRADE UNIONS, THIS STUDY SEEKS TO DESCRIBE THE PROCESS OF GOVERMMENTAL POLICY MAKING IN THE FIFTH REPUBLIC AND, MOST IMPORTANTLY, TO DETERMINE THE INFLUENCE OF THE MAJOR PARTICIPANTS IN POLICY FORMULATION.

09317 VERNET, $D$

ADVANCING FRANCE?: THE DILEMMA OF FRENCH FOREIGN POLICY

INTERMATIONAL AFFAIRS, 68(4) (OCT 92), 655-664.

THE SPECIAL POSITION EMJOYED BY FRANCE ON THE

INTERNATIONAL SCENE HAS CHANGED DRAMATICALLY SINCE THE END OF THE COLO WAR. GERMAN UNIFICATION AND GERMANY'S PLACE WITHIN THE COMMUNITY PRESENT FRANCE WITH A SET OF NEW CHALLENGES. THE AUTHOR DISCUSSES THE HISTORICAL BACKGROUND TO THE PRESENT FRENCH OBSESSION HITH ITS ROLE IN THE WORLD, AND THE POSSIBLE WAY FORWARD FOR FRANCE WITHIN AN INTEGRATED AND THE PUROPE.

09318 VERNET, $D$.

FRANCE' IN A NEW EUROPE
NATIOMAL INTEREST, 29 (FAL 92), 30-38

NATIONAL INTEREST, 29 (FAL 92 ), 30-38. SOVIET EMPIRE IN SHAMBLES, FRENCH DIPLOMACY IS PERPLEXED WITH FRANCE CONTEMPLATING A EUROPE IN HHICH ALL THE OLD ROAD SIGNS HAVE BEEN ALTERED AND THE PRETENSES WHICH SUSTAINED FRANCE IN ITS DELUSIONS OF POWER ARE GONE. THIS ARTICLE EXPLORES FRANCE'S RELATIONSHIP WITH GERMANY AND BETWEEN THE EC AND THE FORMER COMMUNIST COUNTRIES. THE AMERICAN QUESTION AND NUCLEAR MATTERS ARE DETAILED. THE ARTICLE CONCLUDES THA THE SUCCESS OF FRENCH FOREIGN POLICY NOW PRESUPPOSES NO ONLY THAT FRANCE WILL HAVE THE MEANS TO MAKE HER VOICE HEARD BU ALSO THAT EUROPE WILL AGREE TO AMPLIFY IT THROUGHOUT THE WORLD.

09319 VERMEY, S.; PAPAGEORGIOU, F.

PREFECTURE COUNCILS IN GREECE: DECENTRALIZATION IN THE EUROPEAN COMMUNITY CONTEXT

REGIONAL POLITICS \& POLICY, 2(1,2) (SPR 92), 109-138. GREECE MUST RANK AS THE MOST CENTRALI IED STATE HITHIN THE EUROPEAN COMMUNITY. THE NEW NEEDS OF EUROPEAN COMHUNITY MEMBERSHIP HAVE THROWN THE DEFICIENCIES OF THE SYSTEM INTO SHARP RELIEF. THIS ARTICLE EXPLORES THE DIFFICULTIES ENCOUNTERED BY THE OVER-CENTRALIZED BUREAUCRACY IN PLANNING AND IMPLEMENTING REGIONAL DEVELDPMENT PROGRAMS. THE GREEK ADMINISTRATIVE DIVISION INTO PREFECTURES AND SUB-PREFECTURES IS EXAMINED. THE ARTICLE CONCLUDES THAT SUBSTANIAL

DECENTRALIZATION SEEMS TO BE A NECESSITY FOR THE DEVELOPMENT OF A MORE RATIONAL PLANNING PROCESS.

09320 VEROUGSTRAETE, I.

JUDICIAL POL ITIICS IN BELGIUM
WEST EUROPEAN POLITICS, 15(3) (JUL 92), 93-108.

THE JUDICIARY IN BELGIUM IS AN INDEPENDENT BRANCH OF GOVERNMENT AND HAS SUCCEEDED IN MAINTAINING ITS INDEPENDENCE AGAINST MANY ODDS. NOT BEING BOUND BY ANY PARTICULAR METHOD OF INTERPRETATION AND ABLE TO CONTROL. TO A CERTAIN EXTENT, THE MACHINERY OF GOVERNMENT, THE JUDGES HAVE BEEN CAUTIOUSLY INHOVATIVE, WHENEVER NECESSARY. THE PUBLIC HAS NOT BEEN HOSTILE TO SUCH INNOVATIONS. CONSTITUTIONAL LAW, MORALS, 
JUDGES HAVE BEEN MOST HILLING OR COMPELLED TO TAKE CREATIVE STEPS. BECAUSE THESE INDIVIDUAL DECISIONS ARE DRAFTED AS APPLICATIONS OF EXISTING GENERAL PRINCIPLES AND STATUTES AND CRITICISM HAS BEEN VOICED ABOUT THIS HIDDEN, CAUTIOUS LEGAL ACTIVISH.

09321 VERSI, A.

KENYA: THE REFORMERS

MEW AFRICAN, (287) (AUG 91), 6-10,40

KENYA IS ONE OF THE YERY FEW AFRICAN COUNTRIES THAT HAS ACHIEYED POI ITICAL STABILITY AND ECONOMIC GROWTH. FOR MANY YEARS, THE ONE-PARTY SYSTEM, COUPLED WITH A CAPITALIST, FREEMARKET ORIENTED APPROACH, SEEMED TO HORK VERY WELL UNDER PRESIDENT MOI. HOWEVER, MAJOR CRACKS BEGAN TO APPEAR AFTER THE 1988 ELECTIONS. NOW THE PEOPLE WANT REFORM WITHOUT VIOLENCE. KENYA'S SUBSTANTIAL MIDDLE CLASS IS BEGINNING TO RALLY AROUND SUCH FIGURES AS KENNETH MATIBA, CHARLES RUBIA, AND OGINGA ODINGA HHO HAVE BRAVELY DECLARED THEIR OPPOSITION TO THE ONE-PARTY RULE OF PRESIDENT MOI AND HIS KANU PARTY. THESE OPPOSITION LEADERS HAVE UNDERGONE CONSIDERABLE CRITICISM AND REPRESSION AT THE HANDS OF THE GOVERHMENT.

09322 VICKERS, $G$

EL SALVADOR: A MEGOTIATED REVOLUTION

REPORT ON THE AMERICAS, 25(5) (MAY 92), 4-8

IN EL SALVADOR. THE PEACE ACCORDS MARKED THE END OF MILITARY CONFLICT AND SET THE PARAMETERS OF POLITICAL STRUGGLE, BUT THEY DID NOT RESOLVE THE FUNDAMENTAL CAUSES OF THE CIVIL WAR. THE POLITICAL BATTLE OVER LAND AND ECONOMIC RESOURCES RAGES ON. PEASANTS OCCUPY LAND IN THE CONFLICTIVE ZONE OF CHALATENANGO AND THE KEY POLITICAL BATTLES WILL BE OVER SOCIAL AND ECONOMIC POLICY THERE. THIS REPORT SUGGESTS, HOHEVER, THAT GIVEN THE EXCESSES AND DESTRUCTION OF THE LAST DECADE, TO BE ABLE TO SAY THAT PARAMETERS EXIST AT ALL IS NO SMALL ACHIEVEMENT.

09323 VICKERS, G.R.; SPENCE, J.

TWO YEARS AFTER THE FALL: MICARAGUA'S BALANCING ACT THO YEARS AFTER THE FALL: NICARAGUA'S BALANCINC

THE STUNMING DEFEAT OF THE SAMDINISTA MATIONAL

LIBERATION FRONT (FSLN) BY THE UNITED NICARAGUAN OPPOSITION (UNO) IN THE 1990 NATIONAL ELECTIONS SCRAMBLED THE POL ITICAL AND SOCIAL ORDER OF NICARAGUA. INITIALLY, THE PROSPECTS FOR STABILITY WERE PROMISING. THE GOVERMMENT TRANSITION WENT PEACEFULLY, A DECADE-OLD WAR ENDED, AND THE U.S. -BACKED CONTRAS WERE OFFICIALLY DEMOBILIZED. BUT THO YEARS AFTER THE ELECTION, THE EFFECTS OF WAR AND THE IMPOSITION OF A HARSH STABILIZATION PLAN HAVE PRECIPITATED NEN OUTBREAKS OF VIOLENCE THAT THREATEN A FRAGILE POLITICAL BALANCE. WITH FOREIGN FINANCIAL AID MUCH LESS THAN ORIGINALLY ANTICIPATED, NICARAGUA'S DEVASTATED ECONOMY ALSO REMAINS FAR FROM RECOVERY. IN THIS ENVIRONMENT, STRANGE POLITICAL ALLIANCES AND SHIFTING STRATEGIC ALIGNMENTS HAVE BECOME COMMONPLACE. IN THE ARENA OF EXISTING INSTITUTIONAL STRUCTURES

INDIVIDUAL PLAYERS AND TRADITIONAL PARTIES--LIBERALS,

CONSERVATIVES, SOCIAL CHRISTIIANS, AND SANDINISTAS--COMPETE FOR POHER. IN ANOTHER ARENA, THOSE HHO FEEL UNREPRESENTED BY ANY TRADITIONAL POLITICAL INSTITUIION ARE BANDING TOGETHER IN GROUPS DETERMINED NOT BY IDEOLOGY, BUT BY SHARED ECONOMIC CONDITIONS.

09324 VIETA, K.T

BOYCOTT IS MOST UNFORTUNATE

WEST AFRICA, (3884) (FEB 92), 324-325.

THE AUTHOR INTERVIEWS PE ROWLAND AYAGITAM II, THE

SPEAKER OF GHANA'S CONSULTATIVE ASSEMBLY. THE SPEAKER

DISCUSSES THE DRAFTING OF GHANA'S NEH CONSTITUTION AND THE

CONSULTATIVE ASSEMBLY'S ROLE IN THE PROCESS.

09325 VIGILANTE, $R$.

THE CASE FOR BUSH

NEW REPUBLIC, 207(10) (AUG 92), 19-21.

THE AUTHOR $207(10)$ ( AUG 92), 19-21.

BUSH BECAUSE HE IS A MUCH BETTER PRESIDENT THAN A POLITICIAN.

BUSH BECAUSE HE IS A MUCH BETTER PRESIDENT THAN A POLITICIAN.

REGARDING THE ECONOMY, CIVIL RIGHTS, AND SOCIAL POLICY.

09326 VILANILAM, J.

FOREIGN POLLICY INFLUENCE ON IRANIAN NEWS REPORTING; FOREIGN POLICY INFLUENCE ON IRANIAN NEWS REPORTING;
REPORTING A REVOLUTION--THE IRANIAN REVOLUTION AND THE REPORT ING A

ZED BOOKS, 1989, 140-157

THIS CHAPTER CONSIDERS HOW FOREIGN POLICY INTERESTS OF THE REPORTING COUNTRY WILL AFFECT THE SELECTION AND PRESENTATION OF NEWS OF INTERNATIONAL SIGNIFICANCE WITHIN THE FRAMEWORK OF THE NEH INTERNATIONAL INFORMATION AND COMMUNICATION ORDER (NIICD). IT EXAMINES THE FOREIGN POLICY INFLUENCE ON THE REPORTING OF THE IRANIAN REVOLUTION AND CONCLUDES THAT THE NEWSPAPERS WERE NOT REPORTING A REVOLUTION, BUT WERE LEADING READERS THROUGH A SET OF SELECTED EVENTS, ISSUES. AND PERSONALITIES TO SOME PREDETERMINED CONCLUSIONS ABOUT THE FUTURE OF IRAN WHICH WERE IN KEEPING WITH THE FOREIGN POLICY INTERESTS IF THE UNITED
STATES.

09327 VILANILAM, J.

KHOMEINI AND THE SHAH: DISTORTIONS IN THEIR IMAGES: REPORTING A REVOLUTION-THE IRANIAN REVOLUTION AND THE NIICO DEBATE

SAGE PUBLICATIONS, , 1989, 120-139.

THIS CHAPTER EXAMINES PRESS COVERAGE OF THE IRANIAN REVOLUTION WITH EMPHASIS ON THE NEW YORK TIMES AND THE TIMES OF INDIA. IT ARGUES THAT BOTH PAPERS DISTORTED THE TRUTH USING "COMMUNIST," "MEDIEVAL," "THEOCRATIC FASCIST," "BLOODUSING "COMMUNIST," "MEDIEVAL," "THEOCRATIC FASCIST," "BLOODREFER TO THE AYATOLLAH KHOMEINI WHILE DOWNPLAYING THE SHORTCOMINGS OF THE SHAH. THE CHAPTER CONSIDERS PRESS COVERAGE ON SEVERAL RELATED ISSUES INCLUDING: THE SHAH'S MODERNIZATION; KHOMEINI AND THE VEIL; ISLAMIC JUSTICE AND
FUNDAMENTALISH; VIOLENCE; RELIGION AND THE REVOLUTION; AND FUNDAMENTALISM; VIOLENCE; RELIGION

09328 VILANILAM, J. REPORTING A REVOLUTION--THE IRANIAN REVOLUTION AND THE NIICO DEBAT ZED BOOKS, , 1989, 203.

THIS BOOK DEALS WITH THE MANHER IN WHICH TWO CULTURALLY DISTINCT AND GEOGRAPHICALLY DISTANT PRESS SYSTEMS--THAT OF INDIA AND THE U.S. --PRESENT FOREIGN NEWS. IT FOCUSES ON THE IRANIAN REVOLUTION AS A CASE STUOY AND USES CONTENT ANALYSIS OF THE NEW YORK TIMES AND THE TIMES OF INDIA AS ITS MAIN SOURCE OF DATA. THE PERIOD OF THE REVOLUTION WAS ALSO THE TIME WHEN THE DEBATE ON THE NEW INTERNATIONAL INFORMATION AND COMMUNICATION ORDER (NIICO) WAS INITIATED. THIS DEBATE DREW THE WORLD'S ATTENTION TO THE IMBALANCE, DISTORTIONS, HRONG CONCEPTS, AND OTHER DRAWBACKS INHERENT IN THE INTERNATIONAL FLOW OF NEWS. THE AUTHOR'S ANALYSIS PROVIDES EVIDENCE FOR THE STRONG INFLUENCE OF THE "HOME" COUNIRY'S FOREIGN POLICY ON THE HAY THE THO NEWSPAPERS REPORTED THE IRANIAN REVOLUTION.

09329 VILAS, C.

LATIN AMERICAN POPULISM: A STRUCTURAL APPROACH SCIENCE AND SOCIETY, 56(4) (WIN 92), 389-420.

THE AUTHOR EXAMINES POPUI IST MOVEMENTS AND IDEOLOGY, USING AS CONTEXT BOTH THE CLASSICAL EUROPEAN AND NORTH' AMERICAN POPULIST EXPERIENCES, AND THE SPECIFIC REALITIES OF CENTRAL AND SOUTH AMERICA. HE ARGUES THAT POPULISM MUST NOT BE VIEWED ONLY AS A SOCIAL AND POLITICAL MOVEMENT. IT IS, MORE FUNDAMENTALLY, A DISTINCT STRATEGY OF CAPITAL ACCUMULATION, INVOLING CRUCIAL ROLES FOR THE STATE, FOR SMALL-SCALE FIRMS. AND FOR POLITICAL MOBILIZATION, AND RELYING ON A CERTAIN KIND OF CONSUMPTION-LED

INDUSTRIALIZATION. TREATING POPULISM AS A PROBLEM IN POLITICAL ECONOMY MAKES POSSIBLE A CLEARER UNDERSTANDING OF ITS CONTRADICTORY NATURE AND PROBABLE OUTCOMES.

09330 VILAS, C.

WHAT FUTURE FOR SOCIALISM?

REPORT ON THE AMERICAS, 25(5) (MAY 92), 13-16.

AS LATIN AMERICA SIMKS EVER DEEPER INTO POVERTY, LEFTIST INTELLECTUALS AND POLITICIANS HAVE YET TO CHAMPION EOUITABLE ALTERNATIVES TO FREE-MARKET ADJUSTMENT. THE AUTHOR SUGGESTS THAT IF WE ADMIT THAT STATE SOCIALISM IN THE SOVIET BLOC WAS NOT THE ONLY, NOR THE BEST VERSION OF SOCIALISM, THE SOVIET COLLAPSE SEEMS NOT SO RELEVANT TO LATIN AMERICA, FROM EITHER AN ECONOMIC OR A POLITICAL PRESEPCTIVE. HE SUGGESTS THAT THE MAIN PROBLEM IS THAT VERY FEH POLITICAL ORGANIZATIONS IN LATIN AMERICA ARE CONCERNED WITH CHANGE, TO SAY NOTHING OF SOCIALISM. HE CONCLUDES THAT THE GULF BETWEEN PEDPLE'S ASPIRATIONS AND THE PREVAILING ORIENTATION OF POLITICAL PARTIES GROWS EVEN WIDER, AND THAT THE VITALITY OF SOCIALISM PARTIES GROWS EVEN WIDER, AND THAT THE VITALITY OF SOCIALISH
LIES IN THE LEFT'S CAPACITY TO ADAPT TO CHANGING REALITIES AND TO ACCEPT THE CHALLENGES OF NEW TIMES.

09331 VILAS, C.M.

FAMILY AFFAIRS: CLASS, LINEAGE, AND POLITICS IN COMILYAFARS: CLASS,

JOURNAL OF LAIIN AMERICAN STUDIES, 24(2) (MAY 92), 309-342.

FOCUSING ON THE NICARAGUAN BOURGEOISIE DURING THE SANDINISTA REVOLUTION AND IMHEDIATELY AFTERHARDS. THE AUTHOR SANDINISTA REVOLUTION AND IMMEDIATELY AFTERHARDS, THE AUTHOR DISCUSSES THE ARTICULATION OF CLASS AND KINSHIP IN NICARAGUA INTO COLLECTIVE POLITICAL BEHAVIOR AND INTO THE ACCESS OF PARTICULAR GROUPS TO STATE POWER, WITH RELATIVE AUTONOMY TO PARTICULAR GROUPS TO STATE POWER, WITH RELATIVE AUTONOMY TO IDEOLOGICAL DEFINITIONS AND TO THE OPEN FEATURES OF SOCIAL CONF.

09332 VILLA, D.

BEYOND GOOD AND EVIL: ARENDT, NIETZCHE, AND THE AESTHETICIZATION DF POLITICAL ACTION

POL ITICAL THEORY, 20(2) (MAY 92), 274-307

THIS ESSAY LOCATES HANHAH ARENDT'S THEORY OF POLITICAL ACTION WITHIN THE BROAD NIETZSCHEAN PROJECT OF OVERCOMING PLATONISH. ARENDT WAS SKEPTICAL OF NIETZSCHE'S SUCCESS ON THIS SCDRE. WHATEVER WE THINK OF HER ASSESSMENT OF 
NIETZSCHE'S INVERTED PLATONISM, WE ARE NEVERTHELESS COMPELLED TO RECOGIZE THE ANTI-PLATONIC IMPULSE BEHIND HER

09333 VILLA, D.R.

POSTMODERNISM AND THE PUBLIC SPHERE

AMERICAN POLITICAL SCIENCE REVIEW, 86(3) (SEP 92), 712-721. THE IDEA OF THE PUBLIC SPHERE, OF AN INSTITUTIONALIZED ARENA OF DISCURSIVE INTERACTION, IS CENTRAL TO DEMOCRATIC THEORY AND PRACTICE. BUT THE MODERN AGE HAS WITNESSED THE EROSION OF A PUBLIC REALM DISTINCT FROM THE STATE AND THE MARKET. IN RESPONSE TO THIS EROSION, PUBLIC REALM THEORY-NOTABLY THE HORK OF ARENDT AND HABERMAS--ATTEMPTS TO THEORIZE THE MINIMAL CONDITIONS NECESSARY FOR A DISCURSIVE REALM FREE OF STRUCTURAL COERCION OR MANIPULATION. THE RESULTING NORMATIVE CONCEPTION OF THE PUBLIC SPHERE HAS COME UNDER SHARP ATTACK BY POSTMODERN THEORISTS-INCLUDING FOUCAULT, LYOTARD, AND BAUDRILLARD--HHO QUESTION THE BASIC PRESUPPOSITIONS OF PUBLIC REALM THEORY. THE AUTHOR EXAMINES THEIR OBJECTIONS AND SHOWS HOW ARENDT'S PUBLIC REALM THEORY THEIR OBJECTIONS AND SHOHS HOW ARENDT'S PUBLIC REALM THEORY
IS LESS CONCERNED WITH THE QUESTION OF LEGITIMATION THAN IS LESS CONCERNED WITH THE QUESTION OF LEGITIMATION THAN
WITH THE THEORIZATION OF AN AGONISTIC POLITICAL SUBJECTIVITY

09334 VINCENT, B.

AVIATION SECURITY AND TERRORISH

TERRORISH, 13(6) (NOV 90), 397-440

THE AUTHOR ASSERTS THAT A SOPHISTICATED SABOTAGE THREAT TO U.S. INTERNATIONAL CIVIL AVIATION HAS BEEN WELL KNOWN TO THE U.S. GOVERMMENT AND AIR CARRIERS SINCE THE EARLY 1980S. HE BELIEVES THAT BOTH THE U.S. GOVERMMENT AND AIR CARRIERS HAVE FAILED TO DO ENOUGH TO COUNTER THIS SABOTAGE THREAT. HE CITES THE FINOINGS OF THE PRESIDENT'S COMMISSION ON AVIATION SECURITY AND TERRORISM (MAY 1990), AND THE ENACTMENT OF THE AVIATION SECURITY IMPROVEMENT ACT (NOV. 1990) TO SUPPORT HIS BELIEFS. THE AUTHOR CONCLUDES BY PROVIDING A RECIPE FOR CORRECTIVE ACTION.

09335 VINTON, L.

POLAND: GOVERMMENT CRISIS ENDS, BUDGET CRISIS BEGINS RFE/RL RESEARCH REPORT, 1(3) (JAN 92), 14-17.

ON DECEMBER 23, 199i, AFTER A STALEMATE OF NEARLY THO MONTHS, THE SEJM APPROVED THE CABINET PROPOSED BY PRIME MINISTER JAN OLSZEWSKI. THE VOTE WAS A REFLECTION OF FRUSTRATION HITH THE LONG INTERREGNUM RATHER THAN A GESTURE OF SUPPORT FOR THE GOVERMMENT. THE NEW GOVERMMENT OF SUPPORT FOR THE GOVERMMENT. THE NEW GOVERNMENT IMMEDIATELY FACED A BUDGETARY CRISIS AND THREATENED STRIKES. OLSZEWSKI'S GOVERMAENT HAS RELUCTANTLY PLEDGED TO DEFEND THE ECONOMIC ACHIEVEMENTS OF THE PAST THO YEARS EVEN THOUGH HIS ELECTION CAMPAIGN PROMISED A RADICAL TURN-AROUND IN ECONOMIC
POLICY. THUS, THE NEW CABINET SEEMS TO BE STRIVING IN BOTH POLICY. THUS, THE NEW CABINET SEEMS TO BE STRIVING IN
DIRECTIONS AT ONCE, PRODUCING CONSIDERABLE CONFUSION.

09336 VINTON, L.

POLAND: THE ANGUISH OF TRANSITION

RFE/RL RESEARCH REPORT, 1(1) (JAN 92), 91-95.

IN POLAND, 1991 ENDED MUCH AS IT HAD BEGUN: IN CONFLICT OVER THE CHOICE OF A NEW PRIME MINISTER. THE STRUGGLE OVER THE GOVERMMENT REFLECTED CONTINUING UNCERTAINTY ABOUT WHETHER, AND IN WHAT DIRECTION, TO PURSUE THE EMBATTLED ECONOMIC REFORM PROGRAM INITIATED BY POLAND'S FIRST NONCOMMUNIST GOVERNMENT IN LATE 1989. DISAGREEMENT OVER POLAND'S ECONOMIC COURSE DOMINATED POLLITICS THROUGHOUT 1991.

09337 VINTON, L.

POLAND'S GOVERNING COALITION: WILL THE TRUCE HOLD? RFE/RL RESEARCH REPORT, 1 (31) (JUL 92 ), 34-40.

DESPITE THE CONVENTIONAL WISDOM THAT INSTABILITY IS INHERENT IN POLAND'S FRAGMENTED POL ITICAL SCENE, A GOVERNING COALITION BASED ON MAJORITY SUPPORT IN THE PARLIAMENT HAS BEEN FORMED. SEVEN PARTIES THAT HAD WAGED BITTER BATTLES SUDDENLY FOUND THEMSELVES BUILDING A CABINET TOGETHER. MEDIATION BY SOLIDARITY TRADE UNION DEPUTIES WAS ESSENTIAL IN CEMENTING THE NEW COALITION. DESPITE THEIR DIFFERENCES, THE SEVEN PARTNERS SEEM TO SHARE A NUMBER OF BASIC COMHON POSITIONS: FEAR OF PRESIDENTIAL SOLUTIONS AND NEW ELECTIONS, A PRAGMATIC CONSENSUS ON THE OUTLINES OF ECONOMIC POLICY. AND A READINESS TO ESCHEH IDEOLOGICAL CONFLICTS. THE GOVERMMENT'S CHANCES WILL DEPEND ON THE SEVEN PARTIES' WILLINGNESS TO PROLONG THEIR IDEOLOGICAL TRUCE. BUT SEPARATING IDEOLOGICAL AND PRAGMATIC ISSUES MAY PROVE DIFFICULT IN PRACTICE.

09338 VINTON, L.

POLAND'S GOVERMMENT CRISIS: AN EMD IN SIGHT? RFE/RL RESEARCH REPORT, 1 (30) (JUL 92) 15-25. THE FORMATION OF A NEH CABIMET BASED ON A PARLIAMENTARY MAJORITY INDICATES THAT THE POLARIZATION GENERATED BY FORMER PRIME MINISTER JAN OLSZEWSKI AND HIS OUSTED GOVERNMENT HAS EASED, ALTHDUGH THE ISSUE OF SECRET POLICE COLLABORATORS CONTINUES TO DIVIDE POLISH POLITICS INTO TWO CAMPS. PRESIDENT LECH WALESA'S ATTEMPT TO BUILD A GOVERNMENT AROUND A PRIME MINISTER FROM OUTSIDE THE SOLIDARITY TRADITION FAILED TO WIN SUPPORT BUT HELPED TO CLEAR THE AIR. SEEMINGLY AS A LAST RESORT, A DISPARATE COALITION HAS TAKEN SHAPE FROM
PARTIES REPRESENTING THE IDEOLOGICAL SPECTRUM OF THE SOLIDARITY MOVEMENT. ALTHOUGH MUCH POTENTIAL FOR CONFLICT REMAINS, THE FORMATION OF THIS SEVEN-PARTY COALITION MAY AT LAST SIGNAL AN END TO THE CHRONIC CRISIS THAT HAS PARALYZED POLISH POLITICS SINCE THE 1991 ELECTIONS.

09339 VINTON, L.

POLAND'S LITTLE CONSTITUTION CLARIFIES WALESA'S PONERS RFE/RL RESEARCH REPORT, 1(35) (SEP 92), 19-26.

IN JULY 1992, THE SEJM COMPLETED WORK ON A "LITTLE CONSTITUTION" DESIGNED TO CLARIFY THE DIVISION OF POWER WITHIN THE EXECUTIVE BRANCH OF GOVERMMENT. DRAFTED WITH AN EYE TO AVOIDING A REPEAT OF THE CONFLICTS THAT ERUPIED BETHEEN PRESIDENT LECH WALESA AND PRIME MINISTER JAN OLSZEWSKI, THE LITTLE CONSTITUTION REPRESENTS A COMPROMISE BETWEEN PRESIDENTIAL AND PARLIAMENTARY FORMS OF GOVERMMENT. POLISH POLITICAL PRACTICE RATHER THAN CONSTITUTIONAL THEORY SHAPED THE TERMS OF THE DOCUMENT; THE PERSON OF THE INCUMBENT PRESIDENT WAS THE POINT OF REFERENCE FOR BOTH THE DRAFT'S SUPPORTERS AND ITS CRITICS. THE DOCUMENT IS MORE A DRAFT'S SUPPORTERS AND ITS CRITICS. THE DOCUMENT IS MORE
CODIFICATION OF THE STATUS QUO THAN A RADICAL DEPARTURE.

09340 VINTON, L.

POL ISH GOVERNMENT PROPOSES PACT ON STATE FIRMS RFE/RL RESEARCH REPORT, 1(42) (OCT 92), 10-18.

THE GOVERMMENT OF PRIME MINISTER HAMHA SUCHOCKA HAS WEATHERED THE WAVE OF STRIKES THAT BROKE OUT AS IT WAS TAKING OFFICE IN JULY 1992. ALTHOUGH THESE STRIKES WERE PROBABLY NOT THE LAST STAND OF THE INDUSTRIAL WORKING CLASS, THEIR OUTCOME HAS CHASTENED THE EMPLOYEES OF STATE FIRMS. THE SUCHOCKA GOVERNMENT HAS LOST NO TIME IN SETTING ITS PRIORITIES AND DRAFTING SPECIFIC PROGRAMS. THE CENTERPIECE IS THE GOVERNMENT'S PROPOSED "PACT ON STATE FIRMS," A PACKAGE OF ECONOMIC AND LABOR LEGISLATION WITH THO GOALS: (1) TO IMPROVE THE FUNCTIONING OF STATE FIRMS, WHICH HAVE PROVED THE WEAKEST LINK IN POLAND'S ECONOMIC TRANSFORMATION EFFORT, AND (2) TO FORESTALL FURTHER PRDTESTS BY SHIFTING INDUSTRIAL HORKERS' ATTENTION FROM MAKING DEMANDS ON THE STATE TO TAKING RESPONSIBILITY FOR THEIR OWM FIRMS.

09341 VINTON, L.

THE POLIISH GOVERMMENT IN SEARCH OF A PROGRAM

RFE/RL RESEARCH REPORT, 1(13) (MAR 92), 5-12.

TIGHT BUDGETARY CONSTRAINTS HAVE FORCED THE GOVERMMENT OF PRIME MINISTER JAN OLSZEHSKI TO BACK AHAY FROM ELECTION CAMPAIGN PLEDGES TO REVERSE THE POLICIES OF THE PREVIOUS TWO SOLIDARITY GOVERNMENTS. THE NEW GOVERMMENT HAS PLEDGED TO SOL IDARITY GOVERNMENTS. THE NEW GOVERMMENT HAS PLEDGED TO
BATTLE RECESSION, BUT CAUTIOUSLY, BY EMPHASIZING INVESTMENT RATHER THAH COMSUMPTIOH AMD HITHOUT PROYOKIMG RENEWED INFLATION. RISKY EVEN IN THEORY, THIS LIMITED DEPARTURE HAS ANTAGONIZED OPPONENTS HITHOUT FULLY SATISFYING SUPPORTERS, THUS PLACING THE GOVERNMENT'S SURVIVAL IN QUESTION. THE NATURE OF THIS DILEMMA WAS BROUGHT HOME ON MARCH 5,1992 , WHEN THE SEJM UNEXPECTEDLY FAILED TO APPROVE THE
PROGRAM FOR 1992. DISUNITY WITHIN THE CABINET AND PROGRAM FOR 1992. DISUNITY WITHIN THE CABINET AND
CONTROVERSIAL PERSONNEL POL ICIES HAVE FURTHER WEAKENED THE CONTROVERSIAL PERSONNEL POL ICIES HAVE FURTHER WEAKENED THE GOVERMMENT, AND A PREDILECTION FOR BOMBAST HAS SLOWED THE
FORMULATION OF COHERENT PRACTICAL POLICIES, CREATING A FORMULATION OF COHERENT PRAC
GENERAL IMPRESSION OF CHAOS.

09342 VIPOND, $R$.

LIBERTY AND COMMUNITY: CANADIAN FEDERALISM AND THE FAILURE OF THE CONSTITUTION

STATE UNIVERSITY OF NEW YORK PRESS, $1991,249$.

IN ITS ANALYSIS OF NINETEENTH-CENTURY CANADIAN HISTORY, THIS BOOK STUDIES THE POLITICAL IDEAS OF THE ONTARIO LIBERALS WHO OPPOSED JOHN A. MACDONALD'S HAMILTONIAN VISION OF A CENTRALIZED FEDERALISM. WHILE OTHER SCHOLARS HAVE ATTRIBUTED THE RISE OF A "PROVINCIAL RIGHTS" MOVEMENT IN ONTARIO TO PARTISANSHIP OR TO INSTITUTIONAL, ECONOMIC OR SOCIOLOGICAL VARIABLES, THE AUTHOR OF THIS BOOK BELIEVES THAT THE IDEAS OF THE PROVINCIALISTS ARE INTERESTING IN THEIR OWN RIGHT, NEED NOT BE EXPLAINED IN TERMS OF ANY OF THE ABOVE AND HAVE a RELEVANCE THAT TRANSCENDS THE PARTICULAR CONTEXT IN WHICH THEY AROSE. HHILE ONTARIO REMAINS AT CENTER STAGE THROUGHOUT THE BOOK, INSIGHTS ARE ALSO PROVIDED INTO BLAKE'S VIEWS ON THE IRISH QUESTION. THE CONTROVERSIES OVER MIMORITY RIGHTS ON THE PRAIRIES, AND THE IDEAS OF THOMAS COOLEY.

09343 VIROLI, M.

THE REVOLUTION IN THE CONCEPT OF POLITICS POLITICAL THEORY, 20 (AUG 92), 473-495.

"REASON OF STATE" IS THE DOCTRINE THAT ASSERTS THAT THE PRESERVATION OF THE STATE -- UNDERSTOOD SIMPLY AS DOMINION -CAN BE PURSUED BY ANY MEANS, JUST OR UNJUST. THE EMERGENCE OF THIS CONCEPTION WAS A REVOLUTION IN THE SENSE OF POLITICS AS WELL AS THAT OF POLITICAL MIND AND POLITICAL SCIENCE. IN SPITE OF ITS MAGNITUDE, HOWEVER, CONTEMPORARY SCHOLARS HAVE PAID LITTLE OR NO ATTENTION TO IT. THIS ESSAY ARGUES THAT THERE HAS BEEN A REVOLUTION IN THE CONCEPT OF POLITICS. IT ALSO TRIES TO INVESTIGATE ITS HISTORICAL MEANING AND SPECIFY THE ROLE OF SOME OF THE POLITICAL THINKERS WHO CONTRIBUTED TO ITS DEVELOPMENT AND TRIUMPH. 
09344 VISHER, C.A.

PRETRIAL DRUG TESTING: PANACEA OR PANDORA'S BOX? ANMALS OF THE AMERICAN ACADEMY OF POLITICAL AND SOCIAL SCIENCE, 521 (MAY 92), 112-131.

PRETRIAL DRUG TESTING OF ARRESTEES AND DEFENDANTS RELEASED BEFORE TRIAL IS INCREASINGLY BECOMING STANDARD PRACTICE IN STATE AND LOCAL CRIMINAL JUSTICE AGENCIES. THE FEDERAL COURTS ARE ALSO CONSIDERING WHETHER PRETRIAL DRUG TESTING SHOULD BE INITIATED IN EACH OISTRICT. MEANWHILE, RESEARCHERS AND POLICYMAKERS ARE ENGAGED IN A VIGOROUS DEBATE ABOUT THE MERITS AND DRAHBACKS OF PRETRIAL DRUGDESATE ABOUT THE MERITS AND DRAHBACKS OF PRETRIALS. CRITICS CONTEND THAT THE PROGRAMS ARE DIFFICULT TO IMPLEMENT, ARE TOO EXPENSIVE, AND HAVE LITTLE REAL IMPACT ON CRIMINAL BEHAVIOR AND ILLEGAL DRUG USE. REAL IMPACT ON CRIMINAL BEHAVIOR AND ILLEGAL DRUG USE.
PROPONENTS ARGUE THAT PRETRIAL DRUG TESTING ENABLES PROPONENTS ARGUE THAT PRETRIAL DRUG TESTING ENABLES OFFICIALS TO RELIABLY DETECT DRUG USE AND IMPROVE RELEASE BEFORE TRIAL, AND TO ENCOURAGE THESE OFFENDERS TO SEEK TREATMENT. THIS ESSAY REVIEWS STATE AND LOCAL EXPERIENCE WITH PRETRIAL ORUG TESTING, OISCUSSES THE EVALUATIONS THAT ROLE OF PRETRIAL DRUG TESTING IN THE UNITED STATES' NATIONAL DRUG CONTROL POLICY.

09345 VITUG, $M$

FAITH IN THE FOREST

FAR EASTERN ECONOMIC REVIEW, 155(16) (APR 92), 36-37.

ACTIVIST CATHOLIC PRIESTS ARE HARDLY NEW TO THE

PHILIPPINES. BUT A NEN BREED WHICH ESPOUSES A GREEN VERSION OF LIBERATION THEOLOGY HAS ARISEN. A GROWING NUMBER OF PRIESTS ARE TALKING ABOUT RELIGION AND NATURE. THEY SAY IT IS THE ROLE OF THE CHURCH TO BE ON THE FRONT LINE OF THE ENVIRONMENTAL BATTLE THAT IS RAGING IN THE PHILIPPINE COUNTRYSIDE. PRIESTS ARE PREACHING ECOLOGY, LOGGING BANS, AND, IN SOME PROVINCES, HEADING TO THE HILLS TO STOP LOGGERS. SOME HAVE SUCCESSFULLY HALTED ILLEGAL LOGGING, BUT SOME HAVE LOST THEIR LIVES IN THE PROCESS.

09346 VITULLO, A.

ERASING ARAB JERUSALEM

ERASING ARAB JERUSALEM
MIDOLE EAST REPORT, 22 (2) (MAR 92), 24-27.

A GROWING AMOUNT OF EYIDENCE POINTS TO THE EXISTENCE OF AN GROWING AMOUNT OF EVIDENCE POINTS TO THE EXISTENCE OF AN ISRAEL I GOVERNMENT PLAN FOR JEWISH SETTLEMENT IN ARAB EAST JERUSALEM, A CITY ARABS CONSIDER THE CAPITAL OF PALES HAS THE EXPRESS PURPOSE OF CONMECTING ISRAELI BANK, HAS THE EXPRESS PURPOSE OF CONNECTING ISRAELI SETTLEMENTS WHILE SURROUNDING AND CONFINING PALESTINIAN NEIGHBORHOODS. THE ROAD PROJECT IS THE FIRST MAJOR PIECE INFRASTRUCTURE DESIGNED TO PROMOTE THE GHETTOIZATION OF PALESTINIANS. THE PALESTINIAN COMMUNITY, INCLUDING ITS
LEADERHSIP, SEEMS WITHDRAWN AND CONFUSED; NOT DEFEATED BUT WITHOUT THE RESOURCES TO FACE THE MULTIPLE FRONTS OPENED BY THE ISRAELI GOVERNMENT. FOR ISRAEL, JERUSALEM IS THE PRIORITY ISSUE, SEPARATE AND NON-NEGOTIABLE; FOR

PALESTINIANS, JERUSALEM IS AN INTEGRAL PART OF THE OCCUPIED

TERRITORIES, AN ESSENTIAL COMPONENT OF A POLITICAL SOLUTION.

09347 VITULLO, A.

YITZHAK RABIN AND ISRAEL'S DEATH SQUADS

MIDOLE EAST REPORT, 22(5) (SEP Q1) 40-41.

IN RESPONSE TO A NUMBER OF UNFAVORABLE REPORTS ON ISRAEL'S USE OF THE UNDERCOVER UNITS BY BOTH PALESTINIAN AND ISRAELI HUMAN RIGHTS ORGANIZATIONS, AND BY THE MAJOR INTERNATIONAL PRESS, FOREIGN GOVERNMENTS HAVE BEGAN TO TAKE NOTICE OF WHAT HAS BEEN HAPPENING IN ISRAEL UNDER NEW PRIME MINISTER RABIN. STILL, THESE UNITS ARE EXTREMELY POPULAR WITH THE ISRAELI PUBLIC. THE NUMBER OF NEW APPLICANTS NOW AND PROTEST THE KILLINGS BY UNDERCOVER UNITS CONTINUE.

09348 VIVEKANANDA, F.; EKPO, A.H.

THE POLITICAL ECONOMY' OF HUMAN RIGHTS: A MATERIALISTIC INTERPRETATION

SCANDINAVIAN JOURNAL OF DEVELOPMENT ALTERNATIVES, XI (2)

(JUN 92), 17-32.

THE AUTHORS EXAMINE THE SIGNIFICANCE OF HUMAN RIGHTS

THE AUTHORS EXAMINE THE SIGNIFICANCE OF HUMAN RIGH
WITHIN A BROAD FRAMEWORK INCORPORATING THE THO MAJOR CONTENDING SOCIAL SYSTEMS, CAPITALISM AND SOCIALISM. THEY CONTENDING SOCIAL SYSTEMS, CAPITAL ISM AND SOCIALISM. THEY
DRAH CONCRETE EXAMPLES FROM THE USA, THE SOVIET UNION, AND DRAH CONCRETE EXAMPLES FROM THE USA, THE SOVIET UNION, AND OTHER COUNTRIES IN ORDER TO STRESS THE DISTINCTION BETWEEN
HUMAN AND CIVIL RIGHTS. THEY OFFER SOME RECOMMENDATIONS THAT HOULD ENHANCE THE IMPLEMENTATION OF BOTH HUMAN AND CIVIL HOULD ENH

09349 VLAHOS, M.

CULTURE AND FOREIGN POLICY

FOREIGN POLICY, (82) (SPR 91), 59-78

RECENT EVENTS INOICATE THAT THE WORLDWIDE DOMINATION OF AMERICAN CULTURE IS COMING TO AN END. THE FUTURE CULTURAL CONDITIONS MIGHT BEST BE DESCRIBED AS: PEOPLES' SENSE OF SELF AS INFORMED FUNDAMENTALLY AT THE LEVEL OF CULTURE AREA, NOT AT THE LEVEL OF TRIBE (NATIONALISM) OR HUMANITY (INTERNATIONALISM). THE ARTICLE CONSIDERS THE IMPLICATIONS
OF THIS LONG RUN TREND FOR POLITICS IN THE FUTURE. IT ALSO CONSIDERS SEYERAL SHORT RANGE CHANGES AND PHENOMENA: THE END OF THE COLD WAR; THE ASCENT OF JAPAN; THE PROBLEM OF THE THIRD WORLD; THE USE OF FORCE IN INTERNATIONAL POLITICS; AND HORLD LEADERSHIP.

09350 VOERMAN, $G$

\$AWAY WITH ALL YOUR SUPERSTITUTIONS|': THE END OF COMMUNISM IN THE NETHERLANDS

JOURNAL OF COMMUNIST STUDIES, 7 (4) (DEC 91), 460-476. ON 5 JUNE 1991 THE COMHUNIST PARTY OF THE NETHERLANDS DISSOLVED ITSELF, HAVING DECIDED TO MERGE WITH THE PACIFISTSOCIALIST PARTY AND THE POLITICAL PARTY OF THE RADICALS. THIS WAS THE RESULT OF THE PARTY'S EVOLUTION SINCE THE LATE $1970 S$, WHEN IT TURNED ITS BACK ON AN ORTHODOX STALINIST PAST.
19 TIST AFTER 1980 THE PARTY RENOUNCED, IN TURN, ITS LENINIST AFTER 1980 THE PARTY RENOUNCED, IN TURN, ITS LENINIST CONGRESSES SHOWS HOW THIS REFLECTED A FUNDAMENTAL SHIFT IN THE PARTY'S SOCIAL COMPOSIITION. ITS DISSOLUTION AND MERGER WITH THE PSP AND PPR IN THE GREEN LEFT HAS A LOGICAL CONCLUSION TO THESE DEVELOPMENTS.

09351 VOERMAN, G.; LUCARDIE, P.

THE EXTREME RIGHT IN THE NETHERLANDS: THE CENTRISTS AND THEIR RADICAL RIVALS

EUROPEAN JOURNAL OF POLITICAL RESEARCH, 22(1) (JUL 92), 35-54.

THE EXTREME RIGHT HAS ALWAYS BEEN RELATIVELY WEAK IN THE NETHERLANDS BECAUSE IT HAS NEITHER A STRONG IDEOLOGICAL TRADITION NOR A SOLID SOCIAL BASE. MOREOVER, THE EXTREME RIGHT HAS ALWAYS BEEN FRAGMENTED AND DIVIDED. HISTORICALLY, THREE VARIETIES CAN BE DISTINGUISHED: THEOCRATIC PROTESTANTISM (VERY OLD RIGHT), NEO-FASCISM OR NATIONAL SOCIALISM (OLD RIGHT), AND ETHNOCENTRIC NATIONALISM (NEH RIGHT). THE THIRD VARIETY, WHICH HAS BEEN REPRESENTED BY THE CENTRE DEMOCRATS SINCE 1984, HAS GAINED SOME GROUND IN RECENT YEARS. THROUGH RELIABLE DATA ARE STILL SCARCE, IT SEEMS PLAUSIBLE THAT THE PARTY HAS ATTRACTED NOT ONLY IDEOLOGICALLY-MOTIVATED EXTREMISTS BUT ALSO PROTEST VOTERS, MAINLY IN OLDER UBRAN WORKING CLASS AREAS.

09352 VOERMAN, G.; LUCARDIE, P.

THE NETHERLANDS

EUROPEAN JOURNAL OF POLITICAL RESEARCH, 22(4) (DEC 92), 475-478.

THE AUTHORS BREAK DOWH THE COMPOSITION OF THE NETHERLANDS' EERSTE KAMER (UPPER HOUSE OF PARLIAMENT) BY POLITICAL PARTY, BASED ON THE RESULTS OF THE MAY 1991 ELECTIONS. THEY ALSO REPORT ON THE COMPOSITION OF THE CABINET MEMBERSHIP BY POLITICAL PARTY.

09353 VOGEL, E.F. JAPANESE-AMERICAN RELATIONS AFTER THE COLD WAR DAEDALUS, 121 (4) (FAL 92), 35-60

SINCE THE COLLAPSE OF THE SOVIET UNION AND THE REDUCTION IN THAT EXTERNAL THREAT, JAPAN'S EXAMINATION OF THE JAPANESEAMERICAN RELATIONSHIP HAS BECOME MORE OPEN. THIS COMBINED WITH THE DRIFT IN THE RELATIONSHIP AT THE TOP LEVELS OF BOTH GOVERNMENTS HAS ALLOWED THE EXPRESSION OF POHERFUL EMOTIONS THAT HAD LONG BEEN PARTIALLY SUPPRESSED. THE RESULTING TENSIONS REACHED NEH HEIGHTS DURING THE 1990-91 PERSIAN GULF CRISIS AND AFTER PRESIDENT GEORGE BUSH'S 1992 VISIT TO JAPAN. THESE TWO INCIDENTS ILLUSTRATE THE PROBLEMS IN U.S.JAPANESE RELATIONS SINCE THE COLLAPSE OF THE COMMUNIST THREAT AND THE TRANSFORMATION OF JAPAN INTO AN ECONOMIC

09354 VOGEL, $H$.

THE LONDON SUMHIT AND THE SOVIET UNION

AUSSEN POLITIK, 42(4) (1991), 315-325.

THE PRESENCE OF THE SOVIET UNION AT THE G-7 SUMMIT HELD
THSEN IN LONDON FORCED THE CONSIDERATION OF THE VERY DIFFICULT QUESTIONS OF WHETHER THE NATIONS OF THE WEST SHOULD HELP THE SOVIET UNION, AND HOW THIS AID SHOULD BE CONDUCTED. THIS ARTICLE CONSIDERS THE CHALLENGES AND RISKS SURROUNDING THIS
ISSUE AND MAKES SEVERAL CONCLUSIONS AND SUGGESTIONS. THEY ISSUE AND MAKES SEVERAL CONCLUSIONS AND SUGGESTIONS. THEY
INCLUDE: IT WOULD BE AN ALMOST DOGMATIC ERROR TO MAKE INCLUDE: IT WOULD BE AN ALMOST DOGMATIC ERROR TO MAK WESTERN ASSISTANCE DEPENDENT ON PROOF OF SUCCESSFUL
DECENTRALIZATION AND DECOLONIALIZATION OF THE SOVIET UNION: DECENTRALIZATION AND DECOLONIALIZATION OF THE SOVIET UNION; REGARDLESS OF ITS SCALE, WOULD BE ABLE TO MEET THE CAPITAL REQUIREMENTS OF A RAPID MODERNIZATION AND RESTRUCTURING OF THE SOVIET ECONONY; THE ECONOMIC RELATIONS BETWEEN EASTERM POLITICS: AND, PAST EXPERIENCE HAS DEMONSTRATED THAT POLITICS; AND, PAST EXPERIENCE HAS DEMONSTRATED THAT
ECONOMIC DIPLOMACY IS AN INSTURMENT WHOSE IMPACT IS ECONOMIC DIPLOMACY IS
DIFFICULT TO PREDICT.

09355 VOHRA, A.M. CONFIDENCE BUILDING BETWEEN INDIA AND PAKISTAM SOUTH ASIA JOURNAL, 5(3) (JAN 92), 313-322.

THIS ARTICLE BRIEFLY EXAMINES THE EMNITY AND CONFLIC THAT HAVE CHARACTERIZED RELATIONS BETHEEN INDIA AND PAKISTAN SINCE THE 1947 PARTITION OF SOUTH ASIA. IT THEN CONSIDERS 
EFFORTS, BOTH OFFICIAL AND UNOFFICIAL, TO FACILITATE CONFIDENCE BUILDING BETHEEN THE TWO STATES IN AREAS SUCH AS ARMS CONTROL, SEPARATIST MOVEMENTS, NUCLEAR WEAPONS, AND TRADE.

09356 VOHRA, R.

CHINA'S "OPEN DOOR" AND THE UNITED STATES: FOREIGM

INVESTMENT AND NATIONAL AUTONOMY

CHINA REPORT, 28(3) (JUL 92 ), 193-214.

THIS ARTICLE EXAMINES DENG XIAOPING'S ECONOMIC REFORMS.

IT BRIEFLY CONSIDERS THE LEGACY LEFT TO DENG BY MAO ZEDONG. IT THEN OUTLINES DENG'S EFFORTS TO REFORM AND MODERNIZE CHINA'S AGRICULTURAL AND URBAN SECTORS. SPECIAL EMPHASIS IS PLACED ON THE IMPACT OF FOREIGN INVESTMENT ON CHINA AND THE ROLE THAT THE UNITED STATES HAS PLAYED IN THIS INYESTMENT. IT CONSIDERS ISSUES OF CONTENTION BETHEEN THE UNITED STATES AND CHINA SUCH AS ARMS PROLIFERATION, MARKET ACCESS, AND INTELLECTUAL PRDPERTY RIGHTS. IT CONCLUDES THAT THE NEEDS OF CHINA'S MODERNIZATION PROGRAM HAVE LED THE COUNTRY TO A STAGE WHERE IT IS INTIMATELY INVOLVED WITH THE ECONOMIES OF STAGE WHERE IT IS INTIMATELY INVOLVED WITH THE ECONOMIES OF THE ADVANCED COUNTRIES PARTICULARLY WITH THE UNITED STATES.
HOWEVER, BEIJING HAS DEMONSTRATED AN ABILITY TO FRUSTRATE U. HOWEVER, BEI JING HAS DEMONSTRATED AN ABILITY TO FRUSTRATE
S. LED WESTERN ENDEAVORS TO CHANGE CHINA BY LINKING TRADE S. - LED WESTERN ENDEAVORS TO CHANGE CHINA BY LINKING TRADE WITH HUMAN RIGHTS AND IMPOSING ECONOMIC SANCTIONS. MORE
WORRISOME TO CHINA'S LEADERS IS THE FACT THAT THE COUNTRY IS WORRISOME TO CHINA'S LEADERS IS THE FACT THAT THE COUNTRY IS
RAPIDLY BEING SPLIT BETWEEN THE FAST GROWING COASTAL REGIONS RAPIDLY BEING SPLIT BETWEEN THE FAST GROWING COASTAL REGID
AND THE INLAND AREAS, WHICH ARE LAGGING BEHIND IN THEIR AND THE INLAND
DEVELOPMENT.

09357 VOLCANSEK, M.L.

THE EUROPEAN COURT OF JUSTICE: SUPRANATIONAL POLICY-MAKING WEST EUROPEAN POLITICS, 15(3) (JUL 92), 109-121.

THE EUROPEAN COURT OF JUSTICE, THE JUDICIAL BOOY OF THE EUROPEAN COMMUNITY, IS CHARGED WITH ENSURING UNIFORM INTERPRETATION OF TREATIES. IT HAS TRULY BEEN AN ACTIVIST COURT AND HAS EXTENDED THE REACH OF COMMUNITY LAH BY "CONSTITUTIONALIZING" THE TREATIES, FORCING ECONOMIC INTEGRATION, AND DEFINING HUMAN RIGHTS THAT BIND COMMUNITY INSTITUTIONS. HOWEVER, IF AND WHEN GREATER POWERS DEVOLVE ON THE EUROPEAN PARLIAMENT. THE COURT MAY FIND LESS

ENTHUSIASTIC APPROVAL FOR ITS ACTIVISM.

09358 VOLL, J.O.

CONSERVATIVE AND TRADITIONAL BROTHERHOODS

ANNALS OF THE AMERICAN ACADEMY OF POLITICAL AND SOCIAL SCIENCE, (524) (NOV 92), 66-78.

THE SIGNIFICANCE OF THE MAJOR SUFI BROTHERHOODS IN THE DEVELOPMENT OF MODERN POL ITICAL ISLAM IS OFTEM DEVELOPMENT OF MODERN POLITICAL ISLAM IS OFTEN
UNDERESTIMATED. THE TRADITIONAL BROTHERHOODS PROVIDED THE UNDERESTIMATED. THE TRADITIONAL BROTHERHOODS PROVIDED
BASIS FOR MUCH OF THE MILITANT OPPOSITION TO EUROPEAN BASIS FOR MUCH OF THE MILITANT OPPOSITION TO EUROPEAN
IMPERIAL EXPANSION IN THE 19TH CENTURY AND. THROUGH THESE IMPERIAL EXPANSION IN THE 19TH CENTURY AND, THROUGH THESE
EFFORTS, CREATED SYMBOLS FOR ISLAMIC AUTHENTICITY THAT HAVE EFFORTS, CREATED SYMBOLS FOR ISLAMIC AUTHENTICITY THAT REMAINED IMPORTANT THROUGHOUT THE 2OTH CENTURY. THESE BROTHERHOODS WERE MAJOR CONSERVATIVE FORCES, PRESERVING A
SENSE OF ISLAMIC IDENTITY IN TIMES OF RULE BY NONMUSLIMS OR SENSE OF ISLAMIC IDENTITY IN TIMES OF RULE BY NONHUS SECULARIZING AND WESTERHIZING MUSLIM ELITES AFTER
INDEPENDENCE. TODAY. THE IMPACT OF THIS CONSERVATIVE FORCE INDEPENDENCE. TODAY, THE IMPACT OF THIS CONSERVATIVE FORCE IS TO PROVIDE A FOUNDATION FOR POPULAR SUPPORT FOR
ISLAM. THIS POPULAR SUPPORT IS A MAJOR FACTOR IN ISLAM. THIS POPULAR SUPPORT IS A MAJOR FACTOR IN
TRANSFORMING POLITICAL ISLAM FROM A RADICAL FORCE ON THE PERIPHERY OF THE POLITICAL ARENA INTO THE BASIC FOUNDATION OF MAINSTREAM POLITICS IN MANY ISLAMIC SOCIETIES.

09359 VOLOBUEV, P.V.

PERESTROIKA AND THE OCTOBER REVOLUTION IN SOVIET HISTORIOGRAPHY

RUSSIAN REVIEW, 51(4) (OCT 92), 566-576

THE HISTORY OF THE GREAT OCTOBER SOCIALIST REVOLUTION IS ONE OF THE MOST FREQUENTLY INVESTIGATED TOPICS IN SOVIET HISTORIOGRAPHY. FOR MORE THAN 70 YEARS, A LARGE AMOUNT OF DOCUMENTARY MATERIAL HAS BEEN UNEARTHED AND A HUGE LITERATURE HAS BEEN CREATED THAT PRACTICALLY REDRAHS THE CANYAS OF REVOLUTIONARY EVENTS. NEVERTHELESS, THERE IS STILL NO GENUINELY SCIENTIFIC, TRUTHFUL HISTORY OF THE REYOLUTION. THERE ARE MANY REASONS FOR THIS, BUT CHIEF AMONG THEM IS THE RESTRICTING INFLUENCE OF THE "STALIN SCHOOL OF FALSIFICATION. " THE DECADES-LONG REIGN OF STALINIST MYTHS AND LEGENDS THAT WERE FOISTED UPON AND CREATED BY HISTORIANS, THE DOGMATIC POSTULATES, AND THE IDEOLOGICAL SCHEMA HAD A PERNICIOUS EFFECT ON HISTORICAL RESEARCH INTO THE OCTOBER REVOLUTION. OVERCOMING THESE OBSTACLES WILL NOT BE EASY AND WILL REQUIRE OVERCOMING THESE OBSTACLES WILL NOT BE EASY AND WILL REQUIRE
A GREAT DEAL OF TIME AND EFFORT. PERESTROIKA AND GLASNOST A GREAT DEAL OF TIME AND EFFORT. PERESTROIKA AND GLASNOS
SET THE STAGE FOR A NEW INTERPRETATION OF THE OCTOBER SET THE STAGE FOR A NEW INTERPRETATION OF THE OCTOBER
REVOLUTION, WHICH SEEMS INEVITABLE AS SCHOLARS UNCOVER NEW REVOLUTION, WHICH SEEMS INEVITABLE AS SCHOLARS UNCOV
TRUTHS ABOUT THE PIVOTAL EVENT IN SOVIET HISTORY.

09360 VOLZ, H. FAYZ, M.

PUNITIVE' DAMAGES AND THE DUE PROCESS ClaUSE: THE SEARCH FOR CONSTITUTIONAL STANDARDS

UNIVERSITY OF DETROIT MERCY LAW REVIEN, 69(4) (SUM 92), 459-544.

THE UNITED STATES SUPREME COURT'S DECISION IN PACIFIC MUTUAL INSURANCE CO. V. HASLIP BRINGS PART OF THE ANSHER TO THE RECURRING QUESTION OF WHETHER THE CONSTITUTION PLACES A
hORKABLE LIMITATION ON THE AHARD OF PUNITIVE DAMAGES IN CIVIL SUITS. IN RECENT YEARS, THE COURT HAS HAD THREE OPPORTUNITIES TO ADDRESS WHETHER THE DUE PROCESS CLAUSE OF THE FOURTEENTH AMENDMENT OPERATES TO CONTROL PUNITIVE DAMAGE AHARDS. THIS ARTICLE REVIEWS THESE CASES WITH EMPHASIS ON
THE PACIFIC MUTUAL CASE.

09361 VON DER MEHDEN, F.

MALAYSIA IN 1990: ANOTHER ELECTORAL VICTORY

ASIAN SURVEY, XXXI(2) (FEB 91), 164-171.

MALAYSIA IN 1990 WAS DOMINATED BY ELECTORAL POLITICS. AFTER LONG SPECULATION AS TO WHEN THE NATIONAL ELECTIONS WOULD BE CALLED, THE OCTOBER VOTE WAS OF PRIMARY IMPORTANCE AS THE CULMINATION OF A PERIOD OF BITTER INFIGHTING WITHIN THE MALAY POLITICAL COMMUNITY. THIS ARTICLE EXAMINES THE PREELECTORAL DEVELOPMENTS AND THE ELECTION RESULTS WHICH INDICATE THAT THE UNITED MALAYS NATIONAL ORGANIZATION (UMNO) REMAINED THE RULING PARTY, BUT WITH SOME WARNINGS FOR THE FUTURE. THE ARTICLE ALSO EXAMINES THE ECONOMIC AND FOREIGM POLICY OF MALAYSIA IN 1990.

09362 VON DER MEHDEN, F.

MALAYSIA IN 1991: ECONOMIC GROWTH AND POLITICAL CONSOL IDATION

ASIAN SURVEY, XXXII(2) (FEB 92), 111-118

THIS ARTICLLE RECOUNTS SIGNIFICANT DEVELOPMENTS--BOTH DOMESTIC AND INTERNATIONAL--WHICH HAVE AFFECTED MALAYSIA IN 1991. MALAYSIA CONTINUED TO ENJOY HIGH LEVELS OF ECONOMIC GROWTH AND HAS EARNED INTERNATIONAL PRAISE FOR ITS "SHAR TURNAROUND." 1991 SAW THE END OF THE TWENTY-YEAR-OLD NEW ECONOMIC POLICY (NEP) AND ITS SUCCESSION BY THE TEN-YEAR NEW DEVELOPMENT POLICY (NDP) WHICH PROMISES DEVELOPMENT AND EQUALITY. THE RULING UNMO PARTY SAH INCREASED INFIGHTING AS SEVERAL POLITICANS JOCKEYED FOR THE POSITION OF SUCCESSOR TO PRIME MINISTER MAHATHIR. ON THE STATE LEVEL, SEVERAL STATESINCLUDING KELANTAN AND SABAH--ELECTED TO POHER OPPOSITION PARTIES WHO SOUGHT TO OIMINISH CENTRAL GOVERNMENT POWER. MALAYSIA'S RELATIONS WITH ITS IMMEDIATE NEIGHBORS WERE RELATIVELY CORDIAL. ITS CALL FOR ASSOCIATION OF SOUTHEAST ASIAN NATIONS (ASIAN) BACKING FOR A REGIONAL TRADE GROUPING HAS OPPOSED BY THE UNITED STATES AND OTHER WESTERN COUNTRIES. DISARGEEMENTS OVER THE GULF CRISIS ALSO WIDENED THE GAP BETWEEN MALAYSIA AND THE UNITED STATES.

09363 VON DER MEHDEN, F.R.

MALAYSIA: PREDICTABLE SYSTEM AND UNPREDICTABLE OUTCOME; ASSOCIATION FOR ASIAN STUDIES 1992 ANNUAL MEETING ASSOCIATION FOR ASIAN STUDIES, $1992,155$.

ASSOCIATION FOR ASIAN STUDIES, $1992,155$.
THIS PAPER INITIALLY ANALYZES THE INSTITUTIONAL. THIS PAPER INITIALLY ANALYZES THE INSTITUTIONAL
FRAMEWORK WITHIN WHICH SUCCESSION TO THE PRIME MINISTERSHIP FRAMEWORK WITHIN WHICH SUCCESSION TO THE PRIME MINISTERSH UNITED MALAYS NATIONAL ORGANIZATION (UMNO), PAST POWER
RELATIONSHIPS WITHIN THE PARTY, THE INTERACTION BETHEEN UMNO RELATIONSHIPS WITHIN THE PARTY, THE INTERACTION BETHEEN PATTERN OF SUCCESSION TO LEADERSHIP IN THE COUNTRY. THIS IS FOLLOWED BY AN ASSESSMENT OF POSSIBLE SUCCESSORS TO PRIME MINISTER DR. MAHATHIR AND THEIR STRENGTHS AND WEAKNESSES.

09364 VON DER ROPP, $K$.

EURO-AFRICAN COOPERATION AFTER THE COLD WAR AUSSEN POLITIK, \$3(4) (1992), 402-410

IT HAS BECOME CLEAR THAT THE ASSISTANCE GIVEN TO AFRICA FROM EUROPE HAS NOT TRIGGERED THE DEVELOPMENT DONORS EXPECTED. THE QUESTION NOW UNDER DISCUSSION IN WESTERN EUROPE IS HHETHER THE EFFORT SHOULD BE SUSTAINED. THIS ARTICLE EXAMINES WHETHER THE AFRICAN RECIPIENT COUNTRIES-LIKE THE WESTERN EUROPEANS WITH RESPECT TO THE AMERICAN MARSHALL PLAN OFFER IN 1947--CAN IMPROVE THEIR DEVELOPMENT ABILITY THROUGH MUTUAL COOPERATION AND COORDINATION WITH THE DONORS.

09365 VON DITTMAR, R

SETTING SAIL FOR THE SIMGLE MARKET

EUROPE, 319 (SEP 92), 24-27.

LAST WINTER FINLAND FORMALLY APPLIED FOR MEMBERSHIP IN THE EUROPEAN COMPUNITY. THIS SPRING THE PARLIAMENT BACKED BY THE COUNTRY'S TRADE UNIONS VOTED IN FAVOR OF THE DECISION. THIS ARTICLE SUGGESTS THAT SWEDEN'S APPLICATION WAS A DECIDING FACTOR FOR FINLAND. WHETHER NEGOTIATIONS FOR THE MEMBERSHIP OF FINLAND START IN THE SECOND HALF OF 1992 OR IN IHE FIRST HALF OF 1993 . IT IS EXPECTED THAT ITS APPLICATION WILL BE STUDIED WITH GREAT ANTICIPATION.

09366 VON GLINSKI, G.

GORBACHEY TAKES HOME A COMMITMENT FROM WEST GERMAN TRIBUNE, (1477) (JUL 91), 1 .

MIKHAIL GORBACHEV DID NOT TAKE HOME FRESH LOANS FROM THE LONDON ECONOMIC SUMMIT, BUT HE HAS EVERY REASON FOR SATISFACTION. HE DID BRING HOME A COMMITMENT BY THE WESTERN INDUSTRIAL COUNTRIES TO HELP THE SOVIET UNION WITH EXPERT ADVICE AND ANALYSIS IN ITS TRANSITION TO A MARKET ECONOMY. HOWEVER, THE WESTERN ASSISTANCE IS CONTINGENT ON CONSISTENT AND MEANINGFUL ECONOMIC TRANSFORMATION AND A SETTLEMENT OF RELATIONS BETHEEN THE SOVIET GOVERNMENT IN MOSCON AND THE 
REPUBLICS. THE REAL DECISIONS CONCERNING THE OIRECTION OF REFORMS ARE NOW SOUARELY ON THE SOYIET'S SHOULDERS. THE IMPORTANCE ATTACHED TO THE SOVIET UNION BY THE WEST TENDED TO PUSH INTO THE BACKGROUND OTHER PROBLEMS WITH THE INTERNATIONAL ECONOMIC SUMMIT OUGHT TO HAVE PAID MORE ATTENTION.

09367 VON MARSCHALL, C

WALESA VISIT SYMBOLIZED A NEW CHANCE

GERMAN TRIBUNE, (1511) (APR 92), 2

THE YISIT OF POLISH PRESIDENT LECH WALESA TO GERMANY WAS THE FIRST VISIT BY A POLISH HEAD OF STATE SINCE 1918. AS SUCH, IT SIGNALS AN HISTORIC OPPORTUNITY FOR THE TWO NATIONS TO OVERCOME CENTURIES OF EMNITY AND CONFLICT. IF THE

STRUCTURAL AGREEMENTS FOR COOPERATION BETWEEN GERMANY AND POLAND ARE GIVEN TRUE LIFE BY SHARED EVERYDAY EXPERIENCE BETWEEN GERMANS AND POLES, PERHAPS THE AGE-OLD HATRED OF THE THO PEDPLES WILL ABATE.

09368 VON SCHEVEN, $W$

THE MERGER OF TWO FORMERLY HOSTILE GERMAN ARMIES AUSSEN POLITIK, 43(2) (1992), 164-173.

ONE OF THE UNIQUE PROBLEMS WHICH GERMANY HAS FACING IN THE PROCESS OF UNIFICATION WAS THE MERGER OF THO OPPOSING ARMIES. THE EAST GERMANY ARMY WAS PERCEIVED BY THE WEST GERMAN ARMY AS A CHALLENGE WHICH WAS POLITICALLY AND IDEOLOGICALLY LINKED TO THE SOVIET MILITARY POWER. THE EAST GERMAN ARMY WAS CHARACTERIZED AS A MILITARY TOOL OF THE OPPOSITE ALLIANCE AND ALSO OF THE POLITICAL AND SOCIETAL CLASS ENEMY WHO HAD TO BE RESISTED BY EDUCATION TO HATE. NEVERTHELESS, WHEN BOTH GERMAN STATES DECIDED TO UNITE, THEY ALSO AGREED ON COMBINING THE THO ARMIES. THIS ARTICLE RECOUNTS HOH, AND HITH WHICH SUCCESS THIS TASK HAS BEEN ACCOMPLI ISHED.

09369 VON SCHIRNDING, $K$.

THE SA FOUNDATION--LOOKING TO THE FUTURE

SOUTH AFRICA FOUNDATION REVIEW, 1814) (APR 92), 1-2. ALL ORGANIZATIONS AND GROUPS IN SOUTH AFRICA HAVE BEEN DEEPLY AFFECTED BY THE CHANGES THAT HAVE RECENTLY TAKEN DEEPLY AFFECTED BY THE CHANGES THAT HAVE RECENTLY TAKEN GLACE IN THE COUNRY. THIS ARTICLE, WRITTEN BY THE DI GENERAL OF THE SOUTH AFRICA FOUNDATION, EXAMINES THAT ORGANIZATION'S PRIORI IIES AND GOALS. HE CONCLUDES THAT THE SA FOUNDATION'S TASK IS NOW MORE IMPORTANT THAN EVER BEFORE. NO DEMOCARCY CAN SUCCEED WITHOUT A GROWING ECONOMY AND FOR
SOUTH AFRICA, FOREIGN INVESTMENT AND TRADE ARE A VITAL PART SOUTH AFRICA, FOREIGN INVESTMENT AND TRADE ARE A VITAL PART CONTACTS, AND THE TRACK RECORD AND CREDIBILITY, AS A NONPARTISAN PRIVATE SECTOR VOICE, TO ENCOURAGE FOREIGNERS TO TAKE THE LONG VIEW ABOUT THE REAL POTENTIAL IN SOUTH AFRICA.

09370 VON WEIZSACKER, $R$.

MAASTRICHT: EUROPE OFFERED AN HISTORIC OPPORTUNITY GERMAN TRIBUNE, (1514) (MAY 92), 5

GERMAN PRESIDENT, RICHARD VON WEIZSACKER, DISCUSSES THE IMPLICATIONS OF THE MAASTRICHT SUMMIT AND THE DECISIONS MADE WITH REGARDS TO EUROPEAN POLITICAL AND MONETARY UNION. HE ARGUES THAT MAASTRICHT OFFERS AN HISTORIC CHANCE TO MOVE FORHARD TOHARDS A EUROPEAN STRUCTURE CAPABLE OF DEALING WITH THE PROBLEMS THAT AFFECT EUROPE AS A WHOLE. HE ALSO SEEKS TO CALM THE FEARS OF GERMANS WHO ARGUE THAT THE PLANNED EUROPEAN CURRENCY, THE ECU, WILL NOT BE AS STABLE AS THE GERMAN MARK.

09371 VONBEYME, J.

GERMAN POL ITICAL SCIENCE: THE STATE OF THE ART EUROPEAN JOURNAL OF POLITICAL RESEARCH, 20(3-4) (DEC 91), 239-262.

THE HISTORY OF THE DISCIPLINE OF POLITICAL SCIENCE IN WEST GERMANY IS AS CONTRADICTORY AS THE HISTORY OF THE COUNTRY ITSELF. LONG-TERM, MEDIUM-TERM, AND SHORT-TERM EFFECTS HAVE CONTRIBUTED TO THE ST LONG-TERM EFFECTS WERE EXERTED BY SCIENTIFIC TRADITIONS AND THT HERE FORMED BY EARLY AND FUMDAMENTAL DECISIONS IN THE GERMAN UNIVERSITY SYSTEM. MEDIUM-TERM EFFECTS WERE THE RESULT OF THE NEED TO DEFINE AND ESTABLISH A NEW DISCIPLINE ALONGSIDE ALREADY-ESTABL I SHED AND ESTABLISH A NEW DISCIPLINE ALONGSIDE ALREADY-ESTABLISHED ROLE OF AMERICAN POL ITICAL SCIENCE. SHORT-TERM EFFECTS ARE ROLE OF AMERICAN POLITICAL SCIENCE. SHORT-TERM EFFECTS SCIENCES AND STEM FROM THE POOL ITICAL SYSTEM AND FROM INTERYENTIONS INTO THE UNIVERSITY SYSTEM.

09372 VONBEYME, $K$

THE EFFECTS OF REUNIFICATION ON GERMAN DEMOCRACY: A PRELIMINARY EVALUATION OF A GREAT SOCIAL EXPERIMENT GOVERNMENT AND OPPOSITION, 27(2) (SPR 92), 158-176. THE AUTHOR LOOKS AT SOME OF THE PROBLEMS ACCOMPANYING GERMAN REUNIFICATION AND ANALYZES THE IMPACT OF REUNIFICATION ON GERMAN DEMOCRACY.

09373 VONMOLTKE, K. THE UNITED NATIONS DEVELOPMENT SYSTEM AND ENVIRONMENTAL MAMAGEMEMT
WORLD DEVELOPMENT, 20(4) (APR 92), 619-626.

INTEGRATION OF ENVIRONMENTAL AND DEVELOPMENT TASKS WITHIN THE UNITED NATIONS IS NEEDED. LACKING THE CAPACITY FOR COORDINATION, THE UN DEVELOPMENT SYSTEM DOES NOT EFFICIENTLY HANDLE COMPLEX, CROSS-CUTTING ISSUES, SUCH AS THE ENVIRONMENT. CHANGES IN THE RELATIONSHIP OF THE UNITED NATIONS DEVELOPMENT PROGRAM (UNDP) HITH ITS EXECUTING AGENCIES MAKE A REVIEW OF ITS ENVIRONMENTAL ACTIVITIES AGENCIES MAKE A REVIEN OF ITS ENVIRONMENTAL ACTIVITI IES PARTICULARLY URGENT AS UNDP ASSUMES GREATER DIRECT
RESPONSIBILITY FOR ITS PROJECT PORTFOLIO, IT MUST DEVELOP RESPONSIBILITY FOR ITS PROJECT PORTFOLIO, IT MUST DEVELO THE TECHNICAL SKILLS TO ENSURE THAT THE ENVIRONMENTAL
IMPERATIVE IS RESPECTED. UNDP'S CURRENT APPROACH TO THESE IMPERATIVE IS RESPECTED. UNDP S CURRENT APPROACH TO THESE AND THE MOVE TO MORE SUSTAINABLE PATTERNS OF DEVELDPMENT.

09374 VORONKOY, L.

CONVERSION: INTERNATIONAL ASPECTS

PEACE AND THE SCIENCES, O(0) (DEC 91), 7-12

THE SENSATION OF THE WORLD ENTERING A QUALITATIVELY NEW ERA IS GRADUALLY RIPENING. A "NEW HORLD ORDER" AND ITS DETERMINANTS WILL BE THE TARGET OF SPECIAL BROAD-SCALE AND TIME CONSUMING RESEARCH PROJECTS. NEW DIMENSIONS AND CRITERIA OF MIGHT AND INFLUENCE AS WELL AS A FUTURE ROLE OF MILITARY POWER IN INTERNATIONAL RELATIONS SHOULD BE DETERMINED. THE DEVELOPMENT IN THIS DIRECTION WILL INEVITABLY BE ACCOMPANIED BY DEMILITARIZATION OF WORLD POLITICS AND CONSEUENTLY GROWING ACTUALITY OF CONVERSION.

09375 VORONKOV, L.

ECONOMIC CONVERSION: FROM VISION TO REALITY

PEACE AND THE SCIENCES, 4 (DEC 91), 13-18.

WE ARE LIVING IN A TIME OF PROFOUND CHANGE. THE HORLD IS CHANGING IN WAYS THAT REACH FROM THE GLOBAL AND

PANHISTORICAL RIGHT DOWN INTO THE ORDINARY BUSINESS OF DAYTO-DAY LIFE IN LARGE AND SMALL COMMUNITIES WORLDWIDE.

ECONOMIC CONVERSION LIES AT THE FULCRUM OF THIS CHANGE. IT ECONO CATH APPROACHES TO CONVERSION, IF PROPERLY PLANNED AND IMPLEMENTED, CAN TAKE THE HORLD FROM WHERE IT IT TO WHERE IT SHOULD GO. THIS ARTICLE DISCUSSES ECONOMIC CONVERSION,

SHOULD GO. THIS ARTICLE DISCUSSES ECONOMIC CONVERSION,

09376 VORONTSOY, G.

FROM EAST-WEST CONFLICT TO A COMMON EUROPEAN HOME: THEORY AND PRACTICE

INTERNATIONAL SOCIAL SCIENCE JOURNAL, 131(131) (FEB 92), 107-114.

ECONOMIC, SCIENTIFIC AND TECHNICAL RELATIONS FORM A BASIS FOR THE CONSTRUCTION OF A COMMON EUROPEAN HOME. AT THE PRESENT THERE IS A FRESH IMPULSE WHICH HAVE BEEN GIVEN TO THE PROCESS OF WEST EUROPEAN INTEGRATION WHICH WILL GREATLY INFLUENCE THE SITUATION IN EUROPE AND IN THE WHOLE WORLD. THIS ARTICLE EXPLORES THO FUNDAMENTAL QUESTIONS; WILL THE FORMATION OF AN INTERMAL EC MARKET LEAD TO A FURTHER SPLIT AND DIFFERENTIATION OF FORCES IN EUROPE; AND IF SO, TO WHAT EXTENT, OR WILL IT PROMOTE EUROPEAN CO-OPERATION? IN THE AUTHOR'S YIEW, THE MOST PROMISING OPTION FOR BUILDING A

09377 VOROZHEIKINA, T.

ANOTHER REVOLT OF THE MASSES

SOCIOLOGICAL PERSPECTIVES, (3) (1990), 11-16.

THIS ARTICLE EXPLORES THE TENDENCY IN THE SOVIET UNION TO ANALYZE THE NATIONAL SITUATION IN LIGHT OF PROGRESS IN HESTERN CAPITALIST CENTERS. THE AUTHOR ARGUES THAT THE SOVIET COMPARISON IS ONE-SIDED AND POINTS TO AN ABSENCE OF A THIRD-WORLD THEME IN THE SOVIET CONSCIOUSNESS. THIS "BLIND SPOT" IS PARTICULARLY HARMFUL, IT IS FURTHER ARGUED, BECAUSE OF THE LARGE NON-WHITE POPULATION IN THE USSR. THE AUTHOR PROPOSES GREATER ATTENTION BE PAID TO THE THIRD-WORLD COUNTRIES, PARTICULARLY LATIN AMERICA, FOR SOLIDARITY IN DEVELOPMENT.

09378 VOSHCHANOV, P.

THE SECRET BUSINESS OF THE COMMUNIST PARTY

WORLD PRESS REVIEW, 39(1) (JAN 92), 22-23.

THE COMMUNIST PARTY OF THE SOVIET UNION (CPSU) WAS ALWAYS A PARTY OF DUAL MORALITY. THE GIST OF THE FIRST MORALITY HAS REFLECTED IN PARTY POSTERS AND OFFICIAL CIRCULARS. WHEN MIKHAIL GORBACHEY CAME TO POWER IN 1985, THE CIRCULARS. WHEN MIKHAIL GORBACHEV CAME TO POWER IN 1985, THE

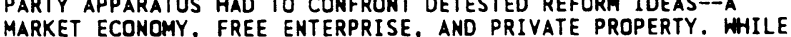
MARKET ECONOMY, FREE ENTERPRISE, AND PRIVATE PROPERTY. WHIL ONE OPIION WAS RADICAL REFORM OF THE PARTY, ITS LEADERS INSTEAD TRIED TO CLING TO POLITICAL POHER BY ESTABLISHI PARTY CONTROL OVER KEY SECTORS OF THE EMERGING MARKET
ECONOMY. THE PARTY BEGAN INDEPENDENT COMMERCIAL VENTURES IM 1988, AND THE EFFORT TO IMPLEMENT SUCH VENTURES ON A WIDE SCALE WAS SET IN MOTION IN MID-1990.

09379 VONLES, J.

NEH ZEALAND

EUROPEAN JOURHAL OF POLITICAL RESEARCH, 22(4) (DEC 92), 479-484. 
THE AUTHOR OUTLINES SOME OF THE MAJOR DOMESTIC POLITICAL ISSUES CONFRONTING THE GOVERMMENT OF PRIME MINISTER J.B.
BOLGER. HE ALSO LISTS THE MEMBERS OF BOLGER'S CABINET.

09380 VRANY, J.

CONVERSION: TRANSFERRING RESOURCES FROM MILITARY TO CIVILIAN PURSUITS

PEACE AND THE SCIENCES, O (DEC 91), 4-6.

WITH THE OPENING UP OF NEW POSSIBIITIES FOR FURTHER STEPS LEADING TOWARDS DISARMAMENT IN NUCLEAR, CHEMICAL AND CONVENTIONAL WEAPONS DISCUSSIONS REVIVED IN BOTH WEST AND EAST ABOUT THE ECONOMIC AMD SOCIAL ASPECTS OF DISARMAMENT AND CONVERSION IN EUROPE. THIS ARTICLE DISCUSSES

TRANSFERRING RESOURCES FROM MILITARY TO CIVILIAN PURSUITS.

09381 WACHTEL, H.M.

COMMON SENSE ABOUT POST-SOVIET ECONOMIC REFORMS

CHALLENGE, 35(1) (JAN 92), 46-48.

THE AUTHOR EXAMINES A PLAN, PROPOSED BY HARVARD

UNIVERSITY AND THE CENTER FOR ECONOMIC AND POLITICAL

UNIVERSITY AND THE CENTER FOR ECONOMIC AND POLITICAL
RESEARCH OF THE USSR, TO REFORM THE POST-SOVIET ECONOMY.

09382 HADOELL, N.; CAIRNS, E.

IDENTITY PREFERENCE IN NORTHERN IRELAND

POLITICAL PSYCHOLOGY, 12(2) (JUN 91), 205-214.

SOCIOPOLITICAL IDENTITY IS SEEN BY MANY AS THE KEY TO UNDERSTANDING THE CONFLICT IN NORTHERN IRELAND AND FOR THIS REASON HAS BEEN THE SUBJECT OF SEVERAL MAJOR SURVEYS. HOWEVER, THESE SURVEYS CAN BE CRITICIZED BECAUSE THEY HAVE NOT EMPLOYED TECHNI QUES THAT PROPERLY ALLOW FOR COMPARISONS BETHEEN THE VARIOUS POSSIBLE IDENTITIES. THE PRESENT STUDY OVERCAME THIS CRITICISM BY MAKING USE OF A PAIRED-COMPARISON TECHNIQUE WHICH ALLOWED THE FOUR IDENTITIES--BRITISH, IRISH, ULSTER, AND NORTHERN IRISH-TO BE PRESENTED TO ALL RESPONDENTS. THE RESULTS SUGGESTED THAT AS EXPECTED THERE WAS POLARIZATION ACROSS ALL IDENTITIES BETWEEN CATHOLICS AND PROTESTANTS AND FURTHER THAT WITHIN THESE TWO GROUPS THE RANK ORDER OF THE VARIOUS IDENTITIES ALSO DIFFERED. IN PARTICULAR, THE TERM "NORTHERN IRISH" HAS SEEN AS CLOSELY RELATED TO THE TERM "IRISH" BY CATHOLICS BUT AS VIRTUALLY SYMONYMOUS WITH THE TERM "BRITISH" BY PROTESTANTS.

09383 WADE, $R$

EAST ASIA'S ECONOMIC SUCCESS: CONFLICTING PERSPECTIVES, PARTIAL INSIGHTS, SHAKY EVIDENCE

WORLD POLITICS, 44(2) (JAN 92), 235-269.

NEO-LIBERAL ECONOMISTS SAY THAT GROWTH IS EASY, PROVIDED THE STATE DOES NOT OBSTRUCT THE NATURAL GROWTH-I NDUCING PROCESSES OF A CAPITALIST ECONOMY. THEY POINT TO THE SUCCESS PROCESSES OF A CAPITALIST ECONOMY. THEY POINT TO THE SUCCESS OF SOUTH KOREA AND TAIWAN AS EVIDENCE THAT THIS PROPOSITION
EVEN HOLDS TRUE FOR POOR ECONOMIES, BUT THE MEO-LIBERALS EVEN HOLDS TRUE FOR POOR ECONOMIES. BUT THE NEO-LIBERALS IGNORE SO MUCH CONTRARY EVIDENCE AS TO SUGGEST THAT THE
LIBERAL PARADIGM HAS ENTERED A DEGENERATIVE STAGE. LIKE LIBERAL PARADIGM HAS ENTERED A DEGENERATIVE STAGE, LIKE
CLASSICAL ECONOMICS IN THE YEARS BEFORE KEYNES' BREAKTHROUGH CLASSICAL ECONOMICS IN THE YEARS BEFORE KEYNES' BREAKT
AND LIKE MUCH OF THE MARXIST WRITINGS OF THE $1970^{\prime} \mathrm{s}$.

09384 WADHVA, $C$.

SAARC COUNTRIES AND THE EUROPEAN COMMUNITY: TOWARDS

STRONGER PARTMERSHIP IN THE 1990

SOUTH ASIA JOURNAL, 5(1) (JUL 92), 17-44.

WORLD TRADE IN THE 1990 S IS BEING INCREASINGLY CONDUCTED THROUGH REGIONAL TRADING BLOCS. THIS PAPER FOCUSES ON THE CURRENT STATE OF ECONOMIC LINKAGES BETWEEN THE NATIONS OF THE SAARC REGION AND THE PRESENT 12-MEMBER EUROPEAN COMMUNITY. THE MAIN AREA OF INTEREST IS ON BILATERAL AND MUTILATERAL TRADE FLOWS. THE FIRST SECTION PROVIDES AN OVERVIEW AND THE SECOND SECTION PRESENTS A REVIEW OF THE RECENT PATTERN OF TRADE BETWEEN SAARC AND THE EC IN THE GLOBAL CONTEXT. THE THIRD SECTION DEALS WITH THE PRESENT INVESTMENT FLOWS AND THE FOURTH SECTION OUTLINES THE FEATURES OF OFFICIAL DEVELOPMENT ASSISTANCE AND THE SCOPE FOR IMPROVING THE PAYOFFS FROM THE EC'S DEVELOPMENT POLICY TOWARDS COUNTRIES OF THE SAARC REGION.

09385 WADLOW, R.

PAN-EUROPEAN INSTITUTIONS AND MEDITERRAMEAN -- MIDDLE EAST SECURITY

PEACE AND THE SCIENCES, \& (DEC 91) 56-58.

IN THE LIGHT OF GULF WAR, THIS ARTICLE OUTLINES SIX POINTS DEALING WITH THE UNITED STATES EFFORTS TO ESTABLISH A PAN-EUROPEAN CONFEDERATION AND ITS RELATION TO MEDITERRANEAN AND MIDDLE-EAST SECURITY. IT BEGINS BY DISCUSSING THE FIRST CHALLENGE TO THE DEVELOPING PAN-EUROP DISCUSSING THE FIRST CHALLENGE TO THE DEVELOPING PAN-EUROPEAN ORDER, PAN EUROPEA
INSTITUTIONS THAT ARE NOT YET IN PLACE FOR DEALING WITH INSTITUTIONS THAT ARE NOT YET IN PLACE FOR DEALING WITH EXTRA-EUROPEAN MATTERS, AND SECURITY AND CO-OPERATION DEVELOPED IN THE EUROPEAN CONTEXT NEEDS TO FLOW OUTHARD ENGLOBING THE MEDITERRANEAN AND THE MIDDLE EAST IN ONE DIRECTION AND ASIA IN THE OTHER. IT CONCLUDES WITH A DISCUSSION OF ECONOMIC AND POLITICAL WEAKNESS OF THE FORMER USSR AND EASTER EUROPE AND THE ROLE OF NON-GOVERMENTAL INSTITUTIONS.

09386 WAENGLER, E.

CANADA FACES THE FUTURE
SWISS REVIEW OF HORLD AFFAIRS, 41(11) (FEB 92), 15.

THE AUTHOR DISCUSSES THE COMPLEX POLITICAL SITUATION IN QUEBEC, WHERE SOME FRENCH CANADIANS CONTINUE TO TALK OF SECESSION. HE ARGUES THAT THE DISINTEGRATION OF CANDA IS NOT AS LIKELY AS RADICALS AND PESSIMISTS ON BOTH SIDES OF THE LINGUISTIC DIVIDING LINE BELIEVE. CANADA'S UNITY WILL PROBABLY NOT BE SAVED BY POLITICIANS BUT BY THE GOOD COMMON SENSE OF THE CANADIAN PEOPLE.

09387 HAEVER, 0.

INTERNATIONAL SOCIETY: THEORETICAL PROMISES UNFULFILLED? COOPERATION \& CONFLICT: NORDIC JOURNAL OF INTERNATIONAL POLITICS, 27 (1) (MAR 92), 97-128.

IN THE STUDY OF INTERMATIONAL RELATIONS THE ENGLISH SCHOOL IS CHARACTERI ZED BY ITS INTEREST IN INTERNATIONAL SOCIETY-THAT IS, A SOCIETY FORMED BY AND OF STATES DEVELOPING RULES AND INSTITUTIONS FOR THE CONDUCT OF THEIR RELATIONS. THIS PERSPECTIVE SEEMS TO HOLD THE PROMISE OF OVERCOMING THE DICHOTOMIES OF REALIST-LIBERALIST AND HISTORICAL-STRUCTURAL APPROACHES. IT POTENTIALLY INCLUDES STUDIES OF THE RELATIVE WEIGHT OF SYSTEMIC (STRUCTURAL AND CONSTANT) PRESSURES RELATIVE TO HISTORICAL PECULIARITIES IN THE EVOLUTION OF DIFFERENT SYSTEMS OF STATES: THE INTERPLAY BETWEEN INTERNATIONAL SOCIETY AND A WORLD SOCIETY OF MANKIND; AND CHARACTERIZATION OF THE DIFFERENT LOGICS OF INTERNATIONAL RELATIONS IN DIFFERENT EPOCHS. AFTER REVIEWING THREE RECENT AND PROMINENT BOOKS FROM THE ENGLISH SCHOOL, THE AUTHOR OF THIS ESSAY CONCLUDES THAT ALTHOUGH EACH BOOK MAKES AN INDIVIOUAL, VALUABLE CONTRIBUTION TO INTERNATIONAL RELATIONS, DEVELOPMENT OF THE THEORY OF INTERNATIONAL SOCIETY IS NOT A VERY DYNAMIC BUSINESS. HE PLEADS FOR THE OPENING OF THE ENGLISH SCHOOL TO CONSIDER PARALLEL AMERICAN INTEREST IN REGIMES, THE SEMIOTICIANS' INSIGHT INTO THE NATURE AND IMPLICATIONS OF SHARING LANGUAGE, AND HISTORICALLY-FOCUSED STUDIES IN CLASSICAL POLITICAL THEORY AND INTERNATIONAL LAW.

09388 WAEVER, 0.

MORDIC NOSTALGIS: MORTHERN EUROPE AFTER THE COLD HAR

INTERNATIONAL AFFAIRS, 68(1) (JAN 92), 77-102.

NORDIC IDENTITY IS IN CRISIS. IN THE PAST, NORDEN REPRESENTED A MODEL OF THE ENLIGHTENED, ANTI-MILITARISTIC SOCIETY THAT WAS SUPERIOR TO THE OLD EUROPE. THESE IDENTITIES HAVE DISINTEGRATED. SUDDEMLY THE SOURCES OF THE IDENTITIES HAVE DISINTEGRATED. SUDDENLY THE SOURCES OF THE
FUTURE ARE TO BE FOUND NOT IN NORDEN, BUT ON THE CONTINENT. FUTURE ARE TO BE FOUND NOT IN NORDEN, BUT ON THE CONTINENT.
THE LESS-EUROPEAN IDENTITY OF NORDEN IS NO LONGER A PROMISE, THE LESS-EUROPEAN IDENTITY OF NORDEN IS ND LONGER A PROMISE
BUT A THREAT OF BEIMG PERIPHERY. THIS ARTICLE LOOKS AT THE BUT A THREAT OF BEIMG PER IPHERY. THIS ARTICLE LOOKS AT THE
PROSPECTS FOR THE EMERGENCE OF A NEW IDENTITY IN NORTHERN EUROPE--A BALTIC REGIONAL IDENTITY.

09389 HAGNER, R.E.

GRAZING THE FEDERAL BUDGETARY COMMONS: THE RATIONAL POL ITICS OF BUDGETARY IRRESPONSIBILITY

JOURAL OF LAW \& POLITICS, IX(1) (FAL 92), 105-120.

THE AUTHOR EXAMINES THE INSTITUTIONAL INCENTIVES AND CAUSES OF FEDERAL BUDGET DEFICITS. HE DISTINGUISHES THE LINK BETWEEN CHOICE AND LIABILITY FOR CHOICE IN THE PRIVATE SECTOR, AT THE LOCAL AND STATE LEVELS OF GOVERNMENT, AND AT THE FEDERAL LEVEL. HE CONCLUDES THAT BUDGET DECISIONS AND CHOICE IN THE FEDERAL GOVERNMENT ARE THE MOST OIVORCED FROM RESPONSIBILITY OR LIABILITY. A BALANCED BUDGET WOULD ACT TO REDUCE THIS TENDENCY BY FORCING SPENDING DECISIONS TO BE TIED TO TAXING DECISIONS.

09390 HAGNER, R.H.

DETERRENCE THEORY DISCUSSION: REPLY TO COMMENTS BY MCGINMIS, O'NEILL, AND RAPOPORT

JOURNAL OF THEORETICAL POLITICS, 4(4) (OCT 92), 485-491.

THE AUTHOR REPLIES TO CRITICS OF HIS PAPER,' "RATIONALITY AND MISPERCEPTION IN DETERRENCE THEORY," WHICH HAS SPARKED A LIVELY DEBATE ABOUT RATIONAL DETERRENCE AND GAME THEORY.

09391 HAGNER, R.H.

RATIONALITY ANO MISPERCEPTION IN DETERRENCE THEORY JOURNAL OF THEORETICAL POLITICS, 4(2) (APR 92), 115-141. AUTHORS OF SEVERAL CASE STUDIES OF INTERNATIONAL CONFLICT HAVE CLAIMED THAT THE FREQUENCY WITH WHICH STATESMEN ARE SURPRISED BY THE RESPONSE OF OTHER GOVERMMENTS TO CHALLENGES IS INCONSISTENT WITH RATIONAL DETERRENCE TO CHALLENGES IS INCONSISTENT WITH RATIONAL DETERRENCE
THEORY. SOME HAVE CONTENDED THAT THE BEHAVIOR OF DECISION THEORY. SOME HAVE CONTENDED THAT THE BEHAVIOR OF DECISION MAKERS IS BETTER EXPLAINED BY THEORIES OF COGNITIVE OR
AFFECTIVE PSYCHOLOGY. THE MAIN ISSUE RAISED BY THESE CRITICS AFFECTIVE PSYCHOLOGY. THE MAIN ISSUE RAISED BY THESE CRITICS
IS DECISION MAKERS' USE OF THE INFORMATION AVAILABLE TO THEM, IS DECISION MAKERS USE OF THE INFORMATION AVAILABLE TO
ESPECIALLY INFORMATION ABOUT THE COMMITMENTS OF OTHER ESPECIALLY INFORMATION ABOUT THE COMMITMENTS OF OTHER
GOVERNMENTS AND THEIR INCENTIVE TO PROTECT THEIR REPUTATIONS GOVERNMENTS AND THEIR INCENTIVE TO PROTECT THEIR REPUTATIONS
BY CARRYING OUT THEIR THREATS. ONLY RECENTLY, HOWEVER, HAVE GAME-THEORETIC TECHNIQUES BEEN DEVELOPED THAT PERMIT THE FORMALIZATION OF THEORIES OF DETERRENCE THAT INCORPORATE INCOMPLETE INFORMATION, LEARNING, AND THE DEVELOPMENT OF REPUTATIONS. THE PURPOSE OF THIS PAPER IS TO RE-EXAMINE THE QUESTION OF HOW MUCH MISPERCEPTION BY FOREIGN POLICY DECISION MAKERS IS CONSISTENT WITH RATIONALITY, IN LIGHT OF THESE NEW DEVELOPMENTS IN GAME THEORY. 
09392 WAGNER, $W$.

A FEW POSITIVE SIGNS AMID SOME DARK BALKANS REMINOERS GERMAN TRIBUNE, 31(1531) (SEP 92), 1-2.

IT WOULD BE EASY TO SCORN OR TO RIDICLE THE MODEST OUTCOME OF THE LONDON CONFERENCE ON THE FORMER YUGOSLAVIA. IT IS TRUE THAT THERE WAS A CERTAIN INCONGRUITY BETHEEN WHAT EMERGED IN RELATION TO THE POHER AND THE MONEY AND THE INFLUENCE ARRAYED AROUND THE CONFERENCE TABLE. THIS ARTICLE ARGUES THAT THE THE AIM OF STOPPING THE BLOOKSHED IN THE BALUES THAT THE THE AIM OF STOPPING THE BLOOKSHED IN THE BALKANS WILL NOT BE ACHIEVED QUICKLY. THE LONDON CONFERENCE THE PREVIOUS POLICY OR MILITARY INTERVENTION IN THE CONFLICT THE PREVIOUS POLICY OR MILITARY INTERVENTION IN THE CONFLICT IN THE HOPE THAT THE BLOODSHED WOULD SOON BE ENDED. ONE NOTE OF OPTIMISM-THE INTERNATIONAL COMMUNITY HAS AT LEAST MADE CONQUESTS AND INSISTS ON THE RESTORATION OF JUSTICE.

09393 WAGNER, $W$

AUTHORITY EVERYWHERE ISN'T WHAT IT USED TO BE GERMAN TRIBUNE, (1516) (MAY 92), 1-2

AT THE VERY MOMENT WHEN THE WEST HAS GROUNDS FOR CELEBRATING ITS GREATEST VICTORY, ALL LEADING WESTERN STATES ARE PLAGUED BY WEAKNESSES OF THEIR OWN. THERE ARE GROWING INDICATIONS EVERYWHERE THAT THE POWERS THAT BE ARE LOSING AUTHORITY WITHOUT NEW FORCES COMING TO THE FORE TO TAKE OVER. IN THE UNITED STATES, THE LOS ANGELES RIOTS, THE ECONOMIC DECLINE, AND THE APPEAL OF ROSS PEROT IN THE PRESIDENTIAL CAMPAIGN ALL POINT TO A GROWING SENSE OF MALAISE AND LOSS OF TRUST IN THE POL ITICAL ESTABLISHMENT. IN FRANCE THE RULING SOCIALISTS STAND NOT THE SLIGHTEST CHANCE OF STAYING THE LARGEST PARTY IN THE NEXT ELECTIONS. THE CONSERVATIVE OPPOSITION CANNOT HOPE TO GAIN A HORKING MAJORITY EITHER, THANKS TO THE APPEAL OF THE ULTRA-RIGHT-WING NATIONAL FRONT. IN ITALY, THE THO LEADING PARTIES, THE CHRISTIAN DEMOCRATS AND THE SOCIALISTS, HAVE SUFFERED SUCH A GREVIOUS LOSS OF PRESTIGE FROM CORRUPTION SCANDALS THAT THEY ARE UNLIKELY EVER TO RECOVER. AS FOR GERMANY, CHANCELLOR KDHL'S FEDERAL EVER TO RECOVER. AS FOR GERMANY, CHANCELLOR KOHL'S FEDERAL
GOVERNMENT IS NOT ALONE IN SUFFERING FROM SIGNS OF WEAR AND GOVERNMENT IS NOT ALONE IN SUFFERING FROM SIGNS OF WEAR
TEAR AND LOSS OF AUTHORITY. THERE IS CONSTANT BICKERING TEAR AND LOSS OF AUTHORITY. THERE IS CONSTANT BICKERING
AMONG THE SOCIAL DEMOCRATS TOO. THE LOSS OF AUTHORITY THAT AMONG THE SOCIAL DEMOCRATS TOO. THE LOSS OF AUTHORITY THAT
THE OLD POLITICAL ELITES ARE SUFFERING SEEMS TO HAVE BEEN A THE OLD POLITICAL ELITES ARE SUFFERING SEEMS TO HAVE BEEN
CONSEQUENCE OF SELF-ASSURED COMPLACENCY AND A RESULTANT SHOWING OF TOO LITTLE INTEREST IN THE CARES AND WOES OF ORDINARY PEOPLE.

09394 WAGNER, $H$

POST-UNIFICATION FOREIGN POLICY: TREMENDOUS TASKS LIE AHEAD GERMAN TRIBUNE, (1515) (MAY 92), 1-2.

GERMAN FOREIGN MINISTER, HANS-DIETRICH GENSCHER

RESIGNED WITH THE CLAIM THAT, IN FOREIGN POLICY TERMS, THE GERMAN HOUSE WAS IN GOOD CONOITION. HOWEVER, A NUMBER OF PROBLEMS WILL FACE GENSCHER'S SUCCESSORS. THEY INCLUDE THE ISSUE OF WHERE EUROPE'S FRONTIERS END; THE NECESSITY TO CONTINUE THE PROCESS OF DISARMAMENT WHICH WAS ONLY BEGUN BEFORE THE SOVIET UNION COLLAPSED; AND THE FUTURE ROLE OF THE UNITED STATES IN EUROPE. GERMANY'S POLICY MAKERS WILL ALSO HAVE TO CONFRONT THE LEGACY OF A FOREIGN POLICY GUIDED ALMOST SOLELY BY PRINCIPLE. ACTING ACCORDING TO PRINCIPLE, GERMANY WAS THE FIRST TO RECOGNIZE THE INDEPENDENCE OF THE STATES IN FORMER YUGOSLAVIA: GERMANY ALSO CUT OFF ARMS SUPPLIES TO TURKEY IN RESPONSE TO TURKISH REPRESSION OF THE KURDS. SUCH DECISIONS WERE NOT ECHOED BY OTHER NATIONS WHOSE FOREIGN POLICY IS DRIVEN MORE BY THE DEMANDS OF REALPOLITIK THAN BY LOFTY PRINCIPLE.

09395 HAH, Y.K.

STUDENT POL ITICS IN UNIVERSITY OF MALAYA, 1949-1951 JOURNAL OF SOUTHEAST ASIAN STUDIES, 23(2) (SEP 92), 346-380.

FROM 1949 TO 1951, RADICALS-TURNED-REVOLUT IONARIES ENGAGED IN POLITICAL ACTIVITIES ON TWO LEVELS AS STUDENTS AT THE UNIVERSITY OF MALAYA. ON ONE LEVEL, THEY PARTICIPATED IN CLANDESTINE POL ITICAL ACTIVITIES DESIGHED TO ADVANCE THE CAUSE OF THE COMMUNIST REVOLUTION IN MALAYA. ON ANOTHER LEVEL, THE STUDENT ACTIVISTS WERE INVOLVED IN OPEN AND LEGITIMATE SOCIO-POLITICAL ACTIVITIES ON CAMPUS. THIS PAPER LEGITIMATE SOCIO-POLITICAL ACTIVITIIES ON CAMPUS. THIS PAPER
FOCUSES ON THE OPEN ACTIVITIES OF THE LEFT-WING STUDENTS AND OTHER POLITICALLY-CONSCIOUS UNDERGRADUATES DURING THE EARLY OTHER POL ITICALLY-CONSCIOUS UNDERGRADUATES DURING
YEARS OF THE UNIVERSITY OF MALAYA IN SINGAPORE.

09396 WAINHRIGHT, H.

THE NEW LEFTT AFTER COMMUNISH

STUDIES IN POLITICAL ECONOMY: A SOCIALIST REVIEW, (38) (SUM 92 ), 155-166.

THIS ARTICLE REFLECTS ON THE SIGNIFICANCE OF THE COLLAPSE OF COMMUNISM IN THE SOVIET UNION AND EASTERN EUROPE. THE AUTHOR ARGUES THAT ONE OF ITS MOST TROUBLING AND SIGNIFICANT ASPECTS IS THE STRONG APPEAL THAT LIBERAL INDIVIDUALISM HAS HAD FOR EVEN THE LEFT INTELLIGENTSIA IN EASTERN EUROPE AND THE EX-SOVIET COUNTRIES. ONE POSSIBLE CAUSE OF THIS PHENOMENON IS THE FAILURE OF THE NEW LEFT IN THE WEST TO THEORIZE ITS DWW DEMOCRATIC PRACTICES, WHICH HAVE OFTEN EMBODIED AN EQUALLY LIBERAL ETHIC, ALBEIT A
SOCIAL OR COLLECTIVE ONE. THEREFORE, A MAJOR TASK OF THE
LEFT TODAY IS TO PRODUCE A THEORY OF THESE PRACTICES AND TO ELABORATE THIS ETHIC AS A NECESSARY BASIS FOR ANY NEW PROGRESSIVE PROJECT.

09397 WAITS, M.J.

PREPARING FOR GLOBAL COMPETITION THROUGH INDUSTRIAL

CLUSTERS
JOURNAL OF STATE GOVERMMENT, 65(3) (SUM 92), 34-37.

A CRUCIAL ELEMENT IN ANY' STATE TRADE PROGRAM IS DEVELOPING A KEEN UNDERSTANDING OF THE STRENGTHS AND WEAKNESSES OF THE STATE'S ECONOMY, INDUSTRIAL COMPOSITION, WEAKNESSES OF THE STATE'S ECONOMY, INDUSTRIAL COMPOSITION, AND INFRASTRUCTURE. ONE WAY OF ACCOMPLISHING THIS IS
THE IDENTIFICATION OF "CLUSTER" INDUSTRIES, GROUPS OF INTERCONNECTED BUSINESSES THAT FORM A SIGNIFICANT ECONOMIC UNIT ARIZONA HAS LAUNCHED A PROGRAM TO IDENT IFY ITS CLUSTER INDUSTRIES AND TO ESTABL ISH OMGOING CONTACTS BETWEEN THOSE INDUSTRIES AND PUBLIC OFFICIALS. BY CONCENTRATING INDUSTRIES AND PUBLIC OFFICIALS. BY CONCENTRATING REALLOPMENT EFFORTS IN THESE AREAS, STATE OFFICIALS HOPE TO REALIZE LONG-TERM
WELL PAYING JOBS.

09398 WALD, K.D.

RELIGIOUS ETHICS AND PUBLIC OPINION: THE IMPACT OF THE BISHOPS' PEACE PASTORAL

REVIEW OF POLITICS, 54(1) (WIN 92), 112-143.

IN THEIR 1983 PASTORAL LETTER ON WAR AND PEACE, THE CATHOLIC BISHOPS ATTEMPTED TO SWAY AMERICAN PUBLIC OPINION ABOUT THE ARMS RACE. POLLING DATA SUGGESTED THAT "THE CHALLENGE OF PEACE" STIMULATED A SHARP BUT SHORT-LIVED REACTION AGAINST MILITARY SPENDING AMONG U.S. CATHOLICS. THE MESSAGE WAS BEST RECEIVED BY CATHOLICS STRONGLY TIED TO THEIR CHURCH, REVERSIMG A HISTORICAL CORRELATION BETHEEM RELIGION AND NATIONALISH. THE PASTORAL MUST BE JUDGED RELATIVELY SUCCESSFUL IN ITS MISSION, IN LIGHT OF THE MANY BARRIERS TO ATTITUDE CHANGE. GREATER SENSITIVITY TO THOSE PERSUASIVE COMMUNICATION BY CHURCH AUTHORITIES.

09399 WALD, P.

"ONE NATION INDIVISIBLE, WITH LIBERTY AND JUSTICE FOR ALL" "ONE NATION INDIVISIBLE, WITH LIBERTY AND JUSTICE FOR ALL" LESSONS FROM THE AMERICAN EXPERIENCE FOR NEH
FORDHAM LAW REVIEW, LIX(2) (NOY 90), 283-297.

BY EXERCISING ITS CONSTITUTIONAL AUTHORITY TO DECIDE CLAIMS BY MINORITIES DENIED LIBERTY AND JUSTICE, THE U.S. FEDERAL JUDICIARY HAS OFTEN OCCUPIED A DEFINITIVE ROLE IN THE PROCESS OF UNIFYING DIVERSE CULTURES AND PEOPLES RULED DIRECTLY ON THE POLITICAL RIGHTS OF RELIGIOUS,
CULTURAL, RACIAL. AND ETHNIC GROUPS TO VOTE, ORGANIZE AND CULTURAL, RACIAL, AND ETHNIC GROUPS TO VOTE, ORGA
EXPRESS THEMSELVES. MOREOVER, IT HAS MEDIATED THE OMNIPRESENT TENSION BETHEEN DEMANDS FOR CONSTANT AND UNIFORM NATIONAL VALUES AND CLAIMS OF CITIZENS BONDED TO DISTINCT WAYS OF LIFE FORMED BY VASTLY DIFFERENT ORIGINS, CREEDS, AND RELIGION. THIS ARTICLE EXAMINES HOW WELL THE COURTS HAVE PERFORMED THEIR UNIQUE MELDING ROLE IN AMERICAN LIFE. THIS EXAMINATION REVEALS LESSONS FOR NEWLY EMERGING DEMOCRACIES,

09400 WALDEN, J.

KNOWLEDGE IS POWER

FAR EASTERN ECONOMIC REVIEW, 155(14) (APR 92), 15.

THE SEPTEMBER 1991 ELECTIONS IN HONG KONG HAS SPARKED OFF A LOCAL VERSION OF CHINA'S HUNDRED FLOWERS MOVEMENT. EACH DAY THE NEW MEDIA REPORTS SOME NEW DEVELOPMENT AS A GOVERNER WILSOH'S ADMINISTRATION. UNFORTUNATELY, IF CHINA'S EXPERIENCE IS TAKEN AS PRECEDENT, THIS BLOSSOMING OF REFORM WILL BE FOLLOWED BY "THOUGHT REFORM" WHEN CHINA TAKES CONTROL OF THE COLONY IN 1997. IN ORDER TO AVOID THIS OUTCOME, THE PEOPLE OF HONG KONG NEED TO ENACT LEGISLATION TO SECURE ACCESS TO OFFICIAL INFORMATION WHILE THERE ARE STILL LOCAL POLITICIANS WILLING TO FIGHT FOR IT. IN ADDITION, THE MASS MEDIA.

09401 WALDER, A.G.

PROPERTY RIGHTS AND STRATIFICATION IN SOCIALIST REDISTRIBUTIVE ECONOMIES

AMERICAN SOCIOLOGICAL REVIEW, 57(4) (AUG 92), 524-539. AMERICAN SOCIOLOGICAL REVIEW, 57 (4) (AUG 92), 524-539. IN THE COMPENSATION THEY PROVIDE EMPLOYEES, DESPITE THE EXPLAIN SUCH INEQUALITIIES IN MARKET ECONOMIES. EXISTING EXPLAIN SUCH INEQUALITIES IN MARKET ECONOMIES. EXISTING THEDRIES OF STRATIFICATION IN SOCIALIST ECONOMIES FOCUS ON THE POWER AND PRIVILEGE OF ELITES, BUT INEQUALITIES AHONG ORGANIZATIONS ARE NOT CREATED BY POLIITICAL PARTICULARISM OR ELITE PONER. IN THIS PAPER, THE AUTHOR SKETCHES ELEMENTS AN INSTITUT IONAL THEORY OF STRATIFICATION ANCHORED IN A CONCEPT OF PROPERTY RIGHTS--THE RIGHT TO DERIVE INCOME FROM
PRODUCTIVE ASSETS. THO ASPECTS OF PROPERTY RIGHTS GUIDE THE ANALYSIS: (1) THE DISPERSION OF PROPERTY RIGHTS ACROSS A HIERARCHY OF GOVERMMENT JURISDICTIONS AND (2) THE EXERCISE OF THOSE RIGHTS BY GOVERNHENT JURISDICTIONS AS THEY EXTRACT REVENUES, PRIMARILY THROUGH TAXATION. THE AUTHOR ANALYZES SURVEY DATA ON THE PROVISION OF HOUSING AND BENEFITS BY HORK 
ORGANIZATIONS IN THE INDUSTRIAL CITY OF TIANJIN, CHINA, TO SUPPORT HIS IDEAS.

09402 WALDMAN, M.

DECEMBER SURPRISE

NEW REPUBLIC, 206 (26) (JUN 92), 23, 26-27

IN DECEMBER 1992 U.S. VOTERS MAY DISCOVER THEY'VE BEEN

HAD AGAIN. THE UNTOLD STORY OF THE 1992 PRESIDENTIAL

ELECTION COULD BE HOW THE BUSH ADMINISTRATION BANK

REGULATORS--FRANTICALLY JIGGERING BALANCE SHEETS HERE,

JUGGLING NUMBERS THERE, AND MOVING VERY SLOWLY IN SEIZING

INSOLVENT BANKS--POSTPONED A COMMERCIAL BANKING CRISIS UNTIL AFTER THE NOVEMBER BALLOTING. THE PROBLEMS PLAGUING THE COMMERCIAL BANKS, LIKE THOSE OF THE THRIFTS, ARE THE LEGACY OF THE $1980^{\prime} \mathrm{S}$.

09403 WALICKI, A.

RUSSIA, BEFORE THE COUP AND AFTER

CRITICAL REVIEW, 5(1) (WIN 91), 1-36

THIS IS A DISCUSSION OF THE SITUATION IN THE SOVIET

UNION AS PERCEIVED BY THE AUTHOR IN THO VISITS, IN MARCH-

APRIL 1991 AND SEPTEMBER 1991. IT IS AN ATTEMPT TO BEGIN TO

APRIL 1991 AND SEPTEMBER 1991. IT IS AN ATTEMPT TO BEGIN
IDENTIFY ELEMENTS OF CONTINUITY AS WELL AS CHANGE IN THE

IDENTIFY ELEMENTS OF CONTINUITY AS WELL AS CHANGE IN THE TRANSITION TO POSTCOMMUNISM, AND TO ASSESS BOTH WHAT LED TO
THE ATTEMPTED COUP AND ITS DEFEAT AND FACTORS BEARING ON THE POSTCOMMUNIST FUTURE. HE CONCLUDES THAT HELPING RUSSIA POSTCOMMUNIST FUTURE. HE CONCLUDES THAT HELPING RUSSIA
RETURN TO EUROPE WOULD HELP THE WORLD AS A WHOLE TO RETURN RETURN TO
TO NORMAL

09404 WALKER, A.

THE PERSISTENCE OF POVERTY UNDER WELFARE STATES AND THE PROSPECTS FOR ITS ABOLITION

INTERNATIONAL JOURNAL OF HEALTH SERVICES, 22(1) (1992),

$1-18$

THE RELATIONSHIP BETWEEN POVERTY AND THE WELFARE STATE IS EXAMINED. THIS ARTICLE ATTEMPTS TO ANSHER THE QUESTION AS TO WHY POVERTY HAS PERSISTED UNDER ALL WELFARE STATES. SEVERAL MAJOR REASONS FOR THE PERSISTENCE OF POVERTY ARE ADVANCED, AND THE AUTHOR ARGUES THAT THE MAIN FACTOR UNDERLYING THE FAILURE TO ABOLISH POVERTY IS THE CONFLICT BETWEEN ECONOMIC POLICY AND SOCIAL POLICY. THE CHALLENGE TO WELFARE STATES FROM THE MEW RIGHT IS EXAMINED--PARTICULARLY THE CONTENTION THAT WELFARE STATES THEMSELVES CREATE POVERTY AND DEPENDENCE--IN THE LIGHT OF EYIDENCE OF THE IMPACT OF THE THATCHER GOVERNMENT'S POLICIES IN BRITAIN. FINALLY, THE AUTHOR PROPOSES AN ALTERNATIVE APPROACH TO THE ABOLITION OF POVERTY, ONE THAT IS BASED ON THE INTEGRATION OF ECONOMIC

AND SOCIAL POLICY.

09405 WALKER, D.B.

GERMANY: CONFRONTING THE AFTERMATH OF REUNIFICATION CUERMANY: CONFRONTING THE AFTERMATH OF REUMI

EVEN WITH ITS HIGH COSTS, UNSETTLING CHANGES, AND PROFOUND UNCERTAINTIES, GERMAN REUNIFICATION IS NOT A CURSE AND THE COUNTRY'S HEALTH HAS NOT BEEN SERIOUSLY MENACED BY IT. THERE ARE SIGNS OF OPTIMISM WITHIN THE GENERALLY DEPRESSED ECONOMIC, SOCIAL. AND POLITICAL AREAS. DESPITE ALL THE NEGATIVES, IT MUST BE UNDERSCORED THAT THE OVERWHELMING MAJORITY OF BOTH EAST AND WEST GERMANS STILL VIEW UNITY AS A POSITIVE DEVELOPMENT.

09406 WALKER, J.

AVOIDING RISK AND RESPONSIBILITY: THE UNITED STATES AND EASTERN EUROPE

CURRENT HISTORY, 91(568) (NOV 92), 364-368.

THE UNITED STATES' RESPONSE TO' THE CHALLENGES IN EASTERN EUROPE HAS BEEN TIMID, REACTIVE, UNIMAGINATIVE, AND WOEFULLY INADEQUATE. WASHINGTON STILL ASPIRES TO LEAD THE WESTERH ALLIANCE, BUT U.S. POL ICYMAKERS SEEM TO THINK THEY CAN DO SO BY KEEPING LARGE MILITARY FORCES SITTING AROUND GERMANY WAITING FOR AN ATTACK ON A MEMBER OF NATO THAT NO ONE EXPECTS. THE UNITED STATES SHOULD BE FAR MORE ENGAGED IN THE ECONOMIC AND POLITICAL RECOVERY OF EASTERN EUROPE.

09407 WALKER, M.

CHANGING THE STAKES

EUROPE, 315 (APR 92), 18-19.

IN THE COLD WAR'S AFTERMATH, GEOFINANCE REPLACES

GEOPOLITICS. THIS ARTICLE SUGGESTS THAT THE REAL ISSUE IS NOT AID, BUT MAKES THE CASE FOR INVESTMENT. THE SUDDENLY DIMINISHED IMPORTANCE OF NUCLEAR WEAPONS WAS EMPHASIZED BY THE GAME OF NUCLEAR STRIP POKER IN WHICH BUSH AND YELTSIN THE GAME OF NUCLEAR STRIP POKER IN WHICH BUSH AND YELTSIN THE OLD GEOPOLITICS OF MILTARY POWER IS DYING AS WE WATCH. BORIS YELTSIN HAS FOUND MUCLEAR STRATEGIYC POWER HAS LITTLE MEANING IN THE NEW AGE OF GEO-FINANCIAL POLITICS.

09408 WALKER, M.

TAKING RUSSIA PRIVATE

EUROPE, 321(321) (NOV 92), 10-13

PRESIDENT YELTSIN CHOSÉ AUGUST 19, THE FIRST ANNIVERSAY OF THE FAILED MOSCOH COUP, TO ANMOUNCE THE NEW PRIVATIZATION PROGRAM TO GIVE EACH OF RUSSIA'S 150 MILLION CITIZENS A SHARE IN THE COUNTRY'S SHRINKING INDUSTRIES. THE DATE WAS
CHOSEN TO SYMBOLIZE THE CRUCIAL POLITICAL CHARACTER OF THIS REFORM, HHOSE AMBITION GOES FAR BEYON THE ECONOMY. THE RUSSIAN VOUCHERS ARE ONLY VALID UNTIL THE END OF THIS YEARBY WHICH TIME THEY ARE SUPPOSED TO BE REDEEMED EITHER FOR SHARES IN AN INDIVIDUAL COMPANY OR IN ONE OF THE MANY MUTUAL FUNDS OR INVESTMENT TRUSTS WHICH ARE SPRINGING UP. THE FORMELY STATE-OWNED ENTERPRISES CAN CHOOSE FROM VARIOUS KINDS OF PRIVATIZATION, WHOSE MAIN COMMON ELEMENT IS TO ENSURE THAT THE MAJORITY OF SHARES ARE RESERVED FOR THE EXISTING WORKERS AND MANAGERS.

09409 WALKER, $M$

THE ESTABLISHMENT REPORTS

FOREIGN POLICY, (89) (WIN 93), 82-95.

REAGANOMICS IS DISCREDITED AND THE CONSERVATIVE MOVEMENT IS EXHAUSTED, JUST AS THE OLD DEMOCRATIC WELFARE POLICIES WERE EXHAUSTED AFTER LYNDON JOHNSON'S GREAT SOCIETY OF THE 1960'S. AFTER THEIR TRIUMPHS OF THE 1980'S, THE REPUBLICANS ARE BEREFT OF ANY STRATEGY TO DEFEND OLD IDEAS THAT DEMONSTRABLY NO LONGER WORK OR, AT LEAST, ARE NOH PAYING THE CYCLICAL PRICE FOR THE OVERHEATED BOOM OF THE LAST DECADE.

CLINTON'S DEMOCRATS ARE ENERGIZED BY THE PROSPECT OF

CLINTON'S DEMOCRATS ARE ENERGIZED BY THE PROSPECT OF
REGAINING POWER, WITH A PURPOSE THAT LOOKS NEW TO AMERICAN

EYES. BUT IT IS ALL FAMILIAR TO ANYONE WHO HAS STUDIED WILLY
BRANDT'S GERMAN SOCIAL DEMOCRATS, GAULLIST FRANCE, OR HAROLD BRAND' S GERMAN SOC

09410 HALKER, M.

THE OLD AMD THE NEW: HOW THE FORMER USSR HAS CHANGED. OR HAS IT?

EUROPE, 315 (APR 92), 10-11.

LIKE A THIRD WORLD CITY WHERE THE LUXURY HIGH-RISES TOWERED OVER THE SHANTYTOWNS, THE FORMER SOVIET UNION WAS SEVERAL CONTRADICTORY SOCIETIES CONFUSINGLY LUMPED INTO ONE. UNTIL THE ECONOMIC REFORMS BECOME SERIOUS TO THE POINT AT WHICH THE PEASANTS ARE GIVEN BACK THEIR LAND AND ALLOWED TO SELL THEIR CROPS FOR WHAT THEY ARE HORTH, THIS SEPARATION OF THE URBAN AND RURAL ECONOMIES, AND THE GULF BETWEEN URBAN AND RURAL HAYS OF LIFE HILL REMAIN. YELTSIN IS EXPENDING HIS POLITICAL CAPITAL AT A TERRIFYING RATE, AS THE FIRST RIOTS BEGIN TO PROTEST THE TRIPLING AND QUINTUPLING OF PRICES THAT HIS BOLD REFORMS REQUIRED. THIS ARTICLE SUGGESTS THAT THE RUSSIANS WILL SURVIVE SOMEHOW, REACHING DOWN INTO ITS TRADITIONAL, AHESOME ENDURENCE.

09411 HALKER, R.S.; FAWELL, H.W.; LEWIS, T.; MCMILLAN, A.;

ROHRABACHER, $D$.

CONGRESSIONAL DIGEST, $71(12)$ (DEC 92), 303, 305, 307, 309,

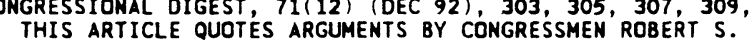

THIS ARTICLE QUOTES ARGUMENTS BY CONGRESSMEN ROBERT S.
HALKER, TOM LEWIS, ALEX MCMILLAN, HARRIS W. FAWELL, AND DANA

HALKER, TOM LEWIS, ALEX MCMILLAN, HARRIS W. FAWELL, AND DAMA
ROHRABACHER AGAINST THE PASSAGE OF H.R. 5231, THE HATIONAL

ROHRABACHER AGAINST

09412 WALKER, $W$

DRUG TRAFFICKING IN ASIA

JOURNAL OF INTERAMERICAN STUDIES AND HORLD AFFAIRS, 34(3)

FAL 92 ), $201-216$

THIS ARTICLE ANALYZES, BY SURVEYING THE EXTANT

LITERATURE, WHAT IS KNOWN ABOUT ASIAN DRUG TRAFFICKING AND SUGGESTS AN AGENDA FOR FUTURE RESEARCH. THE AUTHOR ARGUES THAT THE VAGARIES OF WORLD POLTICS DO NOT IN THEMSELVES GIVE RISE TO THE GLOBAL HEROIN TRADE. HE CONCLUDES THAT REGIME STABILTIY CAN BE PUT TO THE TEST BY EXTERNAL AS WELL AS INTERNAL FACTORS, IN ADOPTING THE GENERAL THEME OF STABILTIY, SCHOLARS WILL CREAT A BODY OF KNOWEDGE ABOUT DRUGS IN ASIA THAT WILL ULTIMATELY OPEN MANY NEW AVENUES FOR INOUIRY.

09413 WALKER, W.; SHARP, M.

IMPERIAL GOVERMMENT OR IMPERIAL JUDICIARY

POLITICAL QUARTERLY (THE), 62(2) (APR 91), 262-272.

THIS ARTICLE DESCRIBES CHARTER 88, WHICH CALLS FOR A NEH CONSTITUTIONAL SETTLEMENT TO ENSHRINE CIVIL AND HUMAN RIGHTS IN THE UK AND TO END UNFETTERED CONTROL BY THE EXECUTIVE THAT IS IN POWER AT THE TIME. OTHER PROPOSED REFORMS ARE ALSO DISCUSSED. THE AUTHOR CONSIDERS THE MOOEL OF THE U.S. SUPREME COURT IN THIS CONTEXT AND CONCLUDES THAT IT DOES NOT PROVIDE A SATISFACTORY EXAMPLE BECAUSE ITS NON-ELECTED JUSTICES ARE ANSWERABLE ONLY TO THEIR OWN INTERPRETATION OF WHAT THE CONSTITUTION SHOULD BE. THIS IS SEEN AS REPLACING ONE FORM OF DOMINANT AUTHORITY WITH ANOTHER.

09414 WALKER, W.

IS THERE A FUTURE FOR SOCIALISM?

JOURMAL OF POLITICAL AND MILITARY SOCIOLOGY, 20(2) (WIM 92), 199-208.

THE DEMISE OF STALINIST AND NEO-STALINIST SOCIALISM AND THE END OF THE COLD WAR REMOVES ONE OF THE MAJOR OBJECTIONS TO SOCIALISM FROM THE ARGUMENTS OF ANTI-SOCIALISTS, AND THUS OPENS AN OPPORTUNITY FOR THE DEVELOPMENT OF A NEW, MORE DEMOCRATIC SOCIALISH. SIMULTANEOUSLY, MOVES TOWARDS A POSSIBLE RAH CAPITALISM IN SOME OF THE FORMER SOVIET REPUBLICS AND EAST EUROPEAN COUNTRIES, AND THE RECENT POL ICIES OF RIGHTWING GOVERNMENTS IN SEVERAL WESTERH 
COUNTRIES ENHANCING A SOCIALLY HARSHER FORM OF CAPITALISM, ARE EXPOSING MILLIONS OF PEOPLE TO THE UGLY FACE OF CAPITALISM, THUS CREATING POTENTIAL FOR THE POPULAR SPREAD OF SOCIALIST IDEAS. AGAINST THIS, CAPITALISM, HHILE TEMPORARILY FALTERING, IS NONE THE LESS STRONGLY EMBEDDED IN MOST ASPECTS OF THE CULTURES OF THE CAPITALIST SOCIETIES, AND ITS RELATIVE STRENGTH ON THE INTERNATIONAL SCENE HAS BEEN INCREASED BY THE DEMISE OF THE SOVIET UNION. THUS THERE BEEN INCREASED BY THE DEMISE OF THE SOVIET UNION. THUS THERE
ARE POWERFUL FORCES BOTH TOWARDS AND AGAINST THE WIDESPREAD REVIVAL OF DEMOCRATIC SOCIALIST IDEAS. THE FUTURE IS REVIVAL OF DEMOCRATIC SOCIALIST IDEAS. THE FUTURE IS
UNCERTAIN BUT INTERESTING. HISTORY IS STILL BEING MADE.

09415 WALKER, $W$

NUCLEAR WEAPONS AMD THE FORMER SOVIET REPUBLICS INTERMATIONAL AFFAIRS 68 (2) (APR 92) 255-278. THE COLLAPSE OF THE SOVIET UNION HAS HEIGHTENED ALARM OVER THE FATE OF THE THOUSANDS OF NUCLEAR WEAPONS DEPLOYED ACROSS IT'S FORMER TERRITORIES. THE HORRY IS THAT THE NEH STATES' PLEDGES TO DISARM MAY BE OVERTURNED AND CENTRAL CONTROL WEAKENED BY ECONOMIC HARDSHIP AND THE LIKELY CONFLICT BETHEEN THE NEW NATIONS. BUT THE POLITICAL CHANGES ALSO BRING GREAT OPPORTUNITIES. THE AUTHOR WRITES THAT THERE IS NOH THE CHANCE TO DE-NUCLEARIZE MUCH OF EURASIA AND TO ACHIEVE DEEP CUTS IN THE US AND RUSSIAN ARSENALS. THE SOVIET UNION'S DEMISE HAS SHOWN THAT ECONOMIC DEVELOPMENT-NOT THE POSSESSION OF NUCLEAR HEAPONS-IS THE MAIN GUARANTOR OF THE SECURITY OF STATES.

09416 WALLACE, M.D.

PREVENTING ACCIDENTAL NUCLEAR WAR: RISKS AND REMEDIES IN A POST-COLD WAR WORLD

DISARMAMENT, XIV(3) (1991), 74-96.

THE AUTHOR ASSESSES THE' RISK OF AN ACCIDENTAL NUCLEAR WAR IN THE POST-COLD WAR ERA AND DISCUSSES SOME OF THE APPROACHES TO AVOIDING SUCH A CATASTROPHE.

09417 WALLACE, $W$.

REDEFINING 'BRITISHNESS': BRITISH FOREIGN POLICY AFTER THE COLD WAR

INTERNATIONAL AFFAIRS, 68(3) (JUL 92), 423-442.

THE TRANSFORMATION OF THE EUROPEAN' INTERNATIONAL ORDER

SINCE 1989 HAS FUNDAMENTALLY ALTERED THE CONTEXT FOR

SINCE 1989 HAS FUNDAMENTALLY ALTERED THE CONTEXT FOR
CONDUCTING BRITISH FOREIGN POLICY. BEHIND THESE RAPID

CONDUCTIMG BRITISH FOREIGN POLICY. BEHIND THESE RAPID

MORE GRADUAL TECHNOLOGICAL AND ECONOMIC CHANGES HAVE FURTHER MORE GRADUAL TECHNOLOGICAL AND ECONOMIC CHANGES HAVE FURTHER
UNDERMINED THE ASSUMPTIONS UNDERLYING BRITISH FOREIGN POLICY. UNDERMINED THE ASSUMPTIONS UNDERLYING BRITISH FOREIGH POL
SOCIAL AND ECONOMIC CHANGE HAS ALSO BEEN ALTERING THE SOCIAL AND ECONOMIC CHANGE HAS ALSO BEEN ALTERING THE
CHARACTER AND COHESION OF THE BRITISH STATE THAT FOREIGN CHARACTER AND COHESION OF THE BRITISH STATE THAT FOR POLICY IS INTENDED TO SERVE. THE BRITISH GOVERNMENT, EXPENDITURE INTO NATIONAL FOREIGN AND DEFENSE POLICIES, NOH MUST PERSUADE ITS AUDIENCE BOTH HITHIN AND OUTSIDE BRITAIN THAT IT STILL HAS A DISTINCTIVE PERSPECTIVE TOWARDS SHARED SECURITY AND ECONOMIC PROBLEMS.

09418 WALLACE, W.L.

RATIONALITY, HUMAN WATURE, AND SOCIETY IN WEBER'S THEORY THEORY AND SOCIETY, 19(2) (APR 90), 199-224.

THIS ARTICLE CONTAINS A SURVEY OF SOME RECENT

INTERPRETATIONS OF RATIONALITY IN MAX WEBER'S THEORY. THE COMMENTATORS DISCUSSED INCLUDE BRUBAKER, KALBERG, LEYINE, SWIDLER, SCHLUCHTER, TENBRUCK, AND HILEY. THEIR YIEWS ARE COMPARED, AND DIFFERENCES AND SIMILARITIES AMONG THE VIEWS ARE NOTED.

09419 WALLER, $H$.

WHAT LIES AHEAD FOR CAMADA

NEW LEADER, LXXV (14) (NOV 92), 9-11.

THE CANADIANS HAYE DELIVERED a RESOUNDING "NO" IN A MATIONAL REFERENDUM ASKING THEM TO APPROVE OR REJECT A SERIES OF CONSTITUTIONAL CHANGES KMOWN AS THE CHARLOTTETOWM ACCORD. THE RESULT IS THAT AFTER YEARS OF CONSTITUTIONAL WRANGLING, THE CANADIANS ARE UNSURE ABOUT WHERE THEIR NATION IS HEADED. QUEBEC'S FEDERALISTS OBJECTED TO CHARLOTTETOWN BECAUSE THEY BELIEVED IT STRENGTHENED LOCAL POWER AT THE BECAUSE THEY BELIEVED IT STRENGTHENED LOCAL POHER AT
EXPENSE OF THE FEDERAL GOVERHMENT AND THE RIGHTS OF EXPENSE OF THE FEDERAL GOVERNMENT AND THE RIGHTS OF
INDIVIDUALS. THE OCTOBER OUTCOME HAS LEFT THE CONSTITUTIONAL INDIVIDUALS. THE OCTOBER OUTCOME HAS LEFT THE CONSTITUTIONAL NEGOTIATIONS IN A LOGJAM: CONCOCTING A COMPROMISE AGREEABLE
TO EVERYONE SEEMS TO BE IMPOSSIBLE AT PRESENT. HOWEVER, THE TO EVERYONE SEEMS TO BE IMPOSSIBLE AT PRESENT. HOWEVER,
DEFEAT OF THE CHARLOTTETWON ACCORD DOES NOT PRESAGE A DEFEAT OF THE CHARLD
BREAKUP OF CANADA.

09420 WALLER, M.

GROUPS, INTERESTS, AND POLITICAL AGGREGATION IN EAST

EUROPE

JOURNAL OF COMMUNIST STUDIES, 8(1) (MAR 92), 128-147.

THE POLITICAL SYSTEMS OF EAST CENTRAL EUROPE ARE STILL SUBJECT TO THE FLUX ARISING FROM THE FALL OF THE COMMUNIST REGIMES. IT IS TAKING TIME FOR CLEAR CONSTITUENCIES TO EMERGE WITH COHERENT LEADERSHIPS IN A STABLE NETWORK OF AUTONOMOUS POLITICAL ACTIVITY. CERTAIN FORMS OF ORGANIZATION DATING FROM THE GESTATION PERIOD HAVE BEEN INFLUENTIAL. IN SOME CASES, THE STRUCTURES OF THE COMHUNIST PERIOD HAVE IN DEVELOPED AN AUTONOMOUS ROLE. SECONDLY, A SERIES OF MAJOR
AGGREGATING FORCES EMERGED IN THE "FORUM" MOVEMENTS. CREATURES OF THE TRANSITION PERIOD, THEY HAD A STRONG INFLUENCE IN SETTING THE STAGE FOR LATER DEVELOPMENTS. THIRDLY. THE END OF THE COMMUNIST MONOPOLY LED TO THE EMERGENCE OF CLUBS AND CIRCLES OFTEN OF A LIBERTARIAN NATURE, REFLECTING THE GENERATIONAL FACTOR IN THE PROCESS OF CHANGE. FINALLY, THE CIRCUMSTANCES OF FLUX HAVE ALLOWED STRONG RELIGIOUS, ETHNIC, AND REGIONAL IDENTITIES TO EMERGE, OR REEMERGE.

09421 WALLES, $M$.

THATCHERISM AND TECHNICAL ADVANCE: REFORM WITHOUT PROGRESS : THATCHERISM AND TECHNICAL ADVANCE:

POLITICAL QUARTERLY (THE), 62(2) (APR 91), 273-284.

THIS ARTICLE ARGUES THAT THE THATCHERITE LAISSEZ-FAIRE ECONOMIC AND POLITICAL POLICIES UNDERVALUED TECHNOLOGICAL ADVANCE AND FAILED TO SPUR PROGRESS IN THIS AREA. THE 1980S, WHEN THATCHER WAS IN POHER, ARE COMPARED WITH THE 1960S, WHEN THERE WAS STRONG CONCERN WITH TECHNOLOGY AS THE HARBINGER OF "THE GOOD LIFE" AND AS A SYMBOL OF BRITAIN'S ABILITY TO REMAIN A GREAT POWER. THE IMPACT OF THATCHER'S LACK OF CONCERN ON ECONOMIC PERFORMANCE IS EXAMINED.

09422 WALLIS, A.D.

NEW LIFE FOR REGIONALISH? MAYBE

NATIONAL CIVIC REVIEW, 81(1) (WIN 92), 19-26.

THE REAL SIGNIFICANCE OF THE INTERMODEL SURFACE

TRANSPORTATION AND EFFICIENCY ACT OF 1991 IS ITS PROVISION FOR THE EMPONERMENT OF REGIONAL AGENCIES TO RECONCILE LANDUSE PATTERNS AND INFRASTRUCTURE NEEDS WITH EXISTING AIR QUALITY REGULATIONS.

09423 HALLOP, M.

RECIPE' FOR DECLINE

NATIONAL INTEREST, 29 (FAL 92), 49-52.

THAT THE THIN STRATEGIES OF RECONSTITUTION AND THE NEW ACQUISITION STRATEGY PROVIDE A RECIPE FOR U.S. MILITARY DECLINE IS THE THESIS OF THIS ARTICLE. THE DEPARTMENT OF DEFENSE HAS ARTICULATED A NEW REGIONAL STRATEGY ANO A DEFENSE HAS ARTICULATED A NEW REGIONAL STRATEGY AND A
SUPPORTING BASE FORCE AS NEW NATIONAL SECURITY STRATEGY SUPPORTING BASE FORCE AS NEW NATIONAL SECURITY STRATEGY.
RECONSTITUTION PROVIDES THE RATIONALE FOR HUGE REDUCTIONS IN RECONSTITUTION PROVIDES THE RATIONALE FOR HUGE REDUCTIONS
U.S. EXISTING FORCES WHILE THE NEH ACQUISITION STRATEGY U.S. EXISTING FORCES HHILE THE NEN ACQUISITION STRATEGY
RATIONALIZES SIMILARLY HUGE REDUCTIONS IN FUTURE MILITARY RATIONALIZES SIMILARLY HUGE REDUCTIONS IN FUTURE MILITARY PROCUREMENT. THE AUTHOR SUGGESTS THAT, TAKEN TOGETHER, THEY
PROVIDE A HIGHLY OPTIMISITC AND TOTALLY MISGUIDED RATIONALE PROVIDE A HIGHLY OPTIMISITC AND TOTALLY MISGUIDED RATIONALE THE MAINTENANCE OF EXISTING FORCES. SINCE THEIR ENUNCIATION, THE MAINTENANCE OF EXISTING FORCES. SINCE THEIR ENUNCIATION, RECONSTITUTION AND THE NEW ACQUISITION STRATEGY HAVE BEEN DOING UNINTENDED DAMAGE BY DISPLACING THE USEFUL PLANNING
THE U.S. SHOULD BE DOING. THE ARTICLE CONCLUDES THAT THE U.S SHOULD BE HONEST ABDUT REQUIREMENTS, CREATE AN OVERALL DEFENSE ACQUISITION PLAN, AND STOP THE TALK OF NEH STRATEGIES WHERE THERE ARE NONE.

09424 WALSH, J.H

CENTRAL EUROPE: MIGRATION AND ENYIRONMENTAL TRENDS IN THE '9OS

MIGRATION WORLD, 19(2) (1991), 407

THE FOCUS OF THIS PAPER IS ON THE MAJOR GLOBAL CONCERNS OF THE 1990S--THE ENVIRONMENT AND IMMIGRATION AND THEIR INTERNATIONAL CONSEQUENCES--AS THESE CONCERNS RELATE TO RECENT POLITICAL DEVELOPMENTS IN CENTRAL EUROPE. SPECIFIC PROBLEMS EXAMINED INCLUDE TOXIC WASTES; POLLUTED AIR, WATER, AND LAND; IMMIGRATION OF THIRD WORLD REFUGEES: AND THE GENERAL ECONOMIC PROBLEMS THAT HAVE EXISTED SINCE THE DEMISE OF COMHUNISH. THE SITUATIONS IN UNIFIED GERMANY, BULGARIA, EVALUATED.

09425 WALSH, $P$.

A LONG SHOT? PEACE IN EAST TIMOR

ARENA, 98 (1992), 35-39.

THE SANTA CRUZ MASSACRE IN MOVEMBER 1991 COULD PROVE TO BE A TURNING POINT, NOT ONLY FOR EAST TIMOR BUT FOR INDONESIA. WHAT DISTINGUISHED THIS FROM OTHER EXCESSES IS ABOVE ALL ITS TIMING AND THE FACT THAT IT HAPPENED IN THE PRESENCE OF FOREIGNERS IN EAST TIMOR. THE MASSACRE ALSO CDINCIDED WITH A MOVEMENT FOR CHANGE IN INDONESIA. THE TRAGEDY HAS DEMONSTRATED THAT THE INTEGRATION OF EAST TIMOR
IS BANKRUPT AND ONLY KEPT IN PLACE AT GUNPOINT. THIS ARTICLE IS BANKRUPT AND ONLY KEPT IN PLACE AT GUNPOINT. THIS ART
EXAMINES THE COMPOSITION OF THE SEVERAL THOUSAND-STRONG EXAMINES THE COMPOSITION OF THE SEVERAL THOUSAND-STRONG

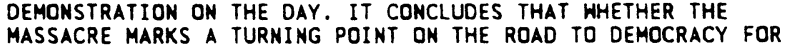
MASSACRE MARKS A TURNING POINT ON THE ROAD TO DEMOCRACY FOR BOTH INDONESIA AND EAST TIMOR
THE INTERNATIONAL COMMUNITY.

09426 WALT, S.M.

REVOLUTION AND HAR

WORLD POLITICS, 44(3) (APR 92), 321-368.

EVEN THOUGH' REVOLUTIONS ARE WATERSHED EVENTS IN INTERNATIONAL POLITICS, THE EXISTING LITERATURE ON REVOLUTIONS FOCUSES PRIMARILY ON THE CAUSES OF REVOLUTION OR ITS EFFECTS ON DOMESTIC POLITICS. ON AN INTERNATIONAL LEVEL, REVOLUTIONS ARE A POTENT CAUSE OF INSTABILITY AND WAR 
beCause they alter the "Balance of threats" between the REVOLUTIONARY STATE AND OTHER MEMBERS OF THE SYSTEM. FIRST, REVOLUTIONS ALTER THE BALANCE OF POWER AND MAKE IT MORE DIFFICULT FOR STATES TO MEASURE IT ACCURATELY. SECONDLY, THEY ENCOURAGE STATES TO EXAGGERATE ONE ANOTHER'S HOST
FURTHER INCREASING PERCEPTIONS OF THREAT. THIRDLY, FURTHER INCREASING PERCEPTIONS OF THREAT. THIRDLY, REVOLUT IONS CAUSE STATES TO EXAGGERATE BOTH THEIR VULNERABILITY AND THAT OF THEIR OPPONENTS, THEREBY ENCOURAGING THEN TO VI THIS COMBINATION OF INSECURITY AND AND FEASIBLE. HOWEVER, IHIS COMBINATION OF INSECURITY AND USUALLY HARDER EITHER TO EXPORT OR REVERSE THAN EITHER SIDE EXPECTS.

09427 WALTER, R.J.

PUBLIC EMPLOYERS' POTENTIAL LIABILITY FROM NEGLIGENCE IN EMPLOYMENT DECISIOMS

PUBLIC ADMINISTRATION REVIEW, 52(5) (SEP 92), 491-496.

INCREASINGLY, PUBLIC SECTOR EMPLOYERS ARE BEING HELD LEGALLY RESPONSIBLE FOR "CARELESS" EMPLOYMENT DECISIONS. IN THIS ARTICLE. THE AUTHOR OFFERS AN OVERVIEW OF THE RISKS PUBLIC EMPLOYERS FACE UNDER CURRENT LIABILITY LANS AND PUBLIC EMPLOYERS FACE UNDER CURRENT LIABILITY LAWS AND RULINGS. "EMPLOYMENT PROCESS NEGLIGENCE" LAWSUITS CAN DECISIONS FAILED TO EXERCISE "REASOMABLE CARE" IN HIRING, DECISIONS FAILED TO EXERCISE "REASONABLE CARE" IN HIRING, THERE IS A CAUSAL LINK BETHEEM THE DECISION AND THE INJURY THERE IS A CAUSAL LINK BETHEEN THE DECISION AND THE INJURY IMMUNITY LAHS ARE RELEVANT IN SOME CASES, SUCH PROTECTIONS IMMUNITY LAWS ARE RELEVANT IN SOME

09428 WALTERS, A

A HARD RUBLE FOR THE NEW REPUBLICS

NATIONAL REVIEH, XLIV(2) (FEB 92), 34-36.

THIS ARTICLE ARGUES THAT THERE' IS A KEYNES, IF NOT KEYNESIAN, SOLUTION FOR CONTEMPORARY RUSSIA AND THE OTHER REPUBLICS THAT EMERGE FROM THE DISINTEGRATING USSR. THE COLLAPSE OF THE EXISTING RUSSIAN RUBLE--CURRENTLY TRADING AT LESS THAN A PENHY A RUBLE--IS AS OBVIOUS AS IT IS DISTRESSING. FOLLOWING KEYNES, THE RUSSIANS WOULD CREATE A HARD NEW RUBLE TO COMPETE HITH THE EXISTING OR OLD RUBLE. A CURRENCY BOARD WOULD BE SET UP WITH THE SOLE FUNCTION OF EXCHANGING THE NEH RUBLE AGAINST A SPECIFIED HARD CURREMCY AT A FIXED RATE. THIS POLICY WOULD KEEP THE OLD IMFLATIMG RUBLE FREELY FLOATING IN A FREE MARKET, TO ENABLE THE GOVERMMENT TO COVER ITS OBLIGATIONS. IT HOULD ALSO BE USEFUL GOVERNMENT TO COVER ITS OBLIGATIONS. IT HOULD ALSO BE USE IN AVOIDING THE SHOCK IMPLIED IN HARDENING THE EXISTING RUBLE. THE PARALLEL HARD AND SOFT RUBLES WOUL
TRANSITION TO A FREE AND OPEN MARKET ECONOMY.

09429 WALTERS, $R$.

THE OFFICE OF TECHNOLOGY ASSESSMENT OF THE UNITED STATES CONGRESS: A MODEL FOR THE FUTURE?

GOVERNMENT AND OPPOSITION, 27 (1) (WIN 92), 89-108.

IN THE UNITED STATES, CONGRESS HAS FOUR AGENCIES TO UNDERTAKE RESEARCH, INCLUDING POLICY IMVESTIGATION, ON ITS BEHALF. ONLY THE OFFICE OF TECHNOLOGY ASSESSMENT (OTA) HAS A MANDATE EXCLUSIVELY TO CONSIDER TECHNOLOGY, BUT THE OTHER THREE AGENCIES--THE CONGRESSIONAL RESEARCH SERVICE, THE GENERAL ACCOUNTING OFFICE, AND THE CONGRESSIONAL BUDGET OFFICE--ALSO SOMETIMES UNDERTAKE WORK ON SCIENCE AND TECHNOLOGY ISSUES. IN THIS PAPER, THE AUTHOR FOCUSES ON THE OPERATIONS OF THE OTA.

09430 HALZER, $M$.

THE TURN

NEW REPUBLIC, 207 (14) (SEP 92), 12, 14-15

THE AUTHOR EXPLAINS THE IMPACT OF THE LEFT'S VICTORY IN ISRAEL'S JUNE 23, 1992, ELECTIONS. HE DECLARES THAT LABOR AND THE LEFT ARE COMMITTEED TO "LITTLER ISRAEL" RATHER THAN THE "GREATER ISRAEL" OF THE PAST. THEIR VICTORY GIVES THEM A CHANCE TO PROVE THAT SUCH A SMALL COUNTRY CAN STILL INSPIRE THE ENTHUSIASM AND DEVOTION MECESSARY TO SUSTAIN IT.

09431 WAMSTED, D.

ISRAEL LOBBY OPPOSING SAUDI F-15 PURCHASE

WASHINGTON REPORT ON MIDDLE EAST AFFAIRS, XI (1) (JUN 92), 26-27.

IN APRIL 1992, ISRAEL'S CONGRESSIONAL SUPPORTERS FOCUSED ON REPORTS THAT THE BUSH ADMINISTRATION PLANS TO SELL AN ADOITIONAL 72 F-15 JET FIGHTERS TO SAUDI ARABIA. MORE THAN 235 MEMBERS OF CONGRESS SIGNED A LETTER TO PRESIDENT BUSH, 235 MEMBERS OF CONGRESS SIGNED A LETTER

09432 WAMSTED, D.J.

LOAN GUARANTEES, AGAIN?

WASHINGTON REPORT' ON MIDDLE EAST AFFAIRS, XI(3) (AUG 92), 29-30.

THE ISRAELI ELECTION AND THE U.S. PRESIDENTIAL ELECTION CAMPAIGH HAVE RESUSCITATED ISRAEL'S CONTROVERSIAL REQUEST FOR \$10 BILLION IN U.S. LOAN GUARANTEES TO PROVIDE HOUSING FOR JEHISH IMMIGRANTS FROM THE FORMER SOVIET UNION.
09433 HAMUTUA, $M$

A BREAK WITH THE PAST?

AFRICA REPORT, 37(1) (JAN 92), 21-24.

KENYA'S PRESIDENT DANIEL ARAP MOI HAS FINALLY AGREED TO THE IDEA OF MULTI-PARTY DEMOCRACY IN HIS COUNTRY, BUT IT TOOK TREMENDOUS PRESSURE FROM WESTERN AID DONORS TO CONVINCE HIM. UNFORTUNATELY, TRANSFORMING A ONE-PARTY STATE INTO AN OPEN SOCIETY WILL NOT AUTOMATICALLY REVERSE THE DECADE-LONG DETERIORATION OF KENYA'S POLITICAL, ECONOMIC, AND SOCIAL INSTITUTIONS.

09434 WAMUTUA, M.

THE POLITICS OF DOOM

AFRICA REPORT, 37(3) (MAY 92), 13-16.

ALTHOUGH PRESIDENT DANIEL ARAP MOI HAS BEEN PRESSURED INTO OPENING KENYAN SOCIETY TO MULTI-PARTY POLITICS, HE HAS MADE IT CLEAR THAT HE WOULD LIKE TO RETURN TO THE STATUS-OUOANTE. CRITICS CHARGE THAT MOI'S GOVERMMENT IS FOMENTING ETHNIC VIOLENCE AND SUPPRESSING POLITICAL ACTIVITY TO TRY TO PROVE THAT PLURALISM WON'T WORK IN KENYA. MEANWHILE. THE PROVE THAT PLURALISM WON T WORK IN KENYA. MEANWHILE, THE BETHEEN THE OLD GUARD AND THE NEH GENERATION.

09435 HANANDI, J.

LOOMING CHALLENGE FOR ASEAN

FAR EASTERM ECONOMIC REYIEH, 155(3) (JAN 92), 15.

THE END OF THE COLD WAR HAS BROUGHT ABOUT' FUNDAMENTAL CHANGES IN THE ASIA-PACIFC REGION--INCLUDING THE END OF THE CAMBODIAN CONFLICT, A THAW ON THE KOREAN PENINSULA AND EASING OF RUSSIAN-JAPANESE TENSIONS. IN THE LIGHT OF THE CHALLENGES THAT THE ASSOCIATION OF SOUTH EAST ASIAN NATIONS (ASEAN) FACES BECAUSE OF THESE CHANGES, OBSERVERS HAVE RAISED QUESTIONS OVER THE REGIONAL ORGANIZATION'S VIABILITY. UNLESS ECONOMIC INTEGRATION--BEGINNING WITH AN ASEAN FREE TRADE AREA--IS ADVANCED, AND MOVES ARE MADE TO INCREASE POLITICAL AND MILITARY COOPERATION, THE ORGANIZATION IS LIKELY TO FADE INTO INSIGNIFICANCE.

09436 WANG, J.; LIN, Z.

CHINESE PERCEPTIONS IN THE POST-COLD WAR ERA: THREE IMAGES OF THE UNITED STATES

ASIAN SURVEY, XXXII(10) (OCT 92), 902-917.

IN ORDER TO SHED LIGHT ON THE EMRGING DEBATE AMONG FOREIGN POLICY-MAKERS IN CHINA, THIS ARTICLE DISTINGUISHES THREE COMPETING IMAGES OF THE UNITED STATES ARTICULATED OVER THE PAST TWO YEARS BY CHINA'S FOREIGN POLICY ANALYSTS. THE FIRST IMAGE IS THE "IDEOLOGICAL PERSPECTIVE." IT VIEHS FIRST IMAGE IS THE "IDEOLOGICAL PERSPECTIVE." IT VIEHS STRUGGLE BETHEEN SOCIALIST AND CAPITALIST SYSTEMS IN THE STRUGGLE BETHEEN SOCIALIST AND CAPITALIST SYSTEMS IN THE
HORLD. ITS PRDPOSED SOLUTIONS VERY MUCH RESEMBLE CHINA'S HORLD. ITS PRDPOSED SOLUT IONS VERY MUCH RESEMBLE CHINA'S EMPHASIZES GEDPOLITICS AND PRAGMATICALLY SEEKS TO ASSESS THE EMPHASIZES GEOPOLITICS AND PRAGMATICALLY SEEKS TO ASSESS THE RELATIVE STRENGTH OF THE UNITED STATES IN THE POST-COLD WAR "BARBARIANS AGAINST BARBARIANS" TO MAKE UP FOR ITS OWM WEAK BARBARIANS AGAINST BARBARIANS" TO MAKE UP FOR
POWER POSITION. THE THIRD IMAGE STRESSES GLOBAL

POWER POSITION. THE THIRD IMAGE STRESSES GLOBAL POLITICS AND INTERDEPENDENCE AND THE FACT THAT INTERHATIONAL POL ITICS AND
ECONOMICS ARE NO LONGER A ZERO-SUM GAME. EMPHASIS IS PLACED ECONOMICS ARE NO LONGER A ZERO-SUM GAME. EMPHASIS IS PLA ON ACCOMHOOATION TO PREVAILING REGIMES AND NORMS. THE ARTICLE CONCLUDES THAT THE EXISTENCE OF THESE THREE IMAGES
DEMONSTRATES THAT CHINESE VIEWS ON WORLD AFFAIRS ARE NOT MONOLITHIC.

09437 WANGNER, $H$.

MOSCOW SUMMIT HAS MORE A VIEW FROM THE VALLEY

GERMAN TRIBUNE, 1479 (AUG 91), 1-2.

THIS ARTICLE DISCUSSES A 1991 MOSCOW SUMAIT IN HHICH PRESIDENT GOVBACHEV AND PRESIDENT BUSH SIGNED THE START TREATY BY TERMS OF WHICH THE SUPERPOWERS HAVE AGREED, FOR THE FIRST TIME EVER, TO DECREASE SOME OF THEIR STRATEGIC WEAPONS. THE GRAVE AND SOLEMN FEATURES OF THE SUMMIT MEETING INCLUDING PRESIDENT BUSH'S TALK OF A "NEW ERA OF PROMISE" THE SUMMIT WAS SUPPOSED THE SOVIET UNION AND ITS REPUBLICS IN THEIR "HISTORIC STRUGGLE FOR DEMOCRACY AND REFORM." THESE SOLEMN NORDS MARKED THE END OF DECADES IN WHICH THE UNITED STATES AND THE SOVIET UNION FOUGHT TOOTH AND NAIL FOR INTERNATIONAL HEGEMONY.

09438 WANK, $S$.

ARISTOCRATS AND POLITICS IN AUSTRIA 1867-1949: A CASE OF HISTORIOGRAPHICAL NEGLECT

EAST EUROPEAN QUARTERLY, XXVI(2) (SUM 92), 133-148.

MANY HISTORIANS HAVE' ASSUMED THAT THE ARISTOCRACY IN THE SECOND-HALF OF THE NINETEENTH CENTURY MARCHED OFF THE STAGE OF HISTORY AS A SPENT POLITICAL FORCE. BUT THIS PAPER OUESTIONS THAT ASSUMPTION FOCUSING ON THE FORMS AND EXTENT OF THE AUSTRIAN NOBILIY''S ADJUSTMENT TO CHAMGED CONDITIONS AFTER 1848. THE AUTHOR DISCUSSES THE PERSISTEMCE OF ARISTOCRATIC POLITICAL POWER AND INFLUENCE IN AUSTRIA EVEN AFTER THE INTRODUCTION OF CONSTITUTIONAL PARLIAMENTARY GOVERNMENT IN THE 1860'S. HE RELIES HEAVILY ON NEWLYPUBLISHED SOURCES THAT PROVIDE AN EMPICIAL BASIS FOR STUDYING THE ARISTOCRACY'S MODE OF POLITICAL OPERATION AND THE UNDERLYING IDEOLOGICAL FOUNDATIONS. 
09439 WANNISKI, J.

THE FUTURE OF RUSSIAN CAPITALISM

FOREIGN AFFAIRS, 71(2) (SPR 92) 17-25.

ALTHOUGH IT HAS OFTEN BEEN ASSUMED THAT RUSSIAN CAPITALISH WOULD FOLLOW THE SWEDISH MODEL. IT IS POSSIBLE WILL BE DIFFERENT FROM ANY NOW IN OPERATION.

09440 WARBURG, G.

THE NILE IN EGYPTIAN-SUDANESE RELATIONS

ORIENT, 32 (4) (DEC 91), 565-572.

EGYPT'S RELATIONSHIP WITH THE SUDAN HAS BEEN AND REMAINS BOTH CLOSE AND CRUCIAL. THE DEPENDENCE OF THE TWO COUNTRIES BOTH CLOSE AND CRUCIAL. THE DEPENDENCE OF THE THO COUNTRIES ON A JOINT SOURCE OF WATER CONTINUES TO PLAY A CENTRAL ROLE. SINCE THE OVERTHROW OF PRESIDENT NUMAYRI, IN 1985 , RELATIONS PRTMEEN THE TWO COUNTRIES HAVE DETERIORATEED CONSIDERABLE, PRIMARILY AS A RESULT OF THE SUDAN'S POLICIES. COMPARED WITH OTHER COUNTRIES, EQYPT IS STILL REALTIVELY WELL OFF AS FAR
AS ITS SOURCES OF WATER ARE CONCERHED. HOWEVER, THE OUTLOOK AS ITS SOURCES OF WATER ARE CONCERNED. HOWEYER, THE QUTLOOK SEEMS GLOOMY UNLESS CONSERVATION PLANS ARE IMPLEMENTED IN
THE VERY NEAR FUTURE OR ALTERNATIVE SOURCES ARE DISCOVERED.

09441 WARBURG, G.

THE SUDAN AND ISRAEL: AN EPISODE IN BILATERAL RELATIONS

MIDDLE EASTERN STUDIES, 28 (2) (APR 92), 385-396.
UNTIL 1948, BOTH PALESTINE AND THE SUDAN WERE

EFFECTIVELY UNDER BRITISH RULE, AND BILATERAL RELATIONS

EXISTED BETHEEN THESE THO COUNTRIES. ALL THIS CHANGED IN THE POST-SECOND WORLD WAR PERIOD, WHEN RELATIONS BETWEEN THE ARAB LEAGUE AND THE JENS IN PALESTINE DETERIORATED RAPIDLY. THE ARAB LEAGUE REFUSED TO RECOGNIZE THE LEGITIMACY OF THE NEW STATE AND DECLARED A GENERAL BOYCOTT ON ALL TRADE AND ON OTHER RELATIONS WITH ISRAEL. IN ORDER TO MAKE IT CLEAR IN CAIRO THAT EGYPT COULD NOT DICTATE THE POLICIES OF THE SUDAN, GREAT BRITAIN BECAME INVOLVED BECAUSE, AT STAKE WERE THE SUDAN'S EXPORTS TO ISRAEL. THIS ARTICLE TRACES THE DEVELOPMENTS IN THE RELATIONSHIPS BETWEEN PALESTINE AND THE SUDAN, AND EXAMINES TRADE POLICY OF THE AREA.

09442 WARD, I.

THE CHANGING ORGAMIZATIONAL MATURE OF AUSTRALIA'S

THE CHANGING ORGA
POLITICAL PARTIES

JOURNAL OF COMMONHEALTH AND COMPARATIVE POLITICS, $X X I X(2)$ JOURNAL OF COMMONHEA

JUL 91), 153-174. OUTWAROLY AUSTRALIA'S TWO MAJOR POLITICAL PARTIES-OTHE
AUSTRALIAN LABOR PARTY (ALP) AND LIBERAL PARTY (LPA)--MIGHT AUSTRALIAN LABOR PARTY (ALP) AND LIBERAL PARTY (LPA)--MIGH
APPEAR TO BE EXTRAORDINARILY RESILIENT AND STABLE. YET, THERE CAN BE LITTLE DOUBT THAT THE LPA AND ALP ARE EACH UNDERGOING MARKED CHANGES. THE ONCE PRAGMATIC LPA NOH CHAMPIONS THE MARKETPLACE WITH A NEWFOUND IDEOLOGICAL ENTHUSIASM. THE ONCE IDEOLOGICALLY FERVENT ALP HAS SHED ITS FORMER FAITH IN PUBLIC OWNERSHIP AND IS NOW RUN BY SUPREMELY PRAGMATIC POLITICIANS. THIS ARTICLE EXPLORES THE CHANGING NATURE OF AUSTRALIAN POLITICAL PARTIES. IT EMPHASIZES "PARTY ORGANIZATION" AS A KEY TO UNDERSTANDING THE CHANGES WHICH THE LPA AND THE ALP ARE UNDERGOING.

09443 HARD, M.; RAJMAIRA, S.

RECIPROCITY AND NORMS IN U.S.-SOVIET FOREIGN POLICY JOURNAL OF CONFLICT RESOLUTION, 36(2) (JUN 92), 342-368.

THIS STUDY EXAMINES THE NATURE OF U.S.-SOVIETT RELATIONS

OVER THE PAST 4 DECADES. THE AUTHORS FOCUS ESPECIALLY ON THE 1980S. THERE HAS BEEN A MARKED SHIFT IN U.S. -SOVIET CONFLICTUAL AND COOPERATIVE FOREIGN POLICY BEHAVIOR QUANTITATIVELY THE CHANGES IN CONFLICTUAL AND COOPERATIVE BEHAVIOR IN THE CONTEXT OF RECIPROCITY AND EVOLVING NORMS. TIME-VARYING PARAMETER ESTIMATES OF MEMORY AND REACTIVITY FOR BOTH COUNTRIES, AS WELL AS THE INTERACTION PROPENSITIES OF SUCCESSIVE HEADS OF STATE, SUGGEST AN INCREASE IN COOPERATION AND A LEVELING OFF OF HOSTILITY BETWEEN THE UNITED STATES AND THE SOVIET UNION SINCE 1985.

09444 WARD, M.D.; DAYIS, D.R.

SIZING UP THE PEACE DIVIDEND: ECONOMIC GROWTH AND MILITARY SPENDING IN THE UNITED STATES, 1948-1996

AMERICAN POLITICAL SCIENCE REVIEN, 86(3) (SEP 92), 748-755. THE AUTHORS EXAMINE THE RELATIONSHIP BETHEEN MILITARY EXPENDI TURES AND ECONOMIC GROWTH IN THE UNITED STATES FROM

1948 TO 1990 , IN ORDER TO GAUGE THE POTENTIAL PEACE DIVIDEND. 1948 TO 1990, IN ORDER TO GAUGE THE POTENTIAL PEACE DIVIDEND.
THE RESULTS SUGGEST THAT MILITARY SPENDING IS A SIGNIFICANT THE RESULTS SUGGEST THAT MILITARY SPENDING IS A SIGNIF
DRAIN ON THE U.S. ECONOMY. THE AUTHORS ALSO EXPLORE THE DRAIN ON THE U.S. ECONOMY. THE AUTHORS ALSO EXPLORE THE
IMPLICATIONS OF A RESTRUCTURED INTERNATIONAL SYSTEM FOR U.S. IMPLICATIONS OF A RESTRUCTURED INTERNATIONAL SYSTEM FOR U.S. MILITARY EXPENDI TURES AND THEIR RESULTANT IMPACT ON GROWTH IN THE 1990'S. SIMULATIONS OF DEMOCRATIC AND
REPUBLICAN PROPOSALS FOR CUTS IN DEFENSE SPENDING SUGGEST INCREASES IN ECONOMIC OUTPUT OF 2.5-4.5\% OVER THE PERIOD 1993-96.

09445 WARD, P.; ORAZAM, F.; SCHMIDT, $S$

HOMEN IN' ELITE POOLS' AND ELITE POSITIONS

SOCIAL SCIENCE QUARTERLY, 73(1) (MAR 92), 31-45.

WOMEN ARE UNDERREPRESENTED IN ELITE POSITIONS IN
GOVERMMENT, INDUSTRY, AND ACADEMIA RELATIVE TO THEIR REPRESENTATION IN THE LABOR FORCE. THIS PAPER USES CHARACTERISTIC EDUCATION, OCCUPATION, AND JOB EXPERIENCE CREDENTIALS OF CURRENT ELITES IN U.S. INSTITUTIONS TO APPROXIMATE THE PROPORTION OF WOMEN IN THE POOL OF POTENTIAL ELITES. HOMEN'S REPRESENTATION IN ELITE POSITIONS IS BROADLY CONSISTENT WITH THEIR REPRESENTATION IN THESE POOLS, AND SUBSTANTIALLY UNTIL EARLY NEXT CENTURY.

09446 WARE, A.

ACTIVIST-LEADER RELATIONS AND THE STRUCTURE OF POLITICAL PARTIES: 'EXCHANGE' MODELS AND VOTE-SEEKING BEHAVIOUR IN PARTIES

BRITISH JOURNAL OF POLITICAL SCIENCE, 22(1) (JAN 92),

THE AUTHOR ANALYZES HOW PARTY ORGANIZATION AFFECTS, AND IS ITSELF AFFECTED BY, THE OBJECTIVES PURSUED BY PARTIES IN LIBERAL DEMOCRACIES, FOCUSING ON PARTY VOTE-SEEKING BEHAVIORS. HE ARGUES THAT IT IS A MISTAKE TO MODEL PAST ACTIVIST-LEADER RELATIONS AS HAVING BEEN PRIMARILY THE PRODUCT OF PARTICULAR KINDS OF EXCHANGES BETWEEN LEADERS AND ACTIVISTS IN A PARTY. SUCH MODELS LIMIT THE UNDERSTANDING OF INTRA-PARTY RELATIONS IN FOUR IMPORTANT RESPECTS: BY FOCUSING EXCLUSIVELY ON THE IDEA OF EXCHANGE AND NOT EXAMINING THE ROLE OF GIFTS; BY NOT CONSIDERING THE ROLE OF SOLIDARY INCENTIVES; BY OMITTING AN ANALYSIS OF LOYALTY; AND BY OVERLDOKING THE ROLE OF HABIT. HOWEVER, EXCHANGE IS NOW BECOMING A FAR MORE SIGNIFICANT ELEMENT IN INTRA-PARTY RELATIONS, AND THIS DEVELOPMENT WILL CONSTRAIN PARTY LEADERS AND INFLUENCE THE GOALS PURSUED BY PARTIES IN THE FUTURE. GREATER RELIANCE ON EXCHANGE BETHEEN LEADERS AND ACTIVISTS MAY LEAD TO PARTIES BECOMING GENERALLY MORE POLICY-SEEKING IN THEIR BEHAVIOR AND ALSO TO THEIR BECOMING LESS MANAGEABLE THAN IN THE PAST.

09447 WARE, A.

LIBERAL DEMOCRACY: ONE FORM OR MANY?

POLITICAL STUDIES, 40 (1992), 130-145.

THIS ARTICLE EXAMINES WHETHER THERE ARE SIGMIFICANT DIFFERENCES BETWEEN LIBERAL DEMOCRACIES WHICH WARRANT THEM BEING CLASSIFIED AS DIFFERENT FORMS OF DEMOCRACY. THE ARTICLE BEGINS BY OUTLINING SIX FEATURES OF LIBERAL DEMOCRACY WHICH ARE CRUCIAL IN UNDERSTANDING HOW THIS TYPE OF GOVERNMENT WORKS. THE SUBSEOUENT SECTION EXAMINES THE ORIGINS OF LIBERAL DEMOCRACY AND CONSIDERS THE RELEVANCE OF ORIGINS OF LIBERAL DEMOCRACY AND CONSIDERS THE RELEVANCE OF ARGUMENTS DERIVED FROM AMERICAN CEXCEPTIONALIAM'. ATTENTION IS THEN FOCUSED ON LIBERAL DEMOCRATIC GOVERNMENTS TODAY AND FINALLY, THE ARTICLE LOOKS AT WHETHER THE FORM OF LIBERAL DEMOCRACY IS CHANGED SUBSTANTIALLY WHEN IT IS TRANSPLANTED INTO A CULTURAL CONTEXT DIFFERENT FROM THE ONE IN WHICH IT ORIGINATED. THE GENERAL CONCLUSION IS THAT THERE IS NO
FOR IDENTIFYING DIFFERENT FORMS OF LIBERAL DEMOCRACY.

09448 WARHOLA, J.H.

CENTRAL VS. LOCAL AUTHORITY IN SOVIET RELIGIOUS AFFAIRS 1964-1989

JOURNAL OF CHURCH \& STATE, 34(1) (WIN 92), 15-38

IN THE SOVIET UNION FROM 1964 TO 1989, SIGNIFICANT ADMINISTRATIVE DISCRETION EXISTED IN THE LOCAL IMPLEMENTATION OF CENTRAL RELIGIOUS POLICY. THAT DISCRETION WAS SYSTEMIC, THOUGH UNDELIBERATE, DESPITE THE EXPLICIT INTENTION OF THE MOSCOW LEADERSHIP TO TIGHTEN CENTRAL CONTROL. OPERATING WITHIN THE CONTEXT OF CONTEMPORANEOUS DOMESTIC AND FOREIGN POLICY, THESE FACTORS HAD THE EFFECT OF INTENSIFYING REPRESSION OF RELIGION BEYOND THE INTENTIONS AND WISHES OF MOSCOW.

09449 WARHURST, J.

THE DEPARTMENT OF PRIME MINISTER AND CABINET IN AUSTRALIA, 1972-90

ROUND TABLE, 324(324) (OCT 92), 501-514.

THE MAJOR PART OF THIS ARTICLE SETS OUT TO EXAMINE THE DEPARTMENT OF PRIME MINISTER AND CABINET IN AUSTRALIA, AS IT HAS EVOLVED SINCE 1972. IT EXAMINES THE DEPARTMENT UNDER HAS EVOLVED SINCE 1972 . IT EXAMINES THE DEPARTMENT UNDER
VARIOUS HEADINGS: STRUCTURE, FUNCTIONS, SIZE, STAFFING, AND VARIOUS HEADINGS: STRUCTURE, FUNCTIONS, SIZE, STAFFING, AND RELATIONS WITH OTHER MINISTERS AND DEPARTMENTS. IT LOOKS
THE PRIME MINISTERS' PRIVATE OFFICE OVER OVER THE SAME THE PRIME MINISTERS' PRIVATE OFFICE OVER OVER THE SAME
PERIOD. DURING THOSE YEARS THE PRIME MINISTER'S DEPARTMENT PERIOD. DURING THOSE YEARS THE PRIME MINISTER'S DEPARTMENT AND PRIVATE OFFICE HAVE BEEN HIGHLY CONTROVERSIAL, CENTR
TO BUREAUCRATIC POLITICS AND WIDER POLITICAL DEBATES.

09450 WARNICK, $P$.

IDEOLOGICAL DIVERSITY AND GOVERMMENT SURVIVAL IN WESTERN EUROPEAN PARLIMENTARY DEMOCRACIES

COMPARATIVE POLITICAL STUDIES, 25(3) (OCT 92), 322-361. THIS STUDY ATTEMPTS TO TEST THE HYPOTHESIS THAT THE IDEOLOGICAL DIVERSITY HITHIN GOVERNMENTS INFLUENCES THEIR SURVIVAL IN OFFICE. IT DEVELOPS AND TESTS MEASURES OF THE CONCEPT BASED ON A WIDE VARIETY OF SOURCES INCLUDING EXPERT SCALES OF PARTY POSITIONS, VOTER-BASED ESTIMATES OF PARTY IDEOLOGIES, AND ASSESSMENTS OF PARTY POSITIONS DERIVED WITH THE AID OF THE EUROPEAN MANIFESTOS PROJECT'S CDDING OF ELECTORAL PLATFORMS. THE KEY FINDINGS ARE THAT NOT ONLY IS 
IDEOLOGICAL DIVERSITY INYERSELY RELATED BY GOVERNMENT SURVIVAL, EVEN WHEN OTHER RELEVANT FACTORS ARE TAKEN INTO ACCOUNT, BUT THAT THIS CONNECTION SERIOUSLY CHALLENGES BARGAINING ENVIRONMENT INTERPRETATIONS OF STABILTIY ADYANCED WITHIN THE PAST TWO YEARS.

09451 WARREN, $M$.

DEMOCRATIC THEORY AND SELF-TRANSFORMATION

AMERICAN POLITICAL SCIENCE REVIEN, 86(1) (MAR 92), 8-23.

DEMOCRATIC THEORIES THAT ARGUE FOR EXPANDING THE SCOP AND DOMAIN OF DEMOCRACY ASSUME THAT DEMOCRATIC EXPERIENCES WILL TRANSFORM INDIVIDUALS IN DEMOCRATIC HAYS AMD THAT THEY WILL BECOME MORE PUBLIC-SPIRITED, TOLERANT, KNOWLEDGEABLE, AND SELF-REFLECTIVE THAN THEY WOULD OTHERHISE BE. THIS ASSUMPTION DEPENDS ON VIENING THE SELF AS SOCIALLY AND DISCURSIVELY CONSTITUTED, A VIEH THAT CONTRASTS HITH THE STANDARD LIBERAL-DEMOCRATIC VIEH OF THE SELF AS

PREPOL ITICALLY CONSTITUTED AND HARROWLY SELF-INTERESTED. THE IMPORTANCE OF THE SOCIAL AND DISCURSIVE VIEN OF THE SELF IS THAT IT HIGHLIGHTS HOW STANDARD ASSUMPTIONS ABOUT THE SELF HELP TO JUSTIFY LIMITS TO DEMOCRATIC PARTICIPATION. AS NOW CONCEPTUALIZED, HOWEVER, THE TRANSFORMATIONAL ASSUMPTION CONCEPTUALIZED, HOWEVER, THE TRANSFORMATIONAL ASSUMPTION THE AUTHOR SKETCHES AN APPROACH THAT DISTINGUISHES CLASSES THE AUTHOR SKETCHES AN APPROACH THAT DISTINGUISHES CLASSES TOANSFORY TRANSFORMATIVE EXPECTATIONS IN DEMOCRATIC THEORY.

09452 WARREN, R.; ROSENTRAUB, M.S.; WESCHLER, L.F BUILDING URBAN GOVERNANCE: AN AGENDA FOR THE 1990'S JOURNAL OF URBAN AFFAIRS, $14(3-4)(1992), 399-422$.

EFFECTIVE AND DEMOCRATIC LOCAL SELF-GOVERNANCE IS THE BASIC BUILDING BLOCK OF THE AMERICAN FEDERAL SYSTEM. IT ALLOWS CITIZENS TO MAKE AND IMPLEMENT IMPORTANT DECISIONS AFFECTING THEIR DAY-TO-DAY LIVES. TO FURTHER THIS PROCESS, AN AGENDA IS NEEDED THAT INCLUDES THE FOLLOWING: A SPHERE OF RELATIVE FISCAL AND POLICY AUTONOMY FOR LOCALITIES IN RELATION TO THE STATE AND NATIONAL GOVERNMENT; EQUALITY OF STATUS AND BROAD EXPANSION OF CITIZEN PARTICIPATION IN FORMAL GOVERNING PROCESSES; LEGITIMIZING OPPORTUNITIES FOR NON-HIERARCHICAL, OPEN, AND SPONTANEOUS FORMS OF COLLECTIVE ACTION; INCORPORATING VOLUNTARY AND NONPROFIT ORGANIZATIONS AND PRIVATE FIRMS AS VALUABLE RESOURCES AND PARTICIPANTS IN THE LOCAL POLITY; AND BUILDING DEMOCRATIC AND FUNCTIONAL GOVERNING STRUCTURES AT THE NEIGHBORHOOD AND METROPOLITAN LEVELS.

09453 WARREN, S.

THE LADY'S NOT FOR TURNIMG: THE DOMESTIC TRIUMPHS OF MARGARET THATCHER

POLICY REVIEW, (60) (SPR 92), 62-69.

DURING HER TENURE AS GREAT BRITAIN'S PRIME MINISTER, MARGARET THATCHER HALTED HER MATION'S SEEMINGLY IMEXORABLE DECLINE AND RESTORED HER PEOPLE'S CONFIDENCE AND SELFRESPECT.

09454 WARSZAWSKI, $D$.

POLAND: JOYLESS ELECTION

NEW POLITICS, 3 (4) (WIN 92), 128-133.

POLAND'S FIRST TRULY DEMOCRATIC ELECTIONS IN OVER 60 YEARS WERE HELD IN OCTOBER 1991. FOR MOST POLES, THE ELECTIDN ITSELF WAS A NON-EVENT. PUBLIC OPINION POLLS CONFIRMED THAT ALMOST $60 \%$ OF THE ELECTORATE DID NOT BOTHER TO VOTE. THIS ARTICLE EXPLORES CURRENT CONDITIONS AND SUGGESTS THAT UNDER THEM ONE CAN HARDLY EXPECT THAT ELECTIONS UNDER A NEW, LESS PROPORTIONAL SYSTEM, WILL BE HELD SOON. THE SPLIT PARLIAMENT WITH ITS SHAKY GOVERNMENT COALITION WILL ALMOST CERTAIMLY FALL UNDER THE SWAY OF WALESA'S STRONG-ARM POLITICS.

09455 WARSZAWSKI, D.

THE ELECTIONS: DON'T LET'S BE SHOCKED

EAST EUROPEAN REPORTER, 5(1) (JAN 92), 19-21.

POLAND'S PARL IAMENTARY ELECTIONS ON 27 OCTOBER 1991 WERE SUPPOSED TO MARK THE OCCASION WHEN THE COUNTRY'S POSTCOMMUNIST DEMOCRACY CAME OF AGE, FINALLY PUTTING AN END TO THE "CONTRACTUAL" SEJM (HITH 65 PERCENT OF ITS SEATS RESERVED FOR THE COMMUNISTS) HHICH HAD SEEMED SUCH A BREAKTHROUGH FOLLOWING THE LAST LEGISLATIVE ELECTIONS IN JUNE 1989 BUT WHICH CAME IN THE LIGHT OF SUBSEQUENT EVENTS IN EASTERN EUROPE TO BE REGARDED AS AN OBSTRUCTIVE ANACHRONISM. YET THE POST-ELECTION MOOD IN EASTERN EUROPE AMONG MANY YOTERS AND POL ITICIANS ALIKE WAS GLOOMY FOR THREE AMONG MANY VOTERS AND POLITICIANS ALIKE WAS GLOOMY FOR THREE MA REMOVE THE LEGISLATIVE LOG-JAM AND SIGNAL A CLEAR DIRECTION WITH REGARDS TO POLAND'S STALLED ECONOMIC REFORM DIRECTION WITH REGARDS TO POLAND'S STALLED ECONOMIC REFORM PROGRAM, THE OVERLY PROPORTIONAL VOIING SYSTEM ENSURED THE REPRESENTATION OF NO LESS THAN 29 DIFFERENT ORGA THE SEJM. SECOND, THERE WAS A SENSE OF SHOCK AND
BEWILDERMENT ESPECIALLY AMONG SUPPORTERS OF POLAND'S FIRST BEWILDERMENT ESPECIALLY AMONG SUPPORTERS OF POLAND'S FIRST
THO POST-COMMUNUST GOVERMMENTS AT THE SUPRISE SUCCESS OF IWO POST-COMMUNUST GOVERNMENTS AT THE SUPRISE SUCCESS OF OF THE ELECTORATE BOTHERING TO VOTE, THERE WAS ALSO UNDERLYING DOUBT OVER THE VERY LEGITIMACY OF POLAND'S FIRST
FREELY-ELECTED PARLIAMENT SINCE 1928.

09456 HARHICK, P

ECONOMIC TRENDS AND GOVERNMENT SURVIVAL IN WEST EUROPEAN PARL IAMENTARY DEMOCRACIES

AMERICAN POLITICAL SCIENCE REVIEN, 86(4) (DEC 92), 875-887. THE AUTHOR INVESTIGATES THE LINKAGE BETHEEN TRENOS IN KEY ECONOMIC INDICATORS (INFLATION, UNEMPLOYMENT, AND GROHTH IN GROSS DOMESTIC PRODUCT) AND GOVERMMENT SURVIVAL IN 16 POSTHAR EUROPEAN PARLIAMENTARY DEMOCRACIES. THE PARTIAL LIKELIHOOD METHOD, WHICH PERMITS VARIATION IN IMDICATOR VALUES OVER THE LIFETIMES OF INDIVIDUAL GOVERMMENTS, CONSTITUTES THE BASIC ANALYTIC TOOL. THE FINOINGS REVEAL OVERALL CAUSAL ROLES FOR BOTH INFLATION AND UNEMPLOYMENT, AS WELL AS IMPORTANT DIFFERENCES IN THESE ROLES BETWEEN SOCIALIST AND BOURGEOIS GOVERMMENTS AND BETWEEN PRE-OIL CRISIS AND POST-OIL CRISIS ERAS. MOST SIGNIFICANTLY, THE INTRODUCTION OF THESE INDICATORS TO THE ANALYSIS HELPS TO RESOLVE THE DEBATE BETHEEN THO RIVAL EXPLANATIONS OF GOVERNMENTAL STABILITY, THE BARGAINING COMPLEXITY HYPOTHESIS GOVERNMENTAL STABILITY, THE BARGAINING COMPLEXITY HYPOTHES
AND THE IDEOLOGICAL DIVERSITY HYPOTHESIS, IN FAVOR OF THE AND THE I ITER.

09457 WARHICK, P.

RISING HAZARDS: AN UNDERLYING DYNAMIC OF PARLIAMENTARY GOVERMMENT

AMERICAN JOURNAL OF POLITICAL SCIENCE, 36(4) (NOV 92),

THIS PAPER UNDERTAKES A QUANTITATIVE EXAMIMATION OF UNDERLYING RATES OF GOVERNMENT TERMINATION IN WEST EUROPEAN PARLIAMENTARY SYSTEMS. A VARIETY OF TESTS IS PERFORMED ON A NEW DATA SET THAT COVERS 116 SYSTEMS OVER THE 1945-89 PERIOD, EACH OF WHICH POINTS TO A GENERAL TENDENCY FOR THE RATE OF TERMINATION OR HAZARD RATE TO INCREASE WITH THE LENGTH OF TIME A GOVERNMENT REMAINS IN POWER. THIS INFORMATION IS INCORPORATED INTO AN EMPIRICAL MODEL OF GOVERNMENT SURVIVAL THAT ALSO INCLUDES IDEOLOGICAL/POLICY DIFFERENCES HITHIN GOVERNMENTS AND THE IMPACT OF ECONOMIC TRENDS.

09458 WARWICK, P.: EASTON, S. THE CABINET STABILITY CONTROVERSY: NEW PERSPECTIVES ON A CLASSIC PROBLEM

AMERICAN JOURNAL OF POLITICAL SCIENCE, 36(16) (FEB 92), 122-146.

EMPIRICAL RESEARCH INTO CABINET STABILTIY OR DURATION HAS BIFURCATED INTO TWO CONTENDING STREAMS: THE "ATTRIBUTES" APPROACH, WHICH EXPLAINS DURATION WITH ATTRIBUTES OR CAUSAL FACTORS, AND THE "EVENTS" APPROACH, HHICH MOOELS THE FACTORS, AND THE "EVENTS" APPROACH, HHICH MOOELS THE
PHENOMENON AS A PROCESS OF RANDOM CABINET COLLAPSES. PHENOMENON AS A PROCESS OF RANDOM CABINET COLLAPSES. MAXIMUM LIKELIHOOD ESTIMATION TO COMBINE THE THO. IN THIS MAXIICLE THE AUTHORS DEMONSTRATE THAT THE CABINET DURATION PHENOMENON IS MORE COMPLEX THAN THE UMIFIED MODEL ALLOWS FOR, PHENOMENON IS MORE COMPLEX THAN THE UNIFIED MODEL ALLOHS AND THE
MODEL.

09459 WASEEM, $M$

PAKISTAN'S LINGERING CRISIS OF DYARCHY

ASIAN SURYEY XXXII (7) (JUI 2 I 617-634.

DESPITE THE SUPPORT OF AN OVERWHELMING MAJORITY IM PAKISTAN'S PARLIAMENT, PRIME MINISTER NAHAZ SHARIF HAS ENCOUNTERED SEVERE DIFFICULTIES IN TERMS OF HIS ABILITY TO GOVERN. AT THE ROOT OF MANY OF SHARIF'S PROBLEMS LIES THE FACT THAT PARLIAMENT IS NOT A SOVEREIGN BODY UNDER THE PREVAILING CONSTITUTIONAL FRAMEWORK, AS DELIMITED BY THE EIGHTH AMENDMENT. THE PRESIDENT HAS BEEN EMPOWERED TO ABROGATE PARLIAMENT AND DISMISS GOVERNMENTS, AND THE FACT THAT THO PARLIAMENTS HAVE ALREADY BEEN ABROGATED (IN 1988 AND 1990) INDICATES THAT THE CONSTITUTION HAS ESTABLISHED THE SUPREMACY OF THE PRESIDENCY OVER PARL IAMENT. NAWAZ SHARIF FACES AN AMOMALOUS SITUATION: ON THE ONE HAND, THE PREVALENT CONSTITUTIONAL FRAMEHORK HAS RENDERED HIS POSITION TO ONE OF PROXY FOR AN EXTRAPARL IAMENTARY FORCE SYMBOLIZED BY THE PRESIDENT, THUS COSTING HIM IN TERMS OF LEGITIMACY AS AN ELECTED LEADER IN HIS OWN RIGHT. ON THE OTHER HAND, IT CONTINUES TO RESTRAIN HIM FROM FOLLOWING A COURSE OF ACTION THAT HOULD PROMOTE A POLICY OF ACCOMHODATION WITH THE OPPOSITION AND ESTABLISH A NORKING RELATIONSHIP WITH IT.

09460 WASLEY, T

WHAT HAS GOVERMMENT DONE TO OUR HEALTH CARE?

CATO INSTITUTE, 1992,162 .

THIS BOOK DEMONSTRATES THAT THE PROBLEMS IN AMERICA'S HEALTH CARE SYSTEM STEM DIRECTLY FROM A LONG HISTORY OF GOVERNMENT INTERVENTION IN THE MEDICAL MARKETPLACE. FROM THE LICENSING OF DOCTORS, TO STATE ACCREDITATION OF MEDICAL SCHOOLS, TO RESTRICTIONS ON THE BUILDING OF HOSPITALS, THE GOVERNMENT HAS SYSTEMATICALLY LIMITED THE SUPPLY OF MEDICAL CARE AND STIFLED INNOVATION IN THE UNITED STATES. THROUGH THE TAX LAHS, REGULATION OF THE INSURANCE INDUSTRY, AND MEDICARE AMD MEDICAID, THE FEDERAL AND STATE GOVERNMENTS HAVE DISTORTED THE SIGNALS OF THE PRICE SYSTEM AND OVERST IMUL ATED THE DEMAND FOR HEALTH CARE. WHEN THE
GOVERMMENT RESTRICTS SUPPLY AND STIMULATES DEMAND, THE 
RESULT IS EXACTLY WHAT IS FOUND IN THE HEALTH CARE INDUSTRY TDOAY: SKYROCKETING PRICES THAT TAKE THEIR GREATEST TOLL ON THE POOR AND UNINSURED. THE BOOK'S LESSON IS THAT GOVERMMENT CONTROL DOES NOT PRODUCE ACCESSIBLE, HIGH-QUALITY HEALTH CARE AT REASONABLE COSTS.

09461 WATANABE, $S$.

OPPOSITION PARTIES EYE TIES TO TAKE POWER

JAPAN TIMES (WEEKLY INTERNATIONAL EDITION), 32(2) (JAN 92),

JAPAN

IN THE OPPOSITION'S ONGOING BID TO DISPLACE THE GOVERNING LPBERAL DEMOCRATIC PARTY (LDP) 1992 COULD BE A

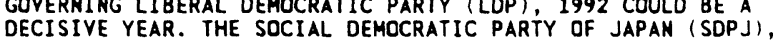
DECISIVE YEAR. THE SOCIAL DEMOCRATIC PARTY OF JAPAN (SDPJ), THE LARGEST OPPOSITION PARTY, HOPES TO START A MAJOR POLITICAL REALIGNMENT IN THE JULY 1992 ELECTIONS. THE SDPJ STRATEGY CALLS FOR UNITING FORCES WITH THE DEMOCRATIC SOCIALIST PARTY, THE UNITED SOCIAL DEMOCRATIC PARTY, AND LDP DEFECTORS TO FORM A NATIONAL COALITION GOVERMMENT BY THE MID1990 'S.

09462 WATANABE, S.

SDPJ SPEAKS WITH SOUND AND FURY; SIGNIFIES NOTHINC JAPAN TIMES (WEEKLY INTERNATIONAL EDITION), 32 (4) (JAN 92 ),

THUS FAR, THE SOCIAL DEMOCRATIC PARTY OF JAPAN (SDPJ) HAS PRODUCED LITTLE MORE THAN SLOGANS AND RESOLUTIONS IN ITS ONGOING BID TO WREST POWER FROM THE GOVERNING LIBERAL DEMOCRATIC PARTY. WHEN MAKOTO TANABE BECAME PARTY CHAIRMAN IN JULY 1991, EXPECTATIONS WERE HIGH THAT HIS "REALISTIC" ATTITUDE IN DEALING WITH OTHER PARTIES WOULD TRANSFORM THE SOPJ. BUT PROGRESS HAS BEEN SO SLOW THAT MANY PEOPLE NOW QUESTION WHETHER TANABE IS CAPABLE OF LEADING THE PARTY IN A NEW DIRECTION.

09463 WATENBERG, $D$.

AND ON THE LEFT... TOM HARKIN

INSIGHT, $7(50)$ (DEC 91$), 6-13$

SENATOR TOM HARKIN OF IOWA HAS BECOME THE LIBERAL'S

SENATOR TOM HARKIN OF IOWA HAS BECOME THE LIBERAL'S
FAVORITE IN THE RACE FOR THE DEMOCRATIC PRESIDENTIAL

FAVORITE IN THE RACE FOR THE DEMOCRATIC PRESIDENTIAL
NOMINATION. WITH NO-HOLDS-BARRED ON THE BUSH ADMINISTRATION

AND A NO-APOLOGIES CAMPAIGN STYLE MODELED ON HARRY TRUMAN,

AND A NO-APOLOGIES CAMPAIGN STYLE MODELED ON HARRY TRUM

HE HAS BEEN DUBBED A PRAIRIE POPULIST. YET HARKIN IS
ARGUABLY THE MOST ANTIMILITARY MEMBER OF THE SENATE, AND HIS

ARGUABLY THE MOST ANTIMILITARY MEMBER OF THE SENATE, AND HIS

RECORD BEARS SCANT RESEMBLANCE TO THAT OF THE ANTICOMMUNIST,

INTERVENTIONIST TRUMAN. HHAT HARKIN DOES SHARE HITH TRUM
IS A LANGUAGE THAT CONTEMPORARY LIBERALS HAVE ALL BUT

FORGOTTEN. HE NEVER SOUNDS POINTY-HEADED OR EFFETE,

SIMPERING, TECHNOCRATIC OR NEW AGE.

09464 WATERBURY, J.

EXPORT-LED GROWTH AND THE CENTER-RIGHT COALITION IN TURKEY COMPARATIVE POLITICS, 24(2) (JAN 92), 127-145.

SINCE 1983, TURKEY'S SHIFT TOWARD EXPORT-LED GROWTH HAS PRESENTED SPECIAL POLITICAL CHALLENGES BECAUSE IT HAS NECESSITATED THE REMAKING OF THE BROAD COALITION THAT HAD BENEFITED FROM IMPORT-SUBSTITUTING INDUSTRIALIZATION. THE NEW COALITION IS MUCH NARROWER AND LIES ON THE CENTER-RIGHT OF THE POLITICAL SPECTRUM. IT IS SUSTAINED BY TARGETED, COMPENSATORY PAYMENTS GENERATED BY REAL GROWTH IN THE ECONOMY. THE CENTER-RIGHT COALITION CAN WIN CONTROL OF THE ELECTORAL SYSTEM THROUGH NATIONAL PLURALITIES. THE DYNAMICS OF COALITION FORMATION AND ELECTORAL CONTROL IN TURKEY MAY HOLO LESSONS FOR SEVERAL OTHER DEVELOPING COUNTRIES. MARKETORIENTED REFORMS WILL BE ACCOMPANIED BY INCREASED

DISCRET IONARY POWERS IN THE EXECUTIVE AND THE USE OF THOSE POWERS TO DIRECT COMPEMSATORY FLOWS TO KEEP SOME STPATEGIC GROUPS IN THE CDALITION HHILE MEUTRAL IZING OTHERS. ECONOMIC GROWTH COMPENSATORY PAYMENTS THAT RUM COUNTER TO ECOMOMIC GROWTH, COMPENSATORY PAYMENTS THAT RUN COUNTER TO ECONOMIC THE ELECTORATE ARE THE ESSENTIAL INGREDIENTS.

09465 WATERMAN, R.W.; WOOD, B.D.

WHAT DO HE DO WITH APPLIED RESEARCH?

PS: POLITICAL SCIENCE AND POLITICS, XXV(3) (SEP 92),

559-564.

THE AUTHORS ASK A FUMDAMENTAL QUESTION FOR THE POLITICAL SCIENCE DISCIPLINE: WHAT DOES ONE DO WITH APPLIED RESEARCH? THEY ANSWER THAT OUESTION BY PRESENTING AN EXAMPLE OF AN THEY ANSHER THAT QUESTION BY PRESENTING AN EXAMPLE OF AN
APPLIIED POLICY PROPOSAL THAT FLOWS NATURALLY FROM THE LAST 40 YEARS OF THE DEVELOPMENT OF BUREAUCRATIC THEORY. THEY 40 YEARS OF THE DEVELOPMENT OF BUREAUCRATIC THEORY
FOCUS ON THE ISSUE OF BUREAUCRATIC ACCOUNTABILITY.

09466 WATERMAN, S.: ZEFADIA, E.

WATERMAN, S.; ZEFADIA, E.
POLITICAL GEOGRAPHY IN PRACTICE II: ISRAELI ELECTORAL REFORMS IN ACTION

POLITICAL GEOGRAPHY, 11(6) (NOV 92), 563-578.

THE AUTHORS SUMMARIZE THE PUBLIC DEBATE IN ISRAEL DURING THE PAST FOUR YEARS OVER THE REFORM OF THE ELECTORAL SYSTEM, OUTLINING THE ISSUES AND THE OBSTACLES TO IMPLEMENTING REFORM. THEY STUDY SEVERAL PROPOSALS FOR ELECTORAL REFORM, IN PARTICULAR WHETHER OISTRICTING IS A PRACTICAL POSSIBILITY WITHIN CONSTRAINTS SPECIFIED BY A COMMITTEE COMPRISING SENIOR MEMBERS OF THE THO LARGEST POLITICAL PARTIES--LIKUD AND LABOUR--AND PROPOSE A DISTRICTING PLAN THAT MEETS THESE
OEMANDS. THEN THEY PRESENT A SERIES OF SIMULATIONS IN THE HYPOTHETICAL CONSTITUENCIES, RELATING TO DISCIPLINED AND UNDISCIPLINED VOTING FOR PARTY CANDIDATES, ANALYZING SOME POSSIBLE EFFECTS OF DISTRICTING ON THE RESULTS OF ISRAELI ELECTIONS. THEY OUTLINE THE RELATIVE BENEFITS AND

DISADVANTAGES TO THE POLITICAL PARTIES.

09467 WATSON, C.

GUERRILLA GROUPS IN COLOMBIA: RECONSTITUTING THE POLITICAL PROCESS

TERRORISM AND POLITICAL VIOLENCE, 4(2) (SUM 92), 84-102.

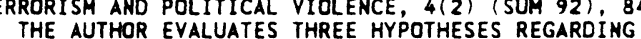

GUERRILLA MOVEMENTS IN COLOMBIA. FIRST, THE ARMED

INSURRECTION IN COLOMBIA ESCALATED DRAMATICALLY IN THE PAST 12 YEARS TO THE POINT THAT IT CREATED A SERIOUS CHALLENGE TO THE CENTRAL GOVERMMENT. THE NATIONAL DIALOGUE OF THE MID1980 'S INDICATED THAT THE REGIME RECOGNIZED THIS THREAT. SECONDLY, THE "NARCOTRAFICANTES" POSED A PARALLEL THREAT THAT SIMULTANEOUSLY STRAINED THE GOVERNMENT'S LEGITIMACY. THIRDLY, THE CRISIS BECAME SO ACUTE THAT THE POLITICAL ELITE COULD NO LONGER EXCLUDE A GUERRILLA GROUP FROM THE POLITICAL
PROCESS WHEN IT OFFERED TO PARTICIPATE AS A LEGITIMATE ACTOR.

09468 HATSON, C.

WAR AND WAITING

AFRICA REPORT, 37 (6) (NOV 92), 51-55.

IN TWO YEARS, A RAG-TAG GUERILLA ARMY MADE UP OF EXILES FROM ALL OVER CENTRAL AFRICA HAS TRANSFORMED ITSELF INTO A TOUGH FIGHTING FORCE, THE RHANDAN PATRIOTIC FRONT (RPF), WHICH NOW OCCUPIES A SHATH OF NORTHERN RHANDA. A DELICATE GOVERMMENT. THE RPF IS DEMANDING THAT REFUGEES BE ALLOWED TO RETURN, THAT FREE ELECTIONS BE HELD, THAT THE GOVERNMENT RESPECT HUMAN RIGHTS, AND THAT PRESIDENT JUVENAL HABYARIMANA'S POWERS BE REDUCED-OR, IT IS PREPARED TO RESUME FIGHTING.

09469 WATSON, $G$.

THE FUSS ABOUT IDEOLOGY

WILSON OUARTERLY, XVI(1) (WIN 92), 130-135.

ELSON OUARTERLY, XVI(1) (WIN 92), 130 -135.
EVERYTHING IS "IDEOLOGICAL"--OR SO MANY IN AND AROUND ACADEMIA WOULD HAVE US BELIEVE. TO ACCEPT THE PROPOSITION, HOHEYER IS TO MOVE TOHARD THE POSITION THAT THERE IS NO MORAL OR CRITICAL KNOWLEDGE, ONLY OPINION.

09470 HATSON, P.

OPIATES, AMPHETAMINES, AND AIDS IN POLAND RFE/RL RESEARCH REPORT, 1 (9) (FEB 92), 67-71

OVER THE PAST SIX OR SEVEN YEARS, LEVELS OF DRUG USE HAVE REMAINED STABLE IN POLAND. BUT THE PROBLEM MAY SOON ESCALATE IF ORGANIZED CRIMINAL GROUPS PRODUCING AMPHETAMINES FOR THE WEST EUROPEAN DRUG MARKET MOVE TO FILL THE GAP IN THE POLISH MARKET CREATED BY THE CLAMPDOWN ON THE CULTIVATION OF THE OPIUM POPPY. A LARGE NUMBER OF POLAND'S INTRAVENOUS DRUG USERS ARE INFECTED WITH THE AIDS VIRUS, AND THE VIRUS IS CONTINUING TO SPREAD. POLAND'S BUDGETARY CRISIS AND CHANGING POLITICAL SITUATION ARE MAKING AN ADEQUATE RESPONSE TO THE DISEASE IMPOSSIBLE.

09471 HATSON, S.

DECENTRALIZING COMMUNITY DEVELOPMENT DECISIONS: A STUDY OF OKLAHOMA'S SMALL CITIES PROGRAY

PUBLIUS: THE JOURNAL OF FEDERALISM, 22(1) (WIN 92), 109-122.

RESEARCH ON THE SMALL CITIES PROGRAM IN OKLAHOMA INDICATES A DEFINTE SHIFT IN SPENDING PRIORITIES. SINCE 1982. OKLAHOMA LOCALITIES DIVERTED CDBG FUMDS PRIMARILY TO INFRASTRUCTURE AND ECONOMIC DEVELOPMENT INSTEAD OF HOUSINGRELATED ACTIVITIES, AND CHANNELED A LARGER AMOUNT OF DOLLARS RELATED ACTIVITIES, AND CHANNELED A LARGER AHOUNT OF DOL
INTO MODERATE-AND MEDIAN-INCOME AREAS. AS A RESULT, THE INTO MODERATE-AND MEDIAN-INCOME AREAS. AS A RESULT, THE
SMALL CITIES PROGRAM IN OKLAYHOMA, UNDER STATE CONTROL WAS
FOUND TO PROVIDE LESS DIRECT AND IMMEDIATE HOUSING AID TO LOWER INCOME CITIZENS.

09472 HATSON, $W$. NORTH AMERICAN FREE TRADE: LESSONS FROM THE TRADE DATA CANADI AN PUBLIC POLICY-ANALYSE DE POLITIQUES, 188(1) (MAR $92), 1-12$.

THE RESULTS OF A DETAILED EXAMINATION OF 1989 TRADE FLOWS BOTH BETWEEN CANADA AND MEXICO AND FROM CANADA AND MEXICO TO THE UNITED STATES ARE EXPLORED IN THIS PAPER. IT FIMDS THAT THERE IS VERY LITTLE TRADE AT PRESENT BETWEEN CANADA AND MEXICO AND THAT CANADIAN-MEXICAN COMPET ITION IN THE U.S. MARKET DHARFS CANADIAN-MEXICAN COMPETIITION IN THE TWO COUNTRIES HOME MARKETS. THE PAPER CONCLUDES THAT THE MAJOR EFFECTS OF A TRAOE DEAL WILL BE FELT IN THE U.S. MARKET; THAT THERE IS LITTLE CANADA CAN DO TO KEEP THE U.S.
FROM GRANTING MEXICO TRADE PRIVILEGES SIMILAR TO THOSE WON UNDER THE FTA; AND THAT THE DOMESTIC DEBATE SHOULD THEREFORE CONCERN HOH TO ADJUST TO A NORTH AMERICAN FREE TRADE AREA, NOT HOW TO AVOID IT.

09473 WATTENBERG, D.

A HOUSE DIVIDED 
INSIGHT, 6(52) (JAN 91), 18-19.

A GROUP OF YOUNG WHITE HOUSE AIDES ARE MAKING WAVES WITH AN "EMPOWERMENT AGENDA" OF POPULAR CAPITALISM: URBAK ENTERPRISE ZONES, EDUCATION VOUCHERS, TENANT MANAGEMENT AND OWNERSHIP OF PUBLIC HOUSING. THE ADVOCATES FOR THE "NEW PARADIGM" HOPE TO BREATHE A POPULIST SPIRIT INTO THE ADMINISTRATION AND REVIVE THE REPUBLICAN PARTY. BUDGET CHIEF RICHARD DARMAN HAS QUICK TO CRITICIZE THE PROPOSALS, BUT FOUND HIMSELF THE ODD MAN OUT AS SEVERAL POWERFUL

CONSERVATIVES SUPPORTED CALLS FOR THE NEW PARADIGM.

09474 WATTENBERG, D.

SKEWED IMAGE OF THE GULF CRISIS

INSIGHT, 7(4) (JAN 91), 8-13.

THE NEWS MEDIA, ESPECIALLY TV NETWORKS, HAVE PORTRAYED THE PUBLIC'S RESPONSE TO THE PERSIAN GULF CRISIS AS FRAGMENTED AND OPPOSED TO THE WAY PRESIDENT BUSH HAS BEEN HANDLING IT. THE PORTRAYAL HAS BEEN CONSISTENTLY ONE OF A NATION DIVIDED: AN EQUATION OF ANTI-BUSH FEELING WITH ANTIWAR FEELING; AND OF A PEOPLE READY FOR WAR, BUT NOT FOR THE WAR FEELING; AND OF A PEOPLE READY FOR WAR, BUT NOT FOR THE MYTHS. ANOTHER MISCONCEPTION IS THAT HOSE WHO OPPOSE BUSH'S HANDLING OF THE CRISIS ARE DOVES.

09475 WATTENBERG, $D$

BOOKS, NOT BULLET

INSIGHT, $7(9)$ (MAR 91), 26-27

DESPITE ITS HARD-LINE STANCE AGAINST THE LIFTING OF SANCTIONS, THE AFRICAN NATIONAL CONGRESS (ANC) APPEARS TO RECOGNIZE THE DEMISE OF APARTHEID IN SOUTH AFRICA. PREPARING FOR THE FUTURE, THE ANC HAS JOINED OTHER BLACK POLITICAL GROUPS IN URGING THAT STUDENTS PROTESTING APARTHEID POLICIES RETURN TO SCHOOL. HHILE THE CALL IS WIDELY PRAISED, SOME WONDER IF THIS ATTEMPT TO RESTORE DISCIPLINE AND A CULTURE OF LEARNING IS TOO LITTLE, TOO LATE.

09476 HATTENBERG, D.

INNER VISION FOR OUR CITIES

INSIGHT, 8(25) (JUN 92), 12-13; 36-37.

HOUSING SECRETARY, JACK KEMPT'S, AGENDA FOR REVIVING THE INNER CITES IS OFF THE MARK IN ONE VITAL RESPECT, SAY SOME CONSERVATIVE SKEPIICS. ENTERPRISE DOESN'T HAVE A CHANGE HHEN BASIC SOCIAL INSTITUTIONS ARE BANKRUPT. KEMPT PREACHES THE MARKET SOLUTION FOR URBAN WELFARE RECIPENTS

09477 WATTENBERG, $D$.

QUAYLE TAKES A PIVOTAL ROLE

INSIGHT, $7(44)$ (NOV 91), 14-16, 39

AS THE HEAD OF THE PRESIDENT'S COUNCIL ON COMPETITIVENESS, VICE-PRESIDENT DAN QUAYLE HAS ASSUMED REAL
POWER. THE GROUP'S TASK IS TO MAKE AGENCIES FACTOR IN THE POWER. THE GROUP'S TASK IS TO MAKE AGENCIES FACTOR IN THE
COSTS OF IMPOSING NEW RULES. THE COUNCIL'S POWER TO DRAG OUT THE REVIEH AND REGULATORY PROCESS AT EVERY STEP ALONG THE THE REVIEH AND REGULATORY PROCESS AT EVERY STEP ALONG THE OF REGULATIONS IT HAS HELPED TO QUASH. PUBLIC INTEREST AND OF REGULATIONS IT HAS HELPED TO QUASH. PUBLIC INTERES ENVIRONMENTAL GROUPS DENOUNCE IT AS A REGULATORY STAR CHAMBER. AT THE SAME TIME, THE COUNCIL HAS WON PRAISE FROM BUSH CRITICS ON THE FREE MARKET RIGHT AS AN INDISPENSABLE, BACK-UP COST-CONTROL SYSTEM FOR AN ADMINI
PANDER ITS HAY INTO COSTLY LEGISLATIOM.

09478 WATTENBERG, $D$

SUPPLY-SIDE BROWHNOSER OR SAYIOR

INSIGHT, 8(6) (APR 92), 12-13: 38 .

JERRY BROWN HAS BEEN DERIDED AS "MOONBEAN," BUT SOME SUPPLY-SIDERS ARE SAYING "BEAM ME UP, JERRY" TO HIS 13 PERCENT FLAT TAX PROPOSAL. STILL THERE ARE QUESTIONS ABOUT WHO WOULD BENEFIT MOST AND BROWN'S CHAMELEONLIKE RECORD. SOME REGARD BROWN'S OPPORTUNISM AS AN ASSET, NOT A LIABILITY. BROWN SEEMS TO BELIEVE THAT YOU HAVE TO LOOK TO THE VOTERS FOR GUIDANCE ON WHAT THEY WANT TO DO, NOT WHERE YOU ARE GOING TO DRAG THEM.

09479 WATTENBERG, D.

THE DAWN OF FREEDOM

INSIGHT, $7(36)$ (SEP 91), 16-18.

HOLDING THE TANKS AT BAY HITH HIS JERRY-BUILT INTERNAL COMMUNICATIONS METHORK OF FAX MACHINES, DESKTOP PUBLISHERS AND INDEPENDENT RADIOS, RUSSIAN PRESIDENT BORIS YELTSIN HAS RESTORED THE GOOD NAME OF MODERN COMMUNICATIONS. SUPPORTERS OF COMMUNICATIONS TECHMOLOGY ARGUE FOR THEIR BELIEF IN THE INEVITABLE TRIUMPH OF LIBERAL DEMOCRACY AS THE RESULT OF THE INEVITABLE TRIUMPH OF LIBERAL DEMOCRACY AS THE RESULT OF DECENTRALIZATION OF INFORMATION AND RELATED TECHNOLOGY ARGUE THAT DEMOCRATIC INSTITUTIONS ALONE ARE COMPATIBLE WITH ARGUE THAT DEMOCRATIC INSTI ITUTIONS ALONE ARE COMPATIBLE WITH THE REALITIES OF DECENTRALIZED, INTERACIIVE COMMUNICATIONS. HOWEVER, OTHERS ARGUE THAT COMHUNICATIONS TECHNOLOGY IS NEUTRAL-IIT CAN BE USED BY TOTALITARIAN STATES AS WELL AS EDUCATION WHICH CREATE A PROPENSITY FOR DEMOCRATIC CHANGE.

09480 HATTENBERG, D.

THE LADY MAC

AMERICAN SPECTATOR, 25(8) (AUG 92), 25-32.
THIS ARTICLE ABOUT HILLARY CLINTON STATES THAT SHE IS BEST THOUGHT OF AS THE WINMIE MANDELA OF AMERICAN POLITICS. SHE HAS LIKENED THE AMERICAN FAMILY TO SLAVERY, THINKS KIDS SHOULD BE ABLE TO SUE THEIR PARENTS TO RESOLVE FAMILY ARGUMENTS, AND DURING HER TENURE AS A FOUNDATION OFFICER GAVE AWAY MILLIONS TO THE LEFT. THE ARTICLE STATES THAT SHE WILL CAUSE HER HUSBAND NO END OF POLITICAL EMBARRASSMENT IF HE WINS THE 1992 ELECTION.

09481 WATTENBERG, D.

WARRIOR OR CRIMINAL?

INSIGHT, 7(6) (FEB 91), 12-13.

THE AMERICAN PUBLIC WAS REINTRODUCED IN SHOCKING FASHION TO ONE OF THE INEVITABILITIES OF WAR WHEN IRAQ PARADED CAPTURED ALLIED AIRMEN BEFORE ITS TV CAMERAS. ALTHOUGH ANY NATION THAT GOES TO WAR MUST EXPECT THAT SOME OF ITS FORCES MUST BE TAKEN, THE IMAGES OF THE BATTERED CREWMEN AND THEIR APPARENTLY COERCED STATEMENTS DENOUNCING THE PERSIAN GULF WAR PROMPTED THE UNITED STATES TO RAISE THE SPECTER OF WAR CRIMES TRIALS. THE TELEVISION STATEMENTS OF THE AIRMAN ALSO BRING INTO QUESTION THE TRAINING GIVEN TO SOLDIERS WHO ARE ARI RISK OF BEING TAKEN PRISONER.

09482 WATTENBERG, D.

WHERE HAVE' DI THE HIPPIES GONE?

INSIGHT, $7(6)$ (FEB 91), 14-15.

THE ANTIWAR DEMONSTRATORS WHO MARCHED ON WASHINGTON AFTER DESERT STORH BEGAN ARE NOTICEABLY DIFFERENT FROM THEIR COUNTERPARTS IN THE PAST: THEY ARE OLDER, CRANKIER, AND DO NOT USE DRUGS. ALSO, THEY ARE NOT DEMEANING U.S. TROOPS OR THE POLICE. THEIR TARGETS ARE THE BUSH ADMINISTRATION,

CLOSELY FOLLOWED BY THE NEWS MEDIA. A SURVEY OF PROTESTERS IN WASHINGTON ON JANUARY 26 FOUND THAT 58 PERCENT HERE 31 OR OLDER.

\section{WAUTHIER, C.}

CALM BEFORE THE TEMPEST

WEST AFRICA, 75(3887) (MAR 92), 458.

TENSION IS LIKELY TO INCREASE IN TOGO AS ELECTION TIME GETS NEAR. A REFERENDUM ON A NEW CONSTITUION AND MUNICIPAL, LEGISLATIVE AND PRESIDENTIAL ELECTIONS ARE SCHEDULED. THIS ARTICLE EXPLORES THE CLAIMS OF THE OPPOSITION PARTIES, AND THE CONTENDERS FOR LEADERSHIP. THE POSSIBILITY OF A COMMON FRONT EVENTUALLY FORMING IS CONSIDERED.

09484 WAUTHIER, C. OPPOSITIOH IN DISARRAY

WEST AFRICA (3911) (AUG 92) 1483-1484

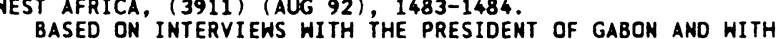
OPPOSITION LEADERS. THE AUTHOR REPORTS ON THE POLITICAL

SITUATION IN THE HEST AFRICAN COUNTRY.

09485 WAYLEN, $G$.

RETHINKING WOMEN'S POLITICAL PARTICIPATION AND PROTEST CHILE 1970-1990

POLITICAL STUDIES, XL(2) (JUN 92), 299-314.

MUCH OF HOMEN'S POLITICAL ACTIVITY CANMOT BE

ACCOMMODATED WITHIN TRADITIONAL POLITICAL SCIENCE SO NEH WAYS OF ANALYZING IT ARE NEEDED. IN ORDER TO CREATE A NEW FRAMEWORK, USING CASE STUDY MATERIAL FROM CHILE, SOME OF THE CONCEPTS EMPLOYED BY SOCIALIST FEMINISTS, PARTICULARLY THE PARTRIARCHAL BARGAIN AND STRATEGIC AND PRACTICAL GENDER INTERESTS, ARE EXPLORED. THESE SHED LIGHT ON WHY WOMEN MOBILIZE, BOTH FOR CONSERVATIVE AND FOR MORE PROGRESSIVE CAUSES. HOWEVER, THIS FRAMEHORK ALONE CANNOT BE MADE TO USE THE INSIGHTS OF' POST-MODERNISM TO DO THIS. THE CONCLUSION IS THAT IT IS POSSIBLE TO UNITE THE MOST HELPFUL ASPECTS OF THE THO PERSPECTIVES.

09486 WEARING, J.

THE BALLOT AND ITS MESSAGE--VOTING IN CANADA

CLARK COPP PITMAN, 1991, 368

THIS BOOK COVERS A WIDE RANGE OF ISSUES THAT TOGETHER PROVIDE AN EXCELLENT OVERVIEH OF VOTING BEHAVIOR IN CANADA. WHILE THE PRINCIPAL FOCUS IS ON THE FEDERAL ELECTIONS OF 1975 TO 1988, THERE IS MATERIAL ON PROVINCIAL ELECTIONS AS WELL. OTHER TOPICS EXAMINED INCLUDE PARTY IDENTIFICATION, IDEOLOGICAL AND SOCIAL FACTORS, CLASS AND VOTING, THE ECONOMY AND VOTING, AND GENDER AND VOTING.

09487 WEATHERFORD, M.S.

MEASURING POL ITICAL LEGITIMACY

AMERICAN POLITICAL SCIENCE REYIEH, 86(1) (MAR 92), 149-168. AMERICAN POLITICAL SCIENCE REVIEW, 86(1) (MAR 92), 149-168. POLITICAL LEGITIMACY IS A KEY CONCEPT IN BOTH MACRO

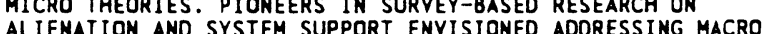
ALIENATION AND SYSTEM SUPPORT ENVISIONED ADORESSING MACRO QUESTIONS ABDUT LEGITIMACY WITH THE SOPHISTICATED EMPIRICISM OF INDIVIDUAL-LEVEL METHODOLOGY BUT FAILED; AND A OF INNOVATIONS IN ITEM WORDING AND QUESTIONNAIRE CONSTRUCTION ONLY LED TO AN EXCESSIVE CONCERN HITH MEASUREMENT ISSUES AT THE INDIVIDUAL LEVEL. THE AUTHOR RETURNS TO AN ENUMERATION OF THE INFORMATIONAL REQUIREMENTS
FOR ASSESSING LEGITIMACY IN HOPES OF FINDING A

CONCEPTUALIZATION THAT BETTER UTILIZES AVAILABLE SURVEY 
INDICATORS TO TAP RELEVANT MACRO DIMENSIONS. THE AUTHOR SPECIFIES FORMAL MEASUREMENT MODELS FOR BOTH CONVENTIONAL AND REVISED CONCEPTUALIZATIONS OF LEGITIMACY ORIENTATIONS AND COMPARES THE FIT OF THE TWO MODELS SYSTEMATICALLY ON A PREFERABLE ON BOTH THEORETICAL AND EMPIRICAL GROUNDS.

09488 WEAVER, $P$.

GOING FOR THE BRONZE

REASON, $24(6)$ (NOV 92), 36-41.

1992 IS THE YEAR OF CHANGE, OF OUTSIDERS, OF WIDESPREAD DISILLUSIONMENT WITH WASHINGTON AND LIBERTARIAN PARTY PRESIDENTIAL CANDIDTATE, ANDRE MARROU, IS POSITIONED TO CATCH THAT WAVE AND RIDE IT, IF NOT TO THE WHITE HOUSE, THEN AT LEAST TO NEW VISIBILITY AND RESPECT. THIS REPORT OF HIS CAMPAIGN REPORTS THAT TALK RADIO IS RECEPTIVE TO MARROU'S POPUL IST MESSAGE. VICE PRESIDENTIAL CANDIDATE, DR. NANCY LORD STRESSES IDEAS AND POLICIES; MARROU AROUSES EMOTION. IT DESCRIBES THE CANDIDATES AS THO INTERESTING, INTELLIGENT, SPIRITED BEARERS OF A VENERABLE POLITICAL MESSAGE THAT REALLY DOES HAVE SOMETHING TO OFFER A MATION THAT HAS STRAYED A LONG WAY FROM THE IDEALS IT STARTED OFF WITH AND FINDS ITSELF SORELY TROUBLED AS A RESULT.

09489 WEAVER, P.

RUNNING ON EMPTY

REASON, $24(5)$ (OCT 92 ), 24-31

THIS ARTICLE EXPLAINS WHY ROSS PEROT THE "OUTSIDER" TURNED OUT TO BE JUST ANOTHER POLITICIAN. IT ARGUES THAT GIVEN PEROT'S HISTORY, NO ONE SHOULD HAVE BEEN SURPRISED WHEN HE QUITE HIS CAMPAIGN AT THE FIRST SIGN OF TROUBLE. WHEN HE QUITE HIS CAMPAIGN AT THE FIRST SIGN OF TROUBLE. MEDIA POLITICS IS THE ULTIMATE EXERCISE IN INSIDERDOM AMD YORTHING ABOUT THE PROCESS OR PEOPLE IS INHOCENT PRINCIPLES. IT IS PONDERED IF AMERICAN VOTERS WOULD HAVE PRINCIPLES. IT IS PONDER
MADE THE SAME CHOICE?

09490 WEBB, J.

THE POLISH GENERAL ELECTION OF 199

ELECTORAL STUDIES, 11(2) (JUN 92), 166-170

ON 27 OCTOBER, POLAND WENT TO THE POLLS IN THE COUNTRY'S FIRST PROPERLY DEMOCRATIC GENERAL ELECTION SINCE 1928. PARLIAMENT'S NEW-FOUND SUPREMACY WAS SHORT-LIVED HOWEVER. THE RESULT WAS THE LEAST CONCLUSIVE OF ALL THE ELECTIONS HELD SO FAR IN THE NEHLY EMANCIPATED DEMOCRACIES. WITHIN HOURS OF THE EMERGENCE OF THE NEW PARLIMENT, POLITICIANS AND POL ITICAL SCIENTISTS WERE TALKING ABOUT A SUPRAPARL IAMENTARY GOYERNMENT OF ECONOMIC EXPERTS TO IMPOSE ORDER ON THE FRAGMENTED POL ITICAL SCENE. THE OFFICIAL ECONOMIC FORECASTS POINT TO THE NEED FOR A STRONG MAN OPTION. IT
REMAINS TO BE SEEN IF WALESA WOULD BE ACCEPTABLE AS A POSTMODERN PILSUDSKI.

09491 WEBB, P.D.

ELECTION CAMPAIGNING, ORGANISATIONAL TRANSFORMATION, AND THE PROFESSIONALISATION OF THE BRITISH LABOUR PARTY EUROPEAN JOURNAL OF POLITICAL RESEARCH, 21(3) (APR 92), 267-288.

THE AUTHOR PROBES THE RELATIONSHIP BETWEEN ELECTION CAMPAIGN INNOVATION AND ORGANIZATIONAL CHANGE WITHIN PARTIES. CAMPAIGN INNOVATION AND ORGANIZATIONAL CHANGE WITHIN PART HOS USING THE CASE OF THE BRITISH LABOR PARTY, HE CONSIDERS HOH ORGANIZATIONAL TRANSFORMATION OF THE PARTY. BROADLY SPEAKING, IT SEEMS REASONABLE TO CONCLUDE THAT THE IT SEEMS REASONABLE TO CONCLUDE THAT THE PROFESSIONALIZATION OF LABOR'S ELECTION CAMPAIGN PERSONNEL HAS HAD SIGNIFICANT IMPLICATIONS BOTH FOR POLICY AND ANDICATE A PARTIAL, BUT NONETHELESS SIGNIFICANT, INDICATE A PARTIAL, BUT NONETHELESS SIGMIF

09492 WEBBER, $M$.

ANGOLA: CONTINUITY AND CHANGE

JOURNAL OF COMMUNIST STUDIES, 8(2) (JUN 92), 126-144.

DURING THE LATE 1970'S AND THE 1980's, THE PEOPLE' REPUBLIC OF ANGOLA (PRA) WAS OFTEN REGARDED AS A CLOSE ALLY OF THE SOVIET UNION, CUBA, AND SOME EAST EUROPEAN REGIMES. CONSEQUENTLY, REFORMS IN THE PRA MIGHT LOGICALLY BE LINKED TO THE PROFOUND POLITICAL AND ECONOMIC UPHEAVALS EXPERIENC BY THE FORMER COMMUNIST COUNTRIES. WHILE THE RELATIONS WITH THE SOVIET UNION AND CUBA DID HAVE AN IMPORTANT INFLUENCE ON THE DEVELOPMENT OF THE PRA, THIS IS AN
INCOMPLETE INTERPRETATION. A DETAILED EXAMINATION OF THE INCOMPLETE INTERPRETATION. A DETAILED EXAMINATION OF REGIME'S POL ITICAL AND ECONOMIC DEVELOPMENT AND AN UNDERSTANDING OF ITS PRAGMATIC EXTERNAL ORIENTATION SUGGES AND, IN SOME RESPECTS, REFLECT A LONG PROCESS OF ADAPTATION.

09493 WEBBER, $M$

SOVIET POLICY IN SUB-SAHARAN AFRICA: THE FINAL PHASE JOURNAL OF MODERN AFRICAN STUDIES, 30(1) (MAR 92), 1-30. THE AUTHOR TRACES THE TRANSFORMATION IN SOVIET POLICY IN SUB-SAHARAN AFRICA DURING THE 1980'S, WHICH LED TO THE USSR BECOMING
$1990^{\prime} \mathrm{S}$.
09494 WEBER, C.

RECONSIDERING STATEHOOD: EXAMINING THE

SOVEREIGNTY/INTERVENTION BOUNDARY

REYIEW OF INTERNATIONAL STUDIES, 18(3) (JUL 92), 199-216. THE AUTHOR SUGGESTS THAT THE REASON WHY INTERVENTION, LIKE SOVEREIGNTY, IS AN ESSENTIALLY UNCONIESTED CONCEPT' HAS O DO HITH THE COUPLING OF THE CONCEPTS SOVEREIGNTY AND OF SOVEREIGNTY/INTERVENTION CIRCULATING IN INTERNATIONAL RELATIONS LITERATURES EFFECT A SILENCE. HE ALSO SUGGESTS EMPLOYED BY INTERMATIONAL RELATIONS THEORISTS INHIBIT EMPLOYED BY INTERNATIONAL RELATIONS THEORISTS INHIBIT CREATIVE RECONCEPTUALIZATIONS OF STATEHOOD. HE CONCLUDES CONVENTIONAL LITERATURE HAS SERIOUS EFFECT FOR ITS STUDY.

09495 WEBER, C.

WRITING SOVEREIGN IDENTITIES: WILSON ADMINISTRATION INTERVENTION IN THE MEXICAN REVOLUTION

ALTERNATIVES, $17(3)$ (SUM 92), 313-338.

ONE OF THE MOST PARADOXICAL ASPECTS OF THE LITERATURE ON INTERNATIONAL RELATIONS IS THAT IT PROPOSES TO ESTABLISH ITS GROUNDS IN WHAT IS IN PRACTICE AN OPEN QUESTION -- STATE SOVEREIGNTY. THIS ARTICLE DEFINES AND DISCUSSES MANY ASPECTS OF SOVEREIGNTY. NEXT, IT DISCUSSES THE WILSOM ADMINISTRATION 'S INTERVENTION IN THE MEXICAN REVOLUTION IN RELATION TO MEXICO'S SOVEREIGN IDENTITY.

09496 HEBER, S.

SHAPING THE POSTWAR BALANCE OF POWER: MULTILATERALISM IN NATO

INTERNATIONAL ORGANIZATION, 46(3) (SUM 92), 633-680.

THIS ARTICLE EXPLORES THE STRUGGLE BETHEEN THO SETS OF IDEAS IN THE TRUMAN AND PARTICULARLY THE EISENHOWER ADMINISTRATION, WHERE THE PRESIDENT SPEARHEADED A DIRECT ADMINISTRATION, WHERE THE PRESIDENT SPEARHEADED A DIRECT MOVE TOWARD GREATER MULTILATERALISM IN NATO THRC

TO SHARE NUCLEAR WEAPONS HITHIN THE ALLIANCE. WLTILATERALISM IN NATO CREATED NEH POSSIBILITIES THAT STATES DID NOT FORESEE AND FUNDAMENTALLY CHANGED THEIR

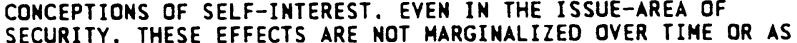
SECURITY, THESE EFFECTS ARE NOT MARG
THE DISTRIBUTION OF POWER CHANGES.

09497 WEBER, $V$

NO MANDATE FOR LEADERSHIP

POLICY REVIEW, (61) (SUM 92), 34-35

IT IS APPARENT IN THE 1992 ELECTION CAMPAIGNS THAT THE REPUBL ICANS HAVE FAILED TO DEFINE A NATIONAL AGENDA FOR THE COUNTRY. EVEN THOUGH THE REPUBLICANS ARE LIKELY TO ELECT AT LEAST 20 NEW CONGRESSMEN IN 1992, RUNNING AGAINST CONGRESSIDNAL PAY RAISES AND CHECK-BOUNCING IS NOT SUFFICIENT AS A POLITICAL AGENDA. IT GIVES THE CANDIDATE NO MANDATE FROM THE VOTERS ON THE MAJOR PUBLIC POLICY ISSUES AND, WITH THE EXCEPTION OF CONGRESSIONAL REFORM, GIVES THE CANDIDATE NO IDEA WHAT TO WORK FOR AFTER ELECTION.

09498 WEEDE, E.

SOME SIMPLE CALCULATIONS ON DEMOCRACY AND WAR INYOLVEMENT JOURNAL OF PEACE RESEARCH, 29(4) (NOV 92), 377-384.

THE EMPIRICAL EVIDENCE ON DEMOCRACY AND HAR INVOLVEMENT INDICATES TWO QUITE ROBUST FINDINGS. FIRST, DEMOCRACIES DO NDT DIFFER FROM OTHER REGIMES IN THEIR DEGREE OF WAR INVOL VEMENT. SECOND, WAR IS EXTREMELY RARE BETWEEN DEMOCRACIES. SO, THE PACIFYING IMPACT OF DEMOCRACY IS RESTRICTED TO RELATIONS BETWEEN DEMOCRACIES. THIS FINDING IS RESTRICTED TO RELATIONS BETWEEN DEMOCRACIES. THIS FINDING
AT ODDS WITH SOME OF THE AUTHOR'S PREVIOUS EMPIRICAL NORK, WHERE ONLY EXTENDED DETERRENCY BY SUPERPOWER ALLIANCE AND SUBORDINATION DF OTHER STATES UNDER SUPERPOWERS HAVE BEEN TREATED AS AS PACIFYING CONDITIONS. IN THIS ARITICLE THE
PREVIDUS DESIGN AND DATA ARE USED AGAIN BUT A PEACE AMONG PREVIOUS DESIGN AND DATA ARE USED AGAIN BUT A 'PEACE AMONG
DEMOCRACIES' PROPOSITION REPLACES THE EARLIER 'PEACE BY DEMOCRACIES' PROPOSITION REPLA
SUBORDINATION' PROPOSITION.

09499 WEFFORT, $F$

THE FUTURE OF SOCIALISM

JOURNAL OF DEMOCRACY, 3(3) ( JUL 92), 90-99.

UNT COULD EVER REVERT TO THE SOCIAL, ECONOMIC, AND POLITICAL FORMS CHARACTERISTIC OF CAPITALISM. IN 1991, THE FINAL HOPES OF THE OLD MODES OF THOUGHT WERE BURIED. THE THINKING MOST AFFECTED IS THAT ASSOCIATED WITH MARX. WITH STATE SOCIALISH HAVING FALLEN, SOCIALISTS NOW FIND THEMSELVES GROPING EXPLAIN TO THEMSELVES AND OTHERS JUST WHAT A SERIOUS SOCIALIST ALTERNATIVE TO CAPITALISM WOULD LOOK LIKE. HOWEVER, SOCIALISTS CAN FEEL AS CONFIDENT AS EVER ABOUT OLD SOCIALIST VALUES SUCH AS EQUALITY AND SOCIAL JUSTICE. IT IS THIS "CUL TURAL" DIMENSION OF SOCIALISM THAT EXPLAINS WHY THERE ARE STILL SO MANY SOCIALISTS IN THE WORLD. IT WILL NOT BE SURPRISING IF SOCIALISTS, GIVEN THEIR LACK OF ALTERNATIVE ECOMOMIC AND SOCIAL THEORIES, EMBRACE IN THE COMING YEARS A CONCEPTION OF SOCIALISM THAT IS NOT BOUND UP WITH A PARTICULAR SYSTEM BUT IS DEFINED PRIMARILY IN TERMS OF VALUES. THE EPOCHAL EVENTS OF 1989-91 HERALDED A REOISCOVERY 
OF POLITICS THAT SHOULD SHAKE UP NOT ONLY LEFTISTS WHO PUT TOO MUCH STOCK IN DETERMINISTIC THEORIES OF HISTORY, BUT ALSO THE MANY NEOCONSERVATIVE APOLOGISTS FOR CAPITALISM WHO AFFIRM THE PRIMACY OF ECONOMIC EXPLANATIONS.

09500 WEI-MING, T.

INTELLECTUAL EFFERVESCENCE IN CHINA

DAEDALUS, 121(2) (SPR 92), 251-292

THE AUTHOR DISCUSSES RECENT CHANGES IN COMMUNIST CHINA, THE POTENTIAL FOR CHINESE-STYLE DEMOCRACY, THE ROLE OF THE CHINESE INTELLIGENTSIA, THE PRACTICE OF PUBLIC DISCUSSION IN CHINA, AND THE MAINLAND DEMOCRACY MOVEMENT.

09501 HEI, J.

CHINA STILL FACING POPULATION PROBLEM

BEIJING REVIEW, 35(52) (DEC 92), 16-18.

TWENTY YEARS AGO, CHINA EMBARKED ON A FAMILY PLANNING

POLICY THAT HAS RESULTED IN 260 MILLION FEWER BIRTHS.
NEYERTHELESS, BY THE END OF THE 2OTH CENTURY, CHINA'S

POPULATION IS EXPECTED TO REACH 1.3 BILLION, RISING TO 1.5

POPULATION IS EXPECTED TO REACH 1.3 BILLION, RISING TO 1.5

BILLION OR MORE BY THE MIDOLE OF THE 21ST CENTURY. THUS,

STRICT ENFORCEMENT OF THE GOVERNMENT'S POPULATION POLICY.

09502 WEIDENBAUM, M.

LEVIATHAN IN RIO

NATIONAL REVIEH, XLIV(8) (APR 92), 44-45; 56

IT IS IRONIC THAT, WHILE THE WORLD HAILS THE ABANDONMENT OF TOTALITARIAN GOVERMMENT IN EASTERN EUROPE, AN AMBITIOUS BUT OVERLOOKED EFFORT IS UNDER WAY TO EXPAND GOVERNMENTAL POHER ON A GLOBAL SCALE. IN THE GUISE OF CLEANING UP THE ENVIRONMENT, THE FIRST UN-SPONSIORED EARTH SUMMIT IS SCHEDULED FOR RIO DE JANEIRO IN JUNE. THE CONFERENCE SECRETARIAT IS PROPOSING AN IMPRESSIVE ARRAY OF GLOBAL GOALS ERADICATING POVERTY, REVERSING THE DESTRUCTION OF RENEWABLE RESOURCES, AND CHANGING THE SYSTEM OF INCENTIVES AND PENALTIES THAT MOTIVATE ECONOMIC BEHAVIOR. THE CAREFUL READER WILL NOTE THAT ENYIRONMENTAL CONCERHS ARE SANDWICHED IN BETWEEN TWO PROPOSALS FOR FUNDAMENTALLY CHANGING THE DISTRIBUTION OF ECONOMIC RESOURCES. THE PLANNERS OF EARTH SUMMIT CANNOT BE ACCUSED OF HAVING A HIDDEN AGENDA. THEIR SHEEPING VISION IS CLEARLY REVEALED IN THEIR LITERATURE.

09503 WEIDENBAUM, $M$

REDUCIMG REGULATION OF THE DEFENSE INDUSTRY

FREEMAN, 42(2) (FEB 92), 52-55.

A MAJOR CUTBACK IN DEFENSE SPENDING, WHICH IS THE OUTLOOK FOR THE EARLY 1990S, IS THE IDEAL TIME TO FOCUS ON FEDERAL REGULATION IN AMERICAN INDUSTRY AND TO RESTORE THE ROLE OF PRIVATE RISK BEARING AND BUSINESS INITIATIVE. THIS ROLE OF PRIVATE RISK BEARING AND BUSINESS INITIATIVE. MILITARY ESTABLISHMENT ASSUMES THE MANAGERIAL DECISIONMAKING MILITARY ESTABLISHMENT ASSUMES THE MANAGERIAL DECISIONMAKI FUNCTIONS OF ITS CONTRACTORS WHICH IS THROUGH PROCUREME LEGISLATION, AND THE RULES GOVERNING THE AWARDING OF GIVES THE GOVERNMENT UNPARALLELED AUTHORITY OVER THE INTERNAL OPERATIONS OF PRIVATE COMPANIES.

09504 WEIDENBAUM, $M$

RETURN OF THE "R" HORD: THE REgULATORY ASSAULT ON THE ECONOMY

POLICY REVIEH, (59) (WIN 92), 40-43.

THOSE WHO WONDER WHY THE U.S. ECONOMY HAS NOT RESPONOED MORE SWIFTLY TO SUCCESSIVE DOSES OF MONETARY STIMULUS OVER THE PAST THO YEARS SHOULD CONSIDER A FACTOR OVERLOOKED BY MANY ECONOMIC ANALYSTS: ANY COMPANY BRAVE ENOUGH TO CONSIDER EMBARKING ON A NEH CAPITAL INVESTMENT FACES A THICKET OF OBSTACLES IN THE FORM OF EXPANDED ENVIRDNMENTAL AND OTHER REGULATIONS. AT FIRST GLANCE, THE REGULATION OF BUSINESS SEEMS TO BE A CHEAP WAY OF ACHIEVING NATIONAL OBJECTIVES. IT APPEARS TO COST THE GOVERNMENT VERY LITTLE AND DOES NOT SEEM TO BE MUCH OF A BURDEN ON THE PUBLIC. HENCE, THERE IS LITTLE PUBLIC PRESSURE TO ANALYZE ITS COSTS AND BENEFITS. BUT THE PUBLIC DOES NOT ESCAPE PAYING. EVERY TIME A GOVERMMENT AGENCY ATTEMPTS TO SAFEGUARD THE ENVIRONMENT, IT IMPOSES A MORE EXPENSIVE METHOD OF PRODUCTION ON BUSINESS AND THE COST OF PRODUCTS RISES.

09505 WEIDENBAUM, M.

THE BUSINESS RESPONSE TO THE GLOBAL MARKETPLACE WASHINGTON OUARTERLY, 15(1) (WIN 92), 173-186.

TECHMOLOGY AND ECONOMICS ARE OUTPACING TRADITIONAL WAYS OF THINKING ABOUT INTERNATIONAL POLITICS. THE KEY STRUCTURAL OF THINKING ABOUT INTERNATIONAL POLITICS. THE KEY STRUCTURAL SHIFT IN WESTERN EUROPE IS THE ECONOMIC INTEGRATION OF COMPLETED IN ITS ESSENTIAL ELEMENTS BY THE END OF 1992. THIS COMPLETED IN ITS ESSENTIAL ELEMENTS BY THE END OF 1992. THIS ARTICLE LOOKS BEYOND 1992 AND EXPLORES BUSINESS POTEM IN EASTERN EUROPE. IT THEN STUDIES THE THREATS AND OPPORTUNITIES FOR BUSINESS AND IMPORTANT PUBLIC POLICY IMPLICATIONS. IT CONCLUDES THAT U.S. PUBL IC POLICY SHOULD
FOCUS ON THE GOVERMMENT'S AREA OF PRIMARY RESPONSIBILITY: FOCUS ON THE GOVERMMENT'S AREA OF PRIMARY
THE EDUCATION OF THE FUTURE HORK FORCE.
09506 WEIDENBAUM, M.

THE FUTURE OF THE U.S. DEFENSE INDUSTRY

CONTEMPORARY POL ICY ISSUES, X(2) (APR 92), 27-34.

DEFENSE CONTRACTORS IN THE UNITED STATES FACE A PAINFUL CHOICE BETHEEN DOWNSIZING OR INVESTING IN NEN HIGH-RISK COMMERCIAL VENTURES. PAST EXPERIENCE REVEALS NUMEROUS FAILED EFFORTS TO PENETRATE COMMERCIAL MARKETS AND FEW SUCCESSES, BECAUSE THE CAPABILITIES REQUIRED TO SUCCEED IN CIVILIAN BUSINESS ARE FUMDAMENTALLY DIFFERENT FROM THOSE NEEDED TO DESIGN AND PRODUCE WEAPON SYSTEMS. DEFENSE FIRMS AND DEFENSE

DIVISIONS OF DIVERSIFIED CORPORATIONS LACK ADEQUATE
KNOWLEDGE OF COMMERCIAL PRODUCTS, PRODUCTION METHODS,

ADVERTISING AMD DISTRIBUTION, FINANCES, AND CUSTOMER DEMAND. GIVEN THE OUTLOOK FOR A SUSTAINED DECLINE IN U.S. MILITARY SPENDING, COMPANIES CATERING TO MILITARY MARKETS SHOULD CUT THEIR COSTS BY REDUCING EXCESS CAPACITY. SMALLER BUT MORE COMPETITIVE POSITIONS CAN BE ACHIEVED THROUGH RESTRUCTURING MERGERS, THE SALE OF ASSETS, AND, IF NECESSARY, CLOSING UNMEEDED FACILITIES. FIRMS THAT IGNORE THE CALLS FOR "CONVERSION" AND DO NOT DISSIPATE THEIR ASSETS IN CIVILIAN MARKETS ALIEN TO THEM STAND THE BEST CHANCE OF SURVIVING DURING A PERIOD OF REDUCED GOVERNMENT SPENDING FOR WEAPONS.

09507 WEIDENFELD, W.; JANMING, J.

EUROPEAN INTEGRATION AFTER THE COLD WAR--PERSPECTIVES OF A NEW ORDER

INTERMATIONAL SOCIAL SCIENCE JOURNAL, 131(131) (FEB 92),

THE CONVENTIONAL ANALYSES OF THE SITUATION IN EUROPE FAILED TO ANTICIPATE THE DYNAMIC FORCE OF DEVELOPMENTS IN EAST AND HEST. BY THE END OF THE 1980S ALL PREDICTIONS BASED ON THE ASSUMPTION THAT EUROPEAN INTEGRATION HAS EXHAUSTED AND THAT THE POSITION OF WESTERN EUROPE IN WORLD POL ITICS ARTICLE EXPLORES THE UNDERLYING STRUCTURE OF CHANGE IN EUROPE.

09508 HEIDNITZER, E.

TUNSIA--ECONOMIC GROWTH THROUGH ARAB COOPERATION?

ORIENT, 32(1) (1991), 237-247.

ONE OF THE GREATEST CHALLENGES TO TUNISIAN POLITICS SINCE GAINING INDEPENDENCE HAS BEEN TO ACHIEYE STEADY ECONOMIC GROWTH. SEEKING THE INFLUX OF FOREIGN CAPITAL, THE TUNISAN LEADERSHIP FOCUSES ON ATTRACTING FUNDS FROM OILEXPORTING COUNTRIES IN THE REGION WHICH BECAME AN IMPORTANT FACTOR IN THEIR ECONOMIC DEVELOPMENT. HOWEVER, THERE ARE LIMITATIONS ON THE ECONOMIC IMPACT OF ARAB CAPITAL. TUNISIA IS SEEXING CLOSER COPORAT IM WITHIM THE MAGHRB REGION. POSSIBILITIES OF FAVORABLE ECONOMIC COOPERATION ARE POSSIBILITIES OF FAVORABLE ECONOMIC COOPERATION ARE
PREVALENT IN THE AREAS OF COMMERCE, INDUSTRY, TOURISM AND PREVALENT IN THE AREAS OF COMMERCE, INDUSTRY, TOURISM AND
EMPLOYMENT. SUSTAINED POLITICAL RESOLVE WITHIN UMA TO ACT IM EMPLOYMENT. SUSTAINED POLITICAL RESOLVE WITHIN UMA TO ACT CONCERT REPRESENTS THE DECISIVE FACTOR IN EXPANDING THE ADVANTAGES OF COOPERATION AS ONE

09509 WEIGEL, G.

DEATH OF A HERESY

NATIONAL REVIEW, XLIV(1) (JAN 92), 42; 44-46; 48.

HERESY OFTEN, XLIVISTS OF THE EXAGGERATION OF ONE PART OF A COMPLEX TRUTH AND COMMUNISH WAS NO EXCEPTION TO THAT RULE. COMMUNISM HAS EYIL NOT JUST BECAUSE OF ITS VIEW OF HISTORY, BUT BECAUSE IT TAUGHT FALSELY ABOUT MAN. THE COMMUNIST HERESEY WAS THE HERESY OF THE POLITICAL. FOCUSING ON COMMUNISH AS SUCH, HELPS ONE GRASP THE CENTRAL TRUTH OF THE REVOLUTION OF 1989 AND THE NEW RUSSIAN REVOLTUION OF 1991; THAT THESE HERE, FIRST AND FOREMOST, REVOLUTIONS OF THE SPIRIT, IN WHICH THE PEOPLE SAID "NO" ON THE BASIS OF A HIGHER AND MORE COMPELLING "YES."

09510 HEIGEL, G.

ON THE ROAD TO ISOLATIONISH?

COMMENTARY, 93(1) (JAN 92), 36-42.

"BACK TO THE FUTURE" MAY WILL DEFINE THE FOREIGN-POLICY DEBATE IN THE 1990S. PERHAPS THE MOST CURIOUS OF THESE RELATED PHENOMENA HAS BEEN THE ISOLATIONIST RENAISSANCE. THIS HAS ONCE AGAIN BECOME A SIGNIFICANT VOICE IN THE ARGUMENT OVER THE NATIONAL INTEREST AND THE NATIONAL PURPOSE. THE MOST VISIBLE CHALLENGE TO THE NEW ISOLATIONISM HAS BEEM MOUNTED BY A CADRE OF ACADEMICS AND COMMENTATORS WHO MIGHT BE STYLED THE "DEMOCRATIC INTERNATIONALISTS." THE REALIST COUNTER-PROPOSAL, FOR A RETURN TO NORMALCY IN THE THE CONDUCT OF OUR FOREIGN POLICY, IS BUILT AROUND THE CONCEPT CONDUCT OF OUR FOREIGN POLICY, IS BUILT AROUND THE CONCEPT MILITARY AND ECONOMIC TERMS. THIS ARTICLE CONCLUDES THAT THE MILITARY AND ECONOMIC TERMS. THIS ARTICLE CONCLUDES THAT THE EXPERIEMENTS WITH PRINCIPLE-FREE REALPOLITIK--HILL SO

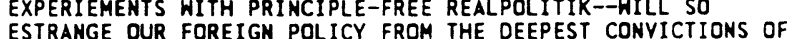
ESTRANGE OUR FOREIGN POLICY FROM THE DEEPEST CONVICTIONS OF THE AMERICAN PEOPLE THAT THEY WILL RETREA IN DIND OF HEMISPHERIC BUNKER NOW BEING DESIGND BY THE KIND OF HEMISPHERIC
BUCHANAN AND HIS TRIBE.

09511 HEIGEL, G.

THE FINAL REVOLUTION--THE RESISTANCE CHURCH AND THE COLLAPSE OF COMMUNISM 
OXFORD UNIVERSITY PRESS, 1992,

THIS BOOK ARGUES THAT THE REVOLUTION WHICH BROUGHT DOWM THE COMMUNIST REGIMES OF EASTERN EUROPE WAS A "REVOLUTION OF CONSCIENCE." THE HUMAN TURN TO THE GOOD, TO THE TRULY HUMAN, AND, ULTIMATELY, TO GOD, WAS THE KEY TO THE POLITICAL REVOLUTION OF 1989. THE AUTHOR EXPLORES HOW THE CATHOLIC CHURCH SHAPED THE MORAL REYOLUTION INSIDE THE POL ITICAL REVOLUTION. HE ALSO EXAMINES THE CENTRAL ROLE PLAYED BY POPE JOHM PAUL II IN CONFRONTING WHAT VACLAY HAYEL CALLED CDMMUNISM'S "CUL TURE OF THE LIE." HE CONCLUDES BY SUGGESTING WHAT THE FUTURE ROLE OF THE CHURCH MIGHT BE IN CONSOLIDATING DEMOCRACY IN THE COUNTRIES OF THE OLD HARSAW PACT.

09512 WEIGLE, M.A.; BUTTERFIELD, J.

CIVIL SOCIETY IN REFORMING COMMUNIST REGIMES: THE LOGIC OF EMERGENCE

COMPARATIVE POLITICS, 25(1) (OCT 92), 1-23.

THE EXPLOSION OF SOCIAL ACTIVISM IN POLAND,

CZECHOSLOVAKIA, HUMGARY, AND THE SOVIET UNION' IN THE LATE 1980 'S PROMPTED MUCH DISCUSSION ABOUT THE FORMATION OF CIVIL SOCIETIES-FIRST IN OPPOSITION TO REFORMING COMHUNIST REGIMES AND THEN IN SUPPORT OF NEWLY-DEMOCRATIZING ONES. THE AUTHORS DISCERH FOUR STAGES IN THE DEVELOPMENT OF CIVIL SOCIETY: DEFENSIVE, EMERGENT, MOBILIZATIONAL, AND INSTITUTIONAL. THEY FOCUS ON THE FIRST TWO IN TERMS OF REGIME TYPE AND SOCIAL RESPONSES TO LIBERALIZING REFORMS. CRISES OF THE COMMUNIST REGIMES RESULTED IN A DEFENSE OF INDIVIDUAL AND SOCIAL AUTONOMY IN THE PRE-REFORM PERIOD. PROMPTED EITHER BY PRESSURE FROM BELOW OR BY REFORMIST PARTY LEADERS, THE OPPORTUNITIES FOR INDEPENDENT SOCIAL

PARTICIPATION INCREASED DURING THE 1980'S, WHEN CIVIL

SOCIETIES EMERGED TO CHALLENGE PARTY RULE.

09513 WEILONG, L.

JAPANESE EMPEROR'S VISIT PROMOTES SINO-JAPANESE FRIENDSHIP BEIJING REVIEH, 35(42) (OCT 92), 7

AT THE INVITATION OF CHINESE PRESIDENT YANG SHANGKUN, JAPANESE EMPEROR AKIHITO AND EMPRESS MICHIKO WILL PAY AN OFFICIAL VISIT TO CHINA IN OCTOBER 1992. THE VISIT, WHICH WILL MARK THE 2OTH ANNIVERSARY OF THE NORMALIZATION OF SINOJAPANESE RELATIONS, IS INTENDED TO PROMOTE MORE CDOPERATION JAPANESE RELATIONS, IS INTENDED TO PROMOTE MORE CDOPERATION
BETWEEN THE TWO COUNTRIES AND TO CONTRIBUTE TO THE PEACE AND BETWEEN THE TWO COUNTRIES AND
STABILITY OF ASIA AS A WHOLE.

09514 WEIMER, D.L.

POLITICAL SCIENCE, PRACTITIONER SKILL, AND PUBLIC MAMAGEMEMT

PUBLIC ADMINISTRATION REVIEH, 52(3) (MAY 92), 240-245.

THE AUTHOR ARGUES THAT CONTEMPORARY POLITICAL SCIENCE CONTRIBUTES LITTLE TO THE STUDY OF PUBL IC MANAGEMENT AND THE IMPROVEMENT OF PRACTITIONER SKILLS. ONE AREA WITH POTENTIAL FOR A SIGNIFICANT CONTRIBUTION IS IN WORK FOCUSED ON THE ROLE OF STRATEGIC THINKING AMONG TOP-LEVEL PUBLIC OFFICIALS. BUT POLITICAL-SCIEMCE APPROACHES BASED ON DEDUCTIVE MODELS ARE PART ICULARLY LIMITED, BECAUSE THEY ARE UNABLE TO TREAT MANAGEMENT AND SKILL AS ENDOGENOUS FACTORS. INDUCTIVE MODELS ROOTED IN CASE STUDIES MIGHT PROVE USEFUL IN THE LONG TERM, BUT THEY FALL FAR SHORT OF WHAT IS ACCEPTABLE TO A "SCIENC OF POLITICS. THE AUTHOR SEES SOME HOPE IN EFFORTS TO MORE ASSESSMENT IS THAT POL ITICAL SCIENCE HAS LITTLE TO OFFER THOSE WHO SEEK INSIGHTS INTD PUBLIC-SECTOR MANAGEMENT.

09515 WEIMER, D.L. (ED.)

POLICY ANALYSIS AND ECONOMICS: DEVELOPMENTS, TENSIONS, PROSPECTS

KLUWER ACADEMIC PUBLISHERS, 1991, 213

THIS COLLECTION OF NINE ARTICLES HIGHLIGHTS THE PROBLEMS THAT HAVE ACCOMPANIED THE EVOLUTION OF ECONOMICS IN THE POSTHAR PERIOD. THE AUTHORS ARGUE THAT THE INSTRUCTION AND PRACTICE OF ECONOMICS HAVE BECOME INCREASINGLY MATHEMATICAL AND THEORETICAL AS ECONOMISTS HAVE TRIED TO DEVELOP A POSITIVE SCIENCE. AS A RESULT, ECONOMICS HAS LESS TO SAY ABOUT "NORMATIYE" PUBLIC POLICY ISSUES. MAJOR GAPS IN THE ECONOMIC PARADIGM MAKE IT DIFFICULT TO APPLY ECONOMICS TO POLICY ISSUES. FURTHERMORE, ECONOMIC ANALYSES EXCLUDE CRITICAL FACTORS THAT UNDERLIE POLICY DEVELOPMENT; INSTITUTIONS, IN PARTICULAR, ARE ALMOST COMPLETELY IGNORED, INSTI IUTIONS, IN PARTICULAR, ARE ALMOST COMPLETELY IGNORED,
EVEN THOUGH POLICY OPTIONS ARE ALMOST ALWAYS DEPENDENT ON EVEN THOUGH POLICY OPTIONS ARE ALMOST ALWAYS DEPENDENT ON
THE PROCESSES THAT ARE AVAILABLE. THE CONTRIBUTORS CALL FOR THE PROCESSES THAT ARE AVAILABLE. THE CONTRIBUTORS CA A REORIENTATION OF ECONOMICS TO SUPPORT PUBLIC POLICY
DEVELOPMENT. TO DO THIS, ECONOMISTS WILL NEED A HIDE ARRAY OF SKILLS INCLUDING THE UNDERSTANDING OF HISTORICAL, OF SKILLS INCLUDING THE UNDERSTANDING OF HISTORICAL,
POLITICAL, MORAL, LEGAL, PHILOSOPHICAL AND ORGANIZATIONAL PERSPECTIVES.

09516 WEIMIN, M.

CHALLENGES FACING AUSTRIA

BEI JING REVIEW, 35 (49) (DEC 92), 15-16.

SINCE HORLD WAR II, THE AUSTRIAN GOVERMMENT HAS

DEDICATED ITSELF TO DEVELOPING THE NATIONAL ECONOMY AND HAS PURSUED A POLICY OF NEUTRALITY IN FOREIGN AFFAIRS. NOW AUSTRIA IS FACED WITH TWO MAJOR QUESTIONS: WHETHER TO JOIN THE EUROPEAN COMHUNITY AND HOW TO ADAPT ITS POLICY OF
NEUTRALITY FOR THE POST-COLD HAR ERA.

09517 WEINBERG, L.; EUBANK, H.L.

TERRORISH AND CHANGES IN POLITICAL PARTY SYSTEMS

TERRORISM AND POLITICAL VIOLENCE, 4(2) (SUM 92), 125-139.

THE AUTHORS STUDY THE RELATIONSHIP BETHEEN CONVENTIONAL PARTY POLITICS AND THE FORMATION OF TERRORIST GROUPS. USING SEVERAL COLLECTIONS OF AGGREGATE DATA. THEY EXAMINE THE EFFECT OF CHANGES IN PARTY POLITICS FROM THE 1960 'S TO THE $1970^{\prime} S$ ON THE APPEARANCES OF TERRORIST GROUPS IN MANY NATIONS. CHANGES IN THE NUMBER OF PARTIES IN THE SYSTEM AS NATIONS. CHANGES IN THE NUMBER OF PARTIES IN THE SYSTEM AS
WELL AS FLUCTUATIONS IN THEIR ELECTORAL PERFORMANCES AND IN WELL AS FLUCTUATIONS IN THEIR ELECTORAL PERFORMANCES AND IN THEIR PARLIAMENTARY REPRESENTATION FROM ONE DECADE TO THE
OTHER ARE LINKED TO THE NUMBER OF TERRORIST GROUPS ACTIVE IM OTHER ARE LINKED TO THE NUMBER OF TERRORIST GROUPS ACTIVE IN
DIFFERENT NATIONS. A PRINCIPAL FINDING IS THAT NATIONS WITH DIFFERENT NATIONS. A PRINCIPAL FINDING IS THAT NATIONS WITH
MANY LEFTIST PARTIES ALSO TEND TO HAVE MANY TERRORIST GROUPS, MANY LEFTIST PARTIES ALSO TEND TO HAVE MANY TERRORIS REGARDLESS
PERSPECTIVE.

09518 WEINBERG, $S$.

THE OCTOBER SURPRISE: ENTER THE PRESS

COLUMBIA JOURNALISM REVIEN, 30(6) (MAR 92), 33-41.

THE AUTHOR CRITIOUES THE COVERAGE BY THREE MAJOR MAGAZINES OF THE SO-CALLED "OCTOBER SURPRISE," THE ALLEGATION THAT THE 1980 REAGAN-BUSH PRESIDENTIAL CAMPAIGN MADE A DEAL WITH IRANIAN REVOLUTIONARIES TO DELAY THE RELEASE OF 52 AMERICAN HOSTAGES UNTIL AFTER THE NOVEMBER ELECTION, THEREBY CONTRIBUTING TO THE DEFEAT OF INCUMBENT PRESIDENT JIMMY CARTER.

09519 WEINBERGER, J

POLITICS AND THE PROBLEM OF TECHNOLOGY: AN ESSAY ON HEIDEGGER AND THE TRADITION OF POLITICAL PHILOSOPHY AMERICAN POLITICAL SCIENCE REVIEW, 86(1) (MAR 92), 112-127. THE AUTHOR EXAMINES HEIDEGGER'S POSTMODERN

INTERPRETATION OF TECHNOLOGY, WITH AN EYE TO EXPOSING ITS HEAKNESSES BY SHOWING THAT HEIDEGGER'S VIEW ENTAILS AN UNDERSTANDING OF THE TRADITION OF POLITICAL PHILOSOPHY THAT CANMOT DO JUSTICE TO THAT TRADITION'S OWN UNDERSTANDING OF THE CHARACTER OF TECHNOLOGY. FIRST, THE AUTHOR CONSIDERS PLATO AND ARISTOTLE AND THEN HOBBES AND LOCKE IN ORDER TO PLATO AND ARISTOTLE AND THEN HOBBES AND LOCKE IN ORDER
SUGGST THAT HEIDEGGER'S VIEW THAT MODERN POLITICS ARE STAMPED BY TECHNOLOGICAL METAPHYSICS CAN BE CHALLENGED ON TWO RELATED GROUNDS: (1) IT ASSUMES INCORRECTLY THAT THE IRADITION IS DOMINATED BY DOGMATIC METAPHYSICS; (2) IT TRADITION IS DOMINATED BY DOGMATIC METAPHYSICS; (2) IT PREVENTS US FROH SEEING HOW SOME IN THE TRADITION BOTH UNDERSTOOD AND DOUBTED THE POSSIBILITY OF A TECHNOLOGICAL STAMP. FINALLY, THE AUTHOR SUGGESTS AN ALTERNATIVE VIEW OF
TECHNOLOGY THAT MIGHT BETTER ACCOUNT FOR THE CHARACTER OF TECHNOLOGY THAT MIGHT BETTER ACC

09520 WEINER, D.

SOCIALIST TRANSITION IN THE CAPITALIST PERIPHERY: A CASE STUDY OF AGRICULTURE IN ZIMBABWE

POLITICAL GEOGRAPHY QUARTERLY, 10(1) (JAN 91), 54-75.

ZIMBABWE'S LIBERATION STRUGGLE YIELDED A GOVERMMENT PUBLICLY COMMITTED TO SOCIALIST TRANSITION. A PRIMARY TRANSFORMATION OBJECTIVE WAS TO DEVELOP BLACK AGRICULTURE THROUGH THE ESTABLISHMENT OF PRODUCER COOPERATIVES AND STATE FARMS WHILE INCREASING SUPPORT TO PEASANT FARMERS. HOWEVER, INTERNAL AND EXTERNAL CONSTRAINTS STIFLED PROSPECTS FOR A RADICAL AGRARIAN RESTRUCTURING, AND LARGE-SCALE CAPITALIST AGRICULTURE WAS MAINTAINED AND SUPPORTED. THE DEVELOPMENT OF CAPITALISM IN ZIMBABWEAN AGRICULTURE IS GENERATING GROWTH BUT INTENSIFYING SPATIAL AND SOCIAL AGRARIAN OIFFERENTIATION. THE STRUGGLE FOR CONTROL OF POLITICAL POWER AND ECONOMIC RESOURCES SHIFTED FROM RACE TO CLASS IN A VERY SHORT PERIOD OF TIME. THIS IS CONSISTENT WITH CLASSICAL MARXIAN INTERPRETATIONS OF THE AGRARIAN QUESTION. IT IS UNLIKELY THAT RURAL ZIMBABWEANS WILL EXPERIENCE ANYTHING RESEMBLING A SOCIALIST TRANSFORMATION IN THE SHORT-TERM.

09521 WEINER, $M$.

SECURITY, STABILTIY, AND INTERMATIONAL MIGRATION INTERNATIONAL SECURITY, $17(3)$ (HIN 92), 91-126.

A SECURITY/STABILTIY FRAMENORK COMPLEMENTS RATHER THAN REPLACES AN ECONOMIC ANALYSIS BY FOCUSING UPON THE ROLE OF STATES IN BOTH CREATING AND RESPONDING TO INTERNATIONAL
MIGRATION. THE OBJECT OF THIS ARTICLE IS TO IDENTIFY SOME OF MIGRATION. THE OBJECT OF THIS ARTICLE IS TO IDENTIFY SOME OF
THE CIRCUMSTANCES IN WHICH SECURITY/STABILTIY CONSIDERATIONS BECOME PARAMOUNT IN HOW STATES DEAL WITH ISSUES OF 8ECOME PARAMOUN IN HON STATES DEAL WITH ISSUES OF INTERNATIONAL MIGRATION. THIS ARTICLE IDENTIFIES TYPES OF SECURITY AND STABILTIY AND ALSO IDENTIFIES THOSE

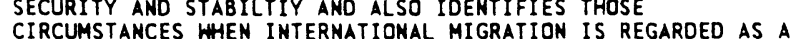
CIRCUMSTANCES WHEN INTERNATIONAL MIGRATION IS REGARDED
THREAT TO A COUNTRY'S SECURITY AND STABILITY. IT ALSO THREAT TO A COUNTRY'S SECURITY AND STABILITY. IT ALSO
CONSIDERS THE VARIOUS WAYS STATES REACT WHEN FACED WITH CONSIDERS THE VARIOUS WAYS STATES REACT WHEN FACED WITH
POPULATION MOVEMENTS THEY REGARD AS A THREAT TO THEIR INTERNATIONAL SECURITY AND INTERMAL STABILTIY.

09522 WEINSTEIN, M.

THE DARK NIGHT OF THE LIBERAL SPIRIT AND THE DAWN OF THE SAVAGE

CANADIAN JOURNAL OF POLITICAL AND SOCIAL THEORY, 15(1-3) 
(1991) 210-224.

THIS AUTHOR UNDERTAKES A CRITIQUE OF CONTEMPORARY AMERICAN LIBERALISM, SPECIFICALLY WHAT IS COMMONLY CALLED "MEO-LIBERALISM," FROM THE FOUNOATION OF A PHENOMENOLOGICAL REFLECTION OF MODERN CONSCIOUSNESS. LIBERALISM, AS A POLITICAL FORMULA FOR SELF-CONSCIOUSLY ORGANIZING SOCIETY, IS FATEFULLY BOUND TO THE CONTINUANCE OF THE MODERN UNDERSTANDING OF LIFE AND CANNOT SURVIVE THE FAILURE TO INSTANTIATE THAT UNDERSTANDING INTO CONSCIOUSNESS, TO MAKE IT THE VERY CONSTITUTION OF CONSCIOUSNESS. THE CURRENT TALK ABOUT A POSTMODERN HISTORICAL PERIOD APPEARS, THEREFORE, TO BE AN ADMISSION THAT LIBERALISM IS A THING OF THE PAST.

09523 WEINTRAUB, S.

NORTH AMERICAN FREE TRADE AND THE EUROPEAN SITUATION COMPARED

INTERNATIONAL MIGRATION REVIEW, XXVI(2) (SUM 92), 506-524. WHILE BOTH THE EUROPEAN COMMUNITY (EC) AND THE NORTH AMERICAN FREE TRADE ASSOCIATION (NAFTA) ARE DESIGNED TO PROVIDE TRADE PREFERENCES TO THE MEMBER COUNTRIES. THE TWO GROUPINGS DIFFER MARKEDLY IN OTHER RESPECTS. THE TREATY OF ROME, ESTABLISHING WHAT IS NOW THE EC, CONSCIOUSLY USED ROME, ESTABLISHING WHAT IS NOW THE EC, CONSCIOUSLY USED EUROPE: WHEREAS, THE NAFTA NEGOTIATIONS SEEK FREE TRADE EUROPE; WHEREAS, THE NAFTA NEGOTIATIONS SEEK FREE TRADE PRECISELY TO MINIMIZE POL ITICAL CONTENT. THE EC CONTAINS PRECISELY TO MINIMIZE POLITICAL CONTENT. THE EC CONTAINS MANY SOCIAL PROVISIONS ABSENT FROM THE NAFTA DISCUSSIONS, THE MOST IMPORTANT OF WHICH IS THE RIGHT OF MIGRATION FROM ONE EC COUNTRY TO ANOTHER. HOWEVER, MIGRATION BETWEEN MEXICO
AND THE UNITED STATES, BOTH LEGAL AND UNDOCUMENTED, IS MORE EXTENSIVE THAN BETWEEN ANY OF THE EC COUNTRIES. THIS MIGRATION IS UNLIKELY TO DIMINISH IN THE NEAR TO MEDIUM TERM BECAUSE OF THE GREAT DISPARITY THAT EXISTS IN THE LEVELS OF INCOME OF THE TWO COUNTRIES. HOWEVER, A REDUCTION IN THE PRESSURE TO EMIGRATE FROM MEXICO OVER THE LONG TERM REQUIRES SUSTAINED ECONOMIC GROWTH THERE, TO WHICH FREE TRADE WITH THE UNITED STATES CAN CONTRIBUTE.

09524 HEINTRAUB, S.

REGIONALISM AND THE GATT: THE NORTH AMERICAN INITIATIVE SAIS REVIEW, 11(1) (WIN 91) 45-57.

THE PROPOSED EUROPEAN COMMON MARKET OF 1992 AND GEORGE BUSH'S VISION OF A FREE TRADE ZONE IN THE WESTERN HEMISPHERE HAVE GIVEN RISE TO QUESTIONS ABOUT THE DURABILITY OF THE MULTILATERAL TRADING SYSTEM. THESE DEVELOPMENTS COINCIDE WITH THE CLIMAX OF THE URUGUAY ROUND OF TRADE NEGOTIATIONS IN THE GENERAL AGREEMENT ON TARIFFS AND TRADE (GATT). THIS IN THE GENERAL AGREEMENT ON TARIFFS AND TRADE (GATT). THI
ARTICLE CONSIDERS A NUMBER OF QUESTIONS PRESENTED BY THE
RELATIONSHIP BETHEEN THESE TWO SETS OF DEVELOPMENTS: THE RELATIONSHIP BETHEEN THESE TWO SETS OF DEVELOPMENTS: THE
REASONS WHY THE U.S. IS ENGAGING IN REGIONALISM AT THIS TIME REASONS WHY THE U.S. IS ENGAGING IN REGIONALISM AT THIS REGIONAL ISM AND AS A SIGNAL OF THE EXPANSIONS OF THE U.S. REGIONALISM AND AS A SIGNAL OF THE EXPANSIONS OF THE COMMITMENT TO REGIONALISH: WHETHER THE EXISTING GATT STRUCTURE IS CAPABLE OF HANDLING THE ISSUES THAT REGIONALISM
WILL RAISE AND THE DEROGATION OF AUTHORITY THAT COULD OCCUR: WILL RAISE AND THE DEROGATION OF AUTHORITY THAT COULD OCCUR AND THE

09525 HEINTRAUB, S

US-MEXICO FREE TRADE: IMPLICATIONS FOR THE UNITED STATES JOURNAL OF INTERAMERICAN STUDIES AND WORLD AFFAIRS, $34(2)$ (SUM 92), 29-52.

THIS ARTICLE IS A DISTILLATION OF THE ARGUMENTS OF THOSE WHO FAVOR THE FTA AND THOSE WHO OPPOSE IT. MOST ATTENTION IS PAID TO THE ECONOMIC AND SOCIAL THEMES BECAUSE THEY DOMINATED THE DEBATE, BUT FOREIGN POLICY CONSIDERATIONS ARE ALSO COVERED. THE ARGUMENTS SUPPORTING THE AGREEMENT ARE DISCUSSED FIRST AND THEN THOSE AGAINST CONCLUDING AN FTA. COMPROMISES ARE ESSENTIAL AND ARE SET FORTH.

09526 WEIR, M.

BOUTROS BOUTROS GHALI--THE UN'S NEW CHIEF

MIDOLE EAST INTERNATIONAL, (416) (DEC 91) 12.

THIS ARTICLE BRIEFLY PROFILES THE UNITED NATIONS' NEW SECRETARY-GENERAL, BOUTROS BOUTROS GHALI. HE SERVED AS EGYPT'S MINISTER OF STATE FROM 1977 TO THE PRESENT AND WAS INSTRUMENTAL IN MANY OF EGYPT'S DIPLOMATIC ACCDMPLISHMENTS DURING THAT TIME INCLUDING THE PEACE ACCORD WITH ISRAEL. HE HAS BEEN DUBBED THE "CHAMPION OF THE HAVE-NOTS." HIS ENTIRE CAREER HAS DEMONSTRATED THAT FAR FROM BEING A MERE EXECUTOR OF HIGHER POLICIES HE HAS BEEN A CONSTANT SOURCE OF INNOVATIVE IDEAS. BUT HE HAS OFTEN HAD DIFFICULTY IN GETTING INNOVATIVE IDEAS. BUT HE HAS OFTEN HAD DIFFICULTY IN GETTING
THEM ACCEPTED BY HIS POLITICAL SUPERIORS AT HOME AND ABROAD. IN THE EXALTED ROLE OF UN SECRETARY-GENERAL HE HILL HAVE IN THE EXALTED ROLE OF UN SECRETARY-GENERAL, HE WILL HAVE GREATER INDEPENDENCE AND AUTHORITY THAN HE HAS EVER ENJOYED; AND WITH THE END OF THE COLD WAR, GREATER GOODHILL FROM THE
MAJOR POWERS THAN WAS EXTENDED TO ANY OF HIS PREDECESSORS.

09527 WEIR, M.

INMOVATION ANO BOUNDARIES IN AMERICAN EMPLOYMENT POLICY POLITICAL SCIENCE QUARTERLY, $107(2)$ (SUM 92), 249-270. THE AUTHOR EXAMINES TWO EPISODES CENTRAL TO THE

DEVELOPMENT OF U.S. EMPLOYMENT POLICY-THE TRANSFORMATION OF KEYNESIAN POLICY IDEAS AFTER THE 1940'S AND THE WAR ON
POVERTY. SHE SHOWS HOW THREE CHARACTERISTICS BECAME DEEPLY EMBEDDED IN EMPLOYMENT POLICY. FIRST, AMERICAN EMPLOYMENT POLICY SETTLED ON A NARROW DEFINITION OF THE PROBLEM TO BE SOLVED; POLICY FOCUSED ON "UNEMPLOYMENT" AS DEFINED BY A SINGLE AGGREGATE NUMBER. SECONOLY, POLICY MAKERS CONCERNED WITH EMPLOYMENT RARELY CONCEIVED OF THEIR TASK AS ONE OF INSTITUTION-BUILDING. FINALLY, EMPLOYMENT ISSUES HERE PARTITIONED INTO AN ECONOMIC COMPONENT AND A SOCIAL COMPONENT, EACH CAST INTO A DISTINCT ORBIT OF POLITICS AND ADMINISTRATION. OVER TIME, THIS INSTITUTIONAL AND POL ITICAL SEGMENTATION LIMITED EMPLOYMENT POLICY AND NARROWED THE POSSIBILITIES FOR ADAPTING POLICY TO NEW POLITICAL AND ECONOMIC CONDITIONS.

09528 WEIR, M.

POLITICS AND JOBS

PRINCETON UNIVERSITY PRESS, 1992, 239.

AMERICANS CLAIM A STRONG ATTACHMENT TO THE WORK ETHIC AND REGULARLY PROFESS SUPPORT FOR GOVERNMENT POLICIES TO PROMOTE EMPLOYMENT. WHY THEN, HAVE EMPLOYMENT POLICIES GAINED ONLY A TENUDUS FOOTHOLD IN THE UNITED STATES? TO GAINED ONLY A TENUDUS FOOTHOLD IN THE UNITED STATES? TO ANSWER THIS QUESTION, THIS BOOK HIGHLIGHTS THO RELATED POL ITICS OF INTEREST FORMATION. RATHER THAN SEEING POLICY AS POLITICS OF INTEREST FORMATION. RATHER THAN SEEING POLICY AS A STRAIGHTFORHARD OUTCOME OF PUBLIC PREFERENCES, THE AUTHOR SHOWS HOW IDEAS FRAME PROBLEMS AND HOW INTERESTS FORM AROUND POSSIBILITIES CREATED BY THE INTERPLAY OF IDEAS AND POLITICS. BY EXAMINING KEYNESIAN MACROECONOMIC POLICY IN THE 19305
AND 1940S, LABOR MARKET POLICIES IN THE 1960 S AND 1970S, THE AND 1940S, LABOR MARKET POLICIES IN THE 1960 S AND 1970 , THE AUTHOR SHOWS HOW EARLY DECISIONS RESTRICTED THE SCOPE LATER INITIATIVES. AS A RESULT POLICIES IN THE 19605 EMPHASIZED RACIAL DIFFERENCES AND THIS DREW OPPOSITION FOR HIGHLIGHTING THE LIMITED CAPACITIES OF THE AMERICAN NATIONAL STATE, EMPLOYMENT POLICY ALSO ATTRACTED CHARGES OF WASTE, FRAUD AND CORRUPTION. BY THE 1970S ANTIPATHY TO THE FEDERAL GOVERNMENT AND RACIAL ANTAGONISM DOMINATED THE POLITICS IN THIS FIELD, AND ANY IDEAS FOR NEW PROGRAMS QUICKLY BECAME ENTANGLED WITH PRE-EXISTING PROBLEMS.

09529 WEIR, S.

BRITAIN AND THE LABOR PARTY NEED REFORM

NEW POLITICS, 3(4) (WIN 92), 71-77.

LABOR PARTY LEADER, NEIL KINMOCK, HAS RELIED HEAVILY ON THE TRADE UNIONS TO PUSH THROUGH HIS TRANSFORMATION OF THE PARTY AND ITS POLICIES. BRITAIN'S TRADE UNIONS CREATED THE LABOR PARTY AT THE TURN OF THE CENTURY AND THEY RETAIN A UNIQUELY CLOSE RELATIONSHIP. IT IS ARGUABLE THAT IT IS THE MAJOR UNIONS, OF BOTH LEFT AND RIGHT, THAT CARRIED THE PARTY SAFEFULLY THROUGH THE POST-1979 CRISIS AND MADE KINNOCK'S
COUNTERREVOLUTION POSSIBLE. THIS ARTICLE SUGGESTS THAT THE COUNTERREVOLUTION POSSIBLE. THIS ARTICLE SUGGESTS

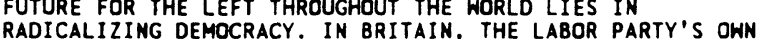
RADICALIZING DEMOCRACY. IN BRITAIN, THE LABOR PARTY'S OWN CLEANSING THE CORRUPT "ANCIEN REGIME" AND CREATING A SOCIETY CLEANSING THE CORRUPT "ANCIEN REGIME" AND CRE
OF SELF-CONFIDENT CITIZENS AND COMMUNITIES.

09530 WEIR, S.

WAITING FOR CHANGE: PUBLIC OPINION AND ELECTORAL REFORM POLITICAL QUARTERLY (THE), 63(2) (APR 92), 197-221.

THE EARLY AND MID-1970'S ARE NOW RECOGNIZED TO HAVE BEEN A PERIOD OF CRITICAL CHANGE IN MODERN BRITISH POLITICS. WHAT HAS BEEN LESS APPARENT IS THAT THE PERIOD WAS TO INITIATE A NEW ERA FOR THE CAUSE OF CONSTITUTIONAL REFORM IN GENERAL, AND ELECTORAL REFORM IN PARTICULAR. IN THIS ARTICLE, THE AUTHOR EXPLORES PUBLIC ATTITUDES TOWARDS ELECTORAL REFORM FROM THE MID-1970S TO THE PRESENT DAY WITHIN THE FRAMEHORK OF HIDE DISILLUSIONMENT.

09531 WEISBERG, J.

NOWHERE MAN

NEW REPUBLIC, 207(24) (DEC 92), 10, 12.

THE AUTHOR PROFILES INDIANA CONGRESSMAN LEE HAMILTON ANO EXPLAINS WHY PRESIDENT-ELECT BILL CLINTON SHOULD NOT APPOINT HAMILTON TO A CABINET POSITION.

09532 WEISBERG, J.

SOUTHERN EXPOSURE

NEW REPUBLIC, 207(19) (NOV 92), 13-15.

THE AUTHOR DISCUSSES THE WORK OF TV PRODUCERS HARRY THOMASON AND LINDA BLOODWORTH-THOMASON IN BILL CLINTON'S PRESIDENTIAL ELECTION CAMPAIGN. THE PAIR DOMINATED THE PRODUCTION OF CLINTON'S CAMPAIGN FILM, AND THEY USED CHARACTERS IN THEIR TV SIT-COMS TO PARROT SOME OF CLINTON'S CHARACTERS IN THEIR TV SIT-COMS TO PARROT SOME OF CLINTON
CAMPAIGN SLOGANS. THEIR ROLE IN THE CAMPAIGN REFLECTS THE MELDING OF POLITICS AND ENTERTAINMENT.

09533 HEISBERG, R.

CARTESIAN LAWYERS AND THE UNSPEAKABLE: THE CASE OF VICHY FRANCE

TIKKUN, 7 (5) (SEP 92), 46-48

THE' VICHY GOVERHMENT'S CRIMES AGAINST JEWS, FOR YEARS DENIED OR IGNORED, HAVE RECENTLY BECOME THE FOCUS OF CONSIDERABLE ATTENTION IN FRANCE. THIS ARTICLE ARGUES THAT 
TO VICHY, WHICH CREATED AND THEN IMPLEMENTED ITS OWH VERSION OF THE RACIAL LAWS, "RESISTANCE" TO GERMAN PRESSURE HAD NOTHING TO DO WITH SAVING JEWS. IT HAD EVERYTHING TO DO WITH SAVING FRENCH GOVERMMENT, FRENCH TRADITIONS, AND FRENCH LAW. CENTROL TO THIS ENTERPRISE WAS PIERRE LAVAL, HIMSELF A LAYYER WO WOULD STOP AT NOTHING TO FURTHER VICHY YALUES AS HE SAH THEM.

09534 WEISBERGER, J. AMERICAN JEWS AND ISRAELI POLICY

NEW POLITICS, IY(1) (SUM 92) 14-21.

WHILE AMERICAN JENS ARE OFTEN PORTRAYED AS BEING ARDENT SUPPORTERS OF ISRAEL, CRACKS ARE BEGINHING TO APPEAR IN THE SPO-ISPAEL MONOLITH. THO MAS AR ISSUES HAYE GALYAMIZED AMERICAN JEWS: THE "WHO IS A JEW" CONTROVERSY OVER ISRAEL'S AMERICAN JENS: THE "WHO IS A JEW" CONTROVERSY OVER ISRAE ISRAEL'S LIKUD GOVERMMENT. THE END RESULT IS THAT EVEN ISRAEL'S LIKUD GOVERNMENT. THE END RESULT IS THAT EVEN MAINSTREAM AMERICAN JEWISH ORGANIZAT IONS HAYE BEEN UNHILLING TO CDME DOWN SQUARELY ON THE ISRAELI SIDE. FURTHERMORE, SOME ORGANIZATIONS HAVE BEGUN TO ABANDON THE OLD IDEA THAT J DEBATES SHOULD TAKE PLACE BEHIND CLOSED DOORS. THE END RESULT IS THAT 1992 IS LIKELY TO BE A DECISIVE

09535 WEISFELDER, R.F.

LESOTHO AND THE INNER PERIPHERY IN THE NEW SOUTH AFRICA

JOURNAL OF MODERN AFRICAN STUDIES, 30(4) (DEC 92), 643-668.

THE PRINCIPLE OF SACROSANCT BORDERS AND TERRITORIAL INTEGRITY, EMBODIED IN THE LEGAL DOCTRINE OF "UTI

POSSIDETIS" (AS YOU NOW POSSESS), HAS ACQUIRED ROBUST AUTHORITY IN AFRICA. IN THIS STUDY, THE AUTHOR SEEKS TO IDENTIFY THE FACTORS THAT SUSTAIN ESTABLISHED STATE STRUCTURES VIA THE DOCTRINE OF "UTI POSSIDETIS" IN SOUTHERN AFRICA, DESPITE THE POSSIBLY DYSFUNCTIONAL ECONOMIC AND POLITICAL RESULTS FOR THE REGION. HE FOCUSES PRIMARILY ON THE CASE OF LESOTHO.

09536 WEISS, A.; HOOOHOUSE, E. REFRAMING INCREMENTALISM: A CONSTRUCTIVE RESPONSE TO THE CRITICS

POLICY SCIENCES, 25(3) (AUG 92), 255-273.

ALTHOUGH THE CONCEPT OF INCREMENTALISM HAS BEEN HIDELY CITED OVER THE PAST THREE DECADES, IT HAS NOT SERVED AS THE BASIS FOR A CUMULATIVELY-DEVELOPING LINE OF EMPIRICAL AND THEORETICAL INOUIRY. AS A RESULT, THE HIGHLY PROMISING INCREMENTALIST FRAMEWORK HAS CONTRIBUTED SURPRISINGLY LITTLE INCREMENTALIST FRAMENORK HAS CONTRIBUTED SURPRISINGLY L PROCESSES CAN BETTER ADAPT TO HUMANS' COGNITIVE LIMITATIONS. PROCESSES CAN BETTER ADAPT TO HUMANS' COGNITIVE LIMITATIONS. ONE INDICATOR OF THE LACK OF PROGRESS IS THAT POLICY SCHOLARS HAVE NEVER MADE A SUSTAINED ATTEMPT TO EXPLAIN HOW PRACTITTIONERS CAN BECOME BETTER INCREMENTALISTS. TO SEE WHETHER THE CONCEPT'S ORIGINAL FORMULATION MAY BE OBSCURING THE WAY TO FURTHER PROGRESS, THE AUTHORS SUMMARIZE ANO APPRAISE FOUR CRITICISMS OF INCREMENTALISH: ITS ALLEGED LACK OF GOAL ORIENTATION, CONSERVATISM, LIMITED RANGE OF APPLICABILITY, AND MEGATIVE STANCE TOWARD ANALYSIS. WHILE QUESTIONING THE VALIDITY OF THE CRITICS' CLAIMS, THE AUTHORS PROPOSE A WAY TO REFRAME THE INCREMENTALIST ENDEAVOR, WITH THE INTENTION OF STIMULATING BOTH ITS CRITICS AND DEFENDERS TO PROCEED WITH THE TASK OF LEARNING MORE ABOUT HOW INDIVIDUALS, ORGANIZATIONS, AND SOCIETIES CAN PROCEED RELATIVELY INTELLIGENTLY DESPITE THE FACT THAT HUMANS RARELY HAVE A GOOD UNDERSTANDING OF COMPLEX PROBLEMS AND POLICY OPTIONS.

09537 WEISS, J.

WHO'S AFRAID OF INDUSTRIAL POLICY?

EUROPE, (317) (JUN 92), 28-29.

THIS ARTICLE EXAMINES THE CURRENT STATE AND FUTURE OF INDUSTRIAL POLICY IN THE UNITED STATES, JAPAN AND THE EUROPEAN COMMUNITY. IT ARGUES THAT WHILE MANY AMERICAN POLITICIANS AVOID THE USING THE TERM INDUSTRIAL POLICY, MANY OF THEIR PROPOSALS FAVOR CERTAIN INDUSTRIES. YET, THERE IS LITTLE CONSENSUS FOR A NATIONAL INDUSTRIAL POL ICY IN THE UNITED STATES. IN JAPAN, THE GOVERNMENT-INDUSTRY COMBINE THAT HAS THRIVED FOR NEARLY FIVE DECADES IS LOOSENING ITS GRIP. IN THE EUROPEAN COMFUNITY THERE REMAINS A HIDE RANGE OF POLICIES IN VARIOUS NATIONS HITH REGARDS TO INDUSTRIAL POLICY. FOR ALL INDUSTRIALIZED NATIONS THE DECADE AHEAD WILL
REQUIRE A MORE COMPREHENSIVE VIEW OF INDUSTRIAL POLICY WHICH REQUIRE A MORE COMPREHENSIVE VIEW OF INDUSTRIAL POLICY WH
ACXNOWLEDGES THE ROLE OF EDUCATION; EFFORTS TO STIMULATE ACXNOWLEDGES THE ROLE OF EDUCATION; EFFORTS TO STIMULATE COMMERCIALIZATION OF TECHNOLOGY-BASED PRODUCTS; AND

09538 WEISS, L.

CRISIS IN HEALTH INSURANCE

POLITICAL AFFAIRS, 71(9) (SEP 92), 7-10.

THIS REPORT OF A CRISIS IN THE INSURANCE INDUSTRY ARGUES THAT THE UNINSURED AND THE UNDERINSURED ARE CREATED BY SYSTEM RELIANT ON PRIVATE HEALTH INSURANCE ACTING AS THE GATEKEEPER TO HEALTH CARE. IT IS A SYSTEM CHARACTERIZED BY INSTITUTIONALIZED RACISM AND SEXISM. MEDICAL UNDERHRITING TRANSFORMS TECHNOLOGICAL ADVANCES IN GENETIC AND MEDICAL
DENY ACCESS TO HEALTH CARE. IT CONCLUDES THAT THE CUMULATIVE SOCIAL EFFECT OF MARKET DRIVEN PRIVATE HEALTH INSURANCE IS TO INSURE THOSE LEAST LIKELY TO NEED HEALTH CARE--AND TO OVER CHARGE, INADEQUATELY INSURE, OR REFUSE TO INSURE THE REST.

09539 WEISS, M.

CRIMES OF THE HEAD

REASON, 23(8) (JAN 92), 28-33.

THAT FEMINIST LEGAL THEORY IS CREATING A GOVERNMENT NOT OF LAWS BUT OF WOMEN IS SUGGESTED IN THIS ARTICLE ABOUT THE NEW, NURTURING, CARING THOUGHT POLICE. IT ALSO SUGGESTS THE THE FEMINIST JURISPRUDES HAVE WEAPONS OTHER THAN RATIONAL PERSUASIDN. BY CREATING NEW SEX CRIMES AND IMBUING THEM WITH THE GRAVENESS OF RAPE, THEY STRIKE TERROR IN THE HEARTS OF POL ITICIANS, MANAGERS, ADADEMICS, AND ANYONE ELSE HHO MIGHT POLITICIANS, MANAGERS, ADADEMICS, AND ANYONE ELSE WHO MIGHT THE COLLABORATION OF MEN AS LEGISLATORS, JUDGES, AND VOTERS. AND THAT COLLABORATION BELIES ALL THE TALK OF MALE/FEMALE, CONMECTED/SEPARATE, RIGHTS-BASED/CARE-BASED DICHOTOMIES. CONNECTED/SEPARATE, RIGHTS-BASED/CARE-BASED DICHOTOMIES. FEMINIST JURISPRUDES SEEM TO HAVE ABANDONED THEIR PRINCIPLES.

09540 WEISS, T. (ED.); BLIGHT, J. (ED.)

THE SUFFERING GRASS: SUPERPOWERS AND REGIONAL CONFLICT IN SOUTHERN AFRICA AND THE CARIBBEAN

LYNNE RIENNER PUBLISHERS, 1992, 175

DETAILED CASE STUDIES OF CONFLICTS IN THE CARIBBEAN BASIN (INCLUDING THE MAINLAND OF CENTRAL AMERICA) AMD SOUTHERN AFRICA PROVIDE INSIGHTS INTO THE ORIGINS AMD EVENTUAL RESOLUTION OF THIRD WORLD STRIFE AND INSTABILITY. EACH REGION PROVIDES THE RAH MATERIAL FOR IN-DEPTH EVALUATIONS OF SOVIET AND U.S. ROLES IN FUELING CONFLICTS AND, MORE RECENTLY, IN WINDING DOWN LONG-STANOING WARS. THE AUTHORS ALSO EXAMINE THE RESPECTIVE POSITIONS OF THE REGIONAL HEGEMONS, CUBA AND SOUTH AFRICA, THE INFLUENCE OF NONSTATE ACTORS, AND THE IMPACT OF ARMS SALES. SIMILARITIES BETWEEN THE TWO REGIONS EMERGE, IN PARTICULAR THE EXTENT TO WHICH INTERNAL FACTORS (POVERTY, ETHNIC TROUBLES, THE LEGACY WHICH INTERNAL FACTORS (POVERTY. ETHNIC TROUBLES, THE LEGACY
OF COLONIALISM) ARE AT THE ROOT OF CONFLICTS AND REMAIN A OF COLONIALISM) ARE AT THE ROOT OF CONFLICTS AND REMAIN A
CONTINUING THREAT TO FUTURE STABILITY. THE BOOK INCLUDES CONTINUING THREAT TO FUTURE STAB
PRESCRIPTIONS FOR U.S. POLICY.

09541 WEISSBOURD, R.

TRUST FUND

NEW REPUBLIC, 207(20) (NOV 92), 24-25

DATA FROM THE NATIONAL OPIMION RESEARCH CENTER'S GENERAL SOCIAL SURVEY INDICATES THAT ADULTS WHO AS CHILDREN SUFFERED THROUGH THE DIVORCE OF THEIR PARENTS ARE SIGNIFICANTLY LESS LIKELY TO SAY THAT "PEOPLE CAN BE TRUSTED" AND MORE LIKELY TO AGREE THAT OTHER PEOPLE ARE "JUST LOOKING OUT FOR THEMSELVES." THE DATA ALSO SUGGEST THAT THESE ADULTS ARE MORE LIKELY TO DISTRUST POLITICIANS THAN ARE ADULTS WHO WERE RAISED IN INTACT FAMILIES. IN THE 1992 PRESIDENTIAL CAMPAIGN, WHERE TRUST HAS BEEN RAISED AS AN ISSUE, BILL CLINTON SEEMS TO BE BENFITTING FROM DIVORCE-DRIVEN DISTRUST AMONG VOTERS. CLINTON HAS MANAGED TO PORTRAY HIMSELF AS A DEVOTED FATHER WHO UNDERSTANDS THE IMPORTANCE OF FAMILY BECAUSE HIS OWN FATHER DIED BEFORE HE WAS BORN AND BECAUSE HE GREW UP WITH AN ABUSIVE, ALCOHOLIC STEP-FATHER.

09542 WEISSERT, C.

POLICY ENTREPRENEURS, POLICY OPPORTUNITIES, AND LEGISLATIVE EFFECTIVENESS

AMERICAN POLITICS QUARTERLY, 19(2) (APR 91), 262-274.

ALTHOUGH THERE IS A GROWING LITERATURE OM POLICY ENTREPRENEURS AND POLICY ENACTMENT, THERE HAS BEEN LITTLE SYSTEMATIC EXAMINATION OF LEGISLATIVE POLICY ENTREPRENEURS AND THE EFFECT OF POLICY ENTREPRENEURSHIP ON A LEGISLATOR'S AND THE EFFECT OF POLICY ENTREPRENEURSHIP ON A LEGISLATOR
STANDING. THIS ARTICLE IDENTIFIES POLICY ENTREPRENEURS IN STANDING. THIS ARTICLE IDENTIFIES POL ICY ENTREPRENEURS
EACH OF THREE SESSIONS OF THE NORTH CAROL INA GENERAL ASSEMBLY AND EXAMINES THE EFFECT OF POLICY ENTREPRENEURSHIP ON LEGISLATORS' EFFECTIIVENESS AS PERCEIVED BY PEERS AND CLOSE OBSERVERS. IT ALSO DEFINES AND IDENTIFIES A SECOND CATE OBSERVES. IT ALSO DEFINES AND IDENTIFIES A SECOND CATEGORY--POL ICY OPPORTUNISTS--LEGISLATORS WHO HAVE NOT EXHIBITED EXPERTISE AND PERSISTENCE NECESSARY FOR POLICY ENTREPRENEURSHIP BUT WHO ARE ASSOCIATED WITH SALIENT ISSUES WHOSE "POLICY WINDOW" HAS OPENED. BOTH POLICY ENTREPRENEURS AND POLICY OPPORTUNISTS BENEFIT FROM INCREASES IN THEIR STANDING, BUT POLICY ENTREPRENEURS MORE THAN THEIR OPPORTUNISTIC PEERS. THE IMPORTANCE OF THE ISSUE CYCLE IS ILLUSTRATED IN THE CHANGING CAST OF LEGISLATIVE POLICY ENTREPRENEU
SESSIONS.

09543 HEISSERT, C.S.

MEDICAID IN THE 1990'S: TRENDS, INMOVATIONS, AND THE FUTURE OF THE PAC-MAN OF STATE BUDGETS

PUBLIUS: THE JOURMAL OF FEDERALISM, 22(3) (SUM 92), 93-110. ESCALATING HEALTH CARE COSTS AND CONGRESSIONALLY MANDATED EXPANSIONS HAVE LED TO LARGE INCREASES IN MEDICAID SPENDING. THESE IMCREASES CAME AT A TIME WHEN STATE BUDGETS WERE ALREADY UNDER RECESSION-INDUCED STRESSES. IN ADOITION, 1991 BROUGHT NEW PRESSURES FOR MEDICAID SPENDING FROM THE 
COURTS AND CLOSER FEDERAL SCRUTINY AND CONTROL OVER REVENUES USED FOR THE PROGRAM'S STATE "MATCH." YET THE MEDICAID PICTURE IS FAR FROM BLEAK. OIVERSITY, INNOVATION, AND AN WAYS THAT EPITOMIZE THE STRENGTHS AND WEAKNESSES OF THE WAYS THAT EPI TOMIZE THE STRENGTHS
AMERICAN INTERGOVERNMENTAL SYSTEM.

09544 WEISSKOFF, R.

INCOME DISTRUBUTION AND THE ENTERPRISE FOR THE AMERICAS INITIATIVE

JOURNAL OF INTERAMERICAN STUDIES AND WORLD AFFAIRS, $33(4$

WIN 92 ), 111-132.

THE ISSUE OF THE DISTRIBUTION OF INCDME IS EMERGING AS CRITICAL COMPONENT IN THE DEBATES REGARDING LATIN AMERICA'S DEVELOPMENT PATH IN THE 1990 S AND AS A FACTOR UNDERLYIMG THE PROPOSED ENTERPRISE OF THE AMERICANS INITIATIVE. THIS ARTICLE ARGUES THAT THE DEGREE OF INCOME INEQUALITY IN THE LATIN AMERICAN SOCIETIES WILL PROVE TO BE AN OBVIOUS OBSTACLE TO SOCIAL PROGRESS WHICH WILL AFFECT THE OPERATION AND OUTCOME OF THE INITIATIVE. SOME OF THE HYPOTHESES AND
RECENT FINDINGS FROM THE RESEARCH ON INCDME DISTRIBUTION IS RECENT FINDINGS FROM THE RESEARCH ON INCDME DISTRIBUTIDN IS
REVIENED. THE CONDITION OF THE GROWTH DECADES OF THE 1960 S REVIENED. THE CONDITION OF THE GROWTH DECADES OF THE 1960S
AND 1970 S WITH THE LOST DECADE OF THE 1980 S ARE CONTRASTED.

09545 WEISSKOPF, T.E. RUSSIA IN'TRANSITION: PERILS OF THE FAST TRACK TO RUSSIA IN

CHALLENGE, 35(6) (NOV 92), 28-37

MANY HESTERN ECONOMISTS HAVE ADVOCATED PROGRAMS OF "SHOCK THERAPY" ECONOMISTS HAVE ADVOCATED PROGRAMS OF "SHOCK THERAPY" AND MASS PRIVATIZATION TO ACCELERATE THE ABANDONMENT OF COMMAND-ADMINISTRATIVE ECONOMIES FOR FREE
MARKETS AND CAPITALIST ENTERPRISE. RUSSIAN PRESIDENT BORIS MARKETS AND CAPITALIST ENTERPRISE. RUSSIAN PRESIDENT BOR
YELTSIN EMBRACED THIS PLAN IN LATE 1991, BUT THE SHOCK YELTSIN EMBRACED THIS PLAN IN LATE 1991, BUT THE SHOCK
THERAPY APPROACH ALLOWS THE FEH TO PROFIT AT THE EXPENSE OF THE MANY. A FAIRER, MORE GRADUAL APPROACH TO REFORM WOULD ENJOY MORE POPULAR SUPPORT AND WOULD REINFORCE POLITICAL DEMOCRACY.

09546 HEISSKOPF, T.E.; BOWLES, S.; GORDON, D.M. WE NEED HANDSHAKES AND ARM-TWISTING TO MOBILIZE OUR RECOVERY

CHALLENGE, 35(2) (MAR 92), 48-54.

LONG-TERM MACROECONOMIC STRATEGY SHOULD CONTRIBUTE TO THE OBJECTIVES OF ASSURING EMPLOYMENT OPPORTUMITIES FOR EVERYONE AND PROMOTING HIGH RATES OF ENYIRONMENTALIYSUSTAINABILE PRODUCTIVITY GROWTH, IN A MANMER CONSISTENT WITH THE BROADER SOCIAL GOALS OF GREATER EOUITY AND GREATER DEMOCRACY. TO ACHIEVE THESE GOALS REQUIRES BUILDING A BROAD POLITICAL CONSENSUS.

09547 HEITZ, R.

CONTINUITIES IN SOVIET FOREIGN POLICY: THE CASE OF

COMPARATIVE STRATEGY, 11(1) (JAN 92), 83-98.

DURING GORBACHEV'S INITIAL YEARS IN POWER MOSCOW'S PLICIES TOWARD THE MOZAMBICAN CONFLICT DID NOT CHANGE APPRECIABLY FROH THOSE PURSUED BY HIS PREDECESSORS. SOVIET OFFICIALS CONTINUED TO DENOUNCE THE ANTI-MARXIST INSURGENTS, THE SOUTH AFRICANS, AND THE AMERICAN MEDIATORS. IN ADDITION, DESPITE FRELIMO'S REPEATED PLEAS FOR INCREASED MILITARY ASSISTARCE, THEY CONTINUED TO PROVIDE ONLY MEASURED LEVELS OF ECONOMIC AND ESPECIALLY MILITARY ASSISTANCE TO THEIR ALLIES. AFTER THE INABILITY OF FRELIMO TO ATTAIN A MILITARY VICTORY BECAME CLEAR, SOVIET RHETORICAL POLICIES DID CHANGE. BEGINNING IN 1988 SOVIET SPOKESMEN SUPPORTED WESTERN AND AFRICAN EFFORTS TO NEGOTIATE A SETTLEMENT TO THE CONFLICT. HOWEVER, THE SOVIET GOVERHMENT CONTINUED TO CRITICIZE THE ANTI-MARXIST INSURGENTS AND PERSISTED IN MAINTAINING A LOW PROFILE IN THE CIVIL WAR. AT PRESENT, SOVIET OFFICIALS HOPE A COMPREHENSIVE PEACE AGREEMENT WOULD REDUCE THEIR COSTS BY DIMINISHING THE LEVEL OF FIGHTING, BUT YET NOT LEAVE THE USSR VULNERABLE TO CHARGES OF HAVING ABANDONED ANOTHER BELEAGUERED ALLY. AMONG OTHER PROBLEMS, SUCH AN ACCUSATION WOULD PATENTLY DISTURB THOSE REPRESENTATIVES OF THE SOVIET ESTABLISHMENT WHO ALREADY BLAME THE GORBACHEV-SHEVARDNADZE

09548 WEITZ, R.

THE CSCE AND YUGOSLAV CONFLICT

RFE/RL RESEARCH REPORT, 1(5) (JAN 92), 24-26.

THE MEMBER GOVERNMENTS OF THE CONFERENCE ON SECURITY AND COOPERATION IN EUROPE (CSCE) MADE STRENUOUS EFFORTS TO PREVENT CIVIL STRIFE IN YUGOSLAVIA. INITIALLY, CSCE MEMBERS PREVENT CIVIL STRIFE IN YUGOSLAVIA. INITIALLY, CSCE MEM TRIED TO DISCOURAGE SECESSIONIST MOVES BY CROATIA AND
SLOVENENIA WHILE BOLSTERING THE YUGOSLAV FEDERAL GOVERMMENT SLOVENENIA WHILE BOLSTERING THE YUGOSLAV FEDERAL GOVE THEN, THE CSCE ATTEMPTED TO CURTAIL THE FIGHTING BY

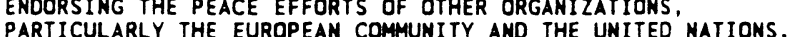
PARTICULARLY THE EUROPEAN COMMUNITY AND THE UNITED NATIONS.
THUS FAR, BOTH STRATEGIES HAVE FAILED. YET CRITICISM OF THE CSCE FOR FAILING TO RESOLVE THE CONFLICT IGNORES THE FACT THAT THE ORGANIZATION'S PURPOSE IS TO PREVENT CONFLICT BY OISCOURAGING SOME PRACTICES (SUCH AS GOVERMMENT ABUSE OF HUMAN RIGHTS) AND PROMOTING OTHERS (SUCH AS TRANSPARENCY IN MILITARY OPERATIONS).
09549 WEITZ, R.

THE CSCE'S NEW LOOK

RFE/RL RESEARCH REPORT, 1(6) (FEB 92), 27-31.

DURING THE LAST TWO YEARS THE CONFERENCE ON SECURITY AND COOPERATION IN EUROPE (CSCE) HAS UNDERGONE A MAJOR EVOLUTION. THE COLLAPSE OF COMMUNISM IN EASTERN EUROPE AND THE SOVIET UNION ALLOWED THE MEMBER GOVERNMENTS TO RESTRUCTURE THE ORGANIZATION AND REDEFINE ITS GOALS. PERMANENT ORGANIZATIONS HAVE BEEN CREATED UNDER THE CSCE'S AUSPICES, AND THE CSCE MEMBERS HAVE AGREED TO ESTABLISH EMERGENCY PROCEDURES TO DEAL WITH INTERNATIONAL CRISES. HOWEVER, THE CSCE IS STILL MORE EFFECTIVE AT PREVENTING CONFLICTS THAN AT MANAGING OR RESOVLING THEM.

09550 WEITZ, R.

THE REAGAN DOCTRINE: DEFEATED MOSCOW IN ANGOLA ORBIS, 36(1) (WIN 92), 57-68.

ANGOLA, ONE OF AFRICA'S MOST INFLUENTIAL AND STRATEGICALLY IMPORTANT STATES, HAS ALSO BEEN ONE OF THE MOST DIVIDED AND CONTENTIOUS COUNTRIES ON THE CONTINENT. IN THE MIDST OF THE COLD WAR, THE UNTIED STATES AND THE USSR, BACKED OPPOSING SIDES IN THE ANGOLAN CONFLICT. BY 1990, MOSCOW REVERSED ITS POL ICY TOWARD ANGOLA AND THIS ARTICL EXPLORES WHY THE SUDDEN SHIFT IN SOVIET STRATEGY. IT CONLCUDES THAT THE MOST INFLUENTIAL FACTOR HAS THE INABILITY OF THE USSR'S REGIONAL ALLIES TO ATTAIN A DECISIVE MILITARY OF THE USSR'S REGIOHAL ALLIES TO ATTAIN A DECISIVE MILITARY AND SOUTH AFRICAN DIPLOMATIC AND MILITARY BACKING.

09551 WEKKIN, G.

WHY CROSSOVER VOTERS ARE NOT "MISCHIEVOUS VOTERS" THE SEGMENTED PARTISANSHIP HYPOTHESIS

AMERICAN POLITICS QUARTERLY, 19(2) (APR 91), 229-247. ALTHOUGH EXTENSIVE CROSSÓVER VOTING IN OPEN PRIMARIES HAS BEEN DOCUMENTED, SCHOLARS HAVE NEVER FOUND EMPIRICAL SUPPORT FOR THE ALLEGATION THAT CONSIDERABLE MISCHIEVOUS CROSSOVER VOTING OCCURS IN SUCH CIRCUMSTANCES. THIS EXPLORATORY STUDY PRESENTS AND EXAMINES THE HYPOTHESIS THAT MISCHIEVOUS CROSSOVER VOTING IS LIMITED BECAUSE MOST CROSSOVER VOTERS ARE SEGMENTED-PARTISAN IDENTIFIERS WHO AT SOME LEVEL OF THE FEDERAL POLITY ACTUALLY IDENTIFY WITH THE PARTY WHOSE PRIMARY THEY INVADE. SEGMENTED PARTISANS DO CAST MOST CROSSOVER VOTES, AND ARE MORE LIKELY THAN CONSISTENT PARTISANS TO EVALUATE THE OPPOSING PARTY FAVORABLY ON THERMOMETER SCALES, TO EVALUATE FAVORABLY ITS PAST GOVERNING PERFORMANCE, AND TO DEFECT TO ITS TICKET DURING GENERAL ELECTIONS. THE HOSTILITY TOHARD THE PARTISAN OUT-GROUP, POSITED IN THE AMERICAN VOTER AND SUPPORTING STUDIES, THUS POSITED IN THE AMERICAN VOTER AND SUPPORTING STUOIES, THUS
IS NOT CHARACTERISTIC OF MOST OF THOSE WHO CAST CROSSOVER VOTES.

09552 WELCH, C.

MILITARY DISENGAGEMENT FROM POLITICS: PARADIGMS, PROCESSES, OR RAMDOM EVEMTS

ARMED FORCES AND SOCIETY, 18(3) (SPR 92), 323-342.

ANALAYSES OF DEMOCRATIZATION AND MILITARY DISENGAGEMENT FROM POLITICS HAVE BURGEONED IN RECENT YEARS WITH THE CRUMBLING OF DICTATORIAL GOVERNMENTS AROUND THE GLOBE. THIS ARTICLE SUMMARIZES MAJOR RESEARCH ISSUES REGARDING THE DISENGAGEMENT OF THE MILITARY FROM DIRECT POLITICAL ROLES. IT IS A PRELIMINARY SUMMATION, INTENDED TO CALL ATTENTION TO AREAS OF COMMONALITY, DISPUTE AND NEGLECT. IT CONCLUDES THA NO PARADIGM FOR THE STUDY OF MILITARY DISENGAGEMENT FROM POLITICS HAS EMERGED AND THAT ALTHOUGH PATTERNS HAVE BEEN DISCERNED, THEY HAVE NEITHER COALESCED INTO A GENERALLY ACCEPTED PARADIGM. ALSO, THAT SOME CASE STUDIES PRESENT DISENGAGEMENT, LIBERALIZATION AND (RE) DEMOCRATIZATION MORE AS RANDOM EVENTS THAN AS MANIFESTATION OF BROADER CURRENTS OF CHANGE.

09553 WELCH, D.

THE ORGANIZATIONAL PROCESS AND BUREAUCRATIC POLITICS PARADIGMS: RETROSPECT AND PROSPEC

INTERNATIONAL SECURITY, 17(2) (FAL 92), 112-146. 1991 MARKED THE THENTIETH ANMIVERSAY OF THE PUBLICATION OF GRAHAM ALLISON'S "ESSENCE OF DECISION: EXPLAINING THE CUBAN MISSILE CRISIS". THE INFLUENCE OF THIS WORK HAS BEEN FELT FAR BEYOND THE STUDY OF INTERNATIONAL POLITICS. DAVID WELCH'S AIM IS TO USE THE BOOK AS A VEHICLE FOR ASSESSING THE CONTRIBUTION TO OUR UNDERSTANDING OF INTERNATIONAL POLITICS OF THAT HHICH IT SPAWNED: THE BUREAUCRATIC POLITICS POLITICS OF THAT HHICH IT SPAWNED: THE BUREAUCRATIC POLI
APPROACH, BROADLY CONSTRUED. ALLISON HIMSELF REPRESENTED APPROACH, BROADLY CONSTRUED. ALLISON HIMSELF REPRESENTED
"ESSENCE OF DECISION" AS EXPERIMENTAL, EXPLORATORY, AND "ESSENCE OF DECISION" AS EXPERIMENTAL, EXPLORATORY, AND PRELIMINARY; HIS PURPOSE WAS TO CHART A COURSE FOR
FOLLOW. FIDELITY TO HIS PROJECT REOUIRES THAT WE FOLLOW. FIDELITY TO HIS PROJECT REQUIRES THAT WE PERIODICALLY TAKE A BEARING AND, IF NECESSARY, MADE
COURSE CORRECTIONS. SUCH IN THE INTENT OF THIS PAPER

09554 HELCH, S.; SIGELMAN, L.

A GENDER GAP AMONG HISPANICS? A COMPARISON HITH BLACKS AND ANGLOS

WESTERN POLITICAL QUARTERLY, 45(1) (MAR 92), 181-200. BASED ON DATA FROM SIX ELECTION-DAY EXIT' POLLS CONDUCTED 
BETWEEN 1980 AND 1988, THE AUTHORS IDENTIFY DIFFERENCES BETWEEN HISPANIC AMERICAN MEN AND WOMEN IN IDEOLOGICAL AND PARTISAN IDENTIFICATION AND IN VOTE CHOICE. THEY FIND THAT HISPANIC WOMEN ARE MORE LIBERAL AND MORE PRO-DEMOCRATIC THAY HISPANIC MEN, BUT THE MAGNITUDE OF THESE DIFFERENCES VARIES CONSIDERABLY. THEY ALSO FIND THAT MALE/FEMALE OIFFERENCES AMERICANS.

09555 WELCH, S.; HIBBING, J.

FINANCIAL CONDITIONS, GENDER, AND VOTING IN AMERICAN NATIONAL ELECTIONS

THE JOURMAL OF POLITICS, 54(1) (FEB 92), 197-213.

DIFFERENCES BETWEEN MEN AND WOMEN IN'THEIR LEVELS AND TYPES OF ECDNOMIC VOTING IS EXPLORED. WOMEN ARE CONSIDERABLY LESS LIKELY THAN MEN TO CAST EGOCENTRIC ECONOMIC VOTES, BUT ARE AS LIKELY, OR PERHAPS MORE SO, TO CAST SOCIOTROPIC ECONOMIC VOTES. SINCE THESE OIFFERENCES DO NOT APPEAR TO BE A RESULT OF SOCIOECONOMIC DIFFERENCES BETWEEN MEN AND WOMEN, THE FINDINGS IN THIS PAPER ILLUMINATE AN ASPECT OF THE GENDER GAP RARELY DESCRIBED. NOT ONLY ARE MEN AND WOMEN DIFFERENT IN MANY POLITICAL ATTITUDES, BUT THEY ALSO HAVE DIFFERENT HAYS OF USING THESE ATTITUDES TO PROVIDE A BASIS FOR POLITICAL ACTION.

09556 WELCH, S.; FOSTER, L.

THE IMPACT OF ECONOMIC CONDITIONS ON THE VOTING BEHAVIOR OF BLACKS

WESTERN POLITICAL QUARTERLY, 45(1) (MAR 92), 221-236.

DESPITE THE OYERHHELMING TENDENCY OF BLACKS TO VOTE

DEMOCRATIC, BLACK VOTING BEHAVIOR, LIKE THAT OF WHITES, CAN BE PREDICTED BY ECONOMIC CRITERIA. IN THE 1984 PRESIDENTIAL ELECTION, BLACXS WERE INFLUENCED BY THEIR PERCEPTIONS OF THE ECONOMIC FORTUMES OF BLACKS AS A GROUP AHD OF THE MATION AS A WHOLE. BLACKS HHO BELIEYED THAT THE ECONOMIC CONDITIONS OF A WHOLE. BLACKS WHO BELIEVED ATAT THE ECONOMIC CONDITIONS OF LIKELY TO VOTE REPUBLICAN THAN WERE OTHER AFRICAN-AMERICANS.

09557 WELDON, J.C. ; FENICHEL, A. (ED.); INGERMAN, S. (ED.) ON THE POLITICAL ECONOMY OF SOCIAL DEMOCRACY--SELECTED ON THE POLITICAL ECONOM

MCGILL-QUEEN'S UNIVERSITY PRESS, 1991, 213.

THE LATE $J C$. HELDON IS RECOGNIZED AS ONE OF NORTH AMERICA'S MOST RESPECTED ECONOMISTS. THESE SELECTED PAPERS HIGHLIGHT HIS INVESTIGATION OF THE ECONOMIC FOUNDATION OF SOCIAL DEMOCRATIC THEORY AS WELL AS HIS EXAMINATION OF THE ROLE OF THE STATE IN THE ECONOMY. THE ISSUES HE ADDRESSED ARE NOW IN THE FOREFRONT OF ECONOMIC POLICY DEBATES IN MOST INDUSTRIALIZED NATIONS.

09558 WELFARE, D.

AN ANACHRONISM WITH RELEVANCE: THE REVIVAL OF THE HOUSE OF LORDS IN THE 1980S AND ITS DEFENSE OF LOCAL GOVERMMENTT PARL IAMENTARY AFFAIRS, 45(2) (APR 92), 205-219.

THE HOUSE OF LORDS IS AN ANACHRONISM WHICH HAS BECOME RELEVANT. IN THE 1990S, A REFORMED AND STRENGTHENED SECOND CHAMBER IS ONCE AGAIN ON THE POLITICAL AGENDA, FOLLOWING A REVERSAL IN THE POSITION OF THE LABOR PARTY WHICH HAS COME ABOUT BECAUSE THE LORDS HAVE DEMONSTRATED IN PRACTICE THE ROLE OF A COUNTERWEIGHT TO AN OVER-MIGHTY EXECUTIVE. THIS ARTICLE EXPLORES: THE PAVING BILL AND ABOLITION;

ORGANIZATION AND SERVICES; LOCAL GOVERNMENT FINANCE; AND, THE RIGHT TO BUY. II CONCLUDES THAT THE RE-EMERGENCE OF AN ACTIVE SECOND CHAMBER IN BRITAIN REQUIRES ONE TO LOOK AFRESH AT ASSUMPTIONS ABOUT THE WORKINGS OF THE BRITISH PARLIAMENTARY SYSTEM.

09559 WELING, H.

LINKIMG DECENTRALIZATION AND CENTRALIZATION: A CRITIQUE OF THE NEW DEVELOPMENT ADMINISTRATION

PUBLIC ADMINISTRATION AND DEVELOPMENT, 12(3) (AUG 92),

223-236.

THIS ARTICLE EXAMINES THE ORIENTATION OF WHAT IS HERE CALLED THE ENEW DEVELOPMENT ADMINISTRATION' (NDA), AS PUT FORTH BY ESMAN (1988) IT DOES SO USING POLITICAL ELASTICITY AOTE NDA'S EMPHASIS UPON DECENTRALIZATION, COMMUNITY DEVELOPMENT, DEREGULATION, PRIVATIZATION, MIMIMAL GOVERMMENT, POPULAR PARTICIPATION AND PRIVAIIZATION, MINIMAL GOVERMMENT, POPULAR PARTICIPAIION AND FLEXIBLE FORMS OF FOREIGN AID. HOWEVER, IT ARGUES THAT INCLUDING STRONG LEADERSHIP, EFFECTIVE BUREAUCRACIES, THE INCLUDING STROMG LEADERSHIP, EFFECTIVE BUREAUCRACIES, THE COOPERATION OF BENEFICIARIES AND THE ABILITY TO SHIFY FROA SOFT TO HARD FORMS OF POWER. WHILE THE IMPORTANCE OF A BUREAUCRATIC REORIENTATION IS GENERALLY RECOGNIZED, NDA SUPPORTERS SEEM UNCLEAR ABOUT THE REQUISITIES NEEDED. WITHOUT ADEQUATE SUPE

09560 WELLER, M.

THE INTERNATIONAL RESPONSE TO THE DISSOLUTION OF THE SOCIALIST FEDERAL REPUBLIC OF YUGOSLAYIA

AMERICAN JOURMAL OF INTERNATIONAL LAH, 86(3) (JUL 92), 569-607.

THE AUTHOR LOOKS AT THE ETHMIC COMPOSITION OF THE
YUGOSLAV REPUBLICS, THE RECENT HISTORY OF YUGOSLAVIA, AND THE INTERNATIONAL RESPONSE TO THE DISSOLUTION OF THE SOCIALIST FEDERAL REPUBLIC OF YUGOSLAVIA.

09561 HELLISZ, C.

THE PLIGHT OF LITHUANIA'S POLES

NEW LEADER, LXXV(13) (OCT 92), 11-12.

INN LITHUANIA, 260,000 POLES MAKE UP ABOUT 7 PER CENT OF LITUANIA'S POPULATION OF 3.7 MILLION. THE POLES HAVE LIVED THERE FOR GENERATIONS AND ARE FIERCELY ATTACHED TO THEIR ANCESTRAL LAND. THEY ARE LARGELY CONCENTRATED IN THO RURAL ANCESTRAL LAND. THEY ARE LARGELY CONCENTRATED IN THO RURAL
PROVINCES THAT SURROUND VILNIUS. IN THE YEAR SINCE LITHUANIA PROVINCES THAT SURROUND VILNIUS. IN THE YEAR SINCE LITHUANIA
TORE ITSELF FREE FROM THE USSR, NUMEROUS POLES SAY THEY HAVE TORE ITSELF FREE FROM THE USSR, NUMEROUS POLES SAY THEY HAYE
FALLEN VICTIM TO A CAMPAIGN TO DEPRIVE THEM OF THEIR LAND, FALLEN VICTIM TO A CAMPAIGN TO DEPRIVE THEM OF THEIR LAND,
THEIR POLITICAL RIGHTS AND THEIR NATIONAL IDENTITY. THE THEIR POLITICAL RIGHTS AND THEIR NATIONAL IDENTITY. THE COLUMN. THE CONFLICT FOLIOWS A FAMILIAR PATTERN IN PRESENTCOLUMN. THE CONFLICT FOLLOWS A FAMILIAR PATTERN IN PRESENTRIVALRIES ARE RESURFACING AFTER DECADES OF COMMUNIST SUPPRESSION. THIS ARTICLE CONCLUDES THAT FOR THE BALTICS, TINY NATIONS WITH LITTLE HISTORY OF INDEPENDENT STATEHOOD THAT ARE SURROUNDED BY POWERFUL NEIGHBORS, THE SITUATION IS PARTICULARLY WORRI SOME.

09562 WELSH, D.

IMPLICATIONS OF THE REFERENDUH

SOUTH AFRICA INTERNATIONAL, 22(4) (APR 92), 180-183.

THE UNEXPECTEDLY WIDE MARGIN OF VICTORY IN THE

REFERENDUM ON POLITICAL REFORM IN SOUTH AFRICA (HELD 17 MARCH 1992) CAN LARGELY BE ASCRIBED TO THE TORRENT OF WARNINGS ABOUT THE DIRE CONSEQUENCES OF A "NO" VOTE, AND TO A PRAGMATIC CHOICE ON THE PART OF WHITE VOTERS OF THE LESSER OF THO EVILS. IN THE PROCESS OF THE REFERENDUM CAMPAIGN, THE LIBERAL DEMOCRATIC PARTY ENTRENCHED ITS REPUTATION AS THE "HONEST BROKER" IN THE NEGOTIATION PROCESS. FOR THE RIGHT WING, CONSOLATION LIES IN THE FACT THAT THEY DID GAIN ONETHIRD OF THE WHITE VOTE. NONETHELESS, THEIR DEFEAT COULD SPLIT THE CONSERVATIVE PARTY, FOR THE NATIONAL PARTY, THE
WAY IS NOW CLEARED FOR A FAIRLY RAPID TRANSITION TOWARD INTERIM GOVERMMENT BY MID-YEAR, WITH ELECTIONS IN TERMS OF INTERIM GOVERNMENT BY MID-YEAR,
AN INTERIM CONSTITUTION BY 1993.

09563 HEN, $Z$.

HATCH AGAINST LEFT DEVIATION

BEI JING REYIEH 35(16) (APR 92),

DENG XIAOPING HAS REITERATED THE NEED TO GUARD AGAINST LEFTIST DEVIATION. LEFTIST TRENDS HAVE NOT DISAPPEARED SINCE THE 1989 POLITICAL VIOLENCE IN BEI JING AND, IF LEFT UNCHECKED, COULD DERAIL CHINA'S REFORM AND OPENING UP, CAUSING ECONOMIC STAGNATION.

09564 WENDT, A.

ANARCHY IS WHAT STATES MAKE OF IT: THE SOCIAL CONSTRUCTION OF POWER POLITICS

INTERNATIONAL ORGANIZATION, 46(2) (SPR 92), 391-426.

THE CLAIM THAT INTERNATIONAL INSTITUTIONS CAN TRANSFORM STATE INTERESTS IS CENTRAL TO NEOL IBERAL CHALLENGES TO THE REALIST ASSUMPTION THAT INTERACTION AND LEARNING AMONG STATES CANMOT FUNDAMENTALLY AFFECT SYSTEM STRUCTURE. SYSTEMATIC DEVELOPMENT OF THIS CLAIM, HOWEVER, HAS BEEN HAMPERED BY THE NEOLIBERAL'S COMMITMENT TO RATIONAL CHOICE THEORY, WHICH TREATS INTERESTS AS EXOGENOUSLY GIVEN AND THUS OFFERS ONLY A WEAK FORM OF INSTITUTIONAL ANALYSIS. A GROWING BOOY OF INTERNATIONAL RELATIONS SCHOLARSHIP POINTS TO WAYS IN HICH THE IDENTITIES AND INTERESTS OF STATES ARE SOCIALLY CONSTRUCTED BY KNOWLEDGEABLE PRACTICE. THIS ARTICLE BUILDS A BRIDGE BETWEEN THIS SCHOLARSHIP AND NEOL IBERALISM BY DEVELOPING A THEORY OF IDENTITY-AND INTEREST-FORMATION IN DEVELOPING A THEORY OF IDENTITY- AND INTEREST-FORMAT
SUPPORT OF THE NEOLIBERAL CLAIM THAT INTERNATIONAL

INSTITUTIONS CAN TRANSFORM STATE INTERESTS.

09565 HENGER, $M$.

OECODING POSTMODERNISM: THE DESPAIR OF INTELLECTUALS AND THE THILIGHT OF THE FUTURE

SOCIAL SCIENCE JOURNAL, 28(3) (1991), 391-405.

THIS ARTICLE DISTINGUISHES POSTMODERNISH FROM ANTIMODERNISM FOR THE PURPOSE OF EXAMINING THE POLITICS OF POSTMODERNISM. IT ARGUES THAT POSTMODERNISM IS, IN PART, A POSTMODERNISM. IT ARGUES THAT POSTMODERNISH IS, IN PART, A
METAPHOR FOR DESPAIR, AND ESPECIALLY INTELLECTUAL DESPAIR. METAPHOR FOR DESPAIR, AND ESPECIALLY INTELLECTUAL DES
THE CRITICAL AND REVOLUTIONARY INTELLECTUAL TRADITIOH THE CRITICAL AND REVOLUTIONARY INTELLECTUAL TRADITION
ESTABLISHED BY MARX AND CARRIED ON BY NEO-MARXISTS IS ESTABLISHED BY MARX AND CARRIED ON BY NEO-MARXISTS IS
CONSIDERED TO BE DOOMED FROM A POSTMODERN PERSPECTIVE. AS A RESULT. INTELLECTUALS ARE IN AN IRON CAGE OF DESPAIR; AND RESULT, INTELLECTUALS ARE IN AN IRON CAGE OF DESPAIR; A NECESSARY CONDITION FOR THEIR LIBERATION.

09566 WENNEMO, I

THE DEVELOPMENT OF FAMILY POLICY: A COMPARISON OF FAMILY BENEFITS AND TAX REDUCTIONS FOR FAMILIES IN 18 OEDC COUNTRIES

ACTA SOCIOLOGICA, 35(3) (1992), 201-218

UNIVERSAL FAMILY SUPPORT HAS BEEN INTRODUCED IN MOST INDUSTRIALIZED NATIONS. THERE HAVE BEEN TWO MAJOR TYPES OF SUPPORT TO FAMILIES: DIFFERENT TYPES OF FAMILY TAX 
REDUCTIONS AND CASH BENEFITS. IN THIS PAPER, PREDICTORS OF THE GROWTH OF FAMILY BENEFITS LEVELS IN THESE SYSTEMS ARE EXAMINED. THE RESULTS INDICATE THAT BENEFIT LEVELS ARE INFLUENCED BY NATIONAL POLICY TRENDS. NEITHER MEASURES OF ECONOMIC DEVELOPMENT NOR FERTILITY DEMONSTRATE ANY CONSISTANT IMPACT ON BENEFIT LEVELS.

09567 WENQI, T

NEW TURN IN POLITICAL DEVELOPMENT

BEIJING REVIEW, 35(42) (OCT 92), 13.

RECENT TALKS BETHEEN SOUTH AFRICAN PRESIDENT F.W.

DEKLERK AND AFRICAN NATIONAL CONGRESS LEADER NELSON MANDELA WERE MORE FRUITFUL THAN MANY OBSERVERS ANTICIPATED. AFTER EIGHT HOURS OF STRENLOUS TALKS, THE THO LEADERS ANNOUNCED THAT THEY HAD REACHED AGREEMENT ON RESUMPTION OF THE CONSTITUTIONAL NEGOTIATIONS.

09568 WENTAO, H.

GROUNDLESS ARGUMENT, DISASTROUS CONSEQUENCE: ON THE U.S. SALE OF F-16 FIGHTER JETS TO TAIHAN

BEIJING REVIEW, 35(41) (OCT 92) 34-35.

ON SEPTEMBER 2, 1992, IGNORING STRONG PROTESTS FROM THE CHINESE GOVERMMENT, THE UNITED STATES ANNOUNCED ITS DECISION
TO SELL F-16 FIGHTER JETS TO TAIWAN. THIS UNJUSTIFIABLE ACT, WHICH IS A VIOLATION OF CHINA'S SOVEREIGNTY AS WELL AS A OIRECT INTRUSION AND INTERFERENCE IN ITS INTERNAL AFFAIRS, HAS JEOPARDIZED THE STABLE AND PEACEFUL ATMOSPHERE ACROSS THE TAIHAN STRAIT. IT HAS SERIOUSLY DAMAGED THE PROCESS OF CHINA'S PEACEFUL REUNIFICATION AND WILL SURELY HAVE A HARMFUL EFFECT ON THE PEACE AND STABILITY OF THE ASIAPACIFIC REGION.

09569 WENZHAO, T

JOHN KING FAIRBANK AND SINO-US RELATIONS

BEIJING REVIEW, 35(21) (MAY 92), 33-35.

IN 1942 AFTER MUCH STUDY, JOHN KING FAIRBANK CONCLUDED THAT THE KUOMINGTANG GOVERMMENT WAS DESTROYING ITSELF AND LOSING POWER. THE U.S. POLICY IN CHINA WAS FAILING, BUT THE AMERICAN PUBLIC HAD NOT REALIZED IT. FAIRBANK POINTED OUT IN HIS ANALYSIS OF CHINESE REALITY THAT THE FIRST THING NEEDED WAS ECONOMIC JUSTICE. OTHER RIGHTS COULD BE MENTIONED ONLY AFTER ONE HAD ENOUGH TO EAT.

09570 WENZONG, L.

U.S. DIPLOMACY OF HUMAN RIGHTS

BEI JING REVIEW, 35(23) ( JUN 92), 11-15.

THE UNITED STATES HAS USED MUMAN RIGHTS AS AN INSTRUMENT TO PURSUE ITS FOREIGN POLICY OBJECTIVES FOR A LONG TIME. BUT MANY PEOPLE WANT TO KNOW WHY THE UNITED STATES, A COUNTRY MANY PEOPLE WANT TO KNOW WHY THE UNITED STATES, A COUNTRY
OFFICIALLY PURSUING A "DIPLOMACY OF HUMAN RIGHTS," HAS NOT OFFICIALLY PURSUING A "DIPLOMACY OF HUMAN RIGHTS," HAS RATIFIED EITHER THE COVENANT ON ECONOMIC, SOCIAL, AND RIGHTS. IN FACT, THE USA HAS SELDOM ACCEDED TO INTERNATIONAL HUMAN RIGHTS CONVENTIONS, ARGUING THAT THEY RUN COUNTER TO ITS DOMESTIC LAWS.

09571 WERZ, $M$

EXTERNAL CULTURAL POLICY; CONTINUITY OR CHANGE

AUSSEN POLITIK, 43(3) (JUL 92), 246-255.

FOLLOWING GERMAN UNIFICATION, GROWING EXPECTATIONS ARE DIRECTED TOWARDS A LARGER GERMANY. FOR MANY COUNTRIES AND PEOPLES IN CENTRAL AND EASTERN EUROPE, GERMANY HAS BECOME THE MOST IMPORTANT BRIDGE THEY WOULD LIKE TO TO CROSS TO REACH THE WESTERN SIDE. THE GERMANS, THEREFORE, ALSO SEEM IMPORTANT AS MEDIATORS, SINCE THEY HAVE TO COPE WITH A SOCIALIST LEGACY IN THEIR OWN COUNTRY WHICH OTHER WESTERM EUROPEAN COUNTRIES HAVE NOT EXPERIENCED THEMSELVES. ALL THIS MAKES THE GERMAN CULTURE AND LANGUAGE AN IMPORTANT FACTOR IN INTERNATIONAL RELATIONS. AGAINST THIS BACKGROUND, THIS ARTICLE EXAMINES THE EXTERNAL CULTURAL POLICY OF' THE FEDERAL REPUBLIC OF GERMANY.

09572 HESCOTT, $S$.

EDUCATE TO AMERICANIZE

CHANGE, 23(2) (MAR 91), 45-46.

THIS ARTICLE BRIEFLY RECOUNTS THE LIFE OF RICHARD HENRY PRATT, AN AMERICAN SOLDIER AMD EDUCATOR WHO RAN THE CARLISLE INDIAN SCHOOL. PRATT WAS OUITE SYMPATHETIC TO THE PLIGHT OF THE AMERICAN INDIAN AND WAS OUTSPOKEN IN HIS CRITICISM OF HYPOCRI TICAL AND UNFAIR U.S. GOVERMMENT POL ICIES TOWARDS NATIVE TRIBES. HOWEVER, HIS EDUCATIONAL THEORY WAS ONE OF NATIVE TRIBES. HOWEVER, HIS EDUCATIONAL THEORY WAS ONE OF COMPLETE ASSIMILATION: HE BELIEVED IT WAS NECESSARY TO TAKE
AWAY THE "INDIAN-NESS" TO SAVE THE HUMAN BEING. HISTORY HAS AWAY THE "INDIAN-NESS" TO SAVE THE HUMAM
PROVEN PRATT AND OTHERS LIKE HIM WRONG.

09573 WESLEY-SHITH, T.

PAPUA NEH GUIMEA IN 1990: A YEAR OF CRISIS

ASIAN SURVEY, XXXI(2) (FEB 91), 188-195.

THE EVENTS OF 1990 PUT CONSIDERABLE STRAIN ON THE CONSTITUTIONAL ORDER IN PAPUA NEW GUINEA (PNG) AND FORCED SOME SIGNIFICANT CHANGES IN DEVELOPMENT POLICY. THE DOWNWARD SPIRAL OF POLITICAL AND ECONOMIC LIFE IN RECENT YEARS HAS BEEN DRIVEN LARGELY BY THE SECESSIONIST STRUGGLE IN BOUgainyillaEA ISLANO IN THE NORTH SOLOMONS PROVINCE. AT THE
HEART OF THE SO-CALLED BOUGAVILLE CRISIS, HHICH HAS CLAIMED SOME 200 LIVES SINCE 1988, ARE TRAUMATIC ISSUES OF ECONOMIC DEVELOPMENT AND SOCIAL CHANGE AFFECTING MANY OTHER COMMUNITIES IN PAPUA NEW GUINEA. IRONICALLY, THE POLICIES ADOPTED BY THE GOVERMMENT IN 1990 TO DEAL WITH THE ECONOMIC IMPACT OF THE BOUGAINVILLAEA CRISIS MAY GENERATE MORE UNREST IN THE FUTURE.

09574 HESLEY-SMITH, T.

PAPUA NEW GUINEA IN 1991: PROBLEMS OF LAW AND ORDER

ASIAN SURVEY, XXXII(2) (FEB 92), 154-161.

1991 WAS A PIVDTAL YEAR FOR PAPUA NEW GUINEA. WITH THE COUNTRY FAST APPROACHING A MINERALS BONANZA, THE GOVERNMENT OF RABBIE NAMALIU INITIATED A WIDE RANGE OF REFORMS DESIGNED TO STEM A RISING TIDE OF POLITICAL, ECONOMIC, AND SOCIAL DECAY. THE MAIN FOCUS OF ATTENTION WAS THE SO-CALLED LAW AND ORDER PROBLEM. THERE HAS BEEN A LONGSTANDING CONCERM IN PAPUA NEH GUINEA (PNG) ABOUT CRIMINAL ACTIVITY AND MANY OF PAPUA NEH GUINEA (PNG) ABOUT CRIMINAL ACTIVITY AND MANY OF
THE NEW REFORMS AIM TO EMPOWER POLICE FORCES, IMPROVE THE OHE NEN REFORMS AIM TO EMPOWER POLICE FORCES, IMPROVE THE OVERBURDENED CRIMINAL JUSTICE SYSTEM, AND STRENGTHEN THE STATE'S ABILITY TO REPATRIATE UNEMPLOYED VAGRANTS. ON THE
ECONOMIC FRONT, PNG HAS ENJOYED RAPID GROWTH IN THE MINERALS SECTOR. THE GOVERMMENT CONTINUES TO WORK ON ECONOMIC SECTOR. THE GOVERNMENT CONTINUES TO WORK ON ECONOMIC
STRATEGIES TO REDUCE UNEMPLOYMENT--THOUGHT TO BE A ROOT CAUSE OF THE LAW AND ORDER PROBLEM. A THREE-YEAR-OLD SECESSIONIST CRISIS ON THE ISLAND BOUGAINVILLE REMAINS UNRESOLVED. DESPITE AN ERRATIC MIX OF MILITARY AND POLITICAL INITIATIVES IN 1991, BOUGAINVILLE CONTINUES TO BE LARGELY ISOLATED FROM THE OUTSIDE WORLD, ITS PROCLAIMED INDEPENDENCE UNRECOGNIZED AND ITS DOMESTIC AFFAIRS IN TURMOIL.

09575 HEST, D.M.

REFORMING CAMPAIGN ADS

PS: POLITICAL SCIENCE AND POLITICS, XXV(1) (MAR 92), 74-77.

THE AUTHOR ARGUES THAT THE PROBLEM OF POLITICAL

COMMERCIALS IS AS MUCH A FUNCTION OF CAMPAIGN STRUCTURE AND VOTER REACTIONS AS CANDIDATE BEHAVIOR. HE REVIEWS VARIOUS SUGGESTIONS FOR REFORMING U.S. ELECTION CAMPAIGNS AND THE ACCOMPANYING ADVERTISING.

09576 WEST, J.

SOCIALISM NEEDS A LENINIST PARTY

POLITICAL AFFAIRS, 71 (4) (JUN 92), 15-19.

THIS ARTICLE SEEKS TO DETERMINE THE CAUSES OF THE

DOWNFALL OF THE COMMUNIST PARTY OF THE SOVIET UNION. IT

CONCLUDES THAT MEMBERS OF THE PARTY WHO WERE "TRUE LENINISTS,

THOSE WHO CONTINUED TO EMPHASIZE THE IMPORTANCE OF THE

WORKING CLASS HERE GRADUALLY SUPPLANTED BY A "NON-CLASS" OF

AUTHORITARIAN ELITES. THE THEORIES OF LENIN WERE DISCARDED AND LENIN HIMSELF BEGAN TO FALL UNDER CRITICISM. THE FUTURE OF THE SOVIET UNION NOW DEPENDS ON HOW WELL THE REAL MARXISTLENINISTS, THE TRUE COMHUNISTS, OF WHOM THERE ARE MANY TENS INDUSTRIAL CENTERS AND STATE AND COLLECTIVE FARMS, THRDUGH IDEOLOGICAL UNIFICATION BASED ON MARXIST-LENINISM.

09577 WEST, J.

THE CPUSA IN THE FIGHT OF EQUALITY AND AFRICAN AMERICAN LIBERATION

POLITICAL AFFAIRS, LXX(2) (FEB 91), 25-30.

CAPITALISM, BY ITS VERY NATURE, NURTURES A RACIALLYDIVIDED, AS WELL AS A CLASS-DIVIDED SOCIETY. ON THE OTHER HAND, THE MARXIST-LENINIST CONCEPT OF SOCIALISM IS ONE THAT, BY ITS VERY NATURE MUST ACHIEVE A UNITED CLASSLESS SOCIETY OF ALL PEOPLES, LIVING TOGETHER IN HARMONY AND PEACE. THIS ARTICLE ARGUES THAT THIS GOAL OF SOCIALISM IS IN ACCORD WITH THE BEST NATIONAL INTERESTS OF THE UNITED STATES. IN THE STRUGGLES AGAINST THE IDEOLOGY OF RACISM AND FOR AFRICANAMERICAN LIBERATION, FOR BLACK-HHITE UNITY, THE COMMUNISTS FORTIFY THE FUNDAMENTAL DEMOCRATIC INTERESTS OF THE UNITED STATES. FURTHERMORE, NO POLITICAL PARTY CAN MATCH THE RECORD, IN WORD AND DEED, IN THEORY AND PRACTICE, OF THE COMMUNIST PARTY USA.

09578 WESTHOLM, A.: NIEMI, R.G. POLITICAL INSTITUTIONS AND POLITICAL SOCIALIZATION: CROSS-NATIONAL STUDY

COMPARATIVE POLITICS, 25(1) (OCT 92), 25-42.

WHY DO THE TENETS OF THE PARTY IDENTIFICATION APPROACH APPLY WITH DIFFERENT FORCE TO DIFFERENT POLITICAL CULTURES? APPLY WITH DIFFERENT FORCE TO DIFFERENT POLITICAL CULTUR POLITICAL SOCIALIZATION RESEARCH AND TEST ITS VALIDITY ON POLITICAL SOCIALIZATION RESEARCH AND TEST ITS VALIDITY DATA FROM EIGHT COUNTRIES. THE MODEL IS FOUND TO HAVE
STRONGER EMPIRICAL SUPPORT THAN A PREVIOUS ONE DEVELOPED BY STRONGER EMPIRICAL SUPPORT THAN A PREVIOUS ONE DEVELOPED BY PERCHERON AND JENNINGS. THE EVIDENCE SUPPORTS THE CONTENTION THAT THE PARTY IDENTIFICATION APPROACH SHOULD NOT BE SIMPLY
REJECTED OR ACCEPTED BUT RATHER INVESTIGATED TO UNDERSTAND REJECTED OR ACCEPTED BUT
WHEN AND WHY IT APPLIES.

09579 HESTHOLM, A.

VOTES FOR SALE: THE LOGIC OF POWER IN JOINT-STOCK COMPANIES SCANDINAVIAN POLITICAL STUDIES, 15(3) (SEP 92), 193-215.

THE JOINT-STOCK COMPANY AS AN INSTITUTION RESTS ON THO 
COLLECTIVE CHOICE. THE ULTIMATE RIGHTS TO POWER ARE VESTED IN A CONSTITUENCY COMPOSED OF THE STOCKHOLDERS. THE CONSTITUENCY ELECTS A BOARD THAT, IN TURN, APPOINTS AN THESE RESPECTS THE JOINT-STOCK COMPANY RESEMBLES A DEMOCRATIC POLITY. ON THE OTHER HAND, IT INCLUDES IMPORTANT ELEMENTS OF MARKET EXCHANGE. UNLIKE MANY OTHER INSTANCES WHERE THE LOGIC OF COLLECTIVE CHOICE APPLIES, THE RIGHTS TO POHER CAN BE FREELY EXCHANGED ON A STOCK MARKET. THIS PAPER POHER CAN BE FREELY EXCHANGED ON A STOCK MARKET. THIS PAP
EXAMINES THE POWER IMPLICATIONS OF THIS COMBINATION OF EXAMINES THE POWER IMPLICATIONS OF THIS COMBINATION OF
PRINCIPLES, USING ILLUSTRATIONS FROM SWEDEN'S CORPORATE PRINCIPLES, USING ILLUSTRATIONS FROM SWEDEN'S CORPORATE
HORLD. ALTHOUGH THERE ARE SIMILARITIES BETWEEN THE SITUATION WORLD. ALTHOUGH THERE ARE SIMILARITIES BETWEEN THE SITUA PARTICIPATE IN THE EXERCISE OF CONTROL ARE RATHER DIFFERENT. WHEREAS A MODEL BASED SOLELY ON INSTRUMENTAL RATIONALITY IS WHEREAS A MODEL BASED SOLELY ON INSTRUMENTAL RATIONALITY IS INSUFFICIENT TO EXPLAIN THE PARTICIPATION OF VOTERS, IT DOES
WELL IN ACCOUNTING FOR THAT OF STOCKHOLDERS. FURTHER, THE WELL IN ACCOUNTING FOR THAT OF STOCKHOLDERS. FURTHER PREREQUISITES OF THE EMERGENCE AND MAINTENANCE OF
PARTICIPATORY NORMS ARE FAVORABLE WITH RESPECT TO VOTERS BUT PARTICIPATORY NORMS ARE FAVORABLE WITH
UNFAVORABLE HITH REGARD TO STOCKHOLDERS

09580 WESTLAKE, M.

BUT IS IT SAFE?

FAR EASTERN ECONOMIC REVIEH, 155(46) (NOV 92), 45-46. WHATEVER THE COMMERIAL PERFORMANCE AND THE PROSPECTS OF THE CARGO BUSINESS DURING 1992, THEY HAVE BEEN OYERSHADOWED BY A SERIES OF ACCIDENTS, PIRACY IN THE STRAITS OF MALACCA AND SHIPS BEING ARRESTED BY CHINESE AUTHORITIES NEAR HONG KONG. SAFETY AT SEA AND IN THE AIR IS NOW A MAJOR ISSUE, WITH A RASH OF SHIP COLLISIONS AND TWO CARGO AIRCRAFT CRASHES WITHIN THE PAST YEAR SERVING TO CONCENTRATE THE A RASH OF PIRACY HAVE ALSO TAKEN A HIGH PRIORITY AS INDICATED BY THE CREATION OF AN INTERNATIONAL MARITIME BUREAU OFFICE IN KUALA LUMPUR TO COORDINATE INFORMATION ON THE SUBJECT. WITH MORE THAN 200 ATTACKS ON SHIPS IN 1991 AND 70 IN 1992 TO LATE OCTOBER, MANY OF THEM IN OR NEAR THE PHILLIP CHANNEL NEAR SINGAPORE, OWNERS HAVE BEEN TRYING TO PUT PRESSURE ON THE GOVERMMENTS OF MALAYSIA, SINGAPORE AND
INDONESIA TO RESOLVE PROBLEMS OF JURISOICTION. THE ISSUE OF INDONESIA TO RESOLVE PROBLEMS OF JURISDICTION. THE ISSUE OF LOCAL OFFICIALS IN SOUTHERN CHINA CONFISCATING CARGOES OF
SHIPS BOUND FOR VIETNAM HAS ALSO DRAHN SOME ATTENTION, BUT LITTLE HAS BEEN DONE TO RESOLVE IT.

09581 WESTLAKE, $M$

CALLING THE HORLD

FAR EASTERN ECONOMIC REYIEW, 156(22) (JUM 92), 33-34. FOR THE BUSINESSMAN OR YISITOR IN TOKYO, HONGKONG OR SINGAPORE, THERE IS NO PROBLEM CALLING OR SENDING FACSIMILE MESSAGES TO MANY PARTS OF THE WORLD. FOR THE RURAL RESIDEN IN MANY PARTS OF ASIA'S LESS DEVELOPED COUNTRIES, IT IS NOT EVEN POSSIBLE TO CALL SOMEONE ON THE OTHER SIDE OF THE VILLAGE. THIS CONTRAST VIVIDLY ILLUSTRATES THE DIFFERENCES BETWEEN TELECOMUUICATIONS MARKETS-DOR BOTH EQUTPMENT AND SERVICES--IN ASIA, THE U.S. AND EUROPE. IT ALSO EXPLAINS THE SCRAMBLE BY THE DEVELOPED WORLD'S TELECOMMUNICATIONS EQUIPMENT MANUFACTURING AND SERVICE PROVIDERS TO JUMP INTO THE VAST POTENTIAL MARKET FOR EVEN THE MOST BASIC TELEPHONE SYSTEMS. IT IS ALSO BECOMING INCREASINGLY CLEAR THAT THE RULES AND ASSUMPTIONS WHICH HAVE FOR YEARS GOVERNED TELECOMMUMICATIONS ARE COLLAPSING. THE ADVANCES IN TECHNOLOGY--ESPECIALLY IN RADIO-BASED SYSTEMS AND CELLULAR TELEPHONES--ARE RENDERING THE OLD RULES AND MONOPOLIES IRRELEVANT. MARKET ESTIMATES INDICATE THAT THE ASIAN MARKET-EXCLUDING JAPAN AND INDOCHINA--TO BE ALMOST US550 BILLION BY 1997 .

09582 HESTLE, B.; NIEDERMAYER, O.

CONTEMPORARY RIGHT -WING EXTREMISM IN WEST GERMANY: THE REPUBLICANS AND THEIR ELECTORATE

EUROPEAN JOURMAL OF POLITICAL RESEARCH, 22(1) (JUL 92), 83-100.

AFTER A FEW REMARKS ON THE DEFINITION AND HISTORY OF RIGHT-WING EXTREMISM IN THE FEDERAL REPUBLIC OF GERMANY, THE AUTHORS OFFER AM OVERVIEH OF THE REPUBLICANS' ORIGINS, ORGANIZATION, MEMBERSHIP, PLATFORM, AND CAMPAIGN STYLE. THEY ALSO EMPIRICALLY TEST A HYPOTHESES DEDUCED FROM VARIOUS THEORETICAL APPROACHES TO EXPLAIN SUPPORT FOR EXTREME RIGHTWHEORETICAL APPROACHES TO EXPLAIN SUPPOR F FOR EXTREME CONSIDERABLE PORTION OF THE REPUBLICANS' ELECTORATE CONSISTS OF PROTEST VOTERS WHO DO NOT HAVE AN EXTREME RIGHT-WING IDEOLOGY THE PARTY HAS BENEFITED FROM SOCIOECDNOMICALLYAND POLITICALLY-MOTIVATED DISSATISFACTION AND FEELINGS OF THREAT, POLITICALLY-MOTIVATED DISSATISFACTION AND FEELINGS OF ADEQUATELY.

09583 HESTOBY, A.; HILL, R.J.

COMMUNISM AND POLITICAL

JOURNAL OF COMMUNIST STUDIES, 8(1) (MAR 92), 160-174

IN ITS MODERN FORM DERIVED FROM MARXISM, COMMUNISH HAS

EVOLVED SEVERAL COMPETING VARIANTS. RESULTING PRIMARILY FROM

THE DIFFERENT TIMES AND CIRCUMSTANCES IN WHICH COMHUNIST

PARTIES HAVE EXISTED AND COME TO POHER. THE HISTORY OF THE

MOVEMENT DISPLAYS MANY PARADOXES, INCLUDING THE OBYIOUS
CONTRAST BETHEEN THE GOALS OF COMMUNIST SOCIETY AND THE REALITY OF COMMUNIST RULE. COMMUNIST REGIMES MUST COMPETE WITH A CAPITALISM THAT HAS PROVED MORE VIBRANT THAN MARXISTS EXPECTED IN AN INTERNATIONAL ENVIRONMENT WHERE COMMUNIST SYSTEMS HAVE BEEN FOUND WANTING. THE COMMUNICATIONS REVOLUTION, IN PARTICULAR, HAS UNDERMINED THE BASIC GROUND RULES OF COMMUNIST POWER. THE CONCEPT OF EVOLUTION RAISES THEORETICAL ISSUES OF RELEVANCE TO THE STUDY OF COMMUNISM, NOTABLY THE ADAPTABILITY OF A SYSTEM TO ITS CHANGING ENVIRONMENT. ON THAT SCORE, THE STALINIST FORM OF COMMUNISM ENVIRONMENT. ON THAT SCORE, THE STALINIST FORM OF COMMUNISM IS DOOMED, BUT SOME OF ITS EFFECTS WIL
THE NEXT STAGE OF POLITICAL EVOLUTIDN.

09584 WETTERGREEN, J.A.

CONSTITUTIONAL PROBLEMS OF AMERICAN BUREAUCRACY BEGINNING HITH I.N.S. V. CHADHA

POL ITICAL COMMUNICATIOY $9(2)$ (1992), 93-110.

THE U.S. SUPREME COURT'S DECISION'IN IMMIGRATION AND NATURALIZATION SERVICE $V$. CHADHA PROVIDES A RARE INSIGHT INTO THE CONSTITUTIONAL ISSUES OF BUREAUCRATIC CONTROL. ON THE SURFACE, THE CHADHA DECISION DEALT WITH A NARROW LEGAL QUESTION: WAS THE IMMIGRATION ACT'S PROVISION OF A SINGLEHOUSE LEGISLATIVE VETO CONSTITUTIONAL? THE SUPREME COURT HELD THIS PROVISION CONTRARY TO THE U.S. CONSTITUTION ON THE GROUNDS THAT THE VETO WAS TANTAMOUNT TO AN ACT OF LEGISLATION THAT WAS NEITHER PASSED UPON BY BOTH HOUSES NOR PRESENTED FOR APPROVAL TO THE PRESIDENT. ALTHOUGH THIS DECISION MAY SEEM NARROH, CHADHA EXPOSED THE ROOTS OF THE CONTEMPORARY U.S. REGIME BECAUSE IT RAISED FUNDAMENTAL QUESTIONS ABOUT AMERICAN FREE GOVERMMENT IN THE CONTEXT OF BUREAUCRACY. CHADHA MADE IT OBVIDUS THAT CONTROL OF THE FEDERAL BUREAUCRACY HAD BECOME A PRESSING CONSTITUTIONAL PROBLEM.

09585 HETTIG, G.

DEVELOPMENTS IN THE FORMER USSR AND EUROPEAN SECURITY AUSSEN POLITIK, 43(3) (JUL 92), 230-236.

THE DEMISE OF THE SOVIET UNION HAS TENDED TO PRODUCE EVEN MORE CHALLENGES TO EUROPEAN SECURITY THAN THOSE POSED BY THE FORMER USSR. AS AN IMPERIAL MILITARY POWER, THE SOVIET UNION WAS A LATENT THREAT TO BOTH ITS "ENEMY COUNTRIES" IN THE WEST AS WELL AS TO ITS SATELLITES. THE COUNTRIES" IN THE WEST AS WELL AS TO ITS SATELLITES. THE THREAT TODAY, ON THE OTHER HAND, EMANATES FROM THE LACK OF
SUCH AN CONCENTRATION OF POWER. THE SUCCESSOR STATES WHICH HAVE EMERGED ON THE TERRITORY OF THE FORMER SOVIET UNION AND HAVE EMERGED ON THE TERRITORY OF THE FORMER SOVIET UNION AY ARE CURRENTLY LINKED IN THE COMMONHEALTH OF INDEPENDENT
STATES, ARE TROUBLED BY INNER CRISES AND CONFLICTS IN THIS STATES, ARE TROUBLED BY INNER CRISES AND CONFLICTS IN THIS
REGION, HOWEVER, REPRESENT A NEN AND BY NO MEANS LESS REGION, HOWEVER, REPRESENT A NEH AND BY NO MEANS LESS SERIOUS RISK FOR EUROPEAN SECURITY. THIS ARTICLE PRESENTS A COMPREHENSIVE PICTURE OF THE RELATED CURRENT PROBLEMS.

09586 WETTIG, G.

SECURITY IN EUROPE: A CHALLENGING TASK

AUSSEN POLITIK, 43(1) (1992), 3-11.

THE POLITICAL CHANGE WHICH HAS TAKEN PLACE IN THE PREVIOUSLY SOCIALIST COUNTRIES, HAS FUNDAMENTALLY CHANGED THE SECURITY UNIFICATION IN EUROPE. OLD PROBLEMS HAVE LARGELY BECOME IRRELEVANT. AT THE SAME TIME NEW CHALLENGES HAVE EMERGED WICH REQUIRE NEH RESPONSES. THIS ARTICLE ANALYZES THE NEW SITUATION AND ITS IMPLICATIONS.

09587 WHALEN, B.

DILEMMA FOR DEMOCRATS

INSIGHT, 7(4) (JAN 91), 16-17

AS DISCUSSION OF THE GULF CRISIS WOUND ITS WAY THROUGH BOTH CHAMBERS OF CONGRESS, AN UGLY REEMERGED HITHIN THE DEMOCRATIC PARTY. FOR ALL THE TALK OF MODERATION, OF MOVING TO THE POLITICAL CENTER TO REBUILD ITS NATIONAL FOLLOWING, AND OF PRESENTING A TOUGHER, MORE RESOLUTE FRONT, THE PARTY DISINTEGRATED INTO A MASS OF BLURRED DISTINCTIONS AND CONFUSED VOICES WHEN THE FOCUS DEBATE WAS FOREIGN AFFAIRS WITH AMERICAN LIVES ON THE LINE IN THE DESERT, DEMOCRATIC POLITICIANS MUST TREAD A NARROW LINE BETWEEN LEADERSHIP AND LOYAL OPPOSITION. THE DIFFICULTY OF THIS TASK WAS QUICKLY DISCOVERED BY THREE DEMOCRATIC PRESIDENTIAL HOPEFULS--MARIO
CUOMO, RICHARD GEPHARDT, AND SAM NUNM--WHO WERE TAKEN TO CUOMO, RICHARD GEPHARDT, AND SAM NUNM--WHO WERE TAKEN TO
TASK FOR LESS THAN ENTHUSIASTIC STATEMENTS ABOUT THE GULF TASK FOR
CRISIS.

09588 WHALEN, $B$.

ENERGETIC POLITICS
INSIGHT, 7 (11) (MAR 91$), 18-19$.

DEMOCRATS FACING A REPUBLICAN PRESIDENT HITH ENORMOUS

WAR DRIVEN POPULARITY WERE QUICK TO ATTACK PRESIDENT BUSH'S PROPOSED ENERGY POLICY. THE PLAN CALLS FOR MORE DOMESTIC OIL PROOUCTION AND LESS CONSUMPTION BUT SAYS LITTLE ABOUT AUTO EFFICIENCY OR CONSERVATION. ALTHOUGH BUSH SEEMS INVINCIBLE NOW. DEMOCRATS HOPE THE ISSUE WILL AT LEAST GIVE THEM A HAY TO GAUGE THE NaTION.

09589 HHALEN, $B$.

GOP GLADIATOR

INSIGHT, 7(16) (APR 91), 26-27

SENATOR PHIL GRAMM OF TEXAS IS TAKING UP THE BATTLE FLAG 
AS CHAIRMAN OF THE NATIONAL REPUBLICAN SENATORIAL COMMITTEE, A JOB THAT WON FEH REWARDS FOR HIS PREDECESSORS. BUT GRAMM IN THE SEMATE, AND HIS ROLE IN NEXT YEARS RACES MAY HELP HIM IN THE SENATE, AND HIS ROLE IN NEXX
ADVANCE HIS PRESIDENTIAL AMBITION.

09590 WHALEN, B.

GORE AND THE HAR

INSIGHT, 7(6) (FEB 91), 18-19.

SENATOR ALBERT GORE JR. VOTED TO APPROVE A RESOLUTION TO

USE MILITARY FORCE AGAINST IRAQ. THE TENNESSEE DEMOCRAT'S

BREAK WITH IS PARTY HAS INCREASED SPECULATION THAT HE WILL RUN FOR PRESIDENT; THE DECISION ALSO PUT HIM IN CONTRAST WITH OTHER POSSIBLE PRESIDENTIAL CONTENDERS. IF GORE RUNS, THE IOHA CAUCUS WILL BE A DIFFICULTY. IF THE GULF WAR GOES WELL, HOWEVER, he MAY haVe a REASON TO WAIT UNTIL 1996.

09591 WHALEN, B.

MAYORAL MALAISE

INSIGHT, $7(10)$ (MAR 91), 18-19.

WHILE PRESIDENT BUSH'S PROPOSAL TO TRANSFER \$21 BILLIOM TO STATE AND LOCAL GOVERMMENTS HAS RECEIVED PRAISE FROM STATE GOVERNORS. THE NATION'S MAYORS AREN'T PLEASED. UNDER THE PLAN, AT LEAST S15 BIDLION OF THAT SUM HOULD BE THE PLAN, AT LEAST S15 BILLION OF THAT SUM WOULD BE CONSOLIDATED INTO ONE BLOCK GRANT TO BE DISTRIBUTED AT THE ISCRET ON OF THE STATES. THE MAYORS HAVE STORMED WASHINGTON THEIR CONTROL OVER FUNDS MADE INCREASINGLY PRECIOUS BY RECESSION AND A FUNDING SQUEEZE.

09592 WHALEN, B.

NOT SO THOROUGHLY MODERATE BILLY

INSIGHT, 7 (36) (SEP 91), 32-34.

ARKANSAS GOVERMOR BILL CLINTON IS VIEWED BY SOME AS THE DEMOCRATIC PARTY'S NEW PRESIDENTIAL HOPE. CLINTON LIKES TO CALL HIMSELF A "NEW CHOICE DEMOCRAT," A PHILOSOPHY LAID OUT AT THE DEMOCRATIC LEADERSHIP CONFERENCE CONVENTION THAT INCLUDES INCREASES IN THE EARNED INCOME TAX CREDIT; A MATIONAL SYSTEM OF APPRENTICESHIPS FOR STUDENTS NOT BOUND FOR COLLEGE: NATIONAL SERVICE FOR YOUNG PEOPLE; HELFARE REFORM; CHILD SUPPORT EMFORCEMENT; NO DRIVER'S LICENSES FOR STUDENTS WHO DROP OUT OF SCHOOL; CHILD CARE VOUCHERS; AND PUBLIC SCHOOL OPTIONS. CLINTON CHARACTERIZES HIMSELF AS A MODERATE-TO-CONSERVATIVE DEMOCRAT, BUT A CLOSE ANALYSIS OF PAST PERFORMANCE REVEALS CHAMELEON-LIKE SHIFTS IN IDEOLOGY AND PRACTICE.

09593 WHALEN, B.

YEUTTER TURNS FIGHTER

INSIGHT, $7(7)$ (FEB 91), 22-23.

SINCE CLAYTON YEUTTER WAS DESIGNATED TO REPLACE LEE

ATWATER AS THE CHAI RMAN OF THE REPUBLICAN NATIONAL COMMITTEE,

HE HAS HAD TROUBLE STAYING OUT OF THE HEADLINES. HE STRUCK A NERVE WHEN HE CARSTISED DEMOCRATS FOR OPPOSING THE HAR. THE REPUBLICAN PARTY ALSO ANGERED DEMOCRATS BY SOLICITING FUNOS TO DEFEAT HAR CRITICS. THESE INCIDENTS SHOH HOW MUCH BOTH PARIIES WANT TO BE ON THE RIGHT SIDE OF THE CONFLICT THEY ALSO MAY INDICATE FURTHER CHALLENGES FOR YEUTT
EFFORT TO GET THE GOP MACHINERY TO RUN SMOOTHLY.

09594 WHEELAND, C

EMPOWERING THE VISION: CITYHIDE STRATEGIC PLANNING NATIONAL CIVIC REVIEH, 80(4) (FAL 91), 393-405.

STRATEGIC PLANNING IS AMONG THE NEHEST LOCAL GOVERMMENT MANAGEMENT TECHMIQUES BORROWED FROM THE PRIVATE SECTOR. ROCK HILL, SOUTH CAROL INA, EMPLOYED A PARTICIPATORY, CITYHIDE STRATEGIC PLANNING APPROACH CALLED "EMPOWERING THE VISION" TO PRODUCE A TEN-YEAR PLAN THAT WILL TRANSFORM THE CITY'S IMAGE.

09595 WHEELER, N.J.

PLURALIST OR SOL IDARIST CONCEPTIONS OF INTERNATIONAL SOCIETY: BULL AND VINCENT ON HUMANITARIAN INTERVENTION MILLENMIUM, 21(3) (HIN 92), 463-488.

THE AUTHOR EXAMINES BULL AMO VINCENT'S THINKING OM THE LEGITIMACY OF HUMANI TARIAM INTERVENTION IN INTERMATIONAL SOCIETY. HUMANITARIAN INTERVENTION POSES THE CONFLICT BETWEEN ORDER AND JUSTICE IN INTERNATIONAL RELATIONS IN ITS STARKEST FORM. THROUGH CASE STUDIES OF THE RESPONSES OF THE INTERMATIONAL COMMUNITY TO HUMAN SUFFERING IN MORTHERM IRAO AND THE FORMER YUGOSLAVIA. THE AUTHOR CONCLUDES THAT BULL AND VINCENT'S WRITINGS ON' HUMANITARIAN INTERVENTION CONTINUE AO PROVIDE VALUABLE INSIGHTS INTO THE CONFL ICT BETWEEN ORDER TO PROVIDE VALUABLE INSIGHTS INT IN INTERMATIONAL RELATIONS.

09596 WHEELWRIGHT, T.

GLOBAL CAPITALISM NOW: DEPRESSION IN THE 19905 ARENA, 98 (1992), 63-75.

TODAY'S GLOBAL POLITICAL SITUATION IS AN UNPRECEDENTED SITUATION IN THE HISTORY OF WORLD CAPITALISM, WHICH IS GIVING RISE TO SPLITS IN THE RULING CLASS--WITH DANGEROUS TENOENCIES TOWARDS NEH FORMS OF FASCISM AS IN THE UNITED STATES, WESTERN AND EASTERN EUROPE. AND THE FORMER SOVIET
UNION. THIS ARTICLE OFFERS HISTORICAL BACKGROUND HHICH LEADS
TO A OISCUSSION OF THE DEPRESSION OF THE 1990S. IT ANALYSES THE SITUATION IN AUSTRALIA, THE UNITED STATES, CANADA, EUROPE, ASIA. AND JAPAN. IT PREDICTS THAT FOR THE REST OF THIS CENTURY' THE STRUGGLE WILL NOT BE BETWEEM CAPITALISM AND COMMUNISM OR SOCIALISM, BUT BETWEEN THO FORMS OF CAPITAL ISMTHE ANGLO VARIETY OF THE UNITED KINGDOM, THE UNITED STATES AND REMMANTS OF THE BRITISH EMPIRE, AND THE STATIST VARIETY OF JAPAN AND GERMAN-DOMONATED EUROPE.

09597 HHELAN, L.

THE CHALLENGE OF LOBBYING FOR CIVIL RIGHTS IN NORTHERN

IRELAND: THE COMMITTEE ON THE ADMINISTRATION OF JUSTICE HUMAN RIGHTS QUARTERLY, 14(2) (MAY 92), 149-170.

THE EMERGENCE OF NATIONAL NONGOVERMMENTAL ORGANIZATIONS (NGOS) IS AN IMPORTANT AND LARGELY UNEXAMINED DEVELOPMENT WITHIN THE INTERMATIONAL HUMAN RIGHTS MOVEMENT. THIS ARTICLE IS A CASE STUDY OF ONE SUCH GROUP: THE COMMITTEE ON THE ADMINISTRATION OF JUSTICE (CAJ), BASED IN BELFAST, NORTHERN IRELANO. CAJ WAS FROMED IN 1981 AND HAS EVOLVED INTO AN EFFECTIVE, MULTIPLE ISSUE CIVIL RIGHTS LOBBY MODELED, IN MANY WAYS, AFTER LIBERTY AND THE AMERICAN CIVIL LIBERTIES UNION. IN ORDER TO FULLY APPRECIATE THE ACCOMPLISHMENTS OF CAJ, THIS ARTICLE OFFERS AN ANALYSIS OF NORTHERN IRELAND'S CAJ, THIS ARTICLE OFFERS AN ANALYSIS OF NORTHERN IRELAND'S OIVISIVE POLITIAL ENVIRONMENT. IT EXAMINES: THE POL ITICAL CONTEXT: CIVIL LIBERTIES; AND, ACTIVITIES OF THE COMMITTEE NOT ONLY SURVIVED, IT HAS FLOURISHED.

09598 WHICKER, M.L.

TOHARD A GRANDER BUDGET THEORY

PUBLIC ADMINISTRATION REYIEH, 52(6) (NOV 92), 601-603.

THE AUTHOR SUMMARIZES THE PRINCIPLES ARTICULATED BY

AARON WILDAVSKY IN HIS WRITINGS ON THE BUDGETARY PROCESS AND OFFERS "AN ACADEMICIAN'S RESPONSE" TO WILDAVSKY.

09599 HHIP, R.

REPRESENTING HOMEN: AUSTRALIAN FEMALE PARLIAMENTARIANS ON THE HORNS OF A DILEMMA

WOMEN AND POLITICS, 11(3) (1991), 1-22.

THIS PAPER EXAMAMINES THE WAY IN WHICH HOMEN ELECTED TO AUSTRALIAN PARLIAMENTS BETHEEN 1921 AMD 1981 PERCEIVED THEIR ROLE IN RELATION TO THE REPRESENTATION OF WOMEN AND THE WAY IN WHICH THEY RESPONDED TO THE CONFLICTING EXPECTATIONS THEY ENCOUNTERED. THE COMMENTS OF THESE WOMEN INDICATE THAT IMPROVED REPRESENTATION IS UNLIKELY TO BE ACHIEVED SIMPLY BY THE ELECTION OF MORE HOMEN TO LEGISLATIVE BODIES. WOMEN MUST BE ELECTED HHO ARE COMMITTED TO THE PURSUIT OF HOMEN'S INTERESTS, BUT THIS IS UNL IKELY TO BE SUFFICIENT WITHOUT A INTERESTS, BUT THIS IS UNLIKELY TO BE SUFF ICIENT WI THOUT A
CHANGE IN THE MALE ESTABLISHED PRIORI IIES OF LEGISLATURES $S O$ CHANGE IN THE MALE ESTABLISHED PRIORI TIES OF LEGI SLATURES
THAT WOMEN'S INTERESTS AND THOSE HHO PURSUE THEM ARE NO THAT WOMEN'S INTERESTS AND
LONGER REGARDED AS MARGINAL.

09600 WHISTNANT, D.

RUBEN DARIO AS A FOCAL CULTURAL FIGURE IN MICARAGUA: THE IDEOLOGICAL USES OF CUL TURAL CAPITAL

LATIN AMERICAN RESEARCH REVIEW, 27(3) (1992), 7-50,

MOST OF THE CRIICAL COMMENTARY OM NITARAGUAN RUBEM DARIO HAS BEEN CALLED CORTH SEMINAL PAN-AMERICAN AND AN INTERMATIONAL LITERARY FIGURE. IN BEGINNING TO SORT THROUGH THE COMPLEXITIES OF HIS CASE. THIS ARTICLE REVIEWS DETAILS CONCERNING DARIO'S SELFIDENTIFICATION WITH NICARAGUA. IT IS THEN POSSIBLE TO PERCEIVE HOW HIS CLASS POSITION AND ASPIRATIONS, AS WELL AS THE POLITICAL INFLUENCES ON HIM DURING HIS FORMATIVE YEARS, AFFECTED THAT IDENTIFICATION.

09601 WITAKER, R.

THE POLITICS OF SECURITY INTELLIGENCE POLICY-MAKING IN CANADA: 11 1984-91

INTELLIGENCE AND NATIONAL SECURITY, 7 (APR 92), 53-76. THE REFORM OF THE CANADIAN SECURITY INTEL IGENCE SYSTEM MOVED CANADA FROM A CLOSE APPROXIMATION OF THE BRITISH MODEL OF ACCOUNTABILITY TO AN INMOVATIVE APPROACH WHICH WAS MUCH CLOSER TO THE AMERICAN MODEL. KEY FACTORS IN BRINGING ABOUT THIS CHANGE WERE THE PRESENCE OF PUBLIC SCANDAL SURROUNDING THE SECURITY SERVICE; A MORE INTENSE POLITICIZATION OF SECURITY ISSUES HITH MORE DIVISIVE DOMESTIC POLITICAL CONSEQUENCES; AND A POLITICAL CUL TURE WITH GROWING STRESS ON LIBERAL VALUES AND INDIVIDUAL RIGHTS. IN THIS ARTICLE. THE RECORD OF THE MEH SYSTEM IS EXAMINED AMD THE EFFECTIVENESS OF THE NEW INSTRUMENTS OF ACCOUNTABILITY ASSESSED.

09602 WHITE, G.

URBAN GOVERNMENT AND MARKET REFORMS IN CHINA PUBLIC ADMINISTRATION AND DEVELOPMENT, 11 (2) (MAR 91), 149-170.

CHINESE REFORMERS WISH THROUGH THEIR ECONOMIC PROGRAMME TO WEW RELATIONSHIP BETWEEN STATE AND ECONOHY. THIS PAPER EXAMINES THESE ISSUES THROUGH A STUDY OF THE IMPACT OF CHINESE ECONOMIC REFORMS ON THE STRUCTURE AND BEHAVIOR OF LOCAL GOVERMMENT, FOCUSING ON URBAN GOVERMMENT AT THE

OISTRICT LEVEL. IT LOOKS AT THREE ASPECTS OF THE ISSUE--THE TREND TOWARDS FINANCIAL DECENTRALIZATION, INSTITUTIONAL 
CHANGES IN DISTRICT ADMINISTRATION AND CHANGES IN THE RELATIONSHIP BETHEEN LOCAL GOVERNMENT AND THE URBAN ECONOMY. IT CONCLUDES (CONTRARY TO ARGUMENTS WHICH REGARD IT CONCLUDES BETHEN LOCAL GOVERNHENT AND THE URBAM ECONOYY. BUREAUCRATIC RESPONSE TO THE REFARMS AS ONE OF PURE INERTIA ANO OBSTRUCTION THAT THE MOST OCAL GOVERNEN THAS CHANGED IN SEVERAL MAJOR WAYS, THE MOST OBVIOUS BEING A TREND TOWARDS INSTITUTIONAL EXPANSION AND PROLIFERATION. FROM THE POINT OF VIEW OF THE REFORA PROCESS, SOME INSTITUTIONAL CHANGES HAYE BEEN POSITIVE, OTHERS NEGATIVE, RESULTING IN A 'DUALISTIC STATE WHICH CONTAINS ELEMENTS OF BOTH OLD AND NEN FORMS OF DEVELOPMENTAL STATE.

09603 WHITE, H.; HIGMARAJA, G.

EXCHANGE RATES, TRADE LIBERALIZATION, AND AID: THE SRI LANKAN EXPERIENCE

HORLD DEVELOPMENT, 20(10) (OCT 92), 1471-1480,

IN 1977, THE SRI LANKAN GOVERMMENT EMBARKED ON AN EXTENSIVE PROGRAM OF LIBERALIZATION, INCLUDING DEVALUATION TO ENSURE A COMPETITIVE REAL EXCHANGE RATE. HOWEVER, THE 1980 'S HERE MARKED BY AN INCREASING DIVERGENCE BETWEEN REAL AND NOMINAL EXCHANGE RATES, THE DEPRECIATION OF THE LATTER NOT BEING MATCHED BY SIMILAR MOVEMENTS OF THE FORMER. THIS PAPER PRESENTS AN ECONOMETRIC MODEL OF REAL EXCHANGE RATE BEHAVIOR IN SRI LAMKA. IT DEMONSTRATES THAT INCREASED AID INFLOWS HAVE MADE A SIGNIFICANT CONTRIBUTION TO THE FAILURE OF THE REAL EXCHANGE RATE TO MATCH THE DEPRECIATION IN THE NOMINAL RATE.

09604 WHITE, H.; MCGILLIVRAY, M.

THE ALLOCATION OF AID AMONG DEYELOPIMG COUNTRIES: A COMMENT ON MCGILLIVRAY'S PERFORMANCE INDEX

WOMMEN ON MCGILLIVRAY'S PERFORMANCE INDEX

MARK MCGILIVRAY HAS PROPOSED AN INDEX THAT HE CLAIMS MARK MCGILLIVRAY HAS PROPOSED AN INDEX THAT HE CLAIMS RANKS DONORS BY THE PROGRESSIVENESS WITH WH THIS PAPER, THEIR DEVELOPMENT AID AMONG RECIPIENTS. IN THIS PAPER, SMALL-COUNTRY BIAS SO THAT A DONOR MAY IMPROVE ITS

SMALL-COUNTRY BIAS, SO THAT A DONOR MAY IMPROVE ITS PERFORMANCE BY TAKING AID FROM A POOR, LARGE COUNTRY AND GIVING IT TO A SMALL,
TO WHITE'S ARGUMENT.

09605 WHITE, J.K.

E.E. SCHATTSCHNEIDER AND THE RESPONSIBLE PARTY MODEL PS: POL ITICAL SCIENCE AND POLITICS, XXV(2) (JUN 92), 167-171.

THE AUTHOR DISCUSSES THE IMPORTANT CONTRIBUTION OF E.E. SCHATTSCHNEIDER TO POLITICAL SCIENCE, FOCUSING ON SCHATTSCHNEIDER'S WRITINGS ABOUT POLITICAL PARTIES

09606 WHITE, J.K.

RESPONSIBLE PARTY GOVERNMENT IN AMERICA

PERSPECTIVES ON POLITICAL SCIENCE, 21(2) (SPR 92), 80-90. THIS ARTICLE CONSIDERS THE CONCEPT OF RESPONSIBILITY AND ACCOUNTABILITY WITH REGARDS TO POLITICAL PARTIES IN AMERICA. EMPHASIS IS PLACED ON THE POHERFUL LEGACY OF THE AMERICAN POLITICAL SCIENCE ASSOCIATION 1946 REPORT, "TOWARD A MORE RESPONSIBLE THO-PARTY SYSTEM." IT ARGUES THAT ANY RETHINKING ABOUT WHETHER RESPONSIBLE PARTY GOYERMMENT IS EITHER ABOUT WHETHER RESPONSIBLE PARTY GOVERMMENT IS EITHER
DESIRABLE OR ATTAINABLE MUST TAKE INTO ACCOUNT THE RECENT
PERSISTENCE OF DIYIDED PARTY CONTROL OF THE FEDERAL PERSISTENCE OF DIVIDED PARTY CONTROL OF THE FEDERAL

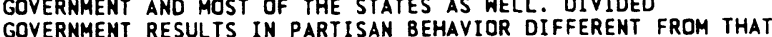
GOVERNMENT RESULTS IN PARTISAN BEHAVIOR DIFFERENT

09607 WHITE, M.J.

BELLIGERENT BEGINNINGS: JOHN F. KENNEDY ON THE OPENING DAY OF THE CUBAN MISSILE CRISIS

JOURNAL OF STRATEGIC STUDISS 15(1) (MAR 92), 30-49.

THE AUTHOR EXAMINES PRESIDENT JOHN $F$. KENMEDY'S INITIAL REACTION TO THE DEPLOYMENT OF SOVIET MISSILES IN CUBA ON OCTOBER 16, 1962, IN ORDER TO TRY TO SEPARATE KENMEDY'S APPRAISE THE PRESIDENT'S CONTRIBUTION TO SOLVING THE PROBLEM.

09608 WHITE, R.

EMPATHIZING HITH SADDAM HUSSEIN

POLITICAL PSYCHOLOGY, $12(2)$ ( 291-308.

TEN ELEMENTS IN THE METHODOLOGY OF REALISTIC EMPATHY ARE CONSIDERED, INCLUDING THE CHESSPLAYER'S TYPE OF EMPATHY AMD TAKING INTO ACCOUNT THE OTHER'S EXPECTABLE MISPERCEPTIONS, ONE'S OWN EXPECTABLE MISPERCEPTIONS, AND THE OTHER'S CULTURAL BACKGROUND. A SOMEHHAT SYSTEMATIC COGNITIVE MAP OF SURPRISINGLY, HIS BASIC MOTIVES INCLUDE MUCH GENUINE FEAR, ESPECIALLY FEAR THAT, WITHOUT STRENGTH AND TOUGHNESS ON HIS PART, IRAO WILL FAR APART AND SYRIA AND IRAN WILL PICK UP THE PIECES. THEY ALSO INCLUDE INTENSE NEEDS FOR POWER AS SUCH, FOR ECONOMIC RECOVERY, AND FOR KEEPING HIS RECENTLY ACQUIRED REPUTATION, IN ARAB EYES, AS THE GREAT, TOUGH CHAMPION OF ALL ARABS IN THEIR STRUGGLE AGAINST ISRAEL, THE UNITED STATES AND THE GREEDY, CORRUPT, SPINELESS RULERS OF THE GULF STATES. PRESENT PERCEIVED PATHS TO THOSE GOALS INCLUDE NONPROVOCATION, WAITING FOR NEW ARAB ALLIES AND FOR GREATER DISUNITY IN THE NON-ARAB HORLD, AND RUTHLESS, ALL-
OUT ATTACK IF ATTACKED OR ABOUT TO BE ATTACKED. IMPLICATIONS FOR NEGOTIATION ARE CONSIDERED.

09609 WHITE, R.W.; MACFARLANE,

BRITISH VIOLENCE AND BRITISH INJUSTICE IN UNDEMOCRATIC NORTHERN IRELAND

TERRORISH AMD POLITICAL YIOLENCE, 4(3) (FAL 92) 117-124. LESLIE MACFARLANE HAS ARGUED THAT CATHOLICS IN NORTHER IRELAND NOW HAVE FULL CIVIL AND POLITICAL RIGHTS ON THE SAME "RESPONSE," ROBERT W. WHITE QUESTIONS THIS POSITION WHILE MACFARLANE DEFENDS IT.

09610 WHITE, S.

RUSSIA'S EXPERIMENT WITH DEMOCRACY

CURRENT HISTORY 91 (567) (OCT 92) 310-313.

THE AUTHOR LOOKS AT THE EMERGING FEATURES OF RUSSIA'S

POST-COMMUNIST SYSTEM AND ASKS IF RUSSIA IS ENTERING A NEH PERIOD OF DEMOCRACY OR SIMPLY POST-COMMUNISM OR EVEN A NEW FORM OF AUTHORITARIANISM.

09611 WHITE, S.

THE SOVIET UNION: GORBACHEV, PERESTROIKA AND SOCIALISM

JOURNAL OF COMMUNIST STUDIES, 8(1) (MAR 92), 23-40.

THE RUSSIAN REVOLUTION OF 1917 WAS ORIGINALLY CONCEIVED AS PART OF A TRANSITION TO SOCIALISM ON A GLOBAL SCALE. THE FAILURE OF THAT STRATEGY LED TO A FAR-REACHING DEBATE ABOUT THE MEANS BY HHICH A RELATIVELY BACKHARD SOVIET RUSSIA COULD ADVANCE BY ITSELF TO A COMMUNIST FUTURE. DURING THE GORBACHEV ERA, THE ISSUE WAS ADORESSED IN TERMS OF THE CONSTRUCTION OF A HUMANE, DEMOCRATIC SOCIALISM, SEEN AS PART OF A GLOBAL PROCESS: INDIVIDUAL SCHOLARS AND PUBLICISTS ADVANCED STILL FURTHER TOWARDS A SOCIALISM THAT WOULD EMBODY A MULTI-PARTY SYSTEM AND A YARIETY OF FORMS OF OWNERSHIP. A MULTI-PARTY SYSTEM AND A VARIETY OF FORMS OF OWNERSHIP. INCREASINGLY, MORE RADICAL COMMENTATORS IDENTIFIED THE
ORIGIN OF SOVIET DIFFICULTIES AS LENINISM ITSELF. THERE HAS, ORIGIN OF SOVIET DIFFICULTIES AS LENINISM ITSELF. THERE HAS,
IN FACT, LITTLE POPULAR SUPPORT FOR A RETURN TO CAPITALISH; BUT THE EXPERIENCE OF SOVIET RULE SHOWED THAT THE AUTHORITIES IN THAT COUNTRY NEEDED THE POLITICAL EXPERIENCE AUTHORITIES IN THAT COUNTRY NEEDED THE POL ITICAL EXPERIEE
OF THE WEST AS MUCH AS THEY NEEDED CAPITAL INVESTMENT.

09612 WHITE, T.

REFORMING THE COUNTRYSIDE

CURRENT HISTORY 91(566) (SEP 92), 273-277

CHINA'S EFFORTS TO MAKE VILLAGES SELF-GOVERNING AND MORE DEMOCRATIC, DESPITE THEIR LIMITATIONS, HAVE FOUND FERTILE GROUND AND' HAVE TAKEN ROOT IN SMALL PATCHES IN THE COUNTRYSIDE. CHINESE PEASANTS, UNL IKE THEIR URBAN WITH A VESTED INTEREST IN HOW VILLAGE AFFAIRS ARE CONDUCTED. IN TIME, THEY MAY TEACH THE URBAN POPULACE A THING OR THO ABOUT THE DEVELOPMENT OF DEMOCRATIC INSTITUTIONS.

09613 HHITEHEAD, J.

THE MULTIPLICATION FACTOR IN U.K. - JAPAN RELATIONS JAPAN TIMES (WEEKLY INTERNATIONAL EDITION), 32(15) (APR 92). 9.

JAPAN AND GREAT BRITAIN HAVE MANY COMMON CONCERNS AND OBJECTIVES IN THE INTERNATIONAL ARENA. THEIR INTERESTS ARE SPREAD AROUND THE GLOBE, SO NEITHER COUNTRY CAN AFFORD TO THINK IN PURELY REGIONAL TERMS. BECAUSE THEY DEPEND HEAVILY ON TRADE, THEY HAVE AN INTEREST IN OPEN MARKETS; AND BECAUSE THEY HAVE EXTENSIVE FOREIGN INVESTMENTS, POL ITICAL STABILITY AND INTERNATIONAL SECURITY ARE IMPORTANT. THEY ALSO HAVE AN INTEREST IN PROMOT ING HUMAN RIGHTS AND GOOD GOVERNMENT, NOT ONLY BECAUSE THESE ARE MORALLY RIGHT BUT ALSO BECAUSE, IN THE LONG RUN, PEACE AND PROSPERITY ARE BEST ASSURED BY FREE, DEMOCRATIC SOCIETIES.

09614 WHITEHEAD, L. LES TO \&LIBERAL DEMOCRACY': A LATIN AMERICAH THE ALTERNA

POL ITICAL STUDIES, 40 (1992), 146-159.
ALTHOUGH SOME CONVENTIONAL LIBERAL DEMOCRATIC REGIMES ARE LIKELY TO BECOME CONSOLIDATED IN LATIN AMERICA, THE ARE LIKELY TO BECOME CONSOLIDATED IN LATIN AMERICA, THE DOMINANT PATTERN IS BETTER UNDERSTOOOD AS THEMOCRACY BY DEFAULT', AND IN A FEW CASES LITTLE MORE THAN FACADE DEMOCRACY IS TO BE EXPECTED. THIS PAPER REVIEWS THE MA POR FACTORS ACCOUNTING FOR THE FRAGILITY, INSTABILITY AND INEFFECTIVENESS OF MANY OF THESE NEN REGIMES. ALTHOUGH CURRENT FISCAL CRISES LEND SOME PLAUSIBIL PAPER ARGUES THAT LIBERAL ANALYSES OF DEMOCRATIZATION, THE PAPER ARGUES TO IN THE LONGER RUN CONSOLIDTED DEMOCRACIES HILL TEND TO

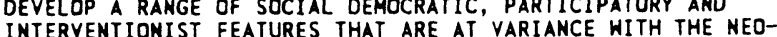
INTERVENTIONIST FEATURES THAT ARE AT VARIANCE WITH THE NEOLIBERAL MODEL. LATIN AMERICAN NATION-STATES POSSESS THE
POTENTIAL FOR SUBSEQUENT EXTENSION AND ENTRENCHMENT.

09615 WHITELEY, P.; SEYD, P.

THE LABOUR YOTE AND LOCAL ACTIVISM: THE IMPACT OF LOCAL CONSTITUENCY CAMPAIGMS

PARLIAMENTARY AFFAIRS, 45(4) (OCT 92), 582-595.

THE MAIM THEME OF THIS ARTICLE IS THAT ONE OF THE KEY REASONS WHY LABOUR LOST THE BRITISH ELECTION IN 1992 WAS 
BECAUSE THE MODERNIZATION STRATEGY HAS INCOMPLETE. IT NEGLECTED THE GRASS-ROOTS PARTY. THE ARTICLE REVIEWS LABOUR'S MODERNIZATION STRATEGY AND EXAMINES THE EVIDENCE THAT LOCAL CAMPAIGNING BY CONSTITUENCY LABOUR PARTIES PLAYED A SIGNIFICANT ROLE IN EXPLAINING THE ELECTORAL SUPP THE PARTY IN 1992. IT EXAMINES THE FUTURE OF THE MODERNI ZATION STRATEGY AND DISCUSSES CHANGES THE PARTY SHOULD MAKE

09616 WHITEMAN, $K$

"POOR MAN'S WAR" UNVEILED

WEST AFRICA, 75(3909) (AUG 92), 1381

MANY COMPARISONS HAVE BEEN DRAWN BETWEEN THO UNFOLDING TRAGEDIES IN ORDER TO STRESS THE ONE MAIM DISSIMILARITY THAT DISTINGUISHED ONE FROM THE OTHER: THE HORLD CARED ABOUT BOSNIA, BT SOMALIA? THIS EDITORIAL EXPLORES WHY THE SOMALIAN SITUATION WHICH HAS BEEN LONG DEVELOPING AND WHICH HAS RESULTED IN WHAT HAS BEEN DESCRIBED AS THE WORST HUMNAN TRAGEDY IN THE WORLD COULD HAVE BEEN HIDDEN FROM TRAGEDY IN THE WORLD COULD HAVE BEEN HIDDEN FROM INTERNATIONAL MEDIA ATTENTION FOR SO LONG. IT SUGGESTS THAT THE NUMBER OF ANSWERS WHICH HAVE BEEN OFFERED ALL SAY MORE ABOUT THE STATUS OF AFRICA GENERALLY THAN ABOUT

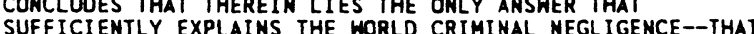
THE REST OF THE WORLD CANNOT BE BLAMED WHEN AFRICANS DEPRIORITISE THEIR OWN PROBLEMS.

09617 WHITEMAN, $K$.

A CONGOLESE COMBACK

WEST AFRICA, 75(3885) (MAR 92), 369

PASCAL LISSOUBA, ONCE PRESIDENT MASSEMBA-DEBAT'S RIGHTHAND MAN, haS RESUMED A ROUGH AND TUMBLE POL ITICAL CAREER WHICH HAS TAKEN HIM BOTH TO THE GIDDY HEIGHTS OF THE PREMIERSHIP AND TO THE DEPTHS OF PUBLIC VILIFICATION AND IMPRI SONMENT. THIS ARTICLE GIVES A BRIEF HISTORY OF THIS MAN AND SUGGESTS THAT HIS COMEBACK IS TIMELY. HE IS A FIRM ADVOCATE OF THE MARKET ECONOMY AND IS HELL AHARE THAT CONGO'S ECONOMIC RECOVERY HILL DEPEND ON THE GOODWLL OF THE DONOR COMMUNITY.

09618 WHITEMAN, $K$.

A NEW CONSTITUTIONAL ORDER?

WEST AFRICA, 75(3887) (MAR 92$), 452$

THIS ARTICLE CONSISTS OF EXCERPTS FROM JERRY RAHLINGS' INDEPENDENCE DAY SPEECH. HE STATES THAT THIS YEAR WILL SEE THE CULUMNATION OF A PROCESS TOHARDS ESTABLISHING A NEN CONSTITUTIONAL ORDER. HE ALSO SAID THAT HE HAD BEEN ASSURED CONSTI IUTIONAL ORDER. HE ALSO SAID THAT HE HAD BEEN BY THE CONSULTATIVE ASSEMBLY THAT ITS TASK WOULD BE ACCOMPLISHED BY THE END OF THE MONTH. THE REFERENDUM WAS TO THEY HEL ON THE 28TH OF APRIL 1992. HE AL SO SUGGESTED THAT IMPORTANT TASK, AND AS REFEREES THEY SHOULD GIVE THEM ALL THE WHISTLES THAT THEY WOULD NEED.

09619 WHITEMAN, K.

DID EYADEMA DO IT?

WEST AFRICA, (3896) (MAY 92), 837

THE AUTHOR REVIEWS THE EVIDENCE SURROUNDING THE 1963 ASSASSINATION OF SYLVANUS EPIPHANIO OLYMPIO, TOGO'S FIRST PRESIDENT. SEVERAL HISTORIES OF TOGO IDENTIFY SERGEANT-CHIEF ETIENNE EYADEMA AS THE ASSASSIN, BUT SOME INVESTIGATORS STILL HAVE QUESTIONS.

09620 WHI TEMAN, $K$.

DREAMS AMD DANGERS

WEST AFRICA, (3907) (AUG 92), 1312

THE 15TH' ECOWAS SUMMIT OPENED ON JULY 27, 1992, WITH

UNACCUSTOMED OPTIMISM. ABDOU DIOUF, THE OUTGOING ECONAS CHAIRMAN, REVIEWED THE PROGRESS MADE IN SEVERAL AREAS, INCLUDING THE LIBERALIZATION OF TRADE AND THE PROPOSED ECOWAS PARLIAMENT. CAPTAIN YALENTIME STRASSER OF SIERRA LEONE SPOKE OF HOW THE CONFLICT IN LIBERIA HAD SPILLED OVER INTO HIS COUNTRY.

09621 WHITEMAN, $K$

IN SOMALIA--A DIPLOMATIC DEBACLE?

NEST AFRICA, 75(3887) (MAR 92), 45

THE SITUATION IN SOMALIA IS AN EXAMPLE OF HOW A CRISIS IN DIPLOMACY CAN RAPIDLY LEAD INTO ARMED CONFLICT, WITH DEVASTATING CONSEQUENCES FOR AN ENTIRE COUNTRY OR' REGION ITALY, THE FORMER COLONIAL POWER IN SOMALIA TRIED VARIDUS ITALY, THE FORMER COLONIAL POWER IN SOMALIA TRIED VARIDUS
DIPLOMATIC MANOUVERS IN THE LATE 1980 S TO AVERT CATASTROPHE. DIPLOMATIC MANOUVERS IN THE LATE 1980S TO AVERT CATASTROPHE IN A PERFECT WORLD THE THO MAIN CONTESTANTS FOR POWER IN GOGADISHU SHOULD BE THE CLOSEST OF ALLIES IN A POST-BARRE REST OF THE WORLD DOCSN'T SEEM TO WANT TO KNOW WHAT IS GOING REST

09622 WHITEMAN, $K$

IT HAS NOT BEEN EASY

HEST AFRICA, (3910) (AUG 92), 1430-1431

IN LESS THAN THO YEARS, MALI HAS ADOPTED NEH DEMOCRATIC INSTITUTIONS IN A PEACEFUL TRANSITION PROCESS. THE COUNTRY
HAS HELD AN ALMOST EXEMPLARY NATIONAL CONFERENCE, A

LEGISLATIVE, AND PRESIDENTIAL ELECTIONS WITHOUT VIOLENCE.

09623 WHITEMAN, K.

OPTIMISM AGAINST ODD

WEST AFRICA, (3908) (AUG 92), 1338

THE 15TH SUMMIT OF THE ECONOMIC COMMUNITY OF WEST

AFRICAN STATES (ECOWAS) IN JULY 1992 WAS MARKED BY AN

ATMOSPHERE OF OPTIMISM. THE ORGANIZATION SEEMS TO HAVE

REACHED A TURNING POINT, WHERE IT MUST EITHER MOVE ON

IMPORTANT ISSUES OR CEASE TO BE A VIABLE REGIONAL GROUPING.

09624 WHITEMAN, $K$.

PARTIES FEEL THEIR MUSCLES

WEST AFRICA, (3899) (JUN 92), 950-951.

REPRESENTATIVES FROM NEARIY 90 POLITICAL PARTIES

ATTENDED AN UNPRECEDENTED CONFERENCE ON DEMOCRACY AND

TRANSITION IN AFRICA IN SENEGAL IN MID-1992. BOTH RULING AND

OPPOSITION PARTIES ATTENDED THE HISTORIC GATHERING.

09625 WHITEMAN, K.

ROLE FOR THE CHAIR

WEST AFRICA, 75(3909) (AUG 92), 1394-1395.

THE CHAIRMANSHIP OF ECOWAS IS NOW AN IMPORTANT POLITICAL INSTITUION AND AS IT CONSOLIDATES AFTER THE NEH TREATY, IT WILL BECOME MORE SO. THE CHAIR HAD BEEN THRUST ON A SOMEWHAT UNHILLING MAJOR-GENERAL BUHARIIN 1985. THIS REPORT EXPLORES THE HISTORY OF THE CHAIR AND OF THE MEN WHO SERVED IN IT.

THE NIGERIA FACTOR IS ALSO EXPLORED.

09626 WHITEMAN, $K$

SALIM ON SECURITY

WEST AFRICA, (3912) (SEP 92), 1524-1525

SALIM SALIM HAS SERVED AS SECRETARY GENERAL OF THE OAU

SINCE 1989. IN THIS ARTICLE, THE AUTHOR EXPLORES SOME OF

SALIM'S STATEMENTS REGARDING AFRICAN SECURITY AND OAU

09627 WHITEMAN, $K$.

SOUTH AFRICA: READY FOR REFERENDUM

HEST AFRICA, 75(3885) (MAR 92), 386.

MARCH 17, 1992 WAS NAMED AS THE DATE ON WHICH WHITE

VOTERS WOULD DPPROVE OR REJECT THE REFORMS INTRODUCED BY

PRESIDENT DE KLERK OVER THE PAST TWO YEARS AND HIS

GOVERMMENT'S CONTINUING INVOL VEMENT IN NEGOTIATIONS LEADING

TO A NEH CONSTITUTION AND A TRANSITIOMAL GOVERMMENT.

PRESIDENT DE KLERK HAS PRDMISED TO CALL AN ELECTION SHOULD

PRESIDENT DE KLERK HAS PRDMISED TO CALL AN ELECTION SHOULD

HE LOSE THE REFERENDUM. VOTERS HILL VOTE ON THE FOLLOHIM

QUESTIONS: "DO YOU SUPPORT CONTINUATION OF THE REFORM

AND WHICH IS AIMED AT A NEW CONSTITUTION THROUGH

AND WHICH IS AIH

09628 WHITEMAN, K

THE DEMOCRACY AXIS

WEST AFRICA, (3898) (JUN 92), 920-921.

IN MAY 1992, TOP OFFICIALS MET AT THE PAN-AFRICAN

CONFERENCE ON DEMOCRACY AND THE MANAGEMENT OF TRANSITION IN AFRICA TO DISCUSS POLITICAL CHANGE ON THE CONTINENT. THE NEW CLOSENESS BETHEEN THE LEADERS OF SENEGAL AND NIGERIA,

PARTICULARLY SENEGALESE MINISTER OF STATE ABDOULAYE HADE AND NIGERIAN PRESIDENT IBRAHIM BABANGIDA, HAS OBVIOUS AT THIS

MEETING AND OTHER RECENT CONSULTATIONS. BOTH BABANGIDA AND SENEGALESE PRESIDENT DIOUF SPOKE TO THE CONFERENCE ABOUT THE PROSPECTS FOR DEMOCRACY IN AFRICA.

09629 WHITEMAN, $K$.

THE LIBERIAN OUESTION

WEST AFRICA, (3908) (AUG 92), 1338-1339.

AT THE 15TH SUMMIT OF THE ECONOMIC COMMUNITY OF WEST

AFRICAN STATES (ECOWAS), THE MEMBERS SHOWED A NEH POLITICAL

COMMITMENT IN THE RESOLUTION THEY ADOPTED REGARDING LIBERIA.

IF ECOWAS FOLLOWS THROUGH ON THE TERMS OF THE RESOLUTION, IT COULD BREATHE NEW LIFE INTO THE ORGANIZATION.

09630 WITEMAN, K.; AZONGA, T.M.

TOWARDS A NEW SOCIETY

WEST AFRICA, (3905) ( JUL 92), 1202-1203.

JOHN FRU NDI IS CHAIRMAN OF THE SOCIAL DEMOCRATIC FRONT, ONE OF CAMEROON'S LARGEST OPPOSITION PARTIES. IN THIS

INTERVIEH, HE DISCUSSES THE POLICIES OF PRESIDENT PAUL BIYA

AND THE PROSPECTS FOR ELECTIONS IN CAMEROON.

09631 HITEMAN, $K$

WAITING FOR THE WHITES

WEST AFRICA, 75(3885) (MAR 92), 361

SHOULD THE WHITES DELIVER IN SOUTH AFRICA, THE CONVENTION FOR A DEMOCRATIC SOUTH AFRICA WILL RESUME ITS WORK ON THE CONSTRUCTION OF A POST-APARTHEID SOUTH AFRICA ON A NEW, MORE CONFIDENT FOOTING. HOWEVER, SHOULD APPROVAL BE WITHHELD, THE PROSPECTS ARE GHASTLY. THIS EDITORIAL

DESCRIBES THE AFRIKANERS WHO ARE LINED UP AGAINST DE KLERK WHICH REMAIN SOMETHING OF AN UNKNOWN QUANTITY. THO MAIN 
OPPONENTS HAVE THE LOOK OF LOSERS ABOUT THEM BUT BOTH HAVE STRONG CONSTITUENCIES. IT HILL NOT BE A HALKOVER FOR DE KLERK.

09632 WHITING, A.S.

CHINA AND JAPAN: POLITICS YERSUS ECONOMICS

ANMALS OF THE AMERICAN ACADEMY OF POLITICAL AND SOCIAL SCIENCE, 519 ( JAN 92), 39-51.

SINO-JAPANESE RELATIONS SUFFER FROM THE HERITAGE OF SINO-JAPANESE RELATIONS SUFFER FROM THE HERITAGE OF CHINESE BITTERNESS OVER PAST JAPANESE EXPANSIONISM AND AGGRESSION. THIS HAS PLACED A POLITICAL BURDEN ON ECONC COMPLEMENTARITY, WHICH PLACES JAPAN FIRST IN CHINA'S AID AND SECOND IN INVESTMENT IN ADOITION TO THE POL ITICAL AID AND SECOND IN INVESTMENT. IN ADOITION TO THE POLIIIICAL
BURDEN, THE ECONOMIC INTERDEPENDENCE IS HIGHLY ASYMMETRICAL, BECAUSE IT IS FAR MORE VALUABLE FOR CHINA THAN FOR JAPAN. SINCE THE TIANANMEN SQUARE MASSACRE, ECONOMIC PRAGMATISH HAS PREVAILED IN BEIJING AS A RESULT OF TOKYO'S MUTING ITS CRITICISM OF THE EVENT AND MOVING TO LIFT SANCTIONS IMPOSED BY THE WEST. YET CHINESE MEMORY AND SUSPICION REMAIN STRONG, HEIGHTENED BY THE DISPUTE OVER ISLANDS IN THE EAST CHINA SEA.

09633 WHITING, A.S.

CHINA'S AMERICAN DILEMMA

ANNALS OF THE AMERICAN ACADEMY OF POLITICAL AND SOCIAL SCIENCE, 519 (JAN 92), 12-25.

THE TIANANMEN CRISIS OF 1989 HAS STIMULATED THE MOST INTENSE DEBATE OVER CHINESE POLICY TOWARD THE UNITED STATES SINCE THE RAPPROCHEMENT BETWEEN THE TWO COUNTRIES IN THE EARLY 1970'S. CHINESE LEADERS HAVE HAD TO WEIGH THE BENEFITS OF CLOSE ECONOMIC AND CULTURAL TIES WITH AMERICA AGAINST THE DISRUPTIVE IDEAS AND VALUES THAT ACCOMPANY THEM. A SECOND ISSUE HAS BEEN DETERMINING CHINA'S RESPONSE TO THE IMPROVEMENT OF THE U.S. STRATEGIC POSITION DUE TO THE COLLAPSE OF COMMUNISH IN EASTERN EUROPE, THE MODERATION OF SOVIET FOREIGN POLICY, AND THE AMERICAN VICTORY IN THE PERSIAN GULF. IN THE FUTURE, BEIJING MAY ALSO HAVE TO DECIDE HOW TO DEAL WITH GROWING AMERICAN SYMPATHY FOR THE HOW TO DEAL WITH GROWING AMERICAN SYMPATHY FOR THE PRESSURE FOR TAIWANESE INDEPENDENCE. THE EVOLUTION OF CHINESE POLICY TOWARD THE USA SINCE THE TIANANMEN CRISIS CHINESE POLICY TOWARD THE USA SINCE THE TIANANMEN SUGGESTS THAT CHINESE LEADERS STILL WANT A STABLE, WAYS TO MAXIMIZE THEIR DIPLOMATIC LEVERAGE OVER WASHINGTON.

09634 WHITING, V.

THE POLITICAL ECONOMY OF FOREIGN INVESTMENT IN MEXICO JOHN HOPKINS UNIVERSITY PRESS, 1992, 384

THIS BOOK EXAMINES DOMESTIC AND INTERHATIONAL FORCES THAT SHAPE POLITICAL CHOICES MADE BY MEXICO. THE AUTHOR CONTENDS THAT NEITHER DEPENDENCY NOR STATISM IS SUFFICIENT TO EXPLAIN FOREIGN INVESTMENT POLICY IN MEXICO. POLITICAL PREFERENCES AND POL ITICAL CHOICES DO MATTER. BUT DOMESTIC AND INTERNATIONAL STRUCTURAL CONSTRAINTS BOUND THE CHOICES OF POLICYMAKERS. GLOBALIZATION OF CAPITAL AND TECHMOLOGY, FOR EXAMPLE, SHAPES POLICY OPTIONS IN A WAY THAT FAYORS LIBERALIZATION. THE BOOK EXAMIMES MEXICD'S NATIONALIST TRADITION AND THE LIMITS OF ITS FOREIGN INVESTMENT POLICIES. THE JOINT VENTURE POLICY AND THE REGULATORY APPARATUS PUT IN PLACE IN THE 1970 S DID NOT SUCCEED IN REPLACING THE CAPITAL, TECHNOLOGY AND MARKETING CAPABILITIES OF FOREIGN FIRMS. THE BOOK ALSO EXPLAINS HOW INTERNATIONAL INDUSTRIAL STRUCTURE LIMITED NATIONAL POLICY AMD CREATED GREATER OPPORTUMITIES FOR LIBERALIZATION.

09635 WHITLOCK, E.

RUSSIA'S' PROGRESS TOWARD AN OPEN ECONOMY

RFE/RL RESEARCH REPORT, 1(47) (NOV 92), 35-39.

RFE/RL RESEARCH REPORT, 1(47) (NOV 92), 35-39.
ON NOVEMBER 3, 1992 , THE LAH ON CURRENCY REGULATION AND

CURRENCY CONTROL WENT INTO EFFECT IN RUSSIA. IT IS ONE OF

SEVERAL MEASURES TAKEN OVER THE PAST FEW MONTHS TO

SEVERAL MEASURES TAKEN OVER THE PAST FEH MONTHS TO

ENVISAGED IN THE GOVERNMENT'S REFORM PROGRAM RELEASED IN

ENVISAGED IN THE GOVERNMENT'S REFORM PROGRAM RELEASED IN
JUNE. IT MARKS THE LATEST STEP TOWARD AN OPEN RUSSIAN

JUNE. IT MARKS THE LATEST STEP TOWARD AN OPEN RUSSIAN
ECONOMY AND A CONVERTIBLE RUBLE. BUT FURTHER PROGRESS TOWARD

ECONOMY AND A CONVERTIBLE RUBLE. BUT FURTHER PROGRESS TOHAR

REMOVING CONTROLS ON FOREIGN ECONOMIC RELATIONS IS BEING

STABILIZATION.

09636 WHITNEY, D.; WARTELLA, E.

" DF THE "POLITICAL CORRECTNESS" DEBATE

JOURNAL OF COMMUNICATION, 42 (2) (SPR 92), 83-95

THIS ARTICLE MAKES THREE POINTS ABOUT HOW THE NATION'S

NEWS MEDIA HAVE COVERED THE ISSUE OF POLITICAL CORRECTNESS

(PC). FIRST, THERE IS NO REASON TO BELIEVE THAT THIS

COVERAGE WOULD BE FIRMLY ANCHORED IN ANY SOCIAL REALITY.

SECOND, THE WAY NEWS MEDIA HAVE APPROACHED THE ISSUE BOTH

REFLECTS AND REINFORCES A LONGER-TERM SHIFT IN THE WAYS IN

WHICH JOURNALISTS COVER THE UNIVERSITY. THIRD, IF COVERAGE

OF PC HAS TO DATE BEEN MISINFORMED, UNPRODUCTIVE, AND HRONG,

IT CAN BE CHANGED.

09637 WHITT, D.

REFORM AS WELL AS RETRENCHMENT? DEFENSE MANAGEMENT AND THE
COMPARATIVE STRATEGY, $11(2)$ (1992), 115-148.

RADICAL ALTERATION OF THE INTERNATIONAL SECURITY ENVIRONMENT HAS PROMPTED A RESPONSE BY THE UNITED STATES IN TERMS OF REVISION IN AMERICAM STRATGY AS WELL AS PLANS FOR RESTRUCTURING MILITARY FORCES. SIMILARLY RELEVANT IS THE QUESTION OF WHETHER CHANGES IN THE THREAT, POLICY, STRATEGY, FORCES, AND BUDGET REOUIRE EQUALLY DRAMATIC REVISION IN THE' CONDUCT OF DECISION-MAKING FOR DEFENSE. THE OLD AND NEW CONDUCT OF DECISION-MAKING FOR DEFENSE. THE OLD AND NEW
WORLD ORDERS ARE CONTRASTED, FOLLOWED BY A DESCRIPTION OF WORLD ORDERS ARE CONTRASTED, FOLLOWED BY A DESCRIPTION OF
THE OFFICIAL OPTIONS FOR FUTURE FORCE CONFIGURATION, PRIOR THE OFFICIAL OPTIONS FOR FUTURE FORCE CONFIGURATION, PRIOR
TO AN EVALUATION OF THE NECESSITY FOR CHANGE IN THE OVERALL TO AN EVALUATION OF THE NECESSI

09638 WHITWORTH, A.

PUBLIC ENTERPRISE REFORM IN PAPUA NEW GUINEA

WORLD DEVELOPMENT, 20(1) (JAN 92), 69-8).

IN 1983. THE GOVERNMENT OF PAPUA NEH GUINEA INTRODUCED A PACKAGE OF' FINANCIAL AND ECONOMIC POLICIES REGARDING THE MAJOR PUBLIC ENTERPRISES. THE CENTRAL PREMISE OF THE REFORM PACKAGE WAS THAT PUBLIC ENTERPRISES WOULD OPERATE MORE EFFICIENTLY IF REQUIRED TO FUNCTION ALONG ESSENTIALLY COMMERCIAL LINES. FINANCIAL DATA FOR 1980-88 INDICATE THAT THERE HAS BEEN A SIGNIFICANT IMPROVEMENT IN THE SECTOR'S FINANCIAL PERFORMANCE OVER THE PERIOD. HHILE ECONOMIC DATA ARE LESS CLEAR-CUT, THE REFORM PACKAGE APPEARS TO HAVE BEEN REASONABLY SUCCESSFUL.

09639 WHOLEY, J.S.; HATRY, H.P.

THE CASE FOR PERFORMANCE MONITORIMG

PUBLIC ADMINISTRATION REVIEW, 52(6) (NOV 92), 604-610. IS PERFORMANCE MONITORING IN PUBLIC PROGRAMS FEASIBLE AND WORTHWHILE? THE AUTHORS ARGUE THAT IT IS AND SUPPORT THEIR ARGUMENT WITH EXAMPLES FROM NATIONAL, STATE, AND LOCAL GOVERMMENTS. AFTER IDENTIFYING SOME OF THE BARRIERS TO EFFECTIVE PERFORMANCE MONITORING, THEY CALL FOR ACTIONS THAT WOULD INCREASE ITS USE AT ALL LEVELS OF GOVERMMENT.

09640 WIBERG, $H$.

CONVERSION RESEARCH IN ACADEMIC AND POLITICAL PERSPECTIVE PEACE AND THE SCIENCES, 1(1) (1992), 42-51.

CONYERSIDN RESEARCH CAM GENERALIY BE SEEM AS THE STUDY OF TRANSFER OF RESOURCES FROM MILITARY TO CIVILIAN USE. RESEARCH RESULTS ON THE ECONOMIC EFFECTS OF ARMAMENTS ALSO TELL US ABOUT THE ANTICIPATED EFFECTS OF DISARMAMENT. THIS ART ICLE EXAMINES EMPLOYMENT AND STATE INTERVENTIDN, THE

CONVERSION OF MANPOWER, AND LEVELS OF DECISION-MAKERS.

09641 WIBERG, H.; JENSEN, K.

MILITARY DEFENCE IN DENMARK: EXPENDITURES AND CONYERSION PROBLEMS

COOPERATION \& CONFLICT: NORDIC JOURMAL OF INTERNATIONAL POLITICS, 27 (4) (DEC 92), 349-375.

DENMARK'S ARMS EXPENDITURES HAVE QUADRUPLED IN ABSOLUTE TERMS SINCE CIRCA 1950, BUT THE PERCENTAGE OF GNP HAS BEEN REDUCED SLIGHTLY DURIMG THAT PERIOD. IF DENMARK'S MILITARY EXPENDITURES ARE REDUCED, THE CONVERSION PROBLEMS WILL PRIMARILY CONCERN MANPOWER BECAUSE APPROXIMATELY 40,000 PERSONS ARE DIRECTLY EMPLOYED BY THE DEFENSE MINISTRY. A REDUCTION OF SOME THREE PERCENT PER ANNUM COULD BE ABSORBED WITHOUT ANYBODY LOSING HIS JOB, BUT A SLOWER REDUCTION MIGHT BE NECESSARY TO AVOID DEMOGRAPHICAL PROBLEMS IN THE ARMED FORCES. THE CLOSING OF AIR AND NAVAL BASES AND REGIMENTS WOULD CREATE LOCAL PROBLEMS. MOST DEFENSE MATERIEL IS IMPORTED, BUT DOMESTIC ORDERS AND SOME COMPENSATION PURCHASES LINKED TO IMPORT EMPLOY ABOUT 5,000 DANES, AND LOST ORDERS WOULD CREATE CONYERSION PROBLEMS. APPROXIMATELY 5,000 ADDITIONAL DANES PRODUCE GOODS AND SERVICES OTHER THAM 5,000 ADDITIONAL DANES PRODUCE GOODS AND SERVICES OTH
"DEFENSE MATERIEL PROPER" FOR THE DEFENSE MINISTRY.

09642 WICKSTROM, B.A.

PRECEDENCE, PRIVILEGE, PREFERENCES, PLUS PARETO PRINCIPLE: SOME EXAMPLES OF EGALITARIAN ETHICS ON ECONOMIC EFFICIENCY PUBLIC CHOICE, 73(1) (JAN 92), 101-116.

IN IHIS ARTICLE IT IS DEMONSTRATED HOW ECONOMIC THEORY OF JUSTICE AS FAIRNESS, PARETO IMPROVEMENTS ON SITUATIONS OF JUSTICE AS FAIRNESS, PARETO IMPROVEMENTS ON SITUATIONS INVOLVING EQUITY, CAN BE USED TO ANALYZE THE ETHICS CONTE MAKES USE OF THE CONCEPT OF A YEIL OF IGNORANCE TO DEFINE A MAKES USE OF THE CONCEPT OF A VEIL OF IGNORANCE TO DEFINE A STATUS QUD. A PROPERTY RIGHT TO AN ABILITY OR A PRIVILEGE IS ABILITY OR PRIVILEGE. THREE DIFFERENT EXAMPLES ARE ABILITY OR PRIVILEGE. THREE DIFFERENT EXAMPLES ARE TRANSFERABLE ABILITIES, AND PRIVILEGES AS INHERENT RIGHTS.

09643 WIDFELDT, A.

NOTES ON RECENT ELECTIONS--THE SWEDISH PARLIAMENTARY ELECTION OF 1991

ELECTORAL STUDIES, 11(1) (MAR 92), 72-77.

ON THE MORNING FOLLOWING THE ELECTION, HELD ON SUNDAY 15 DECEMBER 1991, THE SWEDISH PEOPLE WOKE UP THINKING THEIR COUNTRY WOULD NEVER BE THE SAME AGAIN. THE RESULT HAS HISTORIC IN SEVERAL WAYS. THE SHIFT IN POWER WAS NOT A NEH 
EXPERIENCE, BUT THE ONCE STABLE SHEDISH PARTY SYSTEM WAS TRANSFORMED. THE SOCIAL DEMOCRATS HAD RECORDED THEIR WORS PERFORMANCE FOR OVER 70 YEARS. TWO NEW PARTIES, THE CHRISTIAN DEMOCRATS AND THE POPULIST NEW DEMOCRACY, HAD ENTERED PARLIAMENT. AT THE SAME TIME THE GREEN PARTY, WHICH HAD MADE AN ELECTORAL BREAKTHROUGH IN 1988, HAD LOST ALL THEIR SEATS.

09644 WIDLANSKI, M. ASSAD CASE

NEW REPUBLIC, 206(5) (FEB 92), LEBANON.

LIKE PANAMANIAN DICTATOR MANUEL NORIEGA, SYRIAN PRESIDENT HAFEZ AL-ASSAD IS A MILITARY COMMANDER WHO HAS TIED HIS GOVERNMENT TO THE LUCRATIVE DRUG TRADE. BUT U.S. PRESIDENT GEORGE BUSH SEEMS TO HAVE NO DESIRE TO CHALLENGE ASSAD--AN ASCETIC, CAREFUL LEADER WHO USES DRUGS AS AN INSTRUMENT OF POLICY TO RAISE MUCH-NEEDED FOREIGN CURRENCY FOR HIS AILING ECONOMY AND TO KEEP THE REINS ON RIVAL MILITIAS IN LEBANON.

09645 WIDLANSKI, M.

ISRAELI ELECTIONS: LEFT FACE?

ISRAELI ELECTIONS : LEFT FACE?

1992 IS A BIG ELECTION YEAR IN MANY WESTERN COUNTRIES BUT NOWHERE ELSE HILL THE UPHEAYAL IN EASTERH EUROPE LEAD TO SUCH DIRECT DOMESTIC CONSEQUENCES AS IN ISRAEL. THE MASSIVE INFLUX OF "SOVIET" JEWS HAS SUDDENLY INCREASED THE ISRAELI BODY POLITIC BY 10 PERCENT, WITH UNPREDICTABLE CONSEQUENCES FOR ISRAELI DEMOCRACY. THE ONLY SURE THING IS THAT IT HIL BE ONE OF THE MEANEST ELECTIONS IN ISRAEL'S HISTORY.

09646 WIDNER, J.

THE RISE OF a PARTY-STATE IN KENYA--FROM "HARAMBEE|" TO "NYAYO|"

UNIVERSITY OF CALIFORNIA PRESS, 1992, 294

ALTHOUGH KENYA IS OFTEN CONSIDERED AN AFRICAN SUCCESS STORY, ITS POLITICAL CLIMATE BECAME INCREASINGLY REPRESSIVE UNDER ITS SECOND PRESIDENT, DANIEL ARAP MOI. THIS BOOK CHARTS THE TRANSFORMATION OF THE KENYA AFRICAN NATIONAL UNION (KANU) FROM A WEAK, LOOSELY ORGANIZED POLITICAL PARTY UNDER JOMO KENYATTA INTO AN ARM OF THE PRESIDENT'S OFFICE, WITH "WATCHDOG" YOUTH WINGS AND STRONG SURVEILLANCE AND CONTROL FUNCTIONS, UNDER MOI. THE AUTHOR SUGGESTS THAT SINGLE-PARTY SYSTEMS HAVE AN INHERENT TENDENCY TO BECOME "PARTY-STATES," OR SINGLE-PARTY REGIMES IN WHICH THE HEAD OF EXTENT OF THESE CHANGES DEPEND ON THE COUNTERVAILING POWER EXTENT OF THESE CHANGES DEPEND ON THE COUNTERVAI II
OF INDEPENDENT INTEREST GROUPS, SUCH AS BUSINESS OF INDEPENDENT INTEREST GROUPS, SUCH AS
ASSOCIATIONS, FARMERS OR PROFESSIONALS.

09647 WIDNER, J.A.

KENYA'S SLOH PROGRESS TONARD MULTIPARTY POLITICS CURRENT HISTORY, 91(565) (MAY 92), 214-218

KENYA JOINED THE RANKS OF SUB-SAHARAN AFRICAN COUNTRIES WITH MULTIPARTY POLITICAL SYSTEMS IN DECEMBER 1991, WHEN PRESIDENT DANIEL ARAP MOI ANMOUNCED THAT THE GOVERHMENT WOULD ALLOW OPPOSITION PARTIES TO ORGANIZE, PROVIDED THEY REGISTERED TO DO SO. BUT MOI STOPPED SHORT OF ANNOUNCING A
TRANSITION TO A FULL-FLEDGED MULTIPARTY SYSTEM OR A DATE FOR TRANSITION TO A FULL-FLEDGED MULTIPARTY SYSTEM OR A DATE FOR
ELECTIONS, AND HOPES THAT HE WOULD ALLOW ELECTIONS OUICKLY ELECTIONS, AND HOPES THAT HE WOULD ALLOW ELECTIONS OUICKLY FADED. NONETHELESS, OBSERVER
KENYA'S POLITICAL SITUATION.

09648 HIELAND, L.

THE LEGACY OF YESTERDAY'S POLICIES PROVIDES BIG PROBLEMS FOR BUSH

GERMAN TRIBUNE, 31(1537) (OCT 92), 5 .

THE US ELECTIONS ON 3 NOVEMBER ARE A REFERENDUM ON 12 YEARS OF REAGONOMICS. PRESIDENT BUSH HELPED SHAPE THIS POLICY FOR EIGHT YEARS AND THEN DETERMINED IT HIMSELF FOR FOUR. IT MAY COST HIM HIS JOB. AT THE END OF AN EXHAUSTING ELECTION YEAR, THE AMERICANS HILL HAVE A GOOD IDEA OF THE PROGRAMS AND PERSONALITIES OF THEIR CANDIDATES. DESPITE BUSH'S FOREIGN POLICY ACHIEVMENTS, WHICH HE FEELS SHOULD BE REWARDED WITH A SECOND TERM, A GREAT DEAL ALSO SPEAKS AGAINST

09649 WIENER, J.M.

OREGON'S PLAN FOR HEALTH CARE RATIONING

BROOKINGS REVIEH, 10(1) (HIN 92), 26-31.

OREGON PLANS TO IMPLEMENT A CONTROVERSIAL NEW HEALTH CARE PROGRAM THAT HILL GUARANTEE CARE TO ALL OREGONIANS BELOW THE POVERTY LINE BUT WILL RATION CARE BY DESIGNATING BELOW THE POVERTY LINE BUT WILL RATION CARE BY DESIGNATING
PRIORITIES AND NOT CDVERIMG SERVICES DEEMED "LESS ESSENTIAL. "BRIORITIES AND NOT COVERING SERVICES DEEMED "LESS ESSENT
"BEFORE THE STATE CAN IMPLEMENT ITS PLAN, IT MUST HAVE A WAIVER OF EXISTING FEDERAL REQUIREMENTS. THIS HAS SHIFTED THE FOCUS OF THE DEBATE TO WASHINGTON. AT THE HEART OF THE DEBATE ARE TWO QUESTIONS: CAN HEALTH CARE COSTS BE CONTROLLED ONLY BY RATIONING OR WITHHOLDING MEDICALLYBENEFICIAL SERVICES? ALTHOUGH OREGON'S EFFORT TO PROVIDE HEALTH CARE TO THE UNINSURED IS COMMENDABLE, IS THE STATE'S PLAN A GOOD ONE?
09650 HIESER, B.U.

CHINA'S COMMUNIST PARTY: A MONUMENTAL SHELL

SWISS REVIEW OF WORLD AFFAIRS, 42 (8) (NOV 92), 20

THE CHINESE COMMUNIST PARTY'S RECENT 14TH PARTY CONGRESS REVEALED THE EMPTINESS AT THE ORGANIZATIONAL CORE. THE LEADERSHIP'S CALLS FOR POLITICAL STABILITY SEEM INCREASINGLY LIKE SELF-DELUSION, SINCE THE ECONOMIC REFORMS HAVE LONG SINCE HOLLOWED OUT THE COMMUNIST PARTY IDEOLOGICALLY AND DESTABILIZED THE BEIJING REGIME. THE EMPTY PARTY SHELL MAY CONTINUE TO SERVE THE LEADERS AS A POWER BASE, BUT IN THE FACE OF ONGOING SOCIAL CHANGE THERE IS REASON TO DOUBT ITS DURABILITY.

09651 WIESER, B.U.

DEALING WITH A JANUS-FACED CHINA

SHISS REVIEH OF WORLD AFFAIRS, 41(10) (JAN 92), 26.
AS THE BEIJING REGIME ARROGANTLY PREDICTED AFTER THE TIANANMEN SOUARE MASSACRE, THE REST OF THE WORLD CANNOT SIMPLY IGNORE CHINA. AFTER A SUITABLE PERIOD DURING WHICH PROFOUND INDIGNATION WAS EXPRESSED AT THE BRUTAL SUPPRESSION OF OPPOSITION FORCES, THE WORLD IS NOW GRADUALLY INCLUDING OF OPPOSITION FORCES, THE WORLD IS NOW GRADUALLY INCLUDING CHINA IN THE COMMUNITY OF NATIONS, WITHOUT REQUIRING ANY
GENUINE POLTICAL CONCESSIONS FROM THE CHINESE LEADERSHIP. GENUINE POLTICAL CONCESSIONS FROM THE CHINESE LEADERSHIP.
MEANWHILE, CHINA IS EXHIBITING TWO FACES WHEN IT COMES TO MEANWHILE, CHI

09652 NIESER, B.U.

GEORGE BUSH, CHINA, AND THE ELECTION

SWISS REVIEH OF WORLD AFFAIRS, $42(7)$ (OCT 92$), 5$.

PRESIDENT GEORGE BUSH HAS ANMOUNCED THE SALE OF 150 F-16 JETS TO TAIWAN, CLAIMING THAT IT WILL HELP MAINTAIN THE MILITARY BALANCE BETWEEN TAIWAN AND MAINLAND CHINA, WHICH
HAS BEEN ENDAMGERED BY BEIJING'S PURCHASE OF RUSSIAN SUCHOI27 JETS. IN REALITY, IT IS BUSH'S RE-ELECTION THAT IS ENDANGERED AND HE IS PROMISING ARMS SALES IN HOPES OF BUYING VOTES.

09653 WIEVIORKA, M.

FRANCE FACED HITH TERORISH

TERRORISM, 14(3) (1991), 157--170.

SINCE THE TERRORISM THAT FRANCE HAS EXPERIENCED DURING THE 1970 S AND ESPECIALLY THE 1980 S DIFFERS RADICALLY FROM THAT OF THE 1950 S OR EARLY 1960S, THIS ARTICLE ONLY REVIEWS THE PAST 15 TO 20 YEARS OF TERRORISM IN FRANCE. FRANCE IS AN INTERESTING LABORATORY FOR STUDYING TERRORISM, OR ANTITERRORISM, NOT BECAUSE EXTREME VIOLENCE HAS BEEN COMMITTED ON A LARGE SCALE AS IN LEBANON, BUT BECAUSE, FACED WITH DIVERSE TERRORIST ACTIONS OVER A SHORT PERIOD, FRANCE HAS WORKED OUT AND CONSIDERABLY MODIFIED A POLICY FOR HAS WORKED OUT AND CONSIDERABLY MODIFIED A POLICY FOR
DEALING WITH TERRORISM. THIS ART ICLE DEALS NOT WITH TERRORISM, BUT THE OFFICIAL RESPONSE

09654 WIGGINS, C. BELL, C. F HAMM, K.

INTEREST GROUP AND PARTY INFLUENCE AGENTS IN THE LEGISLATIVE PROCESS: A COMPARATIVE STATE ANALYSIS THE JOUPNAL OF POLITICS, 54(1) (FEB 92), 82-100.

THE INVOLVEMENT AND SUCCESS OF INTEREST GROUPS IN RELATION TO PARTY-ORIENTED INFLUENCE AGENTS IN THE LEGISLATIVE PUBLIC POLICY-MAKING PROCESS IS EXAMINED. PARTY INFLUENCE AGENTS STUDIED ARE THE GOVERNOR, LEGISLATIVE MAJORITY PARTY LEADERSHIP, AND LEGISLATIVE MINORITY PARTY LEADERSHIP. DATA EMPLOYED ARE INTEREST GROUP, GUBERNATORIAL, AND PARTY LEADERSHIP POSITIONS ON A RANDOM SAMPLE OF BILLS CONSIDERED BY THE LEGISLATURES OF CALIFORNIA, IOWA, AND TEXAS, WITH THE ULTIMATE SUCCESS OF EACH AGENT BASED ON THE LEGISLATURE'S FINAL DISPOSITION OF MEASURES IN WHICH AGENTS WERE INVOLVED AND HELD THE SAME OR CONFLICTING POSITIONS.

THIS STUDY SUGGESTS THAT THE GOVERNOR AND LEGISLATIVE MAJORITY PARTY LEADERSHIP CAN EFFECTIVELY OFFSET THE LOBBYING EFFORTS OF INTEREST GROUPS.

09655 WIGHTMAN, G.

THE COLLAPSE OF COMMUNIST RULE IN CZECHOSLOVAKIA AND THE JUNE 1990 PARL I AMENTARY ELECTIONS

CRITICAL SOCIOLOGY, 17(2) (SUM 90), 94-113.

THIS ARTICLE CHRONICLES CZECHOSLOVAKIA'S "VELVET" REVOLUTION: THE TRANSFORMATION FROM A ONE-PARTY REGIME TO A FREE DEMOCRATIC STATE. IT CONCENTRATES ON THE ELECTIONS OF JUNE 1990 AND OUTLINES THE PROCESS OF ELECTORAL REFORM THAT LED TO THE ELECTIONS; THE ELECTORAL CONTENDERS; THE CAMPAIGN; THE ELECTION RESULTS; AND THEIR IMPLICATIONS FOR THE FUTURE OF CZECHOSLOVAKIA.

09656 WIGHTMAN, G.

THE 1992 PARL IAMENTARY ELECTIONS IN CZECHOSLOVAKIA JOURYAL 2 PARLIAMENTARY ELECTIONS IN CZECHOSLOVAKIA ON JUNE 5 AND 6, 1992, THE CITIZENS OF CZECHOSLOVAKIA WENT TO THE POLLS TO ELECT A NEH FEDERAL ASSEMBLY AND NEH PARLIAMENTS FOR THE THO CONSTITUENT REPUBLICS. THE CIVIC DEMOCRATIC PARTY IN COALITION WITH THE CHRISTIAN DEMOCRATIC PARTY WON A THIRD OF THE CZECH VOTE IN THE FEDERAL ASSEMBLY ELECTIONS AND NEARLY 30 PERCENT IN THE CZECH NATIONAL COUNCIL. IN SLOVAKIA, THE VICTOR WAS THE MOVEMENT FOR A 
DEMOCRATIC SLOVAKIA, LED BY VLADIMIR MECIAR.

09657 WILBER, C.K

BREAD, BUTTER, AND INFRASTRUCTURE

COMMONHEAL, CXIX(17) (OCT 92), 11-16.

THE AUTHOR COMPARES THE VIÉS OF THE TWO 1992

PRESIDENTIAL CANDIDATES, GEORGE BUSH AND BILL CLINTON,

REGARDING THE PROBLEMS FACING THE U.S. ECONOMY AND THE WAYS

TO REMEDY THEM.

09658 HILBER, C.K.

HOW WE LOST OUR SHIRT: THE END OF AMERICAN ECONOMIC HEGEMONY

COMMONWEAL, CXIX(12) (JUN 92), 11-14.
ALTHOUGH MANY FACTORS CONTRIBUTED TO THE PROBLEMS NOW ALTHOUGH MANY FACTORS CONTRIBUTED TO THE PROBLEMS
PLAGUING THE U.S. ECONOMY, DRAMATIC CHANGES IN THE PLAGUING THE U.S. ECONOHY, DRAMATIC CHANGES IN THE
INTERNATIONAL ECONOMY AND THE FAILURE OF U.S. ECONOMIC INTERNATIONAL ECONOMY AND THE FAILURE OF U.S. ECONOMIC
POLICY TO RESPOND ADEQUATELY TO THOSE CHANGES MUST HEAD THE POLICY TO RESPOND ADEQUATELY TO THOSE CHANGES MUST HEAD
LIST. IN THE LAST THO DECADES, THE WORLD HAS CHANGED FUNDAMENTALLY, FROM ONE IN WHICH THE USA HAD THE MOST PRODUCTIVE INDUSTRIAL ECONOMY AND, THEREFORE, THE MOST COMPETITIVE TO ONE WHERE THE USA IS MERELY ONE MODERH INDUSTRIAL POWER AMONG MANY. THE INTERNATIONAL ECONOMY HAS BEEN FOREVER ALTERED FROM A WESTERN SYSTEM CHARACTERIZED BY U.S. HEGEMONY AND INOEPENDENCE TO ONE WHERE THE USA IS
INTERDEPENDENT OR EVEN DEPENDENT UPON OTHER COUNTRIES

09659 WILCOX, C. ; GENEST, M

MEMBER PACS AS STRATEGIC ACTOR

POLITY, XXIII(3) (SPR 91), 461-470.

THE PAST DECADE HAS WITNESSED A GREAT DEAL OF RESEARCH

ON THE ROLE OF POLITICAL ACTION COMMITTEES (PACS) IN FUNDINC CONGRESSIONAL CAMPAIGNS. HOWEYER, LITTLE RESEARCH HAS BEEN DONE ON ONE IMPORTANT SUBSET OF PACS: THOSE SPONSORED BY MEMBERS OF CONGRESS. IN THIS NOTE. THE AUTHORS EXAMINE THE CONTRIBUTION BEHAYIOR OF MEMBER PACS IN LIGHT OF THE GARY JACOBSON AMD SAMUEL KERMEL STRATEGIC ACTOR MODEL THE AUTHORS FIND THAT MEMBER PACS GENERALLY BEHAVE AS STRATEGIC
ACTORS, BUT THEIR CONTRIBUTION STRATEGIES VARY ACROSS PARTIES AND CHAMBERS, REFLECTING THE UNIQUE POLITICAL POSITION AND AGENDA OF PAC SPONSORS.

09660 WILCOX, C. ; CLAUSEN, A.

PROFILING HOUSE MEMBERS: THE POLICY DIMENSIONS APPROACH

CONGRESS AND THE PRESIDENCY

WONGRESS AND THE PRESIDENCY, 19 (1) (SPR 92), 65-74.
WITH DECREASING DEBATE, A UNIDIMENSIONAL APPROACH TO THE STUDY OF ROLL-CALL VOTING IN CONGRESS HAS INCREASINGLY STUDY OF ROLL-CALL VOTING IN CONGRESS HAS INCREASINGLY ALTERNATIVE. THE POI ICY DIMENSION APPROACH, AND SUGGEST THAT SUCH AN APPROACH HAS THE ADVANTAGE OF ALLOWING THE SUCH AN APPROACH HAS THE ADVANTAGE OF ALLO
EXAMINATION OF SETS OF POLICY POSITIONS.

09661 HILCOX, C

PUBLIC ATTITUDES TOWARD CHURCH-STATE ISSUES: ELITE-MASS DIFFERENCES

JOURMAL OF CHURCH \& STATE, 34(2) (SPR 92), 259-277.

THIS ESSAY EXAMINES MASS AND ELITE ATTITUDES TOWARO ABSTRACT PRINCIPLES AND CONCRETE APPLICATIONS IN THE CHURCHSTATE AREA. THO CENTRAL FOCI ARE ADDRESSED: (1) ATTITUDES TOWARD ABSTRACT POSITIONS ON CHURCH-STATE ISSUES AND (2) THE CONNECTION BETHEEN THESE ABSTRACT POSITIONS AND CONCRETE ISSUE STANDS FOR BOTH THE MASS AND ELITES.

\section{WILCOX, C.}

THE CAUSES AMD CONSEQUENCES OF FEMINIST CONSCIOUSNESS AMONG WESTERN EUROPEAN WOMEN

COMPARATIVE POLITICAL STUDIES, 23(4) (JAN 91), 519-545. USING DATA FROM THE 1983 EURO-BAROMETER SURVEY, THIS ARTICLE EXAMINES THE EXTENT DETERMINANTS AND CDNSEOUENCES OF FEMINIST CONSCIOUSNESS AMONG WESTERM EUROPEAN WOMEN. THE RESULTS INDICATE A SURPRISIMG DEGREE OF FEMIMIST CONSCIOUSNESS IN HESTERM EUROPE, HITH MORE THAN A THIRD OF WOMEN CLASSIFIED AS FEMINISTS. THE EXTENT OF FEMINISM VARIES ACROSS COUNTRIES, HITH NEARLY HALF OF WOMEN IN FRANCE AND ITALY BUT ONLY A QUARTER OF WOMEN IN BRITAIN CLASSIFIED AS FEMINISTS. AGE, EDUCATION, RELIGIOSITY, AND IDEOLOGY ARE THE STRONGEST PREDICTORS OF FEMINISM, ALTHOUGH THERE IS MEANINGFUL CROSS-HATIONAL VARIATION IN THE DETERMINANTS OF FEMINISM. FINALLY, FEMINIST CONSCIOUSNESS IS ASSOCIATED WITH MORE LIBERAL POSITIIONS ON MOST POLITICAL ISSUED, MORE LIBERAL POSITIONS ON MOST POLITICAL ISSUED, DISADVANTAGED, AND HITH THE WILLINGNESS TO CONSIDER SUPPORTING A LEFTIST PARTY.

09663 WILD, W.

CORNERSTONES OF GERMAN SPACE STRATEGY

SPACE POLICY, 7(1) (FEB , 1 ) 5-8.

THIS ARTICLE OUTLINES THE EXISTING FOALS OF THE GERMAM SPACE AGENCY (DARA) AND THEIR RELATION TO THE WIDER PROGRAH OF THE EUROPEAN SPACE AGENCY. THE AUTHOR DESCRIBES THE HIERARCHY OF GERMAN ACTIVITIES AND THE FINANCIAL CONSTRAINTS WITHIN WHICH THEY ARE CONDUCTED BEFORE OFFERING A GLIMPSE OF THE REVISED GERMAN SPACE PROGRAM WHICH WILL COME INTO EFFECT FOLLONING REUNIFICATION OF THE COUNTRY. GOALS RANGE FROM
SCIENTIFIC INQUIRY AND ENVIRONMENTAL PROTECTION TO ECONOMIC UTILIZATION OF SPACE AND THE USE OF SPACE FOR ARMS CONTROL VERIFICATION.

09664 WILDAYSKY, A.

CAN NORMS RESCUE SELF-INTEREST OR MACRO EXPLANATION BE JOINED TO MICRO

CRITICAL REVIEW, 5(3) (SUM 92), 301-324.

IN THREE RECENT BOOKS, JON ELSTER CONTINUES THE PROJECT THAT BEGAN WHEN HE SHOWED THAT MARXISM LACKED MICRO

FOUNDATIONS. IN HIS LATEST WORK HE SUPPLEMENTS RATIONAL CHOICE THEORY BY MEANS OF NON-RATIONAL NORMS, BEGGING THE QUESTION OF THE SOURCES AND POSSIBLE VARIATIONS AMONG THESE QUESTION OF THE SOURCES AND POSSIBLE VARIATIONS AMONG THESE GIVEN INDIVIDUAL VALUE-PREFERENCES. THIS MOVE INVITES COMPARISON OF ELSTER'S RESULTS HITH THOSE OFFERED BY CULTURAL THEORY. THESE REFLECTIONS SUGGEST THAT IT IS BETTER NORMS INTO THE RATIONAL-CHOICE MODEL ON AN AD HOC BASIS.

09665 WILDAYSKY, A.

ON BEING A DEPARTMENT CHAIR

PS: POLITICAL SCIENCE AND POLITICS, XXV(1) (MAR 92), 83-89.

THE AUTHOR DECLARES THAT THE ROLE OF THE DEPARTMENT

CHAIR IS TO SERVE "THE DEPARTMENTAL INTEREST." HE DELINEATES SOME OF THE WAYS IN WHICH THE DEPARTMENTAL INTEREST MAY BE MANIFESTED IN ORDINARY ADMINISTRATION, POLITICAL

ADMINISTRATION, AND "SUPER-CRISIS."

09666 WILDAVSKY, A.

POLITICAL IMPLICATIONS OF BUDGET REFORM: A RETROSPECTIVE PUBLIC ADMINISTRATION REVIEW, 52(6) (NOV 92), 594-599. AARON WILDAVSKY WROTE "POLITICAL IMPLICATIONS OF BUDGET REFORM," FIRST PUBLISHED IN 1961, AND "THE POLITICS OF THE BUDGETARY PROCESS," WHICH IS A STANDARD WORK IN THE FIELD. IN THIS ESSAY, WILDAVSKY OFFERS REFLECTIONS ON HIS OWN WORK.

09667 WILDING, P.

THE BRITISH WELFARE STATE: THATCHERISM'S ENDURING LEGACY POLICY AND POLITICS, 20(3) (JUL 92), 201-212.

DURING THE 1980 'S, THE THATCHER ADMINISTRATION ATTEMPTED

TO MAKE MAJOR CHANGES IN SOCIAL POLICIES IN GREAT BRITAIN.

TO MAKE MAJOR CHANGES IN SOCIAL POL ICIES IN GREAT BRITAIN. IN THIS PAPER, THE AUTHOR ENDEAVORS TO FORECAST THE ENDUF
IMPACT OF THATCHERISM ON THE BRITISH WELFARE STATE AND IMPACT OF THATCHERISM ON THE BRI
DELINEATES 10 ENDURING LEGACIES.

09668 WILENTZ, A.

NEW REPUBLIC, 206(10) (MAR 92), 18, 20-21.

THE UNITED STATES' HANDLING OF THE RECENT STREAM OF HAITIAN REFUGEES HAS EXCEEDED EVEN THE USUAL CYNICISM AND LACK OF HUMANITY WITH WHICH THE U.S. GOVERMMENT TREATS THOSE WHO SEEK SAFE HARBOR. THE STATE DEPARTMENT, HHILE REFUSING TO RECOGNIZE THE CURRENT HAITIAN GOVERNMENT, HAS MAINTAINED THAT THE HOMELESS HAITIANS ARE ECONOMIC, NOT POLITICAL, REFUGEES.

09669 WILEY, J

THE ISLAMIC MOVEMENT OF IRAQI SHI'AS

LYNNE RIENNER PUBLISHERS, 1992, 200.

BEGINNING IN THE 1950 S HITH A CLANDESTINE CALL TO ISLAM

AND CONTINUING TODAY WITH A MORE REVOLUTIONARY APPROACH,

IRAQ'S ISLAMIC REFORMERS ARE ALTERING WHAT USED TO BE THE TRADITIONAL SHI'A POSITION OF NONINVOLVEMENT IN POLITICS. THE AUTHOR DETAILS THE CONTEMPORARY ISLAMIC MOVEMENT THAT HAS UNITED IRAQI SHI'AS AND SUNHIS ALIKE AND DESCRIBES THE PHILOSOPHY AIMED LARGELY AT ELIMINATING CORRUPTION AND WESTERN INFLUENCE. IN THE PROCESS SHE SHEDS LIGHT ON THE SOCIAL BASES FOR THE ACTIVISTS' REFORMS, THEIR POLITICAL IDEOLOGY, AND THE STRATEGIES OF THE MOVEMENT.

09670 WILHELM, A.

SINO-KOREAN RELATIONS: THE YEARS AHEAD
KOREAN JOURMAL OF DEFENSE ANALYSIS, IV(1) (SUM 92), 85-104. TO UNDERSTAND CHINESE MOTIVATIONS AND PROJECT THEIR INFLUENCE ON SINO-KOREAN RELATIONS, THIS ARTICLE EXPLAINS THE IMPORTANCE OF DOMESTIC POLITICAL, SECURITY AND SOCIAL PRIORITIES OR COUNTERCURRENTS, AS WELL AS THE IMMPORTANCE CHINA ATTACHES TO KOREA AS A NEIGHBOR. THE ISSUES ON THE AGENDA BETWEEN CHINA AND THE THO KOREAS ARE ESSENTIALLY THE AGENDA BETWEEN CHINA AND THE THO KOREAS ARE ESSENT IALLY
SAME AS THOSE OF CONCERN TO THE WEST. HOWEVER, MAJOR SAME AS THOSE OF CONCERN TO THE WEST. HOWEVER, MAJOR
DIFFERENCES EXIST OVER THE PACE AND METHOD FOR RESOLVING DIFFERENCES EXIST OVER THE PACE AND METHOD FOR RESOLYII DISCUSSED IN DETAIL IN THIS ARTICLE.

09671 HILKERSON, J.

ANALYZING COMMITTEE POWER: A CRITIQUE

AMERICAN JOURNAL OF POLITICAL SCIENCE, 35(3) (AUG 91), 613-623.

IN "THE ANALYSIS OF COMMITTEE POHER: AN APPLICATION TO SENATE VOTING ON THE MINIMUM WAGE," KEITH KREHBIEL AND DOUGLAS RIVERS (1989) OFFER A TECHNIQUE FOR ASSESSING COMMITTEE POWER EMPIRICALLY. THIS PAPER CRITIQUES THEIR APPLICATION OF THAT TECHNIQUE TO THE MINIMUM WAGE CASE. ANY ANALYSIS BASED ON ROLL CALL DATA IS NECESSARILY BASED ON 
ASSUMPTIONS ABOUT BEHAVIOR AND AGENDA FORMATION PROCESSES. THIS CRITIQUE ILLUSTRATES SOME CONSIDERATIONS THAT EFFORTS TO APPLY THE TECHNIQUE OF KREHBIEL AND RIVERS, OR ANY EFFOR
TO DRAW INFERENCES ABOUT PREFERENCES FROM VOTING BEHAVIOR, TO DRAW INFERENCES ABOUT PREFERENCES FROM VOTING BEHAVIOR, MUST TAKE INTO ACCOUNT. UPON A FIRST GLANCE, ALTERNATIVE ASSUMPTIONS ABOUT SENATORS' VOTING BEHAVIOR AND BELIEFS DURING THE MINIMUM WAGE DEBATE SEEM EQUALLY PLAUSIBLE. HOWEVER, THEY ARE SHOWN TO LEAD TO OIFFERENT CONCLUSIONS
ABOUT COMMITTEE POHER. ULTIMATELY, THIS CRITIOUE FINDS THAT ABOUT COMMITTEE POWER. ULTIMATELY, THIS CRITIQUE FINDS
THE CONCLUSIONS OF KREHBIEL AND RIVERS TO BE ROBUST.

09672 HILL, $W$.

FROM AUTHORITARIANISM TO POLITICAL DEMOCRACY IN GRENADA: OUESTIONS FOR U.S. POLICY

STUDIES IN COMPARATIVE INTERNATIONAL DEVELOPMENT, 26(3) (FAL 91), 29-58.

IT WAS PREDICTABLE THAT THE 1990 ELECTIONS IN GRENADA WOULD NOT RETURN EITHER WING OF THE NATIONAL PARTY AND INSTEAD HOULD RESULT IN A COALITION GOVERMMENT LED FY THE NATIONAL DEMOCRATIC CONGRESS. CHANGES FOR REAL POLITICAL DEMOCRACY IN GREMADA ARE IMPROVED BUT HILL NOT BE EASILY REALI IED IN THE FACE OF SEVERE ECONOMIC CRISIS AMD A

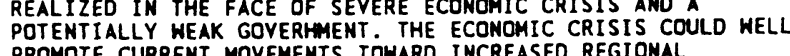
PROMOTE CURRENT MOVEMENTS TOHARD INCREASED REGIONAL INTEGRATION. IT IS IMPORTANT THAT THE 1983-1984 PLEDGE OF
THE UNITED STATES TO PROMOTE DEMOCRACY IN GRENADA BE HONORED.

09673 WILL, W.M.

MATION DIVIDED: THE QUEST FOR CARIBBEAN INTEGRATION

LATIN AMERICAN RESEARCH REVIEW, 26(2) (1991), 3-38.

THE OBJECTIVE OD THIS ARTICLE IS TO EXPLAIN PAST

FAILURES AND PRESENT EFFORTS IN ACHIEVING POLITICAL INTEGRATION IN THE CARIBBEAN REGION. THE FOLLOWIMG PROPOSITIONS ARE USED AS THE BASIS OF THE AUTHOR'S EXPLANATIONS: A) THE FEHER THE MATIONAL UNITS TO BE
INTEGRATED, THE MORE SUCCESSFUL THE INTEGRATION MOVEMENT; B) ENHANCED COMMUNICATION AND POL ITICAL REPRESENTATION AID INTEGRATION; AND C) IF REGIONAL INTEGRATION DOES NOT OCCUR PRIOR TO THE RISE OF INDIVIDUAL NATION-STATE SOVEREIGNTY AND NATIONAL PRIDE. THE NEXT CRITICAL JUNCTURE FOR SUCH DEVELOPMENT TENDS TO OCCUR AFTER THE SYSTEMS HAVE WEAKENED. IT IS SUGGESTED THAT IF THE THIRD GENERALIZATION IS RELEVANT TO THE CARIBBEAN, THEN THE ECONOMIC DECLINE WHICH OCCURRED IN MUCH OF THE REGION DURING THE 1980 S MAY YET PRODUCE POSITIVE REGIOMAL BENEFITS BY INDUCING EFFORTS TOWARD INTEGRATION. IT IS ALSO HYPOTHESIZED THAT THE NATIONS OF THIS REGION HIL REMAIN ONLY PARTIALLY LINKED IN THE NEAR FUTURE AS THE RESULT OF METROPOLITAN INFLUENCES, CULTURAL FUTURE AS THE RESULT OF METROPOLITAN INFLUENCES, CULTURAL PAROCHIALISM, AND THE POLICIES OF SOME INSULAR LEADERS. A AND ON THE POLITICS OF DISINTEGRATION IS PROVIDED.

09674 WILLETS, D.

MODERM CONSERYATISM

POLITICAL OUARTERLY (THE), 63(4) (OCT 93), 413-421.

THE POLITICAL CUTTING EDGE OF CONSERVATISM IS ITS COMMITMENT TO THE FREE MARKET HHICH HAS PROVIDED THE HARD INTELECTUAL CORE OF MODERY CONSERYATISM. IT HAS GIVEN THE INTELECTL CORE OF MODERN COND PURPOSE. AND IT HAS PLAYED A LARGE PART IN THE CONSERVATIVES' RECENT POLITICAL SUCCESS THE SLOGANS OF FREEDOM CHOICE, OPPORTUNITY, AND OHNERSHI MEET THE MDOD OF THE TIMES AND THE MOOD OF THE ELECTORATE. THUS, THIS ARTICLE ARGUES THAT A CRUCIAL TASK FOR THE CONSÉRVATIVE PARTY IS THEREFORE TO ENSURE THAT THE FREEMARKET AGENDA REMAINS AS SUBSTANTIAL AND VIGOROUS IN THE $1990 S$ AS IT WAS DURING THE 1980S. IT OFFERS AN AGENDA FOR THE ' $9 O S$ WHICH IS COMPOSED OF FOUR STRANDS WHICH WOVEN
TOGETHER, MAKE UP THE FABRIC OF A CONSERVATIVE FREE MARKET AGENDA.

09675 WILLEY, $Z$

BEHIND' SCHEDULE AND OVER BUDGET: THE CASE OF MARKETS, WATER, AND ENYIROMMENT

HARVARD JOURNAL OF LAW AND PUBLIC POLICY, 15(2) (SPR 92), 391-429.

HAVE AMERICANS SOMEHOW SUCCEEDED IN MAKING MARKETS AND ENVIRONMENTAL PROTECTION WORK TOGETHER? IN THIS ESSAY, THE AUTHOR EXAMINES THE RELATIONSHIP OF MARKETS, WATER, AMD THE ENVIRONMENT IN ORDER TO ANSWER THIS QUESTION. FIRST, HE OFFERS AN OVERVIEH OF MARKETS FOR ENVIRONMENTAL RESOURCES OR THE LACK THEREDF, AND SURVEYS EXISTING WATER REGULA AND PRICE ADMINISTRATIVE POLICIES. NEXT HE DISCUSSES DIFFERENT ECONOMIC INCENTIVES, DRAWING A SHARP DISTINCTION BETWEEN THOSE WITH PRICES BASED ON ADMINISTRATIVE PROCESSES AND THOSE HITH PRICES BASED ON MARKET PROCESSES. HE EXAMINES MARKETS FOR BOTH HATER QUANTITY AND QUALITY, FOCUSING BARRIERS TO THEIR IMPLEMENTATION. THEN HE SKETCRES AN EXTENSIVE REFORM AGENOA TO REMOVE THESE BARRIERS, ARGUING THAT THE SLATEMATE IN IMPLEMENTING THIS AGENDA IS DUE LARGE PART TO THE POL ITICAL AND LEGAL UNCERTAINTIES CONCERNING OWNERSHIP AND CONTROL OF WATER RESOURCES. SUCH OWNERSHIP UNCERTAINTIES--OFTEN CAST IN TERMS OF CONFLICT BETWEEN "PUBLIC" AND "PRIVATE" VALUES ANO USES--VIOLATE A
CRITICAL PRECONDITION TO THE ORDERLY FUNCTIONING OF MARKETS.
09676 WILLIAMS, D. ASSESSING FUTURE DEMOCRATIC ACCOUNTABILTIY IN NIGERIA: INVESTIGATIVE TRIBUNALS AND NIGERIAN POLITICAL CULTURE SCAMDIMAVIAY JOURMAL OF DEVELOPMENT ALTERMATIVES, 11(3) (SEP 92), 51-66.

PAST PERIODS OF DEMOCRATIC RULE IN NIGERIA HAVE LARGELY FAILED TO PRODUCE PUBLIC OFFICE HOLDERS WHO DEMONSTRATE FAILED TO PRODUCE PUBLIC OFFICE HOLDERS WHO DEMONSTRATE SIGNIFICANT RESPONSIVENESS TO PUBLIC DEMANDS. ON THE OTHER HAND, A COUNTER TRADITION OF INVESTIGATIVE TRIBUNALS HAS THE RULE OF LAH. THE RELATIVE SIGNIFICANCE OF THESE THE RULE OF LAH. THE RELATIVE SIGNIFICANCE OF THESE TRIBUNALS IS EXAMINED IN DETAIL, WITH CONSIDERATION THE IMPACT THEY NILL HOLD FOR THE EMERGENCE OF MORE ACCOUNTABLE DEMOCRACY IN THE NEH THIRD REPUBLIC. FINALLY, I IS HELD THAT ACCOUNTABILITY WILL NEVER FULLY BE ARTICULAIED HELD UP TO SIMILAR SCRUTINY BY THESE TRIBUNALS.

09677 WILLIAMS, D.C.

MEASURING THE IMPACT OF LAND REFORM POLICY IN NIGERIA JOURNAL OF MODERN AFRICAN STUDIES, $30(4)$ (DEC 92 ), $587-608$.
THE IMPERATIVE TO REGULATE AND REDISTRIBUTE LAND HAS BECOME ALMOST UNIVERSAL TO GOVERMMENTS IN THE DEVELOPING WORLD. IN AFRICA, THIS HAS BEEN COUCHED IN LANGUAGE THAT JUSTIFIES INCREASING REGULATORY CONTROL AS THE ONLY VIABLE WAY TO REVOLUTIONIZE THE PRODUCTIVE USE OF LAND FOR NATIONAL DEVELOPMENT. LAND REFORMS OFTEN SIGNIFY ONE ELEMENT OF A LARGER TREND INVOLVING THE EXPANSION OF THE STATE AT THE EXPENSE OF OTHER FORNS OF SOCIETAL AUTHORITY. AS SUCH REPRESENT THE FRONTIER OF A WIDENTNG STRUGGLE OVER THE LAND USE DECREE PROMULGATED IN 1978 BY THE NIGERIAN FEDERAL USE DECREE PROMULGATED IN 1978 BY THE NIGERIAN FEDERAL GOVERMMENT WAS DESIGNED TO POSE A DIRECT CHALLENGE TO ALTERNATIVE SOURCES OF SOCIETAL AUTHORITY BY RELEGATING ALL
PRIVATE LAND TRANSACTIONS TO GOVERNMENTAL AGENCIES. THIS PRIVATE LAND TRANSACTIONS TO GOVERNMENTAL AGENCIES. TH
PAPER ASSESSES THE EXTENT TO WHICH RULES OVER TENURIAL PAPER ASSESSES THE EXTENT TO WHICH RULES OVER TENURIAL PRACTICES ARE BEING DRIVEN BY STATE-IMPOSED REGULATORY CONTROL. THE IMPACT OF THE STATE IS MEASURED IN TERMS OF "REGLEMENTATION" (THE PROGRESSIVE EXPANSION OF RULE-BEARI AUTHORITY BY STATE INSTITUTIONS ) IN LAND ACQUISI
TRANSFER, CONCENTRATION, AND DISPUTE SETTLEMENT.

09678 HILLIAMS, G.

GEORGE MASON AND THE BILLS OF RIGHTS

FREEMAN, 42(2) (FEB 92), 174-177.

THE BILL OF RIGHTS RECEIVED A LOT OF ATTENTION DURING ITS RECENT 200TH ANNIVERSARY, BUT LITTLE RECOGNITION WAS GIVEN TO GEORGE MASON, WHO WAS THE DRIVING FORCE BEHIND THE DOCUMENT. HE IS RELATIVELY UNKNOWN AMONG THE FOUNDERS, BUT HIS INTELLECT WAS RENOWNED AS ONE OF THE FINEST IN THE COLONIES. AT THE CONSTITUTIONAL CONVENTION IN PHILADELPHIA IN 1787 HE WAS ONE OF THE FIVE MOST FREQUENT SPEAKERS, ARGUING PASSIONATELY FOR INDIVIDUAL FREEDOMS AND AGAINST CENTRALIZED GOVERMMENTAL AUTHORITY. THIS ARTICLE OFFERS A AND DEVOTED REPUBLICAN.

09679 WILLIAMS, G.

GREENING THE NEW CANADIAN

STUDIES IN POLITICAL ECONOMY: A SOCIALIST REVIEW, 37(1) (SPR 92 ) , 5-30.

THE $1990 S$ HAS BEEN HERALDED AS THE DECADE OF THE ENVIRONMENT FOR THE ADVANCED CAPITALIST COUNTRIES. THIS ARTICLE SEEKS TO SCOUT THE TERRIAN FOR FUTURE SERIOUS DISCUSSION AND INVESTIGATION OF THE ENVIRONMENT BY THOSE WORKING IN THE POLITICAL ECONOMY TRADITION. IT EXPLORES THE NATIONAL SPECIFICITY OF CANADIAN POPULAR DISCOURSE AS IT THE INADEQUATE TREATMENT OF THE ENVIRONMENT WITHIN THE NEN CANADIAN POLITICAL ECONOMY; AND SOME WAYS IN WHICH THE NEN CANADIAN POL ITICAL ECONOMY CREATIVELY EMPLOY ITS UNIQUE METHOD SO AS TO EXPAMD PRODUCTIVELY THE ACADEMIC AND PUBLIC
CONTEMPORARY ENVIRONMENTAL DEBATES.

09680 WILLIAMS, H.

TABAGO: THE QUEST FOR SELF-DETERMINATION IN THE CARIBBEAM CANADIAN REVIEW OF STUDIES IN NATIONALISM, XIX(1) (1992), $117-127$.

THIS STUDY ANALYZED THE TOBAGONIAN SEPARATIST MOVEMENT IN TRINIDAD AND TOBAGO FROM THE PERSPECTIVE OF THE REGIONAL FACTOR AS A FUNDAMENTAL PRIMORDIAL FEATURE, COMPLEMENTED AND STRENGTHENED BY SECONDARY FACTORS SUCH AS NEGLECT AND EXPLOITATION. IT STUDIES REGIONAL SEPARATISM WHICH EMBRACES FEATURES THAT ARE DISTINGUISHABLE FROM ETHNONATIONALISTBASED SECESSIONIST STRUGGLES. TOBAGONIANS CLAIM THAT THEY ARE UNIOUE BECAUSE THEIR LIFESTYLE REVOLVES AROUND THE VILLAGE WHICH HAS MAINTAINED MOST OF ITS ANCESTRAL FEATURES OF COLLECTIVISM.

09681 WILLIAMS, I

LEBANESE VOTERS TO ELECT FIRST NEW PARLIAMENT SINCE 1972 WASHINGTON REPORT ON MIDOLE EAST AFFAIRS, XI(3) (AUG 92), 40. 
LEBANESE CITIZENS ARE LOOKING FORWARD TO THEIR FIRST PARLIAMENTARY ELECTIONS SINCE 1972, DESPITE CONTROVERSY OVER THE TIMING OF THE ELECTIONS. IT IS REPORTED THAT 128 CANDIDATES, MUSLIMS AND CHRISTIANS, ARE READY TO VIE FOR CANDIDATES, MUSLIMS IN THE PARLIAMENT.

09682 WILLIAMS, I

U.N. SCRUTINIZING LIBYAN SANCTIONS, WESTERN SAHARA, IRAQ-

WASHINGTON REPORT ON MIDOLE EAST AFFAIRS, XI(1) (JUN 92), 39,87

'THE AUTHOR DISCUSSES RECENT UNITED NATIONS' ACTIONS REGARDING SANCTIONS AGAINST LIBYA, THE SITUATION IN HESTERN SAHARA, AND THE REDRAWING OF THE IRAQ-KUWAIT BORDER.

09683 WILLIAMS, J.; MCGINNIS, M.

THE DIMENSION OF SUPERPOWER RIVALRY: A DYNAMIC FACTOR ANALYSIS

JOURNAL OF CONFLICT RESOLUTION, 36(1) (MAR 91), 86-118.

THE SECURITY POLICIES OF THE UNITED STATES AND THE

SOVIET UNION CAN BE INTERPRETED AS MANIFESTATIONS OF

SINGLE RIVALRY SYSTEM. IF EACH STATE'S SECURITY POLICIES ARE

DRIVEN BY THE SAME UNDERLYING FACTORS, THAN ANY EFFORT TO

SEPARATE THE CONTRIBUTIONS OF INTERNAL AND EXTERNAL

DETERMINANTS OF THE ARMS RACE IS ESSENTIALLY MISLEADING. THE

AUTHORS OF THIS PAPER USES DYNAMIC FACTOR ANALYSIS TO

EVALUATE WHETHER AN UNOBSERVABLE DIMENSION OF RIVALRY

EXPLAINS THE DYNAMICS EXHIBITED BY THE MILITARY EXPENDITURES

AND OIPLOMATIC HOSTILITY OF THESE TWO STATES. A ONE-FACTOR

MODEL EXPLAINS MUCH OF THE VARIANCE OF THESE DATA SERIES.

THE RESULTS OF THIS ANALYSIS OUESTION THE YALIDITY OF MANY

STRUCTURAL EQUATION MODELS OF DYADIC INTERACTION.

09684 WILLIAMS, J.8.

CAPITALIST DEVELOPMENT AND HUMAN RIGHTS: SIMGAPORE UNDER LEE KUAN YEH

JOURMAL OF CONTEMPORARY ASIA, 22(3) (1992), 360-372.

THIS ARTICLE CONSIDERS THE RELATIONSHIP BETWEEN FREE

MARKETS AND PROTECTION OF HUMAN RIGHTS IN THE DEVELOPING

WORLD. IT ARGUES THAT MANY THIRD WORLD STATES READILY ACEDE

TO THE IDEA THAT STERN GOVERNMENT IS NECESSARY TO IMPLEMEMT

MARKET-ORIENTED POLICIES. THE ARTICLE EVALUATES THE

THEORETICAL EXPLANATIONS FOR POLITICAL REPRESSION IN THE

CAPITALIST NORLD AND OFFERS A CASE STUDY ANALYSIS OF

SINGAPORE. IT NOTES THAT WHILE SINGAPORE HAS BEEN SUCCESSFUL

IN PROMOTING ECONOMIC GROWTH, THE STATE HAS BECOME

INCREASINGLY AUTHORITARIAN. AL THOUGH THE POL ICIES OF LEADER

LEE KUAN YEW WERE OFTEN FORMULATED ACCORDING TO SINGAPORE'S

UNIQUE CONDITIONS, THE OVERALL EXPERIENCE LENDS CREDENCE TO

THE IDEA THAT POL ITICAL REPRESSION IS PART AND PARCEL OF THE APPROVED MODEL FOR CAPITALIST DEVELOPMENT IN THE LESS DEVELOPED WORLD.

09685 WILLIAMS, M.

REASON AND REALPOLITIK: KANT'S "CRITIQUE OF INTERNATIONAL POLITICS"

CANADIAN JOURNAL OF POLITICAL SCIENCE, 35(1) (MAR 92), 99-120

MOST OF THE SECONDARY LITERATURE DOES MOT HAVE A SUFFICIENT APPRECIATION OF IMMANUEL KANT'S HIDER PHILOSOPHY AND HENCE MISUNDERSTAMDS OR DISTORTS HIS THEORY OF INTERNATIONAL RELATIONS. ONCE THIS BACKGROUND IS MORE FULLY APPRECIATED, KANT'S ANALYSIS BECOMES LARGELY IMMUNE FROM MANY OF THE STANDARD CRITICISMS LEVELLED AGAINST IT. A REINTERPRETATION OF KANT'S CRITIQUE OF INTERNATIONAL POLITICS IS IMPORTANT NOT ONLY FOR THE POSITION WHICH KANT POLITICS IS IMPORTANT NOT ONLY FOR THE POSITION WHICH KANT HAS COME TO OCCUPY IN CONTEMPORARY DEBATES. IT ALSO RAI ARECTICAL ADEQUACY OF THE REALIST THEORY OF INTERNATIONAL

RELATIONS WHICH CONTINUES TO DOMINATE THE DISCIPLINE.

09686 WILLIAMS, M.

RETHINKING THE "LOGIC" OF DETERRENCE

RETHINKING THE "LOGIC" OF DETERRENCE
ALTERNATIVES, 17 (1) (WIN 92), 67-94.

ALW THE CONCEPT OF DETERRENCE HAS BEEN CONSTRUCTED AND DEPLOYED WITHIN THE DOMINANT MODES OF U.S. THINKING ABOUT NUCLEAR STRATEGY IS SHOWN. THIS ARTICLE DEVELOPS AN ANALYSIS OF THE FOUNDATIONS OF THAT THINKING AND EXAMINES THE PRINCIPLES THAT UMDERL IE THE CLAIMS AMD COUNTERCLAIMS ABOUT WHAT DETERRENCE IS. DRAWING UPON THE INSIGHTS OFFERED BY WHAT DETERRENCE IS. DRAWING UPON THE INSIGHTS OF SOME FORMS OF DIALECTICAL PHILOSOPHY, THE AUTHOR DETERRENCE THEORY HAVE RESULTED IN CONSIDERABLE CONFUSION OETERRENCE THEORY HAVE RESU
ABOUT WHAT DETERRENCE IS.

09687 WILLIAMS, M.C.

INDONESIA: HOW LONG SUHARTO?

WORLD TODAY, 48(8-9) (AUG 92), 136-137.

ON JUNE 9,1992 . INDONESIA'S RULING GOLKAR PARTY HAS ONCE AGAIN RETURNED TO POWER WITH TWO-THIRDS OF THE VOTE. THE TWO OPPOSITION PARTIES, THE ISLAMIC DEVELOPMENT UNITY PARTY (PPP) AND THE DEMOCRATIC PARTY (PDI), INCREASED THEIR SHARE OF THE VOTE BUT NOT BY AS MUCH AS SOME OBSERVERS HAD PREDICTED. ALTHOUGH THERE WAS EVIDENCE OF THE DESIRE FOR
CHANGE, ESPECIALLY AMONG THE YOUNGER GENERATION, IT APPEARS THAT SUHARTO WILL NOT RELINOUISH POWER BEFORE THE MID-1990'S.

09688 WILLIAMS, $P$.

CHURCH AND PROTEST IN NICARAGUA AND COSTA RICA CONFLICT, 11(4) (1991), 225-236

BY EXPLORING THE CONTRASTING EXPERIENCES OF THE CATHOLIC CHURCH IN NICARAGUA AND COSTA RICA, THIS ESSAY ATTEMPTS TO SHED LIGHT ON THE QUESTION HOW AND WHY THE CHURCH LEGITIMATES POPULAR PROTEST IN SOME CASES AND NOT IN OTHERS. THE MAIN BOOY OF THE ESSAY DISCUSSES A NUMBER OF FACTORS THAT HELP EXPLAIN THE EXTENT OF CHURCH INVOLVEMENT IN POPULAR PROTEST DURING THE 1970S. THE CONCLUSION ASSESSES THE IMPORTANCE OF THESE FACTORS IN SHAPING THE OUTCOME OF THE CHURCH'S GRASSROOTS INITIATIVES IN SUPPORT OF POLITICAL CHANGE.

09689 WILLIAMS, W

ENDING ETHNIC SOCIALISM

NATIONAL REVIEW, XLIII(4) (MAR 91), 45-48,

APARTHEID, THOUGH REGARDED BY MOST OF THE WOLD AS AN

EXPRESSION OF CAPITALISM, IS IN FACT ETHNIC SOCIALISM. IT IS THE PROTECTION OF ORGANIZED WHITE PRIVILEGES AGAINST THE OPERATION OF FREE-MARKET FORCES. IMPLEMENTING THAT VISION REQUIRED THE USE OF FORCE AGAINST WHITES AS WELL AS BLACKS. TO OVERCOME THIS LEGACY HILL REQUIRE RAPID ECONOMIC GROWTH AT AN ANNUAL RATE OF SIX TO EIGHT PERCENT. FULL PROGRESS AND INTEGRATION WILL LARGELY DEPEND ON HOW WILLING SOUTH AFRICANS ARE TO RESTRICT GOVERHMENT POWER.

09690 WILLIAMSON, J.

ECONOMICS AND GOVERNANCE OF THE NEW DEMOCRACIES

PRESIDENTIAL STUDIES QUARTERLY, XXII (4) (FAL 92), 757-764.

THE AUTHOR ARGUES THAT DEMOCRACY AND A MARKET ECONOMY

ARE COMPLIMENTARY BUT NOT ABSOLUTELY DEPENDENT UPON ONE

ANOTHER. HE FINDS THE BROAD-RANGING ECONOMIC LIBERALIZATION

PROGRAMS IN CZECHOSLOVAKIA, HUNGARY, POLAND, ROMANIA, AND

BULGARIA TO BE "COURAGEOUS AND WELL-CONCEIVED." HE SAY

THE CHALLENGE TO DEMOCRATIC POLITICAL
COUNTRIES IS "TO STAY THE COURSE."

09691 WILPERT, $C$

MIGRATION AND ETHMICITY IN A NON-IMMIGRATION COUNTRY: MIGRATION AND ETHNICITY IN A NOH-

NEW COMMUNITY 18(1) (OCT 91) 49-62.

THE REUNIFICATION OF GERMAMY HAS DRAMATICALIY ALTERED THE POSITION OF SETTLED MINORITIES IN THE FEDERAL REPUBLIC OF GERMANY. ETHNIC GERMANS HAVE BEEN GRANTED RIGHTS DENIED TO MIGRANT WORKERS AND THEIR DESCENDANTS. THERE HAS BEEN A PRONOUNCED GROWTH IN HOSTILITY AND VIOLENCE DIRECTED MAINLY AT TURKS AND YUGOSLAVS, ESPECIALLY BY FORMER CITIZENS OF EAST GERMANY AND OTHER ETHNIC GERMANS. THESE EVENTS HAVE POSED ANEW QUESTIONS OF LEGITIMACY, WHICH THUS FAR HAVE BEEN ANSWERED IN TERMS REMINISCENT OF THE IDEOLOGIES OF WORLD WAR II.

09692 WILSNAK, D

MILITARY INTERVENTION IS NOT A SOLUTIOH

PEACE \& DEMOCRACY NEWS, 11(2) (WIN 92), 17-19.

JUMPING INTO ACTION HITHOUT CAREFUL THOUGHT MAY HAVE THE UNITED STATES ENDORSING ACTIONS THAT IN THE END COST MORE LIVES AND EXPAND THE CONFLICT IN BOSNIA. THE PROBLEMS WITH LIMITED INTERVENTION BEGIN BECAUSE THERE IS RARELY A CLEAR AGREEMENT ON THE GOALS OF SUCH ACTION OR ON WHERE TO DRAH THE LIMIT. THE SEARCH FOR WAYS TO END THE WAR MUST CONTEND WITH THE ARMS TRADE AND THE ECONOMIC FORCES BEHIND IT. NONMILITARY ATERNATIVES ARE PRESENTED IN THIS ARTICLE SINCE MILITARY OPTIONS TEND TO CLOSE OUT OTHER MEANS OF HANDLING MONFLICT.

09693 WILSON, $D$.

BENEFITS AMD BEGGARS

FAR EASTERN ECONOMIC REVIEW, 155(11) (MAR 92), 44 THE VIRTUAL COLLAPSE OR INDEFINITE POSTPONEMENT OF THE URUGUAY ROUND OF THE GATT MAY AROUSE NEW INTEREST IN THE GENERALIZED SYSTEM OF PREFERENCES (GSP). ENTHUSIASM FOR THE GENERALIZED SYSTEM OF PREFERENCES (GSP). ENTHUSIASM FOR THE VITAL REFORM OF THE WORLD TRADE SYSTEM DESIGNED TO HELP DEYELOPING COUMTRIES EARM MORE NEEDED FOREIGN EXCHANGE. THE GSP WAS MEANT TO BRIDGE THE TRADE GAPS OF POORER COUNTRIES, GSP WAS MEANT TO BRIDGE THE TRADE GAPS OF POORER COUNT
BUT WHEN THAT APPEARED TOO AMBITIOUS A GOAL. THE NEW BUT WHEN THAT APPEARED TOO AMBITIOUS A GOAL. THE NEW INDUSTRIES INDUSTRIES, AND STRENGTHEN BUSINESS TIES TO HELP THEIR DEVELOPMENT. BUT THE SCHEME IS CDMPLICATED, HEDGED ABOUT WITH EXCEPIIONS, EXCLUSIONS ANO CUT-OFFS, TOO UNPREDICTABLE FOR INEXPERIENCED EXPORTERS TO COPE WITH, AND CONTROLLED ESSENT IALLY BY IMPORTERS. TRADE LIBERALIZATION, CAREFULLY ACCOMPANIED BY ORDERED ECONOMIC DEREGULATION, IS NOW THE RECIPE FOR PROGRESS. FUNERAL NOTICES FOR THE GSP MAY BE
PREMATURE, BUT ITS FUTURE AS A MAJOR PROP FOR ECONOMIC DEVELOPMENT IS HIGHLY DOUBTFUL.

09694 HILSON, D.

PRESIDENTIAL LIBRARIES: DEVELOPING TO MATURITY 
PRESIDENTIAL STUDIES QUARTERLY, XXI(4) (FAL 91), 771-779. THE PRESIDENTIAL LIBRARY IS A UNIQUELY AMERICAN INSTITUTION, AS UNIQUE AS THE PRESIDENCY ITSELF. THE
FRANKLIN D. ROOSEVELT PRESIDENTIAL LIBRARY--THE FIRST OF THE PRESIDENTIAL LIBRARIES UNDER THE CARE OF THE NATIONAL ARCHIVES--IS NOW MORE THAN FIFTY YEARS OLD AND IS CLEARLY IN A STATE OF MATURITY. THE EIGHT OTHER PRESIDENTIAL LIBRARIES, ESTABLISHED AT VARIOUS TIMES DURING THE PAST FOUR DECADES AND NOW ADMINISTERED BY THE NATIONAL ARCHIVES, ARE THEMSELVES EITHER IN OR APPROACHING THAT STATE OF MATURE DEVELOPMENT. IN THIS ARTICLE, DON HILSON, ARCHIVIST OF THE UNITED STATES, CONSIDERS THE DEVELOPMENT OF THESE RESEARCH AND EDUCA

09695 WILSON, H.

TENGKU MAHMUD MAHYIDOEEN AND THE DILEMHA OF PARTISAN DUALITY

JOURAAL OF SOUTHEAST ASIAN STUDIES, 23(1) (MAR 92), 37-59. DUR NG WORIDEAST ASIAN STUOIES, 23(1) (MAR 92),

DATTANI'S PROUD TRADITION AS AN INDEPENDENT STATE HERE CRYSTALIIIED INTO A POPULAR DESIRE FOR THE SEPARATION OF THE CRYSTALLIZED INTO A POPULAR DESIRE FOR THE SEPARATION OF THE PREDOMINANTLY MALAY SOUTHERN PROVINCES FROM THAILANO. WHEM
THE WAR ENDED, RUMORS ENCOURAGED MALAYS IN THE AREA TO THE WAR ENDED, RUMORS ENCOURAGED MALAYS IN THE AREA TO BELIEVE THAT THE UNITED KINGDOM INTENDED TO ANMEX THIS
REGION TO BRITISH MALAYA AS PART OF A PEACE SETTLEMENT. REGION TO BRITISH MALAYA AS PART OF A PEACE SETTLEMENT.
ALTHOUGH THIS HOPE WAS UNFOUNDED, THE IDEA OF SEPARATION FROM THAILAND CONTINUED TO BE A DREAM FOR A VARIETY OF GROUPS. LEADERSHIP OF THE SEPARATIST MOVEMENT WAS FRAGMENTED, FALLING EITHER INTO AN ISLAMIC FUNDAMENTALIST, MAGICOSPIRITUAL MODE OR INTO A MODERNIZING, ESSENTIALLY SECULAR CATEGORY. BY FAR THE MOST INFLUENTIAL SECULAR LEADER HAS TENGKU MAHHUD MAHYIDOEEN, "THE PRETENDER OF PATTANI." BY THE END OF 1948, THE SEPARATISTS WERE IN DISARRAY AND THEIR GOAL HAD CEASED TO BE CREDIBLE; TO THE EXTENT THAT THIS FATE WAS A REFLECTION OF THE FAILURE OF THEIR LEADERSHIP,

CONSIDERATION OF MAHYIDDEEN'S CHARACTER AND HIS RESPONSE TO THE CHALLENGES HE FACED SHED LIGHT ON THE NATURE OF THE MOVEMENT AND ITS EFFECTIVE CONTAINMENT.

09696 HILSON, J.

TURMOIL IN ASSAM

STUDIES IN CONFLICT AND TERRORISM, 15(4) (1992), 251-266.

THE HUMAN ONSLAUGHT IN ASSAM AND THE FAILURE OF THE

STATE AND CENTRAL GOVERNMENTS TO FORMULATE A SOLUTION HAVE

GIVEN RISE TO AN UPHEAVAL IN THE FORM OF MILITANT ACTIVITIES.

MILITARY OPERATIONS HAVE BEEN CONDUCTED TO ROUT THE

SEPARATIST MAOIST MILITANTS. NEGOTIATIONS FOR A PERMANENT

SOLUTION TO THE TURMOIL ARE CURRENTLY UNDERWAY. THIS ARTICLE

SOLUTION TO THE TURMOIL ARE CURRENTLY UNDERWAY. THIS ARTICLE
TRACES THE ORIGIN, NATURE, AND CONTENT OF THESE DEVELOPMENTS

09697 HILSON, S.

THE MANCHURIAN CRISIS AND MODERATE JAPANESE INTELLECTUALS:

THE JAPAN COUNCIL OF THE INSTITUTE OF PACIFIC RELATIONS

MODERN ASIAN STUDIES, 26(3) (JUL 92), 507-544.

EVER SINCE ITS OCCURRENCE, THE "MANCHURIAN" INCIDENT" OF SEPTEMBER 1931 HAS BEEN INTERPRETED BY BOTH JAPANESE AND NON-JAPANESE WRITERS AS A CRUCIAL EYENT IN MODERN JAPANESE NON-JAPANESE WRITERS, AS A CRUCIAL EVENT IN MODERN JAPANESE IGNORED OR GROSSLY OVERSIMPLIFIED IS THE REACTION BY DIFFERENT GROUPS IN JAPANESE SOCIETY TO THE CONSOLIDATION AND EXTENSION OF JAPANESE CONTROL OF MANCHURIA. THE PURPOSE OF THIS ARTICLE IS TO EXPLORE THE RESPONSES OF ONE GROUP OF MODERATE JAPANESE INTELLECTUALS TO THE MANCHURIAN CRISIS, AND TO SUGGEST SOME EXPLANATIONS FOR THEIR STANCE. THE GROUP WHICH HAS BEEN SELECTED IS THE JAPAN COUNCIL OF THE INSTITUTE OF PACIFIC RELATIONS (IPR), AN INTERNATIONAL ORGANIZATION FORMED IN 1925 TO STUDY PROBLEMS AFFECTING NATIONS IN THE PACIFIC AREA. THE ARTICLE FIRST DESCRIBES THE MANCHURIAN INCIDENT AND SUBSEQUENT EVENTS. IT THEN OFFERS A SHORT SURVEY OF THE RANGE OF NON-GOVERNMENT OPINION IN JAPAN ABOUT THE MANCHURIAN CRISIS.

09698 WILTSHIRE, $K$.

AUSTRALIA'S NEW FEDERALISM: RECIPES FOR MARBLE CAKE PUBLIUS: THE JOURNAL OF FEDERALISH, 22(3) (SUM 92), 165-180

IN JULY 1990, PRIME MINISTER BOB HAHKE ANMOUNCED A PROGRAM TO ACHIEVE CLOSER COOPERATION AMONG AUSTRALIA'S THREE LEVELS OF GOVERMMENT. HIS CONCERN WAS THE DEGREE OF BUREAUCRATIC OVERLAP IN THE AUSTRALIAN FEDERATION AND THE HINDRANCES TO MOBILITY, PORTABILITY, AND UNIFORMITY. HIS HINDRANCES TO MOBILITY, PORTABILITY, AND UNIFORMITY. HIS
ANNOUNCEMENT CAPITALIZED ON DISSATISFACTION HITH AUSTRALIAN ANNOUNCEMENT CAPITALIZED ON DISSATISFACTION HITH AUSTRAL
FEDERALISM, AND ITS TIMING TOOK ADVANTAGE OF A RANGE OF FEDERALISM, AND ITS TIMING TOOK ADVANTAGE OF A RANGE OF
CATALYSTS MAKING THE CURRENT CLIMATE FAVORABLE FOR CHANGE. CATALYSTS MAKING THE CURRENT CLIMATE FAVORABLE FOR CHANGE. THE NEW FEDERALISM UNLEASHED A PROCESS OF REVIEH AND REFORM
ACROSS SOME 40 PROGRAM OR SUB-PROGRAH AREAS OVER AN 18-MONTH ACROSS SOME 40 PROGRAM OR SUB-PROGRAH AREAS OVER AN 18-MOMTH PERIOD; A PRIME OBJECTIVE HAS ROLE CLARIFICATION FOR THE THREE LEVELS OF GOVERMMENT IN SHARED FUNCTIONAL AREAS. THE PROCESS SURVIVED A POLITICAL CHALLENGE THAT TOPPLED THE
PRIME MINISTER, AND CONSTITUTIONAL CHANGE IS NOH PART OF THE AGENDA.
09699 WINANT, H.

RETHIMKING RACE IN BRAZIL

JOURNAL OF LATIN AMERICAN STUDIES, 24(1) (FEB 92), 173-192.

THE MAIN THEORIES OF RACE IN BRAZIL ARE CRITICALLY REVIWED IN THIS ARTICLE IN THE LIGHT OF COMTEMPORARY RACIAL POLITICS. THE ARTICLE FOCUSES LARGELY ON POSTWAR BRAZILIAN RACIAL THEORY, BEGINNING WITH THE PIONEERING UNESCD STUDIES. AS A REINTERPRETATION OF THE EXISTING LITERATURE, THE STAGE IS SET FOR A NEW APPROACH BASED ON RACIAL FORMATION THEORY. THIS THEORY IS OUTLINED AND IT IS SUGGESTED THAT IT OFFERS A MORE ACCURATE VIEW OF THE CHANGING RACIAL ORDER IN CONTEMPORARY BRAZIL.

09700 HINDHOFF-HERITIER, A

CITY OF THE POOR, CITY OF THE RICH: POLITICS AND POLICY IN

NEW YORK CITY
WALTER DE DRUYTER, 1992, 274.

IN ORDER TO ANALYZE THE INTERACTION OF ECONOMIC, SOCIAL AND POLITICAL FORCES IN NEW YORK CITY, THE AUTHOR, IN A FIRST STEP BASIC OUTLINES ASPECTS OF THE ECONOMIC CHANGE AND CONCOMITANT SOCIAL PROBLEMS. IN A SECOND STEP. THE ANALYSIS IS DIRECTED TO THE MOST IMPORTANT POLITICAL INSITUTIONS OF THE CITY, ASKING WHETHER THESE ARE CAPABLE OF OUTBALANCING THE CITY, ASKING WHETHER THESE ARE CAPABLE OF OUTBALANCING PROCESSES OF CHANGE. IN A NEXT STEP. THE ANALYSIS TURNS TO PROCESSES OF CHANGE. IN A NEXT STEP, THE ANALYSIS TURN SOT -GOLAY IN THE CITY. FINALLY, CITY POLICIES ARE

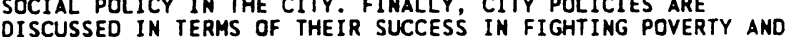
MITIGATING THE SOCIAL POLARIZATION IN THE CITY.

09701 WINEBRENNER, D.

STEEL UNION SCORES A VICTORY

POLITICAL AFFAIRS, 71(4) (MAY 92), 19-25

THE NINETEEN-MONTH STRUGGLE WAGED BY THE UNITED STEELWORKERS OF AMERICA (USWA) AGAINST RAVENSWOOD ALUMINUM COMPANY (RAC) AND THE UNION'S CLEAR-CUT VICTORY IS A TURNING POINT NOT ONLY FOR THE 700,000-MEMBER INDUSTRIAL UNION, BUT FOR WORKERS EVERYWHERE. THE USWA IS A STRONGER UNION AFTER THE "BATTLE OF FORT RAC, " CARRYING OUT A MANDATE FROM THEIR LANDMARK TORONTO CONVENTION. AS THE NINETEEN-MONTH CAMPAIGN TO NOT ONLY SAVE THE UNION BUT MAKE ADVANCES UNFOLDED, MOST USWA OFFICIALS AND LOCAL 5668 MEMBERS AND THEIR FAMILIES DEVELOPED A HIGH-LEVEL OF WORKING-CLASS MILITANCY AND STAMINA AND HERE WILLING TO HOLD OUT ONE DAY LONGER THAN THE COMPANY. MANY CONCLUDED THE CRISIS IN RAVENSHOOD HAS A WORKING CLASS STRUGGLE.

09702 HINETROBE, B.K.

A TAX BY ANY OTHER name: the POLL TAX AND the COMHUNitY CHARGE

PARLIAMENTARY AFFAIRS, 45(3) (JUL 92), 420-427.

ONE POSSIBLE REASON FOR THE DEMISE OF THE POLL TAX IS ITS NAME. BORN AS THE "COMMUNI TY CHARGE" IN 1986, FEH CAN LOCAL GOVERMMENT REVENUE AND REPLACEMENT FOR DOMESTIC RATES, THE COMMUNITY CHARGE CONCEPT WAS ALMOST CERTAINLY DOOMED FROM THE OUTSET. ITS INTRODUCTION AND ADMINISTRATION WERE BADLY MISHANDLED BY THE GOVERNMENT; ITS PRINCIPLES NEVER GAINED POPULAR ACCEPTANCE; THE CAMPAIGN AGAINST IT EMBRACED A BROAD SPECTRUM FROM THE MILITANT TENDENCY TO THE HOME COUNTIES MIDDLE CLASS. BUT WOULD ALL THIS HAVE BEEN EMOU TO ENSURE THE EARLY ABOLI "ION OF THE COMMUNITY CHARGE

09703 WING, K.

SPEECH, PRIVACY, AND THE POWER OF THE PURSE: LESSONS FROM THE ABORTION "GAG RULE" CASE

JOURNAL OF HEALTH POLITICS, POLICY ANO LAN, 17(1) (SPR 92), 163-176.

THE SUPREME COURT HAS REAFFIRMED ITS VIEW THAT THE STATE AND FEDERAL LEGISLATURES HAVE VIRTUALLY UNLIMITED DISCRETION IN LIMITING OR CONDITIONING SOCIAL WELFARE PROGRAMS. THIS ARTICLE SUGGESTS THAT THE FUTURE OF HEALTH POLICY WILL BE DETERMINED LARGELY BY POLITICAL AND CONSTITUTIONAL CONSTRAINTS. WHAT IS FAIR OR DISCRIMINATORY OR EQUITABLE WILL NOT BE DETERMINED BY JUOICIAL NOTIONS OF EQUAL PROTECTION OR DUE PROCESS BUT BY THE COMPLICATED POLITICS OF CONTEMPORARY LEGISLATIVE DECISION MAKING. IT CONCLUDES THAT IF NATIONAL HEALTH INSURANCE WERE TO BE ENACTED TOMORROW, THE ONLY THING THAT IS CLEARLY PREDICTABLE ABOUT SUCH A SCHEME IS THAT IT WOULD NOT ALLOW FUNDING OF ABORTIONS: INDEED, NATIONAL HEALTH INSURANCE COULD HELL MAKE SUCH SERVICES ALMOST IMPOSSIBLE TO OBTAIN.

09704 WING, K.

THE SUPREME COURT'S SPRING TERM: ABORTION, THE RIGHT TO DIE AND THE DECLINE OF PRIVACY RIGHTS

JOURNAL OF HEALTH POLITICS, POLICY AND LAW, 15(4) (NIN 90). $919-928$.

SEVERAL SUPREME COURT DECISIONS IN THE SPRING 1990 TERM WILL HAVE LASTING CONSTITUTIONAL SIGNIFICANCE AS WELL AS IMPORTANT LONG-TERM IMPLICATIONS FOR HEALTH POLICY IN THE
UNITED STATES. IN THE LATEST ROUND OF ABORTION DECISIONS, THE COURT IN HODGSON $V$. MINMESOTA UPHELD A MINNESOTA STATUTE 
THAT REQUIRES AN UNEMANCIPATED MINOR TO GIVE FORTY-EIGHT HOUR NOTICE TO BOTH HER PARENTS PRIOR TO AN ABORTION. IN A COMPANION CASE, OHIO V. AKRON CENTER FOR REPRODUCTIVE HEALTH, THE COURT AFFIRMED THE CONSTITUTIONALITY OF AN OHIO LAH THAT REQUIRES A PHYSICIAN TO PERSONALLY GIVE THENTY-FOUR OUR PARENTAL NOTICE, OR FORTY-EIGHT HOUR "CONSTRUCTIVE NOTICE: BY MAIL, PRIOR TO AN ABORTION FOR AN UNEMANCIPATED OR UNMARRIED MINOR. IN A THIRD CASE, CRUZAN V.MISSOURI DEPARTMENT OF HEALTH, THE COURT UPHELD THE CONSTITUTIONALITY OF A STATE COURT DECISION THAT HAD REFUSED TO ALLOH THE OF A STATE COURT DECISION THAT HAD REFUSED TO ALLOH THE FAMILY OF A WOMAN IN A "PERSISTENT VEGETATIVE STATE" TO CASES HAVE SIGNIFICANT IMPLICATIONS FOR THE RIGHT OF PRIVACY.

09705 WINKEL, J. III; ROEBUCK, D.

TOWARD JUDICAL COMITY: CERTIFICATION IN THE COURTS PUBLIUS: THE JOURNAL OF FEDERALISM, 22(1) (WIN 92), 83-92. CERTIFICATION IS A PROCEDURE WHEREBY FEDERAL COURTS MAY ASK STATE COURTS OF LAST RESORT TO CLARIFY AN AMBIGUOUS PROVISION OF STATE LAW. THE THIRTY-EIGHT STATES THAT AUTHORIZE THE PROCEDURE DIFFER ON WHICH FEDERAL COURTS MAY PARTICIPATE AND WHETHER THE ANSWER TO THE CERTIFICATION QUESTION MUST DETERMINE, OR RESOLVE, THE LAHSUIT. THIS SURVEY RESULTS INDICATE THAT FEDERAL AND STATE JUDGES ALIKE PRAISE CERTIFICATION FOR ITS CONTRIBUTIONS TO INTERSYSTEM HARMONY. IT CONSERVES JUDICIAL RESOURCES, ADVANCES LITIGANT INTERESTS, MINIMIZES INTERPRETIVE MISGUESSES, AND AVOIDS REPETITIVE LITIGATION.

09706 WINKLER, $P$.

A GLIMMER OF HOPE FOR SOMALIA?

SHISS REVIEW OF WORLD AFFAIRS, 42(4) (JUL 92), 24-25. SINCE NOVEMBER 1991, A POWER STRUGGLE HAS BEEN RAGING WITH VARYING INTENSITY IN MOGADISHU, THE SOMALIAN CAPITAL. THROUGH THIS IS THE BEST-KMOWN CONFLICT IN SOMALIA'S COMPLEX CIVIL WAR, IT IS BY NO MEANS THE ONLY ONE. BECAUSE OF NATURE OF SOMALIAN SOCIETY AND THE ONSET OF THE LONGPREDICTED FAMINE, ONLY CAUTIOUS AND HEL
CAMPAIGNS HAVE ANY PROSPECT OF SUCCESS.

09707 HINKLER, P

TROUBLE' IN AND AROUND EGYPT

SWISS REVIEW OF WORLD AFFAIRS, 42(5) (AUG 92), 7-9.

SWISS REVIEW OF WORLD AFFAIRS, 42(5) (AUG 92), 7-9. BETHEEN EGYPT'S CHRISTIAN COPTS AND ISLAMIC FUNDAMENTALISTS. CAIRO'S INTERIOR MINISTER CLAIMED THAT THE MASSACRE OF 16 COPTIC PEASANTS BY MILITANT MUSLIMS NEAR ASSIUT WAS A PERSONAL VENDETTA, BUT HE HAS VEHEMENTLY CONTRADICTED BY THE EGYPTIAN ORGANIZATION FOR HUMAN RIGHTS. IN THE FOREIGN POLICY SPHERE, CAIRO'S PERSISTENT EFFORTS TO MEDIATE BETWEEN LIBYA AND THE UNITED NATIONS MAY BE SEEN, AMONG OTHER THINGS, AS AN ATTEMPT TO OVERRIDE ITS DISAPPOINTMENT WITH THE POSTGULF WAR NEW WORLD ORDER AND TO PREVENT EGYPT'S REGIONAL POSITION FROM DECLINING INTO INSIGNIFICANCE.

09708 WINTER, M.

KOHL SETS HIGH STAKES ON GORBACHEY'S BID

GERMAN TRIBUNE, (1475) (JUL 91), 1-2.

IN THE LAST DAYS BEFORE THE LONDON ECONOMIC SUMMIT GERMAN CHANCELLOR HELMUT KOHL HAS BEEN CANVASSING ECONOMIC AND POLITICAL SUPPORT FOR THE SOVIET UNION. IT HAS KOHL WHO LABORIOUSLY PERSUADED THE OTHER SIX TO INVITE GORBACHEY TO ATTEND THE SUMMIT HHILE SOME HESTERN POWERS HAVE GRUMBLED AT GERMANY'S "GO IT ALONE" TACTICS, MOST AGREE THAT THE SOVIET UNION IS AT A CRUCIAL ECONOMIC CROSSROADS. IF THE WEST REFUSES TO GIVE THE SOVIET UNION A HAND, A PLUNGE INTO ECONOMIC TURMOIL SEEMS UNAVOIDABLE.

09709 HIRLS, D.

CONGRESS AND THE POLITICS OF MILITARY REFORM

ARMED FORCES AND SOCIETY, 17(4) (SUM 91), 487-512.

THIS ESSAY OFFERS A HISTORY AND ANALYSIS OF THE POLITICS OF MILITARY REFORM DURING THE REAGAN PRESIDENCY. UNDER THE LEADERSHIP OF A DIVERSE COALITION WITHIN CONGRESS, MILITARY REFORM BRIEFLY ECLIPSED BOTH THE REAGAN BUILDUP AND NUCLEAR ARMS CONTROL AS THE DOMINANT DEFENSE POLICY AGENDA IN THE MID-1980S. CONGRESSIONAL SPONSORSHIP OF MILITARY REFORM IN THE LAST DECADE WAS A PRODUCT NOT ONLY OF DECENTRALIZATION AND DEMOCRATIZATION OF THE DEFENSE POLICY PROCESS IN
HOUSE AND SENATE, BUT ALSO OF THE DOMESTIC POLITICAL HOUSE AND SENATE, BUT ALSO OF THE DOMESTIC POLIITICAL
CONDITIONS THAT MADE A PARTICULAR MILITARY REFORM AGENDA CONDITIONS THAT MADE A PARTICULAR MILITARY REFORM AGEND ATTRACTIVE TO MANY MEMBERS OF CONGRESS. MILITARY REFORM TO THE DEFENSE POLICY PROCESS IN THE 1980S. AS WELL AS A RARE EXAMPLE OF CONGRESSIONAL INMOVATION IN ANY POLICY ARENA.

09710 WISE, C. ; O'LEARY, R.

IS FEDERALISM DEAD OR ALIVE IN THE SUPREME COURT? IMPLICATIONS FOR PUBLIC ADMINISTRATORS

PUBLIC ADMINISTRATION REVIEH, 52(6) (NOV 92), 559-572.

BASED ON AN ANALYSIS OF SEVERAL CASES DECIDED SINCE THE 1985 GARCIA $V$. SAN ANTONIO METROPOLITAN TRANSIT AUTHORITY ET AL., THE AUTHORS CONCLUDE THAT THE DEATH NOTICES FOR
SPECIAL ATTENTION TO CASES INVOLVING GOVERMMENT LIABILITY, PROGRAM MANAGEMENT, FINANCIAL ADMINISTRATION, AND PERSONNEL POLICIES, THEY FIND THAT COURT DECISIONS HAVE NOT CLEARLY FAVORED EITHER THE NATIONAL OR STATE GOVERNHENTS. MOREOVER, AND THE CONCEPT OF STATE SOVEREIGNTY.

09711 WISEMAN, J.

DEMOCRATIC RESURGENCE IN BLACK AFRICA

CONTEMPORARY REVIEW, 259(1506) (JUL 91), 7-13.

WHILE MUCH ATTENTION HAS BEEN PAID TO THE DEMOCRATIC CHANGES IN EASTERN EUROPE, THE CHANGES IN POLITICAL SYSTEMS OF THE NATIONS OF AFRICA HAVE RECEIVED LITTLE ATTENTION. IN MANY AFRICAN STATES ONE HAS BEEN ABLE TO WITHESS THE POPULAR REJECTION OF THE CLAIMS TO LEGITIMACY OF THE SINGLE-PARTY MOOEL AND THE INSISTENT DEMAND FOR A COMPETITIVE MULTI-PARTY SYSTEN AS THE ONLY VALID ARRANGEMENT FOR ACHIEVING DEMOCRACY.
THIS ARTICLE BRIEFLY EXAMINES THE SOME OF THESE CHANGES AND THIS ARTICLE BRIEFLY EXAMINES THE SOME OF THESE CHANGE
REFORMS INCLUDING THOSE IN: CAPE VERDE, SAO TOME AND PRINCIPE, BENIN, GABON, COTE D'IVOIRE, ZIMBABWE, NAMIBIA, ZAMBIA, ANGOLA, AND MOZAMBIQUE.

09712 WISEMAN, J.A.

EARLY POST-REDEMOCRATIZATION ELECTIONS IN AFRICA ELECTORAL STUDIES, 11(4) (DEC 92), 279-292.

THE RECENT RESURGENCE OF MULTI-PARTY SYSTEMS IN SUBSAHARAN AFRICA HAS CREATED THE CONDITIONS FOR A SIGNIFICANT INCREASE IN THE NUMBER OF COMPETITIVE ELECTIONS INVOLVING CONTENDING POLITICAL PARTIES. ANALYSIS OF SEVEN RECENT COMPETITIVE ELECTIONS INDICATES CONSIDERABLE VARIATION IN THE CONDUCT AND STYLE OF ELECTIONS AND THE NATURE OF COMPETING PARTIES. FOUR OF THE SEVEN ELECTIONS PRODUCED VICTORIES FOR THE OPPOSITION AND PEACEFUL CHANGE OF GOVERNMENT THROUGH THE BALLOT BOX.

09713 WISEMAN, $N$

THE QUESTIONABLE RELEVANCE OF THE CONSTITUTION IN ADVANCING MINORITY CUL TURAL RIGHTS IN MANITOBA CANADIAN JOURNAL OF POLITICAL SCIENCE, XXV(4) (DEC 92), 697-722.

THE AUTHOR ARGUES THAT, TO DATE, CONSTITUTIONAL GUARANTEES FOR FRANCOPHONES AND THE LAWS ABRIDGING OR GUARANTEES FOR FRANCOPHONES AND THE LAWS ABRIDGING OR
EXPANDING THOSE RIGHTS HAVE BEEN LARGELY IRRELEVANT TO THE EXPANDING THOSE RIGHTS HAVE BEEN LARGELY IRRELEVANT TO THE
LINGUISTIC AND POLITICAL WELFARE OF THE FRANCO-MANITOBANS. RINGUISTIC AND POLITICAL WELFARE OF THE FRANCO-MANITOBANS. RATHER THAN STRESSING THE SIGNI FICANCE OF JURISPRUOENCE, THE AUTHOR FOCUSES ON DEMOGRAPHY AND BEHAVIOR. FRANCO-MANITOBANS AS DEFINED BY MOTHER TONGUE, INCREASED IN RELATIVE NUMBERS AFTER THEIR RIGHTS WERE INFRINGED. NOW THAT THEIR RIGHTS HAVE BEEN REINSTATED, FRANCOPHONES ARE DECREASING, ALTHOUGH
THIS PATTERN MIGHT REVERSE ITSELF IN THE FUTURE. MANITOBA'S THIS PATTERN MIGHT REVERSE ITSELL IN THE FUTURE. MANITO
BEHAVIOR HAS BEEN INFLUENCED BY, AND CONTINUES TO BE BEHAVIOR HAS BEEN INFLUENCED BY, ANO CONTINUES TO BE BOUND BY SIMILAR CONSTITUTIONAL OBLIGATIONS.

09714 HISHART, D.

THE BREAKDOWN OF THE JOHNSTON NEGOTIATIONS OVER THE JORDAN WATERS

MIDDLE EASTERN STUDIES, 26(4) (OCT 90), 536-546.

FROM 1953 THROUGH 1956 UNITED STATES AMBASSADOR ERIC JOHNSTON CONDUCTED THE FIRST INTERNATIONAL NEGOT IATIONS INVOLVING THE ARAB STATES AND ISRAEL TOWARD A SETTLEMENT THEIR CONFLICTING CLAIMS TO SURFACE WATER RIGHTS IN THE COMPLETE FRUITION. THIS ARTICLE EXAMINES THE BREAKDOWN OF THESE NEGOTIATIONS WITH THE AID OF RECENTLY DECLASSIFIED STATE DEPARTMENT RECORDS OF THE NEGOTIATIONS. EXAMINATION OF THESE RECORDS SHOWS THAT WHILE ISRAEL HAD REASON TO DESIRE A SETTLEMENT, THERE WAS LITTLE INCENTIVE FOR THE ARAB STATES TO ACCEPT JOHNSTON'S PROPOSALS.

09715 WISHNEVSKY, $J$.

ANTIDEMOCRÁTIC TENDENCIES IN RUSSIAN POLICY-MAKING

RFE/RL RESEARCH REPORT, 1 (45) (NOV 92), 21-25.

BORIS YELTSIN'S GOVERNMENT HAS OFTEN BEEN ACCUSED OF HAVING UNDEMOCRATIC TENDENCIES. INDEED, SOME MEMBERS OF HIS TEAM MAKE NO SECRET OF THEIR DESIRE TO ESTABLISH AN TEAM MAKE NO SECRET OF THEIR DESIRE TO ESTABLISH AN
AUTHORITARIAN SYSTEM IN RUSSIA. THE LEADERSHIP'S LACK OF RESPECT FOR THE LAH AND ITS INABIL ITY TO COMPLETELY SHED ITS
MARXIST-LENINIST PAST. TOGETHER WITH YELTSIN'S TENDENCY TO RULE BY DECREE, SEEM TO BE HINDERING THE PROCESS OF BUILDING RULE BY DECREE, SEEM TO BE HIND
A DEMOCRATIC SOCIETY IN RUSSIA.

09716 HISHNEYSKY, J.

RUSSIA: LIBERAL MEDIA CRITICIZE DEMOCRATS IN POWER RFE/RL RESEARCH REPORT, 1(2) (JAN 92), 6-11.

THE LIBERAL MEDIA WHO HELPED THE DEMOCRATS GAIN POHER IN RUSSIA ARE NOW ATTACKIHG THEIR FORMER HEROES. THEY COMPLAIN THAT THE DEMOCRATIC RUSSIA MOVEMENT WANTS TO ESTABLISH A ONEPARTY SYSTEM, THAT THE RUSSIAN POWER STRUCTURE IS BEGINNING TO RESEMBLE THAT OF THE COMHUNIST PARTY SECRETARIAT, AND THAT THE DEMOCRATS SHOW INSUFFICIENT RESPECT FOR THE LAH
THEY ALSO CLAIM THAT THE PRESS IS LESS FREE UNDER THE REFORMERS THAN IT WAS BEFORE THE COUP. 
09717 HISHNEYSKY 1 .

RUSSIAHS GRIPPED BY "COURT FEYER"

RFE/RL RESEARCH REPORT, 1(10) (MAR 92), 1-6

THREE FATHERS OF DEMOCRATIC REFORM IN THE SOVIET UNION-MIKHAIL GORBACHEV, ALEKSANDR YAKOVLEV, AND EDUARD SHEVARDNADZE--MAY' FACE TRIAL ON CHARGES OF MISUSE OF COMHUNIST PARTY FUNDS. IF THEY SHOULD HAVE TO ANSWER THE CHARGES IN A COURT OF LAW, THE TRIAL IS UNLIKELY TO BE FAIR BY WESTERN STANDARDS. TODAY'S RUSSIAN POLITICIANS SEEM TO BE VERY QUICK TO CALL FOR THEIR OPPONENTS TO BE TRIED. YET HISTORY TEACHES THAT, ONCE A REVOLUTION STARTS TO TURN ON

09718 HISSE, $R$

THE UNCHOSEN

NEW REPUBLIC, 206(24) (JUN 92), 15, 18-19.

FOR THE FIRST TIME SINCE THE SECOND WORLD WAR, ANTISEMITISH HAS RESURFACED AS AN ISSUE IN AMERICAN POLITICS. OTHER AMERICAN MINORITIES MAY BE DISLIKED AND DISCRIMINATED AGAINST MUCH MORE SEVERELY THAN THE JEWS, BUT NONE IS ELEVATED IN THE SAME WAY TO THE LEVEL OF A RESPECTABLE ELEVATED IN THE SAME WAY TO THE LEVEL OF A RESP POLITICAL SCAPEGOAT; AND NONE FACES THE KIND OF INTERNATIONAL OPPROBRIUM THAT ATTACHES TO THE JEHISH STATE. THE CUMULATIVE ASSAULT OF POLITICAL ANTI-SEMITISM FROM RIGHT AND LEFT PUTS ENORMOUS PRESSURE ON THE JEWS, HHO ARE CLEARLY
RELUCTANT TO FACE THE WAR AGAINST THEM, WISHING ONLY THAT IT RELUCTANT TO FACE THE WAR
WOULD STOP AND DISAPPEAR.

09719 HISSE, $R$.

THE 2OTH CENTURY'S MOST SUCCESSFUL IDEOLOGY COMMENTARY, $91(2)$ (FEB 91), 31-35.

AS THE 2OTH CENTURY MEARS ITS END, THE REALIZATION DAWNS THAT ANTI-SEMITISM HAS PROVEN TO BE ITS MOST DURABLE AND SUCCESSFUL IDEOLOGY. THE DISINTEGRATION OF THE SECOND GREAT TOTALITARIAN EMPIRE HAS CONSIGNED COMMUNISM, ALONGSIDE FASCISM, TO THE HISTORICAL DUSTBIN. YET IN THE SHRINKING PANTHEON OF VISIONARY IDEAS THAT AROSE TO EXPLAIN AND TO RECTIFY THE PROBLEMS OF THE 19TH CENTURY, ANTI-SEMITISM MAINTAINS A PROMINENCE. WHAT DEFEATED OR WEAKENED OTHER MAJOR IDEOLOGICAL MOVEMENTS OF THIS CENTURY WAS THE FORCE OF OPPOSITION RANGED AGAINST THEM. BUT THE AGGRESSION OF ANTISEMITISM AGAINST AN ABSUROLY SMALL MINORITY ENSURES THAT IT CANNOT BE COUNTERED BY OPPOSITION IN KIND, AND ITS FOCUS ON A PARTICULAR GROUP--THE JEWS--MAKES IT IRRELEVANT TO THOSE WHO ARE NOT JEHS.

09720 HISTOW, G. : ALLEN, C.; HARDY B.; KMAPP M. FROM PROVIDING TO ENABLING: LOCAL AUTHORITIES AND THE MIXED ECONOMY OF SOCIAL CARE

PUBLIC ADMINISTRATIOH, 7O(1) (SPR 92), 25-46.

GLIC ADMINISTRATION, 70(1) (SPR 92), 25-46. THE SUPPLY OF SOCIAL CARE THROUGH THE SEPARATION OF PURCHASING AND PROVIDING RESPONSIBILITIES, A STUDY OF 24 PURCHASING AND PROVIDING RESPONSIBILITIES. A STUDY OF 24 IMITIAL STEPS TAKEN TO PREPARE FOR THE NEW ENABLING ROLE, INITIAL STEPS TAKEN TO PREPARE FOR THE NEW ENABLING ROLE, INCLUDING THE CREATION OF A MIXED ECONOMY OF CARE. AUTHORITIES INTERPRETED THE ENABLING ROLE IN WAYS SIGNIFICANTLY DIFFERENT FROM THAT OF THE GOVERNMENT. THIS
STUDY RAISES QUESTIONS ABOUT THE EXTENT OF LOCAL DISCRETION STUOY RAISES QUESTIONS ABOUT THE EXTENT OF LOCAL DISCRE IMPLEMENTING AGENCIES MAY DIFFER FROM THOSE OF THE CENTER.

09721 HISTRICH, E.

RESTRUCTURING GOVERNMENT NEH ZEALAND STYLE PUBLIC ADMINISTRATION, 70(1) (SPR 92), 119-154.

THE FOURTH LABOR GOVERMMENT IN NEW ZEALAND HAS CARRIED OUT A RADICAL RESTRUCTURING OF EXECUTIVE GOVERNMENT COMPARABLE TO CORRESPONDING REFORMS IN BRITAIN. THE REFORMS FOLLOW A CONSISTENT BLUEPRINT BASED ON IDEAS OF ECONOMISTS AND PUBLIC CHOICE THEORISTS, ESPECIALLY THOSE RELATING TO AGENCY THEORY AND TRANSACTION COSTS. IMPLEMENTATION HAS ILLUSTRATED THE PROBLEMS OF DEFINING DESIRED OUTPUTS AND OUTCOMES AND IN MAKING THEM USEABLE BY PROFESSIONAL HORKERS AND ELECTED REPRESENTATIVES.

09722 HISTRICH, R.

ONCE AGAIN, ANTI-SEMITISM WITHOUT JEHS

COMMENTARY, 94(2) (AUG 92), 45-49.

IN THE THREE YEARS SINCE THE FALL OF COMMUNISM, THERE HAS BEEN A RESURGENCE OF NATIONALISM AND ANTI-SEMITISM ON THE EUROPEAN CONTINENT, AND PARTICULARLY IN CENTRAL AND
EASTERN EUROPE. THE EXPERIENCE OF COMMUNIST RULE MERELY FROZE RATHER THAN RESOLVED UNDERLYING CONFLICTS AND TENSIONS. IT IS THE LONG-SUPPRESSED NATIONALIST AND POLITICAL TYPES IT IS THE LONG-SUPPRESSED NATIONALIST AND POLITICAL TYPES POST-COMEMITIST WHICH IS IMMEDIATELY SIGNIFICANT IN THE PHREAT BUT IT WOULD BE A BIGGER MISTAKE TO IGNORE THE THREAT, THREAT BUT IT WOULD BE A BIGGER MISTAKE TO IGNORE THE IF ONLY BECAUSE ANT I-SEMITISH IS NOWADAYS MORE OPENLY EXPRESSED AND THEREFORE JEWS
IN THE FORMER SOVIET UNION.

09723 HITTE, E.

BELGIAN FEDERALISM: TOWARDS COMPLEXITY AND ASYMMETRY

WEST EUROPEAN POLITICS, $15(4)$ (OCT 92), 95-117.
FROM THE BEGINNING OF THE THENTIETH CENTURY, TENDENCIES TOHARDS DECENTRALIZATION BEGAN TO TAKE SHAPE IN THE BELGIAN UNITARY STATE. THEY RESULTED IN A FEDERAL CONCEPT IN 1988. THE CONSTITUTIONAL REFORMERS OF 1988 WORKED OUT A STRIKINGLY ORIGINAL CONCEPT. NOT ONLY DO THE CONSTITUENT PARTS DIFFER THOROUGHLY AT THE ECONOMIC, SOCIAL, IDEOLOGICAL AND LINGUISTIC-CULTURAL LEVELS, BUT THERE IS ALSO AN INCREDIBLE DEGREE OF COMPLEXITY AND ASSYMMETRY AMONG THE NEWLY-CREATED INSTI TUTIONS THEMSEL VES, AS WITNESS THE EXTREME CASE OF THE POLITICAL STRUCTURES IN THE BRUSSELS REGION. THIS SUI GENERIS CAN BE UNDERSTOOD ONLY BY LOOKING AT IT AGAINST A BACKGROUND OF THE COMPLEX POLITICAL EVOLUTION OF THE LAST FEW DECADES AND IN PARTICULAR THE EQUALLY COMPLEX PROCESS BY WHICH THE 1988 GOVERNMENT WAS FORMED.

09724 WITTEBOLS, J.H.

MEDIA AND THE INSTITUTIONAL PERSPECTIVE: U.S. AND CANADIAN COVERAGE OF TERRORISM

POLITICAL COMMUNICATION, 9 (4) (1992), 267-278.

THE AUTHOR REPORTS DATA FROM A CONTENT ANALYYSIS OF TELEVISION NEWS COVERAGE OF TERRORIST ACTS AND TESTS A PELPISED TYPOLOGY OF TERRORISH AND MEDIA COVERAGE WITH STORIES FROM NETHORK NEWS IN CANADA AND THE UNITED STATES. STORIES FROM NETWORK NEWS IN CANADA AND THE UNITED STATES. THE TYPOLOGY POSITS THAT MEDIA COVERAGE OF TERRORISH ON THE ACT'S RELATION TO INSTI IUTIONAL POWER BASES. POWER, WHILE INSTITUTIONAL TERROR SEEKS TO MAINTAIN THE POWER, WHILE INSTITUTIONAL TERROR SEEKS TO MAINTAIN THE STATUS QUD AND POWER. TERRORISTS HILL EITHER SEEK OUT OR AVOID MEDIA COVERAGE, DEPENDING ON WHETHER THEY WANT TO CHALLENGE OR REINFORCE INSTITUTIONAL POWER. BECAUSE OF MEDIA'S INTERRELATIONSHIP WITH ECONOMIC AND POLITICAL INSTITUTIONS, COVERAGE OF TERRORISH
OF THESE INSTITUTIONAL PERSPECTIVES.

09725 WITTER, $S$.

VIETNAM I: THE CHALLENGE OF DEVELOPMENT

WORLD TOOAY, 48(11) (NOV 92), 202-204

VIETNAM IS A COUNTRY STRUGGLING TO ACHIEVE ECONOMIC

LIBERALIZATION AND PROSPERITY WITHIN THE FRAMEWORK OF A LONGESTABLISHED CENTRALIST CULTURE. IN THIS ARTICLE, THE AUTHOR DESCRIBES SOME DIFFICULTIES THAT VIETNAM HAS IN DEALING WITH INTERNATIONAL DEVELOPMENT AGENCIES.

09726 WITTKE, T.

EUROPE MOVES TO WEIGH UP THE MAASTRICHT OPTIONS

GERMAN TRIBUNE, 31(1534) (OCT 92), 1.

REPORTS OF FRANCO-GERMAN PLANS TO GO AHEAD ON EUROPEAN

UNION WITHOUT BRITAIN AND OTHERS IF NECESSARY HAVE SET LIGHT

TO A POLITICAL BUSH FIRE. THE VERY IDEA IS TOTALLY OPPOSED

TO A POLITICAL BUSH FIRE. THE VERY IDEA IS TOTALLY OPPOSED

TO THE VIEHS ON EUROPE HELD BY THE FEDERAL GOVERMMENT AND
LEADING GERMAN POLITICAL PARTIES. THIS ARTICLE ARGUES THAT

LEADING GERMAN POLITICAL PARTIES. THIS ARTICLE ARGUES THAT

THE MAASTRICHT TREATY ON EUROPEAN UNION WILL NOT SURVIVE A
SECOND PARLIMENTARY DEFEAT. IT CONCLUDES THAT MEMBERS OF THE

SECDND PARLIMENTARY DEFEAT. IT CDNCLUDES THAT MEMBERS OF THE

EUROPEAN PARLIAMENT NEED CLASSIC PARLIAMENTARY POWERS, AND

CAUSE FAR-REACHING IRRITATION IN LONDON.

09727 WIXMAN, $R$.

MANIPULATING TERRITORY, UNDERMINING RIGHTS

CULTURAL SURVIVAL QUARTERLY, 16(1) (WIN 92), 21-23.

GOVERNMENTS HAVE CREATED A VARIETY OF ETHNIC TERRITORIES -SUCH AS THE AUTONOMOUS REGIONS IN CHINA, ETHNIC STATES IN INDIA, INDEPENDENT HOMELANDS IN SOUTH AFRICA, AND INDIAN RESERVATIONS IN THE UNITED STATES--OSTENSIBLY TO PROTECT ETHNIC RIGHTS. WHILE TERRITORY AND ETHNICITY ARE INTIMATELY BOUND, ALL TOO OFTEN THE MERE EXISTENCE OF AN OFFICIAL POLITICALLY-SANCTIONED ETHNIC TERRITORY FAILS TO ENSURE ETHNIC AND CULTURAL RIGHTS. IN FACT, STATES HAVE OFTEN ESTABLISHED SUCH TERRITORIES SPECIFICALLY TO DENY RECOGNITION OR SUPPORT TO ETHNIC GROUPS.

09728 WOEHLCKE, M.

ENVIRONMENTAL REFUGEES

AUSSEN POLITIK, 43(3) (JUL 92), 287-296.

THE INTERMATIONAL REFUGEE PROBLEM HAS WORSENED DURING RECENT YEARS. PUBLIC INTEREST STILL CONCENTRATES ON POLITICAL REFUGGEES; YET A GROWING NUMBER OF PERSONS ARE INDUCED TO LEAVE THEIR NATIVE COUNTRIES BECAUSE OF MILITARY CONFLICTS AND ECONOMIC WANT. THERE IS STILL LITTLE AWARENESS OF THE FACT THAT SPREADING ECOLOGICAL DAMAGE ALSO LEADS TO MAJOR REFUGEE THE MOVEMENTS.

09729 WOFFORD, H.

THE DEMOCRATIC CHALLENGE

FOREIGN POLICY (86) (SPR 92), 99-113.

SENATOR HARRIS WOFFORD (D-PENNSYL VANIA) OFFERS A DEMENATOR HARRIS WOFFORD (D-PENNSYLVANIA) OFFERS A AMERICAN FOREIGN POI ICY. HE MAINTAINS THAT HISTORIC CHANGES IN THE WORLD, CULMINATING IN THE UNRAVELLING OF THE SOVIET UNION, NOH MAKE IT POSSIBLE FOR MOST OF THE YAST RESOURCES THE UNITED STATES HAS BEEN DEVOTING TO THE MILITARY TO BE ALLOW AMERICANS TO RENEH THE STRENGTH OF THE AMERICAN ECONOMY. AND SUCH RENEWED STRENGTH WILL ENABLE THE UNITED 

STATES TO PLAY A CONSTRUCTIVE AND STILL CRUCIAL ROLE IN AGENDA OF THE DEMOCRATS SHOULD BE TO TURN THESE RELATED POSSIBILITIES INTO REALITY.

09730 WOHLSTETTER, A.

WIDE OPEN SECRET COUP

MATIONAL REVIEW, XLIV (5) (MAR 92), 34-36.

WILL PRESIDENT BUSH OUTLAST SADDAM HUSSEIN? THIS ARTICLE ASKS THIS QUESTION AND STATES THAT ONE YEAR AFTER THE GULF WAR, U.S. POLICY IS BANKRUPT ON ALL FRONTS. IN FACT, THE UNITED STATES' ONLY PLAN TO IMPROVE MATTERS CDULD EASILY MAKE THEM WORSE.

09731 WOKER, $M$

ISRAEL'S TROUBLING HUMAN RIGHTS RECORD

SWISS REVIEW OF WORLD AFFAIRS, 41(12) (MAR 92), 4-5 THE RHETORIC SURROUNDING THE MIDOLE EAST PEACE TALKS HAS HAD LITTLE EFFECT ON THE SITUATION IN THE ISRAELI-OCCUPIED TERRITORIES. A NUMBER OF ORGANIZATIONS, INCLUDING THE INTERNATIONAL COMMITTEE OF THE RED CROSS, HAVE RECENTLY REGISTERED COMPLAINTS ABOUT HUMAN RIGHTS VIOLATIONS IN THE WEST BANK AND GAZA. AMONG THE COMPLAINANTS IS THE ISRAELI HUMAN RIGHTS MONITORING GROUP B'TSELEM, HHICH MAINTAINS A SHARP HATCH ON THE BEHAVIOR OF THE OCCUPATION AUTHORITIES.

09732 WOKER, $M$.

THE STRUGGLE FOR JUDEA AND SAMARIA

SWISS REYIEW OF WORLD AFFAIRS, 41(11) (FEB 92), 23-24. SPOKESMEN FOR THE ISRAELI SETTLEMENT MOVEMENT IN GAZA AND THE HEST BANK ARE VEHEMENTLY OPPOSED TO THE MIDOLE EAST PEACE TALKS. IF THE PALESTINIANS GAIN AUTONOMY, THE SETTLERS PEACE TALKS. IF THE PALESTINIANS GAIN AUTONOMY, THE FONSTRUCTION ACTIVITY, THEY ARE TRYING TO CREATE "FACTS ON THE GROUMD" AND REALIZE THEIR VISION OF A LAND OF ISRAEL THE GROUND" AND REALIZE THEIR VISION OF A LAND OF ISRAEL
STRETCHING FROM THE MEDITERRANEAN TO THE RIVER JORDAN.

09733 HOKER, $M$.

UNCERTAIN FUTURE ON THE GOLAN HEIGHTS

SWISS REVIEW OF WORLD AFFAIRS, 42(1) (APR 92), 9-10.

OCCUPIED BY ISRAEL SINCE 1967, THE GOLAN HEIGHTS ARE THE MAIN BONE OF CONTENTION BETHEEN ISRAEL AND SYRIA IN THE MIDDLE EAST NEGOT IATIONS. THE THINLY-POPULATED REGION BETWEEN LAKE TIBERIAS AND MOUNT HERMON IS OF ENORMOUS STRATEGIC IMPORTANCE TO BOTH COUNTRIES. SINCE THE START OF THE CURRENT PEACE TALKS, BOTH JEHISH AND ARAB INHABITANTS HAVE BEEN INCREASINGLY WORRIED ABOUT THEIR FUTURE.

09734 WOLCHIK, S.L.

THE POLITICS OF EASTERN EUROPE'S MOVE TO THE MARKET CURRENT HISTORY, $91(568$ ) (NOV 92), 390-394.

THE SOMEHHAT OIFFERENT PATHS TO THE MARKET CHOSEN BY POLAND, HUNGARY, AND CZECHOSLOVAKIA REFLECT, IN PART, THEIR DIFFERING ECONOMIC CONDITIONS AND THE HISTORY OF ECONOMIC REFORMS DURING THE COMUUNIST PERIOD AS HELL AS THE BALANCE OF POLITICAL FORCES AMD THE MATURE OF THE COALITIONS THAT EMERGED IMMEDIATELY AFTER THE COMMUMISTS' FALL. THE IMPACT OF ECONOMIC TRAMSFORMATION ON POLITICS HAS BEEN CONDITIONED BY ETHNIC DIFFERENCES AND BY EACH COUNTRY'S EXPERIENCE WITH ECONOMIC REFORM IN THE LAST DECADES OF COMMUNIST RULE. ALL THREE CASES ILLUSTRATE THE DILEMHA THAT ECONOMIC

TRANSFORMATION POSES FOR NEW POLITICAL LEADERS: TRANSFORMING THE ECONOMY IS CRUCIAL IF DEMOCRATIC INSTITUTIONS ARE TO SURVIVE IN THE REGION. BUT THE INEVITABLE SHORT-TERM COSTS OF CHANGE--INFLATION, UNEMPLOYMENT, A DECLINE IN REAL INCOMES, FEWER SOCIAL SERVICES, AND UNCERTAINTY--POSE THREATS TO THE SURVIYAL OF LEADERS ASSOCIATED WITH THE REFORMS AND, IN SOME CASES, TO RECENTLY REESTABLISHED DEMOCRATIC INSTITUTIONS.

09735 WOLF, C.

GETTING TO MARKET

NATIONAL INTEREST, (23) (SPR 91), 43-50,

WHILE THERE IS' GENERAL AGREEMENT ABOUT THE NEED TO TRANSFORM COMMAND ECONOMIES TO MARKET ONES. THERE IS LITTLE TRANSFORM COMMAND ECONOMIES TO MARKET ONES, THERE IS LITTLE
AGREEMENT ON HOW THIS IS TO BE DONE. THIS ARTICLE EXAMIMES AGREEMENT ON HOW THIS IS TO BE DONE. THIS ARTICLE EXAMINES
THIS ISSUE AND VIEHS THE TRANSFORMATION AS A SYSTEMS PROBLEM THIS ISSUE AND VIEHS THE TRANSFORMATION AS A SYSTEMS PROBLE IT OUTLINES SEVERAL COMPONENTS OF THE TRANSFORMATION OF FISCAL REFORM AND BUDGET CONTROL: PRICE AMD WAGE DEREGULATION; PRIVATIZATION, PROPERTY RIGHTS PROTECTION, DEREGULATION; PRIVATIZATION, PROPERTY RIGHTS PROTECTION, BREAKUP OF MONOPOLIES; A SOCIAL SECURITY SYSTEM; AND TRANSFORMATION AND CONSIDERS FUTURE CHALLENGES.

09736 WOLF, N.

FATHER FIGURES

NEW REPUBLIC, 207 (15) (OCT 92), 22, 24-25

THE THO TRULY ENDURING IMAGES OF THE 1992 PRESIDENTIAL CAMPAIGN ARE THE FAMILIES OF BILL CLINTON AND GEORGE BUSH. BY CONTRASTING THE "FAMILY VALUES" OF THE BUSH TRIBE HITH THOSE OF THE CLINTON CLAN. THE REPUBLICANS ARE DELIBERATELY SEEKING TO FRAME THE CAMPAIGN AS A REFERENDUM ON PATRIARCHY,
PITTING THE EQUAL-PARTMERSHIP MARRIAGE AGAINST THE MALEOWNERSHIP MODEL. BUSH IS COURTING A LARGE CONSTITUENCY THAT
SEES CHANGES IN FAMILY PATTERNS AS A WAR AGAINST MEN. HE IS CHAMPIONING THE PATRIARCHICAL-AUTHOR ITARIAN FAMILY, IN WHICH AND ACTIONS OF HIS WIFE AND CHILDREN, RATHER THAN THE FAMILY AND ACTIONS OF HIS WIFE AND CHILDREN, RATHER
AS A DEMOCRACY, WHICH THE CLINTONS REPRESENT.

09737 WOLFE, A.

THE RECENTERING OF AMERICA

CURRENT HISTORY, $91(564)$ (APR 92), 168-172.

CAUGHT BETWEEN EXPECTATIONS FORMED IN AN EARLIER PERIOD AND THE REALITIES OF NEW POLITICAL AND ECONOMIC FORCES, AMERICANS ARE UNSURE HOW TO RESPOND: SOMETIMES THEY GIVE VENT TO POPULIST ANGER; AT OTHER TIMES, RETREAT INTO PRIVATE LIFE; AT OTHERS, VOTE FOR THE MOST CONSERVATIVE CANDIDATES THEY CAN FIND. THEIR CONFUSION IS THE RESULT OF AMERICA'S "DECENTERING;" THE COUNTRY'S INSTITUTIONS AND PRACTICES NO LONGER CORRESPOND TO THE PLEASANT IMAGES OF EARLIER DECADES THAT LINGER IN THE MINDS OF AMERICANS.

09738 WOLFE, C.

ALL TOO POLITICAL

POLITY, XXIIII(2) (WIN 90), 283-290.

THIS ARTICLE CRITIOUES AN EARLIER ARTICLE BY DENHIS GOLDFORD WHICH ATTEMPTS TO PROVE THAT NONINTERPRETIVE JUDICIAL REVIEW IS ACTUAL INTERPRETIVE, AND INDEED A SUPERIOR FORM OF INTERPRETATION. THE AUTHOR DISAGREES WITH GOLDFORD'S CONCLUSION. HE ARGUES THAT THE DOCTRINE OF ORIGINALISM DOES NOT ELIMINATE POLITICAL DELIBERATION. FURTHERMORE, THE NOTION OF NONINTERPRETIVISM IS DANGEROUS IN THAT IT LEADS TO WIDER USE AND ABUSE OF JUDICIAL POWERS.

09739 HOLFE, E.L.III. JAPAN'S LDP CONSIDERS ELECTORAL REFORM: A NEGLECTED POLITICAL DEBT

ASIAN SURYEY, XXXII (9) (SEP 92), 773-786.

A SERIES OF POLITICAL SCANDALS HAVE FORCED JAPAN'S PRIME MINISTER, KIICHI MIYAZAWA, TO TAKE UP THE THORNY MATTER OF MINISTER, KIICHI MIYAZAHA, TO TAKE UP THE THORNY MATTER OF
ELECTORAL REFORM. PUBLIC OPINION SURVEYS SHOW CONSISTENT ELECTORAL REFORM. PUBLIC OPINION SURVEYS SHOH CONSISTENT
SUPPORT FOR REFORM, BUT JAPAN'S RULING LIBERAL DEMOCRATIC SUPPORT FOR REFORM, BUT JAPAN'S RULING LIBERAL DEMOCRATIC ARTICLE EXAMINES THE TORTUOUS LEGISLATIVE PROCESS THAT ARTICLE EXAMINES THE TORTUOUS LEGISLATIVE PROCESS THAT RESULTED IN A HALF-HEARTED "STOP-GAP" MEASURE THAT ONLY ELECTORAL SYSTEM. FOR MANY SENIOR PARTY LEADERS, REFORM IS A OIVERSION FROM MORE PRESSING BUSINESS. HOWEVER, A GRONING NUMBER OF YOUNGER POL ITICIANS SEE REFORM AS A NEGLECTED DEBT WHICH IS DAMAGING TO THE LDP'S CREDIT RATING. THEREFORE. THE SUBCOMMITTEE CHARGED HITH MAKING CHANGES WAS FACED WITH THE UNENVIABLE TASK OF TRYING TO APPEASE BOTH CAMPS WHILE OF MAKING CHANGES WHICH WOULD INEVITABLY JEOPARDIZE THE POLITICAL FUTURE OF SOME LEGISLATORS.

09740 HOLFE, J.M.

CANADA'S LIVEABLE CITIES

SOCIAL POLICY, 23(1) (SUM 92), 56-64

THE UNITED STATES WAS FOUNDED ON THE PRINCIPLES OF "LIFE, LIBERTY, AND THE PURSUIT OF HAPPINESS" WHILE CANADA'S BRITISH NORTH AMERICA ACT CALLS FOR "PEACE, ORDER, AND GOOD GOVERNMENT." YET IT IS HARD TO EXPLAIN CANADA'S MORE LIVABLE CITIES AS SIMPLY THE RESULT OF A MORE PEACEFUL AND LESS INDIVIDUALISTIC CULTURE. CONSCIOUS, ENLIGHTENED POLICIES AND TRADITIONS HAVE LED TO THE CONDITION OF CANADA'S CITIES TODAY. AS U.S. CITIES SEEM TO DRIFT TOWARD AN INCREASING SENSE OF CRISIS, CANADIAN THINKING ABOUT CITIES AND URBAN PLANNING PROVIDE A USEFUL POINT OF COMPARISON.

09741 HOLFFSOHN, M.

ISRAEL'S POLICY TOWARDS SPAIN, 1948-1963

ORIENT, $31(3)$ (SEP 90), 415-430.

ISRAEL'S APPROACH TO SPAIN WAS INITIALLY DOMINATED BY THE MEMORY OF SPAIN'S EXPULSION OF THE JEWS IN 1492 . THE FHE MEMORY OF SPAIN'S EXPULSION OF THE JEWS IN 1492. THE FACT THAT HITLER HAD ASSISTED IN BRINGING FRANCO TO POWER
FURTHER DARKENED THE JEHISH/ISRAEL VIEW OF SPAIN AFTER THE FURTHER DARKENED THE JEHISH/ISRAEL VIEW OF SPAIN AFTER THE
SECOND WORLD WAR. THIS IS WHY THE JEWISH STATE WAS OPPOSED SECOND WORLD HAR. THIS IS WHY THE JEWISH STATE WAS OPPOSED
ACCEPTING FRANCD'S SPAIN IN THE INTERMATIONAL COMMUNITY. IN ACCEPTING FRANCD'S SPAIN IN THE INTERNATIONAL COMYUNITY. IN
THE UN IN 1949 AND 1950 JERUSALEN CAST VOTES AGAINST AN END THE UN IN 1949 AND 1950 JERUSALEN CAST VOTES AGAINST AN
TO THE ANTI-SPANISH BOYCOTT. MADRID, ON THE OTHER HAND, TO THE ANTI-SPANISH BOYCOTT. MADRID, ON THE OTHER HAND, ARGUED THAT IT HAD HELPED TO SAVE JEWISH LIVES DURING THE
HOLOCAUST. A NUMBER OF DIASPORA JEWISH LEADERS AS WELL AS HOLOCAUST. A NUMBER OF DIASPORA JEWISH LEADERS AS WELL AS ISRAELI POL ITICIANS SHARED THIS VIEW AND FAVORED A MORE POSI IVE APPROACH TO SPAIN. THEIR URGINGS REMAINED UNHEED FRAMCE IN 1956) AND THE SUBSEOUENT THREAT TO THE LOCAL FRANCE IN 1956) AND THE SUBSEQUENT THREAT TO THE LOCAL JEWISH COMMUNITY IMPELLED ISRAEL TO ASK FOR SPANISH ASSISTANCE IN THE EVACUATION OF MOROCCAN JEWS. FRANCO
COOPERATED AND GAINED ISRAELI ACCEPTANCE. THIS IS A CASE COOPERATED AND GAINED ISRAELI ACCEPTANCE. THIS IS
STUDY SHOWING HOW AND WHY REALPOLITIK SUPERCEDES MORALPOLITIK.

09742 WOLFSON, M.; MARTELLI, M.; PURI, A.

THE NONLINEAR OYNAMICS OF INTERNATIONAL CONFLICT

JOURNAL OF CONFLICT RESOLUTION, 36(1) (MAR 91), 119-149. AMALYSTS OF THE CAUSE OF HAR HAVE INCREASIMGLY COME TO 
THE CONCLUSION THAT THE OBSTACLE TO FURTHER SCIENTIFIC ADVANCE IS THE ABSENCE OF AN ADEQUATE THEORY. A NONLINEAROYNAMIC MODEL IS PRESENTED THAT RECONCILES BALANCE-OF-POWER AND PREPONDERANCE-OF-POWER THEORIES OF INTERNATIONAL CONFLICT IN TERMS OF THE INTERACTION OF ECONOMIC AND POLITICAL CONSTRAINTS. THIS ARTICLE SHOWS THAT THE APPARENT PARADOX AND COMPLEXITY OF CONFLICT TRAJECTORIES ARISE AS MUCH FROM THE NONLINEAR NATURE OF THE SYSTEM AS FROM THE MULTIPLICITY OF CAUSES. CONVERGENT, EXPLOSIVE, OSCILLATING, AND CHAOTIC REGIMES ARI

09743 WOLFSON, $M$.

TRANSITION FROM A COMMAND ECONOMY: RATIONAL EXPECTATIONS AND COLD TURKEY

CONTEMPORARY POLICY ISSUES, $X(2)$ (APR 92), 35-43.

THE AUTHOR EXPLAINS THE PROBLEMS THAT THE COUNTRIES OF THE FORMER SOVIET BLOC FACE IN ACHIEVING A MARKET ECONOMY. ALTHOUGH THE TRANSITION FROM A COMMAND ECONOMY TO A MARKET ALCONOMY IS PERILOUS, HE ADVISES POLICY MAKERS THAT RETARDING THE TEMPO OF CHANGE HILL INYITE ECONOMIC AND POLITICAL DISASTER.

09744 WOLIN, R. CARL SCHMNITT, POLITICAL EXISTENTIALISM, AND THE TOTAL STATE

THEORY AND SOCIETY, 19(4) (AUG 90), 389-416

THIS ARTICLE EXAMINES THE POLITICAL PHILOSOPHY OF CARL SCHMITT, A LEADING GERMAN THEORIST OF THE WEIMAR YEARS AND SUPPORTER OF ADOLF HITLER, IN THE CONTEXT OF HANNAH ARENDT'S OBSERVATIONS ABOUT HIM IN "THE ORIGINS OF TOTALITARIANISM." THE RESPONSE TO SCHMITT'S WORK BY ENGLISH-SPEAKING COMMENTATORS IS COMPARED TO THE RESPONSE OF GERMANS IN THE POST-WAR PERIOD.

09745 HOL INETZ, S.

PARTY SYSTEM CHANGE: THE CATCH-ALL THESIS REVISITED HEST EUROPEAN POLITICS, 14(1) (JAN 91), 113-128.

THIS ARTICLE RE-EXAMINES KIRCHEIMER'S CATCH-ALL THESIS IN THE LIGHT OF RECENT DISCUSSIONS BY SMITH AND MAIR. KIRCHHEIMER IS BEST UNDERSTOOD AS PRESENTING AN ARGUMENT ABOUT THE CHANGING WAYS IN WHICH PARTIES APPEAL TO VOTERS AND THE EFFECT ON LINKS BETWEEN CITIZENS AND GOVERNMENT. ALTHOUGH TRANSITIONS TO A CATCH-ALL PARTY IS OFTEN TAKEN AS A GENERAL PHENOMENON, KIRCHHEIMER ARGUES THAT ONLY CERTAIN A GENERAL PHENOMENON, KIRCHHEIMER ARGUES THAT ONLY CERTAIN
PARTIES WILL CHANGE IN THIS HAY. HOH PARTIES ADAPT DEPENDS PARTIES WILL CHANGE IN THIS WAY. HOW PARTIES ADAPT DEPENDS
ON PERCEIVED NEEDS. INTERNAL POLITICS AND THE POLITICAL ON PERCEIVED NEEDS. INTERNAL POLITICS AND THE POLITICAL
MARKET IN WHICH THEY OPERATE. PARTIES IN MULTI PARTY, ISSUEMARKET IN WHICH THEY OPERATE. PARTIES IN MULTI-PARTY,
ORIENTED MARKETS WILL EVOLVE AS PROGRAMMATIC PARTIES. VULMERABILITY OF PARTIES REFLECTS NOT ONLY THEIR ORGANIZATION BUT ALSO EXPOSURE TO THE MEDIA AND A FAILURE TO EXPLOIT INNOVATIVE TECHMIQUES.

09746 WOLKOFF, M.J.

IS ECONOMIC DEVELOPMENT DECISION-MAKING RATIONAL? URBAN AFFAIRS QUARTERLY, $27(3)$ (MAR 92) 340-355.

URBAN AFFAIRS QUARTERLY, 27 (3) (MAR 92 ) $340-355$.
EVALUATIONS OF ECONOMIC DEVELOPMENT PROGRAMS HAVE RAISED QUESTIONS ABOUT THE LOGIC BEHIND PROGRAM DESIGN AND THE RATIONALITY OF DECISION CHOICES. IN RESPONSE, ANALYSTS HAVE JUSTIFIED PROGRAM CHOICES AND STRUCTURE ON THE BASIS OF A VARIETY OF ORGANIZATIONAL AND POLITICAL FACTORS INFLUENCINC DECISION MAKERS. ALTHOUGH THESE EXPLANATIONS ARE CONSISTENT WITH OBSERVED OUTCOMES, THEY ARE INCOMPLETE FROM A MODELER'S PERSPECTIVE. THIS PAPER PRESENTS A MODEL OF THE ECONOMIC DEVELOPMENT PROCESS THAT GENERATES SEEMINGLY IRRATIONAL RESULTS DESPITE THE ASSUMPTION THAT ALL ACTORS ARE MAXIMIZING AGENTS. THE KEY FEATURE OF THIS MODEL IS THE RECOGNITION THAT ECONOMIC DEVELOPMENT SUBSIDY AHARDS INFLUENCE THE LIKELIHOOD THAT OTHER FIRMS WILL DEMAND SUBSIDIES.

09747 WOLLSTEIN, J.B.

NATIONAL HEALTH INSURANCE: A MEDICAL DISASTER FREEMAN, 42(10) (OCT 92), 381-387.

THE AUTHOR ARGUES THAT ADVOCATES OF NATIONAL HEALTH INSURANCE ARE REALLY CALLING FOR A FORM OF SOCIALIZED MEDICINE. HE LOOKS AT HOW SOCIALIZED MEDICINE WORKS IN OTHER COUNTRIES AND CONCLUDES THAT IT HAS BEEN A FAILURE.

09748 WOLMAN, H.; HANSON, R.; HILL, E.; HOWLAND, M.; LEDEBUR, L. NATIONAL URBAN ECONOMIC DEVELOPMENT POLICY

JOURNAL OF URBAN AFFAIRS, 14(3-4) (1992), 217-238.

THE AUTHORS ARGUE THAT NATIONAL DEVELOPMENT POLICY MUST ADORESS UMEVEN ECONOMIC PERFORMANCE, DISPARITIES IN UNEMPLOYMENT RATES, AND INCOME INEQUITIES BETWEEN CITY AND SUBURBAN RESIDENTS' AS WELL AS BETWEEN WHITES AND MINORITY GROUPS. THE GOALS OF SUCH A POLICY ARE IMPROVED ECONOMIC PERFORMANCE AND THE REDUCTION OF INTRA-METROPOL ITAN OISPARITIES IN THE ECONOMIC WELL-BEING OF RESIDENTS. THE AUTHORS IDENTIFY FOUR POLICY APPROACHES: PRODUCTIVITYENHANCING POLICIES, COST REDUCTION SUBSIDIES, DEMAND-SIDE POLICIES, AND INSTITUTIONAL POLICY. THEY ARGUE THAT THE MOST EFFECTIVE POLICY SOLUTIONS WILL BE DRAWN FROM PRODUCTIVITY
THE EDUCATION AND TRAINING OF THE LABOR FORCE.

09749 HOLMAN, H.

UNDERSTANDING CROSS NATIONAL POLICY TRANSFERS: THE CASE OF BRITAIN AND THE US

GOVERNANCE, 5(1) (JAN 92), 27-45.

POLICY TRANSFER ACROSS COUNTRIES IS OCCURRING WITH INCREASIMG FREOUENCY. YET, DESPITE THE FACT THAT THE IMPORTANCE OF SUCH POLICY LEARNING IS OFTEN CITED AS ONE OF THE PRIMARY RATIONALES FOR COMPARATIVE POLICY ANALYSIS, POLICY TRANSFER IS AN UNDER-RESEARCHED AREA OF POLITICAL SCIENCE. THIS ARTICLE EXAMINES AND ANALYZES THE ACTUAL PROCESS OF POLICY TRANSFER BETWEEN THE UNITED STATES AND BRITAIN AND CONSIDERS THE RELATIONSHIP BETHEEN POLICY TRANSFER AND THE POLICYMAKING PROCESS.

09750 WOLPIN, M.

THIRD WORLD MILITARY ROLES AND ENVIRONMENTAL SECURITY NEW POLITICAL SCIENCE, 23 (FAL 92), 91-120

WHILE THE ARMED FORCES TEND TO SAFEGUARD AGAINST MILITARY AND ECONOMIC THREATS, THERE IS NO APPARENT REASON TO ASSUME THAT THE NATIONAL SECURITY FUNCTION NECESSARILY CONFIICTS WITH DEFENSE OF ENVIRONMENTAL SECURITY. THIS ARTICLE EXPLORES THREE CENTRAL PROPOSITIONS: HIGH LEVELS OF MILTARIZATIOM AND ARMED FORCES ACTIVITY ARE SEVERELY INJURIOUS TO ENVIRONMENTAL SECURITY; MILITARY SECTORS WILL ADVERSELY AFFECT ENVIRONMENTAL SECURITY EVEN AT MODERATE LEVELS OF ACTIVITY; AND, CERTAIN MILITARY MISSIONS AND ROLES MAY ON BALANCE PROMOTE ENVIRONMENTAL SECURITY PROVIDED THE ARMED FORCES ARE LIMITED IN THEIR INSTITUTIONAL DOMAIN AND ADAPT A NON-PROVOCATIVE DEFENSE STRATEGY. THE ANALYSIS FOCUSES GEO-POLITICALLY ON THE SOUTH, EMPHASIZING CENTRAL AMERICA, ALTHOUGH MUCH OF WHAT IS SAID APPLIES EQUALLY SO TO OTHER REGIONS.

09751 WOMAK, 8.

REFORM IN VIETHAM: BACKHARDS TOWARDS THE FUTURE GOVERNMENT AND OPPOSITION, 27(2) (SPR 92), 177-189,

SINCE ITS VICTORIOUS NATIONAL REUNIFICATION IN 1975-76, THE COMMUNIST PARTY OF VIETNAM HAS BEEN BUFFETED BY INTERHAL AND EXTERNAL CHALLENGES FOR WHICH IT WAS UNPREPARED. AS A RESULT, THE VIETNAMESE LEADERSHIP HAS BEEN MORE CONCERNED REFORM AND INTERNATIONAL OPENNESS HAVE BECOME ESSENTI IAL PARTS OF THESE EFFORTS TO COPE HITH CRISIS, BUT THEY HAVE BEEN STRONGLY TETHERED TO THE NEED TO PRESERVE ORDER AND PREVENT LARGER CRISES.

09752 WONG, C.P.W.

CENTRAL-LOCAL RELATIONS IN AN ERA OF FISCAL DECLINE: THE CENTRAL-LOCAL RELATIONS IN AN ERA OF FISCAL DECLINE: CHINA OUARTERLY, (128) (DEC 91), 691-715.

THE AUTHOR DISPELS SOME WIDELYY-HELD BUT ERRONEOUS VIEWS ON THE AUTHOR DISPELS SOME WIOELY-HELD BUT ERRONEOUS SPHERE, CHANGES INTRODUCED IN THE POST-MAO REFORM ERA HAVE BEEN MUCH LESS FAVORABLE TO LOCAL GOVERMMENTS THAN COMHONLY ASSUMED, AND LOCAL BUDGETS HAVE SHRUNK AS A SHARE OF NATIONAL INCOME. AT THE SAME TIME, LOCAL GOVERMMENTS FACE GREATLY EXPANDED EXPENDITURE RESPONSIBILITIES, MANY STEMMING FROM OBLIGATIONS IMPOSED BY NATIONAL POLICY. THE RESULT IS THAT LOCAL GOVERMMENTS AT ALL LEVELS ARE STARVED FOR REVENUE.

09753 WONG, $K$.

STATE REFORM IN EDUCATION FINANCE: TERRITORIAL AND SOCIAL STRATEGIES

PUBLIUS: THE JOURNAL OF FEDERALISM, 21(3) (SUM 91),

125-142.

AS OF JANUARY 1991, STATE EDUCATION FINANCE SYSTEMS HAD BEEN OVERTURNED BY THE COURTS IN TWELVE STATES AND UPHELD BY THE COURTS IN ANOTHER FOURTEEN. THIS ARTICLE EXAMINES THE WAYS IN WHICH STATES HAVE RESPONDED TO THE CHALLENGE OF EQUITY IN SCHOOL FINANCE. EQUITY REFORMS ARE ROOTED IN TWO KINDS OF INEQUITIES IN PUBLIC ELEMENTARY AND SECONDARY EDUCATION. FIRST, STATE GOVERNMENTS CAN ADDRESS INTERDISTRICT OR TERRITORIAL INEQUITY THAT IS DUE TO THE DISPARITY IN LOCAL TAXABLE HEALTH. SECOND, STATE GOVERNMENTS CAN ADDRESS THE SOCIAL INEQUITY THAT ARISES FROM THE PRESENCE OF SPECIAL-NEEDS POPULATIONS WITHIN A DISTRICT. A REFORM STRATEGY IS LIKELY TO REFLECT A STATE'S RELATIVE EMPHASES ON TERRITORIAL AMD SOCIAL INEOUITIES. THE COMMON TENDENCY, HOWEVER, IS TO FOCUS ON TERRITORIAL EOUITY. THESE TENDENCY, HOWEVER, IS TO FOCUS ON TERRITORIAL EQUITY. THESE
POLICY TENDENCIES ARE SHAPED BY VARIOUS STATE POLITICAL AND POLICY TENDENCIES ARE

09754 WONG, K.S.; WONG, K.C.

BETHEEM THÓ GIANTS

FAR EASTERH ECONOMIC REVIEH, 155(40) (OCT 92), 78.

THE TRADE DISPUTE BETHEEN CHINA AND THE UNITED STATES IS ON THE VERGE OF BECOMING A FULL-BLOWN TRADE HAR, WITH DEVASTATING LONG-TERM CONSEOUENCES FOR HONG KONG AS NELL AS FOR CHINA AND THE UNITED STATES. A HEALTHY TRADE RELATIONSHIP BETHEEN CHINA AND THE U.S. IS VITAL TO HONG KONG. A SEVERE SLOWDOWN IN TRADE BETWEEN THE TWO COUNTRIES WOULD SHARPLY CURTAIL ECONOMIC GROWTH IN THE COLONY. AS 
CONCERN IN HONG KONG GROWS, SO DOES FRUSTRATION FROM BEING ON THE SIDEL INES. THE COLONY PLAYS AN IMPORTANT ENTREPOT ROLE IN MUCH OF THE TRADE BETWEEN CHINA AND THE UNITED STATES, BUT IT IS NOT ENTITLED TO ANY REPRESENTATION TO NEGOTIATIONS BETWEEN PEKING AND WASHINGTON BECAUSE IT IS NOT A DIRECT PARTY IN THE DISPUTE. HONG KONG'S FRUSTRATION IS COMPOUNDED BY THE FACT THAT AMERICAN PROTECTIONISM WILL NOT SOLVE THE DOMESITC STRUCTURAL PROBLEMS IN THE AMERICAN ECONOMY AND THUS WILL ONLY INCREASE ECONOMIC TROUBLES FOR ALL INYOLVED.

09755 HONG, L.

AUTHORITARIANISM AND TRANSITION TO DEMOCRACY IN A THIRD WORLD STATE

CRITICAL SOCIOLOGY, 18(2) (SUM 91), 77-102

THE CELEBRATED RAPID ECONOMIC DEVELOPMENT IN SIMGAPORE HAS BEEN ACCOMPANIED BY GROHING AUTHORITARIANISM UNDER THE LEADERSHIP OF THE PEOPLE'S ACTION PARTY. THIS PAPER SUGGESTS THAT AUTHORITARIAN RULE IN SINGAPORE IS NOT OF THE BUREAUCRATIC-AUTHORITARIAN KIND IDENTIFIED HIIH LATIM BUREAUCRATIC-AUTHORITARIAN KIND IDENTIFIED WITH LATIN
AMERICAN COUNTRIES. SINGAPORE'S HISTORY, INTEGRATION INTO AMERICAN COUNTRIES. SINGAPORE'S HISTORY, INTEGRATION INTO
THE WORLD ECONOMY, AND THE DEVELOPMENT OF ITS POLITY HAVE MADE ITS FORM OF CONTROL UNIOUE. ITS RECENT ATTEMPT AT DEMOCRATIC TRANSITION IS STATE-LED, ALTHOUGH THIS HEGEMONY IS INCREASINGLY UNDER CHALLENGE. AS THE STATE RESPONDS TO THESE CHALLENGES, NEW SITES OF CONTESTATION ARE OPENED UP, WHICH WILL EITHER CONTINUE AUTHORITARIAN RULE OR INCREASE OPPORTUNITIES FOR FURTHER DEMOCRATIZATION.

09756 WONG, $S$.

EMIGRATION AND STABILITY IN HONG KONG

ASIAN SURVEY, XXXII(10) (OCT 92), 918-933.

HITH THE APPROACH OF 1997 THE YEAR HONG KONG REYERTS TO CHINESE SOVEREIGNTY, A GROWING NUMBER OF PEOPLE IN HONG KONG ARE EMIGRATING ELSEWHERE. THIS ARTICLE EXAMINES THIS GROWING EMIGRATION TREND AND ITS IMPLICATIONS. IT CONSIDERS THREE REASONS WHY LARGE-SCALE EMIGRATION COULD BE DETRIMENTAL TO HONG KONG. FIRST, A "BRAIN DRAIN" COULD LEAD TO THE DEPLETION OF THE "FUNCTIONAL CORE" OF THE ECONOMY. SECOND, DEPLETION OF THE "FUNCTIONAL CORE" OF THE ECONOMY. SECOND, SOME ARGUE THAT THE WIDESPREAD DESIRE TO LEAVE HILL ENGENDER
A DOOMSDAY SYNDROME AND LEAD TO A STATE OF ANOHY. THIRD, IT A DOOMSDAY SYNDROME AND LEAD TO A STATE OF ANOHY. THIRD, IIT IS ARGUED THAT DESERTION BY THE ELITES WILL CREATE A CRISIS OF LEGITIMACY AND AN EROSION OF THE MORAL BASIS OF AUTHORI IYY. 1967 ) AS WELL AS THE CURRENT SITUATION. IT CONCLUDES THAT 1967) AS WELL AS THE CURRENT SITUATION. IT CONCLUDES THAT IN THE ECONOAY, BUT IT DOES NOT CONSTITUTE A CRISIS OF IN THE ECONOA
STABILITY.

09757 WOO, J.

EAST ASIA'S AMERICA PROBLEM

WORLD POLICY JOURNAL, VIII(3) (SUM 91), 451-474.

AMERICAN PERSPECTIVES OF EAST ASIA RANGE FROM EUPHORIC PRAISE TO PARANOID CRITICISM. HOWEVER, NEARLY ALL AMERICAN PERCEPTIONS ARE CHARACTERIZED BY A FAILURE TO UNDERSTAND THE ALIEN "OTHER." THIS ESSAY SWITCHES THE OPTIC TO ADOPT THE PERSPECTIVE OF THE OTHER, TO SEE HOW IT ALL LOOKS FROM A DIFFERENT SHORE--FROM EAST ASIA'S SIDE OF THE PACIFIC. BY DOING SO, A PROBLEM THAT IS BARELY MENTIONED IN CONTEMPORARY DISCUSSIONS OF U.S. -EAST ASIAN RELATIONS COMES INTO FOCUS: EAST ASIA'S "AMERICA PROBLEM." WHAT IS MEANT BY THIS IS THAT THE CULTURAL CONSTRUCTS AND CONTRADICTIONS WITH WHICH AMERICANS CONFRONT EAST ASIA'S INDUSTRIAL AND ECONOMIC PROWESS HAVE IMPAIRED THEIR ABILITY TO APPREHEND EAST ASIA. ONLY AFTER THIS OBSTACLE IS OYERCOME CAN RELATIONS BETHEEN THE TWO SIDES MOVE AHEAD TO DEAL WITH THE CHALLENGES OF THE FUTURE.

09758 WOOD, B.

CATCHING THE HAVE

EUROPE, 321(321) (NOV 92), 6-9.

PRIVATIZATION, WHETHER FOR IDEOLOGICAL OR PRAGMATIC REASONS, IS SEEN AS A VITAL COMPONENT IN BOOSTING NATIONAL COMPETITIVENESS. IT IS THE FOREMOST PUBLIC POLICY TREND IN THE WORLD TODAY. THIS ARTICLE EXPLORES THE PROGRESS OF PRIVATIZATION ALL OVER THE WORLD AND OFFERS SPECIFIC EXAMPLES OF ITS OCCURRENCE IN RECENT DECADES. IT CONCLUDES
THAT PRIVATIZATION IS THE TRIUMPH OF ADAM SMITH OVER KARL THAT PRIVATIZATION IS THE TRIUMPH OF ADAM SMITH OVER KARL
MARX, AND THAT IT IS A TREND BORN OF THE BELIEF THAT A MARX, AND THAT IT IS A TREND BORN OF THE BEL IEF THAT A PRIVATIZED FIRM IS NOT ONLY MORE EFFICIENT BUT FAR MORE
FLEXIBLE AND BETTER EOUIPPED TO PROFIT IN A DYNAMIC GLOBAL ECONOMY.

09759 WOOD, B.

THE EASTERN BLOC TWO YEARS LATER

EUROPE, (314) (MAR 92), 12-13.

AFTER THE EUPHORIA OF NEW-FOUND FREEDOM WORE OFF, THE NATIONS OF EASTERN EUROPE HAVE HAD TO CONFRONT SOME HARSH ECONOMIC REALITIES. HITH THE GROWTH OF THE EUROPEAN COMAUNITY SLOWING, 1992 WILL BE ANOTHER DOWN YEAR IN CENTRAL AND EASTERN EUROPE. ONLY HUNGARY AND CZECHOSLOVAKIA ARE ON THE LAUNCH PAD FOR ECONOMIC TAKE-OFF. FOR THE REGION AS A WHOLE LIVING STANDARDS CONTINUE TO ERODE FROM AN ALREADY LOH BASE. INDUSTRIAL OUTPUT IS OFF TWENTY PERCENT, TRADE WITH
WHAT WAS THE SOVIET UNION HAS ALL BUT COLLAPSED, PRIVATIZATION--WITH THE NOTABLE EXCEPTION OF CZECHOSLOVAKIA-HAS HARDLY BEGUN, AND LONG SUPPRESSED ETHNIC ANIMOSITIES HAVE SPRUNG TO THE SURFACE, REVEALING WEAK AND FRAGILE POLITICAL STRUCTURES. THIS ARTICLE BRIEFLY CONSIDERS THE POLITICAL AND ECONOMIC STATE OF POLAND, CZECHOSLOVAKIA, HUNGARY, ROMANIA, BULGARIA, ALBANIA, AND THE YUGOSLAY REPUBLICS.

09760 WOOD, J.E. JR. CEREMONIAL PRAYERS AT PUBLIC SCHOOL GRADUATIONS: LEE $V$. WEI SMAN

JOURNAL OF CHURCH \& STATE, 34(1) (WIN 92), 7-14.

A MAJOR DECISION ON THE ESTABLISHMENT CLAUSE WILL BE HANDED DOWN BY THE U.S. SUPREME COURT WHEN IT RULES ON LEE $V$. WEISMAK, A CASE QUESTIONING THE PROPRIETY OF SAYING PRAYERS AT PUBLIC SCHOOL GRADUATIONS. LEE $Y$. WEISMAN COULD BECOME THE VEHICLE FOR OVERTURNING THE THREE-PRONGED TEST FOR ADJUDICATING THE ESTABLISHMENT CLAUSE USED BY THE COURT SINCE LEMON V. KURTZMAN (1971). IN ITS PLACE, THE COURT
DECIDE TO SUBSTITUTE THE TEST OF GOVERNMENT COERCION.

09761 WOOD, J.E. JR.

RELIGION AND THE U.S. PRESIDENTIAL ELECTION OF 1992 JOURNAL OF CHURCH \& STATE, 34(4) (FAL 92), 721-728.

RELIGION HAS PLAYED A MAJOR ROLE IN MORE THAN ONE-THIRD OF ALL U.S. PRESIDENTIAL ELECTIONS AND HAS HAD PARTICULARLY HIGH VISIBILITY IN THE LAST FIVE PRESIDENTIAL CAMPAIGNS. THE 1992 PRESIDENTIAL ELECTION WITNESSED THE EXACERBATION OF THIS TREND, ESPECIALLY IN THE MOBILIZATION OF THE RELIGIOUS RIGHT IN SUPPORT OF RIGHT-WING POLITICS, THE REPUBLICAK PARTY, AND PRESIDENT GEORGE BUSH.

09762 WOOD, N.; NORTON, P.

DO CANDIDATES MATTER? CONSTITUENCY-SPECIFIC VOTE CHANGES FOR INCUMBENT MPS, 1983-1987

POLITICAL STUDIES, XL (2) ( JUN 92), 227-238.

THE ASSUMPTION THAT CANDIDATES MAKE A DIFFERENCE TO ELECTORAL OUTCOMES IN BRITISH GENERAL ELECTIONS IS TESTED THROUGH A COMPARISON OF THE 1983 AND 1987 GENERAL ELECTIONS. THROUGH A COMPARISON OF THE 1983 AND 1987 GENERAL ELECTIONS.
INCUMBENT'S CONSTITUENCY-SPECIFIC VOTE CHANGE (ICVC) BETWEEN INCUMBENT'S CONSTITUENCY-SPECIFIC VOTE CHANGE (ICVC) BETWEEN
THE JUNE 1983 AND JUNE 1987 BRITISH GENERAL ELECTIONS IS THE JUNE 1983 AND JUNE 1987 BRITISH GENERAL ELECTIONS IS
MEASURED BY SUBTRACTING THE AVERAGE REGIONAL VOTE CHANGE FOR MEASURED BY SUBTRACTING THE AVERAGE REGIONAL VOTE CHANGE
THE INCUMBENT'S PARTY FROM THE CONSTITUENCY VOTE CHANGE THE INCUMBENT'S PARTY FROM THE CONSTI IUENCY VOTE CHANGE
REGISTERED BY THE INCUMBENT. REGRESSION ANALYSIS FINDS ICVC TO BE MOST SIGNIFICANTLY INFLUENCED IN BOTH THE LABOR AND CONSERVATIVE PARTIES BY THE INCUMBENT'S LENTH OF TENURE. VARIABLES INDICATING THE SECURITY OR INSECURITY OF THE SEAT IN ELECTORAL TERMS ARE SIGNIFICANTLY RELATED TO ICVC IN THE CONSERVATIVE BUT NOT IN THE LABOR CASE. THE FINDINGS FOR LABOR INDICATE ICVC TO BE GREATER WHERE ELECTORAL SECURITY IS GREATER. THIS FINDING MIGHT BE EXPLAINED BY SUCCESSFUL CONSERVATIVE PARTY CONCENTRATION ON CONSTI
LABOR INCUMBENTS APPEAR TO BE VULNERABLE.

09763 HOOD, P.C.

FRANCOIS MITTERAND AND THE PERSIAN GULF WAR: THE SEARCH FOR INFLUENCE

FRENCH POLITICS AND SOCIETY, 10(3) (SUM 92), 44-62.

THE AUTHOR ANALYZES FRENCH FOREIGN POLICY DURING THE PERSIAN GULF CRISIS AND WAR. SHE CONSIDERS FRANCE'S OBJECTIVES AND STRATEGIES IN THE CONTEXT OF FRANCOIS MITTERAND'S STRUGGLE TO CONSTRUCT A SUPPORT COALITION THAT WOULD ALLOW FRANCE TO OFFSET THE OVERHHELMING PRESENCE OF THE UNITED STATES. THE EMPHASIS IS ON THE DECISION-MAKING PROCESS THROUGH WHICH MITTERAND TRIED TO STRIKE A DELICATE BALANCE BETHEEN INDEPENDENCE FROM THE UNITED STATES TO PROTECT FRENCH INTERESTS AND COOPERATION WITH THE UNITED STATES TO PROTECT FRANCE'S GREAT POWER STATUS. SHE CONCLUDES WITH SOME OBSERVATIONS CONCERNING THE RELATIVE SUCCESS FRENCH POLICIES, THE FUTURE DIRECTION OF THE EUROPEAN
CDMMUNITY AND EUROPEAN POLITICAL COOPERATION, AND THE FUTURE OF FRANCD-ARAB RELATIONS.

09764 HOOOARD, J.K.

EXTRAYAGANCE AND MEDIOCRITY OF VIRTUE: THEIR OIVERGENCE END THE POSSIBILITY OF DEMAGOGUERY

POLITICAL COMMUNICATION, $9(2)$ (1992), 123-141.

IN "NICOMACHEAN ETHICS," ARISTOTLE REFERS TO SOCRATES
IN FIVE TIMES: FOUR REFERENCES ARE TO THE CONTENTIOUS SOCRATIC DOCTRINE THAT "VIRTUE IS KNOWLEDGE;" THE FIFTH IS IN THE DISCUSSION OF IRONY, "SUCH AS THAT OF WHICH SOCRATES WAS ACCUSED." THESE ISSUES ARE NOT CONJOINED ACCIDENTALLY. MANIFEST APPEARANCES ATTEST THAT INDIVIDUALS CAN DO WORSE THAN THEY KNOW OR KNOH BETTER THAN THEY DO. YET THE OF INCONTINENCE IS ONLY HALF OF THE PROBLEM OF THE DIVERGENCE OF CHARACTER AND INTELLECT, THE MEDIOCRE AND THE
EXTRAVAGANT IN VIRTUE. THE OTHER HALF OF THE PROBLEM IS THE EXTRAVAGANT IN VIRTUE. THE OTHER HALF OF THE PROBLEM IS THE
CAPACITY OF SOME TO DO OR ACT BETTER THAN THEY KNOW, VICE'S CAPACITY OF SOME TO DO OR ACT BETTER THAN THEY KNOW,
ABILITY TO IMITATE VIRTUE, AND THE DISLOYAL TALENT'S

EMPLOYMENT OF DEMAGOGUERY, THE CLEVER VICE OF IRONY.

09765 WOODRUFF, $W$

THE BURDEN OF POWER IN A FRAGMENTED WORLD: AN AMERICAN VIEW 
WORLD TODAY, 48(6) (JUN 92), 103-108.

THE DEMISE OF THE COLD HAR HAS ENDED THE DUEL BETWEEN THO WESTERY IDEOLOGIES CHAMPIONED BY TWO SUPERPOWERS-THE SOVIET UNION AND THE UNITED STATES--AND HAS TERMINATED A REMARKABLE PERIOD OF HISTORY IN WHICH WESTERN POWER WAS UNQUESTIONABLY SUPREME. THE WORLD IS NOW POISED BETWEEN THE GEOPOLITICS OF THE WESTERN AGE AND THE GEOPOLITICS OF A NEH WORLD ORDER IN WHICH REGIONAL, ETHNIC, RELIGIOUS, AND NATIONAL AIMS ARE REASSERTING THEMSEL VES. RELATIVE TO THE STABILITY OF THE COLD WAR, THE WORLD SEEMS TO BE ENTERING A TOPSY-TURVY TIME OF UNPREDICTABLE REGIONAL STRIFE. IF THE WORLD IS BECOMING LESS STABLE THAN IT WAS DURING THE PERIOD OF PAX EUROPA, IT IS BECAUSE THE UNPARALLELED AND UNPRECEDENTED CONSOLIDATION OF THE HORLD BY WESTERN MAN PROVIDED A DEGREE OF POLITICAL AND ECONOMIC CENTRALIZATION THAT HAD NEVER BEEN SEEN BEFORE AND MIGHT NOT BE SEEN AGAIN. IT IS WISHFUL THINKING TO ASSUME THAT THIS WILL NOW BE FOLLOWED BY THE WORLDWIDE TRIUMPH OF PAX AMERICANA.

09766 HOODS, D.

CIVIL SOCIETY IN EUROPE AND AFRICA: LIMITING STATE POHER THROUGH A PUBLIC SPHERE

AFRICAN STUDIES REVIEW, 35(2) (SEP 92), 77-100

THE AUTHOR ARGUES THAT THE DEVELOPMENT OF CIVIL SOCIETY IN EUROPE HAS THE RESULT OF AN EMPIRICAL DIFFERENTIATION IN EUROPE WAS THE RESULT OF AN EMPIRICAL DIFFERENTIATI BETWEEN PUBLIC AND PRIVATE INTERESTS AS WELL AS THE IDEALIIATION OF THIS SEPARATION. AS IN THE WEST EUROPEAN EXPERIENCE IN WHICH THE RISE OF CIVIL SOCIETY WAS LINKED TO THE URBAN CLASSES TO EXPAND THEIR PRIVATE INTERESTS, AFRICAM OF URBAN CLASSES TO EXPAND THEIR PRIVATE INTERESTS, AFRICAN URBAN CLASSES NOW FIND THEIR ECONOMIC STATUS THREATENED BY THE ARBITRARY NATURE OF POST-COLONIAL RULE. IN AN EFFORT TO OVERCOME A PERVASIVE ECONOMIC AND POLITICAL CRISIS, URBA CLASSES--NOTABLY THE MIDDLE CLASS--ARE SEEKING TO GROUND
STATE AUTHORITY IN A MORE DEMOCRATIC AND INSTITUTIONALLYACCDUNTABLE FRAMEHORK. THE AUTHOR FOCUSES FIRST ON THE HISTORICAL ANTECEDENTS OF THE CDNCEPT OF CIVIL SOCIETY IN THE WEST EUROPEAN TRADITION. THEN, HE ARGUES THAT CERTAIN COMPARATIVE PRINCIPLES, DRAWN FROM THE WEST EUROPEAN TRADITION, CAN BE APPLIED TO OTHER HISTORICAL CONTEXTS. FINALLY, THE IDEA OF CIVIL SOCIETY IN AFRICA IS ANALYZED BASED ON SOME COMPARATIVE PRINCIPLES DERIVED FROM THE WEST EUROPEAN EXPERIENCE.

09767 WOODS, D.

THE CENTRE NO LONGER HOLDS: THE RISE OF REgIONAL LEAGUES IN ITALIAN POLITICS

WEST EUROPEAN POLITICS, 15(2) (APR 92), 56-76.

THE PRINCIPAL ARGUMENT IN THIS ARTICLE IS THAT THE RECENT EMERGENCE OF REGIONAL LEAGUES IN ITALIAN POLITICS IS RPIPHEMOMENAL TO BROADER SOCIO-ECONOMIC CHANGES HHICH HAVE EPIPHENOMENAL TO BROADER SOCIO-ECONOMIC CHANGES HHICH HAVE REGIONAL LEAGUES ARE A REFLECTION DF THE DIFFERENTIATION OF REGIONAL LEAGUES ARE A REFLECTION OF THE DIFFERENTIATION OF ITALIAN CIVIL SOCIETY FROM A CENTRALISED POLITICAL AUTHORI AND LOCAL UNITS AS CENTRES OF ECONOMIC AND POLITICAL ANEITIMACY AND REPRESENTATION.

09768 WOODS, T

BREAD WITH FREEDOM AND PEACE... : RAIL WORKERS IN MALAWI, $1954-1975$

JOURNAL OF SOUTHERN AFRICAN STUDIES, 18(4) (DEC 92),

27-739.

THIS ARTICLE EXAMINES THE RELATIONSHIP BETWEEN THE STRUGGLE FOR INDEPENDENCE AND THE EMERGENCE OF LABOR MILITANCY IN MALAWI BY EXAMINING THE HISTORY OF TRADE UNIONISM AMONG THE COUNTRY'S RAIL WORKERS. IT CONCLUDES THAT THE EMERGENCE OF MASS NATIONALISM UNDER THE LEADERSHIP OF THE MALAWI CONGRESS PARTY STIMULATED A GREATER PROLETARIAN CONSCIOUSNESS WICH HEIGHTENED THE RAILWAY WORKERS EXPECTATIONS AND ULTIMATELY LED THEM TO REJECT GOVERMMENT IDEOLOGY AND STRICTURES. ALTHOUGH THE HORKERS WERE UNABLE TO ACHIEVE THEIR OWN AMBITIONS IN BANDA'S REPRESSIVE MALAWI THEY NEVERTHELESS ENGAGED IN ACTIVITIES WHICH WERE VIRTUALLY UNPRECEDENTED IN INDEPENDENT MALAWI. THESE INCIDENTS INDICATE THAT LABORERS REMAIN A POTENT FORCE.

09769 HOODWARD, S.L.

THE TYRANMY OF TIME: EASTERN EUROPE'S RACE TO THE MARKET BROOKINGS REVIEW, 1O(1) (WIN 92), 6-13.

NEW LEADERS IN CENTRAL AND EASTERN EUROPE ARE FEELING THE PINCH BETWEEN THE PRESSURE FOR RAPID ECONOMIC CHANGE AND THE TIME IT TAKES TO CREATE THE STABLE RULES, DEMOCRATIC THE TIME IT TAKES TO CREATE THE STABLE RULES, DEMOCRATIC
GOVERNMENTS AND GUARANTEES OF BASIC RIGHTS NECESSARY FOR GOVERNMENTS, AND GUARANTEES OF BASIC RIGHTS NECESSARY FOR ECONOMIC STABILITY. FOREIGN DEMANDS THAT DEMOCRACY FUNCT

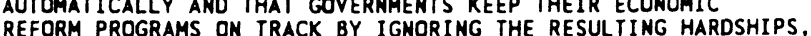
REFORM PROGRAMS ON TRACK BY IGNORING THE RESULTING HARDSHIPS, REFUSING POPULAR PLEAS TO SLOW DOWN OR AT LEAST TO DILUTE THE BITTER ECONOMIC MEDICINE, HAVE AN AIR OF UNREALITY. BOTH THE STAKES AND THE RISKS OF THIS POLITICAL PROCESS ARE HIGH
THE CIVIL WAR IN YUGOSLAVIA, FOR EXAMPLE, IS A NIGHTMARE OF ALL THE TENSIONS AND CONFLICTS THAT THE DUAL TRANSFORMATION CAN UNLEASH.
09770 WOODWARD, S.L.

THE YUGOSLAV WARS

BROOKINGS REVIEW, 10(4) (FAL 92), 54

THE WEST IS STILL STRUGGLING TO DEFINE THE CONFLICT ARISING FROM THE DISINTEGRATION OF YUGOSLAVIA. ITS PERPLEXITY IN SETTLING ON A DEFINITION, AND THEREFORE A COURSE OF ACTION, REVEALS WHY THIS IS THE FIRST BATTLE OF THE "NEW WORLD ORDER." BECAUSE ESTABLI SHED HABITS OF CLASSIFICATION AND RESPONSE ARE CLEARLY UNSUITED TO THIS CHALLENGE, THE INTERNATIONAL COMMUNITY IS REDEFINING ITS OWM ORDER THAT WILL REPLACE THE COLD WAR AS IT RELUCANTLY CONFRONTS THE YUGOSLAV WARS

09771 WOOLDRIDGE, A.

SPOONFUL OF SUGAR

NEW REPUBLIC, 206 (22) (JUN 92), 17-18

THE RECENT REORGANIZATION OF THE BRITISH NATIONAL HEALTH SERVICE (NHS) TEACHES TWO LESSONS: PUBLIC PROVISION AND MARKET MECHANISMS ARE NOT NECESSARILY MUTUALLY EXCLUSIVE; CONSERVATIVES CAN RESTRUCTURE PUBLIC SERVICES AND TAKE ON INTEREST GROUPS HITHOUT COMMITTING POL ITICAL SUICIDE. OVERALL. THE AIM OF THE NHS REFORMS IS TO USE MARKET MECHANISMS TO IMPROVE A PUBLICLY-PROVIDED SERVICE.

09772 WORCESTER, $K$.

BRITISH LABOR'S UNEXPECTED DEFEAT
NEH POLITICS, 13(1) (SUM 92), 66-80.

DESPITE THE PREDICTIONS OF MOST OF THE POLLS, GREAT

BRITAIN'S CONSERVATIVE PARTY WON THE NATIONAL ELECTIONS WITH A RESPECTABLE PARLIAMENTARY MAJORITY. THE OUTCOME WAS DEYASTATING TO THE AMBTA PARTY HHICH HAD EXPECTED THE ELECTION TO RESULT IN A "HUNG PARLIAMENT" IF NOT AN OUTRIGHT LABOR MAJORITY. A DETAILED EXAMINATION OF THE ELECTORAL RESULTS MAKES IT POSSIBLE TO GAIN A DEGREE OF INSIGHT INTO THE CONTEMPORARY SOCIAL AND ELECTORAL DYNAMICS OF GREAT BRITAIN. THE RESULTS SUPPORT CONVENTIONAL WISDOM ABOUT THE LABOR PARTY. IF LABOR HANTS TO GAIN POWER IT HAS TWO BASIC OPTIONS: RESUME ITS RIGHTWARD MARCH, IN THE HOPE OF PERSUADING SOUTHERN ENGLISH VOTERS THAT IT IS A RESPECTABLE VEHICLE FOR THEIR ECONOMIC INTERESTS; OR FORM SOME KIND OF PACT WITH THE LEFT-LEANING LIBERAL DEMOCRATS, AND TAKE UP THE CHALICE OF CONSTITUTIONAL REFORM.

09773 HORCESTER, K.

TRADE UNION STRAGEGIES AND THE ENTERPRISE CULTURE IN BRITAIN

CRITICAL SOCIOLOGY, 18(1) (SPR 91), 37-54.

THE COMBINED IMPACT OF MASS UNEMPLOYMENT, THE POLICIES

OF THE THATCHER GOVERMMENT, AND GLOBAL CAPITALIST

RESTRUCTURING HAVE HAD A PROFOUND IMPACT ON THE POSITIONS OF TRADE UNIONS BOTH IN THE WORKPLACE AND IN THE HIDER SOCIETY. TRADE UNION ELITES IN BRITAIN FOUND THEIR ORGANIZATINS SCORNED, ISOLATED AND EMBATTLED IN THE 1980S. THE EFFORT OF SCORNED, ISOLATED AND EMBATTLED IN THE 1980S. THE EFFORT OF THE THATCHER GOVERNMENT TO IMPLANT AN "ENTERPR ISE CULTURE" LED TO THE EXPULSION OF UNION ELITES FROM THE POLICY-MAKIMG
PROCESS. AT THE SAME TIME, UNDERLYING SCHISMS HITHIN THE PROCESS. AT THE SAME TIME, UNDERLYING SCHISMS HITHIN THE UNION MOVEMENT WERE INTENSIFIED AS ALTERNATIVE APPROACHES

09774 WORLUND, I.

THE SHEDISH PARLIAMENTARY ELECTION OF SEPTEMBER 1991

SCANDINAVIAN POLITICAL STUDIES, 15(2) (JUN 92), 135-143.

RESULTS OF SHEDEN'S PARLIAMENTARY ELECTION OF SEPTEMBER 1991.

09775 WORTHMANN, J.

CHINA AND THE PLACE OF MORALITY IN POLITICS

GERMAN TRIBUNE, (1508) (MAR 92), 1.

THE CHINESE COMMUNIST REGIME' REMAINS COMMITTED TO AN AM IRON-FISTED TOTALITARIAN RULE WITH LITTLE OR NO REGARD FOR HUMAN RIGHTS. THUS, THE ATTEMPTS OF CHINESE DIPLOMATS AND BUSINESSMEN TO INCREASE FRIENDLY CONTACTS HITH THE WEST CREATE A MORAL DILEMMA FOR WESTERN DECISIONMAKERS. THIS ARTICLE CONCLUDES THAT IT IS IMPOSSIBLE TO OISREGARD A POWER AS GREAT AS CHINA. FURTHERMORE, ONCE ACKNOWLEDGING THE REALITY OF THE NECESSITY OF DEALING HITH CHINA, HESTERN DIPLOMATS CAN CAUTIOUSLY ENCOURAGE CAPITALIST REFORM IN CHINA, SECURE IN THE KNOWLEDGE THAT POLITICAL FREEDOM WILL FOLLOW ECONOMIC FREEDOM AND PROSPERITY.

09776 WORTHMANM, J.

CSCE FACES PITFALLS AS MEMBERSHIP INCREASES

GERMAN TRIBUNE, (1510) (APR 92), 2.

WHEN THE CONFERENCE ON SECURITY AND COOPERATION IN EUROPE (CSCE) FIRST MET 20 YEARS AGO, DELEGATES REPRESENTED 35 COUNTRIES. NOW THE CSCE HAS 51 MEMBER-STATES, ALL COMMITTED TO DEMOCRACY AND MARKET ECONOMICS. HOWEVER, THE EUROPEAN WORLD HAS GROWN MORE DISORDERLY AND LESS PEACEFUL. CONFLICTS IN YUGOSLAVIA, MAGORNY KARABAKH, MOLDAVIA AND TURKISH KURDISTAN AL RAISE THE SPECTER OF HIDESPREAD CHAOS AND YIOLENCE. SOME ARE CALIING ON THE CSCE TO TAKE ACTION WITH REGARDS TO THESE CRISES, BUT THE ORGANIZATION, AS YET, LACKS ANY SECURITY OR MILITARY POWER. HOWEVER, THE CSCE 
SEEMS DETERMINED TO DEVELOP THE STRUCTURES NECESSARY TO SECURE PEACE AMD PROSPERITY FOR ALL OF ITS MEMBERS.

09777 WORTHMANN, J. HIGH HOPES OF MIDDLE EAST PROGRESS AS LABOUR REGAINS POWER IN JERUSALEM

THE ELECTION YICTORY OF ISRAEL'S LABOR PARTY HAS AROUSED HOPES THAT THERE HILL BE SOME MOVEMENT IN THE STALLED PEACE HOPES THAT THERE HILL BE SOME MOVEMENT IN THE STALLED PEACE PROCESS. MANY SEE THE LABOR PARTY AND ITS LEADER, YITZHAK
RABIN, AS MORE APPROPRIATE TO THE POST-COLD WAR MIDOLE EAST RABIN, AS MORE APPROPRIATE TO THE POST-COLD WAR MIDOL IRANIANS ARE LOOKING FOR A NEW RELATIONSHIP WITH THE UNITED IRANIANS ARE LOOKING FOR A NEW RELATIONSHIP WITH THE UNITED STATES, THE SYRIANS ARE TRUMPETING PEACE, AND EVEN QADDAFI CANNOT EVADE THE TREND TOHARDS SEEKING BETTER RELATIONS WITH THE WEST. WITH RABIN, THE ISRAELIS WILL BE ABLE TO TAKE ADVANTAGE OF THESE CHANGES. FOR THE FIRST TIME, THE ISRAELIS HAVE CREATED THE REQUIREMENTS ON THEIR SIDE FOR SERIOUS PEACE TALKS

09778 WRABLEY, R.

NATION-BUILDING AND THE PRESIDENCY

PRESIDENTIAL STUDIES QUARTERLY, XXII(2) (SPR 92), 261-278. THE AUTHOR OF THIS ARTICLE EXAMINES THE AMERICAN CONSTITUT IONAL SYSTEM BOTH FROM THE PERCEPTIONS OF THOSE WHO BREATHED LIFE INTO THAT SYSTEM 200 YEARS AGO AND OF THOSE WHO DO SO TODAY. MANY OF THE ISSUES CONFRONTING THE NATION TODAY "REGARDING BALANCE BETHEEN POLIITICAL EQUALITY AND PRIVATE RIGHTS, THE APPROPRIATE ROLE OF THE GOVERNMENT IN THE ECONOMY, THE RELATIONSHIP BETWEEN THE STATES AND THE NATIONAL GOVERNMENT, THE RESPONSIBILITIES OF THE PRESIDENT AND THE CONGRESS. THE INFLUENCES OF THE FACTIONS" WERE ALL OEBATED IN THE FIRST YEARS OF THE CONSTITUTION. THE YIEWS OF ALEXAMDER HAMILTON AMD THOMAS JEFFERSON WERE THE TWO CHIEF ALOXATIMG IDEALS OF AMERICA'S FUTURE. EVENTUALY HAMILTON'S VISION OF A STRONG INDUSTRIAL NATION WON OUT OVER

JEFFERSON'S IDEAL OF A COUNTRY OF YEOMAN FARMERS. HAMILTON'S JEFFERSON'S IDEAL OF A COUNTRY OF YEOMAN FARMERS. HAMI VICTORY WAS MADE SECURE BY HIS PARTY CONTROLLING THE
PRESIDENCY THROUGH THE FOUNDATION YEARS 1789-1801 AND THE COURT FROM 1789-1835.

09779 WREDE, $H$

APPLICABILITY OF THE CSCE EXPERIENCE TO THE MIDDLE EASTERN CONFLICT AREA

JERUSALEM JOURNAL OF INTERNATIONAL RELATIONS, 14(2) (JUN

92), $114-122$.

THE CSCE HAS HAD GRADUAL BUT CONSIDERABLE SUCCESS IN FOSTERING COOPERATION AND STABILITY IN EUROPE. IF CDNCEIVED OF AS A LEARNING PROCESS AND APPLIED CAUTIOUSLY AND MODESTLY, THE CSCE MODEL COULD CONTRIBUTE TO REDUCING TENSIONS IN THE MIDDLE EAST.

09780 WRIGHT, B.; TIERNEY, W.

THE AMERICAN INDIANS IN HIGHER EDUCATION--A HISTORY OF CULTURAL CONFLICT

CHANGE, 23(2) (MAR 91), 11-18.

THIS ARTICLE BRIEFLY EXAMINES THE TRIUMPH ANO CHALLENGE,

AS WELL AS FAILURE AND TRAGEDY, THAT CHARACTERIZES THE HISTORY OF AMERICAN INDIAN HIGHER EDUCATION. THESE

CONFLICTING OUTCOMES REFLECT THE CLASH OF CULTURES, THE CONFRONTATION OF LIFESTYLES, THAT HAS ENSUED ON COLLEGE CAMPUSES SINCE COLONIAL DAYS. THE ARTICLE TRACES THE HISTORY OF INDIAN HIGHER EDUCATION FROM THE SEVENTEENTH CENTURY TO THE PRESENT. FOR CENTURIES, THE MAJOR GOAL OF THIS EDUCATIOH WAS THE "CIVILIZATION" OF THE HEATHEN SAVAGES AND THEIR ASSIMILATION INTO AMERICAN SOCIETY. ONLY IN THE 1970 S DID THE INDIAN PEOPLE BEGIN TO GAIM SOME CONTROL OVER THEIR OWM EDUCATION.

09781 WRIGHT, D.

DEATH TO TWEETY

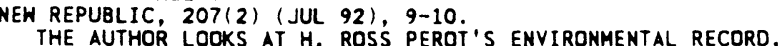

WHICH INCLUDES BUILDING A SHOPPING CENTER AND HOTEL ON THE

HABITAT OF A RARE BIRD, WHICH IS NOW ON THE ENDANGERED

SPECIES LIST.

09782 WRIGHT, E.; CHO, D.

STATE EMPLOYMENT, CLASS LOCATION, AND IDEOLOGICAL
ORIENTATION: A COMPARATIVE ANALYSIS OF THE UNITED STATES

ORIENTATION:

POLITICS AND SOCIETY, 20(2) (JUN 92), 167-196.

ONE OF THE MOST STRIKING DEVELOPMENTS IN MODERH SOCIETIES IS THE GRONTH OF THE STATE. THE OVERARCHING EMPIRICAL QUESTION ADORESSED IN THIS ARTICLE IS: ARE THERE SYSTEMATIC IDEOLOGICAL DIFFEREMCES HITIN AMD ACROSS CLASSES BETWEEN THE STATE AND PRIVATE SECTORS OF EMPLOYMENT? THE FIRST SECTION EXPLORES THE CONCEPTUAL ISSUES AT STAKE IN THE ANALYSIS OF IDEOLOGY AND STATE EMPLOYMENT. THIS IS FOLLOWED IN SECTION 2 WITH A OISCUSSION OF OATA AND METHOOS. SECTIONS 3 AND 4 THEN RESPECTIVELY PRESENT AND INTERPRET THE RESULTS OF THE DATA ANALYSIS.
09783 WRIGHT, J.J. JR. THAILAND'S RETURN TO DEMOCRACY CURRENT HISTORY, $91(569)$ (DEC 92), 418-423.

IN MAY 1992 IN BANGKOK, MORE THAN 50 THAIS DEMONSTRATING AGAINST THE MILITARY-CONTROLLED GOVERNMENT WERE KILLED BY THE ARMED FORCES. THE KILLINGS PUT THE COUNTRY ON A COURSE OF POLITICAL CHANGE THAT CULMINATED IN THE SEPTEMBER ELECTIONS AND THE NAMING OF THE FIRST THAI PRIME MINISTER WHO HAD NEITHER SERVED IN THE MILITARY NOR HAD LINKS WITH THE ARISTOCRACY

09784 WRIGHT, $K$.

CONVERSATIONS WITH PHOCION: THE POLITICAL THOUGHT OF MABLY HISTORY OF POLITICAL THOUGHT, 13(3) (FAL 92), 391-416.

THE OBJECT OF THIS ESSAY IS TO PROVIDE A BRIE INTRODUCTION TO THE 'NEW' MABLY. IT DOES SO THROUGH AN EXAMINATION OF A SINGLE WORK, "ENTRETIENS DE PHOCION", A DIALOGUE FIRST PUBLISHED IN 1763, WHICH INTRODUCED IN PRINT
FOR THE FIRST TIME MOST OF THE MAJOR THEMES OF HIS MATURE FOR THE FIRST TIME MOST OF THE MAJOR THEMES OF HIS MATURE IN HIS LIFETIME. A BRIEF LOOK AT IT PROVIDES THE OPPORTUNITY TO TEST THE COGENCY OF THE CIVIC HUMANIST READING OF MABLY'S THOUGHT, AS WELL AS TO SUGGEST SOMETHING OF THE SPECIFIC CHARACTER OF THE FRENCH CONTRIBUTION TO THE 'ATLANTIC REPUBLICAN TRADITION'.

09785 WRIGHT, M.; BUCK, T.

EMPLOYEE BUY-OUTS AND PRIVATIZATION: ISSUES AND IMPLICATIONS FOR LDCS AND POST-COMMUNIST COUNTRIES OF UK EXPERIENCE

PUBLIC ADMINISTRATION AND DEVELOPMENT, 12(3) (AUG 92), 279-296

PRIVATIZATION HAS BECOME AN INTERNATIONAL PHENOMENON. THIS PAPER DISCUSSES THE SCOPE FOR PRIVATIZATION BUY-OUTS IN LDCS AND \$POST COMMUNIST' ECONOMIES IN THE LIGHT OF CONCEPTUAL ISSUES AND UK EXPERIENCE. THE POSITIVE ASPECTS OF PRIVATIZATION BY MANAGEMENT AND EMPLOYEE BUY-OUTS, AS WELL PRIVATIZATION BY MANAGEMENT AND EMPLOYEE BUY-OUTS, AS WELL
AS THE POTENTIAL PROBLEMS WITH BUY-OUTS ARE DETAIILD. THE
PAPER CONCLUDES THAT THERE ARE MEANS BY WHICH MANY OF THE PAPER CONCLUDES THAT THERE ARE MEANS BY WHICH MANY OF THE
POTENTIAL PROBLEMS CAN BE DEALT WITH AND THE PAPER ADDRESSES POTENTIA
THESE.

09786 WRIGHT, M.; BUCK, T. PRIVATIZATION UNDER MRS. THATCHER: AN EXTENSION TO THE PRIVATIZA

PUBLIC ADMINISTRATION (LONDON), 70(2) (SUM 92), 287-291.

THE AUTHORS REVIEN AND CRITIQUE THE LITERATURE ON

PRIVATIZATION IN GREAT BRITAIN DURING THE THATCHER REGIME.

09787 WRIGHT, R.

ISLAM, DEMOCRACY, AND THE WEST

FOREIGN AFFAIRS, 71 ( 3 ) (SUM 92), 131-145.

THIRTEEN YEARS AFTER THE IRANIAN REVOLUTION, ISLAM IS ONCE AGAIN EMERGING AS A POWERFUL POLITICAL IDIOM. THE NEW BURST OF ISLAMIC ACTIVISM HAS REACHED SUCH PROPORTIONS THAT ISLAM IS INCREASINGLY--BUT ERRONEOUSLY--PERCEIVED AS ONE OF THE FUTURE IDEOLOGICAL RIVALS TO WESTERN DEMOCRACY. THE LATEST PHASE OF ISLAMIC ACTIVISM BEGAN IN THE LATE 1980'S AND DIFFERS DISTINCTLY FROM THAT OF THE LATE 1970'S AND EARLY 1980'S. THE THO MOST CONSPICUOUS DIFFERENCES ARE THE CONSTITUENCY AND TACTICS OF THE NEW ISLAMISTS.

09788 WRIGHT, $S$. AFRICA' IN THE POST-COLD HAR WORLD

TRANSAFRICA FORUM, $9(2)$ (SUM 92) 25-37.

THIS ESSAY PROVIDES AN ANALYTICAL OVERVIEW OF THE NEH CHALLENGES FACING AFRICAN COUNTRIES IN THE POST-COLD WAR WORLD AND CONSIDERS POSSIBLE NEW DIRECTIONS AND ADJUSTMENTS TO BE TAKEN IN RESHAPING FOREIGN POL ICY. THE FIRST SECTION
ADDRESSES PROBLEMS RELATED TO THEORETICAL DILEMMAS CREATED ADDRESSES PROBLEMS RELATED TO THEORETICAL DILEMMAS
BY THESE EVENTS, WHICH MUST BE TACKLED TO IMPROVE BY THESE EVENTS, WHICH MUST BE TACKLED TO IMPROVE
UNDERSTANDING OF AFRICAN FOREIGN POLICY DYNAMICS. THE SECOND UNDERSTANDING OF AFRICAN FOREIGN POL ICY DYNAMICS. THE SECTION FOCUSES ON SPECIFIC RELATIONS WITHIN GROUPS OF
COUNTRIES AS WELL AS REPERCUSSIONS OF THE CHANGING INTERNAL COUNTRIES AS WELL AS REPERCUSSIONS

09789 WRIGHT, T.

LATIN AMERICA IN THE ERA OF THE CUBAN REVOLUTIOM PRAEGER PUBLISHERS, $1991,248$.

THIS STUDY DESCRIBES AND EXPLAINS THE VAST IMPACT THAT THE CUBAN REVOLUTION HAD ON LATIN AMERICA AND ON U.S. - LATIN AMERICAN RELATIONS DURING THE PAST THREE DECADES. THE AUTHOR INTEGRATES DIVERSE AND COMPLEX POLITICAL EVENTS INTO A COMPREHENSIVE WHOLE--PROVIOING A BROAD PERSPECTIVE ON THIS CRITICAL PERIOD IN LATIN AMERICAN POLITICS. AMONG THE CURRENTS EXAMINED ARE THE DESTABILIZING IMPACT OF "FIDELISMO, " THE RISE OF RURAL AND URBAN GUERRILLA WARFARE, THE ALLIANCE FOR PROGRESS, THE GROWTH OF U.S. MILITARY INVOL VEMENT IN LATIN AMERICA, THE PERUVIAN MILITARY "REVOLUTION," THE ALLENDE REGIME IN CHILE. THE TERRORIST MILITARY REGIMES OF ARGENTINA AND CHILE, AND THE SANDINISTA REVOLUTION IN NICARAGUA. 
09790 HRIGHT, TP. JR.

THE PROBLEM OF EMPIRICISM IM COMPARATIVE POLITICAL RESEARCH BY MUSLIMS: A RESEARCH AGENOA

AMERICAN JOURNAL OF ISLAMIC SOCIAL SCIENCES, 9(3) (FAL 92), 0-50.

THE AUTHOR CRITIQUES THE CONCEPTS aND VALUE ASSUMPTIONS OF THE EXISTING LITERATURE IN THE ACADEMIC FIELD OF COMPARATIVE POLITICS TO REVEAL THE BUILT-UP EUROPEAN (JUDEOCHRISTIAN OR SECULAR-HUMANIST) BIASES AND THEN TO SUGGEST AN AGENDA OF ISSUES ON WHICH MUSLIM AND NON-MUSLIM SCHOLARS MIGHT AGREE.

09791 WRINKLE, R.; LONGORIA, T.; MEIER, K.; POLINARD, J. MEXICAN AMERICANS AND MUNICIPAL EMPLOYMENT: THE IMPACT OF DISTRICT ELECTIONS ON STATUS AMD PAY LEVELS

STATE AND LOCAL GOVERMMENT REVIEW, 24(1) (WIN 92), 36-42. THE IMPACT OF CHANGE FROM AT-LARGE TO DISTRICTED SYSTEMS OF ELECTION IN EIGHT TEXAS CITIES IN TERMS OF THE EMPLOYMENT AND PAY STATUS OF MEXICAN AMERICANS IN THE MUNICIPAL WORK FORCE IS EXAMINED. THE STUDY FINDS THAT THE REPRESENTATIOM OF MEXICAN AMERICANS IN THE MUNICIPAL WORK FORCE IS ENHANCED FOR CERTAIN AREAS OF EMPLOYMENT AS WELL AS FOR PAY. MEXICAN FOR CERTAIN AREAS OF EMPLOYMENT AS HELL AS FOR PAY. MEXICAA AMERICANS FARE BETTER IN THE POST-DIS
OID IN THE ERA BEFORE DISTRICTING.

09792 WRONG, T.

MULLAH'S DAY

MEW REPUBLIC, 206(7) (FEB 92), 18-20.

ALGERIANS ARE BRACING FOR MORE VIOLENCE AND UNREST AS THE ISLAMIC SALVATION FRONT AND THE MILITARY VIE FOR DOMINATION. EDUCATED, PROFESSIONAL WOMEN WOULD BE AMONG THOSE TO SUFFER THE MOST IF THE FUMDAMENTALIST MUSLIMS GAIN CONTROL.

09793 HRONKA, J.

HUMAN RIGHTS AND SOCIAL POLICY IN THE TWENTY-FIRST CENTURY UNIVERSITY PRESS OF AMERICA, 1992, 274.

THE HISTORY AND PRACTICE OF HUMAN RIGHTS FROM ANCIENT TIMES UNTIL THE PRESENT IS TRACED IN THIS BOOK. I IDENTIFIES MAJOR SOURCES AND STAGES OF THIS QUEST HHICH HAS CULMINATED IN THE ADOPTION BY THE UNITED NATIONS OF A UNIVERSAL DECLARATION OF HUMAN RIGHTS. THIS DECLARATION IS BEIMG PERCEIVED AS CUSTOMARY INTERMATIONAL LAH. THE AUTHOR OFFERS A COMPARISON OF HUMAM RIGHTS AS DEFINED BY THE UNITED DECLARATOM ARD BY THE CONSTUTHONS OF THE UMITED STATES AMD ITS FIFTY STATES. THIS COMPARISON REVEALS GAPS BETWEEN THE STANDARDS OF THE UNIVERSAL DECLARATION AND THOSE OF TH U.S. CONSTITUION.

09794 WU, E.

RUSSIA: POTENTIAL TURNS INTO PROFITS

FREE CHINA REVIEH $42(12)$ (DEC 92 ) 32-41.

ALTHOUGH RUSSIA IS IN THE MIDST OF MASSIVE POLITICAL REFORMS AMD ECOMOMIC RESTRCTURIMG ITASS COMSIDERED ONE OF THE WORLO'S LARGEST POTENTIA MARKETS TAIWAN AND RUSSIA HAVE BEEN SLOW TO DEVELOP BILATERAL RELATIONS, BUT EXCHANGES ARE BEGINNING TO ACCELERATE, ESPECIALLY IN THE AREA OF ECONOMIC AND TRADE RELATIONS.

09795 WULIGER, R.

A WORLD ECONOMY: PARADIGMS LOST AND FOUND CHALLENGE, 35(1) (JAN 92), 4-12.

THE GLOBAL ECONOMIC LIBERALISM OF ALFRED MARSHALL AND JOHN MAYMARD KEYMES WAS REBORN AT THE IMF/WORLD BANK'S 1991 ANMUAL MEETING. OBSERVERS ARE WONDERING HHETHER THIS IS A LAST-DITCH BRAVURA STAND FOR ECONOMIC LIBERALISM BEFORE THE ONSLAUGHT OF SANITIZED FASCISM OR IF ECOMOMIC INTERDEPENDENCE AND HARMONY WILL SUCCEED WITH THIS SECOND COMING.

09796 HURFEL, D.

CHANGE OR CONTINUITY IN THE PHILIPPINES?

CURRENT HISTORY, $91(569)$ (DEC 92), 424-429.

ALTHOUGH THE MAY 1992 ELECTION STRENGTHENED DEMOCRACY IN THE PHILIPPINES, IT HAS NOT A MAJOR TURNING POINT. THERE WAS SO MUCH DISSATISFACTION WITH THE ELECTORAL PROCESS THAT THE EVENTS OF MAY AND JUNE DID NOT CONSTITUTE THE CONCLUSIVE CONSOLIDATION OF DEMOCRACY THAT MANY PARTICIPANTS AND ANALYSTS HAD HOPED FOR. THAT CONSOL IDATION NON DEPENDS ON HOH PRESIDENT FIDEL RAMOS USES HIS POHER AND HOH EFFECTIVELY HE DEALS WITH THE COUNTRY'S MANY ECONOMIC, SOCIAL, AND POL ITICAL PROBLEMS.

09797 HYSLING, A.

POYERTY AMD DECAY IN PERU

SWISS REVIEH OF WORLD AFFAIRS, 42(7) (OCT 92), 24-25. PERU'S ECONOMIC AND SOCIAL MISERY IS DUE MAINLY TO THE FAILURE OF ITS POLITICAL CLASS. THE GOVERNMENT HAS NOT DONE ITS JO8. THE LAH DOES NOT PROTECT THE PEOPLE; THE ROADS ARE POOR OR CRUMBLING; THE EDUCATION AND HEALTH CARE SYSTEMS ARE WRECKED. EYEN THE LIFT PROVIDED BY THE CAPTURE OF ABIMAEL GUZMAN, THE FOUNDER AND HEAD OF THE SHINING PATH GUERRILLAS, MAY NOT BE ENOUGH TO TURN THINGS AROUND. SO FAR, PRESIDENT
ALBERTO FUJIMORI'S POLICIES HAVE BEEN INCONSISTENT AND HE
HAS INTRODUCED NO FUMDAMENTAL IMPROVEMENTS.

09798 WYZAN, M.L.

BULGARIA: SHOCK THERAPY FOLLOWED BY A STEEP RECESSION RFE/RL RESEARCH REPORT, 1(45) (NOV 92), 46-53.

IN FEBRUARY 1991 BULGARIA. HIT BY THE SEVEREST EXTERNAL ECONOMIC SHOCKS IN EASTERN EUROPE, INITIATED A TOUGH ECONOMIC STABILIZATION PROGRAM, AT THE BEHEST OF THE INTERNATIONAL MONETARY FUND. LIBERALIZATION, A UNIFIED EXCHANGE RATE AND CURRENT ACCOUNT BUDGET DEFICIT, AND TIGHT CREDIT. DESPITE WESTERN PRAISE FOR THE PROGRAM'S ACCOMPLISHMENTS, THE ECONOMY NOW IS AFFL ICTED WITH A RECESSION FAR MORE SEVERE THAN ANTICIPATED AND WITH A CRUSHING DEBT-SERVICE BURDEN. UNOER PREVAILING CONDITIONS MOST POLICY ALTERNATIVES WOULD LEAD TO HYPERINFLATIION. HOHEVER, THERE ARE GROUNDS FOR GUARDED OPTIMISM BECAUSE THE WORST SHOCKS ARE PROBABLY OVER AND AN AGREEMENT WITH PRIVATE INTERMATIONAL CREDITORS MAY BE IN THE OFFING.

09799 WYZAN, M.L.

BULGARIAN LAW LOWERS FOREIGN INVESTMENT BARRIERS

RFE/RL RESEARCH REPORT, 1(13) (MAR 92), 41-43.

IN JANUARY 1992, BULGARIA'S MATIONAL ASSEMBLY PASSED A LAW ON FOREIGN INVESTMENT THAT ELIMINATES MANY LEGAL BARRIERS IN THE HAY OF POTENTI IAL FOREIGN INVESTORS. BUT NUMEROUS DISINCENTIVES REMAIN FOR FOREIGN INVESTORS, INCLUDING THE CURRENT ECONOMIC DOWHTURM, THE SMALL DOMESTIC MARKET, THE DEBT TO THE LONDON CLUB, AND AN UNSTABLE, UNDERVALUED CURRENCY. HHEN THE ECONOMYY IMPROVES, THE NEHLYFAVORABLE ATTITUDE OF INTERMATIONAL FINANCIAL ORGANIZATIONS AND WESTERN GOVERNMENTS TOWARD BULGARIA SHOULD BEGIN TO TAKE ROOT AMONG PRIVATE INYESTORS AS HELL.

09800 XIA, L.

WHY AN INCREASE IN VIOLENCE AGAINST FOREIGMERS BEIJING REVIEH, 35(51) (DEC 21), 15-16.

IN 1992, GERMAN NEO-NAZIS MURDERED AT LEAST 16 PEOPLE, AND APPROXIMATELY 1800 MINORITY INDIVIDUALS AND FOREIGNERS WERE THE VICTIMS OF EXTREMIST ATTACKS. SOME OBSERVERS CONTEND THAT THE GERMAN GOVERMMENT INDIRECTLY ENCOURAGES THE VIOLENCE BY NOT TAKING A STRONG STAND AGAINST IT. ALTHOUGH THE NATIONAL POLITICAL PARTIES AND THE FEDERAL GOVERNMENT HAVE CONDEMMED IT, THEY HAVE NOT TAKEN FORCEFUL ACTION TO END IT.

09801 XIA, Z.

THE' WEST TURNS TOUGH WITH YUGOSLAVIA

BEIJING REVIEW, 35(31) (AUG 92), 13-14.

WITH THE SITUATION IN BOSNIA-HERZEGOVINA CONTINUING TO DETERIORATE, THE WEST HAS TOUGHENED ITS ATTITUDE TOHARDS THE DETERIORATE, THE HEST HAS VUGHENED ITS AT TITUDE TOHARDS THE SERBIAN-DOMIMATED YUGOSLAV FEDERATION. ON MAY 11 , 1992, THE
EUROPEAN COMHUNITY MEMBER DECIDED TO RECALL THEIR EUROPEAN COMMUNITY MEMBERS DECIDED TO RECALL THEIR SUITE. IN LATE MAY. THE UNITED STATES AND THE E.C. URGED THE SUITE. IN LATE MAY, THE UNITED STATES AND THE E.C. URGED THE YUGOSLAVIA AND SUSPEND AIR LINKS AND OTHER ECONOMIC YUGOSLAVIA AND SUSPEND AIR
EXCHANGES WITH THE COUNTRY.

09802 XIAN, $H$.

PEACE PROCESS MEETS OBSTRUCTION

BEIJING REVIEW, 35(47) (NOY 92), 15

ON OCTOBER 30, 1992, FIGHTING BROKE OUT BETHEEN THE NATIONAL UNION FOR THE TOTAL INDEPENDENCE OF ANGOLA (UNITA) AND THE RULING PEOPLE'S MOVEMENT FOR THE LIBERATION OF ANGOLA (MPLA), ENDING A CEASE-FIRE AND RAISING FEARS OF RENEWED CIVIL' HAR. THE OUTBREAK WAS TRIGGERED BY UNITA LEADER JONAS SAVIMBI'S REFUSAL TO ACCEPT THE RESULTS OF THE 1992 ELECTIONS, WHICH FAVORED THE MPLA.

09803 XIANG, L.

IS GERMANY IN THE WEST OR IN CENTRAL EUROPE?

ORBIS, 36(3) (SUM 92), 411-422.

THE MOST IMPORTANT GERMAN QUESTION TODAY IS: WHO

CONTROLS CENTRAL EUROPE? A CLOSELY RELATED ISSUE IS: WILL THE FEDERAL REPUBLIC OF GERMANY MAINTAIN ITS HESTHARD ORIENTATION? THIS ARTICLE EXPLORES THE LURE OF CENTRAL EUROPE, GERMAN NATIONALISM, NATIONALISM AND NATO AMD WESTERN EUROPE'S REACTION. IT COMCLUDES THAT HASHINGTON WHOULD INITIATE THE RESTRUCTURING OF NATO BY ANMOUNCING ITS INTENT TO SHARE NATO'S LEADERSHIP WITH THE MAJOR POWERS OF WTETERM EURARE BY COMPELLING AMERICA'S NATO PARTEERS TO BEGIN THINKING ABOUT ARRANGEMENTS FOR THEIR COAMON SECURITY, BEGIN THINKING ABOUT ARRANGEMENTS FOR THEIR COMMON

IT WILL ALS

09804 XIANGSHENG, $F$.

DISARMAMENT AND DEMOBILIZATION IN CHINA
PEACE AND THE SCIENCES, 4 (DECC 91 ) 29-30.

PEACE AND THE SCIENCES, 4 (DEC 91 ), $29-30$.
FOR SOME TIME NOW DISARMAMENT HAS BEEN A CATCHWORD IN EUROPEAN POLITICS. ALMOST EVERY EUROPEAM KNOWS THE STORY INSIDE OUT. CHINA HAS ALSO DISARMED CONSIDERABLY, AND IT FIRST DID SO AT A TIME WHEN THE GUIDING STAR OF DISARMAMENT WAS STILL A LONG WAY AHAY FROM EUROPE. THIS PAPER OUTLINES 
CHINESE disARMAMENT FROM THE AUTHOR'S PERSOHAL PERSPECTIVE.

09805 XIANZHI, G.; SHUZENG, $Y$

UNDERDEVELOPED COUNTRIES BECOME POORER

BEI JING REVIEH, 35(48) (NOV 92), 16-17.

THE ECONOMIC SITUATION IN THE UNDERDEVELOPED COUNTRIES CONTINUES TO DETERIORATE FOR A NUMBER REASONS--THE UNJUST INTERNATIONAL POLITICAL AND ECONOMIC ORDER BEING THE MOST FUNDAMENTAL CAUSE.

09806 XIAD, C.

PREMIER LI PENG AND HIS FAMILY

BEIJING REVIEW, 35(5-6) (FEB 92), 23-24, 29-30.

BEI THE AUTHOR PROFILES CHINESE PREMIER LI PENG AND

DESCRIBES LI'S LEADERSHIP STYLE.

09807 XIAOBING, $Y$

NCP SESSION ON REFORM AND OPENING

BEI JING REVIEH, 35(12) (MAR 92), 5.

THE FIFTH SESSION OF THE SEVENTH NPC HELD, WHICH BEGAN IN BEIJING ON MARCH 20, FOCUSED ON THE QUESTION OF HOW TO FURTHER REFORM AND OPENING UP. IT URGED THE NATION TO SPARE NO EFFORT IN BREAKING NEW GROUND AND ABSORB USEFUL FOREIGN MATERIAL AND TECHNOLOGY SO AS TO INCREASE CHINA'S OVERALL NATIONAL STRENGTH AND IMPROVE LIVING STANDARDS. ADOPTING A NEH STEP TOWARDS REFORM OF THE POLITICAL STRUCTURE, THE GOVERNMENT HAS RECENTLY DECLARED THAT A GOVERNMENT

FUNCTIONARY SYSTEM HILL BE CARRIED OUT ON FULL SCALE IN 1995.

09808 XIAOBING, Y.

NEW SITUATION AND NEW PLANS

BEIJING REVIEW, 35(14) (APR 92), 18-21.

THE FIFTH SESSION OF THE SEVENTH MATIONAL PEOPLE'S CONGRESS (NPC) HAS HELD FROM MARCH 20 TO APRIL 3, 1992. THE NPC DEPUTIES DISCUSSED A RANGE OF TOPICS, INCLUDING PLANS FOR CHINA'S CONTINUED ECONOMIC REFORM AND THE OPENING OF SPECIFIC ECONOMIC CENTERS TO THE OUTSIDE WORLD.

09809 XIAOBING, Y.

STREAMLINING THE GOVERNMENT

STREAMLINING THE GOVERNMENT
BEIJING REVIEH, 35(21) (MAY 92), 21-23

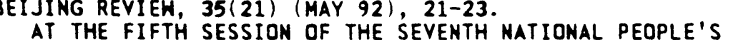
CONGRESS HELD FROM MARCH 20 TO APRIL 3, DEPUTIES STRESSED CONGRESS HELD FROM MARCH 20 TO APRIL 3, DEPUTIES STRESSED THE NEED TO ELIMINATE THE NEGATIVE FACTORS OF THE CURRENT ADMINISTRATIVE STRUCTURE THAT HINDER ECONOMIC DEVELOPMENT. THE PROBLEMS OF OVERSTAFFING AND ALSO OF BUREAUCRACY ARE ADORESSED IN THIS ARTICLE WHICH STATES THAT THE INDISTINC DIVISION OF LABOR AND THE BUCK-PASSING ATT ITUDE TAKEN BETWEEN DEPARTMENTS HAVE
AT THE GRASS-RDOTS LEVEL.

09810 XIAODONG, $Z$

BRAZIL CAUGHT IN A POLITICAL CRISIS

BEIJING REVIEW, 35 (37) (SEP 92), 15

THE BRAZILIAN DEMOCRATIC MOVEMENT, A MAJOR OPPOSITION

PARTY, IS LEADING THOSE WHO ARE CALLING FOR THE IMPEACHMEN

OF PRESIDENT FERNANDO COLLOR DE MELLO, DUE TO CHARGES OF CORRUPTION.

09811 XIAODONG, $Z$.

CENTRAL ASIA ON THE RISE

BEIJING REVIEH, 35(31) (AUG 92), 16-17.

THE BREAK-UP OF THE SOVIET UNION HAS PROVIDED THE CENTRAL ASIAN REPUBLICS A CONSIDERABLE DEGREE OF INDEPENDENCE, WHICH THEY ARE NOT WELL PREPARED TO HANDLE. NEVERTHELESS, THEY ARE MAKING EFFORTS TO ASSERT THEMSELYES REGIOMALLY A COYMOM RELIGIOUS BACKGROUND, BASED OY MUSLIM TIES, IS PROVING TO BE AN IMPORTANT FACTOR IN STIMULATING NEIGHBORING MUSLIM COUNTRIES.

09812 XIAODONG, Z.

COMPROMISE PUTS E.C. BACK TOGETHER

BEIJING REVIEW, 35 (52) (DEC 92), 12.

EUROPEAN COMMUNITY (E.C.) LEADERS MET FOR A SUMMIT IN EDINBURGH ON DECEMBER 11 AND 12, 1992, AND MANAGED TO TEMPORARILY BREAK THE DEADLOCK OVER EUROPEAN UNION. THEY AGREED TO AGREED TO GRANT DENHARK EXEMPTIONS FROM THE MAASTRICHT TREATY TO GRANT DEMHARK EXEMPTIONS FROM THE MAASTRICHT NO POLITICAL UNION. IN GENERAL. THE SUMMIT PROVED THAT THE E.C. MEMBERS CAN REACH AGREEMENT ON TECHNICAL ISSUES BUT STILL. MEMBERS CAN REACH AGREEMENT ON TECHNICAL

09813 XIAODONG, $Z$.

MAFTA AND ITS IMPACT

BEIJING REVIEH, 35(36) (SEP 92), 13-14.

ON AUGUST 12, THE UNITED STATES, MEXICO AND CANADA CONCLUOED A HISTORIC PACT--THE NORTH AMERICAN FREE TRADE AGREEMENT (NAFTA). THE NEH ACCORD, WHICH CAPPED MORE THAN 14 MONTHS OF NEGOTIATIONS, WAS A RESULT OF U.S. STRATEGIC ADJUSTMENTS UNDER THE POST-COLD HAR SITUATION. IT HAS THE POTENTIAL TO INFLUENCE THE ENTIRE WORLD ECONOMIC STRUCTURE. RESPONSES TO THE PACT IN CANADA WERE MIXED. THIS ARTICLE
REPORTS ON THE EXPECTED IMPACT OF THE NEW FREE TRADE AGREEMENT.

09814 XIAODONG, $Z$.

PAKISTAN STIMULATES INDUSTRIAL GROWTH

BEI JING REVIEW, 35(16) (APR 92), 14.

ALTHOUGH PAKISTAN IS WELL ON ITS WAY TO

INOUSTRIALIZATION, IT IS FAR FROM A FULLY-DEVELOPED NATION.

THE MAJOR OBSTACLE TO CONTINUED INDUSTRIALIZATION AND

DEVELOPMENT IS THE AVAILABILITY OF CAPITAL. SO, PAKISTANI

OEVELOPMENT IS THE AVAILABILITY OF CAPITAL. SO, PAKISTANI
PRIME MINISTER NAWAZ SHARIF HAS LAUNCHED A BOLD ECONOMIC

REFORM TO MEET THAT CHALLENGE. THE GOVERNMENT IS OFFERING

INCENTIVES TO CAPITAL-INTENSIVE PROJECTS THAT UTILIZE

ADVANCED TECHNOLOGY, MANAGERIAL SKILLS, AND MARKETING

EXPERTISE. IN ADDITION. TAX BREAKS ARE AYAILABLE FOR

INVESTORS WHO ESTABLISH ENTERPRISES IN RURAL AREAS.

09815 XIAODONG, $Z$.

PRESIDENT YELTSIN'S HOT POTATO

BEI JING REVIEN, 35(37) (SEP 92), 16

IN SEPTEMBER 1992, RUSSIAN PRESIDENT BORIS YELTSIN AND JAPANESE FOREIGN MINISTER MICHIO WATANABE MET TO DISCUSS THE FATE OF FOUR ISLANDS--KUNASHIRI, ETOROFU, SHIKOTAN, AND HABOMAI--THAT THE SOVIET UNION SEIZED FROM JAPAN AT THE CLOSE OF WORLD HAR II. THE THO FAILED TO COME TO AN AGREEMENT, BUT YELTSIN WAS CRITICIZED BY SOME RUSSIANS FOR EVEN CONSIDERING THE POSSIBILITY OF GIVING UP THE TERRITORY.

09816 XIAOBONG, $Z$.

REFORM: THE ONLY WAY OUT

BEI JING REVIEW, 35(17) (APR 92), 17.

THE GOVERNMENT OF MARASIMHA RAO HAS BROUGHT POLITICAL

STABILITY TO INDIA, BUT MANY CHALLENGES LIE AHEAD. RAO

IMPLEMENT A "SECOND INDUSTRIAL AND AGRICULTURAL REVOLUTION."

09817 XIAODONG, $Z$.

SINO-U.S. TRADE HAR AVERTED

BEIJING REVIEW, $35(43)$ (OCT 92), 8.

ON OCTOBER 10, 1992, CHINA AND THE UNITED STATES SIGNED

A MEMORANDUM OF UNDERSTANDING, AVERTING A DAMAGING TRADE WAR

A MEMORANDUM OF UNDERSTANDING, AVERTING A DAMAGING TRADE WAR

BETHEEN THE THO COUNTRIES. UNDER THE ACCORD, A VARIETY
CHINESE LICENSING REQUIREMENTS, QUOTAS, CONTROLS, AND

RESTRICTIONS WILL BE PHASED OUT'.

09818 XIAODONG, Z

THE BUMPY ROAD TO CAMBODIAN PEACE

BEIJING REVIEW, 35(49) (DEC 92), 13-14.

DESPITE INTERNATIONAL EFFORTS TO PROMOTE PEACE IM

CAMBODIA DURING THE PAST YEAR, THE CAMBODIAN PEACE PROCESS

IS STILL BEING CHALLENGED BY FACTIONAL CONFLICTS AND

DISAGREEMENTS. A GENERAL ELECTION IS SCHEDULED FOR MAY 1993, BUT MANY QUESTIONS REMAIN.

09819 XIAODONG, Z.

TORY HINS ANOTHER BOUT

BEIJING REVIEW, 35(17) (APR 92), 14-15.

THE AUTHOR REPORTS ON THE ELECTION OF JOHN MAJOR,

BRITAIN'S YOUNGEST PRIME MINISTER IN THIS CENTURY. THE

PRIMARY ISSUES WERE ECONOMIC, WITH MORE VOTERS APPARENTLY

FAVORING MAJOR'S MIXED MARKET ECONOMICS AND CONSERVATIVE IDEOLOGY THAN THE LABOR PARTY'S NEO-SOCIAL DEMOCRATIC DOCTRINE.

09820 XIAODONG, $Z$.

U.S. JET SALES DENOUNCED WORLDWIDE

BEI JING REVIEH, $35(38)$ (SEP 92) 15-16.

IN SEPTEMBER 1992, THE BUSH ADMINISTRATION ANMOUMCED

THAT IT WOULD SELL 150 F-16 FIGHTER JETS TO TAIHAIN--A

CONTROVERSIAL DECISION THAT TRIGGERED NEGATIVE REACTIONS

SURYEYS THE REACTIONS OF PAKISTAM THA A T THA T THE

BANGLADESH, SINGAPORE, INDIA, AUSTRALIA, AND SHITZERLAND.

09821 XIAODONG, Z.

VOTE FOR STROMG LEADERSHIP

BEIJING REVIEH, 35(30) (JUL 91), 14-15.

ON MAY 11, 1992, FIDEL RAMOS', THE PHILLIPINES' FORMER DEFENSE SECRETARY AND CORAZON AQUINO'S HAND-PICKED CANDIDATE,

WAS ELECTED PRESIDENT. PHILIPPINE ELECTIONS HAVE

WAS ELECTED PRESIDENT. PHILIPPINE ELECTIONS HAVE

1992 ELECTION SEEMED TO BE AN EXCEPIION AS OBSERVERS CALLED

IT THE MOST ORDERLY IN DECADES.

09822 XIAOGONG, C.

THE HORLD IN TRANSITION

BEIJING REVIEH, 35(5-6) (FEB 92), 13-15.

THE DRAMATIC EYEMTS IN EASTERY EUROPE AND THE FORMER

SOVIET UNION HAVE ENDED THE OLD HORLD PATTERN CHARACTERIZED

BY THE WASHINGTON-MOSCOW BIPOLAR SYSTEM AND HAVE BROKEN THE

STRAINED INTERNATIONAL STABILITY. THE WORLD IS IN THE

EMBRYONIC STAGE OF DEVELOPMENT OF A MULTI -POLAR HORLD. THE

SOLE REMAINING SUPERPOWER AND SEVERAL OTHER POWERS ARE

DEPENDENT UPON ONE ANOTHER BUT ALSO STRUGGLE AGAINST EACH 
other, producing a "DEtente amidst tURBUlenCe."

09823 XIAOGUAMG, L.

JAPAN SEEKS GREATER ROLE IN THE WORLD

BEI JING REVIEW, 35(5-6) (FEB 92), 10-12.

TOKYO IS PURSUING ITS GOAL OF' BECOMING A WORLD LEADER BY PLAYING A MORE ACTIVE POLITICAL ROLE IN INTERNATIONAL AFFAIRS, GAINING MORE INDEPENDENCE FROM THE UNITED STATES, AND PROMOTING ITS OWN VERSION OF A NEW WORLD ORDER.

09824 XIAONONGM $C$.

DILEMMAS OF ECONOMIC REFORM IN CHINA

WORLD AFFAIRS, 154(4) (SPR 92), 155-159.

REFORM IN CHINA HAS SET IN MOTION CERTAIN TRENDS THAT NOW APPEAR TO BE IRREVERSIBLE. DEMOCRACY MAY WELL HAVE BECOME INEVITABLE, AND IN THE NOT TOO DISTANT FUTURE. THIS ARTICLE EXAMINES THE FIRST DECADE OF REFORM--CONSOLIDATING THE REGIME; IRREVERSIBLE TRENDS IN THE REFORM; THE REGIME' BASE OF SUPPORT; AND, DEMOCRATIZATION--NECESSARY

BASE OF SUPPORT; AND, DEFOCRATIZATION--NECESSARY PRECONDITION FOR FURTHER ECONOMIC REFORM IT CONCLUDES THAT OF THE DEMOCATIC WORLD.

09825 XIMEI, C.; DELIANG, 0.

ASEAN SET'S NEW TARGETS FOR CO-OPERATION

BEIJING REVIEW, $35(8)$ (FEB 92), 15.

THE ASSOCIATION OF SOUTHEAST ASIAN NATIONS (ASEAN) HAS

ENTERED A NEW PHASE IN THE POL ITICAL AND EOCNOMIC CO-

OPERATION AMONG ITS MEMBER STATES. DURING A SUMMIT MEETING THE HEADS OF GOVERNMENT SIGNED THE SINGAPORE DECLARAIION TO SECURE REGIONAL PEACE AND PROSPERITY. THEY ALSO SIGNED A FRAMEWORK AGREEMENT ON ENHANCING ASEAN ECONOMIC CO-OPEATION WHICH SPECIFIED NEW TARGETS FOR ECONOMIC DEVELOPMENT. POLITICAL OBSERVERS SAY THAT THE SUMMIT HAS A SUCCESS BECAUSE THE DECLARATION AND OTHER DOCUMENTS ADOPTED DEMONSTRATED THE STRONG CONSENSUS HITHIN THE GROUPING ON STRENGTHENING CD-OPERATION IN VARIOUS FIELDS AND THE HILL OF THE ASEAN LEADERS TO POOL THEIR EFFORTS TO MAKE THE GROUPING STRONGER.

09826 XIN, R.

WESTERN ECONOMIC GROWTH REMAINS SLUGGISH

BEI JING REVIEH, 35(47) (NOV 92), 12-13.

CONTRARY TO EXPECTATIONS, THE EUROPEAN COMMUNITY, THE UNITED STATES, AND JAPAN ARE STILL SUFFERING FROM SLOW GROHTH, SLUGGISH ECONOMIES, AND RISING UNEMPLOYMENT. DESPITE GOVERMMENT INTERVENTION AND ECONOMIC POLICIES DESIGNED TO STIMULATE GROWTH, PROSPECTS FOR A RECOVERY IN 1993 ARE STILL QUESTIONABLE.

09827 XIN, W.

NIGERIA FACES PAINFUL CHOICES

BEI ING REVIEH, 35(37) (SEP 92), 17.

ON THE SEVENTH ANMIVERSARY OF PRESIDENT IBRAHIH

BABANGIDA'S MILITARY GOVERMMENT, NIGERIA IS AT A CROSSROADS BOTH POLITICALLY AND ECONOMICALLY, WITH PAINFUL CHOICES AHEAD. NIGERIA'S ECONOMIC DEPRESSIOM AND THE WIDESPREAD FRAUD IN THE 1992 PRESIDENTIAL PRIMARIES HAVE SHAKEN THE CONFIDENCE OF MANY NIGERIANS IN THE COUNTRY'S STRUCTURAL ADJUSTMENT PROGRAM AND IN THE PROSPECTS FOR A RETURN TO CIVILIAN RULE IN 1993.

09828 XIN, $\mathrm{H}$

ROGACHEV: SINO-RUSSIAN SUMMIT AHEAD

BEIJING REVIEW, 35(16) (APR 92), 8-9.

IN APRIL 1992, RUSSIA'S NEW AMBASSADOR TO CHINA, IGOR ROGACHEV, PRESENTED HIS OIPLOMATIC CREDENTIALS TO CHINESE PRESIDENT YANG SHANGKUN. HE EXPRESSED CONFIDENCE THAT SINORUSSIAN DISAGREEMENTS OVER THEIR MUTUAL BORDERS WOULD SOON BE RESOLVED AND THAT THE TWO COUNTRIES WILL ENJOY FRIENDLY RELATIONS IN THE FUTURE.

09829 XINGHAO, D

MANAGING SINO-AMERICAN RELATIONS IN A CHANGING WORLD ASIAN SURVEY, 31(12) (DEC 91), 1155-1169.

IT IS URGENT THAT BOTH THE U.S. AND CHINA ADAPT THEMSELVES TO THE CHANGING HORLD, TAKE A REALISTIC ATTITUDE TOWARD EACH OTHER, REDEFINE THE BASIS OF THEIR RELATIONS, STRENGTHEN THEIR TIES BASED ON THE FOUNDATION BUILT OVER THE PAST 20 YEARS, AND REVITALIZE THE MACHANISMS FOR MANAGING THEIR BILATERAL RELATIONSHIP. THIS ARTICLE EXPLORES MULTIPOLARITY AND NEW HORLD ORDER INFLUENCES IN CHINA. IT MULTIPOLARITY AND NEW HORLD ORDER INFLUENCES IN CHINA. I CONCLUDES THAT IN FOREIGN RELATIONS AND FOREIGN POLICY DECISION MAKING, IDEOLOGY SHOULD COME SECOND TO SECURITY AND DEVELOPMENT. DIFFERENT SOCIAL SYSTEMS AND
NOT BE ALLOWED TO STAND BETHEEN NATIONS.

09830 XINHUA, $H$.

TRENDS TOHARD GLOBALIZATION AND A GLOBAL THINK TANK FUTURES, 24(3) (APR 92), 261-267.

NEW TRENDS TOWARDS GLOBALIZATION ARE IRREYERSIBLE. THE FORMATION OF THE BASIS FOR A GLOBAL SOCIAL SYSTEM IS FACILITATED BY SCIENCE AND TECHNOLOGY AND OTHER FORCES, A NEH STAGE IN THE DEVELOPMENT OF A GLOBAL THINK TANK HAS BEEN
REACHED. THESE TRENDS HAVE BEEN RELATED IN THE INITIAL STAGES OF DEYELOPMENT BUT A MEW TURNING POINT IS APPEARING AFTER NEARLY TWO DECADES. CHINA'S THINK TANK HAS PERCEIVED THAT LEARNING FROM THE WORLD AND PARTICIPATING IN A THINK TANK AT THE GLOBAL LEVEL ARE IMPERATIVE UNDER THE CIRCUMSTANCES OF GLOBALIZATION.

09831 XINWEN, $K$

DANISH VOTE CHALLENGES E.C. UNITY

BEIJING REVIEH, 35(25) (JUN 92), 16

EUROPE'S AMBITION TO FORGE A' POL ITICAL AND ECONOMIC

UNION ENCOUNTERED A SETBACK ON JUNE 2, 1992, WHEN DENMARK

REJECTED THE MAASTRICHT TREATY IN A NATIONAL REFERENDUM.

NEVERTHELESS, THE OTHER 11 EUROPEAN COMMUNITY MEMBERS VOWED

TO RATIFY THE TREATY HITHOUT CHANGES, EVEN IF IT MEANS

LEAVING DENMARK BEHIND.

09832 XIREN, $G$

WHY IS U.S. ECONOMIC RECOVERY UNSTABLE

BEI JING REVIEW, 35(38) (SEP 92), 33-34.

IN THE SPRING OF 1992 THE U.S. ECONOMY APPEARED TO BE ON THE WAY TO RECOVERY, AND AMERICAN ECONOMISTS WERE PREDICTING AN END TO THE THREE-YEAR RECESSION. BUT THE RECOVERY PROVED TO BE ILLUSORY BECAUSE THE BUSH ADMINISTRATION, THE FEDERAL RESERVE BOARD, AND ECONOMISTS UNDERESTIMATED THE DEPTH OF GES EMERGED BEFORE OLD ONES COULD BE COMPLETELY SOLVED.

09833 XIUQING, $Z$.

REAPING BENEFITS FROM ECONOMIC REFORM

BEIJING REVIEW, 35(51) (DEC 21), 16

THE DRIVE FOR ECONOMIC REFORM IS SHEEPING ACROSS LAOS AND GRADUALLY CHANGING THE COUNTRY'S ECONOMY. SINCE 80 PERCENT OF THE LAOTIANS ARE FARMERS, THE GOVERNMENT IS EMPHASIZING AGRICULTURAL REFORM TO LINK RENUMERATION WITH OUTPUT, DEVELOP A DIVERSIFIED RURAL ECONOMY, INCREASE AGRICULTURAL INVESTMENT, RAISE PRICES FOR AGRICULTURAL PRODUCTS, BUILD IRRIGATION WORKS, INCREASE THE AREA OF CULTIVATED LAND, AND EMPLOY PREFERENTIAL AGRICULTURAL TAX POLICIES.

09834 XU, C.; CHUNRU, H.; TAYLOR, D.C.

SUSTAINABLE AGRICULITURAL DEVELOPMENT IN CHINA

WORLD DEVELOPMENT, 20(8) (AUG 92), 1127-1144.

AN IMMENSE AND INCREASINGLY WELL-TO-DO POPULATION HAS

FORCED CHINA TO ABANDON SOME OF THE PRINCIPLES OF ORGANIC

FARMING THAT CHARACTERIZED CHINESE AGRICULTURE FOR CENTURIES.

THE ENVIRONMENTAL AND FOSSIL-FUEL ENERGY PROBLEMS

ACCOMPANYING CHINA'S REMARKABLE RURAL ECONOMIC DEVELOPMENT

DURING THE 1980'S HAVE LED TO AN INTENSIVE REEXAMINATION OF

DURING THE 1980 'S HAVE LED TO AN INTENSIVE REEXAMINATION OF
THE COUNTRY'S AGRICUL TURAL DEVELOPMENT POLICIES. WHAT HAS

THE COUNTRY'S AGRICUL TURAL DEVELOPMENT POLICIES. WWAT
EMERGED IS THE CONCEPT OF "ECOLOGICAL" AGRICULTURAL

EMERGED IS THE CONCEPT OF "ECOLOGICAL" AGRICULTURAL
DEVELOPMENT INVOLVING THE HYBRID PURSUIT OF "CONVENTIONAL

DEVELOPMENT INVOLVING THE HYBRID PURSUIT OF "CONVENTIONAL

INMOVATIVE" AND MODERN TECHNOLDGIES FROM THE WEST ALONG WI

DESCRIBE THE BACKGROUND AND CURRENT STATUS OF CHINESE

AGRICUL TURAL DEVELOPMENT, CHARACTERI ZE AND PRESENT

AGRICUL TURAL DEVELOPMENT; CHARACTERIZE AND PRESENT

AGRICULTURAL DEVELOPMENT, AND HIGHLIGHT SIMILARITIES AND

AGRICULTURAL DEVELOPMENT, AND HIGHLIGHT SIMILARITIES CONTRASTS BETWEEN CHINESE ECOLOGICAL A
SUSTAINABLE AGRICULTURE IN THE WEST.

09835 XUDONG, $H$.

STRIKES AND AND TOUGH ISSUES REMAIN

BEIJING REVIEW, 35(22) (JUN 92), 17

IN GERMANY, 1992 WAS A YEAR OF NEGOTIATIONS BETWEEN LABOR AND MANAGMENT. THE LARGEST STRIKE SINCE 1974 CONTINUED FOR 11 DAYS AND CAME TO AND END HHEN THE PUBLIC SECTOR UNIONS ON MAY 7 ACCEPTED THE NEW PROPOSAL OF COMPROMISE PRESENTED BY THE GOVERMMENT. HOWEVER, THE GERMAN GOVERMMENT HAS NOT RESOL VED THE OPEN AND DEEP CRISIS. THIS ARICLE EXPLORES THE FIRST FOUND OF STRIKE AND SUGGESTS THAT MANY BELIEVE THAT THE VARIOUS PROBLEMS HAVE RESULTED FROM THE QUICK UNIFICATION OF THE THO GERMANYS

09836 YABLOKOV

DISARMING SOVIET INDUSTRY

WORLD PRESS REVIEN, 39(8) (AUG 92), 42

THE AUTHOR OUTLINES SOME OF RUSSIA'S OPTIONS AS IT STRUGGLES HITH THE PROBLEM OF HOW TO MAINTAIN A REASONABLE LEVEL OF ECONOMIC STABILITY WHILE IT PHASES OUT MUCH OF THE MILITARY PRODUCTION THAT WAS THE MAINSTAY OF THE SOVIET ECONOMY.

09837 YAHIA, H.

INTERVIEH: FOREIGN MINISTER OF TUNISIA

AMERICAH-ARAB AFFAIRS, (36) (SPR 91) 48-51.

HABIB BEN YAHIA, FOREIGN MINISTER OF TUNISIA SINCE FABIB BEN YAHIA, FOREIGN MINISTER OF TUNISIA SINCE INTERNATIONAL, SUB JECTS. HE DECLARES OPTIMISH THAT THE PRESENT OFFERS A RARE OPPORTUNITY TO SOLVE THE ARAB-ISRAEL CONFLICT. HE STRESSES THE ELIMINATION, OR AT LEAST LIMITATION, OF ARMS OF MASS DESTRUCTION IN THE MIDDLE EAST. HE ARGUES THAT THE MAGHREB COUHTRIES HAVE A POSITIVE AND 
SUBSTANTIVE ROLE TO PLAY IN THE NEGOTIATIONS BETWEEN ISRAEL AND THE PALESTINIANS. HE HOPES THAT TUNISIAN-AMERICAN RELATIONS WILL IMPROVE, ESPECIALLY AS TUNISIAN SOCIETY BECOMES MORE DEMOCRATIC. HE PRAISES HIS NATION'S LONG TRADITION OF NON-VIOLENCE, AND BLAMES RECENT DISORDER ON

"FRINGE ELEMENTS" WITHIN TUNISIA.

09838 YAHUDA, M.

CHINESE FOREIGN POLICY AND THE COLLAPSE OF COMMUNISH

SAIS REVIEW, 12(1) (WIN 92), 125-138.

CHINA'S LEADERS MUST CONTEND WITH THE COLLAPSE OF

COMUUNISM AS WELL AS WITH THEIR POST-TIANANMEN INTERNATIONAL

ISOLATION. THIS ESSAY CONSIDERS THE INTERNATIONAL DIMENSION OF CHINA'S LEGITIMACY PROBLEM, AND EXAMINES HOW CHINA'S RULERS HAVE ADDRESSED THIER CDUNTRY'S INTERNATION

PREDICAMENT SINCE THE TIANANMEN TRAGEDY. IT CONCLUDES WITH AN ASSESSMENT OF THE DILEMMAS CONFRONTING BEIJING AND DISMISSES THE CONSEQUENCES THAT THESE MAY HAVE FOR THE INTERNATIONAL COMMUNITY.

09839 YAKOVENKD, A.

BUILDING SECURITY IN EUROPE AFTER THE HELSINKI-2 MEETING PEACE AND THE SCIENCES, 4 (DEC 91), 40-45.

RECENT FUNDAMENTAL SHIFTS IN THE SYSTEM OF INTERSTATE RELATIONS, ACCELERATING PROCESSES OF SCIENCE AND TECHNOLOGY DEVELOPMENT, GROWING INTERDEPENDENCE OF THE HORLD AND AGGRAVATING GLOBAL PROBLEMS HAVE LED MANY STATES TO RETHINK IN A RADICAL WAY THEIR IDEAS OF EFFECTIVE WAYS TO MAINTAIN NATIONAL SECURITY BOTH IN THE CONCEPTUAL CONTEXT AND IN THE CONTEXT OF PRACTICAL POLICY. THIS ARTICLE OISCUSSES THE CONCEPT OF BUILDING IN EUROPE AFTER THE HELSINKI-2 MEETING.

09840 YAN, L.

FAIRBANK'S UNDERSTANOING OF SINO-AMERICAN RELATIONS BEI JING REVIEN, $35(22$ ) (JUN 92), 33-35.

IN THIS ARTICLE, JOHN KING FAIRBANK'S UNDERSTANDING OF SINO-AMERICAN RELATIONS IS CONCENTRATED ON IN THO AREAS: HIS COMPREHENSION OF CHINESE SOCIETY INCLUDING HISTORY, CUL
POLITICS, AND ECONOMY; AND HIS EXAMINATION OF AMERICAN POLITICS, AND ECONOMY; AND HIS EXAMINATION OF AMERICAN
POLICIES TOWARD CHINA. HE ADDRESSES MISUNDERSTANDING AND POLICIES TOWARD CHINA. HE ADDRESSES MISUNDERSTANDING CONFRONTATION AND THEN DETAILS THE HISTORY, CULTURE, RELATIONS.

09841 YAN, $S$.

AHAITING THE ULTIMATE SANCTION

FAR EASTERN ECONOMIC REVIEW, 151(26) (JUN 91), 21

A SERIES OF RECENT, AND OFTEN SEEMINGLY UNCONNECTED, EVENTS HAVE FANNED SPECULATION BOTH INSIDE CHINA AND BEYOND THAT THE COUNTRY'S LEADERSHIP MIGHT HAVE BEEN SEEKING RECONCILIATION AROUND THE SECOND ANNIVERSARY OF THE 4 JUNE CRACKDOWN. EVENTS WHICH BODE WELL FOR REFORMERS INCLUDE THE APPOINTMENT OF REFORM-MINDED OFFICIALS TO HIGH GOVERNMENT POSITIONS, AND RECENT STATEMENTS BY GOVERNMENT LEADERS (INCLUDING CONSERVATIVE PRIME MINISTER LI PENG) CALLING FOR MORE REFORM. HOWEVER, THE FORCES OF CHANGE ARE STILL RESISTED BY A LARGE SEGMENT OF THE "GERONTOCRACY" WHICH CURRENTLY RULES CHINA. IN ADDITION, THE PREMIUM PLACED ON POLITICAL ECONOMIC STABILITY BY GOVERNMENT LEADERS LEAVES LITTLE ROOM FOR MEANINGFUL CHANGE.

09842 YANDLE, 8.

ESCAPING ENYIROMMENTAL FEUDALISM

HARVARD JOURNAL OF LAW AND PUBLIC POLICY, 15(2) (SPR 92), $517-539$

U.S. ENVIRONMENTAL POLICY IS A MODERN-DAY FORM OF FEUDALISM, A SYSTEM OF LAND-USE CONTROL THAT MIXES THE LAH OF THE MANOR HITH SPECIAL INTEREST GROUP EFFORTS TO OBTAIN LEGISLATIVE FAVORS. IN THIS ESSAY, THE AUTHOR EXAMINES THIS NEW ENVIRONMENTAL FEUDALISH, FOCUSING ON THE COASE THEOREM. PROPERTY RIGHTS TO ENVIRONMENTAL ASSETS, AND TRANSACTION PROPERTY RIGHTS TO ENVIRONMENTAL ASSETS, AND TRANSACTI
COSTS. HE STUDIES BOTH THE COASIAN ARGUMENT AND THE INTELLLCTUAL DEBATE BEHIND IT. COMMON-LAW RULES AND TRANSACTION COSTS ARE CENTRAL TO THE OISCUSSION, WHICH TRANSACTION COSTS ARE CENTRAL TO THE DISCUSSION, WHICH INCLUDES A THEORET ICAL COMPARISON OF THOSE COSTS UNDER DIFFERING LEGAL REGIMES. THE AUTHOR DISCUSSES THE LAW OF NUISANCE AND EARLY COMMON-LAH REMEDIES FOR ENVIRONMENTAL DAMAGE. ROOTED IN PRE-FEUDAL TIMES, THE COMMON LAH HAS DELIVERED RULES AND REMEDIES TO MODERY TIMES. THE SOMEWHAT CONFUSING SYSTEM OF RULES THAT DEAL WITH PRIVATE AND PUBLIC NUISANCE FORM ONE FOCAL POINT. RULES DEALING WITH THE MANAGEMENT OF COMMONS FORM A SECOND AREA OF EMPHASIS. THE AUTHOR EXPLAINS MORE RECENT TRANSFORMATIONS OF THE COMMONAUTHOR EXPLAINS MORE RECENT TRANSFORMATIONS OF THE LAW RULES IN NUISANCE LAW AND THE RESULT OF THIS TRANSFORMATIO
FEUDALISM.

09843 YANG, $H$.

SUMMARY OF SYMPOSIUM WITH THE U.S. NATIONAL DEFENSE UNIVERSITY

BEI JING REVIEN, $35(50)$ (DEC 92 ), $31-32$.
THE AUTHOR SUMMARIZES DISCUSSIONS AT A CONFERENCE OF

CHINESE EXPERTS AND TEACHERS FROM THE U.S. NATIONAL DEFENSE

UNIVERSITY HELD IN MAY 1992. THE PARTICIPANTS OISCUSSED
SECURITY IN ASIA, INCLUDING THE FUTURE OF U.S. MILITARY INTERESTS IN THE REGION AND THE EMERGENCE OF JAPAN AS A SUPERPOWER.

09844 YANG, S.C. UNITED GERMANY

AND DYSPHOR

KOREA \& WORLD AFFAIRS, 16(3) (FAL 92), 436-462.

DIFFICULTIES STEMMING FROM GERMANY'S SHIFT REUNIFICATION. HE ARGUES THAT KOREA SHOULD LEARN FROM THE GERMAN EXPERIENCE. ARGUES THAT KOREA SHOULD LEARN FROM THE GERMAN EXPERIENCE. ALTERNATIVE TO THE CURRENT OFFICIAL AND/OR UNOFFICIAL MODELS AND FORMULAS FOR KOREAN UNIFICATION.

09845 YANKELOVICH, $D$.

DFTER THE ELECTION

PORIGU AFFAIRS AFTER THE ELECTION

PROPONENTS OF THE "END OF HISTORY" ARE TOO NARROWLY
THE

FOCUSED ON GEOPOLITICS. THE NEXT CHAPTER IN AMERICAN HISTORY WILL FEATURE DIFFERENT PLAYERS AND THEMES THAN IN THE PAST. FOREIGN POLICY AND ECONOMIC POLICY WILL BECOME EVEN MORE INTERTHINED. THE DRAMA WILL FOCUS ON RESTORING AMERICA'S COMPETITIVE VITALITY, NOT ITS MILITARY STRENGTH. THE DOMINANT NOTE HILL BE PRAGMATISM, NOT IDEOLOGY. THE COMPETITION WILL BE HITH GERMANY AND JAPAN RATHER THAN THE SOVIET UNION. THE QUESTION OF DOMESTIC OR INTERMATIONAL HILL BE BRUSHED ASIDE AS IRRELEVANT, SINCE THE U.S. ECONOMY WILL STAND OR FALL IN THE INTERHATIONAL ARENA. AMERICA'S MORAL FERYOR WILL BE REDIRECTED FROM ANTI-COMMUNISM TO A NEW TYPE OF PATRIOTISM CENTERED ON IMPROVING THE QUALITY OF AMERICA'S GOODS AND SERVICES.

09846 YANNIAN, D.

SPEED UP REFORM, OPEN THE DOORS WIDER

BEIJING REVIEW, 35(10) (MAR 92), 7,9

THE CALL FROM CHINA'S LEADERS TÓ OUICKEN THE REFORM AND OPENING HAS BEEN TRANSLATED INTO MASS ACTION AS CHINA BUSTLES WITH RENEWED ECONOMIC ACTIVITY. THE NEH COMMITMENT TO REFORM IS POSSIBLE BECAUSE CHINA ENJOYS POLITICAL, TO REFORM IS POSSIBLE BECAUSE CHINA ENJOYS POLITICAL, ECONOMIC, EXPERIENCE; ENJOYS SOUND GOVERNMENT POLICIES; AND BENEFITS FROM BROAD PUBLIC UNDERSTANDING OF THE NEED FOR REFORM AND THE OPEN POLICY.

09847 YANOW, D.

SILENCES IN PUBLIC POLICY DISCOURSE: ORGANIZATIONAL AND POLICY MYTHS

JOURNAL OF PUBLIC ADMINISTRATION RESEARCH AND THEORY, 2(4) OCT 92 ), 399-423.

POLICY MYTHS ARE CONSTRUCTED AT THOSE POINTS WHERE THE IMPLEMENTING AGENCY IS MOST VULNERABLE. THEY FILL SILENCES IN DISCOURSE ABOUT PUBLIC POLICY MATTERS. THESE MYTHS ALSO FACILITATE THE TACIT UNDERSTANDING OF AND COMMUNICATION ABOUT VERBOTEN GOALS. THESE POINTS ARE ILLUSTRATED IN A CASE ANALYSIS OF THE ISRAEL CORPORATION OF COMMUNITY CENTERS, AN AGENCY CREATED TO IMPLEMENT NATIONAL SOCIAL POLICIES.

09848 YANZHONG, G.

LATIN AMERICAN INTEGRATION GAINS SPEED

BEIJING REVIEW, 35(3) (JAN 92), 14-15.

LATIN AMERIA ACCELERATED THE PACE OF INTEGRATION IN 1991 IN CONFORMITY WITH THE TREND OF DEVELOPMENT IN THE WORLD AT LARGE, HITH THE RESULT THAT THE ECONOMIC DEVELOPMENT IN THE REGION WAS SPURRED AT THE START OF THE NEW DECADE. THIS ARTICLE EXPLORES LATIN AMERICAN INTEGRATION WHICH WAS MANIFESTED BY ENUMERATED CHARACTERISTICS IN THE PAST YEAR. FIRST, SUB-REGIONAL INTEGRATION HAS MADE IMPORTANT PROGRESS AND SECCOND, PROGRESS HAS FOUND EXPRESSION NOT ONLY IN EDUCATIONAL AND SCIENTIFIC FIELDS.

09849 YAPING, J.

RABIN WINS WITH PEACE PROMISES

RABIN WINS WITH PEACE PROMISES
BEIJING REYIEH, $35(28)$ (JUL 92), 15-16

LABOR PARTY LEADER YITZHAK RABIN SWEPT TO VICTORY IN ISRAEL'S JUNE 1992 ELECTIONS, ENDING 15 YEARS OF RIGHT-WING RULE BY THE LIKUD AND BRINGING NEW HOPE TO BOTH ISRAELIS AND RULE BY THE LIKUD AND BRINGING NEW HOPE TO BOTH I

09850 YAPING, J.

TROOPS LAW AROUSES CONCERN IM ASIAN COUNTRIES

BEI JING REVIEH, $35(26)$ ( JUN 92), 9

DISREGARDING STRONG OPPOSITIÓN AT HOME AND ABROAD, THE JAPANESE HOUSE OF REPRESENTATIVES HAS PASSED A BILL AUTHORI IING THE OVERSEAS DEPLOYMENT OF THE SELF-DEFENSE AUTHORIZING THE OVERSEAS DEPLOYMENT OF THE SELF-DEFENSE KOMEITO, AND THE DEMOCRATIC SOCIALIST PARTY VOTED IN FAVOR OF THE BILL, WHILE THE JAPANESE COMMUNIST PARTY REPRESENTATIVES OPPOSED IT.

09851 YARBROUGH, J. RACE AND THE MORAL FOUNDATION OF THE AMERICAN REPUBLIC: ANOTHER LOOK AT THE DECLARATION AND THE NOTES ON VIRGINIA 
THE JOURNAL OF POLITICS, 53(1) (FEB 91), 90-105.

IN THE DECLARATION OF IMDEPEMDEMCE AS WELL AS IN HIS PUBLIC WRITINGS AND PRIVATE CORRESPONDENCE, THOMAS JEFFERSON ARTICULATED PRINCIPLES AND EXPRESSED OPINIONS HHICH HAVE THE UTMOST RELEVANCE FOR RACIAL JUSTICE. THIS PAPER EXPLORES THE IMPLICATIONS OF JEFFERSON'S VIEWS AS EXPRESSED IN THE DECLARATION OF INDEPENDENCE AND COMPARES THEM WITH WHAT HE SAYS ABOUT SLAVERY AND THE BLACK RACE ELSEWHERE, ESPECIALLY IN THE NOTES ON THE STATE OF VIRGINIA. THE AUTHOR ARGUES THAT HE SELF-EVIDENT TRUTHS OF THE DECLARATION ARE MORALLY SUPERIOR TO JEFFERSON'S SO-CALLED SCIENTIFIC ATTEMPT TO DERIVE VALUES FROM "FACTS," WHICH IS HIS ILL-CONCEIVED AND CONTRADICTORY PROJECT IN QUERY \#14 OF THE NOTES.

09852 YASMANN, $V$.

THE KGB AND INTERNAL SECURITY

RFE/RL RESEARCH REPORT, 1 (1) (JAN 92), 19-21.

THE USSR COMMITTEE FOR STATE SECURITY (KGB) UNDERWENT

RADICAL CHANGES IN 1991, CULMINATING IN THE MOST

COMPREHENSIVE REORGANIZATION OF THE EXTERMAL AND INTERNAL

SECURITY SERVICES SIMCE 1959. THE CHANGES WERE PRECIPITATED

BY THE END OF THE COLD WAR, THE DISINTEGRATION OF THE SOVIET

BY THE END OF THE COLD WAR, THE DISINTEGRATION OF THE SOVIET
UNION, THE CHANGING SHAPE OF EUROPE, AND THE TRANSFORMATION

UNION, THE CHANGING SHAPE OF EURDPE, AND THE TRANSFORMA

OF THE SOVIET POLITICAL REGIME. WHATEVER HAPPENS IN THE

FUTURE AND WHATEVER FORM ANY FUTURE UNION MAY TAKE, THE
RUSSIAN STATE WILL REMAIN AN INTELLIGENCE SUPERPOWER BECAUSE

IT IS THE HOME BASE OF THE ENTIRE KGB FOREIGN INTELLIGENCE

APPARATUS AND THE MILITARY MAIN INTELLIGENCE ADMINISTRATION (GRU).

09853 YASSINE, A.

CENSORSHIP AND THE ARAB WORLD

SWISS REVIEW OF WORLD AFFAIRS, 42(2) (MAY 92), 9-11. HHEN SALMON RUSHDIE WROTE BOOKS THAT ISLAMIC LEADERS LIKED, HE WAS HERALDED THROUGHOUT THE ARAB WORLD. WHEN HE WROTE A BOOK THAT THE AYATOLLAH KHOMEINI VIEHED AS BLASPHEMOUS, THE MUSLIM LEADER ISSUED A DEATH HARRANT FOR RUSHDIE. THIS EPISODE ILLUSTRATES AN IMPORTANT FEATURE OF ISLAMIC PHILOSOPHY, OF WHICH KHOMEINI IS ONLY THE LATEST AND ARGUABLY THE MOST MEDIA-CONSCIOUS REPRESENTATIVE: AUTHORS ARE TOLERATED AND EVEN HONORED ONLY SO LONG AS THEIR VIENS HAPPEN TO COINCIDE HITH THOSE OF THE RULING RELIGIOUS ESTABLISHMENT. THOSE WHO HAVE OTHER VIEWS OR WISH TO OFFER A DIFFERENT IMAGE OF REALITY MUST BE "ELIMINATED."

09854 YAWNGHWE, C.

MYSTIFICATION AND RATIONALITY: LEGITIMACY ANO THE STATE IM THE THIRD HORLD

JOURNAL OF CONTEMPORARY ASIA, 22(2) (1992), 169-186. THIS ARTICLE FOCUSES ON THE CRISIS OF LEGITIMACY WHICH IS PERCEIVED BY SCHOLARS AS AFFLICTING THE INDUSTRIALLY ADVANCED, CAPITALIST SOCIETIES OF THE WEST, IT OFFERS A GENERAL SURVEY OF CURRENT THOUGHTS ON LEGITIMACY AND AN EXAMINATION OF SOME OF ITS SIGNIFICANT ASPECTS AND DIMENSIONS WITH REFERENCE TO STATE-SOCIETY RELATIONS IN THE THIRD HORLD. IT CONCLUDES THAT THE MYSTIFICATION OF THE STATE, IN MOST THIRD WORLD COUNTRIES, HHETHER CAPITALISTORIENTED OR OTHERHISE, HAS RESULTED IN A DYSFUNCTIONAL GAP BETWEEN THE STATE AND THE REST OF SOCIETY. IN THESE NATIONAL FORMATIONS, THE STATE SPHERE IS "SEPARATED" FROM THE REST OF SOCIETY. HITHIN SUCH A DYSFUNCTIONAL CONFIGURATION IN WHICH THE STATE STANDS ABOVE THE REST OF SOCIETY, AND THE LATTER IS REPRESSED AND KEPT AT ARMS LENGTH FROM THE SPHERE OF THE STATE (AND ITS RESOURCES), IT IS OBVIOUSLY NOT CREDIBLE TO ATTRIBUTE TO THIRD WORLD STATES AND THEIR RULING REGIMES THE QUALITY OF LEGITIMACY IN THE FASHION THAT WOULD BE MEANINGFUL OR ACADEMICALLY USEFUL.

09855 YEBOAH-AFARI, A. ENSURING FAIRPLAY

WEST AFRICA, (3904) (JUL 92), 1172-1173.

THE LEADERS OF THE CHRISTIAN CHURCHES IN GHANA HAVE EXPRESSED THEIR DISQUIET OVER SOME ASPECTS OF THE ARRANGEMENTS FOR THE RETURN TO CIVILIAN CONSTIITUTIONAL DEMOCRATIC RULE. ONE AREA OF CONCERN TO THE CHURCHES IS THE NEED TO ENSURE A LEVEL PLAYING FIELO FOR ALL ASPIRANTS TO POL ITICAL OFFICE.

09856 YEBOAH-AFARI, A. GHAMA: HOPE FOR PEACE TALKS

WEST AFRICA, 75(3925) (DEC 92), 2096-2097.

THE NEW PATRIOTIC PARTY HAS DECIDED NOT TO CHALLENGE THE RESULT OF THE NOVEMBER 3 PRESIDENTIAL ELECTIONS IN COURT IN RESULT OF THE NOVEMBER 3 PRESIDENTIAL ELECTIONS IN COURT IN SPITE OF WHAT IT SAIO WAS CONCLUSIVE EVIDENCE OF THE MASSIVE RIGGING OF THE PRESIDENTIAL BALLOTING. A STATEMENT ISSUED BY THE PARTY SAID THAT PARTY TOOK THIS DECISION TO PROTEC WITNESSES, NOT BECAUSE OF THE LACK OF EVIDENCE. THE STATEMENT DESCRIBED THE PRESENT ATMOSPHERE OF GHANA AS BEING CHARACTERI ZED BY INTIMIDATION, HARASSMENT AND ATTACKS ON,
AND THE ARRESTS OF, THE FOLLOWERS AND SUPPORTERS OF THE NPP AND THE ARRESTS OF, THE FOLLOWERS AND SUPPORTERS OF THE NPP
IN PARTICULAR AND OF OTHER OPPOSTION PAPRTIES IN GENERAL, BY THE PARAMILITARY ORGANS OF THE RULING PNDC.
09857 YEBOAH-AFARI HISTORIC RALIY

WEST AFRICA, (3926) (DEC 92), 2144.

ON DECEMBER 8, 1992, GHANA'S FOUR OPPOSITION PARTIES PARTICIPATED IN A MASS RALLY PRIOR TO THE PARLIAMENTARY ELECTIONS. THE PARTY LEADERS PLEDGED TO PUBLISH PROOF THAT THE RECENT PRESIDENTIAL ELECTION HAD BEEN RIGGED AMD PROMISED TO BOYCOTT THE PARLIAMENTARY ELECTIONS IF THE GOVERNMENT DID NOT DESTROY THE OLD VOTING ROLLS AND REREGISTER THE VOTERS.

09858 YEBOAH-AFARI, A. THE POSTPONEMENT AND THE BOYCOTT WEST AFRICA, 75(3924) (NOV 92), 2054-2055.

IF THE THINKING IN SOME QUARTERS HAD BEEN THAT THE RESCHEDULING OF THE PARLIAMENTARY ELECTIONS IN GHANA WOULD HELP INFLUENCE THE OPPOSITION PARTIES TO CHAMGE THEIR DECISION TO BOYCOTT THEM, THE EARLY INDICATIONS HERE THAT IT WAS THE WRONG BAIT. THE FEELING IS THAT UNLESS THE SITUATION IMPROVES AS REGARDS THE IHADEQUACIES OF THE ELECTORAL SYSTEM, THE FOUR PARTIES WILL STILL HOLD ON TO THEIR BOYCOTT. THE THE FOUR PARTIES WILL STILL HOLD ON TO THEIR BOYCOTT. THE
BOYCOTT IS TURNING OUT TO BE AN EVEN MORE EFFECTIVE WEAPON BDYCOTT IS TURNING OUT TO BE AN EVEN MORE EFFECTIVE WEAPON
THAN THE OPPOSITION PARTIES PERHAPS ENVISAGED, JUDGING FROM THAN THE OPPOSITION PARTIES PERHAPS ENVISAGED, JUDGING FROM POPULACE, MOT TO MAKE GHANA A ONE-PARTY STATE.

09859 YEH, K.C.

MACROECONOMIC ISSUES IN CHINA IN THE 1990'S

CHINA QUARTERLY, (131) (SEP 92), 501-544.

IN 1981, THE CHINESE LEADERSHIP SET THE GOAL OF QUADRUPLING CHINA'S 1980 PER CAPITA GNP BY THE YEAR 2000 IN ORDER TO RAISE THE PEOPLE'S STANDARD OF LIVING. IN ADOITION CHINESE PLANNERS ARE VERY CONCERNED WITH ECONOMIC EFFICIENCY AND PRICE STABILITY. IN THIS ESSAY, THE AUTHOR BRIEFLY REVIEWS THE GROWTH RECORD OF THE 1980'S AND, AGAINST THIS BACKGROUND, RAISES SOME CRITICAL QUESTIONS CONCERNING CHINA'S ECONOMIC FUTURE IN THE 1990'S. AFTER DISCUSSING THE PRIMARY PROBLEM OF CONTROLLING CHINA'S POPULATION, HE EXAMINES THE SOURCES OF ECONOMIC GROWTH AND EXPLORES HOW THEY MIGHT ACCELERATE OR CONSTRAIN CHINA'S GRONTH IN THE NEXT DECADE. HE DISCUSSES THE PROBLEM OF INFLATION IN THE TRANSITION TO A MARKET-BASED ECONOMY AND CONCLUDES WITH COMMENTS ON THE TEN-YEAR PROGRAM AND THE EIGHTH FIVE-YEAR PLAH.

09860 YETIV, S.A.

THE OUTCOMES OF OPERATIONS DESERT SHIELD AND DESERT STORM: SOME ANTECEDENT CAUSES

POLITICAL SCIENCE QUARTERLY, 107(2) (SUM 92), 195-212. THE SUCCESSFUL CONTAINMENT AND REVERSAL OF IRAO's 1990 INVASION OF KUWAIT WAS RELATED TO DEVELOPMENTS SET IN MOTION BY THE IRAN-IRAQ WAR OF 1980-88. THESE EARLIER DEVELOPMENTS BY THE IRAN-IRAQ WAR OF 1980-88. THESE EARLIER DEVELOPMEM
LAID PART OF THE SECURITY-POLITICAL FOUNDATION FOR THE LAID PART OF THE SECURITY-POLITICAL FOUNDATION FOR THE

09861 YI, Z

IRAN'S DIPLOMACY IS QUIETLY CHANGING

BEI JING REVIEW, 35(25) (JUN 92), 14-15.

IRAN IS SUBTLY CHANGING ITS DOMESTIC AND FOREIGM POLICIES, ABANDONING THE POST-REVOLUTION ATTITUDE THAT IT NEEDS NEITHER THE EAST NOR THE WEST. ON APRIL 17, 1992, PRESIDENT HASHEMI RAFSANJANI DECLARED THAT HIS ADMINISTRATION WOULD COOPERATE WITH ANY AND ALL COUNTRIES THAT ARE READY TO ESTABLISH BILATERAL RELATIONS WITH IRAN. THE DISINTEGRATION OF THE SOVIET UNION IS PROVIDING AN OPPORTUNITY FOR IRAN TO DEVELOP RELATIONS WITH THE MUSLIM COUNTRIES IN CENTRAL ASIA. IN COOPERATION WITH AZERBAI JAN, KAZAKHSTAN, TURKMENISTAN, AND RUSSIA, IRAN HAS ESTABLISHED THE CASPIAN SEA COOPERATIVE GROUP, WITH HEADQUARTERS IN TEHRAN.

09862 YIMIN, $S$.

RUSSIA WOOS HEST TO BECOME WORLD POWER

BEIJING REVIEH, 35(26) (JUN 92), 10-12.

RUSSIA'S FOREIGN POLICY IS INTENDED TO RE-ESTABLISH IT AS A WORLD POWER THROUGH COOPERATION WITH THE WEST. HOWEVER, THIS AMBITION IS BEING COUNTERED BY THO FACTORS: DOMESTIC OPPOSITION TO THE GOVERNMENT'S PRO-WESTERN STANCE AND THE WEST'S VIGILANCE AGAINST RUSSIA'S POTENTIAL RE-EMERGENCE AS A GREAT POWER.

09863 YING, J.

U.S. INFLUENCE DIMINISHES IN EUROPE

BEI JING REVIEH, 35(32) (AUG 92), 16-17.

THE COLLPSE OF THE USSR HAS ELIMINATED THE SOVIET THREAT AS THE COMMON BINDING FORCE FOR THE U.S. -EUROPEAN ALLIANCE. WESTERN EUROPE IS NO LONGER FACED WITH A MILITARY CHALLENGE FROM THE EAST; INSTEAD. IT IS PLAGUED BY SOCIAL UNREST ECONOMIC CRISES; INSTEAD, IT IS PLAGUED BY SOC TERR TOR ADJUSTMENT IN U.S. -EUROPEAN RELATIONS. THE FOCUS OF THE POSTCOLD WAR INTERNATIONAL RELATIONS IS TILTING TOWARD ECONOMIC RIVALRY. THE U.S. -EUROPEAN RELATIONSHIP IS CHANGING FROM ONE OF PROTECTOR-PROTEGE TO ONE OF EQUAL POLITICAL PARTNERS AND 
ECONOMIC RIVALS.

09864 YISHAI, Y.

FROM AN IRON TRIANGLE TO AN IRON DUET? HEALTH POLICY MAKING IN ISRAEL

EUROPEAN JOURNAL OF POLITICAL RESEARCH, 21(1-2) (FEB 92), 91-108

THIS PAPER ADDRESSES FIVE CONSTRUCTS OF POLICY MAKING: POLICY CURTAIN, IRON TRIANGLE, ISSUE NETWORK, POLICY COMMUNITY, ANO IRON DUET. THE FIVE CONSTRUCTS ARE
DIFFERENTIATED BY TWD VARIABLES: EXCLUSION (DENOTING THE DIFFERENT IATED BY TWO VARIABLES: EXCLUSION (DENOTING THE
DEGREE OF OPENMESS TO NEW PARTICIPANTS) AND INTERDEPENDENCE (PERTAINING TO THE RELATIONSHIP BETHEEN PARTICIPANTS). A POLICY CURTAIN PREVAILS IN THE PRE-AGENDA STAGE, DENOTING BOTH EXCLUSION AND LACK OF DEPENDENCE. AN IRON TRIANGLE IS CHARACTERIZED BY EXCLUSION AND INTERDEPENDENCE. AN ISSUE NETWORK PORTRAYS INCLUSION AND LACK OF INTERDEPENDENCE. A POLICY COMMUNITY FEATURES INCLUSION AND INTERDEPENDENCE. AN IRON DUET COMBINES CHARACTERISTICS OF AN IRON TRIANGLE, AN ISSUE NETWORK, AND A POLICY COMMUNITY. THIS PAPER SUGGESTS THAT THE FIVE CONSTRUCTS ARE NOT ONLY PRODUCTS OF THE POLITICAL ENVIRONMENT BUT ARE AFFECTED BY THE DISTRIBUTION OF RESOURCES AND PRIMACY OF VALUES WITHIN A SPECIFIC ISSUEAREA. IT FURTHER ARGUES THAT A SEOUENTIAL DEVELOPMENT MAY OCCUR FOLLOWING ALTERATIONS IN THE DIVISION OF POWER AMONG STATE AGENCIES AND ORGANIZED GROUPS. THE INVOLVEMENT OF POWERFUL GROUPS OF PROFESSIONALS IN A POLICY COMMUNITY, PRODUCED BY MUTUAL DEPENDENCE OF STATE AND ASSOCIATION, MAY LEAD TO THE FORMATION OF A POLICY (IRON) DUET. THE HISTORICAL EVOLUTION OF SPECIALIZATION ENTITLEMENT IN ISRAEL I HEALTH POLICY IS USED AS A CASE STUDY.

09865 YISHAI, Y.

IMTEREST GROUPS AND BUREACRATS IN A PARTY-DEMOCRACY: CASE OF ISRAEL

PUBLIC ADMINISTRATION, 70(2) (SUM 92), 241-268.

THE RELATION BETHEEN INTEREST GROUPS AND STATE

BUREAUCRATS IN A PARTY DEMOCRACY TENDS TO BE BASED ON PARENTELA TIES INYOLVING PARTY MEDITATION AND RESULTING IN DEEP AND RECIPROCAL COMMITMENT. THE CONTACTS BETWEEN ADMINISTRATORS AND INTEREST GROUPS IN ISRAEL PRESENT A DEVIANT CASE. THE PAPER SHOWS THAT DESPITE THE FACT THAT ISRAEL PORTRAYS THE CHARACTERISTICS OF A PARTY-DEMOCRACY, INTEREST GROUPS GRAVITATE TOWARDS THE ADMINISTRATION RATHER THAN TOWARD POLITICAL PARTIES. SENIOR GOVERMENT OFFICIAL INTERACT EXTENSIVELY WITH INTEREST GROUPS; BUT AT THE SAME TIME THEY TEND TO DISCOUNT THE GROUPS' ACTIVITY. THESE DEVIATIONS HAVE BEEN EXPLAINED BY THE LIMITED SCOPE OF ADMINISTRATIVE CULTURE.

09866 YISHAI, Y.

INTEREST GROUPS AND BUREAUCRATS IN A PARTY DEMOCRACY: THE CASE OF ISRAE

PUBLIC ADMINISTRATION (LONDON), 70(2) (SUM 92), 269-285. THE RELATIONSHIP BETWEEN INTEREST GROUPS AND STATE BUREAUCRATS IN A PARTY DEMOCRACY TENDS TO BE BASED ON PARENTELA TIES INVOLVING PARTY MEDIATION AND RESULTING IN DEEP AND RECIPROCAL COMMITMENT. BUT THE RELATIONS BETWEEN ADMINISTRATORS AND INTEREST GROUPS IN ISRAEL PRESENT A DEVIANT CASE. EVEN THOUGH ISRAEL PORTRAYS THE

CHARACTERISTICS OF A PARTY DEMOCRACY, INTEREST GROUPS GRAYITATE TOHARDS THE ADMIMISTRATIOM RATHER THAM TOWARD POL ITAT TOWARS THE ADMY DEMTRATACY, INTEREST GROUPS POLIENSIVELY WITH INTEREST GROUPS. BUT OFFICIALS INTERACT EXTENSIVELY WITH INTEREST GROUPS; BUT, AT THE SAME TIME,
THEY TEND TO DISCOUNT THE GROUPS
CACTIVITY. THESE DEVIATIONS CAN BE EXPLAINED BY THE LIMITED SCOPE OF INTEREST GROUP DEMANDS AND

09867 YIWEL, J.

ECONOHICS ACCELERATING REFORMS

BEIJING REVIEH, 35(20) (MAY 92), 17-22

CHINESE ECONOMISTS HAVE REPSONDED TO THE REMARKS MADE BY DENG XIAOPING, THE CHIEF ARCHITECT OF CHINA'S POLICY OF DENG XIAOPING, THE CHIEF ARCHITECT OF CHINA'S POLICY OF REFORM AND OPENING TO THE OUTSIDE WORLD, DURING HIS
SOUTH CHINESE ECONOMISTS TO DISCUSS THE IDEAS PRESENTED BY DENG, CHINESE ECONOMISTS TO OISCUSS THE IDEAS PRESENTED BY DENG, THIS ARTICLE IS A SUM
OVER 40 ECONOMISTS

09868 YOICHI, $T$.

AN ENVIRONMENTAL MANDATE FOR RICE SELF-SUFFICIENCY JAPAN QUARTERLY, XXXIX(1) (JAN 92), 34-44.

THE AUTHOR EXPLAINS THE IMPORTANCE OF RICE TO THE JAPANESE PEOPLE AND THE CONSEQUENCES OF LIBERALIZING JAPAN'S RICE MARKET. THEN HE EXAMINES WHAT GATT'S FREE-TRADE PRINCIPLE HAS MEANT AND SUGGESTS A NEW GOVERNING PRINCIPLE FOR INTERHATIONAL AGRICULTURAL TRADE THAT WOULD COMPENSATE FOR THE DEFICIENCIES OF FREE TRADE.

09869 YONGCHUH, 0.

THE U.S.-RUSSIAN PARTNERSHIP AFTER THE COLD HAR BEIJING REVIEW, 35(51) (DEC 21), 33-35.
THE AUTHOR EXAMINES THE STATUS OF U.S.-RUSSIAN RELATIONS IN THE POST-COLD WAR ERA, FOCUSING ON "THE CHARTER FOR AMERICAN-RUSSIAN PARTNERSHIP AND FRIENDSHIP" SIGNED BY RUSSIAN PRESIDENT BORIS YELTSIN AND U.S. PRESIDENT GEORGE BUSH IN JUNE 1992.

09870 YOON, B.L.

REVERSE BRAIN DRAIN IN SOUTH KOREA: STATE-LED MODEL STUDIES IN COMPARATIVE INTERNATIONAL OEVELOPMENT, $27(1)$

(SPR 92 ), 4-26.

KOREA'S REVERSE BRAIN DRAIN (RBD) HAS BEEN AN ORGANIZED GOVERMMENT EFFORT, RATHER THAN A SPONTANEOUS SOCIAL PHENOMENON, IN THAT VARIOUS POLICIES AND THE POLITICAL SUPPORT OF PRESIDENT PARK CHUNG-HEE WERE INSTRUMENTAL IN OF KOREA'S RBD POLICIES ARE THE CREATION OF A CONDUCIVE OF KOREA'S RBD POLICIES ARE THE CREATION OF A CONDUCIVE DOMESTIC ENVIRONMENT (I.E., GOVERMMENT-SPONSORED STRATEGIC
$R+D$ INSTITUTION-BUILDING, LEGAL AND ADMINISTRATIVE REFORMS) R+D INSTITUTION-BUILDING, LEGAL AND ADMINISTRATIVE REFORMS)
AND THE EMPOWERMENT OF RETURNEES (VIA EXCEPTIONALLY GOOD MATERIAL BENEFITS, GUARANTEES OF RESEARCH AUTONOMY ETC) PRESIDENT PARK PLAYED THE CARDINAL ROLE IN EMPOHERING REPATRIATES AT THE EXPENSE OF HIS OWH CIVIL BUREAUCRACY, AND HIS CAPACITY FOR SUCH PATRONAGE DERIVED FROM KOREA'S BUREAUCRATIC-AUTHORITARIAN POLITICAL SYSTEM. RETURNING SCIENTISTS AND ENGINEERS DIRECTLY BENEFITED FROM THIS POLITICAL SYSTEM AS WELL AS PARK'S PERSONAL GUARDIANSHIP. FOR PARK, EMPOWERMENT OF RETURNING "BRAINS" WAS NECESSARY TO ACCOMPLISH HIS NATIONAL INDUSTRIALIZATION PLAN, THEREBY ENHANCING HIS POLITICAL LEGITIMACY IN DOMESTIC POLITICS. AN ALLIANCE WITH THE R+D CADRE WAS FUNCTIONALLY NECESSARY TO SUCCESSFULLY CONSOLIDATE STRONG PRESIDENTIAL POWER, AND POLITICALLY NON-THREATENING DUE TO THE PARTICULAR FORM OF "PACT OF DOMINATION" IN KOREA'S POWER STRUCTURE. RBD IN KOREA WILL CONTINUE IN THE NEAR FUTURE GIVEN THE NATION'S LOCAL INDUSTRIAL AND EDUCATIONAL SECTORS. KOREA'S FUTURE RBD, LOCAL INDUSTRIAL AND EDUCATIONAL SECTORS. KOREA'S FUTURE HOWEVER, NEEDS TO PAY CLOSER ATTENTION TO THE FOLLOWING
FOUR PROBLEMS: RESEARCH AUTONOMY; EQUALITY ISSUES; SKILLFOUR PROBLEMS: RESEARCH AUTONOMY; EQUALITY ISSUES; SKILL-
BASED REPATRIATION OF TECHNICIANS AND ENGINEERS RATHER THAN BASED REPATRIATION OF TECHNICIANS AND ENGINEERS RATHER THAN
PH.DS: AND SUBSIDIES TO SMALL AND MEDIUM IMDUSTRY FOR RBD.

09871 YOPO H, B.

THE RIO GROUP: DECLINE OR CONSOLIDATION OF THE LATIN AMERICAN CONCERTACION POLICY?

JOURNAL OF INTERAMERICAN STUDIES AND WORLD AFFAIRS, $33(4)$ HIN 92 ), $27-44$.

UPON ENTERING THE DECADE OF THE 1990S, THERE WAS A REgIONAL CONSENSUS THAT THE MECANISMO PERMANENTE DE CONSULTA $Y$ CONCERTACION POLITICA, INCLUDING ITS COMPOSITION, FUNCTIONS AND GOALS, NEEDED TO BE REVISED IN LIGHT' OF THE MAJOR CHANGES THAT HAD TAKEN PLACE BOTH IN THE INTERNATIONAL SYSTEM AND WITHIN THE REGION IN RECENT YEARS--CHANGES WHICH SIGNIFICANTLY ALTERED THE DIRECTIONS AND PRIORITIES OF THE FOREIGN POLICIES OF THE VARIOUS COUNTRIES IN THE RIO GROUP. SO IT WAS THAT THE SUMNMIT MEETING IN CARACAS TOUCHED UPON SOME OF THE MAJOR CHALLENGES TO THIS ORGANIZATION COMMITTED TO A REGIONAL CONCERTACION. AFTER AN EXAMINATION OF THE EVENTS THAT FOLLOWED, THIS ARTICLE CONCLUDES THAT UNDER THE SECOND GENERATION OF GOVERMMENTS THAT NOW TAKE PART IN THIS PROCESS, THE ORGANIZATION IS CONSOLIDATING ITSELF, AND IS TEMPERING ITS NATURE AND BASIC GOALS WITH PERCEPTIVENESS AND SENSITIVITY.

09872 YOST, D.S.

THE HISTORY OF NATO THEATER NUCLEAR FORCE POLICY: KEY FINDINGS FROM THE SANDIA CONFERENCE

JOURNAL OF STRATEGIC STUDIES, $15(2)$ (JUN 92), 228-261.

THE AUTHOR REPORTS ON A 1990 CONFERENCE ON NATO THEATER NUCLEAR FORCE (TNF) POLICY HOSTED BY SANDIA NATIONAL
LABORATORIES IN LIVERMORE, CALIFORNIA. DRAWING ON BOTH THE LABORATORIES IN LIVERMORE, CALIFORNIA. DRAWING ON BOTH THE
PRESENTATIONS AND THE PANEL OISCUSSIONS, HE SUMMARIZES THE PRESENTATIONS AND THE PANEL DISCUSSIONS, HE SUMMARIZES THE
MAJOR CONCLUSIONS ABOUT THE CONFERENCE'S PRIMARY THEMES: THE MAJOR CONCLUSIONS ABOUT THE CONFERENCE'S PRIMARY THEMES: THE
HISTORICAL PATTERN OF NATO TNF POLICIES; THE ROLE OF STUDIES, HISTORICAL PATTERN OF NATO TNF POL ICIES; THE ROLE OF ST
ANALYSES, AND EXERCISES IN FORMULATING THOSE POLICIES: ANALYSES, AND EXERCISES IN FORMULATING THOSE POLICIES; OTHER DETERMINANTS OF NATO TNF POLICIES; ENDURING UNRESOL VED
ISSUES IN TNF STRATEGIC PLANNING; AND THE FUTURE OF NATO TNF ISSUES

09873 YOST, D.S.

U.S. MILITARY POWER AND ALLIANCE RELATIONS ANMALS OF THE AMERICAN ACADEMY OF POLITICAL AND SOCIAL SCIENCE, (517) (SEP 91),80-93.

DUE IO THE COLPAPS OF COMMUNISM AND RELATED DEVELOPMENTS, FORWARD-DEPLOYED U.S. FORCES WILL PROBABLY BE REDUCED SUBSTANTIALY IN THE COMING DECADE. BUT OTHER COMPONENTS OF ALLIANCE RELATIONS: GENERAL-PURPOSE CONVENTIONAL FORCES, NUCLEAR DETERRENCE FORCES, GLOBAL SURVEILLANCE AND COMMUNICATIONS CAPABILITIES, AND MILITARY RESEARCH AND DEVELOPMENT. BURDEN-SHARING AND DECISION-MAKING WILL BECOME MORE CHALLENGING ALLIANCE PROBLEMS IN AN INCREASINGLY MULTIPOLAR AND FLUID INTERNATIONAL CONTEXT. FIVE FACTORS DESERVE PARTICULAR ATTENTION, ESPECIALLY HITH REGARD 
PERSIAN GULF WAR AND ITS AFTERMATH; GERMAN POLITICAL AND SECURITY CHOICES; WEST EUROPEAN POLITICAL AND ECONOMIC INTEGRATION; THE INTERNAL EVOLUTION OF THE SOVIET UNION AND EASTERN EUROPE; AND INTRA-WESTERN POLITICAL DIFFERENCES. DURING A TIME OF UNPREDICTABLE FLUX IN INTERNATIONAL POLITICS, THE MOST PRUDENT COURSE FOR THE UNITED STATES IS TO RETAIN THE ALLIANCE TIES ESTABLISHED AND MAINTAINED AT GREAT COST IN THE PAST AND TO ADAPT THEM TO NEH REQUIREMENTS

09874 YOUNG, $B$

WITH AXES IN THEIR EYES: RENTIERISM AND MARKET REFORM IN YUGOSLAYIA

STUDIES IN COMPARATIVE COMMUNISM, XXY(3) (SEP 92), 274-286. ETHNIC NATIONALISM, IN YUGOSLAVIA AND ELSEWHERE, IS NOT SEEN AS A RATIONAL PHENOMENON BUT AS A RESULT OF ANCIENT TRIBAL DIVISIONS AND A CULTURAL PREDILECTION TO FRATRICIDE. SUCH AN EXPLANATION ADDS VERY LITTLE TO THE UNDERSTANDING OF EAST EUROPEAN POLITICS IN THE POST-COMMUNIST ERA. AS AN ALTERMATIVE TO THE PRIMORDIAL TRIBALIST VIEN, THE AUTHOR POSITS THAT YUGOSLAV SOCIETY CAN BETTER BE UNDERSTOOD AS A RENT-BASED NESTED HIERARCHY OF PATRON-CLIENT LINKAGES. IN
SUCH A SOCIETY THE INSTITUTIONAL DIVISION BETWEEN STATE AND SUCH A SOCIETY THE INSTITUTIONAL DIVISION BETWEEN STATE
MARKET, BETWEEN POLITICS AND ECONOMICS, REOUIRED FOR A MARKET, BETWEEN POLITICS AND ECONOMICS, REQUIRED FOR A
MARKET-BASED SOCIETY HAS NOT AND CANNOT TAKE PLACE. RATHER THAN AN BEING AN UNFORTUNATE IDIOSYNCRASY THAT MIGHT HAVE BEENOMY AND MULTIPARTY POLITICS. ETHNIC YIOLENCE IM ECONOMY AND MULTIPARTY POLITICS. ETHNIC VIOLENCE IN
YUGOSLAVIA WAS PRODUCED BY ILL-CONSIDERED MARKET REFORM AND YUGOSLAVIA WAS PRO
POLITICAL DRIFT.

09875 YOUNG, $C$. GROHING PAINS

AMERICAN SPECTATOR, 2419) (SEP 91) 29-30.

LESS THAN A YEAR AFTER THE SOVIET UNION RECEIVED ITS OWN (FAR MORE VERBOSE AMD LESS CLEAR-CUT) VERSION OF THE FIRST AMENDMENT, THE LAH ON THE PRESS, INDEPENDENT NEWSPAPERS HAVE BECOME A VISIBLE AND UNRULY PRESENCE ON THE SCENE. THEY RANGE FROM DIGNIFIED PUBLICATIONS OF NEWBORN PARTIES TO THE FRANKLY SENSATIONALIST AND AVIDLY READ TABLOIDS. AS IS THE CASE WITH FREE NEWSPAPERS ANYWHERE, THE KEY WORD IS UNCERTAINTY.

09876 YOUNG, $C$

THE STRATEGY OF POLITICAL LIBERALIZATION: A COMPARATIVE VIEW OF GORBACHEV'S REFORMS

WORLD POLITICS, 45(1) (OCT 92), 47-65

THE AUTHOR RECOUNTS THREE WEST EUROPEAN CASES FROM THE LATE NINETEENTH AND EARLY TWENTIETH CENTURIES TO SHOW THAT POLITICAL LIBERALIZATION DOES NOT NECESSARILY REQUIRE A POLITICAL LIBERALIZATION DOES NOT NECESSARILY REQUIRE
REFORMER'S COMMITMENT TO DEMOCRACY. UNDER THE RIGHT CIRCUMSTANCES, EVEN CONSERVATIVE POLITICIANS MAY FIND LIBERALIZATION TO BE A RATIONAL AND ACCEPTABLE MEANS TO
SECURE THEIR POWER AND DEFEAT POWERFUL OPPONENTS, DESPITE SECURE THEIR POWER AND DEFEAT POWERFUL OPPONENTS. DESPIT THE RISK OF FUTURE UPHEAVALS. SUCH CIRCUMSTANCES HERE PRESENT IN THE SOVIET UNION IN THE LATE 1980'S, WHEN MIKHAIL GORBACHEV AND HIS SUPPORTERS USED THE STRATEGY OF POLITICAL LIBERALIZATION TO REMO
THE PARTY APPARATUS.

09877 YOUNG, C.

UPDATING THE POZNER FILE: AN INTERVIEW

AMERICAN SPECTATOR, 24(5) (MAY 91), 38-40.

THIS ARTICLE IS AN INTERVIEW HITH VLADIMIR POZNER, PROMINENT SOVIET TELEVISION PERSONALITY AND AUTHOR WHO RECENTLY LEFT THE RANKS DF THE COMMUNIST PARTY. HE SPEAKS OF GOVERNMENT ATTEMPTS TO MAINTAIN CONTROL OVER THE MEDIA; THE INCREASING CRIES FOR INDEPENDENCE IN THE BALTICS AND ELSEWHERE; AND THE FUTURE OF THE USSR.

09878 YOUNG, $C$

VICTIMHODD IS POHERFUL

REASON, 24(5) (OCT 92 ), 18-23.

THIS ARTICLE SUGGESTS THAT BOTH FEMINISTS AMD

ANTIFEMINISTS SEE ADVANTAGES IN KEEPING WOMEN DOHN. IN MATTERS OF SEX, THE LEFT-WING AND RIGHT-WING IMAGES OF FEMALE VICTIMIZZATION ACHIEVE A TRULY UNCANNY RESEMBLANCE. IT ALSO INDICATES THAT BOTH THE FEMINISTS WHO SELL THE IMAGE OF WOMAN AS VICTIM AND THEIR ANTIFEMINIST COUNTERPARTS ARE AFTER POWER AND THAT TAKING A LOOK AT SOME OF YOUR OWM DECISIONS THAT CONTRIBUTED TO YOUR UNHAPPINESS IS LESS APPEALING THAN DENOUNCING MEN OR FEMINISTS. IT CONCLUDES APPEALING THAN DENOUNCING MEN OR FEMINISTS. IT CONCLUDES
THAT MEN ARE VICTIMS TOO AND THAT WE'RE JUST A FEW STEPS THAT MEN ARE VICTIMS TOO AND THAT WE'RE JUST A FEW STEPS
AWAY FROM A BRAVE NEW WORLD IN WHICH EVERYONE IS EVERYONE'S AWAY FROH A BRAVE NEW WORLD IN
VICTIM AND NO ONE IS TO BLAME.

09879 YOUNG, $H$

FRUITS OF LABOUR

NEW REPUBLIC, 206 (15) (APR 92), 16, 18-19,

THE AUTHOR DISCUSSES THE UPCOMING PARLIAMENTARY ELECTION IN GREAT BRITAIN AND WHAT, IF ANYTHING, IT MIGHT PORTEND ABOUT THE NOVEMBER 1992 PRESIDENTIAL ELECTION IN THE UNITED STATES.
09880 YOUNG, H.P.; WOLF, A.

GLOBAL HARMING NEGOTIATIONS: DOES FAIRMESS MATTER? GLOBAL HARMING NEGOTIATIONS: DOES FAIRME

BROOKINGS REVIEN, 10(2) (SPR 92), 46-51. AT THE CENTER OF INTERNATIONAL GLOBAL HARMING
NEGOTIATIONS ARE ISSUES OF SHARING THE COSTS AND RESPONSIBILITIES FOR REDUCING RISK. THE QUESTIONS OF EQUITY AND THE FAIRNESS OF A COST-SHARING PLAN ARE CRUCIAL. MINISTERS TO THE 1990 U.N. WORLD CLIMATE CONFERENCE ACKNOWLEDGED THAT "THE PRINCIPLE OF EQUITY AMD THE COMMON BUT DIFFERENTIATED RESPONSIBILITY OF COUNTRIES SHOULD BE THE BASIS OF ANY GLOBAL RESPONSE TO CLIMATE CHANGE." THE SUCCESS OR FAILURE OF FUTURE GLOBAL WARMING NEGOTIATIONS MAY HINGE ON THE DELEGATES' ABILITY TO GIVE SATISFACTORY EXPRESSION TO THIS ELUSIVE CONCEPT OF EQUITY.

09881 YOUNG, M.; LAUNER, M.

REFLECTING GLASNOST IN THE SOVIET MEDIA: THE RECONTEXTUALIZATION OF CHERMOBYL

JOURNAL OF COMMUNICATION, 41 (2) (SPR 91), 102-124. A CRITICAL EVENT HITH ENORMOUS REPERCUSSIONS FOR BOTH THE SOVIET ECONOMIC AND INFORMATION SPHERES HAS THE EXPLOSION AT THE CHERNOBYL NUCLEAR STATION OF APRIL 26, 1986. EXPLOSION AT THE CHERNOBYL NUCLEAR STATION OF APRIL $26,1986.0$
PRESS COVERAGE OF THIS ACCIDENT WAS A HATERSHED IN SOVIET POLICY. THIS ARTICLE ASSESSES HOW MEDIA TREATMENTS OF POLICY. THIS ARTICLE ASSESSES HOW MEDIA TREATMENTS OF CHERNOBYL CHANGED THE DEVELOPING CONCEPT OF GLASNOST WHILE REFLECTING THE EXISTING CONCEPTION OF SOVIET MEDIA POLICY. IT REVIENS SOVIET NEWS COVERAGE AND ANAL YZES TWO DOCUMENTARY FILMS IN THE CONTEXT OF SOVIET CULTURAL VALUES AND POLITICAL
STAKES. IN CONCLUDES THAT THE RHETORICAL RECONSIRUCTION OF STAKES. IN CONCLUDES THAT THE RHETORICAL RECONSTRUCTION OF CHERNOBYL CONTRIBUTED TO THE LEGITIMATION OF NUCLEAR PONEF AND THE ENVIRONMENT AS PUBLIC ISSUES. FURTHERMORE, THE CHERNOBYL TRAGEDY WAS THEMATICALLY RECONSTRUCTED AS A
TRIUMPH OF TECHNOLOGY AND HUMAN COURAGE UNDER THE GUIDIMG HAND OF THE COMHUNIST PARTY.

09882 YOUNG, $T$.

REFORMING NATO'S COMMAND AND CONTROL STRUCTURES ARMS CONTROL, 12(3) (DEC 91), 27-43.

THAT THE POLITICAL RAMIFICATIONS EMANATING FROM THE ENDING OF THE COLD HAR NECESSITATE A REVAMPING OF THE ALLIANCE COMMAND AND CONTROL (C-2) ORGANIZATION IS ARGUED IN THIS ARTICLE. THE PROCESS OF NATIONAL DISINTEGRATION AND THE ALTERNATION OF BORDERS CANNOT NECESSARILY BE CONTROLLED TO THE BENEFIT OF THE WEST IN ALL CASES. IT SUGGESTS THAT IF NATO'S SUPPORTERS HISH IT BE BE CAPABLE OF RESPONDING TO THE NEW CRISES IN, NOT TO MENTION OUTSIDE, EUROPE, AND THEREBY MAINTAIN A POSITION WHEREBY TO EXERT A POSITIVE FORCE TO RESOLVE CONFLICTS, THEN THE MEANS TO EXERCISE C-2 OVER ALLIANCE MILITARY' FORCES MUST CHANGE.

09883 YOUNG, $T$.

THE NEED FOR SUBSTRATEGIC WEAPONS

ORBIS, 36(2) (SPR 92), 211-226.

THE PROBLEM ASSOCIATED WITH THE FUTURE ROLE FOR NUCLEAR WEAPONS IN NATO STRATEGY IS ANALYZED. NATO CONTINUES TO HAVE A NEED FOR NUCLEAR FORCES THAT SERVE POL ITICAL ENDS AS OPPOSED TO WARFIGHTING SYSTEMS. THIS ARTICLE WARHS THAT IF THE ALLIANCE CONTINUES TO ADHERE TO ITS CURRENT PRACTICE OF REDUCING NUMBERS AND CAPABILITIES OF NUCLEAR WEAPONS AND AVOIDING ALLIANCE-SPONSORED WAR GAMES INVOLVING NUCLEAR SCENARIOS, NATO COULD FIND ITSELF ILL-PREPARED TO MEET FUTURE SECURITY CHALLENGES TO ITS EUROPEAN MEMBERS. IT FINDS THAT NATO MUST RETAIN THE NUCLEAR ELEMENT OF ITS DECLARED STRATEGY IF IT IS TO PROVIDE FOR ITS EUROPEAN MEMEBERS' ULTIMATE SECURITY IN THIS QUICKLY EVOLVING AND POTENTIALLY UNSTABLE SECURITY ENVIRONMENT.

\section{YSMAL, C.} FRANCE

EUROPEAN JOURNAL OF POLITICAL RESEARCH, 22(4) (DEC 92 ), 401-407.

THE MEMBERS OF PRIME MINISTER MICHEL ROCARD'S CABINET

ARE LISTED ALONG HITH THEIR SEX AND THEIR PARTY AFFILIATION.

FOLLOWING A CABINET RESHUFFLE ON OCTOBER 2, 1990, ROCARD'S

CABINET WAS 70 PERCENT SOCIALIST

$09885 \mathrm{YU}, \mathrm{G}$.

LAPSING INTO CIVIL HAR AGAIN

BEIJING REVIEW, 35(48) (NOV 92), 16-17

RECENT ATTEMPTS TO ENFORCE A TEMPORARY CEASE-FIRE IN

LIBERIA HAVE FAILED, AND THE COUNTRY SEEMS DESTINED TO

SUFFER FROM WIDESPREAD CIVIL WAR.

09886 YU, P.K.

MODELS OF DEMOCRATS IN ISLAND CHINA/MAINLAND RELATIONS

JOURHAL OF CONTEMPORARY ASIA, 22(2) (1992), 224-233.

THIS ARTICLE DEVELOPS SIX MODELS OF DEMOCRATS. THEY VARY FROM A SIMPLE WILLINGMESS TO LISTEN TO THE OPINION OF OTHERS TO A "DETERMINATION TO ALLOH MAXIMUM PARTICIPATION FOR ALL BY LETTING EACH PERSON GO HIS OWN WAY AS HE DEEMS FIT." I ARGUES THAT THERE IS A CLOSE RELATIONSHIP BETWEEN THE KIND OF DEMOCRACY THAT IS PUT INTO PRACTICE OR HAS BEEN PRACTICED IN THE REPUBLIC OF CHINA (ROC) AND THAT OF THE PEOPLE'S REPUBLIC OF CHINA (PRC). THE ARTICLE EXPLICATES WHICH 
MODEL (S) OF DEMOCRATS BEST FIT THE ROC'S PRESIDENT CHIANG CHING-KUD AND PRESIDENT LEE TENG-HUI. EMPHASIS IS PLACED ON THE EVER CHANGING RELATIONSHIP BETWEEN BOTH SIDES OF THE TAIWAN STRAIT SINCE MARCH 1986.

09887 YUAN, J.; EDEN, L.

EXPORT PROCESSING ZONES IN ASIA: A COMPARATIVE STUDY ASIAN SURVEY, XXXII(11) (NOV 92), 1026-1045.

ASIAN SURVEY, XXXII (11) (NOV 92), 1026-1045.
THE RAPID SPREAD OF EXPORT PROCESSING ZONES (EPZS) THROUGHOUT THE THIRD WORLD REPRESENTS AN IMPORTANT POLICY CHANGE IN THE GLOBAL ECONOMY AND IN NORTH-SOUTH RELATIONS. HOWEVER, LITTLE WORK HAS BEEN DONE AT DEVELOPING A POLITICAL HOWEVER, LITTLE WORK HAS BEEN DONE AT DEVELOPING A POLI
ECDNOMY MODEL THAT WOULD RELATE EPZ PERFORMANCE IN A ECONOMY MODEL THAT HOULD RELATE EPZ PERFORMANCE IN A PREDICTABLE FASHION TO CERTAIN ECONOMIC, POL IT ICAL AND
SOCIAL VARIABLES. THE PURPOSE OF THIS STUOY IS TO DEVELOP SOCIAL VARIABLES. THE PURPOSE OF THIS STUDY IS TO DEVELOP
SUCH A MODEL. THE AUTHORS FOCUS ON THREE GROUPS OF VARIABLES SUCH A MODEL. THE AUTHORS FOCUS ON THREE GROUPS OF VARIABLES THE INTERNATIONAL. ENVIRONMENT, DOMESTIC CONDITIONS, AND THE
ROLE OF THE STATE. THEY USE THE MODEL TO COMPARE PERFORMANCE ROLE OF THE STATE. THEY USE THE MODEL TO COMPARE PERFORMANCE IN EXPORT PROCESSING ZONES IN TAIWAN, SOUTH KOREA AND CHINA. THEY CONCLUDE THAT FOR EPZS TO CONTRIBUTE IN A POSITIVE
FASHION TO LDC DEVELOPMENT, THE STATE CAN AND SHOULD PLAY AN IMPORTANT ROLE IN SEVERAL AREAS INCLUDING SETTING CLEARLY DEFINED AND REALISTIC OBJECTIVES FOR ITS PROCESSING ZONES, SELECTING APPROPRIATE SITES, AND ADJUSTING TO INTERNATIONAL AND DOMESTIC CHANGES.

09888 YUANCHAO, L.

THE POLITICS OF ARTILLERY SHELLING: A STUDY OF THE TAIWAM STRAIT CRISES

BEIJING REVIEH, 35(36) (SEP 92), 32-38.

THE ARTILLERY BOMBARDMENT BY THE CHINESE PEOPLE'S LIBERATION ARMY (PLA) SHORE BATTERIES IN THE 1950 S AND THE ENSUING TAIWAN STRAIT CRISES THAT BROUGHT CHINA AND THE UNITED STATES TO THE BRINK OF WAR ARE STILL SUBJECTS OF INTEREST FOR HISTORIANS, POLITICAL SCIENTISTS AND MILITARY INTEREST FOR HISTORIANS, POLITICAL SCIENTISTS AND MILITARY STRATEGISTS. THE THO TAIWAN STRAIT CRISES OF 1954 AND 1958
ARE VIEWED BY WESTERN SCHOLARS AS SUCCESSFUL EXAMPLES OF U.S ARE VIEWED BY WESTERN SCHOLARS AS SUCCESSFUL EXAMPLES OF U. CRISIS MANAGEMENT, HOWEVER, THE AUTHOR ARGUES THAT CHINA
HAD SPECIFIC AND LIMITED POLICY OBJECTIVES WHEN IT SHELLED JINMEN AND MAZU, OBJECTIVES THAT WERE LARGELY ACHIEVED.

09889 YUANYUAN, $Z$.

MITTERAMD IN SARAJEYO TO SHOH E.C. ROLE

BEIJING REVIEW, $35(28$ ) (JUL 92), 17 .

ON JUNE 27, 1992, FRENCH PRESIDENT FRANCOIS MITTERAND FLEW TO CROATIA AND VISITED SARAJEVO, PUBLICLY DECLARING THAT THE OBJECTIVE OF HIS VISIT HAS HUMANITARIAN. HOWEVER, SOME OBSERVERS SUGGESTED THAT HE HAD DEEPER MOTIVES. THEY ARGUED THAT MITTERAND WAS TRYING TO CORRECT FRANCE'S PROSERBIAN IMAGE AND TO RE-ESTABLISH THE CREDIBILITY OF BOTH FRANCE AND THE EUROPEAN COMMUNITY. MOREOVER, MITTERAND'S TRIP WAS IN RESPONSE TO AN AMERICAN CHALLENGE, SINCE THE UNITED STATES HAS MADE IT CLEAR THAT MORE INTERNATIONAL INTERVENTION IS NEEDED TO RESOLVE THE CRISIS.

09890 YUANYUAN, $Z$

TOUGH MISSION FOR FRENCH GOVERMMENT

BEIJING REVIEW, 35(31) (AUG 92) 15.

THE GROWTH OF FRANCE'S ECONOMY HAS ACCELERATED SINCE PIERRE BEREGOVOY WAS APPOINTED PRIME MINISTER IN APRIL 1992 , BUT IT IS UNCLEAR WHETHER THIS TREND CAN BE SUSTAINED. BEREGOVOY HAS DEVOTED HIMSELF TO THE ECONOMY AND HAS PURSUED A POLICY OF REDUCING INFLATION AND STABILIZING THE FRANC. HIS CONTINUED SUCCESS IN GUIDING THE ECONOMY IS IMPORTANT TO THE SOCIALIST PARTY'S CHANCES IN THE UPCOMING GENERAL ELECTIONS.

09891 YUJUN, R.

AFGHAN ISSUE: SETTLEMENT IN SIGHT

BEIJING REVIEW, 35(15) (APR 92), 14.

IN MARCH 1992, A U.N. OFFICIAL ANNOUNCED THAT AN AFGHAN INTERIM GOVERHMENT WOULD PROBABLY BE IN PLACE THREE MONTHS AHEAD OF THE U.N. SCHEDULE. THIS SHOULD HELP ACCELERATE THE SEARCH FOR A POLITICAL SETTLEMENT OF THE AFGHAN SITUATION.

09892 YUJUN, R.

ECO USHERS IN NEW ERA OF DEVELOPMENT

BEIJING REVIEW, $35(10)$ ) (MAR 92), 15.

THE ECONOMIC COOPERATION ORGANIZATION (ECO)--FOUNDED BY IRAN PAKISTAN, AND TURKEY--RECENTLY ADMITTED THE FORMER SOVIET CENTRAL ASIAN REPUBLICS TO MEMBERSHIP. ECO AIMS TO EVENTUALLY EMBRACE ALMOST ALL THE MUSLIM-DOMINATED COUNTRIES STRETCHING FROM THE INDIAN OCEAN TO THE BLACK SEA. ITS LONGRANGE GOALS ARE FULL-SCALE ECOMOMIC AND POLITICAL COOPERATION.

09893 YUK-HAI, L.

THE CHINESE RESISTANCE MOVEMENT IN THE PHILIPPINES DURING THE JAPANESE OCCUPATION

JOURNAL OF SOUTHEAST ASIAN STUDIES, 23(2) (SEP 92), 308-321.

THE CHINESE COMMUNITY IN THE PHILIPPINES BEFORE THE OUTBREAK OF THE PACIFIC WAR WAS RELATIVELY SMALL AND HOMOGENEOUS IN COMPARISON HITH THOSE IN OTHER SOUTHEAST
ASIAN COUNTRIES. WHEN THE JAPANESE OCCUPIED THE PHILIPPINE ISLANDS, THEY FOUND A CHINESE COMHUNITY OF LESS THAN ONE PERCENT OF THE TOTAL POPULATION. ALTHOUGH THIS SHALL ALIEN GROUP DID NOT APPEAR TO BE A SERIOUS THREAT TO THE JAPANESE, AUTHORITIES, THE CHINESE MAINTAINED SEVERAL GUERRILLA GROUPS, WHICH FORMED PART OF THE RESISTANCE MOVMENT DURING THE THREE AND ONE-HALF YEARS OF JAPANESE OCCUPATION. THE CHINESE

FOUGHT AGAINST THE JAPANESE NOT DUE TO LOYALTY TO THEIR
FILIPIND HOSTS BUT DUE TO HOSTILITY TOWARDS THE INVADERS.

09894 YUNCHENG, Y.

CHINESE PREMIER'S VISIT TO VIETNAM: FIRST IN 21 YEARS BEI JING REVIEW, 35(49) (DEC 92), 7

IN DECEMBER, 1992 CHINESE PREMIER LI PENG PAID AM

OFFICIAL VISIT TO VIETNAM TO MARK THE FIRST ANNIVERSARY OF

THE NORMALIZATION OF BILATERAL RELATIONS. DURING THE VISIT, II AND VIETNAMESE PRIME MINISTER VO VAN KIET EXCHANGED VIEHS ON ISSUES OF MUTUAL CONCERN.

09895 YUNG LEE, H.

SOUTH KOREA IN 1991: UNPRECEDENTED OPPORTUNITY, INCREASING CHALLENGE

ASIAN SURVEY, XXXII(1) (JAN 92), 64-73.

SOUTH KOREANS HELD GREAT EXPECTATIONS IN 1991 BUT ALSO EXPERIENCED DISAPPOINTMENTS AS THE YEAR PROGRESSED. THOUGH THE GOVERMMENT ACHIEVED SOME SUCCESS IN THE FOREIGN POLICY ARENA, SOUTH KOREAN DOMESTIC POLITICS HAVE BEEN

DISAPPOINTING TO MANY CITIZENS. ALSO DISCUSSED IN THIS ARTICLE ARE INTER-KOREAN RELATIONS AND FOREIGN POLICY.

09896 YUXIN, G.

CHINA TURNS TO MARKET ECONOMY

BEIJING REVIEW, 35(45) (NOV 92), 7.

THE 14TH NATIONAL CONGRESS OF THE COMHUNIST PARTY OF CHINA DECLARED THAT CHINA WILL ESTABLISH A SOCIALIST MARKET ECONOMIC SYSTEM, AS ADVOCATED BY DENG XIAOPING. BASED ON THE COMPETITIVE MARKET, THIS ECONOMIC SYSTEM, WHICH WILL HAVE DISTINCTLY CHINESE CHARACTERISTICS, WILL BE VERY EFFECTIVE IN THE RATIONAL ALLOCATION OF SOCIAL RESOURCES, THE PROMOTION OF SCIENTIFIC AND TECHNOLOGICAL PROGRESS, AND THE PROMOTION OF SCIENTIFIC AND TECHNOLOCIC
ACCELERATION OF ECONOMIC DEVELOPMENT.

09897 ZAAL, N.

THE AMBiVALENCE of AUTHORITY aND SECRET LIVES OF TEARS: TRAMSRACIAL CHILD PLACEMENTS AND THE HISTORICAL DEVELOPMENT OF SOUTH AFRICAN LAH

INTERMATIONAL JOURNAL OF PUBLIC ADMINISTRATION, 15(7) 1992), 372-404.

THE NEGATIVE ATTITUDES TOWARDS RACIALLY MIXED FAMILIAL GROUPS WHICH UNDERLAY MANY MID-TWENTIETH CENTURY SOUTH AFRICAN STATUTES HAD DEEP HISTORICAL ROOTS. THE MYTHOLOGY ABOUT THE UNDESIRABILITY OF THESE GROUPS LIVED ON INTO THE TWENTIETH CENTURY. DURING THE PERIOD 1960-1990 THERE WAS A SERIES OF GOVERNMENT ATTEMPTS TO PREVENT THE ARTIFICIAL CREATION OF MIXED FAMILIAL GROUPS BY PROHIBITING TRANSRACIAL ADOPIIONS. IN THE EARLY 1990S, AS A WHITE MINORITY FEARS FOR ITS FUTURE, THERE HAS BEEN AN UNHITTING RETURN TO THE KIND OF SELECTIVELY ACQUISITIVE CHILD PLACEMENT STRATEGIES ONCE UTILIZED BY THE DUTCH EAST INDIA COMPANY.

09898 ZAFFIRO, J.J.

U.S. RELATIONS HITH BOTSHANA: 1966-1989

TRANSAFRICA FORUM, $9(3)$ (FAL 92), 57-74.

THE INFLUENCES OF SOVIET COMHUNISM AND SOUTH AFRICA'S APARTHEID POLICIES HAVE PERMEATED THE SOUTHERM AFRICAN REGION AND DISTORTED BILATERAL RELATION BETHEEN THE UNITED STATES AND INDIVIDUAL COUNTRIES, SUCH AS BOTSWANA. BOTSWANA, WHICH HAS A DEMOCRATIC POLITICAL SYSTEM, HAS INSTITUTED POLICIES TO IMPROVE DOMESTIC CONDITIONS AND IS IN A POSITION POL ICIES TO IMPROVE DOMESTIC CONDITIONS AND IS IN A POSI TO BE AN ALLY OF THE UNITED STATES. TRADITIONALLY, U.S.
POLICY TOWARD BOTSWANA HAS EMPHASIZED SUPPORT FOREIGN AID, POL ICY TOWARD BOTSWANA HAS EMPHASIZED SUPPORT FOREIGN INVESTMENT, TRADE, AND DIPLOMATIC RELATIONS, HITH THE
MOTIVATION COMING PREDOMINANTLY FROM EAST-WEST COMPETITION MOT IVATION COMING PREDOMINANTLY FROM EAST-HEST COMPETITION
AND/OR CONCERN ABOUT SOUTH AFRICA. NOW THE END OF THE COLD WAR AND THE POLITICAL CHANGES WITHIN SOUTH AFRICA SUGGEST THAT THESE INFLUENCES WILL HAVE LESS IMPACT ON THE FOREIGN
RELATIONS OF BOTSWANA AND OTHER FRONTLINE STATES. IF THE USA RELATIONS OF BOTSWANA AND OTHER FRONTLINE STATES. IF THE
IS TO PLAY A CREDIBLE ROLE WITHIN THE REGION, AMERICAN IS TO PLAY A CREDIBLE ROLE WITHIN THE REGION, AMERICAN
FOREIGN POLICY TOWARD BOTSWANA AND OTHER FRONTLINE STATES FOREIGN POLICY TOWARD BOTSWANA AND OTHER FRONTLINE STATES
SHOULD BE BASED ON A MORE SOPHISTICATED ASSESSMENT OF THE SHOULD BE BASED ON A MORE SOPHISTICATED ASSESSMENT OF THE
ECONOMIC, SOCIAL, AND POLITICAL REALITIES IN EACH COUNTRY.

09899 ZAGALSKY, L.

PUT A SAFETY CAP ON TESTING

BULLETIN OF THE ATOMIC SCIENTISTS, 48(2) (MAR 92), 24-29. NOH THAT PEACE HAS BROKEN OUT, "SAFETY" IS THE' WEAPONS DESIGNERS' FAVORITE REASON TO CONTINUE NUCLEAR TESTING. A PHASE-OUT OF NUCLEAR TESTING MAY BE MORE POLITICALLY REALISTIC THAN AN IMMEDIATE BAN. THIS ARTICLE CONCLUDES THAT THIS CAN BE TAKEN CARE OF WITH JUST A FEW MORE EXPLOSIONS NOT ANOTHER ENDLESS ROUND. INSTEAD OF A VAGUE, OPEN-ENDED TESTING PROGRAM, THE NATION NEEDS A RATIONAL POLICY AIMED AT ACHIEVING A COMPREHENSIVE TEST BAN AS SOON AS POSSIBLE. ANY ADDITIONAL TESTING SHOULD MOVE CLOSER TO THAT GOAL. 
09900 ZAGARE, $F$

MATO, RATIONAL ESCALATION AND FLEXIBLE RESPONSE JOURMAL OF PEACE RESEARCH, 29(4) (NOY 92) 345-464. A MULII-STAGE ESCALATION MODEL IS DEVELOPED IN WHICH A MUTI-STAGE ESCALATION MODEL IS DEVELOPED IN WHICH EACH STAGE IS TAKEN AS A PSYCHOLOGICALLY DISTINCT AND EMPIRICALLY FEASIBLE MODE OF CONFLICT AVAILABLE TO TWO
STATES IN A HOSTILE, DETERRENT RELATIONSHIP. EACH STAGE IS DEFINED BY A GENERIC, EXTENSIVE-FORM GAME OF MUTUAL DETERRENCE IN WHICH THE CREDIBILITY OF EACH PLAYER'S THREAT IS ALLOWED TO VARY. THREE-STAGE GAMES EXHIBIT THE SAME STABILTIY-INSTABILITY PARADOX REVEALED IN TWO-STAGE STRUCTURES AND CONTINUE TO SUPPORT THE ARGUMENT THAT ESCALATION DOMINANCE AT ANY STAGE OF THE GAME IS USUALLY DESTABILIZING. THE IMPLICATIONS OF THE MODEL FOR NATO STRATEGY AND ARMS CONTROL UNDER A VARIETY OF CONDITIONS ARE DISCUSSED. ASSUMPTIONS ABOUT END GAME CREDIBILTIY ARE SHOWM TO BE CRITICAL IN DETERMINING THE WISDOM OF ELIMINATING EITHER ONE OR THO CONFLICT STAGES.

09901 ZAGORSKI, A.

POST-SOYIET NUCLEAR PROL IFERATION RISKS SECURITY DIALOGUE, 23(3) (SEP 92), 27-40.

BELRUS, KAZAHKSTAN AND UKRAINE HAVE PLEDGED TO ELIMINATE ALL MUCLEAR WEAPONS WHICH LEAVES RUSSIA AS THE SOLE SUCCESSOR NUCLEAR STATE. UNCERTAINTY ACCOMPANIES THE MPLEMENATION OF THIS POL ICY THIS ARTICLE DISCUSSES CHALLENGES IN EXTERNAL PROL IFERATION. IN A DISINTEGRATING CIS THE MILITARY-INDUSTRIAL COMPLEX MAY BE ENCOURAGED TO SEEK FOREIGN CUSTOMERS; AND THE LACK OF AN EFFECTIVE EXPOR CONTROL SYSTEM OVER THE ENTIRE CIS AREA. IT CONCLUDES THAT ADEQUATE COOPERATIVE MEASURES MUST BE FOUND TO CHANNEL THE INTERNAL MOTIVATION OF CIS ACTORS TOWARDS INTEGRATION INTO THE INTERNATIONAL MARKET.

09902 ZAGORSKI, $P$.

OEMOCRACY VS. NATIONAL SECURITY: CIVIL-MILITARY RELATIONS IN LATIN AMERICA

LYNNE RIENNER PUBLISHERS, 1992, 270.

SINCE THE MID-1980S, MANY LATIN AMERICAN COUNTRIES HAVE BEEN STRUGGLING TO CONSOLIDATE RECENT DEMOCRATIC GAINS. THIS BOOK TREATS ONE OF THE KEY PROBLEMS IN THAT PROCESS: ESTABLISHING CIVILIAN CONTROL OVER THE ARMED FORCES. THE BOOK FOCUSES ON FIVE COUNTRIES--ARGENTINA, BRAZIL, URUGUAY, CHILE, AND PERU--THAT HAVE HAD SIMILAR EXPERIENCES WITH MILITARY GOVERNMENTS AND SIMILAR TRANSITIONS TO DEMOCRACY. AVOIDING THE USUAL COUNTRY-BY-COUNTRY APPROACH, THE ADOPTS A DIRECTLY COMPARATIVE FRAMEWORK. CHAPTERS ON CONTEMPORARY LATIN AMERICAN MILITARY AS AN INSTITUTION AND STRATEGIES FOR EFFECTING CIVILIAN CONTROL ARE FOLLOWED BY
ANALYSES OF CRITICAL ISSUES IN CIVIL-MILITARY RELATIONS. ANALYSES OF CRITICAL ISSUES IN CIVIL-MILITARY RELATIONS,
EACH "CRITICAL ISSUE" CHAPTER DISSECTS A KEY AREA OF EACH "CRITICAL ISSUE" CHAPTER DISSECTS A KEY AREA OF CONFLICT BETWEEN THE ARMED FORCES AND CIVILIAN GOVERNMENTS AND INCLUDES A CASE

09903 ZAIDI, S.

A NEW SOUTH ASIA

SOUTH ASIA JOURNAL, 5(1) (JUL 92), 65-74.

SINCE THE END OF THE BIPOLAR WORLD THERE HAS BEEN AN UPSURGE OF NATIONALITIES PRESSING FOR AND ACHIEVING POLITICAL EXPRESSION. THE INDIAN STATE, AND SOUTH ASIA IN GENERAL, IS AN EXEMPLARY GROUND FOR THE PLAY OF THESE FORCES AND WITH THE SPREAD OF SCHOOL ING IT IS BOUND TO BECOME MORE SO. HOWEVER, THE FETISH OF INOIA'S UNITY AND INTEGRITY IS NOT ONLY UNCHALLENGED WITHIN THE INDIAN ESTABLISHMENT, THE OPTION IS LITERALLY ALMOST UNTHINKABLE. THIS ARTICLE SUGGESTS THAT ACCOMMODATING NATIONALITY IS NOT THE SAME AS STOKING NATIONALISM. IT ALSO SUGGESTS THAT INDIA AND PAKISTAN ARE NOT NATIONS, BUT EMPIRES--THAT TWO CULTTURAL GROUPS ARE IN CONTENTION FOR CONTROL OVER THE INDIAN QUASIEMPIRE. IT CONCLUDES THAT THE GENERAL MIXING OF POPULATIONS ENTAIL AN EXPLOSIVE EXPRESSION OF INDIGENOUS NATIONALITY WHEN THE LOWER NATIVE ORDERS FIND THEIR VOICE.

09904 ZAITSEV, V.K.

PROBLEMS OF RUSSIAN ECONOMIC REFORMS AMD PROSPECTS FOR ECONOMIC COOPERATIOY BETHEEM THE RUSSIAN FAR EAST AMD NORTHWEST PACIFIC COUNTRIES

JOURNAL OF NORTHEAST ASIAN STUDIES, $X(4)$ (WIN 92), 35-42. UNDER RUSSIA'S NEW POL ITICAL LEADERSHIP, RUSSIAN POLICY WILL EXPERIENCE A GREAT SHIFT IN PRIORITIES TOWARD THE ASIAPACIFIC REGION. IN GENERAL TERMS, IT WILL UNDOUBTEDLY BECDME PACIFIC REGION. IN GENERAL TERMS, IT WILL UNDOUBTEDLY
MORE PRAGMATIC, REDUCING TO A CONSIDERABLE DEGREE ITS MORE PRAGMATIC, REDUCING TO A CONSIDERABLE DEGREE ITS
MILITARY ASPECT AND COMPROMISIMG BETHEEN ECONOMIC RATIONALE MILITARY ASPECT AND COMPROMISING BETHEEN ECONOMIC RATIONALE AND SECURITY NEEDS. IN VIEW OF ECONOMIC REALITY, THE RUSSI LEADERSHIP SEEMS TO REALIZE THAT THE ONLY VIABLE WAY TO
DEVELOP SIBERIA AND THE RUSSIAN FAR EAST IS TO MAKE THE BEST DEVELOP SIBERIA AND THE RUSSIAN FAR EAST IS TO MAKE THE BEST USE OF THE ECONOMIC DYNAMISH OF THE ASIA-PACIFIC REGION. IT
IS WIDELY ACKNOWLEDGED THAT THE DEVELOPMENT OF SIBERIAN AND IS WIDELY ACKNOWLEDGED THAT THE DEVELOPMENT OF SIBERIA FAR EASTERN NATURAL RESOURCES IN AN ENVIRONMENTALLYAND DIRECT PARTICIPATION OF JAPAN, THE REPUBLIC OF KOREA, AND OTHER ASIAN-PACIFIC COUNTRIES.
09905 ZAK, M.

CAN ISRAEL HURDLE THE BARRIERS TO PEACE?

HORLD PRESS REYIEH, 39(9) (SEP 92) 20

THE AUTHOR ENUMERATES SOME FACTORS THAT WILL INFLUENCE ISRAELI PRIME MINISTER YITZHAK RABIN'S ABILITY TO REACH A SETTLEMENT WITH THE PALESTINIANS. THESE INCLUDE THE ISSUE OF BORDERS, ISRAEL I RELATIONS WITH SAUDI ARABI, THE SITUATION
IN LEBANON, THE POSITION OF THE EUROPEAN COMMUNITY, AND THE ISRAELI DESIRE FOR LOAN GUARANTEES FROM THE UNITED STATES.

09906 ZAKI, M. BEHAVIOR AND DETERMINANTS OF THE CURRENCY TO DEMAND DEPOSITS RATIO IN EGYPT

JOURNAL OF DEVELOPING AREAS, 26(3) (APR 92), 301-322. THE CRUCIAL ROLE THAT THE DEMAND FDR MONEY PLAYS IN STABILIZATION POLICIES ADVANCED BY THE MONETARY AUTHORITIES IS WIDELY RECOGNIZED AND ACCEPTED. SINCE THERE APPEARS TO BE NO STUDY AVAILABLE ON THE BEHAVIOR AND DETERMINANTS OF THE CURRENCY TO DEMAND DEPOSITS RATIO (C/DD) IN EGYPT, THIS PAPER WILL ATTEMPT TO PROVIDE ONE. THE PAPER REVIÉWS THE THEORETICAL IMPORTANCE AND POLICY IMPLICATIONS OF THE C/DD THEORETICAL IMPORTANCE AND POLICY IMPLICATIONS OF THE C/DD IN LIGHT OF THE BEHAVIOR OF THE RATIO IN EGYPT OVER NEARLY
FOUR DECADES (1952-1987). IT EVALUATES THE MAIN DETERMINANTS FOUR DECADES (1952-1987). IT EVALUATES THE MAIN DETERMINANTS
OF THE C/DD IN EGYPT AMD PRESENTS THE MOOEL AND DISCUSSES OF THE C/DD IN EGYPT AND PRESENTS THE MOOEL AND DISCUSSES
THE RESULTS. IT CONCLUDES THAT THE C/DD IS ONE OF THE MAJOR THE RESULTS. IT CONCLUDES THAT THE C/DD IS ONE OF THE MAJ
FACTORS INFLUENCING THE AMOUNT OF MONEY THAT THE BANKING FACTORS INFLUENCING THE AMOUNT OF MONEY THAT THE BANKING SYSTEM CAN CREATE, AND IF IT PROVES TO BE UNSTABLE, ITS PREDICTION WOULD BE NECESSARY TO BE ABLE TO DET

09907 ZALLER, J.; FELDMAN, S.

A SIMPLE THEORY OF THE SURVEY RESPONSE: ANSWERING QUESTIONS VERSUS REVEALING PREFERENCES

AMERICAN JOURNAL OF POLITICAL SCIENCE, 36(3) (AUG 92), 579-616.

OPINION RESEARCH IS BESET BY THO MAJOR TYPES OF "ARTIFACTUAL" VARIANCE: HUGE AMOUNTS OF OVERTIME RESPONSE INSTABILITY AND THE COMMON TENDENCY FOR SEEMINGLY TRIVIAL CHANGES IN QUESTIONAIRE FORM TO AFFECT THE EXPRESSION OF ATTITUDES. THIS ARTICLE PROPOSES A SIMPLE MODEL THAT CONVERTS THIS ANOMALOUS "ERROR VARIANCE" INTO SOURCES OF SUBSTANTIVE INSIGHT INTO THE NATURE OF PUBLIC OPINION. THE MODEL ABANDONS THE CONVENTIONAL BUT IMPLAUSIBLE NOTION THAT MOST PEOPLE POSSESS OPINIONS AT THE LEVEL OF SPECIFICITY OF TYPICAL SURVEY ITEMS AND THAT MOST RESPOND TO SURVEY QUESTIONS ON THE BASIS OF WHATEVER IDEAS ARE AT THE TOP OF THIER HEADS AT TH MOMENT OF ANSHERING. NUMEROUS EMPIRICAL REGULARITIES ARE SHOWN TO BE CONSISTENT WITH THESE ASSUMPTIONS.

09908 ZALLER, J.

INFORMATION, VALUES, AND OPINION

AMERICAN POLITIICAL SCIENCE REVIEH, 85(4) (DEC 91), AMERICAN POL

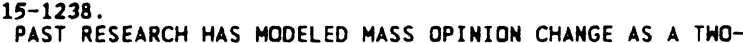
STEP PROCESS INVOLVING THE RECEPTION OF POLITICAL STEP PROCESS INVOLVING THE RECEPTION OF POL ITICAL COMMUNICATION AND THE ACCEPTANCE OR REJECTION OF THAT CDMMUNICATION. IN THIS PAPER, THE AUTHOR PROPOSES A TWOMESSAGE VERSION OF THE RECEPTION-ACCEPTANCE MODEL IN WHICH
CITIZENS ARE EXPOSED TO TWO OPPOSING COMHUNICATION FLOWS, CITIZENS ARE EXPOSED TO TWO OPPOSING COMMUNICATION FLOWS,
EITHER OR BOTH OF WHICH MAY AFFECT THEIR OPINIONS. VARIATION OVER TIME IN THE RELATIVE IMTEMSITY OF THE OPPOSING COMMUNICATIONS, ALONG WITH CITIZEN DIFFERENCES IN ATTENTION TO POLITICS AND IN POL ITICAL VALUES, INTERACT IN THE MODEL TO EXPLAIN BOTH CROSS-SECTIONAL PATTERNS OF MASS OPINION AND OPINION CHANGE ACROSS SURVEYS. THE MODEL, WHICH IS APPLIED TO DATA ON THE VIETNAM WAR, ILLUSTRATES TWO RESEARCH PROBLEMS: HOW COMPLEX INFORMATION FLOWS DIFFUSE THROUGH A MASS AUDIENCE AND HOW THIS INFORMATION SHAPES MASS BELIEF SYSTEMS.

09909 ZALLER, J.R

THE NATURE AND ORIGINS OF MASS OPINION

CAMBRIDGE UNIVERSITY PRESS, 1992, 368.

THIS BOOK DEVELOPS A COMPREHENSIVE THEORY TO EXPLAIN HOW PEOPLE ACQUIRE POLITICAL INFORMATION FROM THE MASS MEDIA AND CONVERT IT INTO POLITICAL PREFERENCES. USING NUMEROUS SPECIFIC EXAMPLES, THE AUTHOR APPLIES THIS THEORY IN ORDER TO EXPLAIN THE DYMAMICS OF PUBLIC OPINION ON A BROAD RANGE OF SUBJECTS. THESE INCLUDE BOTH DOMESTIC AND FOREIGN POLICY, TRUST IN GOVERNMENT, RACIAL EQUALITY, PRESIDENTIAL APPROVAL, AND VOTING BEHAVIOR IN U.S. HOUSE, SENATE AND PRESIDENTIAL ELECTIONS. PARTICULARLY PERPLEXING CHARACTERISTICS OF PUBLIC ELECTIONS. PARTI ICULARLY PERPLEXING CHARACTERISTICS OF PUBLIC
OPINION ARE ALSO EXAMINED, SUCH AS THE HIGH DEGREE OF RANDOM OPINION ARE ALSO EXAMINED, SUCH AS THE HIGH DEGREE OF RAND FLUCTUATIONS IN POLITICAL ATTITUDES OBSERVED IN OPINION SURVEYS AND THE CHANGES IN ATTITUDD
THE WORDING OF SURVEY QUESTIONS

09910 ZAMORA, T.A.

NEW JOBS FOR OLD LABS?

BULLETIN OF THE ATOMIC SCIENTISTS, 48(9) (NOV 92), 14-21.

RECENT ARMS CONTROL AGREEMENTS AND CHANGES IN

INTERNATIONAL POLITICS HAVE RAISED OUESTIONS ABOUT THE 
FUTURE OF THE UNITED STATES' MUCLEAR HEAPONS LABORATORIES-LOS ALAMOS, LAWRENCE LIVERMORE, SANDIA, AND THE NEVADA TEST SITE. SINCE THE SOVIET UNION COLLAPSED, ALL NUCLEAR HEAPONS PREVIOUSLY PLANHED FOR PROOUCTION HAVE BEEN CANCELED AND NO NEW ORDERS HAVE TAKEN THEIR PLACE. MOREOVER, FEH NEW ORDERS ARE LIKELY TO ARISE, SINCE CONGRESS AND THE' PRESIDENT HAVE AGREED ON LEGISLATION HALTING TESTING BY SEPTEMBER 30, 1996. THIS SITUATION CREATES AN EXCELLENT OPPORTUNITY TO

REORGANIZE THE RESEARCH FACILITIES AHAY FROM NUCLEAR WEAPONS REORGANIZE THE RESEARCH FACILITIES AHAY FROM
AND TOWARD MORE PRESSING NATIONAL CONCERNS.

09911 ZANEGIN, B.

BEYOND THE GEOPOLITICAL CRASH OF THE 1990S--TOWAROS A NEW EQUILIBRIUM?

SECURITY DIALOGUE, 23(4) (DEC 92), 13-20.

RUSSIA'S NEW-BORN DEMOCRACY HAS BEEN TRYING TO COPY WESTERN PATTERNS. THE REGIME HAS PURSUED A PRO-WESTERN POLICY, BUT WITHOUT THE TRUST AND SUPPORT OF LARGE GROUPS OF THE POPULATION. TRANSFORMATION OR COLLAPSE OF THE REGIME MAY BE INEVITABLE. THE DISINTEGRATION OF THE SOVIET UNION HAS HAD CATASTROPHIC EFFECTS INTERNATIONALLY: DESTABLIZATION AND NATIONALISH. NUMEROUS ARMED CONFLICTS AND WARS MAY PROVE TO BE THE VANGUARD BATTLES OF WORLD WAR III. RUSSIA WILL EVENTUALLY RESUME ITS POSITION AS A STRUCTURE-SHAPING POWER, BUT FIRST THE RUSSIAN PEOPLE WILL HAVE TO REDRESS THE FATAL MISTAKES MADE BY THE CURRENT PRO-WESTERN REGIME.

09912 ZANG, $X$.

PROFESSIONALISM AND THE LEADERSHIP TRANSITION IN THE POSTMAO CHINESE ARMY

JOURNAL OF NORTHEAST ASIAN STUDIES, $X(3)$ (FAL 91), 46-60. MANY CHINA EXPERTS CLAIM THAT THERE WAS A LEADERSHIP TRANSITION IN THE CHINESE ARMY IN THE 1980 S AND THAT THE FORMATION OF THE POST-MAO MILITARY ELITE REPRESENTS THE EMERGENCE OF TECHMOCRACY IN THE PEOPLE'S LIBERATION ARMY (PLA). HOWEVER, THEIR ARGUMENTS ARE NOT SUPPORTED BY (PLA). HOWEVER, THEIR ARGUMENTS ARE NOT SUPPORTED BY
SUFFICIENT DATA. THIS ARTICLE ANALYZED 224 TO CHINESE ARMY SUFFICIENT DATA. THIS ARTICLE ANALYZED 224 TO CHINESE ARM
LEADERS' BIOGRAPHIES AND FOUND THAT THERE WAS INDEED A LEADERS' BIOGRAPHIES AND FOUND THAT THERE WAS INDEED A
LEADERSHIP TRANSITION IN THE POST-MAO CHINESE ARMY AND THAT LEADERSHIP TRANSITION IN THE POST-MAO CHINESE ARMY THE CURRENT PLA ELITE CAN BEST CHARACTERIZED AS A
BUREAUCRATIC TECHNOCRRACY RATHER THAN JUST AS A TECHNOCRACY.

09913 ZANGA, L.

ALBANIA AFRAID OF WAR OVER KOSOVO

RFE/RL RESEARCH REPORT, 1 (46) (NOV 917, 20-23.

TIRANA IS SHOWING EVIDENCE OF A POLICY REVERSAL IN ITS APPROACH TO THE PROBLEM OF KOSOVO AND IS EMPHASIZING THE POSSIBILITY OF FINDING A PEACEFUL MEANS TO DEAL HITH THE QUESTION. EVEN ALBANIA'S RECOGNITION OF THE SELF-PROCLAIMED "REPUBLIC OF KOSOVO" IS UNDER SCRUTINY. DIPLOMATIC PRESSURE BY THE WEST AND ALBANIA'S FEAR OF OPEN HOSTILITIES HAVE LED TO THE REAPPRAISAL.

09914 ZANGA, L.

ALBANIA AND KOSOVO

RFE/RL RESEARCH REPORT, 1(39) (OCT 92), 26-29.

THE CHANGES IN THE ALBANIAN MEDIA SINCE THE DANM OF DEMOCRACY HAVE BEEN RATHER MODEST. THE ALBANIAN DEMOCRATIC PARTY'S PARTY-STATE, RATHER THAN THE COMMUNIST PARTY-STATE, CONTROL THE BROADCASTING MEDIA. THE PRESS IS MORE INDEPENDENT, BUT THE EXISTENCE OF MANY PUBLICATIONS IS CONSTANTLY THREATENED BY FINANCIAL PROBLEMS AND A SHORTAGE OF MATERIALS, ESPECIALLY NEWSPRINT. THUS, THE DEVELOPMENT OF ANYTHING RESEMBLING WESTERN-STYLE MEDIA IS PROCEEDING VERY SLOWLY LIKE ALL OTHER SECTORS OF THE ALBANIAN ECONOMY THE MEDIA RELY ON FOREIGN ASSISTANCE FOR THEIR VERY SURVIVAL. STILL, IF THE PRESENT STATE OF THE MEDIA IN ALBANIA IS LESS THAN IDEAL, THE SITUATION IN THE PREDOMINANTLY ALBANIANTHAN IDEAL, THE SITUATION IN THE PREDOMINANTLY ALBANIAN-
POPULATED SERBIAN PROVINCE OF KOSOVO IS HOPELESS. THERE, THE ALBANIAN-LANGUAGE MEDIA FACES TOTAL EXTINCTION UNDER SERBIAN ALBANIAN-LANG
REPRESSION.

09915 ZANGA, L.

ALBANIA REDUCED TO TOTAL DEPEMDENCE ON FOREIGN FOOD AID

RFE/RL RESEARCH REPORT, I(8) (FEB 92), 46-48.

ALBANIA'S ECONOMY IS IN A STATE OF ALMOST COMPLETE

PARALYSIS, AMD THE COUNTRY IS RELYING TOTALLY ON FOOD AID

PARALYSIS, AND THE COUNTRY IS RELYING TOTALLY ON FOOD AID

AHD OTHER FORMS OF ASSISTANCE FROM ABROAD. THUS FAR ITALY

HAS BEEN THE PRIMARY DONOR, BUT THE EUROPEAN COMMUNI ITY AMD

THE GROUP OF 24 INDUSTRIALIZED NATIONS ARE PREPARING

09916 ZANGA, L.

ALBANIA: BETWEEN DEMOCRACY AND CHAOS

RFE/RL RESEARCH REPORT, 1(1) (JAN 92), 74-77.

THE DEMOCRATIC TRANSFORMATION OF AL BANIA CONTINUED AT A RAPID PACE DURING 1991. IN EARLY 1991, CIVIL WAR THREATENED AS THE COUNTRY CAME TO THE BRINK OF POLITICAL, SOCIAL, AND ECONOMIC COLLAPSE. THE EMERGENCE OF OPPOSITION PARTIES AND THE FIRST MULTI-PARTY ELECTIONS IN LATE MARCH OFFICIALLY ENDED ALBANIA'S 50 YEARS OF STALINIST RULE.

09917 ZANGA, L.

ALBANIA: FALL OF GOVERMMENT PLUNGES COUNTRY INTO CHAOS
RFE/RL RESEARCH REPORT, 1(2) (JAN 92), 17-19.

THE COALITION GOVERNMENT OF PRIME MINISTER YLLI BUFI FELL ON DECEMBER 4, 1991, AFTER THE ALBANIAN DEMOCRATIC PARTY ANNOUNCED THAT IT HAS RESIGNING ITS PORTFOLIOS. THE COUNTRY IMMEDIATELY PLUNGED INTO YET ANOTHER CRISIS, WITH RIOTING AND LOOTING OF FOOD DEPOTS. OPPOSITION LEADER SALI BERISHA'S DECISION TO RESIGN FROM THE GOVERMMENT MET HITH RESISTANCE FROM THE PARTY'S OTHER LEADERS AND REVEALED THE GROWING DIVISIOHS HIHIY THE PARTY AS A HHOLE REVEALED THE THE DEMOCRATS' DEMANDS WERE MET, INCLUDING RESCHEDUL ING THE THE DEMOCRATS DEMANDS WERE MET, INCLUDING RESCHEDULING THE
GENERAL ELECTIONS. PRESIDENT RAMIZ ALIA APPROVED A CARETAKER GENERAL ELECTIONS. PRESIDENT RAMIZ ALIA APPROVED A CARETAKE
GOVERNMENT COMPOSED OF INDEPENDENTS AND HEADED BY VILSON GOVERNMEN

09918 ZANGA, L.

ALBANIA'S LEADING WRITER RETURNS HOME

RFE/RL RESEARCH REPORT, 1(28) (JUL 92), 11-15.

THE MAY 1992 HOMECOMING OF ALBANIA's LEADING WRITER,

ISMAIL KADARE, WAS REGARDED AS A SIGNIFICANT EVENT BY HIS

COUNTRYMEN. KADARE, HHO RETURNED AFTER 18 MONTHS OF EXILE IN FRANCE, IS A CONTROVERSIAL FIGURE OF CONSIDERABLE INFLUENCE. ALTHOUGH HE HAS PROFESSED NOT TO BE INTERESTED IN POLITICS, HE IS BOUND TO HAVE AN IMPACT ON ALBANIAN POLITICAL LIFE THROUGH HIS STANDS ON VARIOUS ISSUES.

09919 ZANGA, L.

ALBANIA'S LOCAL ELECTIONS

RFE/RL RESEARCH REPORT, 1 (37) (SEP 92), 27-30.

ALBANIA'S SOCIALISTS (FORMERLY THE COMMUNISTS) MADE IMPRESSIVE GAINS IN THE COUNTRY'S FIRST DEMOCRATIC LOCAL ELECTIONS. THE RESULT IS A NEH AND DIFFICULT POLITICAL SITUATION IN WHICH A LARGE PORTION OF LOCAL GOVERMMENT IS IN THE HANDS OF THE SOCIALISTS, WHILE THE DEMOCRATS CONTINUE TO DOMINATE THE NATIONAL GOVERNMENT AND THE PARLIAMENT. AN ANALYSIS OF THE VOTING RETURNS INDICATES THAT THE SOCIALISTS SUCCEEDED BY RETAINING THE ALLEGIANCE OF THOSE WHO HAD VOTED FOR THE PARTY DURING THE EARLIER NATIONAL ELECTIONS WHILE MANY WHO HAD PREVIOUSLY VOTED FOR THE DEMOCRATIC PARTY CHOSE MANY WHO HAD PREVIOUSLY VOTED FOR THE DEMOCRATIC PARTY CHOSE TO STAY HDME DURING THE LOCAL ELECTIONS. CDNTINUED ECONOMIC
HARDSHIP, GENERAL APATHY, AN INTRAPARTY SPLIT, AND ADMITTED HARDSHIP, GENERAL APATHY, AN INTRAPARTY SPLIT, AND ADMITTED
MISTAKES BY THE DEMOCRATS ARE FACTORS THAT CONTRIBUTED TO MISTAKES BY THE DEMC
THE POOR SHOWING.

09920 ZANGA, L.

ALBANIAN POLITICAL TURMOIL

RFE/RL RESEARCH REPORT, 1(31) (JUL 92), 14-19.

ALBANIA'S POLITICAL SCENE IS IN TURMOIL. THE DEMOCRATIC PARTY IS BESET BY INTERNAL DIFFERENCES AND HAS SHAKEN BY THE EXPULSION OF ITS CO-FOUNDER, GRAMOZ PASHKO, FROM ITS PARLIAMENTARY GROUP. ALTHOUGH THE SOCIALIST PARTY HAS LOST MEMBERS, IT IS MORE UNITED THAN ITS COMPETITION AND MAY GAIN SUPPORT IF THE DEMOCRATS FAIL TO DELIVER THE ECONOMIC RECOVERY THEY PROMISED IN THE ELECTION CAMPAIGN.

09921 ZANGA, L.

ALBANIAN RECONCILIATION PLAN SPARKS INTENSE DEBATE RFE/RL RESEARCH REPORT, 1(10) (MAR 92), 12-16.

A GROUP OF INTELLECTUALS FROM ALBANIA AND KOSOVO HAS PROPOSED AN INITIATIVE INTENDED TO PROMOTE SOCIAL ORDER IN ALBANIA. CALLED "THE ASSEMBLY FOR NATIONAL RECONCILIATION AND UNIFICATION," IT WOULD HELP THE COUNTRY OVERCOME ITS PRESENT DEEP SPIRI TUAL, SOCIAL, AND POLITICAL CRISIS PEACEFULLY THROUGH THE UNIFICATION OF ALL ALBANIANS CONSIDERABLE CONTROVERSY SURROUNDS THE INITIATIVE.

09922 ZANGA, L.

ALBANIAN-GREEK RELATIONS REACH A LOH POINT

RFE/RL RESEARCH REPORT, 1(15) (APR 92), 18-21.

ALBANIAN-GREEK RELATIONS HAVE DETERIORATED, WITH POLEMICS ESCALATING TO A NEW HIGH AND EACH SIDE ACCUSING THE OTHER OF DISCRIMINATING AGAINST ITS NATIONALS. THERE ARE TWO BASIC PROBLEMS: THE INFLUX OF TENS OF THOUSANDS OF ALBANIAN REFUGEES INTO GREECE AND THE RENEWED CONFLICT OVER ETHN
GREEKS IN ALBANIA. THESE DEVELOPMENTS COME AT A MOST GREEKS IN ALLANIA. THESE DEVELOPMENTS COME AT A MOST
INOPPORTUNE TIME FOR ALBANIA, WHICH IS ON THE VERGE OF INOPPORTUNE TIME FOR ALBANIA,
POLITICAL AND ECONOMIC CHAOS.

09923 ZANGA, L.

RENEWED ITALIAN INTEREST IN ALBANIA

RENEWED ITALIAN INTEREST IN ALBANIA
RFE/RL RESEARCH REPORT, $1(19)$ (MAY 92), 22-25.

ALTHOUGH OPERATION PELICAN, ITALY'S MASSIVE EMERGENCY HUMANITARIAN AID PROGRAM TO ALBANIA HAS OFFICIALLY ENDED, ITALY REMAINS EAGER TO RESUME ITS TRADITIONAL ROLE AS ITALY REMAINS EAGER TO RESUME ITS TRADITIONAL ROLE AS

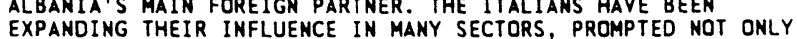
EXPANDING THEIR INFLUENCE IN MANY SECTORS, PROMPTED NOT ONLY BY A DESIRE TO AVERT A FRESH INFLUX OF ALBANIAN REFUGEES BUT
ALSO BY THE EMERGENCE OF ECONOMIC AND OTHER OPPORTUNITIES.

09924 ZANGA, L.

THE QUESTION OF KOSOVAR SOVEREIGNTY

RFE/RL RESEARCH REPORT, 1 (43) (OCT 92), 21-26

KOSOVD'S FUTURE STATUS REMAINS ONE OF THE MOST DIFFICULT ISSUES CONFRONTING THE DISINTEGRATING YUGOSLAVIA. THE SERBS ARE INSISTING THAT THE PROVINCE REMAIN AN INTEGRAL PART OF 
SERBIA, WHILE KOSOVO'S ALBANIANS WANT SOVEREIGNTY. THE TWO SIDES ARE DEADLOCKED, NO SOLUTION IS IN SIGHT, AND TIME SEEMS TO BE RUNNING OUT.

09925 ZANKER, A.

GEOPOLITICS: THE FORGOTTEN DIMENSION

SWISS REVIEW OF WORLD AFFAIRS, $42(6)$ (SEP 92), 4-5

WITH THE DISAPPEARANCE OF THE BIPOLAR STRUCTURES

ASSOCIATED WITH THE COLD WAR, DEBATE OVER THE EUROPEAN

COMMUNITY, ITS AIMS, AND ITS LIMITATIONS NEEDS A BROADER PERSPECTIVE THAN ONE FOCUSED EXCLUSIVELY ON DOMESTIC EUROPEAN POLITICS. RELYING ON THE CONCEPTS AND PREMISES OF GEOPOLITICS, THE AUTHOR OF THIS ESSAY VIEHS THE EUROPE OF

09926 ZARTMAN, I.; RIODELL, R. AID PERFORMANCE AND PROSPECTS; EUROPE AND AFRICA: THE NEW PHASE

LYNNE RIENNER PUBLISHERS, 1992, 139-158.

ROGER RIDDELL'S OBJECTIVE IN THIS CHAPTER IS TO GIVE AN OVERVIEW OF RECENT TRENDS IN FOREIGN AID TO SUB-SAHARAN AFRICA AND THEN TO DISCUSS THE PROSPECTS FOR AID TO THE AFRICA AND THEN TO DISCUSS THE PROSPECTS FOR AID TO THE
SUBREGION TO THE MID-1990S, PLACING PARTICULAR EMPHASIS ON SUBREGION TO THE MID-1990S, PLACING PARTICULAR EMPHASIS ON
EUROPEAN-AFRICAN RELATIONS. THE CHAPTER ADORESSES AID TO SUBEUROPEAN-AFRICAN RELATIONS. THE CHAPTER ADDRESSES AID TO
SAHRAN AFRICA IN THE 1980 S AND IN THE $1990 \mathrm{~S}$ AND CONCLUDES THAT EUROPE WILL CONTINUE TO BE A MAJOR DONOR TO SUB-SAHARAN AFRICA.

09927 ZARTMAN, I.

EUROPE AND AFRICA: THE NEW PHASE

LYNE RIENNER PUBLISHERS, 1992,213

HITH THE 1992 STATE OF EUROPEAN UNIFICATION AND THE FOURTH LIME AGREEMENT, SIGNED IN 1990. EUROPE AND AFRICA ARE ENTERING A NEW PHASE IN THEIR POSTCOLONIAL RELATIONS. EUROPE IS TURNING INWARD TO CONSOLIDATE ITS INTEGRATION; AFRICA IS PULLING AHAY, RETAINING ONLY AN INCREASED AID COMMITMENT FROM ITS FORMER COLONIAL METROPOLE. THIS BOOK EXAMINES THE CONSEQUENCES OF THESE TWO TENDENCIES AND LOOKS FORWARD THROUGHOUT THE $1990 S$ TO IDENTIFY LIKELY TRENDS IN MATTERS RELATED TO SECURITY, TRADE, INVESTMENT, AID, THE FRANC ZONE, AND OTHER ONGOING NEGOTIATIONS BETHEEN THE COUNTRIES OF EUROPE AND SUB-SAHARAN AFRICA.

09928 ZARTMAN, I.; ECONOMOU, P.; GITTELMAN, M.; HUBNEH, M. EUROPE 1992 AND FOREIGN DIRECT INVESTMENT IN AFRICA; EUROPE AND AFRICA: THE NEW PHASE

LYNHE REINNER PUBLISHERS, 1992, 95-120.

EUROPE 1992 CONFRONTS AFRICA NOT ONLY WITH CHALLENGES AND OPPORTUNITIES, BUT ALSO POSSIBILITIES OF SERIOUS MARKET AND OPPORTUNITIES, BUT ALSO POSSIBILITIES OF SERIOUS AND FOREIGN INVESTMENT LOSSES. IF THE CHALLENGES AND OPPORTUNITIES ARE TO BE MET, AFRICA MUST ORGANIZE ITSELF TO
BE ON COMPETITIVE GROUND. IT NEEDS TO BUILD ON THE RECENT BE ON COMPETITIVE GROUND. IT NEEDS TO BUILD ON THE RECENT POSITIVE CHANGES IN POLICY AND ATTITUDE TOWARD FOREIGN IMPROVE THE ECONOMIC AND POLITICAL ENVIRONMENT. THIS CHAPTER IMPROVE THE ECONOMIC AND POLITICAL ENVIRONMENT. THIS CHAPTER EXAMINES THE HISTORY OF FOREIGN DIRECT INVESTMENT IN AFRIC
FROM 1970 TO 1988 AND OFFERS A TYPOLOGY OF FOREIGN DIRECT FROM 1970 TO 1988 AND OFFERS A TYPOLOGY OF FOREIGN DIRECT
INVESTMENT. IT CLOSES WITH SUGGESTED WAYS TO DEVELOP NEH INVESTMENT. IT CLOSES WITH SUGGESTED WAYS TO
STRATEGIES TO LURE INVESTORS INTO THE REGION.

09929 ZARTMAN, I.; KUHNE, W.

LOOKING SOUTHH AFTER THE END OF THE COLD WAR; EUROPE AND AFRICA: THE NEW PHASE

LYNNE RIENNER PUBLISHERS, $1992,7-26$

AN OVERVIEH DEMONSTRATES THE CHANGED ENVIRONMENT OF AFRICAN POLITICS-HOWEVER, IT RAISES A MUMBER OF DIFFICULT QUESTIONS. THIS CHAPTER TREATS THE EASTERN BLOC DISENGAGEMENT FROM AFRICA, THE FAILURE OF MARXISM-LENINISM AND THE FUTURE IDEOLOGICAL DEBATE, AND FINALLY THE IMPLICATIONS OF EUROPEAN RECONSTRUCTION AND DISARMAMENT FOR DEVELOPMENT ASSISTANCE TO THE AFRICAN COUMTRIES. IT

09930 ZARTMAN, I

NEGOTIATION AND THE SOUTH AFRICAN CONFLICT

SAIS REVIEN, 11(1) (WIN 91), 113-131.

SOUTH AFRICA IS UNDERGOING A MASSIVE SOCIAL AND RACIAL UPHEAVAL, AND THE WHOLE WORLD IS HAITING FOR THE FORMAL TRANSFER OF POWER FROM THE WHITE MINORITY TO THE BLACK MAJORITY. YET. THE FORMAL RESTRUCTURING OF POWER THROUGH A GRAND NATIONAL CONSTITUTIONAL CONFERENCE WILL COME ONLY AT THE END OF A LONG PROCESS MARKED BY MYRIAD SMALLER THE END OF A LONG PROCESS MARKED BY MYRIAD SMALLER
NEGOT IATIONS AT ALL LEVELS. THIS ARTICLE CONSIDERS THESE NEGOTIATIONS AT ALL LEVELS. THIS ARTICLE CONSIDERS THESE SMALLER, INITIAL NEGOTIATIONS AND ARGUES THAT THE STANDARD ANALYSES OF THE WAY POWER IS TRANSFERRED MUST BE AUGMENTED
BY THE MEWER NOTIONS OF RENEGOTIATION AND REGIME CHANGE. THE BY THE NEWER NOTIONS OF RENEGOTIATION AND REGIME CHANGE
ARTICLE USES THESE THO FRAMEHORKS TO ANALYZE CONFLICT ARTICLE USES THESE THO FRAMEHORKS TO ANALY
RESOLUTION IN THE CONTEXT OF SOUTH AFRICA.

09931 ZARTMAN, I.; SANDBERG, E.; SHAMBAUGH IV, G. PROSPECTS FOR NORTH-SOUTH NEGOTIATIONS IN A CHANGING INTERNATIONAL POLITICAL ECONOMY; EUROPE AND AFRICA: THE NEW PHASE

LYNNE RIENNER PUBLISHERS, 1992, 159-178.
THROUGHOUT THE POST-WORLD WAR II ERA, NORTH-SOUTH NEGOTIATIONS HAYE FAILED TO PROVIDE SOUTHERN STATES WITH MANY OF THE TRADE AND AID BENEFITS THEY SOUGHT. THERE HAVE BEEN, HOWEVER, A LIMITED NUMBER OF SUCCESSFUL CASES OF NORTHSOUTH BARGAINING. EACH OF THESE CASES SHARES A SET OF COMMON BARGAINING CONDITIONS UNDER WHICH SUCCESSFUL OUTCOMES FOR SOUTHERN STATES HERE ACHIEVED. IN THIS CHAPTER THE AUTHORS IDENTIFY THE CONDITIONS UNDER WHICH SOUTHERM STATES WERE ABLE TO BARGAIN SUCCESSFULLY WITH NORTHERN STATES. THEY ALSO DEMONSTRATE HOW PROBABLE CHANGES IN THE INTERNATIONAL POL ITICAL ECONONY OF THE 1990 S WILL INFLUENCE BARGAINING OUTCOMES IN FUTURE NORTH-SOUTH RELATIONS.

09932 ZARTMAN, I.; DE MELO, J.; DEVARAJAN, S. RELATIVE PERFORMANCE OF CFA FRANC ZONE MEMBERS AND OTHER COUNTRIES; EUROPE AND AFRICA: THE NEW PHASE

LYNNE RIENNER PUBLISHERS, 1992, 121-138.

AMONG THE MANY FACETS OF EUROPE'S RELATIONS WITH AFRICA, THE LINK BETWEEN FRANCE AND THE THIRTEEN MEMBERS OF THE CFA FRANC ZONE STANDS OUT AS A UNIQUE INSTITUTION. THE AUTHORS REASSESS THE BENEFITS AND COSTS OF THE CFA ZONE AND REASSESS THE BENEFITS AND CDSTS OF THE CFA ZONE AND
ADDRESSES WHETHER ON AVERAGE CFA COUNTRIES FARED HORSE THAN ADDRESSES WHETHER ON AVERAGE CFA COUNTRIES FARED WORSE THA A GROUP OF 'COMPARATOR' COUNTRIES. THEY TAKE A CLOSER LOOK AT THE ADJUSTMENT EXPERIENCE OF FCA COUNTRIES VIS-A-VIS THEIR COMPARATORS. THEIR CONCLUDING REMARKS INCLUDE A THEIR EMPIRICAL RESULTS AND THE PROPOSED CHANGES IN EUROPE THEIR EMPIRIC 1992

09933 ZARTMAN, I.; BADIANE, 0.

THE COMMON AGRICULTURAL POLICY AND AFRICAN COUNTRIES EUROPE AND AFRICA: THE NEW PHASE

LYNNE RIENNER PUBLISHERS, 1992, 75-94.

A NUMBER OF FACTORS EXPLAIN THE INTEREST OF DEVELOPING COUNTRIES, PARTICULARLY AFRICAN, IN THE COMMON AGRICULTURAL POLICY (CAP) OF THE EUROPEAN COMMUNITY (EC). THE MOST IMPORTANT OF THESE FACTORS ARE EXAMINED. THE OBJECTIVE OF THIS CHAPTER IS TO ANALYZE THE IMPACT OF THE CAP ON AFRICAN ECONOMIES, TAKING INTO CONSIDERATION THE LINKAGES BETWEEN THE CAP, WORLDWIDE AGRICULTURAL PROTECTIONISM, AND ECONOMIC POLICIES IN DEVELOPING COUNTRIES. IT OFFERS A REVIEW OF THE CONCEPTION AND EVOLUTION OF THE CAP, A DISCUSSION OF WHY AFRICAN COUNTRIES ARE ESPECIALLY VULNERABLE TO IT, AND AN ANALYSIS OF ITS EFFECTS.

09934 ZARTMAN, I.; OBASANJO, 0. THE NEED

LYNWE RIENNER PUBLISHERS, 1992, 179-186,

BY THE END OF 1992, THE THELVE MEMBER STATES OF THE EUROPEAN COMMUNITY (EC) RESOLVED TO COMPLETE THE CREATION OF EUROPEAN COMNONIY MARET BY REMOVING ALL THE REMAINING BARRIERS TO THE FREE FLOW OF GOODS AND SERVICES HITHIN THE BARRIERS TO THE COMPLET RE FLW TF GOODS AND SERVICES WITHIN THE EC. THE COMPLETION OF THE SINGLE MARKET WILL ACCENTUATE THE EC'S POSITION AS THE HORLD'S LEADING TRADING BLOC. HOW THIS COMMUNITY OF WEST AFRICAN STATES (ECONAS) IS EXAMINED BY COMMUNITY OF WEST AFRICAN STATES (ECOWAS) IS EXAMINED BY GENERAL OLOUSEGUN OBASANJO. HE HONDERS IF AFRICA HILL NOW, UNDER THE PRESSUE OF DEVELOPMENTS FROM OUTSIDE, BE SPURRED INTO ACCELERATING THEIR EFFORTS AT

09935 ZARTMAN, I.W.

CONFLICT AND RESOLUTION: CONTEST, COST, AND CHANGE ANNALS OF THE AMERICAN ACADEMY OF POLITICAL AND SOCIAL SCIENCE, (518) (NOV 91), 11-22.

REGIONAL CONFLICTS CAN BE THOUGHT OF IN THREE DIFFERENT WAYS. EACH SUGGESTING A DIFFERENT APPROACH TO THEIR RESOLUTION. ONE IS A CLASH OF CONFLICTING UNILATERAL SOLUTIONS, WHICH THEN REQUIRE A FORMULA FOR A JOINT OR MULTILATERAL OUTCOME SATISFACTORY TO BOTH PARTIES. A SECOND IS A SUCCESSION OF OPPOSING POLICIES BASED ON COST-BENEFIT CALCULATIONS, HHICH THEN REOUIRE A RIPE MOMENT--COMPRISING SPECIFIC COMPONENTS OF MUTUALLY HURTING STALEMATE, IMPENDING CATASTROPHE, AND A FORMULA FOR A WAY OUT--FOR RESOLUTION. A THIRD IS AN EVENT IN A PRDCESS OF CHANGE, REQUIRING THE NEGOTIATION OF A NEW REGIME TO REPLACE AN OLD ONE THAT PREVIOUSLY EMBODIED CERTAIN EXPECTATIONS AND BEHAVIORS. THE AUTHOR ILLUSTRATES THESE DIFFERENT NOTIONS WITH MANY

EXAMPLES OF REGIONAL CONFLICTS AND POSSIBLE RESOLUTIONS.

09936 ZARTMAN, I.W.

DEMOCRACY AND ISLAM: THE CULTURAL DIALECTIC

DEMOCRACY AND ISLAM: THE CUL TURAL OIALECTIC ANNALS OF THE AMERICAN ACADEMY OF P

CURRENT HISTORY IS MARKED BY THE MEETING OF TWO POWERFUL CURRENTS DEMOCRACY AND POL ITICAL ISLAM. ISLAM ITSELF IS THE SUBJECT OF A CULTURAL DIALECTIC BETHEEN A MODERN AND AN AUTHENTISTIC FORH, FROM WHICH A SYNTHESIS TENDS TO ARISE, ONLY TO BE ATTACKED AGAIN BY A NEW AUTHENTISTIC ANTITHESIS. POLITICAL ISLAM IS THE CURRENT ANTITHESIS, ATTACKING THE UNPOPULAR STATES FOR IMPIETY AND MATERIAL ISH. DEMOCRACY IS ALSO RISING IN POPULARITY AS A CRITERION OF GOOD GOVERMMENT, WITH SPECIAL MEANING AS THE CONSUMMATION OF NATIONALISM FOR 
NEW STATES RECENTLY FREE FROM COLONIAL RULE. THE THO CURRENTS ARE NOT NECESSARILY INCOMPATIBLE, BUT THEY HAVE OTHER WHENEVER THEY MEET.

09937 ZASLAVSKY, $V$. NATIONALISM AND DEMOCRATIC TRANSITION IN POSTCOMMUNIST SOCIETIES

DAEDALUS, 121(2) (SPR 92), 97-121.

THE AUTHOR EXAMINES SOVIET NATIONALITY POLICY AND WHY IT LED TO THE CURRENT MATIONALITY PROBLEMS THROUGHOUT THE FORMER SOVIET UNION.

09938 ZEBICH-KNOS, M.

GIVING BUSINESSES WHAT THEY NEED

PS: POLITICAL SCIENCE AND POLITICS, 25(4) (DEC 92), $727-733$.

IT IS TIME FOR A PRELIMINARY LOOK AT HOW POLITCAL SCIENCE, BOTH IN ITS TEACHING AND RESEARCH COMPONENTS, CAN CONTRIBUTE TO MEETING THE NEEDS OF THE BUSINESS COMMUNITY. THE STRENGTHENING OF THIS LINK WILL BECOME MORE FEASIBLE AS THE GLOBAL ECONOMIC ARENA BECOMES THE NORM IN WHICH BUSINESS IS CONDUCTED IN A MANNER IN WHICH UNDERSTANDING OF FOREIGN POLITICAL SITUATIONS IS CRITICAL. THIS ARTICLE SUGGESTS THAT MANY POLITICAL SCIENTISTS HAVE YEARS OF ACCUMULATED KNOWLEDGE THAT, IF CHANNELED IN AN APPLIED MANNER, CAN BE OF ENORMOUS PRACTICAL USE TO THE BUSINESS COMMUNITY.

09939 ZEITUNG, S.

OECD CONFIDENT RECOVERY IS ON THE WAY, INFLATION WILL DECLINE

GERMAN TRIBUNE, (1475) ( JUL 91), 8

CONDITIONS IN THE ORGANIZATION FOR ECONOMIC COOPERATION AND DEVELOPMENT (OECD) COUNTRIES AGAIN FAVOR STRONG GROWTH, SAYS AN OECD REVIEW. THIS UPSHING HOULD FOLLOW A MARKED SLOWING DOWN OF ECONOMIC ACTIVITY DURING THE FIRST HALF OF 1991. THE OECD BELIEVES THAT WHEN THIS EXPECTED ECONOMIC UPSWING TAKES PLACE IT WILL BE NECESSARY TO DRAH IN THE MONETARY REINS TO PREVENT OVERHEATING IN SOME MEMBER COUNTRIES. THE POST-GULF WAR SURGE OF CONFIDENCE, THE DECLINE IN INTEREST RATES OF SOME COUNTRIES, ANO THE EXPECTATION OF LOWER INFLA
PREDICTIONS OF RECOVERY.

09940 ZELISTCHEV, $N$

THE NEW WAY OF thINKINg politically and the "house of EUROPE AS A UNION"

PEACE AMD THE SCIENCES, 1(1) (SEP 92) 25

THE BEGINNING OF A NEW WAY OF THINKING POLITICALLY IS TO BE FOUND IN THE POLICY OF PEACEFUL CO-EXISTENCE OF THE STATES. IN THE FORMER SOVIET UNION, THE IDEA OF PEACEFUL COEXISTENCE HAS DEVELOPED. THREE FUNDAMENTAL PRINCIPLES OF THE NEW WAY OF THINKING POLITICALLY IS POINTED OUT IN THIS ARTICLE: COMMON HUMAN VALUES ARE THE PRIORITIES TO BE PUT BEFORE NATIONAL, REGIONAL AND CLASS INTERESTS; THE PRIORITY OF COMMON HUMAN VALUES INSEPARABLY CONNECTED WITH THE PRINCIPLES OF THE DE-IDEOLOGIZATION OF INTER-REGIONAL RELATIONSHIPS; AND THE PRINCIPLE OF ELECTORAL FREEDOM. THIS PAPER PREDICTS THAT THE PRINCIPLES OF THE NEH WAY OF THINKING POLITICALLY WILL BE REALIZED MAINLY ON THE EUROPEAN CONTINENT.

09941 ZELLER, L.H.

THE 1992 ELECTION RESULTS: WHAT DO THEY MEAN?

NATIONAL CIVIC REVIEN, 81(4) (FAL 92), 512-513.

THE AUTHOR ANALYZES THE RESULTS OF THE 1992 MATIOMAL ELECTIONS AND HAT THEY REVEAL ABOUT VOTER APATHY, TURNOUT, AND OTHER TRENDS.

09942 ZELLER, L.H. (ED.)

NEW ZEALANDERS REJECT WINMER TAKES ALL VOTING SYSTEM

NATIONAL CIVIC REVIEW, 81(3) (SUM 92), 389

IN A NATIONAL REFERENDUM, NEW ZEALAND VOTERS REJECTED THE U.S. -STYLE PLURALITY VOTING SYSTEM BY A STUNHING MARGIM OF 85 PERCENT TO 15 PERCENT. SEVENTY PERCENT INDICATED A PREFERENCE FOR THE GERMAN-STYLE MIXED MEMBER PROPORTIONAL REPRESENTATION SYSTEM.

09943 ZELLER, R.

BRITAIN HANDLES DRUGS DIFFERENTLY

SHISS REYIEW OF WORLD AFFAIRS, 42(4) (JUL 92), 18-20.

THE AUTHOR COMPARES GREAT BRITAIN'S LENIENT DRUG POLICY

WITH THE MORE REPRESSIVE APPRDACHES USED IN MOST HESTERH

COUNTRIES, INCLUDING THE UNITED STATES.

09944 ZEMAN, M.

POST-TOTALITARIAN TRANSITION. RISK AND OPPORTUNITY

FUTURES, $24(2)$ (MAR 22$)$ (118-121.

THE RISK OF (MAR 92), 118-121.

IDENTIFIED AS THE POPUL ISTIC SYMDROME IN THIS ARTICLE. IN A SHORT-TERM PERSPECTIVE. THE TOTALITARIAN PSYCHOLOGY, THOUGH USUALLY DISGUISED, STILL PREVAILS. THE OPPORTUNITY LIES IN A LONGER-TERM PRIVATIZATION PROCESS, WHICH IS AN ECONOMIC AND SOCIAL TASK, NAMELY THOUGH COMBINING EDUCATION PROGRAMS WITH
THE PARTICIPATION OF THE HORKFORCE. THE ARTICLE DEVELOPS THIS ARGUMENT IN ESSAY SCENARIO FORM.

09945 ZERZAN, J.

TONALITY AND THE TOTALITY

NEH POLITICAL SCIENCE, (20) (SUM 91), 97-116.

THIS ESSAY EXAMINES THE QUESTION OF MUSIC'S PERENMIAL COMBINATION OF FREE EXPRESSION HITH SOCIAL REGULATION. THIS FORMS THE BASIS OF AN HISTORICAL TREATMENT OF THAT WHICH IS OUR SENSE OF MUSIC, WESTERN TONALITY. PUT IN CONTEXT, THE STANDARDIZED GRAMMAR OF TONALITY, TO A LARGE EXTENT, ANSHERS STANDARDIZED GRAMMAR OF TONALITY, TO A LARGE EXTENT, ANSWERS THE QUESTION OF WHAT IT IS THAT MUSIC SAYS. AND THE DEPTH OF FEAR THAT "WE SHALL NEVER BE RID OF GOD SO LONG AS WE STILL BEAR THAT "WE SHALL "

09946 ZHANG, $B$

THE STATE CENTRAL ECONOMIC BUREAUCRACIES AND THE OUTCOME OF SYSTEMIC ECONOMIC REFORM: AN INSTITUTIONAL EXPLANATION FOR THE SOVIET AND CHINESE EXPERIENCES

GOVERNANCE, 5(3) (JUL 92), 312-341.

THIS ARTICLE USES AN INSTITUTIONAL APPROACH TO EXPLAIN THE DIFFERENT ECONOMIC REFORM OUTCOMES IN THE SOVIET UNION AND CHINA. IT STUDIES HOW THE DIFFERENT INSTITUTIONAL POSITIONS OF THE SOVIET AND CHINESE CENTRAL ECONOMIC BUREAUCRACIES GIVE THEM DIFFERENT POWER RESOURCES TO RESIST ECONOMIC REFORM POLITICS. THE ARTICLE SHOWS THAT CRUCIAL DIFFERENCES BETHEEN THE THO REGIMES IN HISTORICAL

EXPERIENCES, ECONOMIC DEVELOPMENT STRATGIES, AND IDEOLOGIES ON BUREAUCRATIC RATIONALITY CREATED DIFFERENT LEVELS OF INSTITUTIONAL PARTICIPATION BY THE TWO CENTRAL ECONOMIC BUREAUCRACIES IN STATE ECONOMIC POLICYMAKING, AND DIFFERENT ECONOMIC MANAGEMENT STRUCTURES.

09947 ZHANG, $Y$

CHINA'S ENTRY INTO INTERNATIONAL SOCIETY: BEYOND THE STANDARD OF "CIVILIZATION"

REYIEH OF INTERNATIOMAL STUDIES, 17(1) (JAM 91) 3-16. THIS ESSAY JOINS THE DEBATE ON WHEN AN DHOW CHIMA-THE MIDDLE KINGDOM RECLUSIVE IN THE FAR EAST UP TO THE MIDDLE OF THE NINETEENTH CENTURY--ENTERED INTERNATIONAL SOCIETY. IT EXAMINES THO CONTENDING VIEWS ADVOCATED BY IMMANUEL HSU AND GERRIT GONG ON CHINA'S ENTRANCE INTO THE FAMILY OF NATIONS. IT PRDPOSES TO LOOK BEYOND THE HORIZON OF THE STANDARD OF "CITOPOSES TO LOOK BEYOND THE HORIZON OF THE STANDARO OF WHEN AND HOW CHINA GAINED ENTRY. AND IT ARGUES THAT THE WHEN AND HOW CHINA GAINED ENTRY. AND IT ARGUES THAT THE CHANGING RULES OF THE EMERGING GLOBAL INTERNATIONAL SOCIETY WERE AS IMPORTANT AS ADJUSTMENTS AND ADAPTATIONS MADE BY CHINA IN

09948 ZHAOLIN, D

U.S. AND THE E.C. AVOID TRADE WAR

BEI JING REVIEH, 35 (49) (DEC 92), 17

ON NOVEMBER 20, 1992, THE UNITED STATES AND THE EUROPEAN COMAUNITY (EC) REACHED AN AGREEMENT ON REDUCING FARM

SUBSIDIES, THEREBY AVERTING AN IMMINENT TRANS-ATLANTIC TRADE WAR.

09949 ZHENGXIN, L.

MORE STATEMENTS THAN SUBSTANCE

BEIJING REVIEN, 35(29) (JUL 92), 13-14.

THE 1992 SUMMIT MEETING OF THE SEVEN INDUSTRIALIZED NATIONS (G-7) WAS HELD IN JULY IN MUNICH, GERMANY. THE TALKS FOCUSED ON SUCH KEY ISSUES AS GLOBAL ECONOMIC GROWTH, AID TO RUSSIA, THE YUGOSLAV CRISIS, AND WORLD TRADE NEGOTIATIONS. THE SEVEN FAILED TO AGREE ON THE MAJOR TRADE ISSUES BUT EXTENDED A GENEROUS HAND TO RESCUE THE FALTERING RUSSIAN ECONOMY.

09950 ZHIGUO, H.; JIPENG, L.

THE EMERGENCE AND DEVELOPMENT OF A SHARE SYSTEM: AN INVESTIGATION REPORT ON CHINA'S SHARE ECONOMY

SOCIAL SCIENCES IN CHINA, XII(4) (NOV 91), 10-31.

THE AUTHORS DISCUSS THE BACKGROUND, DEVELOPMENT, AND PROBLEMS OF SHARE-ISSUING ENTERPRISES IN CHINA. AFTER THE SHIFT FROM A PRODUCT ECONOMY TO A COMMODITY ECONOMY, CHINESE ENTERPRISES A FUNDS, SO SOME BEGAN TO RAISE FUNDS IN THE MARKET BY ISSUING SHARES. THE MAJORITY OF CHINA'S SHARE-ISSUING ENTERPRISES NOH HAVE THREE CONSPICUOUS CHARACTERISTICS: (1) SPONTANEITY, WITH NO UNIFIED REGULATION BY THE STATE; (2) INSULARITY, WITH SHARES SOLD ONLY TO THE WORKERS AND STAFF OF THE SHAREISSUIMG ENTERPRISES: AND (3) FRINGE BENEFITS, WHICH IN THE ISSUING ENTERPRISES; AND (3) FRINGE BENEFITS, WHICH IN THE DISGUISED BONUSES TO WORKERS AND STAFF. THE AUTHORS COMPARE DISGUISED BONUSES TO WORKERS ANO STAFF. THE AUTHORS COMPARE CHINA'S INCIPIENT SYSTEM HITH THE MATURE SHARE SYSTEMS OEVELOPED COUNTRIES AND PROPOSE INTRODUCING THE SHARE
ECONOMIC SYSTEM INTO CHINA IN A COMPREHENSIVE MANNER.

09951 ZHIMIAN, $X$

LONG ROAD AHEAD FOR EUROPEAN UNION

BEIJING REVIEW, 35(41) (OCT 92), 26.

IN A REFERENDUM ON SEPTEMBER 20, 1992, FRENCH VOTERS 
NARROWLY APPROVED THE MAASTRICHT TREATY ON EUROPEAN UNION. FRENCH APPROVAL OF THE TREATY EVOKED POSITIVE RESPONSES THROUGHOUT EUROPE AND THE HORLD AT LARGE. NEVERTHELESS EUROPEAN UNION IS FAR FROM A CERTAINTY, DUE TO LUKEWARM SUPPORT IN BOTH GERMANY AND GREAT BRITAIN.

09952 ZHINIAN, Z

TIME FOR TOLERANCE AND RECONSTRUCTION

BEI JING REVIEW, 35(20) (MAY 92), 14-16.

AFTER NEARLY 14 YEARS OF CIVIL STRIFE, AFGHANISTAN'S

GUERRILLAS HAVE FINALLY WON, BUT PEACE HAS YET TO BE

ESTABLISHED ON A SURE AND SOUND FOUNDATION. SINCE LAST YEAR, THERE HAS BEEN A CONSENSUS IN THE INTERNATIONAL COMMUMITY THAT THE AFGHAN CONFLICT SHOULD BE SETTLED POLITICALLY. TO AVOID FURTHER INTERNECINE FIGHTING AMONG RIVAL OUERRILLAS, THE INTERMATIONAL COMMUNITY HAS TRIED HARD TO BRING A COMPROMISE TO THE COUNTRY.

09953 ZHIPING, Z.

REFORM OF CHINA'S FINANCIAL AND ACCOUNTING SYSTEM

BEI JING REVIEW, $35(49)$ (DEC 92), 18-21.

THE CHINESE GOVERMMENT HAS ADOPTED A SERIES OF REFORM MEASURES DESIGNED TO MAKE CHINA'S FINANCIAL AND ACCOUNTING SYSTEMS CONFORM TO INTERNATIONAL PRACTICES AND STANDARDS, SYSTEMS CONFORM TO INTERNATIONAL PRACTICES AND STANDARDS, WHICH WILL FACILITATE ECONOMIC EXCHANGES WITH OTHER COUNTRIES. THE REFORMS INCLUDE COMPOUND BUDGETING, SHARING TAX REVENUES BETHEEN CENTRAL AND LOCAL GOVERMMENTS, AND NEH ACCOUNTING NORMS FOR ENTERPRISES.

09954 ZHITONG, H.

CHINA PUTS FORWARD PROPOSAL FOR NUKE DISARMAMENT BEIJING REVIEH, 35(45) (NOV 92), 13-15.

CHINESE AMBASSADOR HOU ZHITONG ADDRESSED THE FIRST CONMITTEE OF THE 47TH SESSION OF THE UNITED NATIONS GENERAL ASSEMBLY ON OCTOBER 21, 1992. ZHITONG PRESENTED CHINA'S THREE-POINT PROPOSAL FOR THE PROHIBITION AND COMPLETE DESTRUCTION OF MUCLEAR HEAPONS. HE ALSO CALLED ON ALL NUCLEAR POWERS TO COMMIT THEMSELVES NOT TO BE THE FIRST TO USE NUCLEAR HEAPONS AND TO SUPPORT THE ESTABLISHMENT OF NUCLEAR-WEAPON-FREE ZONES.

09955 ZHIXIAN, $X$

SINO-JAPANESE RELATIONS CONTINUE ENHANCED

BEI JING REVIEN, 35(41) (OCT 92), 23-25.

THE AUTHOR IDENTIFIES FOUR STAGES IN THE DEVELOPMENT OF SINO-JAPANESE DIPLOMATIC RELATIONS SINCE THEY HERE NORMALIZED IN 1972.

09956 ZHONG, Y. THE TRANSFORMATION OF THE SOVIET MILITARY AND THE AUGUST COUP COUP

FORCES AND SOCIETY, 19(1) (FAL 92), 47-70.

THIS ARTICLE ARGUES THAT THE SOVIET MILTARY DURING THE REFORM PERIOD EXPANDED ITS PARTICIPATION IN POLITICS IN TERMS OF BOTH THE SCOPE OF ISSUES INVOLVED AND THE MEANS EMPLOYED. IN ADDITION, THE SOVIET ARMY DURING THE SAME PEPRIOD ALSO ENDED ITS YEARS OF RELATIVE INSULATION FROM SOCIETY AND UNDERHENT A PROCESS OF CIVILIANIZATION, MANIFESTED IN INCREASED INTERACTIONS WITH CIVILIAN' SOCIETY AND UNPRECEDENTED CIVILIAN INTRUSTION IN MILITARY AFFAIRS TRADITIONALLY RESERVED EXCLUSIVELY FOR THE MILITARY. THESE THO DEVELOPMENTS PROVIDE CRUCIAL CLUES TO THE FAILED COUP ATTEMPT IN AUGUST 1991 IN THE FORMER SOVIET UNION.

09957 ZHONGJIE, Y.; DELIANG, $S$

POLICY CHANGES BOOST ECONOMIC RECOVERY

BEI JING REVIEW, 35(21) (MAY 92), 16-17.

MOST LATIN AMERICAN COUNTRIES HAVE ONCE AGAIN BOUNCED

BACK ECONOMICALLY SINCE THEIR ECONOMIC RECESSION TOUCHED

BOTTOM LAST YEAR. SOME OF THEIR ECONOMIES HAVE SHOWH A RAPID GROWTH. THE DEBT BURDEN WHICH WAS SERIOUSLY AFFECTING

ECONOMIC DEVELOPMENT TENDS TO BE ALLEVIATED AND LAST YEAR

FOREIGN INVESTMENT IN THE LATIN AMERICAN REGION INCREASED BY USS10 BILLION MORE THAN THAT OF 1990S. THIS ARTICLE EXPLORES CLOSER TIES WITH THE UNITED STATES.

09958 ZHONGYUN, $Z$.

WILL A PAX AMERICANA PREVAIL?

BEI JING REVIEN, 35(17) (APR 92), 34-37

THE AUTHOR BRIEFLY SUMMARIZES THE UNITED STATES' RISE TO

INTERNATIONAL POWER AND EXAMINES THE POSSIBILITY THAT IT

WILL DOMINATE THE NEH WORLD ORDER AS THE SOLE REMAINING

WILL DOMINATE

09959 ZHU, J.: LI, H.; ZHAO, X

PUBLIC POLITICAL COMSCIOUSHESS IM CHINA: AN EMPIRICAL PROFILE

ASIAN SURVEY, XXX(10) (OCT 90), 992-1006.

HISTORICALLY, THE CHINESE PEOPLE HAVE HAD A TRADITION OF POLITICAL APATHY AND IGNORANCE. THIS STUDY EXAMINES RECENT EMPIRICAL SURVEYS OF CHINESE CITIZENS AND PRESENTS AN EMPIRICAL PROFILE OF THEIR POLITICAL CHARACTERISTICS. THE STUDY PROVIDES EMPIRICAL EVIDENCE FOR THE FIRST TIME IN THE
DIVERSITY EXISTS IN CHINA. THE CHINESE POPULATION IS NOT (AND PERHAPS NEVER WAS) A HOMOGENEOUS COMMUNITY COMFORTABLE TO COMMUNIST IDEOLOGY. INSTEAD, THE POPULATION HAS BEEN SEGMENTED BOTH SOCIALLY AND POLITICALLY, AND THE SEGMENTATION IS MORE COMPLEX THAN WAS EARLIER THOUGHT.

09960 ZIELCKE, A. NEW EXPECTATIONS AND DEMANDS WEIGH HEAVILY ON THE NEW GERMANY

GERMAN TRIBUNE, (1533) (SEP 92), 2.

UNIFIED GERMANY IS HAVING DIFFICULTY DEFINING ITS INTERNATIONAL ROLE AND FINOING ITS IDENTITY IN THE NEW WORLD ORDER. MOST GERMANS WOULD BE HAPPY IF THEIR COUNTRY COULD CONTINUE TO PLAY THE ROLE AT WHICH THE FORMER FEDERAL REPUBLIC WAS SUCH A MASTER--THAT OF THE POLITICAL DWARF AND THE ECONOMIC GIANT. BUT GERMANY'S ECONOMIC STATUS IS NOW IN JEOPARDY, AND IT SEEMS CERTAIN THAT IT WILL BE FORCED TO

PLAY A MORE SIGNIFICANT ROLE IN WORLD AFFAIRS IN THE FUTURE.

09961 ZIELONKA-GOEI, M.

MEMBERS MARGINALISING THEMSELVES? INTRA-PARTY MEMBERS MARGINALISING THEMSELVES?

WEST EUROPEAN POL ITICS, 15 (2) (APR 92), 93-106.

ON THE BASIS OF DUTCH RESEARCH DATA; THE ROLE OF THE ORDINARY PARTY MEMBER IN INTRA-PARTY DECISION-MAKING IS ASSESSED IN THIS ARTICLE. THE DATA SHOW THAT DUTCH PARTY MEMBERS DO FEEL MARGINALISED WHERE THEIR INFLUENCE ON INTRAPARTY POLICY-MAKING IS CONCERMED. HOWEVER, THIS IS NOT BECAUSE THEY FEEL THEY DO NOT HAVE SUFFICIENT OPPORTUNITIES TO PARTICIPATE IN INTERNAL DECISION-MAKING, BUT RATHER BECAUSE THEY DO NOT ACTUALLY USE THE OPPORTUNITIES HHICH ARE AVAILABLE: PARTY MEMBERS APPEAR TO MARGINALISE THEMSELVES.

09962 ZIEMKE, C.

PEACE HITHOUT STRINGS? INTERHAR NAVAL ARMS CONTROL REVISITED

WASHINGTON OUARTERLY, 15(4) (FAL 92), 87-106.

RECENT ANALYSIS HAS TENDED TO STUDY INTERHAR NAVAL ARMS CONTROL AS A PRECURSOR TO STRATEGIC ARMS LIMITATION RATHER THAN ON ITS OWN TERMS: AS AN EXERCISE IN CONVENTIONAL AND, IN SOME RESPECTS, REGIONAL ARMS CONTROL. THIS PAPER REVISITS INTERHAR NAVAL ARMS CONTROL WITH SEVERAL GOALS: TO LIBERATE INTERWAR ARMS CONTROL FROM THE CONTEXT OF STRATEGIC NUCLEAR AMRS CONTROL. TO ASSESS THE EFFECT OF THE INTERHAR TREATIES AMRS CONTROL; TO ASSESS THE EFFECT OF THE INTERHAR TREATIES LIMITING NAVIES ON THE COMING OF WORLD WAR II AND THE TREATY

NAVIES ABILITY TO FIGHT; AND FINALLY, TO DETERMINE WHAT PRESENT AND FUTURE ARMS-CONTROL AGENDAS.

09963 ZIESEMER, B

FORMER SOVIET REPUBLICS "NEED MORE THAN TALKS"

GERMAN TRIBUNE, 1539 (NOV 92 ), 1,4

EFFORTS CONTINUE TO WORK OUT WAYS OF HELPING THE COUNTRIES OF THE FORMER SOVIET UNION TRANSFORM THEIR ECONOMIC SYSTEMS. THE THIRD INTERNATIONAL COORDINATION CONFERENCE FOR THE 12 NEWLY INDEPENDENT STATES OF THE FORMER USSR HAS HELD IN TOKYO AT THE END OF OCTOBER. THIS ARTICLE STATES THAT A HANDFUL OF LARGE CONFERENCES SUCH AS THIS ONE ARE JUST NOT ENOUGH. THERE NEEDS TO BE CONSTANT COORDINATION AND SPECIALISTS NEED TO SPEND TIME IN THE RESPECTIVE REPUBLICS.

09964 ZIJIAN, Z.

PREMIER LI VISITS EUROPE AND THE U.N.

BEI JING REVIEW, 35(5-6) (FEB 92) 4-5.

IN JANUARY AND FEBRUARY 1992, CHINESE PREMIER LI PENG VISITED THE UNITED NATIONS, ITALY, SHITZERLAND, PORTUGAL, AND SPAIN. HIS PURPOSE WAS TO PROMOTE MUTUAL UNDERSTANDING AND COOPERATION WITH THE HEST EUROPEAN COUNTRIES AND TO STRENGTHEN CHINA'S ROLE IN INTERNATIONAL AFFAIRS.

09965 ZIMBALIST, A.

TEETERING ON THE BRINK: CUBA'S CURRENT ECONOMIC AND POLITICAL CRISIS

JOURNAL OF LATIN AMERICAN STUDIES, 24(2) (MAY 92), 407-418. CUBA IS IN THE MIDST OF THE WORST CRISIS OF THE REVOLUTION, AND THE PROXIMATE CAUSE OF ITS PREDICAMENT IS NOT HARD TO IDENTIFY. CUBA HAS A SMALL AND HEAYILY TRADEDEPENDENT ECONOMY. DUE TO THE U.S. EMBARGO. THE DRAMATIC DEPENDENT ECONOMY. DUE TO THE U.S. EMBARGO, THE DRAMATI
REDUCTION OF IMPORTS FROM FORMER CMEA COUNTRIES, AND REDUCTION OF IMPORTS FROM FORMER CMEA COUNTRIES, AND
RESTRICTED ACCESS TO OTHER MARKETS, CUBA'S ECONOMY AND ITS RESTRICTED ACCESS TO OTHER MARKETS, CUBA'S ECONOMY AND
PEOPLE ARE STRUGGLING TO SURVIVE. A MUMBER OF REFORMS PEOPLE ARE STRUGGLING TO SURVIVE. A NUMBER OF REFORMS INITIATED PRIOR TO 1989 ARE BEING CONTINUED, OTHERS BEING ACCELERATED, AND SOME NEW PROGRAMS ARE BEING
IMPLEMENTED. IN GENERAL, THE GOVERNMENT'S RESPONSE TO THE IMPLEMENTED. IN GENERAL, THE GOVERMMENT'S
CRISIS HAS BEEN DELIBERATE BUT INADEQUATE.

09966 ZIMBALIST, A. WHY DID THE U.S. INVADE PAMAMA? RADICAL AMERICA, 23(2) (1990), 7-14.

IN THIS ARTICLE THE AUTHOR EXPLORES THE U.S. INVASION OF PANAMA AND OUSTING OF PRESIDENT NORIEGA. U.S. INVOL VEMENT IN THE COUP AGAINST NORIEGA IS DISCUSSED. THE HISTORY OS U.S. 
COOPERATION WITH NORIEGA PRIOR TO THE COUP IS EXAMINED; IT IS ARGUED THAT THE U.S. TURNAROUND REGARDING NORIEGA OCCURRED BECAUSE HE WANTED TO WIDEN HIS ROLE IN THE REGION. ALSO DISCUSSED ARE ECONOMIC SANCTIONS ENACTED AGAINST THE NORIEGA REGIME.

09967 ZIMMERMAN, J.F.

FINANCING NATIONAL POLICY THROUGH MANDATES
NATIONAL CIVIC REVIEN, 81(3) (SUM 92), 366-373

DESPITE RHETORICAL CLAIMS TO THE CONTRARY, DURING THE PAST TWD DECADES. THE FEDERAL GOVERNMENT HAS RESISTED FEH PAST TWO DECADES, THE FEDERAL GOVERNMENT HAS RESISTED FEH STATE AND EXAMINES THE CHARACTERISTICS AND PARAMETERS OF THIS POLICYEXAMINES THE CH

09968 ZIMMERMAN, J.F.

FORMAL MECHANISMS URGED FOR CITIZEN PARTICIPATION IN

PLANNING POLICY DEVELOPMENT (CANADA)

NATIONAL CIVIC REVIEH, 81(1) (WIN 92), 75-76.

THE MUNICIPAL PLANNING POLICY BRANCH OF THE ONTARIO MINISTRY OF MUNICIPAL AFFAIRS HAS RELEASED A REPORT ENTITLED "PUBLIC PARTICIPATION IN MUNICIPAL PLANNING POLICY DEVELOPMENT," WHICH DESCRIBES AND ASSESSES HOW 10 ONTARIO MUNICIPALITIES ARE INVOLVING, OR HAVE INVOLVED, CITIZENS IN DEVELOPING AND INFLUENCING BROAD PLANNING POLICIES.

09969 ZIMMERMAN, J.F.

NEH YORK'S BALLOT-ACCESS LAW LIMITS CHOICE

NATIONAL CIVIC REVIEW, 81(1) (WIN 92) 65-67

NEW YORK STATE'S NOTORIOUSLY BYZANTINE BALLOT-ACCESS LAW GENERATES HALF OF ALL THE ELECTION-LAW LITIGATION IN THE UNITED STATES. ACCORDING TO COMMON CAUSE, 37 WOULD-BE CANDIDATES FOR MAJOR PARTY NOMINATIONS WERE DENIED ACCESS TO THE BALLOT IN THE 1990 ELECTIONS FOR CONGRESS AND THE STATE LEGISLATURE IN NEH YORK CITY.

09970 ZIMMERMAN, J.F.

STATE-LOCAL REVENUES TOP \$1 TRILLION IN FY'90

STATE-LOCAL REVENUES TOP \$1 TRILLION IN FY

DURING FISCAL YEAR 1990 STATE AND LOCAL GOVERNMENT REVENUES EXCEEDED THE ONE TRILLION DOLLAR MARK FOR THE FIRST TIME. ACCORDING TO A PRELIMINARY GOVERMMENT FINANCES REPORT ISSUED BY THE UNITED STATES BUREAU OF THE CENSUS.

09971 ZIMMERMAN, J.F.

VOTER TURNOUT IN MOST POPULATION CATEGORIES DOWN IN 1990

CONGRESSIONAL ELECTIONS

NATIONAL CIVIC REVIEH, 81 (1) (WIN 92), 69-71.

A REPORT ISSUED BY THE UNITED STATES BUREAU OF THE CENSUS REVEALS THAT 45\% OF THE NATION'S VOTING-AGE POPULATION INOICATED THAT THEY VOTED IN THE 1990 CONGRESSIONAL ELECTIONS.

09972 ZIMMERMAN, S.

FAMILY POLICIES AND FAMILY HELL-BEING--THE ROLE OF POLITICAL CULTURE

SAGE PUBLICATIONS, 1992, 224.

THIS BOOK SEEKS TO ASSESS THE EFFECTS OF EXISTING GOVERNMENT POLICIES ON FAMILIES AND TO PREDICT THE EFFECTS OF FUTURE POLICIES ON THE FAMILY. CHALLENGING THE VIEW THAT GOVERNMENTAL SOCIAL PROGRAMS HAVE BEEN DETRIMENTAL TO FAMILY LIFE, THE AUTHOR PROVIDES EMPIRICAL EVIDENCE TO SHOW THAT ATTITUDES TOWARD THE GOVERNMENT'S ROLE IN RELATION TO FAMILIES ARE ASSOCIATED WITH THE POLITICAL CULTURES OF DIFFERENT STATES SHE ALSO ILUSTRATES THE RELATIONSHIP BETWEEN STATES' POLITICAL CULTURES AND THE KINDS OF FAMILY POLICIES STATES ENACT. IMPORTANT GUIDELINES ARE SUGGESTED TO POLICIES STATES ENACT. IMPORTANT GUIDELINES ARE SUGGESTED TO AIDE IN THE DEVLOPMENT OF A POL ICY AGENDA THAT WILL ENHANCE HHERE THEY LIVE.

09973 ZIMMERMANM, M.

DECLINE AND FALL: BUT WHEN DID THE SOVIET UNION'S BEGIN? GERMAN TRIBUNE, (1496) (DEC 91), 2

EUROPEANS ARE WATCHING TWO HISTORIC TRANSFORMATIONS TAKE PLACE IN THE WORLD AROUND THEM: THE DISINTEGRATION OF THE SOVIET UNION, AND THE INTEGRATION OF WESTERN EUROPE. WHILE IT II IS IMPOSSIBLE TO DETERMINE EXACTLY WHEN THE SOVIET EUROPEANS SOME VALUABLE LESSONS. THESE INCLUDE: EUROPEANS SHOULD STOP ORGANIZING THEMSELYES IN CLOSED SOCIETIES. WHETHER A COUNTRY ZING THEMSELVES IN CLOSED SOCIETIES. AND WHETHER THE ENGAGES IN FREE TRADE WITH OTHER COUNTRIES ANO WHETHER THE CITIZENS OF ONE STATE ARE WELCOMED BY THOSE SUBJECTED THEMSELVES DEPEND ON HHETHER ENTIRE NATIONS

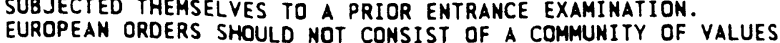
BASED IN SOME IDEOLOGY THEY SHOULD PERCEIVE THEMSELYES AS BASED IN SOME IDEOLOGY. THEY SHOULD PERCEIVE THEMSELVES AS LEGAL COMMUNITIES: ALL ARE WELCOME WHO A
BY THE RULES OF CIVILIZED COOPERATION.

09974 ZINMEI, $W$.

SITUATION IN AFRICA: AN OVERVIEH

BEIJING REVIEH, 35(9) (MAR 92), 15-17.
IN 1991, CHANGES IN U.S. -SOVIET RELATIONS CONTRIBUTED TO THE DE-ESCALATION OF VIOLENCE IN SOME OF AFRICA'S HOT SPOTS. HOWEVER, AT LEAST 26 AFRICAN COUNTRIES CONTINUED TO EXPERIENCE POLITICAL VIOLENCE AND/OR CIVIL WAR IN 1991.

09975 ZIQIN, Z

DEBT HOLDS DOWN ECONOMIC GROWTH

BEIJING REVIEW, 35(50) (DEC 92), 16-17.

DURING THE 1980 'S SERIOUS INFLATION AND CAPITAL FLIGHT

PLAGUED ALL THE LATIN AMERICAN COUNTRIES. THESE TWO PROBLEMS,

CAUSED BY A HEAVY DEBT BURDEN, HAVE NOW BECOME MAJOR

OBSTACLES TO THEIR ECONOMIC DEVELOPMENT. WITHOUT SOME RELIEF

FROM THE DEBT BURDEN, LATIN AMERICA'S ECONOMIC PROBLEMS WILL REMAIN DIFFICULT TO SOLVE.

09976 ZIRING, L.

1990: THE FALL OF BENAZIR BHUTTO

ASIAN SURVEY, XXXI (2) (FEB 91), 113-124.

THIS ARTICLE EXAMINES THE KEY POLITICAL EVENTS IM

PAKISTAN DURING THE YEAR 1990. IT RECOUNTS THE INCREASING

OISORDER AND PROTEST THAT LED TO THE DISMISSAL OF BENAZIR

BHUTTO AS PRIME MINISTER. IT TRACES THE CONFLICT BETWEEN

BHUTTO AND HER POLITICAL ENEMIES IN THE GOVERNMENT AND ARMED

FORCES. IT RECOUNTS THE OCTOBER PARLIAMENTARY ELECTIONS, AND

DESCRIBES THE NEW GOVERMMENT AND NATIONAL ASSEMBLY.

09977 ZISCHERKM F. JR.

MICHIGAN'S PROPOSED ASSISTED SUICIDE LEGISLATION: STRONG PUBLIC POLICY OR LEGISLATIVE RHETORIC?

UNIVERSITY OF DETROIT LAW REVIEW, 69(1) (FAL 91) 33-54.

TODAY SUICIDE OR ATTEMPTED SUICIDE IS NOT PUNISHABLE AS

A CRIME IN ANY JURISDICTION WITHIN THE UNITED STATES, THIS COMMENT EXAMINES THE PROPOSED MICHIGAN BILL CRIMINALIZING ASSISTED SUICIDE. ADDITIONALLY SUICIDE LAH, SUICIDE RIGHTS AND MICHIGAN COMMON LAN ARE CANVASED. A STATE OF WASHINGTON PROPOSAL THAT WOULD LEGALIZE ASSISTED SUICIDE FOR THE TERMINALLY ILL IS REYIEWED FOR CONTRAST.

09978 ZIVOJINOVIC, D

ISLAM IN THE BALKANS" ORIGINS AND CONTEMPORARY IMPLICATIONS MEDITERRANEAN QUARTERLY: JOURNAL OF GLOBAL ISSUES, $3(4)$

(FAL 92 ), $51-65$

THE AMBITIONS OF ISLAMIC MOVEMENTS IN THE BALKANS, NOTABLY IM BOSNIA-HERCEGOVINA HHICH IS THE FOCUS OF THIS AMALYIS CONTRADICT THE CIVILIZED QUALITIES OF CLASSICAL ISLAM IN THE MOST REPRESSIVE AUTHORITARIAN, AND ANTIDEMOCRATIC WAYS, THREATENING NOT ONLY SERVIAN AND ANTIDEMORATIC WAYS, THREATENING NOT ONLY SERVIAN AND STABILTIY. THIS ARTICLE ATTEMPTS TO EXPLAIN THE REAL STAKES THAT ARE INVOLVED IN THIS CONFLICT. IT OFFERS A BRIEF SURVEY OF HISTORICAL DEVELOPMENTS WHICH UNDERSCORE THE IMPORTANCE OF EARLIER EXPERIENCE. IT EXPLORES THE IMPLICATIONS OF SECRET AND OFFICIAL DOCUMENTS WHICH HAVE SURFACED RECENTLY HHOSE CONTENTS CONFIRM EARLIER EXPRESSED CONCERNS, FEARS, AND DIRE EXPECTATIONS OF NON-MUSLIMS.

09979 ZLENKO, A.

INDEPENDENT UKRAINE: RISK OR STABILITY?

RUSI JOURNAL, 137 (2) (APR 92), 38-42.

UKRAINE IS NOW ESTABLISHING HER PLACE ON THE

INTERNATIONAL STAGE FOLLOWING THE DISINTEGRATION OF THE FORMER SOVIET UNION. IN THIS ARTICLE, FOREIGN MINISTER ZLENKO OUTLINES UKRAINE'S FOREIGN POLICY OBJECTIVES AND DISCUSSES HER PLACE IN EUROPE, MILITARY CONCERNS, NUCLEAR POLICY, UKRAINE'S RELATIONSHIP WITH RUSSIA AND THE CIS, AND THE COUNTRY'S ECONOMIC PREDICAMENT. HE CONCLUDES THAT, HITH THE FUU COOPERATIOH OF THE INTERNATIONAL COMHUNITY UKITH HILL BECOME A CONSTRUCTIVE AND RELIABLE PARTNER IN THE HORLD.

09980 ZONG, $Q$.

UNCTAD: COOPERATION AND DEVELOPMENT

BEI JING REVIEW, 35(11) (MAR 92), 12-13.

THE EIGHTH SESSION OF THE UN CONFERENCE ON TRADE AND DEVELOPMENT (UNCTAD), ENDED WITH A DECLARATION AND FINAL DIFFERENCES ON SOME ISSUES, IT DID ACHIEVE POSITIVE RESULTS. DIFFERENCES ON SOME ISSUES, IT DID ACHIEVE POSITIVE RESUL ECONOMIC GROWTH AND RID THE DEVELOPING COUNTRIES OF POVERTY ECONOMIC GROWTH AND RID THE DEVELOPING COUNTRIES OF POVERTY,
OIFFERENCES STILL EXIST BETWEEN THE NORTH AND THE SOUTH. THE FINAL DECLARATION STATES THAT THE CONFEREES DECIDED TO ESTABLISH A NEW PARTNERSHIP FOR DEVELOPMENT, WHICH COMMITS ALL MEMBER STATES TO ENGAGE IN A CONTINUOUS AND CONSTRUCTIVE WORLD.

09981 ZSCHALER, M.

SPD BECOMES PREOCCUPIED WITH SELF

GERMAN TRIBUNE, (1536) (OCT Q2)

LIKE ALMOST NO OTHER GERMAN DOMESTIC POLICY CONFLICT THE DISPUTE OVER ASYLUM LAWS HAS EXPOSED THE HEAKNESS OF POLITICS IN BONN. ALTHOUGH THIS APPLIES TO ALL PARTIES, IT IS PART ICULARLY RELEVANT TO THE SOCIAL DEMOCRATS. INSIODE AND OUTSIDE THE SDP INSTITUTIONS, THE PROTAGONISTS OF PURISM AND OF POPULIST REALISM ARE TAKING UP THEIR POSITIONS. 
09982 ZUBAIDA, S

ISLAM, THE STATE \& DEMOCRACY: CONTRASTING CONCEPTIONS OF SOCIETY IN EGYP

MIDOLE EAST REPORT, 22(6) (NOV 92), 2-10.

THE QUEST FOR DEMOCRATIZATION ANO HUMAN RIGHTS IN THE MIDDLE EAST HAS PROMINENTLY FEATURED THE TERM "CIVIL SOCIETY. " THIS ARTICLE EXPLORES THO CONTRASTING CONCEPTS OF CIVIL SOCIETY, AND, THE APPLICATION TO THE GOVERNMENT TO LICENSE TWO HUMAN RIGHTS ASSOCIATIONS - ONE ARAB AND THE OTHER EGYPTIAN. STATE DISCRETION, UNIONS AND SYNDICATES, THE ECONOMIC SPHERE, THE ISLAMIC SECTOR, AND "SOCIAL ISLAM" AS AN OBSTACLE ARE EACH EXAMINED IN THE CONTEXT OF ISLAM AND THE STATE AND DEMOCRACY.

09983 ZUBEK, $V$

THE TRESHOLD OF POLAND'S TRANSISTION: 1989 ELECTORAL CAMPAIGN AS THE LAST ACT OF A UNITED SOLIDARITY

STUDIES IN COMPARATIVE COMMUNISM, 29 (4) (DEC 91), 355-376.

SOLIDARITY'S FOUNDATIONS BEGAN TO TAKE SHAPE FROM THE MID-1970S ON, WHEN A QUALITATIVE CHANGE BEGAN TO EMERGE HITHIN POLAND'S DISPARATE OPPOSITIONAL MILIEUS. BEHIND THE WAIN IMPETUS FOR CHANGE WAS THE RAPID DETERIORATION OF THE MAIN IMPETUS FOR CHANGE WAS THE RAPID DETERIORATION OF THE
ECONOMY AND THE DEMORALIZAING COLLAPSE OF THE GIEREK SYSTEM. ECONOMY AND THE DEMORALIZAING COLLAPSE OF THE GIEREK SYSTE
THIS ARTICLE EXAMINES WHAT IT CALLS THE THOUSAND HEADED THIS ARTICLE EXAMINES WHAT IT CALLS THE THOUSAND HEADED
MONSTER'S ACHILLES HEEL AND THEN, THE ARRIVING AT THE MONSTER'S ACHILLES HEEL AND THEN, THE ARRIVING AT THE AGREEMENT AND THE ELECTORAL AGREEMENT. THE IDEOLOGICAL
PLATFORM, RESOURCES, AND TACTICS OF THE SOL IDARITY MOVEMENT ARE STUDIED AND THE ARTICLE CONCLUDES THAT WHILE AN OPEN ERUPTION OF THE INTERFACTIONAL STRUGGLE HAS SOMEWHAT DELAYED, WITH THE ADVENT OF THE NEH YEAR THE STRUGGLE ERUPTED WITH A VENGEANCE.

09984 ZUBOK, $Y$

RUSSIA'S NEW FOREIGN POLICY

HORLD POLICY JOURNAL, IX(2) (SPR 92), 191-218.

THE COLAPSE OF A GREAT POHER CREATES DANGEROUS VACUUMS

AT MANY DIFFERNT LEVELS -- INTERNATIONAL, REGIONAL, AND

INDEED IN THE VERY PSYCHES OF ITS CITIZENS. THE WEAKNESS OF DEFEATED NATIONS CAN THUS PRODUCE EITHER MILITANT BACKLASH OR, IF SHREWDLY PARLAYED, PEACEFUL RECOVERY. AS A WEAK RUSSIA MANEUVERS IN THE VACUUM CREATED BY THE COLLAPSE OF THE SOVIET UNION, IT TOO MUST DECIDE HOW TO HANDLE ITS DIMINISHED GLOBAL STATUS AND CRAFT A NEW FOREIGN POL ICY ACCORDINGLY ECONOMY IDEOLOGY, AMD LEADERSHIP ALL POINT RUSSIA TOHARD A FOREIGN POLICY OF COOPERATION, NOT ISOLATION OR EXPANSION. WITH WESTERN ASSISTANCE AND DOMESTIC SHREWDNESS, RUSSIA MAY SUCCESSFULLY ENTER THE NEXT MILLENNIUM AS A PEACEFUL AND RAPIDLY DEVELOPING EURASIAN PONER.

09985 ZUCKERMAN, A.S.; HERZOG, H.; SHAMIR, M. THE POL ITICAL BASES OF ACTIVISM IM THE ISRAELI LABOR AND THE POLITICAL

POLITICAL SCIENCE QUARTERLY, 107 (2) (SUM 92), 303-324.

THE AUTHORS EXAMINE THREE DIMENSIONS OF THE ACTIVISTS' SOCIAL AND POLITICAL HORLDS, FOCUSING ON THE ISRAELI LABOR AND HERUT PARTIES. THE FIRST DETAILS THE EXTENT TO WHICH THE ETHNIC DIVISIONS THAT DISTINGUISH HERUTNIKS AND LABORITES INFLUENCE THEIR SOCIAL IDENTIFICATIONS, THEIR PERCEPTIONS OF ETHNIC DISCRIMINATION AND CONFLICTS IN ISRAEL, AND THEIR CHOICE OF FRIENDS AND ALLIES. THEN THEY EXPLORE TWO COMPONENTS OF THE ACTIVIST'S POLITICAL WORK--ENGAGING IN SOCIAL CONTACTS AND ATTENOING PARTY MEETINGS. FINALLY, THEY
EXAMINE THE EXTENT TO WHICH ACTIVISTS SEEK TO ASSIST CITIZENS IN SOLVING PROBLEMS WITH GOVERNMENT AGENCIES AND THE EXTENT TO WHICH ACTIVISTS PARTICIPATE IN THE ORGANIZED LIFE OF THEIR POLITICAL PARTY.

09986 ZUCKERT, C. THE POLITICS OF DERRIDEAN DECONSTRUCTION POLITY, XXIII (3) (SPR 91), 335-356.

THE TERH "DECONSTRUCTION," ACCORDING TO ONE OF ITS CHAMPIONS, JACQUES DERRIDA, IS MORE THAN MERELY A METHOD FOR INTERPRETING TEXTS; IT IS A MODE OF POLITICAL ACTION AS WELL, THOUGH IT IS NOT "POLITICAL ACTION" AS THAT TERM IS ORDINARILY UNDERSTOOD. THIS ARTICLE EXPLORES DERRIDA'S CLAIM THAT THE DECONSTRUCTION OF TEXTS IS ESSENTIALLY AND EMPHATICALLY A POLITICAL ACT. IT REYIEHS THE RATIOMALE FOR DECONSTRUCTION AS A WAY OF READING TEXTS AND SHOWS WHY THIS RATIONALE LEADS DERRIDA TO CLAIM THE DECONSTRUCTION HAS POLITICAL CONSEQUENCES--THAT IT IS A NEW WAY OF CONSTITUTIMG POLITICAL CONSEQUENCES--THAT IT IS A NEW WAY OF CONST
"THE WORLD." THE AUTHOR GOES ON TO ASSESS WHAT THESE POLITICAL CONSEQUENCES ACTUALLY ARE.

09987 ZUCKERT, $M$.

COMPLETING THE CONSTITUTION: THE FOURTEENTH AMENDMENT AND CONSTITUTIONAL RIGHTS

PUBLIUS: THE JOURNAL OF FEDERALISM, 22(2) (SPR 92), 69-92. ALTHOUGH THE FOURTEENTH AMENDMENT HAS BEEN THE VEHICLE FOR A NUMBER OF TRANSFORMATIONS IN THE PROTECTION OF RIGHTS, THERE HAS BEEN NO CONSENSUS ON WHAT IT MEANS. THE AMENDMEN IS SOMETIMES HELD TO HAVE REVOLUTIONI ZED THE CONSTITUTION, IN EFFECT REPLACING THE TRADITIONAL FEDERAL SYSTEM HITH A
MORE NATIOMAL SYSTEM. IT IS ALSO ARGUED THAT THE AMENDMENT ESSENTIALLY REAFFIRMED THE PREWAR CONSTITUTION. THE TRUTH APPEARS TO LIE WITH NEITHER SIDE: THE DRAFTERS OF THE AMENDMENT ATTEMPTED TO "COMPLETE THE CONSTITUTION," NEITHER TO REFORM IT RADICALLY, NOR TO REAFFIRM IT SIMPLY. IN DOING SO, THEY UNWITTINGLY FOLLOWED IN THE TRACKS OF THE ORIGINIAL "FATHER OF THE CONSTITUTION," JAMES MADISON, WHO BELIEVED THE ORIGINAL CONSTITUTION TO BE DEFECTIVE IN IMPORTANT WAYS. PROPER ATTENTION TO THE CONTEXT AND THE STRUCTURE OF THE TEXT OF THE AMENDMENT REVEALS JUST HOW THE AMENDMENT WAS TO "COMPLETE THE CONSTITUTION." SO EXAMINED, THE AMENDMENT REVEALS ITSELF TO BE A PRECISELY STATED, CLEARLY DRAFTED TEXT, CONTAINING A NUMBER OF NEH CONSTITUTIONAL PRINCIPLES. PROTECTION FOR RIGHTS ALREADY POSSESSED IN SOME SENSE, BUT THEREFORE UNPROTECTED IN THE OLD CONSTITUTION.

09988 ZUCKERT, M.

THE VIRTUOUS POLITY, THE ACCOUNTABLE POLITY: LIBERTY AND RESPONSIBILITY IN "THE FEDERAL IST"

PUBLIUS: THE JOURNAL OF FEDERALISM, 22(1) (WIN 92), 123-142.

"THE FEDERALIST" CLAIMED to PRESENT a REPUbLICAN RESPONSE TO THE TYPICAL POLITICAL PROBLEMS FACED BY REPUBLICS. THAT SOLUTION REQUIRED A DEPARTURE FROM ALL MODELS OF REPUBLICS KNOWN AT THAT ATHE, AND IN PARTICULAR A BREAK WITH ANTI-FEDERALIST MODELS THAT POSITED HEAVY RELIANCE ON RESPONSIBLITY, UNDERSTOOD AS EITHER POLITICAL
ACCOUNTABILITY OR AS MORAL AND POLITICAL VIRTUE. "THE FEDERALIST" CHALLENGES THE ANTI-FEDERALIST NOTION THAT A "NOGAP POLITY" IS THE MEANS TO SAFE AND EFFECTIVE REPUBLICANISH. IT ALSO CHALLENGES THOSE WHO BELIEVE THAT VIRTUE OF PEOPLE OR RULERS IS THE PRECONDITION OF A REPUBLICAN POLITY. THIS ARTICLE SUGGESTS THAT PUBLIUS DOES REQUIRE QUASI-VIRTUES OF CERTAIN SORTS--AND THUS DOES NOT RELY ENTIRELY ON CALCULATING SELF-INTEREST-BUT THESE ARE SIGNIFICANTLY DIFFERENT FROM THE VIRTUES POSITED BY EARLIER REPUBLICAN THEORISTS OR CERTAIN CONTEMPORARY INTERPRETERS OF "THE FEDERALIST."

09989 ZUCKETT, M.

COMPLETING THE CONSTITUTION: THE FOURTEENTH AMENDMENT AND CONSTITUTIONAL RIGHTS

PUBLIUS: THE JOURNAL OF FEDERALISM, 22(2) (SPR 92), 69-92. THE DRAFTERS OF THE CONSTITUTION ATTEMPTED TO COMPLETE

THE CONSTITUTION, NEITHER TO REFORM IT RADICALLY, NOR TO REAFFIRM IT SIMPLY. PROPER ATTENTION TO THE CONTEXT AND THE STRUCTURE OF THE TEXT OF THE FOURTEENTH AMENDMENT REVEALS JUST HOW THE AMENDMENT HAS TO COMPLETE THE CONSTITUION. SO EXAMINED, THE AMENDMENT REVEALS ITSELF TO BE A PRECISLY STATED, CLEARLY DRAFTED TEXT, CONTAINING A NUMBER OF NEW CONSTITUTIONAL PRINCIPLES. PROPERLY UNDERSTOOD, THE CONSTITUTIONAL PRINCIPLES. PROPERLY UNDERSTOOD, THE ALREADY POSSESSED IN SOME SENSE, BUT THEREFORE UNPROTECTED ALREADY POSSESSED IN SOME

09990 ZUKROWSKA, $K$

PRIMARY STEPS IN RESHAPING THE MILITARY INDUSTRY IN EASTERN EUROPE IN THE 1990 S

PEACE AND THE SCIENCES, 4 (DEC 91), 22-28.

THE PRIMARY STEPS IN RESHAPING THE MILITARY INDUSTRY IN EASTERN EUROPE IN THE 1990'S ARE DISCUSSED IN THIS ARTICLE. BEGINNING WITH A STATEMENT ABOUT WHAT IS KNOWN AND WHAT IS STILL UNKNOHN, THE ARTICLE THEN DISCUSSES THE CHANGING CONDITIONS FOR MILITARY PROCUREMENT. THE QUESTION OF HOW DIFFERENCES IN PRODUCTION PATTERNS INFLUENCE THE ADJUSTMENT TO NEW CONDITIONS IS ALSO ADDRESSED.

09991 ZUNES, S.

FACTORS SHAPING THE US-ISRAELI ALLIANCE

NEW POL ITICAL SCIENCE, 21-22 (SPR 92), 91-116.

THE SPECIAL RELATIONSHIP BETWEEN THE UNITED STATES AND

ISRAEL HAS BECOME THE FOCUS OF AN INCREASINGLY NUMBER OF

SCHOLARS IN RECENT YEARS AS IT BECOMES INCREASINGLY

CONTROVERSIAL WITH THE AMERICAN PUBLIC. THERE ARE INCREASING QUESTIONS RAISED OVER THE NATURE OF U.S. POLICY. THE EXTENT OF UNITED STATES SUPPORT OF ISRAEL HAS BEEN WELL DOCUMENTED AND IS SUBJECTED TO A BRIEF OVERVIEW. WHAT THIS PAPER SEEKS TO ESTABLISH IS WHY SUCH A RELATIONSHIP EXISTS AND WHY IT HAS SUCH WIDESPREAD SUPPORT BY THE POLITICAL LEADERSHIP OF THE UNITED STATES, DESPITE SERIOUS RISKS TO BOTH COUNTRIES.

09992 ZUPAN, $M$.

MEASURING THE IDEOLOGICAL PREFERENCES OF U.S. PRESIDENTS: A PROPOSED (EXTREMELLY SIMPLE) METHOD

PUBLIC CHOICE $73(3)$ (APR 92 ) 351-362

THIS ARTICLE PROPOSES A METHOD FOR MEASURING THE IDEOLOGICAL PREFERENCES OF U.S. PRESIDENTS. IT SUGGESTS DATA ANO METHODOLOGY FOR DEVELOPING A PRESIDENTIAL ADA RATING. THESE ARE INTENDED TO BE A FIRST STEP TOWARD TESTING THE EXPLANATORY POHER OF THE CONGRESSIONAL DOMINANCE THEORY RELATIVE TO OTHER, BROADER CONCEPTIONS OF BUREAUCRATIC/REGULATORY POLICY OUTCOMES. 
09993 ZUROFF, E. WHITEWASHING THE HOLOCAUST: LITHUANIA AND THE REHABILITATION OF HISTORY

NATIONAL REVIEW, XLIV(1) (JAN 92), 43-46.

WHILE THERE WERE SOME BRAVE LITHUANIANS WHO AT GREAT RISK EXTENDED ASSISTANCE TO JEWS. THE NUMBER OF THEIR COMPATRIOTS WHO ACTIVELY COLLABORATED IN OR CARRIED OUT THE MURDERS WAS IMMEASURABLY GREATER. AFTER THE HAR THE LITHUANIAN PEOPLE WERE SPARED A PAINFUL CONFRONTATION WITH THE SCOPE AND EXTENT OF THEIR COLLABORATION. THE RECENT EMERGENCE OF LITHUANIAN INDEPEDENCE, HOWEVER, BROUGHT THIS ISSUE TO THE SURFACE. THIS ARTICLE SUGGESTS THAT RECENT GESTURES BY LILTHUANIANS MAY BE PART OF A CONCERTED EFFORT TO MAXIMIZE POL ITICAL GAIN WITH MINIMAL POLITICAL COSTS. IT CONCLUDES THAT AS LONG AS LITHUANIA HOPES FOR AID FROM THE WEST THAT THE FREEDOM AND WELFARE OF ITS JEWISH CITIZENS ARE RELATIVELY ASSURED.

09994 ZUZOWSKI, R.

THE IMPACT OF NATIONALISM ON COMMUNISM: THE CASE OF POLAND CANADIAN REVIEH OF STUDIES IN NATIONALISM, XIX(1) (1992), 9-17.

SINCE THE EARLY TWENTIETH CENTURY, NATIONALISM HAS BECOME A UNIVERSAL IDEOLOGY. THIS ESSAY ANALYZES THE IMPACT OF NATIONALISM ON COMMUNISM, PARTICULARLY IN POLAND. IT ARGUES THAT THE COHWUNIST IDEA, BY ITSELF, IS TOO NARROW, WEAK, AND AMBIGUOUS TO SUCCEED IN REAL LIFE. COUPLED WITH NATIONALISM IT CAN BECOME AN EFFICACIOUS POLITICAL FORCE. WHEN NATIONALISH CLASHES WITH COMHUNISM, POLITICAL TENSION RESULTS THAT WEAKENS THE LATTER IDEOLOGY.

09995 ZVIAGELSKAIA, I.D.

STEPS VERSUS' SOLUTIONS IN THE ARAB-ISRAELI CONFLICT ANNALS OF THE AMERICAN ACADEMY OF POLITICAL AND SOCIAL SCIENCE, (518) (NOV 91), 109-117.

PARTIAL SOLUTIONS CAN BE WAY-STATIONS EN ROUTE TO THE COMPLETE RESOLUTION OF A REGIONAL COMFLICT OR THEY CAN ACTUALLY HINDER RESOLUTION BY PROVIDING COMFORTABLE RESTING PLACES WITH NO INCENTIVES TO MOVE ON. THE STEP-BY-STEP PEACE PROCESS IN THE MIDDLE EAST RECOGNIZED LOCAL AND GLOBAL REALITIES, BUT IT LEFT THE CONFLICT STUCK AFTER THE CAMP DAVID ACCORDS AND THE EGYPTIAN-I SRAELI PEACE TREATY. SADDAM HUSSEIN ERRED IN BELIEVING THAT THE END OF THE COLD WAR PRESENTED AM OPPORTUMITY TO CARRY OUT AGGRESS ON WITH IMPUNITY, BUT THERE WILL BE OTHER SADOAM HUSSEINS AS LONG AS A GENERAL SETTLEMENT IS NOT REACHED IN THE REGION. WHAT IS NEEDED IS JOINT U.S.-SOVIET ACTION AND A BALANCED FORMULA THAT PROVIDES FOR THE RETURN OF A FEW PALESTINIANS TO ISRAEL IN EXCHAMGE FOR THE MAINTENANCE OF SOME ISRAEL I SETTLEMENTS ON THE WEST BANK, SEALED BY AN INTERMATIONAL CONFERENCE.

09996 ZWANE, $B$

SHAZILAND REYIEWS ITS POLITICAL SYSTEM

PARLIAMENTARIAN

SWAZILAND'S PRIME MINISTER HAS HARNED DIE-HARD

CONSERVATIVES WHO WANT TO RETAIN THE COUNTRY'S PRESENT POLITICAL SYSTEM THAT CHANGE IS INEVITABLE, DUE TO THE GENERAL MOVEMENT TOWARD POLITICAL REFORM THROUGHOUT AFRICA. IN 1991, KING MSHATI III APPOINTED THE TINKHUNDLA REVIEW COMMITTEE TO STUDY SWAZILAND'S POLITICAL SYSTEM AND LAY THE GROUNDWORK FOR REFORM.

09997 ZWEIG, D.

INTERNATIONALIZING CHINA'S COUNTRYSIDE: THE POLITICAL

ECONOMY OF EXPORTS FROM RURAL INDUSTRY

CHINA QUARTERLY, (128) (DEC 91) 716-741.

THE AUTHOR DISCUSSES HOW CHINA'S OPEN POLICY HAS

AFFECTED THE DOMESTIC POLITICAL ECONOMY, OPPORTUNITY

STRUCTURES, AND THE NATURE OF POL ITICAL COMFLICT AMD

COMPETITION WITHIN CHINA BY FOCUSING ON HOH THE DECISION TO

PROMOTE EXPORTS FROM TOWNSHIP AND VILLAGE ENTERPRISES

(TVE'S) HAS GENERATED NEW OPPORTUNITIES, INEQUALITIES, AND

POLITICAL COMPETITION IN RURAL POLICY AND WITHIN RURAL CHINA.

09998 ZWERLING, C. : SILVER, H.

RACE AND JOB DISMISSALS IN A FEDERAL BUREAUCRACY

AMERICAN SOCIOLOGICAL REVIEH, 57(5) (OCT 92), 651-660.

THE AUTHORS EXAMINE THE RACIAL DIFFERENTIAL IN JOB

DISMISSALS IN THE FEDERAL GOVERNMENT. THEY FIND THAT BLACKS

ARE MORE THAN THICE AS LIKELY TO BE FIRED, AFTER CONTROLLING FOR HUMAN CAPITAL VARIABLES, JOB TENURE, DETAILED JOB TITLE, UNION PROTECTION, ABSENTEEISM, AND THE INCIDENCE OF ACCIDENTS, INJURIES, AND DISCIPLINARY ACTIONS. THAT BLACK POSTAL WORKERS IN A LARGE NORTHEASTERN CITY WERE MORE LIKELY TO BE FIRED THAN THEIR WHITE COUNTERPARTS SUGGESTS THAT RACIAL DIFFERENTIALS IN JOB OISMISSALS ARE AT LEAST AS GREAT IN THE PRIVATE SECTOR. A THEORY OF JOB DISMISSALS SHOULD CONSIDER EMPLOYER PRACTICES AS HELL AS HORKER

CHARACTERISTICS.

09999 ZWICK, P. MAINSTREAMING POLITICAL SCIENCE INSTRUCTION: AN ADOITIVE

PS: POLITICAL SCIENCE AND POLITICS, 25(4) (DEC 92),
714-717.

INTERACTING WITH A BROAD CROSS SECTION OF ACADEMICS FROM MANY DISCIPINES AND INSTITUTIONS HAS UNDERSCORED FOR PETER ZHICK THE WIDESPREAD DISCONTENT AND CONCERN ABOUT RECENT TRENDS IN HIGHER EDUCATION, ESPECIALLY THE NARROWNESS OF OUR
CONCEPTION OF SCHOLARSHIP AND THE CONCOMITANT DEPRECIATION OF THE VALUE OF INSTRUCTION IN HIGHER EDUCATION. HE ALSO BELIEVES THAT AS VALIO AS MANY RECENT CRITIQUES OF HIGHER EDUCATION HAVE BEEN, THERE HAS BEEN LITTLE DISCERNIBLE MOVEMENT TOWARD A BROADER, MORE INCLUSIVE DEFINITIOY SCHOLARSHIP BECAUSE THE PROPOSED REMEDIES REQUIRE WHOLESALE OISCIPLINARY CHANGE. THERE IS A POL ITICAL SCIENCE ESTABL I SHMENT THAT FEELS THREATENED BY THOSE WHO WOULD QUESTION THE RECOGNITION AND REHARD SYSTEM THAT IS THE FOU TOTION REJECT DEMANDS FOR CHANGE. HE OFFERS AN ADOITIVE APPROACH FER MAINSTREAMING POLITICAL SCIENCE INSTRUCTION.

10000 ZYCHER, 8

DEBT, LIES, AND REAGANOMICS

NATIONAL REVIEW, XLIV(24) (DEC 92), 41-43.

ONGOING MYTH-MAKING HAS AS ITS CENTRAL FEATURES THE ARGUMENTS THAT THE PUBLIC DEBT ACQUIRED DURING THE 19805 LAID THE FOUNDATION FOR FUTURE ECONOMIC WEAKNESS, AND THAT THE REAGAN ECONOMIC POLICIES ENCOURAGED THE ACCUMULATION OF PRIVATE DEBT FOR UNPRODUCTIVE PURPOSES. THIS ARTICLE EXAMINES THE RELATIONSHIP BETWEEN THE AMOUNT OF FEDERAL BORROWING AND THE AMOUNT OF FEDERAL CAPITAL EXPENDITURES DURING FY 1982-89. IT SUGGESTS THAT THE FUNDAMENTAL ISSUE IN THE DEFICIT DEBATE IS THE SIZE OF THE FEDERAL BUDGET. THE ARTICLE ALSO EXPLORES PRIYATE DEBT AND CONCLUDES THAT THE MYTHS ABOUT THE REAGAN YEARS ARE AS DAMAGING AS THEY ARE DISHONEST. 